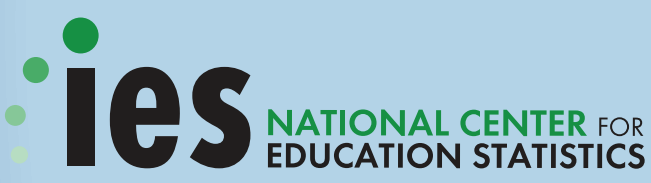

Institute of Education Sciences

NCES 2015-011

U.S. DEPARTMENT OF EDUCATION

\section{Digest of}

Education Statistics
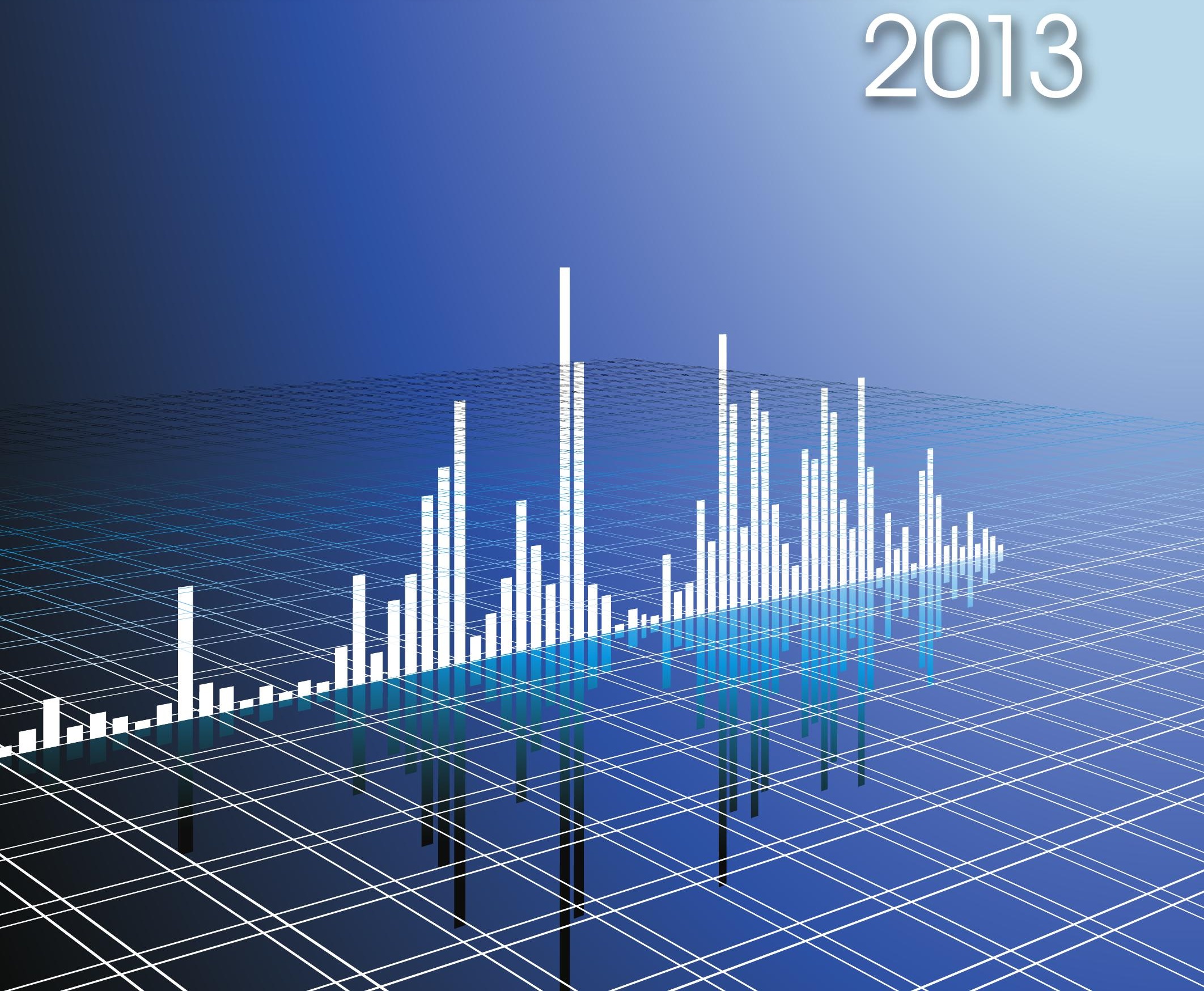



\section{Digest of Education Statistics 2013}

May 2015

Thomas D. Snyder

National Center for Education Statistics

Sally A. Dillow

American Institutes for Research 


\title{
U.S. Department of Education
}

Arne Duncan

Secretary

\section{Institute of Education Sciences}

Sue Betka

Acting Director

\author{
National Center for Education Statistics \\ Peggy G. Carr \\ Acting Commissioner
}

The National Center for Education Statistics (NCES) is the primary federal entity for collecting, analyzing, and reporting data related to education in the United States and other nations. It fulfills a congressional mandate to collect, collate, analyze, and report full and complete statistics on the condition of education in the United States; conduct and publish reports and specialized analyses of the meaning and significance of such statistics; assist state and local education agencies in improving their statistical systems; and review and report on education activities in foreign countries.

NCES activities are designed to address high-priority education data needs; provide consistent, reliable, complete, and accurate indicators of education status and trends; and report timely, useful, and highquality data to the U.S. Department of Education, the Congress, the states, other education policymakers, practitioners, data users, and the general public. Unless specifically noted, all information contained herein is in the public domain.

We strive to make our products available in a variety of formats and in language that is appropriate to a variety of audiences. You, as our customer, are the best judge of our success in communicating information effectively. If you have any comments or suggestions about this or any other NCES product or report, we would like to hear from you. Please direct your comments to

NCES, IES, U.S. Department of Education

$1990 \mathrm{~K}$ Street NW

Washington, DC 20006-5651

May 2015

The NCES Home Page address is http://nces.ed.gov.

The NCES Publications and Products address is http://nces.ed.gov/pubsearch.

This report was prepared for the National Center for Education Statistics under Contract No. ED-IES-12-D0002 with American Institutes for Research. Mention of trade names, commercial products, or organizations does not imply endorsement by the U.S. Government.

\section{Suggested Citation}

Snyder, T.D., and Dillow, S.A. (2015). Digest of Education Statistics 2013 (NCES 2015-01 1). National Center for Education Statistics, Institute of Education Sciences, U.S. Department of Education. Washington, DC.

\section{Content Contact}

Thomas D. Snyder

(202) 502-7452

tom.snyder@ed.gov 


\section{FOREWORD}

The 2013 edition of the Digest of Education Statistics is the 49th in a series of publications initiated in 1962. The Digest has been issued annually except for combined editions for the years 1977-78, 1983-84, and 1985-86. Its primary purpose is to provide a compilation of statistical information covering the broad field of American education from prekindergarten through graduate school. The Digest includes a selection of data from many sources, both government and private, and draws especially on the results of surveys and activities carried out by the National Center for Education Statistics (NCES). To qualify for inclusion in the Digest, material must be nationwide in scope and of current interest and value. The publication contains information on a variety of subjects in the field of education statistics, including the number of schools and colleges, teachers, enrollments, and graduates, in addition to data on educational attainment, finances, federal funds for education, libraries, and international comparisons. Supplemental information on population trends, attitudes on education, education characteristics of the labor force, government finances, and economic trends provides background for evaluating education data. Although the Digest contains important information on federal education funding, more detailed information on federal activities is available from federal education program offices.

The Digest contains seven chapters: All Levels of Education, Elementary and Secondary Education, Postsecondary Education, Federal Funds for Education and Related Activities, Outcomes of Education, International Comparisons of Education, and Libraries and Technology. Each chapter is divided into a number of topical subsections. Preceding the seven chapters is an Introduction that provides a brief overview of current trends in American education, which supplements the tabular materials in chapters 1 through 7 . The Digest concludes with three appendixes. The first appendix, Guide to Sources, provides a brief synopsis of the surveys used to generate the Digest tables; the second, Definitions, is included to help readers understand terms used in the Digest; and the third, Index of Table Numbers, allows readers to quickly locate tables on specific topics.

In addition to providing updated versions of many statistics that have appeared in previous years, this edition incorporates new material on the following topics:

- Number, percentage, and percentage distribution of total resident population and population under 18 years old, by nativity and race/ethnicity (including selected subgroups) (table 101.30)
- Number of persons 25 to 34 years old, percentage with a bachelor's or higher degree, and percentage distribution, by undergraduate field of study and selected student characteristics (table 104.60)

- Percentage distribution of spring 2002 high school sophomores, by highest level of education completed through 2012 and selected student characteristics (table 104.90)

- First-time kindergartners' primary type of child care arrangement prior to kindergarten entry, by selected child, family, and school characteristics (table 202.65)

- Public school enrollment in prekindergarten through grade 8 and public school enrollment in grades 9 through 12 , by region, state, and jurisdiction (tables 203.25 and 203.30)

- Enrollment and percentage distribution of enrollment in public elementary and secondary schools, by race/ethnicity and level of education (table 203.60)

- Children 3 to 21 years old served under Individuals with Disabilities Education Act (IDEA), Part B, by race/ethnicity and type of disability (table 204.50)

- Number and percentage distribution of teachers in public and private elementary and secondary schools, by selected teacher characteristics (table 209.10)

- Functional age of public schools' main instructional buildings and percentage of schools with permanent and portable (temporary) buildings, by selected school characteristics and condition of permanent and portable buildings (table 217.10)

- Percentage of public schools with plans for major repair, renovation, or replacement of building systems or features in the next 2 years and percentage distribution of schools with such plans, by selected school characteristics, type of system or feature, and main reason for the plans (table 217.15)

- Public high school graduates, by race/ethnicity (including historical and projected data) (table 219.30)

- Average National Assessment of Educational Progress (NAEP) science scale scores of 8th-graders with various attitudes toward science and percentage reporting these attitudes, by selected student characteristics (table 223.25)

- Number and percentage of high school graduates who took foreign language courses in high school and average number of credits earned, by language and number of credits (table 225.70)

- A variety of topics related to crime, environment, and security at elementary and secondary schools:

- School-associated homicides, suicides, and other violent deaths (table 228.10)

- Nonfatal criminal victimization of students ages 12-18 (tables 228.20, 228.25, and 228.30)

- Reports by students in grades 9-12 of being threatened or injured with a weapon on school property (table 228.40), with state-level data for public school students (table 228.50) 
- Reports by teachers of being threatened with injury or physically attacked by a student (table 228.70), with state-level data for public school teachers (table 228.80)

- Incidents of crime recorded by public schools and reported by the schools to the police (tables 229.10 , 229.30, and 229.40)

- Violent crime incidents and serious violent crime incidents recorded and reported to the police by public schools (table 229.50)

- Selected discipline problems reported by public schools (table 230.10)

- Reports by students ages 12-18 of gang presence at school (table 230.20)

- Reports by students ages 12-18 of being the target of hate-related words and seeing hate-related graffiti at school (tables 230.30 and 230.35)

- Reports by students ages 12-18 of being bullied at school or cyber-bullied anywhere during the school year (tables 230.40, 230.45, 230.50, 230.55, and 230.60)

- Public school reports of selected types of cyber-bullying problems (table 230.65)

- Reports by students ages 12-18 of fearing attack or harm at school and of avoiding places, school activities, or classes because of fear of attack or harm (tables 230.70 and 230.80)

- Teachers' agreement that student misbehavior and student tardiness/class cutting interfered with their teaching and that other teachers and their principal enforced school rules (tables 230.90 and 230.92), with statelevel data for public school teachers (table 230.95)

- Reports by students in grades 9-12 of being in physical fights (tables 231.10 and 231.20), with state-level data for public school students (table 231.30)

- Reports by students in grades 9-12 of carrying a weapon (tables 231.40 and 231.50), with state-level data for public school students (table 231.60)

- Reports by students ages 12-18 of having access to a loaded gun without adult permission (table 231.70)

- Reports by students in grades 9-12 of using alcohol (tables 232.10 and 232.20), with state-level data for public school students (table 232.30)

- Reports by students in grades 9-12 of using marijuana (tables 232.40 and 232.50), with state-level data for public school students (table 232.60)

- Reports by students in grades 9-12 that illegal drugs were made available to them on school property (table 232.70), with state-level data for public school students (table 232.80)
- Public schools taking serious disciplinary actions in response to specific offenses (table 233.10)

- Public schools with security staff present and with security staff routinely carrying a firearm (table 233.70)

- Reports by students ages 12-18 of various security measures at school (table 233.80)

- Number and percentage distribution of students enrolled in degree-granting postsecondary institutions, by distance education participation, level of enrollment, and control and level of institution (table 311.15)

- Number and percentage of undergraduate students taking night, weekend, or online classes, by selected characteristics (table 311.20)

- Number and percentage of graduate students taking night, weekend, or online classes, by selected characteristics (table 311.30)

- Selected statistics for degree-granting postsecondary institutions that primarily offer online programs, by control of institution and selected characteristics (table 311.33)

- On-campus crimes, arrests, and referrals for disciplinary action at degree-granting postsecondary institutions, by location of incident, control and level of institution, and type of incident (table 329.10)

- On-campus crimes, arrests, and referrals for disciplinary action per 10,000 full-time-equivalent (FTE) students at degree-granting postsecondary institutions, by whether institution has residence halls, control and level of institution, and type of incident (table 329.20)

- Percentage of undergraduate students ages 18 to 24 in their 4 th (senior) year or above who had ever received federal loans, nonfederal loans, or Parent Loans for Undergraduates (PLUS), and average cumulative amount borrowed, by selected student characteristics and control and level of institution (table 331.95)

- Among 25- to 34-year-olds with a bachelor's or higher degree, percentage who were employed in any occupation, by undergraduate field of study, sex, race/ethnicity, nativity, and citizenship status (table 505.20)

- Among employed 25- to 34-year-olds with a bachelor's degree in a science, technology, engineering, or mathematics (STEM) field, percentage with STEM and non-STEM occupations, by sex, race/ethnicity, nativity, and citizenship status (table 505.30)

The Digest can be accessed from http://nces.ed.gov/programs/digest.

Thomas D. Snyder

Supervisor

Annual Reports and Information Staff 


\section{Contents}

Page

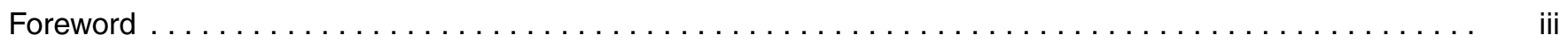

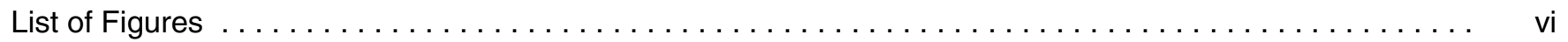

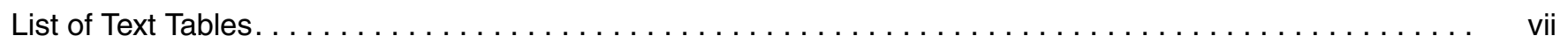

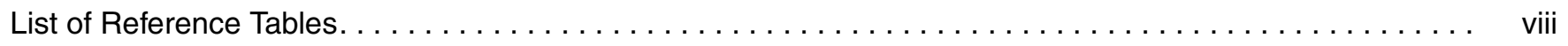

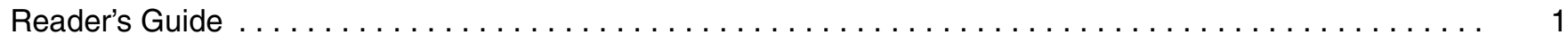

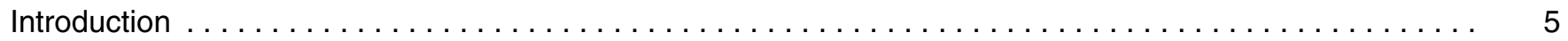

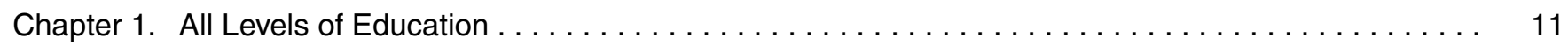

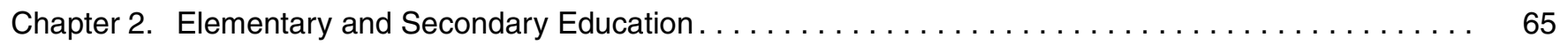

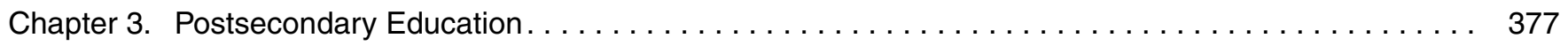

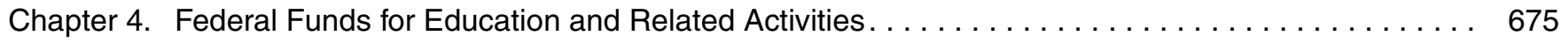

Chapter 5. Outcomes of Education $\ldots \ldots \ldots \ldots \ldots \ldots \ldots \ldots \ldots \ldots \ldots \ldots \ldots \ldots \ldots \ldots \ldots \ldots \ldots$

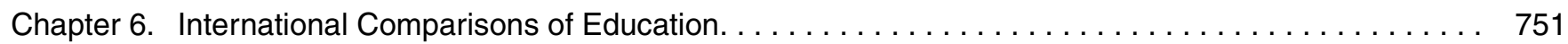

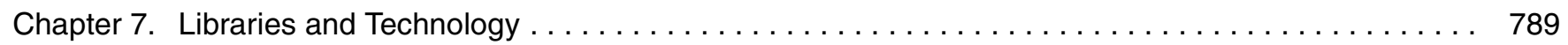

Appendix A. Guide to Sources. . . . . . . . . . . . . . . . . . . . . . . . . . . . . . . 799

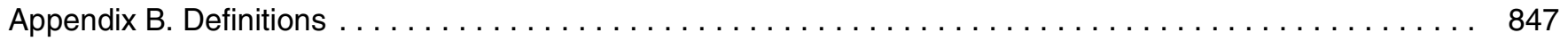

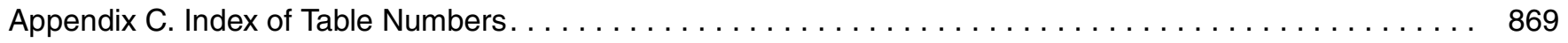




\section{List of Figures}

Figure

Page

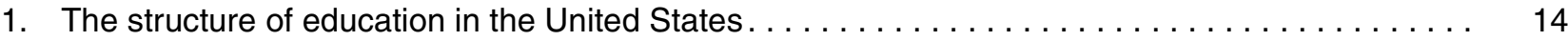

2. Enrollment, total expenditures in constant dollars, and expenditures as a percentage of the gross domestic product (GDP), by level of education: Selected years, 1965-66 through 2012-13 . . .

3. Percentage of persons 25 years old and over, by highest level of educational attainment: Selected

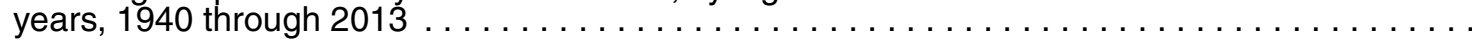

4. Percentage of persons 25 through 29 years old, by highest level of educational attainment:

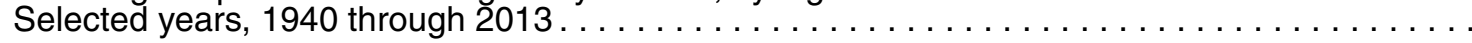

5. Highest level of education attained by persons 25 through 29 years old: March $2013 \ldots \ldots \ldots$

6. Percentage of persons 25 through 29 years old, by selected levels of educational attainment and

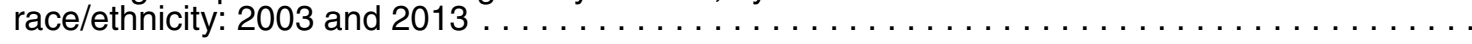

7. Enrollment, number of teachers, pupil/teacher ratio, and expenditures in public elementary and

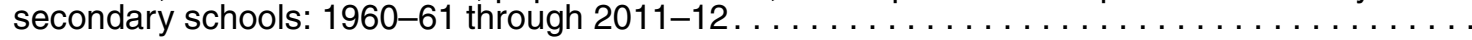

8. Percentage change in public elementary and secondary enrollment, by state: Fall 2006 to fall 2011

9. Total and full-day preprimary enrollment of 3- to 5-year-olds: October 1970 through October $2012 \ldots$

10. Percentage of revenue for public elementary and secondary schools, by source of funds: 1970-71

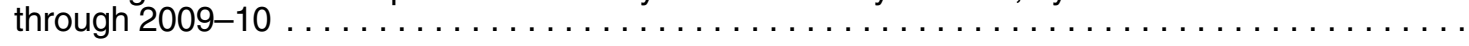

11. Current expenditure per pupil in fall enrollment in public elementary and secondary schools:

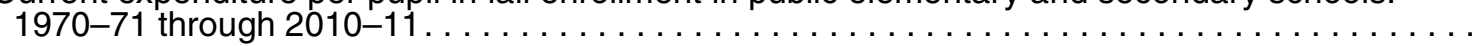

12. Enrollment, degrees conferred, and expenditures in degree-granting postsecondary institutions:

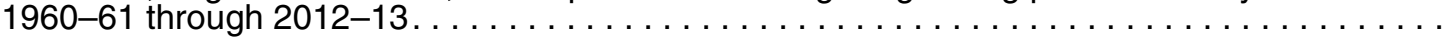

13. Percentage change in total enrollment in degree-granting postsecondary institutions, by state: Fall

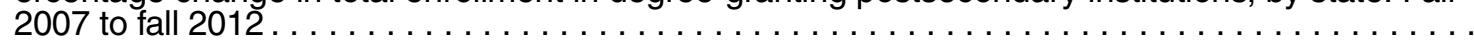

14. Enrollment in degree-granting postsecondary institutions, by age: Fall 1970 through fall $2023 \ldots$

15. Ratio of full-time-equivalent (FTE) students to total FTE staff and to FTE faculty in degree-granting institutions, by control of institution: 1991,2001 , and $2011 \ldots \ldots \ldots \ldots \ldots \ldots \ldots \ldots \ldots \ldots$

16. Bachelor's degrees conferred by postsecondary institutions in selected fields of study:

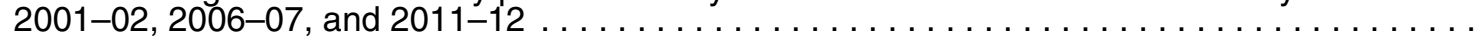

17. Percentage distribution of total revenues of public degree-granting postsecondary institutions, by

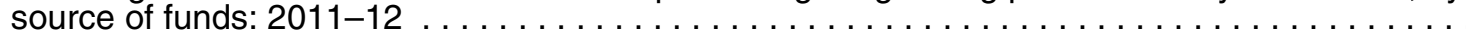

18. Percentage distribution of total revenues of private nonprofit degree-granting postsecondary

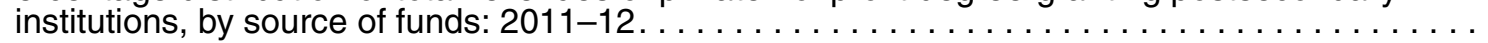

19. Percentage distribution of total revenues of private for-profit degree-granting postsecondary

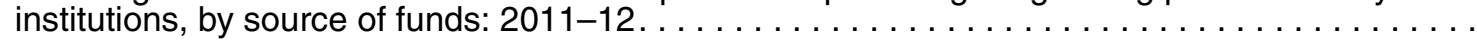

20. Federal on-budget funds for education, by level or other educational purpose: Selected years,

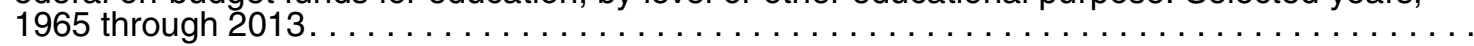

21. Percentage of federal on-budget funds for education, by agency: Fiscal year $2012 \ldots \ldots \ldots \ldots$

22. Unemployment rates of persons 25 to 34 years old, by highest level of educational attainment:

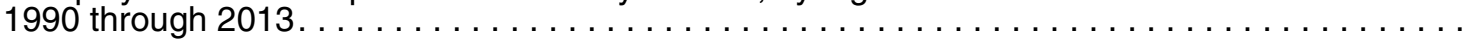

23. Employment to population ratios of persons 25 to 34 years old, by highest level of educational

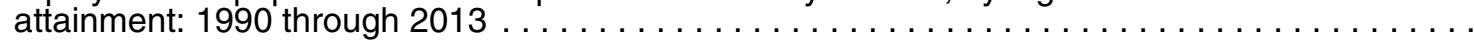

24. Percentage distribution of 2011-12 high school dropouts and high school completers not enrolled in college, by labor force status: October 2012

25. Median annual earnings of full-time year-round workers 25 years old and over, by highest level of

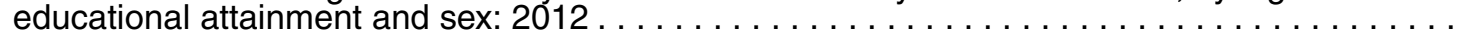

26. Median annual salaries of bachelor's degree recipients employed full time 1 year after graduation,

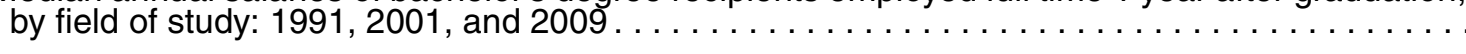

27. Percentage change in enrollment, by major areas of the world and level of education: 2000 to 2011 .

28. Percentage of the population 25 to 34 years old with a bachelor's or higher degree, by OECD

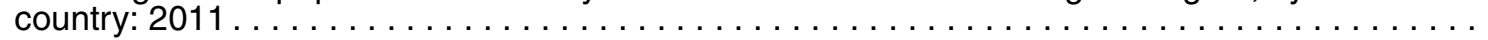

29. Public direct expenditures on education institutions as a percentage of gross domestic product (GDP), by OECD country: 2010 


\section{List of Text Tables}

A. Total elementary and secondary school enrollment, by overall trends: Selected years, $1949-50$ to

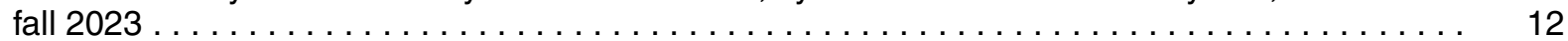

B. Number of public school staff, by selected categories: $1969-70,1980$, and $2011 \ldots \ldots \ldots \ldots 66$

C. Postsecondary students denied access to Title IV financial aid because eligibility was suspended due to a drug-related conviction: $2009-10 \ldots \ldots \ldots \ldots \ldots \ldots \ldots \ldots \ldots \ldots \ldots \ldots \ldots \ldots$

D. Federal on-budget funding for education, by category: Selected fiscal years, 1965 through 2012 . 675

E. Median annual earnings of full-time year-round workers 25 years old and over, by selected levels of educational attainment and sex: Selected years, 1995 through $2012 \ldots \ldots \ldots \ldots \ldots \ldots \ldots 702$

F. Population and enrollment at different levels in major areas of the world: 2000 and $2011 \ldots \ldots 752$ 


\section{List of Reference Tables}

\section{Chapter 1. All Levels of Education}

\section{Population}

Table

101.10. Estimates of resident population, by age group: 1970 through $2012 \ldots \ldots \ldots \ldots \ldots \ldots \ldots \ldots$

101.20. Estimates of resident population, by race/ethnicity and age group: Selected years, 1980 through 2012 . 19

101.30. Number, percentage, and percentage distribution of total resident population and population under 18 years old, by nativity and race/ethnicity (including selected subgroups): 2002, 2007, and 2012 . . 20

101.40. Estimated total and school-age resident populations, by state: Selected years, 1970 through 2012 . .

\section{Characteristics of Households With Children}

102.10. Number and percentage distribution of family households, by family structure and presence of own children under 18: Selected years, 1970 through $2012 \ldots \ldots \ldots \ldots \ldots \ldots \ldots \ldots$

102.20. Number and percentage of family households with own children under age 18, under age 6 , and

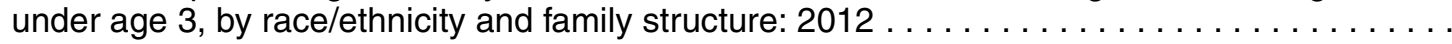

102.30. Median household income, by state: Selected years, 1990 through $2012 \ldots \ldots \ldots \ldots \ldots \ldots$

102.40. Poverty rates for all persons and poverty status of 5 - to 17-year-olds, by region and state:

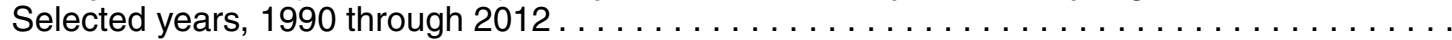

102.50. Official and supplemental measures of poverty status for all persons, persons in families, and related children under age 18, by race/ethnicity: Selected years, 1960 through $2012 . \ldots \ldots$.

102.60. Number and percentage of children under age 18 living in poverty, by family structure and race/

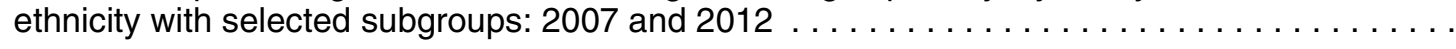

\section{Enrollment Rates}

103.10. Percentage of the population 3 to 34 years old enrolled in school, by sex, race/ethnicity, and age

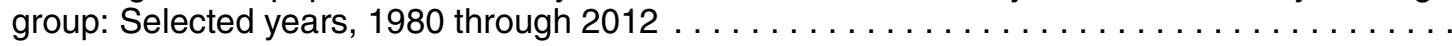

103.20. Percentage of the population 3 to 34 years old enrolled in school, by age group: Selected years,

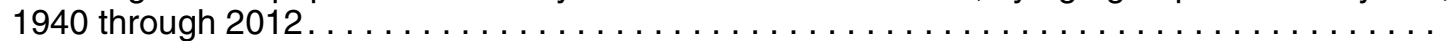

\section{Educational Attainment}

104.10. Rates of high school completion and bachelor's degree attainment among persons age 25 and over, by race/ethnicity and sex: Selected years, 1910 through $2013 \ldots \ldots \ldots \ldots \ldots \ldots$

104.20. Percentage of persons 25 to 29 years old with selected levels of educational attainment, by race/

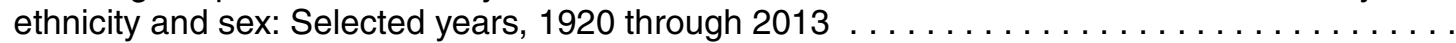

104.30. Number of persons age 18 and over, by highest level of educational attainment, sex, race/

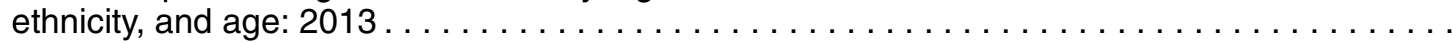

104.40. Percentage of persons 18 to 24 years old and age 25 and over, by educational attainment and race/ethnicity (including selected subgroups): 2007 and $2012 \ldots \ldots \ldots \ldots \ldots \ldots \ldots \ldots$

104.50. Persons age 25 and over who hold a bachelor's or higher degree, by sex, race/ethnicity, age

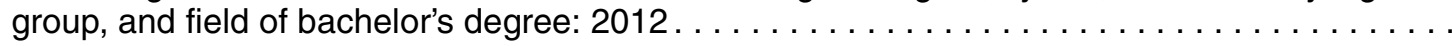

104.60. Number of persons 25 to 34 years old, percentage with a bachelor's or higher degree, and percentage distribution, by undergraduate field of study and selected student characteristics: $2012 \ldots \ldots \ldots$.

104.70. Percentage distribution of 6- to 18-year-olds, by parent's highest level of educational attainment, household type, and child's race/ethnicity: 2007 and $2012 \ldots \ldots \ldots \ldots \ldots \ldots \ldots \ldots$

104.80. Percentage of persons 18 to 24 years old and age 25 and over, by educational attainment and

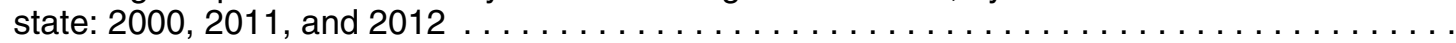

104.85. Rates of high school completion and bachelor's degree attainment among persons age 25 and

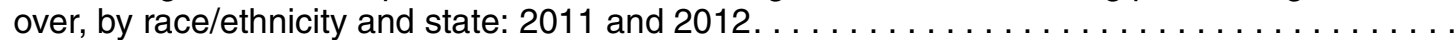


104.88. Rates of high school completion and bachelor's degree attainment among persons age 25 and

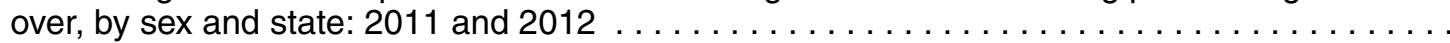

104.90. Percentage distribution of spring 2002 high school sophomores, by highest level of education completed through 2012 and selected student characteristics: $2012 \ldots \ldots \ldots \ldots \ldots \ldots$

104.95. Number of persons age 25 and over in metropolitan areas with populations greater than 1 million and rates of high school completion and bachelor's degree attainment among persons in this

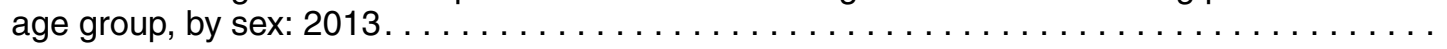

\section{Summary of Enrollment, Teachers, and Schools}

105.10. Projected number of participants in educational institutions, by level and control of institution: Fall 2013 .

105.20. Enrollment in educational institutions, by level and control of institution, enrollment level, and attendance status and sex of student: Selected years, fall 1990 through fall $2023 \ldots \ldots \ldots \ldots$. . . .

105.30. Enrollment in educational institutions, by level and control of institution: Selected years, 1869-70

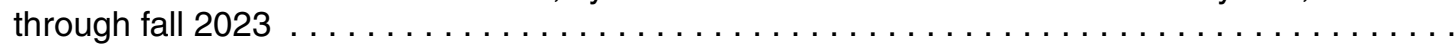

105.40. Number of teachers in elementary and secondary schools, and instructional staff in degree-granting postsecondary institutions, by control of institution: Selected years, fall 1970 through fall $2023 \ldots$. . .

105.50. Number of educational institutions, by level and control of institution: Selected years, 1980-81

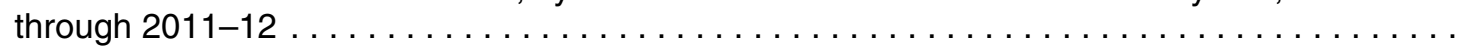

\section{Summary of Finances}

106.10. Expenditures of educational institutions related to the gross domestic product, by level of

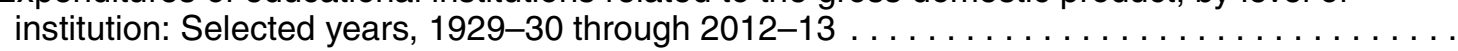

106.20. Expenditures of educational institutions, by level and control of institution: Selected years,

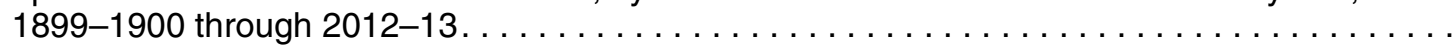

106.30. Amount and percentage distribution of direct general expenditures of state and local governments, by function: Selected years, $1970-71$ through $2010-11 \ldots \ldots \ldots \ldots \ldots \ldots$.

106.40. Direct general expenditures of state and local governments for all functions and for education, by level of education and state: $2009-10$ and $2010-11 \ldots \ldots \ldots \ldots \ldots \ldots \ldots \ldots \ldots \ldots$

106.50. Direct general expenditures per capita of state and local governments for all functions and for education, by level of education and state: $2009-10$ and $2010-11 \ldots \ldots \ldots \ldots \ldots \ldots$

106.60. Gross domestic product, state and local expenditures, national income, personal income, disposable personal income, median family income, and population: Selected years, 1929 through 2013 . . . . .

106.70. Gross domestic product price index, Consumer Price Index, education price indexes, and federal budget composite deflator: Selected years, 1919 through $2013 \ldots \ldots \ldots \ldots \ldots \ldots \ldots \ldots$

\section{Chapter 2. Elementary and Secondary Education}

\section{Historical}

201.10. Historical summary of public elementary and secondary school statistics: Selected years,

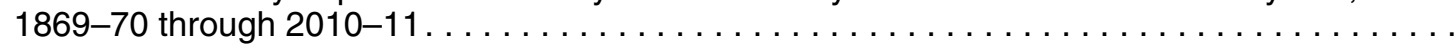

201.20. Enrollment in grades 9 through 12 in public and private schools compared with population 14 to 17 years of age: Selected years, $1889-90$ through fall $2013 \ldots \ldots \ldots \ldots \ldots \ldots \ldots \ldots$

\section{Enrollment Status and Child Care Arrangements of Young Children}

202.10. Enrollment of 3-, 4-, and 5-year-old children in preprimary programs, by level of program, control of program, and attendance status: Selected years, 1965 through $2012 \ldots \ldots \ldots \ldots \ldots \ldots$

202.20. Percentage of 3-, 4-, and 5-year-old children enrolled in preprimary programs, by attendance status, level of program, and selected child and family characteristics: $2012 \ldots \ldots \ldots \ldots \ldots$

202.30. Number of children under 6 years old and not yet enrolled in kindergarten, percentage in centerbased programs, average weekly hours in nonparental care, and percentage in various types of primary care arrangements, by selected child and family characteristics: $2005 \ldots \ldots \ldots \ldots$. 
202.40. Child care arrangements of 3- to 5-year-old children who are not yet in kindergarten, by age and

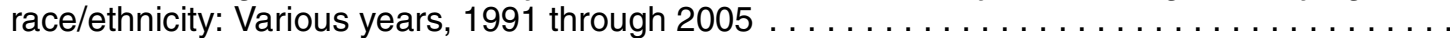

202.50. Percentage distribution of children at about 2 and 4 years of age, by type of child care arrangement and selected child and family characteristics: $2003-04$ and $2005-06 \ldots \ldots \ldots$. . .

202.60. Percentage distribution of quality rating of child care arrangements of children at about 4 years of age, by type of arrangement and selected child and family characteristics: $2005-06 \ldots \ldots \ldots$. .

202.65. First-time kindergartners' primary type of child care arrangement prior to kindergarten entry, by selected child, family, and school characteristics: $2010-11 \ldots \ldots \ldots \ldots \ldots \ldots \ldots \ldots$

202.70. Children of prekindergarten through second-grade age, by enrollment status, selected maternal characteristics, and household income: 1995,2001 , and $2005 \ldots \ldots \ldots \ldots \ldots \ldots \ldots$

\section{Enrollment in Public Schools}

203.10. Enrollment in public elementary and secondary schools, by level and grade: Selected years, fall

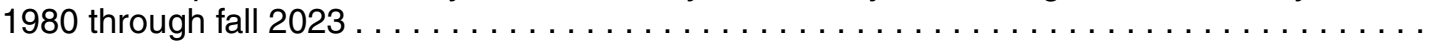

203.20. Enrollment in public elementary and secondary schools, by region, state, and jurisdiction: Selected

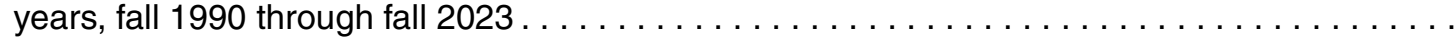

203.25. Public school enrollment in prekindergarten through grade 8 , by region, state, and jurisdiction:

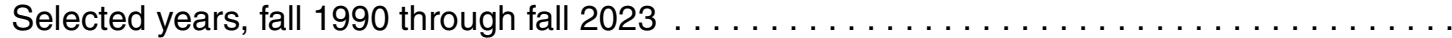

203.30. Public school enrollment in grades 9 through 12, by region, state, and jurisdiction: Selected years,

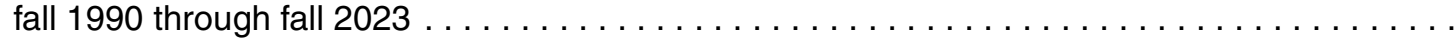

203.40. Enrollment in public elementary and secondary schools, by level, grade, and state or jurisdiction:

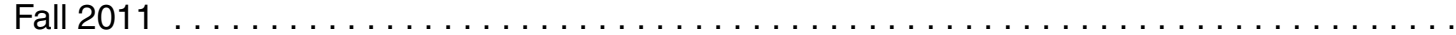

203.45. Enrollment in public elementary and secondary schools, by level, grade, and state or jurisdiction:

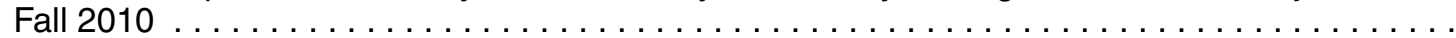

203.50. Enrollment and percentage distribution of enrollment in public elementary and secondary schools, by race/ethnicity and region: Selected years, fall 1995 through fall 2023

203.60. Enrollment and percentage distribution of enrollment in public elementary and secondary schools, by race/ethnicity and level of education: Fall 1998 through fall $2023 \ldots \ldots \ldots \ldots \ldots \ldots \ldots$

203.70. Percentage distribution of enrollment in public elementary and secondary schools, by race/

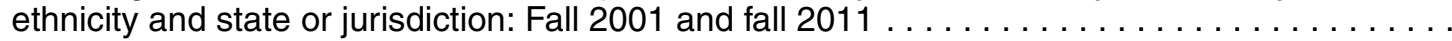

203.80. Average daily attendance in public elementary and secondary schools, by state or jurisdiction:

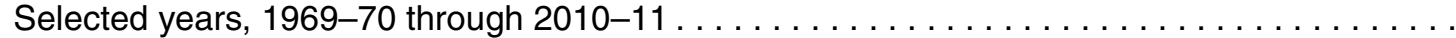

203.90. Average daily attendance (ADA) as a percentage of total enrollment, school day length, and school year length in public schools, by school level and state: $2007-08$ and $2011-12 \ldots \ldots \ldots \ldots$

\section{Participation in Public School Services}

204.10. Number and percentage of public school students eligible for free or reduced-price lunch, by state:

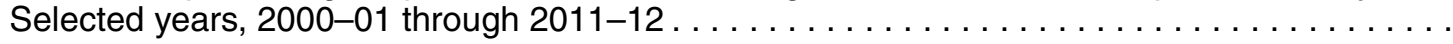

204.20. Number and percentage of public school students participating in programs for English language learners, by state: Selected years, $2002-03$ through $2011-12 \ldots \ldots \ldots \ldots \ldots \ldots \ldots$

204.30. Children 3 to 21 years old served under Individuals with Disabilities Education Act (IDEA), Part B, by type of disability: Selected years, $1976-77$ through $2011-12 \ldots \ldots \ldots \ldots \ldots \ldots \ldots$

204.40. Children 3 to 21 years old served under Individuals with Disabilities Education Act (IDEA), Part B, by race/ethnicity and age group: $2000-01$ through $2011-12 \ldots \ldots \ldots \ldots \ldots \ldots \ldots$

204.50. Children 3 to 21 years old served under Individuals with Disabilities Education Act (IDEA), Part B, by race/ethnicity and type of disability: 2010-11 and 2011-12

204.60. Percentage distribution of students 6 to 21 years old served under Individuals with Disabilities Education Act (IDEA), Part B, by educational environment and type of disability: Selected years, fall 1989 through fall 2011

204.70. Number and percentage of children served under Individuals with Disabilities Education Act (IDEA), Part B, by age group and state or jurisdiction: Selected years, 1990-91 through 2011-12 . . . . . 
204.80. Number of gifted and talented students in public elementary and secondary schools, by sex, race/

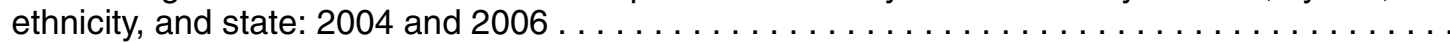

204.90. Percentage of gifted and talented students in public elementary and secondary schools, by sex,

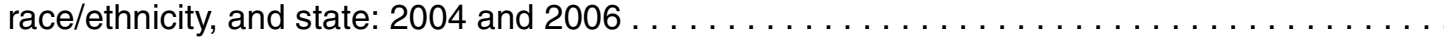

\section{Private School Education}

205.10. Private elementary and secondary school enrollment and private enrollment as a percentage of total enrollment in public and private schools, by region and grade level: Selected years, fall 1995

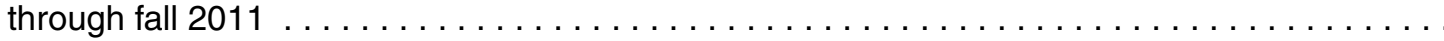

205.20. Enrollment and percentage distribution of students enrolled in private elementary and secondary schools, by school orientation and grade level: Selected years, fall 1995 through fall $2011 \ldots$. .

205.30. Percentage distribution of students enrolled in private elementary and secondary schools, by school orientation and selected characteristics: Fall 2009 and fall $2011 \ldots \ldots \ldots \ldots \ldots \ldots$.

205.40. Number and percentage distribution of private elementary and secondary students, teachers, and schools, by orientation of school and selected characteristics: Fall 1999, fall 2009, and fall $2011 . .$.

205.50. Private elementary and secondary enrollment, number of schools, and average tuition, by school level, orientation, and tuition: Selected years, 1999-2000 through $2011-12 . \ldots \ldots \ldots \ldots \ldots$

205.60. Private elementary and secondary school full-time-equivalent (FTE) staff and student to FTE staff ratios, by orientation of school, school level, and type of staff: $2007-08$ and $2011-12 \ldots \ldots \ldots$.

205.70. Enrollment and instructional staff in Catholic elementary and secondary schools, by level:

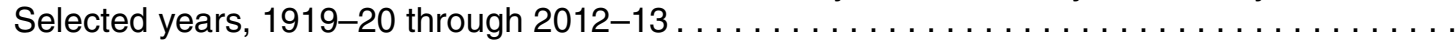

205.80. Private elementary and secondary schools, enrollment, teachers, and high school graduates, by

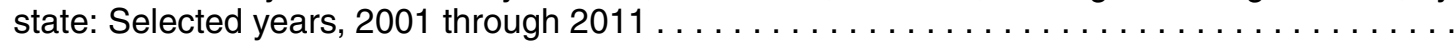

\section{Homeschooling and School Choice}

206.10. Number and percentage of homeschooled students ages 5 through 17 with a grade equivalent of kindergarten through 12th grade, by selected child, parent, and household characteristics: 2003 ,

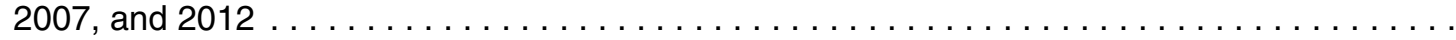

206.20. Percentage distribution of students ages 5 through 17 attending kindergarten through 12th grade, by school type or participation in homeschooling and selected child, parent, and household

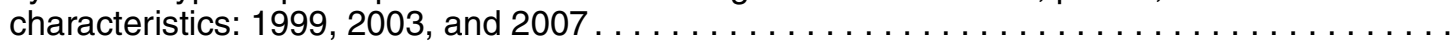

\section{Parent Involvement in Education}

207.10. Number of 3- to 5-year-olds not yet enrolled in kindergarten and percentage participating in home literacy activities with a family member, by type and frequency of activity and selected child and

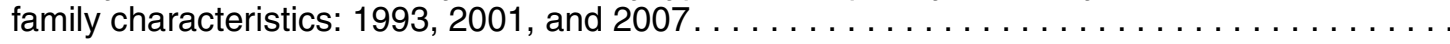

207.20. Percentage of kindergartners through fifth-graders whose parents reported doing educationrelated activities with their children in the past month, by selected child, parent, and school

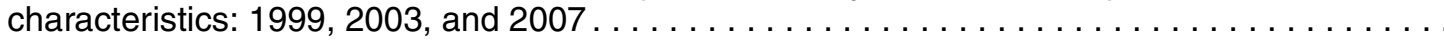

207.30. Percentage of kindergartners through fifth-graders whose parents reported doing educationrelated activities with their children in the past week, by selected child, parent, and school

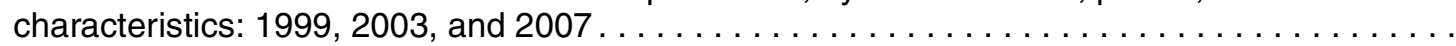

207.40. Percentage of elementary and secondary school children whose parents were involved in school activities, by selected child, parent, and school characteristics: 1999, 2003, and 2007 . . . . .

\section{Teachers and Pupil/Teacher Ratios}

208.10. Public elementary and secondary pupil/teacher ratios, by selected school characteristics:

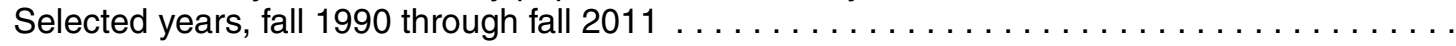

208.20. Public and private elementary and secondary teachers, enrollment, pupil/teacher ratios, and new teacher hires: Selected years, fall 1955 through fall 2023. 
208.30. Public elementary and secondary teachers, by level and state or jurisdiction: Selected years, fall

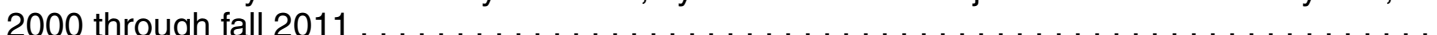

208.40. Public elementary and secondary teachers, enrollment, and pupil/teacher ratios, by state or

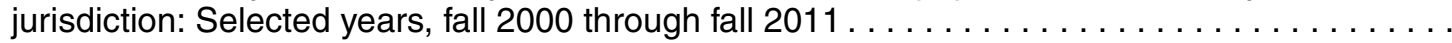

\section{Teacher Characteristics, Class Sizes, and Assignments}

209.10. Number and percentage distribution of teachers in public and private elementary and secondary schools, by selected teacher characteristics: Selected years, 1987-88 through 2011-12 . . . .

209.20. Number, highest degree, and years of full-time teaching experience of teachers in public and private elementary and secondary schools, by selected teacher characteristics: 1999-2000

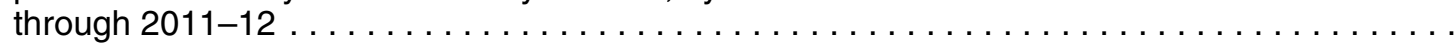

209.30. Highest degree earned, years of full-time teaching experience, and average class size for teachers in public elementary and secondary schools, by state: $2011-12 \ldots \ldots \ldots \ldots \ldots \ldots$

209.50. Percentage of public school teachers of grades 9 through 12 , by field of main teaching assignment
and selected demographic and educational characteristics: $2011-12 \ldots \ldots \ldots \ldots \ldots \ldots \ldots$

209.50. Percentage of public school teachers of grades 9 through 12 , by field of main teaching assignment
and selected demographic and educational characteristics: $2011-12 \ldots \ldots \ldots \ldots \ldots \ldots \ldots$

\section{Teacher Attitudes and Teacher Mobility}

210.10. Percentage of teachers indicating that certain issues are serious problems in their schools, by level and control of school: Selected years, $1987-88$ through $2011-12 \ldots \ldots \ldots \ldots \ldots \ldots \quad 140$

210.20. Percentage of teachers agreeing with statements about teaching and school conditions, by control and level of school: Selected years, 1993-94 through $2011-12 \ldots \ldots \ldots \ldots \ldots \ldots$

210.30. Mobility of public and private elementary and secondary teachers, by selected teacher and school characteristics: Selected years, $1987-88$ through $2008-09 \ldots \ldots \ldots \ldots \ldots \ldots \ldots \ldots$

\section{Teacher Salaries}

211.10. Average salaries for full-time teachers in public and private elementary and secondary schools,

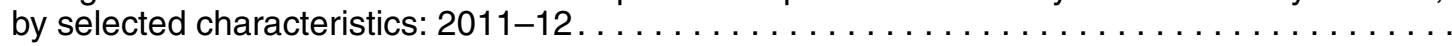

211.20. Average base salary for full-time teachers in public elementary and secondary schools, by highest degree earned and years of full-time teaching: Selected years, 1990-91 through 2011-12. . .

211.30. Average base salary for full-time public elementary and secondary school teachers with a bachelor's degree as their highest degree, by years of full-time teaching experience and state:

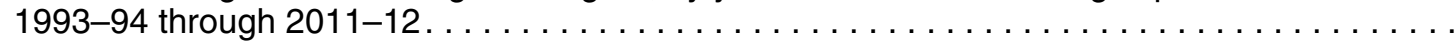

211.40. Average base salary for full-time public elementary and secondary school teachers with a master's degree as their highest degree, by years of full-time teaching experience and state:

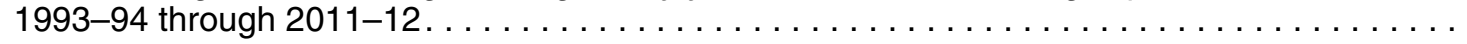

211.50. Estimated average annual salary of teachers in public elementary and secondary schools:

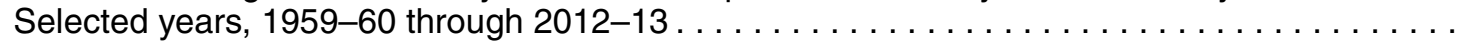

211.60. Estimated average annual salary of teachers in public elementary and secondary schools, by

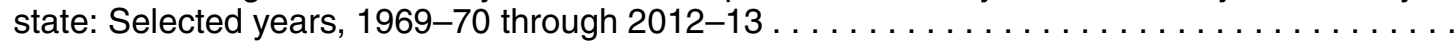

\section{School Principals}

212.10. Number, highest degree, average years of experience, and salaries of principals in public and private elementary and secondary schools, by selected characteristics: 1993-94, 2003-04, and 2011-12 . .

\section{School Staff}

213.10. Staff employed in public elementary and secondary school systems, by type of assignment:

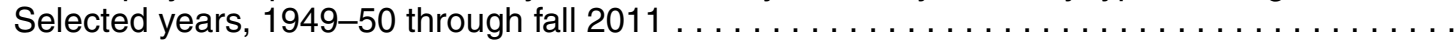

213.20. Staff employed in public elementary and secondary school systems, by type of assignment and

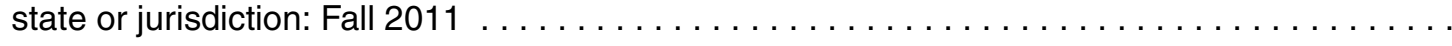

213.30. Staff employed in public elementary and secondary school systems, by type of assignment and

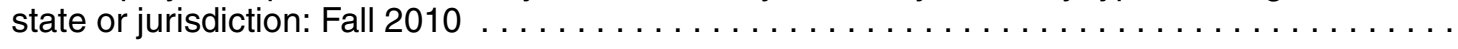


213.40. Staff, teachers, and teachers as a percentage of staff in public elementary and secondary school systems, by state or jurisdiction: Selected years, fall 2000 through fall $2011 \ldots \ldots \ldots \ldots \ldots$

213.50. Staff, enrollment, and pupil/staff ratios in public elementary and secondary school systems, by state or jurisdiction: Selected years, fall 2000 through fall $2011 \ldots \ldots \ldots \ldots \ldots \ldots \ldots$

\section{Overview of Schools and School Districts}

214.10. Number of public school districts and public and private elementary and secondary schools:

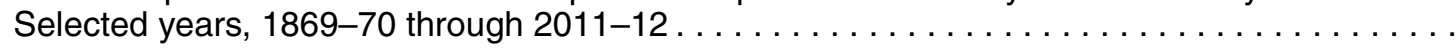

214.20. Number and percentage distribution of regular public school districts and students, by enrollment size of district: Selected years, $1979-80$ through $2011-12 \ldots \ldots \ldots \ldots \ldots \ldots \ldots \ldots \ldots$

214.30. Number of public elementary and secondary education agencies, by type of agency and state or

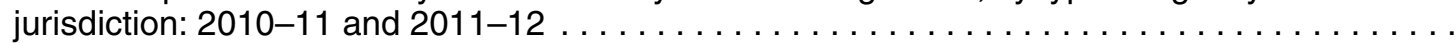

214.40. Public elementary and secondary school enrollment, number of schools, and other selected

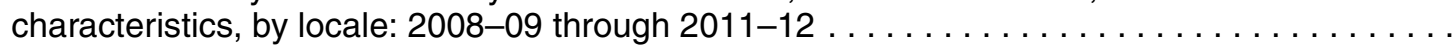

\section{Large School Districts}

215.10. Selected statistics on enrollment, teachers, dropouts, and graduates in public school districts enrolling more than 15,000 students: Selected years, 1990 through $2011 \ldots \ldots \ldots \ldots \ldots$.

215.20. Revenues, expenditures, poverty rate, and Title I allocations of public school districts enrolling more than 15,000 students: $2010-11$ and fiscal year $2013 \ldots \ldots \ldots \ldots \ldots \ldots \ldots \ldots \ldots$

215.30. Enrollment, poverty, and federal funds for the 100 largest school districts, by enrollment size in

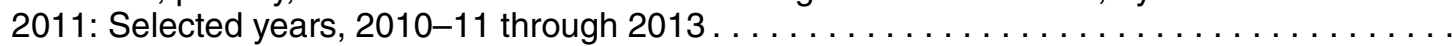

\section{Public Schools}

216.10. Public elementary and secondary schools, by level of school: Selected years, 1967-68 through 2011-12 .

216.20. Number and enrollment of public elementary and secondary schools, by school level, type, and charter and magnet status: Selected years, 1990-91 through $2011-12 \ldots \ldots \ldots \ldots \ldots \ldots$.

216.30. Number and percentage distribution of public elementary and secondary students and schools, by traditional or charter school status and selected characteristics: Selected years, 1999-2000

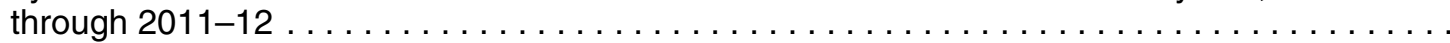

216.40. Number and percentage distribution of public elementary and secondary schools and enrollment, by level, type, and enrollment size of school: 2009-10, 2010-11, and 2011-12. . . . . . .

216.45. Average enrollment and percentage distribution of public elementary and secondary schools, by level, type, and enrollment size: Selected years, 1982-83 through $2011-12 \ldots \ldots \ldots \ldots \ldots$.

216.50. Number and percentage distribution of public elementary and secondary school students, by percentage of minority enrollment in the school and student's racial/ethnic group: Selected

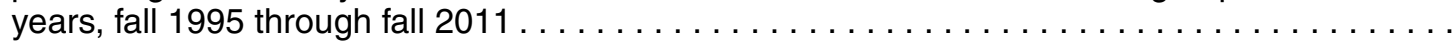

216.55. Number and percentage distribution of public elementary and secondary school students, by percentage of student's racial/ethnic group enrolled in the school and student's racial/ethnic

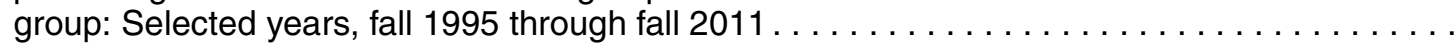

216.60. Number and percentage distribution of public school students eligible for free or reduced-price lunch, by school level, locale, and student race/ethnicity: $2011-12 \ldots \ldots \ldots \ldots \ldots \ldots \ldots$

216.70. Public elementary and secondary schools, by level, type, and state or jurisdiction: 1990-91, 2000-01, 2010-11, and 2011-12 . . . . . . . . . . . . . . . . . . . . .

216.75. Public elementary schools, by grade span, average school enrollment, and state or jurisdiction: 2011-12 .

216.80. Public secondary schools, by grade span, average school enrollment, and state or jurisdiction: 2011-12. .

216.90. Public elementary and secondary charter schools and enrollment, by state: Selected years,

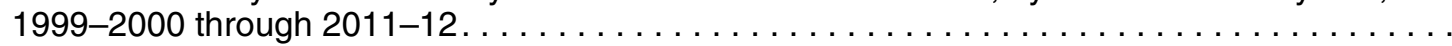

216.95. Number and enrollment of public elementary and secondary schools that have closed, by school level, type, and charter status: Selected years, 1995-96 through $2011-12 \ldots \ldots \ldots \ldots \ldots$. 


\section{School Facilities}

217.10. Functional age of public schools' main instructional buildings and percentage of schools with permanent and portable (temporary) buildings, by selected school characteristics and condition

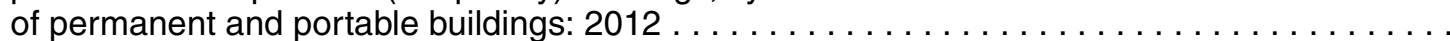

217.15. Percentage of public schools with plans for major repair, renovation, or replacement of building systems or features in the next 2 years and percentage distribution of schools with such plans, by selected school characteristics, type of system or feature, and main reason for the plans: $2012-13 \ldots \ldots \ldots$.

217.20. Percentage of public schools with enrollment under, at, or over capacity, by selected school

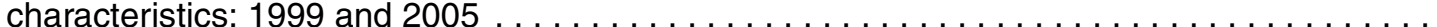

\section{Computers and Technology}

218.10. Number and internet access of instructional computers and rooms in public schools, by selected school characteristics: Selected years, 1995 through $2008 \ldots \ldots \ldots \ldots \ldots \ldots \ldots \ldots \ldots$

218.20. Percentage of public school districts with students enrolled in technology-based distance education courses and number of enrollments in such courses, by instructional level and district characteristics: 2002-03, 2004-05, and 2009-10 . . . . . . . . . . . . . . . . . . .

\section{High School Completers and Dropouts}

219.10. High school graduates, by sex and control of school: Selected years, 1869-70 through 2023-24 . .

219.20. Public high school graduates, by region, state, and jurisdiction: Selected years, 1980-81 through 2023-24 .

219.30. Public high school graduates, by race/ethnicity: 1998-99 through $2023-24 \ldots \ldots \ldots \ldots \ldots$

219.35. Averaged freshman graduation rates for public secondary schools, by state or jurisdiction:

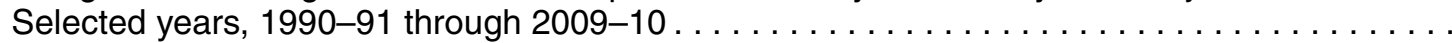

219.40. Public high school graduates and averaged freshman graduation rate, by race/ethnicity and state

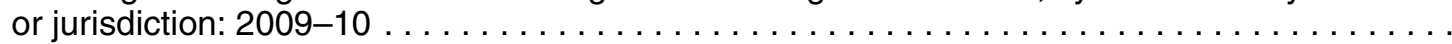

219.50. Number and percentage of 9th- to 12th-graders who dropped out of public schools, by race/

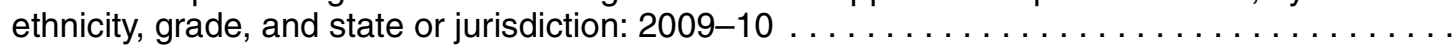

219.60. Number of people taking the general educational development (GED) test and percentage distribution of those who passed, by age group: 1971 through $2012 \ldots \ldots \ldots \ldots \ldots \ldots \ldots$

219.70. Percentage of high school dropouts among persons 16 through 24 years old (status dropout rate), by sex and race/ethnicity: Selected years, 1960 through 2012

219.75. Percentage of high school dropouts among persons 16 through 24 years old (status dropout rate), by income level, and percentage distribution of status dropouts, by labor force status and years

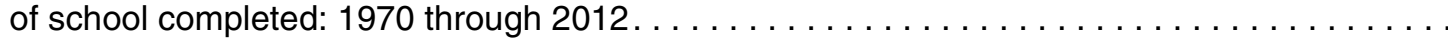

219.80. Percentage of high school dropouts among persons 16 through 24 years old (status dropout rate) and number of status dropouts, by noninstitutionalized or institutionalized status, birth in or

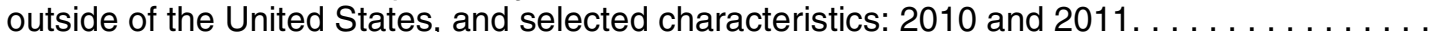

219.90. Number and percentage distribution of 14- through 21-year-old students served under Individuals with Disabilities Education Act, Part B, who exited school, by exit reason, age, and type of

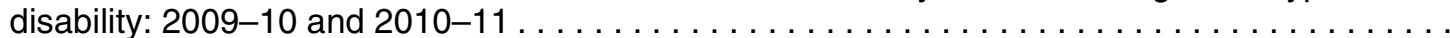

\section{Skills of Young Children}

220.10. Percentage of children demonstrating specific cognitive and motor skills at about 9 months of age,

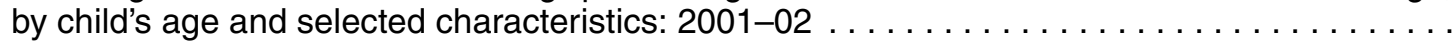

220.20. Percentage of children demonstrating specific cognitive skills, motor skills, and secure emotional attachment to parents at about 2 years of age, by selected characteristics: $2003-04 \ldots \ldots \ldots$.

220.30. Children's reading, language, mathematics, color knowledge, and fine motor skills at about 4

220.40. First-time kindergartners' reading, mathematics, science, cognitive flexibility, and approaches to
learning scale scores in fall and spring of the kindergarten year, by selected child, family, and

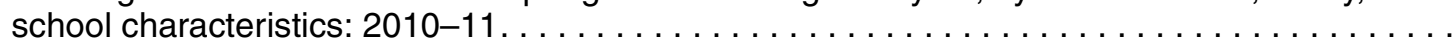


220.50. Number and percentage distribution of kindergartners, by fall 2010 kindergarten entry status and selected child, family, and school characteristics: $2010-11 \ldots \ldots \ldots \ldots \ldots \ldots \ldots \ldots$

220.60. Kindergartners' reading, mathematics, science, cognitive flexibility, and approaches to learning scale scores in fall and spring of the kindergarten year, by fall 2010 kindergarten entry status: 2010-11 .

220.70. Mean reading scale scores and specific reading skills of fall 1998 first-time kindergartners, by time of assessment and selected characteristics: Selected years, fall 1998 through spring 2007 . .

220.80. Mean mathematics and science scale scores and specific mathematics skills of fall 1998 first-time kindergartners, by time of assessment and selected characteristics: Selected years, fall 1998

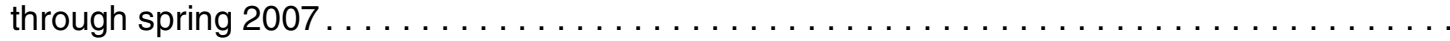

\section{Reading Achievement}

221.10. Average National Assessment of Educational Progress (NAEP) reading scale score, by grade and selected student and school characteristics: Selected years, 1992 through $2013 . \ldots \ldots \ldots \ldots$. . . .

221.20. Percentage of students at or above selected National Assessment of Educational Progress (NAEP) reading achievement levels, by grade and selected student characteristics: Selected

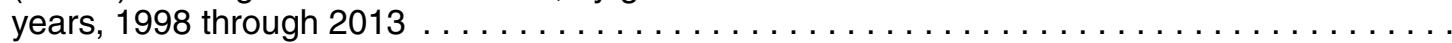

221.30. Average National Assessment of Educational Progress (NAEP) reading scale score and percentage distribution of students, by age, amount of reading for school and for fun, and time spent on homework and watching TV/video: Selected years, 1984 through $2012 \ldots \ldots \ldots \ldots$. . . .

221.40. Average National Assessment of Educational Progress (NAEP) reading scale score of 4th-grade public school students and percentage attaining reading achievement levels, by state: Selected

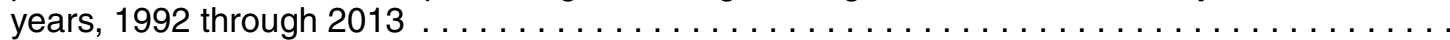

221.50. Average National Assessment of Educational Progress (NAEP) reading scale score and percentage of 4 th-grade public school students, by race/ethnicity and state: $2013 \ldots \ldots \ldots \ldots$

Average National Assessment of Educational Progress (NAEP) reading scale score of 8th-grade public school students and percentage attaining reading achievement levels, by locale and state:

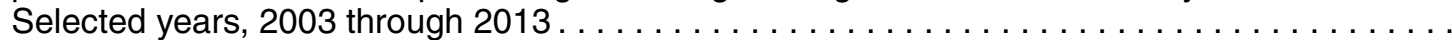

221.70. Average National Assessment of Educational Progress (NAEP) reading scale scores of 4th- and 8th-graders in public schools and percentage scoring at or above selected reading achievement levels, by English language learner (ELL) status and state: $2013 \ldots \ldots \ldots \ldots \ldots \ldots \ldots$

221.75. Average National Assessment of Educational Progress (NAEP) reading scale score and standard deviation, by selected student characteristics, percentile, and grade: Selected years, 1992 through 2013 ........

221.80. Average National Assessment of Educational Progress (NAEP) reading scale scores of 4th- and 8th-grade public school students and percentage attaining reading achievement levels, by race/ ethnicity and jurisdiction or specific urban district: 2009,2011 , and $2013 \ldots \ldots \ldots \ldots \ldots \ldots$

221.85. Average National Assessment of Educational Progress (NAEP) reading scale score, by age and selected student characteristics: Selected years, 1971 through $2012 \ldots \ldots \ldots \ldots \ldots \ldots \ldots$

221.90. Percentage of students at or above selected National Assessment of Educational Progress (NAEP) reading score levels, by age, sex, and race/ethnicity: Selected years, 1971 through $2012 \ldots \ldots \ldots$.

\section{Mathematics Achievement}

222.10. Average National Assessment of Educational Progress (NAEP) mathematics scale score, by grade and selected student and school characteristics: Selected years, 1990 through $2013 \ldots$

222.20. Percentage of students at or above selected National Assessment of Educational Progress (NAEP) mathematics achievement levels, by grade and selected student characteristics:

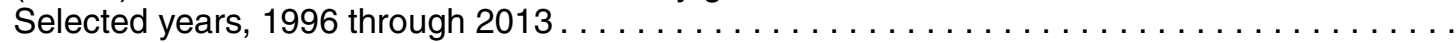

222.30. Average National Assessment of Educational Progress (NAEP) mathematics scale score of 8thgraders with various attitudes toward mathematics and percentage reporting these attitudes, by

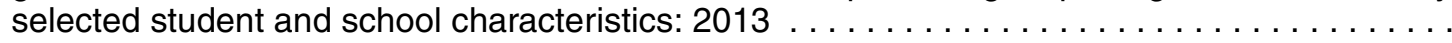

222.40. Average National Assessment of Educational Progress (NAEP) mathematics scale score of high school graduates at grade 12, by highest mathematics course taken in high school and selected

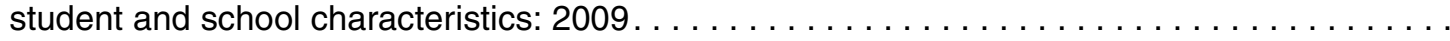


222.50. Average National Assessment of Educational Progress (NAEP) mathematics scale score of 4thgrade public school students and percentage attaining mathematics achievement levels, by

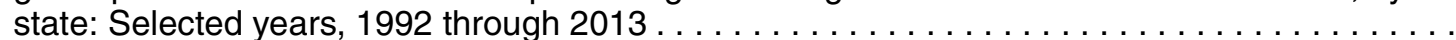

222.60. Average National Assessment of Educational Progress (NAEP) mathematics scale score of 8thgrade public school students and percentage attaining mathematics achievement levels, by

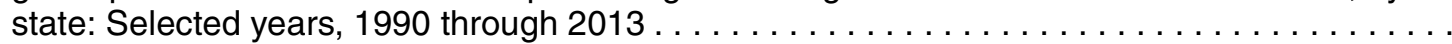

222.70. Average National Assessment of Educational Progress (NAEP) mathematics scale score of 8th-grade public school students, by race/ethnicity, highest level of parental education, and state: $2013 \ldots \ldots$

222.80. Average National Assessment of Educational Progress (NAEP) mathematics scale scores of 4thand 8th-grade public school students and percentage attaining achievement levels, by race/ ethnicity and jurisdiction or specific urban district: 2009,2011 , and $2013 \ldots \ldots \ldots \ldots \ldots \ldots$

222.85. Average National Assessment of Educational Progress (NAEP) mathematics scale score, by age and selected student characteristics: Selected years, 1973 through $2012 \ldots \ldots \ldots \ldots \ldots \ldots$

222.90. Percentage of students at or above selected National Assessment of Educational Progress (NAEP) mathematics score levels, by age, sex, and race/ethnicity: Selected years, 1978 through 2012 . . . . .

222.95. National Assessment of Educational Progress (NAEP) mathematics performance of 17-year-olds, by highest mathematics course taken, sex, and race/ethnicity: Selected years, 1978 through 2012 . . .

\section{Science Achievement}

223.10. Average National Assessment of Educational Progress (NAEP) science scale score, standard deviation, and percentage of students attaining science achievement levels, by grade level, selected student and school characteristics, and percentile: 2009 and $2011 \ldots \ldots \ldots \ldots \ldots$

223.20. Average National Assessment of Educational Progress (NAEP) science scale scores of 8th-grade public school students, by race/ethnicity and state: 2009 and $2011 \ldots \ldots \ldots \ldots \ldots \ldots \ldots$

223.25. Average National Assessment of Educational Progress (NAEP) science scale scores of 8thgraders with various attitudes toward science and percentage reporting these attitudes, by

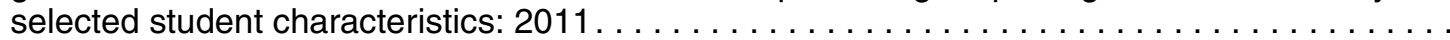

223.30. Average National Assessment of Educational Progress (NAEP) science scale scores of 12thgraders with various educational goals and attitudes toward science, and percentage reporting these goals and attitudes, by selected student characteristics: $2009 \ldots \ldots \ldots \ldots \ldots \ldots \ldots$

\section{Achievement in Other Subjects}

224.10. Average National Assessment of Educational Progress (NAEP) arts scale score of 8th-graders, percentage distribution by frequency of instruction, and percentage participating in selected

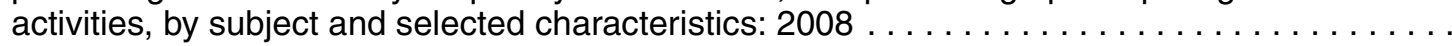

224.20. Average National Assessment of Educational Progress (NAEP) civics scale score and percentage of students attaining civics achievement levels, by grade level and selected student

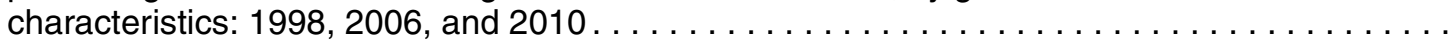

224.30. Average National Assessment of Educational Progress (NAEP) economics scale score of 12thgraders, percentage attaining economics achievement levels, and percentage with different levels of economics coursework, by selected characteristics: 2006 and $2012 \ldots \ldots \ldots \ldots \ldots$

224.40. Average National Assessment of Educational Progress (NAEP) geography scale score, standard deviation, and percentage of students attaining geography achievement levels, by grade level, selected student characteristics, and percentile: 1994, 2001, and $2010 \ldots \ldots \ldots \ldots \ldots \ldots$

224.50. Average National Assessment of Educational Progress (NAEP) U.S. history scale score, standard deviation, and percentage of students attaining achievement levels, by grade level, selected characteristics, and percentile: Selected years, 1994 through $2010 \ldots \ldots \ldots \ldots \ldots \ldots \ldots$

224.60. Average National Assessment of Educational Progress (NAEP) writing scale score of 8th- and 12th-graders, standard deviation, and percentage of students attaining writing achievement levels, by selected student and school characteristics and percentile: $2011 \ldots \ldots \ldots \ldots \ldots$. 


\section{Coursetaking and Grades}

225.10. Average number of Carnegie units earned by public high school graduates in various subject fields, by sex and race/ethnicity: Selected years, 1982 through $2009 \ldots \ldots \ldots \ldots \ldots \ldots$. . . . . . . . .

225.20. Average number of Carnegie units earned by public high school graduates in career/technical education courses in various occupational fields, by sex and race/ethnicity, and percentage distribution of students, by units earned: Selected years, 2000 through $2009 . \ldots \ldots \ldots \ldots$. . . .

225.30. Percentage of public and private high school graduates taking selected mathematics and science courses in high school, by sex and race/ethnicity: Selected years, 1982 through 2009 . . . . .

225.40. Percentage of public and private high school graduates taking selected mathematics and science courses in high school, by selected student and school characteristics: Selected years, 1990 through 2009 ....

225.50. Percentage of public and private high school graduates earning minimum credits in selected combinations of academic courses, by sex and race/ethnicity: Selected years, 1982 through 2009 . . . . . . . . . .

225.60. Number and percentage of public high school graduates taking dual credit, Advanced Placement (AP), and International Baccalaureate (IB) courses in high school and average credits earned, by selected student and school characteristics: 2000,2005 , and $2009 \ldots \ldots \ldots \ldots \ldots \ldots$.

225.70. Number and percentage of high school graduates who took foreign language courses in high school and average number of credits earned, by language and number of credits: 2000, 2005, and 2009. . . . .

225.80. Percentage distribution of elementary and secondary school children, by average grades and selected child and school characteristics: 1996,2003 , and $2007 \ldots \ldots \ldots \ldots \ldots \ldots \ldots$

\section{College Admission Tests}

226.10. SAT mean scores of college-bound seniors, by race/ethnicity: Selected years, 1986-87 through 2012-13.

226.20. SAT mean scores of college-bound seniors, by sex: $1966-67$ through $2012-13 \ldots \ldots \ldots \ldots$

226.30. SAT mean scores and percentage distribution of college-bound seniors, by selected student characteristics: Selected years, $1995-96$ through $2012-13 \ldots \ldots \ldots \ldots \ldots \ldots \ldots \ldots$

226.40. Mean SAT scores of college-bound seniors and percentage of graduates taking SAT, by state:

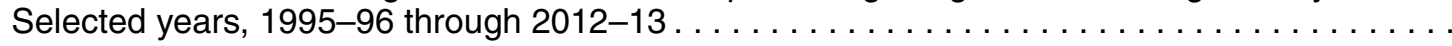

226.50. ACT score averages and standard deviations, by sex and race/ethnicity, and percentage of ACT
test takers, by selected composite score ranges and planned fields of postsecondary study:

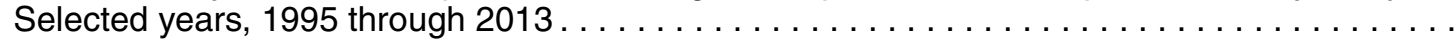

\section{Student Activities, Homework, and Attendance}

227.10. Percentage of 9th-grade students participating in various school-sponsored and non-school-

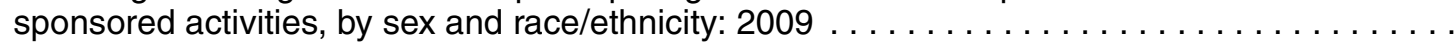

227.20. Percentage of high school seniors who say they engage in various activities, by selected student

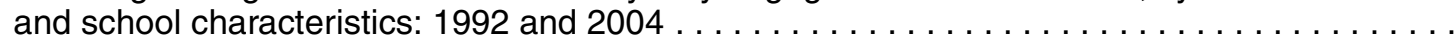

227.30. Percentage of high school seniors who participate in various school-sponsored extracurricular activities, by selected student characteristics: 1992 and $2004 \ldots \ldots \ldots \ldots \ldots \ldots \ldots \ldots$

227.40. Percentage of elementary and secondary school students who do homework outside of school, whose parents check that homework is done, and whose parents help with homework, by frequency and selected student and school characteristics: 2003 and $2007 \ldots \ldots \ldots \ldots \ldots$

227.50. Percentage of 4th-, 8th-, and 12th-graders absent from school in the last month, by selected student and school characteristics and number of days absent: 2002, 2009, and $2013 \ldots \ldots$.

\section{School Crime Victims}

228.10. School-associated violent deaths of all persons, homicides and suicides of youth ages $5-18$ at school, and total homicides and suicides of youth ages 5-18, by type of violent death: 1992-93

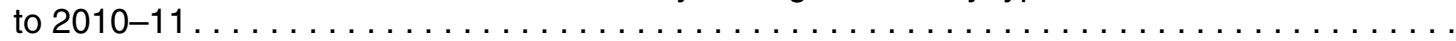

228.20. Number of nonfatal victimizations against students ages $12-18$ and rate of victimization per 1,000 students, by type of victimization, location, and year: 1992 through $2012 \ldots \ldots \ldots \ldots \ldots \ldots$

228.25. Number of nonfatal victimizations against students ages 12-18 and rate of victimization per 1,000 students, by type of victimization, location, and selected student characteristics: $2012 \ldots \ldots \ldots$ 
228.30. Percentage of students ages 12-18 who reported criminal victimization at school during the previous 6 months, by type of victimization and selected student and school characteristics:

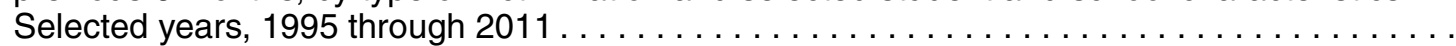

228.40. Percentage of students in grades 9-12 who reported being threatened or injured with a weapon on school property during the previous 12 months, by selected student characteristics and number of times threatened or injured: Selected years, 1993 through $2011 \ldots \ldots \ldots \ldots \ldots$

228.50. Percentage of public school students in grades 9-12 who reported being threatened or injured with a weapon on school property at least one time during the previous 12 months, by state:

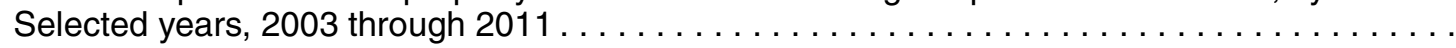

228.70. Number and percentage of public and private school teachers who reported that they were threatened with injury or physically attacked by a student from school during the previous 12 months, by selected teacher and school characteristics: Selected years, 1993-94 through 2011-12 . . . . . . . . . .

228.80. Percentage of public school teachers who reported that they were threatened with injury or physically attacked by a student from school during the previous 12 months, by state: Selected

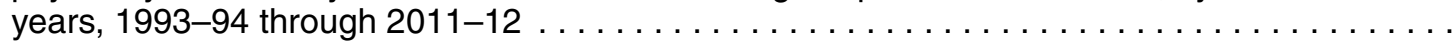

\section{School Crime Incidents}

229.10. Percentage of public schools recording incidents of crime at school and reporting incidents to police, number of incidents, and rate per 1,000 students, by type of crime: Selected years,

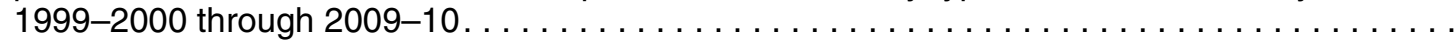

229.20. Number and percentage of public schools recording at least one crime incident that occurred at school, and number and rate of incidents, by school characteristics and type of incident:

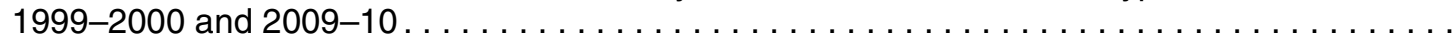

229.30. Percentage of public schools recording incidents of crime at school, number of incidents, and rate per 1,000 students, by type of crime and selected school characteristics: $2009-10 \ldots \ldots \ldots$.

229.40. Percentage of public schools reporting incidents of crime at school to the police, number of incidents, and rate per 1,000 students, by type of crime and selected school characteristics: 2009-10. . . . .

229.50. Percentage distribution of public schools, by number of violent incidents of crime at school recorded and reported to the police and selected school characteristics: $2009-10 \ldots \ldots \ldots$

229.60. Percentage distribution of public schools, by number of serious violent incidents of crime at school recorded and reported to the police and selected school characteristics: $2009-10 \ldots \ldots \ldots$.

\section{School Environment}

230.10. Percentage of public schools reporting selected discipline problems that occurred at school, by frequency and selected school characteristics: Selected years, 1999-2000 through 2009-10. .

230.20. Percentage of students ages 12-18 who reported that gangs were present at school during the school year, by selected student and school characteristics and urbanicity: Selected years, 2001 through $2011 \ldots \ldots$.

230.30. Percentage of students ages 12-18 who reported being the target of hate-related words and seeing hate-related graffiti at school during the school year, by selected student and school

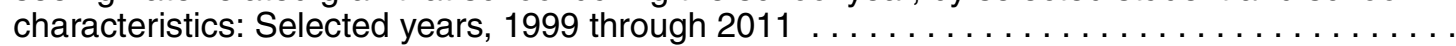

230.35. Percentage of students ages 12-18 who reported being the target of hate-related words at school, by type of hate-related word and selected student and school characteristics: $2011 \ldots$

230.40. Percentage of students ages 12-18 who reported being bullied at school or cyber-bullied anywhere during the school year, by type of bullying at school, reports of injury, and selected

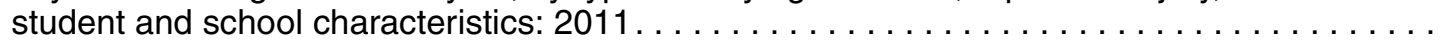

230.45. Percentage of students ages 12-18 who reported being bullied at school during the school year, by type of bullying and selected student and school characteristics: Selected years, 2005 through 2009. . . . .

230.50. Percentage of students ages 12-18 who reported being bullied at school during the school year and, among bullied students, percentage who reported being bullied in various locations, by

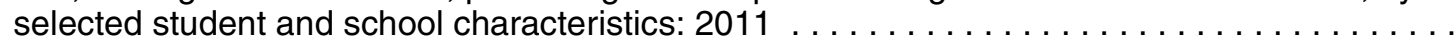

230.55. Percentage of students ages 12-18 who reported being cyber-bullied anywhere during the school year, by type of cyber-bullying and selected student and school characteristics: $2011 \ldots \ldots \ldots$ 
230.60. Among students ages 12-18 who reported being bullied at school or cyber-bullied anywhere during the school year, percentage reporting various frequencies of bullying and the notification of an adult at school, by selected student and school characteristics: $2011 \ldots \ldots \ldots \ldots \ldots$.

230.65. Percentage of public schools reporting selected types of cyber-bullying problems occurring at school or away from school at least once a week, by selected school characteristics: $2009-10 . \ldots \ldots \ldots$.

230.70. Percentage of students ages 12-18 who reported being afraid of attack or harm, by location and selected student and school characteristics: Selected years, 1995 through $2011 \ldots \ldots \ldots \ldots$. .

230.80. Percentage of students ages $12-18$ who reported avoiding one or more places in school or avoiding school activities or classes because of fear of attack or harm, by selected student and school characteristics: Selected years, 1995 through $2011 \ldots \ldots \ldots \ldots \ldots \ldots \ldots \ldots$.

230.90. Percentage of public and private school teachers who agreed that student misbehavior and student tardiness and class cutting interfered with their teaching, by selected teacher and school characteristics: Selected years, $1987-88$ through $2011-12 \ldots \ldots \ldots \ldots \ldots \ldots \ldots \ldots$

230.92. Percentage of public and private school teachers who agreed that other teachers and the principal enforced school rules, by selected teacher and school characteristics: Selected years, 1987-88

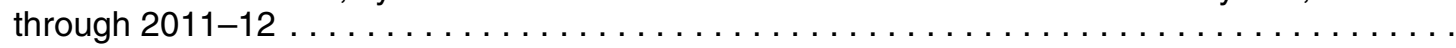

230.95. Percentage of public school teachers who agreed that student misbehavior and student tardiness and class cutting interfered with their teaching and that other teachers and the principal enforced

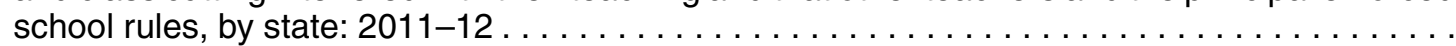

\section{Fights and Weapons}

231.10. Percentage of students in grades 9-12 who reported having been in a physical fight at least one time during the previous 12 months, by location and selected student characteristics: Selected

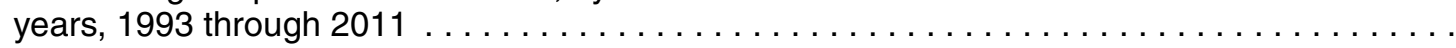

231.20. Percentage distribution of students in grades 9-12, by number of times they reported having been in a physical fight anywhere or on school property during the previous 12 months and selected

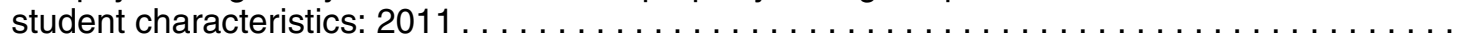

231.30. Percentage of public school students in grades 9-12 who reported having been in a physical fight at least one time during the previous 12 months, by location and state: Selected years, 2003 through $2011 \ldots$

231.40. Percentage of students in grades 9-12 who reported carrying a weapon at least 1 day during the previous 30 days, by location and selected student characteristics: Selected years, 1993 through $2011 \ldots \ldots \ldots$.

231.50. Percentage distribution of students in grades 9-12, by number of days they reported carrying a weapon anywhere or on school property during the previous 30 days and selected student characteristics: 2011

231.60. Percentage of public school students in grades 9-12 who reported carrying a weapon at least 1 day during the previous 30 days, by location and state: Selected years, 2003 through $2011 \ldots$

231.70. Percentage of students ages 12-18 who reported having access to a loaded gun, without adult permission, at school or away from school during the school year, by selected student and

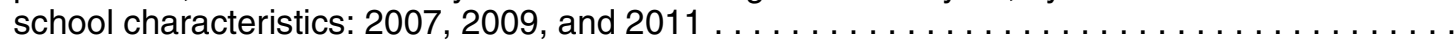

\section{Alcohol, Illicit Drugs, and Cigarettes}

232.10. Percentage of students in grades 9-12 who reported using alcohol at least 1 day during the previous 30 days, by location and selected student characteristics: Selected years, 1993 through $2011 \ldots$

232.20. Percentage distribution of students in grades $9-12$, by number of days they reported using alcohol anywhere or on school property during the previous 30 days and selected student characteristics: $2011 \ldots \ldots \ldots$

232.30. Percentage of public school students in grades 9-12 who reported using alcohol at least 1 day during the previous 30 days, by location and state: Selected years, 2003 through $2011 \ldots \ldots$.

232.40. Percentage of students in grades 9-12 who reported using marijuana at least one time during the previous 30 days, by location and selected student characteristics: Selected years, 1993 through $2011 \ldots \ldots \ldots$.

232.50. Percentage distribution of students in grades 9-12, by number of times they reported using marijuana anywhere or on school property during the previous 30 days and selected student characteristics: 2011 .

232.60. Percentage of public school students in grades 9-12 who reported using marijuana at least one
time during the previous 30 days, by location and state: Selected years, 2003 through $2011 \ldots$ 
232.70. Percentage of students in grades 9-12 who reported that illegal drugs were made available to them on school property during the previous 12 months, by selected student characteristics:

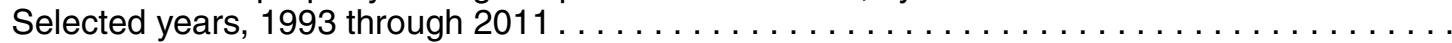

232.80. Percentage of public school students in grades 9-12 who reported that illegal drugs were made available to them on school property during the previous 12 months, by state: Selected years, 2003 through $2011 \ldots$

232.90. Percentage of high school seniors reporting use of alcohol and illicit drugs, by frequency of use and substance used: Selected years, 1975 through $2012 \ldots \ldots \ldots \ldots \ldots \ldots \ldots \ldots \ldots$

232.95. Percentage of 12- to 17-year-olds reporting use of illicit drugs, alcohol, and cigarettes during the past 30 days and the past year, by substance used, sex, and race/ethnicity: Selected years, 1985 through $2011 \ldots \ldots$.

\section{Discipline, Safety, and Security Measures}

233.10. Number and percentage of public schools that took a serious disciplinary action in response to specific offenses, number of serious actions taken, and percentage distribution of actions, by type of offense, school level, and type of action: Selected years, 1999-2000 through 2009-10 . . . . .

233.30. Number of students suspended and expelled from public elementary and secondary schools, by

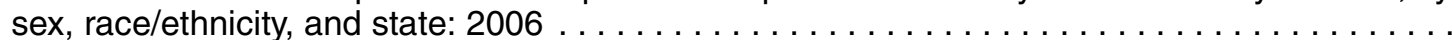

233.40. Percentage of students suspended and expelled from public elementary and secondary schools,

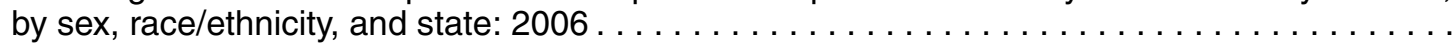

233.50. Percentage of public and private schools with various safety and security measures, by school

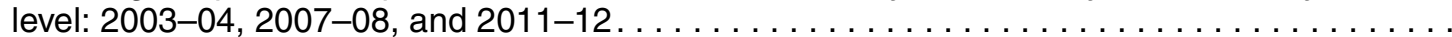

233.60. Percentage of public and private schools with various safety and security measures, by school

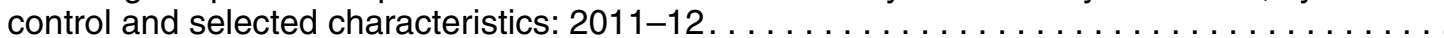

233.70. Percentage of public schools with one or more full-time or part-time security staff present at least once a week, and percentage of schools with security staff routinely carrying a firearm, by selected school characteristics: $2005-06,2007-08$, and $2009-10 \ldots \ldots \ldots \ldots \ldots \ldots \ldots$

233.80. Percentage of students ages 12-18 who reported various security measures at school: Selected years, 1999 through 2011

\section{State Regulations}

234.10. Age range for compulsory school attendance and special education services, and policies on year-round schools and kindergarten programs, by state: Selected years, 2000 through 2014 .

234.20. Minimum amount of instructional time per year and policy on textbook selection, by state:

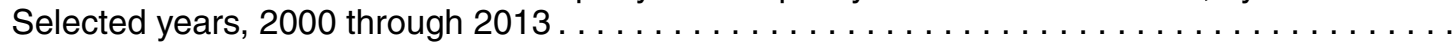

234.30. Course credit requirements and exit exam requirements for a standard high school diploma and the use of other high school completion credentials, by state: $2013 \ldots \ldots \ldots \ldots \ldots \ldots \ldots$

234.40. States that use criterion-referenced tests (CRTs) aligned to state standards, by subject area and

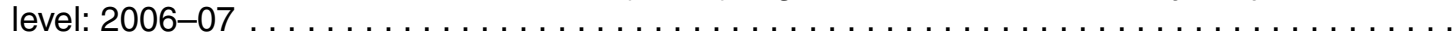

234.50. Required testing for initial certification of elementary and secondary school teachers, by type of

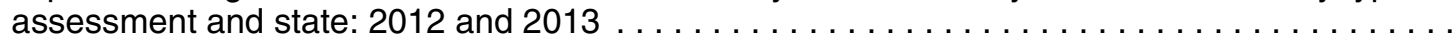

\section{Revenues}

235.10. Revenues for public elementary and secondary schools, by source of funds: Selected years,

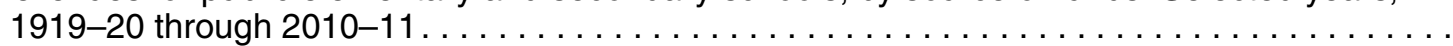

235.20. Revenues for public elementary and secondary schools, by source of funds and state or

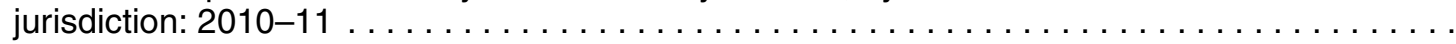

235.30. Revenues for public elementary and secondary schools, by source of funds and state or

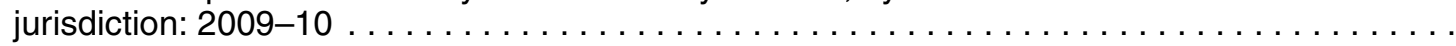

235.40. Public elementary and secondary revenues and expenditures, by type of locale: $2010-11 \ldots \ldots$ 


\section{Expenditures}

236.10. Summary of expenditures for public elementary and secondary education and other related programs, by purpose: Selected years, $1919-20$ through $2010-11 \ldots \ldots \ldots \ldots \ldots \ldots \ldots$

236.15. Current expenditures and current expenditures per pupil in public elementary and secondary

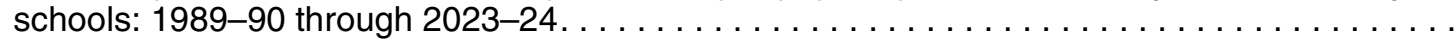

236.20. Total expenditures for public elementary and secondary education and other related programs, by function and subfunction: Selected years, 1990-91 through $2010-11 \ldots \ldots \ldots \ldots \ldots \ldots$.

236.25. Current expenditures for public elementary and secondary education, by state or jurisdiction:

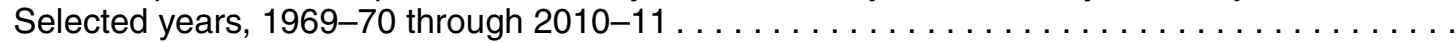

236.30. Total expenditures for public elementary and secondary education and other related programs, by

236.30. Total expenditures for public elementary and secondary education and other related programs, by

236.40. Total expenditures for public elementary and secondary education and other related programs, by

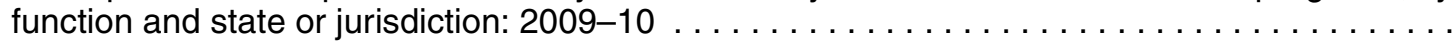

236.50. Expenditures for instruction in public elementary and secondary schools, by subfunction and state

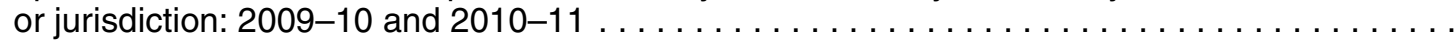

236.55. Total and current expenditures per pupil in public elementary and secondary schools: Selected

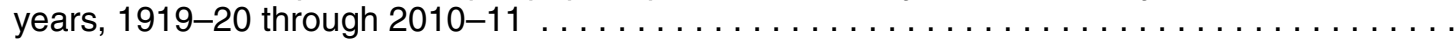

236.60. Total and current expenditures per pupil in fall enrollment in public elementary and secondary schools, by function and subfunction: Selected years, 1990-91 through $2010-11 \ldots \ldots \ldots$.

236.65. Current expenditure per pupil in fall enrollment in public elementary and secondary schools, by state or jurisdiction: Selected years, $1969-70$ through $2010-11 \ldots \ldots \ldots \ldots \ldots \ldots \ldots$

236.70. Current expenditure per pupil in average daily attendance in public elementary and secondary
schools, by state or jurisdiction: Selected years, $1969-70$ through $2010-11 \ldots \ldots \ldots \ldots \ldots$

236.70. Current expenditure per pupil in average daily attendance in public elementary and secondary
schools, by state or jurisdiction: Selected years, $1969-70$ through $2010-11 \ldots \ldots \ldots \ldots$

236.75. Total and current expenditures per pupil in fall enrollment in public elementary and secondary education, by function and state or jurisdiction: $2010-11 \ldots \ldots \ldots \ldots \ldots \ldots \ldots$

236.80. Total and current expenditures per pupil in fall enrollment in public elementary and secondary education, by function and state or jurisdiction: $2009-10 \ldots \ldots \ldots \ldots \ldots \ldots \ldots \ldots$

236.90. Students transported at public expense and current expenditures for transportation: Selected

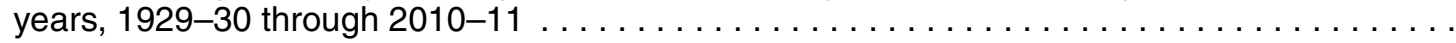

\section{Chapter 3. Postsecondary Education}

\section{Overview and Historical}

301.10. Enrollment, staff, and degrees/certificates conferred in degree-granting and non-degree-granting postsecondary institutions, by control and level of institution, sex of student, type of staff, and

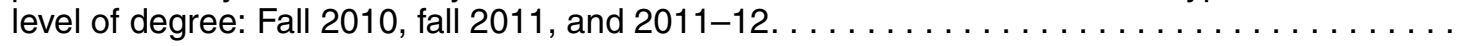

301.20. Historical summary of faculty, enrollment, degrees, and finances in degree-granting postsecondary institutions: Selected years, $1869-70$ through $2011-12 \ldots \ldots \ldots \ldots \ldots \ldots$

\section{Enrollment Rates}

302.10. Recent high school completers and their enrollment in 2-year and 4-year colleges, by sex: 1960

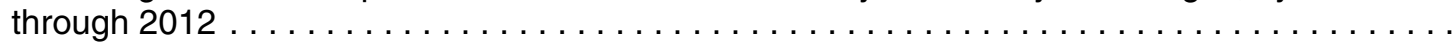

302.20. Percentage of recent high school completers enrolled in 2- and 4-year colleges, by race/ethnicity:

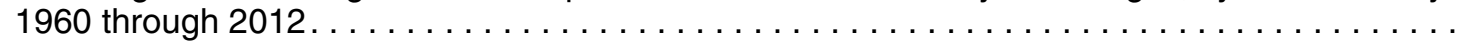

302.30. Percentage of recent high school completers enrolled in 2-year and 4-year colleges, by income

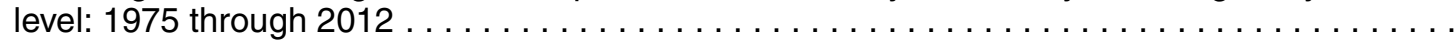

302.40. Number of high schools with 12th-graders and percentage of high school graduates attending 4-year colleges, by selected high school characteristics: Selected years, 1998-99 through 2011-12 . . . . .

302.50. Estimated rate of 2009-10 high school graduates attending degree-granting institutions, by state: 2010 . .

302.60. Percentage of 18- to 24-year-olds enrolled in degree-granting institutions, by level of institution and sex and race/ethnicity of student: 1967 through $2012 \ldots \ldots \ldots \ldots \ldots \ldots \ldots \ldots$ 


\section{Total Fall Enrollment-General}

303.10. Total fall enrollment in degree-granting postsecondary institutions, by attendance status, sex of student, and control of institution: Selected years, 1947 through $2023 \ldots \ldots \ldots \ldots \ldots \ldots \ldots$

303.20. Total fall enrollment in all postsecondary institutions participating in Title IV programs and annual percentage change in enrollment, by degree-granting status and control of institution: 1995 through 2012 . . . . . . .

303.25. Total fall enrollment in degree-granting postsecondary institutions, by control and level of

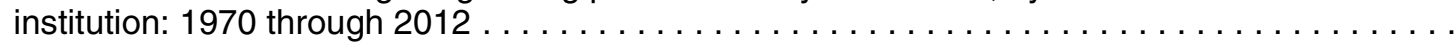

303.30. Total fall enrollment in degree-granting postsecondary institutions, by level and control of institution, attendance status, and sex of student: Selected years, 1970 through 2023 . . . . .

303.40. Total fall enrollment in degree-granting postsecondary institutions, by attendance status, sex, and

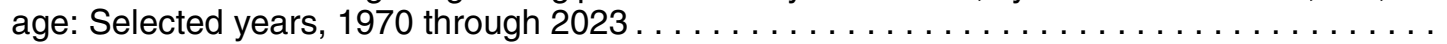

303.45. Total fall enrollment in degree-granting postsecondary institutions, by level of enrollment, sex, attendance status, and age of student: 2007,2009 , and $2011 \ldots \ldots \ldots \ldots \ldots \ldots \ldots$

303.50. Total fall enrollment in degree-granting postsecondary institutions, by level of enrollment, control and level of institution, attendance status, and age of student: $2011 \ldots \ldots \ldots \ldots \ldots \ldots$

303.55. Total fall enrollment in degree-granting postsecondary institutions, by control and level of

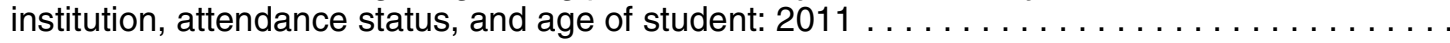

303.60. Total fall enrollment in degree-granting postsecondary institutions, by level of enrollment, sex of

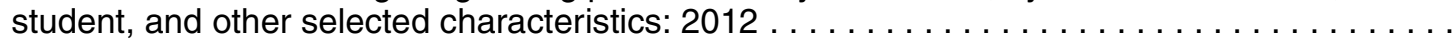

303.65. Total fall enrollment in degree-granting postsecondary institutions, by level of enrollment, sex of

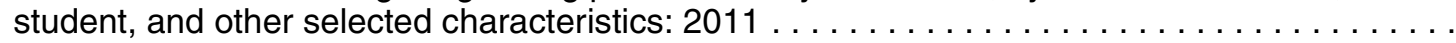

303.70. Total undergraduate fall enrollment in degree-granting postsecondary institutions, by attendance status, sex of student, and control and level of institution: Selected years, 1970 through 2023. . .

303.80. Total postbaccalaureate fall enrollment in degree-granting postsecondary institutions, by attendance status, sex of student, and control of institution: 1967 through $2023 \ldots \ldots \ldots \ldots$. . .

303.90. Fall enrollment and number of degree-granting postsecondary institutions, by control and religious affiliation of institution: Selected years, 1980 through $2012 \ldots \ldots \ldots \ldots \ldots \ldots \ldots$

\section{Total Fall Enrollment-State-Level}

304.10. Total fall enrollment in degree-granting postsecondary institutions, by state or jurisdiction:

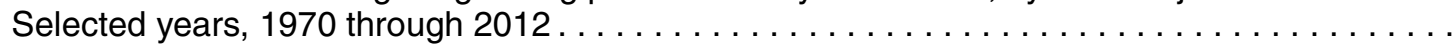

304.15. Total fall enrollment in public degree-granting postsecondary institutions, by state or jurisdiction:

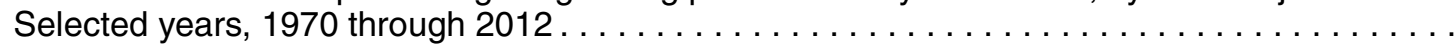

304.20. Total fall enrollment in private degree-granting postsecondary institutions, by state or jurisdiction:

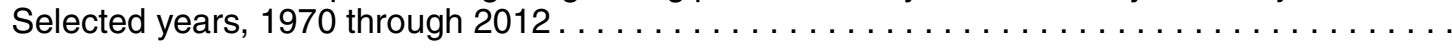

304.30. Total fall enrollment in degree-granting postsecondary institutions, by attendance status, sex, and

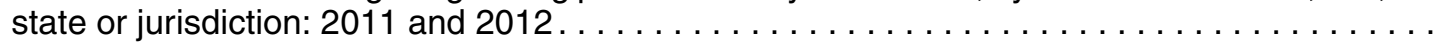

304.35. Total fall enrollment in public degree-granting postsecondary institutions, by attendance status,

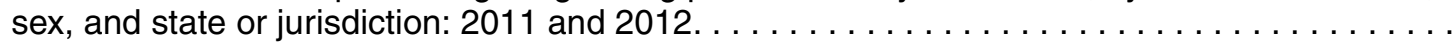

304.40. Total fall enrollment in private degree-granting postsecondary institutions, by attendance status,

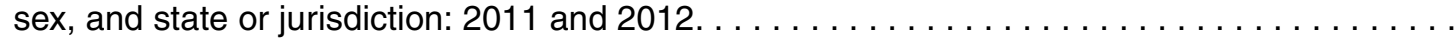

304.45. Total fall enrollment in private nonprofit degree-granting postsecondary institutions, by attendance
status, sex, and state or jurisdiction: 2011 and $2012 \ldots \ldots \ldots \ldots \ldots \ldots \ldots \ldots \ldots \ldots \ldots \ldots \ldots \ldots \ldots$

304.45. Total fall enrollment in private nonprofit degree-granting postsecondary institutions, by attendance
status, sex, and state or jurisdiction: 2011 and $2012 \ldots \ldots \ldots \ldots \ldots \ldots \ldots \ldots \ldots \ldots \ldots \ldots \ldots \ldots \ldots$

304.50. Total fall enrollment in private for-profit degree-granting postsecondary institutions, by attendance

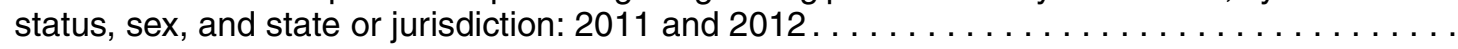

304.60. Total fall enrollment in degree-granting postsecondary institutions, by control and level of

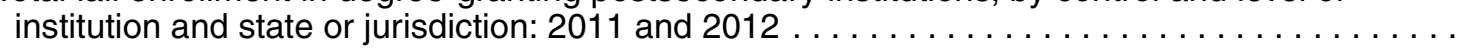

304.70. Total fall enrollment in degree-granting postsecondary institutions, by level of enrollment and state

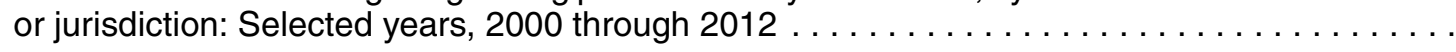

304.80. Total fall enrollment in degree-granting postsecondary institutions, by control, level of enrollment, level of institution, and state or jurisdiction: 2012. 


\section{First-Time Students and Admissions}

305.10. Total fall enrollment of first-time degree/certificate-seeking students in degree-granting postsecondary institutions, by attendance status, sex of student, and level and control of

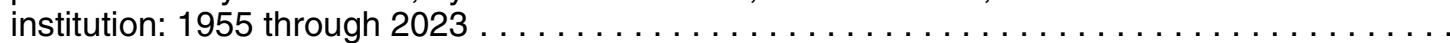

305.20. Total fall enrollment of first-time degree/certificate-seeking students in degree-granting postsecondary institutions, by attendance status, sex of student, control of institution, and state

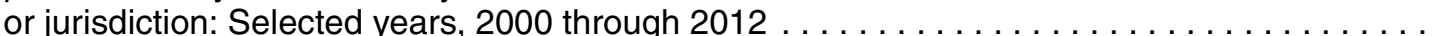

305.30. Number and percentage of degree-granting postsecondary institutions with first-year undergraduates using various selection criteria for admission, by control and level of institution:

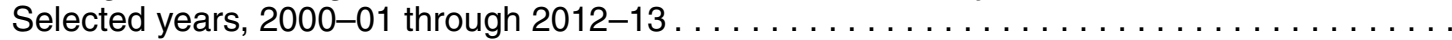

305.40. Acceptance rates; number of applications, admissions, and enrollees; and enrollees' SAT and ACT scores for degree-granting postsecondary institutions with first-year undergraduates, by

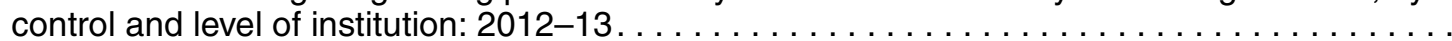

\section{Enrollment of Racial/Ethnic Groups}

306.10. Total fall enrollment in degree-granting postsecondary institutions, by level of enrollment, sex, attendance status, and race/ethnicity of student: Selected years, 1976 through 2012 . . . . . .

306.20. Total fall enrollment in degree-granting postsecondary institutions, by level and control of institution and race/ethnicity of student: Selected years, 1976 through $2012 \ldots \ldots \ldots \ldots \ldots$

306.30. Fall enrollment of U.S. residents in degree-granting postsecondary institutions, by race/ethnicity:
1998 through $2023 \ldots \ldots \ldots \ldots \ldots \ldots \ldots \ldots \ldots \ldots \ldots \ldots \ldots \ldots \ldots \ldots \ldots \ldots \ldots \ldots \ldots \ldots \ldots \ldots \ldots \ldots \ldots \ldots$$\ldots \ldots$

306.30. Fall enrollment of U.S. residents in degree-granting postsecondary institutions, by race/ethnicity:

306.40. Fall enrollment of males and females and specific racial/ethnic groups in degree-granting postsecondary institutions, by control and level of institution and percentage of U.S. resident

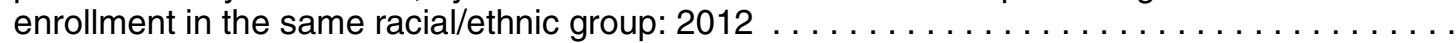

306.50. Total fall enrollment in degree-granting postsecondary institutions, by control and level of institution, level of enrollment, and race/ethnicity of student: $2012 \ldots \ldots \ldots \ldots \ldots \ldots \ldots$

306.60. Fall enrollment in degree-granting postsecondary institutions, by race/ethnicity of student and

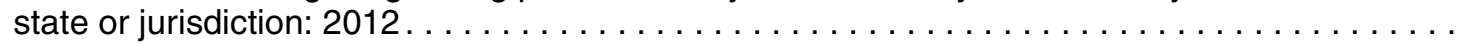

306.70. Fall enrollment in degree-granting postsecondary institutions, by race/ethnicity of student and

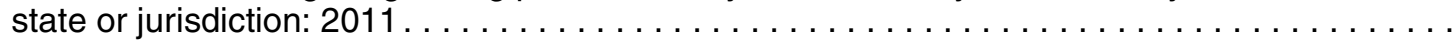

\section{Full-Time-Equivalent Fall Enrollment}

307.10. Full-time-equivalent fall enrollment in degree-granting postsecondary institutions, by control and

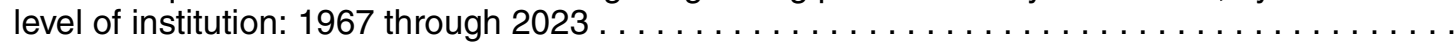

307.20. Full-time-equivalent fall enrollment in degree-granting postsecondary institutions, by control and level of institution and state or jurisdiction: 2000,2010 , and $2012 \ldots \ldots \ldots \ldots \ldots \ldots \ldots$

307.30. Full-time-equivalent fall enrollment in degree-granting postsecondary institutions, by control of institution and state or jurisdiction: 2000,2010 , and $2012 \ldots \ldots \ldots \ldots \ldots \ldots \ldots \ldots \ldots \ldots \ldots \ldots \ldots \ldots$

\section{Twelve-Month Enrollment}

308.10. Total 12-month enrollment in degree-granting postsecondary institutions, by control and level of institution and state or jurisdiction: $2010-11$ and $2011-12 \ldots \ldots \ldots \ldots \ldots \ldots \ldots \ldots \ldots$

308.20. Total 12-month enrollment in degree-granting postsecondary institutions, by control of institution and state or jurisdiction: Selected years, $2004-05$ through $2011-12 \ldots \ldots \ldots \ldots \ldots \ldots$

\section{Student Residence and Migration}

309.10. Residence and migration of all first-time degree/certificate-seeking undergraduates in degreegranting postsecondary institutions, by state or jurisdiction: Fall $2012 \ldots \ldots \ldots \ldots \ldots \ldots \ldots$ 
309.20. Residence and migration of all first-time degree/certificate-seeking undergraduates in degreegranting postsecondary institutions who graduated from high school in the previous 12 months,

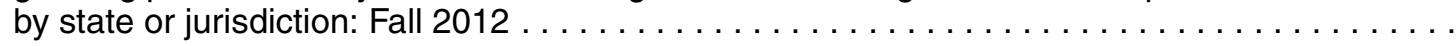

309.30. Residence and migration of all first-time degree/certificate-seeking undergraduates in 4-year degree-granting postsecondary institutions who graduated from high school in the previous 12

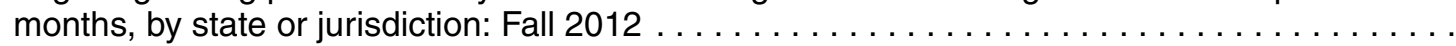

\section{Study Abroad and Foreign Students}

310.10. Number of U.S. students studying abroad and percentage distribution, by sex, race/ethnicity, and other selected characteristics: Selected years, 1996-97 through $2010-11 \ldots \ldots \ldots \ldots \ldots$.

310.20. Foreign students enrolled in institutions of higher education in the United States, by continent, region, and selected countries of origin: Selected years, 1980-81 through $2011-12 \ldots \ldots \ldots$.

\section{Programs and Courses}

311.10. Number and percentage distribution of students enrolled in postsecondary institutions, by level, disability status, and selected student characteristics: $2007-08$ and $2011-12 \ldots \ldots \ldots \ldots \ldots$.

311.15. Number and percentage of students enrolled in degree-granting postsecondary institutions, by distance education participation, location of student, level of enrollment, and control and level of

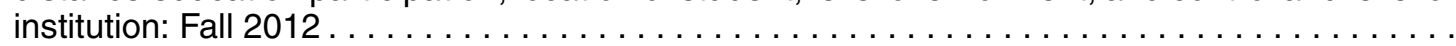

311.20. Number and percentage of undergraduate students taking night, weekend, or online classes, by

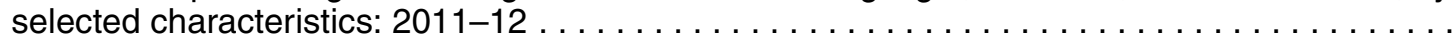

311.30. Number and percentage of graduate students taking night, weekend, or online classes, by

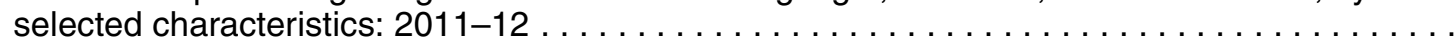

311.33. Selected statistics for degree-granting postsecondary institutions that primarily offer online programs, by control of institution and selected characteristics: $2012 \ldots \ldots \ldots \ldots \ldots \ldots \ldots$

311.40. Percentage of first-year undergraduate students who reported taking remedial education courses, by selected student and institution characteristics: 2003-04, 2007-08, and 2011-12 . . . . .

311.50. Percentage of degree-granting postsecondary institutions with first-year undergraduates offering remedial services, by control and level of institution: 1989-90 through $2012-13 \ldots \ldots \ldots \ldots$.

311.60. Enrollment in postsecondary education, by level of enrollment, level of institution, student age,

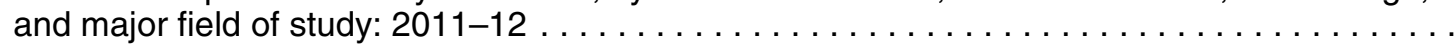

311.70. Course enrollments in languages other than English compared with total enrollment at degreegranting postsecondary institutions, by enrollment level, institution level, and language: Selected

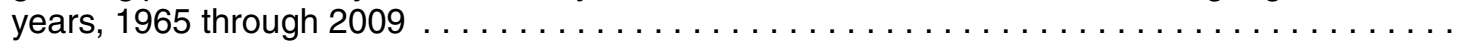

311.80. Number and percentage distribution of course enrollments in languages other than English at degreegranting postsecondary institutions, by language and enrollment level: 2002, 2006, and 2009. . . .

311.90. Graduate enrollment in science and engineering programs in degree-granting postsecondary

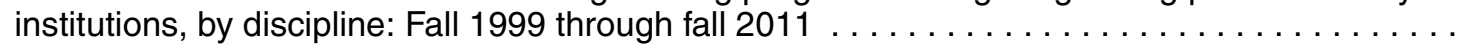

\section{Large Institutions and Institutions Serving Specific Groups}

312.10. Enrollment of the 120 largest degree-granting college and university campuses, by selected

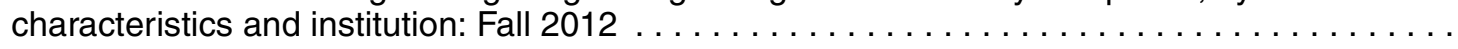

312.20. Selected statistics for degree-granting postsecondary institutions enrolling more than 15,000 students in 2012, by selected institution and student characteristics: Selected years, 1990

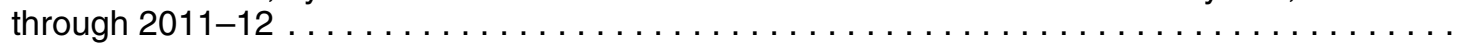

312.30. Enrollment and degrees conferred in degree-granting women's colleges, by selected

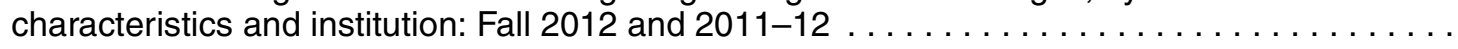

312.40. Enrollment and degrees conferred in degree-granting postsecondary institutions that serve large
proportions of Hispanic undergraduate students, by institution level and control, percentage
Hispanic, degree level, and other selected characteristics: Fall 2012 and $2011-12 \ldots \ldots \ldots$

312.40. Enrollment and degrees conferred in degree-granting postsecondary institutions that serve large
proportions of Hispanic undergraduate students, by institution level and control, percentage
Hispanic, degree level, and other selected characteristics: Fall 2012 and $2011-12 \ldots \ldots \ldots$

312.40. Enrollment and degrees conferred in degree-granting postsecondary institutions that serve large
proportions of Hispanic undergraduate students, by institution level and control, percentage
Hispanic, degree level, and other selected characteristics: Fall 2012 and $2011-12 \ldots \ldots \ldots$ 312.50. Fall enrollment and degrees conferred in degree-granting tribally controlled postsecondary institutions,
by state and institution: Selected years, fall 2000 through fall 2012 , and $2010-11$ and $2011-12 \ldots$ 


\section{Historically Black Colleges and Universities}

313.10. Fall enrollment, degrees conferred, and expenditures in degree-granting historically Black colleges and universities, by institution: 2011, 2012, and 2011-12 . . . . . . . . . . . .

313.20. Fall enrollment in degree-granting historically Black colleges and universities, by sex of student and level and control of institution: Selected years, 1976 through $2012 \ldots \ldots \ldots \ldots \ldots \ldots \ldots$

313.30. Selected statistics on degree-granting historically Black colleges and universities, by control and level of institution: Selected years, 1990 through $2012 \ldots \ldots \ldots \ldots \ldots \ldots \ldots \ldots \ldots$

\section{Staff}

314.10. Total and full-time-equivalent (FTE) staff and FTE student/FTE staff ratios in postsecondary institutions participating in Title IV programs, by degree-granting status, control of institution, and

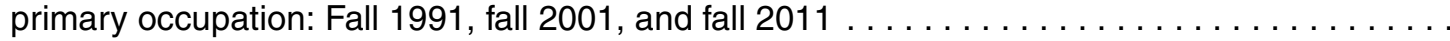

314.20. Employees in degree-granting postsecondary institutions, by sex, employment status, control and level of institution, and primary occupation: Selected years, fall 1991 through fall $2011 \ldots \ldots$.

314.30. Employees in degree-granting postsecondary institutions, by employment status, sex, control and

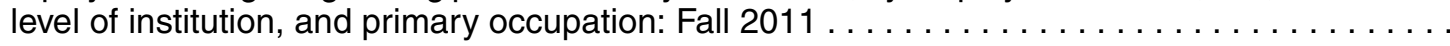

314.40. Employees in degree-granting postsecondary institutions, by race/ethnicity, sex, employment status, control and level of institution, and primary occupation: Fall $2011 \ldots \ldots \ldots \ldots \ldots \ldots$

314.50. Ratios of full-time-equivalent (FTE) students to FTE staff and FTE faculty in public degreegranting postsecondary institutions, by level of institution and state or jurisdiction: Fall $2011 \ldots$

314.60. Ratios of full-time-equivalent (FTE) students to FTE staff and FTE faculty in private degreegranting postsecondary institutions, by level of institution and state or jurisdiction: Fall $2011 \ldots$

\section{Faculty and Instructional Staff}

315.10. Number of instructional faculty in degree-granting postsecondary institutions, by employment status, sex, control, and level of institution: Selected years, fall 1970 through fall $2011 \ldots \ldots$.

315.20. Full-time instructional faculty in degree-granting postsecondary institutions, by race/ethnicity, sex, and academic rank: Fall 2007 , fall 2009 , and fall $2011 \ldots \ldots \ldots \ldots \ldots \ldots \ldots \ldots \ldots \ldots \ldots \ldots \ldots$

315.30. Percentage distribution of full-time faculty and instructional staff in degree-granting postsecondary institutions, by level and control of institution, selected instruction activities, and number of classes

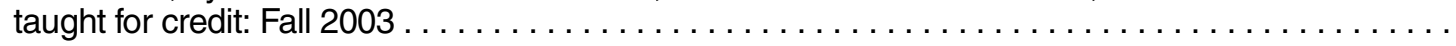

315.40. Percentage distribution of part-time faculty and instructional staff in degree-granting postsecondary institutions, by level and control of institution, selected instruction activities, and number of classes

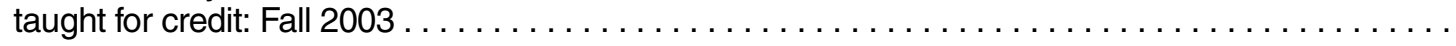

315.50. Full-time and part-time faculty and instructional staff in degree-granting postsecondary institutions, by level and control of institution and selected characteristics: Fall 1992, fall 1998, and fall 2003 . . . .

315.60. Full-time and part-time faculty and instructional staff in degree-granting postsecondary institutions, by race/ethnicity, sex, and selected characteristics: Fall $2003 \ldots \ldots \ldots \ldots \ldots$. .

315.70. Full-time and part-time faculty and instructional staff in degree-granting postsecondary institutions, by field and faculty characteristics: Fall 1992, fall 1998, and fall $2003 \ldots \ldots \ldots$.

315.80. Full-time and part-time faculty and instructional staff in degree-granting postsecondary institutions, by race/ethnicity, sex, and program area: Fall 1998 and fall $2003 \ldots \ldots \ldots \ldots \ldots$

\section{Faculty Salaries and Benefits}

316.10. Average salary of full-time instructional faculty on 9-month contracts in degree-granting postsecondary institutions, by academic rank, control and level of institution, and sex:

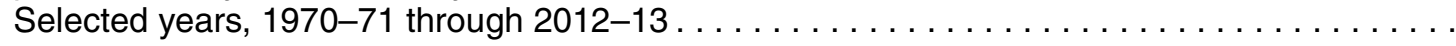

316.20. Average salary of full-time instructional faculty on 9-month contracts in degree-granting postsecondary institutions, by academic rank, sex, and control and level of institution:

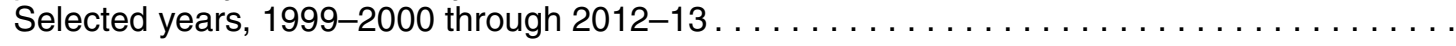


316.40. Average salary of full-time instructional faculty on 9-month contracts in degree-granting postsecondary institutions, by control and level of institution and state or jurisdiction: $2011-12 \ldots \ldots \ldots \ldots \ldots$.

316.50. Average salary of full-time instructional faculty on 9-month contracts in 4-year degree-granting postsecondary institutions, by control and classification of institution, academic rank of faculty, and state or jurisdiction: $2012-13$

316.60. Average salary of full-time instructional faculty on 9-month contracts in 4-year degree-granting
postsecondary institutions, by control and classification of institution, academic rank of faculty,

316.60. Average salary of full-time instructional faculty on 9-month contracts in 4-year degree-granting
postsecondary institutions, by control and classification of institution, academic rank of faculty, and state or jurisdiction: 2011-12

316.70. Average benefit expenditure for full-time instructional faculty on 9-month contracts in degreegranting postsecondary institutions, by type of benefit and control of institution: Selected years,

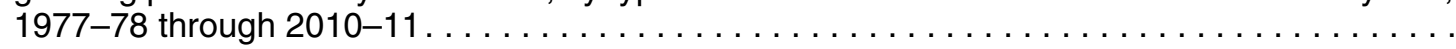

316.80. Percentage of full-time instructional faculty with tenure for degree-granting postsecondary institutions with a tenure system, by academic rank, sex, and control and level of institution:

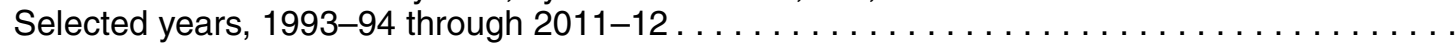

\section{Institutions}

317.10. Degree-granting postsecondary institutions, by control and level of institution: Selected years,

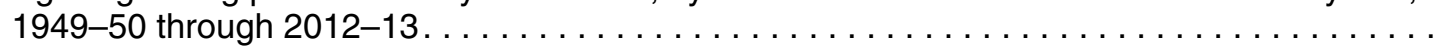

317.20. Degree-granting postsecondary institutions, by control and level of institution and state or

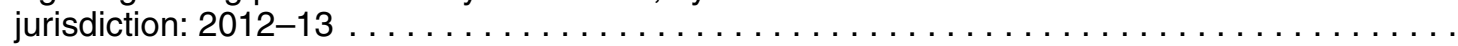

Number of non-degree-granting Title IV institutions offering postsecondary education, by control

317.30. Number of non-degree-granting Title IV institutions offering postsecondary education, by control
of institution and state or jurisdiction: Selected years, $2000-01$ through $2012-13 \ldots \ldots \ldots \ldots$ enrollment size, control, and level of institution: Fall $2012 \ldots \ldots \ldots \ldots \ldots \ldots \ldots \ldots \ldots \ldots$

317.50. Degree-granting postsecondary institutions that have closed their doors, by control and level of

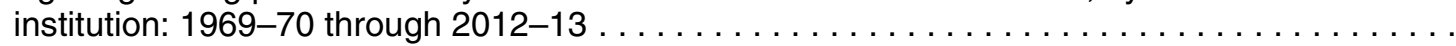

\section{Summary of Degrees Conferred}

318.10. Degrees conferred by degree-granting postsecondary institutions, by level of degree and sex of

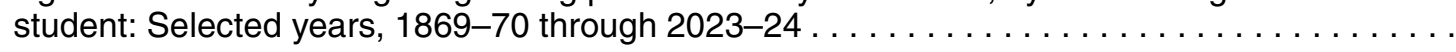

318.20. Bachelor's, master's, and doctor's degrees conferred by degree-granting institutions, by field of

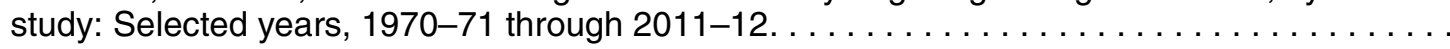

318.30. Bachelor's, master's, and doctor's degrees conferred by postsecondary institutions, by sex of

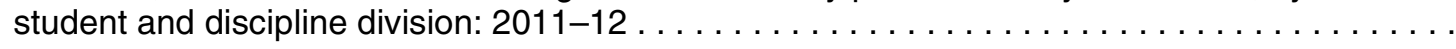

318.40. Degrees/certificates conferred by postsecondary institutions, by control of institution and level of

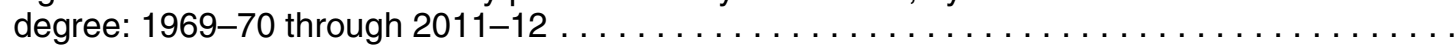

318.50. Degrees conferred by postsecondary institutions, by control of institution, level of degree, and field

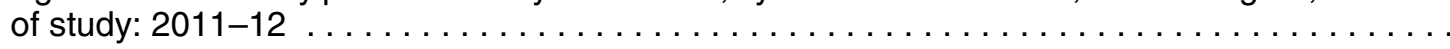

318.60. Number of postsecondary institutions conferring degrees, by control, level of degree, and field of

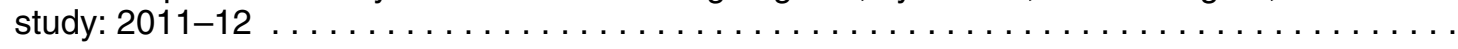

\section{Degrees Conferred-State-Level}

319.10. Degrees conferred by postsecondary institutions, by control, level of degree, and state or

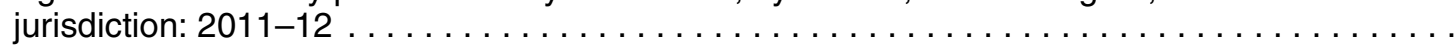

319.20. Degrees conferred by postsecondary institutions, by level of degree and state or jurisdiction:

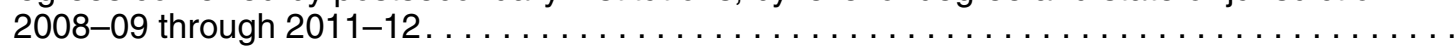

319.30. Bachelor's degrees conferred by postsecondary institutions, by field of study and state or

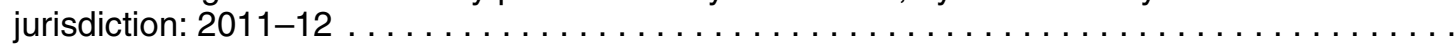

319.40. Master's degrees conferred by postsecondary institutions, by field of study and state or

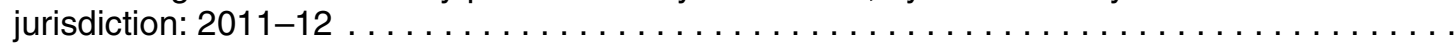




\section{Certificates Below the Associate's Degree Level}

320.10. Certificates below the associate's degree level conferred by postsecondary institutions, by length of curriculum, sex of student, institution level and control, and discipline division: 2011-12 . . .

320.20. Certificates below the associate's degree level conferred by postsecondary institutions, by race/

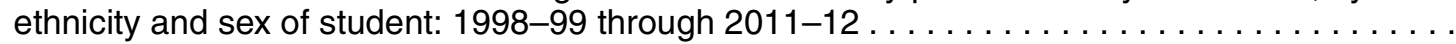

\section{Associate's Degrees}

321.10. Associate's degrees conferred by postsecondary institutions, by sex of student and discipline

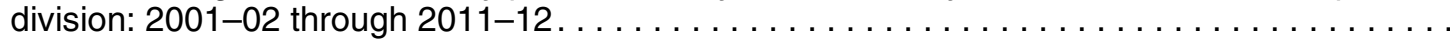

321.20. Associate's degrees conferred by postsecondary institutions, by race/ethnicity and sex of student:

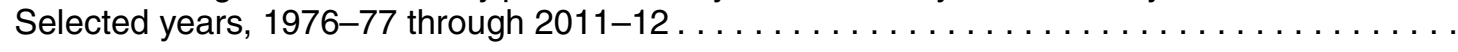

321.30. Associate's degrees conferred by postsecondary institutions, by race/ethnicity and field of study:

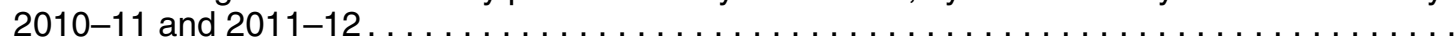

321.40. Associate's degrees conferred to males by postsecondary institutions, by race/ethnicity and field

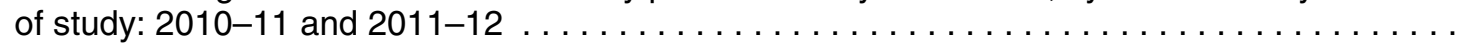

321.50. Associate's degrees conferred to females by postsecondary institutions, by race/ethnicity and

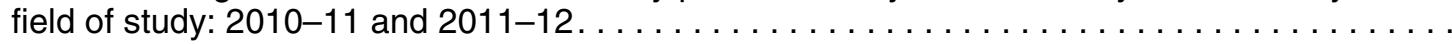

\section{Bachelor's Degrees}

322.10. Bachelor's degrees conferred by postsecondary institutions, by field of study: Selected years,

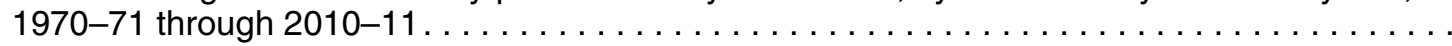

322.20. Bachelor's degrees conferred by postsecondary institutions, by race/ethnicity and sex of student:

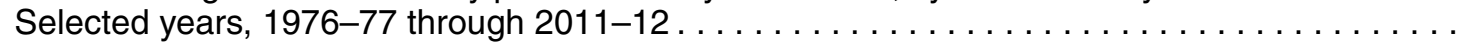

322.30. Bachelor's degrees conferred by postsecondary institutions, by race/ethnicity and field of study:

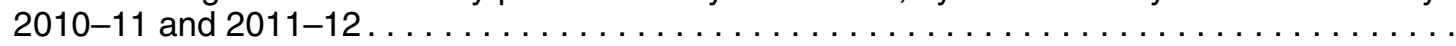

322.40. Bachelor's degrees conferred to males by postsecondary institutions, by race/ethnicity and field
of study: $2010-11$ and $2011-12 \ldots \ldots \ldots \ldots \ldots \ldots \ldots \ldots \ldots \ldots \ldots \ldots \ldots \ldots \ldots \ldots \ldots \ldots \ldots \ldots \ldots \ldots \ldots$

322.40. Bachelor's degrees conferred to males by postsecondary institutions, by race/ethnicity and field
of study: $2010-11$ and $2011-12 \ldots \ldots \ldots \ldots \ldots \ldots \ldots \ldots \ldots \ldots \ldots \ldots \ldots \ldots \ldots \ldots \ldots \ldots \ldots \ldots \ldots \ldots \ldots \ldots$

322.50. Bachelor's degrees conferred to females by postsecondary institutions, by race/ethnicity and field

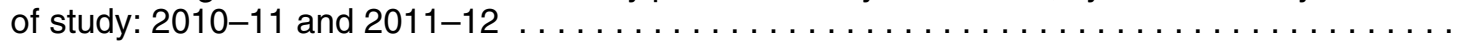

\section{Master's Degrees}

323.10. Master's degrees conferred by postsecondary institutions, by field of study: Selected years,

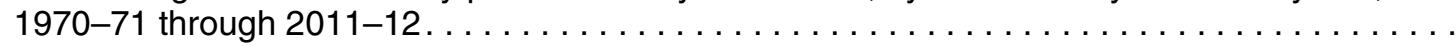

323.20. Master's degrees conferred by postsecondary institutions, by race/ethnicity and sex of student:

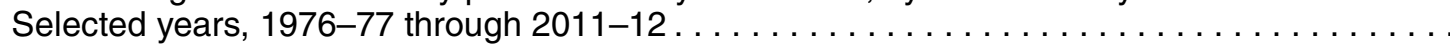

323.30. Master's degrees conferred by postsecondary institutions, by race/ethnicity and field of study: 2010-11 and 2011-12 . . . . . . . . . . . . . . . . . . . . . . . . . . . .

323.40. Master's degrees conferred to males by postsecondary institutions, by race/ethnicity and field of

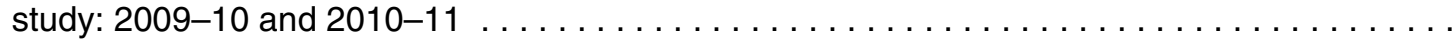

323.50. Master's degrees conferred to females by postsecondary institutions, by race/ethnicity and field

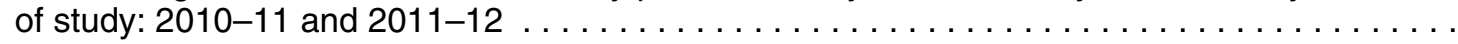

\section{Doctor's Degrees}

324.10. Doctor's degrees conferred by postsecondary institutions, by field of study: Selected years,

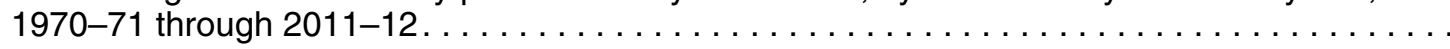

324.20. Doctor's degrees conferred by postsecondary institutions, by race/ethnicity and sex of student:

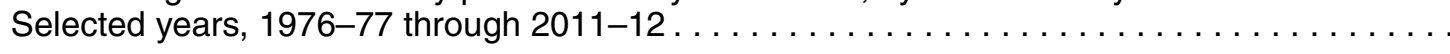

324.25. Doctor's degrees conferred by postsecondary institutions, by race/ethnicity and field of study:

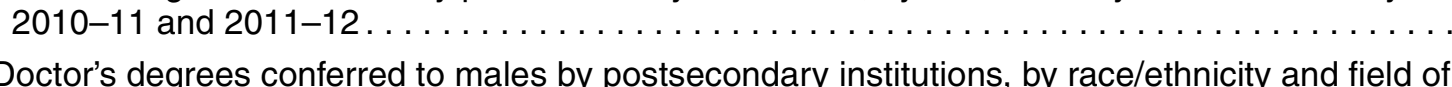

324.30. Doctor's degrees conferred to males by postsecondary institutions, by race/ethnicity and field of
study: $2010-11$ and $2011-12 \ldots \ldots \ldots \ldots \ldots \ldots \ldots \ldots \ldots \ldots \ldots \ldots \ldots \ldots \ldots \ldots \ldots \ldots \ldots \ldots \ldots$$\ldots$ 
324.35. Doctor's degrees conferred to females by postsecondary institutions, by race/ethnicity and field of

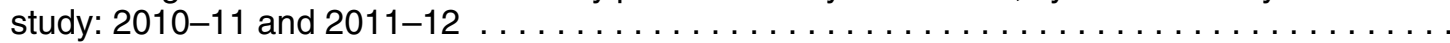

324.40. Number of postsecondary institutions conferring doctor's degrees in dentistry, medicine, and law, and

number of such degrees conferred, by sex of student: Selected years, 1949-50 through 2011-12..
324.50. Degrees conferred by postsecondary institutions in selected professional fields, by sex of student,

Control of institution, and field of study: Selected years, $1985-86$ through $2011-12 \ldots \ldots \ldots$
324.55. Degrees conferred by postsecondary institutions in selected professional fields, by race/ethnicity

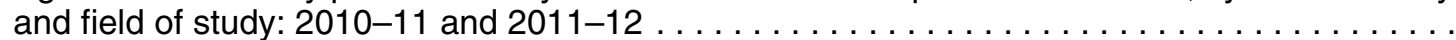

324.60. Degrees conferred to males by postsecondary institutions in selected professional fields, by race/

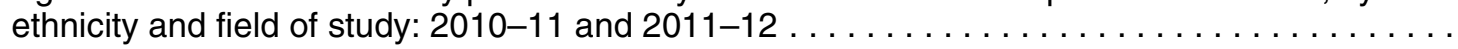

324.70. Degrees conferred to females by postsecondary institutions in selected professional fields, by race/ethnicity and field of study: $2010-11$ and $2011-12 \ldots \ldots \ldots \ldots \ldots \ldots \ldots$

324.80. Statistical profile of persons receiving doctor's degrees, by field of study and selected

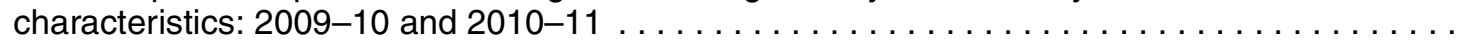

324.90. Doctor's degrees conferred by the 60 institutions conferring the most doctor's degrees, by rank
order: $2002-03$ through $2011-12 \ldots \ldots \ldots \ldots \ldots \ldots \ldots \ldots \ldots \ldots \ldots \ldots \ldots \ldots \ldots \ldots \ldots \ldots \ldots \ldots \ldots \ldots \ldots \ldots$

\section{Trends in Degrees by Field}

325.10. Degrees in agriculture and natural resources conferred by postsecondary institutions, by level of degree and sex of student: $1970-71$ through $2011-12 \ldots \ldots \ldots \ldots \ldots \ldots \ldots \ldots \ldots \ldots \ldots$

325.15. Degrees in architecture and related services conferred by postsecondary institutions, by level of degree and sex of student: Selected years, $1949-50$ through $2011-12 \ldots \ldots \ldots \ldots \ldots \ldots$

325.20. Degrees in the biological and biomedical sciences conferred by postsecondary institutions, by level of degree and sex of student: Selected years, 1951-52 through $2011-12 \ldots \ldots \ldots \ldots$.

325.22. Degrees in biology, microbiology, and zoology conferred by postsecondary institutions, by level of degree: 1970-71 through 2011-12 . .

325.25. Degrees in business conferred by postsecondary institutions, by level of degree and sex of

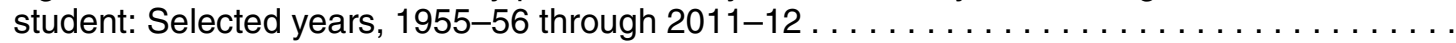

325.30. Degrees in communication, journalism, and related programs and in communications technologies conferred by postsecondary institutions, by level of degree and sex of student:

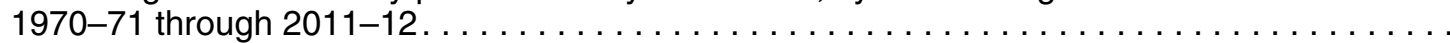

325.35. Degrees in computer and information sciences conferred by postsecondary institutions, by level of degree and sex of student: $1970-71$ through $2011-12 \ldots \ldots \ldots \ldots \ldots \ldots \ldots \ldots \ldots \ldots$

325.40. Degrees in education conferred by postsecondary institutions, by level of degree and sex of

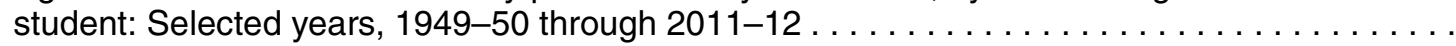

325.45. Degrees in engineering and engineering technologies conferred by postsecondary institutions, by level of degree and sex of student: Selected years, 1949-50 through $2011-12 \ldots \ldots \ldots \ldots$.

325.47. Degrees in chemical, civil, electrical, and mechanical engineering conferred by postsecondary

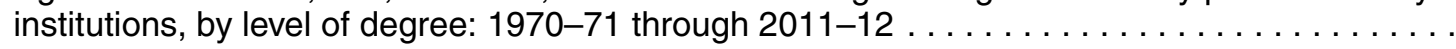

325.50. Degrees in English language and literature/letters conferred by postsecondary institutions, by level of degree and sex of student: Selected years, 1949-50 through $2011-12 \ldots \ldots \ldots \ldots$.

325.55. Degrees in foreign languages and literatures conferred by postsecondary institutions, by level of degree and sex of student: Selected years, 1959-60 through $2011-12 \ldots \ldots \ldots \ldots \ldots \ldots$

325.57. Degrees in French, German, Italian, and Spanish language and literature conferred by postsecondary institutions, by level of degree: Selected years, 1949-50 through $2011-12 \ldots \ldots \ldots \ldots \ldots \ldots$

325.59. Degrees in Arabic, Chinese, Korean, and Russian language and literature conferred by postsecondary

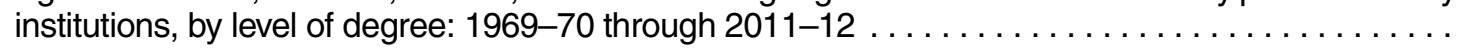

325.60. Degrees in the health professions and related programs conferred by postsecondary institutions, by level of degree and sex of student: $1970-71$ through $2011-12 \ldots \ldots \ldots \ldots \ldots \ldots \ldots$

325.65. Degrees in mathematics and statistics conferred by degree-granting institutions, by level of degree and sex of student: Selected years, $1949-50$ through $2011-12 \ldots \ldots \ldots \ldots \ldots \ldots$ 
325.70. Degrees in the physical sciences and science technologies conferred by postsecondary institutions, by level of degree and sex of student: Selected years, 1959-60 through $2011-12 \ldots \ldots \ldots \ldots$.

325.72. Degrees in chemistry, geology and earth science, and physics conferred by postsecondary institutions,

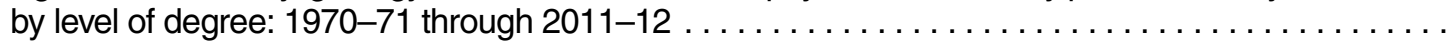

325.80. Degrees in psychology conferred by postsecondary institutions, by level of degree and sex of

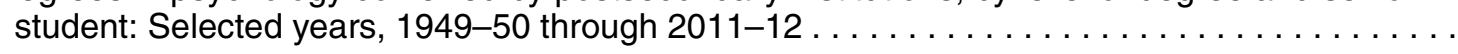

325.85. Degrees in public administration and social services conferred by postsecondary institutions, by level of degree and sex of student: $1970-71$ through $2011-12 \ldots \ldots \ldots \ldots \ldots \ldots \ldots$

325.90. Degrees in the social sciences and history conferred by postsecondary institutions, by level of degree and sex of student: $1970-71$ through $2011-12 \ldots \ldots \ldots \ldots \ldots \ldots \ldots \ldots \ldots \ldots$

325.92. Degrees in economics, history, political science and government, and sociology conferred by postsecondary institutions, by level of degree: Selected years, 1949-50 through 2011-12 . . .

325.95. Degrees in visual and performing arts conferred by postsecondary institutions, by level of degree

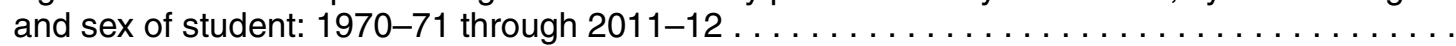

\section{Completion Rates}

326.10. Graduation rates of first-time, full-time bachelor's degree-seeking students at 4-year postsecondary institutions, by race/ethnicity, time to completion, sex, and control of institution: Selected cohort entry

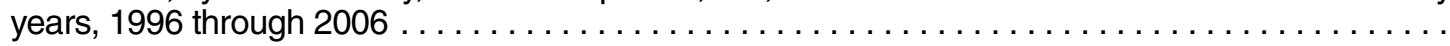

326.20. Graduation rates of first-time, full-time degree/certificate-seeking students at 2-year postsecondary institutions who completed a credential within 150 percent of normal time, by race/ethnicity, sex, and control of institution: Selected cohort entry years, 2000 through $2009 \ldots \ldots \ldots \ldots \ldots \ldots \ldots$

326.30. Retention of first-time degree-seeking undergraduates at degree-granting postsecondary institutions, by attendance status, level and control of institution, and percentage of applications

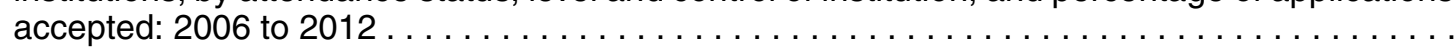

326.40. Percentage distribution of first-time postsecondary students starting at 2- and 4-year institutions during the 2003-04 academic year, by highest degree attained, enrollment status, and selected

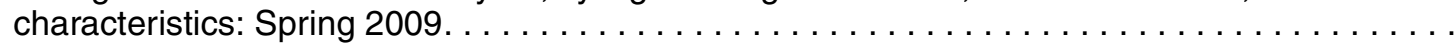

\section{Achievement and Admissions Testing}

327.10. Average scores and standard deviations on Graduate Record Examination (GRE) general and

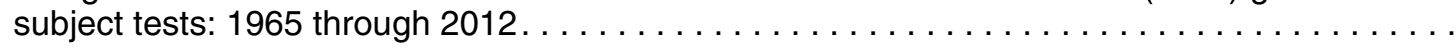

\section{Security and Crime}

329.10. On-campus crimes, arrests, and referrals for disciplinary action at degree-granting postsecondary institutions, by location of incident, control and level of institution, and type of incident: 2001

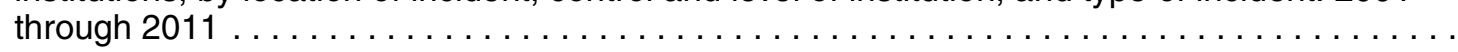

329.20. On-campus crimes, arrests, and referrals for disciplinary action per 10,000 full-time-equivalent (FTE) students at degree-granting postsecondary institutions, by whether institution has residence halls, control and level of institution, and type of incident: 2001 through $2011 \ldots \ldots$.

\section{Student Charges}

330.10. Average undergraduate tuition and fees and room and board rates charged for full-time students in degree-granting postsecondary institutions, by level and control of institution: 1963-64

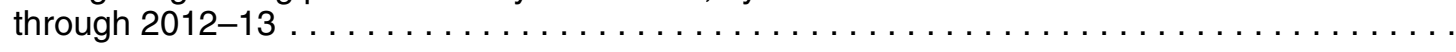

330.20. Average undergraduate tuition and fees and room and board rates charged for full-time students in degree-granting postsecondary institutions, by control and level of institution and state or

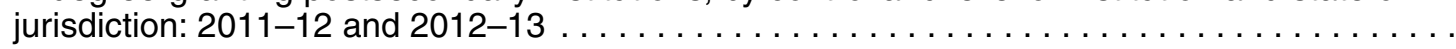

330.30. Average undergraduate tuition, fees, room, and board rates for full-time students in degreegranting postsecondary institutions, by percentile, control, and level of institution: Selected

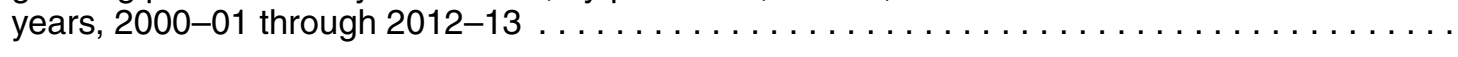


330.40. Average total cost of attendance for first-time, full-time undergraduate students in degree-granting postsecondary institutions, by control and level of institution, living arrangement, and component

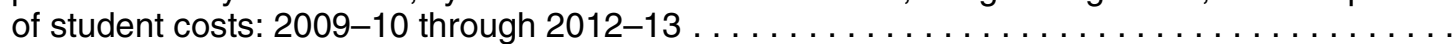

330.50. Average graduate tuition and required fees in degree-granting postsecondary institutions, by control of institution and percentile: $1989-90$ through $2012-13 \ldots \ldots \ldots \ldots \ldots \ldots \ldots$

\section{Financial Aid for Undergraduates}

331.10. Percentage of undergraduates receiving financial aid, by type and source of aid and selected

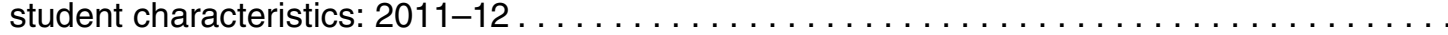

331.20. Full-time, first-time degree/certificate-seeking undergraduate students enrolled in degreegranting postsecondary institutions, by participation and average amount awarded in financial aid programs, and control and level of institution: 2000-01 through 2011-12............

331.30. Average amount of grant and scholarship aid and average net price for first-time, full-time students receiving Title IV aid, and percentage distribution of students, by control and level of institution and income level: $2009-10,2010-11$ and $2011-12 \ldots \ldots \ldots \ldots \ldots \ldots \ldots \ldots$

331.40. Average amount of financial aid awarded to full-time, full-year undergraduates, by type and source of aid and selected student characteristics: $2011-12 \ldots \ldots \ldots \ldots \ldots \ldots \ldots \ldots \ldots \ldots \ldots$

331.45. Average amount of financial aid awarded to part-time or part-year undergraduates, by type and source of aid and selected student characteristics: $2011-12 \ldots \ldots \ldots \ldots \ldots \ldots \ldots$

331.50. Amount borrowed, aid status, and sources of aid for full-time and part-time undergraduates, by

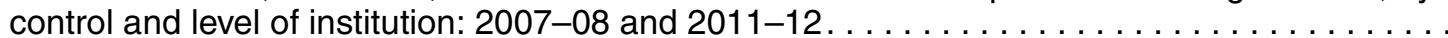

331.60. Percentage of full-time, full-year undergraduates receiving financial aid, by type and source of aid and control and level of institution: Selected years, 1992-93 through $2011-12 \ldots \ldots \ldots \ldots$. . .

331.70. Average amount of financial aid awarded to full-time, full-year undergraduates, by type and source of aid and control and level of institution: Selected years, 1992-93 through 2011-12 . . . . . .

331.80. Percentage of part-time or part-year undergraduates receiving financial aid, by type and source of aid and control and level of institution: Selected years, 1992-93 through 2011-12 . . . . .

331.90. Percentage of full-time and part-time undergraduates receiving federal aid, by aid program and

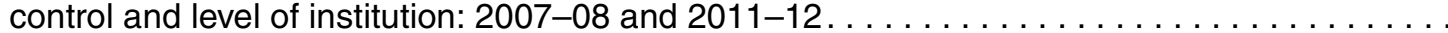

331.95. Percentage of undergraduate students ages 18 to 24 in their 4 th (senior) year or above who had ever received federal loans, nonfederal loans, or Parent Loans for Undergraduates (PLUS), and the average cumulative amount borrowed, by selected student characteristics and control and level of institution: $1989-90,1999-2000$, and $2011-12 \ldots \ldots \ldots \ldots \ldots \ldots \ldots \ldots \ldots$

\section{Financial Aid for Postbaccalaureate Students}

332.10. Amount borrowed, aid status, and sources of aid for full-time, full-year postbaccalaureate students, by level of study and control and level of institution: Selected years, 1992-93 through 2011-12 . . . . . .

332.20. Amount borrowed, aid status, and sources of aid for part-time or part-year postbaccalaureate students, by level of study and control and level of institution: Selected years, 1992-93 through 2011-12 . . . .

332.30. Percentage of full-time, full-year postbaccalaureate students receiving financial aid, by type of aid, level of study, and control and level of institution: Selected years, 1992-93 through 2011-12 . .

332.40. Percentage of part-time or part-year postbaccalaureate students receiving financial aid, by type of aid, level of study, and control and level of institution: Selected years, 1992-93 through 2011-12 ......

332.50. Number of postsecondary students who entered the student loan repayment phase, number of students who defaulted, and student loan cohort default rates, by 2-year or 3-year default period and level and control of institution: Fiscal years 2009 through $2011 \ldots \ldots \ldots \ldots \ldots \ldots \ldots$

\section{Revenues}

333.10. Revenues of public degree-granting postsecondary institutions, by source of revenue and level of

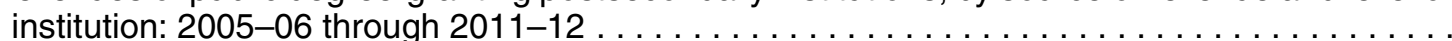

333.20. Revenues of public degree-granting postsecondary institutions, by source of revenue and state or

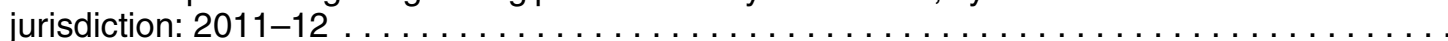


333.25. Revenues of public degree-granting postsecondary institutions, by source of revenue and state or

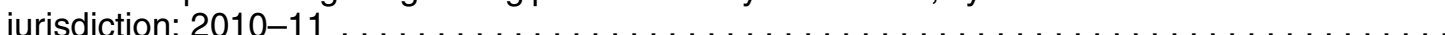

333.30. Appropriations from state and local governments for public degree-granting postsecondary

333.40. Total revenue of private nonprofit degree-granting postsecondary institutions, by source of funds

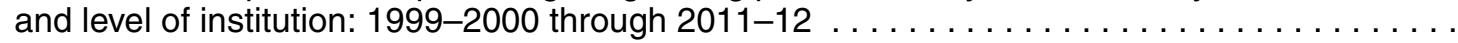

333.50. Total revenue of private nonprofit degree-granting postsecondary institutions, by source of funds

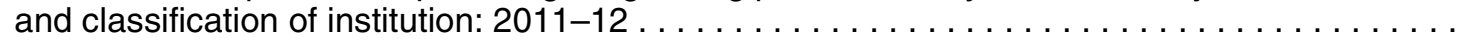

333.55. Total revenue of private for-profit degree-granting postsecondary institutions, by source of funds and level of institution: Selected years, $1999-2000$ through $2011-12 \ldots \ldots \ldots \ldots \ldots \ldots$

333.60. Total revenue of private for-profit degree-granting postsecondary institutions, by source of funds

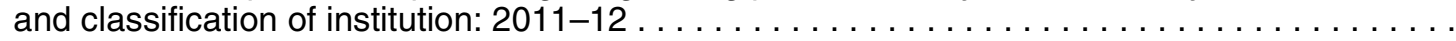

333.70. Revenue received from the federal government by the 120 degree-granting postsecondary institutions receiving the largest amounts, by control and rank order: $2011-12 \ldots \ldots \ldots \ldots$

333.80. Voluntary support for degree-granting postsecondary institutions, by source and purpose of

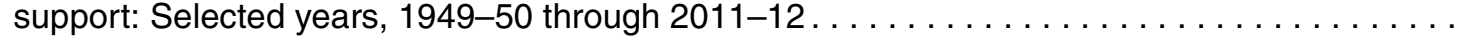

333.90. Endowment funds of the 120 degree-granting postsecondary institutions with the largest

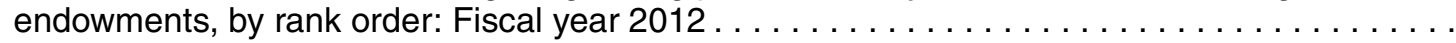

\section{Expenditures}

334.10. Expenditures of public degree-granting postsecondary institutions, by purpose of expenditure and

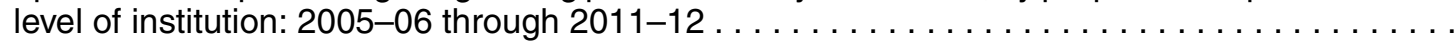

334.20. Expenditures of public degree-granting postsecondary institutions, by level of institution, purpose of expenditure, and state or jurisdiction: $2008-09$ through $2011-12 \ldots \ldots \ldots \ldots \ldots \ldots \ldots$

334.30. Total expenditures of private nonprofit degree-granting postsecondary institutions, by purpose and level of institution: $1999-2000$ through $2011-12 \ldots \ldots \ldots \ldots \ldots \ldots \ldots \ldots \ldots \ldots \ldots \ldots \ldots \ldots$

334.40. Total expenditures of private nonprofit degree-granting postsecondary institutions, by purpose

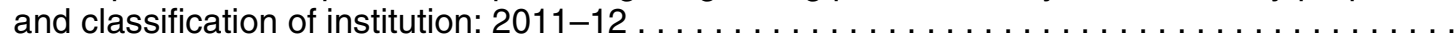

334.50. Total expenditures of private for-profit degree-granting postsecondary institutions, by purpose and

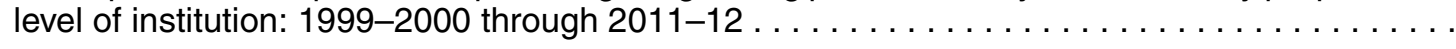

334.60. Total expenditures of private for-profit degree-granting postsecondary institutions, by purpose and classification of institution: 2011-12

334.70. Total expenditures of private nonprofit and for-profit degree-granting postsecondary institutions,
by state or jurisdiction: Selected years, $1999-2000$ through $2011-12 \ldots \ldots \ldots \ldots \ldots \ldots \ldots$

334.70. Total expenditures of private nonprofit and for-profit degree-granting postsecondary institutions,
by state or jurisdiction: Selected years, $1999-2000$ through $2011-12 \ldots \ldots \ldots \ldots \ldots \ldots$

\section{Chapter 4. Federal Funds for Education and Related Activities}

\section{On-Budget and Off-Budget Support}

401.10. Federal support and estimated federal tax expenditures for education, by category: Selected

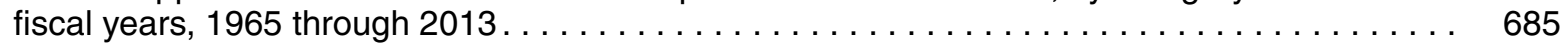

401.20. Federal on-budget funds for education, by agency: Selected fiscal years, 1970 through $2012 \ldots 687$

401.30. Federal on-budget funds for education, by level/educational purpose, agency, and program:

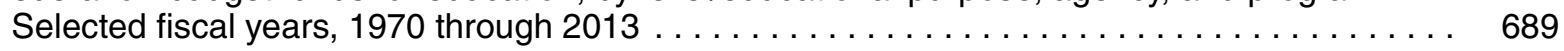

401.60. U.S. Department of Education appropriations for major programs, by state or jurisdiction: Fiscal year 2012 . 696

401.70. Appropriations for Title I and selected other programs under the No Child Left Behind Act of 2001, by program and state or jurisdiction: Fiscal years 2012 and $2013 \ldots \ldots \ldots \ldots \ldots \ldots \ldots$

\section{Federal Obligations for Research and Development}

402.10. Federal obligations for research, development, and R\&D plant, by category of obligation, performers, and fields of science: Fiscal years 2005 through $2013 \ldots \ldots \ldots \ldots \ldots \ldots \ldots$ 


\section{Chapter 5. Outcomes of Education}

\section{Labor Force Status by Educational Attainment}

501.10. Labor force participation, employment, and unemployment of persons 25 to 64 years old, by sex, race/ethnicity, age group, and educational attainment: 2010, 2011, and $2012 \ldots \ldots \ldots \ldots .706$

501.20. Labor force participation, employment, and unemployment of persons 16 to 24 years old who are not enrolled in school, by age group, sex, race/ethnicity, and educational attainment: 2010, 2011, and 2012 .

501.30. Number and percentage of persons 16 to 24 years old who were neither enrolled in school nor working, by educational attainment, age group, family poverty status, and race/ethnicity: $2013 \ldots$. .

501.40. Percentage distribution of 25- to 34-year-olds with various levels of educational attainment, by labor force status, sex, race/ethnicity, and U.S. nativity and citizenship status: $2012 \ldots \ldots \ldots$.

501.50. Employment to population ratios of persons 16 to 64 years old, by age group and educational

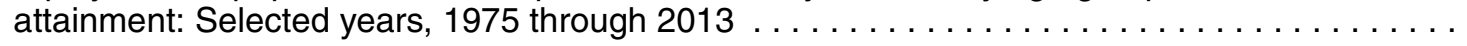

501.60. Employment to population ratios of males 16 to 64 years old, by age group and educational

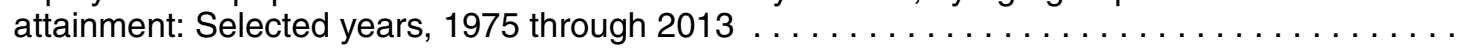

501.70. Employment to population ratios of females 16 to 64 years old, by age group and educational

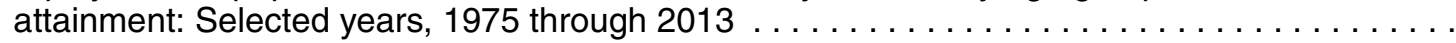

501.80. Unemployment rates of persons 16 to 64 years old, by age group and educational attainment:

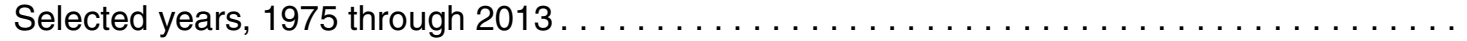

501.85. Unemployment rates of males 16 to 64 years old, by age group and educational attainment:

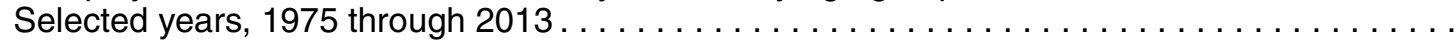

501.90. Unemployment rates of females 16 to 64 years old, by age group and educational attainment:

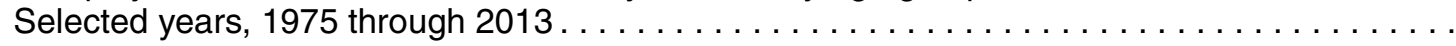

\section{Occupation and Earnings by Educational Attainment}

502.10. Occupation of employed persons 25 years old and over, by highest level of educational attainment

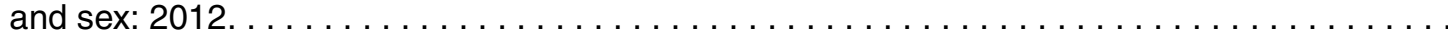

502.20. Median annual earnings of full-time year-round workers 25 years old and over, by highest level of

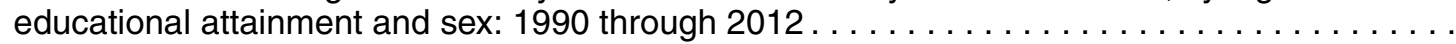

502.30. Median annual earnings of full-time year-round workers 25 to 34 years old and full-time yearround workers as a percentage of the labor force, by sex, race/ethnicity, and educational

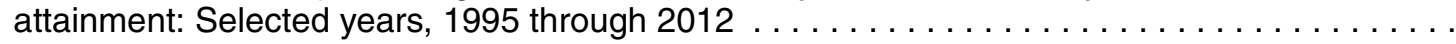

502.40. Distribution of earnings and median earnings of persons 25 years old and over, by highest level

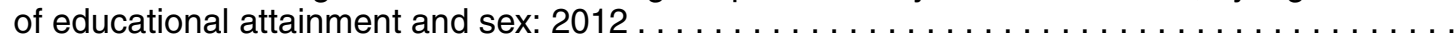

\section{Employment of Students}

503.10. Percentage of high school students age 16 and over who were employed, by age group, sex, race/ ethnicity, family income, nativity, and hours worked per week: Selected years, 1970 through 2012 ...

503.20. Percentage of college students 16 to 24 years old who were employed, by attendance status, hours worked per week, and control and level of institution: Selected years, October 1970 through 2012 . . .

503.30. Percentage of college students 16 to 24 years old who were employed, by attendance status, hours worked per week, and selected characteristics: October 2010 through $2012 \ldots \ldots \ldots$. .

\section{Labor Force Status of Recent High School Completers and Dropouts}

504.10. Labor force status of 2010, 2011, and 2012 high school completers, by college enrollment status,

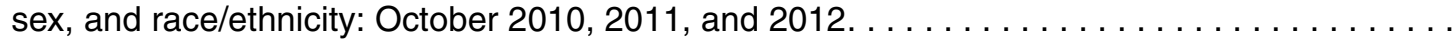

504.20. Labor force status of high school dropouts, by sex and race/ethnicity: October, selected years,

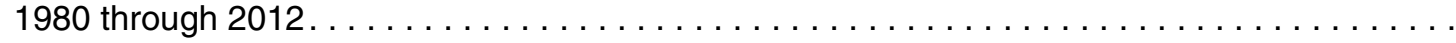

504.30. Among special education students out of high school up to 8 years, percentage attending and completing postsecondary education, living independently, and working competitively, by type of disability: 2007 and 2009 . . . 


\section{Labor Market Outcomes for Recent Bachelor's Degree Completers}

505.10. Number, percentage distribution, unemployment rates, and median earnings of 25- to 29-year-old bachelor's degree holders and percentage of degree holders among all 25- to 29-year-olds, by

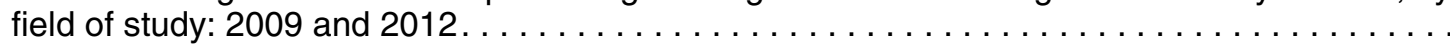

505.20. Among 25- to 34-year-olds with a bachelor's or higher degree, percentage who were employed in any occupation, by undergraduate field of study, sex, race/ethnicity, nativity, and citizenship

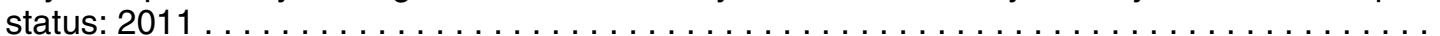

505.30. Among employed 25- to 34-year-olds with a bachelor's degree in a science, technology, engineering, or mathematics (STEM) field, percentage with STEM and non-STEM occupations, by sex, race/ethnicity, nativity, and citizenship status: $2011 \ldots \ldots \ldots \ldots \ldots \ldots \ldots \ldots \ldots$

505.40. Percentage distribution of recipients of bachelor's degrees in various fields of study 1 year after graduation, by time to completion, enrollment and employment status, and occupation: 2001 and 2009 . . .

505.50. Percentage, selected employment characteristics, and annual salaries of bachelor's degree recipients employed full time 1 year after graduation, by field of study: 1991, 2001, and 2009. .

\section{Attitudes of Young Adults}

506.10. Percentage of 1972 high school seniors, 1992 high school seniors, and 2004 high school seniors who felt that certain life values were "very important," by sex: Selected years, 1972 through 2004 . . . . .

\section{Skills of Adults and Continuing Education}

507.10. Literacy skills of adults, by type of literacy, proficiency levels, and selected characteristics: 1992

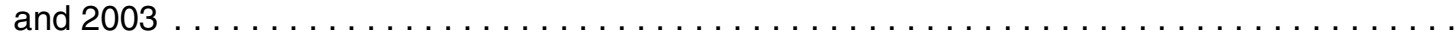

507.20. Participants in state-administered adult basic education, secondary education, and English as a second language programs, by type of program and state or jurisdiction: Selected fiscal years,

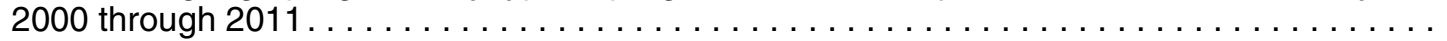

507.30. Participation of employed persons, 17 years old and over, in career-related adult education during the previous 12 months, by selected characteristics of participants: 1995, 1999, and $2005 \ldots$

507.40. Participation rate of persons, 17 years old and over, in adult education during the previous 12 months, by selected characteristics of participants: Selected years, 1991 through 2005 . . . . .

\section{Chapter 6. International Comparisons of Education}

\section{Population, Enrollment, and Teachers}

601.10. Population, school enrollment, and number of teachers, by major areas of the world and level of

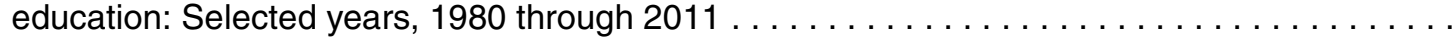

601.20. Selected population and enrollment statistics for countries with populations of at least 10 million in 2011, by continent and country: Selected years, 1990 through $2011 \ldots \ldots \ldots \ldots \ldots \ldots$

601.30. School-age populations as a percentage of total population, by age group and OECD or other

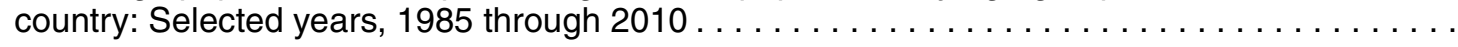

601.40. Percentage of population enrolled in secondary and postsecondary education, by age group and OECD or other country: Selected years, 2002 through $2011 \ldots \ldots \ldots \ldots \ldots \ldots \ldots \ldots$

601.50. Pupil/teacher ratios in public and private elementary and secondary schools, by level of education

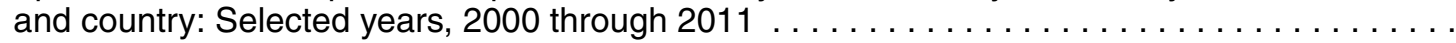

601.60. Teachers' statutory teaching and total working time and average class size in public elementary and secondary schools, by level of education and country: $2011 \ldots \ldots \ldots \ldots \ldots \ldots \ldots$ 


\section{Achievement and Instruction}

602.10. Average reading literacy scale scores of fourth-graders and percentage whose schools emphasize reading skills and strategies at or before second grade or at third grade, by sex and

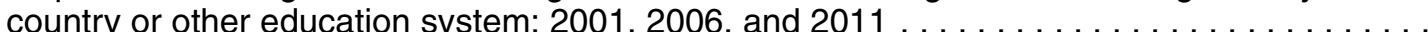

602.20. Average fourth-grade scores and annual instructional time in mathematics and science, by

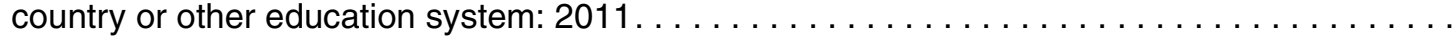

Average eighth-grade scores and annual instructional time in mathematics and science, by

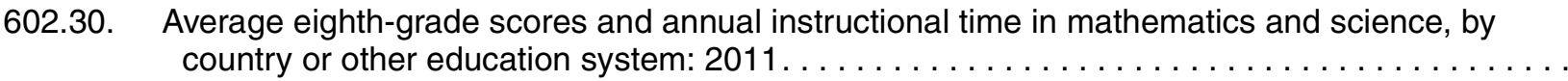

602.40. Average reading literacy, mathematics literacy, and science literacy scores of 15-year-old students, by sex and country or other education system: 2009 and $2012 \ldots \ldots \ldots \ldots \ldots \ldots$

602.50. Average reading literacy scores of 15 -year-old students and percentage attaining reading literacy proficiency levels, by country or other education system: $2012 \ldots \ldots \ldots \ldots \ldots \ldots \ldots$

602.60. Average mathematics literacy scores of 15-year-old students and percentage attaining mathematics literacy proficiency levels, by country or other education system: $2012 \ldots \ldots \ldots$.

602.70. Average science literacy scores of 15 -year-old students and percentage attaining science literacy proficiency levels, by country or other education system: $2012 \ldots \ldots \ldots \ldots \ldots \ldots \ldots$

\section{Attainment, Degrees, and Outcomes}

603.10. Percentage of the population 25 to 64 years old who completed high school, by age group and

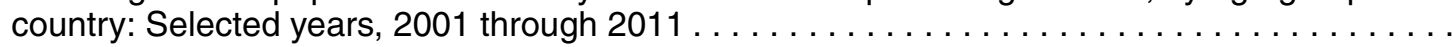

603.20. Percentage of the population 25 to 64 years old who attained selected levels of postsecondary

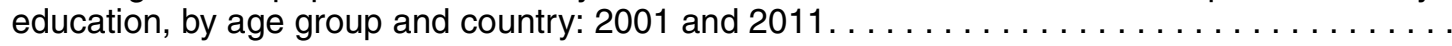

603.30. Percentage of the population 25 to 64 years old who attained a bachelor's or higher level degree, by age group and country: Selected years, 1999 through $2011 \ldots \ldots \ldots \ldots \ldots \ldots \ldots$

603.40. Percentage of the population 25 to 64 years old who attained a postsecondary vocational degree, by age group and country: Selected years, 1999 through $2011 \ldots \ldots \ldots \ldots \ldots \ldots \ldots$

603.50. Number of bachelor's degree recipients per 100 persons at the typical age of graduation, by sex

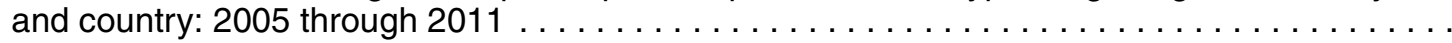

603.60. Percentage of bachelor's and higher level degrees awarded to women, by field of study and

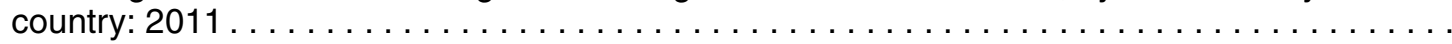

603.70. Percentage of bachelor's degrees awarded in mathematics, science, and engineering, by field of

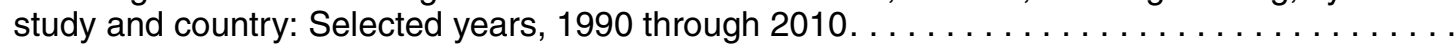

603.80. Percentage of graduate degrees awarded in mathematics, science, and engineering, by field of

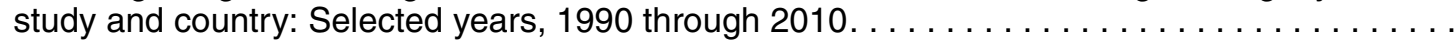

603.90. Employment to population ratios of 25- to 64-year-olds, by sex, highest level of educational

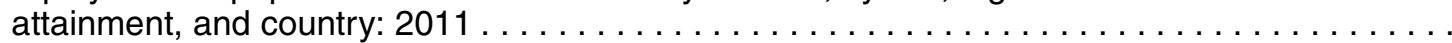

\section{Finances}

605.10. Gross domestic product per capita and public and private education expenditures per full-time-equivalent (FTE) student, by level of education and country: Selected years, 2005 through $2010 \ldots \ldots \ldots \ldots$.

605.20. Public and private direct expenditures on education institutions as a percentage of gross domestic product, by level of education and country: Selected years, 1995 through $2010 \ldots \ldots \ldots \ldots$. . .

\section{Chapter 7. Libraries and Technology}

\section{Libraries}

701.10. Selected statistics on public school libraries/media centers, by level of school: Selected years,

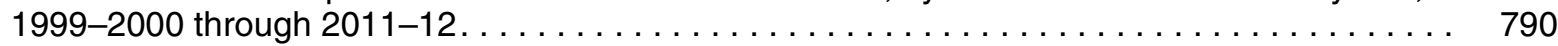

701.20. Selected statistics on public school libraries/media centers, by level and enrollment size of school: 2011-12 . 791

701.30. Selected statistics on public school libraries/media centers, by state: $2011-12 \ldots \ldots \ldots \ldots 2$ 
701.40. Collections, staff, and operating expenditures of degree-granting postsecondary institution libraries: Selected years, 1981-82 through 2011-12.

701.50. Collections, staff, operating expenditures, public service hours, and reference services of the 60

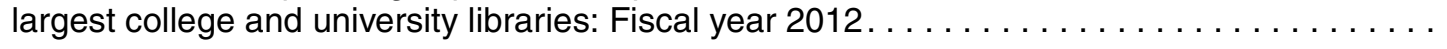

701.60. Public libraries, books and serial volumes, library visits, circulation, and reference transactions,

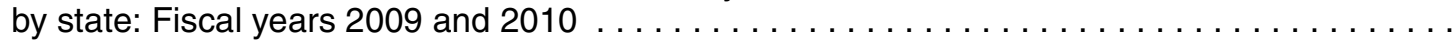

\section{Computer and Internet Use}

702.10. Number and percentage of persons 3 years old and over using the Internet and percentage distribution by means of internet access from home and main reason for not having high-speed access, by selected characteristics of students and other users: $2012 \ldots \ldots \ldots \ldots \ldots \ldots$. 



\section{READER'S GUIDE}

\section{Data Sources}

The data in this volume were obtained from many different sources-including students and teachers, state education agencies, local elementary and secondary schools, and colleges and universities - using surveys and compilations of administrative records. Users should be cautious when comparing data from different sources. Differences in aspects such as procedures, timing, question phrasing, and interviewer training can affect the comparability of results across data sources.

Most of the tables present data from surveys conducted by the National Center for Education Statistics (NCES) or conducted by other agencies and organizations with support from NCES. Some tables also include other data published by federal and state agencies, private research organizations, or professional organizations. Brief descriptions of the surveys and other data sources used in this volume can be found in Appendix A: Guide to Sources. For each NCES and nonNCES data source, the Guide to Sources also provides information on where to obtain further details about that source.

Data are obtained primarily from two types of surveys: universe surveys and sample surveys. In universe surveys, information is collected from every member of the population. For example, in a survey regarding certain expenditures of public elementary and secondary schools, data would be obtained from each school district in the United States. When data from an entire population are available, estimates of the total population or a subpopulation are made by simply summing the units in the population or subpopulation. As a result, there is no sampling error, and observed differences are reported as true.

Since a universe survey is often expensive and time consuming, many surveys collect data from a sample of the population of interest (sample survey). For example, the National Assessment of Educational Progress (NAEP) assesses a representative sample of students rather than the entire population of students. When a sample survey is used, statistical uncertainty is introduced, because the data come from only a portion of the entire population. This statistical uncertainty must be considered when reporting estimates and making comparisons. For information about how NCES accounts for statistical uncertainty when reporting sample survey results, see "Data Analysis and Interpretation," later in this Reader's Guide.

\section{Common Measures and Indexes}

Various types of statistics derived from universe and sample surveys are reported. Many tables report the size of a population or a subpopulation, and often the size of a subpopulation is expressed as a percentage of the total population.

In addition, the average (or mean) value of some characteristic of the population or subpopulation may be reported. The average is obtained by summing the values for all members of the population and dividing the sum by the size of the population. An example is the average annual salary of fulltime instructional faculty at degree-granting postsecondary institutions. Another measure that is sometimes used is the median. The median is the midpoint value of a characteristic at or above which 50 percent of the population is estimated to fall, and at or below which 50 percent of the population is estimated to fall. An example is the median annual earnings of young adults who are full-time year-round workers. Some tables also present an average per capita, or per person, which represents an average computed for every person in a specified group or population. It is derived by dividing the total for an item (such as income or expenditures) by the number of persons in the specified population. An example is the per capita expenditure on education in each state.

Many tables report financial data in dollar amounts. Unless otherwise noted, all financial data are in current dollars, meaning not adjusted for changes in the purchasing power of the dollar over time due to inflation. For example, 1991-92 teacher salaries in current dollars are the amounts that the teachers earned in 1991-92, without any adjustments to account for inflation. Constant dollar adjustments attempt to remove the effects of price changes (inflation) from statistical series reported in dollars. For example, if teacher salaries over a 20-year period are adjusted to constant 2012-13 dollars, the salaries for all years are adjusted to the dollar values that presumably would exist if prices in each year were the same as in 2012-13, in other words, as if the dollar had constant purchasing power over the entire period. Any changes in the constant dollar amounts would reflect only changes in real values. Constant dollar amounts are computed using price indexes. Price indexes for inflation adjustments can be found in table 106.70. Each table that presents constant dollars includes a note indicating which index was used for the inflation adjustments; in most cases, the Consumer Price Index was used.

When presenting data for a time series, some tables include both actual and projected data. Actual data are data that have 
already been collected. Projected data can be used when data for a recent or future year are not yet available. Projections are estimates that are based on recent trends in relevant statistics and patterns associated with correlated variables. Unless otherwise noted, all data in this volume are actual.

\section{Standard Errors}

Using estimates calculated from data based on a sample of the population requires consideration of several factors before the estimates become meaningful. When using data from a sample, some margin of error will always be present in estimations of characteristics of the total population or subpopulation because the data are available from only a portion of the total population. Consequently, data from samples can provide only an approximation of the true or actual value. The margin of error of an estimate, or the range of potential true or actual values, depends on several factors such as the amount of variation in the responses, the size and representativeness of the sample, and the size of the subgroup for which the estimate is computed. The magnitude of this margin of error is measured by what statisticians call the "standard error" of an estimate.

When data from sample surveys are reported, the standard error is calculated for each estimate. In the tables, the standard error for each estimate generally appears in parentheses next to the estimate to which it applies. In order to caution the reader when interpreting findings, estimates from sample surveys are flagged with a "!" when the standard error is between 30 and 50 percent of the estimate, and suppressed with a "t" when the standard error is 50 percent of the estimate or greater. The term "coefficient of variation (CV)" refers to the ratio of the standard error to the estimate; for example, if an estimate has a $\mathrm{CV}$ of 30 percent, this means that the standard error is equal to 30 percent of the value of the estimate.

\section{Nonsampling Errors}

In addition to standard errors, which apply only to sample surveys, all surveys are subject to nonsampling errors. Nonsampling errors may arise when individual respondents or interviewers interpret questions differently; when respondents must estimate values, or when coders, keyers, and other processors handle answers differently; when people who should be included in the universe are not; or when people fail to respond, either totally or partially. Total nonresponse means that people do not respond to the survey at all, while partial nonresponse (or item nonresponse) means that people fail to respond to specific survey items. To compensate for nonresponse, adjustments are often made. For universe surveys, an adjustment made for either type of nonresponse, total or partial, is often referred to as an imputation, which is often a substitution of the "average" questionnaire response for the nonresponse. For universe surveys, imputations are usually made separately within various groups of sample members that have similar survey characteristics. For sample surveys, total nonresponse is handled through nonresponse adjustments to the sample weights. For sample surveys, imputation for item nonresponse is usually made by substituting for a missing item the response to that item of a respondent having characteristics that are similar to those of the nonrespondent. For additional general information about imputations, see the NCES Statistical Standards (NCES 2003-601). Appendix A: Guide to Sources includes some information about specific surveys' response rates, nonresponse adjustments, and other efforts to reduce nonsampling error. Although the magnitude of nonsampling error is frequently unknown, idiosyncrasies that have been identified are noted in the appropriate tables.

\section{Data Analysis and Interpretation}

When estimates are from a sample, caution is warranted when drawing conclusions about one estimate in comparison to another, or about whether a time series of estimates is increasing, decreasing, or staying the same. Although one estimate may appear to be larger than another, a statistical test may find that the apparent difference between them is not reliably measurable due to the uncertainty around the estimates. In this case, the estimates will be described as having no measurable difference, meaning that the difference between them is not statistically significant.

Whether differences in means or percentages are statistically significant can be determined using the standard errors of the estimates. In reports produced by NCES, when differences are statistically significant, the probability that the difference occurred by chance is less than 5 percent, according to NCES standards.

Data presented in the text do not investigate more complex hypotheses, account for interrelationships among variables, or support causal inferences. We encourage readers who are interested in more complex questions and in-depth analysis to explore other NCES resources, including publications, online data tools, and public- and restricted-use datasets at http://nces.ed.gov.

In text that reports estimates based on samples, differences between estimates (including increases and decreases) are stated only when they are statistically significant. To determine whether differences reported are statistically significant, two-tailed $t$ tests at the .05 level are typically used. The $t$ test formula for determining statistical significance is adjusted when the samples being compared are dependent. The $t$ test formula is not adjusted for multiple comparisons, with the exception of statistical tests conducted using the NAEP Data Explorer (http://nces.ed.gov/nationsreportcard/ naepdata/). When the variables to be tested are postulated to form a trend, the relationship may be tested using linear regression, logistic regression, or ANOVA trend analysis instead of a series of $t$ tests. These alternate methods of analysis test for specific relationships (e.g., linear, quadratic, or cubic) among variables. For more information on data analysis, please see the NCES Statistical Standards, Standard 5-1, available at http://nces.ed.gov/statprog/2002/std5 1.asp. 
A number of considerations influence the ultimate selection of the data years to include in the tables and to feature in the text. To make analyses as timely as possible, the latest year of available data is shown. The choice of comparison years is often also based on the need to show the earliest available survey year, as in the case of NAEP and the international assessment surveys. The text typically compares the most current year's data with those from the initial year and then with those from a more recent year. In the case of surveys with long time frames, such as surveys measuring enrollment, changes over the course of a decade may be noted in the text. Where applicable, the text may also note years in which the data begin to diverge from previous trends. In figures and tables, intervening years are selected in increments in order to show the general trend.

\section{Rounding and Other Considerations}

All calculations are based on unrounded estimates. Therefore, the reader may find that a calculation, such as a difference or a percentage change, cited in the text or a figure may not be identical to the calculation obtained by using the rounded values shown in the accompanying tables. Although values reported in the tables are generally rounded to one decimal place (e.g., 76.5 percent), values reported in the text are generally rounded to whole numbers (with any value of 0.50 or above rounded to the next highest whole number). Due to rounding, cumulative percentages may sometimes equal 99 or 101 percent rather than 100 percent.

\section{Race and Ethnicity}

The Office of Management and Budget (OMB) is responsible for the standards that govern the categories used to collect and present federal data on race and ethnicity. The OMB revised the guidelines on racial/ethnic categories used by the federal government in October 1997, with a January 2003 deadline for implementation. The revised standards require a minimum of these five categories for data on race: American Indian or Alaska Native, Asian, Black or African American, Native Hawaiian or Other Pacific Islander, and White. The standards also require the collection of data on the ethnicity categories Hispanic or Latino and Not Hispanic or Latino. It is important to note that Hispanic origin is an ethnicity rather than a race, and therefore persons of Hispanic origin may be of any race. Origin can be viewed as the heritage, nationality group, lineage, or country of birth of the person or the person's parents or ancestors before their arrival in the United States. The race categories White, Black, Asian, Native Hawaiian or Other Pacific Islander, and American Indian or Alaska Native exclude persons of Hispanic origin unless otherwise noted.

For a description of each racial/ethnic category, please see the "Racial/ethnic group" entry in Appendix B: Definitions. Some of the category labels are shortened for more concise presentation in text, tables, and figures. American Indian or Alaska Native is denoted as American Indian/ Alaska Native (except when separate estimates are available for American Indians alone or Alaska Natives alone); Black or African American is shortened to Black; and Hispanic or Latino is shortened to Hispanic. When discussed separately from Asian estimates, Native Hawaiian or Other Pacific Islander is shortened to Pacific Islander.

Many of the data sources used for this volume are federal surveys that collect data using the OMB standards for racial/ ethnic classification described above; however, some sources have not fully adopted the standards, and some tables include historical data collected prior to the adoption of the OMB standards. Asians and Pacific Islanders are combined into a single category for years in which the data were not collected separately for the two groups. The combined category can sometimes mask significant differences between the two subgroups. For example, prior to 2011, NAEP collected data that did not allow for separate reporting of estimates for Asians and Pacific Islanders. The population counts presented in table 101.20, based on the U.S. Census Bureau's Current Population Reports, indicate that 96 percent of all Asian/Pacific Islander 5- to 17-year-olds were Asian in 2010. Thus, the combined category for Asians/Pacific Islanders is more representative of Asians than of Pacific Islanders.

Some surveys give respondents the option of selecting either an "other" race category, a "two or more races" or "multiracial" category, or both. Where possible, tables present data on the "two or more races" category; however, in some cases this category may not be separately shown because the information was not collected or due to other data issues. Some tables include the "other" category. Any comparisons made between persons of one racial/ethnic group and persons of "all other racial/ethnic groups" include only the racial/ethnic groups shown in the reference table. In some surveys, respondents are not given the option to select more than one race. In these surveys, respondents of two or more races must select a single race category. Any comparisons between data from surveys that give the option to select more than one race and surveys that do not offer such an option should take into account the fact that there is a potential for bias if members of one racial group are more likely than members of the others to

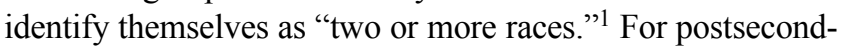
ary data, foreign students are counted separately and are therefore not included in any racial/ethnic category.

In addition to the major racial/ethnic categories, several tables include Hispanic ancestry subgroups (such as Mexican, Puerto Rican, Cuban, Dominican, Salvadoran, Other Central American, and South American) and Asian ancestry subgroups (such as Asian Indian, Chinese, Filipino, Japanese, Korean, and Vietnamese). In addition, selected tables include "two or more races" subgroups (such as White and Black, White and Asian, and White and American Indian/Alaska Native).

\footnotetext{
${ }^{1}$ For discussion of such bias in responses to the 2000 Census, see Parker, J. et al. (2004). Bridging Between Two Standards for Collecting Information on Race and Ethnicity: An Application to Census 2000 and Vital Rates. Public Health Reports, 119(2): 192-205. Available at http://www.pubmed central.nih.gov/articlerender.fcgi?artid=1497618.
} 


\section{Limitations of the Data}

Due to large standard errors, some differences that seem substantial are not statistically significant and, therefore, are not cited in the text. This situation often applies to estimates involving American Indians/Alaska Natives and Pacific Islanders. The relatively small sizes of these populations pose many measurement difficulties when conducting statistical analysis. Even in larger surveys, the numbers of American Indians/Alaska Natives and Pacific Islanders included in a sample are often small. Researchers studying data on these two populations often face small sample sizes that increase the size of standard errors and reduce the reliability of results. Readers should keep these limitations in mind when comparing estimates presented in the tables.

As mentioned, caution should be exercised when comparing data from different sources. Differences in sampling, data collection procedures, coverage of target population, timing, phrasing of questions, scope of nonresponse, interviewer training, and data processing and coding mean that results from different sources may not be strictly comparable. For example, the racial/ethnic categories presented to a respondent, and the way in which the question is asked, can influence the response, especially for individuals who consider themselves of mixed race or ethnicity. In addition, data on American Indians/Alaska Natives are often subject to inaccuracies that can result from respondents self-identifying their race/ethnicity. Research on the collection of race/ethnicity data suggests that the categorization of American Indian and Alaska Native is the least stable self-identification. ${ }^{2}$

${ }^{2}$ See U.S. Department of Labor, Bureau of Labor Statistics (1995). A Test of Methods for Collecting Racial and Ethnic Information (USDL 95-428). Washington DC: Author. 


\section{INTRODUCTION}

The Introduction provides a brief overview of current trends in American education, highlighting key data that are presented in more detail later in this volume. Topics outlined include the participation of students, teachers, and faculty in U.S. educational institutions; the performance of U.S. elementary/secondary students overall and in comparison to students in other countries; the numbers of high school graduates and postsecondary degrees; and the amounts of expenditures on education at the elementary/secondary and postsecondary levels.

In fall 2013, about 75.4 million people were enrolled in American schools and colleges (table 105.10). About 4.5 million people were employed as elementary and secondary school teachers or as college faculty, in full-time equivalents (FTE). Other professional, administrative, and support staff at educational institutions totaled 5.3 million. All data for 2013 in this Introduction are projected, except for data on educational attainment. Some data for other years are projected or estimated as noted. In discussions of historical trends, different time periods and specific years are cited, depending on the timing of important changes as well as the availability of relevant data.

\section{Elementary/Secondary Education}

\section{Enrollment}

A pattern of annual increases in total public elementary and secondary school enrollment began in 1985, but enrollment stabilized at 49.3 million between 2006 and 2008, before beginning to increase again (table 105.30). Overall, public school enrollment rose 26 percent, from 39.4 million to 49.8 million, between 1985 and 2013. Private school enrollment fluctuated during this period, with the fall 2013 enrollment of 5.1 million being 8 percent lower than the enrollment of 5.6 million in 1985. About 9 percent of elementary and secondary school students were enrolled in private schools in 2013, reflecting a decrease from 12 percent in 1985.

In public schools between 1985 and 2013, there was a 30 percent increase in elementary enrollment (prekindergarten through grade 8), compared with an 18 percent increase in secondary enrollment (grades 9 through 12) (table 105.30). Part of the higher growth in public elementary school enrollment resulted from the expansion of prekindergarten enrollment (table 203.10). Between fall 1985 and fall 2011, enrollment in prekindergarten increased 753 percent, while enrollment in other elementary grades (including kindergarten through grade 8 plus ungraded elementary programs) increased 25 percent. The number of children enrolled in prekindergarten increased from 0.2 million in 1985 to 1.3 million in 2011, and the number enrolled in other elementary grades increased from 26.9 million to 33.5 million. Public secondary school enrollment declined 8 percent from 1985 to 1990 , but then increased 33 percent from 1990 to 2007, before declining 3 percent from 2007 to 2013 (table 105.30). Between 1990 and 2013, the net increase in public secondary school enrollment was 29 percent, compared with an 18 percent increase in public elementary school enrollment. Over the most recent 10-year period (between 2003 and 2013), public school enrollment rose 2 percent. Elementary enrollment was 3 percent higher in 2013 than in 2003, and secondary enrollment was 2 percent higher.

Since the enrollment rates of 5- and 6-year-olds, 7- to 13year-olds, and 14- to 17-year-olds changed by about 3 or fewer percentage points from 1985 to 2012, increases in public elementary and secondary school enrollment primarily reflect increases in the number of children in these age groups (tables 101.10 and 103.20). For example, the enrollment rate of 7- to 13-year-olds decreased from 99 to 98 percent between 1985 and 2012, but the number of 7- to 13year-olds increased by 25 percent. Increases in both the enrollment rate of 3- and 4-year-old children (from 39 percent in 1985 to 54 percent in 2012) and the number of children in this age group (from 7.1 million to 8.1 million) also contributed to overall enrollment increases.

The National Center for Education Statistics (NCES) projects record levels of public elementary and secondary enrollment from 2013 (49.8 million) through at least 2023 (52.1 million) (table 105.30). For public schools, the projected fall 2013 enrollment is expected to be a new record, and new records are expected every year through 2023, the last year for which NCES enrollment projections have been developed. Public elementary school enrollment (prekindergarten through grade 8 ) is projected to increase by 5 percent between 2013 and 2023. Public secondary school enrollment (grades 9 through 12) is expected to increase 3 percent between 2013 and 2023. Overall, total public school enrollment is expected to increase 5 percent between 2013 and 2023 . 


\section{Teachers}

A projected 3.5 million full-time-equivalent (FTE) elementary and secondary school teachers were engaged in classroom instruction in fall 2013 (table 105.40). This number is about 1 percent higher than in fall 2003. The 2013 projected number of FTE teachers includes 3.1 million public school teachers and 0.4 million private school teachers.

Both public school enrollment and the number of public school teachers were about 2 percent higher in 2013 than they were in 2003 (table 208.20). In fall 2003, the number of public school pupils per teacher was 15.9, compared with a projected number of 16.0 public school pupils per teacher in fall 2013.

The average salary for public school teachers in 2012-13 was $\$ 56,383$ in current dollars (i.e., dollars that are not adjusted for inflation) (table 211.50). In constant (i.e., inflation-adjusted) dollars, the average salary decreased 1 percent between 1990-91 and 2012-13.

\section{Student Performance}

Most of the student performance data in the Digest are drawn from the National Assessment of Educational Progress (NAEP). The NAEP assessments have been conducted using three basic designs: the national main NAEP, state NAEP, and long-term trend NAEP. The national main NAEP and state NAEP provide current information about student performance in subjects including reading, mathematics, science, and writing, while long-term trend NAEP provides information on performance since the early 1970s in reading and mathematics only. Results from long-term trend NAEP are included in the discussion in chapter 2 of the Digest, while the information in this Introduction includes only selected results from the national main and state NAEP.

The main NAEP reports current information for the nation and specific geographic regions of the country. The assessment program includes students drawn from both public and private schools and reports results for student achievement at grades 4, 8, and 12. The main NAEP assessments follow the frameworks developed by the National Assessment Governing Board and use the latest advances in assessment methodology. The state NAEP is identical in content to the national main NAEP, but the state NAEP reports information only for public school students. Chapter 2 presents more information on the NAEP designs and methodology, and additional details appear in Appendix A: Guide to Sources.

\section{Reading}

The main NAEP assessment data are reported on a scale of 0 to 500. In 2013, the average reading score for 4th-grade students (222) was not measurably different from the 2011 score, but it was higher than the scores on assessments between 1992 (217) and 2009 (221) (table 221.10). At grade 4 , only the average reading scores for White students were higher in 2013 (232) than in both 2011 (231) and 1992 (224). The 2013 scores for Black (206), Hispanic (207), and Asian/
Pacific Islander (235) 4th-graders were not measurably different from the 2011 scores, but the 2013 scores were higher than the 1992 scores $(192,197$, and 216, respectively). For 8th-grade students, the average reading score in 2013 (268) was more than 2 points higher than in 2011 (265), was 8 points higher than in 1992 (260), and was higher than the average scores in all previous years. At grade 8, the average reading scores for White (276), Black (250), Hispanic (256), and Asian/Pacific Islander (280) students were higher in 2013 than in 2011 and 1992. At grade 12, average scores did not change measurably from 1992 to 2009 for White, Black, Hispanic, Asian/Pacific Islander, or American Indian/ Alaska Native students.

While there was no measurable change from 2011 to 2013 in the average score for 4th-grade public school students nationally, average scores were higher in 2013 than in 2011 in Colorado, the Department of Defense dependents schools, Indiana, Iowa, Maine, Minnesota, Tennessee, Washington, and the District of Columbia; scores were lower in 2013 than in 2011 in Massachusetts, Montana, and North Dakota (table 221.40). At grade 8, although the average reading score for public school students nationally was 2 points higher in 2013 than in 2011, only 12 states (Arkansas, California, Florida, Hawaii, Iowa, Nevada, New Hampshire, Oregon, Pennsylvania, Tennessee, Utah, and Washington) plus the District of Columbia and the Department of Defense dependents schools had higher scores in 2013 than in 2011 (table 221.60). In the other states, scores did not change measurably from 2011 to 2013.

\section{Mathematics}

The 2013, the average NAEP mathematics scores for 4thgrade and 8th-grade students were higher than the average scores in all previous assessment years (table 222.10). The average 4th-grade NAEP mathematics score increased from 213 in 1990 (the first assessment year) to 242 in 2013, an increase of 28 points (based on unrounded scores). During that same period, the average 8th-grade score increased by 22 points, from 263 to 285 . At grade 4, the average mathematics scores in 2013 for White (250) and Hispanic students (231) were higher than the scores in both 2011 and 1990. The 2013 score for Black 4th-graders (224) was not measurably different from the 2011 score, but it was higher than the 1990 score. The 2013 score for Asian 4th-graders (259) was also not measurably different from the 2011 score; prior to 2011, separate data on Asians were not available. At grade 8, the average mathematics scores in 2013 for all racial/ethnic groups were not measurably different from the 2011 scores. However, the 2013 scores for White (294), Black (263), and Hispanic (272) 8th-graders were higher than the scores in 1990.

NAEP results also permit state-level comparisons of the mathematics achievement of 4th- and 8th-grade students in public schools (tables 222.50 and 222.60). The average mathematics scores for 4th-grade public school students increased from 2011 to 2013 in 14 states (Arizona, Colorado, Delaware, Hawaii, Indiana, Iowa, Minnesota, 
Nebraska, New York, North Dakota, Tennessee, Washington, West Virginia, and Wyoming) and the District of Columbia and did not decrease for any states. At grade 8, scores were higher in 2013 than in 2011 in five states (Florida, Hawaii, New Hampshire, Pennsylvania, and Tennessee), the District of Columbia, and the Department of Defense dependents schools, and scores decreased in three states (Montana, Oklahoma, and South Dakota).

\section{Science}

NAEP has assessed the science abilities of students in grades 4,8 , and 12 in both public and private schools since 1996. As of 2009, however, NAEP science assessments are based on a new framework, so results from these assessments cannot be compared to results from earlier science assessments. The average eighth-grade science score increased from 150 in 2009 to 152 in 2011 (table 223.10). Average scores for both male and female students were higher in 2011 than in 2009. Male students scored 5 points higher on average than female students in 2011, which was not significantly different from the 4-point gap in 2009. Score gaps between White and Black students and between White and Hispanic students narrowed from 2009 to 2011. The 5-point gain from 2009 to 2011 for Hispanic students was larger than the 1-point gain for White students, narrowing the score gap from 30 points to 27 points. Black students scored 3 points higher in 2011 than in 2009. The 35-point score gap between White and Black students in 2011 was smaller than the 36-point gap in 2009. The average scores of Asian/Pacific Islander and American Indian/Alaska Native students were not significantly different in 2011 from their scores in 2009.

\section{International Comparisons}

The 2011 Trends in International Mathematics and Science Study (TIMSS) assessed students' mathematics and science performance at grade 4 in 45 countries and at grade 8 in 38 countries. In addition to countries, a number of subnational entities-including the public school systems in several U.S. states-also participated in TIMSS as separate education systems. Results for the participating states are included in the discussion in chapter 6 of the Digest, while this Introduction includes only results for the United States and other countries. TIMSS assessments are curriculum based and measure what students have actually learned against the subject matter that is expected to be taught in the participating countries by the end of grades 4 and 8 . At both grades, TIMSS scores are reported on a scale of 0 to 1,000 , with the scale average set at 500 .

On the 2011 TIMSS, the average mathematics scores of U.S. 4th-graders (541) and 8th-graders (509) were higher than the scale average (tables 602.10 and 602.30). U.S. 4thgraders scored higher in mathematics, on average, than their counterparts in 37 countries and lower than those in 3 countries (table 602.20). Average mathematics scores in the other 4 countries were not measurably different from the U.S. average. At grade 8, the average U.S. mathematics score was higher than the average scores of students in 27 countries in
2011 and below the average scores of students in 4 countries (table 602.30). Average 8th-grade mathematics scores in the other 6 countries were not measurably different from the U.S. average. The average science scores of both U.S. 4thgraders (544) and U.S. 8th-graders (525) were higher than the TIMSS scale average of 500 in 2011 . The average U.S. 4 th-grade science score was higher than the average scores of students in 39 countries and lower than those of students in 5 countries. At grade 8, the average U.S. science score was higher than the average scores of students in 28 countries, lower than those in 6 countries, and not measurably different from those in the other 3 countries.

The Program for International Student Assessment (PISA), coordinated by the Organization for Economic Cooperation and Development (OECD), has measured the performance of 15-year-old students in reading, mathematics, and science literacy every 3 years since 2000. PISA assesses 15-year-old students' application of reading, mathematics, and science literacy to problems within a real-life context. In 2012, PISA assessed students in the 34 OECD countries as well as in a number of other education systems. Some subnational entities participated as separate education systems, including public school systems in the U.S. states of Connecticut, Florida, and Massachusetts. Results for the participating U.S. states are included in the discussion in chapter 6 , while this Introduction includes only results for the United States in comparison with other OECD countries. PISA scores are reported on a scale of 0 to 1,000 .

On the 2012 PISA assessment, U.S. 15-year-olds' average score in reading literacy was 498 , which was not measurably different from the OECD average of 496 (table 602.50). The average reading literacy score in the United States was lower than the average score in 13 of the 33 other OECD countries, higher than the average score in 10 of the other OECD countries, and not measurably different from the average score in 10 of the OECD countries. In all countries, females outperformed males in reading (table 602.40). The U.S. gender gap in reading (31 points) was smaller than the OECD average gap ( 38 points) and smaller than the gaps in 14 of the OECD countries.

In mathematics literacy, U.S. 15-year-olds' average score of 481 on the 2012 PISA assessment was lower than the OECD average score of 494 (table 602.60). The average mathematics literacy score in the United States was lower than the average in 21 of the 33 other OECD countries, higher than the average in 5 OECD countries, and not measurably different from the average in 7 OECD countries. In 25 of the OECD countries, males outperformed females in mathematics literacy (table 602.40). In the United States, however, the average score of males (484) was not measurably different from that of females (479).

In science literacy, U.S. 15-year-olds' average score of 497 was not measurably different from the OECD average score of 501 (table 602.70). The average science literacy score in the United States was lower than the average in 15 OECD countries, higher than the average in 8 OECD countries, and not measurably different from the average in $10 \mathrm{OECD}$ countries. 
The Progress in International Reading Literacy Study (PIRLS) measures the reading knowledge and skills of 4thgraders over time. On the 2011 PIRLS, U.S. 4th-graders had an average reading literacy score of 556 (table 602.10). The U.S. average score in 2011 was 14 points higher than in 2001 and 16 points higher than in 2006. In all three assessment years, the U.S. average score was higher than the PIRLS scale average. (PIRLS scores are reported on a scale from 0 to 1,000, with the scale average set at 500.) In 2011, PIRLS assessed 4th-grade reading literacy in 40 countries. The average reading literacy score of 4th-graders in the United States was higher than the average score in 33 of the 39 other participating countries, lower than the average score in 3 countries, and not measurably different from the average in the remaining 3 countries.

\section{High School Graduates and Dropouts}

About 3,323,000 high school students are expected to graduate during the 2014-15 school year (table 219.10), including about 3,031,000 public school graduates and 291,000 private school graduates. High school graduates include only recipients of diplomas, not recipients of equivalency credentials. The number of high school graduates projected for 2014-15 is lower than the record high in 2011-12, but exceeds the baby boom era's high point in 1975-76, when 3,142,000 students earned diplomas. In 2011-12, an estimated 80.8 percent of public high school students graduated on time-that is, received a diploma 4 years after beginning their freshman year (table 219.35).

The number of General Educational Development (GED) credentials issued by the states to GED test passers rose from 330,000 in 1977 to 487,000 in 2000 (table 219.60). A record number of 648,000 GED credentials were issued in 2001. In 2002, there were revisions to the GED test and to the data reporting procedures. In 2001, test takers were required to successfully complete all five components of the GED or else begin the five-part series again with the new test that was introduced in 2002. Prior to 2002, reporting was based on summary data from the states on the number of GED credentials issued. As of 2002, reporting has been based on individual GED candidate- and test-level records collected by the GED Testing Service. Between 2002 and 2012, the number of persons passing the GED tests increased by 22 percent, from 330,000 to $401,000 .^{1}$

The percentage of dropouts among 16- to 24-year-olds has decreased over the past two decades. This percentage, known as the status dropout rate, includes all people in the 16- to 24year-old age group who are not enrolled in school and who have not completed a high school program, regardless of when they left school. (People who left school but went on to receive a GED credential are not treated as dropouts in this measure.) Between 1990 and 2012, the status dropout rate declined from

\footnotetext{
${ }^{1}$ Information on changes in GED test series and reporting is based on the 2003 edition of Who Passed the GED Tests?, by the GED Testing Service of the American Council on Education, as well as communication with staff of the GED Testing Service.
}

12.1 percent to 6.6 percent (table 219.70). Although the status dropout rate declined for both Blacks and Hispanics during this period, their rates in 2012 (7.5 and 12.7 percent, respectively) remained higher than the rate for Whites (4.3 percent). This measure is based on the civilian noninstitutionalized population, which excludes people in prisons, people in the military, and other people not living in households.

\section{Postsecondary Education}

\section{College Enrollment}

College enrollment was 20.6 million in fall 2012, which was about 2 percent lower than the record enrollment in fall 2010 (table 105.30). College enrollment is expected to set new records from fall 2015 through fall 2023. Between fall 2012 and fall 2023, enrollment is expected to increase by 15 percent. Despite decreases in the size of the traditional college-age population (18 to 24 years old) during the late 1980 s and early 1990s, total enrollment increased during this period (tables 101.10 and 105.30). The traditional college-age population rose 10 percent between 2002 and 2012, and total college enrollment increased 24 percent during the same period. Between 2002 and 2012, the number of full-time students increased by 28 percent, compared with a 19 percent increase in part-time students (table 303.10). During the same time period, the number of males enrolled increased 24 percent, and the number of females enrolled increased 25 percent.

\section{Faculty}

In fall 2011, degree-granting institutions-defined as postsecondary institutions that grant an associate's or higher degree and are eligible for Title IV federal financial aid programs-employed 1.5 million faculty members, including 0.8 million full-time and 0.8 million part-time faculty (table 314.30). In addition, degree-granting institutions employed 0.4 million graduate assistants.

\section{Postsecondary Degrees}

During the 2013-14 academic year, postsecondary degrees are projected to number 1,031,000 associate's degrees; 1,844,000 bachelor's degrees; 791,000 master's degrees; and 177,000 doctor's degrees (table 318.10). The doctor's degree total includes most degrees formerly classified as first-professional, such as M.D., D.D.S., and law degrees. Between 2001-02 and 2011-12 (the last year of actual data), the number of degrees conferred increased at all levels. The number of associate's degrees was 71 percent higher in 2011-10 than in 2001-02, the number of bachelor's degrees was 39 percent higher, the number of master's degrees was 55 percent higher, and the number of doctor's degrees was 42 percent higher.

Between 2001-02 and 2011-12, the number of bachelor's degrees awarded to males increased 39 percent, while the number of bachelor's degrees awarded to females increased 38 percent. Females earned 57 percent of all bach- 
elor's degrees in 2011-12, the same percentage as in 2001-02. Between 2001-02 and 2011-12, the number of White students earning bachelor's degrees increased 26 percent, compared with the larger increases of 59 percent for Black students, 104 percent for Hispanic students, and 52 percent for Asian/Pacific Islander students (table 322.20). The number of American Indian/Alaska Native students earning bachelor's degrees increased 25 percent over the same period. In 2011-12, White students earned 70 percent of all bachelor's degrees awarded (vs. 77 percent in 2001-02), Black students earned 11 percent (vs. 9 percent in 2001-02), Hispanic students earned 10 percent (vs. 7 percent in 2001-02), and Asian/Pacific Islander students earned about 7 percent (increasing their share of the degrees from 6.6 percent in 2001-02 to 7.3 percent in 2011-12). American Indian/Alaska Native students earned about 1 percent of the degrees in both years.

\section{Undergraduate Prices}

For the 2012-13 academic year, annual prices for undergraduate tuition, room, and board were estimated to be $\$ 15,022$ at public institutions, $\$ 39,173$ at private nonprofit institutions, and $\$ 23,158$ at private for-profit institutions (table 330.10). Between 2002-03 and 2012-13, prices for undergraduate tuition, room, and board at public institutions rose 39 percent, and prices at private nonprofit institutions rose 27 percent, after adjustment for inflation. Prices for total tuition, room, and board at private for-profit institutions decreased 7 percent between 2002-03 and 2012-13.

\section{Educational Attainment}

The U.S. Census Bureau collects annual statistics on the educational attainment of the population. Between 2003 and 2013 , the percentage of the adult population 25 years of age and over who had completed high school rose from 85 percent to 88 percent, and the percentage of adults with a bachelor's degree increased from 27 percent to 32 percent (table 104.10). High school completers include those people who graduated from high school with a diploma, as well as those who completed high school through equivalency programs. The percentage of young adults (25- to 29-year-olds) who had completed high school increased from 87 percent in 2003 to 90 percent in 2013 (table 104.20). The percentage of young adults who had completed a bachelor's degree increased from 28 percent in 2003 to 34 percent in 2013.

\section{Education Expenditures}

Expenditures for public and private education, from prekindergarten through graduate school (excluding postsecondary schools not awarding associate's or higher degrees), are estimated at \$1.2 trillion for 2012-13 (table 106.10). Expenditures of elementary and secondary schools are expected to total $\$ 669$ billion, while those of degree-granting postsecondary institutions are expected to total $\$ 496$ billion. Total expenditures for education are expected to amount to 7.2 percent of the gross domestic product in 2012-13, about the same as in 2002-03, but lower than the percentage in 2009-10 (7.6 percent). 



\section{CHAPTER 1}

\section{All Levels of Education}

This chapter provides a broad overview of education in the United States. It brings together material from preprimary, elementary, secondary, and postsecondary education, as well as from the general population, to present a composite picture of the American educational system. Tables feature data on the total number of people enrolled in school, the number of teachers, the number of schools, and total expenditures for education at all levels. This chapter also includes statistics on education-related topics such as educational attainment, computer and internet usage, family characteristics, and population. Economic indicators and price indexes have been added to facilitate analyses.

Many of the statistics in this chapter are derived from the statistical activities of the National Center for Education Statistics (NCES). In addition, substantial contributions have been drawn from the work of other groups, both governmental and nongovernmental, as shown in the source notes of the tables. Information on survey methodologies is contained in Appendix A: Guide to Sources and in the publications cited in the table source notes.

\section{The U.S. System of Education}

The U.S. system of education can be described as having three levels of formal education (elementary, secondary, and postsecondary) (figure 1). Students may spend 1 to 3 years in preprimary programs (prekindergarten $[\mathrm{PK}]$ and kindergarten $[\mathrm{K}]$ ), which may be offered either in separate schools or in elementary schools that also offer higher grades. (In Digest of Education Statistics tables, prekindergarten and kindergarten are generally defined as a part of elementary education.) Following kindergarten, students ordinarily spend from 6 to 8 years in elementary school. The elementary school program is followed by a 4- to 6-year program in secondary school. Students normally complete the entire program through grade 12 by age 18 . Education at the elementary and secondary levels is provided in a range of institutional settings - including elementary schools (preprimary schools, middle schools, and schools offering broader ranges of elementary grades); secondary schools (junior high schools, high schools, and senior high schools); and combined elementary/secondary schools - that vary in structure from locality to locality.

High school graduates who decide to continue their education may enter a specialized career/technical institution, a 2-year community or junior college, or a 4-year college or university. A 2-year college normally offers the first 2 years of a standard 4-year college curriculum and a selection of terminal career and technical education programs. Academic courses completed at a 2-year college are usually transferable for credit at a 4-year college or university. A career/ technical institution offers postsecondary technical training programs of varying lengths leading to a specific career.

An associate's degree requires at least 2 years of postsecondary coursework, and a bachelor's degree normally requires 4 years of postsecondary coursework. At least 1 year of coursework beyond the bachelor's is necessary for a master's degree, while a doctor's degree usually requires a minimum of 3 or 4 years beyond the bachelor's.

Professional schools differ widely in admission requirements and program length. Medical students, for example, generally complete a bachelor's program of premedical studies at a college or university before they can enter the 4-year program at a medical school. Law programs normally require 3 years of coursework beyond the bachelor's degree level.

\section{Enrollment}

Total enrollment in public and private elementary and secondary schools (prekindergarten through grade 12) grew rapidly during the 1950s and 1960s, reaching a peak year in 1971 (table A, table 105.30, and figure 2). This enrollment rise reflected what is known as the "baby boom," a dramatic increase in births following World War II. Between 1971 and 1984, total elementary and secondary school enrollment decreased every year, reflecting the decline in the size of the school-age population over that period. After these years of decline, enrollment in elementary and secondary schools started increasing in fall 1985, began hitting new record levels in the mid-1990s, and continued to reach new record levels every year through 2006. Enrollment in fall 2011 (54.8 million) was about the same as in fall 2010 (54.9 million) but slightly lower than in fall 2006 (55.3 million). However, a pattern of annual enrollment increases is projected to begin with a slight increase in fall 2015 (no substantial change from fall 2014) and continue at least through fall 2023 (the last year for which NCES has projected school enrollment), when enrollment is expected to reach 57.0 million. 
Table A. Total elementary and secondary school enrollment, by overall trends: Selected years, 1949-50 to fall 2023

\begin{tabular}{|c|c|}
\hline Trend and year & $\begin{array}{r}\text { Number of students } \\
\text { (in millions) }\end{array}$ \\
\hline 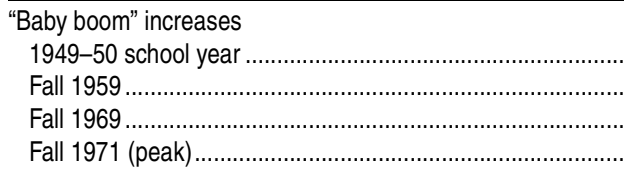 & $\begin{array}{l}28.5 \\
40.9 \\
51.1 \\
51.3\end{array}$ \\
\hline 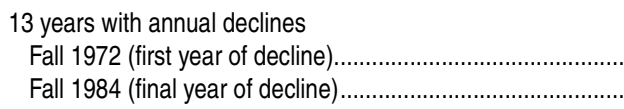 & $\begin{array}{l}50.7 \\
44.9\end{array}$ \\
\hline 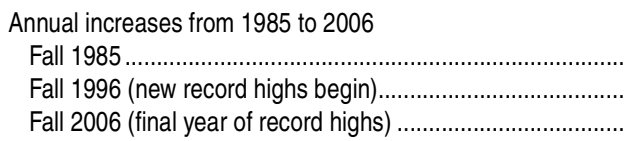 & $\begin{array}{l}45.0 \\
51.5 \\
55.3\end{array}$ \\
\hline Slight declines or stable enrollment & $\begin{array}{l}55.2 \\
54.9 \\
54.8 \\
54.7\end{array}$ \\
\hline 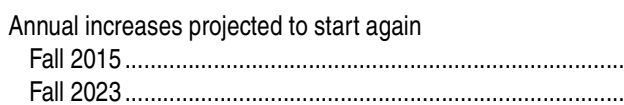 & $\begin{array}{l}54.7 \\
57.0\end{array}$ \\
\hline
\end{tabular}

SOURCE: U.S. Department of Education, National Center for Education Statistics, Biennial Survey of Education in the United States, 1949-50; Statistics of Public Elementary and Secondary School Systems, 1959 through 1972; Common Core of Data (CCD), 1984 through 2011; Private School Universe Survey (PSS), 1997-98 through 2011-12; and National Elementary and Secondary Enrollment Projection Model, 1972 through 2023.

Between 1985 and 2012, the total public and private school enrollment rate decreased by 3 percentage points for 5- and 6year-olds. The enrollment rate for 7 - to 13 -year-olds decreased from 99 percent in 1985 to 98 percent in 2012; however, the enrollment rate for 14- to 17-year-olds increased from 95 to 97 percent during this period (table 103.20). Since these enrollment rates changed by 3 or fewer percentage points between 1985 and 2012, increases in public and private elementary and secondary school enrollment primarily reflect increases in the number of children in these age groups. Between 1985 and 2012, the number of 5- and 6-year-olds increased by 19 percent, the number of 7- to 13 -year-olds increased by 25 percent, and the number of 14- to 17 -year-olds increased by 12 percent (table 101.10). Increases in the enrollment rate of prekindergarten-age children (ages 3 and 4) from 39 percent in 1985 to 54 percent in 2012 (table 103.20) and in the number of 3- and 4year-olds from 7.1 million to 8.1 million (table 101.10) also contributed to overall prekindergarten through grade 12 enrollment increases.

Public school enrollment at the elementary level (prekindergarten through grade 8) rose from 29.9 million in fall 1990 to 34.2 million in fall 2003 (table 105.30). After a decrease of less than 1 percent between fall 2003 and fall 2004 , elementary enrollment generally increased to a projected total of 35.1 million for fall 2013. Public elementary enrollment is projected to increase about 5 percent overall between 2013 and 2023. Public school enrollment at the secondary level (grades 9 through 12) rose from 11.3 million in 1990 to 15.1 million in 2007, but then declined 3 percent to a projected enrollment of 14.6 million in 2013 .
Public secondary enrollment is projected to increase about 3 percent between 2013 and 2023. Total public elementary and secondary enrollment is projected to increase every year from 2014 to 2023.

The percentage of students in private elementary and secondary schools declined from 11.7 percent in fall 2001 to 9.6 percent in fall 2011 (table 105.30). In fall 2013, an estimated 5.1 million students were enrolled in private schools at the elementary and secondary levels.

Total enrollment in public and private degree-granting postsecondary institutions reached 14.5 million in fall 1992 and decreased to 14.3 million in fall 1995 (table 105.30). Total enrollment increased 47 percent between 1995 and 2010 (to 21.0 million), but declined 2 percent between 2010 and 2012 (to 20.6 million). Total enrollment is expected to increase 15 percent between fall 2012 and fall 2023, reaching 23.8 million. The percentage of students who attended private institutions rose from 23 to 28 percent between 2002 and 2012. In fall 2012, about 5.8 million students attended private institutions, with about 4.0 million in nonprofit institutions and 1.8 million in for-profit institutions (table 303.10). Enrollment increases in degree-granting postsecondary institutions have been driven by both increases in population and some increases in enrollment rates. Although the percentage of 18and 19-year-olds enrolled in degree-granting postsecondary institutions in 2002 was not measurably different from the percentage in 2012 (45 and 47 percent, respectively), the number of 18- and 19-year-olds rose 7 percent (tables 101.10 and 103.20). The enrollment rate of 20- to 24-year-olds rose from 34 to 40 percent, and the number of 20- to 24-year-olds rose 12 percent during the same period.

\section{Educational Attainment}

The percentages of adults 25 years old and over completing high school and higher education have been rising. Between 2003 and 2013, the percentage of the population 25 years old and over who had completed at least high school increased from 85 to 88 percent, and the percentage who had completed a bachelor's or higher degree increased from 27 to 32 percent (table 104.10 and figure 3 ). In 2013, about 8 percent of people 25 years old or over held a master's degree as their highest degree and 3 percent held a doctor's or firstprofessional degree (table 104.30).

Among young adults (25- to 29-year-olds), the percentage who had completed at least high school increased from 87 percent in 2003 to 90 percent in 2013 (table 104.20 and figure 4). The percentage of young adults who had completed a bachelor's or higher degree increased from 28 percent in 2003 to 34 percent in 2013. In 2013, about 6 percent of young adults held a master's degree as their highest degree and 2 percent held a doctor's or first-professional degree (table 104.30 and figure 5).

In both 2003 and 2013, the educational attainment of young adults differed by race/ethnicity. From 2003 to 2013, the percentage of Hispanic 25- to 29-year-olds who had completed at least high school increased from 62 to 76 per- 
cent (table 104.20 and figure 6). During this period, there were no measurable changes in the percentages of White, Black, and Asian 25- to 29-year-olds who had completed high school. In 2013, the percentage of 25- to 29-year-olds who had completed high school was higher for Whites (94 percent) and Asians (95 percent) than for Blacks (90 percent); the percentage for Hispanics (76 percent) was lower than for Whites, Asians, and Blacks. In 2013, the percentage of bachelor's degree holders also varied among 25- to 29year-olds of different racial/ethnic groups, with 60 percent of Asians in this age group holding a bachelor's or higher degree, compared with 40 percent of Whites, 20 percent of Blacks, and 16 percent of Hispanics. From 2003 to 2013, the percentage of 25- to 29-year-olds who held a bachelor's or higher degree increased for Whites and Hispanics, but showed no measurable change for Blacks and Asians.

\section{Teachers and Faculty}

A projected 3.5 million elementary and secondary school full-time-equivalent (FTE) teachers were engaged in classroom instruction in the fall of 2013 (table 105.40), which was about 1 percent higher than in 2003. The number of FTE public school teachers in 2013 was about 3.1 million, and the number of FTE private school teachers was about 0.4 million. FTE faculty at degree-granting postsecondary institutions totaled a projected 1.0 million in 2013, including 0.6 million at public institutions and 0.4 million at private institutions (table 105.10).

\section{Expenditures}

Expenditures of educational institutions were an estimated \$1.2 trillion for the 2012-13 school year (table 106.20 and figure 2). Elementary and secondary schools spent about 57 percent of this total ( $\$ 669$ billion), and colleges and universities spent the remaining 43 percent ( $\$ 496$ billion). After adjustment for inflation, total expenditures of all educational institutions rose by an estimated 15 percent between 2002-03 and 2012-13. Inflation-adjusted expenditures of degree-granting postsecondary institutions rose by an estimated 29 percent. Expenditures of elementary and secondary schools were about 7 percent higher in 2012-13 than in 2002-03. In 2012-13, expenditures of educational institutions were an estimated 7.2 percent of the gross domestic product (table 106.10). 
Figure 1. The structure of education in the United States

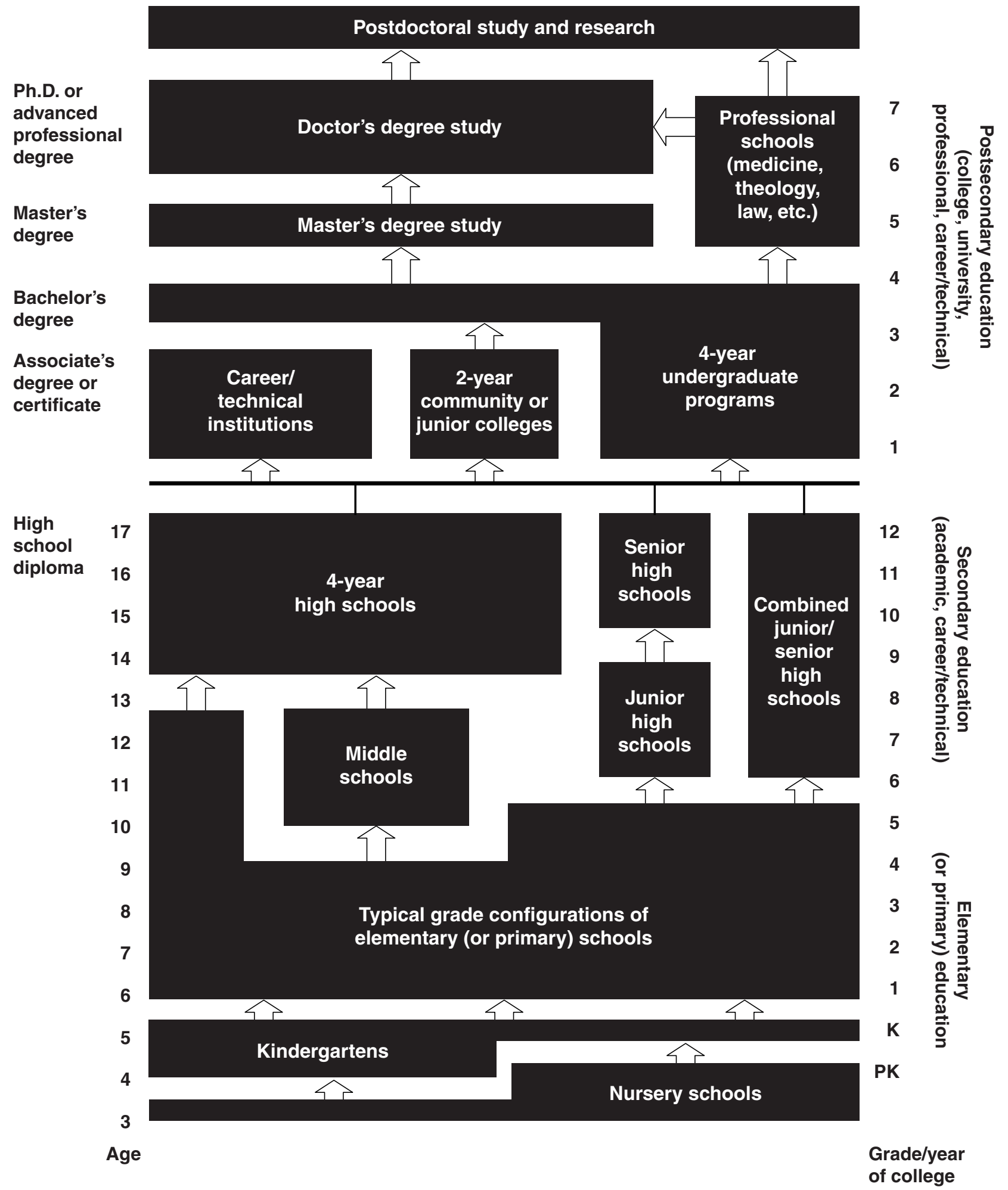

NOTE: Figure is not intended to show relative number of institutions nor relative size of enrollment for the different levels of education. Figure reflects typical patterns of progression rather than all possible variations. Adult education programs, while not separately delineated above, may provide instruction at the adult basic, adult secondary, or postsecondary education levels. SOURCE: U.S. Department of Education, National Center for Education Statistics, Annual Reports Program. 
Figure 2. Enrollment, total expenditures in constant dollars, and expenditures as a percentage of the gross domestic product (GDP), by level of education: Selected years, 1965-66 through 2012-13

\section{Enrollment, in millions}
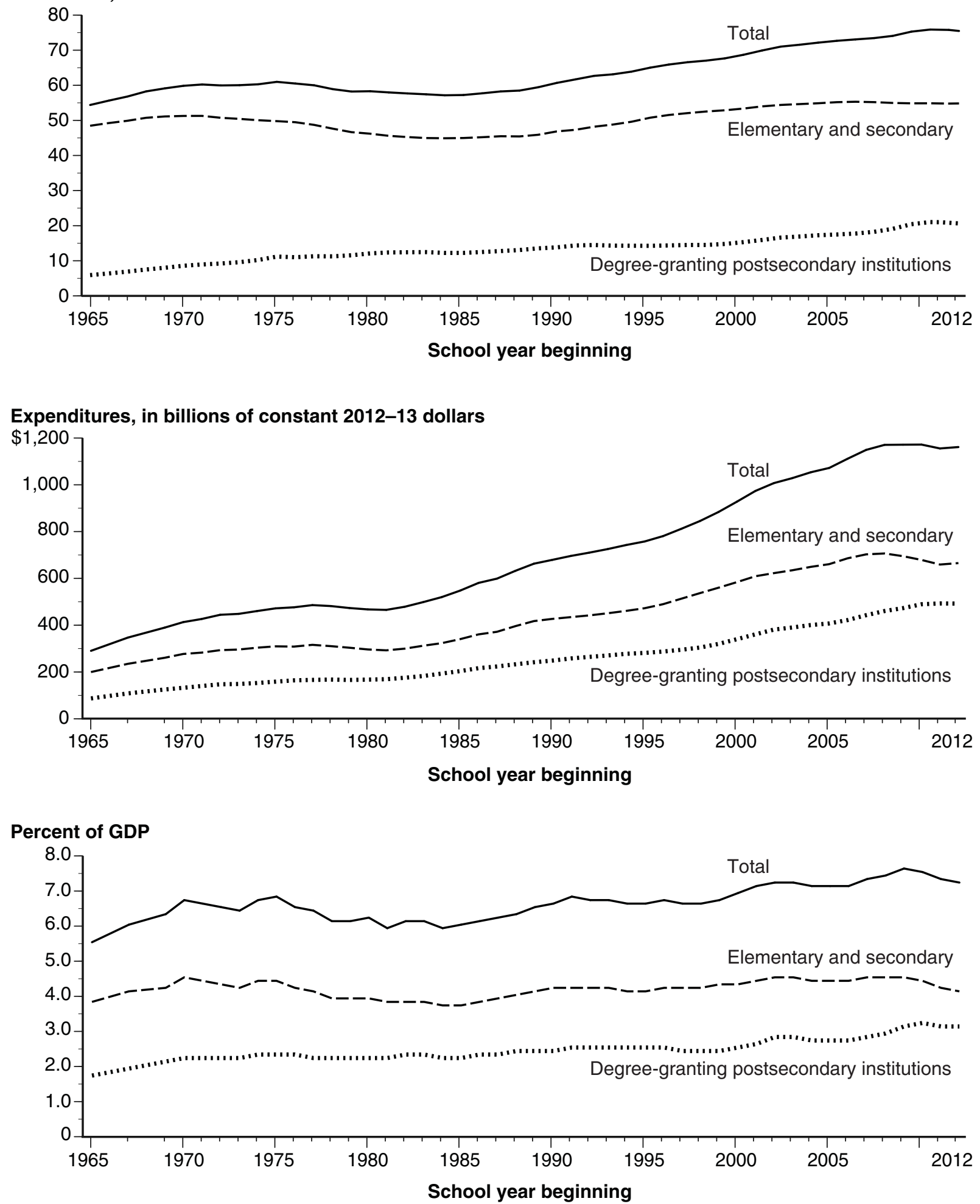

NOTE: Elementary and secondary enrollment data for school year 2012 (2012-13) are projected. Elementary and secondary expenditure data for school years 2011 and 2012 (2011-12 and 2012-13) are estimated. Postsecondary expenditure data for school year 2012 (2012-13) are estimated.

SOURCE: U.S. Department of Education, National Center for Education Statistics, Statistics of State School Systems, 1965-66 through 1969-70; Statistics of Public Elementary and Secondary School Systems, 1965 through 1980; Revenues and Expenditures for Public Elementary and Secondary Education, 1970-71 through 1986-87; Common Core of Data (CCD), "State Nonfiscal Survey of Public Elementary and Secondary Education," 1981-82 through 2011-12, and "National Public Education Financial Survey," 1987-88 through 2010-11; Private School Universe Survey (PSS), 1989-90 through 2011-12; National Elementary and Secondary Enrollment Projection Model, 1972 through 2023 ; Higher Education General Information Survey (HEGIS), "Fall Enrollment in Institutions of Higher Education" and "Financial Statistics of Institutions of Higher Education" surveys, 1965-66 through 1985-86; Integrated Postsecondary Education Data System (IPEDS), "Fall Enrollment Survey" (IPEDS-EF:86-99) and "Finance Survey" (IPEDS-F:FY87-99); and IPEDS Spring 2001 through Spring 2013 , Enrollment and Finance components. U.S. Department of Commerce, Bureau of Economic Analysis, National Income and Product Accounts Tables, retrieved February 5, 2014, from http://www.bea.gov/iTable/ index nipa.cfm. 


\section{Figure 3. Percentage of persons 25 years old and over, by highest level of educational attainment: Selected years, 1940 through 2013}

\section{Percent}

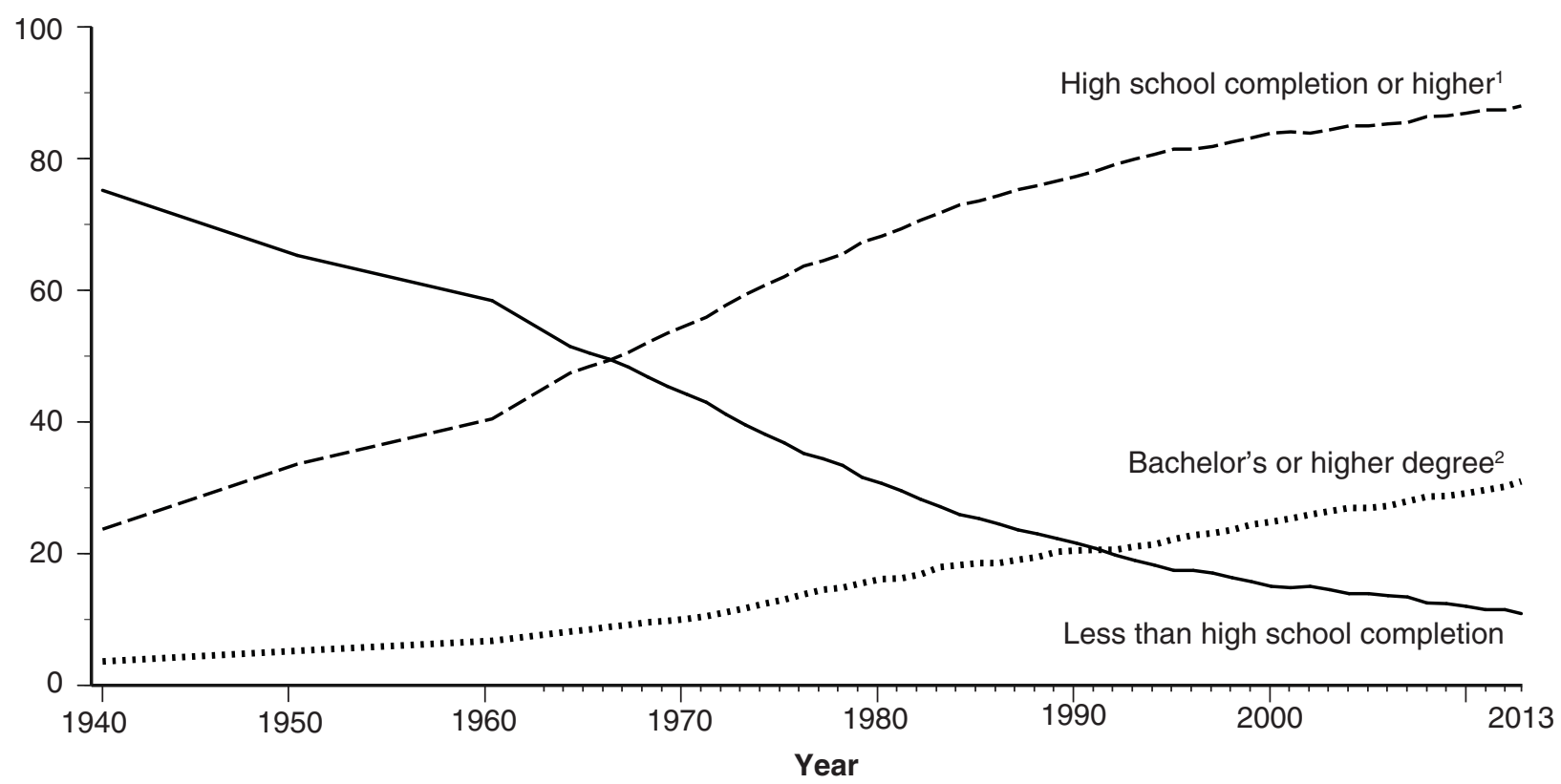

${ }^{1}$ Includes high school completion through equivalency programs, such as a GED program. For years prior to 1993, includes all persons with 4 or more years of high school. ${ }^{2}$ For years prior to 1993 , includes all persons with 4 or more years of college.

SOURCE: U.S. Department of Commerce, Census Bureau, U.S. Census of Population: 1960, Vol. I, Part 1; J.K. Folger and C.B. Nam, Education of the American Population (1960 Census Monograph); Current Population Reports, Series P-20, various years; and Current Population Survey (CPS), March 1961 through March 2013.

Figure 4. Percentage of persons 25 through 29 years old, by highest level of educational attainment: Selected years, 1940 through 2013

\section{Percent}

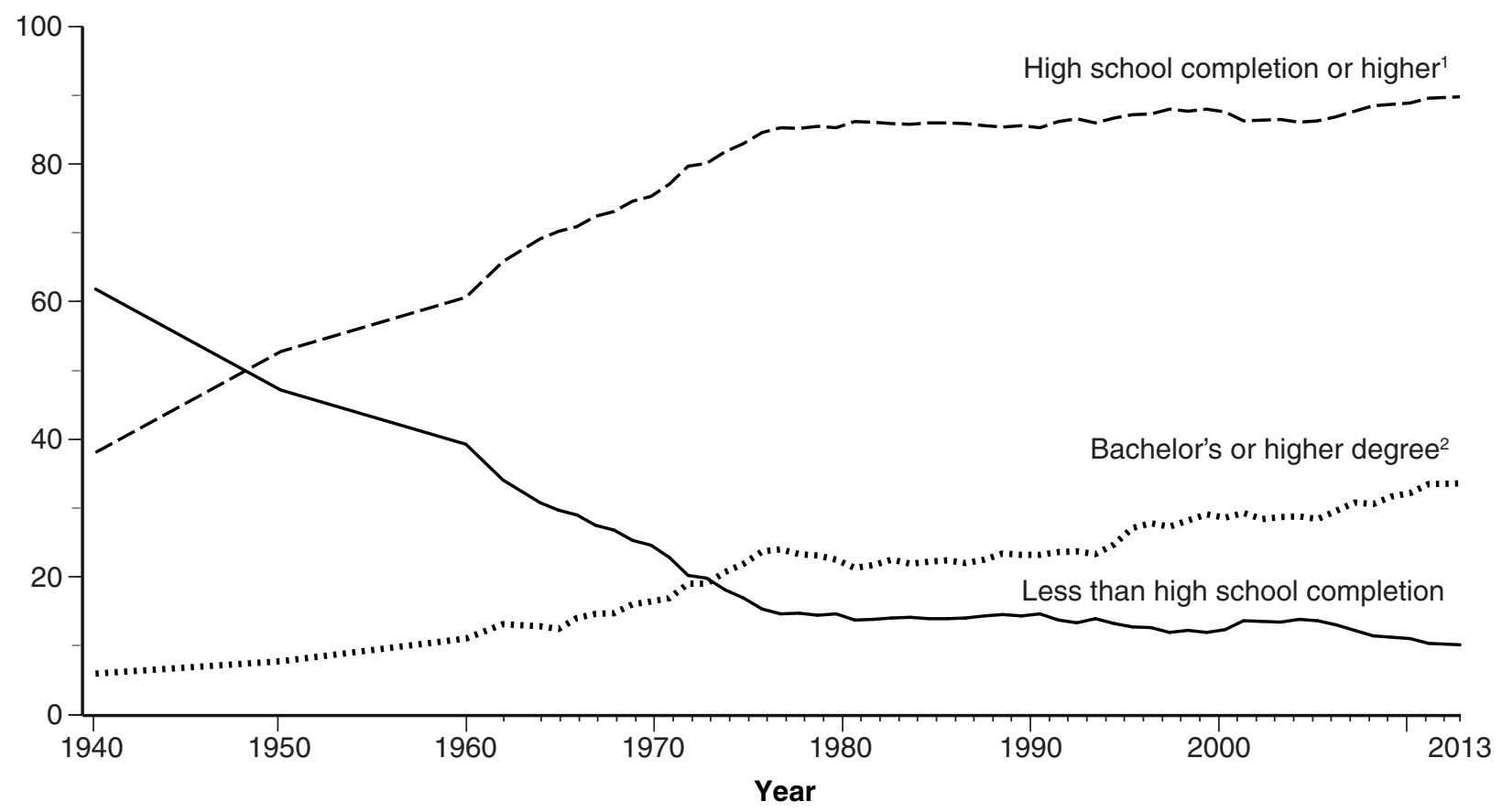

${ }^{1}$ Includes high school completion through equivalency programs, such as a GED program. For years prior to 1993, includes all persons with 4 or more years of high school. ${ }^{2}$ For years prior to 1993 , includes all persons with 4 or more years of college.

SOURCE: U.S. Department of Commerce, Census Bureau, U.S. Census of Population: 1960, Vol. I, Part 1; J.K. Folger and C.B. Nam, Education of the American Population (1960 Census Monograph); Current Population Reports, Series P-20, various years; and Current Population Survey (CPS), March 1961 through March 2013. 
Figure 5. Highest level of education attained by persons 25 through 29 years old: March 2013

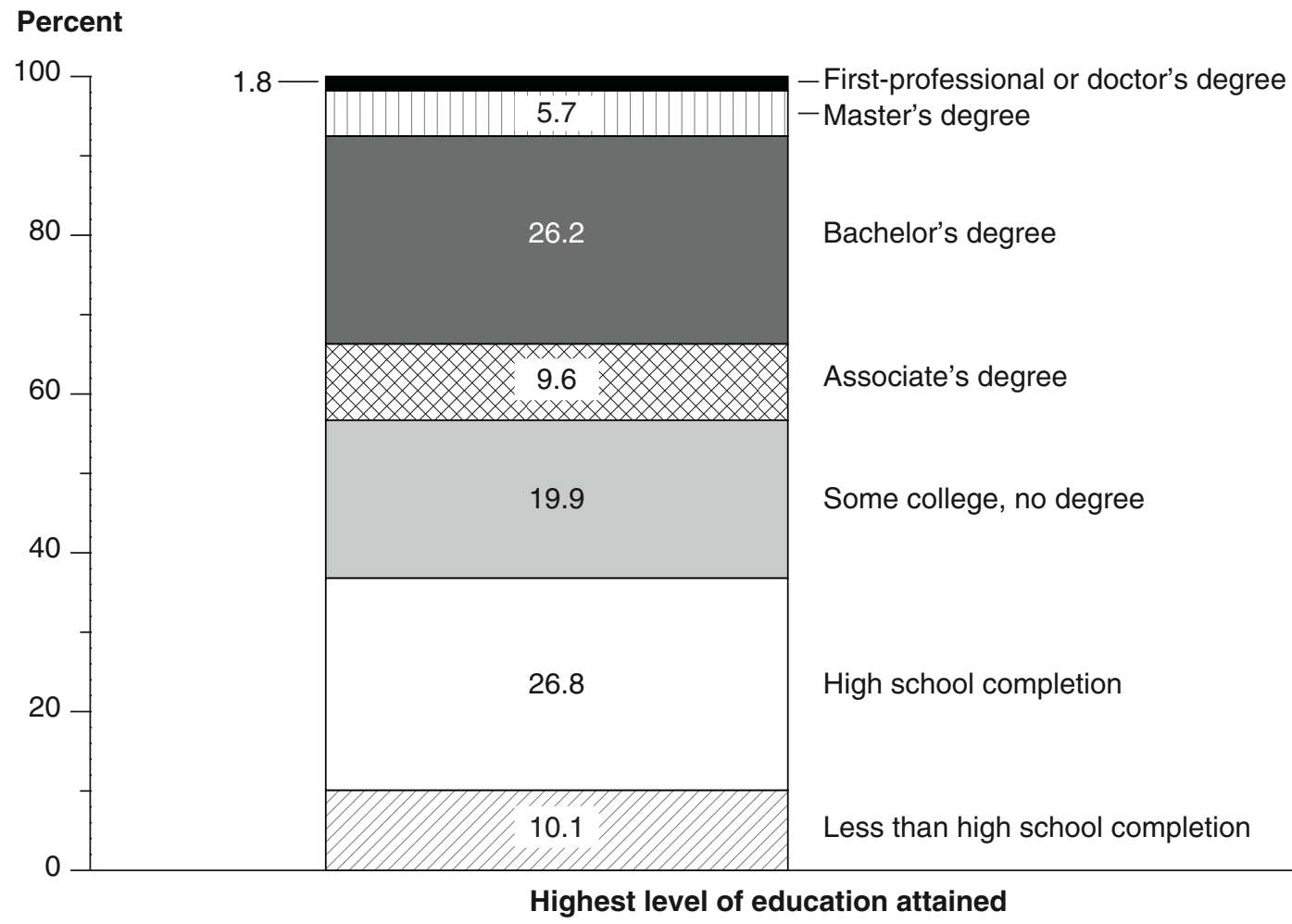

NOTE: High school completion includes equivalency programs, such as a GED program. Detail may not sum to totals because of rounding. SOURCE: U.S. Department of Commerce, Census Bureau, Current Population Survey (CPS), March 2013.

Figure 6. Percentage of persons 25 through 29 years old, by selected levels of educational attainment and race/ethnicity: 2003 and 2013

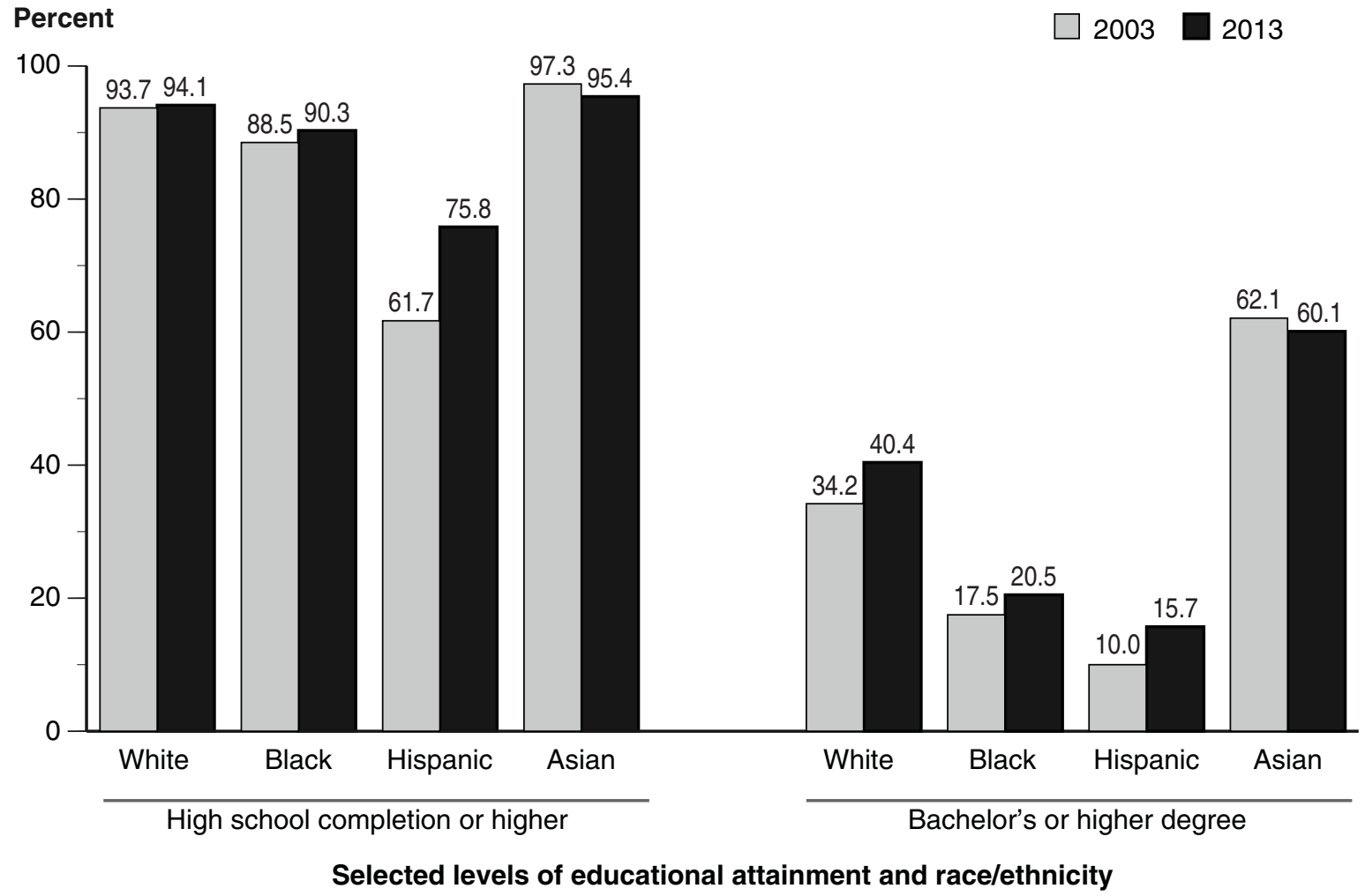

NOTE: High school completion includes equivalency programs, such as a GED program. Race categories exclude persons of Hispanic ethnicity. SOURCE: U.S. Department of Commerce, Census Bureau, Current Population Survey (CPS), March 2003 and March 2013. 
18 CHAPTER 1: All Levels of Education

Population

Table 101.10. Estimates of resident population, by age group: 1970 through 2012

[In thousands]

\begin{tabular}{|c|c|c|c|c|c|c|c|c|c|c|c|}
\hline Year & $\begin{array}{r}\text { Total, } \\
\text { all ages }\end{array}$ & $\begin{array}{r}\text { Total, } \\
3 \text { to } 34 \\
\text { years old }\end{array}$ & $\begin{array}{r}3 \text { and } 4 \\
\text { years old }\end{array}$ & $\begin{array}{r}5 \text { and } 6 \\
\text { years old }\end{array}$ & $\begin{array}{r}7 \text { to } 13 \\
\text { years old }\end{array}$ & $\begin{array}{r}14 \text { to } 17 \\
\text { years old }\end{array}$ & $\begin{array}{r}18 \text { and } 19 \\
\text { years old }\end{array}$ & $\begin{array}{r}20 \text { and } 21 \\
\text { years old }\end{array}$ & $\begin{array}{r}22 \text { to } 24 \\
\text { years old }\end{array}$ & $\begin{array}{r}25 \text { to } 29 \\
\text { years old }\end{array}$ & $\begin{array}{r}30 \text { to } 34 \\
\text { years old }\end{array}$ \\
\hline 1 & 2 & 3 & 4 & 5 & 6 & 7 & 8 & 9 & 10 & 11 & 12 \\
\hline $1970 \ldots \ldots \ldots$ & 205,052 & 109,592 & 6,961 & 7,703 & 28,969 & 15,924 & 7,510 & 7,210 & 9,992 & 13,736 & 11,587 \\
\hline $1971 \ldots \ldots$ & 207,661 & 111,202 & 6,805 & 7,344 & 28,892 & 16,328 & 7,715 & 7,350 & 10,809 & 14,041 & 11,917 \\
\hline 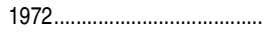 & 209,896 & 112,807 & 6,789 & 7,051 & 28,628 & 16,639 & 7,923 & 7,593 & 10,560 & 15,240 & 12,383 \\
\hline $1973 \ldots \ldots \ldots$ & 211,909 & 114,426 & 6,938 & 6,888 & 28,158 & 16,867 & 8,114 & 7,796 & 10,725 & 15,786 & 13,153 \\
\hline $1974 \ldots \ldots \ldots \ldots \ldots \ldots \ldots \ldots$ & 213,854 & 116,075 & 7,117 & 6,864 & 27,600 & 17,035 & 8,257 & 8,003 & 10,972 & 16,521 & 13,704 \\
\hline $1975 \ldots \ldots \ldots \ldots$ & 215,973 & 117,435 & 6,912 & 7,013 & 26,905 & 17,128 & 8,478 & 8,196 & 11,331 & 17,280 & 14,191 \\
\hline 1976 & 218,035 & 118,474 & 6,436 & 7,195 & 26,321 & 17,119 & 8,659 & 8,336 & 11,650 & 18,274 & 14,485 \\
\hline 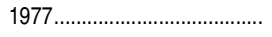 & 220,239 & 119,261 & 6,190 & 6,978 & 25,877 & 17,045 & 8,675 & 8,550 & 11,949 & 18,277 & 15,721 \\
\hline $1978 \ldots \ldots \ldots \ldots \ldots \ldots . .$. & 222,585 & 119,833 & 6,208 & 6,500 & 25,594 & 16,946 & 8,677 & 8,730 & 12,216 & 18,683 & 16,280 \\
\hline 1979 & 225,055 & 120,544 & 6,252 & 6,256 & 25,175 & 16,611 & 8,751 & 8,754 & 12,542 & 19,178 & 17,025 \\
\hline $1980 \ldots \ldots$ & 227,225 & 121,132 & 6,366 & 6,291 & 24,800 & 16,143 & 8,718 & 8,669 & 12,716 & 19,686 & 17,743 \\
\hline $1981 \ldots \ldots \ldots$ & 229,466 & 121,999 & 6,535 & 6,315 & 24,396 & 15,609 & 8,582 & 8,759 & 12,903 & 20,169 & 18,731 \\
\hline $1982 \ldots \ldots \ldots$ & 231,664 & 121,823 & 6,658 & 6,407 & 24,121 & 15,057 & 8,480 & 8,768 & 12,914 & 20,704 & 18,714 \\
\hline 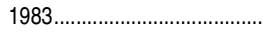 & 233,792 & 122,302 & 6,877 & 6,572 & 23,709 & 14,740 & 8,290 & 8,652 & 12,981 & 21,414 & 19,067 \\
\hline $1984 \ldots \ldots \ldots \ldots \ldots \ldots \ldots \ldots \ldots \ldots \ldots . .$. & 235,825 & 122,254 & 7,045 & 6,694 & 23,367 & 14,725 & 7,932 & 8,567 & 12,962 & 21,459 & 19,503 \\
\hline $1985 \ldots \ldots \ldots$ & 237,924 & 122,512 & 7,134 & 6,916 & 22,976 & 14,888 & 7,637 & 8,370 & 12,895 & 21,671 & 20,025 \\
\hline $1986 \ldots \ldots \ldots \ldots \ldots \ldots \ldots \ldots \ldots \ldots$ & 240,133 & 122,688 & 7,187 & 7,086 & 22,992 & 14,824 & 7,483 & 8,024 & 12,720 & 21,893 & 20,479 \\
\hline 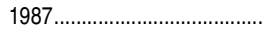 & 242,289 & 122,672 & 7,132 & 7,178 & 23,325 & 14,502 & 7,502 & 7,742 & 12,450 & 21,857 & 20,984 \\
\hline 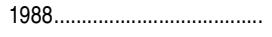 & 244,499 & 122,713 & 7,176 & 7,238 & 23,791 & 14,023 & 7,701 & 7,606 & 12,048 & 21,739 & 21,391 \\
\hline 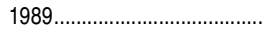 & 246,819 & 122,655 & 7,315 & 7,184 & 24,228 & 13,536 & 7,898 & 7,651 & 11,607 & 21,560 & 21,676 \\
\hline $1990 \ldots \ldots$ & 249,623 & 122,787 & 7,359 & 7,244 & 24,785 & 13,329 & 7,702 & 7,886 & 11,264 & 21,277 & 21,939 \\
\hline 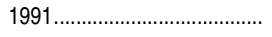 & 252,981 & 123,210 & 7,444 & 7,393 & 25,216 & 13,491 & 7,208 & 8,029 & 11,205 & 20,923 & 22,301 \\
\hline $1992 \ldots \ldots \ldots \ldots$ & 256,514 & 123,722 & 7,614 & 7,447 & 25,752 & 13,775 & 6,949 & 7,797 & 11,391 & 20,503 & 22,494 \\
\hline 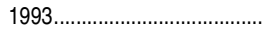 & 259,919 & 124,371 & 7,887 & 7,549 & 26,212 & 14,096 & 6,985 & 7,333 & 11,657 & 20,069 & 22,584 \\
\hline 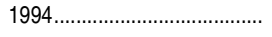 & 263,126 & 124,976 & 8,089 & 7,725 & 26,492 & 14,637 & 7,047 & 7,071 & 11,585 & 19,740 & 22,590 \\
\hline 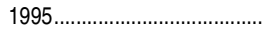 & 266,278 & 125,478 & 8,107 & 8,000 & 26,825 & 15,013 & 7,182 & 7,103 & 11,197 & 19,680 & 22,372 \\
\hline 1996 & 269,394 & 125,924 & 8,022 & 8,206 & 27,168 & 15,443 & 7,399 & 7,161 & 10,715 & 19,864 & 21,945 \\
\hline 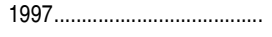 & 272,647 & 126,422 & 7,915 & 8,232 & 27,683 & 15,769 & 7,569 & 7,309 & 10,601 & 19,899 & 21,446 \\
\hline 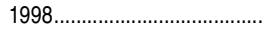 & 275,854 & 126,939 & 7,841 & 8,152 & 28,302 & 15,829 & 7,892 & 7,520 & 10,647 & 19,804 & 20,953 \\
\hline 1999 & 279,040 & 127,446 & 7,772 & 8,041 & 28,763 & 16,007 & 8,094 & 7,683 & 10,908 & 19,575 & 20,603 \\
\hline 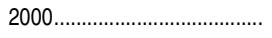 & 282,162 & 128,041 & 7,724 & 7,972 & 29,082 & 16,144 & 8,199 & 7,995 & 11,122 & 19,280 & 20,524 \\
\hline 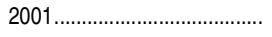 & 284,969 & 128,467 & 7,630 & 7,883 & 29,210 & 16,280 & 8,235 & 8,290 & 11,467 & 18,819 & 20,652 \\
\hline $2002 \ldots \ldots \ldots \ldots \ldots \ldots \ldots$ & 287,625 & 128,955 & 7,617 & 7,750 & 29,251 & 16,506 & 8,237 & 8,342 & 11,902 & 18,691 & 20,658 \\
\hline 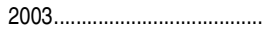 & 290,108 & 129,346 & 7,678 & 7,661 & 29,153 & 16,694 & 8,325 & 8,324 & 12,267 & 18,772 & 20,472 \\
\hline 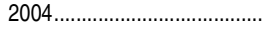 & 292,805 & 129,965 & 7,885 & 7,652 & 28,806 & 17,054 & 8,457 & 8,312 & 12,534 & 19,107 & 20,160 \\
\hline $2005 \ldots \ldots \ldots \ldots \ldots \ldots \ldots$ & 295,517 & 130,280 & 7,973 & 7,721 & 28,527 & 17,358 & 8,482 & 8,392 & 12,568 & 19,535 & 19,724 \\
\hline 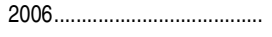 & 298,380 & 130,754 & 7,937 & 7,942 & 28,327 & 17,549 & 8,567 & 8,507 & 12,529 & 20,110 & 19,285 \\
\hline 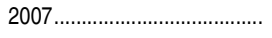 & 301,231 & 131,417 & 8,002 & 8,040 & 28,256 & 17,597 & 8,730 & 8,500 & 12,578 & 20,543 & 19,171 \\
\hline 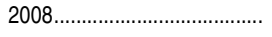 & 304,094 & 132,269 & 8,033 & 8,012 & 28,426 & 17,395 & 9,014 & 8,555 & 12,626 & 20,903 & 19,305 \\
\hline 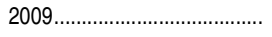 & 306,772 & 133,202 & 8,059 & 8,088 & 28,569 & 17,232 & 9,146 & 8,691 & 12,693 & 21,078 & 19,645 \\
\hline $2010^{1}$ & 309,326 & 134,095 & 8,189 & 8,138 & 28,729 & 17,064 & 9,060 & 8,955 & 12,747 & 21,144 & 20,069 \\
\hline $2011^{1} \ldots \ldots \ldots \ldots \ldots \ldots \ldots$ & 311,588 & 134,873 & 8,224 & 8,163 & 28,753 & 16,867 & 8,912 & 9,188 & 12,967 & 21,284 & 20,514 \\
\hline 2012 & 313,914 & 135,493 & 8,095 & 8,231 & 28,778 & 16,719 & 8,777 & 9,171 & 13,412 & 21,398 & 20,911 \\
\hline
\end{tabular}

${ }^{1}$ Revised from previously published figures.

NOTE: Resident population includes civilian population and armed forces personnel residing within the United States; it excludes armed forces personnel residing overseas. Detail may not sum to totals because of rounding. Population estimates as of July 1 of the indicated reference year.
SOURCE: U.S. Department of Commerce, Census Bureau, Current Population Reports, Series P-25, Nos. 1000, 1022, 1045, 1057, 1059, 1092, and 1095; 2000 through 2009 Population Estimates, retrieved August 14, 2012, from http://www.census.gov/popest/data/national/asrh/2011/ index.html; and 2010 through 2012 Population Estimates, retrieved November 1, 2013, from http://www.census.gov/popest/data/national/asrh/2012/2012-nat-detail.html. (This table was prepared November 2013.) 
Table 101.20. Estimates of resident population, by race/ethnicity and age group: Selected years, 1980 through 2012

\begin{tabular}{|c|c|c|c|c|c|c|c|c|c|c|c|c|c|c|c|c|}
\hline \multirow[b]{2}{*}{ Year and age group } & \multicolumn{8}{|c|}{ Number (in thousands) } & \multicolumn{8}{|c|}{ Percentage distribution } \\
\hline & Total & White & Black & $\begin{array}{r}\text { His- } \\
\text { panic }\end{array}$ & Asian & $\begin{array}{r}\text { Pacific } \\
\text { Islander }\end{array}$ & $\begin{array}{r}\text { American } \\
\text { Indian/ } \\
\text { Alaska } \\
\text { Native }\end{array}$ & $\begin{array}{r}\text { Two or } \\
\text { more } \\
\text { races }\end{array}$ & Total & White & Black & $\begin{array}{r}\text { His- } \\
\text { panic }\end{array}$ & Asian & $\begin{array}{r}\text { Pacific } \\
\text { Islander }\end{array}$ & $\begin{array}{r}\text { American } \\
\text { Indian/ } \\
\text { Alaska } \\
\text { Native }\end{array}$ & $\begin{array}{l}\text { Two or } \\
\text { more } \\
\text { races }\end{array}$ \\
\hline 1 & 2 & 3 & 4 & 5 & 6 & 7 & 8 & 9 & 10 & 11 & 12 & 13 & 14 & 15 & 16 & $\overline{17}$ \\
\hline $\begin{array}{l}\text { Total } \\
1980 \\
1990 \\
1995 \\
2000^{2}\end{array}$ & $\begin{array}{l}227,225 \\
249,623 \\
266,278 \\
282,162 \\
295,517\end{array}$ & $\begin{array}{l}181,140 \\
188,725 \\
194,389 \\
195,702 \\
196,621\end{array}$ & $\begin{array}{l}26,215 \\
29,439 \\
32,500 \\
34,406 \\
36,147\end{array}$ & $\begin{array}{l}14,869 \\
22,573 \\
28,158 \\
35,662 \\
43,024\end{array}$ & $\begin{array}{r}3,665 \\
7,092 \\
9,188 \\
10,469 \\
12,658\end{array}$ & $\begin{array}{r}(1) \\
(1) \\
(1) \\
370 \\
434\end{array}$ & $\begin{array}{l}1,336 \\
1,793 \\
2,044 \\
2,102 \\
2,186\end{array}$ & $\begin{array}{r}- \\
- \\
3,452 \\
4,447\end{array}$ & $\begin{array}{l}100.0 \\
100.0 \\
100.0 \\
100.0 \\
100.0\end{array}$ & $\begin{array}{l}79.7 \\
75.6 \\
73.0 \\
69.4 \\
66.5\end{array}$ & $\begin{array}{l}11.5 \\
11.8 \\
12.2 \\
12.2 \\
12.2\end{array}$ & $\begin{array}{r}6.5 \\
9.0 \\
10.6 \\
12.6 \\
14.6\end{array}$ & $\begin{array}{l}1.6 \\
2.8 \\
3.5 \\
3.7 \\
4.3\end{array}$ & $\begin{array}{l}(1) \\
(1) \\
(1) \\
0.1 \\
0.1\end{array}$ & $\begin{array}{l}0.6 \\
0.7 \\
0.8 \\
0.7 \\
0.7\end{array}$ & $\begin{array}{l}- \\
\overline{-} \\
1.2 \\
1.5\end{array}$ \\
\hline 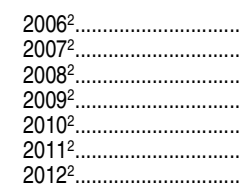 & $\begin{array}{l}298,380 \\
301,231 \\
304,094 \\
306,772 \\
309,326 \\
311,588 \\
313,914\end{array}$ & $\begin{array}{l}196,833 \\
197,011 \\
197,184 \\
197,275 \\
197,389 \\
197,530 \\
197,706\end{array}$ & $\begin{array}{l}36,521 \\
36,906 \\
37,291 \\
37,657 \\
38,009 \\
38,365 \\
38,727\end{array}$ & $\begin{array}{l}44,606 \\
46,197 \\
47,794 \\
49,327 \\
50,748 \\
51,881 \\
53,028\end{array}$ & $\begin{array}{l}13,098 \\
13,527 \\
13,956 \\
14,361 \\
14,763 \\
15,188 \\
15,620\end{array}$ & $\begin{array}{l}448 \\
461 \\
475 \\
488 \\
500 \\
510 \\
521\end{array}$ & $\begin{array}{l}2,203 \\
2,220 \\
2,237 \\
2,252 \\
2,269 \\
2,289 \\
2,309\end{array}$ & $\begin{array}{l}4,671 \\
4,909 \\
5,158 \\
5,411 \\
5,648 \\
5,825 \\
6,004\end{array}$ & $\begin{array}{l}100.0 \\
100.0 \\
100.0 \\
100.0 \\
100.0 \\
100.0 \\
100.0\end{array}$ & $\begin{array}{l}66.0 \\
65.4 \\
64.8 \\
64.3 \\
63.8 \\
63.4 \\
63.0\end{array}$ & $\begin{array}{l}12.2 \\
12.3 \\
12.3 \\
12.3 \\
12.3 \\
12.3 \\
12.3\end{array}$ & $\begin{array}{l}14.9 \\
15.3 \\
15.7 \\
16.1 \\
16.4 \\
16.7 \\
16.9\end{array}$ & $\begin{array}{l}4.4 \\
4.5 \\
4.6 \\
4.7 \\
4.8 \\
4.9 \\
5.0\end{array}$ & $\begin{array}{l}0.2 \\
0.2 \\
0.2 \\
0.2 \\
0.2 \\
0.2 \\
0.2\end{array}$ & $\begin{array}{l}0.7 \\
0.7 \\
0.7 \\
0.7 \\
0.7 \\
0.7 \\
0.7\end{array}$ & $\begin{array}{l}1.6 \\
1.6 \\
1.7 \\
1.8 \\
1.8 \\
1.9 \\
1.9\end{array}$ \\
\hline 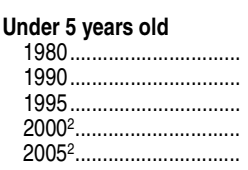 & $\begin{array}{l}16,451 \\
18,856 \\
19,627 \\
19,178 \\
19,917\end{array}$ & $\begin{array}{l}11,904 \\
12,757 \\
12,415 \\
11,253 \\
10,847\end{array}$ & $\begin{array}{l}2,413 \\
2,825 \\
3,050 \\
2,753 \\
2,706\end{array}$ & $\begin{array}{l}1,677 \\
2,497 \\
3,245 \\
3,748 \\
4,607\end{array}$ & $\begin{array}{l}319 \\
593 \\
734 \\
686 \\
839\end{array}$ & $\begin{array}{l}(1) \\
(1) \\
(1) \\
30 \\
35\end{array}$ & $\begin{array}{l}137 \\
184 \\
182 \\
171 \\
171\end{array}$ & $\begin{array}{r}- \\
\overline{-} \\
538 \\
712\end{array}$ & $\begin{array}{l}100.0 \\
100.0 \\
100.0 \\
100.0 \\
100.0\end{array}$ & $\begin{array}{l}72.4 \\
67.7 \\
63.3 \\
58.7 \\
54.5\end{array}$ & $\begin{array}{l}14.7 \\
15.0 \\
15.5 \\
14.4 \\
13.6\end{array}$ & $\begin{array}{l}10.2 \\
13.2 \\
16.5 \\
19.5 \\
23.1\end{array}$ & $\begin{array}{l}1.9 \\
3.1 \\
3.7 \\
3.6 \\
4.2\end{array}$ & $\begin{array}{l}(1) \\
(1) \\
(1) \\
0.2 \\
0.2\end{array}$ & $\begin{array}{l}0.8 \\
1.0 \\
0.9 \\
0.9 \\
0.9\end{array}$ & $\begin{array}{l}- \\
\overline{-} \\
2.8 \\
3.6\end{array}$ \\
\hline 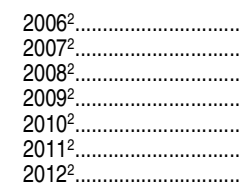 & $\begin{array}{l}19,939 \\
20,126 \\
20,271 \\
20,245 \\
20,189 \\
20,128 \\
19,999\end{array}$ & $\begin{array}{l}10,707 \\
10,645 \\
10,557 \\
10,395 \\
10,276 \\
10,150 \\
10,023\end{array}$ & $\begin{array}{l}2,690 \\
2,716 \\
2,753 \\
2,776 \\
2,780 \\
2,781 \\
2,762\end{array}$ & $\begin{array}{l}4,739 \\
4,899 \\
5,032 \\
5,101 \\
5,124 \\
5,158 \\
5,155\end{array}$ & $\begin{array}{l}849 \\
868 \\
885 \\
890 \\
895 \\
909 \\
920\end{array}$ & $\begin{array}{l}36 \\
37 \\
38 \\
39 \\
39 \\
39 \\
40\end{array}$ & $\begin{array}{l}172 \\
174 \\
176 \\
176 \\
176 \\
174 \\
172\end{array}$ & $\begin{array}{l}745 \\
787 \\
831 \\
868 \\
900 \\
917 \\
928\end{array}$ & $\begin{array}{l}100.0 \\
100.0 \\
100.0 \\
100.0 \\
100.0 \\
100.0 \\
100.0\end{array}$ & $\begin{array}{l}53.7 \\
52.9 \\
52.1 \\
51.3 \\
50.9 \\
50.4 \\
50.1\end{array}$ & $\begin{array}{l}13.5 \\
13.5 \\
13.6 \\
13.7 \\
13.8 \\
13.8 \\
13.8\end{array}$ & $\begin{array}{l}23.8 \\
24.3 \\
24.8 \\
25.2 \\
25.4 \\
25.6 \\
25.8\end{array}$ & $\begin{array}{l}4.3 \\
4.3 \\
4.4 \\
4.4 \\
4.4 \\
4.5 \\
4.6\end{array}$ & $\begin{array}{l}0.2 \\
0.2 \\
0.2 \\
0.2 \\
0.2 \\
0.2 \\
0.2\end{array}$ & $\begin{array}{l}0.9 \\
0.9 \\
0.9 \\
0.9 \\
0.9 \\
0.9 \\
0.9\end{array}$ & $\begin{array}{l}3.7 \\
3.9 \\
4.1 \\
4.3 \\
4.5 \\
4.6 \\
4.6\end{array}$ \\
\hline $\begin{array}{l}5 \text { to } 17 \text { years old } \\
1980 \ldots \ldots \\
1990 \ldots \\
1995 \ldots \ldots \\
2000^{2} \ldots \ldots\end{array}$ & $\begin{array}{l}47,232 \\
45,359 \\
49,838 \\
53,198 \\
53,606\end{array}$ & $\begin{array}{r}35,220 \\
- \\
- \\
33,008 \\
31,379\end{array}$ & $\begin{array}{r}6,840 \\
- \\
7,9 \overline{4} \\
7,9987\end{array}$ & $\begin{array}{r}4,005 \\
- \\
\overline{-} \\
8,700 \\
10,207\end{array}$ & $\begin{array}{r}790 \\
- \\
\overline{-} \\
1,829 \\
2,047\end{array}$ & $\begin{array}{l}(1) \\
- \\
85 \\
92\end{array}$ & $\begin{array}{r}377 \\
- \\
522 \\
499\end{array}$ & $\begin{array}{r}- \\
- \\
1,059 \\
1,396\end{array}$ & $\begin{array}{r}100.0 \\
\overline{-} \\
100.0 \\
100.0\end{array}$ & $\begin{array}{r}74.6 \\
- \\
62.0 \\
58.5\end{array}$ & $\begin{array}{r}14.5 \\
\overline{-} \\
15.0 \\
14.9\end{array}$ & $\begin{array}{r}8.5 \\
\overline{-} \\
16.4 \\
19.0\end{array}$ & $\begin{array}{c}1.7 \\
- \\
3.4 \\
3.8\end{array}$ & $\begin{array}{l}(1) \\
\overline{-} \\
0.2 \\
0.2\end{array}$ & $\begin{array}{c}0.8 \\
\overline{-} \\
\overline{1.0} \\
0.9\end{array}$ & $\begin{array}{l}- \\
\overline{-} \\
2.0 \\
2.6\end{array}$ \\
\hline $\begin{array}{l}2006^{2} \\
2007^{2} \ldots \ldots \\
2008^{2} \ldots \ldots \ldots \ldots \\
2009^{2} \ldots \ldots \ldots \ldots \\
2010^{2} \ldots \ldots \\
2011^{2} \\
2012^{2}\end{array}$ & $\begin{array}{l}53,819 \\
53,893 \\
53,833 \\
53,890 \\
53,931 \\
53,783 \\
53,729\end{array}$ & $\begin{array}{l}31,069 \\
30,679 \\
30,226 \\
29,851 \\
29,497 \\
29,175 \\
28,884\end{array}$ & $\begin{array}{r}7,972 \\
7,916 \\
7,813 \\
7,726 \\
7,643 \\
7,543 \\
7,477\end{array}$ & $\begin{array}{l}10,602 \\
10,988 \\
11,346 \\
11,717 \\
12,057 \\
12,238 \\
12,442\end{array}$ & $\begin{array}{l}2,110 \\
2,166 \\
2,227 \\
2,290 \\
2,349 \\
2,392 \\
2,438\end{array}$ & $\begin{array}{r}94 \\
96 \\
98 \\
99 \\
101 \\
101 \\
102\end{array}$ & $\begin{array}{l}494 \\
489 \\
483 \\
478 \\
475 \\
470 \\
467\end{array}$ & $\begin{array}{l}1,479 \\
1,559 \\
1,641 \\
1,729 \\
1,809 \\
1,863 \\
1,919\end{array}$ & $\begin{array}{l}100.0 \\
100.0 \\
100.0 \\
100.0 \\
100.0 \\
100.0 \\
100.0\end{array}$ & $\begin{array}{l}57.7 \\
56.9 \\
56.1 \\
55.4 \\
54.7 \\
54.2 \\
53.8\end{array}$ & $\begin{array}{l}14.8 \\
14.7 \\
14.5 \\
14.3 \\
14.2 \\
14.0 \\
13.9\end{array}$ & $\begin{array}{l}19.7 \\
20.4 \\
21.1 \\
21.7 \\
22.4 \\
22.8 \\
23.2\end{array}$ & $\begin{array}{l}3.9 \\
4.0 \\
4.1 \\
4.2 \\
4.4 \\
4.4 \\
4.5\end{array}$ & $\begin{array}{l}0.2 \\
0.2 \\
0.2 \\
0.2 \\
0.2 \\
0.2 \\
0.2\end{array}$ & $\begin{array}{l}0.9 \\
0.9 \\
0.9 \\
0.9 \\
0.9 \\
0.9 \\
0.9\end{array}$ & $\begin{array}{l}2.7 \\
2.9 \\
3.0 \\
3.2 \\
3.4 \\
3.5 \\
3.6\end{array}$ \\
\hline $\begin{array}{l}18 \text { to } 24 \text { years old } \\
1980 \ldots \\
1990 \\
20950^{2} \ldots\end{array}$ & $\begin{array}{l}30,103 \\
26,853 \\
25,482 \\
27,315 \\
29,442\end{array}$ & $\begin{array}{r}23,278 \\
- \\
\overline{-} \\
16,913 \\
17,741\end{array}$ & $\begin{array}{r}3,872 \\
- \\
\overline{-} \\
3,780 \\
4,092\end{array}$ & $\begin{array}{r}2,284 \\
- \\
\overline{-} \\
4,786 \\
5,406\end{array}$ & $\begin{array}{r}468 \\
- \\
\overline{-} \\
1,158 \\
1,351\end{array}$ & $\begin{array}{l}(1) \\
\frac{1}{50} \\
57\end{array}$ & $\begin{array}{r}201 \\
- \\
239 \\
263\end{array}$ & $\begin{array}{r}- \\
\overline{-} \\
389 \\
531\end{array}$ & $\begin{array}{r}100.0 \\
\overline{-} \\
100.0 \\
100.0\end{array}$ & $\begin{array}{r}77.3 \\
- \\
61.9 \\
60.3\end{array}$ & $\begin{array}{r}12.9 \\
- \\
\overline{1} .8 \\
13.9\end{array}$ & $\begin{array}{r}7.6 \\
- \\
17.5 \\
18.4\end{array}$ & $\begin{array}{c}1.6 \\
- \\
4.2 \\
4.6\end{array}$ & \begin{tabular}{l|}
$(1)$ \\
$\overline{-}$ \\
0.2 \\
0.2
\end{tabular} & $\begin{array}{l}0.7 \\
\overline{-} \\
0.9 \\
0.9\end{array}$ & $\begin{array}{l}- \\
\overline{-} \\
1.4 \\
1.8\end{array}$ \\
\hline $\begin{array}{l}2006^{2} \\
2007^{2} \\
2008^{2} \\
2009^{2} \\
2010^{2} \\
2011^{2} \\
2012^{2}\end{array}$ & $\begin{array}{l}29,603 \\
29,808 \\
30,194 \\
30,530 \\
30,762 \\
31,067 \\
31,360\end{array}$ & $\begin{array}{l}17,693 \\
17,668 \\
17,712 \\
17,705 \\
17,616 \\
17,613 \\
17,608\end{array}$ & $\begin{array}{l}4,133 \\
4,189 \\
4,283 \\
4,363 \\
4,435 \\
4,560 \\
4,658\end{array}$ & $\begin{array}{l}5,522 \\
5,636 \\
5,813 \\
6,006 \\
6,183 \\
6,305 \\
6,442\end{array}$ & $\begin{array}{l}1,377 \\
1,408 \\
1,445 \\
1,481 \\
1,517 \\
1,538 \\
1,558\end{array}$ & $\begin{array}{l}59 \\
60 \\
62 \\
64 \\
66 \\
66 \\
66\end{array}$ & $\begin{array}{l}265 \\
266 \\
266 \\
266 \\
266 \\
272 \\
276\end{array}$ & $\begin{array}{l}555 \\
581 \\
613 \\
645 \\
678 \\
714 \\
753\end{array}$ & $\begin{array}{l}100.0 \\
100.0 \\
100.0 \\
100.0 \\
100.0 \\
100.0 \\
100.0\end{array}$ & $\begin{array}{l}59.8 \\
59.3 \\
58.7 \\
58.0 \\
57.3 \\
56.7 \\
56.1\end{array}$ & $\begin{array}{l}14.0 \\
14.1 \\
14.2 \\
14.3 \\
14.4 \\
14.7 \\
14.9\end{array}$ & $\begin{array}{l}18.7 \\
18.9 \\
19.3 \\
19.7 \\
20.1 \\
20.3 \\
20.5\end{array}$ & $\begin{array}{l}4.7 \\
4.7 \\
4.8 \\
4.9 \\
4.9 \\
5.0 \\
5.0\end{array}$ & $\begin{array}{l}0.2 \\
0.2 \\
0.2 \\
0.2 \\
0.2 \\
0.2 \\
0.2\end{array}$ & $\begin{array}{l}0.9 \\
0.9 \\
0.9 \\
0.9 \\
0.9 \\
0.9 \\
0.9\end{array}$ & $\begin{array}{l}1.9 \\
2.0 \\
2.0 \\
2.1 \\
2.2 \\
2.3 \\
2.4\end{array}$ \\
\hline $\begin{array}{c}25 \text { years old and over } \\
1980 \ldots \\
1990 \\
20950^{2}\end{array}$ & $\begin{array}{l}133,438 \\
158,555 \\
171,332 \\
182,471 \\
192,551\end{array}$ & $\begin{array}{l}110,737 \\
125,653 \\
131,839 \\
134,529 \\
136,655\end{array}$ & $\begin{array}{l}13,091 \\
16,322 \\
18,250 \\
19,879 \\
21,361\end{array}$ & $\begin{array}{r}6,903 \\
11,447 \\
14,519 \\
18,427 \\
22,804\end{array}$ & $\begin{array}{l}2,088 \\
4,190 \\
5,628 \\
6,796 \\
8,421\end{array}$ & 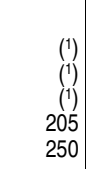 & $\begin{array}{r}620 \\
944 \\
1,096 \\
1,170 \\
1,253\end{array}$ & $\begin{array}{r}- \\
\overline{-} \\
1,465 \\
1,808\end{array}$ & $\begin{array}{l}100.0 \\
100.0 \\
100.0 \\
100.0 \\
100.0\end{array}$ & $\begin{array}{l}83.0 \\
79.2 \\
76.9 \\
73.7 \\
71.0\end{array}$ & $\begin{array}{r}9.8 \\
10.3 \\
10.7 \\
10.9 \\
11.1\end{array}$ & $\begin{array}{r}5.2 \\
7.2 \\
8.5 \\
10.1 \\
11.8\end{array}$ & $\begin{array}{l}1.6 \\
2.6 \\
3.3 \\
3.7 \\
4.4\end{array}$ & $\begin{array}{l}(1) \\
(1) \\
(1) \\
0.1 \\
0.1\end{array}$ & \begin{tabular}{l|}
0.5 \\
0.6 \\
0.6 \\
0.6 \\
0.7
\end{tabular} & $\begin{array}{l}\overline{-} \\
\overline{-} \\
0.8 \\
0.9\end{array}$ \\
\hline 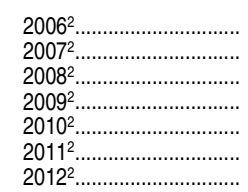 & $\begin{array}{l}195,019 \\
197,404 \\
199,795 \\
202,107 \\
204,444 \\
206,609 \\
208,826\end{array}$ & $\begin{array}{l}137,364 \\
138,020 \\
138,689 \\
139,324 \\
140,000 \\
140,592 \\
141,192\end{array}$ & $\begin{array}{l}21,726 \\
22,083 \\
22,441 \\
22,792 \\
23,150 \\
23,480 \\
23,830\end{array}$ & $\begin{array}{l}23,744 \\
24,674 \\
25,603 \\
26,504 \\
27,383 \\
28,181 \\
28,988\end{array}$ & $\begin{array}{r}8,762 \\
9,086 \\
9,400 \\
9,700 \\
10,002 \\
10,349 \\
10,704\end{array}$ & $\begin{array}{l}259 \\
268 \\
277 \\
285 \\
294 \\
304 \\
314\end{array}$ & $\begin{array}{l}1,272 \\
1,292 \\
1,312 \\
1,332 \\
1,352 \\
1,373 \\
1,395\end{array}$ & $\begin{array}{l}1,893 \\
1,981 \\
2,074 \\
2,170 \\
2,262 \\
2,331 \\
2,403\end{array}$ & $\begin{array}{l}100.0 \\
100.0 \\
10.0 \\
100.0 \\
100.0 \\
100.0 \\
100.0\end{array}$ & $\begin{array}{l}70.4 \\
69.9 \\
69.4 \\
68.9 \\
68.5 \\
68.0 \\
67.6\end{array}$ & $\begin{array}{l}11.1 \\
11.2 \\
11.2 \\
11.3 \\
11.3 \\
11.4 \\
11.4\end{array}$ & $\begin{array}{l}12.2 \\
12.5 \\
12.8 \\
13.1 \\
13.4 \\
13.6 \\
13.9\end{array}$ & $\begin{array}{l}4.5 \\
4.6 \\
4.7 \\
4.8 \\
4.9 \\
5.0 \\
5.1\end{array}$ & $\begin{array}{l}0.1 \\
0.1 \\
0.1 \\
0.1 \\
0.1 \\
0.1 \\
0.2\end{array}$ & $\begin{array}{l}0.7 \\
0.7 \\
0.7 \\
0.7 \\
0.7 \\
0.7 \\
0.7\end{array}$ & $\begin{array}{l}1.0 \\
1.0 \\
1.0 \\
1.1 \\
1.1 \\
1.1 \\
1.2\end{array}$ \\
\hline
\end{tabular}

-Not available.

1 Included under Asian.

${ }^{2}$ Data on persons of two or more races were collected beginning in 2000. Direct comparability of the data (other than Hispanic) prior to 2000 with the data for 2000 and later years is limited by the extent to which people reporting more than one race in later years had been reported in specific race groups in earlier years.

NOTE: Resident population includes civilian population and armed forces personnel residing within the United States; it excludes armed forces personnel residing overseas. Race catego- ries exclude persons of Hispanic ethnicity. Detail may not sum to totals because of rounding Some data have been revised from previously published figures. Population estimates as of July 1 of the indicated reference year.

SOURCE: U.S. Department of Commerce, Census Bureau, Current Population Reports, Series P-25, Nos. 1092 and 1095; 2000 through 2009 Population Estimates, retrieved August 14, 2012 , from http://www.census.gov/popest/data/national/asrh/2011/index.html; and 2010 through 2012 Population Estimates, retrieved November 1, 2013, from http://www.census.gov/popest/datal national/asrh/2012/2012-nat-detail.html. (This table was prepared November 2013.) 


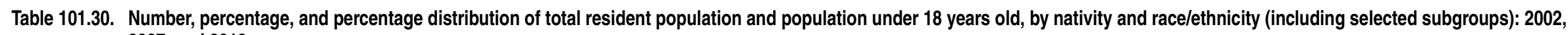
2007, and 2012

[Numbers in thousands. Standard errors appear in parentheses]

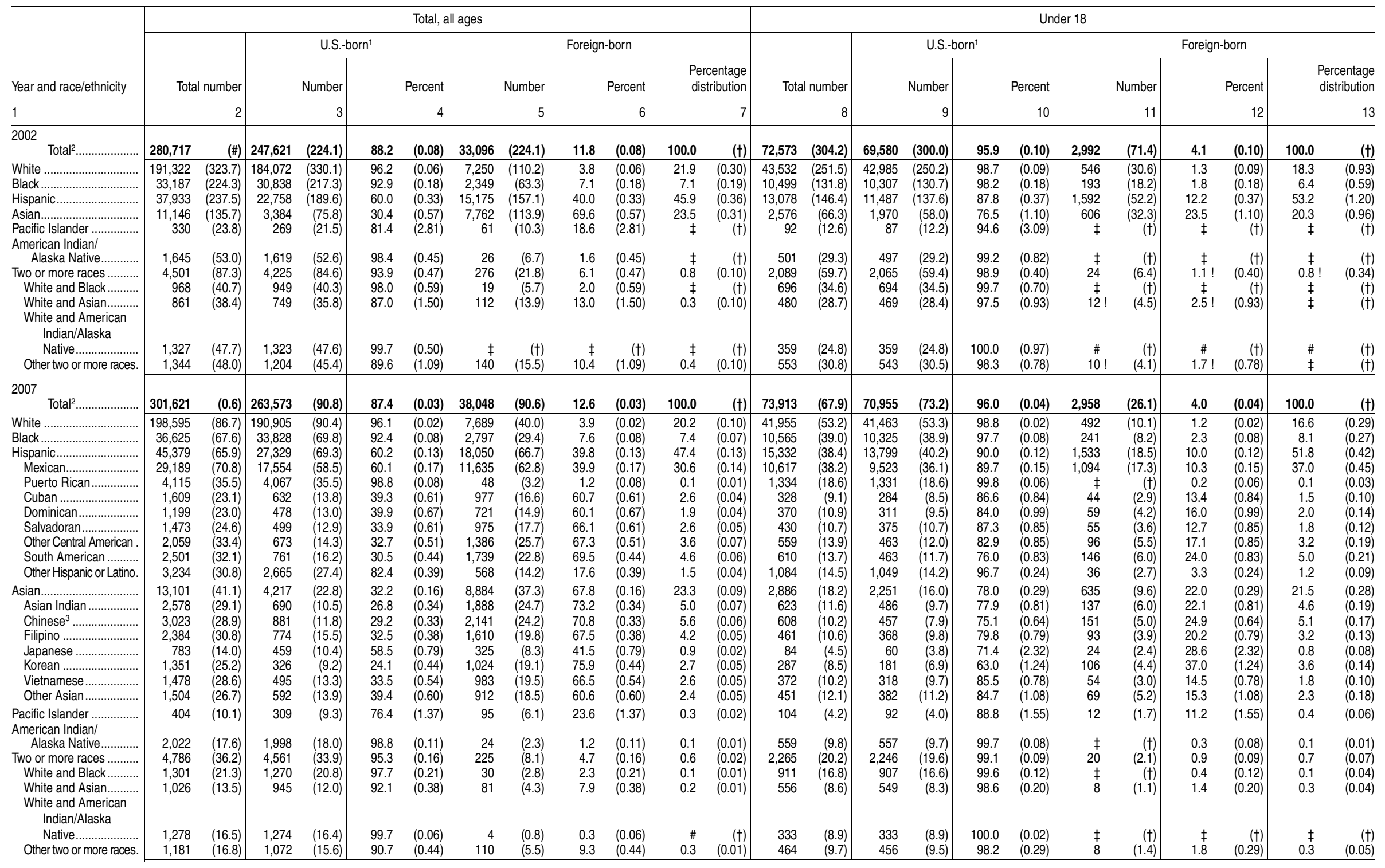

See notes at end of table. 


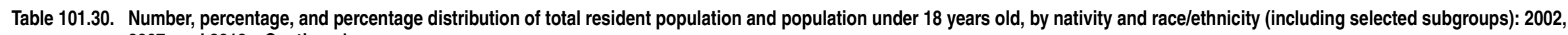
2007, and 2012-Continued

[Numbers in thousands. Standard errors appear in parentheses]

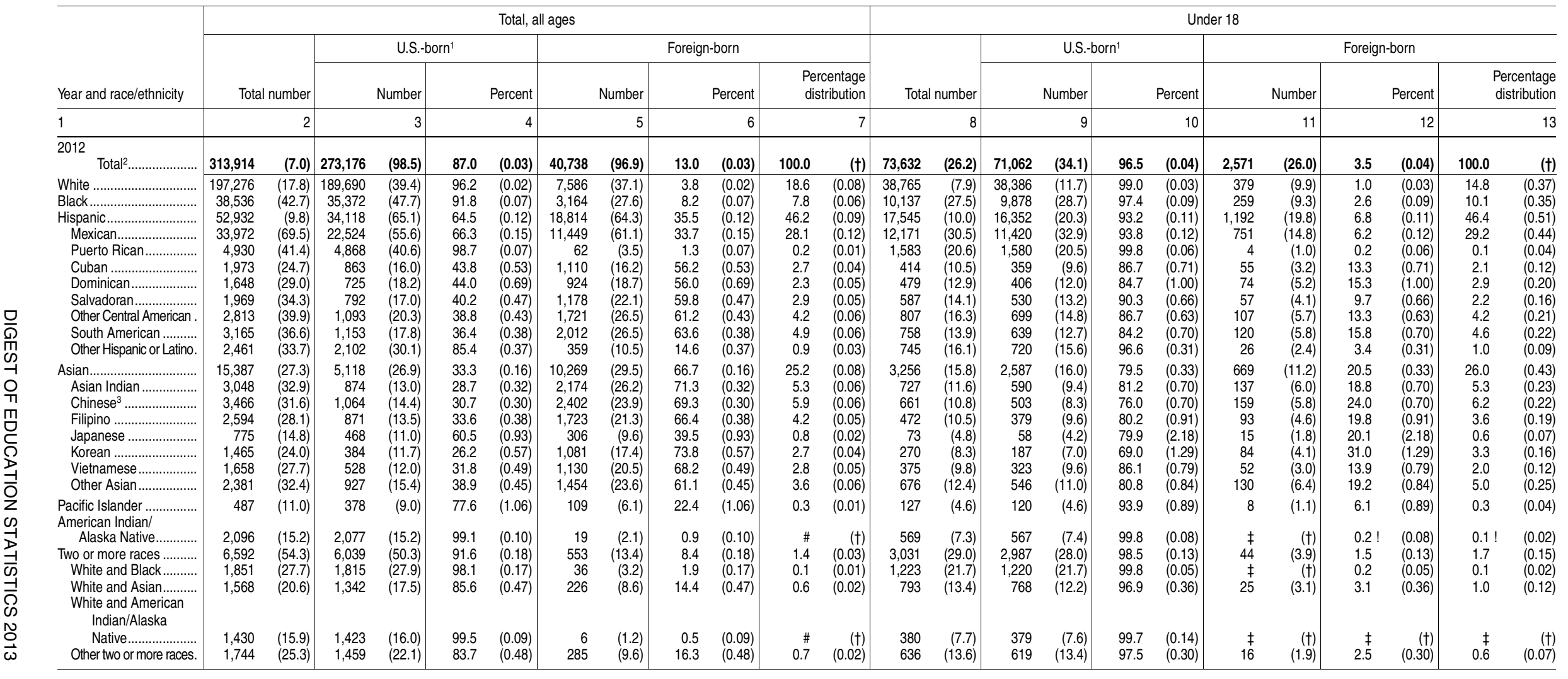

†Not applicable.

\#Rounds to zero.

†Reporting standards not met. Either there are too few cases for a reliable estimate or the coefficient of variation (CV) is 50 percent or greater.

IIncludes those born in the 50 states, the District of Columbia, Puerto Rico, American Samoa, Guam, the U.S. Virgin Islands, and the Northern Marianas, as well as those born abroad to U.S.-citizen parents.
${ }^{2}$ Total includes other racial/ethnic groups not shown separately.

"Excludes Taiwanese. Taiwanese is included in the "Other Asian" category.
NOTE: Data are from the American Community Survey and may differ from data shown in other tables obtained from the Current Population Survey. Race categories exclude persons of Hispanic ethnicity. Detail may not sum to totals because of rounding. SOURCE: U.S. Department of Commerce, Census Bureau, American Community Survey (ACS), 2002, 2007, and 2012. (This table was prepared February 2014.) 
22 CHAPTER 1: All Levels of Education

Population

Table 101.40. Estimated total and school-age resident populations, by state: Selected years, 1970 through 2012

[In thousands]

\begin{tabular}{|c|c|c|c|c|c|c|c|c|c|c|c|c|c|c|c|c|}
\hline \multirow[b]{2}{*}{ State } & \multicolumn{8}{|c|}{ Total, all ages } & \multicolumn{8}{|c|}{ 5- to 17 -year-olds } \\
\hline & $1970^{1}$ & $1980^{1}$ & $1990^{1}$ & $2000^{2}$ & $2005^{2}$ & $2010^{2}$ & $2011^{2}$ & $2012^{2}$ & $1970^{1}$ & $1980^{1}$ & $1990^{1}$ & $2000^{2}$ & $2005^{2}$ & $2010^{2}$ & $2011^{2}$ & $2012^{2}$ \\
\hline 1 & 2 & 3 & 4 & 5 & 6 & 7 & 8 & o & 10 & 11 & 12 & 13 & 14 & 15 & 16 & 17 \\
\hline United States. & 203,302 & 226,546 & 248,765 & 282,162 & 295,517 & 309,326 & 311,588 & 313,914 & 52,540 & 47,407 & 45,178 & 53,198 & 53,606 & 53,931 & 53,783 & 53,729 \\
\hline Alabama ............... & 3,444 & 3,894 & 4,040 & 4,452 & 4,570 & 4,785 & 4,804 & 4,822 & 934 & 866 & 774 & 828 & 822 & 826 & 824 & 819 \\
\hline Alaska............. & 303 & 402 & 550 & 628 & 667 & 714 & 724 & 731 & 88 & 92 & 117 & 143 & 136 & 134 & 134 & 132 \\
\hline Arizona ................. & 1,775 & 2,718 & 3,665 & 5,161 & 5,839 & 6,411 & 6,467 & 6,553 & 486 & 578 & 686 & 989 & 1,083 & 1,174 & 1,172 & 1,181 \\
\hline Arkansas.............. & 1,923 & 2,286 & 2,351 & 2,679 & 2,781 & 2,923 & 2,939 & 2,949 & 498 & 496 & 455 & 500 & 503 & 514 & 514 & 517 \\
\hline California . & 19,971 & 23,668 & 29,786 & 33,988 & 35,828 & 37,334 & 37,684 & 38,041 & 4,999 & 4,681 & 5,344 & 6,775 & 6,844 & 6,763 & 6,725 & 6,699 \\
\hline 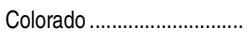 & 2,210 & 2,890 & 3,294 & 4,327 & 4,632 & 5,048 & 5,116 & 5,188 & 589 & 592 & 607 & 808 & 827 & 882 & 888 & 894 \\
\hline Connecticut... & 3,032 & 3,108 & 3,287 & 3,412 & 3,507 & 3,577 & 3,587 & 3,590 & 768 & 638 & 520 & 619 & 632 & 614 & 607 & 600 \\
\hline Delaware.............. & 548 & 594 & 666 & 786 & 845 & 900 & 908 & 917 & 148 & 125 & 114 & 143 & 147 & 150 & 149 & 149 \\
\hline District of Columbia .... & 757 & 638 & 607 & 572 & 567 & 605 & 619 & 632 & 164 & 109 & 80 & 82 & 75 & 68 & 69 & 71 \\
\hline Florida........... & 6,791 & 9,746 & 12,938 & 16,048 & 17,842 & 18,846 & 19,082 & 19,318 & 1,609 & 1,789 & 2,011 & 2,709 & 2,896 & 2,925 & 2,926 & 2,931 \\
\hline zorgia.. & 4,588 & 5,463 & 6,478 & 8,227 & 8,926 & 9,715 & 9,812 & 9,920 & 1,223 & 1,231 & 1,230 & 1,581 & 1,684 & 1,804 & 1,806 & 1,815 \\
\hline Hawaii... & 770 & 965 & 1,108 & 1,214 & 1,293 & 1,364 & 1,378 & 1,392 & 204 & 198 & 196 & 217 & 214 & 217 & 215 & 214 \\
\hline Idaho..... & 713 & 944 & 1,007 & 1,299 & 1,428 & 1,571 & 1,584 & 1,596 & 200 & 213 & 228 & 272 & 284 & 307 & 309 & 311 \\
\hline Illinois..... & 11,110 & 11,427 & 11,431 & 12,434 & 12,610 & 12,840 & 12,860 & 12,875 & 2,859 & 2,401 & 2,095 & 2,369 & 2,330 & 2,289 & 2,268 & 2,248 \\
\hline Indiana... & 5,195 & 5,490 & 5,544 & 6,092 & 6,279 & 6,490 & 6,516 & 6,537 & 1,386 & 1,200 & 1,056 & 1,152 & 1,165 & 1,172 & 1,169 & 1,166 \\
\hline wa & 2,825 & 2,914 & 2,777 & 2,929 & 2,964 & 3,050 & 3,064 & 3,074 & 743 & 604 & 525 & 544 & 527 & 525 & 526 & 527 \\
\hline Kansas............. & 2,249 & 2,364 & 2,478 & 2,694 & 2,745 & 2,859 & 2,870 & 2,886 & 573 & 468 & 472 & 525 & 511 & 521 & 521 & 521 \\
\hline 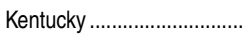 & 3,221 & 3,661 & 3,687 & 4,049 & 4,183 & 4,347 & 4,367 & 4,380 & 844 & 800 & 703 & 730 & 31 & 741 & 740 & 739 \\
\hline 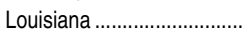 & 3,645 & 4,206 & 4,222 & 4,472 & 4,577 & 4,544 & 4,575 & 4,602 & 1,041 & 969 & 891 & 902 & 854 & 802 & 802 & 803 \\
\hline Maine & 994 & 1,125 & 1,228 & 1,277 & 1,319 & 1,328 & 1,329 & 1,329 & 260 & 243 & 223 & 231 & 221 & 204 & 202 & 199 \\
\hline $\mathrm{M}$ & 3,924 & 4,217 & 4,781 & 5,311 & 5,592 & 5,788 & 5,840 & 5,885 & 1,038 & 895 & 803 & 1,004 & 1,016 & 987 & 981 & 979 \\
\hline husetts. & 5,689 & 5,737 & 6,016 & 6,361 & 6,403 & 6,563 & 6,607 & 6,646 & 1,407 & 1,153 & 940 & 1,104 & 1,086 & 1,052 & 1,043 & 1,036 \\
\hline Michigan ............... & 8,882 & 9,262 & 9,295 & 9,952 & 10,051 & 9,878 & 9,877 & 9,883 & 2,450 & 2,067 & 1,754 & 1,924 & 1,883 & 1,741 & 1,714 & 1,691 \\
\hline Minnesota ........... & 3,806 & 4,076 & 4,376 & 4,934 & 5,120 & 5,311 & 5,347 & 5,379 & 1,051 & 865 & 829 & 958 & 934 & 928 & 926 & 928 \\
\hline Mississippi ... & 2,217 & 2,521 & 2,575 & 2,848 & 2,906 & 2,969 & 2,977 & 2,985 & 635 & 599 & 550 & 571 & 553 & 543 & 540 & 542 \\
\hline Missouri. & 4,678 & 4,917 & 5,117 & 5,607 & 5,790 & 5,996 & 6,009 & 6,022 & 1,183 & 1,008 & 944 & 1,059 & 1,046 & 1,034 & 1,029 & 1,024 \\
\hline Montana. & 694 & 787 & 799 & 904 & 940 & 991 & 998 & 1,005 & 197 & 167 & 163 & 175 & 164 & 161 & 161 & 161 \\
\hline Nebraska. & 1,485 & 1,570 & 1,578 & 1,714 & 1,761 & 1,830 & 1,842 & 1,856 & 389 & 324 & 309 & 333 & 322 & 327 & 329 & 331 \\
\hline $\mathrm{N}$ & 489 & 800 & 1,202 & 2,019 & 2,432 & 2,704 & 2,720 & 2,759 & 127 & 160 & 204 & 369 & 436 & 477 & 476 & 480 \\
\hline New Hampshire ......... & 738 & 921 & 1,109 & 1,240 & 1,298 & 1,317 & 1,318 & 1,321 & 189 & 196 & 194 & 235 & 232 & 217 & 212 & 209 \\
\hline $\mathrm{N}$ & 7,171 & 7,365 & 7,748 & 8,431 & 8,652 & 8,803 & 8,835 & 8,865 & 1,797 & 1,528 & 1,269 & 1,526 & 1,558 & 1,522 & 1,510 & 1,499 \\
\hline New & 1,017 & 1,303 & 1,515 & 1,821 & 1,932 & 2,065 & 2,079 & 2,086 & 311 & 303 & 320 & 378 & 365 & 374 & 372 & 371 \\
\hline New York............. & 18,241 & 17,558 & 17,991 & 19,002 & 19,133 & 19,399 & 19,502 & 19,570 & 4,358 & 3,552 & 3,000 & 3,451 & 3,337 & 3,163 & 3,129 & 3,096 \\
\hline North Carolina .. & 5,084 & 5,882 & 6,632 & 8,082 & 8,705 & 9,559 & 9,651 & 9,752 & 1,323 & 1,254 & 1,147 & 1,429 & 1,529 & 1,647 & 1,657 & 1,667 \\
\hline North Dakota ... & 618 & 653 & 639 & 642 & 646 & 674 & 685 & 700 & 175 & 136 & 127 & 121 & 109 & 105 & 106 & 108 \\
\hline ol & 10,657 & 10,798 & 10,847 & 11,364 & 11,463 & 11,538 & 11,541 & 11,544 & 2,820 & 2,307 & 2,012 & 2,133 & 2,085 & 2,004 & 1,984 & 1,969 \\
\hline Oklahoma .... & 2,559 & 3,025 & 3,146 & 3,454 & 3,549 & 3,759 & 3,784 & 3,815 & 640 & 622 & 609 & 656 & 639 & 665 & 670 & 675 \\
\hline Oregon............... & 2,092 & 2,633 & 2,842 & 3,430 & 3,613 & 3,838 & 3,868 & 3,899 & 534 & 525 & 521 & 624 & 622 & 628 & 628 & 628 \\
\hline Pennsylvania..... & 11,801 & 11,864 & 11,883 & 12,284 & 12,450 & 12,711 & 12,744 & 12,764 & 2,925 & 2,376 & 1,996 & 2,192 & 2,137 & 2,059 & 2,039 & 2,020 \\
\hline Rhode Island ... & 950 & 947 & 1,003 & 1,050 & 1,068 & 1,053 & 1,051 & 1,050 & 225 & 186 & 159 & 184 & 180 & 166 & 164 & 161 \\
\hline So & 2,591 & 3,122 & 3,486 & 4,024 & 4,270 & 4,636 & 4,673 & 4,724 & 720 & 703 & 662 & 746 & 757 & 777 & 777 & 784 \\
\hline & 666 & 691 & 696 & 756 & 775 & 816 & 824 & 833 & 187 & 147 & 144 & 152 & 143 & 143 & 144 & 145 \\
\hline & 3,926 & 4,591 & 4,877 & 5,704 & 5,991 & 6,357 & 6,400 & 6,456 & 1,002 & 972 & 882 & 1,025 & 1,059 & 1,087 & 1,088 & 1,090 \\
\hline Texas & 11,199 & 14,229 & 16,986 & 20,944 & 22,778 & 25,243 & 25,632 & 26,059 & 3,002 & 3,137 & 3,437 & 4,278 & 4,470 & 4,945 & 4,994 & 5,044 \\
\hline Utah. & 1,059 & 1,461 & 1,723 & 2,245 & 2,458 & 2,775 & 2,814 & 2,855 & 312 & 350 & 457 & 511 & 532 & 608 & 619 & 630 \\
\hline & 445 & 511 & 563 & 610 & 621 & 626 & 627 & 626 & 118 & 109 & 102 & 113 & 106 & 97 & 95 & 93 \\
\hline & 4,651 & 5,347 & 6,189 & 7,106 & 7,577 & 8,025 & 8,104 & 8,186 & 1,197 & 1,114 & 1,060 & 1,281 & 1,320 & 1,344 & 1,344 & 1,347 \\
\hline Washir & 3,413 & 4,132 & 4,867 & 5,911 & 6,257 & 6,744 & 6,823 & 6,897 & 881 & 826 & 893 & 1,121 & 1,119 & 1,141 & 1,138 & 1,142 \\
\hline West Virginia... & 1,744 & 1,950 & 1,793 & 1,807 & 1,820 & 1,854 & 1,855 & 1,855 & 442 & 414 & 337 & 300 & 288 & 283 & 282 & 281 \\
\hline Wisconsin ...... & 4,418 & 4,706 & 4,892 & 5,374 & 5,546 & 5,690 & 5,710 & 5,726 & 1,203 & 1,011 & 927 & 1,027 & 1,001 & 979 & 972 & 967 \\
\hline Wyoming.... & 332 & 470 & 454 & 494 & 514 & 564 & 567 & 576 & 92 & 101 & 101 & 98 & 91 & 95 & 95 & 97 \\
\hline
\end{tabular}

${ }^{1}$ As of April 1.

${ }^{2}$ Estimates as of July 1 .

NOTE: Resident population includes civilian population and armed forces personnel residing within the United States and within each state; it excludes armed forces personne residing overseas. Some data have been revised from previously published figures. Detail may not sum to totals because of rounding.
SOURCE: U.S. Department of Commerce, Census Bureau, Current Population Reports, Series P-25, No. 1095; CPH-L-74 (1990 data); 2000 through 2009 Population Estimates, retrieved August 17, 2012, from http://www.census.gov/popest/data/state/asrh/2011/index.html; and 2010 through 2012 Population Estimates, retrieved November 4, 2013, from http:// www.census.gov/popest/data/state/asrh/2012/SC-EST2012-ALLDATA6.html. (This table was prepared November 2013. 
Table 102.10. Number and percentage distribution of family households, by family structure and presence of own children under $18:$ Selected years, 1970 through 2012

[Standard errors appear in parentheses]

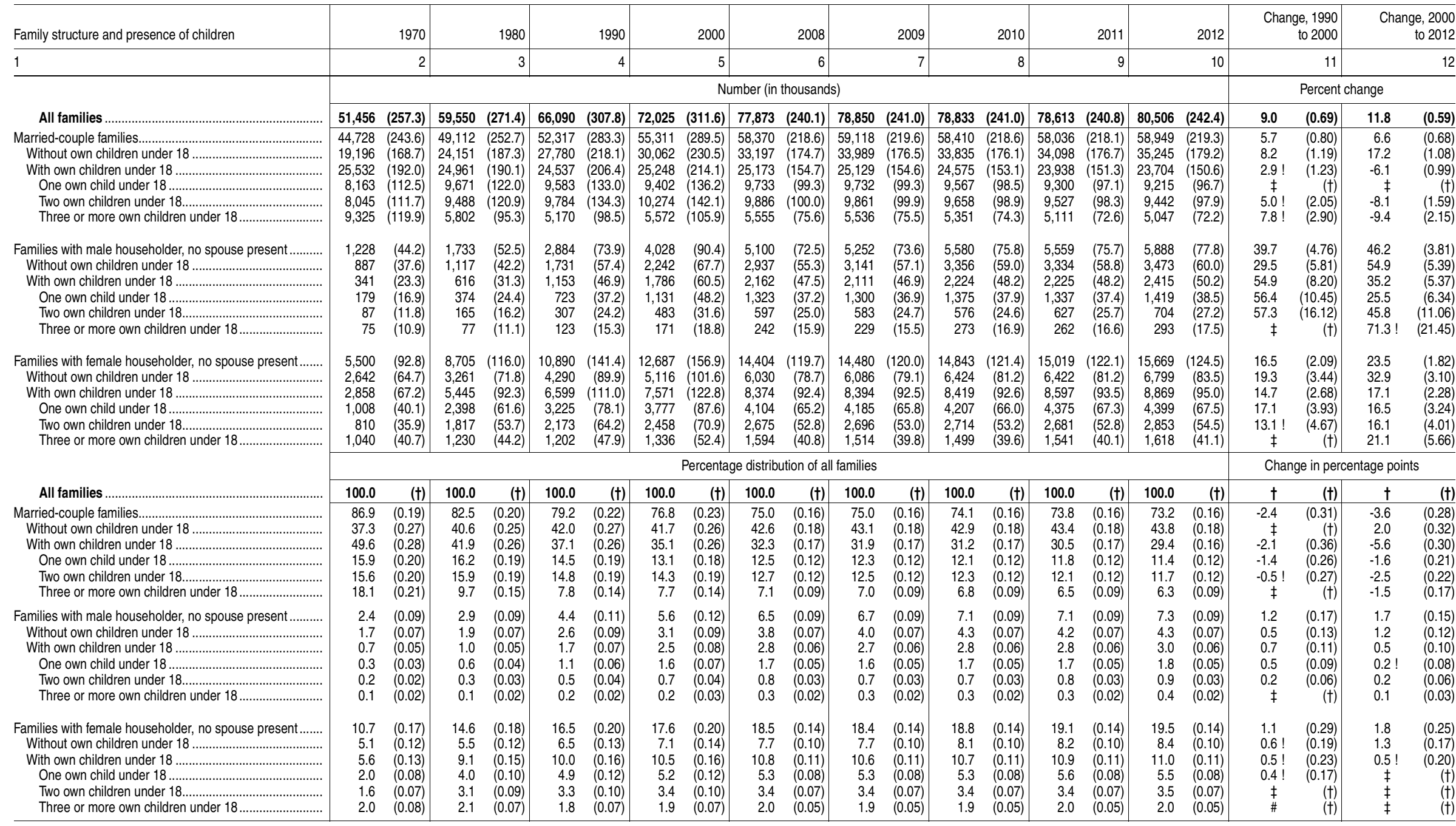

†Not applicable.
\#Rounds to zero.

!Interpret data with caution. The coefficient of variation (CV) for this estimate is between 30 and 50 percent.

fReporting standards not met. The coefficient of variation (CV) for this estimate is 50 percent or greater.

NOTE: A family household consists of two or more people who are related by birth, marriage, or adoption and are residing

SOURCE: U.S. Department of Commerce, Census Bureau, Current Population Reports, Series P20, Household and Family Characteristics: 1995; and America's Families and Living Arrangements. 2000 and 2008-2012, Cusent Population Survey cps2012.html. (This table was prepared August 2013.)
cpser 
Table 102.20. Number and percentage of family households with own children under age 18, under age 6 , and under age 3, by race/ethnicity and family structure: 2012

[Standard errors appear in parentheses]

\begin{tabular}{|c|c|c|c|c|c|c|c|c|c|c|c|c|c|c|c|c|c|c|c|c|c|c|c|c|}
\hline \multirow[b]{3}{*}{ Race/ethnicity and family structure } & & & \multicolumn{14}{|c|}{ Families with own children under 18} & \multicolumn{4}{|c|}{ Families with own children under 6} & \multicolumn{4}{|c|}{ Families with own children under 3} \\
\hline & \multirow{2}{*}{\multicolumn{2}{|c|}{$\begin{array}{r}\text { All families } \\
\text { (in thousands) }\end{array}$}} & \multirow{2}{*}{\multicolumn{2}{|c|}{$\begin{array}{r}\text { Total } \\
\text { (in thousands) }\end{array}$}} & \multirow{2}{*}{\multicolumn{2}{|c|}{$\begin{array}{l}\text { Percent of } \\
\text { all families }\end{array}$}} & \multirow{2}{*}{\multicolumn{2}{|c|}{$\begin{array}{r}\text { Percentage } \\
\text { distribution }\end{array}$}} & \multicolumn{8}{|c|}{ Families (in thousands), by number of children } & \multirow{2}{*}{\multicolumn{2}{|c|}{$\begin{array}{r}\text { Total } \\
\text { (in thousands) }\end{array}$}} & \multirow{2}{*}{\multicolumn{2}{|c|}{$\begin{array}{r}\text { Percent of } \\
\text { all families }\end{array}$}} & \multirow{2}{*}{\multicolumn{2}{|c|}{$\begin{array}{r}\text { Total } \\
\text { (in thousands) }\end{array}$}} & \multirow{2}{*}{\multicolumn{2}{|c|}{$\begin{array}{l}\text { Percent of } \\
\text { all families }\end{array}$}} \\
\hline & & & & & & & & & \multirow{2}{*}{\multicolumn{2}{|c|}{$\begin{array}{r}1 \text { child } \\
\text { under } 18 \\
6\end{array}$}} & \multicolumn{2}{|c|}{$\begin{array}{r}2 \text { children } \\
\text { under } 18\end{array}$} & \multicolumn{2}{|c|}{$\begin{array}{r}3 \text { children } \\
\text { under } 18\end{array}$} & \multicolumn{2}{|c|}{$\begin{array}{r}4 \text { or more } \\
\text { under } 18\end{array}$} & & & & & & & & \\
\hline 1 & & 2 & & 3 & & 4 & & 5 & & & & 7 & & 8 & & 9 & & 10 & & 11 & & 12 & & 13 \\
\hline All races ${ }^{1} . . . \ldots \ldots \ldots \ldots \ldots . . . . . .$. & 80,506 & (242.4) & 34,989 & (178.6) & 43.5 & $(0.18)$ & 100.0 & $(\dagger)$ & 15,033 & $(122.1)$ & 12,999 & $(114.0)$ & 4,967 & $(71.6)$ & 1,990 & $(45.6)$ & 15,343 & $(123.3)$ & 19.1 & $(0.14)$ & 8,606 & (93.6) & 10.7 & $(0.11)$ \\
\hline Married-couple families.................. & 58,949 & $(219.3)$ & 23,704 & (150.6) & 40.2 & $(0.21)$ & 67.7 & $(0.26)$ & 9,215 & (96.7) & 9,442 & (97.9) & 3,627 & $(61.3)$ & 1,420 & (38.5) & 10,676 & (103.8) & 18.1 & $(0.16)$ & 6,104 & $(79.2)$ & 10.4 & $(0.13)$ \\
\hline $\begin{array}{l}\text { Families with male householder, } \\
\text { no spouse present }\end{array}$ & & (77.8) & 2,415 & $(50.2)$ & & $(0.66)$ & 6.9 & $(0.14)$ & 1,419 & & 704 & (27.2) & 225 & (15.4) & 68 & (8.5) & 1,031 & (32.9) & 17.5 & $(0.51)$ & 618 & (25.5) & 10.5 & $(0.41)$ \\
\hline $\begin{array}{l}\text { Families with female householder, } \\
\text { no spouse present }\end{array}$ & 15,669 & (124.5) & 8,869 & $(95.0)$ & 56.6 & $(0.41)$ & 25.3 & $(0.24)$ & 4,399 & (67.5) & 2,853 & (54.5) & 1,116 & (34.2) & 502 & (23.0) & 3,636 & (61.4) & 23.2 & $(0.35)$ & 1,884 & (44.4) & 12.0 & $(0.27)$ \\
\hline ite, non-His & 54,146 & (212.7) & 20,790 & $(141.9)$ & 38.4 & $(0.21)$ & 100.0 & $(\dagger)$ & 9,098 & (96.1) & 7,889 & (89.7) & 2,820 & (54.2) & 982 & (32.1) & 8,748 & (94.3) & 16.2 & $(0.16)$ & 5,003 & (71.9) & 9.2 & $(0.13)$ \\
\hline ililes.................. & 43,376 & $(195.2)$ & 15,467 & (123.8) & 35.7 & $(0.24)$ & 74.4 & $(0.31)$ & 6,086 & (79.1) & 6,212 & (79.9) & 2,326 & $(49.2)$ & 843 & (29.7) & 6,780 & (83.4) & 15.6 & $(0.18)$ & 3,934 & $(63.8)$ & 9.1 & $(0.14)$ \\
\hline $\begin{array}{l}\text { Families with ma } \\
\text { no spouse } p\end{array}$ & 3,231 & (57.9) & 1,399 & (38.3) & 43.3 & $(0.89)$ & 6.7 & $(0.18)$ & 864 & (30.1) & 411 & (20.8) & 106 & (10.6) & 18 & (4.4) & 524 & (23.5) & 16.2 & $(0.67)$ & 306 & (17.9) & 9.5 & $(0.53)$ \\
\hline $\begin{array}{l}\text { Families with female householder, } \\
\text { no spouse present }\end{array}$ & 7,539 & (87.8) & 3,924 & $(63.8)$ & 52.0 & $(0.59)$ & 18.9 & $(0.28)$ & 2,148 & (47.3) & 1,266 & (36.4) & 388 & (20.2) & 121 & (11.3) & 1,444 & (38.9) & 19.2 & $(0.46)$ & 763 & (28.3) & 10.1 & $(0.36)$ \\
\hline Black$^{2} \ldots \ldots \ldots \ldots \ldots$ & 9,651 & (86.1) & 4,920 & $(65.0)$ & 51.0 & $(0.50)$ & 100.0 & $(\dagger)$ & 2,255 & $(45.3)$ & 1,597 & (38.4) & 690 & (25.5) & 377 & (18.9) & 2,122 & (44.0) & 22.0 & $(0.41)$ & 1,132 & $(32.5)$ & 11.7 & $(0.32)$ \\
\hline Married-couple families................... & 4,361 & (61.6) & 1,907 & (41.8) & 43.7 & $(0.73)$ & 38.8 & $(0.68)$ & 801 & (27.4) & 672 & (25.1) & 285 & (16.4) & 149 & (11.9) & 831 & (27.9) & 19.1 & $(0.58)$ & 473 & $(21.1)$ & 10.8 & $(0.46)$ \\
\hline $\begin{array}{l}\text { Families with male householder, } \\
\text { no spouse present }\end{array}$ & 956 & (29.9) & 388 & (19.1) & 40.6 & $(1.55)$ & 7.9 & $(0.37)$ & 213 & (14.2) & 107 & (10.1) & 45 & (6.5) & 23 & (4.7) & 172 & (12.8) & 18.0 & $(1.21)$ & 92 & (9.4) & 9.6 & $(0.93)$ \\
\hline $\begin{array}{l}\text { Families with female householder, } \\
\text { no spouse present }\end{array}$ & 4,334 & (61.4) & 2,625 & $(48.7)$ & 60.6 & $(0.72)$ & 53.4 & $(0.69)$ & 1,242 & $(34.0)$ & 818 & (27.7) & 360 & (18.4) & 205 & (13.9) & 1,119 & (32.3) & 25.8 & $(0.65)$ & 567 & (23.1) & 13.1 & $(0.50)$ \\
\hline Hispanic..... & 11,585 & (86.8) & 6,912 & (73.1) & 59.7 & $(0.44)$ & 100.0 & $(\dagger)$ & 2,649 & (48.4) & 2,517 & (47.2) & 1,203 & (33.3) & 544 & (22.6) & 3,372 & (54.0) & 29.1 & $(0.41)$ & 1,851 & $(40.9)$ & 16.0 & $(0.33)$ \\
\hline Married-couple families...................... & 7,222 & (74.3) & 4,367 & $(60.5)$ & 60.5 & $(0.56)$ & 63.2 & $(0.57)$ & 1,513 & $(37.2)$ & 1,686 & (39.1) & 804 & $(27.4)$ & 364 & (18.5) & 2,121 & (43.6) & 29.4 & $(0.52)$ & 1,157 & $(32.7)$ & 16.0 & $(0.42)$ \\
\hline $\begin{array}{l}\text { Families with male householder, } \\
\text { no spouse present ...................... }\end{array}$ & 1,277 & $(34.3)$ & 505 & $(21.8)$ & 39.5 & $(1.34)$ & 7.3 & $(0.31)$ & 285 & (16.4) & 142 & (11.6) & 60 & (7.6) & 18 & (4.1) & 282 & $(16.3)$ & 22.1 & $(1.13)$ & 190 & (13.4) & 14.9 & $(0.97)$ \\
\hline $\begin{array}{l}\text { Families with female householder, } \\
\text { no spouse present }\end{array}$ & 3,086 & (51.9) & 2,040 & (42.8) & 66.1 & $(0.83)$ & 29.5 & $(0.54)$ & 851 & (28.1) & 689 & (25.4) & 339 & (17.9) & 162 & (12.4) & 970 & $(30.0)$ & 31.4 & $(0.82)$ & 504 & (21.8) & 16.3 & $(0.65)$ \\
\hline Asian². & 4,149 & (55.9) & 1,960 & (41.0) & 47.2 & $(0.76)$ & 100.0 & $(\dagger$ & 859 & (28.0) & 859 & (28.0) & 190 & (13.4) & 52 & $(7.0)$ & 920 & (28.9) & 22.2 & $(0.63)$ & 532 & 22.2) & 12.8 & $0.51)$ \\
\hline Married-c & 3,298 & (51.2) & 1,678 & (38.2) & 50.9 & $(0.85)$ & 85.6 & $(0.77)$ & 698 & (25.3) & 782 & (26.7) & 161 & (12.3) & 38 & (6.0) & 813 & (27.2) & 24.7 & $(0.73)$ & 471 & (20.9) & 14.3 & $(0.59)$ \\
\hline $\begin{array}{l}\text { Families with male householder, } \\
\text { no spouse present }\end{array}$ & 320 & (17.3) & 69 & (8.1) & 21.6 & (2.24) & 3.5 & $(0.41)$ & 44 & (6.5) & 19 & (4.3) & $4 !$ & (2.0) & $\ddagger$ & $(t)$ & 32 & (5.5) & 10.0 & $(1.64)$ & 23 & (4.7) & 7.2 & (1.41) \\
\hline $\begin{array}{l}\text { Families with female } h \\
\text { no spouse presen }\end{array}$ & 531 & (22.2) & 212 & (14.1) & 39.9 & $(2.07)$ & 10.8 & $(0.68)$ & 118 & (10.6) & 58 & (7.4) & 24 & (4.8) & 12 & (3.4) & 75 & (8.4) & 14.1 & (1.47) & 37 & (5.9) & 7.0 & $(1.08)$ \\
\hline
\end{tabular}

ele householder,

.

White, non-Hispanic

Families with male householder,

Families with female householder,

no spouse present.

Married-couple families

milies with male householder,

no

spanic

Families with male householder

no spouse present .................

Married-couple families...........................

no spouse present

NOTE: A family household consists of two or more people who are related by birth, marriage, or adoption and are residing together. Own children are never-married sons and daughters, including stepchildren and adopted children, of the householder or married couple. Detail may not sum to totals because of rounding. Survey (CPS), Annual Social and Economic Supplement, retrieved August 25, 2013, from hitp://www.census.gov/hhes/families/data cps2012.html. (This table was prepared August 2013.) 
Table 102.30. Median household income, by state: Selected years, 1990 through 2012

[In constant 2012 dollars. Standard errors appear in parentheses]

\begin{tabular}{|c|c|c|c|c|c|c|c|c|c|c|c|c|c|c|c|c|}
\hline State & $1990^{1}$ & $2000^{2}$ & & 2005 & & 2007 & & 2008 & & 2009 & & 2010 & & 2011 & & 2012 \\
\hline 1 & 2 & 3 & & 4 & & 5 & & 6 & & 7 & & 8 & & 9 & & 10 \\
\hline United States .................... & $\$ 53,737$ & $\$ 57,868$ & $\$ 54,400$ & $(\$ 70)$ & $\$ 56,200$ & $(\$ 50)$ & $\$ 55,500$ & $(\$ 50)$ & $\$ 53,800$ & $(\$ 50)$ & $\$ 52,700$ & $(\$ 40)$ & $\$ 51,600$ & $(\$ 50)$ & $\$ 51,400$ & $(\$ 30)$ \\
\hline 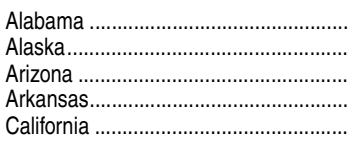 & $\begin{array}{l}42,189 \\
74,034 \\
49,239 \\
37,809 \\
64,004\end{array}$ & $\begin{array}{l}47,039 \\
71,066 \\
55,889 \\
44,347 \\
65,446\end{array}$ & $\begin{array}{l}43,400 \\
66,100 \\
52,100 \\
41,200 \\
63,100\end{array}$ & $\begin{array}{r}(380) \\
(1,290) \\
(460) \\
(430) \\
(230)\end{array}$ & $\begin{array}{l}44,900 \\
71,200 \\
55,200 \\
42,200 \\
66,400\end{array}$ & $\begin{array}{r}(290) \\
(1,070) \\
(340) \\
(500) \\
(200)\end{array}$ & $\begin{array}{l}45,500 \\
73,000 \\
54,300 \\
41,400 \\
65,100\end{array}$ & $\begin{array}{r}(440) \\
(1,240) \\
(330) \\
(460) \\
(150)\end{array}$ & $\begin{array}{l}43,300 \\
71,700 \\
52,200 \\
40,500 \\
63,100\end{array}$ & $\begin{array}{r}(340) \\
(1,520) \\
(310) \\
(410) \\
(180)\end{array}$ & $\begin{array}{l}42,600 \\
68,000 \\
49,300 \\
40,300 \\
60,800\end{array}$ & $\begin{array}{r}(300) \\
(1,330) \\
(340) \\
(410) \\
(230)\end{array}$ & $\begin{array}{l}42,300 \\
69,200 \\
47,700 \\
39,600 \\
58,500\end{array}$ & $\begin{array}{r}(340) \\
(1,210) \\
(340) \\
(470) \\
(170)\end{array}$ & & $\begin{array}{r}(290) \\
(1,150) \\
(370) \\
(300) \\
(220)\end{array}$ \\
\hline 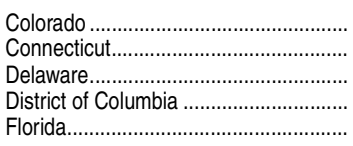 & $\begin{array}{l}53,888 \\
74,593 \\
62,353 \\
54,937 \\
49,137\end{array}$ & $\begin{array}{l}65,046 \\
74,323 \\
65,292 \\
55,296 \\
53,493\end{array}$ & $\begin{array}{l}59,600 \\
71,700 \\
61,700 \\
55,500 \\
49,900\end{array}$ & $\begin{array}{r}(400) \\
(580) \\
(1,010) \\
(1,380) \\
(190)\end{array}$ & $\begin{array}{l}61,100 \\
73,100 \\
60,500 \\
60,200 \\
52,900\end{array}$ & $\begin{array}{r}(440) \\
(550) \\
(1,060) \\
(1,340) \\
(230)\end{array}$ & $\begin{array}{l}60,800 \\
73,200 \\
61,800 \\
61,800 \\
51,000\end{array}$ & $\begin{array}{r}(400) \\
(730) \\
(1,040) \\
(1,560) \\
(230)\end{array}$ & $\begin{array}{l}59,300 \\
71,800 \\
60,900 \\
63,500 \\
47,900\end{array}$ & $\begin{array}{r}(460) \\
(650) \\
(1,130) \\
(1,110) \\
(190)\end{array}$ & $\begin{array}{l}56,900 \\
67,400 \\
58,800 \\
64,100 \\
46,800\end{array}$ & $\begin{array}{l}(470) \\
(700) \\
(960) \\
(990) \\
(210)\end{array}$ & $\begin{array}{l}56,500 \\
67,100 \\
60,000 \\
64,400 \\
45,200\end{array}$ & $\begin{array}{r}(380) \\
(530) \\
(980) \\
(1,490) \\
(250)\end{array}$ & & $\begin{array}{r}(360) \\
(530) \\
(970) \\
(1,240) \\
(210)\end{array}$ \\
\hline 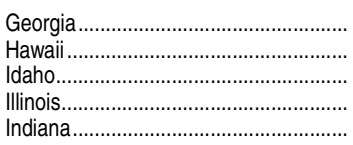 & $\begin{array}{l}51,887 \\
69,423 \\
45,157 \\
57,664 \\
51,486\end{array}$ & $\begin{array}{l}58,473 \\
68,653 \\
51,775 \\
64,202 \\
57,280\end{array}$ & $\begin{array}{l}53,600 \\
68,300 \\
48,700 \\
59,100 \\
51,700\end{array}$ & $\begin{array}{r}(310) \\
(1,410) \\
(600) \\
(240) \\
(360)\end{array}$ & $\begin{array}{l}54,400 \\
70,600 \\
51,200 \\
59,900 \\
52,500\end{array}$ & $\begin{array}{r}(330) \\
(1,290) \\
(510) \\
(250) \\
(250)\end{array}$ & $\begin{array}{l}54,200 \\
71,700 \\
50,700 \\
60,000 \\
51,200\end{array}$ & $\begin{array}{r}(270) \\
(1,210) \\
(620) \\
(240) \\
(350)\end{array}$ & $\begin{array}{l}50,900 \\
68,600 \\
48,100 \\
57,800 \\
48,600\end{array}$ & $\begin{array}{r}(270) \\
(1,020) \\
(620) \\
(260) \\
(300)\end{array}$ & $\begin{array}{l}48,900 \\
66,400 \\
45,800 \\
55,800 \\
47,000\end{array}$ & $\begin{array}{r}(300) \\
(1,000) \\
(640) \\
(280) \\
(290)\end{array}$ & & $\begin{array}{l}(280) \\
(640) \\
(820) \\
(320) \\
(280)\end{array}$ & & $\begin{array}{l}(230) \\
(990) \\
(560) \\
(250) \\
(260)\end{array}$ \\
\hline 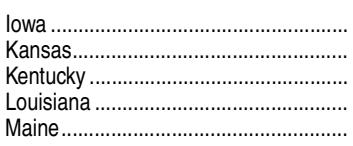 & $\begin{array}{l}46,895 \\
48,794 \\
40,289 \\
39,243 \\
49,800\end{array}$ & $\begin{array}{l}54,389 \\
55,980 \\
46,400 \\
44,876 \\
51,317\end{array}$ & $\begin{array}{l}51,300 \\
50,500 \\
44,000 \\
43,200 \\
50,300\end{array}$ & $\begin{array}{l}(370) \\
(520) \\
(340) \\
(410) \\
(690)\end{array}$ & $\begin{array}{l}52,400 \\
52,500 \\
44,600 \\
45,300 \\
50,800\end{array}$ & $\begin{array}{l}(390) \\
(430) \\
(350) \\
(310) \\
(480)\end{array}$ & $\begin{array}{l}52,200 \\
53,500 \\
44,300 \\
46,600 \\
49,700\end{array}$ & $\begin{array}{l}(420) \\
(310) \\
(290) \\
(410) \\
(580)\end{array}$ & $\begin{array}{l}51,400 \\
51,200 \\
42,900 \\
45,500 \\
49,000\end{array}$ & $\begin{array}{l}(280) \\
(440) \\
(350) \\
(410) \\
(610)\end{array}$ & & $\begin{array}{l}(410) \\
(560) \\
(320) \\
(450) \\
(610)\end{array}$ & & $\begin{array}{l}(430) \\
(470) \\
(290) \\
(330) \\
(500)\end{array}$ & & $\begin{array}{l}(260) \\
(320) \\
(250) \\
(410) \\
(550)\end{array}$ \\
\hline 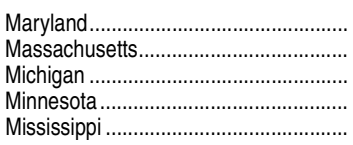 & $\begin{array}{l}70,419 \\
66,067 \\
55,461 \\
55,263 \\
36,001\end{array}$ & $\begin{array}{l}72,853 \\
69,592 \\
61,552 \\
64,920 \\
43,173\end{array}$ & $\begin{array}{l}72,400 \\
67,300 \\
54,100 \\
61,200 \\
38,700\end{array}$ & $\begin{array}{l}(430) \\
(500) \\
(320) \\
(260) \\
(440)\end{array}$ & $\begin{array}{l}69,100 \\
53,100 \\
61,800 \\
40,200\end{array}$ & $\begin{array}{l}(500) \\
(340) \\
(260) \\
(410) \\
(460)\end{array}$ & $\begin{array}{l}69,700 \\
51,800 \\
61,100 \\
40,300\end{array}$ & $\begin{array}{l}(400) \\
(390) \\
(270) \\
(340) \\
(440)\end{array}$ & $\begin{array}{l}68,600 \\
48,400 \\
59,500 \\
39,200\end{array}$ & $\begin{array}{l}(450) \\
(440) \\
(230) \\
(360) \\
(450)\end{array}$ & & $\begin{array}{l}(590) \\
(260) \\
(200) \\
(290) \\
(410)\end{array}$ & & $\begin{array}{l}(500) \\
(560) \\
(200) \\
(300) \\
(360)\end{array}$ & & $\begin{array}{l}(390) \\
(200) \\
(410) \\
(360)\end{array}$ \\
\hline 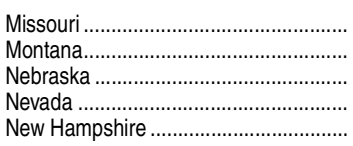 & $\begin{array}{l}47,133 \\
41,100 \\
46,514 \\
55,445 \\
64,953\end{array}$ & $\begin{array}{l}45,508 \\
54,087 \\
61,433 \\
68,166\end{array}$ & $\begin{array}{l}49,400 \\
46,200 \\
51,600 \\
57,800 \\
66,800\end{array}$ & $\begin{array}{l}(260) \\
(690) \\
(540) \\
(640) \\
(710)\end{array}$ & $\begin{array}{l}40,<00 \\
52,100 \\
61,000 \\
69,100\end{array}$ & $\begin{array}{l}(330) \\
(690) \\
(460) \\
(630) \\
(770)\end{array}$ & $\begin{array}{l}46,600 \\
53,000 \\
60,100 \\
68,000\end{array}$ & $\begin{array}{r}(240) \\
(820) \\
(530) \\
(510) \\
(1,060)\end{array}$ & $\begin{array}{l}48,400 \\
45,300 \\
50,700 \\
57,100 \\
64,800\end{array}$ & $\begin{array}{l}(340) \\
(700) \\
(520) \\
(640) \\
(900)\end{array}$ & & $\begin{array}{l}(320) \\
(720) \\
(580) \\
(510) \\
(730)\end{array}$ & & $\begin{array}{l}(330) \\
(670) \\
(430) \\
(630) \\
(880)\end{array}$ & & $\begin{array}{l}(250) \\
(660) \\
(350) \\
(500) \\
(930)\end{array}$ \\
\hline 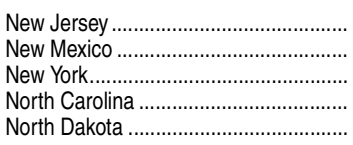 & $\begin{array}{l}73,174 \\
43,065 \\
58,938 \\
47,642 \\
41,503\end{array}$ & $\begin{array}{l}47,036 \\
59,796 \\
53,996 \\
47,685\end{array}$ & $\begin{array}{l}72,500 \\
44,100 \\
58,200 \\
47,900 \\
48,300\end{array}$ & $\begin{array}{l}(380) \\
(540) \\
(300) \\
(230) \\
(500)\end{array}$ & $\begin{array}{l}45,900 \\
59,300 \\
49,500 \\
48,500\end{array}$ & $\begin{array}{l}(390) \\
(460) \\
(230) \\
(290) \\
(810)\end{array}$ & & $\begin{array}{l}(330) \\
(590) \\
(250) \\
(270) \\
(630)\end{array}$ & & $\begin{array}{l}(430) \\
(670) \\
(260) \\
(240) \\
(650)\end{array}$ & & $\begin{array}{r}(490) \\
(470) \\
(240) \\
(240) \\
(1,010)\end{array}$ & & $\begin{array}{l}(450) \\
(500) \\
(250) \\
(320) \\
(780)\end{array}$ & & $\begin{array}{l}(550) \\
(230) \\
(240) \\
(940)\end{array}$ \\
\hline 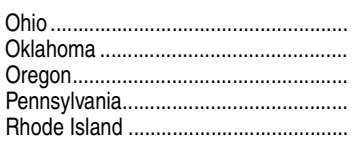 & $\begin{array}{l}51,324 \\
42,154 \\
48,721 \\
51,973 \\
57,537\end{array}$ & $\begin{array}{l}56,438 \\
46,026 \\
56,383 \\
55,267 \\
58,001\end{array}$ & $\begin{array}{l}51,200 \\
43,600 \\
50,500 \\
52,400 \\
60,500\end{array}$ & $\begin{array}{l}(240) \\
(400) \\
(420) \\
(280) \\
(980)\end{array}$ & $\begin{array}{l}51,600 \\
46,000 \\
54,000 \\
53,800 \\
59,300\end{array}$ & $\begin{array}{l}(200) \\
(270) \\
(460) \\
(200) \\
(910)\end{array}$ & $\begin{array}{l}51,200 \\
45,700 \\
53,500 \\
54,100 \\
59,400\end{array}$ & $\begin{array}{r}(210) \\
(460) \\
(340) \\
(170) \\
(1,160)\end{array}$ & $\begin{array}{l}48,600 \\
44,600 \\
51,900 \\
53,000 \\
57,900\end{array}$ & $\begin{array}{l}(230) \\
(330) \\
(410) \\
(190) \\
(990)\end{array}$ & & $\begin{array}{l}(190) \\
(260) \\
(350) \\
(280) \\
(800)\end{array}$ & & $\begin{array}{r}(200) \\
(380) \\
(440) \\
(180) \\
(1,050)\end{array}$ & & $\begin{array}{r}(180) \\
(280) \\
(490) \\
(160) \\
(1,090)\end{array}$ \\
\hline $\begin{array}{l}\text { South Carolina } \\
\text { South Dakota } \\
\text { Tennessee } \\
\text { Texas } \\
\text { Utah }\end{array}$ & $\begin{array}{l}46,943 \\
40,233 \\
44,353 \\
48,302 \\
52,690\end{array}$ & $\begin{array}{l}51,100 \\
48,619 \\
50,105 \\
55,020 \\
63,011\end{array}$ & $\begin{array}{l}46,200 \\
47,400 \\
45,700 \\
49,600 \\
56,400\end{array}$ & $\begin{array}{l}(440) \\
(640) \\
(340) \\
(180) \\
(680)\end{array}$ & $\begin{array}{l}48,000 \\
48,100 \\
46,900 \\
52,700 \\
61,000\end{array}$ & $\begin{array}{l}(430) \\
(640) \\
(230) \\
(210) \\
(510)\end{array}$ & $\begin{array}{l}47,600 \\
49,100 \\
46,500 \\
53,400 \\
60,400\end{array}$ & $\begin{array}{l}(410) \\
(760) \\
(280) \\
(140) \\
(460)\end{array}$ & $\begin{array}{l}45,400 \\
48,200 \\
44,700 \\
51,700 \\
59,000\end{array}$ & $\begin{array}{l}(370) \\
(790) \\
(290) \\
(160) \\
(520)\end{array}$ & & $\begin{array}{l}(270) \\
(780) \\
(260) \\
(220) \\
(400)\end{array}$ & & $\begin{array}{l}(350) \\
(990) \\
(260) \\
(240) \\
(500)\end{array}$ & & $\begin{array}{l}(400) \\
(590) \\
(350) \\
(160) \\
(450)\end{array}$ \\
\hline 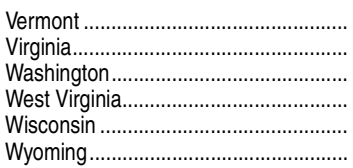 & $\begin{array}{l}53,265 \\
59,587 \\
55,752 \\
37,180 \\
52,640 \\
48,445\end{array}$ & $\begin{array}{l}56,300 \\
64,322 \\
63,080 \\
40,922 \\
60,345 \\
52,216\end{array}$ & $\begin{array}{l}53,700 \\
63,800 \\
57,900 \\
39,300 \\
55,400 \\
54,300\end{array}$ & $\begin{array}{r}(860) \\
(390) \\
(460) \\
(570) \\
(280) \\
(1,090)\end{array}$ & $\begin{array}{l}55,300 \\
66,000 \\
61,600 \\
41,000 \\
56,000 \\
57,300\end{array}$ & $\begin{array}{l}(790) \\
(400) \\
(340) \\
(510) \\
(250) \\
(890)\end{array}$ & $\begin{array}{l}55,600 \\
65,300 \\
61,900 \\
40,500 \\
55,600 \\
56,700\end{array}$ & $\begin{array}{r}(640) \\
(280) \\
(370) \\
(660) \\
(230) \\
(1,290)\end{array}$ & $\begin{array}{l}55,300 \\
63,500 \\
60,500 \\
40,100 \\
53,500 \\
56,400\end{array}$ & $\begin{array}{r}(620) \\
(310) \\
(340) \\
(460) \\
(260) \\
(1,220)\end{array}$ & $\begin{array}{l}52,000 \\
63,900 \\
58,600 \\
40,200 \\
51,600 \\
56,400\end{array}$ & $\begin{array}{r}(950) \\
(290) \\
(350) \\
(570) \\
(320) \\
(1,210)\end{array}$ & $\begin{array}{l}53,900 \\
63,200 \\
58,000 \\
39,300 \\
51,400 \\
57,500\end{array}$ & $\begin{array}{r}(880) \\
(310) \\
(350) \\
(540) \\
(270) \\
(1,170)\end{array}$ & $\begin{array}{l}53,000 \\
61,700 \\
57,600 \\
40,200 \\
51,100 \\
54,900\end{array}$ & $\begin{array}{l}(770) \\
(250) \\
(360) \\
(420) \\
(200) \\
(910)\end{array}$ \\
\hline
\end{tabular}

'Based on 1989 incomes collected in the 1990 census.

2Based on 1999 incomes collected in the 2000 census.

NOTE: Constant dollars adjusted by the Consumer Price Index research series using current methods (CPI-U-RS).

SOURCE: U.S. Department of Commerce, Census Bureau, 1990 Summary Tape File 3 (STF 3), "Median Household Income in 1989," retrieved May 12, 2005 (https://www.census.gov/ hhes/www/income/data/historical/state/state1.html); Decennial Census, 2000, Summary Social, Economic, and Housing Characteristics; Census 2000 Summary File 4 (SF 4), retrieved March 28, 2005 (http://factfinder2.census.gov/faces/tableservices/isf/pages/product view.xhtml?pid=DEC 00 SF4 PCT089\&prodType=table); and American Community Survey, 2005 through 2012. (This table was prepared December 2013.) 
Table 102.40. Poverty rates for all persons and poverty status of 5- to 17-year-olds, by region and state: Selected years, 1990 through 2012 [Standard errors appear in parentheses]

\begin{tabular}{|c|c|c|c|c|c|c|c|c|c|c|c|c|c|c|c|c|c|c|}
\hline \multirow[b]{3}{*}{ Region and state } & \multicolumn{6}{|c|}{ Percent of persons in poverty } & \multicolumn{12}{|c|}{ Poverty status of related children ${ }^{1} 5$ through 17 years old } \\
\hline & \multirow[b]{2}{*}{$1990^{2}$} & \multirow[b]{2}{*}{$2000^{3}$} & \multirow{2}{*}{\multicolumn{2}{|c|}{$2011^{4}$}} & \multirow{2}{*}{\multicolumn{2}{|c|}{$2012^{4}$}} & \multirow{2}{*}{\multicolumn{2}{|c|}{$\begin{array}{r}1990,,^{2} \\
\text { percent } \\
\text { in poverty }\end{array}$}} & \multirow{2}{*}{\multicolumn{2}{|c|}{$\begin{array}{r}2000,,^{3} \\
\text { percent } \\
\text { in poverty }\end{array}$}} & \multicolumn{4}{|c|}{$2011^{4}$} & \multicolumn{4}{|c|}{$2012^{4}$} \\
\hline & & & & & & & & & & & $\begin{array}{r}\text { in } \\
\text { (in tho }\end{array}$ & & & & $\begin{array}{c}\text { in } \\
\text { (in thou }\end{array}$ & $\begin{array}{l}\text { mber } \\
\text { verty } \\
\text { ands) }\end{array}$ & & $\begin{array}{l}\text { ercent } \\
\text { overty } \\
\end{array}$ \\
\hline 1 & 2 & 3 & & 4 & & 5 & & - & & 7 & & 8 & & 9 & & 10 & & 11 \\
\hline United States .... & 13.1 & 12.4 & 15.9 & $0.06)$ & 15.8 & $0.07)$ & 17.0 & $(0.02)$ & 15.4 & $(0.01)$ & 10,884 & 72.4) & 0.7 & (0.14) & 11,060 & (77.8) & 21.0 & $0.14)$ \\
\hline 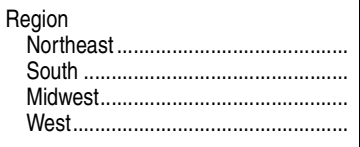 & $\begin{array}{l}10.6 \\
15.7 \\
12.0 \\
12.6\end{array}$ & & $\begin{array}{l}13.3 \\
17.4 \\
14.9 \\
16.1\end{array}$ & $\begin{array}{l}(0.10) \\
(0.08) \\
(0.12) \\
(0.11)\end{array}$ & $\begin{array}{l}13.6 \\
17.3 \\
14.9 \\
16.1\end{array}$ & $\begin{array}{l}(0.11) \\
(0.09) \\
(0.10) \\
(0.10)\end{array}$ & $\begin{array}{l}14.3 \\
20.5 \\
14.9 \\
16.2\end{array}$ & $\begin{array}{l}(0.54) \\
(0.90) \\
(0.58) \\
(0.79)\end{array}$ & $\begin{array}{l}14.3 \\
17.6 \\
12.0 \\
16.2\end{array}$ & $\begin{array}{l}(0.39) \\
(0.64) \\
(0.37) \\
(0.54)\end{array}$ & $\begin{array}{l}1,521 \\
4,584 \\
2,163 \\
2,618\end{array}$ & $\begin{array}{l}(21.7) \\
(34.8) \\
(29.3) \\
(30.1)\end{array}$ & $\begin{array}{l}17.2 \\
23.1 \\
19.0 \\
20.7\end{array}$ & $\begin{array}{l}(0.24) \\
(0.17) \\
(0.26) \\
(0.24)\end{array}$ & $\begin{array}{l}1,567 \\
4,644 \\
2,160 \\
2,689\end{array}$ & $\begin{array}{l}(21.6) \\
(43.8) \\
(26.2) \\
(27.9)\end{array}$ & $\begin{array}{l}17.9 \\
23.3 \\
19.0 \\
21.2\end{array}$ & $\begin{array}{l}(0.25) \\
(0.22) \\
(0.22) \\
(0.22)\end{array}$ \\
\hline Alabama ... & $\begin{array}{r}18.3 \\
9.0 \\
15.7 \\
19.1 \\
12.5\end{array}$ & $\begin{array}{r}16.1 \\
9.4 \\
13.9 \\
15.8 \\
14.2\end{array}$ & $\begin{array}{l}19.1 \\
10.2 \\
19.1 \\
18.7 \\
16.6\end{array}$ & $\begin{array}{l}(0.42) \\
(0.80) \\
(0.39) \\
(0.49) \\
(0.14)\end{array}$ & $\begin{array}{l}18.7 \\
11.3 \\
18.3 \\
19.0 \\
16.8\end{array}$ & $\begin{array}{l}(0.36) \\
(0.77) \\
(0.27) \\
(0.46) \\
(0.13)\end{array}$ & $\begin{array}{r}23.2 \\
9.6 \\
20.3 \\
23.8 \\
17.2\end{array}$ & $\begin{array}{l}(0.16) \\
(0.27) \\
(0.15) \\
(0.20) \\
(0.06)\end{array}$ & $\begin{array}{l}20.3 \\
10.3 \\
17.8 \\
20.1 \\
18.5\end{array}$ & & $\begin{array}{r}209 \\
18 \\
297 \\
123 \\
1,429\end{array}$ & $\begin{array}{r}(7.6) \\
(2.8) \\
(9.9) \\
(5.1) \\
(17.9)\end{array}$ & $\begin{array}{l}25.7 \\
14.0 \\
26.0 \\
24.4 \\
21.7\end{array}$ & $\begin{array}{l}(1.02) \\
(0.27)\end{array}$ & $\begin{array}{r}203 \\
18 \\
285 \\
129 \\
1,505\end{array}$ & $\begin{array}{r}(6.3) \\
(2.1) \\
(7.1) \\
(5.3) \\
(19.5)\end{array}$ & $\begin{array}{l}24.9 \\
13.7 \\
24.7 \\
25.5 \\
22.9\end{array}$ & $\begin{array}{l}(0.77) \\
(1.59) \\
(0.59) \\
(1.04) \\
(0.30)\end{array}$ \\
\hline Colorado & $\begin{array}{r}11.7 \\
6.8 \\
8.7 \\
16.9 \\
12.7\end{array}$ & $\begin{array}{r}9.3 \\
7.9 \\
9.2 \\
20.2 \\
12.5\end{array}$ & $\begin{array}{l}13.3 \\
10.9 \\
12.2 \\
18.9 \\
17.0\end{array}$ & $\begin{array}{l}(0.32) \\
(0.35) \\
(0.68)\end{array}$ & $\begin{array}{l}13.6 \\
10.8\end{array}$ & $\begin{array}{l}(0.28) \\
(0.34) \\
(0.70)\end{array}$ & $\begin{array}{r}13.7 \\
9.8 \\
11.0\end{array}$ & $\begin{array}{l}(0.13) \\
(0.15) \\
(0.27) \\
(0.59) \\
(0.10)\end{array}$ & $\begin{array}{r}10.0 \\
9.6 \\
10.9 \\
30.4 \\
16.6\end{array}$ & & $\begin{array}{r}136 \\
84 \\
24 \\
20 \\
663\end{array}$ & $\begin{array}{r}(6.9) \\
(4.2) \\
(2.6) \\
(2.1) \\
(11.8)\end{array}$ & 15.6 & & $\begin{array}{r}155 \\
82 \\
21 \\
19 \\
687\end{array}$ & $\begin{array}{r}(6.1) \\
(4.5) \\
(2.5) \\
(1.8) \\
(12.4)\end{array}$ & $\begin{array}{l}17.7 \\
13.9 \\
14.2\end{array}$ & $\begin{array}{l}(0.69) \\
(0.76) \\
(1.66) \\
(2.55) \\
(0.43)\end{array}$ \\
\hline Georgia & $\begin{array}{r}14.7 \\
8.3 \\
13.3 \\
11.9 \\
10.7\end{array}$ & 13.0 & $\begin{array}{l}19.1 \\
12.0\end{array}$ & & & & 18.9 & & $\begin{array}{l}16.1 \\
12.9 \\
12.6\end{array}$ & & $\begin{array}{r}437 \\
37 \\
49 \\
436 \\
231\end{array}$ & & 24.5 & & $\begin{array}{r}453 \\
34 \\
59 \\
430 \\
224\end{array}$ & $\begin{array}{r}(11.2) \\
(3.3) \\
(4.7) \\
(11.1) \\
(7.7)\end{array}$ & $\begin{array}{l}25.2 \\
16.5 \\
19.2 \\
19.4 \\
19.7\end{array}$ & $\begin{array}{l}(0.61) \\
(1.60) \\
(1.52) \\
(0.51) \\
(0.67)\end{array}$ \\
\hline & $\begin{array}{l}11.5 \\
11.5 \\
19.0 \\
23.6 \\
10.8\end{array}$ & $\begin{array}{r}9.1 \\
9.9 \\
15.8\end{array}$ & 12.8 & & 12.6 & & $\begin{array}{l}12.6 \\
128\end{array}$ & & $\begin{array}{r}9.5 \\
10.4 \\
19.4\end{array}$ & & $\begin{array}{r}82 \\
82 \\
185 \\
210 \\
34\end{array}$ & & $\begin{array}{l}16.1 \\
16.3 \\
25.8 \\
26.6 \\
17.2\end{array}$ & & $\begin{array}{r}74 \\
85 \\
178 \\
216 \\
33\end{array}$ & $\begin{array}{l}(4.8) \\
(4.4) \\
(6.7) \\
(7.4) \\
(3.4)\end{array}$ & $\begin{array}{l}14.4 \\
16.7 \\
24.7 \\
27.3 \\
17.2\end{array}$ & $\begin{array}{l}(0.92) \\
(0.87) \\
(0.96) \\
(0.93) \\
(1.76)\end{array}$ \\
\hline Maryland & $\begin{array}{r}8.3 \\
8.9 \\
13.1 \\
10.2 \\
25.2\end{array}$ & $\begin{array}{r}8.5 \\
9.3 \\
10.5 \\
7.9 \\
19.9\end{array}$ & $\begin{array}{l}10.1 \\
11.7 \\
17.0 \\
11.6 \\
22.5\end{array}$ & $(0.25)$ & 10.1 & $(0.27)$ & 10.5 & & $\begin{array}{r}9.8 \\
11.4 \\
12.7 \\
8.7 \\
26.0\end{array}$ & & $\begin{array}{l}356 \\
116 \\
155\end{array}$ & $\begin{array}{r}(5.9) \\
(6.0) \\
(10.7) \\
(5.9)\end{array}$ & $\begin{array}{l}12.5 \\
14.1 \\
21.4 \\
12.7 \\
28.9\end{array}$ & & $\begin{array}{l}119 \\
153 \\
381 \\
118 \\
170\end{array}$ & $\begin{array}{l}(5.4) \\
(5.9) \\
(9.6) \\
(6.3) \\
(6.9)\end{array}$ & $\begin{array}{l}12.4 \\
15.0 \\
23.1 \\
12.9 \\
31.7\end{array}$ & $\begin{array}{l}(0.57) \\
(0.58) \\
(0.59)\end{array}$ \\
\hline New Hampshire ................................... & $\begin{array}{r}13.3 \\
16.1 \\
11.1 \\
10.2 \\
6.4\end{array}$ & $\begin{array}{r}9.7 \\
10.5 \\
6.5\end{array}$ & $\begin{array}{r}11.9 \\
16.1 \\
8.8\end{array}$ & $\begin{array}{l}(0.50) \\
(0.52)\end{array}$ & 9.6 & $\begin{array}{l}(0.48) \\
(0.64)\end{array}$ & $\begin{array}{l}16.2 \\
18.4 \\
12.0\end{array}$ & $\begin{array}{l}(0.26) \\
(0.16)\end{array}$ & $\begin{array}{r}14.4 \\
17.1 \\
11.1 \\
12.3 \\
6.7\end{array}$ & & $\begin{array}{r}199 \\
26 \\
44 \\
100 \\
22\end{array}$ & & 19.9 & & $\begin{array}{r}207 \\
28 \\
45 \\
97 \\
26\end{array}$ & $\begin{array}{l}(8.0) \\
(2.8) \\
(3.2) \\
(5.0) \\
(2.7)\end{array}$ & $\begin{array}{l}20.7 \\
18.0 \\
14.0 \\
20.7 \\
12.8\end{array}$ & $\begin{array}{l}(0.77) \\
(1.75) \\
(0.99)\end{array}$ \\
\hline & $\begin{array}{r}7.6 \\
20.6 \\
13.0 \\
13.0 \\
14.4\end{array}$ & $\begin{array}{r}8.5 \\
18.4 \\
14.6 \\
12.3 \\
11.9\end{array}$ & $\begin{array}{l}10.3 \\
21.4 \\
15.8 \\
17.6 \\
11.0\end{array}$ & $\begin{array}{l}(0.16) \\
(0.26) \\
(0.68)\end{array}$ & & $\begin{array}{l}(0.21) \\
(0.58) \\
(0.15) \\
(0.26) \\
(0.63)\end{array}$ & $\begin{array}{l}18.1 \\
16.0 \\
15.9\end{array}$ & & $\begin{array}{l}10.5 \\
23.6 \\
19.1\end{array}$ & & $\begin{array}{r}193 \\
103 \\
655 \\
374 \\
9\end{array}$ & $\begin{array}{r}(6.9) \\
(4.8) \\
(13.5)\end{array}$ & $\begin{array}{r}21.4 \\
22.8 \\
8.6\end{array}$ & & $\begin{array}{r}204 \\
98 \\
662 \\
385 \\
12\end{array}$ & $\begin{array}{r}(6.6) \\
(4.6) \\
(11.3) \\
(9.5) \\
(1.7)\end{array}$ & $\begin{array}{l}13.7 \\
26.6 \\
21.9 \\
23.4 \\
11.0\end{array}$ & $\begin{array}{l}(0.45) \\
(1.25) \\
(0.36) \\
(0.58) \\
(1.56)\end{array}$ \\
\hline . & $\begin{array}{r}12.5 \\
16.7 \\
12.4 \\
11.1 \\
9.6\end{array}$ & $\begin{array}{l}10.6 \\
14.7 \\
11.6 \\
11.0 \\
11.9\end{array}$ & $\begin{array}{l}16.4 \\
17.5 \\
16.9 \\
13.6 \\
14.3\end{array}$ & $\begin{array}{l}(0.26) \\
(0.45) \\
(0.38) \\
(0.24) \\
(0.67)\end{array}$ & $\begin{array}{l}13.9 \\
13.8\end{array}$ & $\begin{array}{l}(0.24) \\
(0.58)\end{array}$ & $\begin{array}{l}13.4 \\
14.5 \\
12.3\end{array}$ & $\begin{array}{l}(0.15) \\
(0.08) \\
(0.30)\end{array}$ & 15.6 & & $\begin{array}{r}422 \\
139 \\
131 \\
349 \\
29\end{array}$ & $\begin{array}{r}(11.0) \\
(6.3) \\
(5.8) \\
(12.0) \\
(2.1)\end{array}$ & $\begin{array}{l}21.6 \\
17.5 \\
18.0\end{array}$ & & $\begin{array}{r}415 \\
151 \\
121 \\
368 \\
28\end{array}$ & $\begin{array}{r}(9.7) \\
(6.8) \\
(6.4) \\
(11.4) \\
(2.4)\end{array}$ & $\begin{array}{l}21.6 \\
22.7 \\
19.6 \\
18.6 \\
17.7\end{array}$ & $\begin{array}{l}(0.50) \\
(1.03) \\
(1.04) \\
(0.56) \\
(1.50)\end{array}$ \\
\hline South Carolina & $\begin{array}{l}15.4 \\
15.9 \\
15.7 \\
18.1 \\
11.4\end{array}$ & $\begin{array}{r}14.1 \\
13.2 \\
13.5 \\
15.4 \\
9.4\end{array}$ & $\begin{array}{l}18.9 \\
12.8 \\
18.1 \\
18.3 \\
13.7\end{array}$ & $\begin{array}{l}(0.35) \\
(0.82) \\
(0.29) \\
(0.16) \\
(0.55)\end{array}$ & $\begin{array}{l}17.8 \\
12.3\end{array}$ & $\begin{array}{l}(0.32) \\
(0.69) \\
(0.30) \\
(0.17) \\
(0.45)\end{array}$ & $\begin{array}{l}20.0 \\
18.7 \\
19.5 \\
23.4 \\
10.9\end{array}$ & $\begin{array}{l}(0.09) \\
(0.16)\end{array}$ & $\begin{array}{r}17.9 \\
15.5 \\
16.6 \\
19.3 \\
8.9\end{array}$ & $\begin{array}{l}(0.12) \\
(0.21) \\
(0.10) \\
(0.06) \\
(0.09)\end{array}$ & $\begin{array}{r}195 \\
20 \\
258 \\
1,217 \\
91\end{array}$ & $\begin{array}{r}(6.8) \\
(2.2) \\
(7.6) \\
(18.2) \\
(6.9)\end{array}$ & $\begin{array}{l}25.6 \\
14.5 \\
24.2 \\
24.7 \\
14.9\end{array}$ & & $\begin{array}{r}193 \\
21 \\
260 \\
1,208 \\
86\end{array}$ & $\begin{array}{r}(6.7) \\
(2.1) \\
(8.6) \\
(18.5) \\
(5.5)\end{array}$ & $\begin{array}{l}25.0 \\
15.3 \\
24.4 \\
24.3 \\
14.0\end{array}$ & $\begin{array}{l}(0.86) \\
(1.46) \\
(0.78) \\
(0.37) \\
(0.90)\end{array}$ \\
\hline $\begin{array}{l}\text { Wisconsin } \\
\text { Wyoming }\end{array}$ & $\begin{array}{r}9.9 \\
10.2 \\
10.9 \\
19.7 \\
10.7 \\
11.9\end{array}$ & $\begin{array}{r}9.4 \\
9.6 \\
10.6 \\
17.9 \\
8.7 \\
11.4\end{array}$ & $\begin{array}{l}11.0 \\
11.6 \\
14.0 \\
18.6 \\
13.6 \\
11.2\end{array}$ & $\begin{array}{l}(0.75) \\
(0.22) \\
(0.27) \\
(0.60) \\
(0.37) \\
(0.76)\end{array}$ & $\begin{array}{l}17.3 \\
12.9 \\
12.6\end{array}$ & $\begin{array}{l}(0.29) \\
(0.74)\end{array}$ & $\begin{array}{l}24.0 \\
13.3 \\
12.6\end{array}$ & $\begin{array}{r}(0.26) \\
(0.12)\end{array}$ & $\begin{array}{l}22.9 \\
10.0 \\
12.5\end{array}$ & & $\begin{array}{r}10 \\
189 \\
188 \\
65 \\
165 \\
13\end{array}$ & $(1.3)$ & $\begin{array}{l}10.7 \\
14.3 \\
16.9 \\
23.6 \\
17.4 \\
13.9\end{array}$ & $(1.45$ & $\begin{array}{r}11 \\
197 \\
188 \\
56 \\
148 \\
15\end{array}$ & $\begin{array}{l}(2.0) \\
(6.9) \\
(7.8) \\
(4.1) \\
(6.9) \\
(1.6)\end{array}$ & 15.9 & $\begin{array}{l}(2.21) \\
(0.52) \\
(0.70) \\
(1.50) \\
(0.72) \\
(1.69)\end{array}$ \\
\hline
\end{tabular}

${ }^{1}$ Related children in a family include all children in the household who are related to the householder by birth, marriage, or adoption (except a child who is the spouse of the householder). The householder is the person (or one of the people) who owns or rents (maintains) the housing unit.

${ }^{2}$ Based on 1989 incomes and family sizes collected in the 1990 census. May differ from Current Population Survey data that are shown in other tables.

${ }^{3}$ Based on 1999 incomes and family sizes collected in the 2000 census. May differ from Current Population Survey data that are shown in other tables.

${ }^{4}$ Based on income and family size data from the American Community Survey (ACS). May differ from Current Population Survey data that are shown in other tables. ACS respondents were interviewed throughout the given year and reported the income they received during the previous 12 months.
NOTE: For information about how the Census Bureau determines who is in poverty, see http://www.census.gov/hhes/www/poverty/about/overview/measure.html. Detail may not sum to totals because of rounding.

SOURCE: U.S. Department of Commerce, Census Bureau, 1990 Summary Tape File 3 (STF 3), "Median Household Income in 1989" and "Poverty Status in 1989 by Family Type and Age"; Decennial Census, 1990, Minority Economic Profiles, unpublished data; Decennial Census, 2000, Summary Social, Economic, and Housing Characteristics; Census 2000 Summary File 4 (SF 4), "Poverty Status in 1999 of Related Children Under 18 Years by Family Type and Age"; and American Community Survey, 2011 and 2012. (This table was prepared January 2014.) 
Table 102.50. Official and supplemental measures of poverty status for all persons, persons in families, and related children under age 18, by race/ethnicity: Selected years, 1960 through 2012

[Standard errors appear in parentheses]

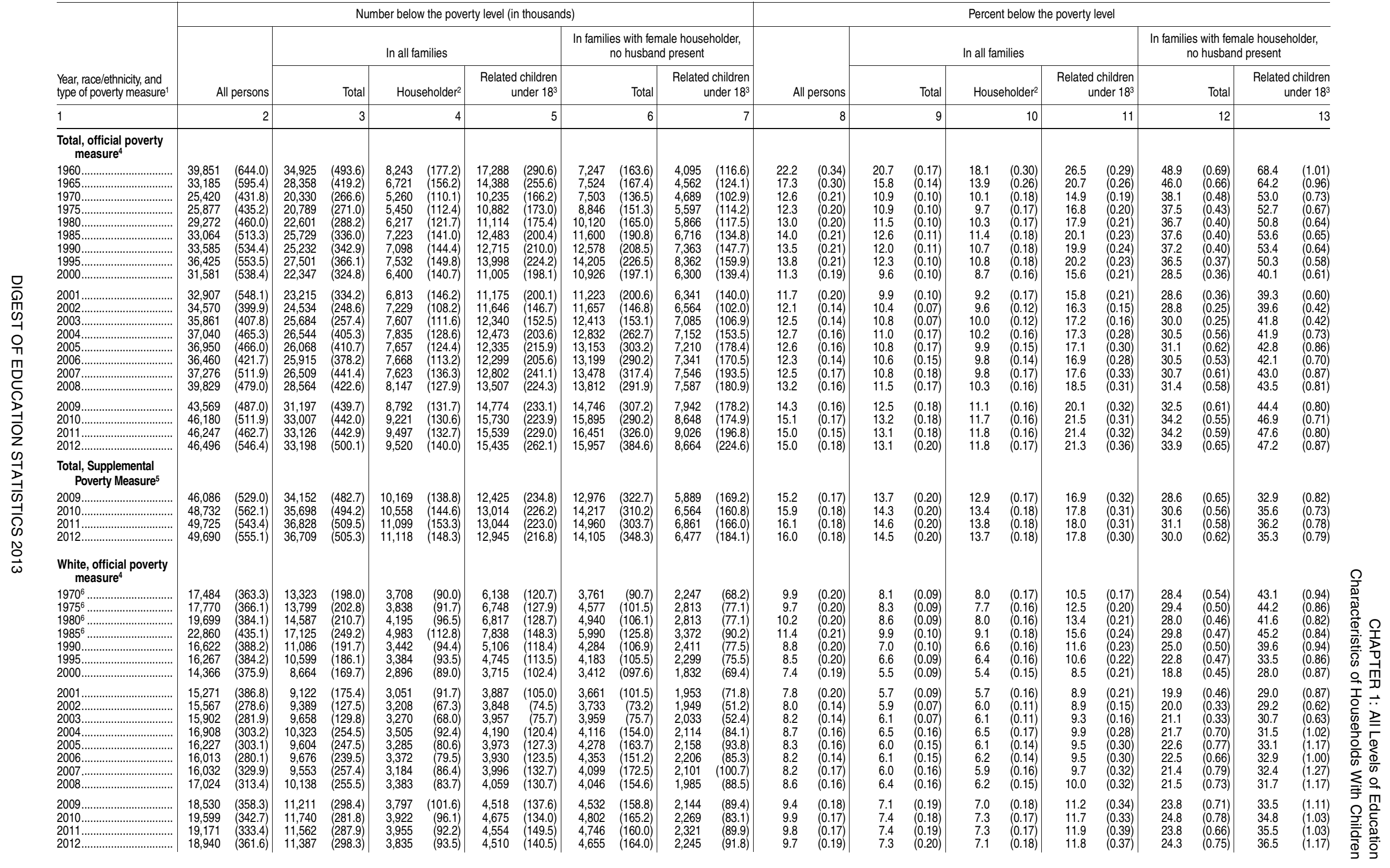



[Standard errors appear in parentheses]

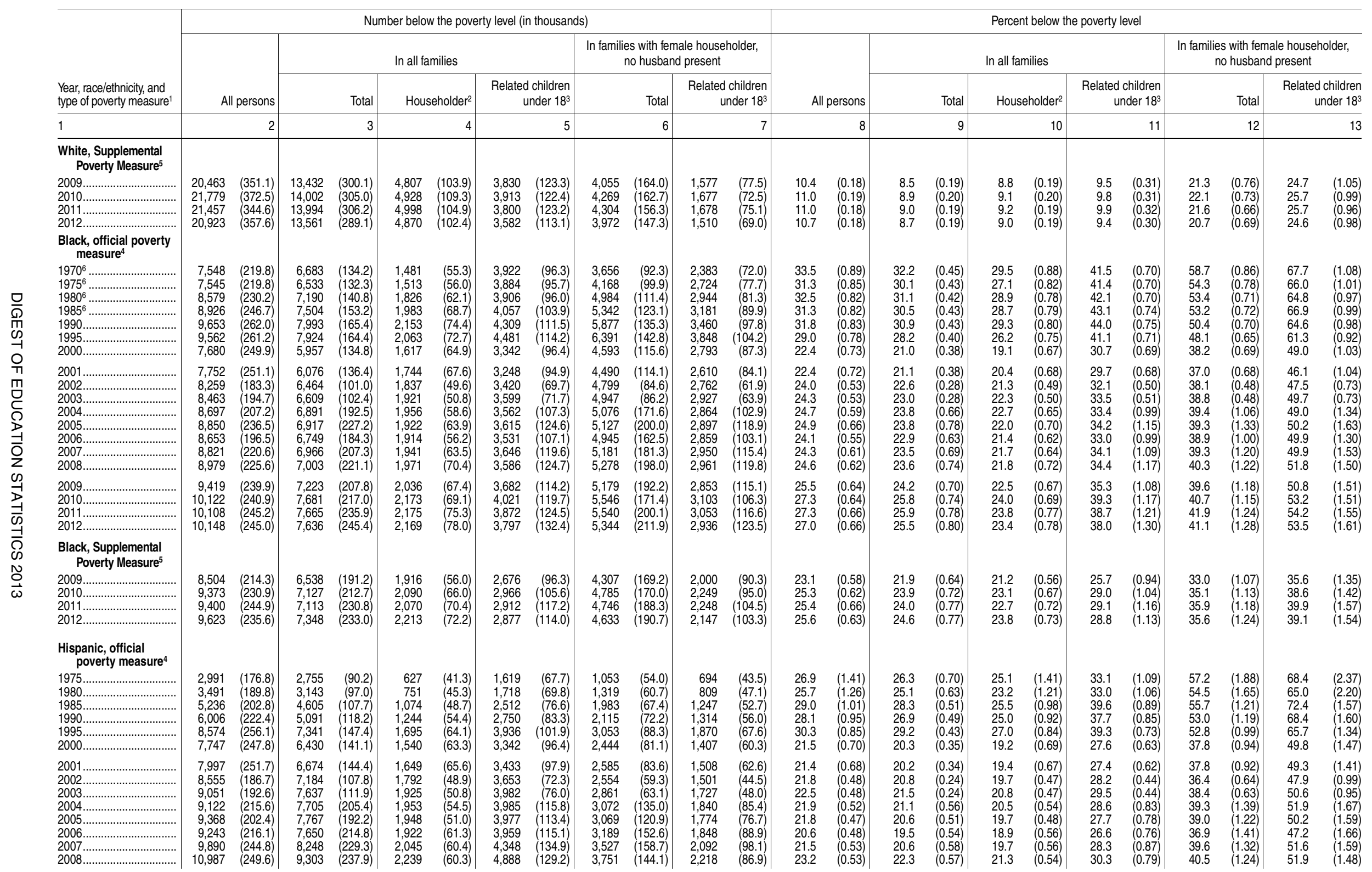

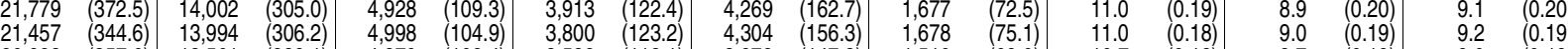
\begin{tabular}{ll|ll|ll}
9.8 & $(0.31)$ & 22.1 & $(0.73)$ & 25.7 & $(0.99)$ \\
9.9 & $(0.32)$ & 21.6 & $(0.66)$ & 25.7 & $(0.96)$ \\
\hline & & 20.7 & $(0.69)$ & 24.6 & $(0.98)$
\end{tabular} measure

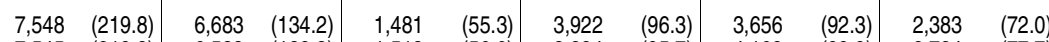

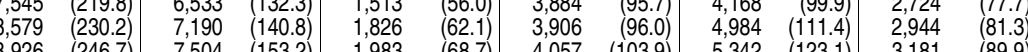

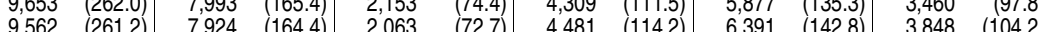
\begin{tabular}{rrrr|rr|rrrrrr}
7,680 & $(249.9)$ & 5,957 & $(134.8)$ & 1,617 & $(64.9)$ & 3,342 & $(96.4)$ & 4,593 & $(115.6)$ & 2,793 & $(87.3)$
\end{tabular}

$1950 . \ldots \ldots \ldots \ldots \ldots \ldots \ldots \ldots$ $\begin{array}{lllll}7,752 & (251.1) & 6,076 & (136.4) & 1,744\end{array}$

\begin{tabular}{r|rr|rr|rr}
$(67.6)$ & 3,248 & $(94.9)$ & 4,490 & $(114.1)$ & 2,610 & $(84.1)$ \\
\hline$(496)$ & 3,420 & $(69.7)$ & 4,799 & $(84.6$ & 2762 & $(619$
\end{tabular}

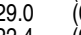
$0.73)$

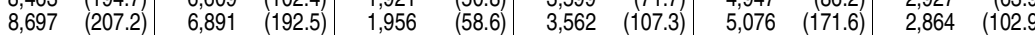
$24.3(0.53)$ \begin{tabular}{|ll|lll|ll|ll|ll|ll|}
8,979 & $(225.6)$ & 7,003 & $(221.1)$ & 1,971 & $(70.4)$ & 3,586 & $(124.7)$ & 5,278 & $(198.0)$ & 2,961 & $(119.8)$ \\
\hline
\end{tabular} 


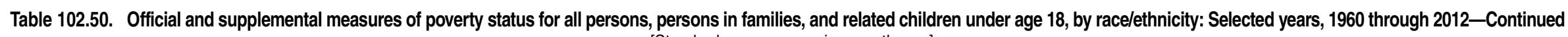
[Standard errors appear in parentheses]

\begin{tabular}{|c|c|c|c|c|c|c|c|c|c|c|c|c|c|c|c|c|c|c|c|c|c|c|c|c|}
\hline \multirow{4}{*}{$\begin{array}{l}\text { Year, race/ethnicity, and } \\
\text { type of poverty measure }\end{array}$} & \multicolumn{12}{|c|}{ Number below the poverty level (in thousands) } & \multicolumn{12}{|c|}{ Percent below the poverty level } \\
\hline & \multirow{2}{*}{\multicolumn{2}{|c|}{ All persons }} & \multicolumn{6}{|c|}{ In all families } & \multicolumn{4}{|c|}{$\begin{array}{l}\text { In families with female householder, } \\
\text { no husband present }\end{array}$} & & & \multicolumn{6}{|c|}{ In all families } & \multicolumn{4}{|c|}{$\begin{array}{l}\text { In families with female householder, } \\
\text { no husband present }\end{array}$} \\
\hline & & & & Total & \multicolumn{2}{|c|}{ Householder $^{2}$} & \multicolumn{2}{|c|}{$\begin{array}{r}\text { Related children } \\
\text { under } 18^{3}\end{array}$} & \multicolumn{2}{|r|}{ Total } & \multicolumn{2}{|c|}{$\begin{array}{r}\text { Related children } \\
\text { under } 18^{3}\end{array}$} & \multicolumn{2}{|c|}{ All persons } & \multicolumn{4}{|c|}{ Householder $^{2}$} & \multicolumn{2}{|c|}{$\begin{array}{r}\text { Related children } \\
\text { under } 18^{3}\end{array}$} & \multicolumn{2}{|r|}{ Total } & \multicolumn{2}{|c|}{$\begin{array}{r}\text { Related children } \\
\text { under } 18^{3}\end{array}$} \\
\hline & & 2 & & 3 & & 4 & & 5 & & 6 & & 7 & & 8 & & 9 & & 10 & & 11 & & 12 & & 13 \\
\hline 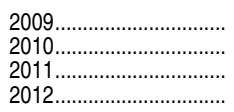 & $\begin{array}{l}12,350 \\
13,243 \\
13,244 \\
13,616\end{array}$ & $\begin{array}{l}(267.3) \\
(254.4) \\
(263.5) \\
(278.2)\end{array}$ & $\begin{array}{l}10,345 \\
11,188 \\
11,143 \\
11,358\end{array}$ & $\begin{array}{l}(254.8) \\
(242.8) \\
(253.2) \\
(276.3)\end{array}$ & $\begin{array}{l}2,369 \\
2,557 \\
2,651 \\
2,807\end{array}$ & $\begin{array}{l}(62.7) \\
(64.4) \\
(59.5) \\
(71.8)\end{array}$ & $\begin{array}{l}5,419 \\
5,881 \\
5,820 \\
5,773\end{array}$ & $\begin{array}{l}(138.6) \\
(139.4) \\
(146.1) \\
(145.5)\end{array}$ & $\begin{array}{l}4,176 \\
4,643 \\
4,996 \\
4,816\end{array}$ & $\begin{array}{l}(169.1) \\
(167.5) \\
(182.1) \\
(187.7)\end{array}$ & $\begin{array}{l}2,437 \\
2,715 \\
2,955 \\
2,809\end{array}$ & $\begin{array}{l}(100.1) \\
(107.1) \\
(120.5) \\
(114.9)\end{array}$ & $\begin{array}{l}25.3 \\
26.6 \\
25.3 \\
25.6\end{array}$ & $\begin{array}{l}(0.55) \\
(0.51) \\
(0.50) \\
(0.52)\end{array}$ & $\begin{array}{l}24.2 \\
25.6 \\
24.3 \\
24.6\end{array}$ & $\begin{array}{l}(0.59) \\
(0.55) \\
(0.56) \\
(0.59)\end{array}$ & $\begin{array}{l}22.7 \\
24.0 \\
22.9 \\
23.5\end{array}$ & $\begin{array}{l}(0.56) \\
(0.54) \\
(0.50) \\
(0.54)\end{array}$ & $\begin{array}{l}32.5 \\
34.5 \\
33.7 \\
33.3\end{array}$ & $\begin{array}{l}(0.83) \\
(0.81) \\
(0.84) \\
(0.84)\end{array}$ & $\begin{array}{l}40.6 \\
44.5 \\
44.0 \\
42.8\end{array}$ & $\begin{array}{l}(1.33) \\
(1.24) \\
(1.22) \\
(1.19)\end{array}$ & $\begin{array}{l}52.2 \\
57.0 \\
56.8 \\
54.7\end{array}$ & $\begin{array}{l}(1.61) \\
(1.49) \\
(1.57) \\
(1.49)\end{array}$ \\
\hline \multicolumn{25}{|l|}{$\begin{array}{l}\text { Hispanic, Supplemental } \\
\text { Poverty Measure }^{5}\end{array}$} \\
\hline 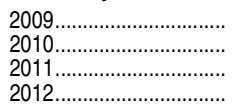 & \multirow[t]{2}{*}{$\begin{array}{l}13,390 \\
13,864 \\
14,652 \\
14,799\end{array}$} & \multirow[t]{2}{*}{$\begin{array}{l}(282.3) \\
(278.0) \\
(305.0) \\
(273.5)\end{array}$} & \multirow[t]{2}{*}{$\begin{array}{l}11,294 \\
11,686 \\
12,478 \\
12,443\end{array}$} & \multirow[t]{2}{*}{$\begin{array}{l}(272.3) \\
(261.4) \\
(286.2) \\
(264.0)\end{array}$} & \multirow[t]{2}{*}{$\begin{array}{l}2,686 \\
2,793 \\
3,097 \\
3,170\end{array}$} & \multirow[t]{2}{*}{$\begin{array}{l}(64.7) \\
(63.2) \\
(72.0) \\
(69.8)\end{array}$} & \multirow[t]{2}{*}{$\begin{array}{l}4,913 \\
5,122 \\
5,261 \\
5,212\end{array}$} & \multirow[t]{2}{*}{$\begin{array}{l}(132.8) \\
(135.5) \\
(133.8) \\
(127.6)\end{array}$} & \multirow[t]{2}{*}{$\begin{array}{l}3,845 \\
4,340 \\
4,918 \\
4,492\end{array}$} & \multirow[t]{2}{*}{$\begin{array}{l}(168.2) \\
(160.0) \\
(180.6) \\
(172.7)\end{array}$} & \multirow[t]{2}{*}{$\begin{array}{l}1,956 \\
2,236 \\
2,482 \\
2,315\end{array}$} & \multirow[t]{2}{*}{$\begin{array}{l}(89.2) \\
(93.6) \\
(99.6) \\
(99.3)\end{array}$} & $\begin{array}{l}27.4 \\
27.8 \\
28.0 \\
27.9\end{array}$ & $\begin{array}{l}(0.58) \\
(0.56) \\
(0.58) \\
(0.52)\end{array}$ & $\begin{array}{l}26.4 \\
26.7 \\
27.3 \\
26.9\end{array}$ & $\begin{array}{l}(0.63) \\
(0.59) \\
(0.63) \\
(0.56)\end{array}$ & $\begin{array}{l}25.8 \\
26.2 \\
26.7 \\
26.5\end{array}$ & $\begin{array}{l}(0.59) \\
(0.53) \\
(0.62) \\
(0.52)\end{array}$ & $\begin{array}{l}29.5 \\
30.0 \\
30.5 \\
30.1\end{array}$ & $\begin{array}{l}(0.80) \\
(0.79) \\
(0.77) \\
(0.74)\end{array}$ & $\begin{array}{l}37.4 \\
41.6 \\
43.3 \\
39.9\end{array}$ & $\begin{array}{l}(1.36) \\
(1.19) \\
(1.24) \\
(1.16)\end{array}$ & $\begin{array}{l}41.9 \\
46.9 \\
47.7 \\
45.1\end{array}$ & $\begin{array}{l}(1.57) \\
(1.51) \\
(1.44) \\
(1.49)\end{array}$ \\
\hline $\begin{array}{l}\text { Asian, official poverty } \\
\text { measure }^{4}\end{array}$ & & & & & & & & & & & & & & & & & & & & & & & & \\
\hline $\begin{array}{l}1990^{7} \\
1995^{7} \\
2000^{7} \ldots \ldots \ldots \ldots \ldots \ldots \ldots \ldots \ldots \ldots \ldots \ldots \ldots\end{array}$ & $\begin{array}{r}851 \\
1,379 \\
1,210\end{array}$ & $\begin{array}{r}(88.5) \\
(111.1) \\
(108.8)\end{array}$ & $\begin{array}{r}706 \\
1,087 \\
863\end{array}$ & $\begin{array}{l}(40.5) \\
(50.7) \\
(46.8)\end{array}$ & $\begin{array}{l}167 \\
258 \\
227\end{array}$ & $\begin{array}{l}(19.5) \\
(24.3) \\
(23.7)\end{array}$ & $\begin{array}{l}352 \\
520 \\
390\end{array}$ & $\begin{array}{l}(28.4) \\
(34.7) \\
(31.2)\end{array}$ & $\begin{array}{l}127 \\
253 \\
272\end{array}$ & $\begin{array}{l}(17.0) \\
(24.1) \\
(26.0)\end{array}$ & $\begin{array}{r}77 \\
139 \\
151\end{array}$ & $\begin{array}{l}(13.2) \\
(17.8) \\
(19.3)\end{array}$ & $\begin{array}{r}12.2 \\
14.6 \\
9.8\end{array}$ & $\begin{array}{l}(1.22) \\
(1.12) \\
(0.86)\end{array}$ & $\begin{array}{r}11.3 \\
12.9 \\
8.0\end{array}$ & $\begin{array}{l}(0.60) \\
(0.55) \\
(0.41)\end{array}$ & $\begin{array}{r}11.0 \\
12.3 \\
7.8\end{array}$ & $\begin{array}{l}(1.20) \\
(1.08) \\
(0.77)\end{array}$ & $\begin{array}{l}16.9 \\
18.5 \\
12.3\end{array}$ & $\begin{array}{l}(1.24) \\
(1.10) \\
(0.91)\end{array}$ & $\begin{array}{l}20.1 \\
28.7 \\
22.8\end{array}$ & $\begin{array}{l}(2.40) \\
(2.29) \\
(1.90)\end{array}$ & $\begin{array}{l}31.2 \\
41.8 \\
37.0\end{array}$ & $\begin{array}{l}(4.45) \\
(4.07) \\
(3.74)\end{array}$ \\
\hline 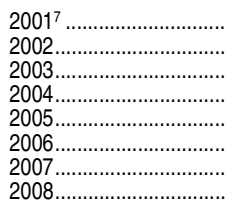 & $\begin{array}{l}1,242 \\
1,143 \\
1,372 \\
1,184 \\
1,391 \\
1,301 \\
1,329 \\
1,528\end{array}$ & $\begin{array}{r}(110.2) \\
(75.4) \\
(82.1) \\
(76.3) \\
(85.4) \\
(95.4) \\
(80.5) \\
(89.1)\end{array}$ & $\begin{array}{r}854 \\
751 \\
992 \\
799 \\
960 \\
881 \\
916 \\
1,154\end{array}$ & $\begin{array}{l}(46.5) \\
(31.0) \\
(35.8) \\
(70.5) \\
(80.0) \\
(86.5) \\
(79.6) \\
(88.6)\end{array}$ & $\begin{array}{l}225 \\
207 \\
305 \\
228 \\
286 \\
252 \\
255 \\
334\end{array}$ & $\begin{array}{l}(23.6) \\
(16.1) \\
(19.6) \\
(21.4) \\
(23.6) \\
(24.1) \\
(23.2) \\
(24.8)\end{array}$ & $\begin{array}{l}344 \\
297 \\
313 \\
256 \\
309 \\
335 \\
340 \\
410\end{array}$ & $\begin{array}{l}(29.2) \\
(19.3) \\
(19.9) \\
(32.4) \\
(34.1) \\
(42.0) \\
(39.2) \\
(41.7)\end{array}$ & $\begin{array}{l}190 \\
152 \\
226 \\
126 \\
182 \\
186 \\
205 \\
205\end{array}$ & $\begin{array}{l}(21.6) \\
(13.8) \\
(16.9) \\
(23.6) \\
(30.1) \\
(34.5) \\
(36.6) \\
(34.2)\end{array}$ & $\begin{array}{r}99 \\
83 \\
107 \\
47 \\
65 \\
89 \\
95 \\
85\end{array}$ & $\begin{array}{l}(15.6) \\
(10.2) \\
(11.5) \\
(11.9) \\
(15.1) \\
(20.7) \\
(21.5) \\
(18.7)\end{array}$ & $\begin{array}{r}10.2 \\
10.1 \\
11.7 \\
9.8 \\
11.2 \\
10.0 \\
10.2 \\
11.8\end{array}$ & $\begin{array}{l}(0.8 \\
0.6 \\
0.6 \\
0.6 \\
0.6 \\
0.7 \\
0.6 \\
0.6\end{array}$ & $\begin{array}{r}8.1 \\
7.7 \\
9.7 \\
7.5 \\
8.9 \\
7.8 \\
8.1 \\
10.1\end{array}$ & $\begin{array}{l}(0.42) \\
(0.30) \\
(0.33) \\
(0.67) \\
(0.73) \\
(0.76) \\
(0.70) \\
(0.76)\end{array}$ & $\begin{array}{r}7.7 \\
7.4 \\
10.0 \\
7.3 \\
9.0 \\
7.6 \\
7.8 \\
9.8\end{array}$ & $\begin{array}{l}(0.77) \\
(0.55) \\
(0.61) \\
(0.69) \\
(0.73) \\
(0.72) \\
(0.70) \\
(0.71)\end{array}$ & $\begin{array}{r}11.2 \\
11.4 \\
11.7 \\
9.2 \\
11.1 \\
11.7 \\
11.8 \\
14.1\end{array}$ & $\begin{array}{l}(0.89) \\
(0.69) \\
(0.70) \\
(1.16) \\
(1.19) \\
(1.15) \\
(1.33) \\
(1.41)\end{array}$ & $\begin{array}{l}14.7 \\
15.3 \\
22.6 \\
12.6 \\
17.9 \\
18.0 \\
16.8 \\
16.1\end{array}$ & $\begin{array}{l}(1.54) \\
(1.28) \\
(1.48) \\
(2.20) \\
(2.77) \\
(2.99) \\
(2.77) \\
(2.38)\end{array}$ & $\begin{array}{l}26.3 \\
30.3 \\
35.5 \\
17.0 \\
26.2 \\
36.8 \\
32.2 \\
25.5\end{array}$ & $\begin{array}{l}(3.54) \\
(3.09 \\
(3.07) \\
(4.09) \\
(5.06 \\
6.58 \\
(5.77) \\
(4.53)\end{array}$ \\
\hline 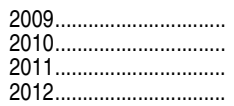 & $\begin{array}{l}1,684 \\
1,672 \\
1,871 \\
1,813\end{array}$ & $\begin{array}{r}(96.8) \\
(95.0) \\
(114.8) \\
(113.6)\end{array}$ & $\begin{array}{l}1,201 \\
1,211 \\
1,317 \\
1,268\end{array}$ & $\begin{array}{r}(87.4) \\
(90.2) \\
(99.8) \\
(109.7)\end{array}$ & $\begin{array}{l}327 \\
323 \\
385 \\
361\end{array}$ & $\begin{array}{l}(23.6) \\
(23.4) \\
(29.4) \\
(29.4)\end{array}$ & $\begin{array}{l}434 \\
434 \\
422 \\
422\end{array}$ & $\begin{array}{l}(39.7) \\
(42.0) \\
(44.2) \\
(46.4)\end{array}$ & $\begin{array}{l}227 \\
281 \\
295 \\
257\end{array}$ & $\begin{array}{l}(36.1) \\
(45.4) \\
(58.4) \\
(45.0)\end{array}$ & $\begin{array}{r}88 \\
118 \\
124 \\
95\end{array}$ & $\begin{array}{l}(16.0) \\
(19.6) \\
(34.0) \\
(21.9)\end{array}$ & $\begin{array}{r}12.3 \\
11.9 \\
12.16 \\
11.4\end{array}$ & $\begin{array}{l}(0.70) \\
(0.68) \\
(0.74) \\
(0.70)\end{array}$ & $\begin{array}{r}10.0 \\
9.9 \\
9.8 \\
9.2\end{array}$ & $\begin{array}{l}(0.72) \\
(0.74) \\
(0.74) \\
(0.78)\end{array}$ & $\begin{array}{l}9.3 \\
9.3 \\
9.6 \\
9.0\end{array}$ & $\begin{array}{l}(0.65) \\
(0.66) \\
(0.72) \\
(0.69)\end{array}$ & $\begin{array}{l}13.7 \\
13.7 \\
12.7 \\
12.5\end{array}$ & $\begin{array}{l}(1.24) \\
(1.31) \\
(1.32) \\
(1.37)\end{array}$ & $\begin{array}{l}17.4 \\
21.7 \\
20.6 \\
18.3\end{array}$ & $\begin{array}{l}(2.64) \\
(3.09) \\
(3.53) \\
(2.81)\end{array}$ & $\begin{array}{l}25.8 \\
35.1 \\
34.4 \\
28.8\end{array}$ & $\begin{array}{l}(4.25) \\
(4.61) \\
(6.88) \\
(5.46)\end{array}$ \\
\hline $\begin{array}{l}\text { Asian, Supplemental } \\
\text { Poverty Measure }^{5}\end{array}$ & & & & & & & & & & & & & & & & & & & & & & & & \\
\hline 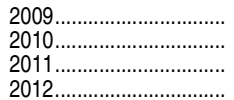 & $\begin{array}{l}2,403 \\
2,264 \\
2,618 \\
2,628\end{array}$ & $\begin{array}{l}(109.7) \\
(113.2) \\
(125.6) \\
(127.7)\end{array}$ & $\begin{array}{l}1,894 \\
1,748 \\
2,006 \\
2,018\end{array}$ & $\begin{array}{l}(102.8) \\
(113.4) \\
(114.5) \\
(123.4)\end{array}$ & $\begin{array}{l}529 \\
504 \\
620 \\
556\end{array}$ & $\begin{array}{l}(28.1) \\
(29.8) \\
(34.5) \\
(33.6)\end{array}$ & $\begin{array}{l}547 \\
441 \\
475 \\
556\end{array}$ & $\begin{array}{l}(42.3) \\
(42.4) \\
(40.5) \\
(48.0)\end{array}$ & $\begin{array}{l}308 \\
347 \\
357 \\
368\end{array}$ & $\begin{array}{l}(43.0) \\
(50.0) \\
(52.5) \\
(49.0)\end{array}$ & $\begin{array}{r}107 \\
106 \\
94 \\
122\end{array}$ & $\begin{array}{l}(17.7) \\
(17.1) \\
(21.3) \\
(23.4)\end{array}$ & $\begin{array}{l}17.6 \\
16.2 \\
17.0 \\
16.5\end{array}$ & $\begin{array}{l}(0.78) \\
(0.80) \\
(0.80) \\
(0.79\end{array}$ & $\begin{array}{l}15.8 \\
14.3 \\
14.9 \\
14.7\end{array}$ & $\begin{array}{l}(0.84) \\
(0.91) \\
(0.84) \\
(0.87)\end{array}$ & $\begin{array}{l}15.0 \\
14.5 \\
15.5 \\
13.9\end{array}$ & $\begin{array}{l}(0.76) \\
(0.84) \\
(0.84) \\
(0.78)\end{array}$ & $\begin{array}{l}17.3 \\
13.9 \\
14.2 \\
16.5\end{array}$ & $\begin{array}{l}(1.30) \\
(1.32) \\
(1.20) \\
(1.43)\end{array}$ & $\begin{array}{l}23.5 \\
26.8 \\
25.0 \\
26.2\end{array}$ & $\begin{array}{l}(3.00) \\
(3.25) \\
(3.27) \\
(2.80)\end{array}$ & $\begin{array}{l}31.5 \\
31.5 \\
26.1 \\
37.1\end{array}$ & $\begin{array}{l}(4.46) \\
(4.30) \\
(5.25) \\
(5.47)\end{array}$ \\
\hline
\end{tabular}

All data for 2008 and earlier years are based on the official poverty measure. Supplemental Poverty Measure (SPM) data are

2Refers to the person who owns or rents (maintains) the housing unit.

作 4 The official poverty measure consists of a set of thresholds for families of differed children who have ever been married. to before-tax cash income to determine a family's poverty status. For more information about how the Census Bureau determines who is in poverty, see http://www.census.gov/hhes/www/poverty/about/overview/measure.html.

The Supplemental Poverty Measure (SPM) extends the information provided by the official poverty measure by adding to family income the value of benefits from many government programs designed to assist low-income families, subtracting taxes and necessary expenses such as child care costs (for working families) and medical expenses, and adjusting pov-
erty thresholds for differences in housing costs. To match the population included in the current official poverty measure,
SPM estimates presented in this table exclude unrelated children under age 15. For more information about the SPM, see http://www.census.gov/hhes/povmeas/methodology/supplemental/research/Short_ResearchSPM2011.pdf. IIncludes persons of Hispanic ethnicity.

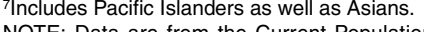

Survey and may differ from data shown in other tables obtained from the Decennial Census and the American Community Survey. Race categories exclude persons of Hispanic ethnicity except SOURCE: U.S. Department of Commerce, Census Bureau, Current Population Reports, Series P-60, Poverty in the United States, selected years, 1960 through 2002; Current Population Survey (CPS), Annual Social and Economic Supplement 1991 through 2013; and Supplemental Poverty Measure (SPM) Research Files, 2009 through 2012. (This table was prepared 
Table 102.60. Number and percentage of children under age 18 living in poverty, by family structure and race/ethnicity with selected subgroups: 2007 and 2012

[Standard errors appear in parentheses]

\begin{tabular}{|c|c|c|c|c|c|c|c|c|c|c|}
\hline \multirow[b]{2}{*}{ Year and race/ethnicity } & \multirow{2}{*}{\multicolumn{2}{|c|}{$\begin{array}{r}\text { Number of related } \\
\text { children }{ }^{1} \text { living in poverty } \\
\text { (in thousands) }\end{array}$}} & \multicolumn{8}{|c|}{ Percent of related children ${ }^{1}$ living in poverty, by family structure } \\
\hline & & & \multicolumn{2}{|c|}{ Total, all families } & \multicolumn{2}{|c|}{ Married-couple household ${ }^{2}$} & \multicolumn{2}{|c|}{$\begin{array}{r}\text { Mother-only household, } \\
\text { no spouse present }{ }^{2}\end{array}$} & \multicolumn{2}{|c|}{$\begin{array}{l}\text { Father-only household, } \\
\text { no spouse present }{ }^{2}\end{array}$} \\
\hline 1 & & 2 & & 3 & & 4 & & 5 & & 6 \\
\hline 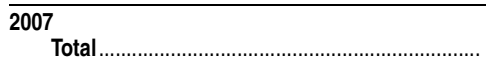 & 12,671 & (86.3) & 17.5 & $(0.11)$ & 8.1 & $(0.09)$ & 41.4 & $(0.26)$ & 19.7 & $(0.33)$ \\
\hline 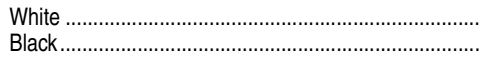 & $\begin{array}{l}4,158 \\
3,503\end{array}$ & $\begin{array}{l}(47.7) \\
(38.0)\end{array}$ & $\begin{array}{l}10.1 \\
34.1\end{array}$ & $\begin{array}{l}(0.11) \\
(0.31)\end{array}$ & $\begin{array}{r}5.0 \\
11.2\end{array}$ & $\begin{array}{l}(0.08) \\
(0.36)\end{array}$ & $\begin{array}{l}31.4 \\
48.6\end{array}$ & $\begin{array}{l}(0.33) \\
(0.46)\end{array}$ & $\begin{array}{l}14.5 \\
28.4\end{array}$ & $\begin{array}{l}(0.39) \\
(1.12)\end{array}$ \\
\hline 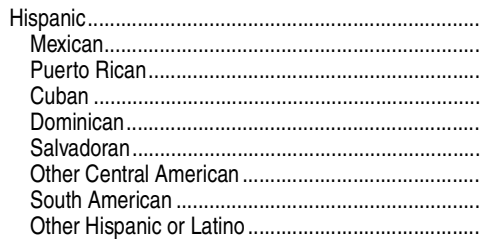 & $\begin{array}{r}4,058 \\
2,958 \\
411 \\
41 \\
124 \\
83 \\
135 \\
85 \\
221\end{array}$ & $\begin{array}{r}(41.1) \\
(36.2) \\
(11.7) \\
(3.7) \\
(7.4) \\
(5.8) \\
(7.4) \\
(6.3) \\
(8.6)\end{array}$ & $\begin{array}{l}27.1 \\
28.6 \\
31.6 \\
12.7 \\
34.1 \\
19.8 \\
25.2 \\
14.3 \\
20.9\end{array}$ & $\begin{array}{l}(0.25) \\
(0.31) \\
(0.78) \\
(1.10) \\
(1.70) \\
(1.29) \\
(1.20) \\
(0.96) \\
(0.72)\end{array}$ & $\begin{array}{r}17.7 \\
20.4 \\
10.4 \\
7.0 \\
13.6 \\
10.9 \\
14.9 \\
9.1 \\
9.4\end{array}$ & $\begin{array}{l}(0.27) \\
(0.34) \\
(0.82) \\
(1.00) \\
(1.71) \\
(1.46) \\
(1.12) \\
(0.93) \\
(0.67)\end{array}$ & $\begin{array}{l}48.7 \\
50.5 \\
52.1 \\
28.6 \\
50.9 \\
41.8 \\
45.6 \\
29.8 \\
43.0\end{array}$ & $\begin{array}{l}(0.51) \\
(0.65) \\
(1.33) \\
(3.06) \\
(2.52) \\
(3.28) \\
(2.49) \\
(2.53) \\
(1.71)\end{array}$ & $\begin{array}{l}24.3 \\
25.1 \\
27.1 \\
13.4 \\
23.0 \\
17.3 \\
24.3 \\
17.6 \\
23.8\end{array}$ & $\begin{array}{l}(0.67) \\
(0.84) \\
(2.56) \\
(3.45) \\
(4.84) \\
(3.14) \\
(4.13) \\
(3.81) \\
(2.51)\end{array}$ \\
\hline 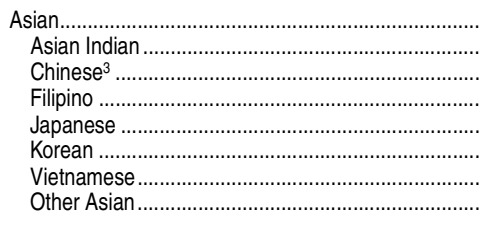 & $\begin{array}{r}316 \\
47 \\
63 \\
22 \\
8 \\
31 \\
56 \\
89\end{array}$ & $\begin{array}{r}(10.8) \\
(4.6) \\
(4.3) \\
(2.9) \\
(1.6) \\
(3.6) \\
(4.6) \\
(7.5)\end{array}$ & $\begin{array}{r}11.1 \\
7.5 \\
10.5 \\
5.0 \\
9.9 \\
10.8 \\
15.2 \\
19.9\end{array}$ & $\begin{array}{l}(0.36) \\
(0.72) \\
(0.68) \\
(0.63) \\
(1.80) \\
(1.20) \\
(1.06) \\
(1.45)\end{array}$ & $\begin{array}{r}8.1 \\
6.4 \\
8.4 \\
2.7 \\
7.3 \\
7.4 \\
10.6 \\
14.8\end{array}$ & $\begin{array}{l}(0.36) \\
(0.70) \\
(0.60) \\
(0.46) \\
(1.68) \\
(0.88) \\
(0.95) \\
(1.53)\end{array}$ & $\begin{array}{l}30.6 \\
21.3 \\
26.1 \\
16.3 \\
25.4 \\
36.1 \\
35.7 \\
45.0\end{array}$ & $\begin{array}{l}(1.80) \\
(4.37) \\
(2.42) \\
(2.95) \\
(7.06) \\
(5.81) \\
(3.82) \\
(4.19)\end{array}$ & $\begin{array}{c}15.8 \\
20.1 \\
17.8 \\
7.9 ! \\
\ddagger \\
9.0 ! \\
15.4 \\
19.3\end{array}$ & $\begin{array}{r}(1.87) \\
(5.00) \\
(4.29) \\
(3.49) \\
(\dagger) \\
(4.13) \\
(4.26) \\
(3.87)\end{array}$ \\
\hline 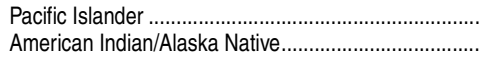 & $\begin{array}{r}26 \\
176\end{array}$ & $\begin{array}{l}(3.1) \\
(7.5)\end{array}$ & $\begin{array}{l}25.6 \\
32.7\end{array}$ & $\begin{array}{l}(2.79) \\
(1.17)\end{array}$ & $\begin{array}{l}18.6 \\
17.9\end{array}$ & $\begin{array}{l}(3.41) \\
(1.34)\end{array}$ & $\begin{array}{l}37.7 \\
51.5\end{array}$ & $\begin{array}{l}(5.63) \\
(1.85)\end{array}$ & $\begin{array}{l}35.6 \\
30.5\end{array}$ & $\begin{array}{l}(9.64) \\
(3.38)\end{array}$ \\
\hline 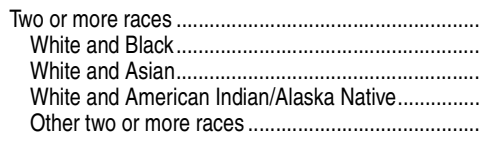 & $\begin{array}{r}395 \\
216 \\
32 \\
64 \\
83 \\
\end{array}$ & $\begin{array}{r}(11.9) \\
(8.1) \\
(2.8) \\
(5.1) \\
(5.2) \\
\end{array}$ & $\begin{array}{r}17.9 \\
24.4 \\
5.8 \\
19.8 \\
18.4 \\
\end{array}$ & $\begin{array}{l}(0.50) \\
(0.85) \\
(0.50) \\
(1.28) \\
(1.05) \\
\end{array}$ & $\begin{array}{r}5.2 \\
5.5 \\
2.4 \\
10.2 \\
6.1 \\
\end{array}$ & $\begin{array}{l}(0.33) \\
(0.60) \\
(0.30) \\
(1.12) \\
(0.80) \\
\end{array}$ & $\begin{array}{l}38.5 \\
41.0 \\
25.5 \\
41.7 \\
36.3 \\
\end{array}$ & $\begin{array}{l}(1.07) \\
(1.32) \\
(2.92) \\
(2.88) \\
(2.21) \\
\end{array}$ & $\begin{array}{l}19.8 \\
20.3 \\
11.2 \\
26.2 \\
18.8\end{array}$ & $\begin{array}{l}(1.82) \\
(2.76) \\
(2.75) \\
(3.70) \\
(3.71) \\
\end{array}$ \\
\hline $\begin{array}{l}2012 \\
\text { Total } \ldots \ldots \ldots . . . .\end{array}$ & 16,029 & (105.7) & 22.2 & $(0.14)$ & 11.1 & $(0.11)$ & 46.1 & $(0.22)$ & 27.1 & $(0.37)$ \\
\hline 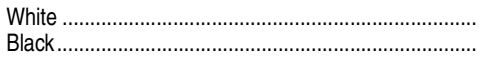 & $\begin{array}{l}5,026 \\
3,874\end{array}$ & $\begin{array}{l}(51.8) \\
(36.4)\end{array}$ & $\begin{array}{l}13.2 \\
39.1\end{array}$ & $\begin{array}{l}(0.14) \\
(0.33)\end{array}$ & $\begin{array}{r}6.8 \\
14.9\end{array}$ & $\begin{array}{l}(0.10) \\
(0.46)\end{array}$ & $\begin{array}{l}36.5 \\
52.7\end{array}$ & $\begin{array}{l}(0.31) \\
(0.42)\end{array}$ & $\begin{array}{l}19.2 \\
37.9\end{array}$ & $\begin{array}{l}(0.42) \\
(1.08)\end{array}$ \\
\hline 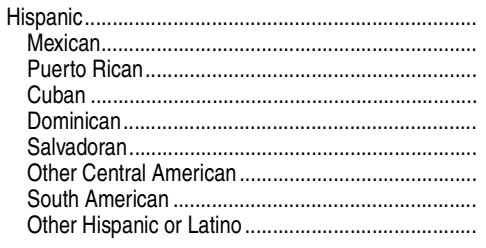 & $\begin{array}{r}5,762 \\
4,192 \\
545 \\
99 \\
178 \\
157 \\
268 \\
139 \\
184\end{array}$ & $\begin{array}{r}(47.6) \\
(39.2) \\
(14.8) \\
(5.5) \\
(7.5) \\
(8.1) \\
(10.5) \\
(8.2) \\
(8.4)\end{array}$ & $\begin{array}{l}33.4 \\
35.1 \\
35.1 \\
24.3 \\
37.7 \\
27.2 \\
34.1 \\
18.6 \\
25.2\end{array}$ & $\begin{array}{l}(0.27) \\
(0.30) \\
(0.75) \\
(1.07) \\
(1.32) \\
(1.15) \\
(1.02) \\
(0.97) \\
(0.98)\end{array}$ & $\begin{array}{l}22.5 \\
25.2 \\
14.0 \\
13.3 \\
18.6 \\
18.4 \\
22.4 \\
11.7 \\
14.2\end{array}$ & $\begin{array}{l}(0.29) \\
(0.33) \\
(0.80) \\
(1.37) \\
(1.60) \\
(1.30) \\
(1.37) \\
(0.93) \\
(1.08)\end{array}$ & $\begin{array}{l}52.7 \\
54.3 \\
54.2 \\
44.8 \\
52.6 \\
42.6 \\
53.1 \\
37.8 \\
46.1\end{array}$ & $\begin{array}{l}(0.51) \\
(0.55) \\
(1.22) \\
(2.52) \\
(2.02) \\
(2.53) \\
(1.86) \\
(2.33) \\
(1.98)\end{array}$ & $\begin{array}{l}33.9 \\
35.3 \\
34.5 \\
28.1 \\
34.8 \\
25.0 \\
35.2 \\
19.7 \\
30.6\end{array}$ & $\begin{array}{l}(0.78) \\
(0.99) \\
(2.55) \\
(4.59) \\
(5.19) \\
(3.27) \\
(2.90) \\
(3.12) \\
(3.06)\end{array}$ \\
\hline 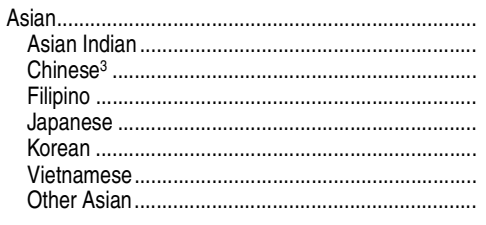 & $\begin{array}{r}435 \\
52 \\
77 \\
31 \\
4 \\
29 \\
67 \\
176\end{array}$ & $\begin{array}{r}(13.6) \\
(4.2) \\
(4.2) \\
(2.6) \\
(1.0) \\
(2.8) \\
(4.5) \\
(9.5)\end{array}$ & $\begin{array}{r}13.5 \\
7.2 \\
11.8 \\
6.5 \\
6.2 \\
10.8 \\
18.0 \\
26.3\end{array}$ & $\begin{array}{l}(0.41) \\
(0.56) \\
(0.63) \\
(0.56) \\
(1.37) \\
(0.98) \\
(1.08) \\
(1.28)\end{array}$ & $\begin{array}{r}10.3 \\
6.1 \\
9.5 \\
3.6 \\
3.7 ! \\
7.8 \\
12.9 \\
21.6\end{array}$ & $\begin{array}{l}(0.34) \\
(0.54) \\
(0.59) \\
(0.53) \\
(1.23) \\
(0.79) \\
(0.98) \\
(1.11)\end{array}$ & $\begin{array}{l}32.8 \\
26.1 \\
26.2 \\
18.4 \\
27.7 ! \\
42.9 \\
39.4 \\
46.0\end{array}$ & $\begin{array}{l}(1.22) \\
(3.99) \\
(2.37) \\
(2.44) \\
(8.72) \\
(6.36) \\
(2.72) \\
(3.27)\end{array}$ & $\begin{array}{c}23.9 \\
22.0 \\
16.9 \\
8.9 \\
\ddagger \\
24.3 ! \\
31.3 \\
36.5\end{array}$ & $\begin{array}{r}(2.18) \\
(6.18) \\
(3.90) \\
(2.44) \\
(+) \\
(11.23) \\
(5.50) \\
(4.95)\end{array}$ \\
\hline $\begin{array}{l}\text { Pacific Islander } \\
\text { American Indian/Alaska Native }\end{array}$ & $\begin{array}{r}31 \\
197\end{array}$ & $\begin{array}{l}(3.0) \\
(6.8)\end{array}$ & $\begin{array}{l}24.7 \\
36.0\end{array}$ & $\begin{array}{l}(2.38) \\
(1.07)\end{array}$ & $\begin{array}{l}18.2 \\
19.2\end{array}$ & $\begin{array}{l}(2.63) \\
(1.35)\end{array}$ & $\begin{array}{l}36.7 \\
50.5\end{array}$ & $\begin{array}{l}(4.63) \\
(1.78)\end{array}$ & $\begin{array}{l}34.7 \\
46.1\end{array}$ & $\begin{array}{l}(9.10) \\
(2.70)\end{array}$ \\
\hline 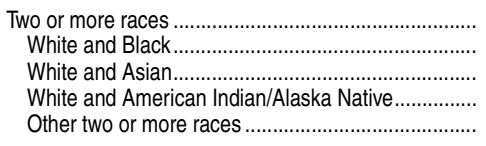 & $\begin{array}{r}662 \\
349 \\
69 \\
89 \\
154\end{array}$ & $\begin{array}{r}(15.1) \\
(10.4) \\
(4.3) \\
(4.5) \\
(7.7)\end{array}$ & $\begin{array}{r}22.3 \\
29.3 \\
8.8 \\
24.1 \\
24.9\end{array}$ & $\begin{array}{l}(0.43) \\
(0.71) \\
(0.48) \\
(1.15) \\
(1.07)\end{array}$ & $\begin{array}{r}9.1 \\
10.4 \\
5.5 \\
12.8 \\
11.6\end{array}$ & $\begin{array}{l}(0.38) \\
(0.69) \\
(0.45) \\
(1.22) \\
(0.90)\end{array}$ & $\begin{array}{l}42.4 \\
44.2 \\
27.5 \\
43.5 \\
43.8\end{array}$ & $\begin{array}{l}(0.88) \\
(1.23) \\
(2.15) \\
(2.18) \\
(1.98)\end{array}$ & $\begin{array}{l}29.7 \\
31.4 \\
16.0 \\
37.2 \\
30.5\end{array}$ & $\begin{array}{l}(1.88) \\
(3.07) \\
(3.09) \\
(3.60) \\
(3.88)\end{array}$ \\
\hline
\end{tabular}

†Not applicable.

!nterpret data with caution. The coefficient of variation (CV) for this estimate is between 30 and 50 percent.

fReporting standards not met (too few cases for a reliable estimate).

${ }^{1}$ Related children in a family include all children in the household who are related to the householder by birth, marriage, or adoption (except a child who is the spouse of the householder) The householder is the person (or one of the people) who owns or rents (maintains) the housing unit. This table includes only children related to the householder. It excludes unrelated children and householders who are themselves under the age of 18 .

${ }^{2}$ To determine family structure, children are classified by their parents' marital status or, if no parents are present in the household, by the marital status of the householder who is related to the children. Mother-only households are those that have only a female householder, and father-only households are those that have only a male householder.

"Excludes Taiwanese. Taiwanese is included in "Other Asian."

NOTE: Data may differ from Current Population Survey data that are shown in other tables. American Community Survey respondents were interviewed throughout the given year and reported the income they received during the previous 12 months. For information about how the Census Bureau determines who is in poverty, see http://www.census.gov/hhes/www/ poverty/about/overview/measure.html. Detail may not sum to totals because of rounding. Race categories exclude persons of Hispanic ethnicity.

SOURCE: U.S. Department of Commerce, Census Bureau, American Community Survey, 2007 and 2012. (This table was prepared January 2014.) 
Table 103.10. Percentage of the population 3 to 34 years old enrolled in school, by sex, race/ethnicity, and age group: Selected years, 1980 through 2012 [Standard errors appear in parentheses]

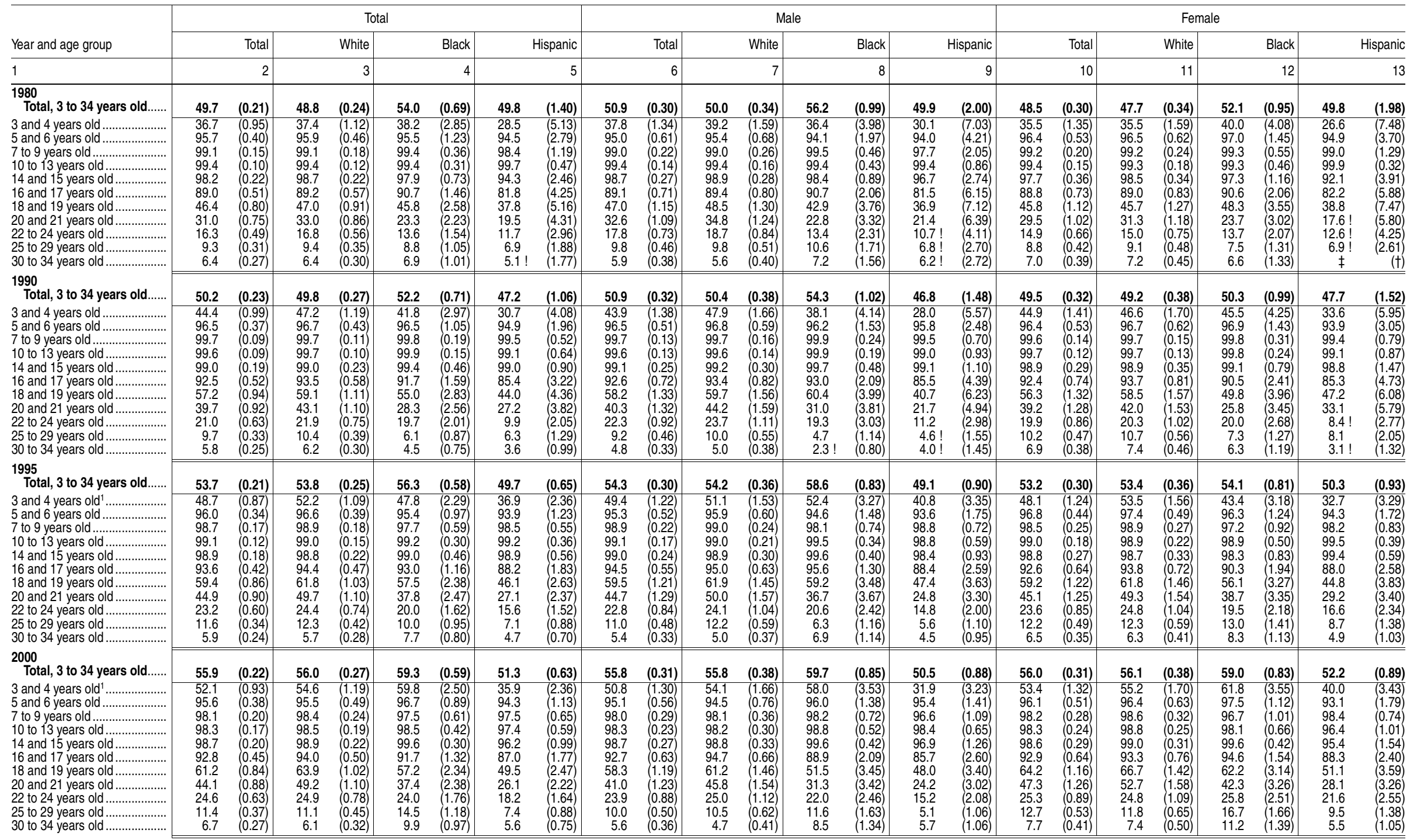

See notes at end of table. 


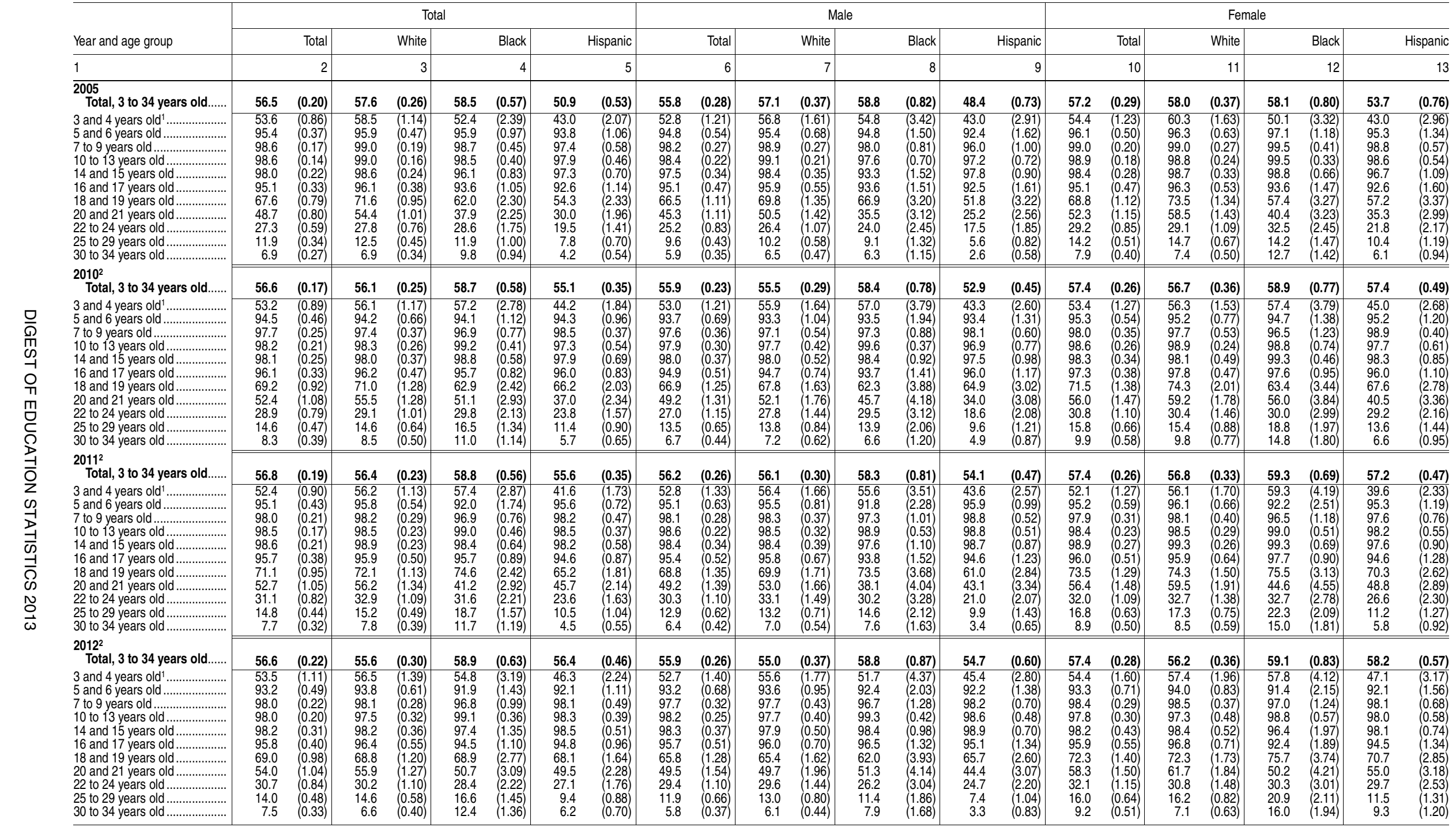

\section{†Not applicable.}

!Interpret data with caution. The coefficient of variation (CV) for this estimate is between 30 and 50 percent. †Reporting standards not met. The coefficient of variation (CV) for this estimate is 50 percent or greater.
${ }_{\text {Beginning in } 1994 \text {, preprimary enrollment data were collected using new procedures. Data may not be comparable to figures }}$

for earlier years.
2Beginning in 2010 , standard errors were computed using replicate weights, which produced more precise values than the methodology used in prior years.
NOTE: Includes enrollment in any type of graded public, parochial, or other private schools. Includes nursery schools, preschools, kindergartens, elementary schools, high schools, colleges, universities, and professional schools. Attendance may be on either a full-time or part-time basis and during the day or night. Total includes persons from other racial/ethnic groups
not shown separately. Race categories exclude persons of Hispanic ethnicity. Some data have been revised from previously published figures.

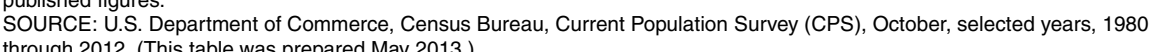


Table 103.20. Percentage of the population 3 to 34 years old enrolled in school, by age group: Selected years, 1940 through 2012

[Standard errors appear in parentheses]

\begin{tabular}{|c|c|c|c|c|c|c|c|c|c|c|c|c|c|c|c|c|c|c|c|c|c|c|c|c|c|c|c|c|c|c|c|}
\hline \multirow[b]{2}{*}{ Year } & \multirow{2}{*}{\multicolumn{2}{|c|}{$\begin{array}{r}\text { Total, } \\
3 \text { to } 34 \\
\text { years old }\end{array}$}} & \multirow{2}{*}{\multicolumn{2}{|c|}{$\begin{array}{r}3 \text { and } 4 \\
\text { years old }\end{array}$}} & \multirow{2}{*}{\multicolumn{2}{|c|}{$\begin{array}{r}5 \text { and } 6 \\
\text { years old }\end{array}$}} & \multirow{2}{*}{\multicolumn{2}{|c|}{$\begin{array}{r}7 \text { to } 13 \\
\text { years old }\end{array}$}} & \multicolumn{6}{|c|}{14 to 17 years old } & \multicolumn{6}{|c|}{18 and 19 years old } & \multicolumn{6}{|c|}{20 to 24 years old } & \multirow{2}{*}{\multicolumn{2}{|c|}{$\begin{array}{r}25 \text { to } 29 \\
\text { years old }\end{array}$}} & \multirow{2}{*}{\multicolumn{2}{|c|}{$\begin{array}{r}30 \text { to } 34 \\
\text { years old }\end{array}$}} & \\
\hline & & & & & & & & & & Total & & and 15 & & and 17 & & Total & $\begin{array}{l}\text { In elen } \\
\text { and sec }\end{array}$ & $\begin{array}{l}\text { nentary } \\
\text { ondary }\end{array}$ & & $\begin{array}{l}\text { higher } \\
\text { ucation }\end{array}$ & & Total & & and 21 & & 22 to 24 & & & & & \\
\hline 1 & & 2 & & 3 & & 4 & & 5 & & 6 & & 7 & & 8 & & 9 & & 10 & & 11 & & 12 & & 13 & & 14 & & 15 & & 16 & \\
\hline $1940 .$. & - & $(\dagger)$ & - & $(\dagger)$ & - & $(+)$ & 95.0 & $(-)$ & 79.3 & $(-)$ & - & $(\dagger)$ & - & $(\dagger)$ & 28.9 & $(-)$ & - & $(\dagger)$ & - & $(\dagger)$ & 6.6 & $(-)$ & - & $(\dagger)$ & - & (†) & - & $(\dagger)$ & - & $(\dagger)$ & \\
\hline $1945 \ldots$ & - & $(t)$ & - & $(\dagger)$ & - & $(t)$ & 98.1 & $(-)$ & 78.4 & $(-)$ & - & $(t)$ & - & $(t)$ & 20.7 & $(-)$ & - & $(+)$ & - & $(t)$ & 3.9 & $(-)$ & - & $(t)$ & - & $(t)$ & - & $(t)$ & - & $(\dagger)$ & \\
\hline $1947 \ldots$ & - & $(t)$ & - & $(\dagger)$ & 73.8 & $(-)$ & 98.5 & $(-)$ & 79.3 & $(-)$ & 91.6 & $(-)$ & 67.6 & $(-)$ & 24.3 & $(-)$ & - & $(\dagger)$ & - & $(t)$ & 10.2 & $(-)$ & - & $(\dagger)$ & - & $(\dagger)$ & 3.0 & $(-)$ & 1.0 & $(-)$ & \\
\hline $1948 .$. & - & $(t)$ & - & $(\dagger)$ & 74.7 & $(-)$ & 98.1 & $(-)$ & 81.8 & $(-)$ & 92.7 & $(-)$ & 71.2 & $(-)$ & 26.9 & $(-)$ & - & $(\dagger)$ & - & $(\dagger)$ & 9.7 & $(-)$ & - & $(t)$ & - & $(t)$ & 2.6 & $(-)$ & 0.9 & $(-)$ & \\
\hline 1949. & - & $(t)$ & - & ( $\dagger$ ) & 76.2 & $(-)$ & 98.6 & $(-)$ & 81.6 & $(-)$ & 93.5 & $(-)$ & 69.5 & $(-)$ & 25.3 & $(-)$ & - & $(t)$ & - & $(t)$ & 9.2 & $(-)$ & - & $(\dagger)$ & - & (†) & 3.8 & $(-)$ & 1.1 & $(-)$ & \\
\hline 1950. & - & $(+)$ & - & $(\dagger)$ & 74.4 & $(-)$ & 98.7 & $(-)$ & 83.7 & $(-)$ & 94.7 & $(-)$ & 71.3 & $(-)$ & 29.4 & $(-)$ & - & $(\dagger)$ & - & $(\dagger)$ & 9.0 & $(-)$ & - & $(\dagger)$ & - & (†) & 3.0 & $(-)$ & 0.9 & $(-)$ & \\
\hline $1951 .$. & - & $(\mathrm{t})$ & - & $(\dagger)$ & 73.6 & $(-)$ & 99.1 & $(-)$ & 85.2 & $(-)$ & 94.8 & $(-)$ & 75.1 & $(-)$ & 26.2 & $(-)$ & - & $(t)$ & - & $(t)$ & 8.6 & $(-)$ & - & $(t)$ & - & (t) & 2.5 & $(-)$ & 0.7 & $(-)$ & \\
\hline 1952. & - & $(t)$ & - & $(t)$ & 75.2 & $(-)$ & 98.8 & $(-)$ & 85.2 & $(-)$ & 96.2 & $(-)$ & 73.4 & $(-)$ & 28.8 & $(-)$ & - & $(\dagger)$ & - & $(t)$ & 9.7 & $(-)$ & - & $(t)$ & - & (t) & 2.6 & $(-)$ & 1.2 & $(-)$ & \\
\hline 1953.. & - & $(t)$ & - & $(t)$ & 78.6 & $(-)$ & 99.4 & $(-)$ & 85.9 & $(-)$ & 96.5 & $(-)$ & 74.7 & $(-)$ & 31.2 & $(-)$ & - & $(+)$ & - & $(t)$ & 11.1 & $(-)$ & - & $(t)$ & - & (t) & 2.9 & $(-)$ & 1.7 & $(-)$ & \\
\hline $1954 \ldots$ & - & $(t)$ & - & $(\dagger)$ & 77.3 & $(-)$ & 99.4 & $(-)$ & 87.1 & $(-)$ & 95.8 & $(-)$ & 78.0 & $(-)$ & 32.4 & $(-)$ & - & $(t)$ & - & $(t)$ & 11.2 & $(-)$ & - & $(\dagger)$ & - & (t) & 4.1 & $(-)$ & 1.5 & $(-)$ & \\
\hline 1955.. & - & $(t)$ & - & $(\dagger)$ & 78.1 & $(-)$ & 99.2 & $(-)$ & 86.9 & $(-)$ & 95.9 & $(-)$ & 77.4 & $(-)$ & 31.5 & $(-)$ & - & $(t)$ & - & $(t)$ & 11.1 & $(-)$ & - & $(\dagger)$ & - & $(t)$ & 4.2 & $(-)$ & 1.6 & $(-)$ & \\
\hline $1956 .$. & - & $(t)$ & - & $(t)$ & 77.6 & $(-)$ & 99.3 & $(-)$ & 88.2 & $(-)$ & 96.9 & $(-)$ & 78.4 & $(-)$ & 35.4 & $(-)$ & - & $(t)$ & - & $(t)$ & 12.8 & $(-)$ & - & $(t)$ & - & (t) & 5.1 & $(-)$ & 1.9 & $(-)$ & \\
\hline $1957 .$. & - & $(t)$ & - & $(\dagger)$ & 78.6 & $(-)$ & 99.5 & $(-)$ & 89.5 & $(-)$ & 97.1 & $(-)$ & 80.5 & $(-)$ & 34.9 & $(-)$ & - & $(\dagger)$ & - & $(t)$ & 14.0 & $(-)$ & - & $(\dagger)$ & - & $(t)$ & 5.5 & $(-)$ & 1.8 & $(-)$ & \\
\hline $1958 \ldots$. & - & $(t)$ & - & $(\dagger)$ & 80.4 & $(-)$ & 99.5 & $(-)$ & 89.2 & $(-)$ & 96.9 & $(-)$ & 80.6 & $(-)$ & 37.6 & $(-)$ & - & $(\dagger)$ & - & $(t)$ & 13.4 & $(-)$ & - & $(\dagger)$ & - & $(t)$ & 5.7 & $(-)$ & 2.2 & $(-)$ & \\
\hline $1959 \ldots$ & - & $(t)$ & - & $(t)$ & 80.0 & $(-)$ & 99.4 & $(-)$ & 90.2 & $(-)$ & 97.5 & $(-)$ & 82.9 & $(-)$ & 36.8 & $(-)$ & - & $(t)$ & - & $(t)$ & 12.7 & $(-)$ & 18.8 & $(-)$ & 8.6 & $(-)$ & 5.1 & $(-)$ & 2.2 & $(-)$ & \\
\hline 1960. & - & $(t)$ & - & $(\dagger)$ & 80.7 & $(-)$ & 99.5 & $(-)$ & 90.3 & $(-)$ & 97.8 & $(-)$ & 82.6 & $(-)$ & 38.4 & $(-)$ & - & $(t)$ & - & $(t)$ & 13.1 & $(-)$ & 19.4 & $(-)$ & 8.7 & $(-)$ & 4.9 & $(-)$ & 2.4 & $(-)$ & \\
\hline $1961 \ldots$ & - & (t) & - & $(\dagger)$ & 81.7 & $(-)$ & 99.3 & $(-)$ & 91.4 & $(-)$ & 97.6 & $(-)$ & 83.6 & $(-)$ & 38.0 & $(-)$ & - & $(\dagger)$ & - & $(t)$ & 13.7 & $(-)$ & 21.5 & $(-)$ & 8.4 & $(-)$ & 4.4 & $(-)$ & 2.0 & $(-)$ & \\
\hline 1962. & - & $(t)$ & - & $(\dagger)$ & 82.2 & $(-)$ & 99.3 & $(-)$ & 92.0 & $(-)$ & 98.0 & $(-)$ & 84.3 & $(-)$ & 41.8 & $(-)$ & - & $(\dagger)$ & - & $(t)$ & 15.6 & $(-)$ & 23.0 & $(-)$ & 10.3 & $(-)$ & 5.0 & $(-)$ & 2.6 & $(-)$ & \\
\hline 1963.. & - & $(t)$ & - & $(\dagger)$ & 82.7 & $(-)$ & 99.3 & $(-)$ & 92.9 & $(-)$ & 98.4 & $(-)$ & 87.1 & $(-)$ & 40.9 & $(-)$ & 10.9 & $(-)$ & 29.8 & $(-)$ & 17.3 & $(-)$ & 25.0 & $(-)$ & 11.4 & $(-)$ & 4.9 & $(-)$ & 2.5 & $(-)$ & \\
\hline $1964 .$. & - & $(t)$ & 9.5 & $(-)$ & 83.3 & $(-)$ & 99.0 & $(-)$ & 93.1 & $(-)$ & 98.6 & $(-)$ & 87.7 & $(-)$ & 41.6 & $(-)$ & 11.0 & $(-)$ & 30.6 & $(-)$ & 16.8 & $(-)$ & 26.3 & $(-)$ & 9.9 & $(-)$ & 5.2 & $(-)$ & 2.6 & $(-)$ & \\
\hline 1965. & 55.5 & $(-)$ & 10.6 & $(-)$ & 84.9 & $(-)$ & 99.4 & $(-)$ & 93.2 & $(-)$ & 98.9 & $(-)$ & 87.4 & $(-)$ & 46.3 & $(-)$ & 11.2 & $(-)$ & 35.0 & $(-)$ & 19.0 & $(-)$ & 27.6 & $(-)$ & 13.2 & $(-)$ & 6.1 & $(-)$ & 3.2 & $(-)$ & \\
\hline $1966 .$. & 56.1 & $(-)$ & 12.5 & $(-)$ & 85.8 & $(-)$ & 99.3 & $(-)$ & 93.7 & $(-)$ & 98.6 & $(-)$ & 88.5 & $(-)$ & 47.2 & $(-)$ & 10.8 & $(-)$ & 36.3 & $(-)$ & 19.9 & $(-)$ & 29.9 & $(-)$ & 13.2 & $(-)$ & 6.5 & $(-)$ & 2.7 & $(-)$ & \\
\hline $1967 \ldots$ & 56.6 & $(-)$ & 14.2 & $(-)$ & 87.4 & $(-)$ & 99.3 & $(-)$ & 93.7 & $(-)$ & 98.2 & $(-)$ & 88.8 & $(-)$ & 47.6 & $(-)$ & 11.7 & $(-)$ & 36.0 & $(-)$ & 22.0 & $(-)$ & 33.3 & $(-)$ & 13.6 & $(-)$ & 6.6 & $(-)$ & 4.0 & $(-)$ & \\
\hline $1968 \ldots$ & 56.7 & $(-)$ & 15.7 & $(-)$ & 87.6 & $(-)$ & 99.1 & $(-)$ & 94.2 & $(-)$ & 98.0 & $(-)$ & 90.2 & $(-)$ & 50.4 & $(-)$ & 12.4 & $(-)$ & 38.0 & $(-)$ & 21.4 & $(-)$ & 31.2 & $(-)$ & 13.8 & $(-)$ & 7.0 & $(-)$ & 3.9 & $(-)$ & \\
\hline $1969 \ldots$ & 57.0 & $(-)$ & 16.1 & $(-)$ & 88.4 & $(-)$ & 99.2 & $(-)$ & 94.0 & $(-)$ & 98.1 & $(-)$ & 89.7 & $(-)$ & 50.2 & $(-)$ & 11.2 & $(-)$ & 39.0 & $(-)$ & 23.0 & $(-)$ & 34.1 & $(-)$ & 15.4 & $(-)$ & 7.9 & $(-)$ & 4.8 & $(-)$ & \\
\hline 1970 & 56.4 & $(0.22)$ & 20.5 & $(0.74)$ & 89.5 & $(0.54)$ & 99.2 & $(0.07)$ & 94.1 & $(0.27)$ & 98.1 & $(0.22)$ & 90.0 & $(0.50)$ & 47.7 & $(0.87)$ & 10.5 & $(0.53)$ & 37.3 & $(0.84)$ & 21.5 & $(0.48)$ & 31.9 & $(0.87)$ & 14.9 & $(0.53)$ & 7.5 & $(0.33)$ & 4.2 & $0.27)$ & \\
\hline 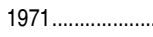 & 56.2 & $(0.22)$ & 21.2 & $(0.76)$ & 91.6 & $(0.50)$ & 99.1 & $(0.08)$ & 94.5 & $(0.26)$ & 98.6 & $(0.19)$ & 90.2 & $(0.49)$ & 49.2 & $(0.85)$ & 11.5 & $(0.54)$ & 37.7 & $(0.83)$ & 21.9 & $(0.47)$ & 32.2 & $(0.85)$ & 15.4 & $(0.52)$ & 8.0 & $(0.33)$ & 4.9 & D.29) & \\
\hline $1972 .$. & 54.9 & $(0.22)$ & 24.4 & $(0.81)$ & 91.9 & $(0.51)$ & 99.2 & $(0.08)$ & 93.3 & $(0.28)$ & 97.6 & $(0.24)$ & 88.9 & $(0.51)$ & 46.3 & $(0.84)$ & 10.4 & $(0.51)$ & 35.9 & $(0.81)$ & 21.6 & $(0.46)$ & 31.4 & $(0.81)$ & 14.8 & $(0.51)$ & 8.6 & $(0.34)$ & 4.6 & $(0.28)$ & \\
\hline $1973 \ldots$. & 53.5 & $(0.22)$ & 24.2 & $(0.80)$ & 92.5 & $(0.50)$ & 99.2 & $(0.08)$ & 92.9 & $(0.29)$ & 97.5 & $(0.25)$ & 88.3 & $(0.52)$ & 42.9 & $(0.82)$ & 10.0 & $(0.50)$ & 32.9 & $(0.78)$ & 20.8 & $(0.44)$ & 30.1 & $(0.79)$ & 14.5 & $(0.50)$ & 8.5 & $(0.33)$ & 4.5 & $(0.27)$ & \\
\hline 1974. & 53.6 & $(0.22)$ & 28.8 & $(0.85)$ & 94.2 & $(0.44)$ & 99.3 & $(0.07)$ & 92.9 & $(0.29)$ & 97.9 & $(0.23)$ & 87.9 & $(0.52)$ & 43.1 & $(0.81)$ & 9.9 & $(0.49)$ & 33.2 & $(0.77)$ & 21.4 & $(0.45)$ & 30.2 & $(0.77)$ & 15.1 & $(0.51)$ & 9.6 & $(0.34)$ & 5.7 & $(0.29)$ & \\
\hline $1975 \ldots$ & 53.7 & $(0.22)$ & 31.5 & $(0.89)$ & 94.7 & $(0.42)$ & 99.3 & $(0.08)$ & 93.6 & $(0.27)$ & 98.2 & $(0.21)$ & 89.0 & $(0.50$ & 46.9 & $(0.81)$ & 10.2 & $(0.49)$ & 36.7 & $(0.78)$ & 22.4 & $(0.45)$ & 31.2 & $(0.77)$ & 16.2 & $(0.52)$ & 10.1 & $(0.34$ & 6.6 & 03 & \\
\hline $1976 \ldots$ & 53.1 & $(0.21)$ & 31.3 & $(0.91)$ & 95.5 & $(0.38)$ & 99.2 & $(0.08)$ & 93.7 & $(0.27)$ & 98.2 & $(0.21)$ & 89.1 & $(0.50)$ & 46.2 & $(0.80)$ & 10.2 & $(0.49)$ & 36.0 & $(0.77)$ & 23.3 & $(0.45)$ & 32.0 & $(0.77)$ & 17.1 & $(0.52)$ & 10.0 & $(0.33)$ & 6.0 & $(0.29)$ & \\
\hline $1977 \ldots$ & 52.5 & $(0.21)$ & 32.0 & $(0.94)$ & 95.8 & $(0.38)$ & 99.4 & $(0.07)$ & 93.7 & $(0.28)$ & 98.5 & $(0.20)$ & 88.9 & $(0.50)$ & 46.2 & $(0.80)$ & 10.4 & $(0.49)$ & 35.7 & $(0.77)$ & 22.9 & $(0.44)$ & 31.8 & $(0.76)$ & 16.5 & $(0.51)$ & 10.8 & $(0.34)$ & 6.9 & $(0.30)$ & \\
\hline 1978. & 51.2 & $(0.21)$ & 34.2 & $(0.95)$ & 95.3 & $(0.42)$ & 99.1 & $(0.09)$ & 93.7 & $(0.28)$ & 98.4 & $(0.20)$ & 89.1 & $(0.50)$ & 45.4 & $(0.80)$ & 9.8 & $(0.48)$ & 35.6 & $(0.77)$ & 21.8 & $(0.43)$ & 29.5 & $(0.74)$ & 16.3 & $(0.50)$ & 9.4 & $(0.32)$ & 6.4 & $(0.28)$ & \\
\hline $1979 \ldots$ & 50.3 & $(0.21)$ & 35.1 & $(0.95)$ & 95.8 & $(0.40)$ & 99.2 & $(0.08)$ & 93.6 & $(0.28)$ & 98.1 & $(0.22)$ & 89.2 & $(0.50)$ & 45.0 & $(0.80)$ & 10.3 & $(0.49)$ & 34.6 & $(0.76)$ & 21.7 & $(0.43)$ & 30.2 & $(0.74)$ & 15.8 & $(0.49)$ & 9.6 & $(0.32)$ & 6.4 & $(0.28)$ & \\
\hline 1980 & 49.7 & $(0.21)$ & 36.7 & $(0.95)$ & 95.7 & $(0.40)$ & 99.3 & $(0.08)$ & 93.4 & $(0.29)$ & 98.2 & $(0.22)$ & 89.0 & $(0.51)$ & 46.4 & $(0.80)$ & 10.5 & $(0.49)$ & 35.9 & $(0.77)$ & 22.3 & $(0.43)$ & 31.0 & $(0.75)$ & 16.3 & $(0.49)$ & 9.3 & $(0.31)$ & 6.4 & $(0.27)$ & \\
\hline 1981.. & 48.9 & $(0.21)$ & 36.0 & $(0.93)$ & 94.0 & $(0.46)$ & 99.2 & $(0.08)$ & 94.1 & $(0.28)$ & 98.0 & $(0.24)$ & 90.6 & $(0.47)$ & 49.0 & $(0.81)$ & 11.5 & $(0.51)$ & 37.5 & $(0.78)$ & 22.5 & $(0.42)$ & 31.6 & $(0.74)$ & 16.5 & $(0.48)$ & 9.0 & $(0.30)$ & 6.9 & $(0.27)$ & \\
\hline 1982. & 48.6 & $(0.22)$ & 36.4 & $(0.97)$ & 95.0 & $(0.45)$ & 99.2 & $(0.09)$ & 94.4 & $(0.29)$ & 98.5 & $(0.22)$ & 90.6 & $(0.51)$ & 47.8 & $(0.86)$ & 11.3 & $(0.54)$ & 36.5 & $(0.83)$ & 23.5 & $(0.45)$ & 34.0 & $(0.81)$ & 16.8 & $(0.51)$ & 9.6 & $(0.32)$ & 6.3 & $(0.28)$ & \\
\hline $1983 \ldots$. & 48.4 & $(0.22)$ & 37.5 & $(0.96)$ & 95.4 & $(0.43)$ & 99.2 & $(0.09)$ & 95.0 & $(0.28)$ & 98.3 & $(0.23)$ & 91.7 & $(0.50)$ & 50.4 & $(0.87)$ & 12.8 & $(0.58)$ & 37.6 & $(0.84)$ & 22.7 & $(0.45)$ & 32.5 & $(0.80)$ & 16.6 & $(0.51)$ & 9.6 & $(0.32)$ & 6.4 & $(0.28)$ & \\
\hline $1984 \ldots$ & 47.9 & $(0.22)$ & 36.3 & $(0.94)$ & 94.5 & $(0.46)$ & 99.2 & $(0.09)$ & 94.7 & $(0.29)$ & 97.8 & $(0.26)$ & 91.5 & $(0.51)$ & 50.1 & $(0.89)$ & 11.5 & $(0.57)$ & 38.6 & $(0.87)$ & 23.7 & $(0.46)$ & 33.9 & $(0.82)$ & 17.3 & $(0.52)$ & 9.1 & $(0.30)$ & 6.3 & $(0.27)$ & \\
\hline
\end{tabular}

See notes at end of table. 
[Standard errors appear in parentheses]

\begin{tabular}{|c|c|c|c|c|c|c|c|c|c|c|c|c|c|c|c|c|c|c|c|c|c|c|c|c|c|c|c|c|c|c|}
\hline \multirow[b]{2}{*}{ Year } & \multirow{2}{*}{\multicolumn{2}{|c|}{$\begin{array}{r}\text { Total, } \\
3 \text { to } 34 \\
\text { years old }\end{array}$}} & \multirow{2}{*}{\multicolumn{2}{|c|}{$\begin{array}{r}3 \text { and } 4 \\
\text { years old }\end{array}$}} & \multirow{2}{*}{\multicolumn{2}{|c|}{$\begin{array}{r}5 \text { and } 6 \\
\text { years old }\end{array}$}} & \multirow{2}{*}{\multicolumn{2}{|c|}{$\begin{array}{r}7 \text { to } 13 \\
\text { years old }\end{array}$}} & \multicolumn{6}{|c|}{14 to 17 years old } & \multicolumn{6}{|c|}{18 and 19 years old } & \multicolumn{6}{|c|}{20 to 24 years old } & \multirow{2}{*}{\multicolumn{2}{|c|}{$\begin{array}{r}25 \text { to } 29 \\
\text { years old }\end{array}$}} & \multirow{2}{*}{\multicolumn{2}{|c|}{$\begin{array}{l}30 \text { to } 34 \\
\text { years old }\end{array}$}} \\
\hline & & & & & & & & & & Total & & 5 & & 17 & & Total & & & & & & Total & & d 21 & & 22 to 24 & & & & \\
\hline 1 & & 2 & & 3 & & 4 & & 5 & & 6 & & 7 & & 8 & & 9 & & 10 & & 11 & & 12 & & 13 & & 14 & & 15 & & $\overline{16}$ \\
\hline & 3 & 22) & 38.9 & 95) & 1 & 38) & 2 & 9) & 9 & $(0.28)$ & 1 & 4) & 7 & 50) & 6 & 1) & 2 & $(0.57)$ & .4 & $(0.89)$ & .0 & $(0.47)$ & 3 & 4) & 9 & $(0.52)$ & 2 & $(0.31)$ & 1 & $0.26)$ \\
\hline & 2 & $(0.22)$ & 3.9 & .95) & & & & & 9 & & 6 & & 3 & & 6 & & & & .5 & $(0.90)$ & 3.6 & $(0.47)$ & 0 & $(0.84)$ & 7.9 & $(0.54)$ & 8 & $(0.30)$ & 0 & .25) \\
\hline & 6 & $(0.22)$ & 3 & .95 & 1 & & & & 0 & 28) & 6 & & & & 6 & & & & .5 & $(0.90)$ & .5 & 49) & 7 & $(0.89)$ & .5 & $(0.5$ & 0 & (v) & 8 & 25) \\
\hline & 3.7 & $(0.24)$ & 38.2 & $(1.02)$ & 5.0 & 41) & .7 & 6) & 1 & $(0.31)$ & 3.9 & $(0.22)$ & 6 & $.55)$ & 6 & $(0.98)$ & 3.9 & $.68)$ & 1.8 & $(0.97)$ & 6.1 & $(0.54)$ & 9.1 & $(0.98)$ & 18.2 & $(0.60)$ & 3 & $(0.32)$ & .9 & $0.27)$ \\
\hline & 49.0 & $(0.23)$ & 39.1 & $(0.97)$ & 95.2 & $(0.43)$ & 99.3 & $(0.08)$ & 95.7 & $(0.28)$ & 98.8 & $(0.21)$ & 92.7 & $(0.50)$ & 56.0 & (0.92) & 14.4 & $(0.65)$ & 41.6 & $(0.91)$ & 27.0 & $(0.53)$ & 38.5 & $(0.94)$ & 19.9 & $(0.60)$ & 9.3 & $(0.32)$ & 5.7 & $(0.25)$ \\
\hline & 2 & 23) & 4 & .99 & 96.5 & 37) & 9.6 & (100) & .8 & 28) & 0 & $(0.19)$ & 92.5 & 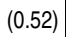 & 2 & $(0.94)$ & 5 & 60.77 & 7 & $(0.94)$ & 6 & $(0.54)$ & 7 & $(0.8$ & .0 & 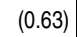 & 9.7 & $(0.33)$ & 8 & .25) \\
\hline & .7 & $(0.23)$ & 0.5 & $(0.96)$ & & 41) & & .0 & 0 & $(0.27)$ & 3.8 & $(0$. & 3 & 0.4 & 6 & $(0.96)$ & & & 10 & $(0.97)$ & .2 & 5) & .0 & $(0.9$ & 2.2 & $(0.64)$ & 0.2 & $(0.3$ & & 6) \\
\hline & .4 & $(0.23)$ & 9.7 & $(0.95)$ & .5 & ) & .4 & 8) & 17 & $(025)$ & 9.1 & $(0.1$ & 1 & $(046)$ & .4 & $(0.96)$ & 1 & & 1.3 & $(0.98)$ & 6 & & 4.0 & $(0.95)$ & 3.7 & & 9.8 & $(0.3$ & .1 & $(0.26)$ \\
\hline & .8 & $(0.23)$ & 40.4 & $(0.93)$ & 4 & & & & 5 & $(0.25)$ & .9 & & .0 & 1 & 6 & & 2 & & 1.4 & & .8 & $(0.56)$ & 2.7 & $(0.97)$ & 3.6 & $(0.65)$ & 10.2 & $(0.35)$ & .9 & $0.25)$ \\
\hline $994 \ldots$. & 3.3 & $(0.23)$ & $47.3^{1}$ & $(0.94$ & 96.7 & i) & 4 & $(0.0$ & 96.6 & i) & 98.8 & in & 4 & $(0.43)$ & 0.2 & $(0.94)$ & 2 & 0.1 & 43.9 & $(0$. & .0 & $(0.55)$ & .9 & $(0.8$ & 24.0 & ( & 0.8 & $(0.3$ & .7 & 7) \\
\hline & 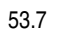 & $(0.21)$ & 1 & (c & ) & & & 0 & 3 & ( & 9 & (018) & 6 & I0 & 4 & 0. & 3 & & 1 & $(0.8$ & 5 & (C & .9 & $(0.8$ & 2 & $(0$ & 6 & $(0.3$ & .9 & 4) \\
\hline & 1 & 3) & 31 & i & & & & & 4 & 26 & 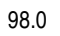 & & 8 & $(0.4$ & & & & & 1.9 & & .5 & & 4.4 & & 4.8 & & .9 & $(0.36)$ & .1 & $0.25)$ \\
\hline & 6 & $(0.22)$ & 1 & ( & 3.5 & & & . & 6 & $(0.2$ & 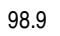 & & 3 & 10.4 & & (0. & & & .7 & $(0$. & 3 & & .9 & 0. & .4 & & .8 & & 7 & \\
\hline & 8 & $(0.22)$ & .11 & $(0.92$ & 95.6 & in & & $(0.1)$ & 1 & $(0.24)$ & 4 & $(0.2$ & .9 & $(0.4$ & .2 & $(0.84)$ & 7 & 1. & 46.4 & $(0.86)$ & 3.0 & $(0.54)$ & 4.8 & $(0.8$ & 4.9 & $(0.65)$ & 1.9 & $(0.36$ & 6 & $(0.27)$ \\
\hline & 56.0 & $(0.22)$ & $54.2^{1}$ & $(0.93$ & 96.0 & i. & 7 & $(0.1$ & 95.8 & $(0.24)$ & 98.2 & $(0.23$ & 93.6 & $(0.42)$ & 60.6 & $(0.84)$ & 16.5 & $(0.64)$ & 44.1 & $(0.85)$ & 32.8 & $(0.54)$ & 45.3 & $(0.90)$ & 24.5 & $(0.64)$ & 11.1 & $(0.36$ & 2 & (0.27) \\
\hline & & תר & & 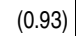 & & & & & & 2 & & & & & & (0. & & & & & 5 & & & & D & & 4 & (0. & & \\
\hline & 4 & $(0.20)$ & 41 & $(0.88$ & 3 & (C & & $(0.1$ & 8 & $0.23)$ & 1.1 & $(0.2$ & 4 & $(0.4$ & & $\begin{array}{l}(0.79) \\
\end{array}$ & & & 1.0 & $(0.8$ & 1.1 & (c) & 6.1 & $(0.8$ & .5 & $(0.6$ & 1.8 & $(0.3$ & 9 & $(0.26)$ \\
\hline & 6.2 & $(0.20)$ & $3^{1}$ & $(0.80$ & 95.5 & & 3 & $(0.1$ & 96.4 & $(0.21)$ & 98.4 & $(0.20)$ & .3 & ing & 3 & $(0.79)$ & 0 & $(0.6$ & 45.3 & $(0.82)$ & 4.4 & $(0.50)$ & 47.8 & $(0.83)$ & 5.6 & $(0.59)$ & 2.1 & $(0.35)$ & 6 & $(0.25)$ \\
\hline & 6.2 & $(0.20)$ & $55.1^{1}$ & $(0.85)$ & 94.5 & (i) & 3 & $(0.11)$ & 96.2 & $(0.21)$ & 97.5 & & .9 & 101 & 4.5 & $(0.80)$ & 9 & ing & 6.6 & $(0.84)$ & 35.6 & $(0.50)$ & 3.3 & $(0.83)$ & 7.8 & $(0.59)$ & 1.8 & $(0.34)$ & .8 & $(0.26)$ \\
\hline 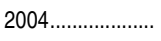 & 56.2 & $(0.20)$ & $54.0^{1}$ & $(0.85)$ & 95.4 & . & 3.4 & $(0.11$ & 96.5 & $(0.21)$ & 98.5 & $(0.19)$ & 94.5 & $(0.36)$ & 64.4 & $(0.80)$ & 16.6 & $(0.62)$ & 47.8 & $(0.83)$ & 35.2 & $(0.49)$ & 48.9 & $(0.82)$ & 26.3 & $(0.58)$ & 13.0 & $(0.35)$ & 6.6 & $(0.26)$ \\
\hline & & (0 & & & & & & & & & & & & & & & & & & & & & 7 & & 3 & & .9 & & & \\
\hline & 3.0 & $(0.20)$ & $55.7^{1}$ & $(0.86$ & 4.6 & & & (0. & 96.4 & $(0.21)$ & 3 & & 6 & $(0.3$ & .5 & $(0.77)$ & 3 & & 3.2 & $(0.8$ & 0 & (C) & 7.5 & $(0.81)$ & 3.7 & $(0.58)$ & .7 & $(0.33)$ & .2 & $(0.27)$ \\
\hline & 1 & $(0.20)$ & 15 & & & & & (0. & & & & & & & & & & & 9 & & & & 48.4 & & 3 & & 4 & & 2 & \\
\hline & 2 & $(0.2$ & & & & & & & & & & & & & & & & & 8.6 & & 9 & & 0.1 & $(0$. & 3.2 & & 3.2 & $(0.3$ & 3 & 10. \\
\hline$\cdots$ & 56.5 & $(0.20)$ & $52.4^{1}$ & $(0.85$ & 94.1 & $(0.44$ & 98.2 & $(0.1$ & 96.3 & $(0.22)$ & 98.0 & $(0.23)$ & 94.6 & $(0.3$ & 68.9 & $(0.73)$ & 19.1 & $(0.6$ & 49.8 & $(0.79)$ & 38.7 & $(0.50)$ & 51.7 & $(0.81)$ & 30.4 & $(0.60)$ & 13.5 & $(0.34)$ & 8.1 & (0.28) \\
\hline & & $(0$ & & & & & & & & & & & & & & & & & & & & & & & & & & & & \\
\hline & & $(0.1$ & & & & & & & & & & & & & & & & & .1 & & & & 2.7 & & .1 & & 4.8 & & .7 & \\
\hline $12^{2} \ldots \ldots \ldots$ & 56.6 & $(0.22)$ & $53.5^{1}$ & $(1.11)$ & 93.2 & $(0.49)$ & 98.0 & $(0.17)$ & 97.0 & $(0.28)$ & 98.2 & $(0.31)$ & 95.8 & $(0.40)$ & 69.0 & $(0.98)$ & 21.7 & $(0.77)$ & 47.3 & $(0.96)$ & 40.2 & $(0.72)$ & 54.0 & $(1.04)$ & 30.7 & $(0.84)$ & 14.0 & $(0.48)$ & 7.5 & (0.33) \\
\hline
\end{tabular}

\section{†Not available.}

'Beginning in 1994, preprimary enrollment data were collected using new procedures. Data may not be comparable to fig-

ures for earlier years.
${ }^{2}$ Beginning in 2010 , standard errors were computed using replicate weights, which produced more precise values than the

NOTE: Data for 1940 are for April. Data for all other years are as of October. Includes enrollment in any type of graded pub-
lic, parochial, or other private schools. Includes nursery schools, kindergartens, elementary schools, high schools, colleges, il, parochial, or other private schools. Includes nursery schools, kindergartens, elementary schools, high schools, colleges,
Universities, and professional schools. Attendance may be on either a full-time or part-time basis and during the day or night. Some data have been revised from previously published figures.

SOURCE: U.S. Department of Commerce, Census Bureau, Historical Statistics of the United States, Colonial Times to 1970; Current Population Reports, Series P-20, various years; CPS Historical Time Series Tables on School Enrollment, vey, October, 1970 through 2012 (This able was prepared May 2013) 
Table 104.10. Rates of high school completion and bachelor's degree attainment among persons age 25 and over, by race/ethnicity and sex: Selected years, 1910 through 2013

[Standard errors appear in parentheses]

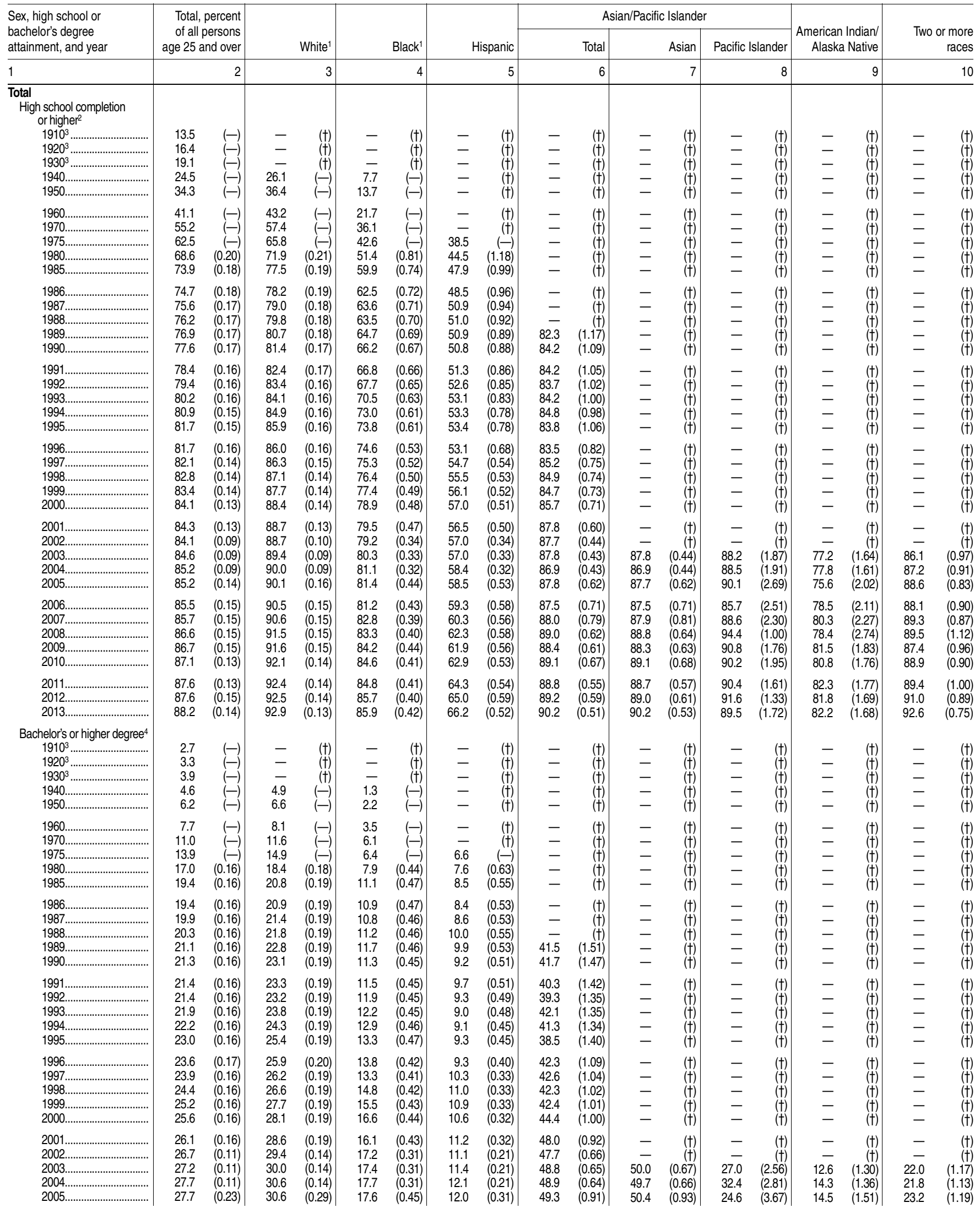


Table 104.10. Rates of high school completion and bachelor's degree attainment among persons age 25 and over, by race/ethnicity and sex: Selected years, 1910 through 2013-Continued

[Standard errors appear in parentheses]

\begin{tabular}{|c|c|c|c|c|c|c|c|c|c|c|c|c|c|c|c|c|c|c|}
\hline \multirow{2}{*}{$\begin{array}{l}\text { Sex, high school or } \\
\text { bachelor's degree } \\
\text { attainment, and year }\end{array}$} & \multirow{2}{*}{\multicolumn{2}{|c|}{$\begin{array}{r}\text { Total, percent } \\
\text { of all persons } \\
\text { age } 25 \text { and over }\end{array}$}} & \multirow{2}{*}{\multicolumn{2}{|c|}{ White $^{1}$}} & \multirow{2}{*}{\multicolumn{2}{|c|}{ Black $^{1}$}} & \multirow{2}{*}{\multicolumn{2}{|c|}{ Hispanic }} & \multicolumn{6}{|c|}{ Asian/Pacific Islander } & \multirow{2}{*}{\multicolumn{2}{|c|}{$\begin{array}{r}\text { American Indian/ } \\
\text { Alaska Native }\end{array}$}} & \multirow{2}{*}{\multicolumn{2}{|c|}{$\begin{array}{r}\text { Two or more } \\
\text { races }\end{array}$}} \\
\hline & & & & & & & & & & Total & & Asian & Pacific & slander & & & & \\
\hline 1 & & 2 & & 3 & & 4 & & 5 & & 6 & & 7 & & 8 & & 9 & & 10 \\
\hline 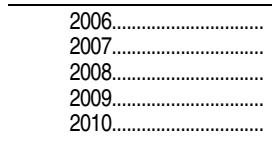 & $\begin{array}{l}28.0 \\
28.7 \\
29.4 \\
29.5 \\
29.9\end{array}$ & $\begin{array}{l}(0.20) \\
(0.21) \\
(0.21) \\
(0.21) \\
(0.19)\end{array}$ & $\begin{array}{l}31.0 \\
31.8 \\
32.6 \\
32.9 \\
33.2\end{array}$ & $\begin{array}{l}(0.25) \\
(0.27) \\
(0.26) \\
(0.26) \\
(0.24)\end{array}$ & $\begin{array}{l}18.6 \\
18.7 \\
19.7 \\
19.4 \\
20.0\end{array}$ & $\begin{array}{l}(0.47) \\
(0.51) \\
(0.51) \\
(0.45) \\
(0.51)\end{array}$ & $\begin{array}{l}12.4 \\
12.7 \\
13.3 \\
13.2 \\
13.9\end{array}$ & $\begin{array}{l}(0.32) \\
(0.31) \\
(0.29) \\
(0.34) \\
(0.31)\end{array}$ & $\begin{array}{l}49.1 \\
51.2 \\
51.9 \\
51.6 \\
51.6\end{array}$ & $\begin{array}{l}(1.04) \\
(1.02) \\
(0.95) \\
(0.91) \\
(1.04)\end{array}$ & $\begin{array}{l}50.0 \\
52.5 \\
52.9 \\
52.8 \\
52.8\end{array}$ & $\begin{array}{l}(1.06) \\
(1.03) \\
(0.97) \\
(0.95) \\
(1.09)\end{array}$ & $\begin{array}{l}26.9 \\
23.8 \\
28.4 \\
28.3 \\
25.6\end{array}$ & $\begin{array}{l}(3.42) \\
(3.30) \\
(2.86) \\
(2.68) \\
(2.89)\end{array}$ & $\begin{array}{l}12.9 \\
13.1 \\
14.9 \\
17.5 \\
16.0\end{array}$ & $\begin{array}{l}(1.60) \\
(1.24) \\
(1.52) \\
(2.08) \\
(1.77)\end{array}$ & $\begin{array}{l}23.1 \\
23.7 \\
24.4 \\
25.5 \\
25.3\end{array}$ & $\begin{array}{l}(1.28) \\
(1.30) \\
(1.36) \\
(1.34) \\
(1.30)\end{array}$ \\
\hline $\begin{array}{l}2011 \ldots \ldots \ldots \ldots \ldots \ldots \ldots \ldots \\
2012 \ldots \ldots \ldots \ldots \ldots \ldots \ldots \\
2013 \ldots \ldots \ldots \ldots \ldots \ldots \ldots \ldots . . .\end{array}$ & $\begin{array}{l}30.4 \\
30.9 \\
31.7\end{array}$ & $\begin{array}{l}(0.19) \\
(0.21) \\
(0.21)\end{array}$ & $\begin{array}{l}34.0 \\
34.5 \\
35.2\end{array}$ & $\begin{array}{l}(0.24) \\
(0.27) \\
(0.26)\end{array}$ & $\begin{array}{l}20.2 \\
21.4 \\
22.0\end{array}$ & $\begin{array}{l}(0.50) \\
(0.53) \\
(0.49)\end{array}$ & $\begin{array}{l}14.1 \\
14.5 \\
15.1\end{array}$ & $\begin{array}{l}(0.34) \\
(0.35) \\
(0.34)\end{array}$ & $\begin{array}{l}49.5 \\
50.7 \\
52.5\end{array}$ & $\begin{array}{l}(0.92) \\
(0.92) \\
(0.92)\end{array}$ & $\begin{array}{l}50.8 \\
51.9 \\
53.9\end{array}$ & $\begin{array}{l}(0.96) \\
(0.94) \\
(0.93)\end{array}$ & $\begin{array}{l}22.1 \\
24.5 \\
25.6\end{array}$ & $\begin{array}{l}(2.73) \\
(2.75) \\
(2.66)\end{array}$ & $\begin{array}{l}16.1 \\
16.7 \\
15.4\end{array}$ & $\begin{array}{l}(1.73) \\
(1.82) \\
(1.72)\end{array}$ & $\begin{array}{l}27.4 \\
27.1 \\
30.6\end{array}$ & $\begin{array}{l}(1.27) \\
(1.34) \\
(1.35)\end{array}$ \\
\hline $\begin{array}{l}\text { Males } \\
\text { High school completion } \\
\text { or higher }{ }^{2}\end{array}$ & & & & & & & & & & & & & & & & & & \\
\hline 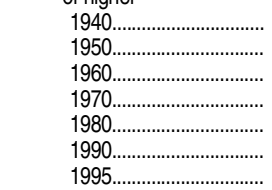 & $\begin{array}{l}22.7 \\
32.6 \\
39.5 \\
55.0 \\
69.2 \\
77.7 \\
81.7\end{array}$ & $\begin{array}{r}(-) \\
(-) \\
(-) \\
(-) \\
(0.29) \\
(0.24) \\
(0.22)\end{array}$ & $\begin{array}{l}24.2 \\
34.6 \\
41.6 \\
57.2 \\
72.4 \\
81.6 \\
86.0\end{array}$ & $\begin{array}{r}(-) \\
(-) \\
(-) \\
(-) \\
(0.31) \\
(0.25) \\
(0.22)\end{array}$ & $\begin{array}{r}6.9 \\
12.6 \\
20.0 \\
35.4 \\
51.2 \\
65.8 \\
73.5\end{array}$ & $\begin{array}{r}(-) \\
(-) \\
(-) \\
(-) \\
(1.21) \\
(1.01) \\
(0.91)\end{array}$ & $\begin{array}{r}- \\
- \\
- \\
44.9 \\
50.3 \\
52.9\end{array}$ & $\begin{array}{r}(\dagger) \\
(\dagger) \\
(\dagger) \\
(\dagger) \\
(1.71) \\
(1.25) \\
(1.11)\end{array}$ & $\begin{array}{r}- \\
- \\
- \\
\overline{-} \\
86.0 \\
85.8\end{array}$ & $\begin{array}{r}(\dagger) \\
(\dagger) \\
(\dagger) \\
(\dagger) \\
(\dagger) \\
(1.49) \\
(1.46)\end{array}$ & $\begin{array}{l}- \\
- \\
- \\
- \\
-\end{array}$ & $\begin{array}{l}(t) \\
(\dagger) \\
(t) \\
(\dagger) \\
(t) \\
(t) \\
(t)\end{array}$ & $\begin{array}{l}- \\
- \\
- \\
- \\
-\end{array}$ & $\begin{array}{r}(t) \\
(t) \\
(t) \\
(t) \\
(t) \\
(t) \\
(t)\end{array}$ & $\begin{array}{l}- \\
- \\
- \\
- \\
-\end{array}$ & $\begin{array}{l}(\dagger) \\
(\dagger) \\
(\dagger) \\
(\dagger) \\
(\dagger) \\
(t) \\
(t)\end{array}$ & $\begin{array}{l}- \\
- \\
- \\
- \\
- \\
-\end{array}$ & $\begin{array}{l}(t) \\
(t) \\
(t) \\
(t) \\
(t) \\
(t) \\
(t)\end{array}$ \\
\hline 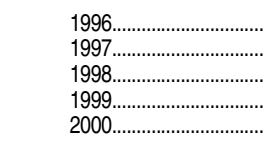 & $\begin{array}{l}81.9 \\
82.0 \\
82.8 \\
83.4 \\
84.2\end{array}$ & $\begin{array}{l}(0.23) \\
(0.21) \\
(0.20) \\
(0.20) \\
(0.19)\end{array}$ & $\begin{array}{l}86.1 \\
86.3 \\
87.1 \\
87.7 \\
88.5\end{array}$ & $\begin{array}{l}(0.23) \\
(0.21) \\
(0.21) \\
(0.20) \\
(0.20)\end{array}$ & $\begin{array}{l}74.6 \\
73.8 \\
75.4 \\
77.2 \\
79.1\end{array}$ & $\begin{array}{l}(0.80) \\
(0.79) \\
(0.77) \\
(0.74) \\
(0.72)\end{array}$ & $\begin{array}{l}53.0 \\
54.9 \\
55.7 \\
56.0 \\
56.6\end{array}$ & $\begin{array}{l}(0.97) \\
(0.76) \\
(0.74) \\
(0.75) \\
(0.73)\end{array}$ & $\begin{array}{l}86.2 \\
87.5 \\
87.9 \\
86.9 \\
88.4\end{array}$ & $\begin{array}{l}(1.10) \\
(1.00) \\
(0.98) \\
(1.00) \\
(0.94)\end{array}$ & $\begin{array}{l}- \\
- \\
- \\
-\end{array}$ & $\begin{array}{l}(\dagger) \\
(t) \\
(\dagger) \\
(t) \\
(t)\end{array}$ & $\begin{array}{l}- \\
- \\
- \\
-\end{array}$ & $\begin{array}{l}(t) \\
(\dagger) \\
(\dagger) \\
(\dagger) \\
(t)\end{array}$ & $\begin{array}{l}- \\
- \\
- \\
-\end{array}$ & $\begin{array}{l}(\dagger) \\
(\dagger) \\
(\dagger) \\
(\dagger) \\
(\dagger)\end{array}$ & $\begin{array}{l}- \\
- \\
- \\
-\end{array}$ & $\begin{array}{l}(\dagger) \\
(\dagger) \\
(\dagger) \\
(\dagger) \\
(\dagger)\end{array}$ \\
\hline $\begin{array}{l}2001 \ldots \ldots \ldots \\
2002 \ldots \ldots \ldots \ldots \\
2003 \ldots \ldots \ldots \ldots \ldots \ldots \\
2004 \ldots \ldots \ldots \ldots \ldots \ldots \\
2005\end{array}$ & $\begin{array}{l}84.4 \\
83.8 \\
84.1 \\
84.8 \\
84.9\end{array}$ & $\begin{array}{l}(0.19) \\
(0.14) \\
(0.13) \\
(0.13) \\
(0.19)\end{array}$ & $\begin{array}{l}88.6 \\
88.5 \\
89.0 \\
89.9 \\
89.9\end{array}$ & $\begin{array}{l}(0.19) \\
(0.14) \\
(0.14) \\
(0.13) \\
(0.20)\end{array}$ & $\begin{array}{l}80.6 \\
79.0 \\
79.9 \\
80.8 \\
81.4\end{array}$ & $\begin{array}{l}(0.69) \\
(0.51) \\
(0.50) \\
(0.49) \\
(0.60)\end{array}$ & $\begin{array}{l}55.6 \\
56.1 \\
56.3 \\
57.3 \\
57.9\end{array}$ & $\begin{array}{l}(0.72) \\
(0.48) \\
(0.46) \\
(0.45) \\
(0.69)\end{array}$ & $\begin{array}{l}90.6 \\
89.8 \\
89.8 \\
88.8 \\
90.4\end{array}$ & $\begin{array}{l}(0.78) \\
(0.58) \\
(0.58) \\
(0.59) \\
(0.65)\end{array}$ & $\begin{array}{r}- \\
89.8 \\
88.8 \\
90.5\end{array}$ & $\begin{array}{r}(\dagger) \\
(\dagger) \\
(0.59) \\
(0.60) \\
(0.66)\end{array}$ & $\begin{array}{r}- \\
89.8 \\
88.9 \\
88.5\end{array}$ & $\begin{array}{r}(\dagger) \\
(\dagger) \\
(2.61) \\
(2.65) \\
(3.62)\end{array}$ & $\begin{array}{r}- \\
76.5 \\
77.1 \\
75.6\end{array}$ & $\begin{array}{r}(\dagger) \\
(\dagger) \\
(2.33) \\
(2.31) \\
(2.57)\end{array}$ & $\begin{array}{r}- \\
87.2 \\
87.8 \\
89.0\end{array}$ & $\begin{array}{r}(\dagger) \\
(\dagger) \\
(1.36) \\
(1.29) \\
(1.19)\end{array}$ \\
\hline 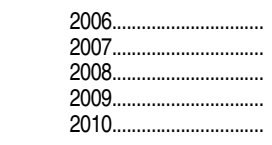 & $\begin{array}{l}85.0 \\
85.0 \\
85.9 \\
86.2 \\
86.6\end{array}$ & $\begin{array}{l}(0.20) \\
(0.21) \\
(0.19) \\
(0.19) \\
(0.17)\end{array}$ & $\begin{array}{l}90.2 \\
90.2 \\
91.1 \\
91.4 \\
91.8\end{array}$ & $\begin{array}{l}(0.21) \\
(0.22) \\
(0.20) \\
(0.20) \\
(0.19)\end{array}$ & $\begin{array}{l}80.7 \\
82.5 \\
82.1 \\
84.2 \\
84.2\end{array}$ & $\begin{array}{l}(0.63) \\
(0.55) \\
(0.61) \\
(0.60) \\
(0.57)\end{array}$ & $\begin{array}{l}58.5 \\
58.2 \\
60.9 \\
60.6 \\
61.4\end{array}$ & $\begin{array}{l}(0.77) \\
(0.80) \\
(0.72) \\
(0.72) \\
(0.68)\end{array}$ & $\begin{array}{l}89.5 \\
90.0 \\
91.0 \\
90.8 \\
91.4\end{array}$ & $\begin{array}{l}(0.84) \\
(0.81) \\
(0.66) \\
(0.66) \\
(0.78)\end{array}$ & $\begin{array}{l}89.7 \\
90.1 \\
90.8 \\
90.7 \\
91.5\end{array}$ & $\begin{array}{l}(0.86) \\
(0.82) \\
(0.69) \\
(0.68) \\
(0.79)\end{array}$ & $\begin{array}{l}85.8 \\
88.1 \\
95.8 \\
92.1 \\
89.3\end{array}$ & $\begin{array}{l}(3.10) \\
(2.75) \\
(1.40) \\
(2.18) \\
(2.84)\end{array}$ & $\begin{array}{l}78.1 \\
78.3 \\
77.3 \\
80.0 \\
78.9\end{array}$ & $\begin{array}{l}(2.77) \\
(3.58) \\
(3.37) \\
(2.33) \\
(2.46)\end{array}$ & $\begin{array}{l}88.0 \\
89.4 \\
89.6 \\
87.3 \\
88.1\end{array}$ & $\begin{array}{l}(1.36) \\
(1.28) \\
(1.21) \\
(1.26) \\
(1.36)\end{array}$ \\
\hline 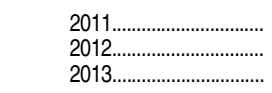 & $\begin{array}{l}87.1 \\
87.3 \\
87.6\end{array}$ & $\begin{array}{l}(0.18) \\
(0.19) \\
(0.17)\end{array}$ & $\begin{array}{l}92.0 \\
92.2 \\
92.7\end{array}$ & $\begin{array}{l}(0.17) \\
(0.18) \\
(0.17)\end{array}$ & $\begin{array}{l}84.2 \\
85.1 \\
84.9\end{array}$ & $\begin{array}{l}(0.55) \\
(0.56) \\
(0.62)\end{array}$ & $\begin{array}{l}63.6 \\
64.0 \\
64.6\end{array}$ & $\begin{array}{l}(0.71) \\
(0.73) \\
(0.66)\end{array}$ & $\begin{array}{l}90.6 \\
90.6 \\
91.6\end{array}$ & $\begin{array}{l}(0.68) \\
(0.68) \\
(0.57)\end{array}$ & $\begin{array}{l}90.6 \\
90.5 \\
91.7\end{array}$ & $\begin{array}{l}(0.69) \\
(0.70) \\
(0.57)\end{array}$ & $\begin{array}{l}91.5 \\
93.3 \\
89.3\end{array}$ & $\begin{array}{l}(2.22) \\
(1.84) \\
(2.48)\end{array}$ & $\begin{array}{l}80.6 \\
81.8 \\
81.0\end{array}$ & $\begin{array}{l}(2.35) \\
(2.39) \\
(2.11)\end{array}$ & $\begin{array}{l}88.1 \\
90.2 \\
93.3\end{array}$ & $\begin{array}{l}(1.40) \\
(1.45) \\
(1.03)\end{array}$ \\
\hline $\begin{array}{l}\text { Bachelor's or higher } \\
\text { degree } \\
1940 \ldots \ldots \\
1950 \ldots \ldots \\
1960 \ldots \ldots \\
1970 \ldots \\
1980 \ldots\end{array}$ & $\begin{array}{r}5.5 \\
7.3 \\
9.7 \\
14.1 \\
20.9 \\
24.4 \\
26.0\end{array}$ & $\begin{array}{r}(-) \\
(-) \\
(-) \\
(-) \\
(0.26) \\
(0.25) \\
(0.25)\end{array}$ & $\begin{array}{r}5.9 \\
7.9 \\
10.3 \\
15.0 \\
22.7 \\
26.7 \\
28.9\end{array}$ & $\begin{array}{r}(-) \\
(-) \\
(-) \\
(-) \\
(0.29) \\
(0.28) \\
(0.29)\end{array}$ & $\begin{array}{r}1.4 \\
2.1 \\
3.5 \\
6.8 \\
7.7 \\
11.9 \\
13.7\end{array}$ & $\begin{array}{r}(-) \\
(-) \\
(-) \\
(-) \\
(0.65) \\
(0.69) \\
(0.71)\end{array}$ & $\begin{array}{r}- \\
- \\
- \\
- \\
9.2 \\
9.8 \\
10.1\end{array}$ & $\begin{array}{r}(\dagger) \\
(\dagger) \\
(t) \\
(t) \\
(0.99) \\
(0.74) \\
(0.67)\end{array}$ & $\begin{array}{r}- \\
- \\
- \\
\overline{-} \\
45.9 \\
42.3\end{array}$ & $\begin{array}{r}(\dagger) \\
(\dagger) \\
(\dagger) \\
(\dagger) \\
(\dagger) \\
(2.14) \\
(2.06)\end{array}$ & $\begin{array}{l}- \\
- \\
- \\
- \\
-\end{array}$ & $\begin{array}{l}(t) \\
(t) \\
(t) \\
(t) \\
(t) \\
(t) \\
(t)\end{array}$ & $\begin{array}{l}- \\
- \\
- \\
- \\
-\end{array}$ & $\begin{array}{l}(t) \\
(t) \\
(t) \\
(t) \\
(t) \\
(t) \\
(t)\end{array}$ & $\begin{array}{l}- \\
- \\
- \\
- \\
-\end{array}$ & $\begin{array}{l}(t) \\
(t) \\
(t) \\
(t) \\
(\dagger) \\
(t) \\
(t)\end{array}$ & $\begin{array}{l}- \\
- \\
- \\
- \\
-\end{array}$ & $\begin{array}{l}(t) \\
(t) \\
(t) \\
(t) \\
(t) \\
(t) \\
(t)\end{array}$ \\
\hline $\begin{array}{l}1996 \ldots \ldots \\
1997 \ldots \ldots \\
1998 \ldots \ldots \\
1999 \ldots \ldots \\
2000\end{array}$ & $\begin{array}{l}26.0 \\
26.2 \\
26.5 \\
27.5 \\
27.8\end{array}$ & $\begin{array}{l}(0.26) \\
(0.24) \\
(0.24) \\
(0.24) \\
(0.24)\end{array}$ & $\begin{array}{l}28.8 \\
29.0 \\
29.3 \\
30.6 \\
30.8\end{array}$ & $\begin{array}{l}(0.30) \\
(0.28) \\
(0.28) \\
(0.28) \\
(0.28)\end{array}$ & $\begin{array}{l}12.5 \\
12.5 \\
14.0 \\
14.3 \\
16.4\end{array}$ & $\begin{array}{l}(0.61) \\
(0.60) \\
(0.62) \\
(0.62) \\
(0.65)\end{array}$ & $\begin{array}{l}10.3 \\
10.6 \\
11.1 \\
10.7 \\
10.7\end{array}$ & $\begin{array}{l}(0.59) \\
(0.47) \\
(0.47) \\
(0.46) \\
(0.45)\end{array}$ & $\begin{array}{l}46.9 \\
48.0 \\
46.0 \\
46.3 \\
48.1\end{array}$ & $\begin{array}{l}(1.59) \\
(1.51) \\
(1.50) \\
(1.48) \\
(1.47)\end{array}$ & $\begin{array}{l}- \\
- \\
- \\
-\end{array}$ & $\begin{array}{l}(t) \\
(t) \\
(t) \\
(t) \\
(t)\end{array}$ & $\begin{array}{l}- \\
- \\
- \\
-\end{array}$ & $\begin{array}{l}(t) \\
(t) \\
(t) \\
(t) \\
(t)\end{array}$ & $\begin{array}{l}- \\
- \\
- \\
-\end{array}$ & $\begin{array}{l}(\dagger) \\
(\dagger) \\
(\dagger) \\
(\dagger) \\
(\dagger)\end{array}$ & $\begin{array}{l}- \\
- \\
- \\
-\end{array}$ & $\begin{array}{l}(\dagger) \\
(t) \\
(t) \\
(t) \\
(t)\end{array}$ \\
\hline 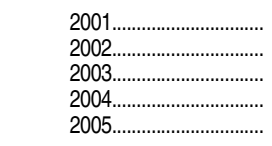 & $\begin{array}{l}28.0 \\
28.5 \\
28.9 \\
29.4 \\
28.9\end{array}$ & $\begin{array}{l}(0.24) \\
(0.17) \\
(0.17) \\
(0.17) \\
(0.29)\end{array}$ & $\begin{array}{l}30.9 \\
31.7 \\
32.3 \\
32.9 \\
32.4\end{array}$ & $\begin{array}{l}(0.28) \\
(0.20) \\
(0.20) \\
(0.20) \\
(0.37)\end{array}$ & $\begin{array}{l}15.9 \\
16.5 \\
16.8 \\
16.6 \\
16.0\end{array}$ & $\begin{array}{l}(0.64) \\
(0.47) \\
(0.47) \\
(0.46) \\
(0.64)\end{array}$ & $\begin{array}{l}11.1 \\
11.0 \\
11.2 \\
11.8 \\
11.8\end{array}$ & $\begin{array}{l}(0.45) \\
(0.30) \\
(0.29) \\
(0.30) \\
(0.43)\end{array}$ & $\begin{array}{l}52.9 \\
51.5 \\
52.8 \\
52.9 \\
53.0\end{array}$ & $\begin{array}{l}(1.33) \\
(0.96) \\
(0.96) \\
(0.93) \\
(1.10)\end{array}$ & $\begin{array}{r}\overline{-} \\
54.2 \\
54.0 \\
54.3\end{array}$ & $\begin{array}{r}(\dagger) \\
(\dagger) \\
(0.98) \\
(0.95) \\
(1.13)\end{array}$ & $\begin{array}{r}- \\
25.7 \\
31.9 \\
25.1\end{array}$ & $\begin{array}{r}(\dagger) \\
(\dagger) \\
(3.76) \\
(3.94) \\
(4.70)\end{array}$ & $\begin{array}{r}- \\
\overline{-} \\
13.1 \\
15.6 \\
17.0\end{array}$ & $\begin{array}{r}(\dagger) \\
(\dagger) \\
(1.85) \\
(1.99) \\
(2.30)\end{array}$ & $\begin{array}{r}\overline{-} \\
21.9 \\
20.7 \\
23.1\end{array}$ & $\begin{array}{r}(\dagger) \\
(\dagger) \\
(1.69) \\
(1.60) \\
(1.67)\end{array}$ \\
\hline 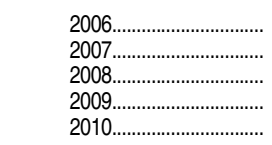 & $\begin{array}{l}29.2 \\
29.5 \\
30.1 \\
30.1 \\
30.3\end{array}$ & $\begin{array}{l}(0.24) \\
(0.25) \\
(0.25) \\
(0.28) \\
(0.23)\end{array}$ & $\begin{array}{l}32.8 \\
33.2 \\
33.8 \\
33.9 \\
34.2\end{array}$ & $\begin{array}{l}(0.31) \\
(0.33) \\
(0.33) \\
(0.36) \\
(0.30)\end{array}$ & $\begin{array}{l}17.5 \\
18.1 \\
18.7 \\
17.9 \\
17.9\end{array}$ & $\begin{array}{l}(0.63) \\
(0.62) \\
(0.67) \\
(0.57) \\
(0.59)\end{array}$ & $\begin{array}{l}11.9 \\
11.8 \\
12.6 \\
12.5 \\
12.9\end{array}$ & $\begin{array}{l}(0.40) \\
(0.37) \\
(0.39) \\
(0.41) \\
(0.37)\end{array}$ & $\begin{array}{l}51.9 \\
54.2 \\
54.9 \\
54.8 \\
54.6\end{array}$ & $\begin{array}{l}(1.33) \\
(1.31) \\
(1.24) \\
(1.14) \\
(1.26)\end{array}$ & $\begin{array}{l}53.1 \\
55.8 \\
56.1 \\
56.5 \\
56.2\end{array}$ & $\begin{array}{l}(1.35) \\
(1.32) \\
(1.24) \\
(1.17) \\
(1.30)\end{array}$ & $\begin{array}{l}26.6 \\
19.2 \\
27.5 \\
23.0 \\
18.0\end{array}$ & $\begin{array}{l}(4.67) \\
(4.14) \\
(3.64) \\
(3.35) \\
(3.74)\end{array}$ & $\begin{array}{l}13.7 \\
12.7 \\
14.6 \\
16.1 \\
13.5\end{array}$ & $\begin{array}{l}(2.07) \\
(1.89) \\
(2.15) \\
(2.96) \\
(2.61)\end{array}$ & $\begin{array}{l}22.6 \\
21.5 \\
22.7 \\
24.4 \\
24.8\end{array}$ & $\begin{array}{l}(1.75) \\
(1.81) \\
(1.62) \\
(1.92) \\
(1.86)\end{array}$ \\
\hline 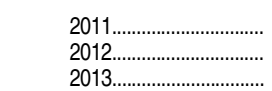 & $\begin{array}{l}30.8 \\
31.4 \\
32.0\end{array}$ & $\begin{array}{l}(0.23) \\
(0.27) \\
(0.25)\end{array}$ & $\begin{array}{l}35.0 \\
35.5 \\
36.0\end{array}$ & $\begin{array}{l}(0.29) \\
(0.33) \\
(0.31)\end{array}$ & $\begin{array}{l}18.4 \\
19.5 \\
20.2\end{array}$ & $\begin{array}{l}(0.64) \\
(0.62) \\
(0.64)\end{array}$ & $\begin{array}{l}13.1 \\
13.3 \\
13.9\end{array}$ & $\begin{array}{l}(0.44) \\
(0.45) \\
(0.43)\end{array}$ & $\begin{array}{l}52.4 \\
53.1 \\
55.1\end{array}$ & $\begin{array}{l}(1.15) \\
(1.26) \\
(1.17)\end{array}$ & $\begin{array}{l}54.0 \\
54.4 \\
56.9\end{array}$ & $\begin{array}{l}(1.21) \\
(1.29) \\
(1.20)\end{array}$ & $\begin{array}{l}19.1 \\
24.1 \\
23.1\end{array}$ & $\begin{array}{l}(3.55) \\
(3.34) \\
(3.32)\end{array}$ & $\begin{array}{r}14.1 \\
16.1 \\
14.0\end{array}$ & $\begin{array}{l}(1.98) \\
(2.27) \\
(2.13)\end{array}$ & $\begin{array}{l}25.7 \\
25.2 \\
29.0\end{array}$ & $\begin{array}{l}(1.91) \\
(1.85) \\
(1.78)\end{array}$ \\
\hline $\begin{array}{l}\text { Females } \\
\text { High school completion } \\
\text { or higher }{ }^{2} \\
1940 \\
1950\end{array}$ & $\begin{array}{l}26.3 \\
36.0 \\
42.5 \\
55.4 \\
68.1 \\
77.5 \\
81.6\end{array}$ & $\begin{array}{r}(-) \\
(-) \\
(-) \\
(-) \\
(0.28) \\
(0.23) \\
(0.21)\end{array}$ & $\begin{array}{l}28.1 \\
38.2 \\
44.7 \\
57.7 \\
71.5 \\
81.3 \\
85.8\end{array}$ & $\begin{array}{r}(-) \\
(-) \\
(-) \\
(-) \\
(0.30) \\
(0.24) \\
(0.22)\end{array}$ & $\begin{array}{r}8.4 \\
14.7 \\
23.1 \\
36.6 \\
51.5 \\
66.5 \\
74.1\end{array}$ & $\begin{array}{r}(-) \\
(-) \\
(-) \\
(-) \\
(1.08) \\
(0.90) \\
(0.81)\end{array}$ & $\begin{array}{r}- \\
- \\
- \\
44.2 \\
51.3 \\
53.8\end{array}$ & $\begin{array}{r}(\dagger) \\
(\dagger) \\
(\dagger) \\
(\dagger) \\
(1.63) \\
(1.23) \\
(1.09)\end{array}$ & $\begin{array}{r}- \\
- \\
- \\
- \\
82.5 \\
81.9\end{array}$ & $\begin{array}{r}(\dagger) \\
(\dagger) \\
(\dagger) \\
(\dagger) \\
(\dagger) \\
(1.57) \\
(1.54)\end{array}$ & $\begin{array}{l}- \\
- \\
- \\
- \\
- \\
-\end{array}$ & $\begin{array}{l}(t) \\
(t) \\
(t) \\
(t) \\
(t) \\
(t) \\
(t)\end{array}$ & $\begin{array}{l}- \\
- \\
- \\
- \\
-\end{array}$ & $\begin{array}{l}(t) \\
(t) \\
(t) \\
(t) \\
(t) \\
(t) \\
(t)\end{array}$ & $\begin{array}{l}- \\
- \\
- \\
- \\
- \\
-\end{array}$ & $\begin{array}{l}(t) \\
(t) \\
(t) \\
(t) \\
(\dagger) \\
(t) \\
(t) \\
(t)\end{array}$ & $\begin{array}{l}- \\
- \\
- \\
- \\
-\end{array}$ & $\begin{array}{l}(t) \\
(t) \\
(t) \\
(t) \\
(t) \\
(t) \\
(t)\end{array}$ \\
\hline
\end{tabular}


Table 104.10. Rates of high school completion and bachelor's degree attainment among persons age 25 and over, by race/ethnicity and sex: Selected years, 1910 through 2013-Continued

[Standard errors appear in parentheses]

\begin{tabular}{|c|c|c|c|c|c|c|c|c|c|c|c|c|c|c|c|c|c|c|}
\hline \multirow{2}{*}{$\begin{array}{l}\text { Sex, high school or } \\
\text { bachelor's degree } \\
\text { attainment, and year }\end{array}$} & \multirow{2}{*}{\multicolumn{2}{|c|}{$\begin{array}{r}\text { Total, percent } \\
\text { of all persons } \\
\text { age } 25 \text { and over }\end{array}$}} & \multirow{2}{*}{\multicolumn{2}{|c|}{ White $^{1}$}} & \multirow{2}{*}{\multicolumn{2}{|c|}{ Black $^{1}$}} & \multirow{2}{*}{\multicolumn{2}{|c|}{ Hispanic }} & \multicolumn{6}{|c|}{ Asian/Pacific Islander } & \multirow{2}{*}{\multicolumn{2}{|c|}{$\begin{array}{r}\text { American Indian/ } \\
\text { Alaska Native }\end{array}$}} & \multirow{2}{*}{\multicolumn{2}{|c|}{$\begin{array}{r}\text { Two or more } \\
\text { races }\end{array}$}} \\
\hline & & & & & & & & & & Total & & Asian & Pacific & slander & & & & \\
\hline 1 & & 2 & & 3 & & 4 & & 5 & & 6 & & 7 & & 8 & & 9 & & 10 \\
\hline 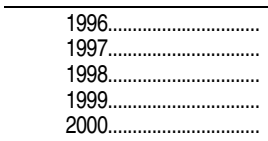 & $\begin{array}{l}81.6 \\
82.2 \\
82.9 \\
83.3 \\
84.0\end{array}$ & $\begin{array}{l}(0.22) \\
(0.20) \\
(0.19) \\
(0.19) \\
(0.19)\end{array}$ & $\begin{array}{l}85.9 \\
86.3 \\
87.1 \\
87.6 \\
88.4\end{array}$ & $\begin{array}{l}(0.22) \\
(0.20) \\
(0.20) \\
(0.19) \\
(0.19)\end{array}$ & $\begin{array}{l}74.6 \\
76.5 \\
77.1 \\
77.5 \\
78.7\end{array}$ & $\begin{array}{l}(0.71) \\
(0.68) \\
(0.67) \\
(0.66) \\
(0.64)\end{array}$ & $\begin{array}{l}53.3 \\
54.6 \\
55.3 \\
56.3 \\
57.5\end{array}$ & $\begin{array}{l}(0.97) \\
(0.76) \\
(0.75) \\
(0.73) \\
(0.71)\end{array}$ & $\begin{array}{l}81.0 \\
82.9 \\
82.3 \\
82.8 \\
83.4\end{array}$ & $\begin{array}{l}(1.21) \\
(1.11) \\
(1.09) \\
(1.06) \\
(1.03)\end{array}$ & $\begin{array}{l}- \\
- \\
- \\
-\end{array}$ & $\begin{array}{l}(\dagger) \\
(\dagger) \\
(\dagger) \\
(\dagger) \\
(t)\end{array}$ & $\begin{array}{l}- \\
- \\
- \\
-\end{array}$ & $\begin{array}{l}(t) \\
(t) \\
(t) \\
(t) \\
(t)\end{array}$ & $\begin{array}{l}- \\
- \\
- \\
-\end{array}$ & $\begin{array}{l}(\dagger) \\
(\dagger) \\
(\dagger) \\
(\dagger) \\
(\dagger)\end{array}$ & $\begin{array}{l}- \\
- \\
- \\
-\end{array}$ & $\begin{array}{l}(\dagger) \\
(\dagger) \\
(\dagger) \\
(\dagger) \\
(\dagger)\end{array}$ \\
\hline $\begin{array}{l}2001 \ldots \ldots \ldots \\
2002 \ldots \ldots \ldots \ldots \ldots \ldots \\
2003 \ldots \ldots \ldots \ldots \\
2004 \ldots \ldots \ldots \ldots \ldots \ldots \\
2005\end{array}$ & $\begin{array}{l}84.2 \\
84.4 \\
85.0 \\
85.4 \\
85.5\end{array}$ & $\begin{array}{l}(0.18) \\
(0.13) \\
(0.13) \\
(0.12) \\
(0.15)\end{array}$ & $\begin{array}{l}88.8 \\
88.9 \\
89.7 \\
90.1 \\
90.3\end{array}$ & $\begin{array}{l}(0.19) \\
(0.13) \\
(0.13) \\
(0.12) \\
(0.18)\end{array}$ & $\begin{array}{l}78.6 \\
79.4 \\
80.7 \\
81.2 \\
81.5\end{array}$ & $\begin{array}{l}(0.64) \\
(0.45) \\
(0.44) \\
(0.43) \\
(0.53)\end{array}$ & $\begin{array}{l}57.4 \\
57.9 \\
57.8 \\
59.5 \\
59.1\end{array}$ & $\begin{array}{l}(0.70) \\
(0.48) \\
(0.46) \\
(0.46) \\
(0.63)\end{array}$ & $\begin{array}{l}85.2 \\
85.7 \\
86.1 \\
85.3 \\
85.4\end{array}$ & $\begin{array}{l}(0.91) \\
(0.64) \\
(0.62) \\
(0.63) \\
(0.76)\end{array}$ & $\begin{array}{r}- \\
86.1 \\
85.1 \\
85.2\end{array}$ & $\begin{array}{r}(\dagger) \\
(\dagger) \\
(0.64) \\
(0.64) \\
(0.78)\end{array}$ & $\begin{array}{r}- \\
86.9 \\
88.1 \\
91.7\end{array}$ & $\begin{array}{r}(\dagger) \\
(\dagger) \\
(2.63) \\
(2.76) \\
(2.46)\end{array}$ & $\begin{array}{r}- \\
- \\
77.9 \\
78.6 \\
75.6\end{array}$ & $\begin{array}{r}(\dagger) \\
(\dagger) \\
(2.30) \\
(2.24) \\
(2.29)\end{array}$ & $\begin{array}{r}- \\
85.1 \\
86.5 \\
88.1\end{array}$ & $\begin{array}{r}(\dagger) \\
(\dagger) \\
(1.38) \\
(1.29) \\
(1.12)\end{array}$ \\
\hline $\begin{array}{l}2006 \ldots \ldots \ldots \\
2007 \ldots \ldots \ldots \ldots \\
2008 \ldots \ldots \ldots \ldots \ldots \\
2009 \ldots \ldots \ldots \ldots \\
2010 \ldots \ldots \ldots \ldots\end{array}$ & $\begin{array}{l}85.9 \\
86.4 \\
87.2 \\
87.1 \\
87.6\end{array}$ & $\begin{array}{l}(0.16) \\
(0.15) \\
(0.17) \\
(0.16) \\
(0.15)\end{array}$ & $\begin{array}{l}90.8 \\
91.0 \\
91.8 \\
91.9 \\
92.3\end{array}$ & $\begin{array}{l}(0.17) \\
(0.16) \\
(0.18) \\
(0.17) \\
(0.17)\end{array}$ & $\begin{array}{l}81.5 \\
83.0 \\
84.2 \\
84.2 \\
85.0\end{array}$ & $\begin{array}{l}(0.51) \\
(0.49) \\
(0.49) \\
(0.48) \\
(0.46)\end{array}$ & $\begin{array}{l}60.1 \\
62.5 \\
63.7 \\
63.3 \\
64.4\end{array}$ & $\begin{array}{l}(0.59) \\
(0.56) \\
(0.61) \\
(0.59) \\
(0.59)\end{array}$ & $\begin{array}{l}85.6 \\
86.1 \\
87.2 \\
86.4 \\
87.2\end{array}$ & $\begin{array}{l}(0.82) \\
(0.93) \\
(0.75) \\
(0.73) \\
(0.72)\end{array}$ & $\begin{array}{l}85.6 \\
86.0 \\
87.0 \\
86.3 \\
87.1\end{array}$ & $\begin{array}{l}(0.81) \\
(0.97) \\
(0.78) \\
(0.75) \\
(0.75)\end{array}$ & $\begin{array}{l}85.7 \\
89.1 \\
93.0 \\
89.7 \\
90.9\end{array}$ & $\begin{array}{l}(3.08) \\
(2.40) \\
(1.57) \\
(2.33) \\
(2.41)\end{array}$ & $\begin{array}{l}78.9 \\
81.9 \\
79.2 \\
82.7 \\
82.5\end{array}$ & $\begin{array}{l}(2.18) \\
(1.91) \\
(2.95) \\
(1.96) \\
(1.95)\end{array}$ & $\begin{array}{l}88.2 \\
89.2 \\
89.5 \\
87.6 \\
89.7\end{array}$ & $\begin{array}{l}(1.11) \\
(1.22) \\
(1.53) \\
(1.16) \\
(1.13)\end{array}$ \\
\hline 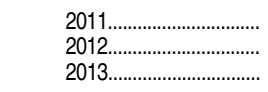 & $\begin{array}{l}88.0 \\
88.0 \\
88.6\end{array}$ & $\begin{array}{l}(0.15) \\
(0.17) \\
(0.16)\end{array}$ & $\begin{array}{l}92.8 \\
92.7 \\
93.2\end{array}$ & $\begin{array}{l}(0.16) \\
(0.18) \\
(0.16)\end{array}$ & $\begin{array}{l}85.3 \\
86.1 \\
86.6\end{array}$ & $\begin{array}{l}(0.50) \\
(0.46) \\
(0.46)\end{array}$ & $\begin{array}{l}65.1 \\
66.0 \\
67.9\end{array}$ & $\begin{array}{l}(0.57) \\
(0.65) \\
(0.55)\end{array}$ & $\begin{array}{l}87.1 \\
87.9 \\
89.0\end{array}$ & $\begin{array}{l}(0.64) \\
(0.64) \\
(0.61)\end{array}$ & $\begin{array}{l}87.0 \\
87.8 \\
88.9\end{array}$ & $\begin{array}{l}(0.66) \\
(0.66) \\
(0.63)\end{array}$ & $\begin{array}{l}89.5 \\
90.1 \\
89.6\end{array}$ & $\begin{array}{l}(2.25) \\
(2.11) \\
(2.01)\end{array}$ & $\begin{array}{l}83.8 \\
81.8 \\
83.1\end{array}$ & $\begin{array}{l}(2.00) \\
(1.84) \\
(2.16)\end{array}$ & $\begin{array}{l}90.7 \\
91.6 \\
92.0\end{array}$ & $\begin{array}{l}(1.22) \\
(1.13) \\
(0.95)\end{array}$ \\
\hline $\begin{array}{l}\text { Bachelor's or higher } \\
\text { degree } \\
1940 \ldots \ldots \\
1950 \ldots \ldots \\
1960 \ldots \\
1970 \ldots \\
1980 \ldots\end{array}$ & $\begin{array}{r}3.8 \\
5.2 \\
5.8 \\
8.2 \\
13.6 \\
18.4 \\
20.2\end{array}$ & $\begin{array}{r}(-) \\
(-) \\
(-) \\
(-) \\
(0.20) \\
(0.21) \\
(0.22)\end{array}$ & $\begin{array}{r}4.0 \\
5.4 \\
6.0 \\
8.6 \\
14.4 \\
19.8 \\
22.1\end{array}$ & $\begin{array}{r}(-) \\
(-) \\
(-) \\
(-) \\
(0.23) \\
(0.25) \\
(0.26)\end{array}$ & $\begin{array}{r}1.2 \\
2.4 \\
3.6 \\
5.6 \\
8.1 \\
10.8 \\
13.0\end{array}$ & $\begin{array}{r}(-) \\
(-) \\
(-) \\
(-) \\
(0.59) \\
(0.59) \\
(0.62)\end{array}$ & $\begin{array}{l}- \\
- \\
- \\
- \\
6.2 \\
8.7 \\
8.4\end{array}$ & $\begin{array}{r}(\dagger) \\
(\dagger) \\
(\dagger) \\
(\dagger) \\
(0.79) \\
(0.69) \\
(0.61)\end{array}$ & $\begin{array}{r}- \\
- \\
- \\
\overline{-} \\
37.8 \\
35.0\end{array}$ & $\begin{array}{r}(t) \\
(\dagger) \\
(t) \\
(t) \\
(t) \\
(2.01) \\
(1.90)\end{array}$ & $\begin{array}{l}- \\
- \\
- \\
- \\
-\end{array}$ & $\begin{array}{l}(t) \\
(t) \\
(t) \\
(t) \\
(t) \\
(t) \\
(t)\end{array}$ & $\begin{array}{l}- \\
- \\
- \\
- \\
- \\
-\end{array}$ & $\begin{array}{l}(t) \\
(t) \\
(t) \\
(t) \\
(t) \\
(t) \\
(t)\end{array}$ & $\begin{array}{l}- \\
- \\
- \\
- \\
- \\
-\end{array}$ & $\begin{array}{l}(t) \\
(t) \\
(t) \\
(t) \\
(t) \\
(t) \\
(t)\end{array}$ & $\begin{array}{l}- \\
- \\
- \\
- \\
-\end{array}$ & $\begin{array}{l}(t) \\
(t) \\
(t) \\
(t) \\
(t) \\
(t) \\
(t)\end{array}$ \\
\hline $\begin{array}{l}1996 \ldots \ldots \ldots \\
1997 \ldots \ldots \ldots \\
1998 \ldots \ldots \ldots \ldots \\
1999 \ldots \ldots \\
2000\end{array}$ & $\begin{array}{l}21.4 \\
21.7 \\
22.4 \\
23.1 \\
23.6\end{array}$ & $\begin{array}{l}(0.23) \\
(0.21) \\
(0.21) \\
(0.22) \\
(0.22)\end{array}$ & $\begin{array}{l}23.2 \\
23.7 \\
24.1 \\
25.0 \\
25.5\end{array}$ & $\begin{array}{l}(0.27) \\
(0.25) \\
(0.25) \\
(0.26) \\
(0.26)\end{array}$ & $\begin{array}{l}14.8 \\
14.0 \\
15.4 \\
16.5 \\
16.8\end{array}$ & $\begin{array}{l}(0.58) \\
(0.56) \\
(0.58) \\
(0.59) \\
(0.59)\end{array}$ & $\begin{array}{r}8.3 \\
10.1 \\
10.9 \\
11.0 \\
10.6\end{array}$ & $\begin{array}{l}(0.53) \\
(0.46) \\
(0.47) \\
(0.46) \\
(0.44)\end{array}$ & $\begin{array}{l}38.0 \\
37.4 \\
38.9 \\
39.0 \\
41.0\end{array}$ & $\begin{array}{l}(1.50) \\
(1.43) \\
(1.39) \\
(1.37) \\
(1.37)\end{array}$ & $\begin{array}{l}- \\
- \\
- \\
-\end{array}$ & $\begin{array}{l}(t) \\
(t) \\
(t) \\
(t) \\
(t)\end{array}$ & $\begin{array}{l}- \\
- \\
- \\
-\end{array}$ & $\begin{array}{l}(t) \\
(t) \\
(t) \\
(t) \\
(t)\end{array}$ & $\begin{array}{l}- \\
- \\
- \\
-\end{array}$ & $\begin{array}{l}(\dagger) \\
(\dagger) \\
(\dagger) \\
(\dagger) \\
(t)\end{array}$ & $\begin{array}{l}- \\
- \\
- \\
-\end{array}$ & $\begin{array}{l}(\dagger) \\
(\dagger) \\
(\dagger) \\
(\dagger) \\
(\dagger)\end{array}$ \\
\hline 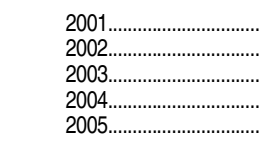 & $\begin{array}{l}24.3 \\
25.1 \\
25.7 \\
26.1 \\
26.5\end{array}$ & $\begin{array}{l}(0.22) \\
(0.15) \\
(0.15) \\
(0.15) \\
(0.23)\end{array}$ & $\begin{array}{l}26.5 \\
27.3 \\
27.9 \\
28.4 \\
28.9\end{array}$ & $\begin{array}{l}(0.26) \\
(0.19) \\
(0.19) \\
(0.19) \\
(0.30)\end{array}$ & $\begin{array}{l}16.3 \\
17.7 \\
18.0 \\
18.5 \\
18.9\end{array}$ & $\begin{array}{l}(0.58) \\
(0.42) \\
(0.43) \\
(0.43) \\
(0.51)\end{array}$ & $\begin{array}{l}11.3 \\
11.2 \\
11.6 \\
12.3 \\
12.1\end{array}$ & $\begin{array}{l}(0.45) \\
(0.31) \\
(0.30) \\
(0.31) \\
(0.42)\end{array}$ & $\begin{array}{l}43.4 \\
44.2 \\
45.3 \\
45.2 \\
46.0\end{array}$ & $\begin{array}{l}(1.26) \\
(0.91) \\
(0.89) \\
(0.88) \\
(1.08)\end{array}$ & $\begin{array}{r}- \\
46.3 \\
45.7 \\
46.8\end{array}$ & $\begin{array}{r}(\dagger) \\
(t) \\
(0.92) \\
(0.90) \\
(1.10)\end{array}$ & $\begin{array}{r}- \\
28.0 \\
32.9 \\
24.1\end{array}$ & $\begin{array}{r}(\dagger) \\
(t) \\
(3.50) \\
(4.01) \\
(4.08)\end{array}$ & $\begin{array}{r}- \\
12.2 \\
13.1 \\
12.2\end{array}$ & $\begin{array}{r}(\dagger) \\
(\dagger) \\
(1.81) \\
(1.84) \\
(2.00)\end{array}$ & $\begin{array}{r}- \\
22.2 \\
22.7 \\
23.3\end{array}$ & $\begin{array}{r}(\dagger) \\
(\dagger) \\
(1.61) \\
(1.59) \\
(1.43)\end{array}$ \\
\hline 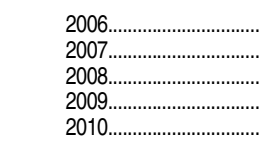 & $\begin{array}{l}26.9 \\
28.0 \\
28.8 \\
29.1 \\
29.6\end{array}$ & $\begin{array}{l}(0.22) \\
(0.23) \\
(0.24) \\
(0.21) \\
(0.21)\end{array}$ & $\begin{array}{l}29.3 \\
30.6 \\
31.5 \\
31.9 \\
32.4\end{array}$ & $\begin{array}{l}(0.28) \\
(0.29) \\
(0.29) \\
(0.26) \\
(0.26)\end{array}$ & $\begin{array}{l}19.5 \\
19.2 \\
20.5 \\
20.6 \\
21.6\end{array}$ & $\begin{array}{l}(0.55) \\
(0.59) \\
(0.58) \\
(0.56) \\
(0.63)\end{array}$ & $\begin{array}{l}12.9 \\
13.7 \\
14.1 \\
14.0 \\
14.9\end{array}$ & $\begin{array}{l}(0.39) \\
(0.44) \\
(0.37) \\
(0.41) \\
(0.42)\end{array}$ & $\begin{array}{l}46.6 \\
48.6 \\
49.3 \\
48.8 \\
49.1\end{array}$ & $\begin{array}{l}(1.11) \\
(1.07) \\
(0.99) \\
(0.98) \\
(1.12)\end{array}$ & $\begin{array}{l}47.3 \\
49.5 \\
50.1 \\
49.7 \\
49.9\end{array}$ & $\begin{array}{l}(1.15) \\
(1.10) \\
(1.02) \\
(1.02) \\
(1.19)\end{array}$ & $\begin{array}{l}27.2 \\
27.9 \\
29.3 \\
32.9 \\
32.2\end{array}$ & $\begin{array}{l}(4.03) \\
(4.16) \\
(3.82) \\
(3.74) \\
(4.11)\end{array}$ & $\begin{array}{l}12.3 \\
13.4 \\
15.1 \\
18.8 \\
18.2\end{array}$ & $\begin{array}{l}(1.81) \\
(1.53) \\
(1.75) \\
(1.91) \\
(1.83)\end{array}$ & $\begin{array}{l}23.6 \\
25.8 \\
26.1 \\
26.6 \\
25.7\end{array}$ & $\begin{array}{l}(1.70) \\
(1.58) \\
(1.92) \\
(1.67) \\
(1.59)\end{array}$ \\
\hline $\begin{array}{l}2011 \ldots \ldots \ldots \ldots \ldots \ldots \ldots . . . \\
2012 \ldots \ldots \ldots \ldots \ldots \ldots \ldots \ldots . . . \\
2013 \ldots \ldots \ldots \ldots \ldots \ldots \ldots \ldots . . .\end{array}$ & $\begin{array}{l}30.1 \\
30.6 \\
31.4\end{array}$ & $\begin{array}{l}(0.22) \\
(0.23) \\
(0.24)\end{array}$ & $\begin{array}{l}33.1 \\
33.5 \\
34.4\end{array}$ & $\begin{array}{l}(0.28) \\
(0.30) \\
(0.31)\end{array}$ & $\begin{array}{l}21.7 \\
22.9 \\
23.4\end{array}$ & $\begin{array}{l}(0.60) \\
(0.61) \\
(0.61)\end{array}$ & $\begin{array}{l}15.2 \\
15.8 \\
16.2\end{array}$ & $\begin{array}{l}(0.43) \\
(0.45) \\
(0.42)\end{array}$ & $\begin{array}{l}47.0 \\
48.6 \\
50.2\end{array}$ & $\begin{array}{l}(1.04) \\
(0.93) \\
(0.94)\end{array}$ & $\begin{array}{l}48.0 \\
49.7 \\
51.3\end{array}$ & $\begin{array}{l}(1.07) \\
(0.94) \\
(0.96)\end{array}$ & $\begin{array}{l}24.7 \\
24.9 \\
28.0\end{array}$ & $\begin{array}{l}(3.52) \\
(3.70) \\
(3.44)\end{array}$ & $\begin{array}{l}17.9 \\
17.2 \\
16.6\end{array}$ & $\begin{array}{l}(2.17) \\
(2.13) \\
(2.05)\end{array}$ & $\begin{array}{l}28.9 \\
28.8 \\
32.0\end{array}$ & $\begin{array}{l}(1.70) \\
(1.88) \\
(1.89)\end{array}$ \\
\hline
\end{tabular}

-Not available.

†Not applicable.

${ }^{1}$ Includes persons of Hispanic ethnicity for years prior to 1980.

${ }^{2}$ Data for years prior to 1993 are for persons with 4 or more years of high school. Data for later years are for high school completers-i.e., those persons who graduated from high school with a diploma as well as those who completed high school through equivalency programs, such as a GED program.

${ }^{3}$ Estimates based on Census Bureau reverse projection of 1940 census data on education by age.

${ }^{4}$ Data for years prior to 1993 are for persons with 4 or more years of college.
NOTE: Beginning in 2005, standard errors were computed using replicate weights, which produced more precise values than the methodology used in prior years. For 1960 and prior years, data were collected in April. For all other years, data were collected in March. Race categories exclude persons of Hispanic ethnicity except where otherwise noted. SOURCE: U.S. Department of Commerce, Census Bureau, U.S. Census of Population: 1960, Vol. I, Part 1; J.K. Folger and C.B. Nam, Education of the American Population (1960 Census Monograph); Current Population Reports, Series P-20, various years; and Current Population Survey (CPS), March 1970 through March 2013. (This table was prepared February 2014.) 
Table 104.20. Percentage of persons 25 to 29 years old with selected levels of educational attainment, by race/ethnicity and sex: Selected years, 1920 through 2013

[Standard errors appear in parentheses]

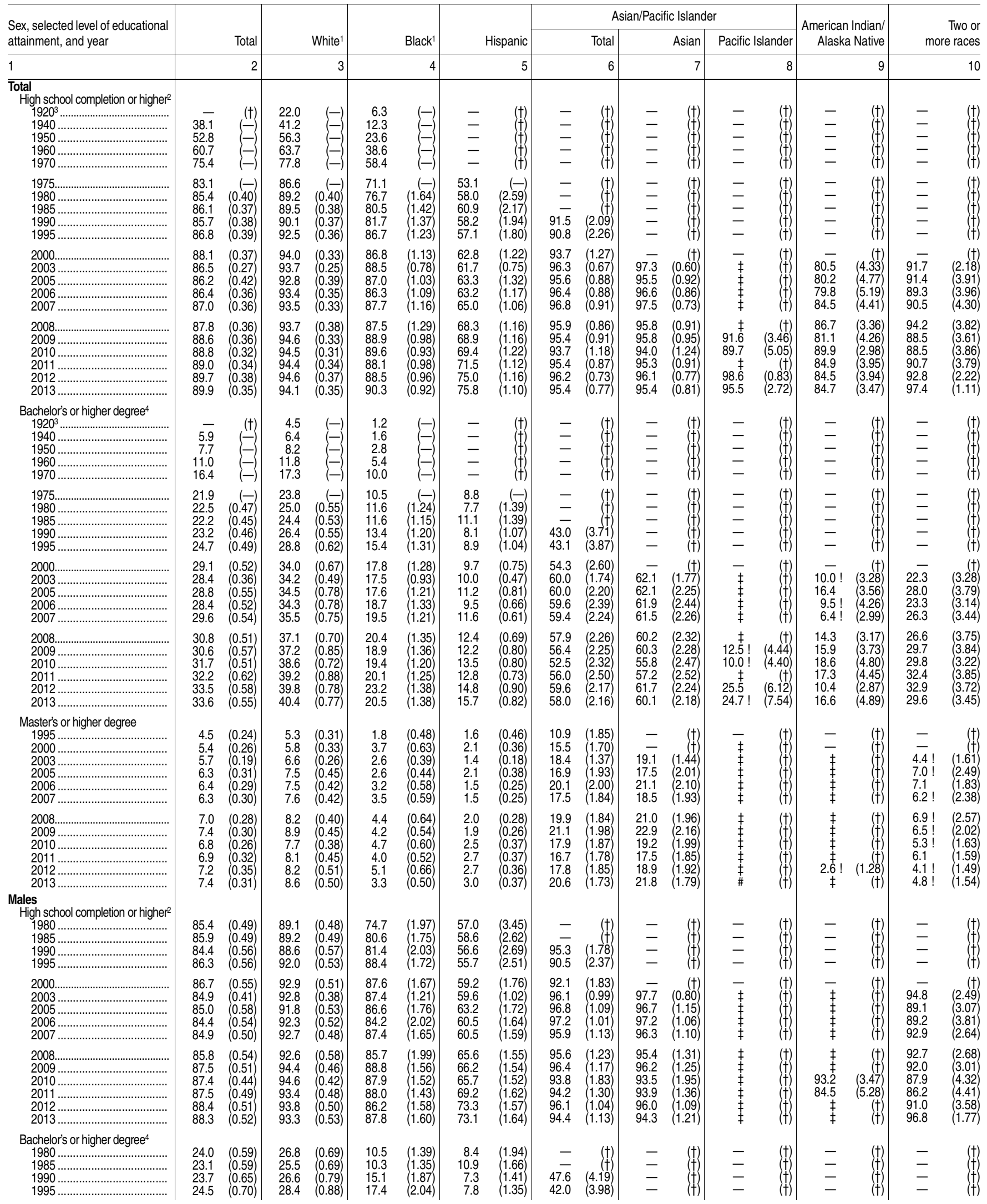

See notes at end of table. 
Table 104.20. Percentage of persons 25 to 29 years old with selected levels of educational attainment, by race/ethnicity and sex: Selected years, 1920 through 2013-Continued

[Standard errors appear in parentheses]

\begin{tabular}{|c|c|c|c|c|c|c|c|c|c|c|c|c|c|c|c|c|c|c|}
\hline \multirow{2}{*}{$\begin{array}{l}\text { Sex, selected level of educational } \\
\text { attainment, and year }\end{array}$} & \multirow{2}{*}{\multicolumn{2}{|c|}{ Total }} & \multirow{2}{*}{\multicolumn{2}{|c|}{ White $^{1}$}} & \multirow{2}{*}{\multicolumn{2}{|c|}{ Black $^{1}$}} & \multirow{2}{*}{\multicolumn{2}{|c|}{ Hispanic }} & \multicolumn{6}{|c|}{ Asian/Pacific Islander } & \multirow{2}{*}{\multicolumn{2}{|c|}{$\begin{array}{r}\text { American Indian/ } \\
\text { Alaska Native }\end{array}$}} & \multirow{2}{*}{\multicolumn{2}{|c|}{$\begin{array}{l}\text { Two or } \\
\text { more races }\end{array}$}} \\
\hline & & & & & & & & & & Total & & Asian & Pacific & nder & & & & \\
\hline 1 & & 2 & & 3 & & 4 & & 5 & & 6 & & 7 & & 8 & & 9 & & 10 \\
\hline $\begin{array}{l}2000 \\
2003 \\
2005 \\
2006\end{array}$ & $\begin{array}{l}27.9 \\
26.0 \\
25.5 \\
25.3 \\
26.3\end{array}$ & $\begin{array}{l}(0.73) \\
0.50) \\
0.68 \\
0.67) \\
0.72\end{array}$ & $\begin{array}{l}32.3 \\
31.4 \\
30.7 \\
31.4 \\
31.9\end{array}$ & $\begin{array}{l}0.93) \\
0.68 \\
0.98 \\
0.98 \\
0.98\end{array}$ & $\begin{array}{l}18.4 \\
17.7 \\
14.2 \\
15.2 \\
18.9\end{array}$ & $\left.\begin{array}{l}(1.96) \\
1.39 \\
1.57 \\
1.66 \\
1.86\end{array}\right)$ & $\begin{array}{r}8.3 \\
8.4 \\
10.2 \\
6.9 \\
8.6\end{array}$ & $\begin{array}{l}(0.98) \\
0.58) \\
0.99) \\
0.70 \\
0.71)\end{array}$ & $\begin{array}{l}55.5 \\
59.2 \\
58.5 \\
58.7 \\
58.5\end{array}$ & $\begin{array}{l}(3.37) \\
2.52 \\
3.11 \\
3.46 \\
(3.45)\end{array}$ & $\begin{array}{l}61 . \overline{7} \\
61.0 \\
60.9 \\
60.4\end{array}$ & $\left.\begin{array}{r}(\dagger) \\
(2.58) \\
3.17 \\
3.52 \\
3.54\end{array}\right)$ & $\begin{array}{l}\bar{\ddagger} \\
\ddagger \\
\ddagger \\
\ddagger \\
\ddagger\end{array}$ & $\left.\begin{array}{c}(t) \\
+ \\
+ \\
+ \\
+\end{array}\right)$ & $\begin{array}{l}- \\
\ddagger \\
\ddagger \\
\ddagger \\
\ddagger\end{array}$ & $\left.\begin{array}{c}(t) \\
+ \\
+ \\
+ \\
+ \\
+\end{array}\right)$ & $\begin{array}{l}17 \overline{5} \\
24.5 \\
20.8 \\
23.3\end{array}$ & $\left.\begin{array}{r}(\dagger) \\
4.27 \\
4.13 \\
4.65 \\
4.88\end{array}\right)$ \\
\hline $\begin{array}{l}2008 \\
2009 \\
2010 \\
2011 \\
2012\end{array}$ & $\begin{array}{l}26.8 \\
26.6 \\
27.8 \\
28.4 \\
29.8 \\
30.2\end{array}$ & $\begin{array}{l}(0.64) \\
(0.66) \\
0.68) \\
0.82) \\
0.82 \\
0.68)\end{array}$ & $\begin{array}{l}32.6 \\
32.6 \\
34.8 \\
35.5 \\
36.0 \\
37.1\end{array}$ & $\begin{array}{l}(0.89) \\
(1.04) \\
0.96) \\
1.16 \\
1.06) \\
1.00)\end{array}$ & $\begin{array}{l}19.0 \\
14.8 \\
15.0 \\
17.0 \\
19.1 \\
17.4\end{array}$ & $\left.\begin{array}{l}(1.94) \\
(1.82) \\
1.72 \\
1.83 \\
1.74 \\
1.63\end{array}\right)$ & $\begin{array}{r}10.0 \\
11.0 \\
10.8 \\
9.6 \\
12.5 \\
13.1\end{array}$ & $\begin{array}{l}(0.86) \\
(1.04) \\
1.06) \\
0.90) \\
1.20) \\
1.06)\end{array}$ & $\begin{array}{l}54.1 \\
55.2 \\
49.0 \\
50.8 \\
55.0 \\
53.0\end{array}$ & $\begin{array}{l}(3.41) \\
(3.07) \\
3.12 \\
3.42 \\
3.15 \\
3.03)\end{array}$ & $\begin{array}{l}55.8 \\
59.2 \\
52.3 \\
52.1 \\
56.9 \\
55.1\end{array}$ & $\begin{array}{l}(3.53) \\
(3.24) \\
(3.31) \\
3.55) \\
3.16 \\
(3.13)\end{array}$ & $\begin{array}{l}\ddagger \\
\ddagger \\
\ddagger \\
\ddagger \\
\ddagger \\
\ddagger\end{array}$ & $\left.\begin{array}{l}(\dagger) \\
(t) \\
+ \\
+ \\
+ \\
+ \\
+\end{array}\right)$ & $\begin{array}{r}\ddagger \\
\ddagger \\
18.9 ! \\
15.4 ! \\
\ddagger \\
\ddagger\end{array}$ & $\begin{array}{r}(\dagger) \\
(\dagger) \\
(7.12) \\
(4.80) \\
(\dagger) \\
(\dagger)\end{array}$ & $\begin{array}{l}25.7 \\
24.6 \\
24.9 \\
34.1 \\
30.4 \\
29.3\end{array}$ & $\left.\begin{array}{l}(4.45) \\
(5.77) \\
4.91 \\
6.62 \\
5.44 \\
4.61\end{array}\right)$ \\
\hline 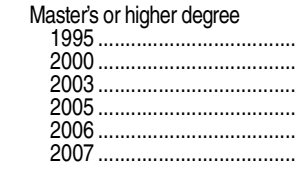 & $\begin{array}{l}4.9 \\
4.7 \\
5.0 \\
5.2 \\
5.1 \\
5.0\end{array}$ & $\begin{array}{l}(0.35) \\
0.34) \\
(0.25) \\
0.38) \\
0.37) \\
0.39)\end{array}$ & $\begin{array}{l}5.6 \\
4.9 \\
5.8 \\
6.2 \\
5.8 \\
5.7\end{array}$ & $\begin{array}{l}(0.45) \\
0.43) \\
(0.34) \\
0.55) \\
0.51 \\
0.50)\end{array}$ & $\begin{array}{l}2.2 ! \\
2.1 ! \\
1.6 \\
1.1 ! \\
1.7 ! \\
3.3\end{array}$ & $\begin{array}{l}(0.80) \\
0.72) \\
(0.46) \\
0.43 \\
0.52 \\
0.99)\end{array}$ & $\begin{array}{l}2.0 ! \\
1.5 \\
1.2 \\
1.7 \\
1.1 \\
0.6 !\end{array}$ & $\begin{array}{l}(0.70) \\
0.43) \\
(0.22) \\
0.46) \\
0.32 \\
0.19)\end{array}$ & $\begin{array}{l}12.6 \\
17.2 \\
19.3 \\
19.7 \\
20.5 \\
18.4\end{array}$ & $\left.\begin{array}{l}(2.68) \\
2.56) \\
(2.03) \\
3.13 \\
2.68 \\
2.89\end{array}\right)$ & $\begin{array}{r}-\overline{-} \\
20.6 \\
20.5 \\
21.8 \\
19.3\end{array}$ & $\begin{array}{r}(t) \\
\left(\begin{array}{l}(t) \\
(.15) \\
3.30 \\
2.83 \\
(3.00)\end{array}\right)\end{array}$ & $\begin{array}{l}- \\
\bar{\ddagger} \\
\ddagger \\
\ddagger \\
\ddagger\end{array}$ & $\begin{array}{c}(t) \\
(t) \\
(t) \\
(t) \\
(t) \\
(t)\end{array}$ & $\begin{array}{l}- \\
\bar{\ddagger} \\
\ddagger \\
\ddagger \\
\ddagger\end{array}$ & $\begin{array}{l}(t) \\
(t) \\
(t) \\
(t \\
(t) \\
(t)\end{array}$ & $\begin{array}{l}- \\
\bar{\ddagger} \\
\ddagger \\
\ddagger \\
5.9 ! \\
9.8 !\end{array}$ & $\begin{array}{r}(t) \\
(\dagger) \\
(\dagger) \\
(t) \\
2.66 \\
4.28)\end{array}$ \\
\hline $\begin{array}{l}2008 \\
2009 \\
2010 \\
2011\end{array}$ & $\begin{array}{l}5.3 \\
6.1 \\
5.2 \\
5.1 \\
5.6 \\
5.7\end{array}$ & $\begin{array}{l}(0.34) \\
0.37 \\
0.32 \\
0.38) \\
(0.42) \\
0.38)\end{array}$ & $\begin{array}{l}5.9 \\
7.4 \\
6.3 \\
5.9 \\
6.3 \\
6.3\end{array}$ & $\begin{array}{l}(0.49) \\
0.60) \\
0.50) \\
0.49) \\
(0.59) \\
0.53)\end{array}$ & $\begin{array}{l}3.4 \\
3.2 \\
2.9 \\
1.9 \\
2.7 \\
1.5 !\end{array}$ & $\begin{array}{l}(0.90) \\
0.73) \\
0.69) \\
(0.54) \\
(0.72) \\
(0.56)\end{array}$ & $\begin{array}{l}1.2 \\
1.2 \\
1.5 \\
1.8 \\
2.4 \\
2.1\end{array}$ & $\begin{array}{l}(0.32) \\
0.28) \\
0.39 \\
0.41) \\
(0.50) \\
0.43)\end{array}$ & $\begin{array}{l}20.9 \\
20.4 \\
15.0 \\
18.0 \\
16.2 \\
20.8\end{array}$ & $\begin{array}{l}(2.94) \\
2.48 \\
2.19 \\
2.58) \\
(2.46) \\
2.49)\end{array}$ & $\begin{array}{l}22.1 \\
22.0 \\
16.2 \\
19.1 \\
17.2 \\
22.1\end{array}$ & $\begin{array}{l}\left(\begin{array}{l}3.07) \\
2.69 \\
2.36\end{array}\right. \\
(2.71) \\
(2.60) \\
(2.60)\end{array}$ & $\begin{array}{l}\ddagger \\
\ddagger \\
\ddagger \\
\ddagger \\
\ddagger \\
\ddagger\end{array}$ & $\begin{array}{l}(t) \\
(t) \\
(t) \\
(t) \\
(t)\end{array}$ & $\begin{array}{l}\ddagger \\
\ddagger \\
\ddagger \\
\ddagger \\
\ddagger \\
\ddagger\end{array}$ & $\begin{array}{c}(t) \\
+ \\
+ \\
(t) \\
(t) \\
(t)\end{array}$ & $\begin{array}{r}7.8 ! \\
5.0 ! \\
\# \\
\ddagger \\
\ddagger \\
5.9 !\end{array}$ & $\begin{array}{r}(2.85) \\
2.38 \\
(\dagger) \\
(\dagger) \\
(\dagger) \\
(2.47)\end{array}$ \\
\hline 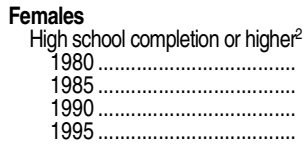 & $\begin{array}{l}85.5 \\
86.4 \\
87.0 \\
87.4\end{array}$ & $\begin{array}{l}(0.48) \\
0.47) \\
(0.51) \\
0.54)\end{array}$ & $\begin{array}{l}89.2 \\
89.9 \\
91.7 \\
93.0\end{array}$ & $\begin{array}{l}(0.48) \\
(0.48) \\
(0.49) \\
0.50)\end{array}$ & $\begin{array}{l}78.3 \\
80.5 \\
82.0 \\
85.3\end{array}$ & $\begin{array}{l}(1.71) \\
1.61) \\
(1.85) \\
1.75)\end{array}$ & $\begin{array}{l}58.9 \\
63.1 \\
59.9 \\
58.7\end{array}$ & $\begin{array}{l}(3.38) \\
2.48) \\
(2.79) \\
2.60)\end{array}$ & $\begin{array}{r}- \\
85.1 \\
91.2\end{array}$ & $\begin{array}{r}(t) \\
(t) \\
(2.82) \\
(2.50)\end{array}$ & $\begin{array}{l}\overline{-} \\
\overline{-}\end{array}$ & $\begin{array}{l}(t) \\
(t) \\
(t) \\
(t)\end{array}$ & $\begin{array}{l}- \\
- \\
-\end{array}$ & $\begin{array}{l}(t) \\
(\dagger) \\
(t) \\
(t)\end{array}$ & $\begin{array}{l}- \\
\overline{-} \\
-\end{array}$ & $\begin{array}{l}(t) \\
(t) \\
(t) \\
(t)\end{array}$ & $\begin{array}{l}- \\
- \\
-\end{array}$ & $\begin{array}{l}(t) \\
(\dagger) \\
(t) \\
(\dagger)\end{array}$ \\
\hline $\begin{array}{l}2000 \\
2003 \\
2005 \\
2006\end{array}$ & $\begin{array}{l}89.4 \\
88.2 \\
87.4 \\
88.5 \\
89.1\end{array}$ & $\begin{array}{l}(0.49) \\
(0.37) \\
0.44 \\
0.44 \\
0.45)\end{array}$ & $\begin{array}{l}95.2 \\
94.5 \\
93.8 \\
94.6 \\
94.2\end{array}$ & $\begin{array}{l}(0.43) \\
(0.33) \\
0.47 \\
0.41 \\
0.44)\end{array}$ & $\begin{array}{l}86.2 \\
89.4 \\
87.3 \\
88.0 \\
87.9\end{array}$ & $\left.\begin{array}{l}(1.53) \\
(1.01) \\
1.22 \\
1.14 \\
1.46\end{array}\right)$ & $\begin{array}{l}66.4 \\
64.2 \\
63.4 \\
66.6 \\
70.7\end{array}$ & $\left.\begin{array}{l}(1.69) \\
(1.11) \\
1.54) \\
1.41 \\
1.30\end{array}\right)$ & $\begin{array}{l}95.2 \\
96.5 \\
94.6 \\
95.6 \\
97.7\end{array}$ & $\left.\begin{array}{l}(1.39) \\
(0.90) \\
1.36 \\
1.44 \\
1.05)\end{array}\right)$ & $\begin{array}{l}-\overline{-} \\
96.9 \\
94.4 \\
96.0 \\
98.5\end{array}$ & $\begin{array}{r}(\dagger) \\
(0.88) \\
1.41 \\
1.31 \\
0.68)\end{array}$ & $\begin{array}{l}\bar{\ddagger} \\
\ddagger \\
\ddagger \\
\ddagger \\
\ddagger\end{array}$ & $\begin{array}{l}(\dagger) \\
(t) \\
+ \\
+ \\
(t)\end{array}$ & 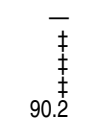 & $\begin{array}{r}(t) \\
(t) \\
(t) \\
(+) \\
(4.49)\end{array}$ & $\begin{array}{l}-\overline{-} \\
88.6 \\
94.2 \\
89.4 \\
87.9\end{array}$ & 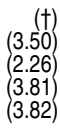 \\
\hline 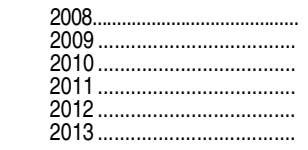 & $\begin{array}{l}89.9 \\
89.8 \\
90.2 \\
90.7 \\
91.1 \\
91.5\end{array}$ & $\begin{array}{l}(0.39) \\
0.41 \\
0.39 \\
0.36 \\
0.44) \\
0.38)\end{array}$ & $\begin{array}{l}94.7 \\
94.8 \\
94.4 \\
95.5 \\
95.3 \\
94.9\end{array}$ & $\begin{array}{l}(0.44) \\
0.44) \\
0.42 \\
0.42 \\
0.46 \\
0.43)\end{array}$ & $\begin{array}{l}89.2 \\
89.0 \\
91.1 \\
88.2 \\
90.6 \\
92.5\end{array}$ & $\left.\begin{array}{l}(1.43) \\
1.12 \\
0.96 \\
1.24 \\
1.11 \\
0.95\end{array}\right)$ & $\begin{array}{l}71.9 \\
72.5 \\
74.1 \\
74.3 \\
76.9 \\
78.8\end{array}$ & $\left(\begin{array}{l}1.34) \\
1.34 \\
1.53 \\
1.26 \\
1.39 \\
1.17\end{array}\right)$ & $\begin{array}{l}96.1 \\
94.5 \\
93.6 \\
96.6 \\
96.3 \\
96.2\end{array}$ & $\begin{array}{l}(1.12) \\
1.20 \\
1.25 \\
0.89 \\
0.98 \\
0.96)\end{array}$ & $\begin{array}{l}96.2 \\
95.3 \\
94.5 \\
96.6 \\
96.1 \\
96.3\end{array}$ & $\left.\begin{array}{l}1.18) \\
1.18 \\
1.27 \\
0.92 \\
1.04 \\
(1.01)\end{array}\right)$ & $\begin{array}{l}\ddagger \\
\ddagger \\
\ddagger \\
\ddagger \\
\ddagger \\
\ddagger\end{array}$ & $\left.\begin{array}{c}(t) \\
+ \\
+ \\
+ \\
+ \\
+ \\
+\end{array}\right)$ & $\begin{array}{l}84.2 \\
83.4 \\
86.8 \\
85.3 \\
85.8 \\
82.0\end{array}$ & $\begin{array}{l}(4.68) \\
4.81 \\
4.80) \\
6.02 \\
4.53 \\
(5.40)\end{array}$ & $\begin{array}{l}95.9 \\
84.8 \\
89.1 \\
94.0 \\
94.7 \\
98.2\end{array}$ & $\left.\begin{array}{l}(2.44) \\
3.57 \\
3.55 \\
2.52 \\
2.35 \\
1.15\end{array}\right)$ \\
\hline $\begin{array}{l}\text { Bachelor's or higher degree }{ }^{4} \\
1980 \\
1985\end{array}$ & $\begin{array}{l}21.0 \\
21.3 \\
22.8 \\
24.9\end{array}$ & $\left.\begin{array}{l}(0.56) \\
0.57 \\
0.64) \\
0.70\end{array}\right)$ & $\begin{array}{l}23.2 \\
23.3 \\
26.2 \\
29.2\end{array}$ & $\left.\begin{array}{l}0.65) \\
0.67) \\
0.78 \\
0.89\end{array}\right)$ & $\begin{array}{l}12.4 \\
12.6 \\
11.9 \\
13.7\end{array}$ & $\left.\begin{array}{l}1.36) \\
1.35 \\
1.56 \\
1.70\end{array}\right)$ & $\begin{array}{r}6.9 \\
11.2 \\
9.1 \\
10.1\end{array}$ & $\left(\begin{array}{l}1.74) \\
1.62 \\
1.64) \\
1.59\end{array}\right)$ & $\begin{array}{r}- \\
37.4 \\
44.5\end{array}$ & 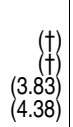 & $\begin{array}{l}\overline{-} \\
\overline{-}\end{array}$ & $\left(\begin{array}{c}t \\
+ \\
+ \\
+ \\
+\end{array}\right)$ & $\begin{array}{l}- \\
- \\
-\end{array}$ & $\begin{array}{c}(t) \\
+ \\
(t) \\
(t)\end{array}$ & $\begin{array}{l}- \\
\overline{-}\end{array}$ & $\left.\begin{array}{l}(t \\
( \\
+ \\
( \\
(t\end{array}\right)$ & $\begin{array}{l}- \\
- \\
-\end{array}$ & $\left(\begin{array}{c}(t) \\
(t) \\
(t)\end{array}\right.$ \\
\hline $\begin{array}{l}2000 \\
2003 \\
2005 \\
2007\end{array}$ & $\begin{array}{l}30.1 \\
30.9 \\
32.2 \\
31.6 \\
33.0\end{array}$ & $\begin{array}{l}(0.73) \\
0.53 \\
0.75) \\
0.70) \\
0.72)\end{array}$ & $\begin{array}{l}35.8 \\
37.1 \\
38.2 \\
37.2 \\
39.2\end{array}$ & $\begin{array}{l}(0.96) \\
0.71) \\
1.00 \\
0.99 \\
1.03)\end{array}$ & $\begin{array}{l}17.4 \\
17.4 \\
20.5 \\
21.7 \\
20.0\end{array}$ & $\left.\begin{array}{l}(1.69) \\
1.25 \\
1.68 \\
1.77 \\
1.38\end{array}\right)$ & $\begin{array}{l}11.0 \\
12.0 \\
12.4 \\
12.8 \\
15.4\end{array}$ & $\left.\begin{array}{l}(1.12) \\
0.75 \\
1.07 \\
1.05 \\
1.10\end{array}\right)$ & $\begin{array}{l}53.1 \\
60.7 \\
61.4 \\
60.4 \\
60.3\end{array}$ & $\begin{array}{l}(3.26) \\
2.39 \\
3.06 \\
2.76 \\
(2.83)\end{array}$ & $\begin{array}{l}62 . \overline{4} \\
63.1 \\
62.8 \\
62.5\end{array}$ & $\left.\begin{array}{r}(\dagger) \\
(2.44) \\
3.11 \\
2.82 \\
(2.88)\end{array}\right)$ & $\begin{array}{l}\overline{ } \\
\ddagger \\
\ddagger \\
\ddagger \\
\ddagger\end{array}$ & $\left.\begin{array}{l}(t) \\
+ \\
+ \\
+ \\
+ \\
+\end{array}\right)$ & $\begin{array}{l}\overline{ } \\
\ddagger \\
\ddagger \\
\ddagger \\
\ddagger\end{array}$ & $\left.\begin{array}{l}(t) \\
(t \\
+ \\
+ \\
+\end{array}\right)$ & $\begin{array}{l}26.9 \\
32.1 \\
25.7 \\
29.6\end{array}$ & $\begin{array}{r}(\dagger) \\
(4.89) \\
5.70 \\
4.72 \\
(5.17)\end{array}$ \\
\hline $\begin{array}{l}2008 \ldots \ldots \ldots \ldots \ldots \ldots \ldots \ldots \ldots \ldots \ldots \\
2009 \\
2010 \\
2011 \\
2012\end{array}$ & $\begin{array}{l}34.9 \\
34.8 \\
35.7 \\
36.1 \\
37.2 \\
37.0\end{array}$ & $\left.\begin{array}{l}(0.71) \\
0.78 \\
0.68) \\
0.71 \\
0.69 \\
0.71\end{array}\right)$ & $\begin{array}{l}41.7 \\
42.0 \\
42.4 \\
43.0 \\
43.6 \\
43.8\end{array}$ & $\begin{array}{l}(0.98) \\
1.12 \\
0.96 \\
1.03 \\
0.97 \\
0.95)\end{array}$ & $\begin{array}{l}21.6 \\
22.6 \\
23.3 \\
22.9 \\
26.7 \\
23.2\end{array}$ & $\left.\begin{array}{l}1.57) \\
1.75 \\
1.72 \\
1.62 \\
1.78 \\
2.03\end{array}\right)$ & $\begin{array}{l}15.5 \\
13.8 \\
16.8 \\
16.8 \\
17.4 \\
18.6\end{array}$ & $\left(\begin{array}{l}1.11) \\
1.09 \\
1.20 \\
1.10 \\
1.10 \\
1.10\end{array}\right)$ & $\begin{array}{l}61.6 \\
57.6 \\
55.8 \\
61.0 \\
64.0 \\
62.4\end{array}$ & $\begin{array}{l}(2.67) \\
3.00 \\
2.93 \\
2.74) \\
2.38 \\
(2.51)\end{array}$ & $\begin{array}{l}64.4 \\
61.3 \\
58.9 \\
62.0 \\
66.2 \\
64.3\end{array}$ & $\left.\begin{array}{l}(2.71) \\
3.03 \\
3.00 \\
2.75 \\
2.46 \\
(2.54)\end{array}\right)$ & $\begin{array}{l}\ddagger \\
\ddagger \\
\ddagger \\
\ddagger \\
\ddagger \\
\ddagger\end{array}$ & $\left.\begin{array}{c}(t) \\
+ \\
+ \\
+ \\
+ \\
+ \\
+\end{array}\right)$ & $\begin{array}{l}12.2 ! \\
16.3 \\
18.4 ! \\
19.7 ! \\
14.0 ! \\
16.4 !\end{array}$ & $\begin{array}{l}(3.69) \\
4.42 \\
6.68 \\
6.64) \\
4.55 \\
6.57)\end{array}$ & $\begin{array}{l}27.7 \\
35.0 \\
34.0 \\
31.2 \\
35.5 \\
30.0\end{array}$ & $\left.\begin{array}{l}(5.57) \\
5.07 \\
4.96 \\
4.36 \\
5.50 \\
5.26\end{array}\right)$ \\
\hline $\begin{array}{l}\text { Master's or higher degree } \\
1995 \ldots \ldots \ldots \ldots \\
2000 \ldots \ldots \ldots \ldots \ldots \ldots \\
2003 \\
2005\end{array}$ & $\begin{array}{l}4.1 \\
6.2 \\
6.4 \\
7.3 \\
7.8 \\
7.6\end{array}$ & $\begin{array}{l}(0.32) \\
0.38 \\
0.28 \\
0.44) \\
0.42 \\
0.43)\end{array}$ & $\begin{array}{l}5.0 \\
6.7 \\
7.4 \\
8.8 \\
9.2 \\
9.4\end{array}$ & $\begin{array}{l}(0.42) \\
0.50) \\
0.38 \\
0.64) \\
0.63) \\
0.63)\end{array}$ & $\begin{array}{l}1.4 ! \\
4.9 \\
3.3 \\
4.0 \\
4.5 \\
3.7\end{array}$ & $\begin{array}{l}(0.59) \\
0.96 \\
0.59 \\
0.70 \\
0.93 \\
0.66)\end{array}$ & $\begin{array}{l}1.2 ! \\
2.7 \\
1.7 \\
2.6 \\
2.0 \\
2.6\end{array}$ & $\begin{array}{l}0.58) \\
0.58 \\
0.30 \\
0.51 \\
0.41 \\
0.53)\end{array}$ & $\begin{array}{r}8.9 \\
13.9 \\
17.5 \\
14.4 \\
19.7 \\
16.5\end{array}$ & $\begin{array}{l}(2.50) \\
2.26 \\
1.86) \\
2.08 \\
2.33 \\
(2.39)\end{array}$ & $\begin{array}{r}- \\
17.7 \\
15.0 \\
20.4 \\
17.7\end{array}$ & $\begin{array}{r}(t) \\
(t) \\
(1.93) \\
(2.15) \\
2.44) \\
(2.54)\end{array}$ & $\begin{array}{l}- \\
\bar{\ddagger} \\
\ddagger \\
\ddagger \\
\ddagger\end{array}$ & $\begin{array}{c}(t) \\
+ \\
+ \\
+ \\
+ \\
+ \\
(t)\end{array}$ & $\begin{array}{l}- \\
\bar{\ddagger} \\
\ddagger \\
\ddagger \\
\ddagger\end{array}$ & $\begin{array}{l}(t \\
+ \\
+ \\
+ \\
+ \\
+ \\
(t) \\
(t)\end{array}$ & $\begin{array}{c}- \\
\overline{7} .3 ! \\
10.0 ! \\
8.3 ! \\
\ddagger\end{array}$ & $\begin{array}{r}(\dagger) \\
(\dagger \\
2.86 \\
4.26 \\
2.89 \\
(\dagger)\end{array}$ \\
\hline $\begin{array}{l}2008 \\
2009 \\
2010 \\
2011 \\
2012\end{array}$ & $\begin{array}{l}8.7 \\
8.8 \\
8.5 \\
8.8 \\
8.8 \\
9.2\end{array}$ & $\begin{array}{l}(0.44) \\
0.45 \\
0.39 \\
0.48 \\
0.45 \\
0.44)\end{array}$ & $\begin{array}{r}10.4 \\
10.4 \\
9.2 \\
10.4 \\
10.0 \\
10.8\end{array}$ & $\begin{array}{l}(0.64) \\
0.66 \\
0.56) \\
0.72 \\
0.67 \\
0.71)\end{array}$ & $\begin{array}{l}5.2 \\
5.1 \\
6.2 \\
5.8 \\
7.1 \\
4.8\end{array}$ & $\begin{array}{l}(0.87) \\
0.80 \\
0.94) \\
0.85 \\
1.00 \\
0.74)\end{array}$ & $\begin{array}{l}2.9 \\
2.7 \\
3.8 \\
3.8 \\
3.0 \\
4.0\end{array}$ & $\left.\begin{array}{l}(0.46) \\
0.43 \\
0.56) \\
0.63) \\
0.45 \\
0.59\end{array}\right)$ & $\begin{array}{l}18.9 \\
21.7 \\
20.6 \\
15.4 \\
19.3 \\
20.4\end{array}$ & $\begin{array}{l}(2.30) \\
(2.45) \\
2.60) \\
1.98 \\
2.23) \\
1.91)\end{array}$ & $\begin{array}{l}19.9 \\
23.7 \\
21.8 \\
15.9 \\
20.4 \\
21.6\end{array}$ & $\begin{array}{l}(2.44) \\
(2.70 \\
2.75 \\
(2.03) \\
2.31) \\
(2.00)\end{array}$ & $\begin{array}{l}\ddagger \\
\ddagger \\
\ddagger \\
\ddagger \\
\ddagger \\
\ddagger\end{array}$ & $\begin{array}{l}(t) \\
+ \\
+ \\
+ \\
+ \\
+\end{array}$ & $\begin{array}{l}\ddagger \\
\ddagger \\
\ddagger \\
\ddagger \\
\ddagger \\
\ddagger\end{array}$ & $\begin{array}{c}(t) \\
+ \\
+ \\
(t) \\
(t) \\
(t)\end{array}$ & $\begin{array}{c}\ddagger \\
7.9 ! \\
10.0 ! \\
9.9 \\
6.3 ! \\
3.3 !\end{array}$ & $\begin{array}{r}(\dagger) \\
(2.84) \\
3.06 \\
2.61 \\
2.49 \\
1.56)\end{array}$ \\
\hline
\end{tabular}

-Not available.

†Not applicable.

!Interpret data with caution. The coefficient of variation (CV) for this estimate is between 30 and 50 percent.

$\ddagger$ Reporting standards not met. Either there are too few cases for a reliable estimate or the coefficient of variation $(\mathrm{CV})$ is 50 percent or greater.

Includes persons of Hispanic ethnicity for years prior to 1980.

2Data for years prior to 1993 are for persons with 4 or more years of high school. Data for later years are for high school completers-i.e., those persons who graduated from high school with a diploma as well as those who completed high school through equivalency programs, such as a GED program.
${ }^{3}$ Estimates based on Census Bureau reverse projection of 1940 census data on education by age. ${ }^{4}$ Data for years prior to 1993 are for persons with 4 or more years of college.

NOTE: Beginning in 2005, standard errors were computed using replicate weights, which produced more precise values than the methodology used in prior years. For 1960 and prior years, data were collected in April. For all other years, data were collected in March. Race categories exclude persons of Hispanic ethnicity except where otherwise noted.

SOURCE: U.S. Department of Commerce, Census Bureau, U.S. Census of Population: 1960, Vol I, Part 1; J.K. Folger and C.B. Nam, Education of the American Population (1960 Census Monograph); Current Population Reports, Series P-20, various years; and Current Population Survey (CPS), March 1970 through March 2013. (This table was prepared October 2013.) 
Table 104.30. Number of persons age 18 and over, by highest level of educational attainment, sex, race/ethnicity, and age: 2013

[Numbers in thousands. Standard errors appear in parentheses]

\begin{tabular}{|c|c|c|c|c|c|c|c|c|c|c|c|c|c|c|c|c|c|c|c|c|}
\hline \multirow[b]{2}{*}{ Sex, race/ethnicity, and age } & \multirow{2}{*}{\multicolumn{2}{|c|}{ Total }} & \multirow{2}{*}{\multicolumn{2}{|c|}{$\begin{array}{r}\text { Elementary school } \\
\text { (kindergarten- } \\
\text { 8th grade) }\end{array}$}} & \multicolumn{6}{|c|}{ High school } & \multicolumn{10}{|c|}{ Postsecondary education } \\
\hline & & & & & & 3 years & & $\begin{array}{l}\text { years, } \\
\text { pletion }\end{array}$ & & mpletion & & $\begin{array}{c}\text { college, } \\
\text { degree }\end{array}$ & Associa & $s$ degree & Bachelo & $s$ degree & Mast & $s$ degree & $\begin{array}{l}\text { First- } \\
\text { or doc }\end{array}$ & $\begin{array}{l}\text { ssional } \\
\text { degree }\end{array}$ \\
\hline 1 & & 2 & & 3 & & 4 & & 5 & & 6 & & 7 & & 8 & & 9 & & 10 & & 11 \\
\hline Total, 18 and over...... & 236,929 & $\begin{array}{l}(99.1) \\
\end{array}$ & 10,367 & (191.3) & 15,811 & (222.5) & 3,581 & $\begin{array}{l}(101.3) \\
\end{array}$ & 69,985 & $(427.8)$ & 46,467 & $(312.0)$ & 22,196 & (237.1) & 44,378 & $\begin{array}{l}(351.6) \\
\end{array}$ & 17,586 & $\begin{array}{l}\text { (221.5) } \\
\end{array}$ & 6,558 & $(145.5)$ \\
\hline 18 and 19 years old .............. & 7,876 & (79.3) & 97 & (20.3) & 2,485 & $(61.7)$ & 572 & $(33.5)$ & 2,129 & (55.9) & 2,480 & $(64.6)$ & 81 & $(12.7)$ & $\ddagger$ & $(\dagger)$ & $\ddagger$ & $(t)$ & $\ddagger$ & $(t)$ \\
\hline 20 to 24 years old ...................... & 22,153 & (21.6) & 349 & (35.5) & 1,316 & $(57.9)$ & 425 & (30.9) & 6,152 & (104.6) & 9,182 & $(145.3)$ & 1,747 & (67.7) & 2,774 & (77.6) & 191 & (21.7) & $\ddagger$ & $(t)$ \\
\hline 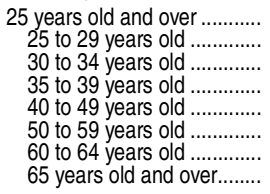 & $\begin{array}{r}206,899 \\
21,138 \\
20,659 \\
19,221 \\
41,717 \\
43,266 \\
17,611 \\
43,287\end{array}$ & $\begin{array}{r}(52.7) \\
40.0 \\
41.1 \\
31.3 \\
41.9 \\
(71.3 \\
(110.0) \\
(95.8)\end{array} \mid$ & $\begin{array}{r}9,922 \\
545 \\
750 \\
846 \\
1,601 \\
1,753 \\
7,91 \\
3,635 \\
\end{array}$ & $\left.\begin{array}{r}(179.4 \\
39.5 \\
43.7 \\
47.5 \\
57.1 \\
61.4 \\
39.4 \\
87.2\end{array}\right)$ & $\begin{array}{r}12,011 \\
1,264 \\
1,201 \\
1,096 \\
2,135 \\
2,232 \\
737 \\
3,347\end{array}$ & $\begin{array}{r}(198.2 \\
(55.8 \\
54.4 \\
48.7 \\
73.2 \\
71.7 \\
43.7 \\
82.9\end{array}$ & $\begin{array}{r}2,585 \\
330 \\
321 \\
225 \\
509 \\
493 \\
140 \\
566 \\
\end{array}$ & $\begin{array}{l}(86.6 \\
28.6 \\
25.7 \\
21.8 \\
32.0 \\
37.3 \\
15.1 \\
42.9\end{array}$ & $\begin{array}{r}61,704 \\
5,667 \\
5,284 \\
4,877 \\
11,766 \\
13,758 \\
5,232 \\
15,120\end{array}$ & $\begin{array}{r}(404.2) \\
(97.6) \\
(102.1 \\
(97.1) \\
(152.3 \\
178.9 \\
114.2 \\
(181.5) \\
\end{array}$ & $\begin{array}{r}34,805 \\
4,198 \\
3,521 \\
3,228 \\
6,876 \\
7,199 \\
3,194 \\
6,590 \\
\end{array}$ & $\begin{array}{r}(282.7) \\
(100.0) \\
(85.7) \\
(73.2) \\
(117.4) \\
120.2 \\
(77.8) \\
(126.7)\end{array}$ & $\begin{array}{r}20,367 \\
2,033 \\
2,203 \\
2,022 \\
4,631 \\
4,581 \\
1,813 \\
3,085 \\
\end{array}$ & $\begin{array}{r}(226.3) \\
(67.7) \\
68.2 \\
58.5 \\
96.4 \\
93.7 \\
64.5 \\
(90.5) \\
\end{array}$ & $\begin{array}{r}41,575 \\
5,533 \\
4,820 \\
4,327 \\
9,164 \\
8,179 \\
3,338 \\
6,214\end{array}$ & $\begin{array}{r}(337.0 \\
(110.8) \\
(92.4 \\
(83.3 \\
(138.3 \\
(139.5 \\
(81.2 \\
(129.5) \\
\end{array}$ & $\begin{array}{r}17,395 \\
1,197 \\
1,960 \\
1,931 \\
3,745 \\
3,586 \\
1,721 \\
3,254 \\
\end{array}$ & $\begin{array}{r}(218.7) \\
(55.5 \\
64.2 \\
62.7 \\
92.2 \\
88.2 \\
86.2 \\
65.4 \\
(90.4)\end{array}$ & $\begin{array}{r}6,536 \\
372 \\
599 \\
668 \\
1,289 \\
1,485 \\
646 \\
1,478 \\
\end{array}$ & $\begin{array}{r}(144.7) \\
(33.6 \\
37.2 \\
39.3 \\
56.6 \\
64.1 \\
46.8 \\
(64.8)\end{array}$ \\
\hline Males, 18 and over........ & 114,447 & (83.4) & 5,219 & (117.9) & 8,069 & (144.5) & 1,909 & $(66.0)$ & 34,637 & (249.5) & 21,983 & (197.9) & 9,558 & (154.4) & 21,112 & (206.6) & 7,879 & (132.9) & 4,080 & (106.5) \\
\hline 18 and 19 years old ................ & 4,008 & (58.4) & $\ddagger$ & $(\dagger)$ & 1,361 & $(43.4)$ & 327 & (24.3) & 1,135 & $(40.9)$ & 1,088 & $(41.9)$ & $\ddagger$ & $(\dagger)$ & $\ddagger$ & $(t)$ & $\ddagger$ & $(\dagger)$ & $\ddagger$ & $(\dagger)$ \\
\hline 20 to 24 years old ...................... & 11,134 & (20.9) & 207 & (23.1) & 721 & $(38.7)$ & 256 & (23.8) & 3,487 & $(81.6)$ & 4,387 & (94.5) & 753 & (44.2) & 1,238 & (57.0) & 75 & (15.9) & $\ddagger$ & $(+)$ \\
\hline 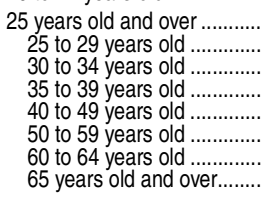 & $\begin{array}{l}99,305 \\
10,628 \\
10,189 \\
9,461 \\
20,481 \\
21,025 \\
8,224 \\
19,298 \\
\end{array}$ & $\begin{array}{r}(51.6) \\
(41.1 \\
40.3 \\
30.4 \\
40.5 \\
(50.9) \\
(102.1) \\
(95.8)\end{array}$ & $\begin{array}{r}4,963 \\
304 \\
439 \\
496 \\
874 \\
887 \\
355 \\
1,609 \\
\end{array}$ & $\begin{array}{r}(109.3) \\
(27.2 \\
30.2 \\
35.0 \\
42.8 \\
42.2 \\
26.4 \\
(49.9) \\
\end{array}$ & $\begin{array}{r}5,988 \\
746 \\
623 \\
542 \\
1,219 \\
1,149 \\
355 \\
1,353 \\
\end{array}$ & $\begin{array}{r}(133.5 \\
44.1 \\
39.7 \\
34.1 \\
57.5 \\
51.7 \\
29.0 \\
54.6 \\
\end{array}$ & $\begin{array}{r}1,326 \\
195 \\
183 \\
135 \\
275 \\
266 \\
59 \\
212 \\
\end{array}$ & $\begin{array}{l}(54.4) \\
22.1 \\
18.3 \\
15.8 \\
22.8 \\
22.5 \\
10.4 \\
23.2 \\
\end{array}$ & $\begin{array}{r}30,014 \\
3,183 \\
2,875 \\
2,696 \\
6,123 \\
6,965 \\
2,344 \\
5,828 \\
\end{array}$ & $\begin{array}{r}(227.4) \\
(68.0) \\
(68.1) \\
(62.8) \\
(101.4) \\
(118.8) \\
(75.8) \\
(100.9) \\
\end{array}$ & $\begin{array}{r}16,508 \\
2,104 \\
1,780 \\
1,613 \\
3,260 \\
3,439 \\
1,438 \\
2,873 \\
\end{array}$ & $\begin{array}{r}(185.8) \\
(70.5) \\
58.7 \\
53.0 \\
73.3 \\
86.0 \\
57.9 \\
(80.4) \\
\end{array}$ & $\begin{array}{r}8,775 \\
889 \\
975 \\
836 \\
2,028 \\
1,923 \\
818 \\
1,305 \\
\end{array}$ & $\begin{array}{r}(142.1) \\
(43.7 \\
46.0 \\
38.5 \\
63.3 \\
6.1 \\
(42.9) \\
(56.4) \\
\end{array}$ & $\begin{array}{r}19,860 \\
2,604 \\
2,255 \\
1,959 \\
4,260 \\
3,825 \\
1,657 \\
3,299 \\
\end{array}$ & $\begin{array}{r}(202.5 \\
68.6 \\
64.0 \\
50.6 \\
83.6 \\
(91.7 \\
60.0 \\
89.4) \\
\end{array}$ & $\begin{array}{r}7,804 \\
421 \\
734 \\
837 \\
1,676 \\
1,660 \\
792 \\
1,684 \\
\end{array}$ & $\begin{array}{r}(132.7 \\
(35.8 \\
38.8 \\
38.0 \\
55.7 \\
57.5 \\
46.5 \\
63.3 \\
\end{array}$ & $\begin{array}{r}4,068 \\
183 \\
322 \\
347 \\
766 \\
909 \\
406 \\
1,134 \\
\end{array}$ & $\begin{array}{r}(106.3) \\
(21.7 \\
26.3 \\
26.6 \\
39.8 \\
50.6 \\
34.8 \\
(52.4) \\
\end{array}$ \\
\hline Females, 18 and over ... & 122,482 & (58.6) & 5,149 & (108.7) & 7,742 & (132.4) & 1,672 & (63.3) & 35,348 & (284.9) & 24,484 & $\begin{array}{l}\text { (205.8) } \\
\end{array}$ & 12,637 & (162.2) & 23,266 & $\begin{array}{l}(236.0) \\
\end{array}$ & 9,707 & (150.6) & 2,478 & $\overline{(74.0)}$ \\
\hline 18 and 19 years old ............... & 3,869 & (58.1) & 49 & (12.3) & 1,124 & $(43.4)$ & 245 & (21.6) & 994 & $(37.0)$ & 1,391 & $(45.8)$ & 51 & $(10.3)$ & $\ddagger$ & $(t)$ & $\ddagger$ & $(t)$ & $\ddagger$ & $(t)$ \\
\hline 20 to 24 years old ..................... & 11,019 & $(6.8)$ & 142 & $(19.3)$ & 595 & $(39.0)$ & 169 & (19.3) & 2,664 & $(68.0)$ & 4,794 & (95.1) & 994 & $(49.4)$ & 1,536 & $(60.7)$ & 116 & (17.5) & $\ddagger$ & $(\dagger)$ \\
\hline 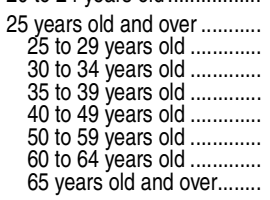 & $\begin{array}{r}107,594 \\
10,510 \\
10,470 \\
9,759 \\
21,236 \\
22,241 \\
9,387 \\
23,990\end{array}$ & $\begin{array}{r}(12.5) \\
(6.3) \\
5.6 \\
55.6 \\
5.4 \\
(44.7) \\
(44.2 \\
(0.5)\end{array}$ & $\begin{array}{r}4,958 \\
242 \\
311 \\
351 \\
727 \\
866 \\
436 \\
2,026 \\
\end{array}$ & $\begin{array}{r}(105.2) \\
(24.3 \\
24.6 \\
23.2 \\
31.7 \\
38.8 \\
(28.2 \\
62.6\end{array}$ & $\begin{array}{r}6,023 \\
518 \\
578 \\
554 \\
917 \\
1,082 \\
382 \\
1,993 \\
\end{array}$ & $\begin{array}{r}(119.2) \\
(30.0 \\
33.6 \\
30.8 \\
41.5 \\
46.8 \\
(28.6 \\
65.6\end{array}$ & $\begin{array}{r}1,259 \\
136 \\
137 \\
90 \\
234 \\
227 \\
81 \\
354 \\
\end{array}$ & $\begin{array}{l}(55.5) \\
15.6 \\
17.7 \\
13.3 \\
18.9 \\
25.3 \\
11.8 \\
32.8\end{array}$ & $\begin{array}{r}31,690 \\
2,484 \\
2,408 \\
2,181 \\
5,642 \\
6,793 \\
2,889 \\
9,292\end{array}$ & $\begin{array}{r}(271.0) \\
(64.5) \\
(63.5) \\
(59.2) \\
(93.0) \\
(107.2) \\
(73.4) \\
(132.3)\end{array}$ & $\begin{array}{r}18,298 \\
2,094 \\
1,740 \\
1,615 \\
3,616 \\
3,760 \\
1,756 \\
3,717\end{array}$ & $\left.\begin{array}{r}(173.5) \\
(57.0) \\
54.5 \\
46.9 \\
72.5 \\
80.8 \\
52.6 \\
86.7\end{array}\right)$ & $\begin{array}{r}11,592 \\
1,143 \\
1,228 \\
1,186 \\
2,603 \\
2,657 \\
994 \\
1,780\end{array}$ & $\left.\begin{array}{r}(150.9) \\
(48.3 \\
44.9 \\
43.4 \\
66.9 \\
74.1 \\
46.5 \\
64.7\end{array}\right)$ & $\begin{array}{r}21,715 \\
2,929 \\
2,565 \\
2,368 \\
4,904 \\
4,354 \\
1,681 \\
2,914\end{array}$ & $\begin{array}{r}(223.0) \\
75.0 \\
59.7 \\
58.9 \\
94.2 \\
94.0 \\
54.8 \\
(80.6)\end{array}$ & $\begin{array}{r}9,591 \\
776 \\
1,226 \\
1,094 \\
2,069 \\
1,926 \\
929 \\
1,570\end{array}$ & $\begin{array}{r}(148.6 \\
(41.8) \\
47.7 \\
45.5 \\
65.4 \\
62.4 \\
46.0 \\
(61.5)\end{array}$ & $\begin{array}{r}2,469 \\
189 \\
277 \\
321 \\
523 \\
575 \\
240 \\
344 \\
\end{array}$ & $\begin{array}{l}74.1 \\
22.1 \\
24.6 \\
25.3 \\
32.1 \\
34.0 \\
25.4 \\
31.7\end{array}$ \\
\hline White, 18 and over .......... & 156,352 & (123.3) & 2,948 & (104.0) & 7,812 & (149.0) & 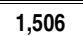 & (73.3) & $\begin{array}{l}45,896 \\
\end{array}$ & (356.7) & 30,958 & $\begin{array}{l}\text { (271.4) } \\
\end{array}$ & 15,923 & (211.9) & 33,119 & (297.0) & 13,241 & (185.6) & 4,949 & $\overline{~(122.6)}$ \\
\hline 18 and $19 y$ & 4,292 & $(63.1)$ & $50 !$ & (15.4) & 1,370 & $(46.1)$ & 241 & (22. & 1,116 & & & & 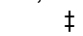 & $(t)$ & $\ddagger$ & $(\dagger)$ & $\ddagger$ & $(t)$ & $\ddagger$ & $(\dagger)$ \\
\hline 20 to 24 years old ...................... & 12,375 & (35.6) & 92 & (21.8) & 478 & (35.6) & 140 & (17.6) & 3,113 & (79.9) & 5,347 & $(106.6)$ & 1,066 & $(55.7)$ & 2,000 & (64.9) & 129 & (18.3) & $\ddagger$ & $(\dagger)$ \\
\hline 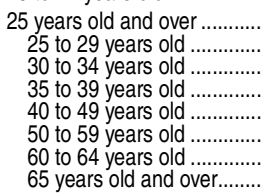 & $\begin{array}{r}139,685 \\
12,126 \\
12,044 \\
11,102 \\
26,571 \\
30,549 \\
13,161 \\
34,131\end{array}$ & $\begin{array}{r}(102.5) \\
(43.5 \\
444.1 \\
44.3 \\
55.2 \\
51.6 \\
94.5 \\
97.8)\end{array} \mid$ & $\begin{array}{r}2,805 \\
100 \\
90 \\
99 \\
244 \\
371 \\
190 \\
1,712\end{array}$ & $\begin{array}{l}(96.6 \\
17.5 \\
18.5 \\
15.8 \\
26.2 \\
28.6 \\
22.4 \\
(72.2)\end{array}$ & $\begin{array}{r}5,964 \\
508 \\
402 \\
333 \\
892 \\
1,161 \\
374 \\
2,293\end{array}$ & $\begin{array}{r}(139.6) \\
34.2 \\
33.0 \\
30.4 \\
51.0 \\
57.0 \\
29.8 \\
(77.0)\end{array}$ & $\begin{array}{r}1,125 \\
109 \\
99 \\
59 \\
182 \\
228 \\
60 \\
387\end{array}$ & $\begin{array}{l}63.7 \\
16.9 \\
14.7 \\
11.5 \\
20.5 \\
26.9 \\
13.2 \\
(36.2\end{array}$ & $\begin{array}{r}41,667 \\
2,850 \\
2,844 \\
2,677 \\
7,328 \\
9,794 \\
3,885 \\
12,289\end{array}$ & $\begin{array}{r}(347.7) \\
(78.7) \\
76.4 \\
(70.9) \\
(124.7) \\
158.4 \\
103.2 \\
171.1)\end{array}$ & $\begin{array}{r}24,154 \\
2,370 \\
2,127 \\
1,928 \\
4,500 \\
5,197 \\
2,470 \\
5,562\end{array}$ & $\begin{array}{r}(257.0) \\
(79.2) \\
(70.8) \\
59.7) \\
(96.9) \\
(111.1) \\
(74.5) \\
(119.3)\end{array}$ & $\begin{array}{r}14,818 \\
1,286 \\
1,479 \\
1,356 \\
3,246 \\
3,506 \\
1,434 \\
2,510\end{array}$ & $\begin{array}{r}(202.0) \\
56.8 \\
55.7 \\
51.5 \\
83.9 \\
77.9 \\
63.3 \\
83.9\end{array}$ & $\begin{array}{r}31,105 \\
3,865 \\
3,305 \\
2,952 \\
6,678 \\
6,267 \\
2,742 \\
5,296\end{array}$ & $\begin{array}{r}(290.2) \\
(91.7 \\
78.5 \\
(69.2) \\
(114.8 \\
121.9 \\
(76.0) \\
(123.3)\end{array}$ & $\begin{array}{r}13,111 \\
802 \\
1,319 \\
1,256 \\
2,619 \\
2,858 \\
1,443 \\
2,814\end{array}$ & $\begin{array}{r}(183.9 \\
(51.9 \\
52.5 \\
50.4 \\
74.5 \\
80.8 \\
62.2 \\
87.6)\end{array}$ & $\begin{array}{r}4,936 \\
236 \\
379 \\
442 \\
883 \\
1,166 \\
564 \\
1,267\end{array}$ & $\begin{array}{r}(121.9 \\
(28.9 \\
28.5 \\
31.5 \\
45.9 \\
58.0 \\
43.8 \\
(59.8)\end{array}$ \\
\hline Black, 18 and over ......... & 27,416 & (85.7) & 846 & (51.9) & 2,614 & (86.9) & 681 & (44. & $\begin{array}{l}9,208 \\
\end{array}$ & $\begin{array}{ll}(144.0) \\
\end{array}$ & 6,6361 & $\begin{array}{l}(119.0) \\
\end{array}$ & 2,428 & (64.9) & 3,471 & \begin{tabular}{|c|}
$(90.7)$ \\
\end{tabular} & 1,445 & (62.3) & 362 & 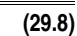 \\
\hline 18 and 1 & 1,155 & $(35$. & $\ddagger$ & $(\dagger)$ & 401 & $(25$ & 104 & (14. & 349 & (23.1) & 255 & $(20)-20-1)$ & $\ddagger$ & $(t)$ & $\ddagger$ & $(\dagger$ & $\ddagger$ & $(t)$ & $\ddagger$ & $(\dagger)$ \\
\hline 20 to 24 years old ..................... & 3,221 & (27.2) & $\ddagger$ & $(\dagger)$ & 255 & (28.6) & 91 & (16.8) & 1,066 & $(49.0)$ & 1,406 & $(55.3)$ & 183 & (23.0) & 195 & (24.4) & $\ddagger$ & $(t)$ & $\ddagger$ & $(\dagger)$ \\
\hline 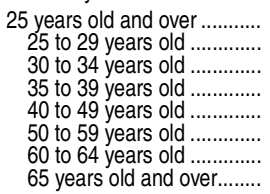 & $\begin{array}{r}23,041 \\
2,649 \\
2,514 \\
2,326 \\
5,042 \\
4,942 \\
1,817 \\
3,750\end{array}$ & $\begin{array}{l}63.3 \\
23.3 \\
29.5 \\
22.8 \\
28.5 \\
54.4 \\
49.7 \\
38.3\end{array}$ & $\begin{array}{r}811 \\
\neq \\
\neq \\
\neq \\
88 \\
88 \\
164 \\
61 \\
412\end{array}$ & $\left.\begin{array}{r}(50.4 \\
+ \\
+ \\
+ \\
+ \\
(18.3 \\
20.4 \\
10.0 \\
26.6\end{array}\right)$ & $\begin{array}{r}1,959 \\
163 \\
180 \\
160 \\
308 \\
454 \\
161 \\
534\end{array}$ & $\begin{array}{r}68.5 \\
17.5 \\
19.8 \\
18.3 \\
26.1 \\
30.0 \\
17.7 \\
29.3\end{array}$ & $\begin{array}{r}486 \\
\ddagger \\
\neq \\
\ddagger \\
\neq 0 \\
90 \\
118 \\
\ddagger \\
94\end{array}$ & 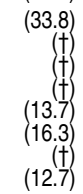 & $\begin{array}{r}7,794 \\
913 \\
775 \\
727 \\
1,659 \\
1,723 \\
628 \\
1,368\end{array}$ & $\begin{array}{r}(124.3) \\
(41.4) \\
39.0 \\
34.7 \\
53.8 \\
50.8 \\
33.4 \\
(42.9)\end{array}$ & $\begin{array}{r}4,699 \\
697 \\
556 \\
529 \\
1,085 \\
9951 \\
374 \\
508\end{array}$ & $\begin{array}{l}(95.1) \\
37.4 \\
31.1 \\
31.6 \\
45.7 \\
42.0 \\
23.0 \\
(28.5)\end{array}$ & $\begin{array}{r}2,233 \\
240 \\
266 \\
228 \\
588 \\
472 \\
162 \\
276\end{array}$ & $\begin{array}{l}(62.7) \\
20.8 \\
22.3 \\
20.6 \\
33.0 \\
28.6 \\
17.3 \\
(21.1)\end{array}$ & $\begin{array}{r}3,267 \\
456 \\
438 \\
390 \\
807 \\
654 \\
226 \\
294\end{array}$ & $\begin{array}{l}(88.5) \\
34.0 \\
30.3 \\
27.2 \\
40.4 \\
37.2 \\
(22.3 \\
(22.0)\end{array}$ & $\begin{array}{r}1,433 \\
71 \\
178 \\
201 \\
347 \\
304 \\
129 \\
202\end{array}$ & $\begin{array}{l}(61.9) \\
11.9 \\
19.3 \\
19.0 \\
25.8 \\
24.3 \\
15.7 \\
(19.4)\end{array}$ & $\begin{array}{r}359 \\
\neq \\
\neq \\
\neq \\
69 \\
692 \\
102 \\
36 \\
62\end{array}$ & $\begin{array}{r}(29.7) \\
(+) \\
+ \\
+ \\
+ \\
(12.2 \\
15.4 \\
8.0 \\
(9.4)\end{array}$ \\
\hline
\end{tabular}


Table 104.30. Number of persons age 18 and over, by highest level of educational attainment, sex, race/ethnicity, and age: 2013—Continued

[Numbers in thousands. Standard errors appear in parentheses]

\begin{tabular}{|c|c|c|c|c|c|c|c|c|c|c|c|c|c|c|c|c|c|c|c|c|}
\hline \multirow[b]{2}{*}{ Sex, race/ethnicity, and age } & \multirow{2}{*}{\multicolumn{2}{|c|}{ Total }} & \multirow{2}{*}{\multicolumn{2}{|c|}{$\begin{array}{r}\text { Elementary school } \\
\text { (kindergarten- } \\
\text { 8th grade) }\end{array}$}} & \multicolumn{6}{|c|}{ High school } & \multicolumn{10}{|c|}{ Postsecondary education } \\
\hline & & & & & \multicolumn{2}{|c|}{1 to 3 years } & \multicolumn{2}{|c|}{$\begin{array}{r}4 \text { years, } \\
\text { no completion }\end{array}$} & \multicolumn{2}{|c|}{ Completion } & \multicolumn{2}{|c|}{$\begin{array}{r}\text { Some college, } \\
\text { no degree }\end{array}$} & \multicolumn{2}{|c|}{ Associate's degree } & \multicolumn{2}{|c|}{ Bachelor's degree } & \multicolumn{2}{|c|}{ Master's degree } & \multicolumn{2}{|c|}{$\begin{array}{l}\text { First-professional } \\
\text { or doctor's degree }\end{array}$} \\
\hline 1 & & 2 & & 3 & & 4 & & 5 & & 6 & & 7 & & 8 & & 9 & & 10 & & 11 \\
\hline Hispanic, 18 and over... & 35,441 & (35.6) & 5,836 & (135.7) & 4,510 & $(97.5)$ & 1,127 & (43.9) & 10,911 & (160.7) & 5,973 & (98.1) & 2,440 & $(66.0)$ & 3,361 & $(90.8)$ & 992 & (41.7) & 290 & $(24.0)$ \\
\hline 18 and 19 years old ............... & 1,760 & $(35.0)$ & $\ddagger$ & $(\dagger)$ & 547 & $(29.1)$ & 179 & (17.8) & 477 & $(30.2)$ & 515 & (28.9) & $\ddagger$ & $(t)$ & $\ddagger$ & $(t)$ & $\ddagger$ & $(t)$ & $\ddagger$ & $(\dagger)$ \\
\hline 20 to 24 years old ...................... & 4,551 & $(6.3)$ & 228 & (26.9) & 513 & $(32.8)$ & 152 & $(16.0)$ & 1,565 & $(50.2)$ & 1,498 & $(47.0)$ & 340 & (25.8) & 236 & (23.1) & $\ddagger$ & $(t)$ & $\ddagger$ & $(t)$ \\
\hline 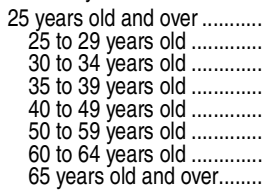 & $\begin{array}{r}29,130 \\
4,402 \\
4,195 \\
3,978 \\
6,853 \\
4,911 \\
1,579 \\
3,213 \\
\end{array}$ & $\begin{array}{r}(11.8 \\
34.5 \\
34.0 \\
28.2 \\
38.3 \\
50.4 \\
41.8 \\
(8.5)\end{array}$ & $\begin{array}{r}5,591 \\
390 \\
609 \\
684 \\
1,195 \\
1,098 \\
452 \\
1,163\end{array}$ & $\begin{array}{r}(127.0) \\
(30.6 \\
39.7 \\
41.0 \\
50.3 \\
48.8 \\
(29.2 \\
(37.5)\end{array}$ & $\begin{array}{r}3,450 \\
538 \\
558 \\
549 \\
814 \\
473 \\
162 \\
356\end{array}$ & 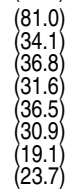 & $\begin{array}{r}797 \\
139 \\
163 \\
114 \\
189 \\
108 \\
\ddagger \\
58 \\
\end{array}$ & $\begin{array}{r}(40.0) \\
17.3 \\
19.1 \\
14.2 \\
17.5 \\
13.8 \\
(\dagger \\
(10.4)\end{array}$ & $\begin{array}{r}8,869 \\
1,551 \\
1,321 \\
1,178 \\
2,116 \\
1,445 \\
415 \\
843\end{array}$ & $\begin{array}{r}(144.6) \\
(51.3 \\
43.9 \\
45.7 \\
66.1 \\
51.4 \\
(27.4 \\
(34.4)\end{array} \mid$ & $\begin{array}{r}3,960 \\
766 \\
612 \\
530 \\
884 \\
658 \\
217 \\
294\end{array}$ & 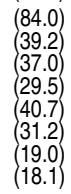 & $\begin{array}{r}2,079 \\
328 \\
303 \\
292 \\
521 \\
362 \\
105 \\
168\end{array}$ & $\begin{array}{l}(61.1) \\
25.5 \\
26.9 \\
23.3 \\
32.4 \\
24.4 \\
13.6 \\
15.7\end{array}$ & $\begin{array}{r}3,121 \\
558 \\
470 \\
448 \\
775 \\
531 \\
121 \\
219\end{array}$ & 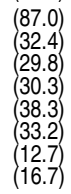 & $\begin{array}{r}978 \\
103 \\
122 \\
146 \\
265 \\
183 \\
73 \\
87\end{array}$ & $\left.\begin{array}{c}(41.2 \\
(1.5 \\
(14.1 \\
14.8 \\
18.4 \\
17.2 \\
11.7 \\
12.5\end{array}\right)$ & $\begin{aligned} 285 \\
\ddagger \\
39 \\
\ddagger \\
94 \\
53 \\
\ddagger \\
\ddagger\end{aligned}$ & $\left.\begin{array}{r}(23.4) \\
(\dagger) \\
(8.6 \\
(\dagger) \\
(12.9 \\
(8.5 \\
(\dagger) \\
+\end{array}\right)$ \\
\hline Asian, 18 and over ........ & 12,475 & (93.4) & 602 & (43.3) & 487 & (33.8) & 158 & $\overline{~(20.1)}$ & 2,338 & (76.8) & 1,822 & (59.3) & 873 & (41.6) & 3,652 & (91.0) & 1,660 & (65.9) & 882 & $(46.8)$ \\
\hline 18 and 19 years old ............... & 371 & (19.9) & $\ddagger$ & $(\dagger)$ & 95 & $(11.6)$ & $\ddagger$ & $(\dagger)$ & 87 & (11.3) & 159 & (16.4) & $\ddagger$ & $(\dagger)$ & $\ddagger$ & $(t)$ & $\ddagger$ & $(t)$ & $\ddagger$ & $(\dagger)$ \\
\hline 20 to 24 years old ...................... & 1,211 & $(28.7)$ & $\ddagger$ & $(\dagger)$ & $\ddagger$ & $(t)$ & $\ddagger$ & $(t)$ & 151 & (19.5) & 588 & $(31.5)$ & 87 & (12.7) & 287 & (23.9) & $\ddagger$ & $(t)$ & $\ddagger$ & $(t)$ \\
\hline 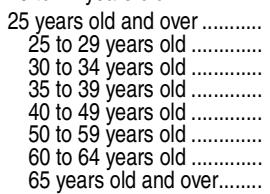 & $\begin{array}{r}10,894 \\
1,344 \\
1,352 \\
1,358 \\
2,385 \\
2,300 \\
781 \\
1,645\end{array}$ & $\begin{array}{l}(84.4) \\
32.2 \\
33.0 \\
37.9 \\
46.4 \\
45.3 \\
(30.1 \\
(34.9)\end{array}$ & $\begin{array}{r}585 \\
\neq \\
\neq \\
\neq \\
60 \\
99 \\
78 \\
278\end{array}$ & 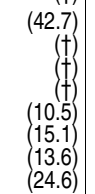 & $\begin{array}{r} \\
358 \\
\ddagger \\
\neq \\
\neq \\
\neq \\
71 \\
90 \\
\ddagger \\
97\end{array}$ & $\begin{array}{r}(30.0) \\
(t) \\
(t) \\
(t) \\
(15.3) \\
14.8 \\
(t) \\
(13.0)\end{array}$ & 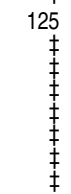 & $\left.\begin{array}{r}(19.0) \\
(\dagger \\
+ \\
+ \\
+ \\
+ \\
+ \\
+ \\
+\end{array}\right)$ & $\begin{array}{r}2,101 \\
172 \\
181 \\
168 \\
406 \\
516 \\
228 \\
430\end{array}$ & $\left.\begin{array}{l}(70.1) \\
16.3 \\
16.9 \\
18.3 \\
28.1 \\
29.2 \\
21.8 \\
(26.3)\end{array}\right)$ & $\begin{array}{r}1,075 \\
206 \\
118 \\
113 \\
226 \\
214 \\
66 \\
132\end{array}$ & $\left.\begin{array}{l}(46.2) \\
19.2 \\
15.7 \\
13.1 \\
21.9 \\
21.2 \\
10.3 \\
15.8\end{array}\right)$ & $\begin{array}{r}782 \\
96 \\
88 \\
105 \\
178 \\
137 \\
84 \\
94\end{array}$ & $\begin{array}{l}(39.4) \\
13.8 \\
13.9 \\
13.5 \\
19.0 \\
16.7 \\
12.8 \\
13.1\end{array}$ & $\begin{array}{r}3,364 \\
513 \\
494 \\
455 \\
742 \\
606 \\
206 \\
347\end{array}$ & $\left.\begin{array}{l}(85.4) \\
31.8 \\
27.4 \\
29.5 \\
33.0 \\
31.4 \\
(18.6 \\
24.9\end{array}\right)$ & $\begin{array}{r}1,624 \\
211 \\
307 \\
292 \\
450 \\
189 \\
53 \\
122\end{array}$ & $\begin{array}{r}(65.0 \\
21.2 \\
(26.1 \\
(24.9) \\
32.0 \\
(18.3 \\
(8.8) \\
(15.1)\end{array}$ & $\begin{array}{r}881 \\
83 \\
120 \\
151 \\
224 \\
151 \\
\ddagger \\
120\end{array}$ & $\begin{array}{r}(46.7) \\
12.2 \\
18.9 \\
17.1 \\
23.5 \\
17.5 \\
(\dagger \\
(17.1)\end{array}$ \\
\hline
\end{tabular}

†Not applicable.

fReporting standards not met. Either there are too few cases for a reliable estimate or the coefficient of variation $(\mathrm{CV})$ is 50 percent or greater.
NOTE: Total includes other racial/ethnic groups not shown separately. Race categories exclude persons of Hispanic ethnicity. SOURCE: U.S. Department of Commerce, Census Bureau, Current Population Survey (CPS), March 2013. (This table was prepared February 2014.) 
Table 104.40. Percentage of persons 18 to 24 years old and age 25 and over, by educational attainment and race/ethnicity (including selected subgroups): 2007 and 2012

[Standard errors appear in parentheses]

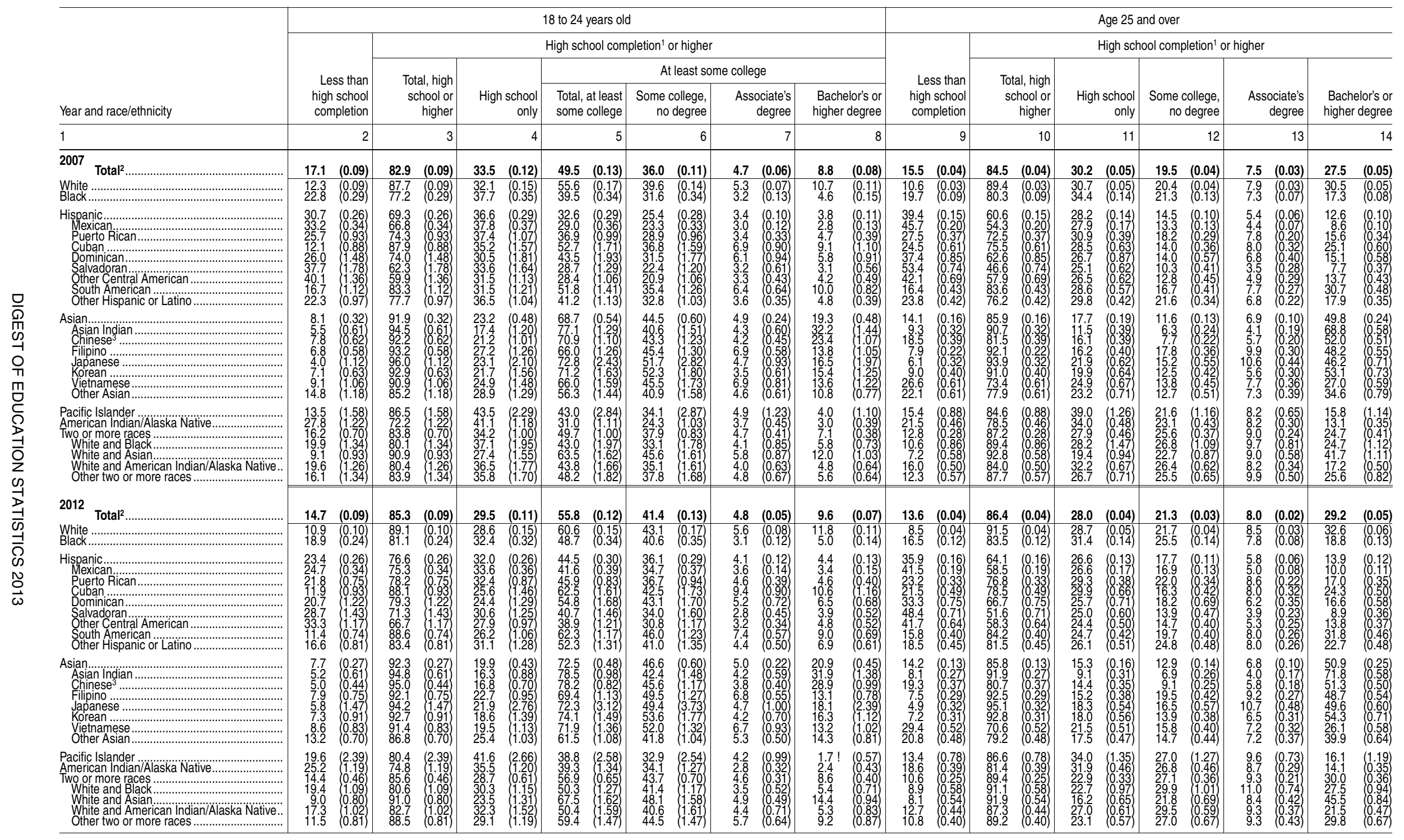

!Interpret data with caution. The coefficient of variation (CV) for this estimate is between 30 and 50 percent.

${ }_{2}^{1}$ High school completers include diploma recipients and those completing high school through alternative credentials, such as a GED. 2Total includes other racial/ethnic groups not shown separately,
'Excludes Taiwanese. Taiwanese is included in "Other Asian."
NOTE: Race categories exclude persons of Hispanic ethnicity. Detail may not sum to totals because of rounding. SOURCE: U.S. Department of Commerce, Census Bureau, American Community Survey, 2007 and 2012. (This table was prepared
February 2014.) 
Table 104.50. Persons age 25 and over who hold a bachelor's or higher degree, by sex, race/ethnicity, age group, and field of bachelor's degree: 2012

[Standard errors appear in parentheses]

\begin{tabular}{|c|c|c|c|c|c|c|c|c|c|c|c|c|c|c|c|c|c|c|c|c|c|c|}
\hline \multirow[b]{2}{*}{ Field of bachelor's degree } & \multirow{2}{*}{\multicolumn{2}{|c|}{ Total' $^{1}$}} & \multicolumn{4}{|c|}{ Sex } & \multicolumn{10}{|c|}{ Race/ethnicity ${ }^{1}$} & \multicolumn{6}{|c|}{ Age } \\
\hline & & & \multicolumn{2}{|r|}{ Males } & \multicolumn{2}{|c|}{ Females } & \multicolumn{2}{|r|}{ White } & \multicolumn{2}{|r|}{ Black } & \multicolumn{2}{|r|}{ Hispanic } & \multicolumn{2}{|c|}{$\begin{array}{r}\text { Asian/Pacific } \\
\text { Islander } \\
\end{array}$} & \multicolumn{2}{|c|}{$\begin{array}{r}\text { American Indian/ } \\
\text { Alaska Native }\end{array}$} & \multicolumn{2}{|c|}{25 to 29 years old } & \multicolumn{2}{|c|}{30 to 49 years old } & \multicolumn{2}{|c|}{$\begin{array}{r}50 \text { years old } \\
\text { and over }\end{array}$} \\
\hline 1 & & 2 & & 3 & & 4 & & 5 & & 6 & & 7 & & 8 & & 9 & & 10 & & 11 & & 12 \\
\hline Total population, 25 and over (in thousands).. & 208,841 & $(47.5)$ & 100,655 & $(28.5)$ & 108,186 & $(29.5)$ & 140,914 & (12.8) & 23,783 & $(22.8)$ & 28,924 & $(20.0)$ & 10,893 & $(18.1)$ & 1,284 & $(10.9)$ & 21,186 & $(22.7)$ & 83,438 & $(30.0)$ & 104,217 & $(38.9)$ \\
\hline Percent of population with bachelor's degree ....... & 29.2 & $(0.02)$ & 29.2 & $(0.06)$ & 29.2 & $(0.06)$ & 32.6 & $(0.06)$ & 18.8 & $(0.13)$ & 13.9 & $(0.11)$ & 49.9 & $(0.24)$ & 14.1 & $(0.35)$ & 31.8 & $(0.17)$ & 31.8 & $(0.08)$ & 26.5 & $(0.05)$ \\
\hline Bachelor's degree holders & & & & & & & & & & & umber (in & thousand & & & & & & & & & & \\
\hline Total.... & 60,946 & $(117.0)$ & 29,400 & $(64.4)$ & 31,545 & $(68.1)$ & 45,909 & $(83.4)$ & 4,462 & $(29.9)$ & 4,028 & (33.8) & 5,438 & $(30.1)$ & 181 & (4.8) & 6,738 & $(36.8)$ & 26,547 & (69.7) & 27,660 & $(60.0)$ \\
\hline Agriculture/forestry .. & 644 & (9.5) & 443 & (8.0) & 201 & (5.2) & 549 & $(8.7)$ & 23 & (2.1) & 25 & (2.2) & 38 & (2.4) & 3 & $(0.6)$ & 62 & (2.6) & 238 & (6.1) & 343 & (6.4) \\
\hline Art/architecture .................. & 2,941 & (18.8) & 1,271 & $(10.6)$ & 1,670 & (15.4) & 2,300 & (16.8) & 136 & (4.9) & 205 & (6.9) & 241 & $(7.0)$ & 7 & $(1.0)$ & 433 & (9.7) & 1,329 & (14.7) & 1,179 & $(12.8)$ \\
\hline Business/management .......... & 12,488 & (43.0) & 7,065 & (34.9) & 5,423 & (26.5) & 9,196 & $(38.0)$ & 1,086 & (12.7) & 944 & (12.7) & 1,063 & $(14.0)$ & 32 & (2.1) & 1,320 & $(14.0)$ & 5,997 & $(30.8)$ & 5,170 & $(27.1)$ \\
\hline Communications .................................................... & 2,189 & (18.3) & 914 & (10.5) & 1,274 & (14.1) & 1,732 & (15.3) & 179 & $(6.9)$ & 143 & (4.9) & 97 & (4.1) & 5 & $(1.0)$ & 359 & (7.6) & 1,211 & (14.6) & 618 & $(9.4)$ \\
\hline Computer and information sciences .......................... & 1,701 & (18.1) & 1,205 & (14.2) & 497 & (9.1) & 994 & (13.0) & 158 & (5.7) & 119 & (4.2) & 394 & (8.9) & 3 & (0.7) & 227 & (7.8) & 1,074 & (13.6) & 401 & (6.7) \\
\hline Education & 8,517 & (36.6) & 2,108 & (19.7) & 6,409 & (28.5) & 7,014 & (32.5) & 618 & (9.3) & 487 & (9.7) & 280 & (5.9) & 34 & (2.1) & 581 & (10.7) & 2,604 & $(21.0)$ & 5,331 & (28.1) \\
\hline Engineering & 4,759 & (27.1) & 4,101 & $(25.8)$ & 658 & $(10.2)$ & 3,188 & (21.2) & 193 & $(7.0)$ & 347 & (8.0) & 938 & (12.3) & 9 & (1.1) & 467 & $(9.0)$ & 2,073 & (17.7) & 2,218 & (17.4) \\
\hline 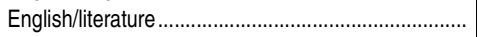 & 1,994 & (17.7) & 677 & (9.5) & 1,316 & (14.5) & 1,639 & (14.7) & 98 & (4.9) & 86 & (3.9) & 134 & (5.3) & 4 & $(0.8)$ & 203 & $(5.8)$ & 794 & (10.1) & 996 & (12.4) \\
\hline Foreign languages ............................................. & 675 & (9.4) & 188 & (5.2) & 487 & (7.6) & 505 & (7.6) & 28 & (2.3) & 66 & (3.2) & 65 & (3.4) & $\dagger$ & $(t)$ & 74 & (3.6) & 255 & $(5.9)$ & 345 & $(5.6)$ \\
\hline 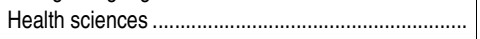 & 4,316 & (24.9) & 766 & (11.1) & 3,550 & $(21.7)$ & 3,138 & (20.3) & 358 & (8.8) & 256 & (7.8) & 490 & (8.2) & 13 & (1.2) & 445 & (8.3) & 1,840 & (19.4) & 2,030 & (15.7) \\
\hline Liberal arts/humanities ............................................ & 890 & (10.7) & 354 & (7.3) & 536 & (8.9) & 663 & $(9.5)$ & 63 & (3.1) & 77 & (3.5) & 70 & (3.9) & 3 & (0.7) & 84 & (4.4) & 396 & (7.2) & 411 & (6.9) \\
\hline Mathematics/statistics .................................. & 930 & (11.5) & 551 & (8.7) & 379 & $(7.0)$ & 706 & $(9.6)$ & 55 & (2.9) & 39 & (2.6) & 117 & $(5.0)$ & $\dagger$ & $(\dagger)$ & 87 & (3.6) & 330 & (6.3) & 513 & (8.2) \\
\hline Natural sciences (biological and physical) ................. & 4,748 & (25.3) & 2,741 & (18.4) & 2,007 & $(16.5)$ & 3,476 & (20.1) & 265 & (7.2) & 256 & (6.5) & 651 & $(10.5)$ & 13 & (1.3) & 575 & (9.8) & 2,049 & $(16.0)$ & 2,124 & $(16.7)$ \\
\hline Philosophy/religion/theology ......................... & 823 & (10.9) & 578 & (9.0) & 245 & (5.9) & 651 & (10.2) & 65 & (3.2) & 43 & (2.7) & 47 & (2.7) & $\dagger$ & $(\dagger)$ & 86 & (4.0) & 305 & $(7.0)$ & 432 & (7.5) \\
\hline Pre-professional......... & 967 & (11.7) & 583 & (9.2) & 384 & (8.5) & 678 & $(9.4)$ & 146 & (5.8) & 99 & (4.5) & 23 & (1.9) & 5 & $(1.0)$ & 161 & (5.5) & 540 & (9.7) & 266 & $(5.9)$ \\
\hline Psychology …………………………………..... & 2,832 & (19.7) & 901 & (11.1) & 1,931 & $(16.9)$ & 2,158 & (17.2) & 240 & (5.9) & 219 & (5.4) & 148 & (4.4) & 12 & (1.4) & 394 & (8.5) & 1,353 & (13.6) & 1,085 & $(11.9)$ \\
\hline Social sciences/history ...................................... & 5,871 & (29.7) & 3,352 & (19.5) & 2,519 & (18.9) & 4,591 & (24.4) & 401 & (8.6) & 359 & (8.2) & 401 & (7.9) & 16 & (1.3) & 673 & $(9.0)$ & 2,448 & (18.0) & 2,750 & $(19.0)$ \\
\hline 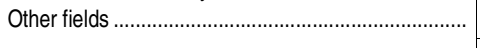 & 3,661 & (22.4) & 1,601 & $(15.7)$ & 2,060 & $(17.3)$ & 2,732 & $(19.3)$ & 350 & (8.2) & 257 & (7.0) & 244 & (5.8) & 17 & (1.4) & 506 & (8.5) & 1,709 & $(15.3)$ & 1,446 & $(13.2)$ \\
\hline & & & & & & & & & & Perce & ntage dist & ribution, b & y field & & & & & & & & & \\
\hline Total... & 100.0 & $(t)$ & 100.0 & $(\dagger)$ & 100.0 & (t) & 100.0 & (t) & 100.0 & $(t)$ & 100.0 & (t) & 100.0 & (t) & 100.0 & (t) & 100.0 & (t) & 100.0 & (t) & 100.0 & (t) \\
\hline Agriculture/forestry …․․ & 1.1 & $(0.02)$ & 1.5 & $(0.03)$ & 0.6 & $(0.02)$ & 1.2 & $(0.02)$ & 0.5 & $(0.05)$ & 0.6 & $(0.05)$ & 0.7 & $(0.04)$ & 1.5 & $(0.35)$ & 0.9 & $(0.04)$ & 0.9 & $(0.02)$ & 1.2 & $(0.02)$ \\
\hline Art/architecture & 4.8 & $(0.03)$ & 4.3 & $(0.03)$ & 5.3 & $(0.05)$ & 5.0 & $(0.04)$ & 3.1 & $(0.11)$ & 5.1 & $(0.17)$ & 4.4 & $(0.13)$ & 3.7 & $(0.51)$ & 6.4 & $(0.14)$ & 5.0 & $(0.06)$ & 4.3 & $(0.05)$ \\
\hline Business/management & 20.5 & $(0.06)$ & 24.0 & $(0.11)$ & 17.2 & $(0.08)$ & 20.0 & $(0.07)$ & 24.3 & $(0.27)$ & 23.4 & $(0.27)$ & 19.6 & $(0.22)$ & 17.7 & $(1.10)$ & 19.6 & $(0.18)$ & 22.6 & $(0.10)$ & 18.7 & $(0.09)$ \\
\hline Communications..................................................... & 3.6 & $(0.03)$ & 3.1 & $(0.03)$ & 4.0 & $(0.04)$ & 3.8 & $(0.03)$ & 4.0 & $(0.15)$ & 3.5 & $(0.12)$ & 1.8 & $(0.08)$ & 2.9 & $(0.55)$ & 5.3 & $(0.12)$ & 4.6 & $(0.05)$ & 2.2 & $(0.03)$ \\
\hline Computer and information sciences ........................... & 2.8 & $(0.03)$ & 4.1 & $(0.05)$ & 1.6 & $(0.03)$ & 2.2 & $(0.03)$ & 3.5 & $(0.13)$ & 3.0 & $(0.10)$ & 7.2 & $(0.16)$ & 1.9 & $(0.38)$ & 3.4 & $(0.11)$ & 4.0 & $(0.05)$ & 1.4 & $(0.02)$ \\
\hline Education......................... & 14.0 & $(0.05)$ & 7.2 & $(0.07)$ & 20.3 & $(0.08)$ & 15.3 & $(0.06)$ & 13.8 & $(0.18)$ & 12.1 & $(0.22)$ & 5.1 & $(0.11)$ & 19.1 & (1.11) & 8.6 & $(0.15)$ & 9.8 & $(0.07)$ & 19.3 & $(0.10)$ \\
\hline 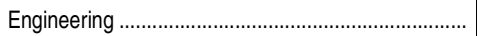 & 7.8 & $(0.04)$ & 13.9 & $(0.08)$ & 2.1 & $(0.03)$ & 6.9 & $(0.04)$ & 4.3 & $(0.15)$ & 8.6 & $(0.18)$ & 17.3 & $(0.20)$ & 4.8 & $(0.58)$ & 6.9 & $(0.13)$ & 7.8 & $(0.06)$ & 8.0 & $(0.06)$ \\
\hline 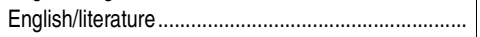 & 3.3 & $(0.03)$ & 2.3 & $(0.03)$ & 4.2 & $(0.04)$ & 3.6 & $(0.03)$ & 2.2 & $(0.11)$ & 2.1 & $(0.10)$ & 2.5 & $(0.10)$ & 2.4 & $(0.43)$ & 3.0 & $(0.08)$ & 3.0 & $(0.04)$ & 3.6 & $(0.04)$ \\
\hline Foreign languages.......... & 1.1 & $(0.01)$ & 0.6 & $(0.02)$ & 1.5 & $(0.02)$ & 1.1 & $(0.02)$ & 0.6 & $(0.05)$ & 1.6 & $(0.08)$ & 1.2 & $(0.06)$ & $0.5 !$ & $(0.17)$ & 1.1 & $(0.05)$ & 1.0 & $(0.02)$ & 1.2 & $(0.02)$ \\
\hline Health sciences .................................................... & 7.1 & $(0.04)$ & 2.6 & $(0.04)$ & 11.3 & $(0.07)$ & 6.8 & $(0.05)$ & 8.0 & $(0.18)$ & 6.4 & $(0.18)$ & 9.0 & $(0.14)$ & 6.9 & $(0.67)$ & 6.6 & $(0.12)$ & 6.9 & $(0.07)$ & 7.3 & $(0.05)$ \\
\hline 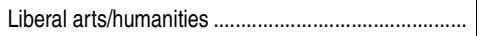 & 1.5 & $(0.02)$ & 1.2 & $(0.02)$ & 1.7 & $(0.03)$ & 1.4 & $(0.02)$ & 1.4 & $(0.07)$ & 1.9 & $(0.08)$ & 1.3 & $(0.07)$ & 1.7 & $(0.36)$ & 1.2 & $(0.07)$ & 1.5 & $(0.03)$ & 1.5 & $(0.03)$ \\
\hline Mathematics/statistics ..... & 1.5 & $(0.02)$ & 1.9 & $(0.03)$ & 1.2 & $(0.02)$ & 1.5 & $(0.02)$ & 1.2 & $(0.06)$ & 1.0 & $(0.06)$ & 2.1 & $(0.09)$ & 0.9 & $(0.21)$ & 1.3 & $(0.05)$ & 1.2 & $(0.02)$ & 1.9 & $(0.03)$ \\
\hline Natural sciences (biological and physical).............. & 7.8 & $(0.04)$ & 9.3 & $(0.06)$ & 6.4 & $(0.05)$ & 7.6 & $(0.04)$ & 5.9 & (0.16) & 6.4 & $(0.16)$ & 12.0 & $(0.18)$ & 7.0 & $(0.67)$ & 8.5 & $(0.14)$ & 7.7 & $(0.06)$ & 7.7 & $(0.06)$ \\
\hline Philosophy/religion/theology & 1.4 & $(0.02)$ & 2.0 & $(0.03)$ & 0.8 & $(0.02)$ & 1.4 & $(0.02)$ & 1.5 & $(0.07)$ & 1.1 & $(0.07)$ & 0.9 & $(0.05)$ & 1.7 & $(0.36)$ & 1.3 & $(0.06)$ & 1.1 & $(0.03)$ & 1.6 & $(0.03)$ \\
\hline 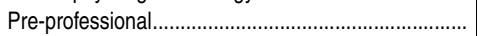 & 1.6 & $(0.02)$ & 2.0 & $(0.03)$ & 1.2 & $(0.03)$ & 1.5 & $(0.02)$ & 3.3 & $(0.13)$ & 2.5 & $(0.11)$ & 0.4 & $(0.04)$ & 2.8 & $(0.55)$ & 2.4 & $(0.08)$ & 2.0 & $(0.04)$ & 1.0 & $(0.02)$ \\
\hline Psychology & 4.6 & $(0.03)$ & 3.1 & $(0.04)$ & 6.1 & $(0.05)$ & 4.7 & $(0.04)$ & 5.4 & $(0.13)$ & 5.4 & $(0.13)$ & 2.7 & $(0.08)$ & 6.4 & $(0.76)$ & 5.8 & $(0.12)$ & 5.1 & $(0.05)$ & 3.9 & $(0.04)$ \\
\hline Social sciences/history & 9.6 & $(0.04)$ & 11.4 & $(0.06)$ & 8.0 & $(0.05)$ & 10.0 & $(0.05)$ & 9.0 & $(0.18)$ & 8.9 & $(0.17)$ & 7.4 & $(0.14)$ & 8.8 & $(0.69)$ & 10.0 & $(0.12)$ & 9.2 & $(0.06)$ & 9.9 & $(0.06)$ \\
\hline Other fields & 6.0 & $(0.04)$ & 5.4 & $(0.05)$ & 6.5 & $(0.05)$ & 5.9 & $(0.04)$ & 7.8 & $(0.18)$ & 6.4 & $(0.17)$ & 4.5 & $(0.11)$ & 9.2 & $(0.74)$ & 7.5 & $(0.12)$ & 6.4 & $(0.06)$ & 5.2 & $(0.05)$ \\
\hline
\end{tabular}

†Not applicable.

ret data with caution. The coefficient of variation (CV) for this estimate is between 30 and 50 percent.

'Totals include other racial/ethnic groups not separately shown.
NOTE: Race categories exclude persons of Hispanic ethnicity. Detail may not sum to totals because of rounding.

SOURCE: U.S. Department of Commerce, Census Bureau, American Community Survey, 2012. (This table was prepared January 2014.) 
Table 104.60. Number of persons 25 to 34 years old, percentage with a bachelor's or higher degree, and percentage distribution, by undergraduate field of study and selected student characteristics: 2012

[Standard errors appear in parentheses]

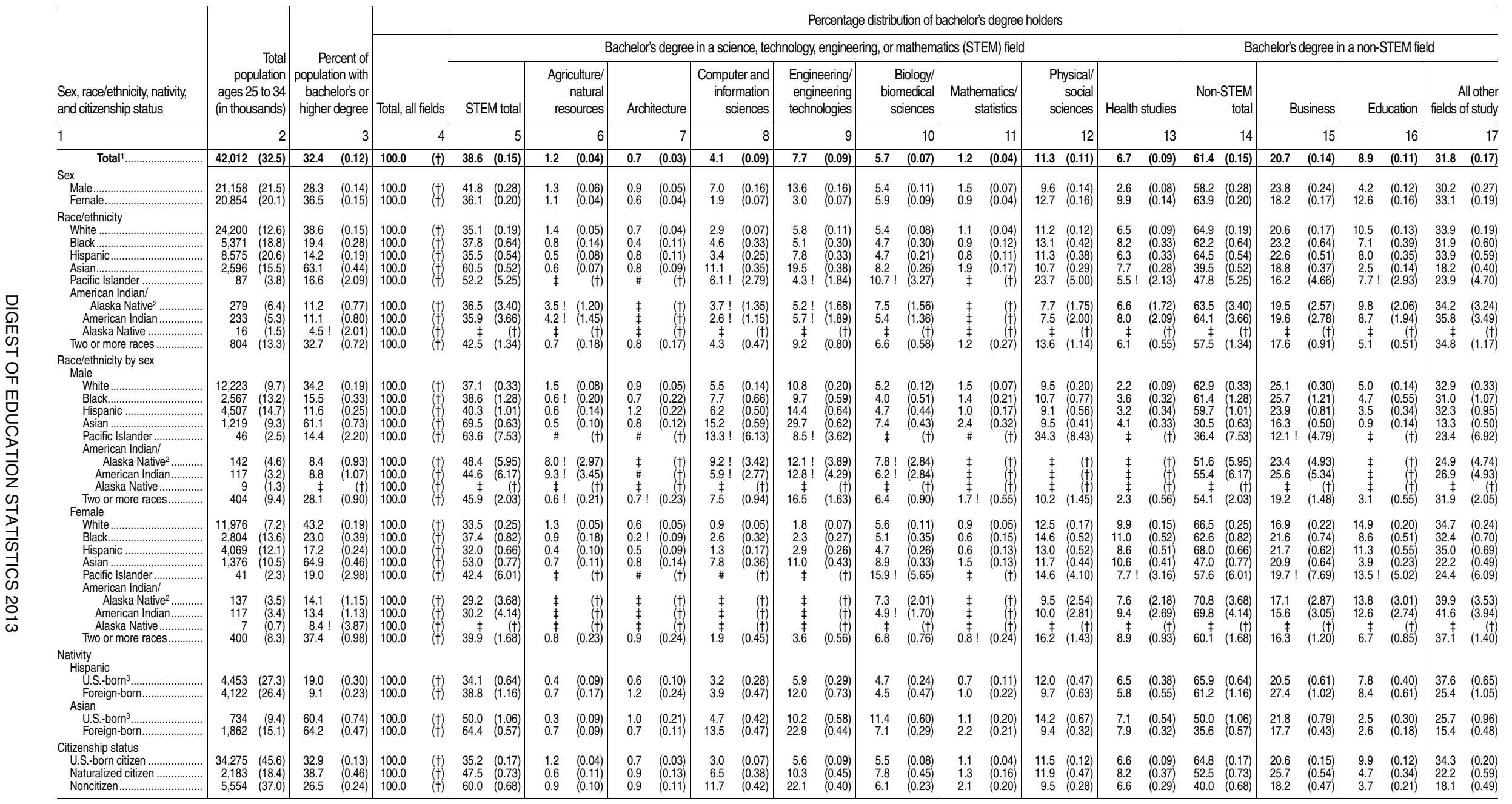

†Not applicable.

\#Rounds to zero.

!Interpret data with caution. The coefficient of variation (CV) for this estimate is between 30 and 50 percent.
†Reporting standards not met. Either there are too few cases for a reliable estimate or the coefficient of variation (CV) is 50 †Reporting standard
percent or greater.

percent or greater.
Total includes other racial//ethnic groups not shown separately.

${ }_{2}^{2}$ Includes persons reporting American Indian alone, persons reporting Alaska Native alone, and persons from American Indian and/or Alaska Native tribes specified or not specified.

Includes those born in the 50 states, the District of Columbia, Puerto Rico, American Samoa, Guam, the U.S. Virgin Islands, and the Northern Marianas, as well as those born abroad to U.S.-citizen parents.
NOTE: Estimates are for the entire population in the indicated age range, including persons living in households and persons living in group quarters (such as college residence halls, residential treatment centers, military barracks, and correctional facilities). The first bachelor's degree major reported by respondents was used to classity their field of study, even though they were able to report a second bachelor's degree major and may possess advanced degrees in other fields. STEM fields, as tions, except that management of STEM activities was counted as a STEM field instead of a business field. Detail may not sum to totals because of rounding. Race categories exclude persons of Hispanic ethnicity. SOURCE: U.S. Department of Commerce, Census Bureau, American Community Survey (ACS), 2012. (This table was pre-
pared January 2014.) 
Table 104.70. Percentage distribution of 6- to 18-year-olds, by parent's highest level of educational attainment, household type, and child's race/ethnicity: 2007 and 2012

[Standard errors appear in parentheses]

\begin{tabular}{|c|c|c|c|c|c|c|c|c|c|c|c|c|c|c|c|c|c|c|}
\hline \multirow{3}{*}{ Year, household type, and race/ethnicity } & \multicolumn{18}{|c|}{ Highest level of education attained by any parent residing with child 1} \\
\hline & \multirow{2}{*}{\multicolumn{2}{|c|}{ Total, all levels }} & \multirow{2}{*}{\multicolumn{2}{|c|}{$\begin{array}{r}\text { Less than } \\
\text { high school completion }\end{array}$}} & \multirow{2}{*}{\multicolumn{2}{|c|}{$\begin{array}{l}\text { High school } \\
\text { completion }\end{array}$}} & \multirow{2}{*}{\multicolumn{2}{|c|}{$\begin{array}{r}\text { Some college, } \\
\text { no degree }\end{array}$}} & \multirow{2}{*}{\multicolumn{2}{|c|}{ Associate's degree }} & \multicolumn{8}{|c|}{ Bachelor's or higher degree } \\
\hline & & & & & & & & & & & & Total & Bachelo & degree & Mast & degree & Doct & degree \\
\hline 1 & & 2 & & 3 & & 4 & & 5 & & 6 & & 7 & & 8 & & 9 & & 10 \\
\hline \multicolumn{19}{|l|}{2007} \\
\hline Total, both household types.............. & 100.0 & $(t)$ & 11.0 & $(0.08)$ & 23.5 & $(0.11)$ & 21.1 & $(0.11)$ & 10.4 & $(0.07)$ & 34.1 & (0.13) & 20.1 & $(0.10)$ & 9.3 & $(0.07)$ & 4.7 & \\
\hline 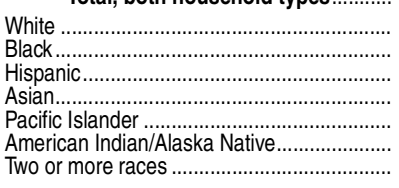 & $\begin{array}{l}100.0 \\
100.0 \\
100.0 \\
100.0 \\
100.0 \\
100.0 \\
100.0\end{array}$ & 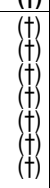 & $\begin{array}{r}3.9 \\
12.4 \\
32.7 \\
10.4 \\
9.9 \\
13.3 \\
5.4\end{array}$ & $\begin{array}{l}(0.06) \\
(0.24) \\
(0.28) \\
(0.37) \\
(1.57) \\
(0.91) \\
(0.34)\end{array}$ & $\begin{array}{l}20.6 \\
32.0 \\
27.9 \\
15.0 \\
37.6 \\
32.6 \\
20.8\end{array}$ & $\begin{array}{l}(0.12) \\
(0.33) \\
0.29) \\
(0.44) \\
(3.16) \\
(1.09) \\
(0.59)\end{array}$ & $\begin{array}{l}21.3 \\
26.7 \\
17.7 \\
10.5 \\
24.0 \\
25.4 \\
26.8\end{array}$ & $\begin{array}{l}(0.12) \\
(0.34) \\
0.23) \\
(0.34) \\
(2.62) \\
(0.97) \\
0.70)\end{array}$ & $\begin{array}{r}10.7 \\
11.6 \\
10.1 \\
7.1 \\
7.9 \\
11.3 \\
11.0 \\
11.5\end{array}$ & $\begin{array}{l}(0.09) \\
(0.20) \\
0.14) \\
(0.28) \\
1.90) \\
(0.82) \\
(0.43)\end{array}$ & $\begin{array}{l}42.7 \\
18.8 \\
14.5 \\
56.2 \\
17.2 \\
17.6 \\
35.5\end{array}$ & $\begin{array}{l}(0.16) \\
(0.27) \\
0.21) \\
0.55 \\
(2.17) \\
0.96 \\
0.71)\end{array}$ & $\begin{array}{r}24.9 \\
12.2 \\
9.6 \\
28.8 \\
8.0 \\
10.1 \\
20.8\end{array}$ & $\begin{array}{l}(0.14) \\
(0.23) \\
0.17) \\
(0.54) \\
(1.43) \\
(0.77) \\
(0.52)\end{array}$ & $\begin{array}{r}12.0 \\
4.9 \\
3.2 \\
15.8 \\
8.2 \\
5.6 \\
8.9\end{array}$ & $\begin{array}{l}(0.10) \\
(0.15) \\
(0.09) \\
(0.35) \\
(1.62) \\
(0.56) \\
0.37)\end{array}$ & $\begin{array}{c}5.8 \\
1.7 \\
1.8 \\
11.6 \\
1.0 ! \\
1.9 \\
5.7\end{array}$ & $\begin{array}{l}(0.07) \\
(0.08 \\
0.07) \\
0.34 \\
0.41 \\
0.32 \\
0.31)\end{array}$ \\
\hline 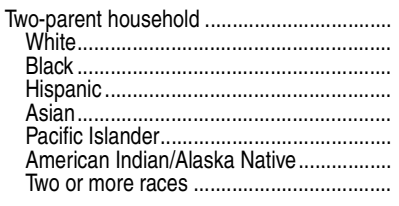 & $\begin{array}{l}100.0 \\
100.0 \\
100.0 \\
100.0 \\
100.0 \\
100.0 \\
100.0 \\
100.0\end{array}$ & $\begin{array}{l}(\dagger) \\
(+) \\
(\dagger) \\
+ \\
+ \\
+ \\
+ \\
(\dagger) \\
(+)\end{array}$ & $\begin{array}{r}7.4 \\
2.0 \\
3.6 \\
29.5 \\
7.7 \\
5.2 ! \\
7.5 \\
1.7\end{array}$ & $\begin{array}{l}(0.09) \\
(0.05) \\
(0.24) \\
0.34 \\
(0.36) \\
(1.56) \\
(0.95) \\
(0.24)\end{array}$ & $\begin{array}{l}19.1 \\
17.0 \\
23.1 \\
27.0 \\
13.3 \\
35.9 \\
29.1 \\
15.1\end{array}$ & $\begin{array}{l}(0.13) \\
(0.14) \\
(0.52) \\
0.35) \\
(0.46 \\
(3.93) \\
(1.52) \\
(0.70)\end{array}$ & $\begin{array}{r}19.6 \\
19.9 \\
26.6 \\
17.4 \\
9.7 \\
23.2 \\
25.2 \\
23.6\end{array}$ & $\begin{array}{l}(0.13) \\
(0.14) \\
(0.56) \\
0.28) \\
0.39 \\
(3.24) \\
(1.49) \\
(0.90)\end{array}$ & $\begin{array}{r}11.0 \\
11.8 \\
13.2 \\
7.9 \\
7.8 \\
15.9 \\
12.5 \\
12.1\end{array}$ & $\begin{array}{l}(0.10) \\
(0.11) \\
(0.44) \\
0.21 \\
0.35) \\
(2.80) \\
(1.05) \\
(0.50)\end{array}$ & $\begin{array}{l}42.9 \\
49.3 \\
33.5 \\
18.2 \\
61.6 \\
19.8 \\
25.7 \\
47.6\end{array}$ & $\begin{array}{l}(0.15) \\
(0.17) \\
(0.55) \\
0.27 \\
0.53 \\
(2.81) \\
(1.48) \\
(1.00)\end{array}$ & $\begin{array}{r}24.5 \\
28.0 \\
20.4 \\
11.7 \\
30.6 \\
9.8 \\
14.4 \\
26.5\end{array}$ & $\begin{array}{l}(0.12) \\
(0.16 \\
0.44) \\
(0.21) \\
0.53 \\
(2.27) \\
(1.24) \\
(0.71)\end{array}$ & $\begin{array}{r}12.1 \\
14.2 \\
9.6 \\
4.1 \\
17.7 \\
8.5 \\
8.1 \\
12.4\end{array}$ & $\begin{array}{l}(0.09) \\
(0.12) \\
(0.34) \\
(0.13) \\
(0.39 \\
(1.59) \\
(0.84) \\
(0.54)\end{array}$ & $\begin{array}{c}6.3 \\
7.0 \\
3.6 \\
2.4 \\
13.3 \\
1.5 ! \\
3.2 \\
8.7\end{array}$ & $\begin{array}{l}(0.07) \\
(0.08) \\
0.21 \\
(0.11) \\
0.41 \\
0.62) \\
(0.56) \\
(0.49)\end{array}$ \\
\hline 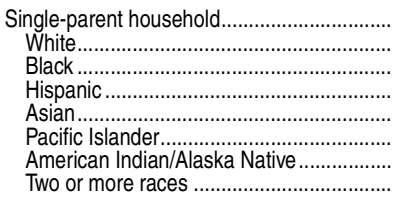 & $\begin{array}{l}100.0 \\
100.0 \\
100.0 \\
100.0 \\
100.0 \\
100.0 \\
100.0 \\
100.0 \\
\end{array}$ & 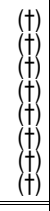 & $\begin{array}{l}18.6 \\
10.0 \\
17.5 \\
38.6 \\
23.0 \\
18.1 \\
19.7 \\
10.9 \\
\end{array}$ & $\begin{array}{l}(0.19) \\
(0.16) \\
(0.35) \\
(0.53) \\
(1.30) \\
(3.77) \\
(1.29) \\
(0.80) \\
\end{array}$ & $\begin{array}{l}32.6 \\
31.9 \\
37.1 \\
29.5 \\
23.1 \\
40.4 \\
36.4 \\
29.3 \\
\end{array}$ & $\begin{array}{l}(0.20) \\
0.25) \\
(0.44) \\
(0.46) \\
(1.15) \\
(5.73) \\
(1.60) \\
(1.11) \\
\end{array}$ & $\begin{array}{l}24.4 \\
25.8 \\
26.8 \\
18.3 \\
14.3 \\
25.4 \\
25.7 \\
31.4 \\
\end{array}$ & $\begin{array}{l}(0.21) \\
0.25) \\
(0.44) \\
0.402 \\
(0.82) \\
(4.78) \\
(1.37) \\
(0.94) \\
\end{array}$ & $\begin{array}{r}8.9 \\
10.8 \\
8.3 \\
5.8 \\
8.4 \\
3.2 ! \\
9.3 \\
10.5 \\
\end{array}$ & $\begin{array}{l}(0.12) \\
0.17) \\
(0.22) \\
0.21 \\
(0.75) \\
(1.21) \\
(1.12) \\
(0.66) \\
\end{array}$ & $\begin{array}{r}15.5 \\
21.6 \\
10.4 \\
7.9 \\
31.1 \\
12.9 \\
8.8 \\
17.8 \\
\end{array}$ & $\begin{array}{l}(0.16) \\
0.22) \\
(0.29) \\
0.26 \\
(1.26) \\
(3.33) \\
(1.05) \\
0.90) \\
\end{array}$ & $\begin{array}{r}10.7 \\
14.7 \\
7.5 \\
5.8 \\
20.5 \\
4.9 ! \\
5.3 \\
12.5 \\
\end{array}$ & $\begin{array}{l}(0.13) \\
0.19) \\
(0.26) \\
(0.21) \\
(1.6) \\
(1.81) \\
(0.85) \\
(0.84) \\
\end{array}$ & $\begin{array}{l}3.5 \\
5.0 \\
2.2 \\
1.5 \\
6.9 \\
7.7 ! \\
3.0 \\
3.8 \\
\end{array}$ & $\begin{array}{l}(0.07) \\
0.10) \\
(0.12) \\
(0.10) \\
(0.66) \\
(3.00) \\
(0.58) \\
(0.41) \\
\end{array}$ & $\begin{array}{l}1.3 \\
1.9 \\
0.6 \\
0.6 \\
3.7 \\
\ddagger \\
0.6 ! \\
1.5 \\
\end{array}$ & 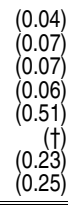 \\
\hline 2012 Total, both household types........... & 100.0 & $(t)$ & 11.0 & $(0.08)$ & 19.5 & $(0.09)$ & 22.6 & (0.12) & 10.6 & $(0.08)$ & 36.3 & (0.14) & 20.8 & $(0.10)$ & 10.7 & $(0.08)$ & 4.8 & $(0.04)$ \\
\hline 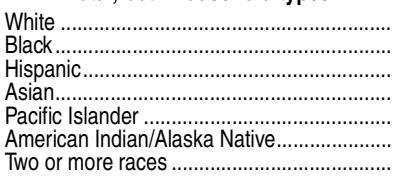 & $\begin{array}{l}100.0 \\
100.0 \\
100.0 \\
100.0 \\
100.0 \\
100.0 \\
100.0\end{array}$ & 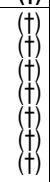 & $\begin{array}{r}3.5 \\
11.0 \\
29.8 \\
10.1 \\
5.2 \\
10.8 \\
4.7\end{array}$ & $\begin{array}{l}(0.07) \\
(0.23) \\
(0.22) \\
(0.31) \\
(1.02) \\
(0.72) \\
(0.24)\end{array}$ & $\begin{array}{l}16.6 \\
24.9 \\
24.9 \\
11.8 \\
30.9 \\
27.1 \\
16.3\end{array}$ & $\begin{array}{l}(0.12) \\
(0.27) \\
0.25) \\
(0.40) \\
(2.79) \\
(0.88) \\
(0.50)\end{array}$ & $\begin{array}{l}21.8 \\
30.7 \\
21.1 \\
11.8 \\
31.2 \\
30.8 \\
27.0\end{array}$ & $\begin{array}{l}(0.15) \\
(0.30) \\
0.22) \\
(0.33) \\
2.68) \\
(1.17) \\
0.61)\end{array}$ & $\begin{array}{r}11.9 \\
11.2 \\
7.3 \\
7.1 \\
11.6 \\
12.0 \\
11.8\end{array}$ & $\begin{array}{l}(0.10) \\
(0.24) \\
0.15) \\
(0.27) \\
1.83) \\
(0.79) \\
(0.41)\end{array}$ & $\begin{array}{l}46.1 \\
22.2 \\
16.9 \\
59.3 \\
21.2 \\
19.3 \\
40.2\end{array}$ & $\begin{array}{l}(0.18) \\
(0.32) \\
0.22) \\
(0.51) \\
2.30) \\
(0.91) \\
0.60)\end{array}$ & $\begin{array}{l}26.1 \\
13.7 \\
10.9 \\
28.8 \\
14.0 \\
12.3 \\
22.5\end{array}$ & $\begin{array}{l}(0.16) \\
(0.27) \\
0.18) \\
(0.43) \\
(2.08) \\
(0.86) \\
(0.41)\end{array}$ & $\begin{array}{r}13.8 \\
6.5 \\
4.2 \\
19.3 \\
4.7 \\
5.4 \\
11.5\end{array}$ & $\begin{array}{l}(0.10) \\
(0.16) \\
0.10) \\
(0.42) \\
(1.15) \\
(0.45) \\
(0.39)\end{array}$ & $\begin{array}{r}6.2 \\
1.9 \\
1.8 \\
11.3 \\
2.5 ! \\
1.5 \\
6.2\end{array}$ & $\begin{array}{l}(0.07) \\
(0.09 \\
0.06 \\
0.31 \\
0.96 \\
0.32 \\
(0.25)\end{array}$ \\
\hline 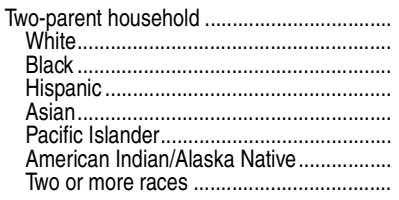 & $\begin{array}{l}100.0 \\
100.0 \\
100.0 \\
100.0 \\
100.0 \\
100.0 \\
100.0 \\
100.0\end{array}$ & $\begin{array}{c}(+) \\
(+) \\
+ \\
+ \\
(\dagger) \\
+ \\
+ \\
(\dagger) \\
(\dagger) \\
(\dagger)\end{array}$ & $\begin{array}{r}7.2 \\
1.7 \\
2.7 \\
25.4 \\
8.3 \\
2.5 ! \\
3.5 \\
1.5\end{array}$ & $\begin{array}{l}(0.08) \\
(0.05) \\
(0.19) \\
(0.29) \\
(0.31) \\
(0.97) \\
(0.56) \\
(0.19)\end{array}$ & $\begin{array}{l}15.2 \\
12.7 \\
16.6 \\
23.9 \\
10.2 \\
28.2 \\
23.1 \\
10.2\end{array}$ & $\begin{array}{l}(0.12) \\
(0.13) \\
0.42 \\
(0.38) \\
0.39 \\
(3.50) \\
(1.24) \\
(0.50)\end{array}$ & $\begin{array}{l}19.9 \\
19.6 \\
26.6 \\
20.5 \\
10.6 \\
29.4 \\
30.9 \\
22.4\end{array}$ & $\begin{array}{l}(0.14) \\
(0.18) \\
0.57) \\
(0.30) \\
0.37 \\
(3.60) \\
(1.75) \\
(0.68)\end{array}$ & $\begin{array}{r}11.1 \\
12.1 \\
13.8 \\
8.0 \\
6.9 \\
13.8 \\
14.7 \\
11.8\end{array}$ & $\begin{array}{l}(0.10) \\
(0.12) \\
0.41) \\
(0.23) \\
0.30 \\
(2.59) \\
(1.25) \\
(0.50)\end{array}$ & $\begin{array}{l}46.5 \\
53.8 \\
40.2 \\
22.1 \\
64.1 \\
26.1 \\
27.8 \\
54.1\end{array}$ & $\begin{array}{l}(0.16) \\
(0.19) \\
0.59) \\
0.29 \\
0.54) \\
(3.22) \\
(1.46) \\
(0.74)\end{array}$ & $\begin{array}{l}25.6 \\
29.5 \\
23.0 \\
13.9 \\
29.8 \\
16.5 \\
16.7 \\
28.0\end{array}$ & $\begin{array}{l}(0.13) \\
(0.18) \\
(0.51) \\
(0.23) \\
(0.48) \\
(2.84) \\
(1.32) \\
(0.66)\end{array}$ & $\begin{array}{r}14.2 \\
16.6 \\
12.8 \\
5.8 \\
21.7 \\
6.3 \\
8.9 \\
16.7\end{array}$ & $\begin{array}{l}(0.10) \\
(0.12) \\
(0.40) \\
(0.15) \\
(0.48) \\
(1.63) \\
(0.85) \\
(0.58)\end{array}$ & $\begin{array}{r}6.7 \\
7.7 \\
4.5 \\
2.5 \\
12.6 \\
3.3 ! \\
2.2 \\
9.4\end{array}$ & $\begin{array}{l}(0.06) \\
(0.08) \\
0.23 \\
0.09 \\
0.35 \\
1.36 \\
(0.44) \\
(0.41)\end{array}$ \\
\hline 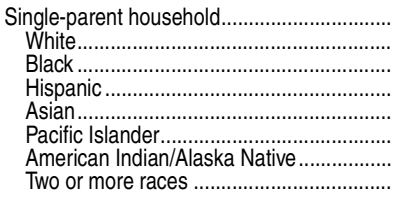 & $\begin{array}{l}100.0 \\
100.0 \\
100.0 \\
100.0 \\
100.0 \\
100.0 \\
100.0 \\
100.0\end{array}$ & 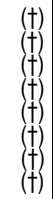 & $\begin{array}{r}18.1 \\
8.8 \\
15.4 \\
36.5 \\
19.0 \\
11.2 \\
17.6 \\
9.2\end{array}$ & $\begin{array}{l}(0.19) \\
(0.22) \\
(0.34) \\
0.47) \\
(1.02) \\
(2.45) \\
(1.19) \\
(0.54)\end{array}$ & $\begin{array}{l}27.6 \\
27.7 \\
29.4 \\
26.6 \\
19.5 \\
37.0 \\
30.8 \\
24.9\end{array}$ & $\begin{array}{l}(0.17) \\
0.24) \\
(0.39) \\
0.38 \\
1.20 \\
(4.51) \\
1.35) \\
(0.84)\end{array}$ & $\begin{array}{l}27.8 \\
28.4 \\
32.8 \\
21.9 \\
17.7 \\
35.3 \\
30.6 \\
33.6\end{array}$ & $\begin{array}{l}(0.21) \\
(0.29) \\
(0.46) \\
0.36) \\
(1.03) \\
(4.79) \\
(1.42) \\
(0.92)\end{array}$ & $\begin{array}{r}9.6 \\
11.4 \\
9.8 \\
6.3 \\
7.8 \\
6.6 \\
9.5 \\
11.9\end{array}$ & $\begin{array}{l}(0.12) \\
(0.20) \\
(0.26) \\
0.20 \\
(0.74) \\
(1.88) \\
(0.98) \\
(0.60)\end{array}$ & $\begin{array}{c}16.9 \\
23.7 \\
12.5 \\
8.8 \\
36.1 \\
9.9 ! \\
11.5 \\
20.4\end{array}$ & $\begin{array}{l}(0.16) \\
(0.28) \\
(0.29) \\
0.24 \\
(1.30) \\
(3.26) \\
1.17) \\
(0.74)\end{array}$ & $\begin{array}{c}11.6 \\
16.0 \\
8.8 \\
6.3 \\
23.9 \\
8.3 ! \\
8.4 \\
14.6\end{array}$ & $\begin{array}{l}(0.13) \\
(0.23) \\
(0.25) \\
0.20) \\
(1.17) \\
(3.23 \\
(1.06) \\
(0.64)\end{array}$ & $\begin{array}{r}4.0 \\
5.8 \\
3.2 \\
1.8 \\
7.5 \\
\neq \\
2.2 \\
4.1\end{array}$ & $\begin{array}{r}(0.08) \\
(0.14) \\
(0.14) \\
(0.10) \\
0.64) \\
(+) \\
(0.39) \\
(0.35)\end{array}$ & $\begin{array}{c}1.3 \\
2.0 \\
0.5 \\
0.6 \\
4.7 \\
\ddagger \\
1.0 ! \\
1.7\end{array}$ & $\begin{array}{r}(0.04) \\
(0.09) \\
(0.06) \\
0.06 \\
(0.53) \\
(\dagger) \\
(0.39) \\
(0.24)\end{array}$ \\
\hline
\end{tabular}

\section{†Not applicable.}

Rerpret data with caution. The coefficient of variation (CV) for this estimate is between 30 and 50 percent. †Reporting standards not met (too few cases for a reliable estimate).

NOTE: Table includes only 6- to 18-year-olds who resided with at least one parent (including an adoptive or stepparent). Race 2Includes adoptive and stepparents, but excludes parents not residing in the same household as their children.
. categories exclude persons of Hispanic ethnicity. Detail may not sum to totals because of rounding.
SOURCE: U.S. Department of Commerce, Census Bureau, American Community Survey, 2007 and 2012. (This table was prepared January 2014.) 
[Standard errors appear in parentheses]

\begin{tabular}{|c|c|c|c|c|c|c|c|c|c|c|c|c|c|c|c|c|c|c|}
\hline \multirow[b]{4}{*}{ State } & \multicolumn{3}{|c|}{$\begin{array}{l}\text { Percent of } 18 \text { - to } 24 \text {-year-olds } \\
\text { who were high school completers }{ }^{1}\end{array}$} & \multicolumn{15}{|c|}{ Percent of population 25 years old and over, by educational attainment } \\
\hline & \multirow[b]{3}{*}{2000} & \multirow[b]{3}{*}{2011} & \multirow[b]{3}{*}{2012} & \multicolumn{5}{|c|}{2000} & \multicolumn{5}{|c|}{2011} & \multicolumn{5}{|c|}{2012} \\
\hline & & & & \multirow{2}{*}{$\begin{array}{r}\text { Less than } \\
\text { high school } \\
\text { completion }\end{array}$} & \multirow{2}{*}{$\begin{array}{r}\text { High school } \\
\text { completion } \\
\text { or higher }\end{array}$} & \multicolumn{3}{|c|}{ Bachelor's or higher degree } & \multirow{2}{*}{$\begin{array}{r}\text { Less than } \\
\text { high school } \\
\text { completion }\end{array}$} & \multirow{2}{*}{$\begin{array}{r}\text { High school } \\
\text { completion } \\
\text { or higher }\end{array}$} & \multicolumn{3}{|c|}{ Bachelor's or higher degree } & \multirow{2}{*}{$\begin{array}{r}\text { Less than } \\
\text { high school } \\
\text { completion }\end{array}$} & \multirow{2}{*}{$\begin{array}{r}\text { High school } \\
\text { completion } \\
\text { or higher }\end{array}$} & \multicolumn{3}{|c|}{ Bachelor's or higher degree } \\
\hline & & & & & & Total & $\begin{array}{r}\text { Bachelor's } \\
\text { degree }\end{array}$ & $\begin{array}{r}\text { Graduate } \\
\text { degree }\end{array}$ & & & Total & $\begin{array}{r}\text { Bachelor's } \\
\text { degree }\end{array}$ & $\begin{array}{r}\text { Graduate } \\
\text { degree }\end{array}$ & & & Total & $\begin{array}{r}\text { Bachelor's } \\
\text { degree }\end{array}$ & $\begin{array}{r}\text { Graduate } \\
\text { degree }\end{array}$ \\
\hline
\end{tabular}

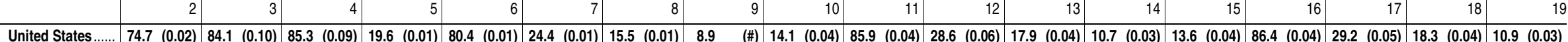

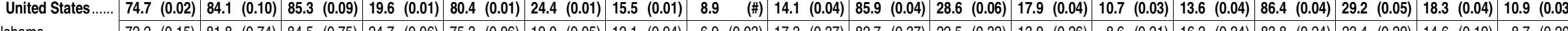

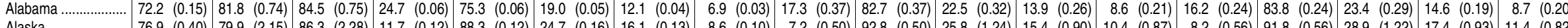

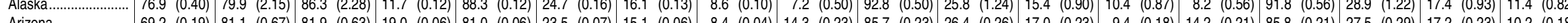

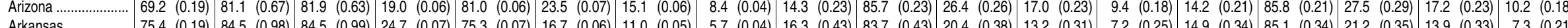

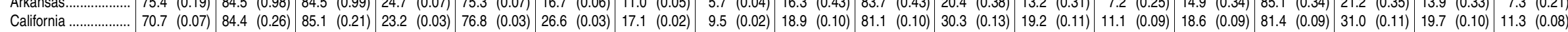

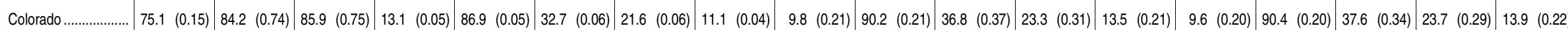

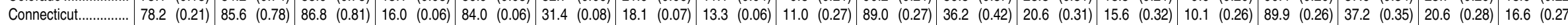

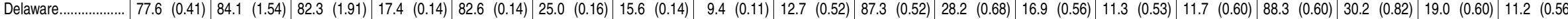

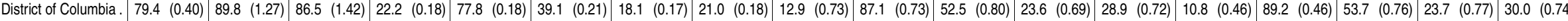

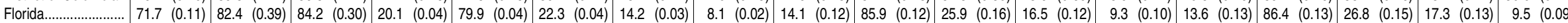

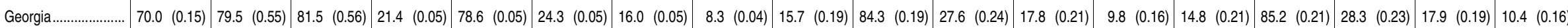

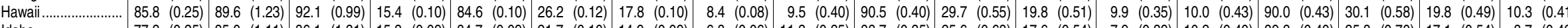

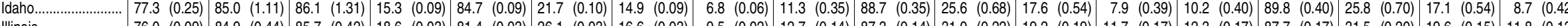

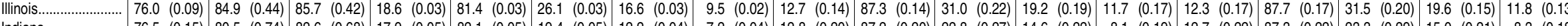

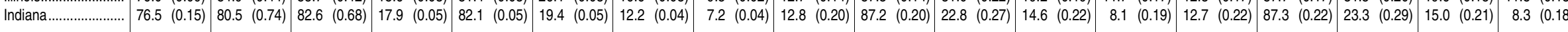

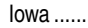

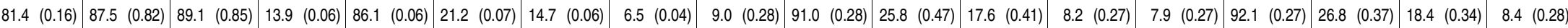
Kansas. Kentucky

Kentucky.....

Maine..............

Maryland.

Massachusetts.

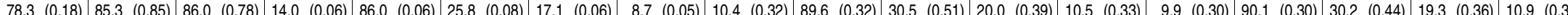

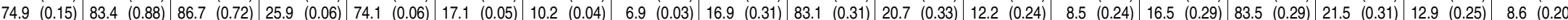
Michigan ....

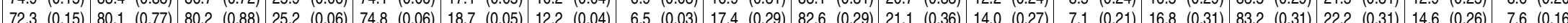

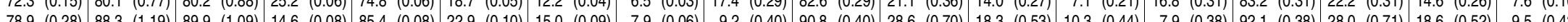

Minnesota

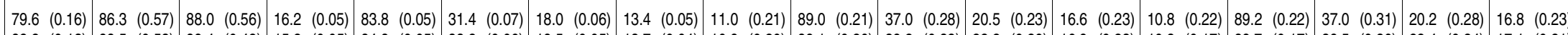

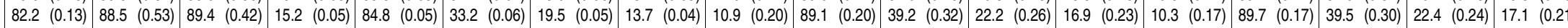
Mississippi...

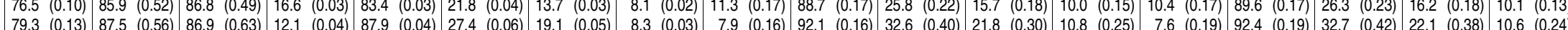

Missouri.

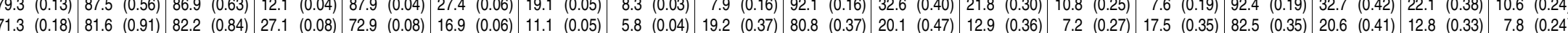

Missouri

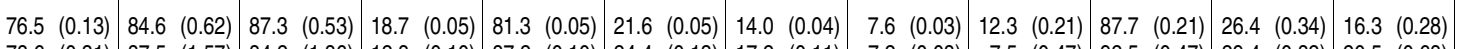

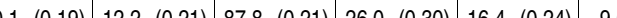

Montana...

Nebraska

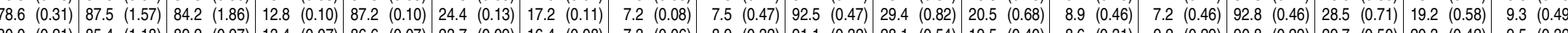

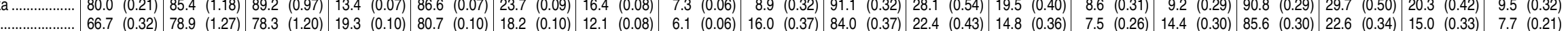

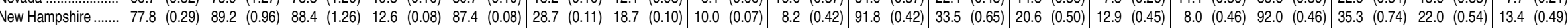

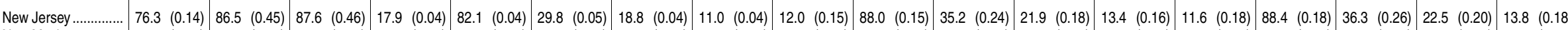

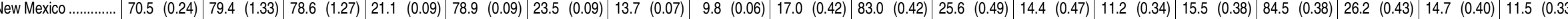

New York.............

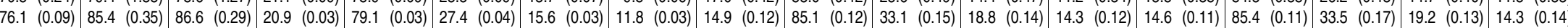

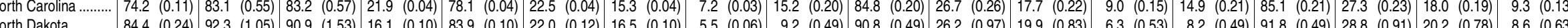
\begin{tabular}{l|lllllllllllll}
6.3 & $(0.53)$ & 8.2 & $(0.49)$ & 91.8 & $(0.49)$ & 28.8 & $(0.91)$ & 20.2 & $(0.78)$ & 8.6 & $(0.63)$
\end{tabular}

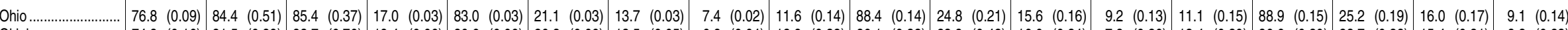

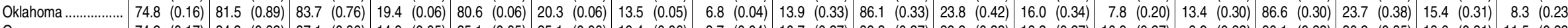

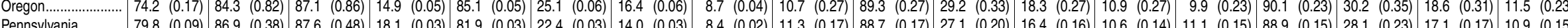

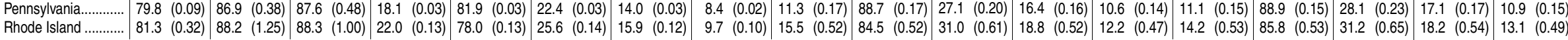


Table 104.80. Percentage of persons 18 to 24 years old and age 25 and over, by educational attainment and state: 2000, 2011, and 2012-Continued

[Standard errors appear in parentheses]

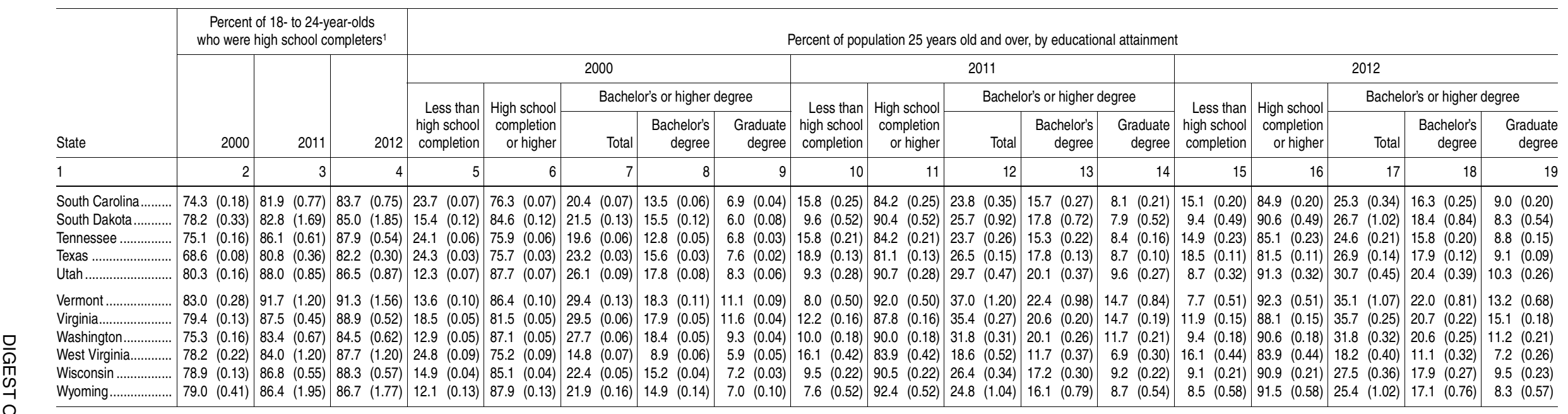

\section{\#Rounds to zero.}

. NOTE: Detail may not sum to totals because of rounding.
SOURCE: U.S. Department of Commerce, Census Bureau, Census 2000 Summary File 3, retrieved October 11, 2006, from http: $/$ factfinder2.census.gov/faces/tableservices/jstpages/productview.xhtml?pid=DEC 00 SF3 QTP20\&prodType=table; Census Briefs, data. (This table was prepared January 2014.) 
Table 104.85. Rates of high school completion and bachelor's degree attainment among persons age 25 and over, by race/ethnicity and state: 2011 and 2012

[Standard errors appear in parentheses]

\begin{tabular}{|c|c|c|c|c|c|c|c|c|c|c|c|c|c|c|c|c|c|c|c|c|c|c|c|c|}
\hline \multirow[b]{2}{*}{ Year and state } & \multicolumn{12}{|c|}{ Percent with high school completion or higher } & \multicolumn{12}{|c|}{ Percent with bachelor's degree or higher } \\
\hline & \multirow{2}{*}{\multicolumn{2}{|c|}{ Total $^{1}$}} & \multirow{2}{*}{\multicolumn{2}{|c|}{\begin{tabular}{r|} 
White \\
3
\end{tabular}}} & \multirow{2}{*}{\multicolumn{2}{|c|}{$\begin{array}{r}\text { Black } \\
4\end{array}$}} & \multicolumn{2}{|r|}{ Hispanic } & \multirow{2}{*}{\multicolumn{2}{|c|}{ an }} & \multicolumn{2}{|c|}{$\begin{array}{r}\text { Two or more } \\
\text { races }\end{array}$} & \multicolumn{2}{|r|}{ Total $^{1}$} & \multicolumn{2}{|r|}{ White } & \multirow{2}{*}{\multicolumn{2}{|c|}{ Black }} & \multicolumn{2}{|r|}{ Hispanic } & \multicolumn{2}{|r|}{ Asian } & \multicolumn{2}{|c|}{ Two or more races } \\
\hline 1 & & & & & & & & 5 & & & & 7 & & 8 & & 9 & & & & 11 & & 12 & & $\overline{13}$ \\
\hline 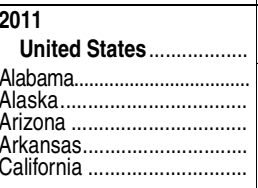 & $\begin{array}{l}85.9 \\
82.7 \\
92.8 \\
85.7 \\
83.7 \\
81.1\end{array}$ & $\begin{array}{l}(0.04) \\
0.37) \\
0.50 \\
0.23 \\
0.43 \\
0.10)\end{array}$ & $\begin{array}{l}91.1 \\
85.0 \\
96.4 \\
93.4 \\
86.3 \\
93.9\end{array}$ & $\begin{array}{l}(0.03) \\
(0.39) \\
0.51 \\
0.21 \\
0.38 \\
0.10)\end{array}$ & $\begin{array}{l}82.7 \\
78.6 \\
87.5 \\
90.0 \\
79.2 \\
88.6\end{array}$ & $\begin{array}{l}(0.11) \\
(0.69) \\
6.06 \\
(.82) \\
(1.00) \\
(0.32)\end{array}$ & $\begin{array}{l}63.1 \\
57.8 \\
92.6 \\
65.3 \\
54.6 \\
58.5\end{array}$ & $\begin{array}{l}(0.16) \\
(2.68) \\
(2.68) \\
0.70 \\
(3.20 \\
0.29)\end{array}$ & $\begin{array}{l}85.2 \\
87.6 \\
72.5 \\
83.2 \\
84.2 \\
85.8\end{array}$ & $\begin{array}{l}(0.16) \\
(2.30) \\
4.85 \\
1.50 \\
4.54 \\
0.26)\end{array}$ & $\begin{array}{l}88.7 \\
87.5 \\
92.0 \\
94.0 \\
81.6 \\
90.8\end{array}$ & $\begin{array}{l}(0.25) \\
(2.56) \\
3.72 \\
1.25 \\
3.42 \\
0.62)\end{array}$ & $\begin{array}{l}\mathbf{2 8 . 6} \\
22.5 \\
25.8 \\
26.4 \\
20.4 \\
30.3\end{array}$ & $\begin{array}{l}(0.06) \\
(0.32) \\
1.24 \\
0.26 \\
0.38 \\
0.13)\end{array}$ & $\begin{array}{l}31.8 \\
25.2 \\
29.6 \\
32.5 \\
21.8 \\
39.3\end{array}$ & $\begin{array}{l}(0.07) \\
(0.38) \\
1.44 \\
0.35 \\
0.44) \\
0.22)\end{array}$ & $\begin{array}{l}\mathbf{1 8 . 7} \\
14.6 \\
26.9 \\
21.4 \\
15.8 \\
23.0\end{array}$ & $\begin{array}{l}(0.11) \\
(0.55) \\
8.07 \\
1.23 \\
1.03 \\
0.42)\end{array}$ & $\begin{array}{r}13.4 \\
12.6 \\
27.7 \\
10.0 \\
8.5 \\
10.7\end{array}$ & $\begin{array}{l}(0.12) \\
(1.79) \\
5.79 \\
0.39 \\
1.45 \\
0.18)\end{array}$ & $\begin{array}{l}50.3 \\
51.2 \\
24.5 \\
48.1 \\
36.9 \\
48.7\end{array}$ & \begin{tabular}{l|}
$(0.26)$ \\
$(3.82$ \\
$(4.68)$ \\
2.42 \\
4.24 \\
0.39
\end{tabular} & $\begin{array}{l}28.3 \\
19.9 \\
15.5 \\
27.6 \\
18.3 \\
32.4\end{array}$ & $\left.\begin{array}{l}(0.37) \\
(2.933) \\
4.32 \\
2.47 \\
3.61 \\
0.86\end{array}\right)$ \\
\hline 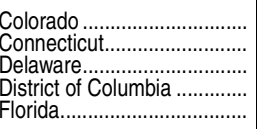 & $\begin{array}{l}90.2 \\
89.0 \\
87.3 \\
87.1 \\
85.9\end{array}$ & $\begin{array}{l}(0.21) \\
0.27 \\
0.52 \\
0.73 \\
0.12)\end{array}$ & $\begin{array}{l}95.3 \\
93.0 \\
89.7 \\
99.8 \\
91.0\end{array}$ & $\begin{array}{l}(0.16) \\
0.27 \\
0.52 \\
0.12 \\
0.13)\end{array}$ & $\begin{array}{l}88.6 \\
83.0 \\
84.6 \\
80.7 \\
79.4\end{array}$ & $\left.\begin{array}{l}(1.19) \\
(0.90) \\
1.42 \\
1.25 \\
0.39\end{array}\right)$ & $\begin{array}{l}68.3 \\
67.8 \\
67.5 \\
65.2 \\
75.0\end{array}$ & $\begin{array}{l}(0.98) \\
(1.41 \\
4.48 \\
4.30 \\
0.35)\end{array}$ & $\begin{array}{l}86.6 \\
87.7 \\
88.0 \\
84.8 \\
85.0\end{array}$ & $\left.\begin{array}{l}1.47 \\
1.65 \\
2.62 \\
4.85 \\
0.96\end{array}\right)$ & $\begin{array}{l}92.1 \\
90.9 \\
92.1 \\
98.6 \\
86.9\end{array}$ & $\left(\begin{array}{l}1.41 \\
(1.90 \\
4.98 \\
11.13 \\
1.10\end{array}\right)$ & $\begin{array}{l}36.8 \\
36.2 \\
28.2 \\
52.5 \\
25.9\end{array}$ & $\begin{array}{l}(0.37) \\
0.42 \\
0.68 \\
0.80 \\
0.16)\end{array}$ & $\begin{array}{l}42.4 \\
40.4 \\
30.6 \\
90.2 \\
29.0\end{array}$ & $\begin{array}{l}(0.42) \\
0.52 \\
0.86 \\
0.90 \\
0.21)\end{array}$ & $\begin{array}{l}25.0 \\
17.4 \\
17.9 \\
22.8 \\
16.0\end{array}$ & $\begin{array}{l}2.15) \\
1.18 \\
1.54 \\
1.26 \\
0.44)\end{array}$ & $\begin{array}{l}13.2 \\
14.9 \\
12.3 \\
36.2 \\
20.4\end{array}$ & $\begin{array}{l}0.64) \\
1.15 \\
2.31 \\
3.69 \\
0.38\end{array}$ & $\begin{array}{l}46.6 \\
61.6 \\
69.5 \\
77.2 \\
45.9\end{array}$ & $\left.\begin{array}{l}(2.52) \\
2.68 \\
3.93 \\
4.27 \\
1.12\end{array}\right)$ & $\begin{array}{l}36.1 \\
29.3 \\
25.3 ! \\
74.5 \\
25.1\end{array}$ & $\left.\begin{array}{l}(2.66) \\
3.27 \\
7.89 \\
4.46 \\
1.38\end{array}\right)$ \\
\hline 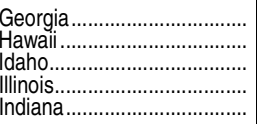 & $\begin{array}{l}84.3 \\
90.5 \\
88.7 \\
87.3 \\
87.2\end{array}$ & $\begin{array}{l}(0.19) \\
0.40 \\
0.35 \\
0.14 \\
0.20)\end{array}$ & $\begin{array}{l}87.9 \\
96.0 \\
92.1 \\
92.8 \\
89.0\end{array}$ & $\begin{array}{l}(0.25) \\
0.51 \\
0.37 \\
0.13 \\
0.21)\end{array}$ & $\begin{array}{l}83.8 \\
98.9 \\
86.6 \\
83.4 \\
82.9\end{array}$ & $\begin{array}{l}(0.41) \\
(0.79 \\
6.15 \\
(0.48 \\
0.78)\end{array}$ & $\begin{array}{l}54.4 \\
86.5 \\
53.6 \\
61.4 \\
61.7\end{array}$ & $\left(\begin{array}{l}1.45 \\
1.81 \\
2.14 \\
0.70 \\
1.69\end{array}\right)$ & $\begin{array}{l}84.8 \\
87.5 \\
86.6 \\
89.0 \\
84.4\end{array}$ & $\left.\begin{array}{l}(1.14) \\
0.74 \\
3.75 \\
0.83 \\
2.16\end{array}\right)$ & $\begin{array}{l}89.4 \\
91.6 \\
83.7 \\
90.9 \\
87.1\end{array}$ & $\left(\begin{array}{l}1.71 \\
(1.10 \\
4.88 \\
1.48 \\
(2.24)\end{array}\right)$ & $\begin{array}{l}27.6 \\
29.7 \\
25.6 \\
31.0 \\
22.8\end{array}$ & $\begin{array}{l}(0.24) \\
0.55 \\
0.68) \\
0.22) \\
0.27)\end{array}$ & $\begin{array}{l}31.0 \\
40.8 \\
27.1 \\
34.6 \\
23.4\end{array}$ & $\begin{array}{l}(0.32) \\
1.61 \\
0.78 \\
0.31 \\
0.30)\end{array}$ & $\begin{array}{l}21.5 \\
31.9 \\
32.8 \\
19.3 \\
15.0\end{array}$ & $\begin{array}{l}(0.44) \\
6.05 \\
9.80 \\
0.47 \\
1.00)\end{array}$ & $\begin{array}{r}13.0 \\
19.9 \\
9.1 \\
12.2 \\
12.9\end{array}$ & $\left.\begin{array}{l}0.80) \\
2.21 \\
1.17 \\
0.47 \\
1.01\end{array}\right)$ & $\begin{array}{l}49.9 \\
31.4 \\
58.9 \\
60.7 \\
58.9\end{array}$ & $\left(\begin{array}{l}1.70 \\
0.98 \\
4.88 \\
1.50 \\
2.33\end{array}\right)$ & $\begin{array}{l}32.8 \\
17.4 \\
14.8 \\
34.6 \\
27.5\end{array}$ & $\left.\begin{array}{l}(3.12) \\
1.44 \\
4.27 \\
2.19 \\
2.84\end{array}\right)$ \\
\hline 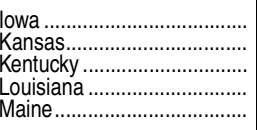 & $\begin{array}{l}91.0 \\
89.6 \\
83.1 \\
82.6 \\
90.8\end{array}$ & $\begin{array}{l}0.28) \\
0.32 \\
0.31 \\
0.29 \\
0.40)\end{array}$ & $\begin{array}{l}92.7 \\
93.0 \\
83.5 \\
86.9 \\
91.2\end{array}$ & $\begin{array}{l}(0.24) \\
0.28 \\
0.35 \\
0.33 \\
0.43)\end{array}$ & $\begin{array}{l}82.0 \\
87.9 \\
82.9 \\
74.9 \\
78.1\end{array}$ & $\begin{array}{c}(2.94) \\
(1.58 \\
1.06 \\
0.50 \\
7.34)\end{array}$ & $\begin{array}{l}56.6 \\
57.5 \\
64.4 \\
73.2 \\
77.9\end{array}$ & $\left.\begin{array}{l}(3.16) \\
2.15 \\
2.83 \\
2.35 \\
7.44\end{array}\right)$ & $\begin{array}{l}86.5 \\
77.6 \\
83.9 \\
74.9 \\
73.9\end{array}$ & $\begin{array}{l}(2.66) \\
3.02 \\
4.34 \\
2.64 \\
5.47)\end{array}$ & $\begin{array}{l}87.7 \\
87.4 \\
86.2 \\
80.9 \\
88.2\end{array}$ & $\left.\begin{array}{l}(3.28) \\
(2.87 \\
3.12 \\
(3.33 \\
4.12\end{array}\right)$ & $\begin{array}{l}25.8 \\
30.5 \\
20.7 \\
21.1 \\
28.6\end{array}$ & $\begin{array}{l}0.47) \\
0.51 \\
0.33 \\
0.36 \\
0.70)\end{array}$ & $\begin{array}{l}26.0 \\
32.7 \\
20.9 \\
24.9 \\
28.8\end{array}$ & $\begin{array}{l}(0.52) \\
0.52 \\
0.32 \\
0.51 \\
0.71)\end{array}$ & $\begin{array}{l}19.4 \\
19.1 \\
15.1 \\
12.7 \\
17.5 !\end{array}$ & $\begin{array}{l}(2.85) \\
2.17 \\
1.12 \\
0.51 \\
7.33)\end{array}$ & $\begin{array}{l}12.3 \\
12.3 \\
13.9 \\
15.4 \\
24.1\end{array}$ & $\left.\begin{array}{l}1.84) \\
1.45 \\
1.94 \\
1.68 \\
6.39\end{array}\right)$ & $\begin{array}{l}54.0 \\
43.4 \\
57.7 \\
36.9 \\
31.1\end{array}$ & $\left.\begin{array}{l}(4.88) \\
3.15 \\
4.78 \\
3.41 \\
6.53\end{array}\right)$ & $\begin{array}{l}15.8 ! \\
24.1 \\
24.9 \\
22.3 \\
21.5 !\end{array}$ & $\begin{array}{l}(5.19) \\
(2.94) \\
4.63 \\
3.83 \\
(6.93)\end{array}$ \\
\hline 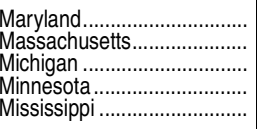 & $\begin{array}{l}89.0 \\
89.1 \\
88.7 \\
92.1 \\
80.8\end{array}$ & $\begin{array}{l}0.21) \\
0.20 \\
0.17 \\
0.16 \\
0.37)\end{array}$ & $\begin{array}{l}92.6 \\
92.4 \\
90.6 \\
94.5 \\
85.5\end{array}$ & $\begin{array}{l}(0.21) \\
0.18 \\
0.17 \\
0.15 \\
0.41)\end{array}$ & $\begin{array}{l}88.1 \\
81.9 \\
82.2 \\
79.2 \\
74.9\end{array}$ & $\begin{array}{l}(0.38) \\
(0.99 \\
0.66 \\
(1.79 \\
0.71)\end{array}$ & $\begin{array}{l}62.4 \\
6.6 \\
70.7 \\
63.1 \\
49.4\end{array}$ & $\begin{array}{l}(1.53) \\
(1.11 \\
1.46 \\
(2.70 \\
(3.94)\end{array}$ & $\begin{array}{l}89.5 \\
81.9 \\
89.2 \\
78.7 \\
68.3\end{array}$ & $\left.\begin{array}{l}(0.98) \\
1.08 \\
1.19 \\
1.91 \\
4.30\end{array}\right)$ & $\begin{array}{l}91.3 \\
85.7 \\
86.8 \\
88.5 \\
88.7\end{array}$ & $\left.\begin{array}{l}(1.45) \\
(2.34 \\
1.20 \\
(3.03 \\
3.71\end{array}\right)$ & $\begin{array}{l}37.0 \\
39.2 \\
25.8 \\
32.6 \\
20.1\end{array}$ & $\begin{array}{l}(0.28) \\
0.32 \\
0.22 \\
0.40 \\
0.47)\end{array}$ & $\begin{array}{l}41.1 \\
41.6 \\
26.8 \\
33.6 \\
23.4\end{array}$ & $\begin{array}{l}(0.42) \\
0.37 \\
0.25 \\
0.42 \\
0.62)\end{array}$ & $\begin{array}{l}27.2 \\
23.7 \\
15.9 \\
19.4 \\
14.5\end{array}$ & $\begin{array}{l}(0.60) \\
1.31 \\
0.50 \\
1.99 \\
0.63)\end{array}$ & $\begin{array}{r}21.2 \\
17.1 \\
17.1 \\
14.6 \\
8.6\end{array}$ & $\left.\begin{array}{l}1.23 \\
0.88 \\
1.25 \\
1.77 \\
1.68\end{array}\right)$ & $\begin{array}{l}61.0 \\
55.0 \\
61.7 \\
46.9 \\
29.3\end{array}$ & $\left(\begin{array}{l}1.61 \\
1.22 \\
2.09 \\
2.21 \\
4.10\end{array}\right)$ & $\begin{array}{l}44.4 \\
37.7 \\
22.5 \\
34.5 \\
24.9\end{array}$ & $\begin{array}{l}(3.27) \\
(2.99 \\
1.76 \\
3.72 \\
(5.37)\end{array}$ \\
\hline 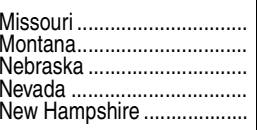 & $\begin{array}{l}87.7 \\
92.5 \\
91.1 \\
84.0 \\
91.8\end{array}$ & $\begin{array}{l}0.21) \\
0.47 \\
0.32 \\
0.37 \\
0.42)\end{array}$ & $\begin{array}{l}88.9 \\
93.0 \\
95.0 \\
92.3 \\
92.2\end{array}$ & $\begin{array}{l}(0.23) \\
0.47 \\
0.23 \\
0.39 \\
0.38)\end{array}$ & $\begin{array}{r}83.5 \\
\ddagger \\
84.9 \\
86.2 \\
72.4\end{array}$ & $\begin{array}{l}(0.71) \\
(t) \\
(2.75 \\
1.57 \\
9.02)\end{array}$ & $\begin{array}{l}66.2 \\
88.3 \\
48.7 \\
57.7 \\
83.4\end{array}$ & $\begin{array}{l}(1.76) \\
(3.59 \\
2.79 \\
1.20 \\
(4.36)\end{array}$ & $\begin{array}{r}87.9 \\
\neq \\
76.2 \\
87.6 \\
89.3\end{array}$ & $\left.\begin{array}{l}(1.68) \\
(+) \\
(5.01 \\
1.44 \\
5.30\end{array}\right)$ & $\begin{array}{l}88.0 \\
92.6 \\
91.1 \\
90.1 \\
86.1\end{array}$ & $\left.\begin{array}{l}(1.47) \\
(3.14 \\
4.82 \\
1.87 \\
5.01\end{array}\right)$ & $\begin{array}{l}26.4 \\
29.4 \\
28.1 \\
22.4 \\
33.5\end{array}$ & $\begin{array}{l}(0.34) \\
0.82 \\
0.54 \\
0.43 \\
0.65)\end{array}$ & $\begin{array}{l}27.2 \\
30.4 \\
29.8 \\
26.7 \\
33.1\end{array}$ & $\begin{array}{l}(0.32) \\
0.88 \\
0.61 \\
0.64 \\
0.67)\end{array}$ & $\begin{array}{r}17.8 \\
\neq \\
22.6 \\
16.7 \\
30.2\end{array}$ & $\begin{array}{l}(0.98) \\
(\dagger) \\
(3.22) \\
1.75 \\
(7.39)\end{array}$ & $\begin{array}{r}17.9 \\
19.0 \\
9.4 \\
8.1 \\
24.5\end{array}$ & $\left.\begin{array}{l}1.71) \\
4.79 \\
1.48 \\
0.60 \\
4.05\end{array}\right)$ & $\begin{array}{r}59.4 \\
\neq \\
38.7 \\
33.9 \\
63.3\end{array}$ & $\begin{array}{c}(2.89) \\
(\dagger \\
(5.50 \\
2.01 \\
(5.44)\end{array}$ & $\begin{array}{l}17.3 \\
16.8 ! \\
24.7 \\
24.3 \\
29.6\end{array}$ & $\begin{array}{l}(2.19) \\
5.50 \\
5.37 \\
3.10 \\
4.61)\end{array}$ \\
\hline 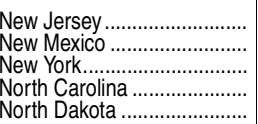 & $\begin{array}{l}88.0 \\
83.0 \\
85.1 \\
84.8 \\
90.8\end{array}$ & $\begin{array}{l}(0.15) \\
0.42 \\
0.12 \\
0.20 \\
0.49\end{array}$ & $\begin{array}{l}92.4 \\
94.2 \\
91.8 \\
88.9 \\
91.4\end{array}$ & $\begin{array}{l}(0.18) \\
0.40 \\
0.12 \\
0.21 \\
0.51)\end{array}$ & $\begin{array}{r}85.4 \\
90.8 \\
81.7 \\
81.5 \\
\ddagger\end{array}$ & $\begin{array}{r}(0.45) \\
(2.41 \\
0.38 \\
0.45 \\
(\dagger)\end{array}$ & $\begin{array}{l}70.9 \\
70.3 \\
65.6 \\
53.6 \\
69.4\end{array}$ & $\left.\begin{array}{l}(0.62) \\
0.91 \\
0.53 \\
1.24 \\
(5.63)\end{array}\right)$ & $\begin{array}{l}91.1 \\
93.1 \\
77.9 \\
82.0 \\
90.5\end{array}$ & $\begin{array}{l}(0.49) \\
2.59 \\
0.59 \\
1.68 \\
4.69)\end{array}$ & $\begin{array}{l}89.0 \\
87.9 \\
85.1 \\
85.3 \\
92.4\end{array}$ & $\left.\begin{array}{l}1.49) \\
3.67 \\
1.25 \\
1.95 \\
3.76\end{array}\right)$ & $\begin{array}{l}35.2 \\
25.6 \\
33.1 \\
26.7 \\
26.2\end{array}$ & $\begin{array}{l}0.24) \\
0.49 \\
0.15 \\
0.26) \\
0.97)\end{array}$ & $\begin{array}{l}38.3 \\
39.0 \\
38.7 \\
30.5 \\
26.9\end{array}$ & $\begin{array}{l}(0.34) \\
0.88 \\
0.21 \\
0.33 \\
1.00)\end{array}$ & $\begin{array}{r}22.1 \\
16.8 \\
20.8 \\
16.7 \\
\ddagger\end{array}$ & $\begin{array}{r}(0.66) \\
3.25 \\
0.40 \\
0.56 \\
(\dagger)\end{array}$ & $\begin{array}{r}15.7 \\
12.8 \\
15.9 \\
10.7 \\
\ddagger\end{array}$ & $\begin{array}{r}0.58) \\
0.66 \\
0.38 \\
0.64 \\
(\dagger)\end{array}$ & $\begin{array}{l}67.9 \\
54.3 \\
46.5 \\
49.5 \\
70.8\end{array}$ & $\begin{array}{r}(0.97) \\
5.10 \\
0.80 \\
(2.26) \\
(12.06)\end{array}$ & $\begin{array}{r}32.2 \\
26.6 \\
36.3 \\
27.0 \\
\ddagger\end{array}$ & $\begin{array}{r}(2.35) \\
4.44 \\
1.51 \\
(2.44) \\
(\dagger)\end{array}$ \\
\hline 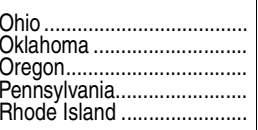 & $\begin{array}{l}88.4 \\
86.1 \\
89.3 \\
88.7 \\
84.5\end{array}$ & $\begin{array}{l}(0.14) \\
0.33 \\
0.27 \\
0.17 \\
0.52)\end{array}$ & $\begin{array}{l}89.5 \\
88.9 \\
92.6 \\
90.7 \\
88.3\end{array}$ & $\begin{array}{l}(0.15) \\
0.37 \\
0.25 \\
0.16 \\
0.48)\end{array}$ & $\begin{array}{l}83.0 \\
85.4 \\
87.8 \\
83.2 \\
80.0\end{array}$ & $\left(\begin{array}{l}0.50) \\
1.25 \\
2.14 \\
(0.63) \\
(2.84)\end{array}\right.$ & $\begin{array}{l}73.7 \\
57.2 \\
59.2 \\
65.6 \\
61.7\end{array}$ & $\begin{array}{l}(1.25) \\
1.84 \\
1.88 \\
1.30 \\
(2.72)\end{array}$ & $\begin{array}{l}88.9 \\
83.9 \\
86.6 \\
82.5 \\
69.1\end{array}$ & $\begin{array}{l}(1.23) \\
3.26 \\
1.47 \\
0.93 \\
4.61)\end{array}$ & $\begin{array}{l}86.8 \\
85.6 \\
87.6 \\
90.4 \\
76.0\end{array}$ & $\left(\begin{array}{c}1.47 \\
1.07 \\
1.62 \\
1.31 \\
6.68\end{array}\right)$ & $\begin{array}{l}24.8 \\
23.8 \\
29.2 \\
27.1 \\
31.0\end{array}$ & $\begin{array}{l}(0.21) \\
0.42 \\
0.33 \\
0.20 \\
0.61)\end{array}$ & $\begin{array}{l}25.4 \\
25.4 \\
30.8 \\
28.3 \\
33.8\end{array}$ & $\begin{array}{l}(0.23) \\
0.44 \\
0.37 \\
0.22 \\
0.71)\end{array}$ & $\begin{array}{l}15.0 \\
19.7 \\
22.4 \\
14.8 \\
19.6\end{array}$ & $\begin{array}{l}(0.58) \\
1.70 \\
2.87 \\
0.65 \\
(2.69)\end{array}$ & $\begin{array}{l}18.5 \\
11.9 \\
11.0 \\
13.2 \\
13.2\end{array}$ & $\left.\begin{array}{l}1.26) \\
1.26 \\
0.84 \\
0.96 \\
1.64\end{array}\right)$ & $\begin{array}{l}65.0 \\
42.8 \\
44.3 \\
53.0 \\
38.7\end{array}$ & $\left(\begin{array}{l}1.81 \\
4.01 \\
2.49 \\
1.35 \\
(5.55)\end{array}\right.$ & $\begin{array}{l}24.9 \\
20.9 \\
27.4 \\
27.9 \\
20.5\end{array}$ & $\left.\begin{array}{l}(2.34) \\
1.82 \\
2.78 \\
2.32 \\
5.26\end{array}\right)$ \\
\hline $\begin{array}{l}\text { South Carolina..................... } \\
\text { South Dakota..................... } \\
\text { Tennessee ……………….... } \\
\text { Texas }\end{array}$ & $\begin{array}{l}84.2 \\
90.4 \\
84.2 \\
81.1 \\
90.7\end{array}$ & $\begin{array}{l}(0.25) \\
0.52 \\
0.21 \\
0.13 \\
0.28)\end{array}$ & $\begin{array}{l}88.0 \\
92.2 \\
85.6 \\
92.6 \\
94.6\end{array}$ & $\begin{array}{l}(0.28) \\
0.52 \\
0.24 \\
0.14 \\
0.24)\end{array}$ & $\begin{array}{l}78.0 \\
42.9 \\
82.2 \\
86.3 \\
80.9\end{array}$ & $\begin{array}{r}(0.55) \\
(11.29) \\
(0.58) \\
(4.73) \\
(4.72)\end{array}$ & $\begin{array}{l}63.5 \\
65.6 \\
61.0 \\
60.3 \\
64.7\end{array}$ & $\begin{array}{l}(2.75) \\
7.07 \\
2.02 \\
0.32 \\
1.95)\end{array}$ & $\begin{array}{l}80.6 \\
84.2 \\
84.6 \\
86.1 \\
87.7\end{array}$ & $\left.\begin{array}{l}(3.07) \\
6.33 \\
2.16 \\
0.56 \\
2.38\end{array}\right)$ & $\begin{array}{l}75.3 \\
85.9 \\
84.4 \\
89.9 \\
91.8\end{array}$ & $\left.\begin{array}{l}(4.05) \\
(5.91) \\
2.24 \\
1.14 \\
2.41\end{array}\right)$ & $\begin{array}{l}23.8 \\
25.7 \\
23.7 \\
26.5 \\
29.7\end{array}$ & $\begin{array}{l}(0.35) \\
0.92 \\
0.26) \\
0.15 \\
0.47)\end{array}$ & $\begin{array}{l}28.3 \\
26.5 \\
24.8 \\
35.0 \\
32.2\end{array}$ & $\begin{array}{l}(0.44) \\
1.01 \\
0.29 \\
0.23 \\
0.53)\end{array}$ & $\begin{array}{r}12.8 \\
\ddagger \\
18.3 \\
20.2 \\
15.4\end{array}$ & $\begin{array}{l}(0.52) \\
(t) \\
(0.72 \\
0.53 \\
3.58)\end{array}$ & $\begin{array}{l}13.9 \\
21.4 \\
12.4 \\
12.0 \\
12.3\end{array}$ & $\left.\begin{array}{l}1.65) \\
6.37 \\
1.41 \\
0.22 \\
1.17\end{array}\right)$ & $\begin{array}{l}37.9 \\
56.6 \\
49.1 \\
51.9 \\
41.8\end{array}$ & $\begin{array}{l}3.06 \\
7.71 \\
3.35 \\
1.04 \\
3.20 \\
(.20) \\
\end{array}$ & $\begin{array}{l}20.6 \\
16.4 ! \\
21.4 \\
33.1 \\
32.9\end{array}$ & $\left.\begin{array}{l}(3.26) \\
6.37 \\
2.39 \\
1.59 \\
5.00\end{array}\right)$ \\
\hline 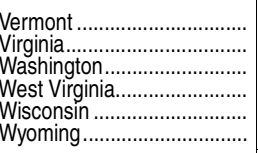 & $\begin{array}{l}92.0 \\
87.8 \\
90.0 \\
83.9 \\
90.5 \\
92.4 \\
\end{array}$ & $\begin{array}{l}(0.50) \\
0.16 \\
0.18 \\
0.42 \\
0.22 \\
0.52) \\
\end{array}$ & $\begin{array}{l}92.2 \\
90.5 \\
93.8 \\
83.9 \\
92.6 \\
93.4 \\
\end{array}$ & $\begin{array}{l}(0.52) \\
0.17 \\
0.18 \\
0.45 \\
0.19 \\
0.45)\end{array}$ & $\begin{array}{r}\ddagger \\
82.6 \\
87.3 \\
85.0 \\
78.4 \\
\ddagger \\
\end{array}$ & $\begin{array}{r}(\dagger) \\
0.46 \\
1.37 \\
2.16 \\
1.26 \\
(\dagger) \\
\end{array}$ & 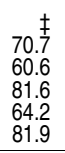 & $\begin{array}{r}(\dagger) \\
(1.21 \\
(1.20) \\
4.76 \\
1.74 \\
(3.43)\end{array}$ & $\begin{array}{r}\ddagger \\
90.8 \\
84.0 \\
83.1 \\
82.1 \\
98.8 \\
\end{array}$ & $\begin{array}{r}(+) \\
(0.85) \\
0.89 \\
4.82 \\
2.42 \\
(0.94) \\
\end{array}$ & $\begin{array}{l}97.2 \\
89.8 \\
93.1 \\
82.5 \\
88.8 \\
71.2 \\
\end{array}$ & $\begin{array}{r}(1.60) \\
1.44 \\
1.13 \\
3.75 \\
(2.35) \\
(12.71)\end{array}$ & $\begin{array}{l}37.0 \\
35.4 \\
31.8 \\
18.6 \\
26.4 \\
24.8 \\
\end{array}$ & $\left.\begin{array}{l}1.20) \\
0.27 \\
0.31 \\
0.52 \\
0.34 \\
1.04\end{array}\right)$ & $\begin{array}{l}37.1 \\
38.5 \\
33.6 \\
18.5 \\
27.5 \\
25.9 \\
\end{array}$ & $\begin{array}{l}1.17) \\
0.32 \\
0.36 \\
0.50 \\
0.36 \\
1.11\end{array}$ & $\begin{array}{r}\ddagger \\
20.0 \\
21.4 \\
16.6 \\
12.2 \\
\ddagger\end{array}$ & 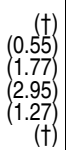 & $\begin{array}{l}\ddagger \\
24.1 \\
12.4 \\
32.6 \\
12.3 \\
13.8 \\
\end{array}$ & $\begin{array}{r}(\dagger) \\
1.08 \\
0.79 \\
5.99 \\
1.38 \\
2.84\end{array}$ & $\begin{array}{r}\ddagger \\
5.8 \\
43.8 \\
63.0 \\
50.5 \\
63.8 \\
\end{array}$ & $\begin{array}{r}(+) \\
(1.39) \\
1.26 \\
7.87 \\
(3.16 \\
(10.32)\end{array}$ & $\begin{array}{l}18.1 ! \\
35.3 \\
28.1 \\
12.6 \\
20.5 \\
\ddagger\end{array}$ & $\begin{array}{r}(6.05) \\
3.04 \\
1.94 \\
2.93 \\
3.38 \\
(\dagger) \\
\end{array}$ \\
\hline
\end{tabular}


Table 104.85. Rates of high school completion and bachelor's degree attainment among persons age 25 and over, by race/ethnicity and state: 2011 and $2012-$ Continued

[Standard errors appear in parentheses]

\begin{tabular}{|c|c|c|c|c|c|c|c|c|c|c|c|c|c|c|c|c|c|c|c|c|c|c|c|c|}
\hline \multirow{3}{*}{$\frac{\text { Year and state }}{1}$} & \multicolumn{12}{|c|}{ Percent with high school completion or higher } & \multicolumn{12}{|c|}{ Percent with bachelor's degree or higher } \\
\hline & \multirow{2}{*}{\multicolumn{2}{|c|}{$\begin{array}{r}\text { Total }^{1} \\
2\end{array}$}} & \multirow{2}{*}{\multicolumn{2}{|c|}{$\begin{array}{r}\text { White } \\
3\end{array}$}} & \multirow{2}{*}{\multicolumn{2}{|c|}{$\begin{array}{r}\text { Black } \\
4\end{array}$}} & \multicolumn{2}{|c|}{ Hispanic } & \multicolumn{2}{|r|}{ Asian } & \multicolumn{2}{|c|}{$\begin{array}{r}\text { Two or more } \\
\text { races }\end{array}$} & \multicolumn{2}{|r|}{ Total $^{1}$} & \multicolumn{2}{|r|}{ White } & \multirow{2}{*}{\multicolumn{2}{|c|}{$\begin{array}{r}\text { Black } \\
10\end{array}$}} & \multicolumn{2}{|r|}{ Hispanic } & \multicolumn{2}{|r|}{ Asian } & \multicolumn{2}{|c|}{ Two or more races } \\
\hline & & & & & & & & 5 & & 6 & & 7 & & 8 & & 9 & & & & 11 & & 12 & & 13 \\
\hline 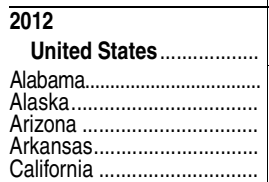 & $\begin{array}{l}86.4 \\
83.8 \\
91.8 \\
85.8 \\
85.1 \\
81.4\end{array}$ & $\begin{array}{l}(0.04) \\
(0.24) \\
0.56 \\
0.21 \\
0.34 \\
0.09)\end{array}$ & $\begin{array}{l}91.5 \\
86.1 \\
95.8 \\
93.4 \\
87.8 \\
94.1\end{array}$ & $\begin{array}{l}(0.04) \\
(0.28) \\
0.58 \\
0.18 \\
0.32 \\
0.09\end{array}$ & $\begin{array}{l}83.5 \\
79.9 \\
90.3 \\
89.8 \\
80.2 \\
88.4\end{array}$ & $\begin{array}{l}(0.12) \\
(0.67) \\
5.49 \\
0.89 \\
(0.66) \\
0.40)\end{array}$ & $\begin{array}{l}64.1 \\
60.7 \\
90.0 \\
64.9 \\
53.5 \\
59.4\end{array}$ & $\begin{array}{l}(0.16) \\
(2.38) \\
(3.88 \\
0.65 \\
3.11 \\
0.25)\end{array}$ & $\begin{array}{l}85.8 \\
90.6 \\
79.5 \\
90.4 \\
88.3 \\
86.1\end{array}$ & $\left.\begin{array}{l}(0.13) \\
(1.91 \\
3.50 \\
1.05 \\
2.35 \\
0.23\end{array}\right)$ & $\begin{array}{l}89.4 \\
83.7 \\
84.4 \\
91.9 \\
88.0 \\
91.8\end{array}$ & $\begin{array}{l}(0.25) \\
(2.71) \\
(4.11) \\
1.29 \\
2.34 \\
(0.46)\end{array}$ & $\begin{array}{l}29.2 \\
23.4 \\
28.9 \\
27.5 \\
21.2 \\
31.0\end{array}$ & $\begin{array}{l}(0.05) \\
(0.29) \\
(1.22) \\
0.29 \\
0.35 \\
0.11)\end{array}$ & $\begin{array}{l}32.6 \\
26.1 \\
35.1 \\
33.1 \\
22.7 \\
40.3\end{array}$ & $\begin{array}{l}(0.06) \\
(0.36) \\
(1.45) \\
0.38 \\
0.41 \\
0.19\end{array}$ & $\begin{array}{l}18.8 \\
14.9 \\
26.7 \\
22.5 \\
14.8 \\
22.2\end{array}$ & $\begin{array}{l}(0.13) \\
(0.54) \\
6.87 \\
1.48 \\
1.09 \\
0.47)\end{array}$ & $\begin{array}{r}13.9 \\
14.7 \\
19.8 \\
11.7 \\
8.1 \\
11.2\end{array}$ & $\begin{array}{l}(0.12) \\
\left(\begin{array}{l}1.65) \\
4.72 \\
0.42 \\
1.29 \\
0.15\end{array}\right)\end{array}$ & $\begin{array}{l}50.9 \\
54.4 \\
19.7 \\
57.1 \\
46.4 \\
48.9\end{array}$ & $\begin{array}{l}(0.25) \\
(4.42 \\
4.55 \\
1.73 \\
4.72 \\
0.40)\end{array}$ & $\begin{array}{l}30.0 \\
23.3 \\
17.5 \\
30.5 \\
28.4 \\
36.1\end{array}$ & $\begin{array}{l}(0.36) \\
(3.04) \\
4.28 \\
2.74 \\
4.10 \\
0.89\end{array}$ \\
\hline 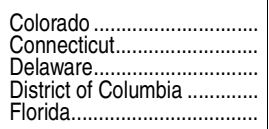 & $\begin{array}{l}90.4 \\
89.9 \\
88.3 \\
89.2 \\
86.4\end{array}$ & $\left.\begin{array}{l}(0.20) \\
0.26 \\
0.60 \\
0.46 \\
0.13\end{array}\right)$ & $\begin{array}{l}95.7 \\
93.2 \\
90.9 \\
99.4 \\
91.3\end{array}$ & $\left.\begin{array}{l}0.15 \\
0.22 \\
0.71 \\
0.18 \\
0.13\end{array}\right)$ & $\begin{array}{l}88.8 \\
87.5 \\
85.7 \\
83.6 \\
80.3\end{array}$ & $\left(\begin{array}{l}1.24) \\
0.82 \\
(.25) \\
(0.93 \\
0.30)\end{array}\right.$ & $\begin{array}{l}67.9 \\
70.4 \\
65.7 \\
72.2 \\
76.1\end{array}$ & $\begin{array}{l}(0.97) \\
(1.22 \\
3.90 \\
2.58 \\
(0.38)\end{array}$ & $\begin{array}{l}83.7 \\
89.4 \\
91.2 \\
93.8 \\
85.5\end{array}$ & $\left.\begin{array}{l}(1.84) \\
1.28 \\
2.74 \\
1.58 \\
0.81\end{array}\right)$ & $\begin{array}{l}94.6 \\
91.3 \\
90.1 \\
93.7 \\
88.4\end{array}$ & $\begin{array}{l}(1.24) \\
(2.09 \\
(5.82) \\
(3.43 \\
(1.16)\end{array}$ & $\begin{array}{l}37.6 \\
37.2 \\
30.2 \\
53.7 \\
26.8\end{array}$ & $\left.\begin{array}{l}(0.34) \\
0.35 \\
0.82 \\
0.76 \\
0.15\end{array}\right)$ & $\begin{array}{l}43.4 \\
41.1 \\
32.2 \\
89.5 \\
30.0\end{array}$ & $\left.\begin{array}{l}(0.41) \\
0.41 \\
0.99 \\
0.85 \\
0.18\end{array}\right)$ & $\begin{array}{l}25.8 \\
19.2 \\
20.8 \\
25.4 \\
16.7\end{array}$ & $\left(\begin{array}{c}2.10 \\
1.16 \\
1.69 \\
1.35 \\
0.39\end{array}\right)$ & $\begin{array}{l}12.6 \\
16.7 \\
20.0 \\
35.5 \\
21.3\end{array}$ & $\begin{array}{l}(0.57) \\
0.99 \\
2.93 \\
3.13 \\
0.37)\end{array}$ & $\begin{array}{l}48.8 \\
62.8 \\
65.8 \\
81.2 \\
47.3\end{array}$ & $\left.\begin{array}{l}(2.13) \\
2.29 \\
4.64 \\
2.65 \\
1.23\end{array}\right)$ & $\begin{array}{l}38.9 \\
33.4 \\
22.0 \\
64.1 \\
29.4\end{array}$ & $\left.\begin{array}{l}2.76 \\
4.25 \\
6.34 \\
8.30 \\
1.85\end{array}\right)$ \\
\hline 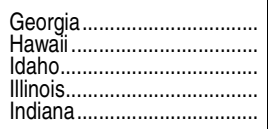 & $\begin{array}{l}85.2 \\
90.0 \\
89.8 \\
87.7 \\
87.3\end{array}$ & $\begin{array}{l}(0.21) \\
0.43 \\
0.40 \\
0.17 \\
0.22)\end{array}$ & $\begin{array}{l}88.5 \\
97.1 \\
92.8 \\
93.2 \\
89.1\end{array}$ & $\left.\begin{array}{l}(0.22) \\
0.39 \\
0.35 \\
0.14 \\
0.22\end{array}\right)$ & $\begin{array}{r}84.1 \\
99.1 \\
\ddagger \\
84.1 \\
84.3\end{array}$ & $\begin{array}{l}(0.28) \\
(0.78) \\
(+) \\
(0.36 \\
0.74)\end{array}$ & $\begin{array}{l}59.7 \\
86.9 \\
58.7 \\
61.4 \\
61.3\end{array}$ & $\left.\begin{array}{l}(1.39) \\
2.00 \\
2.54 \\
0.77 \\
(1.59)\end{array}\right)$ & $\begin{array}{l}88.7 \\
86.9 \\
88.3 \\
90.2 \\
85.8\end{array}$ & $\left.\begin{array}{l}(0.99) \\
0.81 \\
3.24 \\
0.67 \\
1.97\end{array}\right)$ & $\begin{array}{l}88.8 \\
89.8 \\
87.2 \\
92.2 \\
86.1\end{array}$ & $\left.\begin{array}{l}(1.54) \\
(1.18 \\
3.22 \\
1.25 \\
1.98\end{array}\right)$ & $\begin{array}{l}28.3 \\
30.1 \\
25.8 \\
31.5 \\
23.3\end{array}$ & $\left.\begin{array}{l}(0.23) \\
0.58 \\
0.70 \\
0.20 \\
0.29\end{array}\right)$ & $\begin{array}{l}32.3 \\
41.4 \\
27.5 \\
35.1 \\
24.1\end{array}$ & $\left.\begin{array}{l}(0.27) \\
1.33 \\
0.78 \\
0.22 \\
0.31\end{array}\right)$ & $\begin{array}{r}20.5 \\
34.3 \\
19 \\
19.1 \\
16.3\end{array}$ & $\begin{array}{l}(0.49) \\
(4.90) \\
(+) \\
(0.56) \\
0.89)\end{array}$ & $\begin{array}{r}13.9 \\
22.9 \\
8.0 \\
12.6 \\
12.8\end{array}$ & $\begin{array}{l}(0.80) \\
2.38 \\
1.10 \\
0.44 \\
1.08)\end{array}$ & $\begin{array}{l}53.2 \\
30.6 \\
42.5 \\
64.0 \\
51.6\end{array}$ & $\left.\begin{array}{l}(1.49) \\
0.94 \\
6.05 \\
1.10 \\
2.82\end{array}\right)$ & $\begin{array}{l}31.4 \\
21.7 \\
17.1 \\
38.2 \\
25.1\end{array}$ & $\left.\begin{array}{l}(2.21) \\
1.10 \\
4.07 \\
2.70 \\
3.20\end{array}\right)$ \\
\hline 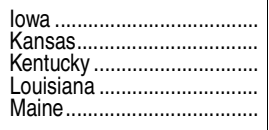 & $\begin{array}{l}92.1 \\
90.1 \\
83.5 \\
83.2 \\
92.1\end{array}$ & $\left.\begin{array}{l}(0.27) \\
0.30 \\
0.29 \\
0.31 \\
0.38\end{array}\right)$ & $\begin{array}{l}93.7 \\
93.2 \\
83.9 \\
87.3 \\
92.6\end{array}$ & $\left.\begin{array}{l}0.24 \\
0.23 \\
0.32 \\
0.31 \\
0.37\end{array}\right)$ & $\begin{array}{l}84.1 \\
88.3 \\
84.3 \\
76.2 \\
81.2\end{array}$ & $\left(\begin{array}{c}2.90 \\
1.50 \\
1.06 \\
0.71 \\
6.01\end{array}\right)$ & $\begin{array}{l}60.6 \\
59.5 \\
71.0 \\
70.3 \\
85.6\end{array}$ & $\left.\begin{array}{l}(3.12) \\
(2.15 \\
2.59 \\
2.09 \\
5.21\end{array}\right)$ & $\begin{array}{l}85.0 \\
88.0 \\
83.1 \\
81.2 \\
60.1\end{array}$ & $\begin{array}{r}(3.02) \\
2.22 \\
3.15 \\
2.08 \\
(12.00)\end{array}$ & $\begin{array}{l}87.2 \\
91.4 \\
78.1 \\
83.2 \\
88.7\end{array}$ & $\left.\begin{array}{l}(4.37) \\
(1.94) \\
3.21 \\
(2.06 \\
4.21\end{array}\right)$ & $\begin{array}{l}26.8 \\
30.2 \\
21.5 \\
22.2 \\
28.0\end{array}$ & $\left.\begin{array}{l}(0.37) \\
0.44 \\
0.31 \\
0.31 \\
0.71\end{array}\right)$ & $\begin{array}{l}27.1 \\
32.5 \\
21.9 \\
26.1 \\
28.1\end{array}$ & $\begin{array}{l}(0.400 \\
0.50 \\
0.33 \\
0.41 \\
0.72\end{array}$ & $\begin{array}{l}18.1 \\
17.7 \\
13.7 \\
13.1 \\
36.0\end{array}$ & $\left(\begin{array}{l}2.80 \\
(1.70) \\
1.00 \\
0.47 \\
(8.69)\end{array}\right)$ & $\begin{array}{l}13.7 \\
11.7 \\
16.9 \\
17.8 \\
24.6\end{array}$ & $\left.\begin{array}{l}(1.66) \\
1.11 \\
2.05 \\
1.67 \\
6.77)\end{array}\right)$ & $\begin{array}{l}56.7 \\
46.4 \\
52.0 \\
44.9 \\
26.6\end{array}$ & $\begin{array}{l}(4.33) \\
3.81 \\
3.63 \\
2.82 \\
7.60)\end{array}$ & $\begin{array}{l}21.8 \\
22.2 \\
20.1 \\
24.0 \\
25.8\end{array}$ & $\begin{array}{l}(4.42 \\
3.33 \\
3.19 \\
2.86 \\
(5.13)\end{array}$ \\
\hline 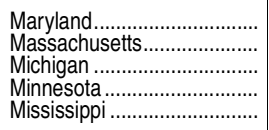 & $\begin{array}{l}89.2 \\
89.7 \\
89.6 \\
92.4 \\
82.5\end{array}$ & $\left.\begin{array}{l}0.22 \\
0.17 \\
0.17 \\
0.19 \\
0.35\end{array}\right)$ & $\begin{array}{l}92.8 \\
92.9 \\
91.3 \\
94.9 \\
86.4\end{array}$ & $\left.\begin{array}{l}0.21 \\
0.18 \\
0.15 \\
0.16 \\
0.44\end{array}\right)$ & $\begin{array}{l}88.5 \\
81.6 \\
84.3 \\
80.8 \\
76.3\end{array}$ & $\begin{array}{c}(0.36) \\
(1.05) \\
0.58 \\
(1.69 \\
0.63)\end{array}$ & $\begin{array}{l}62.8 \\
68.5 \\
70.3 \\
64.5 \\
70.1\end{array}$ & $\left.\begin{array}{l}(1.66) \\
0.98 \\
1.55 \\
2.85 \\
2.74\end{array}\right)$ & $\begin{array}{l}89.6 \\
84.7 \\
87.9 \\
80.1 \\
78.7\end{array}$ & $\begin{array}{l}(0.74) \\
0.98 \\
1.26 \\
1.89 \\
4.71)\end{array}$ & $\begin{array}{l}93.2 \\
88.6 \\
86.5 \\
90.3 \\
85.6\end{array}$ & $\left(\begin{array}{l}1.15 \\
1.38 \\
1.32 \\
2.04 \\
4.27\end{array}\right)$ & $\begin{array}{l}37.0 \\
39.5 \\
26.3 \\
32.7 \\
20.6\end{array}$ & $\left.\begin{array}{l}(0.31) \\
0.30 \\
0.23 \\
0.42 \\
0.41\end{array}\right)$ & $\begin{array}{l}41.8 \\
42.0 \\
27.4 \\
33.8 \\
23.9\end{array}$ & $\begin{array}{l}(0.40 \\
0.33 \\
0.25 \\
0.43 \\
0.59\end{array}$ & $\begin{array}{l}25.9 \\
20.3 \\
16.7 \\
19.8 \\
14.9\end{array}$ & $\begin{array}{l}(0.58) \\
(1.17 \\
0.54 \\
(2.05) \\
0.59)\end{array}$ & $\begin{array}{r}21.5 \\
16.7 \\
15.3 \\
16.7 \\
9.4\end{array}$ & $\left.\begin{array}{l}(1.07) \\
0.88 \\
1.01 \\
1.65 \\
1.76\end{array}\right)$ & $\begin{array}{l}60.5 \\
57.4 \\
62.4 \\
47.5 \\
33.2\end{array}$ & $\left.\begin{array}{l}(1.29) \\
1.22 \\
2.22 \\
2.55 \\
5.31\end{array}\right)$ & $\begin{array}{l}38.3 \\
36.3 \\
24.1 \\
23.9 \\
26.2\end{array}$ & $\begin{array}{l}(2.59) \\
2.68 \\
2.19 \\
3.65 \\
4.82)\end{array}$ \\
\hline 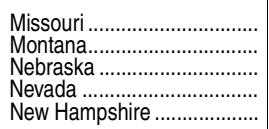 & $\begin{array}{l}87.8 \\
92.8 \\
90.8 \\
85.6 \\
92.0\end{array}$ & $\left.\begin{array}{l}(0.21) \\
0.46 \\
0.29 \\
0.30 \\
0.46\end{array}\right)$ & $\begin{array}{l}89.3 \\
93.8 \\
94.5 \\
92.8 \\
92.6\end{array}$ & $\left.\begin{array}{l}(0.22) \\
0.41 \\
0.25 \\
0.25 \\
0.43\end{array}\right)$ & $\begin{array}{r}81.8 \\
\ddagger \\
81.0 \\
87.2 \\
88.6\end{array}$ & $\left.\begin{array}{r}(0.85) \\
(+) \\
(2.59) \\
(1.09 \\
5.43\end{array}\right)$ & $\begin{array}{l}69.0 \\
79.8 \\
54.2 \\
63.1 \\
85.7\end{array}$ & $\begin{array}{l}(1.98) \\
4.09 \\
3.05 \\
1.24 \\
(3.18)\end{array}$ & $\begin{array}{r}83.1 \\
\ddagger \\
80.7 \\
88.6 \\
77.0\end{array}$ & $\left.\begin{array}{r}(1.94) \\
(+) \\
(3.28 \\
1.15 \\
6.02\end{array}\right)$ & $\begin{array}{l}86.1 \\
91.2 \\
88.3 \\
89.9 \\
87.3\end{array}$ & $\begin{array}{l}(2.00) \\
3.41 \\
4.80 \\
1.81 \\
(5.15)\end{array}$ & $\begin{array}{l}26.0 \\
28.5 \\
29.7 \\
22.6 \\
35.3\end{array}$ & $\left.\begin{array}{l}(0.30) \\
0.71 \\
0.50 \\
0.34 \\
0.74\end{array}\right)$ & $\begin{array}{l}27.1 \\
29.9 \\
31.5 \\
27.1 \\
35.6\end{array}$ & $\left.\begin{array}{l}(0.31) \\
0.73 \\
0.60 \\
0.50 \\
0.72\end{array}\right)$ & $\begin{array}{l}16.4 \\
\ddagger \\
20.2 \\
16.2 \\
22.8 !\end{array}$ & $\begin{array}{r}(0.83) \\
(+) \\
(2.81) \\
1.49 \\
(7.88)\end{array}$ & $\begin{array}{r}18.4 \\
13.8 \\
10.3 \\
8.2 \\
25.1\end{array}$ & $\left.\begin{array}{l}(1.82) \\
3.79 \\
1.74 \\
0.55 \\
4.42\end{array}\right)$ & $\begin{array}{r}52.4 \\
\neq \\
51.1 \\
35.9 \\
44.8\end{array}$ & $\left.\begin{array}{l}(3.20) \\
+ \\
4.47 \\
1.67 \\
5.63\end{array}\right)$ & $\begin{array}{l}22.1 \\
23.6 \\
25.4 \\
22.9 \\
28.7\end{array}$ & $\left.\begin{array}{l}(2.26) \\
5.90 \\
5.38 \\
3.32 \\
5.22\end{array}\right)$ \\
\hline 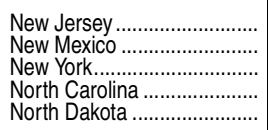 & $\begin{array}{l}88.4 \\
84.5 \\
85.4 \\
85.1 \\
91.8\end{array}$ & $\left.\begin{array}{l}(0.18) \\
0.38 \\
0.11 \\
0.21 \\
0.49\end{array}\right)$ & $\begin{array}{l}92.9 \\
94.3 \\
92.3 \\
89.0 \\
92.5\end{array}$ & $\left.\begin{array}{l}0.16 \\
0.35 \\
0.11 \\
0.20 \\
0.44\end{array}\right)$ & $\begin{array}{r}85.9 \\
83.9 \\
82.5 \\
82.2 \\
\ddagger\end{array}$ & $\begin{array}{r}(0.54) \\
(.25) \\
0.34 \\
0.40 \\
(\dagger)\end{array}$ & $\begin{array}{l}71.1 \\
74.4 \\
65.5 \\
54.0 \\
83.6\end{array}$ & $\begin{array}{l}(0.74) \\
0.80 \\
(0.48) \\
1.45 \\
4.67)\end{array}$ & $\begin{array}{r}92.5 \\
82.0 \\
77.6 \\
84.6 \\
\ddagger\end{array}$ & $\begin{array}{r}(0.44) \\
3.07 \\
0.56 \\
1.34 \\
(\dagger)\end{array} \mid$ & $\begin{array}{r}89.8 \\
95.2 \\
84.7 \\
89.3 \\
100.0\end{array}$ & $\begin{array}{r}(1.86) \\
2.44 \\
1.15 \\
1.64 \\
(\#)\end{array}$ & $\begin{array}{l}36.3 \\
26.2 \\
33.5 \\
27.3 \\
28.8\end{array}$ & $\left.\begin{array}{l}(0.26) \\
0.43 \\
0.17 \\
0.23 \\
0.91\end{array}\right)$ & $\begin{array}{l}39.9 \\
38.9 \\
39.2 \\
31.2 \\
29.3\end{array}$ & $\begin{array}{l}(0.32) \\
0.70 \\
0.21 \\
0.27 \\
0.96)\end{array}$ & $\begin{array}{r}21.1 \\
26.9 \\
21.6 \\
17.1 \\
\ddagger\end{array}$ & $\begin{array}{r}(0.61) \\
(4.42 \\
(0.46 \\
(0.52) \\
(\dagger)\end{array}$ & $\begin{array}{l}16.4 \\
13.6 \\
16.6 \\
11.0 \\
25.6\end{array}$ & $\begin{array}{l}(0.58) \\
0.655 \\
0.36 \\
0.67) \\
7.37\end{array}$ & $\begin{array}{r}68.2 \\
50.3 \\
44.8 \\
52.8 \\
\ddagger\end{array}$ & $\begin{array}{r}(1.00) \\
4.88 \\
0.72 \\
1.93 \\
(\dagger)\end{array} \mid$ & $\begin{array}{l}38.2 \\
41.2 \\
33.9 \\
29.7 \\
16.3 !\end{array}$ & $\begin{array}{l}2.77) \\
4.74 \\
1.57 \\
2.47 \\
(.17)\end{array}$ \\
\hline 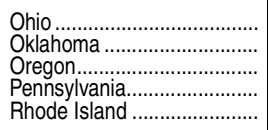 & $\begin{array}{l}88.9 \\
86.6 \\
90.1 \\
88.9 \\
85.8\end{array}$ & $\left.\begin{array}{l}(0.15) \\
0.30 \\
0.23 \\
0.15 \\
0.53\end{array}\right)$ & $\begin{array}{l}90.2 \\
89.6 \\
93.3 \\
90.9 \\
89.0\end{array}$ & $\left.\begin{array}{l}0.15 \\
0.28 \\
0.22 \\
0.13 \\
0.48\end{array}\right)$ & $\begin{array}{l}82.8 \\
88.4 \\
90.2 \\
84.5 \\
82.9\end{array}$ & $\left(\begin{array}{l}0.51 \\
1.66 \\
1.65 \\
0.55 \\
2.53\end{array}\right)$ & $\begin{array}{l}72.2 \\
55.8 \\
61.9 \\
68.3 \\
65.6\end{array}$ & $\begin{array}{l}(1.39) \\
2.07 \\
1.53 \\
1.40 \\
(2.21)\end{array}$ & $\begin{array}{l}88.2 \\
83.2 \\
87.4 \\
80.8 \\
75.0\end{array}$ & $\left.\begin{array}{l}(1.35) \\
2.52 \\
1.30 \\
1.13 \\
3.44\end{array}\right)$ & $\begin{array}{l}86.2 \\
89.1 \\
90.0 \\
86.5 \\
80.5\end{array}$ & $\left(\begin{array}{c}1.46 \\
1.08 \\
1.64 \\
1.91 \\
4.10\end{array}\right)$ & $\begin{array}{l}25.2 \\
23.7 \\
30.2 \\
28.1 \\
31.2\end{array}$ & $\left.\begin{array}{l}(0.19) \\
0.38 \\
0.35 \\
0.23 \\
0.65\end{array}\right)$ & $\begin{array}{l}26.1 \\
26.0 \\
31.7 \\
29.3 \\
34.2\end{array}$ & $\begin{array}{l}(0.20) \\
0.47 \\
0.37 \\
0.24 \\
0.79\end{array}$ & $\begin{array}{l}15.3 \\
17.7 \\
21.8 \\
16.3 \\
18.8\end{array}$ & $\begin{array}{l}(0.57) \\
(1.46 \\
3.05 \\
0.65 \\
(3.00)\end{array}$ & $\begin{array}{r}16.0 \\
9.2 \\
13.8 \\
14.9 \\
11.2\end{array}$ & $\left.\begin{array}{l}(1.14) \\
1.09 \\
1.09 \\
1.00 \\
1.81)\end{array}\right)$ & $\begin{array}{l}60.4 \\
45.9 \\
46.1 \\
54.6 \\
47.9\end{array}$ & $\left.\begin{array}{l}(1.86) \\
3.74 \\
2.34 \\
1.60 \\
3.72\end{array}\right)$ & $\begin{array}{l}22.9 \\
19.7 \\
26.4 \\
26.9 \\
21.4\end{array}$ & $\left.\begin{array}{l}1.99 \\
1.39 \\
2.25 \\
2.17 \\
4.41\end{array}\right)$ \\
\hline 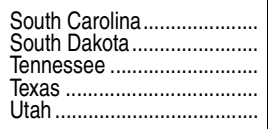 & $\begin{array}{l}84.9 \\
90.6 \\
85.1 \\
81.5 \\
91.3\end{array}$ & $\left.\begin{array}{l}(0.20) \\
0.49 \\
0.23 \\
0.11 \\
0.32\end{array}\right)$ & $\begin{array}{l}88.5 \\
92.6 \\
86.6 \\
92.7 \\
94.9\end{array}$ & $\left.\begin{array}{l}0.23 \\
0.53 \\
0.25 \\
0.13 \\
0.22\end{array}\right)$ & $\begin{array}{r}78.6 \\
\ddagger \\
82.8 \\
87.4 \\
89.0\end{array}$ & $\left.\begin{array}{r}(0.59) \\
(t) \\
(0.63) \\
0.31 \\
2.95\end{array}\right)$ & $\begin{array}{l}64.9 \\
69.5 \\
62.2 \\
61.3 \\
66.4\end{array}$ & $\begin{array}{l}(2.22) \\
(5.55) \\
1.81 \\
0.29 \\
(1.90)\end{array}$ & $\begin{array}{l}80.5 \\
67.5 \\
84.0 \\
86.5 \\
83.4\end{array}$ & $\left.\begin{array}{l}(2.23) \\
9.91 \\
1.68 \\
0.56 \\
2.28\end{array}\right)$ & $\begin{array}{l}88.9 \\
90.9 \\
85.5 \\
91.6 \\
92.7\end{array}$ & $\begin{array}{l}(2.41) \\
4.99 \\
1.91 \\
(0.90 \\
(2.36)\end{array}$ & $\begin{array}{l}25.3 \\
26.7 \\
24.6 \\
26.9 \\
30.7\end{array}$ & $\left.\begin{array}{l}(0.34) \\
1.02 \\
0.21 \\
0.14 \\
0.45\end{array}\right)$ & $\begin{array}{l}29.6 \\
28.2 \\
26.0 \\
35.6 \\
32.7\end{array}$ & $\begin{array}{l}(0.411 \\
1.10 \\
0.25 \\
0.21 \\
0.51)\end{array}$ & $\begin{array}{r}14.2 \\
\ddagger \\
17.3 \\
20.9 \\
35.8\end{array}$ & $\begin{array}{l}(0.56) \\
(t) \\
(0.66 \\
(0.47 \\
(5.02)\end{array}$ & $\begin{array}{r}18.7 \\
\ddagger \\
13.7 \\
12.1 \\
14.3\end{array}$ & $\begin{array}{r}(1.76) \\
(+) \\
(1.33 \\
0.22 \\
(1.13)\end{array}$ & $\begin{array}{l}39.4 \\
54.1 \\
48.7 \\
53.9 \\
46.3\end{array}$ & $\begin{array}{r}(2.84) \\
(10.46 \\
(2.32 \\
0.99 \\
2.66)\end{array}$ & $\begin{array}{l}27.3 \\
21.3 ! \\
21.8 \\
32.1 \\
34.3\end{array}$ & $\begin{array}{l}3.45 \\
9.09 \\
2.31 \\
1.60 \\
4.50)\end{array}$ \\
\hline 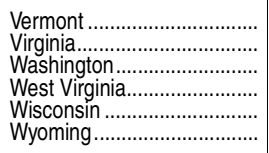 & $\begin{array}{l}92.3 \\
88.1 \\
90.6 \\
83.9 \\
90.9 \\
91.5\end{array}$ & $\left.\begin{array}{l}(0.51) \\
0.15 \\
0.18 \\
0.44 \\
0.21 \\
0.58\end{array}\right)$ & $\begin{array}{l}92.7 \\
91.1 \\
94.3 \\
83.8 \\
93.0 \\
93.4\end{array}$ & $\begin{array}{l}(0.51) \\
0.15 \\
0.14 \\
0.45 \\
0.19 \\
0.61)\end{array}$ & $\begin{array}{r}\ddagger \\
82.6 \\
90.5 \\
86.3 \\
78.0 \\
\ddagger\end{array}$ & 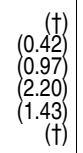 & $\begin{array}{l}80.4 \\
70.8 \\
62.5 \\
73.9 \\
66.7 \\
73.4\end{array}$ & $\begin{array}{l}(7.20) \\
1.31 \\
11.16 \\
5.42 \\
1.95 \\
(3.27)\end{array}$ & $\begin{array}{r}75.4 \\
91.2 \\
85.9 \\
91.1 \\
85.1 \\
\ddagger\end{array}$ & $\left.\begin{array}{r}(10.19 \\
(0.74) \\
0.73 \\
3.73 \\
2.05 \\
(\dagger)\end{array}\right)$ & $\begin{array}{l}94.7 \\
89.4 \\
91.4 \\
87.1 \\
90.4 \\
87.2\end{array}$ & $\begin{array}{l}(3.74) \\
(1.38 \\
(0.93 \\
(3.18 \\
(2.23 \\
(5.16)\end{array}$ & $\begin{array}{l}35.1 \\
35.7 \\
31.8 \\
18.2 \\
27.5 \\
25.4\end{array}$ & $\left.\begin{array}{l}(1.07) \\
0.25 \\
0.32 \\
0.40 \\
0.36 \\
1.02\end{array}\right)$ & $\begin{array}{l}35.0 \\
39.0 \\
33.4 \\
18.2 \\
28.6 \\
26.5\end{array}$ & $\begin{array}{l}(1.09) \\
0.29 \\
0.37 \\
0.41 \\
0.41 \\
(1.11)\end{array}$ & $\begin{array}{r}\ddagger \\
20.2 \\
19.6 \\
11.3 \\
14.1 \\
\ddagger\end{array}$ & 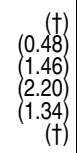 & $\begin{array}{l}25.4 \\
24.4 \\
13.6 \\
22.8 \\
13.1 \\
15.0\end{array}$ & $\left(\begin{array}{l}7.41 \\
1.04 \\
0.67 \\
4.49 \\
1.39 \\
(2.57)\end{array}\right)$ & $\begin{array}{r}49.6 \\
58.5 \\
46.5 \\
58.6 \\
45.6 \\
\ddagger\end{array}$ & $\left.\begin{array}{r}(14.61) \\
(1.15 \\
1.03 \\
7.85 \\
3.42 \\
(\dagger)\end{array}\right)$ & $\begin{array}{l}38.7 \\
40.4 \\
29.8 \\
12.4 \\
30.3 \\
20.9 !\end{array}$ & $\begin{array}{l}(8.40) \\
2.02 \\
1.43 \\
3.04 \\
4.15 \\
(7.07)\end{array}$ \\
\hline
\end{tabular}

†Not applicable.
\#Rounds to zero.

!Interpret data with caution. The coefficient of variation (CV) for this estimate is between 30 and 50 percent. ¥Reporting standards not met. Either there are too few cases for a reliable estimate or the coefficient of variation (CV) is 50 percent or greater.
1Total includes racial/ethnic groups not shown separately.

A 2012 American Community Survey (ACS) 1-Year Public Use Microdata Sample (PUMS) data. (This table was prepared January 2014.) 
[Standard errors appear in parentheses]

\begin{tabular}{|c|c|c|c|c|c|c|c|c|c|c|c|c|c|c|c|c|c|c|c|c|c|c|c|c|}
\hline \multirow[b]{3}{*}{ State } & \multicolumn{12}{|c|}{2011} & \multicolumn{12}{|c|}{2012} \\
\hline & \multicolumn{6}{|c|}{ Percent with high school completion or higher } & \multicolumn{6}{|c|}{ Percent with bachelor's or higher degree } & \multicolumn{6}{|c|}{ Percent with high school completion or higher } & \multicolumn{6}{|c|}{ Percent with bachelor's or higher degree } \\
\hline & & Total & & Male & & Female & & Total & & Male & & Female & & Total & & Male & & Female & & Total & & Male & & Female \\
\hline 1 & & 2 & & 3 & & 4 & & 5 & & 6 & & 7 & & 8 & & 9 & & 10 & & 11 & & 12 & & 13 \\
\hline 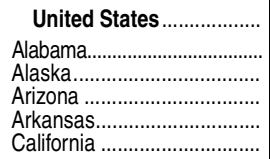 & $\begin{array}{l}85.9 \\
82.7 \\
92.8 \\
85.7 \\
83.7 \\
81.1\end{array}$ & $\begin{array}{l}(0.04) \\
(0.37) \\
(0.50) \\
(0.23) \\
(0.43) \\
(0.10)\end{array}$ & $\begin{array}{l}85.2 \\
81.2 \\
93.7 \\
85.1 \\
82.9 \\
80.9\end{array}$ & $\begin{array}{l}(0.04) \\
(0.48) \\
(0.63) \\
(0.31) \\
(0.56) \\
(0.12)\end{array}$ & $\begin{array}{l}86.5 \\
84.1 \\
91.9 \\
86.3 \\
84.4 \\
81.3\end{array}$ & $\begin{array}{l}(0.04) \\
(0.40) \\
(0.68) \\
(0.31) \\
(0.48) \\
(0.11)\end{array}$ & $\begin{array}{l}\mathbf{2 8 . 6} \\
22.5 \\
25.8 \\
26.4 \\
20.4 \\
30.3\end{array}$ & $\begin{array}{l}(0.06) \\
(0.32) \\
(1.24) \\
(0.26) \\
(0.38) \\
(0.13)\end{array}$ & $\begin{array}{l}28.8 \\
22.5 \\
22.2 \\
27.4 \\
20.5 \\
30.7\end{array}$ & $\begin{array}{l}(0.07) \\
(0.40) \\
(1.37) \\
(0.37) \\
(0.49) \\
(0.18)\end{array}$ & $\begin{array}{l}\mathbf{2 8 . 4} \\
22.5 \\
29.6 \\
25.4 \\
20.2 \\
30.0\end{array}$ & $\begin{array}{l}(0.07) \\
(0.40) \\
(1.61) \\
0.30) \\
0.48) \\
(0.15)\end{array}$ & $\begin{array}{l}86.4 \\
83.8 \\
91.8 \\
85.8 \\
85.1 \\
81.4\end{array}$ & $\begin{array}{l}(0.04) \\
(0.24) \\
(0.56) \\
(0.21) \\
(0.34) \\
(0.09)\end{array}$ & $\begin{array}{l}85.7 \\
82.9 \\
92.2 \\
85.3 \\
84.2 \\
81.1\end{array}$ & $\begin{array}{l}(0.05) \\
(0.37) \\
(0.57) \\
(0.29) \\
(0.48) \\
(0.13)\end{array}$ & $\begin{array}{l}87.0 \\
84.6 \\
91.4 \\
86.2 \\
86.0 \\
81.7\end{array}$ & $\begin{array}{l}(0.04) \\
(0.32) \\
(0.92) \\
(0.25) \\
(0.42) \\
(0.12)\end{array}$ & $\begin{array}{l}\mathbf{2 9 . 2} \\
23.4 \\
28.9 \\
27.5 \\
21.2 \\
31.0\end{array}$ & $\begin{array}{l}(0.05) \\
(0.29) \\
(1.22) \\
0.29) \\
(0.35) \\
(0.11)\end{array}$ & $\begin{array}{l}\mathbf{2 9 . 2} \\
23.3 \\
25.6 \\
28.5 \\
20.6 \\
31.4\end{array}$ & $\begin{array}{l}(0.06) \\
(0.36) \\
(1.48) \\
(0.37) \\
(0.51) \\
(0.16)\end{array}$ & $\begin{array}{l}\mathbf{2 9 . 2} \\
23.4 \\
32.4 \\
26.5 \\
21.8 \\
30.6\end{array}$ & $\begin{array}{l}(0.06) \\
(0.39) \\
(1.57) \\
(0.36) \\
0.44) \\
(0.13)\end{array}$ \\
\hline 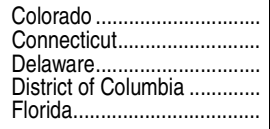 & $\begin{array}{l}90.2 \\
89.0 \\
87.3 \\
87.1 \\
85.9\end{array}$ & $\begin{array}{l}(0.21) \\
(0.27) \\
0.52) \\
0.73) \\
(0.12)\end{array}$ & $\begin{array}{l}89.5 \\
88.4 \\
86.1 \\
85.9 \\
84.9\end{array}$ & $\begin{array}{l}(0.29) \\
(0.39) \\
0.75 \\
0.99) \\
(0.17)\end{array}$ & $\begin{array}{l}91.0 \\
89.5 \\
88.5 \\
88.1 \\
86.9\end{array}$ & $\begin{array}{l}(0.28) \\
(0.30) \\
0.57) \\
(0.90) \\
(0.12)\end{array}$ & $\begin{array}{l}36.8 \\
36.2 \\
28.2 \\
52.5 \\
25.9\end{array}$ & $\begin{array}{l}(0.37) \\
(0.42) \\
0.68) \\
(0.80) \\
(0.16)\end{array}$ & $\begin{array}{l}37.2 \\
36.6 \\
28.2 \\
52.5 \\
26.7\end{array}$ & $\begin{array}{l}(0.45) \\
(0.50) \\
0.92) \\
(1.12) \\
(0.21)\end{array}$ & $\begin{array}{l}36.5 \\
35.8 \\
28.2 \\
52.5 \\
25.1\end{array}$ & $\begin{array}{l}(0.47) \\
0.54) \\
0.97) \\
(0.95) \\
(0.21)\end{array}$ & $\begin{array}{l}90.4 \\
89.9 \\
88.3 \\
89.2 \\
86.4\end{array}$ & $\begin{array}{l}(0.20) \\
(0.26) \\
0.60 \\
(0.46) \\
(0.13)\end{array}$ & $\begin{array}{l}89.7 \\
89.3 \\
87.1 \\
88.9 \\
85.5\end{array}$ & $\begin{array}{l}(0.30) \\
(0.36) \\
0.81 \\
(0.68) \\
(0.20)\end{array}$ & $\begin{array}{l}91.1 \\
90.4 \\
89.3 \\
89.5 \\
87.3\end{array}$ & $\begin{array}{l}(0.23) \\
(0.31) \\
0.67) \\
0.65) \\
(0.14)\end{array}$ & $\begin{array}{l}37.6 \\
37.2 \\
30.2 \\
53.7 \\
26.8\end{array}$ & $\begin{array}{l}(0.34) \\
(0.35) \\
(0.82) \\
(0.76) \\
(0.15)\end{array}$ & $\begin{array}{l}37.7 \\
37.8 \\
29.0 \\
55.5 \\
27.8\end{array}$ & $\begin{array}{l}(0.43) \\
(0.51) \\
1.00 \\
(1.07) \\
(0.21)\end{array}$ & $\begin{array}{l}37.5 \\
36.7 \\
31.3 \\
52.1 \\
25.9\end{array}$ & $\begin{array}{l}(0.43) \\
(0.39) \\
1.06 \\
(0.84) \\
(0.19)\end{array}$ \\
\hline 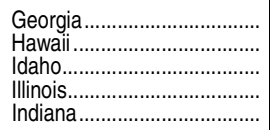 & $\begin{array}{l}84.3 \\
90.5 \\
88.7 \\
87.3 \\
87.2\end{array}$ & $\begin{array}{l}(0.19) \\
(0.40) \\
(0.35) \\
(0.14) \\
0.20)\end{array}$ & $\begin{array}{l}83.2 \\
90.6 \\
87.9 \\
86.9 \\
86.5\end{array}$ & $\begin{array}{l}(0.25) \\
(0.52) \\
(0.49) \\
(0.20) \\
0.30)\end{array}$ & $\begin{array}{l}85.2 \\
90.4 \\
89.4 \\
87.7 \\
87.8\end{array}$ & $\begin{array}{l}(0.26) \\
(0.55) \\
0.50) \\
(0.18) \\
0.27)\end{array}$ & $\begin{array}{l}27.6 \\
29.7 \\
25.6 \\
31.0 \\
22.8\end{array}$ & $\begin{array}{l}(0.24) \\
(0.55) \\
(0.68) \\
(0.22) \\
(0.27)\end{array}$ & $\begin{array}{l}27.7 \\
29.1 \\
26.5 \\
31.1 \\
23.3\end{array}$ & $\begin{array}{l}(0.28) \\
(0.79) \\
0.85 \\
(0.27) \\
(0.34)\end{array}$ & $\begin{array}{l}27.6 \\
30.3 \\
24.6 \\
30.8 \\
22.3\end{array}$ & $\begin{array}{l}(0.37) \\
(0.74) \\
0.93) \\
(0.27) \\
(0.35)\end{array}$ & $\begin{array}{l}85.2 \\
90.0 \\
89.8 \\
87.7 \\
87.3\end{array}$ & $\begin{array}{l}(0.21) \\
(0.43) \\
0.40 \\
(0.17) \\
(0.22)\end{array}$ & $\begin{array}{l}84.0 \\
90.8 \\
89.1 \\
86.9 \\
86.7\end{array}$ & $\begin{array}{l}(0.30) \\
(0.54) \\
0.54) \\
(0.23) \\
0.31)\end{array}$ & $\begin{array}{l}86.2 \\
89.2 \\
90.4 \\
88.4 \\
87.9\end{array}$ & $\begin{array}{l}(0.23) \\
(0.59) \\
0.55) \\
(0.21) \\
0.26)\end{array}$ & $\begin{array}{l}28.3 \\
30.1 \\
25.8 \\
31.5 \\
23.3\end{array}$ & $\begin{array}{l}(0.23) \\
(0.58) \\
0.70) \\
(0.20) \\
(0.29)\end{array}$ & $\begin{array}{l}27.9 \\
27.9 \\
26.5 \\
31.2 \\
23.3\end{array}$ & $\begin{array}{l}(0.27) \\
(0.70) \\
(0.80) \\
(0.26) \\
0.37)\end{array}$ & $\begin{array}{l}28.7 \\
32.2 \\
25.1 \\
31.8 \\
23.4\end{array}$ & $\begin{array}{l}(0.30) \\
(0.82) \\
0.95 \\
(0.25) \\
0.32)\end{array}$ \\
\hline 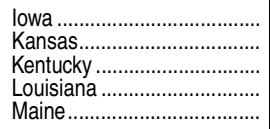 & $\begin{array}{l}91.0 \\
89.6 \\
83.1 \\
82.6 \\
90.8\end{array}$ & $\begin{array}{l}(0.28) \\
(0.32) \\
0.31 \\
0.29) \\
(0.40)\end{array}$ & $\begin{array}{l}90.2 \\
88.6 \\
82.1 \\
80.6 \\
89.6\end{array}$ & $\begin{array}{l}(0.33) \\
(0.44) \\
0.41 \\
(0.37) \\
(0.62)\end{array}$ & $\begin{array}{l}91.7 \\
90.4 \\
84.1 \\
84.4 \\
91.9\end{array}$ & $\begin{array}{l}(0.35) \\
(0.41) \\
0.38) \\
0.35) \\
(0.49)\end{array}$ & $\begin{array}{l}25.8 \\
30.5 \\
20.7 \\
21.1 \\
28.6\end{array}$ & $\begin{array}{l}(0.47) \\
(0.51) \\
0.33 \\
0.36) \\
(0.70)\end{array}$ & $\begin{array}{l}25.1 \\
30.3 \\
20.6 \\
20.3 \\
27.5\end{array}$ & $\begin{array}{l}(0.63) \\
(0.60) \\
0.41 \\
(0.43) \\
(0.84)\end{array}$ & $\begin{array}{l}26.4 \\
30.6 \\
20.9 \\
21.8 \\
29.5\end{array}$ & $\begin{array}{l}(0.56) \\
(0.63) \\
0.41 \\
(0.42) \\
(0.85)\end{array}$ & $\begin{array}{l}92.1 \\
90.1 \\
83.5 \\
83.2 \\
92.1\end{array}$ & $\begin{array}{l}(0.27) \\
(0.30) \\
0.29 \\
(0.31) \\
(0.38)\end{array}$ & $\begin{array}{l}91.6 \\
89.3 \\
82.3 \\
81.3 \\
90.9\end{array}$ & $\begin{array}{l}(0.37) \\
(0.44) \\
0.40 \\
(0.41 \\
(0.56)\end{array}$ & $\begin{array}{l}92.5 \\
90.9 \\
84.6 \\
85.0 \\
93.3\end{array}$ & $\begin{array}{l}(0.32) \\
(0.34) \\
0.36 \\
(0.36) \\
(0.44)\end{array}$ & $\begin{array}{l}26.8 \\
30.2 \\
21.5 \\
22.2 \\
28.0\end{array}$ & $\begin{array}{l}(0.37) \\
(0.44) \\
0.31 \\
0.31 \\
(0.71)\end{array}$ & $\begin{array}{l}26.5 \\
29.6 \\
21.0 \\
21.3 \\
27.0\end{array}$ & $\begin{array}{l}(0.50) \\
(0.63) \\
0.36 \\
(0.51) \\
(0.91)\end{array}$ & $\begin{array}{l}27.1 \\
30.7 \\
22.1 \\
23.0 \\
29.0\end{array}$ & $\begin{array}{l}(0.48) \\
(0.47) \\
0.38 \\
0.36) \\
(0.77)\end{array}$ \\
\hline 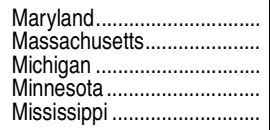 & $\begin{array}{l}89.0 \\
89.1 \\
88.7 \\
92.1 \\
80.8\end{array}$ & $\begin{array}{l}(0.21) \\
(0.20) \\
0.17) \\
(0.16) \\
0.37)\end{array}$ & $\begin{array}{l}88.3 \\
88.8 \\
87.9 \\
91.6 \\
78.3\end{array}$ & $\begin{array}{l}(0.28) \\
(0.23) \\
(0.22) \\
(0.25) \\
0.55)\end{array}$ & $\begin{array}{l}89.7 \\
89.3 \\
89.4 \\
92.6 \\
83.1\end{array}$ & $\begin{array}{l}(0.23) \\
(0.26) \\
0.23) \\
(0.21) \\
(0.42)\end{array}$ & $\begin{array}{l}37.0 \\
39.2 \\
25.8 \\
32.6 \\
20.1\end{array}$ & $\begin{array}{l}(0.28) \\
(0.32) \\
(0.22) \\
(0.40) \\
0.47)\end{array}$ & $\begin{array}{l}36.8 \\
39.8 \\
25.9 \\
32.0 \\
19.0\end{array}$ & $\begin{array}{l}(0.39) \\
(0.42) \\
0.29 \\
(0.56) \\
(0.56)\end{array}$ & $\begin{array}{l}37.2 \\
38.7 \\
25.6 \\
33.3 \\
21.1\end{array}$ & $\begin{array}{l}(0.35) \\
(0.34) \\
0.29) \\
(0.44) \\
(0.54)\end{array}$ & $\begin{array}{l}89.2 \\
89.7 \\
89.6 \\
92.4 \\
82.5\end{array}$ & $\begin{array}{l}(0.22) \\
(0.17) \\
0.17) \\
0.19 \\
0.35)\end{array}$ & $\begin{array}{l}88.2 \\
89.2 \\
89.2 \\
91.8 \\
80.6\end{array}$ & $\begin{array}{l}(0.28) \\
(0.24) \\
0.21) \\
(0.26) \\
(0.54)\end{array}$ & $\begin{array}{l}90.1 \\
90.2 \\
89.9 \\
92.9 \\
84.2\end{array}$ & $\begin{array}{l}(0.25) \\
(0.20) \\
0.20) \\
(0.23) \\
0.37)\end{array}$ & $\begin{array}{l}37.0 \\
39.5 \\
26.3 \\
32.7 \\
20.6\end{array}$ & $\begin{array}{l}(0.31) \\
(0.30) \\
0.23) \\
(0.42) \\
0.41)\end{array}$ & $\begin{array}{l}36.9 \\
39.8 \\
26.4 \\
31.9 \\
18.9\end{array}$ & $\begin{array}{l}(0.41) \\
(0.37) \\
(0.28) \\
(0.54) \\
0.49)\end{array}$ & $\begin{array}{l}37.0 \\
39.2 \\
26.2 \\
33.5 \\
22.1\end{array}$ & $\begin{array}{l}(0.38) \\
(0.36) \\
0.26) \\
0.51 \\
0.52)\end{array}$ \\
\hline 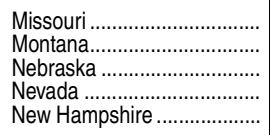 & $\begin{array}{l}87.7 \\
92.5 \\
91.1 \\
84.0 \\
91.8\end{array}$ & $\begin{array}{l}(0.21) \\
0.47 \\
0.32 \\
0.37) \\
0.42)\end{array}$ & $\begin{array}{l}87.4 \\
91.9 \\
90.5 \\
83.6 \\
90.9\end{array}$ & $\begin{array}{l}(0.31) \\
0.64 \\
0.45) \\
(0.49) \\
0.58)\end{array}$ & $\begin{array}{l}88.0 \\
93.2 \\
91.6 \\
84.4 \\
92.6\end{array}$ & $\begin{array}{l}(0.26) \\
0.62 \\
0.37) \\
(0.45) \\
0.45)\end{array}$ & $\begin{array}{l}26.4 \\
29.4 \\
28.1 \\
22.4 \\
33.5\end{array}$ & $\begin{array}{l}(0.34) \\
0.82 \\
0.54) \\
0.43 \\
0.65)\end{array}$ & $\begin{array}{l}26.9 \\
29.5 \\
28.1 \\
22.2 \\
33.0\end{array}$ & $\begin{array}{l}(0.42) \\
0.99 \\
0.74) \\
(0.62) \\
(0.77)\end{array}$ & $\begin{array}{l}25.9 \\
29.3 \\
28.2 \\
22.6 \\
33.9\end{array}$ & $\begin{array}{l}(0.42) \\
0.98) \\
0.77) \\
(0.52) \\
(0.82)\end{array}$ & $\begin{array}{l}87.8 \\
92.8 \\
90.8 \\
85.6 \\
92.0\end{array}$ & $\begin{array}{l}(0.21) \\
0.46 \\
0.29 \\
0.30 \\
0.46)\end{array}$ & $\begin{array}{l}87.3 \\
92.3 \\
90.4 \\
85.6 \\
91.0\end{array}$ & $\begin{array}{l}(0.28) \\
0.59 \\
0.47 \\
(0.44) \\
(0.54)\end{array}$ & $\begin{array}{l}88.2 \\
93.3 \\
91.1 \\
85.6 \\
92.9\end{array}$ & $\begin{array}{l}(0.27) \\
0.57 \\
0.38) \\
(0.38) \\
0.57)\end{array}$ & $\begin{array}{l}26.0 \\
28.5 \\
29.7 \\
22.6 \\
35.3\end{array}$ & $\begin{array}{l}(0.30) \\
0.71) \\
0.50) \\
(0.34) \\
0.74)\end{array}$ & $\begin{array}{l}25.4 \\
27.6 \\
29.2 \\
23.0 \\
34.5\end{array}$ & $\begin{array}{l}(0.37) \\
1.01 \\
(0.68) \\
(0.44) \\
(0.83)\end{array}$ & $\begin{array}{l}26.6 \\
29.4 \\
30.2 \\
22.3 \\
36.1\end{array}$ & $\begin{array}{l}(0.39) \\
0.99 \\
0.75 \\
(0.48) \\
0.95)\end{array}$ \\
\hline 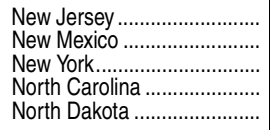 & $\begin{array}{l}88.0 \\
83.0 \\
85.1 \\
84.8 \\
90.8\end{array}$ & $\begin{array}{l}(0.15) \\
(0.42) \\
(0.12) \\
(0.20) \\
0.49)\end{array}$ & $\begin{array}{l}87.7 \\
81.7 \\
84.8 \\
83.3 \\
90.5\end{array}$ & $\begin{array}{l}(0.22) \\
(0.53) \\
(0.18) \\
(0.25) \\
0.72)\end{array}$ & $\begin{array}{l}88.2 \\
84.2 \\
85.3 \\
86.3 \\
91.1\end{array}$ & $\begin{array}{l}(0.19) \\
(0.55) \\
(0.14) \\
(0.25) \\
(0.71)\end{array}$ & $\begin{array}{l}35.2 \\
25.6 \\
33.1 \\
26.7 \\
26.2\end{array}$ & $\begin{array}{l}(0.24) \\
(0.49) \\
0.15 \\
(0.26) \\
0.97)\end{array}$ & $\begin{array}{l}36.4 \\
25.8 \\
32.9 \\
26.3 \\
23.7\end{array}$ & $\begin{array}{l}(0.32) \\
(0.60) \\
(0.22) \\
(0.33) \\
(1.18)\end{array}$ & $\begin{array}{l}34.2 \\
25.3 \\
33.3 \\
27.1 \\
28.7\end{array}$ & $\begin{array}{l}(0.26) \\
(0.60) \\
0.16) \\
(0.32) \\
(1.29)\end{array}$ & $\begin{array}{l}88.4 \\
84.5 \\
85.4 \\
85.1 \\
91.8\end{array}$ & $\left.\begin{array}{l}(0.18) \\
(0.38) \\
0.11 \\
(0.21) \\
0.49\end{array}\right)$ & $\begin{array}{l}88.1 \\
83.5 \\
84.9 \\
83.2 \\
91.2\end{array}$ & $\begin{array}{l}(0.23) \\
(0.55) \\
(0.17) \\
(0.31) \\
0.57)\end{array}$ & $\begin{array}{l}88.6 \\
85.5 \\
85.8 \\
86.7 \\
92.3\end{array}$ & $\begin{array}{l}(0.20) \\
(0.48) \\
(0.13) \\
(0.20) \\
(0.69)\end{array}$ & $\begin{array}{l}36.3 \\
26.2 \\
33.5 \\
27.3 \\
28.8\end{array}$ & $\begin{array}{l}(0.26) \\
(0.43) \\
(0.17) \\
(0.23) \\
(0.91)\end{array}$ & $\begin{array}{l}36.8 \\
26.0 \\
32.9 \\
26.7 \\
27.9\end{array}$ & $\begin{array}{l}(0.34) \\
(0.63) \\
(0.20) \\
(0.28) \\
(1.29)\end{array}$ & $\begin{array}{l}35.8 \\
26.4 \\
34.0 \\
27.9 \\
29.7\end{array}$ & $\begin{array}{l}(0.28) \\
(0.55) \\
0.23 \\
(0.29) \\
(1.14)\end{array}$ \\
\hline 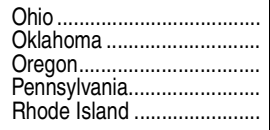 & $\begin{array}{l}88.4 \\
86.1 \\
89.3 \\
88.7 \\
84.5\end{array}$ & $\begin{array}{l}(0.14) \\
0.33) \\
0.27) \\
(0.17) \\
0.52)\end{array}$ & $\begin{array}{l}87.8 \\
85.3 \\
88.5 \\
88.5 \\
83.3\end{array}$ & $\begin{array}{l}(0.20) \\
0.44) \\
(0.39) \\
(0.22) \\
(0.69)\end{array}$ & $\begin{array}{l}88.9 \\
86.8 \\
90.1 \\
88.9 \\
85.6\end{array}$ & $\begin{array}{l}(0.19) \\
0.40 \\
0.33) \\
(0.19 \\
0.67)\end{array}$ & $\begin{array}{l}24.8 \\
23.8 \\
29.2 \\
27.1 \\
31.0\end{array}$ & $\begin{array}{l}(0.21) \\
0.42 \\
0.33 \\
(0.20) \\
0.61)\end{array}$ & $\begin{array}{l}25.5 \\
23.6 \\
29.6 \\
27.3 \\
31.8\end{array}$ & $\begin{array}{l}(0.29) \\
0.52) \\
(0.49) \\
(0.27) \\
(0.81)\end{array}$ & $\begin{array}{l}24.2 \\
23.9 \\
28.8 \\
26.8 \\
30.3\end{array}$ & $\begin{array}{l}(0.29) \\
0.54) \\
0.42) \\
(0.25) \\
(0.78)\end{array}$ & $\begin{array}{l}88.9 \\
86.6 \\
90.1 \\
88.9 \\
85.8\end{array}$ & $\left.\begin{array}{l}(0.15) \\
0.30 \\
0.23 \\
0.15 \\
0.53\end{array}\right)$ & $\begin{array}{l}88.3 \\
86.1 \\
89.1 \\
88.6 \\
85.4\end{array}$ & $\begin{array}{l}(0.18) \\
0.43 \\
(0.36) \\
(0.20) \\
(0.76)\end{array}$ & $\begin{array}{l}89.4 \\
87.1 \\
91.1 \\
89.2 \\
86.2\end{array}$ & $\begin{array}{l}(0.19) \\
0.36 \\
0.26) \\
0.18 \\
0.57)\end{array}$ & $\begin{array}{l}25.2 \\
23.7 \\
30.2 \\
28.1 \\
31.2\end{array}$ & $\begin{array}{l}(0.19) \\
0.38 \\
0.35) \\
(0.23) \\
0.65)\end{array}$ & $\begin{array}{l}25.5 \\
23.3 \\
30.3 \\
28.5 \\
31.7\end{array}$ & $\begin{array}{l}(0.23) \\
0.48 \\
(0.43) \\
(0.30) \\
(0.90)\end{array}$ & $\begin{array}{l}24.9 \\
24.0 \\
30.0 \\
27.7 \\
30.8\end{array}$ & $\begin{array}{l}(0.26) \\
0.48 \\
0.40 \\
(0.26) \\
0.71)\end{array}$ \\
\hline 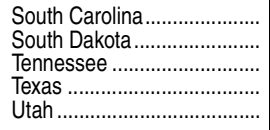 & $\begin{array}{l}84.2 \\
90.4 \\
84.2 \\
81.1 \\
90.7\end{array}$ & $\begin{array}{l}(0.25) \\
(0.52) \\
(0.21) \\
0.13) \\
0.28)\end{array}$ & $\begin{array}{l}82.9 \\
89.5 \\
83.0 \\
80.5 \\
90.0\end{array}$ & $\begin{array}{l}(0.40) \\
(0.69) \\
(0.30) \\
0.17) \\
0.39)\end{array}$ & $\begin{array}{l}85.4 \\
91.3 \\
85.3 \\
81.6 \\
91.4\end{array}$ & $\begin{array}{l}(0.31) \\
(0.67) \\
(0.27) \\
0.17 \\
0.31)\end{array}$ & $\begin{array}{l}23.8 \\
25.7 \\
23.7 \\
26.5 \\
29.7\end{array}$ & $\begin{array}{l}(0.35) \\
(0.92) \\
(0.26) \\
0.15 \\
0.47)\end{array}$ & $\begin{array}{l}23.7 \\
25.1 \\
23.5 \\
26.9 \\
32.7\end{array}$ & $\begin{array}{l}(0.43) \\
(1.09) \\
(0.36) \\
(0.20 \\
0.64)\end{array}$ & $\begin{array}{l}23.8 \\
26.3 \\
23.8 \\
26.1 \\
26.8\end{array}$ & $\begin{array}{l}(0.40) \\
(1.25) \\
(0.30) \\
0.18 \\
0.60)\end{array}$ & $\begin{array}{l}84.9 \\
90.6 \\
85.1 \\
81.5 \\
91.3\end{array}$ & $\begin{array}{l}(0.20) \\
(0.49) \\
(0.23) \\
0.11 \\
0.32)\end{array}$ & $\begin{array}{l}83.8 \\
90.0 \\
84.2 \\
80.8 \\
91.0\end{array}$ & $\begin{array}{l}(0.31) \\
(0.74) \\
(0.30) \\
0.18 \\
(0.41)\end{array}$ & $\begin{array}{l}85.8 \\
91.2 \\
85.9 \\
82.2 \\
91.6\end{array}$ & $\begin{array}{l}(0.29) \\
(0.70) \\
(0.28) \\
0.14 \\
0.42)\end{array}$ & $\begin{array}{l}25.3 \\
26.7 \\
24.6 \\
26.9 \\
30.7\end{array}$ & $\begin{array}{l}(0.34) \\
(1.02) \\
(0.21) \\
(0.14) \\
0.45)\end{array}$ & $\begin{array}{l}25.4 \\
26.1 \\
24.3 \\
27.0 \\
33.0\end{array}$ & $\begin{array}{l}(0.47) \\
(1.33) \\
(0.31) \\
0.18 \\
(0.53)\end{array}$ & $\begin{array}{l}25.3 \\
27.2 \\
24.8 \\
26.9 \\
28.5\end{array}$ & $\begin{array}{l}(0.38) \\
(1.16) \\
(0.29) \\
0.19 \\
0.64)\end{array}$ \\
\hline 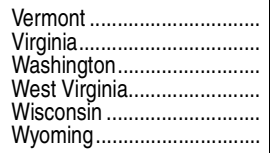 & $\begin{array}{l}92.0 \\
87.8 \\
90.0 \\
83.9 \\
90.5 \\
92.4\end{array}$ & $\begin{array}{l}(0.50) \\
(0.16) \\
(0.18) \\
0.42 \\
0.22) \\
(0.52)\end{array}$ & $\begin{array}{l}90.6 \\
87.0 \\
89.7 \\
82.7 \\
89.5 \\
91.3\end{array}$ & $\begin{array}{l}(0.77) \\
(0.23) \\
(0.26) \\
0.59 \\
0.27) \\
(0.78)\end{array}$ & $\begin{array}{l}93.3 \\
88.5 \\
90.3 \\
85.0 \\
91.4 \\
93.5\end{array}$ & $\begin{array}{l}(0.59) \\
0.21) \\
(0.23) \\
0.52 \\
(0.29) \\
(0.64)\end{array}$ & $\begin{array}{l}37.0 \\
35.4 \\
31.8 \\
18.6 \\
26.4 \\
24.8\end{array}$ & $\begin{array}{l}(1.20) \\
(0.27) \\
(0.31) \\
0.52 \\
(0.34) \\
(1.04)\end{array}$ & $\begin{array}{l}33.0 \\
36.0 \\
32.9 \\
18.7 \\
25.5 \\
23.1\end{array}$ & $\begin{array}{l}(1.46) \\
0.32 \\
(0.40) \\
0.69 \\
(0.43 \\
(1.35)\end{array}$ & $\begin{array}{l}40.9 \\
34.7 \\
30.6 \\
18.6 \\
27.2 \\
26.5\end{array}$ & $\begin{array}{l}(1.52) \\
0.35) \\
0.37) \\
0.57 \\
0.45) \\
(1.23)\end{array}$ & $\begin{array}{l}92.3 \\
88.1 \\
90.6 \\
83.9 \\
90.9 \\
91.5\end{array}$ & $\begin{array}{l}(0.51) \\
(0.15) \\
(0.18) \\
0.44) \\
(0.21) \\
(0.58)\end{array}$ & $\begin{array}{l}90.9 \\
87.4 \\
90.0 \\
83.0 \\
90.0 \\
91.5\end{array}$ & $\begin{array}{l}(0.68) \\
(0.23) \\
(0.25) \\
0.67 \\
(0.29) \\
(0.75)\end{array}$ & $\begin{array}{l}93.6 \\
88.7 \\
91.1 \\
84.8 \\
91.7 \\
91.6\end{array}$ & $\begin{array}{l}(0.63) \\
(0.20) \\
(0.21) \\
0.52 \\
0.23) \\
(0.84)\end{array}$ & $\begin{array}{l}35.1 \\
35.7 \\
31.8 \\
18.2 \\
27.5 \\
25.4\end{array}$ & $\begin{array}{l}(1.07) \\
0.25) \\
(0.32) \\
(0.40) \\
(0.36) \\
(1.02)\end{array}$ & $\begin{array}{l}32.9 \\
36.2 \\
32.4 \\
17.7 \\
26.8 \\
25.0\end{array}$ & $\begin{array}{l}(1.14) \\
(0.32) \\
0.38 \\
0.52 \\
(0.42) \\
(1.23)\end{array}$ & $\begin{array}{l}37.3 \\
35.4 \\
31.3 \\
18.7 \\
28.1 \\
25.8\end{array}$ & $\begin{array}{l}(1.46) \\
0.31 \\
0.39 \\
0.52 \\
0.46 \\
(1.30)\end{array}$ \\
\hline
\end{tabular}


Table 104.90. Percentage distribution of spring 2002 high school sophomores, by highest level of education completed through 2012 and selected student characteristics: 2012

[Standard errors appear in parentheses]

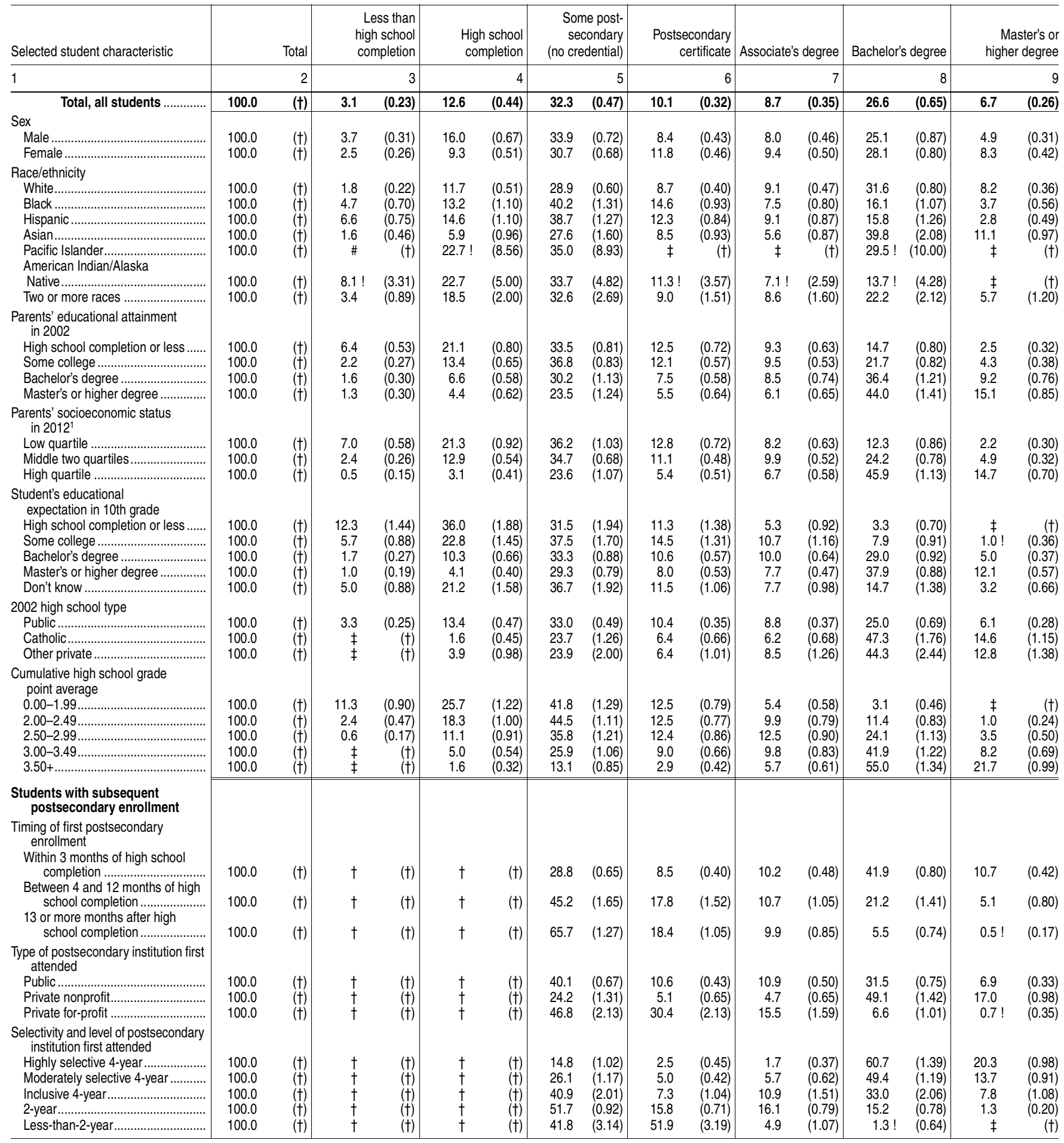

†Not applicable.

\#Rounds to zero.

Interpret data with caution. The coefficient of variation (CV) for this estimate is between 30 and 50 percent.

fReporting standards not met. Either there are too few cases for a reliable estimate or the coefficient of variation $(\mathrm{CV})$ is 50 percent or greater.
1Socioeconomic status (SES) was measured by a composite score on parental education and occupations, and family income.

NOTE: Race categories exclude persons of Hispanic ethnicity. Detail may not sum to totals because of rounding.

SOURCE: U.S. Department of Education, National Center for Education Statistics, Education Longitudinal Study of 2002 (ELS:2002), Third Follow-up. (This table was prepared May 2014.) 
Table 104.95. Number of persons age 25 and over in metropolitan areas with populations greater than 1 million and rates of high school completion and bachelor's degree attainment among persons in this age group, by sex: 2013

[Standard errors appear in parentheses]

\begin{tabular}{|c|c|c|c|c|c|c|c|c|c|c|c|c|c|c|c|c|c|c|}
\hline \multirow[b]{2}{*}{ Metropolitan area } & \multicolumn{6}{|c|}{ Number of persons 25 years old and over (in thousands) } & \multicolumn{6}{|c|}{ Percent with high school completion or higher } & \multicolumn{6}{|c|}{ Percent with bachelor's or higher degree } \\
\hline & & Total & & Males & & Females & & Total & & Male & & Female & & Total & & Male & & Female \\
\hline 1 & & 2 & & 3 & & 4 & & 5 & & 6 & & 7 & & 8 & & 9 & & $\overline{10}$ \\
\hline 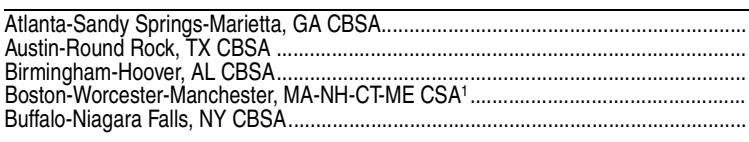 & $\begin{array}{r}3,516 \\
1,282 \\
818 \\
3,885 \\
800\end{array}$ & $\begin{array}{r}(205.4) \\
(88.0) \\
(57.2) \\
(101.4) \\
(49.8)\end{array}$ & $\begin{array}{r}1,648 \\
666 \\
396 \\
1,836 \\
396\end{array}$ & $\begin{array}{r}(101.9) \\
(44.4) \\
(30.1) \\
(58.1) \\
(30.6)\end{array}$ & $\begin{array}{r}1,867 \\
616 \\
422 \\
2,049 \\
404\end{array}$ & $\begin{array}{r}(111.2) \\
(51.7 \\
(31.0) \\
(52.5) \\
(26.0)\end{array}$ & $\begin{array}{l}90.6 \\
87.9 \\
91.9 \\
89.8\end{array}$ & $\begin{array}{l}(1.43) \\
(2.12) \\
(2.21) \\
(1.07) \\
(2.29)\end{array}$ & $\begin{array}{l}89.0 \\
89.2 \\
85.7 \\
92.8 \\
90.9\end{array}$ & $\begin{array}{l}(1.92) \\
(2.99) \\
(2.69) \\
(1.08) \\
(3.03)\end{array}$ & 00.1 & $\begin{array}{l}(1.40) \\
(1.81) \\
(2.66) \\
(1.34) \\
(3.00)\end{array}$ & $\begin{array}{l}49.0 \\
27.7 \\
45.7 \\
26.5\end{array}$ & $\begin{array}{l}4.13 \\
.2 .01 \\
3.91)\end{array}$ & $\begin{array}{l}49.5 \\
27.6\end{array}$ & $\begin{array}{l}(3.11) \\
3.97) \\
(4.57) \\
(2.28) \\
(4.79)\end{array}$ & $\begin{array}{l}39.8 \\
48.5 \\
27.7 \\
44.2 \\
24.9\end{array}$ & $\begin{array}{l}(2.31) \\
(4.16) \\
(4.61) \\
(2.17) \\
(4.64)\end{array}$ \\
\hline 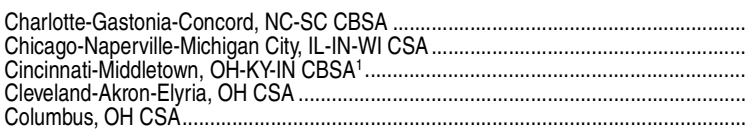 & $\begin{array}{l}1,143 \\
6,339 \\
1,313 \\
1,832 \\
1,133\end{array}$ & $\begin{array}{r}(70.7) \\
(253.9) \\
(71.3) \\
(78.1) \\
(64.4)\end{array}$ & $\begin{array}{r}544 \\
3,045 \\
634 \\
873 \\
551\end{array}$ & $\begin{array}{r}(42.5) \\
(122.1) \\
(39.4) \\
(47.7) \\
(34.8)\end{array}$ & $\begin{array}{r}600 \\
3,295 \\
679 \\
958 \\
583\end{array}$ & $\begin{array}{r}(37.0) \\
(14.9) \\
(38.9) \\
(43.0) \\
(39.3)\end{array}$ & $\begin{array}{l}86.9 \\
90.7 \\
88.9 \\
90.9 \\
93.2\end{array}$ & $\begin{array}{l}(2.69) \\
(1.76) \\
(1.47) \\
(1.42)\end{array}$ & $\begin{array}{l}84.6 \\
90.2 \\
88.6 \\
88.7 \\
92.8\end{array}$ & $\begin{array}{l}(3.44) \\
(.97) \\
(2.10) \\
(2.38) \\
(2.01)\end{array}$ & $\begin{array}{l}89.0 \\
91.2 \\
89.2\end{array}$ & $\begin{array}{l}(2.23) \\
(0.78 \\
(2.09) \\
(1.29) \\
(1.48)\end{array}$ & $\begin{array}{l}33.8 \\
39.0 \\
27.1 \\
29.7 \\
33.0\end{array}$ & & $\begin{array}{l}36.7 \\
40.3 \\
29.5\end{array}$ & $\begin{array}{l}(4.93) \\
(1.80) \\
(2.98) \\
(3.34) \\
(4.30)\end{array}$ & $\begin{array}{l}31.2 \\
37.9 \\
24.9 \\
28.4 \\
31.3\end{array}$ & $\begin{array}{l}(3.72) \\
(1.64) \\
(2.84) \\
(2.80) \\
(4.01)\end{array}$ \\
\hline 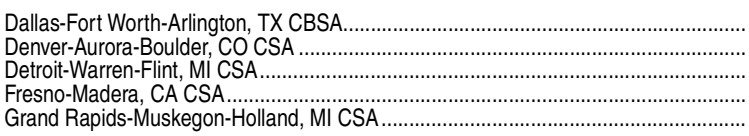 & $\begin{array}{r}4,482 \\
1,968 \\
3,592 \\
734 \\
911\end{array}$ & $\begin{array}{r}(164.3) \\
(47.7) \\
(188.3) \\
(183.2) \\
(164.5)\end{array}$ & $\begin{array}{r}2,268 \\
971 \\
1,718 \\
361 \\
428\end{array}$ & $\begin{array}{l}(96.5) \\
(33.6) \\
(96.3) \\
(84.6 \\
(79.8)\end{array}$ & $\begin{array}{r}2,214 \\
997 \\
1,874 \\
372 \\
483\end{array}$ & $\begin{array}{r}(82.9) \\
(23.6) \\
(99.0) \\
(100.0) \\
(86.5)\end{array}$ & $\begin{array}{l}83.4 \\
91.3 \\
91.9 \\
77.6 \\
95.3\end{array}$ & $\begin{array}{l}(1.43) \\
(0.98) \\
(0.97) \\
(2.49) \\
1.09)\end{array}$ & $\begin{array}{l}82.2 \\
91.1 \\
91.5 \\
75.7 \\
94.4\end{array}$ & $\begin{array}{l}(1.75) \\
(1.10) \\
(1.49) \\
(3.10) \\
1.84)\end{array}$ & $\begin{array}{l}84.7 \\
91.5 \\
92.2\end{array}$ & $\begin{array}{l}(1.46) \\
(1.23) \\
(1.08) \\
(2.95) \\
(1.12)\end{array}$ & $\begin{array}{l}33.4 \\
48.5 \\
32.2 \\
24.9 \\
29.7\end{array}$ & $(3.9$ & & $\begin{array}{l}(2.14) \\
(2.16) \\
(2.21) \\
(3.97) \\
(3.99)\end{array}$ & $\begin{array}{l}33.4 \\
47.2 \\
33.4 \\
27.5 \\
30.4\end{array}$ & $\begin{array}{l}(2.02) \\
(2.12) \\
(2.19) \\
(5.29) \\
(4.77)\end{array}$ \\
\hline 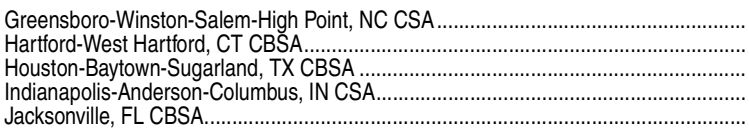 & $\begin{array}{r}1,015 \\
753 \\
4,014 \\
1,254 \\
881\end{array}$ & $\begin{array}{r}(73.6) \\
(35.2) \\
(157.4) \\
(116.1) \\
(61.5)\end{array}$ & $\begin{array}{r}478 \\
351 \\
1,995 \\
600 \\
396\end{array}$ & $\begin{array}{l}(40.4) \\
(17.9) \\
(87.0) \\
(53.5) \\
(33.7)\end{array}$ & $\begin{array}{r}537 \\
402 \\
2,019 \\
654 \\
485\end{array}$ & $\begin{array}{l}(42.3) \\
(20.8) \\
(84.5) \\
(67.2) \\
(36.5)\end{array}$ & $\begin{array}{l}87.8 \\
90.5 \\
83.5 \\
92.8 \\
93.2\end{array}$ & $\begin{array}{l}(2.76) \\
(1.29) \\
1.42 \\
(1.37) \\
(1.47)\end{array}$ & $\begin{array}{l}87.6 \\
88.7 \\
82.8 \\
91.6 \\
94.1\end{array}$ & $\begin{array}{l}(1.75) \\
(1.88) \\
(2.11)\end{array}$ & $\begin{array}{l}88.0 \\
92.0 \\
84.2 \\
94.0 \\
92.6\end{array}$ & $\begin{array}{l}(2.74) \\
(1.48 \\
1.50) \\
(1.45) \\
(1.78)\end{array}$ & $\begin{array}{l}28.9 \\
40.6 \\
29.6 \\
34.5 \\
31.3\end{array}$ & $\begin{array}{l}1.1 \\
3.7 \\
(3.2\end{array}$ & $\begin{array}{l}24.9 \\
38.8 \\
31.4 \\
36.6\end{array}$ & $\begin{array}{l}(3.66) \\
(3.32) \\
(2.00) \\
(4.53) \\
(4.78)\end{array}$ & $\begin{array}{l}32.5 \\
42.2 \\
27.8\end{array}$ & $\begin{array}{l}(4.54) \\
(3.38) \\
(1.85) \\
(3.74) \\
(3.54)\end{array}$ \\
\hline 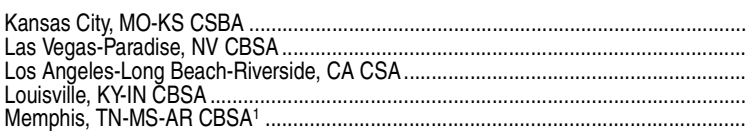 & $\begin{array}{r}1,330 \\
11,282 \\
11805 \\
851 \\
847\end{array}$ & $\begin{array}{r}(62.6) \\
(33.2) \\
(173.3) \\
(84.5) \\
(67.6)\end{array}$ & $\begin{array}{r}639 \\
628 \\
5,719 \\
413 \\
394\end{array}$ & $\begin{array}{r}(34.3) \\
(22.1) \\
(106.7) \\
(52.0) \\
(35.1)\end{array}$ & $\begin{array}{r}691 \\
654 \\
6,086 \\
438 \\
453\end{array}$ & $\begin{array}{l}(35.3) \\
(16.1) \\
(90.2) \\
(37.3) \\
(36.2)\end{array}$ & $\begin{array}{l}92.4 \\
88.9 \\
80.6 \\
90.7 \\
87.2\end{array}$ & $\begin{array}{l}(1.53) \\
(1.12) \\
(0.88) \\
(1.75) \\
(2.71)\end{array}$ & $\begin{array}{l}92.2 \\
88.3 \\
80.3 \\
90.4 \\
86.3\end{array}$ & $\begin{array}{l}(1.88) \\
(1.41) \\
(1.09) \\
(2.23) \\
(3.60)\end{array}$ & $\begin{array}{l}92.6 \\
89.4 \\
80.9\end{array}$ & $\begin{array}{l}(1.54) \\
(1.26) \\
(0.87 \\
(2.03) \\
(3.06)\end{array}$ & $\begin{array}{l}39.0 \\
22.5 \\
30.8 \\
28.4 \\
28.3\end{array}$ & & $\begin{array}{l}38.9 \\
23.0 \\
31.7\end{array}$ & $\begin{array}{l}(3.11) \\
(1.82) \\
(1.23) \\
(4.05) \\
(4.05)\end{array}$ & $\begin{array}{l}39.1 \\
22.0 \\
30.0\end{array}$ & $\begin{array}{l}(2.90) \\
(1.82) \\
(1.13) \\
(3.89) \\
(4.13)\end{array}$ \\
\hline 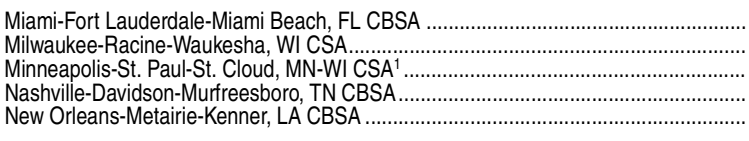 & $\begin{array}{r}4,055 \\
1,177 \\
2,337 \\
1,188 \\
736\end{array}$ & $\begin{array}{r}(140.0) \\
(148.8) \\
(49.0) \\
(211.4) \\
(47.0)\end{array}$ & $\begin{array}{r}1,875 \\
565 \\
1,158 \\
595 \\
338\end{array}$ & $\begin{array}{r}(77.6) \\
(78.9) \\
(35.9) \\
(116.0) \\
(27.7)\end{array}$ & $\begin{array}{r}2,180 \\
612 \\
1,179 \\
593 \\
397\end{array}$ & $\begin{array}{l}(74.5) \\
(72.5) \\
(21.6) \\
(97.4) \\
(29.4)\end{array}$ & $\begin{array}{l}87.8 \\
91.4 \\
93.1 \\
90.5 \\
89.1\end{array}$ & $\begin{array}{l}(1.25) \\
(1.53) \\
(0.72) \\
(2.12 \\
(1.97)\end{array}$ & $\begin{array}{l}90.1 \\
90.8\end{array}$ & $(1.58)$ & & & $\begin{array}{l}40.1 \\
39.5 \\
31.0\end{array}$ & & & & $\begin{array}{l}41.6 \\
36.7 \\
28.8\end{array}$ & $\begin{array}{l}(3.12) \\
(2.05) \\
(4.38) \\
(3.50)\end{array}$ \\
\hline 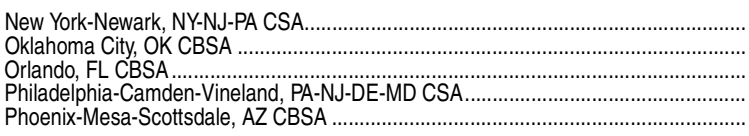 & $\begin{array}{r}14,708 \\
904 \\
1,437 \\
4,132 \\
2,840\end{array}$ & $\begin{array}{r}(208.1) \\
(41.4) \\
(88.6) \\
(110.2) \\
(244.2)\end{array}$ & $\begin{array}{r}6,871 \\
407 \\
702 \\
1,859 \\
1,435\end{array}$ & $\begin{array}{r}(124.1) \\
(26.5) \\
(47.1) \\
(62.5) \\
(126.1)\end{array}$ & $\begin{array}{r}7,837 \\
497 \\
735 \\
2,273 \\
1,405\end{array}$ & $\begin{array}{r}(106.5) \\
(21.5) \\
(48.0) \\
(65.1) \\
(121.9)\end{array}$ & $\begin{array}{l}87.5 \\
91.2 \\
90.7 \\
92.5 \\
85.3\end{array}$ & $\begin{array}{l}(0.56) \\
(1.74) \\
(1.27) \\
(0.69) \\
(1.58)\end{array}$ & $\begin{array}{l}87.5 \\
90.2 \\
88.8 \\
91.5 \\
85.1\end{array}$ & $\begin{array}{l}(0.68) \\
(2.08) \\
(1.98) \\
(0.83) \\
(2.07)\end{array}$ & $\begin{array}{l}87.6 \\
92.1 \\
92.5 \\
93.4 \\
85.5\end{array}$ & $\begin{array}{l}(0.68) \\
(2.39 \\
(1.31) \\
(0.86) \\
(1.74)\end{array}$ & $\begin{array}{l}40.1 \\
26.5 \\
34.9 \\
35.8 \\
32.1\end{array}$ & $\begin{array}{l}(0.91) \\
(2.59)\end{array}$ & $\begin{array}{l}40.9 \\
27.6 \\
34.1\end{array}$ & $\begin{array}{l}(1.19) \\
(3.41) \\
(3.10) \\
(2.00) \\
(3.02)\end{array}$ & $\begin{array}{l}39.4 \\
25.5 \\
35.8 \\
34.1 \\
30.0\end{array}$ & $\begin{array}{l}(0.95) \\
(2.54) \\
(3.21) \\
(1.87) \\
(3.15)\end{array}$ \\
\hline 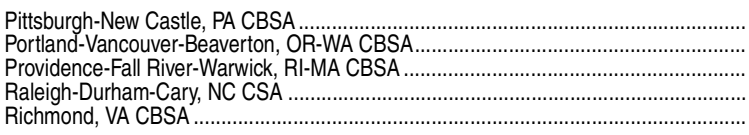 & $\begin{array}{r}1,644 \\
1,455 \\
876 \\
1,259 \\
985\end{array}$ & $\begin{array}{l}(80.8) \\
(64.4) \\
(47.1) \\
(64.6) \\
(71.9)\end{array}$ & $\begin{array}{l}786 \\
693 \\
418 \\
613 \\
466\end{array}$ & $\begin{array}{l}(44.1) \\
(39.7) \\
(24.9) \\
(39.2) \\
(35.1)\end{array}$ & $\begin{array}{l}857 \\
762 \\
459 \\
646 \\
519\end{array}$ & $\begin{array}{l}(47.6) \\
(32.1) \\
(23.8) \\
(37.5) \\
(41.3)\end{array}$ & $\begin{array}{l}92.5 \\
93.4 \\
87.9 \\
88.2 \\
88.5\end{array}$ & $\begin{array}{l}(1.14) \\
(1.15) \\
(1.29) \\
(2.03) \\
(2.50)\end{array}$ & $\begin{array}{l}92.0 \\
92.8 \\
88.4 \\
87.3 \\
88.0\end{array}$ & $\begin{array}{l}(1.54) \\
(1.43) \\
(1.29) \\
(2.72) \\
(2.28)\end{array}$ & $\begin{array}{l}92.8 \\
93.9 \\
87.5 \\
89.1 \\
89.0\end{array}$ & $\begin{array}{l}(1.47) \\
(1.16) \\
(1.82) \\
(2.09) \\
(3.42)\end{array}$ & $\begin{array}{l}35.0 \\
34.6 \\
37.3 \\
42.7 \\
33.3\end{array}$ & & 380 & $\begin{array}{l}(3.15) \\
(3.13) \\
(3.73) \\
(3.65) \\
(4.21)\end{array}$ & 32.2 & $\begin{array}{l}1.91) \\
(3.09) \\
(3.88)\end{array}$ \\
\hline 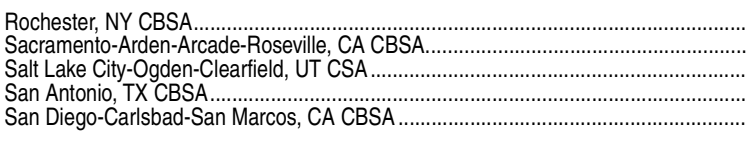 & $\begin{array}{r}698 \\
1,478 \\
1,029 \\
1,432 \\
2,004\end{array}$ & $\begin{array}{l}(47.9) \\
(79.7) \\
(39.8) \\
(82.6) \\
(79.6)\end{array}$ & $\begin{array}{l}336 \\
713 \\
504 \\
678 \\
961\end{array}$ & $\begin{array}{l}(23.4) \\
(45.5) \\
(24.1) \\
(47.3) \\
(44.8)\end{array}$ & $\begin{array}{r}361 \\
765 \\
525 \\
754 \\
1,043\end{array}$ & $\begin{array}{l}(29.7) \\
(42.8) \\
(20.7) \\
(44.5) \\
(45.5)\end{array}$ & $\begin{array}{l}92.3 \\
87.8 \\
92.7 \\
80.7 \\
89.4\end{array}$ & $\begin{array}{l}(2.25) \\
(2.13) \\
(1.15) \\
(2.57) \\
(1.46)\end{array}$ & $\begin{array}{l}92.4 \\
87.8 \\
92.1 \\
79.7 \\
91.1\end{array}$ & $\begin{array}{l}(2.98) \\
(2.78) \\
(1.58) \\
(3.13) \\
(1.63)\end{array}$ & $\begin{array}{l}92.2 \\
87.9 \\
93.2 \\
81.7 \\
87.8\end{array}$ & $\begin{array}{l}(2.72) \\
(2.17) \\
(1.17) \\
(2.57) \\
(1.69)\end{array}$ & $\begin{array}{l}39.7 \\
33.7 \\
33.7 \\
25.5 \\
41.1\end{array}$ & $(3.94)$ & $\begin{array}{l}40.7 \\
35.5 \\
35.3 \\
26.3 \\
43.4\end{array}$ & $\begin{array}{l}(5.04) \\
(4.26) \\
(2.44) \\
(3.3) \\
(2.95)\end{array}$ & $\begin{array}{l}38.8 \\
32.0 \\
32.2\end{array}$ & $\begin{array}{l}(4.53) \\
(3.03) \\
(2.78) \\
(3.01) \\
(2.71)\end{array}$ \\
\hline 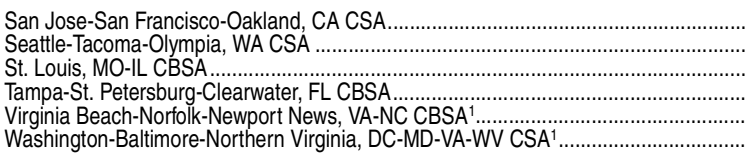 & $\begin{array}{l}5,716 \\
2,939 \\
1,890 \\
2,242 \\
1,052 \\
5,854\end{array}$ & $\begin{array}{r}(197.2) \\
(76.1) \\
(77.5) \\
(223.0) \\
(65.9) \\
(99.7)\end{array}$ & $\begin{array}{r}2,880 \\
1,417 \\
898 \\
1,066 \\
476 \\
2,774\end{array}$ & $\begin{array}{r}(108.3) \\
(47.9) \\
(44.4) \\
(118.5) \\
(38.5) \\
(60.2)\end{array}$ & $\begin{array}{r}2,836 \\
1,521 \\
992 \\
1,176 \\
576 \\
3,080\end{array}$ & $\begin{array}{r}(103.2) \\
(41.7) \\
(40.0) \\
(109.3) \\
(33.3) \\
(51.7)\end{array}$ & $\begin{array}{l}88.5 \\
94.0 \\
91.6 \\
91.7 \\
95.1 \\
91.6\end{array}$ & $\begin{array}{l}(1.06) \\
(0.69) \\
(1.31) \\
(1.02) \\
(1.05) \\
(0.64)\end{array}$ & $\begin{array}{l}87.3 \\
94.1 \\
92.2 \\
91.6 \\
94.0 \\
90.5\end{array}$ & $\begin{array}{l}(1.38) \\
(0.91) \\
(1.70) \\
1.45) \\
(1.34) \\
(0.82)\end{array}$ & $\begin{array}{l}89.7 \\
93.9 \\
91.0 \\
91.8\end{array}$ & $\begin{array}{l}(0.98) \\
(0.85) \\
(1.59) \\
(1.46) \\
(1.11 \\
(0.66)\end{array}$ & $\begin{array}{l}46.2 \\
41.7 \\
34.9 \\
28.1 \\
30.5 \\
49.2\end{array}$ & & $\begin{array}{l}47.3 \\
41.2 \\
35.9\end{array}$ & $\begin{array}{l}(1.94) \\
(2.35) \\
(3.01) \\
(2.67) \\
(4.09) \\
(1.59)\end{array}$ & $\begin{array}{l}45.0 \\
42.2 \\
33.9 \\
26.4\end{array}$ & $\begin{array}{l}(2.53) \\
(2.22) \\
(2.83) \\
(1.52)\end{array}$ \\
\hline
\end{tabular}

'Information on metropolitan status was suppressed for a small portion of sample observations. As a result, population estimates for these areas may be slightly underestimated. rounding. Standard errors were computed using replicate weights.
SOURCE: U.S. Department of Commerce, Census Bureau, Current Population Survey (CPS), March 2013. (This table was prepared February 2014.) 
CHAPTER 1: All Levels of Education

Summary of Enrollment, Teachers, and Schools

Table 105.10. Projected number of participants in educational institutions, by level and control of institution: Fall 2013

[In millions]

\begin{tabular}{|c|c|c|c|c|c|c|c|}
\hline \multirow[b]{2}{*}{ Participants } & \multirow{2}{*}{$\begin{array}{r}\text { All levels } \\
\text { (elementary, } \\
\text { secondary, and } \\
\text { degree-granting } \\
\text { postsecondary) }\end{array}$} & \multicolumn{3}{|c|}{ Elementary and secondary schools } & \multicolumn{3}{|c|}{ Degree-granting postsecondary institutions } \\
\hline & & Total & Public & Private & Total & Public & Private \\
\hline 1 & 2 & 3 & 4 & 5 & 6 & 7 & 8 \\
\hline 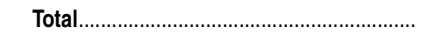 & 85.2 & 61.7 & 55.9 & 5.8 & 23.5 & 16.7 & 6.8 \\
\hline 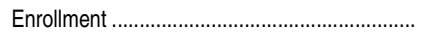 & 75.4 & 54.8 & 49.8 & 5.1 & 20.6 & 14.9 & 5.7 \\
\hline 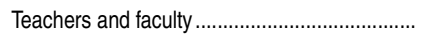 & 4.5 & 3.5 & 3.1 & 0.4 & 1.0 & 0.6 & 0.4 \\
\hline 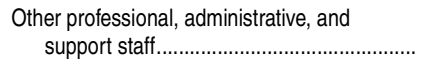 & 5.3 & 3.4 & 3.1 & 0.3 & 1.9 & 1.2 & 0.7 \\
\hline
\end{tabular}

NOTE: Includes enrollments in local public school systems and in most private schools (religiously affiliated and nonsectarian). Excludes federal Bureau of Indian Education schools and Department of Defense schools. Excludes private preprimary enrollment in schools that do not offer kindergarten or above. Degree-granting institutions grant associate's or higher degrees and participate in Title IV federal financial aid programs. Data for teachers and other staff in public and private elementary and secondary schools and col-

leges and universities are reported in terms of full-time equivalents. Detail may not sum to totals because of rounding.

SOURCE: U.S. Department of Education, National Center for Education Statistics, National Elementary and Secondary Enrollment Projection Model, 1972 through 2023; Enrollment in Degree-Granting Institutions Projection Model, 1980 through 2023; Elementary and Secondary Teacher Projection Model, 1973 through 2023; and unpublished projections and estimates. (This table was prepared March 2014.) 
54 CHAPTER 1: All Levels of Education

Summary of Enrollment, Teachers, and Schools

Table 105.20. Enrollment in educational institutions, by level and control of institution, enrollment level, and attendance status and sex of student: Selected years, fall 1990 through fall 2023

[In thousands]

\begin{tabular}{|c|c|c|c|c|c|c|c|c|c|c|c|c|c|c|c|c|}
\hline \multirow{2}{*}{$\begin{array}{l}\text { Level and control of } \\
\text { institution, enrollment level, } \\
\text { and attendance status and } \\
\text { sex of student }\end{array}$} & \multicolumn{4}{|c|}{ Actual } & \multicolumn{12}{|c|}{ Projected } \\
\hline & 1990 & 2000 & 2010 & 2011 & 2012 & 2013 & 2014 & 2015 & 2016 & 2017 & 2018 & 2019 & 2020 & 2021 & 2022 & 2023 \\
\hline 1 & 2 & 3 & 4 & 5 & 6 & 7 & 8 & 9 & 10 & 11 & 12 & 13 & 14 & 15 & 16 & 17 \\
\hline All levels .................. & 60,683 & 68,685 & 75,883 & 75,784 & 75,476 & 75,439 & 75,736 & 75,997 & 76,376 & 77,078 & 77,607 & 78,183 & 78,807 & 79,484 & 80,182 & 80,857 \\
\hline $\begin{array}{c}\text { Elementary and } \\
\text { secondary } \\
\text { schools }^{1} \ldots \ldots . .\end{array}$ & 46,864 & 53,373 & 54,867 & 54,790 & 54,833 & 54,842 & 54,725 & 54,731 & 54,790 & 55,132 & 55,380 & 55,671 & 56,010 & 56,343 & 56,684 & 57,023 \\
\hline 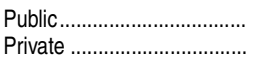 & $\begin{array}{r}41,217 \\
5,648^{2}\end{array}$ & \begin{tabular}{r|}
47,204 \\
$6,169^{2}$
\end{tabular} & $\begin{array}{r}49,484 \\
5,382\end{array}$ & $\begin{array}{r}49,522 \\
5,268\end{array}$ & $\begin{array}{r}49,652 \\
5,181\end{array}$ & $\begin{array}{r}49,750 \\
5,091\end{array}$ & $\begin{array}{r}49,751 \\
4,974\end{array}$ & $\begin{array}{r}49,839 \\
4,892 \\
\end{array}$ & $\begin{array}{r}49,951 \\
4,839 \\
\end{array}$ & $\begin{array}{r}50,280 \\
4,852 \\
\end{array}$ & $\begin{array}{r}50,543 \\
4,837\end{array}$ & $\begin{array}{r}50,834 \\
4,836 \\
\end{array}$ & $\begin{array}{r}51,165 \\
4,844\end{array}$ & $\begin{array}{r}51,485 \\
4,857\end{array}$ & $\begin{array}{r}51,804 \\
4,880\end{array}$ & $\begin{array}{r}52,113 \\
4,910\end{array}$ \\
\hline 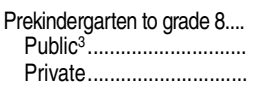 & $\begin{array}{c}34,388 \\
29,876 \\
4,512^{2}\end{array}$ & $\begin{array}{c}38,592 \\
33,686 \\
4,906^{2}\end{array}$ & $\begin{array}{r}38,708 \\
34,625 \\
4,084^{2}\end{array}$ & $\begin{array}{r}38,750 \\
34,773 \\
3,977\end{array}$ & $\begin{array}{r}38,874 \\
34,968 \\
3,906\end{array}$ & $\begin{array}{r}38,967 \\
35,111 \\
3,856\end{array}$ & $\begin{array}{r}38,839 \\
35,062 \\
3,776\end{array}$ & $\begin{array}{r}38,810 \\
35,069 \\
3,741\end{array}$ & $\begin{array}{r}38,867 \\
35,142 \\
3,725\end{array}$ & $\begin{array}{r}39,177 \\
35,412 \\
3,765\end{array}$ & $\begin{array}{r}39,424 \\
35,642 \\
3,782\end{array}$ & $\begin{array}{r}39,687 \\
35,878 \\
3,809\end{array}$ & $\begin{array}{r}39,950 \\
36,115 \\
3,835\end{array}$ & $\begin{array}{r}40,194 \\
36,335 \\
3,859\end{array}$ & $\begin{array}{r}40,470 \\
36,585 \\
3,885\end{array}$ & $\begin{array}{r}40,887 \\
36,967 \\
3,920\end{array}$ \\
\hline 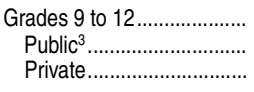 & $\begin{array}{c}12,476 \\
11,341 \\
1,136^{2} \\
\end{array}$ & $\begin{array}{c}14,781 \\
13,517 \\
1,264^{2} \\
\end{array}$ & $\begin{array}{c}16,159 \\
14,860 \\
1,2992 \\
\end{array}$ & $\begin{array}{r}16,040 \\
14,749 \\
1,291 \\
\end{array}$ & $\begin{array}{r}15,959 \\
14,684 \\
1,275 \\
\end{array}$ & $\begin{array}{r}15,874 \\
14,639 \\
1,235 \\
\end{array}$ & $\begin{array}{r}15,886 \\
14,689 \\
1,197 \\
\end{array}$ & $\begin{array}{r}15,921 \\
14,770 \\
1,150 \\
\end{array}$ & $\begin{array}{r}15,924 \\
14,810 \\
1,114 \\
\end{array}$ & $\begin{array}{r}15,955 \\
14,868 \\
1,087 \\
\end{array}$ & $\begin{array}{r}15,955 \\
14,901 \\
1,054 \\
\end{array}$ & $\begin{array}{r}15,984 \\
14,957 \\
1,027 \\
\end{array}$ & $\begin{array}{r}16,060 \\
15,050 \\
1,009 \\
\end{array}$ & $\begin{array}{r}16,149 \\
15,151 \\
998 \\
\end{array}$ & $\begin{array}{r}16,213 \\
15,219 \\
994 \\
\end{array}$ & $\begin{array}{r}16,136 \\
15,146 \\
990 \\
\end{array}$ \\
\hline $\begin{array}{l}\text { Postsecondary } \\
\text { degree-granting } \\
\text { institutions........... }\end{array}$ & 13,819 & 15,312 & 21,016 & 20,994 & $20,643^{4}$ & 20,597 & 21,011 & 21,266 & 21,586 & 21,946 & 22,227 & 22,512 & 22,797 & 23,141 & 23,499 & 23,834 \\
\hline 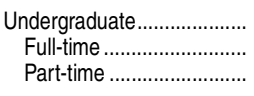 & $\begin{array}{r}11,959 \\
6,976 \\
4,983\end{array}$ & $\begin{array}{r}13,155 \\
7,923 \\
5,232\end{array}$ & $\begin{array}{r}18,079 \\
11,452 \\
6,627\end{array}$ & $\begin{array}{r}18,063 \\
11,359 \\
6,704\end{array}$ & $\begin{array}{r}17,732^{4} \\
11,098^{4} \\
6,635^{4}\end{array}$ & $\begin{array}{r}17,650 \\
11,052 \\
6,598 \\
\end{array}$ & $\begin{array}{r}17,968 \\
11,242 \\
6,726\end{array}$ & $\begin{array}{r}18,155 \\
11,325 \\
6,830\end{array}$ & $\begin{array}{r}18,397 \\
11,448 \\
6,949\end{array}$ & $\begin{array}{r}18,677 \\
11,596 \\
7,082\end{array}$ & $\begin{array}{r}18,904 \\
11,720 \\
7,184\end{array}$ & $\begin{array}{r}19,134 \\
11,850 \\
7,284\end{array}$ & $\begin{array}{r}19,360 \\
11,974 \\
7,386\end{array}$ & $\begin{array}{r}19,634 \\
12,130 \\
7,504\end{array}$ & $\begin{array}{r}19,917 \\
12,296 \\
7,621\end{array}$ & $\begin{array}{r}20,186 \\
12,452 \\
7,734\end{array}$ \\
\hline 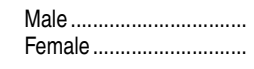 & $\begin{array}{l}5,380 \\
6,579\end{array}$ & $\begin{array}{l}5,778 \\
7,377\end{array}$ & $\begin{array}{r}7,835 \\
10,244\end{array}$ & $\begin{array}{r}7,817 \\
10,246\end{array}$ & $\begin{array}{r}7,714^{4} \\
10,019^{4}\end{array}$ & $\begin{array}{l}7,729 \\
9,921\end{array}$ & $\begin{array}{r}7,759 \\
10,209\end{array}$ & $\begin{array}{r}7,777 \\
10,378\end{array}$ & $\begin{array}{r}7,827 \\
10,571\end{array}$ & $\begin{array}{r}7,899 \\
10,778\end{array}$ & $\begin{array}{r}7,962 \\
10,942\end{array}$ & $\begin{array}{r}8,030 \\
11,104\end{array}$ & $\begin{array}{r}8,095 \\
11,265\end{array}$ & $\begin{array}{r}8,180 \\
11,454\end{array}$ & $\begin{array}{r}8,269 \\
11,648\end{array}$ & $\begin{array}{r}8,353 \\
11,833\end{array}$ \\
\hline 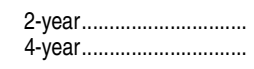 & $\begin{array}{l}5,240 \\
6,719\end{array}$ & $\begin{array}{l}5,948 \\
7,207\end{array}$ & $\begin{array}{r}7,681 \\
10,398\end{array}$ & $\begin{array}{r}7,500 \\
10,563\end{array}$ & $\begin{array}{r}7,164^{4} \\
10,568^{4}\end{array}$ & $\begin{array}{r}7,191 \\
10,459\end{array}$ & $\begin{array}{r}7,320 \\
10,648\end{array}$ & $\begin{array}{r}7,410 \\
10,745\end{array}$ & $\begin{array}{r}7,525 \\
10,873\end{array}$ & $\begin{array}{r}7,655 \\
11,022\end{array}$ & $\begin{array}{r}7,760 \\
11,144\end{array}$ & $\begin{array}{r}7,862 \\
11,272\end{array}$ & $\begin{array}{r}7,957 \\
11,403\end{array}$ & $\begin{array}{r}8,073 \\
11,561\end{array}$ & $\begin{array}{r}8,196 \\
11,721\end{array}$ & $\begin{array}{r}8,313 \\
11,873\end{array}$ \\
\hline 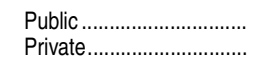 & $\begin{array}{l}9,710 \\
2,250\end{array}$ & $\begin{array}{r}10,539 \\
2,616\end{array}$ & $\begin{array}{r}13,704 \\
4,374\end{array}$ & $\begin{array}{r}13,689 \\
4,374\end{array}$ & $\begin{array}{r}13,4744^{4} \\
4,2594\end{array}$ & $\begin{array}{r}13,428 \\
4,222\end{array}$ & $\begin{array}{r}13,666 \\
4,302\end{array}$ & $\begin{array}{r}13,812 \\
4,343\end{array}$ & $\begin{array}{r}14,000 \\
4,397\end{array}$ & $\begin{array}{r}14,218 \\
4,459\end{array}$ & $\begin{array}{r}14,394 \\
4,510\end{array}$ & $\begin{array}{r}14,571 \\
4,563\end{array}$ & $\begin{array}{r}14,744 \\
4,616\end{array}$ & $\begin{array}{r}14,953 \\
4,681\end{array}$ & $\begin{array}{r}15,169 \\
4,747\end{array}$ & $\begin{array}{r}15,375 \\
4,810\end{array}$ \\
\hline 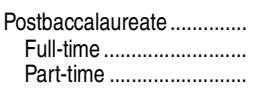 & $\begin{array}{r}1,860 \\
845 \\
1,015\end{array}$ & $\begin{array}{l}2,157 \\
1,087 \\
1,070\end{array}$ & $\begin{array}{l}2,937 \\
1,631 \\
1,307\end{array}$ & $\begin{array}{l}2,931 \\
1,642 \\
1,289\end{array}$ & $\begin{array}{l}2,910^{4} \\
1,6394 \\
1,2711^{4}\end{array}$ & $\begin{array}{l}2,947 \\
1,690 \\
1,258\end{array}$ & $\begin{array}{l}3,043 \\
1,750 \\
1,294\end{array}$ & $\begin{array}{l}3,111 \\
1,787 \\
1,324\end{array}$ & $\begin{array}{l}3,189 \\
1,830 \\
1,359\end{array}$ & $\begin{array}{l}3,269 \\
1,873 \\
1,396\end{array}$ & $\begin{array}{l}3,323 \\
1,898 \\
1,425\end{array}$ & $\begin{array}{l}3,378 \\
1,925 \\
1,453\end{array}$ & $\begin{array}{l}3,437 \\
1,955 \\
1,482\end{array}$ & $\begin{array}{l}3,507 \\
1,992 \\
1,516\end{array}$ & $\begin{array}{l}3,582 \\
2,033 \\
1,549\end{array}$ & $\begin{array}{l}3,648 \\
2,068 \\
1,580\end{array}$ \\
\hline $\begin{array}{l}\text { Male } \\
\text { Female }\end{array}$ & $\begin{array}{l}904 \\
955\end{array}$ & $\begin{array}{r}944 \\
1,213\end{array}$ & $\begin{array}{l}1,210 \\
1,728\end{array}$ & $\begin{array}{l}1,210 \\
1,722\end{array}$ & $\begin{array}{l}1,205^{4} \\
1,705^{4}\end{array}$ & $\begin{array}{l}1,255 \\
1,692\end{array}$ & $\begin{array}{l}1,278 \\
1,765\end{array}$ & $\begin{array}{l}1,296 \\
1,815\end{array}$ & $\begin{array}{l}1,319 \\
1,870\end{array}$ & $\begin{array}{l}1,344 \\
1,925\end{array}$ & $\begin{array}{l}1,361 \\
1,962\end{array}$ & $\begin{array}{l}1,378 \\
2,000\end{array}$ & $\begin{array}{l}1,396 \\
2,041\end{array}$ & $\begin{array}{l}1,419 \\
2,088\end{array}$ & $\begin{array}{l}1,443 \\
2,138\end{array}$ & $\begin{array}{l}1,464 \\
2,184\end{array}$ \\
\hline
\end{tabular}

${ }^{1}$ Includes enrollments in local public school systems and in most private schools (religiously affiliated and nonsectarian). Excludes homeschooled children who were not also enrolled in public and private schools. Private elementary enrollment includes preprimary students in schools offering kindergarten or higher grades.

'Estimated.

Includes prorated proportion of students classified as ungraded.

${ }^{4}$ Data are actual.

NOTE: Postsecondary data for 1990 are for institutions of higher education, while later data are for degree-granting institutions. Degree-granting institutions grant associate's or highe degrees and participate in Title IV federal financial aid programs. The degree-granting classification is very similar to the earlier higher education classification, but it includes more 2- year colleges and excludes a few higher education institutions that did not grant degrees. Detail may not sum to totals because of rounding. Some data have been revised from previously published figures.

SOURCE: U.S. Department of Education, National Center for Education Statistics, Common Core of Data (CCD), "State Nonfiscal Survey of Public Elementary and Secondary Education," 1990-91 through 2011-12; Parent and Family Involvement in Education Survey of the National Household Education Surveys Program (NHES), 2012; Private School Universe Survey (PSS), 1995-96 through 2011-12; National Elementary and Secondary Enrollment Projection Model, 1972 through 2023; Integrated Postsecondary Education Data System (IPEDS), "Fall Enrollment Survey" (IPEDS-EF:90-99); and IPEDS Spring 2001 through Spring 2013, Enrollment component. (This table was prepared January 2014.) 
Table 105.30. Enrollment in educational institutions, by level and control of institution: Selected years, $1869-70$ through fall 2023

[In thousands]

\begin{tabular}{|c|c|c|c|c|c|c|c|c|c|c|c|}
\hline \multirow[b]{2}{*}{ Year } & \multirow[b]{2}{*}{$\begin{array}{r}\text { Total } \\
\text { enrollment, } \\
\text { all levels }\end{array}$} & \multirow[b]{2}{*}{$\begin{array}{r}\text { Elementary } \\
\text { and second- } \\
\text { ary, total }\end{array}$} & \multicolumn{3}{|c|}{ Public elementary and secondary schools } & \multicolumn{3}{|c|}{ Private elementary and secondary schools ${ }^{1}$} & \multicolumn{3}{|c|}{ Degree-granting postsecondary institutions ${ }^{2}$} \\
\hline & & & Total & $\begin{array}{r}\text { Prekinder- } \\
\text { garten } \\
\text { through } \\
\text { grade } 8\end{array}$ & $\begin{array}{r}\text { Grades } 9 \\
\text { through } 12\end{array}$ & Total & $\begin{array}{r}\text { Prekinder- } \\
\text { garten } \\
\text { through } \\
\text { grade } 8\end{array}$ & $\begin{array}{r}\text { Grades } 9 \\
\text { through } 12\end{array}$ & Total & Public & Private \\
\hline 1 & 2 & 3 & 4 & 5 & 6 & 7 & 8 & 9 & 10 & 11 & $\overline{12}$ \\
\hline $1869-70 \ldots \ldots . . .$. & - & - & 6,872 & 6,792 & 80 & - & - & - & 52 & - & - \\
\hline $1879-80 \ldots \ldots \ldots$ & - & - & 9,868 & 9,757 & 110 & - & - & - & 116 & - & - \\
\hline $1889-90 \ldots$ & 14,491 & 14,334 & 12,723 & 12,520 & 203 & 1,611 & 1,516 & 95 & 157 & - & - \\
\hline $1899-1900 \ldots \ldots$ & 17,092 & 16,855 & 15,503 & 14,984 & 519 & 1,352 & 1,241 & 111 & 238 & - & - \\
\hline $1909-10 \ldots \ldots \ldots \ldots \ldots \ldots \ldots \ldots \ldots$ & 19,728 & 19,372 & 17,814 & 16,899 & 915 & 1,558 & 1,441 & 117 & 355 & - & - \\
\hline 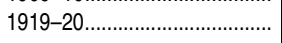 & 23,876 & 23,278 & 21,578 & 19,378 & 2,200 & 1,699 & 1,486 & 214 & 598 & - & - \\
\hline $1929-30 \ldots . .$. & 29,430 & 28,329 & 25.678 & 21,279 & 4.399 & 2.651 & 2,310 & 341 & 1,101 & - & - \\
\hline $1939-40 \ldots$ & 29,539 & 28,045 & 25,434 & 18,832 & 6,601 & 2,611 & 2,153 & 458 & 1,494 & 797 & 698 \\
\hline $1949-50 \ldots \ldots \ldots \ldots . . .$. & 31,151 & 28,492 & 25,111 & 19,387 & 5,725 & 3,380 & 2,708 & 672 & 2,659 & 1,355 & 1,304 \\
\hline Fall $1959 \ldots \ldots \ldots$. & 44,497 & 40,857 & 35,182 & 26,911 & 8,271 & 5,675 & 4,640 & 1,035 & 3,640 & 2,181 & 1,459 \\
\hline Fall $1969 \ldots$. & 59,055 & 51,050 & 45,550 & 32,513 & 13,037 & $5,500^{3}$ & $4,200^{3}$ & $1,300^{3}$ & 8,005 & 5,897 & 2,108 \\
\hline Fall $1979 \ldots \ldots \ldots$ & 58,221 & 46,651 & 41,651 & 28,034 & 13,616 & $5,000^{3}$ & $3,700^{3}$ & $1,300^{3}$ & 11,570 & 9,037 & 2,533 \\
\hline Fall $1985 \ldots \ldots \ldots \ldots$ & 57,226 & 44,979 & 39,422 & 27,034 & 12,388 & 5,557 & 4,195 & 1,362 & 12,247 & 9,479 & 2,768 \\
\hline Fall $1990 \ldots \ldots \ldots . . . .$. & 60,683 & 46,864 & 41,217 & 29,876 & 11,341 & $5,648^{3}$ & $4,512^{3}$ & $1,136^{3}$ & 13,819 & 10,845 & 2,974 \\
\hline Fall $1991 \ldots \ldots \ldots \ldots \ldots$ & 62,087 & 47,728 & 42,047 & 30,503 & 11,544 & 5,681 & 4,550 & 1,131 & 14,359 & 11,310 & 3,049 \\
\hline Fall $1992 \ldots \ldots \ldots . . .$. & 63,181 & 48,694 & 42,823 & 31,086 & 11,737 & $5,870^{3}$ & $4,746^{3}$ & $1,125^{3}$ & 14,487 & 11,385 & 3,103 \\
\hline Fall $1993 \ldots \ldots \ldots . . . .$. & 63,837 & 49,532 & 43,465 & 31,502 & 11,963 & 6,067 & 4,950 & 1,118 & 14,305 & 11,189 & 3,116 \\
\hline 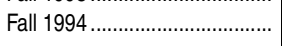 & 64,385 & 50,106 & 44,111 & 31,896 & 12,215 & $5,994^{3}$ & $4,856^{3}$ & $1,138^{3}$ & 14,279 & 11,134 & 3,145 \\
\hline Fall $1995 \ldots \ldots \ldots \ldots$ & 65,020 & 50,759 & 44,840 & 32,338 & 12,502 & 5,918 & 4,756 & 1,163 & 14,262 & 11,092 & 3,169 \\
\hline Fall $1996 \ldots \ldots \ldots \ldots . . .$. & 65,911 & 51,544 & 45,611 & 32,762 & 12,849 & $5,933^{3}$ & $4,755^{3}$ & $1,178^{3}$ & 14,368 & 11,120 & 3,247 \\
\hline Fall $1997 \ldots$ & 66,574 & 52,071 & 46,127 & 33,071 & 13,056 & 5,944 & 4,759 & 1,185 & 14,502 & 11,196 & 3,306 \\
\hline Fall $1998 \ldots$ & 67,033 & 52,526 & 46,539 & 33,344 & 13,195 & $5,988^{3}$ & $4,776^{3}$ & $1,212^{3}$ & 14,507 & 11,138 & 3,369 \\
\hline Fall $1999 \ldots \ldots \ldots . . . . .$. & 67,725 & 52,875 & 46,857 & 33,486 & 13,371 & 6,018 & 4,789 & 1,229 & 14,850 & 11,376 & 3,474 \\
\hline Fall $2000 \ldots . .$. & 68,685 & 53,373 & 47,204 & 33,686 & 13,517 & $6,169^{3}$ & $4,906^{3}$ & $1,264^{3}$ & 15,312 & 11,753 & 3,560 \\
\hline Fall $2001 \ldots .$. & 69,920 & 53,992 & 47,672 & 33,936 & 13,736 & 6,320 & 5,023 & 1,296 & 15,928 & 12,233 & 3,695 \\
\hline Fall $2002 .$. & 71,015 & 54,403 & 48,183 & 34,114 & 14,069 & $6,220^{3}$ & $4,915^{3}$ & $1,306^{3}$ & 16,612 & 12,752 & 3,860 \\
\hline Fall $2003 . . . . .$. & 71,551 & 54,639 & 48,540 & 34,201 & 14,339 & 6,099 & 4,788 & 1,311 & 16,911 & 12,859 & 4,053 \\
\hline 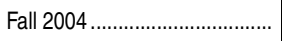 & 72,154 & 54,882 & 48,795 & 34,178 & 14,618 & $6,087^{3}$ & $4,756^{3}$ & $1,331^{3}$ & 17,272 & 12,980 & 4,292 \\
\hline Fall 2005 . & 72,674 & 55,187 & 49,113 & 34,204 & 14,909 & 6,073 & 4,724 & 1,349 & 17,487 & 13,022 & 4,466 \\
\hline Fall $2006 \ldots \ldots \ldots . .$. & 73,066 & 55,307 & 49,316 & 34,235 & 15,081 & $5,991^{3}$ & $4,631^{3}$ & $1,360^{3}$ & 17,759 & 13,180 & 4,579 \\
\hline Fall $2007 \ldots \ldots \ldots \ldots . . . .$. & 73,451 & 55,203 & 49,293 & 34,205 & 15,087 & 5,910 & 4,546 & 1,364 & 18,248 & 13,491 & 4,757 \\
\hline Fall 2008 & 74,076 & 54,973 & 49,266 & 34,286 & 14,980 & $5,707^{3}$ & $4,365^{3}$ & $1,342^{3}$ & 19,103 & 13,972 & 5,131 \\
\hline Fall 2009 ............................. & 75,277 & 54,849 & 49,361 & 34,409 & 14,952 & 5,488 & 4,179 & 1,309 & 20,428 & 14,811 & 5,617 \\
\hline Fall 2010. & 75,883 & 54,867 & 49,484 & 34,625 & 14,860 & $5,382^{3}$ & $4,084^{3}$ & $1,299^{3}$ & 21,016 & 15,143 & 5,873 \\
\hline Fall $2011 \ldots \ldots \ldots . . .$. & 75,784 & 54,790 & 49,522 & 34,773 & 14,749 & 5,268 & 3,977 & 1,291 & 20,994 & 15,110 & 5,884 \\
\hline Fall $2012^{4} \ldots$ & 75,476 & 54,833 & 49,652 & 34,968 & 14,684 & 5,181 & 3,906 & 1,275 & 20,643 & 14,880 & 5,762 \\
\hline Fall $2013^{4} \ldots$ & 75,439 & 54,842 & 49,750 & 35,111 & 14,639 & 5,091 & 3,856 & 1,235 & 20,597 & 14,857 & 5,740 \\
\hline Fall $2014^{4} \ldots \ldots \ldots \ldots \ldots \ldots \ldots$ & 75,736 & 54,725 & 49,751 & 35,062 & 14,689 & 4,974 & 3,776 & 1,197 & 21,011 & 15,140 & 5,871 \\
\hline Fall $2015^{4} \ldots$. & 75,997 & 54,731 & 49,839 & 35,069 & 14,770 & 4,892 & 3,741 & 1,150 & 21,266 & 15,319 & 5,947 \\
\hline Fall $2016^{4} \ldots \ldots$ & 76,376 & 54,790 & 49,951 & 35,142 & 14,810 & 4,839 & 3,725 & 1,114 & 21,586 & 15,545 & 6,041 \\
\hline Fall $2017^{4} \ldots$ & 77,078 & 55,132 & 50,280 & 35,412 & 14,868 & 4,852 & 3,765 & 1,087 & 21,946 & 15,802 & 6,144 \\
\hline Fall $2018^{4} \ldots \ldots \ldots \ldots$ & 77,607 & 55,380 & 50,543 & 35,642 & 14,901 & 4,837 & 3,782 & 1,054 & 22,227 & 16,004 & 6,223 \\
\hline Fall $2019^{4} \ldots \ldots \ldots \ldots \ldots \ldots \ldots \ldots$ & 78,183 & 55,671 & 50,834 & 35,878 & 14,957 & 4,836 & 3,809 & 1,027 & 22,512 & 16,208 & 6,304 \\
\hline Fall $2020^{4} \ldots$ & 78,807 & 56,010 & 51,165 & 36,115 & 15.050 & 4,844 & 3,835 & 1,009 & 22,797 & 16,410 & 6,388 \\
\hline Fall $2021^{4} \ldots$ & 79,484 & 56,343 & 51,485 & 36,335 & 15,151 & 4,857 & 3,859 & 998 & 23,141 & 16,652 & 6,489 \\
\hline Fall $2022^{4} \ldots$ & 80,182 & 56,684 & 51,804 & 36,585 & 15,219 & 4,880 & 3,885 & 994 & 23,499 & 16,905 & 6,594 \\
\hline 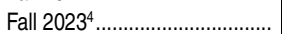 & 80,857 & 57,023 & 52,113 & 36,967 & 15,146 & 4,910 & 3,920 & 990 & 23,834 & 17,143 & 6,691 \\
\hline
\end{tabular}

-Not available.

${ }^{1}$ Beginning in fall 1989, data include estimates for an expanded universe of private schools. Therefore, direct comparisons with earlier years should be avoided.

${ }^{2}$ Data for 1869-70 through 1949-50 include resident degree-credit students enrolled at any time during the academic year. Beginning in 1959, data include all resident and extension students enrolled at the beginning of the fall term.

${ }^{3}$ Estimated.

${ }^{4}$ Projected data. Fall 2012 data for degree-granting institutions are actual.

NOTE: Data for 1869-70 through 1949-50 reflect enrollment for the entire school year. Elementary and secondary enrollment includes students in local public school systems and in most private schools (religiously affiliated and nonsectarian), but generally excludes homeschooled children and students in subcollegiate departments of colleges and in federal schools. Excludes preprimary pupils in private schools that do not offer kindergarten or above. Postsecondary data through 1995 are for institutions of higher education, while later data are for degree-granting institutions. Degree-granting institution grant associate's or higher degrees and participate in Title IV federal financial aid programs. The degree-granting classification is very similar to the earlier higher education classification, but it includes more 2-year colleges and excludes a few higher education institutions that did not grant degrees. Some data have been revised from previously published figures. Detail may not sum to totals because of rounding.

SOURCE: U.S. Department of Education, National Center for Education Statistics, Annual Report of the Commissioner of Education, 1870 to 1910; Biennial Survey of Education in the United States, 1919-20 through 1949-50; Statistics of Public Elementary and Secondary School Systems, 1959 through 1979; Common Core of Data (CCD), "State Nonfiscal Survey of Public Elementary and Secondary Education," 1985-86 through 2011-12; Parent and Family Involvement in Education Survey of the National Household Education Surveys Program (NHES), 2012; Private School Universe Survey (PSS), 1991-92 through 2009-10; National Elementary and Secondary Enrollment Projection Model, 1972 through 2023; Opening (Fall) Enrollment in Higher Education, 1959; ection Model, 1972 through 2023; Opening (Fall) Enroll "Fall in Higher Education, Higher Education" surveys, 1969, 1979, and 1985; Integrated Postsecondary Education Data System (IPEDS), "Fall Enrollment Survey" (IPEDS-EF:90-99); IPEDS Spring 2001 through Spring 2013, Enrollment component; and Enrollment in Degree-Granting Institutions Projection Model, 1980 through 2023. (This table was prepared January 2014.) 
Table 105.40. Number of teachers in elementary and secondary schools, and instructional staff in degree-granting postsecondary institutions, by control of institution: Selected years, fall 1970 through fall 2023

[In thousands]

\begin{tabular}{|c|c|c|c|c|c|c|c|c|c|}
\hline \multirow[b]{2}{*}{ Year } & \multicolumn{3}{|c|}{ All levels } & \multicolumn{3}{|c|}{ Elementary and secondary teachers ${ }^{1}$} & \multicolumn{3}{|c|}{ Degree-granting institutions instructional staff ${ }^{2}$} \\
\hline & Total & Public & Private & Total & Public & Private & Total & Public & Private \\
\hline 1 & 2 & 3 & 4 & 5 & 6 & 7 & 8 & 9 & 10 \\
\hline $1970 \ldots \ldots \ldots \ldots \ldots \ldots$ & 2,766 & 2,373 & 393 & 2,292 & 2,059 & 233 & 474 & 314 & 160 \\
\hline$\ldots \ldots \ldots \ldots \ldots \ldots$ & 3,081 & 2,641 & 440 & 2,453 & 2,198 & $255^{3}$ & 628 & 443 & 185 \\
\hline 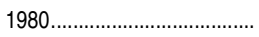 & 3,171 & 2,679 & 492 & 2,485 & 2,184 & 301 & $686^{3,4}$ & $495^{3,4}$ & $191^{3,4}$ \\
\hline 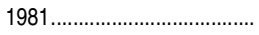 & 3,145 & 2,636 & 509 & 2,440 & 2,127 & $313^{3}$ & 705 & 509 & 196 \\
\hline $1982 \ldots$ & 3,168 & 2,639 & 529 & 2,458 & 2,133 & $325^{3}$ & $710^{3,4}$ & $506^{3,4}$ & $204^{3,4}$ \\
\hline 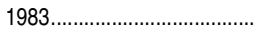 & 3,200 & 2,651 & 549 & 2,476 & 2,139 & 337 & 724 & 512 & 212 \\
\hline$\ldots$ & 3,225 & 2,673 & 552 & 2,508 & 2,168 & $340^{3}$ & $717^{3,4}$ & $505^{3,4}$ & $212^{3,4}$ \\
\hline ……………....... & 3,264 & 2,709 & 555 & 2,549 & 2,206 & 343 & $715^{3,4}$ & $503^{3,4}$ & $212^{3,4}$ \\
\hline$\ldots$ & 3,314 & 2,754 & 560 & 2,592 & 2,244 & $348^{3}$ & $722^{3,4}$ & $510^{3,4}$ & $212^{3,4}$ \\
\hline .................. & 3,424 & 2,832 & 592 & 2,631 & 2,279 & 352 & 793 & 553 & 240 \\
\hline ...…………....... & 3,472 & 2,882 & 590 & 2,668 & 2,323 & 345 & $804^{3}$ & $559^{3}$ & $245^{3}$ \\
\hline$\ldots \ldots \ldots \ldots \ldots \ldots \ldots$ & 3,537 & 2,934 & 603 & 2,713 & 2,357 & 356 & 824 & 577 & 247 \\
\hline$\ldots \ldots \ldots \ldots \ldots \ldots . . .$. & 3,577 & 2,972 & 604 & 2,759 & 2,398 & $361^{3}$ & $817^{3}$ & $574^{3}$ & $244^{3}$ \\
\hline . & 3,623 & 3,013 & 610 & 2,797 & 2,432 & 365 & 826 & 581 & 245 \\
\hline . & 3,700 & 3,080 & 621 & 2,823 & 2,459 & $364^{3}$ & $877^{3}$ & $621^{3}$ & $257^{3}$ \\
\hline 1993......................... & 3,784 & 3,154 & 629 & 2,868 & 2,504 & 364 & 915 & 650 & 265 \\
\hline $1994 \ldots \ldots \ldots$ & 3,846 & 3,205 & 640 & 2,922 & 2,552 & $370^{3}$ & $923^{3}$ & $653^{3}$ & $270^{3}$ \\
\hline $1995 \ldots$ & 3,906 & 3,255 & 651 & 2,974 & 2,598 & 376 & 932 & 657 & 275 \\
\hline$\ldots \ldots \ldots \ldots \ldots$ & 4,006 & 3,339 & 666 & 3,051 & 2,667 & $384^{3}$ & $954^{3}$ & $672^{3}$ & $282^{3}$ \\
\hline 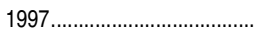 & 4,127 & 3,441 & 687 & 3,138 & 2,746 & 391 & 990 & 695 & 295 \\
\hline$\ldots \ldots \ldots \ldots \ldots \ldots \ldots$ & 4,230 & 3,527 & 703 & 3,230 & 2,830 & $400^{3}$ & $999^{3}$ & $697^{3}$ & $303^{3}$ \\
\hline$\ldots \ldots \ldots \ldots \ldots \ldots$ & 4,347 & 3,624 & 723 & 3,319 & 2,911 & 408 & 1,028 & 713 & 315 \\
\hline 2000 & 4,433 & 3,682 & 750 & 3,366 & 2,941 & 424 & $1,067^{3}$ & $741^{3}$ & $325^{3}$ \\
\hline $2001 \ldots$ & 4,554 & 3,771 & 783 & 3,440 & 3,000 & 441 & 1,113 & 771 & 342 \\
\hline $2002 \ldots$ & 4,631 & 3,829 & 802 & 3,476 & 3,034 & $442^{3}$ & $1,155^{3}$ & $794^{3}$ & $361^{3}$ \\
\hline 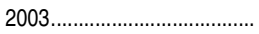 & 4,663 & 3,840 & 823 & 3,490 & 3,049 & 441 & 1,174 & 792 & 382 \\
\hline $2004 \ldots \ldots \ldots \ldots \ldots \ldots \ldots \ldots \ldots$ & 4,774 & 3,909 & 865 & 3,538 & 3,091 & $447^{3}$ & $1,237^{3}$ & $818^{3}$ & $418^{3}$ \\
\hline ……………........ & 4,883 & 3,984 & 899 & 3,593 & 3,143 & 450 & 1,290 & 841 & 449 \\
\hline (1) & 4,944 & 4,021 & 924 & 3,622 & 3,166 & $456^{3}$ & $1,322^{3}$ & $854^{3}$ & $468^{3}$ \\
\hline$\ldots$ & 5,006 & 4,055 & 951 & 3,634 & 3,178 & 456 & 1,371 & 877 & 494 \\
\hline 2008 & 5,059 & 4,107 & 953 & 3,670 & 3,222 & $448^{3}$ & $1,390^{3}$ & $885^{3}$ & $505^{3}$ \\
\hline 2009 & 5,086 & 4,123 & 963 & 3,647 & 3,210 & 437 & 1,439 & 914 & 525 \\
\hline $2010 \ldots \ldots \ldots \ldots$ & 5,032 & 4,044 & 989 & 3,529 & 3,099 & 4293 & $1,504^{3}$ & $945^{3}$ & $559^{3}$ \\
\hline 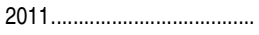 & 5,048 & 4,056 & 991 & 3,524 & 3,103 & 421 & 1,524 & 953 & 570 \\
\hline $2012^{5} \ldots$ & - & - & - & 3,525 & 3,111 & 414 & - & - & - \\
\hline $2013^{5} \ldots \ldots \ldots \ldots \ldots \ldots \ldots \ldots$ & - & - & - & 3,524 & 3,118 & 407 & - & - & - \\
\hline $2014^{5} \ldots \ldots \ldots \ldots \ldots \ldots \ldots \ldots$ & - & - & - & 3,515 & 3,118 & 397 & - & - & - \\
\hline $2015^{5} \ldots \ldots \ldots \ldots \ldots \ldots$ & - & - & - & 3,514 & 3,123 & 391 & - & - & - \\
\hline $2016^{5} \ldots \ldots \ldots \ldots \ldots \ldots \ldots \ldots$ & - & - & - & 3,544 & 3,155 & 390 & - & - & - \\
\hline $2017^{5} \ldots \ldots \ldots \ldots \ldots \ldots \ldots \ldots \ldots$ & - & - & - & 3,593 & 3,199 & 394 & - & - & - \\
\hline $2018^{5}$ & - & - & - & 3,630 & 3,235 & 395 & - & - & - \\
\hline $2019^{5} \ldots \ldots \ldots \ldots \ldots \ldots \ldots \ldots \ldots$ & - & - & - & 3,666 & 3,269 & 397 & - & - & - \\
\hline $2020^{5} \ldots \ldots \ldots \ldots \ldots \ldots \ldots$ & - & - & - & 3,699 & 3,300 & 398 & - & - & - \\
\hline $2021^{5} \ldots \ldots \ldots \ldots \ldots \ldots \ldots$ & - & - & - & 3,736 & 3,335 & 401 & - & - & - \\
\hline $2022^{5} \ldots \ldots \ldots \ldots \ldots \ldots \ldots \ldots \ldots \ldots$ & - & - & - & 3,776 & 3,371 & 405 & - & - & - \\
\hline $2023^{5} \ldots \ldots \ldots \ldots \ldots \ldots \ldots \ldots$ & - & - & - & 3,817 & 3,408 & 409 & - & - & - \\
\hline
\end{tabular}

-Not available.

${ }^{1}$ Includes teachers in local public school systems and in most private schools (religiously affiliated and nonsectarian). Teachers are reported in terms of full-time equivalents.

2Data through 1995 are for institutions of higher education, while later data are for degreegranting institutions. Degree-granting institutions grant associate's or higher degrees and participate in Title IV federal financial aid programs. The degree-granting classification is very similar to the earlier higher education classification, but it includes more 2-year colleges and excludes a few higher education institutions that did not grant degrees. Includes full-time and part-time faculty with the rank of instructor or above in colleges, universities, professional schools, and 2-year colleges. Excludes teaching assistants.

${ }^{3}$ Estimated.

${ }^{4}$ Inclusion of institutions is not consistent with surveys for 1987 and later years.

${ }^{5}$ Projected.
NOTE: Detail may not sum to totals because of rounding. Some data have been revised from previously published figures. Headcounts are used to report data for degree-granting institutions instructional staff.

SOURCE: U.S. Department of Education, National Center for Education Statistics, Statistics of Public Elementary and Secondary Day Schools, 1970 and 1975; Common Core of Data (CCD), "State Nonfiscal Survey of Public Elementary/Secondary Education," 1980 through 2011: Private School Universe Survey (PSS), 1989-90 through 2011-12; Elementary and Secondary Teacher Projection Model, 1973 through 2023; Higher Education General InforSecondary Teacher Projection Model, 1973 through 2023; Higher Education General Infor-
mation Survey (HEGIS), "Fall Staff" survey, 1970 and 1975; Integrated Postsecondary Education Data System (IPEDS), "Fall Staff Survey" (IPEDS-S:87-99); IPEDS Winter 2001-02 through Winter 2011-12, Human Resources component, Fall Staff section; U.S. Equal Opportunity Commission, EEO-6, 1981 and 1983; and unpublished data. (This table was prepared February 2014.) 
Table 105.50. Number of educational institutions, by level and control of institution: Selected years, 1980-81 through 2011-12

\begin{tabular}{|c|c|c|c|c|c|c|c|c|c|c|c|c|c|c|}
\hline Level and control of institution & $1980-81$ & 1990-91 & $\begin{array}{r}1999 \\
2000\end{array}$ & 2000-01 & $2001-02$ & 2003-04 & $2004-05$ & $2005-06$ & $2006-07$ & $2007-08$ & $2008-09$ & $2009-10$ & $2010-11$ & $2011-12$ \\
\hline 1 & 2 & 3 & 4 & 5 & 6 & 7 & 8 & 9 & 10 & 11 & 12 & 13 & 14 & 15 \\
\hline All institutions .................. & - & - & 131,414 & - & 136,465 & 136,819 & - & 138,899 & - & 139,207 & - & 138,925 & - & 136,423 \\
\hline $\begin{array}{l}\text { Elementary and } \\
\text { secondary schools .... }\end{array}$ & 106,746 & 109,228 & 125,007 & - & 130,007 & 130,407 & - & 132,436 & 一 & 132,656 & - & 132,183 & - & 129,189 \\
\hline 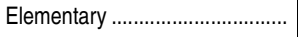 & 72,659 & 74,716 & 86,433 & - & 89,277 & 89,252 & - & 88,896 & - & 88,982 & - & 88,565 & - & 86,386 \\
\hline Secondary & 24,856 & 23,602 & 24,903 & - & 24,884 & 25,476 & - & 26,925 & - & 27,575 & - & 27,427 & - & 27,034 \\
\hline Combined & 5,202 & 8,847 & 12,197 & - & 14,430 & 13,931 & - & 14,964 & - & 14,837 & - & 14,895 & - & 14,799 \\
\hline Other ${ }^{1} \ldots \ldots \ldots \ldots \ldots \ldots \ldots \ldots \ldots \ldots \ldots \ldots \ldots \ldots$ & 4,029 & 2,063 & 1,474 & - & 1,416 & 1,749 & - & 1,651 & - & 1,262 & - & 1,296 & - & 971 \\
\hline 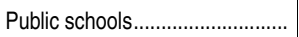 & 85,982 & 84,538 & 92,012 & 93,273 & 94,112 & 95,726 & 96,513 & 97,382 & 98,793 & 98,916 & 98,706 & 98,817 & 98,817 & 98,328 \\
\hline Elementary................................ & 59,326 & 59,015 & 64,131 & 64,601 & 65,228 & 65,758 & 65,984 & 66,026 & 66,458 & 67,112 & 67,148 & 67,140 & 67,086 & 66,689 \\
\hline 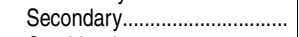 & 22,619 & 21,135 & 22,365 & 21,994 & 22,180 & 22,782 & 23,445 & 23,998 & 23,920 & 24,643 & 24,348 & 24,651 & 24,544 & 24,357 \\
\hline 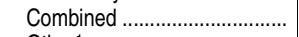 & 1,743 & 2,325 & 4,042 & 5,096 & 5,288 & 5,437 & 5,572 & 5,707 & 5,984 & 5,899 & 5,623 & 5,730 & 6,137 & 6,311 \\
\hline 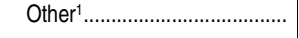 & 2,294 & 2,063 & 1,474 & 1,582 & 1,416 & 1,749 & 1,512 & 1,651 & 2,431 & 1,262 & 1,587 & 1,296 & 1,050 & 971 \\
\hline 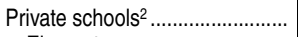 & 20,764 & 24,690 & 32,995 & - & 35,895 & 34,681 & - & 35,054 & - & 33,740 & - & 33,366 & - & 30,861 \\
\hline 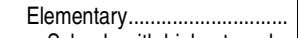 & 13,333 & 15,701 & 22,302 & - & 24,049 & 23,494 & - & 22,870 & - & 21,870 & - & 21,425 & - & 19,697 \\
\hline $\begin{array}{l}\text { Schools with highest grade } \\
\text { of kindergarten................. }\end{array}$ & & & 5,952 & - & 6,622 & 6,297 & - & 6,059 & - & 5,522 & - & 5,275 & - & 4,658 \\
\hline 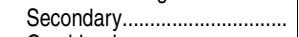 & 2,237 & 2,467 & 2,538 & - & 2,704 & 2,694 & - & 2,927 & - & 2,932 & - & 2,776 & - & 2,677 \\
\hline 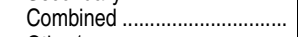 & 3,459 & 6,522 & 8,155 & - & 9,142 & 8,494 & - & 9,257 & - & 8,938 & - & 9,165 & - & 8,488 \\
\hline 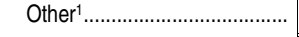 & 1,735 & $(3)$ & $(3)$ & - & $(3)$ & $(3)$ & - & $\left({ }^{3}\right)$ & - & $(3)$ & - & $\left({ }^{3}\right)$ & - & $(3)$ \\
\hline $\begin{array}{l}\text { Postsecondary Title IV } \\
\text { institutions..................... }\end{array}$ & - & - & 6,407 & 6,479 & 6,458 & 6,412 & 6,383 & 6,463 & 6,536 & 6,551 & 6,632 & 6,742 & 7,021 & 7,234 \\
\hline Public & - & - & 2,078 & 2,084 & 2,099 & 2,047 & 2,027 & 2,013 & 2,009 & 2,004 & 1,997 & 1,989 & 2,015 & 2,011 \\
\hline Private ................. & - & - & 4,329 & 4,395 & 4,359 & 4,365 & 4,356 & 4,450 & 4,527 & 4,547 & 4,635 & 4,753 & 5,006 & 5,223 \\
\hline Nonprofit ....... & - & - & 1,936 & 1,950 & 1,941 & 1,913 & 1,875 & 1,866 & 1,848 & 1,815 & 1,809 & 1,809 & 1,812 & 1,830 \\
\hline For-profit ................................. & - & - & 2,393 & 2,445 & 2,418 & 2,452 & 2,481 & 2,584 & 2,679 & 2,732 & 2,826 & 2,944 & 3,194 & 3,393 \\
\hline Title IV non-degree-granting & & & & & & & & & & & & & & \\
\hline institutions............................ & - & - & 2,323 & 2,297 & 2,261 & 2,176 & 2,167 & 2,187 & 2,222 & 2,199 & 2,223 & 2,247 & 2,422 & 2,528 \\
\hline 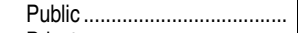 & - & - & 396 & 386 & 386 & 327 & 327 & 320 & 321 & 319 & 321 & 317 & 359 & 362 \\
\hline Private & - & - & 1,927 & 1,911 & 1,875 & 1,849 & 1,840 & 1,867 & 1,901 & 1,880 & 1,902 & 1,930 & 2,063 & 2,166 \\
\hline Nonprofit ............................... & - & - & 255 & 255 & 265 & 249 & 238 & 219 & 208 & 191 & 180 & 185 & 182 & 177 \\
\hline For-profit................................ & - & - & 1,672 & 1,656 & 1,610 & 1,600 & 1,602 & 1,648 & 1,693 & 1,689 & 1,722 & 1,745 & 1,881 & 1,989 \\
\hline Title IV degree-granting & & & & & & & & & & & & & & \\
\hline institutions............................. & 3,231 & 3,559 & 4,084 & 4,182 & 4,197 & 4,236 & 4,216 & 4,276 & 4,314 & 4,352 & 4,409 & 4,495 & 4,599 & 4,706 \\
\hline 2-year colleges............................ & 1,274 & 1,418 & 1,721 & 1,732 & 1,710 & 1,706 & 1,683 & 1,694 & 1,685 & 1,677 & 1,690 & 1,721 & 1,729 & 1,738 \\
\hline Public ................................. & 945 & 972 & 1,068 & 1,076 & 1,085 & 1,086 & 1,061 & 1,053 & 1,045 & 1,032 & 1,024 & 1,000 & 978 & 967 \\
\hline Private ............................... & 329 & 446 & 653 & 656 & 625 & 620 & 622 & 641 & 640 & 645 & 666 & 721 & 751 & 771 \\
\hline Nonprofit........................... & 182 & 167 & 150 & 144 & 135 & 118 & 112 & 113 & 107 & 92 & 92 & 85 & 87 & 100 \\
\hline For-profit ........................... & 147 & 279 & 503 & 512 & 490 & 502 & 510 & 528 & 533 & 553 & 574 & 636 & 664 & 671 \\
\hline 4-year colleges.......................... & 1,957 & 2,141 & 2,363 & 2,450 & 2,487 & 2,530 & 2,533 & 2,582 & 2,629 & 2,675 & 2,719 & 2,774 & 2,870 & 2,968 \\
\hline Public ……..................... & 552 & 595 & 614 & 622 & 628 & 634 & 639 & 640 & 643 & 653 & 652 & 672 & 678 & 682 \\
\hline Private & 1,405 & 1,546 & 1,749 & 1,828 & 1,859 & 1,896 & 1,894 & 1,942 & 1,986 & 2,022 & 2,067 & 2,102 & 2,192 & 2,286 \\
\hline Nonprofit........................... & 1,387 & 1,482 & 1,531 & 1,551 & 1,541 & 1,546 & 1,525 & 1,534 & 1,533 & 1,532 & 1,537 & 1,539 & 1,543 & 1,553 \\
\hline For-profit ........................... & 18 & 64 & 218 & 277 & 318 & 350 & 369 & 408 & 453 & 490 & 530 & 563 & 649 & 733 \\
\hline
\end{tabular}

-Not available.

†Not applicable.

'Includes special education, alternative, and other schools not classified by grade span. Because of changes in survey definitions, figures for "other" schools are not comparable from year to year.

${ }^{2}$ Data for 1980-81 and 1990-91 include schools with first or higher grades. Data for 1997-98 and later years include schools with kindergarten or higher grades.

3ncluded in the elementary, secondary, and combined categories.

NOTE: Postsecondary data for 1980-81 and 1990-91 are for institutions of higher education, while later data are for Title IV degree-granting and non-degree-granting institutions. Degreegranting institutions grant associate's or higher degrees and participate in Title IV federal financial aid programs. The degree-granting classification is very similar to the earlier higher educa- tion classification, but it includes more 2-year colleges and excludes a few higher education institutions that did not grant degrees.

SOURCE: U.S. Department of Education, National Center for Education Statistics, Common Core of Data (CCD), "Public Elementary/Secondary School Universe Survey," 1989-90 through 2011-12; Private Schools in American Education; Statistics of Public Elementary and Secondary Day Schools, 1980-81; Schools and Staffing Survey (SASS), "Private School Data File," 1990-91; Private School Universe Survey (PSS), 1995-96 through 2011-12; Higher Education General Information Survey (HEGIS), "Institutional Characteristics of Colleges and Universities" survey, 1980-81; Integrated Postsecondary Education Data System (IPEDS), "Institutional Characteristics Survey" (IPEDS-IC:90-99); and IPEDS Fall 2001 through Fall 2011, Institutional Characteristics component. (This table was prepared January 2014.) 
Table 106.10. Expenditures of educational institutions related to the gross domestic product, by level of institution: Selected years, 1929-30 through 2012-13

\begin{tabular}{|c|c|c|c|c|c|c|c|c|}
\hline \multirow[b]{3}{*}{ Year } & \multirow{3}{*}{$\begin{array}{r}\text { Gross domestic } \\
\text { product (GDP) } \\
\text { (in billions of } \\
\text { current dollars) }\end{array}$} & \multirow[b]{3}{*}{ School year } & \multicolumn{6}{|c|}{ Expenditures for education in current dollars } \\
\hline & & & \multicolumn{2}{|c|}{ All educational institutions } & \multicolumn{2}{|c|}{$\begin{array}{l}\text { All elementary and } \\
\text { secondary schools }\end{array}$} & \multicolumn{2}{|c|}{$\begin{array}{c}\text { All degree-granting } \\
\text { postsecondary institutions }\end{array}$} \\
\hline & & & $\begin{array}{r}\text { Amount } \\
\text { (in millions) }\end{array}$ & $\begin{array}{r}\text { As a } \\
\text { percent of GDP }\end{array}$ & $\begin{array}{r}\text { Amount } \\
\text { (in millions) }\end{array}$ & $\begin{array}{r}\text { As a } \\
\text { percent of GDP }\end{array}$ & $\begin{array}{r}\text { Amount } \\
\text { (in millions) }\end{array}$ & $\begin{array}{r}\text { As a } \\
\text { percent of GDP }\end{array}$ \\
\hline 1 & 2 & 3 & 4 & 5 & 6 & 7 & 8 & 9 \\
\hline $\begin{array}{l}1929 \\
1939 \ldots \\
1949 \\
1959 \ldots \\
1961\end{array}$ & \begin{tabular}{r||}
$\$ 104.6$ \\
93.5 \\
272.8 \\
522.5 \\
563.3
\end{tabular} & $\begin{array}{l}1929-30 \\
1939-40 \\
1949-50 \\
1959-60 \\
1961-62\end{array}$ & $\begin{array}{r}- \\
\$ 8,494 \\
22,314 \\
26,828\end{array}$ & $\begin{array}{l}- \\
- \\
3.1 \\
4.3 \\
4.8\end{array}$ & $\begin{array}{r}- \\
\$ 6,249 \\
16,713 \\
19,673\end{array}$ & $\begin{array}{l}- \\
2.3 \\
3.2 \\
3.5\end{array}$ & $\begin{array}{r}\$ 632 \\
758 \\
2,246 \\
5,601 \\
7,155\end{array}$ & $\begin{array}{l}0.6 \\
0.8 \\
0.8 \\
1.1 \\
1.3\end{array}$ \\
\hline 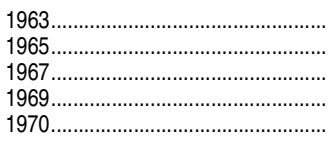 & \begin{tabular}{r||}
638.6 \\
743.7 \\
861.7 \\
$1,019.9$ \\
$1,075.9$
\end{tabular} & $\begin{array}{l}1963-64 \\
1965-66 \\
1967-68 \\
1969-70 \\
1970-71\end{array}$ & $\begin{array}{l}32,003 \\
40,558 \\
51,558 \\
64,227 \\
71,575\end{array}$ & $\begin{array}{l}5.0 \\
5.5 \\
6.0 \\
6.3 \\
6.7\end{array}$ & $\begin{array}{l}22,825 \\
28,048 \\
35,077 \\
43,183 \\
48,200\end{array}$ & $\begin{array}{l}3.6 \\
3.8 \\
4.1 \\
4.2 \\
4.5\end{array}$ & $\begin{array}{r}9,178 \\
12,509 \\
16,481 \\
21,043 \\
23,375\end{array}$ & $\begin{array}{l}1.4 \\
1.7 \\
1.9 \\
2.1 \\
2.2\end{array}$ \\
\hline 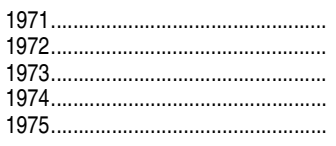 & $\begin{array}{l}1,167.8 \\
1,282.4 \\
1,428.5 \\
1,548.8 \\
1,688.9\end{array}$ & $\begin{array}{l}1971-72 \\
1972-73 \\
1973-74 \\
1974-75 \\
1975-76\end{array}$ & $\begin{array}{r}76,510 \\
82,908 \\
91,084 \\
103,903 \\
114,004\end{array}$ & $\begin{array}{l}6.6 \\
6.5 \\
6.4 \\
6.7 \\
6.8\end{array}$ & $\begin{array}{l}50,950 \\
54,952 \\
60,370 \\
68,846 \\
75,101\end{array}$ & $\begin{array}{l}4.4 \\
4.3 \\
4.2 \\
4.4 \\
4.4\end{array}$ & $\begin{array}{l}25,560 \\
27,956 \\
30,714 \\
35,058 \\
38,903\end{array}$ & $\begin{array}{l}2.2 \\
2.2 \\
2.2 \\
2.3 \\
2.3\end{array}$ \\
\hline 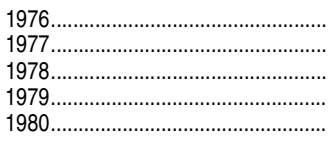 & $\begin{array}{l}1,877.6 \\
2,086.0 \\
2,356.6 \\
2,632.1 \\
2,862.5\end{array}$ & $\begin{array}{l}1976-77 \\
1977-78 \\
1978-79 \\
1979-80 \\
1980-81\end{array}$ & $\begin{array}{l}121,793 \\
132,515 \\
143,733 \\
160,075 \\
176,378\end{array}$ & $\begin{array}{l}6.5 \\
6.4 \\
6.1 \\
6.1 \\
6.2\end{array}$ & $\begin{array}{r}79,194 \\
86,544 \\
93,012 \\
103,162 \\
112,325\end{array}$ & $\begin{array}{l}4.2 \\
4.1 \\
3.9 \\
3.9 \\
3.9\end{array}$ & $\begin{array}{l}42,600 \\
45,971 \\
50,721 \\
56,914 \\
64,053\end{array}$ & $\begin{array}{l}2.3 \\
2.2 \\
2.2 \\
2.2 \\
2.2\end{array}$ \\
\hline 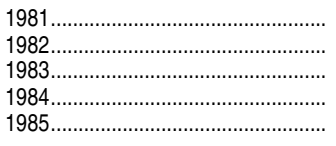 & $\begin{array}{l}3,210.9 \\
3,345.0 \\
3,638.1 \\
4,040.7 \\
4,346.7\end{array}$ & $\begin{array}{l}1981-82 \\
1982-83 \\
1983-84 \\
1984-85 \\
1985-86\end{array}$ & $\begin{array}{l}190,825 \\
204,661 \\
220,993 \\
239,351 \\
259,336\end{array}$ & $\begin{array}{l}5.9 \\
6.1 \\
6.1 \\
5.9 \\
6.0\end{array}$ & $\begin{array}{l}120,486 \\
128,725 \\
139,000 \\
149,400 \\
161,800\end{array}$ & $\begin{array}{l}3.8 \\
3.8 \\
3.8 \\
3.7 \\
3.7\end{array}$ & $\begin{array}{l}70,339 \\
75,936 \\
81,993 \\
89,951 \\
97,536\end{array}$ & $\begin{array}{l}2.2 \\
2.3 \\
2.3 \\
2.2 \\
2.2\end{array}$ \\
\hline 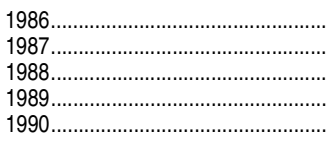 & $\begin{array}{l}4,590.1 \\
4,870.2 \\
5,252.6 \\
5,657.7 \\
5,979.6\end{array}$ & $\begin{array}{l}1986-87 \\
1987-88 \\
1988-89 \\
1989-90 \\
1990-91\end{array}$ & $\begin{array}{l}280,964 \\
301,786 \\
333,245 \\
365,825 \\
395,318\end{array}$ & $\begin{array}{l}6.1 \\
6.2 \\
6.3 \\
6.5 \\
6.6\end{array}$ & $\begin{array}{l}175,200 \\
187,999 \\
209,377 \\
231,170 \\
249,230\end{array}$ & $\begin{array}{l}3.8 \\
3.9 \\
4.0 \\
4.1 \\
4.2\end{array}$ & $\begin{array}{l}105,764 \\
113,787 \\
123,867 \\
134,656 \\
146,088\end{array}$ & $\begin{array}{l}2.3 \\
2.3 \\
2.4 \\
2.4 \\
2.4\end{array}$ \\
\hline 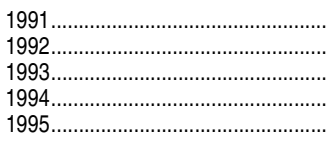 & $\begin{array}{l}6,174.0 \\
6,539.3 \\
6,878.7 \\
7,308.7 \\
7,664.0\end{array}$ & $\begin{array}{l}1991-92 \\
1992-93 \\
1993-94 \\
1994-95 \\
1995-96\end{array}$ & $\begin{array}{l}417,944 \\
439,676 \\
460,756 \\
485,169 \\
508,523\end{array}$ & $\begin{array}{l}6.8 \\
6.7 \\
6.7 \\
6.6 \\
6.6\end{array}$ & $\begin{array}{l}261,755 \\
274,435 \\
287,407 \\
302,200 \\
318,046\end{array}$ & $\begin{array}{l}4.2 \\
4.2 \\
4.2 \\
4.1 \\
4.1\end{array}$ & $\begin{array}{l}156,189 \\
165,241 \\
173,351 \\
182,969 \\
190,476\end{array}$ & $\begin{array}{l}2.5 \\
2.5 \\
2.5 \\
2.5 \\
2.5\end{array}$ \\
\hline 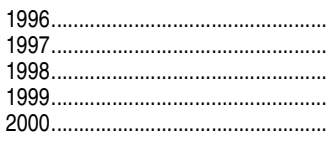 & \begin{tabular}{r||}
$8,100.2$ \\
$8,608.5$ \\
$9,089.1$ \\
$9,665.7$ \\
$10,289.7$
\end{tabular} & $\begin{array}{r}1996-97 \\
1997-98 \\
1998-99 \\
1999-2000 \\
2000-01\end{array}$ & $\begin{array}{l}538,854 \\
570,471 \\
603,847 \\
649,322 \\
705,017\end{array}$ & $\begin{array}{l}6.7 \\
6.6 \\
6.6 \\
6.7 \\
6.9\end{array}$ & $\begin{array}{l}338,951 \\
361,615 \\
384,638 \\
412,538 \\
444,811\end{array}$ & $\begin{array}{l}4.2 \\
4.2 \\
4.2 \\
4.3 \\
4.3\end{array}$ & $\begin{array}{l}199,903 \\
208,856 \\
219,209 \\
236,784 \\
260,206\end{array}$ & $\begin{array}{l}2.5 \\
2.4 \\
2.4 \\
2.4 \\
2.5\end{array}$ \\
\hline 2002 & $\begin{array}{l}10,625.3 \\
10,980.2 \\
11,512.2 \\
12,277.0 \\
13,095.4\end{array}$ & $\begin{array}{l}2001-02 \\
2002-03 \\
2003-04 \\
2004-05 \\
2005-06\end{array}$ & $\begin{array}{l}752,780 \\
795,691 \\
830,293 \\
875,988 \\
925,246\end{array}$ & $\begin{array}{l}7.1 \\
7.2 \\
7.2 \\
7.1 \\
7.1\end{array}$ & $\begin{array}{l}472,064 \\
492,807 \\
513,542 \\
540,969 \\
571,669\end{array}$ & $\begin{array}{l}4.4 \\
4.5 \\
4.5 \\
4.4 \\
4.4\end{array}$ & $\begin{array}{l}280,715 \\
302,884 \\
316,751 \\
335,019 \\
353,577\end{array}$ & $\begin{array}{l}2.6 \\
2.8 \\
2.8 \\
2.7 \\
2.7\end{array}$ \\
\hline 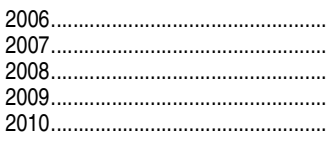 & $\begin{array}{l}13,857.9 \\
14,480.3 \\
14,720.3 \\
14,417.9 \\
14,958.3\end{array}$ & $\begin{array}{l}2006-07 \\
2007-08 \\
2008-09 \\
2009-10 \\
2010-11\end{array}$ & $\begin{array}{r}984,034 \\
1,054,904 \\
1,089,670 \\
1,100,902 \\
1,123,424\end{array}$ & $\begin{array}{l}7.1 \\
7.3 \\
7.4 \\
7.6 \\
7.5\end{array}$ & $\begin{array}{l}608,495 \\
646,414 \\
658,926 \\
654,418 \\
652,215\end{array}$ & $\begin{array}{l}4.4 \\
4.5 \\
4.5 \\
4.5 \\
4.4\end{array}$ & $\begin{array}{l}375,539 \\
408,490 \\
430,744 \\
446,484 \\
471,209\end{array}$ & $\begin{array}{l}2.7 \\
2.8 \\
2.9 \\
3.1 \\
3.2\end{array}$ \\
\hline 20112 & $\begin{array}{l}15,533.8 \\
16,244.6\end{array}$ & $\begin{array}{l}2011-12^{1} \\
2012-13^{2}\end{array}$ & $\begin{array}{l}1,140,000 \\
1,165,000\end{array}$ & $\begin{array}{l}7.3 \\
7.2\end{array}$ & $\begin{array}{l}652,000 \\
669,000\end{array}$ & $\begin{array}{l}4.2 \\
4.1\end{array}$ & $\begin{array}{l}488,444 \\
496,000\end{array}$ & $\begin{array}{l}3.1 \\
3.1\end{array}$ \\
\hline
\end{tabular}

-Not available

${ }^{1}$ Data for elementary and secondary education are estimated; data for degree-granting institutions are actual.

${ }^{2}$ Estimated by the National Center for Education Statistics based on teacher and enrollment data, and actual expenditures for prior years.

NOTE: Total expenditures for public elementary and secondary schools include current expenditures, interest on school debt, and capital outlay. Data for private elementary and secondary schools are estimated. Expenditures for colleges and universities in 1929-30 and 1939-40 include current-fund expenditures and additions to plant value. Public and private degree-granting institutions data for 1949-50 through 1995-96 are for current-fund expenditures. Data for private degree-granting institutions for 1996-97 and later years are for total expenditures. Postsecondary data through 1995-96 are for institutions of higher education, while later data are for degree-granting institutions. Degree-granting institutions grant associate's or higher degrees and participate in Title IV federal financial aid programs. The degree-granting classification is very similar to the earlier higher education classification, but it includes more 2-year colleges and excludes a few higher education institutions that did not grant degrees. Some data have been revised from previously published figures. Detail may not sum to totals because of rounding.

SOURCE: U.S. Department of Education, National Center for Education Statistics, Biennial Survey of Education in the United States, 1929-30 through 1949-50; Statistics of State School Systems, 1959-60 through 1969-70; Revenues and Expenditures for Public Elementary and Secondary Education, 1970-71 through 1986-87; Common Core of Data (CCD), "National Public Education Financial Survey," 1987-88 through 2010-11; Higher (CCD), "National Public Education Financial Survey," 1987-88 through 2010-11; Higher
Education General Information Survey (HEGIS), Financial Statistics of Institutions of Higher Education, 1965-66 through 1985-86; Integrated Postsecondary Education Data System (IPEDS), "Finance Survey" (IPEDS-F:FY87-99); and IPEDS Spring 2001 through Spring 2013, Finance component. U.S. Department of Commerce, Bureau of Economic Analysis, National Income and Product Accounts Tables, retrieved February 5, 2014, from http://www.bea.gov/iTable/index nipa.cfm. (This table was prepared February 2014.) 
Table 106.20. Expenditures of educational institutions, by level and control of institution: Selected years, 1899-1900 through 2012-13

[In millions]

\begin{tabular}{|c|c|c|c|c|c|c|c|c|c|c|c|}
\hline \multirow[b]{3}{*}{ School year } & \multicolumn{7}{|c|}{ Current dollars } & \multicolumn{4}{|c|}{ Constant 2012-13 dollars ${ }^{1}$} \\
\hline & \multirow[b]{2}{*}{ Total } & \multicolumn{3}{|c|}{ Elementary and secondary schools } & \multicolumn{3}{|c|}{ Degree-granting postsecondary institutions } & \multirow[b]{2}{*}{ Total } & \multicolumn{2}{|c|}{$\begin{array}{l}\text { Elementary and } \\
\text { secondary schools }\end{array}$} & \multirow{2}{*}{$\begin{array}{r}\text { Degree- } \\
\text { granting post- } \\
\text { secondary } \\
\text { institutions }\end{array}$} \\
\hline & & Total & Public & Private $^{2}$ & Total & Public & Private & & Total & Public & \\
\hline 1 & 2 & 3 & 4 & 5 & 6 & 7 & 8 & 9 & 10 & 11 & 12 \\
\hline 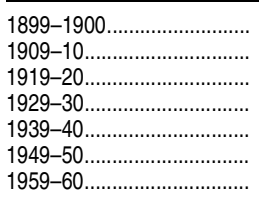 & $\begin{array}{r}- \\
- \\
- \\
- \\
\overline{-} \\
22,494 \\
\end{array}$ & \begin{tabular}{r|} 
\\
- \\
- \\
- \\
$\$ 6,249$ \\
16,713
\end{tabular} & $\begin{array}{r}\$ 215 \\
426 \\
1,036 \\
2,317 \\
2,344 \\
5,838 \\
15,613\end{array}$ & \begin{tabular}{r|}
- \\
- \\
- \\
$\overline{-}$ \\
$\$ 411$ \\
1,100
\end{tabular} & \begin{tabular}{r|}
- \\
- \\
$\overline{-}$ \\
$\$ 632$ \\
758 \\
2,246 \\
5,601
\end{tabular} & $\begin{array}{r}- \\
- \\
\overline{-} \\
\$ 292 \\
392 \\
1,154 \\
3,131\end{array}$ & \begin{tabular}{r|}
- \\
$\overline{-}$ \\
$\$ 341$ \\
367 \\
1,092 \\
2,470
\end{tabular} & $\begin{array}{r}- \\
- \\
- \\
- \\
\overline{-} \\
\$ 82,978 \\
175,693\end{array}$ & \begin{tabular}{r|}
- \\
$\overline{-}$ \\
$\overline{-}$ \\
$\overline{\bar{y}}$ \\
$\$ 61,041$ \\
131,595
\end{tabular} & \begin{tabular}{r|}
- \\
- \\
$\$ 12,578$ \\
31,314 \\
38,805 \\
57,026 \\
122,934
\end{tabular} & $\begin{array}{r}- \\
- \\
\overline{-} \\
\$ 8,545 \\
12,556 \\
21,937 \\
44,099\end{array}$ \\
\hline $\begin{array}{l}1969-70 \\
1970-71 \ldots \ldots \\
1971-72 \ldots \\
1972-73 \ldots \ldots \\
1973-74 \ldots\end{array}$ & $\begin{array}{l}64,227 \\
71,575 \\
76,510 \\
82,908 \\
91,084\end{array}$ & $\begin{array}{l}43,183 \\
48,200 \\
50,950 \\
54,952 \\
60,370\end{array}$ & $\begin{array}{l}40,683 \\
45,500 \\
48,050 \\
51,852 \\
56,970\end{array}$ & $\begin{array}{l}2,500 \\
2,700 \\
2,900 \\
3,100 \\
3,400\end{array}$ & $\begin{array}{l}21,043 \\
23,375 \\
25,560 \\
27,956 \\
30,714\end{array}$ & $\begin{array}{l}13,250 \\
14,996 \\
16,484 \\
18,204 \\
20,336\end{array}$ & $\begin{array}{r}7,794 \\
8,379 \\
9,075 \\
9,752 \\
10,377\end{array}$ & $\begin{array}{l}393,354 \\
416,842 \\
430,151 \\
448,068 \\
451,956\end{array}$ & $\begin{array}{l}264,476 \\
280,708 \\
286,451 \\
296,985 \\
299,556\end{array}$ & $\begin{array}{l}249,165 \\
264,984 \\
270,147 \\
280,231 \\
282,685\end{array}$ & $\begin{array}{l}128,878 \\
136,133 \\
143,700 \\
151,084 \\
152,400\end{array}$ \\
\hline 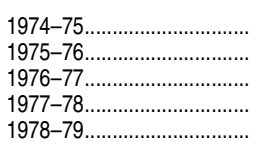 & $\begin{array}{l}103,903 \\
114,004 \\
121,793 \\
132,515 \\
143,733\end{array}$ & $\begin{array}{l}68,846 \\
75,101 \\
79,194 \\
86,544 \\
93,012\end{array}$ & $\begin{array}{l}64,846 \\
70,601 \\
74,194 \\
80,844 \\
86,712\end{array}$ & $\begin{array}{l}4,000 \\
4,500 \\
5,000 \\
5,700 \\
6,300\end{array}$ & $\begin{array}{l}35,058 \\
38,903 \\
42,600 \\
45,971 \\
50,721\end{array}$ & $\begin{array}{l}23,490 \\
26,184 \\
28,635 \\
30,725 \\
33,733\end{array}$ & $\begin{array}{l}11,568 \\
12,719 \\
13,965 \\
15,246 \\
16,988\end{array}$ & $\begin{array}{l}464,131 \\
475,585 \\
480,085 \\
489,481 \\
485,443\end{array}$ & $\begin{array}{l}307,531 \\
313,294 \\
312,165 \\
319,675 \\
314,138\end{array}$ & $\begin{array}{l}289,663 \\
294,522 \\
292,456 \\
298,621 \\
292,860\end{array}$ & $\begin{array}{l}156,600 \\
162,291 \\
167,920 \\
169,806 \\
171,305\end{array}$ \\
\hline $\begin{array}{l}1979-80 \\
1980-81 \ldots \\
1981-82 \\
1982-83 \\
1983-84\end{array}$ & $\begin{array}{l}160,075 \\
176,378 \\
190,825 \\
204,661 \\
220,993\end{array}$ & $\begin{array}{l}103,162 \\
112,325 \\
120,486 \\
128,725 \\
139,000\end{array}$ & $\begin{array}{r}95,962 \\
104,125 \\
111,186 \\
118,425 \\
127,500\end{array}$ & $\begin{array}{r}7,200 \\
8,200 \\
9,300 \\
10,300 \\
11,500\end{array}$ & $\begin{array}{l}56,914 \\
64,053 \\
70,339 \\
75,936 \\
81,993\end{array}$ & $\begin{array}{l}37,768 \\
42,280 \\
46,219 \\
49,573 \\
53,087\end{array}$ & $\begin{array}{l}19,146 \\
21,773 \\
24,120 \\
26,363 \\
28,907\end{array}$ & $\begin{array}{l}477,036 \\
471,058 \\
469,119 \\
482,411 \\
502,316\end{array}$ & $\begin{array}{l}307,429 \\
299,990 \\
296,199 \\
303,421 \\
315,946\end{array}$ & $\begin{array}{l}285,972 \\
278,090 \\
273,336 \\
279,143 \\
289,807\end{array}$ & $\begin{array}{l}169,607 \\
171,068 \\
172,920 \\
178,990 \\
186,370\end{array}$ \\
\hline 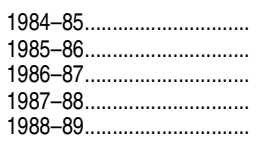 & $\begin{array}{l}239,351 \\
259,336 \\
280,964 \\
301,786 \\
333,245\end{array}$ & $\begin{array}{l}149,400 \\
161,800 \\
175,200 \\
187,999 \\
209,377\end{array}$ & $\begin{array}{l}137,000 \\
148,600 \\
160,900 \\
172,699 \\
192,977\end{array}$ & $\begin{array}{l}12,400 \\
13,200 \\
14,300 \\
15,300 \\
16,400\end{array}$ & $\begin{array}{r}89,951 \\
97,536 \\
105,764 \\
113,787 \\
123,867\end{array}$ & $\begin{array}{l}58,315 \\
63,194 \\
67,654 \\
72,641 \\
78,946\end{array}$ & $\begin{array}{l}31,637 \\
34,342 \\
38,110 \\
41,145 \\
44,922\end{array}$ & $\begin{array}{l}523,551 \\
551,365 \\
584,372 \\
602,708 \\
636,154\end{array}$ & $\begin{array}{l}326,794 \\
343,997 \\
364,396 \\
375,459 \\
399,696\end{array}$ & $\begin{array}{l}299,670 \\
315,933 \\
334,654 \\
344,903 \\
368,388\end{array}$ & $\begin{array}{l}196,757 \\
207,367 \\
219,976 \\
227,249 \\
236,459\end{array}$ \\
\hline $\begin{array}{l}1989-90 \\
1990-91 \ldots \\
1991-92 \\
1992-93 \\
1993-94\end{array}$ & $\begin{array}{l}365,825 \\
395,318 \\
417,944 \\
439,676 \\
460,757\end{array}$ & $\begin{array}{l}231,170 \\
249,230 \\
261,755 \\
274,435 \\
287,407\end{array}$ & $\begin{array}{l}212,770 \\
229,430 \\
241,055 \\
252,935 \\
265,307\end{array}$ & $\begin{array}{l}18,400 \\
19,800 \\
20,700 \\
21,500 \\
22,100\end{array}$ & $\begin{array}{l}134,656 \\
146,088 \\
156,189 \\
165,241 \\
173,351\end{array}$ & $\begin{array}{r}85,771 \\
92,961 \\
98,847 \\
104,570 \\
109,310\end{array}$ & $\begin{array}{l}48,885 \\
53,127 \\
57,342 \\
60,671 \\
64,041\end{array}$ & $\begin{array}{l}666,544 \\
682,942 \\
699,613 \\
713,699 \\
729,034\end{array}$ & $\begin{array}{l}421,197 \\
430,564 \\
438,162 \\
445,473 \\
454,749\end{array}$ & $\begin{array}{l}387,672 \\
396,358 \\
403,511 \\
410,574 \\
419,782\end{array}$ & $\begin{array}{l}245,346 \\
252,378 \\
261,451 \\
268,226 \\
274,284\end{array}$ \\
\hline $\begin{array}{l}1994-95 \\
1995-96 \ldots \\
1996-97 \\
1997-98 \ldots \\
1998-99\end{array}$ & $\begin{array}{l}485,169 \\
508,523 \\
538,854 \\
570,471 \\
603,847\end{array}$ & $\begin{array}{l}302,200 \\
318,046 \\
338,951 \\
361,615 \\
384,638\end{array}$ & $\begin{array}{l}279,000 \\
293,646 \\
313,151 \\
334,315 \\
355,838\end{array}$ & $\begin{array}{l}23,200 \\
24,400 \\
25,800 \\
27,300 \\
28,800\end{array}$ & $\begin{array}{l}182,969 \\
190,476 \\
199,903^{2} \\
208,856^{2} \\
219,209^{2}\end{array}$ & $\begin{array}{l}115,465 \\
119,525 \\
125,978 \\
132,846 \\
140,539\end{array}$ & $\begin{array}{l}67,504 \\
70,952 \\
73,925^{2} \\
76,010^{2} \\
78,670^{2}\end{array}$ & $\begin{array}{l}746,269 \\
761,474 \\
784,510 \\
815,989 \\
849,030\end{array}$ & $\begin{array}{l}464,833 \\
476,250 \\
493,474 \\
517,246 \\
540,815\end{array}$ & $\begin{array}{l}429,148 \\
439,713 \\
455,912 \\
478,196 \\
500,321\end{array}$ & $\begin{array}{l}281,436 \\
285,224 \\
291,036^{2} \\
298,743^{2} \\
308,216\end{array}$ \\
\hline 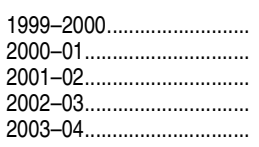 & $\begin{array}{l}649,322 \\
705,017 \\
752,780 \\
795,691 \\
830,293\end{array}$ & $\begin{array}{l}412,538 \\
444,811 \\
472,064 \\
492,807 \\
513,542\end{array}$ & $\begin{array}{l}381,838 \\
410,811 \\
435,364 \\
454,907 \\
474,242\end{array}$ & $\begin{array}{l}30,700 \\
34,000 \\
36,700 \\
37,900 \\
39,300\end{array}$ & $\begin{array}{l}236,784 \\
260,206 \\
280,715 \\
302,884 \\
316,751\end{array}$ & $\begin{array}{l}152,325 \\
170,345 \\
183,436 \\
197,026 \\
205,069\end{array}$ & $\begin{array}{r}84,459 \\
89,861 \\
97,280 \\
105,858 \\
111,682\end{array}$ & $\begin{array}{r}887,355 \\
931,551 \\
977,356 \\
1,010,855 \\
1,032,230\end{array}$ & $\begin{array}{l}563,769 \\
587,736 \\
612,895 \\
626,067 \\
638,442\end{array}$ & $\begin{array}{l}521,815 \\
542,812 \\
565,247 \\
577,919 \\
589,583\end{array}$ & $\begin{array}{l}323,586 \\
343,814 \\
364,461 \\
384,788 \\
393,789\end{array}$ \\
\hline 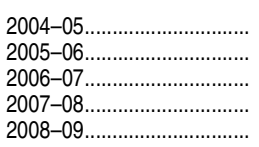 & $\begin{array}{r}875,988 \\
925,246 \\
984,034 \\
1,054,904 \\
1,089,670\end{array}$ & $\begin{array}{l}540,969 \\
571,669 \\
608,495 \\
646,414 \\
658,926\end{array}$ & $\begin{array}{l}499,569 \\
528,269 \\
562,195 \\
597,314 \\
610,326\end{array}$ & $\begin{array}{l}41,400 \\
43,400 \\
46,300 \\
49,100 \\
48,600\end{array}$ & $\begin{array}{l}335,019 \\
353,577 \\
375,539 \\
408,490 \\
430,744\end{array}$ & $\begin{array}{l}215,794 \\
226,550 \\
238,829 \\
261,046 \\
273,030\end{array}$ & $\begin{array}{l}119,225 \\
127,027 \\
136,710 \\
147,444 \\
157,714\end{array}$ & $\begin{array}{l}1,057,225 \\
1,075,709 \\
1,115,217 \\
1,152,819 \\
1,174,414\end{array}$ & $\begin{array}{l}652,892 \\
664,633 \\
689,614 \\
706,413 \\
710,171\end{array}$ & $\begin{array}{l}602,927 \\
614,176 \\
637,142 \\
652,756 \\
657,791\end{array}$ & $\begin{array}{l}404,333 \\
411,076 \\
425,603 \\
446,406 \\
464,243\end{array}$ \\
\hline 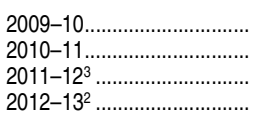 & $\begin{array}{l}1,100,902 \\
1,123,424 \\
1,140,000 \\
1,165,000\end{array}$ & $\begin{array}{l}654,418 \\
652,215 \\
652,000 \\
669,000\end{array}$ & $\begin{array}{l}607,018 \\
604,215 \\
605,000 \\
621,000\end{array}$ & $\begin{array}{l}47,400 \\
48,000 \\
47,000 \\
47,000\end{array}$ & $\begin{array}{l}446,484 \\
471,209 \\
488,444 \\
496,000\end{array}$ & $\begin{array}{l}281,368 \\
296,114 \\
305,534 \\
310,000\end{array}$ & $\begin{array}{l}165,115 \\
175,095 \\
182,910 \\
186,000\end{array}$ & $\begin{array}{l}1,175,149 \\
1,176,000 \\
1,159,000 \\
1,165,000\end{array}$ & $\begin{array}{l}698,553 \\
682,000 \\
663,000 \\
669,000\end{array}$ & $\begin{array}{l}647,957 \\
632,000 \\
615,000 \\
621,000\end{array}$ & $\begin{array}{l}476,595 \\
493,000 \\
497,000 \\
496,000\end{array}$ \\
\hline
\end{tabular}

\section{-Not available.}

${ }^{1}$ Constant dollars based on the Consumer Price Index, prepared by the Bureau of Labor Statistics, U.S. Department of Labor, adjusted to a school-year basis.

${ }^{2}$ Estimated by the National Center for Education Statistics based on teacher and enrollment data, and actual expenditures for prior years.

${ }^{3}$ Data for elementary and secondary education are estimated; data for degree-granting institutions are actual.

NOTE: Total expenditures for public elementary and secondary schools include current expenditures, interest on school debt, and capital outlay. Expenditures for public and private colleges and universities in 1929-30 and 1939-40 include current-fund expenditures and additions to plant value. Public and private degree-granting institutions data for 1949-50 through 1995-96 are for current-fund expenditures. Data for private degree-granting institutions for 1996-97 and later years are for total expenditures. Data for public degree-granting institutions for 1996-97 through 2000-01 are for current expenditures: data for later years are for total expenditures. Postsecondary data through 1995-96 are for institutions of higher education, while later data are for degree-granting institutions.
Degree-granting institutions grant associate's or higher degrees and participate in Title IV federal financial aid programs. The degree-granting classification is very similar to the earlier higher education classification, but it includes more 2-year colleges and excludes a few higher education institutions that did not grant degrees. Some data have been revised from previously published figures. Detail may not sum to totals because of rounding.

SOURCE: U.S. Department of Education, National Center for Education Statistics, Annual Report of the Commissioner of Education, 1899-1900 and 1909-10; Biennial Survey of Education in the United States, 1919-20 through 1949-50; Statistics of State School Systems, 1959-60 and 1969-70; Revenues and Expenditures for Public Elementary and Secondary Education, 1970-71 through 1986-87; Common Core of Data (CCD), "National Public Education Financial Survey," 1987-88 through 2010-11; Higher Education General Information Survey (HEGIS), Financial Statistics of Institutions of Higher Education, 1965-66 through 1985-86; Integrated Postsecondary Education Data System (IPEDS), "Finance Survey," (IPEDS-F:FY87-99); IPEDS Spring 2001 through Spring 2013, Finance component; and unpublished tabulations. (This table was prepared February 2014.) 
Table 106.30. Amount and percentage distribution of direct general expenditures of state and local governments, by function: Selected years, 1970-71 through 2010-11

\begin{tabular}{|c|c|c|c|c|c|c|c|c|c|c|}
\hline Function & $1970-71$ & 1980-81 & 1990-91 & $2000-01$ & $2005-06$ & $2006-07$ & $2007-08$ & $2008-09$ & $2009-10$ & 2010-11 \\
\hline 1 & 2 & 3 & 4 & 5 & 6 & 7 & 8 & 9 & 10 & 11 \\
\hline & \multicolumn{10}{|c|}{ Amount (in millions of current dollars) } \\
\hline Total direct general expenditures.. & $\$ 150,674$ & $\$ 407,449$ & $\$ 908,108$ & $\$ 1,621,757$ & $\$ 2,116,464$ & $\$ 2,258,229$ & $\$ 2,400,204$ & $2,494,986$ & $2,538,214$ & $2,583,101$ \\
\hline Education and public libraries........................................ & 60,174 & 147,649 & 313,744 & 571,374 & 739,410 & 785,162 & 837,675 & 863,137 & 870,272 & 872,711 \\
\hline 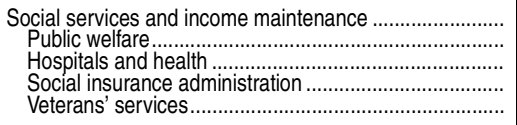 & $\begin{array}{r}30,376 \\
18,226 \\
11,205 \\
945 \\
\dagger\end{array}$ & $\begin{array}{r}92,555 \\
54,121 \\
36,101 \\
2,276 \\
57\end{array}$ & $\begin{array}{r}214,919 \\
130,402 \\
81,110 \\
3,250 \\
157\end{array}$ & $\begin{array}{r}396,086 \\
257,380 \\
134,010 \\
4,359 \\
337\end{array}$ & $\begin{array}{r}551,721 \\
367,395 \\
178,777 \\
4,556 \\
992\end{array}$ & $\begin{array}{r}582,852 \\
384,769 \\
193,072 \\
3,981 \\
1,031\end{array}$ & $\begin{array}{r}618,353 \\
404,624 \\
208,557 \\
4,089 \\
1,083\end{array}$ & $\begin{array}{r}658,155 \\
431,884 \\
220,768 \\
4,570 \\
933\end{array}$ & $\begin{array}{r}686,981 \\
456,804 \\
224,227 \\
5,157 \\
794\end{array}$ & $\begin{array}{r}728,709 \\
492,007 \\
230,506 \\
5,256 \\
941\end{array}$ \\
\hline 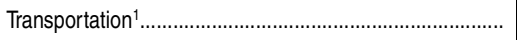 & 19,819 & 39,231 & 75,410 & 130,422 & 160,460 & 170,976 & 181,322 & 183,966 & 186,924 & 182,520 \\
\hline 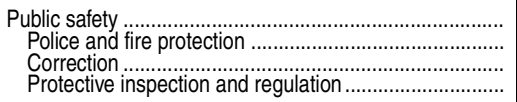 & $\begin{array}{r}9,416 \\
7,531 \\
1,885 \\
\dagger\end{array}$ & $\begin{array}{r}31,233 \\
21,283 \\
7,393 \\
2,557\end{array}$ & $\begin{array}{r}79,932 \\
46,568 \\
27,356 \\
6,008\end{array}$ & $\begin{array}{r}146,544 \\
84,554 \\
52,370 \\
9,620\end{array}$ & $\begin{array}{r}187,929 \\
111,971 \\
62,645 \\
13,312\end{array}$ & $\begin{array}{r}203,259 \\
120,916 \\
68,092 \\
14,250\end{array}$ & $\begin{array}{r}217,201 \\
129,360 \\
72,904 \\
14,937\end{array}$ & $\begin{array}{r}225,564 \\
135,951 \\
74,795 \\
14,818\end{array}$ & $\begin{array}{r}224,594 \\
137,407 \\
73,000 \\
14,187\end{array}$ & $\begin{array}{r}225,583 \\
138,584 \\
73,151 \\
13,847\end{array}$ \\
\hline 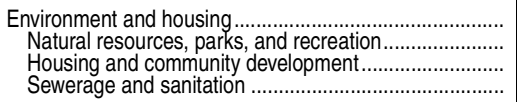 & $\begin{array}{r}11,832 \\
5,191 \\
2,554 \\
4,087\end{array}$ & $\begin{array}{r}35,223 \\
13,239 \\
7,086 \\
14,898\end{array}$ & $\begin{array}{l}76,167 \\
28,505 \\
16,648 \\
31,014\end{array}$ & $\begin{array}{r}124,203 \\
50,082 \\
27,402 \\
46,718\end{array}$ & $\begin{array}{r}163,867 \\
59,939 \\
42,014 \\
61,914\end{array}$ & $\begin{array}{r}179,196 \\
66,243 \\
45,937 \\
67,016\end{array}$ & $\begin{array}{r}191,972 \\
70,562 \\
50,974 \\
70,436\end{array}$ & $\begin{array}{r}197,164 \\
72,079 \\
49,173 \\
75,911\end{array}$ & $\begin{array}{r}199,466 \\
69,474 \\
53,460 \\
76,532\end{array}$ & $\begin{array}{r}202,632 \\
67,765 \\
56,121 \\
78,746\end{array}$ \\
\hline 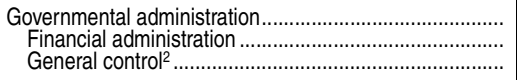 & $\begin{array}{r}6,703 \\
2,271 \\
4,432\end{array}$ & $\begin{array}{r}20,001 \\
7,230 \\
12,771\end{array}$ & $\begin{array}{l}48,461 \\
16,995 \\
31,466\end{array}$ & $\begin{array}{l}85,910 \\
30,007 \\
55,903\end{array}$ & $\begin{array}{r}110,407 \\
37,666 \\
72,741\end{array}$ & $\begin{array}{r}119,396 \\
39,631 \\
79,765\end{array}$ & $\begin{array}{r}126,997 \\
40,995 \\
86,003\end{array}$ & $\begin{array}{r}128,467 \\
40,646 \\
87,821\end{array}$ & $\begin{array}{r}127,214 \\
40,519 \\
86,695\end{array}$ & $\begin{array}{r}124,511 \\
39,689 \\
84,823\end{array}$ \\
\hline Interest on general debt................................................. & 5,089 & 17,131 & 52,234 & 73,836 & 86,001 & 93,586 & 100,055 & 105,053 & 105,765 & 108,658 \\
\hline \multirow[t]{2}{*}{ Other direct general expenditures, not elsewhere } & 7,265 & 24,426 & 47,242 & 93,382 & 116,670 & 123,802 & 126,630 & 133,481 & 136,997 & 137,777 \\
\hline & \multicolumn{10}{|c|}{ Amount (in millions of constant 2012-13 dollars) ${ }^{3}$} \\
\hline Total direct general expenditures. & $\$ 877,502$ & $\$ 1,088,188$ & $\$ 1,568,833$ & $\$ 2,142,862$ & $\$ 2,460,651$ & $\$ 2,559,283$ & $\$ 2,622,991$ & $2,689,028$ & $2,709,399$ & $\$ 2,703,035$ \\
\hline $\mathrm{s}$ & 350,444 & 394,331 & 542,019 & 754,969 & 859,656 & 889,836 & 915,427 & 930,266 & 928,966 & 913,231 \\
\hline 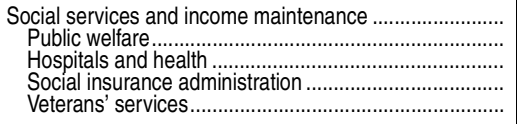 & $\begin{array}{r}176,905 \\
106,145 \\
65,256 \\
5,504 \\
\dagger\end{array}$ & $\begin{array}{r}247,190 \\
144,543 \\
96,416 \\
6,079 \\
152\end{array}$ & $\begin{array}{r}371,291 \\
225,280 \\
140,124 \\
5,615 \\
271\end{array}$ & $\begin{array}{r}523,356 \\
340,082 \\
177,070 \\
5,759 \\
445\end{array}$ & $\begin{array}{r}641,444 \\
427,142 \\
207,851 \\
5,297 \\
1,153\end{array}$ & $\begin{array}{r}660,555 \\
436,064 \\
218,811 \\
4,512 \\
1,168\end{array}$ & $\begin{array}{r}675,748 \\
442,181 \\
227,916 \\
4,468 \\
1,184\end{array}$ & $\begin{array}{r}709,342 \\
465,473 \\
237,938 \\
4,925 \\
1,006\end{array}$ & $\begin{array}{r}733,312 \\
487,612 \\
239,349 \\
5,505 \\
847\end{array}$ & $\begin{array}{r}762,544 \\
514,851 \\
241,208 \\
5,500 \\
984\end{array}$ \\
\hline Transportation $^{1} \ldots$ & 115,423 & 104,776 & 130,277 & 172,330 & 186,554 & 193,770 & 198,152 & 198,273 & 199,531 & 190,994 \\
\hline 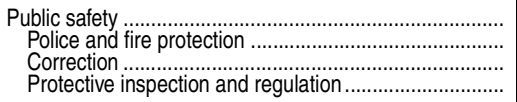 & $\begin{array}{r}54,837 \\
43,859 \\
10,978 \\
\dagger\end{array}$ & $\begin{array}{r}83,415 \\
56,841 \\
19,745 \\
6,829\end{array}$ & $\begin{array}{r}138,089 \\
80,450 \\
47,260 \\
10,379\end{array}$ & $\begin{array}{r}193,632 \\
111,723 \\
69,198 \\
12,711\end{array}$ & $\begin{array}{r}218,490 \\
130,180 \\
72,833 \\
15,477\end{array}$ & $\begin{array}{r}230,356 \\
137,036 \\
77,170 \\
16,150\end{array}$ & $\begin{array}{r}237,361 \\
141,367 \\
79,671 \\
16,323\end{array}$ & $\begin{array}{r}243,107 \\
146,524 \\
80,612 \\
15,971\end{array}$ & $\begin{array}{r}239,741 \\
146,675 \\
77,923 \\
15,144\end{array}$ & $\begin{array}{r}236,057 \\
145,019 \\
76,547 \\
14,490\end{array}$ \\
\hline 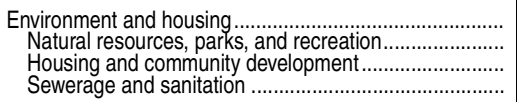 & $\begin{array}{l}68,908 \\
30,232 \\
14,874 \\
23,802\end{array}$ & $\begin{array}{l}94,071 \\
35,358 \\
18,925 \\
39,789\end{array}$ & $\begin{array}{r}131,585 \\
49,245 \\
28,761 \\
53,579\end{array}$ & $\begin{array}{r}164,112 \\
66,175 \\
36,207 \\
61,730\end{array}$ & $\begin{array}{r}190,515 \\
69,686 \\
48,847 \\
71,982\end{array}$ & $\begin{array}{r}203,086 \\
75,074 \\
52,061 \\
75,950\end{array}$ & $\begin{array}{r}209,791 \\
77,112 \\
55,706 \\
76,974\end{array}$ & $\begin{array}{r}212,498 \\
77,685 \\
52,997 \\
81,815\end{array}$ & $\begin{array}{r}212,918 \\
74,159 \\
57,065 \\
81,694\end{array}$ & $\begin{array}{r}212,040 \\
70,911 \\
58,727 \\
82,402\end{array}$ \\
\hline 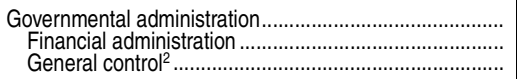 & $\begin{array}{l}39,037 \\
13,226 \\
25,811\end{array}$ & $\begin{array}{l}53,417 \\
19,309 \\
34,108\end{array}$ & $\begin{array}{l}83,720 \\
29,360 \\
54,360\end{array}$ & $\begin{array}{r}113,514 \\
39,649 \\
73,865\end{array}$ & $\begin{array}{r}128,361 \\
43,791 \\
84,570\end{array}$ & $\begin{array}{r}135,313 \\
44,915 \\
90,398\end{array}$ & $\begin{array}{r}138,785 \\
44,800 \\
93,985\end{array}$ & $\begin{array}{r}138,458 \\
43,807 \\
94,651\end{array}$ & $\begin{array}{r}135,794 \\
43,252 \\
92,542\end{array}$ & $\begin{array}{r}130,292 \\
41,531 \\
88,761\end{array}$ \\
\hline 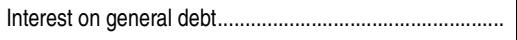 & 29,638 & 45,752 & 90,239 & 97,561 & 99,987 & 106,062 & 109,343 & 113,223 & 112,898 & 113,703 \\
\hline \multirow[t]{2}{*}{ 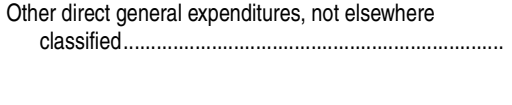 } & 42,310 & 65,235 & 81,615 & 123,388 & 135,644 & 140,306 & 138,384 & 143,862 & 146,237 & 144,174 \\
\hline & \multicolumn{10}{|c|}{ Percentage distribution } \\
\hline senditures.... & 100.0 & 100.0 & 100.0 & 100.0 & 100.0 & 100.0 & 100.0 & 100.0 & 100.0 & 100.0 \\
\hline Education and public libraries......................................... & 39.9 & 36.2 & 34.5 & 35.2 & 34.9 & 34.8 & 34.9 & 34.6 & 34.3 & 33.8 \\
\hline 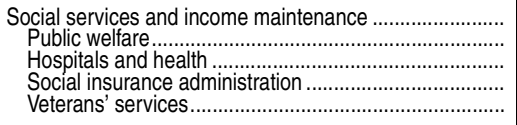 & $\begin{array}{r}20.2 \\
12.1 \\
7.4 \\
0.6 \\
\dagger\end{array}$ & $\begin{array}{r}22.7 \\
13.3 \\
8.9 \\
0.6 \\
\#\end{array}$ & $\begin{array}{r}23.7 \\
14.4 \\
8.9 \\
0.4 \\
\#\end{array}$ & $\begin{array}{r}24.4 \\
15.9 \\
8.3 \\
0.3 \\
\#\end{array}$ & $\begin{array}{r}26.1 \\
17.4 \\
8.4 \\
0.2 \\
\#\end{array}$ & $\begin{array}{r}25.8 \\
17.0 \\
8.5 \\
0.2 \\
\#\end{array}$ & $\begin{array}{r}25.8 \\
16.9 \\
8.7 \\
0.2 \\
\#\end{array}$ & $\begin{array}{r}26.4 \\
17.3 \\
8.8 \\
0.2 \\
\#\end{array}$ & $\begin{array}{r}27.1 \\
18.0 \\
8.8 \\
0.2 \\
\#\end{array}$ & $\begin{array}{r}28.2 \\
19.0 \\
8.9 \\
0.2 \\
\#\end{array}$ \\
\hline Transportation ${ }^{1} \ldots . .$. & 13.2 & 9.6 & 8.3 & 8.0 & 7.6 & 7.6 & 7.6 & 7.4 & 7.4 & 7.1 \\
\hline $\begin{array}{l}\text { Public safety } \\
\text { Police and fire protection } \\
\text { Correction } \\
\text { Protective inspection and regulation }\end{array}$ & $\begin{array}{r}6.2 \\
5.0 \\
1.3 \\
\dagger\end{array}$ & $\begin{array}{l}7.7 \\
5.2 \\
1.8 \\
0.6\end{array}$ & $\begin{array}{l}8.8 \\
5.1 \\
3.0 \\
0.7\end{array}$ & $\begin{array}{l}9.0 \\
5.2 \\
3.2 \\
0.6\end{array}$ & $\begin{array}{l}8.9 \\
5.3 \\
3.0 \\
0.6\end{array}$ & $\begin{array}{l}9.0 \\
5.4 \\
3.0 \\
0.6\end{array}$ & $\begin{array}{l}9.0 \\
5.4 \\
3.0 \\
0.6\end{array}$ & $\begin{array}{l}9.0 \\
5.4 \\
3.0 \\
0.6\end{array}$ & $\begin{array}{l}8.8 \\
5.4 \\
2.9 \\
0.6\end{array}$ & $\begin{array}{l}8.7 \\
5.4 \\
2.8 \\
0.5\end{array}$ \\
\hline $\begin{array}{l}\text { Environment and housing } \\
\text { Natural resources, parks, and recreati } \\
\text { Housing and community development } \\
\text { Sewerage and sanitation }\end{array}$ & $\begin{array}{l}7.9 \\
3.4 \\
1.7 \\
2.7\end{array}$ & $\begin{array}{l}8.6 \\
3.2 \\
1.7 \\
3.7\end{array}$ & $\begin{array}{l}8.4 \\
3.1 \\
1.8 \\
3.4\end{array}$ & $\begin{array}{l}7.7 \\
3.1 \\
1.7 \\
2.9\end{array}$ & $\begin{array}{l}7.7 \\
2.8 \\
2.0 \\
2.9\end{array}$ & $\begin{array}{l}7.9 \\
2.9 \\
2.0 \\
3.0\end{array}$ & $\begin{array}{l}8.0 \\
2.9 \\
2.1 \\
2.9\end{array}$ & $\begin{array}{l}7.9 \\
2.9 \\
2.0 \\
3.0\end{array}$ & $\begin{array}{l}7.9 \\
2.7 \\
2.1 \\
3.0\end{array}$ & $\begin{array}{l}7.8 \\
2.6 \\
2.2 \\
3.0\end{array}$ \\
\hline 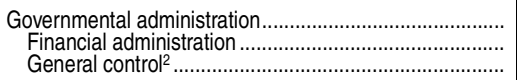 & $\begin{array}{l}4.4 \\
1.5 \\
2.9\end{array}$ & $\begin{array}{l}4.9 \\
1.8 \\
3.1\end{array}$ & $\begin{array}{l}5.3 \\
1.9 \\
3.5\end{array}$ & $\begin{array}{l}5.3 \\
1.9 \\
3.4\end{array}$ & $\begin{array}{l}5.2 \\
1.8 \\
3.4\end{array}$ & $\begin{array}{l}5.3 \\
1.8 \\
3.5\end{array}$ & $\begin{array}{l}5.3 \\
1.7 \\
3.6\end{array}$ & $\begin{array}{l}5.1 \\
1.6 \\
3.5\end{array}$ & $\begin{array}{l}5.0 \\
1.6 \\
3.4\end{array}$ & $\begin{array}{l}4.8 \\
1.5 \\
3.3\end{array}$ \\
\hline Interest on general debt................................................ & 3.4 & 4.2 & 5.8 & 4.6 & 4.1 & 4.1 & 4.2 & 4.2 & 4.2 & 4.2 \\
\hline 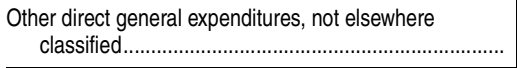 & 4.8 & 6.0 & 5.2 & 5.8 & 5.5 & 5.5 & 5.3 & 5.3 & 5.4 & 5.3 \\
\hline
\end{tabular}

$†$ Not applicable. \#Rounds to zero.

${ }^{1}$ As of 2005-06, no longer includes transit subsidies.

2Includes judicial and legal expenditures and expenditures on general public buildings and other governmental administration.

${ }^{3}$ Constant dollars based on the Consumer Price Index, prepared by the Bureau of Labor Statistics, U.S. Department of Labor, adjusted to a school-year basis.
NOTE: Excludes monies paid by states to the federal government. Some data have been revised from previously published figures. Detail may not sum to totals because of rounding. SOURCE: U.S. Department of Commerce, Census Bureau, Governmental Finances. Retrieved August 27, 2013, from http://www.census.gov/govs/local/. (This table was prepared August 2013.) 
Table 106.40. Direct general expenditures of state and local governments for all functions and for education, by level of education and state: 2009-10 and 2010-11

[In millions of current dollars. Standard errors appear in parentheses]

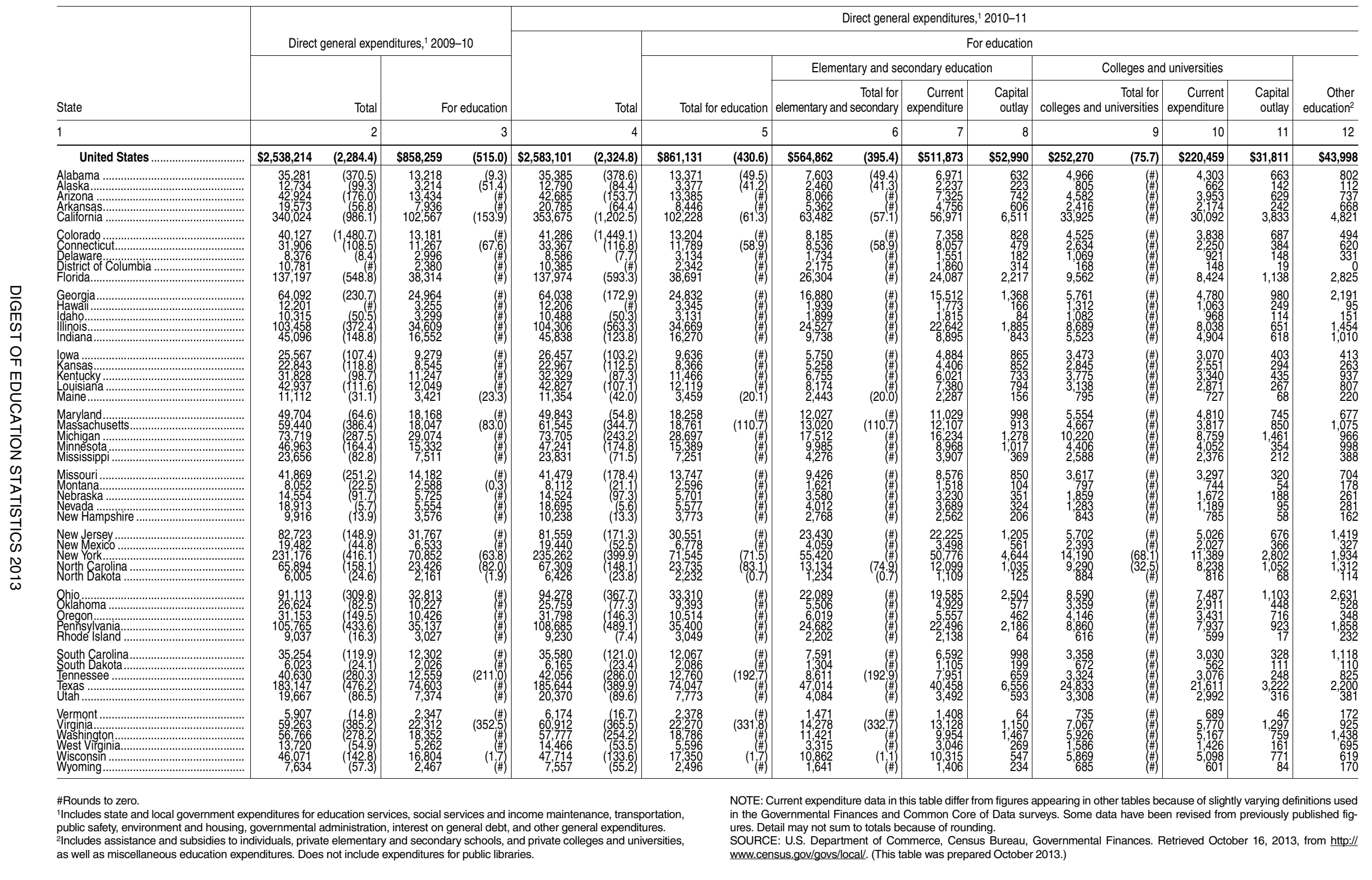


Table 106.50. Direct general expenditures per capita of state and local governments for all functions and for education, by level of education and state: $2009-10$ and $2010-11$

[Amounts in current dollars]

\begin{tabular}{|c|c|c|c|c|c|c|c|c|c|c|c|c|}
\hline \multirow[b]{4}{*}{ State } & \multicolumn{3}{|c|}{ Direct general expenditures, ${ }^{1} 2009-10$} & \multicolumn{9}{|c|}{ Direct general expenditures, ${ }^{1}$ 2010-11 } \\
\hline & \multirow[b]{3}{*}{$\begin{array}{r}\text { Total } \\
\text { amount } \\
\text { per capita }\end{array}$} & \multicolumn{2}{|c|}{ For education } & \multirow[b]{3}{*}{$\begin{array}{r}\text { Total } \\
\text { amount } \\
\text { per capita }\end{array}$} & \multicolumn{8}{|c|}{ For education } \\
\hline & & \multirow[b]{2}{*}{$\begin{array}{r}\text { Amount } \\
\text { per capita }\end{array}$} & \multirow[b]{2}{*}{$\begin{array}{r}\text { As a } \\
\text { percent } \\
\text { of all } \\
\text { functions }\end{array}$} & & \multicolumn{2}{|c|}{ All education } & \multicolumn{2}{|c|}{$\begin{array}{c}\text { Elementary and } \\
\text { secondary education }\end{array}$} & \multicolumn{2}{|c|}{$\begin{array}{c}\text { Colleges } \\
\text { and universities }\end{array}$} & \multicolumn{2}{|c|}{ Other education ${ }^{2}$} \\
\hline & & & & & $\begin{array}{r}\text { Amount } \\
\text { per capita }\end{array}$ & $\begin{array}{r}\text { As a } \\
\text { percent } \\
\text { of all } \\
\text { functions }\end{array}$ & $\begin{array}{r}\text { Amount } \\
\text { per capita }\end{array}$ & $\begin{array}{r}\text { As a } \\
\text { percent } \\
\text { of all } \\
\text { functions }\end{array}$ & $\begin{array}{r}\text { Amount } \\
\text { per capita }\end{array}$ & $\begin{array}{r}\text { As a } \\
\text { percent } \\
\text { of all } \\
\text { functions }\end{array}$ & $\begin{array}{r}\text { Amount } \\
\text { per capita }\end{array}$ & $\begin{array}{r}\text { As a } \\
\text { percent } \\
\text { of all } \\
\text { functions }\end{array}$ \\
\hline 1 & 2 & 3 & 4 & 5 & 6 & 7 & 8 & 9 & 10 & 11 & 12 & 13 \\
\hline United States .. & $\$ 8,206$ & $\$ 2,775$ & 33.8 & $\$ 8,290$ & $\$ 2,764$ & 33.3 & $\$ 1,813$ & 21.9 & $\$ 810$ & 9.8 & $\$ 141$ & 1.7 \\
\hline Alabama ............. & 7,373 & 2,762 & 37.5 & 7,368 & 2,784 & 37.8 & 1,197 & 16.2 & 1,034 & 14.0 & 167 & 2.3 \\
\hline 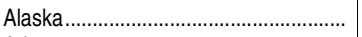 & 17,831 & 4,500 & 25.2 & 17,698 & 4,672 & 26.4 & 3,404 & 19.2 & 1,113 & 6.3 & 155 & 0.9 \\
\hline Arizona & 6,693 & 2,095 & 31.3 & 6,585 & 2,065 & 31.4 & 1,244 & 18.9 & 707 & 10.7 & 114 & 1.7 \\
\hline 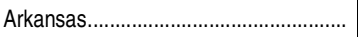 & 6,699 & 2,716 & 40.5 & 7,074 & 2,875 & 40.6 & 1,825 & 25.8 & 785 & 11.1 & 227 & 3.2 \\
\hline California ......................................... & 9,107 & 2,747 & 30.2 & 9,383 & 2,712 & 28.9 & 1,684 & 17.9 & 900 & 9.6 & 128 & 1.4 \\
\hline Colorado ........... & 7,950 & 2,611 & 32.8 & 8,069 & 2,580 & 32.0 & 1,600 & 19.8 & 884 & 11.0 & 96 & 1.2 \\
\hline 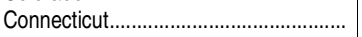 & 8,923 & 3,151 & 35.3 & 9,318 & 3,292 & 35.3 & 2,384 & 25.6 & 736 & 7.9 & 173 & 1.9 \\
\hline 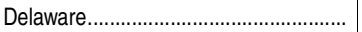 & 9,309 & 3,330 & 35.8 & 9,465 & 3,455 & 36.5 & 1,911 & 20.2 & 1,179 & 12.5 & 365 & 3.9 \\
\hline District of Columbia ................................. & 17,822 & 3,934 & 22.1 & 16,805 & 3,790 & 22.6 & 3,519 & 20.9 & 271 & 1.6 & 0 & 0.0 \\
\hline 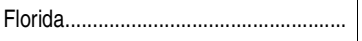 & 7,283 & 2,034 & 27.9 & 7,240 & 2,030 & 28.0 & 1,380 & 19.1 & 502 & 6.9 & 148 & 2.0 \\
\hline Georgia & 6,599 & 2,570 & 38.9 & 6,524 & 2,530 & 38.8 & 1,720 & 26.4 & 587 & 9.0 & 223 & 3.4 \\
\hline 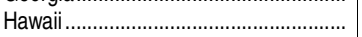 & 8,949 & 2,387 & 26.7 & 8,878 & 2,433 & 27.4 & 1,410 & 15.9 & 954 & 10.7 & 69 & 0.8 \\
\hline (n) & 6,566 & 2,100 & 32.0 & 6,617 & 1,975 & 29.9 & 1,198 & 18.1 & 682 & 10.3 & 95 & 1.4 \\
\hline Illinois & 8,056 & 2,695 & 33.5 & 8,105 & 2,694 & 33.2 & 1,906 & 23.5 & 675 & 8.3 & 113 & 1.4 \\
\hline 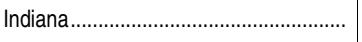 & 6,948 & 2,550 & 36.7 & 7,034 & 2,497 & 35.5 & 1,494 & 21.2 & 847 & 12.0 & 155 & 2.2 \\
\hline lowa ......... & 8,382 & 3,042 & 36.3 & 8,640 & 3,147 & 36.4 & 1,878 & 21.7 & 1,134 & 13.1 & 135 & 1.6 \\
\hline 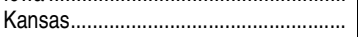 & 7,989 & 2,989 & 37.4 & 7,999 & 2,914 & 36.4 & 1,831 & 22.9 & 991 & 12.4 & 92 & 1.1 \\
\hline Kentucky & 7,322 & 2,587 & 35.3 & 7,399 & 2,624 & 35.5 & 1,546 & 20.9 & 864 & 11.7 & 214 & 2.9 \\
\hline 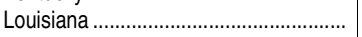 & 9,446 & 2,651 & 28.1 & 9,361 & 2,649 & 28.3 & 1,787 & 19.1 & 686 & 7.3 & 176 & 1.9 \\
\hline Maine & 8,372 & 2,577 & 30.8 & 8,548 & 2,604 & 30.5 & 1,840 & 21.5 & 598 & 7.0 & 166 & 1.9 \\
\hline 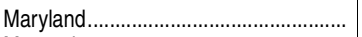 & 8,591 & 3,140 & 36.6 & 8,552 & 3,133 & 36.6 & 2,064 & 24.1 & 953 & 11.1 & 116 & 1.4 \\
\hline 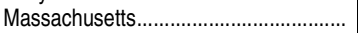 & 9,067 & 2,753 & 30.4 & 9,343 & 2,848 & 30.5 & 1,976 & 21.2 & 708 & 7.6 & 163 & 1.7 \\
\hline Michigan & 7,464 & 2,944 & 39.4 & 7,463 & 2,906 & 38.9 & 1,773 & 23.8 & 1,035 & 13.9 & 98 & 1.3 \\
\hline 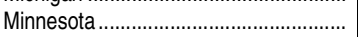 & 8,843 & 2,887 & 32.6 & 8,839 & 2,879 & 32.6 & 1,868 & 21.1 & 824 & 9.3 & 187 & 2.1 \\
\hline 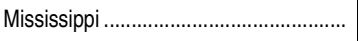 & 7,965 & 2,529 & 31.7 & 8,001 & 2,434 & 30.4 & 1,435 & 17.9 & 869 & 10.9 & 130 & 1.6 \\
\hline 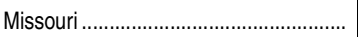 & 6,983 & 2,365 & 33.9 & 6,901 & 2,287 & 33.1 & 1,568 & 22.7 & 602 & 8.7 & 117 & 1.7 \\
\hline 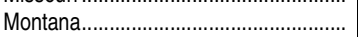 & 8,125 & 2,612 & 32.1 & 8,127 & 2,601 & 32.0 & 1,624 & 20.0 & 799 & 9.8 & 178 & 2.2 \\
\hline 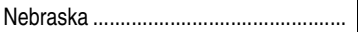 & 7,953 & 3,128 & 39.3 & 7,882 & 3,094 & 39.3 & 1,943 & 24.7 & 1,009 & 12.8 & 142 & 1.8 \\
\hline 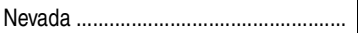 & 6,994 & 2,054 & 29.4 & 6,865 & 2,048 & 29.8 & 1,473 & 21.5 & 471 & 6.9 & 103 & 1.5 \\
\hline New Hampshire ...................................... & 7,530 & 2,716 & 36.1 & 7,766 & 2,862 & 36.9 & 2,100 & 27.0 & 639 & 8.2 & 123 & 1.6 \\
\hline New Jersey.... & 9,401 & 3,610 & 38.4 & 9,246 & 3,463 & 37.5 & 2,656 & 28.7 & 646 & 7.0 & 161 & 1.7 \\
\hline 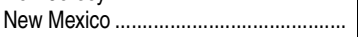 & 9,430 & 3,162 & 33.5 & 9,336 & 3,255 & 34.9 & 1,949 & 20.9 & 1,149 & 12.3 & 157 & 1.7 \\
\hline 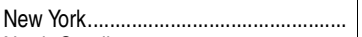 & 11,919 & 3,653 & 30.6 & 12,086 & 3,676 & 30.4 & 2,847 & 23.6 & 729 & 6.0 & 99 & 0.8 \\
\hline North Carolina ......................................... & 6,892 & 2,450 & 35.6 & 6,970 & 2,458 & 35.3 & 1,360 & 19.5 & 962 & 13.8 & 136 & 1.9 \\
\hline North Dakota ............................................ & 8,902 & 3,203 & 36.0 & 9,396 & 3,263 & 34.7 & 1,804 & 19.2 & 1,293 & 13.8 & 167 & 1.8 \\
\hline Ohio & 7,897 & 2,844 & 36.0 & 8,166 & 2,885 & 35.3 & 1,913 & 23.4 & 744 & 9.1 & 228 & 2.8 \\
\hline Oklahoma & 7,081 & 2,720 & 38.4 & 6,794 & 2,477 & 36.5 & 1,452 & 21.4 & 886 & 13.0 & 139 & 2.1 \\
\hline 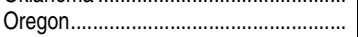 & 8,116 & 2,716 & 33.5 & 8,212 & 2,715 & 33.1 & 1,555 & 18.9 & 1,071 & 13.0 & 90 & 1.1 \\
\hline 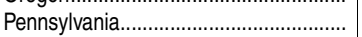 & 8,316 & 2,763 & 33.2 & 8,529 & 2,778 & 32.6 & 1,937 & 22.7 & 695 & 8.2 & 146 & 1.7 \\
\hline 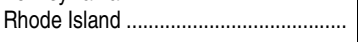 & 8,586 & 2,876 & 33.5 & 8,780 & 2,900 & 33.0 & 2,094 & 23.9 & 586 & 6.7 & 220 & 2.5 \\
\hline 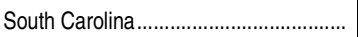 & 7,603 & 2,653 & 34.9 & 7,604 & 2,579 & 33.9 & 1,622 & 21.3 & 718 & 9.4 & 239 & 3.1 \\
\hline South Dakota & 7,376 & 2,481 & 33.6 & 7,482 & 2,532 & 33.8 & 1,583 & 21.2 & 816 & 10.9 & 133 & 1.8 \\
\hline 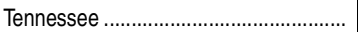 & 6,391 & 1,975 & 30.9 & 6,568 & 1,993 & 30.3 & 1,345 & 20.5 & 519 & 7.9 & 129 & 2.0 \\
\hline 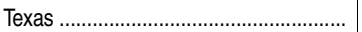 & 7,252 & 2,954 & 40.7 & 7,231 & 2,884 & 39.9 & 1,831 & 25.3 & 967 & 13.4 & 86 & 1.2 \\
\hline Utah & 7,086 & 2,657 & 37.5 & 7,230 & 2,759 & 38.2 & 1,450 & 20.1 & 1,174 & 16.2 & 135 & 1.9 \\
\hline Vermont ...... & 9,437 & 3,750 & 39.7 & 9,855 & 3,796 & 38.5 & 2,349 & 23.8 & 1,173 & 11.9 & 275 & 2.8 \\
\hline 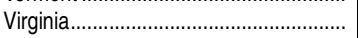 & 7,386 & 2,781 & 37.6 & 7,523 & 2,751 & 36.6 & 1,763 & 23.4 & 873 & 11.6 & 114 & 1.5 \\
\hline 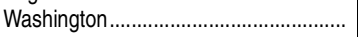 & 8,419 & 2,722 & 32.3 & 8,459 & 2,750 & 32.5 & 1,672 & 19.8 & 868 & 10.3 & 211 & 2.5 \\
\hline West Virginia......................................... & 7,399 & 2,838 & 38.4 & 7,797 & 3,016 & 38.7 & 1,787 & 22.9 & 855 & 11.0 & 375 & 4.8 \\
\hline Wisconsin & 8,095 & 2,952 & 36.5 & 8,354 & 3,038 & 36.4 & 1,902 & 22.8 & 1,028 & 12.3 & 108 & 1.3 \\
\hline Wyoming & 13,521 & 4,369 & 32.3 & 13,301 & 4,393 & 33.0 & 2,888 & 21.7 & 1,206 & 9.1 & 299 & 2.2 \\
\hline
\end{tabular}

${ }^{1}$ Includes state and local government expenditures for education services, social services and income maintenance, transportation, public safety, environment and housing, governmental administration, interest on general debt, and other general expenditures.

Includes assistance and subsidies to individuals, private elementary and secondary schools, and private colleges and universities, as well as miscellaneous education expenditures. Does not include expenditures for public libraries.
NOTE: Per capita amounts for 2010-11 are based on population estimates for July 2011. Per capita amounts for 2009-10 are based on the latest population estimates for July 2010 and have been revised from previously published figures. Detail may not sum to totals because of rounding.

SOURCE: U.S. Department of Commerce, Census Bureau, Governmental Finances, retrieved October 25, 2013, from http://www.census.gov/govs/local/; and GCT-T1 Population Estimates, retrieved October 26, 2013, from http://www.census.gov/popest/datal national/totals/2011/index.html. (This table was prepared October 2013). 
Table 106.60. Gross domestic product, state and local expenditures, national income, personal income, disposable personal income, median family income, and population: Selected years, 1929 through 2013

\begin{tabular}{|c|c|c|c|c|c|c|c|c|c|c|c|c|c|}
\hline \multirow[b]{2}{*}{ Year } & \multicolumn{2}{|c|}{$\begin{array}{l}\text { Gross domestic } \\
\text { product (in billions) }\end{array}$} & \multicolumn{2}{|c|}{$\begin{array}{l}\text { State and local direct } \\
\text { general expenditures } \\
\text { (in millions) }{ }^{1}\end{array}$} & \multirow[b]{2}{*}{$\begin{array}{r}\text { National } \\
\text { income } \\
\text { (in billions) }\end{array}$} & \multirow[b]{2}{*}{$\begin{array}{r}\text { Personal } \\
\text { income } \\
\text { (in billions) }\end{array}$} & \multirow{2}{*}{$\begin{array}{r}\text { Disposable } \\
\text { personal } \\
\text { income } \\
\text { (in billions } \\
\text { of chained } \\
2009 \\
\text { dollars) } \\
\end{array}$} & \multicolumn{2}{|c|}{$\begin{array}{l}\text { Disposable personal } \\
\text { income per capita }\end{array}$} & \multicolumn{2}{|c|}{ Median family income } & \multicolumn{2}{|c|}{ Population (in thousands) } \\
\hline & $\begin{array}{r}\text { Current } \\
\text { dollars }\end{array}$ & $\begin{array}{r}\text { Chained } \\
2009 \\
\text { dollars }^{2}\end{array}$ & $\begin{array}{r}\text { All direct } \\
\text { general } \\
\text { expenditures }\end{array}$ & $\begin{array}{r}\text { Education } \\
\text { expenditures }\end{array}$ & & & & $\begin{array}{r}\text { Current } \\
\text { dollars }\end{array}$ & $\begin{array}{r}\text { Chained } \\
2009 \\
\text { dollars }^{2}\end{array}$ & $\begin{array}{r}\text { Current } \\
\text { dollars }\end{array}$ & $\begin{array}{r}\text { Constant } \\
2012 \\
\text { dollars }^{3}\end{array}$ & $\begin{array}{r}\text { Midyear } \\
\text { data }^{4}\end{array}$ & $\begin{array}{r}\text { Resident as } \\
\text { of July } 1^{5}\end{array}$ \\
\hline 1 & 2 & 3 & 4 & 5 & 6 & 7 & 8 & 9 & 10 & 11 & 12 & 13 & 14 \\
\hline 1929. & $\$ 104.6$ & $\$ 1,055.6$ & - & - & - & $\$ 85.3$ & $\$ 843.1$ & $\$ 685$ & $\$ 6,917$ & - & - & 121,878 & 121,767 \\
\hline 1939. & 93.5 & $1,162.6$ & - & - & - & 73.6 & 923.2 & 551 & 7,046 & - & - & 131,028 & 130,880 \\
\hline 1940. & 102.9 & $1,265.0$ & $\$ 9,229$ & $\$ 2,638$ & - & 79.4 & 986.2 & 588 & 7,464 & - & - & 132,122 & 132,122 \\
\hline 1950. & 300.2 & $2,181.9$ & 22,787 & 7,177 & 267.0 & 233.9 & $1,521.9$ & 1,417 & 10,033 & $\$ 3,319$ & - & 151,684 & 152,271 \\
\hline $1960 .$. & 543.3 & $3,105.8$ & 51,876 & 18,719 & 479.9 & 422.5 & $2,146.9$ & 2,083 & 11,877 & 5,620 & $\$ 38,130$ & 180,760 & 180,671 \\
\hline 1970. & $1,075.9$ & $4,717.7$ & 131,332 & 52,718 & 940.1 & 864.6 & $3,413.4$ & 3,713 & 16,643 & 9,867 & 52,068 & 205,089 & 205,052 \\
\hline 1971. & $1,167.8$ & $4,873.0$ & 150,674 & 59,413 & $1,017.0$ & 932.1 & $3,570.4$ & 3,998 & 17,191 & 10,285 & 51,996 & 207,692 & 207,661 \\
\hline $1972 .$. & $1,282.4$ & $5,128.8$ & 168,550 & 65,814 & $1,123.0$ & $1,023.6$ & $3,741.3$ & 4,287 & 17,822 & 11,116 & 54,561 & 209,924 & 209,896 \\
\hline 1973 & $1,428.5$ & $5,418.2$ & 181,357 & 69,714 & $1,257.0$ & $1,138.5$ & $3,968.6$ & 4,747 & 18,725 & 12,051 & 55,666 & 211,939 & 211,909 \\
\hline 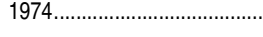 & $1,548.8$ & $5,390.2$ & 198,959 & 75,833 & $1,350.8$ & $1,249.3$ & $3,923.7$ & 5,135 & 18,344 & 12,902 & 54,179 & 213,898 & 213,854 \\
\hline 1975 & $1,688.9$ & $5,379.5$ & 230,721 & 87,858 & $1,451.1$ & $1,366.9$ & $4,020.2$ & 5,645 & 18,614 & 13,719 & 53,234 & 215,981 & 215,973 \\
\hline $1976 \ldots$ & $1,877.6$ & $5,669.3$ & 256,731 & 97,216 & $1,614.8$ & $1,498.1$ & $4,144.0$ & 6,079 & 19,002 & 14,958 & 54,884 & 218,086 & 218,035 \\
\hline 1977 & $2,086.0$ & $5,930.6$ & 274,215 & 102,780 & $1,798.7$ & $1,654.2$ & $4,274.8$ & 6,613 & 19,406 & 16,009 & 55,253 & 220,289 & 220,239 \\
\hline 1978 & $2,356.6$ & $6,260.4$ & 296,984 & 110,758 & $2,029.9$ & $1,859.5$ & $4,470.5$ & 7,322 & 20,080 & 17,640 & 56,975 & 222,629 & 222,585 \\
\hline 1979 & $2,632.1$ & $6,459.2$ & 327,517 & 119,448 & $2,248.2$ & $2,077.9$ & $4,557.8$ & 8,037 & 20,248 & 19,587 & 57,734 & 225,106 & 225,055 \\
\hline (1) & $2,862.5$ & $6,443.4$ & 369,086 & 133,211 & $2,426.8$ & $2,316.8$ & $4,590.6$ & 8,861 & 20,159 & 21,023 & 55,775 & 227,726 & 227,225 \\
\hline $1981 \ldots$ & $3,210.9$ & $6,610.6$ & 407,449 & 145,784 & $2,722.1$ & $2,595.9$ & $4,705.7$ & 9,785 & 20,459 & 22,388 & 54,233 & 230,008 & 229,466 \\
\hline 1982. & $3,345.0$ & $6,484.3$ & 436,733 & 154,282 & $2,840.4$ & $2,778.8$ & $4,803.4$ & 10,442 & 20,685 & 23,433 & 53,534 & 232,218 & 231,664 \\
\hline $1983 .$. & $3,638.1$ & $6,784.7$ & 466,516 & 163,876 & $3,060.5$ & $2,969.7$ & $4,971.0$ & 11,170 & 21,214 & 24,580 & 53,856 & 234,333 & 233,792 \\
\hline 1984 & $4,040.7$ & $7,277.2$ & 505,008 & 176,108 & $3,444.0$ & $3,281.3$ & $5,314.0$ & 12,284 & 22,480 & 26,433 & 55,638 & 236,394 & 235,825 \\
\hline 198 & $4,346.7$ & $7,585.7$ & 553,899 & 686 & 84.2 & $3,515.9$ & 76.3 & 12,991 & 22,961 & 27,735 & 56,441 &, 506 & 237,924 \\
\hline $1986 .$. & $4,590.1$ & $7,852.1$ & 605,623 & 210,819 & $3,848.2$ & $3,725.1$ & 87.9 & 13,661 & 23,632 & 29,458 & 58,881 & 240,683 & 240,133 \\
\hline $1987 .$. & $4,870.2$ & $8,123.9$ & 657,134 & 226,619 & $4,119.2$ & $3,955.3$ & $5,811.1$ & 14,274 & 23,930 & 30,970 & 59,880 & 242,843 & 242,289 \\
\hline 1988 & $5,252.6$ & $8,465.4$ & 704,921 & 242,683 & $4,493.4$ & $4,275.3$ & $6,083.9$ & 15,386 & 24,826 & 32,191 & 60,038 & 245,061 & 244,499 \\
\hline 1989 & $5,657.7$ & $8,777.0$ & 762,360 & 263,898 & $4,782.2$ & $4,618.2$ & $6,268.8$ & 16,380 & 25,340 & 34,213 & 61,170 & 247,387 & 246,819 \\
\hline 199 & $5,979.6$ & $8,945.4$ & 834,818 & 288,148 & 36.1 & $4,904.5$ & 3.6 & 17,235 & 25,556 & 35,353 & 60,207 & 250,181 & 249,623 \\
\hline $1991 \ldots \ldots \ldots$ & $6,174.0$ & $8,938.9$ & 908,108 & 309,302 & $5,186.1$ & $5,071.1$ & $6,438.5$ & 17,688 & 25,395 & 35,939 & 59,086 & 253,530 & 252,981 \\
\hline 1992 & $6,539.3$ & $9,256.7$ & 981,253 & 324,652 & $5,499.7$ & $5,410.8$ & $6,714.3$ & 18,684 & 26,134 & 36,573 & 58,642 & 256,922 & 256,514 \\
\hline 1993 & $6,878.7$ & $9,510.8$ & $1,033,167$ & 342,287 & $5,754.8$ & $5,646.8$ & $6,823.6$ & 19,211 & 26,216 & 36,959 & 57,831 & 260,282 & 259,919 \\
\hline 1994 & $7,308.7$ & $9,894.7$ & $1,077,665$ & 353,287 & $6,140.2$ & $5,934.7$ & $7,010.8$ & 19,906 & 26,611 & 38,782 & 59,415 & 263,455 & 263,126 \\
\hline (n) & $7,664.0$ & $10,163.7$ & $1,146,188$ & 378,273 & $6,479.5$ & $6,276.5$ & $7,245.9$ & 20,753 & 27,180 & 40,611 & 60,754 & 266,588 & 266,278 \\
\hline $1996 \ldots$ & $8,100.2$ & $10,549.5$ & $1,189,356$ & 398,859 & $6,899.4$ & $6,661.9$ & $7,476.2$ & 21,615 & 27,719 & 42,300 & 61,640 & 269,714 & 269,394 \\
\hline 1997 & $8,608.5$ & $11,022.9$ & $1,247,436$ & 419,053 & $7,380.4$ & $7,075.0$ & $7,751.4$ & 22,527 & 28,398 & 44,568 & 63,572 & 272,958 & 272,647 \\
\hline 1998 & $9,089.1$ & $11,513.4$ & $1,314,496$ & 450,365 & $7,857.3$ & $7,587.7$ & $8,208.3$ & 23,759 & 29,724 & 46,737 & 65,748 & 276,154 & 275,854 \\
\hline 1999 & $9,665.7$ & $12,071.4$ & $1,398,533$ & 483,259 & $8,324.4$ & $7,983.8$ & $8,477.8$ & 24,617 & 30,351 & 48,831 & 67,290 & 279,328 & 279,040 \\
\hline $2000 \ldots$ & $0,289.7$ & $12,565.2$ & $1,502,768$ & 521,612 & $8,907.0$ & $8,632.8$ & $8,902.5$ & 26,206 & 31,525 & 50,732 & 67,643 & 282,398 & 282,162 \\
\hline $2001 \ldots \ldots$. & $10,625.3$ & $12,684.4$ & $1,621,757$ & 563,572 & $9,184.6$ & $8,987.1$ & $9,149.3$ & 27,179 & 32,077 & 51,407 & 66,671 & 285,225 & 284,969 \\
\hline 2002 & $10,980.2$ & $12,909.7$ & $1,732,478$ & 594,694 & $9,436.8$ & $9,149.5$ & $9,431.7$ & 28,127 & 32,754 & 51,680 & 65,959 & 287,955 & 287,625 \\
\hline 2003 & $11,512.2$ & $13,270.0$ & $1,817,513$ & 621,335 & $9,865.1$ & $9,487.6$ & $9,691.0$ & 29,201 & 33,345 & 52,680 & 65,767 & 290,626 & 290,108 \\
\hline 2004 & $12,277.0$ & $13,774.0$ & $1,903,915$ & 655,182 & $10,541.9$ & $10,049.2$ & $10,036.7$ & 30,700 & 34,224 & 54,061 & 65,715 & 293,262 & 292,805 \\
\hline 2005. & $13,095.4$ & $14,235.6$ & $2,007,490$ & 688,314 & $11,240.8$ & $10,610.3$ & $10,190.5$ & 31,763 & 34,428 & 56,194 & 66,092 & 295,993 & 295,517 \\
\hline 2006 & $13,857.9$ & $14,615.2$ & $2,117,161$ & 728,917 & $12,005.6$ & $11,389.8$ & $10,596.4$ & 33,591 & 35,461 & 58,407 & 66,514 & 298,818 & 298,380 \\
\hline 2007 & $14,480.3$ & $14,876.8$ & $2,255,229$ & 773,676 & $12,322.3$ & $11,995.7$ & $10,821.8$ & 34,829 & 35,870 & 61,355 & 67,944 & 301,696 & 301,231 \\
\hline 2008 & $14,720.3$ & $14,833.6$ & $2,401,417$ & 826,061 & $12,430.8$ & $12,430.6$ & $10,988.4$ & 36,104 & 36,082 & 61,521 & 65,607 & 304,543 & 304,094 \\
\hline 2009 & $14,417.9$ & $14,417.9$ & $2,494,986$ & 851,149 & $12,124.5$ & $12,082.1$ & $10,937.2$ & 35,598 & 35,598 & 60,088 & 64,323 & 307,240 & 306,772 \\
\hline $2010 \ldots$ & $14,958.3$ & $14,779.4$ & $2,538,214$ & 858,259 & $12,739.5$ & $12,435.2$ & 60.8 & 36,296 & 35,706 & 60,236 & 63,434 & 309,776 & 309,326 \\
\hline $2011 \ldots \ldots \ldots$ & $15,533.8$ & $15,052.4$ & $2,583,101$ & 861,131 & $13,395.7$ & $13,191.3$ & $11,324.6$ & 37,776 & 36,293 & 60,974 & 62,248 & 312,036 & 311,588 \\
\hline 2012 & $16,244.6$ & $15,470.7$ & - & - & $13,971.6$ & $13,743.8$ & $11,551.6$ & 38,965 & 36,756 & 62,241 & 62,241 & 314,278 & 313,914 \\
\hline 2013 & $16,803.0$ & $15,767.1$ & - & - & 一 & $14,133.5$ & $11,637.8$ & 39,410 & 36,767 & - & - & 316,524 & - \\
\hline
\end{tabular}

-Not available.

'Data for years prior to 1963 include expenditures for government fiscal years ending during that particular calendar year. Data for 1963 and later years are the aggregations of expenditures for government fiscal years that ended on June 30 of the stated year. General expenditures exclude expenditures of publicly owned utilities and liquor stores, and of insurance-trust activities. Intergovernmental payments between state and local governments are excluded. Payments to the federal government are included.

${ }^{2}$ Constant dollars based on a chain-price index, which uses the geometric mean of output weights of adjacent time periods compiled over a time series. Chain-price indexes reflect changes in prices, while implicit price deflators reflect both changes in prices and in the composition of output. More information is available at https://www.bea.gov/scb/

account_articles/national/0597od/maintext.htm. improvements in methodology made to the current CPI-U since 1978 into a single, uniform series. See Census Bureau, Money Income in the United States: 1999 (www.census.gov/prod/ 2000pubs/p60-209.pdf).
${ }^{4}$ Population of the United States including armed forces overseas. Includes Alaska and Hawaii beginning in 1960 .

${ }^{5}$ Resident population of the United States. Includes Alaska and Hawaii beginning in 1958. Data for 1990 and later years include revisions based on the 2000 census. Excludes overseas armed personnel.

NOTE: Gross domestic product (GDP) data are adjusted by the GDP chained weight price deflator. Personal income data are adjusted by the personal consumption deflator. Some data have been revised from previously published figures.

SOURCE: U.S. Department of Commerce, Census Bureau, Current Population Reports, Income, Poverty, and Health Insurance in the United States, retrieved February 5, 2014, from http://www.census.gov/hhes/www/income/data/historical/families/; Population Estimates, retrieved November 1, 2013, from http://www.census.gov/popest/data/national/asrh/2012/ retrieved November 1, 2013, from http://www.census.gov/popest/data/national/asrh/2012/ from http://www.census.gov/govs/locall. U.S. Department of Commerce, Bureau of Economic from http://www.census.gov/govs/locall. U.S. Department of Commerce, Bureau of Economic http://www.bea.gov/iTable/index nipa.cfm. (This table was prepared February 2014.) 
64 CHAPTER 1: All Levels of Education

Summary of Finances

Table 106.70. Gross domestic product price index, Consumer Price Index, education price indexes, and federal budget composite deflator: Selected years, 1919 through 2013

\begin{tabular}{|c|c|c|c|c|c|c|c|c|c|}
\hline \multicolumn{3}{|c|}{ Calendar year } & \multicolumn{5}{|c|}{ School year } & \multicolumn{2}{|c|}{ Federal fiscal year } \\
\hline Year & $\begin{array}{r}\text { Gross domestic } \\
\text { product } \\
\text { price index }\end{array}$ & $\begin{array}{r}\text { Consumer } \\
\text { Price Index }\end{array}$ & Year & $\begin{array}{r}\text { Consumer } \\
\text { Price Index }\end{array}$ & $\begin{array}{r}\text { Higher } \\
\text { Education } \\
\text { Price Index }\end{array}$ & $\begin{array}{r}\text { Research and } \\
\text { Development } \\
\text { Index }\end{array}$ & \begin{tabular}{|r||} 
Academic \\
Library \\
Operations Index
\end{tabular} & Year & $\begin{array}{r}\text { Federal budget } \\
\text { composite } \\
\text { deflator }\end{array}$ \\
\hline 1 & 2 & 3 & 4 & 5 & 6 & 7 & 8 & 9 & 10 \\
\hline 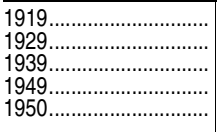 & \begin{tabular}{r|}
$9.8 \overline{99}$ \\
8.049 \\
13.622 \\
13.746
\end{tabular} & $\begin{array}{l}17.3 \\
17.1 \\
13.9 \\
23.8 \\
24.1\end{array}$ & \begin{tabular}{||c|}
$1919-20 \ldots \ldots \ldots \ldots \ldots \ldots .$. \\
$1929-30 \ldots \ldots \ldots \ldots \ldots \ldots .$. \\
$1939-40 \ldots \ldots \ldots \ldots \ldots \ldots .$. \\
$1949-50 \ldots \ldots \ldots \ldots \ldots \ldots . .$. \\
$1950-51 \ldots \ldots \ldots \ldots \ldots \ldots .$. \\
\end{tabular} & $\begin{array}{l}19.1 \\
17.1 \\
14.0 \\
23.7 \\
25.1\end{array}$ & $\begin{array}{l}\bar{z} \\
\overline{-} \\
\overline{-}\end{array}$ & $\begin{array}{l}\bar{z} \\
\overline{-} \\
-\end{array}$ & \begin{tabular}{l||}
$\overline{-}$ \\
$\overline{-}$ \\
$\overline{-}$ \\
-
\end{tabular} & \begin{tabular}{|l}
$1919 \ldots \ldots \ldots \ldots \ldots \ldots \ldots .$. \\
$1929 \ldots \ldots \ldots \ldots \ldots \ldots \ldots .$. \\
$1939 \ldots \ldots \ldots \ldots \ldots \ldots \ldots \ldots .$. \\
$1949 \ldots \ldots \ldots \ldots \ldots \ldots \ldots \ldots .$. \\
$1950 \ldots \ldots \ldots \ldots \ldots \ldots \ldots . .$.
\end{tabular} & $\begin{array}{r}\overline{-} \\
\overline{-} \\
0.0960 \\
0.1006\end{array}$ \\
\hline 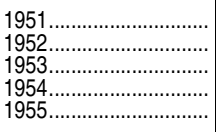 & $\begin{array}{l}14.675 \\
14.996 \\
15.190 \\
15.346 \\
15.566\end{array}$ & $\begin{array}{l}26.0 \\
26.5 \\
26.7 \\
26.9 \\
26.8\end{array}$ & $\mid$\begin{tabular}{|}
$1951-52 \ldots \ldots \ldots \ldots \ldots \ldots$ \\
$1952-53 \ldots \ldots \ldots \ldots \ldots \ldots \ldots$ \\
$1953-54 \ldots \ldots \ldots \ldots \ldots \ldots \ldots$ \\
$1954-55 \ldots \ldots \ldots \ldots \ldots \ldots \ldots$ \\
$1955-56 \ldots \ldots \ldots \ldots \ldots \ldots \ldots \ldots \ldots \ldots \ldots$
\end{tabular} & $\begin{array}{l}26.3 \\
26.7 \\
26.9 \\
26.8 \\
26.9\end{array}$ & $\begin{array}{l}\bar{z} \\
\overline{-} \\
-\end{array}$ & $\begin{array}{l}- \\
z \\
-\end{array}$ & \begin{tabular}{l||}
- \\
$\overline{-}$ \\
$\overline{-}$
\end{tabular} & 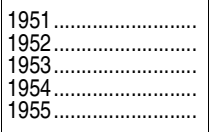 & $\begin{array}{l}0.1006 \\
0.1003 \\
0.1078 \\
0.1115 \\
0.1152\end{array}$ \\
\hline 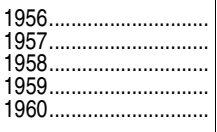 & $\begin{array}{l}16.101 \\
16.663 \\
17.050 \\
17.277 \\
17.516\end{array}$ & $\begin{array}{l}27.2 \\
28.1 \\
28.9 \\
29.1 \\
29.6\end{array}$ & \begin{tabular}{|}
$1956-57 \ldots \ldots \ldots \ldots \ldots$ \\
$1957-58 \ldots \ldots \ldots \ldots \ldots \ldots$ \\
$1958-59 \ldots \ldots \ldots \ldots \ldots \ldots$ \\
$1959-60 \ldots \ldots \ldots \ldots \ldots \ldots$ \\
$1960-61 \ldots \ldots \ldots \ldots \ldots \ldots$
\end{tabular} & $\begin{array}{l}27.7 \\
28.6 \\
29.0 \\
29.4 \\
29.8\end{array}$ & $\begin{array}{r}\bar{Z} \\
\overline{-} \\
25.6\end{array}$ & $\begin{array}{r}\bar{Z} \\
\bar{Z} \\
26.7\end{array}$ & $\begin{array}{l}- \\
\overline{-} \\
\overline{-} \\
-\end{array}$ & \begin{tabular}{|}
$1956 \ldots \ldots \ldots \ldots \ldots$ \\
$1957 \ldots \ldots \ldots \ldots \ldots \ldots \ldots$ \\
$1958 \ldots \ldots \ldots \ldots \ldots \ldots \ldots \ldots$ \\
$1959 \ldots \ldots \ldots \ldots \ldots \ldots \ldots \ldots \ldots \ldots$ \\
$1960 \ldots \ldots \ldots \ldots \ldots \ldots \ldots \ldots \ldots \ldots$
\end{tabular} & $\begin{array}{l}0.1202 \\
0.1260 \\
0.1335 \\
0.1389 \\
0.1410\end{array}$ \\
\hline 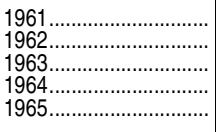 & $\begin{array}{l}17.709 \\
17.927 \\
18.129 \\
18.407 \\
18.744\end{array}$ & $\begin{array}{l}29.9 \\
30.2 \\
30.6 \\
31.0 \\
31.5\end{array}$ & $\mid$\begin{tabular}{|}
$1961-62 \ldots \ldots \ldots \ldots \ldots \ldots$ \\
$1962-63 \ldots \ldots \ldots \ldots \ldots \ldots .$. \\
$1963-64 \ldots \ldots \ldots \ldots \ldots \ldots .$. \\
$1964-65 \ldots \ldots \ldots \ldots \ldots \ldots .$. \\
$1965-66 \ldots \ldots \ldots \ldots \ldots \ldots \ldots$
\end{tabular} & $\begin{array}{l}30.1 \\
30.4 \\
30.8 \\
31.2 \\
31.9\end{array}$ & $\begin{array}{l}26.5 \\
27.6 \\
28.6 \\
29.8 \\
31.3\end{array}$ & $\begin{array}{l}27.5 \\
28.5 \\
29.5 \\
30.7 \\
32.0\end{array}$ & $\begin{array}{l}- \\
\overline{-} \\
\overline{-} \\
-\end{array}$ & 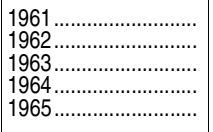 & $\begin{array}{l}0.1441 \\
0.1442 \\
0.1502 \\
0.1527 \\
0.1550\end{array}$ \\
\hline 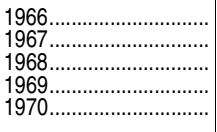 & $\begin{array}{l}19.270 \\
19.830 \\
20.673 \\
21.692 \\
22.835\end{array}$ & $\begin{array}{l}32.4 \\
33.4 \\
34.8 \\
36.7 \\
38.8\end{array}$ & $\mid$\begin{tabular}{|}
$1966-67 \ldots \ldots \ldots \ldots \ldots \ldots$. \\
$1967-68 \ldots \ldots \ldots \ldots \ldots \ldots \ldots .$. \\
$1968-69 \ldots \ldots \ldots \ldots \ldots \ldots \ldots .$. \\
$1969-70 \ldots \ldots \ldots \ldots \ldots \ldots . .$. \\
$1970-71 \ldots \ldots \ldots \ldots \ldots \ldots \ldots .$.
\end{tabular} & $\begin{array}{l}32.9 \\
34.0 \\
35.7 \\
37.8 \\
39.7\end{array}$ & $\begin{array}{l}32.9 \\
34.9 \\
37.1 \\
39.5 \\
42.1\end{array}$ & $\begin{array}{l}33.8 \\
35.7 \\
38.0 \\
40.3 \\
42.7\end{array}$ & $\begin{array}{l}- \\
\overline{-} \\
\overline{-} \\
-\end{array}$ & $\mid \begin{array}{r}1966 \ldots \ldots \ldots \ldots \ldots \ldots . . . \\
1967 \ldots \ldots \ldots \ldots \ldots \ldots \ldots \ldots . . \\
1968 \ldots \ldots \ldots \ldots \ldots \ldots \ldots \ldots . . \\
1969 \ldots \ldots \ldots \ldots \ldots \ldots \ldots \ldots . . \\
1970 \ldots \ldots \ldots \ldots \ldots \ldots \ldots . .\end{array}$ & $\begin{array}{l}0.1593 \\
0.1629 \\
0.1689 \\
0.1795 \\
0.1897\end{array}$ \\
\hline 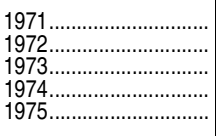 & $\begin{array}{l}23.996 \\
25.038 \\
26.399 \\
28.763 \\
31.435\end{array}$ & $\begin{array}{l}40.5 \\
41.8 \\
44.4 \\
49.3 \\
53.8\end{array}$ & $\mid$\begin{tabular}{|}
$\mid$ \\
$1971-72 \ldots \ldots \ldots \ldots \ldots \ldots$ \\
$1972-73 \ldots \ldots \ldots \ldots \ldots \ldots .$. \\
$1973-74 \ldots \ldots \ldots \ldots \ldots \ldots .$. \\
$1974-75 \ldots \ldots \ldots \ldots \ldots \ldots .$. \\
$1975-76 \ldots \ldots \ldots \ldots \ldots \ldots .$.
\end{tabular} & $\begin{array}{l}41.2 \\
42.8 \\
46.6 \\
51.8 \\
55.5\end{array}$ & $\begin{array}{l}44.3 \\
46.7 \\
49.9 \\
54.3 \\
57.8\end{array}$ & $\begin{array}{l}45.0 \\
47.1 \\
50.1 \\
54.8 \\
59.0\end{array}$ & $\begin{array}{c}- \\
\overline{-} \\
\overline{-} \\
57.3\end{array}$ & 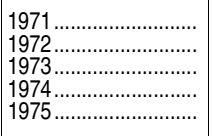 & $\begin{array}{l}0.2029 \\
0.2164 \\
0.2265 \\
0.2453 \\
0.2694\end{array}$ \\
\hline 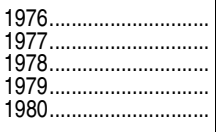 & $\begin{array}{l}33.161 \\
35.213 \\
37.685 \\
40.795 \\
44.485\end{array}$ & $\begin{array}{l}56.9 \\
60.6 \\
65.2 \\
72.6 \\
82.4\end{array}$ & 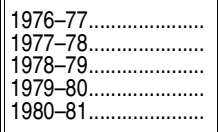 & $\begin{array}{l}58.7 \\
62.6 \\
68.5 \\
77.6 \\
86.6\end{array}$ & $\begin{array}{l}61.5 \\
65.7 \\
70.5 \\
77.5 \\
85.8\end{array}$ & $\begin{array}{l}62.7 \\
66.8 \\
71.7 \\
78.3 \\
86.6\end{array}$ & $\begin{array}{l}61.6 \\
65.8 \\
71.4 \\
78.5 \\
86.1\end{array}$ & 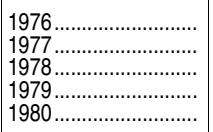 & $\begin{array}{l}0.2886 \\
0.3096 \\
0.3291 \\
0.3573 \\
0.3949\end{array}$ \\
\hline 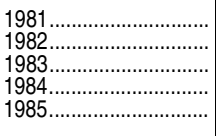 & $\begin{array}{l}48.663 \\
51.630 \\
53.664 \\
55.570 \\
57.347\end{array}$ & $\begin{array}{r}90.9 \\
96.5 \\
99.6 \\
103.9 \\
107.6\end{array}$ & 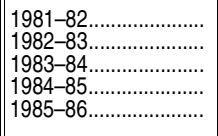 & $\begin{array}{r}94.1 \\
98.2 \\
101.8 \\
105.8 \\
108.8\end{array}$ & $\begin{array}{r}93.9 \\
100.0 \\
104.8 \\
110.8 \\
116.3\end{array}$ & $\begin{array}{r}94.0 \\
100.0 \\
104.3 \\
109.8 \\
115.2\end{array}$ & \begin{tabular}{r||}
94.0 \\
100.0 \\
105.1 \\
111.2 \\
117.6
\end{tabular} & \begin{tabular}{|l|}
$1981 \ldots \ldots \ldots \ldots \ldots \ldots \ldots . .$. \\
$1982 \ldots \ldots \ldots \ldots \ldots \ldots \ldots \ldots . .$. \\
$1983 \ldots \ldots \ldots \ldots \ldots \ldots \ldots \ldots . .$. \\
$1984 \ldots \ldots \ldots \ldots \ldots \ldots \ldots \ldots . .$. \\
$1985 \ldots \ldots \ldots \ldots \ldots \ldots \ldots \ldots . .$.
\end{tabular} & $\begin{array}{l}0.4387 \\
0.4717 \\
0.4949 \\
0.5165 \\
0.5334\end{array}$ \\
\hline 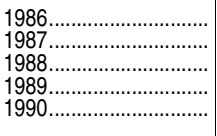 & $\begin{array}{l}58.510 \\
59.941 \\
62.042 \\
64.455 \\
66.848\end{array}$ & $\begin{array}{l}109.6 \\
113.6 \\
118.3 \\
124.0 \\
130.7\end{array}$ & $\mid$\begin{tabular}{|r}
$1986-87 \ldots \ldots \ldots \ldots \ldots \ldots .$. \\
$1987-88 \ldots \ldots \ldots \ldots \ldots \ldots .$. \\
$1988-89 \ldots \ldots \ldots \ldots \ldots \ldots .$. \\
$1989-90 \ldots \ldots \ldots \ldots \ldots \ldots . .$. \\
$1990-91 \ldots \ldots \ldots \ldots \ldots \ldots \ldots .$.
\end{tabular} & $\begin{array}{l}111.2 \\
115.8 \\
121.2 \\
127.0 \\
133.9\end{array}$ & $\begin{array}{l}120.9 \\
126.2 \\
132.8 \\
140.8 \\
148.2\end{array}$ & $\begin{array}{l}120.0 \\
126.8 \\
132.1 \\
139.0 \\
145.8\end{array}$ & $\begin{array}{l}124.2 \\
130.0 \\
138.6 \\
147.4 \\
155.7\end{array}$ & \begin{tabular}{|l|}
$1986 \ldots \ldots \ldots \ldots \ldots \ldots \ldots \ldots .$. \\
$1987 \ldots \ldots \ldots \ldots \ldots \ldots \ldots \ldots . .$. \\
$1988 \ldots \ldots \ldots \ldots \ldots \ldots \ldots \ldots . .$. \\
$1989 \ldots \ldots \ldots \ldots \ldots \ldots \ldots \ldots .$. \\
$1990 \ldots \ldots \ldots \ldots \ldots \ldots \ldots \ldots .$.
\end{tabular} & $\begin{array}{l}0.5477 \\
0.5631 \\
0.5820 \\
0.6043 \\
0.6226\end{array}$ \\
\hline 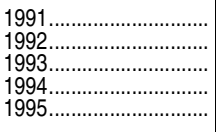 & $\begin{array}{l}69.063 \\
70.639 \\
72.322 \\
73.859 \\
75.402\end{array}$ & $\begin{array}{l}136.2 \\
140.3 \\
144.5 \\
148.2 \\
152.4\end{array}$ & $\mid$\begin{tabular}{|}
$1991-92 \ldots \ldots \ldots \ldots \ldots \ldots$. \\
$1992-93 \ldots \ldots \ldots \ldots \ldots \ldots \ldots$. \\
$1993-94 \ldots \ldots \ldots \ldots \ldots \ldots .$. \\
$1994-95 \ldots \ldots \ldots \ldots \ldots \ldots .$. \\
$1995-96 \ldots \ldots \ldots \ldots \ldots \ldots \ldots$.
\end{tabular} & $\begin{array}{l}138.2 \\
142.5 \\
146.2 \\
150.4 \\
154.5\end{array}$ & $\begin{array}{l}153.5 \\
157.9 \\
163.3 \\
168.1 \\
173.0\end{array}$ & $\begin{array}{l}150.6 \\
155.2 \\
160.1 \\
165.4 \\
170.8\end{array}$ & $\begin{array}{l}163.3 \\
169.8 \\
176.7 \\
183.9 \\
192.6\end{array}$ & \begin{tabular}{|}
$1991 \ldots \ldots \ldots \ldots \ldots \ldots .$. \\
$1992 \ldots \ldots \ldots \ldots \ldots \ldots \ldots \ldots .$. \\
$1993 \ldots \ldots \ldots \ldots \ldots \ldots \ldots \ldots .$. \\
$1994 \ldots \ldots \ldots \ldots \ldots \ldots \ldots \ldots .$. \\
$1995 \ldots \ldots \ldots \ldots \ldots \ldots \ldots \ldots .$.
\end{tabular} & $\begin{array}{l}0.6515 \\
0.6758 \\
0.6958 \\
0.7087 \\
0.7294\end{array}$ \\
\hline 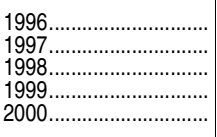 & $\begin{array}{l}76.776 \\
78.097 \\
78.944 \\
80.071 \\
81.894\end{array}$ & $\begin{array}{l}156.9 \\
160.5 \\
163.0 \\
166.6 \\
172.2\end{array}$ & 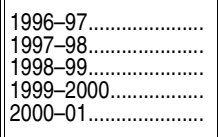 & $\begin{array}{l}158.9 \\
161.7 \\
164.5 \\
169.3 \\
175.1\end{array}$ & $\begin{array}{l}178.4 \\
184.7 \\
189.1 \\
196.9 \\
208.7\end{array}$ & $\begin{array}{l}\overline{-} \\
\overline{-} \\
-\end{array}$ & \begin{tabular}{l||}
- \\
$=$ \\
$=$ \\
-
\end{tabular} & 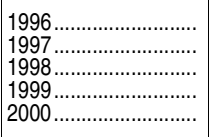 & $\begin{array}{l}0.7452 \\
0.7602 \\
0.7670 \\
0.7768 \\
0.7962\end{array}$ \\
\hline 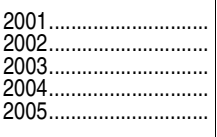 & $\begin{array}{l}83.767 \\
85.055 \\
86.754 \\
89.130 \\
91.989\end{array}$ & $\begin{array}{l}177.1 \\
179.9 \\
184.0 \\
188.9 \\
195.3\end{array}$ & $\mid$\begin{tabular}{|c}
$\mid 2001-02 \ldots \ldots \ldots \ldots \ldots \ldots$ \\
$2002-03 \ldots \ldots \ldots \ldots \ldots \ldots .$. \\
$2003-04 \ldots \ldots \ldots \ldots \ldots \ldots$ \\
$2004-05 \ldots \ldots \ldots \ldots \ldots \ldots . .$. \\
$2005-06 \ldots \ldots \ldots \ldots \ldots \ldots . .$.
\end{tabular} & $\begin{array}{l}178.2 \\
182.1 \\
186.1 \\
191.7 \\
199.0\end{array}$ & $\begin{array}{l}212.7 \\
223.5 \\
231.7 \\
240.8 \\
253.1\end{array}$ & $\begin{array}{l}\overline{-} \\
\overline{-} \\
\overline{-}\end{array}$ & \begin{tabular}{l||}
- \\
$=$ \\
$=$ \\
-
\end{tabular} & 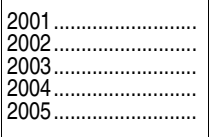 & $\begin{array}{l}0.8175 \\
0.8313 \\
0.8544 \\
0.8774 \\
0.9080\end{array}$ \\
\hline $\begin{array}{l}2006 \ldots \ldots \ldots \\
2007 \ldots \ldots \ldots \ldots \ldots \ldots \ldots \\
2008 \ldots \ldots \ldots \ldots \ldots \ldots \ldots \ldots \\
2009 \ldots \ldots \ldots \ldots \ldots \ldots \ldots \ldots \\
2010\end{array}$ & $\begin{array}{r}94.816 \\
97.338 \\
99.208 \\
100.000 \\
101.215\end{array}$ & $\begin{array}{l}201.6 \\
207.3 \\
215.3 \\
214.5 \\
218.1\end{array}$ & $\mid$\begin{tabular}{|l}
$2006-07 \ldots \ldots \ldots \ldots \ldots \ldots .$. \\
$2007-08 \ldots \ldots \ldots \ldots \ldots \ldots .$. \\
$2008-09 \ldots \ldots \ldots \ldots \ldots \ldots . .$. \\
$2009-10 \ldots \ldots \ldots \ldots \ldots \ldots . .$. \\
$2010-11 \ldots \ldots \ldots \ldots \ldots \ldots . .$.
\end{tabular} & $\begin{array}{l}204.1 \\
211.7 \\
214.7 \\
216.7 \\
221.1\end{array}$ & $\begin{array}{l}260.3 \\
273.2 \\
279.3 \\
281.8 \\
288.4\end{array}$ & $\begin{array}{l}- \\
- \\
- \\
-\end{array}$ & \begin{tabular}{l||}
- \\
- \\
- \\
-
\end{tabular} & $\mid \begin{array}{l}2006 \ldots \ldots \ldots \ldots \ldots \ldots \\
2007 \ldots \ldots \ldots \ldots \ldots \ldots \ldots \ldots . . . \\
2008 \ldots \ldots \ldots \ldots \ldots \ldots \ldots \ldots . . . \\
2009 \ldots \ldots \ldots \ldots \ldots \ldots \ldots . . . \\
2010 \ldots \ldots \ldots \ldots \ldots \ldots \ldots . . .\end{array}$ & $\begin{array}{l}0.9394 \\
0.9643 \\
0.9980 \\
1.0000 \\
1.0118\end{array}$ \\
\hline $\begin{array}{l}2011 \ldots \ldots \ldots \\
2012 \\
2013\end{array}$ & $\begin{array}{l}103.203 \\
105.008 \\
106.486\end{array}$ & $\begin{array}{l}224.9 \\
229.6 \\
233.0\end{array}$ & $\mid$\begin{tabular}{||c|}
$2011-12 \ldots \ldots \ldots \ldots \ldots \ldots .$. \\
$2012-13 \ldots \ldots \ldots \ldots \ldots \ldots . .$. \\
$2013-14 \ldots \ldots \ldots \ldots \ldots \ldots . .$.
\end{tabular} & $\begin{array}{r}227.6 \\
231.4 \\
-\end{array}$ & $\begin{array}{r}293.2 \\
- \\
-\end{array}$ & $\begin{array}{l}- \\
-\end{array}$ & \begin{tabular}{l||}
- \\
-
\end{tabular} & $\mid \begin{array}{l}2011 \ldots \ldots \ldots \ldots \ldots . . \\
2012 \ldots \ldots \ldots \ldots \ldots \ldots \ldots . . \\
2013 \ldots \ldots \ldots \ldots \ldots \ldots \ldots . .\end{array}$ & $\begin{array}{l}1.0317 \\
1.0511 \\
1.0682\end{array}$ \\
\hline
\end{tabular}

- Not available.

${ }^{1}$ Index for urban wage earners and clerical workers through 1977; 1978 and later figures are for all urban consumers.

${ }^{2}$ Consumer Price Index adjusted to a school-year basis (July through June).

${ }^{3}$ Beginning in 2001-02, components of index were weighted through a regression methodology. NOTE: Some data have been revised from previously published figures.

SOURCE: U.S. Department of Commerce, Bureau of Economic Analysis, National Income and Product Accounts, retrieved April 15, 2014, from http://www.bea.gov/iTable/iTable.cfm?
Req $\mid D=9 \& s t e p=1$ \#reqid $=9 \&$ step $=3 \&$ isuri $=1 \& 903=4$. U.S. Department of Labor, Bureau of Labor Statistics, Consumer Price Index, retrieved April 15, 2014, from http://data.bls.gov/ cgi-bin/surveymost. Commonfund Institute, Higher Education Price Index, retrieved April 15, 2014, from https://www.commonfund.org/Commonfundlnstitute/HEPI/Pages/default.aspx? RootFolder=\%2FCommonfundlnstitute\%2FHEPI\%2FHEPI\%20Documents \%2F2012\&Folder $\mathrm{CTID}=\&$ View $=\{86 \mathrm{E} 7741 \mathrm{D}-\mathrm{E} 445-47 \mathrm{E} 7-8 \mathrm{DD} 5-7 \mathrm{~A} 168 \mathrm{C} 4 \mathrm{~A} 701 \mathrm{E}\}$. U.S. Office of Management and Budget, Composite Deflator, retrieved April 15, 2014, from http://www.whitehouse.gov/ omb/budget/Historicals. (This table was prepared April 2014.) 


\section{CHAPTER 2 Elementary and Secondary Education}

This chapter contains a variety of statistics on public and private elementary and secondary education. Data are presented for enrollments, teachers and other school staff, schools, dropouts, achievement, school violence, and revenues and expenditures. These data are derived from surveys, censuses, and administrative data collections conducted by the National Center for Education Statistics (NCES) and other public and private organizations. The information ranges from counts of students and schools to state graduation requirements.

\section{Enrollments}

Public elementary and secondary school enrollment rose from 49.3 million in 2006 to 49.5 million in 2011, an increase of less than 1 percent (table 203.10 and figure 7). Public elementary enrollment (prekindergarten through grade 8 ) was 2 percent higher in 2011 (34.8 million) than in 2006 (34.2 million), while public secondary enrollment was 2 percent lower in 2011 (14.7 million) than in 2006 (15.1 million). Although public school enrollment increased slightly overall between 2006 and 2011, there were increases in enrollment for some racial/ethnic groups and decreases for other groups (table 203.50). Between 2006 and 2011, the enrollment of Hispanic students increased 16 percent and the enrollment of Asian/Pacific Islander students increased 8 percent. In contrast, the enrollment of White students decreased 8 percent, the enrollment of Black students decreased 7 percent, and the enrollment of American Indian/ Alaska Native students decreased 8 percent.

From 2006 to 2011, changes in public school enrollment varied from state to state (table 203.20 and figure 8). Increases occurred in 28 states and the District of Columbia from 2006 to 2011, while decreases occurred in 22 states. The largest public school enrollment increases occurred in Utah (14 percent) and Texas ( 9 percent), and 4 other states had increases of at least 5 percent. The largest decrease in public school enrollment occurred in Michigan (a decrease of 9 percent), and 5 other states had decreases of at least 5 percent.

Enrollments in private elementary and secondary schools decreased by an estimated 12 percent between 2006 and 2011, from 6.0 million to 5.3 million (table 208.20). In 2011, private school students made up about 10 percent of all elementary and secondary school students.
In 2012, about 64 percent of 3- to 5-year-olds were enrolled in preprimary education (nursery school and kindergarten), the same as the percentage in 2000 (table 202.10 and figure 9). However, the percentage of children in fullday programs increased from 2000 to 2012. In 2012, about 60 percent of the children enrolled in preprimary education attended a full-day preprimary program, compared with 53 percent in 2000 .

A higher percentage of 4-year-old children ( 57 percent) were cared for primarily in center-based programs during the day in 2005-06 than had no regular nonparental care (20 percent) or were cared for primarily in home-based settings by relatives ( 13 percent) or by nonrelatives ( 8 percent) (table 202.50). There were differences in the average quality of care children received in these settings. A higher percentage of children in Head Start and other center-based programs (35 percent) received high-quality care than those in homebased relative and nonrelative care (9 percent), according to the ratings of trained observers (table 202.60).

The Individuals with Disabilities Education Act (IDEA), enacted in 1975, mandates that children and youth ages 3-21 with disabilities be provided a free and appropriate public school education. The percentage of total public school enrollment that represents children served by federally supported special education programs increased from 8.3 percent to 13.8 percent between 1976-77 and 2004-05 (table 204.30). Much of this overall increase can be attributed to a rise in the percentage of students identified as having specific learning disabilities from 1976-77 (1.8 percent) to 2004-05 (5.7 percent). The overall percentage of students being served in programs for those with disabilities decreased between 2004-05 (13.8 percent) and 2011-12 (12.9 percent). However, there were different patterns of change in the percentages served with some specific conditions between 2004-05 and 2011-12. The percentage of children identified as having other health impairments (limited strength, vitality, or alertness due to chronic or acute health problems such as a heart condition, tuberculosis, rheumatic fever, nephritis, asthma, sickle cell anemia, hemophilia, epilepsy, lead poisoning, leukemia, or diabetes) rose from 1.1 to 1.5 percent of total public school enrollment, the percentage with autism rose from 0.4 to 0.9 percent, and the percentage with developmental delay rose from 0.7 to 0.8 percent. The percentage of children with specific learning disabilities declined from 5.7 percent to 4.7 percent of total 
public school enrollment during this period. In fall 2011, some 95 percent of 6- to 21-year-old students with disabilities were served in regular schools; 3 percent were served in a separate school for students with disabilities; 1 percent were placed in regular private schools by their parents; and less than 1 percent each were served in one of the following environments: in a separate residential facility, homebound or in a hospital, or in a correctional facility (table 204.60).

\section{Teachers and Other School Staff}

During the 1970s and early 1980s, public school enrollment decreased, while the number of teachers generally increased. For public schools, the number of pupils per teacher-that is, the pupil/teacher ratio 1 - declined from 22.3 in 1970 to 17.9 in 1985 (table 208.20 and figure 7). After enrollment started increasing in 1985, the public school pupil/teacher ratio continued to decline, reaching 17.2 in 1989. After a period of relative stability during the late 1980s through the mid-1990s, the ratio declined from 17.3 in 1995 to 15.4 in 2009. The public school pupil/teacher ratio increased to 16.0 in 2011. By comparison, the pupil/ teacher ratio for private schools was 12.5 in 2011. The average class size in 2011-12 was 21.2 pupils for public elementary schools and 26.8 pupils for public secondary schools (table 209.30).

In 2011-12, some 76 percent of public school teachers were female, 44 percent were under age 40 , and 56 percent had a master's or higher degree (table 209.10). Compared with public school teachers, a lower percentage of private school teachers had a master's or higher degree (43 percent).

Public school principals tend to be older and have more advanced credentials than public school teachers. In 2011-12, some 20 percent of public school principals were under age 40, and 98 percent of public school principals had a master's or higher degree (table 212.10). Compared with public school principals, a lower percentage of private school principals had a master's or higher degree (69 percent). A lower percentage of principals than of teachers were female: About 52 percent of public school principals were female, compared with 76 percent of teachers. At private schools, 55 percent of principals were female in 2011-12, compared with 75 percent of teachers.

From 1969-70 to 1980, there was an 8 percent increase in the number of public school teachers, compared with a 48 percent increase in the number of all other public school staff $^{2}$ (table B and table 213.10). Consequently, the percentage of staff who were teachers declined from 60 per-

\footnotetext{
${ }^{1}$ The pupil/teacher ratio is based on all teachers-including teachers for students with disabilities and other special teachers - and all students enrolled in the fall of the school year. Unlike the pupil/teacher ratio, the average class size excludes students and teachers in classes that are exclusively for special education students. Class size averages are based on surveys of teachers reporting on the counts of students in their classes.

2“All other public school staff" includes administrative staff, principals, librarians, guidance counselors, secretaries, custodial staff, food service workers, school bus drivers, and other professional and nonprofessional staff.
}

cent in 1969-70 to 52 percent in 1980. From 1980 to 2011 , the number of teachers and the number of all other staff grew at more similar rates (42 and 53 percent, respectively) than they did in the 1970s. As a result, the proportion of teachers among total staff was 2 percentage points lower in 2011 than in 1980, in contrast to the decrease of 8 percentage points during the 1970s. Two staff categories increased more than 100 percent between 1980 and 2011-instructional aides, which rose 118 percent, and instruction coordinators, which rose 229 percent. Taken together, the percentage of staff with direct instructional responsibilities (teachers and instructional aides) increased from 60 to 62 percent between 1980 and 2011. In 2011, there were 8 pupils per staff member (total staff) at public schools, compared with 10 pupils per staff member in 1980 (table 213.10). At private schools in 2011-12, the number of pupils per staff member was 6 (table 205.60).

\begin{tabular}{|c|c|c|c|}
\hline Selected staff category & 1969-70 & 1980 & 2011 \\
\hline 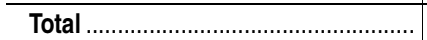 & 3,361 & 4,168 & 6,139 \\
\hline 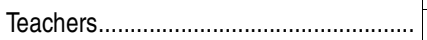 & 2,016 & 2,184 & 3,103 \\
\hline 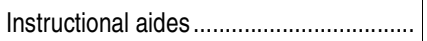 & 57 & 326 & 710 \\
\hline Instruction coordinators............................... & 32 & 21 & 68 \\
\hline
\end{tabular}

SOURCE: U.S. Department of Education, National Center for Education Statistics, Statistics of State School Systems, 1969-70; Statistics of Public Elementary and Secondary Schools, 1980; and Common Core of Data (CCD), "State Nonfiscal Survey of Public Elementary/Secondary Education," 2011-12.

\section{Schools}

During most of the last century, the trend to consolidate small schools brought declines in the total number of public schools in the United States. In 1929-30, there were approximately 248,000 public schools, compared with about 98,000 in 2011-12 (table 214.10). However, the number of public schools has increased in recent decades: between 1988-89 and 2006-07, there was an increase of approximately 15,600 schools. Since $2006-07$, the number of public schools has remained relatively stable, varying by about 500 schools or less from year to year.

While the total number of public schools in the country has remained between 98,000 and 99,000 in recent years, new schools have opened and some schools have closed. In 2011-12, there were 1,840 school closures (table 216.95). The schools that closed had enrolled about 301,000 students in the prior school year (2010-11). Of the schools that closed, 1,340 were regular schools, 87 were special education schools, 11 were vocational schools, and 402 were alternative schools. The number of schools that closed in 2011-12 was higher than the number in 2000-01 $(1,193)$; however, the number of annual school closures has fluctuated during this period, ranging from around 1,200 to 2,200. School closures do not necessarily reflect the number of school buildings that have been closed, since a single school may share a building with another school, or one school may have multiple buildings. 
Since the early 1970s, public school systems have been shifting away from junior high schools (schools consisting of either grades 7 and 8 or grades 7 to 9) and moving toward middle schools (a subset of elementary schools beginning with grade 4,5 , or 6 and ending with grade 6,7 , or 8 ) (table 216.10). Although the number of all elementary schools (schools beginning with grade 6 or below and having no grade higher than 8) was similar in 1970-71 and 2000-01 (64,000 in 1970-71 and 64,600 in 2000-01), the number of middle schools was 462 percent higher in 2000-01 than in 1970-71 (11,700 vs. 2,100). During the same period, the number of junior high schools declined by 57 percent (from 7,800 in 1970-71 to 3,300 in 2000-01). Between 2001-02 and 2011-12, the number of all elementary schools rose by 2 percent to 66,700 , while the subset of middle schools rose by 8 percent to 13,000 . During the same period, the number of junior high schools declined by 13 percent to 2,900 .

The average number of students in public elementary schools in 2011-12 (479) was higher than in 2001-02 (477) (table 216.45). The average enrollment size of public secondary schools decreased from 718 in 2001-02 to an average of 690 students in 2011-12. The average size of regular public secondary schools-which exclude alternative, special education, and vocational education schoolsdecreased from 807 in 2001-02 to 788 in 2011-12.

\section{High School Graduates and Dropouts}

About 3,323,000 high school students are expected to graduate during the 2014-15 school year (table 219.10), including about 3,031,000 public school graduates and 291,000 private school graduates. High school graduates include only recipients of diplomas, not recipients of equivalency credentials. The 2014-15 projection of high school graduates is lower than the record high of 3,452,000 graduates for 2011-12, but exceeds the baby boom era's high point in 1975-76, when 3,142,000 students earned diplomas. In 2011-12, an estimated 80.8 percent of public high school students graduated on time- that is, received a diploma 4 years after beginning their freshman (9th-grade) year (table 219.35).

The number of General Educational Development (GED) credentials issued by the states to GED test passers rose from 330,000 in 1977 to 487,000 in 2000 (table 219.60). A record number of 648,000 GED credentials were issued in 2001. In 2002 , there were revisions to the GED test and to the data reporting procedures. In 2001, test takers were required to successfully complete all five components of the GED or else begin the five-part series again with the new test that was introduced in 2002. Prior to 2002, reporting was based on summary data from the states on the number of GED credentials issued. As of 2002, reporting has been based on individual GED candidate- and test-level records collected by the GED Testing Service. In 2012, some 401,000 people passed the GED tests, up from 330,000 in 2002, the first year of the new test series. ${ }^{3}$

The percentage of dropouts among 16- to 24-year-olds has decreased over the past 20 years (table 219.70). This percentage, known as the status dropout rate, includes all people in the 16- to 24-year-old age group who are not enrolled in school and who have not completed a high school program, regardless of when they left school. (People who left school but went on to receive a GED credential are not treated as dropouts.) Between 1990 and 2012, the status dropout rate declined from 12.1 to 6.6 percent. Although the status dropout rate declined for both Blacks and Hispanics during this period, their rates ( 7.5 and 12.7 percent, respectively) remained higher than the rate for Whites ( 4.3 percent) in 2012. This measure is based on the civilian noninstitutionalized population, which excludes people in prisons, people in the military, and other people not living in households.

\section{Achievement}

Most of the student performance data in the Digest are drawn from the National Assessment of Educational Progress (NAEP). The NAEP assessments have been conducted using three basic designs: the national main NAEP, state NAEP (which includes the Trial Urban District Assessment), and national long-term trend NAEP. The main NAEP reports current information for the nation and specific geographic regions of the country. The assessment program includes students drawn from both public and private schools and reports results for student achievement at grades 4, 8, and 12. The main NAEP assessments follow the frameworks developed by the National Assessment Governing Board and use the latest advances in assessment methodology. Because the assessment items reflect curricula associated with specific grade levels, the main NAEP uses samples of students at those grade levels.

Since 1990, NAEP assessments have also been conducted at the state level. Each participating state receives assessment results that report on the performance of students in that state. In its content, the state assessment is identical to the assessment conducted nationally. From 1990 through 2001, the national sample was a subset of the combined sample of students assessed in each participating state along with an additional sample from the states that did not participate in the state assessment. For mathematics, reading, science, and writing assessments since 2002, a combined sample of public schools has been selected for 4th- and 8th-grade national NAEP and state NAEP (including the Trial Urban District Assessment).

NAEP long-term trend assessments are designed to give information on the changes in the basic achievement level of America's youth since the early 1970s. They are administered nationally and report student performance in reading and mathematics at ages 9, 13, and 17. Measuring long-term trends of stu-

\footnotetext{
${ }^{3}$ Information on changes in GED test series and reporting is based on the 2003 edition of Who Passed the GED Tests?, by the GED Testing Service of the American Council on Education, as well as communication with staff of the GED Testing Service.
} 
dent achievement requires the precise replication of past procedures. For example, students of specific ages are sampled in order to maintain consistency with the original sample design. Similarly, the long-term trend instrument does not evolve based on changes in curricula or in educational practices. The differences in procedures between the main NAEP and the long-term trend NAEP mean that their results cannot be compared directly.

\section{Reading}

The main NAEP reading assessment data are reported on a scale of 0 to 500 (table 221.10). In 2013, the average reading score for 4th-grade students (222) was not measurably different from the 2011 score, but it was higher than the scores on assessments between 1992 (217) and 2009 (221). At grade 4, only the average reading scores for White students were higher in 2013 (232) than in both 2011 (231) and 1992 (224). The 2013 scores for Black (206), Hispanic (207), and Asian/ Pacific Islander (235) 4th-graders were not measurably different from the 2011 scores, but the 2013 scores were higher than the 1992 scores $(192,197$, and 216, respectively). The difference in the reading scale scores of White and Black 4th- graders decreased from 32 points in 1992 to 26 points in 2013. For 8th-grade students, the average reading score in 2013 (268) was more than 2 points higher than in 2011 (265), was 8 points higher than in 1992 (260), and was higher than the average scores in all previous years. At grade 8, the 2013 average reading scores for White (276), Black (250), Hispanic (256), and Asian/Pacific Islander (280) students were higher than in 2011 and 1992. The difference in the reading scale scores of White and Hispanic 8th- graders decreased from 26 points in 1992 to 21 points in 2013.

While there was no measurable change from 2011 to 2013 in the average score for 4th-grade public school students nationally, average scores were higher in 2013 than in 2011 in Colorado, the Department of Defense dependents schools, Indiana, Iowa, Maine, Minnesota, Tennessee, Washington, and the District of Columbia; scores were lower in 2013 than in 2011 in Massachusetts, Montana, and North Dakota (table 221.40). At grade 8, the average reading score for public school students nationally was 2 points higher in 2013 than in 2011, and 12 states (Arkansas, California, Florida, Hawaii, Iowa, Nevada, New Hampshire, Oregon, Pennsylvania, Tennessee, Utah, and Washington) plus the District of Columbia and the Department of Defense dependents schools had higher scores in 2013 than in 2011 (table 221.60). In the other states, scores did not change measurably from 2011 to 2013.

Reported on a scale of 0 to 500, NAEP long-term trend results in reading are available for 13 assessment years going back to the first in 1971. The average reading score for 9-yearolds was higher in 2012 (221) than in assessment years prior to 2008 , increasing 5 points since 2004 and 13 points in comparison to 1971 (table 221.85). The average score for 13-yearolds in 2012 (263) was higher than in all previous assessment years, except for 1992 . The average reading score for 17 -year- olds was higher in 2012 (287) than in 2004 (283), but was not significantly different from the score in 1971 (285).

White, Black, and Hispanic 9-, 13-, and 17-year-olds all had higher average reading scores in 2012 than they did in the first assessment year (which is 1975 for Hispanic students because separate data for Hispanics were not collected in 1971). Average reading scores were higher in 2012 than in 2004 for White, Black, and Hispanic students at all three ages (table 221.85). Reading results for 2012 continued to show gaps in scores between White and Black students (ranging from 23 to 26 points, depending on age) and between White and Hispanic students (about 21 points at all three ages). The White-Black and the White-Hispanic reading gaps were smaller in 2012 than in 1971 (1975 for Hispanic students) at all three ages. For example, the WhiteBlack reading gap for 17-year-olds was 53 points in 1971 compared with 26 points in 2012. Similarly the White-Hispanic reading gap for 17 -year-olds narrowed from 41 points in 1975 to 21 points in 2012 .

In 2012, female 9-, 13-, and 17-year-old students continued to have higher average reading scores than male students at all three ages (table 221.85). The gap between male and female 9-year-olds was 5 points in 2012; this was narrower than the gap in 1971 (13 points). The 8-point gender gap for 13-year-olds in 2012 was not significantly different from the gap in 1971. At age 17, the 8-point gap between males and females in 2012 was not significantly different from the gap in 1971.

\section{Mathematics}

The main NAEP mathematics assessment data for 4th- and 8th-graders are reported on a scale of 0 to 500. In 2013, the average NAEP mathematics scores for 4th-grade and 8thgrade students were higher than the average scores in all previous assessment years (table 222.10). From 1990 (the first assessment year) to 2013, the average 4th-grade NAEP mathematics score increased by 28 points, from 213 to 242 . During that same period, the average 8th-grade score increased by 22 points, from 263 to 285 . At grade 4 , the average mathematics scores in 2013 for White (250) and Hispanic students (231) were higher than the scores in both 2011 and 1990. The 2013 score for Black 4th-graders (224) was not measurably different from the 2011 score, but it was higher than the 1990 score. Prior to 2011, separate data on Asians were not available; the 2013 score for Asian 4th-graders (259) was also not measurably different from the 2011 score. The difference in the mathematics scale scores of White and Black 4th-graders decreased from 32 points in 1990 to 26 points in 2013. At grade 8, the mathematics scores of White (294), Black (263), and Hispanic (272) students were higher in 2013 than in 1990. However, the 31-point gap between the mathematics scores of White and Black 8th-graders in 2013 was not significantly different from the 33-point gap in 1990.

NAEP results also permit state-level comparisons of the mathematics achievement of 4th- and 8th-grade students in public schools (tables 222.50 and 222.60). The average 
mathematics scores for 4th-grade public school students increased from 2011 to 2013 in 14 states (Arizona, Colorado, Delaware, Hawaii, Indiana, Iowa, Minnesota, Nebraska, New York, North Dakota, Tennessee, Washington, West Virginia, and Wyoming), the District of Columbia, and the Department of Defense dependents schools, and scores did not decrease for any states. At grade 8, scores were higher in 2013 than in 2011 in five states (Florida, Hawaii, New Hampshire, Pennsylvania, and Tennessee), the District of Columbia, and the Department of Defense dependents schools, and scores decreased in three states (Montana, Oklahoma, and South Dakota).

NAEP long-term trend mathematics results, reported on a scale of 0 to 500, are available for 12 assessment years, going back to the first in 1973. In 2012, the average mathematics score for 9-year-olds (244) was higher than in all previous assessment years prior to 2008 (table 222.85). The average score for 9-year-olds in 2012 was 5 points higher than in 2004 and 25 points higher than in 1973. The average mathematics score for 13-year-olds in 2012 (285) was higher than in all previous assessment years. For 13-yearolds, the average score in 2012 was 6 points higher than in 2004 and 19 points higher than in 1973. In contrast, the average score for 17-year-olds in 2012 (306) was not significantly different from the scores in 2004 and 1973.

White, Black, and Hispanic 9-, 13-, and 17-year-olds all had higher average mathematics scores in 2012 than in 1973 (table 222.85). In comparison to 2004, average mathematics scores were higher in 2012 for White 9-, 13-, and 17-yearolds, Hispanic 9- and 13-year-olds, and Black 13-year-olds. Mathematics results for 2012 continued to show score gaps between White and Hispanic students (ranging from 17 to 21 points [based on unrounded scores], depending on age) and between White and Black students (ranging from 25 to 28 points). Across all three age groups, both the White-Black and White-Hispanic gaps in mathematics scores were lower in 2012 than in 1973. For example, among 17-year-olds, the White-Black gap was 40 points in 1973 compared to 26 points in 2012, and the White-Hispanic gap was 33 points in 1973 compared to 19 points in 2012.

While there was no significant difference between the average mathematics scores of male and female 9- and 13-yearolds in 2012, male students did score higher than female students at age 17 (table 222.85). At both age 9 and age 13, the gap between males and females in 2012 was not significantly different from the gap in 1973. At age 17, the 4-point gender score gap in 2012 was smaller than the gap in 1973 (8 points).

\section{Science}

NAEP has assessed the science abilities of students in grades 4,8 , and 12 in both public and private schools since 1996. As of 2009, however, NAEP science assessments are based on a new framework, so results from these assessments cannot be compared to results from earlier science assessments. Scores are based on a scale ranging from 0 to 300. In 2009, White 4th-graders had a higher average science score
(163) than did Black (127), Hispanic (131), Asian/Pacific Islander (160), and American Indian/Alaska Native (135) 4thgraders (table 223.10). The average science score was higher for male 4th-graders (151) than for female 4th-graders (149). In 2009, the pattern of differences in average science scores by students' race/ethnicity at grade 8 was similar to the pattern at grade 4 . The average science score also was higher for male 8th-graders (152) than for female 8th-graders (148). At grade 12, average scores for White (159) and Asian/Pacific Islander (164) students were higher than the scores for Black (125), Hispanic (134), and American Indian/Alaska Native (144) students. The average science score in 2009 for male 12th-graders (153) was higher than the score for female 12th-graders (147). In 2011, a science assessment was conducted at grade 8 only. The average 8th-grade science score increased from 150 in 2009 to 152 in 2011. While there were no significant changes from 2009 to 2011 in the average scores for Asian/Pacific Islander or American Indian/Alaska Native 8th-graders, average scores increased 1 point for White 8th-graders, 3 points for Black 8th-graders, and 5 points for Hispanic 8th-graders. The average science score of White 8th-graders continued to be higher than the average scores of 8th-graders in all other racial/ ethnic groups in 2011, but score gaps between White and Black 8th-graders and between White and Hispanic 8th-graders narrowed from 2009 to 2011 . Average scores for both male and female 8th-graders were higher in 2011 than in 2009. In 2011, the average score was 5 points higher for male 8th-graders than for female 8th-graders, which was not significantly different from the 4-point gap in 2009.

\section{Skills of Young Children}

In addition to student performance data available through NAEP, the Digest presents data from other surveys to provide additional perspectives on student achievement. Differences among demographic groups in the acquisition of cognitive skills have been demonstrated at relatively early ages in the Early Childhood Longitudinal Survey's Birth Cohort (ECLS-B) study as well as its Kindergarten Class (ECLS-K) studies.

In 2003-04, about 64 percent of 2-year-olds demonstrated proficiency in expressive vocabulary, which measured toddlers' ability to communicate using gestures, words, and sentences (table 220.20). The percentage of 2year-olds demonstrating expressive vocabulary was higher for females (69 percent) than for males (59 percent). Also, a higher percentage of White (71 percent) and Asian (62 percent) 2-year-olds demonstrated expressive vocabulary than of Black, Hispanic, or American Indian/Alaska Native 2year-olds (56, 54, and 50 percent, respectively). The percentage of 2-year-olds from families with high socioeconomic status (SES) who demonstrated expressive vocabulary (75 percent) was higher than the percentage of children from low-SES families who did so (52 percent).

Patterns of differences were also observed by race/ethnicity and SES for children at about 4 years of age (48 to 57 months old). In 2005-06, average early reading scores were 
higher for White (27) and Asian (31) 48- to 57-month-old children than for Black (23), Hispanic (21), and American Indian/Alaska Native (20) children (table 220.30). Also, high-SES children (33) had higher average early reading scores than low-SES children (19) at this age. These same patterns were observed among 48- to 57-month-old children with respect to average mathematics scores. White (32) and Asian (35) 48- to 57-month-old children had higher mathematics scores than Black (27), Hispanic (26), and American Indian/Alaska Native children (23). High-SES 48- to 57month-old children (36) had higher average mathematics scores than low-SES children (24).

Children who enrolled in kindergarten for the first time in 2010-11 showed similar patterns of score differences by race/ethnicity and SES. In fall 2010, average mathematics scores were higher for first-time kindergartners from highSES families (36) than for those from low-SES families (22) (table 220.40). White (32) and Asian (35) first-time kindergartners had higher mathematics scores than their Black (26), Hispanic (25), and American Indian/Alaska Native (26) counterparts. Similarly, reading scores in fall 2010 were higher for White (37) and Asian (40) first-time kindergartners than for their Black (33), Hispanic (30), and American Indian/Alaska Native (31) counterparts. High-SES children (42) had higher average early reading scores than low-SES children (28).

\section{SAT Scores of College-Bound Seniors}

The SAT (formerly known as the Scholastic Assessment Test and the Scholastic Aptitude Test) is not designed as an indicator of student achievement, but rather as an aid for predicting how well students will do in college. Between 1998-99 and 2004-05, the mathematics SAT average score increased by 9 points, but it decreased 6 points between 2004-05 and 2012-13 (table 226.20). The critical reading average score decreased 9 points between 1999-2000 (505) and 2011-12 (496). The writing average score in 2012-13 (488) was 9 points lower than in 2005-06 (497), the year in which the SAT writing section was introduced.

\section{Coursetaking in High School}

The average number of science and mathematics courses completed by public high school graduates increased between 1982 and 2009. The average number of mathematics courses (Carnegie units) completed in high school rose from 2.6 in 1982 to 3.9 in 2009, and the number of science courses rose from 2.2 to 3.5 (table 225.10). The average number of courses in career/technical areas completed by public high school graduates was lower in 2009 (2.5 units) than in 2000 (2.9 units). As a result of the increased academic course load, the percentage of public and private high school graduates completing the 1983 National Commission on Excellence recommendations (4 units of English, 3 units of social studies, 3 units of science, 3 units of mathematics, and 2 units of foreign language) rose from 10 percent in 1982 to 62 percent in 2009 (table 225.50).

\section{School Violence}

In 2009-10, about 85 percent of public schools had a criminal incident, which is defined as theft, vandalism, drug possession, weapons possession, a serious violent crime, or a less serious violent crime such as a fight without weapons (table 229.20). In 2009-10, some 74 percent of schools reported one or more violent incidents, 44 percent of schools reported one or more thefts/larcenies, and 46 percent reported vandalism. The percentage of schools reporting a serious violent crime in 2009-10 (16 percent) was lower than the percentage of schools reporting a serious violent crime in 1999-2000 (20 percent). Also, the percentage of schools reporting an incident of vandalism was lower in 2009-10 (46 percent) than in 1999-2000 (51 percent). Overall, there were 4 criminal incidents reported per 100 students in 2009-10, which was lower than the 5 criminal incidents per 100 students reported in 1999-2000.

\section{Revenues and Expenditures}

The state share of revenues for public elementary and secondary schools generally grew from the 1930s through the mid-1980s, while the local share declined during the same time period (table 235.10 and figure 10). ${ }^{4}$ However, this pattern changed in the late 1980s, when the local share began to increase at the same time the state share decreased. Between 1986-87 and 1993-94, the state share declined from 49.7 percent to 45.2 percent, while the local share rose from 43.9 percent to 47.8 percent. Between 1993-94 and 2000-01, the state share rose again to 49.7 percent, the highest share since 1986-87, but declined every school year thereafter until 2005-06, when the state share was 46.5 percent. Overall, between 2000-01 and 2010-11, the federal share increased from 7.3 percent to 12.5 percent, while the state share decreased from 49.7 to 44.1 percent. The local share in 2010-11 (43.4) was higher than the percentage in 2000-01 (43.0).

After adjustment for inflation, current expenditures per student in fall enrollment at public schools rose during the 1980s, remained stable during the first part of the 1990s, and then rose again (table 236.55 and figure 11). There was an increase of 37 percent from 1980-81 to 1990-91, followed by minor fluctuations from 1990-91 to 1994-95 and then an increase of 31 percent from 1994-95 to 2010-11. In 2010-11, current expenditures per student in fall enrollment were $\$ 10,658$ in unadjusted dollars. In 2007-08, the expenditure for public school student transportation was $\$ 854$ per student transported (also in unadjusted dollars), and 55 percent of students were transported at public expense (table 236.90).

${ }^{4}$ For data on individual years from 1980-81 through 1988-89, see Digest of Education Statistics 2011 (NCES 2012-001), table 180. 
Figure 7. Enrollment, number of teachers, pupil/teacher ratio, and expenditures in public elementary and secondary schools: 1960-61 through 2011-12

Fall enrollment, in millions
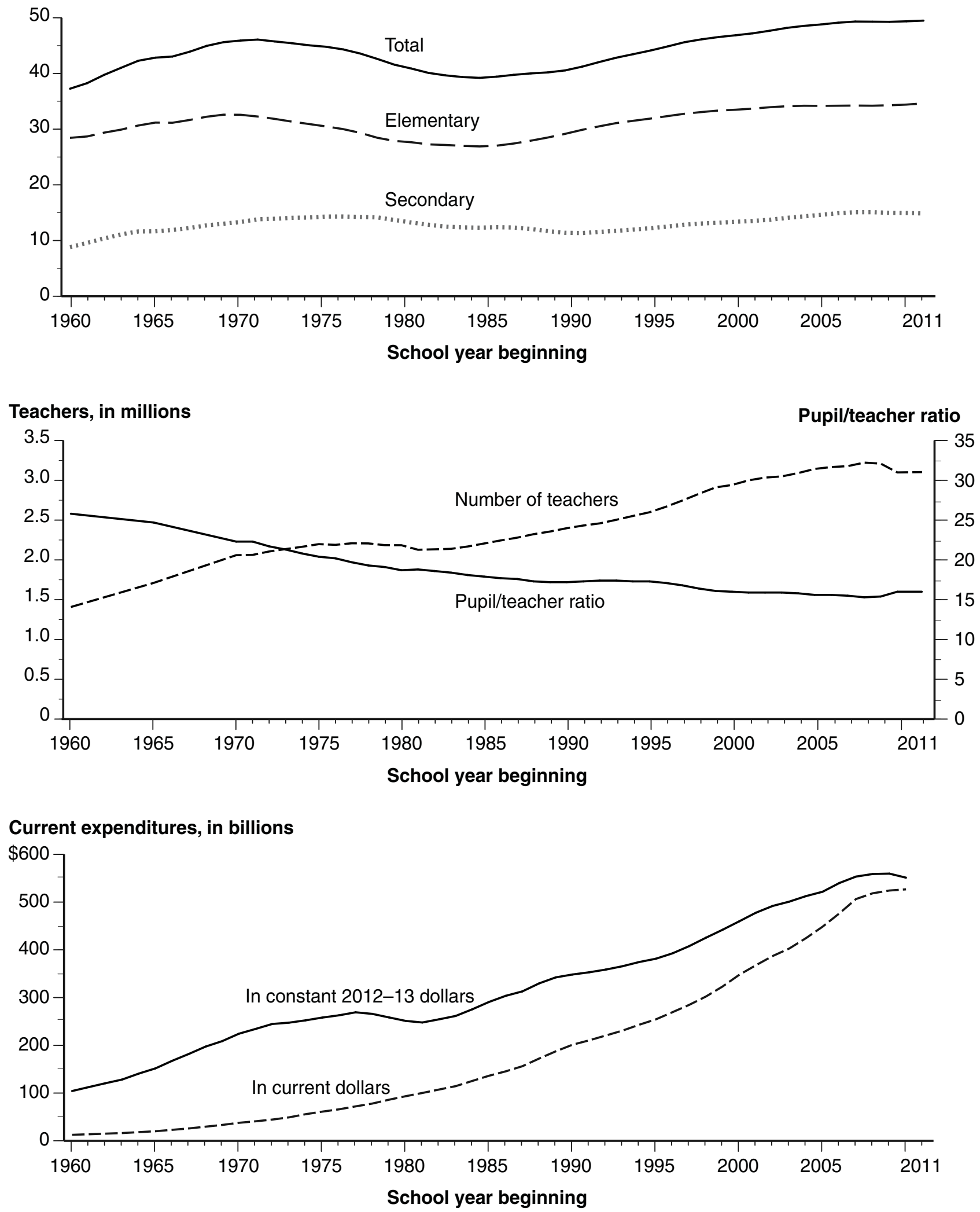

SOURCE: U.S. Department of Education, National Center for Education Statistics, Statistics of State School Systems, 1959-60 through 1969-70; Statistics of Public Elementary and Secondary Day Schools, 1959-60 through 1980-81; Revenues and Expenditures for Public Elementary and Secondary Education, 1970-71 through 1980-81; and Common Core of Data (CCD), "State Nonfiscal Survey of Public Elementary/Secondary Education," 1981-82 through 2011-12, and "National Public Education Financial Survey," $1989-90$ through 2010-11. 
Figure 8. Percentage change in public elementary and secondary enrollment, by state: Fall 2006 to fall 2011

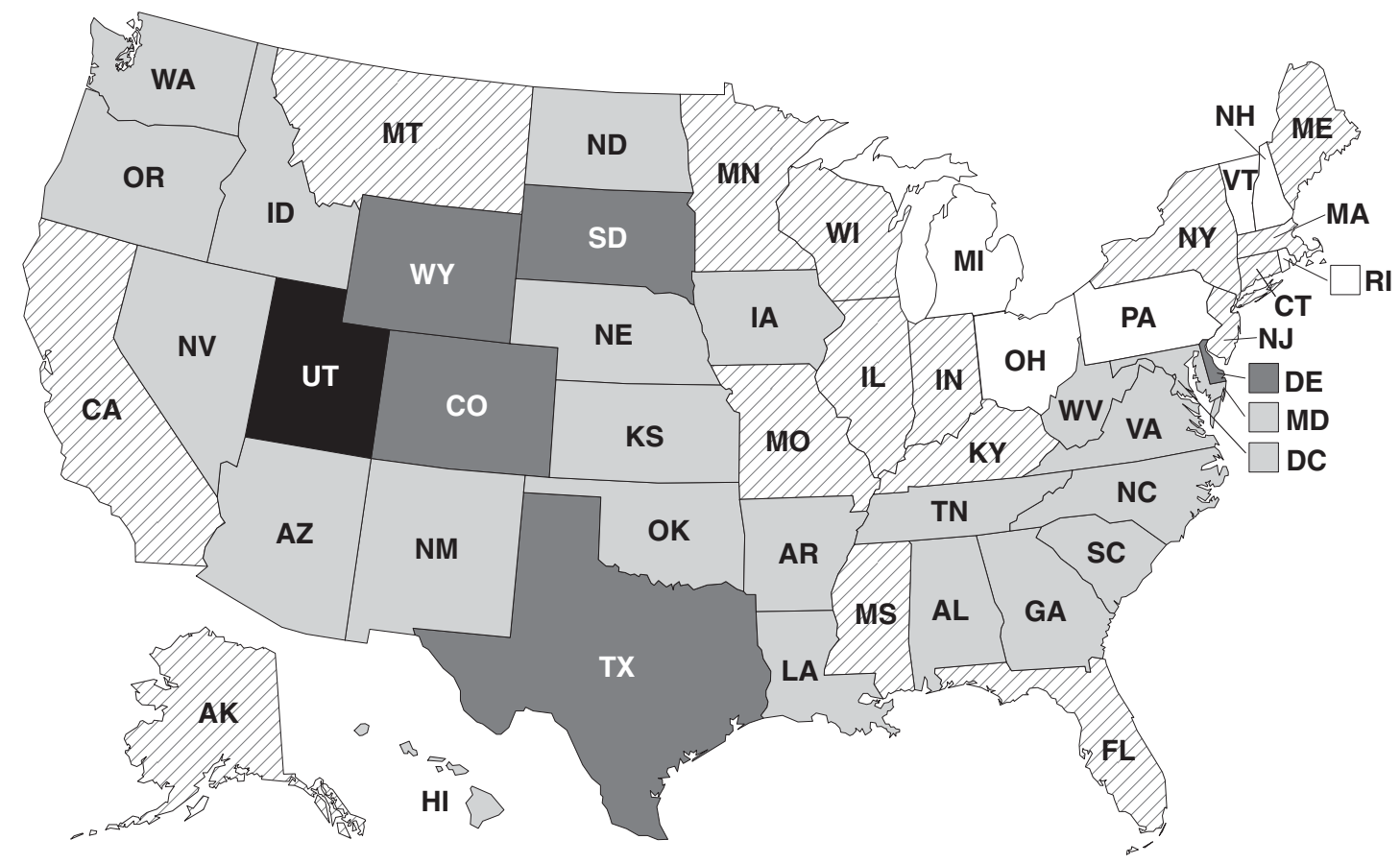

Percent change

Increase of more than 10 percent (1 state) Increase of 5 to 10 percent (5 states) Increase of less than 5 percent (22 states \& DC)
Decrease of less than 5 percent (16 states) Decrease of 5 to 10 percent (6 states)

SOURCE: U.S. Department of Education, National Center for Education Statistics, Common Core of Data (CCD), "State Nonfiscal Survey of Public Elementary/Secondary Education," 2006-07 and 2011-12.

Figure 9. Total and full-day preprimary enrollment of 3- to 5-year-olds: October 1970 through October 2012

\section{Enrollment, in millions}

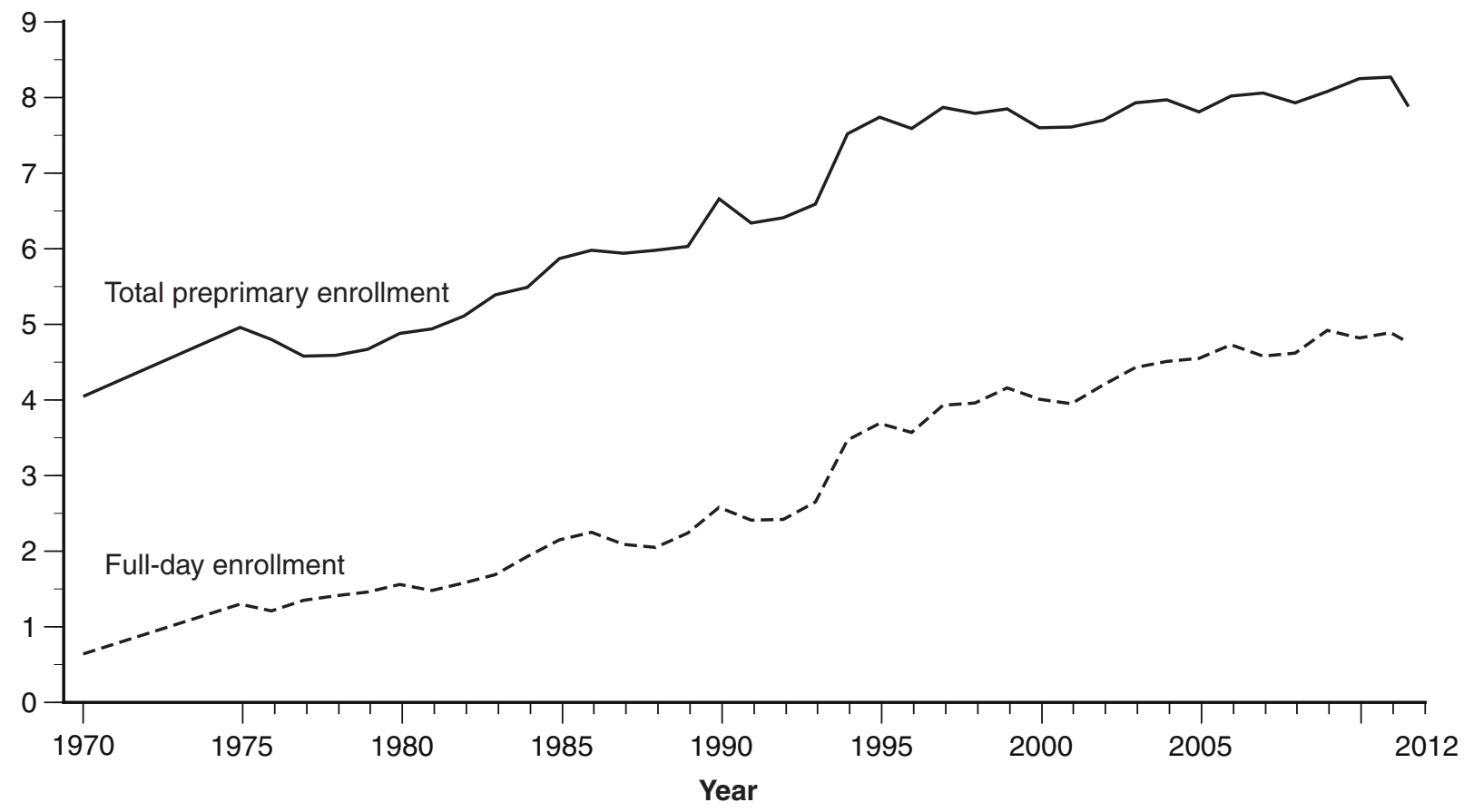

SOURCE: U.S. Department of Education, National Center for Education Statistics, Preprimary Enrollment, 1970 and 1975. U.S. Department of Commerce, Census Bureau, Current Population Survey (CPS), October 1976 through October 2012. 
Figure 10. Percentage of revenue for public elementary and secondary schools, by source of funds: 1970-71 through 2010-11

\section{Percent of revenue}

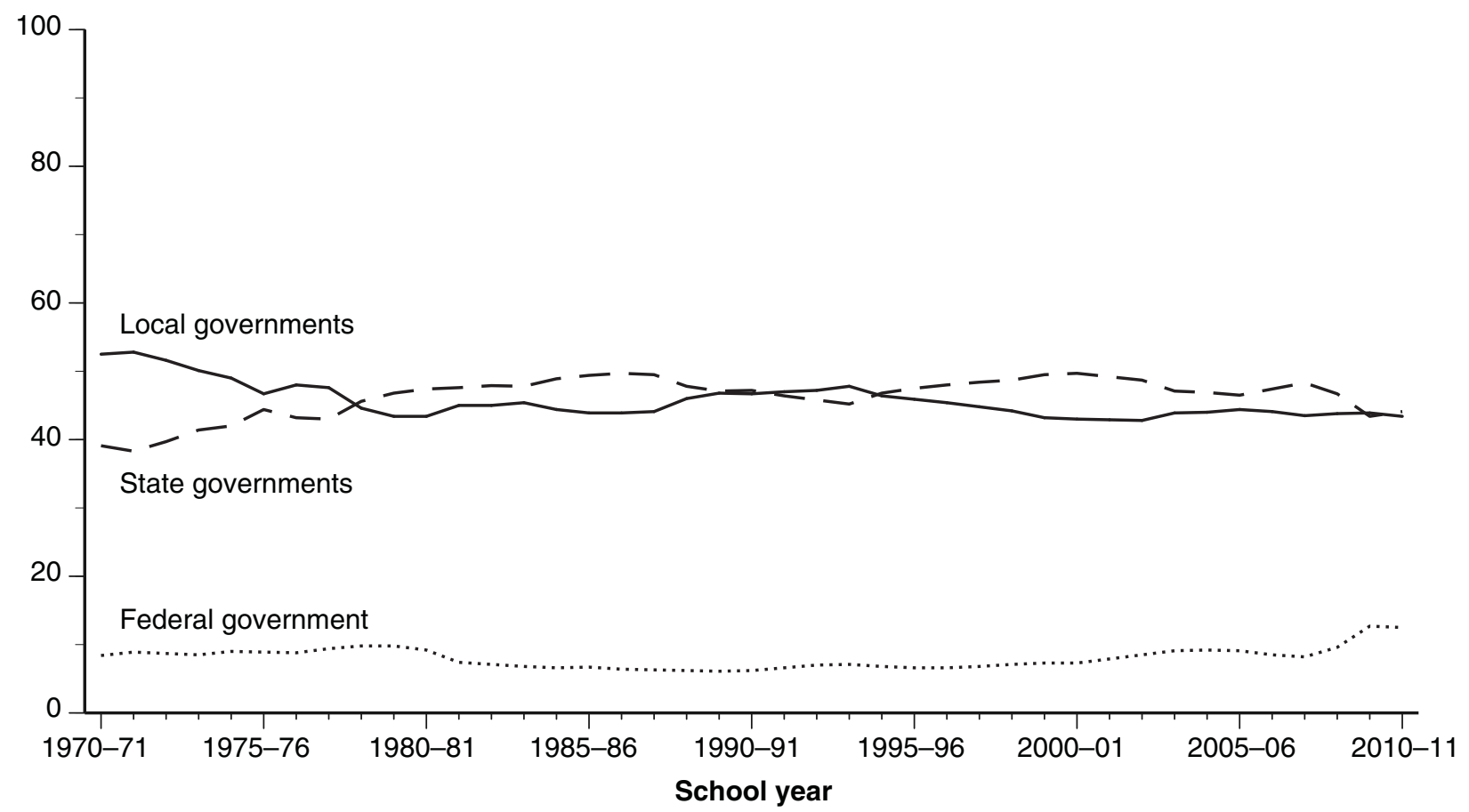

SOURCE: U.S. Department of Education, National Center for Education Statistics, Revenues and Expenditures for Public Elementary and Secondary Education, 1970-71 through 1986-87; and Common Core of Data (CCD), "National Public Education Financial Survey," 1987-88 through 2010-11.

Figure 11. Current expenditure per pupil in fall enrollment in public elementary and secondary schools: 1970-71 through 2010-11

Per pupil expenditure

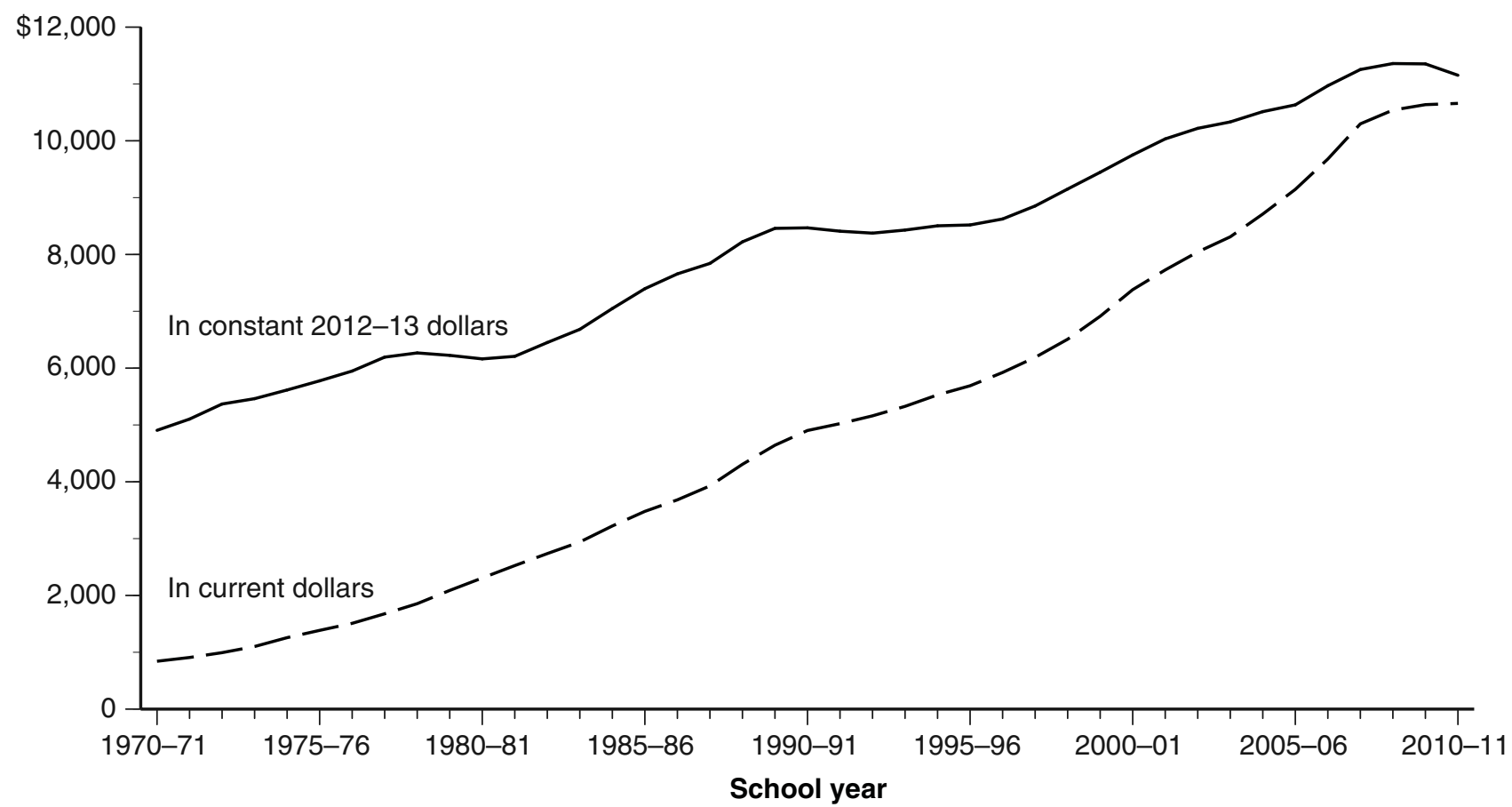

SOURCE: U.S. Department of Education, National Center for Education Statistics, Revenues and Expenditures for Public Elementary and Secondary Education, 1970-71 through 1986-87; and Common Core of Data (CCD), "National Public Education Financial Survey," 1987-88 through 2010-11. 


\begin{tabular}{|c|c|c|c|c|c|c|c|c|c|c|c|c|c|c|c|c|c|c|c|}
\hline Selected characteristic & $\begin{array}{r}1869- \\
70 \\
\end{array}$ & $\begin{array}{r}1879- \\
80 \\
\end{array}$ & $\begin{array}{r}1889- \\
90 \\
\end{array}$ & $\begin{array}{r}1899- \\
1900\end{array}$ & $\begin{array}{r}1909- \\
10 \\
\end{array}$ & $\begin{array}{r}1919- \\
20 \\
\end{array}$ & $\begin{array}{r}1929- \\
30 \\
\end{array}$ & $\begin{array}{r}1939- \\
40 \\
\end{array}$ & $\begin{array}{r}1949- \\
50\end{array}$ & $\begin{array}{r}1959- \\
60 \\
\end{array}$ & $\begin{array}{r}1969- \\
70 \\
\end{array}$ & $\begin{array}{r}1979- \\
80 \\
\end{array}$ & $\begin{array}{r}1989- \\
90 \\
\end{array}$ & $\begin{array}{r}1999- \\
2000\end{array}$ & $\begin{array}{r}2006- \\
07\end{array}$ & $\begin{array}{r}2007- \\
08 \\
\end{array}$ & $\begin{array}{r}2008- \\
09\end{array}$ & $\begin{array}{r}2009- \\
10 \\
\end{array}$ & $\begin{array}{r}2010- \\
11\end{array}$ \\
\hline 1 & 2 & 3 & 4 & 5 & 6 & 7 & 8 & 9 & 10 & 11 & 12 & 13 & 14 & 15 & 16 & 17 & 18 & 19 & 20 \\
\hline \multicolumn{20}{|l|}{ Population, pupils, and instructional staff } \\
\hline Total population (in thousands) ${ }^{1}$. & 38,558 & 50,156 & 62,622 & 75,995 & 90,490 & 104,514 & 121,878 & 131,028 & 149,188 & 177,830 & 201,385 & 225,055 & 246,819 & 279,040 & 298,380 & 301,231 & 304,094 & 306,772 & 309,326 \\
\hline ald lin the & 11,683 & 15,066 & 18,473 & 21,573 & 24,011 & 27,571 & 31,414 & 30,151 & 30,223 & 43,881 & 52,386 & 48,043 & 44,947 & 52,811 & 53,819 & 53,893 & 53,833 & 53,890 & 53,931 \\
\hline 5- to 17 -year-olds as a percent of total population.... & 30.3 & 30.0 & 29.5 & 28.4 & 26.5 & 26.4 & 25.8 & 23.0 & 20.3 & 24.7 & 26.0 & 21.3 & 18.2 & 18.9 & 18.0 & 17.9 & 17.7 & 17.6 & 17.4 \\
\hline Total enrollment in elementary and secondary schools & $7,562^{3}$ & 9,867 & 12,723 & 15,503 & 17,814 & 21,578 & 25,678 & 25,434 & 25,112 & 36,087 & 45,550 & 41,651 & 40,543 & 46,857 & 49,316 & 49,293 & 49,266 & 49,361 & 49,484 \\
\hline Prekir & $7,481^{3}$ & 9,757 & 12,520 & 14,984 & 16,899 & 19,378 & 21,279 & 18,833 & 19,387 & 27,602 & 32,513 & 28,034 & 29,152 & 33,486 & 34,235 & 34,205 & 34,286 & 34,409 & 34,625 \\
\hline Grades $9-12$ (in thousands). & $80^{3}$ & 110 & 203 & 519 & 915 & 2,200 & 4,399 & 6,601 & 5,725 & 8,485 & 13,037 & 13,616 & 11,390 & 13,371 & 15,081 & 15,087 & 14,980 & 14,952 & 14,860 \\
\hline rollmen & $19.6^{3}$ & 19.7 & 20.3 & 20.4 & 19.7 & 20.6 & 21.1 & 19.4 & 16.8 & 20.3 & 22.6 & 18.5 & 16.4 & 16.8 & 16.5 & 16.4 & 16.2 & 16.1 & 16.0 \\
\hline Enrolln & $64.7^{3}$ & 65.5 & 68.9 & 71.9 & 74.2 & 78.3 & 81.7 & 84.4 & 83.1 & 82.2 & 87.0 & 86.7 & 90.2 & 88.7 & 91.6 & 91.5 & 91.5 & 91.6 & 91.8 \\
\hline Percent of total $\mathrm{e}$ & $1.1^{3}$ & $\begin{array}{r}1.1 \\
1.1\end{array}$ & 1.6 & 3.3 & 5.1 & 10.2 & 17.1 & 26.0 & 22.8 & 23.5 & 28.6 & 32.7 & 28.1 & 28.5 & 30.6 & 30.6 & 30.4 & 30.3 & 30.0 \\
\hline High school graduates (in thousands) .... & - & - & 22 & 62 & 111 & 231 & 592 & 1,143 & 1,063 & 1,627 & 2,589 & 2,748 & 2,320 & 2,554 & 2,892 & 3,001 & 3,039 & 3,128 & 3,144 \\
\hline rerace daily attendance (in thousands) & 4,077 & 6,144 & 8,154 & 10,633 & 12,827 & 16,150 & 21,265 & 22,042 & २2,284 & 32,477 & 41,934 & 38,289 & 37,799 & 43,807 & 46,133 & 46,156 & 6,173 & 45,919 & 46,168 \\
\hline ) .................... & 539 & 801 & 1,098 & 1,535 & 2,011 & 2,615 & 3,673 & 3,858 & 3,964 & 5,782 & 7,501 & $6,835^{4}$ & - & 7,858 & 8,267 & 8,261 & 8,264 & 8,199 & 8,244 \\
\hline ………....... & 59.3 & 62.3 & 64.1 & 68.6 & 72.1 & 74.8 & 82.8 & 86.7 & 88.7 & 90.0 & 90.4 & $90.1^{4}$ & - & 94.3 & - & 93.1 & & - & \\
\hline 烈 & 132.2 & 130.3 & 134.7 & 144.3 & 157.5 & 161.9 & 172.7 & 175.0 & 177.9 & 178.0 & 178.9 & $178.5^{4}$ & - & 179.4 & 179.2 & 179.0 & 179.0 & 178.6 & 178.6 \\
\hline Average number of days attended per pupil …………………………..... & 78.4 & 81.1 & 86.3 & 99.0 & 113.0 & 121.2 & 143.0 & 151.7 & 157.9 & 160.2 & 161.7 & $160.8^{4}$ & - & 169.2 & - & 166.6 & - & & - \\
\hline Total ful & - & - & - & - & - & 678 & 880 & 912 & 963 & 1,457 & 2,286 & 2,406 & 2,986 & 3,819 & 4,187 & 4,214 & 4,278 & 4,279 & 4,151 \\
\hline St & - & - & - & - & - & 7 & 7 & 5 & - & $\bar{c}$ & - & $\overline{-}$ & & - & - & - & & - & - \\
\hline Principals (in thousands) & 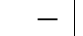 & - & - & - & - & 14 & 31 & 32 & 43 & 64 & 91 & 106 & 126 & 137 & 154 & 158 & 160 & 168 & 165 \\
\hline \multicolumn{20}{|l|}{ Teachers, teacher aides, librarians, and guidance counselors } \\
\hline & 201 & 287 & 364 & 423 & 523 & 657 & 843 & 875 & 920 & 1,393 & 2,195 & 2,300 & 2,860 & 3,682 & 4,033 & 4,056 & 4,118 & 4,111 & 3,986 \\
\hline Males & 78 & 123 & 126 & 127 & 110 & 93 & 140 & 195 & 196 & 4044 & $711^{4}$ & $782^{4}$ & & - & - & - & - & - & - \\
\hline Female & 123 & 164 & 238 & 296 & 413 & 585 & 703 & 681 & 724 & 9894 & $1,484^{4}$ & $1,518^{4}$ & & - & - & - & - & - & - \\
\hline 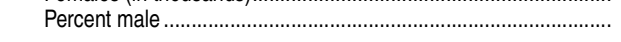 & 38.7 & 42.8 & 34.5 & 29.9 & 21.1 & 14.1 & 16.6 & 22.2 & 21.3 & $29.0^{4}$ & $32.4^{4}$ & $34.0^{4}$ & & - & - & - & - & - & - \\
\hline Total reven & \multicolumn{19}{|c|}{ Amounts in current dollars } \\
\hline Total re & - & - & $\$ 143$ & $\$ 220$ & $\$ 433$ & $\$ 970$ & $\$ 2,089$ & $\$ 2,261$ & $\mid \$ 5,437$ & $\$ 14,747$ & $\$ 40,267$ & $\$ 96,881$ & $\$ 208,548$ & $\$ 372,944$ & $\$ 555,711$ & $\$ 584,684$ & $\$ 592,422$ & $\$ 596,391$ & $\$ 604,293$ \\
\hline $\mathrm{Fe}$ & - & - & 然 & - & - & 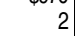 & & 40 & 156 & 652 & 3,220 & 9,504 & 12,701 & 27,098 & 47,151 & 47,788 & 56,670 & 75,998 & 75,541 \\
\hline & - & - & - & - & - & 160 & 354 & 684 & 2,166 & 5,768 & 16,063 & 45,34 & 98,239 & 184,613 & 263,609 & 282,623 & 276,526 & 258,864 & 266,786 \\
\hline uding intermediate.... & - & - & - & - & - & 808 & 1,728 & 1,536 & 3,116 & 8,327 & 20,985 & 42,029 & 97,608 & 161,233 & 244,951 & 254,273 & 259,226 & 261,529 & 261,965 \\
\hline \multicolumn{20}{|l|}{ Percentage distribution of revenue receipts } \\
\hline & - & - & - & - & - & 0.3 & 0.4 & 1.8 & 2.9 & 4.4 & 8.0 & 9.8 & 6.1 & 7.3 & 8.5 & 8.2 & 9.6 & 12.7 & 12.5 \\
\hline & - & - & - & - & - & 16.5 & 16.9 & 30.3 & 39.8 & 39.1 & 39.9 & 46.8 & 47.1 & 49.5 & 47.4 & 48.3 & 46.7 & 43.4 & 44.1 \\
\hline Local sources, including intermediate.... & - & - & - & - & - & 83.2 & 82.7 & 68.0 & 57.3 & 56.5 & 52.1 & 43.4 & 46.8 & 43.2 & 44.1 & 43.5 & 43.8 & 43.9 & 43.4 \\
\hline Total ex & $\$ 63$ & $\$ 78$ & $\$ 141$ & $\$ 215$ & $\$ 426$ & $\$ 1,036$ & $\$ 2,317$ & $\$ 2,344$ & $\$ 5,838$ & $\$ 15,613$ & $\$ 40,683$ & $\$ 95,962$ & $\$ 212,770$ & $\$ 381,838$ & $\$ 562,195$ & $\$ 597,314$ & $\$ 610,326$ & $\$ 607,018$ & $\$ 604,215$ \\
\hline & - & -1 & 114 & 180 & 356 & 861 & 1,844 & 1,942 & 4,687 & $12,329^{7}$ & $34,218^{7}$ & $86,984^{7}$ & 188,2297 & $323,889^{7}$ & $476,814^{7}$ & & & $524,715^{7}$ & $527,166^{7}$ \\
\hline & - & - & 26 & 35 & 70 & 154 & 371 & 258 & 1,014 & 2,662 & 4,659 & 6,506 & 17,781 & 43,357 & 62,863 & 66,426 & 65,890 & 56,715 & 50,928 \\
\hline Interes & - & - & - & - & - & 18 & 93 & 131 & 101 & 490 & 1,171 & 1,874 & 3,776 & 9,135 & 14,713 & 15,695 & 17,049 & 17,232 & 17,934 \\
\hline 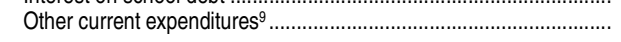 & - & - & - & - & - & 3 & 10 & 13 & 36 & 133 & 636 & $598^{10}$ & 2,983 & 5,457 & 7,804 & 8,308 & 8,464 & 8,356 & 8,187 \\
\hline \multicolumn{20}{|l|}{ Percentage distribution of total expenditures } \\
\hline & - & - & & & & & & & 80.3 & $79.0^{7}$ & $84.1^{7}$ & $90.6^{7}$ & $88.5^{7}$ & 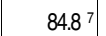 & $84.8^{7}$ & 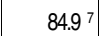 & $85.0^{7}$ & $86.4^{7}$ & $87.2^{7}$ \\
\hline & ( & - & 18.7 & 16.5 & 16.4 & 14.8 & 16.0 & 11.0 & 17.4 & 17.0 & 11.5 & 6.8 & 8.4 & 11.4 & 11.2 & 11.1 & 10.8 & 9.3 & 8.4 \\
\hline & - & - & - & - & - & 1.8 & 4.0 & 5.6 & 1.7 & 3.1 & 2.9 & 2.0 & 1.8 & 2.4 & 2.6 & 2.6 & 2.8 & 2.8 & 3.0 \\
\hline 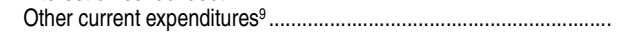 & - & - & - & - & - & 0.3 & 0.4 & 0.6 & 0.6 & 0.8 & 1.6 & $0.6^{10}$ & 1.4 & 1.4 & 1.4 & 1.4 & 1.4 & 1.4 & 1.4 \\
\hline
\end{tabular}


Table 201.10. Historical summary of public elementary and secondary school statistics: Selected years, 1869-70 through 2010-11-Continued

\begin{tabular}{|c|c|c|c|c|c|c|c|c|c|c|c|c|c|c|c|c|c|c|c|}
\hline Selected characteristic & $\begin{array}{r}1869- \\
70\end{array}$ & $\begin{array}{r}1879- \\
80\end{array}$ & $\begin{array}{r}1889- \\
90\end{array}$ & $\begin{array}{r}1899- \\
1900\end{array}$ & $\begin{array}{r}1909- \\
10\end{array}$ & $\begin{array}{r}1919- \\
20\end{array}$ & $\begin{array}{r}1929- \\
30\end{array}$ & $\begin{array}{r}1939- \\
40\end{array}$ & $\begin{array}{r}1949- \\
50\end{array}$ & $\begin{array}{r}1959- \\
60\end{array}$ & $\begin{array}{r}1969- \\
70\end{array}$ & $\begin{array}{r}1979- \\
80\end{array}$ & $\begin{array}{r}1989- \\
90\end{array}$ & $\begin{array}{r}1999- \\
2000\end{array}$ & $\begin{array}{r}2006- \\
07\end{array}$ & $\begin{array}{r}2007- \\
08\end{array}$ & $\begin{array}{r}2008- \\
09\end{array}$ & $\begin{array}{r}2009- \\
10\end{array}$ & $\begin{array}{r}2010- \\
11\end{array}$ \\
\hline 1 & 2 & 3 & 4 & 5 & 6 & 7 & 8 & 9 & 10 & 11 & 12 & 13 & 14 & 15 & 16 & 17 & 18 & 19 & 20 \\
\hline \multicolumn{20}{|l|}{$\begin{array}{l}\text { Teacher salaries; income and expenditures per pupil and } \\
\text { per capita }\end{array}$} \\
\hline $\begin{array}{l}\text { Annual salary of classroom teachers }{ }^{11} \ldots \ldots \ldots \ldots . . . . . . . . . . . . \\
\text { Personal income per member of labor force }\end{array}$ & $\$ 189$ & $\$ 195$ & $\$ 252$ & $\$ 325$ & $\$ 485$ & $\$ 871$ & $\begin{array}{r}\$ 1,420 \\
1,726\end{array}$ & $\begin{array}{r}\$ 1,441 \\
1,320\end{array}$ & $\begin{array}{r}\$, 010 \\
3,378\end{array}$ & $\begin{array}{r}\$ 4,995 \\
5,738\end{array}$ & $\begin{array}{r}\$ 8,626 \\
9,640\end{array}$ & $\begin{array}{r}\$ 15,970 \\
19,621\end{array}$ & $\begin{array}{r}\$ 31,367 \\
36,793\end{array}$ & $\begin{array}{r}\$ 41,807 \\
56,762\end{array}$ & $\begin{array}{r}\$ 51,052 \\
75,216\end{array}$ & $\begin{array}{r}\$ 52,800 \\
78,340\end{array}$ & $\begin{array}{r}\$ 54,319 \\
80,568\end{array}$ & $\begin{array}{r}\$ 55,202 \\
78,383\end{array}$ & $\begin{array}{r}\$ 55,623 \\
80,806\end{array}$ \\
\hline . & 2 & 2 & 2 & 3 & 5 & 10 & 19 & 18 & 39 & 88 & 202 & 426 & 862 & 1,368 & 1,884 & 1,983 & 2,007 & 1,979 & 1,953 \\
\hline & & & $\leftarrow$ & & & - & 770 & 626 & $\begin{array}{r}1,592 \\
-1\end{array}$ & 2,550 & 4,412 & 9,990 & 19,449 & 29,953 & 40,236 & 40,906 & 40,878 & 39,523 & 41,185 \\
\hline $\mathrm{CL}$ & - & - & 14 & 17 & 28 & 53 & 87 & 88 & 210 & 375 & 816 & 2,272 & 4,980 & 7,394 & 10,336 & 10,982 & 11,239 & 11,427 & 11,418 \\
\hline Total exp & 16 & 13 & 17 & 20 & 33 & 64 & 108 & 106 & 260 & 471 & 955 & 2,491 & 5,547 & 8,589 & 12,015 & 12,759 & 13,033 & 13,035 & 12,908 \\
\hline ation & & - & & & - & - & 4,416 & 3,720 & 10,658 & 13,964 & 21,188 & 58,719 & 127,000 & 190,793 & 260,241 & 266,971 & 269,219 & 264,040 & 275,935 \\
\hline Curren & - & - & 0.10 & 0.12 & 0.18 & 0.33 & 0.50 & 0.50 & 1.17 & 2.11 & 4.56 & 12.73 & - & 41.22 & 57.68 & 61.36 & 62.79 & 64.00 & 63.94 \\
\hline \multirow{2}{*}{ 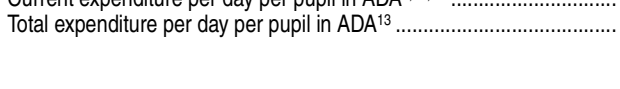 } & 0.12 & 0.10 & 0.13 & 0.14 & 0.21 & 0.40 & 0.63 & 0.60 & 1.46 & 2.65 & 5.34 & 13.95 & - & 47.90 & 67.06 & 71.30 & 72.83 & 73.02 & 72.30 \\
\hline & \multicolumn{19}{|c|}{ Amounts in constant 2012-13 dollars' } \\
\hline Annual & & - & & & - & $\$ 10,400$ & & & $\$ 28,922$ & & & & $\$ 56,216$ & $\$ 56,198$ & $\$ 57,858$ & $\$ 57,701$ & $\$ 58,543$ & $\$ 58,925$ & $\$ 58,206$ \\
\hline force & - & - & - & - & - & & $\begin{array}{c}+2,050 \\
22,951\end{array}$ & 21,493 & $\begin{array}{r}2 \times 0,1425 \\
32,455\end{array}$ & 44,439 & 58,075 & 57,516 & 65,940 & 76,300 & 85,243 & 85,611 & 86,834 & $\begin{array}{r}40,060 \\
83,669\end{array}$ & 84,558 \\
\hline Total & - & - & - & - & - & 118 & 253 & 291 & 376 & 680 & 1,217 & 1,250 & 1,545 & 1,839 & 2,135 & 2,167 & 2,163 & 2,112 & 2,044 \\
\hline $\mathrm{N}$ & - & - & - & - & - & - & 10,243 & 10,191 & 15,297 & 19,751 & 26,579 & 29,2 & 34,857 & 40,263 & 45,600 & 44,703 & 44,057 & 42,188 & 43,097 \\
\hline Curren & - & - & - & - & - & 637 & 1,153 & 1,435 & 2,021 & 2,905 & 4,8 & 6,6 & 8,925 & 9,939 & 11,714 & 12,001 & 12,113 & 12,198 & 11,948 \\
\hline & - & - & - & - & - & 764 & 1,442 & 1,722 & 2,502 & 3,648 & & 7, & 9,941 & 11,545 & 13,617 & 13,943 & 14,046 & 13,914 & 13,507 \\
\hline $\mathrm{Nat}$ & - & - & - & - & - & - & 58,705 & 60,578 & 102,409 & 108,146 & 127,642 & 172,124 & 227,609 & 256,466 & 294,934 & 291,751 & 290,157 & 281,847 & 288,747 \\
\hline & - & - & - & - & - & 3.9 & 6.6 & 8.1 & 11.2 & 16.3 & 27.5 & 37.3 & - & 51.5 & 65.4 & 67.1 & 67.7 & 68.3 & 66.9 \\
\hline Total expenditure per day per pupil in $\mathrm{ADA}^{13}$ & - & - & - & - & - & 4.8 & 8.4 & 9.8 & 14.0 & 20.5 & 32.2 & 40.9 & - & 59.9 & 76.0 & 77.9 & 78.5 & 77.9 & 75.7 \\
\hline
\end{tabular}

\section{-Not available.}

'Data on population and labor force are from the Census Bureau, and data on personal income and national income are from the Bureau of Economic Analysis, U.S. Department of Commerce. Population data through 1900 are based on total population fom the decen fal ( Duly 1. Data for later years are for resident population that excludes armed forces overseas, ${ }^{3}$ Data for $1870-71$

Estimated by the National Center for Education Statistics.

mployed rather than number of position

Prior to 1919-20, includes interest on school debt.

"Because of he modificalion of the scope of "current expenditures for elementary and secondary schools," data for 1959-60 and Be

Includes summer schools, community colleges, and adult educat school building authorities.

. Beginning in 1959-60, also includes community services.

${ }^{\circ}$ Excludes community colleges and adult education.

Prior to 1959-60, average includes supervisors, principals, teachers, and other nonsupervisory instructional staff. Data for $1959-60$ and later years are estimated by the National Education Association.
${ }^{12}$ Excludes current expenditures not allocable to pupil costs.

${ }^{14} \mathrm{Exp}$ enditure figure is the sum of curcent expenditures allocable to pupil costs, capital outlay, and interest on school deb ${ }^{15}$ Per-day rates derived by dividing annual rates by average length of term.

${ }^{16}$ Constant dollars based on the Consumer Price Index, prepared by the Bureau of Labor Statistics, U.S. Department of Labor, (a)

NOTE: Some data have been revised from previously published figures. Beginning in 1959-60, data include Alaska and Hawaii. Detail may not sum to totals because of rounding.

SOURCE: U.S. Department of Education, National Center for Education Statistics, Annual Report of the United States Commissioner of Education, 1869-70 through 1909-10; Biennial Survey of Education in the United States, 1919-20 through 1949-50: Statistics of State School Systems, 1959-60 and 1969-70; Statistics of Public Elementary and Secondary School Systems, (SASS), "Public School Questionnaire" 1999-200 and 2007-08. Common Core of Data (CCD) "State Nonfiscal Survey of Public Elementary/Secondary Education" 1989-90 through 2011-12, and "National Public Financial Survey" 1989-90 through 2010-11. U.S. Department of Commerce, Census Bureau, retrieved November 1, 2013, from http://www.census.gov/popes data/national/asth/2012/2012-nat-detail.htm. U.S. Department of Commerce, Bureau of Economic Analysis, retrieved February, 5, 2014, from hitp://www.bea.gov/Table/index nipa.clm. U.S. Department of Labor, Bureau of Labor Statistics, retrieved April 15, 2014, from http://www.bls.gov/webapps/legacy/cpsatab1.htm. (This table was prepared April 2014.) 
Table 201.20. Enrollment in grades 9 through 12 in public and private schools compared with population 14 to 17 years of age: Selected years, 1889-90 through fall 2013

[In thousands]

\begin{tabular}{|c|c|c|c|c|c|c|c|c|c|c|c|c|c|c|c|}
\hline \multirow[b]{3}{*}{ Year } & \multicolumn{13}{|c|}{ Enrollment, grades 9 to $12^{1}$} & \multirow{3}{*}{$\begin{array}{r}\text { Population } \\
14 \text { to } \\
17 \text { years } \\
\text { of age }{ }^{2}\end{array}$} & \multirow{3}{*}{$\begin{array}{r}\text { Enrollment } \\
\text { as a } \\
\text { ratio of } \\
\text { population } \\
14 \text { to } \\
17 \text { years } \\
\text { of age }^{3}\end{array}$} \\
\hline & & \multicolumn{6}{|c|}{ Public schools } & \multicolumn{6}{|c|}{ Private schools } & & \\
\hline & All schools & Total & 9th grade & 10th grade & 11th grade & 12th grade & & Total & 9th grade & 10th grade & 11th grade & 12th grade & & & \\
\hline 1 & 2 & 3 & 4 & 5 & 6 & 7 & 8 & 9 & 10 & 11 & 12 & 13 & 14 & 15 & 16 \\
\hline $\begin{array}{l}1889-90 \ldots \ldots \ldots \ldots \\
1899-1900 \ldots \ldots \ldots \\
1909-10 \ldots \ldots \ldots \ldots \\
1919-20 \ldots \ldots \ldots \ldots . . \\
1929-30 \ldots \ldots \ldots \ldots \ldots . .\end{array}$ & $\begin{array}{r}298 \\
630 \\
1,032 \\
2,414 \\
4,741\end{array}$ & $\begin{array}{r}203 \\
519 \\
915 \\
2,200 \\
4,399\end{array}$ & \begin{tabular}{r|}
- \\
$\overline{-}$ \\
917 \\
1,627
\end{tabular} & \begin{tabular}{r|}
$\overline{-}$ \\
$\bar{z}$ \\
1,192
\end{tabular} & $\begin{array}{r}- \\
\bar{Z} \\
396 \\
880\end{array}$ & $\begin{array}{r}- \\
\bar{Z} \\
3 \overline{2} \\
701\end{array}$ & \begin{tabular}{c|}
- \\
$\overline{-}$ \\
0 \\
0
\end{tabular} & \begin{tabular}{r|}
95 \\
111 \\
117 \\
214 \\
$341^{4}$ \\
\end{tabular} & $\begin{array}{l}\overline{-} \\
\overline{-} \\
\overline{-}\end{array}$ & $\begin{array}{l}- \\
\overline{-} \\
- \\
-\end{array}$ & $\begin{array}{l}\overline{-} \\
\overline{-} \\
\overline{-}\end{array}$ & $\begin{array}{l}- \\
= \\
= \\
-\end{array}$ & $\begin{array}{l} \\
\overline{-} \\
\overline{-} \\
-\end{array}$ & $\begin{array}{l}5,355 \\
6,152 \\
7,220 \\
7,736 \\
9,341\end{array}$ & $\begin{array}{r}5.6 \\
10.2 \\
14.3 \\
31.2 \\
50.7\end{array}$ \\
\hline $\begin{array}{l}1939-40 \ldots \ldots \ldots \ldots . . . \\
1949-50 \ldots \ldots \ldots \ldots . . . \\
\text { Fall } 1959 \ldots \ldots \ldots \ldots \ldots . . \\
\text { Fall } 1963 \ldots \ldots \ldots \ldots \ldots . . .\end{array}$ & $\begin{array}{r}7,059 \\
6,397 \\
9,306 \\
12,170\end{array}$ & $\begin{array}{r}6,601 \\
5,725 \\
8,271 \\
10,883\end{array}$ & $\begin{array}{r}2,011 \\
1,761 \\
-\end{array}$ & $\begin{array}{r}1,767 \\
1,513 \\
-\end{array}$ & $\begin{array}{r}1,486 \\
1,275 \\
-\end{array}$ & $\begin{array}{r}1,282 \\
1,134 \\
-\end{array}$ & $\begin{array}{l}55 \\
42 \\
- \\
-\end{array}$ & $\begin{array}{r}458^{5} \\
672 \\
1,035 \\
1,287\end{array}$ & $\begin{array}{l}\bar{z} \\
\overline{-}\end{array}$ & $\begin{array}{l}\bar{z} \\
\overline{-}\end{array}$ & $\begin{array}{l}\bar{z} \\
\overline{-}\end{array}$ & $\begin{array}{l}- \\
\text { - } \\
-\end{array}$ & $\begin{array}{l}\bar{z} \\
\overline{-}\end{array}$ & $\begin{array}{r}9,720 \\
8,405 \\
11,155 \\
13,492\end{array}$ & $\begin{array}{l}72.6 \\
76.1 \\
83.4 \\
90.2\end{array}$ \\
\hline 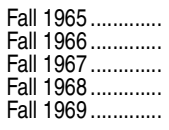 & $\begin{array}{l}13,002 \\
13,280 \\
13,647 \\
14,123 \\
14,337\end{array}$ & $\begin{array}{l}11,602 \\
11,880 \\
12,247 \\
12,723 \\
13,037\end{array}$ & $\begin{array}{l}3,215 \\
3,318 \\
3,395 \\
3,508 \\
3,568\end{array}$ & $\begin{array}{l}2,993 \\
3,111 \\
3,221 \\
3,310 \\
3,405\end{array}$ & $\begin{array}{l}2,741 \\
2,756 \\
2,879 \\
2,986 \\
3,047\end{array}$ & $\begin{array}{l}2,477 \\
2,508 \\
2,525 \\
2,650 \\
2,732\end{array}$ & $\begin{array}{l}176 \\
187 \\
226 \\
268 \\
285\end{array}$ & $\begin{array}{l}1,400^{6} \\
1,400^{6} \\
1,400^{6} \\
1,400^{6} \\
1,300^{6}\end{array}$ & $\begin{array}{l}- \\
\overline{-} \\
\overline{-}\end{array}$ & $\begin{array}{l}- \\
\overline{-} \\
-\end{array}$ & $\begin{array}{l}\overline{-} \\
\bar{z} \\
-\end{array}$ & $\begin{array}{l}- \\
= \\
- \\
-\end{array}$ & $\begin{array}{l}- \\
\overline{-} \\
\overline{-}\end{array}$ & $\begin{array}{l}14,146 \\
14,398 \\
14,727 \\
15,170 \\
15,549\end{array}$ & $\begin{array}{l}91.9 \\
92.2 \\
92.7 \\
93.1 \\
92.2\end{array}$ \\
\hline 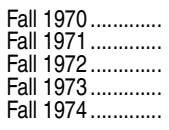 & $\begin{array}{l}14,647 \\
15,053 \\
15,148 \\
15,344 \\
15,403\end{array}$ & $\begin{array}{l}13,336 \\
13,753 \\
13,848 \\
14,044 \\
14,103\end{array}$ & $\begin{array}{l}3,654 \\
3,781 \\
3,779 \\
3,801 \\
3,832\end{array}$ & $\begin{array}{l}3,458 \\
3,571 \\
3,648 \\
3,650 \\
3,675\end{array}$ & $\begin{array}{l}3,128 \\
3,200 \\
3,248 \\
3,323 \\
3,302\end{array}$ & $\begin{array}{l}2,775 \\
2,864 \\
2,873 \\
2,918 \\
2,955\end{array}$ & $\begin{array}{l}321 \\
337 \\
299 \\
352 \\
339\end{array}$ & \begin{tabular}{l|}
1,311 \\
$1,300^{6}$ \\
$1,300^{6}$ \\
$1,300^{6}$ \\
$1,300^{6}$
\end{tabular} & $\begin{array}{l}- \\
\overline{-} \\
- \\
-\end{array}$ & $\begin{array}{l}- \\
- \\
- \\
-\end{array}$ & $\begin{array}{l}\overline{-} \\
\bar{z} \\
-\end{array}$ & $\begin{array}{l}- \\
- \\
- \\
-\end{array}$ & $\begin{array}{l}- \\
\overline{-} \\
\overline{-}\end{array}$ & $\begin{array}{l}15,924 \\
16,328 \\
16,639 \\
16,867 \\
17,035\end{array}$ & $\begin{array}{l}92.0 \\
92.2 \\
91.0 \\
91.0 \\
90.4\end{array}$ \\
\hline 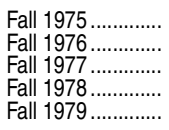 & $\begin{array}{l}15,604 \\
15,656 \\
15,546 \\
15,441 \\
14,916\end{array}$ & $\begin{array}{l}14,304 \\
14,314 \\
14,203 \\
14,088 \\
13,616\end{array}$ & $\begin{array}{l}3,879 \\
3,825 \\
3,779 \\
3,726 \\
3,526\end{array}$ & $\begin{array}{l}3,723 \\
3,738 \\
3,686 \\
3,610 \\
3,532\end{array}$ & $\begin{array}{l}3,354 \\
3,373 \\
3,388 \\
3,312 \\
3,241\end{array}$ & $\begin{array}{l}2,986 \\
3,015 \\
3,026 \\
3,023 \\
2,969\end{array}$ & $\begin{array}{l}362 \\
363 \\
324 \\
416 \\
348\end{array}$ & $\begin{array}{l}1,300^{6} \\
1,342 \\
1,343 \\
1,353 \\
1,300^{6}\end{array}$ & $\begin{array}{l}- \\
\overline{-} \\
- \\
-\end{array}$ & $\begin{array}{l}- \\
- \\
- \\
-\end{array}$ & $\begin{array}{l}- \\
\bar{z} \\
\overline{-}\end{array}$ & $\begin{array}{l}- \\
= \\
=\end{array}$ & $\begin{array}{l}- \\
\overline{-} \\
\overline{-} \\
-\end{array}$ & $\begin{array}{l}17,128 \\
17,119 \\
17,045 \\
16,946 \\
16,611\end{array}$ & $\begin{array}{l}91.1 \\
91.5 \\
91.2 \\
91.1 \\
89.8\end{array}$ \\
\hline 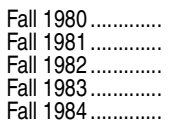 & $\begin{array}{l}14,570 \\
14,164 \\
13,805 \\
13,671 \\
13,704\end{array}$ & $\begin{array}{l}13,231 \\
12,764 \\
12,405 \\
12,271 \\
12,304\end{array}$ & $\begin{array}{l}3,377 \\
3,286 \\
3,248 \\
3,330 \\
3,440\end{array}$ & $\begin{array}{l}3,368 \\
3,218 \\
3,137 \\
3,103 \\
3,145\end{array}$ & $\begin{array}{l}3,195 \\
3,039 \\
2,917 \\
2,861 \\
2,819\end{array}$ & $\begin{array}{l}2,925 \\
2,907 \\
2,787 \\
2,678 \\
2,599\end{array}$ & $\begin{array}{l}366 \\
314 \\
315 \\
299 \\
300\end{array}$ & $\begin{array}{l}1,339 \\
1,400^{6} \\
1,400^{6} \\
1,400 \\
1,400^{6}\end{array}$ & $\begin{array}{l}- \\
\overline{-} \\
\overline{-}\end{array}$ & $\begin{array}{l}- \\
z \\
z \\
-\end{array}$ & $\begin{array}{l}- \\
\bar{z} \\
\overline{-}\end{array}$ & $\begin{array}{l}- \\
= \\
=\end{array}$ & $\begin{array}{l}- \\
\bar{z} \\
\overline{-}\end{array}$ & $\begin{array}{l}16,143 \\
15,609 \\
15,057 \\
14,740 \\
14,725\end{array}$ & $\begin{array}{l}90.3 \\
90.7 \\
91.7 \\
92.7 \\
93.1\end{array}$ \\
\hline $\begin{array}{l}\text { Fall } 1985 \ldots \ldots \ldots \ldots . . . \\
\text { Fall } 1986 \ldots \ldots \ldots \ldots . . . \\
\text { Fall } 1987 \ldots \ldots \ldots \ldots . . . \\
\text { Fall } 1988 \ldots \ldots \ldots \ldots . . . \\
\text { Fall } 1989 \ldots \ldots \ldots \ldots . . .\end{array}$ & $\begin{array}{l}13,750 \\
13,669 \\
13,323 \\
12,893 \\
12,524\end{array}$ & $\begin{array}{l}12,388 \\
12,333 \\
12,076 \\
11,687 \\
11,393\end{array}$ & $\begin{array}{l}3,439 \\
3,256 \\
3,143 \\
3,106 \\
3,141\end{array}$ & $\begin{array}{l}3,230 \\
3,215 \\
3,020 \\
2,895 \\
2,868\end{array}$ & $\begin{array}{l}2,866 \\
2,954 \\
2,936 \\
2,749 \\
2,629\end{array}$ & $\begin{array}{l}2,550 \\
2,601 \\
2,681 \\
2,650 \\
2,473\end{array}$ & $\begin{array}{l}303 \\
308 \\
296 \\
288 \\
281\end{array}$ & $\begin{array}{l}1,362 \\
1,336^{6} \\
1,247 \\
1,206^{6} \\
1,131\end{array}$ & $\begin{array}{l}\bar{z} \\
\bar{z} \\
\overline{\overline{0}}\end{array}$ & $\begin{array}{c}\bar{z} \\
\bar{z} \\
\overline{2} \\
284\end{array}$ & $\begin{array}{l}\bar{Z} \\
\overline{-} \\
267\end{array}$ & $\begin{array}{l}\bar{Z} \\
\overline{-} \\
273\end{array}$ & $\begin{array}{c}- \\
\overline{-} \\
\overline{5} \\
5\end{array}$ & $\begin{array}{l}14,888 \\
14,824 \\
14,502 \\
14,023 \\
13,536\end{array}$ & $\begin{array}{l}92.4 \\
92.2 \\
91.9 \\
91.9 \\
92.5\end{array}$ \\
\hline $\begin{array}{l}\text { Fall } 1990 \\
\text { Fall } 1991 \ldots \ldots \ldots . . . . . . . \\
\text { Fall } 1992 \ldots \ldots \ldots \ldots . . . \\
\text { Fall } 1993 \ldots \ldots \ldots \ldots . . . \\
\text { Fall } 1994 \ldots \ldots \ldots \ldots . . .\end{array}$ & $\begin{array}{l}12,476 \\
12,675 \\
12,862 \\
13,081 \\
13,354\end{array}$ & $\begin{array}{l}11,341 \\
11,544 \\
11,737 \\
11,963 \\
12,215\end{array}$ & $\begin{array}{l}3,169 \\
3,313 \\
3,352 \\
3,487 \\
3,604\end{array}$ & $\begin{array}{l}2,896 \\
2,915 \\
3,027 \\
3,050 \\
3,131\end{array}$ & $\begin{array}{l}2,612 \\
2,645 \\
2,656 \\
2,751 \\
2,748\end{array}$ & $\begin{array}{l}2,381 \\
2,392 \\
2,431 \\
2,424 \\
2,488\end{array}$ & $\begin{array}{l}284 \\
278 \\
272 \\
250 \\
244\end{array}$ & $\begin{array}{l}1,136^{6} \\
1,131 \\
1,125^{6} \\
1,118^{6} \\
1,138^{6}\end{array}$ & $\frac{30 \overline{9}}{312}$ & $\begin{array}{c}286 \\
286 \\
-\end{array}$ & $\begin{array}{l}272 \\
\overline{266} \\
-\end{array}$ & $\frac{260}{24 \overline{9}}$ & $\frac{-}{5}$ & $\begin{array}{l}13,329 \\
13,491 \\
13,775 \\
14,096 \\
14,637\end{array}$ & $\begin{array}{l}93.6 \\
94.0 \\
93.4 \\
92.8 \\
91.2\end{array}$ \\
\hline 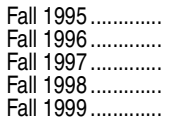 & $\begin{array}{l}13,665 \\
14,027 \\
14,241 \\
14,407 \\
14,600\end{array}$ & $\begin{array}{l}12,502 \\
12,849 \\
13,056 \\
13,195 \\
13,371\end{array}$ & $\begin{array}{l}3,704 \\
3,801 \\
3,819 \\
3,856 \\
3,935\end{array}$ & $\begin{array}{l}3,237 \\
3,323 \\
3,376 \\
3,382 \\
3,415\end{array}$ & $\begin{array}{l}2,826 \\
2,930 \\
2,972 \\
3,021 \\
3,034\end{array}$ & $\begin{array}{l}2,487 \\
2,586 \\
2,673 \\
2,722 \\
2,782\end{array}$ & $\begin{array}{l}247 \\
208 \\
216 \\
214 \\
205\end{array}$ & $\begin{array}{l}1,163 \\
1,178^{6} \\
1,185 \\
1,212^{6} \\
1,229\end{array}$ & $\begin{array}{l}325 \\
326 \\
336\end{array}$ & $\begin{array}{l}304 \\
\frac{306}{313} \\
31\end{array}$ & $\begin{array}{l}276 \\
283 \\
2 \overline{9}\end{array}$ & $\frac{255}{266}$ & $\frac{2}{4}$ & $\begin{array}{l}15,013 \\
15,443 \\
15,769 \\
15,829 \\
16,007\end{array}$ & $\begin{array}{l}91.0 \\
90.8 \\
90.3 \\
91.0 \\
91.2\end{array}$ \\
\hline $\begin{array}{l}\text { Fall } 2000 \ldots \ldots \ldots . . . \\
\text { Fall 2001 .............. } \\
\text { Fall 2002 ............ } \\
\text { Fall 2003 ........... } \\
\text { Fall 2004 ............ }\end{array}$ & $\begin{array}{l}14,781 \\
15,032 \\
15,374 \\
15,651 \\
15,949\end{array}$ & $\begin{array}{l}13,517 \\
13,736 \\
14,069 \\
14,339 \\
14,618\end{array}$ & $\begin{array}{l}3,963 \\
4,012 \\
4,105 \\
4,190 \\
4,281\end{array}$ & $\begin{array}{l}3,491 \\
3,528 \\
3,584 \\
3,675 \\
3,750\end{array}$ & $\begin{array}{l}3,083 \\
3,174 \\
3,229 \\
3,277 \\
3,369\end{array}$ & $\begin{array}{l}2,803 \\
2,863 \\
2,990 \\
3,046 \\
3,094\end{array}$ & $\begin{array}{l}177 \\
159 \\
161 \\
150 \\
122\end{array}$ & $\begin{array}{l}1,264^{6} \\
1,296 \\
1,306^{6} \\
1,311 \\
1,331^{6}\end{array}$ & $\begin{array}{r}350 \\
351 \\
-\end{array}$ & $\begin{array}{l}\overline{333} \\
\overline{334}\end{array}$ & $\begin{array}{l}3 \overline{16} \\
31 \overline{7}\end{array}$ & $\frac{29 \overline{3}}{30 \overline{4}}$ & $\frac{-3}{5}$ & $\begin{array}{l}16,144 \\
16,280 \\
16,506 \\
16,694 \\
17,054\end{array}$ & $\begin{array}{l}91.6 \\
92.3 \\
93.1 \\
93.8 \\
93.5\end{array}$ \\
\hline 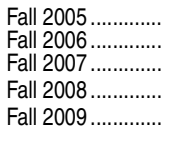 & $\begin{array}{l}16,258 \\
16,441 \\
16,451 \\
16,322 \\
16,261\end{array}$ & $\begin{array}{l}14,909 \\
15,081 \\
15,087 \\
14,980 \\
14,952\end{array}$ & $\begin{array}{l}4,287 \\
4,260 \\
4,200 \\
4,123 \\
4,080\end{array}$ & $\begin{array}{l}3,866 \\
3,882 \\
3,863 \\
3,822 \\
3,809\end{array}$ & $\begin{array}{l}3,454 \\
3,551 \\
3,558 \\
3,548 \\
3,541\end{array}$ & $\begin{array}{l}3,180 \\
3,277 \\
3,375 \\
3,400 \\
3,432\end{array}$ & $\begin{array}{r}121 \\
110 \\
92 \\
87 \\
90\end{array}$ & $\begin{array}{l}1,349 \\
1,360^{6} \\
1,364 \\
1,342^{6} \\
1,309\end{array}$ & $\begin{array}{r}356 \\
- \\
357 \\
- \\
333\end{array}$ & $\begin{array}{c}\frac{348}{347} \\
-3 \\
330\end{array}$ & $\begin{array}{c}326 \\
334 \\
- \\
324\end{array}$ & $\begin{array}{r}315 \\
324 \\
- \\
319\end{array}$ & $\begin{array}{c}\frac{3}{2} \\
\frac{3}{3}\end{array}$ & \begin{tabular}{l|l|}
17,358 \\
17,549 \\
17,597 \\
17,395 \\
17,232
\end{tabular} & $\begin{array}{l}93.7 \\
93.7 \\
93.5 \\
93.8 \\
94.4\end{array}$ \\
\hline $\begin{array}{l}\text { Fall } 2010 \ldots \ldots \ldots . . . \\
\text { Fall } 2011 \ldots \ldots \ldots \ldots \\
\text { Fall } 2012^{7} \ldots \ldots \ldots \ldots . . . . . \\
\text { Fall } 2013^{7} \ldots \ldots \ldots \ldots . . . . .\end{array}$ & $\begin{array}{l}16,159 \\
16,040 \\
15,959 \\
15,874\end{array}$ & $\begin{array}{l}14,860 \\
14,749 \\
14,684 \\
14,639\end{array}$ & $\begin{array}{l}4,008 \\
3,957 \\
3,978 \\
4,003\end{array}$ & $\begin{array}{l}3,800 \\
3,751 \\
3,704 \\
3,724\end{array}$ & $\begin{array}{l}3,538 \\
3,546 \\
3,501 \\
3,456\end{array}$ & $\begin{array}{l}3,472 \\
3,452 \\
3,459 \\
3,415\end{array}$ & $\begin{array}{l}42 \\
43 \\
42 \\
42\end{array}$ & $\begin{array}{l}1,299^{7} \\
1,291 \\
1,275 \\
1,235\end{array}$ & $\begin{array}{r}- \\
330 \\
- \\
-\end{array}$ & $\begin{array}{r}- \\
325 \\
- \\
-\end{array}$ & $\begin{array}{r}- \\
318 \\
- \\
-\end{array}$ & $\begin{array}{r}- \\
315 \\
- \\
-\end{array}$ & $\begin{array}{c}- \\
4 \\
-\end{array}$ & $\begin{array}{r}17,064 \\
16,867 \\
16,719 \\
-\end{array}$ & $\begin{array}{r}94.7 \\
95.1 \\
95.5 \\
-\end{array}$ \\
\hline
\end{tabular}

-Not available.

'Includes a relatively small number of secondary ungraded students.

${ }^{2}$ Data for 1890 through 1950 are from the decennial censuses of population. Later data are Census Bureau estimates as of July 1 preceding the opening of the school year.

${ }^{3}$ Gross enrollment ratio based on school enrollment of all ages in grades 9 to 12 divided by the 14 to 17-year-old population. Differs from enrollment rates in other tables, which are based on the enrollment of persons in the given age group only.

${ }^{4}$ Data are for $1927-28$.

${ }^{5}$ Data are for $1940-41$.

${ }^{6}$ Estimated.

NOTE: Includes enrollment in public schools that are a part of state and local school systems and also in most private schools, both religiously affiliated and nonsectarian. The enrollment for ungraded public school students was estimated based on the secondary proportion of ungraded students in prior years. The enrollment of ungraded private school students was estimated based on the secondary proportion of ungraded students in individual high schools. Some data have been revised from previously published figures. Detail may not sum to totals because of rounding. SOURCE: U.S. Department of Education, National Center for Education Statistics, Annual Report of the Commissioner of Education, 1890 through 1910; Biennial Survey of Education in the United States, 1919-20 through 1949-50; Statistics of State School Systems, 1951-52 through 1957-58; Statistics of Public Elementary and Secondary School Systems, 1959 through 1980; Statistics of Nonpublic Elementary and Secondary Schools, 1959 through 1980; Common Core of Data (CCD), "State Nonfiscal Survey of Public Elementary/Secondary Education," 1981-82 through 2011-12; Schools and Staffing Survey, Private School Data File, 1987-88; Private School Universe Survey (PSS), 1989-90 through 2011-12; National Elementary and Secondary Enrollment Projection Model, 1972 through 2023; and unpublished data. U.S. Department of Commerce, Census Bureau, Current Population Reports, Series P-25, Nos. 1000, 1022, 1045, 1057, 1059, 1092, and 1095; 2000 through 2009 Population Estimates, retrieved August 14, 2012, from http://www.census.gov/popest/data/national/asrh/2011/index.html; and 2010 through 2012 Population Estimates, retrieved November 1, 2013, from http://www.census.gov/popest/ data/national/asrh/2012/2012-nat-detail.html. (This table was prepared January 2014.) 
CHAPTER 2: Elementary and Secondary Education 77

Enrollment Status and Child Care Arrangements of Young Children

Table 202.10. Enrollment of 3-, 4-, and 5-year-old children in preprimary programs, by level of program, control of program, and attendance status: Selected years, 1965 through 2012

[Standard errors appear in parentheses]

\begin{tabular}{|c|c|c|c|c|c|c|c|c|c|c|c|c|c|c|c|c|c|c|c|c|}
\hline \multirow[b]{3}{*}{ Age and year } & \multirow{3}{*}{\multicolumn{2}{|c|}{$\begin{array}{r}\text { Total 3- to } \\
5 \text {-year-old } \\
\text { population } \\
\text { (in thousands) }\end{array}$}} & \multirow{3}{*}{\multicolumn{2}{|c|}{$\begin{array}{r}\text { Total enrollment } \\
\text { (in thousands) }\end{array}$}} & \multirow{3}{*}{\multicolumn{2}{|c|}{$\begin{array}{l}\text { Percent } \\
\text { enrolled }\end{array}$}} & \multicolumn{8}{|c|}{ Enrollment, by level and control (in thousands) } & \multirow{2}{*}{\multicolumn{4}{|c|}{$\begin{array}{l}\text { Enrollment, by attendance status } \\
\text { (in thousands) }\end{array}$}} & \multirow{3}{*}{\multicolumn{2}{|c|}{$\begin{array}{r}\text { Full-day as a } \\
\text { percent of total } \\
\text { enrollmen }\end{array}$}} \\
\hline & & & & & & & \multicolumn{4}{|c|}{ Nursery school enrollment } & \multicolumn{4}{|c|}{ Kindergarten enrollment } & & & & & & \\
\hline & & & & & & & & Public & & Private & & Public & & Private & & Full-day & & Part-day & & \\
\hline 1 & & 2 & & 3 & & 4 & & 5 & & 6 & & 7 & & 8 & & 9 & & 10 & & 11 \\
\hline $\begin{array}{l}\text { Total, } 3 \text { to } 5 \\
\text { years old }\end{array}$ & & & & & & & & & & & & & & & & & & & & \\
\hline $\begin{array}{l}1965 \ldots \\
1970\end{array}$ & $\begin{array}{l}12,549 \\
10,949\end{array}$ & $\begin{array}{l}(144.5) \\
(109.4)\end{array}$ & $\begin{array}{l}3,407 \\
4,104\end{array}$ & $\begin{array}{l}(87.1) \\
(71.5)\end{array}$ & $\begin{array}{l}27.1 \\
37.5\end{array}$ & $\begin{array}{l}(0.69) \\
(0.65)\end{array}$ & $\begin{array}{l}127 \\
332\end{array}$ & $\begin{array}{l}(19.6) \\
(25.3)\end{array}$ & $\begin{array}{l}393 \\
762\end{array}$ & $\begin{array}{l}(34.1) \\
(37.6)\end{array}$ & $\begin{array}{l}2,291 \\
2,498\end{array}$ & $\begin{array}{l}(75.6) \\
(62.0)\end{array}$ & $\begin{array}{l}596 \\
511\end{array}$ & $\begin{array}{l}(41.6) \\
(31.1)\end{array}$ & $\overline{698}$ & $\begin{array}{r}(t) \\
(36.1)\end{array}$ & $3, \overline{05}$ & $\begin{array}{r}(\dagger) \\
(68.3)\end{array}$ & $1 \overline{-}$ & $\begin{array}{r}(t) \\
(0.83)\end{array}$ \\
\hline $1975 \ldots \ldots \ldots \ldots$ & 10,185 & (105.8) & 4,955 & $(71.2)$ & 48.7 & $(0.70)$ & 570 & (32.7) & 1,174 & (45.5) & 2,682 & $(62.7)$ & 528 & (31.6) & 1,295 & $(47.4)$ & 3,659 & $(68.3)$ & 26.1 & $(0.88)$ \\
\hline $1980 \ldots$ & 9,284 & (102.6) & 4,878 & $(68.8)$ & 52.5 & $(0.74)$ & 628 & (34.6) & 1,353 & (48.6) & 2,438 & $(60.6)$ & 459 & (29.9) & 1,551 & $(51.4)$ & 3,327 & $(66.1)$ & 31.8 & $0.95)$ \\
\hline $1985 \ldots$ & 10,733 & (115.6) & 5,865 & (77.6) & 54.6 & $(0.72)$ & 846 & (42.0) & 1,631 & $(56.0)$ & 2,847 & $(68.8)$ & 541 & (34.1) & 2,144 & $(62.3)$ & 3,722 & $(74.2)$ & 36.6 & $(0.95)$ \\
\hline 1990. & 11,207 & (124.2) & 6,659 & $(82.3)$ & 59.4 & $(0.73)$ & 1,199 & (51.8) & 2,180 & $(66.4)$ & 2,772 & (72.3) & 509 & (34.9) & 2,577 & $(70.6)$ & 4,082 & $(80.7)$ & 38.7 & $(0.95)$ \\
\hline $1995^{1}$. & 12,518 & (131.5) & 7,739 & (86.6) & 61.8 & $(0.69)$ & 1,950 & (64.6) & 2,381 & (69.9) & 2,800 & (74.2) & 608 & (38.3) & 3,689 & $(81.2)$ & 4,051 & (83.4) & 47.7 & $(0.90)$ \\
\hline $2000^{1}$. & 11,858 & (133.0) & 7,592 & (86.3) & 64.0 & $(0.70)$ & 2,146 & (69.2) & 2,180 & $(69.7)$ & 2,701 & $(75.4)$ & 565 & (38.3) & 4,008 & $(85.1)$ & 3,584 & $(82.6)$ & 52.8 & $(0.95)$ \\
\hline $2005^{1}$ & 12,134 & (144.6) & 7,801 & (82.7) & 64.3 & $(0.68)$ & 2,409 & (68.8) & 2,120 & (65.5) & 2,804 & $(72.7)$ & 468 & (33.2) & 4,548 & $(83.5)$ & 3,253 & $(76.4)$ & 58.3 & $(0.87)$ \\
\hline $2009^{1}$. & 12,718 & (147.8) & 8,076 & $(85.0)$ & 63.5 & $(0.67)$ & 2,703 & (72.3) & 1,945 & (63.6) & 3,144 & (76.2) & 284 & (26.1) & 4,916 & $(86.0)$ & 3,160 & $(76.3)$ & 60.9 & $(0.85)$ \\
\hline $2010^{1,}$ & 12,949 & $(80.4)$ & 8,246 & (107.3) & 63.7 & $(0.66)$ & 2,749 & (89.3) & 2,048 & $(69.0)$ & 3,080 & $(75.6)$ & 369 & (33.2) & 4,813 & $(98.5)$ & 3,432 & $(88.5)$ & 58.4 & $(0.92)$ \\
\hline $2011^{1,2}$ & 12,965 & (81.8) & 8,260 & (105.0) & 63.7 & $(0.72)$ & 2,876 & (74.5) & 2,035 & $(79.7)$ & 2,947 & $(74.4)$ & 402 & (38.3) & 4,884 & (107.6) & 3,376 & $(87.0)$ & 59.1 & $(0.98)$ \\
\hline $2012^{1,2}$ & 12,259 & (114.8) & 7,883 & (101.5) & 64.3 & $(0.85)$ & 2,712 & (78.4) & 1,890 & $(74.3)$ & 2,926 & $(73.7)$ & 355 & $(30.0)$ & 4,760 & $(97.2)$ & 3,123 & $(85.1)$ & 60.4 & $(0.95)$ \\
\hline 3 years old & & & & & & & & & & & & & & & & & & & & \\
\hline 1965. & 4,149 & (84.9) & 203 & $(24.3)$ & 4.9 & $(0.59)$ & 41 & (11.1) & 153 & $(21.2)$ & $\ddagger$ & (†) & $\ddagger$ & $(t)$ & - & $(t)$ & - & $(t)$ & - & $(\dagger)$ \\
\hline $1970 .$. & 3,516 & (63.2) & 454 & (28.1) & 12.9 & $(0.80)$ & 110 & (14.6) & 322 & $(24.1)$ & $\ddagger$ & (†) & $\ddagger$ & $(t)$ & 142 & $(16.5)$ & 312 & (23.8) & 31.3 & (3.07) \\
\hline $1975 \ldots$ & 3,177 & $(60.2)$ & 683 & (32.7) & 21.5 & $(1.03)$ & 179 & (18.3) & 474 & (28.3) & $\ddagger$ & (†) & $\ddagger$ & $(t)$ & 259 & $(21.8)$ & 423 & (27.0) & 37.9 & (2.62) \\
\hline 1980. & 3,143 & $(60.7)$ & 857 & $(35.7)$ & 27.3 & (1.14) & 221 & (20.5) & 604 & $(31.6)$ & $\ddagger$ & $(\dagger)$ & $\ddagger$ & $(t)$ & 321 & $(24.3)$ & 536 & $(30.2)$ & 37.5 & $(2.36)$ \\
\hline $1985 \ldots$ & 3,594 & (68.2) & 1,035 & $(40.8)$ & 28.8 & $(1.14)$ & 278 & (24.1) & 679 & (35.3) & 52 & $(10.8)$ & $\ddagger$ & $(t)$ & 350 & $(26.7)$ & 685 & $(35.4)$ & 33.8 & (2.21) \\
\hline 1990 & 3,692 & $(72.7)$ & 1,205 & $(45.1)$ & 32.6 & $(1.22)$ & 347 & (28 & 840 & $(40$ & $\ddagger$ & $(\dagger)$ & $\ddagger$ & $(t)$ & 447 & $(31.4)$ & 758 & $(38.9)$ & 37.1 & $(2.20)$ \\
\hline $1995^{1}$ & 4,148 & $(77.4)$ & 1,489 & $(49.2)$ & 35.9 & (1.19) & 511 & (33.7) & 947 & $(43.0)$ & $\ddagger$ & $(\dagger)$ & $\ddagger$ & $(t)$ & 754 & (39.6) & 736 & $(39.2)$ & 50.6 & $(2.06)$ \\
\hline $2000^{1}$. & 3,929 & (78.2) & 1,541 & $(50.5)$ & 39.2 & (1.29) & 644 & (38.3) & 854 & $(42.7)$ & $\ddagger$ & $(\dagger)$ & $\ddagger$ & $(t)$ & 761 & $(40.9)$ & 779 & (41.3) & 49.4 & $(2.10)$ \\
\hline $2005^{1}$ & 4,151 & (86.3) & 1,715 & $(49.7)$ & 41.3 & $(1.20)$ & 777 & (39.4) & 869 & (41.1) & $\ddagger$ & $(\dagger)$ & $\ddagger$ & $(t)$ & 901 & $(41.6)$ & 814 & $(40.1)$ & 52.5 & $(1.89)$ \\
\hline $2009^{1}$.. & 4,361 & (88.4) & 1,776 & $(50.8)$ & 40.7 & (1.17) & 837 & $(40.7)$ & 861 & $(41.2)$ & $\ddagger$ & $(t)$ & $\ddagger$ & $(t)$ & 1,024 & $(43.8)$ & 752 & $(39.1)$ & 57.7 & (1.84) \\
\hline 2010 & 4,492 & (59.4) & 1,7 & $(59.5)$ & 38. & $(1.25)$ & 824 & & 8 & & $\ddagger$ & (t) & $\ddagger$ & $(t)$ & 861 & & 857 & (4 & 50.1 & (2.21) \\
\hline 2011 & 4,292 & (96.0) & 1,651 & $(67.8)$ & 38.5 & $(1.19)$ & 77 & & 798 & $(4$ & $\stackrel{+}{\ddagger}$ & $(\dagger)$ & $\stackrel{+}{\ddagger}$ & $(t)$ & 928 & (53.1) & 723 & $(50.9)$ & 56.2 & (2.37) \\
\hline $2012^{1,2} \ldots \ldots \ldots \ldots \ldots \ldots \ldots$ & 3,983 & $(218.7)$ & 1,614 & $(97.2)$ & 40.5 & $(1.52)$ & 822 & (64.1) & 730 & $(50.2)$ & $\ddagger$ & $(t)$ & $\ddagger$ & $(t)$ & 823 & (57.9) & 791 & $(60.3)$ & 51.0 & (2.04) \\
\hline & & & & & & & & & & & & & & & & & & & & \\
\hline 1965. & 4,238 & $(85.8)$ & 683 & $(41.8)$ & 16.1 & $(0.99)$ & 68 & (14.3) & 213 & (24.9) & 284 & $(28.4)$ & 118 & (18.7) & - & $(\dagger)$ & - & $(†)$ & - & $(t)$ \\
\hline 1970. & 3,620 & (64.1) & 1,007 & $(38.0)$ & 27.8 & (1.05) & 176 & (18.3) & 395 & $(26.5)$ & 318 & $(24.0)$ & 117 & 5.0) & 230 & $(20.7)$ & 776 & $(34.8)$ & 22.8 & $(1.87)$ \\
\hline 1 & 3,499 & (63.1) & 1,418 & $(41.0)$ & 40.5 & $(1.17)$ & 332 & $(24.5)$ & 644 & $(32.3)$ & 313 & (23.8) & 129 & 5.7) & 411 & $(26.9)$ & 1,008 & $(37.8)$ & 29.0 & $(1.70)$ \\
\hline 1980. & 3,072 & $(60.0)$ & 1,423 & $(39.5)$ & 46.3 & $(1.29)$ & 363 & (25.6) & 701 & (33.3) & 239 & $(21.2)$ & 120 & (15.4) & 467 & $(28.5)$ & 956 & $(36.7)$ & 32.8 & (1.78) \\
\hline 1985. & 3,598 & (68.2) & 1,766 & (45.1) & 49.1 & $(1.25)$ & 496 & (31.1) & 859 & (38.5) & 276 & $(24.0)$ & 135 & (17.1) & 643 & (34.6) & 1,123 & $(41.8)$ & 36.4 & (1.72) \\
\hline $1990 \ldots$ & 3,723 & $(73.0)$ & 2,087 & $(48.0)$ & 56.1 & $(1.29)$ & 695 & (37.7) & 1,144 & $(44.6)$ & 157 & $(19.4)$ & 91 & 14.9) & 716 & $(38.1)$ & 1,371 & $(46.6)$ & 34.3 & $(1.65)$ \\
\hline $1995^{1}$ & 4,145 & $(77.4)$ & 2,553 & $(49.9)$ & 61.6 & $(1.20)$ & 1,054 & (44.6) & 1,208 & $(46.6)$ & 207 & (22.3) & 84 & (14.5) & 1,104 & $(45.3)$ & 1,449 & $(48.9)$ & 43.3 & $(1.56)$ \\
\hline $2000^{1}$. & 3,940 & (78.3) & 2,491 & $(50.0)$ & 63.2 & (1.27) & 1,144 & $(47.0)$ & 1,121 & $(46.8)$ & 227 & $(24.2)$ & $\ddagger$ & $(t)$ & 1,182 & (47.5) & 1,374 & $(49.4)$ & 47.4 & (1.63) \\
\hline $2005^{1}$ & 4,028 & (85.1) & 2,593 & $(47.6)$ & 64.4 & $(1.18)$ & 1,295 & (46.4) & 1,083 & (44.1) & 215 & (22.3) & $\ddagger$ & $(t)$ & 1,332 & $(46.8)$ & 1,336 & $(46.8)$ & 51.4 & (1.52) \\
\hline $2009^{1}$. & 4,176 & $(86.6)$ & 2,674 & $(48.6)$ & 64.0 & (1.16) & 1,512 & $(48.6)$ & 905 & $(41.7)$ & 256 & $(24.3)$ & $\ddagger$ & $(t)$ & 1,372 & $(47.5)$ & 1,326 & $(47.1)$ & 51.3 & (1.51) \\
\hline $2010^{1,2}$ & 4,358 & (57.7) & 2,988 & $(67.2)$ & 68.6 & 5) & 1,5 & ( & 1,016 & $(4$ & 331 & 5) & 55 & & 1,405 & $(55.6)$ & 1,584 & $2.1)$ & 47.0 & $(1.61)$ \\
\hline $2011^{1,2}$ & 4,473 & (76.0) & 2,946 & $(76.8)$ & 65.9 & $(1.28)$ & 1,624 & (61.0) & 976 & (56.1) & 284 & (28.2) & 62 & (15.3) & 1,392 & $(63.7)$ & 1,553 & $(56.7)$ & 47.3 & $(1.60)$ \\
\hline $2012^{1,2} \ldots \ldots \ldots \ldots$ & 4,031 & (124.6) & 2,675 & $(87.8)$ & 66.4 & $(1.31)$ & 1,510 & (65.4) & 915 & (48.3) & 196 & $(23.0)$ & 54 & (12.3) & 1,351 & $(67.9)$ & 1,324 & $(56.2)$ & 50.5 & (1.67) \\
\hline & & & & & & & & & & & & & & & & & & & & \\
\hline 1965. & 4,162 & (85.1) & 2,521 & $(55.1)$ & 60 & (132) & 18 & (7.4) & $27 !$ & $(9.1)$ & 2,002 & $(56.3)$ & 474 & $35.8)$ & - & $(\dagger)$ & - & $(\dagger)$ & - & $(\dagger)$ \\
\hline 1970. & 3,814 & $(65.8)$ & 2,643 & $(40.2)$ & 69.3 & $(1.05)$ & 45 & (9.4) & 45 & (9.4) & 2,168 & (43.2) & 384 & (26.2) & 326 & $(24.4)$ & 2,317 & $(42.5)$ & 12.3 & $(0.90)$ \\
\hline 1975. & 3,509 & (63.2) & 2,854 & $(32.6)$ & 81.3 & $(0.93)$ & 59 & $(10.7)$ & 57 & $(10.6)$ & 2,358 & (39.2) & 381 & (26.0) & 625 & $(32.0)$ & 2,228 & $(40.2)$ & 21.9 & $(1.09)$ \\
\hline $1980 .$. & 3,069 & $(60.0)$ & 2,598 & $(28.6)$ & 84.7 & $(0.93)$ & 44 & $(9.4)$ & 48 & $(9.8)$ & 2,183 & $(35.9)$ & 322 & (24.3) & 763 & $(34.2)$ & 1,835 & $(38.8)$ & 29.4 & (1.28) \\
\hline $1985 \ldots \ldots \ldots \ldots \ldots$ & 3,542 & (67.7) & 3,065 & $(30.6)$ & 86.5 & $(0.86)$ & 73 & $(12.7)$ & 94 & (14.4) & 2,519 & $(40.6)$ & 379 & (27.7) & 1,151 & $(41.9)$ & 1,914 & $(44.6)$ & 37.6 & (1.32) \\
\hline 1990. & 3,792 & (73.7) & 3,3 & $(30.8)$ & 88 & (1) & 1 & ( & 15 & (21 & 2,604 & $(45.2)$ & 411 & 3) & 1,4 & $(47.2)$ & 1,953 & $(48.7)$ & 42.0 & (1.35) \\
\hline $1995^{1}$. & 4,224 & (78.1) & 3,697 & $(34.2)$ & 87. & $(0.81)$ & 385 & $(29$ & 226 & (23.3) & 2,578 & $(50.5)$ & 507 & (33.7) & 1,830 & (51.3) & 1,867 & $(51.4)$ & 49.5 & (1.31) \\
\hline $2000^{1}$. & 3,989 & (78.7) & 3,495 & $(34.3)$ & 87.6 & $(0.86)$ & 359 & $(29.8)$ & 206 & (23.1) & 2,447 & $(50.8)$ & 484 & (34.1) & 2,065 & $(52.1)$ & 1,431 & $(50.0)$ & 59.1 & (1.37) \\
\hline $2005^{1}$... & 3,955 & (84.3) & 3,418 & (33.7) & 86.4 & $(0.85)$ & 337 & (27.5) & 168 & (19.9) & 2,535 & $(47.3)$ & 378 & (29.0) & 2,316 & $(48.5)$ & 1,102 & $(44.2)$ & 67.7 & (1.25) \\
\hline $2009^{1} \ldots \ldots \ldots \ldots \ldots$ & 4,180 & $(86.6)$ & 3,601 & $(35.0)$ & 86.1 & $(0.84)$ & 354 & (28.2) & 179 & (20.5) & 2,827 & $(47.4)$ & 242 & (23.6) & 2,519 & $(49.6)$ & 1,082 & $(44.3)$ & 70.0 & (1.20) \\
\hline $2010^{1,2}$ & 4,099 & (57.9) & 3,540 & $(56.2)$ & 86.3 & $(0.92)$ & 338 & & 214 & $(23.5)$ & 2,695 & (58.4) & 292 & (30.3) & 2,548 & $(60.1)$ & 992 & $(44.6)$ & 72.0 & $(1.20)$ \\
\hline $2011^{1,2}$. & 4,201 & (69.1) & 3,663 & $(67.6)$ & 87.2 & $(0.85)$ & 481 & (36.4) & 261 & (29.4) & 2,610 & $(67.6)$ & 312 & (31.4) & 2,564 & (67.6) & 1,099 & $(54.3)$ & 70.0 & (1.36) \\
\hline $2012^{1,2}$. & 4,245 & (77.0) & 3,594 & (71.1) & 84.6 & $(0.94)$ & 379 & (33.0) & 245 & (27.3) & 2,681 & (70.1) & 289 & (27.4) & 2,585 & (72.9) & 1,008 & $(50.4)$ & 71.9 & (1.34) \\
\hline
\end{tabular}

-Not available.

†Not applicable.

Interpret data with caution. The coefficient of variation (CV) for this estimate is between 30 and 50 percent.

₹Reporting standards not met. Either there are too few cases for a reliable estimate or the coefficient of variation (CV) is 50 percent or greater.

${ }^{1}$ Beginning in 1994, preprimary enrollment data were collected using new procedures. Data may not be comparable to figures for earlier years.

${ }^{2}$ Beginning in 2010, standard errors were computed using replicate weights, which produced more precise values than the methodology used in prior years.

${ }^{3}$ Enrollment data include only those students in preprimary programs.
NOTE: Preprimary programs provide educational experiences for children and include kindergarten, preschool, and nursery school programs. Enrollment data for 5-year-olds include only those students in preprimary programs and do not include those enrolled in primary programs. Data are based on sample surveys of the civilian noninstitutional population. Detail may not sum to totals because of rounding. Some data have been revised from previously published figures.

SOURCE: U.S. Department of Education, National Center for Education Statistics, Preprimary Enrollment, 1965, 1970, and 1975. U.S. Department of Commerce, Census Bureau, Current Population Survey (CPS), October, 1980 through 2012. (This table was prepared May 2013.) 
Table 202.20. Percentage of 3-, 4-, and 5-year-old children enrolled in preprimary programs, by attendance status, level of program, and selected child and family characteristics: 2012

[Standard errors appear in parentheses]

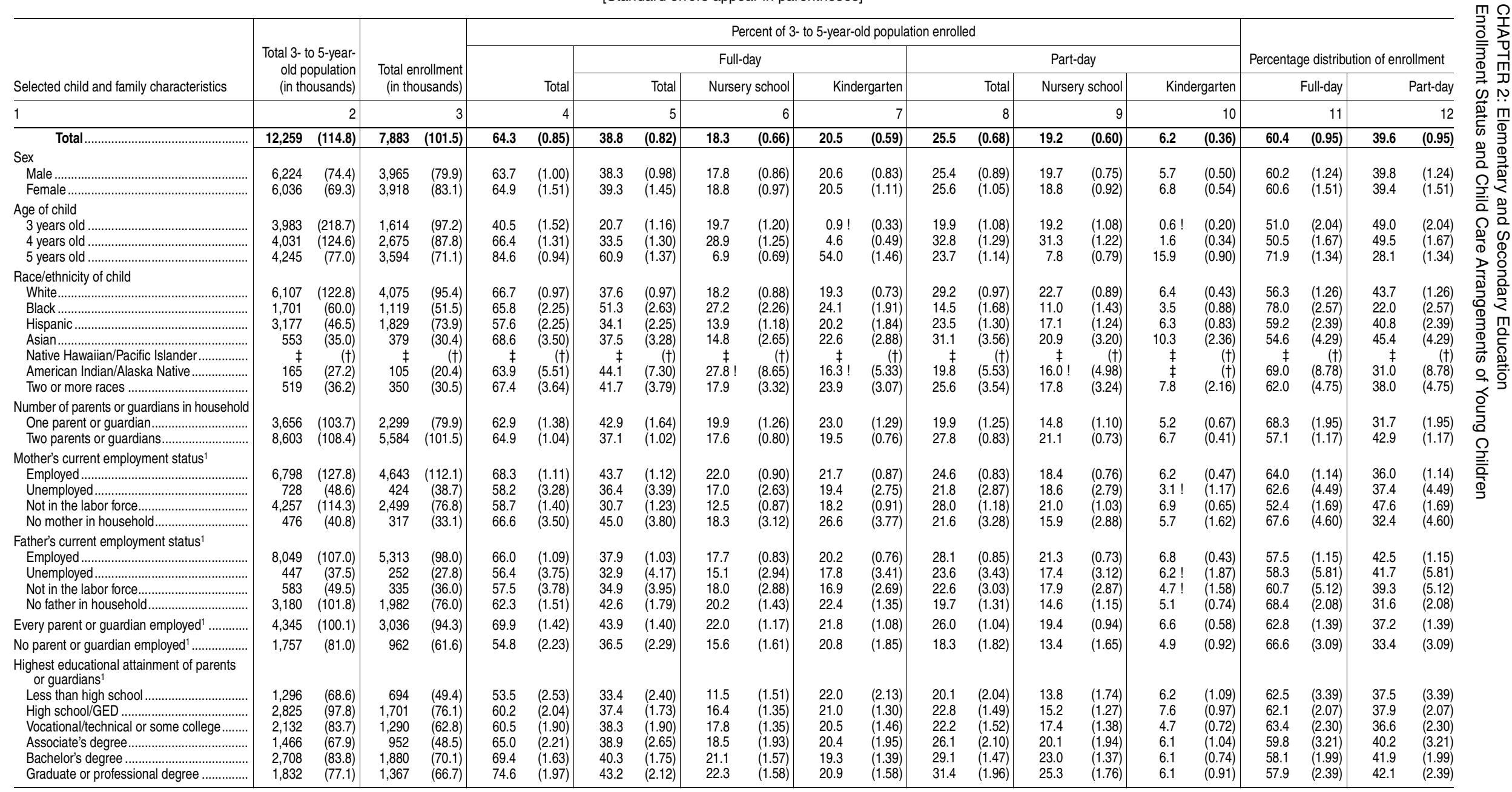

\section{†Not applicable}

with caution. The coefficient of variation (CV) for this estimate is between 30 and 50 percent.

Reporting standards not met. Either there are too few cases for a reliable estimate or the coefficient of variation $(\mathrm{CV})$ is 50 percent or greater.

NOTE: Preprimary programs provide educational experiences for children and include kindergarten, preschool, and nursery school programs. Enrolment data for 5 -year-olds include only those students in preprimary programs and do not include veys of the civilian noninstitutional population. Detail may not sum to totals because of rounding.
SOURCE: U.S. prepared May 2013.) 
Table 202.30. Number of children under 6 years old and not yet enrolled in kindergarten, percentage in center-based programs, average weekly hours in nonparental care, and percentage in various types of primary care arrangements, by selected child and family characteristics: 2005

[Standard errors appear in parentheses]

\begin{tabular}{|c|c|c|c|c|c|c|c|c|c|c|c|c|c|c|c|c|c|c|c|c|}
\hline \multirow[b]{4}{*}{$\begin{array}{l}\text { Selected child and family } \\
\text { characteristic }\end{array}$} & \multirow{4}{*}{\multicolumn{2}{|c|}{$\begin{array}{r}\text { Number } \\
\text { of children, } \\
\text { ages } 0 \text { to } 5 \\
\text { (in thousands) }\end{array}$}} & \multirow{4}{*}{\multicolumn{2}{|c|}{$\begin{array}{r}\text { Percent in } \\
\text { center-based } \\
\text { programs }\end{array}$}} & \multirow{4}{*}{\multicolumn{2}{|c|}{$\begin{array}{r}\text { Average } \\
\text { hours } \\
\text { per week in } \\
\text { nonparental } \\
\text { care }^{1}\end{array}$}} & \multicolumn{14}{|c|}{ Percentage distribution, by type of primary care arrangement } \\
\hline & & & & & & & \multirow{3}{*}{\multicolumn{2}{|c|}{$\begin{array}{l}\text { Parental } \\
\text { care only }\end{array}$}} & \multicolumn{12}{|c|}{ Nonparental care } \\
\hline & & & & & & & & & \multicolumn{4}{|c|}{ Center-based care } & \multicolumn{4}{|c|}{ Nonrelative care } & \multirow{2}{*}{\multicolumn{2}{|c|}{ Relative }} & \multirow{2}{*}{\multicolumn{2}{|c|}{$\begin{array}{r}\text { Multiple } \\
\text { arrangements }^{2}\end{array}$}} \\
\hline & & & & & & & & & \multicolumn{2}{|c|}{ Head Start } & \multicolumn{2}{|c|}{$\begin{array}{r}\text { Other } \\
\text { center-based }\end{array}$} & \multicolumn{2}{|c|}{$\begin{array}{r}\text { Family } \\
\text { child care (in } \\
\text { another home) }\end{array}$} & \multicolumn{2}{|c|}{$\begin{array}{r}\text { Sitter (in child's } \\
\text { home) }\end{array}$} & & & & \\
\hline 1 & & 2 & & 3 & & 4 & & 5 & & 6 & & 7 & & 8 & & 9 & & 10 & & 11 \\
\hline Total preschool children.. & 20,665 & $(9.0)$ & 36.1 & $(0.60)$ & 29.3 & $(0.37)$ & 39.8 & $(0.76)$ & 5.1 & 0.40) & 27.3 & $(0.49)$ & 8.3 & $(0.39)$ & 2.3 & $(0.24)$ & 15.4 & $(0.66)$ & 1.7 & $(0.18)$ \\
\hline 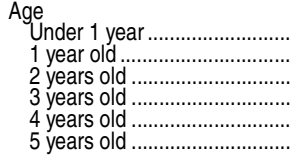 & $\begin{array}{l}3,519 \\
3,988 \\
4,093 \\
4,070 \\
3,873 \\
1,123\end{array}$ & 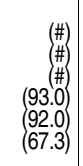 & $\begin{array}{l}12.0 \\
16.9 \\
28.7 \\
42.5 \\
69.2 \\
68.7\end{array}$ & $\begin{array}{l}1.13 \\
1.34 \\
1.84 \\
1.67 \\
1.36 \\
(3.51)\end{array}$ & $\begin{array}{l}30.9 \\
31.2 \\
29.6 \\
28.9 \\
27.9 \\
26.9\end{array}$ & $\begin{array}{l}(0.95) \\
0.81 \\
0.75 \\
0.64) \\
0.67) \\
(1.28)\end{array}$ & $\begin{array}{l}57.7 \\
48.5 \\
44.9 \\
34.0 \\
20.9 \\
21.1\end{array}$ & $\left.\begin{array}{l}(1.81) \\
1.89 \\
1.97 \\
1.46 \\
1.44 \\
(3.17\end{array}\right)$ & $\begin{array}{r}1.2 ! \\
0.7 ! \\
3.5 \\
5.3 \\
13.2 \\
10.4\end{array}$ & $\begin{array}{l}(0.57) \\
0.25 \\
0.98 \\
0.75 \\
1.12 \\
(2.22)\end{array}$ & $\begin{array}{l}10.0 \\
15.0 \\
22.7 \\
33.2 \\
48.2 \\
48.4\end{array}$ & $\begin{array}{l}(1.07) \\
1.32 \\
1.66 \\
1.64 \\
1.29 \\
(3.33)\end{array}$ & $\begin{array}{l}9.2 \\
11.1 \\
10.7 \\
7.6 \\
4.0 \\
4.6 !\end{array}$ & $\left.\begin{array}{l}(0.90) \\
1.09 \\
1.13 \\
0.91 \\
0.73 \\
(1.44)\end{array}\right)$ & $\begin{array}{l}3.2 \\
3.4 \\
2.4 \\
1.7 \\
1.2 ! \\
\ddagger\end{array}$ & $\begin{array}{r}0.60) \\
0.57 \\
0.49 \\
0.38) \\
0.50) \\
(\dagger)\end{array}$ & $\begin{array}{l}17.2 \\
19.1 \\
14.3 \\
16.7 \\
10.4 \\
13.6\end{array}$ & $\left.\begin{array}{l}(1.42) \\
1.52 \\
1.17 \\
1.35 \\
1.29 \\
(2.91)\end{array}\right)$ & $\begin{array}{l}1.5 ! \\
2.2 \\
1.5 \\
1.5 \\
2.2 \\
\ddagger\end{array}$ & $\left.\begin{array}{r}(0.47) \\
0.50 \\
0.38 \\
0.36 \\
0.44 \\
(t)\end{array}\right)$ \\
\hline 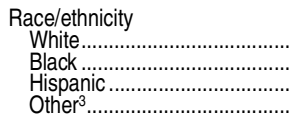 & $\begin{array}{r}11,488 \\
2,962 \\
4,283 \\
1,933\end{array}$ & 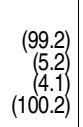 & $\begin{array}{l}37.8 \\
43.8 \\
25.2 \\
37.9\end{array}$ & $\begin{array}{l}(0.87) \\
2.44 \\
1.28 \\
(2.72)\end{array}$ & $\begin{array}{l}27.1 \\
35.9 \\
28.8 \\
31.8\end{array}$ & $\begin{array}{l}(0.48) \\
0.85 \\
0.76 \\
0.91)\end{array}$ & $\begin{array}{l}37.7 \\
30.8 \\
50.9 \\
41.5\end{array}$ & $\left.\begin{array}{l}0.97 \\
2.67 \\
1.43 \\
(2.80)\end{array}\right)$ & $\begin{array}{r}2.8 \\
13.3 \\
6.2 \\
3.8\end{array}$ & $\left.\begin{array}{l}(0.35) \\
2.10 \\
0.76 \\
0.94\end{array}\right)$ & $\begin{array}{l}30.4 \\
28.8 \\
16.8 \\
29.6\end{array}$ & $\begin{array}{l}(0.82) \\
2.32 \\
1.01 \\
(2.43)\end{array}$ & $\begin{array}{r}10.1 \\
6.6 \\
6.4 \\
4.8\end{array}$ & $\left.\begin{array}{l}(0.59) \\
1.05 \\
0.80 \\
0.76\end{array}\right)$ & $\begin{array}{l}3.1 \\
\ddagger \\
1.5 \\
1.3\end{array}$ & $\begin{array}{r}(0.35) \\
(\dagger) \\
(0.32) \\
(0.35)\end{array}$ & $\begin{array}{l}14.1 \\
17.8 \\
16.7 \\
17.1\end{array}$ & $\begin{array}{l}0.82 \\
2.76 \\
0.96 \\
(2.03)\end{array}$ & $\begin{array}{l}1.8 \\
1.7 ! \\
1.4 \\
1.9 !\end{array}$ & $\left.\begin{array}{l}(0.26) \\
0.57 \\
0.35 \\
0.68\end{array}\right)$ \\
\hline $\begin{array}{l}\text { Number of parents in the } \\
\text { household }\end{array}$ & & & & & & & & & & & & & & & & & & & & \\
\hline 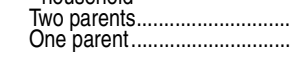 & $\begin{array}{r}16,275 \\
4,055\end{array}$ & $\left(\begin{array}{l}114.0) \\
112.6\end{array}\right)$ & $\begin{array}{l}34.4 \\
42.2\end{array}$ & $\left(\begin{array}{l}0.70 \\
1.94\end{array}\right)$ & $\begin{array}{l}27.0 \\
35.1\end{array}$ & $\left(\begin{array}{l}0.42) \\
0.77)\end{array}\right.$ & $\begin{array}{l}43.3 \\
26.1\end{array}$ & $\left(\begin{array}{l}0.90) \\
(1.68)\end{array}\right.$ & $\begin{array}{r}3.4 \\
11.1\end{array}$ & $\begin{array}{l}0.33) \\
(1.42)\end{array}$ & $\begin{array}{l}27.7 \\
26.3\end{array}$ & $\left(\begin{array}{l}0.58) \\
1.61)\end{array}\right.$ & $\begin{array}{l}8.6 \\
7.8\end{array}$ & $\left(\begin{array}{l}0.44) \\
1.06)\end{array}\right.$ & $\begin{array}{r}2.4 \\
\ddagger\end{array}$ & $\begin{array}{r}(0.24) \\
(\dagger)\end{array}$ & $\begin{array}{l}12.9 \\
25.3\end{array}$ & $\begin{array}{l}0.66) \\
(2.28)\end{array}$ & $\begin{array}{l}1.7 \\
1.8\end{array}$ & $\left(\begin{array}{l}0.20) \\
0.41\end{array}\right)$ \\
\hline 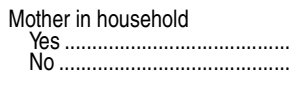 & $\begin{array}{r}19,982 \\
683\end{array}$ & $\left.\begin{array}{l}(65.8) \\
63.8\end{array}\right)$ & $\begin{array}{l}35.7 \\
45.2\end{array}$ & $\left(\begin{array}{l}0.59 \\
4.17\end{array}\right)$ & $\begin{array}{l}28.9 \\
38.5\end{array}$ & $\left(\begin{array}{l}0.38) \\
1.87\end{array}\right)$ & $\begin{array}{l}40.1 \\
30.9\end{array}$ & $\left(\begin{array}{l}0.78) \\
(3.95)\end{array}\right)$ & $\begin{array}{l}4.9 \\
9.9\end{array}$ & $\left.\begin{array}{l}(0.42) \\
(2.44)\end{array}\right)$ & $\begin{array}{l}27.3 \\
27.4\end{array}$ & $\left(\begin{array}{l}0.47) \\
3.62\end{array}\right)$ & $\begin{array}{l}8.5 \\
3.5 !\end{array}$ & $\left(\begin{array}{l}0.40) \\
1.26\end{array}\right)$ & $\begin{array}{r}2.3 \\
\ddagger\end{array}$ & $\begin{array}{r}(0.23) \\
(\dagger)\end{array}$ & $\begin{array}{l}15.2 \\
22.5\end{array}$ & $\left(\begin{array}{l}0.67) \\
3.75\end{array}\right)$ & $\begin{array}{l}1.7 \\
3.0 !\end{array}$ & $\left.\begin{array}{l}0.18 \\
1.38\end{array}\right)$ \\
\hline 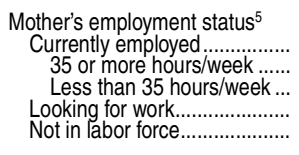 & $\begin{array}{r}11,328 \\
7,038 \\
4,290 \\
1,416 \\
7,238\end{array}$ & $\begin{array}{l}(197.3) \\
(185.0) \\
156.5 \\
(11.3) \\
173.7)\end{array}$ & $\begin{array}{l}43.8 \\
47.5 \\
37.7 \\
22.6 \\
25.7\end{array}$ & $\left.\begin{array}{l}(0.81) \\
1.15 \\
1.52 \\
2.91 \\
1.03\end{array}\right)$ & $\begin{array}{l}32.3 \\
37.1 \\
22.7 \\
26.0 \\
16.7\end{array}$ & $\begin{array}{l}(0.40) \\
0.42 \\
0.64 \\
1.46 \\
(0.69)\end{array}$ & $\begin{array}{l}20.9 \\
14.9 \\
30.8 \\
55.0 \\
67.3\end{array}$ & $\left.\begin{array}{l}(0.97) \\
1.06 \\
2.00 \\
4.48 \\
1.13\end{array}\right)$ & $\begin{array}{l}5.4 \\
5.7 \\
5.1 \\
4.9 \\
4.2\end{array}$ & $\begin{array}{l}(0.64) \\
0.72 \\
0.99 \\
1.11 \\
0.50)\end{array}$ & $\begin{array}{l}33.1 \\
36.3 \\
27.9 \\
17.1 \\
20.2\end{array}$ & $\left.\begin{array}{l}(0.81 \\
1.14 \\
1.43 \\
2.66 \\
0.91\end{array}\right)$ & $\begin{array}{r}13.7 \\
16.6 \\
8.9 \\
3.7 \\
1.3\end{array}$ & $\begin{array}{l}(0.68) \\
0.89 \\
0.99 \\
1.03 \\
0.26)\end{array}$ & $\begin{array}{l}3.0 \\
2.4 \\
3.9 \\
\ddagger \\
1.2\end{array}$ & $\begin{array}{l}(0.32) \\
0.32 \\
(0.64) \\
(t) \\
(0.22)\end{array}$ & $\begin{array}{c}21.4 \\
22.0 \\
20.5 \\
16.7 ! \\
5.2\end{array}$ & $\left.\begin{array}{l}(0.92) \\
1.28 \\
1.38 \\
5.17 \\
0.61)\end{array}\right)$ & $\begin{array}{l}2.4 \\
2.1 \\
2.9 \\
\ddagger \\
0.7\end{array}$ & $\begin{array}{l}(0.29) \\
0.35 \\
0.49 \\
(\dagger) \\
(0.19)\end{array}$ \\
\hline $\begin{array}{l}\text { Mother's highest education } \\
\text { Less than high school ............. } \\
\text { High school/GED ............... } \\
\text { Vocational/technical or some }\end{array}$ & $\begin{array}{l}1,961 \\
5,590\end{array}$ & $\begin{array}{r}(99.4) \\
(182.6)\end{array}$ & $\begin{array}{l}18.1 \\
30.3\end{array}$ & $\left(\begin{array}{l}1.58 \\
1.49\end{array}\right)$ & $\begin{array}{l}26.0 \\
29.2\end{array}$ & $\left(\begin{array}{l}1.58) \\
0.73)\end{array}\right)$ & $\begin{array}{l}64.8 \\
45.4\end{array}$ & $\left(\begin{array}{l}2.31) \\
(1.77)\end{array}\right)$ & $\begin{array}{l}9.9 \\
8.0\end{array}$ & $\begin{array}{l}1.33) \\
0.96)\end{array}$ & $\begin{array}{r}8.0 \\
20.0\end{array}$ & $\left(\begin{array}{l}1.03 \\
1.25\end{array}\right)$ & $\begin{array}{l}4.0 \\
6.3\end{array}$ & $\left(\begin{array}{l}0.89) \\
0.73)\end{array}\right)$ & $\begin{array}{c}\# \\
1.2 !\end{array}$ & $\begin{array}{r}(\dagger) \\
(0.42)\end{array}$ & $\begin{array}{l}12.2 \\
17.3\end{array}$ & $\left(\begin{array}{l}1.70) \\
1.32\end{array}\right)$ & $\begin{array}{l}1.0 ! \\
1.8\end{array}$ & $\left.\begin{array}{l}(0.45) \\
0.39\end{array}\right)$ \\
\hline 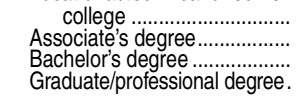 & $\begin{array}{l}4,122 \\
1,466 \\
4,593 \\
2,250\end{array}$ & $\begin{array}{r}(145.7) \\
(78.9) \\
(123.1) \\
(121.2)\end{array}$ & $\begin{array}{l}34.3 \\
37.1 \\
45.2 \\
47.1\end{array}$ & $\left.\begin{array}{l}1.80 \\
2.76 \\
1.55 \\
1.80\end{array}\right)$ & $\begin{array}{l}30.1 \\
28.2 \\
27.9 \\
30.0\end{array}$ & $\left.\begin{array}{l}(1.02) \\
1.04 \\
0.63 \\
0.75\end{array}\right)$ & $\begin{array}{l}39.8 \\
31.6 \\
33.2 \\
25.7\end{array}$ & $\left.\begin{array}{l}(2.17) \\
2.90 \\
1.33 \\
1.89\end{array}\right)$ & $\begin{array}{l}4.5 \\
3.5 ! \\
1.9 ! \\
1.2 !\end{array}$ & $\left.\begin{array}{l}0.68 \\
1.22 \\
0.57 \\
0.41\end{array}\right)$ & $\begin{array}{l}26.3 \\
29.9 \\
38.2 \\
40.3\end{array}$ & $\left.\begin{array}{l}1.59) \\
2.48 \\
1.39 \\
1.75\end{array}\right)$ & $\begin{array}{r}7.9 \\
15.5 \\
9.9 \\
11.6\end{array}$ & $\begin{array}{l}(0.94) \\
1.96 \\
0.86 \\
1.62)\end{array}$ & $\begin{array}{l}1.3 ! \\
1.4 ! \\
3.6 \\
6.5\end{array}$ & $\begin{array}{l}(0.42) \\
0.56 \\
0.58) \\
(0.99)\end{array}$ & $\begin{array}{l}18.5 \\
16.6 \\
11.5 \\
13.0\end{array}$ & $\left(\begin{array}{l}1.76 \\
2.27 \\
1.01 \\
1.69\end{array}\right)$ & $\begin{array}{l}1.8 \\
1.5 ! \\
1.8 \\
1.7\end{array}$ & $\left.\begin{array}{l}0.47) \\
0.62 \\
0.37 \\
0.47\end{array}\right)$ \\
\hline 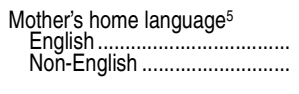 & $\begin{array}{r}16,778 \\
3,205\end{array}$ & $\left(\begin{array}{l}117.0) \\
103.3)\end{array}\right)$ & $\begin{array}{l}38.1 \\
23.5\end{array}$ & $\left.\begin{array}{l}(0.63) \\
(1.61)\end{array}\right)$ & $\begin{array}{l}29.1 \\
26.9\end{array}$ & $\begin{array}{l}(0.41) \\
(0.97)\end{array}$ & $\begin{array}{l}36.7 \\
57.9\end{array}$ & $\left(\begin{array}{l}0.86) \\
1.76)\end{array}\right)$ & $\begin{array}{l}4.5 \\
7.1\end{array}$ & $\left(\begin{array}{l}0.49) \\
1.02)\end{array}\right.$ & $\begin{array}{l}29.5 \\
15.9\end{array}$ & $\left(\begin{array}{l}0.53) \\
(1.25)\end{array}\right.$ & $\begin{array}{l}9.1 \\
5.5\end{array}$ & $\left(\begin{array}{l}0.44) \\
(0.82)\end{array}\right.$ & $\begin{array}{l}2.5 \\
1.0\end{array}$ & $(0.26)$ & $\begin{array}{l}15.9 \\
11.5\end{array}$ & $\left(\begin{array}{l}0.77) \\
0.99)\end{array}\right.$ & $\begin{array}{l}1.8 \\
1.0 !\end{array}$ & $\left(\begin{array}{l}0.21) \\
0.31)\end{array}\right.$ \\
\hline 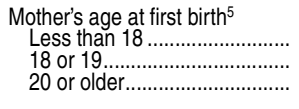 & $\begin{array}{r}1,744 \\
2,529 \\
15,709\end{array}$ & $\left(\begin{array}{l}117.6) \\
135.1 \\
140.0)\end{array}\right)$ & $\begin{array}{l}27.7 \\
28.4 \\
37.8\end{array}$ & $\left.\begin{array}{l}(2.84) \\
2.14 \\
0.68\end{array}\right)$ & $\begin{array}{l}32.8 \\
30.6 \\
28.3\end{array}$ & $\left.\begin{array}{l}1.40) \\
1.13 \\
0.43\end{array}\right)$ & $\begin{array}{l}50.3 \\
46.6 \\
37.9\end{array}$ & $\left.\begin{array}{l}(3.11) \\
2.81 \\
0.74)\end{array}\right)$ & $\begin{array}{r}10.4 \\
7.6 \\
3.9\end{array}$ & $\left.\begin{array}{l}(1.81) \\
1.23 \\
0.43\end{array}\right)$ & $\begin{array}{l}15.4 \\
17.6 \\
30.2\end{array}$ & $\left.\begin{array}{l}(2.31) \\
1.90 \\
0.65\end{array}\right)$ & $\begin{array}{l}4.8 \\
7.1 \\
9.1\end{array}$ & $\left.\begin{array}{l}1.03 \\
1.33 \\
0.46\end{array}\right)$ & $\begin{array}{l} \pm .+9 \\
2.5\end{array}$ & $\left(\begin{array}{r}(t) \\
(0.34) \\
0.24)\end{array}\right.$ & $\begin{array}{l}15.9 \\
19.4 \\
14.4\end{array}$ & $\left.\begin{array}{l}(1.91) \\
2.80 \\
0.70\end{array}\right)$ & $\begin{array}{l}1.1 ! \\
0.8 ! \\
1.9\end{array}$ & $\left.\begin{array}{l}(0.53) \\
0.34 \\
0.21)\end{array}\right)$ \\
\hline $\begin{array}{l}\text { Household income } \\
\$ 15,000 \text { or less } \ldots \ldots \ldots \ldots \ldots \ldots . . . \\
\$ 15,001 \text { to } \$ 25,000 \ldots \ldots \ldots \ldots . . . \\
\$ 25,001 \text { to } \$ 35,000 \ldots \ldots \ldots \ldots \ldots \\
\$ 35,001 \text { to } \$ 50,000 \ldots \ldots \ldots \ldots \ldots . . \\
\text { More than } \$ 50,000 \ldots \ldots \ldots \ldots \ldots . .\end{array}$ & $\begin{array}{l}3,142 \\
2,770 \\
2,313 \\
2,943 \\
9,498\end{array}$ & $\begin{array}{r}(79.3) \\
(9.2) \\
(94.5) \\
(111.8) \\
(112.8)\end{array}$ & $\begin{array}{l}29.7 \\
29.0 \\
30.8 \\
28.3 \\
43.9\end{array}$ & $\left.\begin{array}{l}(2.19) \\
2.53 \\
2.06 \\
1.83 \\
0.95\end{array}\right)$ & $\begin{array}{l}31.4 \\
31.0 \\
28.7 \\
29.5 \\
28.4\end{array}$ & $\left(\begin{array}{l}1.11 \\
1.16 \\
1.01 \\
1.03 \\
0.42\end{array}\right)$ & $\begin{array}{l}48.2 \\
48.9 \\
44.2 \\
48.5 \\
30.6\end{array}$ & $\left.\begin{array}{l}(2.35) \\
2.44 \\
2.22 \\
2.41 \\
1.03\end{array}\right)$ & $\begin{array}{r}11.0 \\
8.5 \\
9.0 \\
4.2 \\
1.5\end{array}$ & $\left.\begin{array}{l}(1.61) \\
1.02 \\
1.52 \\
0.91 \\
0.27)\end{array}\right)$ & $\begin{array}{l}16.6 \\
19.2 \\
19.1 \\
21.2 \\
37.1\end{array}$ & $\left.\begin{array}{l}1.80 \\
2.18 \\
1.89 \\
1.60 \\
0.88\end{array}\right)$ & $\begin{array}{r}4.7 \\
4.5 \\
6.7 \\
6.7 \\
11.5\end{array}$ & $\begin{array}{l}(0.90) \\
0.70 \\
1.39 \\
0.97 \\
0.71)\end{array}$ & $\begin{array}{l}1.7 ! \\
1.5 ! \\
0.7 ! \\
0.8 ! \\
3.6\end{array}$ & $\begin{array}{l}(0.67) \\
0.63 \\
0.31 \\
0.29 \\
0.38)\end{array}$ & $\begin{array}{l}16.9 \\
15.9 \\
18.4 \\
16.7 \\
13.7\end{array}$ & $\left.\begin{array}{l}(2.31) \\
1.68 \\
1.99 \\
1.51 \\
0.84\end{array}\right)$ & $\begin{array}{l}0.9 ! \\
1.5 ! \\
1.9 \\
2.0 \\
1.9\end{array}$ & $\left.\begin{array}{l}0.35 \\
0.57 \\
0.52 \\
0.58 \\
0.26\end{array}\right)$ \\
\hline $\begin{array}{l}\text { Poverty status }{ }^{6} \\
\text { Above poverty threshold ........ } \\
\text { At or below poverty threshold. }\end{array}$ & $\begin{array}{r}15,900 \\
4,766\end{array}$ & $\left(\begin{array}{l}60.9) \\
60.7)\end{array}\right.$ & $\begin{array}{l}38.4 \\
28.3\end{array}$ & $\left(\begin{array}{l}0.77) \\
1.80\end{array}\right)$ & $\begin{array}{l}29.0 \\
30.2\end{array}$ & $\begin{array}{l}(0.37) \\
(0.96)\end{array}$ & $\begin{array}{l}36.6 \\
50.5\end{array}$ & $\left(\begin{array}{l}0.87) \\
1.93\end{array}\right)$ & $\begin{array}{r}3.5 \\
10.4\end{array}$ & $\begin{array}{l}(0.36) \\
(1.15)\end{array}$ & $\begin{array}{l}30.6 \\
16.4\end{array}$ & $\left.\begin{array}{l}0.65) \\
1.51\end{array}\right)$ & $\begin{array}{l}9.6 \\
3.9\end{array}$ & $\left(\begin{array}{l}0.51) \\
0.63)\end{array}\right)$ & $\begin{array}{l}2.5 \\
1.7 !\end{array}$ & $\begin{array}{l}(0.24) \\
0.54)\end{array}$ & $\begin{array}{l}15.3 \\
15.9\end{array}$ & $\left(\begin{array}{l}0.72 \\
1.75\end{array}\right)$ & $\begin{array}{l}1.9 \\
1.1\end{array}$ & $\left.\begin{array}{l}0.22) \\
0.29\end{array}\right)$ \\
\hline 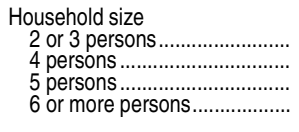 & $\begin{array}{l}5,469 \\
7,723 \\
4,279 \\
3,194\end{array}$ & $\left(\begin{array}{l}137.6 \\
172.4 \\
165.9 \\
138.4)\end{array}\right)$ & $\begin{array}{l}38.2 \\
39.5 \\
34.0 \\
26.8\end{array}$ & $\left.\begin{array}{l}1.48 \\
1.17 \\
1.85 \\
1.90\end{array}\right)$ & $\begin{array}{l}32.5 \\
28.4 \\
26.8 \\
27.6\end{array}$ & $\left.\begin{array}{l}0.57) \\
0.56 \\
0.85 \\
0.95\end{array}\right)$ & $\begin{array}{l}30.6 \\
38.1 \\
44.3 \\
53.7\end{array}$ & $\begin{array}{l}(1.27) \\
1.26 \\
2.14 \\
(2.36)\end{array}$ & $\begin{array}{l}5.9 \\
4.2 \\
5.6 \\
5.4\end{array}$ & $\left.\begin{array}{l}0.90) \\
0.56 \\
0.84 \\
0.90\end{array}\right)$ & $\begin{array}{l}28.9 \\
31.9 \\
24.2 \\
17.7\end{array}$ & $\left.\begin{array}{l}1.36 \\
0.95 \\
1.65 \\
1.70\end{array}\right)$ & $\begin{array}{r}11.6 \\
8.7 \\
7.2 \\
3.3\end{array}$ & $\begin{array}{l}(0.94) \\
0.65 \\
1.01 \\
0.62)\end{array}$ & $\begin{array}{l}2.2 \\
2.3 \\
3.1 \\
1.4\end{array}$ & $\begin{array}{l}(0.39) \\
0.35 \\
0.69 \\
(0.35)\end{array}$ & $\begin{array}{l}18.5 \\
13.3 \\
14.4 \\
16.7\end{array}$ & $\left(\begin{array}{l}1.07) \\
1.14 \\
1.28 \\
(2.53)\end{array}\right.$ & $\begin{array}{l}2.2 \\
1.7 \\
1.2 \\
1.8\end{array}$ & $\begin{array}{l}(0.41) \\
0.33 \\
0.31 \\
(0.41)\end{array}$ \\
\hline 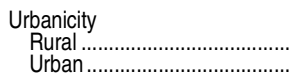 & $\begin{array}{r}4,328 \\
16,337\end{array}$ & $\begin{array}{l}(5.4) \\
(7.5)\end{array}$ & $\begin{array}{l}32.5 \\
37.0\end{array}$ & $\begin{array}{l}(1.93) \\
(0.58)\end{array}$ & $\begin{array}{l}29.7 \\
29.1\end{array}$ & $\left.\begin{array}{l}(0.91) \\
0.37\end{array}\right)$ & $\begin{array}{l}37.5 \\
40.4\end{array}$ & $\begin{array}{l}(2.00) \\
(0.88)\end{array}$ & $\begin{array}{l}5.8 \\
4.9\end{array}$ & $\begin{array}{l}(0.82) \\
(0.43)\end{array}$ & $\begin{array}{l}22.5 \\
28.6\end{array}$ & $\left(\begin{array}{l}1.78) \\
0.54\end{array}\right)$ & $\begin{array}{r}10.6 \\
7.7\end{array}$ & $\left(\begin{array}{l}1.04) \\
(0.44)\end{array}\right.$ & $\begin{array}{l}1.4 ! \\
2.5\end{array}$ & $\begin{array}{l}(0.58) \\
(0.27)\end{array}$ & $\begin{array}{l}20.0 \\
14.2\end{array}$ & $\left(\begin{array}{l}1.68) \\
0.70\end{array}\right)$ & $\begin{array}{l}2.2 \\
1.6\end{array}$ & $\begin{array}{l}0.48) \\
0.18)\end{array}$ \\
\hline
\end{tabular}

†Not applicable.

\#Rounds to zero.

!nterpret data with caution. The coefficient of variation (CV) for this estimate is between 30 and 50 percent.

\#Reporting standards not met. The coefficient of variation (CV) for this estimate is 50 percent or greater.

${ }^{1}$ Mean hours per week per child, among preschool children enrolled in any type of nonparental care arrangement. For children with more than one arrangement, the hours of each weekly arrangement were summed to calculate the total amount of time in child care per week. ${ }^{2}$ Children who spend equal hours per week in multiple nonparental care arrangements. IIncludes persons of all other races and two or more races.
${ }^{4}$ Excludes children living apart from their parents.

${ }^{5}$ Excludes children living in households with no mother or female guardian present. ${ }^{6}$ Poverty status was determined by household income and number of persons in household. NOTE: A child's "primary arrangement" was defined as the regular nonparental care arrangement or early childhood education program in which the child spent the most time per week. Race categories exclude persons of Hispanic ethnicity. Detail may not sum to totals because of rounding. Standard errors appear in parentheses.

SOURCE: U.S. Department of Education, National Center for Education Statistics, Early Childhood Program Participation Survey of the National Household Education Surveys Program (ECPP-NHES:2005). (This table was prepared October 2006.) 
80 CHAPTER 2: Elementary and Secondary Education

Enrollment Status and Child Care Arrangements of Young Children

Table 202.40. Child care arrangements of 3- to 5-year-old children who are not yet in kindergarten, by age and race/ethnicity: Various years, 1991 through 2005

[Standard errors appear in parentheses]

\begin{tabular}{|c|c|c|c|c|c|c|c|c|c|c|c|c|c|c|c|c|}
\hline \multirow[b]{2}{*}{ Child care arrangement } & \multirow{2}{*}{\multicolumn{2}{|c|}{ Total }} & \multicolumn{6}{|c|}{ Age } & \multicolumn{8}{|c|}{ Race/ethnicity } \\
\hline & & & & ears old & & ars old & & ars old & & White & & Black & & Hispanic & & Other ${ }^{1}$ \\
\hline 1 & & 2 & & 3 & & 4 & & 5 & & 6 & & 7 & & 8 & & 9 \\
\hline 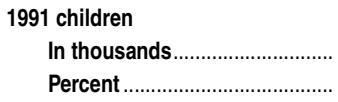 & $\begin{array}{l}8,402 \\
100.0\end{array}$ & $\begin{array}{r}(40.9) \\
(\dagger)\end{array}$ & $\begin{array}{r}3,733 \\
44.4\end{array}$ & $\begin{array}{r}(7.1) \\
(0.21)\end{array}$ & $\begin{array}{r}3,627 \\
43.2\end{array}$ & $\begin{array}{l}(14.6) \\
(0.24)\end{array}$ & $\begin{array}{r}1,042 \\
12.4\end{array}$ & $\begin{array}{l}(38.6) \\
(0.40)\end{array}$ & $\begin{array}{r}5,850 \\
69.6\end{array}$ & $\begin{array}{l}(59.9) \\
(0.67)\end{array}$ & $\begin{array}{r}1,236 \\
14.7\end{array}$ & $\begin{array}{l}(41.0) \\
(0.47)\end{array}$ & $\begin{array}{r}999 \\
11.9\end{array}$ & $\begin{array}{l}(31.3) \\
(0.37)\end{array}$ & $\begin{array}{r}317 \\
3.8\end{array}$ & $\begin{array}{l}(34.6) \\
(0.41)\end{array}$ \\
\hline 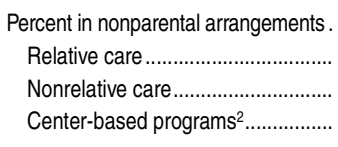 & $\begin{array}{r}100.0 \\
16.9 \\
14.8 \\
52.8\end{array}$ & $\begin{array}{r}(\dagger) \\
(0.60) \\
(0.56) \\
(0.89)\end{array}$ & $\begin{array}{r}100.0 \\
16.2 \\
14.8 \\
42.3\end{array}$ & $\begin{array}{r}(\dagger) \\
(0.72) \\
(0.76) \\
(1.44)\end{array}$ & $\begin{array}{r}100.0 \\
18.0 \\
14.7 \\
60.4\end{array}$ & \begin{tabular}{r|}
$(\dagger)$ \\
$(0.85)$ \\
$(0.79)$ \\
$(1.04)$
\end{tabular} & $\begin{array}{r}100.0 \\
15.6 \\
14.9 \\
63.9\end{array}$ & $\begin{array}{r}(\dagger) \\
(1.34) \\
(1.81) \\
(2.12)\end{array}$ & $\begin{array}{r}100.0 \\
14.8 \\
17.3 \\
54.0\end{array}$ & \begin{tabular}{r|}
$(+)$ \\
$(0.66)$ \\
$(0.76)$ \\
$(0.95)$
\end{tabular} & $\begin{array}{r}100.0 \\
24.1 \\
7.9 \\
58.3\end{array}$ & \begin{tabular}{r|}
$(\dagger)$ \\
$(2.09)$ \\
$(1.20)$ \\
$(2.49)$
\end{tabular} & $\begin{array}{r}100.0 \\
19.6 \\
9.4 \\
38.8\end{array}$ & \begin{tabular}{r|}
$(\dagger)$ \\
$(2.08)$ \\
$(1.27)$ \\
$(2.20)$
\end{tabular} & $\begin{array}{r}100.0 \\
19.4 \\
12.1 \\
52.9\end{array}$ & $\begin{array}{r}(\dagger) \\
(3.87) \\
(2.45) \\
(3.45)\end{array}$ \\
\hline Percent with parental care only .......... & 31.0 & $(0.80)$ & 37.8 & $(1.19)$ & 26.0 & $(1.05)$ & 24.3 & (2.10) & 30.6 & $(0.87)$ & 24.8 & (2.02) & 40.7 & (2.35) & 32.8 & $(4.03)$ \\
\hline $\begin{array}{l}1995 \text { children } \\
\text { In thousands } \\
\text { Percent }\end{array}$ & $\begin{array}{l}9,222 \\
100.0\end{array}$ & $\begin{array}{r}(52.9) \\
(t)\end{array}$ & $\begin{array}{r}4,123 \\
44.7\end{array}$ & $\begin{array}{r}(8.3) \\
(0.25)\end{array}$ & $\begin{array}{r}4,061 \\
44.0\end{array}$ & $\begin{array}{l}(12.5) \\
(0.24)\end{array}$ & $\begin{array}{r}1,038 \\
11.3\end{array}$ & $\begin{array}{l}(48.3) \\
(0.46)\end{array}$ & $\begin{array}{r}6,334 \\
68.7\end{array}$ & $\begin{array}{l}(94.0) \\
(0.94)\end{array}$ & $\begin{array}{r}1,389 \\
15.1\end{array}$ & $\begin{array}{l}(56.1) \\
(0.60)\end{array}$ & $\begin{array}{r}1,042 \\
11.3\end{array}$ & $\begin{array}{l}(38.8) \\
(0.42)\end{array}$ & $\begin{array}{r}457 \\
5.0\end{array}$ & $\begin{array}{l}(39.1) \\
(0.42)\end{array}$ \\
\hline 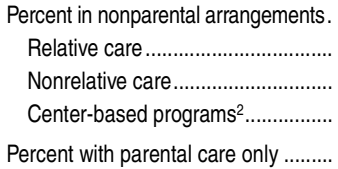 & $\begin{array}{r}100.0 \\
19.4 \\
16.9 \\
55.1 \\
25.9\end{array}$ & $\begin{array}{r}(\dagger) \\
(0.64) \\
(0.84) \\
(0.97) \\
(1.01)\end{array}$ & $\begin{array}{r}100.0 \\
21.4 \\
18.5 \\
40.7 \\
32.0\end{array}$ & $\begin{array}{r}(\dagger) \\
(1.23) \\
(1.35) \\
(1.55) \\
(1.95)\end{array}$ & $\begin{array}{r}100.0 \\
18.4 \\
15.3 \\
64.8 \\
22.1\end{array}$ & $\begin{array}{r}(\dagger) \\
(0.95) \\
(1.03) \\
(1.45) \\
(1.24)\end{array}$ & $\begin{array}{r}100.0 \\
15.2 \\
17.2 \\
74.5 \\
16.2\end{array}$ & $\begin{array}{r}(\dagger) \\
(2.14) \\
(2.19) \\
(2.35) \\
(1.78)\end{array}$ & $\begin{array}{r}100.0 \\
16.5 \\
19.4 \\
56.9 \\
25.2\end{array}$ & $\begin{array}{r}(\dagger) \\
(0.84) \\
(1.04) \\
(1.44) \\
(1.39)\end{array}$ & $\begin{array}{r}100.0 \\
28.7 \\
11.3 \\
59.8 \\
19.9\end{array}$ & $\begin{array}{r}(\dagger) \\
(2.78) \\
(1.65) \\
(3.19) \\
(2.50)\end{array}$ & $\begin{array}{r}100.0 \\
22.8 \\
12.5 \\
37.4 \\
38.4\end{array}$ & $\begin{array}{r}(\dagger) \\
(2.01) \\
(1.64) \\
(2.15) \\
(2.33)\end{array}$ & $\begin{array}{r}100.0 \\
22.6 \\
10.5 \\
56.7 \\
24.2\end{array}$ & $\begin{array}{r}(\dagger) \\
(3.75) \\
(2.74) \\
(5.47) \\
(3.59)\end{array}$ \\
\hline 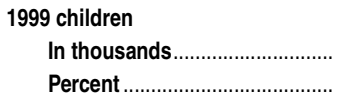 & $\begin{array}{l}8,518 \\
100.0\end{array}$ & $\begin{array}{r}(139.7) \\
(\dagger)\end{array}$ & $\begin{array}{r}3,809 \\
44.7\end{array}$ & $\begin{array}{l}(79.1) \\
(0.93)\end{array}$ & $\begin{array}{r}3,703 \\
43.5\end{array}$ & $\begin{array}{l}(79.9) \\
(0.93)\end{array}$ & $\begin{array}{r}1,006 \\
11.8\end{array}$ & $\begin{array}{l}(54.2) \\
(0.64)\end{array}$ & $\begin{array}{r}5,384 \\
63.2\end{array}$ & $\begin{array}{l}(77.4) \\
(0.91)\end{array}$ & $\begin{array}{r}1,214 \\
14.2\end{array}$ & $\begin{array}{l}(59.2) \\
(0.69)\end{array}$ & $\begin{array}{r}1,376 \\
16.2\end{array}$ & $\begin{array}{l}(52.3) \\
(0.61)\end{array}$ & $\begin{array}{r}545 \\
6.4\end{array}$ & $\begin{array}{l}(38.3) \\
(0.45)\end{array}$ \\
\hline 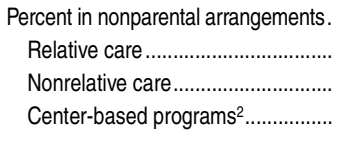 & $\begin{array}{r}100.0 \\
22.8 \\
16.1 \\
59.7\end{array}$ & $\begin{array}{r}(\dagger) \\
(0.77) \\
(0.67) \\
(0.63)\end{array}$ & $\begin{array}{r}100.0 \\
24.3 \\
16.3 \\
45.7\end{array}$ & $\begin{array}{r}(\dagger) \\
(1.28) \\
(1.02) \\
(1.28)\end{array}$ & $\begin{array}{r}100.0 \\
22.0 \\
15.9 \\
69.6\end{array}$ & $\begin{array}{r}(\dagger) \\
(1.14) \\
(1.07) \\
(1.19)\end{array}$ & $\begin{array}{r}100.0 \\
20.2 \\
16.1 \\
76.5\end{array}$ & $\begin{array}{r}(\dagger) \\
(2.06) \\
(2.08) \\
(2.40)\end{array}$ & $\begin{array}{r}100.0 \\
18.7 \\
19.4 \\
60.0\end{array}$ & $\begin{array}{r}(\dagger) \\
(0.90) \\
(0.88) \\
(0.81)\end{array}$ & $\begin{array}{r}100.0 \\
33.4 \\
7.4 \\
73.2\end{array}$ & $\begin{array}{r}(\dagger) \\
(2.58) \\
(1.37) \\
(2.40)\end{array}$ & $\begin{array}{r}100.0 \\
26.5 \\
12.7 \\
44.2\end{array}$ & $\begin{array}{r}(\dagger) \\
(1.86) \\
(1.29) \\
(2.19)\end{array}$ & $\begin{array}{r}100.0 \\
30.0 \\
10.4 \\
66.0\end{array}$ & $\begin{array}{r}(\dagger) \\
(3.97) \\
(1.98) \\
(4.10)\end{array}$ \\
\hline Percent with parental care only .......... & 23.1 & $(0.72)$ & 30.8 & $(1.42)$ & 17.7 & $(0.99)$ & 13.5 & $(1.78)$ & 23.2 & $(0.91)$ & 13.7 & $(1.97)$ & 33.4 & $(2.04)$ & 16.6 & $(3.50)$ \\
\hline 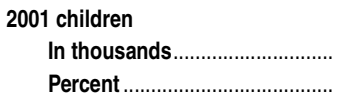 & $\begin{array}{l}8,551 \\
100.0\end{array}$ & $\begin{array}{r}(11.0) \\
(\dagger)\end{array}$ & $\begin{array}{r}3,795 \\
44.4\end{array}$ & $\begin{array}{l}(91.4) \\
(1.06)\end{array}$ & $\begin{array}{r}3,861 \\
45.1\end{array}$ & $\begin{array}{l}(89.0) \\
(1.04)\end{array}$ & $\begin{array}{r}896 \\
10.5\end{array}$ & $\begin{array}{l}(47.0) \\
(0.55)\end{array}$ & $\begin{array}{r}5,313 \\
62.1\end{array}$ & $\begin{array}{l}(68.0) \\
(0.79)\end{array}$ & $\begin{array}{r}1,251 \\
14.6\end{array}$ & $\begin{array}{l}(55.1) \\
(0.64)\end{array}$ & $\begin{array}{r}1,506 \\
17.6\end{array}$ & $\begin{array}{l}(43.5) \\
(0.51)\end{array}$ & $\begin{array}{r}482 \\
5.6\end{array}$ & $\begin{array}{l}(38.3) \\
(0.45)\end{array}$ \\
\hline 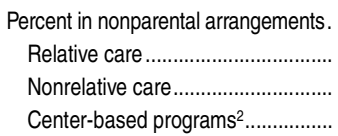 & $\begin{array}{r}100.0 \\
22.8 \\
14.0 \\
56.4\end{array}$ & $\begin{array}{r}(\dagger) \\
(0.89) \\
(0.65) \\
(0.55)\end{array}$ & $\begin{array}{r}100.0 \\
23.6 \\
14.7 \\
42.8\end{array}$ & $\begin{array}{r}(\dagger) \\
(1.39) \\
(1.17) \\
(1.21)\end{array}$ & $\begin{array}{r}100.0 \\
22.5 \\
13.6 \\
65.9\end{array}$ & $\begin{array}{r}(\dagger) \\
(1.33) \\
(0.95) \\
(1.25)\end{array}$ & $\begin{array}{r}100.0 \\
20.9 \\
13.1 \\
73.0\end{array}$ & $\begin{array}{r}(\dagger) \\
(2.66) \\
(2.13) \\
(2.69)\end{array}$ & $\begin{array}{r}100.0 \\
19.6 \\
16.5 \\
59.1\end{array}$ & \begin{tabular}{r|}
$(\dagger)$ \\
$(1.01)$ \\
$(0.98)$ \\
$(0.89)$
\end{tabular} & $\begin{array}{r}100.0 \\
36.7 \\
8.5 \\
63.1\end{array}$ & \begin{tabular}{r|}
$(\dagger)$ \\
$(3.42)$ \\
$(1.65)$ \\
$(2.93)$
\end{tabular} & $\begin{array}{r}100.0 \\
22.8 \\
11.3 \\
39.9\end{array}$ & \begin{tabular}{r|}
$(\dagger)$ \\
$(1.89)$ \\
$(1.43)$ \\
$(1.86)$
\end{tabular} & $\begin{array}{r}100.0 \\
22.8 \\
10.8 \\
61.8\end{array}$ & $\begin{array}{r}(\dagger) \\
(3.54) \\
(2.72) \\
(4.10)\end{array}$ \\
\hline Percent with parental care only .......... & 26.1 & $(0.67)$ & 33.8 & $(1.29)$ & 20.4 & $(1.11)$ & 18.0 & (2.49) & 25.3 & $(0.99)$ & 15.1 & $(2.22)$ & 39.0 & (2.03) & 23.7 & $(3.90)$ \\
\hline $\begin{array}{l}2005 \text { children } \\
\quad \text { In thousands } \\
\quad \text { Percent }\end{array}$ & $\begin{array}{l}9,066 \\
100.0\end{array}$ & $\begin{array}{r}(9.0) \\
(\dagger)\end{array}$ & $\begin{array}{r}4,070 \\
44.9\end{array}$ & $\begin{array}{l}(93.0) \\
(1.03)\end{array}$ & $\begin{array}{r}3,873 \\
42.7\end{array}$ & $\begin{array}{l}(92.0) \\
(1.01)\end{array}$ & $\begin{array}{r}1,123 \\
12.4\end{array}$ & $\begin{array}{l}(67.3) \\
(0.74)\end{array}$ & $\begin{array}{r}5,177 \\
57.1\end{array}$ & $\begin{array}{l}(80.2) \\
(0.89)\end{array}$ & $\begin{array}{r}1,233 \\
13.6\end{array}$ & $\begin{array}{l}(57.1) \\
(0.63)\end{array}$ & $\begin{array}{r}1,822 \\
20.1\end{array}$ & $\begin{array}{l}(50.0) \\
(0.56)\end{array}$ & $\begin{array}{r}834 \\
9.2\end{array}$ & $\begin{array}{l}(54.3) \\
(0.60)\end{array}$ \\
\hline 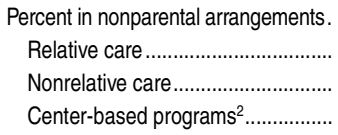 & $\begin{array}{r}100.0 \\
22.6 \\
11.6 \\
57.2\end{array}$ & $\begin{array}{r}(\dagger) \\
(1.02) \\
(0.73) \\
(0.83)\end{array}$ & $\begin{array}{r}100.0 \\
24.0 \\
14.4 \\
42.5\end{array}$ & $\begin{array}{r}(\dagger) \\
(1.44) \\
(1.12) \\
(1.67)\end{array}$ & $\begin{array}{r}100.0 \\
20.8 \\
9.2 \\
69.2\end{array}$ & $\begin{array}{r}(\dagger) \\
(1.56) \\
(1.03) \\
(1.36)\end{array}$ & $\begin{array}{r}100.0 \\
23.8 \\
9.9 \\
68.7\end{array}$ & $\begin{array}{r}(\dagger) \\
(3.17) \\
(2.00) \\
(3.51)\end{array}$ & $\begin{array}{r}100.0 \\
21.4 \\
15.0 \\
59.1\end{array}$ & $\begin{array}{r}(\dagger) \\
(1.34) \\
(1.13) \\
(1.32)\end{array}$ & $\begin{array}{r}100.0 \\
25.0 \\
5.2 \\
66.5\end{array}$ & $\begin{array}{r}(\dagger) \\
(3.42) \\
(1.31) \\
(3.41)\end{array}$ & $\begin{array}{r}100.0 \\
22.6 \\
8.1 \\
43.4\end{array}$ & $\begin{array}{r}(\dagger) \\
(1.79) \\
(1.36) \\
(2.10)\end{array}$ & $\begin{array}{r}100.0 \\
26.4 \\
8.1 \\
61.5\end{array}$ & $\begin{array}{r}(\dagger) \\
(3.29) \\
(1.94) \\
(3.31)\end{array}$ \\
\hline Percent with parental care only .......... & 26.3 & (0.92) & 33.4 & (1.48) & 20.6 & (1.42) & 20.4 & (3.15) & 24.1 & $(1.22)$ & 19.5 & (2.85) & 38.0 & (2.10) & 24.7 & $(3.11)$ \\
\hline
\end{tabular}

†Not applicable.

1 Includes persons of all other races and two or more races.

${ }^{2}$ Center-based programs include day care centers, nursery schools, prekindergartens, preschools, and Head Start programs.

NOTE: Row percents for nonparental and parental care do not add to 100 percent because some children participated in more than one type of nonparental care arrangement. Race categories exclude persons of Hispanic ethnicity. Detail may not sum to totals because of rounding.

SOURCE: U.S. Department of Education, National Center for Education Statistics, Early Childhood Education Survey, Parent Survey, and Early Childhood Program Participation Survey of the National Household Education Surveys Program (ECE-NHES:1991; ParentNHES:1999; and ECPP-NHES:1995, 2001, and 2005). (This table was prepared July 2006.) 
Table 202.50. Percentage distribution of children at about 2 and 4 years of age, by type of child care arrangement and selected child and family characteristics: 2003-04 and 2005-06

[Standard errors appear in parentheses]

\begin{tabular}{|c|c|c|c|c|c|c|c|c|c|c|c|c|c|c|c|c|c|c|c|c|c|c|c|c|c|c|c|c|}
\hline \multirow{4}{*}{ Selected child and family characteristics } & \multicolumn{12}{|c|}{ Children at about 2 years of age in 2003-04 } & \multicolumn{16}{|c|}{ Children at about 4 years of age in 2005-06 } \\
\hline & \multirow{3}{*}{\multicolumn{2}{|c|}{$\begin{array}{r}\text { Percentage } \\
\text { distribution } \\
\text { of children }^{1}\end{array}$}} & \multicolumn{10}{|c|}{ Percentage distribution by primary type of care arrangement ${ }^{2}$} & \multicolumn{16}{|c|}{ Percentage distribution by primary type of care arrangement ${ }^{2}$} \\
\hline & & & \multirow{2}{*}{\multicolumn{2}{|c|}{$\begin{array}{r}\text { No regular } \\
\text { nonparental } \\
\text { care }\end{array}$}} & \multicolumn{4}{|c|}{ Home-based care } & \multirow{2}{*}{\multicolumn{2}{|c|}{$\begin{array}{r}\text { Center-based } \\
\text { care }^{5} \\
\end{array}$}} & \multirow{2}{*}{\multicolumn{2}{|c|}{$\begin{array}{r}\text { Multiple } \\
\text { arrangements }\end{array}$}} & \multirow{2}{*}{\multicolumn{2}{|c|}{$\begin{array}{r}\text { Percentage } \\
\text { distribution } \\
\text { of children }\end{array}$}} & \multirow{2}{*}{\multicolumn{2}{|c|}{$\begin{array}{r}\text { No regular } \\
\text { nonparental } \\
\text { care }\end{array}$}} & \multicolumn{4}{|c|}{ Home-based care } & \multicolumn{6}{|c|}{ Center-based care ${ }^{5}$} & \multirow{2}{*}{\multicolumn{2}{|c|}{$\begin{array}{l}\text { Multiple } \\
\text { gements }\end{array}$}} \\
\hline & & & & & \multicolumn{2}{|c|}{ Relative care ${ }^{3}$} & \multicolumn{2}{|c|}{$\begin{array}{r}\text { Nonrelative } \\
\text { care }^{4}\end{array}$} & & & & & & & & & \multicolumn{2}{|c|}{ Relative care ${ }^{3}$} & \multicolumn{2}{|c|}{$\begin{array}{r}\begin{array}{r}\text { Nonrelative } \\
\text { care }^{4}\end{array}\end{array}$} & \multicolumn{2}{|r|}{ Total } & \multicolumn{2}{|c|}{ Head Start } & \multicolumn{2}{|c|}{$\begin{array}{l}\text { Other than } \\
\text { Head Start }\end{array}$} & & \\
\hline 1 & & 2 & & 3 & & 4 & & 5 & & 6 & & 7 & & 8 & & 9 & & 10 & & 11 & & 12 & & 13 & & 14 & & 15 \\
\hline Total.. & 100.0 & $(t)$ & 50.5 & $(0.74)$ & 18.5 & $(0.62)$ & 14.6 & $(0.51)$ & 15.8 & $(0.50)$ & 0.5 & $(0.10)$ & 100.0 & $(t)$ & 20.0 & $(0.65)$ & 13.1 & $(0.61)$ & 7.6 & $(0.32)$ & 57.4 & $(0.81)$ & 12.6 & $(0.64)$ & 44.8 & (0.71) & 1.9 & $\overline{(0.21)}$ \\
\hline $\begin{array}{l}\text { Sex of child } \\
\text { Male } \\
\text { Female }\end{array}$ & $\begin{array}{l}51.2 \\
48.8\end{array}$ & $\left(\begin{array}{l}0.08) \\
(0.08)\end{array}\right.$ & $\begin{array}{l}50.0 \\
51.1\end{array}$ & $\left(\begin{array}{l}0.96) \\
1.01\end{array}\right)$ & $\begin{array}{l}19.1 \\
18.0\end{array}$ & $(0.79)$ & $\begin{array}{l}14.3 \\
14.9\end{array}$ & $\left(\begin{array}{l}0.61) \\
(0.71)\end{array}\right.$ & $\begin{array}{l}16.3 \\
15.2\end{array}$ & $\left(\begin{array}{l}0.65) \\
(0.63)\end{array}\right.$ & $\begin{array}{l}0.3 \\
0.8\end{array}$ & $\left.\begin{array}{l}(0.07) \\
0.19\end{array}\right)$ & $\begin{array}{l}51.2 \\
48.8\end{array}$ & $\left(\begin{array}{l}0.11) \\
0.11\end{array}\right)$ & $\begin{array}{l}19.3 \\
20.7\end{array}$ & $\left(\begin{array}{l}0.80) \\
(0.90)\end{array}\right)$ & $\begin{array}{l}13.1 \\
13.2\end{array}$ & $\left(\begin{array}{l}0.79) \\
(0.86)\end{array}\right.$ & $\begin{array}{l}7.5 \\
7.7\end{array}$ & $\left(\begin{array}{l}0.51) \\
(0.52)\end{array}\right.$ & $\begin{array}{l}58.0 \\
56.8\end{array}$ & $\left(\begin{array}{l}0.98 \\
(1.02)\end{array}\right)$ & $\begin{array}{l}12.9 \\
12.4\end{array}$ & $\left(\begin{array}{l}0.80) \\
(0.74)\end{array}\right)$ & $\begin{array}{l}45.1 \\
44.4\end{array}$ & $\left(\begin{array}{l}1.02 \\
(0.92)\end{array}\right)$ & $\begin{array}{l}2.1 \\
1.7\end{array}$ & $\left(\begin{array}{l}0.33) \\
0.20\end{array}\right)$ \\
\hline 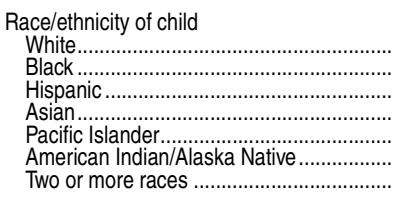 & $\begin{array}{r}53.6 \\
13.7 \\
25.3 \\
2.7 \\
0.2 \\
0.5 \\
4.0\end{array}$ & $\begin{array}{l}(0.54) \\
(0.24) \\
0.37 \\
(0.09) \\
0.04) \\
(0.06) \\
(0.28)\end{array}$ & $\begin{array}{l}50.8 \\
37.3 \\
57.5 \\
55.3 \\
73.2 \\
57.3 \\
46.3\end{array}$ & $\begin{array}{l}1.08) \\
1.39 \\
(1.39) \\
2.17 \\
(9.89) \\
(3.16 \\
(2.87)\end{array}$ & $\begin{array}{l}14.9 \\
25.8 \\
21.4 \\
23.8 \\
23.8 ! \\
17.4 \\
20.0\end{array}$ & $\begin{array}{l}(0.88) \\
(1.51) \\
(1.14) \\
(1.44) \\
(9.95) \\
(3.10) \\
(1.71)\end{array}$ & $\begin{array}{r}17.0 \\
12.0 \\
11.5 \\
10.8 \\
\neq \\
11.6 ! \\
13.2\end{array}$ & $\begin{array}{r}(0.74) \\
1.30 \\
(0.94) \\
(1.05 \\
(+) \\
(3.85 \\
(2.23)\end{array}$ & $\begin{array}{r}16.9 \\
24.2 \\
9.2 \\
9.6 \\
\ddagger \\
13.8 \\
19.3\end{array}$ & $\begin{array}{r}(0.74) \\
(1.15 \\
(.094) \\
(1.39 \\
(t) \\
(2.72) \\
(2.18)\end{array}$ & $\begin{array}{c}0.5 \\
0.8 ! \\
\neq \\
\neq \\
\neq \\
\neq \\
\neq \\
\neq\end{array}$ & $\left.\begin{array}{r}(0.13) \\
! \\
0.24 \\
(+) \\
+ \\
+1 \\
+ \\
+4\end{array}\right)$ & $\begin{array}{r}53.8 \\
13.8 \\
25.1 \\
2.6 \\
0.2 \\
0.5 \\
4.0\end{array}$ & $\begin{array}{l}(0.59) \\
(0.26) \\
(0.42) \\
0.09 \\
0.05 \\
(0.05) \\
(0.28)\end{array}$ & $\begin{array}{l}17.9 \\
16.3 \\
27.3 \\
17.1 \\
22.3 ! \\
19.9 \\
17.9\end{array}$ & $\begin{array}{l}(0.98) \\
(1.38 \\
(1.36) \\
(1.71) \\
(6.82) \\
2.40 \\
(2.14)\end{array}$ & $\begin{array}{l}11.0 \\
13.9 \\
15.9 \\
16.1 \\
45.0 ! \\
14.0 \\
17.6\end{array}$ & $\begin{array}{r}(0.74) \\
(1.49) \\
(1.14) \\
(1.44) \\
(14.27) \\
(2.06) \\
(2.43)\end{array}$ & $\begin{array}{r}9.2 \\
4.4 \\
6.2 \\
3.6 \\
\neq \\
5.2 \\
9.1\end{array}$ & $\begin{array}{r}(0.49) \\
(0.73 \\
(0.78) \\
(0.70 \\
(+) \\
(1.45 \\
(2.16)\end{array}$ & $\begin{array}{l}60.0 \\
62.1 \\
49.3 \\
60.9 \\
19.9 ! \\
59.7 \\
53.6\end{array}$ & $\begin{array}{l}(1.04) \\
(2.08) \\
(1.57) \\
(2.02) \\
7.94 \\
(3.57) \\
(3.47)\end{array}$ & $\begin{array}{r}6.8 \\
25.1 \\
18.6 \\
5.5 \\
\neq \\
31.0 \\
11.1\end{array}$ & 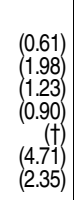 & $\begin{array}{l}53.3 \\
37.0 \\
30.7 \\
55.3 \\
14.9 ! \\
28.7 \\
42.5\end{array}$ & $\begin{array}{l}1.00) \\
1.88 \\
(1.64) \\
2.12 \\
(6.47) \\
5.61 \\
(3.22)\end{array}$ & $\begin{array}{c}1.8 \\
3.3 \\
1.2 \\
2.3 ! \\
\neq \\
\neq \\
1.8 !\end{array}$ & $\begin{array}{r}(0.28) \\
0.65 \\
0.29 \\
(1.05) \\
(\dagger) \\
(0.85)\end{array}$ \\
\hline 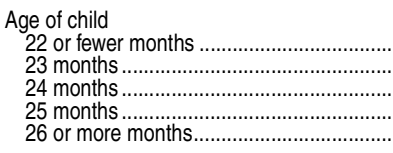 & $\begin{array}{r}1.9 \\
38.3 \\
38.0 \\
12.4 \\
9.4\end{array}$ & $\begin{array}{l}(0.29) \\
1.22 \\
0.89 \\
0.46 \\
0.60)\end{array}$ & $\begin{array}{l}58.6 \\
54.1 \\
49.1 \\
44.9 \\
47.7\end{array}$ & $\begin{array}{c}(4.73) \\
1.16 \\
1.02 \\
1.91 \\
(2.37)\end{array}$ & $\begin{array}{l}21.0 \\
17.0 \\
18.5 \\
23.1 \\
18.6\end{array}$ & $\begin{array}{l}(4.62) \\
0.93 \\
0.95 \\
1.44 \\
(1.82)\end{array}$ & $\begin{array}{l}11.0 ! \\
13.6 \\
15.6 \\
14.7 \\
14.8\end{array}$ & $\begin{array}{l}(3.41) \\
0.91) \\
0.80 \\
1.41 \\
(1.39)\end{array}$ & $\begin{array}{r}9.4 \\
14.5 \\
16.6 \\
16.8 \\
17.9\end{array}$ & $\begin{array}{l}(2.77) \\
(0.85 \\
(0.87 \\
(1.44) \\
(1.60)\end{array}$ & $\begin{array}{l}\ddagger \\
0.7 \\
0.2 ! \\
\ddagger \\
1.1 !\end{array}$ & $\begin{array}{r}(\dagger) \\
(0.16) \\
0.10 \\
(\dagger) \\
(0.54)\end{array}$ & $\begin{array}{l}\ddagger \\
\ddagger \\
\ddagger \\
\neq \\
\neq \\
\ddagger\end{array}$ & $\left.\begin{array}{c}+ \\
+ \\
+ \\
+ \\
+ \\
+\end{array}\right)$ & $\begin{array}{l}\ddagger \\
\ddagger \\
\ddagger \\
\ddagger \\
\ddagger\end{array}$ & 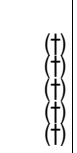 & $\begin{array}{l}\ddagger \\
\ddagger \\
\ddagger \\
\ddagger \\
\ddagger\end{array}$ & 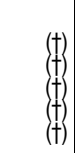 & 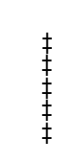 & 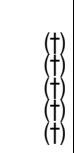 & $\left.\begin{array}{c}(+) \\
+ \\
+ \\
+ \\
+\end{array}\right)$ & $\begin{array}{l}\ddagger \\
\ddagger \\
\ddagger \\
\ddagger \\
\ddagger\end{array}$ & $\begin{array}{l}\ddagger \\
\neq \\
\neq \\
\neq \\
\neq \\
\ddagger\end{array}$ & $\left.\begin{array}{c}(t) \\
+ \\
+ \\
+ \\
+ \\
+\end{array}\right)$ & 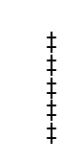 & 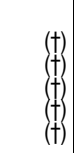 & $\begin{array}{l}\ddagger \\
\ddagger \\
\ddagger \\
\ddagger \\
\ddagger\end{array}$ & $\left(\begin{array}{l}+ \\
+ \\
+ \\
+\end{array}\right)$ \\
\hline $\begin{array}{l}\text { Less than } 48 \text { months } \\
48 \text { to } 52 \text { months } \\
53 \text { to } 57 \text { months } \\
58 \text { or more month }\end{array}$ & $\begin{array}{l}\ddagger \\
\neq \\
\text { 去} \\
\ddagger\end{array}$ & $\left(\begin{array}{c}+ \\
+ \\
+ \\
+ \\
+\end{array}\right)$ & $\begin{array}{l}\ddagger \\
\ddagger \\
\ddagger \\
\ddagger \\
\ddagger\end{array}$ & $\left(\begin{array}{c}+ \\
+ \\
+ \\
+ \\
+\end{array}\right)$ & 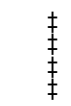 & $\left(\begin{array}{c}+ \\
+ \\
+ \\
+ \\
+\end{array}\right)$ & 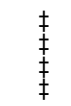 & $\left(\begin{array}{c}+ \\
+ \\
+ \\
+\end{array}\right)$ & $\begin{array}{l}\ddagger \\
\ddagger \\
\ddagger \\
\ddagger \\
\ddagger\end{array}$ & $\left(\begin{array}{c}+ \\
+ \\
+ \\
+\end{array}\right)$ & 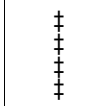 & $\left(\begin{array}{l}+ \\
+ \\
+ \\
+ \\
+\end{array}\right)$ & $\begin{array}{r}16.4 \\
38.1 \\
36.5 \\
9.0\end{array}$ & $\begin{array}{l}(0.57) \\
0.55 \\
0.57 \\
0.41)\end{array}$ & $\begin{array}{l}27.3 \\
19.9 \\
16.5 \\
21.1\end{array}$ & $\left.\begin{array}{l}(1.63) \\
(1.01) \\
0.93 \\
(1.98)\end{array}\right)$ & $\begin{array}{l}13.9 \\
13.0 \\
13.1 \\
12.1\end{array}$ & $\left.\begin{array}{l}(1.48 \\
(0.87 \\
0.83 \\
(1.66)\end{array}\right)$ & $\begin{array}{l}8.7 \\
8.3 \\
6.7 \\
6.4\end{array}$ & $\begin{array}{l}(0.95) \\
(0.60) \\
0.52 \\
(1.09)\end{array}$ & $\begin{array}{l}47.9 \\
56.8 \\
62.2 \\
57.8\end{array}$ & $\left(\begin{array}{c}1.77) \\
1.29 \\
(1.33 \\
(2.80)\end{array}\right)$ & $\begin{array}{l}10.6 \\
12.0 \\
14.4 \\
12.0\end{array}$ & $\left.\begin{array}{l}(1.25) \\
(.79 \\
1.01 \\
(1.70)\end{array}\right)$ & $\begin{array}{l}37.3 \\
44.8 \\
47.8 \\
45.8\end{array}$ & $\left(\begin{array}{l}1.91 \\
1.31 \\
1.23 \\
(2.50)\end{array}\right)$ & $\begin{array}{l}2.2 \\
2.0 \\
1.5 \\
2.7\end{array}$ & $\left.\begin{array}{l}(0.55) \\
0.37 \\
0.25 \\
0.75\end{array}\right)$ \\
\hline 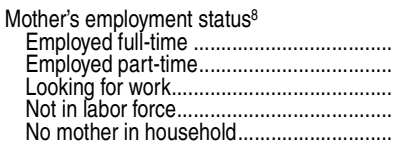 & $\begin{array}{r}34.7 \\
20.2 \\
6.3 \\
38.4 \\
0.4\end{array}$ & $\left.\begin{array}{l}(0.73) \\
0.62 \\
0.35 \\
0.78 \\
0.09\end{array}\right)$ & $\begin{array}{l}15.7 \\
35.4 \\
71.1 \\
86.8 \\
21.2 !\end{array}$ & $\begin{array}{l}(0.89) \\
1.53 \\
2.30 \\
0.75 \\
(7.28)\end{array}$ & $\begin{array}{r}30.4 \\
26.4 \\
11.5 \\
4.8 \\
33.5\end{array}$ & $\begin{array}{l}(1.10) \\
1.53 \\
1.58 \\
0.48 \\
(8.60)\end{array}$ & $\begin{array}{r}26.0 \\
20.5 \\
3.8 \\
3.0 \\
19.5 !\end{array}$ & $\begin{array}{l}(0.86) \\
1.37 \\
0.95 \\
(0.35 \\
(9.29)\end{array}$ & $\begin{array}{l}27.1 \\
16.7 \\
13.4 \\
5.4 \\
25.9 !\end{array}$ & $\begin{array}{l}(0.96) \\
1.23 \\
2.02 \\
(0.46 \\
(8.01)\end{array}$ & $\begin{array}{l}0.8 \\
1.0 ! \\
\ddagger \\
\neq \\
\ddagger\end{array}$ & $\left.\begin{array}{r}(0.21) \\
0.34 \\
+ \\
+ \\
+ \\
+\end{array}\right)$ & $\begin{array}{r}34.7 \\
20.3 \\
6.3 \\
38.3 \\
0.4\end{array}$ & $\left.\begin{array}{l}(0.77) \\
0.63 \\
0.36 \\
0.81 \\
0.10\end{array}\right)$ & $\begin{array}{l}11.3 \\
16.4 \\
22.3 \\
22.4 \\
11.0 !\end{array}$ & $\begin{array}{l}(0.96) \\
1.33 \\
2.33 \\
0.97 \\
(6.13)\end{array}$ & $\begin{array}{r}16.2 \\
14.1 \\
18.5 \\
86 \\
36.2\end{array}$ & $\left.\begin{array}{l}(0.91) \\
(1.20 \\
2.33 \\
(0.63) \\
(9.59)\end{array}\right)$ & $\begin{array}{r}12.1 \\
9.1 \\
5.4 \\
3.3 \\
\ddagger\end{array}$ & $\left.\begin{array}{r}(0.777 \\
0.86 \\
1.23 \\
0.38 \\
(\dagger)\end{array}\right)$ & $\begin{array}{l}58.7 \\
57.3 \\
52.4 \\
57.1 \\
52.5\end{array}$ & $\left.\begin{array}{l}(1.56) \\
1.70 \\
(2.83 \\
0.96 \\
9.42\end{array}\right)$ & $\begin{array}{r}11.5 \\
8.7 \\
25.9 \\
13.7 \\
21.0 !\end{array}$ & $\left.\begin{array}{l}(1.03 \\
1.00 \\
2.87 \\
0.80 \\
8.49\end{array}\right)$ & $\begin{array}{l}47.2 \\
48.6 \\
26.5 \\
43.5 \\
31.5\end{array}$ & $\begin{array}{l}(1.29 \\
(1.65) \\
2.33 \\
11.10 \\
(8.19)\end{array}$ & $\begin{array}{l}1.7 \\
3.1 \\
1.4 ! \\
1.6 \\
\ddagger\end{array}$ & $\begin{array}{r}(0.27) \\
0.57 \\
0.56 \\
0.32 \\
(\dagger)\end{array}$ \\
\hline 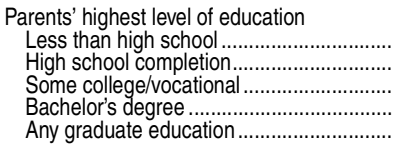 & $\begin{array}{l}12.8 \\
25.7 \\
29.7 \\
16.9 \\
14.9\end{array}$ & $\begin{array}{l}(0.36) \\
0.46 \\
0.48 \\
0.46 \\
0.35)\end{array}$ & $\begin{array}{l}67.6 \\
50.1 \\
46.9 \\
48.6 \\
46.0\end{array}$ & $\left(\begin{array}{c}1.98) \\
1.47 \\
1.51 \\
1.14 \\
1.91\end{array}\right)$ & $\begin{array}{l}17.5 \\
23.1 \\
21.6 \\
14.4 \\
10.5\end{array}$ & $\left(\begin{array}{l}1.45 \\
1.27 \\
1.22 \\
1.18 \\
1.05\end{array}\right)$ & $\begin{array}{r}6.8 \\
12.3 \\
15.1 \\
17.8 \\
20.7\end{array}$ & $\begin{array}{l}(1.08) \\
0.97 \\
0.92 \\
(1.18) \\
1.57)\end{array}$ & $\begin{array}{r}7.7 \\
14.1 \\
15.7 \\
18.6 \\
22.4\end{array}$ & $\begin{array}{l}(0.98) \\
0.87 \\
0.94 \\
1.14 \\
(1.49)\end{array}$ & $\begin{array}{l}\ddagger \\
0.4 \\
0.7 ! \\
0.7 ! \\
0.4 !\end{array}$ & 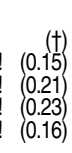 & $\begin{array}{l}10.5 \\
23.1 \\
33.4 \\
16.8 \\
16.2\end{array}$ & $\begin{array}{l}(0.36) \\
0.57 \\
0.64) \\
0.45) \\
0.37)\end{array}$ & $\begin{array}{r}34.2 \\
22.0 \\
21.0 \\
16.0 \\
9.7\end{array}$ & $\left(\begin{array}{l}2.10) \\
1.24 \\
1.24 \\
1.57 \\
0.83)\end{array}\right.$ & $\begin{array}{r}16.4 \\
17.0 \\
15.2 \\
8.4 \\
6.2\end{array}$ & $\left.\begin{array}{l}(1.77) \\
1.20 \\
0.95 \\
(1.02) \\
0.90\end{array}\right)$ & $\begin{array}{r}3.7 \\
6.9 \\
7.1 \\
8.2 \\
11.3\end{array}$ & $\begin{array}{l}1.04) \\
0.69 \\
0.56 \\
(0.93) \\
1.16)\end{array}$ & $\begin{array}{l}43.5 \\
52.1 \\
54.9 \\
65.6 \\
70.8\end{array}$ & $\left.\begin{array}{l}(2.59) \\
1.87 \\
(1.41 \\
1.88 \\
1.57)\end{array}\right)$ & $\begin{array}{r}22.4 \\
21.6 \\
13.3 \\
3.2 \\
2.0\end{array}$ & $\begin{array}{l}(2.13) \\
1.41 \\
(099 \\
0.75 \\
(0.52)\end{array} \mid$ & $\begin{array}{l}21.1 \\
30.6 \\
41.6 \\
62.4 \\
68.8\end{array}$ & $\left.\begin{array}{l}(2.06) \\
1.49 \\
1.26 \\
2.00 \\
(1.67)\end{array}\right)$ & $\begin{array}{l}2.1 ! \\
1.9 \\
1.8 \\
1.8 \\
2.0\end{array}$ & $\begin{array}{l}(0.80) \\
0.34 \\
0.33 \\
0.48 \\
(0.52)\end{array}$ \\
\hline $\begin{array}{l}9 \\
\text { rty threshold.............. } \\
\text { poverty threshold .... }\end{array}$ & $\begin{array}{l}23.9 \\
76.1\end{array}$ & $\left(\begin{array}{l}0.75) \\
0.75)\end{array}\right.$ & $\begin{array}{l}61.8 \\
47.0\end{array}$ & $\left(\begin{array}{l}1.40 \\
0.90\end{array}\right)$ & $\begin{array}{l}18.0 \\
18.7\end{array}$ & $\left(\begin{array}{l}1.15 \\
0.68)\end{array}\right)$ & $\begin{array}{r}7.8 \\
16.7\end{array}$ & $\left.\begin{array}{l}(0.79) \\
(0.62)\end{array}\right)$ & $\begin{array}{l}11.7 \\
17.1\end{array}$ & $\begin{array}{l}(0.92) \\
(0.60)\end{array}$ & $\begin{array}{l}0.7 ! \\
0.5\end{array}$ & $\begin{array}{l}0.24) \\
(0.11)\end{array}$ & $\begin{array}{l}24.8 \\
75.2\end{array}$ & $\begin{array}{l}(0.64) \\
(0.64)\end{array}$ & $\begin{array}{l}27.5 \\
17.5\end{array}$ & $\left(\begin{array}{l}1.277 \\
0.71\end{array}\right)$ & $\begin{array}{l}15.1 \\
12.5\end{array}$ & $\left(\begin{array}{l}1.19 \\
(0.64)\end{array}\right)$ & $\begin{array}{l}4.4 \\
8.6\end{array}$ & $\left(\begin{array}{l}0.54) \\
0.39\end{array}\right)$ & $\begin{array}{l}51.0 \\
59.5\end{array}$ & $\left(\begin{array}{l}1.61 \\
0.86\end{array}\right)$ & $\begin{array}{r}26.3 \\
8.1\end{array}$ & $\left(\begin{array}{l}1.45 \\
0.57\end{array}\right)$ & $\begin{array}{l}24.7 \\
51.4\end{array}$ & $\left(\begin{array}{l}1.20 \\
(0.85)\end{array}\right)$ & $\begin{array}{l}2.0 \\
1.9\end{array}$ & $\begin{array}{l}(0.40) \\
0.22\end{array}$ \\
\hline 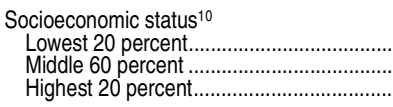 & $\begin{array}{l}20.0 \\
60.0 \\
20.0\end{array}$ & $\begin{array}{l}(0.48) \\
(0.67) \\
0.48)\end{array} \mid$ & $\begin{array}{l}66.7 \\
46.8 \\
45.9\end{array}$ & $\left.\begin{array}{l}(1.43) \\
0.98 \\
(1.75)\end{array}\right)$ & $\begin{array}{l}17.2 \\
21.8 \\
10.2\end{array}$ & $\left.\begin{array}{l}1.20 \\
0.78 \\
0.85\end{array}\right)$ & $\begin{array}{r}6.8 \\
15.1 \\
20.8\end{array}$ & $\left(\begin{array}{l}0.75) \\
0.63 \\
(1.52)\end{array}\right)$ & $\begin{array}{r}8.9 \\
15.8 \\
22.6\end{array}$ & $\left.\begin{array}{l}(0.72) \\
0.58 \\
(1.45)\end{array}\right)$ & $\begin{array}{l}0.4 ! \\
0.6 \\
0.5 !\end{array}$ & $\begin{array}{l}(0.18) \\
(0.15) \\
!(0.21)\end{array}$ & $\begin{array}{l}20.0 \\
60.0 \\
20.0\end{array}$ & $\begin{array}{l}(0.52) \\
(0.67) \\
(0.47)\end{array}$ & $\begin{array}{l}30.5 \\
19.7 \\
10.4\end{array}$ & $\begin{array}{l}(1.31) \\
0.86 \\
(0.93)\end{array}$ & $\begin{array}{r}14.9 \\
15.1 \\
5.4\end{array}$ & $\left.\begin{array}{l}(1.33) \\
0.82 \\
(0.73)\end{array}\right)$ & $\begin{array}{r}5.0 \\
7.4 \\
10.7\end{array}$ & $\begin{array}{l}(0.69) \\
(0.49) \\
(0.91)\end{array}$ & $\begin{array}{l}47.2 \\
56.0 \\
71.6\end{array}$ & $\left.\begin{array}{l}(1.84) \\
(1.09) \\
(1.39)\end{array}\right)$ & $\begin{array}{r}24.9 \\
12.4 \\
1.0\end{array}$ & $\left.\begin{array}{l}(1.58) \\
(0.80) \\
(0.23)\end{array}\right)$ & $\begin{array}{l}22.4 \\
43.6 \\
70.5\end{array}$ & $\left.\begin{array}{l}(1.47) \\
(0.90) \\
(1.42)\end{array}\right)$ & $\begin{array}{l}2.3 \\
1.8 \\
1.9\end{array}$ & $\begin{array}{l}(0.58) \\
(0.23) \\
(0.42)\end{array}$ \\
\hline $\begin{array}{l}\text { TNot applicable. } \\
\text { !Interpret data with caution. The coefficient } \\
\text { tReporting standards not met. Either there } \\
\text { greater. } \\
\text { 'Distribution of weighted Early Childhood L } \\
{ }^{2} \text { Primary type of care arrangement is the ty } \\
{ }^{3} \text { Care provided in the child's home or in ano } \\
{ }^{4} \text { Care provided in the child's home or in ano } \\
{ }^{5} \text { Care provided in places such as early lear } \\
{ }^{6} \text { Children who spent an equal amount of tim } \\
\text { 'Distribution of weighted Early Childhood L } L \\
\text { data on primary care arrangements. }\end{array}$ & gitudin & $\begin{array}{l}\text { Stu } \\
\text { aren } \\
\text { e ho } \\
\text { e ho } \\
\text { s, n } \\
\text { of th } \\
\text { ISt }\end{array}$ & $\begin{array}{l}\text { by a p } \\
\text { ry sch }\end{array}$ & $e$ & $\begin{array}{l}\text { late } \\
\text { pres } \\
\text { ent } \\
\text { vev }\end{array}$ & . & 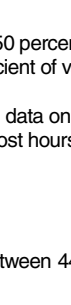 & & & & & & 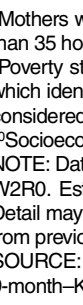 & $\begin{array}{l}\text { ed to } \\
\text { ono } \\
\text { ata a } \\
\text { stim } \\
\text { y no } \\
\text { ious } \\
\text { :U. } \\
\text { Kind }\end{array}$ & hilc & $\begin{array}{l}\text { vert } \\
\text { was } \\
\text { res } \\
\text { at a } \\
\text { cau } \\
\text { es. } \\
\text { Ed }\end{array}$ & $\begin{array}{l}\text { sentat } \\
\text { about } \\
\text { use of }\end{array}$ & & uppr & $b$ & & & ets & & Some & ha & av & $\begin{array}{l}\text { less } \\
\text { was } \\
\text { was } \\
\text { dicity. } \\
\text { ised }\end{array}$ \\
\hline
\end{tabular}




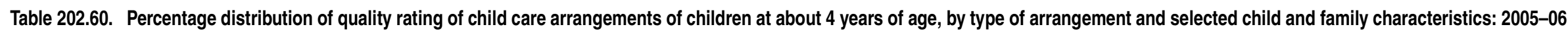

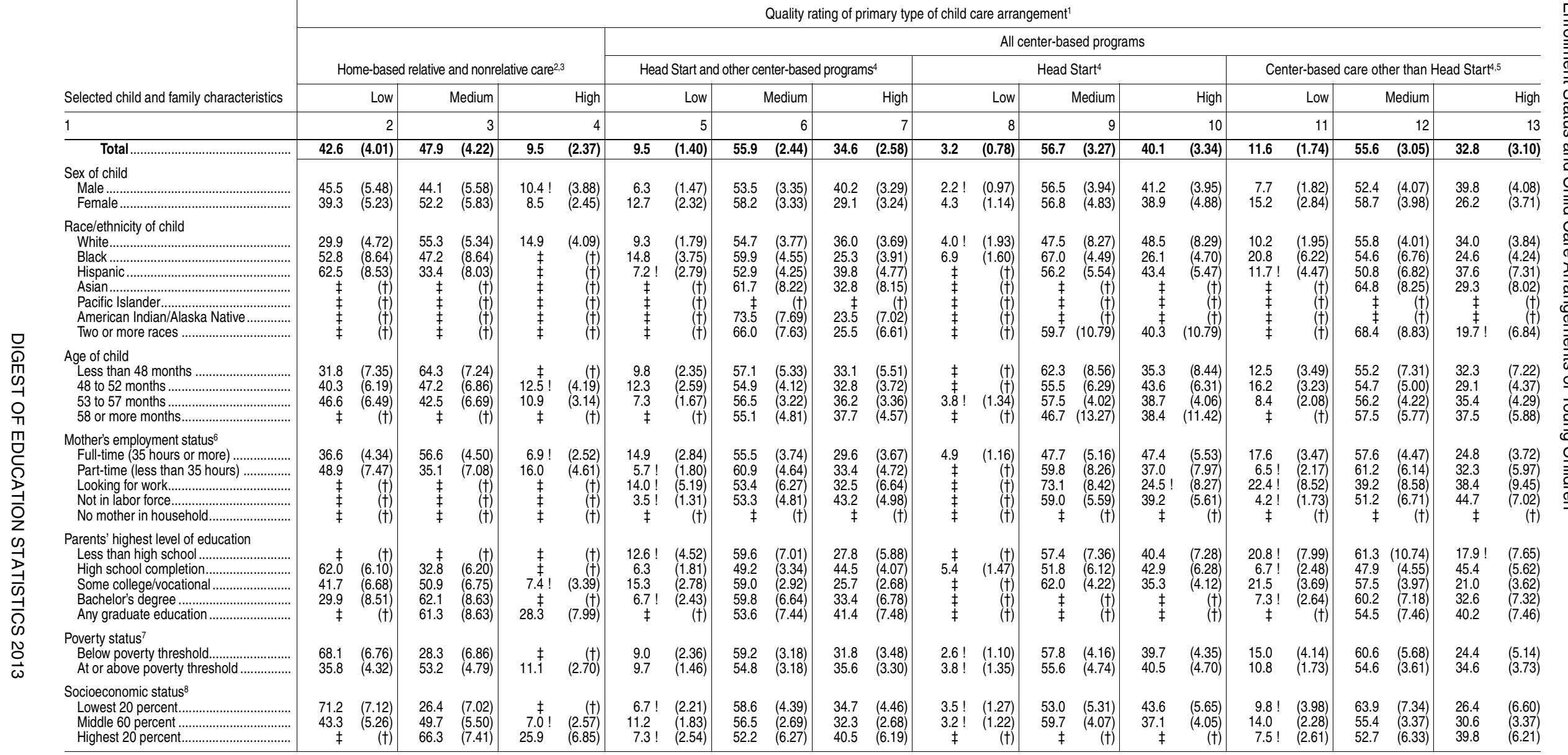

\section{†Not applicable.}

With caution. The coefficient of variation (CV) for this estimate is between 30 and 50 percent †Reporting standards not met. Either there are too few cases for a reliable estimate or the coefficient of variation (CV) is 50 percent or greater.

${ }^{2}$ Care provided in the arrangement is the type of nonparental care in which the child spent the most hours. child.

${ }^{3}$ Quality rating based on the Family Day Care Rating Scale (FDCRS). Low quality = score of 1 but less than 3 . Medium quality $=$ score of 3 but less than 5 . High qually $=$ score of 5 to 7 .

Medium quality $=$ score of 3 but less than 5 . High quality $=$ score of 5 to 7 .

${ }^{5}$ Care provided in places such as early learning centers, nursery schools, and preschools, not classified as Head Start. -Mothers who reported working at least 35 hours per week are defined as employed full time, while those who reported working less than 35 hours per week are defined as employed part time. Those neither employed nor looking for work are not in
the labor force.
7Poverty status based on Census Bureau guidelines from 2002, which identify a dollar amount determined to meet a household's needs, given its size and composition. In 2002, a family of four was considered to live below the poverty threshold if its income was less than or equal to $\$ 18,392$ (in current dollars).
${ }^{8}$ Socioeconomic status (SES) was measured by a composite score based on parental education and occupations, and family

income.
NOTE: Estimates weighted by W33P0. Estimates pertain to children assessed between 44 months and 65 months of age. Rating is for child's primary type of care arrangement, which was the type of nonparental care in which the child spent the ings of care arrangement quality using both the FDCRS and ECERS scales were based on interviewer observations of Radren's interactions with adults and peers, children's exposure to materials and activities, the extent to which and the manner in which routine care needs were met, and the furnishings and displays in the classroom. The FDCRS and ECERS metrics are designed to be equivalent. Race categories exclude persons of Hispanic ethnicity. Detail may not sum to totals because of

SOURCE: U.S. Department of Education, National Center for Education Statistics, Early Childhood Longitudinal Study, Birth Cohort, Longitudinal 9-month-Kindergarten Restricted-Use Data File. (This table was prepared January 2013.) 
Table 202.65. First-time kindergartners' primary type of child care arrangement prior to kindergarten entry, by selected child, family, and school characteristics: 2010-11

[Standard errors appear in parentheses]

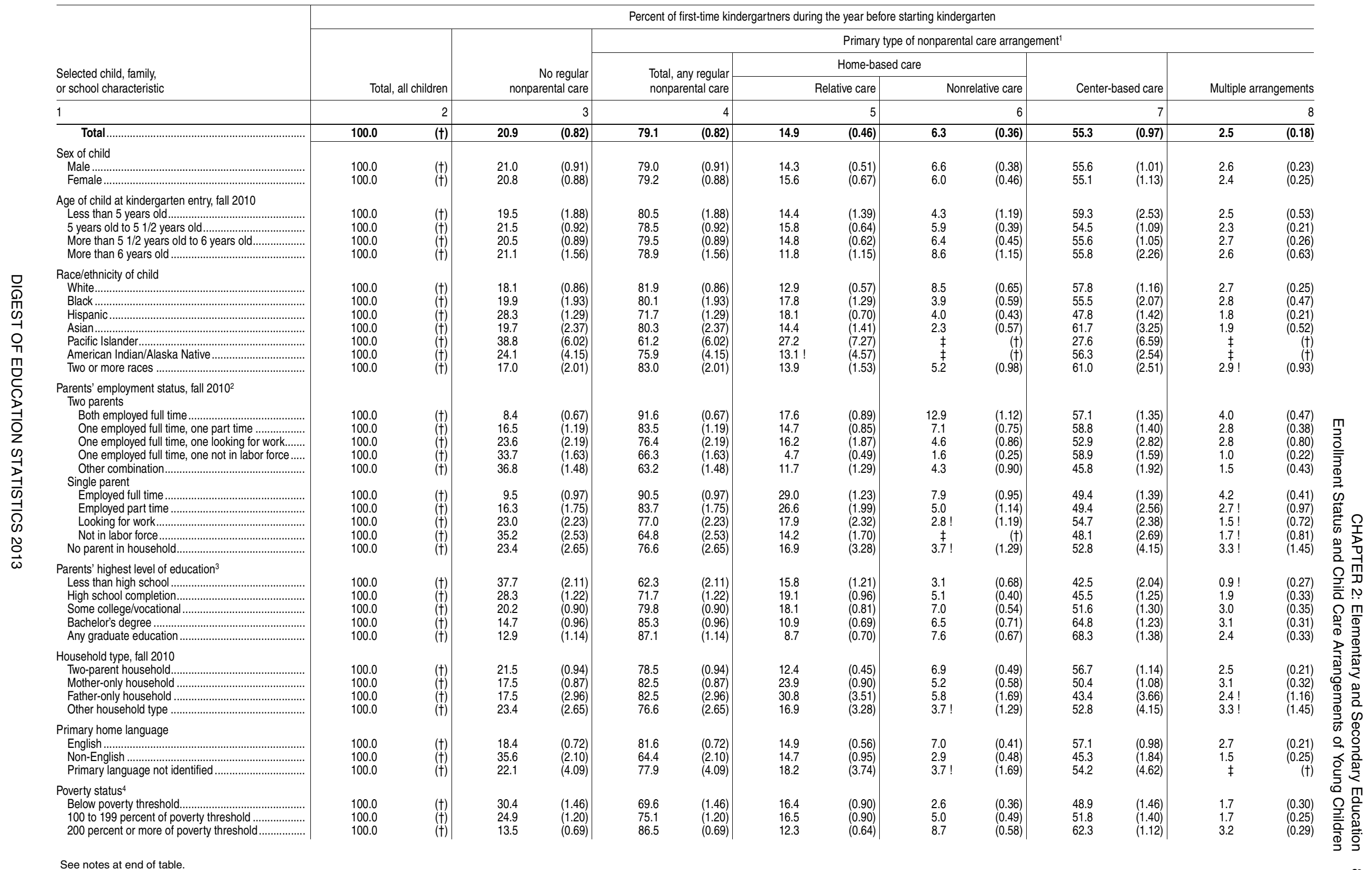




\begin{tabular}{|c|c|c|c|c|c|c|c|c|c|c|c|c|c|c|}
\hline \multirow{4}{*}{$\begin{array}{l}\text { Selected child, family, } \\
\text { or school characteristic }\end{array}$} & \multicolumn{14}{|c|}{ Percent of first-time kindergartners during the year before starting kindergarten } \\
\hline & \multirow{3}{*}{\multicolumn{2}{|c|}{ Total, all children }} & \multirow{3}{*}{\multicolumn{2}{|c|}{$\begin{array}{r}\text { No regular } \\
\text { nonparental care }\end{array}$}} & \multicolumn{10}{|c|}{ Primary type of nonparental care arrangement ${ }^{1}$} \\
\hline & & & & & \multirow{2}{*}{\multicolumn{2}{|c|}{$\begin{array}{l}\text { Total, any regular } \\
\text { nonparental care }\end{array}$}} & \multicolumn{4}{|c|}{ Home-based care } & \multirow{2}{*}{\multicolumn{2}{|c|}{ Center-based care }} & \multirow{2}{*}{\multicolumn{2}{|c|}{ Multiple arrangements }} \\
\hline & & & & & & & & Relative care & \multicolumn{2}{|c|}{ Nonrelative care } & & & & \\
\hline 1 & & 2 & & 3 & & 4 & & 5 & & 6 & & 7 & & \\
\hline 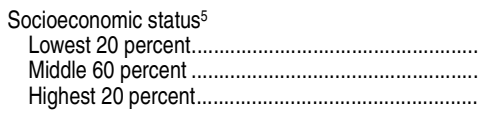 & $\begin{array}{l}100.0 \\
100.0 \\
100.0\end{array}$ & $\begin{array}{l}(t) \\
(+) \\
(t)\end{array}$ & $\begin{array}{l}35.2 \\
19.6 \\
12.3\end{array}$ & $\begin{array}{l}(1.52) \\
(0.71) \\
(1.13)\end{array}$ & $\begin{array}{l}64.8 \\
80.4 \\
87.7\end{array}$ & $\begin{array}{l}(1.52) \\
(0.71) \\
(1.13)\end{array} \mid$ & $\begin{array}{r}15.6 \\
16.9 \\
8.7\end{array}$ & $\begin{array}{l}(0.75) \\
(0.54) \\
(0.67)\end{array}$ & $\begin{array}{l}3.4 \\
6.9 \\
7.1\end{array}$ & $\begin{array}{l}(0.44) \\
(0.45) \\
(0.56)\end{array}$ & $\begin{array}{l}44.3 \\
53.9 \\
69.1\end{array}$ & $\begin{array}{l}(1.28) \\
(1.09) \\
(1.29)\end{array}$ & $\begin{array}{l}1.6 \\
2.7 \\
2.7\end{array}$ & $\begin{array}{l}(0.27) \\
(0.23) \\
(0.29)\end{array}$ \\
\hline 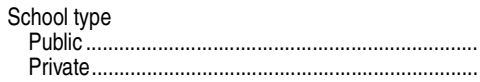 & $\begin{array}{l}100.0 \\
100.0\end{array}$ & $\begin{array}{c}(\dagger) \\
(\dagger)\end{array}$ & $\begin{array}{l}21.8 \\
14.5\end{array}$ & $\left.\begin{array}{l}(0.80) \\
(1.98)\end{array}\right]$ & $\begin{array}{l}78.2 \\
85.5\end{array}$ & $\begin{array}{l}(0.80) \\
(1.98)\end{array}$ & $\begin{array}{r}15.8 \\
8.3\end{array}$ & $\begin{array}{l}(0.51) \\
(0.78)\end{array}$ & $\begin{array}{l}6.2 \\
7.0\end{array}$ & $\begin{array}{l}(0.35) \\
(0.88)\end{array}$ & $\begin{array}{l}53.7 \\
67.9\end{array}$ & $\begin{array}{l}(0.98) \\
(1.69)\end{array}$ & $\begin{array}{l}2.5 \\
2.3\end{array}$ & $\begin{array}{l}(0.20) \\
(0.32)\end{array}$ \\
\hline
\end{tabular}

\section{†Not applicable.}

列

fReporting standards not met. Either there are too few cases for a reliable estimate or the coefficient of variation (CV) is 50

'The type of nonparental care in which the child spent the most hours. Multiple arrangements refers to children who spent an

Parents who reported working at least 35 hours per week are defined as employed full time, while those who reported working less than 35 hours per week are defined as employed part time. Those neither employed nor looking for work are not in Parents highest parent household, by the only parent in a single-parent household, or by any guardian in a household with no parents.
4Poverty status is based on preliminary U.S. Census income thresholds for 2010 which identify incomes determined to meet household needs, given family size and composition. For example, a family of three with one child was below the povert threshold if its annual income was less than $\$ 17,552$ in 2010 .

hold income at the time of data collection.

NOTE: Estimates weighted by W1_2PO. Estimates pertain to a sample of children who were enrolled in kindergarten for the first time in the 2010-11 school year. Two parents may refer to two biological parents, two adoptive parents, or one biological woplive parent and one oher pare Two parner. Single parent panic ethnicity. Detail may not sum to totals because of rounding and survey item nonresponse. dergarten Class of 2010-11 (ECLS-K:2011), Kindergarten Restricted-Use Data File. (This table was prepared January 2014. 
Table 202.70. Children of prekindergarten through second-grade age, by enrollment status, selected maternal characteristics, and household income: 1995 , 2001, and 2005

[Standard errors appear in parentheses]

\begin{tabular}{|c|c|c|c|c|c|c|c|c|c|c|c|c|c|c|c|c|c|c|c|c|c|c|c|c|c|c|c|c|c|c|}
\hline \multirow{2}{*}{$\begin{array}{l}\text { Maternal characteristic and } \\
\text { household income }\end{array}$} & \multicolumn{6}{|c|}{$\begin{array}{l}\text { 3- to 5-year-olds, not enrolled in school } \\
\text { (includes homeschooled students) }\end{array}$} & \multicolumn{6}{|c|}{ Enrolled in nursery school or prekindergarten } & \multicolumn{6}{|c|}{ Enrolled in kindergarten } & \multicolumn{6}{|c|}{ Enrolled in first grade } & \multicolumn{6}{|c|}{ Enrolled in second grade } \\
\hline & & 1995 & & $2001^{1}$ & & $2005^{1}$ & & 1995 & & $2001^{1}$ & & $2005^{1}$ & & 1995 & & $2001^{1}$ & & $2005^{1}$ & & 1995 & & $2001^{2}$ & & $2005^{1}$ & & 1995 & & $2001^{2}$ & & 2005 \\
\hline 1 & & 2 & & 3 & & 4 & & 5 & & 6 & & 7 & & 8 & & 9 & & 10 & & 11 & & 12 & & 13 & & 14 & & 15 & & 16 \\
\hline $\begin{array}{l}\text { Total children } \\
\text { (in thousands)............ }\end{array}$ & 4,586 & $6(102.3)$ & 3,990 & (3.2) & 4,156 & (5.0) & 4,642 & (105.0) & 4,586 & (\#) & 4,926 & (\#) & 4,149 & (75.6) & 3,831 & (\#) & 3,717 & (\#) & 4,025 & $(76.7)$ & 4,333 & (\#) & 4,118 & (\#) & 3,777 & (72.9) & 3,934 & (\#) & 3,900 & (\#) \\
\hline ion & & & & & & & & & & & & & & & & & & & & & & & & & & & & & & \\
\hline $\begin{array}{l}\text { educ } \\
\text { Less } \\
\text { High s } \\
\text { Vocat }\end{array}$ & \begin{tabular}{|r}
100.0 \\
16.3 \\
41.1
\end{tabular} & $\begin{array}{lr}0 & (\dagger) \\
3 & (1.27) \\
1 & (1.51)\end{array}$ & $\begin{array}{r}100.0 \\
16.4 \\
39.7\end{array}$ & $\begin{array}{r}(\dagger) \\
(1.26) \\
(1.59)\end{array}$ & \begin{tabular}{|r|}
00.0 \\
13.8 \\
37.2
\end{tabular} & $\begin{array}{r}(\dagger) \\
(1.24) \\
(2.18)\end{array}$ & $\begin{array}{r}100.0 \\
6.8 \\
30.7\end{array}$ & $\begin{array}{r}(\dagger) \\
\left(\begin{array}{l}(t) \\
(1.27)\end{array}\right.\end{array}$ & $\begin{array}{r}100.0 \\
8.0 \\
26.1\end{array}$ & $\begin{array}{r}(\dagger) \\
(1.26) \\
(1.59)\end{array}$ & $\begin{array}{r}100.0 \\
6.8 \\
24.6\end{array}$ & $\begin{array}{r}(\dagger) \\
(0.76) \\
(1.34)\end{array}$ & $\begin{array}{r}100.0 \\
13.4 \\
36.4\end{array}$ & $\begin{array}{r}(t) \\
(0.93) \\
(1.19)\end{array}$ & $\begin{array}{r}100.0 \\
10.7 \\
30.3\end{array}$ & $\begin{array}{r}(\dagger) \\
(1.31) \\
(1.86)\end{array}$ & $\begin{array}{r}100.0 \\
9.5 \\
27.5\end{array}$ & $\begin{array}{r}(\dagger) \\
(1.16) \\
(1.92)\end{array}$ & \begin{tabular}{|r|}
100.0 \\
12.3 \\
34.9
\end{tabular} & $\begin{array}{r}(\dagger) \\
(0.99) \\
(1.53)\end{array}$ & \begin{tabular}{|r|}
100.0 \\
11.7 \\
30.3
\end{tabular} & $\begin{array}{r}(\dagger) \\
(1.28) \\
(2.17)\end{array}$ & 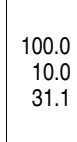 & $\begin{array}{r}(\dagger) \\
(1.20) \\
(2.13)\end{array}$ & $\begin{array}{r}100.0 \\
15.0 \\
35.6\end{array}$ & $\begin{array}{r}(\dagger) \\
(0.81) \\
(1.44)\end{array}$ & \begin{tabular}{|r|}
100.0 \\
13.5 \\
32.8
\end{tabular} & $\begin{array}{r}(\dagger) \\
(1.26) \\
(2.11)\end{array}$ & \begin{tabular}{|r|}
100.0 \\
10.3 \\
29.5
\end{tabular} & $\begin{aligned}(\dagger) \\
(1.21) \\
(1.77)\end{aligned}$ \\
\hline $\begin{aligned} \text { S } \\
\text { Asso } \\
\text { Bach }\end{aligned}$ & $\begin{array}{r}21.3 \\
7.0 \\
11.3\end{array}$ & $\begin{array}{ll}3 & (1.34) \\
0 & (0.79) \\
3 & (0.86)\end{array}$ & $\begin{array}{r}19.1 \\
5.9 \\
14.0\end{array}$ & $\begin{array}{l}(1.30) \\
(0.67) \\
(1.16)\end{array}$ & $\begin{array}{r}21.2 \\
6.8 \\
14.9\end{array}$ & $\begin{array}{l}(1.43) \\
(0.82) \\
(1.20)\end{array}$ & $\begin{array}{r}22.7 \\
8.6 \\
22.0\end{array}$ & $\begin{array}{l}(1.01) \\
(0.72) \\
(1.0)\end{array}$ & $\begin{array}{r}24.6 \\
7.7 \\
22.5\end{array}$ & $\begin{array}{l}(1.30) \\
(0.67) \\
(1.16)\end{array}$ & $\begin{array}{r}19.2 \\
8.4 \\
25.5\end{array}$ & $\begin{array}{l}(1.32) \\
(0.71) \\
(1.13)\end{array}$ & $\begin{array}{r}21.7 \\
7.0 \\
15.1\end{array}$ & $\begin{array}{l}(1.00) \\
(0.68) \\
(0.98)\end{array}$ & $\begin{array}{r}23.5 \\
7.6 \\
20.8\end{array}$ & $\begin{array}{l}(1.84) \\
(1.18) \\
(1.58)\end{array}$ & $\begin{array}{r}20.7 \\
7.7 \\
21.3\end{array}$ & $\begin{array}{l}(1.70) \\
(0.96) \\
(1.42)\end{array}$ & $\begin{array}{r}23.6 \\
7.3 \\
15.7\end{array}$ & $\begin{array}{l}(1.29) \\
(0.81 \\
(1.02)\end{array}$ & $\begin{array}{r}24.3 \\
7.5 \\
19.5\end{array}$ & $\begin{array}{l}(1.87) \\
(1.01) \\
(1.68)\end{array}$ & $\begin{array}{l}19.9 \\
10.3 \\
18.0\end{array}$ & $\begin{array}{l}(1.94) \\
(1.22) \\
(1.23)\end{array}$ & $\begin{array}{r}20.6 \\
7.6 \\
15.0\end{array}$ & $\begin{array}{l}(0.94) \\
(0.60) \\
(0.94)\end{array}$ & $\begin{array}{r}22.5 \\
7.5 \\
15.8\end{array}$ & $\begin{array}{l}(2.18) \\
(0.92) \\
(1.70)\end{array}$ & $\begin{array}{r}19.8 \\
8.0 \\
18.7\end{array}$ & $\begin{array}{l}(1.64) \\
(0.99) \\
(1.46)\end{array}$ \\
\hline $\begin{array}{l}\text { Bach } \\
\text { Grad }\end{array}$ & & & 14.0 & $(1.16)$ & 14.9 & $(1.20)$ & 22.0 & $(1.10)$ & 22.5 & $(1.16)$ & 25.5 & (1.13) & 15.1 & $(0.98)$ & 20.8 & (1.58) & 21.3 & $(1.42)$ & 15.7 & $(1.02)$ & 19.5 & $(1.68)$ & 18.0 & ) & 15.0 & $\begin{array}{l}(0.94) \\
-1097\end{array}$ & 15.8 & $(1.70)$ & 18.7 & (1.46) \\
\hline de & 3.0 & 0 & 5.0 & $(0.63)$ & 6.1 & $(0.73)$ & 9.1 & $(0.70)$ & 11.1 & $(0.63)$ & 15.6 & $(0.94)$ & 6.3 & $(0.69)$ & 7.1 & $(1.02)$ & 13.4 & $(1.43)$ & 6.3 & $(0.49)$ & 6.7 & $(1.04)$ & 10.6 & $(1.22)$ & 6.2 & $(0.67)$ & 7.9 & $(1.28)$ & 13.6 & $(1.62)$ \\
\hline $\begin{array}{r}\text { Mother's } \\
\text { statu } \\
\text { Worki }\end{array}$ & 100.0 & $(t)$ & 100.0 & $(\dagger)$ & 100.0 & $(t)$ & 100.0 & (†) & 100.0 & $(\dagger)$ & 100.0 & $(\dagger)$ & 100.0 & $(\dagger)$ & 100.0 & $(\dagger)$ & 100.0 & $(\dagger)$ & 100.0 & $(\dagger)$ & 100.0 & $(\dagger)$ & 100.0 & $(\mathrm{t})$ & 100.0 & $(\dagger)$ & 100.0 & $(\dagger)$ & 100.0 & (T) \\
\hline $\begin{array}{l}\text { Work } \\
\text { or } \\
\text { Work }\end{array}$ & 33.4 & $4(1.45)$ & 36.7 & $(1.55)$ & 33.5 & $(1.92)$ & 38.5 & $(1.13$ & 43.7 & (1.18) & 39.4 & $(1$. & 35.9 & $(1.05)$ & 38.9 & $(1.99)$ & 36.9 & $(2.25)$ & 38.5 & $(1.49$ & 46.1 & $(2.33)$ & 40.7 & (2.35) & 40.5 & $(1.17)$ & 42.3 & $(2.30)$ & 41.2 & (2.19) \\
\hline 10 & 17.8 & 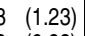 & 19.2 & $(1.3)$ & 21.1 & $(1$. & 23.7 & $(1.08)$ & 22.8 & $(1$. & 24.4 & $(1.36)$ & 20.8 & $(1$ & 22.6 & 7) & 21.5 & 62) & 20.8 & 1 & 19.7 & 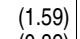 & 20.7 & 7 & 21.4 & ( & 20.1 & 0) & 2.7 & $(1.72)$ \\
\hline $\begin{array}{l}\text { Lookin } \\
\text { Not in }\end{array}$ & $\begin{array}{r}6.8 \\
42.0\end{array}$ & $\left.\begin{array}{ll}8 & (0.83) \\
0 & (1.68)\end{array}\right]$ & $\begin{array}{r}5.7 \\
38.4\end{array}$ & $\left.\begin{array}{l}(0.75) \\
(1.48)\end{array}\right]$ & $\begin{array}{r}8.7 \\
36.8\end{array}$ & $\left.\begin{array}{l}(1.37) \\
(1.79)\end{array}\right)$ & $\begin{array}{r}5.8 \\
32.0\end{array}$ & $\left.\begin{array}{l}(0.71) \\
(1.28)\end{array}\right]$ & $\begin{array}{r}3.9 \\
29.6\end{array}$ & $\left.\begin{array}{l}(0.55) \\
(1.27)\end{array}\right]$ & $\begin{array}{r}4.0 \\
32.2\end{array}$ & $\left.\begin{array}{l}(0.59) \\
(1.35)\end{array}\right]$ & $\begin{array}{r}5.6 \\
37.7\end{array}$ & $\begin{array}{l}(0.70) \\
(1.18)\end{array}$ & $\begin{array}{r}3.9 \\
34.7\end{array}$ & $\begin{array}{l}(0.87) \\
(2.16)\end{array}$ & $\begin{array}{r}7.3 \\
34.3\end{array}$ & $\begin{array}{l}(1.06) \\
(1.99)\end{array}$ & $\begin{array}{r}5.0 \\
35.6\end{array}$ & $\begin{array}{l}(0.66) \\
(1.57)\end{array}$ & $\begin{array}{r}4.1 \\
30.1\end{array}$ & $\left.\begin{array}{l}(0.89) \\
(2.05)\end{array}\right]$ & $\begin{array}{r}5.7 \\
32.8\end{array}$ & $3\left(\begin{array}{l}1.07) \\
(1.97)\end{array}\right.$ & $\begin{array}{r}5.4 \\
32.7\end{array}$ & $\left.\begin{array}{l}(0.70) \\
(1.30)\end{array}\right]$ & $\begin{array}{r}5.1 \\
32.5\end{array}$ & $\begin{array}{l}(1.09) \\
(2.22)\end{array}$ & $\begin{array}{r}4.9 \\
31.2\end{array}$ & $\begin{array}{l}(0.82) \\
(1.99)\end{array}$ \\
\hline & & & & & & & & & & & & & & & & & & & & & & & & & & & & & & \\
\hline & & $7 \quad(1.21)$ & 14.1 & $(1$. & & $(1$. & 16.1 & (1. & $\begin{array}{r}100.0 \\
8.5\end{array}$ & 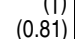 & $\begin{array}{l}100.0 \\
7.5\end{array}$ & $(0$. & $\begin{array}{r}10.0 \\
19.4\end{array}$ & $(1$ & \begin{tabular}{|l}
10.0 \\
8.5
\end{tabular} & $(1$ & $\begin{array}{r}100.0 \\
8.2\end{array}$ & & 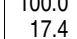 & & 9.1 & & 100.0 & & & & 9.4 & & 0 & $(1$. \\
\hline & 1 & $7 \quad(1)$. & 14 & & 1 & & 10.4 & 10. & 12.7 & 0. & 9.7 & & 12.6 & & 14.1 & (1. & 11 & & 13.2 & & 14.0 & & 10.4 & & 11.6 & $(0.84)$ & 12.4 & & 12.5 & (1. \\
\hline & 19.1 & $1(1$. & 15 & & & & 13.1 & & 11.7 & & 9.9 & & & & 16.6 & & 13 & & 16.6 & & 16.5 & & & & & & & & & \\
\hline & 16.2 & $2(1.00)$ & 13.6 & $(1.0$ & 15.3 & $(1$. & 12.4 & 0. & 9.7 & 0. & 9. & 0. & 15.1 & (1.12) & 12.2 & $(1$ & 11.1 & $(1$ & 14.1 & 10 & 10.3 & $(1$ & 10.7 & $(1$ & 16.1 & 10 & 12.4 & $(1$ & 10.6 & (1. \\
\hline & 11.0 & $0 \quad 0.7$ & 12.0 & $(1$. & 10.3 & (1. & 11.5 & $(0.5$ & 7.5 & $(0$. & 7.7 & $(0$. & 11.7 & 10 & 9.1 & $(1$ & 7 & & 11.1 & & 9.7 & & 9.9 & & 11.3 & & 9.2 & & & \\
\hline & 10.5 & $5(0.6-6$ & 18.8 & $(1$. & 2( & $(1.2)$ & 19.3 & $(0$. & 21.2 & $(1$. & 20.8 & 10 & 14.4 & $(0$ & 20.9 & & & & & & 18.3 & & 20.4 & & 15.0 & $(1$ & 19.6 & $(1$ & 20.3 & $(1.56)$ \\
\hline More than $\$ 75,000 \ldots \ldots$ & 4.7 & $7 \quad(0.70)$ & 12.1 & $(0.99)$ & 15.4 & $(1.30)$ & 17.2 & $(1.06)$ & 28.7 & $(1.09)$ & 34.4 & (1.13) & 11.1 & $(0.62)$ & 18.6 & $(1.30)$ & 30.4 & $(1.54)$ & 12.1 & $(0.73)$ & 22.1 & $(1.86)$ & 28.4 & $+(1.56)$ & 10.1 & $(0.79)$ & 22.3 & $(1.78)$ & 26.7 & (1.83) \\
\hline
\end{tabular}

†Not applicable.
\#Rounds to zero.

${ }^{1}$ Figures exclude children for whom no grade equivalent was available. ${ }_{2}^{2}$ Table includes a very small number of older children enrolled in first and second grade and excludes children for whom no
grade equivalent was available.
${ }^{3}$ Excludes children living in households with no mother or female guardian present.

NOTE: Detail may not sum to totals because of rounding.

SOURCE: U.S. Department of Education, National Center for Education Statistics, Early Childhood Program Participation Survey and Before- and After-School Programs and Activities Survey of the National Household Education Surveys Program 
86 CHAPTER 2: Elementary and Secondary Education

Enrollment in Public Schools

Table 203.10. Enrollment in public elementary and secondary schools, by level and grade: Selected years, fall 1980 through fall 2023

[In thousands]

\begin{tabular}{|c|c|c|c|c|c|c|c|c|c|c|c|c|c|c|c|c|c|c|c|}
\hline \multirow[b]{2}{*}{ Year } & \multirow[b]{2}{*}{$\begin{array}{r}\text { All } \\
\text { grades }\end{array}$} & \multicolumn{12}{|c|}{ Elementary } & \multicolumn{6}{|c|}{ Secondary } \\
\hline & & Total & $\begin{array}{r}\text { Pre- } \\
\text { kinder- } \\
\text { garten }\end{array}$ & $\begin{array}{r}\text { Kinder- } \\
\text { garten }\end{array}$ & $\begin{array}{r}1 s t \\
\text { grade }\end{array}$ & $\begin{array}{l}\text { 2nd } \\
\text { grade }\end{array}$ & $\begin{array}{r}\text { 3rd } \\
\text { grade }\end{array}$ & $\begin{array}{r}\text { 4th } \\
\text { grade }\end{array}$ & $\begin{array}{r}\text { 5th } \\
\text { grade }\end{array}$ & $\begin{array}{r}\text { 6th } \\
\text { grade }\end{array}$ & $\begin{array}{r}7 \text { th } \\
\text { grade }\end{array}$ & $\begin{array}{r}\text { 8th } \\
\text { grade }\end{array}$ & $\begin{array}{r}\text { Un- } \\
\text { graded }\end{array}$ & Total & $\begin{array}{r}\text { 9th } \\
\text { grade }\end{array}$ & $\begin{array}{r}10 \text { th } \\
\text { grade }\end{array}$ & $\begin{array}{l}11 \text { th } \\
\text { grade }\end{array}$ & $\begin{array}{r}12 \text { th } \\
\text { grade }\end{array}$ & $\begin{array}{l}\text { Un- } \\
\text { graded }\end{array}$ \\
\hline 1 & 2 & 3 & 4 & 5 & 6 & 7 & 8 & 9 & 10 & 11 & 12 & 13 & 14 & 15 & 16 & 17 & 18 & 19 & 20 \\
\hline 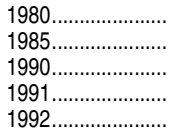 & $\begin{array}{l}40,877 \\
39,422 \\
41,217 \\
42,047 \\
42,823\end{array}$ & $\begin{array}{l}27,647 \\
27,034 \\
29,876 \\
30,503 \\
31,086\end{array}$ & \begin{tabular}{r|}
96 \\
151 \\
303 \\
375 \\
505
\end{tabular} & $\begin{array}{l}2,593 \\
3,041 \\
3,306 \\
3,311 \\
3,313\end{array}$ & \begin{tabular}{l|}
2,894 \\
3,239 \\
3,499 \\
3,556 \\
3,542
\end{tabular} & $\begin{array}{l}2,800 \\
2,941 \\
3,327 \\
3,360 \\
3,431\end{array}$ & \begin{tabular}{l|}
2,893 \\
2,895 \\
3,297 \\
3,334 \\
3,361
\end{tabular} & $\begin{array}{l}3,107 \\
2,771 \\
3,248 \\
3,315 \\
3,342\end{array}$ & $\begin{array}{l}3,130 \\
2,776 \\
3,197 \\
3,268 \\
3,325\end{array}$ & $\begin{array}{l}3,038 \\
2,789 \\
3,110 \\
3,239 \\
3,303\end{array}$ & $\begin{array}{l}3,085 \\
2,938 \\
3,067 \\
3,181 \\
3,299\end{array}$ & $\begin{array}{l}3,086 \\
2,982 \\
2,979 \\
3,020 \\
3,129\end{array}$ & $\begin{array}{l}924 \\
511 \\
541 \\
542 \\
536\end{array}$ & $\begin{array}{l}13,231 \\
12,388 \\
11,341 \\
11,544 \\
11,737\end{array}$ & $\begin{array}{l}3,377 \\
3,439 \\
3,169 \\
3,313 \\
3,352\end{array}$ & \begin{tabular}{l|}
3,368 \\
3,230 \\
2,896 \\
2,915 \\
3,027
\end{tabular} & $\begin{array}{l}3,195 \\
2,866 \\
2,612 \\
2,645 \\
2,656\end{array}$ & $\begin{array}{l}2,925 \\
2,550 \\
2,381 \\
2,392 \\
2,431\end{array}$ & $\begin{array}{l}366 \\
303 \\
284 \\
278 \\
272\end{array}$ \\
\hline 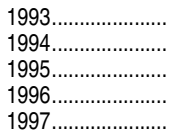 & $\begin{array}{l}43,465 \\
44,111 \\
44,840 \\
45,611 \\
46,127\end{array}$ & $\begin{array}{l}31,502 \\
31,896 \\
32,338 \\
32,762 \\
33,071\end{array}$ & $\begin{array}{l}545 \\
603 \\
637 \\
670 \\
695\end{array}$ & $\begin{array}{l}3,377 \\
3,444 \\
3,536 \\
3,532 \\
3,503\end{array}$ & $\begin{array}{l}3,529 \\
3,593 \\
3,671 \\
3,770 \\
3,755\end{array}$ & $\begin{array}{l}3,429 \\
3,440 \\
3,507 \\
3,600 \\
3,689\end{array}$ & $\begin{array}{l}3,437 \\
3,439 \\
3,445 \\
3,524 \\
3,597\end{array}$ & $\begin{array}{l}3,361 \\
3,426 \\
3,431 \\
3,454 \\
3,507\end{array}$ & $\begin{array}{l}3,350 \\
3,372 \\
3,438 \\
3,453 \\
3,458\end{array}$ & $\begin{array}{l}3,356 \\
3,381 \\
3,395 \\
3,494 \\
3,492\end{array}$ & $\begin{array}{l}3,355 \\
3,404 \\
3,422 \\
3,464 \\
3,520\end{array}$ & $\begin{array}{l}3,249 \\
3,302 \\
3,356 \\
3,403 \\
3,415\end{array}$ & $\begin{array}{l}513 \\
492 \\
500 \\
399 \\
440\end{array}$ & $\begin{array}{l}11,963 \\
12,215 \\
12,502 \\
12,849 \\
13,056\end{array}$ & $\begin{array}{l}3,487 \\
3,604 \\
3,704 \\
3,801 \\
3,819\end{array}$ & $\begin{array}{l}3,050 \\
3,131 \\
3,237 \\
3,323 \\
3,376\end{array}$ & $\begin{array}{l}2,751 \\
2,748 \\
2,826 \\
2,930 \\
2,972\end{array}$ & $\begin{array}{l}2,424 \\
2,488 \\
2,487 \\
2,586 \\
2,673\end{array}$ & $\begin{array}{l}250 \\
244 \\
247 \\
208 \\
216\end{array}$ \\
\hline 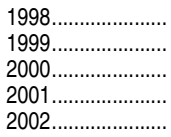 & $\begin{array}{l}46,539 \\
46,857 \\
47,204 \\
47,672 \\
48,183\end{array}$ & $\begin{array}{l}33,344 \\
33,486 \\
33,686 \\
33,936 \\
34,114\end{array}$ & $\begin{array}{l}729 \\
751 \\
776 \\
865 \\
915\end{array}$ & $\begin{array}{l}3,443 \\
3,397 \\
3,382 \\
3,379 \\
3,434\end{array}$ & $\begin{array}{l}3,727 \\
3,684 \\
3,636 \\
3,614 \\
3,594\end{array}$ & $\begin{array}{l}3,681 \\
3,656 \\
3,634 \\
3,593 \\
3,565\end{array}$ & $\begin{array}{l}3,696 \\
3,691 \\
3,676 \\
3,653 \\
3,623\end{array}$ & $\begin{array}{l}3,592 \\
3,686 \\
3,711 \\
3,695 \\
3,669\end{array}$ & $\begin{array}{l}3,520 \\
3,604 \\
3,707 \\
3,727 \\
3,711\end{array}$ & $\begin{array}{l}3,497 \\
3,564 \\
3,663 \\
3,769 \\
3,788\end{array}$ & $\begin{array}{l}3,530 \\
3,541 \\
3,629 \\
3,720 \\
3,821\end{array}$ & $\begin{array}{l}3,480 \\
3,497 \\
3,538 \\
3,616 \\
3,709\end{array}$ & $\begin{array}{l}449 \\
415 \\
334 \\
304 \\
285\end{array}$ & $\begin{array}{l}13,195 \\
13,371 \\
13,517 \\
13,736 \\
14,069\end{array}$ & $\begin{array}{l}3,856 \\
3,935 \\
3,963 \\
4,012 \\
4,105\end{array}$ & $\begin{array}{l}3,382 \\
3,415 \\
3,491 \\
3,528 \\
3,584\end{array}$ & $\begin{array}{l}3,021 \\
3,034 \\
3,083 \\
3,174 \\
3,229\end{array}$ & $\begin{array}{l}2,722 \\
2,782 \\
2,803 \\
2,863 \\
2,990\end{array}$ & $\begin{array}{l}214 \\
205 \\
177 \\
159 \\
161\end{array}$ \\
\hline 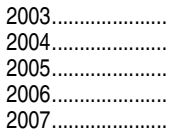 & $\begin{array}{l}48,540 \\
48,795 \\
49,113 \\
49,316 \\
49,293\end{array}$ & $\begin{array}{l}34,201 \\
34,178 \\
34,204 \\
34,235 \\
34,205\end{array}$ & $\begin{array}{r}950 \\
990 \\
1,036 \\
1,084 \\
1,081\end{array}$ & $\begin{array}{l}3,503 \\
3,544 \\
3,619 \\
3,631 \\
3,609\end{array}$ & $\begin{array}{l}3,613 \\
3,663 \\
3,691 \\
3,751 \\
3,750\end{array}$ & $\begin{array}{l}3,544 \\
3,560 \\
3,606 \\
3,641 \\
3,704\end{array}$ & $\begin{array}{l}3,611 \\
3,580 \\
3,586 \\
3,627 \\
3,659\end{array}$ & $\begin{array}{l}3,619 \\
3,612 \\
3,578 \\
3,586 \\
3,624\end{array}$ & $\begin{array}{l}3,685 \\
3,635 \\
3,633 \\
3,602 \\
3,600\end{array}$ & $\begin{array}{l}3,772 \\
3,735 \\
3,670 \\
3,660 \\
3,628\end{array}$ & $\begin{array}{l}3,841 \\
3,818 \\
3,777 \\
3,716 \\
3,701\end{array}$ & $\begin{array}{l}3,809 \\
3,825 \\
3,802 \\
3,766 \\
3,709\end{array}$ & $\begin{array}{l}255 \\
215 \\
205 \\
170 \\
139\end{array}$ & $\begin{array}{l}14,339 \\
14,618 \\
14,909 \\
15,081 \\
15,087\end{array}$ & $\begin{array}{l}4,190 \\
4,281 \\
4,287 \\
4,260 \\
4,200\end{array}$ & $\begin{array}{l}3,675 \\
3,750 \\
3,866 \\
3,882 \\
3,863\end{array}$ & $\begin{array}{l}3,277 \\
3,369 \\
3,454 \\
3,551 \\
3,558\end{array}$ & $\begin{array}{l}3,046 \\
3,094 \\
3,180 \\
3,277 \\
3,375\end{array}$ & $\begin{array}{r}150 \\
122 \\
121 \\
110 \\
92\end{array}$ \\
\hline 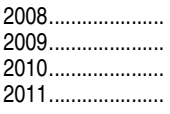 & $\begin{array}{l}49,266 \\
49,361 \\
49,484 \\
49,522 \\
\end{array}$ & $\begin{array}{l}34,286 \\
34,409 \\
34,625 \\
34,773 \\
\end{array}$ & $\begin{array}{l}1,180 \\
1,223 \\
1,279 \\
1,291 \\
\end{array}$ & $\begin{array}{l}3,640 \\
3,678 \\
3,682 \\
3,746 \\
\end{array}$ & $\begin{array}{l}3,708 \\
3,729 \\
3,754 \\
3,773 \\
\end{array}$ & $\begin{array}{l}3,699 \\
3,665 \\
3,701 \\
3,713 \\
\end{array}$ & $\begin{array}{l}3,708 \\
3,707 \\
3,686 \\
3,703 \\
\end{array}$ & $\begin{array}{l}3,647 \\
3,701 \\
3,711 \\
3,672 \\
\end{array}$ & $\begin{array}{l}3,629 \\
3,652 \\
3,718 \\
3,699 \\
\end{array}$ & $\begin{array}{l}3,614 \\
3,644 \\
3,682 \\
3,724 \\
\end{array}$ & $\begin{array}{l}3,653 \\
3,641 \\
3,676 \\
3,696 \\
\end{array}$ & $\begin{array}{l}3,692 \\
3,651 \\
3,659 \\
3,679\end{array}$ & $\begin{array}{r}117 \\
119 \\
77 \\
77 \\
\end{array}$ & $\begin{array}{l}14,980 \\
14,952 \\
14,860 \\
14,749 \\
\end{array}$ & $\begin{array}{l}4,123 \\
4,080 \\
4,008 \\
3,957 \\
\end{array}$ & $\begin{array}{l}3,822 \\
3,809 \\
3,800 \\
3,751 \\
\end{array}$ & $\begin{array}{l}3,548 \\
3,541 \\
3,538 \\
3,546 \\
\end{array}$ & $\begin{array}{l}3,400 \\
3,432 \\
3,472 \\
3,452 \\
\end{array}$ & $\begin{array}{l}87 \\
90 \\
42 \\
43 \\
\end{array}$ \\
\hline & \multicolumn{19}{|c|}{ Projected } \\
\hline 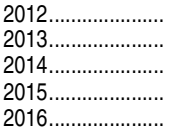 & $\begin{array}{l}49,652 \\
49,750 \\
49,751 \\
49,839 \\
49,951\end{array}$ & $\begin{array}{l}34,968 \\
35,111 \\
35,062 \\
35,069 \\
35,142\end{array}$ & $\begin{array}{l}1,305 \\
1,302 \\
1,264 \\
1,267 \\
1,279\end{array}$ & $\begin{array}{l}3,787 \\
3,777 \\
3,668 \\
3,677 \\
3,713\end{array}$ & $\begin{array}{l}3,794 \\
3,834 \\
3,824 \\
3,713 \\
3,723\end{array}$ & $\begin{array}{l}3,732 \\
3,754 \\
3,793 \\
3,783 \\
3,674\end{array}$ & $\begin{array}{l}3,721 \\
3,741 \\
3,762 \\
3,801 \\
3,791\end{array}$ & $\begin{array}{l}3,707 \\
3,725 \\
3,744 \\
3,766 \\
3,805\end{array}$ & $\begin{array}{l}3,681 \\
3,716 \\
3,734 \\
3,754 \\
3,775\end{array}$ & $\begin{array}{l}3,718 \\
3,699 \\
3,735 \\
3,753 \\
3,772\end{array}$ & $\begin{array}{l}3,744 \\
3,738 \\
3,719 \\
3,755 \\
3,773\end{array}$ & $\begin{array}{l}3,701 \\
3,749 \\
3,743 \\
3,725 \\
3,760\end{array}$ & $\begin{array}{l}77 \\
77 \\
76 \\
76 \\
76\end{array}$ & $\begin{array}{l}14,684 \\
14,639 \\
14,689 \\
14,770 \\
14,810\end{array}$ & $\begin{array}{l}3,978 \\
4,003 \\
4,054 \\
4,048 \\
4,028\end{array}$ & $\begin{array}{l}3,704 \\
3,724 \\
3,746 \\
3,795 \\
3,789\end{array}$ & $\begin{array}{l}3,501 \\
3,456 \\
3,475 \\
3,496 \\
3,541\end{array}$ & $\begin{array}{l}3,459 \\
3,415 \\
3,372 \\
3,390 \\
3,410\end{array}$ & $\begin{array}{l}42 \\
42 \\
42 \\
42 \\
42\end{array}$ \\
\hline $\begin{array}{l}2017 \ldots \ldots \ldots \ldots \\
2018 \ldots \ldots \ldots \ldots \ldots . . . . . . \\
2019 \ldots \ldots \ldots \ldots \ldots . . . \\
2020 \ldots \ldots \ldots \ldots \ldots . . . \\
2021 \ldots \ldots \ldots \ldots \ldots \ldots . . .\end{array}$ & $\begin{array}{l}50,280 \\
50,543 \\
50,834 \\
51,165 \\
51,485\end{array}$ & $\begin{array}{l}35,412 \\
35,642 \\
35,878 \\
36,115 \\
36,335\end{array}$ & $\begin{array}{l}1,342 \\
1,352 \\
1,361 \\
1,370 \\
1,377\end{array}$ & $\begin{array}{l}3,895 \\
3,924 \\
3,951 \\
3,975 \\
3,997\end{array}$ & $\begin{array}{l}3,759 \\
3,943 \\
3,973 \\
4,000 \\
4,025\end{array}$ & $\begin{array}{l}3,683 \\
3,719 \\
3,901 \\
3,931 \\
3,958\end{array}$ & $\begin{array}{l}3,682 \\
3,691 \\
3,727 \\
3,910 \\
3,939\end{array}$ & $\begin{array}{l}3,795 \\
3,686 \\
3,695 \\
3,731 \\
3,914\end{array}$ & $\begin{array}{l}3,814 \\
3,804 \\
3,695 \\
3,704 \\
3,740\end{array}$ & $\begin{array}{l}3,794 \\
3,833 \\
3,823 \\
3,713 \\
3,722\end{array}$ & $\begin{array}{l}3,793 \\
3,814 \\
3,854 \\
3,844 \\
3,733\end{array}$ & $\begin{array}{l}3,779 \\
3,798 \\
3,820 \\
3,860 \\
3,850\end{array}$ & $\begin{array}{l}77 \\
77 \\
78 \\
78 \\
79\end{array}$ & $\begin{array}{l}14,868 \\
14,901 \\
14,957 \\
15,050 \\
15,151\end{array}$ & $\begin{array}{l}4,066 \\
4,086 \\
4,107 \\
4,131 \\
4,174\end{array}$ & $\begin{array}{l}3,770 \\
3,806 \\
3,825 \\
3,844 \\
3,866\end{array}$ & $\begin{array}{l}3,535 \\
3,518 \\
3,552 \\
3,569 \\
3,587\end{array}$ & $\begin{array}{l}3,454 \\
3,449 \\
3,432 \\
3,465 \\
3,482\end{array}$ & $\begin{array}{l}42 \\
42 \\
42 \\
42 \\
42\end{array}$ \\
\hline $\begin{array}{l}2022 \ldots \ldots \ldots \ldots \ldots . . . \\
2023 \ldots \ldots \ldots \ldots \ldots . . .\end{array}$ & $\begin{array}{l}51,804 \\
52,113\end{array}$ & $\begin{array}{l}36,585 \\
36,967\end{array}$ & $\begin{array}{l}1,385 \\
1,391\end{array}$ & $\begin{array}{l}4,018 \\
4,037\end{array}$ & $\begin{array}{l}4,048 \\
4,069\end{array}$ & $\begin{array}{l}3,982 \\
4,005\end{array}$ & $\begin{array}{l}3,966 \\
3,991\end{array}$ & $\begin{array}{l}3,943 \\
3,970\end{array}$ & $\begin{array}{l}3,923 \\
3,953\end{array}$ & $\begin{array}{l}3,759 \\
3,943\end{array}$ & $\begin{array}{l}3,742 \\
3,779\end{array}$ & $\begin{array}{l}3,739 \\
3,748\end{array}$ & $\begin{array}{l}79 \\
80\end{array}$ & $\begin{array}{l}15,219 \\
15,146\end{array}$ & $\begin{array}{l}4,163 \\
4,043\end{array}$ & $\begin{array}{l}3,906 \\
3,896\end{array}$ & $\begin{array}{l}3,608 \\
3,645\end{array}$ & $\begin{array}{l}3,500 \\
3,520\end{array}$ & $\begin{array}{l}42 \\
42\end{array}$ \\
\hline
\end{tabular}

NOTE: Due to changes in reporting and imputation practices, prekindergarten enrollment for years prior to 1992 represent an undercount compared to later years. The total ungraded counts of students were prorated to the elementary and secondary levels based on prior reports. Detail may not sum to totals because of rounding.
SOURCE: U.S. Department of Education, National Center for Education Statistics, Statistics of Public Elementary and Secondary School Systems, 1980-81; Common Core of Data (CCD), "State Nonfiscal Survey of Public Elementary/Secondary Education," 1985-86 through 2011-12; and National Elementary and Secondary Enrollment Projection Model, 1972 through 2023. (This table was prepared January 2014.) 
Table 203.20. Enrollment in public elementary and secondary schools, by region, state, and jurisdiction: Selected years, fall 1990 through fall 2023

\begin{tabular}{|c|c|c|c|c|c|c|c|c|c|c|c|c|c|c|c|c|c|c|c|c|c|}
\hline \multirow[b]{2}{*}{ Region, state, and jurisdiction } & \multicolumn{13}{|c|}{ Actual total enrollment } & \multirow{2}{*}{\begin{tabular}{|r|} 
Percent \\
change \\
in total \\
enrollment, \\
2006 \\
to 2011
\end{tabular}} & \multicolumn{6}{|c|}{ Projected total enrollment } & \multirow{2}{*}{$\begin{array}{r}\text { Percent } \\
\text { change } \\
\text { in total } \\
\text { enrollment, } \\
2011 \\
\text { to } 2023\end{array}$} \\
\hline & Fall 1990 & Fall 2000 & Fall 2001 & Fall 2002 & Fall 2003 & Fall 2004 & Fall 2005 & Fall 2006 & Fall 2007 & Fall 2008 & Fall 2009 & Fall 2010 & Fall 2011 & & Fall 2012 & Fall 2013 & Fall 2014 & Fall 2015 & Fall 2020 & Fall 2023 & \\
\hline
\end{tabular}

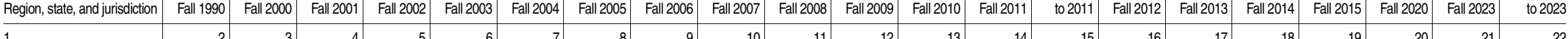

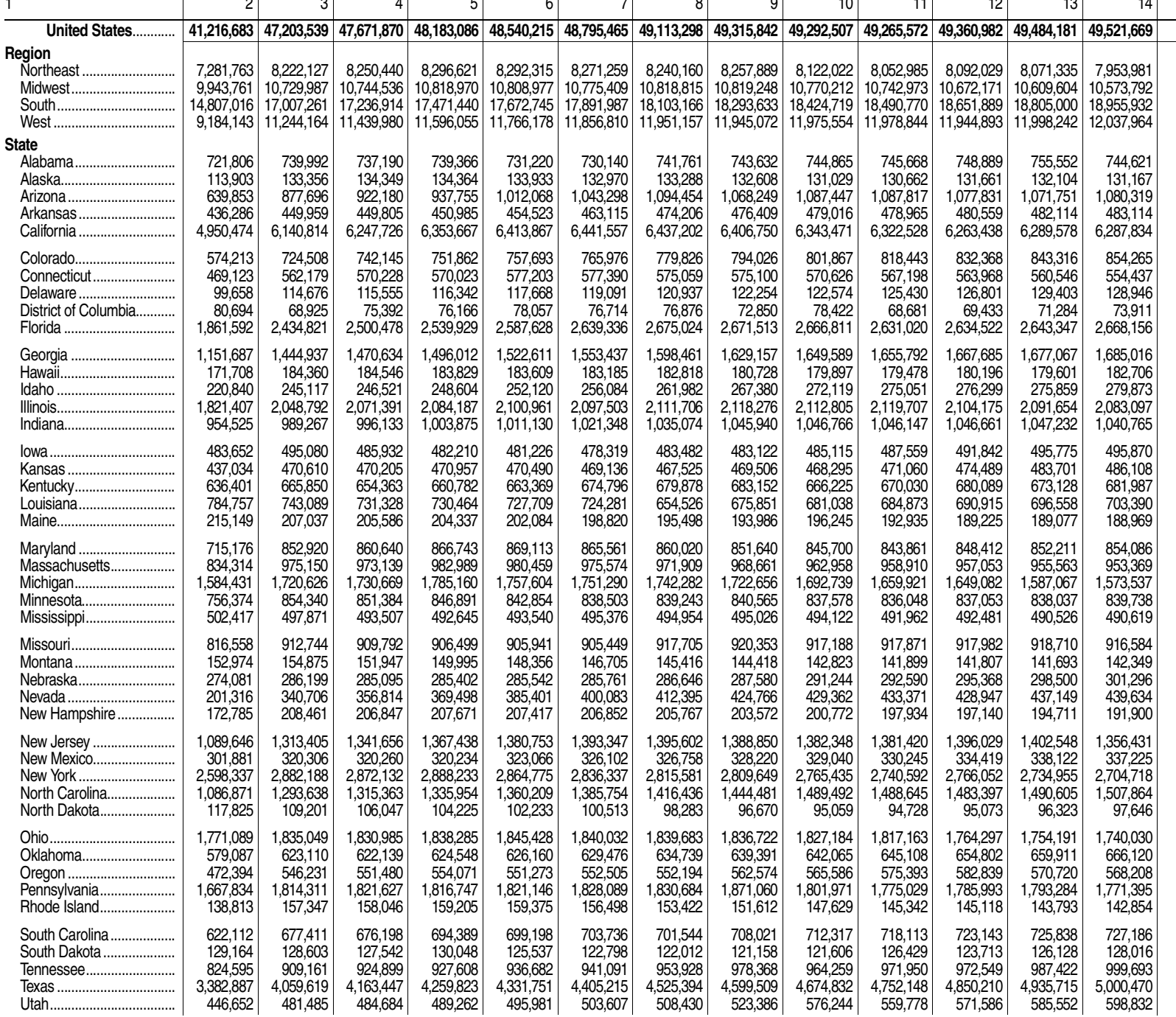

See notes at end of table.

\begin{tabular}{r|r|r|r|r|r|r|}
0.4 & $49,651,900$ & $49,750,400$ & $49,751,300$ & $49,839,400$ & $51,165,200$ & $52,112,800$ \\
\hline
\end{tabular} 5.2

\begin{tabular}{l|r|r|r|r|r|r|}
-3.7 & $7,901,300$ & $7,852,600$ & $7,800,800$ & $7,766,800$ & $7,768,400$ & $7,791,000$ \\
\hline
\end{tabular}

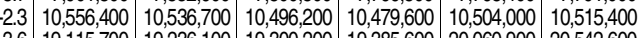
$\begin{array}{llllllll}0.8 & 12,078,600 & 12,125,000 & 12,154,200 & 12,207,300 & 12,832,000 & 13,263,700\end{array}$

\begin{tabular}{|l|r|r|r|r|r|r|}
\hline 0.1 & 742,400 & 739,300 & 734,300 & 730,000 & 715,000 & 712,800 \\
\hline
\end{tabular} \begin{tabular}{r|r|r|r|r|r|r|}
\hline 0.1 & 742,400 & 739,300 & 734,300 & 730,000 & 715,000 & 712,800 \\
-1.1 & 131,000 & 132,300 & 133,400 & 135,000 & 147,200 & 155,200 \\
\hline 1 & 1,08500 & $1,08,200$ & 1,108300 & $1,22,00$ & 122000 & 129500
\end{tabular} \begin{tabular}{l|r|r|r|r|r|r|}
1.1 & $1,088,500$ & $1,098,800$ & $1,108,300$ & $1,122,600$ & $1,226,000$ & $1,295,500$
\end{tabular} \begin{tabular}{r|r|r|r|r|r|r|r|}
1.4 & 486,300 & 487,300 & 486,200 & 484,900 & 485,700 & 488,600 \\
-1.9 & $6,282,200$ & $6,278,800$ & $6,268,600$ & $6,271,000$ & $6,543,800$ & $6,742,400$ \\
\hline & 864,700 & 84,000 & 880,000 & 88800 & &
\end{tabular}

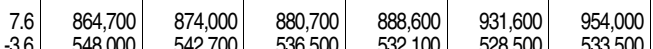
\begin{tabular}{r|r|r|r|r|r|r|r|}
-3.6 & 548,000 & 542,700 & 536,500 & 532,100 & 528,500 & 533,500 \\
5.5 & 129,500 & 130,400 & 131,100 & 132,100 & 138,200 & 140,100 \\
\hline 1.5 & 74,700 & 74,200 & 7300 & 73,00 & 71,000 & 63,000
\end{tabular} \begin{tabular}{r|r|r|r|r|r|r|r|}
1.5 & 74,700 & 74,200 & 73,400 & 73,000 & 71,900 & 69,600 \\
-0.1 & $2,696,300$ & $2,715,800$ & $2,730,200$ & $2,745,000$ & $2,903,500$ & $3,032,800$
\end{tabular}

\begin{tabular}{r|r|r|r|r|r|r|}
3.4 & $1,695,700$ & $1,704,600$ & $1,707,500$ & $1,712,200$ & $1,760,500$ & $1,809,700$ \\
1.1 & 182,600 & 182,600 & 18200 & 181,500 & 130,600 & 178000
\end{tabular}

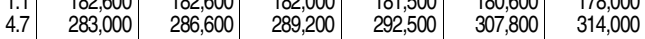
\begin{tabular}{r|r|r|r|r|r|r|}
-1.7 & $2,084,100$ & $2,077,500$ & $2,069,700$ & $2,067,400$ & $2,061,600$ & $2,053,000$ \\
-0.5 & $1,038,100$ & $1,033,500$ & $1,025,200$ & $1,019,100$ & $1,005,100$ & $1,009,500$ \\
\hline
\end{tabular}

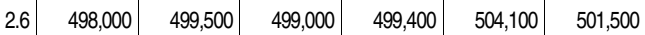

\begin{tabular}{|l|l|l|l|l|l|l|l|}
\hline 3.5 & 488,000 & 489,700 & 490,200 & 491,700 & 498,900 & 499,300 \\
\hline
\end{tabular} \begin{tabular}{r|r|r|r|r|r|r|r|}
-0.5 & 4883,300 & 682,300 & 680,100 & 679,000 & 672,600 & 668,500 \\
\hline 4.1 & 710,400 & 712000 & 709700 & 709,200 & 697,300 & 683,300 \\
\hline
\end{tabular} \begin{tabular}{r|r|r|r|r|r|r|}
\hline 4.1 & 710,400 & 712,000 & 709,700 & 709,200 & 697,900 & 686,300 \\
-2.6 & 187,500 & 186,900 & 186,200 & 185,900 & 187,300 & 187,200 \\
\hline
\end{tabular} \begin{tabular}{|r|r|r|r|r|r|r|}
\hline 0.3 & 857,600 & 862,300 & 866,600 & 873,000 & 934,200 & 969,000 \\
-16 & 950,300 & 945,200 & 938200 & 932,00 & 923,300 & 962,100 \\
\hline
\end{tabular} \begin{tabular}{r|r|r|r|r|r|r|r|}
-1.6 & 950,300 & 945,200 & 938,200 & 932,600 & 923,300 & 926,100 \\
-87 & $1,555,400$ & $1,541,400$ & $1,524,100$ & $1,512,600$ & $1,479,200$ & $1,473,300$ \\
\hline & 0.15 &
\end{tabular} \begin{tabular}{r|r|r|r|r|r|r|}
-8.7 & $1,555,400$ & $1,541,400$ & $1,524,100$ & $1,512,600$ & $1,479,200$ & $1,473,300$ \\
-0.1 & 845,400 & 850,800 & 856,500 & 863,200 & 913,600 & 937,700 \\
& & & &
\end{tabular} \begin{tabular}{|l|l|l|l|l|l|l|l|}
\hline-0.9 & 845,400 & 850,800 & 856,500 & 863,200 & 913,600 & 937,700 \\
\hline & 499,400 & 486,100 & 482,900 & 468,200 & 458,600 \\
\hline
\end{tabular} \begin{tabular}{l|l|l|l|l|l|l|}
-0.4 & 916,300 & 916,700 & 914,400 & 913,800 & 923,500 & 930,000 \\
-14 & 143,100 & 143,800 & 14300 & 14430 & 147,100 & 146,800 \\
\hline
\end{tabular} \begin{tabular}{|l|l|l|l|l|l|l|}
\hline .4 .4 & 143,100 & 143,800 & $14,3,900$ & 144,300 & 147,100 & 146,800 \\
4.8 & 304,100 & 306,200 & 307,000 & 308,700 & 316,700 & 36,400 \\
\hline
\end{tabular} \begin{tabular}{r|r|r|r|r|r|r|}
3.5 & 442,300 & 446,000 & 449,900 & 454,900 & 496,600 & 534,700 \\
-5.7 & 189,000 & 186,300 & 184,600 & 182,700 & 182,400 & 186,400 \\
\hline
\end{tabular} \begin{tabular}{l|r|r|r|r|r|r|}
-2.3 & $1,346,300$ & $1,334,400$ & $1,321,200$ & $1,310,200$ & $1,295,900$ & $1,297,200$
\end{tabular} \begin{tabular}{l|l|l|l|l|l|l|l|}
2.7 .7 & 337,800 & 339,400 & 340,200 & 340,800 & 342,900 & 339,600 \\
\hline
\end{tabular} \begin{tabular}{r|r|r|r|r|r|r|}
-3.7 & $2,691,100$ & $2,676,500$ & $2,662,400$ & $2,654,700$ & $2,657,700$ & $2,652,600$ \\
\hline & 1,515700 & 152400 & 1,530300 & $1,537,900$ & 1,602100 & 1,67300
\end{tabular} \begin{tabular}{rrr|r|r|r|r|r|}
4.4 & $1,515,700$ & $1,524,900$ & $1,530,300$ & $1,537,900$ & $1,602,100$ & $1,672,300$ \\
1.0 & 99,100 & 100,200 & 101,000 & 102,000 & 107,500 & 107,800 \\
\hline
\end{tabular} \begin{tabular}{rrr|r|r|r|r|}
-5.3 & $1,730,300$ & $1,722,700$ & $1,712,100$ & $1,704,200$ & $1,677,000$ & $1,664,100$ \\
\hline 4 & 673000 & 677,000 & 677,900 & 679600 & 689,000 & 690,300
\end{tabular} \begin{tabular}{r|r|r|r|r|r|r|}
4.2 & 673,000 & 677,000 & 677,900 & 679,600 & 689,000 & 690,300 \\
1.0 & 569,900 & 572500 & 573,800 & 576,600 & 603,600 & 626,600 \\
\hline
\end{tabular} \begin{tabular}{r|r|r|r|r|r|r|r|}
1.0 & 569,900 & 572,500 & 573,800 & 576,600 & 603,600 & 626,600 \\
-5.3 & $1,758,500$ & $1,751,600$ & $1,744,500$ & $1,742,000$ & $1,761,000$ & $1,772,200$ \\
-5 & 140,700 & 139,700 & 138,900 & 138,000 & 142,400 & 144,700
\end{tabular} \begin{tabular}{|l|l|l|l|l|l|l|}
\hline 2.7 & 734,700 & 738,800 & 740,900 & 744,300 & 761,100 & 770,600 \\
\hline
\end{tabular} \begin{tabular}{|l|r|r|r|r|r|r|r|}
2.2 & $1,006,500$ & $1,012,600$ & $1,016,700$ & $1,021,400$ & $1,054,200$ & $1,081,100$
\end{tabular} \begin{tabular}{r|r|r|r|r|r|r|}
8.7 & $5,072,200$ & $5,135,400$ & $5,178,400$ & $5,226,300$ & $5,511,100$ & $5,669,000$ \\
14.4 & 612,500 & 624,700 & 634,500 & 643,500 & 683,700 & 704,600
\end{tabular} 


\begin{tabular}{|c|c|c|c|c|c|c|c|c|c|c|c|c|c|c|c|c|c|c|c|c|c|}
\hline \multirow[b]{2}{*}{ Region, state, and jurisdiction } & \multicolumn{13}{|c|}{ Actual total enrollment } & \multirow{2}{*}{$\begin{array}{r}\text { Percent } \\
\text { change } \\
\text { in total } \\
\text { enrollment, } \\
2006 \\
\text { to } 2011\end{array}$} & \multicolumn{6}{|c|}{ Projected total enrollment } & \multirow{2}{*}{\begin{tabular}{|} 
Percent \\
change \\
in total \\
enrollment, \\
2011 \\
to 2023 \\
\end{tabular}} \\
\hline & Fall 1990 & Fall 2000 & Fall 2001 & Fall 2002 & Fall 2003 & Fall 2004 & Fall 2005 & Fall 2006 & Fall 2007 & Fall 2008 & Fall 2009 & Fall 2010 & Fall 2011 & & Fall 2012 & Fall 2013 & Fall 2014 & Fall 2015 & Fall 2020 & Fall 2023 & \\
\hline 1 & 2 & 3 & 4 & 5 & 6 & 7 & 8 & 9 & 10 & 11 & 12 & 13 & 14 & 15 & 16 & 17 & 18 & 19 & 20 & 21 & 22 \\
\hline 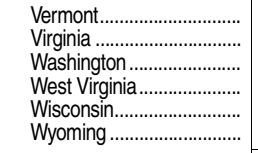 & $\begin{array}{r}95,762 \\
998,601 \\
839,709 \\
322,399 \\
797,621 \\
98,226 \\
\end{array}$ & $\begin{array}{r}102,049 \\
1,144,915 \\
1,004,770 \\
286,367 \\
879,476 \\
89,940 \\
\end{array}$ & $\begin{array}{r}101,179 \\
1,163,091 \\
1,009,200 \\
282,885 \\
879,361 \\
88,128 \\
\end{array}$ & $\begin{array}{r}99,978 \\
1,177,229 \\
1,014,798 \\
288,455 \\
881,231 \\
88,116 \\
\end{array}$ & $\begin{array}{r}99,103 \\
1,192,092 \\
1,021,349 \\
281,215 \\
880,031 \\
87,462 \\
\end{array}$ & $\begin{array}{r}98,352 \\
1,204,739 \\
1,020,005 \\
280,129 \\
864,757 \\
84,733 \\
\end{array}$ & $\begin{array}{r}96,638 \\
1,213,616 \\
1,031,985 \\
280,866 \\
875,174 \\
84,409 \\
\end{array}$ & $\begin{array}{r}95,399 \\
1,220,440 \\
1,026,774 \\
281,939 \\
876,700 \\
85,193 \\
\end{array}$ & $\begin{array}{r}94,038 \\
1,230,857 \\
1,030,247 \\
282,535 \\
874,633 \\
86,422 \\
\end{array}$ & $\begin{array}{r}93,625 \\
1,235,795 \\
1,037,018 \\
282,729 \\
877,750 \\
87,161 \\
\end{array}$ & $\begin{array}{r}91,451 \\
1,245,340 \\
1,035,347 \\
282,662 \\
872,436 \\
88,155 \\
\end{array}$ & $\begin{array}{r}96,858 \\
1,251,440 \\
1,043,788 \\
282,879 \\
872,286 \\
89,009 \\
\end{array}$ & $\begin{array}{r}89,908 \\
1,257,883 \\
1,045,453 \\
282,870 \\
871,105 \\
90,099 \\
\end{array}$ & $\begin{array}{r}-5.8 \\
3.1 \\
1.8 \\
0.3 \\
-0.6 \\
5.8 \\
\end{array}$ & $\begin{array}{r}89,900 \\
1,263,200 \\
1,049,200 \\
282,600 \\
869,400 \\
91,900 \\
\end{array}$ & $\begin{array}{r}89,000 \\
1,269,100 \\
1,052,400 \\
280,000 \\
89,300 \\
93,100 \\
\end{array}$ & $\begin{array}{r}88,200 \\
1,272,700 \\
1,055,500 \\
27,, 000 \\
867,000 \\
94,100 \\
\end{array}$ & $\begin{array}{r}87,800 \\
1,279,200 \\
1,061,300 \\
275,400 \\
867,200 \\
94,800 \\
\end{array}$ & $\begin{array}{r}89,800 \\
1,333,000 \\
1,124,200 \\
262,700 \\
881,300 \\
96,900 \\
\end{array}$ & $\begin{array}{r}91,200 \\
1,370,300 \\
1,177,400 \\
258,100 \\
886,900 \\
94,900 \\
\end{array}$ & $\begin{array}{r}1.4 \\
8.9 \\
12.6 \\
-10.5 \\
1.8 \\
5.3 \\
\end{array}$ \\
\hline 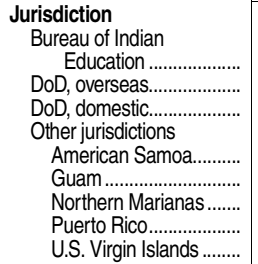 & $\begin{array}{r}- \\
- \\
- \\
12,4663 \\
26,391 \\
6,449 \\
644,744 \\
21,750\end{array}$ & \begin{tabular}{r|}
46,938 \\
73,581 \\
34,174 \\
15,702 \\
32,473 \\
1,004 \\
612,725 \\
19,459
\end{tabular} & $\begin{array}{r}46,476 \\
73,212 \\
32,847 \\
15,897 \\
31,992 \\
10,479 \\
604,177 \\
18,780\end{array}$ & $\begin{array}{r}46,126 \\
72,889 \\
32,115 \\
15,984 \\
- \\
11,251 \\
596,502 \\
18,333\end{array}$ & $\begin{array}{r}45,828 \\
71,053 \\
30,603 \\
15,893 \\
31,572 \\
11,244 \\
584,916 \\
17,716\end{array}$ & $\begin{array}{r}45,828 \\
68,327 \\
29,151 \\
16,126 \\
30,605 \\
11,601 \\
575,648 \\
16,429\end{array}$ & \begin{tabular}{r|}
50,938 \\
62,543 \\
28,329 \\
16,438 \\
30,986 \\
11,718 \\
563,490 \\
16,750
\end{tabular} & $\begin{array}{r}60,891 \\
26,631 \\
16,400 \\
11,695 \\
544,138 \\
16,284\end{array}$ & $\begin{array}{r}57,247 \\
27,548 \\
- \\
- \\
11,299 \\
526,565 \\
15,903\end{array}$ & $\begin{array}{r}40,927 \\
56,768 \\
28,013 \\
- \\
- \\
10,913 \\
503,635 \\
15,768\end{array}$ & $\begin{array}{r}- \\
10,961 \\
493,393 \\
15,493\end{array}$ & $\begin{array}{r}41,962 \\
- \\
- \\
- \\
31,618 \\
11,105 \\
473,735 \\
15,495\end{array}$ & $\begin{array}{r}- \\
- \\
- \\
- \\
31,243 \\
11,011 \\
452,740 \\
15,711\end{array}$ & $\begin{array}{r}- \\
- \\
- \\
- \\
-5.8 \\
-16.8 \\
-3.5\end{array}$ & $\begin{array}{l}- \\
- \\
- \\
- \\
= \\
-\end{array}$ & $\begin{array}{l}- \\
- \\
- \\
- \\
- \\
-\end{array}$ & $\begin{array}{l}- \\
- \\
- \\
- \\
= \\
- \\
-\end{array}$ & $\begin{array}{l}= \\
- \\
- \\
= \\
= \\
-\end{array}$ & $\begin{array}{l}- \\
- \\
- \\
= \\
= \\
-\end{array}$ & $\begin{array}{l}- \\
- \\
- \\
- \\
= \\
-\end{array}$ & $\begin{array}{l}- \\
- \\
- \\
= \\
= \\
=\end{array}$ \\
\hline
\end{tabular}

SOURCE: U.S. Department of Education, National Center for Education Statistics, Common Core of Data (CCD) "State NonNOTE: $\mathrm{DOD}=$ = Department of Defense. Detail may not sum to totals because of rounding. Some data have been revised from fiscal Survey of Public Elementary/Secondary Education" 1990-91 through 2011-12; and State Public Elementary and Secpreviously published figures. ondary Enrollment Projection Model, 1980 through 2023. (This table was prepared December 2013.) 
Table 203.25. Public school enrollment in prekindergarten through grade 8, by region, state, and jurisdiction: Selected years, fall 1990 through fall 2023

\begin{tabular}{|c|c|c|c|c|c|c|c|c|c|c|c|c|c|c|c|c|c|c|c|c|c|c|}
\hline \multirow[b]{2}{*}{ Region, state, and jurisdiction } & \multicolumn{13}{|c|}{ Actual enrollment } & \multirow{2}{*}{\begin{tabular}{|r|} 
Percent \\
change in \\
enrollment, \\
2006 to \\
2011
\end{tabular}} & \multicolumn{6}{|c|}{ Projected enrollment } & \multirow{2}{*}{\begin{tabular}{|r} 
Percent \\
change in \\
enrollment, \\
2011 to \\
2023
\end{tabular}} & \\
\hline & Fall 1990 & Fall 2000 & Fall 2001 & Fall 2002 & Fall 2003 & Fall 2004 & Fall 2005 & Fall 2006 & Fall 2007 & Fall 2008 & Fall 2009 & Fall 2010 & Fall 2011 & & Fall 2012 & Fall 2013 & Fall 2014 & Fall 2015 & Fall 2020 & Fall 2023 & & \\
\hline 1 & 2 & 3 & 4 & 5 & 6 & 7 & 8 & 9 & 10 & 11 & 12 & 13 & 14 & 15 & 16 & 17 & 18 & 19 & 20 & 21 & 22 & \\
\hline United States... & $29,875,914$ & $33,686,421$ & $33,935,922$ & $34,114,245$ & $34,200,741$ & $34,177,565$ & \begin{tabular}{|l|l|}
$34,203,962$ \\
\end{tabular} & $34,234,751$ & $34,205,362$ & $34,285,564$ & $34,409,260$ & $34,624,530$ & $34,772,751$ & 1.6 & $34,967,700$ & $35,111,000$ & \begin{tabular}{|l|}
$35,062,300$ \\
\end{tabular} & $35,069,200$ & $36,114,900$ & $36,966,700$ & 6.3 & \\
\hline 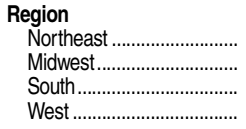 & \begin{tabular}{|r|}
$5,188,795$ \\
$7,129,501$ \\
$10,858,800$ \\
$6,698,818$
\end{tabular} & $\begin{array}{r}5,839,970 \\
7,523,246 \\
12,314,176 \\
8,009,029\end{array}$ & $\begin{array}{r}5,823,249 \\
7,516,458 \\
12,453,658 \\
8,142,557\end{array}$ & $\begin{array}{r}5,809,545 \\
7,534,620 \\
12,573,054 \\
8,197,026\end{array}$ & \begin{tabular}{|r|}
$5,751,561$ \\
$7,501,579$ \\
$12,675,179$ \\
$8,272,422$
\end{tabular} & \begin{tabular}{|r|}
$5,6689,094$ \\
$7,438,674$ \\
$12,780,160$ \\
$8,269,637$
\end{tabular} & $\begin{array}{r}5,622,955 \\
7,425,308 \\
12,881,836 \\
8,273,863\end{array}$ & \begin{tabular}{|r|}
$5,573,729$ \\
$7,404,578$ \\
$12,989,696$ \\
$8,266,748$
\end{tabular} & $\begin{array}{r}5,504,400 \\
7,359,028 \\
13,086,326 \\
8,255,608\end{array}$ & \begin{tabular}{|}
$5,476,224$ \\
$7,373,391$ \\
$13,166,980$ \\
$8,268,969$
\end{tabular} & \begin{tabular}{|r|}
$5,494,080$ \\
$7,361,959$ \\
$13,300,643$ \\
$8,252,578$
\end{tabular} & \begin{tabular}{|r|}
$5,540,276$ \\
$7,349,334$ \\
$13,434,553$ \\
$8,300,367$
\end{tabular} & \begin{tabular}{|r|}
$5,479,174$ \\
$7,358,792$ \\
$13,578,211$ \\
$8,356,574$
\end{tabular} & $\begin{array}{r}-1.7 \\
-0.6 \\
4.5 \\
1.1\end{array}$ & $\begin{array}{r}5,470,500 \\
7,363,300 \\
13,707,500 \\
8,426,300\end{array}$ & \begin{tabular}{|r|}
$5,459,800$ \\
$7,363,700$ \\
$13,795,700$ \\
$8,491,700$
\end{tabular} & $\begin{array}{r}5,424,200 \\
7,323,300 \\
13,791,500 \\
8,523,300\end{array}$ & $\begin{array}{r}5,396,400 \\
7,288,400 \\
13,804,700 \\
8,579,700\end{array}$ & $\begin{array}{r}5,411,600 \\
7,316,500 \\
14,313,400 \\
9,073,400\end{array}$ & $\begin{array}{r}5,477,400 \\
7,356,600 \\
14,716,800 \\
9,415,900\end{array}$ & $\begin{array}{r}\# \\
\# \\
8.4 \\
12.7\end{array}$ & \\
\hline 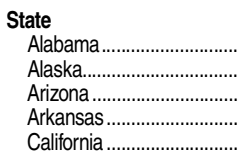 & $\begin{array}{r}527,097 \\
85,297 \\
479,046 \\
313,505 \\
3,613,734\end{array}$ & \begin{tabular}{|r|}
538,634 \\
94,442 \\
640,564 \\
318,023 \\
$4,407,035$
\end{tabular} & \begin{tabular}{|r|}
535,580 \\
94,888 \\
671,652 \\
317,923 \\
$4,478,326$
\end{tabular} & $\begin{array}{r}533,207 \\
94,380 \\
660,359 \\
318,826 \\
4,525,385\end{array}$ & $\begin{array}{r}525,313 \\
93,695 \\
704,322 \\
321,508 \\
4,539,777\end{array}$ & \begin{tabular}{|r|}
521,757 \\
91,981 \\
722,203 \\
328,187 \\
$4,507,355$
\end{tabular} & \begin{tabular}{|r|}
529,347 \\
91,225 \\
739,535 \\
335,446 \\
$4,465,615$ \\
\end{tabular} & $\begin{array}{r}528,664 \\
90,167 \\
759,656 \\
336,552 \\
4,410,105\end{array}$ & $\begin{array}{r}527,259 \\
88,980 \\
771,056 \\
339,920 \\
4,328,968\end{array}$ & \begin{tabular}{|r|}
528,078 \\
89,263 \\
771,79 \\
341,603 \\
$4,306,258$ \\
\end{tabular} & \begin{tabular}{|r|}
529,394 \\
90,824 \\
760,420 \\
344,209 \\
$4,264,022$
\end{tabular} & \begin{tabular}{|r|}
533,612 \\
91,990 \\
751,992 \\
345,808 \\
$4,293,968$
\end{tabular} & $\begin{array}{r}527,006 \\
92,057 \\
759,494 \\
346,022 \\
4,308,447\end{array}$ & \begin{tabular}{r|r}
-0.3 \\
2.1 \\
$\#$ \\
2.8 \\
-2.3
\end{tabular} & \begin{tabular}{|r|}
526,600 \\
93,000 \\
773,000 \\
348,500 \\
$4,327,800$ \\
\end{tabular} & $\begin{array}{r}523,900 \\
94,300 \\
786,440 \\
344,400 \\
4,349,200\end{array}$ & $\begin{array}{r}518,300 \\
95,400 \\
796,200 \\
346,400 \\
4,356,000\end{array}$ & \begin{tabular}{|r|}
512,700 \\
96,700 \\
806,100 \\
344,400 \\
$4,384,400$
\end{tabular} & $\begin{array}{r}506,800 \\
107,000 \\
879,000 \\
344,000 \\
4,627,600\end{array}$ & \begin{tabular}{|r|}
506,600 \\
112,600 \\
936,700 \\
348,500 \\
$4,779,300$
\end{tabular} & $\begin{array}{r}-3.9 \\
22.3 \\
23.3 \\
0.7 \\
10.9\end{array}$ & \\
\hline 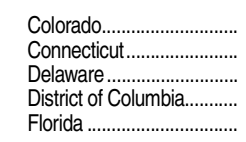 & $\begin{array}{r}419,910 \\
347,396 \\
72,606 \\
61,282 \\
1,369,934\end{array}$ & \begin{tabular}{|r|}
516,566 \\
406,445 \\
80,801 \\
53,692 \\
$1,759,902$
\end{tabular} & \begin{tabular}{|r|}
529,156 \\
410,017 \\
81,274 \\
57,967 \\
$1,797,414$
\end{tabular} & $\begin{array}{r}534,465 \\
405,998 \\
82,221 \\
58,802 \\
1,809,279\end{array}$ & $\begin{array}{r}536,325 \\
407,794 \\
82,898 \\
59,489 \\
1,832,376\end{array}$ & \begin{tabular}{|r|}
540,695 \\
404,169 \\
83,599 \\
57,118 \\
$1,857,798$
\end{tabular} & \begin{tabular}{|r|}
549,875 \\
399,705 \\
84,639 \\
55,646 \\
$1,873,395$ \\
\end{tabular} & $\begin{array}{r}559,041 \\
398,063 \\
84,996 \\
52,391 \\
1,866,562\end{array}$ & $\begin{array}{r}565,726 \\
394,034 \\
85,019 \\
55,836 \\
1,855,859\end{array}$ & \begin{tabular}{|r|}
580,304 \\
392,218 \\
86,811 \\
50,779 \\
$1,849,295$ \\
\end{tabular} & \begin{tabular}{|r|}
591,378 \\
389,964 \\
87,710 \\
51,656 \\
$1,850,901$
\end{tabular} & \begin{tabular}{|r|}
601,077 \\
387,475 \\
90,279 \\
53,548 \\
$1,858,498$
\end{tabular} & $\begin{array}{r}610,854 \\
383,377 \\
90,624 \\
56,195 \\
1,876,102\end{array}$ & $\begin{array}{r}9.3 \\
-3.7 \\
6.6 \\
7.3 \\
0.5\end{array}$ & \begin{tabular}{|r|}
619,100 \\
379,300 \\
92,000 \\
57,300 \\
$1,895,200$ \\
\end{tabular} & \begin{tabular}{|r|}
625,900 \\
376,400 \\
93,300 \\
57,300 \\
$1,910,400$
\end{tabular} & $\begin{array}{r}628,200 \\
372,400 \\
93,900 \\
56,700 \\
1,918,000\end{array}$ & \begin{tabular}{|r|}
630,600 \\
369,500 \\
94,400 \\
56,400 \\
$1,927,500$
\end{tabular} & $\begin{array}{r}653,100 \\
373,400 \\
97,400 \\
55,400 \\
2,068,500\end{array}$ & \begin{tabular}{|r|}
673,800 \\
382,200 \\
98,700 \\
52,900 \\
$2,167,500$ \\
\end{tabular} & $\begin{array}{r}10.3 \\
-0.3 \\
8.9 \\
-5.9 \\
15.5\end{array}$ & \\
\hline 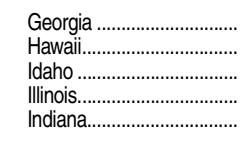 & $\begin{array}{r}849,082 \\
122,840 \\
160,091 \\
1,309,516 \\
675,804\end{array}$ & \begin{tabular}{|r|}
$1,059,983$ \\
132,293 \\
170,421 \\
$1,473,933$ \\
703,261
\end{tabular} & \begin{tabular}{|r|}
$1,075,195$ \\
131,881 \\
171,423 \\
$1,484,201$ \\
711,455
\end{tabular} & \begin{tabular}{|r}
$1,088,561$ \\
130,862 \\
173,249 \\
$1,487,650$ \\
714,003
\end{tabular} & $\begin{array}{r}1,103,181 \\
130,054 \\
175,424 \\
1,492,725 \\
716,819\end{array}$ & \begin{tabular}{|r|}
$1,118,379$ \\
128,788 \\
178,221 \\
$1,483,644$ \\
720,006
\end{tabular} & \begin{tabular}{|r|}
$1,145,446$ \\
127,472 \\
182,829 \\
$1,480,320$ \\
724,467 \\
\end{tabular} & \begin{tabular}{|r|}
$1,166,508$ \\
126,008 \\
187,005 \\
$1,477,679$ \\
730,108
\end{tabular} & \begin{tabular}{|r|}
$1,178,577$ \\
125,556 \\
191,171 \\
$1,472,909$ \\
729,550
\end{tabular} & \begin{tabular}{|r|}
$1,185,684$ \\
125,910 \\
193,554 \\
$1,479,195$ \\
730,021 \\
\end{tabular} & \begin{tabular}{|r|}
$1,194,751$ \\
127,477 \\
194,728 \\
$1,463,713$ \\
730,599
\end{tabular} & $\begin{array}{r}1,202,479 \\
127,525 \\
194,144 \\
1,454,793 \\
729,414\end{array}$ & $\begin{array}{r}1,211,250 \\
131,005 \\
198,064 \\
1,453,156 \\
724,605\end{array}$ & $\begin{array}{r}3.8 \\
4.0 \\
5.9 \\
-1.7 \\
-0.8\end{array}$ & \begin{tabular}{|r|}
$1,217,300$ \\
131,500 \\
201,100 \\
$1,453,700$ \\
722,700
\end{tabular} & \begin{tabular}{|r|}
$1,221,500$ \\
13,400 \\
203,600 \\
$1,452,600$ \\
719,500
\end{tabular} & $\begin{array}{r}1,218,200 \\
130,600 \\
205,400 \\
1,443,300 \\
712,800\end{array}$ & \begin{tabular}{|r|}
$1,217,200$ \\
130,300 \\
206,900 \\
$1,434,200$ \\
704,200
\end{tabular} & $\begin{array}{r}1,266,700 \\
127,700 \\
215,500 \\
1,422,800 \\
702,600\end{array}$ & \begin{tabular}{|r|}
$1,308,600$ \\
126,600 \\
219,500 \\
$1,430,700$ \\
712,200 \\
\end{tabular} & $\begin{array}{r}8.0 \\
-3.4 \\
10.8 \\
-1.5 \\
-1.7\end{array}$ & \\
\hline 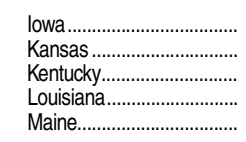 & $\begin{array}{l}344,804 \\
319,648 \\
459,200 \\
586,202 \\
155,203\end{array}$ & $\begin{array}{l}333,750 \\
323,107 \\
471,429 \\
546,579 \\
145,701\end{array}$ & $\begin{array}{l}329,649 \\
322,345 \\
473,491 \\
536,953 \\
143,855\end{array}$ & $\begin{array}{l}325,843 \\
321,795 \\
476,751 \\
536,882 \\
141,776\end{array}$ & $\begin{array}{l}326,831 \\
322,491 \\
478,254 \\
536,390 \\
139,420\end{array}$ & $\begin{array}{l}324,169 \\
321,176 \\
485,794 \\
533,751 \\
136,275\end{array}$ & $\begin{array}{l}326,160 \\
320,513 \\
487,429 \\
482,082 \\
133,491\end{array}$ & $\begin{array}{l}326,218 \\
326,201 \\
487,165 \\
492,116 \\
132,338\end{array}$ & $\begin{array}{l}329,504 \\
326,771 \\
469,373 \\
499,549 \\
130,742\end{array}$ & $\begin{array}{l}335,566 \\
331,079 \\
472,204 \\
504,213 \\
129,324\end{array}$ & $\begin{array}{l}341,333 \\
332,997 \\
484,466 \\
509,883 \\
128,646\end{array}$ & $\begin{array}{l}348,112 \\
342,927 \\
480,334 \\
512,266 \\
128,929\end{array}$ & $\begin{array}{l}350,152 \\
347,129 \\
488,456 \\
518,802 \\
130,046\end{array}$ & $\begin{array}{r}7.3 \\
6.4 \\
0.3 \\
5.4 \\
-1.7\end{array}$ & $\begin{array}{l}353,200 \\
349,000 \\
490,800 \\
524,400 \\
129,600\end{array}$ & $\begin{array}{l}354,800 \\
350,700 \\
490,500 \\
525,400 \\
129,600\end{array}$ & $\begin{array}{l}353,700 \\
350,000 \\
486,300 \\
519,500 \\
129,300\end{array}$ & $\begin{array}{l}353,500 \\
349,500 \\
481,900 \\
515,100 \\
129,100\end{array}$ & $\begin{array}{l}353,500 \\
351,700 \\
474,700 \\
502,000 \\
130,800\end{array}$ & $\begin{array}{l}349,100 \\
352,300 \\
474,200 \\
493,700 \\
130,600\end{array}$ & $\begin{array}{r}-0.3 \\
1.5 \\
-2.9 \\
-4.8 \\
0.4\end{array}$ & \\
\hline 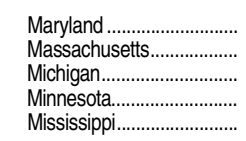 & $\begin{array}{r}526,744 \\
604,234 \\
1,144,878 \\
545,556 \\
371,641\end{array}$ & $\begin{array}{r}609,043 \\
702,575 \\
1,222,482 \\
577,766 \\
363,873\end{array}$ & $\begin{array}{r}610,858 \\
699,495 \\
1,222,763 \\
573,028 \\
361,615\end{array}$ & $\begin{array}{r}610,337 \\
701,050 \\
1,253,811 \\
567,701 \\
360,254\end{array}$ & $\begin{array}{r}605,862 \\
692,130 \\
1,229,121 \\
564,049 \\
360,881\end{array}$ & \begin{tabular}{|r|}
597,417 \\
682,175 \\
$1,211,698$ \\
558,447 \\
361,057
\end{tabular} & \begin{tabular}{|r|}
588,571 \\
675,398 \\
$1,191,397$ \\
557,757 \\
358,030 \\
\end{tabular} & $\begin{array}{r}579,065 \\
670,628 \\
1,170,558 \\
558,445 \\
356,382\end{array}$ & $\begin{array}{r}576,479 \\
666,926 \\
1,136,823 \\
558,180 \\
353,512\end{array}$ & \begin{tabular}{|r|}
576,473 \\
66,538 \\
$1,118,569$ \\
560,184 \\
351,807 \\
\end{tabular} & \begin{tabular}{|r|}
581,785 \\
666,551 \\
$1,114,611$ \\
564,661 \\
351,652
\end{tabular} & \begin{tabular}{|r|}
588,156 \\
666,402 \\
$1,075,584$ \\
569,963 \\
350,885 \\
\end{tabular} & $\begin{array}{r}594,216 \\
666,314 \\
1,070,873 \\
575,544 \\
352,999\end{array}$ & $\begin{array}{r}2.6 \\
-0.6 \\
-8.5 \\
3.1 \\
-0.9\end{array}$ & \begin{tabular}{|r|}
600,600 \\
$66,3,900$ \\
$1,06,000$ \\
583,000 \\
355,800 \\
\end{tabular} & \begin{tabular}{|r|}
608,600 \\
66,000 \\
$1,052,000$ \\
589,400 \\
354,500
\end{tabular} & $\begin{array}{r}613,200 \\
654,300 \\
1,039,300 \\
593,400 \\
350,200\end{array}$ & $\begin{array}{r}620,100 \\
648,700 \\
1,028,500 \\
597,300 \\
346,600\end{array}$ & $\begin{array}{r}663,300 \\
644,400 \\
1,024,100 \\
628,700 \\
334,400\end{array}$ & $\begin{array}{r}690,400 \\
655,600 \\
1,028,000 \\
649,700 \\
327,000\end{array}$ & $\begin{array}{r}16.2 \\
-1.6 \\
-4.0 \\
12.9 \\
-7.4\end{array}$ & \\
\hline 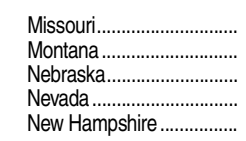 & $\begin{array}{l}588,070 \\
111,169 \\
198,080 \\
149,881 \\
126,301\end{array}$ & $\begin{array}{l}644,766 \\
105,226 \\
195,486 \\
250,720 \\
147,121\end{array}$ & $\begin{array}{l}642,492 \\
102,712 \\
194,653 \\
262,472 \\
144,487\end{array}$ & \begin{tabular}{|l}
634,667 \\
101,177 \\
195,113 \\
270,940 \\
143,616
\end{tabular} & $\begin{array}{l}632,227 \\
100,160 \\
195,417 \\
280,734 \\
142,031\end{array}$ & $\begin{array}{r}628,667 \\
98,673 \\
194,816 \\
288,753 \\
140,241\end{array}$ & $\begin{array}{r}635,142 \\
97,770 \\
195,055 \\
295,989 \\
138,584\end{array}$ & $\begin{array}{r}634,275 \\
97,021 \\
195,769 \\
302,953 \\
136,188\end{array}$ & $\begin{array}{r}631,746 \\
96,354 \\
200,095 \\
307,573 \\
134,359\end{array}$ & $\begin{array}{r}635,411 \\
96,869 \\
202,912 \\
308,328 \\
132,995\end{array}$ & $\begin{array}{r}638,082 \\
97,868 \\
206,860 \\
305,512 \\
132,768\end{array}$ & $\begin{array}{r}642,991 \\
98,491 \\
210,292 \\
307,297 \\
131,576\end{array}$ & $\begin{array}{r}645,376 \\
99,725 \\
213,504 \\
309,360 \\
129,632\end{array}$ & $\begin{array}{l}1.8 \\
2.8 \\
9.1 \\
2.1 \\
-4.8\end{array}$ & $\begin{array}{l}645,900 \\
100,900 \\
216,500 \\
312,500 \\
127,600\end{array}$ & $\begin{array}{l}647,100 \\
101,600 \\
218,700 \\
315,800 \\
126,500\end{array}$ & $\begin{array}{l}644,800 \\
102,000 \\
219,000 \\
318,700 \\
125,200\end{array}$ & $\begin{array}{l}643,700 \\
102,200 \\
21,300 \\
321,500 \\
124,400\end{array}$ & $\begin{array}{l}653,100 \\
103,100 \\
219,600 \\
358,900 \\
128,000\end{array}$ & $\begin{array}{l}657,300 \\
102,300 \\
21,200 \\
390,900 \\
132,900\end{array}$ & $\begin{array}{r}1.8 \\
2.6 \\
2.7 \\
26.4 \\
2.5\end{array}$ & 苋 \\
\hline 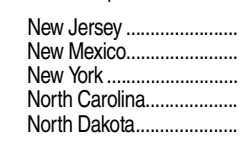 & $\begin{array}{r}783,422 \\
208,087 \\
1,827,418 \\
783,132 \\
84,943\end{array}$ & $\begin{array}{r}967,533 \\
224,89 \\
2,028,906 \\
945,470 \\
72,421\end{array}$ & \begin{tabular}{|r|}
971,774 \\
225,036 \\
$2,016,847$ \\
955,965 \\
70,454
\end{tabular} & $\begin{array}{r}978,609 \\
224,497 \\
2,016,282 \\
963,967 \\
69,089\end{array}$ & $\begin{array}{r}978,440 \\
226,032 \\
1,978,181 \\
974,019 \\
67,870\end{array}$ & \begin{tabular}{|r|}
975,856 \\
227,900 \\
$1,942,575$ \\
985,740 \\
67,122
\end{tabular} & $\begin{array}{r}970,592 \\
229,552 \\
1,90,028 \\
1,003,118 \\
65,638 \\
\end{array}$ & $\begin{array}{r}963,418 \\
230,091 \\
1,887,284 \\
1,027,067 \\
64,395\end{array}$ & $\begin{array}{r}954,418 \\
229,718 \\
1,856,315 \\
1,072,324 \\
63,492\end{array}$ & $\begin{array}{r}956,765 \\
231,415 \\
1,843,080 \\
1,058,926 \\
63,955\end{array}$ & $\begin{array}{r}968,332 \\
235,343 \\
1,847,003 \\
1,053,801 \\
64,576\end{array}$ & \begin{tabular}{|r|}
981,255 \\
239,345 \\
$1,869,150$ \\
$1,058,409$ \\
66,035
\end{tabular} & $\begin{array}{r}947,576 \\
239,481 \\
1,857,574 \\
1,074,063 \\
67,888\end{array}$ & \begin{tabular}{r|}
-1.6 \\
4.1 \\
-1.6 \\
4.6 \\
5.4
\end{tabular} & \begin{tabular}{|r|}
943,900 \\
240,800 \\
$1,86,1300$ \\
$1,080,300$ \\
69,400 \\
\end{tabular} & \begin{tabular}{|r|}
938,100 \\
241,700 \\
$1,86,100$ \\
$1,086,100$ \\
70,600
\end{tabular} & $\begin{array}{r}929,400 \\
241,300 \\
1,850,600 \\
1,085,700 \\
71,700\end{array}$ & $\begin{array}{r}921,200 \\
240,800 \\
1,842,700 \\
1,085,400 \\
72,500\end{array}$ & $\mid \begin{array}{r}915,800 \\
240,100 \\
1,835,100 \\
1,148,900 \\
74,200\end{array}$ & \begin{tabular}{|r|}
929,300 \\
237,300 \\
$1,847,300$ \\
$1,208,500$ \\
73,100 \\
\end{tabular} & $\begin{array}{r}-1.9 \\
-0.9 \\
-0.6 \\
12.5 \\
7.7\end{array}$ & $\mathrm{~m} \stackrel{\stackrel{\mathbb{D}}{\overrightarrow{0}}}{\stackrel{\overrightarrow{0}}{2}}$ \\
\hline 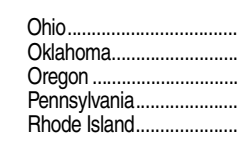 & $\begin{array}{r}1,257,580 \\
424,899 \\
340,243 \\
1,172,164 \\
101,797 \\
\end{array}$ & \begin{tabular}{|r|}
$1,293,646$ \\
445,402 \\
379,264 \\
$1,257,824$ \\
113,545
\end{tabular} & \begin{tabular}{|r|}
$1,286,632$ \\
445,989 \\
381,678 \\
$1,254,692$ \\
112,783
\end{tabular} & $\begin{array}{r}1,283,795 \\
449,030 \\
381,988 \\
1,241,636 \\
112,544\end{array}$ & $\begin{array}{r}1,278,202 \\
450,310 \\
378,052 \\
1,235,624 \\
111,209\end{array}$ & \begin{tabular}{|r|}
$1,267,088$ \\
452,942 \\
376,933 \\
$1,234,828$ \\
107,040
\end{tabular} & $\begin{array}{r}1,261,331 \\
456,954 \\
379,980 \\
1,227,625 \\
103,870\end{array}$ & \begin{tabular}{|r|}
$1,253,193$ \\
459,944 \\
380,576 \\
$1,220,074$ \\
101,996
\end{tabular} & $\begin{array}{r}1,241,322 \\
462,629 \\
383,598 \\
1,205,351 \\
99,159\end{array}$ & \begin{tabular}{|r|}
$1,239,494$ \\
467,960 \\
395,421 \\
$1,194,327$ \\
97,983
\end{tabular} & \begin{tabular}{|r|}
$1,225,346$ \\
476,962 \\
404,451 \\
$1,200,446$ \\
98,184
\end{tabular} & \begin{tabular}{|r|}
$1,222,808$ \\
483,464 \\
392,601 \\
$1,209,766$ \\
97,734
\end{tabular} & $\begin{array}{r}1,217,226 \\
490,196 \\
391,310 \\
1,204,850 \\
97,659\end{array}$ & $\begin{array}{r}-2.9 \\
6.6 \\
2.8 \\
-1.2 \\
-4.3\end{array}$ & \begin{tabular}{|r|}
$1,214,500$ \\
495,600 \\
393,200 \\
$1,205,800$ \\
96,100 \\
\end{tabular} & \begin{tabular}{|r|}
$1,210,500$ \\
497,700 \\
395,500 \\
$1,206,600$ \\
97,100
\end{tabular} & \begin{tabular}{|r|}
$1,199,800$ \\
495,900 \\
396,500 \\
$1,202,900$ \\
97,500
\end{tabular} & $\begin{array}{r}1,190,000 \\
494,900 \\
398,300 \\
1,201,000 \\
97,300\end{array}$ & \begin{tabular}{|r|}
$1,175,500$ \\
495,500 \\
423,500 \\
$1,219,100$ \\
99,900
\end{tabular} & \begin{tabular}{|r|}
$1,169,800$ \\
497,800 \\
442,200 \\
$1,230,500$ \\
102,200
\end{tabular} & $\begin{array}{r}-3.9 \\
1.6 \\
13.0 \\
\# \\
4.6\end{array}$ & 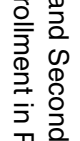 \\
\hline 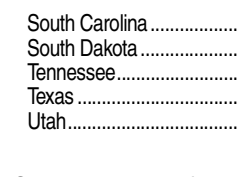 & $\begin{array}{r}452,033 \\
95,165 \\
598,111 \\
2,510,955 \\
324,982\end{array}$ & \begin{tabular}{|r|}
493,226 \\
87,838 \\
668,123 \\
$2,943,047$ \\
333,104
\end{tabular} & \begin{tabular}{|r|}
486,723 \\
86,982 \\
674,507 \\
$3,016,214$ \\
337,974
\end{tabular} & \begin{tabular}{|r}
500,427 \\
89,450 \\
673,337 \\
$3,079,665$ \\
342,607
\end{tabular} & $\begin{array}{r}500,743 \\
86,015 \\
675,277 \\
3,132,584 \\
348,840\end{array}$ & \begin{tabular}{|r|}
504,264 \\
83,891 \\
670,880 \\
$3,184,235$ \\
355,445
\end{tabular} & $\begin{array}{r}498,030 \\
83,530 \\
676,576 \\
3,268,339 \\
357,644\end{array}$ & \begin{tabular}{|r|}
501,273 \\
8,137 \\
691,971 \\
$3,319,782$ \\
371,272
\end{tabular} & $\begin{array}{r}504,566 \\
83,424 \\
681,751 \\
3,374,684 \\
410,258\end{array}$ & $\begin{array}{r}507,602 \\
87,477 \\
684,549 \\
3,446,511 \\
404,469\end{array}$ & \begin{tabular}{|r|}
512,124 \\
85,745 \\
686,668 \\
$3,520,348$ \\
413,343
\end{tabular} & $\mid \begin{array}{r}515,581 \\
87,936 \\
701,707 \\
3,586,609 \\
424,979\end{array}$ & $\begin{array}{r}519,389 \\
90,529 \\
712,749 \\
3,636,852 \\
434,536\end{array}$ & \begin{tabular}{r|}
3.6 \\
8.9 \\
3.0 \\
9.6 \\
17.0
\end{tabular} & \begin{tabular}{|r|}
527,100 \\
91,000 \\
718,900 \\
$3,686,800$ \\
444,100
\end{tabular} & \begin{tabular}{|r|}
530,300 \\
92,100 \\
722,500 \\
$3,729,600$ \\
451,200
\end{tabular} & $\begin{array}{r}529,400 \\
92,700 \\
721,900 \\
3,744,100 \\
455,000\end{array}$ & $\begin{array}{r}528,800 \\
93,400 \\
722,200 \\
3,763,300 \\
458,900\end{array}$ & \begin{tabular}{|r|}
540,100 \\
95,000 \\
748,000 \\
$3,946,000$ \\
478,500
\end{tabular} & \begin{tabular}{|r|}
546,900 \\
94,400 \\
770,600 \\
$4,077,700$ \\
493,900
\end{tabular} & $\begin{array}{r}5.3 \\
4.3 \\
8.1 \\
12.1 \\
13.7\end{array}$ & 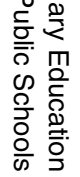 \\
\hline
\end{tabular}




\begin{tabular}{|c|c|c|c|c|c|c|c|c|c|c|c|c|c|c|c|c|c|c|c|c|c|}
\hline \multirow[b]{2}{*}{ Region, state, and jurisdiction } & \multicolumn{13}{|c|}{ Actual enrollment } & \multirow{2}{*}{$\begin{array}{r}\text { Percent } \\
\text { change in } \\
\text { enrollment, } \\
2006 \text { to } \\
2011\end{array}$} & \multicolumn{6}{|c|}{ Projected enrollment } & \multirow{2}{*}{ 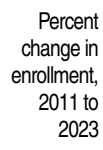 } \\
\hline & Fall 1990 & Fall 2000 & Fall 2001 & Fall 2002 & Fall 2003 & Fall 2004 & Fall 2005 & Fall 2006 & Fall 2007 & Fall 2008 & Fall 2009 & Fall 2010 & Fall 2011 & & Fall 2012 & Fall 2013 & Fall 2014 & Fall 2015 & Fall 2020 & Fall 2023 & \\
\hline 1 & 2 & 3 & 4 & 5 & 6 & 7 & 8 & 9 & 10 & 11 & 12 & 13 & 14 & 15 & 16 & 17 & 18 & 19 & 20 & 21 & 22 \\
\hline 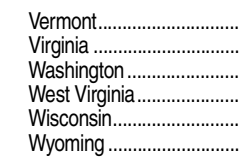 & $\begin{array}{r}70,860 \\
728,280 \\
612,597 \\
224,097 \\
565,457 \\
70,941 \\
\end{array}$ & \begin{tabular}{r|}
70,320 \\
815,748 \\
694,367 \\
201,201 \\
594,740 \\
60,148 \\
\end{tabular} & $\begin{array}{r}69,299 \\
826,184 \\
696,257 \\
199,806 \\
591,804 \\
59,093 \\
\end{array}$ & \begin{tabular}{r|}
68,034 \\
831,504 \\
697,191 \\
200,004 \\
591,703 \\
59,926 \\
\end{tabular} & \begin{tabular}{r|}
66,732 \\
837,258 \\
699,248 \\
198,836 \\
589,812 \\
59,759 \\
\end{tabular} & $\begin{array}{r}65,935 \\
839,687 \\
695,405 \\
197,555 \\
577,5050 \\
57,285 \\
\end{array}$ & \begin{tabular}{r|}
64,6662 \\
841,299 \\
699,482 \\
197,199 \\
583,998 \\
57,195 \\
\end{tabular} & $\begin{array}{r}63,740 \\
841,685 \\
694,858 \\
197,573 \\
584,600 \\
57,995 \\
\end{array}$ & \begin{tabular}{r|}
63,096 \\
850,444 \\
697,407 \\
198,545 \\
585,212 \\
59,243 \\
\end{tabular} & \begin{tabular}{r|}
62,994 \\
855,008 \\
704,794 \\
199,477 \\
589,528 \\
60,635 \\
\end{tabular} & $\begin{array}{r}62,186 \\
864,020 \\
705,387 \\
200,313 \\
593,436 \\
61,825 \\
\end{array}$ & \begin{tabular}{r|}
67,989 \\
871,46 \\
714,172 \\
201,472 \\
598,479 \\
62,786 \\
\end{tabular} & $\begin{array}{r}62,146 \\
881,225 \\
718,184 \\
202,065 \\
602,810 \\
64,057 \\
\end{array}$ & \begin{tabular}{r|r|}
-2.5 \\
4.7 \\
3.4 \\
2.3 \\
3.1 \\
10.5 \\
\end{tabular} & $\begin{array}{r}62,900 \\
888,100 \\
723,700 \\
202,300 \\
604,500 \\
65,700 \\
\end{array}$ & $\begin{array}{r}62,800 \\
894,600 \\
728,400 \\
201,200 \\
605,700 \\
66,700 \\
\end{array}$ & $\begin{array}{r}62,500 \\
895,700 \\
731,000 \\
198,100 \\
602,900 \\
67,100 \\
\end{array}$ & $\begin{array}{r}62,500 \\
898,400 \\
735,400 \\
195,400 \\
602,300 \\
67,600 \\
\end{array}$ & $\begin{array}{r}65,200 \\
938,400 \\
792,900 \\
183,300 \\
615,700 \\
66,500 \\
\end{array}$ & $\begin{array}{r}66,800 \\
970,700 \\
837,200 \\
176,600 \\
620,900 \\
63,900 \\
\end{array}$ & $\begin{array}{r}7.5 \\
10.2 \\
16.6 \\
-12.6 \\
3.0 \\
-0.2 \\
\end{array}$ \\
\hline 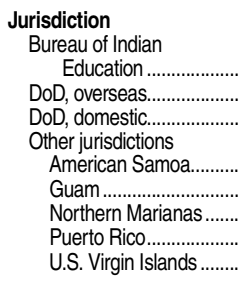 & $\begin{array}{r}9,390 \\
19,276 \\
4,918 \\
480,356 \\
16,249\end{array}$ & $\begin{array}{r}35,746 \\
59,299 \\
30,697 \\
11,895 \\
2,3998 \\
7,809 \\
445,524 \\
13,910\end{array}$ & $\begin{array}{r}35,021 \\
58,750 \\
29,389 \\
11,911 \\
23,133 \\
8,015 \\
438,15 \\
13,1421\end{array}$ & $\begin{array}{r}34,392 \\
58,214 \\
28,759 \\
11,838 \\
\overline{-1} \\
42979 \\
429,413 \\
12,933\end{array}$ & $\begin{array}{r}33,671 \\
56,226 \\
27,500 \\
11,772 \\
22,551 \\
8,192 \\
418,649 \\
12,738\end{array}$ & $\begin{array}{r}33,671 \\
53,720 \\
26,195 \\
11,873 \\
21,1,786 \\
8,416 \\
408,671 \\
11,650\end{array}$ & $\begin{array}{r}36,133 \\
48,691 \\
25,558 \\
11,766 \\
21,946 \\
8,427 \\
399,447 \\
11,728\end{array}$ & $\begin{array}{r}47,589 \\
24,052 \\
11,763 \\
\overline{8,504} \\
382,647 \\
11,237\end{array}$ & $\begin{array}{r}44,418 \\
24,807 \\
- \\
- \\
8,140 \\
372,514 \\
10,770\end{array}$ & $\begin{array}{r}30,612 \\
43,931 \\
25,255 \\
- \\
- \\
7,816 \\
355,115 \\
10,567\end{array}$ & $\begin{array}{r}- \\
7,743 \\
347,638 \\
10,409\end{array}$ & $\begin{array}{r}31,985 \\
- \\
- \\
- \\
21,561 \\
7,688 \\
334,613 \\
10,518\end{array}$ & $\begin{array}{r}- \\
- \\
- \\
- \\
21,223 \\
7,703 \\
318,924 \\
10,576\end{array}$ & $\begin{array}{r}- \\
- \\
- \\
- \\
-9.4 \\
-16.7 \\
-5.9\end{array}$ & $\begin{array}{l}- \\
- \\
- \\
- \\
- \\
- \\
-\end{array}$ & $\begin{array}{l}- \\
- \\
- \\
- \\
- \\
- \\
-\end{array}$ & $\begin{array}{l}- \\
- \\
- \\
- \\
- \\
= \\
-\end{array}$ & $\begin{array}{l}- \\
- \\
- \\
- \\
- \\
- \\
-\end{array}$ & $\begin{array}{l}- \\
- \\
- \\
- \\
= \\
- \\
-\end{array}$ & $\begin{array}{l}- \\
- \\
- \\
- \\
- \\
- \\
-\end{array}$ & $\begin{array}{l}- \\
= \\
- \\
z \\
z \\
z\end{array}$ \\
\hline
\end{tabular}

-Not available. \#Rounds to zero.
NOTE: DoD $=$ Depart

Defense. Detail may not sum to totals because of rounding. Some data have been revised from

SOURCE: U.S. Department of Education, National Center for Education Statistics, Common Core of Data (CCD), State Nonfiscal Survey of Public Elementary/Secondary Education, 1990-91 through 2011-12; and State Public Elementary and Sec-
ondary Enrollment Projection Model, 1980 through 2023. (This table was prepared January 2014.) 
Table 203.30. Public school enrollment in grades 9 through 12, by region, state, and jurisdiction: Selected years, fall 1990 through fall 2023

\begin{tabular}{|c|c|c|c|c|c|c|c|c|c|c|c|c|c|c|c|c|c|c|c|c|c|c|}
\hline \multirow[b]{2}{*}{ Region, state, and jurisdiction } & \multicolumn{13}{|c|}{ Actual enrollment } & \multirow{2}{*}{ 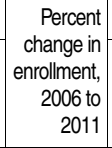 } & \multicolumn{6}{|c|}{ Projected enrollment } & \multirow{2}{*}{$\begin{array}{r}\text { Percent } \\
\text { change in } \\
\text { enrollment, } \\
2011 \text { to } \\
2023\end{array}$} & \\
\hline & Fall 1990 & Fall 2000 & Fall 2001 & Fall 2002 & Fall 2003 & Fall 2004 & Fall 2005 & Fall 2006 & Fall 2007 & Fall 2008 & Fall 2009 & Fall 2010 & Fall 2011 & & Fall 2012 & Fall 2013 & Fall 2014 & Fall 2015 & Fall 2020 & Fall 2023 & & \\
\hline 1 & 2 & 3 & 4 & 5 & 6 & 1 & 8 & 9 & 10 & 11 & 12 & 13 & 14 & 15 & 16 & 17 & 18 & 19 & 20 & 21 & 22 & \\
\hline United States....... & 340,769 & $13,517,118$ & $13,735,948$ & $14,068,841$ & $14,339,474$ & $14,617,900$ & $14,909,336$ & $15,081,091$ & $15,087,145$ & $14,980,008$ & 14,951,722 & $14,859,651$ & 14,748,918 & -2.2 & $14,684,200$ & $14,639,400$ & $14,689,000$ & $14,770,200$ & $|15,050,300|$ & $15,146,100$ & 2.7 & \\
\hline 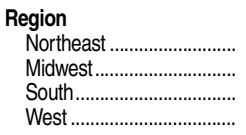 & $\begin{array}{l}2,092,968 \\
2,814,260 \\
3,948,216 \\
2,485,325\end{array}$ & \begin{tabular}{|l|}
$2,382,157$ \\
$3,206,741$ \\
$4,693,085$ \\
$3,235,135$
\end{tabular} & $\begin{array}{l}2,427,191 \\
3,228,078 \\
4,783,256 \\
3,297,423\end{array}$ & $\begin{array}{l}2,487,076 \\
3,284,350 \\
4,898,386 \\
3,399,029\end{array}$ & $\begin{array}{l}2,540,754 \\
3,307,398 \\
4,997,566 \\
3,493,756\end{array}$ & $\begin{array}{l}2,582,165 \\
3,336,735 \\
5,111,827 \\
3,587,173\end{array}$ & $\begin{array}{l}2,617,205 \\
3,393,507 \\
5,221,330 \\
3,677,294\end{array}$ & \begin{tabular}{|}
$2,684,160$ \\
$3,414,670$ \\
$5,303,937$ \\
$3,678,324$
\end{tabular} & \begin{tabular}{|l|}
$2,617,622$ \\
$3,411,184$ \\
$5,338,393$ \\
$3,719,944$
\end{tabular} & $\begin{array}{l}2,576,761 \\
3,369,582 \\
5,323,790 \\
3,709,875\end{array}$ & $\begin{array}{l}2,597,949 \\
3,310,212 \\
5,351,246 \\
3,692,315\end{array}$ & $\begin{array}{l}2,531,059 \\
3,260,270 \\
5,370,447 \\
3,697,875\end{array}$ & $\begin{array}{l}2,474,807 \\
3,215,000 \\
5,377,721 \\
3,681,390\end{array}$ & $\begin{array}{l}-7.8 \\
-5.8 \\
1.4 \\
0.1\end{array}$ & $\begin{array}{l}2,430,800 \\
3,193,000 \\
5,408,100 \\
3,652,300\end{array}$ & \begin{tabular}{|l|}
$2,392,800$ \\
$3,173,000$ \\
$5,440,400$ \\
$3,633,300$
\end{tabular} & $\begin{array}{l}2,376,600 \\
3,172,900 \\
5,508,600 \\
3,630,900\end{array}$ & $\begin{array}{l}2,370,400 \\
3,191,200 \\
5,580,900 \\
3,627,600\end{array}$ & $\begin{array}{l}2,356,800 \\
3,187,500 \\
5,747,400 \\
3,758,600\end{array}$ & \begin{tabular}{|l|}
$2,313,600$ \\
$3,158,800$ \\
$5,825,900$ \\
$3,847,800$
\end{tabular} & $\begin{array}{r}-6.5 \\
-1.7 \\
8.3 \\
4.5\end{array}$ & \\
\hline 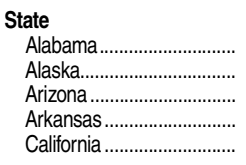 & $\begin{array}{r}194,709 \\
28,606 \\
160,807 \\
122,781 \\
1,336,740\end{array}$ & \begin{tabular}{|r|}
201,358 \\
38,914 \\
237,132 \\
131,936 \\
$1,733,779$
\end{tabular} & \begin{tabular}{|r|}
201,610 \\
39,461 \\
250,528 \\
131,882 \\
$1,769,400$
\end{tabular} & \begin{tabular}{|r|}
206,159 \\
39,984 \\
277,396 \\
132,159 \\
$1,828,282$
\end{tabular} & $\begin{array}{r}205,907 \\
40,238 \\
307,746 \\
133,015 \\
1,874,090\end{array}$ & $\begin{array}{r}208,383 \\
40,989 \\
321,095 \\
134,928 \\
1,934,202\end{array}$ & $\begin{array}{r}212,414 \\
42,063 \\
354,919 \\
138,40 \\
1,971,587\end{array}$ & \begin{tabular}{|r|}
214,968 \\
42,441 \\
308,593 \\
139,87 \\
$1,996,645$
\end{tabular} & $\begin{array}{r}217,606 \\
42,049 \\
316,391 \\
139,096 \\
2,014,503\end{array}$ & $\begin{array}{r} \\
217,590 \\
41,399 \\
316,068 \\
137,362 \\
2,016,270\end{array}$ & \begin{tabular}{|r|}
219,495 \\
40,837 \\
317,411 \\
136,350 \\
$1,999,416$
\end{tabular} & \begin{tabular}{|r|}
221,940 \\
40,114 \\
319,759 \\
136,306 \\
$1,995,610$
\end{tabular} & $\begin{array}{r}217,615 \\
39,110 \\
320,825 \\
137,092 \\
1,979,387\end{array}$ & $\begin{array}{r}1.2 \\
-7.8 \\
4.0 \\
-2.0 \\
-0.9\end{array}$ & $\begin{array}{r}215,800 \\
38,000 \\
315,500 \\
137,800 \\
1,954,400\end{array}$ & $\begin{array}{r}215,400 \\
38,000 \\
312,400 \\
139,000 \\
1,929,600\end{array}$ & $\begin{array}{r}216,000 \\
38,100 \\
312,100 \\
139,700 \\
1,912,600\end{array}$ & \begin{tabular}{|r|}
217,300 \\
38,300 \\
316,600 \\
140,500 \\
$1,886,600$
\end{tabular} & $\begin{array}{r}208,100 \\
40,200 \\
347,000 \\
141,700 \\
1,916,200\end{array}$ & \begin{tabular}{|r|}
206,100 \\
42,600 \\
358,800 \\
140,100 \\
$1,963,100$
\end{tabular} & $\begin{array}{r}-5.3 \\
8.9 \\
11.8 \\
2.2 \\
-0.8\end{array}$ & \\
\hline 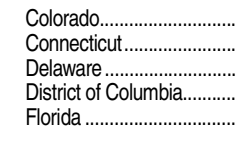 & $\begin{array}{r}154,303 \\
121,727 \\
27,052 \\
19,412 \\
491,658\end{array}$ & $\begin{array}{r}207,942 \\
155,734 \\
33,875 \\
15,233 \\
674,919\end{array}$ & $\begin{array}{r}212,989 \\
160,211 \\
34,281 \\
17,425 \\
703,064\end{array}$ & $\begin{array}{r}217,397 \\
164,025 \\
34,121 \\
17,364 \\
730,650\end{array}$ & $\begin{array}{r}221,368 \\
169,409 \\
34,770 \\
18,568 \\
755,252\end{array}$ & $\begin{array}{r}225,281 \\
173,221 \\
35,492 \\
19,56 \\
781,538\end{array}$ & \begin{tabular}{|r|}
229,951 \\
175,354 \\
36,298 \\
21,23 \\
801,629 \\
\end{tabular} & $\begin{array}{r}234,985 \\
177,037 \\
37,258 \\
20,459 \\
804,951\end{array}$ & $\begin{array}{r}236,141 \\
176,592 \\
37,555 \\
22,586 \\
810,952\end{array}$ & $\begin{array}{r}238,139 \\
174,980 \\
38,619 \\
17,902 \\
781,725\end{array}$ & $\begin{array}{r}240,990 \\
174,004 \\
39,091 \\
17,77 \\
783,621\end{array}$ & $\begin{array}{r}242,239 \\
173,071 \\
39,124 \\
17,736 \\
784,849\end{array}$ & $\begin{array}{r}243,411 \\
171,060 \\
38,322 \\
17,716 \\
792,054\end{array}$ & $\begin{array}{r}3.6 \\
-3.4 \\
2.9 \\
-13.4 \\
-1.6\end{array}$ & $\begin{array}{r}245,600 \\
168,700 \\
37,500 \\
17,400 \\
801,000\end{array}$ & $\begin{array}{r}248,100 \\
166,200 \\
37,100 \\
16,800 \\
805,400\end{array}$ & $\begin{array}{r}252,500 \\
164,100 \\
37,200 \\
16,700 \\
812,200\end{array}$ & $\begin{array}{r}258,000 \\
162,600 \\
37,700 \\
16,600 \\
817,500\end{array}$ & $\begin{array}{r}278,600 \\
155,100 \\
40,700 \\
16,500 \\
835,000\end{array}$ & $\begin{array}{r}280,200 \\
151,300 \\
41,400 \\
16,800 \\
865,300\end{array}$ & $\begin{array}{r}15.1 \\
-11.6 \\
8.0 \\
-5.2 \\
9.2\end{array}$ & \\
\hline 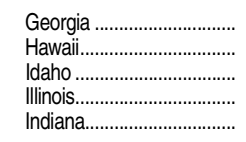 & $\begin{array}{r}302,605 \\
48,868 \\
60,749 \\
511,891 \\
278,721\end{array}$ & $\begin{array}{r}384,954 \\
52,067 \\
74,696 \\
574,859 \\
286,006\end{array}$ & $\begin{array}{r}395,439 \\
52,665 \\
75,098 \\
587,190 \\
284,678\end{array}$ & $\begin{array}{r}407,451 \\
52,967 \\
75,355 \\
596,537 \\
289,872\end{array}$ & $\begin{array}{r}419,430 \\
53,555 \\
76,696 \\
608,236 \\
294,311\end{array}$ & $\begin{array}{r}435,058 \\
54,397 \\
77,863 \\
613,859 \\
301,342\end{array}$ & \begin{tabular}{|r|}
453,015 \\
55,346 \\
79,153 \\
631,36 \\
310,607
\end{tabular} & $\begin{array}{r}462,649 \\
54,720 \\
80,375 \\
640,597 \\
315,832\end{array}$ & $\begin{array}{r}471,012 \\
54,341 \\
80,948 \\
639,896 \\
317,216\end{array}$ & $\begin{array}{r}470,108 \\
5,3568 \\
81,497 \\
640,512 \\
316,126\end{array}$ & $\begin{array}{r}472,934 \\
52,719 \\
81,571 \\
640,462 \\
316,062\end{array}$ & $\begin{array}{r}474,588 \\
52,076 \\
81,715 \\
636,861 \\
317,818\end{array}$ & $\begin{array}{r}473,766 \\
51,701 \\
81,809 \\
629,941 \\
316,160\end{array}$ & $\begin{array}{r}2.4 \\
-5.5 \\
1.8 \\
-1.7 \\
0.1\end{array}$ & $\begin{array}{r}478,400 \\
51,100 \\
82,000 \\
630,400 \\
315,300\end{array}$ & $\begin{array}{r}483,100 \\
51,100 \\
83,000 \\
624,900 \\
314,000\end{array}$ & $\begin{array}{r}489,300 \\
51,400 \\
83,900 \\
626,300 \\
312,500\end{array}$ & $\begin{array}{r}495,000 \\
51,100 \\
85,600 \\
633,200 \\
314,800\end{array}$ & $\begin{array}{r}493,800 \\
52,900 \\
92,400 \\
638,800 \\
302,500\end{array}$ & $\begin{array}{r}501,100 \\
51,400 \\
94,500 \\
622,300 \\
297,300\end{array}$ & $\begin{array}{r}5.8 \\
-0.6 \\
15.5 \\
-1.2 \\
-6.0\end{array}$ & \\
\hline lowa .................................... & $\begin{array}{r}138,848 \\
117,386 \\
177,201 \\
198,555 \\
59,946\end{array}$ & \begin{tabular}{|r|}
161,330 \\
147,453 \\
194,421 \\
196,510 \\
61,336
\end{tabular} & $\begin{array}{r}156,283 \\
147,80 \\
180,872 \\
194,375 \\
61,731\end{array}$ & $\begin{array}{r}156,367 \\
149,162 \\
184,031 \\
193,582 \\
62,561\end{array}$ & $\begin{array}{r}154,395 \\
147,999 \\
185,115 \\
191,319 \\
62,664\end{array}$ & $\begin{array}{r}154,150 \\
147,900 \\
189,002 \\
190,530 \\
62,545\end{array}$ & $\begin{array}{r}157,322 \\
147,012 \\
192,449 \\
172,444 \\
62,007\end{array}$ & $\begin{array}{r}156,904 \\
143,305 \\
195,987 \\
183,735 \\
61,648\end{array}$ & $\begin{array}{r}155,611 \\
141,524 \\
196,852 \\
181,489 \\
65,503\end{array}$ & $\begin{array}{r}151,993 \\
139,981 \\
197,826 \\
180,660 \\
63,611\end{array}$ & $\begin{array}{r}150,509 \\
141,492 \\
195,623 \\
181,032 \\
60,579\end{array}$ & $\begin{array}{r}147,663 \\
140,774 \\
192,794 \\
184,292 \\
60,148\end{array}$ & $\begin{array}{r}145,718 \\
138,979 \\
193,531 \\
184,588 \\
58,923\end{array}$ & $\begin{array}{r}-7.1 \\
-3.0 \\
-1.3 \\
0.5 \\
-4.4\end{array}$ & $\begin{array}{r}144,800 \\
139,000 \\
192,500 \\
186,100 \\
58,000\end{array}$ & $\begin{array}{r}144,700 \\
139,100 \\
191,800 \\
186,600 \\
57,300\end{array}$ & $\begin{array}{r}145,400 \\
140,200 \\
193,800 \\
190,200 \\
56,900\end{array}$ & $\begin{array}{r}145,900 \\
142,100 \\
197,200 \\
194,100 \\
56,800\end{array}$ & $\begin{array}{r}150,600 \\
147,100 \\
197,900 \\
195,900 \\
56,500\end{array}$ & $\begin{array}{r}152,400 \\
147,000 \\
194,400 \\
192,600 \\
56,600\end{array}$ & $\begin{array}{r}4.6 \\
5.8 \\
0.4 \\
4.3 \\
-3.9\end{array}$ & \\
\hline 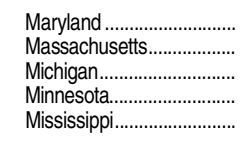 & $\begin{array}{l}188,432 \\
230,080 \\
439,553 \\
210,818 \\
130,776\end{array}$ & $\begin{array}{l}243,877 \\
272,575 \\
498,144 \\
276,574 \\
133,998\end{array}$ & $\begin{array}{l}249,782 \\
27,3644 \\
507,906 \\
278,356 \\
131,892\end{array}$ & $\begin{array}{l}256,406 \\
281,939 \\
531,349 \\
279,190 \\
132,391\end{array}$ & \begin{tabular}{|l}
263,251 \\
288,329 \\
528,483 \\
278,805 \\
132,659
\end{tabular} & $\begin{array}{l}268,144 \\
293,399 \\
539,592 \\
280,056 \\
134,319\end{array}$ & \begin{tabular}{|l|}
271,449 \\
296,511 \\
550,885 \\
281,486 \\
136,924
\end{tabular} & $\begin{array}{l}272,575 \\
298,033 \\
552,098 \\
282,120 \\
138,644\end{array}$ & $\begin{array}{l}269,221 \\
296,032 \\
555,916 \\
279,398 \\
140,610\end{array}$ & $\begin{array}{l}267,388 \\
292,372 \\
541,352 \\
275,864 \\
140,155\end{array}$ & $\begin{array}{l}266,627 \\
290,502 \\
534,471 \\
272,392 \\
140,829\end{array}$ & $\begin{array}{l}264,055 \\
289,161 \\
511,483 \\
268,074 \\
139,641\end{array}$ & $\begin{array}{l}259,870 \\
287,055 \\
502,664 \\
264,194 \\
137,620\end{array}$ & $\begin{array}{l}-4.7 \\
-3.7 \\
-9.0 \\
-6.4 \\
-0.7\end{array}$ & $\begin{array}{l}257,000 \\
286,400 \\
495,500 \\
262,400 \\
135,900\end{array}$ & $\begin{array}{l}253,700 \\
284,500 \\
489,400 \\
261,400 \\
134,900\end{array}$ & $\begin{array}{l}253,400 \\
283,800 \\
484,800 \\
263,200 \\
136,000\end{array}$ & $\begin{array}{l}252,900 \\
283,900 \\
484,100 \\
265,900 \\
136,300\end{array}$ & $\begin{array}{l}270,800 \\
278,900 \\
455,100 \\
284,900 \\
133,800\end{array}$ & $\begin{array}{l}278,600 \\
270,500 \\
445,200 \\
288,000 \\
131,600\end{array}$ & $\begin{array}{r}7.2 \\
-5.8 \\
-11.4 \\
9.0 \\
-4.4\end{array}$ & \\
\hline 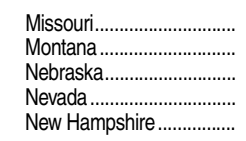 & $\begin{array}{r}228,488 \\
41,805 \\
76,001 \\
51,435 \\
46,484\end{array}$ & $\begin{array}{r}267,978 \\
49,649 \\
90,713 \\
89,986 \\
61,340\end{array}$ & $\begin{array}{r}267,300 \\
49,226 \\
90,442 \\
94,342 \\
62,360\end{array}$ & $\begin{array}{r}271,832 \\
48,818 \\
90,289 \\
98,558 \\
64,055\end{array}$ & $\begin{array}{r}273,714 \\
48,196 \\
90,125 \\
104,667 \\
65,386\end{array}$ & $\begin{array}{r}276,782 \\
48,032 \\
90,945 \\
111,330 \\
66,611\end{array}$ & \begin{tabular}{|r|}
282,5663 \\
47,646 \\
91,591 \\
116,406 \\
67,183
\end{tabular} & $\begin{array}{r}286,078 \\
47,397 \\
91,811 \\
121,813 \\
67,384\end{array}$ & $\begin{array}{r}285,442 \\
46,469 \\
91,149 \\
121,789 \\
66,413\end{array}$ & $\begin{array}{r}282,460 \\
45,030 \\
89,678 \\
125,043 \\
64,939\end{array}$ & $\begin{array}{r}279,900 \\
43,939 \\
88,508 \\
123,435 \\
64,372\end{array}$ & $\begin{array}{r}275,719 \\
43,202 \\
88,208 \\
129,852 \\
63,135\end{array}$ & $\begin{array}{r}271,208 \\
42,624 \\
87,792 \\
130,274 \\
62,268\end{array}$ & $\begin{array}{r}-5.2 \\
-10.1 \\
-4.4 \\
6.9 \\
-7.6\end{array}$ & $\begin{array}{r}270,500 \\
42,200 \\
87,600 \\
129,800 \\
61,400\end{array}$ & $\begin{array}{r}269,500 \\
42,200 \\
87,500 \\
130,200 \\
60,300\end{array}$ & $\begin{array}{r}269,600 \\
41,900 \\
88,000 \\
131,300 \\
59,400\end{array}$ & $\begin{array}{r}270,100 \\
42,100 \\
89,400 \\
133,400 \\
58,200\end{array}$ & $\begin{array}{r}270,400 \\
44,000 \\
97,100 \\
137,700 \\
54,400\end{array}$ & $\begin{array}{r}272,700 \\
44,500 \\
97,200 \\
143,800 \\
53,500\end{array}$ & $\begin{array}{r}0.6 \\
4.4 \\
10.7 \\
10.4 \\
-14.1\end{array}$ & \\
\hline 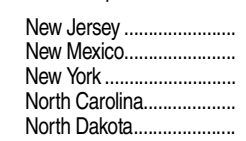 & $\begin{array}{r}306,224 \\
93,794 \\
770,919 \\
303,739 \\
32,882\end{array}$ & \begin{tabular}{|r}
345,872 \\
95,427 \\
853,282 \\
348,168 \\
36,780 \\
\end{tabular} & $\begin{array}{r}369,882 \\
95,224 \\
855,285 \\
359,398 \\
35,593\end{array}$ & $\begin{array}{r}388,829 \\
95,737 \\
871,951 \\
371,987 \\
35,136\end{array}$ & $\begin{array}{r}402,313 \\
97,034 \\
886,594 \\
386,190 \\
34,363\end{array}$ & $\begin{array}{r}417,491 \\
98,202 \\
89,762 \\
400,014 \\
33,391\end{array}$ & $\begin{array}{r}425,010 \\
97,206 \\
906,553 \\
413,318 \\
32,645\end{array}$ & $\begin{array}{r}425,432 \\
98,129 \\
922,365 \\
417,414 \\
32,275\end{array}$ & $\begin{array}{r}427,930 \\
99,322 \\
909,120 \\
417,168 \\
31,567\end{array}$ & $\begin{array}{r}424,655 \\
98,830 \\
897,512 \\
429,719 \\
30,773\end{array}$ & $\begin{array}{r}427,697 \\
99,076 \\
919,049 \\
429,596 \\
30,497\end{array}$ & $\begin{array}{r}421,293 \\
98,777 \\
865,805 \\
432,196 \\
30,288\end{array}$ & $\begin{array}{r}408,855 \\
97,74 \\
847,144 \\
433,801 \\
29,758\end{array}$ & $\begin{array}{r}-3.9 \\
-0.4 \\
-8.2 \\
3.9 \\
-7.8\end{array}$ & $\begin{array}{r}402,400 \\
97,000 \\
829,800 \\
435,400 \\
29,700\end{array}$ & $\begin{array}{r}396,400 \\
97,700 \\
814,400 \\
438,800 \\
29,600\end{array}$ & $\begin{array}{r}391,800 \\
98,900 \\
811,800 \\
444,600 \\
29,300\end{array}$ & $\begin{array}{r}389,000 \\
99,900 \\
812,000 \\
452,500 \\
29,500\end{array}$ & $\begin{array}{r}380,100 \\
102,900 \\
822,700 \\
453,200 \\
33,300\end{array}$ & $\begin{array}{r}368,000 \\
102,300 \\
805,300 \\
463,900 \\
34,700\end{array}$ & $\begin{array}{r}-10.0 \\
4.7 \\
-4.9 \\
6.9 \\
16.6\end{array}$ & m $\stackrel{\overrightarrow{\underline{D}}}{2}$ \\
\hline 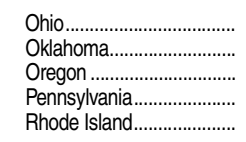 & $\begin{array}{r}513,509 \\
154,188 \\
132,151 \\
495,670 \\
37,016\end{array}$ & \begin{tabular}{|r|}
541,403 \\
177,708 \\
166,967 \\
556,487 \\
43,802
\end{tabular} & $\begin{array}{r}544,353 \\
176,150 \\
169,802 \\
566,935 \\
45,263\end{array}$ & $\begin{array}{r}554,490 \\
175,518 \\
172,083 \\
575,111 \\
46,661\end{array}$ & $\begin{array}{r}567,226 \\
175,850 \\
173,221 \\
585,522 \\
48,166\end{array}$ & $\begin{array}{r}572,944 \\
176,534 \\
175,572 \\
593,261 \\
49,458\end{array}$ & $\begin{array}{r}578,352 \\
177,785 \\
172,514 \\
603,059 \\
49,552\end{array}$ & $\begin{array}{r}583,529 \\
179,447 \\
181,998 \\
650,986 \\
49,616\end{array}$ & $\begin{array}{r}585,862 \\
179,436 \\
181,988 \\
596,620 \\
48,470\end{array}$ & $\begin{array}{r}577,669 \\
177,148 \\
179,972 \\
580,702 \\
47,359\end{array}$ & $\begin{array}{r}538,951 \\
177,840 \\
178,388 \\
585,547 \\
46,934\end{array}$ & $\begin{array}{r}531,383 \\
176,447 \\
178,119 \\
583,518 \\
46,059\end{array}$ & $\begin{array}{r}522,804 \\
175,924 \\
176,898 \\
566,545 \\
45,195\end{array}$ & $\begin{array}{r}-10.4 \\
-2.0 \\
-2.8 \\
-13.0 \\
-8.9\end{array}$ & $\begin{array}{r}515,800 \\
177,300 \\
176,700 \\
552,700 \\
44,500\end{array}$ & $\begin{array}{r}512,200 \\
179,300 \\
177,000 \\
545,000 \\
42,500\end{array}$ & $\begin{array}{r}512,300 \\
182,000 \\
177,300 \\
541,700 \\
41,400\end{array}$ & $\begin{array}{r}514,200 \\
184,700 \\
178,200 \\
541,000 \\
41,500\end{array}$ & $\begin{array}{r}501,600 \\
193,500 \\
180,100 \\
542,000 \\
42,500\end{array}$ & $\begin{array}{r}494,300 \\
192,400 \\
184,700 \\
541,600 \\
42,500\end{array}$ & $\begin{array}{r}-5.5 \\
9.4 \\
4.4 \\
-4.4 \\
-6.0\end{array}$ & 垔 \\
\hline 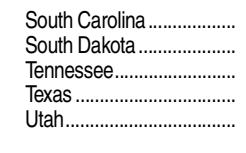 & $\begin{array}{r}170,079 \\
33,999 \\
226,484 \\
871,932 \\
121,670\end{array}$ & \begin{tabular}{|r|}
184,185 \\
40,765 \\
241,038 \\
$1,116,572$ \\
148,381
\end{tabular} & $\begin{array}{r}189,475 \\
40,560 \\
250,392 \\
1,147,233 \\
146,710\end{array}$ & $\begin{array}{r}193,962 \\
40,598 \\
254,271 \\
1,180,158 \\
146,655\end{array}$ & $\begin{array}{r}198,455 \\
39,522 \\
261,405 \\
1,199,167 \\
147,141\end{array}$ & $\begin{array}{r}199,472 \\
38,907 \\
270,211 \\
1,220,980 \\
148,162\end{array}$ & \begin{tabular}{|r|}
203,514 \\
38,482 \\
277,352 \\
$1,257,055$ \\
150,786
\end{tabular} \mid & \begin{tabular}{|r|}
206,748 \\
38,021 \\
286,397 \\
$1,279,727$ \\
152,114
\end{tabular} & $\begin{array}{r}207,751 \\
38,182 \\
282,508 \\
1,300,148 \\
165,986\end{array}$ & $\begin{array}{r}210,511 \\
38,952 \\
287,401 \\
1,305,637 \\
155,309\end{array}$ & $\begin{array}{r}211,019 \\
37,968 \\
285,881 \\
1,329,862 \\
158,243\end{array}$ & \begin{tabular}{|r|}
210,257 \\
38,192 \\
285,715 \\
$1,349,106$ \\
160,573
\end{tabular} & $\begin{array}{r}207,797 \\
37,487 \\
286,944 \\
1,363,618 \\
164,296\end{array}$ & $\begin{array}{r}0.5 \\
-1.4 \\
0.2 \\
6.6 \\
8.0\end{array}$ & $\begin{array}{r}207,600 \\
37,200 \\
287,600 \\
1,385,400 \\
168,400\end{array}$ & $\begin{array}{r}208,500 \\
37,200 \\
290,100 \\
1,405,900 \\
173,500\end{array}$ & $\mid \begin{array}{r}211,500 \\
37,300 \\
294,800 \\
1,434,300 \\
179,500\end{array}$ & \begin{tabular}{|r|}
215,600 \\
37,200 \\
299,200 \\
$1,463,000$ \\
184,600
\end{tabular} & $\begin{array}{r}221,000 \\
40,500 \\
306,200 \\
1,565,100 \\
205,200\end{array}$ & $\begin{array}{r}223,700 \\
41,500 \\
310,500 \\
1,591,300 \\
210,700\end{array}$ & $\begin{array}{r}7.7 \\
10.7 \\
8.2 \\
16.7 \\
28.2\end{array}$ & 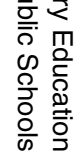 \\
\hline
\end{tabular}




\begin{tabular}{|c|c|c|c|c|c|c|c|c|c|c|c|c|c|c|c|c|c|c|c|c|c|}
\hline \multirow[b]{2}{*}{ Region, state, and jurisdiction } & \multicolumn{13}{|c|}{ Actual enrollment } & \multirow{2}{*}{$\begin{array}{r}\text { Percent } \\
\text { change in } \\
\text { enrollment, } \\
2006 \text { to } \\
2011\end{array}$} & \multicolumn{6}{|c|}{ Projected enrollment } & \multirow{2}{*}{$\begin{array}{r}\text { Percent } \\
\text { change in } \\
\text { enrollment, } \\
2011 \text { to } \\
2023\end{array}$} \\
\hline & Fall 1990 & Fall 2000 & Fall 2001 & Fall 2002 & Fall 2003 & Fall 2004 & Fall 2005 & Fall 2006 & Fall 2007 & Fall 2008 & Fall 2009 & Fall 2010 & Fall 2011 & & Fall 2012 & Fall 2013 & Fall 2014 & Fall 2015 & Fall 2020 & Fall 2023 & \\
\hline 1 & 2 & 3 & 4 & 5 & 6 & 7 & 8 & 9 & 10 & 11 & 12 & 13 & 14 & 15 & 16 & 17 & 18 & 19 & 20 & 21 & 22 \\
\hline Vermont... & 24,902 & 31,729 & 31,880 & 31,944 & 32,371 & 32,417 & 31,976 & 31,659 & 30,942 & 30,631 & 29,265 & 28,869 & 27,762 & -12.3 & 26,900 & 26,200 & 25,700 & 25,300 & 24,600 & 24,400 & -12.1 \\
\hline Virginia .... & 270,321 & 329,167 & 336,907 & 345,725 & 354,834 & 365,052 & 372,317 & 378,755 & 380,413 & 380,787 & 381,320 & 379,994 & 376,658 & -0.6 & 375,100 & 374,500 & 377,000 & 380,800 & 394,600 & 399,600 & 6.1 \\
\hline Washington..... & 227,112 & 310,403 & 312,943 & 317,607 & 322,101 & 324,600 & 332,503 & 331,916 & 332,840 & 332,224 & 329,960 & 329,616 & 327,269 & -1.4 & 325,500 & 324,000 & 324,500 & 325,900 & 331,300 & 340,200 & 4.0 \\
\hline West Virginia.... & 98,292 & 85,166 & 83,079 & 82,451 & 82,379 & 82,574 & 83,677 & $\begin{array}{r}84,366 \\
\end{array}$ & 83,990 & 83,252 & 82,349 & 81,407 & 80,805 & -4.2 & 80,300 & 79,600 & 80,000 & 80,000 & 79,400 & 76,500 & -5.3 \\
\hline Wisconsin........ & 232,164 & 284,736 & 287,557 & 289,528 & 290,219 & 286,807 & 291,176 & 292,100 & 289,421 & 284,222 & 279,000 & 273,807 & 268,295 & -8.1 & 264,800 & 263,600 & 264,100 & 264,800 & 265,700 & 266,100 & -0.8 \\
\hline Wyoming ... & 27,285 & 29,792 & 29,035 & 28,190 & 27,703 & 27,448 & 27,214 & 27,198 & 27,179 & 26,526 & 26,330 & 26,223 & 26,042 & -4.3 & 26,200 & 26,500 & 26,900 & 27,200 & 30,400 & 31,000 & 19.0 \\
\hline \multicolumn{22}{|l|}{$\begin{array}{l}\text { Jurisdiction } \\
\text { Bureau of Indian }\end{array}$} \\
\hline $\begin{array}{l}\text { Bureau of Indian } \\
\text { Education .... }\end{array}$ & - & & & & 12,157 & 12,157 & 14,805 & & & 10,315 & 9,970 & 9,977 & - & - & - & - & - & - & - & & - \\
\hline DoD, overseas...... & - & 14,282 & 14,462 & 14,675 & 14,827 & 14,607 & 13,852 & 13,302 & 12,829 & 12,837 & 年, & - & - & - & - & - & - & - & - & - & $=$ \\
\hline DoD, domes & - & 3,477 & 3,458 & 3,356 & 3,103 & 2,956 & 2,771 & 2,579 & 2,741 & 2,758 & - & - & - & - & - & - & - & - & - & - & - \\
\hline $\begin{array}{l}\text { Other jurisdictic } \\
\text { American Sa }\end{array}$ & 3,073 & 3,807 & 3,986 & 4,146 & 4,121 & 4,253 & 4,672 & 4637 & - & - & - & - & - & - & - & - & - & - & -1 & - & - \\
\hline $\begin{array}{l}\text { American samoa... } \\
\text { Guam...................... }\end{array}$ & 7,115 & $\begin{array}{l}8,775 \\
8,70\end{array}$ & $\begin{array}{l}3,880 \\
8,859\end{array}$ & 4,146 & $\begin{array}{l}4,121 \\
9,021\end{array}$ & $\begin{array}{l}4,533 \\
8,919\end{array}$ & $\begin{array}{l}4,6 / 2 \\
9,040\end{array}$ & 4,037 & - & - & 二 & 10,057 & 10,020 & - & - & - & - & - & - & - & - \\
\hline Northern Marianas & 1,531 & 2,195 & 2,464 & 2,872 & 3,052 & 3,185 & 3,291 & 3,191 & 3,159 & 3,097 & 3,218 & 3,417 & 3,308 & 3.7 & - & - & - & - & - & - & - \\
\hline Puerto Ricc & 164,378 & 167,201 & 166,062 & 167,089 & 166,267 & 166,977 & 164,043 & 161,491 & 154,051 & 148,520 & 145,755 & 139,122 & 133,816 & -17.1 & - & - & - & - & - & - & - \\
\hline U.S. Virgin Islands ..... & 5,501 & 5,549 & 5,359 & 5,400 & 4,978 & 4,779 & 5,022 & 5,047 & 5,133 & 5,201 & 5,084 & 4,977 & 5,135 & 1.7 & - & - & - & - & - & - & - \\
\hline
\end{tabular}

NOTE: DoD = Department of Defense. Detail may not sum to totals because of rounding. Some data have been revised from previously published figures.
SOURCE: U.S. Department of Education, National Center for Education Statistics, Common Core of Data (CCD), "State Nonfiscal Survey of Public Elementary/Secondary Education," 1990-91 through 2011-12; and State Put
ondary Enrollment Projection Model, 1980 through 2023. (This table was prepared January 2014.) 
Table 203.40. Enrollment in public elementary and secondary schools, by level, grade, and state or jurisdiction: Fall 2011

\begin{tabular}{|c|c|c|c|c|c|c|c|c|c|c|c|c|c|c|c|c|c|c|c|}
\hline \multirow[b]{2}{*}{ State or jurisdiction } & \multirow[b]{2}{*}{$\begin{array}{r}\text { Total, } \\
\text { all grades }\end{array}$} & \multicolumn{12}{|c|}{ Elementary } & \multicolumn{6}{|c|}{ Secondary } \\
\hline & & Total & \begin{tabular}{r|}
$\begin{array}{r}\text { Prekinder- } \\
\text { garten }\end{array}$ \\
\end{tabular} & $\begin{array}{r}\text { Kinder- } \\
\text { garten }\end{array}$ & Grade 1 & Grade 2 & Grade 3 & Grade 4 & Grade 5 & Grade 6 & Grade 7 & Grade 8 & $\begin{array}{r}\text { Elementary } \\
\text { ungraded }\end{array}$ & Total & Grade 9 & Grade 10 & Grade 11 & Grade 12 & $\begin{array}{r}\begin{array}{r}\text { Secondary } \\
\text { ungraded }\end{array} \\
\text {. }\end{array}$ \\
\hline 1 & 2 & 3 & 4 & 5 & 6 & 7 & 8 & 9 & 10 & 11 & 12 & 13 & 14 & 15 & 16 & 17 & 18 & 19 & 20 \\
\hline United States ....... & \begin{tabular}{|l|}
$49,521,669$ \\
\end{tabular} & \begin{tabular}{|l|}
$44,772,751$ \\
\end{tabular} & \begin{tabular}{|l|}
$1,290,977$ \\
\end{tabular} & \begin{tabular}{|l|}
$3,746,415$ \\
\end{tabular} & $3,772,639$ & $3,713,225$ & \begin{tabular}{|l|}
$3,703,314$ \\
\end{tabular} & $3,671,865$ & $3,699,119$ & \begin{tabular}{|l|}
$3,723,575$ \\
\end{tabular} & $3,695,995$ & $3,679,111$ & 76,516 & \begin{tabular}{|l|}
$14,748,918$ \\
\end{tabular} & \begin{tabular}{|l|}
$3,956,990$ \\
\end{tabular} & $3,751,378$ & \begin{tabular}{|l|}
$3,545,841$ \\
\end{tabular} & $3,451,876$ & 42,833 \\
\hline Alabama .......................... & 744,621 & 527,006 & 8,282 & 57,602 & 57,859 & 56,315 & 55,991 & 56,491 & 58,415 & 59,082 & 59,050 & 57,919 & 0 & 217,615 & 61,412 & 55,908 & 50,785 & 49,510 & 0 \\
\hline Alaska............... & 131,167 & 92,057 & 2,755 & 10,453 & 10,143 & 9,961 & 9,835 & 9,667 & 9,891 & 9,901 & 9,924 & 9,527 & 0 & 39,110 & 9,833 & 9,546 & 9,813 & 9,918 & 0 \\
\hline Arizona …………………....... & $1,080,319$ & 759,494 & 8,860 & 84,433 & 85,535 & 83,843 & 83,546 & 82,566 & 83,185 & 83,150 & 82,879 & 81,294 & 203 & 320,825 & 82,089 & 80,788 & 76,751 & 81,179 & 18 \\
\hline Arkansas......................... & 483,114 & 346,022 & 14,466 & 37,305 & 37,491 & 36,702 & 36,452 & 36,662 & 36,856 & 36,592 & 36,832 & 36,339 & 325 & 137,092 & 38,078 & 35,729 & 32,711 & 30,441 & 133 \\
\hline California & $6,287,834$ & $4,308,447$ & 73,630 & 488,070 & 489,961 & 471,993 & 467,539 & 462,082 & 452,305 & 466,942 & 464,260 & 467,626 & 4,039 & $1,979,387$ & 501,073 & 494,739 & 487,113 & 494,144 & 2,318 \\
\hline Colorado ........... & 854,265 & 610,854 & 31,091 & 66,361 & 66,398 & 65,598 & 65,956 & 64,560 & 64,089 & 63,492 & 62,153 & 61,156 & 0 & 243,411 & 62,358 & 60,662 & 58,993 & 61,398 & 0 \\
\hline Connecticut...................... & 554,437 & 383,377 & 16,022 & 38,840 & 40,396 & 40,051 & 40,946 & 40,138 & 41,078 & 41,431 & 41,964 & 42,511 & 0 & 171,060 & 45,140 & 43,145 & 42,098 & 40,677 & 0 \\
\hline 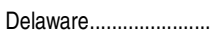 & 128,946 & 90,624 & 1,402 & 10,116 & 10,220 & 9,943 & 10,138 & 9,691 & 9,900 & 9,887 & 9,758 & 9,569 & 0 & 38,322 & 11,168 & 9,809 & 8,775 & 8,570 & 0 \\
\hline District of Columbia ..... & 73,911 & 56,195 & 10,831 & 6,358 & 5,757 & 5,102 & 4,805 & 4,643 & 4,816 & 4,560 & 4,248 & 4,328 & 747 & 17,716 & 6,050 & 4,313 & 3,708 & 3,190 & 455 \\
\hline Florida & $2,668,156$ & $1,876,102$ & 54,938 & 203,302 & 203,496 & 200,381 & 206,732 & 195,625 & 202,733 & 204,229 & 204,288 & 200,378 & 0 & 792,054 & 218,469 & 203,907 & 195,307 & 174,371 & 0 \\
\hline Georgia.. & $1,685,016$ & $1,211,250$ & 45,353 & 133,372 & 131,044 & 128,319 & 128,647 & 128,827 & 131,075 & 130,164 & 127,664 & 126,785 & 0 & 473,766 & 144,204 & 124,998 & 105,939 & 98,625 & 0 \\
\hline Hawaii ....... & 182,706 & 131,005 & 1,492 & 16,827 & 15,156 & 14,810 & 14,672 & 14,353 & 13,598 & 13,919 & 13,274 & 12,783 & 121 & 51,701 & 14,830 & 13,443 & 12,241 & 11,084 & 103 \\
\hline Idaho............................. & 279,873 & 198,064 & 1,338 & 21,901 & 22,557 & 22,068 & 21,845 & 21,835 & 21,818 & 21,765 & 21,765 & 21,172 & 0 & 81,809 & 21,479 & 20,996 & 19,911 & 19,423 & 0 \\
\hline Illinois............................ & $2,083,097$ & $1,453,156$ & 80,723 & 145,489 & 151,937 & 153,299 & 153,362 & 151,870 & 153,769 & 155,517 & 153,362 & 153,828 & 0 & 629,941 & 165,849 & 163,897 & 155,148 & 145,047 & 0 \\
\hline Indiana........ & $1,040,765$ & 724,605 & 9,540 & 78,166 & 79,365 & 79,264 & 77,866 & 78,627 & 81,987 & 80,259 & 79,945 & 79,586 & 0 & 316,160 & 81,801 & 82,495 & 77,793 & 74,071 & 0 \\
\hline lowa. & 495,870 & 350,152 & 26,930 & 40,187 & 35,807 & 35,364 & 35,320 & 34,951 & 35,116 & 35,509 & 35,470 & 35,498 & 0 & 145,718 & 36,726 & 36,333 & 35,590 & 37,069 & 0 \\
\hline Kansas....................... & 486,108 & 347,129 & 18,110 & 37,557 & 36,798 & 36,180 & 36,215 & 35,608 & 35,992 & 35,816 & 35,455 & 35,291 & 4,107 & 138,979 & 36,197 & 35,081 & 33,699 & 32,478 & 1,524 \\
\hline Kentucky ……………...... & 681,987 & 488,456 & 28,107 & 52,325 & 52,552 & 51,269 & 51,309 & 49,894 & 51,330 & 51,087 & 50,194 & 50,043 & 346 & 193,531 & 52,499 & 49,938 & 47,027 & 43,928 & 139 \\
\hline Louisiana ......................... & 703,390 & 518,802 & 29,422 & 56,037 & 56,214 & 54,202 & 53,607 & 58,304 & 51,709 & 55,279 & 51,739 & 52,289 & 0 & 184,588 & 54,775 & 48,355 & 42,370 & 39,088 & 0 \\
\hline Maine ............................ & 188,969 & 130,046 & 5,048 & 13,644 & 13,826 & 13,714 & 13,457 & 13,533 & 13,885 & 14,038 & 14,317 & 14,584 & 0 & 58,923 & 14,695 & 14,686 & 14,655 & 14,887 & 0 \\
\hline M & 854,086 & 594,216 & 28,850 & 64,727 & 64,300 & 63,976 & 63,421 & 63,118 & 61,111 & 61,901 & 60,895 & 61,917 & 0 & 259,870 & 71,862 & 65,895 & 61,824 & 60,289 & 0 \\
\hline Massachusetts......... & 953,369 & 666,314 & 28,116 & 67,956 & 69,906 & 70,561 & 70,826 & 70,404 & 71,355 & 71,483 & 71,950 & 72,758 & 999 & 287,055 & 76,690 & 72,220 & 70,685 & 67,460 & 0 \\
\hline Michigan ........................ & $1,573,537$ & $1,070,873$ & 37,020 & 107,852 & 112,451 & 113,884 & 111,984 & 112,465 & 115,681 & 117,691 & 117,802 & 118,628 & 5,415 & 502,664 & 129,661 & 130,276 & 119,607 & 120,498 & 2,622 \\
\hline Minnesota ..................... & 839,738 & 575,544 & 14,568 & 64,133 & 63,117 & 63,340 & 62,311 & 60,917 & 61,972 & 61,580 & 62,032 & 61,574 & 0 & 264,194 & 64,074 & 63,908 & 64,629 & 71,583 & 0 \\
\hline 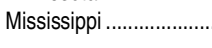 & 490,619 & 352,999 & 3,842 & 41,048 & 39,291 & 38,456 & 37,067 & 37,715 & 37,983 & 38,800 & 37,689 & 36,071 & 5,037 & 137,620 & 37,856 & 35,235 & 31,952 & 29,115 & 3,462 \\
\hline Missouri.. & 916,584 & 645,376 & 29,931 & 69,864 & 69,325 & 68,320 & 67,473 & 67,274 & 68,154 & 68,500 & 68,122 & 68,413 & 0 & 271,208 & 71,813 & 69,041 & 65,879 & 64,475 & 0 \\
\hline Montana..... & 142,349 & 99,725 & 1,475 & 11,697 & 11,013 & 11,015 & 10,825 & 10,739 & 10,780 & 00,566 & 10,842 & 10,773 & 0 & 42,624 & 11,326 & 10,841 & 10,249 & 10,208 & 0 \\
\hline Nebraska ...................... & 301,296 & 213,504 & 12,907 & 23,795 & 22,951 & 23,099 & 22,428 & 22,279 & 21,949 & 21,738 & 21,243 & 21,115 & 0 & 87,792 & 21,965 & 21,986 & 21,509 & 22,332 & 0 \\
\hline Nevada ........................... & 439,634 & 309,360 & 4,408 & 33,502 & 34,405 & 33,644 & 33,316 & 33,608 & 34,001 & 33,911 & 34,177 & 33,745 & 643 & 130,274 & 33,511 & 33,402 & 33,017 & 30,322 & 22 \\
\hline New Hampshire ............. & 191,900 & 129,632 & 3,228 & 11,915 & 13,680 & 13,859 & 13,902 & 14,190 & 14,237 & 14,607 & 14,850 & 15,164 & 0 & 62,268 & 16,641 & 15,537 & 15,179 & 14,911 & 0 \\
\hline $\mathrm{Ne}$ & $1,356,431$ & 947,576 & 36,581 & 90,955 & 96,939 & 98,784 & 97,569 & 96,459 & 98,000 & 97,384 & 99,004 & 98,968 & 36,933 & 408,855 & 104,553 & 98,853 & 96,668 & 94,059 & 14,722 \\
\hline New Mexico ....................... & 337,225 & 239,481 & 7,652 & 26,954 & 26,643 & 26,175 & 25,639 & 25,703 & 25,786 & 25,270 & 25,223 & 24,436 & 0 & 97,744 & 29,325 & 25,734 & 22,014 & 20,671 & 0 \\
\hline New York.... & $2,704,718$ & $1,857,574$ & 49,569 & 197,458 & 199,702 & 199,594 & 199,611 & 196,082 & 198,007 & 201,429 & 200,192 & 201,190 & 14,740 & 847,144 & 226,304 & 218,032 & 196,644 & 190,732 & 15,432 \\
\hline North Carolina .............. & $1,507,864$ & $1,074,063$ & 33,603 & 117,944 & 117,693 & 107,431 & 117,034 & 116,325 & 118,534 & 117,223 & 115,038 & 113,238 & 0 & 433,801 & 125,149 & 111,972 & 102,663 & 94,017 & 0 \\
\hline North Dakota .................... & 97,646 & 67,888 & 1,706 & 8,236 & 7,521 & 7,490 & 7,229 & 7,028 & 7,029 & 6,887 & 7,326 & 7,436 & 0 & 29,758 & 7,483 & 7,551 & 7,376 & 7,348 & 0 \\
\hline Ohio.... & $1,740,030$ & $1,217,226$ & 29,015 & 131,323 & 130,527 & 129,983 & 129,674 & 130,406 & 133,152 & 134,459 & 134,468 & 134,219 & 0 & 522,804 & 148,538 & 135,373 & 121,027 & 117,866 & 0 \\
\hline Oklahoma ……………....... & 666,120 & 490,196 & 42,145 & 53,053 & 53,145 & 50,090 & 49,523 & 48,690 & 48,456 & 48,469 & 47,869 & 47,321 & 1,435 & 175,924 & 48,154 & 45,332 & 42,450 & 39,447 & 541 \\
\hline Oregon & 568,208 & 391,310 & 7,262 & 41,478 & 42,402 & 42,474 & 42,463 & 42,072 & 42,885 & 43,193 & 43,428 & 43,653 & 0 & 176,898 & 43,968 & 44,249 & 42,783 & 45,898 & 0 \\
\hline Pennsylvania................... & $1,771,395$ & $1,204,850$ & 12,887 & 128,804 & 129,881 & 131,128 & 130,624 & 129,845 & 133,069 & 135,198 & 136,390 & 135,598 & 1,426 & 566,545 & 144,339 & 144,453 & 138,146 & 138,265 & 1,342 \\
\hline Rhode Island ..................... & 142,854 & 97,659 & 1,979 & 10,164 & 10,762 & 10,989 & 10,799 & 10,827 & 10,841 & 10,222 & 9,930 & 11,146 & 0 & 45,195 & 12,277 & 11,492 & 10,868 & 10,558 & 0 \\
\hline
\end{tabular}


Table 203.40. Enrollment in public elementary and secondary schools, by level, grade, and state or jurisdiction: Fall 2011-Continued

\begin{tabular}{|c|c|c|c|c|c|c|c|c|c|c|c|c|c|c|c|c|c|c|c|}
\hline \multirow[b]{2}{*}{ State or jurisdiction } & \multirow[b]{2}{*}{$\begin{array}{r}\text { Total, } \\
\text { all grades }\end{array}$} & \multicolumn{12}{|c|}{ Elementary } & \multicolumn{6}{|c|}{ Secondary } \\
\hline & & Total & $\begin{array}{r}\text { Prekinder- } \\
\text { garten }\end{array}$ & $\begin{array}{c}\text { Kinder- } \\
\text { garten } \\
\end{array}$ & Grade 1 & Grade 2 & Grade 3 & Grade 4 & Grade 5 & Grade 6 & Grade 7 & Grade 8 & $\begin{array}{r}\text { Elementary } \\
\text { ungraded }\end{array}$ & Total & Grade 9 & Grade 10 & Grade 11 & Grade 12 & $\begin{array}{r}\text { Secondary } \\
\text { ungraded }\end{array}$ \\
\hline 1 & 2 & 3 & 4 & 5 & 6 & 7 & 8 & 9 & 10 & 11 & 12 & 13 & 14 & 15 & 16 & 17 & 18 & 19 & 20 \\
\hline South Carolina............... & 727,186 & 519,389 & 23,551 & 56,065 & 55,995 & 54,373 & 53,730 & 54,157 & 55,713 & 56,312 & 55,250 & 54,243 & 0 & 207,797 & 60,710 & 54,075 & 48,328 & 44,684 & $\overline{0}$ \\
\hline outh Dakota ................... & 128,016 & 90,529 & 2,996 & 11,375 & 10,326 & 9,787 & 9,531 & 9,364 & 9,207 & 9,437 & 9,367 & 9,139 & 0 & 37,487 & 10,209 & 9,740 & 8,876 & 8,662 & 0 \\
\hline …………....... & 999,693 & 712,749 & 27,982 & 79,803 & 77,853 & 75,660 & 75,220 & 75,146 & 76,079 & 75,908 & 75,373 & 73,725 & 0 & 286,944 & 76,970 & 73,216 & 69,121 & 67,637 & 0 \\
\hline Texas. . & $5,000,470$ & $3,636,852$ & 249,524 & 379,446 & 392,291 & 383,411 & 379,421 & 375,756 & 377,729 & 372,846 & 366,149 & 360,279 & 0 & $1,363,618$ & 394,326 & 347,268 & 323,387 & 298,637 & 0 \\
\hline Utah ........................... & 598,832 & 434,536 & 11,972 & 48,953 & 48,829 & 48,768 & 48,039 & 46,758 & 46,198 & 45,951 & 45,097 & 43,971 & 0 & 164,296 & 42,540 & 41,498 & 40,565 & 39,693 & 0 \\
\hline Vermont... & 89,908 & 62,146 & 5,559 & 6,062 & 6,232 & 6,185 & 6,165 & 6,158 & 6,304 & 6,283 & 6,552 & 6,646 & 0 & 27,762 & 7,017 & 6,869 & 6,946 & 6,930 & 0 \\
\hline Virginia................ & $1,257,883$ & 881,225 & 31,805 & 95,574 & 95,019 & 95,322 & 93,829 & 93,770 & 94,316 & 94,863 & 93,366 & 93,361 & 0 & 376,658 & 100,701 & 95,596 & 91,037 & 89,324 & 0 \\
\hline Washington ..................... & $1,045,453$ & 718,184 & 12,268 & 78,014 & 78,889 & 78,338 & 77,865 & 77,051 & 78,848 & 79,109 & 78,911 & 78,891 & 0 & 327,269 & 83,237 & 80,316 & 79,627 & 84,089 & 0 \\
\hline West Virginia.................. & 282,870 & 202,065 & 15,280 & 21,172 & 21,026 & 20,623 & 20,225 & 20,748 & 20,491 & 21,085 & 20,637 & 20,778 & 0 & 80,805 & 22,569 & 20,479 & 19,259 & 18,498 & 0 \\
\hline Wisconsin ... & 871,105 & 602,810 & 54,438 & 60,875 & 60,572 & 60,984 & 60,216 & 60,094 & 60,958 & 61,818 & 61,442 & 61,413 & 0 & 268,295 & 67,542 & 65,510 & 66,851 & 68,392 & 0 \\
\hline 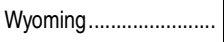 & 90,099 & 64,057 & 518 & 7,873 & 7,441 & 7,104 & 7,115 & 6,790 & 6,747 & 6,833 & 6,840 & 6,796 & 0 & 26,042 & 6,955 & 6,661 & 6,248 & 6,178 & 0 \\
\hline $\begin{array}{l}\text { Bureau of Indian } \\
\text { Education....... }\end{array}$ & - & - & - & - & - & - & - & - & - & - & - & - & - & - & - & - & - & - & - \\
\hline $\begin{array}{l}\text { DoD, overseas ................... } \\
\text { DoD, domestic .............. }\end{array}$ & - & $=$ & $=$ & - & - & - & - & - & - & - & $=$ & - & - & - & - & - & - & $=$ & - \\
\hline $\begin{array}{l}\text { Other jurisdictions } \\
\text { American Samoa }\end{array}$ & & & & & & & & & & & & & & & & & & & \\
\hline Guam... & 31,243 & 21,223 & $\overline{13}$ & $2,21 \overline{6}$ & $2,33 \overline{7}$ & $2, \overline{328}$ & $2,4 \overline{18}$ & 2,334 & $2, \overline{358}$ & 2,364 & 2,383 & $2,47 \overline{2}$ & $\overline{0}$ & 10,020 & $3,1 \overline{01}$ & 3,269 & 2,089 & 1,561 & 0 \\
\hline $\begin{array}{l}\text { Northe } \\
\text { Puerto }\end{array}$ & $\begin{array}{r}11,011 \\
452,740\end{array}$ & $\begin{array}{r}7,703 \\
318,924\end{array}$ & $\begin{array}{r}462 \\
1060\end{array}$ & $\begin{array}{r}608 \\
29287\end{array}$ & $\begin{array}{r}736 \\
35.333\end{array}$ & $\begin{array}{r}762 \\
32808\end{array}$ & $\begin{array}{r}792 \\
31.990\end{array}$ & $\begin{array}{r}814 \\
33.638\end{array}$ & $\begin{array}{r}851 \\
34.920\end{array}$ & $\begin{array}{r}849 \\
35415\end{array}$ & $\begin{array}{r}944 \\
37989\end{array}$ & $\begin{array}{r}841 \\
36.488\end{array}$ & $\begin{array}{r}44 \\
9996\end{array}$ & $\begin{array}{r}3,308 \\
133816\end{array}$ & $\begin{array}{r}962 \\
35472\end{array}$ & $\begin{array}{r}950 \\
34.152\end{array}$ & $\begin{array}{r}742 \\
30.914\end{array}$ & $\begin{array}{r}654 \\
28278\end{array}$ & 000 \\
\hline U.S. Virgin Islands..... & $\begin{array}{r}452, / 40 \\
15,711\end{array}$ & $\begin{array}{r}318,924 \\
10,576\end{array}$ & 1,060 & $\begin{array}{r}r 9,287 \\
1,114\end{array}$ & $\begin{array}{r}r 5,303 \\
1,101\end{array}$ & $\begin{array}{r}r<, 008 \\
1,145\end{array}$ & $\begin{array}{r}r,, 190 \\
1,148\end{array}$ & $\begin{array}{r}r 3,000 \\
1,251\end{array}$ & $\begin{array}{r}r 4,920 \\
1,217\end{array}$ & $\begin{array}{r}r 5,415 \\
1,200\end{array}$ & $\begin{array}{r}r,, 289 \\
1,274\end{array}$ & $\begin{array}{r}r 6,488 \\
1,126\end{array}$ & $\begin{array}{r}9,996 \\
0\end{array}$ & $\begin{array}{r}133,810 \\
5,135\end{array}$ & $\begin{array}{r}1,746 \\
1,746\end{array}$ & $\begin{array}{r}r 4,152 \\
1,215\end{array}$ & $\begin{array}{r}r, 014 \\
1,056\end{array}$ & $\begin{array}{r}r 0,210 \\
1,118\end{array}$ & 00 \\
\hline
\end{tabular}

-Not available.

NT. $\mathrm{DOD}=\mathrm{Department}$ of Defense. The total ungraded counts of students were prorated to the elementary and secondary

SOURCE: U.S. Department of Education, National Center for Education Statistics, Common Core of Data (CCD), "State Nonlevels based on prior reports. 
Table 203.45. Enrollment in public elementary and secondary schools, by level, grade, and state or jurisdiction: Fall 2010

\begin{tabular}{|c|c|c|c|c|c|c|c|c|c|c|c|c|c|c|c|c|c|c|c|c|}
\hline \multirow[b]{2}{*}{ State or jurisdiction } & \multirow[b]{2}{*}{$\begin{array}{r}\text { Total, } \\
\text { all grades }\end{array}$} & \multicolumn{12}{|c|}{ Elementary } & \multicolumn{6}{|c|}{ Secondary } & \\
\hline & & Total & $\begin{array}{r}\text { Prekinder- } \\
\text { garten }\end{array}$ & $\begin{array}{r}\text { Kinder- } \\
\text { garten }\end{array}$ & Grade 1 & Grade 2 & Grade 3 & Grade 4 & Grade 5 & Grade 6 & Grade 7 & Grade 8 & \begin{tabular}{|r|} 
Elementary \\
ungraded
\end{tabular} & Total & Grade 9 & Grade 10 & Grade 11 & Grade 12 & $\begin{array}{r}\text { Secondary } \\
\text { ungraded }\end{array}$ & \\
\hline 1 & 2 & 3 & 4 & 5 & 6 & 7 & 8 & 9 & 10 & 11 & 12 & 13 & 14 & 15 & 16 & 17 & 18 & 19 & 20 & \\
\hline United States ....... & $49,484,181$ & $34,624,530$ & \begin{tabular}{|l|}
$1,278,678$ \\
\end{tabular} & $3,682,092$ & $3,753,951$ & $3,700,668$ & $3,685,833$ & \begin{tabular}{|l|}
$3,711,341$ \\
\end{tabular} & $3,717,521$ & $3,682,052$ & $\begin{array}{l}3,676,309 \\
\end{array}$ & $3,659,405$ & 76,680 & $14,859,651$ & $4,007,857$ & $\begin{array}{l}3,799,883 \\
\end{array}$ & $3,538,482$ & $\begin{array}{l}3,471,888 \\
\end{array}$ & 41,541 & \\
\hline Alabama ......................... & 755,552 & 533,612 & 8,179 & 57,665 & 58,448 & 56,699 & 57,216 & 59,117 & 59,897 & 59,157 & 59,242 & 57,992 & 0 & 221,940 & 62,615 & 57,644 & 51,962 & 49,719 & 0 & \\
\hline Alaska.............................. & 132,104 & 91,990 & 2,990 & 10,120 & 9,991 & 10,006 & 9,787 & 9,917 & 9,988 & 9,933 & 9,636 & 9,622 & 0 & 40,114 & 10,023 & 9,723 & 10,725 & 9,643 & 0 & \\
\hline Arizona ……………........ & $1,071,751$ & 751,992 & 8,554 & 82,860 & 84,473 & 83,544 & 82,485 & 82,862 & 82,690 & 82,305 & 81,445 & 80,636 & 138 & 319,759 & 82,304 & 79,842 & 76,275 & 81,326 & 12 & \\
\hline Arkansas........................... & 482,114 & 345,808 & 14,059 & 37,701 & 37,651 & 36,770 & 36,624 & 36,873 & 36,628 & 36,591 & 36,306 & 36,237 & 368 & 136,306 & 37,807 & 35,280 & 32,739 & 30,330 & 150 & \\
\hline California & $6,289,578$ & $4,293,968$ & 72,404 & 468,036 & 477,086 & 470,001 & 461,967 & 463,691 & 469,800 & 467,271 & 463,505 & 476,639 & 3,568 & $1,995,610$ & 510,011 & 502,452 & 488,530 & 492,545 & 2,072 & \\
\hline Colorado .... & 843,316 & 601,077 & 30,593 & 65,182 & 65,665 & 65,885 & 64,238 & 63,819 & 63,328 & 61,755 & 60,928 & 59,684 & 0 & 242,239 & 62,258 & 60,775 & 58,307 & 60,899 & 0 & \\
\hline Connecticut...................... & 560,546 & 387,475 & 15,921 & 39,670 & 40,830 & 41,203 & 40,254 & 41,155 & 41,550 & 41,930 & 42,616 & 42,346 & 0 & 173,071 & 45,908 & 43,573 & 42,209 & 41,381 & 0 & \\
\hline Delaware........ & 129,403 & 90,279 & 1,626 & 9,810 & 10,157 & 10,127 & 9,796 & 9,797 & 9,897 & 9,847 & 9,718 & 9,504 & 0 & 39,124 & 11,416 & 10,147 & 9,097 & 8,464 & 0 & \\
\hline District of Columbia ....... & 71,284 & 53,548 & 9,581 & 5,939 & 5,240 & 4,915 & 4,873 & 4,877 & 4,825 & 4,391 & 4,439 & 4,307 & 161 & 17,736 & 5,858 & 4,516 & 3,851 & 3,407 & 104 & \\
\hline Florida.............................. & $2,643,347$ & $1,858,498$ & 52,779 & 197,097 & 200,806 & 196,620 & 205,650 & 200,682 & 200,738 & 202,303 & 200,147 & 201,676 & 0 & 784,849 & 214,993 & 205,142 & 186,399 & 178,315 & 0 & \\
\hline Georgia.......... & $1,677,067$ & $1,202,479$ & 42,816 & 132,008 & 130,171 & 127,744 & 129,879 & 131,326 & 131,057 & 127,442 & 126,242 & 123,794 & 0 & 474,588 & 145,043 & 124,239 & 104,914 & 100,392 & 0 & \\
\hline Hawaii ............. & 179,601 & 127,525 & 1,393 & 16,028 & 14,754 & 14,540 & 14,234 & 13,457 & 14,171 & 13,285 & 12,982 & 12,567 & 114 & 52,076 & 15,164 & 13,466 & 12,527 & 10,818 & 101 & \\
\hline Idaho............................ & 275,859 & 194,144 & 1,821 & 21,144 & 21,865 & 21,577 & 21,592 & 21,575 & 21,434 & 21,563 & 20,985 & 20,588 & 0 & 81,715 & 22,062 & 20,451 & 19,840 & 19,362 & 0 & \\
\hline Illinois............................... & $2,091,654$ & $1,454,793$ & 78,260 & 146,225 & 153,996 & 151,647 & 153,926 & 153,781 & 154,636 & 153,748 & 154,281 & 154,293 & 0 & 636,861 & 169,967 & 169,365 & 150,576 & 146,953 & 0 & \\
\hline Indiana...... & $1,047,232$ & 729,414 & 11,652 & 76,765 & 81,397 & 78,857 & 78,972 & 82,387 & 80,081 & 79,585 & 79,928 & 79,790 & 0 & 317,818 & 84,139 & 81,558 & 77,285 & 74,836 & 0 & \\
\hline lowa. & 495,775 & 348,112 & 27,211 & 39,306 & 35,369 & 35,121 & 34,939 & 35,071 & 35,336 & 35,080 & 35,416 & 35,263 & 0 & 147,663 & 36,984 & 36,540 & 36,435 & 37,704 & 0 & \\
\hline Kansas....... & 483,701 & 342,927 & 17,318 & 37,023 & 36,520 & 36,357 & 35,648 & 35,991 & 35,898 & 35,372 & 35,244 & 34,220 & 3,336 & 140,774 & 37,010 & 35,639 & 33,676 & 33,180 & 1,269 & \\
\hline Kentucky ......................... & 673,128 & 480,334 & 24,260 & 51,091 & 52,207 & 50,855 & 51,279 & 51,189 & 50,980 & 49,988 & 49,633 & 48,525 & 327 & 192,794 & 52,668 & 50,262 & 46,008 & 43,723 & 133 & \\
\hline Louisiana ....................... & 696,558 & 512,266 & 29,657 & 54,276 & 55,750 & 53,975 & 53,842 & 58,778 & 52,976 & 51,813 & 51,676 & 49,523 & 0 & 184,292 & 57,941 & 46,689 & 41,224 & 38,438 & 0 & \\
\hline Maine ................................. & 189,077 & 128,929 & 4,247 & 13,819 & 13,647 & 13,405 & 13,420 & 13,728 & 13,858 & 14,034 & 14,413 & 14,358 & 0 & 60,148 & 14,836 & 14,996 & 15,001 & 15,315 & 0 & \\
\hline Maryland... & 852,211 & 588,156 & 29,377 & 62,704 & 63,635 & 63,086 & 62,640 & 60,765 & 61,641 & 60,475 & 61,862 & 61,971 & 0 & 264,055 & 72,700 & 67,923 & 62,877 & 60,555 & 0 & \\
\hline Massachusetts.... & 955,563 & 666,402 & 27,747 & 67,496 & 70,973 & 70,797 & 70,312 & 71,140 & 71,402 & 71,404 & 72,667 & 71,588 & 876 & 289,161 & 77,787 & 73,101 & 70,557 & 67,716 & 0 & \\
\hline Michigan ......... & $1,587,067$ & $1,075,584$ & 28,187 & 112,835 & 116,028 & 112,653 & 112,875 & 115,722 & 117,035 & 117,129 & 118,958 & 118,831 & 5,331 & 511,483 & 132,050 & 133,238 & 121,344 & 122,236 & 2,615 & \\
\hline Minnesota... & 838,037 & 569,963 & 14,405 & 62,961 & 63,218 & 62,116 & 60,648 & 61,627 & 61,130 & 60,831 & 61,321 & 61,706 & 0 & 268,074 & 63,935 & 65,013 & 65,465 & 73,661 & 0 & \\
\hline Mississippi .... & 490,526 & 350,885 & 3,447 & 38,923 & 39,740 & 37,607 & 38,157 & 38,295 & 39,155 & 37,607 & 37,048 & 36,113 & 4,793 & 139,641 & 38,666 & 36,364 & 31,579 & 29,668 & 3,364 & \\
\hline Missouri... & 918,710 & 642,991 & 28,495 & 69,376 & 68,974 & 67,818 & 67,296 & 68,313 & 68,709 & 67,913 & 69,153 & 66,944 & 0 & 275,719 & 73,080 & 69,794 & 66,855 & 65,990 & 0 & \\
\hline Montana & 141,693 & 98,491 & 1,351 & 11,115 & 11,066 & 10,813 & 10,693 & 10,751 & 10,535 & 10,713 & 10,725 & 10,729 & 0 & 43,202 & 11,569 & 10,733 & 10,584 & 10,316 & 0 & \\
\hline Nebraska ........................... & 298,500 & 210,292 & 12,656 & 23,411 & 23,134 & 22,390 & 22,150 & 21,901 & 21,680 & 21,103 & 20,992 & 20,875 & 0 & 88,208 & 22,567 & 21,998 & 21,407 & 22,236 & 0 & بִ \\
\hline Nevada .......................... & 437,149 & 307,297 & 4,444 & 32,454 & 33,809 & 33,492 & 33,600 & 34,047 & 33,754 & 34,054 & 33,947 & 33,070 & 626 & 129,852 & 33,780 & 34,199 & 32,645 & 29,207 & 21 & m \\
\hline New Hampshire ............. & 194,711 & 131,576 & 3,097 & 11,970 & 14,120 & 13,913 & 14,187 & 14,294 & 14,602 & 14,795 & 15,191 & 15,407 & 0 & 63,135 & 16,832 & 15,994 & 15,290 & 15,019 & 0 & \\
\hline New J & $1,402,548$ & 981,255 & 53,564 & 92,413 & 99,976 & 98,791 & 97,716 & 98,641 & 99,344 & 100,245 & 100,225 & 99,630 & 40,710 & 421,293 & 106,281 & 103,267 & 98,237 & 97,358 & 16,150 & \\
\hline New Mexico ..................... & 338,122 & 239,345 & 7,980 & 26,688 & 26,660 & 26,087 & 25,906 & 25,955 & 25,615 & 25,329 & 24,656 & 24,469 & 0 & 98,777 & 29,179 & 26,451 & 22,553 & 20,594 & 0 & m乏 \\
\hline New York.......... & $2,734,955$ & $1,869,150$ & 51,649 & 194,607 & 202,889 & 201,820 & 198,573 & 198,720 & 201,761 & 199,937 & 202,305 & 203,761 & 13,128 & 865,805 & 235,380 & 227,380 & 197,541 & 191,528 & 13,976 & \\
\hline North Carolina ............... & $1,490,605$ & $1,058,409$ & 23,510 & 115,782 & 108,078 & 117,107 & 117,747 & 118,617 & 117,170 & 115,186 & 113,310 & 111,112 & 790 & 432,196 & 126,090 & 111,889 & 102,676 & 91,541 & 0 & \\
\hline North Dakota ........................ & 96,323 & 66,035 & 1,529 & 7,449 & 7,484 & 7,197 & 6,915 & 6,974 & 6,676 & 7,141 & 7,372 & 7,298 & 0 & 30,288 & 7,591 & 7,701 & 7,415 & 7,581 & 0 & Фి \\
\hline Ohio.. & $1,754,191$ & $1,222,808$ & 30,047 & 129,964 & 132,638 & 130,425 & 130,593 & 133,202 & 134,109 & 133,615 & 135,005 & 133,210 & 0 & 531,383 & 152,198 & 138,532 & 121,707 & 118,946 & 0 & \\
\hline Oklahoma .......................... & 659,911 & 483,464 & 40,688 & 52,114 & 52,420 & 50,070 & 48,899 & 48,519 & 48,490 & 47,809 & 47,418 & 45,737 & 1,300 & 176,447 & 48,131 & 45,564 & 42,620 & 39,634 & 498 & \\
\hline Oregon ……………........... & 570,720 & 392,601 & 9,392 & 40,656 & 42,508 & 42,322 & 42,013 & 42,924 & 43,144 & 43,280 & 43,528 & 42,834 & 0 & 178,119 & 44,540 & 44,289 & 43,078 & 46,212 & 0 & \\
\hline Pennsylvania................... & $1,793,284$ & $1,209,766$ & 16,294 & 128,120 & 131,170 & 130,253 & 129,292 & 132,497 & 134,499 & 134,782 & 135,869 & 135,876 & 1,114 & 583,518 & 150,150 & 148,716 & 141,866 & 141,710 & 1,076 & $\overline{\bar{n}}$ m \\
\hline 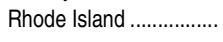 & 143,793 & 97,734 & 2,054 & 10,057 & 11,070 & 10,745 & 10,755 & 10,865 & 10,195 & 9,889 & 11,150 & 10,954 & 0 & 46,059 & 12,888 & 11,814 & 10,891 & 10,466 & 0 & $\frac{2}{5}$ \\
\hline
\end{tabular}


Table 203.45. Enrollment in public elementary and secondary schools, by level, grade, and state or jurisdiction: Fall 2010—Continued

\begin{tabular}{|c|c|c|c|c|c|c|c|c|c|c|c|c|c|c|c|c|c|c|c|}
\hline \multirow[b]{2}{*}{ State or jurisdiction } & \multirow[b]{2}{*}{$\begin{array}{r}\text { Total, } \\
\text { all grades }\end{array}$} & \multicolumn{12}{|c|}{ Elementary } & \multicolumn{6}{|c|}{ Secondary } \\
\hline & & Total & $\begin{array}{r}\text { Prekinder- } \\
\text { garten }\end{array}$ & $\begin{array}{c}\text { Kinder- } \\
\text { garten }\end{array}$ & Grade 1 & Grade 2 & Grade 3 & Grade 4 & Grade 5 & Grade 6 & Grade 7 & Grade 8 & $\begin{array}{r}\text { Elementary } \\
\text { ungraded }\end{array}$ & Total & Grade 9 & Grade 10 & Grade 11 & Grade 12 & $\begin{array}{r}\text { Secondary } \\
\text { ungraded }\end{array}$ \\
\hline 1 & 2 & 3 & 4 & 5 & 6 & 7 & 8 & 9 & 10 & 11 & 12 & 13 & 14 & 15 & 16 & 17 & 18 & 19 & 20 \\
\hline South Carolina............... & 725,838 & 515,581 & 24,188 & 54,624 & 55,328 & 53,846 & 54,100 & 55,636 & \begin{tabular}{|c|}
55,887 \\
\end{tabular} & 54,788 & 54,280 & 52,904 & 0 & 210,257 & 62,161 & 54,685 & 48,708 & 44,703 & $\overline{0}$ \\
\hline South Dakota................ & 126,128 & 87,936 & 1,974 & 11,049 & 9,903 & 9,498 & 9,233 & 9,140 & 9,321 & 9,331 & 9,212 & 9,275 & 0 & 38,192 & 10,307 & 9,779 & 9,043 & 9,063 & 0 \\
\hline Tennessee .................... & 987,422 & 701,707 & 28,787 & 76,642 & 76,706 & 74,788 & 74,793 & 75,481 & 75,057 & 74,615 & 73,363 & 71,475 & 0 & 285,715 & 76,010 & 73,509 & 68,755 & 67,441 & 0 \\
\hline Texas ........................... & $4,935,715$ & $3,586,609$ & 249,122 & 374,195 & 387,899 & 379,910 & 375,454 & 374,111 & 372,509 & 361,700 & 357,395 & 354,314 & 0 & $1,349,106$ & 391,554 & 344,241 & 314,911 & 298,400 & 0 \\
\hline Utah ................................. & 585,552 & 424,979 & 10,376 & 48,043 & 48,770 & 48,122 & 46,753 & 46,127 & 45,822 & 44,797 & 43,942 & 42,227 & 0 & 160,573 & 41,419 & 40,964 & 39,446 & 38,744 & 0 \\
\hline Vermont.. & 96,858 & 67,989 & 10,678 & 6,259 & 6,213 & 6,171 & 6,214 & 6,291 & 6,294 & 6,484 & 6,628 & 6,757 & 0 & 28,869 & 7,139 & 7,287 & 7,329 & 7,114 & 0 \\
\hline Virginia........................... & $1,251,440$ & 871,446 & 30,821 & 92,899 & 95,368 & 93,687 & 93,328 & 93,965 & 94,182 & 92,762 & 92,557 & 91,877 & 0 & 379,994 & 102,407 & 96,918 & 91,403 & 89,266 & 0 \\
\hline Washington .................... & $1,043,788$ & 714,172 & 12,056 & 75,933 & 78,598 & 77,707 & 76,802 & 78,546 & 79,062 & 78,531 & 78,489 & 78,448 & 0 & 329,616 & 84,449 & 81,990 & 79,465 & 83,712 & 0 \\
\hline West Virginia & 282,879 & 201,472 & 14,660 & 21,256 & 21,167 & 20,299 & 20,786 & 20,493 & 20,842 & 20,595 & 20,919 & 20,455 & 0 & 81,407 & 22,785 & 21,037 & 19,155 & 18,430 & 0 \\
\hline Wisconsin ..................... & 872,286 & 598,479 & 50,200 & 60,721 & 61,262 & 60,226 & 59,981 & 61,015 & 61,420 & 61,053 & 61,264 & 61,337 & 0 & 273,807 & 68,383 & 66,490 & 69,076 & 69,858 & 0 \\
\hline Wyoming................ & 89,009 & 62,786 & 582 & 7,611 & 7,124 & 7,064 & 6,801 & 6,694 & 6,711 & 6,766 & 6,776 & 6,657 & 0 & 26,223 & 6,842 & 6,724 & 6,424 & 6,233 & $\underline{\underline{0}}$ \\
\hline $\begin{array}{l}\text { Bureau of Indian } \\
\text { Education.......... }\end{array}$ & 41,962 & 31,985 & - & 4,721 & 4,042 & 3,794 & 3,554 & 3,397 & 3,292 & 3,195 & 2,998 & 2,992 & 0 & 9,977 & 2,802 & 2,663 & 2,309 & 2,203 & 0 \\
\hline 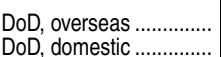 & - & - & - & 二 & - & - & - & - & - & - & - & - & - & - & - & - & - & - & - \\
\hline Other jurisdictions & & & & & & & & & & & & & & & & & & - & \\
\hline American Samoa ....... & & & 68 & $21 \overline{2}$ & $-\overline{2}$ & & $-\overline{0}$ & $\overline{-12}$ & 2011 & $-\overline{0}$ & - & $-\overline{771}$ & - & - & $-\overline{1}$ & - & - & - & 0 \\
\hline $\begin{array}{l}\text { Guam } \\
\text { Northern Marianas..... }\end{array}$ & $\begin{array}{l}31,618 \\
11,105\end{array}$ & $\begin{array}{r}21,561 \\
7,688\end{array}$ & $\begin{array}{r}68 \\
462\end{array}$ & $\begin{array}{r}2,102 \\
604\end{array}$ & $\begin{array}{r}2,324 \\
775\end{array}$ & $\begin{array}{r}2,290 \\
782\end{array}$ & $\begin{array}{r}2,302 \\
818\end{array}$ & $\begin{array}{r}2,412 \\
841\end{array}$ & $\begin{array}{r}2,441 \\
855\end{array}$ & $\begin{array}{r}2,469 \\
826\end{array}$ & $\begin{array}{r}2,382 \\
856\end{array}$ & $\begin{array}{r}2,771 \\
816\end{array}$ & $\begin{array}{r}0 \\
53\end{array}$ & $\begin{array}{r}10,057 \\
3,417\end{array}$ & $\begin{array}{l}3,404 \\
1,088\end{array}$ & $\begin{array}{r}2,713 \\
873\end{array}$ & $\begin{array}{r}2,096 \\
740\end{array}$ & $\begin{array}{r}1,844 \\
716\end{array}$ & $\begin{array}{l}0 \\
0\end{array}$ \\
\hline Puerto Rico.................. & 473,735 & 334,613 & 866 & 30,968 & 36,217 & 33,432 & 34,442 & 36,919 & 36,860 & $\begin{array}{l}37,066 \\
\end{array}$ & 40,264 & 37,481 & 10,098 & 139,122 & 36,913 & 35,093 & 32,470 & 29,640 & 5,006 \\
\hline U.S. Virgin & 15,495 & 10,518 & - & 1,063 & 1,099 & 1,138 & 1,182 & 1,243 & 1,217 & 1,183 & 1,234 & 1,159 & 0 & 4,977 & 1,677 & 1,120 & 1,098 & 1,082 & 0 \\
\hline
\end{tabular}

-Not available.

of Defense. The total ungraded counts of students were prorated to the elementary and secondary

SOURCE: U.S. Department of Education, National Center for Education Statistics, Common Core of Data (CCD), "State NonNels based on prior reports. 
Table 203.50. Enrollment and percentage distribution of enrollment in public elementary and secondary schools, by race/ethnicity and region: Selected years, fall 1995 through fall 2023

\begin{tabular}{|c|c|c|c|c|c|c|c|c|c|c|c|c|c|c|}
\hline \multirow[b]{2}{*}{ Region and year } & \multicolumn{7}{|c|}{ Enrollment (in thousands) } & \multicolumn{7}{|c|}{ Percentage distribution } \\
\hline & Total & White & Black & Hispanic & $\begin{array}{r}\text { Asian/ } \\
\text { Pacific } \\
\text { Islander }\end{array}$ & $\begin{array}{r}\text { American } \\
\text { Indian/ } \\
\text { Alaska } \\
\text { Native }\end{array}$ & $\begin{array}{r}\text { Two or } \\
\text { more races }\end{array}$ & Total & White & Black & Hispanic & $\begin{array}{r}\text { Asian/ } \\
\text { Pacific } \\
\text { Islander }\end{array}$ & $\begin{array}{r}\text { American } \\
\text { Indian/ } \\
\text { Alaska } \\
\text { Native }\end{array}$ & $\begin{array}{r}\text { Two or } \\
\text { more races }\end{array}$ \\
\hline 1 & 2 & 3 & 4 & 5 & 6 & 7 & 8 & 9 & 10 & 11 & 12 & 13 & 14 & $\overline{15}$ \\
\hline 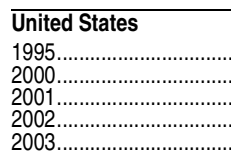 & $\begin{array}{l}44,840 \\
47,204 \\
47,672 \\
48,183 \\
48,540\end{array}$ & $\begin{array}{l}29,044 \\
28,878 \\
28,735 \\
28,618 \\
28,442\end{array}$ & $\begin{array}{l}7,551 \\
8,100 \\
8,177 \\
8,299 \\
8,349\end{array}$ & $\begin{array}{l}6,072 \\
7,726 \\
8,169 \\
8,594 \\
9,011\end{array}$ & $\begin{array}{l}1,668 \\
1,950 \\
2,028 \\
2,088 \\
2,145\end{array}$ & $\begin{array}{l}505 \\
550 \\
564 \\
583 \\
593\end{array}$ & $\begin{array}{l}\bar{z} \\
\overline{-} \\
-\end{array}$ & $\begin{array}{l}100.0 \\
100.0 \\
100.0 \\
100.0 \\
100.0\end{array}$ & $\begin{array}{l}64.8 \\
61.2 \\
60.3 \\
59.4 \\
58.6\end{array}$ & $\begin{array}{l}16.8 \\
17.2 \\
17.2 \\
17.2 \\
17.2\end{array}$ & $\begin{array}{l}13.5 \\
16.4 \\
17.1 \\
17.8 \\
18.6\end{array}$ & $\begin{array}{l}3.7 \\
4.1 \\
4.3 \\
4.3 \\
4.4\end{array}$ & $\begin{array}{l}1.1 \\
1.2 \\
1.2 \\
1.2 \\
1.2\end{array}$ & $\begin{array}{l}t \\
f \\
t\end{array}$ \\
\hline 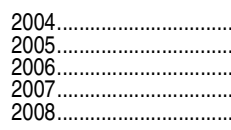 & $\begin{array}{l}48,795 \\
49,113 \\
49,316 \\
49,293 \\
49,266\end{array}$ & $\begin{array}{l}28,318 \\
28,005 \\
27,801 \\
27,456 \\
27,057\end{array}$ & $\begin{array}{l}8,386 \\
8,445 \\
8,422 \\
8,392 \\
8,358\end{array}$ & $\begin{array}{r}9,317 \\
9,787 \\
10,166 \\
10,454 \\
10,563\end{array}$ & $\begin{array}{l}2,183 \\
2,279 \\
2,332 \\
2,396 \\
2,451\end{array}$ & $\begin{array}{l}591 \\
598 \\
595 \\
594 \\
589\end{array}$ & $\begin{array}{c}\bar{z} \\
\bar{z} \\
247\end{array}$ & $\begin{array}{l}100.0 \\
100.0 \\
100.0 \\
100.0 \\
100.0\end{array}$ & $\begin{array}{l}58.0 \\
57.0 \\
56.4 \\
55.7 \\
54.9\end{array}$ & $\begin{array}{l}17.2 \\
177.2 \\
17.1 \\
17.0 \\
17.0\end{array}$ & $\begin{array}{l}19.1 \\
19.9 \\
20.6 \\
21.2 \\
21.4\end{array}$ & $\begin{array}{l}4.5 \\
4.6 \\
4.7 \\
4.9 \\
5.0\end{array}$ & $\begin{array}{l}1.2 \\
1.2 \\
1.2 \\
1.2 \\
1.2\end{array}$ & $\begin{array}{c}t \\
t \\
t \\
0.5\end{array}$ \\
\hline $\begin{array}{l}2009 . \\
2010 \ldots \ldots \\
2011 \\
2012^{2} \\
2013^{2}\end{array}$ & $\begin{array}{l}49,361 \\
49,484 \\
49,522 \\
49,652 \\
49,750\end{array}$ & $\begin{array}{l}26,702 \\
25,933 \\
25,602 \\
25,334 \\
25,066\end{array}$ & $\begin{array}{l}8,245 \\
7,917 \\
7,827 \\
7,775 \\
7,728\end{array}$ & $\begin{array}{l}10,991 \\
11,439 \\
11,759 \\
12,157 \\
12,510\end{array}$ & $\begin{array}{l}2,484 \\
2,466 \\
2,513 \\
2,532 \\
2,553\end{array}$ & $\begin{array}{l}601 \\
566 \\
547 \\
539 \\
533\end{array}$ & $\begin{array}{l}3381 \\
1,164 \\
1,272 \\
1,315 \\
1,360\end{array}$ & $\begin{array}{l}100.0 \\
100.0 \\
100.0 \\
100.0 \\
100.0\end{array}$ & $\begin{array}{l}54.1 \\
52.4 \\
51.7 \\
51.0 \\
50.4\end{array}$ & $\begin{array}{l}16.7 \\
16.0 \\
15.8 \\
15.7 \\
15.5\end{array}$ & $\begin{array}{l}22.3 \\
23.1 \\
23.7 \\
24.5 \\
25.1\end{array}$ & $\begin{array}{l}5.0 \\
5.0 \\
5.1 \\
5.1 \\
5.1\end{array}$ & $\begin{array}{l}1.2 \\
1.1 \\
1.1 \\
1.1 \\
1.1\end{array}$ & $\begin{array}{l}0.71 \\
2.4 \\
2.6 \\
2.6 \\
2.7\end{array}$ \\
\hline $\begin{array}{l}2014^{2} \\
2015^{2} \\
2016^{2} \\
2017^{2} \\
2018^{2}\end{array}$ & $\begin{array}{l}49,751 \\
49,839 \\
49,951 \\
50,280 \\
50,543\end{array}$ & $\begin{array}{l}24,766 \\
24,497 \\
24,250 \\
24,108 \\
23,952\end{array}$ & $\begin{array}{l}7,675 \\
7,638 \\
7,597 \\
7,611 \\
7,618\end{array}$ & $\begin{array}{l}12,814 \\
13,148 \\
13,481 \\
13,854 \\
14,188\end{array}$ & $\begin{array}{l}2,565 \\
2,587 \\
2,613 \\
2,651 \\
2,681\end{array}$ & $\begin{array}{l}526 \\
522 \\
516 \\
513 \\
511\end{array}$ & $\begin{array}{l}1,405 \\
1,448 \\
1,494 \\
1,543 \\
1,592\end{array}$ & $\begin{array}{l}100.0 \\
100.0 \\
100.0 \\
100.0 \\
100.0\end{array}$ & $\begin{array}{l}49.8 \\
49.2 \\
48.5 \\
47.9 \\
47.4\end{array}$ & $\begin{array}{l}15.4 \\
15.3 \\
15.2 \\
15.1 \\
15.1\end{array}$ & $\begin{array}{l}25.8 \\
26.4 \\
27.0 \\
27.6 \\
28.1\end{array}$ & $\begin{array}{l}5.2 \\
5.2 \\
5.2 \\
5.3 \\
5.3\end{array}$ & $\begin{array}{l}1.1 \\
1.0 \\
1.0 \\
1.0 \\
1.0\end{array}$ & $\begin{array}{l}2.8 \\
2.9 \\
3.0 \\
3.1 \\
3.2\end{array}$ \\
\hline $\begin{array}{l}2019^{2} \\
2020^{2} \\
2021^{2} \\
2022^{2} \\
2023^{2}\end{array}$ & $\begin{array}{l}50,834 \\
51,165 \\
51,485 \\
51,804 \\
52,113\end{array}$ & $\begin{array}{l}23,818 \\
23,719 \\
23,622 \\
23,539 \\
23,477\end{array}$ & $\begin{array}{l}7,642 \\
7,682 \\
7,734 \\
7,791 \\
7,845\end{array}$ & $\begin{array}{l}14,506 \\
14,806 \\
15,086 \\
15,346 \\
15,572\end{array}$ & $\begin{array}{l}2,717 \\
2,754 \\
2,788 \\
2,824 \\
2,865\end{array}$ & $\begin{array}{l}510 \\
510 \\
511 \\
513 \\
515\end{array}$ & $\begin{array}{l}1,643 \\
1,694 \\
1,744 \\
1,791 \\
1,838\end{array}$ & $\begin{array}{l}100.0 \\
100.0 \\
100.0 \\
100.0 \\
100.0\end{array}$ & $\begin{array}{l}46.9 \\
46.4 \\
45.9 \\
45.4 \\
45.1\end{array}$ & $\begin{array}{l}15.0 \\
15.0 \\
15.0 \\
15.0 \\
15.1\end{array}$ & $\begin{array}{l}28.5 \\
28.9 \\
29.3 \\
29.6 \\
29.9\end{array}$ & $\begin{array}{l}5.3 \\
5.4 \\
5.4 \\
5.5 \\
5.5\end{array}$ & $\begin{array}{l}1.0 \\
1.0 \\
1.0 \\
1.0 \\
1.0\end{array}$ & $\begin{array}{l}3.2 \\
3.3 \\
3.4 \\
3.5 \\
3.5\end{array}$ \\
\hline 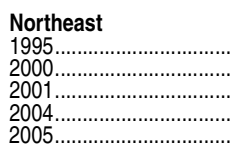 & $\begin{array}{l}7,894 \\
8,222 \\
8,254 \\
8,271 \\
8,240\end{array}$ & $\begin{array}{l}5,497 \\
5,545 \\
5,527 \\
5,384 \\
5,317\end{array}$ & $\begin{array}{l}1,202 \\
1,270 \\
1,273 \\
1,292 \\
1,282\end{array}$ & $\begin{array}{r}878 \\
1,023 \\
1,050 \\
1,155 \\
1,189\end{array}$ & $\begin{array}{l}295 \\
361 \\
378 \\
414 \\
425\end{array}$ & $\begin{array}{l}21 \\
24 \\
25 \\
27 \\
27\end{array}$ & $\begin{array}{l}- \\
- \\
\overline{-}\end{array}$ & $\begin{array}{l}100.0 \\
100.0 \\
100.0 \\
100.0 \\
100.0\end{array}$ & $\begin{array}{l}69.6 \\
67.4 \\
67.0 \\
65.1 \\
64.5\end{array}$ & $\begin{array}{l}15.2 \\
15.4 \\
15.4 \\
15.6 \\
15.6\end{array}$ & $\begin{array}{l}11.1 \\
12.4 \\
12.7 \\
14.0 \\
14.4\end{array}$ & $\begin{array}{l}3.7 \\
4.4 \\
4.6 \\
5.0 \\
5.2\end{array}$ & $\begin{array}{l}0.3 \\
0.3 \\
0.3 \\
0.3 \\
0.3\end{array}$ & $t$ \\
\hline 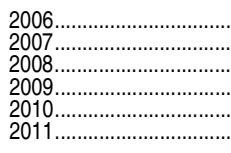 & $\begin{array}{l}8,258 \\
8,122 \\
8,053 \\
8,092 \\
8,071 \\
7,954\end{array}$ & $\begin{array}{l}5,281 \\
5,148 \\
5,041 \\
5,010 \\
4,876 \\
4,745\end{array}$ & $\begin{array}{l}1,279 \\
1,250 \\
1,226 \\
1,230 \\
1,208 \\
1,166\end{array}$ & $\begin{array}{l}1,230 \\
1,246 \\
1,267 \\
1,308 \\
1,364 \\
1,394\end{array}$ & $\begin{array}{l}440 \\
451 \\
467 \\
487 \\
500 \\
510\end{array}$ & $\begin{array}{l}28 \\
27 \\
27 \\
27 \\
27 \\
27\end{array}$ & $\begin{array}{r}- \\
\overline{25} \\
30 \\
96 \\
113\end{array}$ & $\begin{array}{l}100.0 \\
100.0 \\
100.0 \\
100.0 \\
100.0 \\
100.0\end{array}$ & $\begin{array}{l}64.0 \\
63.4 \\
62.6 \\
61.9 \\
60.4 \\
59.7\end{array}$ & $\begin{array}{l}15.5 \\
15.4 \\
15.2 \\
15.2 \\
15.0 \\
14.7\end{array}$ & $\begin{array}{l}14.9 \\
15.3 \\
15.7 \\
16.2 \\
16.9 \\
17.5\end{array}$ & $\begin{array}{l}5.3 \\
5.6 \\
56.8 \\
6.0 \\
6.2 \\
6.4\end{array}$ & $\begin{array}{l}0.3 \\
0.3 \\
0.3 \\
0.3 \\
0.3 \\
0.3\end{array}$ & $\begin{array}{l}t \\
t \\
0.3^{1} \\
0.4^{1} \\
1.2 \\
1.4\end{array}$ \\
\hline 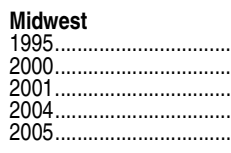 & $\begin{array}{l}10,512 \\
10,730 \\
10,746 \\
10,775 \\
10,819\end{array}$ & $\begin{array}{l}8,335 \\
8,208 \\
8,144 \\
7,983 \\
7,950\end{array}$ & $\begin{array}{l}1,450 \\
1,581 \\
1,602 \\
1,634 \\
1,654\end{array}$ & $\begin{array}{l}438 \\
610 \\
657 \\
793 \\
836\end{array}$ & $\begin{array}{l}197 \\
239 \\
248 \\
269 \\
283\end{array}$ & $\begin{array}{l}92 \\
92 \\
94 \\
96 \\
96\end{array}$ & $\begin{array}{l}- \\
\bar{z} \\
-\end{array}$ & $\begin{array}{l}100.0 \\
100.0 \\
100.0 \\
100.0 \\
100.0\end{array}$ & $\begin{array}{l}79.3 \\
76.5 \\
75.8 \\
74.1 \\
73.5\end{array}$ & $\begin{array}{l}13.8 \\
14.7 \\
14.9 \\
15.2 \\
15.3\end{array}$ & $\begin{array}{l}4.2 \\
5.7 \\
6.1 \\
7.4 \\
7.7\end{array}$ & $\begin{array}{l}1.9 \\
2.2 \\
2.3 \\
2.5 \\
2.6\end{array}$ & $\begin{array}{l}0.9 \\
0.9 \\
0.9 \\
0.9 \\
0.9\end{array}$ & $\begin{array}{l}t \\
t \\
t \\
t\end{array}$ \\
\hline $\begin{array}{l}2006 \\
2007 \\
2008 \\
2009 \\
2011\end{array}$ & $\begin{array}{l}10,819 \\
10,770 \\
10,743 \\
10,672 \\
10,610 \\
10,574\end{array}$ & $\begin{array}{l}7,894 \\
7,808 \\
7,734 \\
7,622 \\
7,327 \\
7,240\end{array}$ & $\begin{array}{l}1,655 \\
1,642 \\
1,632 \\
1,606 \\
1,505 \\
1,485\end{array}$ & $\begin{array}{r}883 \\
922 \\
963 \\
1,000 \\
1,077 \\
1,127\end{array}$ & $\begin{array}{l}290 \\
300 \\
314 \\
318 \\
312 \\
321\end{array}$ & $\begin{array}{l}97 \\
99 \\
99 \\
98 \\
94 \\
90\end{array}$ & $\begin{array}{c}\bar{z} \\
\overline{\overline{29}} \\
294 \\
311\end{array}$ & $\begin{array}{l}100.0 \\
100.0 \\
100.0 \\
100.0 \\
100.0 \\
100.0\end{array}$ & $\begin{array}{l}73.0 \\
72.5 \\
72.0 \\
71.4 \\
69.1 \\
68.5\end{array}$ & $\begin{array}{l}15.3 \\
15.2 \\
15.2 \\
15.0 \\
14.2 \\
14.0\end{array}$ & $\begin{array}{r}8.2 \\
8.6 \\
99.0 \\
9.4 \\
10.2 \\
10.7\end{array}$ & $\begin{array}{l}2.7 \\
2.8 \\
2.9 \\
3.0 \\
2.9 \\
3.0\end{array}$ & $\begin{array}{l}0.9 \\
0.9 \\
0.9 \\
0.9 \\
0.9 \\
0.9\end{array}$ & $\begin{array}{l}t \\
t \\
0.3^{1} \\
2.8^{1} \\
2.9^{2}\end{array}$ \\
\hline $\begin{array}{l}\text { South } \\
1995 \ldots \ldots . \\
2000 \ldots \ldots . \\
2001 \ldots \ldots \\
2004 \ldots . . \\
2005 \ldots \ldots .\end{array}$ & $\begin{array}{l}16,118 \\
17,007 \\
17,231 \\
17,892 \\
18,103\end{array}$ & $\begin{array}{l}9,565 \\
9,501 \\
9,477 \\
9,410 \\
9,381\end{array}$ & $\begin{array}{l}4,236 \\
4,516 \\
4,556 \\
4,704 \\
4,738\end{array}$ & $\begin{array}{l}1,890 \\
2,468 \\
2,649 \\
3,155 \\
3,334\end{array}$ & $\begin{array}{l}280 \\
352 \\
373 \\
432 \\
456\end{array}$ & $\begin{array}{l}148 \\
170 \\
175 \\
191 \\
194\end{array}$ & $\begin{array}{l}- \\
\bar{z} \\
-\end{array}$ & $\begin{array}{l}100.0 \\
100.0 \\
100.0 \\
100.0 \\
100.0\end{array}$ & $\begin{array}{l}59.3 \\
55.9 \\
55.0 \\
52.6 \\
51.8\end{array}$ & $\begin{array}{l}26.3 \\
26.6 \\
26.4 \\
26.3 \\
26.2\end{array}$ & $\begin{array}{l}11.7 \\
14.5 \\
15.4 \\
17.6 \\
18.4\end{array}$ & $\begin{array}{l}1.7 \\
2.1 \\
2.2 \\
2.4 \\
2.5\end{array}$ & $\begin{array}{l}0.9 \\
1.0 \\
1.0 \\
1.1 \\
1.1\end{array}$ & $\begin{array}{l}t \\
t \\
t \\
t\end{array}$ \\
\hline 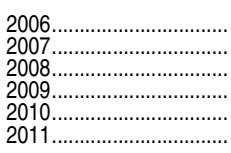 & $\begin{array}{l}18,294 \\
18,425 \\
18,491 \\
18,652 \\
18,805 \\
18,956\end{array}$ & $\begin{array}{l}9,358 \\
9,287 \\
9,190 \\
9,074 \\
8,869 \\
8,830\end{array}$ & $\begin{array}{l}4,729 \\
4,751 \\
4,771 \\
4,710 \\
4,545 \\
4,535\end{array}$ & $\begin{array}{l}3,522 \\
3,674 \\
3,790 \\
4,039 \\
4,206 \\
4,353\end{array}$ & $\begin{array}{l}485 \\
511 \\
537 \\
555 \\
555 \\
577\end{array}$ & $\begin{array}{l}200 \\
201 \\
203 \\
219 \\
207 \\
198\end{array}$ & $\begin{array}{l}\bar{z} \\
\overline{55} \\
424 \\
463\end{array}$ & $\begin{array}{l}100.0 \\
100.0 \\
100.0 \\
100.0 \\
100.0 \\
100.0\end{array}$ & $\begin{array}{l}51.2 \\
50.4 \\
49.7 \\
48.6 \\
47.2 \\
46.6\end{array}$ & $\begin{array}{l}25.9 \\
25.8 \\
25.8 \\
25.3 \\
24.2 \\
23.9\end{array}$ & $\begin{array}{l}19.3 \\
19.9 \\
20.5 \\
21.7 \\
22.4 \\
23.0\end{array}$ & $\begin{array}{l}2.6 \\
2.8 \\
2.9 \\
3.0 \\
3.0 \\
3.0\end{array}$ & $\begin{array}{l}1.1 \\
1.1 \\
1.1 \\
1.2 \\
1.1 \\
1.0\end{array}$ & $\begin{array}{l}t \\
t \\
t \\
0.3^{1} \\
2.3^{1} \\
2.4\end{array}$ \\
\hline 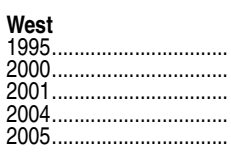 & $\begin{array}{l}10,316 \\
11,244 \\
11,441 \\
11,857 \\
11,951\end{array}$ & $\begin{array}{l}5,648 \\
5,624 \\
5,586 \\
5,541 \\
5,356\end{array}$ & $\begin{array}{l}662 \\
733 \\
746 \\
757 \\
771\end{array}$ & $\begin{array}{l}2,866 \\
3,625 \\
3,813 \\
4,213 \\
4,428\end{array}$ & $\begin{array}{r}896 \\
998 \\
1,028 \\
1,069 \\
1,115\end{array}$ & $\begin{array}{l}244 \\
264 \\
269 \\
277 \\
281\end{array}$ & $\begin{array}{l}\bar{z} \\
\overline{-} \\
-\end{array}$ & $\begin{array}{l}100.0 \\
100.0 \\
100.0 \\
100.0 \\
100.0\end{array}$ & $\begin{array}{l}54.7 \\
50.0 \\
48.8 \\
46.7 \\
44.8\end{array}$ & $\begin{array}{l}6.4 \\
6.5 \\
6.5 \\
6.4 \\
6.5\end{array}$ & $\begin{array}{l}27.8 \\
32.2 \\
33.4 \\
35.5 \\
37.1\end{array}$ & $\begin{array}{l}8.7 \\
8.9 \\
9.0 \\
9.0 \\
9.3\end{array}$ & $\begin{array}{l}2.4 \\
2.4 \\
2.3 \\
2.3 \\
2.4\end{array}$ & $\begin{array}{l}t \\
t \\
t\end{array}$ \\
\hline 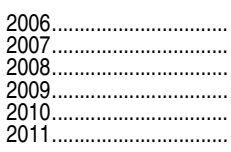 & $\begin{array}{l}11,945 \\
11,966 \\
11,979 \\
11,945 \\
11,998 \\
12,038\end{array}$ & $\begin{array}{l}5,268 \\
5,213 \\
5,092 \\
4,997 \\
4,861 \\
4,787\end{array}$ & $\begin{array}{l}759 \\
750 \\
728 \\
699 \\
659 \\
642\end{array}$ & $\begin{array}{l}4,531 \\
4,611 \\
4,543 \\
4,645 \\
4,792 \\
4,886\end{array}$ & $\begin{array}{l}1,117 \\
1,134 \\
1,133 \\
1,124 \\
1,100 \\
1,105\end{array}$ & $\begin{array}{l}270 \\
267 \\
261 \\
256 \\
237 \\
233\end{array}$ & $\begin{array}{l}- \\
222 \\
223 \\
349 \\
385\end{array}$ & $\begin{array}{l}100.0 \\
100.0 \\
100.0 \\
100.0 \\
100.0 \\
100.0\end{array}$ & $\begin{array}{l}44.1 \\
43.5 \\
42.5 \\
41.8 \\
40.5 \\
39.8\end{array}$ & $\begin{array}{l}6.4 \\
6.3 \\
6.1 \\
5.9 \\
5.5 \\
5.3\end{array}$ & $\begin{array}{l}37.9 \\
38.5 \\
37.9 \\
38.9 \\
39.9 \\
40.6\end{array}$ & $\begin{array}{l}9.4 \\
9.5 \\
9.5 \\
9.4 \\
9.2 \\
9.2\end{array}$ & $\begin{array}{l}2.3 \\
2.2 \\
2.2 \\
2.1 \\
2.0 \\
1.9\end{array}$ & $\begin{array}{r}t \\
t \\
1.91 \\
1.91 \\
2.99 \\
3.2\end{array}$ \\
\hline
\end{tabular}

-Not available.

†Not applicable.

${ }^{1}$ For this year, data on students of two or more races were reported by only a small number of states. Therefore, the data are not comparable to figures for 2010 and later years.

${ }^{2}$ Projected.

NOTE: Race categories exclude persons of Hispanic ethnicity. Enrollment data for students not reported by race/ethnicity were prorated by state and grade to match state totals. Prior to 2008 , data on students of two or more races were not collected. Some data have been revised from previously published figures. Detail may not sum to totals because of rounding.

SOURCE: U.S. Department of Education, National Center for Education Statistics, Common Core of Data (CCD), "State Nonfiscal Survey of Public Elementary and Secondary Education," 1995-96 through 2011-12; and National Elementary and Secondary Enrollment by Race/Ethnicity Projection Model, 1972 through 2023. (This table was prepared December 2013.) 
Table 203.60. Enrollment and percentage distribution of enrollment in public elementary and secondary schools, by race/ethnicity and level of education: Fall 1998 through fall 2023

\begin{tabular}{|c|c|c|c|c|c|c|c|c|c|c|c|c|c|c|c|c|c|c|}
\hline \multirow[b]{3}{*}{$\begin{array}{l}\text { Level of education } \\
\text { and year }\end{array}$} & \multicolumn{9}{|c|}{ Enrollment (in thousands) } & \multicolumn{9}{|c|}{ Percentage distribution } \\
\hline & \multirow[b]{2}{*}{ Total } & \multirow[b]{2}{*}{ White } & \multirow[b]{2}{*}{ Black } & \multirow[b]{2}{*}{$\begin{array}{r}\text { His- } \\
\text { panic }\end{array}$} & \multicolumn{3}{|c|}{ Asian/Pacific Islander } & \multirow{2}{*}{\begin{tabular}{|r|} 
American \\
Indian/ \\
Alaska \\
Native
\end{tabular}} & \multirow{2}{*}{$\begin{array}{r}\text { Two or } \\
\text { more } \\
\text { races }\end{array}$} & \multirow[b]{2}{*}{ Total } & \multirow[b]{2}{*}{ White } & \multirow[b]{2}{*}{ Black } & \multirow[b]{2}{*}{$\begin{array}{r}\text { His- } \\
\text { panic }\end{array}$} & \multicolumn{3}{|c|}{ Asian/Pacific Islander } & \multirow{2}{*}{\begin{tabular}{|r|} 
American \\
Indian/ \\
Alaska \\
Native
\end{tabular}} & \multirow{2}{*}{$\begin{array}{l}\text { Two or } \\
\text { more } \\
\text { races }\end{array}$} \\
\hline & & & & & Total & Asian & $\begin{array}{r}\text { Pacific } \\
\text { Islander }\end{array}$ & & & & & & & Total & Asian & $\begin{array}{r}\text { Pacific } \\
\text { Islander }\end{array}$ & & \\
\hline r & 2 & 3 & 4 & 5 & 6 & 7 & 8 & 9 & 10 & 11 & 12 & 13 & 14 & 15 & 16 & 17 & 18 & $\overline{19}$ \\
\hline 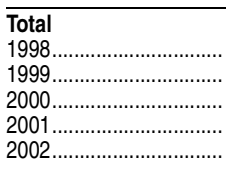 & $\begin{array}{l}46,539 \\
46,857 \\
47,204 \\
47,672 \\
48,183\end{array}$ & $\begin{array}{l}29,239 \\
29,035 \\
28,878 \\
28,735 \\
28,618\end{array}$ & $\begin{array}{l}7,945 \\
8,066 \\
8,100 \\
8,177 \\
8,299\end{array}$ & $\begin{array}{l}6,981 \\
7,327 \\
7,726 \\
8,169 \\
8,594\end{array}$ & $\begin{array}{l}1,839 \\
1,887 \\
1,950 \\
2,028 \\
2,088\end{array}$ & $\begin{array}{l}- \\
- \\
- \\
-\end{array}$ & $\begin{array}{l}- \\
- \\
- \\
- \\
-\end{array}$ & $\begin{array}{l}534 \\
542 \\
550 \\
564 \\
583\end{array}$ & $\begin{array}{l}- \\
\overline{-} \\
\overline{-}\end{array}$ & $\begin{array}{l}100.0 \\
100.0 \\
100.0 \\
100.0 \\
100.0\end{array}$ & $\begin{array}{l}62.8 \\
62.0 \\
61.2 \\
60.3 \\
59.4\end{array}$ & \begin{tabular}{l|}
17.1 \\
17.2 \\
17.2 \\
17.2 \\
17.2
\end{tabular} & 15.0 & 4.0 & $\begin{array}{l}t \\
t \\
\dagger \\
t \\
t\end{array}$ & $\begin{array}{l}t \\
t \\
\dagger \\
\dagger \\
\dagger\end{array}$ & $\begin{array}{l}1.1 \\
1.2 \\
1.2 \\
1.2 \\
1.2\end{array}$ & $\begin{array}{l}t \\
t \\
t \\
t \\
t\end{array}$ \\
\hline 0. & $\begin{array}{l}48,540 \\
48,795 \\
49,113 \\
49,316 \\
49,293\end{array}$ & $\begin{array}{l}28,442 \\
28,318 \\
28,005 \\
27,801 \\
27,456\end{array}$ & $\begin{array}{l}8,349 \\
8,386 \\
8,445 \\
8,422 \\
8,392\end{array}$ & $\begin{array}{r}9,011 \\
9,317 \\
9,787 \\
10,166 \\
10,454\end{array}$ & $\begin{array}{l}2,145 \\
2,183 \\
2,279 \\
2,332 \\
2,396\end{array}$ & $\begin{array}{l}- \\
- \\
- \\
-\end{array}$ & $\begin{array}{l}- \\
- \\
- \\
-\end{array}$ & $\begin{array}{l}593 \\
591 \\
598 \\
595 \\
594\end{array}$ & $\begin{array}{l}- \\
\overline{-} \\
\overline{-} \\
-\end{array}$ & $\begin{array}{l}100.0 \\
100.0 \\
100.0 \\
100.0 \\
100.0\end{array}$ & $\begin{array}{l}58.6 \\
58.0 \\
57.0 \\
56.4 \\
55.7\end{array}$ & $\begin{array}{l}17.2 \\
17.2 \\
17.2 \\
17.1 \\
17.0\end{array}$ & & 4.4 & $\begin{array}{l}t \\
t \\
\dagger \\
t \\
t\end{array}$ & $\begin{array}{l}\dagger \\
\dagger \\
\dagger \\
\dagger \\
\dagger\end{array}$ & $\begin{array}{l}1.2 \\
1.2 \\
1.2 \\
1.2 \\
1.2\end{array}$ & $\begin{array}{l}t \\
t \\
t \\
t \\
t\end{array}$ \\
\hline $\begin{array}{l}2008 \text {. } \\
2009 \ldots \\
2010 \ldots \\
2011 \ldots \ldots \\
2012^{2}\end{array}$ & $\begin{array}{l}49,266 \\
49,361 \\
49,484 \\
49,522 \\
49,652\end{array}$ & $\begin{array}{l}27,057 \\
26,702 \\
25,933 \\
25,602 \\
25,334\end{array}$ & $\begin{array}{l}8,358 \\
8,245 \\
7,917 \\
7,827 \\
7,775\end{array}$ & $\begin{array}{l}10,563 \\
10,991 \\
11,439 \\
11,759 \\
12,157\end{array}$ & $\begin{array}{l}2,451 \\
2,484 \\
2,466 \\
2,513 \\
2,532\end{array}$ & $\begin{array}{l}2,405 \\
2,435 \\
2,296 \\
2,334 \\
2,344\end{array}$ & $\begin{array}{r}46 \\
49 \\
171 \\
179 \\
188\end{array}$ & $\begin{array}{l}589 \\
601 \\
566 \\
547 \\
539\end{array}$ & $\begin{array}{r}2477^{1} \\
338{ }^{1} \\
1,164 \\
1,272 \\
1,315\end{array}$ & $\begin{array}{l}100.0 \\
100.0 \\
100.0 \\
100.0 \\
100.0\end{array}$ & $\begin{array}{l}54.9 \\
54.1 \\
52.4 \\
51.7 \\
51.0\end{array}$ & $\begin{array}{l}17.0 \\
16.7 \\
16.0 \\
15.8 \\
15.7\end{array}$ & & 5.0 & $\begin{array}{l}4.9 \\
4.9 \\
4.6 \\
4.7 \\
4.7\end{array}$ & $\begin{array}{l}0.1 \\
0.1 \\
0.3 \\
0.4 \\
0.4\end{array}$ & $\begin{array}{l}1.2 \\
1.2 \\
1.1 \\
1.1 \\
1.1\end{array}$ & $\begin{array}{l}0.5^{1} \\
0.7^{1} \\
2.4^{1} \\
2.6 \\
2.6\end{array}$ \\
\hline $2017^{2}$ & $\begin{array}{l}49,750 \\
49,751 \\
49,839 \\
49,951 \\
50,280\end{array}$ & $\begin{array}{l}25,066 \\
24,766 \\
24,497 \\
24,250 \\
24,108\end{array}$ & $\begin{array}{l}7,728 \\
7,675 \\
7,638 \\
7,597 \\
7,611\end{array}$ & $\begin{array}{l}12,510 \\
12,814 \\
13,148 \\
13,481 \\
13,854\end{array}$ & $\begin{array}{l}2,553 \\
2,565 \\
2,587 \\
2,613 \\
2,651\end{array}$ & $\begin{array}{l}2,355 \\
2,359 \\
2,373 \\
2,390 \\
2,419\end{array}$ & $\begin{array}{l}198 \\
207 \\
215 \\
223 \\
232\end{array}$ & $\begin{array}{l}533 \\
526 \\
522 \\
516 \\
513\end{array}$ & $\begin{array}{l}1,360 \\
1,405 \\
1,448 \\
1,494 \\
1,543\end{array}$ & & $\begin{array}{l}50.4 \\
49.8 \\
49.2 \\
48.5 \\
47.9\end{array}$ & $\begin{array}{l}15.5 \\
15.4 \\
15.3 \\
15.2 \\
15.1\end{array}$ & & 51 & $\begin{array}{l}4.7 \\
4.7 \\
4.8 \\
4.8 \\
4.8\end{array}$ & 0.4 & $\begin{array}{l}1.1 \\
1.1 \\
1.0 \\
1.0 \\
1.0\end{array}$ & $\begin{array}{l}2.7 \\
2.8 \\
2.9 \\
3.0 \\
3.1\end{array}$ \\
\hline 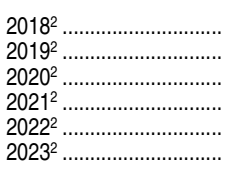 & \begin{tabular}{|l}
50,543 \\
50,834 \\
51,165 \\
51,485 \\
51,804 \\
52,113
\end{tabular} & $\begin{array}{l}23,952 \\
23,818 \\
23,719 \\
23,622 \\
23,539 \\
23,477\end{array}$ & $\begin{array}{l}7,618 \\
7,642 \\
7,682 \\
7,734 \\
7,791 \\
7,845\end{array}$ & $\begin{array}{l}14,188 \\
14,506 \\
14,806 \\
15,086 \\
15,346 \\
15,572\end{array}$ & $\begin{array}{l}2,681 \\
2,717 \\
2,754 \\
2,788 \\
2,824 \\
2,865\end{array}$ & $\begin{array}{l}2,441 \\
2,468 \\
2,498 \\
2,526 \\
2,556 \\
2,593\end{array}$ & $\begin{array}{l}240 \\
249 \\
256 \\
263 \\
268 \\
272\end{array}$ & $\begin{array}{l}511 \\
510 \\
510 \\
511 \\
513 \\
515\end{array}$ & $\begin{array}{l}1,592 \\
1,643 \\
1,694 \\
1,744 \\
1,791 \\
1,838\end{array}$ & & $\begin{array}{l}47.4 \\
46.9 \\
46.4 \\
45.9 \\
45.4 \\
45.1\end{array}$ & $\begin{array}{l}15.1 \\
15.0 \\
15.0 \\
15.0 \\
15.0\end{array}$ & & 5.3 & $\begin{array}{l}4.8 \\
4.9 \\
4.9 \\
4.9 \\
4.9 \\
5.0\end{array}$ & 0.5 & $\begin{array}{l}1.0 \\
1.0 \\
1.0 \\
1.0 \\
1.0 \\
1.0\end{array}$ & $\begin{array}{l}3.2 \\
3.2 \\
3.3 \\
3.4 \\
3.5 \\
3.5\end{array}$ \\
\hline $\begin{array}{l}\text { ekindergarten } \\
\text { through grade } 8\end{array}$ & $\begin{array}{l}33,344 \\
33,486 \\
33,686 \\
33,936 \\
34,114\end{array}$ & $\begin{array}{l}20,585 \\
20,327 \\
20,130 \\
19,960 \\
19,764\end{array}$ & $\begin{array}{l}5,864 \\
5,952 \\
5,981 \\
6,004 \\
6,042\end{array}$ & $\begin{array}{l}5,237 \\
5,512 \\
5,830 \\
6,159 \\
6,446\end{array}$ & $\begin{array}{l}1,271 \\
1,303 \\
1,349 \\
1,409 \\
1,447\end{array}$ & $\begin{array}{l}- \\
- \\
- \\
-\end{array}$ & $\begin{array}{l}- \\
- \\
- \\
-\end{array}$ & $\begin{array}{l}387 \\
391 \\
397 \\
405 \\
415\end{array}$ & $\begin{array}{l}- \\
\overline{-} \\
- \\
-\end{array}$ & & $\begin{array}{l}61.7 \\
60.7 \\
59.8 \\
588\end{array}$ & $\begin{array}{l}17.6 \\
17.8 \\
17.8 \\
17.7 \\
17.7\end{array}$ & & 3. & $\begin{array}{l}\dagger \\
t \\
\dagger\end{array}$ & $t$ & $\begin{array}{l}1.2 \\
1.2 \\
1.2 \\
1.2 \\
1.2\end{array}$ & $\begin{array}{l}t \\
t \\
t \\
t \\
t\end{array}$ \\
\hline 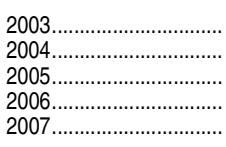 & $\begin{array}{l}34,201 \\
34,178 \\
34,204 \\
34,235 \\
34,205\end{array}$ & $\begin{array}{l}19,558 \\
19,368 \\
19,051 \\
18,863 \\
18,680\end{array}$ & $\begin{array}{l}6,015 \\
5,983 \\
5,954 \\
5,882 \\
5,821\end{array}$ & $\begin{array}{l}6,729 \\
6,909 \\
7,216 \\
7,465 \\
7,633\end{array}$ & $\begin{array}{l}1,569 \\
1,611 \\
1,660\end{array}$ & $\begin{array}{l}- \\
- \\
- \\
-\end{array}$ & $\begin{array}{l}- \\
- \\
- \\
- \\
-\end{array}$ & $\begin{array}{l}415 \\
413 \\
412 \\
414 \\
412\end{array}$ & $\begin{array}{l}- \\
- \\
- \\
-\end{array}$ & & $\begin{array}{l}55.7 \\
55.1 \\
54.6\end{array}$ & $\begin{array}{l}17.6 \\
17.5 \\
17.4 \\
17.2 \\
17.0\end{array}$ & & & $\begin{array}{l}t \\
t \\
t \\
t \\
t\end{array}$ & $t$ & $\begin{array}{l}1.2 \\
1.2 \\
1.2 \\
1.2 \\
1.2\end{array}$ & $\begin{array}{l}t \\
t \\
t \\
t \\
t\end{array}$ \\
\hline $2012^{2}$ & $\begin{array}{l}34,286 \\
34,409 \\
34,625 \\
34,773 \\
34,968\end{array}$ & $\begin{array}{l}18,501 \\
18,316 \\
17,823 \\
17,654 \\
17,506\end{array}$ & $\begin{array}{l}5,793 \\
5,713 \\
5,495 \\
5,470 \\
5,454\end{array}$ & $\begin{array}{l}7,689 \\
7,977 \\
8,314 \\
8,558 \\
8,866\end{array}$ & & $\begin{array}{l}1,674 \\
1,697 \\
1,589 \\
1,616 \\
1,629\end{array}$ & $\begin{array}{r}31 \\
33 \\
122 \\
128 \\
135\end{array}$ & $\begin{array}{l}410 \\
419 \\
394 \\
384 \\
380\end{array}$ & $\begin{array}{l}187^{1} \\
254^{1} \\
887 \\
963 \\
997\end{array}$ & & & & & $\begin{array}{l}5.0 \\
5.0\end{array}$ & $\begin{array}{l}4.9 \\
4.9 \\
4.6 \\
4.6 \\
4.7\end{array}$ & 0.1 & $\begin{array}{l}1.2 \\
1.2 \\
1 .\end{array}$ & $\begin{array}{l}0.5^{1} \\
0.7^{1} \\
2.6^{1} \\
2.8 \\
2.9\end{array}$ \\
\hline 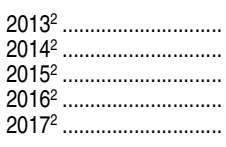 & $\begin{array}{l}35,111 \\
35,062 \\
35,069 \\
35,142 \\
35,412\end{array}$ & $\begin{array}{l}17,342 \\
17,115 \\
16,899 \\
16,737 \\
16,668\end{array}$ & $\begin{array}{l}5,439 \\
5,392 \\
5,366 \\
5,356 \\
5,403\end{array}$ & $\begin{array}{l}9,137 \\
9,331 \\
9,539 \\
9,738 \\
9,969\end{array}$ & $\begin{array}{l}1,786 \\
1,790 \\
1,805 \\
1,818 \\
1,839\end{array}$ & $\begin{array}{l}1,645 \\
1,644 \\
1,653 \\
1,662 \\
1,678\end{array}$ & $\begin{array}{l}141 \\
147 \\
152 \\
156 \\
161\end{array}$ & $\begin{array}{l}365 \\
362 \\
363\end{array}$ & $\begin{array}{l}1,031 \\
1,065 \\
1,095 \\
1,130 \\
1,170\end{array}$ & & $\begin{array}{l}48.2 \\
47.6 \\
47.1\end{array}$ & $\begin{array}{l}15.2 \\
15.3\end{array}$ & & $\begin{array}{l}5.1 \\
5.1 \\
5.1\end{array}$ & $\begin{array}{l}4.7 \\
4.7 \\
4.7 \\
4.7 \\
4.7\end{array}$ & 0.4 & $\begin{array}{l}1.1 \\
1.1 \\
1.0 \\
1.0 \\
1.0\end{array}$ & $\begin{array}{l}2.9 \\
3.0 \\
3.1 \\
3.2 \\
3.3\end{array}$ \\
\hline 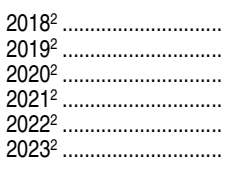 & \begin{tabular}{|l}
35,642 \\
35,878 \\
36,115 \\
36,335 \\
36,585 \\
36,967
\end{tabular} & $\begin{array}{l}16,592 \\
16,546 \\
16,515 \\
16,487 \\
16,476 \\
16,517\end{array}$ & $\begin{array}{l}5,451 \\
5,503 \\
5,550 \\
5,586 \\
5,623 \\
5,680\end{array}$ & $\begin{array}{r}10,166 \\
10,330 \\
10,480 \\
10,623 \\
10,779 \\
10,985\end{array}$ & $\begin{array}{l}1,860 \\
1,886 \\
1,919 \\
1,953 \\
1,985 \\
2,028\end{array}$ & $\begin{array}{l}1,695 \\
1,720 \\
1,749 \\
1,780 \\
1,809 \\
1,848\end{array}$ & $\begin{array}{l}165 \\
167 \\
170 \\
172 \\
176 \\
180\end{array}$ & $\begin{array}{l}364 \\
366\end{array}$ & & & & & & $\begin{array}{l}5.2 \\
5.3 \\
5.3 \\
5.4\end{array}$ & $\begin{array}{l}4.8 \\
4.8 \\
4.8 \\
\end{array}$ & 0.5 & $\begin{array}{l}1.0 \\
1.0 \\
1.0 \\
1.0\end{array}$ & $\begin{array}{l}3.4 \\
3.5 \\
3.6 \\
3.6 \\
3.7 \\
3.7\end{array}$ \\
\hline 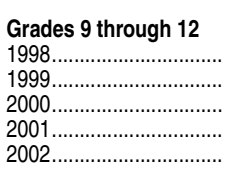 & $\begin{array}{l}13,195 \\
13,371 \\
13,517 \\
13,736 \\
14,069\end{array}$ & $\begin{array}{l}8,655 \\
8,708 \\
8,747 \\
8,774 \\
8,854\end{array}$ & $\begin{array}{l}2,081 \\
2,114 \\
2,119 \\
2,173 \\
2,257\end{array}$ & $\begin{array}{l}1,744 \\
1,815 \\
1,896 \\
2,011 \\
2,148\end{array}$ & $\begin{array}{l}567 \\
584 \\
601 \\
619 \\
642\end{array}$ & $\begin{array}{l}- \\
- \\
- \\
- \\
-\end{array}$ & $\begin{array}{l}- \\
- \\
- \\
-\end{array}$ & $\begin{array}{l}147 \\
151 \\
153 \\
159 \\
168\end{array}$ & $\begin{array}{l}- \\
\overline{-} \\
- \\
-\end{array}$ & & $\begin{array}{l}65.6 \\
65.1 \\
64.7 \\
63.9 \\
62.9\end{array}$ & & & & $\begin{array}{l}t \\
t \\
t\end{array}$ & $t$ & $\begin{array}{l}1.1 \\
1.1 \\
1.1 \\
1.2 \\
1.2\end{array}$ & $\begin{array}{l}t \\
t \\
\dagger \\
+ \\
t\end{array}$ \\
\hline 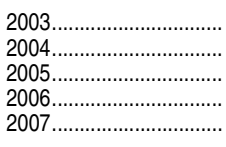 & $\begin{array}{l}14,339 \\
14,618 \\
14,909 \\
15,081 \\
15,087\end{array}$ & $\begin{array}{l}8,884 \\
8,950 \\
8,954 \\
8,938 \\
8,776\end{array}$ & $\begin{array}{l}2,334 \\
2,403 \\
2,490 \\
2,540 \\
2,571\end{array}$ & $\begin{array}{l}2,282 \\
2,408 \\
2,570 \\
2,701 \\
2,821\end{array}$ & $\begin{array}{l}663 \\
679 \\
709 \\
720 \\
736\end{array}$ & $\begin{array}{l}- \\
- \\
- \\
-\end{array}$ & $\begin{array}{l}- \\
- \\
- \\
- \\
-\end{array}$ & $\begin{array}{l}177 \\
178 \\
186 \\
181 \\
183\end{array}$ & $\begin{array}{l}- \\
- \\
- \\
-\end{array}$ & $\begin{array}{l}100.0 \\
100.0 \\
100.0 \\
100.0 \\
100.0\end{array}$ & $\begin{array}{l}62.0 \\
61.2 \\
60.1 \\
59.3 \\
58.2\end{array}$ & $\begin{array}{l}16.3 \\
16.4 \\
16.7 \\
16.8 \\
17.0\end{array}$ & $\begin{array}{l}17.2 \\
17.9 \\
18.7\end{array}$ & $\begin{array}{l}4.6 \\
4.6 \\
4.8\end{array}$ & $\begin{array}{l}t \\
t \\
t \\
t \\
t\end{array}$ & t & $\begin{array}{l}1.2 \\
1.2 \\
1.2 \\
1.2 \\
1.2\end{array}$ & $\begin{array}{l}+ \\
\dagger \\
\dagger \\
t \\
+\end{array}$ \\
\hline $\begin{array}{l}2008 \\
2009 \ldots \\
2010 \ldots \\
2011 \ldots \ldots \\
2012^{2}\end{array}$ & $\begin{array}{l}14,980 \\
14,952 \\
14,860 \\
14,749 \\
14,684\end{array}$ & $\begin{array}{l}8,556 \\
8,385 \\
8,109 \\
7,948 \\
7,828\end{array}$ & $\begin{array}{l}2,565 \\
2,532 \\
2,422 \\
2,357 \\
2,320\end{array}$ & $\begin{array}{l}2,874 \\
3,014 \\
3,125 \\
3,202 \\
3,290\end{array}$ & $\begin{array}{l}746 \\
754 \\
755 \\
769 \\
768\end{array}$ & $\begin{array}{l}731 \\
738 \\
707 \\
719 \\
715\end{array}$ & $\begin{array}{l}15 \\
16 \\
49 \\
50 \\
53\end{array}$ & $\begin{array}{l}179 \\
182 \\
171 \\
163 \\
159\end{array}$ & $\begin{array}{r}591 \\
84{ }^{1} \\
277 \\
309 \\
318\end{array}$ & $\begin{array}{l}100.0 \\
100.0 \\
100.0 \\
100.0 \\
100.0\end{array}$ & $\begin{array}{l}57.1 \\
56.1 \\
54.6 \\
53.9 \\
53.3\end{array}$ & $\begin{array}{l}17.1 \\
16.9 \\
16.3 \\
16.0 \\
15.8\end{array}$ & $\begin{array}{l}21.2 \\
21.0 \\
21.7 \\
22.4\end{array}$ & 5.0 & $\begin{array}{l}4.9 \\
4.9 \\
4.8 \\
4.9 \\
4.9\end{array}$ & $\begin{array}{l}0.1 \\
0.1 \\
0.3\end{array}$ & $\begin{array}{l}1.2 \\
1.2 \\
1.2 \\
1.1 \\
1.1\end{array}$ & $\begin{array}{l}0.4^{1} \\
0.6^{1} \\
1.9 \\
2.1 \\
2.2\end{array}$ \\
\hline
\end{tabular}


Table 203.60. Enrollment and percentage distribution of enrollment in public elementary and secondary schools, by race/ethnicity and level of education: Fall 1998 through fall 2023-Continued

\begin{tabular}{|c|c|c|c|c|c|c|c|c|c|c|c|c|c|c|c|c|c|c|}
\hline \multirow[b]{3}{*}{$\begin{array}{l}\text { Level of education } \\
\text { and year }\end{array}$} & \multicolumn{9}{|c|}{ Enrollment (in thousands) } & \multicolumn{9}{|c|}{ Percentage distribution } \\
\hline & \multirow[b]{2}{*}{ Total } & \multirow[b]{2}{*}{ White } & \multirow[b]{2}{*}{ Black } & \multirow[b]{2}{*}{$\begin{array}{r}\text { His- } \\
\text { panic }\end{array}$} & \multicolumn{3}{|c|}{ Asian/Pacific Islander } & \multirow{2}{*}{$\begin{array}{r}\text { American } \\
\text { Indian/ } \\
\text { Alaska } \\
\text { Native }\end{array}$} & \multirow{2}{*}{$\begin{array}{c}\text { Two or } \\
\text { more } \\
\text { races }\end{array}$} & \multirow[b]{2}{*}{ Total } & \multirow[b]{2}{*}{ White } & \multirow[b]{2}{*}{ Black } & \multirow[b]{2}{*}{$\begin{array}{r}\text { His- } \\
\text { panic }\end{array}$} & \multicolumn{3}{|c|}{ Asian/Pacific Islander } & \multirow{2}{*}{$\begin{array}{r}\text { American } \\
\text { Indian/ } \\
\text { Alaska } \\
\text { Native }\end{array}$} & \multirow{2}{*}{$\begin{array}{l}\text { Two or } \\
\text { more } \\
\text { races }\end{array}$} \\
\hline & & & & & Total & Asian & $\begin{array}{r}\text { Pacific } \\
\text { Islander }\end{array}$ & & & & & & & Total & Asian & $\begin{array}{r}\text { Pacific } \\
\text { Islander }\end{array}$ & & \\
\hline 1 & 2 & 3 & 4 & 5 & 6 & 7 & 8 & 9 & 10 & 11 & 12 & 13 & 14 & 15 & 16 & 17 & 18 & 19 \\
\hline 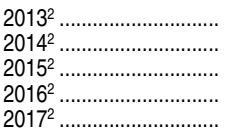 & $\begin{array}{l}14,639 \\
14,689 \\
14,770 \\
14,810 \\
14,868\end{array}$ & $\begin{array}{l}7,724 \\
7,651 \\
7,598 \\
7,513 \\
7,440\end{array}$ & $\begin{array}{l}2,289 \\
2,283 \\
2,271 \\
2,241 \\
2,208\end{array}$ & $\begin{array}{l}3,373 \\
3,483 \\
3,610 \\
3,743 \\
3,886\end{array}$ & $\begin{array}{l}767 \\
775 \\
782 \\
794 \\
812\end{array}$ & $\begin{array}{l}710 \\
715 \\
719 \\
728 \\
741\end{array}$ & $\begin{array}{l}56 \\
60 \\
63 \\
67 \\
71\end{array}$ & $\begin{array}{l}158 \\
157 \\
157 \\
154 \\
150\end{array}$ & $\begin{array}{l}329 \\
340 \\
353 \\
364 \\
373\end{array}$ & $\begin{array}{l}100.0 \\
100.0 \\
100.0 \\
100.0 \\
100.0\end{array}$ & $\begin{array}{l}52.8 \\
52.1 \\
51.4 \\
50.7 \\
50.0\end{array}$ & $\begin{array}{l}15.6 \\
15.5 \\
15.4 \\
15.1 \\
14.8\end{array}$ & $\begin{array}{l}23.0 \\
23.7 \\
24.4 \\
25.3 \\
26.1\end{array}$ & $\begin{array}{l}5.2 \\
5.3 \\
5.3 \\
5.4 \\
5.5\end{array}$ & $\begin{array}{l}4.9 \\
4.9 \\
4.9 \\
4.9 \\
5.0\end{array}$ & $\begin{array}{l}0.4 \\
0.4 \\
0.4 \\
0.4 \\
0.5\end{array}$ & $\begin{array}{l}1.1 \\
1.1 \\
1.1 \\
1.0 \\
1.0\end{array}$ & $\begin{array}{l}2.2 \\
2.3 \\
2.4 \\
2.5 \\
2.5\end{array}$ \\
\hline $\begin{array}{l}2018^{2} \\
2019^{2} \\
2020^{2} \\
2021^{2} \\
2022^{2} \\
2023^{2}\end{array}$ & $\begin{array}{l}14,901 \\
14,957 \\
15,050 \\
15,151 \\
15,219 \\
15,146\end{array}$ & $\begin{array}{l}7,360 \\
7,271 \\
7,204 \\
7,135 \\
7,062 \\
6,960\end{array}$ & $\begin{array}{l}2,167 \\
2,139 \\
2,132 \\
2,148 \\
2,168 \\
2,166\end{array}$ & $\begin{array}{l}4,023 \\
4,176 \\
4,325 \\
4,463 \\
4,566 \\
4,586\end{array}$ & $\begin{array}{l}821 \\
831 \\
835 \\
836 \\
839 \\
837\end{array}$ & $\begin{array}{l}746 \\
749 \\
748 \\
745 \\
746 \\
745\end{array}$ & $\begin{array}{l}76 \\
82 \\
86 \\
90 \\
92 \\
92\end{array}$ & $\begin{array}{l}147 \\
144 \\
143 \\
142 \\
141 \\
140\end{array}$ & $\begin{array}{l}382 \\
396 \\
412 \\
427 \\
442 \\
457\end{array}$ & $\begin{array}{l}100.0 \\
100.0 \\
100.0 \\
100.0 \\
100.0 \\
100.0\end{array}$ & $\begin{array}{l}49.4 \\
48.6 \\
47.9 \\
47.1 \\
46.4 \\
46.0\end{array}$ & $\begin{array}{l}14.5 \\
14.3 \\
14.2 \\
14.2 \\
14.2 \\
14.3\end{array}$ & $\begin{array}{l}27.0 \\
27.9 \\
28.7 \\
29.5 \\
30.0 \\
30.3\end{array}$ & $\begin{array}{l}5.5 \\
5.6 \\
5.5 \\
5.5 \\
5.5 \\
5.5\end{array}$ & $\begin{array}{l}5.0 \\
5.0 \\
5.0 \\
4.9 \\
4.9 \\
4.9\end{array}$ & $\begin{array}{l}0.5 \\
0.5 \\
0.6 \\
0.6 \\
0.6 \\
0.6\end{array}$ & $\begin{array}{l}1.0 \\
1.0 \\
0.9 \\
0.9 \\
0.9 \\
0.9\end{array}$ & $\begin{array}{l}2.6 \\
2.6 \\
2.7 \\
2.8 \\
2.9 \\
3.0\end{array}$ \\
\hline
\end{tabular}

-Not available.

†Not applicable.

'For this year, data on students of two or more races were reported by only a small number of states. Therefore, the data are not comparable to figures for 2010 and later years.

2Projected.

NOTE: Race categories exclude persons of Hispanic ethnicity. Enrollment data for students not reported by race/ethnicity were prorated by state and grade to match state totals. Prio to 2008 , data on students of two or more races were not collected separately. Total counts of ungraded students were prorated to prekindergarten through grade 8 and grades through 12 based on prior reports. Some data have been revised from previously published figures. Detail may not sum to totals because of rounding.

SOURCE: U.S. Department of Education, National Center for Education Statistics, Common Core of Data (CCD), "State Nonfiscal Survey of Public Elementary and Secondary Education," 1998-99 through 2011-12; and National Elementary and Secondary Enrollment by Race/Ethnicity Projection Model, 1972 through 2023. (This table was prepared April 2014.) 
100 CHAPTER 2: Elementary and Secondary Education

Enrollment in Public Schools

Table 203.70. Percentage distribution of enrollment in public elementary and secondary schools, by race/ethnicity and state or jurisdiction: Fall 2001 and fall 2011

\begin{tabular}{|c|c|c|c|c|c|c|c|c|c|c|c|c|c|c|}
\hline \multirow[b]{2}{*}{ State or jurisdiction } & \multicolumn{6}{|c|}{ Percentage distribution, fall 2001} & \multicolumn{8}{|c|}{ Percentage distribution, fall 2011} \\
\hline & Total & White & Black & Hispanic & $\begin{array}{r}\text { Asian/ } \\
\text { Pacific } \\
\text { Islander }\end{array}$ & $\begin{array}{r}\text { American } \\
\text { Indian/ } \\
\text { Alaska } \\
\text { Native }\end{array}$ & Total & White & Black & Hispanic & Asian & $\begin{array}{r}\text { Pacific } \\
\text { Islander }\end{array}$ & $\begin{array}{r}\text { American } \\
\text { Indian/ } \\
\text { Alaska } \\
\text { Native }\end{array}$ & $\begin{array}{r}\text { Two or } \\
\text { more races }\end{array}$ \\
\hline 1 & 2 & 3 & 4 & 5 & 6 & 7 & 8 & 9 & 10 & 11 & 12 & 13 & 14 & 15 \\
\hline United States ........... & 100.0 & 60.3 & 17.2 & 17.1 & 4.2 & 1.2 & 100.0 & 51.7 & 15.8 & 23.7 & 4.7 & 0.4 & 1.1 & 2.6 \\
\hline 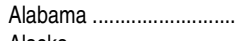 & 100.0 & 60.5 & 36.5 & 1.5 & 0.8 & 0.7 & 100.0 & 58.1 & 34.2 & 4.7 & 1.3 & $\#$ & 0.8 & 0.8 \\
\hline Alaska................................... & 100.0 & 60.4 & 4.7 & 3.6 & 5.9 & 25.5 & 100.0 & 50.9 & 3.6 & 6.2 & 6.1 & 2.2 & 23.5 & 7.5 \\
\hline Arizona .............................. & 100.0 & 51.3 & 4.7 & 35.3 & 2.1 & 6.6 & 100.0 & 42.1 & 5.4 & 42.8 & 2.8 & 0.3 & 5.1 & 1.6 \\
\hline 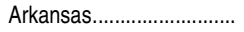 & 100.0 & 71.1 & 23.3 & 4.2 & 0.9 & 0.5 & 100.0 & 64.4 & 21.2 & 10.2 & 1.4 & 0.5 & 0.7 & 1.6 \\
\hline California & 100.0 & 35.0 & 8.4 & 44.5 & 11.2 & 0.9 & 100.0 & 26.0 & 6.5 & 52.1 & 11.2 & 0.6 & 0.7 & 2.9 \\
\hline Colorado & 100.0 & 66.8 & 5.7 & 23.3 & 3.0 & 1.2 & 100.0 & 56.1 & 4.8 & 31.9 & 3.1 & 0.2 & 0.8 & 3.1 \\
\hline Connecticut....................... & 100.0 & 69.2 & 13.8 & 13.7 & 3.0 & 0.3 & 100.0 & 60.9 & 13.0 & 19.5 & 4.4 & 0.1 & 0.3 & 1.8 \\
\hline 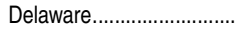 & 100.0 & 59.6 & 31.1 & 6.6 & 2.4 & 0.3 & 100.0 & 49.5 & 31.6 & 13.1 & 3.4 & 0.1 & 0.5 & 1.8 \\
\hline District of Columbia ........... & 100.0 & 4.6 & 84.4 & 9.4 & 1.6 & $\#$ & 100.0 & 7.7 & 76.4 & 13.1 & 1.4 & 0.1 & 0.1 & 1.1 \\
\hline 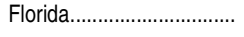 & 100.0 & 52.5 & 24.9 & 20.4 & 1.9 & 0.3 & 100.0 & 42.4 & 23.0 & 28.6 & 2.5 & 0.1 & 0.4 & 3.0 \\
\hline (..................... & 100.0 & 53.8 & 38.2 & 5.5 & 2.4 & 0.2 & 100.0 & 44.1 & 37.0 & 12.2 & 3.4 & 0.1 & 0.2 & 3.0 \\
\hline 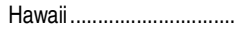 & 100.0 & 20.3 & 2.4 & 4.5 & 72.3 & 0.4 & 100.0 & 14.3 & 2.4 & 6.4 & 34.2 & 33.9 & 0.5 & 8.2 \\
\hline Idaho & 100.0 & 85.4 & 0.8 & 11.2 & 1.3 & 1.3 & 100.0 & 78.0 & 1.0 & 16.3 & 1.3 & 0.3 & 1.3 & 1.7 \\
\hline 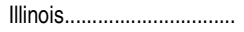 & 100.0 & 59.0 & 21.2 & 16.2 & 3.5 & 0.2 & 100.0 & 50.8 & 18.0 & 23.7 & 4.2 & 0.1 & 0.3 & 2.8 \\
\hline Indiana & 100.0 & 83.0 & 11.8 & 3.9 & 1.0 & 0.2 & 100.0 & 72.5 & 12.2 & 9.0 & 1.7 & 0.1 & 0.3 & 4.3 \\
\hline lowa .............. & 100.0 & 89.6 & 4.1 & 4.0 & 1.7 & 0.5 & 100.0 & 80.7 & 5.1 & 8.9 & 2.1 & 0.2 & 0.5 & 2.6 \\
\hline 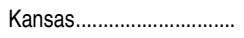 & 100.0 & 77.8 & 8.9 & 9.8 & 2.2 & 1.3 & 100.0 & 67.4 & 7.3 & 17.2 & 2.5 & 0.2 & 1.1 & 4.3 \\
\hline Kentucky ........................... & 100.0 & 87.7 & 10.3 & 1.1 & 0.7 & 0.2 & 100.0 & 81.1 & 10.8 & 4.3 & 1.4 & 0.1 & 0.1 & 2.2 \\
\hline Louisiana ............................ & 100.0 & 48.7 & 47.8 & 1.6 & 1.3 & 0.7 & 100.0 & 47.4 & 45.1 & 4.0 & 1.5 & 0.1 & 0.8 & 1.2 \\
\hline 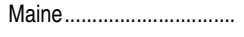 & 100.0 & 96.2 & 1.4 & 0.6 & 1.1 & 0.7 & 100.0 & 91.8 & 3.0 & 1.6 & 1.6 & 0.1 & 0.8 & 1.1 \\
\hline 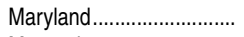 & 100.0 & 52.4 & 37.2 & 5.4 & 4.6 & 0.4 & 100.0 & 42.5 & 35.4 & 12.1 & 5.9 & 0.1 & 0.3 & 3.7 \\
\hline Massachusetts................... & 100.0 & 75.7 & 8.6 & 10.8 & 4.5 & 0.3 & 100.0 & 67.0 & 8.3 & 16.1 & 5.7 & 0.1 & 0.2 & 2.5 \\
\hline 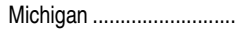 & 100.0 & 73.4 & 20.0 & 3.6 & 2.0 & 1.0 & 100.0 & 69.2 & 18.8 & 6.2 & 2.7 & 0.1 & 0.8 & 2.2 \\
\hline 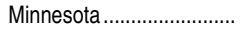 & 100.0 & 82.0 & 7.0 & 3.8 & 5.2 & 2.0 & 100.0 & 73.0 & 9.2 & 7.4 & 6.2 & 0.1 & 1.8 & 2.3 \\
\hline Mississippi .......................... & 100.0 & 47.3 & 51.0 & 0.9 & 0.7 & 0.2 & 100.0 & 46.0 & 49.6 & 2.6 & 1.0 & $\#$ & 0.2 & 0.6 \\
\hline 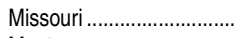 & 100.0 & 79.0 & 17.5 & 2.0 & 1.2 & 0.3 & 100.0 & 74.2 & 16.8 & 4.9 & 1.9 & 0.2 & 0.5 & 1.7 \\
\hline 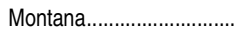 & 100.0 & 85.9 & 0.6 & 1.9 & 1.0 & 10.6 & 100.0 & 80.9 & 1.0 & 3.7 & 0.9 & 0.3 & 11.6 & 1.7 \\
\hline 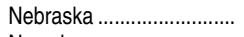 & 100.0 & 81.8 & 6.9 & 8.2 & 1.6 & 1.6 & 100.0 & 70.2 & 6.7 & 16.4 & 2.1 & 0.1 & 1.5 & 3.1 \\
\hline 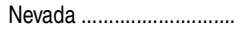 & 100.0 & 54.5 & 10.3 & 27.4 & 6.1 & 1.7 & 100.0 & 37.4 & 9.6 & 39.6 & 5.6 & 1.3 & 1.1 & 5.3 \\
\hline New Hampshire ................. & 100.0 & 95.0 & 1.2 & 2.1 & 1.5 & 0.2 & 100.0 & 89.1 & 1.9 & 3.9 & 2.8 & 0.1 & 0.3 & 1.9 \\
\hline New Jersey ......................... & 100.0 & 59.4 & 17.9 & 16.0 & 6.6 & 0.2 & 100.0 & 51.1 & 16.2 & 22.5 & 9.0 & 0.2 & 0.1 & 0.8 \\
\hline New Mexico ........................ & 100.0 & 34.3 & 2.4 & 51.0 & 1.1 & 11.3 & 100.0 & 25.9 & 2.0 & 59.5 & 1.2 & 0.1 & 10.2 & 1.1 \\
\hline 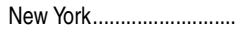 & 100.0 & 54.8 & 19.9 & 18.6 & 6.2 & 0.4 & 100.0 & 48.2 & 18.5 & 23.3 & 8.4 & 0.2 & 0.5 & 0.8 \\
\hline North Carolina ..................... & 100.0 & 60.0 & 31.3 & 5.2 & 1.9 & 1.5 & 100.0 & 52.4 & 26.4 & 13.5 & 2.5 & 0.1 & 1.5 & 3.7 \\
\hline North Dakota .......................... & 100.0 & 88.7 & 1.1 & 1.3 & 0.8 & 8.1 & 100.0 & 83.2 & 2.6 & 2.9 & 1.2 & 0.2 & 9.1 & 0.9 \\
\hline Ohio & 100.0 & 80.1 & 16.7 & 1.9 & 1.2 & 0.1 & 100.0 & 73.7 & 16.2 & 3.8 & 1.8 & $\#$ & 0.1 & 4.3 \\
\hline 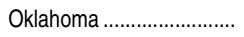 & 100.0 & 63.7 & 10.8 & 6.5 & 1.5 & 17.5 & 100.0 & 53.7 & 9.8 & 13.1 & 1.9 & 0.3 & 16.6 & 4.7 \\
\hline 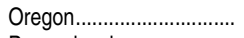 & 100.0 & 79.1 & 3.0 & 11.5 & 4.2 & 2.2 & 100.0 & 65.3 & 2.5 & 21.1 & 3.9 & 0.6 & 1.8 & 4.7 \\
\hline Pennsylvania....................... & 100.0 & 77.7 & 15.3 & 4.8 & 2.1 & 0.1 & 100.0 & 70.6 & 15.3 & 8.7 & 3.3 & 0.1 & 0.2 & 1.9 \\
\hline Rhode Island ....................... & 100.0 & 73.4 & 8.1 & 14.8 & 3.2 & 0.6 & 100.0 & 64.0 & 8.1 & 21.6 & 2.9 & 0.2 & 0.6 & 2.7 \\
\hline South Carolina ..................... & 100.0 & 54.9 & 41.6 & 2.3 & 1.0 & 0.3 & 100.0 & 53.2 & 35.6 & 6.7 & 1.4 & 0.1 & 0.3 & 2.7 \\
\hline 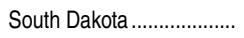 & 100.0 & 86.2 & 1.3 & 1.4 & 1.0 & 10.2 & 100.0 & 78.4 & 2.6 & 3.9 & 1.5 & 0.1 & 11.7 & 1.7 \\
\hline Tennessee .......................... & 100.0 & 71.8 & 24.8 & 2.1 & 1.2 & 0.2 & 100.0 & 67.1 & 23.3 & 6.6 & 1.7 & 0.1 & 0.2 & 1.0 \\
\hline 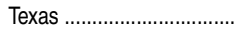 & 100.0 & 40.9 & 14.4 & 41.7 & 2.8 & 0.3 & 100.0 & 30.6 & 12.8 & 50.8 & 3.5 & 0.1 & 0.4 & 1.7 \\
\hline 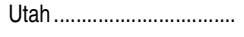 & 100.0 & 84.7 & 1.0 & 9.9 & 2.8 & 1.5 & 100.0 & 77.5 & 1.3 & 15.3 & 1.8 & 1.5 & 1.2 & 1.4 \\
\hline Vermont & 100.0 & 95.8 & 1.2 & 1.0 & 1.5 & 0.5 & 100.0 & 92.5 & 1.9 & 1.4 & 1.7 & 0.1 & 0.4 & 2.1 \\
\hline 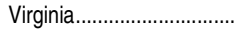 & 100.0 & 62.8 & 27.1 & 5.5 & 4.3 & 0.3 & 100.0 & 53.5 & 23.8 & 11.9 & 6.0 & 0.1 & 0.3 & 4.3 \\
\hline 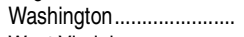 & 100.0 & 73.5 & 5.4 & 10.9 & 7.5 & 2.6 & 100.0 & 60.3 & 4.6 & 19.6 & 7.1 & 0.9 & 1.5 & 6.0 \\
\hline West Virginia......................... & 100.0 & 94.5 & 4.4 & 0.4 & 0.6 & 0.1 & 100.0 & 91.7 & 5.0 & 1.2 & 0.7 & $\#$ & 0.1 & 1.2 \\
\hline 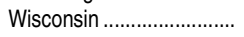 & 100.0 & 80.1 & 10.2 & 5.0 & 3.4 & 1.4 & 100.0 & 73.7 & 9.8 & 9.7 & 3.5 & 0.1 & 1.3 & 1.9 \\
\hline 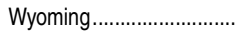 & 100.0 & 87.3 & 1.4 & 7.2 & 0.9 & 3.2 & 100.0 & 80.5 & 1.1 & 12.6 & 0.8 & 0.1 & 3.2 & 1.7 \\
\hline Bureau of Indian Education & 100.0 & 0.0 & 0.0 & 0.0 & 0.0 & 100.0 & - & - & - & - & - & - & - & - \\
\hline 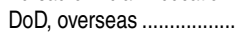 & 100.0 & 61.6 & 19.1 & 9.3 & 9.1 & 1.0 & - & - & - & - & - & - & - & - \\
\hline DoD, domestic .................... & 100.0 & 51.6 & 25.8 & 18.5 & 3.5 & 0.6 & - & - & - & - & - & - & - & - \\
\hline Other jurisdictions & & & & & & & & & & & & & & \\
\hline American Samoa .......... & 100.0 & 0.0 & 0.0 & 0.0 & 100.0 & 0.0 & - & - & - & - & - & - & - & - \\
\hline 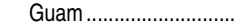 & 100.0 & 1.5 & 0.3 & 0.2 & 97.9 & 0.1 & 100.0 & 0.7 & 0.2 & 0.1 & 23.7 & 73.2 & \# & 2.1 \\
\hline Northern Marianas........ & 100.0 & 0.4 & 0.1 & 0.0 & 99.6 & 0.0 & 100.0 & 0.7 & 0.0 & $\#$ & 39.1 & 59.8 & 0.0 & 0.4 \\
\hline Puerto Rico ....................... & 100.0 & 0.0 & 0.0 & 100.0 & 0.0 & 0.0 & 100.0 & 0.1 & $\#$ & 99.8 & $\#$ & $\#$ & 0.1 & $\#$ \\
\hline U.S. Virgin Islands......... & - & - & - & - & - & - & 100.0 & 1.5 & 78.1 & 18.8 & 0.3 & 0.1 & 0.1 & 1.0 \\
\hline
\end{tabular}

-Not available.

\#Rounds to zero.

NOTE: Percentage distribution based on students for whom race/ethnicity was reported, which may be less than the total number of students in the state. Race categories exclude persons of Hispanic ethnicity. DoD = Department of Defense. Detail may not sum to totals because of rounding.
SOURCE: U.S. Department of Education, National Center for Education Statistics, Common Core of Data (CCD), "State Nonfiscal Survey of Public Elementary/Secondary Education," 2001-02 and 2011-12. (This table was prepared March 2014.) 
Table 203.80. Average daily attendance in public elementary and secondary schools, by state or jurisdiction: Selected years, 1969-70 through 2010-11

\begin{tabular}{|c|c|c|c|c|c|c|c|c|c|c|c|c|c|}
\hline State or jurisdiction & $1969-70$ & $1979-80$ & $1989-90$ & 1999-2000 & $2002-03$ & 2003-04 & 2004-05 & $2005-06$ & $2006-07$ & $2007-08$ & $2008-09$ & $2009-10$ & $2010-11$ \\
\hline 1 & 2 & 3 & 4 & 5 & 6 & 7 & 8 & 9 & 10 & 11 & 12 & 13 & 14 \\
\hline 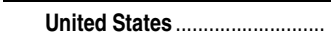 & $41,934,376$ & $38,288,911$ & $37,799,296$ & $43,806,726$ & $45,017,360$ & $45,325,731$ & $45,625,458$ & $45,931,617$ & $46,132,663$ & $46,155,880$ & $46,173,477$ & $45,919,206$ & $46,168,400$ \\
\hline Alabama . & 777,123 & 711,432 & 683,833 & 725,212 & 701,235 & 706,446 & 706,588 & 714,197 & 714,302 & 731,161 & 712,179 & 698,208 & 709,225 \\
\hline Alaska............................ & 72,489 & 79,945 & 98,213 & 122,412 & 123,145 & 122,341 & 121,699 & 122,010 & 120,988 & 119,882 & 119,330 & 120,118 & 119,949 \\
\hline Arizona ......... & 391,526 & 481,905 & 557,252 & 782,851 & 868,547 & 878,891 & 911,640 & 933,663 & 972,404 & 973,689 & 999,386 & 968,764 & 964,683 \\
\hline Arkansas.. & 414,158 & 423,610 & 403,025 & 422,958 & 418,775 & 425,571 & 430,290 & 435,278 & 436,804 & 439,347 & 439,432 & 435,676 & 443,118 \\
\hline California $^{1}$......................... & $4,418,423$ & $4,044,736$ & $4,893,341$ & $5,957,216$ & $6,312,362$ & $6,384,882$ & $6,373,959$ & $6,349,270$ & $6,351,774$ & $6,365,266$ & $6,365,278$ & $6,017,381^{2}$ & $6,029,786^{2}$ \\
\hline olorado & 500,388 & 513,475 & 519,419 & 656,700 & 709,349 & 673,285 & 700,485 & 712,476 & 722,168 & 735,549 & 747,845 & 762,190 & 763,147 \\
\hline Connecticut... & 618,881 & 507,362 & 439,524 & 533,779 & 557,701 & 561,530 & 559,478 & 558,423 & 555,428 & 553,445 & 549,776 & 548,787 & 537,104 \\
\hline 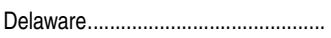 & 120,819 & 94,058 & 89,838 & 106,444 & 109,945 & 108,751 & 110,393 & 113,986 & 113,992 & 116,472 & 119,092 & 119,879 & 121,959 \\
\hline District of Columbia ... & 138,600 & 91,576 & 71,468 & 65,371 & 61,236 & 65,625 & 70,817 & 59,137 & 61,799 & 61,636 & 68,447 & 68,217 & 69,575 \\
\hline 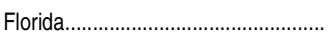 & $1,312,693$ & $1,464,461$ & $1,646,583$ & $2,175,453$ & $2,362,841$ & $2,418,329$ & $2,463,323$ & $2,494,778$ & $2,527,431$ & $2,494,397$ & $2,468,060$ & $2,493,694$ & $2,541,022$ \\
\hline Georgia. & $1,019,427$ & 989,433 & $1,054,097$ & $1,326,713$ & $1,400,007$ & $1,424,004$ & $1,460,767$ & $1,499,317$ & $1,542,305$ & $1,561,935$ & $1,569,767$ & $1,596,180$ & $1,621,397$ \\
\hline Hawaii..... & 168,140 & 151,563 & 157,360 & 171,180 & 169,797 & 167,739 & 169,825 & 168,009 & 165,415 & 166,179 & 166,118 & 165,766 & 169,926 \\
\hline Idaho.. & 170,920 & 189,199 & 203,987 & 230,828 & 234,244 & 237,095 & 241,590 & 247,009 & 251,278 & 255,523 & 258,712 & 262,238 & 263,001 \\
\hline Illinois... & $2,084,844$ & $1,770,435$ & $1,587,733$ & $1,789,089$ & $1,855,417$ & $1,862,274$ & $1,862,046$ & $1,871,619$ & $1,879,288$ & $1,881,810$ & $1,881,276$ & $1,887,561$ & $1,863,017$ \\
\hline Indiana... & $1,111,043$ & 983,444 & 884,568 & 929,281 & 942,506 & 943,735 & 944,944 & 966,967 & 976,373 & 969,976 & 973,342 & 976,503 & 976,225 \\
\hline lowa & 624,403 & 510,081 & 450,224 & 471,384 & 459,761 & 457,771 & 456,559 & 477,491 & 481,528 & 492,922 & 451,403 & 455,579 & 444,525 \\
\hline Kansas...... & 470,296 & 382,019 & 388,986 & 426,853 & 419,285 & 415,529 & 411,455 & 407,812 & 422,142 & 418,751 & 418,495 & 435,745 & 434,648 \\
\hline Kentucky.... & 647,970 & 619,868 & 569,795 & 565,693 & 569,538 & 570,911 & 574,380 & 580,937 & 583,102 & 585,775 & 585,556 & 587,102 & 593,323 \\
\hline Louisiana . & 776,555 & 727,601 & 727,125 & 701,957 & 674,949 & 674,333 & 670,238 & 648,243 & 625,916 & 631,163 & 637,764 & 643,374 & 654,093 \\
\hline 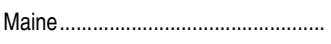 & 225,146 & 211,400 & 195,089 & 194,554 & 188,776 & 187,492 & 184,374 & 180,223 & 178,870 & 175,161 & 173,357 & 168,213 & 165,067 \\
\hline Mar & 785,989 & 686,336 & 620,617 & 791,133 & 809,398 & 808,557 & 804,696 & 800,553 & 795,473 & 793,881 & 793,333 & 795,577 & 798,953 \\
\hline Massachusetts... & $1,056,207$ & 935,960 & 763,231 & 913,502 & 921,201 & 932,417 & 930,338 & 930,151 & 933,697 & 917,181 & 913,976 & 912,792 & 910,568 \\
\hline 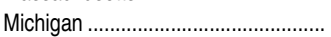 & $1,991,235$ & $1,758,427$ & $1,446,996$ & $1,574,894$ & $1,591,900$ & $1,590,555$ & $1,583,496$ & $1,574,023$ & $1,556,297$ & $1,528,815$ & $1,498,107$ & $1,477,312$ & $1,452,125$ \\
\hline Minnesota.... & 864,595 & 748,606 & 699,001 & 818,819 & 813,660 & 792,896 & 788,354 & 787,521 & 791,417 & 790,206 & 791,427 & 785,455 & 786,838 \\
\hline 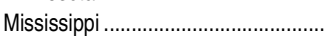 & 524,623 & 454,401 & 476,048 & 468,746 & 461,269 & 463,470 & 463,816 & 461,112 & 462,251 & 461,459 & 460,797 & 460,327 & 460,894 \\
\hline & 906,132 & 777,269 & 729,693 & 836,105 & 040 & 851,749 & 114 & 859,441 & 858,821 & 52,106 & 580 &, 460 &, 997 \\
\hline Montana.......... & 162,664 & 144,608 & 135,406 & 142,313 & 133,988 & 132,356 & 130,998 & 129,948 & 128,872 & 132,104 & 131,982 & 130,704 & 130,949 \\
\hline 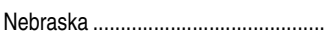 & 314,516 & 270,524 & 254,754 & 261,767 & 269,499 & 260,352 & 260,725 & 262,805 & 263,800 & 264,810 & 266,536 & 269,590 & 271,468 \\
\hline Nevada ..................... & 113,421 & 134,995 & 173,149 & 305,067 & 346,512 & 364,409 & 378,186 & 383,403 & 395,536 & 395,355 & 406,792 & 405,097 & 406,965 \\
\hline New Hampshire ....... & 140,203 & 154,187 & 154,915 & 200,283 & 200,184 & 202,352 & 201,242 & 199,952 & 198,004 & 195,383 & 192,890 & 191,969 & 188,913 \\
\hline $\mathrm{Ne}$ & $1,322,124$ & $1,140,111$ & 997,561 & $1,222,438$ & $1,312,610$ & $1,336,869$ & $1,341,156$ & $1,358,562$ & $1,348,279$ & $1,340,220$ & $1,342,419$ & $1,343,405$ & $1,339,012$ \\
\hline New & 259,997 & 253,453 & 290,245 & 323,963 & 320,189 & 319,637 & 322,046 & 323,964 & 327,244 & 326,034 & 327,562 & 331,152 & 334,272 \\
\hline New York & $3,099,192$ & $2,530,289$ & $2,244,110$ & $2,595,070$ & $2,614,977$ & $2,599,902$ & $2,581,772$ & $2,556,705$ & $2,542,259$ & $2,520,932$ & $2,510,519$ & $2,516,922$ & $2,513,770$ \\
\hline 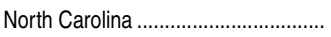 & $1,104,295$ & $1,072,150$ & $1,012,274$ & $1,185,737$ & $1,242,234$ & $1,264,266$ & $1,289,444$ & $1,319,335$ & $1,343,357$ & $1,364,608$ & $1,374,267$ & $1,366,164$ & $1,451,133$ \\
\hline 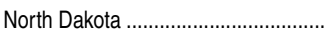 & 141,961 & 118,986 & 109,659 & 105,123 & 97,879 & 96,231 & 94,823 & 92,843 & 91,078 & 91,972 & 91,816 & 91,114 & 92,440 \\
\hline Ohio & $2,246,282$ & $1,849,283$ & $1,584,735$ & $1,659,903$ & $1,683,337$ & $1,700,533$ & $1,719,566$ & $1,730,080$ & $1,691,206$ & $1,660,981$ & $1,628,515$ & $1,609,008$ & $1,601,188$ \\
\hline Oklahoma .. & 560,993 & 548,065 & 543,170 & 586,266 & 581,767 & 583,932 & 587,188 & 591,486 & 596,172 & 596,450 & 603,375 & 610,019 & 616,775 \\
\hline Oregon....... & 436,736 & 418,593 & 419,771 & 479,321 & 487,544 & 486,073 & 506,638 & 513,650 & 516,258 & 515,834 & 518,119 & 515,644 & 517,373 \\
\hline Pennsylvania... & $2,169,225$ & $1,808,630$ & $1,524,839$ & $1,684,913$ & $1,694,148$ & $1,701,096$ & $1,698,795$ & $1,702,566$ & $1,701,044$ & $1,693,569$ & $1,680,772$ & $1,661,990$ & $1,668,916$ \\
\hline 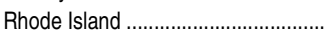 & 163,205 & 139,195 & 125,934 & 144,422 & 144,813 & 143,792 & 143,939 & 139,001 & 138,993 & 134,737 & 131,963 & 131,538 & 131,494 \\
\hline & 600,292 & 569,612 & 569,029 & 624,456 & 629,997 & 635,750 & 639,950 & 647,703 & 652,803 & 656,996 & 662,231 & 664,136 & 664,133 \\
\hline South Dakota ................... & 158,543 & 124,934 & 119,823 & 122,252 & 118,383 & 116,651 & 115,148 & 114,673 & 114,863 & 114,723 & 114,209 & 115,242 & 119,449 \\
\hline Tennessee & 836,010 & 806,696 & 761,766 & 844,878 & 850,322 & 859,522 & 868,129 & 881,414 & 889,312 & 891,430 & 895,335 & 896,130 & 899,382 \\
\hline Texas. & $2,432,420$ & $2,608,817$ & $3,075,333$ & $3,706,550$ & $3,940,776$ & $4,016,791$ & $4,084,792$ & $4,186,812$ & $4,255,963$ & $4,322,975$ & $4,393,893$ & $4,473,236$ & $4,551,084$ \\
\hline Utah ........................... & 287,405 & 312,813 & 408,917 & 448,096 & 451,063 & 456,183 & 464,645 & 478,233 & 488,514 & 503,562 & 513,884 & 528,608 & 540,683 \\
\hline & 97,772 & 95,045 & 87,832 & 98,894 & 95,868 & 95,160 & 93,608 & 92,508 & 91,437 & 89,880 & 87,931 & 86,378 & 85,501 \\
\hline Virginia............ & 995,580 & 955,105 & 989,197 & $1,195,123$ & $1,109,459$ & $1,118,446$ & $1,133,882$ & $1,141,790$ & $1,142,342$ & $1,150,316$ & $1,154,689$ & $1,159,105$ & $1,165,907$ \\
\hline 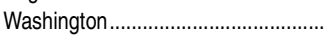 & 764,735 & 710,929 & 755,141 & 925,696 & 933,702 & 937,656 & 941,238 & 946,824 & 947,857 & 947,791 & 953,719 & 960,084 & 965,191 \\
\hline West Virginia.......... & 372,278 & 353,264 & 301,947 & 273,277 & 260,365 & 266,078 & 271,197 & 271,780 & 272,045 & 267,989 & 269,623 & 268,872 & 270,961 \\
\hline 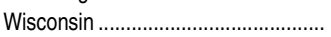 & 880,609 & 770,554 & 711,466 & 825,699 & 831,939 & 826,864 & 831,809 & 834,177 & 835,072 & 823,754 & 823,595 & 817,284 & 825,622 \\
\hline 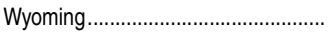 & 81,293 & 89,471 & 91,277 & 86,092 & 79,921 & 78,652 & 77,878 & 77,757 & 79,090 & 79,788 & 81,006 & 80,717 & 81,654 \\
\hline 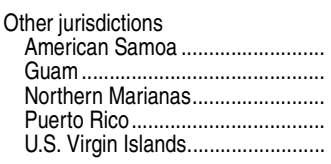 & $\begin{array}{r}-\overline{2} \\
20,315 \\
- \\
-\end{array}$ & $\begin{array}{r}\overline{-} \\
656,709 \\
-\end{array}$ & $\begin{array}{r}11,448 \\
23,883 \\
6,809 \\
597,436 \\
18,924\end{array}$ & $\begin{array}{r}15,102 \\
- \\
8,712 \\
540,676 \\
18,676\end{array}$ & $\begin{array}{r}15,243 \\
- \\
9,739 \\
535,874 \\
16,187\end{array}$ & $\begin{array}{r}15,123 \\
28,301 \\
10,047 \\
534,941 \\
15,878\end{array}$ & $\begin{array}{r}15,302 \\
- \\
10,301 \\
540,365 \\
15,841\end{array}$ & $\begin{array}{r}15,237 \\
29,617 \\
10,871 \\
522,655 \\
15,241\end{array}$ & $\begin{array}{r}14,606 \\
29,515 \\
10,277 \\
531,273 \\
14,927\end{array}$ & $\begin{array}{r}14,646 \\
28,358 \\
9,927 \\
494,880 \\
15,903\end{array}$ & $\begin{array}{r}14,646 \\
28,521 \\
9,815 \\
477,918 \\
15,768\end{array}$ & $\begin{array}{r}14,403 \\
28,075 \\
9,900 \\
466,483 \\
15,493\end{array}$ & $\begin{array}{r}15,451 \\
28,765 \\
9,965 \\
411,164 \\
15,747\end{array}$ \\
\hline
\end{tabular}

-Not available.

'Data for California for 1989-90 and earlier years are not strictly comparable with those for other states because California's attendance figures included excused absences.

${ }^{2}$ Excludes average daily attendance for regional occupational programs and summer school programs that were reported in prior years.
NOTE: Some data have been revised from previously published figures.

SOURCE: U.S. Department of Education, National Center for Education Statistics, Statistics of State School Systems, 1969-70; Revenues and Expenditures for Public Elementary and Secondary Education, 1979-80, and Common Core of Data (CCD), "National Public Education Financial Survey," 1989-90 through 2010-11. (This table was prepared August 2013.) 
102 CHAPTER 2: Elementary and Secondary Education

Enrollment in Public Schools

Table 203.90. Average daily attendance (ADA) as a percentage of total enrollment, school day length, and school year length in public schools, by school level and state: 2007-08 and 2011-12

[Standard errors appear in parentheses]

\begin{tabular}{|c|c|c|c|c|c|c|c|c|c|c|c|c|c|c|c|c|c|c|c|c|}
\hline \multirow[b]{3}{*}{ State } & \multicolumn{4}{|c|}{$2007-08$} & \multicolumn{16}{|c|}{ 2011-12 } \\
\hline & \multirow{2}{*}{\multicolumn{2}{|c|}{$\begin{array}{l}\text { ADA as } \\
\text { percent of } \\
\text { enrollment }\end{array}$}} & \multirow{2}{*}{\multicolumn{2}{|c|}{$\begin{array}{l}\text { Average hours } \\
\text { in school day }\end{array}$}} & \multicolumn{8}{|c|}{$\begin{array}{l}\text { Total elementary, secondary, and combined } \\
\text { elementary/secondary schools }\end{array}$} & \multicolumn{4}{|c|}{ ementary schools } & \multicolumn{4}{|c|}{ Seconda } \\
\hline & & & & & & $\begin{array}{l}\text { ADA as } \\
\text { rcent of } \\
\text { rollment }\end{array}$ & $\begin{array}{l}\text { Averag } \\
\text { in sch }\end{array}$ & $\begin{array}{l}\text { e hours } \\
\text { ool day }\end{array}$ & $\begin{array}{l}\text { Ave } \\
\text { in sc }\end{array}$ & & $\begin{array}{l}\text { Aver } \\
\text { in s }\end{array}$ & $\begin{array}{l}\text { ours } \\
\text { year }\end{array}$ & & $\begin{array}{l}\text { ADA as } \\
\text { cent of } \\
\text { ollment }\end{array}$ & $\begin{array}{l}\text { Aver } \\
\text { in s }\end{array}$ & & & $\begin{array}{l}\text { ADA as } \\
\text { rcent of } \\
\text { rollment }\end{array}$ & & \\
\hline 1 & & 2 & & 3 & & 4 & & 5 & & 6 & & 7 & & 8 & & 9 & & 10 & & 11 \\
\hline United States.. & 93.1 & $(0.22)$ & 6.6 & $(0.02)$ & 93.9 & 0.12 & 6.7 & $(0.01)$ & 179 & $(0.1)$ & 1,203 & (2.0) & 94.9 & $(0.12)$ & 6.7 & $(0.01)$ & 91.7 & (0.34) & 6.7 & $(0.02)$ \\
\hline Alabama. & 93.8 & $(1.24)$ & 7.0 & $(0.07)$ & 94.4 & $(0.94)$ & 7.0 & $(0.04)$ & 181 & $(0.8)$ & 271 & (8.5) & 95.3 & $(0.92)$ & 7.1 & $(0.04)$ & 94.6 & $(0.65)$ & 6.9 & $0.13)$ \\
\hline laska..... & 9.9 & $(1.22)$ & 6.5 & $(0.05)$ & 91.4 & $(1.19)$ & 67 & $(0.17)$ & 177 & 1.3) & 183 & $(37.3)$ & $\ddagger$ & $(t)$ & $\ddagger$ & $(t)$ & $\ddagger$ & $(\dagger)$ & $\ddagger$ & $(\dagger)$ \\
\hline izona ..... & 89.0 & $(2.95)$ & 6.4 & $(0.09)$ & 91.7 & 99) & 6.7 & $(0.08)$ & 179 & 3) & ,201 & (12.5) & 93.5 & $(0.53)$ & 6.9 & $(0.06)$ & 87.9 & (2.40) & 6.5 & $(0.26)$ \\
\hline rkansas. & 91.8 & (1.35) & 6.9 & $(0.06)$ & 94.2 & $(0.58)$ & 7.0 & $(0.07)$ & 180 & $(0.5)$ & 1,261 & (14.1) & 94.7 & $(0.36)$ & 7.0 & $(0.08)$ & 92.9 & (1.93) & 6.9 & $(0.14)$ \\
\hline California . & 93.2 & $(0.71)$ & 6.2 & $(0.07)$ & 93.1 & $(0.46)$ & 6.2 & $(0.05)$ & 180 & $(0.3)$ & 1,121 & $(9.0)$ & 94.7 & $(0.51)$ & 6.3 & $(0.06)$ & 89.7 & $(1.08)$ & 6.3 & $(0.08)$ \\
\hline lora & 9 & $0.44)$ & 7.0 & $(0.05)$ & 3.1 & 1) & 7.1 & $(0.06)$ & 172 & (1.4) & 215 & (7.7) & 4.6 & $(0.59)$ & .0 & $(0.07)$ & 38.0 & $2.57)$ & .1 & .10) \\
\hline onnec & .9 & $(2.98)$ & 65 & $(0.09)$ & 94.9 & $(0.47)$ & 66 & $(0.04)$ & 181 & $(0.1)$ & 1,201 & (7.5) & 95.4 & $(0.61)$ & 6 & $(0.05)$ & 94.3 & $(0.33)$ & 7 & $0.09)$ \\
\hline laware. & .8 & (1.75) & 7 & $(0.09)$ & 93.5 & $(0.50)$ & 7.0 & $(0.10)$ & 182 & (1.2) & 269 & (23.7) & 94.1 & $(0.50)$ & 7.0 & $(0.12)$ & 93.8 & $(0.71)$ & 7.0 & $(0.09)$ \\
\hline istrict of C & 91.2 & $(1.27)$ & 6.9 & $(0.21)$ & $\ddagger$ & $(t)$ & $\ddagger$ & $(\dagger)$ & $\ddagger$ & $(\dagger)$ & $\ddagger$ & $(\dagger)$ & $\ddagger$ & $(\dagger)$ & $\ddagger$ & $(t)$ & $\ddagger$ & (t) & $\ddagger$ & $(t)$ \\
\hline Florida.... & 92.7 & $(0.74)$ & 6.4 & $(0.08)$ & 93.2 & $(0.52)$ & 6.6 & $(0.06)$ & 181 & (1.2) & 1,193 & $(14.2)$ & 94.3 & $(0.49)$ & 6.6 & $(0.08)$ & 90.7 & $(0.84)$ & 6.7 & $(0.09)$ \\
\hline eorgia. & 3 & $(1.28)$ & 6.8 & $(0.06)$ & 4.3 & $(0.53)$ & 7.0 & $(0.04)$ & 178 & $(0.4)$ & 242 & (8.5) & 95.0 & $(0.59)$ & 6.9 & $(0.05)$ & t & (t) & $\mp$ & (†) \\
\hline i & 7 & $(4.58)$ & & $(0.1$ & $\ddagger$ & (t) & $\ddagger$ & (t) & $\ddagger$ & $(\dagger)$ & $\ddagger$ & $(\dagger)$ & $\ddagger$ & (t) & $\ddagger$ & $(t)$ & $\ddagger$ & (t) & $\ddagger$ & $(t)$ \\
\hline ho..... & 2.4 & $(2.27)$ & & $(0.09)$ & 94.1 & (1.01) & 6.7 & (0.13) & 166 & (5.1) & 110 & $(21.7)$ & 94.4 & $(0.75)$ & 6.7 & $(0.08)$ & 93.1 & .83) & 6.7 & $0.20)$ \\
\hline linois...... & 94.0 & $(0.71)$ & 6.5 & $(0.05)$ & 94.1 & $(0.40)$ & 6.5 & $(0.04)$ & 176 & $(0.4)$ & ,151 & $(7.7)$ & 95.1 & $(0.29)$ & .5 & $(0.05)$ & 92.4 & $(1.29)$ & 8 & $(0.08)$ \\
\hline Indiana......... & 95.7 & $(0.51)$ & 6.8 & $(0.06)$ & 95.9 & $(0.20)$ & 6.8 & $(0.05)$ & 180 & $(0.1)$ & 1,226 & $(9.1)$ & 96.1 & $(0.25)$ & 6.7 & $(0.05)$ & 95.5 & $(0.31)$ & 7.0 & $(0.07)$ \\
\hline 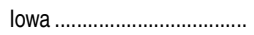 & & 6 & 6.9 & $(0.6$ & .7 & 1036 & & $(12$ & & 2) & 1,213 & (21.8) & 4 & $(0.21)$ & & 1 & 3.6 & (1.39) & & 47) \\
\hline$\ldots \ldots .$. & 5.4 & $(0.52)$ & 0 & $(0.07)$ & 94.9 & ( & 7 & $(0.0$ & 1 & (2.6) & 245 & $(17.9)$ & .5 & $(0.53)$ & 0 & $(0.04)$ & 4.0 & $0.4 c$ & 11 & $(0.04)$ \\
\hline tucky & 3.1 & $(1.89)$ & 7 & $(0.06)$ & 3.2 & (1) & 0 & & 179 & $(1.0)$ & 211 & (11.6) & 5.9 & $(0.22)$ & 8 & $(0.07)$ & 7.0 & $(4.87)$ & 8 & $(0.14)$ \\
\hline 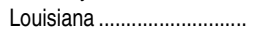 & 0.3 & $(2.31)$ & 1.1 & $(0 . C$ & 2.8 & $(0.7$ & 7.2 & $(0.07)$ & & .1) & ,283 & (10.7) & 93.0 & $(0.88)$ & 3 & $(0.07)$ & 3.5 & $0.42)$ & .1 & $0.14)$ \\
\hline Maine.. & 90.3 & (2.41) & 6.5 & $(0.06)$ & 94.2 & $(0.73)$ & 6.6 & $(0.06)$ & 176 & $(0.2)$ & 1,156 & (10.7) & 94.4 & $(1.00)$ & 6.6 & $(0.07)$ & 93.8 & $(0.45$ & 6.3 & $(0.08)$ \\
\hline The & 1 & $(0,44)$ & 6.6 & $(0$. & $\ddagger$ & & $\ddagger$ & $(\dagger)$ & $t$ & $(t)$ & t & & $\ddagger$ & $(t)$ & $\ddagger$ & & + & & ‡ & $(\dagger)$ \\
\hline as & 6 & $(0.5$ & & (0. & 3.5 & $(0.62)$ & 4 & $(0.07)$ & 180 & $(0.2)$ & 1,157 & (13.3) & 4.4 & $(0.63)$ & 4 & $(0.07)$ & 0.3 & $2.55)$ & 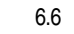 & .05) \\
\hline & 3.0 & $(1.01)$ & 6 & $(0.08)$ & 91.6 & $(0.7$ & 0 & $(0.03)$ & 177 & $(0.5)$ & 1,196 & $(5.9)$ & 2.3 & $(0.99)$ & 0 & $(0.03)$ & 9.4 & $(1.28)$ & .7 & $(0.07)$ \\
\hline to & 93.1 & $(0.91)$ & 63 & $(0.12)$ & 93.1 & $(0.49)$ & f & $(0.08)$ & 173 & (1.3) & 111 & $(14.0)$ & 96.1 & $(0.19)$ & 6 & $(0.07)$ & 39.5 & $(1.21)$ & 0 & $(0.20)$ \\
\hline Mississippi .... & 92.1 & $(2.00)$ & 7.0 & $(0.12)$ & 94.4 & $(0.47)$ & 7.2 & $(0.09)$ & 181 & (0.4) & 1,312 & (16.4) & 94.9 & $(0.57)$ & 3 & $(0.06)$ & 93.7 & $(0.86)$ & 7.2 & $(0.24)$ \\
\hline & & & & & & & & & & & & & 6 & & & & 1.3 & & .8 & \\
\hline & 91.3 & $(1.39)$ & 68 & $(0.05)$ & 3.9 & & & & & $(0.4)$ & 189 & $(11$ & 1.3 & (0.79) & 6 & $(0.09)$ & 3.0 & $(0$. & 7 & $0.08)$ \\
\hline & 9 & & & $(0$. & & & & & & & & & & & & & .5 & (0. & & 19) \\
\hline & 93.5 & $(1.27)$ & 6.3 & $(0.06)$ & 3.9 & $(0$. & 6.5 & $(0.07)$ & 180 & (1.1) & 1,164 & (10.9) & 94.5 & $(0.30)$ & .4 & $(0.10)$ & 93.9 & $(0.70$ & 6.5 & $(0.07)$ \\
\hline New $\mathrm{H}$ & 92.2 & $(1.75)$ & 6.5 & $(0.0$ & 91.1 & (2. & 6 & $(0$ & 180 & $(0.3)$ & ,181 & (10.3) & 95.9 & $(0.45)$ & 6.5 & $(0.07)$ & 75.1 & (12.63 & 6.7 & $(0.05)$ \\
\hline & 4.6 & 259) & & 1005 & 93.5 & & & & & (0.2) & 1 & & 93.7 & & & & 92.6 & & & 07) \\
\hline & .9 & $(1.7$ & & $(0$. & 8 & 10 & & $(0$ & 1 & $(0.6)$ & 216 & $(15$ & 8 & $(0.80)$ & & $(0.08)$ & 8.5 & 2.4 & .1 & $(0.14)$ \\
\hline & 2.7 & $(1$ & & $(0.09)$ & .7 & 4) & & 10 & & $(0.2)$ & 206 & (10.6) & 3.6 & (1.28) & 6 & $(0.07)$ & 0.0 & 1.32) & 6.8 & $(0.07)$ \\
\hline & 92.6 & $(1.7$ & 6.7 & $(0.06)$ & 94.7 & $(0.37)$ & & $(0.04)$ & 1 & $(0.2)$ & 240 & (7.4) & 5.2 & $(0.23)$ & 8 & $(0.04)$ & $\ddagger$ & (†) & $\ddagger$ & (†) \\
\hline North D & 95.9 & $(0.59)$ & 6.6 & $(0.04)$ & 95.2 & $(0.46)$ & 6.5 & $(0.06)$ & 177 & $(0.3)$ & 1,159 & (10.0) & 96.4 & $(0.35)$ & .4 & $(0.08)$ & 95.5 & $(0.45)$ & 6.6 & $(0.14)$ \\
\hline & & & & & & & & & & & & & & & & & & & & Ul) \\
\hline & 92.1 & $(2.2$ & & $(0.0$ & 94.4 & & & $(0.6$ & & $(0.7)$ & & $(8$ & 9 & $(0.38)$ & 7 & & 3.3 & $.74)$ & 8 & $(0.10)$ \\
\hline & & 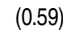 & & $(0)$. & & & & & & & & & & & & & 1.1 & & 7 & $0.06)$ \\
\hline & 94.9 & (c & & $(0$. & 94.4 & & 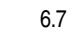 & $(0$. & 1 & $(0.3)$ & 12 & (9 & 94.9 & $(0.38)$ & 7 & $(0.06)$ & 2.9 & $(0.56)$ & 6.9 & $(0.14)$ \\
\hline Rhode Island .... & 93.7 & $(1.27)$ & 6.3 & $(0.03)$ & 94.6 & $(0.36)$ & 6.4 & $(0.05)$ & 180 & $(0.1)$ & 1,150 & (8.2) & 95.1 & (0.38) & 6.3 & $(0.05)$ & $\ddagger$ & $(\dagger)$ & $\ddagger$ & (†) \\
\hline & & (07 & & $(0$ & 95.6 & & 7.0 & & & (0.4) & & & 2 & $(0.2$ & & & 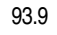 & 201) & .1 & .05) \\
\hline & 3.6 & & & $(0$. & & & & & & & & & 7 & & & & 3.6 & & 9 & $0.17)$ \\
\hline Tenn & 94.9 & $(0.23)$ & 7.0 & $(0.0$ & 94.6 & & 7.1 & $(0.03)$ & T & $(0.4)$ & 272 & (7.8) & 95.0 & $(0.28)$ & 1 & $(0.04)$ & 4.2 & 1.45) & .0 & $(0.02)$ \\
\hline & 94.1 & $(1$ & & $(0$. & 95.2 & $(0$. & 1 & $(0.6$ & 11 & $(0.7)$ & 7 & $(8$ & 95.9 & $(0.41)$ & 3 & $(0.03)$ & 4.8 & & 3 & $(0.06)$ \\
\hline Utah & 91.4 & (1.56) & 6.3 & $(0.29$ & 93.3 & $(0.8$ & 6.5 & $(0.08$ & 179 & (0.3) & 1,165 & (13.5) & 94.4 & $(0.80)$ & 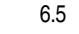 & $(0.08)$ & 93.6 & (0.74) & 6 & $(0.09)$ \\
\hline & & 14 & & $(0$. & & & & & & & & & & & & & 1.7 & & & $0.12)$ \\
\hline & 7 & $(0.4$ & & $(0.6$ & & & & $(0$. & 18 & (3.4) & 2 & (18. & & & 7 & & 3.3 & & 6 & D.10) \\
\hline & & & & $(0$. & & & & & & (0.3) & 1,129 & & & 10 & & & 3.0 & & 1 & $(019)$ \\
\hline W & 94.0 & $(0.99)$ & 6.9 & $(0.6$ & 94.9 & & 7 & $(0$. & 1 & $(0.4)$ & 1,272 & & 96.2 & $(0.27)$ & .0 & 07) & 39.8 & (1.98) & 3 & $(0.09)$ \\
\hline & 95.0 & $(0.5$ & 6.9 & $(0.0$ & 94.9 & $(0$. & 6.9 & $(0.1$ & 17 & $(0.2)$ & 1,234 & (19. & 95.7 & $(0.21)$ & 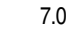 & $(0.03)$ & 91.9 & $(1.08)$ & .0 & $(0.12)$ \\
\hline Wyoming....... & 92.4 & (1.15) & 6.9 & $(0.05)$ & 93.6 & $(0.81)$ & 7.0 & $(0.04)$ & 174 & $(0.5)$ & 1,209 & $(6.5)$ & 94.8 & $(0.78)$ & 6.9 & $(0.05)$ & 89.9 & (2.19) & 7.0 & $(0.08)$ \\
\hline
\end{tabular}

†Not applicable.

†Reporting standards not met. Either the response rate is under 50 percent or there are too few cases for a reliable estimate.

NOTE: Averages reflect data reported by schools rather than state requirements. Schoolreported length of day may exceed state requirements, and there is a range of statistical error in reported estimates.
SOURCE: U.S. Department of Education, National Center for Education Statistics, Schools and Staffing Survey (SASS), "Public School Data File," 2007-08 and 2011-12. (This table was prepared May 2013.) 
Table 204.10. Number and percentage of public school students eligible for free or reduced-price lunch, by state: Selected years, 2000-01 through 2011-12

\begin{tabular}{|c|c|c|c|c|c|c|c|c|c|c|c|c|}
\hline \multirow[b]{2}{*}{ State } & \multicolumn{4}{|c|}{ Number of students } & \multicolumn{4}{|c|}{$\begin{array}{l}\text { Number of students eligible for } \\
\text { free/reduced-price lunch }\end{array}$} & \multicolumn{4}{|c|}{$\begin{array}{l}\text { Percent of students eligible for } \\
\text { free/reduced-price lunch }\end{array}$} \\
\hline & $2000-01$ & $2005-06$ & $2010-11$ & 2011-12 & $2000-01$ & $2005-06$ & $2010-11$ & 2011-12 & $2000-01$ & $2005-06$ & $2010-11$ & $2011-12$ \\
\hline 1 & 2 & 3 & 4 & 5 & 6 & 7 & 8 & 9 & 10 & 11 & 12 & 13 \\
\hline United States ............. & $46,579,068$ & $48,403,390$ & $48,941,267$ & $48,995,8121$ & $17,839,867{ }^{1}$ & $20,333,474$ & $23,544,479$ & $24,291,646^{1}$ & $38.3^{1}$ & 42.0 & 48.1 & $499.6^{1}$ \\
\hline Alabama ............... & 728,351 & 741,544 & 730,427 & 731,556 & 335,143 & 383,219 & 402,386 & 420,447 & 46.0 & 51.7 & 55.1 & 57.5 \\
\hline Alaska................ & 105,333 & 103,498 & 132,104 & 131,166 & 32,468 & 41,872 & 50,701 & 53,238 & 30.8 & 40.5 & 38.4 & 40.6 \\
\hline Arizona ....... & $877,696^{2}$ & 955,320 & $1,067,210$ & $1,024,454$ & $274,277^{2}$ & 492,450 & 482,044 & 511,885 & $31.2^{2}$ & 51.5 & 45.2 & 50.0 \\
\hline Arkansas.......... & 449,959 & 474,206 & 482,114 & 483,114 & 205,058 & 250,641 & 291,608 & 294,324 & 45.6 & 52.9 & 60.5 & 60.9 \\
\hline California .............. & $6,050,753$ & $6,311,900$ & $6,169,427$ & $6,202,862^{2}$ & $2,820,611$ & $3,063,627$ & $3,335,885$ & $3,353,964^{2}$ & 46.6 & 48.5 & 54.1 & $54.1^{2}$ \\
\hline Colorado .......... & 724,349 & 779,825 & 842,864 & 853,610 & 195,148 & 258,264 & 336,426 & 348,896 & 26.9 & 33.1 & 39.9 & 40.9 \\
\hline Connecticut... & $562,179^{2}$ & 575,051 & 552,919 & 543,883 & $143,030^{2}$ & 152,669 & 190,554 & 194,339 & $25.4^{2}$ & 26.5 & 34.5 & 35.7 \\
\hline Delaware............. & 114,676 & 120,937 & 128,342 & 128,470 & 37,766 & 43,682 & 61,564 & 62,774 & 32.9 & 36.1 & 48.0 & 48.9 \\
\hline District of Columbia .... & 68,380 & 66,498 & 71,263 & 72,329 & 47,839 & 41,050 & 52,027 & 45,199 & 70.0 & 61.7 & 73.0 & 62.5 \\
\hline 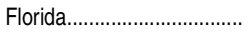 & $2,434,755$ & $2,674,998$ & $2,641,555$ & $2,668,037$ & $1,079,009$ & $1,224,228$ & $1,479,519$ & $1,535,670$ & 44.3 & 45.8 & 56.0 & 57.6 \\
\hline Georgia.. & $1,444,937$ & $1,598,461$ & $1,676,419$ & $1,682,447$ & 624,511 & 795,394 & 961,954 & 986,865 & 43.2 & 49.8 & 57.4 & 58.7 \\
\hline Hawaii... & 184,357 & 184,925 & 179,601 & 182,705 & 80,657 & 74,926 & 84,106 & 90,021 & 43.8 & 40.5 & 46.8 & 49.3 \\
\hline Idaho..... & 244,755 & 260,343 & 275,815 & 276,969 & 85,824 & 99,093 & 124,104 & 135,642 & 35.1 & 38.1 & 45.0 & 49.0 \\
\hline Illinois............... & $2,048,792^{2}$ & $1,976,077$ & $1,973,401$ & $2,068,926$ & $759,973^{2}$ & 785,715 & 921,471 & $1,014,713$ & $37.1^{2}$ & 39.8 & 46.7 & 49.0 \\
\hline 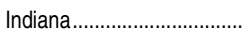 & 977,219 & $1,034,719$ & $1,038,817$ & $1,037,779$ & 285,267 & 373,433 & 485,728 & 497,663 & 29.2 & 36.1 & 46.8 & 48.0 \\
\hline lowa.. & 492,021 & 481,094 & 484,856 & 485,358 & 131,553 & 154,416 & 188,486 & 194,146 & 26.7 & 32.1 & 38.9 & 40.0 \\
\hline Kansas.... & 462,594 & 466,263 & 479,953 & 481,519 & 154,693 & 180,919 & 228,852 & 235,362 & 33.4 & 38.8 & 47.7 & 48.9 \\
\hline Kentucky ............... & 626,723 & 641,682 & 673,128 & 677,628 & 298,334 & 336,287 & 380,773 & 368,355 & 47.6 & 52.4 & 56.6 & 54.4 \\
\hline Louisiana ................... & 741,162 & 654,388 & 695,772 & 702,301 & 433,068 & 400,596 & 460,546 & 471,347 & 58.4 & 61.2 & 66.2 & 67.1 \\
\hline Maine.......... & 198,532 & 189,572 & 183,477 & $178,989^{2}$ & 60,162 & 65,877 & 78,915 & $76,985^{2}$ & 30.3 & 34.8 & 43.0 & $43.0^{2}$ \\
\hline Maryland............ & 852,911 & 860,018 & 852,202 & 854,060 & 255,872 & 272,069 & 341,557 & 356,631 & 30.0 & 31.6 & 40.1 & 41.8 \\
\hline Massachusetts....... & 979,590 & 971,907 & 955,301 & 952,044 & 237,871 & 274,515 & 326,849 & 334,511 & 24.3 & 28.2 & 34.2 & 35.1 \\
\hline 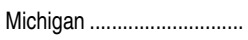 & $1,703,260$ & $1,711,532$ & $1,551,861$ & $1,532,809$ & 504,044 & 609,754 & 719,800 & 735,010 & 29.6 & 35.6 & 46.4 & 48.0 \\
\hline Minnesota... & 854,154 & 838,998 & 837,930 & 839,645 & 218,867 & 253,938 & 306,136 & 311,645 & 25.6 & 30.3 & 36.5 & 37.1 \\
\hline Mississippi ........... & 497,421 & 494,744 & 489,462 & 487,870 & 319,670 & 344,107 & 345,734 & 348,664 & 64.3 & 69.6 & 70.6 & 71.5 \\
\hline Missouri ...... & 912,247 & 915,844 & 902,375 & 885,138 & 315,608 & 358,428 & 406,358 & 411,750 & 34.6 & 39.1 & 45.0 & 46.5 \\
\hline Montana.................... & 154,438 & 143,093 & 140,497 & 142,349 & 47,415 & 50,172 & 57,836 & 57,349 & 30.7 & 35.1 & 41.2 & 40.3 \\
\hline Nebraska ........ & 286,138 & 286,610 & 298,276 & 301,296 & 87,045 & 99,387 & 127,114 & 132,010 & 30.4 & 34.7 & 42.6 & 43.8 \\
\hline Nevada ............... & 282,621 & 410,531 & 436,840 & 438,745 & 92,978 & 170,039 & 219,904 & 237,212 & 32.9 & 41.4 & 50.3 & 54.1 \\
\hline New Hampshire.. & 206,919 & 203,998 & 194,001 & 190,784 & 31,212 & 35,087 & 48,904 & 50,123 & 15.1 & 17.2 & 25.2 & 26.3 \\
\hline $\mathrm{Ner}$ & $1,312,983$ & $1,395,600$ & $1,356,882$ & $1,316,792$ & 357,728 & 373,946 & 444,735 & 467,798 & 27.2 & 26.8 & 32.8 & 35.5 \\
\hline New Mexico ....... & 320,303 & 326,755 & 335,810 & 333,331 & 174,939 & 181,916 & 227,077 & 228,227 & 54.6 & 55.7 & 67.6 & 68.5 \\
\hline New York.............. & $2,859,927$ & $2,812,964$ & $2,722,761$ & $2,685,751$ & $1,236,945$ & $1,260,933$ & $1,315,564$ & $1,334,698$ & 43.3 & 44.8 & 48.3 & 49.7 \\
\hline North Carolina ... & $1,194,371$ & $1,356,570$ & $1,487,699$ & $1,497,711$ & 470,316 & 603,316 & 747,978 & 784,268 & 39.4 & 44.5 & 50.3 & 52.4 \\
\hline North Dakota ............ & 109,201 & 98,284 & 94,273 & 94,018 & 31,840 & 29,064 & 29,929 & 30,870 & 29.2 & 29.6 & 31.7 & 32.8 \\
\hline Ohio.. & $1,745,237$ & $1,836,982$ & $1,747,851$ & $1,738,642$ & 494,829 & 597,517 & 745,121 & 758,106 & 28.4 & 32.5 & 42.6 & 43.6 \\
\hline Oklahoma .. & 623,110 & 632,812 & 659,376 & 665,243 & 300,179 & 346,070 & 398,917 & 406,908 & 48.2 & 54.7 & 60.5 & 61.2 \\
\hline Oregon............ & 535,617 & 534,814 & 553,468 & 540,266 & 186,203 & 230,737 & 280,174 & 287,214 & 34.8 & 43.1 & 50.6 & 53.2 \\
\hline Pennsylvania....... & $1,798,977$ & $1,813,760$ & $1,742,608$ & $1,732,035$ & 510,121 & 574,951 & 686,641 & 696,531 & 28.4 & 31.7 & 39.4 & 40.2 \\
\hline Rhode Island ............. & 157,347 & 151,686 & 142,575 & 141,456 & 52,209 & 53,521 & 61,127 & 62,082 & 33.2 & 35.3 & 42.9 & 43.9 \\
\hline South Carolina..... & 677,411 & 700,397 & 722,203 & 726,003 & 320,254 & 361,567 & 395,033 & 412,345 & 47.3 & 51.6 & 54.7 & 56.8 \\
\hline South Dakota .............. & 128,598 & 121,999 & 125,883 & 128,016 & 37,857 & 39,059 & 46,718 & 49,469 & 29.4 & 32.0 & 37.1 & 38.6 \\
\hline Tennessee ............... & $909,161^{2}$ & 934,444 & 987,078 & 964,832 & $436,298^{2}$ & 448,431 & 542,953 & 554,768 & $48.0^{2}$ & 48.0 & 55.0 & 57.5 \\
\hline Texas ........................... & $4,059,353$ & $4,523,575$ & $4,916,401$ & $5,000,193$ & $1,823,029$ & $2,181,697$ & $2,471,212$ & $2,552,819$ & 44.9 & 48.2 & 50.3 & 51.1 \\
\hline Utah & 470,265 & 508,399 & 585,552 & 598,294 & 135,428 & 164,255 & 223,943 & 284,910 & 28.8 & 32.3 & 38.2 & 47.6 \\
\hline Vermont & 102,049 & 96,638 & 85,144 & 83,451 & 23,986 & 25,487 & 31,339 & 32,748 & 23.5 & 26.4 & 36.8 & 39.2 \\
\hline Virginia.... & $1,067,710$ & $1,167,860$ & $1,250,206$ & $1,227,099$ & 320,233 & 377,725 & 458,879 & 480,821 & 30.0 & 32.3 & 36.7 & 39.2 \\
\hline 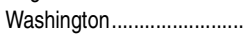 & $1,004,770^{2}$ & $1,031,967$ & $1,043,466$ & $1,041,934$ & $326,295^{2}$ & 376,198 & 418,065 & 463,246 & $32.5^{2}$ & 36.5 & 40.1 & 44.5 \\
\hline West Virginia........ & 286,285 & 280,699 & 282,879 & 282,870 & 143,446 & 137,878 & 145,605 & 149,407 & 50.1 & 49.1 & 51.5 & 52.8 \\
\hline Wisconsin ..................... & 859,276 & 864,207 & 872,164 & 869,670 & 219,276 & 256,645 & 342,660 & 354,527 & 25.5 & 29.7 & 39.3 & 40.8 \\
\hline Wyoming........ & 89,895 & 84,402 & 88,779 & 89,363 & 43,483 & 26,707 & 32,968 & 33,145 & 48.4 & 31.6 & 37.1 & 37.1 \\
\hline
\end{tabular}

1U.S. total includes imputation for nonreporting states.

${ }^{2}$ Imputation for survey nonresponse. State-level imputations for 2000-01 were based on the reported percentages for 2001-02 applied to the 2000-01 enrollments. State-leve imputations for 2011-12 were based on the reported percentages for 2010-11 applied to the 2011-12 enrollments.
NOTE: Table reflects counts of students enrolled in all schools for which both enrollment data and free/reduced-price lunch eligibility data were reported. Some data have been revised from previously published figures.

SOURCE: U.S. Department of Education, National Center for Education Statistics, Common Core of Data (CCD), "Public Elementary/Secondary School Universe Survey," 2000-01, 2005-06, 2010-11, and 2011-12. (This table was prepared September 2013.) 
104 CHAPTER 2: Elementary and Secondary Education

Participation in Public School Services

Table 204.20. Number and percentage of public school students participating in programs for English language learners, by state: Selected years, 2002-03 through 2011-12

\begin{tabular}{|c|c|c|c|c|c|c|c|c|c|c|c|c|c|c|}
\hline \multirow[b]{2}{*}{ State } & \multicolumn{7}{|c|}{ Number of public school students participating in programs for English language learners } & \multicolumn{7}{|c|}{ Percent of students participating in programs for English language learners } \\
\hline & $2002-03$ & $2005-06$ & $2007-08$ & $2008-09$ & $2009-10$ & $2010-11$ & $2011-12$ & $2002-03$ & $2005-06$ & $2007-08$ & $2008-09$ & $2009-10$ & $2010-11$ & $2011-12$ \\
\hline 1 & 2 & 3 & 4 & 5 & 6 & 7 & 8 & 9 & 10 & 11 & 12 & 13 & 14 & 15 \\
\hline United States.... & $4,118,918$ 1 & $4,421,4891$ & $4,153,870^{1}$ & $4,439,514^{1}$ & $4,364,510^{1}$ & $4,370,0041$ & $4,389,3251$ & 8.71 & $9.2^{1}$ & $8.6^{1}$ & 9.21 & $9.1^{1}$ & $9.1^{1}$ & $9.1^{1}$ \\
\hline Alabama. & 10,568 & 16,550 & 20,943 & 19,523 & 19,497 & 17,559 & 17,895 & 1.5 & 2.2 & 2.8 & 2.6 & 2.6 & 2.4 & 2.4 \\
\hline laska..... & 16,351 & 20,743 & 16,752 & 11,937 & 14,581 & 14,894 & 14,538 & 12.3 & 15.6 & 12.8 & 9.2 & 11.1 & 11.3 & 11.1 \\
\hline izona .. & 140,664 & 166,195 & 143,482 & 118,868 & 78,793 & 70,716 & 70,527 & 15.9 & 17.6 & 14.6 & 12.1 & 8.2 & 7.5 & 7.5 \\
\hline rkansas & 15,146 & 20,700 & 25,896 & 27,629 & 29,735 & 31,457 & 32,671 & 3.4 & 4.4 & 5.4 & 5.8 & 6.3 & 6.6 & 6.9 \\
\hline California .... & $1,587,771$ & $1,557,935$ & $1,517,559^{2}$ & $1,498,660$ & $1,468,815^{3}$ & $1,445,496^{2}$ & $1,415,623$ & 25.7 & 25.0 & $24.5^{2}$ & 24.3 & $24.1^{3}$ & $23.6^{2}$ & 23.2 \\
\hline olorado ......... & 86,118 & 99,790 & 84,900 & 88,254 & 94,391 & 98,809 & 101,262 & 11.5 & 12.8 & 10.7 & 10.9 & 11.4 & 11.8 & 12.0 \\
\hline onnecticut.......................... & 21,970 & 28,662 & 29,424 & 28,886 & 29,266 & 29,671 & 29,318 & 4.0 & 5.2 & 5.4 & 5.4 & 5.4 & 5.6 & 5.6 \\
\hline elaware........ & 3,445 & 5,900 & 7,179 & 7,111 & 7,615 & 6,766 & 6,972 & 3.1 & 5.2 & 6.3 & 6.1 & 6.5 & 5.6 & 5.9 \\
\hline istrict of Columbia & 5,363 & 4,274 & 4,092 & 4,370 & 4,203 & 3,741 & 3,745 & 7.9 & 7.2 & 7.0 & 9.9 & 9.6 & 8.4 & 8.4 \\
\hline 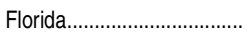 & 203,659 & 221,624 & 231,326 & 226,037 & 230,440 & 229,659 & 234,347 & 8.0 & 8.3 & 8.7 & 8.6 & 8.8 & 8.7 & 8.8 \\
\hline eorgis & 70,464 & 86,615 & 81,008 & 82,000 & 86,668 & 80,965 & 83,400 & 4.7 & 5.4 & 4.9 & 5.0 & 5.2 & 4.9 & 5.0 \\
\hline Hawaii... & 12,853 & 18,106 & 16,959 & 18,564 & 18,097 & 19,092 & 24,750 & 7.0 & 9.9 & 9.4 & 10.3 & 10.0 & 10.6 & 13.5 \\
\hline Idaho....... & 18,747 & 18,184 & 16,660 & 17,657 & 15,931 & 15,361 & 15,143 & 7.5 & 6.9 & 6.3 & 6.6 & 6.0 & 5.8 & 5.7 \\
\hline Illinois.... & 168,591 & $172,375^{2}$ & 156,673 & 204,737 & 179,850 & 174,335 & 170,626 & 8.2 & $8.2^{2}$ & 7.5 & 9.7 & 8.6 & 8.4 & 8.2 \\
\hline Indiana & 42,560 & 56,400 & 46,092 & 45,527 & 48,364 & 48,574 & 50,082 & 4.3 & 5.5 & 4.5 & 4.4 & 4.7 & 4.7 & 5.0 \\
\hline wa & 13,961 & 15,156 & 19,442 & 20,334 & 20,867 & 21,733 & 22,503 & 2.9 & 3.1 & 4.0 & 4.2 & 4.2 & 4.4 & 4.5 \\
\hline Kansas.. & 17,942 & 24,671 & 31,760 & 34,095 & 38,011 & 39,323 & 41,052 & 3.8 & 5.3 & 6.8 & 7.2 & 8.0 & 8.1 & 8.5 \\
\hline entucky ........ & 6,343 & 10,138 & 12,896 & 14,589 & 14,244 & 16,351 & 16,878 & 1.0 & 1.5 & 1.9 & 2.2 & 2.1 & 2.4 & 2.5 \\
\hline Louisiana ........ & 11,042 & 11,942 & 8,545 & 12,223 & 12,499 & 11,617 & 12,348 & 1.5 & 1.8 & 1.3 & 1.9 & 1.9 & 1.7 & 1.9 \\
\hline Maine .... & 2,575 & 3,332 & 3,803 & $4,128^{2}$ & 4,467 & 4,792 & 5,104 & 1.2 & 1.7 & 2.0 & $2.2^{2}$ & 2.4 & 2.5 & 2.7 \\
\hline aryland........ & 27,311 & 31,416 & $36,971^{2}$ & $39,919^{2}$ & 43,179 & 45,500 & 51,574 & 3.2 & 3.7 & $4.4^{2}$ & $4.7^{2}$ & 5.1 & 5.3 & 6.0 \\
\hline setts... & 50,578 & 50,007 & 53,788 & 47,198 & 49,612 & 52,610 & 2,354 & 6.1 & 6.2 & 6.7 & 5.9 & 6.3 & 6.7 & 7.9 \\
\hline$\ldots \ldots . .$. & 54,961 & 60,212 & 47,139 & 55,593 & 53,565 & 50,773 & 52,811 & 3.2 & 3.7 & 3.0 & 3.6 & 3.5 & 3.5 & 3.7 \\
\hline Minnesota ....... & 51,224 & 53,661 & 55,377 & 55,738 & 54,349 & 40,778 & 54,034 & 6.1 & 6.6 & 6.9 & 7.0 & 6.8 & 5.1 & 6.8 \\
\hline Mississipp & 2,250 & 2,859 & 5,428 & 6,543 & 6,061 & 5,617 & 6,175 & 0.5 & 0.6 & 1.1 & 1.3 & 1.2 & 1.1 & 1.3 \\
\hline Missouri.. & 13,121 & 18,745 & $16,4722^{2}$ & 15,468 & 19,393 & 20,411 & 3,169 & 1.4 & 2.0 & $1.8^{2}$ & 1.7 & 2.2 & 2.3 & 2.6 \\
\hline Montana... & 6,642 & 6,711 & 6,721 & 4,549 & 3,806 & 3,299 & 3,318 & 4.4 & 4.6 & 4.7 & 3.2 & 2.7 & 2.3 & 2.3 \\
\hline Nebraska ... & 13,803 & 17,449 & 19,128 & 18,388 & 19,323 & 20,062 & 17,532 & 4.9 & 6.1 & 6.6 & 6.3 & 6.6 & 6.7 & 5.8 \\
\hline 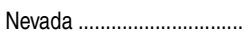 & 58,753 & 63,856 & 46,602 & 75,952 & 67,868 & 83,351 & 84,125 & 15.9 & 15.5 & 10.9 & 17.6 & 16.0 & 19.4 & 19.6 \\
\hline New Hampshire ....... & 3,270 & $2,877^{2}$ & 3,201 & 3,496 & 3,821 & 3,965 & 3,892 & 1.6 & $1.4^{2}$ & 1.6 & 1.8 & 1.9 & 2.0 & 2.0 \\
\hline Jew Jercey & 57,548 & 50,426 & 52,5592 & 53,960 & 55,450 & 52,580 & 53,543 & 4.3 & 3.7 & $3.9^{2}$ & 4.0 & 4.1 & 3.8 & 4.0 \\
\hline $\mathrm{Ner}$ & 65,317 & 62,682 & 61,173 & $55,978^{2}$ & 51,257 & 52,029 & 53,071 & 20.4 & 19.2 & 18.6 & $17.0^{2}$ & 15.5 & 15.7 & 16.1 \\
\hline .......... & 178,704 & 193,701 & 209,449 & 183,736 & 200,433 & 207,708 & 204,898 & 6.2 & 6.9 & 7.7 & 6.8 & 7.4 & 7.8 & 7.8 \\
\hline lin & 59,712 & 73,206 & 126,792 & 113,155 & 105,651 & 102,397 & 98,264 & 4.5 & 5.3 & 8.9 & 7.8 & 7.3 & 7.1 & 6.7 \\
\hline North Dakota ............ & 883 & $2,213^{2}$ & 2,645 & 3,540 & 3,031 & 2,788 & 2,589 & 0.9 & $2.3^{2}$ & 2.8 & 3.7 & 3.3 & 3.0 & 2.7 \\
\hline & 25,610 & 29,222 & 34,167 & 35,362 & 36,527 & 35,170 & 5,729 & 1.4 & 1.7 & 2.0 & 2.0 & 2.2 & 2.1 & 2.2 \\
\hline Oklahoma. & 40,179 & 47,380 & 37,744 & $38,314^{2}$ & 39,259 & 41,431 & 44,593 & 6.4 & 7.5 & 5.9 & $5.9^{2}$ & 6.0 & 6.3 & 6.7 \\
\hline Oregon & 52,331 & 64,603 & 61,999 & 62,857 & 61,625 & 58,662 & 63,790 & 9.5 & 12.1 & 11.0 & 11.2 & 11.0 & 10.5 & 11.3 \\
\hline Pennsylvania.......... & $30,731^{2}$ & $39,598^{2}$ & 44,564 & 44,853 & 44,359 & 44,729 & 44,242 & $1.7^{2}$ & $2.3^{2}$ & 2.6 & 2.7 & 2.6 & 2.7 & 2.7 \\
\hline Rhode Island .... & 10,050 & 7,090 & 6,672 & $6,466^{2}$ & 6,340 & 7,161 & 7,724 & 6.4 & 5.1 & 5.0 & $4.9^{2}$ & 4.9 & 5.5 & 6.1 \\
\hline Sout & 7,467 & 14,372 & 13,531 & 31,422 & 34,661 & 36,360 & 38,986 & 1.1 & 2.1 & 1.9 & 4.4 & 4.8 & 5.1 & 5.4 \\
\hline South Dakota... & 4,522 & 5,110 & $3,994^{2}$ & 3,580 & 4,005 & 4,383 & 4,736 & 3.5 & 4.2 & $3.3^{2}$ & 2.8 & 3.2 & 3.5 & 3.7 \\
\hline Tenness & $26,808^{2}$ & $28,251^{2}$ & 25,670 & 27,433 & 27,550 & 29,680 & 30,996 & $3.0^{2}$ & $3.0^{2}$ & 2.7 & 2.8 & 2.8 & 3.0 & 3.1 \\
\hline 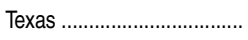 & 625,946 & 702,436 & 445,334 & 704,142 & 708,615 & 718,350 & 722,043 & 14.9 & 15.8 & 9.7 & 15.2 & 15.0 & 15.0 & 14.9 \\
\hline Utah & 43,269 & 49,915 & 46,398 & 43,957 & 46,591 & 41,805 & 32,423 & 9.0 & 10.1 & 8.3 & 8.3 & 8.5 & 7.7 & 5.9 \\
\hline & 1,057 & 1,771 & $1,675^{2}$ & $1,645^{2}$ & 1,525 & 1,510 & 1,447 & 1.1 & 1.9 & $1.9^{2}$ & $1.9^{2}$ & 1.7 & 1.6 & 1.6 \\
\hline & 49,780 & 72,184 & 84,080 & 86,745 & 86,475 & 87,752 & 91,431 & 4.3 & 6.0 & 6.9 & 7.1 & 7.0 & 7.1 & 7.4 \\
\hline W & 70,431 & 75,103 & 80,694 & 82,711 & 65,101 & 90,282 & 82,070 & 6.9 & 7.3 & 7.8 & 8.0 & 6.3 & 8.7 & 7.9 \\
\hline Wes & 1,281 & 1,942 & 2,335 & 1,617 & 1,605 & 1,786 & 1,914 & 0.5 & 0.7 & 0.8 & 0.6 & 0.6 & 0.6 & 0.7 \\
\hline Wisc & 25,764 & 30,130 & 43,782 & 47,798 & 45,041 & 43,562 & 44,362 & 2.9 & 3.4 & 5.0 & 5.5 & 5.2 & 5.0 & 5.1 \\
\hline Wyoming .............................. & 3,483 & 3,068 & 2,395 & 2,271 & 2,098 & 2,602 & 2,706 & 4.1 & 3.6 & 2.8 & 2.6 & 2.4 & 2.9 & 3.0 \\
\hline
\end{tabular}

1U.S. total includes imputation for nonreporting states.

Imputation for survey nonresponse. State-level imputations were based on the percentages reported by the state for other years applied to the enrollment for the given year. ${ }^{3}$ Based on data reported by the California Education Agency (http://www.cde.ca.gov/ds/sd/ cb/cefelfacts.asp).

NOTE: Includes students served in regular school districts, excluding regional education service agencies and supervisory union administrative centers, state-operated agencies, federally operated agencies, and other types of local education agencies, such as independent charter schools.

SOURCE: U.S. Department of Education, National Center for Education Statistics, Common Core of Data (CCD), Local Education Agency Universe Survey, 2002-03 through 2011-12. (This table was prepared September 2013.) 
Table 204.30. Children 3 to 21 years old served under Individuals with Disabilities Education Act (IDEA), Part B, by type of disability: Selected years, 1976-77 through 2011-12

\begin{tabular}{|c|c|c|c|c|c|c|c|c|c|c|c|c|c|c|c|}
\hline Type of disability & $\mid 1976-77$ & $1980-81$ & 1990-91 & $2000-01$ & 2001-02 & $2002-03$ & 2003-04 & $2004-05$ & $2005-06$ & $2006-07$ & $2007-08^{1}$ & $2008-09^{1}$ & 2009-10 & 2010-11 & $2011-12$ \\
\hline 1 & 2 & 3 & 4 & 5 & 6 & 7 & 8 & 9 & 10 & 11 & 12 & 13 & 14 & 15 & 16 \\
\hline & \multicolumn{15}{|c|}{ Number served (in thousands) } \\
\hline All disabilities..... & 3,694 & 4,144 & 4,710 & 6,296 & 6,407 & 6,523 & 6,634 & 6,720 & 6,718 & 6,687 & 6,597 & 6,483 & 6,481 & 6,436 & 6,401 \\
\hline Autism .......................... & - & - & - & 93 & 114 & 137 & 163 & 191 & 223 & 258 & 296 & 336 & 378 & 417 & 455 \\
\hline Deaf-blindness............. & - & 3 & 1 & 1 & 2 & 2 & 2 & 2 & 2 & 2 & 2 & 2 & 2 & 2 & 2 \\
\hline Developmental delay ........ & - & - & - & 213 & 242 & 283 & 305 & 332 & 339 & 333 & 357 & 354 & 368 & 382 & 393 \\
\hline Emotional disturbance..................... & 283 & 347 & 389 & 480 & 483 & 485 & 489 & 489 & 477 & 464 & 442 & 420 & 407 & 390 & 373 \\
\hline Hearing impairments ...................... & 88 & 79 & 58 & 77 & 78 & 78 & 79 & 79 & 79 & 80 & 79 & 78 & 79 & 78 & 78 \\
\hline Intellectual disability.... & 961 & 830 & 534 & 624 & 616 & 602 & 593 & 578 & 556 & 534 & 500 & 478 & 463 & 448 & 435 \\
\hline Multiple disabilities..... & - & 68 & 96 & 131 & 136 & 138 & 140 & 140 & 141 & 142 & 138 & 130 & 131 & 130 & 132 \\
\hline Orthopedic impairments... & 87 & 58 & 49 & 82 & 83 & 83 & 77 & 73 & 71 & 69 & 67 & 70 & 65 & 63 & 61 \\
\hline Other health impairments ${ }^{2} \ldots \ldots \ldots \ldots . . . .$. & 141 & 98 & 55 & 303 & 350 & 403 & 464 & 521 & 570 & 610 & 641 & 659 & 689 & 716 & 743 \\
\hline Preschool disabled ${ }^{3} \ldots$ & $\dagger$ & $\dagger$ & 390 & $\dagger$ & $t$ & $\dagger$ & $\dagger$ & $\dagger$ & $\dagger$ & $\dagger$ & $t$ & $t$ & $\dagger$ & $\dagger$ & $\dagger$ \\
\hline Specific learning disabilities...... & 796 & 1,462 & 2,129 & 2,860 & 2,861 & 2,848 & 2,831 & 2,798 & 2,740 & 2,665 & 2,569 & 2,476 & 2,431 & 2,361 & 2,303 \\
\hline Speech or language impairments.. & 1,302 & 1,168 & 985 & 1,388 & 1,391 & 1,412 & 1,441 & 1,463 & 1,468 & 1,475 & 1,454 & 1,426 & 1,416 & 1,396 & 1,373 \\
\hline in injury.......................... & - & - & - & 16 & 22 & 22 & 23 & 24 & 24 & 25 & 25 & 26 & 25 & 26 & 26 \\
\hline \multirow[t]{2}{*}{ 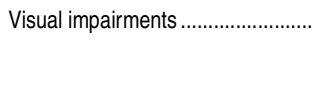 } & 38 & 31 & 23 & 29 & 28 & 29 & 28 & 29 & 29 & 29 & 29 & 29 & 29 & 28 & 28 \\
\hline & \multicolumn{15}{|c|}{ Percentage distribution of children served } \\
\hline All disabilities..... & 100.0 & 100.0 & 100.0 & 100.0 & 100.0 & 100.0 & 100.0 & 100.0 & 100.0 & 100.0 & 100.0 & 100.0 & 100.0 & 100.0 & 100.0 \\
\hline Autism & - & - & - & 1.5 & 1.8 & 2.1 & 2.5 & 2.8 & 3.3 & 3.9 & 4.5 & 5.2 & 5.8 & 6.5 & 7.1 \\
\hline s.............................. & - & 0.1 & \# & \# & \# & \# & \# & \# & \# & \# & \# & \# & \# & \# & \# \\
\hline 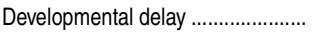 & - & - & - & 3.4 & 3.8 & 4.3 & 4.6 & 4.9 & 5.0 & 5.0 & 5.4 & 5.5 & 5.7 & 5.9 & 6.1 \\
\hline Emotional disturbance .................... & 7.7 & 8.4 & 8.3 & 7.6 & 7.5 & 7.4 & 7.4 & 7.3 & 7.1 & 6.9 & 6.7 & 6.5 & 6.3 & 6.1 & 5.8 \\
\hline tts ..................... & 2.4 & 1.9 & 1.2 & 1.2 & 1.2 & 1.2 & 1.2 & 1.2 & 1.2 & 1.2 & 1.2 & 1.2 & 1.2 & 1.2 & 1.2 \\
\hline lity........................... & 26.0 & 20.0 & 11.3 & 9.9 & 9.6 & 9.2 & 8.9 & 8.6 & 8.3 & 8.0 & 7.6 & 7.4 & 7.1 & 7.0 & 6.8 \\
\hline$\ldots \ldots \ldots \ldots$ & - & 1.6 & 2.0 & 2.1 & 2.1 & 2.1 & 2.1 & 2.1 & 2.1 & 2.1 & 2.1 & 2.0 & 2.0 & 2.0 & 2.1 \\
\hline - & 2.4 & 1.4 & 1.0 & 1.3 & 1.3 & 1.3 & 1.2 & 1.1 & 1.1 & 1.0 & 1.0 & 1.1 & 1.0 & 1.0 & 1.0 \\
\hline ments ${ }^{2} \ldots . .$. & 3.8 & 2.4 & 1.2 & 4.8 & 5.5 & 6.2 & 7.0 & 7.7 & 8.5 & 9.1 & 9.7 & 10.2 & 10.6 & 11.1 & 11.6 \\
\hline Presch & $\dagger$ & $\dagger$ & 8.3 & $\dagger$ & $t$ & $\dagger$ & $\dagger$ & $\dagger$ & $\dagger$ & $\dagger$ & $\dagger$ & $\dagger$ & $\dagger$ & $\dagger$ & $\dagger$ \\
\hline s............... & 21.5 & 35.3 & 45.2 & 45.4 & 44.7 & 43.7 & 42.7 & 41.6 & 40.8 & 39.9 & 38.9 & 38.2 & 37.5 & 36.7 & 36.0 \\
\hline Speecl & 35.2 & 28.2 & 20.9 & 22.0 & 21.7 & 21.6 & 21.7 & 21.8 & 21.8 & 22.1 & 22.0 & 22.0 & 21.8 & 21.7 & 21.4 \\
\hline Traum & - & - & - & 0.2 & 0.3 & 0.3 & 0.4 & 0.4 & 0.4 & 0.4 & 0.4 & 0.4 & 0.4 & 0.4 & 0.4 \\
\hline \multirow[t]{2}{*}{ 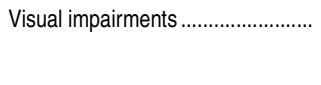 } & 1.0 & 0.7 & 0.5 & 0.5 & 0.4 & 0.4 & 0.4 & 0.4 & 0.4 & 0.4 & 0.4 & 0.4 & 0.4 & 0.4 & 0.4 \\
\hline & \multicolumn{15}{|c|}{ Number served as a percent of total enrollment ${ }^{4}$} \\
\hline All disabilities ........... & 8.3 & 10.1 & 11.4 & 13.3 & 13.4 & 13.5 & 13.7 & 13.8 & 13.7 & 13.6 & 13.4 & 13.2 & 13.1 & 13.0 & 12.9 \\
\hline Autism .............................. & - & - & - & 0.2 & 0.2 & 0.3 & 0.3 & 0.4 & 0.5 & 0.5 & 0.6 & 0.7 & 0.8 & 0.8 & 0.9 \\
\hline Deaf-blindness.... & - & \# & \# & \# & \# & \# & \# & \# & \# & \# & \# & \# & \# & \# & \# \\
\hline Developmental delay ...... & - & - & - & 0.5 & 0.5 & 0.6 & 0.6 & 0.7 & 0.7 & 0.7 & 0.7 & 0.7 & 0.7 & 0.8 & 0.8 \\
\hline Emotional disturbance.... & 0.6 & 0.8 & 0.9 & 1.0 & 1.0 & 1.0 & 1.0 & 1.0 & 1.0 & 0.9 & 0.9 & 0.9 & 0.8 & 0.8 & 0.8 \\
\hline Hearing in & 0.2 & 0.2 & 0.1 & 0.2 & 0.2 & 0.2 & 0.2 & 0.2 & 0.2 & 0.2 & 0.2 & 0.2 & 0.2 & 0.2 & 0.2 \\
\hline Intellec & 2.2 & 2.0 & 1.3 & 1.3 & 1.3 & 1.2 & 1.2 & 1.2 & 1.1 & 1.1 & 1.0 & 1.0 & 0.9 & 0.9 & 0.9 \\
\hline & - & 0.2 & 0.2 & 0.3 & 0.3 & 0.3 & 0.3 & 0.3 & 0.3 & 0.3 & 0.3 & 0.3 & 0.3 & 0.3 & 0.3 \\
\hline Orth & 0.2 & 0.1 & 0.1 & 0.2 & 0.2 & 0.2 & 0.2 & 0.2 & 0.1 & 0.1 & 0.1 & 0.1 & 0.1 & 0.1 & 0.1 \\
\hline Other health impairments ${ }^{2} . . . . . . . . . . . .$. & 0.3 & 0.2 & 0.1 & 0.6 & 0.7 & 0.8 & 1.0 & 1.1 & 1.2 & 1.2 & 1.3 & 1.3 & 1.4 & 1.4 & 1.5 \\
\hline Preschool dis & $\dagger$ & $\dagger$ & 0.9 & $\dagger$ & $\dagger$ & $\dagger$ & $\dagger$ & $\dagger$ & $\dagger$ & $\dagger$ & $\dagger$ & $\dagger$ & $\dagger$ & $\dagger$ & . \\
\hline & 1.8 & 3.6 & 5.2 & 6.1 & 6.0 & 5.9 & 5.8 & 5.7 & 5.6 & 5.4 & 5.2 & 5.0 & 4.9 & 4.8 & 4.7 \\
\hline Speech & 2.9 & 2.9 & 2.4 & 2.9 & 2.9 & 2.9 & 3.0 & 3.0 & 3.0 & 3.0 & 2.9 & 2.9 & 2.9 & 2.8 & 2.8 \\
\hline dry........................ & - & - & - & \# & \# & \# & \# & \# & \# & 0.1 & 0.1 & 0.1 & 0.1 & 0.1 & 0.1 \\
\hline Visual impairments...... & 0.1 & 0.1 & 0.1 & 0.1 & 0.1 & 0.1 & 0.1 & 0.1 & 0.1 & 0.1 & 0.1 & 0.1 & 0.1 & 0.1 & 0.1 \\
\hline
\end{tabular}

\section{-Not available.}

†Not applicable.

\#Rounds to zero.

'Data do not include Vermont, for which 2007-08 and 2008-09 data were not available. In 2006-07, the total number of 3- to 21-year-olds served in Vermont was 14,010.

2Other health impairments include having limited strength, vitality, or alertness due to chronic or acute health problems such as a heart condition, tuberculosis, rheumatic fever, nephritis, asthma, sickle cell anemia, hemophilia, epilepsy, lead poisoning, leukemia, or diabetes.

${ }^{3}$ For 1990-91, preschool children are not included in the counts by disability condition but are separately reported. For other years, preschool children are included in the counts by disability condition.

${ }^{4}$ Based on the total enrollment in public schools, prekindergarten through 12th grade. For total enrollment in public schools, see table 203.20.

NOTE: Prior to October 1994, children and youth with disabilities were served under Chapter 1 of the Elementary and Secondary Education Act as well as under the Individuals with Disabilities
Education Act (IDEA), Part B. Data reported in this table for years prior to 1994-95 include children ages 0-21 served under Chapter 1. Data are for the 50 states and the District of Columbia only. Increases since 1987-88 are due in part to new legislation enacted in fall 1986, which added a mandate for public school special education services for 3- to 5-year-old children with to totals because of rounding.

to totals because of rounding. to Congress on the Implementation of the Individuals with Disabilities Education Act, selected years, 1979 through 2006; and Individuals with Disabilities Education Act (IDEA) database, retrieved March 21, 2013, from http://www.ideadata.org/PartBdata.asp. National Center for Education Statistics, Statistics of Public Elementary and Secondary School Systems, 1977-78 and 1980-81; Common Core of Data (CCD), "State Nonfiscal Survey of Public Elementary/Secondary Education," 1990-91 through 2011-12. (This table was prepared April 2013.) 
106 CHAPTER 2: Elementary and Secondary Education

Participation in Public School Services

Table 204.40. Children 3 to 21 years old served under Individuals with Disabilities Education Act (IDEA), Part B, by race/ethnicity and age group: 2000-01 through 2011-12

\begin{tabular}{|c|c|c|c|c|c|c|c|c|}
\hline Age group and year & Total & White & Black & Hispanic & Asian $^{1}$ & Pacific Islander & $\begin{array}{r}\text { American Indian/ } \\
\text { Alaska Native }\end{array}$ & Two or more races \\
\hline 1 & 2 & 3 & 4 & 5 & 6 & 7 & 8 & 9 \\
\hline & \multicolumn{8}{|c|}{ Number of children served } \\
\hline $\begin{array}{l}3 \text { to } 21 \text { years old } \\
2000-01 \\
2001-02 \ldots \ldots \ldots \ldots \ldots \ldots \ldots \ldots \ldots \\
2002-03 \ldots\end{array}$ & $\begin{array}{l}6,295,709 \\
6,407,417 \\
6,522,977 \\
6,633,902 \\
6,718,630\end{array}$ & $\begin{array}{l}3,957,589 \\
3,989,528 \\
4,014,340 \\
4,035,880 \\
4,044,491\end{array}$ & $\begin{array}{l}1,259,348 \\
1,281,803 \\
1,311,270 \\
1,334,666 \\
1,355,550\end{array}$ & $\begin{array}{r}877,655 \\
928,776 \\
980,590 \\
1,035,463 \\
1,081,697\end{array}$ & $\begin{array}{l}121,044 \\
123,434 \\
130,252 \\
137,544 \\
144,339\end{array}$ & $\begin{array}{l}- \\
- \\
- \\
-\end{array}$ & $\begin{array}{l}80,073 \\
83,876 \\
86,525 \\
90,349 \\
92,553\end{array}$ & $\begin{array}{l}- \\
- \\
- \\
-\end{array}$ \\
\hline 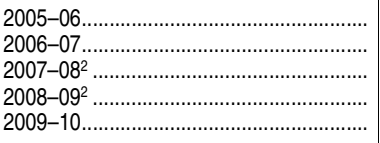 & $\begin{array}{l}6,712,614 \\
6,686,386 \\
6,574,368 \\
6,461,938 \\
6,461,226\end{array}$ & $\begin{array}{l}4,003,865 \\
3,948,853 \\
3,833,922 \\
3,725,896 \\
3,659,194\end{array}$ & $\begin{array}{l}1,346,177 \\
1,335,870 \\
1,307,462 \\
1,273,996 \\
1,262,799\end{array}$ & $\begin{array}{l}1,119,140 \\
1,154,217 \\
1,181,130 \\
1,200,290 \\
1,252,493\end{array}$ & $\begin{array}{l}149,954 \\
153,265 \\
158,623 \\
162,630 \\
167,144\end{array}$ & $\begin{array}{l}- \\
- \\
- \\
-\end{array}$ & $\begin{array}{l}93,478 \\
94,181 \\
93,231 \\
93,672 \\
92,646\end{array}$ & $\begin{array}{r}- \\
- \\
5,454^{3} \\
26,950^{3}\end{array}$ \\
\hline 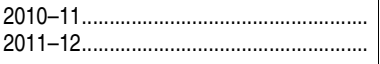 & $\begin{array}{l}6,435,141 \\
6,401,242\end{array}$ & $\begin{array}{l}3,518,169 \\
3,436,105\end{array}$ & $\begin{array}{l}1,214,849 \\
1,196,679\end{array}$ & $\begin{array}{l}1,310,031 \\
1,352,435\end{array}$ & $\begin{array}{l}145,896 \\
147,697\end{array}$ & $\begin{array}{l}19,581 \\
19,203\end{array}$ & $\begin{array}{l}91,258 \\
88,665\end{array}$ & $\begin{array}{l}135,357 \\
160,458\end{array}$ \\
\hline 3 to 5 years old & $\begin{array}{l}5,703,619 \\
6,014,006 \\
5,711,348 \\
5,670,680 \\
\end{array}$ & $\begin{array}{r}400,650 \\
453,531 \\
416,034 \\
408,973 \\
\\
3,556,939 \\
3,550,334 \\
3,102,135 \\
3,027,132 \\
\end{array}$ & $\begin{array}{r}93,281 \\
102,310 \\
102,097 \\
103,051 \\
\\
1,166,067 \\
1,243,867 \\
1,112,752 \\
1,093,628 \\
\end{array}$ & $\begin{array}{r}78,070 \\
112,883 \\
153,033 \\
158,507 \\
\\
799,585 \\
1,006,257 \\
1,156,998 \\
1,193,928 \\
\end{array}$ & $\begin{array}{r}13,203 \\
20,791 \\
23,189 \\
23,023 \\
\\
107,841 \\
129,163 \\
122,707 \\
124,674 \\
\end{array}$ & $\begin{array}{r}- \\
-\overline{ } \\
2,159 \\
2,146 \\
\\
- \\
- \\
17,422 \\
17,057 \\
\end{array}$ & $\begin{array}{l}6,886 \\
9,093 \\
9,141 \\
8,729 \\
\\
73,187 \\
84,385 \\
82,117 \\
79,936 \\
\end{array}$ & $\begin{array}{r}- \\
- \\
18,140 \\
26,133 \\
\\
- \\
- \\
117,217 \\
134,325 \\
\end{array}$ \\
\hline & \multicolumn{8}{|c|}{ Percentage distribution of children served } \\
\hline 3 to 21 years old & $\begin{array}{l}100.0 \\
100.0 \\
100.0 \\
100.0 \\
100.0\end{array}$ & $\begin{array}{l}62.9 \\
62.3 \\
61.5 \\
60.8 \\
60.2\end{array}$ & $\begin{array}{l}20.0 \\
20.0 \\
20.1 \\
20.1 \\
20.2\end{array}$ & $\begin{array}{l}13.9 \\
14.5 \\
15.0 \\
15.6 \\
16.1\end{array}$ & $\begin{array}{l}1.9 \\
1.9 \\
2.0 \\
2.1 \\
2.1\end{array}$ & $\begin{array}{c}\dagger \\
\dagger \\
+ \\
\dagger \\
+\end{array}$ & $\begin{array}{l}1.3 \\
1.3 \\
1.3 \\
1.4 \\
1.4\end{array}$ & $\begin{array}{l}\dagger \\
\dagger \\
\dagger \\
\dagger \\
\dagger\end{array}$ \\
\hline 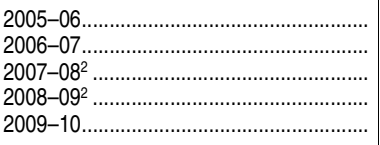 & $\begin{array}{l}100.0 \\
100.0 \\
100.0 \\
100.0 \\
100.0\end{array}$ & $\begin{array}{l}59.6 \\
59.1 \\
58.3 \\
57.7 \\
56.6\end{array}$ & $\begin{array}{l}20.1 \\
20.0 \\
19.9 \\
19.7 \\
19.5\end{array}$ & $\begin{array}{l}16.7 \\
17.3 \\
18.0 \\
18.6 \\
19.4\end{array}$ & $\begin{array}{l}2.2 \\
2.3 \\
2.4 \\
2.5 \\
2.6\end{array}$ & $\begin{array}{c}\dagger \\
\dagger \\
\dagger \\
\dagger \\
\dagger\end{array}$ & $\begin{array}{l}1.4 \\
1.4 \\
1.4 \\
1.4 \\
1.4\end{array}$ & $\begin{array}{c}{ }^{\dagger} \\
t \\
t^{3} \\
0.1^{3} \\
0.4^{3}\end{array}$ \\
\hline \multirow[t]{2}{*}{ 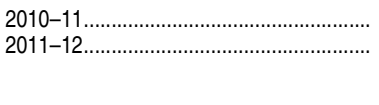 } & $\begin{array}{l}100.0 \\
100.0 \\
\end{array}$ & $\begin{array}{l}54.7 \\
53.7 \\
\end{array}$ & $\begin{array}{l}18.9 \\
18.7 \\
\end{array}$ & $\begin{array}{l}20.4 \\
21.1\end{array}$ & $\begin{array}{l}2.3 \\
2.3 \\
\end{array}$ & $\begin{array}{l}0.3 \\
0.3 \\
\end{array}$ & $\begin{array}{l}1.4 \\
1.4 \\
\end{array}$ & $\begin{array}{l}2.1 \\
2.5 \\
\end{array}$ \\
\hline & \multicolumn{8}{|c|}{ Number served as a percent of total enrollment ${ }^{4}$} \\
\hline $\begin{array}{l}3 \text { to } 21 \text { years old } \\
2000-01 \ldots \ldots \ldots \\
2001-02 \ldots \ldots \ldots \ldots \\
2002-03 \ldots\end{array}$ & $\begin{array}{l}13.3 \\
13.4 \\
13.5 \\
13.7 \\
13.8\end{array}$ & $\begin{array}{l}13.7 \\
13.9 \\
14.0 \\
14.2 \\
14.3\end{array}$ & $\begin{array}{l}15.5 \\
15.7 \\
15.8 \\
16.0 \\
16.1\end{array}$ & $\begin{array}{l}11.4 \\
11.4 \\
11.4 \\
11.5 \\
11.5\end{array}$ & $\begin{array}{l}6.2 \\
6.1 \\
6.2 \\
6.4 \\
6.5\end{array}$ & $\begin{array}{l}t \\
t \\
\dagger \\
+ \\
t\end{array}$ & $\begin{array}{l}14.6 \\
14.9 \\
14.8 \\
15.2 \\
15.7\end{array}$ & $\begin{array}{l}\dagger \\
\dagger \\
\dagger \\
\dagger \\
\dagger\end{array}$ \\
\hline 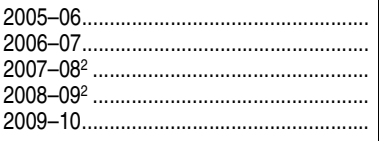 & $\begin{array}{l}13.7 \\
13.6 \\
13.3 \\
13.1 \\
13.1\end{array}$ & $\begin{array}{l}14.3 \\
14.2 \\
14.0 \\
13.8 \\
13.7\end{array}$ & $\begin{array}{l}15.9 \\
15.9 \\
15.6 \\
15.2 \\
15.2\end{array}$ & $\begin{array}{l}11.4 \\
11.3 \\
11.3 \\
11.4 \\
11.5\end{array}$ & $\begin{array}{l}6.6 \\
6.6 \\
6.6 \\
6.6 \\
6.7\end{array}$ & $\begin{array}{c}\dagger \\
\dagger \\
\dagger \\
\dagger \\
\dagger\end{array}$ & $\begin{array}{l}15.6 \\
15.8 \\
15.7 \\
15.9 \\
15.6\end{array}$ & $\begin{array}{c}t \\
t \\
t \\
2.2^{3} \\
8.0^{3}\end{array}$ \\
\hline $\begin{array}{l}2010-11 \\
2011-12\end{array}$ & $\begin{array}{l}13.0 \\
12.9\end{array}$ & $\begin{array}{l}13.6 \\
13.4\end{array}$ & $\begin{array}{l}15.4 \\
15.3\end{array}$ & $\begin{array}{l}11.5 \\
11.5\end{array}$ & $\begin{array}{l}6.4 \\
6.3\end{array}$ & $\begin{array}{l}11.5 \\
10.7\end{array}$ & $\begin{array}{l}16.2 \\
16.2\end{array}$ & $\begin{array}{l}11.7 \\
12.6\end{array}$ \\
\hline
\end{tabular}

-Not available.

†Not applicable.

${ }^{1}$ For years prior to 2010-11, Asian data include Pacific Islanders.

2Data do not include Vermont, for which 2007-08 and 2008-09 data were not available.

${ }^{3}$ For 2008-09 and 2009-10, data on children of two or more races were reported by only a small number of states. Therefore, these data are not comparable to figures for $2010-11$ and 2011-12.

${ }^{4}$ Based on the total enrollment in public schools, prekindergarten through 12th grade, by race/ethnicity. For total enrollment in public schools by race/ethnicity, see table 203.50 .
NOTE: Data include only those children served for whom race/ethnicity was reported. Race categories exclude persons of Hispanic ethnicity. Detail may not sum to totals because of rounding.

SOURCE: U.S. Department of Education, Office of Special Education Programs, Individuals with Disabilities Education Act (IDEA) database, retrieved May 17, 2013, from https:// www.ideadata.org/PartBChildCount.asp; and National Center for Education Statistics, Common Core of Data (CCD), "State Nonfiscal Survey of Public Elementary and Secondary Education," 2000-01 through 2011-12. (This table was prepared May 2013.) 
Table 204.50. Children 3 to 21 years old served under Individuals with Disabilities Education Act (IDEA), Part B, by race/ethnicity and type of disability: 2010-11 and 2011-12

\begin{tabular}{|c|c|c|c|c|c|c|c|c|c|c|c|c|c|c|c|c|}
\hline \multirow[b]{2}{*}{ Type of disability } & \multicolumn{8}{|c|}{$2010-11$} & \multicolumn{8}{|c|}{ 2011-12 } \\
\hline & Total & White & Black & Hispanic & Asian & $\begin{array}{r}\text { Pacific } \\
\text { Islander }\end{array}$ & $\begin{array}{r}\text { American } \\
\text { Indian/ } \\
\text { Alaska } \\
\text { Native }\end{array}$ & $\begin{array}{r}\text { Two or more } \\
\text { races }\end{array}$ & Total & White & Black & Hispanic & Asian & $\begin{array}{r}\text { Pacific } \\
\text { Islander }\end{array}$ & $\begin{array}{r}\text { American } \\
\text { Indian/ } \\
\text { Alaska } \\
\text { Native }\end{array}$ & $\begin{array}{r}\text { Two or more } \\
\text { races }\end{array}$ \\
\hline \multirow[t]{2}{*}{1} & 2 & 3 & 4 & 5 & 6 & 7 & 8 & 9 & 10 & 11 & 12 & 13 & 14 & 15 & 16 & 17 \\
\hline & \multicolumn{16}{|c|}{ Number of children served } \\
\hline All disabilities.... & $6,437,297$ & $3,518,029$ & $1,214,830$ & $1,311,765$ & 145,912 & 19,581 & 91,823 & $\mid 135,357$ & $6,404,630$ & $3,436,115$ & $1,196,695$ & $1,355,780$ & \begin{tabular}{|c|}
147,704 \\
\end{tabular} & 19,203 & 88,675 & 160,458 \\
\hline Autism ............................... & 417,576 & 256,646 & 56,150 & 67,967 & 22,473 & 1,194 & 3,162 & 9,984 & 455,349 & 274,355 & 61,628 & 77,714 & 24,592 & 1,151 & 3,418 & 12,491 \\
\hline 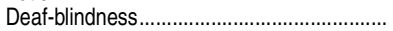 & 1,512 & & 155 & 355 & 69 & 10 & 24 & 32 & 1,583 & 890 & 158 & 397 & 65 & 16 & 26 & 31 \\
\hline Developmental delay .................................... & 381,575 & 216,587 & 70,905 & 63,804 & 10,489 & 1,866 & 8,068 & 9,856 & 393,138 & 215,164 & 73,250 & 68,045 & 10,578 & 1,806 & 7,830 & 16,465 \\
\hline Emotional disturbance ................................... & 389,299 & 210,011 & 106,474 & 52,310 & 3,430 & 1,083 & 5,860 & 10,131 & 373,154 & 199,929 & 100,412 & 51,698 & 3,224 & 980 & 5,381 & 11,530 \\
\hline Hearing impairments ................................... & 78,134 & 39,360 & 11,517 & 20,505 & 3,962 & 397 & 937 & 1,456 & 78,448 & 38,409 & 11,412 & 21,617 & 4,156 & 402 & 841 & 1,611 \\
\hline 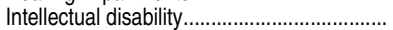 & 448,120 & 212,415 & 127,322 & 83,070 & 9,904 & 1,203 & 6,199 & 8,007 & 434,586 & 203,247 & 120,492 & 85,206 & 10,018 & 1,239 & 5,679 & 8,705 \\
\hline Multiple disabilities..................................... & 130,158 & 76,727 & 25,553 & 20,251 & 3,549 & 420 & 1,577 & 2,081 & 132,986 & 76,726 & 24,901 & 22,483 & 3,681 & 471 & 1,952 & 2,772 \\
\hline Orthopedic impairments ..... & 63,266 & 35,123 & 7,776 & 16,112 & 2,248 & 182 & 563 & 1,262 & 61,716 & 33,919 & 7,430 & 15,875 & 2,289 & 180 & 534 & 1,489 \\
\hline Other health impairments ${ }^{1} \ldots . .$. & 716,116 & 457,138 & 128,143 & 94,004 & 9,563 & 2,285 & 8,743 & 16,240 & 742,866 & 465,223 & 134,232 & 102,785 & 10,083 & 2,032 & 8,771 & 19,740 \\
\hline Specific learning disabilities......................... & $2,361,044$ & $1,172,937$ & 478,072 & 584,252 & 34,786 & 8,072 & 38,736 & 44,189 & $2,302,961$ & $1,118,435$ & 464,337 & 591,664 & 34,192 & 8,064 & 36,988 & 49,281 \\
\hline Speech or language impairments.................. & $\begin{array}{r}1,396,282 \\
-25,727\end{array}$ & 808,295 & 194,225 & 299,096 & 43,731 & 2,703 & 17,225 & 31,007 & $1,372,870$ & 778,171 & 189,926 & 307,379 & 43,075 & 2,692 & 16,570 & 35,057 \\
\hline 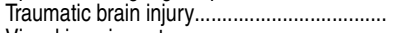 & 25,727 & 16,039 & 4,031 & 4,086 & 595 & 75 & 345 & 556 & 25,969 & 16,006 & 4,041 & 4,254 & 609 & 77 & 329 & 653 \\
\hline \multirow[t]{2}{*}{ 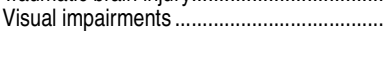 } & 28,488 & 15,884 & 4,507 & 5,953 & 1,113 & 91 & 384 & 556 & 29,004 & 15,641 & 4,476 & 6,663 & 1,142 & 93 & 356 & 633 \\
\hline & \multicolumn{16}{|c|}{ Percentage distribution of children served } \\
\hline All disabilities............. & 100.0 & 100.0 & 100.0 & 100.0 & 100.0 & 100.0 & 100.0 & 100.0 & 100.0 & 100.0 & 100.0 & 100.0 & \begin{tabular}{|c|}
100.0 \\
-1
\end{tabular} & 100.0 & 100.0 & 100.0 \\
\hline Autism & 6.5 & 7.3 & 4.6 & 5.2 & 15.4 & 6.1 & 3.4 & 7.4 & 7.1 & 8.0 & 5.1 & 5.7 & 16.6 & 6.0 & 3.9 & 7.8 \\
\hline Deaf-blindness........................................ & \# & \# & \# & \# & \# & 0.1 & \# & $\#$ & \# & $\#$ & \# & \# & $\#$ & 0.1 & \# & \# \\
\hline Developmental delay ................................... & 5.9 & 6.2 & 5.8 & 4.9 & 7.2 & 9.5 & 8.8 & 7.3 & 6.1 & 6.3 & 6.1 & 5.0 & 7.2 & 9.4 & 8.8 & 10.3 \\
\hline Emotional disturbance .................................. & 6.0 & 6.0 & 8.8 & 4.0 & 2.4 & 5.5 & 6.4 & 7.5 & 5.8 & 5.8 & 8.4 & 3.8 & 2.2 & 5.1 & 6.1 & 7.2 \\
\hline Hearing impairments ........................................ & 1.2 & 1.1 & 0.9 & 1.6 & 2.7 & 2.0 & 1.0 & 1.1 & 1.2 & 1.1 & 1.0 & 1.6 & 2.8 & 2.1 & 0.9 & 1.0 \\
\hline 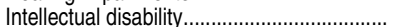 & 7.0 & 6.0 & 10.5 & 6.3 & 6.8 & 6.1 & 6.8 & 5.9 & 6.8 & 5.9 & 10.1 & 6.3 & 6.8 & 6.5 & 6.4 & 5.4 \\
\hline 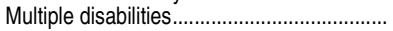 & 2.0 & 2.2 & 2.1 & 1.5 & 2.4 & 2.1 & 1.7 & 1.5 & 2.1 & 2.2 & 2.1 & 1. & 2.5 & 2.5 & 2.2 & 1.7 \\
\hline Orthopedic impairments ................................. & 1.0 & 1.0 & 0.6 & 1.2 & 1.5 & 0.9 & 0.6 & 0.9 & 1.0 & 1.0 & 0.6 & 1. & 1.5 & 0.9 & 0.6 & 0.9 \\
\hline Other health impairments ${ }^{1}$........................... & 11.1 & 13.0 & 10.5 & 7.2 & 6.6 & 11.7 & 9.5 & 12.0 & 11.6 & 13.5 & 11.2 & 7.6 & 6.8 & 10.6 & 9.9 & 12.3 \\
\hline Specific learning disabilities.......................... & 36.7 & 33.3 & 39.4 & 44.5 & 23.8 & 41.2 & 42.2 & 32.6 & 36.0 & 32.5 & 38.8 & 43.6 & 23.1 & 42.0 & 41.7 & 30.7 \\
\hline Speech or language impairments.................. & 21.7 & 23.0 & 16.0 & 22.8 & 30.0 & 13.8 & 18.8 & 22.9 & 21.4 & 22.6 & 15.9 & 22.7 & 29.2 & 14.0 & 18.7 & 21.8 \\
\hline Traumatic brain injury..... & 0.4 & 0.5 & 0.3 & 0.3 & 0.4 & 0.4 & 0.4 & 0.4 & 0.4 & 0.5 & 0.3 & 0.3 & 0.4 & 0.4 & 0.4 & 0.4 \\
\hline \multirow[t]{2}{*}{ 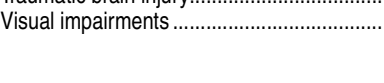 } & 0.4 & 0.5 & 0.4 & 0.5 & 0.8 & 0.5 & 0.4 & 0.4 & 0.5 & 0.5 & 0.4 & 0.5 & 0.8 & 0.5 & 0.4 & 0.4 \\
\hline & \multicolumn{16}{|c|}{ Number served as a percent of total enrollment ${ }^{2}$} \\
\hline All disabilities.......................................... & 13.0 & 13.6 & 15.4 & 11.5 & 6.4 & 11.5 & 16.3 & 11.7 & 12.9 & 13.4 & 15.3 & 11.5 & 6.3 & 10.7 & 16.2 & 12.6 \\
\hline 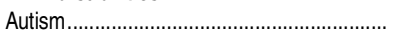 & 0.8 & 1.0 & 0.7 & 0.6 & 1.0 & 0.7 & 0.6 & 0.9 & 0.9 & 1.1 & 0.8 & 0.7 & 1.1 & 0.6 & 0.6 & 1.0 \\
\hline Deaf-blindness................................................ & \# & $\#$ & $\#$ & $\#$ & \# & $\#$ & $\#$ & $\#$ & $\#$ & $\#$ & $\#$ & \# & $\#$ & \# & \# & $\#$ \\
\hline 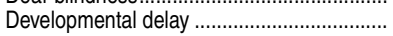 & 0.8 & 0.8 & 0.9 & 0.6 & 0.5 & 1.1 & 1.4 & 0.8 & 0.8 & 0.8 & 0.9 & 0.6 & 0.5 & 1.0 & 1.4 & 1.3 \\
\hline 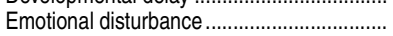 & 0.8 & 0.8 & 1.3 & 0.5 & 0.1 & 0.6 & 1.0 & 0.9 & 0.8 & 0.8 & 1.3 & 0.4 & 0.1 & 0.5 & 1.0 & 0.9 \\
\hline Hearing impairments ....................... & 0.2 & 0.2 & 0.1 & 0.2 & 0.2 & 0.2 & 0.2 & 0.1 & 0.2 & 0.2 & 0.1 & 0.2 & 0.2 & 0.2 & 0.2 & 0.1 \\
\hline ty ...………………....... & 0.9 & 0.8 & 1.6 & 0.7 & 0.4 & 0.7 & 1.1 & 0.7 & 0.9 & 0.8 & 1.5 & 0.7 & 0.4 & 0.7 & 1.0 & 0.7 \\
\hline 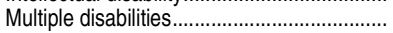 & 0.3 & 0.3 & 0.3 & 0.2 & 0.2 & 0.2 & 0.3 & 0.2 & 0.3 & 0.3 & 0.3 & 0.2 & 0.2 & 0.3 & 0.4 & 0.2 \\
\hline Orthopedic impairments .............................. & 0.1 & 0.1 & 0.1 & 0.1 & 0.1 & 0.1 & 0.1 & 0.1 & 0.1 & 0.1 & 0.1 & 0.1 & 0.1 & 0.1 & 0.1 & 0.1 \\
\hline 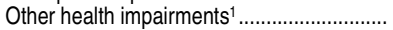 & 1.4 & 1.8 & 1.6 & 0.8 & 0.4 & 1.3 & 1.5 & 1.4 & 1.5 & 1.8 & 1.7 & 0.9 & 0.4 & 1.1 & 1.6 & 1.6 \\
\hline Specific learning disabilities......................... & 4.8 & 4.5 & 6.0 & 5.1 & 1.5 & 4.7 & 6.9 & 3.8 & 4.7 & 4.4 & 5.9 & 5.0 & 1.5 & 4.5 & 6.8 & 3.9 \\
\hline Speech or language impairments....................... & 2.8 & 3.1 & 2.5 & 2.6 & 1.9 & 1.6 & 3.0 & 2.7 & 2.8 & 3.0 & 2.4 & 2.6 & 1.8 & 1.5 & 3.0 & 2.8 \\
\hline Traumatic brain injury............................... & 0.1 & 0.1 & 0.1 & 0.0 & $\#$ & $\#$ & 0.1 & $\#$ & 0.1 & 0.1 & 0.1 & \# & \# & $\#$ & 0.1 & 0.1 \\
\hline 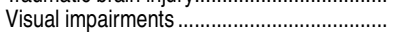 & 0.1 & 0.1 & 0.1 & 0.1 & $\#$ & 0.1 & 0.1 & $\#$ & 0.1 & 0.1 & 0.1 & 0.1 & $\#$ & 0.1 & 0.1 & $\#$ \\
\hline
\end{tabular}

\#Rounds to zero.

Other health impairments include having limited strength, vitality, or alertness due to chronic or acute health problems such as a heart condition, tuberculosis, rheumatic fever, nephritis, asthma, sickle cell anemia, hemophilia, epilepsy, lead poisoning, leukemia, or diabetes.

dents from Bureau of Indian Education and Puerto Rican schools. For these reasons, totals may differ from those shown other tables. Race categories exclude persons of Hispanic ethnicity. Detail may not sum to totals because of rounding. SOURCE: U.S. Department of Education, Office of Special Education Programs, Individuals with Disabilities Education Act
(IDEA) database, retrieved June 10, 2013, from http://www sideadata org/PartBdata. asp: and National Center for Education (IDEA) database, retrieved June 10, 2013, from http://www.ideadata.org/PartBdata.asp; and National Center for Education
Statistics, Common Core of Data (CCD), "State Nonfiscal Survey of Public Elementary/Secondary Education," 2010-11 and 2011-12. (This table was prepared June 2013.)

NOTE: Data includee/ethnicity, see table 203.50. are for the 50 states and the District of Columbia, data limitations result in inclusion of a small (but unknown) number of stu- 
108 CHAPTER 2: Elementary and Secondary Education

Participation in Public School Services

Table 204.60. Percentage distribution of students 6 to 21 years old served under Individuals with Disabilities Education Act (IDEA), Part B, by educational environment and type of disability: Selected years, fall 1989 through fall 2011

\begin{tabular}{|c|c|c|c|c|c|c|c|c|c|}
\hline \multirow[b]{2}{*}{ Type of disability } & \multirow[b]{2}{*}{$\begin{array}{r}\text { All } \\
\text { environments }\end{array}$} & \multicolumn{3}{|c|}{ Regular school, time inside general class } & \multirow{2}{*}{$\begin{array}{r}\text { Separate } \\
\text { school for } \\
\text { students with } \\
\text { disabilities }\end{array}$} & \multirow[b]{2}{*}{$\begin{array}{r}\text { Separate } \\
\text { residential } \\
\text { facility }\end{array}$} & \multirow{2}{*}{$\begin{array}{r}\text { Parentally } \\
\text { placed in } \\
\text { regular private } \\
\text { schools }^{1}\end{array}$} & \multirow[b]{2}{*}{$\begin{array}{r}\text { Homebound/ } \\
\text { hospital } \\
\text { placement }\end{array}$} & \multirow[b]{2}{*}{$\begin{array}{r}\text { Correctional } \\
\text { facility }\end{array}$} \\
\hline & & $\begin{array}{r}\text { Less than } \\
40 \text { percent }\end{array}$ & 40-79 percent & $\begin{array}{l}\text { More than } \\
80 \text { percent }\end{array}$ & & & & & \\
\hline 1 & 2 & 3 & 4 & 5 & 6 & 7 & 8 & 9 & 10 \\
\hline All students with disabilities & $\begin{array}{l}100.0 \\
100.0 \\
100.0 \\
100.0 \\
100.0 \\
100.0 \\
100.0 \\
100.0 \\
100.0 \\
100.0 \\
100.0 \\
100.0 \\
100.0 \\
100.0 \\
100.0 \\
100.0 \\
100.0 \\
\end{array}$ & $\begin{array}{l}24.9 \\
25.0 \\
22.4 \\
21.5 \\
21.4 \\
20.4 \\
20.0 \\
20.3 \\
19.5 \\
19.2 \\
19.0 \\
18.5 \\
17.9 \\
16.7 \\
16.4 \\
15.4 \\
14.9 \\
\end{array}$ & $\begin{array}{l}37.5 \\
36.4 \\
28.5 \\
28.5 \\
28.3 \\
28.8 \\
29.9 \\
29.8 \\
29.8 \\
28.5 \\
28.7 \\
27.7 \\
26.5 \\
25.1 \\
23.8 \\
22.4 \\
21.4 \\
\end{array}$ & $\begin{array}{l}31.7 \\
33.1 \\
44.8 \\
45.7 \\
46.1 \\
46.8 \\
46.0 \\
45.9 \\
46.5 \\
48.2 \\
48.2 \\
49.9 \\
51.5 \\
54.2 \\
54.8 \\
56.8 \\
58.5 \\
\end{array}$ & $\begin{array}{l}4.5 \\
4.2 \\
3.0 \\
3.1 \\
3.0 \\
2.9 \\
2.9 \\
2.9 \\
3.0 \\
2.9 \\
2.9 \\
2.8 \\
3.0 \\
2.9 \\
2.9 \\
3.0 \\
2.9 \\
\end{array}$ & $\begin{array}{l}1.0 \\
0.9 \\
0.7 \\
0.7 \\
0.7 \\
0.7 \\
0.7 \\
0.7 \\
0.7 \\
0.7 \\
0.7 \\
0.7 \\
0.6 \\
0.6 \\
0.4 \\
0.4 \\
0.4 \\
\end{array}$ & $\begin{array}{l}- \\
- \\
- \\
- \\
- \\
- \\
- \\
- \\
- \\
- \\
- \\
- \\
- \\
- \\
1.0 \\
1.1 \\
1.1\end{array}$ & $\begin{array}{l}0.6 \\
0.5 \\
0.6 \\
0.5 \\
0.5 \\
0.5 \\
0.5 \\
0.5 \\
0.5 \\
0.4 \\
0.5 \\
0.5 \\
0.4 \\
0.4 \\
0.4 \\
0.4 \\
0.4 \\
\end{array}$ & $\begin{array}{l}- \\
- \\
- \\
- \\
- \\
- \\
- \\
- \\
- \\
- \\
0.4 \\
0.4 \\
0.4\end{array}$ \\
\hline 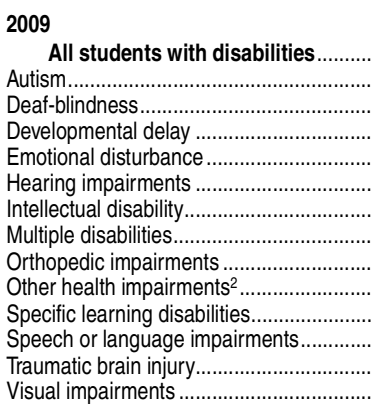 & $\begin{array}{l}100.0 \\
100.0 \\
100.0 \\
100.0 \\
100.0 \\
100.0 \\
100.0 \\
100.0 \\
100.0 \\
100.0 \\
100.0 \\
100.0 \\
100.0 \\
100.0\end{array}$ & \begin{tabular}{r|}
14.6 \\
34.8 \\
33.3 \\
16.2 \\
22.2 \\
14.7 \\
48.2 \\
45.5 \\
23.6 \\
10.8 \\
8.0 \\
4.6 \\
21.5 \\
12.0
\end{tabular} & \begin{tabular}{r|}
20.7 \\
18.3 \\
13.3 \\
20.5 \\
18.8 \\
17.0 \\
26.7 \\
16.2 \\
16.3 \\
23.8 \\
26.6 \\
5.6 \\
23.8 \\
13.5
\end{tabular} & $\begin{array}{l}59.4 \\
37.4 \\
21.6 \\
61.6 \\
40.6 \\
54.6 \\
17.4 \\
13.2 \\
52.2 \\
61.4 \\
63.3 \\
86.3 \\
46.4 \\
62.6\end{array}$ & $\begin{array}{r}3.0 \\
8.0 \\
19.1 \\
0.9 \\
13.2 \\
8.2 \\
6.3 \\
19.6 \\
5.1 \\
1.6 \\
0.6 \\
0.3 \\
5.2 \\
6.2\end{array}$ & $\begin{array}{r}0.4 \\
0.6 \\
9.9 \\
0.1 \\
2.0 \\
4.0 \\
0.4 \\
1.9 \\
0.2 \\
0.2 \\
0.1 \\
\# \\
0.6 \\
3.6\end{array}$ & $\begin{array}{l}1.2 \\
0.7 \\
0.6 \\
0.6 \\
0.2 \\
1.3 \\
0.3 \\
0.4 \\
0.9 \\
1.1 \\
0.9 \\
3.1 \\
0.7 \\
1.4\end{array}$ & \begin{tabular}{l|}
0.4 \\
0.3 \\
2.3 \\
0.2 \\
1.1 \\
0.2 \\
0.5 \\
2.9 \\
1.7 \\
0.9 \\
0.2 \\
0.1 \\
1.7 \\
0.7
\end{tabular} & $\begin{array}{r}0.4 \\
\# \\
0.2 \\
\# \\
2.0 \\
0.1 \\
0.3 \\
0.2 \\
0.1 \\
0.3 \\
0.4 \\
\# \\
0.2 \\
\#\end{array}$ \\
\hline 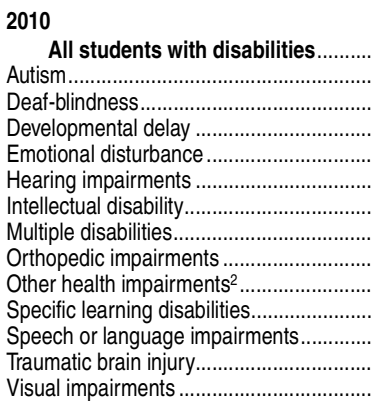 & $\begin{array}{l}100.0 \\
100.0 \\
100.0 \\
100.0 \\
100.0 \\
100.0 \\
100.0 \\
100.0 \\
100.0 \\
100.0 \\
100.0 \\
100.0 \\
100.0 \\
100.0 \\
\end{array}$ & \begin{tabular}{r|}
14.2 \\
34.1 \\
33.4 \\
16.1 \\
21.3 \\
14.1 \\
47.7 \\
46.0 \\
22.9 \\
10.6 \\
7.4 \\
4.7 \\
20.9 \\
11.8 \\
\end{tabular} & $\begin{array}{r}\mathbf{2 0 . 0} \\
18.1 \\
11.9 \\
19.6 \\
18.3 \\
16.7 \\
26.8 \\
15.9 \\
16.2 \\
23.0 \\
25.5 \\
5.5 \\
23.6 \\
13.3 \\
\end{array}$ & $\begin{array}{l}60.5 \\
38.5 \\
22.9 \\
62.5 \\
42.2 \\
56.2 \\
17.9 \\
13.0 \\
53.3 \\
62.5 \\
65.2 \\
86.5 \\
47.4 \\
63.8 \\
\end{array}$ & $\begin{array}{r}3.0 \\
7.9 \\
18.2 \\
0.9 \\
13.1 \\
8.2 \\
6.2 \\
19.7 \\
4.9 \\
1.6 \\
0.6 \\
0.3 \\
5.1 \\
5.5 \\
\end{array}$ & $\begin{array}{r}0.4 \\
0.5 \\
9.6 \\
0.1 \\
2.0 \\
3.4 \\
0.4 \\
1.8 \\
0.2 \\
0.2 \\
0.1 \\
\# \\
0.5 \\
3.7 \\
\end{array}$ & $\begin{array}{l}1.2 \\
0.6 \\
0.7 \\
0.6 \\
0.2 \\
1.2 \\
0.2 \\
0.4 \\
0.8 \\
1.0 \\
0.9 \\
2.9 \\
0.7 \\
1.3 \\
\end{array}$ & \begin{tabular}{l|}
0.4 \\
0.3 \\
3.3 \\
0.2 \\
1.1 \\
0.2 \\
0.5 \\
3.1 \\
1.7 \\
0.9 \\
0.2 \\
0.1 \\
1.7 \\
0.6 \\
\end{tabular} & $\begin{array}{r}\mathbf{0 . 3} \\
\# \\
\# \\
\# \\
1.9 \\
0.1 \\
0.3 \\
0.2 \\
0.1 \\
0.3 \\
0.3 \\
\# \\
0.1 \\
\# \\
\end{array}$ \\
\hline 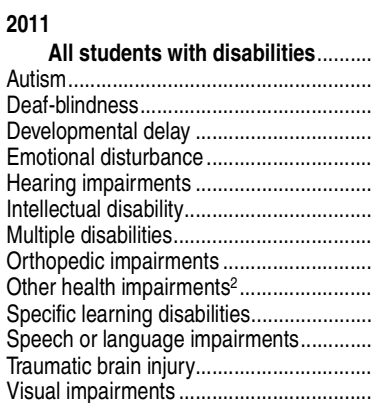 & $\begin{array}{l}100.0 \\
100.0 \\
100.0 \\
100.0 \\
100.0 \\
100.0 \\
100.0 \\
100.0 \\
100.0 \\
100.0 \\
100.0 \\
100.0 \\
100.0 \\
100.0\end{array}$ & \begin{tabular}{r|}
14.0 \\
33.7 \\
32.5 \\
16.3 \\
20.6 \\
13.0 \\
48.8 \\
46.2 \\
22.2 \\
10.0 \\
6.8 \\
4.5 \\
20.5 \\
11.3
\end{tabular} & $\begin{array}{r}19.8 \\
18.2 \\
10.5 \\
19.6 \\
18.0 \\
16.8 \\
26.6 \\
16.4 \\
16.3 \\
22.7 \\
25.1 \\
5.5 \\
22.8 \\
13.1\end{array}$ & $\begin{array}{l}61.1 \\
39.0 \\
27.0 \\
62.5 \\
43.2 \\
56.7 \\
17.0 \\
13.0 \\
54.0 \\
63.5 \\
66.2 \\
86.9 \\
48.5 \\
64.3\end{array}$ & $\begin{array}{r}3.0 \\
7.7 \\
18.1 \\
0.8 \\
13.2 \\
8.6 \\
6.2 \\
19.2 \\
4.7 \\
1.6 \\
0.5 \\
0.3 \\
5.2 \\
5.9\end{array}$ & $\begin{array}{r}0.3 \\
0.5 \\
8.4 \\
0.1 \\
1.9 \\
3.4 \\
0.4 \\
1.7 \\
0.2 \\
0.2 \\
0.1 \\
\# \\
0.5 \\
3.8\end{array}$ & $\begin{array}{l}1.1 \\
0.6 \\
0.7 \\
0.6 \\
0.2 \\
1.3 \\
0.3 \\
0.3 \\
0.8 \\
1.0 \\
0.8 \\
2.6 \\
0.8 \\
1.1\end{array}$ & $\begin{array}{l}0.4 \\
0.3 \\
2.8 \\
0.2 \\
1.1 \\
0.2 \\
0.5 \\
3.0 \\
1.7 \\
0.9 \\
0.1 \\
0.1 \\
1.7 \\
0.6\end{array}$ & $\begin{array}{r}0.3 \\
\# \\
\# \\
\# \\
1.8 \\
0.1 \\
0.2 \\
0.1 \\
0.1 \\
0.3 \\
0.3 \\
\# \\
0.1 \\
\#\end{array}$ \\
\hline
\end{tabular}

\section{-Not available.}

${ }^{1}$ Students who are enrolled by their parents or guardians in regular private schools and have their basic education paid through private resources, but receive special education services at public expense. These students are not included under "Regular school, time inside general class" (columns 3 through 5).

2Other health impairments include having limited strength, vitality, or alertness due to chronic or acute health problems such as a heart condition, tuberculosis, rheumatic fever, nephritis, asthma, sickle cell anemia, hemophilia, epilepsy, lead poisoning, leukemia, or diabetes.
NOTE: Data are for the 50 United States, the District of Columbia, and the Bureau of Indian Education schools. Detail may not sum to totals because of rounding. Some data have been revised from previously published figures.

SOURCE: U.S. Department of Education, Office of Special Education Programs, Individuals with Disabilities Education Act (IDEA) database. Retrieved May 22, 2013, from https:// www.ideadata.org/DACAnalyticTool/Intro 2.asp. (This table was prepared May 2013.) 
Table 204.70. Number and percentage of children served under Individuals with Disabilities Education Act (IDEA), Part B, by age group and state or jurisdiction: Selected years, 1990-91 through 2011-12

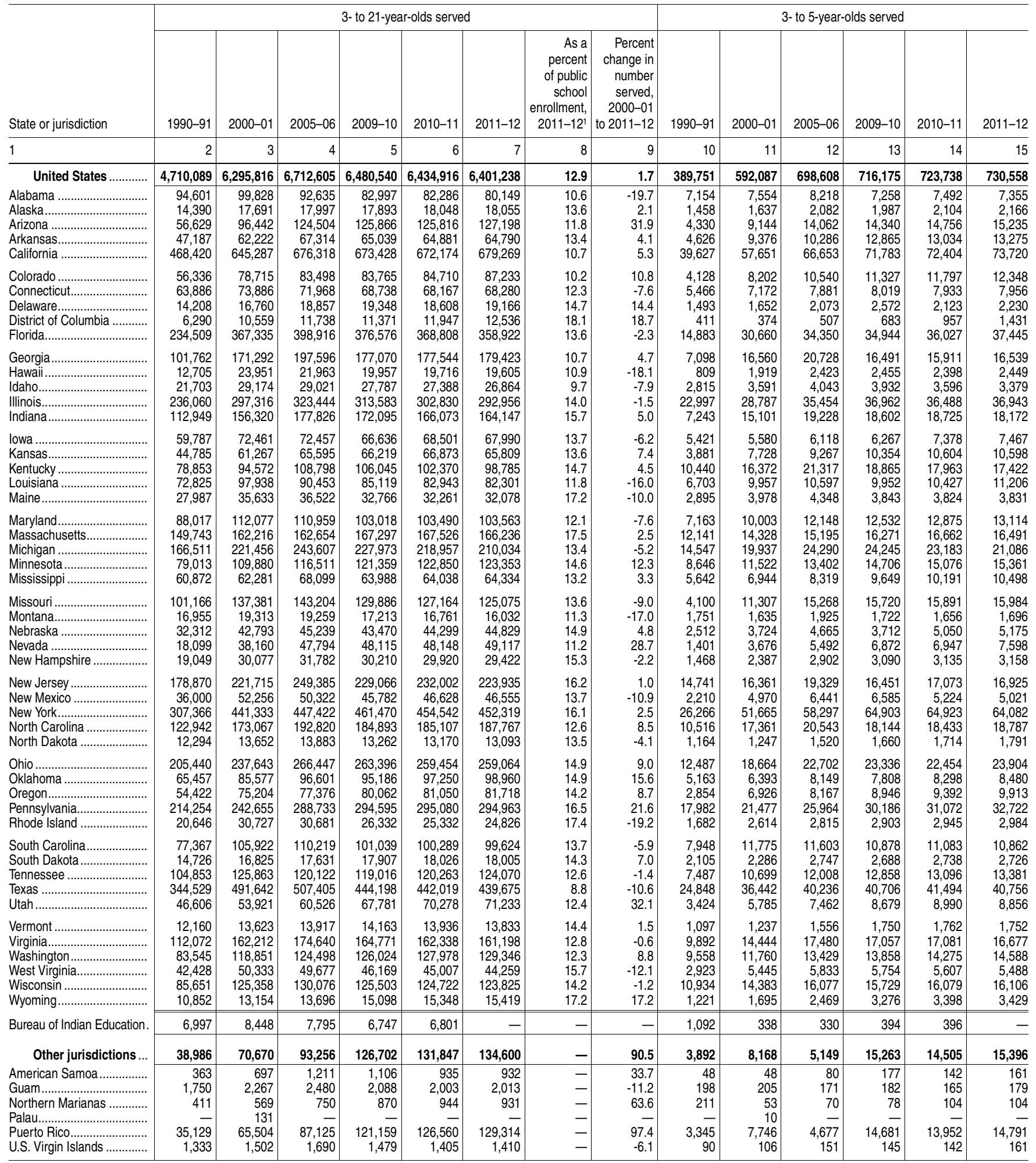

-Not available.

${ }^{1}$ Based on the total enrollment in public schools, prekindergarten through 12th grade. For total enrollment in public schools, see table 203.10 .

NOTE: Prior to October 1994, children and youth with disabilities were served under Chapter 1 of the Elementary and Secondary Education Act as well as under the Individuals with Disabilities Education Act (IDEA), Part B. Data reported in this table for 1990-91 include children ages $0-21$ served under Chapter 1 . Some data have been revised from previously published figures.
SOURCE: U.S. Department of Education, Office of Special Education Programs, Annual Report to Congress on the Implementation of the Individuals with Disabilities Education Act, selected years, 1992 through 2006, and Individuals with Disabilities Education Act (IDEA) database, retrieved May 12, 2013, from https://www.ideadata.org/StateLevelFiles.asp. National Center for Education Statistics, Common Core of Data (CCD), "State Nonfiscal Survey of Public Elementary/Secondary Education,” 2011-12. (This table was prepared May 2013.) 
[Standard errors appear in parentheses]

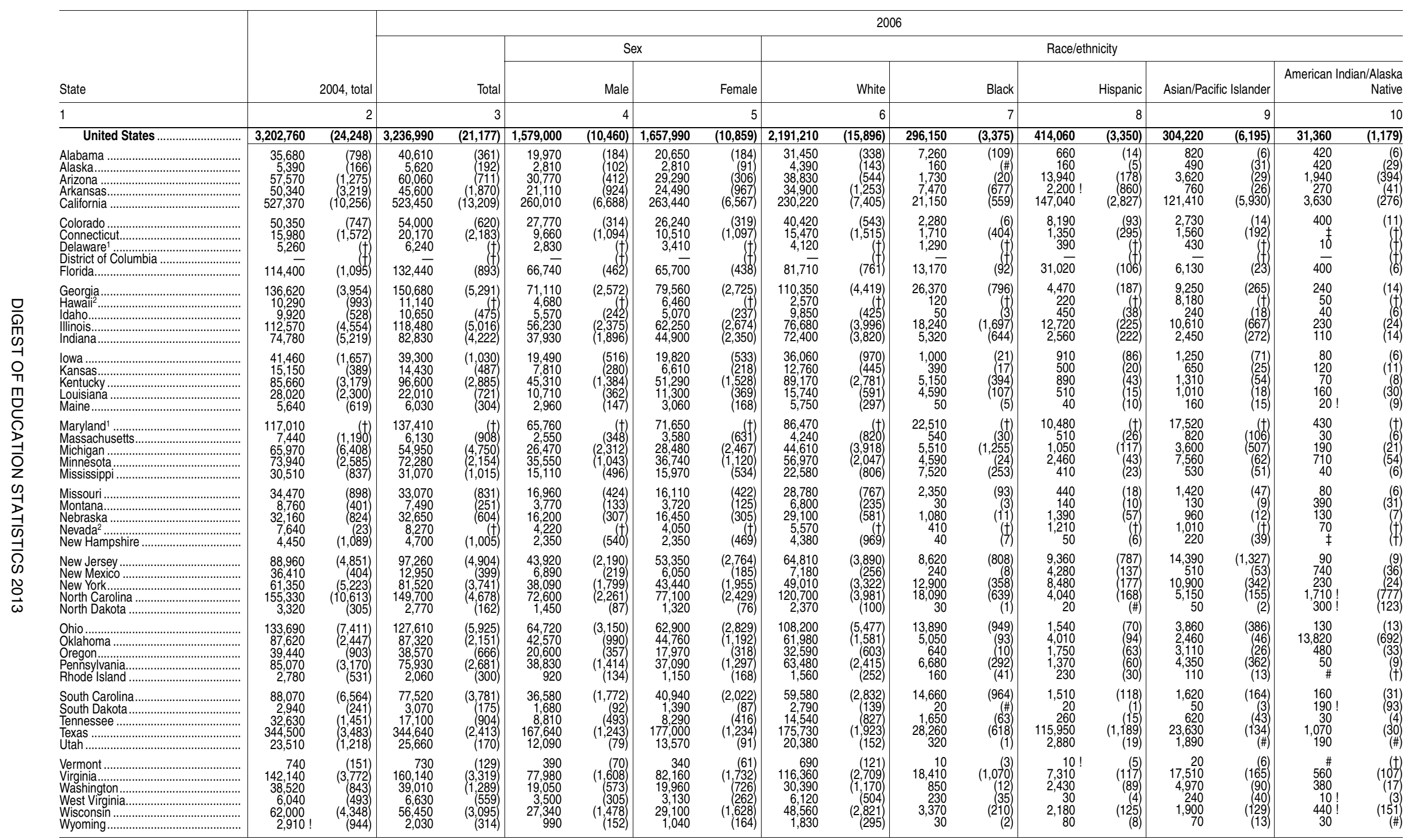

\section{-Not available.}

1Data are based on universe counts of schools and school districts; therefore, these figures do not have standard errors. †Not applicable.
\#Rounds to zero.

!Interpret data with caution. The coefficient of variation (CV) for this estimate is between 30 and 50 percent. †Reporting standards not met. Either there are too few cases for a reliable estimate or the coefficient of variation (CV) is 50 perNOTE: Race categories exclude persons of Hispanic ethnicity. Detail may not sum to totals because of rounding. SOURCE: U.S. Depa
revised May 2008) cent or greater. 
Table 204.90. Percentage of gifted and talented students in public elementary and secondary schools, by sex, race/ethnicity, and state: 2004 and 2006

[Standard errors appear in parentheses]

\begin{tabular}{|c|c|c|c|c|c|c|c|c|c|c|c|c|c|c|c|c|c|c|c|c|c|c|c|c|c|c|c|c|c|c|c|c|}
\hline \multirow[b]{3}{*}{ State } & & & & & & \multicolumn{20}{|c|}{ Race/ethnicity } \\
\hline & \multicolumn{4}{|c|}{ Total } & \multicolumn{4}{|c|}{ Male } & \multicolumn{4}{|c|}{ Female } & \multicolumn{4}{|c|}{ White } & \multicolumn{4}{|c|}{ Black } & \multicolumn{4}{|c|}{ Hispanic } & \multicolumn{4}{|c|}{ Asian/Pacific Islander } & \multicolumn{4}{|c|}{ American Indian/Alaska Native } \\
\hline & & 2004 & & 2006 & & 2004 & & 06 & & 2004 & & 2006 & & 2004 & & 2000 & & 2004 & & 006 & & 2004 & & 006 & & 2004 & & 2006 & & 2004 & & (2006 \\
\hline 1 & & - & & 3 & & & & & & 6 & & 7 & & & & & & 10 & & 11 & & 12 & & 13 & & 14 & & 15 & & 16 & & \\
\hline Un & & 05) & ( & $(0.04)$ & 3 & .05) & 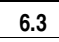 & $(0.04)$ & 0 & 06) & 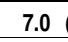 & $(0.05)$ & & .07) & .0 & $(0.07)$ & & .05) & & .05) & 3 & 05) & & $(0.04)$ & 11.9 & .20) & 1 & 2 & 2 & .20) & 2 & \\
\hline ……………………… & $\begin{array}{l}5.9 \\
9.9 \\
8.4\end{array}$ & $\left.\begin{array}{l}0.19 \\
0.17 \\
0.65 \\
0.18\end{array}\right)$ & $\begin{array}{l}5.5 \\
4.1 \\
6.3 \\
9.5 \\
8.3\end{array}$ & $\begin{array}{l}0.06 \\
0.19 \\
0.11 \\
0.43 \\
0.21)\end{array}$ & $\begin{array}{l}4.6 \\
3.9 \\
5.9 \\
8.8 \\
8.0\end{array}$ & $\left.\begin{array}{l}0.11) \\
0.19 \\
0.17 \\
0.63 \\
0.16\end{array}\right)$ & $\begin{array}{l}4.0 \\
6.3 \\
8.6 \\
8.0\end{array}$ & $\begin{array}{l}0.06 \\
0.19 \\
0.12 \\
0.41 \\
0.21)\end{array}$ & $\begin{array}{r}4.9 \\
4.2 \\
5.9 \\
11.0 \\
8.8\end{array}$ & $\begin{array}{l}(0.11) \\
0.19 \\
0.177 \\
0.677 \\
0.20)\end{array}$ & $\begin{array}{r}5.7 \\
4.3 \\
6.3 \\
10.5 \\
8.6\end{array}$ & $\begin{array}{l}(0.07) \\
0.19 \\
0.11 \\
0.50 \\
0.23\end{array}$ & $\begin{array}{r}6.3 \\
5.8 \\
8.4 \\
11.2 \\
12.0\end{array}$ & $\left.\begin{array}{l}(0.16) \\
0.22 \\
0.26 \\
0.80 \\
0.36\end{array}\right)$ & $\begin{array}{r}7.1 \\
5.8 \\
9.1 \\
10.7 \\
11.9 \\
\end{array}$ & $\begin{array}{l}(0.11) \\
0.22 \\
0.21 \\
0.53 \\
0.42)\end{array}$ & $\begin{array}{l}4 \\
1 \\
5 \\
1 \\
6\end{array}$ & $\left.\begin{array}{l}0.03 \\
0.14 \\
0.90 \\
0.16\end{array}\right)$ & 4.3 & $\left.\begin{array}{l}0.02 \\
0.06 \\
0.73 \\
0.16\end{array}\right)$ & $\begin{array}{l}2.3 \\
2.3 \\
3.3 \\
5.8 ! \\
5.1\end{array}$ & $\begin{array}{l}(0.17) \\
0.11 \\
0.13 \\
2.39 \\
0.13\end{array}$ & $\begin{array}{l}9 \\
.5 \\
.5 \\
.8 ! \\
8\end{array}$ & 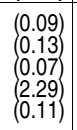 & $\begin{array}{r}9.4 \\
4.5 \\
13.9 \\
10.6 \\
14.6\end{array}$ & $\left.\begin{array}{l}0.45 \\
0.54 \\
0.78 \\
0.56\end{array}\right)$ & $\begin{array}{l}10.3 \\
16.1\end{array}$ & $\left.\begin{array}{l}0.21 \\
0.62 \\
(0.89\end{array}\right)$ & & & 5.8 & \\
\hline 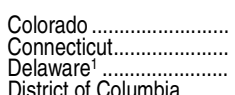 & $\begin{array}{l}6.7 \\
3.0 \\
4.6 \\
\end{array}$ & $\left(\begin{array}{l}0.11 \\
0.32 \\
(+)\end{array}\right)$ & $\begin{array}{l}6.8 \\
3.8 \\
5.6\end{array}$ & $\left(\begin{array}{l}0.11) \\
0.41)\end{array}\right.$ & $\begin{array}{l}6.6 \\
2.9 \\
4.0 \\
\end{array}$ & & $\begin{array}{l}6.9 \\
3.5 \\
4.9 \\
\end{array}$ & $\left.\begin{array}{r}0.11) \\
0.40 \\
(+f\end{array}\right)$ & $\begin{array}{l}6.8 \\
3.2 \\
5.3 \\
-\end{array}$ & & $\begin{array}{l}6.8 \\
4.0 \\
6.3 \\
-\end{array}$ & & $\begin{array}{l}7.9 \\
3.5 \\
6.1 \\
-\end{array}$ & & & & $\begin{array}{l}2 \\
7 \\
2 \\
- \\
\end{array}$ & & 50 & & $\begin{array}{l}3.9 \\
1.4 \\
1.7 \\
-\end{array}$ & & & $\left(\begin{array}{c}0.07) \\
0.42 \\
(t)\end{array}\right)$ & $\begin{array}{r}9.6 \\
51.7 \\
11.5 \\
-\end{array}$ & & & & & & $\begin{array}{l}3 \\
\frac{1}{7} \\
7\end{array}$ & \\
\hline & $\overline{4.5}$ & $(0.06)$ & 4.7 & $(0.05)$ & $\overline{4.5}$ & $(0.06)$ & $4 . \overline{7}$ & $(0.05)$ & $4 . \overline{5}$ & $(0.05)$ & 4.8 & $(0.05)$ & $5 . \overline{7}$ & $(0.11)$ & $6 . \overline{1}$ & $(0.10)$ & 2.0 & .02 & $2 . \overline{0}$ & $(0.02)$ & $4 . \overline{0}$ & .02 & $\overline{4}$ & $(0.03)$ & $8 . \overline{8}$ & $(0.08)$ & $\overline{9.3}$ & .06) & 4.6 & 12 & .0 & \\
\hline 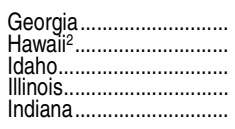 & $\begin{array}{l}8.9 \\
5.7 \\
3.9 \\
5.4 \\
7.1\end{array}$ & $\begin{array}{l}(0.30) \\
0.57 \\
0.23 \\
0.22 \\
0.49)\end{array}$ & $\begin{array}{l}9.3 \\
6.2 \\
4.2 \\
5.8 \\
7.9\end{array}$ & $\begin{array}{l}(0.35) \\
(t) \\
0.20 \\
0.24 \\
0.40)\end{array}$ & $\begin{array}{l}8.3 \\
4.4 \\
3.9 \\
5.0 \\
6.3\end{array}$ & $\begin{array}{l}0.29) \\
0.42 \\
0.21 \\
0.20 \\
0.44)\end{array}$ & $\begin{array}{l}8.6 \\
5.1 \\
4.3 \\
5.4 \\
7.0\end{array}$ & $\begin{array}{l}(0.33) \\
(+) \\
(0.20 \\
0.23 \\
0.36)\end{array}$ & $\begin{array}{l}9.5 \\
7.0 \\
3.9 \\
5.8 \\
7.9\end{array}$ & $\begin{array}{l}(0.31) \\
0.74 \\
0.24 \\
0.24 \\
0.55)\end{array}$ & $\begin{array}{l}10.0 \\
7.5 \\
4.1 \\
6.3 \\
8.8\end{array}$ & $\left.\begin{array}{l}(0.39) \\
(+) \\
0.21 \\
0.28 \\
0.49\end{array}\right)$ & $\begin{array}{r}13.6 \\
7.7 \\
4.4 \\
6.7 \\
7.7\end{array}$ & $\left.\begin{array}{l}(0.59) \\
0.95 \\
0.26 \\
0.33 \\
0.52\end{array}\right)$ & $\begin{array}{r}14.1 \\
9.7 \\
4.7 \\
7.0 \\
8.7\end{array}$ & $\begin{array}{l}10 \\
10 \\
0\end{array}$ & $\begin{array}{l}.7 \\
.9 \\
.7 \\
.5 \\
.8\end{array}$ & $\begin{array}{l}0.15) \\
0.53 \\
0.20 \\
0.18 \\
0.78)\end{array}$ & . & $\begin{array}{l}(0.15) \\
(+) \\
0.14 \\
0.40 \\
0.54)\end{array}$ & $\begin{array}{l}2.6 \\
2.6 \\
0.9 \\
2.8 \\
3.8\end{array}$ & & 9 & $\left.\begin{array}{r}(0.17) \\
(t) \\
(0.12 \\
0.08 \\
0.39\end{array}\right)$ & $\begin{array}{r}18.8 \\
5.5 \\
6.9 \\
13.1 \\
15.5 \\
\end{array}$ & $\begin{array}{l}0.41) \\
0.59 \\
0.38 \\
0.98 \\
2.71)\end{array}$ & $\begin{array}{r}19.3 \\
5.8 \\
6.1 \\
13.3 \\
14.1\end{array}$ & $\begin{array}{l}(0.71) \\
(t) \\
(0.46 \\
0.97 \\
2.08)\end{array}$ & & (6) & $\begin{array}{l}6 \\
8 \\
0\end{array}$ & \\
\hline 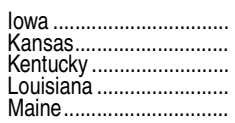 & $\begin{array}{r}8.5 \\
3.3 \\
13.0 \\
3.9 \\
3.0\end{array}$ & $\left.\begin{array}{l}(0.38) \\
0.11 \\
0.54 \\
0.32 \\
0.36\end{array}\right)$ & $\begin{array}{r}8.2 \\
3.0 \\
14.6 \\
3.4 \\
3.2\end{array}$ & $\left.\begin{array}{l}0.26) \\
0.12 \\
0.50 \\
0.13 \\
0.19\end{array}\right)$ & $\begin{array}{r}8.2 \\
3.5 \\
11.9 \\
3.8 \\
2.9\end{array}$ & $\left.\begin{array}{l}0.37 \\
0.11 \\
0.51 \\
0.31 \\
0.33\end{array}\right)$ & $\begin{array}{r}7.9 \\
3.2 \\
13.2 \\
3.2 \\
3.1\end{array}$ & $\left.\begin{array}{l}0.25) \\
0.13 \\
0.47 \\
0.13 \\
0.18\end{array}\right)$ & $\begin{array}{r}8.9 \\
3.1 \\
14.2 \\
4.0 \\
3.2\end{array}$ & $\left.\begin{array}{l}(0.40) \\
0.11 \\
0.57 \\
0.44 \\
0.39\end{array}\right)$ & $\begin{array}{r}8.5 \\
2.9 \\
16.1 \\
3.5 \\
3.4\end{array}$ & & $\begin{array}{r}9.0 \\
3.9 \\
14.2 \\
5.5 \\
3.1\end{array}$ & $\begin{array}{l}(0.41) \\
0.15 \\
0.62 \\
0.60 \\
0.37)\end{array}$ & $\begin{array}{r}8.8 \\
3.6 \\
15.8 \\
4.8 \\
3.3\end{array}$ & $\left.\begin{array}{l}(0.30) \\
0.16 \\
0.64 \\
0.26 \\
0.20\end{array}\right)$ & $\begin{array}{l}6 \\
1 \\
2 \\
9 \\
3\end{array}$ & $\begin{array}{l}(0.33) \\
0.05 \\
0.54 \\
0.07 \\
0.22)\end{array}$ & 30 & $\begin{array}{l}0.11 \\
0.04 \\
0.60 \\
0.04 \\
0.12)\end{array}$ & $\begin{array}{l}4.2 \\
1.2\end{array}$ & & & 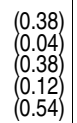 & \begin{tabular}{|r|}
13.5 \\
5.5 \\
20.2 \\
11.7 \\
3.8
\end{tabular} & & & & & & & \\
\hline & $\begin{array}{r}13.8 \\
0.8 \\
3.9 \\
8.1 \\
6.0\end{array}$ & $\begin{array}{r}\left(\begin{array}{r}(t) \\
0.13 \\
0.37 \\
0.37 \\
0.19\end{array}\right) \\
\end{array}$ & $\begin{array}{r}16.1 \\
0.7 \\
3.4 \\
8.8 \\
6.1\end{array}$ & $\begin{array}{r}(t) \\
0.10 \\
0.29 \\
0.28 \\
0.20)\end{array}$ & $\begin{array}{r}12.9 \\
0.7 \\
3.6 \\
7.7 \\
5.7\end{array}$ & $\begin{array}{r}(\dagger) \\
\left(\begin{array}{l}0 \\
0.35 \\
0.35 \\
0.36 \\
0.18\end{array}\right)\end{array}$ & $\begin{array}{r}15.0 \\
0.6 \\
3.2 \\
8.4 \\
5.8\end{array}$ & $\begin{array}{r}(\dagger) \\
\left(\begin{array}{l}(\dagger) \\
0.28 \\
0.26 \\
0.19\end{array}\right)\end{array}$ & $\begin{array}{r}14.7 \\
0.9 \\
4.3 \\
8.6 \\
6.3\end{array}$ & $\begin{array}{c}(t) \\
\left(\begin{array}{c}(14) \\
0.40 \\
0.38 \\
0.22\end{array}\right) \\
\end{array}$ & $\begin{array}{r}17.2 \\
0.8 \\
3.7 \\
9.2 \\
6.4\end{array}$ & $\begin{array}{r}\left(\begin{array}{r}(t) \\
0.15 \\
0.32 \\
0.32 \\
0.22\end{array}\right) \\
\end{array}$ & $\begin{array}{r}17.0 \\
0.8 \\
4.1 \\
8.3 \\
9.1\end{array}$ & $\begin{array}{c}(t) \\
\left(\begin{array}{l}(14) \\
0.41 \\
0.44 \\
0.38\end{array}\right)\end{array}$ & $\begin{array}{r}21.1 \\
0.6 \\
3.8 \\
8.8 \\
9.6\end{array}$ & $\begin{array}{r}(t) \\
(0.12 \\
0.34 \\
0.36 \\
0.41)\end{array}$ & $\begin{array}{l}7 \\
7 \\
0 \\
2 \\
3\end{array}$ & 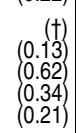 & 2.9 & 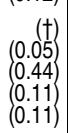 & $\begin{array}{c}14.5 \\
0.8 ! \\
2.7 \\
4.5 \\
5.0\end{array}$ & & 4.5 & $\begin{array}{c}(t) \\
\left(\begin{array}{l}(t) \\
0.18 \\
0.18 \\
0.37\end{array}\right) \\
\end{array}$ & $\begin{array}{r}33.8 \\
1.9 \\
10.1 \\
13.7 \\
10.7\end{array}$ & 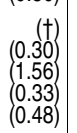 & $\begin{array}{r}37.8 \\
1.7 \\
8.1 \\
16.5 \\
13.5\end{array}$ & $\begin{array}{r}(\dagger) \\
(0.24) \\
1.30\end{array}$ & $\begin{array}{l}.8 \\
.9 \\
.8 \\
.7\end{array}$ & 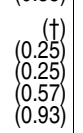 & & \\
\hline 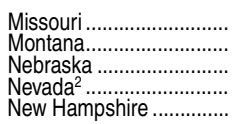 & $\begin{array}{r}3.8 \\
5.6 \\
11.4 \\
1.9 \\
2.3\end{array}$ & $\begin{array}{l}(0.12) \\
0.28) \\
0.31 \\
0.01 \\
0.55)\end{array}$ & $\begin{array}{r}3.6 \\
5.2 \\
11.4 \\
1.9 \\
2.6\end{array}$ & $\begin{array}{r}0.11) \\
0.20 \\
0.24 \\
(t) \\
(0.54)\end{array}$ & $\begin{array}{r}3.8 \\
5.4 \\
10.9 \\
2.1 \\
2.1\end{array}$ & $\left.\begin{array}{l}0.12 \\
0.26 \\
0.30 \\
0.01 \\
0.49\end{array}\right)$ & $\begin{array}{r}3.5 \\
5.0 \\
11.0 \\
1.9 \\
2.5\end{array}$ & $\begin{array}{r}0.11) \\
0.20 \\
0.24 \\
(t) \\
(0.56)\end{array}$ & $\begin{array}{r}3.8 \\
5.9 \\
11.9 \\
1.8 \\
2.5 !\end{array}$ & $\begin{array}{l}(0.13) \\
0.31 \\
0.32 \\
0.01 \\
(0.62)\end{array}$ & $\begin{array}{r}3.6 \\
5.3 \\
11.8 \\
1.9 \\
2.7\end{array}$ & $\begin{array}{c}(0.11) \\
0.21 \\
0.27 \\
(+) \\
0.54)\end{array}$ & $\begin{array}{r}4.3 \\
6.0 \\
12.8 \\
2.8 \\
2.3\end{array}$ & $\begin{array}{l}(0.15) \\
0.31 \\
0.38 \\
0.01 \\
0.56)\end{array}$ & $\begin{array}{r}4.0 \\
5.7 \\
13.3 \\
3.0 \\
2.6\end{array}$ & & $\begin{array}{l}7 \\
8 \\
4 \\
8 \\
6\end{array}$ & $\begin{array}{c}(0.05) \\
0.21 \\
0.06 \\
(\#) \\
(0.11)\end{array}$ & 15 & $\begin{array}{c}(0.08) \\
0.22 \\
0.05 \\
(+) \\
(0.19)\end{array}$ & $\begin{array}{l}1.4 \\
3.3 \\
4.5 \\
0.8 \\
1.0\end{array}$ & & & $\begin{array}{r}(0.09) \\
(0.29) \\
(0.24) \\
(t) \\
(0.10)\end{array}$ & $\begin{array}{r}9.0 \\
9.9 \\
17.0 \\
2.8 \\
5.8\end{array}$ & $\begin{array}{l}(0.33) \\
0.77) \\
0.25 \\
0.02 \\
1.25)\end{array}$ & & $(036)$ & & & & \\
\hline ……… & $\begin{array}{r}6.9 \\
10.7 \\
2.2 \\
10.9 \\
3.1\end{array}$ & $\left.\begin{array}{l}(0.38) \\
0.26 \\
0.18 \\
0.83 \\
0.30\end{array}\right)$ & $\begin{array}{r}7.0 \\
4.0 \\
2.9 \\
10.8 \\
2.8\end{array}$ & $\begin{array}{l}0.35) \\
0.14 \\
0.13 \\
0.42 \\
0.18)\end{array}$ & $\begin{array}{r}6.2 \\
10.9 \\
2.0 \\
10.3 \\
3.0\end{array}$ & $\begin{array}{l}(0.34) \\
0.27 \\
0.17 \\
0.81 \\
0.30\end{array}$ & $\begin{array}{r}6.1 \\
4.1 \\
2.6 \\
10.2 \\
2.9\end{array}$ & $\left.\begin{array}{l}0.31) \\
0.15 \\
0.12 \\
0.40 \\
0.19\end{array}\right)$ & $\begin{array}{r}7.7 \\
10.5 \\
2.3 \\
11.6 \\
3.2\end{array}$ & $\begin{array}{l}(0.42) \\
0.26 \\
0.19 \\
0.85 \\
0.32)\end{array}$ & $\begin{array}{r}7.9 \\
3.8 \\
3.2 \\
11.3 \\
2.8\end{array}$ & $\left.\begin{array}{l}(0.43) \\
0.14 \\
0.15 \\
0.47 \\
0.18\end{array}\right)$ & $\begin{array}{r}8.4 \\
12.6 \\
3.4 \\
15.7 \\
2.8\end{array}$ & $\begin{array}{l}(0.53) \\
0.42 \\
0.31 \\
1.17 \\
0.23)\end{array}$ & $\begin{array}{r}8.4 \\
7.1 \\
3.3 \\
15.4 \\
2.8\end{array}$ & & $\begin{array}{l}3 \\
6 \\
8 \\
9 \\
3\end{array}$ & $\begin{array}{l}0.18 \\
0.07 \\
0.27 \\
0.05)\end{array}$ & 1.7 & $\begin{array}{l}0.36) \\
0.11 \\
0.09 \\
0.20 \\
0.09\end{array}$ & $\begin{array}{r}3.4 \\
11.4 \\
0.4 \\
3.0 \\
1.5\end{array}$ & & & $\begin{array}{l}\left(\begin{array}{l}0.33 \\
0.11 \\
0.04 \\
(0.18 \\
0.13\end{array}\right) \\
\end{array}$ & \begin{tabular}{|r|}
12.2 \\
13.6 \\
1.7 \\
16.5 \\
8.1
\end{tabular} & $\begin{array}{l}1.13) \\
1.09 \\
0.18 \\
2.76 \\
0.38)\end{array}$ & $\begin{array}{r}13.9 \\
12.0 \\
5.5 \\
17.3 \\
5.4\end{array}$ & $\begin{array}{l}0.19 \\
0.98 \\
(0.26)\end{array}$ & $\begin{array}{l}3 \\
\frac{2}{4}\end{array}$ & $\left(\begin{array}{l}0.179 \\
0.29)\end{array}\right.$ & $\begin{array}{l}4.8 \\
2.1 \\
1.5 \\
\ddagger \\
3.3 !\end{array}$ & \\
\hline$\ldots$ & $\begin{array}{r}7.4 \\
14.0 \\
7.1 \\
4.8 \\
1.8\end{array}$ & $\begin{array}{l}(0.40) \\
0.45 \\
0.20 \\
0.19 \\
0.38)\end{array}$ & $\begin{array}{r}7.3 \\
13.7 \\
6.9 \\
4.5 \\
1.4\end{array}$ & $\begin{array}{l}0.33 \\
0.39 \\
0.16 \\
0.17 \\
0.21)\end{array}$ & $\begin{array}{r}7.3 \\
13.1 \\
7.3 \\
4.9 \\
1.6\end{array}$ & $\left.\begin{array}{l}0.40 \\
0.41 \\
0.20 \\
0.20 \\
0.35\end{array}\right)$ & $\begin{array}{r}7.2 \\
13.0 \\
7.2 \\
4.5 \\
1.2\end{array}$ & $\left.\begin{array}{l}0.34) \\
0.36 \\
0.17 \\
0.17 \\
0.18\end{array}\right)$ & $\begin{array}{r}7.6 \\
15.0 \\
6.9 \\
4.8 \\
2.1\end{array}$ & $\begin{array}{l}\left(\begin{array}{l}0.40 \\
0.50 \\
0.21 \\
0.99 \\
0.41\end{array}\right) \\
\end{array}$ & $\begin{array}{r}7.4 \\
14.4 \\
6.6 \\
4.5 \\
1.6\end{array}$ & $\begin{array}{l}(0.35) \\
0.47 \\
0.16 \\
0.18 \\
0.24)\end{array}$ & $\begin{array}{r}7.6 \\
16.6 \\
8.0 \\
5.3 \\
2.0\end{array}$ & $\begin{array}{l}(0.48) \\
(0.56 \\
0.24 \\
0.23 \\
0.44)\end{array}$ & $\begin{array}{r}7.8 \\
16.2 \\
8.0 \\
5.0 \\
1.5\end{array}$ & & & $\begin{array}{l}0.37) \\
0.22 \\
0.05 \\
0.16 \\
0.47)\end{array}$ & $\begin{array}{l}4.7 \\
7.4 \\
3.5 \\
2.4 \\
1.2 !\end{array}$ & $\left.\begin{array}{l}0.37) \\
0.23 \\
0.09 \\
0.15\end{array}\right)$ & $\begin{array}{l}3.5 \\
7.0 \\
1.8 \\
1.8 \\
1.2\end{array}$ & & & $\begin{array}{l}(0.28) \\
0.23 \\
0.09 \\
0.12 \\
0.13)\end{array}$ & \begin{tabular}{|r|}
13.6 \\
23.6 \\
11.6 \\
9.5 \\
2.2
\end{tabular} & \{ & $\begin{array}{r}14.0 \\
21.5 \\
11.1 \\
9.7 \\
2.3\end{array}$ & $\begin{array}{l}(1.64) \\
0.60 \\
0.21 \\
0.96 \\
(0.30)\end{array}$ & $\begin{array}{c}5.6 \\
11.3 \\
3.6 \\
2.2 \\
0.9 !\end{array}$ & & $\begin{array}{l}4 \\
8 \\
9 \\
9\end{array}$ & \\
\hline : & $\begin{array}{r}12.7 \\
2.2 \\
3.3 \\
8.0 \\
4.6\end{array}$ & $\begin{array}{l}(0.98) \\
0.20 \\
0.18 \\
0.10 \\
0.29)\end{array}$ & $\begin{array}{r}11.0 \\
2.7 \\
1.7 \\
7.6 \\
5.0\end{array}$ & $\begin{array}{l}0.57) \\
0.17 \\
0.10 \\
0.07 \\
0.05)\end{array}$ & $\begin{array}{r}11.7 \\
2.3 \\
3.1 \\
7.5 \\
4.3\end{array}$ & $\left.\begin{array}{l}(0.89) \\
0.20 \\
0.18 \\
0.10 \\
0.28\end{array}\right)$ & $\begin{array}{r}10.1 \\
2.8 \\
1.7 \\
7.2 \\
4.6\end{array}$ & $\left.\begin{array}{l}0.52 \\
0.18 \\
0.10 \\
0.07 \\
0.05\end{array}\right)$ & $\begin{array}{r}13.9 \\
2.1 \\
3.5 \\
8.5 \\
5.0\end{array}$ & $\left.\begin{array}{l}(1.07) \\
0.20 \\
0.18 \\
0.11 \\
0.29\end{array}\right)$ & $\begin{array}{r}11.9 \\
2.5 \\
1.7 \\
8.0 \\
5.5\end{array}$ & $\begin{array}{l}(0.68) \\
0.18 \\
0.09 \\
0.08 \\
0.06)\end{array}$ & $\begin{array}{r}17.8 \\
2.4 \\
2.9 \\
11.2 \\
4.5\end{array}$ & $\begin{array}{l}(1.29) \\
0.21 \\
0.21 \\
0.21 \\
0.29)\end{array}$ & $\begin{array}{r}15.9 \\
2.9 \\
2.0 \\
10.8 \\
4.9\end{array}$ & $\left.\begin{array}{l}(0.95) \\
0.19 \\
0.13 \\
0.17 \\
0.06\end{array}\right)$ & $\begin{array}{l}5.9 \\
1.2 \\
4.5 \\
4.9 \\
5.1\end{array}$ & $\left.\begin{array}{l}(0.70) \\
0.16 \\
0.15 \\
0.14 \\
0.26\end{array}\right)$ & $\begin{array}{l}5.1 \\
0.9 \\
0.7\end{array}$ & $\left.\begin{array}{l}(0.39) \\
0.03 \\
0.03 \\
0.11 \\
0.03\end{array}\right)$ & $\begin{array}{l}5.1 \\
0.6 \\
1.6 \\
5.6 \\
4.4\end{array}$ & & & $\left.\begin{array}{l}(0.56) \\
0.04 \\
0.04 \\
0.07 \\
0.05\end{array}\right)$ & $\begin{array}{r}21.6 \\
3.3 \\
7.9 \\
16.4 \\
11.7\end{array}$ & $\begin{array}{l}(3.32) \\
0.37 \\
0.77 \\
0.28 \\
0.81)\end{array}$ & $\begin{array}{r}19.3 \\
4.2 \\
4.2 \\
16.0 \\
12.0\end{array}$ & $\left.\begin{array}{l}2.33 \\
0.31 \\
0.37\end{array}\right)$ & $\begin{array}{c}8.3 \\
\neq\end{array}$ & $\begin{array}{c}(1.29) \\
(t) \\
(0.41)\end{array}$ & $\begin{array}{l}8.2 \\
1.4 ! \\
1.4 \\
7.1 \\
2.7\end{array}$ & \\
\hline 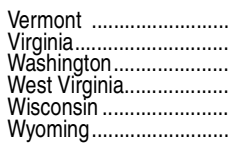 & $\begin{array}{r}0.8 \\
12.1 \\
3.8 \\
2.2 \\
6.8 \\
3.2 !\end{array}$ & $\begin{array}{l}(0.17) \\
0.38 \\
0.10 \\
0.19 \\
0.47 \\
1.04)\end{array}$ & $\left.\begin{array}{r}0.8 \\
12.6 \\
3.9 \\
2.2 \\
6.4 \\
2.2\end{array}\right\}$ & $\begin{array}{l}0.15) \\
0.32 \\
0.13 \\
0.21 \\
0.35 \\
0.35)\end{array}$ & $\begin{array}{r}0.8 \\
11.5 \\
3.6 \\
2.3 \\
6.4 \\
2.8 !\end{array}$ & $\begin{array}{l}(0.17) \\
0.36 \\
0.10 \\
0.20 \\
0.44 \\
0.90\end{array}$ & $\begin{array}{r}0.9 \\
12.0 \\
3.7 \\
2.2 \\
6.1 \\
2.0\end{array}$ & $\left.\begin{array}{l}0.16) \\
0.30 \\
0.12 \\
0.22 \\
0.33 \\
0.32\end{array}\right)$ & $\begin{array}{r}0.9 \\
12.8 \\
3.9 \\
2.0 \\
7.3 \\
3.7 !\end{array}$ & $\left.\begin{array}{l}0.17) \\
0.40 \\
0.10 \\
0.18 \\
0.51 \\
(1.19\end{array}\right)$ & $\begin{array}{r}0.8 \\
13.3 \\
4.1 \\
2.1 \\
6.8 \\
2.3\end{array}$ & $\begin{array}{l}(0.15) \\
0.37 \\
0.16 \\
0.21 \\
0.41 \\
0.39\end{array} \mid$ & $\begin{array}{r}0.8 \\
14.9 \\
4.2 \\
2.2 \\
7.8 \\
3.5 !\end{array}$ & $\begin{array}{l}(0.17) \\
(0.55 \\
0.14 \\
0.19 \\
0.55 \\
(1.14)\end{array}$ & $\begin{array}{r}0.8 \\
15.6 \\
4.4 \\
2.2 \\
7.1 \\
2.3\end{array}$ & $\begin{array}{l}(0.15) \\
0.50) \\
0.19 \\
0.21 \\
0.45 \\
0.39)\end{array}$ & $\begin{array}{l}0.4 ! \\
4.6 \\
1.4\end{array}$ & $!(0.16)$ & $\begin{array}{l}0.5 ! \\
5.2 \\
1.4 \\
1.6 \\
3.7 \\
2.0\end{array}$ & $\left.\begin{array}{l}(0.16) \\
0.35 \\
0.02 \\
0.32 \\
0.25 \\
0.19\end{array}\right)$ & $\begin{array}{l}\# \\
6.7 \\
1.8 \\
1.6 \\
2.4 \\
1.2\end{array}$ & $\begin{array}{l}(t) \\
(0.65) \\
0.12 \\
0.37 \\
0.23 \\
0.29)\end{array}$ & $\begin{array}{l}1.3 ! \\
7.5 \\
1.7 \\
0.9\end{array}$ & $\left.\begin{array}{l}(0.57) \\
0.23 \\
0.09 \\
0.23 \\
0.21 \\
0.11\end{array}\right)$ & $\begin{array}{r}0.2 ! \\
24.5 \\
5.0 \\
9.3 \\
6.7 \\
3.6\end{array}$ & $\left.\begin{array}{l}(0.10) \\
0.83 \\
0.09 \\
1.90 \\
0.55 \\
0.31\end{array}\right)$ & $\begin{array}{r}1.4 ! \\
26.4 \\
5.8 \\
10.9 \\
6.1 \\
6.7\end{array}$ & $\left.\begin{array}{l}!(0.41) \\
(0.46 \\
0.12 \\
2.21 \\
0.44 \\
(1.35)\end{array}\right)$ & $\begin{array}{c}\# \\
8.3 \\
1.6 \\
3.9 ! \\
4.6 ! \\
\ddagger\end{array}$ & 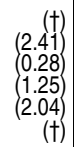 & $\begin{array}{r}\# \\
13.3 \\
1.4 \\
2.9 ! \\
3.2 ! \\
1.0\end{array}$ & \\
\hline
\end{tabular}

-Not available.

†Not applicable.

Interpret data with caution. The coefficient of variation (CV) for this estimate is between 30 and 50 percent. †Reporting stan
cent or greater.
1Data are based on universe counts of schools and school districts; therefore, these figures do not have standard errors. NOTE. ROC are based on universe counts of schools and school districts; therefore, these figures do not have standard errors. SOURCE: US. Department of Education, Office for Civil Right pared June 2008.) 
Table 205.10. Private elementary and secondary school enrollment and private enrollment as a percentage of total enrollment in public and private schools, by region and grade level: Selected years, fall 1995 through fall 2011

[Standard errors appear in parentheses]

\begin{tabular}{|c|c|c|c|c|c|c|c|c|c|c|c|c|c|c|c|c|c|c|c|c|}
\hline \multirow[b]{3}{*}{ Grade level and year } & & & & & \multicolumn{16}{|c|}{ Private enrollment, by region } \\
\hline & \multicolumn{4}{|c|}{ Total private enrollment } & \multicolumn{4}{|c|}{ Northeast } & \multicolumn{4}{|c|}{ Midwest } & \multicolumn{4}{|c|}{ South } & \multicolumn{4}{|c|}{ West } \\
\hline & \multicolumn{2}{|c|}{ In thousands } & \multicolumn{2}{|c|}{$\begin{array}{r}\text { Percent of total } \\
\text { enrollment }\end{array}$} & \multicolumn{2}{|c|}{ In thousands } & \multicolumn{2}{|c|}{$\begin{array}{r}\text { Percent of total } \\
\text { enrollment in } \\
\text { Northeast }\end{array}$} & \multicolumn{2}{|c|}{ In thousands } & \multicolumn{2}{|c|}{$\begin{array}{r}\text { Percent of total } \\
\text { enrollment in } \\
\text { Midwest }\end{array}$} & \multicolumn{2}{|c|}{ In thousands } & \multicolumn{2}{|c|}{$\begin{array}{r}\text { Percent of total } \\
\text { enrollment in } \\
\text { South }\end{array}$} & \multicolumn{2}{|c|}{ In thousands } & \multicolumn{2}{|c|}{$\begin{array}{r}\text { Percent of total } \\
\text { enrollment in } \\
\text { West }\end{array}$} \\
\hline 1 & & 2 & & 3 & & 4 & & 5 & & 6 & & 7 & & 8 & & 9 & & 10 & & 11 \\
\hline 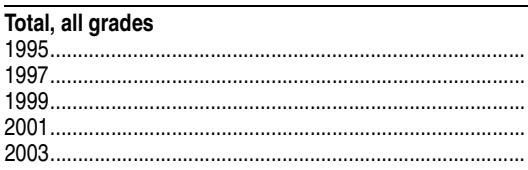 & $\begin{array}{l}5,918 \\
5,944 \\
6,018 \\
6,320 \\
6,099\end{array}$ & $\begin{array}{l}(31.8) \\
(18.5) \\
(30.2) \\
(40.3) \\
(41.2)\end{array}$ & $\begin{array}{l}11.7 \\
11.4 \\
11.4 \\
11.7 \\
11.2\end{array}$ & $\begin{array}{l}(0.06) \\
(0.04) \\
(0.06) \\
(0.08) \\
(0.08)\end{array}$ & $\begin{array}{l}1,509 \\
1,496 \\
1,507 \\
1,581 \\
1,513\end{array}$ & $\begin{array}{r}(18.8) \\
(8.3) \\
(7.9) \\
(9.5) \\
(25.8)\end{array}$ & $\begin{array}{l}16.0 \\
15.6 \\
15.5 \\
16.1 \\
15.4\end{array}$ & $\begin{array}{l}(0.20) \\
(0.09) \\
(0.08) \\
(0.10) \\
(0.27)\end{array}$ & $\begin{array}{l}1,525 \\
1,528 \\
1,520 \\
1,556 \\
1,460\end{array}$ & $\begin{array}{l}(14.2) \\
(11.6) \\
(10.3) \\
(22.9) \\
(15.1)\end{array}$ & $\begin{array}{l}12.7 \\
12.5 \\
12.4 \\
12.6 \\
11.9\end{array}$ & $\begin{array}{l}(0.12) \\
(0.10) \\
(0.09) \\
(0.19) \\
(0.12)\end{array}$ & $\begin{array}{l}1,744 \\
1,804 \\
1,863 \\
1,975 \\
1,944\end{array}$ & $\begin{array}{l}(12.8) \\
(11.3) \\
(26.7) \\
(21.4) \\
(21.0)\end{array}$ & $\begin{array}{r}9.8 \\
9.8 \\
10.0 \\
10.3 \\
9.9\end{array}$ & $\begin{array}{l}(0.07) \\
(0.06) \\
(0.14) \\
(0.11) \\
(0.11)\end{array}$ & $\begin{array}{l}1,141 \\
1,116 \\
1,127 \\
1,208 \\
1,182\end{array}$ & $\begin{array}{r}(11.5) \\
(5.2) \\
(5.4) \\
(23.4) \\
(19.1)\end{array}$ & $\begin{array}{r}10.0 \\
9.4 \\
9.2 \\
9.6 \\
9.1\end{array}$ & $\begin{array}{l}(0.10) \\
(0.04) \\
(0.04) \\
(0.19) \\
(0.15)\end{array}$ \\
\hline 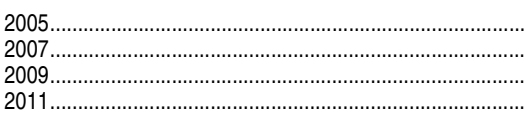 & $\begin{array}{l}6,073 \\
5,910 \\
5,488 \\
5,268\end{array}$ & $\begin{array}{l}(42.4) \\
(28.4) \\
(35.9) \\
(24.9)\end{array}$ & $\begin{array}{r}11.0 \\
10.7 \\
10.0 \\
9.7\end{array}$ & $\begin{array}{l}(0.08) \\
(0.05) \\
(0.07) \\
(0.04)\end{array}$ & $\begin{array}{l}1,430 \\
1,426 \\
1,310 \\
1,252\end{array}$ & $\begin{array}{r}(7.7) \\
(11.0) \\
(15.7) \\
(18.0)\end{array}$ & $\begin{array}{l}14.8 \\
14.9 \\
14.0 \\
13.7\end{array}$ & $\begin{array}{l}(0.08) \\
(0.12) \\
(0.17) \\
(0.17)\end{array}$ & $\begin{array}{l}1,434 \\
1,352 \\
1,296 \\
1,263\end{array}$ & $\begin{array}{r}(21.0) \\
(8.3) \\
(25.9) \\
(17.1)\end{array}$ & $\begin{array}{l}11.7 \\
11.2 \\
10.8 \\
10.7\end{array}$ & $\begin{array}{l}(0.17) \\
(0.07) \\
(0.22) \\
(0.13)\end{array}$ & $\begin{array}{l}1,976 \\
1,965 \\
1,842 \\
1,747\end{array}$ & $\begin{array}{r}(24.7) \\
(21.5) \\
(17.6) \\
(2.6)\end{array}$ & $\begin{array}{l}9.8 \\
9.6 \\
9.1 \\
8.5\end{array}$ & $\begin{array}{l}(0.12) \\
(0.11) \\
(0.09) \\
(0.01)\end{array}$ & $\begin{array}{l}1,234 \\
1,167 \\
1,041 \\
1,006\end{array}$ & $\begin{array}{r}(26.3) \\
(12.3) \\
(8.0) \\
(0.4)\end{array}$ & $\begin{array}{l}9.4 \\
8.9 \\
8.0 \\
7.8\end{array}$ & $\begin{array}{r}(0.20) \\
(0.09) \\
(0.06) \\
(\#)\end{array}$ \\
\hline 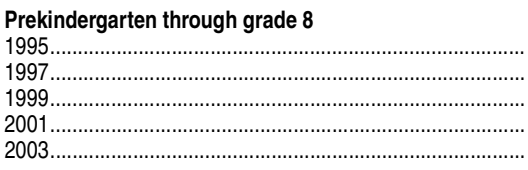 & $\begin{array}{l}4,756 \\
4,759 \\
4,789 \\
5,023 \\
4,788\end{array}$ & $\begin{array}{l}(28.4) \\
(17.3) \\
(23.1) \\
(36.1) \\
(30.3)\end{array}$ & $\begin{array}{l}12.8 \\
12.6 \\
12.5 \\
12.9 \\
12.3\end{array}$ & $\begin{array}{l}(0.08) \\
(0.05) \\
(0.06) \\
(0.09) \\
(0.08)\end{array}$ & $\begin{array}{l}1,174 \\
1,165 \\
1,168 \\
1,216 \\
1,131\end{array}$ & $\begin{array}{r}(16.8) \\
(8.3) \\
(7.5) \\
(9.4) \\
(7.8)\end{array}$ & $\begin{array}{l}17.2 \\
16.8 \\
16.7 \\
17.3 \\
16.4\end{array}$ & $\begin{array}{l}(0.25) \\
(0.12) \\
(0.11) \\
(0.14) \\
(0.11)\end{array}$ & $\begin{array}{l}1,238 \\
1,235 \\
1,222 \\
1,253 \\
1,167\end{array}$ & $\begin{array}{r}(13.5) \\
(11.0) \\
(8.4) \\
(21.2) \\
(13.6)\end{array}$ & $\begin{array}{l}14.3 \\
14.1 \\
13.9 \\
14.3 \\
13.5\end{array}$ & $\begin{array}{l}(0.16) \\
(0.13) \\
(0.10) \\
(0.24) \\
(0.16)\end{array}$ & $\begin{array}{l}1,413 \\
1,449 \\
1,487 \\
1,584 \\
1,547\end{array}$ & $\begin{array}{l}(11.9) \\
(10.0) \\
(19.6) \\
(17.8) \\
(18.6)\end{array}$ & $\begin{array}{l}10.7 \\
10.8 \\
10.9 \\
11.3 \\
10.9\end{array}$ & $\begin{array}{l}(0.09) \\
(0.07) \\
(0.14) \\
(0.13) \\
(0.13)\end{array}$ & $\begin{array}{l}931 \\
909 \\
913 \\
969 \\
944\end{array}$ & $\begin{array}{r}(9.2) \\
(4.4) \\
(4.4) \\
(21.2) \\
(18.1)\end{array}$ & $\begin{array}{l}11.1 \\
10.5 \\
10.4 \\
10.6 \\
10.2\end{array}$ & $\begin{array}{l}(0.11) \\
(0.05) \\
(0.05) \\
(0.23) \\
(0.20)\end{array}$ \\
\hline 2005 & $\begin{array}{l}4,724 \\
4,546 \\
4,179 \\
3,977\end{array}$ & $\begin{array}{l}(33.0) \\
(21.9) \\
(33.2) \\
(18.2)\end{array}$ & $\begin{array}{l}12.1 \\
11.7 \\
10.8 \\
10.3\end{array}$ & $\begin{array}{l}(0.09) \\
(0.06) \\
(0.09) \\
(0.04)\end{array}$ & $\begin{array}{r}1,063 \\
1,047 \\
938 \\
898\end{array}$ & $\begin{array}{r}(6.6) \\
(6.3) \\
(12.6) \\
(12.8)\end{array}$ & $\begin{array}{l}15.9 \\
16.0 \\
14.6 \\
14.1\end{array}$ & $\begin{array}{l}(0.10) \\
(0.10) \\
(0.20) \\
(0.17)\end{array}$ & $\begin{array}{r}1,142 \\
1,065 \\
1,016 \\
967\end{array}$ & $\begin{array}{r}(19.3) \\
(7.7) \\
(25.1) \\
(12.8)\end{array}$ & $\begin{array}{l}13.3 \\
12.6 \\
12.1 \\
11.7\end{array}$ & $\begin{array}{l}(0.23) \\
(0.09) \\
(0.30) \\
(0.14)\end{array}$ & $\begin{array}{l}1,551 \\
1,525 \\
1,424 \\
1,337\end{array}$ & $\begin{array}{r}(21.2) \\
(17.7) \\
(16.2) \\
(1.8)\end{array}$ & $\begin{array}{r}10.7 \\
10.4 \\
9.8 \\
9.0\end{array}$ & $\begin{array}{l}(0.15) \\
(0.12) \\
(0.11) \\
(0.01)\end{array}$ & $\begin{array}{l}969 \\
909 \\
802 \\
774\end{array}$ & $\begin{array}{r}(15.0) \\
(8.1) \\
(7.2) \\
(0.3)\end{array}$ & $\begin{array}{r}10.5 \\
9.9 \\
8.8 \\
8.6\end{array}$ & $\begin{array}{r}(0.16) \\
(0.09) \\
(0.08) \\
(\#)\end{array}$ \\
\hline 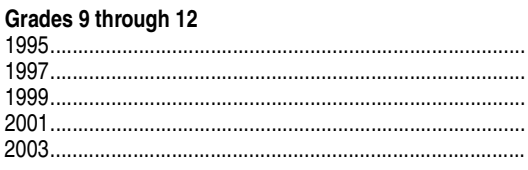 & $\begin{array}{l}1,163 \\
1,185 \\
1,229 \\
1,296 \\
1,311\end{array}$ & $\begin{array}{r}(4.6) \\
(2.4) \\
(8.3) \\
(6.7) \\
(24.7)\end{array}$ & $\begin{array}{l}8.5 \\
8.3 \\
8.4 \\
8.6 \\
8.4\end{array}$ & $\begin{array}{l}(0.03) \\
(0.02) \\
(0.06) \\
(0.04) \\
(0.16)\end{array}$ & $\begin{array}{l}335 \\
331 \\
340 \\
365 \\
382\end{array}$ & $\begin{array}{r}(2.9) \\
(0.5) \\
(1.1) \\
(0.8) \\
(24.0)\end{array}$ & $\begin{array}{l}13.0 \\
12.5 \\
12.6 \\
13.1 \\
13.1\end{array}$ & $\begin{array}{l}(0.11) \\
(0.02) \\
(0.04) \\
(0.03) \\
(0.83)\end{array}$ & $\begin{array}{l}287 \\
293 \\
299 \\
302 \\
294\end{array}$ & $\begin{array}{l}(0.9) \\
(0.7) \\
(2.5) \\
(2.0) \\
(4.1)\end{array}$ & $\begin{array}{l}8.6 \\
8.5 \\
8.6 \\
8.6 \\
8.2\end{array}$ & $\begin{array}{l}(0.03) \\
(0.02) \\
(0.07) \\
(0.06) \\
(0.11)\end{array}$ & $\begin{array}{l}331 \\
354 \\
376 \\
390 \\
397\end{array}$ & $\begin{array}{l}(2.1) \\
(1.7) \\
(7.6) \\
(4.4) \\
(3.0)\end{array}$ & $\begin{array}{l}7.1 \\
7.2 \\
7.5 \\
7.5 \\
7.4\end{array}$ & $\begin{array}{l}(0.04) \\
(0.03) \\
(0.15) \\
(0.08) \\
(0.06)\end{array}$ & $\begin{array}{l}209 \\
207 \\
215 \\
239 \\
238\end{array}$ & $\begin{array}{l}(2.3) \\
(1.2) \\
(1.8) \\
(4.5) \\
(3.5)\end{array}$ & $\begin{array}{l}6.8 \\
6.4 \\
6.3 \\
6.8 \\
6.4\end{array}$ & $\begin{array}{l}(0.08) \\
(0.04) \\
(0.05) \\
(0.13) \\
(0.09)\end{array}$ \\
\hline 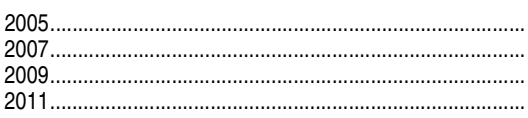 & $\begin{array}{l}1,349 \\
1,364 \\
1,309 \\
1,291\end{array}$ & $\begin{array}{r}(18.1) \\
(12.0) \\
(6.5) \\
(15.4)\end{array}$ & $\begin{array}{l}8.3 \\
8.3 \\
8.0 \\
8.1\end{array}$ & $\begin{array}{l}(0.11) \\
(0.07) \\
(0.04) \\
(0.09)\end{array}$ & $\begin{array}{l}367 \\
379 \\
372 \\
353\end{array}$ & $\begin{array}{l}(1.7) \\
(8.8) \\
(5.7) \\
(5.2)\end{array}$ & $\begin{array}{l}12.3 \\
12.7 \\
12.6 \\
12.6\end{array}$ & $\begin{array}{l}(0.06) \\
(0.30) \\
(0.20) \\
(0.16)\end{array}$ & $\begin{array}{l}292 \\
287 \\
280 \\
295\end{array}$ & $\begin{array}{r}(5.0) \\
(1.3) \\
(2.2) \\
(14.4)\end{array}$ & $\begin{array}{l}7.9 \\
7.8 \\
7.7 \\
8.4\end{array}$ & $\begin{array}{l}(0.14) \\
(0.04) \\
(0.06) \\
(0.38)\end{array}$ & $\begin{array}{l}425 \\
440 \\
418 \\
411\end{array}$ & $\begin{array}{l}(7.2) \\
(5.5) \\
(1.7) \\
(1.8)\end{array}$ & $\begin{array}{l}7.5 \\
7.6 \\
7.3 \\
7.1\end{array}$ & $\begin{array}{l}(0.13) \\
(0.10) \\
(0.03) \\
(0.03)\end{array}$ & $\begin{array}{l}265 \\
257 \\
239 \\
232\end{array}$ & $\begin{array}{r}(15.7) \\
(5.7) \\
(1.1) \\
(0.1)\end{array}$ & $\begin{array}{l}6.7 \\
6.5 \\
6.1 \\
5.9\end{array}$ & $\begin{array}{r}(0.40) \\
(0.14) \\
(0.03) \\
(\#)\end{array}$ \\
\hline
\end{tabular}

\#Rounds to zero.

NOTE: Includes enrollment in prekindergarten through grade 12 in schools that offer kindergarten or higher grade. Ungraded

SOURCE: U.S. Department of Education, National Center for Education Statistics, Private School Universe Survey (PSS) students are prorated into prekindergarten through grade 8 and grades 9 through 12. Detail may not sum to totals because of Survey of Public Elementary/Secondary Edurounding. cation," 1995-96 through 2011-12. (This table was prepared May 2014.) 


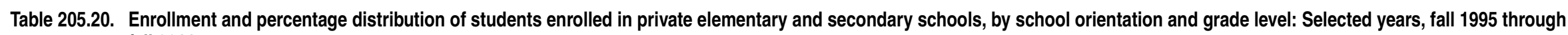
fall 2011

[Standard errors appear in parentheses]

\begin{tabular}{|c|c|c|c|c|c|c|c|c|c|c|c|c|c|c|c|c|c|c|c|c|}
\hline \multirow[b]{2}{*}{ Grade level and year } & \multirow{2}{*}{\multicolumn{2}{|c|}{$\begin{array}{r}\text { Total private } \\
\text { enrollment }\end{array}$}} & \multicolumn{8}{|c|}{ Catholic } & \multicolumn{8}{|c|}{ Other religious } & \multirow{2}{*}{\multicolumn{2}{|c|}{ Nonsectarian }} \\
\hline & & & & Total & \multicolumn{2}{|c|}{ Parochial } & \multicolumn{2}{|r|}{ Diocesan } & \multicolumn{2}{|c|}{$\begin{array}{r}\text { Private } \\
\text { (independent) }\end{array}$} & \multicolumn{4}{|c|}{$\begin{array}{r}\text { Conservative } \\
\text { Christian }\end{array}$} & \multicolumn{2}{|c|}{ Affiliated $^{1}$} & \multicolumn{2}{|c|}{ Unaffiliated $^{1}$} & & \\
\hline \multirow[t]{2}{*}{1} & & 2 & & 3 & & 4 & & 5 & & 6 & & 7 & & 8 & & 9 & & 10 & & 11 \\
\hline & \multicolumn{20}{|c|}{ Enrollment } \\
\hline 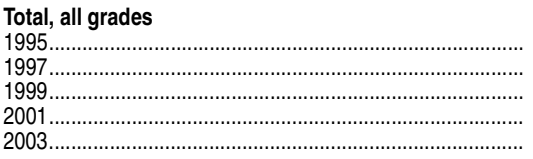 & $\begin{array}{l}5,918,040 \\
5,944,320 \\
6,018,280 \\
6,319,650 \\
6,099,220\end{array}$ & $\begin{array}{l}(31,815) \\
(18,543) \\
(30,179) \\
(40,272) \\
(41,219)\end{array}$ & $\begin{array}{l}2,660,450 \\
2,665,630 \\
2,660,420 \\
2,672,650 \\
2,520,120\end{array}$ & $\begin{array}{r}(6,878) \\
(5,472) \\
(4,831) \\
(12,460) \\
(10,580)\end{array}$ & $\begin{array}{l}1,458,990 \\
1,438,860 \\
1,397,570 \\
1,309,890 \\
1,183,250\end{array}$ & $\begin{array}{l}(2,079) \\
(5,331) \\
(4,421) \\
(5,626) \\
(9,937)\end{array}$ & $\begin{array}{l}850,560 \\
873,780 \\
880,650 \\
979,050 \\
963,140\end{array}$ & $\begin{array}{r}(5,674) \\
(761) \\
(\dagger) \\
(6,976) \\
(4,754)\end{array}$ & $\begin{array}{l}350,900 \\
352,990 \\
382,190 \\
338,710 \\
373,740\end{array}$ & $\begin{array}{l}(1,176) \\
(1,405) \\
(1,945) \\
(3,152) \\
(3,996)\end{array}$ & $\begin{array}{l}2,094,690 \\
2,097,190 \\
2,193,370 \\
2,328,160 \\
2,228,230\end{array}$ & $\begin{array}{l}(16,956) \\
(13,733) \\
(27,176) \\
(17,281) \\
(19,674)\end{array}$ & $\begin{array}{l}786,660 \\
823,610 \\
871,060 \\
937,420 \\
889,710\end{array}$ & $\begin{array}{l}(8,815) \\
(7,342) \\
(4,827) \\
(6,070) \\
(8,852)\end{array}$ & $\begin{array}{l}697,280 \\
646,500 \\
646,280 \\
663,190 \\
650,530\end{array}$ & $\begin{array}{l}(4,886) \\
(3,104) \\
(4,894) \\
(8,636) \\
(5,860)\end{array}$ & $\begin{array}{l}610,750 \\
627,080 \\
676,030 \\
727,550 \\
688,000\end{array}$ & $\begin{array}{l}(11,831) \\
(11,133) \\
(24,593) \\
(13,303) \\
(14,805)\end{array}$ & \multicolumn{2}{|c|}{$\begin{array}{rr}1,162,900 & (18,443) \\
1,181,510 & (12,013) \\
1,164,500 & (8,156) \\
1,318,840 & (27,300) \\
1,350,870 & (29,197)\end{array}$} \\
\hline $2005, \ldots$ & $\begin{array}{l}6,073,240 \\
5,910,210 \\
5,488,490 \\
5,268,090\end{array}$ & $\begin{array}{l}(42,446) \\
(28,363) \\
(35,857) \\
(24,908)\end{array}$ & $\begin{array}{l}2,402,800 \\
2,308,150 \\
2,160,220 \\
2,087,870\end{array}$ & $\begin{array}{r}(9,293) \\
(6,083) \\
(3,494) \\
(14,426)\end{array}$ & $\begin{array}{r}1,062,950 \\
945,860 \\
856,440 \\
804,410\end{array}$ & $\begin{array}{l}(6,355) \\
(5,361) \\
(3,088) \\
(3,686)\end{array}$ & $\begin{array}{l}956,610 \\
969,940 \\
909,010 \\
899,810\end{array}$ & $\begin{array}{r}(6,325) \\
(1,788) \\
(4,393) \\
(14,320)\end{array}$ & $\begin{array}{l}383,230 \\
392,340 \\
394,770 \\
383,650\end{array}$ & $\begin{array}{r}(3,996) \\
(3,432) \\
(1,087) \\
(459)\end{array}$ & $\begin{array}{l}2,303,330 \\
2,283,210 \\
2,076,220 \\
1,991,950\end{array}$ & $\begin{array}{l}(22,368) \\
(20,628) \\
(32,751) \\
(21,814)\end{array}$ & $\begin{array}{l}957,360 \\
883,180 \\
737,020 \\
730,570\end{array}$ & $\begin{array}{l}(9,561) \\
(6,616) \\
(1,891) \\
(4,721)\end{array}$ & $\begin{array}{l}696,910 \\
527,040 \\
516,310 \\
565,340\end{array}$ & $\begin{array}{l}(6,677) \\
(3,512) \\
(4,366) \\
(2,990)\end{array}$ & $\begin{array}{l}649,050 \\
872,990 \\
822,890 \\
696,040\end{array}$ & $\begin{array}{l}(14,200) \\
(18,217) \\
(31,180) \\
(20,419)\end{array}$ & $\begin{array}{l}1,367,120 \\
1,318,850 \\
1,252,050 \\
1,188,270\end{array}$ & $\begin{array}{r}(27,558) \\
(18,235) \\
(8,849) \\
(5,376)\end{array}$ \\
\hline 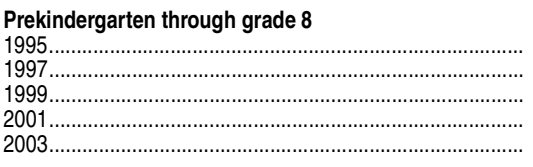 & $\begin{array}{l}4,755,540 \\
4,759,060 \\
4,788,990 \\
5,023,160 \\
4,788,070\end{array}$ & $\begin{array}{l}(28,435) \\
(17,323) \\
(23,055) \\
(36,096) \\
(30,338)\end{array}$ & $\begin{array}{l}2,041,990 \\
2,046,620 \\
2,033,900 \\
2,002,080 \\
1,886,530\end{array}$ & $\begin{array}{r}(5,249) \\
(5,469) \\
(4,830) \\
(10,751) \\
(11,055)\end{array}$ & $\begin{array}{l}1,368,340 \\
1,352,620 \\
1,317,300 \\
1,226,960 \\
1,208,320\end{array}$ & $\begin{array}{l}(2,079) \\
(5,331) \\
(4,421) \\
(4,494) \\
(9,937)\end{array}$ & $\begin{array}{l}575,190 \\
598,380 \\
607,860 \\
687,540 \\
670,910\end{array}$ & $\begin{array}{r}(3,528) \\
(761) \\
(+) \\
(6,96) \\
(4,754)\end{array}$ & $\begin{array}{r}98,460 \\
95,620 \\
108,740 \\
117,580 \\
107,300\end{array}$ & $\begin{array}{r}(1,176) \\
(1,393) \\
(1,943) \\
(2,978) \\
(337)\end{array}$ & $\begin{array}{l}1,752,510 \\
1,744,500 \\
1,818,260 \\
1,926,870 \\
1,835,930\end{array}$ & $\begin{array}{l}(14,834) \\
(12,194) \\
(19,897) \\
(15,459) \\
(16,931)\end{array}$ & $\begin{array}{l}651,050 \\
678,660 \\
713,020 \\
765,080 \\
722,460\end{array}$ & $\begin{array}{l}(7,219) \\
(5,957) \\
(3,748) \\
(5,110) \\
(6,517)\end{array}$ & $\begin{array}{l}574,820 \\
529,050 \\
529,280 \\
535,850 \\
519,310\end{array}$ & $\begin{array}{l}(4,581) \\
(2,504) \\
(3,866) \\
(7,370) \\
(4,134)\end{array}$ & $\begin{array}{l}526,630 \\
536,790 \\
575,970 \\
625,940 \\
594,160\end{array}$ & $\begin{array}{l}(11,121) \\
(10,120) \\
(17,632) \\
(12,240) \\
(13,504)\end{array}$ & $\begin{array}{r}961,040 \\
967,940 \\
936,820 \\
1,064,210 \\
1,065,620\end{array}$ & $\begin{array}{r}(17,471) \\
(11,050) \\
(7,302) \\
(24,703) \\
(15,379)\end{array}$ \\
\hline 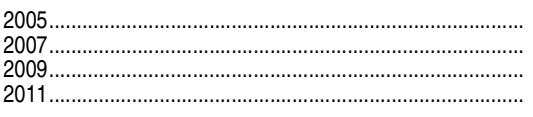 & $\begin{array}{l}4,724,310 \\
4,545,910 \\
4,179,060 \\
3,976,960\end{array}$ & $\begin{array}{l}(33,034) \\
(21,853) \\
(33,168) \\
(18,241)\end{array}$ & $\begin{array}{l}1,779,830 \\
1,685,220 \\
1,541,830 \\
1,481,620\end{array}$ & $\begin{array}{l}(9,318) \\
(5,288) \\
(3,250) \\
(3,867)\end{array}$ & $\begin{array}{l}993,390 \\
878,830 \\
782,050 \\
737,090\end{array}$ & $\begin{array}{l}(6,355) \\
(4,562) \\
(3,085) \\
(3,675)\end{array}$ & $\begin{array}{l}673,110 \\
688,260 \\
642,720 \\
630,970\end{array}$ & $\begin{array}{r}(6,286) \\
(1,640) \\
(846) \\
(321)\end{array}$ & $\begin{array}{l}113,330 \\
118,130 \\
117,050 \\
113,560\end{array}$ & $\begin{array}{r}(2,896) \\
(3,104) \\
(578) \\
(459)\end{array}$ & $\begin{array}{l}1,865,430 \\
1,833,540 \\
1,665,680 \\
1,583,610\end{array}$ & $\begin{array}{l}(19,380) \\
(18,364) \\
(30,216) \\
(16,558)\end{array}$ & $\begin{array}{l}764,920 \\
698,930 \\
579,190 \\
568,150\end{array}$ & $\begin{array}{l}(8,028) \\
(5,885) \\
(1,685) \\
(3,607)\end{array}$ & $\begin{array}{l}561,320 \\
417,610 \\
401,430 \\
443,780\end{array}$ & $\begin{array}{l}(5,730) \\
(3,218) \\
(3,952) \\
(2,604)\end{array}$ & $\begin{array}{l}539,190 \\
717,000 \\
685,050 \\
571,690\end{array}$ & $\begin{array}{l}(12,633) \\
(16,573) \\
(28,928) \\
(15,197)\end{array}$ & $\begin{array}{r}1,079,050 \\
1,027,150 \\
971,550 \\
911,730\end{array}$ & $\begin{array}{r}(15,497) \\
(11,379) \\
(8,113) \\
(3,469)\end{array}$ \\
\hline 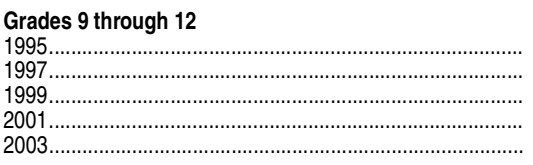 & $\begin{array}{l}1,162,500 \\
1,185,260 \\
1,229,290 \\
1,296,480 \\
1,311,150\end{array}$ & $\begin{array}{r}(4,625) \\
(2,374) \\
(8,260) \\
(6,669) \\
(24,733)\end{array}$ & $\begin{array}{l}618,460 \\
619,010 \\
626,520 \\
640,570 \\
633,590\end{array}$ & $\begin{array}{r}(2,786) \\
(96) \\
(70) \\
(2,317) \\
(3,888)\end{array}$ & $\begin{array}{l}90,650 \\
86,240 \\
80,270 \\
82,930 \\
74,930\end{array}$ & $\begin{array}{r}(+) \\
(+) \\
(+) \\
(2,293) \\
(+)\end{array}$ & $\begin{array}{l}275,370 \\
275,400 \\
272,790 \\
291,520 \\
292,230\end{array}$ & $\begin{array}{r}(2,786) \\
(\dagger) \\
(\dagger) \\
(\dagger) \\
(\dagger)\end{array}$ & $\begin{array}{l}252,440 \\
257,370 \\
273,460 \\
266,130 \\
266,430\end{array}$ & $\begin{array}{r}(\dagger) \\
(96) \\
(70) \\
(338) \\
(3,888)\end{array}$ & $\begin{array}{l}342,180 \\
352,690 \\
375,100 \\
401,290 \\
392,310\end{array}$ & $\begin{array}{l}(3,174) \\
(2,261) \\
(7,920) \\
(3,527) \\
(4,195)\end{array}$ & $\begin{array}{l}135,610 \\
144,950 \\
158,040 \\
172,340 \\
167,250\end{array}$ & $\begin{array}{l}(2,338) \\
(1,660) \\
(1,640) \\
(2,633) \\
(3,144)\end{array}$ & $\begin{array}{l}122,460 \\
117,450 \\
117,000 \\
127,340 \\
131,220\end{array}$ & $\begin{array}{r}(645) \\
(848) \\
(1,237) \\
(1,625) \\
(1,924)\end{array} \mid$ & $\begin{array}{r}84,120 \\
90,290 \\
100,060 \\
101,600 \\
93,840\end{array}$ & $\begin{array}{l}(1,720) \\
(1,221) \\
(7,461) \\
(1,852) \\
(2,031)\end{array}$ & $\begin{array}{l}201,860 \\
213,560 \\
227,670 \\
254,620 \\
285,250\end{array}$ & $\begin{array}{r}(1,495) \\
(1,860) \\
(2,208) \\
(4,465) \\
(23,952)\end{array}$ \\
\hline 2005 2007 2009 & $\begin{array}{l}1,348,930 \\
1,364,300 \\
1,309,430 \\
1,291,130\end{array}$ & $\begin{array}{r}(18,073) \\
(11,958) \\
(6,480) \\
(15,396) \\
\end{array}$ & $\begin{array}{l}622,970 \\
622,930 \\
618,390 \\
606,250\end{array}$ & $\begin{array}{r}(1,538) \\
(1,377) \\
(4,409) \\
(14,313) \\
\end{array}$ & $\begin{array}{l}69,560 \\
67,030 \\
74,380 \\
67,320\end{array}$ & $\begin{array}{r}(\dagger) \\
(1,201) \\
(42) \\
(10)\end{array}$ & $\begin{array}{l}283,510 \\
281,680 \\
266,290 \\
268,840 \\
\end{array}$ & $\begin{array}{r}(700) \\
(566) \\
(4,311) \\
(14,313) \\
\end{array}$ & $\begin{array}{l}269,900 \\
274,210 \\
277,720 \\
270,090 \\
\end{array}$ & $\begin{array}{r}(1,341) \\
(364) \\
(920) \\
(\dagger) \\
\end{array}$ & $\begin{array}{l}437,900 \\
449,680 \\
410,540 \\
408,330 \\
\end{array}$ & $\begin{array}{l}(6,541) \\
(3,796) \\
(4,285) \\
(5,747) \\
\end{array}$ & \begin{tabular}{|l|}
192,440 \\
184,260 \\
157,830 \\
162,420 \\
\end{tabular} & $\begin{array}{r}(3,404) \\
(1,768) \\
(362) \\
(1,349)\end{array}$ & \begin{tabular}{|l|}
135,590 \\
109,430 \\
114,880 \\
121,560 \\
\end{tabular} & $\begin{array}{r}(1,493) \\
(374) \\
(1,074) \\
(513)\end{array}$ & \begin{tabular}{|l|}
109,860 \\
156,000 \\
137,840 \\
124,350 \\
\end{tabular} & $\begin{array}{l}(5,190) \\
(3,052) \\
(4,111) \\
(5,792)\end{array}$ & $\begin{array}{l}288,070 \\
291,700 \\
280,500 \\
276,550 \\
\end{array}$ & $\begin{array}{r}(16,551) \\
(11,156) \\
(1,880) \\
(3,485) \\
\end{array}$ \\
\hline & & & & & & & & & Perce & centage d & listribution & & & & & & & & & \\
\hline $\begin{array}{l}\text { Total, all grades } \\
1995 \ldots \ldots \\
1997 \ldots \ldots \\
1999 \ldots \ldots \\
2001 \ldots\end{array}$ & $\begin{array}{l}100.0 \\
100.0 \\
100.0 \\
100.0 \\
100.0\end{array}$ & $\begin{array}{l}(+) \\
(+) \\
(\dagger) \\
(\dagger) \\
(\dagger)\end{array}$ & $\begin{array}{l}45.0 \\
44.8 \\
44.2 \\
42.3 \\
41.3\end{array}$ & $\begin{array}{l}(0.19) \\
(0.13) \\
(0.24) \\
(0.25) \\
(0.27)\end{array}$ & $\begin{array}{l}24.7 \\
24.2 \\
23.2 \\
20.7 \\
19.4\end{array}$ & $\begin{array}{l}(0.13) \\
(0.09) \\
(0.14) \\
(0.14) \\
(0.17)\end{array}$ & $\begin{array}{l}14.4 \\
14.7 \\
14.6 \\
15.5 \\
15.8\end{array}$ & $\begin{array}{l}(0.08) \\
(0.05) \\
(0.07) \\
(0.12) \\
(0.14)\end{array}$ & $\begin{array}{l}5.9 \\
5.9 \\
6.4 \\
6.1 \\
6.1\end{array}$ & $\begin{array}{l}(0.03) \\
(0.03) \\
(0.04) \\
(0.04) \\
(0.07)\end{array}$ & $\begin{array}{l}35.4 \\
35.3 \\
36.4 \\
36.8 \\
36.5\end{array}$ & $\begin{array}{l}(0.19) \\
(0.18) \\
(0.28) \\
(0.22) \\
(0.25)\end{array}$ & $\begin{array}{l}13.3 \\
13.9 \\
14.5 \\
14.8 \\
14.6\end{array}$ & $\begin{array}{l}(0.12) \\
(0.12) \\
(0.09) \\
(0.13) \\
(0.13)\end{array}$ & $\begin{array}{l}11.8 \\
10.9 \\
10.7 \\
10.5 \\
10.7\end{array}$ & $\begin{array}{l}(0.08) \\
(0.06) \\
(0.08) \\
(0.13) \\
(0.10)\end{array}$ & $\begin{array}{l}10.3 \\
10.5 \\
11.2 \\
11.5 \\
11.3\end{array}$ & $\begin{array}{l}(0.18) \\
(0.17) \\
(0.36) \\
(0.18) \\
(0.22)\end{array}$ & $\begin{array}{l}19.7 \\
19.9 \\
19.3 \\
20.9 \\
22.1\end{array}$ & $\begin{array}{l}(0.23) \\
(0.17) \\
(0.11) \\
(0.33) \\
(0.36)\end{array}$ \\
\hline 2005 & $\begin{array}{l}100.0 \\
100.0 \\
100.0 \\
100.0\end{array}$ & $\begin{array}{l}(\dagger) \\
(\dagger) \\
(\dagger) \\
(\dagger)\end{array}$ & $\begin{array}{l}39.6 \\
39.1 \\
39.4 \\
39.6\end{array}$ & $\begin{array}{l}(0.26) \\
(0.20) \\
(0.25) \\
(0.25)\end{array}$ & $\begin{array}{l}17.5 \\
16.0 \\
15.6 \\
15.3\end{array}$ & $\begin{array}{l}(0.13) \\
(0.11) \\
(0.11) \\
(0.09)\end{array}$ & $\begin{array}{l}15.8 \\
16.4 \\
16.6 \\
17.1\end{array}$ & $\begin{array}{l}(0.14) \\
(0.09) \\
(0.13) \\
(0.25)\end{array}$ & $\begin{array}{l}6.3 \\
6.6 \\
7.2 \\
7.3\end{array}$ & $\begin{array}{l}(0.07) \\
(0.06) \\
(0.05) \\
(0.04)\end{array}$ & $\begin{array}{l}37.9 \\
38.6 \\
37.8 \\
37.8\end{array}$ & $\begin{array}{l}(0.25) \\
(0.25) \\
(0.37) \\
(0.28)\end{array}$ & $\begin{array}{l}15.8 \\
14.9 \\
13.4 \\
13.9\end{array}$ & $\begin{array}{l}(0.14) \\
(0.12) \\
(0.09) \\
(0.09)\end{array}$ & $\begin{array}{r}11.5 \\
8.9 \\
9.4 \\
10.7\end{array}$ & $\begin{array}{l}(0.09) \\
(0.06) \\
(0.07) \\
(0.08)\end{array}$ & 10.7 & $\begin{array}{l}(0.20) \\
(0.26) \\
(0.48) \\
(0.34)\end{array}$ & $\begin{array}{l}22.5 \\
22.3 \\
22.8 \\
22.6\end{array}$ & $\begin{array}{l}(0.34) \\
(0.25) \\
(0.16) \\
(0.15)\end{array}$ \\
\hline 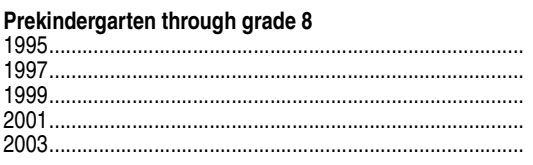 & $\begin{array}{l}100.0 \\
100.0 \\
100.0 \\
100.0 \\
100.0\end{array}$ & $\begin{array}{l}(+) \\
(\dagger) \\
(\dagger) \\
(\dagger) \\
(\dagger)\end{array}$ & $\begin{array}{l}42.9 \\
43.0 \\
42.5 \\
40.5 \\
39.4\end{array}$ & $\begin{array}{l}(0.20) \\
(0.15) \\
(0.23) \\
(0.27) \\
(0.25)\end{array}$ & $\begin{array}{l}28.8 \\
28.4 \\
27.5 \\
24.4 \\
23.1\end{array}$ & $\begin{array}{l}(0.17) \\
(0.12) \\
(0.16) \\
(0.17) \\
(0.18)\end{array} \mid$ & $\begin{array}{l}12.1 \\
12.6 \\
12.7 \\
13.7 \\
14.0\end{array}$ & $\begin{array}{l}(0.06) \\
(0.05) \\
(0.06) \\
(0.14) \\
(0.13)\end{array}$ & $\begin{array}{l}2.1 \\
2.0 \\
2.3 \\
2.3 \\
2.2\end{array}$ & $\begin{array}{l}(0.02) \\
(0.03) \\
(0.04) \\
(0.05) \\
(0.01)\end{array} \mid$ & $\begin{array}{l}36.9 \\
36.7 \\
38.0 \\
38.4 \\
38.3\end{array}$ & $\begin{array}{l}(0.22) \\
(0.20) \\
(0.26) \\
(0.25) \\
(0.23)\end{array}$ & $\begin{array}{l}13.7 \\
14.3 \\
14.9 \\
15.2 \\
15.1\end{array}$ & $\begin{array}{l}(0.13) \\
(0.13) \\
(0.09) \\
(0.15) \\
(0.12)\end{array}$ & $\begin{array}{l}12.1 \\
11.1 \\
11.1 \\
10.7 \\
10.8\end{array}$ & $\begin{array}{l}(0.09) \\
(0.06) \\
(0.07) \\
(0.14) \\
(0.09)\end{array}$ & $\begin{array}{l}11.1 \\
11.3 \\
12.0 \\
12.5 \\
12.4\end{array}$ & $\begin{array}{l}(0.21) \\
(0.19) \\
(0.32) \\
(0.20) \\
(0.24)\end{array}$ & $\begin{array}{l}20.2 \\
20.3 \\
19.6 \\
21.2 \\
22.3\end{array}$ & $\begin{array}{l}(0.28) \\
(0.19) \\
(0.12) \\
(0.37) \\
(0.22)\end{array}$ \\
\hline
\end{tabular}




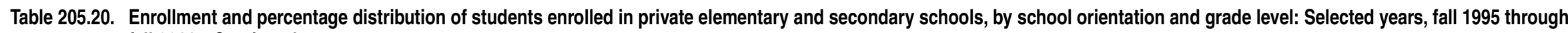
fall 2011-Continued

[Standard errors appear in parentheses]

\begin{tabular}{|c|c|c|c|c|c|c|c|c|c|c|c|c|c|c|c|c|c|c|c|c|}
\hline \multirow[b]{2}{*}{ Grade level and year } & \multirow{2}{*}{\multicolumn{2}{|c|}{$\begin{array}{r}\text { Total private } \\
\text { enrollment }\end{array}$}} & \multicolumn{8}{|c|}{ Catholic } & \multicolumn{8}{|c|}{ Other religious } & \multirow{2}{*}{\multicolumn{2}{|c|}{ Nonsectarian }} \\
\hline & & & & Total & & arochial & & ocesan & (indep & $\begin{array}{l}\text { Private } \\
\text { endent) }\end{array}$ & & Total & Cons & $\begin{array}{l}\text { ervative } \\
\text { hristian }\end{array}$ & & iliated ${ }^{1}$ & & filiated ${ }^{1}$ & & \\
\hline 1 & & 2 & & 3 & & 4 & & 5 & & 6 & & 7 & & 8 & & 9 & & 10 & & 11 \\
\hline 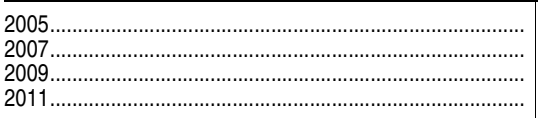 & $\begin{array}{l}100.0 \\
100.0 \\
100.0 \\
100.0\end{array}$ & $\begin{array}{c}(\dagger) \\
(\dagger) \\
(\dagger) \\
(\dagger)\end{array}$ & $\begin{array}{l}37.7 \\
37.1 \\
36.9 \\
37.3\end{array}$ & $\begin{array}{l}(0.25) \\
(0.20) \\
(0.29) \\
(0.18)\end{array}$ & $\begin{array}{l}21.0 \\
19.3 \\
18.7 \\
18.5\end{array}$ & $\begin{array}{l}(0.14) \\
(0.13) \\
(0.15) \\
(0.11)\end{array}$ & $\begin{array}{l}14.2 \\
15.1 \\
15.4 \\
15.9\end{array}$ & $\begin{array}{l}(0.15) \\
(0.09) \\
(0.12) \\
(0.08)\end{array}$ & $\begin{array}{l}2.4 \\
2.6 \\
2.8 \\
2.9\end{array}$ & $\begin{array}{l}(0.06) \\
(0.07) \\
(0.03) \\
(0.02)\end{array}$ & $\begin{array}{l}39.5 \\
40.3 \\
39.9 \\
39.8\end{array}$ & $\begin{array}{l}(0.21) \\
(0.27) \\
(0.43) \\
(0.24)\end{array}$ & $\begin{array}{l}16.2 \\
15.4 \\
13.9 \\
14.3\end{array}$ & $\begin{array}{l}(0.16) \\
(0.14) \\
(0.11) \\
(0.08)\end{array}$ & $\begin{array}{r}11.9 \\
9.2 \\
9.6 \\
11.2\end{array}$ & $\begin{array}{l}(0.09) \\
(0.07) \\
(0.10) \\
(0.08)\end{array}$ & $\begin{array}{l}11.4 \\
15.8 \\
16.4 \\
14.4\end{array}$ & $\begin{array}{l}(0.22) \\
(0.30) \\
(0.57) \\
(0.32)\end{array}$ & $\begin{array}{l}22.8 \\
22.6 \\
23.2 \\
22.9\end{array}$ & $\begin{array}{l}(0.23) \\
(0.21) \\
(0.20) \\
(0.11)\end{array}$ \\
\hline 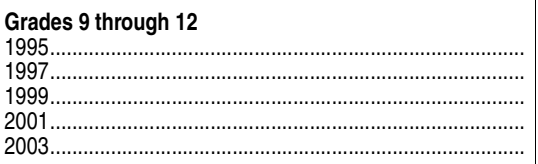 & $\begin{array}{l}100.0 \\
100.0 \\
100.0 \\
100.0 \\
100.0\end{array}$ & $\begin{array}{c}(+) \\
(+) \\
(+) \\
(+) \\
(t)\end{array}$ & $\begin{array}{l}53.2 \\
52.2 \\
51.0 \\
49.4 \\
48.3\end{array}$ & $\begin{array}{l}(0.20) \\
(0.10) \\
(0.34) \\
(0.26) \\
(0.91)\end{array}$ & $\begin{array}{l}7.8 \\
7.3 \\
6.5 \\
6.4 \\
5.7\end{array}$ & $\begin{array}{l}(0.03) \\
(0.01) \\
(0.04) \\
(0.17) \\
(0.11)\end{array}$ & $\begin{array}{l}23.7 \\
23.2 \\
22.2 \\
22.5 \\
22.3\end{array}$ & $\begin{array}{l}(0.20) \\
(0.05) \\
(0.15) \\
(0.12) \\
(0.42)\end{array}$ & $\begin{array}{l}21.7 \\
21.7 \\
22.2 \\
20.5 \\
20.3\end{array}$ & $\begin{array}{l}(0.09) \\
(0.04) \\
(0.15) \\
(0.10) \\
(0.44)\end{array}$ & $\begin{array}{l}29.4 \\
29.8 \\
30.5 \\
31.0 \\
29.9\end{array}$ & $\begin{array}{l}(0.20) \\
(0.16) \\
(0.45) \\
(0.19) \\
(0.59)\end{array}$ & $\begin{array}{l}11.7 \\
12.2 \\
12.9 \\
13.3 \\
12.8\end{array}$ & $\begin{array}{l}(0.18) \\
(0.13) \\
(0.14) \\
(0.17) \\
(0.32)\end{array}$ & $\begin{array}{r}10.5 \\
9.9 \\
9.5 \\
9.8 \\
10.0\end{array}$ & $\begin{array}{l}(0.06) \\
(0.08) \\
(0.11) \\
(0.12) \\
(0.23)\end{array}$ & $\begin{array}{l}7.2 \\
7.6 \\
8.1 \\
7.8 \\
7.2\end{array}$ & $\begin{array}{l}(0.14) \\
(0.10) \\
(0.56) \\
(0.13) \\
(0.20)\end{array}$ & $\begin{array}{l}17.4 \\
18.0 \\
18.5 \\
19.6 \\
21.8\end{array}$ & $\begin{array}{l}(0.12) \\
(0.14) \\
(0.19) \\
(0.28) \\
(1.43)\end{array}$ \\
\hline 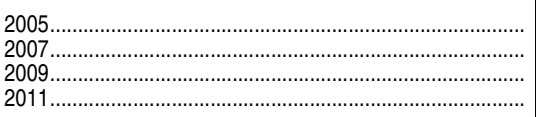 & $\begin{array}{l}100.0 \\
100.0 \\
100.0 \\
100.0\end{array}$ & $\begin{array}{c}(+) \\
(+) \\
(+) \\
(t)\end{array}$ & $\begin{array}{l}46.2 \\
45.7 \\
47.2 \\
47.0\end{array}$ & $\begin{array}{l}(0.60) \\
(0.40) \\
(0.25) \\
(0.63)\end{array}$ & $\begin{array}{l}5.2 \\
4.9 \\
5.7 \\
5.2\end{array}$ & $\begin{array}{l}(0.07) \\
(0.09) \\
(0.03) \\
(0.06)\end{array}$ & $\begin{array}{l}21.0 \\
20.6 \\
20.3 \\
20.8\end{array}$ & $\begin{array}{l}(0.28) \\
(0.18) \\
(0.27) \\
(0.88)\end{array}$ & $\begin{array}{l}20.0 \\
20.1 \\
21.2 \\
20.9\end{array}$ & $\begin{array}{l}(0.27) \\
(0.17) \\
(0.12) \\
(0.25)\end{array}$ & $\begin{array}{l}32.5 \\
33.0 \\
31.4 \\
31.6\end{array}$ & $\begin{array}{l}(0.52) \\
(0.33) \\
(0.25) \\
(0.49)\end{array}$ & $\begin{array}{l}14.3 \\
13.5 \\
12.1 \\
12.6\end{array}$ & $\begin{array}{l}(0.28) \\
(0.16) \\
(0.06) \\
(0.18)\end{array}$ & $\begin{array}{r}10.1 \\
8.0 \\
8.8 \\
9.4\end{array}$ & $\begin{array}{l}(0.16) \\
(0.07) \\
(0.08) \\
(0.13)\end{array}$ & $\begin{array}{r}8.1 \\
11.4 \\
10.5 \\
9.6\end{array}$ & $\begin{array}{l}(0.37) \\
(0.22) \\
(0.28) \\
(0.43)\end{array}$ & $\begin{array}{l}21.4 \\
21.4 \\
21.4 \\
21.4\end{array}$ & $\begin{array}{l}(0.97) \\
(0.65) \\
(0.15) \\
(0.35)\end{array}$ \\
\hline
\end{tabular}

†Not applicable.

Weclitions of schools with a specific religious orientation other than Catholic or conservative affiliated schools have a religious orientation or purpose but are not classified as Catholic, conservative Chrisan, or affiliated.
NOTE: Includes enrollment in prekindergarten through grade 12 in schools that offer kindergarten or higher grade. Ungraded rounding. 1995-96: through 2011-12. (This table was prepared April 2013.) 
Table 205.30. Percentage distribution of students enrolled in private elementary and secondary schools, by school orientation and selected characteristics: Fall 2009 and fall 2011

[Standard errors appear in parentheses]

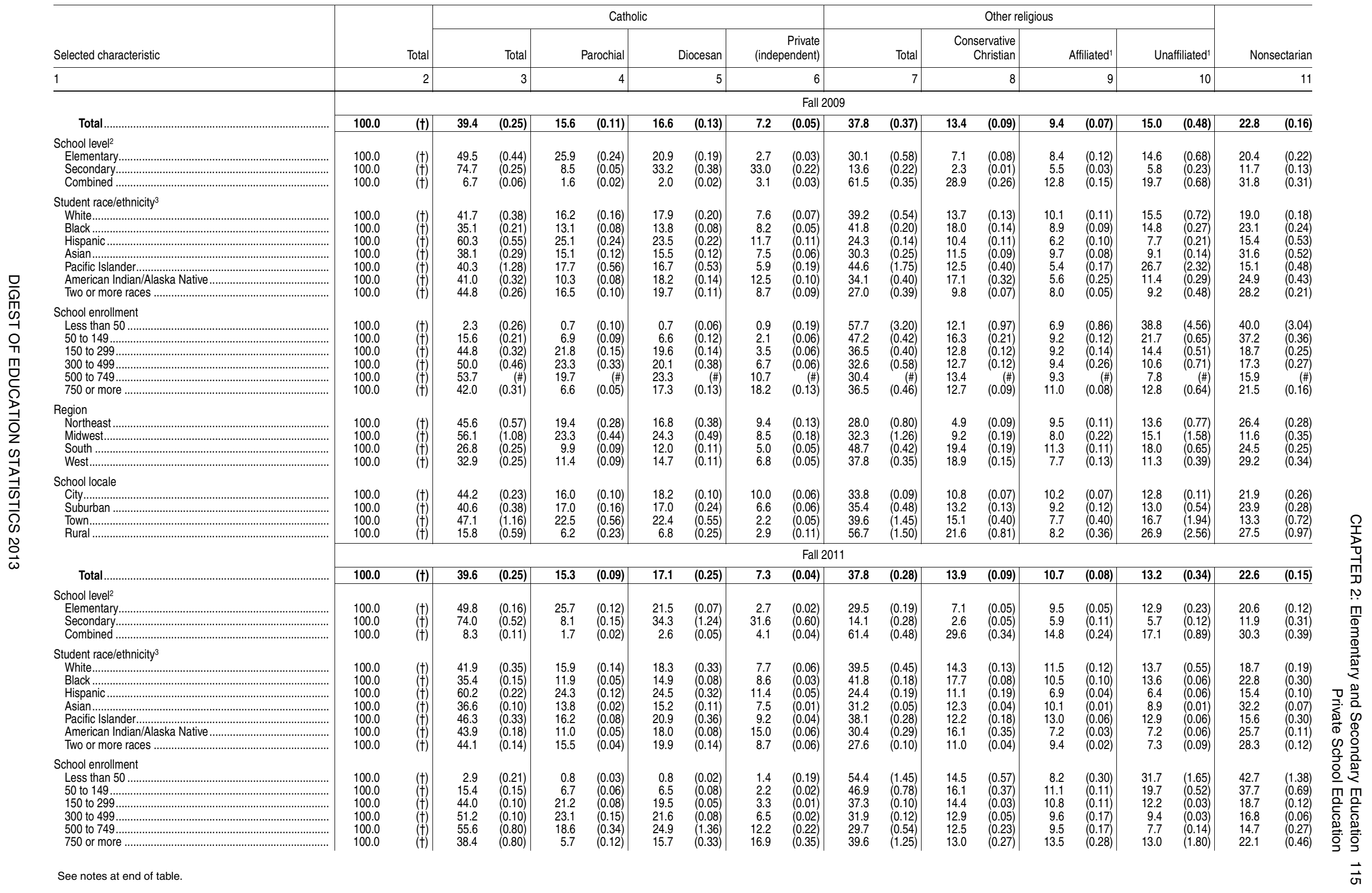




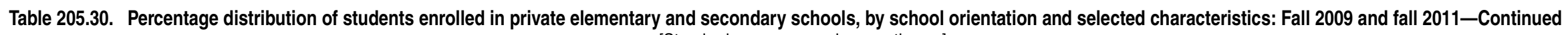
[Standard errors appear in parentheses]

\begin{tabular}{|c|c|c|c|c|c|c|c|c|c|c|c|c|c|c|c|c|c|c|c|c|}
\hline \multirow[b]{2}{*}{ Selected characteristic } & \multirow{2}{*}{\multicolumn{2}{|c|}{ Total }} & \multicolumn{8}{|c|}{ Catholic } & \multicolumn{8}{|c|}{ Other religious } & \multirow{2}{*}{\multicolumn{2}{|c|}{ Nonsectarian }} \\
\hline & & & & Total & & Darochial & & iocesan & (inde) & $\begin{array}{l}\text { Private } \\
\text { endent) }\end{array}$ & & Total & & $\begin{array}{l}\text { ervative } \\
\text { hristian }\end{array}$ & & Iffiliated 1 & & ffiliated ${ }^{1}$ & & \\
\hline 1 & & 2 & & 3 & & 4 & & 5 & & 6 & & 7 & & 8 & & 9 & & 10 & & 11 \\
\hline 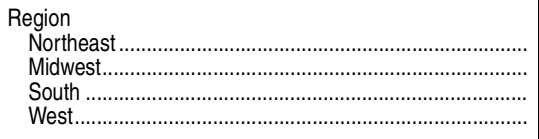 & $\begin{array}{l}100.0 \\
100.0 \\
100.0 \\
100.0\end{array}$ & 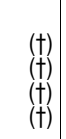 & $\begin{array}{l}43.3 \\
56.8 \\
27.8 \\
34.0\end{array}$ & $\begin{array}{l}(0.66) \\
(0.79) \\
(0.04) \\
(0.01)\end{array}$ & $\begin{array}{r}17.0 \\
24.3 \\
9.8 \\
11.2\end{array}$ & $\left.\begin{array}{l}(0.25) \\
(0.38) \\
(0.011 \\
(0.01)\end{array}\right]$ & $\begin{array}{l}16.5 \\
24.5 \\
12.9 \\
15.8\end{array}$ & $\begin{array}{l}(0.27) \\
(0.94) \\
(0.02) \\
(0.01)\end{array}$ & $\begin{array}{l}9.8 \\
8.0 \\
5.1 \\
7.0\end{array}$ & $\begin{array}{l}(0.14) \\
(0.13) \\
(0.01) \\
(0.00)\end{array}$ & $\begin{array}{l}30.9 \\
31.5 \\
47.9 \\
36.8\end{array}$ & $\begin{array}{l}(0.89) \\
(0.90) \\
(0.07) \\
(0.02)\end{array}$ & $\begin{array}{r}4.7 \\
10.2 \\
20.2 \\
18.8\end{array}$ & $\begin{array}{l}(0.07) \\
(0.32) \\
(0.06) \\
(0.01)\end{array}$ & $\begin{array}{r}11.9 \\
8.9 \\
12.2 \\
9.0\end{array}$ & $\begin{array}{l}(0.30) \\
(0.18) \\
(0.02) \\
(0.01)\end{array}$ & $\begin{array}{r}14.2 \\
12.4 \\
15.5 \\
9.0\end{array}$ & $\begin{array}{l}(1.24) \\
(0.66) \\
(0.02) \\
(0.02)\end{array}$ & $\begin{array}{l}25.8 \\
11.6 \\
24.3 \\
29.2\end{array}$ & $\begin{array}{l}(0.28) \\
(0.43) \\
(0.09) \\
(0.01)\end{array}$ \\
\hline 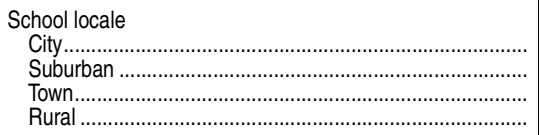 & $\begin{array}{l}100.0 \\
100.0 \\
100.0 \\
100.0\end{array}$ & 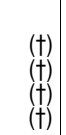 & $\begin{array}{l}44.2 \\
40.9 \\
49.4 \\
16.7\end{array}$ & $\begin{array}{l}(0.37) \\
(0.14) \\
(0.43) \\
(0.47)\end{array}$ & $\begin{array}{r}15.4 \\
16.8 \\
23.9 \\
6.3\end{array}$ & $\begin{array}{l}(0.10) \\
(0.15) \\
(0.21) \\
(0.18)\end{array}$ & $\begin{array}{r}19.3 \\
17.0 \\
23.4 \\
7.2\end{array}$ & $\begin{array}{l}(0.53) \\
(0.06) \\
(0.20) \\
(0.20)\end{array}$ & $\begin{array}{l}9.5 \\
7.2 \\
2.1 \\
3.2\end{array}$ & $\begin{array}{l}(0.06) \\
(0.02) \\
(0.02) \\
(0.09)\end{array}$ & $\begin{array}{l}33.9 \\
35.0 \\
39.3 \\
57.2\end{array}$ & $\begin{array}{l}(0.23) \\
(0.08) \\
(0.53) \\
(1.41)\end{array}$ & $\begin{array}{l}10.4 \\
13.8 \\
16.8 \\
23.4\end{array}$ & $\begin{array}{l}(0.07) \\
(0.05) \\
(0.36) \\
(0.76)\end{array}$ & $\begin{array}{r}11.1 \\
11.1 \\
8.6 \\
9.7\end{array}$ & $\begin{array}{l}(0.10) \\
(0.10) \\
(0.08) \\
(0.28)\end{array}$ & $\begin{array}{l}12.4 \\
10.2 \\
14.0 \\
24.1\end{array}$ & $\begin{array}{l}(0.08) \\
(0.04) \\
(0.67) \\
(2.10)\end{array}$ & $\begin{array}{l}21.9 \\
24.0 \\
11.3 \\
26.2\end{array}$ & $\begin{array}{l}(0.17) \\
(0.15) \\
(0.10) \\
(0.98)\end{array}$ \\
\hline
\end{tabular}

\section{†Not applicable.}

${ }^{1}$ Affiliated schools belong to associations of schools with a specific religious orientation other than Catholic or conservative Christian. Unaffiliated schools have a religious orientation or purpose but are not classified as Catholic, conservative Christian, or affiliated.

3Race//ethnicity was not collected for prekindergarten students (788,370 out of 5,488,490 students in 2009 and 773,240 out of 5,268,090 students in 2011). Percentage distribution is based on the students for whom race/ethnicity was reported.

not sum to totals because of rounding. 2009-10 and 2011-12. (This table was prepared April 2013.) grade level. 
Table 205.40. Number and percentage distribution of private elementary and secondary students, teachers, and schools, by orientation of school and selected characteristics: Fall 1999, fall 2009, and fall 2011

[Standard errors appear in parentheses]

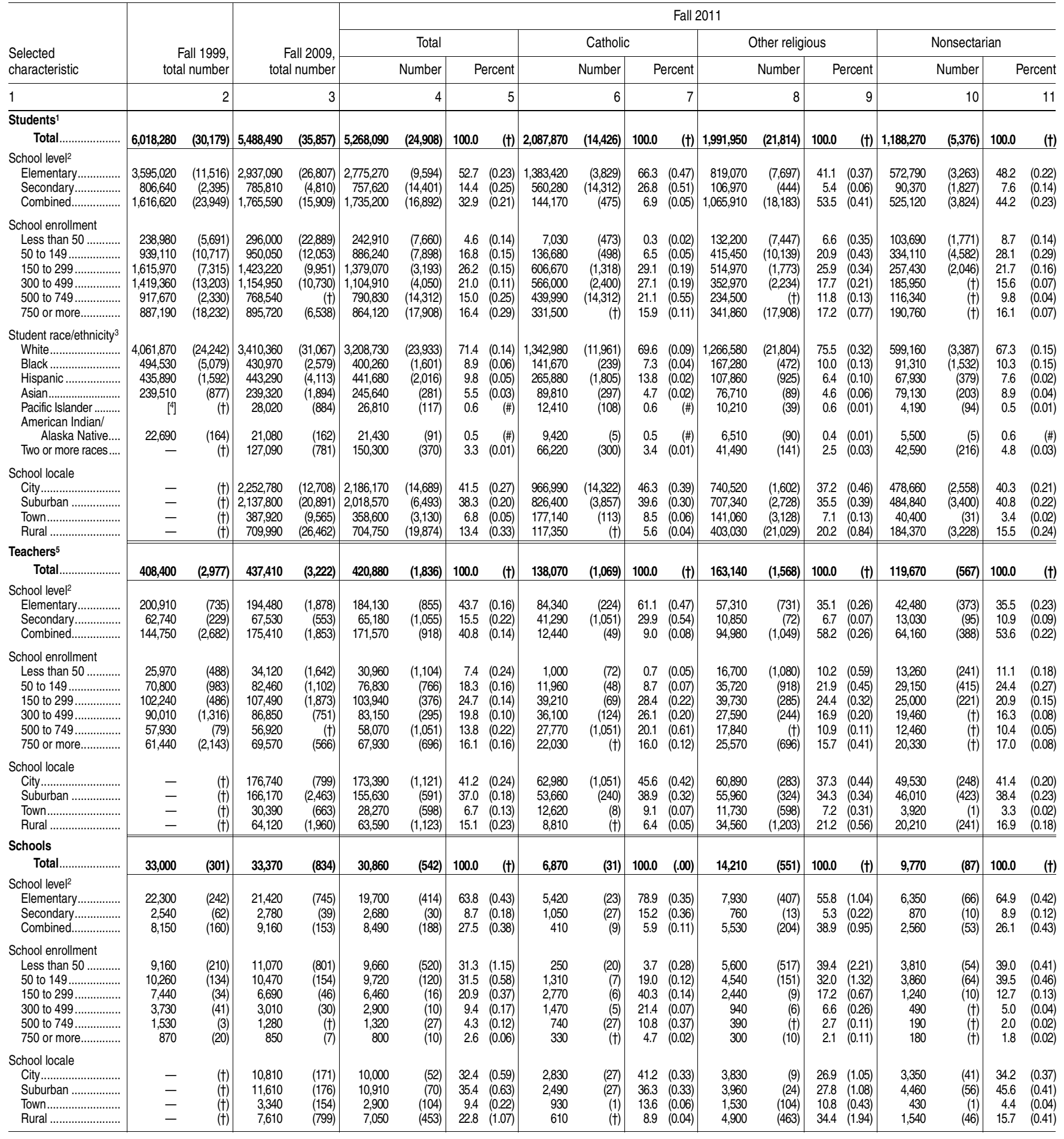

-Not available.

†Not applicable.

Rounds to zero.

'Includes students in prekindergarten through grade 12 in schools that offer kindergarten or higher grade.

${ }^{2}$ Elementary schools have grade 6 or lower and no grade higher than 8 . Secondary schools have no grade lower than 7 . Combined schools include those that have grades lower than 7 and higher than 8 , as well as those that do not classify students by grade level.

${ }^{3}$ Race/ethnicity was not collected for prekindergarten students $(773,000$ in fall 2011). Percentage distribution is based on the students for whom race/ethnicity was reported.
${ }^{4}$ For 1999, Pacific Islander students are included under Asian. Prior to 2009, data were not collected on Pacific Islander students as a separate category.

${ }^{5}$ Reported in full-time equivalents (FTE). Excludes teachers who teach only prekindergarten students.

NOTE: Tabulation includes schools that offer kindergarten or higher grade. Detail may not sum to totals because of rounding.

SOURCE: U.S. Department of Education, National Center for Education Statistics, Private School Universe Survey (PSS), 1999-2000, 2009-10, and 2011-12. (This table was prepared April 2013.) 
Table 205.50. Private elementary and secondary enrollment, number of schools, and average tuition, by school level, orientation, and tuition: Selected years, 1999-2000 through 2011-12

[Standard errors appear in parentheses]

\begin{tabular}{|c|c|c|c|c|c|c|c|c|c|c|c|c|c|c|c|c|c|c|c|c|}
\hline \multirow{2}{*}{$\begin{array}{l}\text { School orientation } \\
\text { and tuition }\end{array}$} & \multicolumn{8}{|c|}{ Kindergarten through 12 th-grade enrollment ${ }^{1}$} & \multirow{2}{*}{\multicolumn{2}{|c|}{ Total schools }} & \multicolumn{8}{|c|}{ Average tuition charged² (in current dollars) } & \multirow{2}{*}{\multicolumn{2}{|c|}{$\begin{array}{l}\text { Average tuition } \\
\text { charged }^{2} \text { (in constant } \\
\text { 2012-13 dollars), total }\end{array}$}} \\
\hline & & Total & & Elementary & & Secondary & & Combined & & & & Total & \multicolumn{2}{|c|}{ Elementary } & \multicolumn{2}{|c|}{ Secondary } & \multicolumn{2}{|r|}{ Combined } & & \\
\hline 1 & & 2 & & 3 & & 4 & & 5 & & 6 & & 7 & & 8 & & 9 & & 10 & & 11 \\
\hline \multicolumn{21}{|l|}{ 1999-2000 } \\
\hline Total... & 262,850 & $(131,001)$ & $2,920,680$ & $(55,057)$ & 818,920 & $(34,102)$ & $1,523,240$ & $(88,816)$ & 27,220 & (239) & $\$ 4,980$ & (157) & $\$ 3,740$ & (249) & $\$ 6,080$ & (175) & $\$ 6,760$ & (261) & $\$ 6,820$ & (215) \\
\hline Catholic.................................................... & $\begin{array}{l}2,548,710 \\
1,871,850\end{array}$ & $\begin{array}{l}(23,352) \\
(86,782)\end{array}$ & $\begin{array}{r}1,810,330 \\
831,060\end{array}$ & $\begin{array}{l}(18,134) \\
(41,035)\end{array}$ & $\begin{array}{l}616,200 \\
115,010\end{array}$ & $\begin{array}{l}(25,935) \\
(10,981)\end{array}$ & $\begin{array}{l}122,190 \\
925,780\end{array}$ & $\begin{array}{l}(15,613) \\
(66,926) \\
\end{array}$ & $\begin{array}{r}8,100 \\
13,270\end{array}$ & $\begin{array}{r}(24) \\
(237) \\
(76)\end{array}$ & $\begin{array}{r}3,340 \\
4,440 \\
11120\end{array}$ & $\begin{array}{r}(57) \\
(153) \\
(735)\end{array}$ & $\begin{array}{r}2,600 \\
4,070 \\
4\end{array}$ & $\begin{array}{r}(47) \\
(130) \\
\end{array}$ & $\begin{array}{r}4,830 \\
6,400\end{array}$ & $\begin{array}{r}(92) \\
(456)\end{array}$ & $\begin{array}{r}6,890 \\
4,520\end{array}$ & $\begin{array}{l}(690) \\
(280) \\
\end{array}$ & $\begin{array}{r}4,570 \\
6,080\end{array}$ & $\begin{array}{r}(78) \\
(210)\end{array}$ \\
\hline Nonsectarii & 842,290 & $(61,373)$ & 279,290 & $(28,987)$ & 87,720 & $(11,774)$ & 475,270 & $(43,377)$ & 5,850 & (76) & 11,120 & (775) & 10,130 & $(1,921)$ & 14,450 & $(1,461)$ & 11,090 & (801) & 15,220 & $(1,061)$ \\
\hline \multicolumn{21}{|l|}{ 2003-04 } \\
\hline Total... & $5,059,450$ & $(104,287)$ & $2,675,960$ & (55,714) & 832,320 & $(54,051)$ & $1,551,170$ & $(82,059)$ & 28,380 & (262) & $\$ 6,600$ & (145) & $\$ 5,050$ & (120) & $\$ 8,410$ & (433) & $\$ 8,300$ & (290) & $\$ 8,220$ & $(180)$ \\
\hline Catholic...................... & $\begin{array}{l}2,320,040 \\
1,746,460 \\
090,940\end{array}$ & $\begin{array}{l}(49,156) \\
(63,090) \\
(1519)\end{array}$ & $\begin{array}{r}1,645,680 \\
714,860\end{array}$ & $\begin{array}{l}(41,231) \\
(28,935) \\
(30,820)\end{array}$ & $\begin{array}{l}584,250 \\
107,980 !\end{array}$ & $\begin{array}{l}(32,236) \\
(33,776) \\
(27556)\end{array}$ & $\begin{array}{r}90,110 \\
923,630\end{array}$ & $\begin{array}{l}(14,746) \\
(48,379) \\
\end{array}$ & $\begin{array}{r}7,920 \\
13,660\end{array}$ & $\begin{array}{r}(35) \\
(203) \\
(36)\end{array}$ & $\begin{array}{r}4,250 \\
5,840\end{array}$ & $\begin{array}{r}(96) \\
(144) \\
(370)\end{array}$ & $\begin{array}{r}3,530 \\
5,400 \\
1\end{array}$ & $\begin{array}{l}(106) \\
(161) \\
\end{array}$ & $\begin{array}{r}6,050 \\
9,540\end{array}$ & $\begin{array}{r}(131) \\
(163) \\
(1088)\end{array}$ & $\begin{array}{r}5,800 \\
5,750\end{array}$ & $\begin{array}{l}(883) \\
(230) \\
(480)\end{array}$ & $\begin{array}{r}5,290 \\
7,270\end{array}$ & $\begin{array}{l}(119) \\
(179)\end{array}$ \\
\hline$\ldots \ldots \ldots \ldots \ldots \ldots \ldots \ldots \ldots$ & & $(71,519)$ & 315,430 & $(30,820)$ & 140,080 & $(27,556)$ & 537,440 & $(59,332)$ & 6,810 & (136) & 13,420 & (379) & 12,170 & (468) & 17,410 & $(1,988)$ & 13,110 & (480) & 16,720 & (472) \\
\hline \multicolumn{21}{|l|}{ 2007-08 } \\
\hline Total... & $5,165,280$ & (104,435) & $2,462,980$ & (58,830) & 850,750 & (38,553) & $1,851,550$ & (91,348) & 28,220 & (328) & $\$ 8,550$ & (176) & $\$ 6,730$ & (181) & $\$ 10,550$ & (356) & $\$ 10,050$ & (372) & $\$ 9,360$ & $\overline{(193)}$ \\
\hline ss than $\$ 3$ & 1,12 & 888) & 750,020 & $(35,402)$ & & (t) & 342,100 & $(35,615)$ & 10.03 & (344) & 2,710 & (61) & 2,900 & (54) & $\ddagger$ & $(\dagger)$ & 2,350 & (134) & 2,9 & (67) \\
\hline & $1,790,410$ & 350) & $1,066,750$ & $(45,444)$ & 143,510 & $(19,815)$ & $5 \varepsilon$ & & 9,1 & (341) & 5,2 & (42) & 5,220 & (49) & 5,080 & $(80)$ & 5,2 & (89) & & (46) \\
\hline & $1,155,290$ & $(60,342)$ & 366,470 & $(37,396)$ & 455,840 & $(33,376)$ & & 4) & 4,46 & (232) & 8,26 & (101) & 9,230 & (287) & 7,660 & (105) & 8,0 & (192) & 9,0 & (110) \\
\hline$\ldots \ldots$ & 503,380 & $(45,776)$ & 169,970 & $(26,731)$ & & $(t)$ & 237,85 & $(37,089)$ & 1,98 & (154) & 13,640 & (319) & 15,730 & (696) & $\ddagger$ & $(t)$ & 12,9 & (318) & 14,930 & (350) \\
\hline$\$ 15,000$ or 1 & 593,900 & $(50,049)$ & 109,770 & $(19,266)$ & 125,660 & $(15,623)$ & 358,470 & $(43,060)$ & 2,65 & (187) & 25,890 & (768) & 25,360 & $(1,940)$ & 28,400 & $(1,327)$ & 25,180 & $(1,061)$ & 28,350 & (840) \\
\hline Catholic... & $2,224,470$ & $(49,385)$ & $1,457,960$ & $(32,114)$ & 620,840 & $(32,581)$ & 145,680 & $(25,445)$ & 7,400 & (34) & 6,020 & (180) & 4,940 & (212) & 7,830 & (232) & 9,070 & (964) & 6,590 & (197) \\
\hline & 619,410 & $(37,867)$ & 571,560 & 3) & & & $\ddagger$ & (†) & & (132) & & (55) & & (57) & $\ddagger$ & (†) & $\ddagger$ & (t) & & $(60)$ \\
\hline & 826,120 & $(37,974)$ & 683,980 & $(32,576)$ & 111,770 & $(16,043)$ & $\ddagger$ & $(+)$ & 3,0 & (131) & 4,9 & (49) & 4,8 & (57) & 5,150 & (80) & $\ddagger$ & $(t)$ & & (53) \\
\hline & 607,980 & $(49,329)$ & 165,120 & $(28,123)$ & 395,900 & $(30,158)$ & $\ddagger$ & $(\dagger)$ & 1,1 & (102) & 7,68 & (116) & 7,790 & (240) & 7,650 & (117) & $\ddagger$ & (t) & 8,410 & (127) \\
\hline$\$ 1$ & & $(t)$ & & $(t)$ & $\ddagger$ & $(t)$ & $\ddagger$ & $(t)$ & $\ddagger$ & $(t)$ & $\ddagger$ & $(t)$ & $\ddagger$ & $(t)$ & $\ddagger$ & $(t)$ & $\ddagger$ & $(t)$ & $\ddagger$ & $(t)$ \\
\hline$\$ 15,000$ & & & $\ddagger$ & & $\ddagger$ & $(t)$ & $\ddagger$ & $(t)$ & $\ddagger$ & $(\dagger)$ & $\ddagger$ & (t) & $\ddagger$ & (t) & $\ddagger$ & (t) & $\ddagger$ & $(t)$ & $\ddagger$ & (†) \\
\hline Other re & $1,975,980$ & $(81,216)$ & 709,730 & $(36,666)$ & 128,550 & $(15,136)$ & $1,137,700$ & $(75,038)$ & 13,950 & (282) & 7,120 & (237) & 6,580 & (241) & 10,490 & $(1,336)$ & 7,070 & (359) & 7,800 & (260) \\
\hline & 430,010 & & 172,660 & $(1$ & & & & & 6,180 & (291) & 2,52 & (106) & 2,550 & (167) & $\ddagger$ & $(t)$ & & & 2,760 & (116) \\
\hline & 860,370 & $(5$ & 340,150 & $(27,800)$ & & & 489,390 & b) & 5,0 & (257) & 5,3 & (75) & 5,570 & (111) & $\ddagger$ & $(t)$ & & (101) & 5,8 & (82) \\
\hline & 384,850 & & 103,280 & $(15,561)$ & 57,150 & $(10,809)$ & 224,420 & $(33,273)$ & 1,640 & (137) & 8,0 & (155) & 8,810 & (430) & 7,680 & (188) & 7,790 & (164) & 8,8 & (170) \\
\hline$\ldots \ldots$ & 167,770 & $(25,960)$ & & $(t)$ & & $(t)$ & $\neq$ & $(t)$ & 620 & (83) & 13,230 & (401) & $\ddagger$ & $(t)$ & $\ddagger$ & $(t)$ & $\ddagger$ & $(t)$ & 14,490 & (439) \\
\hline$\$ 1$ & & $(24,657)$ & & $(+)$ & $\ddagger$ & $(+)$ & $\ddagger$ & $(+)$ & 480 & (91) & 22,88 & $(1,053)$ & $\ddagger$ & $(t)$ & $\ddagger$ & $(t)$ & $\ddagger$ & $(t)$ & 25,050 & $(1,153)$ \\
\hline Nonsec & 964,830 & $(55,074)$ & 295,280 & $(25,191)$ & 101,370 & $(12,739)$ & 568,180 & $(48,321)$ & 6,860 & (119) & 17,320 & (555) & 15,940 & (702) & 27,300 & $(1,506)$ & 16,250 & (795) & 18,960 & (608) \\
\hline & 72,890 & & & & & & 59,910 & $(10,584)$ & 1,030 & (125) & 1,61 & & & & & & 1,640 & (467) & 1,760 & (423) \\
\hline & 103,930 & $(18$, & 42,610 & $(7,8$ & & & & & 1,0 & (143) & 6,2 & 52) & 8,090 & (687) & & & & $(t)$ & 6,890 & (386) \\
\hline & 162,450 & $(2$ & 98,070 & $(16,434)$ & & & & & 1,650 & (168) & 10,9 & (530) & 12,110 & (792) & & & & $(t)$ & 12,000 & (581) \\
\hline$\$ 1$ & 208,670 & $(29$, & 77,450 & $(15,7$ & & & 126,610 & $(25,784)$ & 1,150 & (124) & 14,8 & (567) & 17,750 & $(1,501)$ & & $(\dagger)$ & 30 & (336) & 16,300 & (621) \\
\hline$\$ 15,0000$ & 416,900 & $(39,779)$ & 71,360 & $(14,776)$ & $85,870^{+}$ & $(13,205)$ & 259,670 & $(38,826)$ & 2,000 & (157) & 26,500 & (943) & 25,010 & $(1,422)$ & 31,220 & $(1,647)$ & 25,350 & $(1,334)$ & 29,010 & $(1,033)$ \\
\hline \multicolumn{21}{|l|}{ 2011-12 } \\
\hline Total. & 4,479,530 & $(105,651)$ & $2,133,810$ & $(59,964)$ & 731,620 & $\begin{array}{ll}(53,646) \\
\end{array}$ & $1,614,100$ & $(98,602)$ & 26,230 & (541) & $\$ 10,740$ & (316) & $\$ 7,770$ & (211) & $\$ 13,030$ & \begin{tabular}{l|l} 
(727) \\
\end{tabular} & $\$ 13,640$ & (753) & $\$ 10,940$ & $\overline{(321)}$ \\
\hline Less than $\$ 3,50$ & 618,710 & $(45,753)$ & 404,700 & $(36,956)$ & $42,580 !$ & $(13,642)$ & 171,430 & $(23,140)$ & 7,950 & (581) & 2,19 & (112) & 2,4 & (139) & 1,370 & (392) & 1,8 & (182) & 2,230 & (114) \\
\hline & $1,351,550$ & $(64,739)$ & 946,810 & $(56,403)$ & & & 364,520 & $(30,056)$ & 7,800 & (326) & 5,300 & (58) & 5,350 & $(6$ & & & 5,2 & (118) & 5,400 & (59) \\
\hline & & $(80,517)$ & 467,040 & $(41,842)$ & 275,980 & $(29,528)$ & 424,800 & $(62,852)$ & 5,070 & (279) & 8,560 & (124) & 9,090 & $(23$ & $7,980^{+}$ & (172) & 8,3 & (251) & 8,720 & (126) \\
\hline & 534,560 & (4 & 143,500 & $(18,976)$ & 208,750 & $(38,977)$ & 182,31 & $(36,985)$ & 1,840 & (150) & 13,400 & (207) & 15,050 & $(45$ & 11,960 & (225) & 13,750 & (348) & 13,650 & (211) \\
\hline$\$ 15$ & 806880 & & & $(25,2$ & & & 471, & 1653 & & (194) & & & & & & $(2,487)$ & & $(1,274)$ & & \\
\hline Cathol & $1,892,480$ & $(59,899)$ & $1,244,480$ & $(36,762)$ & 511,870 & $(43,761)$ & 136,130 & $(19,283)$ & 6,7 & (39) & & (185) & 5 & & 9,790 & (405) & 10,230 & $(1,230)$ & 7,020 & (188) \\
\hline & 307,610 & $(35,03$ & 259,330 & $(3$ & & & & & 1,7 & & 2,5 & (123) & & (12 & $\ddagger$ & $(t)$ & $\ddagger$ & & & (125) \\
\hline$\$ 3,500$ & 781,420 & $(53,974$ & 716,630 & $(50,260$ & & & $\ddagger$ & $(†)$ & 3,070 & (187) & 5,110 & (68) & 5,120 & (72) & $\ddagger$ & ( & $\ddagger$ & $(+)$ & 5,200 & (69) \\
\hline$\$ 6$ & 516,660 & $(48,76$ & 243,570 & $(35,924)$ & 234,460 & $(29,418)$ & $\ddagger$ & $(+)$ & 1,320 & (126) & 7,850 & (139) & 7,820 & (210) & 7,970 & (199) & $\ddagger$ & $(\dagger)$ & 8,000 & (141) \\
\hline $999 \ldots . .$. & 221,150 & $(36,032)$ & & $(t)$ & 177,560 & $(34,919)$ & $\ddagger$ & $(t)$ & 440 & (68) & 12,290 & (240) & + & $(t)$ & 12,020 & (252) & $I_{t}$ & & 12,520 & (245) \\
\hline$\$ 15,000$ or more ......................... & & & & $(\mathrm{t})$ & t & $\left(t^{\prime}\right)$ & & $(\mathrm{t})$ & & $(t) \mid$ & $\ddagger$ & (t) & & $(\mathrm{t})$ & $\ddagger$ & $(\mathrm{t})$ & $\ddagger$ & $(t)$ & $\ddagger$ & (t) \\
\hline
\end{tabular}

See notes at end of table. 


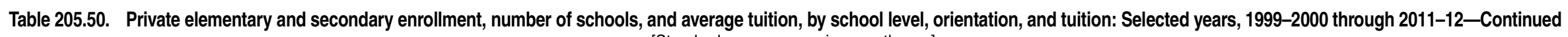
[Standard errors appear in parentheses]

\begin{tabular}{|c|c|c|c|c|c|c|c|c|c|c|c|c|c|c|c|c|c|c|c|c|}
\hline \multirow{2}{*}{$\begin{array}{l}\text { School orientation } \\
\text { and tuition }\end{array}$} & \multicolumn{8}{|c|}{ Kindergarten through 12th-grade enrollment ${ }^{1}$} & & & \multicolumn{8}{|c|}{ Average tuition charged² (in current dollars) } & \multirow{2}{*}{\multicolumn{2}{|c|}{$\begin{array}{l}\text { Average tuition } \\
\text { charged (in constant } \\
2012-13 \text { dollars), total }\end{array}$}} \\
\hline & & Total & & Elementary & & Secondary & & Combined & \multicolumn{2}{|c|}{ Total schools } & \multicolumn{4}{|c|}{ Elementary } & \multicolumn{2}{|c|}{ Secondary } & \multicolumn{2}{|r|}{ Combined } & & \\
\hline 1 & & 2 & & 3 & & 4 & & 5 & & 6 & & 7 & & 8 & & 9 & & 10 & & 11 \\
\hline 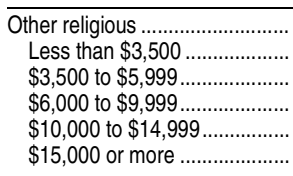 & $\begin{array}{r}1,604,900 \\
243,840 \\
507,660 \\
532,720 \\
165,130 \\
155,550\end{array}$ & $\begin{array}{l}34,424) \\
25,511) \\
38,017) \\
31,948) \\
32,486) \\
33,317)\end{array}$ & $\begin{array}{r}99,930 \\
36,240 \\
4,270 \\
4,110 \\
\neq \\
\ddagger\end{array}$ & $\begin{array}{r}(38,479) \\
(19,015) \\
(23,446) \\
(26,978) \\
(\dagger) \\
(\dagger)\end{array}$ & $\begin{array}{r}116,660 \\
\ddagger \\
\ddagger \\
40,740 \\
\ddagger \\
\ddagger\end{array}$ & $\begin{array}{r}(31,187) \\
(\dagger) \\
(\dagger) \\
(7,928) \\
(\dagger) \\
(\dagger)\end{array}$ & $\begin{array}{r}286,370 \\
347,870 \\
\ddagger \\
\ddagger\end{array}$ & $\begin{array}{r}(77,923) \\
(13,231) \\
(28,337) \\
(59,370) \\
(\dagger) \\
(\dagger)\end{array}$ & $\begin{array}{r}13,040 \\
5,190 \\
4,280 \\
2,220 \\
630 \\
720\end{array}$ & $\begin{array}{r}(259) \\
(228) \\
(89) \\
(126)\end{array}$ & $\begin{array}{r}2,090 \\
5,540 \\
8,460 \\
13,490 \\
25,000\end{array}$ & $\begin{array}{r}(397) \\
(156) \\
(101) \\
(186) \\
(359) \\
(2,243)\end{array}$ & $\begin{array}{r}7,960 \\
1,860 \\
5,980 \\
9,010 \\
\ddagger \\
\ddagger\end{array}$ & \begin{tabular}{r|}
$(447)$ \\
$(245)$ \\
$(183)$ \\
$(269)$ \\
$(\dagger)$ \\
$(\dagger)$
\end{tabular} & $\begin{array}{r}16,520 \\
\ddagger \\
\ddagger \\
8,030 \\
\ddagger \\
\ddagger\end{array}$ & \begin{tabular}{r|}
$2,288)$ \\
$(\dagger)$ \\
$(t)$ \\
$(196)$ \\
$(\dagger)$ \\
$(\dagger)$
\end{tabular} & $\begin{array}{r}8,160 \\
2,440 \\
5,220 \\
8,280 \\
\ddagger \\
\ddagger\end{array}$ & $\begin{array}{r}(518) \\
(169) \\
(123) \\
(260) \\
(\dagger) \\
(\dagger)\end{array}$ & $\begin{array}{r}8,850 \\
2,130 \\
5,640 \\
8,620 \\
13,740 \\
25,460\end{array}$ & $\begin{array}{r}(405) \\
(159) \\
(103) \\
(190) \\
(366) \\
(2,285)\end{array}$ \\
\hline 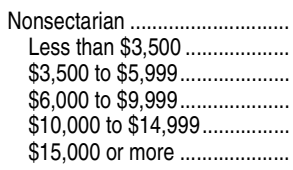 & $\begin{array}{r}982,140 \\
67,260 \\
\ddagger \\
118,440 \\
148,280 \\
585,680\end{array}$ & $\begin{array}{r}(67,032) \\
(15,092) \\
(\dagger) \\
(21,597) \\
(33,642) \\
(66,696)\end{array} \mid$ & $\begin{array}{r}279,400 \\
\ddagger \\
\ddagger \\
79,370 \\
59,130 \\
115,850\end{array}$ & $\begin{array}{r}(21,508) \\
(t) \\
(t) \\
(7,976) \\
(11,788) \\
(20,781)\end{array}$ & $\begin{array}{r}103,090 \\
\neq \\
\ddagger \\
\neq \\
\ddagger \\
74,630\end{array}$ & $\begin{array}{r}(19,049) \\
(\dagger) \\
(\dagger) \\
(\dagger) \\
(\dagger) \\
(16,406)\end{array}$ & $\begin{array}{r}599,650 \\
47,370 ! \\
\ddagger \\
\neq \\
\ddagger \\
395,200\end{array}$ & $\begin{array}{r}(61,512) \\
(14,470) \\
(+) \\
(\dagger) \\
(+) \\
(61,972)\end{array}$ & $\begin{array}{r}6,430 \\
1,040 \\
\ddagger \\
1,530 \\
770 \\
2,640\end{array}$ & $\begin{array}{r}(68) \\
(140) \\
(\dagger) \\
(119) \\
(106) \\
(165)\end{array}$ & $\begin{array}{r}21,510 \\
740 ! \\
\ddagger \\
12,130 \\
14,950 \\
29,160\end{array}$ & $\left.\begin{array}{r}(1,018) \\
(285) \\
(+) \\
(628) \\
(418) \\
(1,092)\end{array}\right]$ & $\begin{aligned} 18,170 \\
\ddagger \\
\ddagger \\
13,140 \\
15,960 \\
25,490\end{aligned}$ & $\begin{array}{r}(906) \\
(\dagger \\
(\dagger) \\
(683) \\
(908) \\
(1,219)\end{array}$ & $\begin{array}{r}25,180 \\
\neq \\
\neq \\
\neq \\
\neq \\
\neq \\
32,120\end{array}$ & $\begin{array}{r}(2,907) \\
(+) \\
(+) \\
(+) \\
(t) \\
(3,206)\end{array}$ & $\begin{array}{r}22,440 \\
490 ! \\
\ddagger \\
\ddagger \\
\ddagger \\
29,670\end{array}$ & $\begin{array}{r}(1,503) \\
(244) \\
(\dagger) \\
(\dagger) \\
(\dagger) \\
(1,368)\end{array}$ & $\begin{array}{c}21,910 \\
750 ! \\
\ddagger \\
12,350 \\
15,230 \\
29,700\end{array}$ & $\begin{array}{r}(1,037) \\
(290) \\
(+) \\
(640) \\
(426) \\
(1,112)\end{array}$ \\
\hline
\end{tabular}

†Not applicable.

. Thterpret data with caution. The coefficient of variation (CV) for this estimate is between 30 and 50 percent. †Reporting standards not met. Either there are too few cases for a reliable estimate or the coefficient of variation (CV) is 50 percent or greater.

列
NOTE: Excludes schools not offering first or higher grade. Elementary schools have grade 6 or lower and no grade higher than 8. Secondary schools have no grade lower than 7 . Combined schools include those that have grades lower than 7 and higher than 8 , as well as those that do not classify students by grade level. Excludes prekindergarten students. Includes a small percentage of schools reporting ditlon of 0 , hese pivate schools are often under contract to public school distics to provide speSOU previously published figures.

vate School Data File," 1999-2000, 2003-04, 2007-08, and 2011-12. (This table was prepared in June 2013.) 


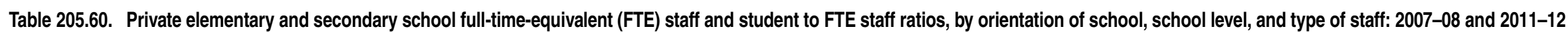

[Standard errors appear in parentheses]

\begin{tabular}{|c|c|c|c|c|c|c|c|c|c|c|c|c|c|c|c|c|c|c|}
\hline \multirow[b]{3}{*}{ Type of staff } & & & \multicolumn{16}{|c|}{ 2011-12 } \\
\hline & \multirow{2}{*}{\multicolumn{2}{|c|}{ Total, 2007-08 }} & \multicolumn{8}{|c|}{ Total } & \multicolumn{8}{|c|}{ Catholic } \\
\hline & & & \multicolumn{4}{|c|}{ Elementary ${ }^{1}$} & \multicolumn{2}{|r|}{ Secondary $^{2}$} & \multicolumn{2}{|r|}{ Combined $^{3}$} & \multicolumn{4}{|c|}{ Elementary ${ }^{1}$} & \multicolumn{2}{|r|}{ Secondary ${ }^{2}$} & \multicolumn{2}{|r|}{ Combined $^{3}$} \\
\hline 1 & & 2 & & 3 & & 4 & & 5 & & 6 & & 7 & & 8 & & 9 & & 10 \\
\hline Number of schools ................. & 28,220 & (328) & 26,230 & (541) & 15,000 & (434) & 2,820 & (153) & 8,400 & (220) & 6,760 & (39) & 5,300 & (24) & 1,040 & (37) & 410 & $\overline{(26)}$ \\
\hline \multirow[t]{2}{*}{ Enrollment (in thousands) .................. } & 5,165 & (104) & 4,480 & (106) & 2,134 & (60) & 732 & (54) & 1,614 & (99) & 1,892 & (60) & 1,244 & (37) & 512 & $(44 \mathrm{M})$ & 136 & (19) \\
\hline & & & \multicolumn{16}{|c|}{ Number of FTE staff } \\
\hline Total FTE staff .. & 786,250 & $(16,261)$ & 733,560 & $(17,373)$ & 296,720 & $(8,627)$ & 118,740 & $(8,321)$ & 318,100 & $(17,125)$ & 224,790 & $(7,201)$ & 138,980 & $(3,830)$ & 62,650 & $(5,069)$ & 23,160 & $(2,739)$ \\
\hline Principals..................... & 30,550 & $(463)$ & 26,290 & (497) & 12,670 & (319) & 3,040 & (159) & 10,580 & (410) & 7,070 & (115) & 5,240 & (83) & 1,250 & (50) & 580 & (66) \\
\hline 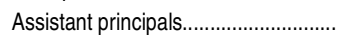 & 13,120 & (487) & 11,280 & (418) & 4,160 & (274) & 2,510 & (253) & 4,610 & (326) & 3,270 & (208) & 1,470 & (147) & 1,460 & (138) & 350 & (68) \\
\hline 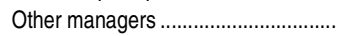 & 26,110 & (952) & 25,950 & (872) & 9,710 & (511) & 5,160 & (479) & 11,070 & (707) & 6,690 & (410) & 3,010 & (252) & 2,710 & (312) & 970 & (142) \\
\hline Instruction coordinators...................... & 7,850 & (538) & 7,630 & (733) & 2,310 & (296) & $1,440 !$ & (443) & 3,880 & (572) & 1,280 & (176) & 550 & (124) & 500 & (107) & 230 & (54) \\
\hline 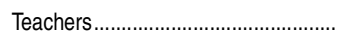 & 436,910 & $(8,665)$ & 413,140 & $(9,516)$ & 174,930 & $(4,690)$ & 64,390 & $(4,936)$ & 173,810 & $(10,001)$ & 130,210 & $(3,981)$ & 82,300 & $(2,281)$ & 36,000 & $(2,853)$ & 11,900 & $(1,567)$ \\
\hline 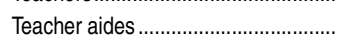 & 53,740 & $(2,591)$ & 52,440 & $(3,563)$ & 25,210 & $(1,664)$ & 2,370 & $(384)$ & 24,860 & $(2,940)$ & 14,260 & $(1,102)$ & 11,350 & (720) & $450 !$ & (136) & $2,460 !$ & $(763)$ \\
\hline Other aides & 11,350 & $(1,251)$ & 11,060 & $(2,290)$ & 3,480 & (374) & $1,250 !$ & (400) & $6,330 !$ & $(2,122)$ & 2,040 & (281) & 1,800 & (260) & $70 !$ & (28) & $\ddagger$ & $(\dagger)$ \\
\hline Guidance counselors......................... & 11,780 & $(506)$ & 11,040 & $(501)$ & 2,140 & (188) & 3,590 & (288) & 5,310 & $(390)$ & 4,220 & (259) & 1,390 & (146) & 2,320 & (209) & 500 & (86) \\
\hline Librarians/media specialists................ & 12,190 & (351) & 11,190 & (393) & 5,230 & (228) & 1,610 & (134) & 4,350 & (319) & 4,300 & (164) & 3,080 & (147) & 900 & (78) & 320 & (51) \\
\hline Library/media center aides................. & 4,150 & (261) & 2,650 & (443) & 1,320 & (246) & $\ddagger$ & $(\dagger)$ & 900 & (152) & 1,210 & (215) & 910 & (220) & 200 & (46) & $100 !$ & (30) \\
\hline Nurses .............................................. & 8,340 & (399) & 7,600 & (372) & 3,010 & (203) & 1,680 & (246) & 2,900 & (279) & 2,890 & (180) & 2,070 & (158) & 600 & (122) & 230 & (51) \\
\hline 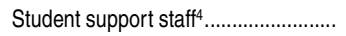 & 24,920 & $(1,236)$ & 23,010 & $(1,629)$ & 5,510 & (482) & 4,190 & (617) & 13,300 & $(1,516)$ & 4,420 & (468) & 2,210 & (230) & 1,350 & (254) & $860 !$ & (298) \\
\hline 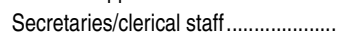 & 50,360 & $(1,441)$ & 42,730 & $(1,382)$ & 15,420 & (586) & 8,210 & (753) & 19,090 & $(1,203)$ & 13,460 & (584) & 7,080 & (208) & 5,160 & (471) & 1,220 & (186) \\
\hline Food service personnel .................... & 28,080 & $(1,019)$ & 25,040 & $(1,196)$ & 9,620 & (549) & 5,220 & (583) & 10,210 & (998) & 10,470 & (625) & 6,530 & (435) & 3,000 & (383) & 940 & (142) \\
\hline Custodial and maintenance................ & 45,660 & $(1,469)$ & 38,300 & $(1,482)$ & 14,450 & (614) & 7,230 & (527) & 16,630 & $(1,369)$ & 12,820 & (576) & 7,410 & (325) & 4,210 & (393) & 1,210 & (185) \\
\hline \multirow[t]{2}{*}{ Other employees ${ }^{5} \ldots \ldots \ldots \ldots \ldots \ldots \ldots \ldots$} & 21,140 & $(2,717)$ & 24,230 & $(3,023)$ & 7,550 & $(1,820)$ & 6,420 & $(1,602)$ & 10,260 & $(1,975)$ & 6,180 & $(1,381)$ & $2,570 !$ & (921) & 2,480 & (735) & $1,120 !$ & (508) \\
\hline & & & \multicolumn{16}{|c|}{ Students per FTE staff member } \\
\hline Total FTE staff .. & 7 & $(0.1)$ & 6 & (0.1) & 7 & $(0.1)$ & 6 & $(0.3)$ & 5 & $(0.2)$ & 8 & (0.1) & 9 & (0.1) & 8 & (0.2) & 6 & $(0.6)$ \\
\hline 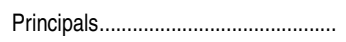 & 169 & (2.9) & 170 & (3.4) & 168 & $(4.1)$ & 241 & (16.1) & 153 & (6.4) & 268 & (7.7) & 237 & (7.2) & 409 & (28.9) & 235 & $(23.1)$ \\
\hline Assistant principals................................. & 394 & (12.3) & 397 & $(14.5)$ & 512 & $(30.9)$ & 292 & (20.2) & 350 & (23.5) & 579 & (28.4) & 847 & (77.4) & 352 & (19.1) & 394 & $(69.0)$ \\
\hline 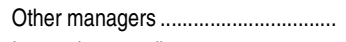 & 198 & $(6.0)$ & 173 & (6.0) & 220 & (11.2) & 142 & (11.0) & 146 & $(9.3)$ & 283 & (14.1) & 413 & (33.4) & 189 & (15.0) & 140 & (21.5) \\
\hline 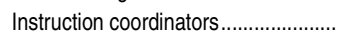 & 658 & $(43.1)$ & 587 & $(54.5)$ & 925 & $(125.5)$ & 507 & (128.0) & 416 & $(64.9)$ & 1,480 & (198.3) & 2,253 & $(653.7)$ & 1,022 & $(226.7)$ & $605 !$ & (223.6) \\
\hline 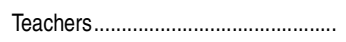 & 12 & $(0.1)$ & 11 & $(0.2)$ & 12 & $(0.2)$ & 11 & $(0.5)$ & 9 & $(0.2)$ & 15 & $(0.2)$ & 15 & $(0.3)$ & 14 & $(0.3)$ & 11 & $(0.5)$ \\
\hline Teacher aides .................................... & 96 & (4.8) & 85 & (5.9) & 85 & (5.0) & 308 & (57.9) & 65 & (8.9) & 133 & (10.6) & 110 & (6.3) & $\ddagger$ & $(\dagger)$ & $\ddagger$ & $(\dagger)$ \\
\hline 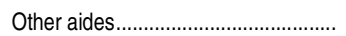 & 455 & (52.2) & 405 & (78.2) & 614 & $(64.7)$ & $\ddagger$ & $(\dagger)$ & $255 !$ & $(80.4)$ & 929 & (144.9) & 692 & (107.9) & $\ddagger$ & $(\dagger)$ & $\ddagger$ & $(\mathrm{t})$ \\
\hline 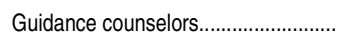 & 439 & $(16.1)$ & 406 & (15.0) & 998 & (84.7) & 204 & (9.3) & 304 & (16.0) & 448 & $(21.0)$ & 894 & $(96.6)$ & 220 & (7.9) & 270 & $(34.6)$ \\
\hline Librarians/media specialists............... & 424 & $(9.5)$ & 400 & (13.0) & 408 & (15.7) & 455 & (35.2) & 371 & (20.6) & 440 & (17.9) & 404 & (22.0) & 571 & (30.4) & 421 & (46.3) \\
\hline Library/media center aides.................. & 1,243 & (75.1) & 1,692 & $(229.0)$ & 1,615 & $(281.5)$ & $1,696 !$ & $(636.7)$ & 1,803 & (329.9) & 1,570 & (259.6) & 1,374 & $(328.5)$ & 2,512 & $(665.0)$ & $1,416 !$ & (510.9) \\
\hline Nurses............................................. & 619 & (26.1) & 590 & (31.8) & 709 & $(41.8)$ & 434 & $(83.1)$ & 556 & (55.8) & 654 & (45.4) & 602 & (39.8) & $860 !$ & (269.8) & 594 & (152.5) \\
\hline Student support staff $\ldots \ldots \ldots \ldots \ldots$ & 207 & $(9.9)$ & 195 & (14.1) & 387 & (32.3) & 174 & (26.7) & 121 & (12.7) & 428 & $(49.0)$ & 562 & (61.8) & 380 & (98.6) & $\ddagger$ & $(\dagger)$ \\
\hline Secretaries/clerical staff..................... & 103 & (2.1) & 105 & (2.6) & 138 & (4.2) & 89 & (4.9) & 85 & (3.5) & 141 & (4.6) & 176 & (5.9) & 99 & (5.2) & 112 & (13.1) \\
\hline 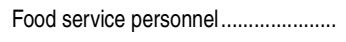 & 184 & (6.2) & 179 & (7.8) & 222 & (12.1) & 140 & (15.9) & 158 & (13.9) & 181 & (9.1) & 191 & (12.0) & 171 & (17.8) & 144 & (26.5) \\
\hline Custodial and maintenance................. & 113 & (2.8) & 117 & (3.8) & 148 & $(5.0)$ & 101 & $(5.4)$ & 97 & (6.2) & 148 & (4.5) & 168 & $(5.8)$ & 122 & (6.2) & 113 & (15.5) \\
\hline 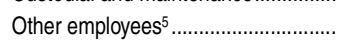 & 244 & $(29.0)$ & 185 & (24.0) & 283 & (62.5) & 114 & (32.0) & 157 & $(37.1)$ & 306 & (71.6) & $\ddagger$ & $(t)$ & $206 !$ & (66.7) & $\ddagger$ & $(t)$ \\
\hline
\end{tabular}

See notes at end of table. 
Table 205.60. Private elementary and secondary school full-time-equivalent (FTE) staff and student to FTE staff ratios, by orientation of school, school level, and type of staff: 2007-08 and 2011-12-Continued

[Standard errors appear in parentheses]

\begin{tabular}{|c|c|c|c|c|c|c|c|c|c|c|c|c|c|c|c|c|}
\hline \multirow[b]{3}{*}{ Type of staff } & \multicolumn{16}{|c|}{ 2011-12 } \\
\hline & \multicolumn{8}{|c|}{ Other religious orientation } & \multicolumn{8}{|c|}{ Nonsectarian } \\
\hline & & Total & & Elementary ${ }^{1}$ & & Secondary ${ }^{2}$ & & Combined $^{3}$ & & Total & & Elementary ${ }^{1}$ & & Secondary ${ }^{2}$ & & Combined $^{3}$ \\
\hline 1 & & 11 & & 12 & & 13 & & 14 & & 15 & & 16 & & 17 & & 18 \\
\hline Number of schools .............. & 13,040 & (550) & 6,860 & (433) & 890 & (146) & 5,290 & (226) & 6,430 & (68) & 2,840 & (48) & 890 & (19) & 2,700 & (65) \\
\hline \multirow[t]{2}{*}{ 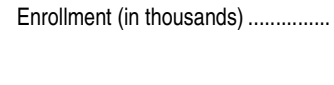 } & 1,605 & $(84)$ & 610 & (38) & 117 & $(31)$ & 878 & (78) & 982 & (67) & 279 & (22) & 103 & (19) & 600 & (62) \\
\hline & \multicolumn{16}{|c|}{ Number of FTE staff } \\
\hline Total FTE staff . & 254,000 & $(11,431)$ & 92,610 & $(6,078)$ & 25,040 & $(6,246)$ & 136,350 & $(10,252)$ & 254,770 & $(14,961)$ & 65,140 & $(3,983)$ & 31,050 & $(4,110)$ & 158,590 & $(13,610)$ \\
\hline Principals........................ & 11,990 & (419) & 4,760 & (291) & 840 & (141) & 6,390 & $(350)$ & 7,230 & (249) & 2,670 & $(106)$ & 950 & (63) & 3,610 & $(215)$ \\
\hline Assistant principals........................... & 4,000 & $(300)$ & 1,320 & (177) & $540 !$ & (228) & 2,140 & (221) & 4,020 & (338) & 1,380 & (165) & 510 & (108) & 2,130 & (278) \\
\hline Other managers .............................. & 8,790 & (592) & 3,230 & (280) & $1,120 !$ & (377) & 4,440 & (375) & 10,470 & (734) & 3,470 & (322) & 1,330 & (238) & 5,670 & (620) \\
\hline Instruction coordinators.................... & 2,790 & (470) & 790 & (135) & $\ddagger$ & $(t)$ & 1,470 & (236) & 3,560 & (529) & 960 & (200) & $410 !$ & (125) & 2,190 & (487) \\
\hline Teachers...................................... & 154,650 & $(6,944)$ & 56,490 & $(3,508)$ & 13,990 & $(3,896)$ & 84,170 & $(6,547)$ & 128,280 & $(8,136)$ & 36,140 & $(2,384)$ & 14,400 & $(2,231)$ & 77,740 & $(7,508)$ \\
\hline Teacher aides ..................................... & 12,200 & $(1,070)$ & 7,250 & $(987)$ & $310 !$ & (132) & 4,630 & (522) & 25,980 & $(3,077)$ & 6,610 & $(809)$ & 1,610 & (354) & 17,760 & $(2,705)$ \\
\hline Other aides...................................... & 2,990 & $(585)$ & 780 & (158) & $320 !$ & (140) & 1,900 & (512) & $6,020 !$ & $(2,194)$ & 900 & (203) & $870 !$ & (384) & $4,260 !$ & $(2,068)$ \\
\hline Guidance counselors....................... & 3,080 & (276) & 370 & (67) & $600 !$ & (183) & 2,120 & (208) & 3,740 & $(370)$ & 380 & (104) & 670 & (112) & 2,690 & $(328)$ \\
\hline Librarians/media specialists .............. & 3,630 & (240) & 1,290 & (134) & 390 & (112) & 1,960 & (199) & 3,260 & (283) & 870 & (98) & 320 & $(63)$ & 2,070 & (252) \\
\hline Library/media center aides............... & $730 !$ & (330) & 240 & (63) & $\ddagger$ & $(\dagger)$ & 320 & (88) & 710 & (146) & $170 !$ & (60) & $\ddagger$ & $(t)$ & 470 & (132) \\
\hline Nurses......................................... & 1,740 & (182) & 530 & (71) & $400 !$ & (121) & 810 & (115) & 2,960 & (310) & 410 & (74) & 690 & (190) & 1,860 & (258) \\
\hline Student support staff ${ }^{4} .$. & 4,050 & (436) & 1,550 & (245) & $810 !$ & (405) & 1,680 & (335) & 14,540 & $(1,529)$ & 1,750 & (342) & 2,030 & (448) & 10,760 & $(1,372)$ \\
\hline Secretaries/clerical staff...... & 16,000 & (966) & 5,510 & (457) & $1,610 !$ & (593) & 8,890 & (730) & 13,270 & $(1,017)$ & 2,830 & (293) & 1,450 & (333) & 8,980 & $(900)$ \\
\hline Food service personnel.................... & 8,290 & (813) & 2,300 & (238) & 1,050 & (264) & 4,940 & (718) & 6,280 & $(886)$ & 790 & (155) & $1,170 !$ & (392) & 4,320 & (756) \\
\hline Custodial and maintenance.............. & 13,150 & (904) & 4,250 & (358) & 1,410 & (323) & 7,480 & (804) & 12,330 & $(1,101)$ & 2,790 & (347) & 1,600 & (348) & 7,930 & (998) \\
\hline \multirow[t]{2}{*}{ Other employees ${ }^{5} \ldots \ldots \ldots \ldots \ldots \ldots$} & 5,910 & $(1,690)$ & $\ddagger$ & $(\mathrm{t})$ & $970 !$ & (450) & 2,990 & (762) & 12,130 & $(2,194)$ & 3,020 & (831) & $2,970 !$ & $(1,293)$ & 6,150 & $(1,810)$ \\
\hline & \multicolumn{16}{|c|}{ Students per FTE staff member } \\
\hline Total FTE staff & 6 & $(0.2)$ & 7 & (0.2) & 5 & $(0.5)$ & 6 & $(0.2)$ & 4 & (0.1) & 4 & (0.2) & 3 & (0.4) & 4 & $(0.2)$ \\
\hline Principals........................................... & 134 & $(5.5)$ & 128 & (6.4) & 140 & $(26.9)$ & 137 & $(8.9)$ & 136 & $(7.6)$ & 105 & (7.9) & 108 & $(21.6)$ & 166 & $(13.0)$ \\
\hline Assistant principals........................... & 402 & (30.3) & 464 & $(58.8)$ & 217 & $(49.8)$ & 410 & $(44.2)$ & 245 & (18.1) & 203 & (23.1) & 202 & (42.8) & 282 & $(30.8)$ \\
\hline Other managers ................................. & 183 & (11.8) & 189 & (16.7) & 104 & (17.1) & 198 & (16.3) & 94 & $(6.1)$ & 80 & $(5.5)$ & 78 & (16.8) & 106 & (11.1) \\
\hline Instruction coordinators............................... & 575 & (88.4) & 769 & $(136.5)$ & $\ddagger$ & $(t)$ & 598 & $(107.7)$ & 276 & $(40.2)$ & 291 & (64.2) & $250 !$ & $(116.8)$ & 274 & $(66.3)$ \\
\hline Teachers ............................................ & 10 & $(0.3)$ & 11 & $(0.3)$ & 8 & (1.1) & 10 & $(0.4)$ & 8 & $(0.2)$ & 8 & $(0.3)$ & 7 & $(0.7)$ & 8 & $(0.3)$ \\
\hline Teacher aides ..................................... & 132 & (12.6) & 84 & $(9.7)$ & $\ddagger$ & $(\dagger)$ & 190 & (23.3) & 38 & (4.8) & 42 & $(5.9)$ & 64 & (16.6) & 34 & (6.1) \\
\hline Other aides...................................... & 536 & $(110.3)$ & 785 & $(171.8)$ & $\ddagger$ & $(t)$ & $462 !$ & (141.0) & $163 !$ & (64.9) & 310 & (82.7) & $\ddagger$ & $(t)$ & $\ddagger$ & $(t)$ \\
\hline Guidance counselors........................ & 520 & (36.9) & 1,653 & $(313.9)$ & 195 & (46.5) & 415 & (24.6) & 263 & $(20.3)$ & 743 & (219.1) & 154 & (22.6) & 223 & (20.8) \\
\hline Librarians/media specialists ............. & 442 & (26.3) & 475 & $(37.3)$ & $301 !$ & (99.7) & 448 & $(39.1)$ & 301 & $(15.9)$ & 322 & $(29.6)$ & 319 & (44.4) & 290 & $(20.1)$ \\
\hline Library/media center aides.............. & 2,196 & $(593.2)$ & 2,512 & (626.7) & $\ddagger$ & $(t)$ & $2,711 !$ & $(866.0)$ & 1,381 & $(257.5)$ & $\ddagger$ & (†) & $\ddagger$ & $(t)$ & 1,262 & (352.2) \\
\hline Nurses ........................................... & 922 & $(107.2)$ & 1,154 & (131.9) & $\ddagger$ & $(t)$ & 1,080 & (160.3) & 331 & $(34.0)$ & 679 & $(160.0)$ & $149 !$ & $(54.5)$ & 322 & $(46.9)$ \\
\hline 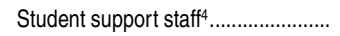 & 396 & $(43.6)$ & 394 & $(51.9)$ & $143 !$ & (65.7) & 521 & (105.2) & 68 & $(7.4)$ & 160 & $(33.7)$ & 51 & (14.7) & 56 & $(7.4)$ \\
\hline Secretaries/clerical staff ................... & 100 & $(4.6)$ & 111 & $(6.7)$ & 73 & (11.9) & 99 & $(6.0)$ & 74 & (3.5) & 99 & (7.3) & 71 & $(11.0)$ & 67 & (4.6) \\
\hline Food service personnel................... & 194 & (17.2) & 265 & (27.7) & $\ddagger$ & $(\dagger)$ & 178 & (21.3) & 156 & (19.4) & 354 & (82.1) & $88 !$ & (32.9) & 139 & (24.1) \\
\hline Custodial and maintenance.............. & 122 & $(6.7)$ & 143 & (10.7) & 82 & (16.4) & 117 & $(9.1)$ & 80 & (4.6) & 100 & $(9.0)$ & 64 & $(11.3)$ & 76 & (6.7) \\
\hline 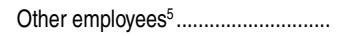 & 271 & (64.9) & $311 !$ & (131.9) & $\ddagger$ & $(\dagger)$ & $294 !$ & $(90.0)$ & 81 & (18.5) & $93 !$ & $(36.7)$ & $\ddagger$ & $(t)$ & $98 !$ & $(45.5)$ \\
\hline
\end{tabular}

†Not applicable.

Therpret data with caution. The coefficient of variation (CV) for this estimate is between 30 and 50 percent.

政

${ }^{2} S$ chools with no grade lower than 7.

Schools with grades lower than 7 and higher than 8 , as well as schools that do not classify students by grade level. pathologists.
5Includes other employees not identified by function.

mated bat stan chn part-time staff; this percentage was estbe strictly comparable with data reported elsewhere. Excludes all prekindergarten students from calculations, but includes kindergarten students attending schools that offer first or higher grade. Includes only schools that offer first or higher grade. Detail may not sum to totals because of rounding. Some data have been revised from previously published figures. SOURCE: U.S. Department of Education, National Center for Education Statistics, Schools and Staffing Survey (SASS), "Pri- 
122 CHAPTER 2: Elementary and Secondary Education

Private School Education

Table 205.70. Enrollment and instructional staff in Catholic elementary and secondary schools, by level: Selected years, 1919-20 through 2012-13

\begin{tabular}{|c|c|c|c|c|c|c|c|c|c|c|}
\hline \multirow[b]{2}{*}{ School year } & \multicolumn{3}{|c|}{ Number of schools } & \multicolumn{4}{|c|}{ Enrollment ${ }^{1}$} & \multicolumn{3}{|c|}{ Instructional staff ${ }^{2}$} \\
\hline & Total & Elementary $^{3}$ & Secondary & Total & $\begin{array}{r}\text { Pre- } \\
\text { kindergarten }\end{array}$ & Elementary & Secondary & Total & Elementary ${ }^{3}$ & Secondary \\
\hline 1 & 2 & 3 & 4 & 5 & 6 & 7 & 8 & 9 & 10 & 11 \\
\hline 1919-20............................... & 8,103 & 6,551 & 1,552 & $1,925,521$ & $\left({ }^{4}\right)$ & $1,795,673$ & 129,848 & 49,516 & 41,592 & 7,924 \\
\hline $1929-30 \ldots \ldots \ldots \ldots \ldots \ldots$ & 10,046 & 7,923 & 2,123 & $2,464,467$ & $(4)$ & $2,222,598$ & 241,869 & 72,552 & 58,245 & 14,307 \\
\hline 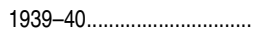 & 10,049 & 7,944 & 2,105 & $2,396,305$ & $\left({ }^{4}\right)$ & $2,035,182$ & 361,123 & 81,057 & 60,081 & 20,976 \\
\hline $1949-50$ & 10,778 & 8,589 & 2,189 & $3,066,387$ & $\left({ }^{4}\right)$ & $2,560,815$ & 505,572 & 94,295 & 66,525 & 27,770 \\
\hline Fall 1960 & 12,893 & 10,501 & 2,392 & $5,253,791$ & $(4)$ & $4,373,422$ & 880,369 & 151,902 & 108,169 & 43,733 \\
\hline 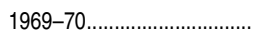 & 11,352 & 9,366 & 1,986 & $4,367,000$ & $(4)$ & $3,359,000$ & $1,008,000$ & $195,400^{5}$ & $133,200^{5}$ & $62,200^{5}$ \\
\hline 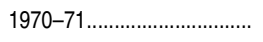 & 11,350 & 9,370 & 1,980 & $4,363,566$ & $(4)$ & $3,355,478$ & $1,008,088$ & 166,208 & 112,750 & 53,458 \\
\hline 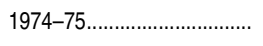 & 10,127 & 8,437 & 1,690 & $3,504,000$ & $(4)$ & $2,602,000$ & 902,000 & 150,179 & 100,011 & 50,168 \\
\hline $1975-76$ & 9,993 & 8,340 & 1,653 & $3,415,000$ & $\left({ }^{4}\right)$ & $2,525,000$ & 890,000 & 149,276 & 99,319 & 49,957 \\
\hline $1979-80 \ldots \ldots \ldots \ldots \ldots \ldots \ldots \ldots$ & 9,640 & 8,100 & 1,540 & $3,139,000$ & $(4)$ & $2,293,000$ & 846,000 & 147,294 & 97,724 & 49,570 \\
\hline $1980-81 \ldots \ldots \ldots \ldots$ & 9,559 & 8,043 & 1,516 & $3,106,000$ & $\left({ }^{4}\right)$ & $2,269,000$ & 837,000 & 145,777 & 96,739 & 49,038 \\
\hline 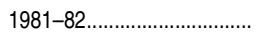 & 9,494 & 7,996 & 1,498 & $3,094,000$ & $(4)$ & $2,266,000$ & 828,000 & 146,172 & 96,847 & 49,325 \\
\hline $1982-83 \ldots \ldots \ldots \ldots \ldots \ldots \ldots \ldots$ & 9,432 & 7,950 & 1,482 & $3,007,189$ & $\left({ }^{4}\right)$ & $2,211,412$ & 795,777 & 146,460 & 97,337 & 49,123 \\
\hline 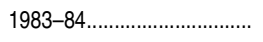 & 9,401 & 7,937 & 1,464 & $2,969,000$ & $(4)$ & $2,179,000$ & 790,000 & 146,913 & 98,591 & 48,322 \\
\hline 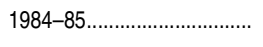 & 9,325 & 7,876 & 1,449 & $2,903,000$ & $(4)$ & $2,119,000$ & 784,000 & 149,888 & 99,820 & 50,068 \\
\hline $1985-86$ & 9,220 & 7,790 & 1,430 & $2,821,000$ & $\left({ }^{4}\right)$ & $2,061,000$ & 760,000 & 146,594 & 96,741 & 49,853 \\
\hline $1986-87 \ldots \ldots \ldots \ldots \ldots \ldots \ldots \ldots$ & 9,102 & 7,693 & 1,409 & $2,726,000$ & $\left({ }^{4}\right)$ & $1,998,000$ & 728,000 & 141,930 & 93,554 & 48,376 \\
\hline 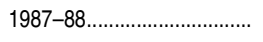 & 8,992 & 7,601 & 1,391 & $2,690,668$ & 67,637 & $1,942,148$ & 680,883 & 139,887 & 93,199 & 46,688 \\
\hline 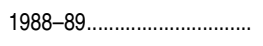 & 8,867 & 7,505 & 1,362 & $2,627,745$ & 76,626 & $1,911,911$ & 639,208 & 137,700 & 93,154 & 44,546 \\
\hline $1989-90 \ldots \ldots \ldots \ldots \ldots \ldots$ & 8,719 & 7,395 & 1,324 & $2,588,893$ & 90,023 & $1,892,913$ & 605,957 & 136,900 & 94,197 & 42,703 \\
\hline $1990-91 \ldots \ldots \ldots \ldots \ldots \ldots \ldots \ldots \ldots$ & 8,587 & 7,291 & 1,296 & $2,575,815$ & 100,376 & $1,883,906$ & 591,533 & 131,198 & 91,039 & 40,159 \\
\hline 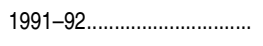 & 8,508 & 7,239 & 1,269 & $2,550,863$ & 107,939 & $1,856,302$ & 586,622 & 153,334 & 109,084 & 44,250 \\
\hline 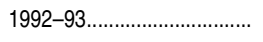 & 8,423 & 7,174 & 1,249 & $2,567,630$ & 122,788 & $1,860,937$ & 583,905 & 154,816 & 109,825 & 44,991 \\
\hline $1993-94 \ldots \ldots \ldots \ldots \ldots \ldots \ldots \ldots \ldots \ldots$ & 8,345 & 7,114 & 1,231 & $2,576,845$ & 132,236 & $1,859,947$ & 584,662 & 157,201 & 112,199 & 45,002 \\
\hline 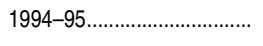 & 8,293 & 7,055 & 1,238 & $2,618,567$ & 143,360 & $1,877,782$ & 597,425 & 164,219 & 117,620 & 46,599 \\
\hline 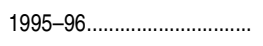 & 8,250 & 7,022 & 1,228 & $2,635,210$ & 144,099 & $1,884,461$ & 606,650 & 166,759 & 118,753 & 48,006 \\
\hline 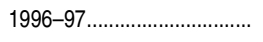 & 8,231 & 7,005 & 1,226 & $2,645,462$ & 148,264 & $1,885,037$ & 612,161 & 153,276 & 107,548 & 45,728 \\
\hline 1997-98................................ & 8,223 & 7,004 & 1,219 & $2,648,859$ & 150,965 & $1,879,737$ & 618,157 & 152,259 & 105,717 & 46,542 \\
\hline $1998-99 \ldots \ldots \ldots \ldots \ldots \ldots$ & 8,217 & 6,990 & 1,227 & $2,648,844$ & 152,356 & $1,876,211$ & 620,277 & 153,081 & 105,943 & 47,138 \\
\hline 1999-2000 ............................... & 8,144 & 6,923 & 1,221 & $2,653,038$ & 152,622 & $1,877,236$ & 623,180 & 157,134 & 109,404 & 47,730 \\
\hline $2000-01 \ldots \ldots \ldots$ & 8,146 & 6,920 & 1,226 & $2,647,301$ & 155,742 & $1,863,682$ & 627,877 & 160,731 & 111,937 & 48,794 \\
\hline $2001-02 \ldots \ldots \ldots \ldots \ldots \ldots \ldots$ & 8,114 & 6,886 & 1,228 & $2,616,330$ & 159,869 & $1,827,319$ & 629,142 & 155,658 & 108,485 & 47,173 \\
\hline 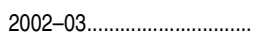 & 8,000 & 6,785 & 1,215 & $2,553,277$ & 157,250 & $1,765,893$ & 630,134 & 163,004 & 112,884 & 50,120 \\
\hline $2003-04 \ldots \ldots \ldots \ldots \ldots \ldots \ldots \ldots \ldots$ & 7,955 & 6,727 & 1,228 & $2,484,252$ & 150,422 & $1,708,501$ & 625,329 & 162,337 & 112,303 & 50,034 \\
\hline 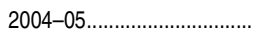 & 7,799 & 6,574 & 1,225 & $2,420,590$ & 150,905 & $1,642,868$ & 626,817 & 160,153 & 107,764 & 52,389 \\
\hline $2005-06 \ldots \ldots \ldots \ldots \ldots \ldots \ldots \ldots \ldots$ & 7,589 & 6,386 & 1,203 & $2,325,220$ & 146,327 & $1,568,687$ & 610,206 & $152,502^{6}$ & $103,481^{6}$ & $49,021^{6}$ \\
\hline $2006-07 \ldots \ldots \ldots \ldots \ldots \ldots \ldots \ldots$ & 7,498 & 6,288 & 1,210 & $2,320,651$ & 152,429 & $1,544,695$ & 623,527 & 159,135 & 107,682 & 51,453 \\
\hline 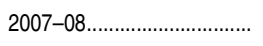 & 7,378 & 6,165 & 1,213 & $2,270,913$ & 152,980 & $1,494,979$ & 622,954 & 160,075 & 107,217 & 52,858 \\
\hline $2008-09$ & 7,248 & 6,028 & 1,220 & $2,192,531$ & 153,325 & $1,434,949$ & 604,257 & 157,615 & 105,518 & 52,097 \\
\hline 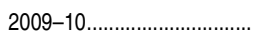 & 7,094 & 5,889 & 1,205 & $2,119,341$ & 150,262 & $1,375,982$ & 593,097 & 154,316 & 103,460 & 50,856 \\
\hline 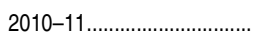 & 6,980 & 5,774 & 1,206 & $2,065,872$ & 152,846 & $1,336,560$ & 576,466 & 151,473 & 102,365 & 49,108 \\
\hline $2011-12 \ldots \ldots \ldots \ldots \ldots \ldots \ldots \ldots \ldots$ & 6,841 & 5,636 & 1,205 & $2,031,455$ & 154,282 & $1,303,028$ & 574,145 & 151,395 & 100,365 & 51,030 \\
\hline $2012-13 \ldots \ldots \ldots$ & 6,685 & 5,472 & 1,213 & $2,001,740$ & 156,233 & $1,278,010$ & 567,497 & 151,405 & 100,633 & 50,772 \\
\hline
\end{tabular}

${ }^{1}$ Elementary enrollment is for kindergarten through grade 8, and secondary enrollment is for grades 9 through 12 .

${ }^{2}$ From 1919-20 through fall 1960, includes part-time teachers. From 1969-70 through 1993-94, excludes part-time teachers. Beginning in 1994-95, reported in full-time equivalents (FTE). Prekindergarten teachers not counted separately but may be included with elementary teachers.

IIncludes middle schools.

${ }^{4}$ Prekindergarten enrollment was not reported separately, but may be included in elementary enrollment.

${ }^{5}$ Includes estimates for the nonreporting schools.
${ }^{6}$ Excludes the Archdiocese of New Orleans.

NOTE: Data collected by the National Catholic Educational Association and data collected by the National Center for Education Statistics are not directly comparable because survey procedures and definitions differ.

SOURCE: National Catholic Educational Association, A Statistical Report on Catholic Elementary and Secondary Schools for the Years 1967-68 to 1969-70; A Report on Catholic Schools, 1970-71 through 1973-74; A Statistical Report on U.S. Catholic Schools, 1974-75 through 1980-81; and United States Catholic Elementary and Secondary Schools, 1981-82 through 2012-13, retrieved May 9, 2013, from http://www.ncea.org/ news/AnnualDataReport.asp. (This table was prepared May 2013.) 
Table 205.80. Private elementary and secondary schools, enrollment, teachers, and high school graduates, by state: Selected years, 2001 through 2011

[Standard errors appear in parentheses]

\begin{tabular}{|c|c|c|c|c|c|c|c|c|c|c|c|c|c|c|c|c|c|c|}
\hline \multirow[b]{2}{*}{ State } & \multirow{2}{*}{\multicolumn{2}{|c|}{ Schools, fall 2011}} & \multicolumn{12}{|c|}{ Enrollment in prekindergarten through grade 12} & \multirow{2}{*}{\multicolumn{2}{|c|}{$\begin{array}{r}\text { Teachers, }{ }^{1} \\
\text { fall } 2011\end{array}$}} & \multirow{2}{*}{\multicolumn{2}{|c|}{$\begin{array}{r}\text { High school } \\
\text { graduates, } \\
2010-11\end{array}$}} \\
\hline & & & & Fall 2001 & & Fall 2003 & & Fall 2005 & & Fall 2007 & & Fall 2009 & & Fall 2011 & & & & \\
\hline 1 & & 2 & & 3 & & 4 & & 5 & & 6 & & 7 & & 8 & & 9 & & 10 \\
\hline United States ....... & 30,860 & (542) & $6,319,650$ & $(40,272)$ & $6,099,220$ & $(41,219)$ & $6,073,240$ & $0(42,446)$ & $5,910,210$ & $(28,363)$ & $5,488,490$ & $(35,857)$ & $5,268,090$ & $(24,908)$ & 420,880 & $(1,836)$ & 305,840 & $(3,479)$ \\
\hline 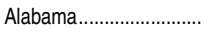 & 400 & (1) & 92,380 & $(3,926)$ & 99,580 & $(12,130)$ & 92,280 & $0 \quad(5,892)$ & 83,840 & (103) & 95,570 & $(11,745)$ & 81,070 & (49) & 6,210 & (1) & 4,720 & $\overline{(\dagger)}$ \\
\hline 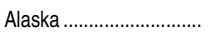 & 50 & $(t)$ & 7,420 & $(\dagger)$ & 7,370 & (424) & 7,500 & $(1,028)$ & 4,990 & $(t)$ & $7,510 !$ & ! $(2,740)$ & 5,170 & $(t)$ & 420 & $(\dagger)$ & 220 & $(\dagger)$ \\
\hline Arizona .......................... & 340 & (5) & 78,660 & $(18,218)$ & 75,360 & $(16,426)$ & 66,840 & $(t)$ & 64,910 & $(\dagger)$ & 55,390 & $(\dagger)$ & 53,120 & (229) & 3,810 & (16) & 2,650 & $(\dagger)$ \\
\hline Arkansas ......... & $230 !$ & (73) & 32,570 & $(\dagger)$ & 31,300 & $(t)$ & 35,390 & $0 \quad(5,858)$ & 40,120 & $(11,961)$ & 28,900 & $(1,371)$ & 29,930 & $(1,245)$ & 2,640 & (337) & 1,490 & $(\dagger)$ \\
\hline California ............................ & 3,480 & (2) & 757,750 & $(8,415)$ & 740,460 & $(8,703)$ & 737,490 & $(15,529)$ & 703,810 & $(6,129)$ & 623,150 & $(4,185)$ & 608,070 & (69) & 44,270 & (12) & 34,380 & (1) \\
\hline 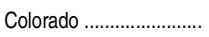 & 410 & (2) & 64,700 & $(\dagger)$ & 62,080 & (476) & 70,770 & $(1,160)$ & 64,740 & (†) & 63,720 & $(3,486)$ & 61,140 & (148) & 4,880 & (4) & 2,890 & (†) \\
\hline 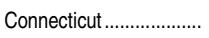 & 410 & (18) & 82,320 & $(t)$ & 102,960 & $(25,024)$ & 76,220 & $(1,619)$ & 85,150 & $(9,241)$ & 72,540 & (464) & 66,320 & (142) & 7,080 & (68) & 5,960 & $(\dagger)$ \\
\hline 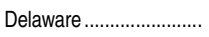 & 120 & $(t)$ & 31,690 & $(1,023)$ & 33,020 & $(2,649)$ & 29,830 & $(t)$ & 32,520 & $(2,701)$ & 26,640 & $(\dagger)$ & 25,090 & $(t)$ & 2,060 & $(\dagger)$ & 1,770 & $(\dagger)$ \\
\hline District of Columbia........ & 80 & $(\dagger)$ & $33,660 !$ & ! $(14,373)$ & 23,510 & $(6,121)$ & 19,880 & $(t)$ & 19,640 & $(\dagger)$ & 17,810 & $(t)$ & 16,950 & $(t)$ & 1,960 & $(\dagger)$ & 1,510 & $(\dagger)$ \\
\hline Florida & 1,880 & (2) & 365,890 & $(8,301)$ & 398,720 & $(14,590)$ & 396,790 & $0 \quad(7,429)$ & 391,660 & $(6,123)$ & 343,990 & $(1,023)$ & 340,960 & (230) & 26,430 & (37) & 20,060 & $(\dagger)$ \\
\hline Georgia . & 710 & $(\dagger)$ & 137,060 & $(4,550)$ & 144,850 & $(6,527)$ & 152,600 & $(10,394)$ & 157,430 & $(9,185)$ & 150,300 & $(6,251)$ & 138,080 & $(t)$ & 13,010 & $(\dagger)$ & 7,760 & $(\dagger)$ \\
\hline Hawaii ........ & 130 & $(\dagger)$ & 42,980 & (220) & 39,940 & $(\dagger)$ & 32,810 & $(\dagger)$ & 37,300 & $(290)$ & 37,130 & $(\dagger)$ & 37,530 & $(t)$ & 3,010 & $(\dagger)$ & 2,760 & $(\dagger)$ \\
\hline Idaho..... & 120 & (4) & 12,050 & $(\dagger)$ & 12,570 & $(t)$ & 15,320 & $0 \quad(2,518)$ & $24,700 !$ & $(11,608)$ & 18,680 & $(4,814)$ & 13,670 & (193) & 990 & (17) & 580 & (4) \\
\hline Illinois ............... & 1,570 & (53) & 357,390 & $(19,293)$ & 316,430 & $(1,698)$ & 317,940 & $(4,263)$ & 312,270 & $(6,638)$ & 289,720 & $(9,237)$ & 271,030 & $(1,289)$ & 19,150 & (221) & 14,500 & (49) \\
\hline Indiana & 970 & (198) & 129,240 & (326) & 124,500 & (455) & 139,370 & $(17,870)$ & 119,910 & $(2,284)$ & 120,770 & $(5,919)$ & 129,120 & $(12,177)$ & 8,900 & (995) & 5,620 & (374) \\
\hline lowa........... & 300 & (51) & 51,540 & $(\dagger)$ & 53,850 & $(4,634)$ & 60,960 & $(8,311)$ & 47,820 & $(\dagger)$ & 45,160 & $(t)$ & 63,840 & $(14,665)$ & 4,700 & $(1,078)$ & $\ddagger$ & $(\dagger)$ \\
\hline Kansas....... & $400 !$ & (193) & 51,540 & $(8,341)$ & 47,710 & $(2,151)$ & 47,130 & $(1,654)$ & 47,780 & $(2,414)$ & 44,680 & $(1,668)$ & 43,100 & $(1,640)$ & 3,530 & (446) & 2,260 & $(\dagger)$ \\
\hline Kentucky ...... & 330 & (1) & 85,230 & $(3,227)$ & 82,100 & $(1,525)$ & 78,880 & o $\quad(1,228)$ & 76,140 & $(2,074)$ & 70,590 & $(2,132)$ & 69,410 & (12) & 5,240 & (1) & 4,130 & $(t)$ \\
\hline Louisiana... & 390 & (2) & 159,910 & $(11,381)$ & 155,780 & $(3,515)$ & 138,270 & (525) & 137,460 & $(t)$ & 147,040 & $(9,890)$ & 125,720 & (108) & 8,830 & (5) & 7,510 & $(t)$ \\
\hline Maine ............. & 160 & $(\dagger)$ & 20,820 & (174) & 24,740 & $(3,629)$ & 20,680 & $(337)$ & 21,260 & (143) & 18,310 & $(\dagger)$ & 18,350 & $(\dagger)$ & 2,000 & $(\dagger)$ & 2,600 & $(\dagger)$ \\
\hline Maryland. & 740 & (8) & 175,740 & $(t)$ & 172,360 & $(t)$ & 170,350 & $0 \quad(4,201)$ & 165,760 & $(1,160)$ & 45,690 & (160) & 137,450 & (564) & 12,430 & (42) & 8,830 & $(\dagger)$ \\
\hline 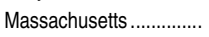 & 800 & (44) & 177,490 & $(9,836)$ & 164,390 & $(6,636)$ & 157,770 & $\quad(3,273)$ & 151,640 & $(2,516)$ & 137,110 & $(1,169)$ & 130,940 & $(1,596)$ & 14,060 & (323) & 10,130 & $(\dagger)$ \\
\hline Michigan........................... & 790 & (7) & 198,380 & $(\dagger)$ & 180,080 & $(t)$ & 166,950 & (407) & 159,100 & $(2,047)$ & 153,230 & $(5,828)$ & 135,580 & (544) & 9,290 & (52) & 7,290 & $(\dagger)$ \\
\hline Minnesota .................... & 500 & $(t)$ & 112,310 & $(2,993)$ & 106,010 & $(3,011)$ & 104,730 & o $\quad(3,467)$ & 101,740 & $(3,903)$ & 89,530 & $(t)$ & 87,620 & $(\dagger)$ & 6,420 & $(\dagger)$ & 4,710 & $(\dagger)$ \\
\hline Mississippi...................... & 220 & $(\dagger)$ & 67,380 & $(10,106)$ & 57,110 & $(2,981)$ & 57,930 & $(4,104)$ & 55,270 & $(\dagger)$ & 54,650 & $(2,458)$ & 52,060 & $(\dagger)$ & 4,120 & $(\dagger)$ & 3,250 & $(\dagger)$ \\
\hline 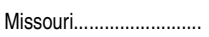 & $1,270 !$ & (468) & 138,140 & $(4,321)$ & 141,530 & $(9,966)$ & 137,810 & $(10,580)$ & 125,610 & $(3,685)$ & 117,970 & $(2,065)$ & 130,130 & $8,715)$ & 10,510 & (951) & 7,530 & (89) \\
\hline 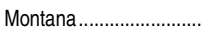 & 110 & $(\dagger)$ & 12,930 & $(1,895)$ & 12,510 & $(2,091)$ & $\ddagger$ & $(t)$ & $15,030 !$ & $(5,465)$ & 10,390 & $(1,221)$ & 10,550 & $(\dagger)$ & 980 & $(\dagger)$ & 430 & $(t)$ \\
\hline 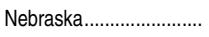 & 220 & $(\dagger)$ & 45,590 & (618) & 41,650 & $(t)$ & 42,420 & $(t)$ & 40,320 & $(t)$ & 39,040 & $(t)$ & 40,750 & $(\dagger)$ & 2,840 & $(\dagger)$ & 2,300 & $(\dagger)$ \\
\hline 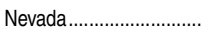 & 160 & $(t)$ & 20,370 & (385) & 23,930 & $(\dagger)$ & 29,120 & $(t)$ & 29,820 & $(2,009)$ & 25,060 & $(t)$ & 26,130 & $(†)$ & 1,590 & $(\dagger)$ & 900 & $(\dagger)$ \\
\hline New Hampshire .............. & 280 & $(\dagger)$ & 38,650 & $(t)$ & 33,780 & $(t)$ & 33,220 & $(t)$ & 30,920 & $(t)$ & 26,470 & $(t)$ & 27,350 & $(†)$ & 2,670 & $(t)$ & 2,520 & $(t)$ \\
\hline 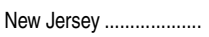 & 1,290 & (18) & 282,450 & $(4,182)$ & 269,530 & $(7,577)$ & 256,160 & $(8,439)$ & 253,250 & $(5,016)$ & 232,020 & $(16,536)$ & 210,220 & $(1,211)$ & 16,850 & (208) & 12,980 & (71) \\
\hline New Mexico........................ & 170 & (1) & 26,510 & $(\dagger)$ & 29,310 & $(3,928)$ & 25,030 & (141) & 27,290 & $(1,388)$ & 23,730 & $(507)$ & 22,680 & (10) & 1,940 & (2) & 1,280 & $(\dagger)$ \\
\hline 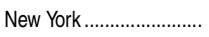 & 1,930 & (31) & 559,670 & $(1,669)$ & 515,620 & $(4,071)$ & 510,750 & $(3,596)$ & 518,850 & $(7,196)$ & 486,310 & $(5,211)$ & 487,810 & $(19,574)$ & 41,450 & (821) & 30,440 & $(1,462)$ \\
\hline North Carolina................. & 640 & $(t)$ & 116,500 & $(4,112)$ & 126,230 & $(11,439)$ & 117,280 & $(11,681)$ & 121,660 & $(2,226)$ & 110,740 & $(1,851)$ & 119,070 & $(\dagger)$ & 10,680 & $(\dagger)$ & 6,310 & $(\dagger)$ \\
\hline North Dakota.................... & 50 & $(\dagger)$ & 7,180 & $(\dagger)$ & 6,840 & $(\dagger)$ & 7,290 & $(t)$ & 7,430 & $(t)$ & 7,750 & $(t)$ & 7,770 & $(\dagger)$ & 590 & $(\dagger)$ & 410 & $(\dagger)$ \\
\hline Ohio .................. & 970 & (59) & 290,370 & $(7,180)$ & 270,660 & $(7,094)$ & 254,530 & o $\quad(9,821)$ & 239,520 & $(2,741)$ & 246,250 & $(24,214)$ & 213,990 & $(3,419)$ & 15,270 & (396) & 12,860 & (124) \\
\hline 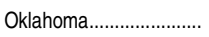 & 180 & (10) & 46,570 & $(8,723)$ & 34,300 & $(2,013)$ & 35,350 & $0 \quad(1,194)$ & 40,320 & $(5,032)$ & 34,000 & (716) & 35,750 & $(847)$ & 3,000 & (72) & 1,760 & (17) \\
\hline Oregon ................ & 430 & $(\dagger)$ & 71,500 & $(15,519)$ & 54,320 & $(\dagger)$ & 69,620 & $(14,139)$ & 66,260 & $(5,188)$ & 56,820 & $(3,502)$ & 53,200 & $(\dagger)$ & 3,820 & $(t)$ & 2,970 & $(\dagger)$ \\
\hline 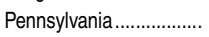 & 2,320 & $(60)$ & 374,490 & $(t)$ & 357,580 & $(3,364)$ & 332,740 & $(3,918)$ & 324,020 & $(6,253)$ & 301,640 & $(5,036)$ & 276,300 & $(3,668)$ & 21,960 & (468) & 16,370 & (90) \\
\hline Rhode Island..................... & 140 & $(\dagger)$ & 30,970 & $(t)$ & 31,960 & $(t)$ & 30,600 & $(\dagger)$ & 28,260 & $(1,096)$ & 24,940 & $(\dagger)$ & 25,420 & (†) & 2,360 & $(\dagger)$ & 2,020 & $(\dagger)$ \\
\hline South Carolina ............... & 380 & $(\dagger)$ & 70,950 & $(\dagger)$ & 73,800 & $(t)$ & 70,240 & $(1,797)$ & 71,430 & $(1,043)$ & 62,320 & (311) & 60,890 & $(†)$ & 5,000 & $(\dagger)$ & 2,960 & $(\dagger)$ \\
\hline South Dakota ................... & 70 & $(†)$ & 11,740 & $(t)$ & 11,980 & $(\dagger)$ & 12,700 & $(t)$ & 12,280 & $(\dagger)$ & 11,470 & $(\dagger)$ & 12,490 & $(†)$ & 970 & $(\dagger)$ & 650 & $(\dagger)$ \\
\hline Tennessee..................... & 510 & (1) & 98,790 & $(t)$ & 93,390 & $(t)$ & 105,240 & $\quad(2,531)$ & 117,540 & $(12,851)$ & 98,310 & $(4,176)$ & 92,430 & (34) & 8,150 & (2) & 5,860 & $(\dagger)$ \\
\hline Texas .................................. & 1,500 & (18) & 314,210 & $(12,244)$ & 271,380 & $(2,758)$ & 304,170 & $(20,453)$ & 296,540 & $(4,132)$ & 313,360 & $(11,968)$ & 285,320 & $(2,046)$ & 23,360 & (101) & 12,840 & (489) \\
\hline Utah & 160 & (2) & 20,040 & $(t)$ & 19,990 & $(t)$ & 21,220 & $(t)$ & 20,860 & $(t)$ & 21,990 & $(1,558)$ & 18,660 & (55) & 1,620 & (6) & 1,210 & (1) \\
\hline Vermont......... & 110 & $(\dagger)$ & 14,090 & $(\dagger)$ & 12,730 & $(\dagger)$ & 11,530 & $(t)$ & 12,600 & (232) & 10,350 & $(\dagger)$ & 9,030 & $(\dagger)$ & 1,200 & $(\dagger)$ & 1,000 & $(\dagger)$ \\
\hline 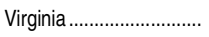 & 750 & (2) & 129,470 & $(t)$ & 131,160 & $(6,936)$ & 155,220 & $(14,290)$ & 143,140 & $(7,988)$ & 128,140 & $(2,581)$ & 123,780 & (82) & 10,980 & (11) & 6,400 & (1) \\
\hline 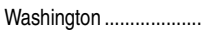 & 630 & (5) & 91,150 & $(2,028)$ & 101,130 & $(7,935)$ & 119,640 & $(13,187)$ & 104,070 & $(3,054)$ & 94,340 & (625) & 93,630 & (234) & 7,130 & (21) & 4,210 & (30) \\
\hline West Virginia ..................... & 120 & (1) & 16,560 & $(t)$ & 15,300 & $(\dagger)$ & 16,120 & $(t)$ & 14,980 & $(\dagger)$ & 13,860 & $(\dagger)$ & 13,430 & (1) & 1,130 & (1) & 660 & (1) \\
\hline Wisconsin & 840 & $(\dagger)$ & 162,220 & $(9,080)$ & 159,240 & $(11,743)$ & 142,280 & (137) & 138,290 & $(1,597)$ & 130,510 & $(t)$ & 127,250 & $(t)$ & 9,150 & $(†)$ & 5,420 & $(\dagger)$ \\
\hline 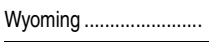 & 40 & $(\mathrm{t})$ & 2,430 & $(\dagger)$ & 2,600 & $(\dagger)$ & 2,310 & $(t)$ & 2,930 & $(t)$ & 2,910 & $(\dagger)$ & 2,740 & $(t)$ & 260 & $(\dagger)$ & 30 & $(\dagger)$ \\
\hline
\end{tabular}

†Not applicable.

!Interpret data with caution. The coefficient of variation (CVV) for this estimate is between 30 and 50 percent.

‡Reporting standards not met. The coefficient of variation (CV) for this estimate is 50 percent or greater.

${ }^{1}$ Reported in full-time equivalents (FTE). Excludes teachers who teach only prekindergarten students.
NOTE: Includes special education, vocational/technical education, and alternative schools Tabulation includes schools that offer kindergarten or higher grade. Includes enrollment of students in prekindergarten through grade 12 in schools that offer kindergarten or higher grade. Detail may not sum to totals because of rounding.

SOURCE: U.S. Department of Education, National Center for Education Statistics, Private School Universe Survey (PSS), 2001-02 through 2011-12. (This table was prepared May 2013.) 
Table 206.10. Number and percentage of homeschooled students ages 5 through 17 with a grade equivalent of kindergarten through 12 th grade, by selected child, parent, and household characteristics: 2003, 2007, and 2012

[Standard errors appear in parentheses]

\begin{tabular}{|c|c|c|c|c|c|c|c|c|c|c|c|c|c|c|c|c|c|c|}
\hline \multirow[b]{2}{*}{ Selected child, parent, or household characteristic } & \multicolumn{6}{|c|}{2003} & \multicolumn{6}{|c|}{2007} & \multicolumn{6}{|c|}{2012} \\
\hline & \multicolumn{2}{|c|}{$\begin{array}{r}\text { Number of students } 1 \\
\text { (in thousands) }\end{array}$} & \multicolumn{2}{|c|}{$\begin{array}{r}\text { Number } \\
\text { homeschooled } 2 \\
\text { (in thousands) }\end{array}$} & \multicolumn{2}{|c|}{$\begin{array}{r}\text { Percent } \\
\text { homeschooled }\end{array}$} & \multicolumn{2}{|c|}{$\begin{array}{r}\text { Number of students }{ }^{1} \\
\text { (in thousands) }\end{array}$} & \multicolumn{2}{|c|}{$\begin{array}{r}\text { Number } \\
\text { homeschooled } \\
\text { (in thousands) }\end{array}$} & \multicolumn{2}{|c|}{$\begin{array}{r}\text { Percent } \\
\text { homeschooled }\end{array}$} & \multicolumn{2}{|c|}{$\begin{array}{r}\text { Number of students }{ }^{1} \\
\text { (in thousands) }\end{array}$} & \multicolumn{2}{|c|}{$\begin{array}{r}\text { Number } \\
\text { homeschooled } \\
\text { (in thousands) }\end{array}$} & \multicolumn{2}{|c|}{$\begin{array}{r}\text { Percent } \\
\text { homeschooled }\end{array}$} \\
\hline 1 & & 2 & & 3 & & 4 & & 5 & & 6 & & 7 & & 8 & & 9 & & 10 \\
\hline Total. & 50,707 & \begin{tabular}{|c|}
$(89.3)$ \\
\end{tabular} & 1,096 & $\begin{array}{l}(92.3) \\
\end{array}$ & 2.2 & $\begin{array}{l}(0.18) \\
\end{array}$ & 51,135 & (155.3) & 1,520 & $\begin{array}{l}(118.0) \\
\end{array}$ & 3.0 & $\begin{array}{l}(0.23) \\
\end{array}$ & 51,657 & \begin{tabular}{|c|}
$(98.7)$ \\
\end{tabular} & $1,773^{3}$ & (115.7) & $3.4^{3}$ & $(0.23)$ \\
\hline $\begin{array}{l}\text { Sex of child } \\
\text { Male } \\
\text { Fale }\end{array}$ & $\begin{array}{l}25,819 \\
24,888\end{array}$ & $\left(\begin{array}{l}286.8 \\
277.7\end{array}\right)$ & $\begin{array}{l}569 \\
527\end{array}$ & $\left.\begin{array}{l}61.9 \\
(58.2)\end{array}\right)$ & $\begin{array}{l}2.2 \\
2.1\end{array}$ & $\begin{array}{l}(0.24) \\
0.23)\end{array}$ & $\begin{array}{l}26,286 \\
24,849\end{array}$ & $\left.\begin{array}{l}(355.6 \\
(386.9)\end{array}\right)$ & $\begin{array}{l}639 \\
881\end{array}$ & $\left(\begin{array}{l}75.1 \\
(97.4)\end{array}\right)$ & $\begin{array}{l}2.4 \\
3.5\end{array}$ & $\left(\begin{array}{l}0.28) \\
0.39)\end{array}\right.$ & $\begin{array}{l}26,620 \\
25,037\end{array}$ & $\left(\begin{array}{l}318.2 \\
(314.0\end{array}\right)$ & $\begin{array}{l}499 \\
583\end{array}$ & $\left.\begin{array}{l}(48.0) \\
63.4\end{array}\right)$ & $\begin{array}{l}1.9 \\
2.3\end{array}$ & $\begin{array}{l}(0.18) \\
0.25)\end{array}$ \\
\hline 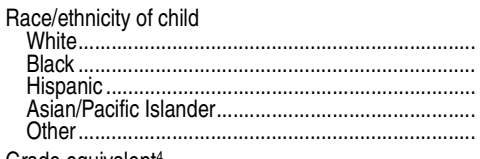 & $\begin{array}{r}31,584 \\
7,985 \\
8,075 \\
1,432 \\
1,631\end{array}$ & $\left.\begin{array}{r}(187.2) \\
(45.7) \\
(35.1) \\
(114.5 \\
127.7)\end{array}\right)$ & $\begin{array}{r}843 \\
\ddagger \\
\ddagger \\
\neq \\
\neq\end{array}$ & $\left.\begin{array}{r}(77.5) \\
+ \\
+ \\
+ \\
+ \\
+\end{array}\right)$ & $\begin{array}{r}2.7 \\
\ddagger \\
\neq \\
\neq \\
\ddagger\end{array}$ & $\left.\begin{array}{r}(0.25) \\
+ \\
+ \\
+ \\
+ \\
+\end{array}\right)$ & $\begin{array}{r}29,815 \\
7,523 \\
9,589 \\
1,580 \\
2,629\end{array}$ & $\left.\begin{array}{r}(197.9) \\
114.0 \\
(84.8 \\
(122.9 \\
141.0)\end{array}\right)$ & $\begin{aligned} 1,171 \\
\ddagger \\
147 \\
\ddagger \\
\ddagger\end{aligned}$ & 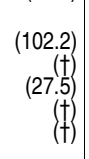 & $\begin{array}{r}3.9 \\
\ddagger \\
1.5 \\
\ddagger \\
\ddagger\end{array}$ & $\left.\begin{array}{r}(0.34) \\
(\dagger \\
(0.29 \\
(\dagger \\
\dagger\end{array}\right)$ & $\begin{array}{r}26,978 \\
7,191 \\
11,814 \\
2,849 \\
2,825\end{array}$ & $\begin{array}{r}(161.7) \\
(45.8) \\
(5.1) \\
(118.4) \\
(120.0)\end{array} \mid$ & $\begin{array}{r}893 \\
\ddagger \\
72 \\
\ddagger \\
\ddagger\end{array}$ & 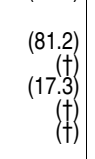 & $\begin{aligned} 3.3 \\
\ddagger \\
0.6 \\
\ddagger \\
\ddagger\end{aligned}$ & $\begin{array}{r}(0.30) \\
(\dagger \\
(0.15 \\
(\dagger \\
(\dagger)\end{array}$ \\
\hline 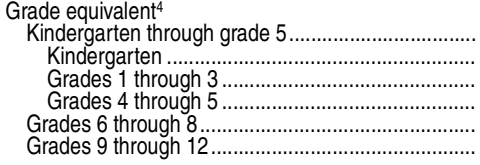 & $\begin{array}{r}24,269 \\
3,643 \\
12,098 \\
8,528 \\
12,472 \\
13,958\end{array}$ & 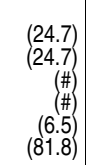 & $\begin{array}{r}472 \\
\ddagger \\
214 \\
160 \\
302 \\
315\end{array}$ & $\left.\begin{array}{l}(55.3) \\
(t) \\
(33.3 \\
30.1 \\
44.9 \\
47.0\end{array}\right)$ & $\begin{array}{l}1.9 \\
\ddagger \\
1.8 \\
1.9 \\
2.4 \\
2.3\end{array}$ & $\left.\begin{array}{r}(0.23) \\
(\dagger \\
(0.28 \\
0.35 \\
0.36 \\
0.33\end{array}\right)$ & $\begin{array}{r}23,529 \\
3,669 \\
11,965 \\
7,895 \\
12,435 \\
15,161\end{array}$ & $\begin{array}{r}(68.1) \\
(67.9 \\
(2.4) \\
2.1 \\
(0.7) \\
(129.3)\end{array}$ & $\begin{array}{r}717 \\
\ddagger \\
406 \\
197 \\
371 \\
422\end{array}$ & $\begin{array}{l}(83.8) \\
(+) \\
(64.5) \\
41.4 \\
65.3) \\
(58.2)\end{array}$ & $\begin{array}{l}3.0 \\
\ddagger \\
+ \\
3.4 \\
2.5 \\
3.0 \\
2.8\end{array}$ & $\begin{array}{l}(0.36) \\
(+) \\
(0.54) \\
0.52 \\
(0.53 \\
(0.38)\end{array}$ & $\begin{array}{r}25,842 \\
5,295 \\
12,101 \\
8,446 \\
12,006 \\
13,808\end{array}$ & $\begin{array}{l}(141.1) \\
136.2 \\
135.0 \\
128.1 \\
139.1 \\
(112.0)\end{array} \mid$ & $\begin{array}{r}423 \\
\ddagger \\
203 \\
142 \\
317 \\
341\end{array}$ & $\left.\begin{array}{l}(61.1) \\
(+1 \\
(45.6 \\
26.1 \\
44.3 \\
42.8\end{array}\right)$ & $\begin{aligned} 1.6 \\
\ddagger \\
1.7 \\
1.7 \\
2.6 \\
2.5\end{aligned}$ & $\begin{array}{l}(0.24) \\
(\dagger \\
(0.38 \\
0.31 \\
0.37 \\
0.31)\end{array}$ \\
\hline 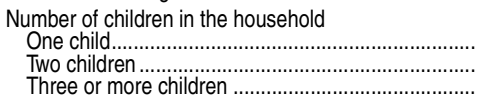 & $\begin{array}{r}8,033 \\
20,530 \\
22,144\end{array}$ & $\left.\begin{array}{l}(218.1) \\
319.4 \\
362.8\end{array}\right)$ & $\begin{array}{l}110 \\
306 \\
679\end{array}$ & $\left(\begin{array}{l}22.3 \\
45.1 \\
(80.2)\end{array}\right)$ & $\begin{array}{l}1.4 \\
1.5 \\
3.1\end{array}$ & $\left.\begin{array}{l}(0.27) \\
0.22 \\
0.36\end{array}\right)$ & $\begin{array}{r}8,463 \\
20,694 \\
21,979\end{array}$ & $\left.\begin{array}{l}(227.1) \\
(295.3 \\
(331.0\end{array}\right)$ & $\begin{array}{l}197 \\
414 \\
909\end{array}$ & $\begin{array}{r}(32.5) \\
(67.2) \\
(102.4)\end{array}$ & $\begin{array}{l}2.3 \\
2.0 \\
4.1\end{array}$ & $\left.\begin{array}{l}(0.38) \\
0.32 \\
(0.46)\end{array}\right)$ & $\begin{array}{l}10,899 \\
20,337 \\
20,421\end{array}$ & $\left.\begin{array}{l}(182.6) \\
251.8 \\
(209.6)\end{array}\right)$ & $\begin{array}{l}179 \\
314 \\
589\end{array}$ & $\left(\begin{array}{l}21.4) \\
44.5 \\
63.5\end{array}\right)$ & $\begin{array}{l}1.6 \\
1.5 \\
2.9\end{array}$ & $\begin{array}{l}(0.19) \\
0.22 \\
(0.30)\end{array}$ \\
\hline 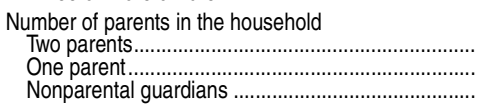 & $\begin{array}{r}35,936 \\
13,260 \\
1,511\end{array}$ & $\left.\begin{array}{l}(315.1) \\
319.2 \\
100.1\end{array}\right)$ & $\begin{array}{r}886 \\
196 \\
\ddagger\end{array}$ & $\left.\begin{array}{r}(82.7) \\
42.6 \\
(\dagger\end{array}\right)$ & $\begin{array}{r}2.5 \\
1.5 \\
\ddagger\end{array}$ & $\left.\begin{array}{r}(0.23) \\
0.32 \\
(\dagger\end{array}\right)$ & $\begin{array}{r}37,219 \\
11,777 \\
2,139\end{array}$ & $\left.\begin{array}{l}(300.7) \\
296.8 \\
(203.2\end{array}\right)$ & $\begin{array}{r}1,357 \\
118 \\
\ddagger\end{array}$ & $\left.\begin{array}{r}(111.5) \\
(28.4) \\
(\dagger\end{array}\right)$ & $\begin{aligned} 3.6 \\
1.0 \\
\ddagger\end{aligned}$ & $\left.\begin{array}{r}(0.30) \\
0.24 \\
(\dagger\end{array}\right)$ & $\begin{array}{r}34,252 \\
15,436 \\
1,968\end{array}$ & $\left.\begin{array}{l}254.7) \\
250.8 \\
(112.5\end{array}\right)$ & $\begin{array}{r}908 \\
137 \\
\ddagger\end{array}$ & $\left.\begin{array}{r}(79.2) \\
34.5 \\
(\dagger\end{array}\right)$ & $\begin{array}{r}2.7 \\
0.9 \\
\ddagger\end{array}$ & $\left.\begin{array}{c}(0.23) \\
0.22 \\
(\dagger)\end{array}\right)$ \\
\hline 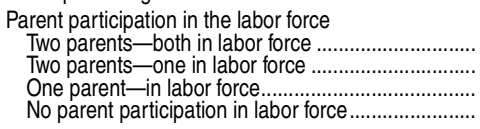 & $\begin{array}{r}25,108 \\
10,545 \\
12,045 \\
3,008\end{array}$ & $\left.\begin{array}{l}(373.1) \\
297.2 \\
267.9 \\
(171.4)\end{array}\right)$ & $\begin{array}{r}274 \\
594 \\
174 \\
\ddagger\end{array}$ & $\left.\begin{array}{r}(44.1) \\
73.7 \\
39.8 \\
(\dagger\end{array}\right)$ & $\begin{array}{r}1.1 \\
5.6 \\
1.4 \\
\ddagger\end{array}$ & $\left.\begin{array}{r}(0.18) \\
0.67 \\
0.33 \\
(\dagger)\end{array}\right)$ & $\begin{array}{r}26,055 \\
10,754 \\
10,020 \\
4,308\end{array}$ & $\left.\begin{array}{l}318.3 \\
286.1 \\
277.1 \\
(228.9\end{array}\right)$ & $\begin{array}{r}518 \\
808 \\
127 \\
\ddagger\end{array}$ & $\begin{array}{r}(76.2) \\
94.3 \\
29.5 \\
(\dagger)\end{array}$ & $\begin{array}{r}2.0 \\
7.5 \\
1.3 \\
\ddagger\end{array}$ & $\begin{array}{r}(0.29) \\
(0.82 \\
0.30 \\
(\dagger)\end{array}$ & $\begin{array}{r}22,884 \\
11,581 \\
13,083 \\
4,108\end{array}$ & $\left.\begin{array}{l}(293.3 \\
275.2 \\
238.6 \\
187.3\end{array}\right)$ & $\begin{array}{l}295 \\
618 \\
96 \\
74 !\end{array}$ & $\left.\begin{array}{l}(41.3) \\
70.1 \\
19.2 \\
26.9\end{array}\right)$ & $\begin{array}{l}1.3 \\
5.3 \\
0.7 \\
1.8\end{array}$ & $\begin{array}{l}(0.18) \\
0.60 \\
0.15 \\
0.65\end{array}$ \\
\hline 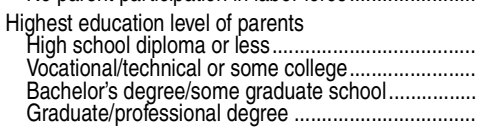 & $\begin{array}{r}16,106 \\
16,068 \\
10,849 \\
7,683\end{array}$ & $\left.\begin{array}{l}(272.3) \\
323.4 \\
275.0 \\
239.5\end{array}\right)$ & $\begin{array}{l}269 \\
338 \\
309 \\
180\end{array}$ & $\left(\begin{array}{l}51.6 \\
57.7 \\
48.5 \\
41.6\end{array}\right)$ & $\begin{array}{l} \\
1.7 \\
2.1 \\
2.8 \\
2.3\end{array}$ & $\left.\begin{array}{l}(0.32) \\
0.36 \\
0.45 \\
(0.55)\end{array}\right)$ & $\begin{array}{l}14,306 \\
14,581 \\
11,448 \\
10,800\end{array}$ & $\left.\begin{array}{l}(292.9) \\
326.5 \\
276.5 \\
(236.0\end{array}\right)$ & $\begin{array}{l}208 \\
559 \\
444 \\
309\end{array}$ & $\begin{array}{l}(35.5) \\
77.5 \\
64.7 \\
(50.0)\end{array}$ & $\begin{array}{l}1 \\
1.5 \\
3.8 \\
3.9 \\
2.9\end{array}$ & $\begin{array}{l}(0.24) \\
(0.52 \\
0.57 \\
0.46\end{array}$ & $\begin{array}{r}16,762 \\
15,621 \\
11,675 \\
7,599\end{array}$ & $\begin{array}{r}(83.8) \\
(173.9) \\
168.4 \\
(34.1)\end{array}$ & $\begin{array}{l}270 \\
344 \\
275 \\
192\end{array}$ & $\begin{array}{l}(53.3) \\
38.4 \\
41.9 \\
(26.5)\end{array}$ & $\begin{array}{l}1.6 \\
2.2 \\
2.4 \\
2.5\end{array}$ & $\left.\begin{array}{l}(0.32 \\
0.24 \\
0.36 \\
0.35\end{array}\right)$ \\
\hline 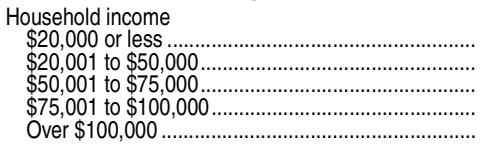 & $\begin{array}{r}9,079 \\
16,515 \\
10,961 \\
6,432 \\
7,718\end{array}$ & $\begin{array}{l}\left(\begin{array}{l}146.2 \\
336.1 \\
282.2 \\
238.0 \\
212.6\end{array}\right) \\
-1\end{array}$ & $\begin{array}{r}164 \\
430 \\
264 \\
169 \\
\ddagger\end{array}$ & $\begin{array}{r}(38.9 \\
60.3 \\
51.1 \\
42.9 \\
(\dagger)\end{array}$ & $\begin{array}{r}1.8 \\
2.6 \\
2.4 \\
2.6 \\
\ddagger\end{array}$ & $\left.\begin{array}{r}(0.43) \\
0.36 \\
0.46 \\
0.66 \\
(\dagger\end{array}\right)$ & $\begin{array}{r}8,488 \\
13,648 \\
10,289 \\
6,899 \\
11,811\end{array}$ & $\begin{array}{l}(201.2 \\
306.1 \\
232.9 \\
210.8 \\
(228.2)\end{array}$ & $\begin{array}{l}186 \\
420 \\
414 \\
264 \\
236\end{array}$ & $\begin{array}{l}(42.1 \\
59.8 \\
58.8 \\
57.2 \\
(57.5)\end{array}$ & $\begin{array}{l}2.2 \\
3.1 \\
4.0 \\
3.8 \\
2.0\end{array}$ & $\left.\begin{array}{l}(0.50) \\
(0.42 \\
0.57 \\
0.83 \\
0.49\end{array}\right)$ & $\begin{array}{r}7,593 \\
13,973 \\
9,406 \\
6,916 \\
13,769\end{array}$ & $\left.\begin{array}{l}(39.6 \\
84.7 \\
23.9 \\
29.5 \\
(56.5)\end{array}\right)$ & $\begin{array}{r}59 \\
321 \\
278 \\
211 \\
214\end{array}$ & $\left(\begin{array}{l}12.1 \\
44.2 \\
40.8 \\
42.4 \\
34.4\end{array}\right)$ & $\begin{array}{l}0.8 \\
2.3 \\
3.0 \\
3.0 \\
1.6\end{array}$ & $\begin{array}{l}(0.16 \\
0.32 \\
0.44 \\
0.61 \\
0.25)\end{array}$ \\
\hline 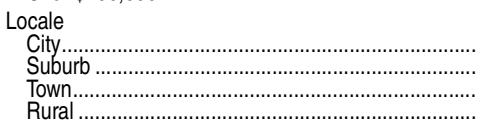 & $\begin{array}{l}- \\
z\end{array}$ & $\left(\begin{array}{c}(t) \\
+ \\
+ \\
(t)\end{array}\right)$ & $\begin{array}{l}\tau \\
z\end{array}$ & $\left(\begin{array}{c}+ \\
+ \\
+ \\
+\end{array}\right)$ & $\begin{array}{l}- \\
\overline{-} \\
-\end{array}$ & 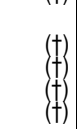 & $\begin{array}{r}15,998 \\
18,988 \\
5,574 \\
10,576\end{array}$ & $\left.\begin{array}{l}(292.3 \\
291.3 \\
209.4 \\
110.9\end{array}\right)$ & $\begin{array}{l}327 \\
503 \\
168 \\
523\end{array}$ & $\begin{array}{l}(40.4) \\
78.8 \\
37.1 \\
75.9)\end{array}$ & $\begin{array}{l} \\
2.0 \\
2.6 \\
3.0 \\
4.9\end{array}$ & $\begin{array}{l}(0.26) \\
0.41 \\
0.65 \\
(0.71)\end{array}$ & $\begin{array}{r}15,191 \\
19,356 \\
4,839 \\
12,271\end{array}$ & $\begin{array}{l}(236.0) \\
330.6 \\
197.9 \\
(249.1)\end{array}$ & $\begin{array}{l}226 \\
303 \\
112 \\
441\end{array}$ & $\left.\begin{array}{l}(28.0) \\
44.6 \\
30.8 \\
65.0\end{array}\right)$ & $\begin{array}{l}1.5 \\
1.6 \\
2.3 \\
3.6\end{array}$ & $\left.\begin{array}{l}0.18 \\
0.22 \\
0.63 \\
0.52\end{array}\right)$ \\
\hline
\end{tabular}

\section{-Not available.}

†Not applicable.

fReporting standards not met (too few cases for a reliable estimate).

Refers to all students in public and private schools and homeschooled students.

Numbers and percentages of homeschoolers exclude students who were enrolled in school for more than 25 hours a week The were homeschooled only due to a temporary iliness.

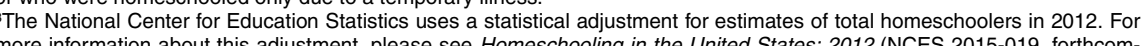
2012 (NCES 2015-019, forthcom-
${ }^{4}$ Students whose grade equivalent was "ungraded" were excluded from the grade analysis. The percentage of students with an "ungraded" grade equivalent was 0.02 percent in 2003 and 2007. There were no students with an "ungraded" grade equivalent in 2012.

NOTE: While National Household Education Surveys Program (NHES) administrations prior to 2012 were administered via telephone with an interviewer, NHES:2012 used self-administered paper-and-pencil questionnaires that were mailed to respondents. Measurable differences in estimates between 2012 and prior years could reflect actual changes in the popula-
tion, or the changes could be due to the mode change from telephone to mail. Race categories exclude persons of Hispanic ethnicity. Detail may not sum to totals because of rounding. Some data have been revised from previously published figures. tion Survey of the National Household Education Surveys Program (PFI-NHES.2003, 2007, and 2012). (This table was prepared November 2014.) 


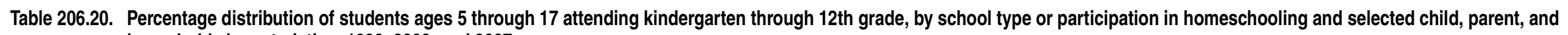
household characteristics: 1999, 2003, and 2007

[Standard errors appear in parentheses]

\begin{tabular}{|c|c|c|c|c|c|c|c|c|c|c|c|c|c|c|c|c|c|c|c|c|c|c|c|c|}
\hline \multirow[b]{3}{*}{ Selected child, parent, or household characteristic } & \multicolumn{8}{|c|}{1999} & \multicolumn{8}{|c|}{2003} & \multicolumn{8}{|c|}{2007} \\
\hline & \multicolumn{4}{|c|}{ Public school } & \multirow{2}{*}{\multicolumn{2}{|c|}{ Private school }} & \multirow{2}{*}{\multicolumn{2}{|c|}{ Homeschooled $^{1}$}} & \multicolumn{4}{|c|}{ Public school } & \multirow{2}{*}{\multicolumn{2}{|c|}{ Private school }} & \multirow{2}{*}{\multicolumn{2}{|c|}{ Homeschooled $^{1}$}} & \multicolumn{4}{|c|}{ Public school } & \multirow{2}{*}{\multicolumn{2}{|c|}{ Private school }} & \multirow{2}{*}{\multicolumn{2}{|c|}{ Homeschooled }} \\
\hline & \multicolumn{2}{|c|}{ Assigned } & \multicolumn{2}{|r|}{ Chosen } & & & & & \multicolumn{2}{|c|}{ Assigned } & \multicolumn{2}{|r|}{ Chosen } & & & & & \multicolumn{2}{|c|}{ Assigned } & \multicolumn{2}{|r|}{ Chosen } & & & & \\
\hline 1 & & 2 & & 3 & & 1 & & 5 & & 6 & & 7 & & 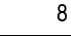 & & 9 & & 10 & & 11 & \multicolumn{2}{|r|}{12} & & 13 \\
\hline 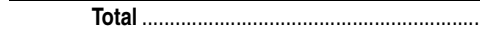 & 74.1 & $(0.45)$ & 14.3 & $(0.33)$ & 10.0 & $(0.28)$ & 1.7 & $(0.14)$ & 72.1 & $(0.57)$ & 15.0 & (0.41) & 10.8 & $(0.39)$ & 2.2 & $(0.18)$ & 70.6 & $(0.70)$ & 15.0 & (0.55) & 11.4 & $(0.45)$ & 2.9 & $(0.23)$ \\
\hline $\begin{array}{l}\text { Sex of child } \\
\text { Male } \\
\text { Female }\end{array}$ & $\begin{array}{l}74.8 \\
73.4\end{array}$ & $\begin{array}{l}(0.60) \\
(0.61)\end{array}$ & $\begin{array}{l}13.9 \\
14.6\end{array}$ & $\begin{array}{l}(0.44) \\
(0.45)\end{array}$ & $\begin{array}{r}9.7 \\
10.3\end{array}$ & $\begin{array}{l}(0.34) \\
(0.41)\end{array}$ & $\begin{array}{l}1.6 \\
1.8\end{array}$ & $\begin{array}{l}(0.17) \\
(0.19)\end{array}$ & $\begin{array}{l}72.1 \\
72.1\end{array}$ & $\begin{array}{l}(0.70) \\
(0.78)\end{array}$ & $\begin{array}{l}15.0 \\
14.9\end{array}$ & $\begin{array}{l}(0.56) \\
(0.54)\end{array}$ & $\begin{array}{l}10.7 \\
10.8\end{array}$ & $\begin{array}{l}(0.48) \\
(0.51)\end{array}$ & $\begin{array}{l}2.2 \\
2.1\end{array}$ & $\begin{array}{l}(0.24) \\
(0.23)\end{array}$ & $\begin{array}{l}70.7 \\
70.5\end{array}$ & $\begin{array}{l}(1.05) \\
(0.88)\end{array}$ & $\begin{array}{l}15.3 \\
14.7\end{array}$ & $\begin{array}{l}0.79) \\
b .64)\end{array}$ & $\begin{array}{l}11.5 \\
11.2\end{array}$ & $\begin{array}{l}0.73) \\
0.54)\end{array}$ & $\begin{array}{l}2.4 \\
3.5\end{array}$ & $\begin{array}{l}(0.28) \\
(0.39)\end{array}$ \\
\hline Race/ethnicity of child & & & & & & & & & & & & & & & & & & & & & & & & \\
\hline 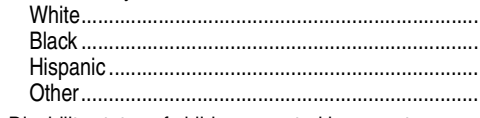 & $\begin{array}{l}75.0 \\
70.2 \\
76.0 \\
69.5\end{array}$ & $\begin{array}{l}(0.54) \\
(1.24) \\
(1.02) \\
(2.20)\end{array}$ & $\begin{array}{l}11.2 \\
22.6 \\
17.6 \\
17.6\end{array}$ & $\begin{array}{l}(0.35) \\
(1.22) \\
(0.91) \\
(1.99)\end{array}$ & $\begin{array}{r}11.8 \\
6.2 \\
5.2 \\
11.0\end{array}$ & $\begin{array}{l}(0.39) \\
(0.47) \\
(0.40) \\
(1.35)\end{array}$ & $\begin{array}{l}2.0 \\
1.0 \\
1.1 \\
1.9 !\end{array}$ & $\begin{array}{l}(0.19) \\
(0.31) \\
(0.25) \\
(0.65)\end{array}$ & $\begin{array}{l}72.7 \\
66.6 \\
77.2 \\
67.1\end{array}$ & $\begin{array}{l}(0.67) \\
(1.49) \\
(1.17) \\
(2.59)\end{array}$ & $\begin{array}{l}12.4 \\
23.4 \\
15.0 \\
18.7\end{array}$ & $\begin{array}{l}(0.47) \\
(1.45) \\
(0.99) \\
(1.94)\end{array}$ & $\begin{array}{r}12.2 \\
8.6 \\
7.1 \\
11.3\end{array}$ & $\begin{array}{l}(0.48) \\
(0.85) \\
(0.66) \\
(1.61)\end{array}$ & $\begin{array}{l}2.7 \\
1.3 ! \\
0.7 ! \\
3.0 !\end{array}$ & $\begin{array}{l}(0.25) \\
(0.42) \\
(0.26) \\
(1.02)\end{array}$ & $\begin{array}{l}69.9 \\
68.4 \\
74.6 \\
70.4\end{array}$ & $\begin{array}{l}(0.80) \\
(2.30) \\
(1.41) \\
(2.23)\end{array}$ & $\begin{array}{l}12.0 \\
23.0 \\
17.5 \\
16.7\end{array}$ & $\begin{array}{l}(0.46) \\
(2.20) \\
(1.25) \\
(1.79)\end{array}$ & $\begin{array}{r}14.2 \\
7.8 \\
6.3 \\
9.4\end{array}$ & $\begin{array}{l}(0.61) \\
(1.33) \\
(0.57) \\
(1.12)\end{array}$ & $\begin{array}{l}3.9 \\
0.8 ! \\
1.5 \\
3.3\end{array}$ & $\begin{array}{l}(0.34) \\
(0.28) \\
(0.29) \\
(0.86)\end{array}$ \\
\hline Disability status of child as reported by parent & & & & & & & & & & & & & & & & & & & & & & & & \\
\hline . & $\begin{array}{l}74.8 \\
73.9\end{array}$ & $\begin{array}{l}(0.93) \\
(0.51)\end{array}$ & $\begin{array}{l}15.3 \\
14.0\end{array}$ & $\begin{array}{l}(0.78) \\
(0.36)\end{array}$ & $\begin{array}{r}8.0 \\
10.5\end{array}$ & $\begin{array}{l}(0.49) \\
(0.34)\end{array}$ & $\begin{array}{l}1.8 \\
1.7\end{array}$ & $\begin{array}{l}(0.27) \\
(0.16)\end{array}$ & $\begin{array}{l}72.4 \\
72.0\end{array}$ & $\begin{array}{l}(1.12) \\
(0.67)\end{array}$ & $\begin{array}{l}16.2 \\
14.5\end{array}$ & $\begin{array}{l}(0.75) \\
(0.51)\end{array}$ & $\begin{array}{r}9.2 \\
11.3\end{array}$ & $\begin{array}{l}(0.70) \\
(0.44)\end{array}$ & $\begin{array}{l}2.2 \\
2.1\end{array}$ & $\begin{array}{l}(0.35) \\
(0.21)\end{array}$ & $\begin{array}{l}72.7 \\
69.9\end{array}$ & $\begin{array}{l}(1.35) \\
(0.76)\end{array}$ & $\begin{array}{l}14.0 \\
15.3\end{array}$ & $\begin{array}{l}(0.91) \\
(0.63)\end{array}$ & $\begin{array}{l}10.5 \\
11.7\end{array}$ & $\begin{array}{l}(0.96) \\
(0.48)\end{array}$ & $\begin{array}{l}2.6 \\
3.1\end{array}$ & $\begin{array}{l}(0.48) \\
(0.28)\end{array}$ \\
\hline Grade equ & & & & & & & & & & & & & & & & & & & & & & & & \\
\hline 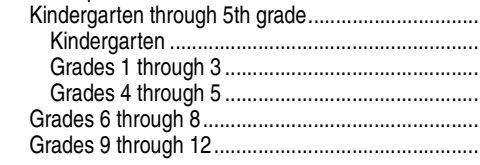 & $\begin{array}{l}71.5 \\
66.2 \\
72.2 \\
72.9 \\
77.4 \\
75.7\end{array}$ & $\begin{array}{l}(0.61) \\
(1.67) \\
(0.87) \\
(1.17) \\
(0.79) \\
(0.75)\end{array}$ & $\begin{array}{l}15.1 \\
15.4 \\
15.3 \\
14.6 \\
11.5 \\
15.1\end{array}$ & $\begin{array}{l}(0.43) \\
(1.13) \\
(0.67) \\
(0.79) \\
(0.65) \\
(0.60)\end{array}$ & $\begin{array}{r}11.6 \\
15.9 \\
10.9 \\
10.7 \\
9.5 \\
7.5\end{array}$ & $\begin{array}{l}(0.41) \\
(1.29) \\
(0.53) \\
(0.77) \\
(0.47) \\
(0.44)\end{array}$ & $\begin{array}{l}1.1 \\
1.6 \\
1.7\end{array}$ & $\begin{array}{l}(0.20) \\
(0.52) \\
(0.29) \\
(0.28) \\
(0.24) \\
(0.24)\end{array}$ & $\begin{array}{l}70.1 \\
69.0 \\
70.0 \\
70.7 \\
73.3 \\
74.6\end{array}$ & $\begin{array}{l}(0.70) \\
(1.50) \\
(1.18) \\
(1.12) \\
(1.03) \\
(0.97)\end{array}$ & $\begin{array}{l}16.2 \\
15.5 \\
16.2 \\
16.5 \\
14.1 \\
13.6\end{array}$ & $\begin{array}{l}(0.56) \\
(1.18) \\
(0.96) \\
(0.96) \\
(0.81) \\
(0.76)\end{array}$ & $\begin{array}{r}11.8 \\
12.8 \\
12.1 \\
10.9 \\
10.2 \\
9.5\end{array}$ & $\begin{array}{l}(0.53) \\
(1.21) \\
(0.73) \\
(0.76) \\
(0.59) \\
(0.63)\end{array}$ & $\begin{array}{l}1.9 \\
2.7\end{array}$ & $\begin{array}{l}(0.23) \\
(0.64) \\
(0.28) \\
(0.35) \\
(0.36) \\
(0.33)\end{array}$ & $\begin{array}{l}68.5 \\
66.4 \\
68.4 \\
69.7 \\
74.4 \\
70.8\end{array}$ & $\begin{array}{l}(1.16) \\
(2.20) \\
(1.68) \\
(1.62) \\
(1.44) \\
(1.07)\end{array}$ & $\begin{array}{l}16.2 \\
14.7 \\
15.9 \\
17.5 \\
11.6 \\
15.9\end{array}$ & $\begin{array}{l}(1.04) \\
(1.60) \\
(1.63) \\
(1.34) \\
(0.81) \\
(0.84)\end{array}$ & $\begin{array}{l}12.2 \\
15.8 \\
12.3 \\
10.3 \\
11.0 \\
10.5\end{array}$ & $\begin{array}{l}(0.69) \\
(1.61) \\
(0.93) \\
(1.08) \\
(1.14) \\
(0.75)\end{array}$ & $\begin{array}{l}3.0 \\
3.1 \text { ! } \\
3.4 \\
2.5 \\
2.9 \\
2.8\end{array}$ & $\begin{array}{c}(0.36) \\
(0.96) \\
(0.54) \\
(0.52) \\
(0.52) \\
(0.38)\end{array}$ \\
\hline Dumber & & & & & & & & & & & & & & & & & & & & & & & & \\
\hline$\cdots \cdots \cdots \cdot$. & $\begin{array}{l}74.5 \\
73.5 \\
71.6\end{array}$ & $\begin{array}{l}(0.54) \\
(0.78) \\
(2.70)\end{array}$ & $\begin{array}{l}12.0 \\
18.2 \\
21.9\end{array}$ & $\begin{array}{l}(0.35) \\
(0.55) \\
(2.72)\end{array}$ & $\begin{array}{r}11.5 \\
7.3 \\
5.1\end{array}$ & $\begin{array}{l}(0.37) \\
(0.47) \\
(0.84)\end{array}$ & $\begin{array}{r}2.1 \\
0.9 \\
\ddagger\end{array}$ & $\begin{array}{l}(0.21) \\
(0.16) \\
(\dagger)\end{array}$ & $\begin{array}{l}71.8 \\
72.9 \\
73.2\end{array}$ & $\begin{array}{l}(0.67) \\
(1.09) \\
(3.05)\end{array}$ & $\begin{array}{l}13.6 \\
18.0 \\
20.1\end{array}$ & $\begin{array}{l}(0.51) \\
(0.98) \\
(2.59)\end{array}$ & $\begin{array}{r}12.1 \\
7.6 \\
5.8\end{array}$ & $\begin{array}{l}(0.47) \\
(0.67) \\
(1.36)\end{array}$ & $\begin{array}{r}2.5 \\
1.5 \\
\ddagger\end{array}$ & $\begin{array}{r}(0.23) \\
(0.32) \\
(\dagger)\end{array}$ & $\begin{array}{l}69.5 \\
73.6 \\
72.2\end{array}$ & $\begin{array}{l}(0.73) \\
(1.39) \\
(5.91)\end{array}$ & $\begin{array}{l}13.8 \\
17.2 \\
23.0\end{array}$ & $(0.1)$ & $\begin{array}{r}12.9 \\
8.1 \\
2.6\end{array}$ & $\begin{array}{l}(0.52) \\
(1.18) \\
(0.74)\end{array}$ & $\begin{array}{l}3.6 \\
1.0 \\
2.1 !\end{array}$ & $\begin{array}{l}(0.30) \\
(0.24) \\
(0.81)\end{array}$ \\
\hline Highe & & & & & & & & & & & & & & & & & & & & & & & & \\
\hline & 1 & $(1.38)$ & 18.0 & $(1.4$ & 2.7 & $(0$. & $0.2 !$ & $(0$. & 76.9 & $(2.0$ & 18.9 & $(1$. & $2.9 !$ & $(1$. & $\ddagger$ & ) & 83.3 & & 12.7 & & 3.5 ! & & 0.5 ! & $(0$ \\
\hline & & & & & & & & & & & & & 19 & & 18 & & & & & & 4 & & & \\
\hline & 75.8 & 0.7 & 1 & $(0.63)$ & 7 & 10 & 1 & & & & & & & & & & & & 15 & & & & & \\
\hline & & $(1.06)$ & 1 & $(0.75)$ & 15.8 & $(0$ & & (c & & (1. & & $(0$ & 16 & $(0$ & 2.8 & $(0$. & 66.8 & (1 & 14.8 & (1. & 14.3 & $(0$. & 1 & 10. \\
\hline Grad & 65.0 & $(1.14)$ & 12.4 & $(0.77)$ & 20.2 & $(0.91)$ & 2. & $(0.54)$ & 63.6 & $(1.50)$ & 13.5 & (1. & 20.5 & $(1.28)$ & 2.3 & $(0.55)$ & 59.2 & (1.37) & 15.9 & (1. & 22.4 & (1.22) & 2.5 & $(0.41)$ \\
\hline & & & & & & & & & & & & & & & & & & & & & & & & \\
\hline & & (1.16) & 1 & (1. & 4.3 & 10 & & 10 & 3 & (1 & 17 & & 3 & & 2.3 & & & & 1 & & 3 & & & \\
\hline & & & & 10 & & & & & & & & & & & & & & & & & & & & \\
\hline Al & 72.5 & $(0.57)$ & 11.8 & $(0.34)$ & 14.0 & $(0.47)$ & 1.6 & $(0.18)$ & 69.8 & $(0.70)$ & 13.8 & $(0.54$ & 14.6 & $(0.54)$ & 1.8 & $(0.21)$ & 67.6 & $(0.75)$ & 13.8 & $(0.48)$ & 15.7 & $(0.34)$ & 2.9 & $(0.30)$ \\
\hline Urban & & & & & & & & & & & & & & & & & & & & & & & & \\
\hline & - & $(t)$ & - & (t) & - & ( & - & f) & - & (t) & - & $(t)$ & - & (t) & - & (t) & 61.7 & & 22.1 & & 14.2 & & 2.0 & $(0.26)$ \\
\hline & & †) & - & & - & & - & f) & - & $(\dagger)$ & - & & - & $(\dagger)$ & - & ) & & & & & & & & \\
\hline & & $(t)$ & - & (1) & - & $(t)$ & - & $(\dagger)$ & - & (†) & - & 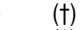 & - & $(\dagger)$ & - & $(t)$ & & & 2.4 & & 7.1 & & & $(0.66)$ \\
\hline Rura & - & $(t)$ & 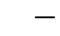 & $(t)$ & - & $(t)$ & - & $(t)$ & - & $(t)$ & - & (II) & - & $(t)$ & - & $(t)$ & 76.7 & $(1.36)$ & 11.5 & $(1.03)$ & 6.8 & $(1.09)$ & 4.9 & $(0.71)$ \\
\hline & & & & & & & & & & & & & & & & & & & & & & & & \\
\hline & 72.8 & (1.06 & 13 & & 12.6 & I0 & 1.1 & & 71. & (1. & I & & 14.6 & & 1.8 & & 72.5 & & 11.8 & & 13. & & & (C \\
\hline & 75.4 & & & & 0 & & & & & & & & 8.3 & & 0 & & & & & & & & & \\
\hline & 74 & $(0$. & & 10. & 16 & 10 & 1 & & & & 1 & & 13 & & 2. & & & & & & 12.8 & & & $(0.53)$ \\
\hline West... & 72.7 & $(0.95)$ & 17.7 & (0.73) & 7.5 & $(0.49)$ & 2.0 & $(0.34)$ & 71.9 & $(1.07)$ & 17.9 & $(0.97)$ & 8.3 & $(0.59)$ & 2.0 & $(0.34)$ & 67.0 & $(1.40)$ & 20.3 & (1.17) & 9.4 & $(0.75)$ & 3.1 & $(0.42)$ \\
\hline
\end{tabular}

\section{-Not available.}

IInterpret data with caution. The coefficient of variation (CV) for this estimate is between 30 and 50 percent. fReporting standards not met. The coefficient of variation (CV) for this estimate is 50 percent or greater.

${ }^{1}$ Excludes students who were enrolled in school for more than 25 hours a week; also excluded in 1999 and 2003 are students who were homeschooled only due to a temporary illness and, in 2007, students who were homeschooled primarily due to a temporary illness.
${ }^{2}$ Students whose grade equivalent was "ungraded" were excluded from the grade analysis. The percentage of students with an "ungraded" grade equivalent was 0.03 percent in 1999 and 0.02 percent in 2003 and 2007.

Cories exclude persons of Hispanic ethnicity. Detail may not sum to totals SOURCE: U.S. Department of Education, National Center for Education Statistics, Parent Survey (Parent:1999) and Parent and Family Involvement in Education Survey (PFl:2003 and PFI:2007) of the National Household Education Surveys Program. (This table was prepared July 2010.) 
Table 207.10. Number of 3- to 5-year-olds not yet enrolled in kindergarten and percentage participating in home literacy activities with a family member, by type and frequency of activity and selected child and family characteristics: 1993, 2001, and 2007

[Standard errors appear in parentheses]

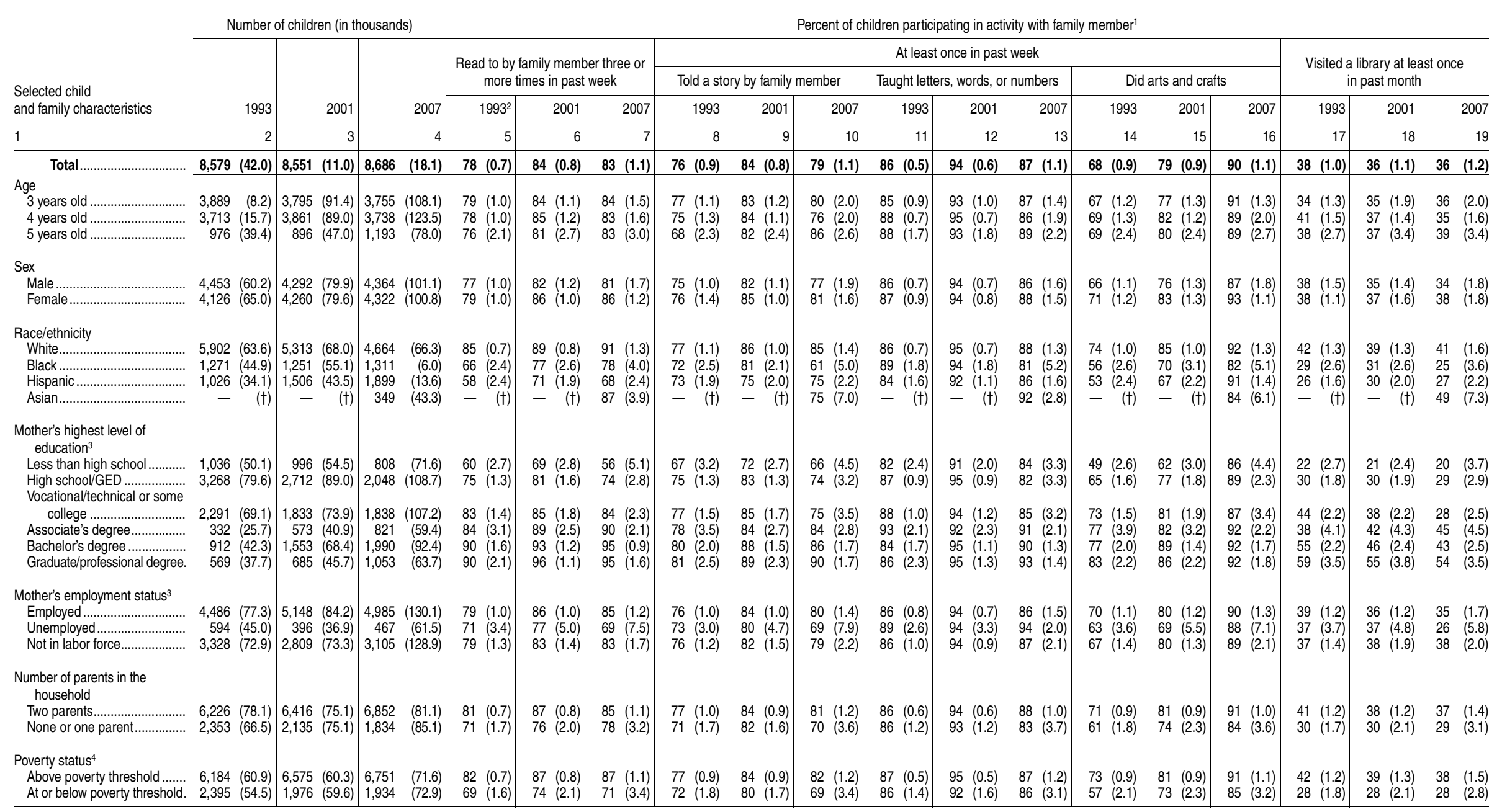

\section{-Not available.}

'The respondent was the parent most knowledgeable about the child's care and education. Responding parents reported on their own activities and the activities of their spouse/other adults in the household.

2 In 1993, there were two versions of the survey question that asked how often the child was read to. Each respondent was asked one version of the question. Percentages represent all respondents who indicated a frequency of three or more times in the past week in response to either version of the question.
${ }^{3}$ Excludes children living in households with no mother or female guardian present.

NOTE: Totals include other racial/ethnic groups not separately shown. Race categories exclude persons of Hispanic ethnicity. Detail may not sum to totals because of rounding. Some data have been revised from previously published figures.

SOURCE: U.S. Department of Education, National Center for Education Statistics, School Readiness Survey, Early Childhood Program Participation Survey, and Parent and Family Involvement in Education Survey of the National Household Education Surveys Program (SR-NHES:1993, ECPP-NHES:2001, and PFI-NHES:2007). (This table was prepared September 2009.) 


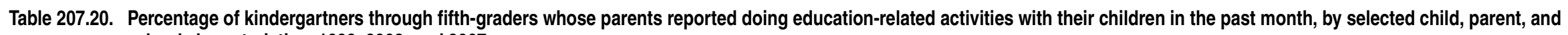
school characteristics: 1999, 2003, and 2007

[Standard errors appear in parentheses]

\begin{tabular}{|c|c|c|c|c|c|c|c|c|c|c|c|c|c|c|c|c|c|c|c|c|c|c|c|c|c|c|c|c|c|c|}
\hline \multirow{2}{*}{$\begin{array}{l}\text { Selected child, parent, or } \\
\text { school characteristic }\end{array}$} & \multicolumn{6}{|c|}{ Visited a library } & \multicolumn{6}{|c|}{$\begin{array}{l}\text { Went to a play, concert, or } \\
\text { ther live show }\end{array}$} & \multicolumn{6}{|c|}{$\begin{array}{l}\text { Visited an art gallery, museum, or } \\
\text { historical site }\end{array}$} & \multicolumn{6}{|c|}{ Visited a zoo or aquarium } & \multicolumn{6}{|c|}{$\begin{array}{l}\text { Attended an event sponsored by a community, } \\
\text { religious, or ethnic group } 1\end{array}$} \\
\hline & & 1999 & & 2003 & & 2007 & & 1999 & & 2003 & & 2007 & & 1999 & & 2003 & & 2007 & & 1999 & & 2003 & & 2007 & & 1999 & & 2003 & & 2007 \\
\hline 1 & & 2 & & 3 & & 4 & & 5 & & 6 & & 7 & & 8 & & 9 & & 10 & & 11 & & 12 & & 13 & & 14 & & 15 & & 16 \\
\hline Total......................... & 48.6 & $(0.64)$ & 50.2 & $(0.80)$ & 48.8 & (1.12) & 32.1 & $(0.55)$ & 35.5 & $(0.87)$ & 31.4 & $(0.87)$ & 22.2 & $(0.67)$ & 22.2 & $(0.83)$ & 26.3 & $(1.09)$ & 14.1 & $(0.47)$ & 16.5 & $(0.69)$ & 19.0 & $(0.80)$ & 52.8 & $(0.63)$ & 62.0 & $(0.80)$ & 58.9 & (1.14) \\
\hline 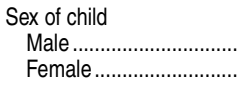 & $\begin{array}{l}47.2 \\
50.1\end{array}$ & $\begin{array}{l}(0.91) \\
(1.02)\end{array}$ & $\begin{array}{l}47.3 \\
53.1\end{array}$ & $\begin{array}{l}(1.08) \\
(1.11)\end{array}$ & $\begin{array}{l}46.8 \\
50.9\end{array}$ & $\begin{array}{l}(1.66) \\
(1.52)\end{array}$ & $\begin{array}{l}30.5 \\
33.7\end{array}$ & $\begin{array}{l}(0.84) \\
(0.81)\end{array}$ & $\begin{array}{l}33.6 \\
37.5\end{array}$ & $\begin{array}{l}(1.09) \\
(1.09)\end{array}$ & $\begin{array}{l}28.7 \\
34.5\end{array}$ & $\begin{array}{l}(1.06) \\
(1.57)\end{array}$ & $\begin{array}{l}22.3 \\
22.1\end{array}$ & $\begin{array}{l}(0.93) \\
(0.89)\end{array}$ & $\begin{array}{l}23.1 \\
21.2\end{array}$ & $\begin{array}{l}(1.12) \\
(1.07)\end{array}$ & $\begin{array}{l}27.1 \\
25.4\end{array}$ & $\begin{array}{l}(1.80) \\
(1.30)\end{array}$ & $\begin{array}{l}13.9 \\
14.3\end{array}$ & $\begin{array}{l}(0.70) \\
(0.70)\end{array}$ & $\begin{array}{l}16.3 \\
16.7\end{array}$ & $\begin{array}{l}(0.88) \\
(0.87)\end{array}$ & $\begin{array}{l}18.5 \\
19.6\end{array}$ & $\begin{array}{l}(0.95) \\
(1.41)\end{array}$ & $\begin{array}{l}50.9 \\
54.8\end{array}$ & $\begin{array}{l}(0.89) \\
(0.95)\end{array}$ & $\begin{array}{l}61.0 \\
63.0\end{array}$ & $\begin{array}{l}(1.08) \\
(1.09)\end{array}$ & $\begin{array}{l}57.3 \\
60.6\end{array}$ & $\begin{array}{l}(1.48) \\
(1.49)\end{array}$ \\
\hline 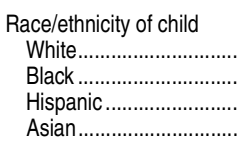 & $\begin{array}{r}48.9 \\
47.8 \\
43.9 \\
-\end{array}$ & $\begin{array}{r}(0.85) \\
(1.76) \\
(1.65) \\
(\dagger)\end{array}$ & $\begin{array}{r}49.1 \\
52.3 \\
48.2 \\
-\end{array}$ & $\begin{array}{r}(1.03) \\
(2.50) \\
(1.77) \\
(\dagger)\end{array}$ & $\begin{array}{l}48.5 \\
56.1 \\
44.6 \\
60.3\end{array}$ & $\begin{array}{l}(1.22) \\
(3.95) \\
(2.14) \\
(5.29)\end{array}$ & $\begin{array}{r}33.9 \\
31.3 \\
24.4 \\
-\end{array}$ & $\begin{array}{l}(0.72) \\
(1.60) \\
(1.10) \\
(\dagger)\end{array}$ & $\begin{array}{r}37.2 \\
36.7 \\
28.0 \\
-\end{array}$ & $\begin{array}{r}(1.26) \\
(2.23) \\
(1.53) \\
(\dagger)\end{array}$ & $\begin{array}{l}32.8 \\
34.5 \\
25.1 \\
29.2\end{array}$ & $\left.\begin{array}{l}(1.13) \\
(3.02) \\
(1.67) \\
(4.76)\end{array}\right)$ & $\begin{array}{r}22.3 \\
21.0 \\
20.6 \\
-\end{array}$ & $\begin{array}{r}(0.76) \\
(1.52) \\
(1.26) \\
(\dagger)\end{array}$ & $\begin{array}{r}21.2 \\
24.4 \\
20.8 \\
-\end{array}$ & $\left.\begin{array}{r}(1.09) \\
(1.97) \\
(1.38) \\
(\dagger)\end{array}\right]$ & $\begin{array}{l}25.4 \\
32.7 \\
23.5 \\
27.9\end{array}$ & $\begin{array}{l}(1.18) \\
(5.13) \\
(2.13) \\
(4.22)\end{array}$ & $\begin{array}{l}12.0 \\
15.7 \\
19.7 \\
-\end{array}$ & $\begin{array}{r}(0.54) \\
(1.24) \\
(1.02) \\
(\dagger)\end{array}$ & $\begin{array}{r}13.6 \\
18.9 \\
23.7 \\
-\end{array}$ & $\begin{array}{r}(0.85) \\
(1.55) \\
(1.32) \\
(\dagger)\end{array}$ & $\begin{array}{l}15.3 \\
24.2 \\
25.4 \\
23.7\end{array}$ & $\begin{array}{l}(0.85) \\
(2.72) \\
(1.97) \\
(3.61)\end{array} \mid$ & $\begin{array}{r}54.6 \\
53.0 \\
45.8 \\
-\end{array}$ & $\begin{array}{r}(0.81) \\
(1.40) \\
(1.32) \\
(\dagger)\end{array}$ & $\begin{array}{r}64.6 \\
66.3 \\
49.3 \\
-\end{array}$ & $\begin{array}{r}(1.12) \\
(2.35) \\
(1.75) \\
(\dagger)\end{array}$ & $\begin{array}{l}63.1 \\
61.7 \\
44.9 \\
58.6\end{array}$ & $\begin{array}{l}(1.19) \\
(4.59) \\
(2.17) \\
(5.15)\end{array}$ \\
\hline $\begin{array}{l}\text { Highest education level of } \\
\text { parents/guardians in } \\
\text { the household }\end{array}$ & & & & & & & & & & & & & & & & & & & & & & & & & & & & & & \\
\hline $\begin{array}{l}\text { Less than high school... } \\
\text { High school/GED } \\
\text { Vocational/technical or }\end{array}$ & $\begin{array}{l}34.5 \\
40.3\end{array}$ & $\begin{array}{l}(2.33) \\
(1.42)\end{array}$ & $\begin{array}{l}36.1 \\
44.5\end{array}$ & $\begin{array}{l}(3.39) \\
(1.64)\end{array}$ & $\begin{array}{l}37.3 \\
41.5\end{array}$ & $\begin{array}{l}(3.49) \\
(3.52)\end{array}$ & $\begin{array}{l}17.5 \\
25.9\end{array}$ & $\begin{array}{l}(1.63) \\
(1.13)\end{array}$ & $\begin{array}{l}20.0 \\
28.6\end{array}$ & $\begin{array}{l}(3.10) \\
(1.83)\end{array}$ & $\begin{array}{l}20.2 \\
22.0\end{array}$ & $\begin{array}{l}(2.66) \\
(2.31)\end{array}$ & $\begin{array}{l}12.1 \\
16.0\end{array}$ & $\begin{array}{l}(1.64) \\
(1.04)\end{array}$ & $\begin{array}{r}9.3 \\
17.8\end{array}$ & $\begin{array}{l}(1.75) \\
(1.73)\end{array}$ & $\begin{array}{l}17.8 \\
22.2\end{array}$ & $\begin{array}{l}(2.25) \\
(3.58)\end{array}$ & $\begin{array}{l}15.2 \\
12.8\end{array}$ & $\begin{array}{l}(1.65) \\
(0.98)\end{array}$ & $\begin{array}{l}15.3 \\
16.5\end{array}$ & $\begin{array}{l}(2.05) \\
(1.18)\end{array}$ & $\begin{array}{l}17.3 \\
17.6\end{array}$ & $\begin{array}{l}(2.22) \\
(2.21)\end{array}$ & $\begin{array}{l}36.7 \\
42.6\end{array}$ & $\begin{array}{l}(2.32) \\
(1.23)\end{array}$ & $\begin{array}{l}34.3 \\
50.5\end{array}$ & $\begin{array}{l}(3.06) \\
(1.81)\end{array}$ & $\begin{array}{l}35.5 \\
46.0\end{array}$ & $\begin{array}{l}(3.86) \\
(3.23)\end{array}$ \\
\hline $\begin{array}{l}\text { some } \\
\text { Associate } \\
\text { Bachelor's }\end{array}$ & $\begin{array}{l}47.2 \\
50.4\end{array}$ & $\begin{array}{l}(1.41) \\
(2.12)\end{array}$ & $\begin{array}{l}44.3 \\
47.4\end{array}$ & $\begin{array}{l}(2.04) \\
(3.04)\end{array}$ & $\begin{array}{l}43.5 \\
46.6\end{array}$ & $\begin{array}{l}(2.46) \\
(2.74)\end{array}$ & $\begin{array}{l}30.2 \\
35.5\end{array}$ & $\begin{array}{l}(1.30) \\
(2.10)\end{array}$ & $\begin{array}{l}32.8 \\
41.1\end{array}$ & $\begin{array}{l}(1.89) \\
(3.24)\end{array}$ & $\begin{array}{l}29.6 \\
31.0\end{array}$ & $\begin{array}{l}(2.15) \\
(2.46)\end{array}$ & $\begin{array}{l}20.4 \\
22.0\end{array}$ & $\begin{array}{l}(1.21) \\
(1.77)\end{array}$ & $\begin{array}{l}19.1 \\
22.0\end{array}$ & $\begin{array}{l}(1.32) \\
(2.40)\end{array}$ & $\begin{array}{l}18.6 \\
22.3\end{array}$ & $\begin{array}{l}(2.00) \\
(2.72)\end{array}$ & $\begin{array}{l}11.9 \\
14.3\end{array}$ & $\begin{array}{l}(0.90) \\
(1.42)\end{array}$ & $\begin{array}{l}15.2 \\
15.4\end{array}$ & $\begin{array}{l}(1.29) \\
(2.09)\end{array}$ & $\begin{array}{l}16.4 \\
19.3\end{array}$ & $\begin{array}{l}(1.95) \\
(2.56)\end{array}$ & $\begin{array}{l}53.7 \\
53.6\end{array}$ & $\begin{array}{l}(1.43) \\
(2.26)\end{array}$ & $\begin{array}{l}62.1 \\
67.0\end{array}$ & $\begin{array}{l}(1.64) \\
(2.85)\end{array}$ & $\begin{array}{l}58.2 \\
58.7\end{array}$ & $\begin{array}{l}(2.61) \\
(2.84)\end{array}$ \\
\hline $\begin{array}{l}\text { graduate school ...... } \\
\text { Graduate/professional }\end{array}$ & 57.6 & (1.52) & 57.7 & $(1.74)$ & 51.9 & (1.89) & 40.0 & $(1.24)$ & 40.1 & $(1.61)$ & 37.1 & (1.85) & 29.1 & (1.37) & 27.6 & (1.70) & 32.1 & $(2.07)$ & 15.2 & $(1.03)$ & 16.0 & (1.32) & 21.1 & (1.79) & 64.6 & (1.22) & 71.3 & (1.63) & 66.7 & (2.07) \\
\hline 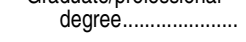 & 62.9 & (1.53) & 65.2 & (2.04) & 62.2 & (1.86) & 43.3 & $(1.77)$ & 47.2 & (2.53) & 40.0 & $(2.20)$ & 34.7 & (1.73) & 31.7 & (2.02) & 34.7 & (1.96) & 17.9 & $(1.33)$ & 20.7 & (1.82) & 20.3 & $(1.61)$ & 65.3 & (1.68) & 75.6 & (1.55) & 72.3 & $(1.63)$ \\
\hline $\begin{array}{l}\text { Family income (in current } \\
\text { dollars) }\end{array}$ & & & & & & & & & & & & & & & & & & & & & & & & & & & & & & \\
\hline & 42.7 & $(4.27)$ & 38.2 & (5.63) & 46.5 & (8.03) & 24.9 & (2.73) & 25.7 & (4.94) & $18.6 !$ & $(6.08)$ & 16.5 & (2.76) & 13.2 & (3.10) & $21.4 !$ & $(7.05)$ & 16.6 & (2.77) & 18.7 & (3.99) & $12.3 !$ & (4.18) & 37.3 & (3.55) & 52.9 & (4.65) & 43.5 & (8.42) \\
\hline & & $(2.86)$ & 42.2 & (4.99) & 34.9 & (5.37) & 21.1 & (2.34) & 28.5 & (4.74) & 23.5 & $(5.99)$ & 17.7 & & 22.8 & (4.79) & 23.6 & & 14.5 & & 23.8 & & 22.7 & & & & 51.6 & & .5 & \\
\hline & & $(2.51)$ & 49.1 & $(4.27)$ & 35.6 & $(4.75)$ & & $(2.3$ & 27.3 & (3.2 & 21.0 & $(4$. & 18.2 & $(1.99)$ & 20.7 & $(4.2)-3-1)$ & & $(2.93)$ & 15.3 & (2.06) & 20.9 & (3.46) & 17.6 & & & & 49.1 & & & \\
\hline$\$ 1$ & 43.0 & $(3.07)$ & 44.4 & (3.95) & 52.1 & (9.98) & 25.9 & $(2.37)$ & 32.9 & (3.75) & 18.6 & (3.76) & 13.3 & (1.74) & 18.9 & (2.83) & $26.2 !$ & (11.91) & 13.7 & $(1.61)$ & 17.1 & $(2.61)$ & 14.6 & $(3.78)$ & 47.2 & $(2.78)$ & 52.1 & $(4.19)$ & 39.0 & $(7.73)$ \\
\hline & 38.9 & (2.10) & 48.4 & (3.57) & 45.3 & (5.05) & 26.3 & $(2.0$ & 26.0 & $(3.3$ & 301 & $(4.1$ & 18.7 & $(1.85)$ & 16.3 & $(2$. & 21.2 & $(3.97)$ & 14.7 & $(1.50)$ & 4 & & 20.4 & $(3.84)$ & 7.7 & (2.53) & 57.8 & & 52.6 & $(5.02)$ \\
\hline & 45.3 & $(2.27)$ & 51.0 & (3.71) & 45.4 & (5.59) & 30.4 & $(2.3$ & 27.1 & $(3.3$ & 0 & $(3.9$ & 20.7 & $(1.97)$ & 20.8 & (3.) & 20 & $(5.61)$ & 14.4 & $(1.70)$ & 9 & & 24.0 & & 50.0 & & 56.7 & & & o) \\
\hline & 49.2 & $(2.55)$ & 44.9 & (3.17) & 45.9 & $\begin{array}{l}(5.09) \\
\end{array}$ & 31.3 & (2.66) & 33.2 & (3.2 & 30 & $(4.5$ & 21.4 & (1.97) & 18.3 & $(2$. & 23 & $(4.51)$ & 11.9 & (1.42) & 17.1 & & 20.4 & & & & 59.7 & & & \\
\hline & 51.9 & $(2.30)$ & 45.6 & $(4.30)$ & 49.0 & (3.80) & 34.4 & $(2.6$ & 31.4 & $(3.7$ & & $(3.8$ & 23.5 & $(2)$. & 16.8 & $(2.5$ & 19 & $(4.2$ & 13.2 & $(1.4$ & 11.6 & & & & 59.1 & $(2)$. & 70.7 & & & $(4.46)$ \\
\hline$\$ 4$ & 52.1 & (2.03) & 52.2 & (3.00) & 47.0 & (3.92) & 32.5 & $(1.7$ & 35.8 & $(2.9$ & 31 & $(3.2$ & 22.5 & (1.51) & 20.9 & (2.41) & 26 & (3.75) & 13.1 & (1.24) & 14.8 & (2.05) & 20.9 & $(4.10)$ & 58.5 & (2.01) & 63.1 & (2.54) & 56.4 & $\begin{array}{l}\text { (3.28) } \\
\text { (1) }\end{array}$ \\
\hline$\$ 5$ & 51.5 & (1.67) & 50.0 & $(1.65)$ & 49.2 & (2.28) & 34.5 & $(1.47)$ & 39.0 & $(1.5$ & 31 & $(1.8$ & 23.1 & $(1.37)$ & 23.1 & $(1.4$ & 23. & $(1.64)$ & 12.2 & $(0.86)$ & 9 & $(1.27)$ & 15.8 & $(1$. & 57.6 & (1.72) & 64.5 & (1.42) & 61.2 & $(200)$ \\
\hline Over $\$ 75,000 \ldots \ldots \ldots$ & 55.5 & (1.61) & 55.8 & (1.69) & 53.5 & (1.66) & 44.5 & $(1.45)$ & 42.6 & (1.66) & 38.1 & (1.42) & 31.6 & (1.75) & 27.3 & (1.43) & 33.1 & (1.48) & 15.8 & $(0.86)$ & 16.9 & (1.31) & 20.3 & $(1.17)$ & 61.9 & (1.33) & 67.9 & (1.42) & 67.6 & (1.51) \\
\hline $\begin{array}{l}\text { Child attending public } \\
\text { school .......................... }\end{array}$ & 47.5 & $(0.68)$ & 49.2 & $(0.87)$ & 47.6 & $(1.22)$ & 30.4 & (0.58) & 34.9 & $(0.88)$ & 31.0 & $(0.93)$ & 21.0 & $(0.70)$ & 21.2 & $(0.92)$ & 24.9 & (1.12) & 13.7 & $(0.49)$ & 16.3 & (0.71) & 19.1 & $(0.88)$ & 51.2 & $(0.68)$ & 60.6 & $(0.85)$ & 56.9 & $(1.25)$ \\
\hline $\begin{array}{l}\text { Child attending private } \\
\text { school ........................... }\end{array}$ & 56.4 & (1.78) & 57.0 & (2.31) & 57.0 & (2.86) & 44.3 & (1.80) & 40.0 & (2.55) & 34.3 & (2.65) & 31.0 & (1.55) & 29.0 & (2.04) & 35.6 & (2.82) & 17.1 & (1.28) & 17.9 & (1.85) & 18.5 & $(2.05)$ & 64.8 & (1.92) & 72.2 & (2.15) & 71.8 & (2.77) \\
\hline $\begin{array}{l}\text { TNot applicable. } \\
\text { !nterpret data with caut } \\
1 \text { In } 1999 \text { and } 2007 \text {, a si } \\
\text { group. In 2003, attenda }\end{array}$ & & & & & & & & & & & & & & & & & & & & Nat & & & & & & - & eth & thnic & an & \\
\hline
\end{tabular}


Table 207.30. Percentage of kindergartners through fifth-graders whose parents reported doing education-related activities with their children in the past week, by selected child, parent, and school characteristics: 1999, 2003, and 2007

[Standard errors appear in parentheses]

\begin{tabular}{|c|c|c|c|c|c|c|c|c|c|c|c|c|c|c|c|c|c|c|c|c|c|c|c|c|}
\hline \multirow[b]{2}{*}{ Selected child, parent, or school characteristic } & \multicolumn{6}{|c|}{ Told child a story } & \multicolumn{6}{|c|}{ Did arts and crafts } & \multicolumn{6}{|c|}{ Discussed family history/ethnic heritage } & \multicolumn{6}{|c|}{ Played board games or did puzzles } \\
\hline & & 1999 & & 2003 & & 2007 & & 1999 & & 2003 & & 2007 & & 1999 & & 2003 & & 2007 & & 1999 & & 2003 & & 2007 \\
\hline 1 & & 2 & & 3 & & 4 & & 5 & & 6 & & 7 & & 8 & & 9 & & 10 & & 11 & & 12 & & 13 \\
\hline Total.... & 1.4 & $(0.60)$ & 4.9 & $0.66)$ & 0.3 & (1.11) & 68.0 & $(0.60)$ & 4.9 & (0.70) & 5.7 & $(1.00)$ & 54.9 & $(0.67)$ & 53.1 & $(0.89)$ & 53.5 & (1.10) & - & (t) & 72.9 & $(0.68)$ & 69.0 & $(0.99)$ \\
\hline 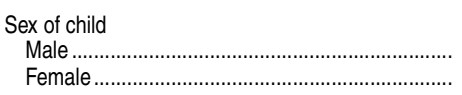 & $\begin{array}{l}69.1 \\
69.7\end{array}$ & $\begin{array}{l}(0.76) \\
(0.89)\end{array}$ & $\begin{array}{l}73.3 \\
76.6\end{array}$ & $\begin{array}{l}(0.86) \\
(0.96)\end{array}$ & $\begin{array}{l}68.7 \\
72.0\end{array}$ & $\begin{array}{l}(1.51) \\
(1.47)\end{array}$ & $\begin{array}{l}64.2 \\
71.9\end{array}$ & $\begin{array}{l}(0.81) \\
(0.90)\end{array}$ & $\begin{array}{l}69.7 \\
80.2\end{array}$ & $\begin{array}{l}(0.98) \\
(1.01)\end{array}$ & $\begin{array}{l}70.3 \\
81.7\end{array}$ & $\begin{array}{l}(1.32) \\
(1.33)\end{array}$ & $\begin{array}{l}53.4 \\
56.5\end{array}$ & $.91)$ & $\begin{array}{l}51.1 \\
55.1\end{array}$ & $\begin{array}{l}(1.16) \\
(1.28)\end{array}$ & $\begin{array}{l}52.9 \\
54.3\end{array}$ & $\begin{array}{l}(1.48) \\
(1.45)\end{array}$ & $\overline{-}$ & $\begin{array}{l}(\dagger) \\
(\dagger)\end{array}$ & $\begin{array}{l}71.8 \\
74.1\end{array}$ & $\begin{array}{l}(0.92) \\
(1.05)\end{array}$ & $\begin{array}{l}69.0 \\
69.0\end{array}$ & $\begin{array}{l}(1.49) \\
(1.43)\end{array}$ \\
\hline 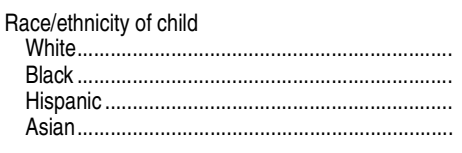 & $\begin{array}{r}70.9 \\
64.8 \\
66.6 \\
-\end{array}$ & $\begin{array}{r}(0.80) \\
(1.73) \\
(1.49) \\
(\dagger)\end{array}$ & $\begin{array}{r}76.0 \\
69.6 \\
74.2 \\
-\end{array}$ & $\begin{array}{r}(0.96) \\
(2.00) \\
(1.55) \\
(\dagger)\end{array}$ & $\begin{array}{l}73.2 \\
61.6 \\
67.6 \\
68.9\end{array}$ & $\begin{array}{l}(1.20) \\
(3.81) \\
(2.46) \\
(5.08)\end{array}$ & $\begin{array}{r}72.4 \\
58.6 \\
59.4 \\
-\end{array}$ & $\begin{array}{r}(0.73) \\
(1.82) \\
(1.33) \\
(\dagger)\end{array}$ & $\begin{array}{r}75.4 \\
68.1 \\
79.6 \\
-\end{array}$ & $\begin{array}{r}(0.89) \\
(2.14) \\
(1.45) \\
(\dagger)\end{array}$ & $\begin{array}{l}74.9 \\
73.0 \\
81.2 \\
66.5\end{array}$ & $\begin{array}{l}(1.23) \\
(3.53) \\
(1.66) \\
(4.74)\end{array}$ & $\begin{array}{r}52.6 \\
60.2 \\
53.6 \\
-\end{array}$ & $\begin{array}{l}89) \\
05) \\
44) \\
(\dagger)\end{array}$ & $\begin{array}{r}44.7 \\
66.6 \\
64.5 \\
-\end{array}$ & $\begin{array}{r}(1.13) \\
(2.45) \\
(1.71) \\
(\dagger)\end{array}$ & $\begin{array}{l}45.6 \\
66.9 \\
61.1 \\
73.6\end{array}$ & $\begin{array}{l}(1.28) \\
(3.59) \\
(2.22) \\
(4.14)\end{array}$ & $\begin{array}{l}- \\
\overline{-} \\
-\end{array}$ & \begin{tabular}{l|l}
$(\dagger)$ \\
$(+)$ \\
$(+)$ \\
$(\dagger)$
\end{tabular} & $\begin{array}{r}73.8 \\
72.9 \\
68.5 \\
-\end{array}$ & $\begin{array}{r}(0.87) \\
(1.92) \\
(1.82) \\
(\dagger)\end{array}$ & $\begin{array}{l}69.0 \\
72.8 \\
67.5 \\
61.7\end{array}$ & $\begin{array}{l}(1.19) \\
(3.14) \\
(2.33) \\
(4.88)\end{array}$ \\
\hline 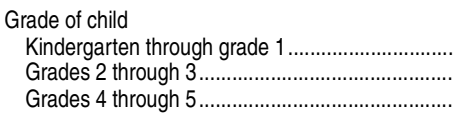 & $\begin{array}{l}77.6 \\
67.7 \\
62.3\end{array}$ & $\begin{array}{l}(1.11) \\
(1.05) \\
(1.09)\end{array}$ & $\begin{array}{l}84.5 \\
74.5 \\
66.4\end{array}$ & $\begin{array}{l}(0.93) \\
(1.21) \\
(1.20)\end{array}$ & $\begin{array}{l}74.1 \\
70.7 \\
66.1\end{array}$ & $\begin{array}{l}(1.81) \\
(1.94) \\
(1.60)\end{array}$ & $\begin{array}{l}75.9 \\
66.4 \\
61.1\end{array}$ & $\begin{array}{l}(0.95) \\
(1.20) \\
(1.19)\end{array}$ & $\begin{array}{l}89.3 \\
74.0 \\
62.2\end{array}$ & $\begin{array}{l}(0.84) \\
(1.12) \\
(1.36)\end{array}$ & $\begin{array}{l}89.1 \\
75.4 \\
62.6\end{array}$ & $\begin{array}{l}(1.08) \\
(1.84) \\
(1.80)\end{array}$ & $\begin{array}{l}49.6 \\
56.4 \\
59.1\end{array}$ & $\begin{array}{l}(1.30) \\
(1.26) \\
(1.12)\end{array}$ & $\begin{array}{l}47.7 \\
54.7 \\
56.5\end{array}$ & $\begin{array}{l}(1.38) \\
(1.34) \\
(1.42)\end{array}$ & $\begin{array}{l}45.7 \\
55.7 \\
59.3\end{array}$ & $\begin{array}{l}(2.03) \\
(1.93) \\
(1.78)\end{array}$ & $\begin{array}{l}- \\
- \\
-\end{array}$ & $\begin{array}{c}(\dagger) \\
(\dagger) \\
(\dagger)\end{array}$ & $\begin{array}{l}77.5 \\
72.7 \\
68.9\end{array}$ & $\begin{array}{l}(1.17) \\
(1.09) \\
(1.18)\end{array}$ & $\begin{array}{l}73.5 \\
68.9 \\
64.6\end{array}$ & $\begin{array}{l}(1.71) \\
(1.70) \\
(1.83)\end{array}$ \\
\hline 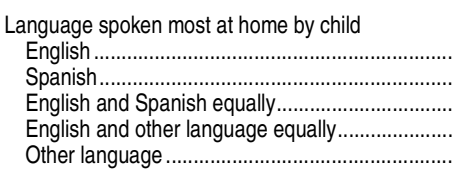 & $\begin{array}{l}70.0 \\
57.7 \\
62.8 \\
83.9 \\
73.1\end{array}$ & $\begin{array}{l}(0.64) \\
(2.73) \\
(3.49) \\
(6.72) \\
(5.33)\end{array}$ & $\begin{array}{r}75.4 \\
65.6 \\
76.6 \\
\ddagger \\
81.7\end{array}$ & $\begin{array}{r}(0.73) \\
(2.85) \\
(3.83) \\
(\dagger) \\
(6.95)\end{array}$ & $\begin{array}{r}71.0 \\
60.7 \\
67.5 \\
\ddagger \\
80.3\end{array}$ & $\begin{array}{r}(1.22) \\
(3.74) \\
(4.69) \\
(\dagger) \\
(8.34)\end{array}$ & $\begin{array}{l}69.3 \\
52.1 \\
53.7 \\
61.9 \\
61.1\end{array}$ & $\begin{array}{l}(0.64) \\
(2.73) \\
(4.27) \\
(9.53) \\
(6.67)\end{array}$ & $\begin{array}{r}74.4 \\
81.7 \\
78.7 \\
\ddagger \\
76.7\end{array}$ & $\begin{array}{r}(0.72) \\
(2.16) \\
(3.88) \\
(+) \\
(4.81)\end{array}$ & $\begin{array}{r}74.6 \\
84.5 \\
85.7 \\
\ddagger \\
84.4\end{array}$ & $\begin{array}{r}(1.04) \\
(2.84) \\
(3.23) \\
(\dagger) \\
(5.61)\end{array}$ & $\begin{array}{l}55.2 \\
47.3 \\
52.6 \\
74.0 \\
61.5\end{array}$ & $\begin{array}{l}.71) \\
.94) \\
.40) \\
.71) \\
.29)\end{array}$ & $\begin{array}{r}51.5 \\
60.2 \\
77.3 \\
\ddagger \\
75.1\end{array}$ & $\begin{array}{r}(0.93) \\
(3.11) \\
(4.18) \\
(+) \\
(6.13)\end{array}$ & $\begin{array}{r}52.0 \\
62.2 \\
63.2 \\
\ddagger \\
74.8\end{array}$ & $\begin{array}{r}(1.10) \\
(3.48) \\
(3.98) \\
(+) \\
(8.83)\end{array}$ & $\begin{array}{l}- \\
\overline{-} \\
- \\
-\end{array}$ & $\begin{array}{l}(\dagger) \\
(t) \\
(t) \\
(\dagger) \\
(t)\end{array}$ & $\begin{array}{r}73.7 \\
58.1 \\
75.2 \\
\ddagger \\
74.8\end{array}$ & $\begin{array}{r}(0.73) \\
(3.10) \\
(3.73) \\
(+) \\
(7.43)\end{array}$ & $\begin{array}{r}68.8 \\
69.2 \\
76.9 \\
\ddagger \\
\quad \neq \\
66.3\end{array}$ & $\begin{array}{r}(1.06) \\
(3.62) \\
(4.06) \\
(\dagger) \\
(10.40)\end{array}$ \\
\hline 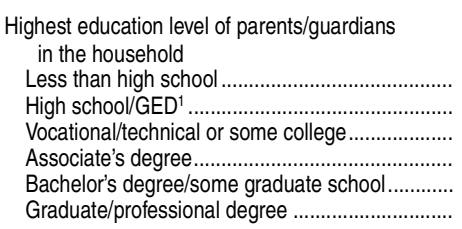 & $\begin{array}{l}61.9 \\
66.5 \\
70.2 \\
70.0 \\
74.2 \\
71.4\end{array}$ & $\begin{array}{l}(2.30) \\
(1.28) \\
(1.23) \\
(2.04) \\
(1.39) \\
(1.73)\end{array}$ & $\begin{array}{l}67.2 \\
71.3 \\
75.9 \\
76.0 \\
77.3 \\
78.6\end{array}$ & $\begin{array}{l}(3.16) \\
(1.59) \\
(1.54) \\
(2.00) \\
(1.60) \\
(1.64)\end{array}$ & $\begin{array}{l}59.3 \\
66.9 \\
70.0 \\
68.9 \\
70.6 \\
77.9\end{array}$ & $\begin{array}{l}(4.90) \\
(2.62) \\
(2.56) \\
(2.58) \\
(2.11) \\
(1.91)\end{array}$ & $\begin{array}{l}54.4 \\
64.3 \\
68.3 \\
71.9 \\
73.3 \\
73.3\end{array}$ & $\begin{array}{l}(2.13) \\
(1.27) \\
(1.18) \\
(1.88) \\
(1.10) \\
(1.53)\end{array}$ & $\begin{array}{l}74.8 \\
75.5 \\
76.2 \\
73.6 \\
74.0 \\
73.9\end{array}$ & $\begin{array}{l}(3.20) \\
(1.32) \\
(1.51) \\
(2.47) \\
(1.48) \\
(1.72)\end{array}$ & $\begin{array}{l}80.1 \\
78.6 \\
76.4 \\
72.3 \\
74.2 \\
74.1\end{array}$ & $\begin{array}{l}(4.60) \\
(2.44) \\
(2.15) \\
(3.13) \\
(1.31) \\
(1.99)\end{array}$ & $\begin{array}{l}45.1 \\
47.6 \\
57.7 \\
56.7 \\
61.5 \\
61.4\end{array}$ & $\begin{array}{l}(2.43) \\
(1.46) \\
(1.41) \\
(2.31) \\
(1.57) \\
(1.56)\end{array}$ & $\begin{array}{l}60.4 \\
54.9 \\
50.8 \\
50.9 \\
47.3 \\
60.1\end{array}$ & $\begin{array}{l}(2.98) \\
(1.91) \\
(1.75) \\
(3.16) \\
(1.74) \\
(2.16)\end{array}$ & $\begin{array}{l}52.1 \\
56.3 \\
53.1 \\
48.7 \\
51.8 \\
55.9\end{array}$ & $\begin{array}{l}(2.06) \\
(1.87)\end{array}$ & $\begin{array}{l}- \\
\overline{-} \\
\overline{-} \\
-\end{array}$ & $\begin{array}{l}(t) \\
(t) \\
(t) \\
(t) \\
(t) \\
(t)\end{array}$ & $\begin{array}{l}66.8 \\
73.2 \\
71.6 \\
70.1 \\
75.8 \\
74.9\end{array}$ & $\begin{array}{l}(3.16) \\
(1.39) \\
(1.58) \\
(2.50) \\
(1.27) \\
(1.82)\end{array}$ & $\begin{array}{l}67.6 \\
72.8 \\
69.0 \\
64.9 \\
69.4 \\
66.8\end{array}$ & $\begin{array}{l}(3.97) \\
(2.47) \\
(2.44) \\
(2.77) \\
(1.65) \\
(1.88)\end{array}$ \\
\hline 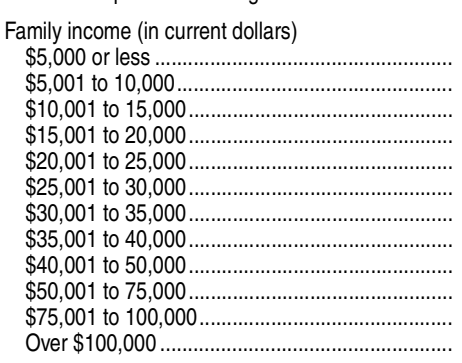 & $\begin{array}{r}67.5 \\
69.6 \\
66.7 \\
62.3 \\
68.1 \\
70.6 \\
69.3 \\
72.5 \\
69.0 \\
70.9 \\
- \\
-\end{array}$ & $\begin{array}{r}(4.39) \\
(2.30) \\
(2.62) \\
(2.29) \\
(2.34) \\
(2.32) \\
(1.85) \\
(1.94) \\
(1.82) \\
(1.43) \\
(\dagger) \\
(\dagger)\end{array}$ & $\begin{array}{l}79.5 \\
70.9 \\
70.0 \\
76.9 \\
71.6 \\
74.2 \\
73.3 \\
74.5 \\
75.7 \\
74.9 \\
74.7 \\
78.6\end{array}$ & $\begin{array}{l}(4.52) \\
(3.88) \\
(3.62) \\
(3.45) \\
(2.86) \\
(2.86) \\
(2.88) \\
(3.68) \\
(2.20) \\
(1.53) \\
(2.02) \\
(1.52)\end{array}$ & $\begin{array}{l}63.9 \\
58.6 \\
72.4 \\
64.6 \\
67.0 \\
67.6 \\
69.5 \\
69.3 \\
73.0 \\
69.1 \\
72.4 \\
75.3\end{array}$ & $\begin{array}{l}(7.52) \\
(7.15) \\
(4.17) \\
(7.55) \\
(5.11) \\
(5.92) \\
(4.44) \\
(4.21) \\
(2.88) \\
(2.00) \\
(2.29) \\
(1.86)\end{array}$ & $\begin{array}{r}55.9 \\
58.4 \\
61.2 \\
64.1 \\
63.9 \\
68.7 \\
66.1 \\
71.6 \\
72.2 \\
72.5 \\
- \\
-\end{array}$ & $\begin{array}{r}(4.38) \\
(2.93) \\
(2.99) \\
(2.70) \\
(2.42) \\
(2.42) \\
(2.51) \\
(1.96) \\
(1.87) \\
(1.41) \\
(\dagger) \\
(\dagger)\end{array}$ & $\begin{array}{l}78.9 \\
75.3 \\
74.6 \\
76.1 \\
80.6 \\
71.9 \\
78.1 \\
75.5 \\
71.9 \\
75.3 \\
71.2 \\
75.1\end{array}$ & $\begin{array}{l}(4.61) \\
(3.30) \\
(4.03) \\
(3.74) \\
(2.33) \\
(3.47) \\
(2.72) \\
(2.97) \\
(2.48) \\
(1.55) \\
(1.98) \\
(1.87)\end{array}$ & $\begin{array}{l}76.7 \\
78.9 \\
83.8 \\
79.6 \\
73.0 \\
84.3 \\
73.8 \\
80.5 \\
75.8 \\
75.5 \\
73.0 \\
72.5\end{array}$ & $\begin{array}{l}(7.70) \\
(5.56) \\
(3.94) \\
(4.10) \\
(5.58) \\
(3.45) \\
(4.98) \\
(2.81) \\
(2.89) \\
(1.94) \\
(2.03) \\
(1.89)\end{array}$ & $\begin{array}{r}56.9 \\
55.8 \\
53.8 \\
- \\
-\end{array}$ & $\begin{array}{r}(4.27) \\
(3.46) \\
(2.48) \\
(2.78) \\
(2.82) \\
(2.34) \\
(2.68) \\
(2.33) \\
(1.83) \\
(1.37) \\
(\dagger) \\
(\dagger)\end{array}$ & $\begin{array}{l}71.0 \\
63.7 \\
58.8 \\
57.3 \\
60.4 \\
52.3 \\
52.9 \\
44.6 \\
55.0 \\
49.6 \\
48.8 \\
50.1\end{array}$ & $\begin{array}{l}(4.75) \\
(4.64) \\
(4.30) \\
(3.48) \\
(3.71) \\
(4.08) \\
(3.86) \\
(3.73) \\
(2.94) \\
(1.99) \\
(2.28) \\
(1.93)\end{array} \mid$ & $\begin{array}{l}50.3 \\
62.5 \\
58.9 \\
58.7 \\
61.0 \\
58.4 \\
65.2 \\
52.9 \\
54.9 \\
44.4 \\
49.4 \\
55.4\end{array}$ & $\begin{array}{l}(6.49) \\
(5.61) \\
(6.60) \\
(5.19) \\
(5.16) \\
(4.25) \\
(3.81) \\
(3.17) \\
(2.27) \\
(2.77) \\
(2.09)\end{array} \mid$ & $\begin{array}{l}- \\
- \\
- \\
- \\
- \\
- \\
- \\
- \\
- \\
- \\
-\end{array}$ & $\begin{array}{l}(t) \\
(t) \\
(t) \\
(t) \\
(t) \\
(t) \\
(t) \\
(t) \\
(t) \\
(t) \\
(t) \\
(t) \\
(t)\end{array}$ & $\begin{array}{l}71.7 \\
73.8 \\
72.1 \\
73.3 \\
74.7\end{array}$ & $\begin{array}{l}(3.94) \\
(3.82) \\
(4.15) \\
(3.34) \\
(2.95) \\
(3.42) \\
(3.24) \\
(4.03) \\
(2.62) \\
(1.51) \\
(2.30) \\
(1.81)\end{array} \mid$ & $\begin{array}{l}77.8 \\
74.3 \\
71.8 \\
72.2 \\
72.4 \\
63.5 \\
67.7 \\
62.5 \\
65.8 \\
66.6 \\
70.5 \\
69.1\end{array}$ & $\begin{array}{l}(5.04) \\
(5.79) \\
(4.83) \\
(5.36) \\
(4.21) \\
(5.93) \\
(4.55) \\
(4.25) \\
(3.55) \\
(2.26) \\
(2.41) \\
(1.69)\end{array}$ \\
\hline $\begin{array}{l}\text { Child attending public school } \\
\text { Child attending private school }\end{array}$ & $\begin{array}{l}68.8 \\
73.7\end{array}$ & $\begin{array}{l}(0.65) \\
(1.58)\end{array}$ & $\begin{array}{l}75.0 \\
74.2\end{array}$ & $\begin{array}{l}(0.68) \\
(2.09)\end{array}$ & $\begin{array}{l}69.6 \\
75.2\end{array}$ & $\begin{array}{l}(1.19) \\
(2.51)\end{array}$ & $\begin{array}{l}67.5 \\
71.6\end{array}$ & $\begin{array}{l}(0.66) \\
(1.64)\end{array}$ & $\begin{array}{l}75.2 \\
72.1\end{array}$ & $\begin{array}{l}(0.72) \\
(1.94)\end{array}$ & $\begin{array}{l}75.9 \\
74.8\end{array}$ & $\begin{array}{l}(0.99) \\
(2.76)\end{array}$ & $\begin{array}{l}54.5 \\
58.2\end{array}$ & $\begin{array}{l}(0.73) \\
(1.68)\end{array}$ & $\begin{array}{l}52.4 \\
58.1\end{array}$ & $\begin{array}{l}(0.98) \\
(2.17)\end{array}$ & $\begin{array}{l}54.0 \\
50.6\end{array}$ & $\begin{array}{l}(1.16) \\
(2.72)\end{array}$ & $\overline{-}$ & $\begin{array}{l}(\dagger) \\
(\dagger)\end{array}$ & $\begin{array}{l}73.4 \\
69.1\end{array}$ & $\begin{array}{l}(0.74) \\
(1.99)\end{array}$ & $\begin{array}{l}68.9 \\
69.6\end{array}$ & $\left(\begin{array}{l}(1.06) \\
(2.40)\end{array}\right.$ \\
\hline
\end{tabular}

\section{-Not available.}

†Not applicable.

1GED = General Educational Development.

NOTE: The respondent was the parent most knowledgeable about the child's education. Responding parents reported on

include other racial/ethnic groups not separately shown. Race categories exclude persons of Hispanic ethnicity. Some data have been revised from previously published figures.

their own activities and the activities of their spouse/other adults in the household. Excludes homeschooled children. Totals 
Table 207.40. Percentage of elementary and secondary school children whose parents were involved in school activities, by selected child, parent, and school characteristics: 1999, 2003, and 2007

[Standard errors appear in parentheses]

\begin{tabular}{|c|c|c|c|c|c|c|c|c|c|c|c|c|c|c|c|c|c|c|c|c|c|c|c|c|}
\hline \multirow[b]{3}{*}{ Selected child, parent, or school characteristic } & \multicolumn{24}{|c|}{ Percent of children whose parents report the following types of involvement in school activities } \\
\hline & \multicolumn{8}{|c|}{1999} & \multicolumn{8}{|c|}{2003} & \multicolumn{8}{|c|}{2007} \\
\hline & \multicolumn{2}{|c|}{$\begin{array}{r}\text { Attended a } \\
\text { general school } \\
\text { meeting }\end{array}$} & \multicolumn{2}{|c|}{$\begin{array}{r}\text { Attended } \\
\text { parent-teacher } \\
\text { conference }\end{array}$} & \multicolumn{2}{|c|}{$\begin{array}{l}\text { Attended a } \\
\text { class event }\end{array}$} & \multicolumn{2}{|c|}{$\begin{array}{r}\text { Volunteered at } \\
\text { school }\end{array}$} & \multicolumn{2}{|c|}{$\begin{array}{r}\text { Attended a } \\
\text { general school } \\
\text { meeting }\end{array}$} & \multicolumn{2}{|c|}{$\begin{array}{r}\text { Attended } \\
\text { parent-teacher } \\
\text { conference }\end{array}$} & \multicolumn{2}{|c|}{$\begin{array}{l}\text { Attended a } \\
\text { class event }\end{array}$} & \multicolumn{2}{|c|}{$\begin{array}{r}\text { Volunteered at } \\
\text { school }\end{array}$} & \multicolumn{2}{|c|}{$\begin{array}{r}\text { Attended a } \\
\text { general school } \\
\text { meeting }\end{array}$} & \multicolumn{2}{|c|}{$\begin{array}{r}\text { Attended } \\
\text { parent-teacher } \\
\text { conference }\end{array}$} & \multicolumn{2}{|c|}{$\begin{array}{l}\text { Attended a } \\
\text { class event }\end{array}$} & \multicolumn{2}{|c|}{$\begin{array}{r}\text { Volunteered at } \\
\text { school }\end{array}$} \\
\hline 1 & & 2 & & 3 & & 4 & & 5 & & 6 & & 7 & & 8 & & 9 & & 10 & & 11 & & 12 & & 13 \\
\hline Total & 78.3 & (0.49) & 72.8 & $(0.45)$ & 65.4 & $(0.44)$ & 36.8 & $(0.40)$ & 87.7 & $(0.37)$ & 77.1 & (0.42) & 69.9 & (0.42) & 41.8 & $(0.60)$ & 89.4 & (0.48) & 78.1 & (0.52) & 74.5 & $(0.57)$ & 46.4 & $(0.63)$ \\
\hline $\begin{array}{l}\text { Sex of child } \\
\text { Male } \\
\text { Female. }\end{array}$ & $\begin{array}{l}78.0 \\
78.6\end{array}$ & $\begin{array}{l}(0.62) \\
(0.69)\end{array}$ & $\begin{array}{l}74.0 \\
71.5\end{array}$ & $\begin{array}{l}(0.60) \\
(0.56)\end{array}$ & $\begin{array}{l}63.4 \\
67.4\end{array}$ & $\begin{array}{l}(0.62) \\
(0.59)\end{array}$ & $\begin{array}{l}36.7 \\
37.0\end{array}$ & $\begin{array}{l}(0.65) \\
(0.61)\end{array}$ & $\begin{array}{l}87.4 \\
87.9\end{array}$ & $\begin{array}{l}(0.49) \\
(0.55)\end{array}$ & $\begin{array}{l}77.7 \\
76.5\end{array}$ & $\begin{array}{l}(0.63) \\
(0.63)\end{array}$ & $\begin{array}{l}67.4 \\
72.6\end{array}$ & $\begin{array}{l}(0.75) \\
(0.63)\end{array}$ & $\begin{array}{l}41.2 \\
42.4\end{array}$ & $\begin{array}{l}(0.87) \\
(0.83)\end{array}$ & $\begin{array}{l}89.3 \\
89.6\end{array}$ & $\begin{array}{l}(0.70) \\
(0.59)\end{array}$ & $\begin{array}{l}79.2 \\
76.8\end{array}$ & $\begin{array}{l}(0.65) \\
(0.94)\end{array}$ & $\begin{array}{l}71.5 \\
77.7\end{array}$ & $\begin{array}{l}(0.90) \\
(0.82)\end{array}$ & $\begin{array}{l}44.8 \\
48.1\end{array}$ & $\begin{array}{l}(0.95) \\
(1.01)\end{array}$ \\
\hline Race/ethnicity of child & & & & & & & & & & & & & & & & & & & & & & & & \\
\hline White... & 80.5 & $(0.54)$ & 73.6 & $(0.48)$ & 71.6 & (0.53) & 42.7 & $(0.51)$ & 88.7 & $(0.51)$ & 76.4 & $(0.62)$ & 74.1 & $(0.65)$ & 48.4 & $(0.82)$ & 90.9 & (0.52) & 77.8 & (0.64) & 80.1 & $(0.68)$ & 54.2 & $(0.85)$ \\
\hline 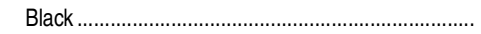 & 74.5 & (1.12) & 71.1 & $(1.23)$ & 53.8 & $(1.29)$ & 26.2 & $(1.21)$ & 88.7 & $(0.85)$ & 78.7 & $(1.35)$ & 63.3 & (1.54) & 32.0 & $(1.65)$ & 86.7 & (1.77) & 77.3 & $(1.98)$ & 64.7 & (2.31) & 35.0 & (1.89) \\
\hline 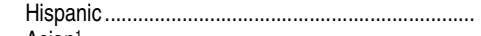 & 73.1 & (1.18) & 71.0 & $(1.05)$ & 51.5 & $(1.02)$ & 24.5 & $(0.90)$ & 82.6 & $(1.05)$ & 78.1 & (1.10) & 60.9 & (1.36) & 27.7 & $(1.23)$ & 86.7 & (1.14) & 80.2 & $(1.05)$ & 65.0 & $(1.46)$ & 31.8 & (1.34) \\
\hline Asian $1 .$. & - & $(t)$ & - & $(t)$ & - & $(\dagger)$ & - & $(\dagger)$ & - & $(t)$ & - & $(t)$ & - & $(t)$ & - & $(t)$ & 91.0 & (2.06) & 79.9 & $(2.87)$ & 71.4 & (2.89) & 45.8 & (3.78) \\
\hline Pacific Islander ${ }^{1}$. & - & $(t)$ & - & $(t)$ & - & $(t)$ & - & $(t)$ & - & $(\dagger)$ & - & $(\dagger)$ & - & $(\dagger)$ & - & $(\dagger)$ & $\ddagger$ & $(t)$ & $\ddagger$ & $(\dagger)$ & $\ddagger$ & $(\dagger)$ & $\ddagger$ & $(t)$ \\
\hline American Indian/Alaska Native' & - & $(\dagger)$ & - & $(t)$ & - & $(t)$ & - & $(t)$ & - & $(\dagger)$ & - & $(\dagger)$ & - & (†) & - & $(\dagger)$ & 94.2 & (2.96) & 79.7 & (7.16) & 80.8 & (9.63) & 58.4 & (12.64) \\
\hline Other ${ }^{2} \ldots$ & 76.7 & (2.00) & 73.2 & (1.94) & 62.4 & (2.01) & 30.7 & $(1.94)$ & 87.5 & (1.63) & 77.6 & (2.25) & 68.5 & (2.32) & 37.2 & (2.16) & 89.2 & (1.76) & 73.6 & (3.48) & 75.7 & (2.83) & 44.8 & (3.13) \\
\hline $\begin{array}{l}\text { Highest education level of parents/guardians in } \\
\text { the household }\end{array}$ & & & & & & & & & & & & & & & & & & & & & & & & \\
\hline Less than high school.. & 57.4 & (1.77) & 60.0 & (1.78) & 37.8 & $(1.68)$ & 12.9 & $(1.05)$ & 69.8 & (2.04) & 67.8 & (2.50) & 42.4 & (2.42) & 15.6 & (2.04) & 75.2 & (2.37) & 69.7 & (2.65) & 48.1 & (3.06) & 19.5 & (3.37) \\
\hline 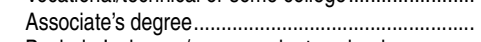 & 81.7 & $(1.14)$ & 75.8 & $(1.39)$ & 68.7 & $(1.57)$ & 41.5 & (1.53) & 88.6 & $(1.27)$ & 76.6 & $(1.68)$ & 73.0 & (1.76) & 39.7 & $(1.67)$ & 91.9 & $(1.18)$ & 80.2 & $(1.75)$ & 76.9 & (2.14) & 45.3 & (2.32) \\
\hline Bachelor's degree/some graduate school... & 87.0 & $(0.73)$ & 79.6 & $(0.84)$ & 75.8 & $(0.93)$ & 49.6 & $(1.10)$ & 92.0 & $(0.75)$ & 79.8 & $(0.89)$ & 80.1 & $(0.95)$ & 53.9 & $(1.29)$ & 93.6 & $(0.75)$ & 81.4 & (1.00) & 83.2 & $(0.95)$ & 57.1 & (1.44) \\
\hline Graduate/professional degree ... & 89.4 & $(0.70)$ & 76.2 & $(1.09)$ & 79.2 & $(0.98)$ & 55.1 & (1.21) & 94.6 & $(0.74)$ & 79.4 & $(0.99)$ & 80.8 & $(1.09)$ & 61.8 & (1.57) & 95.6 & $(0.64)$ & 82.3 & (1.13) & 87.3 & $(0.95)$ & 64.1 & (1.33) \\
\hline Family income (in current dollars) & & & & & & & & & & & & & & & & & & & & & & & & \\
\hline$\$ 5,000$ or less... & 67.0 & (2.83) & 66.7 & (3.14) & 47.4 & (2.87) & 17.6 & (2.09) & 77.7 & (2.84) & 72.4 & (4.15) & 55.6 & (3.91) & 27.3 & $(4.09)$ & 76.3 & (4.85) & 66.1 & (5.32) & 44.7 & $(6.01)$ & 27.8 & (5.24) \\
\hline$\$ 5,001$ to $10,000 \ldots$ & 66.8 & (2.13) & 67.6 & (2.25) & 50.7 & (2.23) & 23.3 & $(1.91)$ & 79.3 & (3.26) & 75.7 & (3.28) & 59.9 & $(3.60)$ & 30.4 & (3.35) & 80.0 & (3.45) & 76.0 & $(3.81)$ & 56.2 & (4.56) & 26.3 & (4.53) \\
\hline$\$ 10,00$ & 67.1 & (1.64) & 70.0 & (1.62) & 49.9 & (2.15) & 20.4 & (1.40) & 80.0 & (2.41) & 75.6 & (2.35) & 53.4 & (2.99) & 22.5 & (2.44) & 76.7 & (4.46) & 73.0 & $(4.57)$ & 56.8 & (4.12) & 28.8 & (3.69) \\
\hline$\$ 15,001$ to $20,000 \ldots$ & 71.1 & (1.76) & 70.4 & (1.52) & 55.1 & (1.89) & 25.3 & $(1.70)$ & 81.1 & (2.60) & 74.2 & (2.23) & 57.5 & (2.28) & 25.6 & (2.84) & 81.9 & $(3.07)$ & 83.0 & $(2.54)$ & 58.9 & (4.17) & 17.4 & (2.12) \\
\hline$\$ 20,001$ to $25,000 \ldots$ & 70.6 & (1.90) & 67.0 & (1.62) & 53.4 & (1.76) & 26.2 & (1.63) & 83.5 & $(1.64)$ & 79.1 & $(1.89)$ & 62.4 & (1.99) & 27.0 & (2.39) & 84.8 & (2.26) & 78.9 & (2.38) & 64.7 & (2.96) & 29.9 & (3.18) \\
\hline$\$ 25,001$ to 30,000 .. & 74.3 & $(1.35)$ & 71.6 & $(1.31)$ & 59.1 & $(1.71)$ & 30.9 & (1.69) & 85.7 & $(1.46)$ & 75.9 & (2.41) & 64.2 & (2.23) & 33.8 & (2.86) & 85.5 & (3.09) & 76.6 & (3.20) & 63.4 & $(3.20)$ & 35.9 & (3.53) \\
\hline$\$ 30,001$ to $35,000 \ldots$ & 79.0 & $(1.60)$ & 73.8 & (1.72) & 67.6 & $(1.69)$ & 37.9 & $(1.84)$ & 84.5 & (1.59) & 76.3 & (1.94) & 64.7 & (2.32) & 33.5 & (2.51) & 85.6 & (2.75) & 72.4 & $(3.23)$ & 67.6 & (2.59) & 31.5 & (2.80) \\
\hline$\$ 35,001$ to 40,000 & 79.4 & $(1.38)$ & 73.7 & $(1.38)$ & 68.4 & $(1.64)$ & 36.1 & $(1.84)$ & 83.4 & (2.50) & 74.7 & (2.10) & 70.9 & $(2.41)$ & 37.3 & (3.50) & 88.0 & $(1.65)$ & 74.9 & (2.85) & 69.9 & $(2.57)$ & 32.8 & (2.52) \\
\hline$\$ 40,001$ to 50,000 & 81.6 & $(1.07)$ & 75.1 & (1.13) & 72.8 & $(1.25)$ & 40.1 & $(1.26)$ & 87.5 & $(1.18)$ & 79.3 & (1.42) & 68.5 & (2.11) & 40.0 & $(1.89)$ & 88.8 & $(1.57)$ & 79.4 & $(2.05)$ & 74.3 & $(2.09)$ & 40.8 & (2.36) \\
\hline$\$ 50,001$ to 75,000 .. & 84.6 & (0.78) & 74.8 & $(0.91)$ & 72.6 & $(0.90)$ & 43.8 & $(1.05)$ & 89.9 & $(0.79)$ & 76.9 & $(0.96)$ & 74.5 & (1.04) & 46.0 & (1.27) & 92.0 & (0.73) & 78.6 & $(0.96)$ & 79.0 & (1.15) & 51.7 & (1.18) \\
\hline Over $\$ 75,000$ & 88.5 & $(0.68)$ & 77.3 & $(0.74)$ & 79.3 & $(0.80)$ & 54.9 & $(1.02)$ & 93.9 & $(0.57)$ & 78.6 & $(0.89)$ & 79.3 & (0.73) & 56.8 & (1.01) & 95.0 & $(0.40)$ & 79.9 & $(0.87)$ & 85.4 & $(0.66)$ & 62.0 & (1.10) \\
\hline Child attending public school..... & 76.8 & (0.54) & 71.4 & (0.50) & 63.5 & $(0.48)$ & 33.8 & $(0.41)$ & 86.7 & $(0.40)$ & 75.9 & $(0.45)$ & 68.0 & $(0.47)$ & 38.5 & $(0.64)$ & 88.5 & (0.53) & 76.9 & $(0.59)$ & 72.6 & $(0.66)$ & 42.7 & $(0.69)$ \\
\hline en to grade 8). & 81.7 & $(0.57)$ & 80.9 & $(0.45)$ & 66.9 & $(0.55)$ & 38.1 & $(0.48)$ & 90.9 & $(0.40)$ & 85.1 & $(0.42)$ & 71.7 & $(0.57)$ & 42.8 & $(0.74)$ & 91.7 & $(0.59)$ & 85.1 & $(0.69)$ & 76.1 & $(0.79)$ & & \\
\hline Secondary (grades 9 to 12 )... & 65.8 & $(0.99)$ & 50.1 & $(1.10)$ & 55.9 & $(0.97)$ & 24.0 & $(0.77)$ & 76.9 & $(1.06)$ & 54.8 & $(1.02)$ & 59.4 & $(1.06)$ & 28.5 & $(0.98)$ & 82.0 & (1.12) & 59.9 & (1.14) & 65.5 & $(1.20)$ & 30.6 & (1.05) \\
\hline Child attendir & 91.4 & $(0.80)$ & 85.0 & $(0.95)$ & 81.7 & $(1.09)$ & 63.8 & $(1.35)$ & 95.7 & $(0.61)$ & 86.6 & $(1.03)$ & 85.6 & (1.23) & 68.7 & $(1.57)$ & 96.3 & $(1.08)$ & 86.5 & (1.84) & 88.1 & $(1.27)$ & 74.1 & (1.75) \\
\hline$n$ to grade 8 ).... & 93.0 & $(0.73)$ & 90.2 & $(0.81)$ & 84.2 & (1.11) & 68.8 & (1.37) & 96.6 & $(0.69)$ & 91.6 & $(0.92)$ & 88.4 & $(1.22)$ & 73.4 & (1.90) & 96.8 & (1.46) & 92.5 & (1.61) & 89.2 & $(1.65)$ & 80.3 & (1.87) \\
\hline 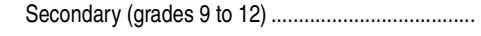 & 85.9 & (2.09) & 66.9 & (2.74) & 73.0 & (2.62) & 46.3 & (3.23) & 93.0 & $(1.56)$ & 72.2 & (2.54) & 77.6 & (2.93) & 55.2 & (2.78) & 95.2 & (1.11) & 71.2 & (4.05) & 85.2 & (2.21) & 58.6 & (3.50) \\
\hline
\end{tabular}


130 CHAPTER 2: Elementary and Secondary Education

Teachers and Pupil/Teacher Ratios

Table 208.10. Public elementary and secondary pupil/teacher ratios, by selected school characteristics: Selected years, fall 1990 through fall 2011

\begin{tabular}{|c|c|c|c|c|c|c|c|c|c|c|c|c|c|c|c|c|c|c|c|c|c|}
\hline $\begin{array}{l}\text { Selected school } \\
\text { characteristic }\end{array}$ & 1990 & 1992 & 1993 & 1994 & 1995 & 1996 & 1997 & 1998 & 1999 & 2000 & 2001 & 2002 & 2003 & 2004 & 2005 & 2006 & 2007 & 2008 & 2009 & $2010^{1}$ & 2011 \\
\hline 1 & 2 & 3 & 4 & 5 & 6 & 7 & 8 & 9 & 10 & 11 & 12 & 13 & 14 & 15 & 16 & 17 & 18 & 19 & 20 & 21 & 22 \\
\hline All schools ......... & 17.4 & 17.7 & 17.8 & 17.7 & 17.8 & 17.6 & 17.2 & 16.9 & 16.6 & 16.4 & 16.3 & 16.2 & 16.4 & 16.2 & 16.0 & 15.8 & 15.7 & 15.7 & 16.0 & 16.4 & 16.3 \\
\hline Enrollment size of school & & & & & & & & & & & & & & & & & & & & & \\
\hline Under $300 \ldots \ldots \ldots . . .$. & 14.0 & 14.1 & 14.3 & 14.1 & 14.1 & 14.0 & 13.7 & 13.6 & 13.3 & 13.1 & 12.9 & 12.8 & 13.0 & 12.8 & 12.7 & 12.7 & 12.7 & 12.5 & 12.6 & 12.9 & 12.8 \\
\hline 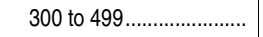 & 17.0 & 17.0 & 17.3 & 17.2 & 17.1 & 16.9 & 16.5 & 16.2 & 15.8 & 15.5 & 15.4 & 15.3 & 15.5 & 15.2 & 15.0 & 14.9 & 15.0 & 14.8 & 15.2 & 15.4 & 15.4 \\
\hline 500 to $999 \ldots \ldots \ldots \ldots$ & 18.0 & 18.1 & 18.2 & 18.1 & 18.2 & 17.9 & 17.5 & 17.1 & 16.8 & 16.7 & 16.5 & 16.5 & 16.6 & 16.4 & 16.2 & 15.9 & 15.9 & 15.9 & 16.3 & 16.7 & 16.7 \\
\hline 1,000 to $1,499 \ldots \ldots \ldots \ldots$ & 17.9 & 18.6 & 18.5 & 18.6 & 18.7 & 18.5 & 18.1 & 17.7 & 17.6 & 17.4 & 17.4 & 17.4 & 17.6 & 17.3 & 16.9 & 16.7 & 16.5 & 16.5 & 16.8 & 17.3 & 17.1 \\
\hline 1,500 or more ................. & 19.2 & 20.0 & 19.7 & 19.9 & 20.0 & 20.0 & 19.7 & 19.3 & 19.3 & 19.1 & 19.0 & 18.9 & 19.2 & 19.1 & 18.8 & 18.6 & 18.1 & 18.3 & 18.7 & 19.5 & 19.0 \\
\hline Regular schools .............. & 17.6 & 17.8 & 17.9 & 17.8 & 17.9 & 17.7 & 17.3 & 17.0 & 16.7 & 16.5 & 16.4 & 16.3 & 16.5 & 16.3 & 16.1 & 15.9 & 15.8 & 15.8 & 16.1 & 16.5 & 16.4 \\
\hline Alternative ........................ & 14.2 & 16.5 & 17.4 & 18.0 & 16.6 & 16.6 & 16.5 & 16.4 & 15.8 & 15.2 & 14.9 & 14.9 & 15.0 & 14.4 & 14.0 & 14.7 & 13.5 & 14.2 & 14.3 & 14.8 & 14.7 \\
\hline Special education ........... & 6.5 & 7.0 & 7.4 & 6.9 & 7.2 & 7.4 & 7.6 & 7.3 & 7.2 & 7.0 & 6.4 & 7.0 & 7.3 & 7.4 & 6.2 & 6.6 & 7.1 & 6.8 & 7.1 & 6.9 & 7.1 \\
\hline $\begin{array}{l}\text { Percent of students } \\
\quad \text { eligible for free or } \\
\text { reduced-price lunch }\end{array}$ & 13.0 & 13.0 & 13.1 & 12.9 & 12.7 & 12.9 & 12.9 & 13.1 & 13.0 & 12.7 & 12.7 & 9.9 & 10.3 & 11.5 & 12.0 & 13.3 & 11.3 & 10.7 & 10.2 & 11.7 & 11.8 \\
\hline 25 percent or less .......... & - & - & - & - & - & - & - & - & - & - & - & - & - & 16.8 & 16.4 & 16.4 & 16.3 & 16.1 & 16.5 & 16.9 & 17.5 \\
\hline 26 percent to 50 percent... & - & - & - & - & - & - & - & - & - & - & - & - & - & 16.2 & 16.1 & 15.8 & 15.7 & 15.7 & 16.1 & 16.5 & 16.2 \\
\hline 51 percent to 75 percent... & - & - & - & - & - & - & - & - & - & - & - & - & - & 15.9 & 15.6 & 15.3 & 15.2 & 15.4 & 15.8 & 16.2 & 15.8 \\
\hline More than 75 percent..... & - & - & - & - & - & - & - & - & - & - & - & - & - & 15.9 & 15.5 & 15.4 & 15.0 & 15.1 & 15.6 & 16.0 & 15.5 \\
\hline evel and size & & & & & & & & & & & & & & & & & & & & & \\
\hline Elementary schools ....... & 18.1 & 18.1 & 18.2 & 18.0 & 18.1 & 17.8 & 17.4 & 17.0 & 16.7 & 16.5 & 16.3 & 16.2 & 16.3 & 16.0 & 15.8 & 15.6 & 15.6 & 15.5 & 15.9 & 16.3 & 16.3 \\
\hline Regular ............................ & 18.2 & 18.1 & 18.3 & 18.0 & 18.1 & 17.9 & 17.4 & 17.0 & 16.7 & 16.5 & 16.3 & 16.2 & 16.3 & 16.0 & 15.8 & 15.6 & 15.6 & 15.5 & 15.9 & 16.3 & 16.3 \\
\hline Under $300 \ldots \ldots \ldots \ldots . . . .$. & 16.0 & 15.9 & 16.0 & 15.7 & 15.7 & 15.6 & 15.3 & 15.1 & 14.6 & 14.4 & 14.1 & 13.9 & 14.0 & 13.7 & 13.6 & 13.5 & 13.7 & 13.5 & 13.7 & 14.0 & 14.0 \\
\hline 300 to $499 \ldots \ldots \ldots . . . .$. & 17.6 & 17.5 & 17.7 & 17.5 & 17.5 & 17.2 & 16.8 & 16.4 & 16.1 & 15.8 & 15.6 & 15.5 & 15.6 & 15.3 & 15.2 & 15.1 & 15.2 & 15.0 & 15.4 & 15.6 & 15.7 \\
\hline $999 \ldots \ldots \ldots \ldots . . .$. & 18.8 & 18.7 & 18.8 & 18.5 & 18.6 & 18.3 & 17.8 & 17.4 & 17.1 & 16.9 & 16.8 & 16.7 & 16.8 & 16.5 & 16.3 & 16.0 & 16.0 & 16.0 & 16.5 & 16.9 & 16.9 \\
\hline 1,000 to $1,499 \ldots \ldots$. & 19.5 & 19.7 & 19.7 & 19.6 & 19.7 & 19.4 & 18.8 & 18.4 & 18.3 & 18.1 & 18.0 & 18.0 & 18.1 & 17.7 & 17.2 & 17.0 & 16.7 & 16.8 & 17.2 & 17.8 & 17.7 \\
\hline 1,500 or more .......... & 19.9 & 20.3 & 21.2 & 20.4 & 20.9 & 21.2 & 20.7 & 19.9 & 20.0 & 20.5 & 20.2 & 20.3 & 20.8 & 20.5 & 19.6 & 19.4 & 18.0 & 18.1 & 18.5 & 19.3 & 19.0 \\
\hline Secondary schools ......... & 16.6 & 17.3 & 17.3 & 17.5 & 17.6 & 17.5 & 17.3 & 17.0 & 16.8 & 16.6 & 16.6 & 16.7 & 16.9 & 16.8 & 16.6 & 16.4 & 16.3 & 16.2 & 16.4 & 16.8 & 16.5 \\
\hline Regular ............................ & 16.7 & 17.4 & 17.4 & 17.6 & 17.7 & 17.6 & 17.4 & 17.1 & 16.9 & 16.7 & 16.7 & 16.8 & 17.0 & 16.9 & 16.8 & 16.6 & 16.4 & 16.3 & 16.6 & 16.9 & 16.7 \\
\hline Under $300 \ldots \ldots \ldots \ldots . . .$. & 12.3 & 12.3 & 12.6 & 12.7 & 12.8 & 12.7 & 12.5 & 12.5 & 12.0 & 12.0 & 11.9 & 12.0 & 12.3 & 12.0 & 12.2 & 12.0 & 12.1 & 11.9 & 11.9 & 12.2 & 12.0 \\
\hline 300 to $499 . . . . . . . . . . . .$. & 14.9 & 15.3 & 15.5 & 15.7 & 15.7 & 15.5 & 15.3 & 15.1 & 14.6 & 14.5 & 14.4 & 14.4 & 14.7 & 14.7 & 14.6 & 14.4 & 14.4 & 14.3 & 14.3 & 14.6 & 14.6 \\
\hline 500 to $999 \ldots \ldots \ldots \ldots . . .$. & 16.1 & 16.7 & 16.7 & 16.8 & 16.9 & 16.7 & 16.4 & 16.2 & 16.0 & 15.8 & 15.7 & 15.8 & 16.0 & 15.9 & 15.8 & 15.6 & 15.4 & 15.4 & 15.6 & 15.8 & 15.7 \\
\hline 1,000 to $1,499 \ldots \ldots$. & 17.2 & 17.9 & 17.8 & 17.9 & 18.0 & 17.9 & 17.5 & 17.2 & 17.1 & 16.8 & 16.8 & 16.9 & 17.2 & 17.0 & 16.8 & 16.5 & 16.5 & 16.3 & 16.6 & 16.9 & 16.6 \\
\hline 1,500 or more .......... & 19.3 & 20.0 & 19.6 & 19.9 & 20.0 & 20.0 & 19.7 & 19.3 & 19.2 & 18.9 & 18.8 & 18.8 & 19.0 & 19.0 & 18.8 & 18.5 & 18.2 & 18.2 & 18.6 & 19.3 & 18.8 \\
\hline Combined schools ......... & 14.5 & 14.8 & 15.3 & 15.1 & 15.0 & 14.7 & 14.4 & 13.4 & 13.4 & 13.7 & 13.4 & 13.5 & 13.8 & 13.9 & 14.1 & 14.7 & 13.4 & 13.9 & 14.0 & 15.4 & 14.4 \\
\hline 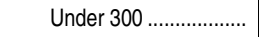 & 8.9 & 9.3 & 9.6 & 9.3 & 9.0 & 8.7 & 8.6 & 8.9 & 9.1 & 9.2 & 9.1 & 9.1 & 9.5 & 9.2 & 9.5 & 10.1 & 9.2 & 8.9 & 9.1 & 9.2 & 9.4 \\
\hline 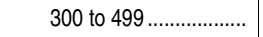 & 14.2 & 14.4 & 14.8 & 14.4 & 14.7 & 14.3 & 14.0 & 13.6 & 13.8 & 13.5 & 13.1 & 13.1 & 14.4 & 13.4 & 13.9 & 14.3 & 13.7 & 13.9 & 13.8 & 13.6 & 13.3 \\
\hline 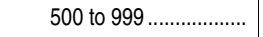 & 16.3 & 15.6 & 16.5 & 16.6 & 16.6 & 16.6 & 16.2 & 15.5 & 14.9 & 15.8 & 15.6 & 16.0 & 15.4 & 15.8 & 15.9 & 16.0 & 15.2 & 15.6 & 15.8 & 16.9 & 15.6 \\
\hline 1,000 to $1,499 \ldots \ldots \ldots . .$. & 17.8 & 18.6 & 18.6 & 18.3 & 18.2 & 18.4 & 18.0 & 16.9 & 16.9 & 17.5 & 18.1 & 17.7 & 17.5 & 17.4 & 16.4 & 17.3 & 15.9 & 16.7 & 17.9 & 19.2 & 18.1 \\
\hline 1,500 or more ................ & 17.7 & 18.9 & 18.8 & 19.5 & 19.6 & 19.3 & 19.3 & 18.7 & 19.2 & 18.6 & 18.9 & 19.1 & 19.2 & 18.7 & 20.0 & 20.3 & 18.0 & 21.7 & 21.7 & 25.7 & 23.4 \\
\hline Ungraded.. & 6.4 & 6.9 & 7.1 & 6.7 & 6.9 & 5.9 & 6.2 & 5.9 & 5.3 & 7.0 & 6.3 & 6.8 & 9.6 & 8.0 & 7.7 & 7.2 & 7.3 & 5.5 & 8.5 & 5.3 & 6.0 \\
\hline $\begin{array}{l}\text { Level, type, and percent of } \\
\text { students eligible for free } \\
\text { or reduced-price lunch }\end{array}$ & & & & & & & & & & & & & & & & & & & & & \\
\hline Elementary, regular & & & & & & & & & & & & & & & & & & & & & \\
\hline 25 percent or less ...... & - & - & - & - & - & - & - & - & - & - & - & - & - & 16.6 & 16.4 & 16.2 & 16.2 & 16.0 & 16.4 & 16.8 & 17.4 \\
\hline 26 to 50 percent .......... & - & - & - & - & - & - & - & - & - & - & - & - & - & 16.0 & 15.8 & 15.5 & 15.6 & 15.6 & 16.0 & 16.4 & 16.3 \\
\hline 51 to 75 percent .......... & - & - & - & - & - & - & - & - & - & - & - & - & - & 15.7 & 15.5 & 15.1 & 15.2 & 15.2 & 15.7 & 16.0 & 15.9 \\
\hline More than 75 percent.... & - & - & - & - & - & - & - & - & - & - & - & - & - & 16.0 & 15.6 & 15.4 & 15.1 & 15.2 & 15.8 & 16.1 & 15.7 \\
\hline Secondary, regular & & & & & & & & & & & & & & & & & & & & & \\
\hline 25 percent or less ...... & - & - & - & - & - & - & - & - & - & - & - & - & - & 17.5 & 17.0 & 16.9 & 16.8 & 16.6 & 16.8 & 17.2 & 17.8 \\
\hline 26 to 50 percent .......... & - & - & - & - & - & - & - & - & - & - & - & - & - & 16.9 & 16.8 & 16.4 & 16.4 & 16.2 & 16.5 & 16.8 & 16.4 \\
\hline 51 to 75 percent .......... & - & - & - & - & - & - & - & - & - & - & - & - & - & 16.9 & 16.7 & 16.3 & 16.1 & 16.4 & 16.5 & 17.1 & 16.1 \\
\hline More than 75 percent. & - & - & - & - & - & - & - & - & - & - & - & - & - & 16.2 & 16.7 & 16.2 & 15.7 & 15.9 & 16.0 & 16.5 & 15.5 \\
\hline
\end{tabular}

-Not available

IIncludes imputations for California and Wyoming

NOTE: Pupi/teacher ratios are based on data reported by types of schools rather than by instructional programs within schools. Only includes schools that reported both enrollment and teacher data. Ratios are based on data reported by schools and may differ from data reported in other tables that reflect aggregate totals reported by states.
SOURCE: U.S. Department of Education, National Center for Education Statistics, Common Core of Data (CCD), "Public Elementary/Secondary School Universe Survey," 1990-91 through 2011-12. (This table was prepared March 2014.) 
Table 208.20. Public and private elementary and secondary teachers, enrollment, pupi/teacher ratios, and new teacher hires: Selected years, fall 1955 through fall 2023

\begin{tabular}{|c|c|c|c|c|c|c|c|c|c|c|c|c|}
\hline \multirow[b]{2}{*}{ Year } & \multicolumn{3}{|c|}{ Teachers (in thousands) } & \multicolumn{3}{|c|}{ Enrollment (in thousands) } & \multicolumn{3}{|c|}{ Pupil/teacher ratio } & \multicolumn{3}{|c|}{$\begin{array}{l}\text { Number of new teacher hires } \\
\quad \text { (in thousands) }{ }^{1}\end{array}$} \\
\hline & Total & Public & Private & Total & Public & Private & Total & Public & Private & Total & Public & Private \\
\hline 1 & 2 & 3 & 4 & 5 & 6 & 7 & 8 & 9 & 10 & 11 & 12 & 13 \\
\hline 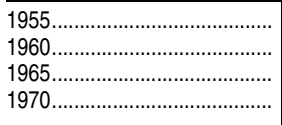 & $\begin{array}{l}1,286 \\
1,600 \\
1,933 \\
2,292 \\
\end{array}$ & $\begin{array}{l}1,141 \\
1,408 \\
1,710 \\
2,059\end{array}$ & $\begin{array}{l}145^{2} \\
192^{2} \\
223 \\
233\end{array}$ & $\begin{array}{l}35,280 \\
42,181 \\
48,473 \\
51,257\end{array}$ & $\begin{array}{l}30,680 \\
36,281 \\
42,173 \\
45,894 \\
\end{array}$ & $\begin{array}{l}4,600^{2} \\
5,900^{2} \\
6,300^{2} \\
5,363\end{array}$ & $\begin{array}{l}27.4 \\
26.4 \\
25.1 \\
22.4\end{array}$ & \begin{tabular}{l|}
26.9 \\
25.8 \\
24.7 \\
22.3
\end{tabular} & \begin{tabular}{l|}
$31.7^{2}$ \\
$30.7^{2}$ \\
28.3 \\
23.0
\end{tabular} & $\begin{array}{l}- \\
- \\
- \\
-\end{array}$ & $\begin{array}{l}- \\
- \\
- \\
-\end{array}$ & $\begin{array}{l}\overline{-} \\
\overline{-} \\
-\end{array}$ \\
\hline 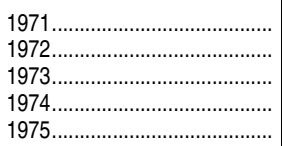 & $\begin{array}{l}2,293 \\
2,337 \\
2,372 \\
2,410 \\
2,453\end{array}$ & $\begin{array}{l}2,063 \\
2,106 \\
2,136 \\
2,165 \\
2,198\end{array}$ & $\begin{array}{l}230^{2} \\
231^{2} \\
236^{2} \\
245^{2} \\
255^{2}\end{array}$ & $\begin{array}{l}51,271 \\
50,726 \\
50,445 \\
50,073 \\
49,819\end{array}$ & $\begin{array}{l}46,071 \\
45,726 \\
45,445 \\
45,073 \\
44,819\end{array}$ & $\begin{array}{l}5,200^{2} \\
5,000^{2} \\
5,000^{2} \\
5,000^{2} \\
5,000^{2}\end{array}$ & $\begin{array}{l}22.4 \\
21.7 \\
21.3 \\
20.8 \\
20.3\end{array}$ & $\begin{array}{l}22.3 \\
21.7 \\
21.3 \\
20.8 \\
20.4\end{array}$ & $\begin{array}{l}22.6^{2} \\
21.6^{2} \\
21.2^{2} \\
20.4^{2} \\
19.6^{2}\end{array}$ & $\begin{array}{l}- \\
- \\
- \\
- \\
-\end{array}$ & $\begin{array}{l}- \\
- \\
- \\
-\end{array}$ & $\begin{array}{l}- \\
\overline{-} \\
\overline{-} \\
-\end{array}$ \\
\hline 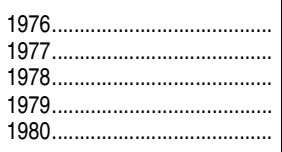 & $\begin{array}{l}2,457 \\
2,488 \\
2,479 \\
2,461 \\
2,485\end{array}$ & $\begin{array}{l}2,189 \\
2,209 \\
2,207 \\
2,185 \\
2,184\end{array}$ & $\begin{array}{l}268 \\
279 \\
272 \\
276^{2} \\
301\end{array}$ & $\begin{array}{l}49,478 \\
48,717 \\
47,637 \\
46,651 \\
46,208\end{array}$ & $\begin{array}{l}44,311 \\
43,577 \\
42,551 \\
41,651 \\
40,877\end{array}$ & $\begin{array}{l}5,167 \\
5,140 \\
5,086 \\
5,000^{2} \\
5,331\end{array}$ & $\begin{array}{l}20.1 \\
19.6 \\
19.2 \\
19.0 \\
18.6\end{array}$ & $\begin{array}{l}20.2 \\
19.7 \\
19.3 \\
19.1 \\
18.7\end{array}$ & \begin{tabular}{l|}
19.3 \\
18.4 \\
18.7 \\
$18.1^{2}$ \\
17.7
\end{tabular} & $\begin{array}{l}- \\
- \\
- \\
-\end{array}$ & $\begin{array}{l}- \\
- \\
-\end{array}$ & $\begin{array}{l}- \\
- \\
- \\
-\end{array}$ \\
\hline 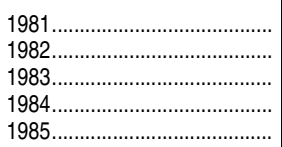 & $\begin{array}{l}2,440 \\
2,458 \\
2,476 \\
2,508 \\
2,549\end{array}$ & $\begin{array}{l}2,127 \\
2,133 \\
2,139 \\
2,168 \\
2,206\end{array}$ & $\begin{array}{l}313^{2} \\
325^{2} \\
337 \\
340^{2} \\
343\end{array}$ & $\begin{array}{l}45,544 \\
45,166 \\
44,967 \\
44,908 \\
44,979\end{array}$ & $\begin{array}{l}40,044 \\
39,566 \\
39,252 \\
39,208 \\
39,422\end{array}$ & $\begin{array}{l}5,500^{2} \\
5,600^{2} \\
5,715^{2} \\
5,700^{2} \\
5,557\end{array}$ & $\begin{array}{l}18.7 \\
18.4 \\
18.2 \\
17.9 \\
17.6\end{array}$ & $\begin{array}{l}18.8 \\
18.6 \\
18.4 \\
18.1 \\
17.9\end{array}$ & $\begin{array}{l}17.6^{2} \\
17.2^{2} \\
17.0^{2} \\
16.8^{2} \\
16.2^{2}\end{array}$ & $\begin{array}{l}- \\
- \\
- \\
- \\
-\end{array}$ & $\begin{array}{l}- \\
- \\
- \\
-\end{array}$ & $\begin{array}{l}- \\
- \\
- \\
-\end{array}$ \\
\hline 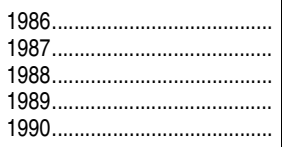 & $\begin{array}{l}2,592 \\
2,631 \\
2,668 \\
2,713 \\
2,759\end{array}$ & $\begin{array}{l}2,244 \\
2,279 \\
2,323 \\
2,357 \\
2,398\end{array}$ & $\begin{array}{l}348^{2} \\
352 \\
345^{2} \\
356 \\
361^{2}\end{array}$ & $\begin{array}{l}45,205 \\
45,488 \\
45,430 \\
46,141 \\
46,864\end{array}$ & $\begin{array}{l}39,753 \\
40,008 \\
40,189 \\
40,543 \\
41,217\end{array}$ & $\begin{array}{l}5,452^{2} \\
5,479^{2} \\
5,242^{2} \\
5,599^{2} \\
5,648^{2}\end{array}$ & $\begin{array}{l}17.4 \\
17.3 \\
17.0 \\
17.0 \\
17.0\end{array}$ & $\begin{array}{l}17.7 \\
17.6 \\
17.3 \\
17.2 \\
17.2\end{array}$ & $\begin{array}{l}15.7^{2} \\
15.6^{2} \\
15.2^{2} \\
15.7^{2} \\
15.6^{2}\end{array}$ & $\begin{array}{l}- \\
- \\
- \\
- \\
-\end{array}$ & $\begin{array}{l}- \\
- \\
- \\
-\end{array}$ & $\begin{array}{l}- \\
- \\
- \\
-\end{array}$ \\
\hline $\begin{array}{l}1991 \ldots \\
1992 \\
1993 \ldots \ldots \\
1994 \ldots \ldots \\
1995 \ldots \ldots\end{array}$ & $\begin{array}{l}2,797 \\
2,823 \\
2,868 \\
2,922 \\
2,974\end{array}$ & $\begin{array}{l}2,432 \\
2,459 \\
2,504 \\
2,552 \\
2,598\end{array}$ & $\begin{array}{l}365 \\
364^{2} \\
364 \\
370^{2} \\
376\end{array}$ & $\begin{array}{l}47,728 \\
48,694 \\
49,532 \\
50,106 \\
50,759\end{array}$ & $\begin{array}{l}42,047 \\
42,823 \\
43,465 \\
44,111 \\
44,840\end{array}$ & $\begin{array}{l}5,681 \\
5,870^{2} \\
6,067 \\
5,994^{2} \\
5,918\end{array}$ & $\begin{array}{l}17.1 \\
17.2 \\
17.3 \\
17.1 \\
17.1\end{array}$ & $\begin{array}{l}17.3 \\
17.4 \\
17.4 \\
17.3 \\
17.3\end{array}$ & $\begin{array}{l}15.6 \\
16.1^{2} \\
16.7 \\
16.2^{2} \\
15.7\end{array}$ & $\begin{array}{l}- \\
- \\
- \\
- \\
-\end{array}$ & $\begin{array}{l}- \\
- \\
- \\
-\end{array}$ & $\begin{array}{l}- \\
- \\
- \\
-\end{array}$ \\
\hline 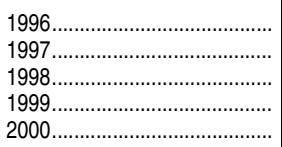 & $\begin{array}{l}3,051 \\
3,138 \\
3,230 \\
3,319 \\
3,366\end{array}$ & $\begin{array}{l}2,667 \\
2,746 \\
2,830 \\
2,911 \\
2,941\end{array}$ & $\begin{array}{l}384^{2} \\
391^{2} \\
400^{2} \\
408 \\
424^{2}\end{array}$ & $\begin{array}{l}51,544 \\
52,071 \\
52,526 \\
52,875 \\
53,373\end{array}$ & $\begin{array}{l}45,611 \\
46,127 \\
46,539 \\
46,857 \\
47,204\end{array}$ & $\begin{array}{l}5,933^{2} \\
5,944 \\
5,988^{2} \\
6,018 \\
6,169^{2}\end{array}$ & $\begin{array}{l}16.9 \\
16.6 \\
16.3 \\
15.9 \\
15.9\end{array}$ & $\begin{array}{l}17.1 \\
16.8 \\
16.4 \\
16.1 \\
16.0\end{array}$ & $\begin{array}{l}15.5^{2} \\
15.2^{2} \\
15.0^{2} \\
14.7^{2} \\
14.5^{2}\end{array}$ & $\begin{array}{c}- \\
- \\
- \\
305 \\
-\end{array}$ & $\begin{array}{r}- \\
- \\
- \\
222 \\
-\end{array}$ & $\begin{array}{l}- \\
\overline{-} \\
\frac{83}{-}\end{array}$ \\
\hline 2001 & $\begin{array}{l}3,440 \\
3,476 \\
3,490 \\
3,536 \\
3,593\end{array}$ & $\begin{array}{l}3,000 \\
3,034 \\
3,049 \\
3,091 \\
3,143\end{array}$ & $\begin{array}{l}441 \\
442^{2} \\
441 \\
445^{2} \\
450\end{array}$ & $\begin{array}{l}53,992 \\
54,403 \\
54,639 \\
54,882 \\
55,187\end{array}$ & $\begin{array}{l}47,672 \\
48,183 \\
48,540 \\
48,795 \\
49,113\end{array}$ & $\begin{array}{l}6,320 \\
6,220^{2} \\
6,099 \\
6,087^{2} \\
6,073\end{array}$ & $\begin{array}{l}15.7 \\
15.7 \\
15.7 \\
15.5 \\
15.4\end{array}$ & $\begin{array}{l}15.9 \\
15.9 \\
15.9 \\
15.8 \\
15.6\end{array}$ & $\begin{array}{l}14.3^{2} \\
14.1^{2} \\
13.8^{2} \\
13.7^{2} \\
13.5\end{array}$ & $\begin{array}{c}- \\
- \\
311 \\
- \\
-\end{array}$ & $\begin{array}{r}- \\
- \\
236 \\
- \\
-\end{array}$ & $\begin{array}{l}- \\
\overline{74} \\
- \\
-\end{array}$ \\
\hline $\begin{array}{l}2006 \\
2007 \\
2008 \ldots 10 \\
2010\end{array}$ & $\begin{array}{l}3,622 \\
3,634 \\
3,670 \\
3,647 \\
3,529\end{array}$ & $\begin{array}{l}3,166 \\
3,178 \\
3,222 \\
3,210 \\
3,099\end{array}$ & $\begin{array}{l}456^{2} \\
456 \\
448^{2} \\
437 \\
429^{2}\end{array}$ & $\begin{array}{l}55,307 \\
55,203 \\
54,973 \\
54,849 \\
54,867\end{array}$ & $\begin{array}{l}49,316 \\
49,293 \\
49,266 \\
49,361 \\
49,484\end{array}$ & $\begin{array}{l}5,991^{2} \\
5,910^{2} \\
5,707^{2} \\
5,488 \\
5,382^{2}\end{array}$ & $\begin{array}{l}15.3 \\
15.2 \\
15.0 \\
15.0 \\
15.5\end{array}$ & $\begin{array}{l}15.6 \\
15.5 \\
15.3 \\
15.4 \\
16.0\end{array}$ & $\begin{array}{l}13.2^{2} \\
13.0^{2} \\
12.8^{2} \\
12.5^{2} \\
12.5^{2}\end{array}$ & $\begin{array}{r}327 \\
- \\
- \\
-\end{array}$ & $\begin{array}{r}246 \\
- \\
- \\
-\end{array}$ & $\begin{array}{l}\overline{-} \\
- \\
- \\
-\end{array}$ \\
\hline $20112^{3}$ & $\begin{array}{l}3,524 \\
3,525 \\
3,524 \\
3,515 \\
3,514\end{array}$ & $\begin{array}{l}3,103 \\
3,111 \\
3,118 \\
3,118 \\
3,123\end{array}$ & $\begin{array}{l}421 \\
414 \\
407 \\
397 \\
391\end{array}$ & $\begin{array}{l}54,790 \\
54,833 \\
54,842 \\
54,725 \\
54,731\end{array}$ & $\begin{array}{l}49,522 \\
49,652 \\
49,750 \\
49,751 \\
49,839\end{array}$ & $\begin{array}{l}5,268 \\
5,181 \\
5,091 \\
4,974 \\
4,892\end{array}$ & $\begin{array}{l}15.5 \\
15.6 \\
15.6 \\
15.6 \\
15.6\end{array}$ & $\begin{array}{l}16.0 \\
16.0 \\
16.0 \\
16.0 \\
16.0\end{array}$ & $\begin{array}{l}12.5 \\
12.5 \\
12.5 \\
12.5 \\
12.5\end{array}$ & $\begin{array}{l}241 \\
245 \\
239 \\
232 \\
241\end{array}$ & $\begin{array}{l}173 \\
171 \\
170 \\
166 \\
175\end{array}$ & $\begin{array}{l}68 \\
74 \\
69 \\
66 \\
67\end{array}$ \\
\hline $2016^{3}$ & $\begin{array}{l}3,544 \\
3,593 \\
3,630 \\
3,666 \\
3,699\end{array}$ & $\begin{array}{l}3,155 \\
3,199 \\
3,235 \\
3,269 \\
3,300\end{array}$ & $\begin{array}{l}390 \\
394 \\
395 \\
397 \\
398\end{array}$ & $\begin{array}{l}54,790 \\
55,132 \\
55,380 \\
55,671 \\
56,010\end{array}$ & $\begin{array}{l}49,951 \\
50,280 \\
50,543 \\
50,834 \\
51,165\end{array}$ & $\begin{array}{l}4,839 \\
4,852 \\
4,837 \\
4,836 \\
4,844\end{array}$ & $\begin{array}{l}15.5 \\
15.3 \\
15.3 \\
15.2 \\
15.1\end{array}$ & $\begin{array}{l}15.8 \\
15.7 \\
15.6 \\
15.5 \\
15.5\end{array}$ & $\begin{array}{l}12.4 \\
12.3 \\
12.3 \\
12.2 \\
12.2\end{array}$ & $\begin{array}{l}272 \\
293 \\
289 \\
292 \\
291\end{array}$ & $\begin{array}{l}202 \\
217 \\
214 \\
217 \\
216\end{array}$ & $\begin{array}{l}70 \\
76 \\
74 \\
75 \\
76\end{array}$ \\
\hline $\begin{array}{l}2021^{3} \\
2022^{3} \\
2023^{3}\end{array}$ & $\begin{array}{l}3,736 \\
3,776 \\
3,817\end{array}$ & $\begin{array}{l}3,335 \\
3,371 \\
3,408\end{array}$ & $\begin{array}{l}401 \\
405 \\
409\end{array}$ & $\begin{array}{l}56,343 \\
56,684 \\
57,023\end{array}$ & $\begin{array}{l}51,485 \\
51,804 \\
52,113\end{array}$ & $\begin{array}{l}4,857 \\
4,880 \\
4,910\end{array}$ & $\begin{array}{l}15.1 \\
15.0 \\
14.9\end{array}$ & $\begin{array}{l}15.4 \\
15.4 \\
15.3\end{array}$ & $\begin{array}{l}12.1 \\
12.1 \\
12.0\end{array}$ & $\begin{array}{l}296 \\
303 \\
308\end{array}$ & $\begin{array}{l}219 \\
225 \\
227\end{array}$ & $\begin{array}{l}77 \\
79 \\
80\end{array}$ \\
\hline
\end{tabular}

-Not available.

${ }^{1} \mathrm{~A}$ teacher is considered to be a new hire for a public or private school if the teacher had not taught in that control of school in the previous year. A teacher who moves from a public to private or a private to public school is considered a new teacher hire, but a teacher who moves from one public school to another public school or one private school to another private school is not considered a new teacher hire.

2Estimated.

3Projected. school teachers and enrollment include prekindergarten through grade 12 in schools offering kindergarten or higher grades. Counts of public school teachers and enrollment include prekindergarten through grade 12. The pupil/teacher ratio includes teachers for students with disabilities and other special teachers, while these teachers are generally excluded from class size calculations. Ratios for public schools reflect totals reported by states and differ from totals reported for schools or school districts. Some data have been revised from previously published figures. Detail may not sum to totals because of rounding.

SOURCE: U.S. Department of Education, National Center for Education Statistics, Statistics of Public Elementary and Secondary Day Schools, 1955-56 through 1980-81; Common Core of Data (CCD), "State Nonfiscal Survey of Public Elementary/Secondary Education," 1981-82 through 2011-12; Private School Universe Survey (PSS), 1989-90 through 2011-12; Schools and Staffing Survey (SASS), "Public School Teacher Data File" and "Private School Teacher Data File," 1999-2000 through 2011-12; Elementary and Secondary Teacher Projection Model, 1973 through 2023; and New Teacher Hires Projection Model, 1988 through 2023. (This table was prepared February 2014.) 
132 CHAPTER 2: Elementary and Secondary Education

Teachers and Pupil/Teacher Ratios

Table 208.30. Public elementary and secondary teachers, by level and state or jurisdiction: Selected years, fall 2000 through fall 2011

\begin{tabular}{|c|c|c|c|c|c|c|c|c|c|c|c|c|c|}
\hline \multirow[b]{2}{*}{ State or jurisdiction } & \multirow[b]{2}{*}{ Fall 2000} & \multirow[b]{2}{*}{ Fall 2005} & \multirow[b]{2}{*}{ Fall 2007} & \multirow[b]{2}{*}{ Fall 2008} & \multirow[b]{2}{*}{ Fall 2009} & \multicolumn{4}{|c|}{ Fall 2010} & \multicolumn{4}{|c|}{ Fall 2011} \\
\hline & & & & & & Total & Elementary & Secondary & Ungraded & Total & Elementary & Secondary & Ungraded \\
\hline 1 & 2 & 3 & 4 & 5 & 6 & 7 & 8 & 9 & 10 & 11 & 12 & 13 & 14 \\
\hline United States .............. & $2,941,461^{1}$ & $3,143,003^{1}$ & $3,178,142^{1}$ & $3,222,154^{1}$ & $3,209,672^{1}$ & $3,099,095^{1}$ & $1,708,057^{1}$ & $1,199,589$ & 191,449 & $3,103,263^{1}$ & $1,734,606^{1}$ & $1,194,504$ & 174,153 \\
\hline $\begin{array}{l}\text { Alabama } \\
\text { Alaska... } \\
\text { Arizona } \\
\text { Arkansas. } \\
\text { California }\end{array}$ & $\begin{array}{c}48,194^{2} \\
7,880 \\
44,438 \\
31,947 \\
298,021^{2}\end{array}$ & \begin{tabular}{|c|}
57,757 \\
7,912 \\
51,376 \\
32,997 \\
$309,222^{2}$
\end{tabular} & $\begin{array}{c}50,420 \\
7,613 \\
54,032 \\
33,882 \\
305,230^{2}\end{array}$ & $\begin{array}{r}47,818 \\
7,927 \\
54,696 \\
37,162 \\
303,647\end{array}$ & \begin{tabular}{|c|}
47,492 \\
8,083 \\
51,947 \\
37,240 \\
$316,299^{2}$
\end{tabular} & \begin{tabular}{|c|}
49,363 \\
8,171 \\
50,031 \\
34,273 \\
$260,806^{2}$
\end{tabular} & \begin{tabular}{|c|}
28,057 \\
5,340 \\
35,188 \\
17,701 \\
$176,602^{2}$
\end{tabular} & $\begin{array}{r}21,306 \\
2,830 \\
14,843 \\
14,077 \\
84,199\end{array}$ & $\begin{array}{r}0 \\
0 \\
0 \\
2,496 \\
5\end{array}$ & \begin{tabular}{|c|}
47,723 \\
8,088 \\
50,800 \\
33,983 \\
268,6892 \\
\end{tabular} & \begin{tabular}{|c|}
26,963 \\
4,309 \\
36,058 \\
17,407 \\
174,1942
\end{tabular} & \begin{tabular}{r|}
20,759 \\
3,779 \\
14,742 \\
13,974 \\
85,727
\end{tabular} & $\begin{array}{r}0 \\
0 \\
0 \\
2,601 \\
8,768\end{array}$ \\
\hline 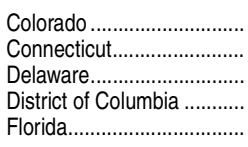 & $\begin{array}{r}41,983 \\
41,044 \\
7,469 \\
4,949 \\
132,030\end{array}$ & $\begin{array}{c}45,841 \\
39,687 \\
7,998 \\
5,481^{3} \\
158,962\end{array}$ & $\begin{array}{r}47,761 \\
39,304 \\
8,198 \\
6,347 \\
168,737\end{array}$ & $\begin{array}{r}48,692 \\
48,463 \\
8,322 \\
5,321 \\
186,361\end{array}$ & $\begin{array}{r}49,060 \\
43,593 \\
8,640 \\
5,854 \\
183,827\end{array}$ & $\begin{array}{r}48,543 \\
42,951 \\
8,933 \\
5,925 \\
175,609\end{array}$ & $\begin{array}{r}27,971 \\
27,890 \\
4,457 \\
3,395 \\
76,415\end{array}$ & $\begin{array}{r}20,572 \\
14,030 \\
4,476 \\
2,049 \\
66,619\end{array}$ & $\begin{array}{r}0 \\
1,032 \\
0 \\
481 \\
32,575\end{array}$ & $\begin{array}{r}48,078 \\
43,805 \\
8,587 \\
6,278 \\
175,006\end{array}$ & $\begin{array}{r}27,656 \\
29,185 \\
4,255 \\
3,781 \\
76,703\end{array}$ & $\begin{array}{r}20,421 \\
13,310 \\
4,332 \\
1,930 \\
65,633\end{array}$ & $\begin{array}{r}0 \\
1,310 \\
0 \\
568 \\
32,670\end{array}$ \\
\hline 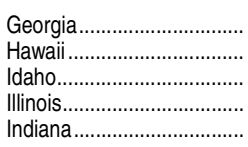 & $\begin{array}{r}91,043 \\
10,927 \\
13,714 \\
127,620 \\
59,226\end{array}$ & $\begin{array}{r}108,535 \\
11,226 \\
14,521 \\
133,857 \\
60,592\end{array}$ & $\begin{array}{r}116,857 \\
11,397 \\
15,013 \\
136,571 \\
62,334\end{array}$ & $\begin{array}{r}118,839 \\
11,295 \\
15,148 \\
135,704 \\
62,668\end{array}$ & $\begin{array}{r}115,918 \\
11,472 \\
15,201 \\
138,483 \\
62,258\end{array}$ & $\begin{array}{c}112,460 \\
11,396 \\
15,673 \\
132,983 \\
58,121^{2}\end{array}$ & $\begin{array}{c}68,631 \\
6,191 \\
7,486 \\
90,610 \\
32,216^{2}\end{array}$ & $\begin{array}{r}43,775 \\
5,127 \\
8,186 \\
42,373 \\
25,843\end{array}$ & $\begin{array}{r}54 \\
78 \\
0 \\
0 \\
62\end{array}$ & $\begin{array}{r}111,133 \\
11,458 \\
15,990 \\
131,777 \\
62,339\end{array}$ & $\begin{array}{r}52,141 \\
6,278 \\
7,640 \\
89,868 \\
42,599\end{array}$ & $\begin{array}{r}43,441 \\
5,113 \\
8,351 \\
41,910 \\
19,740\end{array}$ & $\begin{array}{r}15,551 \\
68\end{array}$ \\
\hline 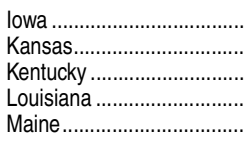 & $\begin{array}{l}34,636 \\
32,742 \\
39,589 \\
49,915 \\
16,559\end{array}$ & $\begin{array}{l}35,181 \\
33,608 \\
42,413 \\
44,660 \\
16,684\end{array}$ & 36,089 & & $\begin{array}{l}35,842 \\
34,700\end{array}$ & & $\begin{array}{l}24,039 \\
16,985\end{array}$ & $\begin{array}{r}10,604 \\
16,792 \\
9,883 \\
15,460 \\
4,788\end{array}$ & $\begin{array}{r}0 \\
867 \\
10,765 \\
0 \\
0\end{array}$ & & $\begin{array}{l}24,093 \\
19,700 \\
21,169 \\
33,214 \\
10,286\end{array}$ & $\begin{array}{r}10,565 \\
17,024 \\
9,907 \\
15,443 \\
4,602\end{array}$ & $\begin{array}{r}0 \\
684 \\
10,783\end{array}$ \\
\hline 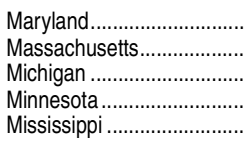 & $\begin{array}{l}52,433 \\
67,432\end{array}$ & & $\begin{array}{l}59,320 \\
70,719\end{array}$ & $\begin{array}{l}58,940 \\
70,398\end{array}$ & 58,463 & 58,428 & & $\begin{array}{l}24,004 \\
23,313 \\
34,850 \\
23,577 \\
12,891\end{array}$ & $\begin{array}{r}0 \\
0 \\
18,030 \\
1,466 \\
4,149\end{array}$ & $\begin{array}{l}57,589 \\
69,342 \\
86,997 \\
52,832 \\
32,007\end{array}$ & & $\begin{array}{l}23,401 \\
23,571 \\
34,385 \\
23,338 \\
12,557\end{array}$ & $\begin{array}{r}0 \\
0 \\
17,475 \\
1,503 \\
4,058\end{array}$ \\
\hline 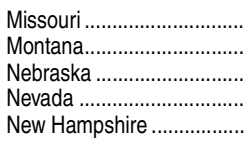 & & & & & & & $\begin{array}{r}34,305 \\
7,054\end{array}$ & $\begin{array}{r}32,430 \\
3,307 \\
8,506 \\
8,041 \\
4,963\end{array}$ & $\begin{array}{r}0 \\
0 \\
0 \\
2,956 \\
0\end{array}$ & & $\begin{array}{r}34,141 \\
6,981\end{array}$ & $\begin{array}{r}32,111 \\
3,172 \\
8,340 \\
7,769 \\
4,869\end{array}$ & $\begin{array}{r}3,046 \\
0\end{array}$ \\
\hline 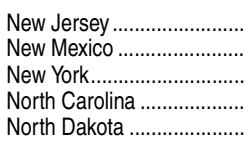 & $\begin{array}{r}99,061 \\
21,042 \\
206,961 \\
83,680 \\
8,141\end{array}$ & $\begin{array}{r}112,673 \\
22,021 \\
218,989 \\
95,664 \\
8,003\end{array}$ & $\begin{array}{r}111,500 \\
22,300 \\
211,854 \\
106,562 \\
8,068\end{array}$ & $\begin{array}{r}114,713 \\
22,825 \\
217,944\end{array}$ & $\begin{array}{c}115,248 \\
22,724 \\
214,804 \\
105,0364 \\
8,366\end{array}$ & & $\begin{array}{r}59,333 \\
9,832 \\
101,708 \\
49,681 \\
5,431\end{array}$ & $\begin{array}{r}38,278 \\
8,563 \\
69,357 \\
47,549 \\
2,986\end{array}$ & $\begin{array}{r}12,591 \\
4,043 \\
40,541 \\
1,128 \\
0\end{array}$ & & $\begin{array}{r}58,767 \\
9,739\end{array}$ & $\begin{array}{r}37,691 \\
8,182 \\
87,687 \\
31,706 \\
3,026\end{array}$ & $\begin{array}{r}13,262 \\
4,035 \\
271 \\
1,003 \\
0\end{array}$ \\
\hline 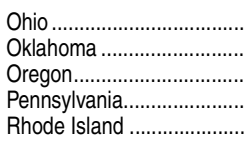 & $\begin{array}{r}118,361 \\
41,318 \\
28,094 \\
116,963 \\
10,645\end{array}$ & $\begin{array}{c}117,982 \\
41,833 \\
28,346 \\
122,397 \\
14,180^{2}\end{array}$ & $\begin{array}{r}109,766 \\
46,735 \\
30,013 \\
135,234 \\
11,271\end{array}$ & $\begin{array}{r}112,845 \\
46,571 \\
30,152 \\
129,708 \\
11,316\end{array}$ & $\begin{array}{r}111,378 \\
42,615 \\
28,768 \\
130,984 \\
11,366\end{array}$ & $\begin{array}{r}109,282 \\
41,278 \\
28,109 \\
129,911 \\
11,212\end{array}$ & 53,650 & $\begin{array}{r}51,887 \\
18,986 \\
8,392 \\
58,513 \\
5,918\end{array}$ & $\begin{array}{r}3,745 \\
0 \\
0 \\
9,824 \\
0\end{array}$ & $\begin{array}{r}107,972 \\
41,349 \\
26,791 \\
124,646 \\
11,414\end{array}$ & & $\begin{array}{r}49,614 \\
18,804 \\
7,990 \\
55,684 \\
5,942\end{array}$ & $\begin{array}{r}6,292 \\
0 \\
0 \\
9,530 \\
0\end{array}$ \\
\hline 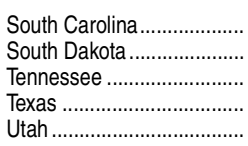 & $\begin{array}{r}45,380 \\
9,397 \\
57,164 \\
274,826 \\
22,008\end{array}$ & $\begin{array}{r}48,212 \\
9,129 \\
59,596 \\
302,425 \\
22,993\end{array}$ & $\begin{array}{r}47,382 \\
9,416 \\
64,659 \\
321,929 \\
24,336\end{array}$ & $\begin{array}{r}49,941 \\
9,244 \\
64,926 \\
327,905 \\
23,657\end{array}$ & $\begin{array}{r}46,980 \\
9,326 \\
65,361 \\
333,164 \\
25,615\end{array}$ & $\begin{array}{r}45,210 \\
9,512 \\
66,558 \\
334,997 \\
25,677\end{array}$ & $\begin{array}{r}31,715 \\
6,056 \\
45,093 \\
167,161 \\
12,859\end{array}$ & $\begin{array}{r}13,495 \\
2,573 \\
19,315 \\
133,218 \\
10,132\end{array}$ & $\begin{array}{r}0 \\
883 \\
2,151 \\
34,618 \\
2,686\end{array}$ & $\begin{array}{r}46,782 \\
9,247 \\
66,382 \\
324,282 \\
25,970\end{array}$ & $\begin{array}{r}32,577 \\
5,890 \\
45,212 \\
162,768 \\
13,032\end{array}$ & $\begin{array}{r}14,205 \\
2,514 \\
19,066 \\
130,424 \\
10,333\end{array}$ & $\begin{array}{r}0 \\
843 \\
2,104 \\
31,090 \\
2,605\end{array}$ \\
\hline 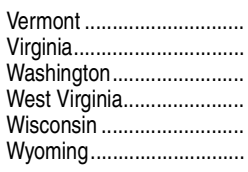 & $\begin{array}{c}8,414 \\
86,977^{2} \\
51,098 \\
20,930 \\
60,165 \\
6,783 \\
\end{array}$ & $\begin{array}{r}8,851 \\
103,944 \\
53,508 \\
19,940 \\
60,127 \\
6,706 \\
\end{array}$ & $\begin{array}{r}58,914 \\
6,915 \\
\end{array}$ & 7,000 & $\begin{array}{r}30,4<0 \\
7,166 \\
\end{array}$ & 7,127 & $\begin{array}{r}9,509 \\
28,529 \\
3,767\end{array}$ & & $\begin{array}{r}1,761 \\
0 \\
2,317 \\
0 \\
148 \\
0\end{array}$ & & $\begin{array}{r}3,360 \\
41,909 \\
28,113 \\
9,483 \\
27,873 \\
4,461 \\
\end{array}$ & $\begin{array}{r}3,206 \\
48,923 \\
22,934 \\
10,765 \\
28,209 \\
3,385\end{array}$ & $\begin{array}{r}1,798 \\
0 \\
2,072 \\
0 \\
163 \\
0\end{array}$ \\
\hline Bureau of Indian Education. & - & - & - & - & - & - & - & - & - & - & - & - & . \\
\hline $\begin{array}{l}\text { DoD, overseas } \\
\text { DoD, domestic }\end{array}$ & $\begin{array}{l}5,105 \\
2,399\end{array}$ & $\begin{array}{l}5,726 \\
2,033\end{array}$ & $\begin{array}{l}4,147 \\
2,243\end{array}$ & $\begin{array}{l}4,551 \\
2,145\end{array}$ & - & $\begin{array}{l}- \\
-\end{array}$ & $\begin{array}{l}- \\
-\end{array}$ & $\begin{array}{l}- \\
-\end{array}$ & $\begin{array}{l}- \\
-\end{array}$ & - & $\begin{array}{l}- \\
-\end{array}$ & - & - \\
\hline $\begin{array}{l}\text { Other jurisdictions } \\
\text { American Samoa ............. } \\
\text { Guam ......................... } \\
\text { Northern Marianas......... } \\
\text { Puerto Rico.................. } \\
\text { U.S. Virgin Islands.......... }\end{array}$ & $\begin{array}{r}820 \\
1,975 \\
526 \\
37,620 \\
1,511\end{array}$ & $\begin{array}{r}989 \\
1,804 \\
614 \\
42,036 \\
1,434\end{array}$ & $\begin{array}{r}- \\
- \\
550 \\
40,826 \\
1,518\end{array}$ & $\begin{array}{r}- \\
- \\
514 \\
39,356 \\
1,331\end{array}$ & $\begin{array}{r}- \\
- \\
552 \\
39,102 \\
1,425\end{array}$ & $\begin{array}{r}-\overline{3} \\
1,843 \\
607 \\
36,506 \\
1,457\end{array}$ & $\begin{array}{r}- \\
911 \\
338 \\
16,865 \\
617\end{array}$ & $\begin{array}{r}- \\
932 \\
266 \\
14,151 \\
471\end{array}$ & $\begin{array}{r}- \\
0 \\
3 \\
5,490 \\
369\end{array}$ & $\begin{array}{r}-\overline{2} \\
2,291 \\
496 \\
33,079 \\
1,217\end{array}$ & $\begin{array}{r}-\overline{925} \\
292 \\
15,140 \\
522\end{array}$ & $\begin{array}{r}-\overline{991} \\
200 \\
12,618 \\
399\end{array}$ & $\begin{array}{r}- \\
375 \\
4 \\
5,321 \\
296\end{array}$ \\
\hline
\end{tabular}

-Not available.

${ }^{1}$ Includes imputed values for states.

Includes imputations for underreporting of prekindergarten teachers.

${ }^{3}$ Imputed.

${ }^{4}$ Includes imputations for underreporting of kindergarten teachers.
NOTE: Distribution of elementary and secondary teachers determined by reporting units. Teachers reported in full-time equivalents (FTE). DoD = Department of Defense. Some data have been revised from previously published figures.

SOURCE: U.S. Department of Education, National Center for Education Statistics, Common Core of Data (CCD), "State Nonfiscal Survey of Public Elementary/Secondary Education," 2000-01 through 2011-12. (This table was prepared August 2013.) 
Table 208.40. Public elementary and secondary teachers, enrollment, and pupil/teacher ratios, by state or jurisdiction: Selected years, fall 2000 through fall 2011

\begin{tabular}{|c|c|c|c|c|c|c|c|c|c|c|c|c|c|}
\hline \multirow[b]{2}{*}{ State or jurisdiction } & \multicolumn{4}{|c|}{ Pupil/teacher ratio } & \multicolumn{3}{|c|}{ Fall 2009} & \multicolumn{3}{|c|}{ Fall 2010} & \multicolumn{3}{|c|}{ Fall 2011} \\
\hline & Fall 2000 & Fall 2006 & Fall 2007 & Fall 2008 & Teachers & Enrollment & $\begin{array}{r}\text { Pupil/ } \\
\text { teacher } \\
\text { ratio }\end{array}$ & Teachers & Enrollment & $\begin{array}{r}\text { Pupil/ } \\
\text { teacher } \\
\text { ratio }\end{array}$ & Teachers & Enrollment & $\begin{array}{r}\text { Pupil/ } \\
\text { teacher } \\
\text { ratio }\end{array}$ \\
\hline 1 & 2 & 3 & 4 & 5 & 6 & 7 & 8 & 9 & 10 & 11 & 12 & 13 & 14 \\
\hline United States ............. & $16.0^{1}$ & $15.6^{1}$ & $15.5^{1}$ & $15.3^{1}$ & $3,209,672^{1}$ & \begin{tabular}{|l|}
$49,360,982$ \\
\end{tabular} & $15.4^{1}$ & $3,099,095^{1}$ & $49,484,181$ & $16.0^{1}$ & $3,103,263{ }^{1}$ & $49,521,669$ & $16.0^{1}$ \\
\hline 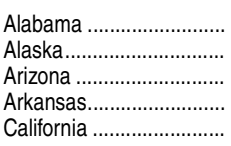 & $\begin{array}{l}15.4^{2} \\
16.9^{2} \\
19.8 \\
14.1^{2} \\
20.6^{2}\end{array}$ & \begin{tabular}{l|}
13.2 \\
16.8 \\
20.3 \\
13.6 \\
$20.8^{2}$
\end{tabular} & \begin{tabular}{l|}
14.8 \\
17.2 \\
20.1 \\
14.1 \\
$20.8^{2}$
\end{tabular} & \begin{tabular}{l|}
15.6 \\
16.5 \\
19.9 \\
12.9 \\
$20.8^{2}$
\end{tabular} & \begin{tabular}{|c|}
47,492 \\
8,083 \\
51,947 \\
37,240 \\
$316,299^{2}$ \\
\end{tabular} & $\begin{array}{r}748,889 \\
131,661 \\
1,077,831 \\
480,559 \\
6,263,438\end{array}$ & \begin{tabular}{l|}
15.8 \\
16.3 \\
20.7 \\
12.9 \\
19.82
\end{tabular} & $\begin{array}{c}49,363 \\
8,171 \\
50,031 \\
34,273 \\
260,806^{2}\end{array}$ & \begin{tabular}{r|}
755,552 \\
132,104 \\
$1,071,751$ \\
482,114 \\
$6,289,578$
\end{tabular} & \begin{tabular}{l|}
15.3 \\
16.2 \\
21.4 \\
14.1 \\
$24.1^{2}$
\end{tabular} & \begin{tabular}{|c|}
47,723 \\
8,088 \\
50,800 \\
33,983 \\
$268,689^{2}$
\end{tabular} & $\begin{array}{r}744,621 \\
131,167 \\
1,080,319 \\
483,114 \\
6,287,834\end{array}$ & $\begin{array}{l}15.6 \\
16.2 \\
21.3 \\
14.2 \\
23.4^{2}\end{array}$ \\
\hline 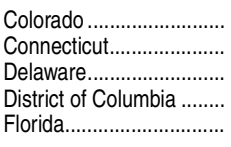 & $\begin{array}{l}17.3 \\
13.7 \\
15.4 \\
13.9 \\
18.4\end{array}$ & $\begin{array}{l}16.9 \\
14.7 \\
15.2 \\
13.5^{3} \\
16.4^{3}\end{array}$ & $\begin{array}{l}16.8 \\
14.5 \\
15.0 \\
12.4 \\
15.8\end{array}$ & $\begin{array}{l}16.8 \\
11.7 \\
15.1 \\
12.9 \\
14.1\end{array}$ & $\begin{array}{r}49,060 \\
43,593 \\
8,640 \\
5,854 \\
183,827\end{array}$ & $\begin{array}{r}832,368 \\
563,968 \\
126,801 \\
69,433 \\
2,634,522\end{array}$ & $\begin{array}{l}17.0 \\
12.9 \\
14.7 \\
11.9 \\
14.3\end{array}$ & $\begin{array}{r}48,543 \\
42,951 \\
8,933 \\
5,925 \\
175,609\end{array}$ & $\begin{array}{r}843,316 \\
560,546 \\
129,403 \\
71,284 \\
2,643,347\end{array}$ & $\begin{array}{l}17.4 \\
13.1 \\
14.5 \\
12.0 \\
15.1\end{array}$ & $\begin{array}{r}48,078 \\
43,805 \\
8,587 \\
6,278 \\
175,006\end{array}$ & $\begin{array}{r}854,265 \\
554,437 \\
128,946 \\
73,911 \\
2,668,156\end{array}$ & $\begin{array}{l}17.8 \\
12.7 \\
15.0 \\
11.8 \\
15.2\end{array}$ \\
\hline 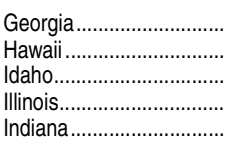 & $\begin{array}{l}15.9 \\
16.9 \\
17.9 \\
16.1 \\
16.7\end{array}$ & $\begin{array}{l}14.3 \\
16.0 \\
18.1 \\
15.0 \\
17.0\end{array}$ & $\begin{array}{l}14.1 \\
15.8 \\
18.1 \\
15.5 \\
16.8\end{array}$ & $\begin{array}{l}13.9 \\
15.9 \\
18.2 \\
15.6 \\
16.7\end{array}$ & $\begin{array}{r}115,918 \\
11,472 \\
15,201 \\
138,483 \\
62,258\end{array}$ & $\begin{array}{r}1,667,685 \\
180,196 \\
276,299 \\
2,104,175 \\
1,046,661\end{array}$ & $\begin{array}{l}14.4 \\
15.7 \\
18.2 \\
15.2 \\
16.8\end{array}$ & $\begin{array}{c}112,460 \\
11,396 \\
15,673 \\
132,983 \\
58,121^{2}\end{array}$ & $\begin{array}{r}1,677,067 \\
179,601 \\
275,859 \\
2,091,654 \\
1,047,232\end{array}$ & $\begin{array}{l}14.9 \\
15.8 \\
17.6 \\
15.7 \\
18.0^{2}\end{array}$ & $\begin{array}{r}111,133 \\
11,458 \\
15,990 \\
131,777 \\
62,339\end{array}$ & $\begin{array}{r}1,685,016 \\
182,706 \\
279,873 \\
2,083,097 \\
1,040,765\end{array}$ & $\begin{array}{l}15.2 \\
15.9 \\
17.5 \\
15.8 \\
16.7\end{array}$ \\
\hline 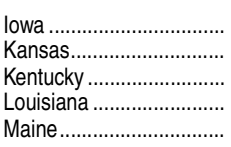 & $\begin{array}{l}14.3 \\
14.4 \\
16.8 \\
14.9 \\
12.5\end{array}$ & $\begin{array}{l}13.6 \\
13.3 \\
15.8 \\
14.7 \\
11.5\end{array}$ & $\begin{array}{l}13.4 \\
13.2 \\
15.3 \\
14.0 \\
11.9\end{array}$ & $\begin{array}{l}13.6 \\
13.1 \\
15.4 \\
13.9 \\
12.1\end{array}$ & $\begin{array}{l}35,842 \\
34,700 \\
41,981 \\
49,646 \\
16,331\end{array}$ & $\begin{array}{l}491,842 \\
474,489 \\
680,089 \\
690,915 \\
189,225\end{array}$ & $\begin{array}{l}13.7 \\
13.7 \\
16.2 \\
13.9 \\
11.6\end{array}$ & $\begin{array}{l}34,642 \\
34,644 \\
42,042 \\
48,655 \\
15,384\end{array}$ & $\begin{array}{l}495,775 \\
483,701 \\
673,128 \\
696,558 \\
189,077\end{array}$ & $\begin{array}{l}14.3 \\
14.0 \\
16.0 \\
14.3 \\
12.3\end{array}$ & $\begin{array}{l}34,658 \\
37,407 \\
41,860 \\
48,657 \\
14,888\end{array}$ & $\begin{array}{l}495,870 \\
486,108 \\
681,987 \\
703,390 \\
188,969\end{array}$ & $\begin{array}{l}14.3 \\
13.0 \\
16.3 \\
14.5 \\
12.7\end{array}$ \\
\hline 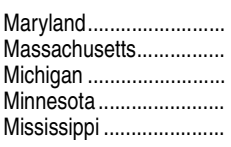 & $\begin{array}{l}16.3 \\
14.5 \\
17.7^{2} \\
16.0 \\
16.1\end{array}$ & $\begin{array}{l}14.6 \\
13.2 \\
17.6 \\
16.2 \\
15.3\end{array}$ & $\begin{array}{l}14.3 \\
13.6 \\
17.6 \\
15.8 \\
14.7\end{array}$ & $\begin{array}{l}14.3 \\
13.6 \\
17.5 \\
15.7 \\
14.7\end{array}$ & $\begin{array}{l}58,463 \\
69,909 \\
92,691 \\
52,839 \\
33,103\end{array}$ & $\begin{array}{r}848,412 \\
957,053 \\
1,649,082 \\
837,053 \\
492,481\end{array}$ & $\begin{array}{l}14.5 \\
13.7 \\
17.8 \\
15.8 \\
14.9\end{array}$ & $\begin{array}{l}58,428 \\
68,754 \\
88,615 \\
52,672 \\
32,255\end{array}$ & $\begin{array}{r}852,211 \\
955,563 \\
1,587,067 \\
838,037 \\
490,526\end{array}$ & $\begin{array}{l}14.6 \\
13.9 \\
17.9 \\
15.9 \\
15.2\end{array}$ & $\begin{array}{l}57,589 \\
69,342 \\
86,997 \\
52,832 \\
32,007\end{array}$ & $\begin{array}{r}854,086 \\
953,369 \\
1,573,537 \\
839,738 \\
490,619\end{array}$ & $\begin{array}{l}14.8 \\
13.7 \\
18.1 \\
15.9 \\
15.3\end{array}$ \\
\hline 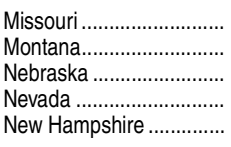 & $\begin{array}{l}14.1 \\
14.9 \\
13.6 \\
18.6 \\
14.5\end{array}$ & $\begin{array}{l}13.6 \\
13.9 \\
13.4 \\
18.5 \\
13.1\end{array}$ & $\begin{array}{l}13.4 \\
13.6 \\
13.3 \\
18.3 \\
13.0\end{array}$ & $\begin{array}{l}13.5 \\
13.6 \\
13.3 \\
19.7 \\
12.6\end{array}$ & $\begin{array}{l}67,796 \\
10,521 \\
22,256 \\
22,104 \\
15,491\end{array}$ & $\begin{array}{l}917,982 \\
141,807 \\
295,368 \\
428,947 \\
197,140\end{array}$ & $\begin{array}{l}13.5 \\
13.5 \\
13.3 \\
19.4 \\
12.7\end{array}$ & $\begin{array}{l}66,735 \\
10,361 \\
22,345 \\
21,839 \\
15,365\end{array}$ & $\begin{array}{l}918,710 \\
141,693 \\
298,500 \\
437,149 \\
194,711\end{array}$ & $\begin{array}{l}13.8 \\
13.7 \\
13.4 \\
20.0 \\
12.7\end{array}$ & $\begin{array}{l}66,252 \\
10,153 \\
22,182 \\
21,132 \\
15,049\end{array}$ & $\begin{array}{l}916,584 \\
142,349 \\
301,296 \\
439,634 \\
191,900\end{array}$ & $\begin{array}{l}13.8 \\
14.0 \\
13.6 \\
20.8 \\
12.8\end{array}$ \\
\hline 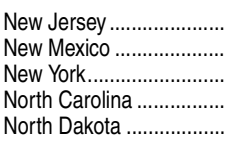 & $\begin{array}{l}13.3 \\
15.2 \\
13.9 \\
15.5 \\
13.4\end{array}$ & $\begin{array}{l}12.4 \\
14.9 \\
12.8 \\
12.9 \\
12.1\end{array}$ & $\begin{array}{l}12.4 \\
14.8 \\
13.1 \\
14.0 \\
11.8\end{array}$ & $\begin{array}{l}12.0 \\
14.5 \\
12.6 \\
13.6 \\
11.6\end{array}$ & $\begin{array}{c}115,248 \\
22,724 \\
214,804 \\
105,0364 \\
8,366\end{array}$ & $\begin{array}{r}1,396,029 \\
334,419 \\
2,766,052 \\
1,483,397 \\
95,073\end{array}$ & $\begin{array}{l}12.1 \\
14.7 \\
12.9 \\
14.1 \\
11.4\end{array}$ & $\begin{array}{r}110,202 \\
22,437 \\
211,606 \\
98,357 \\
8,417\end{array}$ & $\begin{array}{r}1,402,548 \\
338,122 \\
2,734,955 \\
1,490,605 \\
96,323\end{array}$ & $\begin{array}{l}12.7 \\
15.1 \\
12.9 \\
15.2 \\
11.4\end{array}$ & $\begin{array}{r}109,719 \\
21,957 \\
209,527 \\
97,308 \\
8,525\end{array}$ & \begin{tabular}{r|}
$1,356,431$ \\
337,225 \\
$2,704,718$ \\
$1,507,864$ \\
97,646
\end{tabular} & $\begin{array}{l}12.4 \\
15.4 \\
12.9 \\
15.5 \\
11.5\end{array}$ \\
\hline $\begin{array}{l}\text { Ohio } \\
\text { Oklahoma } \\
\text { Oregon }\end{array}$ & $\begin{array}{l}15.5 \\
15.1 \\
19.4 \\
15.5 \\
14.8\end{array}$ & $\begin{array}{l}16.6 \\
15.1 \\
18.8 \\
15.2 \\
13.3\end{array}$ & $\begin{array}{l}16.6 \\
13.7 \\
18.8 \\
13.3 \\
13.1\end{array}$ & $\begin{array}{l}16.1 \\
13.9 \\
19.1 \\
13.7 \\
12.8\end{array}$ & $\begin{array}{r}111,378 \\
42,615 \\
28,768 \\
130,984 \\
11,366\end{array}$ & $\begin{array}{r}1,764,297 \\
654,802 \\
582,839 \\
1,785,993 \\
145,118\end{array}$ & $\begin{array}{l}15.8 \\
15.4 \\
20.3 \\
13.6 \\
12.8\end{array}$ & $\begin{array}{r}109,282 \\
41,278 \\
28,109 \\
129,911 \\
11,212\end{array}$ & $\begin{array}{r}1,754,191 \\
659,911 \\
570,720 \\
1,793,284 \\
143,793\end{array}$ & $\begin{array}{l}16.1 \\
16.0 \\
20.3 \\
13.8 \\
12.8\end{array}$ & $\begin{array}{r}107,972 \\
41,349 \\
26,791 \\
124,646 \\
11,414\end{array}$ & $\begin{array}{r}1,740,030 \\
666,120 \\
568,208 \\
1,771,395 \\
142,854\end{array}$ & $\begin{array}{l}16.1 \\
16.1 \\
21.2 \\
14.2 \\
12.5\end{array}$ \\
\hline $\begin{array}{l}\text { South Carolina } \\
\text { South Dakota } \\
\text { Tennessee } \\
\text { Texas }\end{array}$ & $\begin{array}{l}14.9 \\
13.7 \\
15.9^{2} \\
14.8 \\
21.9\end{array}$ & $\begin{array}{l}14.4 \\
13.4 \\
15.7 \\
14.8 \\
22.1\end{array}$ & $\begin{array}{l}15.0 \\
12.9 \\
14.9 \\
14.5 \\
23.7\end{array}$ & $\begin{array}{l}14.4 \\
13.7 \\
15.0 \\
14.5 \\
23.7\end{array}$ & $\begin{array}{r}46,980 \\
9,326 \\
65,361 \\
333,164 \\
25,615\end{array}$ & $\begin{array}{r}723,143 \\
123,713 \\
972,549 \\
4,850,210 \\
571,586\end{array}$ & $\begin{array}{l}15.4 \\
13.3 \\
14.9 \\
14.6 \\
22.3\end{array}$ & $\begin{array}{r}45,210 \\
9,512 \\
66,558 \\
334,997 \\
25,677\end{array}$ & $\begin{array}{r}725,838 \\
126,128 \\
987,422 \\
4,935,715 \\
585,552\end{array}$ & $\begin{array}{l}16.1 \\
13.3 \\
14.8 \\
14.7 \\
22.8\end{array}$ & $\begin{array}{r}46,782 \\
9,247 \\
66,382 \\
324,282 \\
25,970\end{array}$ & $\begin{array}{r}727,186 \\
128,016 \\
999,693 \\
5,000,470 \\
598,832\end{array}$ & $\begin{array}{l}15.5 \\
13.8 \\
15.1 \\
15.4 \\
23.1\end{array}$ \\
\hline 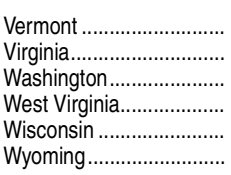 & \begin{tabular}{l|}
12.1 \\
$13.2^{2}$ \\
19.7 \\
13.7 \\
14.6 \\
13.3 \\
\end{tabular} & $\begin{array}{l}10.8 \\
15.3 \\
19.1 \\
14.4 \\
14.8 \\
12.6 \\
\end{array}$ & $\begin{array}{l}10.7 \\
17.1 \\
19.1 \\
13.9 \\
14.8 \\
12.5 \\
\end{array}$ & $\begin{array}{l}10.7 \\
17.3 \\
19.1 \\
14.0 \\
14.7 \\
12.5 \\
\end{array}$ & $\begin{array}{r}8,734 \\
70,827 \\
53,448 \\
20,299 \\
58,426 \\
7,166\end{array}$ & $\begin{array}{r}91,451 \\
1,245,340 \\
1,035,347 \\
282,662 \\
872,436 \\
88,155\end{array}$ & $\begin{array}{l}10.5 \\
17.6 \\
19.4 \\
13.9 \\
14.9 \\
12.3 \\
\end{array}$ & $\begin{array}{r}8,382 \\
70,947 \\
53,934 \\
20,338 \\
57,625 \\
7,127\end{array}$ & $\begin{array}{r}96,858 \\
1,251,440 \\
1,043,788 \\
282,879 \\
872,286 \\
89,009\end{array}$ & $\begin{array}{l}11.6 \\
17.6 \\
19.4 \\
13.9 \\
15.1 \\
12.5 \\
\end{array}$ & $\begin{array}{r}8,364 \\
90,832 \\
53,119 \\
20,247 \\
56,245 \\
7,847\end{array}$ & $\begin{array}{r}89,908 \\
1,257,883 \\
1,045,453 \\
282,870 \\
871,105 \\
90,099\end{array}$ & $\begin{array}{l}10.7 \\
13.8 \\
19.7 \\
14.0 \\
15.5 \\
11.5\end{array}$ \\
\hline $\begin{array}{l}\text { Bureau of Indian } \\
\text { Education .......... }\end{array}$ & - & - & - & - & - & 41,351 & - & - & 41,962 & - & - & - & - \\
\hline 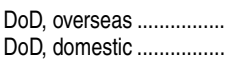 & $\begin{array}{l}14.4 \\
14.2\end{array}$ & $\begin{array}{l}11.7 \\
13.1\end{array}$ & $\begin{array}{l}13.8 \\
12.3\end{array}$ & $\begin{array}{l}12.5 \\
13.1\end{array}$ & $\begin{array}{l}- \\
-\end{array}$ & - & $\begin{array}{l}- \\
-\end{array}$ & $\begin{array}{l}- \\
-\end{array}$ & $\begin{array}{l}- \\
-\end{array}$ & $\begin{array}{l}- \\
-\end{array}$ & - & $\begin{array}{l}- \\
-\end{array}$ & - \\
\hline $\begin{array}{l}\text { Other jurisdictions } \\
\text { American Samoa ......... } \\
\text { Guam ..................... } \\
\text { Northern Marianas...... } \\
\text { Puerto Rico............... } \\
\text { U.S. Virgin Islands....... }\end{array}$ & $\begin{array}{l}19.1 \\
16.4 \\
19.0 \\
16.3 \\
12.9\end{array}$ & $\begin{array}{r}16.9 \\
2 \overline{-} \\
20.2 \\
13.5 \\
10.6\end{array}$ & $\begin{array}{r}- \\
20.5 \\
12.9 \\
10.5\end{array}$ & $\begin{array}{r}- \\
21 . \overline{2} \\
12.8 \\
11.8\end{array}$ & $\begin{array}{r}- \\
- \\
552 \\
39,102 \\
1,425\end{array}$ & $\begin{array}{r}- \\
- \\
10,961 \\
493,393 \\
15,493\end{array}$ & $\begin{array}{r}- \\
\overline{-} \\
19.9 \\
12.6 \\
10.9\end{array}$ & $\begin{array}{r}- \\
1,843 \\
607 \\
36,506 \\
1,457\end{array}$ & $\begin{array}{r}- \\
31,618 \\
11,105 \\
473,735 \\
15,495\end{array}$ & $\begin{array}{r}-\overline{1} \\
18.3 \\
13.0 \\
10.6\end{array}$ & $\begin{array}{r}- \\
2,291 \\
496 \\
33,079 \\
1,217\end{array}$ & $\begin{array}{r}- \\
31,243 \\
11,011 \\
452,740 \\
15,711\end{array}$ & $\begin{array}{r}13.6 \\
22.2 \\
13.7 \\
12.9\end{array}$ \\
\hline
\end{tabular}

-Not available.

IIncludes imputed values for states.

${ }^{2}$ Includes imputations to correct for underreporting of prekindergarten teachers/enrollment 3Imputed.

${ }^{4}$ Includes imputations to correct for underreporting of kindergarten teachers.

NOTE: Teachers reported in full-time equivalents (FTE). DoD = Department of Defense. The pupil/teacher ratio includes teachers for students with disabilities and other special teachers, while these teachers are generally excluded from class size calculations. Ratios reflect totals reported by states and differ from totals reported for schools or school districts.

SOURCE: U.S. Department of Education, National Center for Education Statistics, Common Core of Data (CCD), "State Nonfiscal Survey of Public Elementary/Secondary Education," 2000-01 through 2011-12. (This table was prepared August 2013.) 
Table 209.10. Number and percentage distribution of teachers in public and private elementary and secondary schools, by selected teacher characteristics: Selected years, $1987-88$ through 2011-12

[Standard errors appear in parentheses]

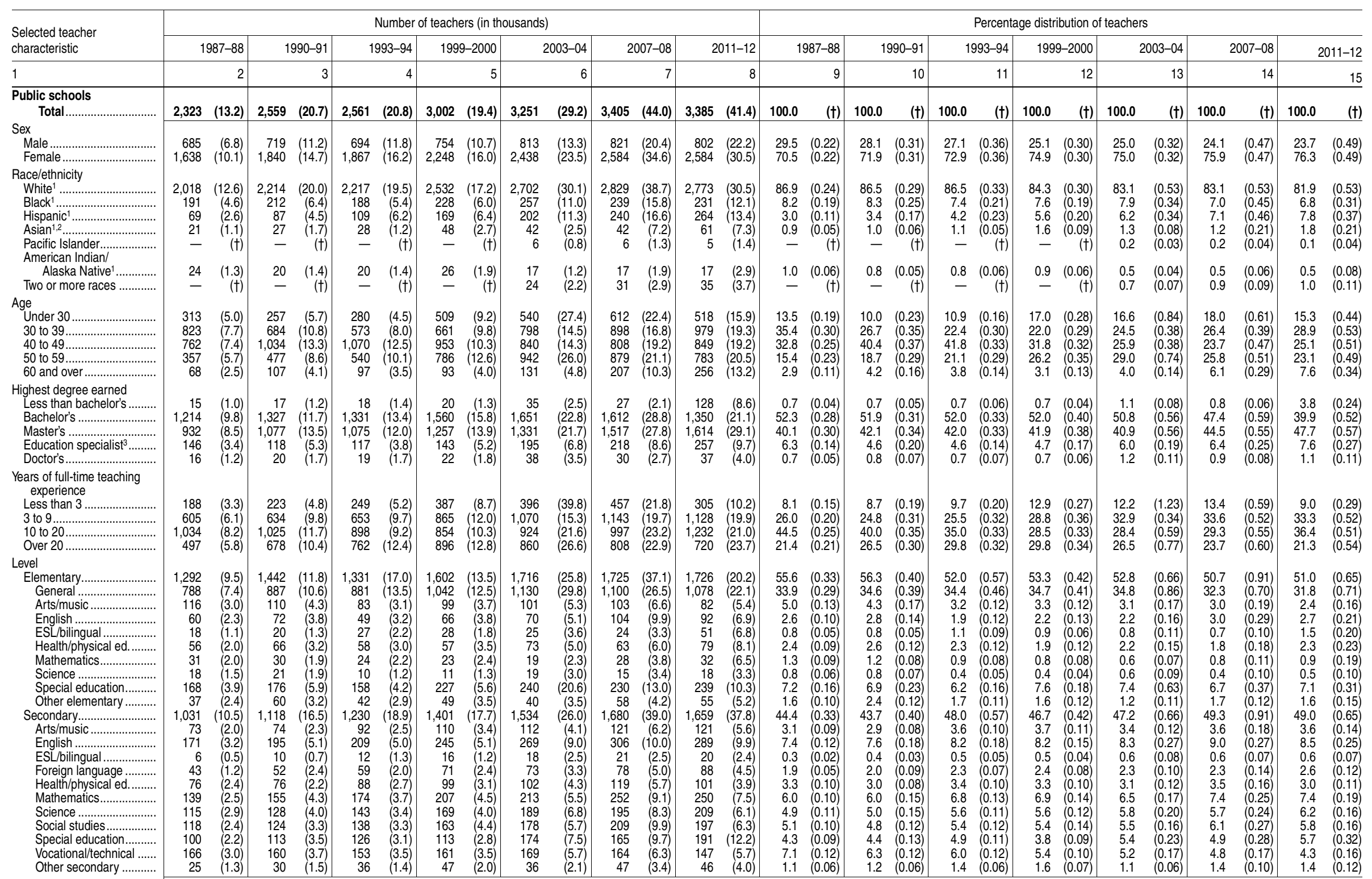


Table 209.10. Number and percentage distribution of teachers in public and private elementary and secondary schools, by selected teacher characteristics: Selected years, 1987-88 through 2011-12-Continued

[Standard errors appear in parentheses]

\begin{tabular}{|c|c|c|c|c|c|c|c|c|c|c|c|c|c|c|c|c|c|c|c|c|c|c|c|c|c|c|c|c|}
\hline \multirow{2}{*}{$\begin{array}{l}\text { Selected teacher } \\
\text { characteristic }\end{array}$} & \multicolumn{14}{|c|}{ Number of teachers (in thousands) } & \multicolumn{14}{|c|}{ Percentage distribution of teachers } \\
\hline & \multicolumn{2}{|c|}{$1987-88$} & \multicolumn{2}{|c|}{$1990-91$} & \multicolumn{2}{|c|}{$1993-94$} & \multicolumn{2}{|c|}{$1999-2000$} & \multicolumn{2}{|c|}{ 2003-04 } & \multicolumn{2}{|c|}{$2007-08$} & \multicolumn{2}{|c|}{ 2011-12 } & \multicolumn{2}{|c|}{$1987-88$} & \multicolumn{2}{|c|}{$1990-91$} & \multicolumn{2}{|c|}{$1993-94$} & \multicolumn{2}{|c|}{ 1999-2000 } & \multicolumn{2}{|c|}{ 2003-04 } & \multicolumn{2}{|c|}{$2007-08$} & \multicolumn{2}{|r|}{$2011-12$} \\
\hline 1 & & 2 & & 3 & & 4 & & 5 & & 6 & & 7 & & 8 & & 9 & & 10 & & 11 & & 12 & & 13 & & 14 & & 15 \\
\hline $\begin{array}{r}\text { rivate schools } \\
\text { Total............ }\end{array}$ & 77 & (8.5) & 356 & 7.2) & 78 & 5.6) & 19 & (10.6) & 7 & 10.3) & 190 & (9.2) & 465 & (11.1) & 100.0 & $(t)$ & 100.0 & $(t)$ & 100.0 & $(t)$ & 100.0 & $(t)$ & 100.0 & $(\dagger)$ & 100.0 & $(t)$ & 100.0 & $(\dagger)$ \\
\hline $\begin{array}{l}\text { Sex } \\
\text { Male ................ } \\
\text { Female ......... }\end{array}$ & $\begin{array}{r}67 \\
240\end{array}$ & $(3.3)$ & $\begin{array}{r}82 \\
275\end{array}$ & & $\begin{array}{r}93 \\
285\end{array}$ & & $\begin{array}{l}107 \\
342\end{array}$ & $(3.8)$ & 110 & $(8.4)$ & 27 & & $\begin{array}{l}117 \\
348\end{array}$ & $\begin{array}{r}(6.9) \\
(10.1)\end{array}$ & $\begin{array}{l}21.8 \\
78.2\end{array}$ & $\begin{array}{l}(0.86) \\
(0.86)\end{array}$ & $\begin{array}{l}2.9 \\
7.1\end{array}$ & $\begin{array}{l}(0.74) \\
(0.74)\end{array}$ & $\begin{array}{l}24.6 \\
75.4\end{array}$ & $\begin{array}{l}(0.43) \\
(0.43)\end{array}$ & $\begin{array}{l}23.9 \\
76.1\end{array}$ & $(0.48)$ & 83.6 & $\begin{array}{l}1.93) \\
1.93)\end{array}$ & 26.0 & $\begin{array}{l}0.78) \\
0.78)\end{array}$ & $\begin{array}{l}25.2 \\
74.8\end{array}$ & $\begin{array}{l}(1.33) \\
(1.33)\end{array}$ \\
\hline $\begin{array}{l}\mathrm{Hi} \\
\mathrm{As} \\
\mathrm{Pa} \\
\mathrm{Ar}\end{array}$ & $\begin{array}{r}285 \\
7 \\
9 \\
4 \\
-\end{array}$ & $\begin{array}{r}(8.3) \\
(0.8) \\
(1.1) \\
(0.8) \\
(\dagger)\end{array}$ & $\begin{array}{r}329 \\
9 \\
12 \\
5 \\
-\end{array}$ & $\begin{array}{r}(7.0) \\
(1.0) \\
(1.0) \\
(0.6) \\
(t)\end{array}$ & $\begin{array}{r}348 \\
12 \\
12 \\
5 \\
-\end{array}$ & $\begin{array}{r}(1.0) \\
(1.0) \\
(0.6) \\
(\dagger)\end{array}$ & $\begin{array}{r}402 \\
17 \\
21 \\
7 \\
-\end{array}$ & $\begin{array}{r}(1.4) \\
(1.5) \\
(0.6) \\
(t)\end{array}$ & $\begin{array}{r}411 \\
19 \\
23 \\
9 \\
\ddagger\end{array}$ & $\begin{array}{r}(12.0) \\
(2.9) \\
(3.1) \\
(1.0) \\
(\dagger)\end{array}$ & $\begin{array}{r}423 \\
20 \\
29 \\
11 \\
\pm\end{array}$ & $\begin{array}{r}(1.5) \\
(t)\end{array}$ & $\begin{array}{r}411 \\
17 \\
24 \\
9 \\
\ddagger\end{array}$ & $\begin{array}{r}(11.1) \\
(2.4) \\
(2.4) \\
(1.4) \\
(\dagger)\end{array}$ & $\begin{array}{r}92.8 \\
2.3 \\
2.8 \\
1.2\end{array}$ & $\begin{array}{r}(0.50) \\
(0.27) \\
(0.36) \\
(0.26) \\
(\dagger)\end{array}$ & $\begin{array}{r}92.2 \\
2.7 \\
3.3 \\
1.5 \\
-\end{array}$ & $\begin{array}{r}(0.46) \\
(0.28) \\
(0.26) \\
(0.18) \\
(\dagger)\end{array}$ & $\begin{array}{r}91.9 \\
3.1 \\
3.2 \\
1.4 \\
-\end{array}$ & $\begin{array}{r}(0.41) \\
(0.27) \\
(0.26) \\
(0.16) \\
(t)\end{array}$ & $\begin{array}{r}89.5 \\
3.7 \\
4.7 \\
1.6\end{array}$ & $\begin{array}{r}(0.42) \\
(0.29) \\
(0.30) \\
(0.14) \\
(\dagger)\end{array}$ & $\begin{array}{c}88.0 \\
4.0 \\
4.8 \\
1.8 \\
0.2 !\end{array}$ & $\begin{array}{l}(0.99) \\
(0.65) \\
(0.71) \\
(0.20) \\
(0.07)\end{array} \mid$ & $\begin{array}{r}86.4 \\
4.0 \\
5.9 \\
2.2 \\
0.3 !\end{array}$ & $\begin{array}{l}(0.80) \\
(0.44) \\
(0.38) \\
(0.29) \\
(0.14)\end{array}$ & $\begin{array}{r}88.3 \\
3.6 \\
5.2 \\
1.8 \\
\ddagger\end{array}$ & $\begin{array}{r}(0.69) \\
(0.54) \\
0.51) \\
(0.31) \\
(\dagger)\end{array}$ \\
\hline $\begin{array}{l}\text { Ala } \\
\text { Two or }\end{array}$ & 3 & $\begin{array}{r}(0.4) \\
(t)\end{array}$ & 1 & $\begin{array}{r}(0.3) \\
(t)\end{array}$ & $\frac{2}{-}$ & $\begin{array}{r}(0.3) \\
(t)\end{array}$ & $\stackrel{2}{-}$ & $\begin{array}{r}(0.4) \\
(t)\end{array}$ & $\begin{array}{l}\ddagger \\
3 \\
3 !\end{array}$ & $\begin{array}{l}(\mathrm{t}) \\
\text { l.4) }\end{array}$ & $\begin{array}{l}\ddagger \\
4 \\
4\end{array}$ & $\begin{array}{r}(t) \\
(0.6)\end{array}$ & $\begin{array}{l}\ddagger \\
4\end{array}$ & $\begin{array}{r}(\dagger) \\
(0.9)\end{array}$ & 0.9 & $\begin{array}{r}(0.12) \\
(t)\end{array}$ & 0.4 & $\begin{array}{r}(0.09) \\
(\dagger)\end{array}$ & 0.4 & $\begin{array}{r}(0.07) \\
(t)\end{array}$ & $\stackrel{0.6}{-}$ & $\begin{array}{r}(0.08) \\
(\dagger)\end{array}$ & $\begin{array}{c}\ddagger \\
0.6 !\end{array}$ & $\begin{array}{r}(t) \\
(0.28)\end{array}$ & $\begin{array}{r}\ddagger \\
0.7\end{array}$ & $(0.12)$ & $\begin{array}{r}\ddagger \\
0.8\end{array}$ & $\begin{array}{r}(+) \\
(0.19)\end{array}$ \\
\hline $\begin{array}{l}\text { Age } \\
\text { Und } \\
30 \text { t } \\
40 \text { t } \\
50 \text { t } \\
60 \mathrm{a}\end{array}$ & $\begin{array}{r}67 \\
106 \\
84 \\
34 \\
16\end{array}$ & $\begin{array}{l}(2.6) \\
(3.6) \\
(3.4) \\
(2.2) \\
(1.7)\end{array}$ & $\begin{array}{r}60 \\
100 \\
121 \\
53 \\
23\end{array}$ & (2) & $\begin{array}{r}65 \\
94 \\
131 \\
66 \\
22\end{array}$ & & $\begin{array}{r}87 \\
101 \\
131 \\
106 \\
25\end{array}$ & $\begin{array}{l}(3.1) \\
(3.2) \\
(4.2) \\
(3.2) \\
(1.2)\end{array}$ & $\begin{array}{r}88 \\
103 \\
119 \\
121 \\
37\end{array}$ & $\begin{array}{r}(3.7) \\
(5.8) \\
(7.1) \\
(11.1) \\
(4.7)\end{array}$ & $\begin{array}{r}80 \\
109\end{array}$ & $\begin{array}{l}(5.2) \\
(3.6) \\
(4.5) \\
(3.1)\end{array}$ & $\begin{array}{r}78 \\
112 \\
110 \\
99 \\
66\end{array}$ & $\begin{array}{l}(6.8) \\
(6.2) \\
(6.3) \\
(5.0) \\
(5.0)\end{array}$ & $\begin{array}{r}21.8 \\
34.5 \\
27.4 \\
11.1 \\
5.3\end{array}$ & $\begin{array}{l}(0.81) \\
(0.78) \\
(0.57) \\
(0.49)\end{array}$ & $\begin{array}{r}16.7 \\
28.1 \\
33.9 \\
14.8 \\
6.4\end{array}$ & $\begin{array}{l}(0.61) \\
(0.78) \\
(0.74) \\
(0.55) \\
(0.41)\end{array}$ & $\begin{array}{r}17.2 \\
24.8 \\
34.8 \\
17.4 \\
5.8\end{array}$ & $\begin{array}{l}(0.60) \\
(0.487 \\
(0.27)\end{array}$ & $\begin{array}{r}19.3 \\
22.4 \\
29.2 \\
23.5 \\
5.7\end{array}$ & $\begin{array}{l}(0.43) \\
(0.50) \\
(0.62) \\
(0.46) \\
(0.24)\end{array}$ & $\begin{array}{r}22.0 \\
25.4 \\
25.8 \\
8.0\end{array}$ & $\begin{array}{l}(0.78) \\
(1.36) \\
(1.41) \\
(2.07) \\
(0.99)\end{array} \mid$ & $\begin{array}{l}16.3 \\
22.3 \\
23.8 \\
26.2 \\
11.5\end{array}$ & $\begin{array}{l}(0.91) \\
(0.65) \\
(0.87) \\
(0.62)\end{array}$ & $\begin{array}{l}16.7 \\
24.0 \\
23.8 \\
21.3 \\
14.2\end{array}$ & $\begin{array}{l}(1.48) \\
(1.07) \\
(1.06) \\
(1.06) \\
(1.05)\end{array}$ \\
\hline $\begin{array}{l}\text { Highest } \\
\text { Less t } \\
\text { Bache } \\
\text { Maste } \\
\text { Educa } \\
\text { Docto }\end{array}$ & $\begin{array}{r}13 \\
189 \\
92 \\
9 \\
4\end{array}$ & $\begin{array}{l}(1.4) \\
(5.1) \\
(3.8) \\
(0.9) \\
(0.7)\end{array}$ & $\begin{array}{r}23 \\
221 \\
96 \\
11 \\
6\end{array}$ & $(1.6)$ & $\begin{array}{r}25 \\
223 \\
113 \\
11 \\
6\end{array}$ & & $\begin{array}{r}33 \\
258 \\
136 \\
14 \\
8\end{array}$ & $\begin{array}{l}(5.8) \\
(4.5) \\
(1.0) \\
(0.8)\end{array}$ & $\begin{array}{r}43 ! \\
259 \\
138 \\
17 \\
10\end{array}$ & $\begin{array}{r}(11.2) \\
(6.1) \\
(2.4) \\
(1.2)\end{array}$ & $\begin{array}{l}14 \\
12\end{array}$ & & $\begin{array}{r}39 \\
225 \\
166 \\
23 \\
11\end{array}$ & $\begin{array}{l}(5.2) \\
(6.7) \\
(7.5) \\
(2.3) \\
(2.0)\end{array}$ & $\begin{array}{r}4.4 \\
61.4 \\
29.8 \\
3.0 \\
1.5\end{array}$ & $\begin{array}{l}(0.75) \\
(0.73) \\
(0.30) \\
(0.23)\end{array}$ & $\begin{array}{r}6.4 \\
61.9 \\
27.0 \\
2.9 \\
1.8\end{array}$ & $\begin{array}{l}(0.45) \\
(0.90) \\
(0.71) \\
(0.24) \\
(0.22)\end{array}$ & $\begin{array}{r}6.7 \\
59.0 \\
29.8 \\
2.9 \\
1.7\end{array}$ & & $\begin{array}{r}7.3 \\
57.5 \\
30.3 \\
3.1 \\
1.8\end{array}$ & $\begin{array}{l}(0.46) \\
(0.64) \\
(0.58) \\
(0.19) \\
(0.16)\end{array}$ & $\begin{array}{c}9.2 ! \\
55.5 \\
29.5 \\
3.6 \\
2.2\end{array}$ & $\begin{array}{l}(4.41) \\
(2.90) \\
(1.35) \\
(0.54) \\
(0.26)\end{array} \mid$ & $\begin{array}{r}8.1 \\
53.9 \\
32.8\end{array}$ & $\begin{array}{l}(0.95) \\
(0.84) \\
(0.25) \\
(0.38)\end{array}$ & $\begin{array}{r}8.4 \\
48.5 \\
35.8 \\
5.0 \\
2.3\end{array}$ & $\begin{array}{l}(1.07) \\
(1.37) \\
(1.16) \\
(0.48) \\
(0.41)\end{array}$ \\
\hline $\begin{array}{r}\text { Years } \\
\text { ex }\end{array}$ & & & & & & & & & & & & & & & & & & & & & & & & & & & & \\
\hline $\begin{array}{l}\text { Less } \\
3 \text { to } \\
10 \text { to } \\
\text { Over }\end{array}$ & $\begin{array}{r}59 \\
115 \\
92 \\
42\end{array}$ & $\begin{array}{l}(2.1) \\
(4.1) \\
(3.8) \\
(2.4)\end{array}$ & $\begin{array}{r}73 \\
123 \\
107 \\
53\end{array}$ & (2.5) & $\begin{array}{r}112 \\
59\end{array}$ & & $\begin{array}{r}122 \\
80\end{array}$ & $\left.\begin{array}{l}(3.6) \\
(2.6)\end{array}\right]$ & 86 & $\begin{array}{r}(14.6) \\
(6.0) \\
(5.8) \\
(8.0)\end{array}$ & & & $\begin{array}{r}91 \\
145 \\
129 \\
100\end{array}$ & & & $\begin{array}{l}(0.60) \\
(0.88) \\
(0.80)\end{array}$ & $\begin{array}{l}20.4 \\
34.6 \\
30.0 \\
14.9\end{array}$ & $\begin{array}{l}(0.72) \\
(0.69) \\
(0.78) \\
(0.67)\end{array}$ & $\begin{array}{l}20.9 \\
33.9 \\
29.6 \\
15.6\end{array}$ & $\begin{array}{l}(0.54) \\
(0.60) \\
(0.60) \\
(0.51)\end{array}$ & $\begin{array}{l}23.9 \\
31.0 \\
27.2 \\
17.8\end{array}$ & $\begin{array}{l}(0.52) \\
(0.55) \\
(0.52) \\
(0.45)\end{array}$ & $\begin{array}{l}24.8 \\
33.0 \\
23.9 \\
18.3\end{array}$ & $\begin{array}{l}(2.75) \\
(1.23) \\
(1.19) \\
(1.87)\end{array}$ & & $\begin{array}{l}(0.99) \\
(0.82) \\
(0.86) \\
(0.75)\end{array}$ & $\begin{array}{l}19.5 \\
31.3 \\
27.7 \\
21.4\end{array}$ & $\begin{array}{l}(1.76) \\
(0.94) \\
(1.06) \\
(1.47)\end{array}$ \\
\hline 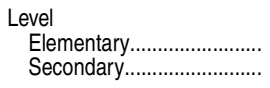 & $\begin{array}{l}179 \\
128\end{array}$ & $(4.7)$ & $\begin{array}{l}225 \\
131\end{array}$ & & 157 & & $\begin{array}{l}261 \\
188\end{array}$ & $\begin{array}{l}(5.8) \\
(6.2)\end{array}$ & $\begin{array}{l}263 \\
204\end{array}$ & (13.4) & 231 & $(7.1)$ & 219 & $(9.9)$ & $\begin{array}{l}5.3 \\
41.7\end{array}$ & $(0.92)$ & 36.8 & $(0.72)$ & $\begin{array}{l}58.4 \\
41.6\end{array}$ & $(0.57)$ & $\begin{array}{l}58.1 \\
41.9\end{array}$ & $(0.66)$ & 43.6 & $\begin{array}{l}(3.06) \\
(3.06)\end{array}$ & 47.2 & $(1.03)$ & $\begin{array}{l}57.8 \\
47.2\end{array}$ & $\begin{array}{l}(1.67) \\
(1.67)\end{array}$ \\
\hline
\end{tabular}

\section{- Not available.}

†Not applicable.

†Reporting standards not met. Either there are too few cases for a reliable estimate or the coefficient of variation $(\mathrm{CV})$ is 50 percent or greater.

two or more races was introduced in $2003-04$.

2Includes Pacific Islander for years 1987-88 through 1999-2000.
${ }^{3}$ Education specialist degrees or certificates are generally awarded for 1 year's work beyond the master's level. Includes certificate of advanced graduate studies.

NOFe Eata are based on a head count of full-time and part-time teachers rather than on SOURCE: U.S. Department of Education, National Center for Education Statistics, Schools and Staffing Survey (SASS), "Public School Teacher Data File," 1987-88 through 2011-12; "Private School Teacher Data File," 1987-88 through 2011-12; and "Charter School Teacher Data File," 1999-2000. (This table was prepared July 2013.) 
Table 209.20. Number, highest degree, and years of full-time teaching experience of teachers in public and private elementary and secondary schools, by selected teacher characteristics:

1999-2000 through 2011-12

[Standard error appears in parentheses]

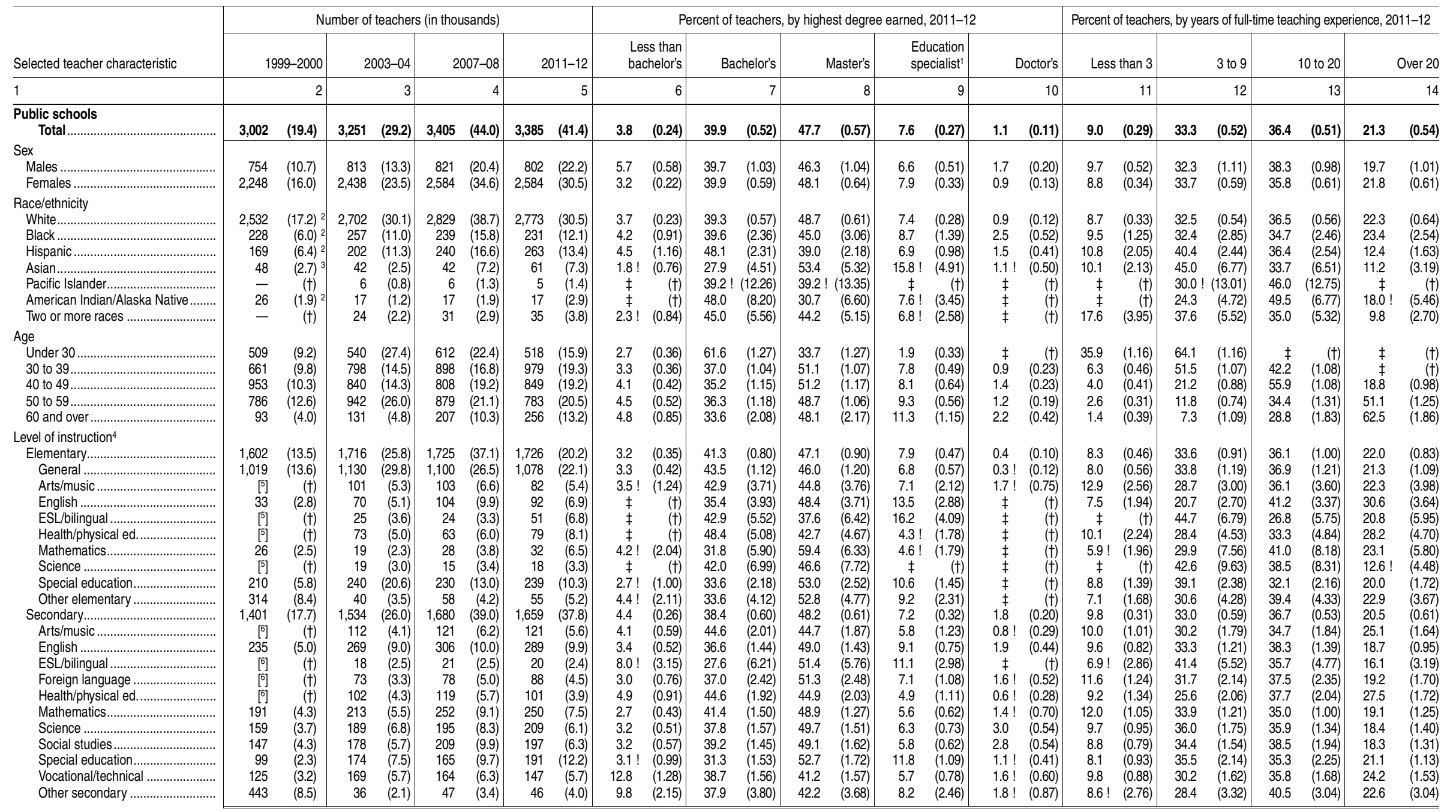


Table 209.20. Number, highest degree, and years of full-time teaching experience of teachers in public and private elementary and secondary schools, by selected teacher characteristics: 1999-2000 through 2011-12-Continued

[Standard error appears in parentheses]

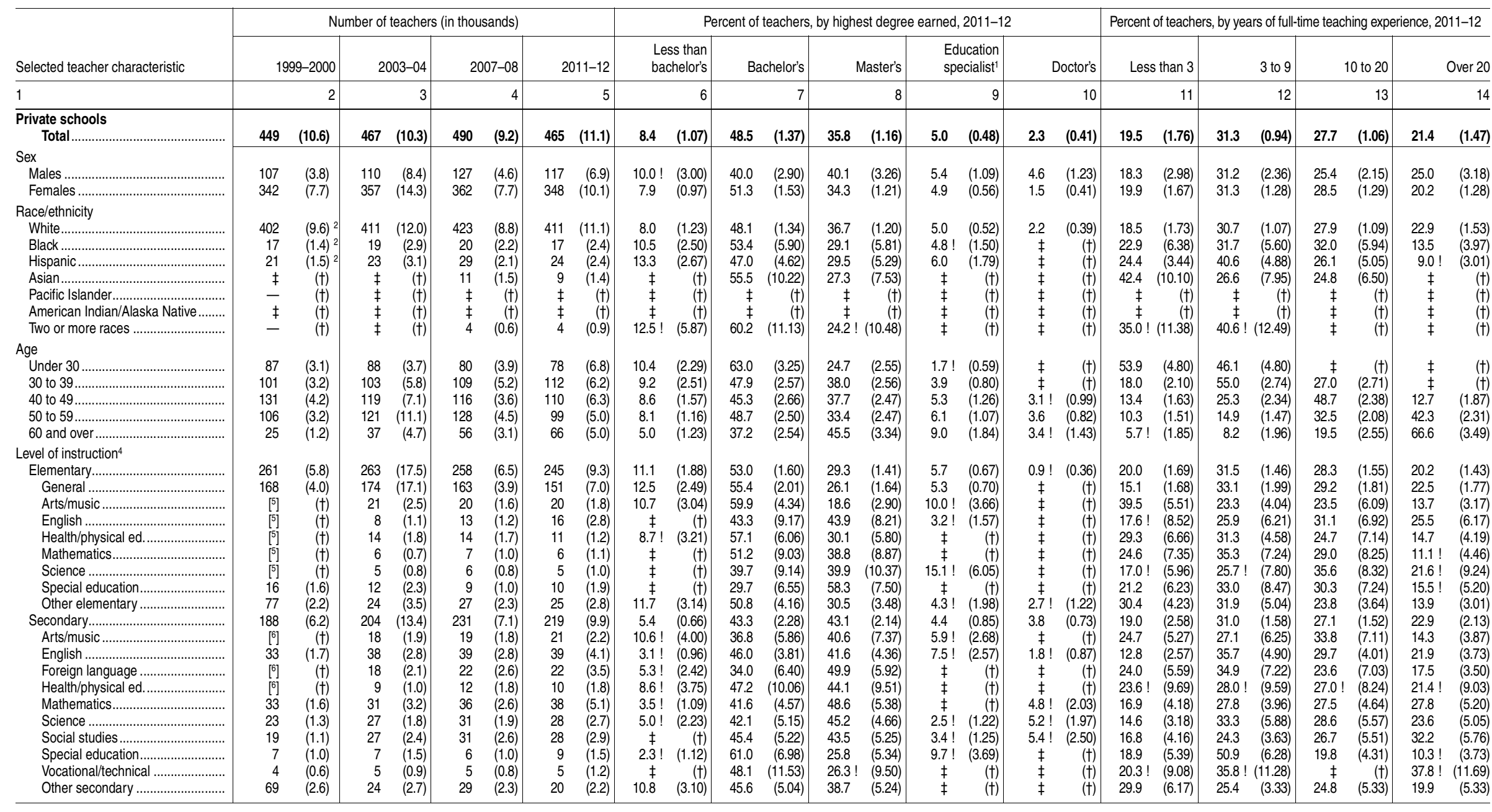

\section{-Not available.}

†Not applicable.

The coefficient of variation (CV) for this estimate is between 30 and 50 percent

andards not met. Either there are too few cases for a reliable estimate or the coefficient of variation (CV) is 50 Ercent or greater.

(t) 2Data for 1999-2000 are only roughly comparable to data for later years, because the new category of two or more races was introduced in $2003-04$.
3Includes Pacific Islander

3Includes Pacific Islander.
4Teachers were classified as elementary or secondary on the basis of the grades they taught, rather than on the level of the school in which they taught. In general, elementary teachers include those teaching prekindergarten through grade 5 and those teaching multiple grades, with a preponderance of grades taught being kindergarten through grade 6. In general, secondary teachers include those teaching any of grades 7 through 12 and those teaching multiple grades, with a preponderance of grades taught being grades 7 through 12 and usually with no grade taught being lower than grade

${ }_{6}$ Included under Other secondary.

NOTE: Excludes prekindergarten teachers. Data are based on a head count of full-time and part-time teachers rather than on the number of full-time-equivalent teachers reported in other tables. Detail may not sum to totals because of rounding and cell suppression. Race categories exclude persons of Hispanic ethnicity.

SOURCE: U.S. Department of Education, National Center for Education Statistics, Schools and Staffing Survey (SASS) "Public School Teacher Data File," 1999-2000, 2003-04, 2007-08, and 2011-12; "Private School Teacher Data File," 1999-2000, 2003-04, 2007-08, and 2011-12; and Chatrer School Teacher Data File," 1999-2000. (This table was prepared 
Table 209.30. Highest degree earned, years of full-time teaching experience, and average class size for teachers in public elementary and secondary schools, by state: 2011-12

[Standard errors appear in parentheses]

\begin{tabular}{|c|c|c|c|c|c|c|c|c|c|c|c|c|c|c|c|c|c|c|c|c|c|c|}
\hline \multirow[b]{2}{*}{ State } & \multirow{2}{*}{\multicolumn{2}{|c|}{$\begin{array}{r}\text { Total number } \\
\text { of teachers } \\
\text { (in thousands) }\end{array}$}} & \multicolumn{8}{|c|}{ Percent of teachers, by highest degree earned } & \multicolumn{8}{|c|}{ Percent of teachers, by years of full-time teaching experience } & \multicolumn{4}{|c|}{ Average class size, by level of instruction ${ }^{1}$} \\
\hline & & & \multicolumn{2}{|c|}{ Less than bachelor's } & \multicolumn{2}{|c|}{ Bachelor's } & \multicolumn{2}{|r|}{ Master's } & \multicolumn{2}{|c|}{$\begin{array}{r}\text { Education } \\
\text { specialist }^{2} \text { or doctor's }^{-}\end{array}$} & \multicolumn{2}{|c|}{ Less than 3} & \multicolumn{2}{|r|}{3 to 9} & \multicolumn{2}{|c|}{10 to 20} & \multicolumn{2}{|r|}{ Over 20} & \multicolumn{2}{|c|}{ Elementary } & \multicolumn{2}{|c|}{ Secondary } \\
\hline 1 & & 2 & & 3 & & 4 & & 5 & & 6 & & 7 & & 8 & & 9 & & 10 & & 11 & & 12 \\
\hline United States.. & $3,385.2$ & (41.42) & 3.8 & $(0.24)$ & 39.9 & (0.52) & 47.7 & $(0.57)$ & 8.7 & $(0.28)$ & 9.0 & $(0.29)$ & 33.3 & (0.52) & 36.4 & $(0.51)$ & 21.3 & $(0.54)$ & 21.2 & $(0.18)$ & 26.8 & $(0.22)$ \\
\hline 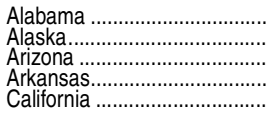 & $\begin{array}{r}45.0 \\
7.5 \\
61.7 \\
37.7 \\
285.5\end{array}$ & $\begin{array}{l}(2.61) \\
0.70 \\
2.61 \\
(2.01) \\
(7.27)\end{array}$ & $\begin{array}{l}3.8 ! \\
4.4 ! \\
4.6 \\
3.7 ! \\
4.8\end{array}$ & $\left.\begin{array}{l}(1.51) \\
1.78 \\
1.16 \\
1.45 \\
0.91\end{array}\right)$ & $\begin{array}{l}34.5 \\
45.6 \\
44.4 \\
54.7 \\
43.4\end{array}$ & $\begin{array}{l}(2.69) \\
4.44 \\
3.67 \\
3.66 \\
(2.33)\end{array}$ & $\begin{array}{l}52.8 \\
41.9 \\
44.1 \\
35.0 \\
39.2\end{array}$ & $\begin{array}{l}2.81 \\
4.01 \\
3.49 \\
3.13 \\
(2.18)\end{array}$ & $\begin{array}{r}8.9 \\
8.2 \\
6.9 \\
6.6 \\
12.7\end{array}$ & $\begin{array}{l}1.64) \\
2.37 \\
1.71 \\
1.72 \\
(1.56)\end{array}$ & $\begin{array}{r}8.0 \\
12.9 \\
16.4 \\
11.5 \\
9.4\end{array}$ & $\begin{array}{l}(1.28) \\
3.30 \\
2.29 \\
2.03 \\
(1.29)\end{array}$ & $\begin{array}{l}30.9 \\
30.8 \\
38.0 \\
28.9 \\
29.1\end{array}$ & $\begin{array}{l}(2.75) \\
4.15 \\
2.75 \\
3.38 \\
(2.13)\end{array}$ & $\begin{array}{l}39.2 \\
39.6 \\
28.5 \\
32.3 \\
42.3\end{array}$ & $\begin{array}{l}(2.85) \\
4.16 \\
2.60 \\
3.93 \\
(2.25)\end{array} \mid$ & $\begin{array}{l}21.9 \\
16.7 \\
17.2 \\
27.3 \\
19.1\end{array}$ & $\left.\begin{array}{l}(2.34) \\
3.76 \\
2.02 \\
3.37 \\
1.89\end{array}\right)$ & $\begin{array}{l}19.2 \\
18.3 \\
24.1 \\
20.4 \\
25.0\end{array}$ & $\begin{array}{l}(0.42) \\
1.35 \\
0.67 \\
0.73 \\
0.52)\end{array}$ & $\begin{array}{l}27.4 \\
18.7 \\
27.7 \\
25.4 \\
32.0\end{array}$ & $\begin{array}{l}(0.94) \\
1.22 \\
0.96 \\
1.69 \\
0.53\end{array}$ \\
\hline 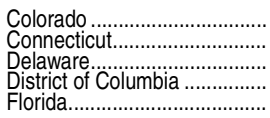 & $\begin{array}{r}55.9 \\
44.9 \\
9.3 \\
\vdots \\
\ddagger\end{array}$ & 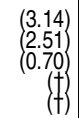 & 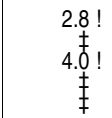 & $\begin{array}{r}(1.00) \\
(t) \\
(1.50 \\
(t) \\
(\dagger)\end{array}$ & $\begin{array}{r}36.1 \\
15.3 \\
34.5 \\
\ddagger \\
\ddagger\end{array}$ & $\begin{array}{r}3.51 \\
1.86 \\
4.36 \\
(\dagger) \\
(\dagger)\end{array}$ & $\begin{array}{r}49.9 \\
64.4 \\
49.7 \\
\ddagger \\
\ddagger\end{array}$ & $\begin{array}{r}(4.26) \\
3.01 \\
4.55 \\
(7) \\
(7)\end{array}$ & $\begin{array}{r}11.2 \\
17.7 \\
11.8 \\
\ddagger \\
\ddagger\end{array}$ & $\begin{array}{r}(2.79) \\
(2.37) \\
2.85 \\
(\dagger) \\
(\dagger)\end{array}$ & $\begin{array}{r}10.8 \\
10.0 \\
12.6 \\
\ddagger \\
\ddagger\end{array}$ & $\begin{array}{r}(2.25) \\
1.43 \\
(3.31) \\
(+)\end{array}$ & $\begin{array}{r}33.4 \\
29.1 \\
35.0 \\
\ddagger \\
\ddagger\end{array}$ & $\begin{array}{r}(3.50) \\
2.66 \\
3.59 \\
(t) \\
(\dagger)\end{array}$ & $\begin{array}{r}42.9 \\
37.1 \\
33.8 \\
\ddagger \\
\ddagger\end{array}$ & $\begin{array}{r}(3.96) \\
(2.43 \\
(4.04) \\
(+5) \\
(7)\end{array}$ & $\begin{array}{r}12.9 \\
23.8 \\
18.6 \\
\ddagger \\
\ddagger\end{array}$ & $\begin{array}{r}(2.51) \\
3.34 \\
2.75 \\
(\dagger) \\
(\dagger)\end{array}$ & $\begin{array}{r}22.8 \\
19.6 \\
20.3 \\
\ddagger\end{array}$ & $\begin{array}{r}(1.29) \\
0.68 \\
0.82 \\
(†) \\
(\dagger)\end{array}$ & $\begin{array}{r}29.1 \\
22.0 \\
25.8 \\
\ddagger \\
\ddagger\end{array}$ & $\begin{array}{r}(1.25) \\
0.71 \\
(2.09) \\
(\dagger)\end{array}$ \\
\hline 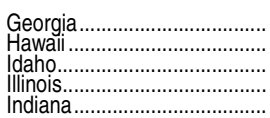 & $\begin{array}{r}123.3 \\
1 \neq \\
16.3 \\
140.9 \\
64.0\end{array}$ & $\begin{array}{l}(3.97) \\
\text { (t) } \\
(1.83) \\
9.09 \\
(2.98)\end{array}$ & $\begin{array}{l}3.4 ! \\
\pm \\
4.6 \\
2.7 ! \\
2.2\end{array}$ & $\begin{array}{l}(1.15) \\
\text { (t) } \\
(1.37 \\
0.81 \\
0.52)\end{array}$ & $\begin{array}{r}29.5 \\
\ddagger \\
55.6 \\
32.6 \\
43.6\end{array}$ & $\left.\begin{array}{r}(3.48) \\
(4) \\
3.30 \\
2.53 \\
3.04\end{array}\right)$ & $\begin{array}{r}43.5 \\
. \\
35.3 \\
57.8 \\
47.4\end{array}$ & $\begin{array}{l}(3.79) \\
(+) \\
(3.18 \\
2.44 \\
3.29)\end{array}$ & $\begin{array}{r}23.6 \\
\ddagger \\
4.4 \\
7.0 \\
6.9\end{array}$ & $\begin{array}{r}(3.00) \\
(t) \\
(1.20) \\
1.34 \\
1.45)\end{array}$ & $\begin{array}{r}6.3 \\
\ddagger \\
10.4 \\
9.3 \\
10.0\end{array}$ & $\begin{array}{l}(1.70) \\
(+) \\
(1.93 \\
1.56 \\
1.92)\end{array}$ & $\begin{array}{l}34.2 \\
\$ .4 \\
30.4 \\
36.4 \\
26.1\end{array}$ & $\left.\begin{array}{r}(3.42) \\
(1) \\
(3.18) \\
2.59 \\
2.42\end{array}\right)$ & $\begin{array}{r}39.8 \\
\ddagger \\
35.2 \\
34.4 \\
35.6\end{array}$ & $\left.\begin{array}{l}(3.34) \\
(4) \\
(3.02 \\
2.85 \\
3.01\end{array}\right)$ & $\begin{array}{r}19.7 \\
\ddagger \\
24.0 \\
20.0 \\
28.3\end{array}$ & $\begin{array}{l}(2.58) \\
\left(\begin{array}{l}(+) \\
(2.89 \\
2.51 \\
3.02\end{array}\right)\end{array}$ & $\begin{array}{l}21.0 \\
24 \\
24.5 \\
22.9 \\
21.4\end{array}$ & $\begin{array}{r}(0.91) \\
(4) \\
(0.63 \\
1.26 \\
0.45)\end{array} \mid$ & $\begin{array}{l}27.5 \\
\ddagger \\
25.4 \\
27.7 \\
27.3\end{array}$ & $\left.\begin{array}{l}(1.42) \\
(+1 \\
(2.13 \\
1.00 \\
1.07\end{array}\right)$ \\
\hline 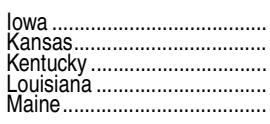 & $\begin{array}{l}36.1 \\
36.5 \\
46.8 \\
44.5 \\
18.4\end{array}$ & $\begin{array}{l}(2.28) \\
2.27 \\
2.51 \\
2.39 \\
0.90)\end{array}$ & $\begin{array}{l}3.5 ! \\
3.8 \\
5.1 \\
3.5 ! \\
4.9 !\end{array}$ & $\left.\begin{array}{l}(1.22 \\
0.83 \\
1.22 \\
1.72 \\
1.60\end{array}\right)$ & $\begin{array}{l}52.8 \\
43.8 \\
17.5 \\
61.9 \\
46.3\end{array}$ & $\left.\begin{array}{l}(3.89 \\
3.52 \\
2.24 \\
3.12 \\
3.41\end{array}\right)$ & $\begin{array}{l}39.7 \\
47.0 \\
57.5 \\
27.0 \\
42.8\end{array}$ & $\left.\begin{array}{l}3.60) \\
3.66 \\
2.58 \\
2.68 \\
3.30\end{array}\right)$ & $\begin{array}{r}4.1 ! \\
50.4 \\
20 \\
7.6 \\
6.0\end{array}$ & $\left.\begin{array}{l}(1.26) \\
1.38 \\
2.11 \\
1.55 \\
1.36\end{array}\right)$ & $\begin{array}{r}8.8 \\
12.5 \\
10.1 \\
8.6 \\
5.8\end{array}$ & $\begin{array}{l}(1.85) \\
2.98 \\
1.83 \\
1.51 \\
(1.47)\end{array}$ & $\begin{array}{l}29.0 \\
27.4 \\
32.2 \\
31.2 \\
24.1\end{array}$ & $\begin{array}{l}(2.98) \\
3.00 \\
2.82 \\
3.13 \\
(2.57)\end{array}$ & $\begin{array}{l}33.0 \\
32.7 \\
38.5 \\
33.4 \\
39.4\end{array}$ & $\left.\begin{array}{l}(2.77) \\
(3.15 \\
(2.81 \\
3.31 \\
3.32\end{array}\right)$ & $\begin{array}{l}29.2 \\
27.4 \\
19.2 \\
26.8 \\
30.6\end{array}$ & $\left.\begin{array}{l}2.55) \\
2.83 \\
2.02 \\
3.10 \\
2.81\end{array}\right)$ & $\begin{array}{l}20.3 \\
20.4 \\
23.3 \\
19.0 \\
17.6\end{array}$ & $\begin{array}{l}(0.93) \\
0.86 \\
1.92 \\
0.80 \\
0.64)\end{array}$ & $\begin{array}{l}27.4 \\
24.6 \\
26.6 \\
23.4 \\
19.9\end{array}$ & $\left.\begin{array}{l}(1.35) \\
1.21 \\
1.09 \\
0.78 \\
1.76\end{array}\right)$ \\
\hline 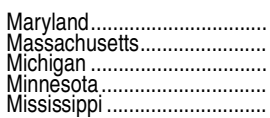 & $\begin{array}{l}79 \\
79.2 \\
96.7 \\
62.3 \\
37.6\end{array}$ & 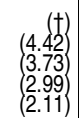 & $\begin{array}{l}3.7 \\
2.9 \\
2.3 \\
4.4 \\
5.3\end{array}$ & $\left.\begin{array}{r}(t) \\
1.08 \\
0.55 \\
0.77 \\
1.45\end{array}\right)$ & $\begin{array}{r}\text { 吉 } \\
21.8 \\
29.8 \\
35.3 \\
54.4\end{array}$ & $\left.\begin{array}{r}(t) \\
2.33 \\
2.50 \\
2.06 \\
3.87\end{array}\right)$ & $\begin{array}{l}\text { 声 } \\
67.5 \\
62.9 \\
50.1 \\
35.2\end{array}$ & 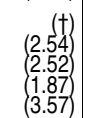 & $\begin{array}{r}\mathbf{f} \\
6.8 \\
5.0 \\
10.2 \\
5.1\end{array}$ & 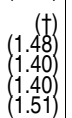 & $\begin{array}{r}12 . \bar{\ddagger} \\
7.3 \\
9.5 \\
10.3\end{array}$ & $\left.\begin{array}{l}1.96 \\
1.00 \\
1.20 \\
1.97\end{array}\right)$ & $\begin{array}{l}33 . \bar{\ddagger} \\
31.4 \\
27.4 \\
41.0\end{array}$ & 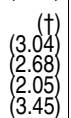 & $\begin{array}{l}36.8 \\
42.7 \\
40.3 \\
30.5\end{array}$ & 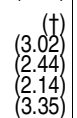 & $\begin{array}{r}\ddagger \\
17.4 \\
18.7 \\
22.9 \\
18.2\end{array}$ & $\begin{array}{l}\left(\begin{array}{c}(t) \\
3.09 \\
2.12 \\
2.00 \\
3.18\end{array}\right) \\
\end{array}$ & $\begin{array}{l}19.9 \\
23.8 \\
22.8 \\
21.6\end{array}$ & $\begin{array}{l}1.72 \\
0.93 \\
0.70 \\
1.01)\end{array} \mid$ & $\begin{array}{l}24.7 \\
28.9 \\
29.9 \\
22.8\end{array}$ & $\begin{array}{l}\left(\begin{array}{c}(t) \\
(.8) \\
0.81 \\
0.86 \\
1.15\end{array}\right)\end{array}$ \\
\hline 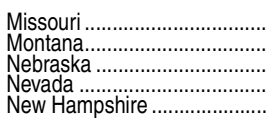 & $\begin{array}{l}68.7 \\
12.4 \\
23.9 \\
25.2 \\
15.7\end{array}$ & $\begin{array}{l}(2.34) \\
0.90 \\
(1.73 \\
2.63 \\
(1.05)\end{array}$ & $\begin{array}{l}4.4 \\
6.4 \\
5.5 \\
4.5 ! \\
3.0 !\end{array}$ & $\left.\begin{array}{l}(0.91) \\
1.52 \\
1.31 \\
1.85 \\
1.12\end{array}\right)$ & $\begin{array}{l}33.3 \\
55.2 \\
44.9 \\
25.1 \\
40.2\end{array}$ & $\left.\begin{array}{l}(2.90) \\
3.34 \\
3.29 \\
3.92 \\
3.49\end{array}\right)$ & $\begin{array}{l}57.5 \\
34.6 \\
45.9 \\
49.8 \\
48.7\end{array}$ & $\left.\begin{array}{l}(2.96) \\
3.39 \\
3.15 \\
4.26 \\
3.55\end{array}\right)$ & $\begin{array}{l}4.8 \\
3.8 ! \\
3.7 \\
20.6 \\
8.1\end{array}$ & $\begin{array}{l}(0.94) \\
1.66 \\
0.98 \\
3.23 \\
(1.82)\end{array}$ & $\begin{array}{c}10.4 \\
9.6 \\
10.6 \\
6.5 ! \\
8.1\end{array}$ & $\begin{array}{l}(1.90) \\
2.33 \\
1.74 \\
2.17 \\
(1.54)\end{array}$ & $\begin{array}{l}35.3 \\
31.3 \\
27.2 \\
39.0 \\
32.8\end{array}$ & $\left.\begin{array}{l}(2.21) \\
3.17 \\
2.52 \\
4.02 \\
3.41\end{array}\right)$ & $\begin{array}{l}35.2 \\
30.5 \\
34.6 \\
36.2 \\
31.5\end{array}$ & $\begin{array}{l}(2.31) \\
(3.04 \\
2.63 \\
4.29 \\
3.57\end{array}$ & $\begin{array}{l}19.2 \\
28.6 \\
27.6 \\
18.2 \\
27.5\end{array}$ & $\left.\begin{array}{l}(2.31) \\
3.65 \\
2.54 \\
3.55 \\
3.54\end{array}\right)$ & $\begin{array}{l}20.2 \\
18.9 \\
17.9 \\
25.3 \\
20.4\end{array}$ & $\begin{array}{l}(0.83) \\
0.80 \\
0.72 \\
1.41 \\
3.09\end{array}$ & $\begin{array}{l}26.8 \\
21.7 \\
23.5 \\
34.5 \\
21.7\end{array}$ & $\left.\begin{array}{l}(1.18) \\
(1.81 \\
0.99 \\
1.54 \\
1.16\end{array}\right)$ \\
\hline 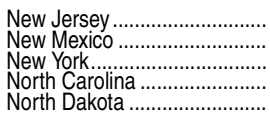 & $\begin{array}{r}125.2 \\
21.7 \\
241.4 \\
104.3 \\
10.3\end{array}$ & $\begin{array}{r}(4.16) \\
(2.83 \\
(14.58) \\
(5.71) \\
0.74)\end{array}$ & $\begin{array}{l}3.0 \\
4.3 ! \\
2.8 ! \\
4.1 ! \\
6.9\end{array}$ & $\left.\begin{array}{l}(0.74) \\
(2.01 \\
1.00 \\
1.57 \\
1.63\end{array}\right)$ & $\begin{array}{r}48.5 \\
43.3 \\
4.4 \\
54.2 \\
59.2\end{array}$ & $\begin{array}{l}(2.47) \\
3.80 \\
1.09 \\
3.16 \\
3.08)\end{array}$ & $\begin{array}{l}40.8 \\
42.1 \\
84.2 \\
33.8 \\
30.1\end{array}$ & $\begin{array}{l}2.30 \\
3(.72) \\
1.56 \\
2.80 \\
2.60)\end{array}$ & $\begin{array}{r}7.6 \\
10.3 \\
8.6 \\
7.8 \\
3.9\end{array}$ & $\begin{array}{l}(1.60) \\
(2.82 \\
1.32 \\
1.84 \\
(1.13)\end{array}$ & $\begin{array}{r}7.3 \\
8.0 ! \\
5.3 \\
8.4 \\
12.2\end{array}$ & $\left.\begin{array}{l}(1.24) \\
2.46 \\
1.38 \\
1.52 \\
2.09\end{array}\right)$ & $\begin{array}{l}35.4 \\
30.9 \\
30.0 \\
35.8 \\
24.6\end{array}$ & $\left.\begin{array}{l}(2.45) \\
(3.73 \\
2.81 \\
3.13 \\
(3.06)\end{array}\right)$ & $\begin{array}{l}37.4 \\
40.3 \\
45.5 \\
34.8 \\
30.6\end{array}$ & $\left.\begin{array}{l}(2.66) \\
5.11 \\
2.35 \\
(3.05 \\
3.28\end{array}\right)$ & $\begin{array}{l}20.0 \\
20.8 \\
19.1 \\
21.1 \\
32.6\end{array}$ & $\left.\begin{array}{l}(2.03) \\
5.19 \\
2.41 \\
2.74 \\
3.45\end{array}\right)$ & $\begin{array}{l}18.5 \\
19.8 \\
20.7 \\
18.8 \\
17.8\end{array}$ & $\begin{array}{l}(0.81) \\
0.76 \\
1.36 \\
0.65 \\
0.60)\end{array}$ & $\begin{array}{l}23.9 \\
23.7 \\
25.1 \\
25.8 \\
19.2\end{array}$ & $\left.\begin{array}{l}(0.68) \\
(1.58 \\
0.96 \\
1.25 \\
1.41\end{array}\right)$ \\
\hline 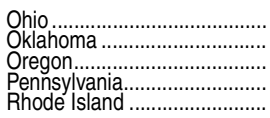 & $\begin{array}{r}122.1 \\
46.2 \\
31.8 \\
148.8 \\
\ddagger\end{array}$ & $\begin{array}{r}(4.29) \\
(2.49 \\
(1.28 \\
(7.48 \\
(\dagger)\end{array}$ & $\begin{array}{l}5.3 \\
4.3 \\
4.2 ! \\
4.5 ! \\
\ddagger\end{array}$ & $\left.\begin{array}{r}1.17) \\
1.04 \\
1.53 \\
1.94 \\
(\dagger\end{array}\right)$ & $\begin{array}{r}24.0 \\
65.6 \\
26.3 \\
32.9 \\
\ddagger\end{array}$ & $\left.\begin{array}{r}(1.79 \\
2.66 \\
3.18 \\
2.52 \\
(\dagger)\end{array}\right)$ & $\begin{array}{r}64.5 \\
26.9 \\
59.8 \\
53.9 \\
\ddagger\end{array}$ & $\begin{array}{r}(2.16) \\
2.56 \\
3.62 \\
3.34 \\
(\dagger)\end{array}$ & $\begin{array}{l}6.2 \\
3.2 ! \\
9.7 \\
8.7 \\
\ddagger\end{array}$ & $\left.\begin{array}{c}1.28) \\
1.12 \\
1.94 \\
1.77 \\
(\dagger)\end{array}\right)$ & $\begin{array}{r}7.1 \\
9.8 \\
7.2 \\
6.2 \\
\ddagger\end{array}$ & $\left(\begin{array}{r}1.11 \\
1.84 \\
1.54 \\
1.78 \\
(\dagger)\end{array}\right)$ & $\begin{array}{r}28.8 \\
30.1 \\
37.0 \\
37.0 \\
\ddagger\end{array}$ & $\begin{array}{r}2.48 \\
2.58 \\
3.58 \\
2.55 \\
(\dagger)\end{array}$ & $\begin{array}{r}40.8 \\
36.9 \\
35.6 \\
35.8 \\
\ddagger\end{array}$ & $\begin{array}{r}(2.67) \\
(2.93 \\
3.58 \\
2.17 \\
(\dagger)\end{array}$ & $\begin{array}{r}23.3 \\
23.3 \\
20.2 \\
21.0 \\
\ddagger\end{array}$ & $\begin{array}{r}(2.00) \\
2.27 \\
2.45 \\
2.30 \\
(\dagger)\end{array}$ & $\begin{array}{r}21.3 \\
20.7 \\
26.4 \\
22.4 \\
\ddagger\end{array}$ & $\begin{array}{c}(0.99) \\
0.56 \\
0.96 \\
0.99 \\
(\dagger)\end{array}$ & $\begin{array}{r}26.7 \\
23.7 \\
30.0 \\
25.2 \\
\ddagger\end{array}$ & $\left.\begin{array}{r}(0.85) \\
0.88 \\
1.05 \\
0.96 \\
(\dagger\end{array}\right)$ \\
\hline 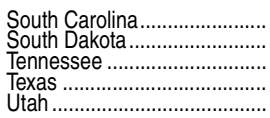 & $\begin{array}{r}51.8 \\
10.8 \\
76.5 \\
350.8 \\
27.9\end{array}$ & $\begin{array}{r}(1.76) \\
(0.92) \\
(2.91) \\
(22.99 \\
(1.67)\end{array}$ & $\begin{array}{l}3.0 ! \\
2.3 ! \\
4.4 ! \\
3.3 \\
4.2\end{array}$ & $\left.\begin{array}{l}(1.34) \\
0.73 \\
1.52 \\
0.65 \\
(1.10)\end{array}\right)$ & $\begin{array}{l}28.8 \\
68.8 \\
35.1 \\
66.4 \\
56.8\end{array}$ & $\left.\begin{array}{l}(3.14) \\
3.52 \\
3.54 \\
2.09 \\
3.96\end{array}\right)$ & $\begin{array}{l}57.9 \\
26.6 \\
46.3 \\
25.8 \\
27.3\end{array}$ & $\begin{array}{l}(3.95) \\
3.13 \\
3.44 \\
2.12 \\
(3.88)\end{array}$ & $\begin{array}{c}10.3 \\
2.3 ! \\
14.2 ! \\
4.6 \\
11.7 !\end{array}$ & $\begin{array}{l}2.15 \\
1.14 \\
2.83 \\
0.77 \\
(3.94)\end{array}$ & $\begin{array}{r}8.4 \\
8.8 \\
10.6 \\
8.9 \\
15.0\end{array}$ & $\left.\begin{array}{l}(1.58) \\
(1.65) \\
1.80 \\
0.95 \\
2.43\end{array}\right)$ & $\begin{array}{l}30.5 \\
24.6 \\
34.0 \\
40.4 \\
39.9\end{array}$ & $\begin{array}{l}(3.22) \\
2.76 \\
3.66 \\
2.05 \\
(4.49)\end{array}$ & $\begin{array}{l}32.3 \\
32.9 \\
34.1 \\
31.1 \\
25.6\end{array}$ & $\begin{array}{l}(3.54) \\
(3.63 \\
(3.48) \\
(1.88 \\
(4.52)\end{array}$ & $\begin{array}{l}28.9 \\
33.7 \\
21.3 \\
19.7 \\
19.5\end{array}$ & $\begin{array}{l}(3.38) \\
3.38 \\
3.28 \\
1.74 \\
(3.12)\end{array}$ & $\begin{array}{l}19.1 \\
20.4 \\
17.7 \\
18.2 \\
27.4\end{array}$ & $\begin{array}{l}(0.75) \\
0.66 \\
0.52 \\
0.82 \\
(2.09)\end{array}$ & $\begin{array}{l}26.0 \\
22.3 \\
26.9 \\
26.9 \\
31.5\end{array}$ & $\left.\begin{array}{l}(1.98) \\
1.31 \\
1.60 \\
1.07 \\
1.29\end{array}\right)$ \\
\hline 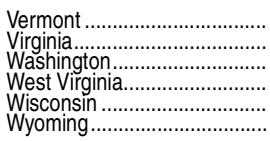 & $\begin{array}{r}9.4 \\
88.5 \\
55.5 \\
24.2 \\
66.8 \\
8.5\end{array}$ & $\begin{array}{l}(0.34) \\
3.35 \\
3.15 \\
(0.79 \\
3.42 \\
0.57)\end{array}$ & $\begin{array}{l}6.6 \\
3.3 ! \\
2.9 \\
3.1 \\
2.7 \\
7.0 !\end{array}$ & $\begin{array}{l}1.46 \\
1.07 \\
0.59 \\
0.90 \\
0.79 \\
(3.08)\end{array}$ & $\begin{array}{l}35.4 \\
47.5 \\
23.1 \\
46.6 \\
36.7 \\
44.3\end{array}$ & $\begin{array}{l}2.78 \\
3.08 \\
2.61 \\
4.82 \\
2.96 \\
4.47)\end{array}$ & $\begin{array}{l}52.0 \\
41.6 \\
62.9 \\
43.2 \\
55.1 \\
41.2\end{array}$ & $\left.\begin{array}{l}(2.87) \\
3.17 \\
2.92 \\
4.71 \\
2.98 \\
4.18\end{array}\right)$ & $\begin{array}{r}6.0 \\
7.6 \\
11.1 \\
7.1 \\
5.5 \\
7.5 !\end{array}$ & $\left.\begin{array}{l}1.59) \\
1.26 \\
1.96 \\
1.73 \\
(2.74) \\
2.74\end{array}\right)$ & $\begin{array}{c}12.9 \\
9.1 \\
6.2 \\
12.0 \\
10.5 \\
7.6 !\end{array}$ & $\left.\begin{array}{l}(1.60) \\
1.68 \\
1.45 \\
2.26 \\
1.67 \\
2.62\end{array}\right)$ & $\begin{array}{l}22.1 \\
31.5 \\
32.2 \\
31.2 \\
26.2 \\
25.2\end{array}$ & $\left.\begin{array}{l}(2.38) \\
3.20 \\
3.00 \\
4.12 \\
3.12 \\
4.09\end{array}\right)$ & $\begin{array}{l}37.0 \\
34.2 \\
34.8 \\
30.5 \\
42.1 \\
35.1\end{array}$ & $\begin{array}{l}(2.56) \\
(2.73 \\
(2.82) \\
(3.82) \\
3.24 \\
(3.73)\end{array}$ & $\begin{array}{l}28.0 \\
25.2 \\
26.8 \\
26.3 \\
21.3 \\
32.1\end{array}$ & $\left.\begin{array}{l}(2.73) \\
2.43 \\
3.03 \\
3.24 \\
2.73 \\
4.30\end{array}\right)$ & $\begin{array}{l}16.6 \\
20.4 \\
23.7 \\
18.7 \\
20.8 \\
17.0\end{array}$ & $\left.\begin{array}{l}(0.40) \\
1.27 \\
0.60 \\
1.00 \\
0.55 \\
1.05\end{array}\right)$ & $\begin{array}{l}19.8 \\
23.8 \\
29.7 \\
24.0 \\
27.9 \\
19.6\end{array}$ & $\begin{array}{l}(1.25) \\
0.90 \\
0.99 \\
1.65 \\
0.95 \\
1.22\end{array}$ \\
\hline
\end{tabular}

District of $\mathrm{Col}$

(2.98)

\begin{tabular}{rr}
46.8 \\
4.5 & $(2.519$ \\
18.4 & $(0.90)$ \\
\hline
\end{tabular}

$1.5+\left(\begin{array}{ll}1.22 \\ 1.72 \\ 1.60\end{array}\right.$

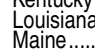

Masssachuse..........

New Jersey.

North Carolin

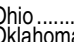

ennsylva

South Carolina

Vermont

Wisconsin

$\begin{array}{ll}8.5 & 0.57\end{array}$

†Not applicable.

(

ondary teachers include those teaching any of grades 7 through 12 and those teaching multiple grades, with a preponderance of grades taught being grades 7 through 12 and usually with no grade taught being lower than grade 5 .

'Education specialist degrees or certificates are generally awarded for 1 year's work beyond the master's level. Includes certificate of advanced graduate studies.
NOTE: Data are based on a head count of all teachers rather than on the number of full-time-equivalent teachers appearing

cases for a reliable estimate, or the may be suppressed because the response rate is under 50 percent, there are too tew "Elementary teachers are those who taught self-contained classes at the elementary level, and secondary teachers are those who taught departmentalized classes (e.g., science, art, social science, or other course subjects) at the secondary level. school in which they taught. In general, elementary teachers include those teaching prekindergarten through grade 5 and E. D. Department of Education, National Center for Education Statistics, Schools and Staffing Survey (SASS), those teaching multiple grades, with a preponderance of grades taught being kindergarten through grade 6 . In general, sec- 
CHAPTER 2: Elementary and Secondary Education 139

Teacher Characteristics, Class Sizes, and Assignments

Table 209.50. Percentage of public school teachers of grades 9 through 12, by field of main teaching assignment and selected demographic and educational characteristics: 2011-12

[Standard errors appear in parentheses]

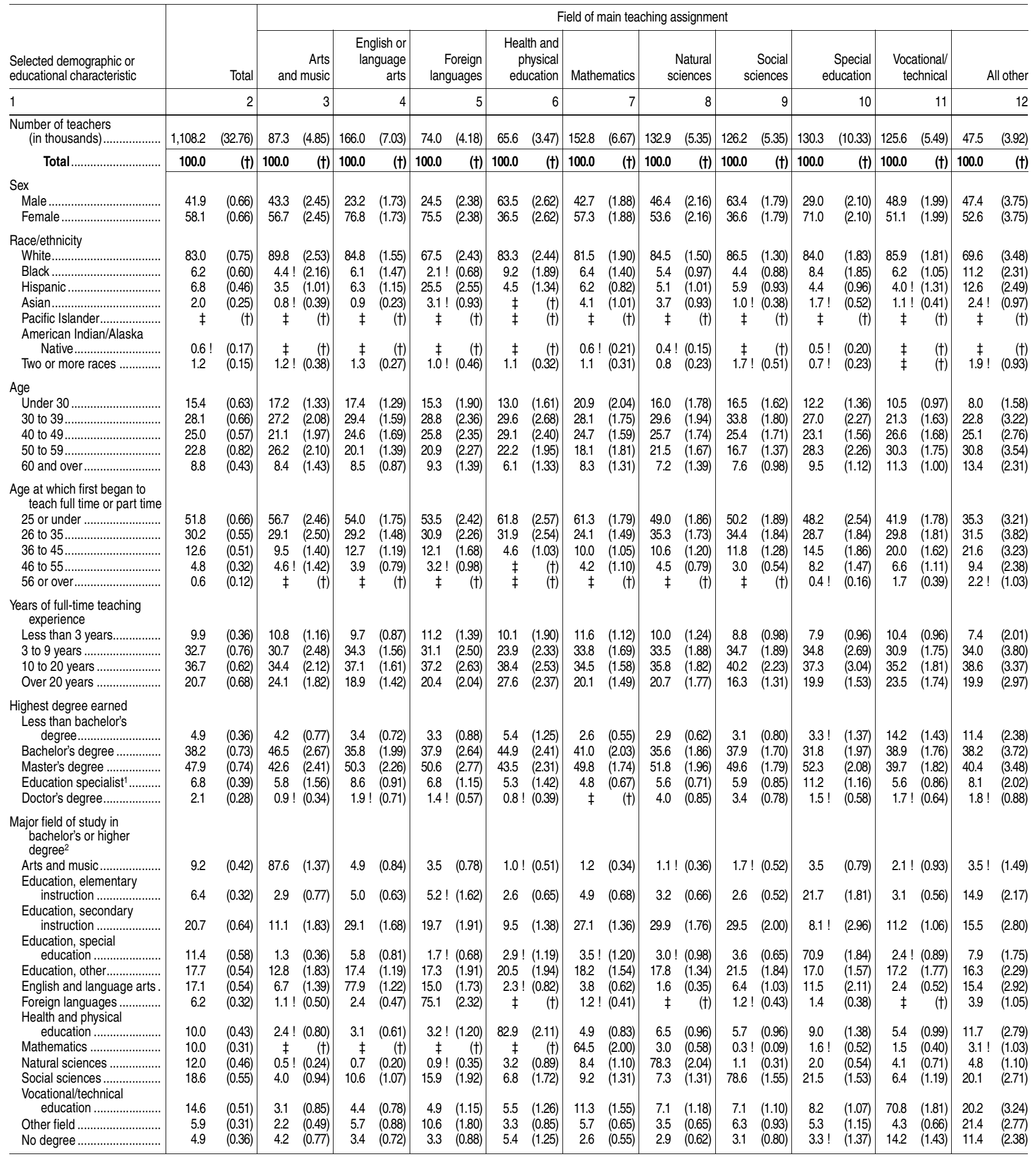

†Not applicable.

!nterpret data with caution. The coefficient of variation (CV) for this estimate is between 30 and 50 percent.

$\ddagger$ Reporting standards not met. Either there are too few cases for a reliable estimate or the coefficient of variation (CV) is 50 percent or greater.

'Education specialist degrees or certificates are generally awarded for 1 year's work

beyond the master's level. Includes certificates of advanced graduate studies.
2Data may sum to more than 100 percent because (1) a teacher who reported more than one major is represented in more than one field of study and (2) a teacher with multiple degrees in different fields of study is represented in more than one field of study.

NOTE: Race categories exclude persons of Hispanic ethnicity. Detail may not sum to totals because of rounding.

SOURCE: U.S. Department of Education, National Center for Education Statistics, Schools and Staffing Survey (SASS), "Public School Teacher Data File," 2011-12. (This table was prepared May 2013.) 


\begin{tabular}{|c|c|c|c|c|c|c|c|c|c|c|c|c|c|c|c|c|c|c|c|c|c|c|c|c|}
\hline \multirow[b]{2}{*}{ Control of school and issue } & \multirow[b]{2}{*}{$\begin{array}{r}1987-88 \\
\text { total }\end{array}$} & \multirow[b]{2}{*}{$\begin{array}{r}1993-94 \\
\text { total }\end{array}$} & \multirow[b]{2}{*}{$\begin{array}{r}1999-2000 \\
\text { total } \\
\end{array}$} & \multicolumn{5}{|c|}{ 2003-04 } & \multicolumn{8}{|c|}{$2007-08$} & \multicolumn{8}{|c|}{ 2011-12 } \\
\hline & & & & & Total' $^{1}$ & $\begin{array}{r}\text { ementary } \\
\text { schools }\end{array}$ & & & & Total & & tary & & & & & & Total & & $\begin{array}{l}\text { mentary } \\
\text { schools }\end{array}$ & & & & \\
\hline 1 & 2 & 3 & 4 & & 5 & 6 & & 7 & & 8 & & 9 & & 10 & & 11 & & 12 & & 13 & & 14 & & 15 \\
\hline 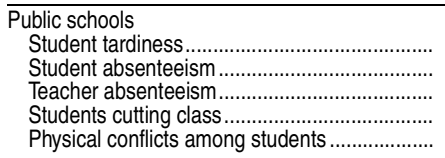 & $\begin{array}{rr}10.5 & (0.18) \\
16.4 & (0.23) \\
2.3 & (0.09) \\
5.9 & (0.16) \\
5.8 & (0.18)\end{array}$ & \begin{tabular}{rr|}
10.5 & $(0.28)$ \\
14.4 & $(0.29)$ \\
1.5 & $(0.09)$ \\
5.1 & $(0.12)$ \\
8.2 & $(0.25)$
\end{tabular} & \begin{tabular}{rr|}
10.2 & $(0.22)$ \\
13.9 & $(0.26)$ \\
2.2 & $(0.10)$ \\
4.7 & $(0.12)$ \\
4.8 & $(0.19)$
\end{tabular} & $\begin{array}{r}13.8 \\
13.1 \\
1.1 \\
5.5 \\
12.1\end{array}$ & $\begin{array}{l}(0.29) \\
(0.31) \\
(0.08) \\
(0.23) \\
0.29)\end{array}$ & \begin{tabular}{rr|}
9.8 & $(0.38)$ \\
8.3 & $(0.36)$ \\
0.9 & $(0.12)$ \\
1.5 & $(0.17)$ \\
13.7 & $(0.43)$
\end{tabular} & $\begin{array}{r}23.1 \\
23.7 \\
1.7 \\
14.5 \\
9.3\end{array}$ & $\begin{array}{l}(0.58) \\
(0.59) \\
(0.15) \\
(0.59) \\
0.38)\end{array}$ & $\begin{array}{r}9.8 \\
11.7 \\
1.5 \\
4.0 \\
-\end{array}$ & $\begin{array}{r}(0.33) \\
(0.36) \\
(0.15) \\
(0.20) \\
(\dagger)\end{array}$ & $\begin{array}{l}5.8 \\
6.5 \\
1.2 \\
0.5\end{array}$ & $\begin{array}{r}(0.37) \\
(0.42) \\
(0.20) \\
(0.12) \\
(\dagger)\end{array} \mid$ & $\begin{array}{r}17.9 \\
21.4 \\
2.0 \\
10.9 \\
-\end{array}$ & $\begin{array}{r}(0.65) \\
(0.63) \\
(0.20) \\
(0.52) \\
(\dagger)\end{array} \mid$ & $\begin{array}{r}9.0 \\
14.2 \\
2.3 \\
4.0 \\
-\end{array}$ & $\begin{array}{r}(1.36) \\
(0.95) \\
(0.48) \\
(0.64) \\
(\dagger)\end{array}$ & $\begin{array}{r}11.9 \\
13.9 \\
1.6 \\
4.9 \\
-\end{array}$ & $\begin{array}{r}(0.33) \\
(0.35) \\
(0.14) \\
(0.22) \\
(\dagger)\end{array}$ & $\begin{array}{l}8.5 \\
8.6 \\
1.3 \\
1.2 \\
-\end{array}$ & $\begin{array}{r}(0.49) \\
(0.49) \\
(0.16) \\
(0.16) \\
(t)\end{array} \mid$ & $\begin{array}{r}17.6 \\
22.6 \\
1.8 \\
10.8 \\
-\end{array}$ & $\begin{array}{r}(0.55) \\
(0.63) \\
(0.20) \\
(0.47) \\
(\dagger)\end{array}$ & $\begin{array}{r}16.4 \\
21.9 \\
3.3 \\
10.4 \\
-\end{array}$ & $\begin{array}{r}(1.11) \\
(1.48) \\
(0.58) \\
(1.05) \\
(\dagger)\end{array}$ \\
\hline $\begin{array}{l}\text { Vandal } \\
\text { Studen } \\
\text { Studen } \\
\text { Studen }\end{array}$ & $\begin{array}{rr}3.7 & (0.12) \\
6.1 & (0.15) \\
6.9 & (0.17) \\
11.4 & (0.18) \\
8.0 & (0.14)\end{array}$ & $\begin{array}{ll}4.1 & (0.17) \\
6.7 & (0.23) \\
7.3 & (0.24) \\
9.3 & (0.17) \\
5.7 & (0.14)\end{array}$ & $\begin{array}{ll}2.4 & (0.11) \\
3.4 & (0.15) \\
3.7 & (0.12) \\
7.4 & (0.14) \\
6.0 & (0.11)\end{array}$ & $\begin{array}{l}3.7 \\
3.7 \\
2.4 \\
3.0 \\
4.5\end{array}$ & $\begin{array}{l}(0.17) \\
(0.16) \\
(0.12) \\
0.10) \\
(0.14)\end{array}$ & \begin{tabular}{rr|}
2.9 & $(0.23)$ \\
2.5 & $(0.21)$ \\
$\ddagger$ & $(t)$ \\
0.3 & $(0.07)$ \\
0.5 & $(0.10)$
\end{tabular} & $\begin{array}{r}5.9 \\
6.3 \\
7.0 \\
9.0 \\
13.0\end{array}$ & $\begin{array}{l}(0.24) \\
(0.33) \\
(0.34) \\
(0.28) \\
(0.35)\end{array}$ & $\begin{array}{l}= \\
= \\
= \\
-\end{array}$ & $\begin{array}{l}(t) \\
(t) \\
(t) \\
(t) \\
(t)\end{array}$ & $\begin{array}{l}- \\
= \\
= \\
-\end{array}$ & 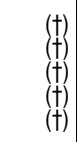 & $\begin{array}{l}- \\
- \\
- \\
-\end{array}$ & $\begin{array}{c}(t) \\
(t) \\
(t) \\
(t) \\
(t)\end{array}$ & $\begin{array}{l}- \\
\overline{-}\end{array}$ & $\begin{array}{l}(t) \\
(t) \\
(t) \\
(t) \\
(t)\end{array}$ & $\begin{array}{l}- \\
z \\
z \\
-\end{array}$ & $\begin{array}{l}(t) \\
(t) \\
(t) \\
(t) \\
(t)\end{array}$ & $\begin{array}{l}= \\
= \\
= \\
-\end{array}$ & 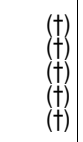 & $\begin{array}{l}- \\
= \\
- \\
-\end{array}$ & $\begin{array}{l}(t) \\
(t) \\
(t) \\
(t) \\
(t)\end{array}$ & $\begin{array}{l}- \\
\overline{-} \\
\overline{-}\end{array}$ & $\begin{array}{l}(+) \\
(+) \\
(+) \\
+t\end{array}$ \\
\hline & $\begin{array}{rr}1.7 & (0.06) \\
8.1 & (0.21) \\
- & (\dagger) \\
- & (\dagger) \\
- & (\dagger)\end{array}$ & \begin{tabular}{rr|}
2.8 & $(0.12)$ \\
11.1 & $(0.26)$ \\
18.5 & $(0.35)$ \\
5.8 & $(0.16)$ \\
23.6 & $(0.35)$
\end{tabular} & $\begin{array}{rr}0.8 & (0.06) \\
\overline{-} & (\dagger) \\
17.2 & (0.34) \\
4.6 & (0.11) \\
20.6 & (0.30)\end{array}$ & $\begin{array}{r}0.5 \\
11.8 \\
21.6 \\
3.3 \\
16.6\end{array}$ & & $\begin{array}{rr}\ddagger & (\dagger) \\
9.3 & (0.39) \\
18.6 & 0.62) \\
0.4 & (0.08) \\
9.9 & (0.40)\end{array}$ & $\begin{array}{r}1.2 \\
17.1 \\
28.3 \\
9.6 \\
30.4\end{array}$ & & $\begin{array}{r}\bar{z} \\
\bar{z} \\
16.5\end{array}$ & 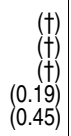 & $\begin{array}{r}\bar{z} \\
\overline{0} .8 \\
10.0\end{array}$ & 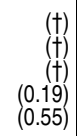 & $\begin{array}{r}\overline{-} \\
\overline{\overline{7}} \\
28.5\end{array}$ & 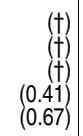 & $\begin{array}{r}- \\
\overline{-} \\
5.3 \\
21.4\end{array}$ & 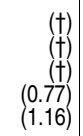 & $\begin{array}{r}\overline{-} \\
\bar{z} .1 \\
20.0\end{array}$ & 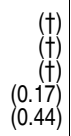 & $\begin{array}{r}\bar{z} \\
\overline{0} \\
13.9\end{array}$ & 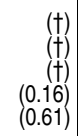 & $\begin{array}{r}\bar{z} \\
\overline{6.3} \\
31.4\end{array}$ & $\begin{array}{r}(\dagger) \\
(\dagger \\
(\dagger) \\
(0.39) \\
(0.74)\end{array}$ & $\begin{array}{l}\overline{-} \\
\overline{7} \\
7.7 \\
27.3\end{array}$ & 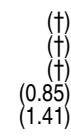 \\
\hline & $\begin{array}{ll}- & (t) \\
= & (t) \\
= & (t) \\
- & (t)\end{array} \mid$ & $\begin{array}{rr}27.6 & (0.45) \\
19.5 & (0.52) \\
28.8 & (0.39) \\
- & (\dagger)\end{array}$ & $\begin{array}{rr}23.7 & (0.36) \\
19.2 & (0.43) \\
29.5 & (0.36) \\
- & (\dagger)\end{array}$ & $\begin{array}{r}21.6 \\
21.4 \\
26.8 \\
-\end{array}$ & $\begin{array}{r}(0.42) \\
(0.45) \\
(0.46) \\
(\dagger)\end{array}$ & $\begin{array}{rr}22.4 & (0.64) \\
23.7 & (0.68) \\
- & (t)\end{array}$ & $\begin{array}{l}26.3 \\
19.0 \\
33.5\end{array}$ & $\begin{array}{r}(0.59) \\
(0.57) \\
(0.69) \\
(\dagger)\end{array}$ & & $\begin{array}{l}(0.49) \\
(0.59) \\
(0.56) \\
(0.20)\end{array}$ & 3.4 & $\left.\begin{array}{l}(0.83) \\
(0.84) \\
(0.30)\end{array}\right]$ & $\begin{array}{r}24.0 \\
20.2 \\
30.5 \\
2.8\end{array}$ & $\begin{array}{l}(0.77) \\
(0.21)\end{array}$ & $\begin{array}{r}23.5 \\
26.7 \\
28.5 \\
4.2\end{array}$ & $\begin{array}{l}(1.42) \\
(1.36) \\
(1.45) \\
(0.50)\end{array}$ & $\begin{array}{r}24.6 \\
29.0 \\
30.2 \\
5.0\end{array}$ & $\begin{array}{l}(0.54) \\
(0.59) \\
(0.59) \\
(0.25)\end{array}$ & $\begin{array}{r}22.1 \\
29.5 \\
27.1 \\
5.1\end{array}$ & $\begin{array}{l}(0.77) \\
(0.86) \\
(0.86) \\
(0.38)\end{array}$ & $\begin{array}{r}28.3 \\
26.8 \\
35.4 \\
4.4\end{array}$ & $\begin{array}{l}(0.65) \\
(0.79) \\
(0.85) \\
(0.37)\end{array}$ & $\begin{array}{r}29.4 \\
32.4 \\
34.9 \\
6.3\end{array}$ & $\begin{array}{l}(1.55) \\
(2.00) \\
(1.54) \\
(0.63)\end{array}$ \\
\hline students ................. & $\begin{array}{ll}3.6 & (0.38) \\
3.7 & (0.39) \\
0.8 & (0.13) \\
0.9 & (0.16) \\
1.3 & (0.19)\end{array}$ & $\begin{array}{ll}2.6 & (0.23) \\
2.2 & (0.19) \\
0.8 & (0.10) \\
0.7 & (0.11) \\
1.5 & (0.15)\end{array}$ & $\begin{array}{ll}2.9 & (0.21) \\
2.5 & (0.22) \\
0.8 & (0.11) \\
0.8 & (0.12) \\
1.0 & (0.18)\end{array}$ & $\begin{array}{l}2.8 \\
1.9 \\
\ddagger \\
0.5 \\
2.4\end{array}$ & 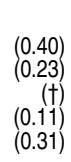 & $\begin{array}{rr}2.1 & (0.45) \\
0.9 & (0.17) \\
\ddagger & (t) \\
\ddagger & (\dagger) \\
2.7 & (0.55)\end{array}$ & $\begin{array}{r}5.0 \\
4.0 \\
\ddagger \\
\neq \\
\ddagger\end{array}$ & $\left.\begin{array}{r}(0.83) \\
(0.75) \\
(t) \\
(+) \\
(t)\end{array}\right)$ & $\begin{array}{l}2.5 \\
2.0 \\
0.5 \\
0.5 ! \\
-\end{array}$ & $\begin{array}{r}(0.28) \\
(0.23) \\
(0.13) \\
(0.18) \\
(\dagger)\end{array}$ & $\begin{array}{r}0.3 \\
\ddagger\end{array}$ & $\begin{array}{r}(0.37) \\
(0.23) \\
!(0.08) \\
(+) \\
(\dagger)\end{array} \mid$ & $\begin{array}{r}3.0 \\
3.9 \\
\ddagger \\
1.1 ! \\
-\end{array}$ & $\begin{array}{r}(0.83) \\
(0.99) \\
(+) \\
!(0.41) \\
(t)\end{array}$ & $\begin{array}{r}2.6 \\
2.3 \\
1.0 ! \\
\ddagger \\
-\end{array}$ & $\begin{array}{r}(0.47) \\
(0.40) \\
!(0.32 \\
(\dagger \\
(\dagger)\end{array} \mid$ & $\begin{array}{l}3.8 \\
3.0 \\
0.5 \\
0.7 \\
-\end{array}$ & $\begin{array}{r}(0.59) \\
(0.34) \\
(0.12) \\
0.20) \\
(t)\end{array}$ & $\begin{array}{r}3.7 \\
2.1 \\
\ddagger \\
\ddagger \\
-\end{array}$ & $\left.\begin{array}{r}(0.61) \\
(0.44) \\
(+) \\
+ \\
(+)\end{array}\right)$ & $\begin{array}{l}4.9 \\
4.6 \\
0.7 ! \\
\ddagger \\
-\end{array}$ & $\begin{array}{r}(1.11) \\
(0.99) \\
!(0.28) \\
(\dagger \\
(\dagger)\end{array}$ & $\begin{array}{l}\ddagger \\
\ddagger \\
\ddagger \\
\ddagger \\
-\end{array}$ & $\begin{array}{l}(\dagger) \\
(+) \\
(+) \\
(\dagger) \\
(t)\end{array}$ \\
\hline Student $\mathrm{C}$ & $\begin{array}{ll}1.3 & (0.18) \\
1.3 & (0.19) \\
0.6 & (0.12) \\
3.6 & (0.30) \\
1.8 & (0.24)\end{array}$ & $\begin{array}{ll}1.2 & (0.11) \\
0.4 & (0.06) \\
3.1 & (0.19) \\
1.3 & (0.15)\end{array}$ & $\begin{array}{ll}0.4 & (0.09) \\
3.1 & (0.16) \\
1.8 & (0.14)\end{array}$ & $\begin{aligned} 0.4 \\
0.5 \\
\ddagger \\
0.7 \\
1.1\end{aligned}$ & $\begin{array}{r}(0.10) \\
(0.11) \\
(\dagger) \\
(0.17) \\
(0.25)\end{array}$ & $\begin{array}{cc}\neq & (t) \\
\neq & (t) \\
\neq & (t) \\
\# & (t) \\
\# & (t)\end{array}$ & $\begin{array}{c}1.3 ! \\
\ddagger \\
\ddagger \\
3.3 \\
5.2\end{array}$ & $\begin{array}{l}(0.86) \\
(1.31)\end{array}$ & $\begin{array}{l}z \\
z \\
- \\
-\end{array}$ & $\begin{array}{l}(t) \\
(t) \\
(t) \\
(t) \\
(t)\end{array}$ & $\begin{array}{l}\bar{z} \\
\text { - }\end{array}$ & $\begin{array}{l}(+⿱ 亠 䒑 \\
+ \\
(+) \\
(t)\end{array}$ & $\begin{array}{l}\bar{z} \\
\overline{-}\end{array}$ & 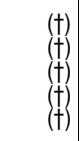 & - & $\begin{array}{l}(t) \\
(t) \\
(t) \\
(t) \\
(t)\end{array}$ & $\begin{array}{l}- \\
z \\
z \\
-\end{array}$ & $\begin{array}{l}(t) \\
(t) \\
(t) \\
(t) \\
(t)\end{array}$ & $\begin{array}{l}= \\
= \\
z \\
-\end{array}$ & $\begin{array}{l}(t) \\
(t) \\
(t) \\
(t) \\
(t)\end{array}$ & $\begin{array}{l}\overline{-} \\
\bar{z} \\
\overline{-}\end{array}$ & $\begin{array}{l}(t) \\
(t)\end{array}$ & $\begin{array}{l}\bar{z} \\
\overline{-}\end{array}$ & $\begin{array}{l}(t) \\
(\dagger) \\
(\dagger) \\
(t) \\
(t)\end{array}$ \\
\hline & $\begin{array}{rr}0.4 & (0.11) \\
2.0 & (0.24) \\
- & (t) \\
- & (t) \\
- & (t)\end{array}$ & $\begin{array}{ll}0.3 & (0.06) \\
2.3 & (0.25) \\
3.4 & (0.27) \\
0.6 & (0.09) \\
4.5 & (0.28)\end{array}$ & $\begin{array}{cr}0.3 & (0.06) \\
- & (t) \\
3.8 & (0.31) \\
0.5 & (0.10) \\
4.3 & (0.29)\end{array}$ & $\begin{array}{l}\# \\
2.4 \\
5.1 \\
0.3 ! \\
3.0\end{array}$ & $\begin{array}{r}(\dagger) \\
(0.40) \\
(0.37) \\
(0.09) \\
0.39\end{array}$ & $\begin{array}{rr}\# & (\dagger) \\
1.1 & (0.29) \\
3.6 & (0.54) \\
\ddagger & (t) \\
1.4 & (0.23)\end{array}$ & $\begin{array}{r}\# \\
4.0 \\
6.3 \\
\ddagger \\
6.6\end{array}$ & $\begin{array}{r}(0.84) \\
(1.05) \\
(+) \\
(0.95)\end{array}$ & $\begin{array}{l}- \\
\overline{-} \\
0.4 ! \\
3.9\end{array}$ & $\begin{array}{r}(t) \\
(t) \\
(t) \\
(0.20) \\
0.34)\end{array}$ & $\begin{array}{l}\overline{-} \\
\overline{0} \\
0.4 \\
1.7\end{array}$ & $\begin{array}{r}(t) \\
(t) \\
(t) \\
\left(\begin{array}{l}1 \\
(1) \\
0.30\end{array}\right)\end{array}$ & $\begin{array}{l}- \\
\bar{z} \\
0.5 ! \\
6.9\end{array}$ & 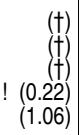 & $\begin{array}{l}- \\
\bar{z} \\
\ddagger \\
5.1\end{array}$ & $\begin{array}{r}(\dagger) \\
(\dagger \\
(+) \\
(+) \\
(0.74)\end{array}$ & $\begin{array}{l}- \\
\overline{-} \\
0.3 ! \\
3.6\end{array}$ & $\begin{array}{r}(t) \\
(t) \\
(t) \\
(0.13 \\
0.38)\end{array}$ & $\begin{array}{l}- \\
\overline{-} \\
\bar{\ddagger} \\
1.7\end{array}$ & $\begin{array}{r}(t) \\
(t) \\
(t) \\
(t) \\
(0.42)\end{array}$ & $\begin{array}{l}- \\
\overline{-} \\
\bar{\ddagger} \\
7.1\end{array}$ & $\begin{array}{r}(\dagger \\
(\dagger \\
(\dagger) \\
(+) \\
(1.32)\end{array}$ & $\begin{array}{c}- \\
\overline{-} \\
\bar{\ddagger} \\
\ddagger\end{array}$ & $\begin{array}{l}(1) \\
(t) \\
(t)\end{array}$ \\
\hline Poor student health ..................................... & $\begin{array}{ll}= & (t) \\
= & (t) \\
= & (t) \\
- & (t)\end{array} \mid$ & $\left.\begin{array}{rr}4.0 & (0.26) \\
2.7 & (0.23) \\
4.1 & (0.28) \\
- & (\dagger)\end{array}\right)$ & $\begin{array}{rr}3.4 & (0.30) \\
2.1 & (0.21) \\
4.9 & (0.36) \\
- & (t)\end{array}$ & $\begin{array}{l}2.5 \\
2.2 \\
3.5 \\
-\end{array}$ & $\begin{array}{r}(0.37) \\
(0.26) \\
(0.30) \\
(t)\end{array}$ & $\begin{array}{cc}1.7 & (0.31) \\
2.1 & (0.53) \\
- & (\dagger)\end{array}$ & $\begin{array}{l}3.6 \\
3.4 \\
6.8 \\
-\end{array}$ & $\begin{array}{l}(0.77) \\
(0.78) \\
(0.99)\end{array}$ & $\begin{array}{l}2.5 \\
2.0 \\
3.6 \\
0.7\end{array}$ & $\begin{array}{l}(0.21) \\
(0.34) \\
(0.13)\end{array}$ & & $\begin{array}{l}(0.28) \\
(0.33) \\
!(0.12)\end{array}$ & $\begin{array}{r}2.8 \\
2.0 \\
6.2 \\
\ddagger\end{array}$ & $\begin{array}{r}(1.51 \\
(\dagger)\end{array}$ & $\begin{array}{l}3.0 \\
2.6 \\
4.4 \\
1.0\end{array}$ & $\begin{array}{l}(0.44) \\
(0.85) \\
(0.25)\end{array}$ & $\begin{array}{l}2.7 \\
2.6 \\
3.9 \\
0.8\end{array}$ & $\begin{array}{l}(0.32) \\
(0.33) \\
(0.411 \\
(0.21)\end{array} \mid$ & $\begin{array}{l}1.8 \\
2.7 \\
2.0 \\
0.4 !\end{array}$ & $\begin{array}{l}(0.52) \\
(0.41) \\
!(0.17)\end{array}$ & $\begin{array}{l}3.2 \\
2.8 \\
6.7 \\
0.5 !\end{array}$ & $\begin{array}{l}(0.80) \\
(0.79) \\
!(1.07) \\
!(0.25)\end{array}$ & $\begin{array}{l}\ddagger \\
\ddagger \\
\ddagger \\
\ddagger\end{array}$ & $\left(\begin{array}{l}11 \\
(+) \\
(+)\end{array}\right.$ \\
\hline
\end{tabular}

\section{-Not available.} †Not applicable.

!Interpret data with caution. The coefficient of variation (CV) for this estimate is between 30 and 50 percent. Reporting standards not met. Data may be suppressed because the response rate is under 50 percent, there are too few cases for a reliable estimate, or the coefficient of variation (CV) is 50 percent or greater.
NOTE: Elementary schools are those with any of grades kindergarten through grade 6 and none of grades 9 through 12 . Secondary schools have any of grades 7 through 12 , and none of grades kindergarten through grade 6 . Combined schools have bounCE: US and secondary grades, or have all students in ungraded classooms.

"Public School Teacher Data Filo" sation, Nations Center for Education Statistics, Schools and Staffing Survey (SASS), years, 1987-88 through 2011-12; and "Charter School Teacher Data File," 1999-2000. (This table was prepared May 2013.) 
Table 210.20. Percentage of teachers agreeing with statements about teaching and school conditions, by control and level of school: Selected years, 1993-94 through 2011-12

[Standard errors appear in parentheses]

\begin{tabular}{|c|c|c|c|c|c|c|c|c|c|c|c|c|c|c|c|c|c|c|}
\hline \multirow[b]{3}{*}{ Statement about conditions } & \multicolumn{9}{|c|}{ Public school teachers } & \multicolumn{9}{|c|}{ Private school teachers } \\
\hline & \multirow[b]{2}{*}{$\begin{array}{r}1993-94 \\
\text { total }\end{array}$} & \multirow[b]{2}{*}{$\begin{array}{r}1999-2000 \\
\text { total }\end{array}$} & \multirow[b]{2}{*}{$\begin{array}{r}2003-04 \\
\text { total }\end{array}$} & \multirow[b]{2}{*}{$\begin{array}{r}2007-08 \\
\text { total }\end{array}$} & \multicolumn{5}{|c|}{$2011-12$} & \multirow[b]{2}{*}{$\begin{array}{r}1993-94 \\
\text { total }\end{array}$} & \multirow[b]{2}{*}{$\begin{array}{r}1999-2000 \\
\text { total }\end{array}$} & \multirow[b]{2}{*}{$\begin{array}{r}2003-04 \\
\text { total }\end{array}$} & \multirow[b]{2}{*}{$\begin{array}{r}2007-08 \\
\text { total }\end{array}$} & \multicolumn{5}{|c|}{$2011-12^{1}$} \\
\hline & & & & & & Total & $\begin{array}{r}\text { Elementary } \\
\text { schools }\end{array}$ & $\begin{array}{r}\text { Secondary } \\
\text { schools }\end{array}$ & $\begin{array}{r}\text { Combined } \\
\text { schools }\end{array}$ & & & & & & Total & \begin{tabular}{|r|} 
Elementary \\
schools
\end{tabular} & & $\begin{array}{l}\text { condary } \\
\text { schools }\end{array}$ \\
\hline 1 & 2 & 3 & 4 & 5 & & 6 & 7 & 8 & & 10 & 11 & 12 & 13 & & 14 & 15 & & 16 \\
\hline & \multicolumn{18}{|c|}{ Percent of teachers somewhat agreeing or strongly agreeing with statement } \\
\hline $\begin{array}{l}\text { The school administration's behavior toward the staff is } \\
\text { supportive...... }\end{array}$ & $79.2(0.36)$ & $78.8(0.38)$ & $85.2(0.33)$ & $87.7(0.39)$ & 83.6 & $(0.44)$ & $84.0(0.67)$ & $83.2(0.57)$ & $82.0(1.18)$ & $88.2(0.42)$ & $87.3(0.45)$ & $91.1(0.78)$ & $93.1(0.43)$ & & $(0.90)$ & $88.1(1.20)$ & 85.5 & $(2.41)$ \\
\hline $\begin{array}{l}\text { My principal enforces school rules for student conduct and } \\
\text { backs me up when I need it.......................................... }\end{array}$ & $80.8(0.35)$ & $82.2(0.33)$ & $87.2(0.34)$ & $88.0(0.37)$ & 83.7 & (0.43) & $84.5(0.64)$ & $82.2(0.59)$ & $83.1(1.27)$ & $88.4(0.41)$ & $88.3(0.39)$ & $92.2(0.75)$ & $92.2(0.57)$ & & $(0.98)$ & $90.1(1.00)$ & 87.0 & $(2.21)$ \\
\hline In this school, staff members are recognized for a job well done. & $67.9(0.39)$ & $68.3(0.42)$ & $75.5(0.38)$ & $76.7(0.56)$ & 74.3 & $(0.45)$ & $75.6(0.69)$ & $72.5(0.58)$ & $71.0(1.60)$ & $81.1(0.40)$ & $78.9(0.50)$ & $83.8(1.14)$ & $84.0(0.66)$ & 80.6 & $(1.04)$ & $80.7(1.48)$ & 79.9 & $(2.27)$ \\
\hline $\begin{array}{l}\text { Principal } k \\
\text { comm }\end{array}$ & $80.5(0.36)$ & $83.2(0.28)$ & $87.3(0.30)$ & $88.4(0.33)$ & 84.7 & $(0.41)$ & $85.8(0.60)$ & $83.1(0.54)$ & $82.7(1.20)$ & $88.6(0.38)$ & $88.4(0.43)$ & $91.9(0.68)$ & $91.7(0.53)$ & 87.6 & $(0.96)$ & $88.2(0.91)$ & 85.7 & $(1.55)$ \\
\hline $\begin{array}{l}\text { Most of my coll } \\
\text { the central }\end{array}$ & & $84.7(0.26)$ & $88.1(0.26)$ & $88.3(0.35)$ & 87.7 & (0.38) & $90.1(0.52)$ & $83.5(0.49)$ & $84.5(1.47)$ & $93.2(0.37)$ & $92.2(0.31)$ & $93.8(0.49)$ & $93.7(0.44)$ & 92.9 & $(0.66)$ & $93.0(0.82)$ & 89.6 & $(1.75)$ \\
\hline There is & $77.5(0.31)$ & $78.4(0.32)$ & $83.2(0.36)$ & $84.3(0.33)$ & 82.3 & $(0.41)$ & $84.3(0.61)$ & $78.9(0.53)$ & $80.2(1.11)$ & $90.5(0.29)$ & $89.0(0.42)$ & $91.2(0.77)$ & $91.7(0.63)$ & 88.8 & $(0.83)$ & $88.8(1.05)$ & 87.0 & (1.45) \\
\hline receive a great deal of & $52.5(0.38)$ & $57.9(0.40)$ & $61.1(0.50)$ & $64.3(0.52)$ & 58.6 & $(0.63)$ & $61.9(0.87)$ & $52.8(0.69)$ & $55.1(2.04)$ & $84.6(0.41)$ & $84.0(0.49)$ & $86.1 \quad(2.33)$ & $87.7(0.60)$ & 85.0 & $(0.97)$ & $85.8(1.18)$ & 80.2 & $(2.73)$ \\
\hline $\begin{aligned} \operatorname{mak} \\
\mathrm{co}\end{aligned}$ & $85.0(0.25)$ & $84.1(0.24)$ & $86.3(0.31)$ & $\begin{array}{ll}- & (t)\end{array}$ & 90.0 & (0.32) & $92.7(0.39)$ & $85.8(0.48)$ & $85.8(1.25)$ & $85.2(0.44)$ & $81.4(0.55)$ & $84.6(0.90)$ & & 87.3 & $(0.90)$ & $89.9(0.96)$ & 83.4 & $(1.59)$ \\
\hline Routine & $70.8(0.38)$ & $71.1(0.30)$ & $70.8(0.44)$ & $69.0(0.53)$ & 69.2 & (0.53) & $70.5(0.70)$ & $67.3(0.66)$ & $65.9(2.10)$ & $40.1 \quad(0.65)$ & $44.5(0.57)$ & $40.7(2.70)$ & $42.7(0.97)$ & 41.1 & (1.50) & 43.9 (1.64) & 46.2 & (3.22) \\
\hline $\begin{array}{r}\text { Level of } s \\
\text { teach }\end{array}$ & 44.1 & $40.8(0.42)$ & $37.2(0.52)$ & $36.0(0.57)$ & 40.7 & (0.65) & $40.1(0.96)$ & $41.9(0.82)$ & $.3(1.58)$ & $22.4(0.43)$ & $24.1(0.61)$ & $20.7(2.47)$ & $20.6(0.72)$ & 22.0 & $(1.05)$ & $23.7(1.39)$ & 20.4 & $(2.78)$ \\
\hline $\begin{array}{l}\text { Amount of } \\
\text { interfe }\end{array}$ & $27.9(0.32)$ & $31.5(0.35)$ & $33.4(0.45)$ & $33.4(0.64)$ & 37.6 & $(0.51)$ & $32.3(0.76)$ & $47.1(0.69)$ & $42.4(1.56)$ & $8.6(0.42)$ & $15.0(0.43)$ & $16.9(1.11)$ & $17.9(0.72)$ & 18.8 & $(1.06)$ & $17.8(1.05)$ & 21.4 & $(2.45)$ \\
\hline $\begin{array}{l}\text { Rules for } \mathrm{s} \\
\text { in this }\end{array}$ & $61.8(0.42)$ & $62.6(0.39)$ & $71.1(0.46)$ & $70.6(0.55)$ & 67.6 & (0.51) & $75.2(0.76)$ & $53.4(0.71)$ & $62.0(2.06)$ & $77.6(0.50)$ & $75.9(0.51)$ & $81.0(1.52)$ & $80.1(0.81)$ & 77.4 & (1.49) & $80.2(1.72)$ & 68.3 & $(2.78)$ \\
\hline Lam cati & $44.9(0.45)$ & $39.4(0.36)$ & $45.9(0.46)$ & $50.9(0.64)$ & 47.0 & $(0.50)$ & $45.0(0.71)$ & $50.7(0.70)$ & 49.0 & $41.6(0.59)$ & $42.6(0.73)$ & $50.6(1.76)$ & $51.7(0.86)$ & 49.5 & (1.44) & $41.8(1.84)$ & 56.5 & $(2.28)$ \\
\hline ece & $73.1 \quad(0.42)$ & $75.0(0.32)$ & $79.0(0.42)$ & $82.2(0.55)$ & 79.4 & $(0.45)$ & $79.6(0.68)$ & $78.9(0.59)$ & 79.5 (1.42) & $85.7(0.44)$ & $89.0(0.38)$ & $91.8(0.74)$ & $92.1(0.54)$ & 90.8 & $(0.68)$ & $90.3(0.84)$ & 91.9 & $(1.25)$ \\
\hline $\begin{aligned} \text { worry a } \\
\text { perfo }\end{aligned}$ & $\begin{array}{ll}- & (\dagger)\end{array}$ & $28.8(0.37)$ & $31.2(0.43)$ & $30.9(0.58)$ & 44.0 & $(0.54)$ & $45.3(0.78)$ & $41.1(0.60)$ & $43.8(2.05)$ & $\begin{array}{ll}- & (\dagger)\end{array}$ & $6.7(0.29)$ & $7.8(0.68)$ & $7.6(0.46)$ & 9.8 & $(0.75)$ & $11.0(0.96)$ & 9.8 & $(1.38)$ \\
\hline $\begin{array}{l}\text { State or dis } \\
\text { on my }\end{array}$ & & $-\quad(t)$ & $\begin{array}{ll}- & (t)\end{array}$ & $49.3(0.62)$ & 47.5 & (0.52) & $50.8(0.74)$ & $41.0(0.63)$ & $46.2(1.86)$ & $-\quad(t)$ & $\begin{array}{ll}- & (t)\end{array}$ & $\begin{array}{ll}- & (t)\end{array}$ & $41.1(0.80)$ & 38.9 & (1.19) & $46.9(1.35)$ & 33.8 & $(2.53)$ \\
\hline $\begin{array}{l}\text { I am giver } \\
\text { needs }\end{array}$ & & $60.9(0.33)$ & $64.5(0.47)$ & $67.2(0.57)$ & 65.5 & (0.51) & $63.9(0.73)$ & $68.2(0.61)$ & $67.6(1.74)$ & $(\mathrm{t})$ & $67.1(0.58)$ & $71.8(2.00)$ & $68.4(0.84)$ & 66.9 & $(1.22)$ & 63.5 (1.71) & 67.6 & $(2.70)$ \\
\hline $\begin{array}{l}\text { Stress and } \\
\text { aren't re }\end{array}$ & & $-\quad(t)$ & - & $18.9(0.38)$ & 22.0 & (0.49) & $21.9(0.72)$ & $21.4(0.62)$ & $25.5(2.10)$ & $(\mathrm{t})$ & - & $\begin{array}{ll}- & (t)\end{array}$ & $10.1(0.52)$ & 11.9 & $(0.82)$ & $12.5(1.12)$ & 12.9 & $(1.93)$ \\
\hline $\begin{array}{l}\text { Teachers at this } \\
\text { satisfied grc }\end{array}$ & $(\dagger)$ & $-\quad(t)$ & $\begin{array}{ll}- & (t)\end{array}$ & $79.4(0.47)$ & 75.7 & (0.53) & $76.0(0.75)$ & $75.7(0.71)$ & $74.5(1.66)$ & $-\quad(t)$ & $-\quad(t)$ & - & $89.0(0.55)$ & 87.5 & $(0.93)$ & $85.2(1.22)$ & 87.7 & $(1.88)$ \\
\hline I like the way things ar & $(t)$ & $\begin{array}{ll}- & (t)\end{array}$ & $\begin{array}{ll}- & (t)\end{array}$ & $77.1(0.55)$ & 72.9 & $(0.51)$ & $73.6(0.73)$ & $72.4(0.62)$ & $69.6(2.22)$ & $\begin{array}{ll}- & (t)\end{array}$ & $\begin{array}{ll}- & (t)\end{array}$ & $\begin{array}{ll}- & (t)\end{array}$ & $84.5(0.66)$ & 79.6 & (1.12) & 78.6 (1.32) & 79.0 & $(2.35)$ \\
\hline $\begin{array}{l}\text { If I could get a higher paying jok } \\
\text { possible .......................... }\end{array}$ & $(\dagger) \mid$ & $-\quad(t)$ & $(t)$ & $26.0(0.45)$ & 29.6 & (0.59) & $29.3(0.83)$ & $29.7(0.61)$ & $32.0(1.52)$ & - & $(t)$ & $(t)$ & $18.3(0.73)$ & 21.6 & $(1.05)$ & $23.6(1.29)$ & 19.1 & (1.77) \\
\hline hink a & $(\dagger)$ & $\begin{array}{ll}- & (\dagger)\end{array}$ & $(\dagger)$ & $28.5(0.53)$ & 29.1 & $(0.51)$ & $29.0(0.76)$ & $28.2(0.71)$ & $33.6(1.87)$ & $(+)$ & $(\dagger)$ & - & $23.8(0.92)$ & 25.6 & $(1.31)$ & $28.2(1.58)$ & 24.1 & $(2.27)$ \\
\hline I am generally satisfied with being a t & $(\dagger)$ & $89.7(0.24)$ & $90.9(0.29)$ & $92.8(0.31)$ & 90.2 & $(0.33)$ & $90.1(0.48)$ & $90.4(0.42)$ & $89.8(1.39)$ & $(\dagger)$ & $93.3(0.26)$ & $95.2(0.56)$ & $95.7(0.43)$ & 94.2 & $(0.60)$ & $94.1(0.78)$ & 93.0 & $(1.37)$ \\
\hline
\end{tabular}

\section{-Not available.}

'Data for combined private schools in 2011-12 are included in the total, but not shown separately due to low response rates (under 50 percent).
NOTE: Elementary schools are those with any of grades kindergarten through grade 6 and none of grades 9 through 12 . Secondary schools have any of grades 7 through 12 , and none of grades kindergarten through grade 6. Combined schools have both elementary and secondary grades, or have all students in ungraded classrooms.

SOURCE: U.S. Department of Education, National Center for Education Statistics, Schools and Staffing Survey (SASS), "Public School Teacher Data File, selected years 1993-94 through 2011-12; "Private School Teacher Data File," selecte years 1993-94 through 2011-12; and "Charter School Teacher Data File," 1999-2000. (This table was prepared May 2013.) 


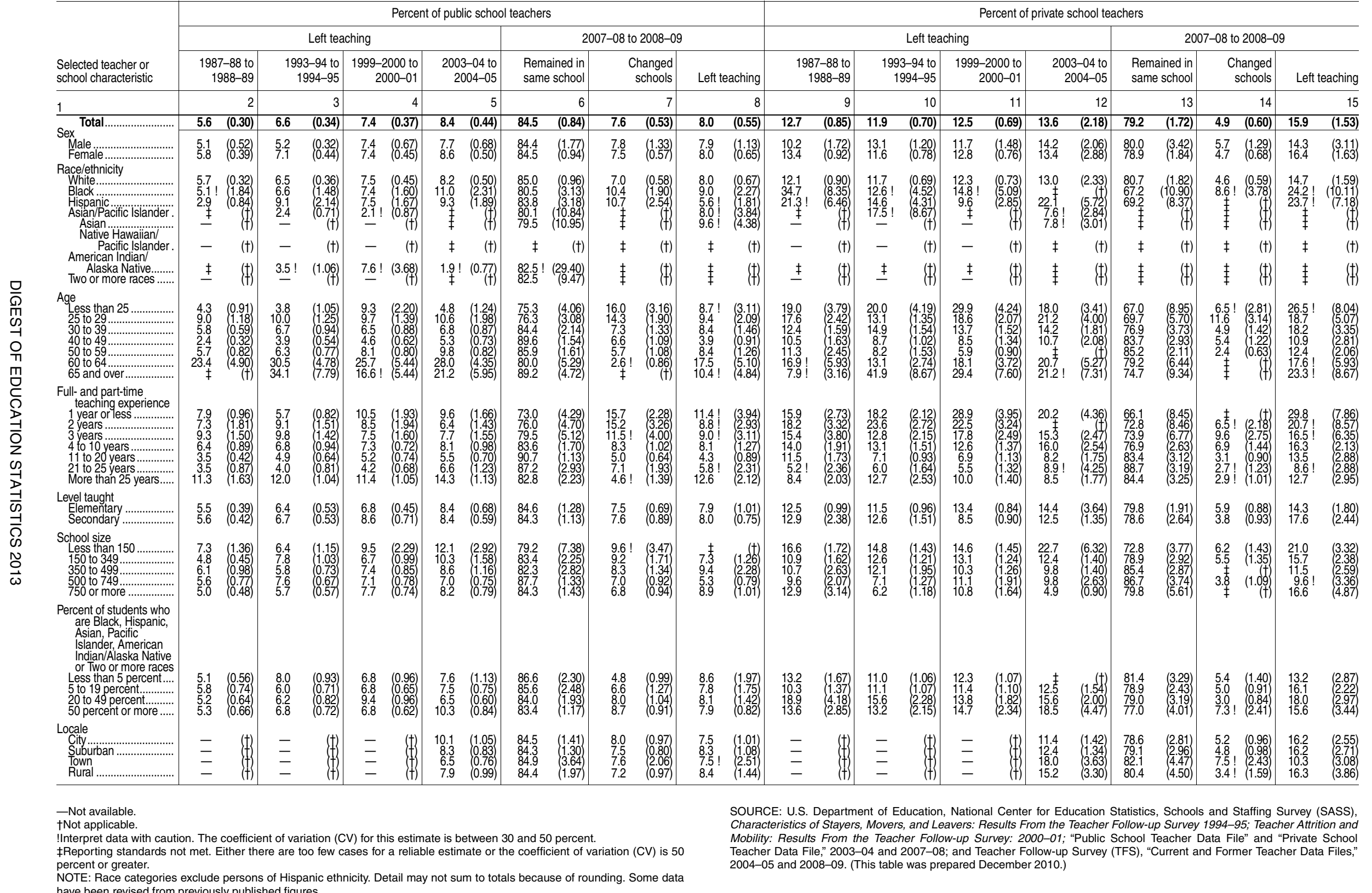


Table 211.10. Average salaries for full-time teachers in public and private elementary and secondary schools, by selected characteristics: 2011-12

[Amounts in current dollars. Standard errors appear in parentheses]

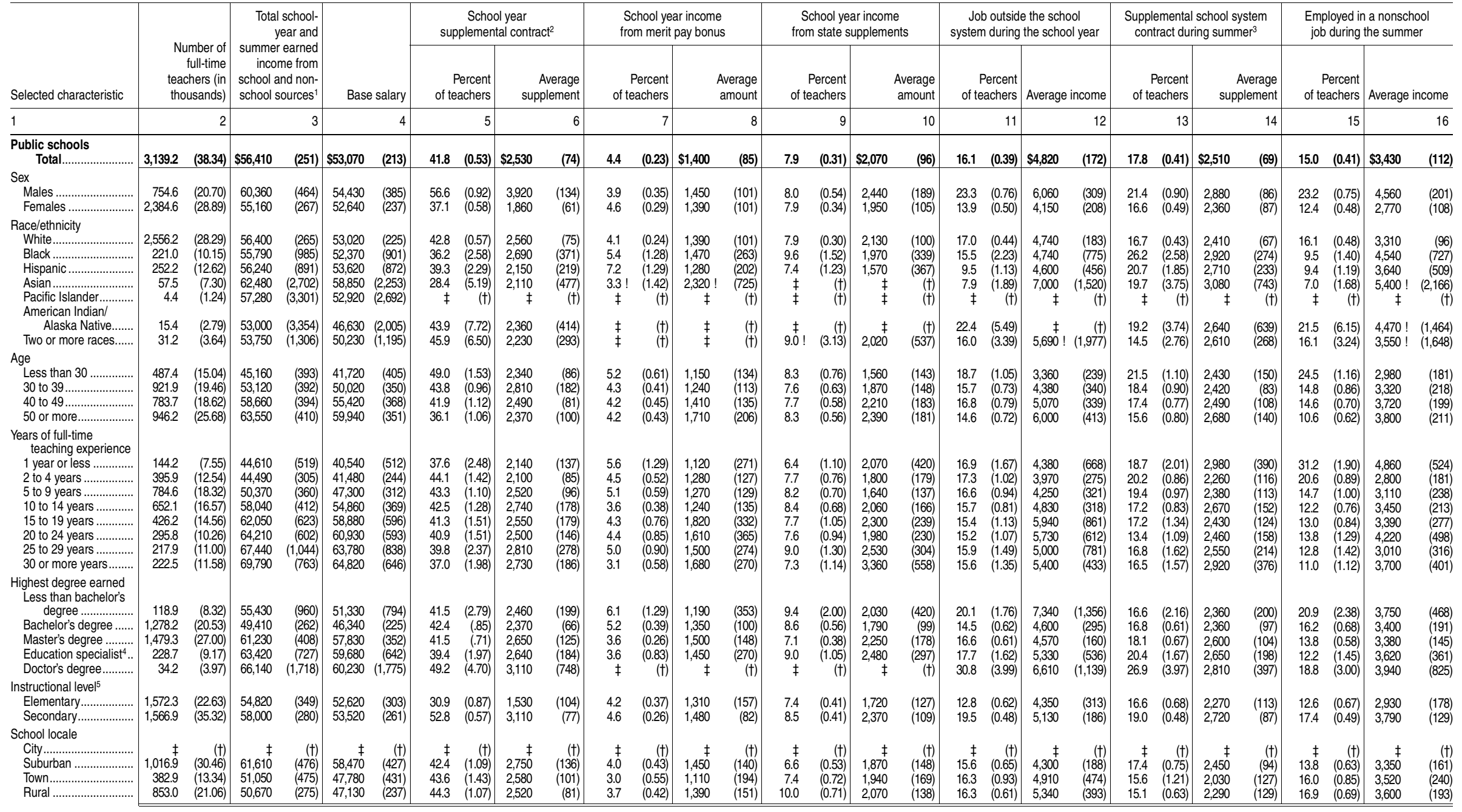

See notes at end of table. 


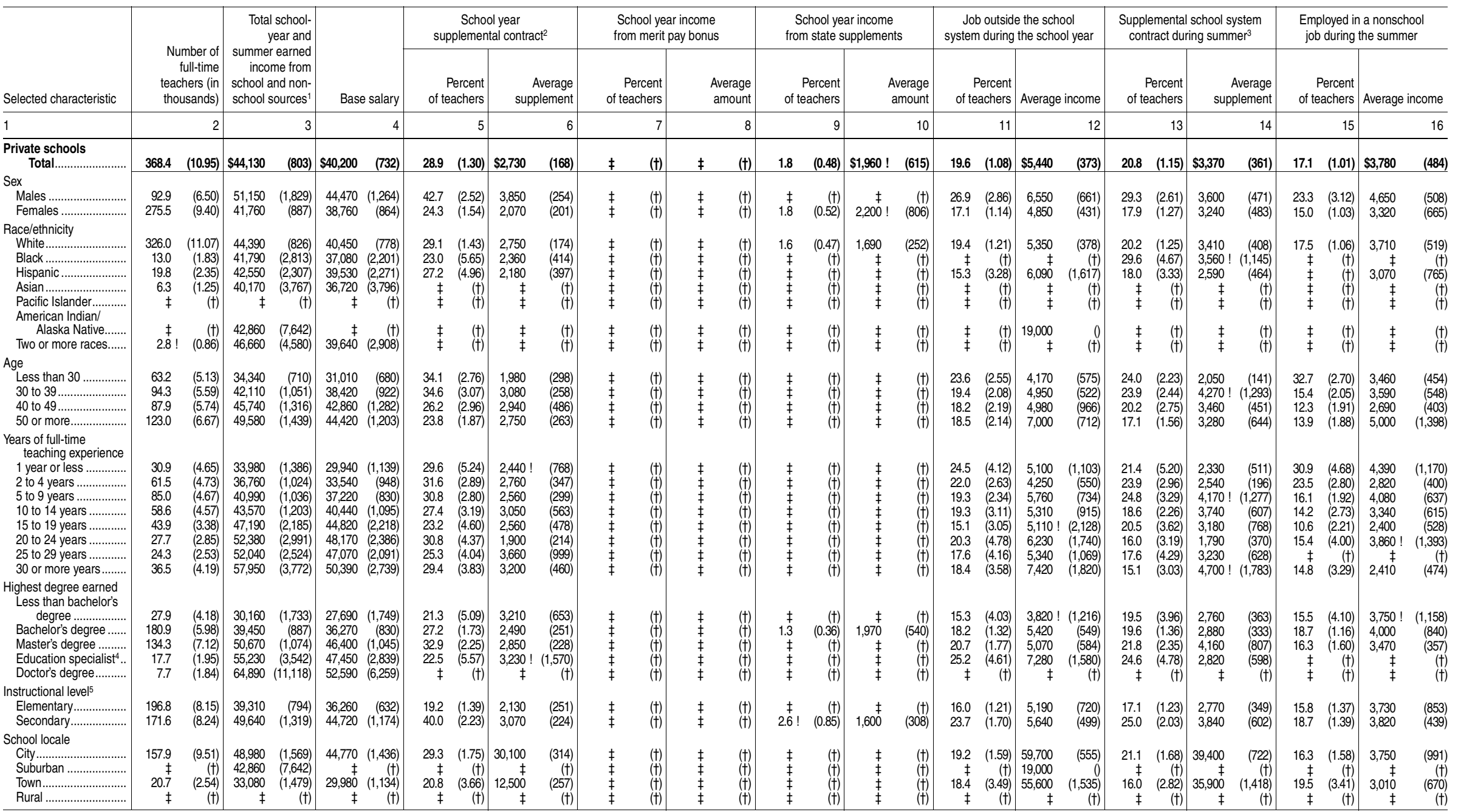

†Not applicable.

The coefficient of variation (CV) for this estimate is between 30 and 50 percent Reporting standards not met. Data may be suppressed because the response rate is under 50 percent, there are too few cases for a reliable estimate, or the coefficient of variation (CV) is 50 percent or greater.

Includes compensation for extracurricular or additional activities such as coaching, student activity sponsorship, or teaching evening classes.

. tificates of advanced graduate studies.
${ }^{5}$ Teachers were classified as elementary or secondary on the basis of the grades they taught, rather than on the level of the school in which they taught. In general, elementary teachers include those teaching prekindergarten through grade 5 and ondary teachers include those teaching any of grades 7 through 12 and those teaching multiple grades, with a preponderance of grades taught being grades 7 through 12 and usually with no grade taught being lower than grade 5 .

NOTE: This table includes regular full-time teachers only; it excludes other staff even when they have full-time teaching duties (regular part-time teachers, tinerant teachers, long-term substitutes, administrators, library media specialists, other professional staff, and support staff). Race categories exclude persons of Hispanic ethnicity. Detail may not sum to totals because of
rounding and missing values in cells with too few cases to report. SOURCE: Us 


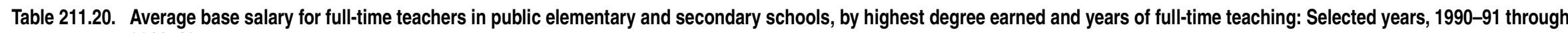
2011-12

[Standard errors appear in parentheses]

\begin{tabular}{|c|c|c|c|c|c|c|c|c|c|c|c|c|c|c|c|c|c|c|c|c|c|c|}
\hline \multirow{3}{*}{$\begin{array}{l}\text { Years of full-time } \\
\text { teaching experience }\end{array}$} & \multirow{3}{*}{\multicolumn{2}{|c|}{$\begin{array}{r}\text { Number of } \\
\text { full-time teachers }\end{array}$}} & \multicolumn{10}{|c|}{ Salary (current dollars) } & \multicolumn{10}{|c|}{ Salary (constant 2012-13 dollars) } \\
\hline & & & \multicolumn{10}{|c|}{ Highest degree earned } & \multicolumn{10}{|c|}{ Highest degree earned } \\
\hline & & & \multicolumn{2}{|c|}{ All teachers' } & \multicolumn{2}{|c|}{ Bachelor's degree } & \multicolumn{2}{|c|}{ Master's degree } & \multicolumn{2}{|c|}{\begin{tabular}{|l|} 
Education specialist \\
\end{tabular}} & \multicolumn{2}{|c|}{ Doctor's degree } & \multicolumn{2}{|c|}{ All teachers ${ }^{1}$} & \multicolumn{2}{|c|}{ Bachelor's degree } & \multicolumn{2}{|c|}{ Master's degree } & \multicolumn{2}{|c|}{\begin{tabular}{|l|} 
Education specialist $^{2}$ \\
\end{tabular}} & \multicolumn{2}{|c|}{ Doctor's degree } \\
\hline 1 & & 2 & & 3 & & 4 & & 5 & & 6 & & 7 & & 8 & & 9 & & 10 & & 11 & & 12 \\
\hline $\begin{array}{l}1990-91 \\
\text { Total... }\end{array}$ & 336,750 & $(20,958)$ & $\$ 31,330$ & (97) & $\$ 27,740$ & (103) & $\$ 34,960$ & (125) & $\$ 34,960$ & (391) & $\$ 40,070$ & (817) & $\$ 54,130$ & (168) & $\$ 47,920$ & (178) & $\$ 60,390$ & (216) & $\$ 64,320$ & (675) & $\$ 69,220$ & $(1,411)$ \\
\hline 1 year or less... & 94,000 & $(3,014)$ & 22,210 & (200) & 21,510 & (207) & 26,440 & (863) & 26,630 & (982) & $\ddagger$ & $(\dagger)$ & 38,370 & (346) & 37,160 & (358) & 45,670 & $(1,491)$ & 46,000 & $(1,697)$ & $\ddagger$ & $(\dagger)$ \\
\hline ears... & 86,900 & $(2,963)$ & 120 & (162) & 21,650 & (147) & 060 & (505) & $\ddagger$ & (t) & $\ddagger$ & (†) & 38,210 & (280) & 37,400 & (255) & 43,300 & (873) & $\ddagger$ & (†) & $\ddagger$ & (†) \\
\hline ars & 80,340 & $(2,542)$ & 010 & (177) & 22,440 & (174) & 0 & (695) & $\neq$ & (t) & $\ddagger$ & (t) & 39,750 & (306) & & (301) & & $1,200)$ & $\ddagger$ & (†) & $\ddagger$ & (t) \\
\hline jears... & 79,610 & $(3,271)$ & 960 & (236) & 23,150 & (246) & 26,340 & (526) & 9,160 & $(1,489)$ & $\ddagger$ & $(t)$ & 41,390 & (408) & 9,990 & (425) & 45,500 & (909) & 50,380 & $(2,573)$ & $\ddagger$ & $(\dagger)$ \\
\hline ears...... & 83,540 & $(3,238)$ & 080 & (202) & 24,070 & (240) & 2 & (436) & 870 & $2,195)$ & $\ddagger$ & (†) & 43,340 & (348) & & (415) & & (754) & ,600 & $3,792)$ & $\ddagger$ & (†) \\
\hline 9 vears & 316,210 & $(6,805)$ & 500 & (109) & 25010 & (135) & 880 & (237) & 210 & (761) & $\ddagger$ & $(t)$ & 45,780 & (188) & & (234) & & (410) & & & $\ddagger$ & $(\dagger)$ \\
\hline 1( &, 300 & $(7,843)$ & 620 & (161) & 27,320 & (172) & 60 & (299) & 40 & (592) & 37,900 & $(1,943)$ & 51,170 & (278) & 0 & (297) & & (517) & & ,023) & 65,480 & $(3,356)$ \\
\hline to 1 & 4,930 & $(7,580)$ & 590 & (209) & 30,820 & (253) & & (248) & & (842) & 40,340 & $(1,548)$ & 20 & (361) & & (437) & & (429) & & 154) & 90 & ,675) \\
\hline & .330 & $(8,038)$ & 960 & (202) & 3 & (274) & & $(24$ & & (838) & 43,740 & (391) & & (350) & & (474) & & (419) & & & & (,404) \\
\hline to 2 & ,140 & $(6,214)$ & 100 & (305) & 34,770 & (409) & 30 & (370) & 460 & $(1,257)$ & 43,110 & $(2,179)$ & ,830 & (528) & 30 & (707) & 00 & (639) & 60 & ,172) & 4,480 & $3,765)$ \\
\hline & ,460 & $(4,766)$ & & (380) &, 040 & (451) & & (489) & 900 & $(1,596)$ & $\ddagger$ & $(\dagger)$ & 66,560 & (656) & & (779) & & (846) & 670 & $2,757)$ & $\ddagger$ & $(\dagger)$ \\
\hline 35 years or & 30,980 & $(2,515)$ & 39,150 & (888) & 34,120 & $(1,258)$ & 41,730 & $1,116)$ & $\ddagger$ & $(t)$ & $\ddagger$ & $(\dagger)$ & 67,640 & $(1,535)$ & 58,940 & $(2,174)$ & 72,100 & $(1,927)$ & $\mp$ & $(\mathrm{t})$ & $\ddagger$ & $(t)$ \\
\hline $\begin{array}{l}\text { 999-2000 } \\
\text { Total..... }\end{array}$ & $2,742,210$ & $(20,301)$ & $\$ 39,890$ & (118) & $\$ 35,310$ & (116) & $\$ 44,700$ & (174) & 17,990 & (439) & $\$ 48,180$ & $(\mathbf{1 , 4 1 8 )}$ & $\$ 54,510$ & (162) & $\$ 48,250$ & (159) & $\$ 61,090$ & (237) & $\$ 65,580$ & (601) & $\$ 65,840$ & $(1,938)$ \\
\hline 1 year or less... & 72,710 & $(5,492)$ & 9,280 & (166) & 28.110 & (150) & 4.010 & (446) & 33,360 & $(1,009)$ & $\ddagger$ & (†) & 40,020 & (226) & 8,420 & (205) & 46,470 & (610) & 45,580 & $(1,379)$ & $\ddagger$ & $(\dagger)$ \\
\hline & 0 & $(5,678)$ & & (179) & & (165) & & & $\ddagger$ & (t) & $\ddagger$ & (†) & & (245) & & (226) & & 52) & $\ddagger$ & $(t)$ & $\ddagger$ & $(\dagger)$ \\
\hline & 5,290 & $(4,630)$ & 690 & (169) & ,650 & (199) & & 70) & 540 & 341) & $\ddagger$ & (†) & 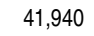 & (231) & 40,520 & (272) & 50 & (505) & 10 & B32) & $\ddagger$ & $(t)$ \\
\hline 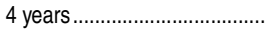 & 3,840 & $(5,657)$ & 380 & (258) & 30,810 & (232) & 870 & (665) & 130 & $(1,354)$ & $\ddagger$ & (t) & , 250 & (352) & 211 & (318) & 49,020 & (909) & 0,730 & 1,851) & $\ddagger$ & $(\dagger)$ \\
\hline & & $(4,3$ & & (2) & & 7) & & & & $(1,915)$ & $\ddagger$ & $(t)$ & & & & (392) & & & & & $\ddagger$ & $(\dagger)$ \\
\hline 6 to 9 &, 840 & $(8,205)$ & 960 & (167) & & (190) & & 40) &, 170 & (836) & 260 & 302) & 10 & (229) & 44,6 & (260) & & 328) & & 43) & 6,380 & $3,145)$ \\
\hline 10 to & .,730 & $(6,298)$ & 340 & (257) & 36,160 & (386) & 070 & (334) & 1,840 & (988) & 36,500 & $(2,313)$ & ,760 & (351) & 9,420 & (528) & 90 & (457) & 270 & ,350) & 49,880 & $(3,161)$ \\
\hline & 740 & $(8,067)$ & & (225) & & (318) & & & & (916) & & (872) & & & & (435) & & & & & & ,192) \\
\hline$\cdots$ &, 730 & $(6,993)$ & 650 & (264) & 000 & (279) & & 83) & .000 & $(1,055)$ & 430 & $1,319)$ & 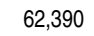 & 361) & 56 & (381) & s & (524) & & ,441) & 45,680 & $1,802)$ \\
\hline ............... & , 170 & $(7,167)$ & 540 & (276) &, 750 & (333) & 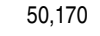 & (399) & 230 & (968) & 8,150 & $(2,437)$ & 330 & (377) & 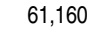 & (455) & 50 & (545) & 20 & , 323) & 52,140 & $(3,331)$ \\
\hline &, 470 & $(5,488)$ & & (346) & & (634) & & & & $(1,126)$ & $\ddagger$ & $(t)$ & & $(4 \pi$ & & (866) & & (602) & & & $\ddagger$ & $(t)$ \\
\hline 35 years or more...... & 51,990 & $(3,006)$ & 50,620 & (673) & 46,690 & $(1,359)$ & 52,270 & (923) & 56,200 & $(2,797)$ & $\ddagger$ & $(t)$ & 69,170 & (920) & 63,810 & $(1,858)$ & 71,430 & $(1,262)$ & 76,810 & $(3,823)$ & $\ddagger$ & $(\mathrm{t})$ \\
\hline $\begin{array}{l}\text { 2003-04 } \\
\text { Total............. }\end{array}$ & $2,948,230$ & $(28,203)$ & $\$ 44,360$ & (245) & $\$ 39,200$ & (300) & $\$ 49,440$ & (202) & $\$ 52,940$ & (458) & $\$ 53,750$ & $(1,295)$ & $\$ 55,150$ & (304) & $\$ 48,730$ & (373) & $\$ 61,460$ & (251) & $\$ 65,810$ & (570) & $\$ 66,820$ & $(1,609)$ \\
\hline & 7,920 & $(17,391)$ & & (381) & 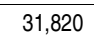 & (342) & & 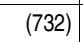 & & $, 030)$ & 37,320 & $1,690)$ & 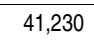 & (474) & & (425) & 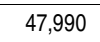 & (910) & 55,0 & $6,253)$ & 46,400 & $(2,101)$ \\
\hline & & $(17,695)$ & & & & & & & & & $\ddagger$ & $(t)$ & & & & & & & & & $\ddagger$ & $(\dagger)$ \\
\hline & 3,140 & $(9,009)$ & & (349) & & (282) & & (683) & & & $\ddagger$ & $(\dagger)$ & & (434) & & (351) & & (849) & 150 & $3,944)$ & $\ddagger$ & $(\dagger)$ \\
\hline 4 years ............................. & 159,490 & $(6,723)$ & 260 & (265) & 34,560 & (279) & 4 & (530) & & 9) & $\ddagger$ & $(t)$ & ,080 & (330) & & (347) & 80 & (658) & 00 & 36) & $\ddagger$ & $(\dagger)$ \\
\hline & 3,180 & $(6,194)$ & & (403) & & (324) & & & & & $\ddagger$ & $(t)$ & & ) & & (403) & & 3) & & & $\ddagger$ & $(t)$ \\
\hline &, 590 & $(13,85$ & & (201) & & & & & & & t,270 & 21) & & & & (260) & & (372) & & ,627) & 30 & $2,885)$ \\
\hline ars......... & 433,530 & $(14,595)$ & 44,330 & (257) & 39,730 & (267) & 47,900 & (393) & 50,000 & (956) & 55,040 & $(3,584)$ & 55,110 & (320) & 49,400 & (332) & 59,550 & (488) & 2,160 & $(1,189)$ & 68,420 & $(4,456)$ \\
\hline & 3,970 & $(9,606)$ & 200 & (356) & & (482) & & (469) & 250 & $(1,349)$ & & $(3,443)$ & & (443) & & (599) & & (583) & & & & ,280) \\
\hline & 5,980 & & & & & & & & & (999) & & & & & & (466) & & (724) & & & 66,610 & ,390) \\
\hline 25 to 29 years......... & 283,460 & $(11,809)$ & 52,790 & (281) & 48,650 & (488) & 55,000 & (411) & 70 & (975) & 65,210 & $(3,524)$ & 30 & (349) & 60,480 & (607) & 68,380 & (511) & 60 & $(1,213)$ & 81,070 & $(4,382)$ \\
\hline & 223,710 & $(11,435)$ & 56,280 & (428) & 51,310 & (606) & 58,070 & (566) & 62,450 & $(1,389)$ & 60,830 & $(2,664)$ & , 970 & (532) & 63,800 & (754) & 72,200 & (703) & ,640 & $(1,727)$ & 75,620 & $(3,312)$ \\
\hline 35 years or more.... & 66,310 & $(3,427)$ & 58,220 & (755) & 55,360 & $1,296)$ & 59,150 & (978) & 61,260 & $(2,224)$ & $\ddagger$ & $(t)$ & 72,380 & (938) & 68,820 & $(1,612)$ & 73,530 & $1,216)$ & 76,160 & $(2,765)$ & $\ddagger$ & \\
\hline
\end{tabular}

See notes at end of table. 


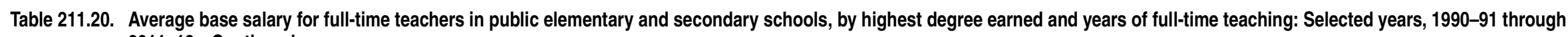
2011-12-Continued

[Standard errors appear in parentheses]

\begin{tabular}{|c|c|c|c|c|c|c|c|c|c|c|c|c|c|c|c|c|c|c|c|c|c|c|}
\hline \multirow{3}{*}{$\begin{array}{l}\text { Years of full-time } \\
\text { teaching experience }\end{array}$} & \multirow{3}{*}{\multicolumn{2}{|c|}{$\begin{array}{r}\text { Number of } \\
\text { full-time teachers }\end{array}$}} & \multicolumn{10}{|c|}{ Salary (current dollars) } & \multicolumn{10}{|c|}{ Salary (constant 2012-13 dollars) } \\
\hline & & & \multicolumn{10}{|c|}{ Highest degree earned } & \multicolumn{10}{|c|}{ Highest degree earned } \\
\hline & & & \multicolumn{2}{|c|}{ All teachers ${ }^{1}$} & \multicolumn{2}{|c|}{ Bachelor's degree } & \multicolumn{2}{|c|}{ Master's degree } & \multicolumn{2}{|c|}{ Education specialist $t^{2}$} & \multicolumn{2}{|c|}{ Doctor's degree } & \multicolumn{2}{|c|}{ All teachers ${ }^{1}$} & \multicolumn{2}{|c|}{ Bachelor's degree } & \multicolumn{2}{|c|}{ Master's degree } & \multicolumn{2}{|c|}{ Education specialist ${ }^{2}$} & \multicolumn{2}{|c|}{ Doctor's degree } \\
\hline 1 & & 2 & & 3 & & 4 & & 5 & & 6 & & 7 & & 8 & & 9 & & 10 & & 11 & & 12 \\
\hline $\begin{array}{r}2007-08 \\
\text { Total... }\end{array}$ & $3,114,690$ & $(41,111)$ & $\$ 49,630$ & (203) & $\$ 43,650$ & (220) & $\$ 54,810$ & (281) & $\$ 58,420$ & (722) & $\$ 59,150$ & $1,620)$ & $\$ 54,230$ & (222) & $\$ 47,700$ & (241) & $\$ 59,900$ & (307) & $\$ 63,850$ & (789) & $\$ 64,650$ & $(1,770)$ \\
\hline 1 year or less & 211,500 & $(12,029)$ & 38,210 & (332) & 36,670 & (308) & 42,840 & $(807)$ & 47,410 & $(3,584)$ & $\ddagger$ & $(t)$ & 41,750 & (362) & 40,080 & (336) & 46,820 & (882) & 51,820 & $(3,916)$ & 47,810 & $(4,388)$ \\
\hline is. & 185,130 & $(10,587)$ & 38,640 & (334) & 5,900 & (340) & 2,640 & (717) & 47,420 & $(4,082)$ & $\ddagger$ & $(t)$ & 42,230 & (365) & 0,330 & (371) & 46 & (783) & 820 & $(4,461)$ & $\ddagger$ & $(t)$ \\
\hline & 177,230 & $(7,735)$ & 40,070 & (374) & 770 & (358) & 1 & (864) & 30 & $1010)$ & $t$ & $(t)$ & 43,790 & (408) & & (391) & & (945) & & & $\ddagger$ & $(t)$ \\
\hline & 174,350 & $(7,951)$ & 180 & (377) & S & (428) & 30 & (577) & 90 & 3) & $\ddagger$ & $(t)$ & 45,000 & (412) & & (468) & & (631) & 10 & $, 506)$ & $\ddagger$ & $(\dagger)$ \\
\hline & 148,540 & $(7,995)$ & 42,830 & (534) & 0 & (476) & 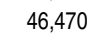 & (869) & 70 & 0) & $\ddagger$ & $(t)$ & 46,810 & (583) & & (520) & & (950) & & ,939) & $\ddagger$ & $(\dagger)$ \\
\hline ....... & 557,050 & $(14,475)$ & 46,330 & (252) & & (379) & & & & 28) & 850 & ,349) & $50->$ & (275) & & (414) & & (482) & & 33) & 760 & 567) \\
\hline 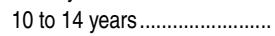 & 508,300 & $(14,867)$ & 50,470 & (377) & 30 & (436) & 53,4 & (559) & 50 & 220) &, 400 & $4,124)$ & 55,150 & (412) & 0 & (477) & 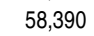 & (611) & & ,333) & 00 & $(4,507)$ \\
\hline & 350,690 & $(12,953)$ & 55,000 & (484) & 48,50 & (553) & & (722) & & 3) & 280 & $3,462)$ & 6 & (529) & & (604) & & (789) & & & & 883) \\
\hline & 288,110 & $(11,954)$ & 7,830 & (636) & & (783) & & (794) & & & ,960 & $6,394)$ & & (695) & & (856) & & (868) & & & 270 & $(6,988)$ \\
\hline 25 to $29 y$ & 221,950 & $(8,609)$ & 260 & (740) & $T<0$ & (830) & 280 & $(1,068)$ & 830 & 6) & $\ddagger$ & $(t)$ & 65,850 & (809) & 9,480 & (907) & 99,150 & $(1,167)$ & & 3,613) & $\ddagger$ & $(\dagger)$ \\
\hline 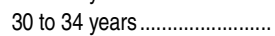 & 197,490 & $(8,304)$ & 1,120 & (754) & 1,860 & (997) & 64,280 & (998) & 63,820 & $(1,555)$ & $\ddagger$ & $(\dagger)$ & 66,790 & (824) & 9,960 & $(1,089)$ & 70,250 & $(1,090)$ &, 740 & $(1,699)$ & $\ddagger$ & $(\dagger)$ \\
\hline 35 years & 94,340 & $(7,055)$ & 61,920 & $(1,067)$ & 55,350 & $(1,561)$ & 64,400 & $(1,499)$ & 68,780 & $(3,364)$ & $\ddagger$ & (†) & 67,660 & $(1,166)$ & 60,490 & $1,706)$ & 70,370 & $(1,639)$ & 75,160 & $(3,676)$ & $\ddagger$ & $(t)$ \\
\hline $\begin{array}{r}2011-12 \\
\text { Total. }\end{array}$ & $3,139,250$ & $(38,342)$ & $\$ 53,070$ & (213) & $\$ 46,340$ & (225) & $\$ 57,830$ & (352) & $\$ 59,680$ & (642) & , 230 & ,775) & $\$ 53,950$ & (217) & $\$ 47,110$ & (229) & $\$ 58,790$ & (358) & $\$ 60,670$ & (652) & $\$ 61,230$ & $(1,804)$ \\
\hline 1 year or le & 144,240 & $(7,545)$ & 40,540 & (512) & 38,490 & (578) & 45,240 & $(1,122)$ & 49,140 & $(3,732)$ & $\ddagger$ & (t) & 41,210 & (520) & 39,130 & (587) & 46,000 & $(1,140)$ & 49,960 & $(3,795)$ & 46,040 & $(3,557)$ \\
\hline & 118,520 & $(5,799)$ & 39,740 & 356) & & (381) & & & & 1) & $\ddagger$ & (t) & 40 & 62) & & (388) & & $(738)$ & & 25) & $\ddagger$ & $(t)$ \\
\hline & 126,030 & $(7,109)$ & 11470 & $(150)$ & & (478) & & & & & $\ddagger$ & (†) & 2 & $(458)$ & & (486) & & (814) & & & $\ddagger$ & $(\dagger)$ \\
\hline . & 151,350 & $(8,219)$ & 42,840 & (422) & 40,280 & (461) & 340 & (637) & 60 & $(2$ & $\ddagger$ & (t) & 43,550 & (429) & 50 & (468) & 46,700 & (648) & 30 & 57) & $\ddagger$ & $(t)$ \\
\hline & 174,140 & $(8,549)$ & 43,830 & (789) & & (422) & & $(1,610)$ & & (1) & $\ddagger$ & (†) & 44,560 & (802) & & (429) & 10 & $(1,636)$ & & & $\ddagger$ & $(\dagger)$ \\
\hline 6 to 9 year & 610,420 & $(16,507)$ & 48,290 & (327) & 150 & (419) & & $(157)$ & 80 & & 340 & ,507) & 101 & (332) & & (426) & $502+2$ & $(464)$ & & $1,258)$ & 190 & $(2,549)$ \\
\hline 10 to 1 & 652,140 & $(16,569)$ & 54,860 & (369) & & (537) & & & & & & & 770 & (375) & & (546) & 59,230 & (550) & 40 & 62) & 62,210 & $(2,590)$ \\
\hline & 426,250 & $(14,564)$ & 58,880 & (596) & 51,290 & (749) & & (775) & 6 & $(1,673)$ & 4,420 & $(3,910)$ & 59,860 & (606) & 2,1 & (762) & 00 & $(788)$ &, 520 & 01) & 65,490 & $(3,975)$ \\
\hline & 295,760 & $(10,25$ & , & $(59$ & & (849) & & $(8$ & & & ,630 & 4,095) & & & & (863) & & (886) & & $1,693)$ & 68,760 & $(4,163)$ \\
\hline 25 to 2 & 217,870 & $(11,000)$ & 63,780 & (838) & 56,890 & $(1,046)$ & 67,550 & ( & 69,410 & $(2,890)$ & $\ddagger$ & $(\dagger)$ & 64,840 & (852) & 57,840 & $(1,063)$ & 68,680 & $(1,274)$ & 70,570 & $(2,938)$ & $\ddagger$ & $(t)$ \\
\hline & 142,630 & $(9,117)$ & 65,610 & (791) & 58,510 & $(1,069)$ & 69,420 & $(1,083)$ & 67,260 & $(2,406)$ & $\ddagger$ & $(\dagger)$ & 66,700 & (804) & 59,490 & $(1,087)$ & 70,580 & $(1,101)$ & 68,380 & $(2,446)$ & $\ddagger$ & $(t)$ \\
\hline 35 years or more.............. & 79,900 & $(5,008)$ & 63,400 & (947) & 59,560 & $(1,548)$ & 66,120 & $(1,133)$ & 64,660 & $(2,385)$ & $\ddagger$ & $(\dagger)$ & 64,460 & (962) & 60,560 & $(1,573)$ & 67,220 & $(1,151)$ & 65,740 & $(2,424)$ & $\ddagger$ & r $>2>$ \\
\hline
\end{tabular}

†Not applicable.

Reporting standards not met (too few cases for a reliable estimate).

Includes teachers with levels of education below the bachelor's degree (not shown separately).

Education specialist degrees or certificates are generally awarded for 1 year's work beyond the master's level. Includes certificate of advanced graduate studies.

Cer adjusted to a school-year basis.
NOTE: This table includes regular full-time teachers only; it excludes other staff even when they have full-time teaching duties (regular part-time teachers, itinerant teachers, long-term substitutes, administrators, library media specialists, other professional staff, and support staff). Some data have been revised from previously published figures. Detail may not sum to totals because of rounding.

SOURCE: U.S. Department of Education, National Center for Education Statistics, Schools and Staffing Survey (SASS), Public School Teacher Da 


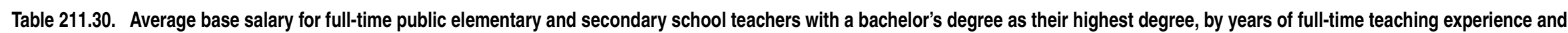
state: 1993-94 through 2011-12

[Amounts in current dollars. Standard errors appear in parentheses]

\begin{tabular}{|c|c|c|c|c|c|c|c|c|c|c|c|c|c|c|c|c|c|c|c|c|c|c|c|c|}
\hline \multirow[b]{2}{*}{ State } & \multirow{2}{*}{\multicolumn{2}{|c|}{ 993-94, total }} & \multirow{2}{*}{\multicolumn{2}{|c|}{ 1999-2000, total }} & \multirow{2}{*}{\multicolumn{2}{|c|}{$2003-04$, total }} & \multicolumn{6}{|c|}{$2007-08$} & \multicolumn{12}{|c|}{ 2011-12 } \\
\hline & & & & & & & & Total & 2 or $f$ & years & Over & ars & & tal & or & ver years & & ars & 6 to & ars & 11 & ars & & \\
\hline 1 & & 2 & & 3 & & 4 & & & & 6 & & 7 & & 8 & & 9 & & & & 11 & & 12 & & \\
\hline United & 150 & (97) & 5,310 & 116) & 9,200 & $300)$ & 3,650 & (220) & $\$ 36,7$ & 262) & $\$ 54,170$ & 463) & 6,340 & 25) $\mathrm{s}$ & $\$ 38,3$ & 41) & 0,03 & 56) & 4,0 & 156) & $\$ 50,440$ & 456) & 6,62 & \\
\hline 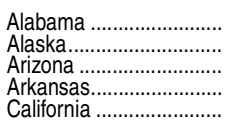 & 050 & $\begin{array}{l}(151) \\
308 \\
347 \\
199 \\
(412)\end{array}$ &, 110 & $\left(\begin{array}{l}209 \\
491 \\
345 \\
301\end{array}\right)$ & & $\begin{array}{l}(256) \\
720 \\
556) \\
328 \\
704)\end{array}$ & 0 & $\left.\begin{array}{l}747 \\
571 \\
418 \\
966)\end{array}\right)$ & 44 & (997) & b & $\begin{array}{l}932 \\
770 \\
(984 \\
235)\end{array}$ & ) & $\begin{array}{r}(641) \\
(2,016) \\
(644)\end{array}$ & $\begin{array}{l}32 \\
37 \\
47\end{array}$ & $\left.\begin{array}{l}\left(\begin{array}{l}1,151 \\
(3,481\end{array}\right) \\
3,537\end{array}\right)$ & & $\begin{array}{r}(1,2 \\
(1,2 \\
19\end{array}$ & $\begin{array}{r}40,150 \\
\neq \\
35,650 \\
39,540 \\
58,570\end{array}$ & $\begin{array}{r}(594) \\
(t) \\
(770)\end{array}$ & & $\begin{array}{r}(807) \\
(942) \\
(1,129)\end{array}$ & & 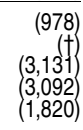 \\
\hline 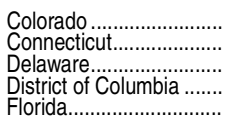 & 400 & $\begin{array}{l}(391) \\
645 \\
375 \\
(645) \\
(229)\end{array}$ & $\begin{array}{l}37,620 \\
40,980 \\
33,650\end{array}$ & $\begin{array}{l}(428) \\
883 \\
893 \\
593 \\
(407)\end{array}$ & $\begin{array}{l}, 380 \\
, 210 \\
, 450 \\
460\end{array}$ & $\begin{array}{r}(699) \\
(1,997) \\
(991) \\
(1,290) \\
(624)\end{array}$ & 880 & $\begin{array}{r}(884) \\
(1,286) \\
(960) \\
(2,025) \\
(554)\end{array}$ & $\begin{array}{r}42,830 \\
\ddagger \\
42,180 \\
36,030\end{array}$ & $\begin{array}{r}(621) \\
(1,348 \\
(\dagger \\
(425) \\
(473)\end{array}$ & $55,480^{+}$ & 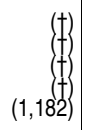 & 声 & $\left(\begin{array}{l}1, \\
1, \\
1,\end{array}\right.$ & $\begin{array}{r}33,270 \\
\vdots \\
39,020 \\
\ddagger \\
\ddagger\end{array}$ & & & $\begin{array}{r}(763) \\
(1,365) \\
(+)\end{array}$ & & & $\ddagger$ & & & \\
\hline 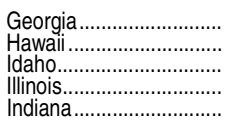 & $\begin{array}{l}610 \\
480 \\
400\end{array}$ & $\begin{array}{l}(215) \\
460 \\
252 \\
277 \\
(329)\end{array}$ & $\begin{array}{l}33,610 \\
36,710 \\
31,500 \\
35,250 \\
30,760\end{array}$ & $\begin{array}{l}(373) \\
533 \\
208 \\
563 \\
296)\end{array}$ & 10 & $\begin{array}{l}(490) \\
887 \\
627 \\
791 \\
640)\end{array}$ & $\begin{array}{l}4 \\
4 \\
3 \\
3\end{array}$ & $\begin{array}{l}(760) \\
922 \\
609 \\
836 \\
(786)\end{array}$ & $\begin{array}{l}34,5 \\
38,6 \\
31,1 \\
36,0 \\
32,8\end{array}$ & $\begin{array}{r}(573) \\
(1,496) \\
619 \\
926 \\
(452)\end{array}$ & $\begin{array}{r}54,330 \\
\ddagger \\
48,450 \\
52,950 \\
\ddagger\end{array}$ & $(t)$ & $\begin{array}{r}2,490 \\
\ddagger \\
8,680\end{array}$ & $\begin{array}{r}(1,032) \\
(t) \\
(794) \\
(1,156) \\
1,489)\end{array}$ & & (701) & $\begin{array}{r}37,820 \\
\ddagger \\
33,770 \\
11570\end{array}$ & $\begin{array}{r}(858) \\
(t) \\
(2,284) \\
1,299 \\
(996)\end{array}$ & $\begin{array}{r}40,760 \\
\quad \neq \\
32,270 \\
46,120 \\
39,960\end{array}$ & $\begin{array}{r}(922) \\
(\dagger) \\
(491) \\
(1,710) \\
1,273)\end{array}$ & & $\left.\begin{array}{r}(1,243) \\
(+) \\
(1,178 \\
2,868 \\
1,457)\end{array}\right)$ & $\begin{array}{r}\ddagger \\
7 \\
47,650 \\
54690\end{array}$ & \\
\hline 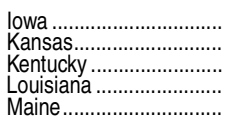 & ,910 & $\begin{array}{l}(319) \\
135 \\
457 \\
159 \\
(330)\end{array}$ & $\begin{array}{l}27 \\
28 \\
34\end{array}$ & $\begin{array}{l}279 \\
264 \\
358 \\
476 \\
775)\end{array}$ & & $\begin{array}{l}(696) \\
326 \\
468 \\
489 \\
606)\end{array}$ & & $\begin{array}{l}5000 \\
476 \\
608 \\
462 \\
651)\end{array}$ & $\begin{array}{l}34, \\
33, \\
36, \\
31,\end{array}$ & $\begin{array}{r}(827) \\
(523) \\
(1,011 \\
825 \\
(573)\end{array}$ & $\begin{array}{r}40,400 \\
42,250 \\
\quad \neq \\
44,800 \\
46,260\end{array}$ & $\begin{array}{r}(903) \\
880 \\
(\dagger) \\
(1,061 \\
1,321)\end{array}$ & & $\begin{array}{r}(759) \\
438 \\
896) \\
(614) \\
(1,023)\end{array}$ & & $\begin{array}{r}(1,926) \\
955 \\
716 \\
798 \\
(+)\end{array}$ & & $\begin{array}{r}(850) \\
445 \\
(496) \\
(1,105) \\
(1,538)\end{array}$ & $\begin{array}{r}39,280 \\
37,610 \\
\neq 1 \\
42,510 \\
38,000\end{array}$ & $\begin{array}{r}(1,164) \\
(872) \\
(t) \\
(1,134) \\
1,033)\end{array}$ & & $\begin{array}{r}(1,378) \\
659 \\
(+) \\
(980) \\
(891)\end{array}$ & $\begin{array}{r}100 \\
30 \\
\neq \\
440\end{array}$ & 385 \\
\hline 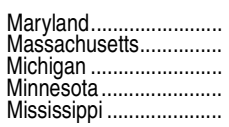 & $\begin{array}{l}x, 170 \\
, 010 \\
, 640\end{array}$ & $\begin{array}{l}(476) \\
309 \\
670 \\
419 \\
(106)\end{array}$ & & $\left.\begin{array}{l}683 \\
464 \\
838 \\
685 \\
186\end{array}\right)$ & $\begin{array}{l}42,960 \\
43,930 \\
45,230\end{array}$ & $\left.\begin{array}{r}(1,313) \\
(964) \\
682 \\
566 \\
(425)\end{array}\right)$ & & $\begin{array}{r}(1,213) \\
(917) \\
(1,612) \\
(593) \\
(344)\end{array}$ & 32 & $\left.\begin{array}{l}492 \\
970 \\
664 \\
574 \\
434\end{array}\right)$ & & $\begin{array}{r}(1,644) \\
2,309 \\
1,506) \\
(924) \\
(850)\end{array}$ & t & $\begin{array}{r}(2,123) \\
1,588) \\
1,184) \\
(520)\end{array}$ & $\begin{array}{r}\ddagger \\
46,220 \\
36,620 \\
35,830 \\
31,890\end{array}$ & $\begin{array}{r}(5,390 \\
1,186 \\
2,261 \\
(761)\end{array}$ & 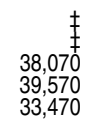 & $\begin{array}{r}(839) \\
(1,387) \\
(490)\end{array}$ & $\begin{array}{r}\ddagger \\
\ddagger \\
5,250 \\
1,950 \\
4,080\end{array}$ & $\left.\begin{array}{r}1,873) \\
1,915 \\
(658)\end{array}\right)$ & & (t) & & \\
\hline ……..... & $\begin{array}{l}2,580 \\
, 350 \\
1,280\end{array}$ & $\begin{array}{l}(286) \\
199 \\
388 \\
285 \\
(437)\end{array}$ & $\begin{array}{l}27,9 \\
26,0 \\
344, \\
34,2\end{array}$ & $\begin{array}{l}378) \\
256 \\
254 \\
434 \\
542)\end{array}$ & & $\begin{array}{l}(547) \\
522 \\
435 \\
700 \\
644)\end{array}$ & & $\begin{array}{l}(553) \\
597 \\
805 \\
619 \\
(843)\end{array}$ & & $\begin{array}{r}(632) \\
591 \\
379 \\
(462) \\
(1,139)\end{array}$ & & $\begin{array}{l}512 \\
045 \\
524 \\
143 \\
050)\end{array}$ & & $\begin{array}{r}(941) \\
(1,155) \\
(912) \\
(1,913) \\
(1,394)\end{array}$ & $\begin{array}{r}36,210 \\
28,560 \\
33,970 \\
\ddagger \\
\neq\end{array}$ & $\left.\begin{array}{r}2,581 \\
1,128 \\
1,111 \\
(\dagger\end{array}\right)$ & $\begin{array}{l}00 \\
10 \\
40\end{array}$ & $\left.\begin{array}{r}(891) \\
(1,454) \\
(775) \\
(\dagger)\end{array}\right)$ & & $\begin{array}{l}, 290) \\
, 242 \\
, 238 \\
, 527) \\
, 527)\end{array}$ & & $\left.\begin{array}{l}1,713 \\
1,354 \\
2,994 \\
(1,568)\end{array}\right)$ & $\begin{array}{l}570 \\
990 \\
\vdots \\
980\end{array}$ & $\begin{array}{r}22 \\
19 \\
44\end{array}$ \\
\hline$(\ldots \ldots \ldots \ldots .$. & $\begin{array}{l}, 260 \\
, 650 \\
, 4010\end{array}$ & $\begin{array}{r}(744) \\
(224) \\
(1,152) \\
(220) \\
(193)\end{array}$ & $\begin{array}{l}46,7 \\
29,2 \\
41,6 \\
31,9 \\
25,9\end{array}$ & $\left.\begin{array}{r}(653) \\
(363) \\
(1,094) \\
(331) \\
279\end{array}\right)$ & $\begin{array}{l}310 \\
630\end{array}$ & $\begin{array}{r}(1,049) \\
(470) \\
(1,074) \\
(479) \\
(490)\end{array}$ & $\begin{array}{l}30 \\
30 \\
20 \\
50\end{array}$ & $\begin{array}{r}(1,091) \\
(596) \\
(2,004) \\
(469) \\
(695)\end{array}$ & $\begin{array}{l}45, \\
32, \\
43, \\
30, \\
27,\end{array}$ & $\left.\begin{array}{r}(977) \\
(844) \\
(1,652 \\
499 \\
(579\end{array}\right)$ & $\begin{array}{r}72,840 \\
48,430 \\
\ddagger \\
48,70 \\
38,920\end{array}$ & $(2,642)$ & 460 & $\begin{array}{r}(1,391) \\
(747) \\
(2704)\end{array}$ & $\begin{array}{r}50,880 \\
34,900 \\
\ddagger \\
32,770 \\
33,570\end{array}$ & $\begin{array}{l}(895) \\
7222\end{array}$ & $\begin{array}{r}9,590 \\
6,750 \\
\ddagger \\
1,620 \\
5,190\end{array}$ & $\begin{array}{r}(920) \\
(1,639) \\
(t)\end{array}$ & $\begin{array}{l}54,610 \\
42,620 \\
35,09 \\
\quad 50 \\
38,220\end{array}$ & $\begin{array}{r}(1,178) \\
(851) \\
(\dagger) \\
(613) \\
(1,096)\end{array}$ & $\begin{array}{l}, 830 \\
:, 480 \\
\ddagger \\
, 660 \\
, 230\end{array}$ & $\left.\begin{array}{r}(2,276) \\
(1,418 \\
(\dagger)\end{array}\right)$ &, 950 & \\
\hline 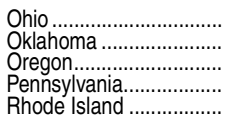 & 310 & $\begin{array}{l}(399) \\
108 \\
440 \\
523 \\
522)\end{array}$ & $\begin{array}{l}35,120 \\
27,400 \\
38,370 \\
42,620 \\
43,900\end{array}$ & $\begin{array}{l}(583) \\
(224) \\
613 \\
826 \\
357)\end{array}$ & & $\begin{array}{l}(891) \\
211 \\
865 \\
963 \\
(834)\end{array}$ & $\begin{array}{l}880 \\
930 \\
780 \\
680\end{array}$ & $\begin{array}{r}(1,567) \\
(226) \\
(1,282) \\
(1,162) \\
(1,362)\end{array}$ & $\begin{array}{l}32 \\
32\end{array}$ & $\begin{array}{r}(1,976) \\
458 \\
655 \\
780 \\
(\dagger)\end{array}$ & $\begin{array}{r}54,890 \\
41,410 \\
52,750 \\
64,470 \\
\ddagger\end{array}$ & $\begin{array}{r}(2,001) \\
(4777 \\
(1,869) \\
(\dagger, 680 \\
(\dagger)\end{array}$ & $\begin{array}{r}6,700 \\
1,260 \\
+210 \\
\ddagger\end{array}$ & $\begin{array}{r}(1,116) \\
(371) \\
(1,653) \\
(1,485) \\
(\dagger)\end{array}$ & $\begin{array}{r}34,980 \\
33,260 \\
\ddagger \\
41,180 \\
\ddagger\end{array}$ & $\begin{array}{r}(1,085) \\
(868) \\
\left(\begin{array}{l}1 \\
(1)\end{array}\right)\end{array}$ & $\begin{array}{r}33,360 \\
\ddagger \\
44,250 \\
\ddagger\end{array}$ & $\begin{array}{r}(878) \\
(469) \\
(\dagger) \\
(1,367) \\
(\dagger)\end{array}$ & $\begin{array}{r}43,670 \\
33,750 \\
\ddagger \\
47,540 \\
\ddagger\end{array}$ & $\begin{array}{r}(1,507) \\
(416) \\
(\dagger) \\
(1,414)\end{array}$ & $\begin{array}{r}1,930 \\
8,100 \\
4,330 \\
8,910 \\
\ddagger\end{array}$ & $\begin{array}{r}(1,642) \\
(409) \\
(2,170) \\
2,455 \\
(\dagger)\end{array}$ & $\begin{array}{r}50 \\
60 \\
40 \\
50 \\
\ddagger\end{array}$ & $\begin{array}{l}2,284 \\
1,104 \\
1,849 \\
2,919\end{array}$ \\
\hline $\begin{array}{c}\ldots \ldots \ldots \ldots \ldots . . \\
\ldots \ldots \ldots \ldots . . \\
\ldots \ldots \ldots \ldots . .\end{array}$ & $\begin{array}{l}25,120 \\
22,000 \\
25,650\end{array}$ & $\left.\begin{array}{l}(280) \\
1866 \\
291 \\
295 \\
(195)\end{array}\right)$ & $\begin{array}{l}29,820 \\
26,000 \\
30,830 \\
31770\end{array}$ & $\left.\begin{array}{l}(300) \\
230 \\
378 \\
386\end{array}\right)$ & & $\left.\begin{array}{l}(483) \\
301 \\
432 \\
278 \\
525)\end{array}\right)$ & $\begin{array}{l}37,150 \\
32,180 \\
37,420\end{array}$ & $\left.\begin{array}{l}(606) \\
445 \\
553 \\
480 \\
863\end{array}\right)$ & & $\left.\begin{array}{l}(625) \\
422 \\
481 \\
706\end{array}\right)$ & $\begin{array}{l}45,920 \\
36,250 \\
43,350 \\
48,800 \\
48,750\end{array}$ & $\left.\begin{array}{r}(1,013) \\
(784) \\
(1,430)\end{array}\right)$ & $\begin{array}{l}39,380 \\
34,870 \\
39,420\end{array}$ & $\begin{array}{r}(1,077) \\
(601) \\
877) \\
(440) \\
(1,087)\end{array}$ & & $\begin{array}{l}(668) \\
.513 \\
.730)\end{array}$ & & $\begin{array}{r}(601) \\
(639) \\
(1,322) \\
(571) \\
(411)\end{array}$ & & $\begin{array}{r}(1,103) \\
(490) \\
(1,301) \\
(590) \\
(1,059)\end{array}$ & & $\begin{array}{r}(+) \\
(900) \\
832\end{array}$ & & $\begin{array}{l}1 \\
45 \\
20\end{array}$ \\
\hline 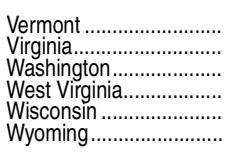 & $\begin{array}{l}29,410 \\
33,150 \\
26,980 \\
31,490 \\
27,310\end{array}$ & $\begin{array}{l}(494) \\
378 \\
490 \\
183 \\
351 \\
(247)\end{array}$ & $\begin{array}{l}33,470 \\
34,060 \\
36,330 \\
30,040 \\
35,470 \\
29,470\end{array}$ & $\left.\begin{array}{l}7333 \\
424 \\
359 \\
246 \\
331\end{array}\right)$ & $\begin{array}{l}37,520 \\
40,040\end{array}$ & $\left.\begin{array}{l}(840) \\
583 \\
916 \\
344 \\
634 \\
576\end{array}\right)$ & $\begin{array}{l}43,430 \\
43,440 \\
44,650 \\
34,410 \\
41,390 \\
45,750\end{array}$ & $\begin{array}{r}(1,005) \\
(569 \\
905 \\
475 \\
(859) \\
(543)\end{array}$ & $\begin{array}{r}\ddagger \\
37,7170 \\
37,220 \\
29,030 \\
32,020 \\
38,230\end{array}$ & 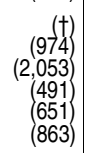 & $\begin{array}{l}52,160 \\
54,320 \\
53,950 \\
40,660 \\
49,630 \\
51,210\end{array}$ & $\begin{array}{r}1,25 \\
1,39 \\
1,44 \\
(58\end{array}$ & $\begin{array}{l}, 240 \\
, 860 \\
, 590 \\
, 360 \\
, 790 \\
, 610\end{array}$ & $\begin{array}{r}(1,416) \\
(999) \\
(1,439) \\
(646) \\
(840) \\
(1,105)\end{array}$ & 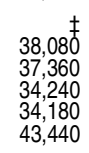 & 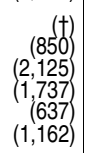 & $\begin{array}{r}\ddagger \\
38,200 \\
39,280 \\
34,120 \\
38,830 \\
47,530\end{array}$ & $\begin{array}{r}(t) \\
(710) \\
(1,702) \\
(595) \\
(1,124) \\
(1,083)\end{array}$ & $\begin{array}{r}\ddagger \\
41,220 \\
42,010 \\
36,830 \\
42,470 \\
48,910\end{array}$ & $\begin{array}{r}(\dagger) \\
(1,203) \\
(878) \\
(775) \\
(1,338) \\
1,480)\end{array}$ & & $\left.\begin{array}{l}(2,079) \\
2,085 \\
2,364) \\
1,158 \\
1,598 \\
1,212\end{array}\right)$ & & $\begin{array}{l}614 \\
447) \\
11\end{array}$ \\
\hline
\end{tabular}

†Not applicable.

ards not met. Data may be suppressed because the response rate is under 50 percent, there are too few NOTE: This table estimate, or the coefficient of variation (CV) is 50 percent or greater.

(regular part-time teachers, itinerant teachers, long-term substitutes, administrators, library media specialists, other professional staff, and support staff).
SOURCE: U.S. Department of Education, National Center for Education Statistics, Schools and Staffing Survey (SASS) "Public School Teacher Data File," 1993-94, 1999-2000, 2003-04, 2007-08, and 2011-12; and "Public Charter Schoo Teacher Data File," 1999-2000. (This table was prepared June 2013.) 


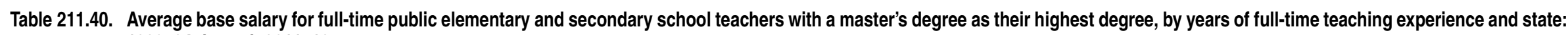
1993-94 through 2011-12

[Amounts in current dollars. Standard errors appear in parentheses]

\begin{tabular}{|c|c|c|c|c|c|c|c|c|c|c|c|c|c|c|c|c|c|c|c|c|c|c|c|c|}
\hline \multirow[b]{2}{*}{ State } & \multirow{2}{*}{\multicolumn{2}{|c|}{ 1993-94, total }} & \multirow{2}{*}{\multicolumn{2}{|c|}{ 1999-2000, total }} & \multirow{2}{*}{\multicolumn{2}{|c|}{ 2003-04, total }} & \multicolumn{8}{|c|}{$2007-08$} & \multicolumn{10}{|c|}{ 2011-12 } \\
\hline & & & & & & & & Total & 6 & ears & 11 to & ears & 0 & ears & & Total & 50 & ars & 6 to & ars & 11 & ars & & ver \\
\hline 1 & & 2 & & 3 & & 4 & & 5 & & 6 & & 7 & & 8 & & 9 & & 10 & & 11 & & 12 & & 13 \\
\hline s... & $48>>2>>$ & 54) & 4,70 & (174) & 9,440 & (202) & $s$ & (281) § & 0,54 & 80) & $s$ & (493) & $\$$ & 576) & $\$ 57,830$ & 352) & 5 & (650) & 5 & 514) & $08,-2-2-1$ & 504) & $s$ & 604) \\
\hline S...………… & 280 & $\left.\begin{array}{l}(3 / 3) \\
302 \\
322 \\
636\end{array}\right)$ & 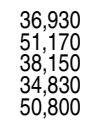 & & & $\begin{array}{r}(383) \\
\left(\begin{array}{r}1 \\
053 \\
531 \\
639 \\
(761)\end{array}\right) \\
\end{array}$ & & $\left.\begin{array}{l}(701 \\
678 \\
(982)\end{array}\right)$ & $\begin{array}{l}50 \\
50 \\
30\end{array}$ & $\begin{array}{r}(828) \\
(1,141) \\
(877) \\
(1,355) \\
1,076)\end{array}$ & $\begin{array}{l}0 \\
0 \\
0\end{array}$ & $\begin{array}{r}(480) \\
965 \\
(853) \\
(1,150) \\
1,477)\end{array}$ & & | & & $\left.\begin{array}{l}6600 \\
921 \\
9811\end{array}\right)$ & & $\begin{array}{r}(723) \\
(937 \\
(1,334)\end{array}$ & & 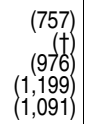 & & & $\begin{array}{c}7 \\
20 \\
50\end{array}$ & 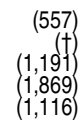 \\
\hline Columbia ........ & 550 & $\left.\begin{array}{l}(364) \\
416 \\
535 \\
828 \\
487\end{array}\right)$ & 0 & $\begin{array}{l}445) \\
590 \\
910 \\
472 \\
476)\end{array}$ & $\begin{array}{l}0 \\
0 \\
0\end{array}$ & $\begin{array}{r}(641) \\
994 \\
(913) \\
(1,568) \\
(784)\end{array}$ & $\begin{array}{l}0 \\
0 \\
0\end{array}$ & $\begin{array}{r}(1,069) \\
(762) \\
(1,117) \\
(1,933) \\
(985)\end{array}$ & , 800 & $\left.\begin{array}{r}(1,719) \\
1,079 \\
1,679 \\
(\dagger) \\
(920)\end{array}\right)$ & $\begin{array}{l}4,760 \\
, 270 \\
, 270 \\
, 100 \\
5,760\end{array}$ & $\begin{array}{r}1,43 \\
2,24 \\
(2,14 \\
(93\end{array}$ & & $(1,329)$ & $\begin{array}{r}760 \\
040 \\
730 \\
\ddagger \\
\ddagger\end{array}$ & $\begin{array}{r}(1,280) \\
(996) \\
(1,420 \\
(\dagger) \\
(\dagger)\end{array}$ & & & & (t) & & & & \\
\hline 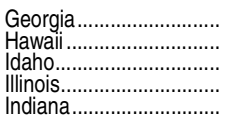 & $\begin{array}{l}590 \\
400\end{array}$ & $\begin{array}{l}(227) \\
731 \\
440 \\
588 \\
(292)\end{array}$ & & $\begin{array}{l}524 \\
524 \\
772 \\
953 \\
(413)\end{array}$ & $\begin{array}{l}0 \\
0 \\
0\end{array}$ & $\begin{array}{r}(752) \\
967 \\
(857) \\
(1,253) \\
(670)\end{array}$ & 0 & $\begin{array}{r}(799) \\
(1,513) \\
(981) \\
(1,503) \\
(686)\end{array}$ & $\begin{array}{r}, 020 \\
\ddagger \\
, 150 \\
, 930 \\
, 470\end{array}$ & $\begin{array}{r}(1,214) \\
(t) \\
(1,707) \\
1,513 \\
1,128)\end{array}$ & $\begin{array}{r}53,320 \\
\neq \\
51,410 \\
62,610 \\
49,100\end{array}$ & 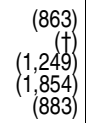 & 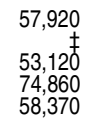 & $\begin{array}{r}(1,278) \\
(\dagger)\end{array}$ & $\begin{array}{r}0,700 \\
\ddagger \\
5,920 \\
4,670 \\
5,360\end{array}$ & $\begin{array}{c}(1,002) \\
(\dagger) \\
(1,724) \\
1,520 \\
(735)\end{array}$ & $\begin{array}{r}43,240 \\
\ddagger \\
\ddagger \\
49,030 \\
39,610\end{array}$ & $\begin{array}{r}(1,809) \\
(\dagger) \\
(+) \\
(2,082) \\
(943)\end{array}$ & $\begin{array}{r}6,510 \\
\ddagger \\
7,300\end{array}$ & & $\begin{array}{r}53,010 \\
\quad \neq \\
49,020\end{array}$ & $\left.\begin{array}{l}(1,253) \\
(2,067\end{array}\right)$ & & $\begin{array}{r}(2,025) \\
(+) \\
(2,258)\end{array}$ \\
\hline 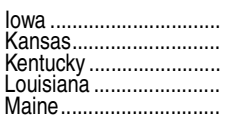 & , & $\left.\begin{array}{l}(571) \\
314 \\
396 \\
262 \\
499\end{array}\right)$ & & $\begin{array}{l}(494) \\
428 \\
310 \\
806 \\
458)\end{array}$ & & $\begin{array}{l}(608) \\
755 \\
457 \\
558 \\
677)\end{array}$ & $\begin{array}{l}46 \\
46 \\
44 \\
44\end{array}$ & $\begin{array}{l}8544 \\
(733)\end{array}$ & $\begin{array}{r}750 \\
7 \\
3,970\end{array}$ & $\begin{array}{r}(1,073) \\
1,390) \\
(762) \\
(4) \\
(871)\end{array}$ & & $\left.\begin{array}{l}(1,487) \\
1,036 \\
1,162 \\
1,135) \\
1,030\end{array}\right)$ & & $\begin{array}{r}(1,111) \\
1,519 \\
866 \\
(974) \\
(1,138)\end{array}$ & & $\begin{array}{r}(1,509) \\
1,090 \\
(751) \\
(986) \\
(1,145)\end{array}$ & $\begin{array}{r}\ddagger \\
39,350 \\
45,830 \\
41,670 \\
\ddagger\end{array}$ & , 1,4527 & & $\begin{array}{r}(1,819) \\
(638) \\
(922) \\
(1,824) \\
(769)\end{array}$ & & $\begin{array}{l}.543) \\
\text {,461) } \\
\text { (975) } \\
\text {,344) } \\
394)\end{array}$ & & $\begin{array}{l}64) \\
554 \\
855 \\
102\end{array}$ \\
\hline & & $\left.\begin{array}{l}406 \\
254 \\
488 \\
552\end{array}\right)$ & & $\begin{array}{r}(1,055) \\
(370) \\
651 \\
674 \\
(326)\end{array}$ & & $\begin{array}{r}(1,307) \\
(714) \\
906 \\
731 \\
(479)\end{array}$ & & $\begin{array}{r}(1,422) \\
(894) \\
(1,116) \\
(730) \\
(617)\end{array}$ & & $\begin{array}{r}(1,240) \\
(960) \\
(1,790) \\
(1,041) \\
(537)\end{array}$ & & $\begin{array}{r}(2,878) \\
1,225) \\
1,494) \\
(900) \\
(798)\end{array}$ & & $\left(\begin{array}{l}1,880) \\
(1,404\end{array}\right)$ & & 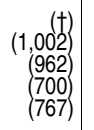 & $\begin{array}{r}\ddagger \\
49,650 \\
54,060 \\
43,830 \\
35,860\end{array}$ & $\begin{array}{r}(\dagger) \\
(1,399)\end{array}$ & & 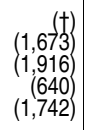 & & $\begin{array}{r}(\dagger) \\
(1,821 \\
(962) \\
(847) \\
(841)\end{array}$ & & $\left.\begin{array}{r}(+) \\
(1,603 \\
1\end{array}\right)$ \\
\hline & 10 & $\begin{array}{l}(625) \\
423 \\
538 \\
353 \\
(505)\end{array}$ & & $\left.\begin{array}{l}747 \\
728 \\
536 \\
429 \\
689\end{array}\right)$ & & $\begin{array}{r}(761) \\
885 \\
(784) \\
(1,03) \\
(977)\end{array}$ & & $\begin{array}{r}(1,020) \\
(908) \\
913 \\
(906) \\
(1,002)\end{array}$ & & $\begin{array}{r}(978) \\
(1,161 \\
1,008)\end{array}$ & & $\begin{array}{l}(1,385) \\
1,589) \\
1,330 \\
(757) \\
(1,528)\end{array}$ & & $\begin{array}{l}2,175) \\
1,290 \\
1,677 \\
1,560 \\
1,134)\end{array}$ & & $\begin{array}{r}(989) \\
(1,393 \\
1,310 \\
1,713 \\
1,169)\end{array}$ & $\begin{array}{r}9,240 \\
\neq \\
9,320 \\
6,770 \\
\ddagger\end{array}$ & $\begin{array}{r}(817) \\
(\dagger)\end{array}$ & & $\begin{array}{r}(1,422) \\
1,213) \\
1,798) \\
(891) \\
(1,329)\end{array}$ & & $\begin{array}{l}1,067) \\
1,652 \\
, 290 \\
1,067 \\
1,303)\end{array}$ & & $\begin{array}{r}(2,342) \\
1,685 \\
2,253 \\
1,751 \\
(987)\end{array}$ \\
\hline ........... & 950 & $\left.\begin{array}{l}(883) \\
281 \\
840 \\
306 \\
730\end{array}\right)$ & & $\left.\begin{array}{l}709 \\
539 \\
923 \\
542\end{array}\right)$ & D & $\left.\begin{array}{r}(1,571) \\
(810) \\
746 \\
641 \\
(789)\end{array}\right)$ & $\begin{array}{l}6 \\
4 \\
6\end{array}$ & $\begin{array}{r}(1,901) \\
(833) \\
(1,698) \\
1,321 \\
(885)\end{array}$ & $\begin{array}{l}70 \\
20 \\
20\end{array}$ & $\begin{array}{l}(2,691) \\
(254) \\
(2,054)\end{array}$ & & $\begin{array}{l}(2,656) \\
(553) \\
(2,458)\end{array}$ & & $(2,065)$ & & & $\begin{array}{r}56,040 \\
37,280 \\
55,820 \\
33,070 \\
\ddagger\end{array}$ & $\begin{array}{r}(1,008) \\
(2,051) \\
2,523 \\
(985)\end{array}$ & & $\begin{array}{l}983 \\
343 \\
897\end{array}$ & & $\left.\begin{array}{l}(1,5966 \\
(2,096 \\
1,693\end{array}\right)$ & & \\
\hline 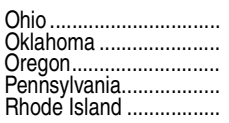 & 41,630 & $\left.\begin{array}{l}(550) \\
186 \\
471 \\
816 \\
303\end{array}\right)$ & $\begin{array}{l}42,180 \\
50,790 \\
48,610\end{array}$ & $\begin{array}{r}(585) \\
261) \\
(588) \\
(1,027) \\
(204)\end{array}$ & $\begin{array}{l}0 \\
0 \\
0\end{array}$ & $\left.\begin{array}{l}689 \\
319 \\
647 \\
925 \\
909\end{array}\right)$ & $\begin{array}{l}55,6 \\
40,2 \\
48, \\
62, \\
65,1\end{array}$ & $\begin{array}{r}(982) \\
(486 \\
(914) \\
(1,667) \\
(1,137)\end{array}$ & $\begin{array}{l}.420 \\
, 550 \\
, 530 \\
, \quad 120 \\
, \quad 120 \\
t\end{array}$ & $\left.\begin{array}{r}(1,058) \\
718 \\
(721) \\
(1,628) \\
(+)\end{array}\right)$ & $\begin{array}{l}58,4 \\
39,3 \\
53,3 \\
64,3 \\
67,9\end{array}$ & $\begin{array}{r}(1,779) \\
(769) \\
(1,396) \\
2,553) \\
(1,212)\end{array}$ & $\begin{array}{l}6 \\
4 \\
5 \\
7\end{array}$ & $(1,473)$ & $\begin{array}{r}7,430 \\
, \quad, 90 \\
i, 620 \\
\ddagger\end{array}$ & $\begin{array}{r}(1,025) \\
7727 \\
936 \\
(1,408 \\
(\dagger)\end{array}$ & $\begin{array}{r}42,660 \\
\ddagger \\
41,170 \\
45,940 \\
\ddagger\end{array}$ & $\begin{array}{r}(1,403) \\
(\dagger) \\
(840 \\
(1,778)\end{array}$ & $\begin{array}{r}9,940 \\
\ddagger \\
9,890 \\
790\end{array}$ & $\left.\begin{array}{l}(1,492) \\
(1,301 \\
(1,157)\end{array}\right)$ & $\begin{array}{r}1,280 \\
9,220 \\
7,300 \\
7,650 \\
\ddagger\end{array}$ & $\left.\begin{array}{r}(1,215) \\
(639) \\
(1,863) \\
1,850 \\
(\dagger)\end{array}\right)$ & & $\left(\begin{array}{l}1,204) \\
1,1615 \\
2,112\end{array}\right)$ \\
\hline$\ldots \ldots$. & (1) & $\left.\begin{array}{l}(208) \\
449 \\
350 \\
355 \\
277\end{array}\right)$ & 38,39 & $\left.\begin{array}{l}(528) \\
443 \\
414 \\
48\end{array}\right)$ & $\begin{array}{l}0 \\
0 \\
0\end{array}$ & $\left.\begin{array}{l}625) \\
801 \\
543 \\
723\end{array}\right)$ & $\begin{array}{l}0 \\
0 \\
0 \\
0\end{array}$ & $\left.\begin{array}{r}(529) \\
764 \\
6994 \\
(61129\end{array}\right)$ & & $\begin{array}{r}(1,209) \\
(1,125) \\
(999) \\
(2,023 \\
(748)\end{array}$ & $\begin{array}{l}0 \\
0 \\
0 \\
0 \\
0 \\
0\end{array}$ & $\begin{array}{r}(812) \\
(1,199) \\
1,1,97) \\
1,242) \\
(866)\end{array}$ & & $\begin{array}{r}(892) \\
(1,224) \\
(964)\end{array}$ & $\begin{array}{l}70 \\
30 \\
50 \\
90 \\
50\end{array}$ & $\begin{array}{r}(966) \\
(910) \\
984 \\
(593) \\
(1,772)\end{array}$ & $\begin{array}{r}38,250 \\
\neq \\
38,260 \\
44,300 \\
36,970\end{array}$ & $\begin{array}{r}(1,216) \\
(\dagger) \\
(947) \\
(1,499) \\
(1,495)\end{array}$ & $\begin{array}{r}41,190 \\
\ddagger \\
40,540\end{array}$ & 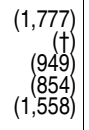 & & $\begin{array}{r}(851) \\
(1,285) \\
(2,096)\end{array}$ & & 79) \\
\hline 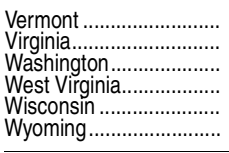 & $\begin{array}{l}38,270 \\
32,130 \\
40,920 \\
32,490\end{array}$ & $\begin{array}{l}594 \\
579 \\
398 \\
195 \\
486 \\
(371)\end{array}$ & $\begin{array}{l}37,260 \\
40,230 \\
43,160 \\
36,590 \\
46,420 \\
36,120 \\
\end{array}$ & $\begin{array}{l}(668) \\
668 \\
364 \\
226 \\
512 \\
(497) \\
\end{array}$ & $\begin{array}{l}43,860 \\
47,970 \\
40,440 \\
47,750 \\
41,610\end{array}$ & $\begin{array}{r}(926) \\
948 \\
500 \\
716 \\
713 \\
(1,014)\end{array}$ & $\begin{array}{l}51,320 \\
50,910 \\
51,800 \\
43,090 \\
52,210 \\
52,990\end{array}$ & $\begin{array}{r}(987) \\
(1,572) \\
(649) \\
477 \\
873 \\
(932)\end{array}$ & $\begin{array}{l}44,100 \\
43,090 \\
47,380 \\
37,120 \\
46,650 \\
49,530\end{array}$ & $\begin{array}{l}(1,742) \\
1,865 \\
1,210 \\
(580) \\
(1,245 \\
1,444)\end{array}$ & $\begin{array}{l}51,310 \\
52,520 \\
55,970 \\
41,910 \\
53,120 \\
52,550\end{array}$ & $\begin{array}{r}(1,494) \\
2,135) \\
(831) \\
(762) \\
(1,604) \\
(1,243) \\
\end{array}$ & $\begin{array}{l}58,670 \\
47,700 \\
58,010 \\
57,580\end{array}$ & $\begin{array}{r}(1,387) \\
2,889 \\
(882) \\
(513) \\
(1,380) \\
(1,495)\end{array}$ & $\begin{array}{l}56,190 \\
51,130 \\
57,670 \\
45,460 \\
55,430 \\
59,390\end{array}$ & $\begin{array}{r}(1,158) \\
1,408 \\
1,077 \\
(805) \\
791 \\
(817)\end{array}$ & $\begin{array}{r}44,410 \\
45,110 \\
44,030 \\
36,640 \\
\ddagger \\
\ddagger\end{array}$ & $\begin{array}{r}(1,916) \\
2,671) \\
1,130 \\
(1,543 \\
(+)\end{array}$ & $\begin{array}{l}80 \\
80 \\
50 \\
30\end{array}$ & $\left.\begin{array}{r}1,587 \\
1,317 \\
3,153 \\
1,333 \\
1,235 \\
(\dagger)\end{array}\right)$ & & $\begin{array}{r}(1,603 \\
11,406 \\
1,133 \\
(924) \\
(1,074)\end{array}$ & & $\begin{array}{r}(1,418) \\
3,502 \\
(785) \\
(1,012) \\
1,797) \\
1,803)\end{array}$ \\
\hline
\end{tabular}

\section{†Not applicable.}

fReporting standards not met. Data may be suppressed because the response rate is under 50 percent, there are too few cases for a reliable estimate, or the coefficient of variation (CV) is 50 percent or greater.

NOTE: This table includes regular full-time teachers only; it excludes other staff even when they have full-time teaching duties (regular part-time teachers, itine
sional staff, and support staff).
SOURCE: U.S. Department of Education, National Center for Education Statistics, Schools and Staffing Survey (SASS) "Public School Teacher Data File," 1993-94, 1999-2000, 2003-04, 2007-08, and 2011-12; and "Public Charter School Teacher Data File," 1999-2000. (This table was prepared June 2013.) 
Table 211.50. Estimated average annual salary of teachers in public elementary and secondary schools: Selected years, 1959-60 through 2012-13

\begin{tabular}{|c|c|c|c|c|c|c|c|c|}
\hline \multirow[b]{3}{*}{ School year } & \multicolumn{5}{|c|}{ Current dollars } & \multicolumn{3}{|c|}{$\begin{array}{l}\text { Average public school teachers' salary in } \\
\text { constant } 2012-13 \text { dollars }\end{array}$} \\
\hline & \multicolumn{3}{|c|}{ Average public school teachers' salary } & \multirow{2}{*}{\begin{tabular}{|} 
Wage and salary \\
accruals per full- \\
time-equivalent \\
(FTE) employee 1
\end{tabular}} & \multirow{2}{*}{$\begin{array}{r}\text { Ratio of average } \\
\text { teachers' salary } \\
\text { to accruals per } \\
\text { FTE employee }\end{array}$} & \multirow[b]{2}{*}{ All teachers } & \multirow[b]{2}{*}{$\begin{array}{r}\text { Elementary } \\
\text { teachers }\end{array}$} & \multirow[b]{2}{*}{$\begin{array}{r}\text { Secondary } \\
\text { teachers }\end{array}$} \\
\hline & All teachers & $\begin{array}{r}\text { Elementary } \\
\text { teachers }\end{array}$ & $\begin{array}{r}\text { Secondary } \\
\text { teachers }\end{array}$ & & & & & \\
\hline 1 & 2 & 3 & 4 & 5 & 6 & 7 & 8 & 9 \\
\hline 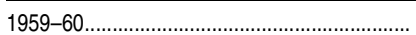 & $\$ 4,995$ & $\$ 4,815$ & $\$ 5,276$ & $\$ 4,749$ & 1.05 & $\$ 39,329$ & $\$ 37,912$ & $\$ 41,542$ \\
\hline $1961-62 \ldots \ldots \ldots$ & 5,515 & 5,340 & 5,775 & 5,063 & 1.09 & 42,448 & 41,101 & 44,449 \\
\hline $1963-64$ & 5,995 & 5,805 & 6,266 & 5,478 & 1.09 & 44,970 & 43,545 & 47,003 \\
\hline 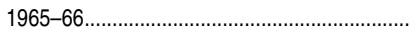 & 6,485 & 6,279 & 6,761 & 5,934 & 1.09 & 47,020 & 45,527 & 49,021 \\
\hline $1967-68$ & 7,423 & 7,208 & 7,692 & 6,533 & 1.14 & 50,498 & 49,035 & 52,328 \\
\hline $1969-70 \ldots \ldots . .$. & 8,626 & 8,412 & 8,891 & 7,486 & 1.15 & 52,830 & 51,519 & 54,453 \\
\hline 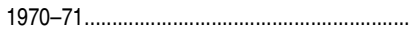 & 9,268 & 9,021 & 9,568 & 7,998 & 1.16 & 53,975 & 52,537 & 55,723 \\
\hline 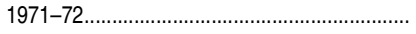 & 9,705 & 9,424 & 10,031 & 8,521 & 1.14 & 54,563 & 52,983 & 56,396 \\
\hline $1972-73 \ldots \ldots$ & 10,174 & 9,893 & 10,507 & 9,056 & 1.12 & 54,985 & 53,466 & 56,784 \\
\hline $1973-74 \ldots \ldots \ldots . .$. & 10,770 & 10,507 & 11,077 & 9,667 & 1.11 & 53,441 & 52,136 & 54,964 \\
\hline $1974-75 \ldots . .$. & 11,641 & 11,334 & 12,000 & 10,411 & 1.12 & 52,000 & 50,628 & 53,603 \\
\hline $1975-76 \ldots \ldots \ldots \ldots \ldots \ldots$ & 12,600 & 12,280 & 12,937 & 11,194 & 1.13 & 52,563 & 51,228 & 53,969 \\
\hline 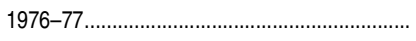 & 13,354 & 12,989 & 13,776 & 11,971 & 1.12 & 52,639 & 51,200 & 54,302 \\
\hline 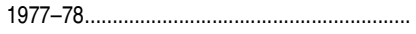 & 14,198 & 13,845 & 14,602 & 12,811 & 1.11 & 52,444 & 51,140 & 53,937 \\
\hline $1978-79 \ldots \ldots \ldots . .$. & 15,032 & 14,681 & 15,450 & 13,807 & 1.09 & 50,769 & 49,584 & 52,181 \\
\hline $1979-80 \ldots \ldots \ldots \ldots . . .$. & 15,970 & 15,569 & 16,459 & 15,050 & 1.06 & 47,592 & 46,397 & 49,049 \\
\hline $1980-81 \ldots \ldots \ldots . .$. & 17,644 & 17,230 & 18,142 & 16,461 & 1.07 & 47,122 & 46,017 & 48,452 \\
\hline $1981-82 \ldots \ldots \ldots . . .$. & 19,274 & 18,853 & 19,805 & 17,795 & 1.08 & 47,383 & 46,348 & 48,688 \\
\hline $1982-83 \ldots \ldots \ldots . .$. & 20,695 & 20,227 & 21,291 & 18,873 & 1.10 & 48,781 & 47,678 & 50,186 \\
\hline $1983-84 \ldots \ldots \ldots \ldots . . . .$. & 21,935 & 21,487 & 22,554 & 19,781 & 1.11 & 49,858 & 48,840 & 51,265 \\
\hline $1984-85 \ldots \ldots \ldots \ldots \ldots . . . .$. & 23,600 & 23,200 & 24,187 & 20,694 & 1.14 & 51,622 & 50,747 & 52,906 \\
\hline $1985-86 \ldots \ldots \ldots \ldots \ldots . . .$. & 25,199 & 24,718 & 25,846 & 21,685 & 1.16 & 53,575 & 52,552 & 54,950 \\
\hline $1986-87 \ldots \ldots \ldots . .$. & 26,569 & 26,057 & 27,244 & 22,700 & 1.17 & 55,261 & 54,196 & 56,665 \\
\hline $1987-88 \ldots \ldots \ldots \ldots \ldots . . . . .$. & 28,034 & 27,519 & 28,798 & 23,777 & 1.18 & 55,988 & 54,959 & 57,514 \\
\hline $1988-89 \ldots \ldots \ldots \ldots \ldots \ldots$ & 29,564 & 29,022 & 30,218 & 24,752 & 1.19 & 56,437 & 55,402 & 57,685 \\
\hline $1989-90 \ldots .$. & 31,367 & 30,832 & 32,049 & 25,762 & 1.22 & 57,152 & 56,177 & 58,394 \\
\hline $1990-91 \ldots \ldots \ldots \ldots \ldots . . . . . .$. & 33,084 & 32,490 & 33,896 & 26,935 & 1.23 & 57,155 & 56,129 & 58,558 \\
\hline $1991-92 \ldots \ldots \ldots \ldots \ldots$ & 34,063 & 33,479 & 34,827 & 28,169 & 1.21 & 57,020 & 56,042 & 58,298 \\
\hline $1992-93 \ldots \ldots \ldots \ldots \ldots . . . .$. & 35,029 & 34,350 & 35,880 & 29,245 & 1.20 & 56,860 & 55,758 & 58,242 \\
\hline $1993-94 \ldots \ldots$. & 35,737 & 35,233 & 36,566 & 30,030 & 1.19 & 56,545 & 55,748 & 57,857 \\
\hline $1994-95 \ldots \ldots . .$. & 36,675 & 36,088 & 37,523 & 30,857 & 1.19 & 56,412 & 55,509 & 57,717 \\
\hline $1995-96 \ldots \ldots \ldots \ldots . . .$. & 37,642 & 37,138 & 38,397 & 31,822 & 1.18 & 56,366 & 55,611 & 57,497 \\
\hline 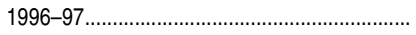 & 38,443 & 38,039 & 39,184 & 33,058 & 1.16 & 55,969 & 55,381 & 57,048 \\
\hline $1997-98 \ldots \ldots \ldots \ldots \ldots . . . .$. & 39,350 & 39,002 & 39,944 & 34,635 & 1.14 & 56,285 & 55,788 & 57,135 \\
\hline $1998-99 \ldots \ldots \ldots \ldots \ldots . . . . .$. & 40,544 & 40,165 & 41,203 & 36,306 & 1.12 & 57,006 & 56,474 & 57,933 \\
\hline $1999-2000 \ldots \ldots \ldots . .$. & 41,807 & 41,306 & 42,546 & 38,176 & 1.10 & 57,133 & 56,448 & 58,143 \\
\hline 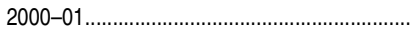 & 43,378 & 42,910 & 44,053 & 39,722 & 1.09 & 57,316 & 56,698 & 58,208 \\
\hline $2001-02$ & 44,655 & 44,177 & 45,310 & 40,579 & 1.10 & 57,977 & 57,356 & 58,827 \\
\hline $2002-03$ & 45,686 & 45,408 & 46,106 & 41,704 & 1.10 & 58,040 & 57,687 & 58,574 \\
\hline $2003-04 \ldots \ldots$ & 46,542 & 46,187 & 46,976 & 43,301 & 1.07 & 57,862 & 57,420 & 58,401 \\
\hline $2004-05 \ldots \ldots . .$. & 47,516 & 47,122 & 47,688 & 44,941 & 1.06 & 57,347 & 56,871 & 57,554 \\
\hline $2005-06 \ldots \ldots \ldots \ldots$ & 49,086 & 48,573 & 49,496 & 46,755 & 1.05 & 57,068 & 56,472 & 57,545 \\
\hline 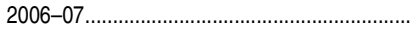 & 51,052 & 50,740 & 51,529 & 48,867 & 1.04 & 57,858 & 57,504 & 58,399 \\
\hline 2007-08 & 52,800 & 52,385 & 53,262 & 50,670 & 1.04 & 57,701 & 57,247 & 58,206 \\
\hline $2008-09$ & 54,319 & 53,998 & 54,552 & 51,608 & 1.05 & 58,544 & 58,198 & 58,795 \\
\hline $2009-10$ & 55,202 & 54,918 & 55,595 & 52,533 & 1.05 & 58,925 & 58,622 & 59,344 \\
\hline $2010-11 \ldots \ldots \ldots . .$. & 55,623 & 55,217 & 56,225 & 53,974 & 1.03 & 58,206 & 57,781 & 58,836 \\
\hline $2011-12$ & 55,418 & 54,704 & 56,226 & - & - & 56,340 & 55,614 & 57,162 \\
\hline $2012-13$ & 56,383 & 55,747 & 57,243 & - & - & 56,383 & 55,747 & 57,243 \\
\hline
\end{tabular}

-Not available.

${ }^{1}$ The average monetary remuneration earned by FTE employees across all industries in a given year, including wages, salaries, commissions, tips, bonuses, voluntary employee contributions to certain deferred compensation plans, and receipts in kind that represent income. Calendar-year data from the U.S. Department of Commerce, Bureau of Economic Analysis, have been converted to a school-year basis by averaging the two appropriate calendar years in each case.

${ }^{2}$ Constant dollars based on the Consumer Price Index, prepared by the Bureau of Labor Statistics,
U.S. Department of Labor, adjusted to a school-year basis. NOTE: Some data have been revised from previously published figures. Standard errors are not available for these estimates, which are based on state reports.

SOURCE: National Education Association, Estimates of School Statistics, 1959-60 through 2012-13; and unpublished tabulations. U.S. Department of Commerce, Bureau of Economic Analysis, National Income and Product Accounts, tables 6.6B-D, retrieved November 2, 2011, from http://www.bea.gov/national/nipaweb/SelectTable.asp. (This table was prepared April 2013.) 
Table 211.60. Estimated average annual salary of teachers in public elementary and secondary schools, by state: Selected years, 1969-70 through 2012-13

\begin{tabular}{|c|c|c|c|c|c|c|c|c|c|c|c|c|c|c|c|}
\hline \multirow[b]{2}{*}{ State } & \multicolumn{7}{|c|}{ Current dollars } & \multicolumn{8}{|c|}{ Constant 2012-13 dollars ${ }^{1}$} \\
\hline & $1969-70$ & $1979-80$ & $1989-90$ & 1999-2000 & 2009-10 & 2011-12 & 2012-13 & $1969-70$ & $1979-80$ & $1989-90$ & 1999-2000 & $2009-10$ & 2011-12 & 2012-13 & $\begin{array}{r}\text { Percent } \\
\text { change, } \\
1999-2000 \\
\text { to } 2012-13\end{array}$ \\
\hline 1 & 2 & 3 & 4 & 5 & 6 & 7 & 8 & 9 & 10 & 11 & 12 & 13 & 14 & 15 & 16 \\
\hline United States... & $\$ 8,626$ & $\$ 15,970$ & $\$ 31,367$ & $\$ 41,807$ & $\$ 55,202$ & $\$ 55,418$ & $\$ 56,383$ & $\$ 52,830$ & $\$ 47,592$ & $\$ 57,152$ & $\$ 57,133$ & $\$ 58,925$ & $\$ 56,340$ & $\$ 56,383$ & -1.3 \\
\hline Alabama. & 6,818 & 13,060 & 24,828 & 36,689 & 47,571 & 48,003 & 47,949 & 41,757 & 38,920 & 45,237 & 50,139 & 50,779 & 48,802 & 47,949 & -4.4 \\
\hline Alaska..... & 10,560 & 27,210 & 43,153 & 46,462 & 59,672 & 62,425 & 65,468 & 64,675 & 81,088 & 78,626 & 63,495 & 63,696 & 3,464 & 65,468 & 3.1 \\
\hline rizona .... & 8,711 & 15,054 & 29,402 & 36,902 & 46,952 & 48,691 & 49,885 & 53,350 & 44,862 & 53,571 & 50,430 & 50,119 & 9,501 & 49,885 & -1.1 \\
\hline rkansas..... & 6,307 & 12,299 & 22,352 & 33,386 & 46,700 & 46,314 & 46,632 & 38,627 & 36,652 & 40,726 & 45,625 & 49,850 & 47,085 & 46,632 & 2.2 \\
\hline California ... & 10,315 & 18,020 & 37,998 & 47,680 & 68,203 & 68,531 & 69,324 & 63,174 & 53,701 & 69,234 & 65,159 & 72,803 & 69,672 & 69,324 & 6.4 \\
\hline olorado. & 7,761 & 16,205 & 30,758 & 38,163 & 49,202 & 49,049 & 49,844 & 47,532 & 48,292 & 56,042 & 52,153 & 52,520 & 49,865 & 49,844 & -4.4 \\
\hline onnecticut... & 9,262 & 16,229 & 40,461 & 51,780 & 64,350 & 69,465 & 69,766 & 56,725 & 48,363 & 73,721 & 70,762 & 68,690 & 0,621 & 9,766 & -1.4 \\
\hline Delaware... & 9,015 & 16,148 & 33,377 & 44,435 & 57,080 & 58,800 & 59,679 & 55,212 & 48,122 & 60,814 & 60,724 & 60,930 & 9,779 & 59,679 & -1.7 \\
\hline District of Columbia .. & 10,285 & 22,190 & 38,402 & 47,076 & 64,548 & 68,720 & 70,906 & 62,990 & 66,128 & 69,970 & 64,334 & 68,901 & 9,864 & 70,906 & 10.2 \\
\hline Florida... & 8,412 & 14,149 & 28,803 & 36,722 & 46,708 & 46,479 & 46,944 & 51,519 & 42,165 & 52,480 & 50,184 & 49,858 & 47,253 & 46,944 & -6.5 \\
\hline eorgia & 7,276 & 13,853 & 28,006 & 41,023 & 53,112 & 52,938 & 52,880 & 44,562 & 41,283 & 51,028 & 56,062 & 56,694 & 3,819 & 52,880 & -5.7 \\
\hline awaii. & 9,453 & 19,920 & 32,047 & 40,578 & 55,063 & 54,070 & 54,300 & 57,895 & 59,363 & 58,391 & 55,453 & 58,777 & 4,970 & 54,300 & -2.1 \\
\hline aho... & 6,890 & 13,611 & 23,861 & 35,547 & 46,283 & 48,551 & 49,734 & 42,198 & 40,562 & 43,475 & 48,578 & 49,404 & 9,359 & 9,734 & 2.4 \\
\hline inois & 9,569 & 17,601 & 32,794 & 46,486 & 62,077 & 57,636 & 59,113 & 8,605 & 52,452 & ,752 & 3,527 & 64 & 3,595 & 9,113 & -6.9 \\
\hline Indiana.. & 8,833 & 15,599 & 30,902 & 41,850 & 49,986 & 50,516 & 51,456 & 54,098 & 46,486 & 56,304 & 57,192 & 53,357 & 1,357 & 51,456 & -10.0 \\
\hline wa & 8,355 & 15,203 & 26,747 & 35,678 & 49,626 & 50,240 & 1,528 & , 170 & 45,306 & 8,734 & 8,757 & 73 & 1,076 & 1,528 & 5.7 \\
\hline Kansas....... & 7,612 & 13,690 & 28,744 & 34,981 & 46,657 & 46,718 & 47,464 & 46,620 & 40,797 & 52,372 & 47,805 & 49,804 & 7,496 & 7,464 & -0.7 \\
\hline entucky ............ & 6,953 & 14,520 & 26,292 & 36,380 & 49,543 & 49,730 & 50,326 & 42,584 & 43,271 & 47,905 & 49,717 & 52,884 & 0,558 & 0,326 & 1.2 \\
\hline ouisiana. & 7,028 & 13,760 & 24,300 & 33,109 & 48,903 & 50,179 & 51,381 & 43,043 & 41,006 & 44,275 & 45,246 & 52,201 & 1,014 & 51,381 & 13.6 \\
\hline Main & 7,572 & 13,071 & 26,881 & 35,561 & 46,106 & 47,338 & 48,119 & 46,375 & 38,952 & 48,978 & 48,597 & 49,216 & 8,126 & 8,119 & -1.0 \\
\hline aryland & 9,383 & 17,558 & 36,319 & 44,048 & 63,971 & 63,634 & 65,265 & 7,466 & 52,324 &, 174 & 0,196 &, 285 & 693 &, 265 & 8.4 \\
\hline Massachusetts. & 8,764 & 17,253 & 34,712 & 46,580 & 69,273 & 71,721 & 73,129 & 3,675 & 1,415 &, 246 & 3,656 & 45 & 915 & 3,129 & 14.9 \\
\hline Michigan ......... & 9,826 & 19,663 & 37,072 & 9,044 & 57,958 & 1,560 &, 560 & 0,179 & 3,597 &, 546 & 7,023 & 67 & 585 &, 560 & -8.2 \\
\hline Minn & 8,658 & 15,912 & 32,190 & 02 & 31 & ,959 & 268 & 026 & 7,419 & 651 & 393 & 67 & 374 & ,268 & 3.4 \\
\hline Mississippi .. & 5,798 & 11,850 & 24,292 & 31,857 & 45,644 & 41,646 & 41,994 & 35,510 & 35,314 & 44,261 & 43,535 & 48,722 & 42,339 & 41,994 & -3.5 \\
\hline & ,799 & 13,682 & 27,094 & 656 & ,317 & 46,406 &, 517 &, 765 &, 773 & 66 & 27 & & 78 & 517 & -2.5 \\
\hline Montana..... & 7,606 & 14,537 & 25,081 & 32,121 & 45,759 & 48,546 & 49,999 & 6,583 & 43,321 & 5,698 & 3,896 & 48,845 & 9,354 & 19,999 & 13.9 \\
\hline ebr & 7,375 & 13,516 & 25,522 & 3,237 & 46,227 & 48,154 & 48,931 & 45,168 & 40,279 & 46,502 & 5,421 & 49,345 & 355 & 8,931 & 7.7 \\
\hline Nevada .......... & 9,215 & 16,295 & 30,590 & 39,390 & 51,524 & 54,559 & 55,957 & 56,437 & 48,560 & 55,736 & 53,830 & 54,999 & 5,467 & 5,957 & 4.0 \\
\hline New Hampshire.. & 7,771 & 13,017 & 28,986 & 37,734 & 51,443 & 54,177 & 55,599 & 47,593 & 38,791 & 52,813 & 51,567 & 54,912 & 55,079 & 55,599 & 7.8 \\
\hline & 9,130 & 17,161 & 35,676 & 15 & 65,130 & 67,078 & ,797 & 5,917 & 51,141 &, 003 & 1,083 & 23 & 94 & 8,797 & -3.2 \\
\hline & 7,796 & 14,887 & 24,756 &, 554 & 46,258 & 45,622 &, 573 & 7,746 & 44,364 & 106 & ,488 & 78 & 381 &, 573 & 4.7 \\
\hline Now & 10,336 & 19,812 & 38,925 & 1,020 & 71,633 & 73,398 & 5,279 & 3,303 & 59,041 & ,923 & 9,723 & 76,464 & 620 & 5,279 & 8.0 \\
\hline North & 7,494 & 14,117 & 27,883 & 39,404 & 46,850 & 45,947 & 45,947 & 45,897 & 42,070 & 50,804 & 3,849 & 50,010 & 6,712 & 5,947 & -14.7 \\
\hline North Dakota .... & 6,696 & 13,263 & 23,016 & 29,863 & 42,964 & 46,058 & 47,344 & 41,010 & 39,525 & 41,936 & 40,810 & 45,862 & 46,825 & 47,344 & 16.0 \\
\hline & 8,300 & 15,269 & 31,218 & 1,436 & 55,958 & 56,715 & 58,092 & 0,833 & 45,503 & 6,880 & 6,626 & 59,732 & 7,659 & 8,092 & 2.6 \\
\hline Oklahc & 6,882 & 13,107 & 23,070 & 31,298 & 47,691 & 44,391 & 44,128 & 42,149 & 39,060 & 42,034 & 42,772 & 50,907 & 5,130 & 4,128 & 3.2 \\
\hline Drego & 8,818 & 16,266 & 30,840 & 42,336 & 55,224 & 57,348 & 58,758 & 54,006 & 48,474 & 56,191 & 57,856 & 58,948 & 8,302 & 8,758 & 1.6 \\
\hline Penns & 8,858 & 16,515 & 33,338 & 48,321 & 59,156 & 61,934 & 63,521 & 54,251 & 49,216 & 60,743 & 66,035 & 63,146 & 2,965 & 3,521 & -3.8 \\
\hline Rhode Island ....... & 8,776 & 18,002 & 36,057 & 47,041 & 59,686 & 62,186 & 63,474 & 53,748 & 53,647 & 65,697 & 64,286 & 63,711 & 63,221 & 33,474 & -1.3 \\
\hline & 27 & 13,063 & 27,217 & 081 & 508 & , 428 & 24 & 24 & 929 & & 308 & & & 924 & -2.8 \\
\hline & 403 & 12,348 & 21,300 & 9,071 & 38,837 & 38,804 & 9,580 & 9,215 & 36,798 & 8,809 & 39,728 & 41,456 & 9,450 & 9,580 & -0.4 \\
\hline Ten & ,050 & 13,972 & 27,052 & 36,328 & 46,290 & 47,082 & 48,289 & 43,178 & 41,637 & 49,290 & 49,645 & 49,412 & 7,866 & 8,289 & -2.7 \\
\hline Texa & 7,255 & 14,132 & 27,496 & 37,567 & 48,261 & 48,373 & 48,110 & 44,433 & 42,114 & 50,099 & 51,339 & 51,516 & 49,178 & 48,110 & -6.3 \\
\hline Utah.... & 7,644 & 14,909 & 23,686 & 34,946 & 45,885 & 48,159 & 49,393 & 46,816 & 44,430 & 43,157 & 47,757 & 48,980 & 48,961 & 49,393 & 3.4 \\
\hline ven & 7,968 & 12,484 & 29,012 & 37,758 & 49,084 & 51,306 & 52,526 & 48,800 & 37,203 & 2,861 & 1,600 & 52,394 & 2,160 & 2,526 & 1.8 \\
\hline Virginia.... & 8,070 & 14,060 & 30,938 & 38,744 & 50,015 & 48,703 & 49,869 & 49,425 & 41,900 & 56,370 & 52,947 & 53,388 & 49,514 & 19,869 & -5.8 \\
\hline Washin & 9,225 & 18,820 & 30,457 & 41,043 & 53,003 & 52,232 & 53,571 & 56,498 & 56,085 & 55,494 & 56,089 & 56,578 & 3,101 & 3,571 & -4.5 \\
\hline & 7,650 & 13,710 & 22,842 & 35,009 & 45,959 & 45,320 & 6,405 & 46,852 & 40,857 & 1,619 & 47,843 & 49,059 & 6,074 & 6,405 & -3.0 \\
\hline & 8,963 & 16,006 & 31,921 & 11,153 & 51,264 & 53,792 & 5,171 & 54,894 & 47,699 & 58,161 & 56,239 & 54,721 & 54,687 & 55,171 & -1.9 \\
\hline Wyoming..... & 8,232 & 16,012 & 28,141 & 34,127 & 55,861 & 57,222 & 57,920 & 50,417 & 47,717 & 51,274 & 46,638 & 59,628 & 58,174 & 57,920 & 24.2 \\
\hline
\end{tabular}

${ }^{1}$ Constant dollars based on the Consumer Price Index (CPI), prepared by the Bureau of Labor Statistics, U.S. Department of Labor, adjusted to a school-year basis. The CPI does not account for differences in inflation rates from state to state.

NOTE: Some data have been revised from previously published figures. Standard errors are not available for these estimates, which are based on state reports

SOURCE: National Education Association, Estimates of School Statistics, 1969-70 through 2012-13. (This table was prepared April 2013.) 
Table 212.10. Number, highest degree, average years of experience, and salaries of principals in public and private elementary and secondary schools, by selected characteristics: $1993-94$, 2003-04, and 2011-12

[Standard errors appear in parentheses]

\begin{tabular}{|c|c|c|c|c|c|c|c|c|c|c|c|c|c|c|}
\hline \multirow[b]{3}{*}{ Selected characteristic } & \multicolumn{3}{|c|}{ Number of principals ${ }^{1}$} & \multicolumn{4}{|c|}{ Percentage distribution by highest degree earned, 2011-12 } & \multicolumn{4}{|c|}{ Average years of experience } & \multicolumn{3}{|c|}{ Average annual salary in constant 2012-13 dollars ${ }^{2}$} \\
\hline & \multirow[b]{2}{*}{$1993-94$} & \multirow[b]{2}{*}{ 2003-04 } & \multirow[b]{2}{*}{ 2011-12 } & \multirow{2}{*}{$\begin{array}{r}\text { Bachelor's } \\
\text { or less }\end{array}$} & \multirow[b]{2}{*}{ Master's } & \multirow{2}{*}{$\begin{array}{l}\text { Education } \\
\text { specialist }^{3}\end{array}$} & \multirow{2}{*}{$\begin{array}{r}\text { Doctor's } \\
\text { and first- } \\
\text { professional } \\
\end{array}$} & \multicolumn{3}{|c|}{ As a principal } & \multirow{2}{*}{$\begin{array}{r}\text { Teaching } \\
\text { experience, } \\
2011-12\end{array}$} & \multirow[b]{2}{*}{$1993-94$} & \multirow[b]{2}{*}{ 2003-04 } & \multirow[b]{2}{*}{ 2011-12 } \\
\hline & & & & & & & & 1993-94 & $2003-04$ & $2011-12$ & & & & \\
\hline 1 & 2 & 3 & 4 & 5 & 6 & 7 & 8 & 9 & 10 & 11 & 12 & 13 & 14 & 15 \\
\hline
\end{tabular}

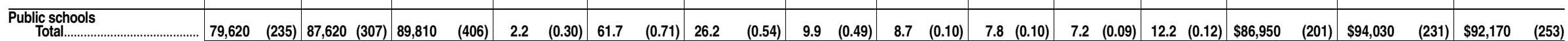

Sex Males.

Females.......
Race/ethnicity

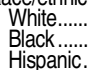

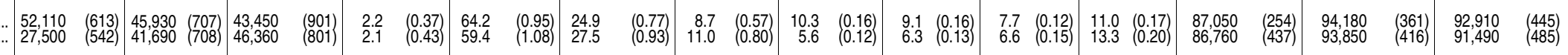

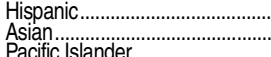

American Indiani Alaska Native
Two or more races....

응

Age Und

Under 40 ...

40 to 44 t...............................................

55 or over...............

School type

Elementary

Combined

School locale

City.........

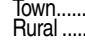

Private schools

Sex

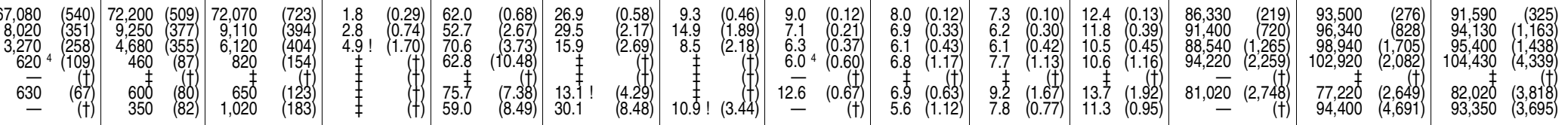

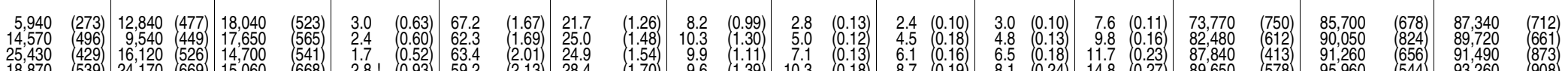

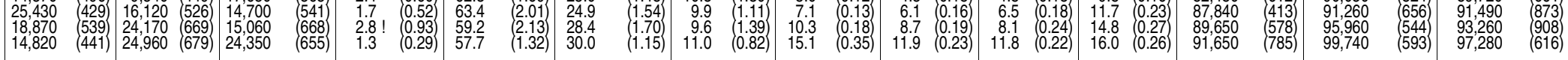
........ 153,68

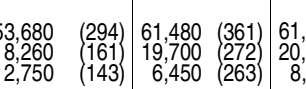
\begin{tabular}{ll|ll|ll|l}
$(443)$ & 1.7 & $(0.30)$ & 62.6 & $(0.93)$ & 26. \\
$(537)$ & 2.2 & $(0.44)$ & 59.6 & $(1.14)$ & 26. \\
$(658)$ & 5.5 & $(1.45)$ & 60.3 & $(2.26)$ & 25.4
\end{tabular}

\section{$11.0 \quad(0.82)$}

$\begin{array}{lll}8.9 & (0.1 \\ 8.0 & (0.1 & 0 \\ 7.5 & (0.29)\end{array}$

\begin{tabular}{l|ll}
7.9 & $(0.13$ \\
29 & 7.5 & 0.19 \\
7.4 & $(0.36$
\end{tabular}

\begin{tabular}{ll|ll|l}
.2 & $(0.13)$ & 12.4 & $(0.16)$ & 85,840 \\
.1 & 0.15 & 1.5 & $(0.14)$ & 89,710 \\
7.1 & $(0.29)$ & 12.2 & $(0.51)$ & 83,730
\end{tabular}

\begin{tabular}{l|rr|rr}
$(267)$ & 93,900 & $(280)$ & 91,220 & $(308)$ \\
$(265)$ & 98,840 & $(550)$ & 98,080 & $(622$ \\
80,520 & $(766)$ & 84,460 & $(1,366$
\end{tabular}

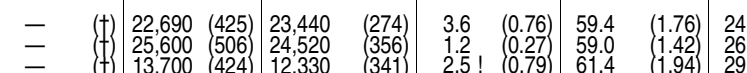
\begin{tabular}{r|rr|r}
$(1.42)$ & 12.3 & $(1.15)$ \\
11.15 & 12.9 & $(0.99$ \\
1.74 & 7.0 & $(0.81$ \\
0.91 & 6.6 & 0.66 & $=$ \\
\hline
\end{tabular}

Males.

Race/ethnicity

Black............

Age Under 40

45 to $49 \ldots \ldots \cdots \cdots \cdots \cdots \cdots \cdots \cdots \cdots \cdots \cdots \cdots \cdots \cdots \cdots$

55 or over..

School type

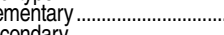

School locale

City...................

Suburban.....
Town...........
Rural ...........

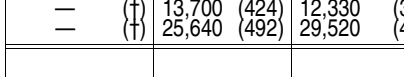

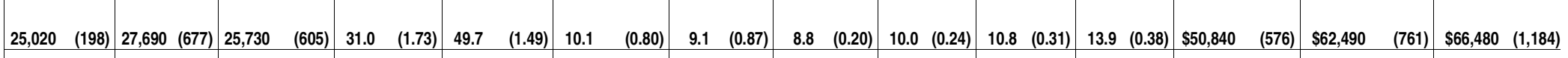

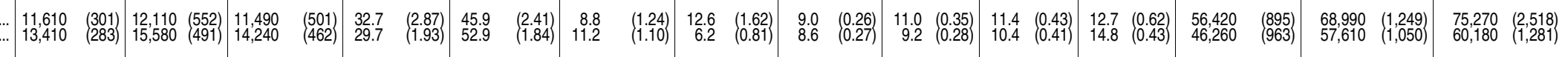

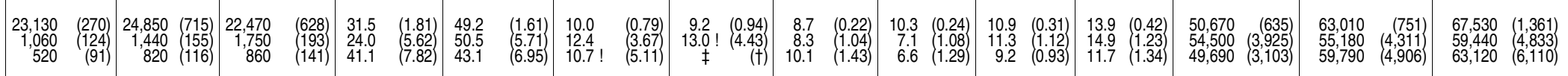

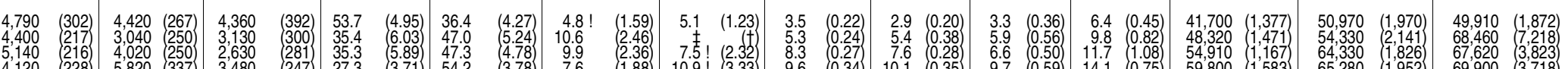

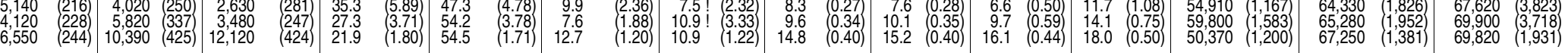

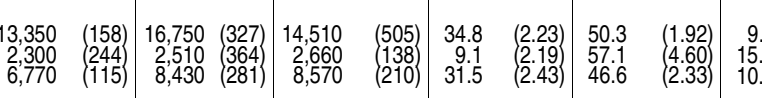

\section{-Not available.}

!Interpret data with caution. The coefficient of variation (CV) for this estimate is between 30 and 50 percent.

$\ddagger$ Reporting standards not met (too few cases for a reliable estimate).

'Counts of principals in this table differ from totals appearing in some other tables because this table reflects counts of full-and part-time principals, while other counts of principals are reported as fuli-time equivalents. ${ }^{2}$ Constant dollars based on the Consumer Price Index, prepared by the Bureau of Labor Statistics, U.S. Department of Labor,
${ }^{3}$ Education specialist degrees or certificates are generally awarded for 1 year's work beyond the master's level. Includes certifcate of advanced graduate studies.

NOTE: Race categories exclude persons of Hispanic ethnicity. Detail may not sum to totals because of rounding and survey item

nonreURCE: U.S. Department of Education, National Center for Education Statistics, Schools and Staffing Survey (SASS), "Public School Principal Data File" and "Private School Principal Data File," 1993-94, 2003-04, and 2011-12. (This table was prepare
June 2013.) 
152 CHAPTER 2: Elementary and Secondary Education School Staff

Table 213.10. Staff employed in public elementary and secondary school systems, by type of assignment: Selected years, 1949-50 through fall 2011 [In full-time equivalents]

\begin{tabular}{|c|c|c|c|c|c|c|c|c|c|c|c|}
\hline \multirow[b]{2}{*}{ School year } & \multirow[b]{2}{*}{ Total } & \multicolumn{3}{|c|}{ School district administrative staff } & \multicolumn{6}{|c|}{ Instructional staff } & \multirow[b]{2}{*}{ Support staff ${ }^{1}$} \\
\hline & & Total & $\begin{array}{r}\text { Officials and } \\
\text { administrators }\end{array}$ & $\begin{array}{r}\text { Instruction } \\
\text { coordinators }\end{array}$ & Total & $\begin{array}{r}\text { Principals and } \\
\text { assistant } \\
\text { principals }\end{array}$ & Teachers & $\begin{array}{r}\text { Instructional } \\
\text { aides }\end{array}$ & Librarians & $\begin{array}{r}\text { Guidance } \\
\text { counselors }\end{array}$ & \\
\hline 1 & 2 & 3 & 4 & 5 & 6 & 7 & 8 & 9 & 10 & 11 & 12 \\
\hline & \multicolumn{11}{|c|}{ Number } \\
\hline $\begin{array}{l}1949-50^{2} \\
1959-60^{2} \\
1969-70^{2} \\
\text { Fall } 1980^{2} \\
\text { Fall } 1990\end{array}$ & $\begin{array}{l}1,300,031 \\
2,089,283 \\
3,360,763 \\
4,168,286 \\
4,494,076\end{array}$ & $\begin{array}{l}33,642 \\
42,423 \\
65,282 \\
78,784 \\
75,868\end{array}$ & $\begin{array}{r}23,868 \\
28,648 \\
33,745 \\
58,230 \\
-\end{array}$ & $\begin{array}{r}9,774 \\
13,775 \\
31,537 \\
20,554 \\
-\end{array}$ & $\begin{array}{r}956,808 \\
1,448,931 \\
2,255,707 \\
2,729,023 \\
3,051,404\end{array}$ & $\begin{array}{r}43,137 \\
63,554 \\
90,593 \\
107,061 \\
127,417\end{array}$ & $\begin{array}{r}913,671 \\
1,353,372 \\
2,016,244 \\
2,184,216 \\
2,398,169\end{array}$ & 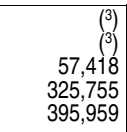 & $\begin{array}{r}\left(3^{3}\right) \\
17,363 \\
42,689 \\
48,018 \\
49,909\end{array}$ & $\begin{array}{r}\left({ }^{3}\right) \\
14,643 \\
48,763 \\
63,973 \\
79,950\end{array}$ & $\begin{array}{r}309,582 \\
597,929 \\
1,039,774 \\
1,360,479 \\
1,366,804\end{array}$ \\
\hline 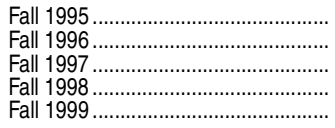 & $\begin{array}{l}4,994,358 \\
5,091,205 \\
5,266,415 \\
5,419,181 \\
5,632,004\end{array}$ & $\begin{array}{l}82,998 \\
81,975 \\
85,267 \\
88,939 \\
94,134\end{array}$ & $\begin{array}{l}49,315 \\
48,480 \\
50,432 \\
52,975 \\
55,467\end{array}$ & $\begin{array}{l}33,683 \\
33,495 \\
34,835 \\
35,964 \\
38,667\end{array}$ & $\begin{array}{l}3,351,528 \\
3,447,580 \\
3,572,955 \\
3,693,630 \\
3,819,057\end{array}$ & $\begin{array}{l}120,629 \\
123,734 \\
126,129 \\
129,317 \\
137,199\end{array}$ & $\begin{array}{l}2,598,220 \\
2,667,419 \\
2,746,157 \\
2,830,286 \\
2,910,633\end{array}$ & $\begin{array}{l}494,289 \\
516,356 \\
557,453 \\
588,108 \\
621,942\end{array}$ & $\begin{array}{l}50,862 \\
51,464 \\
52,142 \\
52,805 \\
53,659\end{array}$ & $\begin{array}{l}87,528 \\
88,607 \\
91,074 \\
93,114 \\
95,624\end{array}$ & $\begin{array}{l}1,559,832 \\
1,561,650 \\
1,608,193 \\
1,636,612 \\
1,718,813\end{array}$ \\
\hline $\begin{array}{l}\text { Fall } 2000 \\
\text { Fall 2001 } \\
\text { Fall 2002 } \\
\text { Fall 2003 } \\
\text { Fall 2004 }\end{array}$ & $\begin{array}{l}5,709,753 \\
5,904,195 \\
5,954,661 \\
5,953,667 \\
6,058,174\end{array}$ & $\begin{array}{r}97,270 \\
109,526 \\
110,777 \\
107,483 \\
111,832\end{array}$ & $\begin{array}{l}57,837 \\
63,517 \\
62,781 \\
63,418 \\
64,101\end{array}$ & $\begin{array}{l}39,433 \\
46,009 \\
47,996 \\
44,065 \\
47,731\end{array}$ & $\begin{array}{l}3,876,628 \\
3,989,211 \\
4,016,963 \\
4,052,739 \\
4,120,063\end{array}$ & $\begin{array}{l}141,792 \\
160,543 \\
164,171 \\
165,233 \\
165,657\end{array}$ & $\begin{array}{l}2,941,461 \\
2,999,528 \\
3,034,123 \\
3,048,652 \\
3,090,925\end{array}$ & $\begin{array}{l}641,392 \\
674,741 \\
663,552 \\
685,118 \\
707,514\end{array}$ & $\begin{array}{l}54,246 \\
54,350 \\
54,205 \\
54,349 \\
54,145\end{array}$ & $\begin{array}{r}97,737 \\
100,049 \\
100,912 \\
99,387 \\
101,822\end{array}$ & $\begin{array}{l}1,735,855 \\
1,805,458 \\
1,826,921 \\
1,793,445 \\
1,826,279\end{array}$ \\
\hline 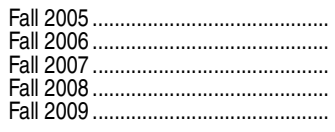 & $\begin{array}{l}6,130,686 \\
6,153,735 \\
6,215,635 \\
6,326,702 \\
6,351,157\end{array}$ & $\begin{array}{l}121,164 \\
118,707 \\
130,046 \\
135,706 \\
138,471\end{array}$ & $\begin{array}{l}62,464 \\
53,722 \\
59,369 \\
62,153 \\
63,969\end{array}$ & $\begin{array}{l}58,700 \\
64,985 \\
70,677 \\
73,553 \\
74,502\end{array}$ & $\begin{array}{l}4,151,236 \\
4,186,968 \\
4,213,729 \\
4,277,674 \\
4,279,488\end{array}$ & $\begin{array}{l}156,454 \\
153,673 \\
157,564 \\
159,897 \\
168,450\end{array}$ & $\begin{array}{l}3,143,003 \\
3,166,391 \\
3,178,142 \\
3,222,154 \\
3,209,672\end{array}$ & $\begin{array}{l}693,792 \\
709,715 \\
718,119 \\
734,010 \\
741,337\end{array}$ & $\begin{array}{l}54,057 \\
54,444 \\
54,385 \\
53,805 \\
52,545\end{array}$ & $\begin{array}{l}103,930 \\
102,745 \\
105,519 \\
107,808 \\
107,484\end{array}$ & $\begin{array}{l}1,858,286 \\
1,848,060 \\
1,871,860 \\
1,913,322 \\
1,933,198\end{array}$ \\
\hline \multirow[t]{2}{*}{ 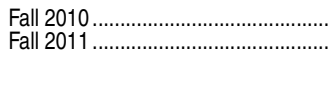 } & $\begin{array}{l}6,195,207 \\
6,138,890 \\
\end{array}$ & $\begin{array}{l}133,833 \\
130,595 \\
\end{array}$ & $\begin{array}{l}64,597 \\
62,884 \\
\end{array}$ & $\begin{array}{l}69,236 \\
67,711 \\
\end{array}$ & $\begin{array}{l}4,151,225 \\
4,133,767 \\
\end{array}$ & $\begin{array}{l}165,047 \\
166,416 \\
\end{array}$ & $\begin{array}{l}3,099,095 \\
3,103,263 \\
\end{array}$ & $\begin{array}{l}731,705 \\
710,335 \\
\end{array}$ & $\begin{array}{l}50,300 \\
48,402 \\
\end{array}$ & $\begin{array}{l}105,079 \\
105,351 \\
\end{array}$ & $\begin{array}{l}1,910,150 \\
1,874,528 \\
\end{array}$ \\
\hline & \multicolumn{11}{|c|}{ Percentage distribution } \\
\hline 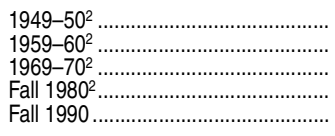 & $\begin{array}{l}100.0 \\
100.0 \\
100.0 \\
100.0 \\
100.0\end{array}$ & $\begin{array}{l}2.6 \\
2.0 \\
1.9 \\
1.9 \\
1.7\end{array}$ & $\begin{array}{l}1.8 \\
1.4 \\
1.0 \\
1.4 \\
-\end{array}$ & \begin{tabular}{l|}
0.8 \\
0.7 \\
0.9 \\
0.5 \\
-
\end{tabular} & $\begin{array}{l}73.6 \\
69.4 \\
67.1 \\
65.5 \\
67.9\end{array}$ & $\begin{array}{l}3.3 \\
3.0 \\
2.7 \\
2.6 \\
2.8\end{array}$ & $\begin{array}{l}70.3 \\
64.8 \\
60.0 \\
52.4 \\
53.4\end{array}$ & 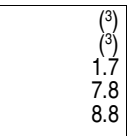 & \begin{tabular}{r|}
$\left({ }^{3}\right)$ \\
0.8 \\
1.3 \\
1.2 \\
1.1
\end{tabular} & $\begin{array}{l}\left({ }^{3}\right) \\
0.7 \\
1.5 \\
1.5 \\
1.8\end{array}$ & $\begin{array}{l}23.8 \\
28.6 \\
30.9 \\
32.6 \\
30.4\end{array}$ \\
\hline $\begin{array}{l}\text { Fall } 1995 . \\
\text { Fall 1996 } \\
\text { Fall 1997 } \\
\text { Fall 1998 } \\
\text { Fall } 1999 \ldots \ldots\end{array}$ & $\begin{array}{l}100.0 \\
100.0 \\
100.0 \\
100.0 \\
100.0\end{array}$ & $\begin{array}{l}1.7 \\
1.6 \\
1.6 \\
1.6 \\
1.7\end{array}$ & $\begin{array}{l}1.0 \\
1.0 \\
1.0 \\
1.0 \\
1.0\end{array}$ & $\begin{array}{l}0.7 \\
0.7 \\
0.7 \\
0.7 \\
0.7\end{array}$ & $\begin{array}{l}67.1 \\
67.7 \\
67.8 \\
68.2 \\
67.8\end{array}$ & $\begin{array}{l}2.4 \\
2.4 \\
2.4 \\
2.4 \\
2.4\end{array}$ & $\begin{array}{l}52.0 \\
52.4 \\
52.1 \\
52.2 \\
51.7\end{array}$ & $\begin{array}{r}9.9 \\
10.1 \\
10.6 \\
10.9 \\
11.0\end{array}$ & $\begin{array}{l}1.0 \\
1.0 \\
1.0 \\
1.0 \\
1.0\end{array}$ & $\begin{array}{l}1.8 \\
1.7 \\
1.7 \\
1.7 \\
1.7\end{array}$ & $\begin{array}{l}31.2 \\
30.7 \\
30.5 \\
30.2 \\
30.5\end{array}$ \\
\hline $\begin{array}{l}\text { Fall } 2000 \\
\text { Fall 2001 } \\
\text { Fall 2002 } \\
\text { Fall 2003 } \\
\text { Fall 2004 }\end{array}$ & $\begin{array}{l}100.0 \\
100.0 \\
100.0 \\
100.0 \\
100.0\end{array}$ & $\begin{array}{l}1.7 \\
1.9 \\
1.9 \\
1.8 \\
1.8\end{array}$ & $\begin{array}{l}1.0 \\
1.1 \\
1.1 \\
1.1 \\
1.1\end{array}$ & $\begin{array}{l}0.7 \\
0.8 \\
0.8 \\
0.7 \\
0.8\end{array}$ & $\begin{array}{l}67.9 \\
67.6 \\
67.5 \\
68.1 \\
68.0\end{array}$ & $\begin{array}{l}2.5 \\
2.7 \\
2.8 \\
2.8 \\
2.7\end{array}$ & $\begin{array}{l}51.5 \\
50.8 \\
51.0 \\
51.2 \\
51.0\end{array}$ & $\begin{array}{l}11.2 \\
11.4 \\
11.1 \\
11.5 \\
11.7\end{array}$ & $\begin{array}{l}1.0 \\
0.9 \\
0.9 \\
0.9 \\
0.9\end{array}$ & $\begin{array}{l}1.7 \\
1.7 \\
1.7 \\
1.7 \\
1.7\end{array}$ & $\begin{array}{l}30.4 \\
30.6 \\
30.7 \\
30.1 \\
30.1\end{array}$ \\
\hline 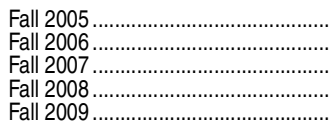 & $\begin{array}{l}100.0 \\
100.0 \\
100.0 \\
100.0 \\
100.0\end{array}$ & $\begin{array}{l}2.0 \\
1.9 \\
2.1 \\
2.1 \\
2.2\end{array}$ & $\begin{array}{l}1.0 \\
0.9 \\
1.0 \\
1.0 \\
1.0\end{array}$ & $\begin{array}{l}1.0 \\
1.1 \\
1.1 \\
1.2 \\
1.2\end{array}$ & $\begin{array}{l}67.7 \\
68.0 \\
67.8 \\
67.6 \\
67.4\end{array}$ & $\begin{array}{l}2.6 \\
2.5 \\
2.5 \\
2.5 \\
2.7\end{array}$ & $\begin{array}{l}51.3 \\
51.5 \\
51.1 \\
50.9 \\
50.5\end{array}$ & $\begin{array}{l}11.3 \\
11.5 \\
11.6 \\
11.6 \\
11.7\end{array}$ & $\begin{array}{l}0.9 \\
0.9 \\
0.9 \\
0.9 \\
0.8\end{array}$ & $\begin{array}{l}1.7 \\
1.7 \\
1.7 \\
1.7 \\
1.7\end{array}$ & $\begin{array}{l}30.3 \\
30.0 \\
30.1 \\
30.2 \\
30.4\end{array}$ \\
\hline \multirow[t]{2}{*}{$\begin{array}{l}\text { Fall } 2010 \\
\text { Fall } 2011\end{array}$} & $\begin{array}{l}100.0 \\
100.0 \\
\end{array}$ & $\begin{array}{l}2.2 \\
2.1 \\
\end{array}$ & $\begin{array}{l}1.0 \\
1.0 \\
\end{array}$ & $\begin{array}{l}1.1 \\
1.1 \\
\end{array}$ & $\begin{array}{l}67.0 \\
67.3 \\
\end{array}$ & $\begin{array}{l}2.7 \\
2.7 \\
\end{array}$ & $\begin{array}{l}50.0 \\
50.6\end{array}$ & $\begin{array}{l}11.8 \\
11.6 \\
\end{array}$ & $\begin{array}{l}0.8 \\
0.8 \\
\end{array}$ & $\begin{array}{l}1.7 \\
1.7 \\
\end{array}$ & $\begin{array}{l}30.8 \\
30.5 \\
\end{array}$ \\
\hline & \multicolumn{11}{|c|}{ Pupils per staff member } \\
\hline 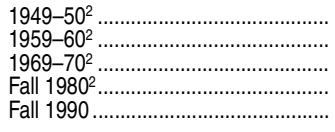 & \begin{tabular}{r|}
19.3 \\
16.8 \\
13.6 \\
9.8 \\
9.2
\end{tabular} & $\begin{array}{l}746.4 \\
829.3 \\
697.7 \\
518.9 \\
543.3\end{array}$ & $\begin{array}{r}1,052.1 \\
1,228.1 \\
1,349.8 \\
702.0 \\
-\end{array}$ & $\begin{array}{r}2,569.2 \\
2,554.1 \\
1,444.3 \\
1,988.8 \\
-\end{array}$ & $\begin{array}{l}26.2 \\
24.3 \\
20.2 \\
15.0 \\
13.5\end{array}$ & $\begin{array}{l}582.1 \\
553.6 \\
502.8 \\
381.8 \\
323.5\end{array}$ & $\begin{array}{l}27.5 \\
26.0 \\
22.6 \\
18.7 \\
17.2\end{array}$ & 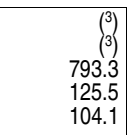 & $\begin{array}{r}\left({ }^{3}\right) \\
2,026.3 \\
1,067.0 \\
851.3 \\
825.8\end{array}$ & $\begin{array}{r}{ }^{(3)} \\
2,402.7 \\
934.1 \\
639.0 \\
515.5\end{array}$ & $\begin{array}{l}81.1 \\
58.8 \\
43.8 \\
30.0 \\
30.2\end{array}$ \\
\hline 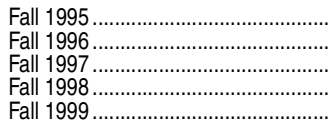 & $\begin{array}{l}9.0 \\
9.0 \\
8.8 \\
8.6 \\
8.3\end{array}$ & $\begin{array}{l}540.3 \\
556.4 \\
541.0 \\
523.3 \\
497.8\end{array}$ & $\begin{array}{l}909.3 \\
940.8 \\
914.6 \\
878.5 \\
844.8\end{array}$ & $\begin{array}{l}1,331.2 \\
1,361.7 \\
1,324.2 \\
1,294.0 \\
1,211.8\end{array}$ & $\begin{array}{l}13.4 \\
13.2 \\
12.9 \\
12.6 \\
12.3\end{array}$ & $\begin{array}{l}371.7 \\
368.6 \\
365.7 \\
359.9 \\
341.5\end{array}$ & $\begin{array}{l}17.3 \\
17.1 \\
16.8 \\
16.4 \\
16.1\end{array}$ & $\begin{array}{l}90.7 \\
88.3 \\
82.7 \\
79.1 \\
75.3\end{array}$ & $\begin{array}{l}881.6 \\
886.3 \\
884.6 \\
881.3 \\
873.2\end{array}$ & $\begin{array}{l}512.3 \\
514.8 \\
506.5 \\
499.8 \\
490.0\end{array}$ & $\begin{array}{l}28.7 \\
29.2 \\
28.7 \\
28.4 \\
27.3\end{array}$ \\
\hline 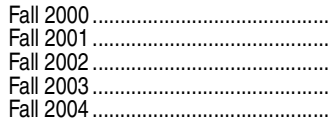 & $\begin{array}{l}8.3 \\
8.1 \\
8.1 \\
8.2 \\
8.1\end{array}$ & $\begin{array}{l}485.3 \\
435.3 \\
435.0 \\
451.6 \\
436.3\end{array}$ & $\begin{array}{l}816.1 \\
750.5 \\
767.5 \\
765.4 \\
761.2\end{array}$ & $\begin{array}{l}1,197.1 \\
1,036.1 \\
1,003.9 \\
1,101.6 \\
1,022.3\end{array}$ & $\begin{array}{l}12.2 \\
12.0 \\
12.0 \\
12.0 \\
11.8\end{array}$ & $\begin{array}{l}332.9 \\
296.9 \\
293.5 \\
293.8 \\
294.6\end{array}$ & $\begin{array}{l}16.0 \\
15.9 \\
15.9 \\
15.9 \\
15.8\end{array}$ & $\begin{array}{l}73.6 \\
70.7 \\
72.6 \\
70.8 \\
69.0\end{array}$ & $\begin{array}{l}870.2 \\
877.1 \\
888.9 \\
893.1 \\
901.2\end{array}$ & $\begin{array}{l}483.0 \\
476.5 \\
477.5 \\
488.4 \\
479.2\end{array}$ & $\begin{array}{l}27.2 \\
26.4 \\
26.4 \\
27.1 \\
26.7\end{array}$ \\
\hline 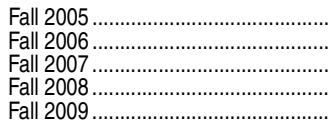 & $\begin{array}{l}8.0 \\
8.0 \\
7.9 \\
7.8 \\
7.8\end{array}$ & $\begin{array}{l}405.3 \\
415.4 \\
379.0 \\
363.0 \\
356.5\end{array}$ & $\begin{array}{l}786.3 \\
918.0 \\
830.3 \\
792.6 \\
771.6\end{array}$ & $\begin{array}{l}836.7 \\
758.9 \\
697.4 \\
669.8 \\
662.5\end{array}$ & $\begin{array}{l}11.8 \\
11.8 \\
11.7 \\
11.5 \\
11.5\end{array}$ & $\begin{array}{l}313.9 \\
320.9 \\
312.8 \\
308.1 \\
293.0\end{array}$ & $\begin{array}{l}15.6 \\
15.6 \\
15.5 \\
15.3 \\
15.4\end{array}$ & $\begin{array}{l}70.8 \\
69.5 \\
68.6 \\
67.1 \\
66.6\end{array}$ & $\begin{array}{l}908.5 \\
905.8 \\
906.4 \\
915.6 \\
939.4\end{array}$ & $\begin{array}{l}472.6 \\
480.0 \\
467.1 \\
457.0 \\
459.2\end{array}$ & $\begin{array}{l}26.4 \\
26.7 \\
26.3 \\
25.7 \\
25.5\end{array}$ \\
\hline 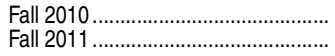 & $\begin{array}{l}8.0 \\
8.1\end{array}$ & $\begin{array}{l}369.7 \\
379.2\end{array}$ & $\begin{array}{l}766.0 \\
787.5\end{array}$ & $\begin{array}{l}714.7 \\
731.4\end{array}$ & $\begin{array}{l}11.9 \\
12.0\end{array}$ & $\begin{array}{l}299.8 \\
297.6\end{array}$ & $\begin{array}{l}16.0 \\
16.0\end{array}$ & $\begin{array}{l}67.6 \\
69.7\end{array}$ & $\begin{array}{r}983.8 \\
1,023.1\end{array}$ & $\begin{array}{l}470.9 \\
470.1\end{array}$ & $\begin{array}{l}25.9 \\
26.4\end{array}$ \\
\hline
\end{tabular}

-Not available.

${ }^{1}$ Includes school district administrative support staff, school and library support staff, student support staff, and other support services staff.

${ }^{2}$ Because of classification revisions, categories other than teachers, principals, librarians, and guidance counselors are only roughly comparable to figures for years after 1980

3Data included in column 8.
NOTE: Data for 1949-50 through 1969-70 are cumulative for the entire school year, rather than counts as of the fall of the year. Detail may not sum to totals because of rounding. Some data have been revised from previously published figures.

SOURCE: U.S. Department of Education, National Center for Education Statistics, Statistics of State School Systems, various years; Statistics of Public Elementary and Secondary Schools, various years; and Common Core of Data (CCD), "State Nonfiscal Survey of Public Elementary/ Secondary Education," 1986-87 through 2011-12. (This table was prepared August 2013.) 
Table 213.20. Staff employed in public elementary and secondary school systems, by type of assignment and state or jurisdiction: Fall 2011 [In full-time equivalents]

\begin{tabular}{|c|c|c|c|c|c|c|c|c|c|c|c|c|}
\hline \multirow[b]{2}{*}{ State or jurisdiction } & \multirow[b]{2}{*}{ Total } & \multicolumn{3}{|c|}{ School district staff } & \multicolumn{6}{|c|}{ School staff } & \multirow[b]{2}{*}{$\begin{array}{r}\text { Student } \\
\text { support staff }\end{array}$} & \multirow[b]{2}{*}{$\begin{array}{r}\text { Other } \\
\text { support } \\
\text { services staf }\end{array}$} \\
\hline & & $\begin{array}{r}\text { Officials and } \\
\text { administrators }\end{array}$ & $\begin{array}{l}\text { Administrative } \\
\text { support staff }\end{array}$ & $\begin{array}{r}\text { Instruction } \\
\text { coordinators }\end{array}$ & $\begin{array}{r}\text { Principals } \\
\text { and assistant } \\
\text { principals }\end{array}$ & $\begin{array}{r}\text { School and } \\
\text { library } \\
\text { support staff }\end{array}$ & Teachers & $\begin{array}{r}\text { Instructional } \\
\text { aides }\end{array}$ & $\begin{array}{r}\text { Guidance } \\
\text { counselors }\end{array}$ & Librarians & & \\
\hline 1 & 2 & 3 & 4 & 5 & 6 & 7 & 8 & 9 & 10 & 11 & 12 & 13 \\
\hline United States ${ }^{1} \ldots \ldots \ldots . .$. & $6,138,890$ & 62,884 & 187,959 & 67,711 & 166,416 & 272,178 & $3,103,263$ & 710,335 & 105,351 & 48,402 & 275,704 & $1,138,687$ \\
\hline 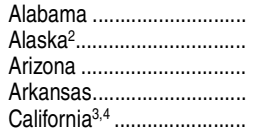 & $\begin{array}{r}92,289 \\
17,747 \\
98,712 \\
72,650 \\
547,188\end{array}$ & $\begin{array}{r}792 \\
668 \\
425 \\
675 \\
3,212\end{array}$ & $\begin{array}{r}1,605 \\
777 \\
881 \\
2,390 \\
21,543\end{array}$ & $\begin{array}{r}956 \\
187 \\
96 \\
806 \\
12,540\end{array}$ & $\begin{array}{r}2,537 \\
659 \\
2,576 \\
1,781 \\
16,148\end{array}$ & $\begin{array}{r}3,824 \\
1,259 \\
5,840 \\
4,965 \\
34,681\end{array}$ & $\begin{array}{r}47,723 \\
8,088 \\
50,800 \\
33,983 \\
268,689\end{array}$ & $\begin{array}{r}6,146 \\
2,458 \\
15,183 \\
8,052 \\
63,886\end{array}$ & $\begin{array}{r}1,773 \\
323 \\
1,252 \\
1,530 \\
7,683\end{array}$ & $\begin{array}{r}1,379 \\
165 \\
515 \\
1,095 \\
797\end{array}$ & $\begin{array}{r}2,316 \\
654 \\
7,649 \\
7,644 \\
16,214\end{array}$ & $\begin{array}{r}23,238 \\
2,508 \\
13,495 \\
9,729 \\
101,796\end{array}$ \\
\hline 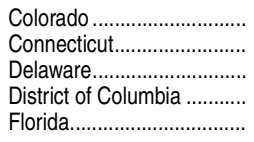 & $\begin{array}{r}100,349 \\
92,955 \\
15,449 \\
11,541 \\
328,709\end{array}$ & $\begin{array}{r}1,156 \\
1,893 \\
67 \\
240 \\
1,923\end{array}$ & $\begin{array}{r}4,390 \\
3,275 \\
79 \\
185 \\
14,359\end{array}$ & $\begin{array}{r}2,505 \\
3,585 \\
244 \\
134 \\
678\end{array}$ & $\begin{array}{r}2,829 \\
2,199 \\
445 \\
584 \\
8,191\end{array}$ & $\begin{array}{r}5,511 \\
2,233 \\
367 \\
512 \\
16,340\end{array}$ & $\begin{array}{r}48,078 \\
43,805 \\
8,587 \\
6,278 \\
175,006\end{array}$ & $\begin{array}{r}14,118 \\
14,253 \\
1,672 \\
1,404 \\
29,659\end{array}$ & $\begin{array}{r}2,159 \\
1,103 \\
290 \\
247 \\
5,555\end{array}$ & $\begin{array}{r}659 \\
757 \\
136 \\
119 \\
2,377\end{array}$ & $\begin{array}{r}5,520 \\
2,906 \\
717 \\
1,026 \\
10,377\end{array}$ & $\begin{array}{r}13,423 \\
16,946 \\
2,844 \\
812 \\
64,244\end{array}$ \\
\hline 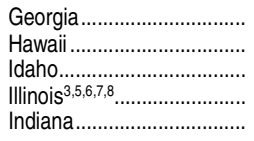 & $\begin{array}{r}224,207 \\
22,065 \\
28,065 \\
213,578 \\
150,191\end{array}$ & $\begin{array}{r}2,257 \\
226 \\
62 \\
2,729 \\
1,207\end{array}$ & $\begin{array}{r}2,520 \\
563 \\
607 \\
2,395 \\
688\end{array}$ & $\begin{array}{r}2,417 \\
640 \\
222 \\
481 \\
3,230\end{array}$ & $\begin{array}{r}6,129 \\
580 \\
662 \\
7,362 \\
3,126\end{array}$ & $\begin{array}{r}10,250 \\
1,360 \\
1,196 \\
3,618 \\
8,271\end{array}$ & $\begin{array}{r}111,133 \\
11,458 \\
15,990 \\
131,777 \\
62,339\end{array}$ & $\begin{array}{r}25,119 \\
2,446 \\
3,001 \\
29,951 \\
16,078\end{array}$ & $\begin{array}{r}3,577 \\
627 \\
547 \\
3,132 \\
1,946\end{array}$ & $\begin{array}{r}2,226 \\
199 \\
71 \\
1,920 \\
868\end{array}$ & $\begin{array}{r}7,375 \\
1,705 \\
806 \\
9,522 \\
12,845 \\
\end{array}$ & $\begin{array}{r}51,204 \\
2,262 \\
4,900 \\
20,692 \\
39,593\end{array}$ \\
\hline 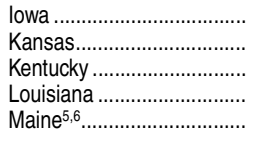 & $\begin{array}{r}69,901 \\
70,631 \\
92,287 \\
100,880 \\
39,946\end{array}$ & $\begin{array}{r}1,221 \\
499 \\
902 \\
380 \\
45\end{array}$ & $\begin{array}{r}1,916 \\
1,349 \\
2,009 \\
2,811 \\
760\end{array}$ & $\begin{array}{r}302 \\
999 \\
995 \\
2,078 \\
205\end{array}$ & $\begin{array}{l}1,789 \\
1,874 \\
3,159 \\
2,879 \\
1,655\end{array}$ & $\begin{array}{l}2,696 \\
2,602 \\
5,033 \\
3,836 \\
1,858\end{array}$ & $\begin{array}{l}34,658 \\
37,407 \\
41,860 \\
48,657 \\
14,888\end{array}$ & $\begin{array}{r}10,907 \\
9,327 \\
12,149 \\
11,448 \\
8,894\end{array}$ & $\begin{array}{l}1,168 \\
1,071 \\
1,496 \\
1,918 \\
1,097\end{array}$ & $\begin{array}{r}496 \\
735 \\
1,105 \\
1,157 \\
386\end{array}$ & $\begin{array}{l}4,207 \\
4,193 \\
2,512 \\
4,856 \\
1,703\end{array}$ & $\begin{array}{r}10,541 \\
10,575 \\
21,067 \\
20,860 \\
8,455\end{array}$ \\
\hline 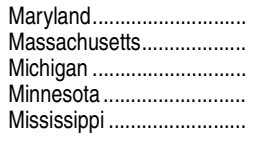 & $\begin{array}{r}113,351 \\
122,880 \\
188,428 \\
109,119 \\
67,850\end{array}$ & $\begin{array}{r}3,410 \\
2,477 \\
3,091 \\
2,074 \\
991\end{array}$ & $\begin{array}{l}2,185 \\
2,919 \\
1,166 \\
2,285 \\
2,041\end{array}$ & $\begin{array}{r}1,526 \\
388 \\
3,372 \\
1,992 \\
632\end{array}$ & $\begin{array}{l}3,577 \\
4,538 \\
4,680 \\
2,120 \\
1,955\end{array}$ & $\begin{array}{r}6,175 \\
6,282 \\
11,796 \\
4,640 \\
2,495\end{array}$ & $\begin{array}{l}57,589 \\
69,342 \\
86,997 \\
52,832 \\
32,007\end{array}$ & $\begin{array}{r}11,099 \\
23,672 \\
21,264 \\
16,841 \\
8,286\end{array}$ & $\begin{array}{l}2,345 \\
2,195 \\
2,196 \\
1,096 \\
1,106\end{array}$ & $\begin{array}{r}1,153 \\
730 \\
631 \\
675 \\
854\end{array}$ & $\begin{array}{r}4,732 \\
8,873 \\
13,310 \\
11,905 \\
3,016\end{array}$ & $\begin{array}{r}19,559 \\
1,465 \\
39,924 \\
12,658 \\
14,469\end{array}$ \\
\hline 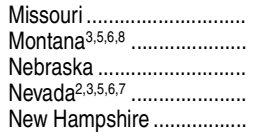 & $\begin{array}{r}132,167 \\
18,790 \\
45,290 \\
32,533 \\
31,971\end{array}$ & $\begin{array}{r}1,403 \\
173 \\
591 \\
31 \\
737\end{array}$ & $\begin{array}{r}12,398 \\
476 \\
1,037 \\
950 \\
729\end{array}$ & $\begin{array}{r}1,031 \\
159 \\
975 \\
1,346 \\
238\end{array}$ & $\begin{array}{r}3,117 \\
519 \\
1,034 \\
978 \\
549\end{array}$ & $\begin{array}{r}411 \\
173 \\
1,894 \\
1,614 \\
810\end{array}$ & $\begin{array}{l}66,252 \\
10,153 \\
22,182 \\
21,132 \\
15,049\end{array}$ & $\begin{array}{r}13,010 \\
2,262 \\
6,345 \\
4,115 \\
6,964\end{array}$ & $\begin{array}{r}2,573 \\
452 \\
796 \\
886 \\
808\end{array}$ & $\begin{array}{r}1,422 \\
356 \\
540 \\
362 \\
313\end{array}$ & $\begin{array}{r}4,197 \\
676 \\
1,435 \\
46 \\
707\end{array}$ & $\begin{array}{r}26,353 \\
3,392 \\
8,462 \\
1,074 \\
5,067\end{array}$ \\
\hline 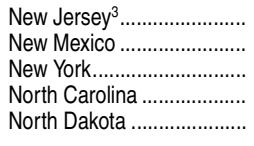 & $\begin{array}{r}202,928 \\
45,907 \\
406,625 \\
188,553 \\
16,401\end{array}$ & $\begin{array}{r}1,388 \\
883 \\
2,952 \\
1,555 \\
473\end{array}$ & $\begin{array}{r}5,657 \\
103 \\
21,141 \\
5,173 \\
256\end{array}$ & $\begin{array}{r}3,147 \\
600 \\
1,750 \\
992 \\
158\end{array}$ & $\begin{array}{r}4,709 \\
1,331 \\
9,226 \\
5,238 \\
451\end{array}$ & $\begin{array}{r}7,992 \\
3,778 \\
8,473 \\
7,260 \\
719\end{array}$ & $\begin{array}{r}109,719 \\
21,957 \\
209,527 \\
97,308 \\
8,525\end{array}$ & $\begin{array}{r}26,780 \\
5,919 \\
35,677 \\
24,036 \\
2,081\end{array}$ & $\begin{array}{r}3,870 \\
801 \\
6,757 \\
3,925 \\
314\end{array}$ & $\begin{array}{r}1,550 \\
260 \\
2,729 \\
2,193 \\
194\end{array}$ & $\begin{array}{r}11,756 \\
3,173 \\
11,860 \\
9,751 \\
809\end{array}$ & $\begin{array}{r}26,359 \\
7,101 \\
96,533 \\
31,121 \\
2,420\end{array}$ \\
\hline 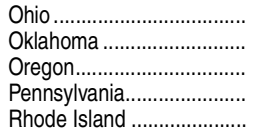 & $\begin{array}{r}243,586 \\
82,719 \\
60,715 \\
254,297 \\
18,743\end{array}$ & $\begin{array}{r}2,406 \\
547 \\
433 \\
2,633 \\
87\end{array}$ & $\begin{array}{r}14,052 \\
2,891 \\
3,060 \\
7,180 \\
517\end{array}$ & $\begin{array}{r}1,708 \\
299 \\
389 \\
1,588 \\
85\end{array}$ & $\begin{array}{r}5,295 \\
2,194 \\
1,558 \\
5,295 \\
451\end{array}$ & $\begin{array}{r}13,998 \\
4,359 \\
4,302 \\
12,015 \\
718\end{array}$ & $\begin{array}{r}107,972 \\
41,349 \\
26,791 \\
124,646 \\
11,414\end{array}$ & $\begin{array}{r}19,845 \\
8,462 \\
9,193 \\
32,169 \\
2,248\end{array}$ & $\begin{array}{r}3,673 \\
1,629 \\
975 \\
4,581 \\
379\end{array}$ & $\begin{array}{r}1,115 \\
1,047 \\
203 \\
1,934 \\
286\end{array}$ & $\begin{array}{r}22,528 \\
4,496 \\
2,160 \\
7,462 \\
525\end{array}$ & $\begin{array}{r}50,994 \\
15,445 \\
11,652 \\
54,795 \\
2,033\end{array}$ \\
\hline $\begin{array}{l}\text { South Carolina ................... } \\
\text { South Dakota } \\
\text { Tennessee ............................ } \\
\text { Texas } \\
\text { Utah }\end{array}$ & $\begin{array}{r}69,272 \\
19,059 \\
127,781 \\
640,166 \\
51,994\end{array}$ & $\begin{array}{r}734 \\
737 \\
176 \\
5,781 \\
403\end{array}$ & $\begin{array}{r}1,426 \\
388 \\
963 \\
22,120 \\
657\end{array}$ & $\begin{array}{r}1,744 \\
155 \\
838 \\
3,338 \\
1,745\end{array}$ & $\begin{array}{r}2,587 \\
413 \\
3,410 \\
21,515 \\
1,330\end{array}$ & $\begin{array}{r}1,179 \\
563 \\
5,065 \\
26,262 \\
2,531\end{array}$ & $\begin{array}{r}46,782 \\
9,247 \\
66,382 \\
324,282 \\
25,970\end{array}$ & $\begin{array}{r}8,471 \\
2,418 \\
16,335 \\
58,460 \\
8,074\end{array}$ & $\begin{array}{r}1,829 \\
324 \\
2,887 \\
10,821 \\
840\end{array}$ & $\begin{array}{r}1,100 \\
125 \\
1,912 \\
4,749 \\
275\end{array}$ & $\begin{array}{r}3,180 \\
1,026 \\
1,325 \\
23,707 \\
1,273\end{array}$ & $\begin{array}{r}240 \\
3,663 \\
28,489 \\
139,132 \\
8,898\end{array}$ \\
\hline 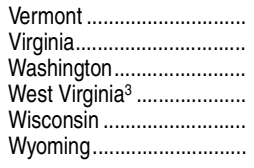 & $\begin{array}{r}18,385 \\
180,086 \\
101,914 \\
39,380 \\
101,533 \\
17,128 \\
\end{array}$ & $\begin{array}{r}137 \\
1,590 \\
2,286 \\
769 \\
997 \\
360 \\
\end{array}$ & $\begin{array}{r}466 \\
4,271 \\
1,903 \\
1,143 \\
2,801 \\
503 \\
\end{array}$ & $\begin{array}{r}227 \\
1,751 \\
317 \\
375 \\
1,164 \\
385 \\
\end{array}$ & $\begin{array}{r}478 \\
4,016 \\
2,802 \\
1,129 \\
2,394 \\
363 \\
\end{array}$ & $\begin{array}{r}879 \\
8,633 \\
4,962 \\
768 \\
4,166 \\
1,014 \\
\end{array}$ & $\begin{array}{r}8,364 \\
90,832 \\
53,119 \\
20,247 \\
56,245 \\
7,847 \\
\end{array}$ & $\begin{array}{r}4,171 \\
19,736 \\
10,176 \\
3,657 \\
10,014 \\
2,403 \\
\end{array}$ & $\begin{array}{r}416 \\
3,338 \\
2,025 \\
740 \\
1,852 \\
428 \\
\end{array}$ & $\begin{array}{r}217 \\
1,789 \\
1,078 \\
344 \\
979 \\
125 \\
\end{array}$ & $\begin{array}{r}902 \\
4,178 \\
3,226 \\
1,682 \\
6,363 \\
679 \\
\end{array}$ & $\begin{array}{r}2,129 \\
39,953 \\
20,020 \\
8,525 \\
14,558 \\
3,021 \\
\end{array}$ \\
\hline Bureau of Indian Education. & - & - & - & - & - & - & - & - & - & - & - & - \\
\hline $\begin{array}{l}\text { DoD, overseas } \\
\text { DoD, domestic }\end{array}$ & - & - & - & - & $\begin{array}{l}- \\
-\end{array}$ & $\begin{array}{l}- \\
-\end{array}$ & $\begin{array}{l}- \\
-\end{array}$ & - & - & $\begin{array}{l}- \\
-\end{array}$ & - & - \\
\hline $\begin{array}{l}\text { Other jurisdictions } \\
\text { American Samoa ............. } \\
\text { Guam ............................. } \\
\text { Northern Marianas......... } \\
\text { Puerto Rico ................... } \\
\text { U.S. Virgin Islands........... }\end{array}$ & $\begin{array}{r}- \\
3,923 \\
1,042 \\
55,797 \\
2,391\end{array}$ & $\begin{array}{r}-\overline{18} \\
9 \\
457 \\
6\end{array}$ & $\begin{array}{r}- \\
251 \\
74 \\
1,910 \\
67\end{array}$ & $\begin{array}{r}-\overline{128} \\
12 \\
1,549 \\
41\end{array}$ & $\begin{array}{r}\overline{92} \\
40 \\
1,108 \\
79\end{array}$ & $\begin{array}{r}- \\
215 \\
67 \\
1,846 \\
84\end{array}$ & $\begin{array}{r}- \\
2,291 \\
496 \\
33,079 \\
1,217\end{array}$ & $\begin{array}{r}6 \\
606 \\
184 \\
79 \\
313\end{array}$ & $\begin{array}{r}\overline{87} \\
36 \\
756 \\
59\end{array}$ & $\begin{array}{r}- \\
37 \\
1 \\
1,047 \\
27\end{array}$ & $\begin{array}{r}- \\
36 \\
30 \\
4,688 \\
83\end{array}$ & $\begin{array}{r}- \\
162 \\
93 \\
9,278 \\
415\end{array}$ \\
\hline
\end{tabular}

一Not available.

${ }^{1}$ Includes imputations for undercounts in states as designated in footnotes 2 through 8.

${ }^{2}$ Includes imputations for instruction coordinators.

Inncludes imputations for library support staff.

${ }^{4}$ Includes imputations for prekindergarten teachers.

Includes imputations for administrative support staff.

${ }^{6}$ Includes imputations for school support staff.
${ }^{7}$ Includes imputations for instructional aides.

${ }^{8}$ Includes imputations for other support services staff.

NOTE: DOD = Department of Defense.

SOURCE: U.S. Department of Education, National Center for Education Statistics, Common Core of Data (CCD), "State Nonfiscal Survey of Public Elementary/Secondary Education," 2011-12. (This table was prepared August 2013.) 
154 CHAPTER 2: Elementary and Secondary Education

School Staff

Table 213.30. Staff employed in public elementary and secondary school systems, by type of assignment and state or jurisdiction: Fall 2010

[In full-time equivalents]

\begin{tabular}{|c|c|c|c|c|c|c|c|c|c|c|c|c|}
\hline \multirow[b]{2}{*}{ State or jurisdiction } & \multirow[b]{2}{*}{ Total } & \multicolumn{3}{|c|}{ School district staff } & \multicolumn{6}{|c|}{ School staff } & \multirow[b]{2}{*}{$\begin{array}{r}\text { Student } \\
\text { support staff }\end{array}$} & \multirow[b]{2}{*}{$\begin{array}{r}\text { Other } \\
\text { support } \\
\text { services staff }\end{array}$} \\
\hline & & $\begin{array}{r}\text { Officials and } \\
\text { administrators }\end{array}$ & $\begin{array}{r}\text { Administrative } \\
\text { support staff }\end{array}$ & $\begin{array}{c}\text { Instruction } \\
\text { coordinators }\end{array}$ & $\begin{array}{r}\text { Principals } \\
\text { and assistant } \\
\text { principals }\end{array}$ & $\begin{array}{r}\text { School and } \\
\text { library } \\
\text { support staff }\end{array}$ & Teachers & $\begin{array}{r}\text { Instructional } \\
\text { aides }\end{array}$ & $\begin{array}{r}\text { Guidance } \\
\text { counselors }\end{array}$ & Librarians & & \\
\hline 1 & 2 & 3 & 4 & 5 & 6 & 7 & 8 & 9 & 10 & 11 & 12 & 13 \\
\hline United States ${ }^{1} \ldots \ldots \ldots \ldots$ & $6,195,207$ & 64,597 & 185,602 & 69,236 & 165,047 & 278,488 & $3,099,095$ & 731,705 & 105,079 & 50,300 & 267,376 & $1,178,684$ \\
\hline 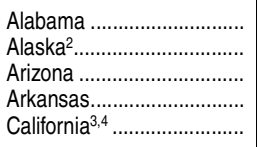 & $\begin{array}{r}95,144 \\
18,102 \\
96,622 \\
72,185 \\
530,337\end{array}$ & $\begin{array}{r}803 \\
709 \\
425 \\
668 \\
3,579\end{array}$ & $\begin{array}{r}1,658 \\
752 \\
852 \\
2,427 \\
21,271\end{array}$ & $\begin{array}{r}1,013 \\
192 \\
98 \\
847 \\
3,391\end{array}$ & $\begin{array}{r}2,606 \\
683 \\
2,471 \\
1,767 \\
15,267\end{array}$ & $\begin{array}{r}3,953 \\
1,338 \\
5,809 \\
3,531 \\
35,532\end{array}$ & $\begin{array}{r}49,363 \\
8,171 \\
50,031 \\
34,273 \\
260,806\end{array}$ & $\begin{array}{r}6,550 \\
2,537 \\
14,386 \\
8,065 \\
63,972\end{array}$ & $\begin{array}{r}1,802 \\
327 \\
1,245 \\
1,527 \\
6,191\end{array}$ & $\begin{array}{r}1,413 \\
163 \\
529 \\
1,088 \\
757\end{array}$ & $\begin{array}{r}2,318 \\
537 \\
7,383 \\
7,697 \\
16,314\end{array}$ & $\begin{array}{r}23,665 \\
2,694 \\
13,393 \\
10,295 \\
103,258\end{array}$ \\
\hline 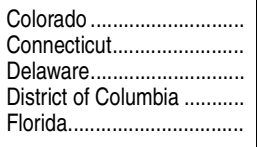 & $\begin{array}{r}101,426 \\
93,088 \\
16,478 \\
11,381 \\
333,183\end{array}$ & $\begin{array}{r}1,174 \\
1,800 \\
366 \\
246 \\
1,920\end{array}$ & $\begin{array}{r}4,487 \\
3,336 \\
463 \\
213 \\
15,448\end{array}$ & $\begin{array}{r}2,434 \\
3,496 \\
226 \\
377 \\
696\end{array}$ & $\begin{array}{r}2,777 \\
2,127 \\
413 \\
491 \\
7,957\end{array}$ & $\begin{array}{r}5,482 \\
2,354 \\
353 \\
647 \\
16,818\end{array}$ & $\begin{array}{r}48,543 \\
42,951 \\
8,933 \\
5,925 \\
175,609\end{array}$ & $\begin{array}{r}14,680 \\
15,637 \\
1,577 \\
1,635 \\
30,031\end{array}$ & $\begin{array}{r}2,100 \\
1,081 \\
281 \\
260 \\
5,859\end{array}$ & $\begin{array}{r}773 \\
781 \\
134 \\
111 \\
2,589\end{array}$ & $\begin{array}{r}5,542 \\
2,725 \\
743 \\
757 \\
10,488\end{array}$ & $\begin{array}{r}13,434 \\
16,799 \\
2,988 \\
721 \\
65,768\end{array}$ \\
\hline 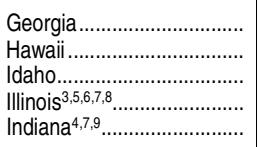 & $\begin{array}{r}227,188 \\
21,704 \\
27,783 \\
215,764 \\
138,802\end{array}$ & $\begin{array}{r}2,300 \\
218 \\
133 \\
2,828 \\
1,096\end{array}$ & $\begin{array}{r}2,553 \\
577 \\
582 \\
2,411 \\
702\end{array}$ & $\begin{array}{r}2,353 \\
573 \\
229 \\
491 \\
2,219\end{array}$ & $\begin{array}{r}6,157 \\
571 \\
701 \\
7,362 \\
2,903\end{array}$ & $\begin{array}{r}10,398 \\
1,232 \\
1,177 \\
3,700 \\
8,554\end{array}$ & $\begin{array}{r}112,460 \\
11,396 \\
15,673 \\
132,983 \\
58,121\end{array}$ & $\begin{array}{r}25,773 \\
2,407 \\
2,991 \\
30,219 \\
23,589\end{array}$ & $\begin{array}{r}3,557 \\
632 \\
564 \\
3,193 \\
1,688\end{array}$ & $\begin{array}{r}2,247 \\
208 \\
98 \\
1,960 \\
646\end{array}$ & $\begin{array}{r}7,493 \\
1,664 \\
692 \\
9,636 \\
2,442\end{array}$ & $\begin{array}{r}51,898 \\
2,225 \\
4,944 \\
20,982 \\
36,842\end{array}$ \\
\hline 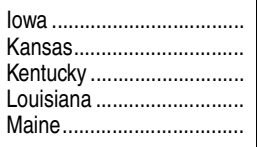 & $\begin{array}{r}69,615 \\
67,751 \\
99,225 \\
100,881 \\
32,549\end{array}$ & $\begin{array}{r}1,237 \\
477 \\
922 \\
380 \\
418\end{array}$ & $\begin{array}{r}1,921 \\
1,407 \\
2,262 \\
2,811 \\
765\end{array}$ & $\begin{array}{r}305 \\
970 \\
1,000 \\
2,079 \\
250\end{array}$ & $\begin{array}{r}1,740 \\
1,807 \\
3,147 \\
2,880 \\
876\end{array}$ & $\begin{array}{l}2,688 \\
2,574 \\
6,050 \\
3,836 \\
1,586\end{array}$ & $\begin{array}{l}34,642 \\
34,644 \\
42,042 \\
48,655 \\
15,384\end{array}$ & $\begin{array}{r}10,531 \\
9,163 \\
14,325 \\
11,448 \\
5,744\end{array}$ & $\begin{array}{r}1,157 \\
1,061 \\
1,515 \\
1,919 \\
575\end{array}$ & $\begin{array}{r}513 \\
797 \\
1,122 \\
1,157 \\
222\end{array}$ & $\begin{array}{l}4,190 \\
4,259 \\
2,866 \\
4,856 \\
1,542\end{array}$ & $\begin{array}{r}10,689 \\
10,592 \\
23,975 \\
20,860 \\
5,187\end{array}$ \\
\hline 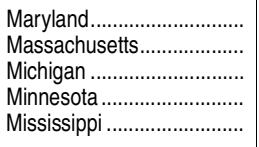 & $\begin{array}{r}115,367 \\
122,057 \\
193,487 \\
108,993 \\
67,866\end{array}$ & $\begin{array}{r}3,328 \\
2,496 \\
3,132 \\
2,072 \\
989\end{array}$ & $\begin{array}{l}2,324 \\
3,010 \\
1,202 \\
2,296 \\
2,033\end{array}$ & $\begin{array}{r}1,792 \\
408 \\
3,347 \\
2,035 \\
649\end{array}$ & $\begin{array}{l}3,635 \\
4,382 \\
4,751 \\
2,103 \\
1,912\end{array}$ & $\begin{array}{r}6,279 \\
6,467 \\
12,077 \\
4,702 \\
2,490\end{array}$ & & $\begin{array}{r}11,360 \\
23,484 \\
21,379 \\
16,759 \\
8,195\end{array}$ & $\begin{array}{l}2,389 \\
2,168 \\
2,249 \\
1,072 \\
1,096\end{array}$ & $\begin{array}{r}1,245 \\
727 \\
746 \\
709 \\
872\end{array}$ & $\begin{array}{r}4,724 \\
8,659 \\
13,435 \\
11,750 \\
2,907\end{array}$ & $\begin{array}{r}19,863 \\
1,502 \\
42,554 \\
12,823 \\
14,469\end{array}$ \\
\hline 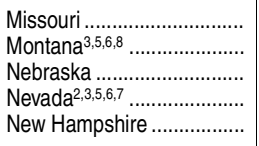 & $\begin{array}{r}128,289 \\
19,249 \\
45,509 \\
33,400 \\
32,955\end{array}$ & $\begin{array}{r}1,395 \\
175 \\
614 \\
30 \\
742\end{array}$ & $\begin{array}{r}8,091 \\
479 \\
1,088 \\
957 \\
718\end{array}$ & $\begin{array}{r}1,081 \\
165 \\
999 \\
1,380 \\
264\end{array}$ & $\begin{array}{r}3,136 \\
534 \\
1,029 \\
993 \\
506\end{array}$ & $\begin{array}{r}460 \\
178 \\
1,921 \\
1,644 \\
862\end{array}$ & $\begin{array}{l}66,735 \\
10,361 \\
22,345 \\
21,839 \\
15,365\end{array}$ & $\begin{array}{r}13,314 \\
2,397 \\
6,506 \\
4,152 \\
7,356\end{array}$ & $\begin{array}{r}2,613 \\
457 \\
811 \\
880 \\
824\end{array}$ & $\begin{array}{r}1,477 \\
369 \\
556 \\
376 \\
330\end{array}$ & $\begin{array}{r}4,435 \\
694 \\
1,372 \\
42 \\
694\end{array}$ & $\begin{array}{r}25,552 \\
3,440 \\
8,268 \\
1,107 \\
5,294\end{array}$ \\
\hline 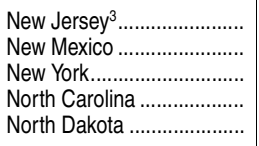 & $\begin{array}{r}202,634 \\
46,519 \\
413,971 \\
193,039 \\
16,239\end{array}$ & $\begin{array}{r}1,394 \\
897 \\
2,921 \\
1,565 \\
474\end{array}$ & $\begin{array}{r}5,602 \\
87 \\
22,216 \\
4,934 \\
245\end{array}$ & $\begin{array}{r}3,138 \\
659 \\
1,979 \\
1,043 \\
179\end{array}$ & $\begin{array}{r}4,651 \\
1,309 \\
9,282 \\
5,101 \\
447\end{array}$ & $\begin{array}{r}8,042 \\
3,841 \\
8,509 \\
7,961 \\
715\end{array}$ & $\begin{array}{r}110,202 \\
22,437 \\
211,606 \\
98,357 \\
8,417\end{array}$ & $\begin{array}{r}26,227 \\
6,009 \\
37,849 \\
26,173 \\
2,071\end{array}$ & $\begin{array}{r}3,904 \\
815 \\
6,979 \\
3,976 \\
309\end{array}$ & $\begin{array}{r}1,585 \\
272 \\
2,775 \\
2,290 \\
193\end{array}$ & $\begin{array}{r}11,844 \\
3,054 \\
11,936 \\
9,806 \\
792\end{array}$ & $\begin{array}{r}26,046 \\
7,138 \\
97,920 \\
31,833 \\
2,397\end{array}$ \\
\hline 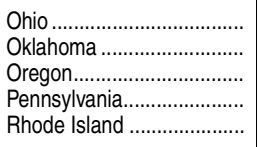 & $\begin{array}{r}241,212 \\
82,262 \\
63,603 \\
266,796 \\
18,632\end{array}$ & $\begin{array}{r}2,110 \\
593 \\
446 \\
2,708 \\
85\end{array}$ & $\begin{array}{r}13,517 \\
3,019 \\
3,194 \\
7,421 \\
486\end{array}$ & $\begin{array}{r}1,676 \\
329 \\
409 \\
1,671 \\
84\end{array}$ & $\begin{array}{r}5,053 \\
2,147 \\
1,584 \\
5,531 \\
452\end{array}$ & $\begin{array}{r}14,053 \\
4,341 \\
4,471 \\
12,589 \\
741\end{array}$ & $\begin{array}{r}109,282 \\
41,278 \\
28,109 \\
129,911 \\
11,212\end{array}$ & $\begin{array}{r}19,333 \\
8,362 \\
9,837 \\
34,314 \\
2,224\end{array}$ & $\begin{array}{r}3,655 \\
1,610 \\
1,032 \\
4,763 \\
384\end{array}$ & $\begin{array}{r}1,217 \\
1,072 \\
306 \\
2,136 \\
298\end{array}$ & $\begin{array}{r}20,543 \\
4,320 \\
2,335 \\
8,351 \\
479\end{array}$ & $\begin{array}{r}50,773 \\
15,194 \\
11,880 \\
57,401 \\
2,187\end{array}$ \\
\hline 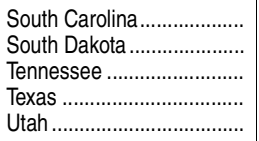 & $\begin{array}{r}65,508 \\
19,545 \\
128,197 \\
665,419 \\
52,341\end{array}$ & $\begin{array}{r}704 \\
764 \\
174 \\
6,563 \\
367\end{array}$ & $\begin{array}{r}775 \\
403 \\
810 \\
22,339 \\
731\end{array}$ & $\begin{array}{r}453 \\
132 \\
836 \\
3,456 \\
1,699\end{array}$ & $\begin{array}{r}2,554 \\
430 \\
3,360 \\
22,360 \\
1,300\end{array}$ & $\begin{array}{r}1,130 \\
582 \\
5,299 \\
27,386 \\
2,718\end{array}$ & $\begin{array}{r}45,210 \\
9,512 \\
66,558 \\
334,997 \\
25,677\end{array}$ & $\begin{array}{r}8,475 \\
2,454 \\
16,243 \\
63,338 \\
8,214\end{array}$ & $\begin{array}{r}1,816 \\
345 \\
2,889 \\
11,212 \\
807\end{array}$ & $\begin{array}{r}1,085 \\
137 \\
1,933 \\
5,097 \\
279\end{array}$ & $\begin{array}{r}3,088 \\
1,051 \\
1,258 \\
24,171 \\
1,505\end{array}$ & $\begin{array}{r}218 \\
3,735 \\
28,836 \\
144,500 \\
9,044\end{array}$ \\
\hline 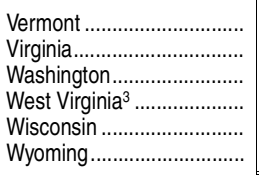 & $\begin{array}{r}18,485 \\
201,047 \\
103,783 \\
39,270 \\
103,901 \\
16,424 \\
\end{array}$ & $\begin{array}{r}135 \\
1,537 \\
2,416 \\
771 \\
973 \\
330 \\
\end{array}$ & $\begin{array}{r}444 \\
4,173 \\
1,916 \\
1,136 \\
2,634 \\
425 \\
\end{array}$ & $\begin{array}{r}235 \\
13,419 \\
358 \\
370 \\
1,326 \\
424 \\
\end{array}$ & $\begin{array}{r}488 \\
4,606 \\
2,800 \\
1,105 \\
2,447 \\
354 \\
\end{array}$ & $\begin{array}{r}902 \\
9,341 \\
5,103 \\
769 \\
4,311 \\
995 \\
\end{array}$ & $\begin{array}{r}8,382 \\
70,947 \\
53,934 \\
20,338 \\
57,625 \\
7,127 \\
\end{array}$ & $\begin{array}{r}4,284 \\
19,388 \\
10,422 \\
3,632 \\
10,292 \\
2,402 \\
\end{array}$ & $\begin{array}{r}413 \\
3,977 \\
2,045 \\
738 \\
1,874 \\
444 \\
\end{array}$ & $\begin{array}{r}212 \\
1,978 \\
1,134 \\
352 \\
1,074 \\
161 \\
\end{array}$ & $\begin{array}{r}900 \\
7,224 \\
3,200 \\
1,590 \\
6,465 \\
612 \\
\end{array}$ & $\begin{array}{r}2,091 \\
64,456 \\
20,455 \\
8,469 \\
14,879 \\
3,151 \\
\end{array}$ \\
\hline Bureau of Indian Education. & - & - & - & - & - & - & - & - & - & - & - & - \\
\hline 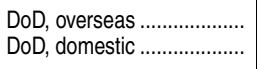 & $\begin{array}{l}- \\
-\end{array}$ & $\begin{array}{l}- \\
-\end{array}$ & - & $\begin{array}{l}- \\
-\end{array}$ & $\begin{array}{l}- \\
-\end{array}$ & $\begin{array}{l}- \\
-\end{array}$ & $\begin{array}{l}- \\
-\end{array}$ & $\begin{array}{l}- \\
-\end{array}$ & $\begin{array}{l}- \\
-\end{array}$ & $\begin{array}{l}- \\
-\end{array}$ & $\begin{array}{l}- \\
-\end{array}$ & $\begin{array}{l}- \\
-\end{array}$ \\
\hline 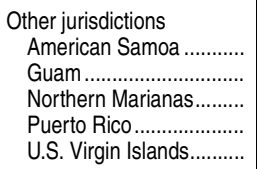 & $\begin{array}{r}- \\
3,383 \\
1,215 \\
59,261 \\
2,918\end{array}$ & $\begin{array}{r}- \\
14 \\
8 \\
450 \\
28\end{array}$ & $\begin{array}{r}196 \\
60 \\
1,835 \\
53\end{array}$ & $\begin{array}{r}- \\
92 \\
10 \\
104 \\
29\end{array}$ & $\begin{array}{r}- \\
82 \\
40 \\
1,464 \\
84\end{array}$ & $\begin{array}{r}- \\
228 \\
77 \\
2,329 \\
62\end{array}$ & $\begin{array}{r}\overline{-} \\
1,843 \\
607 \\
36,506 \\
1,457\end{array}$ & $\begin{array}{r}- \\
631 \\
244 \\
95 \\
367\end{array}$ & $\begin{array}{r}- \\
59 \\
36 \\
828 \\
85\end{array}$ & $\begin{array}{r}-\overline{23} \\
-\overline{-} \\
1,183 \\
30\end{array}$ & $\begin{array}{r}- \\
47 \\
34 \\
3,697 \\
206\end{array}$ & $\begin{array}{r}- \\
168 \\
99 \\
10,770 \\
517\end{array}$ \\
\hline
\end{tabular}

-Not available.

${ }^{1}$ Includes imputations for undercounts in states as designated in footnotes 2 through 9.

${ }^{2}$ Includes imputations for instruction coordinators.

IIncludes imputations for library support staff.

Includes imputations for prekindergarten teachers.

${ }^{5}$ Includes imputations for administrative support staff.

Includes imputations for school support staff.
7 Includes imputations for instructional aides.

8Includes imputations for other support services staff.

Includes imputations for student support staff.

NOTE: $\mathrm{DoD}=$ Department of Defense. Some data have been revised from previously published figures. SOURCE: U.S. Department of Education, National Center for Education Statistics, Common Core of Data (CCD), "State Nonfiscal Survey of Public Elementary/Secondary Education," 2010-11. (This table was prepared May 2012.) 
Table 213.40. Staff, teachers, and teachers as a percentage of staff in public elementary and secondary school systems, by state or jurisdiction: Selected years, fall 2000 through fall 2011

[In full-time equivalents]

\begin{tabular}{|c|c|c|c|c|c|c|c|c|c|c|c|c|c|c|c|}
\hline \multirow[b]{2}{*}{ State or jurisdiction } & \multicolumn{6}{|c|}{ Teachers as a percent of staff } & \multicolumn{3}{|c|}{ Fall 2009} & \multicolumn{3}{|c|}{ Fall 2010} & \multicolumn{3}{|c|}{ Fall 2011} \\
\hline & $\begin{array}{r}\text { Fall } \\
2000\end{array}$ & $\begin{array}{r}\text { Fall } \\
2004\end{array}$ & $\begin{array}{r}\text { Fall } \\
2005\end{array}$ & $\begin{array}{r}\text { Fall } \\
2006\end{array}$ & $\begin{array}{r}\text { Fall } \\
2007\end{array}$ & $\begin{array}{r}\text { Fall } \\
2008\end{array}$ & All staff & Teachers & \begin{tabular}{|r|} 
Teachers \\
as a \\
percent of \\
staff
\end{tabular} & All staff & Teachers & \begin{tabular}{|r|} 
Teachers \\
as a \\
percent of \\
staff
\end{tabular} & All staff & Teachers & $\begin{array}{r}\text { Teachers } \\
\text { as a } \\
\text { percent of } \\
\text { staff }\end{array}$ \\
\hline 1 & 2 & 3 & 4 & 5 & 6 & 7 & 8 & 9 & 10 & 11 & 12 & 13 & 14 & 15 & 16 \\
\hline United States ${ }^{1} .$. & 51.5 & 51.0 & 51.3 & 51.5 & 51.1 & 50.9 & $6,351,157$ & $3,209,672$ & 50.5 & $6,195,207$ & $3,099,095$ & 50.0 & $6,138,890$ & $3,103,263$ & 50.6 \\
\hline 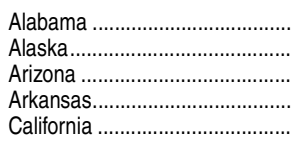 & $\begin{array}{l}53.7^{2} \\
49.3^{2} \\
49.3^{2} \\
50.6^{2} \\
54.1^{2}\end{array}$ & $\begin{array}{l}55.6^{2} \\
44.0^{2} \\
50.0^{2} \\
47.2^{2} \\
53.2^{2}\end{array}$ & $\begin{array}{l}55.7 \\
44.1^{2} \\
51.3 \\
46.7 \\
53.4^{2}\end{array}$ & $\begin{array}{l}51.1 \\
46.9^{2} \\
51.4 \\
49.0^{2} \\
53.0^{2}\end{array}$ & $\begin{array}{l}45.2^{2} \\
45.9^{2} \\
51.6^{2} \\
48.2^{2} \\
52.3^{2}\end{array}$ & $\begin{array}{l}50.1 \\
46.2^{2} \\
51.8^{2} \\
52.1 \\
51.5^{2}\end{array}$ & $\begin{array}{c}94,058 \\
17,743^{2} \\
100,320 \\
74,311 \\
609,655^{2}\end{array}$ & $\begin{array}{r}47,492 \\
8,083 \\
51,947 \\
37,240 \\
316,299^{2}\end{array}$ & $\begin{array}{l}50.5 \\
45.6^{2} \\
51.8^{2} \\
50.1 \\
51.9^{2}\end{array}$ & $\begin{array}{c}95,144 \\
18,102^{2} \\
96,622 \\
72,185 \\
530,337^{2}\end{array}$ & \begin{tabular}{|c|}
49,363 \\
8,171 \\
50,031 \\
34,273 \\
$260,806^{2}$
\end{tabular} & $\begin{array}{l}51.9 \\
45.1^{2} \\
51.8^{2} \\
47.5 \\
49.2^{2}\end{array}$ & \begin{tabular}{|c|}
92,289 \\
$17,747^{2}$ \\
98,712 \\
72,650 \\
$547,188^{2}$
\end{tabular} & $\begin{array}{c}47,723 \\
8,088 \\
50,800 \\
33,983 \\
268,689^{2}\end{array}$ & $\begin{array}{l}51.7 \\
45.6^{2} \\
51.5 \\
46.8 \\
49.1^{2}\end{array}$ \\
\hline 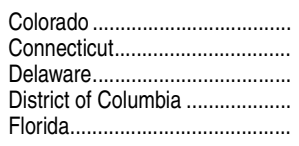 & $\begin{array}{l}50.7 \\
50.0 \\
59.2 \\
46.2 \\
47.8\end{array}$ & $\begin{array}{l}49.4 \\
46.3 \\
52.5 \\
44.3 \\
49.7\end{array}$ & $\begin{array}{l}49.2 \\
46.9 \\
51.7 \\
44.3^{2} \\
50.6\end{array}$ & $\begin{array}{l}48.2 \\
45.1 \\
52.2 \\
44.2 \\
50.6\end{array}$ & $\begin{array}{l}48.1 \\
45.3 \\
52.8 \\
50.6 \\
51.2\end{array}$ & $\begin{array}{l}47.5 \\
52.4 \\
56.2 \\
43.9 \\
54.7\end{array}$ & $\begin{array}{r}103,354 \\
92,877 \\
16,977 \\
11,682 \\
335,446\end{array}$ & $\begin{array}{r}49,060 \\
43,593 \\
8,640 \\
5,854 \\
183,827\end{array}$ & $\begin{array}{l}47.5 \\
46.9 \\
50.9 \\
50.1 \\
54.8\end{array}$ & $\begin{array}{r}101,426 \\
93,088 \\
16,478 \\
11,381 \\
333,183\end{array}$ & $\begin{array}{r}48,543 \\
42,951 \\
8,933 \\
5,925 \\
175,609\end{array}$ & $\begin{array}{l}47.9 \\
46.1 \\
54.2 \\
52.1 \\
52.7\end{array}$ & $\begin{array}{r}100,349 \\
92,955 \\
15,449 \\
11,541 \\
328,709\end{array}$ & $\begin{array}{r}48,078 \\
43,805 \\
8,587 \\
6,278 \\
175,006\end{array}$ & $\begin{array}{l}47.9 \\
47.1 \\
55.6 \\
54.4 \\
53.2\end{array}$ \\
\hline 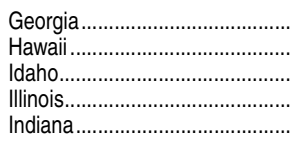 & $\begin{array}{l}49.2 \\
59.5 \\
56.2 \\
51.1^{2} \\
46.7\end{array}$ & $\begin{array}{l}50.1 \\
54.3 \\
55.9 \\
50.2^{2} \\
45.4\end{array}$ & $\begin{array}{l}49.6 \\
53.3 \\
55.8 \\
53.2^{2} \\
45.5\end{array}$ & $\begin{array}{l}49.9 \\
53.5 \\
56.1 \\
63.6^{2} \\
45.6\end{array}$ & $\begin{array}{l}49.7 \\
52.6 \\
55.3 \\
63.7^{2} \\
44.7\end{array}$ & $\begin{array}{l}49.7 \\
52.3 \\
55.6 \\
61.4^{2} \\
44.1\end{array}$ & $\begin{array}{c}234,694 \\
21,677 \\
27,701 \\
221,823^{2} \\
142,724\end{array}$ & $\begin{array}{r}115,918 \\
11,472 \\
15,201 \\
138,483 \\
62,258\end{array}$ & $\begin{array}{l}49.4 \\
52.9 \\
54.9 \\
62.4^{2} \\
43.6\end{array}$ & $\begin{array}{c}227,188 \\
21,704 \\
27,783 \\
215,764^{2} \\
138,802^{2}\end{array}$ & $\begin{array}{c}112,460 \\
11,396 \\
15,673 \\
132,983 \\
58,121^{2}\end{array}$ & $\begin{array}{l}49.5 \\
52.5 \\
56.4 \\
61.6^{2} \\
41.9^{2}\end{array}$ & $\begin{array}{c}224,207 \\
22,065 \\
28,065 \\
213,578^{2} \\
150,191\end{array}$ & $\begin{array}{r}111,133 \\
11,458 \\
15,990 \\
131,777 \\
62,339\end{array}$ & $\begin{array}{l}49.6 \\
51.9 \\
57.0 \\
61.7^{2} \\
41.5\end{array}$ \\
\hline 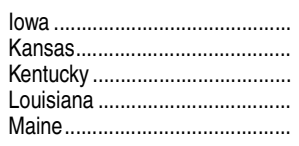 & $\begin{array}{l}51.1 \\
50.9 \\
44.1 \\
49.3 \\
49.7\end{array}$ & $\begin{array}{l}50.7 \\
51.4 \\
43.2 \\
48.5 \\
47.7\end{array}$ & $\begin{array}{l}50.9 \\
51.3 \\
43.3 \\
48.2 \\
47.3\end{array}$ & $\begin{array}{l}51.2 \\
65.7 \\
43.9 \\
48.3 \\
45.7\end{array}$ & $\begin{array}{l}50.3 \\
65.2 \\
43.4 \\
48.8 \\
41.5\end{array}$ & $\begin{array}{l}49.7 \\
64.8 \\
43.4 \\
48.9 \\
43.6\end{array}$ & $\begin{array}{r}72,546 \\
67,531 \\
99,162 \\
102,874 \\
37,317\end{array}$ & $\begin{array}{l}35,842 \\
34,700 \\
41,981 \\
49,646 \\
16,331\end{array}$ & $\begin{array}{l}49.4 \\
51.4 \\
42.3 \\
48.3 \\
43.8\end{array}$ & $\begin{array}{r}69,615 \\
67,751 \\
99,225 \\
100,881 \\
32,549\end{array}$ & $\begin{array}{l}34,642 \\
34,644 \\
42,042 \\
48,655 \\
15,384\end{array}$ & $\begin{array}{l}49.8 \\
51.1 \\
42.4 \\
48.2 \\
47.3\end{array}$ & $\begin{array}{c}69,901 \\
70,631 \\
92,287 \\
100,880 \\
39,946^{2}\end{array}$ & $\begin{array}{l}34,658 \\
37,407 \\
41,860 \\
48,657 \\
14,888\end{array}$ & $\begin{array}{l}49.6 \\
53.0 \\
45.4 \\
48.2 \\
37.3^{2}\end{array}$ \\
\hline 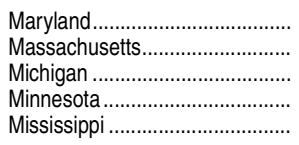 & $\begin{array}{l}54.3 \\
55.1 \\
46.1 \\
51.6^{2} \\
47.9\end{array}$ & $\begin{array}{l}50.9 \\
53.3^{2} \\
48.0 \\
50.0 \\
46.6\end{array}$ & $\begin{array}{l}51.0^{2} \\
53.0^{2} \\
47.9^{2} \\
48.9 \\
46.5\end{array}$ & $\begin{array}{l}51.5 \\
53.6^{2} \\
46.2 \\
48.6 \\
47.0\end{array}$ & $\begin{array}{l}50.8 \\
57.4 \\
46.0 \\
48.9 \\
47.2\end{array}$ & $\begin{array}{l}50.4 \\
56.9 \\
45.5 \\
48.6 \\
46.3\end{array}$ & $\begin{array}{r}115,286 \\
123,167 \\
204,625 \\
109,066 \\
70,782\end{array}$ & $\begin{array}{l}58,463 \\
69,909 \\
92,691 \\
52,839 \\
33,103\end{array}$ & $\begin{array}{l}50.7 \\
56.8 \\
45.3 \\
48.4 \\
46.8\end{array}$ & $\begin{array}{r}115,367 \\
122,057 \\
193,487 \\
108,993 \\
67,866\end{array}$ & $\begin{array}{l}58,428 \\
68,754 \\
88,615 \\
52,672 \\
32,255\end{array}$ & $\begin{array}{l}50.6 \\
56.3 \\
45.8 \\
48.3 \\
47.5\end{array}$ & $\begin{array}{r}113,351 \\
122,880 \\
188,428 \\
109,119 \\
67,850\end{array}$ & $\begin{array}{l}57,589 \\
69,342 \\
86,997 \\
52,832 \\
32,007\end{array}$ & $\begin{array}{l}50.8 \\
56.4 \\
46.2 \\
48.4 \\
47.2\end{array}$ \\
\hline 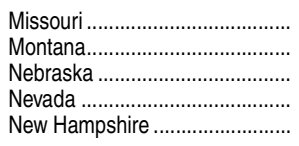 & $\begin{array}{l}53.2 \\
53.5^{2} \\
52.6^{2} \\
58.6 \\
51.1\end{array}$ & $\begin{array}{l}51.9 \\
54.5^{2} \\
51.6 \\
67.0 \\
48.7\end{array}$ & $\begin{array}{l}52.1 \\
52.9^{2} \\
51.9^{2} \\
67.2^{2} \\
48.5\end{array}$ & $\begin{array}{l}51.3 \\
54.7^{2} \\
50.0^{2} \\
67.5^{2} \\
48.2\end{array}$ & $\begin{array}{l}51.2 \\
54.8^{2} \\
50.2^{2} \\
65.8^{2} \\
47.5\end{array}$ & $\begin{array}{l}51.3 \\
54.5^{2} \\
48.8^{2} \\
65.6^{2} \\
47.7\end{array}$ & $\begin{array}{c}132,047 \\
19,434^{2} \\
45,835 \\
33,749^{2} \\
32,911\end{array}$ & $\begin{array}{l}67,796 \\
10,521 \\
22,256 \\
22,104 \\
15,491\end{array}$ & $\begin{array}{l}51.3 \\
54.1^{2} \\
48.6^{2} \\
65.5^{2} \\
47.1^{2}\end{array}$ & $\begin{array}{c}128,289 \\
19,249^{2} \\
45,509 \\
33,400^{2} \\
32,955\end{array}$ & $\begin{array}{l}66,735 \\
10,361 \\
22,345 \\
21,839 \\
15,365\end{array}$ & $\begin{array}{l}52.0 \\
53.8^{2} \\
49.1^{2} \\
65.4^{2} \\
46.6\end{array}$ & $\begin{array}{c}132,167 \\
18,790^{2} \\
45,290^{2} \\
32,533^{2} \\
31,971\end{array}$ & $\begin{array}{l}66,252 \\
10,153 \\
22,182 \\
21,132 \\
15,049\end{array}$ & $\begin{array}{l}50.1 \\
54.0^{2} \\
49.0^{2} \\
65.0^{2} \\
47.1^{2}\end{array}$ \\
\hline 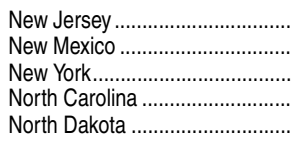 & $\begin{array}{l}53.4 \\
46.8 \\
49.7 \\
51.5 \\
53.9\end{array}$ & $\begin{array}{l}53.8 \\
46.7 \\
54.8^{2} \\
52.2 \\
53.2\end{array}$ & $\begin{array}{l}53.2^{2} \\
45.9 \\
58.6 \\
52.5 \\
52.9\end{array}$ & $\begin{array}{l}54.7^{2} \\
47.3 \\
58.6 \\
54.9 \\
52.8\end{array}$ & $\begin{array}{l}55.3^{2} \\
47.8^{2} \\
56.6 \\
52.4 \\
52.4\end{array}$ & $\begin{array}{l}55.8^{2} \\
47.7 \\
50.9 \\
52.7 \\
52.3\end{array}$ & $\begin{array}{c}213,783^{2} \\
47,565 \\
421,929 \\
200,447^{2} \\
15,983\end{array}$ & $\begin{array}{c}115,248 \\
22,724 \\
214,804 \\
105,036^{2} \\
8,366\end{array}$ & $\begin{array}{l}53.9^{2} \\
47.8^{2} \\
50.9^{2} \\
52.4^{2} \\
52.3^{2}\end{array}$ & $\begin{array}{r}202,634^{2} \\
46,519 \\
413,971 \\
193,039 \\
16,239\end{array}$ & $\begin{array}{r}110,202 \\
22,437 \\
211,606 \\
98,357 \\
8,417\end{array}$ & $\begin{array}{l}54.4^{2} \\
48.2 \\
51.1 \\
51.0 \\
51.8\end{array}$ & $\begin{array}{r}202,928^{2} \\
45,907 \\
406,625 \\
188,553 \\
16,401\end{array}$ & $\begin{array}{r}109,719 \\
21,957 \\
209,527 \\
97,308 \\
8,525\end{array}$ & $\begin{array}{l}54.1^{2} \\
47.8 \\
51.5 \\
51.6 \\
52.0\end{array}$ \\
\hline 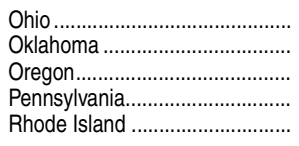 & $\begin{array}{l}53.1 \\
55.0 \\
50.0 \\
52.2 \\
60.0\end{array}$ & $\begin{array}{l}49.2 \\
52.2 \\
48.4 \\
51.1 \\
51.6^{2}\end{array}$ & $\begin{array}{l}49.4 \\
51.1 \\
47.0 \\
50.9 \\
58.4^{2}\end{array}$ & $\begin{array}{l}45.5 \\
51.6 \\
48.1 \\
51.2 \\
63.5^{2}\end{array}$ & $\begin{array}{l}45.1 \\
53.9 \\
46.4 \\
53.1 \\
64.2\end{array}$ & $\begin{array}{l}46.1 \\
53.2 \\
46.3 \\
51.5 \\
60.8\end{array}$ & $\begin{array}{r}244,232 \\
84,740 \\
62,994 \\
253,866 \\
18,825\end{array}$ & $\begin{array}{r}111,378 \\
42,615 \\
28,768 \\
130,984 \\
11,366\end{array}$ & $\begin{array}{l}45.6 \\
50.3 \\
45.7 \\
51.6 \\
60.4\end{array}$ & $\begin{array}{r}241,212 \\
82,262 \\
63,603 \\
266,796 \\
18,632\end{array}$ & $\begin{array}{r}109,282 \\
41,278 \\
28,109 \\
129,911 \\
11,212\end{array}$ & $\begin{array}{l}45.3 \\
50.2 \\
44.2 \\
48.7 \\
60.2\end{array}$ & $\begin{array}{r}243,586 \\
82,719 \\
60,715 \\
254,297 \\
18,743\end{array}$ & $\begin{array}{r}107,972 \\
41,349 \\
26,791 \\
124,646 \\
11,414\end{array}$ & $\begin{array}{l}44.3 \\
50.0 \\
44.1 \\
49.0 \\
60.9\end{array}$ \\
\hline 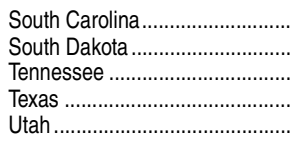 & $\begin{array}{l}65.7^{2} \\
52.0 \\
52.1 \\
50.6 \\
54.1\end{array}$ & $\begin{array}{l}72.2^{2} \\
50.1 \\
51.8 \\
48.5 \\
50.1\end{array}$ & $\begin{array}{l}70.9^{2} \\
48.0 \\
52.2 \\
50.5 \\
50.2\end{array}$ & $\begin{array}{l}71.6^{2} \\
52.4 \\
50.5 \\
50.6 \\
49.9\end{array}$ & $\begin{array}{l}71.7 \\
55.3 \\
51.1 \\
50.6 \\
50.2\end{array}$ & $\begin{array}{l}71.6 \\
50.3 \\
51.2 \\
50.5 \\
48.2\end{array}$ & $\begin{array}{r}67,355 \\
18,631 \\
127,743 \\
662,369 \\
51,844\end{array}$ & $\begin{array}{r}46,980 \\
9,326 \\
65,361 \\
333,164 \\
25,615\end{array}$ & $\begin{array}{l}69.7 \\
50.1 \\
51.2 \\
50.3 \\
49.4\end{array}$ & $\begin{array}{r}65,508 \\
19,545 \\
128,197 \\
665,419 \\
52,341\end{array}$ & $\begin{array}{r}45,210 \\
9,512 \\
66,558 \\
334,997 \\
25,677\end{array}$ & $\begin{array}{l}69.0 \\
48.7 \\
51.9 \\
50.3 \\
49.1\end{array}$ & $\begin{array}{r}69,272 \\
19,059 \\
127,781 \\
640,166 \\
51,994\end{array}$ & $\begin{array}{r}46,782 \\
9,247 \\
66,382 \\
324,282 \\
25,970\end{array}$ & $\begin{array}{l}67.5 \\
48.5 \\
51.9 \\
50.7 \\
49.9\end{array}$ \\
\hline 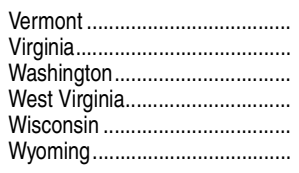 & $\begin{array}{l}47.3 \\
54.1^{2} \\
52.3 \\
54.3 \\
56.3 \\
48.6\end{array}$ & $\begin{array}{l}46.1 \\
52.2 \\
47.5 \\
52.6 \\
58.2 \\
46.7 \\
\end{array}$ & $\begin{array}{l}46.5 \\
44.4 \\
47.0 \\
52.3 \\
57.0 \\
46.2 \\
\end{array}$ & $\begin{array}{l}46.1 \\
37.2 \\
52.2 \\
53.5^{2} \\
56.3 \\
44.6\end{array}$ & $\begin{array}{l}45.6 \\
35.2 \\
52.0 \\
53.0^{2} \\
56.1 \\
44.7\end{array}$ & $\begin{array}{l}45.3 \\
35.1 \\
52.0 \\
52.4 \\
55.7 \\
44.2 \\
\end{array}$ & $\begin{array}{c}19,337 \\
203,301 \\
103,938 \\
39,205^{2} \\
105,229 \\
16,468 \\
\end{array}$ & $\begin{array}{r}8,734 \\
70,827 \\
53,448 \\
20,299 \\
58,426 \\
7,166 \\
\end{array}$ & $\begin{array}{l}45.2 \\
34.8 \\
51.4 \\
51.8^{2} \\
55.5 \\
43.5 \\
\end{array}$ & $\begin{array}{c}18,485 \\
201,047 \\
103,783 \\
39,270^{2} \\
103,901 \\
16,424 \\
\end{array}$ & $\begin{array}{r}8,382 \\
70,947 \\
53,934 \\
20,338 \\
57,625 \\
7,127 \\
\end{array}$ & $\begin{array}{l}45.3 \\
35.3 \\
52.0 \\
51.8^{2} \\
55.5 \\
43.4 \\
\end{array}$ & $\begin{array}{c}18,385 \\
180,086 \\
101,914 \\
39,380^{2} \\
101,533 \\
17,128 \\
\end{array}$ & $\begin{array}{r}8,364 \\
90,832 \\
53,119 \\
20,247 \\
56,245 \\
7,847 \\
\end{array}$ & $\begin{array}{l}45.5 \\
50.4 \\
52.1 \\
51.4^{2} \\
55.4 \\
45.8 \\
\end{array}$ \\
\hline Bureau of Indian Education ........ & - & - & - & - & - & - & - & - & - & - & - & - & - & - & - \\
\hline 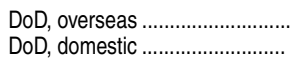 & $\begin{array}{l}66.0 \\
59.2\end{array}$ & $\begin{array}{l}71.4 \\
69.9\end{array}$ & $\begin{array}{l}62.9 \\
55.4\end{array}$ & $\begin{array}{l}62.4 \\
56.9\end{array}$ & $\begin{array}{l}66.2 \\
56.2\end{array}$ & $\begin{array}{l}60.5 \\
55.8\end{array}$ & $\overline{-}$ & $\overline{-}$ & - & - & - & - & - & - & - \\
\hline 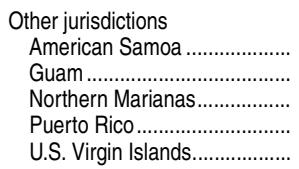 & $\begin{array}{l}50.0 \\
51.5 \\
50.2 \\
54.4 \\
52.1\end{array}$ & $\begin{array}{l}52.1 \\
50.4 \\
49.7 \\
56.0 \\
51.9\end{array}$ & $\begin{array}{l}68.4 \\
52.2 \\
49.8 \\
56.0 \\
53.8\end{array}$ & $\begin{array}{r}52.0 \\
- \\
49.9 \\
55.8 \\
50.7\end{array}$ & $\begin{array}{r}- \\
49.5 \\
56.8 \\
48.4\end{array}$ & $\begin{array}{r}- \\
- \\
49.3 \\
56.2 \\
53.8\end{array}$ & $\begin{array}{r}- \\
- \\
1,155 \\
63,198 \\
2,854\end{array}$ & $\begin{array}{r}- \\
- \\
552 \\
39,102 \\
1,425\end{array}$ & $\begin{array}{r}- \\
47.8 \\
61.9 \\
49.9\end{array}$ & $\begin{array}{r}- \\
3,383 \\
1,215 \\
59,261 \\
2,918\end{array}$ & $\begin{array}{r}- \\
1,843 \\
607 \\
36,506 \\
1,457\end{array}$ & $\begin{array}{r}-\overline{54.5} \\
50.0 \\
61.6 \\
49.9\end{array}$ & $\begin{array}{r}- \\
3,923 \\
1,042 \\
55,797 \\
2,391\end{array}$ & $\begin{array}{r}- \\
2,291 \\
496 \\
33,079 \\
1,217\end{array}$ & $\begin{array}{r}-\overline{58.4} \\
47.6 \\
59.3 \\
50.9\end{array}$ \\
\hline
\end{tabular}

-Not available.

${ }^{1}$ U.S. totals include imputations for underreporting and nonreporting states. 2Includes imputations for underreporting.

NOTE: DoD = Department of Defense. Some data have been revised from previously published figures.
SOURCE: U.S. Department of Education, National Center for Education Statistics, Common Core of Data (CCD), "State Nonfiscal Survey of Public Elementary/Secondary Education," 2000-01 through 2011-12. (This table was prepared August 2013.) 
156 CHAPTER 2: Elementary and Secondary Education School Staff

Table 213.50. Staff, enrollment, and pupil/staff ratios in public elementary and secondary school systems, by state or jurisdiction: Selected years, fall 2000 through fall 2011

\begin{tabular}{|c|c|c|c|c|c|c|c|c|c|c|c|c|c|c|}
\hline \multirow[b]{2}{*}{ State or jurisdiction } & \multicolumn{5}{|c|}{ Pupil/staff ratio } & \multicolumn{3}{|c|}{ Fall 2009} & \multicolumn{3}{|c|}{ Fall 2010} & \multicolumn{3}{|c|}{ Fall 2011} \\
\hline & Fall 2000 & Fall 2005 & Fall 2006 & Fall 2007 & Fall 2008 & Staff & Enrollment & $\begin{array}{r}\text { Pupil/ } \\
\text { staff ratio }\end{array}$ & Staff & Enrollment & $\begin{array}{r}\text { Pupil/ } \\
\text { staff ratio }\end{array}$ & Staff & Enrollment & $\begin{array}{r}\text { Pupil/ } \\
\text { staff ratio }\end{array}$ \\
\hline 1 & 2 & 3 & 4 & 5 & 6 & 7 & 8 & 9 & 10 & 11 & 12 & 13 & 14 & 15 \\
\hline United States ${ }^{1} \ldots$ & 8.3 & 8.0 & 8.0 & 7.9 & 7.8 & $6,351,157$ & $49,360,982$ & 7.8 & $6,195,207$ & $49,484,181$ & 8.0 & $6,138,890$ & $49,521,669$ & 8.1 \\
\hline 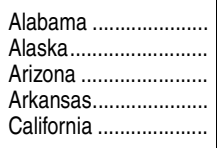 & $\begin{array}{c}8.2^{2} \\
8.3^{2} \\
9.7 \\
7.1^{2} \\
11.1^{2}\end{array}$ & $\begin{array}{c}7.1 \\
7.4^{2} \\
10.9 \\
6.7 \\
11.1^{2}\end{array}$ & $\begin{array}{c}6.8 \\
7.9^{2} \\
10.4 \\
6.7 \\
11.0^{2}\end{array}$ & $\begin{array}{c}6.7^{2} \\
7.9^{2} \\
10.4^{2} \\
6.8^{2} \\
10.9^{2}\end{array}$ & $\begin{array}{c}7.8^{2} \\
7.6^{2} \\
10.3 \\
6.7^{2} \\
10.7^{2}\end{array}$ & $\begin{array}{c}94,058 \\
17,743^{2} \\
100,320 \\
74,311 \\
609,655^{2}\end{array}$ & \begin{tabular}{|r|}
748,889 \\
131,661 \\
$1,077,831$ \\
480,559 \\
$6,263,438$ \\
\end{tabular} & $\begin{array}{c}8.0 \\
7.4^{2} \\
10.7 \\
6.5 \\
10.3^{2}\end{array}$ & $\begin{array}{c}95,144 \\
18,102^{2} \\
96,622 \\
72,185 \\
530,337^{2}\end{array}$ & $\begin{array}{r}755,552 \\
132,104 \\
1,071,751 \\
482,114 \\
6,289,578\end{array}$ & \begin{tabular}{c|}
7.9 \\
$7.3^{2}$ \\
11.1 \\
$6 . .^{2}$ \\
$11.9^{2}$
\end{tabular} & $\begin{array}{c}92,289 \\
17,747^{2} \\
98,712 \\
72,650 \\
547,188^{2}\end{array}$ & \begin{tabular}{|r|}
744,621 \\
131,167 \\
$1,080,319$ \\
483,114 \\
$6,287,834$
\end{tabular} & $\begin{array}{c}8.1 \\
7.4^{2} \\
10.9 \\
6.6^{2} \\
11.5^{2}\end{array}$ \\
\hline 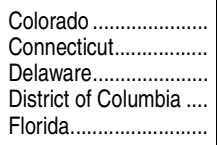 & $\begin{array}{l}8.7 \\
6.8 \\
9.1 \\
6.4 \\
8.8\end{array}$ & $\begin{array}{l}8.4 \\
6.8 \\
7.8 \\
6.2^{2} \\
8.5\end{array}$ & $\begin{array}{l}8.2 \\
6.6 \\
7.9 \\
6.0^{2} \\
8.3\end{array}$ & $\begin{array}{l}8.1 \\
6.6 \\
7.9 \\
6.3 \\
8.1\end{array}$ & $\begin{array}{l}8.0 \\
6.1 \\
8.5 \\
5.7 \\
7.7\end{array}$ & $\begin{array}{r}103,354 \\
92,877 \\
16,977 \\
11,682 \\
335,446\end{array}$ & $\begin{array}{r}832,368 \\
563,968 \\
126,801 \\
69,433 \\
2,634,522\end{array}$ & $\begin{array}{l}8.1 \\
6.1 \\
7.5 \\
5.9 \\
7.9\end{array}$ & $\begin{array}{r}101,426 \\
93,088 \\
16,478 \\
11,381 \\
333,183\end{array}$ & $\begin{array}{r}843,316 \\
560,546 \\
129,403 \\
71,284 \\
2,643,347\end{array}$ & $\begin{array}{l}8.3 \\
6.0 \\
7.9 \\
6.3 \\
7.9\end{array}$ & $\begin{array}{r}100,349 \\
92,955 \\
15,449 \\
11,541 \\
328,709\end{array}$ & $\begin{array}{r}854,265 \\
554,437 \\
128,946 \\
73,911 \\
2,668,156\end{array}$ & $\begin{array}{l}8.5 \\
6.0 \\
8.3 \\
6.4 \\
8.1\end{array}$ \\
\hline 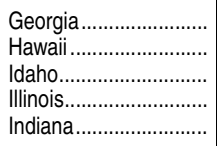 & $\begin{array}{c}7.8 \\
10.0 \\
10.1 \\
8.2^{2} \\
7.8\end{array}$ & $\begin{array}{c}7.3 \\
8.7 \\
10.1 \\
8.4^{2} \\
7.8\end{array}$ & $\begin{array}{c}7.2 \\
8.6 \\
10.2 \\
9.6^{2} \\
7.8\end{array}$ & $\begin{array}{c}7.0 \\
8.3 \\
10.0 \\
9.9^{2} \\
7.5\end{array}$ & $\begin{array}{c}6.9 \\
8.3 \\
10.1 \\
9.6^{2} \\
7.4\end{array}$ & $\begin{array}{c}234,694 \\
21,677 \\
27,701 \\
221,8232 \\
142,724\end{array}$ & $\begin{array}{r}1,667,685 \\
180,196 \\
276,299 \\
2,104,175 \\
1,046,661\end{array}$ & $\begin{array}{c}7.1 \\
8.3 \\
10.0 \\
9.5^{2} \\
7.3\end{array}$ & $\begin{array}{c}227,188 \\
21,704 \\
27,783 \\
215,764^{2} \\
138,802^{2}\end{array}$ & $\begin{array}{r}1,677,067 \\
179,601 \\
275,859 \\
2,091,654 \\
1,047,232\end{array}$ & $\begin{array}{l}7.4 \\
8.3 \\
9.9 \\
9.7^{2} \\
7.5^{2}\end{array}$ & $\begin{array}{c}224,207 \\
22,065 \\
28,065 \\
213,578^{2} \\
150,191\end{array}$ & $\begin{array}{r}1,685,016 \\
182,706 \\
279,873 \\
2,083,097 \\
1,040,765\end{array}$ & $\begin{array}{c}7.5 \\
8.3 \\
10.0 \\
9.8^{2} \\
6.9\end{array}$ \\
\hline 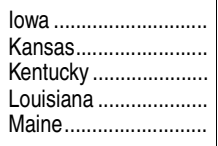 & $\begin{array}{l}7.3 \\
7.3 \\
7.4 \\
7.3 \\
6.2 \\
6.2\end{array}$ & $\begin{array}{l}7.0 \\
7.1 \\
6.9 \\
7.1 \\
5.5\end{array}$ & $\begin{array}{l}6.9 \\
8.7 \\
6.9^{2} \\
7.1 \\
5.3\end{array}$ & $\begin{array}{l}6.8 \\
8.6 \\
6.6^{2} \\
6.8 \\
4.9\end{array}$ & $\begin{array}{l}6.7 \\
8.5 \\
6.7 \\
6.8 \\
5.3\end{array}$ & $\begin{array}{r}72,546 \\
67,531 \\
99,162 \\
102,874 \\
37,317\end{array}$ & $\begin{array}{l}491,842 \\
474,489 \\
680,089 \\
690,915 \\
189,225\end{array}$ & $\begin{array}{l}6.8 \\
7.0 \\
6.9 \\
6.7 \\
5.1\end{array}$ & $\begin{array}{r}69,615 \\
67,751 \\
99,225 \\
100,881 \\
32,549\end{array}$ & $\begin{array}{l}495,775 \\
483,701 \\
673,128 \\
696,558 \\
189,077\end{array}$ & $\begin{array}{l}7.1 \\
7.1 \\
6.8 \\
6.9 \\
5.8\end{array}$ & $\begin{array}{c}69,901 \\
70,631 \\
92,287 \\
100,880 \\
39,946^{2}\end{array}$ & $\begin{array}{l}495,870 \\
486,108 \\
681,987 \\
703,390 \\
188,969\end{array}$ & $\begin{array}{l}7.1 \\
6.9 \\
7.4 \\
7.0 \\
4.7^{2}\end{array}$ \\
\hline $\begin{array}{l}\text { Maryland................ } \\
\text { Massachusetts........... } \\
\text { Michigan .................... } \\
\text { Minnesota ................ } \\
\text { Mississippi .................. }\end{array}$ & $\begin{array}{l}8.8 \\
8.0 \\
8.2^{2} \\
8.2^{2} \\
7.7\end{array}$ & $\begin{array}{l}7.7^{2} \\
7.0^{2} \\
8.5^{2} \\
8.0^{2} \\
7.3\end{array}$ & $\begin{array}{l}7.5 \\
7.1^{2} \\
8.1 \\
7.9 \\
7.2\end{array}$ & $\begin{array}{l}7.2 \\
7.8 \\
8.1 \\
7.7 \\
6.9\end{array}$ & $\begin{array}{l}7.2 \\
7.8 \\
8.0 \\
7.7 \\
6.8\end{array}$ & $\begin{array}{r}115,286 \\
123,167 \\
204,625 \\
109,066 \\
70,782\end{array}$ & $\begin{array}{r}848,412 \\
957,053 \\
1,649,082 \\
837,053 \\
492,481\end{array}$ & $\begin{array}{l}7.4 \\
7.8 \\
8.1 \\
7.7 \\
7.0\end{array}$ & $\begin{array}{r}115,367 \\
122,057 \\
193,487 \\
108,993 \\
67,866\end{array}$ & $\begin{array}{r}852,211 \\
955,563 \\
1,587,067 \\
838,037 \\
490,526\end{array}$ & $\begin{array}{l}7.4 \\
7.8 \\
8.2 \\
7.7 \\
7.2 \\
7\end{array}$ & $\begin{array}{r}113,351 \\
122,880 \\
188,428 \\
109,119 \\
67,850\end{array}$ & $\begin{array}{r}854,086 \\
953,369 \\
1,573,537 \\
839,738 \\
490,619\end{array}$ & $\begin{array}{l}7.5 \\
7.8 \\
8.4 \\
7.7 \\
7.2 \\
7\end{array}$ \\
\hline 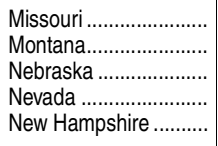 & $\begin{array}{r}7.5 \\
8.0^{2} \\
7.2 \\
10.9 \\
7.4\end{array}$ & $\begin{array}{c}7.1 \\
7.4^{2} \\
7.0^{2} \\
12.7^{2} \\
6.4\end{array}$ & $\begin{array}{c}7.0^{2} \\
7.6^{2} \\
6.7^{2} \\
12.5^{2} \\
6.3^{2}\end{array}$ & $\begin{array}{c}6.9 \\
7.4^{2} \\
6.7^{2} \\
12.1^{2} \\
6.2\end{array}$ & $\begin{array}{c}6.9^{2} \\
7.4^{2} \\
6.5^{2} \\
12.9^{2} \\
6.0^{2}\end{array}$ & $\begin{array}{c}132,047 \\
19,434^{2} \\
45,835 \\
33,7492 \\
32,911\end{array}$ & $\begin{array}{l}917,982 \\
141,807 \\
295,368 \\
428,947 \\
197,140\end{array}$ & $\begin{array}{c}7.0^{2} \\
7.3^{2} \\
6.4^{2} \\
12.7^{2} \\
6.0^{2}\end{array}$ & $\begin{array}{c}128,289 \\
19,249^{2} \\
45,509 \\
33,400^{2} \\
32,955\end{array}$ & $\begin{array}{l}918,710 \\
141,693 \\
298,500 \\
437,149 \\
194,711\end{array}$ & $\begin{array}{c}7.2 \\
7.4^{2} \\
6.6^{2} \\
13.1^{2} \\
5.9\end{array}$ & $\begin{array}{c}132,167 \\
18,790^{2} \\
45,290^{2} \\
32,533^{2} \\
31,971\end{array}$ & $\begin{array}{l}916,584 \\
142,349 \\
301,296 \\
439,634 \\
191,900\end{array}$ & $\begin{array}{c}6.9^{2} \\
7.6^{2} \\
6.7^{2} \\
13.5^{2} \\
6.0^{2}\end{array}$ \\
\hline $\begin{array}{l}\text { New Jersey ................ } \\
\text { New Mexico ............... } \\
\text { New York.................. } \\
\text { North Carolina ............. } \\
\text { North Dakota ............... }\end{array}$ & $\begin{array}{l}7.1 \\
7.1 \\
6.9 \\
8.0 \\
7.2 \\
\end{array}$ & $\begin{array}{l}6.6^{2} \\
6.8 \\
7.5 \\
7.8 \\
6.5\end{array}$ & $\begin{array}{l}6.8^{2} \\
7.1 \\
7.5 \\
7.1 \\
6.4\end{array}$ & $\begin{array}{l}6.9^{2} \\
7.0 \\
7.4 \\
7.3 \\
6.2\end{array}$ & $\begin{array}{l}6.7^{2} \\
6.9 \\
6.4 \\
7.2 \\
6.1\end{array}$ & $\begin{array}{c}213,783^{2} \\
47,565 \\
421,929 \\
200,447^{2} \\
15,983\end{array}$ & $\begin{array}{r}1,396,029 \\
334,419 \\
2,766,052 \\
1,483,397 \\
95,073\end{array}$ & $\begin{array}{l}6.5^{2} \\
7.0 \\
6.6 \\
7.4^{2} \\
5.9\end{array}$ & $\begin{array}{r}202,634^{2} \\
46,519 \\
413,971 \\
193,039 \\
16,239\end{array}$ & $\begin{array}{r}1,402,548 \\
338,122 \\
2,734,955 \\
1,490,605 \\
96,323\end{array}$ & $\begin{array}{l}6.9^{2} \\
7.3 \\
6.6 \\
7.7 \\
5.9\end{array}$ & $\begin{array}{c}202,928^{2} \\
45,907 \\
406,625 \\
188,553 \\
16,401\end{array}$ & $\begin{array}{r}1,356,431 \\
337,225 \\
2,704,718 \\
1,507,864 \\
97,646\end{array}$ & $\begin{array}{l}6.7^{2} \\
7.3 \\
6.7 \\
8.0 \\
6.0\end{array}$ \\
\hline 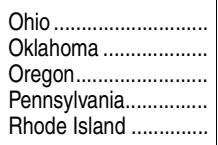 & $\begin{array}{l}8.2 \\
8.3 \\
9.7 \\
8.1 \\
8.9\end{array}$ & $\begin{array}{l}7.7 \\
7.8 \\
9.2 \\
7.6 \\
6.3^{2}\end{array}$ & $\begin{array}{l}7.6 \\
7.8 \\
9.0 \\
7.8 \\
8.5^{2}\end{array}$ & $\begin{array}{l}7.5 \\
7.4 \\
8.8 \\
7.1 \\
8.4\end{array}$ & $\begin{array}{l}7.4 \\
7.4 \\
8.8 \\
7.0 \\
7.8 \\
\end{array}$ & $\begin{array}{r}244,232 \\
84,740 \\
62,994 \\
253,866 \\
18,825\end{array}$ & $\begin{array}{r}1,764,297 \\
654,802 \\
582,839 \\
1,785,993 \\
145,118\end{array}$ & $\begin{array}{l}7.2 \\
7.7 \\
9.3 \\
7.0 \\
7.7\end{array}$ & $\begin{array}{r}241,212 \\
82,262 \\
63,603 \\
266,796 \\
18,632\end{array}$ & $\begin{array}{r}1,754,191 \\
659,911 \\
570,720 \\
1,793,284 \\
143,793\end{array}$ & $\begin{array}{l}7.3 \\
8.0 \\
9.0 \\
6.7 \\
7.7\end{array}$ & $\begin{array}{r}243,586 \\
82,719 \\
60,715 \\
254,297 \\
18,743\end{array}$ & $\begin{array}{r}1,740,030 \\
666,120 \\
568,208 \\
1,771,395 \\
142,854\end{array}$ & $\begin{array}{l}7.1 \\
8.1 \\
9.4 \\
7.0 \\
7.6\end{array}$ \\
\hline 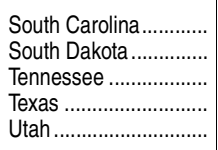 & $\begin{array}{c}9.8^{2} \\
7.1^{2} \\
8.3^{2} \\
7.5^{2} \\
11.8\end{array}$ & $\begin{array}{r}10.3^{2} \\
6.4^{2} \\
8.4 \\
7.6 \\
11.1\end{array}$ & $\begin{array}{r}10.3^{2} \\
7.0 \\
7.9 \\
7.5 \\
11.1\end{array}$ & $\begin{array}{r}10.8 \\
7.1 \\
7.6 \\
7.4 \\
11.9\end{array}$ & $\begin{array}{r}10.3 \\
6.9 \\
7.7 \\
7.3 \\
11.4\end{array}$ & $\begin{array}{r}67,355 \\
18,631 \\
127,743 \\
662,369 \\
51,844\end{array}$ & $\begin{array}{r}723,143 \\
123,713 \\
972,549 \\
4,850,210 \\
571,586\end{array}$ & $\begin{array}{r}10.7 \\
6.6 \\
7.6 \\
7.3 \\
11.0\end{array}$ & $\begin{array}{r}65,508 \\
19,545 \\
128,197 \\
665,419 \\
52,341\end{array}$ & $\begin{array}{r}725,838 \\
126,128 \\
987,422 \\
4,935,715 \\
585,552\end{array}$ & $\begin{array}{r}11.1 \\
6.5 \\
7.7 \\
7.4 \\
11.2\end{array}$ & $\begin{array}{r}69,272 \\
19,059 \\
127,781 \\
640,166 \\
51,994\end{array}$ & $\begin{array}{r}727,186 \\
128,016 \\
999,693 \\
5,000,470 \\
598,832\end{array}$ & $\begin{array}{r}10.5 \\
6.7 \\
7.8 \\
7.8 \\
11.5\end{array}$ \\
\hline 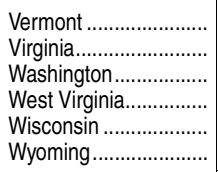 & $\begin{array}{c}5.7 \\
7.1^{2} \\
10.3 \\
7.4 \\
8.2 \\
6.4\end{array}$ & $\begin{array}{l}5.1 \\
5.2 \\
9.1 \\
7.4 \\
8.3 \\
5.8\end{array}$ & $\begin{array}{c}5.0 \\
5.7 \\
10.0 \\
7.7^{2} \\
8.3 \\
5.6\end{array}$ & $\begin{array}{l}4.9 \\
6.0 \\
9.9 \\
7.4^{2} \\
8.3 \\
5.6\end{array}$ & $\begin{array}{l}4.8 \\
6.1 \\
9.9 \\
7.3 \\
8.2 \\
5.5\end{array}$ & $\begin{array}{c}19,337 \\
203,301 \\
103,938 \\
39,205^{2} \\
105,229 \\
16,468\end{array}$ & $\begin{array}{r}91,451 \\
1,245,340 \\
1,035,347 \\
282,662 \\
872,436 \\
88,155 \\
\end{array}$ & $\begin{array}{c}4.7 \\
6.1 \\
10.0 \\
7.2^{2} \\
8.3 \\
5.4 \\
\end{array}$ & $\begin{array}{c}18,485 \\
201,047 \\
103,783 \\
39,270^{2} \\
103,901 \\
16,424\end{array}$ & $\begin{array}{r}96,858 \\
1,251,440 \\
1,043,788 \\
282,879 \\
872,286 \\
89,009 \\
\end{array}$ & \begin{tabular}{c|}
5.2 \\
6.2 \\
10.1 \\
$7.2^{2}$ \\
8.4 \\
5.4
\end{tabular} & $\begin{array}{c}18,385 \\
180,086 \\
101,914 \\
39,380^{2} \\
101,533 \\
17,128\end{array}$ & $\begin{array}{r}89,908 \\
1,257,883 \\
1,045,453 \\
282,870 \\
871,105 \\
90,099 \\
\end{array}$ & $\begin{array}{c}4.9 \\
7.0 \\
10.3 \\
7.2^{2} \\
8.6 \\
5.3 \\
\end{array}$ \\
\hline $\begin{array}{l}\text { Bureau of Indian } \\
\text { Education............... }\end{array}$ & - & - & - & - & - & - & 41,351 & - & - & 41,962 & - & - & - & - \\
\hline $\begin{array}{l}\text { DoD, overseas ............. } \\
\text { DoD, domestic ........... }\end{array}$ & $\begin{array}{l}9.5 \\
8.4\end{array}$ & $\begin{array}{l}6.9 \\
7.7\end{array}$ & $\begin{array}{l}7.3 \\
7.5\end{array}$ & $\begin{array}{l}9.1 \\
6.9\end{array}$ & $\begin{array}{l}7.5 \\
7.3\end{array}$ & - & $\begin{array}{l}- \\
-\end{array}$ & - & - & - & - & - & - & - \\
\hline $\begin{array}{l}\text { Other jurisdictions } \\
\text { American Samoa ..... } \\
\text { Guam .................... } \\
\text { Northern Marianas.. } \\
\text { Puerto Rico ............ } \\
\text { U.S. Virgin Islands... }\end{array}$ & $\begin{array}{l}9.6 \\
8.5 \\
9.6 \\
8.9 \\
6.7\end{array}$ & $\begin{array}{r}11.4 \\
9.0 \\
9.5 \\
7.5 \\
6.3\end{array}$ & $\begin{array}{r}8.8 \\
- \\
10.1 \\
7.6 \\
5.4\end{array}$ & $\begin{array}{r}- \\
\overline{-} \\
10.2 \\
7.3 \\
5.1\end{array}$ & $\begin{array}{r}- \\
\overline{-} \\
10.5 \\
7.2 \\
6.4\end{array}$ & $\begin{array}{r}- \\
- \\
1,155 \\
63,198 \\
2,854\end{array}$ & $\begin{array}{r}- \\
- \\
10,961 \\
493,393 \\
15,493\end{array}$ & $\begin{array}{l}- \\
\overline{9.5} \\
7.8 \\
5.4\end{array}$ & $\begin{array}{r}- \\
3,383 \\
1,215 \\
59,261 \\
2,918\end{array}$ & $\begin{array}{r}- \\
31,618 \\
11,105 \\
473,735 \\
15,495\end{array}$ & $\begin{array}{l}-\overline{9.3} \\
9.1 \\
8.0 \\
5.3\end{array}$ & $\begin{array}{r}- \\
3,923 \\
1,042 \\
55,797 \\
2,391\end{array}$ & $\begin{array}{r}-\overline{3} \\
31,243 \\
11,011 \\
452,740 \\
15,711\end{array}$ & $\begin{array}{r}- \\
8.0 \\
10.6 \\
8.1 \\
6.6\end{array}$ \\
\hline
\end{tabular}

-Not available

${ }^{1}$ U.S. totals include imputations for underreporting and nonreporting states. 2Includes imputations for underreporting.

NOTE: Staff reported in full-time equivalents. DoD = Department of Defense. Some data have been revised from previously published figures.
SOURCE: U.S. Department of Education, National Center for Education Statistics, Common Core of Data (CCD), "State Nonfiscal Survey of Public Elementary/Secondary Education," 2000-01 through 2011-12. (This table was prepared August 2013.) 
CHAPTER 2: Elementary and Secondary Education 157 Overview of Schools and School Districts

Table 214.10. Number of public school districts and public and private elementary and secondary schools: Selected years, 1869-70 through 2011-12

\begin{tabular}{|c|c|c|c|c|c|c|c|c|c|c|}
\hline \multirow[b]{3}{*}{ School year } & \multirow{3}{*}{$\begin{array}{r}\text { Regular } \\
\text { public school } \\
\text { districts }\end{array}$} & \multirow{3}{*}{$\begin{array}{r}\text { Total, all } \\
\text { public and } \\
\text { private } \\
\text { schools }\end{array}$} & \multicolumn{5}{|c|}{ Public schools ${ }^{2}$} & \multicolumn{3}{|c|}{ Private schools ${ }^{2,3}$} \\
\hline & & & \multirow{2}{*}{$\begin{array}{r}\text { Total, all } \\
\text { public } \\
\text { schools }^{4}\end{array}$} & \multirow{2}{*}{$\begin{array}{r}\text { Total, } \\
\text { schools with } \\
\text { reported } \\
\text { grade } \\
\text { spans }^{5}\end{array}$} & \multicolumn{2}{|c|}{$\begin{array}{l}\text { Schools with } \\
\text { elementary grades }\end{array}$} & \multirow{2}{*}{$\begin{array}{r}\text { Schools } \\
\text { with } \\
\text { secondary } \\
\text { grades }\end{array}$} & \multirow{2}{*}{$\begin{array}{r}\text { Total, all } \\
\text { private } \\
\text { schools }\end{array}$} & \multirow{2}{*}{$\begin{array}{r}\text { Schools with } \\
\text { elementary } \\
\text { grades }\end{array}$} & \multirow{2}{*}{$\begin{array}{r}\text { Schools with } \\
\text { secondary } \\
\text { grades }\end{array}$} \\
\hline & & & & & Total & One-teacher & & & & \\
\hline 1 & 2 & 3 & 4 & 5 & 6 & 7 & 8 & 9 & 10 & 11 \\
\hline 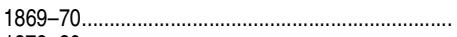 & - & - & 116,312 & - & - & - & - & - & - & - \\
\hline 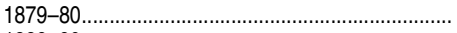 & - & - & 178,122 & - & - & - & - & - & - & - \\
\hline $1889-90 \ldots .$. & - & - & 224,526 & - & - & - & - & - & - & - \\
\hline $1899-1900$ & - & - & 248,279 & - & - & - & - & - & - & - \\
\hline 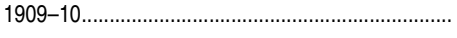 & - & - & 265,474 & - & - & 212,448 & - & - & - & - \\
\hline (1) & - & - & 271,319 & - & - & 187,948 & - & - & - & - \\
\hline (1) & - & - & 248,117 & - & 238,306 & 148,712 & 23,930 & - & $9,275^{6}$ & $3,258^{6}$ \\
\hline …… & $117,108^{7}$ & - & 226,762 & - & - & 113,600 & - & - & $11,306^{6}$ & $3,568^{6}$ \\
\hline 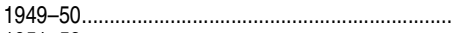 & $83,718^{7}$ & - & - & - & 128,225 & 59,652 & 24,542 & - & $10,375^{6}$ & $3,331^{6}$ \\
\hline 1951-52 & $71,094^{7}$ & - & - & - & 123,763 & 50,742 & 23,746 & - & $10,666^{6}$ & $3,322^{6}$ \\
\hline (1) & $40,520^{7}$ & - & - & - & 91,853 & 20,213 & 25,784 & - & 13,5746 & $4,061^{6}$ \\
\hline 1961-62 & $35,676^{7}$ & 125,634 & 107,260 & - & 81,910 & 13,333 & 25,350 & 18,374 & $14,762^{6}$ & 4,1296 \\
\hline 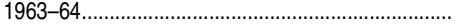 & $31,705^{7}$ & - & 104,015 & - & 77,584 & 9,895 & 26,431 & - & - & $4,451^{6}$ \\
\hline 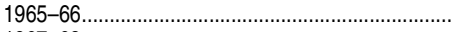 & $26,983^{7}$ & 117,662 & 99,813 & - & 73,216 & 6,491 & 26,597 & 17,8496 & $15,340^{6}$ & $4,606^{6}$ \\
\hline 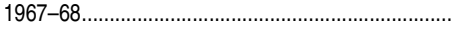 & $22,010^{7}$ & - & - & 94,197 & 70,879 & 4,146 & 27,011 & - & - & - \\
\hline$\ldots$ & $17,995^{7}$ & - & - & 89,372 & 65,800 & 1,815 & 25,352 & - & $14,372^{6}$ & $3,770^{6}$ \\
\hline 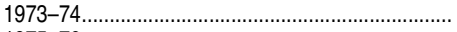 & $16,730^{7}$ & - & - & 88,655 & 65,070 & 1,365 & 25,906 & - & - & - \\
\hline 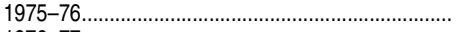 & $16,376^{7}$ & - & 88,597 & 87,034 & 63,242 & 1,166 & 25,330 & - & - & - \\
\hline 1976-77 & $16,271^{7}$ & - & - & 86,501 & 62,644 & 1,111 & 25,378 & $19,910^{6}$ & $16,385^{6}$ & $5,904^{6}$ \\
\hline 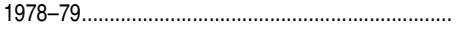 & $16,014^{7}$ & - & - & 84,816 & 61,982 & 1,056 & 24,504 & 19,4896 & $16,097^{6}$ & $5,766^{6}$ \\
\hline $1979-80 \ldots$ & 15,9447 & - & 87,004 & - & - & - & - & - & - & - \\
\hline 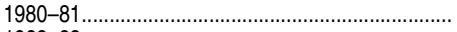 & $15,912^{7}$ & 106,746 & 85,982 & 83,688 & 61,069 & 921 & 24,362 & $20,764^{6}$ & $16,792^{6}$ & $5,678^{6}$ \\
\hline 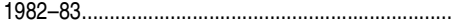 & $15,824^{7}$ & - & 84,740 & 82,039 & 59,656 & 798 & 23,988 & - & - & - \\
\hline 1983-84 & $15,747^{7}$ & 111,872 & 84,178 & 81,418 & 59,082 & 838 & 23,947 & 27,694 & 20,872 & 7,862 \\
\hline 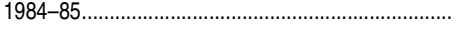 & - & - & 84,007 & 81,147 & 58,827 & 825 & 23,916 & - & - & - \\
\hline (1) & - & - & - & - & - & - & - & 25,616 & 20,252 & 7,387 \\
\hline 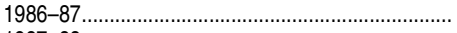 & 15,713 & - & 83,421 & 82,316 & 60,811 & 763 & 23,481 & - & - & - \\
\hline 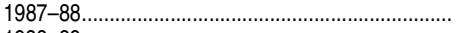 & 15,577 & 110,055 & 83,248 & 81,416 & 59,754 & 729 & 23,841 & 26,807 & 22,959 & 8,418 \\
\hline 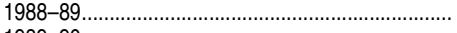 & 15,376 & - & 83,165 & 81,579 & 60,176 & 583 & 23,638 & - & - & - \\
\hline 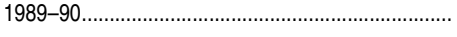 & 15,367 & 110,137 & 83,425 & 81,880 & 60,699 & 630 & 23,461 & 26,712 & 24,221 & 10,197 \\
\hline 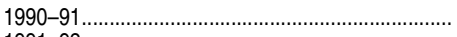 & 15,358 & 109,228 & 84,538 & 82,475 & 61,340 & 617 & 23,460 & 24,690 & 22,223 & 8,989 \\
\hline 1991-92 & 15,173 & 110,576 & 84,578 & 82,506 & 61,739 & 569 & 23,248 & 25,998 & 23,523 & 9,282 \\
\hline $1992-93 \ldots \ldots \ldots \ldots+\ldots$ & 15,025 & - & 84,497 & 82,896 & 62,225 & 430 & 23,220 & - & - & - \\
\hline 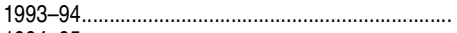 & 14,881 & 111,486 & 85,393 & 83,431 & 62,726 & 442 & 23,379 & 26,093 & 23,543 & 10,555 \\
\hline 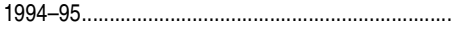 & 14,772 & - & 86,221 & 84,476 & 63,572 & 458 & 23,668 & - & - & - \\
\hline (1) & 14,766 & 121,519 & 87,125 & 84,958 & 63,961 & 474 & 23,793 & 34,394 & 32,401 & 10,942 \\
\hline 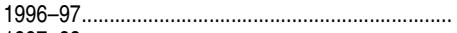 & 14,841 & - & 88,223 & 86,092 & 64,785 & 487 & 24,287 & - & - & - \\
\hline 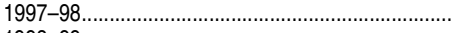 & 14,805 & 123,403 & 89,508 & 87,541 & 65,859 & 476 & 24,802 & 33,895 & 31,408 & 10,779 \\
\hline 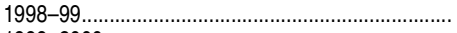 & 14,891 & - & 90,874 & 89,259 & 67,183 & 463 & 25,797 & - & - & - \\
\hline 1999-2000 & 14,928 & 125,007 & 92,012 & 90,538 & 68,173 & 423 & 26,407 & 32,995 & 30,457 & 10,693 \\
\hline (1) & 14,859 & - & 93,273 & 91,691 & 69,697 & 411 & 27,090 & - & - & - \\
\hline 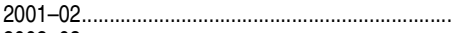 & 14,559 & 130,007 & 94,112 & 92,696 & 70,516 & 408 & 27,468 & 35,895 & 33,191 & 11,846 \\
\hline $2002-03 \ldots \ldots \ldots \ldots$ & 14,465 & - & 95,615 & 93,869 & 71,270 & 366 & 28,151 & - & - & - \\
\hline 2003-04 & 14,383 & 130,407 & 95,726 & 93,977 & 71,195 & 376 & 28,219 & 34,681 & 31,988 & 11,188 \\
\hline 2004-05 & 14,205 & & 96,513 & 95,001 & 71,556 & 338 & 29,017 & - & - & - \\
\hline 2005-06 & 14,166 & 132,436 & 97,382 & 95,731 & 71,733 & 326 & 29,705 & 35,054 & 32,127 & 12,184 \\
\hline 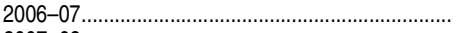 & 13,856 & - & 98,793 & 96,362 & 72,442 & 313 & 29,904 & - & - & - \\
\hline 2007-08 & 13,838 & 132,656 & 98,916 & 97,654 & 73,011 & 288 & 30,542 & 33,740 & 30,808 & 11,870 \\
\hline 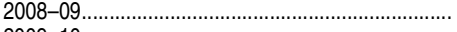 & 13,809 & - & 98,706 & 97,119 & 72,771 & 237 & 29,971 & - & - & - \\
\hline 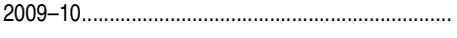 & 13,625 & 132,183 & 98,817 & 97,521 & 72,870 & 217 & 30,381 & 33,366 & 30,590 & 11,491 \\
\hline 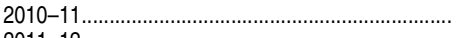 & 13,588 & - & 98,817 & 97,767 & 73,323 & 224 & 30,681 & - & - & - \\
\hline 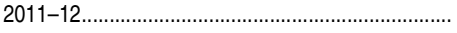 & 13,567 & 129,189 & 98,328 & 97,357 & 73,000 & 205 & 30,668 & 30,861 & 28,184 & 11,165 \\
\hline
\end{tabular}

-Not available

${ }^{1}$ Regular districts exclude regional education service agencies and supervisory union administrative centers, state-operated agencies, federally operated agencies, and other types of local education agencies, such as independent charter schools.

${ }^{2}$ Schools with both elementary and secondary programs are included under elementary schools and also under secondary schools.

${ }^{3}$ Data for most years prior to $1976-77$ are partly estimated. Prior to 1995-96, excludes schools with highest grade of kindergarten.

${ }^{4}$ Includes regular schools and special schools not classified by grade span

${ }^{5}$ Includes elementary, secondary, and combined elementary/secondary schools.

${ }^{6}$ These data cannot be compared directly with the data for years after 1980-81.

${ }^{7}$ Because of expanded survey coverage, data are not directly comparable with figures after 1983-84.
SOURCE: U.S. Department of Education, National Center for Education Statistics, Annual Report of the Commissioner of Education, 1870 through 1910; Biennial Survey of Education in the United States, 1919-20 through 1949-50; Statistics of State School Systems, 1951-52 through 1967-68; Statistics of Public Elementary and Secondary School Systems, 1970-71 through 1980-81; Statistics of Public and Nonpublic Elementary and Secondary Day Schools, 1968-69; Statistics of Nonpublic Elementary and Secondary Schools, 1970-71; Private Schools in American Education; Schools and Staffing Survey (SASS), "Private School Questionnaire," 1987-88 and 1990-91; Private School Universe Survey (PSS), 1989-90 through 2009-10; and Common Core of Data (CCD), "Local Education Agency Universe Survey" and "Public Elementary/Secondary School Universe Survey," 1982-83 through 2011-12. (This table was prepared September 2013.) 
158 CHAPTER 2: Elementary and Secondary Education

Overview of Schools and School Districts

Table 214.20. Number and percentage distribution of regular public school districts and students, by enrollment size of district: Selected years, 1979-80 through 2011-12

\begin{tabular}{|c|c|c|c|c|c|c|c|c|c|c|}
\hline \multirow[b]{2}{*}{ Year } & \multicolumn{10}{|c|}{ Enrollment size of district } \\
\hline & Total & $\begin{array}{r}25,000 \text { or } \\
\text { more }\end{array}$ & $\begin{array}{r}10,000 \text { to } \\
24,999\end{array}$ & $\begin{array}{r}5,000 \text { to } \\
9,999\end{array}$ & $\begin{array}{r}2,500 \text { to } \\
4,999\end{array}$ & $\begin{array}{r}1,000 \text { to } \\
2,499\end{array}$ & 600 to 999 & 300 to 599 & 1 to 299 & $\begin{array}{l}\text { Size not } \\
\text { reported }\end{array}$ \\
\hline \multirow[t]{2}{*}{1} & 2 & 3 & 4 & 5 & 6 & 7 & 8 & 9 & 10 & 11 \\
\hline & \multicolumn{10}{|c|}{ Number of districts } \\
\hline 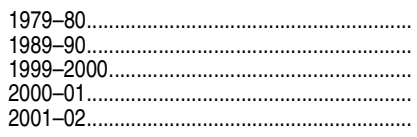 & $\begin{array}{l}15,944 \\
15,367 \\
14,928 \\
14,859 \\
14,559\end{array}$ & $\begin{array}{l}181 \\
179 \\
238 \\
240 \\
243\end{array}$ & $\begin{array}{l}478 \\
479 \\
579 \\
581 \\
573\end{array}$ & $\begin{array}{r}1,106 \\
913 \\
1,036 \\
1,036 \\
1,067\end{array}$ & $\begin{array}{l}2,039 \\
1,937 \\
2,068 \\
2,060 \\
2,031\end{array}$ & $\begin{array}{l}3,475 \\
3,547 \\
3,457 \\
3,448 \\
3,429\end{array}$ & $\begin{array}{l}1,841 \\
1,801 \\
1,814 \\
1,776 \\
1,744\end{array}$ & $\begin{array}{l}2,298 \\
2,283 \\
2,081 \\
2,107 \\
2,015\end{array}$ & $\begin{array}{l}4,223 \\
3,910 \\
3,298 \\
3,265 \\
3,127\end{array}$ & $\begin{array}{l}303 \\
318 \\
357 \\
346 \\
330\end{array}$ \\
\hline 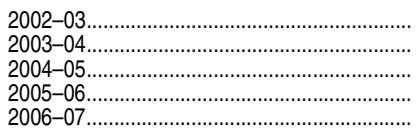 & $\begin{array}{l}14,465 \\
14,383 \\
14,205 \\
14,166 \\
13,856\end{array}$ & $\begin{array}{l}248 \\
256 \\
264 \\
269 \\
275\end{array}$ & $\begin{array}{l}587 \\
594 \\
589 \\
594 \\
598\end{array}$ & $\begin{array}{l}1,062 \\
1,058 \\
1,056 \\
1,066 \\
1,066\end{array}$ & $\begin{array}{l}2,033 \\
2,031 \\
2,018 \\
2,015 \\
2,006\end{array}$ & $\begin{array}{l}3,411 \\
3,421 \\
3,391 \\
3,335 \\
3,334\end{array}$ & $\begin{array}{l}1,745 \\
1,728 \\
1,739 \\
1,768 \\
1,730\end{array}$ & $\begin{array}{l}1,987 \\
1,981 \\
1,931 \\
1,895 \\
1,898\end{array}$ & $\begin{array}{l}3,117 \\
2,994 \\
2,881 \\
2,857 \\
2,685\end{array}$ & $\begin{array}{l}275 \\
320 \\
336 \\
367 \\
264\end{array}$ \\
\hline 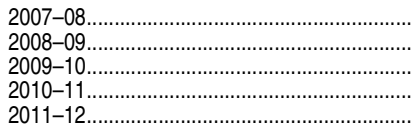 & $\begin{array}{l}13,838 \\
13,809 \\
13,625 \\
13,588 \\
13,567 \\
\end{array}$ & $\begin{array}{l}281 \\
280 \\
284 \\
282 \\
286 \\
\end{array}$ & $\begin{array}{l}589 \\
594 \\
598 \\
600 \\
592 \\
\end{array}$ & $\begin{array}{l}1,062 \\
1,049 \\
1,044 \\
1,052 \\
1,044\end{array}$ & $\begin{array}{l}2,006 \\
1,995 \\
1,985 \\
1,975 \\
1,952 \\
\end{array}$ & $\begin{array}{l}3,292 \\
3,272 \\
3,242 \\
3,224 \\
3,222 \\
\end{array}$ & $\begin{array}{l}1,753 \\
1,766 \\
1,750 \\
1,738 \\
1,755 \\
\end{array}$ & $\begin{array}{l}1,890 \\
1,886 \\
1,891 \\
1,887 \\
1,911 \\
\end{array}$ & $\begin{array}{l}2,692 \\
2,721 \\
2,707 \\
2,687 \\
2,676\end{array}$ & $\begin{array}{l}273 \\
246 \\
124 \\
143 \\
129 \\
\end{array}$ \\
\hline & \multicolumn{10}{|c|}{ Percentage distribution of districts } \\
\hline 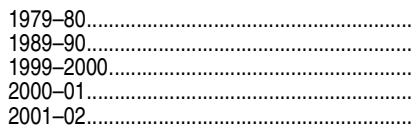 & $\begin{array}{l}100.0 \\
100.0 \\
100.0 \\
100.0 \\
100.0\end{array}$ & $\begin{array}{l}1.1 \\
1.2 \\
1.6 \\
1.6 \\
1.7\end{array}$ & $\begin{array}{l}3.0 \\
3.1 \\
3.9 \\
3.9 \\
3.9\end{array}$ & $\begin{array}{l}6.9 \\
5.9 \\
6.9 \\
7.0 \\
7.3\end{array}$ & $\begin{array}{l}12.8 \\
12.6 \\
13.9 \\
13.9 \\
14.0\end{array}$ & \begin{tabular}{l|}
21.8 \\
23.1 \\
23.2 \\
23.2 \\
23.6
\end{tabular} & \begin{tabular}{l|}
11.5 \\
11.7 \\
12.2 \\
12.0 \\
12.0
\end{tabular} & $\begin{array}{l}14.4 \\
14.9 \\
13.9 \\
14.2 \\
13.8\end{array}$ & $\begin{array}{l}26.5 \\
25.4 \\
22.1 \\
22.0 \\
21.5\end{array}$ & $\begin{array}{l}1.9 \\
2.1 \\
2.4 \\
2.3 \\
2.3\end{array}$ \\
\hline 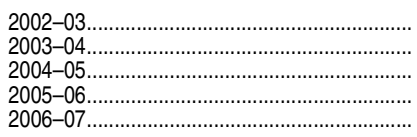 & $\begin{array}{l}100.0 \\
100.0 \\
100.0 \\
100.0 \\
100.0\end{array}$ & $\begin{array}{l}1.7 \\
1.8 \\
1.9 \\
1.9 \\
2.0\end{array}$ & $\begin{array}{l}4.1 \\
4.1 \\
4.1 \\
4.2 \\
4.3\end{array}$ & $\begin{array}{l}7.3 \\
7.4 \\
7.4 \\
7.5 \\
7.7\end{array}$ & $\begin{array}{l}14.1 \\
14.1 \\
14.2 \\
14.2 \\
14.5\end{array}$ & $\begin{array}{l}23.6 \\
23.8 \\
23.9 \\
23.5 \\
24.1\end{array}$ & $\begin{array}{l}12.1 \\
12.0 \\
12.2 \\
12.5 \\
12.5\end{array}$ & $\begin{array}{l}13.7 \\
13.8 \\
13.6 \\
13.4 \\
13.7\end{array}$ & $\begin{array}{l}21.5 \\
20.8 \\
20.3 \\
20.2 \\
19.4\end{array}$ & $\begin{array}{l}1.9 \\
2.2 \\
2.4 \\
2.6 \\
1.9\end{array}$ \\
\hline $2007-08$ & $\begin{array}{l}100.0 \\
100.0 \\
100.0 \\
100.0 \\
100.0\end{array}$ & $\begin{array}{l}2.0 \\
2.0 \\
2.1 \\
2.1 \\
2.1\end{array}$ & $\begin{array}{l}4.3 \\
4.3 \\
4.4 \\
4.4 \\
4.4\end{array}$ & $\begin{array}{l}7.7 \\
7.6 \\
7.7 \\
7.7 \\
7.7 \\
\end{array}$ & $\begin{array}{l}14.5 \\
14.4 \\
14.6 \\
14.5 \\
14.4\end{array}$ & \begin{tabular}{l|}
23.8 \\
23.7 \\
23.8 \\
23.7 \\
23.7
\end{tabular} & $\begin{array}{l}12.7 \\
12.8 \\
12.8 \\
12.8 \\
12.9\end{array}$ & $\begin{array}{l}13.7 \\
13.7 \\
13.9 \\
13.9 \\
14.1\end{array}$ & $\begin{array}{l}19.5 \\
19.7 \\
19.9 \\
19.8 \\
19.7\end{array}$ & $\begin{array}{l}2.0 \\
1.8 \\
0.9 \\
1.1 \\
1.0\end{array}$ \\
\hline 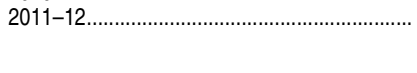 & \multicolumn{10}{|c|}{ Number of students } \\
\hline 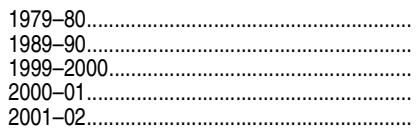 & $\begin{array}{l}41,882,000 \\
40,069,756 \\
46,318,635 \\
46,588,307 \\
46,906,607\end{array}$ & $\begin{array}{l}11,415,000 \\
11,209,889 \\
14,886,636 \\
15,083,671 \\
15,356,867\end{array}$ & $\begin{array}{l}7,004,000 \\
7,107,362 \\
8,656,672 \\
8,750,743 \\
8,756,777\end{array}$ & $\begin{array}{l}7,713,000 \\
6,347,103 \\
7,120,704 \\
7,144,242 \\
7,393,237\end{array}$ & $\begin{array}{l}7,076,000 \\
6,731,334 \\
7,244,407 \\
7,235,089 \\
7,129,358\end{array}$ & $\begin{array}{l}5,698,000 \\
5,763,282 \\
5,620,962 \\
5,597,023 \\
5,576,508\end{array}$ & $\begin{array}{l}1,450,000 \\
1,402,623 \\
1,426,280 \\
1,400,732 \\
1,375,571\end{array}$ & $\begin{array}{r}1,005,000 \\
997,434 \\
911,127 \\
927,146 \\
885,061\end{array}$ & $\begin{array}{l}521,000 \\
510,729 \\
451,847 \\
449,661 \\
433,228\end{array}$ & $\begin{array}{l}\dagger \\
\dagger \\
\dagger \\
\dagger\end{array}$ \\
\hline $2002-03$ & $\begin{array}{l}47,379,395 \\
47,685,982 \\
47,800,967 \\
48,013,931 \\
48,105,666\end{array}$ & $\begin{array}{l}15,690,805 \\
15,939,776 \\
16,182,672 \\
16,376,213 \\
16,496,573\end{array}$ & $\begin{array}{l}8,957,891 \\
9,039,697 \\
8,980,096 \\
9,055,547 \\
9,083,944\end{array}$ & $\begin{array}{l}7,348,643 \\
7,342,745 \\
7,346,960 \\
7,394,010 \\
7,395,889\end{array}$ & $\begin{array}{l}7,150,205 \\
7,160,367 \\
7,134,861 \\
7,114,942 \\
7,092,532\end{array}$ & $\begin{array}{l}5,547,189 \\
5,558,125 \\
5,533,156 \\
5,442,588 \\
5,433,770\end{array}$ & $\begin{array}{l}1,375,070 \\
1,355,563 \\
1,368,546 \\
1,391,314 \\
1,363,287\end{array}$ & $\begin{array}{l}874,163 \\
867,599 \\
851,455 \\
835,430 \\
840,032\end{array}$ & $\begin{array}{l}435,429 \\
422,110 \\
403,221 \\
403,887 \\
399,639\end{array}$ & $\begin{array}{l}\dagger \\
\dagger \\
\dagger \\
t\end{array}$ \\
\hline $2007-08$ & $\begin{array}{l}48,096,140 \\
48,033,126 \\
48,021,335 \\
48,059,830 \\
47,973,834\end{array}$ & $\begin{array}{l}16,669,611 \\
16,634,807 \\
16,788,789 \\
16,803,247 \\
16,934,369\end{array}$ & $\begin{array}{l}8,946,432 \\
9,043,665 \\
9,053,144 \\
9,150,912 \\
9,031,528\end{array}$ & $\begin{array}{l}7,408,553 \\
7,324,565 \\
7,265,111 \\
7,318,413 \\
7,266,770\end{array}$ & $\begin{array}{l}7,103,274 \\
7,079,061 \\
7,034,640 \\
6,973,720 \\
6,907,658\end{array}$ & $\begin{array}{l}5,358,492 \\
5,329,406 \\
5,266,945 \\
5,215,389 \\
5,218,533\end{array}$ & $\begin{array}{l}1,381,342 \\
1,392,110 \\
1,381,415 \\
1,372,759 \\
1,381,289\end{array}$ & $\begin{array}{l}834,295 \\
832,262 \\
835,035 \\
833,764 \\
842,134\end{array}$ & $\begin{array}{l}394,141 \\
397,250 \\
396,256 \\
391,626 \\
391,553\end{array}$ & $\begin{array}{l}\dagger \\
\dagger \\
\dagger \\
\dagger\end{array}$ \\
\hline 2011-12 & \multicolumn{10}{|c|}{ Percentage distribution of students } \\
\hline $\begin{array}{l}1979-80 \\
1989-90 \\
1999-2000 \\
2000-01 \\
2001-02\end{array}$ & $\begin{array}{l}100.0 \\
100.0 \\
100.0 \\
100.0 \\
100.0\end{array}$ & $\begin{array}{l}27.3 \\
28.0 \\
32.1 \\
32.4 \\
32.7\end{array}$ & $\begin{array}{l}16.7 \\
17.7 \\
18.7 \\
18.8 \\
18.7\end{array}$ & $\begin{array}{l}18.4 \\
15.8 \\
15.4 \\
15.3 \\
15.8\end{array}$ & $\begin{array}{l}16.9 \\
16.8 \\
15.6 \\
15.5 \\
15.2\end{array}$ & $\begin{array}{l}13.6 \\
14.4 \\
12.1 \\
12.0 \\
11.9\end{array}$ & $\begin{array}{l}3.5 \\
3.5 \\
3.1 \\
3.0 \\
2.9\end{array}$ & $\begin{array}{l}2.4 \\
2.5 \\
2.0 \\
2.0 \\
1.9\end{array}$ & $\begin{array}{l}1.2 \\
1.3 \\
1.0 \\
1.0 \\
0.9\end{array}$ & $\begin{array}{l} \\
\dagger \\
\dagger \\
\dagger\end{array}$ \\
\hline 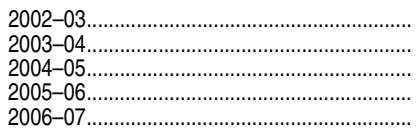 & $\begin{array}{l}100.0 \\
100.0 \\
100.0 \\
100.0 \\
100.0\end{array}$ & $\begin{array}{l}33.1 \\
33.4 \\
33.9 \\
34.1 \\
34.3\end{array}$ & $\begin{array}{l}18.9 \\
19.0 \\
18.8 \\
18.9 \\
18.9\end{array}$ & $\begin{array}{l}15.5 \\
15.4 \\
15.4 \\
15.4 \\
15.4\end{array}$ & $\begin{array}{l}15.1 \\
15.0 \\
14.9 \\
14.8 \\
14.7\end{array}$ & $\begin{array}{l}11.7 \\
11.7 \\
11.6 \\
11.3 \\
11.3\end{array}$ & $\begin{array}{l}2.9 \\
2.8 \\
2.9 \\
2.9 \\
2.8\end{array}$ & $\begin{array}{l}1.8 \\
1.8 \\
1.8 \\
1.7 \\
1.7\end{array}$ & $\begin{array}{l}0.9 \\
0.9 \\
0.8 \\
0.8 \\
0.8\end{array}$ & $\begin{array}{l}\dagger \\
\dagger \\
\dagger \\
\dagger\end{array}$ \\
\hline 2007-08 2008 & $\begin{array}{l}100.0 \\
100.0 \\
100.0 \\
100.0 \\
100.0\end{array}$ & $\begin{array}{l}34.7 \\
34.6 \\
35.0 \\
35.0 \\
35.3\end{array}$ & $\begin{array}{l}18.6 \\
18.8 \\
18.9 \\
19.0 \\
18.8\end{array}$ & $\begin{array}{l}15.4 \\
15.2 \\
15.1 \\
15.2 \\
15.1\end{array}$ & $\begin{array}{l}14.8 \\
14.7 \\
14.6 \\
14.5 \\
14.4\end{array}$ & $\begin{array}{l}11.1 \\
11.1 \\
11.0 \\
10.9 \\
10.9\end{array}$ & $\begin{array}{l}2.9 \\
2.9 \\
2.9 \\
2.9 \\
2.9\end{array}$ & $\begin{array}{l}1.7 \\
1.7 \\
1.7 \\
1.7 \\
1.8\end{array}$ & $\begin{array}{l}0.8 \\
0.8 \\
0.8 \\
0.8 \\
0.8\end{array}$ & $\begin{array}{l}\dagger \\
\dagger \\
\dagger \\
\dagger \\
\dagger\end{array}$ \\
\hline
\end{tabular}

†Not applicable.

NOTE: Size not reported (column 11) includes school districts reporting enrollment of zero. Regular districts exclude regional education service agencies and supervisory union administrative centers, state-operated agencies, federally operated agencies, and other types of local education agencies, such as independent charter schools. Enrollment totals differ from other tables because this table represents data reported by regular school districts rather than states or schools. Detail may not sum to totals because of rounding. SOURCE: U.S. Department of Education, National Center for Education Statistics, Common Core of Data (CCD), "Local Education Agency Universe Survey," 1979-80 through 2011-12. (This table was prepared August 2013.) 
Table 214.30. Number of public elementary and secondary education agencies, by type of agency and state or jurisdiction: 2010-11 and 2011-12

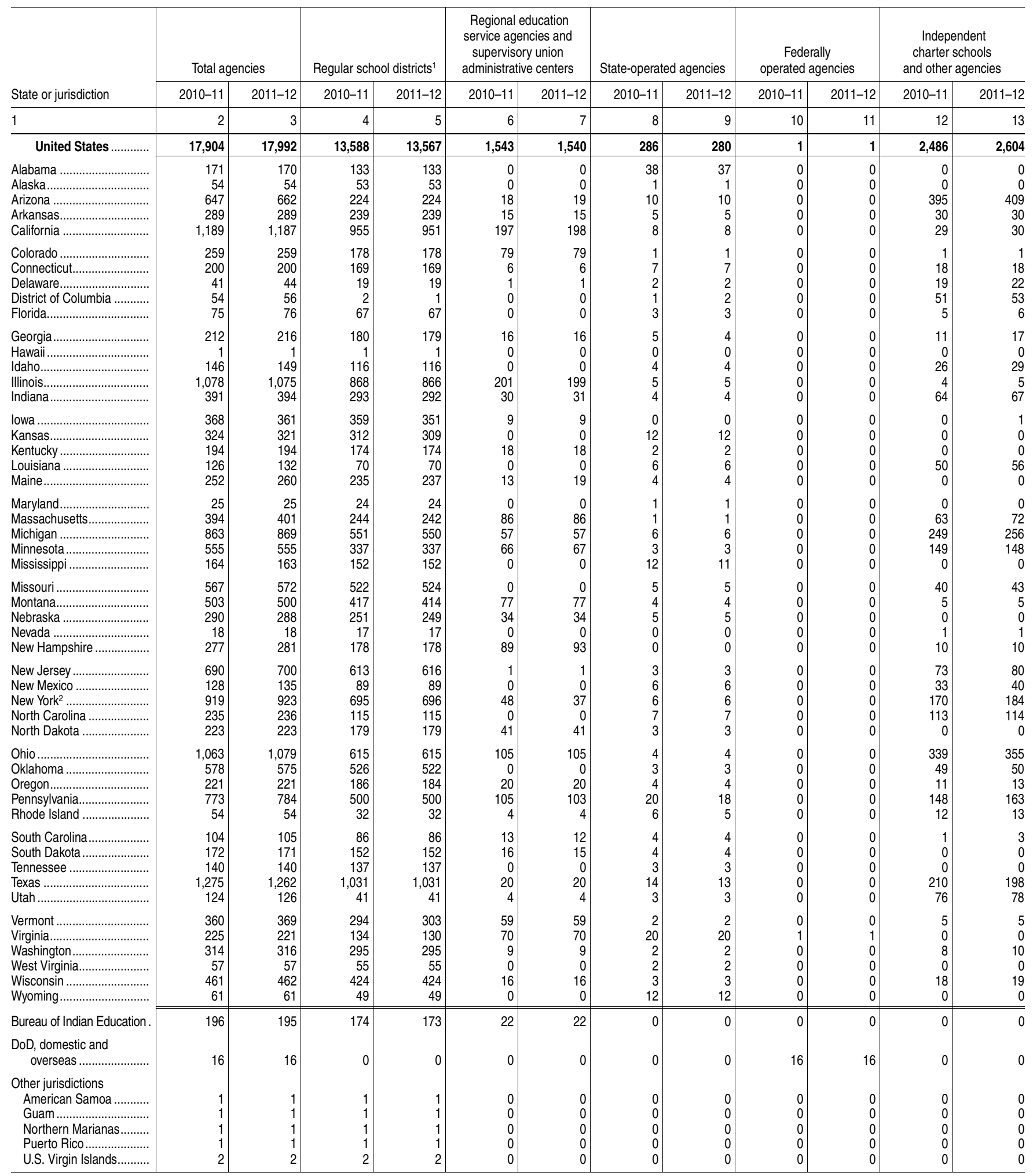

${ }^{1}$ Regular school districts include both independent districts and those that are a dependent segment of a local government. Also includes components of supervisory unions that operate schools, but share superintendent services with other districts.

${ }^{2}$ New York City counted as one school district.
NOTE: DoD = Department of Defense.

SOURCE: U.S. Department of Education, National Center for Education Statistics, Common Core of Data (CCD), "Local Education Agency Universe Survey," 2010-11 and 2011-12. (This table was prepared January 2014.) 
Table 214.40. Public elementary and secondary school enrollment, number of schools, and other selected characteristics, by locale: 2008-09 through 2011-12

\begin{tabular}{|c|c|c|c|c|c|c|c|c|c|c|c|c|c|c|c|c|c|c|}
\hline \multirow{2}{*}{$\begin{array}{l}\text { Enrollment, number of schools, } \\
\text { and other characteristics }\end{array}$} & \multirow[b]{2}{*}{ Total } & \multicolumn{4}{|c|}{ City } & \multicolumn{4}{|c|}{ Suburban } & \multicolumn{4}{|c|}{ Town } & \multicolumn{4}{|c|}{ Rural } & \multirow{2}{*}{$\begin{array}{l}\text { Locale } \\
\text { unknown }\end{array}$} \\
\hline & & Total & Large $^{1}$ & Midsize $^{2}$ & Small ${ }^{3}$ & Total & Large $^{4}$ & Midsize $^{5}$ & Small6 & Total & Fringe $^{7}$ & Distant $^{8}$ & Remote $^{9}$ & Total & Fringe $^{10}$ & Distant ${ }^{11}$ & Remote $^{12}$ & \\
\hline 1 & 2 & 3 & 4 & 5 & 6 & 7 & 8 & 9 & 10 & 11 & 12 & 13 & 14 & 15 & 16 & 17 & 18 & 19 \\
\hline \multicolumn{19}{|l|}{ Fall 2008} \\
\hline $\begin{array}{l}\text { Enrollment (in thousands)................. } \\
\text { Percentage distribution of enrollment, }\end{array}$ & 49,054 & 14,323 & 7,425 & 3,146 & 3,752 & 17,048 & 14,438 & 1,590 & 1,019 & 5,999 & 2,087 & 2,325 & 1,586 & 11,684 & 6,933 & 3,554 & 1,197 & $\dagger$ \\
\hline by race/ethnicity................................ & 100.0 & 100.0 & 100.0 & 100.0 & 100.0 & 100.0 & 100.0 & 100.0 & 100.0 & 100.0 & 100.0 & 100.0 & 100.0 & 100.0 & 100.0 & 100.0 & 100.0 & $\dagger$ \\
\hline 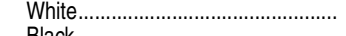 & $\begin{array}{r}54.9 \\
1.60\end{array}$ & 31.8 & 21.2 & 35.0 & 50.3 & $\begin{array}{r}56.5 \\
1.9\end{array}$ & 54.7 & $\begin{array}{r}65.6 \\
10.8\end{array}$ & $\begin{array}{r}67.6 \\
107\end{array}$ & $\begin{array}{l}69.0 \\
112\end{array}$ & $\begin{array}{r}72.8 \\
86\end{array}$ & $\begin{array}{l}68.4 \\
11.7\end{array}$ & 64.8 & 73.5 & $\begin{array}{r}68.8 \\
11.3\end{array}$ & $\begin{array}{r}81.7 \\
8.4\end{array}$ & $\begin{array}{r}76.1 \\
76\end{array}$ & $t^{\dagger}$ \\
\hline 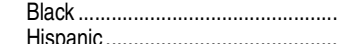 & 16.9 & 27.0 & 30.0 & 29.3 & 19.0 & 14.8 & 15.6 & 10.8 & 10.7 & 11.2 & 8.6 & 13.7 & 10.9 & 10.6 & 12.3 & 8.4 & 7.6 & $\dagger$ \\
\hline Hispanic . & 21.5 & 32.7 & 39.6 & 28.2 & 22.9 & 21.2 & 22.0 & 17.7 & 16.4 & 15.6 & 15.5 & 14.6 & 17.3 & 11.1 & 13.9 & 6.9 & 7.7 & $\dagger$ \\
\hline & 5.0 & 7.1 & 7.9 & 6.1 & 6.2 & 6.2 & 6.6 & 4.2 & 3.6 & 1.9 & 1.7 & 1.2 & 3.1 & 2.3 & 3.3 & 0.8 & 0.7 & \\
\hline American Indian/Alaska Native ........ & 1.2 & 0.8 & 0.8 & 0.7 & 0.9 & 0.5 & 0.5 & 0.7 & 0.9 & 2.1 & 1.1 & 1.9 & 3.7 & 2.2 & 1.2 & 2.1 & 7.8 & $\dagger$ \\
\hline Other................................................ & 0.5 & 0.5 & 0.4 & 0.8 & 0.6 & 0.7 & 0.7 & 1.0 & 0.8 & 0.3 & 0.4 & 0.2 & 0.2 & 0.3 & 0.4 & 0.1 & 0.1 & $\dagger$ \\
\hline Schools.... & 98,706 & 25,675 & 12,927 & 5,780 & 6,968 & 27,168 & 22,482 & 2,786 & 1,900 & 14,228 & 4,258 & 5,639 & 4,331 & 31,635 & 12,625 & 11,792 & 7,218 & $\dagger$ \\
\hline 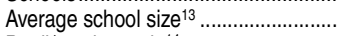 & 517 & 579 & 588 & 575 & 566 & 647 & 662 & 591 & 558 & 450 & 512 & 443 & 396 & 384 & 579 & 311 & 171 & $\dagger$ \\
\hline 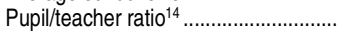 & 15.7 & 16.0 & 16.2 & 15.9 & 15.8 & 15.9 & 15.9 & 16.0 & 16.4 & 15.4 & 15.9 & 15.2 & 15.0 & 15.0 & 15.9 & 14.4 & 12.4 & $\dagger$ \\
\hline Enrollment (percentage distribution)... & 100.0 & 29.2 & 15.1 & 6.4 & 7.6 & 34.8 & 29.4 & 3.2 & 2.1 & 12.2 & 4.3 & 4.7 & 3.2 & 23.8 & 14.1 & 7.2 & 2.4 & $\dagger$ \\
\hline Schools (percentage distribution) ........ & 100.0 & 26.0 & 13.1 & 5.9 & 7.1 & 27.5 & 22.8 & 2.8 & 1.9 & 14.4 & 4.3 & 5.7 & 4.4 & 32.0 & 12.8 & 11.9 & 7.3 & $\dagger$ \\
\hline \multicolumn{19}{|l|}{ Fall 2009} \\
\hline $\begin{array}{l}\text { Enrollment (in thousands)....................... } \\
\text { Percentage distribution of enrollment, }\end{array}$ & 49,082 & 14,377 & 7,511 & 3,174 & 3,692 & 16,873 & 14,296 & 1,574 & 1,003 & 5,899 & 956 & 3,089 & 1,854 & 11,932 & 7,267 & 3,495 & 1,171 & \# \\
\hline by race/ethnicity............................... & 100.0 & 100.0 & 100.0 & 100.0 & 100.0 & 100.0 & 100.0 & 100.0 & 100.0 & 100.0 & 100.0 & 100.0 & 100.0 & 100.0 & 100.0 & 100.0 & 100.0 & 100.0 \\
\hline 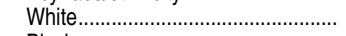 & 54.1 & 31.4 & 21.2 & 34.9 & 49.3 & 55.5 & 53.7 & 64.5 & 66.7 & 68.0 & 71.7 & 69.2 & 64.0 & 72.6 & 67.8 & 81.5 & 76.0 & 44.4 \\
\hline 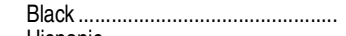 & 16.8 & 26.5 & 29.7 & 27.9 & 18.8 & 14.9 & 15.6 & 11.0 & 10.7 & 11.1 & 6.5 & 12.4 & 11.5 & 10.6 & 12.3 & 8.4 & 7.2 & 16.2 \\
\hline Hispanic... & 22.2 & 33.5 & 39.8 & 29.3 & 24.1 & 22.0 & 22.7 & 18.6 & 16.7 & 16.3 & 18.4 & 14.9 & 17.5 & 11.7 & 14.6 & 7.0 & 7.9 & 34.8 \\
\hline Asian/Pacific Islander............................... & 5.0 & 7.1 & 7.9 & 6.2 & 6.2 & 6.3 & 6.7 & 4.3 & 3.7 & 1.9 & 1.7 & 1.4 & 2.9 & 2.4 & 3.4 & 0.8 & 0.7 & 2.8 \\
\hline American Indian/Alaska Native ........ & 1.2 & 0.8 & 0.8 & 0.7 & 1.0 & 0.6 & 0.5 & 0.7 & 0.9 & 2.2 & 1.2 & 1.6 & 3.6 & 2.1 & 1.2 & 2.1 & 7.7 & 0.6 \\
\hline Other & 0.7 & 0.8 & 0.7 & 1.0 & 0.7 & 0.8 & 0.7 & 1.0 & 1.2 & 0.5 & 0.5 & 0.6 & 0.5 & 0.6 & 0.7 & 0.3 & 0.4 & 1.1 \\
\hline Schools... & 98,817 & 25,767 & 13,234 & 5,705 & 6,828 & 27,041 & 22,395 & 2,771 & 1,875 & 13,986 & 1,926 & 7,069 & 4,991 & 31,946 & 13,156 & 11,687 & 7,103 & 77 \\
\hline Average & 516 & 578 & 583 & 582 & 566 & 642 & 656 & 583 & 555 & 447 & 513 & $\begin{array}{r}462 \\
462\end{array}$ & 399 & 388 & 579 & 308 & 170 & 13 \\
\hline 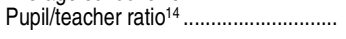 & 16.0 & 16.3 & 16.4 & 16.4 & 16.1 & 16.4 & 16.4 & 16.4 & 16.6 & 15.5 & 16.5 & 15.5 & 15.1 & 15.2 & 16.2 & 14.5 & 12.5 & 5.0 \\
\hline Enrollment (percentage distribution)... & 100.0 & 29.3 & 15.3 & 6.5 & 7.5 & 34.4 & 29.1 & 3.2 & 2.0 & 12.0 & 1.9 & 6.3 & 3.8 & 24.3 & 14.8 & 7.1 & 2.4 & \# \\
\hline Schools (percentage distribution) ........ & 100.0 & 26.1 & 13.4 & 5.8 & 6.9 & 27.4 & 22.7 & 2.8 & 1.9 & 14.2 & 1.9 & 7.2 & 5.1 & 32.3 & 13.3 & 11.8 & 7.2 & 0.1 \\
\hline \multicolumn{19}{|l|}{ Fall 2010} \\
\hline by race/ethnicity......... & 100.0 & 100.0 & 100.0 & 100.0 & 100.0 & 100.0 & 100.0 & 100.0 & 100.0 & 100.0 & 100.0 & 100.0 & 100.0 & 100.0 & 100.0 & 100.0 & 100.0 & 100.0 \\
\hline 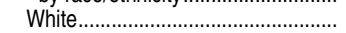 & 52.5 & 30.3 & 20.4 & 34.1 & 47.0 & 53.5 & 51.7 & 62.8 & 64.7 & 66.3 & 70.0 & 67.6 & 62.5 & 70.8 & 65 & 80.3 & 75.3 & 62.1 \\
\hline 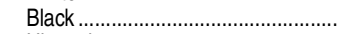 & 16.0 & 25.2 & 28.4 & 25.7 & 18.3 & 14.3 & 15.0 & 10.2 & 10.0 & 10.5 & 6.2 & 11.6 & 10.9 & 10.0 & 11.6 & 7.8 & 6.8 & 16.4 \\
\hline 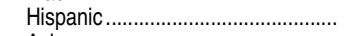 & 23.1 & 34.3 & 40.5 & 30.3 & 25.1 & 22.9 & 23.6 & 19.4 & 18.5 & 17.1 & 18.8 & 15.8 & 18.4 & 12.8 & 15.9 & 7.6 & 8.4 & 12.9 \\
\hline 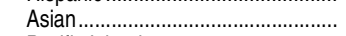 & 4.6 & 6.6 & 7.5 & 5.8 & 5.6 & 5.8 & 6.2 & 3.3 & 3.5 & 1.5 & 1.5 & 1.2 & 1.9 & 2.2 & 3.2 & 0.6 & 0.5 & 4.2 \\
\hline 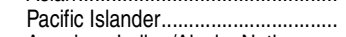 & 0.3 & 0.3 & 0.4 & 0.4 & 0.3 & 0.4 & 0.4 & 0.6 & 0.2 & 0.5 & 0.1 & 0.2 & 1.1 & 0.2 & 0.2 & 0.1 & 0.2 & 0.1 \\
\hline American Indian/Alaska Native........ & 1.1 & 0.8 & 0.8 & 0.7 & 0.9 & 0.5 & 0.5 & 0.7 & 0.8 & 2.0 & 1.0 & 1.5 & 3.3 & 2.0 & 1.1 & 2.0 & 7.4 & 0.9 \\
\hline 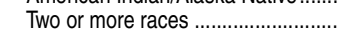 & 2.4 & 2.5 & 2.0 & 3.1 & 2.8 & 2.6 & 2.5 & 3.1 & 2.3 & 2.2 & 2.4 & 2.2 & 2.1 & 2.0 & 2.3 & 1.6 & 1.4 & 3.4 \\
\hline Schoo & 98,817 & 25,879 & 13,279 & 5,737 & 6,863 & 27,108 & 22,425 & 2,805 & 1,878 & 13,838 & 1,906 & 7,004 & 4,928 & 31,952 & 13,348 & 11,593 & 7,011 & 40 \\
\hline chool size ${ }^{13} \ldots \ldots . . . .$. & 517 & 579 & 584 & 583 & 568 & 640 & 655 & 579 & 555 & 447 & 511 & 462 & 400 & 391 & 583 & 307 & 170 & 481 \\
\hline 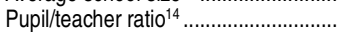 & 16.4 & 16.9 & 17.1 & 17.0 & 16.6 & 16.8 & 16.8 & 16.8 & 17.1 & 15.8 & 16.8 & 15.8 & 15.4 & 15.5 & 16.6 & 14.6 & 12.7 & 16.2 \\
\hline & 100.0 & 29.3 & 15.3 & 6.5 & 7.5 & 34.3 & 29.1 & 3.2 & 2.0 & 11.9 & 1.9 & 6.2 & 3.7 & 24.5 & 15.1 & 7.0 & 2.3 & \# \\
\hline Schools (percentage distribution) ........ & 100.0 & 26.2 & 13.4 & 5.8 & 6.9 & 27.4 & 22.7 & 2.8 & $\begin{array}{l}1.9 \\
\end{array}$ & 14.0 & 1.9 & 7.1 & 5.0 & 32.3 & 13.5 & 11.7 & 7.1 & \# \\
\hline
\end{tabular}


Table 214.40. Public elementary and secondary school enrollment, number of schools, and other selected characteristics, by locale: 2008-09 through 2011-12-Continued

\begin{tabular}{|c|c|c|c|c|c|c|c|c|c|c|c|c|c|c|c|c|c|c|}
\hline \multirow{2}{*}{$\begin{array}{l}\text { Enrollment, number of schools, } \\
\text { and other characteristics }\end{array}$} & \multirow[b]{2}{*}{ Total } & \multicolumn{4}{|c|}{ City } & \multicolumn{4}{|c|}{ Suburban } & \multicolumn{4}{|c|}{ Town } & \multicolumn{4}{|c|}{ Rural } & \multirow{2}{*}{$\begin{array}{r}\text { Locale } \\
\text { unknown }\end{array}$} \\
\hline & & Total & Large $^{1}$ & Midsize $^{2}$ & Small ${ }^{3}$ & Total & Large $^{4}$ & Midsize $^{5}$ & Small6 & Total & Fringe $^{7}$ & Distant $^{8}$ & Remote $^{9}$ & Total & Fringe $^{10}$ & Distant ${ }^{11}$ & Remote $^{12}$ & \\
\hline 1 & 2 & 3 & 4 & 5 & 6 & 7 & 8 & 9 & 10 & 11 & 12 & 13 & 14 & 15 & 16 & 17 & 18 & 19 \\
\hline \multicolumn{19}{|l|}{ Fall 2011} \\
\hline $\begin{array}{l}\text { Enrollment (in thousands).................. } \\
\text { Percentage distribution of enollment, }\end{array}$ & 49,256 & 14,457 & 7,559 & 3,180 & 3,718 & 16,709 & 14,193 & 1,549 & 967 & 5,671 & 907 & 2,953 & 1,812 & 12,418 & 7,859 & 3,416 & 1,143 & $\dagger$ \\
\hline by race/ethnicity.............................. & 100.0 & 100.0 & 100.0 & 100.0 & 100.0 & 100.0 & 100.0 & 100.0 & 100.0 & 100.0 & 100.0 & 100.0 & 100.0 & 100.0 & 100.0 & 100.0 & 100.0 & $\dagger$ \\
\hline 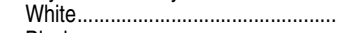 & 51.7 & 29.7 & 20.2 & 33.3 & 46.1 & 52.5 & 50.7 & 61.9 & 63.9 & 65.5 & 69.1 & 66.8 & 61.6 & 70.0 & 65.0 & 79.9 & 75.0 & 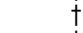 \\
\hline 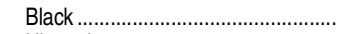 & 15.8 & 24.8 & 27.9 & 25.4 & 18.2 & 14.2 & 14.9 & 9.9 & 9.7 & 10.4 & 6.1 & 11.5 & 10.8 & 10.0 & 11.5 & 7.5 & 6.8 & $t$ \\
\hline Hispanic ..................................... & 23.7 & 34.9 & 41.0 & 31.0 & 25.8 & 23.8 & 24.4 & 20.3 & 19.3 & 17.7 & 19.8 & 16.4 & 19.0 & 13.4 & 16.4 & 8.1 & 8.7 & $\dagger$ \\
\hline Asian & 4.7 & 6.7 & 7.5 & 5.9 & 5.6 & 5.9 & 6.4 & 3.4 & 3.5 & 1.5 & 1.6 & 1.2 & 1.9 & 2.2 & 3.2 & 0.6 & 0.5 & $\dagger$ \\
\hline Pacific Islander................................ & 0.4 & 0.4 & 0.4 & 0.4 & 0.3 & 0.4 & 0.4 & 0.6 & 0.2 & 0.5 & 0.1 & 0.2 & 1.1 & 0.2 & 0.3 & 0.2 & 0.2 & $t$ \\
\hline American Indian/Alaska Native.... & 1.1 & 0.8 & 0.8 & 0.6 & 0.9 & 0.5 & 0.4 & 0.6 & 0.8 & 2.0 & 1.0 & 1.5 & 3.4 & 1.9 & 1.1 & 2.0 & 7.3 & $t$ \\
\hline Two or more races ........................... & 2.6 & 2.7 & 2.2 & 3.3 & 3.1 & 2.8 & 2.7 & 3.3 & 2.7 & 2.4 & 2.3 & 2.5 & 2.3 & 2.2 & 2.5 & 1.8 & 1.6 & $\dagger$ \\
\hline \multicolumn{19}{|l|}{ English language learners } \\
\hline $\begin{array}{l}\text { (in thousands) } \\
\text { English language learners.............. }\end{array}$ & 4,389 & 2,035 & 1,211 & 430 & 394 & 1,604 & 1,439 & 97 & 68 & 336 & 63 & 159 & 114 & 414 & 294 & 77 & 42 & $\dagger$ \\
\hline $\begin{array}{l}\text { Engisn language earners } \\
\text { as a percent of enrollment }{ }^{15} \text {................. }\end{array}$ & 9.1 & 14.2 & 16.7 & 12.6 & 10.9 & 9.0 & 9.4 & 6.4 & 7.6 & 6.2 & 8.4 & 5.7 & 6.1 & 3.9 & 4.7 & 2.5 & 3.9 & $\dagger$ \\
\hline Schools ............................... & & & 13,266 & & & & & 2,760 & 1,817 & & 1,844 & 6,720 & 4,823 & 32,301 & 13,904 & 11,445 & 6,952 & $\dagger$ \\
\hline 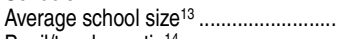 & 520 & 581 & 585 & 588 & 568 & 641 & 656 & 577 & 552 & 448 & 509 & 463 & 402 & 399 & 592 & 307 & 170 & $\dagger$ \\
\hline Pupil/teacher ratio ${ }^{14} \ldots \ldots \ldots \ldots \ldots \ldots$ & 16.3 & 16.9 & 17.1 & 17.0 & 16.4 & 16.6 & 16.5 & 16.6 & 17.0 & 15.9 & 16.9 & 15.9 & 15.4 & 15.5 & 16.5 & 14.6 & 12.5 & $\dagger$ \\
\hline Enrollment (percentage distribution)... & 100.0 & 29.4 & 15.3 & 6.5 & 7.5 & 33.9 & 28.8 & 3.1 & 2.0 & 11.5 & 1.8 & 6.0 & 3.7 & 25.2 & 16.0 & 6.9 & 2.3 & $t$ \\
\hline Schools (percentage distribution) ........ & 100.0 & 26.2 & 13.5 & 5.8 & 7.0 & 27.3 & 22.6 & 2.8 & 1.8 & 13.6 & 1.9 & 6.8 & 4.9 & 32.9 & 14.1 & 11.6 & 7.1 & $\dagger$ \\
\hline
\end{tabular}

\section{†Not applicable.}

\#Rounds to zero.

'Located inside an urbanized area and inside a principal city with a population of at least 250,000 . Located inside an urbanized area and inside a principal city with a population of at least 100,000

${ }^{12}$ Located outside any urbanized area or urban cluster, more than 25 miles from an urbanized area, and more than 10 miles from

an urban cluster.
${ }_{13}$ Average for schools reporting enrollment. Enrollment data were available for 94,820 out of 98,706 schools in 2008-09, 95,222 out of 98,817 schools in 2009-10,95,111 out of 98,817 schools in 2010-11, and 94,743 out of 98,328 schools in 2011-12.

3Located inside an urbanized area and inside a principal city with a population less than $100,000$.

5 Located inside an urbanized area and outside a principal city with a population of at least 100,000, but less than 250,000

${ }^{6}$ Located inside an urbanized area and outside a principal city with a population less than 100,000 .

7Located inside an urban cluster that is 10 miles or less from an urbanized area.

8 Located inside an urban cluster that is more than 10 but less than or equal to 35 miles from an urbanized area.

9Located inside an urban cluster that is more than 35 miles from an urbanized area.

anized area or 2.5 miles or less from an

${ }_{11}$ Located outside

inized area or urban cluster and more than 5 miles but less than or equal to 25 miles from an urban-

${ }^{15}$ Data are based on locales of school districts rather than locales of schools as in the rest of the table. Includes imputed data for NOTE: Detail may not sum to totals because of rounding. Race categories exclude persons of Hispanic ethnicity. Enrollment an ratios are based on data reported by schools and may differ from data reported in other tables that reflect aggregate totals reported by states. Some data have been revised from previously published figures

SOURCE. U.S. Department or Education, Nalonal Center tor Edula Sulistics, Common Core of Data (CCD), "Public Eleverse Su" 2010-11 


\begin{tabular}{|c|c|c|c|c|c|c|c|c|c|c|c|c|c|c|c|c|c|c|c|c|c|c|c|}
\hline \multirow[b]{2}{*}{ Name of district } & \multirow[b]{2}{*}{ State } & \multirow[b]{2}{*}{$\begin{array}{r}\text { Enrollment, } \\
\text { fall } 1990\end{array}$} & \multirow[b]{2}{*}{$\begin{array}{l}\text { Enrollment, } \\
\quad \text { fall } 2000\end{array}$} & \multirow[b]{2}{*}{$\begin{array}{r}\text { Enrollment, } \\
\text { fall } 2010\end{array}$} & \multirow[b]{2}{*}{$\begin{array}{r}\text { Enrollment, } \\
\text { fall } 2011\end{array}$} & \multirow[b]{2}{*}{$\begin{array}{r}\text { Number of } \\
\text { English } \\
\text { language } \\
\text { learners, } \\
2011\end{array}$} & \multirow[b]{2}{*}{$\begin{array}{r}\text { Percent } \\
\text { eligible for } \\
\text { free or } \\
\text { reduced- } \\
\text { price lunch, } \\
2011^{1}\end{array}$} & \multicolumn{7}{|c|}{$\begin{array}{l}\text { Percentage distribution of enrollment, } \\
\text { by race/ethnicity, fall } 2011\end{array}$} & \multicolumn{5}{|c|}{ Teachers and staff, fall 2011} & \multicolumn{3}{|c|}{ Dropouts and graduates, 2008-09 } & \multirow[b]{2}{*}{$\begin{array}{r}\text { Number of } \\
\text { schools, } \\
\text { fall } 2011\end{array}$} \\
\hline & & & & & & & & White & Black & Hispanic & Asian & \begin{tabular}{|} 
Pacific \\
Islander
\end{tabular} & $\begin{array}{r}\text { American } \\
\text { Indian/ } \\
\text { Alaska } \\
\text { Native }\end{array}$ & $\begin{array}{r}\text { Two or } \\
\text { more } \\
\text { races }\end{array}$ & $\begin{array}{r}\text { Number of } \\
\text { classroom } \\
\text { teachers }\end{array}$ & $\begin{array}{r}\text { Pupil } \\
\text { teacher } \\
\text { ratio }\end{array}$ & $\begin{array}{r}\text { Total } \\
\text { number } \\
\text { of staff }\end{array}$ & $\begin{array}{r}\text { Student } \\
\text { staff } \\
\text { ratio }\end{array}$ & \begin{tabular}{|r|} 
Teachers \\
as a \\
percentage \\
of total staff
\end{tabular} & $\begin{array}{r}\text { Percent } \\
\text { dropping } \\
\text { out of } \\
\text { grades } \\
9-12\end{array}$ & 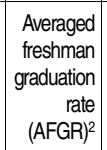 & $\mid \begin{array}{r}\text { Number of } \\
\text { high } \\
\text { school } \\
\text { graduates }\end{array}$ & \\
\hline 1 & 2 & 3 & 4 & 5 & 6 & 7 & 8 & 9 & 10 & 11 & 12 & 13 & 14 & 15 & 16 & 17 & 18 & 19 & 20 & 21 & 22 & 23 & 24 \\
\hline $\begin{array}{l}\text { Districts with more than } \\
15,000 \text { students }{ }^{4} \ldots \ldots \ldots\end{array}$ & $t$ & $16,867,272$ & $20,275,399$ & $21,791,371$ & $21,844,210$ & $2,825,519$ & 51.5 & 35.6 & 21.3 & 32.6 & 6.4 & 0.6 & 0.7 & 2.8 & $\mid 1,286,083$ & 16.9 & $2,474,035$ & 8.8 & 52.0 & - & - & - & 32,652 \\
\hline 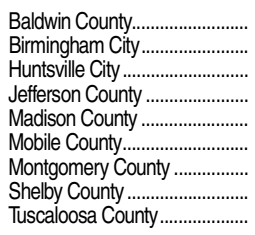 & $\begin{array}{l}A L \\
A L \\
A L \\
A L \\
A L \\
A L \\
A L \\
A L \\
A L\end{array}$ & $\begin{array}{l}17,479 \\
41,710 \\
24,024 \\
40,752 \\
13,861 \\
67,286 \\
35,973 \\
16,096 \\
14,514\end{array}$ & $\begin{array}{l}22,656 \\
37,843 \\
22,382 \\
40,726 \\
15,675 \\
64,976 \\
3,367 \\
20,129 \\
15,666\end{array}$ & $\begin{array}{l}28,199 \\
25,914 \\
23,364 \\
35,860 \\
19,897 \\
62,016 \\
31,464 \\
28,063 \\
17,785\end{array}$ & $\begin{array}{l}28,700 \\
25,091 \\
22,974 \\
35,978 \\
20,012 \\
61,462 \\
31,359 \\
28,304 \\
17,631\end{array}$ & $\begin{array}{r}648 \\
523 \\
724 \\
848 \\
124 \\
914 \\
1,183 \\
1,400 \\
293\end{array}$ & $\begin{array}{l}40.8 \\
88.7 \\
48.5 \\
56.3 \\
34.2 \\
71.3 \\
72.8 \\
34.2 \\
52.7\end{array}$ & \begin{tabular}{r|}
78.5 \\
1.0 \\
46.5 \\
49.9 \\
69.8 \\
43.4 \\
14.1 \\
73.4 \\
67.3
\end{tabular} & $\begin{array}{l}13.8 \\
95.2 \\
42.7 \\
43.0 \\
19.0 \\
50.7 \\
78.0 \\
14.6 \\
28.0\end{array}$ & $\begin{array}{l}4.7 \\
3.2 \\
6.2 \\
5.6 \\
2.7 \\
2.0 \\
4.0 \\
8.9 \\
3.2\end{array}$ & $\begin{array}{l}0.9 \\
0.2 \\
2.3 \\
0.5 \\
1.6 \\
2.3 \\
3.0 \\
1.9 \\
0.6\end{array}$ & $\begin{array}{r}0.1 \\
\# \\
0.2 \\
\# \\
\# \\
\# \\
\# \\
\# \\
\# \\
\#\end{array}$ & $\begin{array}{r}0.6 \\
\# \\
0.5 \\
0.2 \\
5.4 \\
1.1 \\
0.1 \\
0.1 \\
0.2\end{array}$ & $\begin{array}{l}1.4 \\
0.3 \\
1.6 \\
0.8 \\
1.5 \\
0.5 \\
0.8 \\
1.1 \\
0.7\end{array}$ & $\begin{array}{l}1,680 \\
1,516 \\
1,525 \\
2,313 \\
1,252 \\
3,838 \\
1,854 \\
1,852 \\
1,108\end{array}$ & $\begin{array}{l}17.1 \\
16.6 \\
15.1 \\
15.6 \\
16.0 \\
16.0 \\
16.9 \\
15.3 \\
15.9\end{array}$ & $\begin{array}{l}3,267 \\
2,916 \\
2,661 \\
4,511 \\
2,417 \\
7,961 \\
3,477 \\
3,667 \\
2,062\end{array}$ & \begin{tabular}{l|l|}
8.8 \\
8.6 \\
8.6 \\
8.0 \\
8.3 \\
7.7 \\
8.4 \\
7.7 \\
8.6
\end{tabular} & $\begin{array}{l}51.4 \\
52.0 \\
57.3 \\
51.3 \\
51.8 \\
48.2 \\
49.5 \\
50.5 \\
53.7\end{array}$ & $\begin{array}{l}0.7 \\
4.3 \\
1.5 \\
1.5 \\
1.9 \\
1.4 \\
0.6 \\
0.6 \\
2.9\end{array}$ & $\begin{array}{l}72.5 \\
47.4 \\
68.1 \\
68.9 \\
71.7 \\
65.2 \\
52.4 \\
83.3 \\
69.4\end{array}$ & $\begin{array}{r}1,549 \\
1,210 \\
1,351 \\
2,194 \\
1,142 \\
3,369 \\
1,279 \\
1,597 \\
878\end{array}$ & $\begin{array}{r}47 \\
81 \\
50 \\
62 \\
29 \\
109 \\
63 \\
41 \\
34\end{array}$ \\
\hline $\begin{array}{l}\text { Anchorage........................... } \\
\text { Matanuska-Susitna Borough... }\end{array}$ & $\begin{array}{l}\mathrm{AK} \\
\mathrm{AK}\end{array}$ & $\begin{array}{r}41,992 \\
9,810\end{array}$ & $\begin{array}{l}49,526 \\
13,008\end{array}$ & $\begin{array}{l}49,206 \\
17,079\end{array}$ & $\begin{array}{l}48,765 \\
17,480\end{array}$ & $\begin{array}{r}5,291 \\
435\end{array}$ & $\begin{array}{l}40.4 \\
32.8\end{array}$ & $\begin{array}{l}46.2 \\
74.7\end{array}$ & $\begin{array}{l}6.3 \\
2.3\end{array}$ & $\begin{array}{r}10.5 \\
3.0\end{array}$ & $\begin{array}{r}10.6 \\
2.8\end{array}$ & $\begin{array}{l}4.4 \\
1.1\end{array}$ & $\begin{array}{r}8.7 \\
16.0\end{array}$ & $\begin{array}{r}13.2 \\
0.1\end{array}$ & $\begin{array}{r}2,967 \\
914\end{array}$ & $\begin{array}{l}16.4 \\
19.1\end{array}$ & $\begin{array}{l}6,145 \\
1,253\end{array}$ & $\begin{array}{l}7.9 \\
9.4\end{array}$ & $\begin{array}{l}48.3 \\
49.3\end{array}$ & $\begin{array}{l}4.7 \\
7.0\end{array}$ & $\begin{array}{l}74.9 \\
76.4\end{array}$ & $\begin{array}{l}2,967 \\
1,012\end{array}$ & $\begin{array}{l}97 \\
44\end{array}$ \\
\hline 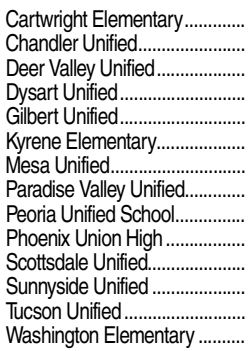 & \begin{tabular}{l|l}
$A Z$ & \\
$A Z$ & \\
$A Z$ & \\
$A Z$ & \\
$A Z$ & $A Z$ \\
$A Z$ & $A Z$ \\
$A Z$ & $A Z$ \\
$A Z$ & $A Z$ \\
$A Z$ &
\end{tabular} & $\begin{array}{r}14,368 \\
11,041 \\
15,899 \\
3,804 \\
10,862 \\
10,483 \\
62,748 \\
26,695 \\
20,850 \\
18,297 \\
19,752 \\
13,067 \\
56,174 \\
22,446\end{array}$ & $\begin{array}{r}17,746 \\
21,73 \\
27,158 \\
5,459 \\
29,188 \\
19,446 \\
73,587 \\
34,882 \\
32,608 \\
22,192 \\
26,958 \\
14,518 \\
61,869 \\
24,723\end{array}$ & $\begin{array}{l}17,672 \\
38,876 \\
35,190 \\
24,175 \\
38,086 \\
17,815 \\
65,123 \\
33,017 \\
36,873 \\
24,949 \\
26,235 \\
17,323 \\
53,275 \\
22,349\end{array}$ & $\begin{array}{l}18,359 \\
33,555 \\
34,662 \\
24,756 \\
38,311 \\
17,731 \\
64,728 \\
33,017 \\
36,620 \\
25,381 \\
25,762 \\
17,615 \\
51,720 \\
22,456\end{array}$ & $\begin{array}{r}4,806 \\
1,768 \\
867 \\
878 \\
684 \\
357 \\
4,560 \\
1,846 \\
950 \\
1,139 \\
936 \\
2,749 \\
4,159 \\
3,552\end{array}$ & $\begin{array}{r}89.5 \\
27.7 \\
20.7 \\
51.3 \\
16.8 \\
27.9 \\
56.9 \\
32.7 \\
38.6 \\
78.1 \\
24.3 \\
7.3 \\
59.8 \\
77.5\end{array}$ & $\begin{array}{r}4.5 \\
57.1 \\
71.9 \\
50.3 \\
70.3 \\
54.1 \\
49.8 \\
62.1 \\
59.4 \\
5.9 \\
69.4 \\
4.6 \\
24.4 \\
34.1\end{array}$ & $\begin{array}{r}4.5 \\
6.5 \\
2.9 \\
8.1 \\
4.1 \\
10.1 \\
4.5 \\
3.0 \\
4.7 \\
9.5 \\
3.4 \\
2.3 \\
5.5 \\
7.7\end{array}$ & $\begin{array}{l}88.7 \\
25.9 \\
17.8 \\
35.6 \\
18.4 \\
21.7 \\
38.5 \\
26.8 \\
29.1 \\
78.8 \\
19.0 \\
88.2 \\
61.2 \\
49.7\end{array}$ & $\begin{array}{l}0.4 \\
8.1 \\
3.4 \\
2.6 \\
4.8 \\
7.4 \\
2.3 \\
3.4 \\
2.6 \\
2.4 \\
5.1 \\
0.5 \\
2.0 \\
2.9\end{array}$ & $\begin{array}{r}0.1 \\
0.2 \\
0.4 \\
0.2 \\
0.3 \\
0.2 \\
\# \\
0.2 \\
0.4 \\
0.1 \\
0.1 \\
0.1 \\
0.4 \\
0.2\end{array}$ & $\begin{array}{l}1.2 \\
1.7 \\
0.9 \\
0.9 \\
1.0 \\
3.4 \\
4.2 \\
1.1 \\
0.9 \\
2.8 \\
2.1 \\
3.9 \\
3.9 \\
4.1\end{array}$ & $\begin{array}{l}0.7 \\
0.6 \\
2.7 \\
2.4 \\
1.2 \\
2.9 \\
0.7 \\
3.5 \\
2.8 \\
0.5 \\
0.9 \\
0.3 \\
2.7 \\
1.3\end{array}$ & $\begin{array}{r}1,167 \\
1,961 \\
1,776 \\
1,237 \\
1,991 \\
1,145 \\
3,224 \\
1,787 \\
2,308 \\
1,412 \\
1,654 \\
931 \\
2,875 \\
1,225\end{array}$ & $\begin{array}{l}15.7 \\
20.2 \\
19.5 \\
20.0 \\
19.2 \\
15.6 \\
20.1 \\
18.5 \\
15.9 \\
18.3 \\
15.6 \\
18.9 \\
18.0 \\
18.3\end{array}$ & $\begin{array}{l}2,124 \\
3,621 \\
3,275 \\
2,143 \\
3,836 \\
1,990 \\
6,700 \\
2,955 \\
4,234 \\
2,188 \\
3,087 \\
1,925 \\
5,432 \\
2,437\end{array}$ & $\begin{array}{r}8.6 \\
10.9 \\
10.6 \\
11.6 \\
10.0 \\
9.0 \\
9.7 \\
11.2 \\
8.6 \\
11.8 \\
8.3 \\
9.2 \\
9.5 \\
9.2\end{array}$ & $\begin{array}{l}55.0 \\
54.2 \\
54.2 \\
57.7 \\
51.9 \\
57.5 \\
48.1\end{array}$ & $\begin{array}{r}\dagger \\
4.1 \\
2.7 \\
3.7 \\
4.1 \\
\dagger \\
\vdots .3 \\
2.0 \\
2.1 \\
4.1 \\
2.2 \\
.2\end{array}$ & $\begin{array}{r}\dagger \\
85.6 \\
76.3 \\
88.4 \\
84.8 \\
\dagger \\
68.8 \\
78.7 \\
80.9 \\
- \\
89.1 \\
57.0 \\
69.0 \\
\dagger\end{array}$ & $\begin{array}{r}\dagger \\
2,083 \\
2,182 \\
1,084 \\
2,503 \\
\dagger \\
4,068 \\
2,263 \\
2,679 \\
4,260 \\
1,924 \\
746 \\
3,417 \\
\dagger \\
\end{array}$ & $\begin{array}{r}21 \\
42 \\
38 \\
25 \\
44 \\
26 \\
84 \\
48 \\
41 \\
15 \\
31 \\
22 \\
104 \\
32\end{array}$ \\
\hline 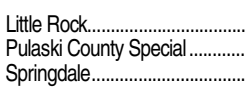 & $\begin{array}{l}A R \\
A R \\
A R\end{array}$ & $\begin{array}{r}25,813 \\
21,495 \\
7,877\end{array}$ & $\begin{array}{l}25,502 \\
18,735 \\
11,422\end{array}$ & & $\begin{array}{l}25,537 \\
17,637 \\
19,976\end{array}$ & $\begin{array}{r}2,085 \\
372 \\
8,298\end{array}$ & $\begin{array}{l}71.0 \\
55.0 \\
66.6\end{array}$ & $\begin{array}{l}20.2 \\
47.8 \\
41.2\end{array}$ & $\begin{array}{r}66.7 \\
42.6 \\
2.2\end{array}$ & $\begin{array}{r}9.8 \\
5.8 \\
44.2\end{array}$ & 2.2 & $\#$ & $\begin{array}{l}0.3 \\
0.3 \\
0.5\end{array}$ & $\begin{array}{l}0.8 \\
1.3 \\
1.5\end{array}$ & $\begin{array}{l}1,737 \\
1,189 \\
1,184\end{array}$ & $\begin{array}{l}14.7 \\
14.8 \\
16.9\end{array}$ & & $\begin{array}{l}6.6 \\
8.4 \\
8.4\end{array}$ & & 3.0 & $\begin{array}{l}65.6 \\
59.6 \\
74.2\end{array}$ & $\begin{array}{r}1,355 \\
875 \\
868\end{array}$ & $\begin{array}{l}49 \\
36 \\
26\end{array}$ \\
\hline 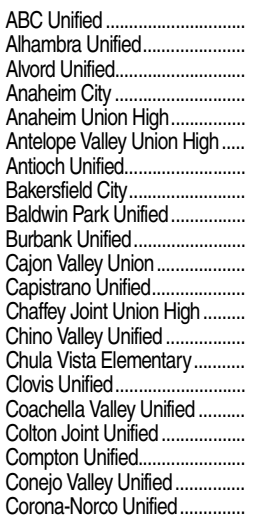 & $\begin{array}{l}C A \\
C A \\
C A \\
C A \\
C A \\
C A \\
C A \\
C A \\
C A \\
C A \\
C A \\
C A \\
C A \\
C A \\
C A \\
C A \\
C A \\
C A \\
C A \\
C A\end{array}$ & $\begin{array}{r}20,972 \\
20,313 \\
14,853 \\
14,972 \\
23,086 \\
10,937 \\
13,045 \\
24,911 \\
15,878 \\
12,057 \\
17,328 \\
26,852 \\
13,505 \\
23,257 \\
17,604 \\
23,224 \\
9,091 \\
16,415 \\
27,585 \\
17,209 \\
23,036\end{array}$ & $\begin{array}{l}22,303 \\
19,776 \\
17,664 \\
22,275 \\
29,363 \\
19,056 \\
20,018 \\
27,674 \\
17,473 \\
11,670 \\
19,059 \\
45,074 \\
19,951 \\
31,763 \\
23,132 \\
32,177 \\
12,636 \\
22,118 \\
31,1037 \\
20,999 \\
37,487\end{array}$ & $\begin{array}{l}630 \\
065 \\
192 \\
427 \\
608 \\
723 \\
495 \\
464\end{array}$ & $\begin{array}{l}20,688 \\
18,290 \\
19,741 \\
19,312 \\
32,704 \\
25,543 \\
18,877 \\
28,321 \\
19,238 \\
16,670 \\
16,057 \\
53,170 \\
25,065 \\
31,313 \\
28,101 \\
33,040 \\
18,406 \\
23,192 \\
24,781 \\
20,722 \\
53,467\end{array}$ & $\begin{array}{r}4,404 \\
5,670 \\
8,585 \\
12,315 \\
7,690 \\
3,377 \\
2,789 \\
9,026 \\
5,521 \\
1,792 \\
5,341 \\
5,496 \\
3,052 \\
4,499 \\
10,298 \\
2,556 \\
10,571 \\
6,574 \\
11,1,86 \\
2,247 \\
7,556\end{array}$ & $\begin{array}{r}18.9 \\
63.1 \\
37.8 \\
35.2 \\
14.6 \\
18.0 \\
25.7 \\
61.1 \\
32.3 \\
28.7 \\
72.8 \\
22.3 \\
5.3 \\
48.7 \\
14.8 \\
28.8 \\
83.3 \\
25.0 \\
44.1 \\
34.7 \\
22.5\end{array}$ & $\begin{array}{r}7.4 \\
2.9 \\
11.9 \\
4.6 \\
12.9 \\
19.8 \\
21.5 \\
10.4 \\
3.7 \\
44.7 \\
46.5 \\
61.1 \\
19.3 \\
22.2 \\
13.2 \\
46.5 \\
1.4 \\
8.0 \\
0.3 \\
62.6 \\
30.5\end{array}$ & $\begin{array}{r}9.5 \\
0.7 \\
4.1 \\
1.5 \\
2.9 \\
18.7 \\
24.1 \\
8.8 \\
3.6 \\
2.4 \\
7.1 \\
1.3 \\
9.1 \\
3.8 \\
4.1 \\
3.3 \\
0.2 \\
5.9 \\
16.9 \\
1.6 \\
6.2\end{array}$ & $\begin{array}{l}54.9 \\
37.8 \\
77.7 \\
86.4 \\
39.2 \\
36.6 \\
24.8 \\
62.0 \\
55.9 \\
68.3 \\
31.6 \\
96.6 \\
81.8 \\
78.8 \\
22.2 \\
50.9\end{array}$ & $\begin{array}{r}36.6 \\
52.2 \\
4.9 \\
6.3 \\
16.0 \\
2.9 \\
9.6 \\
1.3 \\
5.5 \\
9.7 \\
2.9 \\
7.0 \\
7.0 \\
15.5 \\
13.0 \\
14.6 \\
0.3 \\
2.9 \\
0.1 \\
10.3 \\
10.0\end{array}$ & $\begin{array}{l}0.8 \\
0.1 \\
0.4 \\
0.6 \\
0.8 \\
0.3 \\
1.0 \\
0.1 \\
0.2\end{array}$ & $\begin{array}{l}0.3 \\
0.2 \\
0.3 \\
0.2 \\
0.2 \\
0.5 \\
0.8 \\
0.7 \\
0.2 \\
0.2 \\
0.5 \\
0.3 \\
0.3 \\
0.2 \\
0.6 \\
0.8 \\
0.4 \\
0.4 \\
0.2 \\
0.5 \\
0.3\end{array}$ & $\begin{array}{l}2.4 \\
1.6 \\
1.2 \\
0.6 \\
2.0 \\
3.0 \\
5.2 \\
1.1 \\
0.5 \\
3.6 \\
6.0 \\
5.4 \\
1.7 \\
2.2 \\
0.2 \\
3.0 \\
1.1 \\
0.6 \\
3.3 \\
2.6 \\
1.7\end{array}$ & $\begin{array}{r}823 \\
709 \\
733 \\
747 \\
1,264 \\
1,052 \\
806 \\
1,298 \\
883 \\
673 \\
668 \\
2,003 \\
924 \\
1,161 \\
1,352 \\
1,483 \\
834 \\
988 \\
1,066 \\
888 \\
2,140\end{array}$ & $\begin{array}{l}25.1 \\
25.8 \\
26.9 \\
25.9 \\
25.9 \\
24.3 \\
23.4 \\
21.8 \\
21.8 \\
24.8 \\
24.1 \\
26.5 \\
27.1 \\
27.0 \\
20.8 \\
26.3 \\
22.1 \\
23.5 \\
23.3 \\
23.3 \\
25.0\end{array}$ & $\begin{array}{l}1,695 \\
1,433 \\
1,417 \\
1,474 \\
2,566 \\
2,197 \\
1,538 \\
2,335 \\
1,527 \\
1,259 \\
1,335 \\
3,810 \\
1,677 \\
2,283 \\
2,688 \\
3,263 \\
1,600 \\
1,882 \\
2,432 \\
1,526 \\
4,006\end{array}$ & $\begin{array}{l}14.9 \\
13.7 \\
10.5 \\
12.0 \\
11.5\end{array}$ & 48. & $\begin{array}{l}- \\
- \\
- \\
- \\
- \\
- \\
- \\
- \\
-\end{array}$ & $\begin{array}{l}- \\
= \\
- \\
- \\
- \\
- \\
- \\
- \\
- \\
- \\
- \\
- \\
- \\
- \\
\pm \\
- \\
- \\
- \\
- \\
-\end{array}$ & $\begin{array}{l}- \\
= \\
- \\
- \\
- \\
- \\
- \\
- \\
- \\
- \\
- \\
- \\
\pm \\
- \\
- \\
- \\
- \\
-\end{array}$ & $\begin{array}{l}31 \\
18 \\
21 \\
24 \\
21 \\
14 \\
28 \\
41 \\
22 \\
22 \\
30 \\
63 \\
10 \\
36 \\
45 \\
47 \\
23 \\
26 \\
38\end{array}$ \\
\hline
\end{tabular}

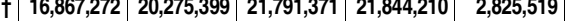
\begin{tabular}{|r|r|r|r|r|r|r|}
\hline 5.5 & 35.6 & 21.3 & 32.6 & 6.4 & 0.6 \\
\hline
\end{tabular}

See notes at end of table. 


\begin{tabular}{|c|c|c|c|c|c|c|c|c|c|c|c|c|c|c|c|c|c|c|c|c|c|c|c|c|}
\hline \multirow[b]{2}{*}{ Name of district } & \multirow[b]{2}{*}{ State } & \multirow[b]{2}{*}{$\begin{array}{r}\text { Enrollment, } \\
\text { fall } 1990\end{array}$} & \multirow[b]{2}{*}{$\begin{array}{l}\text { Enrollment, } \\
\text { fall } 2000\end{array}$} & \multirow[b]{2}{*}{$\begin{array}{r}\text { Enrollment, } \\
\text { fall } 2010\end{array}$} & \multirow[b]{2}{*}{$\begin{array}{r}\text { Enrollment, } \\
\text { fall } 2011\end{array}$} & \multirow[b]{2}{*}{$\begin{array}{r}\text { Number of } \\
\text { English } \\
\text { language } \\
\text { learners, } \\
2011\end{array}$} & & & & $\begin{array}{l}\text { ercentage di } \\
\text { by race/ }\end{array}$ & $\begin{array}{l}\text { tribution } \\
\text { thnicity, }\end{array}$ & $\begin{array}{l}\text { of enrollme } \\
\text { fall } 2011\end{array}$ & & & & Teache & and staff, fa & all 2011 & & Dropouts a & and graduate & es, 2008-09 & & \\
\hline & & & & & & & $\begin{array}{r}\text { eligible for } \\
\text { free or } \\
\text { reduced- } \\
\text { price lunch, } \\
2011^{1}\end{array}$ & White & Black & Hispanic & Asian & \begin{tabular}{|} 
Pacific \\
Islander
\end{tabular} & $\begin{array}{r}\text { American } \\
\text { Indian/ } \\
\text { Alaska } \\
\text { Native }\end{array}$ & $\begin{array}{r}\text { Two or } \\
\text { more } \\
\text { races }\end{array}$ & $\begin{array}{r}\text { Number of } \\
\text { classroom } \\
\text { teachers }\end{array}$ & $\begin{array}{r}\text { Pupil } \\
\text { teacher } \\
\text { ratio }\end{array}$ & $\begin{array}{r}\text { Total } \\
\text { number } \\
\text { of staff }\end{array}$ & $\begin{array}{r}\text { Student } \\
\text { staff } \\
\text { ratio }\end{array}$ & $\begin{array}{r}\text { Teachers } \\
\text { as a } \\
\text { percentage } \\
\text { of total staff }\end{array}$ & $\begin{array}{r}\text { Percent } \\
\text { dropping } \\
\text { out of } \\
\text { grades } \\
9-12\end{array}$ & 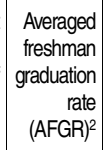 & $\begin{array}{r}\text { Number of } \\
\text { high } \\
\text { school } \\
\text { graduates }^{3}\end{array}$ & $\begin{array}{r}\text { Number of } \\
\text { schools, } \\
\text { fall } 2011\end{array}$ & \\
\hline 1 & 2 & 3 & 4 & 5 & 6 & 7 & 8 & 9 & 10 & 11 & 12 & 13 & 14 & 15 & 16 & 17 & 18 & 19 & 20 & 21 & 22 & 23 & 24 & \\
\hline Cunertino Union & cat & 12027 & 15670 & 18370 & 18650 & & & & & & & & & & & & & & & & & & & \\
\hline & & & & & & \begin{tabular}{ll|l}
1,654 \\
\end{tabular} & 4.4 & 19.2 & 1.0 & 5.3 & 72.8 & 0.2 & 0.2 & 12 & 768 & 24.3 & 1361 . & 137 & 56.5 & - & - & - & 25 & \\
\hline Desert Sands Unified................. & $\mathrm{CA}$ & 16,058 & 23,500 & 29,123 & 29,199 & 7,221 & 51.6 & 23.3 & 2.0 & 70.0 & 2.6 & 0.1 & 0.3 & 1.6 & 1,116 & 26.2 & 2,070 & 14.1 & 53.9 & - & - & - & 34 & \\
\hline 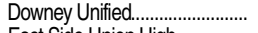 & $\mathrm{CA}$ & 15,418 & 21,474 & 22,844 & 22,782 & 4,245 & 13.1 & 7.0 & 3.1 & 85.9 & 3.2 & 0.3 & 0.3 & 0.2 & 862 & 26.4 & 1,497 & 15.2 & 57.6 & - & - & - & 20 & \\
\hline East Side Union High................. & $\mathrm{CA}$ & 21,973 & 24,282 & 25,676 & 25,638 & 4,809 & 23.6 & 7.9 & 3.3 & 48.1 & 38.1 & 0.8 & 0.4 & 1.5 & 1,089 & 23.5 & 1,788 & 14.3 & 60.9 & - & - & - & 21 & \\
\hline Elk Grove Unified........................... & $\mathrm{CA}$ & 27,246 & 47,736 & 62,455 & 62,126 & 10,860 & 28.8 & 23.7 & 15.6 & 25.5 & 26.4 & 1.8 & 0.6 & 6.4 & 2,610 & 23.8 & 4,928 & 12.6 & 53.0 & - & - & - & 66 & \\
\hline Escondido Union............ & $\mathrm{CA}$ & 14,663 & 19,312 & 19,242 & 19,093 & 8,770 & 63.4 & 21.1 & 2.0 & 64.8 & 4.1 & 0.2 & 0.2 & 7.5 & 808 & 23.6 & 1,650 & 11.6 & 49.0 & - & - & - & 25 & \\
\hline $\begin{array}{l}\text { Fairfield-Suisun Unified............. } \\
\text { Folsom-Cordova Unified..... }\end{array}$ & CA & 20,227 & 22,263 & 21,534 & 21,577 & 3,421 & 27.8 & 20.0 & 18.0 & 36.2 & 13.6 & 1.1 & 1.1 & 10.0 & 834 & 25.9 & 1,524 & 14.2 & 54.7 & - & - & - & 29 & \\
\hline 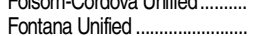 & $\left.\begin{array}{l}\mathrm{CA} \\
\mathrm{CA}\end{array}\right]$ & $\begin{array}{l}12,356 \\
27,043\end{array} \mid$ & $\begin{array}{l}10,271 \\
37,244\end{array}$ & $\begin{array}{r}18,8083 \\
40,841\end{array}$ & $\begin{array}{l}19,154 \\
40,592\end{array}$ & $\begin{array}{r}2,091 \\
15369\end{array}$ & $\begin{array}{l}32.6 \\
173\end{array}$ & $\begin{array}{r}58.1 \\
52\end{array}$ & 7.3 & $\begin{array}{l}16.9 \\
85.1\end{array}$ & $\begin{array}{r}13.4 \\
2.3\end{array}$ & 0.8 & 0.7 & 2.8 & 767 & 25.0 & 1,457 & 13.1 & 52.7 & - & - & - & 33 & \\
\hline Fremont Unified.... & $\mathrm{CA}$ & 27,172 & 31,078 & 32,607 & 32,829 & 5,766 & 17.2 & $\begin{array}{r}0.2 \\
18.5 \\
\end{array}$ & $\begin{array}{l}6.3 \\
45\end{array}$ & $\begin{array}{l}85.1 \\
15.4\end{array}$ & $\begin{array}{r}2.3 \\
597\end{array}$ & $\begin{array}{l}0.3 \\
0.9\end{array}$ & \begin{tabular}{r|r}
0.2 \\
0.5
\end{tabular} & 0.4 & $\begin{array}{r}1,640 \\
1397\end{array}$ & $\begin{array}{l}24.8 \\
23 . \\
\end{array}$ & 3,268 & 12.4 & 50.2 & - & - & - & 43 & \\
\hline Fresno Unified...... & $\mathrm{CA}$ & 71,500 & 79,007 & 74.833 & 74,235 & 17,536 & 63.6 & 12.6 & 9.9 & 63.4 & $\begin{array}{l}5.1 .1 \\
12.5\end{array}$ & $\begin{array}{l}0.9 \\
0.4\end{array}$ & & 0.4 & 1,397 & 23.5 & 2,245 & 14.6 & 62.2 & - & - & - & 41 & \\
\hline Garden Grove Unified.... & $C A$ & 37,969 & 48,742 & 48,659 & 47,999 & 20743 & 49.0 & 10.6 & 08 & 53.4 & 33.8 & $\begin{array}{c}0.4 \\
0.8\end{array}$ & 0.6 & 0.7 & $\begin{array}{r}3,053 \\
1,202\end{array}$ & 24.3 & 6,642 & 11.2 & 46.0 & - & - & - & 106 & \\
\hline Glendale Unified................ & $\mathrm{CA}$ & 25,459 & 30,329 & 26.371 & 26228 & 7.126 & 451 & 550 & 13 & 231 & 18.8 & & 0.2 & 0.3 & 1,823 & 26.3 & 3,553 & 13.5 & 51.3 & - & 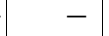 & - & 68 & \\
\hline Grossmont Union High ............. & $\mathrm{CA}$ & 18,647 & 23,639 & 24,224 & 23,677 & 2.972 & 24.8 & 48.4 & 7.1 & 32.9 & 3.3 & $\begin{array}{l}0.1 \\
0.8\end{array}$ & 0.2 & 1.5 & & 23.9 & 2,084 & 12.6 & 52.7 & - & - & - & 33 & \\
\hline & CA & 23267 & 24,646 & 20.942 & 20,849 & 4,395 & 462 & $\begin{array}{r}40.4 \\
4.3 \\
\end{array}$ & 1.1 & 779 & 134 & 0.8 & 0.8 & 6.7 & 974 & 24.3 & 1,933 & 12.3 & 50.4 & - & - & - & 20 & \\
\hline Hayward Unified ............................... & $C A$ & 19,122 & 24,205 & 21,744 & 21,637 & 7,176 & 31.9 & 75 & 138 & 58 & 10.4 & $\begin{array}{l}0.4 \\
37\end{array}$ & 0.2 & 0.8 & 904 & 23.1 & 1,960 & 10.6 & 46.1 & - & - & - & 36 & \\
\hline & $c A$ & 12,811 & 17,451 & 22294 & 2,977 & 3,224 & 608 & 354 & 7.3 & 50 & 年 & 3.1. & 0.5 & 0.9 & 894 & 24.2 & 1,655 & 13.1 & 54.0 & - & - & - & 33 & \\
\hline Hesperia Unified....... & $\mathrm{CA}$ & 12,8113 & 15,451 & $\begin{array}{ll}22,294 \\
23137\end{array}$ & 2,917 & $\begin{array}{r}3,244 \\
45 ? 2\end{array}$ & 0.8 & 35.4 & 7.3 & $\begin{array}{cc}50.4 \\
583\end{array}$ & 2.4 & 0.5 & 1.2 & 2.8 & 888 & 24.8 & 1,853 & 11.9 & 47.9 & - & - & - & 27 & \\
\hline $\begin{array}{l}\text { Hesperna Uniried. } \\
\text { Huntington Beach Union High. }\end{array}$ & $\begin{array}{l}\mathrm{CA} \\
\mathrm{CA}\end{array}$ & $\begin{array}{l}13,039 \\
14,039\end{array}$ & $\begin{array}{l}10,300 \\
14,359\end{array}$ & $\begin{array}{l}2,131 \\
16,320\end{array}$ & $\begin{array}{l}5,3,444 \\
16,442\end{array}$ & $\begin{array}{l}4,522 \\
1,562\end{array}$ & $\begin{array}{r}2.4 \\
5.8\end{array}$ & $\begin{array}{l}28.9 \\
41.4\end{array}$ & $\begin{array}{l}0.0 \\
1.3\end{array}$ & $\begin{array}{l}50.3 \\
23.7\end{array}$ & $\begin{array}{r}1.6 \\
24.0\end{array}$ & $\begin{array}{cc}0.4 \\
0.4\end{array}$ & 0.5 & 2.1 & 873 & 26.8 & 1,859 & 12.6 & 47.0 & - & - & - & 31 & \\
\hline 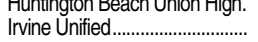 & $\mathrm{CA}$ & 20,735 & 23,961 & 27,262 & 28,179 & 4,279 & $\begin{array}{r}5.0 \\
12.8\end{array}$ & $\begin{array}{l}41.4 \\
35.5\end{array}$ & $\begin{array}{l}1.5 \\
2.3\end{array}$ & 10.1 & & $\begin{array}{l}0.8 \\
0.4\end{array}$ & $\begin{array}{l}5.8 \\
0.4\end{array}$ & $\begin{array}{l}3.1 \\
5.2\end{array}$ & $\begin{array}{l}631 \\
981\end{array}$ & 26.0 & $\begin{array}{r}1,253 \\
2006\end{array}$ & 13.1 & $\begin{array}{r}50.4 \\
489\end{array}$ & - & - & $=$ & $\begin{array}{r}9 \\
35\end{array}$ & \\
\hline Jurupa Unified.... & $\mathrm{CA}$ & 15,419 & 19,839 & 20,088 & 19,884 & 7,410 & 74.6 & 12.7 & 2.5 & 82.1 & $\begin{array}{r}0.1 \\
1.3\end{array}$ & $\begin{array}{l}.4 \\
0.4\end{array}$ & $\begin{array}{l}0.4 \\
0.2\end{array}$ & $\begin{array}{l}5.2 \\
0.9\end{array}$ & 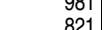 & $\begin{array}{l}28.1 \\
242\end{array}$ & $\begin{array}{l}2,060 \\
1,84\end{array}$ & $\begin{array}{l}14.0 \\
118\end{array}$ & $\begin{array}{l}48.9 \\
487\end{array}$ & - & $=$ & - & 35 & \\
\hline Kern Union High... & $\mathrm{CA}$ & 20,183 & 29,333 & 37,452 & 37,505 & 3,202 & 10.1 & 26.2 & 68 & 60.7 & 3.5 & $\begin{array}{l}.4 \\
0.2\end{array}$ & . & 18 & 1021 & 24.2 & $\begin{array}{l}1,084 \\
3,21\end{array}$ & 11.8 & $\begin{array}{c}48.7 \\
457\end{array}$ & ב & & - & 25 & \\
\hline Lake Elsinore Unified ............. & $\mathrm{CA}$ & 11,000 & 17,178 & 22,065 & 22,171 & 3,138 & 348 & 35.2 & 49 & 527 & 26 & . & 0.0 & $\begin{array}{l}1.0 \\
2.2\end{array}$ & $\begin{array}{l}1,489 \\
097\end{array}$ & 25.2 & 3,267 & 11.5 & 45.7 & & & - & 25 & \\
\hline LodiUnified. & $C A$ & 23,954 & 27.339 & 30,528 & 30319 & 8,355 & 362 & 260 & 76 & 48 & 2.0 & . & & 3.3 & 897 & 24.7 & 1,771 & 12.5 & 50.6 & - & - & -7 & 25 & \\
\hline Long Beach Unified ." & $\mathrm{CA}$ & 71,342 & 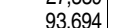 & 84.812 & 83691 & 20,746 & 32.4 & 151 & 15.7 & 53 & ${ }_{111}^{2.9}$ & 0. & 0.5 & 2.5 & 1,322 & 22.9 & 2,560 & 11.8 & 51.7 & - & - & - & 53 & \\
\hline Los Angeles Unified... & $C A$ & 625073 & 721346 & 667273 & 65963 & 152590 & (40) & 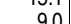 & 95 & 7. & 711.1 & 1.8 & 0.2 & 2.4 & 3,135 & 26.7 & 7,147 & 11.7 & 43.9 & -1 & -1 & - & 92 & \\
\hline Lnwond Unifi & CA & . & 1827 & $0.1,<10$ & 659,0.039 & 152,592 & 4.0 & 9.0 & 9.5 & 73.4 & 6.2 & 0.4 & 0.5 & 1.1 & 28,769 & 22.9 & 62,855 & 10.5 & 45.8 & - & - & - & 939 & \\
\hline Madera Unified................. & CA & $\begin{array}{c}15,469 \\
13708\end{array}$ & 18,237 & 16,360 & 15,515 & 6,641 & 38.3 & 0.5 & 5.6 & 93.4 & 0.2 & 0.3 & $\#$ & $\#$ & 592 & 26.2 & 1,157 & 13.4 & 51.1 & - & - & - & 19 & \\
\hline Mantecallnified ................. & C & 13,728 & 15,957 & 19,576 & 19,936 & 7,135 & 49.9 & 9.3 & 2.3 & 85.7 & 1.5 & 0.1 & 0.5 & 0.7 & 794 & 25.1 & 1,543 & 12.9 & 51.5 & - & - & - & 27 & \\
\hline & CA & 13,356 & 19,746 & 23,406 & 23,309 & 4,803 & 16.6 & 25.1 & 8.4 & 49.6 & 13.6 & 1.0 & 0.9 & 1.6 & 920 & 25.3 & 1,659 & 14.0 & 55.4 & - & - & - & 29 & \\
\hline Modesto City Elementary ..... & C & 17,405 & 18,740 & 15,088 & 15,254 & 6,082 & 76.0 & 19.5 & 3.5 & 66.2 & 4.6 & 0.6 & 0.6 & 4.9 & 710 & 21.5 & 1,346 & 11.3 & 52.7 & $\dagger$ & $\dagger$ & $\dagger$ & 26 & \\
\hline Monteb & CA & 32,938 & 34,794 & 32,046 & 31,319 & 10,180 & 28.9 & 1.8 & 0.3 & 94.9 & 2.5 & 0.1 & 0.3 & 0.2 & 1,188 & 26.4 & 2,428 & 12.9 & 49.0 & - & & & 30 & \\
\hline Moreno Valley Unified... & $\mathrm{CA}$ & 29,064 & 32,730 & 36,901 & 35,692 & 8,990 & 24.5 & 10.1 & 17.5 & 65.6 & 3.9 & 0.7 & 0.3 & 2.0 & 1,456 & 24.5 & 2,694 & 13.2 & 54.0 & - & - & - & 39 & $=$ \\
\hline Mount Diablo Unified... & $\mathrm{CA}$ & 32,840 & 36,648 & 34,116 & 33,977 & 6,682 & 17.4 & 40.5 & 4.6 & 37.3 & 11.5 & 0.9 & 0.5 & 4.8 & 1,500 & 22.7 & 2,539 & 13.4 & 59.1 & - & - & - & 54 & I \\
\hline Murrieta & $\mathrm{CA}$ & 3,990 & 12,065 & 22,318 & 22,693 & 933 & 21.6 & 47.1 & 5.3 & 33.2 & 8.3 & 0.6 & 0.4 & 5.2 & 883 & 25.7 & 1,768 & 12.8 & 49.9 & - & - & - & 20 & $\tau$ \\
\hline Napa Valley Unified.............. & $\mathrm{CA}$ & 13,705 & 16,392 & 18,003 & 18,078 & 3,423 & 31.8 & 32.3 & 2.2 & 51.8 & 8.0 & 0.4 & 0.6 & 4.7 & 769 & 23.5 & 1,430 & 12.6 & 53.8 & - & - & -1 & 33 & $\bar{\pi}$ \\
\hline lesa Unified ......... & $\mathrm{CA}$ & 16,434 & 21,658 & 21,811 & 21,857 & 5,740 & 56.9 & 48.9 & 1.3 & 42.8 & 5.4 & 0.7 & 0.3 & 0.6 & 921 & 23.7 & 1,962 & 11.1 & 46.9 & - & - & - & 31 & $\frac{\pi}{x}$ \\
\hline ified.... & c & 19,179 & 23,610 & 20,421 & 20,208 & 4,500 & 29.5 & 10.3 & 2.7 & 78.3 & 6.2 & 0.6 & 0.2 & 1.8 & 817 & 24.7 & 1,611 & 12.5 & 50.7 & - & - & - & 28 & N \\
\hline Oaklar & C & 52,095 & 54,863 & 46,586 & 46,377 & 14,274 & 61.0 & 8.8 & 30.5 & 41.0 & 14.3 & 1.1 & 0.4 & 3.9 & 2,097 & 22 & 4,200 & 11.0 & 49.9 & 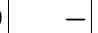 & - & - & 134 & \\
\hline & c & 17,034 & 22,354 & 21,082 & 20,987 & 4,172 & 32.1 & 28.8 & 6.6 & 54.2 & 5.4 & 2.2 & 0.6 & 2.3 & 845 & 24.8 & 1,670 & 12.6 & 50.6 & & 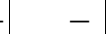 & & 25 & $\frac{T}{D}$ \\
\hline Ontario-Montclair Elementary. & $\mathrm{CA}$ & 21,033 & 26,407 & 22,591 & 22,569 & 11,012 & 83.1 & 4.4 & 2.7 & 88.1 & 2.4 & 0.5 & 0.5 & 1.3 & 1,020 & 22.1 & 1,893 & 11.9 & 53.9 & $\dagger$ & $\dagger$ & $\dagger$ & 32 & \\
\hline ified............................... & $\mathrm{CA}$ & 25,224 & 31,097 & 30,373 & 30,136 & 7,705 & 37.8 & 33.1 & 1.4 & 51.0 & 11.5 & 0.4 & 0.4 & 2.2 & 1,155 & 26.1 & 2,247 & 13.4 & 51.4 & - & - & - & 41 & \\
\hline Oxnard. & $\mathrm{CA}$ & 12,212 & 16,249 & 15,870 & 16,118 & 8,587 & 37.5 & 4.5 & 1.8 & 89.9 & 2.7 & 0.3 & 0.2 & 0.6 & 638 & 25.3 & 1,290 & 12.5 & 49.4 & - & - & - & 21 & 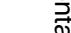 \\
\hline Oxnard Union High.... & $\mathrm{CA}$ & 11,512 & 14,552 & 16,676 & 16,790 & 3,236 & 10.9 & 16.8 & 2.4 & 72.5 & 6.8 & 0.4 & 0.3 & 0.9 & 668 & 25.1 & 1,233 & 13.6 & 54.2 & - & - & - & 10 & $\stackrel{2}{2}$ \\
\hline Paja & $\mathrm{CA}$ & 16,355 & 19,864 & 19,542 & 19,914 & 10,012 & 42.0 & 17.0 & 0.5 & 79.8 & 2.0 & 0.1 & 0.2 & 0.3 & 805 & 24.7 & 1,734 & 11.5 & 46.4 & - & - & - & 33 & \\
\hline gs Unified........... & $\mathrm{CA}$ & 14,427 & 20,847 & 23,626 & 23,676 & 7,372 & 76.7 & 16.1 & 5.4 & 73.3 & 3.4 & 0.2 & 0.5 & 1.1 & 904 & 26.2 & 1,717 & 13.8 & 52.6 & - & - & - & 29 & בै \\
\hline Elementary.......... & $\mathrm{CA}$ & 13,199 & 20,853 & 21,049 & 20,585 & 6,237 & 31.9 & 8.3 & 16.6 & 69.5 & 2.3 & 0.2 & 0.7 & 2.4 & 789 & 26.1 & 1,507 & 13.7 & 52.4 & - & - & 1 & 26 & ㅇ \\
\hline Panama-Buena Vista Union.... & $\mathrm{CA}$ & 10,066 & 12,843 & 16,562 & 16,810 & 2,592 & 57.7 & 27.4 & 11.1 & 51.3 & 8.8 & 0.3 & 0.6 & 0.7 & 587 & 28.6 & 1,495 & 11.2 & 39.3 & - & - & - & 23 & ఐ \\
\hline Paramount Unified.................... & $\mathrm{CA}$ & 12,855 & 16,862 & 15,792 & 15,929 & 5,919 & 5.5 & 1.6 & 8.9 & 87.0 & 1.3 & 0.7 & $\#$ & 0.5 & 616 & 25.9 & 1,204 & 13.2 & 51.1 & - & - & - & 19 & ڤ్ \\
\hline Pasadena Unified.......................... & $\mathrm{CA}$ & 21,802 & $\begin{array}{l}20,5059 \\
23,550\end{array}$ & 19,803 & $\begin{array}{l}19,802 \\
19,0\end{array}$ & 4,240 & $\begin{array}{r}26.6 \\
26.6\end{array}$ & 14.8 & 16.3 & 59.4 & $\begin{array}{l}1.0 \\
5.2\end{array}$ & 0.2 & 0.2 & $\begin{array}{l}3.7 \\
\end{array}$ & 889 & 22.3 & 1,967 & 10.1 & 45.2 & - & $=$ & - & 31 & 1. \\
\hline nda Unified. & $\mathrm{CA}$ & 21,438 & 26,046 & 25,821 & 25,747 & 3,690 & 22.5 & 44.0 & 1.8 & 38.3 & 13.4 & 0.2 & 0.2 & 2.1 & 977 & 26.3 & 1,976 & 13.0 & 49.5 & - & - & - & 34 & $\omega \overrightarrow{0}$ \\
\hline & $\mathrm{CA}$ & 26,918 & 34,4 & 28,298 & 27,737 & 10,970 & 54.0 & 4.1 & 5.6 & 83.1 & 5.7 & 0.1 & 0.2 & 1.1 & 1.180 & 23.5 & 2,361 & 11.7 & 50.0 & - & - & - & 44 & 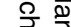 \\
\hline Po & $c$ & 24,662 & 32 & 34.135 & 34,569 & 4,112 & 10.5 & 54.1 & 2.9 & 12.9 & 25.3 & 0.5 & 0.3 & 4.0 & 1.216 & 28 & 2,530 & 13 & 48.1 & - & - & - & 37 & $0 ₹$ \\
\hline Red & $\mathrm{CA}$ & 16,002 & 19,411 & 21,398 & 21,408 & 2,161 & 39.0 & 33.2 & 6.9 & 44.5 & 10.8 & 0.5 & 0.5 & 3.6 & 882 & 24.3 & 1,480 & 14 & 59.6 & - & - & 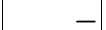 & 25 & 으 \\
\hline Rialto Unified.......................................... & $\mathrm{CA}$ & 19,794 & 28,060 & 27,026 & 26,764 & 7,353 & 36.1 & 4.5 & 13.7 & 78.8 & 1.5 & 0.5 & 0.3 & 0.7 & 1,113 & 24.0 & 2,108 & 12.7 & 52.8 & - & - & - & 30 & \\
\hline See notes at end of table & & & & & & & & & & & & & & & & & & & & & & & & \\
\hline
\end{tabular}




\begin{tabular}{|c|c|c|c|c|c|c|c|c|c|c|c|c|c|c|c|c|c|c|c|c|c|c|c|}
\hline \multirow[b]{2}{*}{ Name of district } & \multirow[b]{2}{*}{ State } & \multirow[b]{2}{*}{$\begin{array}{r}\text { Enrollment, } \\
\text { fall } 1990\end{array}$} & \multirow[b]{2}{*}{$\begin{array}{r}\text { Enrollment, } \\
\text { fall } 2000\end{array}$} & \multirow[b]{2}{*}{$\begin{array}{r}\text { Enrollment, } \\
\text { fall } 2010\end{array}$} & \multirow[b]{2}{*}{$\begin{array}{r}\text { Enrollment, } \\
\text { fall } 2011\end{array}$} & \multirow[b]{2}{*}{$\begin{array}{r}\text { Number of } \\
\text { English } \\
\text { language } \\
\text { learners, } \\
2011\end{array}$} & \multirow[b]{2}{*}{$\begin{array}{r}\text { Percent } \\
\text { eligible for } \\
\text { free or } \\
\text { reduced- } \\
\text { price lunch, } \\
20111^{1}\end{array}$} & \multicolumn{7}{|c|}{$\begin{array}{l}\text { Percentage distribution of enrollment, } \\
\text { by race/ethnicity, fall } 2011\end{array}$} & \multicolumn{5}{|c|}{ Teachers and staff, fall 2011} & Dropouts a & and graduates & es, 2008-09 & \\
\hline & & & & & & & & White & Black & Hispanic & Asian & $\begin{array}{r}\text { Pacific } \\
\text { Islander }\end{array}$ & $\begin{array}{r}\text { American } \\
\text { Indian/ } \\
\text { Alaska } \\
\text { Native } \\
\end{array}$ & $\begin{array}{r}\text { Two or } \\
\text { more } \\
\text { races }\end{array}$ & $\begin{array}{c}\text { Number of } \\
\text { classroom } \\
\text { teachers }\end{array}$ & $\begin{array}{r}\text { Pupil } \\
\text { teacher } \\
\text { ratio }\end{array}$ & $\begin{array}{r}\text { Total } \\
\text { number } \\
\text { of staff }\end{array}$ & $\begin{array}{r}\text { Student } \\
\text { staff } \\
\text { ratio }\end{array}$ & \begin{tabular}{|r} 
Teachers \\
as a \\
percentage \\
of total staff
\end{tabular} & $\begin{array}{r}\text { Percent } \\
\text { dropping } \\
\text { out of } \\
\text { grades } \\
9-12\end{array}$ & \begin{tabular}{|r|} 
Averaged \\
freshman \\
graduation \\
rate \\
$($ AFGR) \\
\end{tabular} & $\begin{array}{r}\text { Number of } \\
\text { high } \\
\text { school } \\
\text { graduates }^{3}\end{array}$ & $\begin{array}{r}\text { Number of } \\
\text { schools, } \\
\text { fall } 2011\end{array}$ \\
\hline 1 & 2 & 3 & 4 & 5 & 6 & 7 & 8 & 9 & 10 & 11 & 12 & 13 & 14 & 15 & 16 & 17 & 18 & 19 & 20 & 21 & 22 & 23 & 24 \\
\hline Riverside Unified..... & $\mathrm{CA}$ & 31,326 & 38,124 & 42,532 & 42,406 & 7,720 & 15.1 & 26.5 & 7.9 & 57.6 & 4.4 & 0.5 & 0.4 & 2.7 & 1,620 & 26.2 & 3,122 & 13.6 & 51.9 & - & - & - & $\overline{49}$ \\
\hline Bumland Inified & $\mathrm{CA}$ & 19,143 & 18,972 & 15,711 & 15,738 & 5,107 & 65.7 & 4.0 & 2.2 & 636 & 28.2 & 0.3 & 0.2 & 1.6 & 659 & 239 & 1,453 & 10.8 & 45.3 & - & - & - & 22 \\
\hline City Unified... & $\mathrm{CA}$ & 49,557 & 52,734 & 47,897 & 47,940 & 12,149 & 35.7 & 18.5 & 17.9 & 6 & 19.1 & 1.7 & 0.8 & 5.4 & 1,673 & 28.7 & 3,350 & 4.3 & 49.9 & - & - & - & 87 \\
\hline ey Unified ... & $\mathrm{CA}$ & 25,130 & 35,199 & 31,724 & 30,885 & 4,524 & 21.4 & 53.5 & 1.6 & 29.6 & 9.9 & 0.3 & 0.3 & 4.8 & 1,125 & 27.5 & 2,056 & 15.0 & 54.7 & - & - & - & 34 \\
\hline & CA & 40,589 & 52,031 & 54,518 & 54,379 & 17,488 & 42.9 & 8.6 & 14.7 & 71.8 & 2.1 & 0.5 & 0.7 & 1.8 & 2,341 & 23.2 & 5,110 & 10.6 & 45.8 & - & - & - & 78 \\
\hline & $\mathrm{CA}$ & 121,107 & 141,804 & 131,785 & 131,044 & 36,453 & 38.8 & 23.2 & 10.7 & 46.2 & 14.1 & 0.7 & 0.3 & 4.8 & 6,706 & 19 & 13,637 & 9.6 & 49.2 & - & - & - & 223 \\
\hline fied.......... & $\mathrm{CA}$ & 61,688 & 59,979 & 55,571 & 56, & 17,083 & 57.3 & 12.0 & 10.6 & 25. & 44.1 & 1.2 & 0.5 & 6.7 & & 15 & 5,1 & 11 & & - & 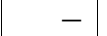 & t & 116 \\
\hline$\ldots$ & $\mathrm{CA}$ & 29,630 & 33,015 & 33,018 & & 8,846 & 29.1 & 25.8 & 3.1 & 52 & 14.3 & 0.5 & 0.5 & 3.3 & 4 & & 2,7 & & & - & - & & 53 \\
\hline n Juan Unified & $\mathrm{CA}$ & 47,690 & 50,266 & 47,116 & 45 & 4,575 & 39.2 & 62.8 & 7.7 & $1 \mathrm{c}$ & 6.1 & 0.9 & 1.3 & 2.0 & 1,961 & 24.1 & 4,237 & 11.2 & & - & - & - & 73 \\
\hline fied. & $\mathrm{CA}$ & 9,108 & 12,804 & 18,642 & 17 & 4,297 & 8.9 & 40.7 & 2.8 & 46.4 & 7.6 & 0.6 & 0.5 & 1.4 & 668 & 28.6 & 1,520 & 6 & 44.0 & - & - & - & 19 \\
\hline ley Unified.... & $\mathrm{CA}$ & 16,119 & 20,742 & 28,987 & & 1,519 & 5.6 & 52.3 & 2.0 & 8.1 & 30.3 & 0.2 & 0.1 & 6.9 & 1,261 & 23 & 2,198 & 3.6 & 57.4 & - & - & - & 35 \\
\hline 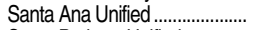 & $\mathrm{CA}$ & 45,964 & 60,643 & 57,319 & 57,250 & 32,170 & 35.9 & 2.8 & 0.5 & 93.1 & 2.9 & 0.1 & 0.1 & 0.5 & 2,276 & 25.2 & 4,077 & 14.0 & 55.8 & - & - & - & 60 \\
\hline Unified.... & $\mathrm{CA}$ & 13,370 & 16,957 & 003 & 326 & 5,113 & 30.9 & 34.0 & 1.3 & 57.9 & 3.3 & 0.1 & 0.6 & 2.8 & 654 & 23.4 & 1,274 & 12.0 & 51.3 & - & - & - & 27 \\
\hline and & $\mathrm{CA}$ & 14,043 & 14,107 & 383 & 289 & 4,739 & 28.9 & 22.8 & 4.0 & 36.2 & 31.4 & 1.1 & 0.6 & 4.0 & 643 & 23.8 & 1,235 & 12.4 & 52.0 & - & - & - & 26 \\
\hline & $\mathrm{CA}$ & 18,262 & 21,181 & 933 & 432 & 1,979 & 31.3 & 57.9 & 1.1 & 29.1 & 9.0 & 0.1 & 0.5 & 2.2 & 789 & 24. & 1,557 & 12.5 & 50.7 & - & 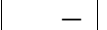 & - & 29 \\
\hline & $\mathrm{CA}$ & 32,687 & 37,573 & 252 & 03 & 10,489 & 44.5 & 8.6 & 11.8 & 60.1 & 13.8 & 0.6 & 3.2 & 1.9 & 1,624 & & 3,3 & & & - & 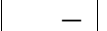 & - & 3 \\
\hline High...... & $\mathrm{CA}$ & 27,894 & 35,330 & 41,426 & 19 & 9,764 & 19.8 & 8.3 & 3.3 & 74.3 & 10.1 & 0.5 & 0.4 & 3.0 & 1,618 & 25 & 3,4 & & & - & - & - & 30 \\
\hline 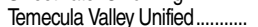 & $\mathrm{CA}$ & 7,596 & 18,980 & 2 & & 1,685 & 17.7 & 47.6 & 3.9 & & 9.4 & 0. & 1.2 & 6.8 & 1.235 & & & & & - & - & - & 33 \\
\hline & $\mathrm{CA}$ & 19,645 & 24,118 & 0 & & 3,627 & 27.9 & 29.4 & 4.0 & & 35.0 & 0.7 & 0.5 & 7.5 & 902 & & & & & - & - & - & 31 \\
\hline $\operatorname{Tr}$ & c & 7,626 & 13,816 & 30 & 2 & 4,135 & 21.1 & 26.4 & 7.2 & 0 & 15.3 & 1. & 0.5 & 3.5 & 10 & 24 & 1,3 & 121 & 53 & - & - & - & 24 \\
\hline 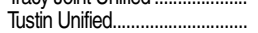 & $\mathrm{C}$ & 10,831 & 16,9 & & & 5,899 & 17.2 & 31. & 2.3 & & 18.1 & 0.5 & 0. & 2 & 11 & & & 15 & & - & & - & 9 \\
\hline 1............... & $\mathrm{CA}$ & - & & 31,632 & 7 & 8,472 & 43.1 & 30.7 & 15.1 & & 9.6 & 1.5 & 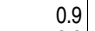 & 4.9 & 1,321 & 23 & 2,8 & & 4 & - & - & - & \\
\hline$\ldots \ldots \ldots$ & $\mathrm{CA}$ & & 11,242 & 687 & 5 & 5,039 & 14.8 & 6.0 & 14.0 & & 3.4 & 0.3 & 0.2 & 3.4 & 756 & 26. & 1,412 & 13.9 & 6 & - & - & - & 1 \\
\hline$\cdots$ & $\mathrm{CA}$ & 19,049 & 20,270 & & & 2,767 & 33.1 & 9.0 & 29.5 & & 20.0 & 1.7 & -1 & & 669 & & 1,3 & & & - & t & - & \\
\hline & $\mathrm{CA}$ & 3 & 17,527 & & & 2,754 & 41.3 & 44.1 & 1.5 & & 3.3 & 0. & 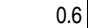 & & 700 & & & & & - & - & - & \\
\hline High...... & $\mathrm{CA}$ & 4,662 & 9,091 & & & 1,316 & 30.1 & 14.6 & 19.4 & & 2.5 & 0.6 & 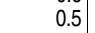 & 9 & 603 & & & & & - & - & - & 10 \\
\hline & $\mathrm{CA}$ & 21 & 23,989 & & & 4,694 & 25.7 & 26.7 & 2.3 & & 5.3 & 0 & 5 & 8 & 1,051 & & & & & - & - & - & \\
\hline & $\mathrm{CA}$ & & 27,651 & & & 6,983 & 17.4 & 27.6 & 4.5 & & 3.8 & 1 . & 5 & 8 & 1,071 & & & & & - & - & - & 3 \\
\hline Unified....... & $\mathrm{CA}$ & 31,292 & 34,499 & 2 & 3 & 10,208 & 32.1 & 11.1 & 20.5 & 50 & 16.3 & 0. & 0.2 & 0.8 & 1,352 & & 2,6 & 3 & & - & & - & 59 \\
\hline & $\mathrm{CA}$ & 7,723 & 10,118 & 14 & & 1,133 & 23.0 & 19.2 & 7.9 & & 11.4 & & 0. & 6 & 609 & & 1 & & & - & & - & 17 \\
\hline William S. Hart Union High.... & $\mathrm{CA}$ & 10,278 & 17,001 & 26,161 & 26,449 & 2,308 & 14.3 & 47.0 & 5.2 & 33.5 & 10.7 & 0.3 & 0.4 & 2.9 & 1,029 & 25.7 & 1,910 & 13.8 & 53.9 & - & - & - & 20 \\
\hline Academy, No. 20 & $\mathrm{co}$ & 10,986 & 17,628 & 23,119 & 23,657 & 335 & 12.0 & 75.6 & 3.0 & 11.9 & 3.7 & 0.4 & 0.4 & 5.0 & 1,419 & 16.7 & 2,888 & 8.2 & 49.1 & 1.1 & 93.1 & 1,554 & 32 \\
\hline & $C$ & & & & & 5,070 & 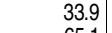 & & 2.0 & & & 0 & & & & & & & & & 1 & 1,950 & 54 \\
\hline & c & & & & & 13,778 & 65.1 & 21.2 & 17.3 & & 4 & 0.4 & 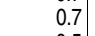 & & 1, & & & 9.1 & & 3.2 & 6 & 1,360 & 59 \\
\hline & C & & & & & 2 & 18.7 & 70.6 & 0.8 & & (a) & 0. & 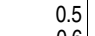 & & 1,7 & & & 100 & & 2.4 & .5 & 2,114 & 55 \\
\hline & $\mathrm{CO}$ & 3,9 & 5 & & & 1,897 & 34.8 & 48.8 & 1.7 & & 2.0 & 0. & 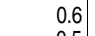 & & 7 & & & 10.0 & & 8.6 & .5 & 554 & 24 \\
\hline & $\mathrm{co}$ & 29,2 & & & & 3,971 & 25.8 & 56.7 & 12.2 & & 8.1 & 0 & 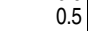 & 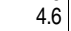 & 2,8 & & & 4 & & 5.4 & 9 & 3,337 & 58 \\
\hline 1. & $\mathrm{co}$ & 30,0 & 32, & 3 & & 2,663 & 52.9 & 53.2 & 7.2 & & 1.9 & 0.3 & & 3 & 1,7 & & 3,5 & 5 & & an & & 72 & 60 \\
\hline & $\mathrm{co}$ & 59,013 & 70,847 & 78,339 & 0 & 25,417 & 72.0 & 20.4 & 14.2 & & 3.4 & 0. & & & 4,5 & & & 5 & & 14. $(4.4)$ & & 893 & 164 \\
\hline , No. RE1.. & $\mathrm{co}$ & 13,125 & 34,918 & 61,465 & 63,114 & 2,345 & 10.9 & 76.5 & 2.0 & 13.2 & 3.9 & 0.1 & 0. & 3.7 & 2,977 & 21. & 6,3 & 10.0 & 47 & 2.8 & & 3,347 & 82 \\
\hline & col & $\begin{array}{r}2,488 \\
2,125\end{array}$ & $\begin{array}{r}r 4,026 \\
6,026\end{array}$ & $\begin{array}{l}14,708 \\
14,408\end{array}$ & 0 & $\begin{array}{r}2,040 \\
402\end{array}$ & 21.1 & $\begin{array}{l}65.0 \\
6.0\end{array}$ & 7.1 & $\begin{array}{l}10.4 \\
17.7\end{array}$ & $\begin{array}{l}3.5 \\
3.4\end{array}$ & 0.4 & 0. & 5.8 & 784 & 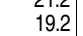 & 1,4 & 10.3 & 5 & 3.7 & & $\mid$ & 02. \\
\hline & ar & 11,657 & & & & 4,029 & 59.7 & 36.7 & 1.9 & 58 & $\begin{array}{l}.4 .6 \\
1.6\end{array}$ & $\begin{array}{l}.4 .2 \\
0.4\end{array}$ & 04 & $\begin{array}{l}.0 \\
1.2\end{array}$ & 1,101 & 18 & 2, & 9.3 & 5 & 5 & & 980 & 31 \\
\hline $\mathrm{Je}$ & & & 8 & & & 5,051 & 31.7 & 68.0 & 1.1 & & 3.1 & 0.2 & & & 4,729 & 18 & 103 & & & & & 5,767 & 163 \\
\hline & & & & & & & & & & & & & & & & & & & & & & 222 & 23 \\
\hline & & & & & & & & & & & & & & & $122-3$ & & & & & & & 年 & 列 \\
\hline & & & & & & & & & & & & & & & & & & & & & & 012 & $\begin{array}{l}40 \\
50\end{array}$ \\
\hline & & & & & & & & & & & & & & & & & & & & & & & $\begin{array}{l}50 \\
37\end{array}$ \\
\hline & & & & & & 3800 & & & & & & & & & & & & & & & & 94 & 52 \\
\hline Thompson, No. R2 & c & $\begin{array}{l}15,019 \\
12,019\end{array}$ & $\begin{array}{l}19,020 \\
14,766\end{array}$ & $\begin{array}{l}15,310 \\
1510\end{array}$ & $\begin{array}{l}20,095 \\
15,655\end{array}$ & $\begin{array}{r}3000 \\
400\end{array}$ & $\begin{array}{l}31.0 \\
36.0\end{array}$ & $\begin{array}{l}65.1 \\
76.6\end{array}$ & 0.9 & $\begin{array}{l}20.4 \\
18.3\end{array}$ & 1.5 & 0.2 & 0.6 & $\begin{array}{l}1.1 \\
1.8\end{array}$ & $\begin{array}{l}1,002 \\
839\end{array}$ & 18 & 1,919 & $\begin{array}{l}.3 .0 \\
8.2\end{array}$ & $43 . /[\mathrm{f}, \mathrm{s}$ & & & 1,106 & $5<$ \\
\hline 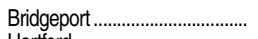 & $\mathrm{CT}$ & 19,687 & 22,432 & 20,2 & 20,1 & 2,546 & 98.8 & 8.4 & 38.8 & 48.6 & 3.0 & 0.1 & 0.8 & 0.2 & 1,339 & 15 & 2,9 & 6.9 & 46.0 & 18 & 53.4 & 937 & 36 \\
\hline & CT & $\begin{array}{l}25,410 \\
17881\end{array}$ & 19549 & . & 20554 & 2567 & . & $\begin{array}{r}9.8 \\
151\end{array}$ & & 380 & 20 & 0 & & 4.5 & 1,559 & & & & & & & 909 & \\
\hline $\mathrm{Ne}$ & CT & 17,881 & 19,549 & 20,003 & 20,554 & $2,567 \mid$ & & 15.1 & 44.5 & 38.0 & 2.2 & 0.0 & 0.2 & 0.2 & 1,615 & $12.7 \mid$ & 3,303 & 6.2 & $48.9 \mid$ & 8.7 & 59.7 & & \\
\hline
\end{tabular}

See notes at end of table. 


\begin{tabular}{|c|c|c|c|c|c|c|c|c|c|c|c|c|c|c|c|c|c|c|c|c|c|c|c|c|}
\hline \multirow[b]{2}{*}{ Name of district } & \multirow[b]{2}{*}{ State } & \multirow[b]{2}{*}{$\begin{array}{r}\text { Enrollment, } \\
\text { fall } 1990 \\
\end{array}$} & \multirow[b]{2}{*}{$\begin{array}{r}\text { Enrollment, } \\
\text { fall } 2000\end{array}$} & \multirow[b]{2}{*}{$\begin{array}{r}\text { Enrollment, } \\
\text { fall } 2010\end{array}$} & \multirow[b]{2}{*}{$\begin{array}{r}\text { Enrollment, } \\
\text { fall } 2011\end{array}$} & \multirow[b]{2}{*}{ 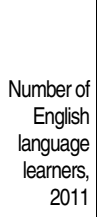 } & \multirow[b]{2}{*}{$\begin{array}{r}\text { Percent } \\
\text { eligible for } \\
\text { free or } \\
\text { reduced- } \\
\text { price lunch, } \\
2011^{11}\end{array}$} & \multicolumn{7}{|c|}{$\begin{array}{l}\text { Percentage distribution of enrollment, } \\
\text { by race/ethnicity, fall } 2011\end{array}$} & \multicolumn{5}{|c|}{ Teachers and staff, fall 2011} & \multicolumn{3}{|c|}{ Dropouts and graduates, 2008-09 } & & \\
\hline & & & & & & & & White & Black & Hispanic & Asian & $\begin{array}{r}\text { Paciific } \\
\text { Islander }\end{array}$ & $\begin{array}{r}\text { American } \\
\text { Indian/ } \\
\text { Alaska } \\
\text { Native } \\
\end{array}$ & $\begin{array}{r}\text { Two or } \\
\text { more } \\
\text { races }\end{array}$ & $\begin{array}{c}\text { Number of } \\
\text { classsoom } \\
\text { teachers }\end{array}$ & $\begin{array}{r}\text { Pupil } \\
\text { teacher } \\
\text { ratio }\end{array}$ & $\begin{array}{r}\text { Total } \\
\text { number } \\
\text { of staff }\end{array}$ & $\begin{array}{r}\text { Student } \\
\text { staff } \\
\text { ratio } \\
\end{array}$ & $\begin{array}{r}\text { Teachers } \\
\text { as a } \\
\text { percentage } \\
\text { of total staff }\end{array}$ & $\begin{array}{r}\text { Percent } \\
\text { dropping } \\
\text { out of } \\
\text { grades } \\
9-12 \\
\end{array}$ & 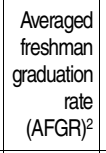 & $\begin{array}{r}\text { Number of } \\
\text { high } \\
\text { school } \\
\text { graduates }^{3}\end{array}$ & $\begin{array}{c}\text { Number of } \\
\text { schools, } \\
\text { fall } 2011 \\
\end{array}$ & \\
\hline 1 & 2 & 3 & 4 & 5 & 6 & 7 & 8 & 9 & 10 & 11 & 12 & 13 & 14 & 15 & 16 & 17 & 18 & 19 & 20 & 21 & 22 & 23 & 24 & \\
\hline $\begin{array}{l}\text { Stamford............................... } \\
\text { Waterbury.................................. }\end{array}$ & $\begin{array}{l}\mathrm{CT} \\
\mathrm{CT}\end{array}$ & $\begin{array}{l}11,574 \\
13,323\end{array}$ & $\begin{array}{l}14,791 \\
16,282\end{array}$ & $\begin{array}{l}15,309 \\
18,152\end{array}$ & $\begin{array}{l}15,493 \\
18,061\end{array}$ & $\begin{array}{l}2,045 \\
1,951\end{array}$ & $\begin{array}{l}48.2 \\
79.2\end{array}$ & $\begin{array}{l}35.8 \\
22.9\end{array}$ & $\begin{array}{l}20.3 \\
26.0\end{array}$ & $\begin{array}{l}34.9 \\
46.9\end{array}$ & $\begin{array}{l}8.3 \\
1.8\end{array}$ & $\begin{array}{r}\# \\
0.1\end{array}$ & $\begin{array}{l}0.1 \\
0.5\end{array}$ & $\begin{array}{l}0.7 \\
1.7\end{array}$ & $\begin{array}{l}1,222 \\
1,339\end{array}$ & $\begin{array}{l}12.7 \\
13.5\end{array}$ & $\begin{array}{l}2,219 \\
2,796\end{array}$ & $\begin{array}{l}7.0 \\
6.5\end{array}$ & $\begin{array}{l}55.1 \\
47.9\end{array}$ & $\begin{array}{ll}2.5 \\
6.3\end{array}$ & $\begin{array}{ll}88.6 \\
68.9\end{array}$ & \begin{tabular}{r|}
1,018 \\
857
\end{tabular} & $\begin{array}{l}21 \\
30\end{array}$ & \\
\hline 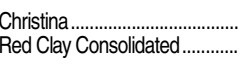 & $\begin{array}{l}\mathrm{DE} \\
\mathrm{DE}\end{array}$ & $\begin{array}{l}17,872 \\
14,551\end{array}$ & $\begin{array}{r}19,882 \\
15,827\end{array}$ & $\begin{array}{l}17,190 \\
15,954\end{array}$ & $\begin{array}{l}16,303 \\
15,970\end{array}$ & $\begin{array}{l}1,224 \\
1,644\end{array}$ & $\begin{array}{l}59.1 \\
50.8\end{array}$ & $\begin{array}{l}35.1 \\
46.4\end{array}$ & $\begin{array}{l}40.5 \\
23.4\end{array}$ & $\begin{array}{l}17.6 \\
24.4\end{array}$ & $\begin{array}{l}4.4 \\
4.7\end{array}$ & $\begin{array}{r}0.1 \\
\#\end{array}$ & $\begin{array}{l}0.3 \\
0.2\end{array}$ & $\begin{array}{l}2.0 \\
0.9\end{array}$ & $\begin{array}{l}1,195 \\
1,002\end{array}$ & $\begin{array}{l}13.6 \\
15.9\end{array}$ & $\begin{array}{l}2,354 \\
1,721\end{array}$ & $\begin{array}{l}6.9 \\
9.3\end{array}$ & $\begin{array}{l}50.8 \\
58.2\end{array}$ & $\begin{array}{r}10.8 \\
5.3\end{array}$ & $\begin{array}{l}51.7 \\
60.9\end{array}$ & $\begin{array}{l}877 \\
814\end{array}$ & $\begin{array}{l}31 \\
27\end{array}$ & \\
\hline District of Columbia ................... & $\mathrm{DC}$ & 80,694 & 68,925 & 44,199 & 44,618 & 3,745 & 54.4 & 10.5 & 71.0 & 14.9 & 1.9 & 0.1 & 0.1 & 1.5 & 3,472 & 12.8 & 6,073 & 7.3 & 57.2 & 8.6 & 65.0 & 2,679 & 127 & \\
\hline $\begin{array}{l}\text { Alachua..................... } \\
\text { Bay........................ }\end{array}$ & $\begin{array}{l}\mathrm{FL} \\
\mathrm{FL}\end{array}$ & $\begin{array}{l}26,387 \\
21,875\end{array}$ & $\begin{array}{l}29,712 \\
25,755\end{array}$ & $\begin{array}{l}27,513 \\
25,935\end{array}$ & $\begin{array}{l}27,480 \\
26,346\end{array}$ & $\begin{array}{l}452 \\
424\end{array}$ & $\begin{array}{l}48.2 \\
51.9\end{array}$ & $\begin{array}{l}46.8 \\
73.4\end{array}$ & $\begin{array}{l}36.0 \\
15.2\end{array}$ & $\begin{array}{l}7.7 \\
4.7\end{array}$ & $\begin{array}{l}4.1 \\
2.2\end{array}$ & $\begin{array}{r}0.1 \\
\#\end{array}$ & $\begin{array}{l}0.2 \\
0.5\end{array}$ & $\begin{array}{l}5.0 \\
4.2\end{array}$ & $\begin{array}{l}1,752 \\
1,733\end{array}$ & $\begin{array}{l}15.7 \\
15.2\end{array}$ & $\begin{array}{l}3,861 \\
3,370\end{array}$ & $\begin{array}{l}7.1 \\
7.8\end{array}$ & $\begin{array}{l}45.4 \\
51.4\end{array}$ & $\begin{array}{l}3.0 \\
0.9\end{array}$ & $\begin{array}{l}76.2 \\
69.5\end{array}$ & $\begin{array}{l}1,864 \\
1,532\end{array}$ & $\begin{array}{l}69 \\
48\end{array}$ & \\
\hline Brevard................................ & $\mathrm{FL}$ & 56,639 & 70,597 & 71,866 & 71,792 & 1,953 & 43.6 & 64.1 & 14.2 & 12.6 & 2.0 & 0.1 & 0.2 & 6.8 & 4,846 & 14.8 & 8,836 & 8.1 & 54.8 & 0.7 & 79.8 & 4,931 & 123 & \\
\hline Broward..... & $\mathrm{FL}$ & 161,100 & 251,129 & 256,472 & 258,478 & 24,143 & 57.1 & 25.7 & 39.1 & 28.6 & 3.5 & 0.1 & 0.3 & 2.6 & 14,533 & 17.8 & 27,041 & 9.6 & 53.7 & 2.4 & 70.9 & 15,663 & 329 & \\
\hline Charlotte.................................. & $\mathrm{FL}$ & 13,030 & 17,170 & 16,640 & 16,424 & 223 & 61.3 & 73.6 & 8.8 & 11.8 & 1.4 & 0.1 & 0.3 & 3.9 & 1,503 & 10.9 & 2,898 & 5.7 & 51.9 & 3.3 & 90.0 & 1,402 & 25 & \\
\hline Citrus ....................................... & $\mathrm{FL}$ & 11,697 & 15,199 & $\begin{array}{r}15,675 \\
25012\end{array}$ & 15,539 & 130 & 58.8 & 82.2 & 4.8 & 7.2 & 1.7 & 0.1 & 0.4 & 3.6 & 1,097 & 14.2 & 2,219 & 7.0 & 49.4 & 1.6 & 73.8 & 1,056 & 23 & \\
\hline Clay..................................... & $\mathrm{FL}$ & 21,933 & 28,115 & 35,812 & 35,659 & 519 & 39.8 & 70.1 & 13.3 & 9.7 & 2.5 & 0.3 & 0.2 & 3.9 & 2,431 & 14.7 & 4,488 & 7.9 & 54.2 & 1.3 & 84.8 & 2,469 & 47 & \\
\hline Collier.................................... & $\begin{array}{cc}\mathrm{FL} \\
\mathrm{FL}\end{array}$ & $\begin{array}{r}20,878 \\
20200\end{array}$ & $\begin{array}{r}34,203 \\
\end{array}$ & $\begin{array}{r}42,919 \\
\end{array}$ & $\begin{array}{r}43,238 \\
35020\end{array}$ & 5,510 & 59.5 & 39.2 & 12.0 & 44.4 & 1.1 & 0.1 & 1.0 & 2.1 & 2,953 & 14.6 & 5,430 & 8.0 & 54.4 & 2.4 & 69.3 & 2,477 & 68 & \\
\hline Dade.. & $\mathrm{Fl}$ & 292,000 & 368,625 & 347,366 & 350,239 & 66,497 & 71.9 & 8.3 & 23.9 & 65.9 & 1.2 & \# & 0.1 & 0.5 & 21,117 & 16.6 & 37,735 & 9.3 & 56.0 & 4.7 & 61.6 & 19,207 & 524 & \\
\hline Duval............. & $\begin{array}{cc}\mathrm{FL} \\
\mathrm{F}\end{array}$ & 111,1000 & 125,846 & $123,997 \mid$ & 125,429 & 3,844 & 52.5 & 39.2 & 44.3 & 8.4 & 4.3 & 0.2 & 0.2 & 3.4 & 7,589 & 16.5 & 12,064 & 10.4 & 62.9 & 5.9 & 59.9 & 5,958 & 195 & \\
\hline Escambia ............................. & 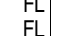 & $\begin{array}{l}43,091 \\
12861\end{array} \mid$ & $\begin{array}{l}45,012 \\
17215\end{array}$ & $\begin{array}{r}40,227 \\
22,684\end{array}$ & $\begin{array}{l}40,496 \\
22,616\end{array}$ & 453 & 61.7 & 49.7 & 35.3 & 4.9 & 2.6 & 0.2 & 1.0 & 6.3 & 3,4 & 11.9 & 6,285 & & & 2.7 & & 2,116 & 72 & \\
\hline 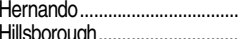 & $\begin{array}{l}\mathrm{FL} \\
\mathrm{FL}\end{array}$ & $\begin{array}{r}12,8,86 \\
12,300\end{array}$ & $\begin{array}{r}17,215 \\
164,311\end{array}$ & $\begin{array}{r}22,684 \\
194,525\end{array}$ & $\begin{array}{r}22,616 \\
-10701\end{array}$ & 593 & 57.9 & 72.3 & 7.2 & 15.3 & 1.6 & 0.1 & 0.4 & 3.2 & 1,51 & 14.9 & 2,765 & 8.2 & & 3.1 & & 1,338 & 34 & \\
\hline & $\begin{array}{l}\mathrm{FL} \\
\mathrm{FL}\end{array}$ & $\begin{array}{r}123,9,00 \\
11838\end{array}$ & 164,311 & 194,525 & 197,041 & 22,474 & 56.8 & 38.5 & 21.5 & 32.5 & 3.3 & 0.1 & 0.3 & 3.7 & 13,862 & 14.2 & 25,472 & 7.7 & 54.4 & 1.1 & 69.1 & 10,415 & 308 & \\
\hline $\begin{array}{l}\text { Indian River............................... } \\
\text { Lake }\end{array}$ & FEl & $\begin{array}{l}11,838 \\
21065\end{array}$ & 14,979 & 17,740 & 17,964 & 1,123 & 55.5 & 59.3 & 16.1 & 19.8 & 1.4 & 0.1 & 0.4 & 2.9 & 1,035 & 17.4 & 1,951 & 9.2 & 53.1 & 1.6 & 76.6 & 1,108 & 30 & \\
\hline & $\mathrm{FL}$ & 21,065 & 29,293 & 41,110 & 41,319 & 1,502 & 56.2 & 58.1 & 15.7 & 20.0 & 2.7 & 0.1 & 0.5 & 3.1 & 2,631 & 15.7 & 5,513 & 7.5 & 47.7 & 3.2 & 78.0 & 2,354 & 59 & \\
\hline$\ldots \cdots \cdots \cdots \cdots$ & $\begin{array}{ll}\mathrm{FL} \\
\mathrm{FL}\end{array}$ & 43,240 & 58,401 & 81,967 & 83,895 & 5,319 & 64.2 & 47.6 & 15.4 & 33.0 & 1.5 & 0.1 & 0.2 & 2.2 & 5,207 & 16.1 & 10,283 & 8.2 & 50.6 & 1.7 & 71.2 & 4,258 & 126 & \\
\hline 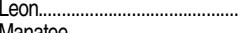 & Fin & 27,241 & 32,050 & & 33,218 & 466 & 45.3 & 46.6 & 42.0 & 4.7 & 3.4 & 0.1 & 0.2 & 3.1 & 2,036 & 16.3 & 4,363 & 7.6 & 46.7 & 3.6 & 73.6 & 1,857 & 60 & \\
\hline Manatee ................................. & & 26,326 & 36,569 & 44,249 & 44,986 & 4,022 & 54.6 & 52.1 & 14.6 & 28.9 & 1.7 & 0.1 & 0.2 & 2.5 & 3,075 & 14.6 & 6,318 & 7.1 & 48.7 & 4.3 & 71.6 & 2,438 & 80 & \\
\hline 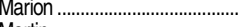 & $\mathrm{F}$ & 29,577 & 38,562 & 41,955 & 42,281 & 1,857 & 65.7 & 55.6 & 19.5 & 18.1 & 1.2 & 0.1 & 0.7 & 4.9 & 2,864 & 14.8 & 6,016 & 7.0 & 47.6 & 3.1 & 64.5 & 2,421 & 64 & \\
\hline Martin ................................... & & 11,808 & 16,308 & 18,170 & 18,368 & 2,178 & 40.7 & 63.7 & 7.7 & 24.2 & 1.6 & $\#$ & 0.3 & 2.4 & 1,174 & 15.7 & 2,339 & 7.9 & 50.2 & 0.7 & 76.8 & 1,242 & 38 & \\
\hline Okaloosa............................ & & 26,140 & 30,344 & 28,695 & 29,385 & 601[ & 38.2 & 70.1 & 12.6 & 7.6 & 2.4 & 0.2 & 0.4[ & 6.7 & 1,871 & 15.7 & 3,010 & 9.8 & 62. & 0.8 & & 2,089 & & \\
\hline Orange & 15 & 103,000 & 150,681 & 176,008 & 180,000 & 28,311 & 54.2 & 31.3 & 27.4 & 33.8 & 4.5 & 0.2 & 0.4[ & 2.5 & 11,30 & 15.9 & 21,976 & 8. & 51.5 & 1.2 & & 9,946 & 243 & \\
\hline Osceola......... & $\mathrm{FL}$ & 19,570 & 34,566 & 53,357 & 54,783 & 9,332 & 63.2 & 27.8 & 11.6 & 54.9 & 2.5 & 0 & 0.6 & 2.3 & 3,288 & 16.7 & 6,634 & & 49 & 1. & & 3,202 & & \\
\hline $\begin{array}{l}\text { Palm Beach............................ } \\
\text { Pasco }\end{array}$ & 然 & $\begin{aligned} 106,000 \\
3381\end{aligned}$ & 153,871 & 174,663 & 176,901 & $\begin{array}{l}18,698 \\
\end{array}$ & 53.5 & 35.9 & 28.7 & 29.0 & 2.8 & 0.2 & 0.6 & 2.8 & 11,68 & 15 & 20,451 & & 57 & & & 10,654 & & \\
\hline $\begin{array}{l}\text { Pasco............................... } \\
\text { Pinellas... }\end{array}$ & & $\begin{array}{l}33,891 \\
0434\end{array}$ & $\begin{array}{r}49,104 \\
113027\end{array}$ & $\begin{array}{r}66,994 \\
104001\end{array}$ & 66,659 & 2,448 & 54.9 & 67.6 & 5.8 & 19.5 & 2.4 & 0.1 & 0.5 & $\begin{array}{ll}4.1 \\
2.7\end{array}$ & 4,779 & 13.9 & 9,503 & 7.0 & 50 & 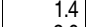 & & 3,6 & 111 & \\
\hline ㄱ..………........... & & 94,364 & 113,027 & $\begin{array}{r}104,001 \\
05,178\end{array}$ & 103,776 & $\begin{array}{l}4,598 \\
0,512\end{array}$ & $\begin{array}{l}53.6 \\
68.6\end{array}$ & 59.2 & $\begin{array}{l}19.1 \\
21.1\end{array}$ & $\begin{array}{l}13.4 \\
273\end{array}$ & 4.0 & 0.2 & 0.4 & 3.7 & 7,289 & 14.2 & 14,075 & 7.4 & 51.8 & 2.6 & 65.8 & 6,711 & 169 & \\
\hline Saint Johns ............................. & $\begin{array}{l}\mathrm{FL} \\
\mathrm{FL}\end{array}$ & $\begin{array}{l}65,218 \\
12080\end{array}$ & 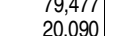 & $\begin{array}{l}95,178 \\
30,710\end{array}$ & $\begin{array}{l}96,070 \\
31,580\end{array}$ & $\begin{array}{r}9,512 \\
240\end{array}$ & $\begin{array}{l}68.3 \\
23.3\end{array}$ & $\begin{array}{l}46.1 \\
80.7\end{array}$ & $\begin{array}{r}21.1 \\
7 .\end{array}$ & $\begin{array}{r}27.3 \\
65\end{array}$ & $\begin{array}{l}1.6 \\
2.9\end{array}$ & $\begin{array}{l}0.1 \\
0.1\end{array}$ & $\begin{array}{l}0.6 \\
0.2\end{array}$ & $\begin{array}{l}3.1 \\
18\end{array}$ & $\begin{array}{l}6,771 \\
2,280\end{array}$ & $\begin{array}{l}14.2 \\
13.8\end{array}$ & $\begin{array}{r}13,342 \\
4,110\end{array}$ & 7.2 & $\begin{array}{l}50.7 \\
55.5\end{array}$ & 5.0 & $\begin{array}{l}68.4 \\
849\end{array}$ & $\begin{array}{l}4,884 \\
1840\end{array}$ & $\begin{array}{r}163 \\
45\end{array}$ & \\
\hline …………….......... & $\mathrm{FL}$ & 22,224 & 29,540 & 39,259 & $\begin{array}{l}39,444 \\
39,1\end{array}$ & 2,659 & 62.9 & 39.5 & 29.7 & 25.2 & 1.7 & 0.2 & 0.4 & $\begin{array}{l}3.4 \\
\end{array}$ & 2,588 & 15.2 & 4,957 & 8.0 & 52.2 & 1.8 & $\begin{array}{l}84.9 \\
67.6\end{array}$ & $\begin{array}{l}1,040 \\
2,052\end{array}$ & $\begin{array}{l}45 \\
50\end{array}$ & \\
\hline Santa Rosa........................... & $\mathrm{FL}$ & 15,741 & 22,633 & 25,533 & 25,885 & 165 & 41.0 & 80.1 & 5.3 & 5.2 & 1.6 & 0.2 & 0.6 & 7.1 & 1,557 & 16.6 & 2,468 & 10.5 & 63.1 & 2.1 & 80.9 & 1,664 & 38 & \\
\hline$\ldots \ldots \ldots \ldots \ldots \ldots \ldots \ldots \ldots$ & $\mathrm{FL}$ & 27,888 & 35,533 & 40,899 & 41,083 & 2,351 & 50.9 & 66.8 & 9.0 & 17.2 & 2.1 & 0.1 & 0.5 & 4.3 & 3,390 & 12.1 & 6,153 & 6.7 & 55.1 & 2.1 & 74.5 & 2,607 & 59 & \\
\hline$\ldots \ldots \ldots \ldots \ldots \ldots \ldots$ & $\mathrm{FL}$ & 49,027 & 60,869 & 64,229 & 64,344 & 2,361 & 45.3 & 56.1 & 13.8 & 22.2 & 4.1 & 0.3 & 0.2 & 3.3 & 4,280 & 15.0 & 7,459 & 0 & 57.4 & 0.4 & 76 & 4,373 & 74 & \\
\hline Volusia.......... & $\mathrm{FL}$ & 48,403 & 61,517 & 61,559 & 61,524 & 3,060 & 57.5 & 61.4 & 15.1 & 17.8 & 1.8 & 0.1 & 0.3 & 3.6 & 4,100 & 15.0 & 7,676 & 8.0 & 53.4 & 1.4 & 63.9 & 3,633 & 93 & \\
\hline Atlanta .................................... & GA & $\begin{array}{r}60,795 \\
24413\end{array}$ & 58,230 & 49,796 & 50,009 & 1,654 & 74.7 & 13.1 & 78.2 & 6.3 & 0.8 & 0.1 & 0.1 & $\begin{array}{r}1.4 \\
1.9\end{array}$ & 3,619 & 13.8 & 6,581 & 7.6 & 55.0 & 9.5 & 53.3 & 2,033 & 108 & $\stackrel{D}{2}$ \\
\hline (nty & GA & 24,413 & 24,739 & 24,961 & 24,730 & 344 & $\begin{array}{l}78.0 \\
63.8\end{array}$ & 20.6 & $\begin{array}{l}72.8 \\
58.3\end{array}$ & 50 & 1.6 & 0.1 & 0.1 & 50 & 1,585 & & 3,525 & 7.0 & & 7.1 & 49.0 & 979 & 43 & $\overrightarrow{\mathrm{D}}$ \\
\hline County ...................... & GA & 34,100 & 35,344 & 35,246 & 35,842 & 622 & 63.8 & 28.0 & 58.3 & 5.6 & 2.0 & 0.1 & 0.2 & 5.9 & 2,603 & 13.8 & 4,710 & 7.6 & 55.3 & 4.7 & 55.3 & 1,528 & 55 & Z \\
\hline ty ..................... & GA & 16,086 & 26,043 & 38,760 & 38,774 & 1,531 & 31.0 & 74.4 & $\begin{array}{r}6.8 \\
710\end{array}$ & 14.0 & 1.6 & 0.1 & 0.3 & 2.8 & 2,377 & 16.3 & 4,515 & 8.6 & 52.7 & 4.2 & 70.2 & 1,880 & 40 & טu \\
\hline $1 \ldots \ldots \ldots \ldots \ldots \ldots \ldots$ & GA & 34,754 & 46,930 & 50,366 & 51,018 & 3,612 & 85.2 & 3.5 & 71.2 & 17.5 & 4.7 & 0.1 & 0.2 & 2.8 & 3,242 & 15.7 & 6,531 & 7.8 & 49.6 & 5.8 & 45.8 & 1,944 & 63 & 2 \\
\hline$\ldots \ldots \ldots \ldots \ldots \ldots \ldots$ & GA & 69,441 & 95,781 & 107,315 & 107,291 & 7,732 & 44.0 & 43.8 & 31.2 & 16.9 & 4.9 & $\#$ & 0.2 & 2.9 & 7,342 & 14.6 & 13,621 & 7.9 & 53.9 & 3.5 & 77.9 & 6,833 & 116 & \\
\hline Inty.................. & GA & 14,096 & 18,756 & 23,722 & 23,792 & 271 & 33.0 & 66.0 & 17.8 & 7.5 & 4.0 & 0.2 & 0.3 & 4.3 & 1,419 & 16.8 & 3,013 & 7.9 & 47.1 & 3.6 & 74.1 & 1,380 & 31 & \\
\hline$y \ldots \ldots \ldots \ldots \ldots \ldots$ & GA & 10,430 & 16,766 & 22,490 & 22,508 & 486 & 43.9 & 65.9 & 21.2 & 7.2 & 1.8 & 0.1 & 0.3 & 36 & 1,434 & 15.7 & 3,056 & 7.4 & 46.9 & 3.3 & 74.1 & 1,217 & 28 & के ठั \\
\hline 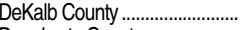 & $\mathrm{GA}$ & 74,404 & 95,958 & 98,115 & 98,088 & 9,707 & 71.1 & 11.0 & 69.0 & 12.7 & 5.5 & 0.1 & 0.2 & 15 & 6,650 & 14.7 & 13,269 & 7.4 & 50.1 & 6.0 & 63.1 & 5,129 & 135 & \\
\hline Dougherty County .................. & GA & 18,877 & 16,799 & 15,906 & 15,945 & 193 & 82.2 & 8.7 & 87.8 & 1.9 & 0.5 & 0.3 & 0.1 & 0.8 & 1,045 & 15.3 & 2,380 & 6.7 & 43.9 & 3.3 & 59.1 & 752 & 27 & 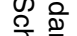 \\
\hline Douglas County....................... & GA & 14,002 & 17,489 & 24,601 & 24,742 & 1,134 & 59.0 & 34.1 & 48.4 & 11.7 & 1.3 & 0.3 & 0.1 & 4.1 & 1,636 & 15.1 & 3,320 & 7.5 & 49.3 & 2.7 & 77.6 & 1,459 & 36 & 学兴 \\
\hline Fayette County .......................... & $\mathrm{GA}$ & 13,105 & 19,590 & 21,274 & 20,539 & 476 & 23.6 & 56.1 & 23.9 & 9.1 & 4.6 & 0.1 & 0.4 & 5.8 & 1,462 & 14.0 & 2,891 & 7.1 & 50.6 & 1.0 & 90.1 & 1,829 & 28 & 으 \\
\hline Forsyth County ..................... & GA & 7,742 & 17,131 & 35,920 & 37,262 & 1,572 & 19.2 & 74.9 & 2.5 & 12.0 & 7.5 & 0.1 & 0.4 & 2.6 & 2,240 & 16.6 & 4,179 & 8.9 & 53.6 & 2.1 & 83.7 & 1,555 & 35 & 0 \\
\hline Fulton County ................................. & $\mathrm{GA} \mid$ & 41,935 & 68,583 & 91,864 & 92,604 & 4,997 & 44.7 & 33.0 & 42.0 & 12.7 & 9.3 & $\#$ & 0.1 & 2.9 & 6,195 & 14.9 & 11,765 & 7.9 & 52.7 & 4.6 & 81.5 & 5,090 & 104 & की \\
\hline See notes at end of tab & & & & & & & & & & & & & & & & & & & & & & & & \\
\hline
\end{tabular}




\begin{tabular}{|c|c|c|c|c|c|c|c|c|c|c|c|c|c|c|c|c|c|c|c|c|c|c|c|}
\hline \multirow[b]{2}{*}{ Name of district } & \multirow[b]{2}{*}{ State } & \multirow[b]{2}{*}{$\begin{array}{r}\text { Enrollment, } \\
\text { fall } 1990\end{array}$} & \multirow[b]{2}{*}{$\begin{array}{r}\text { Enrollment, } \\
\text { fall } 2000\end{array}$} & \multirow[b]{2}{*}{$\begin{array}{r}\text { Enrollment, } \\
\text { fall } 2010\end{array}$} & \multirow[b]{2}{*}{$\begin{array}{r}\text { Enrollment, } \\
\text { fall } 2011\end{array}$} & \multirow[b]{2}{*}{$\begin{array}{r}\text { Number of } \\
\text { English } \\
\text { language } \\
\text { learners, } \\
2011\end{array}$} & \multirow[b]{2}{*}{$\begin{array}{r}\text { Percent } \\
\text { eligible for } \\
\text { free or } \\
\text { reduced- } \\
\text { price lunch, } \\
20111^{1}\end{array}$} & \multicolumn{7}{|c|}{$\begin{array}{l}\text { Percentage distribution of enrollment, } \\
\text { by race/ethnicity, fall } 2011\end{array}$} & \multicolumn{5}{|c|}{ Teachers and staff, fall 2011} & \multicolumn{3}{|c|}{ Dropouts and graduates, 2008-09 } & \multirow[b]{2}{*}{$\begin{array}{r}\text { Number of } \\
\text { schools, } \\
\text { fall } 2011\end{array}$} \\
\hline & & & & & & & & White & Black & Hispanic & Asian & \begin{tabular}{|r|} 
Pacific \\
Islander
\end{tabular} & $\begin{array}{r}\text { American } \\
\text { Indian/ } \\
\text { Alaska } \\
\text { Native }\end{array}$ & $\begin{array}{r}\text { Two or } \\
\text { more } \\
\text { races }\end{array}$ & $\begin{array}{r}\text { Number of } \\
\text { classroom } \\
\text { teachers }\end{array}$ & $\begin{array}{r}\text { Pupil } \\
\text { teacher } \\
\text { ratio }\end{array}$ & $\begin{array}{r}\text { Total } \\
\text { number } \\
\text { of staff }\end{array}$ & $\begin{array}{r}\text { Student/ } \\
\text { staff } \\
\text { ratio }\end{array}$ & $\begin{array}{r}\text { Teachers } \\
\text { as a } \\
\text { percentage } \\
\text { of total staff }\end{array}$ & $\begin{array}{r}\text { Percent } \\
\text { dropping } \\
\text { out of } \\
\text { grades } \\
9-12\end{array}$ & \begin{tabular}{|} 
Averaged \\
freshman \\
graduation \\
rate \\
$($ AFGR) \\
\end{tabular} & $\begin{array}{r}\text { Number of } \\
\text { high } \\
\text { school } \\
\text { graduates }^{3}\end{array}$ & \\
\hline 1 & 2 & 3 & 4 & 5 & 6 & 7 & 8 & 9 & 10 & 11 & 12 & 13 & 14 & 15 & 16 & 17 & 18 & 19 & 20 & 21 & 22 & 23 & 24 \\
\hline 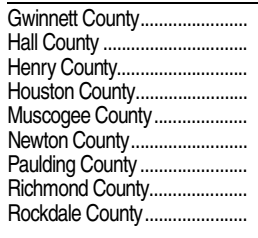 & $\begin{array}{l}\mathrm{GA} \\
\mathrm{GA} \\
\mathrm{GA} \\
\mathrm{GA} \\
\mathrm{GA} \\
\mathrm{GA} \\
\mathrm{GA} \\
\mathrm{GA} \\
\mathrm{GA}\end{array}$ & \begin{tabular}{r|}
64,980 \\
13,833 \\
10,929 \\
16,249 \\
30,125 \\
8,054 \\
7,604 \\
33,660 \\
10,942 \\
\end{tabular} & $\begin{array}{r}111,075 \\
20,330 \\
23,601 \\
21,529 \\
32,916 \\
11,734 \\
16,587 \\
35,424 \\
13,519\end{array}$ & \begin{tabular}{r|}
160,744 \\
25,946 \\
40,909 \\
27,061 \\
32,288 \\
19,478 \\
28,407 \\
32,322 \\
15,864 \\
\end{tabular} & $\begin{array}{l}162,370 \\
26,261 \\
39,909 \\
27,435 \\
32,231 \\
19,168 \\
28,237 \\
31,829 \\
15,608\end{array}$ & $\begin{array}{r}18,968 \\
3,879 \\
686 \\
734 \\
484 \\
476 \\
340 \\
110 \\
601\end{array}$ & $\begin{array}{l}53.7 \\
59.0 \\
49.6 \\
52.4 \\
64.9 \\
65.7 \\
41.5 \\
76.2 \\
63.8\end{array}$ & $\begin{array}{l}30.7 \\
54.7 \\
39.3 \\
50.2 \\
29.2 \\
38.1 \\
67.2 \\
20.2 \\
22.0\end{array}$ & $\begin{array}{r}29.8 \\
4.6 \\
46.2 \\
35.7 \\
57.9 \\
51.5 \\
20.1 \\
72.9 \\
60.4\end{array}$ & $\begin{array}{r}25.1 \\
37.1 \\
7.6 \\
7.0 \\
5.9 \\
5.6 \\
7.4 \\
3.0 \\
12.3\end{array}$ & \begin{tabular}{r|}
10.2 \\
1.4 \\
2.8 \\
2.7 \\
2.2 \\
0.9 \\
0.8 \\
0.9 \\
1.9
\end{tabular} & $\begin{array}{l}0.1 \\
0.1 \\
0.1 \\
0.1 \\
0.1 \\
0.1 \\
0 .\end{array}$ & $\begin{array}{l}0.3 \\
0.2 \\
0.2 \\
0.2 \\
0.2 \\
0.1 \\
0.4 \\
0.1 \\
0.2\end{array}$ & \begin{tabular}{l|}
3.7 \\
1.9 \\
3.8 \\
4.1 \\
4.5 \\
3.6 \\
3.9 \\
2.0 \\
3.1
\end{tabular} & \begin{tabular}{r|}
10,324 \\
1,662 \\
2,629 \\
1,822 \\
2,308 \\
1,230 \\
1,704 \\
2,111 \\
1,082
\end{tabular} & $\begin{array}{l}15.7 \\
15.8 \\
15.2 \\
15.1 \\
14.0 \\
15.6 \\
16.6\end{array}$ & $\begin{array}{l}19,733 \\
3,110 \\
5,013 \\
3,761 \\
5,022\end{array}$ & $\begin{array}{l}8.2 \\
8.4 \\
8.0 \\
7.3 \\
6.4 \\
8.0 \\
8.6 \\
7.4 \\
6.9\end{array}$ & $\begin{array}{l}52.3 \\
53.4 \\
52.4 \\
48.4 \\
46.0 \\
51.1 \\
51.7 \\
48.8 \\
47.9\end{array}$ & $\begin{array}{l}3.4 \\
3.3 \\
5.1 \\
3.6 \\
3.3 \\
2.9 \\
3.5 \\
3.7 \\
2.9\end{array}$ & $\begin{array}{l}71.5 \\
62.2 \\
77.8 \\
76.8 \\
64.7 \\
62.4 \\
71.8 \\
52.9 \\
69.5\end{array}$ & \begin{tabular}{r|}
8,327 \\
1,273 \\
2,395 \\
1,523 \\
1,791 \\
858 \\
1,349 \\
1,529 \\
1,033
\end{tabular} & $\begin{array}{r}133 \\
33 \\
50 \\
39 \\
59 \\
23 \\
33\end{array}$ \\
\hline Hawaii Department of Education.. & $\mathrm{HI}$ & 159,285 & 184,360 & 179,601 & 182,706 & 24,750 & 49.3 & 14.3 & 2.4 & 6.4 & 34.2 & 33.9 & 0.5 & 8.2 & 11,458 & 15.9 & 22,065 & 8.3 & 51.9 & 4.9 & 75.3 & 11,508 & 287 \\
\hline 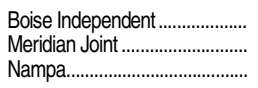 & $\begin{array}{l}\mathrm{ID} \\
\mathrm{ID} \\
\mathrm{ID}\end{array}$ & & $\begin{array}{l}26,598 \\
23,854 \\
11,403\end{array}$ & & & $\begin{array}{l}1,998 \\
1,375 \\
1,062\end{array}$ & $\begin{array}{l}42.4 \\
32.4 \\
64.0\end{array}$ & $\begin{array}{l}79.1 \\
84.1 \\
63.5\end{array}$ & $\begin{array}{l}2.8 \\
1.3 \\
1.5\end{array}$ & $\begin{array}{r}11.0 \\
8.4 \\
32.0\end{array}$ & $\begin{array}{l}4.3 \\
2.2 \\
1.0\end{array}$ & $\begin{array}{l}0.6 \\
0.4 \\
0.9\end{array}$ & $\begin{array}{l}0.5 \\
0.6 \\
1.0\end{array}$ & $\begin{array}{l}1.8 \\
3.0 \\
0.2\end{array}$ & $\begin{array}{r}1,530 \\
1,803 \\
783\end{array}$ & $\begin{array}{l}16.6 \\
20.1 \\
19.9\end{array}$ & 2,719 & $\begin{array}{r}9.4 \\
12.1 \\
11.4\end{array}$ & $\begin{array}{l}56.3 \\
60.1 \\
57.4\end{array}$ & $\begin{array}{l}1.2 \\
1.4 \\
0.8\end{array}$ & $\begin{array}{l}86.9 \\
80.7 \\
70.4\end{array}$ & $\begin{array}{r}1,809 \\
1,887 \\
761\end{array}$ & \\
\hline 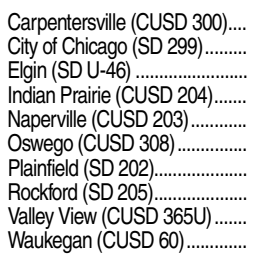 & $\begin{array}{l}\mathrm{IL} \\
\mathrm{L} \\
\mathrm{L} \\
\mathrm{L} \\
\mathrm{L} \\
\mathrm{LL} \\
\mathrm{IL} \\
\mathrm{IL} \\
\mathrm{IL} \\
\mathrm{LL} \\
\mathrm{L}\end{array}$ & $\begin{array}{r}11,196 \\
408,830 \\
27,726 \\
7,670 \\
16,212 \\
4,108 \\
3,324 \\
27,255 \\
11,71 \\
12,116\end{array}$ & $\begin{array}{r}16,711 \\
435,261 \\
36,767 \\
23,173 \\
18,762 \\
6,846 \\
11,986 \\
27,399 \\
13,558 \\
15,510\end{array}$ & $\begin{array}{r}20,678 \\
405,644 \\
40,683 \\
29,522 \\
17,834 \\
16,729 \\
28,921 \\
28,961 \\
17,784 \\
16,462\end{array}$ & $\begin{array}{r}20,810 \\
403,004 \\
40,687 \\
29,286\end{array}$ & $\begin{array}{r}2,492 \\
53,786 \\
7,617 \\
1,458 \\
638 \\
599 \\
1,820 \\
2,939 \\
2,208 \\
4,598\end{array}$ & $\begin{array}{l}39.5 \\
86.7 \\
54.9 \\
14.6 \\
10.9 \\
22.9 \\
20.2 \\
78.5 \\
55.7 \\
61.9\end{array}$ & $\begin{array}{r}53.4 \\
8.9 \\
32.2 \\
56.3 \\
68.5 \\
62.3 \\
59.0 \\
34.2 \\
28.8 \\
4.3\end{array}$ & $\begin{array}{r}5.1 \\
41.6 \\
6.6 \\
9.2 \\
5.2 \\
7.7 \\
8.9 \\
29.7 \\
20.7 \\
15.8\end{array}$ & $\begin{array}{r}32.8 \\
44.4 \\
49.9 \\
10.0 \\
8.3 \\
18.3 \\
22.9 \\
25.9 \\
39.8 \\
76.2\end{array}$ & $\begin{array}{r}5.5 \\
3.3 \\
8.4 \\
20.2 \\
14.6 \\
6.4 \\
5.3 \\
4.0 \\
6.4 \\
1.3\end{array}$ & $\begin{array}{r}0.2 \\
0.1 \\
0.1 \\
\# \\
0.1 \\
\# \\
0.1 \\
\# \\
0.4 \\
0.3\end{array}$ & $\begin{array}{l}0.2 \\
0.4 \\
0.5 \\
0.2 \\
0.2 \\
0.2 \\
0.4 \\
0.2 \\
0.3 \\
0.4\end{array}$ & $\begin{array}{l}2.9 \\
1.4 \\
2.4 \\
4.0 \\
3.1 \\
5.1 \\
3.3 \\
6.0 \\
3.7 \\
1.7\end{array}$ & $\begin{array}{r}1,098 \\
22,460 \\
2,049 \\
1,767 \\
1,048 \\
889 \\
1,623 \\
1,675 \\
1,054 \\
1,070 \\
\mid\end{array}$ & 18.9 & $\begin{array}{r}1,310 \\
26,529 \\
2,353 \\
2,086 \\
1,294 \\
1,018 \\
1,912 \\
1,997 \\
1,292 \\
1,276\end{array}$ & $\begin{array}{l}15.9 \\
15.2 \\
17.3 \\
14.0\end{array}$ & $\begin{array}{l}83.8 \\
84.7 \\
87.1 \\
84.7 \\
81.0 \\
87.3 \\
84.9 \\
83.8 \\
81.6 \\
83.9\end{array}$ & $\begin{array}{r}8.7 \\
15.0 \\
9.1 \\
5.5 \\
5.4 \\
6.0 \\
8.1 \\
22.7 \\
13.7 \\
17.8\end{array}$ & $\begin{array}{c}91.4 \\
60.8 \\
80.2 \\
1.2 \\
100.0^{5} \\
93.3\end{array}$ & $\begin{array}{r}1,326 \\
20,082 \\
2,455 \\
25 \\
1,579 \\
795 \\
1,643 \\
1,367 \\
1,140 \\
811\end{array}$ & $\begin{array}{r}27 \\
641 \\
57\end{array}$ \\
\hline 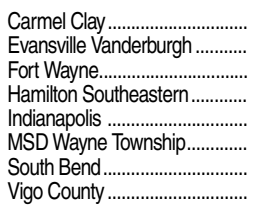 & $\begin{array}{l}\mathbb{N} \\
\mathbb{N} \\
\mathbb{N} \\
\mathbb{N} \\
\mathbb{N} \\
\mathbb{N} \\
\mathbb{N} \\
\mathbb{N}\end{array}$ & $\begin{array}{r}8,449 \\
22,918 \\
31,611 \\
3,113 \\
48,140 \\
12,229 \\
21,425 \\
16,982\end{array}$ & $\begin{array}{r}12,073 \\
22,875 \\
31,143 \\
8,777 \\
41,008 \\
13,263 \\
21,536 \\
16,545\end{array}$ & & & $\begin{array}{r}476 \\
369 \\
2,474 \\
510 \\
4,026 \\
2,148 \\
2,420 \\
189\end{array}$ & $\begin{array}{r}9.7 \\
56.8 \\
69.2 \\
13.7 \\
75.6 \\
70.7 \\
70.0 \\
53.9\end{array}$ & $\begin{array}{l}78.2 \\
73.0 \\
49.1 \\
77.7 \\
22.5 \\
43.3 \\
37.1 \\
83.0\end{array}$ & $\begin{array}{r}3.3 \\
13.7 \\
24.7 \\
7.0 \\
53.7 \\
31.1 \\
34.5 \\
5.6\end{array}$ & $\begin{array}{r}2.2 \\
2.9 \\
13.8 \\
5.1 \\
18.4 \\
18.6 \\
17.7 \\
2.7\end{array}$ & $\begin{array}{r}10.8 \\
1.2 \\
4.0 \\
5.5 \\
0.4 \\
1.0 \\
1.3 \\
1.6\end{array}$ & 0. & 0.2 & $\begin{array}{l}4.9 \\
8.9 \\
7.6 \\
4.3\end{array}$ & $\begin{array}{r}2,160 \\
941 \\
1,170 \\
937\end{array}$ & 16. & & $\begin{array}{l}6.8 \\
6.7 \\
7.3 \\
86\end{array}$ & $\begin{array}{l}41.0 \\
45.3\end{array}$ & $\begin{array}{l}0.5 \\
1.8 \\
0.8\end{array}$ & & $\begin{array}{r}916 \\
1,416 \\
1,898 \\
863 \\
1,159 \\
786 \\
1,109 \\
952\end{array}$ & 17 \\
\hline 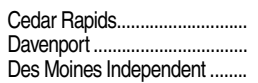 & $\begin{array}{l}\mid A \\
\mid A \\
\mid A\end{array}$ & $\begin{array}{l}17,003 \\
17,846 \\
30,888\end{array}$ & & & & $\begin{array}{r}426 \\
454 \\
5,144\end{array}$ & $\begin{array}{l}42.0 \\
60.6 \\
70.7\end{array}$ & $\begin{array}{l}74.1 \\
58.7 \\
47.2\end{array}$ & $\begin{array}{l}14.4 \\
18.9 \\
17.2\end{array}$ & $\begin{array}{r}4.9 \\
13.1 \\
22.3\end{array}$ & $\begin{array}{l}2.3 \\
1.9 \\
6.4\end{array}$ & $\begin{array}{l}0.2 \\
0.1 \\
0.2\end{array}$ & $\begin{array}{l}0.4 \\
0.4 \\
0.4\end{array}$ & $\begin{array}{l}3.7 \\
7.0 \\
6.3\end{array}$ & $\begin{array}{l}1,150 \\
1,076 \\
2,280\end{array}$ & 14. & $\begin{array}{l}2,515 \\
2,074 \\
4,540\end{array}$ & $\begin{array}{l}6.8 \\
8.2 \\
7.4\end{array}$ & $\begin{array}{l}45.7 \\
51.9 \\
50.2\end{array}$ & $\begin{array}{l}5.6 \\
9.4 \\
7.6\end{array}$ & & $\begin{array}{r}1,071 \\
930 \\
1,607\end{array}$ & $\begin{array}{l}33 \\
33 \\
62\end{array}$ \\
\hline Valloy & \begin{tabular}{l|l} 
KS \\
KS \\
KS \\
KS \\
KS
\end{tabular} & $\begin{array}{r}9,433 \\
22,118 \\
14,870 \\
30,619 \\
47,222\end{array}$ & $\begin{array}{l}17,111 \\
21,173 \\
20,703 \\
30,765 \\
48,228\end{array}$ & $\begin{array}{l}27,822 \\
49,329\end{array}$ & & $\begin{array}{r}360 \\
6,301 \\
1,499 \\
2,165 \\
7,647\end{array}$ & $\begin{array}{r}8.0 \\
89.0 \\
26.4 \\
35.5 \\
76.1\end{array}$ & $\begin{array}{l}14.1 \\
71.9 \\
66.6 \\
35.6\end{array}$ & $\begin{array}{r}3.2 \\
35.6 \\
6.9 \\
8.6 \\
18.5\end{array}$ & $\begin{array}{l}16.0 \\
31.2\end{array}$ & $\begin{array}{l}4.5 \\
3.1 \\
4.8\end{array}$ & \begin{tabular}{r|}
$\#$ \\
0.2 \\
0.1 \\
0.2 \\
0.1
\end{tabular} & $\begin{array}{l}0.3 \\
1.4\end{array}$ & $\begin{array}{l}3.4 \\
1.7 \\
3.2 \\
5.2 \\
8.3\end{array}$ & $\begin{array}{l}1,794 \\
3,063\end{array}$ & 16.1 & 5,872 & $\begin{array}{l}8.6 \\
8.4\end{array}$ & & & & $\begin{array}{r}1,412 \\
911 \\
1,788 \\
2,061 \\
2,635\end{array}$ & $\begin{array}{l}34 \\
43 \\
47 \\
44 \\
90\end{array}$ \\
\hline 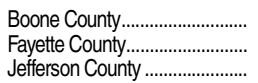 & $\begin{array}{l}\mathrm{KY} \\
\mathrm{KY} \\
\mathrm{KY}\end{array}$ & $\begin{array}{r}9,911 \\
32,083 \\
91,450\end{array}$ & $\begin{array}{r}13,445 \\
33,130 \\
96,860\end{array}$ & $\begin{array}{l}19,306 \\
37,819 \\
97,331\end{array}$ & & $\begin{array}{r}811 \\
3,205 \\
5,302\end{array}$ & $\begin{array}{l}29.3 \\
43.3 \\
58.6\end{array}$ & $\begin{array}{l}86.1 \\
57.2 \\
50.9\end{array}$ & $\begin{array}{r}3.4 \\
23.0 \\
37.0\end{array}$ & $\begin{array}{r}5.3 \\
12.1 \\
6.6\end{array}$ & $\begin{array}{l}2.4 \\
4.0 \\
3.1\end{array}$ & $\begin{array}{l}0.2 \\
0.1 \\
0.1\end{array}$ & $\begin{array}{l}0.2 \\
0.2 \\
0.1\end{array}$ & $\begin{array}{l}2.4 \\
3.4 \\
2.2\end{array}$ & $\begin{array}{l}1,159 \\
2,742 \\
5,904\end{array}$ & $\begin{array}{l}16.9 \\
14.1 \\
16.8\end{array}$ & $\begin{array}{l}2,633 \\
5,711 \\
7,320\end{array}$ & $\begin{array}{r}7.4 \\
6.8 \\
13.6\end{array}$ & $\begin{array}{l}44.0 \\
48.0 \\
80.7\end{array}$ & $\begin{array}{l}1.5 \\
3.5 \\
5.7\end{array}$ & & $\begin{array}{l}1,079 \\
2,101 \\
5,506\end{array}$ & $1 / 3$ \\
\hline 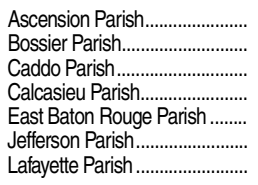 & $\begin{array}{l}\angle A \\
\angle A \\
\angle A \\
L A \\
\angle A \\
\angle A \\
\angle A \\
L A\end{array}$ & $\begin{array}{l}13,001 \\
17,804 \\
51,375 \\
32,917 \\
61,669 \\
58,177 \\
29,403\end{array}$ & $\begin{array}{l}15,038 \\
18,797 \\
45,119 \\
32,261 \\
54,246 \\
50,891 \\
28,931\end{array}$ & $\begin{array}{l}29,953 \\
20,656 \\
41,894 \\
33,063 \\
42,723 \\
45,230 \\
30,218\end{array}$ & $\begin{array}{l}21,037 \\
41,667 \\
32,563 \\
42,854 \\
45,688 \\
30,451\end{array}$ & $\begin{array}{r}308 \\
557 \\
396 \\
285 \\
1,383 \\
3,786 \\
880\end{array}$ & $\begin{array}{l}49.2 \\
45.3 \\
64.9 \\
58.9 \\
82.2 \\
77.4 \\
61.4\end{array}$ & $\begin{array}{l}61.8 \\
60.6 \\
32.2 \\
60.7 \\
10.9 \\
29.7 \\
49.4\end{array}$ & $\begin{array}{l}30.3 \\
27.1 \\
63.3 \\
34.3 \\
81.2 \\
45.6 \\
43.4\end{array}$ & \begin{tabular}{r|r}
5.4 \\
6.8 \\
2.2 \\
2.5 \\
4.1 \\
17.0 \\
4.3
\end{tabular} & $\begin{array}{l}1.0 \\
1.4 \\
1.1 \\
1.1 \\
3.0 \\
4.8 \\
2.0\end{array}$ & \begin{tabular}{r|}
0.1 \\
0.2 \\
0.1 \\
$\#$ \\
0.1 \\
0.3 \\
$\#$
\end{tabular} & $\begin{array}{l}0.3 \\
0.4 \\
0.2 \\
0.2 \\
0.1 \\
0.7 \\
0.3\end{array}$ & $\begin{array}{l}1.0 \\
3.5 \\
0.9 \\
1.1 \\
0.7 \\
1.9 \\
0.5\end{array}$ & $\begin{array}{l}1,356 \\
1,357 \\
2,890 \\
2,381 \\
3,234 \\
3,039 \\
2,040\end{array}$ & $\begin{array}{l}14.4 \\
13.7 \\
13.3 \\
15.0 \\
14.9\end{array}$ & $\begin{array}{l}2,745 \\
2,850 \\
6,609 \\
4,856 \\
6,374 \\
6,466 \\
4,264\end{array}$ & $\begin{array}{l}7.5 \\
7.4 \\
6.3 \\
6.7 \\
6.7 \\
7.1 \\
7.1\end{array}$ & $\begin{array}{l}49.4 \\
47.6 \\
43.7 \\
49.0 \\
50.7 \\
47.0 \\
47.8\end{array}$ & $\begin{array}{r}4.8 \\
5.3 \\
10.0 \\
3.5 \\
9.9 \\
8.1 \\
6.6\end{array}$ & $\begin{array}{l}78.9 \\
71.2 \\
60.5 \\
69.9 \\
51.7 \\
59.7 \\
70.9\end{array}$ & $\begin{array}{l}1,083 \\
1,041 \\
2,126 \\
1,695 \\
1,839 \\
2,093 \\
1,652\end{array}$ & $\begin{array}{l}27 \\
34\end{array}$ \\
\hline
\end{tabular}

Gwinnett Coun Hall County...........
Henry County.

Houston County

Paulding County.

Rockdale County

\begin{tabular}{r|r|r|r|r|r|}
\hline HI & 159,285 & 184,360 & 179,601 & 182,706 & 24,750 \\
\hline
\end{tabular}

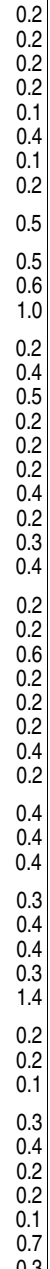

\begin{tabular}{l|l|l|l|}
61.4 & 49.4 & 43.4
\end{tabular}

See notes at end of table. 


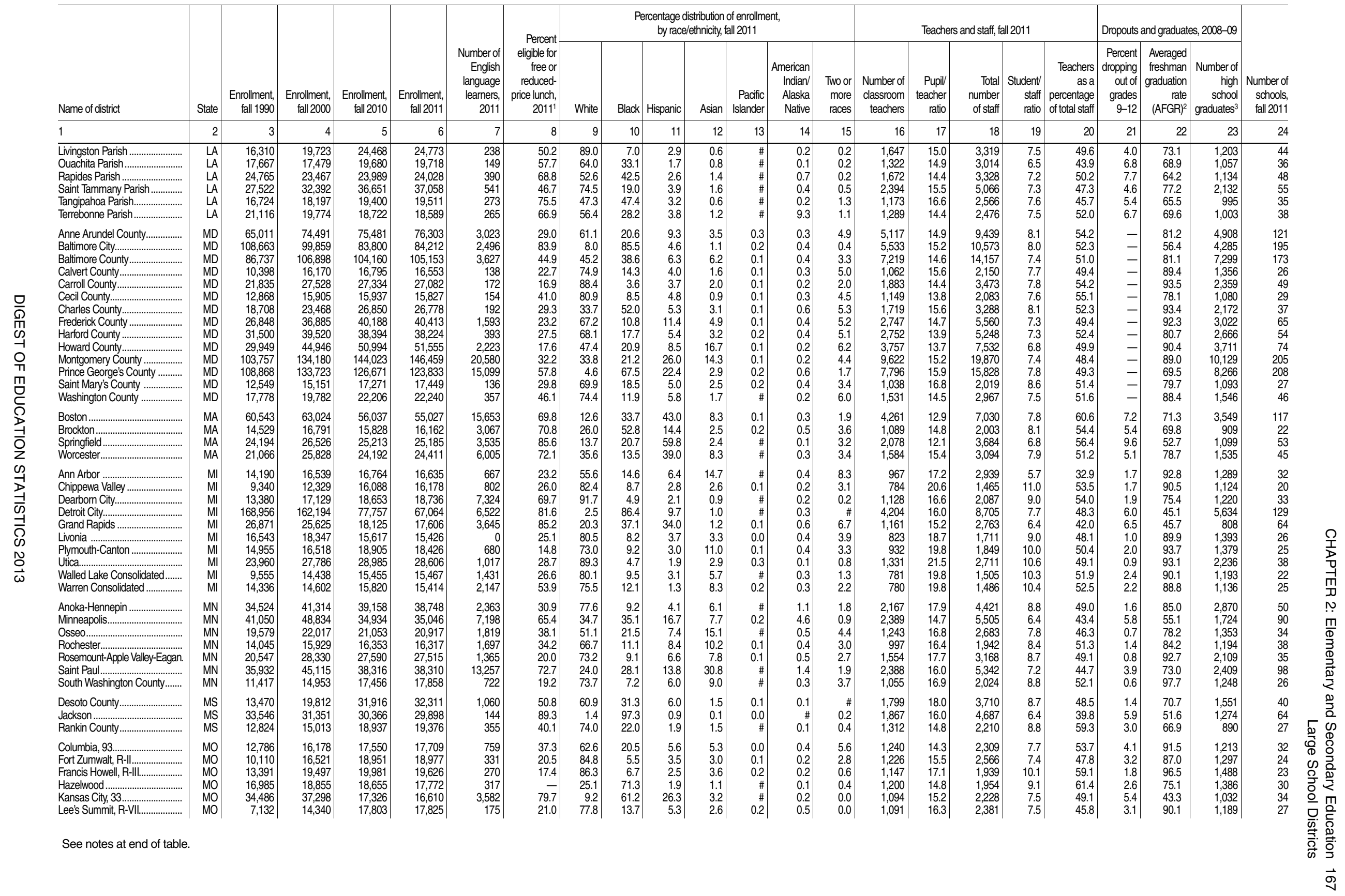




\begin{tabular}{|c|c|c|c|c|c|c|c|c|c|c|c|c|c|c|c|c|c|c|c|c|c|c|c|}
\hline \multirow[b]{2}{*}{ Name of district } & \multirow[b]{2}{*}{ State } & \multirow[b]{2}{*}{$\begin{array}{r}\text { Enrollment, } \\
\text { fall } 1990\end{array}$} & \multirow[b]{2}{*}{$\begin{array}{r}\text { Enrollment, } \\
\text { fall } 2000\end{array}$} & \multirow[b]{2}{*}{$\begin{array}{r}\text { Enrollment, } \\
\text { fall } 2010\end{array}$} & \multirow[b]{2}{*}{$\begin{array}{r}\text { Enrollment, } \\
\text { fall } 2011\end{array}$} & \multirow[b]{2}{*}{$\begin{array}{r}\text { Number of } \\
\text { English } \\
\text { language } \\
\text { learners, } \\
2011\end{array}$} & \multirow[b]{2}{*}{ 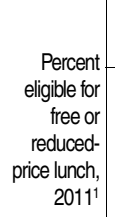 } & \multicolumn{7}{|c|}{$\begin{array}{l}\text { Percentage distribution of enrollment, } \\
\text { by race/ethnicity, fall } 2011\end{array}$} & \multicolumn{5}{|c|}{ Teachers and staff, fall 2011} & \multicolumn{3}{|c|}{ Dropouts and graduates, 2008-09 } & \multirow[b]{2}{*}{$\begin{array}{r}\text { Number of } \\
\text { schools, } \\
\text { fall } 2011\end{array}$} \\
\hline & & & & & & & & White & Black & Hispanic & Asian & $\begin{array}{r}\text { Pacific } \\
\text { Islander }\end{array}$ & $\begin{array}{r}\text { American } \\
\text { Indian/ } \\
\text { Alaska } \\
\text { Native }\end{array}$ & $\begin{array}{r}\text { Two or } \\
\text { more } \\
\text { races }\end{array}$ & $\begin{array}{r}\text { Number of } \\
\text { classroom } \\
\text { teachers }\end{array}$ & $\begin{array}{r}\text { Pupil } \\
\text { teacher } \\
\text { ratio }\end{array}$ & $\begin{array}{r}\text { Total } \\
\text { number } \\
\text { of staff }\end{array}$ & $\begin{array}{r}\text { Student } \\
\text { staff } \\
\text { ratio }\end{array}$ & $\begin{array}{r}\text { Teachers } \\
\text { as a } \\
\text { percentage } \\
\text { of total staff }\end{array}$ & $\begin{array}{r}\text { Percent } \\
\text { dropping } \\
\text { out of } \\
\text { grades } \\
9-12\end{array}$ & \begin{tabular}{|r|} 
Averaged \\
freshman \\
graduation \\
rate \\
$($ AFGR)
\end{tabular} & $\begin{array}{r}\text { Number of } \\
\text { high } \\
\text { school } \\
\text { graduates }^{3}\end{array}$ & \\
\hline 1 & 2 & 3 & 4 & 5 & 6 & 7 & 8 & 9 & 10 & 11 & 12 & 13 & 14 & 15 & 16 & 17 & 18 & 19 & 20 & 21 & 22 & 23 & 24 \\
\hline 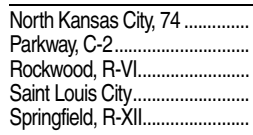 & $\begin{array}{l}\text { MO } \\
\text { MO } \\
\text { MO } \\
\text { MO }\end{array}$ & $\begin{array}{l}15,732 \\
21,542 \\
15,608 \\
43,284 \\
23,631\end{array}$ & \begin{tabular}{l|}
17,258 \\
20,433 \\
21,203 \\
44,412 \\
24,630
\end{tabular} & $\begin{array}{l}18,764 \\
17,458 \\
22,823 \\
25,084 \\
24,730\end{array}$ & $\begin{array}{l}19,133 \\
17,363 \\
22,503 \\
24,665 \\
25,175\end{array}$ & $\begin{array}{r}1,196 \\
622 \\
412 \\
1,764 \\
589\end{array}$ & $\begin{array}{r}46.4 \\
14.4 \\
7.4 \\
79.9 \\
51.5\end{array}$ & $\begin{array}{l}64.8 \\
66.0 \\
80.6 \\
13.5 \\
83.2\end{array}$ & $\begin{array}{r}12.0 \\
14.6 \\
10.2 \\
80.3 \\
7.9\end{array}$ & \begin{tabular}{r|}
12.7 \\
4.3 \\
2.3 \\
3.2 \\
4.2
\end{tabular} & \begin{tabular}{r|}
3.9 \\
11.3 \\
5.9 \\
2.8 \\
2.4
\end{tabular} & \begin{tabular}{r|r}
0.5 \\
0.1 \\
$\#$ \\
0.0 \\
0.4
\end{tabular} & $\begin{array}{l}0.8 \\
0.2 \\
0.2 \\
0.3 \\
0.5\end{array}$ & \begin{tabular}{l|}
5.3 \\
3.5 \\
0.8 \\
0.0 \\
1.4
\end{tabular} & $\begin{array}{l}1,292 \\
1,260 \\
1,465 \\
1,904 \\
1,623\end{array}$ & $\begin{array}{l}14.8 \\
13.8 \\
15.4 \\
13.0 \\
15.5\end{array}$ & $\begin{array}{l}3,110 \\
2,810 \\
3,276 \\
2,658 \\
9,953\end{array}$ & $\begin{array}{l}6.2 \\
6.2 \\
6.9 \\
9.3 \\
2.5\end{array}$ & $\begin{array}{l}41.6 \\
44.8 \\
44.7 \\
71.6 \\
16.3\end{array}$ & \begin{tabular}{r|}
3.1 \\
1.4 \\
1.3 \\
25.9 \\
4.9
\end{tabular} & $\begin{array}{l}93.4 \\
92.0 \\
94.5 \\
51.9 \\
82.7\end{array}$ & $\begin{array}{l}1,268 \\
1,418 \\
1,721 \\
1,643 \\
1,673\end{array}$ & $\begin{array}{l}32 \\
28 \\
31 \\
75 \\
55\end{array}$ \\
\hline 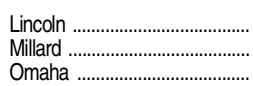 & $\begin{array}{l}\mathrm{NE} \\
\mathrm{NE} \\
\mathrm{NE}\end{array}$ & $\begin{array}{l}27,986 \\
16,764 \\
41,699\end{array}$ & $\begin{array}{l}31,354 \\
19,160 \\
45,197\end{array}$ & $\begin{array}{l}35,896 \\
22,783 \\
49,405\end{array}$ & $\begin{array}{l}36,528 \\
23,074 \\
50,340\end{array}$ & $\begin{array}{r}2,208 \\
268 \\
6,760\end{array}$ & $\begin{array}{l}43.7 \\
18.2 \\
71.3\end{array}$ & $\begin{array}{l}69.8 \\
82.6 \\
33.1\end{array}$ & $\begin{array}{r}6.6 \\
26.9 \\
26.2\end{array}$ & $\begin{array}{r}11.7 \\
6.4 \\
30.5\end{array}$ & $\begin{array}{l}4.5 \\
4.6 \\
3.0\end{array}$ & $\begin{array}{l}0.1 \\
0.3 \\
0.1\end{array}$ & $\begin{array}{l}0.9 \\
0.4 \\
1.2\end{array}$ & $\begin{array}{l}6.4 \\
2.8 \\
5.9\end{array}$ & $\begin{array}{l}2,549 \\
1,513 \\
3,327\end{array}$ & $\begin{array}{l}14.3 \\
15.3 \\
15.1\end{array}$ & $\begin{array}{l}5,267 \\
2,679 \\
6,956\end{array}$ & $\begin{array}{l}6.9 \\
8.6 \\
7.2\end{array}$ & $\begin{array}{l}48.4 \\
56.5 \\
47.8\end{array}$ & $\begin{array}{l}3.9 \\
0.9 \\
5.6\end{array}$ & $\begin{array}{l}79.4 \\
96.8 \\
57.7\end{array}$ & $\begin{array}{l}1,954 \\
1,583 \\
2,293\end{array}$ & $\begin{array}{r}69 \\
37 \\
100\end{array}$ \\
\hline 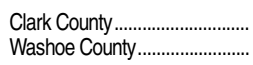 & $\begin{array}{l}\mathrm{NV} \\
\mathrm{NV}\end{array}$ & $\begin{array}{r}121,984 \\
38,466\end{array}$ & $\begin{array}{r}231,655 \\
56,268\end{array}$ & $\begin{array}{r}314,059 \\
64,380\end{array}$ & $\begin{array}{r}313,398 \\
64,740\end{array}$ & $\begin{array}{l}68,577 \\
11,102\end{array}$ & $\begin{array}{l}59.6 \\
44.3\end{array}$ & $\begin{array}{l}30.2 \\
48.3\end{array}$ & $\begin{array}{r}12.3 \\
2.6\end{array}$ & $\begin{array}{l}43.1 \\
37.3\end{array}$ & $\begin{array}{l}6.5 \\
4.7\end{array}$ & $\begin{array}{l}1.5 \\
0.8\end{array}$ & $\begin{array}{l}0.5 \\
1.8\end{array}$ & $\begin{array}{l}5.9 \\
4.5\end{array}$ & $\begin{array}{r}14,822 \\
3,145\end{array}$ & $\begin{array}{l}21.1 \\
20.6\end{array}$ & $\begin{array}{r}17,334 \\
3,555\end{array}$ & $\begin{array}{l}18.1 \\
18.2\end{array}$ & $\begin{array}{r}85.5 \\
88.4\end{array}$ & $=$ & $\overline{-}$ & $\overline{-}$ & $\begin{array}{l}364 \\
105\end{array}$ \\
\hline 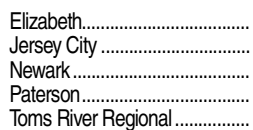 & $\begin{array}{l}N J \\
N J \\
N J \\
N J \\
N J\end{array}$ & $\begin{array}{l}15,266 \\
28,585 \\
48,433 \\
22,109 \\
16,002\end{array}$ & $\begin{array}{l}19,674 \\
31,347 \\
42,150 \\
24,629 \\
17,621\end{array}$ & $\begin{array}{l}24,258 \\
34,505 \\
41,235 \\
31,350 \\
17,285\end{array}$ & $\begin{array}{l}23,386 \\
27,397 \\
35,543 \\
24,365 \\
16,981\end{array}$ & $\begin{array}{r}2,730 \\
2,512 \\
3,143 \\
4,749 \\
123\end{array}$ & $\begin{array}{l}85.5 \\
77.5 \\
85.5 \\
85.7 \\
23.3\end{array}$ & $\begin{array}{r}8.4 \\
10.5 \\
7.9 \\
5.5 \\
79.3\end{array}$ & $\begin{array}{r}21.7 \\
33.6 \\
53.4 \\
28.4 \\
4.8\end{array}$ & $\begin{array}{l}67.8 \\
38.0 \\
37.7 \\
62.2 \\
10.5\end{array}$ & $\begin{array}{r}1.9 \\
16.6 \\
0.8 \\
3.6 \\
3.9\end{array}$ & $\begin{array}{l}0.1 \\
0.8 \\
0.1 \\
0.2 \\
0.1\end{array}$ & $\begin{array}{r}\# \\
0.6 \\
0.2 \\
0.1 \\
0.1\end{array}$ & $\begin{array}{r}\# \\
0.0 \\
\# \\
\# \\
1.3\end{array}$ & $\begin{array}{l}1,846 \\
2,601 \\
2,546 \\
1,845 \\
1,167\end{array}$ & $\begin{array}{r}12.7 \\
10.5 \\
14.0 \\
13.2 \\
14.6\end{array}$ & $\begin{array}{l}3,616 \\
4,898 \\
6,144 \\
3,350 \\
2,154\end{array}$ & $\begin{array}{l}6.5 \\
5.6 \\
5.8 \\
7.3 \\
7.9\end{array}$ & $\begin{array}{l}51.1 \\
53.1 \\
41.4 \\
55.1 \\
54.2\end{array}$ & $\begin{array}{l}6.7 \\
6.4 \\
4.2 \\
4.3 \\
2.2\end{array}$ & $\begin{array}{l}62.2 \\
71.1 \\
75.4 \\
52.7 \\
89.2\end{array}$ & $\begin{array}{r}928 \\
1,41 \\
2,421 \\
991 \\
1,315\end{array}$ & $\begin{array}{l}33 \\
38 \\
74 \\
46 \\
18\end{array}$ \\
\hline 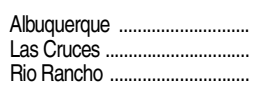 & $\begin{array}{l}\text { NM } \\
\text { NM } \\
\text { NM }\end{array}$ & $\begin{array}{l}88,295 \\
19,216\end{array}$ & $\begin{array}{l}85,276 \\
22,185 \\
10,219\end{array}$ & $\begin{array}{l}95,415 \\
25,488 \\
16,751\end{array}$ & $\begin{array}{l}94,318 \\
25,353 \\
16,870\end{array}$ & $\begin{array}{r}16,253 \\
3,561 \\
609\end{array}$ & $\begin{array}{l}63.8 \\
68.9 \\
50.9\end{array}$ & $\begin{array}{l}22.3 \\
20.9 \\
41.9\end{array}$ & $\begin{array}{l}2.4 \\
2.5 \\
3.4\end{array}$ & $\begin{array}{l}66.0 \\
74.2 \\
46.7\end{array}$ & $\begin{array}{l}2.1 \\
1.1 \\
2.1\end{array}$ & $\begin{array}{l}0.1 \\
0.3 \\
0.0\end{array}$ & $\begin{array}{l}4.4 \\
0.9 \\
3.8\end{array}$ & $\begin{array}{l}2.8 \\
0.1 \\
2.0\end{array}$ & $\begin{array}{l}6,157 \\
1,569 \\
1,032\end{array}$ & $\begin{array}{l}15.3 \\
16.2 \\
16.3\end{array}$ & $\begin{array}{r}12,275 \\
3,223 \\
2,037\end{array}$ & $\begin{array}{l}7.7 \\
7.9 \\
8.3\end{array}$ & $\begin{array}{l}50.2 \\
48.7 \\
50.7\end{array}$ & $\begin{array}{l}2.7 \\
6.6 \\
3.9\end{array}$ & $\begin{array}{l}61.9 \\
63.3 \\
75.8\end{array}$ & $\begin{array}{r}4,784 \\
1,268 \\
915\end{array}$ & $\begin{array}{r}162 \\
41 \\
19\end{array}$ \\
\hline 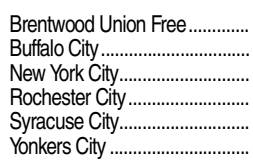 & $\begin{array}{l}N Y \\
N Y \\
N Y \\
N Y \\
N Y \\
N Y\end{array}$ & $\begin{array}{r}11,749 \\
47,224 \\
943,969 \\
32,730 \\
22,561 \\
18,621\end{array}$ & $\begin{array}{r}15,565 \\
45,721 \\
1,066,516 \\
36,294 \\
23,015 \\
26,237\end{array}$ & $\begin{array}{r}16,833 \\
33,543 \\
995,336 \\
32,223 \\
21,247 \\
25,568\end{array}$ & $\begin{array}{r}17,143 \\
32,73 \\
990,145 \\
31,432 \\
20,491 \\
25,326\end{array}$ & $\begin{array}{r}4,706 \\
3,643 \\
142,572 \\
2,899 \\
2,524 \\
3,094\end{array}$ & $\begin{array}{l}61.1 \\
79.0 \\
73.5 \\
87.4 \\
79.4 \\
72.6\end{array}$ & $\begin{array}{r}7.4 \\
22.3 \\
14.9 \\
10.4 \\
25.9 \\
18.2\end{array}$ & $\begin{array}{l}13.9 \\
52.8 \\
28.1 \\
62.0 \\
50.0 \\
21.5\end{array}$ & $\begin{array}{l}76.2 \\
16.1 \\
40.3 \\
24.2 \\
12.8 \\
53.3\end{array}$ & $\begin{array}{r}2.1 \\
5.6 \\
15.6 \\
3.1 \\
6.3 \\
5.6\end{array}$ & $\begin{array}{r}\# \\
\# \\
0.4 \\
\# \\
0.1 \\
\#\end{array}$ & $\begin{array}{l}0.2 \\
1.3 \\
0.6 \\
0.3 \\
1.4 \\
0.3\end{array}$ & $\begin{array}{l}0.1 \\
2.0 \\
0.1 \\
0.1 \\
3.4 \\
0.9\end{array}$ & $\begin{array}{r}1,107 \\
2,751 \\
67,046 \\
2,603 \\
1,557 \\
1,496\end{array}$ & $\begin{array}{l}15.5 \\
11.9 \\
14.8 \\
12.1 \\
13.2 \\
16.9\end{array}$ & $\begin{array}{r}2,224 \\
5,005 \\
125,119 \\
4,742 \\
3,491 \\
3,059\end{array}$ & $\begin{array}{l}7.7 \\
6.5 \\
7.9 \\
6.6 \\
5.9 \\
8.3\end{array}$ & $\begin{array}{l}49.8 \\
55.0 \\
53.6\end{array}$ & \begin{tabular}{r|r}
2.0 \\
9.3 \\
7.4 \\
11.3 \\
11.0 \\
4.7
\end{tabular} & $\begin{array}{l}73.1 \\
61.4 \\
-\overline{43.9} \\
52.3 \\
64.3\end{array}$ & $\begin{array}{r}1,029 \\
1,538 \\
56,655 \\
1,406 \\
847 \\
1,361\end{array}$ & $\begin{array}{r}17 \\
56 \\
1,565 \\
67 \\
32 \\
39\end{array}$ \\
\hline Alamance-Burlington............. & NC & 10,322 & 20,729 & 22,811 & 22,851 & 2,499 & 53.7 & 51.9 & 21.4 & 21.8 & 1.3 & 0.1 & 0.4 & 32 & 1487 & & & & & 80 & & 1349 & \\
\hline & $N C$ & 22026 & & & & 1714 & & & & & & & & & & & & & & & & & \\
\hline & $N C$ & 12,853 & & & & 1.9 & 39.8 & 6 & & & 0 & 1 & 0.4 & 3 & & & & & & & & 1,1591 & $\begin{array}{l}43 \\
38\end{array}$ \\
\hline & & & & & & & & & & & & & & & & & & & & & & & \\
\hline $\mathrm{c}$ & NC & 77,069 & 103,336 & 13 & 14 & 13,866 & 54.7 & & 4 & & 5. & 0 & 0 & 2 & & & & & & & & & 3 \\
\hline & NC & 8,131 & 9,663 & & 16 & 284 & 59.9 & & & 4 & 0 & \# & & 4 & 1,116 & & 2,200 & 4 & & 1 & & 1,027 & 29 \\
\hline & NC & 14,239 & 14, & & 15 & 691 & 52.8 & & & 8 & 3.3 & 0.2 & 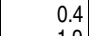 & 4. & 942 & & 1, & & & .0 & & 867 & 25 \\
\hline & NC & $\begin{array}{r}44,612 \\
\end{array}$ & 50, & & 53, & $\begin{array}{r}1,062 \\
383\end{array}$ & 56.1 & & $\begin{array}{r}44.9 \\
31\end{array}$ & $\begin{array}{r}11 \\
5\end{array}$ & 1.7 & .3 & 1.9 & 6.5 & $\begin{array}{l}3,588 \\
1100\end{array}$ & 1 & 7 & 5 & & 8 & & 3,327 & 86 \\
\hline . & $\begin{array}{l}\mathrm{NC} \\
\mathrm{NC}\end{array}$ & $\begin{array}{l}16,426 \\
18,517\end{array}$ & $\begin{array}{l}19, \\
29,\end{array}$ & & $\begin{array}{l}20, \\
33\end{array}$ & $\begin{array}{r}383 \\
4,477\end{array}$ & $\begin{array}{l}43.1 \\
58.7\end{array}$ & & $\begin{array}{r}3.1 \\
50.9\end{array}$ & 22 & $\begin{array}{l}1.0 \\
2.4\end{array}$ & $\begin{array}{l}0.1 \\
0.1\end{array}$ & 0 & $\begin{array}{l}1.1 .9 \\
2.9\end{array}$ & & $\begin{array}{l}1 / 1 \\
15\end{array}$ & $\begin{array}{l}2,3 \\
4,3\end{array}$ & & & $\begin{array}{l}6.4 \\
5.1\end{array}$ & & $\begin{array}{r}1,289 \\
1,813\end{array}$ & $\begin{array}{l}33 \\
55\end{array}$ \\
\hline & NC & 37,6 & & & 53 & 6,300 & 54 & & & & 2. & 0.1 & . & 10 & & & & & & 1 & & 3,150 & 81 \\
\hline & NC & 29,6 & & & 31 & 1,4 & 57 & & & & 1.4 & $\#$ & & 3. & & 17 & & & & & & 55 & 55 \\
\hline & NC & 24,575 & 63 & & 74, & $\begin{array}{l}5,8 \\
5,8\end{array}$ & 54 & & & 1 & $\begin{array}{l}1.4 \\
5.6\end{array}$ & 0.2 & & 3 & & 15 & 9,8 & & & & & & 121 \\
\hline & & 11,8 & 16 & 19 & 19, & 1,327 & 56.1 & & & & 0.6 & & 1. & & & & 2,206 & & & & & 1,108 & 27 \\
\hline & & & & & & 1,0 & 42.2 & & & & & & & & & & 2,528 & & & & & & 36 \\
\hline & & & & & & & & & & & & & & & & & & & & & & & 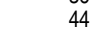 \\
\hline & & & & & & & & & & & & & & & & & & & & & & & \\
\hline $\mathrm{N}$ & NC & & & & & & & & & & & & & & & & & & & & & & \\
\hline & $N C$ & 18 & & & 24 & 324 & 40 & & & 10 & 1.1 & .3 & 0. & 0 & & 1 & 2, & & & & & & 35 \\
\hline & NC & 17, & & & 23, & 968 & 5 & & 48.3 & 0 & 1.3 & $\#$ & 0 & 2. & & 15 & 3, & & & & & & 37 \\
\hline & NC & 13,5 & & & 18, & 1,252 & 53 & & 4.0 & 13 & 1.2 & \# & & 2. & & 16 & 2, & & & & & & 31 \\
\hline & NC & 23,2 & & & 24, & 1,563 & 78 & 15 & 25.4 & 11 & 0.9 & 0.1 & 43 & 3. & & 16 & 2, & & & & & & 42 \\
\hline Ro & NC & 16,403 & 20,472 & 20,4 & 20,3 & 1,444 & 60.2 & & 19.0 & 12 & 1.1 & 0.1 & 0.3 & 2 & 1,3 & 15 & 2,680 & 7. & & 6.1 & & $\begin{array}{l}1,352 \\
\end{array}$ & 35 \\
\hline Un & NC & 12,864 & 22,862 & 40,15 & 40,1 & 2,155 & 34.1 & 67 & 13.2 & 14.2 & 1.7 & 0.1 & 0.3 & 2. & 2,3 & 16 & 4,705 & 8 & & 0 & 87 & 2,136 & 52 \\
\hline & NC & 64,266 & 98,9 & 144,173 & 148,1 & 11,111 & 34.5 & 49 & 24.7 & 15.1 & 6.2 & $\#$ & 0.4 & 4. & $\begin{array}{l}9,4 \\
9,4\end{array}$ & 15 & $\begin{array}{r}4,105 \\
16,592\end{array}$ & 8 & 56 & 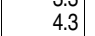 & 84 & 8,186 & 165 \\
\hline & & & & 19,471 & 19,912 & 1,529 & 60.5 & 41.3 & 34.6 & 17.0 & & 0.1 & 0.2 & 5.7 & 1,261 & 15.8 & 2,497 & & 50.5 & 5.6 & 75.5 & 1,170 & \\
\hline
\end{tabular}

See notes at end of table. 


\begin{tabular}{|c|c|c|c|c|c|c|c|c|c|c|c|c|c|c|c|c|c|c|c|c|c|c|c|c|}
\hline \multirow[b]{2}{*}{ Name of district } & \multirow[b]{2}{*}{ State } & \multirow[b]{2}{*}{$\begin{array}{r}\text { Enrollment, } \\
\text { fall } 1990\end{array}$} & \multirow[b]{2}{*}{$\begin{array}{r}\text { Enrollment, } \\
\text { fall } 2000\end{array}$} & \multirow[b]{2}{*}{$\begin{array}{r}\text { Enrollment, } \\
\text { fall } 2010\end{array}$} & \multirow[b]{2}{*}{$\begin{array}{r}\text { Enrollment, } \\
\text { fall } 2011\end{array}$} & \multirow[b]{2}{*}{$\begin{array}{r}\text { Number of } \\
\text { English } \\
\text { language } \\
\text { learners, } \\
2011\end{array}$} & \multirow[b]{2}{*}{$\begin{array}{r}\text { Percent } \\
\text { eligible for } \\
\text { free or } \\
\text { reduced- } \\
\text { price lunch, } \\
2011^{1}\end{array}$} & \multicolumn{7}{|c|}{$\begin{array}{c}\text { Percentage distribution of enrollment, } \\
\text { by race/ethnicity, fall } 2011\end{array}$} & \multicolumn{5}{|c|}{ Teachers and staff, fall 2011} & \multicolumn{3}{|c|}{ Dropouts and graduates, $2008-09$} & \multirow[b]{2}{*}{$\begin{array}{l}\text { Number of } \\
\text { schools, } \\
\text { fall } 2011\end{array}$} & \\
\hline & & & & & & & & White & Black & Hispanic & Asian & \begin{tabular}{|} 
Pacific \\
Islander
\end{tabular} & $\begin{array}{r}\text { American } \\
\text { Indian/ } \\
\text { Alaska } \\
\text { Native }\end{array}$ & $\begin{array}{r}\text { Two or } \\
\text { more } \\
\text { races }\end{array}$ & \begin{tabular}{|r|} 
Number of \\
classroom \\
teachers
\end{tabular} & $\begin{array}{r}\text { Pupill } \\
\text { teacher } \\
\text { ratio }\end{array}$ & $\begin{array}{r}\text { Total } \\
\text { number } \\
\text { of staff }\end{array}$ & $\begin{array}{r}\text { Student } \\
\text { staff } \\
\text { ratio }\end{array}$ & $\begin{array}{r}\text { Teachers } \\
\text { as a } \\
\text { percentage } \\
\text { of total staff }\end{array}$ & $\begin{array}{r}\text { Percent } \\
\text { dropping } \\
\text { out of } \\
\text { grades } \\
9-12\end{array}$ & 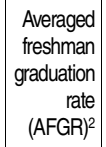 & $\begin{array}{r}\text { Number of } \\
\text { high } \\
\text { school } \\
\text { graduates }^{3}\end{array}$ & & \\
\hline 1 & 2 & 3 & 4 & 5 & 6 & 7 & 8 & 9 & 10 & 11 & 12 & 13 & 14 & 15 & 16 & 17 & 18 & 19 & 20 & 21 & 22 & 23 & 24 & \\
\hline 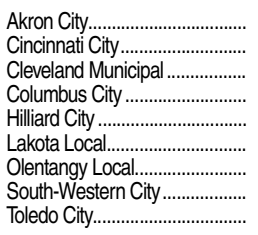 & $\begin{array}{l}\mathrm{OH} \\
\mathrm{OH} \\
\mathrm{OH} \\
\mathrm{OH} \\
\mathrm{OH} \\
\mathrm{OH} \\
\mathrm{OH} \\
\mathrm{OH} \\
\mathrm{OH}\end{array}$ & \begin{tabular}{r|r|}
33,213 \\
51,148 \\
70,019 \\
64,280 \\
6,533 \\
9,356 \\
2,140 \\
16,605 \\
40,452
\end{tabular} & \begin{tabular}{r|}
31,464 \\
46,562 \\
75,684 \\
64,511 \\
12,423 \\
14,659 \\
5,417 \\
19,216 \\
37,738
\end{tabular} & $\begin{array}{l}23,113 \\
33,783 \\
44,74 \\
51,134 \\
15,455 \\
18,135 \\
15,815 \\
20,725 \\
24,283\end{array}$ & \begin{tabular}{l|}
22,678 \\
32,154 \\
42,805 \\
50,488 \\
15,464 \\
17,364 \\
16,690 \\
20,895 \\
23,115
\end{tabular} & \begin{tabular}{r|}
865 \\
1,269 \\
2,598 \\
4,951 \\
1,051 \\
870 \\
305 \\
2,465 \\
321
\end{tabular} & \begin{tabular}{r|r|}
71.6 \\
66.3 \\
82.8 \\
73.2 \\
22.4 \\
15.6 \\
8.0 \\
52.2 \\
70.0
\end{tabular} & $\begin{array}{l}40.2 \\
24.8 \\
14.6 \\
27.4 \\
77.9 \\
75.0 \\
82.3 \\
69.6 \\
40.1\end{array}$ & \begin{tabular}{r|}
46.3 \\
65.7 \\
67.6 \\
57.9 \\
5.5 \\
10.2 \\
3.9 \\
12.0 \\
42.8
\end{tabular} & \begin{tabular}{r|}
2.8 \\
2.9 \\
13.8 \\
6.8 \\
5.2 \\
4.5 \\
2.3 \\
11.5 \\
9.3
\end{tabular} & $\begin{array}{l}3.7 \\
1.0 \\
0.8 \\
2.1 \\
6.3 \\
5.8 \\
7.7 \\
2.1 \\
0.6\end{array}$ & \begin{tabular}{r|r}
0.1 \\
$\#$ \\
$\#$ \\
$\#$ \\
$\#$ \\
0.1 \\
$\#$ \\
0.1 \\
$\#$ \\
\end{tabular} & $\begin{array}{l}0.1 \\
0.1 \\
0.2 \\
0.2 \\
0.1 \\
0.1 \\
0.1 \\
0.2 \\
0.1\end{array}$ & $\begin{array}{l}6.9 \\
5.5 \\
3.0 \\
5.5 \\
4.9 \\
4.3 \\
3.7 \\
4.5 \\
7.1\end{array}$ & $\begin{array}{r}1,569 \\
1,681 \\
3,516 \\
3,187 \\
845 \\
844 \\
879 \\
1,108 \\
1,438\end{array}$ & $\begin{array}{l}14.5 \\
19.1 \\
12.2 \\
15.8 \\
18.3 \\
20.6 \\
19.0 \\
18.9 \\
16.1\end{array}$ & $\begin{array}{l}4,744 \\
4,322 \\
8,736 \\
7,102 \\
1,727 \\
1,722 \\
1,748 \\
2,469 \\
2,952\end{array}$ & \begin{tabular}{r|r|}
4.8 \\
7.4 \\
4.9 \\
7.1 \\
9.0 \\
10.1 \\
9.5 \\
8.5 \\
7.8
\end{tabular} & $\begin{array}{l}33.1 \\
38.9 \\
40.2 \\
44.9 \\
48.9 \\
49.0 \\
50.3 \\
44.9 \\
48.7\end{array}$ & $\begin{array}{r}6.3 \\
5.3 \\
1.9 \\
2.2 \\
1.1 \\
1.6 \\
0.4 \\
3.7 \\
4.2\end{array}$ & \begin{tabular}{|c|}
65.0 \\
52.7 \\
42.3 \\
55.0 \\
86.4 \\
95.1 \\
$100.0^{5}$ \\
70.4 \\
48.9
\end{tabular} & $\begin{array}{r}1,484 \\
1,723 \\
2,187 \\
2,709 \\
968 \\
1,232 \\
733 \\
1,220 \\
1,276\end{array}$ & $\begin{array}{r}53 \\
57 \\
98 \\
119 \\
23 \\
20 \\
23 \\
33 \\
51\end{array}$ & \\
\hline 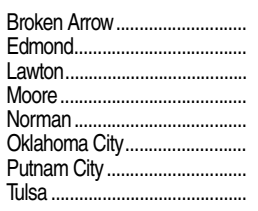 & $\begin{array}{l}O K \\
O K \\
O K \\
O K \\
O K \\
O K \\
O K \\
O K\end{array}$ & $\begin{array}{l}13,872 \\
13,041 \\
17,727 \\
16,630 \\
11,572 \\
36,066 \\
18,071 \\
40,732\end{array}$ & $\begin{array}{r}14,990 \\
17,084 \\
17,338 \\
18,101 \\
12,596 \\
39,750 \\
19,506 \\
42,812\end{array}$ & $\begin{array}{l}16,732 \\
21,344 \\
16,199 \\
22,226 \\
14,644 \\
42,989 \\
19,068 \\
41,501\end{array}$ & $\begin{array}{r}16,985 \\
21,985 \\
15,85 \\
22,672 \\
15,022 \\
43,212 \\
19,213 \\
41,199\end{array}$ & $\begin{array}{r}763 \\
676 \\
679 \\
676 \\
755 \\
12,775 \\
2,133 \\
6,534 \\
6\end{array}$ & $\begin{array}{l}39.9 \\
28.5 \\
58.3 \\
47.0 \\
46.9 \\
87.8 \\
72.5 \\
81.5\end{array}$ & $\begin{array}{l}68.1 \\
67.3 \\
42.9 \\
59.9 \\
66.2 \\
18.5 \\
40.2 \\
29.0\end{array}$ & $\begin{array}{r}4.2 \\
10.6 \\
28.8 \\
7.4 \\
6.4 \\
27.2 \\
26.0 \\
29.3\end{array}$ & $\begin{array}{r}9.7 \\
8.0 \\
14.1 \\
12.0 \\
10.3 \\
45.9 \\
20.5 \\
25.9\end{array}$ & $\begin{array}{l}2.5 \\
4.7 \\
2.2 \\
5.0 \\
3.0 \\
2.4 \\
4.5 \\
1.4\end{array}$ & $\begin{array}{l}0.2 \\
0.2 \\
0.6 \\
0.4 \\
0.2 \\
0.1 \\
0.2 \\
0.2\end{array}$ & $\begin{array}{l}6.4 \\
2.5 \\
6.7 \\
7.8 \\
6.9 \\
4.3 \\
3.9 \\
7.5\end{array}$ & $\begin{array}{l}8.8 \\
6.8 \\
4.6 \\
7.5 \\
7.0 \\
1.6 \\
4.8 \\
6.7\end{array}$ & $\begin{array}{r}956 \\
1,198 \\
1,043 \\
1,320 \\
900 \\
2,567 \\
1,230 \\
2,457\end{array}$ & $\begin{array}{l}17.8 \\
18.4 \\
15.2 \\
17.2 \\
16.7 \\
16.8 \\
15.6 \\
16.8\end{array}$ & $\begin{array}{l}2,035 \\
2,459 \\
2,328 \\
2,553 \\
1,714 \\
5,130 \\
2,156 \\
5,605\end{array}$ & $\begin{array}{l}8.3 \\
8.9 \\
6.8 \\
8.9 \\
8.8 \\
8.4 \\
8.9 \\
7.4\end{array}$ & $\begin{array}{l}47.0 \\
48.7 \\
44.8 \\
51.7 \\
52.5 \\
50.0 \\
57.0 \\
43.8\end{array}$ & $\begin{array}{l}3.6 \\
0.6 \\
3.4 \\
3.4 \\
1.2 \\
4.9 \\
2.1 \\
0.4\end{array}$ & $\begin{array}{l}78.7 \\
89.2 \\
77.5 \\
80.0 \\
82.4 \\
58.3 \\
73.6 \\
58.0\end{array}$ & $\begin{array}{r}921 \\
1,331 \\
1,013 \\
1,233 \\
811 \\
1,657 \\
1,182 \\
1,652\end{array}$ & $\begin{array}{l}23 \\
23 \\
33 \\
31 \\
24 \\
93 \\
27 \\
81\end{array}$ & \\
\hline 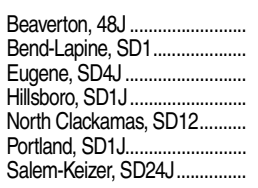 & $\begin{array}{l}O R \\
O R \\
O R \\
O R \\
O R \\
O R \\
O R \\
O R\end{array}$ & $\begin{array}{r}24,874 \\
9,481 \\
17,904 \\
10,396 \\
12,403 \\
53,042 \\
27,756\end{array}$ & $\begin{array}{l}33,600 \\
13,128 \\
18,432 \\
18,315 \\
14,876 \\
53,141 \\
35,108\end{array}$ & $\begin{array}{l}38,902 \\
16,173 \\
11,739 \\
20,923 \\
17,420 \\
45,518 \\
40,403\end{array}$ & $\begin{array}{l}39,736 \\
16,437 \\
17,368 \\
21,286 \\
17,442 \\
46,930 \\
40,756\end{array}$ & $\begin{array}{r}5,645 \\
741 \\
380 \\
3,481 \\
2,533 \\
5,155 \\
8,572\end{array}$ & $\begin{array}{l}40.2 \\
46.9 \\
41.6 \\
47.4 \\
46.6 \\
46.1 \\
60.5\end{array}$ & $\begin{array}{l}52.4 \\
85.2 \\
70.4 \\
52.0 \\
68.9 \\
56.4 \\
51.2\end{array}$ & $\begin{array}{r}2.9 \\
0.8 \\
2.0 \\
2.1 \\
1.7 \\
11.7 \\
1.0\end{array}$ & $\begin{array}{l}23.3 \\
10.1 \\
12.6 \\
34.0 \\
15.9 \\
15.5 \\
38.0\end{array}$ & $\begin{array}{r}13.2 \\
1.2 \\
3.7 \\
6.8 \\
6.6 \\
8.1 \\
2.2\end{array}$ & $\begin{array}{l}0.7 \\
0.2 \\
0.4 \\
0.6 \\
0.7 \\
1.0 \\
1.9\end{array}$ & $\begin{array}{l}0.5 \\
1.0 \\
1.7 \\
0.8 \\
0.9 \\
1.1 \\
1.2\end{array}$ & $\begin{array}{l}6.9 \\
1.5 \\
9.2 \\
3.7 \\
5.3 \\
6.1 \\
4.5\end{array}$ & $\begin{array}{r}1,967 \\
719 \\
734 \\
925 \\
690 \\
2,395 \\
1,813\end{array}$ & $\begin{array}{l}20.2 \\
22.9 \\
23.6 \\
23.0 \\
25.3 \\
19.6 \\
22.5\end{array}$ & $\begin{array}{l}3,876 \\
1,513 \\
1,697 \\
2,078 \\
1,625 \\
5,417 \\
4,107\end{array}$ & $\begin{array}{r}10.3 \\
10.9 \\
10.2 \\
10.2 \\
10.7 \\
8.7 \\
9.9\end{array}$ & $\begin{array}{l}50.7 \\
47.5 \\
43.3 \\
44.5 \\
42.5 \\
44.2 \\
44.1\end{array}$ & $\begin{array}{l}2.8 \\
2.6 \\
1.5 \\
2.0 \\
3.7 \\
8.6 \\
4.5\end{array}$ & $\begin{array}{l}83.0 \\
86.1 \\
91.3 \\
85.3 \\
81.8 \\
68.4 \\
81.7\end{array}$ & $\begin{array}{l}2,459 \\
1,131 \\
1,353 \\
1,293 \\
1,113 \\
2,320 \\
2,474\end{array}$ & $\begin{array}{l}56 \\
28 \\
36 \\
34 \\
31 \\
88 \\
66\end{array}$ & \\
\hline 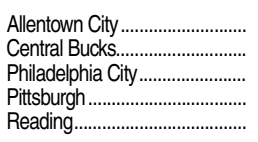 & $\begin{array}{l}P A \\
P A \\
P A \\
P A \\
P A\end{array}$ & $\begin{array}{r}13,519 \\
10,286 \\
190,979 \\
39,896 \\
11,965\end{array}$ & $\begin{array}{r}16,424 \\
17,305 \\
201,190 \\
38,560 \\
15,487\end{array}$ & $\begin{array}{r}17,637 \\
20,432 \\
166,233 \\
27,982 \\
18,194\end{array}$ & $\begin{array}{r}17,560 \\
20,081 \\
154,262 \\
26,653 \\
18,060\end{array}$ & $\begin{array}{r}2,035 \\
90 \\
11,885 \\
547 \\
3,372\end{array}$ & $\begin{array}{r}77.6 \\
6.1 \\
79.4 \\
70.6 \\
90.2\end{array}$ & $\begin{array}{r}14.9 \\
89.3 \\
14.1 \\
33.8 \\
8.8\end{array}$ & $\begin{array}{r}16.7 \\
1.7 \\
56.2 \\
55.4 \\
10.5\end{array}$ & $\begin{array}{r}65.0 \\
2.7 \\
18.3 \\
1.7 \\
77.2\end{array}$ & $\begin{array}{l}1.6 \\
5.3 \\
7.5 \\
2.8 \\
0.7\end{array}$ & $\begin{array}{r}\# \\
0.0 \\
0.0 \\
\# \\
\#\end{array}$ & $\begin{array}{l}0.1 \\
0.1 \\
0.2 \\
0.1 \\
0.1\end{array}$ & $\begin{array}{l}1.6 \\
0.8 \\
3.7 \\
6.1 \\
2.8\end{array}$ & $\begin{array}{l}1,061 \\
1,163 \\
9,299 \\
1,979 \\
1,113\end{array}$ & $\begin{array}{l}16.6 \\
17.3 \\
16.6 \\
13.5 \\
16.2\end{array}$ & $\begin{array}{r}2,274 \\
2,253 \\
20,072 \\
4,157 \\
2,197\end{array}$ & $\begin{array}{l}7.7 \\
8.9 \\
7.7 \\
6.4 \\
8.2\end{array}$ & $\begin{array}{l}46.7 \\
51.6 \\
46.3 \\
47.6 \\
50.7\end{array}$ & $\begin{array}{r}9.1 \\
0.4 \\
7.0 \\
5.6 \\
10.0\end{array}$ & $\begin{array}{l}67.3 \\
96.2 \\
53.5 \\
64.8 \\
55.5\end{array}$ & $\begin{array}{r}1,068 \\
1,529 \\
8,377 \\
1,716 \\
760\end{array}$ & $\begin{array}{r}22 \\
23 \\
251 \\
65 \\
24\end{array}$ & \\
\hline 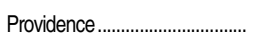 & $\mathrm{RI}$ & 20,908 & 26,937 & 23,573 & 23,518 & 4,095 & 82.2 & 8.9 & 18.4 & 63.6 & 5.3 & 0.1 & 0.9 & 2.9 & 1,647 & 14.3 & 3,025 & 7.8 & 54.4 & 7.5 & 66.9 & 1,462 & 41 & \\
\hline 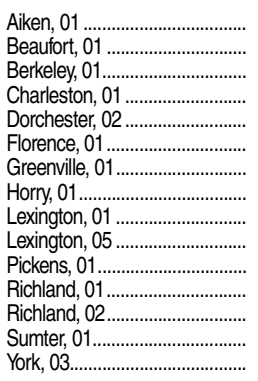 & $\begin{array}{l}\text { SC } \\
\text { SC } \\
\text { SC } \\
\text { SC } \\
\text { SC } \\
\text { SC } \\
\text { SC } \\
\text { SC } \\
\text { SC } \\
\text { SC } \\
\text { SC } \\
\text { SC } \\
\text { SC }\end{array}$ & $\begin{array}{l}23,970 \\
12,518 \\
27,384 \\
43,637 \\
13,735 \\
14,731 \\
51,434 \\
24,080 \\
11,202 \\
11,1683 \\
14,289 \\
27,051 \\
12,788 \\
18,531 \\
12,685\end{array}$ & $\begin{array}{l}25,147 \\
16,721 \\
26,635 \\
44,767 \\
16,678 \\
13,930 \\
59,875 \\
29,894 \\
17,285 \\
15,064 \\
11,938 \\
27,061 \\
17,409 \\
19,063 \\
14,925\end{array}$ & $\begin{array}{l}24,632 \\
19,648 \\
29,400 \\
43,654 \\
22,762 \\
15,919 \\
71,1930 \\
38,534 \\
22,694 \\
16,699 \\
16,319 \\
24,220 \\
25,667 \\
17,060 \\
17,343 \\
\end{array}$ & $\begin{array}{l}24,729 \\
19,992 \\
3,0,085 \\
44,058 \\
23,346 \\
16,027 \\
72,153 \\
38,957 \\
22,990 \\
16,506 \\
16,546 \\
23,942 \\
25,954 \\
16,915 \\
17,217\end{array}$ & $\begin{array}{r}1,344 \\
3,172 \\
1,729 \\
2,357 \\
646 \\
321 \\
7,399 \\
2,585 \\
897 \\
468 \\
560 \\
668 \\
1,366 \\
208 \\
861\end{array}$ & $\begin{array}{l}58.3 \\
52.7 \\
57.4 \\
51.7 \\
40.5 \\
61.6 \\
48.1 \\
63.3 \\
37.1 \\
32.8 \\
46.5 \\
67.7 \\
45.7 \\
70.5 \\
53.7\end{array}$ & $\begin{array}{l}56.0 \\
44.5 \\
53.2 \\
45.0 \\
58.0 \\
42.6 \\
59.0 \\
65.2 \\
79.8 \\
62.4 \\
83.1 \\
18.0 \\
28.5 \\
33.1 \\
52.5\end{array}$ & $\begin{array}{r}33.4 \\
31.4 \\
31.5 \\
44.6 \\
29.6 \\
51.0 \\
23.4 \\
20.6 \\
9.7 \\
27.7 \\
7.2 \\
73.6 \\
59.0 \\
60.8 \\
36.1\end{array}$ & $\begin{array}{r}6.8 \\
20.2 \\
7.6 \\
6.7 \\
5.7 \\
2.2 \\
11.9 \\
8.3 \\
5.6 \\
3.3 \\
4.8 \\
3.7 \\
6.6 \\
3.0 \\
6.4\end{array}$ & $\begin{array}{l}0.7 \\
1.0 \\
1.6 \\
1.4 \\
1.7 \\
1.9 \\
2.2 \\
1.1 \\
1.6 \\
2.6 \\
1.0 \\
0.9 \\
3.0 \\
0.8 \\
1.6\end{array}$ & $\begin{array}{l}0.1 \\
0.2 \\
0.2 \\
0.1 \\
0.4 \\
0.1 \\
0.2 \\
0.2 \\
0.1 \\
0.3 \\
\# \\
0.1 \\
0.2 \\
0.1 \\
0.1\end{array}$ & $\begin{array}{l}0.2 \\
0.3 \\
0.4 \\
0.1 \\
0.5 \\
0.2 \\
0.1 \\
0.3 \\
0.2 \\
0.4 \\
0.1 \\
0.1 \\
0.2 \\
0.2 \\
1.5\end{array}$ & $\begin{array}{l}2.8 \\
2.4 \\
5.4 \\
2.0 \\
4.1 \\
2.0 \\
3.3 \\
4.3 \\
3.0 \\
3.3 \\
3.7 \\
3.5 \\
2.5 \\
2.1 \\
1.8\end{array}$ & $\begin{array}{r}1,508 \\
1,393 \\
1,788 \\
3,222 \\
1,355 \\
1,032 \\
4,376 \\
2,564 \\
1,512 \\
1,147 \\
989 \\
1,760 \\
1,684 \\
1,006 \\
1,124\end{array}$ & $\begin{array}{l}16.4 \\
14.4 \\
16.8 \\
13.7 \\
17.2 \\
15.5 \\
16.5 \\
15.2 \\
15.2 \\
14.4 \\
16.7 \\
13.6 \\
15.4 \\
16.8 \\
15.3\end{array}$ & $\begin{array}{l}2,360 \\
2,094 \\
2,671 \\
4,461 \\
1,885 \\
1,729 \\
6,747 \\
3,986 \\
2,248 \\
1,532 \\
1,386 \\
2,398 \\
2,167 \\
1,672 \\
1,463\end{array}$ & $\begin{array}{r}10.5 \\
9.5 \\
11.3 \\
9.9 \\
12.4 \\
9.3 \\
10.7 \\
9.8 \\
10.2 \\
10.8 \\
11.9 \\
10.0 \\
12.0 \\
10.1 \\
11.8\end{array}$ & $\begin{array}{l}63.9 \\
66.5 \\
66.9 \\
72.2 \\
71.9 \\
59.7 \\
64.9 \\
64.3 \\
67.2 \\
74.8 \\
71.4 \\
73.4 \\
77.7 \\
60.2 \\
76.9\end{array}$ & $\begin{array}{l}4.7 \\
0.9 \\
5.5 \\
2.8 \\
4.2 \\
2.2 \\
3.5 \\
4.8 \\
1.4 \\
1.7 \\
4.0 \\
4.0 \\
2.9 \\
2.8\end{array}$ & $\begin{array}{l}62.5 \\
63.7 \\
64.6 \\
60.2 \\
67.4 \\
67.3 \\
69.0 \\
72.1 \\
73.7 \\
80.8 \\
62.9 \\
58.8 \\
74.4 \\
- \\
67.5\end{array}$ & $\begin{array}{r}1,276 \\
995 \\
1,422 \\
2,158 \\
1,136 \\
900 \\
3,805 \\
2,091 \\
1,206 \\
1,186 \\
855 \\
1,251 \\
1,347 \\
997\end{array}$ & $\begin{array}{l}40 \\
31 \\
39 \\
78 \\
21 \\
22 \\
95 \\
51 \\
27 \\
19 \\
26 \\
50 \\
30 \\
27 \\
28\end{array}$ & 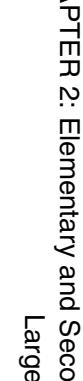 \\
\hline 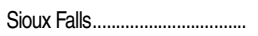 & $\mathrm{SD}$ & 16,092 & 19,097 & 21,390 & 22,827 & 1,978 & 43.6 & 70.9 & 10.0 & 8.1 & 3.2 & 0.1 & 5.7 & 2.0 & 1,403 & 16.3 & 2,726 & 8.4 & 51.5 & 0.6 & 75.6 & 1,289 & 50 & \\
\hline 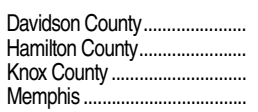 & $\begin{array}{l}\text { TN } \\
\text { TN } \\
\text { TN } \\
\text { TN }\end{array}$ & $\begin{array}{r}68,452 \\
2,2785 \\
50,750 \\
107,103\end{array}$ & $\begin{array}{r}67,669 \\
39,915 \\
51,944 \\
113,730\end{array}$ & $\begin{array}{r}78,782 \\
42,589 \\
57,977 \\
111,834\end{array}$ & $\begin{array}{r}80,393 \\
43,296 \\
58,639 \\
110,952\end{array}$ & $\begin{array}{l}8,697 \\
1,457 \\
1,567 \\
6,409\end{array}$ & $\begin{array}{l}71.0 \\
59.6 \\
45.9 \\
83.8\end{array}$ & $\begin{array}{r}32.3 \\
58.8 \\
76.4 \\
7.3\end{array}$ & $\begin{array}{l}45.8 \\
31.4 \\
14.4 \\
82.4\end{array} \mid$ & $\begin{array}{r}17.3 \\
6.9 \\
5.2 \\
8.5\end{array}$ & $\begin{array}{l}3.9 \\
2.1 \\
2.0 \\
1.3\end{array}$ & $\begin{array}{l}0.1 \\
0.1 \\
0.1 \\
0.1\end{array}$ & $\begin{array}{l}0.1 \\
0.2 \\
0.2 \\
0.1\end{array}$ & $\begin{array}{l}0.5 \\
0.5 \\
1.7 \\
0.4\end{array}$ & $\begin{array}{l}5,377 \\
3,020 \\
3,806 \\
7,027\end{array}$ & $\begin{array}{l}15.0 \\
14.3 \\
15.4 \\
15.8\end{array}$ & $\begin{array}{r}10,209 \\
5,083 \\
6,983 \\
12,316\end{array}$ & $\begin{array}{l}7.9 \\
8.5 \\
8.4 \\
9.0\end{array}$ & $\begin{array}{l}52.7 \\
59.4 \\
54.5 \\
57.1\end{array}$ & $\begin{array}{r}5.7 \\
4.9 \\
4.0 \\
10.5\end{array}$ & $\begin{array}{l}70.4 \\
71.8 \\
79.2 \\
67.3\end{array}$ & $\begin{array}{l}3,978 \\
2,367 \\
3,500 \\
6,559\end{array}$ & $\begin{array}{r}144 \\
78 \\
88 \\
216\end{array}$ & 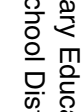 \\
\hline
\end{tabular}




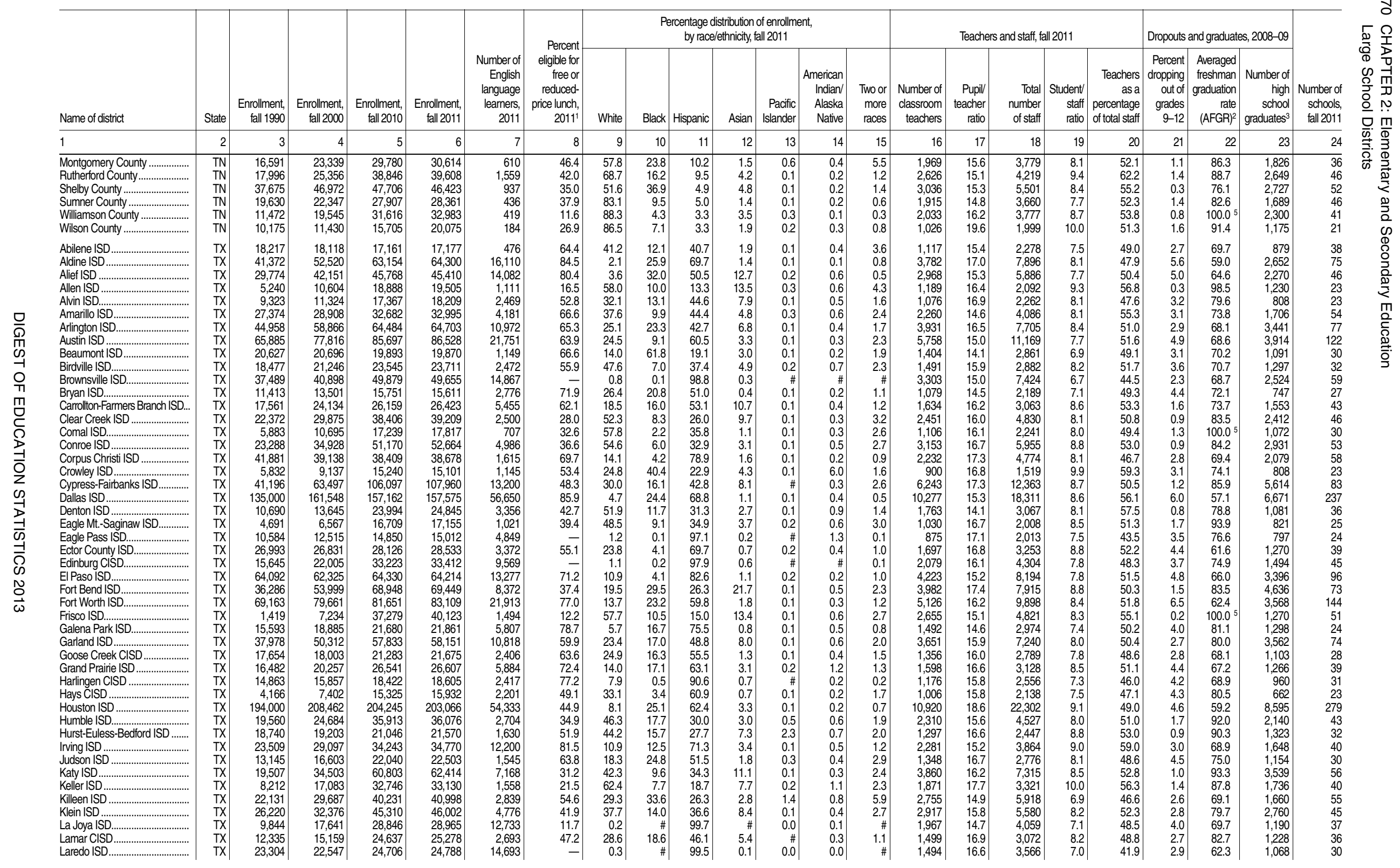

See notes at end of table. 


\begin{tabular}{|c|c|c|c|c|c|c|c|c|c|c|c|c|c|c|c|c|c|c|c|c|c|c|c|c|}
\hline \multirow[b]{2}{*}{ Name of district } & \multirow[b]{2}{*}{ State } & \multirow[b]{2}{*}{$\begin{array}{r}\text { Enrollment, } \\
\text { fall } 1990\end{array}$} & \multirow[b]{2}{*}{$\begin{array}{r}\text { Enrollment, } \\
\text { fall } 2000\end{array}$} & \multirow[b]{2}{*}{$\begin{array}{r}\text { Enrollment, } \\
\text { fall } 2010\end{array}$} & \multirow[b]{2}{*}{$\begin{array}{r}\text { Enrollment, } \\
\text { fall } 2011\end{array}$} & \multirow[b]{2}{*}{$\begin{array}{r}\text { Number of } \\
\text { English } \\
\text { language } \\
\text { learners, } \\
2011\end{array}$} & \multirow[b]{2}{*}{$\begin{array}{r}\text { Percent } \\
\text { eligible for } \\
\text { free or } \\
\text { reduced- } \\
\text { price lunch, } \\
2011^{1}\end{array}$} & & & $\begin{array}{l}\text { rcentage d } \\
\text { by race/ }\end{array}$ & $\begin{array}{l}\text { ribution } \\
\text { hnicity, fa }\end{array}$ & $\begin{array}{l}\text { of enrollme } \\
\text { all } 2011\end{array}$ & & & & Teachers & and staff, fal & 세 2011 & & Dropouts a & and graduates & es, 2008-09 & & \\
\hline & & & & & & & & White & Black & Hispanic & Asian & $\begin{array}{r}\text { Pacific } \\
\text { Islander }\end{array}$ & \begin{tabular}{|r|} 
American \\
Indian/ \\
Alaska \\
Native
\end{tabular} & $\begin{array}{r}\text { Two or } \\
\text { more } \\
\text { races }\end{array}$ & $\begin{array}{c}\text { Number of } \\
\text { classroom } \\
\text { teachers }\end{array}$ & $\begin{array}{r}\text { Pupil } \\
\text { teacher } \\
\text { ratio }\end{array}$ & $\begin{array}{r}\text { Total } \\
\text { number } \\
\text { of staff }\end{array}$ & $\begin{array}{r}\text { Student } \\
\text { staff } \\
\text { ratio }\end{array}$ & $\begin{array}{r}\text { Teachers } \\
\text { as a } \\
\text { percentage } \\
\text { of total staff }\end{array}$ & $\begin{array}{r}\text { Percent } \\
\text { dropping } \\
\text { out of } \\
\text { grades } \\
9-12\end{array}$ & $\begin{array}{r}\text { Averaged } \\
\text { freshman } \\
\text { graduation } \\
\text { rate } \\
(\mathrm{AFGR})^{2}\end{array}$ & $\begin{array}{r}\text { Number of } \\
\text { high } \\
\text { school } \\
\text { graduates }^{3}\end{array}$ & $\begin{array}{l}\text { Number of } \\
\text { schools, } \\
\text { fall } 2011\end{array}$ & \\
\hline 1 & 2 & 3 & 4 & 5 & 6 & 7 & 8 & 9 & 10 & 11 & 12 & 13 & 14 & 15 & 16 & 17 & 18 & 19 & 20 & 21 & 22 & 23 & 24 & \\
\hline Leander ISD & $T \mathrm{TX}$ & 5.419 & 14,499 & 32,152 & 33,309 & 1.403 & 219 & 638 & 39 & 235 & 5.0 & 02 & 03 & 33 & 2159 & 15.4 & 4041 & 82 & 534 & 25 & 927 & 1477 & $\overline{38}$ & \\
\hline & $|x|$ & 20,776 & 39,096 & $51,484]$ & 51,920 & 6.414 & 27.8 & 51.4 & 8.7 & 26.0 & 10.6 & 0.1 & 0.4 & 2.8 & 3,706 & 14.0 & 6.312 & 8.2 & 58.7 & 1.2 & 8 & 3,158 & 69 & \\
\hline Lubbock ISD...... & TX| & 30,991 & 29,026 & 28,905 & 28,790 & 695 & 65.0 & 27.9 & 13.3 & 55.0 & 1.7 . & 0.1 & 0.4 & 1.7 . & 1,931 & 14.9 & 3,296 & 8.7 & 58.6 & 6.2 & 75.2 & 1,603 & 54 & \\
\hline Mansfield ISD ... & $\mathrm{TX}$ & 7,570 & 14,888 & 32,251 & 32,564 & 2.975 & 37.2 & 39.6 & 25.7 & 24.1 & 6.2 & 0.1 & 0.5 & 3.8 & 1,946 & 16.7 & 3,785 & 8.6 & 51.4 & 2.1 & 81.1 & 1,666 & 41 & \\
\hline McAllen ISD........ & $\mathrm{TX}$ & 21,120 & 21,747 & 25,622 & 25,252 & 6,550 & & 5.0 & 0.4 & 92.5 & 1.7 & $\#$ & 0.2 & 0.3 & 1,575 & 16.0 & 3,143 & 8.0 & 50.1 & 4.2 & 68.9 & 1,306 & 34 & \\
\hline McKinney ISD ...... & TX & 5,052 & 12,000 & 24,422 & 24,733 & 2,070 & 29.0 & 55.1 & 12.0 & 25.9 & 3.4 & 0.3 & 0.6 & 2.7 & 1,611 & 15.3 & 2,545 & 9.7 & 63.3 & 1.5 & 88.3 & 1,234 & 32 & \\
\hline Mesquite ISD..... & TX & 25,920 & 32,334 & 37,747 & 38,287 & 5,843 & 68.1 & 20.9 & 24.7 & 49.6 & 2.0 & 0.1 & 0.6 & 2.1 & 2,441 & 15.7 & 4,659 & 8.2 & 52.4 & 1.4 & 78.4 & 2,265 & 47 & \\
\hline Midland ISD...... & TX & 21,082 & 20,522 & 21,736 & 22,628 & 1,805 & 49.1 & 31.1 & 8.4 & 57.8 & 1.3 & \# & 0.3 & 1.0 & 1,388 & 16.3 & 2,667 & 8.5 & 52.1 & 4.8 & 73.1 & 1,212 & 35 & \\
\hline & TX & 11,032 & 12,464 & 15,841 & 15,680 & 4,581 & - & 0.9 & 0.2 & 98.8 & 0.1 & 0.0 & $\#$ & 0.1 & 972 & 16.1 & 2,128 & 7.4 & 45.7 & 1.4 & 70.1 & 756 & 23 & \\
\hline $\begin{array}{l}\text { North East ISD........................... } \\
\text { Northside ISD }\end{array}$ & TX & 39,909 & 50,875 & 66,604 & 67,439 & 4,726 & 45.1 & 31.0 & 7.0 & 55.2 & 3.6 & 0.2 & 0.3 & 2.7 & 4,299 & 15.7 & 8,418 & 8.0 & 51.1 & 1.3 & 81.0 & 3,961 & 75 & \\
\hline & TX & $\begin{array}{r}50,229 \\
2107\end{array}$ & 63,739 & 95,581 & 98,110 & 6,106 & 53.2 & 19.6 & 6.1 & 68.3 & 2.9 & 0.3 & 0.2 & 2.7 & 5,881 & 16.7 & 11,937 & 8.2 & 49.3 & 1.1 & 80.4 & 5,000 & 111 & \\
\hline $\begin{array}{l}\text { Northwest SUD ......................... } \\
\text { Pasadena ISD........................ }\end{array}$ & $\begin{array}{l}T X \\
T X\end{array}$ & $\begin{array}{r}3,197 \\
37,643\end{array}$ & $\begin{array}{r}5,356 \\
42,577\end{array}$ & $\begin{array}{l}15,370 \\
52,218\end{array}$ & $\begin{array}{l}16,626 \\
52,942\end{array}$ & $\begin{array}{r}656 \\
12.572\end{array}$ & $\begin{array}{l}23.5 \\
797\end{array}$ & $\begin{aligned} 68.3 \\
79\end{aligned}$ & $\begin{array}{l}6.5 \\
6.5\end{array}$ & $\begin{array}{l}19.4 \\
81.8\end{array}$ & 2.8 & 0.2 & \begin{tabular}{l|l}
0.7 \\
0.2
\end{tabular} & 2.2 & $\begin{array}{l}1,035 \\
3,376\end{array}$ & $\begin{array}{l}16.1 \\
157\end{array}$ & 1,638 & 10.1 & 63.2 & 2.0 & 85.0 & 597 & 24 & \\
\hline Pearland ISD........ & $T X$ & $\begin{array}{r}r, 040 \\
6,739\end{array}$ & 10,618 & 18769 & 19,205 & $\begin{array}{l}1,014 \\
1,108\end{array}$ & 26.8 & 439 & $\begin{array}{r}0.0 \\
16.4\end{array}$ & $\begin{array}{l}01.0 \\
26.7\end{array}$ & 9.7 & $\begin{array}{l}0.1 \\
0.2\end{array}$ & 0.2 & 0.7 & $\begin{array}{l}3,3 / 6 \\
1083\end{array}$ & $\begin{array}{l}15.7 \\
177\end{array}$ & 7,037 & 7.5 & & & 63.8 & 2,428 & 64 & \\
\hline Pflugerville ISD .... & TX & 6,482 & 14545 & 22763 & 23070 & 3244 & 527 & 250 & 19.4 & 44. & 79 & 0. & 0.6 & 2.5 & 1,083 & 17.7 & 2,133 & 9.0 & 50.8 & 1.6 & 90.6 & 991 & 24 & \\
\hline Pharr-San Juan-Alamo ISD ...... & TX & 18773 & 22,537 & $\begin{array}{l}2<, 000 \\
31508\end{array}$ & 31634 & 12,348 & $3<.1$ & . & . & 年 & 0 & 0.1 & 0.4 & 3.4 & 1,500 & 15.4 & 2,563 & 9.0 & 58.5 & 4.0 & 84.3 & 1,271 & 27 & \\
\hline 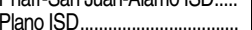 & TX & $\begin{array}{ll}10,710 \\
30585\end{array}$ & . & . & 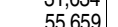 & $\begin{aligned} 1,2,040 \\
5403\end{aligned}$ & 258 & 0 & 0.11 & 年 & 0.2 & 0.0 & $\#$ & $\#$ & 2,047 & 15.5 & 4,325 & 7.3 & 47.3 & 1.6 & 78.6 & 1,594 & 45. & \\
\hline BichardsonISD .............. & TX & - & 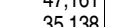 & | & 年 & 年 & 25.0 & 年 & 11.0 & 2.07 & 20.4 & 0.1 & 0.3 & 3.4 & 3,822 & 14.6 & 6,537 & 8.5 & 58.5 & 0.8 & 86.6 & 3,449 & 78 & \\
\hline Round BockJSD.... & TX & 32,555 & $\begin{array}{ll}35,138 \\
31536\end{array}$ & 30,776 & 3r,044 & 5,883 & 56.9 & 28.5 & 23.1 & 38.7 | & 6.9 & 0.1 & 0.3 & 2.4 & 2,417 & 15.3 & 4,672 & 7.9 & 51.7 & 1.9 & 75.6 & 1,922 & 58 & \\
\hline San Antonio ISD .................... & TX & $\begin{array}{l}19,636 \\
60161\end{array}$ & $\begin{array}{l}31,030 \\
57273\end{array}$ & $\begin{array}{l}44, / 16 \\
55116\end{array}$ & 45,034 & 3,095 & 29.2 & 44.7 & 9.1 & 30.1 & 11.5 & 0.2 & 0.5 & 4.0 & 3,001 & 15.0 & 5,525 & 8.2 & 54.3 & 1.9 & 88.2 & 2,545 & 59 & \\
\hline San Antonio ISU ..................... & TX & 60,161 & $\begin{array}{ll}5 /, 2 / 3 \\
26711\end{array}$ & 55,116 & 54,394 & 8,522 & 30.7 & 2.1 & 6.4 & 90.8 & 0.2 & \# & 0.1 & 0.3 & 3,385 & 16.1 & 7,390 & 7.4 & 45.8 & 9.0 & 55.7 & 2,270 & 99 & \\
\hline Socorro ISD ............................ & TX & 14,350 & 26,711 & 42,569 & 43,672 & 7,927 & 72.1 & 5.6 & 2.1 & 90.9 & 0.6 & 0.1 & 0.4 & 0.3 & 2,414 & 18.1 & 4,688 & 9.3 & 51.5 & 2.0 & 77.7 & 2,336 & 44 & \\
\hline Spring Branch ISD ................. & $\mathrm{TX}$ & 26,495 & 31,659 & 32,948 & 33,687 & 10,075 & 58.6 & 28.2 & 5.1 & 58.3 & 6.1 & 0.1 & 0.8 & 1.4 & 2,166 & 15.5 & 4,241 & 7.9 & 51.1 & 2.3 & 78.0 & 1,818 & 49 & \\
\hline Spring ISD..... & TX & 18,537 & 23,034 & 36,323 & 36,513 & 5,910 & 72.6 & 12.9 & 40.3 & 41.4 & 4.1 & 0.1 & 0.3 & 1.0 & 2,084 & 17.5 & 4,516 & 8.1 & 46.2 & 3.5 & 76.1 & 1,718 & 40 & \\
\hline Tyler ISD ............................ & $T X$ & 16,182 & 16,626 & 18,549 & 18,393 & 3,385 & 69.6 & 24.8 & 29.5 & 42.5 & 1.4 & 0.1 & 0.3 & 1.4 & 1,285 & 14.3 & 2,594 & 7.1 & 49.5 & 3.7 & 66.5 & 901 & 28 & \\
\hline 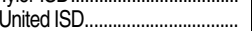 & TX & 12,553 & 27,556 & 41,876 & 42,179 & 16,869 & 74.4 & 1.2 & 0.1 & 98.3 & 0.3 & $\begin{array}{lll}n & n\end{array}$ & 0.1 & 0.1 & 2,504 & 16.8 & 6,001 & 7.0 & 41.7 & 0.4 & 80.4 & 2,140 & 41 & \\
\hline Waco ISD............. & TX & 14,304 & 15,433 & 15,305 & 15,329 & 1,610 & 87.7 & 11.0 & 30.6 & 56.1 & 0.3 & \# & 0.5 & $\begin{array}{l}.1 \\
1.4\end{array}$ & 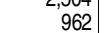 & $\begin{array}{c}10.0 \\
15.9\end{array}$ & 1,987 & 7.7 & 48.4 & 7.5 & 66.9 & $\begin{array}{r}2,140 \\
722\end{array}$ & $\begin{array}{l}41 \\
32\end{array}$ & \\
\hline Weslaco ISD..... & TX & 11,903 & 13,407 & 17,839 & 17,788 & 4,362 & & 1.2 & 0.1 & 98.2 & 0.3 & \# & 0.1 & 0.1 & 1.054 & 16.9 & 2,301 & 7.7 & 45.8 & 2.3 & & 801 & 21 & \\
\hline 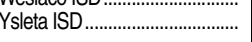 & $\mathrm{TX}$ & 49,974 & 46,394 & 44,746 & 44,376 & 9,645 & 74.6 & 2.2 & 0.8 & 96.6 & 0.1 & $\#$ & 0.1 & 0.2 & 3,074 & 14.4 & 6 & 7.0 & 48.8 & 4.0 & 77.9 & 2,915 & 63 & \\
\hline Alpine..................................... & UT & 38,854 & 47,117 & 67,076 & 69,639 & 2,164 & 29.5 & 86.9 & 0.7 & 8.8 & 1.0 & 1.3 & 0.5 & 0.7 & 2,821 & 24.7 & 5,595 & 12.4 & 50.4 & 2.2 & 76.4 & 3,032 & 80 & \\
\hline Cache. & UT & 12,280 & 13,026 & 15,648 & 15,865 & 527 & 41.8 & 88.5 & 0.6 & 8.2 & 0.6 & 0.5 & 0.4 & 1.1 & 625 & 25.4 & 1,510 & 10.5 & 41.4 & 1.3 & 90.0 & 904 & 27 & \\
\hline Canyons............................... & UT & & & 33,714 & 33,946 & 1,546 & 37.8 & 79.4 & 1.3 & 12.0 & 2.6 & 1.2 & 1.0 & 2.5 & 1,447 & 23.5 & 2,583 & 13.1 & 56.0 & - & - & & 49 & \\
\hline$\ldots$ & UT & 54,558 & 59,578 & 67,452 & 69,285 & 1,467 & 33.4 & 85.2 & 1.4 & 8.7 & 1.6 & 1.1 & 0.5 & 1.4 & 2,792 & 24.8 & 5,895 & 11.8 & 47.4 & 2.9 & 83.9 & 3,837 & 98 & \\
\hline 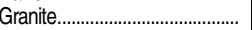 & UT & 78,554 & 71,328 & 70,083 & $\begin{array}{l}69,252 \\
\end{array}$ & 11,665 & 58.4 & 56.1 & 2.9 & 30.9 & 4.3 & 3.7 & 1.5 & 0.5 & 2,982 & 23.2 & 5,972 & 11.6 & 49.9 & 4.9 & 67.2 & 3,601 & 106 & \\
\hline 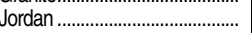 & UT & 64,991 & 73,158 & 50,048 & 50,961 & 1,809 & 37.3 & 80.8 & 0.9 & 11.9 & 1.7 & 1.5 & 0.4 & 2.8 & 2,122 & 24.0 & 4,045 & 12.6 & 52.4 & 2.1 & 85.0 & 4,982 & 54 & \\
\hline$\ldots \ldots \ldots \ldots \ldots \ldots \ldots \ldots \ldots$ & UT & 16,393 & 21,094 & 29,848 & 30,487 & 937 & 70.1 & 86.4 & 0.6 & 10.1 & 0.5 & 0.8 & 0.5 & 1.0 & 1,264 & 24.1 & 2,631 & 11.6 & 48.0 & 2.2 & 86.2 & 1,540 & 42 & \\
\hline 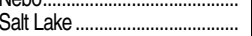 & UT & 24,766 & 25,367 & 24,647 & 25,016 & 618 & 72.4 & 42.4 & 4.3 & 41.1 & 4.3 & 4.5 & 1.3 & 2.1 & $\begin{array}{l}1,154 \\
1,155\end{array}$ & 21.7 & 2,604 & $\begin{array}{l}9.6 \\
9.6\end{array}$ & 44.3 & 7.6 & & 1,117 & 44 & \\
\hline Washington ........................... & UT & 13,264 & 18,374 & 26,091 & 26,883 & 1,552 & 58.9 & 82.2 & 0.9 & 12.1 & 0.7 & 1.8 & 1.8 & 0.5 & 1,171 & 23.0 & 2,308 & 11.6 & 50.7 & 2.8 & & 1,280 & 48 & \\
\hline Weber......................................... & UT & 25,661 & 27,783 & 30,431 & 30,568 & 1,308 & 46.7 & 82.9 & 0.9 & 11.5 & 1.2 & 0.6 & 0.5 & 2.3 & 1,334 & 22.9 & 2,567 & 11.9 & 52.0 & 2.3 & 82.5 & 1,816 & 49 & $\frac{\pi}{2}$ \\
\hline Arlington County....................... & VA & 14,825 & 18,870 & 21,485 & 21,892 & 5,159 & 31.9 & 45.5 & 11.2 & 28.6 & 9.6 & 0.1 & 0.3 & 4.7 & 1,810 & 12.1 & 3,625 & 6.0 & 49.9 & 2.7 & 82.3 & 1,124 & 35 & \\
\hline & VA & 29,533 & & & & 635 & 29.7 & 51.2 & 32.9 & 6.2 & 2.5 & 0.8 & 0 & 6.6 & 2,680 & 14.7 & 5,510 & 7.2 & 48.6 & 1.8 & 78.5 & 2,871 & 47 & \\
\hline ounty.............. & VA & 44,480 & 51,212 & 59,243 & 59,200 & 2,826 & 30.1 & 55.4 & 26.7 & 10.2 & 3.6 & 0.1 & 0.3 & 3.7 & 3,861 & 15.3 & 6,996 & 8.5 & 55.2 & 1.7 & 85.7 & 4,103 & 62 & tי \\
\hline 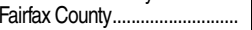 & VA & 128,840 & 156,412 & 174,479 & 177,606 & 36,551 & 25.9 & 43.4 & 10.4 & 21.9 & 19.4 & 0.1 & 0.2 & 4.6 & 13,878 & 12.8 & 28,861 & 6.2 & 48.1 & 2.0 & 89.6 & 12,003 & 209 & E \\
\hline 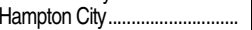 & VA & 21,383 & 23,290 & 21,568 & 21,588 & 372 & 53.1 & 27.6 & 60.4 & 5.2 & 2.3 & 0.1 & 0.3 & 4.0 & 1,605 & 13.4 & 3,207 & 6.7 & 50.1 & 4.2 & 65.6 & 1,357 & 32 & \\
\hline unty $^{6} \ldots . . . \cdots \cdots \cdot \ldots$ & VA & 11,328 & 16,611 & 18,628 & 18,531 & 118 & 18.8 & 83.3 & 9.6 & 2.8 & 1.8 & 0.1 & 0.4 & 2.0 & 1,301 & 14.2 & 2,652 & 7.0 & 49.0 & 1.1 & 88.1 & 1,446 & 26 & \\
\hline 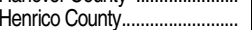 & VA & 32,638 & 41,655 & 49,405 & 49,654 & 2,506 & 38.0 & 44.8 & 37.0 & 6.7 & 7.9 & 0.1 & 0.3 & 3.2 & 3.116 & 15.9 & 4.528 & 11.0 & 68.8 & 3.3 & 80.0 & 3,090 & 79 & \\
\hline unty.................. & VA & 14,485 & 31,804 & 63,142 & 65,585 & 4,639 & 16.6 & 57.0 & 7.0 & 15.1 & 15.4 & 0.1 & 0.6 & 4.7 & 4,702 & 13.9 & 10,320 & 6.4 & 45.6 & 1.0 & 95.1 & 3,389 & 80 & ఐ \\
\hline 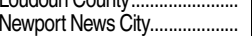 & VA & 28,925 & $\mid$ & $\begin{array}{l}30,488 \\
30,4\end{array}$ & 29,948 & $\begin{array}{l}4,005 \\
883\end{array}$ & $\begin{array}{l}57.3 \\
\end{array}$ & 28.7 & 54.9 & 10.3 & $\begin{array}{r}2.4 \\
2.8\end{array}$ & 0.1 & 0.4 & $\begin{array}{l}4.1 \\
2.7\end{array}$ & $\begin{array}{l}4,716 \\
11,716\end{array}$ & 17.5 & $\begin{array}{r}4,171 \\
4,171\end{array}$ & 7.2 & $\begin{array}{l}40.1 \\
41.1\end{array}$ & $\begin{array}{l}4.7 \\
\end{array}$ & 68.0 & $\begin{array}{l}0,852 \\
1,802\end{array}$ & 44 & 象 \\
\hline 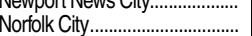 & $\begin{array}{l}\mathrm{VA} \\
\mathrm{VA}\end{array}$ & $\begin{array}{l}20,9<5 \\
36,541\end{array}$ & 37,349 & $\begin{array}{l}30,400 \\
33,787\end{array}$ & $\begin{array}{l}29,948 \\
33,461\end{array}$ & $\begin{array}{l}803 \\
621\end{array}$ & $\begin{array}{l}63.5 \\
63.6\end{array}$ & $\begin{array}{l}20.1 \\
22.3\end{array}$ & $\begin{array}{l}54.9 \\
62.3\end{array}$ & $\begin{array}{r}1.3 \\
6.2\end{array}$ & $\begin{array}{l}2.0 \\
2.1\end{array}$ & $\begin{array}{l}.1 \\
0.4\end{array}$ & $\begin{array}{l}0.4 \\
0.5\end{array}$ & $\begin{array}{l}2.1 \\
6.3\end{array}$ & $\begin{array}{l}1,110 \\
2,332\end{array}$ & 14.4 & $\begin{array}{l}4,348 \\
4,111\end{array}$ & 7.7 & $\begin{array}{l}41.1 \\
53.6\end{array}$ & $\begin{array}{l}4.1 \\
5.6\end{array}$ & $\begin{array}{l}52.9 \\
52.9\end{array}$ & 1,560 & 50 & 10 \\
\hline 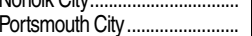 & VA & $\begin{array}{l}30,041 \\
18,405\end{array}$ & $\begin{array}{l}16,473 \\
1,349\end{array}$ & $\begin{array}{l}3,126 \\
15,126\end{array}$ & $\begin{array}{l}30,261 \\
15,261\end{array}$ & $\begin{array}{c}0<1 \\
59\end{array}$ & $\begin{array}{l}70.0 \\
70.5\end{array}$ & 22.4 & $\begin{array}{l}0 . .2 \\
69.2\end{array}$ & $\begin{array}{l}0.2 \\
3.2\end{array}$ & $\begin{array}{l}2.1 \\
0.7\end{array}$ & $\begin{array}{l}0.4 \\
0.2\end{array}$ & . & $\begin{array}{l}0.3 \\
4.0\end{array}$ & $\begin{array}{l}2,302 \\
960\end{array}$ & $\begin{array}{l}14.9 \\
15.9\end{array}$ & 2,051 & $\begin{array}{l}.1 .1 \\
7.4\end{array}$ & 46.8 & 7.4 & $\begin{array}{l}52.9 \\
57.9\end{array}$ & $\begin{array}{l}1,300 \\
826\end{array}$ & 25 & w \\
\hline Jounty................... & VA & 41,888 & 54,646 & 79,358 & 81,937 & 13,868 & 36.5 & 35.4 & 20.6 & 28.9 & 7.5 & 0.2 & 0.4 & 7.0 & 5,160 & 15.9 & 9,311 & 8.8 & 55.4 & 2.2 & 78.5 & 4,590 & 88 & $\stackrel{?}{3} \frac{0}{2}$ \\
\hline & VA & 27,021 & 27,237 & 23454 & 23336 & 967 & 71.4 & $\begin{array}{r}9.7 . \\
9.4\end{array}$ & 816 & 74 & 07 & 0.1 & 0.1 & 0.6 & 1332 & 175 & 3117 & 75 & 427 & 5.1 & 522 & . & 53 & o \\
\hline $\begin{array}{l}\text { Richmond City } \\
\text { Spotsylvanty }\end{array}$ & $\begin{array}{l}\text { VA } \\
\text { VA }\end{array}$ & $\begin{array}{l}27,021 \\
12,227\end{array}$ & $\begin{array}{l}21,23 \prime \\
18,876\end{array}$ & $\begin{array}{l}23,454 \\
23,585\end{array}$ & 23,817 & $\begin{array}{l}967 \\
819\end{array}$ & $\begin{array}{l}11.4 \\
33.2\end{array}$ & $\begin{array}{r}9.4 \\
63.6\end{array}$ & $\begin{array}{l}81.6 \\
18.7\end{array}$ & $\begin{array}{r}1.4 \\
10.5\end{array}$ & $\begin{array}{l}0.1 \\
2.8\end{array}$ & $\begin{array}{l}0.1 \\
0.1\end{array}$ & $\begin{array}{l}0.1 \\
0.3\end{array}$ & $\begin{array}{l}0.6 \\
3.9\end{array}$ & $\begin{array}{l}1,332 \\
1,464\end{array}$ & $\begin{array}{l}17.5 \\
16.3\end{array}$ & $\begin{array}{l}3,635 \\
2,635\end{array}$ & $\begin{array}{l}7.5 \\
9.0\end{array}$ & $\begin{array}{l}42.1 \\
55.5\end{array}$ & $\begin{array}{l}5.1 \\
2.2\end{array}$ & $\begin{array}{l}52.2 \\
83.1\end{array}$ & $\begin{array}{r}991 \\
1,669\end{array}$ & $\begin{array}{l}53 \\
34\end{array}$ & 음 m \\
\hline See notes at end of table. & & & & & & & & & & & & & & & & & & & & & & & & స. \\
\hline
\end{tabular}




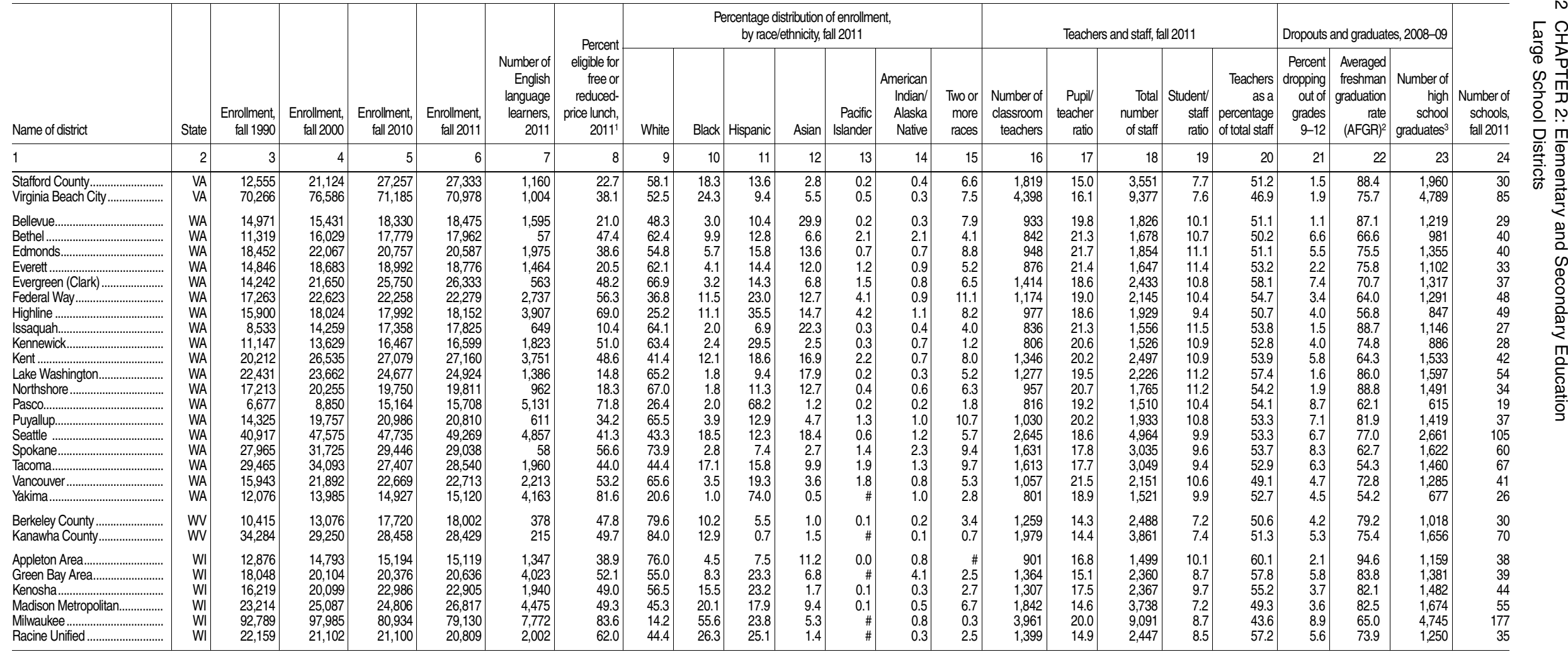

Bellevue.

Edmon

Evergreen (Clark).

Kennewick

Lake Washington

†Not applicable.

\#Rounds to zero.

TPercentages are for those schools that reported on free and reduced-price lunch eligibility

列 stimate the size of an incoming freshman class 3Includes regular diplomas only.

${ }^{4}$ Total for districts reporting data.
${ }^{5}$ Reported data indicated an averaged freshman graduation rate of greater than 100.0 percent. -Number of teachers based on data reported through the "Public Elementary/Secondary School Universe Survey." NOTE: Total enrollment, staff, and teacher data in this table reflect totals reported by school districts and may differ from data derived from summing school-level data to school district aggregates. $\mathrm{SD}=$ independent school district. CISD $=$ consolidated indeSOURCE: U.S. Department of Education, National Center for Education Statistics, Common Core of Data (CCD) "P Public Elemg. tary/Secondary School Universe Survey," 2011-12; "Local Education Agency Universe Survey" 1990-91, 2000-01, 2010-11, and 2011-12; and "Local Education Agency-Level Public-Use Data File on Public School Dropouts: School Year 2008-09." (This table was prepared April 2014.) 
Table 215.20. Revenues, expenditures, poverty rate, and Title I allocations of public school districts enrolling more than 15,000 students: 2010-11 and fiscal year 2013

\begin{tabular}{|c|c|c|c|c|c|c|c|c|c|c|c|c|c|c|c|c|c|c|c|}
\hline \multirow[b]{3}{*}{ Name of district } & \multirow[b]{3}{*}{ State } & \multirow{2}{*}{\multicolumn{4}{|c|}{$\begin{array}{l}\text { Revenues by source of funds, 2010-11 } \\
\text { (in thousands of current dollars) }\end{array}$}} & \multirow{2}{*}{\multicolumn{4}{|c|}{ Percentage distribution of revenues, $2010-11$}} & \multicolumn{5}{|c|}{ Expenditures, 2010-11 (in thousands of current dollars) } & \multirow[b]{3}{*}{ 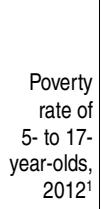 } & \multirow{3}{*}{$\begin{array}{r}\text { Current } \\
\text { expenditure } \\
\text { per pupil, } \\
2010-11 \\
\text { (in current } \\
\text { dollars) }\end{array}$} & \multirow{2}{*}{\multicolumn{2}{|c|}{$\begin{array}{l}\text { Tittl I allocations, } \\
\text { fiscal year } 2013\end{array}$}} & \\
\hline & & & & & & & & & & \multirow[b]{2}{*}{ Total $^{5}$} & \multicolumn{2}{|c|}{ Current expenditures } & \multirow[b]{2}{*}{$\begin{array}{r}\text { Capital } \\
\text { outlay }\end{array}$} & \multirow[b]{2}{*}{$\begin{array}{r}\text { Interest on } \\
\text { school debt }\end{array}$} & & & & & \\
\hline & & Total & Federal & State & Local & Total & Federal & State & Local & & Total & Instruction & & & & & \begin{tabular}{|} 
Total $^{3}$ \\
(in thousands \\
of current \\
dollars)
\end{tabular} & $\begin{array}{r}\text { Per poverty } \\
\text { child } \\
\text { (in current } \\
\text { dollars) }\end{array}$ & \\
\hline 1 & 2 & 3 & 4 & 5 & 6 & 7 & 8 & 9 & 10 & 11 & 12 & 13 & 14 & 15 & 16 & 17 & 18 & $\overline{19}$ & \\
\hline $\begin{array}{l}\text { Districts with more than } \\
15,000 \text { students........... }\end{array}$ & $t$ & $\$ 257,258,502$ & $\$ 35,545,431$ & $\$ 114,543,312$ & $\$ 107,169,759$ & 100.0 & 13.8 & 44.5 & 41.7 & $\$ 260,273,325$ & $\$ 220,978,348$ & $\$ 138,281,066$ & $\$ 24,766,877$ & $\$ 8,676,186$ & 22.5 & $\$ 10,138$ & $\$ 7,027,077$ & $\$ 1,266$ & \\
\hline Baldwin County............................ & $\mathrm{AL}$ & 281,434 & 30,713 & 105,457 & 145,264 & 100.0 & 10.9 & 37.5 & 51.6 & 253,965 & 235,304 & 141,132 & 3,851 & 10,486 & 18.6 & 8,344 & 5,509 & 943 & \\
\hline Birmingham City.............................. & $\mathrm{AL}$ & 279,900 & 53,431 & 131,567 & 94,902 & 100.0 & 19.1 & 47.0 & 33.9 & 378,008 & 276,942 & 150,418 & 87,307 & 3,766 & 44.0 & 10,687 & 15,723 & 1,155 & \\
\hline Huntsville City ............................. & $\mathrm{AL}$ & 247,159 & 32,314 & 114,440 & 100,405 & 100.0 & 13.1 & 46.3 & 40.6 & 264,918 & 224,557 & 131,748 & 37,111 & 1,188 & 24.8 & 9,611 & 6,000 & 911 & \\
\hline Jefferson County ......................... & $\mathrm{AL}$ & 341,757 & 45,412 & 189,286 & 107,059 & 100.0 & 13.3 & 55.4 & 31.3 & 394,774 & 318,139 & 186,974 & 65,835 & 5,448 & 19.3 & 8,872 & 7,566 & 992 & \\
\hline Madison County ........................... & $\mathrm{AL}$ & 182,095 & 19,822 & 104,049 & 58,224 & 100.0 & 10.9 & 57.1 & 32.0 & 176,595 & 163,023 & 96,272 & 3,507 & 6,162 & 13.7 & 8,193 & 2,435 & 762 & \\
\hline Mobile County............................... & $\mathrm{AL}$ & 587,680 & 110,840 & 318,759 & 158,081 & 100.0 & 18.9 & 54.2 & 26.9 & 581,480 & 543,267 & 301,975 & 21,642 & 10,835 & 27.1 & 8,760 & 21,199 & 1,086 & \\
\hline Montgomery County ....................... & $\mathrm{AL}$ & 293,637 & 58,056 & 162,975 & 72,606 & 100.0 & 19.8 & 55.5 & 24.7 & 285,338 & 271,503 & 153,401 & 7,594 & 2,903 & 29.9 & 8,629 & 12,440 & 1,004 & \\
\hline Shelby County............................. & $\mathrm{AL}$ & 284,384 & 24,531 & 144,678 & 115,175 & 100.0 & 8.6 & 50.9 & 40.5 & 261,378 & 239,008 & 143,103 & 10,101 & 6,400 & 10.5 & 8,517 & 3,212 & 937 & \\
\hline Tuscaloosa County........................ & $\mathrm{AL}$ & 170,564 & 21,034 & 94,758 & 54,772 & 100.0 & 12.3 & 55.6 & 32.1 & 153,777 & 144,707 & 84,020 & 4,798 & 1,442 & 20.1 & 8,136 & 3,261 & 860 & \\
\hline Anchorage.................................. & $\mathrm{AK}$ & 732,488 & 114,561 & 407,204 & 210,723 & 100.0 & 15.6 & 55.6 & 28.8 & 770,061 & 711,803 & 401,296 & 30,709 & 27,091 & 11.4 & 14,466 & 13,711 & 2,235 & \\
\hline Matanuska-Susitna Borough... & $\mathrm{AK}$ & 250,574 & 29,859 & 169,244 & 51,471 & 100.0 & 11.9 & 67.5 & 20.5 & 265,235 & 243,201 & 138,676 & 14,721 & 7,201 & 13.0 & 14,240 & 4,550 & 1,813 & \\
\hline Cartwright Elementary............... & $A Z$ & 130,961 & 27,428 & 73,338 & 30,195 & 100.0 & 20.9 & 56.0 & 23.1 & 132,358 & 126,120 & 79,344 & 6,238 & 0 & 40.9 & 7,137 & 8,725 & 1,021 & \\
\hline Chandler Unified......................... & $\mathrm{AZ}$ & 289,864 & 28,955 & 116,353 & 144,556 & 100.0 & 10.0 & 40.1 & 49.9 & 301,044 & 276,264 & 161,091 & 4,289 & 20,491 & 13.5 & 7,106 & 4,863 & 808 & \\
\hline Deer Valley Unified...................... & $\mathrm{AZ}$ & 288,302 & 28,779 & 91,596 & 167,927 & 100.0 & 10.0 & 31.8 & 58.2 & 322,586 & 252,387 & 145,515 & 44,370 & 25,811 & 12.0 & 7,172 & 4,617 & 816 & \\
\hline Dysart Unified............................... & $\mathrm{AZ}$ & 201,865 & 20,061 & 82,313 & 99,491 & 100.0 & 9.9 & 40.8 & 49.3 & 202,120 & 189,446 & 100,585 & 11,379 & 1,130 & 17.4 & 7,836 & 5,123 & 897 & \\
\hline Gilbert Unified............................ & $\mathrm{AZ}$ & 289,867 & 22,884 & 120,509 & 146,474 & 100.0 & 7.9 & 41.6 & 50.5 & 303,817 & 262,545 & 152,940 & 9,154 & 31,562 & 10.3 & 6,893 & 3,444 & 785 & \\
\hline Kyrene Elementary.......................... & $A Z$ & 160,010 & 8,788 & 48,687 & 102,535 & 100.0 & 5.5 & 30.4 & 64.1 & 160,080 & 131,061 & 80,997 & 23,389 & 5,630 & 10.2 & 7,357 & 1,329 & 715 & \\
\hline Mesa Unified................................ & $\mathrm{AZ}$ & 610,696 & 105,472 & 226,297 & 278,927 & 100.0 & 17.3 & 37.1 & 45.7 & 547,057 & 490,380 & 288,930 & 28,885 & 27,750 & 25.2 & 7,530 & 23,412 & 1,161 & \\
\hline Paradise Valley Unified.............. & $\mathrm{AZ}$ & 299,220 & 35,519 & 65,166 & 198,535 & 100.0 & 11.9 & 21.8 & 66.4 & 297,846 & 243,438 & 139,312 & 13,353 & 40,690 & 16.9 & 7,373 & $\begin{array}{r}7,446 \\
\end{array}$ & 1,116 & \\
\hline Peoria Unified .................................. & $\mathrm{AZ}$ & 297,351 & 33,427 & 134,656 & 129,268 & 100.0 & 11.2 & 45.3 & 43.5 & 291,823 & 260,444 & 142,210 & 9,901 & 21,120 & 15.2 & 7,063 & 5,613 & 958 & \\
\hline Phoenix Union High ................... & $\mathrm{AZ}$ & 304,665 & 42,981 & 50,078 & 211,606 & 100.0 & 14.1 & 16.4 & 69.5 & 312,681 & 277,276 & 148,405 & 12,352 & 21,950 & 37.2 & 11,114 & 16,017 & 1,033 & \\
\hline Scottsdale Unified........................... & $A Z$ & 278,958 & 22,041 & 28,562 & 228,355 & 100.0 & 7.9 & 10.2 & 81.9 & 298,870 & 210,883 & 119,375 & 20,117 & 67,656 & $\begin{array}{l}13.3 \\
13.3\end{array}$ & $\begin{array}{r}8,038 \\
\end{array}$ & 3,355 & 807 & \\
\hline Sunnyside Unified ............................. & $\mathrm{AZ}$ & 136,780 & 28,563 & 65,581 & 42,636 & 100.0 & 20.9 & 47.9 & 31.2 & 135,615 & 122,419 & 64,821 & 5,140 & 7,985 & 44.8 & 7,067 & 9,583 & 1,070 & \\
\hline Tucson Unified ............................. & $\mathrm{AZ}$ & 522,657 & 86,179 & 188,104 & 248,374 & 100.0 & 16.5 & 36.0 & 47.5 & 515,127 & 436,947 & 204,052 & 43,711 & 34,442 & 31.0 & 8,202 & 24,783 & 1,081 & 우 \\
\hline Washington Elementary ........... & $\mathrm{AZ}$ & 209,054 & 41,466 & 79,100 & 88,488 & 100.0 & 19.8 & 37.8 & 42.3 & 188,564 & 174,374 & 96,671 & 2,607 & 11,583 & 31.3 & 7,802 & $\begin{array}{r}9,142 \\
9,140\end{array}$ & 1,049 & \\
\hline Little Rock.............................. & $A R$ & 363,053 & 56,111 & 255,534 & 51,408 & 100.0 & 15.5 & 70.4 & 14.2 & 386,146 & 314,484 & 177,104 & 28,078 & 8,141 & 23.1 & 12,244 & 8,506 & 1,227 & \\
\hline Pulaski County Special ............. & $\mathrm{AR}$ & 216,609 & 27,546 & 158,754 & 30,309 & 100.0 & 12.7 & 73.3 & 14.0 & 305,303 & 190,399 & 106,812 & 50,055 & 6,006 & 15.7 & 10,879 & 4,755 & 1,139 & T \\
\hline 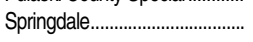 & $A R$ & 189,246 & 23,890 & 142,967 & 22,389 & 100.0 & 12.6 & 75.5 & 11.8 & 209,602 & 163,556 & 98,943 & 19,974 & 5,819 & 27.9 & 8,426 & 5,335 & 958 & N \\
\hline ABC Unified ............ & $\mathrm{CA}$ & 198,950 & 23,970 & 143,412 & 31,568 & 100.0 & 12.0 & 72.1 & 15.9 & 193,331 & 173,538 & 105,858 & 5,211 & 1,039 & 17.6 & 8,391 & 3,133 & 939 & m \\
\hline Alhambra Unified.............................. & $\mathrm{CA}$ & 211,784 & 30,728 & 137,748 & 43,308 & 100.0 & 14.5 & 65.0 & 20.4 & 199,167 & 164,462 & 94,165 & 23,843 & 6,089 & 25.3 & 8,932 & 4,883 & 1,048 & \\
\hline Alvord Unified........................... & $\mathrm{CA}$ & 171,577 & 25,186 & 111,208 & 35,183 & 100.0 & 14.7 & 64.8 & 20.5 & 211,799 & 157,841 & 98,826 & 46,256 & $\begin{array}{l}7,452 \\
\end{array}$ & 23.6 & 7,971 & 5,067 & 936 & సై \\
\hline Anaheim City ............................... & $\mathrm{CA}$ & 167,246 & 18,653 & 84,645 & 63,948 & 100.0 & 11.2 & 50.6 & 38.2 & 178,636 & 144,669 & 90,546 & 19,138 & 2,950 & 30.1 & 7,576 & 6,074 & 939 & (1) \\
\hline Anaheim Union High ................... & $\mathrm{CA}$ & 335,162 & 47,856 & 214,164 & 73,142 & 100.0 & 14.3 & 63.9 & 21.8 & 337,047 & 299,165 & 190,744 & 4,737 & 5,854 & 20.7 & 9,023 & 7,808 & 1,019 & $\stackrel{\varpi ్}{=}$ \\
\hline Antelope Valley Union High..... & $\mathrm{CA}$ & 239,457 & 31,614 & 163,443 & 44,400 & 100.0 & 13.2 & 68.3 & 18.5 & 231,675 & 215,302 & 132,867 & 7,917 & 4,925 & 23.1 & 8,254 & 6,241 & 918 & \\
\hline Antioch Unified................................. & $\mathrm{CA}$ & 153,711 & 20,012 & 95,450 & 38,249 & 100.0 & 13.0 & 62.1 & 24.9 & 158,981 & 145,389 & 95,209 & 10,157 & 2,463 & 17.6 & 7,620 & 3,471 & 879 & 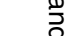 \\
\hline Bakersfield City........................... & $\mathrm{CA}$ & 275,247 & 55,446 & 191,475 & 28,326 & 100.0 & 20.1 & 69.6 & 10.3 & 270,973 & 250,915 & 153,445 & 16,537 & 1,919 & 47.1 & 9,094 & 15,427 & 1,127 & $-\frac{2}{c o}$ \\
\hline Baldwin Park Unified..................... & $\mathrm{CA}$ & 194,644 & 25,675 & 139,883 & 29,086 & 100.0 & 13.2 & 71.9 & 14.9 & 183,120 & 146,983 & 90,503 & 13,076 & 2,871 & 27.5 & 7,378 & 4,217 & 945 & D \\
\hline Burbank Unified........................... & $\mathrm{CA}$ & 155,085 & 11,355 & 87,078 & 56,652 & 100.0 & 7.3 & 56.1 & 36.5 & 140,950 & 132,025 & 85,637 & 5,277 & 1,256 & 13.6 & 7,939 & 1,482 & 719 & 5 \\
\hline Cajon Valley Union ....................... & $\mathrm{CA}$ & 153,489 & 18,139 & 83,292 & 52,058 & 100.0 & 11.8 & 54.3 & 33.9 & 156,598 & 134,544 & 85,789 & 16,834 & 4,987 & 26.7 & 8,375 & 4,601 & 904 & \\
\hline Capistrano Unified............................ & $\mathrm{CA}$ & 416,481 & 29,877 & 116,954 & 269,650 & 100.0 & 7.2 & 28.1 & 64.7 & 404,785 & 385,140 & 258,267 & 5,241 & 2,273 & 8.3 & 7,241 & 4,295 & 803 & 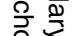 \\
\hline Chaffey Joint Union High .......... & $\mathrm{CA}$ & 245,466 & 23,694 & 153,445 & 68,327 & 100.0 & 9.7 & 62.5 & 27.8 & 211,708 & 192,382 & 122,419 & 5,626 & 4,754 & 17.9 & 7,566 & 4,538 & 912 & \\
\hline Chino Valley Unified .................. & $\mathrm{CA}$ & 273,109 & 24,923 & 163,683 & 84,503 & 100.0 & 9.1 & 59.9 & 30.9 & 254,480 & 228,915 & 144,091 & 11,315 & 7,507 & 13.4 & 7,242 & 3,741 & 805 & \\
\hline Chula Vista Elementary............. & $\mathrm{CA}$ & 271,877 & 27,486 & 121,518 & 122,873 & 100.0 & 10.1 & 44.7 & 45.2 & 237,810 & 219,747 & 140,175 & 4,868 & 9,291 & 17.8 & 7,927 & 5,064 & 977 & \\
\hline 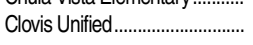 & $\mathrm{CA}$ & 393,586 & 35,062 & 234,714 & 123,810 & 100.0 & $\begin{array}{r}8.9 \\
8.9\end{array}$ & 59.6 & 31.5 & 368,765 & 308,672 & 183,847 & 43,574 & 10,587 & 14.6 & 8,018 & 5,786 & 1,034 & \\
\hline
\end{tabular}




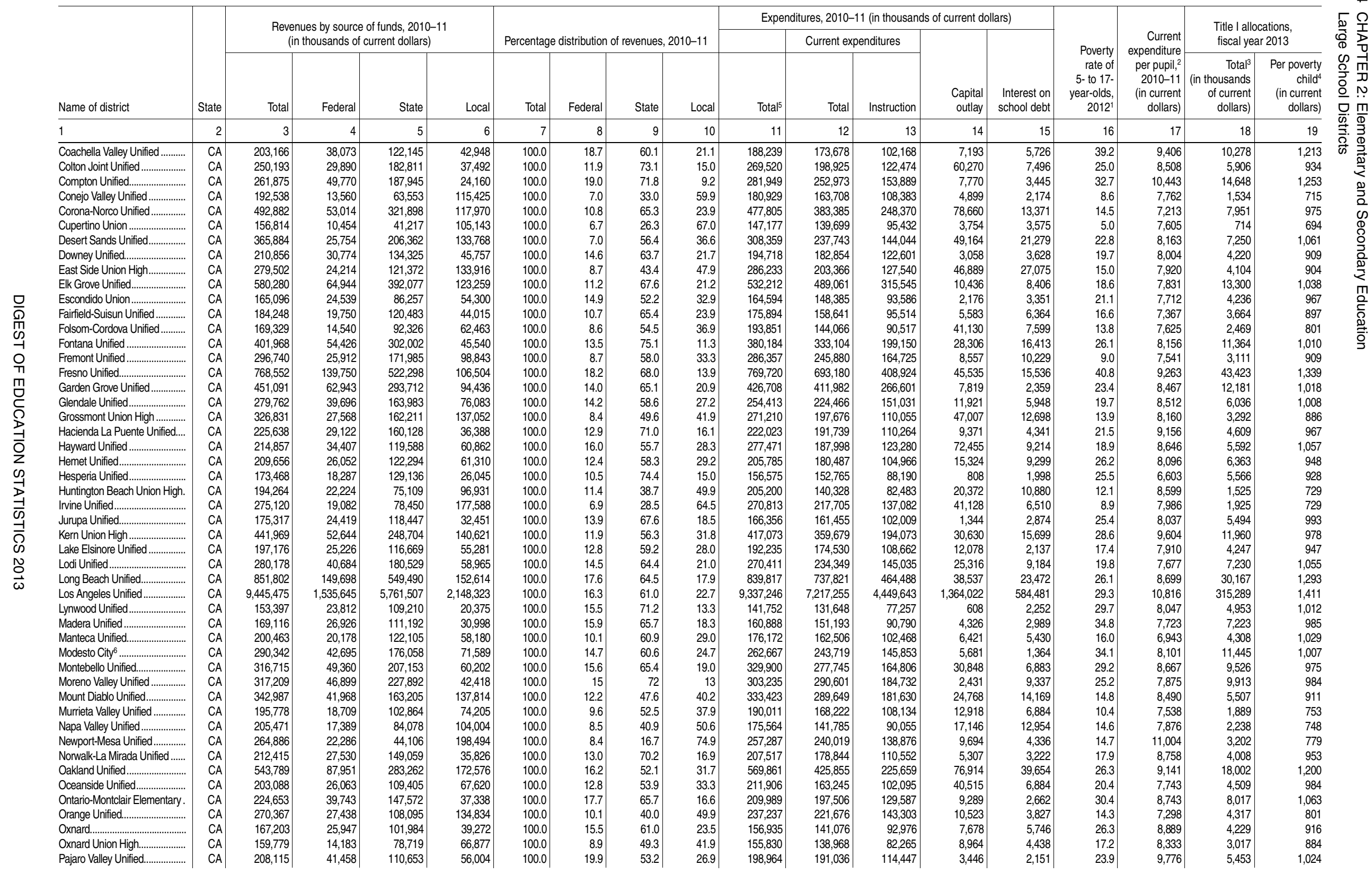

See notes at end of table. 
Table 215.20. Revenues, expenditures, poverty rate, and Title I allocations of public school districts enrolling more than 15,000 students: 2010-11 and fiscal year 2013-Continued

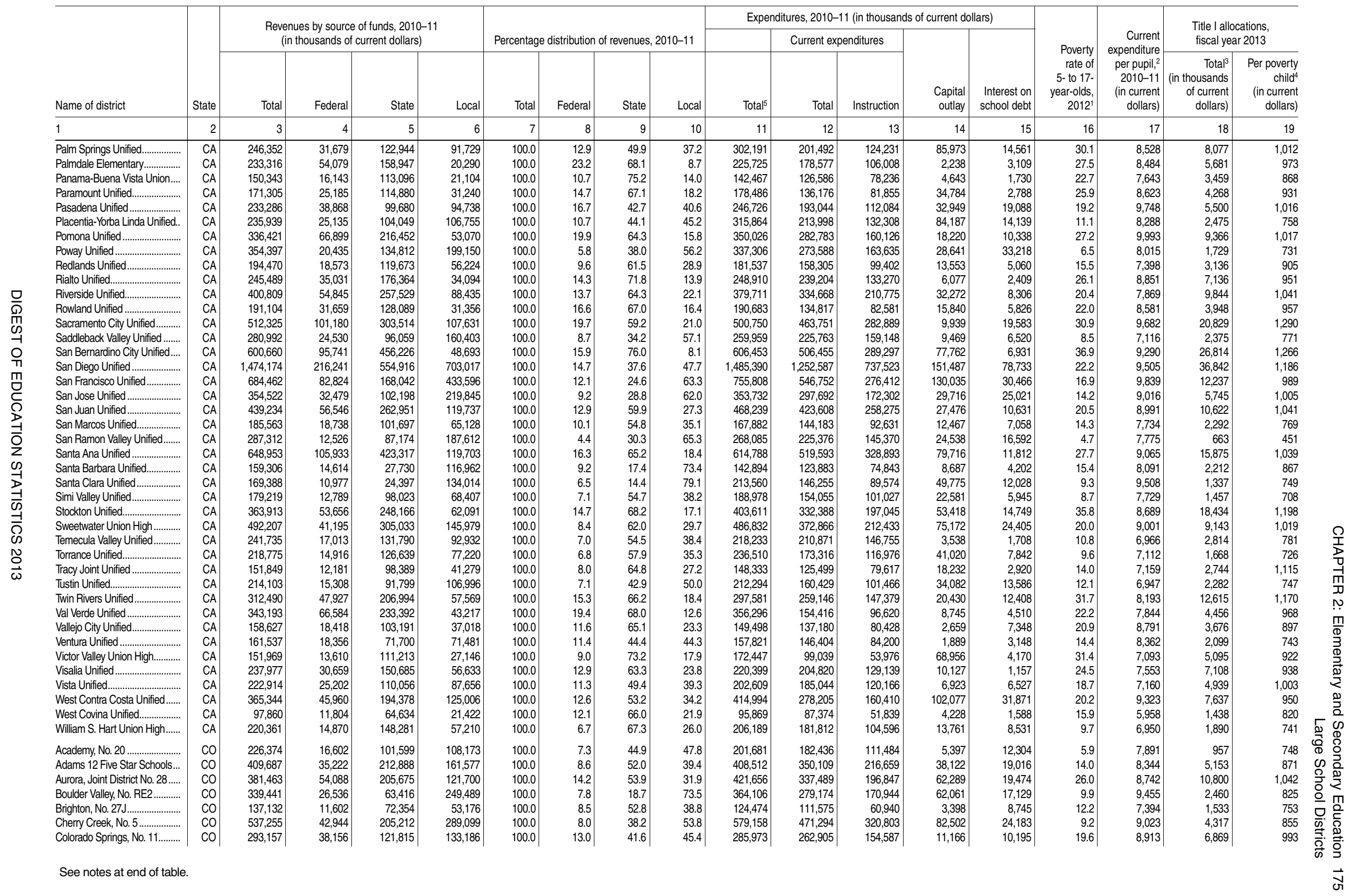




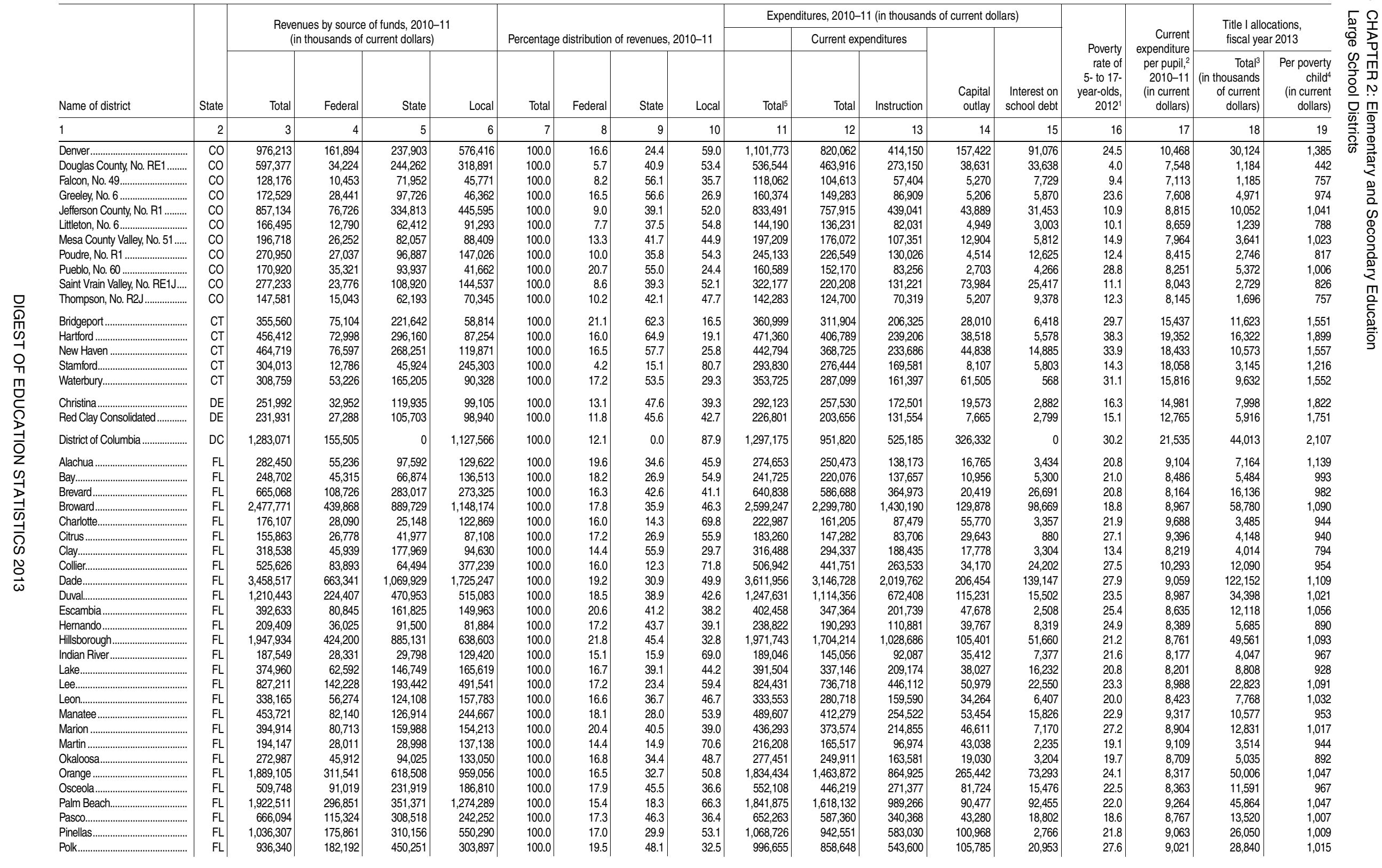

See notes at end of table. 
Table 215.20. Revenues, expenditures, poverty rate, and Title I allocations of public school districts enrolling more than 15,000 students: 2010-11 and fiscal year 2013-Continued

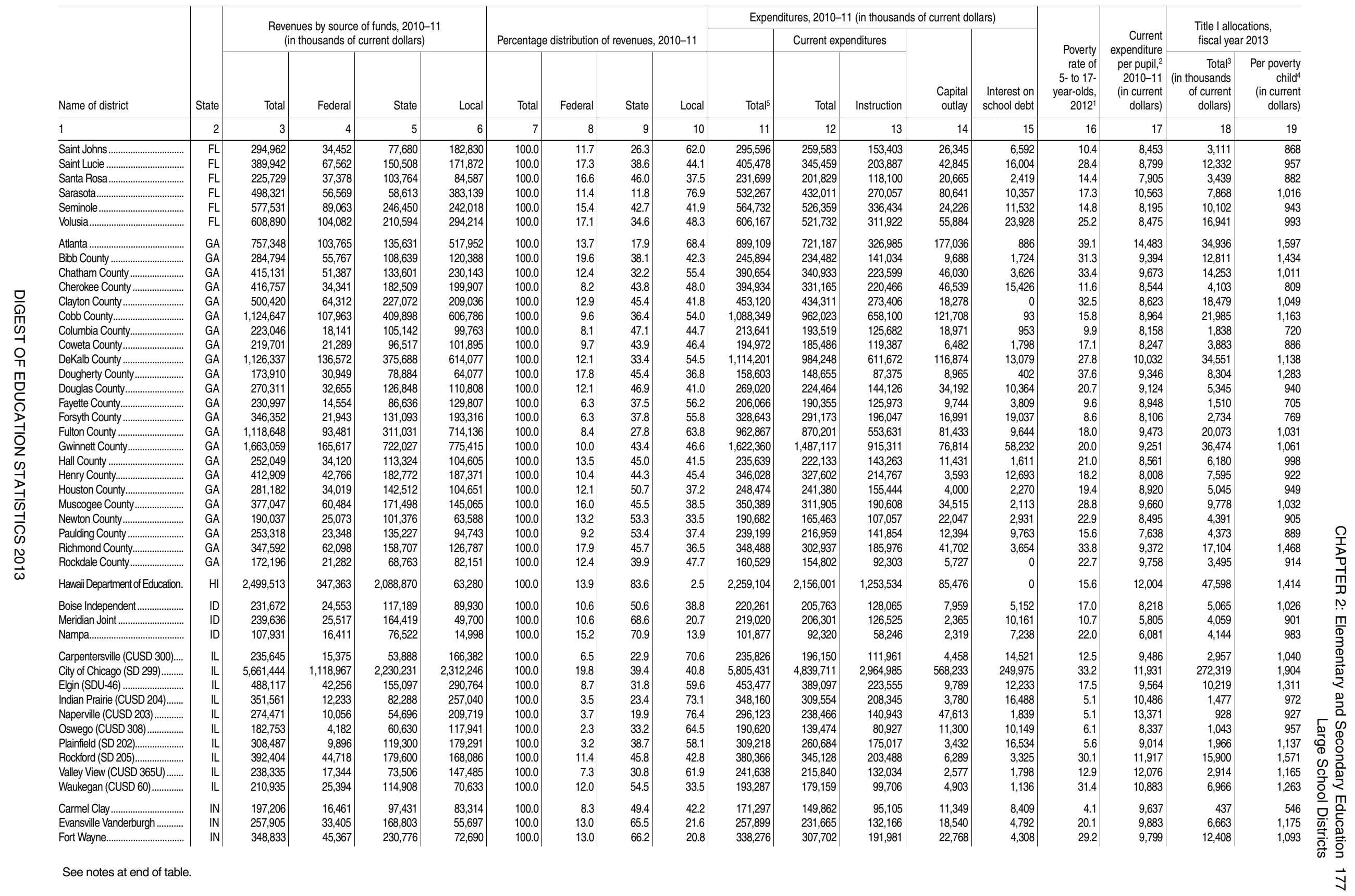




\begin{tabular}{|c|c|c|c|c|c|c|c|c|c|c|c|c|c|c|c|c|c|c|}
\hline \multirow[b]{3}{*}{ Name of district } & \multirow[b]{3}{*}{ State } & \multirow{2}{*}{\multicolumn{4}{|c|}{$\begin{array}{l}\text { Revenues by source of funds, 2010-11 } \\
\text { (in thousands of current dollars) }\end{array}$}} & \multirow{2}{*}{\multicolumn{4}{|c|}{ Percentage distribution of revenues, 2010-11 }} & \multicolumn{5}{|c|}{ Expenditures, 2010-11 (in thousands of current dollars) } & \multirow[b]{3}{*}{ 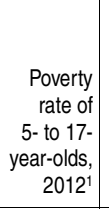 } & \multirow{3}{*}{$\begin{array}{r}\text { Current } \\
\text { expenditure } \\
\text { per pupil, } \\
2010-11 \\
\text { (in current } \\
\text { dollars) } \\
\end{array}$} & \multirow{2}{*}{\multicolumn{2}{|c|}{$\begin{array}{l}\text { Title I allocations, } \\
\text { fiscal year } 2013\end{array}$}} \\
\hline & & & & & & & & & & \multirow[b]{2}{*}{ Total $^{5}$} & \multicolumn{2}{|c|}{ Current expenditures } & \multirow[b]{2}{*}{$\begin{array}{r}\text { Capital } \\
\text { outlay }\end{array}$} & \multirow[b]{2}{*}{$\begin{array}{r}\text { Interest on } \\
\text { school debt }\end{array}$} & & & & \\
\hline & & Total & Federal & State & Local & Total & Federal & State & Local & & \multicolumn{2}{|c|}{ Total Instruction } & & & & & \begin{tabular}{|r|} 
Total $^{3}$ \\
(in thousands \\
of current \\
dollars) \\
\end{tabular} & $\begin{array}{r}\text { Per poverty } \\
\text { child } \\
\text { (in current } \\
\text { dollars) }\end{array}$ \\
\hline 1 & 2 & 3 & 4 & 5 & 6 & 7 & 8 & 9 & 10 & 11 & 12 & 13 & 14 & 15 & 16 & 17 & 18 & 19 \\
\hline Hamilton Southeastern............ & $\mathrm{IN}$ & 189,010 & 3,433 & 109,596 & 75,981 & 100.0 & 1.8 & 58.0 & 40.2 & 150,969 & 137,801 & 82,901 & 11,043 & 92 & 4.4 & 7,374 & 430 & 451 \\
\hline Indianapolis................................ & $\mathrm{IN}$ & 526,156 & 75,821 & 338,008 & 112,327 & 100.0 & 14.4 & 64.2 & 21.3 & 565,152 & 460,050 & 251,854 & 57,250 & 27,488 & 44.6 & 13,908 & 32,916 & 1,516 \\
\hline MSD Wayne Township.............. & $\mathrm{IN}$ & 219,290 & 28,507 & 127,347 & 63,436 & 100.0 & 13.0 & 58.1 & 28.9 & 195,958 & 177,841 & 109,302 & 6,852 & 1,201 & 30.2 & 11,114 & 4,575 & 1,039 \\
\hline South Bend................................ & $\mathrm{IN}$ & 310,761 & 37,437 & 168,334 & 104,990 & 100.0 & 12.0 & 54.2 & 33.8 & 272,386 & 237,188 & 143,704 & 20,623 & 10,237 & 34.4 & 11,861 & 9,581 & 1,034 \\
\hline Vigo County ................................... & $\mathrm{IN}$ & 163,340 & 13,104 & 115,725 & 34,511 & 100.0 & 8.0 & 70.8 & 21.1 & 156,321 & 139,970 & 89,440 & 13,226 & 85 & 21.5 & 8,808 & 4,356 & 1,224 \\
\hline Cedar Rapids........... & $\mid A$ & 228,667 & 29,730 & 92,054 & 106,883 & 100.0 & 13.0 & 40.3 & 46.7 & 241,290 & 183,644 & 120,436 & 45,020 & 1,993 & 15.2 & 10,632 & 3,510 & 1,144 \\
\hline Davenport........... & IA & 198,972 & 25,941 & 87,652 & 85,379 & 100.0 & 13.0 & 44.1 & 42.9 & 190,712 & 167,391 & 115,862 & 19,389 & 0 & 24.9 & 9,791 & 5,087 & 1,141 \\
\hline Des Moines Independent ........ & IA & 413,715 & 58,496 & 193,569 & 161,650 & 100.0 & 14.1 & 46.8 & 39.1 & 404,544 & 332,291 & 217,701 & 52,481 & 4,334 & 25.9 & 10,042 & 11,140 & 1,247 \\
\hline Blue Valley....... & KS & 277,472 & 13,564 & 87,546 & 176,362 & 100.0 & 4.9 & 31.6 & 63.6 & 240,660 & 202,447 & 124,406 & 23,040 & 15,000 & 3.2 & 9,355 & 412 & 492 \\
\hline Kansas City.... & KS & 254,245 & 44,235 & 154,956 & 55,054 & 100.0 & 17.4 & 60.9 & 21.7 & 248,166 & 212,751 & 122,894 & 30,806 & 4,504 & 38.1 & 10,517 & 11,273 & 1,310 \\
\hline Olathe.......................................... & KS & 311,585 & 24,701 & 154,410 & 132,474 & 100.0 & 7.9 & 49.6 & 42.5 & 300,743 & 256,033 & 166,705 & 29,716 & 14,971 & 6.9 & 9,183 & 1,906 & 915 \\
\hline Shawnee Mission...................... & KS & 312,083 & 28,232 & 106,176 & 177,675 & 100.0 & 9.0 & 34.0 & 56.9 & 304,164 & 259,136 & 170,779 & 34,304 & 10,717 & 9.3 & 9,314 & 3,555 & 1,126 \\
\hline Wichita............................................. & KS & 586,367 & 98,180 & 326,792 & 161,395 & 100.0 & 16.7 & 55.7 & 27.5 & 723,975 & 514,018 & 289,113 & 185,327 & 24,517 & 24.6 & 10,420 & 19,324 & 1,381 \\
\hline Boone County..... & $\mathrm{KY}$ & 192,180 & 14,047 & 82,863 & 95,270 & 100.0 & 7.3 & 43.1 & 49.6 & 188,086 & 159,037 & 91,980 & 19,564 & 8,764 & 10.4 & 8,238 & 2,052 & 841 \\
\hline Fayette County.. & $\mathrm{KY}$ & 437,407 & 59,693 & 152,768 & 224,946 & 100.0 & 13.6 & 34.9 & 51.4 & 474,095 & 392,645 & 236,186 & 68,320 & 10,650 & 18.6 & 10,382 & 10,817 & 1,316 \\
\hline Jefferson County ........... & $\mathrm{KY}$ & $1,204,917$ & 201,021 & 453,116 & 550,780 & 100.0 & 16.7 & 37.6 & 45.7 & $1,174,757$ & $1,069,548$ & 567,979 & 77,789 & 18,255 & 23.7 & 10,989 & 35,648 & 1,233 \\
\hline Ascension Parish.... & $L A$ & 213,206 & 24,144 & 89,474 & 99,588 & 100.0 & 11.3 & 42.0 & 46.7 & 227,344 & 206,230 & 125,709 & 16,272 & 4,301 & 13.9 & 10,336 & 3,562 & 1,125 \\
\hline Bossier Parish............. & $L A$ & 221,676 & 26,805 & 98,223 & 96,648 & 100.0 & 12.1 & 44.3 & 43.6 & 219,420 & 199,908 & 120,413 & 12,023 & 6,412 & 20.4 & 9,678 & 5,006 & 1,129 \\
\hline 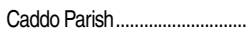 & $\mathrm{LA}$ & 487,940 & 77,995 & 206,617 & 203,328 & 100.0 & 16.0 & 42.3 & 41.7 & 491,104 & 453,410 & 265,217 & 29,285 & 5,017 & 29.7 & 10,823 & 18,909 & 1,421 \\
\hline Calcasieu Parish......................... & $L A$ & 347,421 & 54,007 & 148,278 & 145,136 & 100.0 & 15.5 & 42.7 & 41.8 & 349,827 & 311,818 & 180,928 & 28,381 & 9,230 & 23.9 & 9,431 & 9,844 & 1,181 \\
\hline East Baton Rouge Parish ........ & $L A$ & 565,970 & 104,436 & 166,354 & 295,180 & 100.0 & 18.5 & 29.4 & 52.2 & 624,259 & 538,812 & 314,164 & 71,755 & 350 & 31.0 & 12,612 & 24,200 & 1,299 \\
\hline Jefferson Parish.............................. & $L A$ & 576,039 & 125,960 & 174,346 & 275,733 & 100.0 & 21.9 & 30.3 & 47.9 & 583,007 & 512,002 & 293,286 & 60,285 & 7,054 & 25.6 & 11,320 & 22,593 & 1,290 \\
\hline Lafayette Parish ......................... & $L A$ & 328,765 & 51,849 & 119,529 & 157,387 & 100.0 & 15.8 & 36.4 & 47.9 & 316,869 & 303,355 & 190,356 & 10,033 & 2,778 & 19.4 & 10,039 & 9,271 & 1,233 \\
\hline Livingston Parish ........................... & LA & 222,819 & 26,125 & 142,719 & 53,975 & 100.0 & 11.7 & 64.1 & 24.2 & 231,917 & 211,998 & 136,301 & 16,762 & 2,900 & 15.2 & 8,664 & 4,393 & 1,125 \\
\hline Ouachita Parish....... & $\mathrm{LA}$ & 211,316 & 29,866 & 115,543 & 65,907 & 100.0 & 14.1 & 54.7 & 31.2 & 221,619 & 195,243 & 110,665 & 19,121 & 5,797 & 27.0 & 9,921 & 5,932 & 1,115 \\
\hline Rapides Parish ............................ & $L A$ & 233,739 & 39,532 & 122,914 & 71,293 & 100.0 & 16.9 & 52.6 & 30.5 & 222,517 & 215,588 & 133,648 & 3,113 & 3,133 & 29.9 & 8,987 & 8,520 & 1,155 \\
\hline Saint Tammany Parish .............. & $L A$ & 445,686 & 51,855 & 203,578 & 190,253 & 100.0 & 11.6 & 45.7 & 42.7 & 490,715 & 414,363 & 251,024 & 64,407 & 10,582 & 14.1 & 11,306 & 6,465 & 1,024 \\
\hline Tangipahoa Parish....................... & LA & 178,306 & 35,462 & 101,527 & 41,317 & 100.0 & 19.9 & 56.9 & 23.2 & 177,813 & 172,905 & 99,390 & 4,122 & 587 & 34.2 & 8,913 & 8,544 & 1,150 \\
\hline Terrebonne Parish ....................... & $\mathrm{LA}$ & 179,453 & 36,596 & 84,625 & 58,232 & 100.0 & 20.4 & 47.2 & 32.4 & 169,487 & 166,314 & 104,211 & 2,529 & 110 & 25.1 & 8,883 & 5,870 & 1,127 \\
\hline Anne Arundel County................ & $\mathrm{MD}$ & $1,102,787$ & 78,339 & 360,457 & 663,991 & 100.0 & 7.1 & 32.7 & 60.2 & $1,145,368$ & 982,705 & 616,571 & 125,216 & 17,154 & 8.1 & 13,019 & 10,227 & 1,393 \\
\hline Baltimore City........................... & $\mathrm{MD}$ & $1,441,019$ & 279,303 & 892,935 & 268,781 & 100.0 & 19.4 & 62.0 & 18.7 & $1,452,189$ & $1,297,470$ & 755,350 & 84,383 & 2,752 & 34.3 & 15,483 & 52,113 & 1,663 \\
\hline Baltimore County................... & $\mathrm{MD}$ & $1,555,549$ & 138,275 & 609,619 & 807,655 & 100.0 & 8.9 & 39.2 & 51.9 & $1,537,580$ & $1,380,286$ & 839,877 & 108,662 & 13,101 & 11.4 & 13,252 & 22,755 & 1,569 \\
\hline Calvert County................................. & $\mathrm{MD}$ & 257,113 & 15,675 & 108,766 & 132,672 & 100.0 & 6.1 & 42.3 & 51.6 & 253,840 & 223,808 & 139,883 & 24,048 & 1,636 & 7.6 & 13,326 & 1,504 & 1,115 \\
\hline Carroll County.............................. & $\mathrm{MD}$ & 372,454 & 17,383 & 165,803 & 189,268 & 100.0 & 4.7 & 44.5 & 50.8 & 365,590 & 345,061 & 207,938 & 8,294 & 4,878 & 6.1 & 12,624 & 2,067 & 1,089 \\
\hline 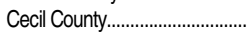 & $\mathrm{MD}$ & 218,948 & 20,775 & 110,329 & 87,844 & 100.0 & 9.5 & 50.4 & 40.1 & 211,397 & 194,289 & 119,965 & 9,376 & 3,359 & 13.1 & 12,191 & 2,809 & 1,150 \\
\hline Charles County........................... & $\mathrm{MD}$ & 375,302 & 21,870 & 172,937 & 180,495 & 100.0 & 5.8 & 46.1 & 48.1 & 363,345 & 341,003 & 189,509 & 13,419 & 3,120 & 9.4 & 12,700 & 3,158 & 1,147 \\
\hline 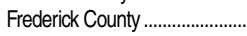 & $\mathrm{MD}$ & 569,945 & 39,408 & 245,681 & 284,856 & 100.0 & 6.9 & 43.1 & 50.0 & 543,073 & 495,060 & 307,758 & 27,635 & 12,187 & 7.7 & 12,319 & 4,006 & 1,189 \\
\hline Harford County ............................. & $\mathrm{MD}$ & 576,683 & 41,605 & 248,376 & 286,702 & 100.0 & 7.2 & 43.1 & 49.7 & 563,405 & 489,522 & 299,865 & 50,282 & 11,390 & 10.3 & 12,750 & 5,652 & 1,235 \\
\hline Howard County.......................... & $\mathrm{MD}$ & 890,726 & 39,988 & 263,585 & 587,153 & 100.0 & 4.5 & 29.6 & 65.9 & 863,087 & 772,020 & 506,984 & 64,858 & 14,626 & 6.6 & 15,139 & 4,442 & 1,188 \\
\hline Montgomery County .................. & $\mathrm{MD}$ & $2,687,215$ & 165,503 & 666,593 & $1,855,119$ & 100.0 & 6.2 & 24.8 & 69.0 & $2,496,790$ & $2,221,014$ & $1,411,717$ & 197,061 & 42,649 & 7.8 & 15,421 & 22,589 & 1,708 \\
\hline Prince George's County............ & $\mathrm{MD}$ & $1,910,110$ & 246,936 & 927,357 & 735,817 & 100.0 & 12.9 & 48.5 & 38.5 & $1,976,560$ & $1,744,944$ & $1,012,380$ & 159,354 & 21,521 & 11.0 & 13,775 & 25,149 & 1,570 \\
\hline Saint Mary's County................... & $\mathrm{MD}$ & 226,049 & 22,467 & 108,687 & 94,895 & 100.0 & 9.9 & 48.1 & 42.0 & 227,674 & 212,780 & 122,987 & 10,632 & 2,379 & 10.9 & 12,320 & 2,495 & 1,140 \\
\hline 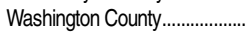 & $\mathrm{MD}$ & 304,441 & 31,388 & 168,218 & 104,835 & 100.0 & 10.3 & 55.3 & 34.4 & 312,774 & 277,376 & 166,098 & 30,475 & 1,849 & 15.2 & 12,491 & 5,110 & 1,368 \\
\hline Boston ................................... & $\mathrm{MA}$ & $1,250,911$ & 151,199 & 325,583 & 774,129 & 100.0 & 12.1 & 26.0 & 61.9 & $1,225,600$ & $1,168,506$ & 704,660 & 34,954 & 11,059 & 32.5 & 20,852 & 40,755 & 1,749 \\
\hline Brockton.................. & MA & 227,784 & 21,669 & 149,784 & 56,331 & 100.0 & 9.5 & 65.8 & 24.7 & 223,684 & 216,791 & 135,900 & 1,301 & 1,256 & 22.0 & 13,697 & 5,203 & 1,389 \\
\hline
\end{tabular}

See notes at end of table. 
Table 215.20. Revenues, expenditures, poverty rate, and Title I allocations of public school districts enrolling more than 15,000 students: 2010-11 and fiscal year 2013-Continued

\begin{tabular}{|c|c|c|c|c|c|c|c|c|c|c|c|c|c|c|c|c|c|c|c|}
\hline \multirow[b]{3}{*}{ Name of district } & \multirow[b]{3}{*}{ State } & \multirow{2}{*}{\multicolumn{4}{|c|}{$\begin{array}{l}\text { Revenues by source of funds, 2010-11 } \\
\text { (in thousands of current dollars) }\end{array}$}} & \multirow{2}{*}{\multicolumn{4}{|c|}{ Percentage distribution of revenues, $2010-11$}} & \multicolumn{5}{|c|}{ Expenditures, 2010-11 (in thousands of current dollars) } & \multirow[b]{3}{*}{ 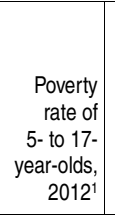 } & \multirow{3}{*}{$\begin{array}{r}\text { Current } \\
\text { expenditure } \\
\text { per pupil, } \\
2010-11 \\
\text { (in current } \\
\text { dollars) } \\
\end{array}$} & \multirow{2}{*}{\multicolumn{2}{|c|}{$\begin{array}{l}\text { Title I allocations, } \\
\text { fiscal year } 2013\end{array}$}} & \\
\hline & & & & & & & & & & \multirow[b]{2}{*}{ Total ${ }^{5}$} & \multicolumn{2}{|c|}{ Current expenditures } & \multirow[b]{2}{*}{$\begin{array}{r}\text { Capital } \\
\text { outlay }\end{array}$} & \multirow[b]{2}{*}{$\begin{array}{r}\text { Interest on } \\
\text { school debt }\end{array}$} & & & & & \\
\hline & & Total & Federal & State & Local & Total & Federal & State & Local & & Total & Instruction & & & & & \begin{tabular}{|} 
Total $^{3}$ \\
(in thousands \\
of current \\
dollars)
\end{tabular} & $\begin{array}{r}\text { Per poverty } \\
\text { child } \\
\text { (in current } \\
\text { dollars) }\end{array}$ & \\
\hline 1 & 2 & 3 & 4 & 5 & 6 & 7 & 8 & 9 & 10 & 11 & 12 & 13 & 14 & 15 & 16 & 17 & 18 & 19 & \\
\hline 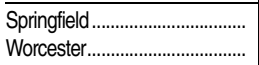 & $\begin{array}{l}\mathrm{MA} \\
\mathrm{MA}\end{array}$ & $\begin{array}{l}479,069 \\
409,239\end{array}$ & $\begin{array}{l}80,982 \\
58,977\end{array}$ & $\begin{array}{l}340,687 \\
240,987\end{array}$ & $\begin{array}{r}57,400 \\
109,275\end{array}$ & $\begin{array}{l}100.0 \\
100.0\end{array}$ & $\begin{array}{l}16.9 \\
14.4\end{array}$ & $\begin{array}{l}71.1 \\
58.9\end{array}$ & $\begin{array}{l}12.0 \\
26.7\end{array}$ & $\begin{array}{l}514,147 \\
422,548\end{array}$ & $\begin{array}{l}440,421 \\
372,261\end{array}$ & $\begin{array}{l}280,451 \\
252,837\end{array}$ & $\begin{array}{l}56,845 \\
28,843\end{array}$ & $\begin{array}{r}10,262 \\
9,705\end{array}$ & $\begin{array}{l}32.8 \\
27.0\end{array}$ & $\begin{array}{l}17,468 \\
15,388\end{array}$ & $\begin{array}{l}19,907 \\
11,385\end{array}$ & $\begin{array}{l}2,048 \\
1,524\end{array}$ & \\
\hline Ann Arbor......... & $\mathrm{Ml}$ & 228,229 & 8,890 & 91,348 & 127,991 & 100.0 & 3.9 & 40.0 & 56.1 & 223,198 & 190,869 & 111,911 & 10,258 & 8.815 & 12.5 & 11,386 & 2,166 & 873 & \\
\hline Chippewa Valley ....................... & $\mathrm{Ml}$ & 169,577 & 11,841 & 102,454 & 55,282 & 100.0 & 7.0 & 60.4 & 32.6 & 179,511 & 135,879 & 87,904 & 16,600 & 24,820 & 11.1 & 8,446 & 1,681 & 845 & \\
\hline Dearborn City............................. & $\mathrm{Ml}$ & 225,748 & 27,801 & 129,968 & 67,979 & 100.0 & 12.3 & 57.6 & 30.1 & 226,104 & 206,156 & 125,313 & 10,104 & 7,344 & 43.8 & 11,052 & 12,947 & 1,323 & \\
\hline Detroit City................................ & $\mathrm{Ml}$ & $1,250,847$ & 451,471 & 561,782 & 237,594 & 100.0 & 36.1 & 44.9 & 19.0 & $1,441,082$ & $1,043,177$ & 557,814 & 255,458 & 131,754 & 51.0 & 13,416 & 154,750 & 2,241 & \\
\hline Grand Rapids.... & $\mathrm{Ml}$ & 267,937 & 45,148 & 133,342 & 89,447 & 100.0 & 16.9 & 49.8 & 33.4 & 263,961 & 226,041 & 124,899 & 3,905 & 8,062 & 31.0 & 12,471 & 14,323 & 1,531 & \\
\hline Livonia ....................................... & $\mathrm{MI}$ & 181,473 & 6,040 & 108,431 & 67,002 & 100.0 & 3.3 & 59.8 & 36.9 & 186,640 & 169,790 & 103,329 & 7,892 & 4,558 & 10.2 & 10,872 & 1,534 & 851 & \\
\hline Plymouth-Canton ....................... & MI & 192,368 & 9,985 & 119,283 & 63,100 & 100.0 & 5.2 & 62.0 & 32.8 & 196,382 & 170,636 & 101,381 & 8,850 & 11,045 & 7.5 & 9,026 & 1,457 & 844 & \\
\hline 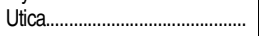 & $\mathrm{Ml}$ & 285,095 & 12,773 & 194,963 & 77,359 & 100.0 & 4.5 & 68.4 & 27.1 & 284,364 & 258,756 & 176,239 & 11,222 & 9,259 & 13.9 & 8,927 & 4,113 & 935 & \\
\hline Walled Lake Consolidated....... & $\mathrm{MI}$ & 181,335 & 7,117 & 102,744 & 71,474 & 100.0 & 3.9 & 56.7 & 39.4 & 170,453 & 158,457 & 101,547 & 3,147 & 6,744 & 11.0 & 10,253 & 1,622 & 841 & \\
\hline Warren Consolidated ................ & $\mathrm{MI}$ & 189,814 & 15,847 & 107,610 & 66,357 & 100.0 & 8.3 & 56.7 & 35.0 & 196,790 & 167,265 & 100,477 & 20,266 & 8,235 & 23.2 & 10,573 & 4,143 & 1,042 & \\
\hline Anoka-Hennepin .............. & MN & 492,983 & 25,569 & 297,750 & 169,664 & 100.0 & 5.2 & 60.4 & 34.4 & 436,895 & 386,185 & 259,798 & 19,985 & 7,187 & 8.7 & 9,862 & 4,067 & 1,055 & \\
\hline Minneapolis................................ & $\mathrm{MN}$ & 644,152 & 84,403 & 336,806 & 222,943 & 100.0 & 13.1 & 52.3 & 34.6 & 607,920 & 497,624 & 345,382 & 59,507 & 18,017 & 29.4 & 14,245 & 24,632 & 1,645 & \\
\hline Osseo Public............................... & $\mathrm{MN}$ & 300,098 & 20,792 & 167,916 & 111,390 & 100.0 & 6.9 & 56.0 & 37.1 & 278,063 & 230,384 & 158,690 & 16,404 & 10,360 & 12.1 & 10,943 & 3,167 & 1,002 & \\
\hline Rochester................................. & $\mathrm{MN}$ & 184,798 & 11,084 & 114,935 & 58,779 & 100.0 & 6.0 & 62.2 & 31.8 & 176,517 & 148,621 & 96,165 & 11,687 & 6,318 & 10.9 & 9,088 & 2,052 & 912 & \\
\hline Rosemount-Apple Valley-Eagan. & $\mathrm{MN}$ & 349,696 & 12,928 & 205,142 & 131,626 & 100.0 & 3.7 & 58.7 & 37.6 & 317,698 & 283,430 & 202,802 & 19,677 & 3,405 & 7.2 & 10,273 & 1,889 & 899 & \\
\hline Saint Paul ................................... & $\mathrm{MN}$ & 616,922 & 85,582 & 374,099 & 157,241 & 100.0 & 13.9 & 60.6 & 25.5 & 610,394 & 528,803 & 371,445 & 33,444 & 15,857 & 29.5 & 13,801 & 24,211 & 1,660 & \\
\hline South Washington County........ & $\mathrm{MN}$ & 207,639 & 9,168 & 118,831 & 79,640 & 100.0 & 4.4 & 57.2 & 38.4 & 220,478 & 161,791 & 106,690 & 27,402 & 15,236 & 5.0 & 9,269 & 890 & 881 & \\
\hline DeSoto County.......................... & MS & 250,637 & 37,455 & 124,193 & 88,989 & 100.0 & 14.9 & 49.6 & 35.5 & 208,945 & 191,590 & 112,516 & 8,372 & 8,420 & 14.2 & 6,003 & 3,576 & 740 & \\
\hline Jackson ........................................... & MS & 282,490 & 71,656 & 120,405 & 90,429 & 100.0 & 25.4 & 42.6 & 32.0 & 319,241 & 261,636 & 146,433 & 47,009 & 9,862 & 39.6 & 8,616 & 15,438 & 1,187 & \\
\hline 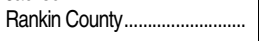 & MS & 162,014 & 23,116 & 71,554 & 67,344 & 100.0 & 14.3 & 44.2 & 41.6 & 142,002 & 133,349 & 79,988 & 4,030 & 3,939 & 14.0 & 7,042 & 2,677 & 889 & \\
\hline Columbia, $93 \ldots . . . . . .$. & MO & 197,178 & 21,528 & 73,165 & 102,485 & 100.0 & 10.9 & 37.1 & 52.0 & 196,354 & 161,329 & 97,341 & 23,593 & 5,851 & 18.1 & 9,193 & 3,399 & 978 & \\
\hline Fort Zumwalt, R-II.. & MO & 191,281 & 14,123 & 77,148 & 100,010 & 100.0 & 7.4 & 40.3 & 52.3 & 196,403 & $\begin{array}{l}176,515 \\
\end{array}$ & 109,983 & 11,270 & 5,931 & 5.5 & 9,314 & 970 & 774 & \\
\hline Francis Howell, R-III.................. & MO & 205,707 & 15,135 & 73,311 & 117,261 & 100.0 & 7.4 & 35.6 & 57.0 & 216,920 & 173,220 & 112,073 & 29,087 & 6,606 & 5.3 & 8,669 & 865 & 764 & ) \\
\hline 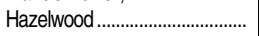 & MO & 225,768 & 21,270 & 86,891 & 117,607 & 100.0 & 9.4 & 38.5 & 52.1 & 199,480 & 183,217 & 106,697 & 3,946 & 8,478 & 18.4 & 9,821 & 4,012 & 1,011 & \\
\hline Kansas City, 33........................ & MO & 259,180 & 60,762 & 60,666 & 137,752 & 100.0 & 23.4 & 23.4 & 53.1 & 270,864 & 243,337 & 134,000 & 11,996 & 2,267 & 39.3 & 14,045 & 15,123 & 1,304 & D \\
\hline Lee's Summit, R-VII.................. & MO & 207,468 & 16,395 & 78,569 & 112,504 & 100.0 & 7.9 & 37.9 & 54.2 & 197,167 & 161,453 & 102,371 & 18,262 & 12,324 & 8.7 & 9,069 & 1,329 & 782 & - \\
\hline North Kansas City, 74 .............. & MO & 216,366 & 19,875 & 72,436 & 124,055 & 100.0 & 9.2 & 33.5 & 57.3 & 204,047 & 177,704 & 104,733 & 9,005 & 11,610 & 12.1 & 9,470 & 2,842 & 1,127 & तु \\
\hline Parkway, C-2 & MO & 222,352 & 5,865 & 47,240 & 169,247 & 100.0 & 2.6 & 21.2 & 76.1 & 252,416 & 206,919 & 115,667 & 33,940 & 7,341 & 6.1 & 11,852 & 1,072 & 766 & u \\
\hline Rockwood, R-VI....................... & MO & 250,132 & 8,514 & 66,894 & 174,724 & 100.0 & 3.4 & 26.7 & 69.9 & 266,737 & 209,242 & 122,859 & 37,955 & 9,766 & 4.7 & 9,168 & 573 & 471 & \\
\hline Saint Louis City......................... & MO & 377,916 & 90,079 & 95,003 & 192,834 & 100.0 & 23.8 & 25.1 & 51.0 & 381,698 & 342,900 & 178,261 & 11,758 & 10,439 & 35.6 & 13,670 & 31,940 & 1,957 & $\frac{\mathrm{m}}{\mathrm{Q}}$ \\
\hline Springfield, R-XII....................... & MO & 239,367 & 35,190 & 77,437 & 126,740 & 100.0 & 14.7 & 32.4 & 52.9 & 231,152 & 201,599 & 123,260 & 16,449 & 11,051 & 23.6 & 8,152 & 7,030 & 1,081 & \\
\hline 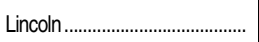 & $\mathrm{NE}$ & 410,068 & 68,148 & 111,640 & 230,280 & 100.0 & 16.6 & 27.2 & 56.2 & 420,226 & 349,608 & 239,957 & 52,900 & 17,625 & 15.8 & 9,739 & 9,156 & 1,405 & \\
\hline Millard......................................... & $\mathrm{NE}$ & 247,034 & 23,770 & 91,616 & 131,648 & 100.0 & 9.6 & 37.1 & 53.3 & 223,590 & 201,286 & 120,272 & 15,144 & 6,017 & 5.3 & 8,835 & 1,669 & 1,266 & 蟋 \\
\hline 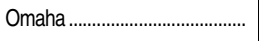 & $\mathrm{NE}$ & 620,026 & 130,856 & 188,449 & 300,721 & 100.0 & 21.1 & 30.4 & 48.5 & 561,788 & 529,106 & 346,350 & 19,755 & 11,644 & 21.9 & 10,710 & 22,826 & 1,681 & 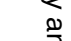 \\
\hline Clark County................................. & NV & $2,927,746$ & 311,131 & $1,642,426$ & 974,189 & 100.0 & 10.6 & 56.1 & 33.3 & $3,022,858$ & $2,597,220$ & $1,546,484$ & 202,283 & 206,687 & 21.7 & 8,270 & 81,535 & 1,072 & \\
\hline 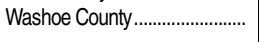 & NV & 618,416 & 71,782 & 363,449 & 183,185 & 100.0 & 11.6 & 58.8 & 29.6 & 620,301 & 546,408 & 312,028 & 45,366 & 24,716 & 16.0 & 8,487 & 11,972 & 1,045 & $\stackrel{\infty}{\infty}$ \\
\hline Elizabeth......................................... & $\mathrm{NJ}$ & 439,500 & 41,355 & 346,430 & 51,715 & 100.0 & 9.4 & 78.8 & 11.8 & 444,221 & 427,229 & 262,724 & 1,923 & 0 & 23.4 & 17,612 & 8,304 & 1,617 & 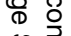 \\
\hline Jersey City ................................... & $\mathrm{NJ}$ & 658,366 & 57,402 & 490,175 & 110,789 & 100.0 & 8.7 & 74.5 & 16.8 & 649,989 & 635,445 & 412,220 & 3,846 & 4,483 & 25.2 & 18,416 & 15,431 & 1,755 & \\
\hline Newark ....................................... & $\mathrm{NJ}$ & $1,037,754$ & 91,883 & 826,802 & 119,069 & 100.0 & 8.9 & 79.7 & 11.5 & $1,055,182$ & 990,665 & 595,737 & 39,798 & 68 & 33.3 & 24,025 & 31,258 & 1,898 & \\
\hline 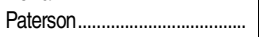 & NJ & 550,405 & 55,170 & 449,740 & 45,495 & 100.0 & 10.0 & 81.7 & 8.3 & 550,139 & 505,148 & 327,980 & 5,833 & 393 & 32.6 & 16,113 & 18,698 & 1,999 & \\
\hline Toms River Regional .................. & $\mathrm{NJ}$ & 229,128 & 10,260 & 76,871 & 141,997 & 100.0 & 4.5 & 33.5 & 62.0 & 227,793 & 221,885 & 132,436 & 804 & 3,287 & 9.4 & 12,837 & 1,967 & 1,150 & 므을 \\
\hline See notes at end of table. & & & & & & & & & & & & & & & & & & & \\
\hline
\end{tabular}




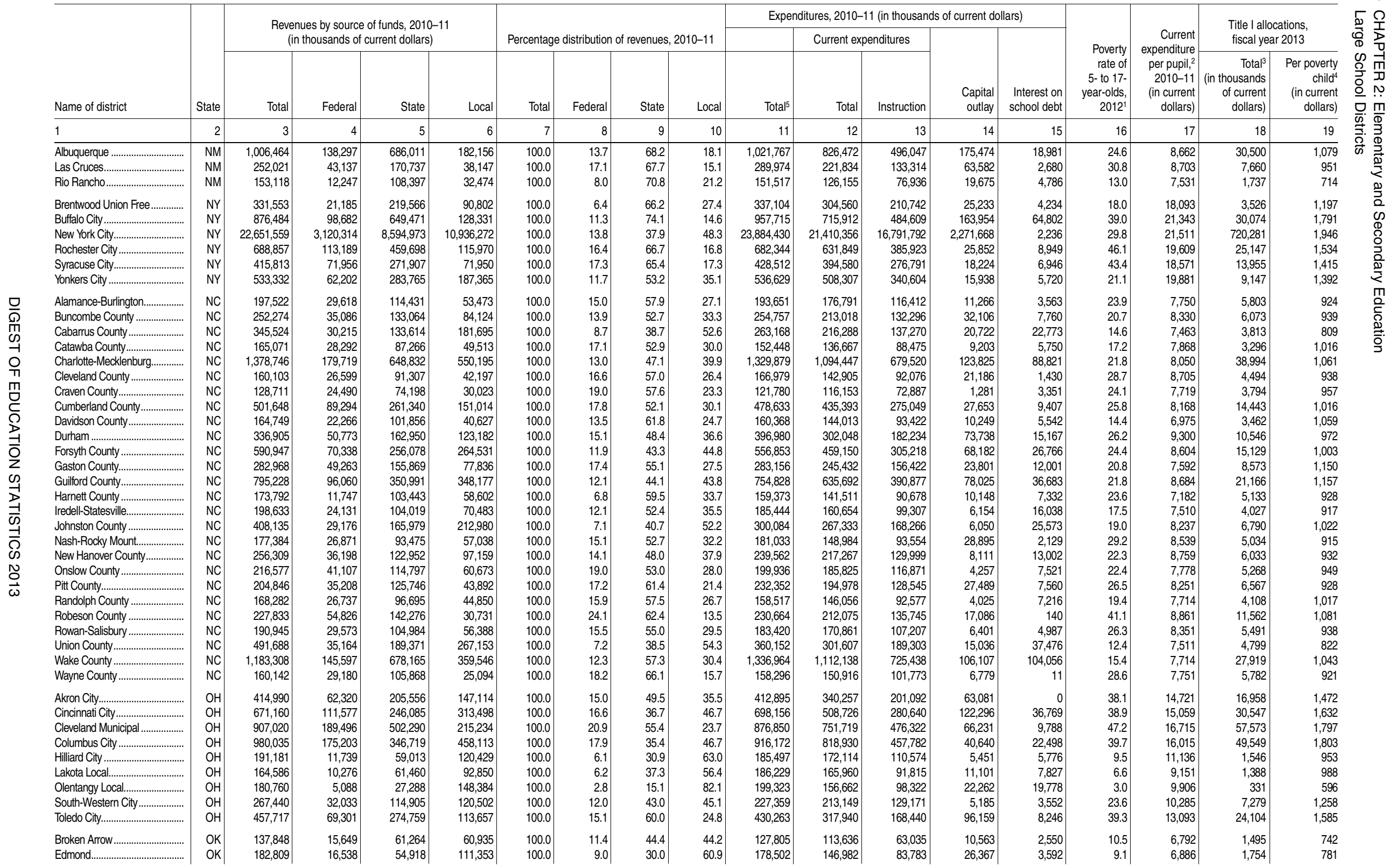

See notes at end of table. 
Table 215.20. Revenues, expenditures, poverty rate, and Title I allocations of public school districts enrolling more than 15,000 students: 2010-11 and fiscal year 2013-Continued

\begin{tabular}{|c|c|c|c|c|c|c|c|c|c|c|c|c|c|c|c|c|c|c|c|}
\hline \multirow[b]{3}{*}{ Name of district } & \multirow[b]{3}{*}{ State } & \multirow{2}{*}{\multicolumn{4}{|c|}{$\begin{array}{l}\text { Revenues by source of funds, 2010-11 } \\
\text { (in thousands of current dollars) }\end{array}$}} & \multirow{2}{*}{\multicolumn{4}{|c|}{ Percentage distribution of revenues, 2010-11 }} & \multicolumn{5}{|c|}{ Expenditures, 2010-11 (in thousands of current dollars) } & \multirow[b]{3}{*}{$\begin{array}{r}\text { Poverty } \\
\text { rate of } \\
5-\text { to } 17- \\
\text { year-olds, } \\
2012^{1}\end{array}$} & \multirow{3}{*}{$\begin{array}{r}\text { Current } \\
\text { expenditure } \\
\text { per pupil, } \\
2010-11 \\
\text { (in current } \\
\text { dollars) }\end{array}$} & \multirow{2}{*}{\multicolumn{2}{|c|}{$\begin{array}{l}\text { Tittle I allocations, } \\
\text { fiscal year } 2013\end{array}$}} & \\
\hline & & & & & & & & & & \multirow[b]{2}{*}{ Total $^{5}$} & \multicolumn{2}{|c|}{ Current expenditures } & \multirow[b]{2}{*}{$\begin{array}{r}\text { Capital } \\
\text { outlay }\end{array}$} & \multirow[b]{2}{*}{$\begin{array}{r}\text { Interest on } \\
\text { school debt }\end{array}$} & & & & & \\
\hline & & Total & Federal & State & Local & Total & Federal & State & Local & & Total & Instruction & & & & & \begin{tabular}{|} 
Total $^{3}$ \\
(in thousands \\
of current \\
dollars) \\
\end{tabular} & $\begin{array}{r}\text { Per poverty } \\
\text { child } \\
\text { (in current } \\
\text { dollars) }\end{array}$ & \\
\hline 1 & 2 & 3 & 4 & 5 & 6 & 7 & 8 & 9 & 10 & 11 & 12 & 13 & 14 & 15 & 16 & 17 & 18 & 19 & \\
\hline Lawton ......................................... & $\mathrm{OK}$ & 143,468 & 33,281 & 76,062 & 34,125 & 100.0 & 23.2 & 53.0 & 23.8 & 140,092 & 130,755 & 72,875 & 7,524 & 678 & 23.7 & 8,072 & 3,811 & 999 & \\
\hline 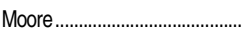 & $\mathrm{OK}$ & 175,380 & 20,599 & 84,550 & 70,231 & 100.0 & 11.7 & 48.2 & 40.0 & 183,991 & 152,725 & 92,629 & 27,575 & 3,152 & 11.1 & 6,871 & 2,300 & 886 & \\
\hline Norman ………………………...... & $\mathrm{OK}$ & 124,989 & 16,104 & 49,918 & 58,967 & 100.0 & 12.9 & 39.9 & 47.2 & 124,700 & 109,474 & 67,169 & 12,985 & 1,878 & 14.2 & 7,476 & 2,233 & 1,042 & \\
\hline Oklahoma City........................... & $\mathrm{OK}$ & 478,115 & 89,428 & 170,862 & 217,825 & 100.0 & 18.7 & 35.7 & 45.6 & 365,985 & 343,826 & 187,020 & 13,625 & 5,847 & 31.6 & 7,998 & 20,883 & 1,314 & \\
\hline Putnam City ................................ & $\mathrm{OK}$ & 166,255 & 25,441 & 69,609 & 71,205 & 100.0 & 15.3 & 41.9 & 42.8 & 152,850 & 135,891 & 80,460 & 14,238 & 2,184 & 21.9 & 7,127 & 4,267 & 983 & \\
\hline Tulsa ........................................ & $\mathrm{OK}$ & 398,371 & 76,180 & 155,238 & 166,953 & 100.0 & 19.1 & 39.0 & 41.9 & 444,830 & 351,482 & 185,792 & 83,098 & 5,280 & 28.4 & 8,469 & 16,489 & 1,229 & \\
\hline Beaverton, $48 \mathrm{~J}$............. & $\mathrm{OR}$ & 384,571 & 43,948 & 165,129 & 175,494 & 100.0 & 11.4 & 42.9 & 45.6 & 382,292 & 335,744 & 207,649 & 18,253 & 26,638 & 12.6 & 8,631 & 5,675 & 987 & \\
\hline Bend-Lapine, SD1 ................... & $\mathrm{OR}$ & 163,401 & 18,776 & 54,056 & 90,569 & 100.0 & 11.5 & 33.1 & 55.4 & 160,692 & 133,367 & 78,506 & 14,768 & 11,787 & 16.2 & 8,246 & 3,752 & 1,302 & \\
\hline Eugene, SD4J .............................. & $\mathrm{OR}$ & 183,385 & 21,851 & 63,656 & 97,878 & 100.0 & 11.9 & 34.7 & 53.4 & 183,797 & 169,995 & 102,961 & 4,455 & 8,286 & 18.3 & 9,782 & 3,889 & 1,125 & \\
\hline Hillsboro, SD1J........................... & $\mathrm{OR}$ & 210,638 & 27,021 & 92,378 & 91,239 & 100.0 & 12.8 & 43.9 & 43.3 & 211,008 & 184,502 & 106,842 & 9,284 & 16,554 & 16.0 & 8,818 & 4,064 & 1,053 & \\
\hline North Clackamas, SD12.......... & $\mathrm{OR}$ & 167,960 & 16,534 & 78,168 & 73,258 & 100.0 & 9.8 & 46.5 & 43.6 & 176,796 & 141,903 & 79,690 & 18,505 & 13,603 & 15.3 & 8,146 & 3,039 & 1,033 & \\
\hline Portland, SD1J.......................... & $\mathrm{OR}$ & 526,515 & 93,813 & 157,902 & 274,800 & 100.0 & 17.8 & 30.0 & 52.2 & 554,184 & 527,521 & 312,730 & 21,095 & 2,044 & 19.8 & 11,513 & 13,520 & 1,246 & \\
\hline Salem-Keizer, SD24J................ & $\mathrm{OR}$ & 399,928 & 59,565 & 226,956 & 113,407 & 100.0 & 14.9 & 56.7 & 28.4 & 479,367 & 379,977 & 231,112 & 78,712 & 19,449 & 27.8 & 9,405 & 15,429 & 1,227 & \\
\hline Allentown City ............................ & $\mathrm{PA}$ & 233,892 & 42,793 & 113,965 & 77,134 & 100.0 & 18.3 & 48.7 & 33.0 & 253,127 & 189,106 & 121,093 & 26,152 & 7,409 & 37.5 & 10,722 & 11,139 & 1,387 & \\
\hline Central Bucks........................ & $\mathrm{PA}$ & 285,202 & 6,757 & 44,162 & 234,283 & 100.0 & 2.4 & 15.5 & 82.1 & 253,451 & 211,143 & 134,588 & 16,479 & 14,164 & 3.8 & 10,334 & 591 & 692 & \\
\hline Philadelphia City......................... & $\mathrm{PA}$ & $2,896,799$ & 636,770 & $1,411,582$ & 848,447 & 100.0 & 22.0 & 48.7 & 29.3 & $3,142,979$ & $1,934,404$ & $1,109,832$ & 203,291 & 98,037 & 37.9 & 11,637 & 176,989 & 1,938 & \\
\hline Pittsburgh ........................................ & $\mathrm{PA}$ & 651,020 & 127,044 & 237,904 & 286,072 & 100.0 & 19.5 & 36.5 & 43.9 & 646,102 & 443,694 & 237,573 & 41,789 & 24,595 & 29.9 & 15,856 & 18,792 & 1,809 & \\
\hline Reading.................................... & $\mathrm{PA}$ & 245,504 & 55,350 & 154,143 & 36,011 & 100.0 & 22.5 & 62.8 & 14.7 & 230,256 & 196,244 & 116,775 & 8,413 & 10,826 & 38.0 & 10,786 & 15,407 & 2,169 & \\
\hline Providence......... & $\mathrm{RI}$ & 434,634 & 79,999 & 223,963 & 130,672 & 100.0 & 18.4 & 51.5 & 30.1 & 421,683 & 394,629 & 227,883 & 3,518 & 15,981 & 37.9 & 16,741 & 21,321 & 1,950 & \\
\hline Aiken, $01 \ldots \ldots . . .$. & $\mathrm{sc}$ & 222,980 & 33,840 & 110,151 & 78,989 & 100.0 & 15.2 & 49.4 & 35.4 & 215,515 & 194,161 & 118,536 & 19,240 & 1,431 & 27.3 & 7,882 & 7,155 & 971 & \\
\hline Beaufort, 01 ................................... & $\mathrm{sC}$ & 271,918 & 25,210 & 76,845 & 169,863 & 100.0 & 9.3 & 28.3 & 62.5 & 287,792 & 222,970 & 126,844 & 46,003 & 17,902 & 22.4 & 11,348 & 5,004 & 956 & \\
\hline Berkeley, $01 \ldots \ldots$ & $\mathrm{sc}$ & 285,092 & 42,152 & 131,312 & 111,628 & 100.0 & 14.8 & 46.1 & 39.2 & 279,747 & 240,665 & 134,497 & 14,734 & 21,510 & 22.6 & 8,186 & 7,226 & 985 & \\
\hline Charleston, 01 ......................... & $\mathrm{sc}$ & 590,054 & 79,180 & 172,564 & 338,310 & 100.0 & 13.4 & 29.2 & 57.3 & 579,363 & 456,750 & 268,604 & 72,516 & 42,873 & 22.7 & 10,463 & 13,637 & 1,189 & \\
\hline 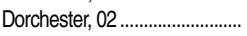 & $\mathrm{sc}$ & 193,993 & 20,603 & 105,926 & 67,464 & 100.0 & 10.6 & 54.6 & 34.8 & 191,593 & 161,988 & 98,678 & 17,623 & 9,441 & 17.3 & 7,117 & 4,097 & 955 & \\
\hline 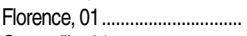 & $\mathrm{sC}$ & 160,531 & 23,152 & 77,473 & 59,906 & 100.0 & 14.4 & 48.3 & 37.3 & 153,754 & 140,351 & 81,855 & 11,171 & 475 & 24.9 & 8,817 & 3,983 & 955 & $\Rightarrow$ \\
\hline Greenville, $01 \ldots \ldots \ldots \ldots$ & $\mathrm{sC}$ & 701,103 & 82,614 & 325,636 & 292,853 & 100.0 & 11.8 & 46.4 & 41.8 & 655,980 & 553,544 & 320,298 & 44,749 & 55,165 & 23.0 & 7,696 & 21,079 & 1,125 & \\
\hline 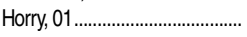 & $\mathrm{sc}$ & 465,365 & 53,707 & 137,457 & 274,201 & 100.0 & 11.5 & 29.5 & 58.9 & 432,741 & 377,305 & 225,279 & 33,191 & 19,769 & 28.6 & 9,791 & 13,020 & 1,148 & \\
\hline Lexington, 01 ............................. & sc & 253,981 & 19,799 & 125,309 & 108,873 & 100.0 & 7.8 & 49.3 & 42.9 & 310,353 & 208,888 & 117,171 & 85,304 & 15,943 & 15.5 & 9,205 & 3,409 & 919 & \\
\hline Lexington, 05 ............................. & $\mathrm{sC}$ & 199,323 & 15,066 & 99,437 & 84,820 & 100.0 & 7.6 & 49.9 & 42.6 & 219,818 & 169,745 & 97,007 & 45,422 & 3,238 & 13.1 & 10,165 & 1,736 & 757 & 罗 \\
\hline Pickens, $01 \ldots \ldots \ldots$ & $\mathrm{sc}$ & 157,184 & 19,713 & 74,152 & 63,319 & 100.0 & 12.5 & 47.2 & 40.3 & 285,337 & 125,196 & 74,560 & 142,676 & 16,762 & 19.3 & 7,672 & 3,325 & 978 & \\
\hline Richland, 01 .............................. & $\mathrm{sc}$ & 358,500 & 44,001 & 104,280 & 210,219 & 100.0 & 12.3 & 29.1 & 58.6 & 330,466 & 291,211 & 164,086 & 14,645 & 23,368 & 30.4 & 12,024 & 9,643 & 1,149 & \\
\hline 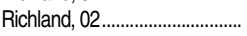 & $\mathrm{sc}$ & 307,962 & 29,266 & 145,421 & 133,275 & 100.0 & 9.5 & 47.2 & 43.3 & 381,275 & 248,565 & 143,546 & 102,860 & 27,511 & 15.3 & 9,684 & 3,751 & 928 & $\frac{\mathrm{m}}{\mathrm{D}}$ \\
\hline Sumter, 01................................. & SC & 88,366 & 15,831 & 38,893 & 33,642 & 100.0 & 17.9 & 44.0 & 38.1 & 112,173 & 73,819 & 36,959 & 19,192 & 18,770 & 26.8 & 8,644 & 5,314 & 1,032 & \\
\hline York, 03..................................... & $\mathrm{sc}$ & 175,627 & 19,829 & 84,938 & 70,860 & 100.0 & 11.3 & 48.4 & 40.3 & 161,370 & 147,649 & 86,169 & 5,485 & 7,236 & 21.9 & 8,513 & 4,092 & 973 & \\
\hline Sioux Falls.................................. & $\mathrm{SD}$ & 203,192 & 30,610 & 59,277 & 113,305 & 100.0 & 15.1 & 29.2 & 55.8 & 196,951 & 175,474 & 110,264 & 14,695 & 4,091 & 12.6 & 8,204 & 4,373 & 1,447 & 7 \\
\hline 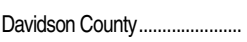 & $\mathrm{TN}$ & 822,265 & 130,054 & 227,502 & 464,709 & 100.0 & 15.8 & 27.7 & 56.5 & 854,181 & 772,094 & 443,775 & 57,005 & 22,636 & 27.6 & 9,800 & 28,958 & 1,121 & \\
\hline Hamilton County...................... & $\mathrm{TN}$ & 383,582 & 57,199 & 126,864 & 199,519 & 100.0 & 14.9 & 33.1 & 52.0 & 383,072 & 368,185 & 231,880 & 6,791 & 5,302 & 26.6 & 8,645 & 14,090 & 1,010 & \\
\hline Knox County .................................. & $\mathrm{TN}$ & 480,087 & 58,015 & 159,097 & 262,975 & 100.0 & 12.1 & 33.1 & 54.8 & 477,726 & 440,035 & 266,898 & 26,774 & 10,064 & 17.9 & 7,590 & 12,224 & 1,004 & \\
\hline 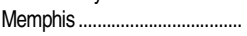 & $\mathrm{TN}$ & $1,170,410$ & 232,924 & 461,795 & 475,691 & 100.0 & 19.9 & 39.5 & 40.6 & $1,187,591$ & $1,062,330$ & 649,810 & 100,911 & 0 & 35.1 & 9,499 & 54,806 & 1,331 & \\
\hline Montgomery County .................. & $\mathrm{TN}$ & 240,573 & 40,774 & 124,364 & 75,435 & 100.0 & 16.9 & 51.7 & 31.4 & 258,520 & 228,488 & 136,771 & 20,635 & 8,918 & 22.6 & 7,673 & 6,695 & 917 & \\
\hline Rutherford County........................ & $\mathrm{TN}$ & 299,765 & 31,514 & 153,727 & 114,524 & 100.0 & 10.5 & 51.3 & 38.2 & 314,935 & 288,200 & 185,424 & 11,616 & 14,505 & 12.9 & 7,419 & 4,444 & 855 & \\
\hline 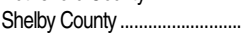 & TN & 398,743 & 35,054 & 180,615 & 183,074 & 100.0 & 8.8 & 45.3 & 45.9 & 446,059 & 377,698 & 236,345 & 41,232 & 17,924 & 10.5 & 7,917 & 6,190 & 1,004 & Ј \\
\hline Sumner County ......................... & $\mathrm{TN}$ & 219,506 & 26,639 & 113,770 & 79,097 & 100.0 & 12.1 & 51.8 & 36.0 & 226,682 & 215,428 & 135,307 & 2,898 & 6,461 & 15.1 & 7,719 & 4,303 & 941 & \\
\hline Williamson County ..................... & $\mathrm{TN}$ & 252,295 & 16,200 & 99,210 & 136,885 & 100.0 & 6.4 & 39.3 & 54.3 & 308,877 & 239,034 & 155,081 & 51,792 & 15,861 & 5.6 & 7,561 & 1,477 & 699 & \\
\hline 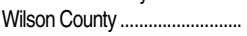 & $\mathrm{TN}$ & 121,079 & 13,070 & 57,337 & 50,672 & 100.0 & 10.8 & $\begin{array}{llll}47.4 & & l & \\
\end{array}$ & 41.9 & 152,132 & 111,665 & 69,316 & 30,614 & 6,153 & 12.8 & 7,110 & 1,611 & 706 & \\
\hline
\end{tabular}




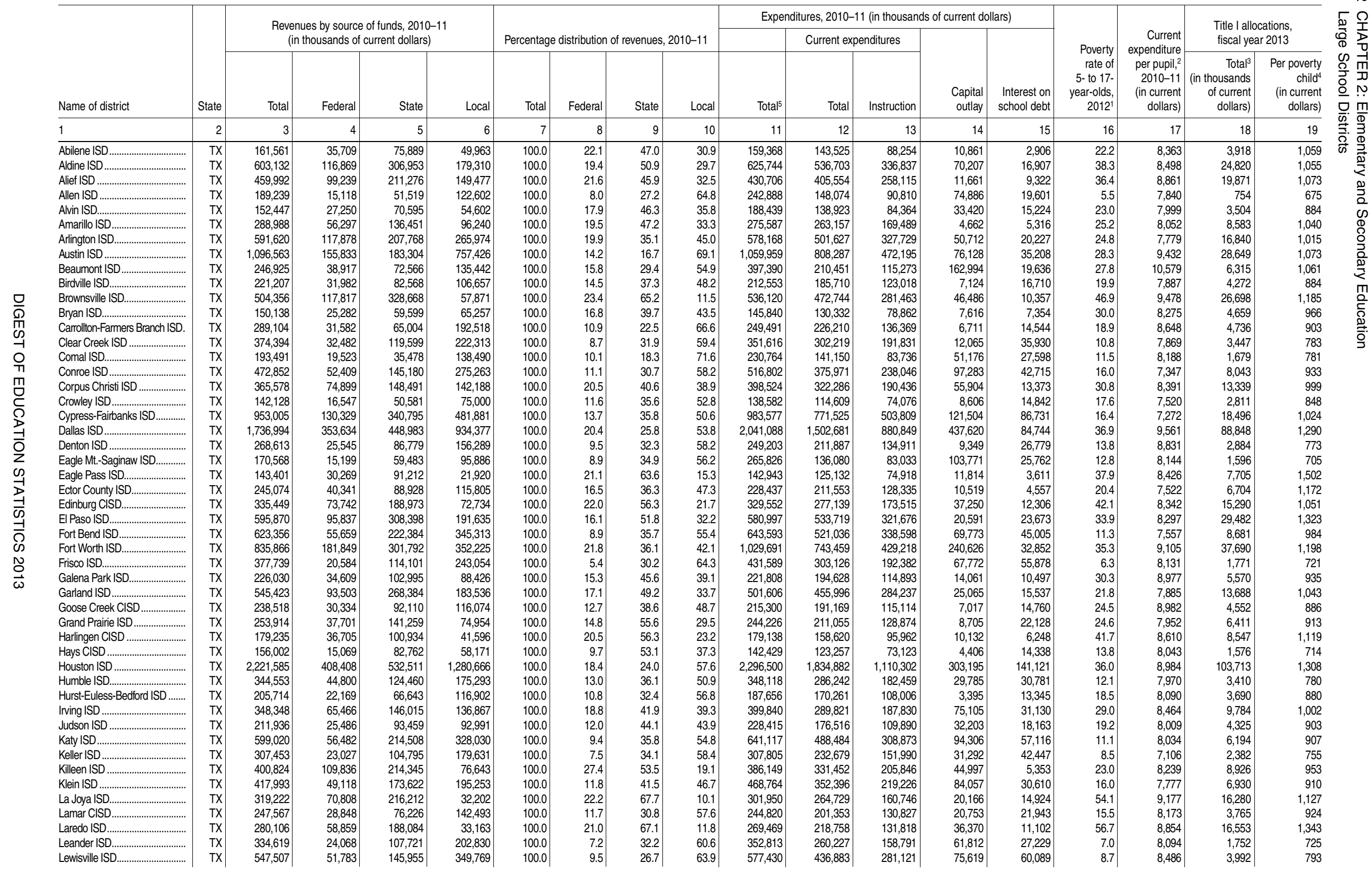

See notes at end of table. 
Table 215.20. Revenues, expenditures, poverty rate, and Title I allocations of public school districts enrolling more than 15,000 students: 2010-11 and fiscal year 2013-Continued

\begin{tabular}{|c|c|c|c|c|c|c|c|c|c|c|c|c|c|c|c|c|c|c|c|}
\hline \multirow[b]{3}{*}{ Name of district } & \multirow[b]{3}{*}{ State } & \multirow{2}{*}{\multicolumn{4}{|c|}{$\begin{array}{l}\text { Revenues by source of funds, 2010-11 } \\
\text { (in thousands of current dollars) }\end{array}$}} & \multirow{2}{*}{\multicolumn{4}{|c|}{ Percentage distribution of revenues, 2010-11 }} & \multicolumn{5}{|c|}{ Expenditures, 2010-11 (in thousands of current dollars) } & \multirow[b]{3}{*}{ 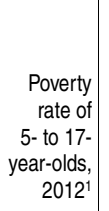 } & \multirow{3}{*}{$\begin{array}{r}\text { Current } \\
\text { expenditure } \\
\text { per pupil, } \\
2010-11 \\
\text { (in current } \\
\text { dollars) }\end{array}$} & \multirow{2}{*}{\multicolumn{2}{|c|}{$\begin{array}{l}\text { Title I allocations, } \\
\text { fiscal year } 2013\end{array}$}} & \\
\hline & & & & & & & & & & & Current exp & nditures & & & & & & & \\
\hline & & Total & Federal & State & Local & Total & Federal & State & Local & Total $^{5}$ & Total & Instruction & $\begin{array}{r}\text { Capital } \\
\text { outlay }\end{array}$ & $\begin{array}{r}\text { Interest on } \\
\text { school debt }\end{array}$ & & & \begin{tabular}{|} 
Total $^{3}$ \\
(in thousands \\
of current \\
dollars)
\end{tabular} & $\begin{array}{r}\text { Per poverty } \\
\text { child } \\
\text { (in current } \\
\text { dollars) }\end{array}$ & \\
\hline 1 & 2 & 3 & 4 & 5 & 6 & 7 & 8 & 9 & 10 & 11 & 12 & 13 & 14 & 15 & 16 & 17 & 18 & 19 & \\
\hline Lubbock ISD ............. & $T X$ & 278,973 & 60,880 & 100,782 & 117,311 & 100.0 & 21.8 & 36.1 & 42.1 & 273.463 & 237,509 & 142,314 & 24,882 & 4,428 & 26.8 & 8,217 & 8,050 & $\overline{1,013}$ & \\
\hline Mansfield ISD .......... & $\mathrm{TX}$ & 309,479 & 26,453 & 132,057 & 150,969 & 100.0 & 8.5 & 42.7 & 48.8 & 358,670 & 238,018 & 151,713 & 85,831 & 33,933 & 14.7 & 7,380 & 3,965 & 789 & \\
\hline McAllen ISD .................................. & $\mathrm{TX}$ & 241,333 & 54,448 & 110,830 & 76,055 & 100.0 & 22.6 & 45.9 & 31.5 & $\begin{array}{ll}223,193 \\
2230\end{array}$ & 208,174 & 129,183 & $\begin{array}{r}r 0,001 \\
5,450\end{array}$ & $\begin{array}{r}r 0,500 \\
5,372\end{array}$ & 39.5 & 8,125 & $\begin{array}{r}0,900 \\
10,830\end{array}$ & 1,027 & \\
\hline McKinney ISD................................. & $\mathrm{TX}$ & 252,797 & 20,011 & 82,241 & 150,545 & 100.0 & 7.9 & 32.5 & 59.6 & 235,445 & 195,909 & 124,636 & 15,071 & 20,827 & 9.7 & 8,022 & 1,900 & 737 & \\
\hline Mesquite ISD ............................... & $\mathrm{TX}$ & 374,417 & 53,304 & 218,500 & 102,613 & 100.0 & 14.2 & 58.4 & 27.4 & 349,664 & 297,734 & 186,048 & 33,182 & 17,280 & 22.9 & 7,888 & 8,323 & 949 & \\
\hline Midland ISD ............................... & $\mathrm{TX}$ & 193,538 & 28,236 & 39,170 & 126,132 & 100.0 & 14.6 & 20.2 & 65.2 & 181,877 & 171,755 & 103,124 & 2,281 & 5,674 & 18.7 & 7,902 & 5,077 & 1,071 & \\
\hline 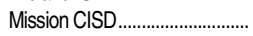 & $\mathrm{TX}$ & 166,170 & 34,878 & 107,542 & 23,750 & 100.0 & 21.0 & 64.7 & 14.3 & 159,027 & 137,058 & 81,070 & 12,347 & 7,516 & 48.6 & 8,652 & 8,219 & 1,121 & \\
\hline North East ISD............................. & $\mathrm{TX}$ & 685,916 & 74,207 & 205,551 & 406,158 & 100.0 & 10.8 & 30.0 & 59.2 & 707,237 & 559,887 & 347,024 & 86,326 & 59,586 & 16.2 & 8,406 & 12,194 & 1,008 & \\
\hline 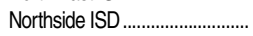 & $\mathrm{TX}$ & 927,836 & 110,664 & 347,503 & 469,669 & 100.0 & 11.9 & 37.5 & 50.6 & 979,384 & 771,040 & 487,709 & 126,224 & 72,962 & 16.9 & 8,067 & 17,862 & 1,035 & \\
\hline Northwest ISD ............................. & $\mathrm{TX}$ & 211,650 & 14,637 & 39,899 & 157,114 & 100.0 & 6.9 & 18.9 & 74.2 & 251,363 & 139,416 & 82,909 & 55,567 & 31,011 & 6.5 & 9,071 & 759 & 675 & \\
\hline Pasadena ISD................................ & $\mathrm{TX}$ & 506,146 & 96,482 & 263,595 & 146,069 & 100.0 & 19.1 & 52.1 & 28.9 & 478,268 & 446,410 & 270,450 & 12,426 & 17,660 & 29.5 & 8,549 & 16,094 & 1,011 & \\
\hline Pearland ISD ............................... & $\mathrm{TX}$ & 169,204 & 18,044 & 65,109 & 86,051 & 100.0 & 10.7 & 38.5 & 50.9 & 149,574 & 130,737 & 77,059 & 3,147 & 14,746 & 9.1 & 6,966 & 1,294 & 703 & \\
\hline Pflugerville ISD........…………....... & $\mathrm{TX}$ & 218,492 & 24,343 & 81,163 & 112,986 & 100.0 & 11.1 & 37.1 & 51.7 & 206,431 & 175,078 & 108,272 & 9,326 & 19,789 & 17.4 & 7,691 & 3,781 & 875 & \\
\hline Pharr-San Juan-Alamo ISD ..... & $\mathrm{TX}$ & 339,164 & 81,710 & 207,198 & 50,256 & 100.0 & 24.1 & 61.1 & 14.8 & 377,113 & 287,822 & 175,583 & 65,639 & 18,373 & 44.9 & 9,135 & 15,313 & 1,116 & \\
\hline Plano ISD................................. & $\mathrm{TX}$ & 633,556 & 56,088 & 103,322 & 474,146 & 100.0 & 8.9 & 16.3 & 74.8 & 662,042 & 468,456 & 308,467 & 113,517 & 48,354 & 9.3 & 8,430 & 4,669 & 804 & \\
\hline Richardson ISD ........................... & $\mathrm{TX}$ & 374,194 & 57,881 & $\begin{array}{r}95,599 \\
\end{array}$ & 220,714 & 100.0 & 15.5 & 25.5 & 59.0 & 334,562 & 295,812 & 193,035 & 19,192 & 17,309 & 25.0 & 8,201 & 9,114 & 960 & \\
\hline Round Rock ISD............................. & $\mathrm{TX}$ & 456,478 & 37,537 & 124,644 & 294,297 & 100.0 & 8.2 & 27.3 & 64.5 & 517,286 & 355,196 & 212,793 & 112,395 & 45,266 & 8.7 & 7,933 & 3,338 & 792 & \\
\hline San Antonio ISD ............................. & $\mathrm{TX}$ & 578,043 & 155,469 & 262,694 & 159,880 & 100.0 & 26.9 & 45.4 & 27.7 & 571,832 & 498,348 & 291,426 & 31,747 & 32,350 & 39.0 & 9,042 & 30,691 & 1,364 & \\
\hline Socorro ISD ................................. & $\mathrm{TX}$ & 383,521 & 56,086 & 230,582 & 96,853 & 100.0 & 14.6 & 60.1 & 25.3 & 364,693 & 323,785 & 198,610 & 13,444 & 24,051 & 25.1 & 7,606 & 11,404 & 996 & \\
\hline Spring Branch ISD ....................... & $\mathrm{TX}$ & 367,647 & 51,265 & $\begin{array}{r}63,802 \\
\end{array}$ & 252,580 & 100.0 & 13.9 & 17.4 & 68.7 & 471,270 & 305,215 & 185,966 & 129,657 & 31,590 & 29.0 & 9,264 & 9,594 & 962 & \\
\hline Spring ISD..................................... & $\mathrm{TX}$ & 344,470 & 50,081 & 179,801 & 114,588 & 100.0 & 14.5 & 52.2 & 33.3 & 351,689 & 294,049 & 180,457 & 22,964 & $\begin{array}{l}32,748 \\
\end{array}$ & 26.1 & 8,095 & 9,036 & 947 & \\
\hline Tyler ISD .......................................... & $\mathrm{TX}$ & 196,670 & 36,967 & 57,467 & 102,236 & 100.0 & 18.8 & 29.2 & 52.0 & 186,108 & 156,972 & 97,137 & 18,769 & 9,140 & 23.9 & 8,463 & 5,193 & 1,012 & \\
\hline 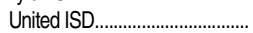 & $\mathrm{TX}$ & 419,054 & 74,851 & 221,798 & 122,405 & 100.0 & 17.9 & 52.9 & 29.2 & 393,304 & 350,195 & 205,097 & 30,049 & $\begin{array}{r}11,362 \\
\end{array}$ & 33.9 & 8,363 & 14,349 & 1,007 & \\
\hline Waco ISD ................................... & $\mathrm{TX}$ & 161,483 & 34,596 & 71,759 & 55,128 & 100.0 & 21.4 & 44.4 & 34.1 & 204,985 & 136,732 & 77,536 & 53,183 & 10,777 & 44.4 & 8,934 & 7,954 & 1,066 & \\
\hline Weslaco ISD .................................. & $\mathrm{TX}$ & 179,298 & 45,227 & 111,091 & 22,980 & 100.0 & 25.2 & 62.0 & 12.8 & 177,677 & 157,009 & 92,714 & 13,923 & 4,299 & 49.1 & 8,801 & 10,440 & 1,274 & \\
\hline 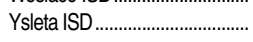 & $\mathrm{TX}$ & 460,228 & 103,922 & 270,046 & 86,260 & 100.0 & 22.6 & 58.7 & 18.7 & 481,684 & 411,001 & 258,209 & 45,656 & 21,137 & 37.2 & 9,185 & 17,499 & 1,181 & \\
\hline Alpine..................................... & UT & 436,619 & 48,206 & 238,928 & 149,485 & 100.0 & 11.0 & 54.7 & 34.2 & 439,198 & 359,583 & 241,842 & 56,997 & 16,922 & 10.7 & 5,361 & 8,614 & 1,048 & \\
\hline 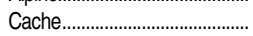 & UT & 106,006 & 12,415 & 64,458 & 29,133 & 100.0 & 11.7 & 60.8 & 27.5 & 109,433 & 96,405 & 63,392 & $\begin{array}{r}7,571 \\
\end{array}$ & 3,655 & 11.1 & 6,161 & 1,469 & 767 & \\
\hline 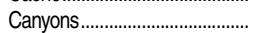 & UT & 273,362 & 20,499 & 116,434 & 136,429 & 100.0 & 7.5 & 42.6 & 49.9 & 249,257 & 208,982 & 124,354 & 26,965 & 6,338 & 12.7 & 6,199 & 4,426 & 832 & \\
\hline Davis................................. & UT & 454,945 & 51,425 & 240,514 & 163,006 & 100.0 & 11.3 & 52.9 & 35.8 & 495,064 & 398,030 & 252,524 & 66,021 & 17,780 & 9.3 & 5,901 & 6,658 & 946 & त \\
\hline 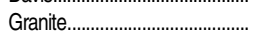 & UT & 474,236 & 68,178 & 243,842 & 162,216 & 100.0 & 14.4 & 51.4 & 34.2 & 536,028 & 421,152 & 278,661 & 97,622 & 3,704 & 21.7 & 6,009 & 18,305 & 1,068 & \\
\hline 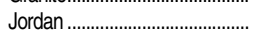 & UT & 339,004 & 36,432 & 174,052 & 128,520 & 100.0 & 10.7 & 51.3 & 37.9 & 341,624 & 276,322 & 178,212 & 54,002 & 4,590 & 9.8 & 5,521 & 4,832 & 846 & بִ \\
\hline 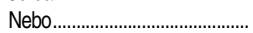 & UT & 213,833 & 18,330 & 130,531 & 64,972 & 100.0 & 8.6 & 61.0 & 30.4 & 229,169 & 173,769 & 104,817 & 43,030 & 7,813 & 10.2 & 5,822 & 2,811 & 815 & 䛔 \\
\hline 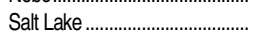 & UT & 237,534 & 36,153 & 84,870 & 116,511 & 100.0 & 15.2 & 35.7 & 49.1 & 231,731 & 185,680 & 118,002 & 25,712 & 4,797 & 26.1 & 7,534 & 6,816 & 933 & \\
\hline 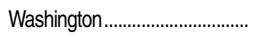 & UT & 214,198 & 26,604 & 96,279 & 91,315 & 100.0 & 12.4 & 44.9 & 42.6 & 200,614 & 168,560 & 106,452 & 19,421 & 9,641 & 21.5 & 6,460 & 6,058 & 933 & \\
\hline 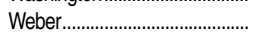 & UT & 209,602 & 18,409 & 129,242 & 61,951 & 100.0 & 8.8 & 61.7 & 29.6 & 203,414 & 183,363 & 122,157 & 14,383 & 4,376 & 9.2 & 6,026 & 2,678 & 862 & \\
\hline Arlington County......................... & $\mathrm{VA}$ & 451,563 & 18,381 & 48,693 & 384,489 & 100.0 & 4.1 & 10.8 & 85.1 & 423,778 & 351,837 & 213,073 & 40,304 & 10,722 & 10.5 & 16,376 & 2,074 & 898 & \\
\hline Chesapeake City..................... & VA & 437,386 & 50,408 & 197,859 & 189,119 & 100.0 & 11.5 & 45.2 & 43.2 & 462,787 & 402,006 & 251,869 & 37,311 & 12,657 & 11.8 & 10,114 & 5,019 & 994 & $\stackrel{2}{丂}$ \\
\hline Chesterfield County.................... & VA & 563,296 & 44,087 & 256,860 & 262,349 & 100.0 & 7.8 & 45.6 & 46.6 & 554,114 & 498,935 & 310,163 & 34,961 & 16,616 & 9.2 & 8,422 & 5,735 & 1,004 & \\
\hline 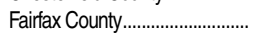 & VA & $2,371,770$ & 136,207 & 459,742 & $1,775,821$ & 100.0 & 5.7 & 19.4 & 74.9 & $2,470,926$ & $2,180,872$ & $1,334,626$ & 205,249 & 66,871 & 7.9 & 12,499 & 19,164 & 1,274 & \\
\hline Hampton City ............................. & $\mathrm{VA}$ & 222,833 & 29,643 & 115,887 & 77,303 & 100.0 & 13.3 & 52.0 & 34.7 & 228,673 & 208,912 & 121,516 & 10,747 & 6,845 & 22.6 & 9,686 & 5,543 & 1,113 & 言 : \\
\hline Hanover County................................. & $\mathrm{VA}$ & 182,082 & 14,455 & 74,571 & 93,056 & 100.0 & 7.9 & 41.0 & 51.1 & 178,753 & 162,134 & 108,419 & 9,969 & 5,546 & 6.0 & 8,704 & 967 & 841 & \\
\hline 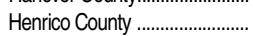 & $\mathrm{VA}$ & 562,102 & 45,035 & 200,929 & 316,138 & 100.0 & 8.0 & 35.7 & 56.2 & 513,107 & 432,610 & 263,653 & 63,704 & 13,097 & 13.1 & 8,756 & 8,045 & 1,137 & \\
\hline Loudoun County................................ & VA & 917,398 & 37,168 & 206,991 & 673,239 & 100.0 & 4.1 & 22.6 & 73.4 & 901,613 & 737,200 & 464,093 & 121,904 & 39,798 & 4.0 & 11,675 & 1,475 & 517 & $\sigma \xi$ \\
\hline Newport News City...................... & VA & 347,118 & 52,474 & 160,270 & 134,374 & 100.0 & 15.1 & 46.2 & 38.7 & 331,144 & 301,801 & 172,489 & 19,408 & 0 & 20.5 & 9,899 & 8,233 & 1,342 & 으 m \\
\hline Norfolk City.................................... & VA & 364,008 & 58,217 & 179,249 & 126,542 & 100.0 & 16.0 & 49.2 & 34.8 & 362,077 & 335,798 & 208,623 & 16,082 & 41 & 27.7 & 9,939 & 14,245 & 1,517 & \\
\hline 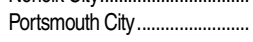 & $\mathrm{VA}$ & 177,927 & 27,126 & 85,544 & 65,257 & 100.0 & 15.2 & 48.1 & 36.7 & 176,471 & 150,039 & 88,479 & 20,304 & 256 & 25.5 & 9,919 & 5,549 & 1,393 & \\
\hline
\end{tabular}




\begin{tabular}{|c|c|c|c|c|c|c|c|c|c|c|c|c|c|c|c|c|c|c|}
\hline \multirow[b]{3}{*}{ Name of district } & \multirow[b]{3}{*}{ State } & \multirow{2}{*}{\multicolumn{4}{|c|}{$\begin{array}{l}\text { Revenues by source of funds, 2010-11 } \\
\text { (in thousands of current dollars) }\end{array}$}} & \multirow{2}{*}{\multicolumn{4}{|c|}{ Percentage distribution of revenues, 2010-11 }} & \multicolumn{5}{|c|}{ Expenditures, 2010-11 (in thousands of current dollars) } & \multirow[b]{3}{*}{$\begin{array}{r}\text { Poverty } \\
\text { rate of } \\
5-\text { to } 17- \\
\text { year-olds, } \\
2012^{1}\end{array}$} & \multirow{3}{*}{$\begin{array}{r}\text { Current } \\
\text { expenditure } \\
\text { per pupil, } \\
2010-11 \\
\text { (in current } \\
\text { dollars) }\end{array}$} & \multirow{2}{*}{\multicolumn{2}{|c|}{$\begin{array}{l}\text { Title I allocations, } \\
\text { fiscal year } 2013\end{array}$}} \\
\hline & & & & & & & & & & & Current exp & nditures & \multirow[b]{2}{*}{$\begin{array}{r}\text { Capital } \\
\text { outlay }\end{array}$} & \multirow[b]{2}{*}{$\begin{array}{r}\text { Interest on } \\
\text { school debt }\end{array}$} & & & & \\
\hline & & Total & Federal & State & Local & Total & Federal & State & Local & Total $^{5}$ & Total & Instruction & & & & & \begin{tabular}{|r|} 
Total $^{3}$ \\
(in thousands \\
of current \\
dollars) \\
\end{tabular} & $\begin{array}{r}\text { Per poverty } \\
\text { child } \\
\text { (in current } \\
\text { dollars) }\end{array}$ \\
\hline 1 & 2 & 3 & 4 & 5 & 6 & 7 & 8 & 9 & 10 & 11 & 12 & 13 & 14 & 15 & 16 & 17 & 18 & 19 \\
\hline Prince William County............... & $\mathrm{VA}$ & 902,165 & 72,626 & 359,029 & 470,510 & 100.0 & 8.1 & 39.8 & 52.2 & 946,518 & 780,750 & 446,555 & 108,251 & 29,010 & 9.2 & 9,838 & 8,879 & 1,141 \\
\hline Richmond City ................................ & $\mathrm{VA}$ & 310,772 & 55,406 & 119,171 & 136,195 & 100.0 & 17.8 & 38.3 & 43.8 & 306,434 & 295,940 & 163,195 & 8,022 & & 33.1 & 12,618 & 17,762 & 2,081 \\
\hline Spotsylvania County .................. & $\mathrm{VA}$ & 256,614 & 20,536 & 107,420 & 128,658 & 100.0 & 8.0 & 41.9 & 50.1 & 235,887 & 219,452 & 129,845 & 4,857 & 10,351 & 10.6 & 9,305 & 2,483 & 925 \\
\hline Stafford County.............................. & VA & 263,420 & 32,627 & 118,766 & 112,027 & 100.0 & 12.4 & 45.1 & 42.5 & 268,128 & 255,643 & 162,101 & 11,690 & 94 & 7.0 & 9,379 & 1,732 & 875 \\
\hline Bellevue................................. & WA & 238,758 & 16,734 & 102,498 & 119,526 & 100.0 & 7.0 & 42.9 & 50.1 & 286,307 & 169,971 & 108,292 & 96,738 & 13,603 & 9.2 & 9,273 & 1,583 & 881 \\
\hline 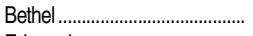 & WA & 193,603 & 17,851 & 121,258 & 54,494 & 100.0 & 9.2 & 62.6 & 28.1 & 211,336 & 164,362 & 95,005 & 35,714 & 9,930 & 11.6 & 9,245 & 2,101 & 913 \\
\hline 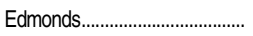 & WA & 229,733 & 20,974 & 120,815 & 87,944 & 100.0 & 9.1 & 52.6 & 38.3 & 227,943 & 182,143 & 112,806 & 30,055 & 13,949 & 14.4 & 8,775 & 3,189 & 929 \\
\hline Everett ………........................ & WA & 226,236 & 20,765 & 122,071 & 83,400 & 100.0 & 9.2 & 54.0 & 36.9 & 242,345 & 180,805 & 110,174 & 37,679 & 23,090 & 15.3 & 9,520 & 3,395 & 1,033 \\
\hline Evergreen (Clark) ............................. & WA & 260,321 & 26,380 & 166,335 & 67,606 & 100.0 & 10.1 & 63.9 & 26.0 & 255,022 & 235,188 & 148,336 & 9,083 & 9,656 & 16.4 & 9,134 & 4,977 & 1,087 \\
\hline 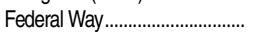 & WA & 241,704 & 24,924 & 144,608 & 72,172 & 100.0 & 10.3 & 59.8 & 29.9 & 266,292 & 205,023 & 129,423 & 50,616 & 10,087 & 17.6 & 9,211 & 4,571 & 1,074 \\
\hline Highline ....................................... & WA & 216,256 & 25,469 & 118,607 & 72,180 & 100.0 & 11.8 & 54.8 & 33.4 & 215,582 & 181,545 & 108,888 & 18,391 & 14,714 & 22.2 & 10,090 & 4,828 & 1,083 \\
\hline Issaquah........................................ & WA & 214,422 & 11,851 & 94,425 & 108,146 & 100.0 & 5.5 & 44.0 & 50.4 & 216,122 & 148,720 & 91,608 & 45,817 & 17,137 & 5.8 & 8,568 & 956 & 825 \\
\hline Kennewick...................................... & WA & 178,336 & 17,635 & $\begin{array}{l}126,652 \\
\end{array}$ & 34,049 & 100.0 & 9.9 & 71.0 & 19.1 & 170,124 & 141,835 & 90,590 & 21,259 & 6,809 & 19.2 & 8,613 & 3,424 & 1,040 \\
\hline Kent .......................................... & WA & 289,826 & 30,324 & 159,005 & 100,497 & 100.0 & 10.5 & 54.9 & 34.7 & 288,454 & 246,704 & 153,990 & 29,952 & 11,161 & 15.9 & 9,111 & 5,175 & 1,087 \\
\hline 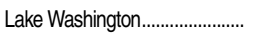 & WA & 278,433 & 19,288 & 137,350 & 121,795 & 100.0 & 6.9 & 49.3 & 43.7 & 352,907 & 219,397 & 141,589 & 108,095 & 23,449 & 6.1 & 8,891 & 1,564 & 868 \\
\hline Puyallup................................ & WA & 216,887 & 16,756 & 129,405 & 70,726 & 100.0 & 7.7 & 59.7 & 32.6 & 217,070 & 187,432 & 110,805 & 16,986 & 11,881 & 9.0 & 8,931 & 1,921 & 940 \\
\hline Seatlle ........................................... & WA & 679,225 & 68,850 & 307,730 & 302,645 & 100.0 & 10.1 & 45.3 & 44.6 & 680,031 & 532,458 & 315,395 & 133,743 & 12,735 & 13.3 & 11,154 & 9,530 & 1,155 \\
\hline 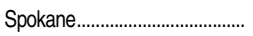 & WA & 340,897 & 47,461 & 193,595 & 99,841 & 100.0 & 13.9 & 56.8 & 29.3 & 353,433 & 294,392 & 182,290 & 41,011 & 10,509 & 21.5 & 9,998 & 9,086 & 1,258 \\
\hline 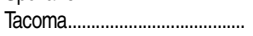 & WA & 359,986 & 53,092 & 181,048 & 125,846 & 100.0 & 14.7 & 50.3 & 35.0 & 377,543 & 323,577 & 196,806 & 39,765 & 13,715 & 20.4 & 11,806 & 9,147 & 1,353 \\
\hline Vancouver ........................................ & WA & 230,326 & 26,965 & 137,726 & 65,635 & 100.0 & 11.7 & 59.8 & 28.5 & 214,599 & 206,777 & 123,339 & $\begin{array}{r}1,078 \\
\end{array}$ & 5,578 & 20.7 & 9,122 & 6,358 & 1,274 \\
\hline Yakima................................... & WA & 169,294 & 33,705 & 112,428 & 23,161 & 100.0 & 19.9 & 66.4 & 13.7 & 176,448 & 154,067 & 99,024 & 17,649 & 4,576 & 32.4 & 10,321 & 6,374 & 1,255 \\
\hline Berkeley County.......................... & wV & 202,580 & 25,248 & 107,195 & 70,137 & 100.0 & 12.5 & 52.9 & 34.6 & 217,016 & 197,253 & 117,339 & 15,131 & 2,853 & 18.9 & 11,132 & 4,633 & 1,286 \\
\hline Kanawha County............................ & wV & 335,555 & 52,038 & 175,083 & 108,434 & 100.0 & 15.5 & 52.2 & 32.3 & 364,009 & 332,978 & 207,415 & 21,648 & 0 & 24.7 & 11,701 & 9,767 & 1,390 \\
\hline Appleton Area....................... & WI & 185,176 & 15,461 & 91,357 & 78,358 & 100.0 & 8.3 & 49.3 & 42.3 & 178,253 & 169,236 & 106,975 & 2,577 & 1,901 & 11.2 & 11,138 & 1,941 & 1,062 \\
\hline Green Bay Area........................... & WI & 265,458 & 29,412 & 150,043 & 86,003 & 100.0 & 11.1 & 56.5 & 32.4 & 259,910 & 234,642 & 146,901 & 12,332 & 2,179 & 18.6 & 11,516 & 5,470 & 1,274 \\
\hline 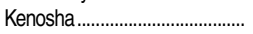 & WI & 297,703 & 28,258 & 164,920 & 104,525 & 100.0 & 9.5 & 55.4 & 35.1 & 312,729 & 283,025 & 179,847 & 19,536 & 7,196 & 18.9 & 12,313 & 6,038 & 1,318 \\
\hline Madison Metropolitan................ & WI & 373,748 & 34,139 & 80,673 & 258,936 & 100.0 & 9.1 & 21.6 & 69.3 & 364,297 & 329,604 & 198,194 & 9,058 & 7,250 & 19.7 & 13,287 & 6,574 & 1,274 \\
\hline Milwaukee ................................... & WI & $1,310,838$ & 265,333 & 706,087 & 339,418 & 100.0 & 20.2 & 53.9 & 25.9 & $1,298,621$ & $1,152,804$ & 665,915 & 23,835 & 25,553 & 37.8 & 14,244 & 78,992 & 1,861 \\
\hline 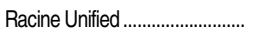 & WI & 274,154 & 30,336 & 159,636 & 84,182 & 100.0 & 11.1 & 58.2 & 30.7 & 286,509 & 264,054 & 169,278 & 14,851 & 1,032 & 22.2 & 12,514 & 7,277 & 1,334 \\
\hline
\end{tabular}

†Not applicable.

Poverty is defined based on the number of persons and related children in the family and their income. For information on poverty thresholds, see hitp.//Www.census.gov/hhes/www/poverty/data/threshld.

the "Local Education Agency (School District) Fiscal year 2013 Departm

school year. school year divided by number of poverty children in 2012 .
Includes other expenditures not shown separately.

Theludes dala for bolh Modesto City Elementary and Modesto City High.

NOTE. Detail may not sum to tolals because of rounding. ISD = independent school district. CISD = consolidated independent school district.

cation Agency Universe Survey" 2011-12. "Lional Center for Education Statistics, Common Core of Data (CCD), "Local Eduunpublished Department of Education budget data. (This table was prepared May 2014.) 
Table 215.30. Enrollment, poverty, and federal funds for the 100 largest school districts, by enrollment size in 2011: Selected years, 2010-11 through 2013

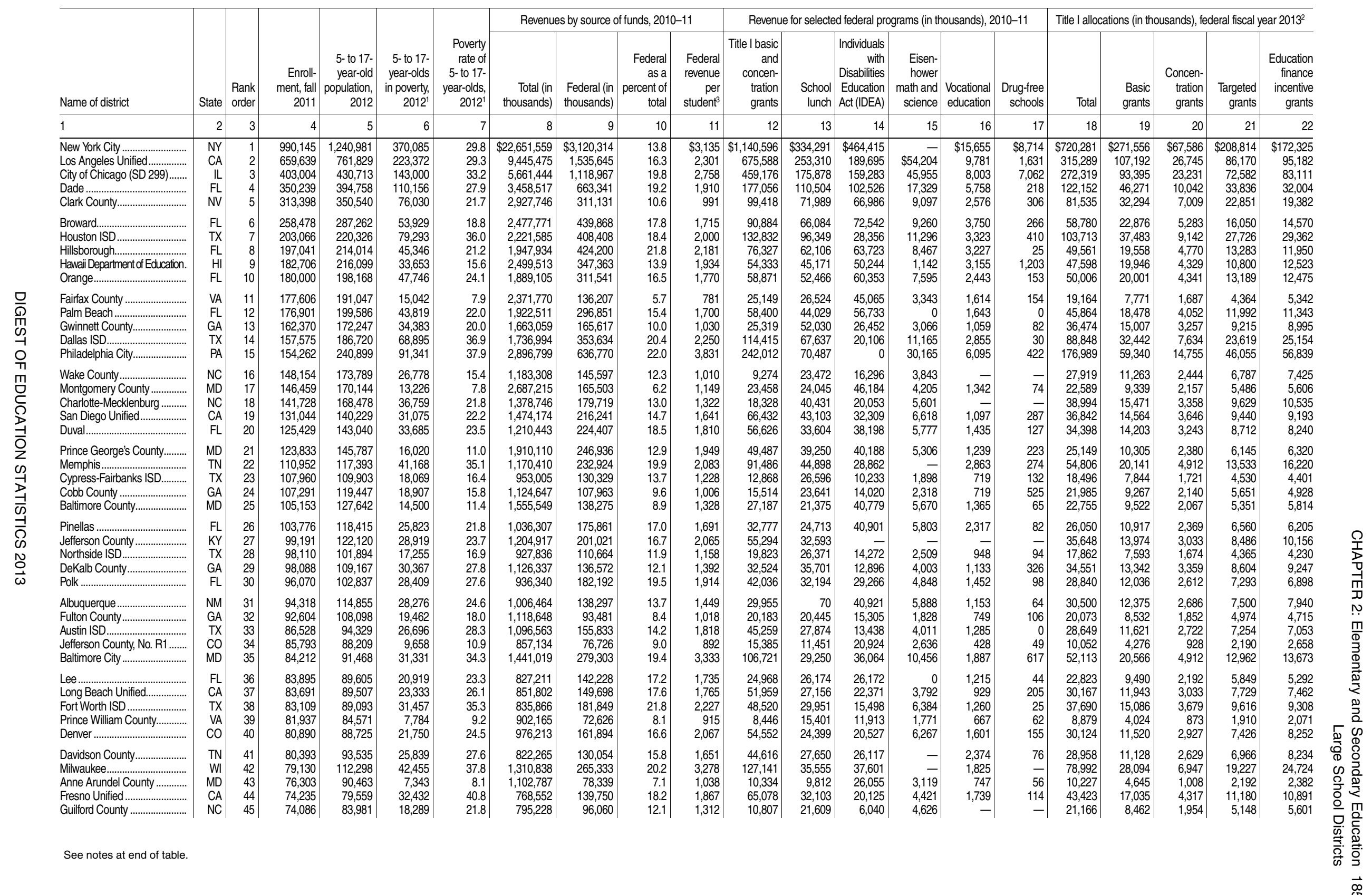




\begin{tabular}{|c|c|c|c|c|c|c|c|c|c|c|c|c|c|c|c|c|c|c|c|c|c|}
\hline \multirow[b]{2}{*}{ Name of district } & \multirow[b]{2}{*}{ State } & \multirow[b]{2}{*}{$\begin{array}{l}\text { Rank } \\
\text { order }\end{array}$} & \multirow[b]{2}{*}{$\begin{array}{r}\text { Enroll- } \\
\text { ment, fall } \\
2011\end{array}$} & \multirow[b]{2}{*}{$\begin{array}{r}5 \text { - to 17- } \\
\text { year-old } \\
\text { population, } \\
2012\end{array}$} & \multirow[b]{2}{*}{$\begin{array}{r}5 \text { - to } 17- \\
\text { year-olds } \\
\text { in poverty, } \\
2012^{1}\end{array}$} & \multirow[b]{2}{*}{$\begin{array}{r}\text { Poverty } \\
\text { rate of } \\
5 \text { - to } 17- \\
\text { year-olds, } \\
2012^{1}\end{array}$} & \multicolumn{4}{|c|}{ Revenues by source of funds, 2010-11 } & \multicolumn{6}{|c|}{ Revenue for selected federal programs (in thousands), 2010-11 } & \multicolumn{5}{|c|}{ Title I allocations (in thousands), federal fiscal year $2013^{2}$} \\
\hline & & & & & & & $\begin{array}{r}\text { Total (in } \\
\text { thousands) }\end{array}$ & $\begin{array}{l}\text { Federal (in } \\
\text { thousands) }\end{array}$ & $\begin{array}{r}\text { Federal } \\
\text { as a } \\
\text { percent of } \\
\text { total }\end{array}$ & $\begin{array}{r}\text { Federal } \\
\text { revenue } \\
\text { per } \\
\text { student }\end{array}$ & $\begin{array}{r}\text { Title I basic } \\
\text { and } \\
\text { concen- } \\
\text { tration } \\
\text { grants }\end{array}$ & $\begin{array}{r}\text { School } \\
\text { lunch }\end{array}$ & \begin{tabular}{|r|} 
Individuals \\
with \\
Disabilities \\
Education \\
Act (IDEA)
\end{tabular} & $\begin{array}{r}\text { Eisen- } \\
\text { hower } \\
\text { math and } \\
\text { science }\end{array}$ & $\begin{array}{l}\text { Vocational } \\
\text { education }\end{array}$ & $\begin{array}{r}\text { Drug-free } \\
\text { schools }\end{array}$ & Total & $\begin{array}{r}\text { Basic } \\
\text { grants }\end{array}$ & $\begin{array}{r}\text { Concen- } \\
\text { tration } \\
\text { grants }\end{array}$ & $\begin{array}{r}\text { Targeted } \\
\text { grants }\end{array}$ & $\begin{array}{r}\text { Education } \\
\text { finance } \\
\text { incentive } \\
\text { grants }\end{array}$ \\
\hline 1 & 2 & 3 & 4 & 5 & 6 & 7 & 8 & 9 & 10 & 11 & 12 & 13 & 14 & 15 & 16 & 17 & 18 & 19 & 20 & 21 & 22 \\
\hline 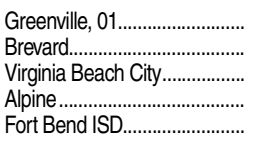 & $\begin{array}{l}\text { SC } \\
F L \\
\text { VA } \\
\text { UT } \\
\text { TX }\end{array}$ & $\begin{array}{l}46 \\
47 \\
48 \\
49 \\
50\end{array}$ & $\begin{array}{l}72,153 \\
71,792 \\
70,978 \\
69,639 \\
69,449\end{array}$ & $\begin{array}{l}81,629 \\
79,162 \\
75,131 \\
76,703 \\
77,845\end{array}$ & $\begin{array}{r}18,739 \\
16,431 \\
8,713 \\
8,221 \\
8,820\end{array}$ & $\begin{array}{l}23.0 \\
20.8 \\
11.6 \\
10.7 \\
11.3\end{array}$ & $\begin{array}{l}701,103 \\
665,068 \\
769,740 \\
436,619 \\
623,356\end{array}$ & $\begin{array}{r}82,614 \\
108,726 \\
88,488 \\
48,206 \\
55,659\end{array}$ & $\begin{array}{r}11.8 \\
16.3 \\
11.5 \\
11.0 \\
8.9\end{array}$ & $\begin{array}{r}1,149 \\
1,513 \\
1,243 \\
719 \\
807\end{array}$ & $\begin{array}{r}24,592 \\
20,759 \\
13,556 \\
5,846 \\
8,040\end{array}$ & $\begin{array}{l}18,170 \\
15,345 \\
11,669 \\
10,584 \\
10,551\end{array}$ & $\begin{array}{r}15,406 \\
24,352 \\
22,018 \\
16,799 \\
7,111\end{array}$ & $\begin{array}{l}2,316 \\
2,895 \\
2,435 \\
1,340 \\
1,108\end{array}$ & $\begin{array}{r}1,179 \\
662 \\
833 \\
684 \\
578\end{array}$ & $\begin{array}{r}101 \\
55 \\
50 \\
0 \\
43\end{array}$ & $\begin{array}{r}21,079 \\
16,136 \\
10,232 \\
8,614 \\
8,681\end{array}$ & $\begin{array}{l}8,336 \\
6,938 \\
4,517 \\
3,641 \\
3,932\end{array}$ & $\begin{array}{r}1,809 \\
1,506 \\
980 \\
841 \\
904\end{array}$ & $\begin{array}{l}4,841 \\
3,954 \\
2,233 \\
1,894 \\
2,058\end{array}$ & $\begin{array}{l}6,093 \\
3,740 \\
2,501 \\
2,237 \\
1,787\end{array}$ \\
\hline 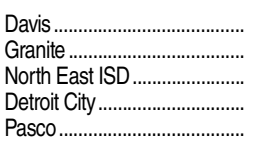 & $\begin{array}{l}\text { UT } \\
\text { UT } \\
\text { TX } \\
\text { MI } \\
\mathrm{FL}\end{array}$ & $\begin{array}{l}51 \\
52 \\
53 \\
54 \\
55\end{array}$ & $\begin{array}{l}69,285 \\
69,252 \\
67,439 \\
67,064 \\
66,659\end{array}$ & $\begin{array}{r}75,387 \\
78,955 \\
74,866 \\
135,355 \\
72,275\end{array}$ & $\begin{array}{r}7,036 \\
17,134 \\
12,094 \\
69,045 \\
13,431\end{array}$ & $\begin{array}{r}9.3 \\
21.7 \\
16.2 \\
51.0 \\
18.6\end{array}$ & $\begin{array}{r}454,945 \\
474,236 \\
685,916 \\
1,250,847 \\
666,094\end{array}$ & $\begin{array}{r}51,425 \\
68,178 \\
74,207 \\
451,471 \\
115,324\end{array}$ & $\begin{array}{l}11.3 \\
14.4 \\
10.8 \\
36.1 \\
17.3\end{array}$ & $\begin{array}{r}762 \\
973 \\
1,114 \\
5,806 \\
1,721\end{array}$ & $\begin{array}{r}4,450 \\
16,771 \\
15,550 \\
199,619 \\
20,772\end{array}$ & $\begin{array}{l}11,386 \\
17,606 \\
14,755 \\
31,071 \\
19,162\end{array}$ & $\begin{array}{l}17,164 \\
18,299 \\
10,189 \\
12,190 \\
22,437\end{array}$ & $\begin{array}{r}1,515 \\
2,721 \\
2,175 \\
0 \\
0\end{array}$ & $\begin{array}{r}615 \\
1,448 \\
664 \\
4,401 \\
761\end{array}$ & $\begin{array}{r}42 \\
174 \\
62 \\
720 \\
2,929\end{array}$ & $\begin{array}{r}6,658 \\
18,305 \\
12,194 \\
154,750 \\
13,520\end{array}$ & $\begin{array}{r}2,983 \\
7,237 \\
5,320 \\
50,842 \\
5,801\end{array}$ & $\begin{array}{r}666 \\
1,571 \\
1,223 \\
12,959 \\
1,369\end{array}$ & $\begin{array}{r}1,412 \\
4,150 \\
2,963 \\
40,302 \\
3,333\end{array}$ & $\begin{array}{r}1,598 \\
5,347 \\
2,689 \\
50,647 \\
3,016\end{array}$ \\
\hline 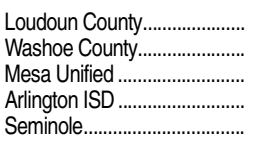 & $\begin{array}{l}\text { VA } \\
\text { NV } \\
\text { AZ } \\
\text { TX } \\
\mathrm{FL}\end{array}$ & $\begin{array}{l}56 \\
57 \\
58 \\
59 \\
60\end{array}$ & $\begin{array}{l}65,585 \\
64,740 \\
64,728 \\
64,703 \\
64,344\end{array}$ & $\begin{array}{l}70,829 \\
71,426 \\
80,101 \\
66,796 \\
72,382\end{array}$ & $\begin{array}{r}2,855 \\
11,461 \\
20,171 \\
16,588 \\
10,715\end{array}$ & $\begin{array}{r}4.0 \\
16.0 \\
25.2 \\
24.8 \\
14.8\end{array}$ & $\begin{array}{l}917,398 \\
618,416 \\
610,696 \\
591,620 \\
577,531\end{array}$ & $\begin{array}{r}37,168 \\
71,782 \\
105,472 \\
117,878 \\
89,063\end{array}$ & $\begin{array}{r}4.1 \\
11.6 \\
17.3 \\
19.9 \\
15.4\end{array}$ & $\begin{array}{r}589 \\
1,115 \\
1,620 \\
1,828 \\
1,387\end{array}$ & $\begin{array}{r}1,473 \\
17,914 \\
36,441 \\
18,642 \\
12,841 \\
\end{array}$ & $\begin{array}{r}5,085 \\
13,545 \\
20,629 \\
19,549 \\
13,805\end{array}$ & $\begin{array}{l}16,949 \\
12,255 \\
19,768 \\
10,420 \\
18,685\end{array}$ & $\begin{array}{r}488 \\
2,554 \\
4,499 \\
1,985 \\
2,477\end{array}$ & $\begin{array}{r}442 \\
758 \\
1,636 \\
844 \\
529\end{array}$ & $\begin{array}{r}21 \\
46 \\
190 \\
6 \\
28\end{array}$ & $\begin{array}{r}1,475 \\
11,972 \\
23,412 \\
16,840 \\
10,102\end{array}$ & $\begin{array}{l}1,475 \\
5,300 \\
9,206 \\
7,185 \\
4,516\end{array}$ & $\begin{array}{r}0 \\
1,224 \\
2,245 \\
1,603 \\
980\end{array}$ & $\begin{array}{r}0 \\
2,991 \\
5,675 \\
4,099 \\
2,367\end{array}$ & $\begin{array}{r}0 \\
2,457 \\
6,287 \\
3,953 \\
2,239\end{array}$ \\
\hline 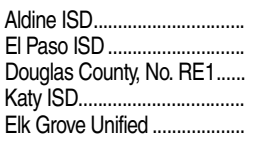 & $\begin{array}{l}\text { TX } \\
\text { TX } \\
\text { CO } \\
\text { TX } \\
\text { CA }\end{array}$ & $\begin{array}{l}61 \\
62 \\
63 \\
64 \\
65\end{array}$ & $\begin{array}{l}64,300 \\
64,214 \\
63,114 \\
62,414 \\
62,126\end{array}$ & $\begin{array}{l}61,405 \\
65,790 \\
66,570 \\
61,366 \\
69,006\end{array}$ & $\begin{array}{r}23,524 \\
22,286 \\
2,678 \\
6,829 \\
12,813\end{array}$ & $\begin{array}{r}38.3 \\
33.9 \\
4.0 \\
11.1 \\
18.6\end{array}$ & $\begin{array}{l}603,132 \\
595,870 \\
597,377 \\
599,020 \\
580,280\end{array}$ & $\begin{array}{r}116,869 \\
95,837 \\
34,224 \\
56,482 \\
64,944\end{array}$ & $\begin{array}{r}19.4 \\
16.1 \\
5.7 \\
9.4 \\
11.2\end{array}$ & $\begin{array}{r}1,851 \\
1,490 \\
557 \\
929 \\
1,040\end{array}$ & $\begin{array}{r}25,863 \\
27,368 \\
1,032 \\
5,300 \\
14,441\end{array}$ & \begin{tabular}{r|}
32,681 \\
20,898 \\
3,575 \\
9,668 \\
14,687
\end{tabular} & $\begin{array}{r}8,878 \\
6,169 \\
11,356 \\
7,371 \\
13,349\end{array}$ & $\begin{array}{r}2,755 \\
2,897 \\
585 \\
912 \\
2,495\end{array}$ & $\begin{array}{r}881 \\
1,403 \\
169 \\
335 \\
497\end{array}$ & $\begin{array}{l}91 \\
36 \\
84 \\
40 \\
57\end{array}$ & $\begin{array}{r}24,820 \\
29,482 \\
1,184 \\
6,194 \\
13,300\end{array}$ & $\begin{array}{r}10,213 \\
11,606 \\
1,184 \\
2,978 \\
5,750\end{array}$ & $\begin{array}{r}2,347 \\
2,958 \\
0 \\
646 \\
1,325\end{array}$ & $\begin{array}{r}6,246 \\
7,718 \\
0 \\
1,394 \\
3,248\end{array}$ & $\begin{array}{r}6,015 \\
7,200 \\
0 \\
1,175 \\
2,978\end{array}$ \\
\hline 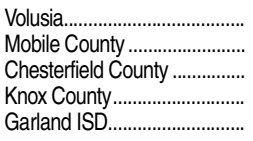 & $\begin{array}{l}\text { FL } \\
\text { AL } \\
\text { VA } \\
\text { TN } \\
\text { TX }\end{array}$ & $\begin{array}{l}66 \\
67 \\
68 \\
69 \\
70\end{array}$ & $\begin{array}{l}61,524 \\
61,462 \\
59,200 \\
58,639 \\
58,151\end{array}$ & $\begin{array}{l}67,795 \\
72,082 \\
62,081 \\
68,116 \\
60,067\end{array}$ & $\begin{array}{r}17,052 \\
19,529 \\
5,711 \\
12,181 \\
13,120\end{array}$ & $\begin{array}{r}25.2 \\
27.1 \\
9.2 \\
17.9 \\
21.8\end{array}$ & $\begin{array}{l}608,890 \\
587,680 \\
563,296 \\
480,087 \\
545,423\end{array}$ & $\begin{array}{r}104,082 \\
110,840 \\
44,087 \\
58,015 \\
93,503\end{array}$ & $\begin{array}{r}17.1 \\
18.9 \\
7.8 \\
12.1 \\
17.1\end{array}$ & $\begin{array}{r}1,691 \\
1,787 \\
744 \\
1,001 \\
1,617\end{array}$ & $\begin{array}{r}24,974 \\
40,040 \\
7,495 \\
19,954 \\
20,717\end{array}$ & $\begin{array}{r}16,662 \\
22,476 \\
6,779 \\
12,943 \\
16,054\end{array}$ & $\begin{array}{r}20,282 \\
24,751 \\
15,182 \\
14,962 \\
9,094\end{array}$ & $\begin{array}{r}2,925 \\
5,016 \\
1,255 \\
- \\
1,987\end{array}$ & $\begin{array}{r}768 \\
1,518 \\
585 \\
1,373 \\
707\end{array}$ & $\begin{array}{r}0 \\
92 \\
19 \\
423 \\
51\end{array}$ & $\begin{array}{r}16,941 \\
21,199 \\
5,735 \\
12,224 \\
13,688\end{array}$ & $\begin{array}{l}7,250 \\
8,316 \\
2,946 \\
5,229 \\
5,877\end{array}$ & $\begin{array}{r}1,599 \\
2,112 \\
0 \\
1,164 \\
1,357\end{array}$ & $\begin{array}{l}4,158 \\
5,230 \\
1,345 \\
2,835 \\
3,360\end{array}$ & $\begin{array}{l}3,933 \\
5,541 \\
1,444 \\
2,996 \\
3,094\end{array}$ \\
\hline 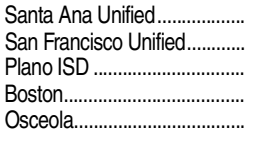 & $\begin{array}{c}\text { CA } \\
\text { CA } \\
\text { TX } \\
\text { MA } \\
\mathrm{FL}\end{array}$ & $\begin{array}{l}71 \\
72 \\
73 \\
74 \\
75\end{array}$ & $\begin{array}{l}57,250 \\
56,310 \\
55,659 \\
55,027 \\
54,783\end{array}$ & $\begin{array}{l}55,247 \\
73,120 \\
62,713 \\
71,810 \\
53,327\end{array}$ & $\begin{array}{r}15,281 \\
12,378 \\
5,809 \\
23,305 \\
11,992\end{array}$ & $\begin{array}{r}27.7 \\
16.9 \\
9.3 \\
32.5 \\
22.5\end{array}$ & $\begin{array}{r}648,953 \\
684,462 \\
633,556 \\
1,250,911 \\
509,748\end{array}$ & $\begin{array}{r}105,933 \\
82,824 \\
56,088 \\
151,199 \\
91,019\end{array}$ & $\begin{array}{r}16.3 \\
12.1 \\
8.9 \\
12.1 \\
17.9\end{array}$ & $\begin{array}{l}1,848 \\
1,490 \\
1,009 \\
2,698 \\
1,706\end{array}$ & $\begin{array}{r}39,310 \\
25,508 \\
6,098 \\
45,802 \\
15,732\end{array}$ & $\begin{array}{r}27,283 \\
13,261 \\
6,976 \\
14,288 \\
18,019\end{array}$ & \begin{tabular}{r|r|}
14,059 \\
0 \\
8,181 \\
19,130 \\
15,157
\end{tabular} & $\begin{array}{r}2,870 \\
4,036 \\
1,018 \\
0 \\
0\end{array}$ & $\begin{array}{r}457 \\
357 \\
532 \\
1,678 \\
555\end{array}$ & $\begin{array}{r}156 \\
73 \\
3 \\
-55\end{array}$ & $\begin{array}{r}15,875 \\
12,237 \\
4,669 \\
40,755 \\
11,591\end{array}$ & $\begin{array}{r}6,771 \\
5,530 \\
2,533 \\
14,827 \\
5,077\end{array}$ & $\begin{array}{r}1,548 \\
1,210 \\
0 \\
3,580 \\
1,191\end{array}$ & $\begin{array}{l}3,907 \\
3,004 \\
1,163 \\
9,306 \\
2,735\end{array}$ & $\begin{array}{r}3,649 \\
2,493 \\
973 \\
13,043 \\
2,587\end{array}$ \\
\hline 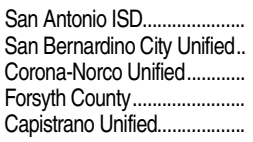 & $\begin{array}{l}\text { TX } \\
\mathrm{CA} \\
\mathrm{CA} \\
\mathrm{NC} \\
\mathrm{CA}\end{array}$ & $\begin{array}{l}76 \\
77 \\
78 \\
79 \\
80\end{array}$ & $\begin{array}{l}54,394 \\
54,379 \\
53,467 \\
53,340 \\
53,170\end{array}$ & $\begin{array}{l}57,732 \\
57,418 \\
56,300 \\
61,770 \\
64,183\end{array}$ & $\begin{array}{r}22,504 \\
21,186 \\
8,154 \\
15,089 \\
5,346\end{array}$ & $\begin{array}{r}39.0 \\
36.9 \\
14.5 \\
24.4 \\
8.3\end{array}$ & $\begin{array}{l}578,043 \\
600,660 \\
492,882 \\
590,947 \\
416,481\end{array}$ & $\begin{array}{r}155,469 \\
95,741 \\
53,014 \\
70,338 \\
29,877\end{array}$ & $\begin{array}{r}26.9 \\
15.9 \\
10.8 \\
11.9 \\
7.2\end{array}$ & $\begin{array}{r}2,821 \\
1,756 \\
997 \\
1,318 \\
562\end{array}$ & $\begin{array}{r}42,648 \\
40,089 \\
8,970 \\
8,594 \\
4,408\end{array}$ & $\begin{array}{r}31,600 \\
22,912 \\
10,855 \\
14,656 \\
4,420\end{array}$ & $\begin{array}{r}9,340 \\
15,935 \\
13,511 \\
4,487 \\
13,750\end{array}$ & $\begin{array}{l}4,078 \\
4,041 \\
1,609 \\
2,200 \\
1,109\end{array}$ & $\begin{array}{r}1,039 \\
601 \\
218 \\
208\end{array}$ & $\begin{array}{r}0 \\
195 \\
62 \\
62\end{array}$ & $\begin{array}{r}30,691 \\
26,814 \\
7,951 \\
15,129 \\
4,295\end{array}$ & $\begin{array}{r}12,389 \\
11,012 \\
3,655 \\
6,322 \\
2,369\end{array}$ & $\begin{array}{r}3,086 \\
2,693 \\
844 \\
1,372 \\
0\end{array}$ & $\begin{array}{l}7,767 \\
6,796 \\
1,865 \\
3,550 \\
1,072\end{array}$ & $\begin{array}{r}7,450 \\
6,313 \\
1,587 \\
3,884 \\
854\end{array}$ \\
\hline 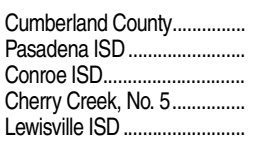 & $\begin{array}{l}\text { NC } \\
\text { TX } \\
\text { TX } \\
\text { CO } \\
\text { TX }\end{array}$ & $\begin{array}{l}81 \\
82 \\
83 \\
84 \\
85\end{array}$ & $\begin{array}{l}53,053 \\
52,942 \\
52,664 \\
52,655 \\
51,920\end{array}$ & $\begin{array}{l}55,198 \\
53,946 \\
54,004 \\
54,786 \\
58,110\end{array}$ & $\begin{array}{r}14,220 \\
15,918 \\
8,617 \\
5,047 \\
5,036\end{array}$ & $\begin{array}{r}25.8 \\
29.5 \\
16.0 \\
9.2 \\
8.7\end{array}$ & $\begin{array}{l}501,648 \\
506,146 \\
472,852 \\
537,255 \\
547,507\end{array}$ & $\begin{array}{l}89,294 \\
96,482 \\
52,409 \\
42,944 \\
51,783\end{array}$ & $\begin{array}{r}17.8 \\
19.1 \\
11.1 \\
8.0 \\
9.5\end{array}$ & $\begin{array}{r}1,675 \\
1,848 \\
1,024 \\
822 \\
1,006\end{array}$ & $\begin{array}{r}8,417 \\
20,809 \\
7,006 \\
5,494 \\
1,479\end{array}$ & $\begin{array}{r}16,341 \\
22,572 \\
8,161 \\
7,156 \\
7,998\end{array}$ & $\begin{array}{r}8,709 \\
6,341 \\
4,725 \\
12,619 \\
7,172\end{array}$ & $\begin{array}{r}2,335 \\
2,214 \\
1,255 \\
995 \\
863\end{array}$ & $\begin{array}{l}- \\
715 \\
417 \\
208 \\
342\end{array}$ & \begin{tabular}{r|}
- \\
0 \\
0 \\
28 \\
18
\end{tabular} & $\begin{array}{r}14,443 \\
16,094 \\
8,043 \\
4,317 \\
3,992\end{array}$ & $\begin{array}{l}6,054 \\
6,910 \\
3,757 \\
2,210 \\
2,192\end{array}$ & $\begin{array}{r}1,322 \\
1,500 \\
815 \\
0 \\
0\end{array}$ & $\begin{array}{r}3,375 \\
3,919 \\
1,853 \\
991 \\
982\end{array}$ & $\begin{array}{r}3,692 \\
3,765 \\
1,617 \\
1,116 \\
818\end{array}$ \\
\hline
\end{tabular}


Table 215.30. Enrollment, poverty, and federal funds for the 100 largest school districts, by enrollment size in 2011: Selected years, 2010-11 through 2013-Continued

\begin{tabular}{|c|c|c|c|c|c|c|c|c|c|c|c|c|c|c|c|c|c|c|c|c|c|}
\hline \multirow[b]{2}{*}{ Name of district } & \multirow[b]{2}{*}{ State } & \multirow[b]{2}{*}{$\begin{array}{l}\text { Rank } \\
\text { order }\end{array}$} & \multirow[b]{2}{*}{$\begin{array}{r}\text { Enroll- } \\
\text { ment, fall } \\
2011\end{array}$} & \multirow[b]{2}{*}{$\begin{array}{r}5 \text { - to } 17- \\
\text { year-old } \\
\text { population, } \\
2012\end{array}$} & \multirow[b]{2}{*}{$\begin{array}{r}5 \text { - to } 17- \\
\text { year-olds } \\
\text { in poverty, } \\
2012^{1}\end{array}$} & \multirow[b]{2}{*}{$\begin{array}{r}\text { Poverty } \\
\text { rate of } \\
5 \text { - to } 17- \\
\text { year-olds, } \\
2012^{1}\end{array}$} & \multicolumn{4}{|c|}{ Revenues by source of funds, 2010-11 } & \multicolumn{6}{|c|}{ Revenue for selected federal programs (in thousands), 2010-11 } & \multicolumn{5}{|c|}{ Tittle I allocations (in thousands), federal fiscal year $2013^{2}$} \\
\hline & & & & & & & $\begin{array}{r}\text { Total (in } \\
\text { thousands) }\end{array}$ & $\begin{array}{c}\text { Federal (in } \\
\text { thousands) }\end{array}$ & \begin{tabular}{|r|} 
Federal \\
as a \\
percent of \\
total
\end{tabular} & $\begin{array}{r}\text { Federal } \\
\text { revenue } \\
\text { per } \\
\text { student }^{3}\end{array}$ & 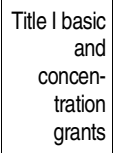 & $\begin{array}{r}\text { School } \\
\text { lunch }\end{array}$ & \begin{tabular}{|r|} 
Individuals \\
with \\
Disabilities \\
Education \\
Act (IDEA)
\end{tabular} & $\begin{array}{r}\text { Eisen- } \\
\text { hower } \\
\text { math and } \\
\text { science }\end{array}$ & \begin{tabular}{|l|} 
Vocational \\
education
\end{tabular} & $\begin{array}{r}\text { Drug-free } \\
\text { schools }\end{array}$ & Total & $\begin{array}{r}\text { Basic } \\
\text { grants }\end{array}$ & $\begin{array}{r}\text { Concen- } \\
\text { tration } \\
\text { grants }\end{array}$ & $\begin{array}{r}\text { Targeted } \\
\text { grants }\end{array}$ & $\begin{array}{r}\text { Education } \\
\text { finance } \\
\text { incentive } \\
\text { grants }\end{array}$ \\
\hline 1 & 2 & 3 & 4 & 5 & 6 & 7 & 8 & 9 & 10 & 11 & 12 & 13 & 14 & 15 & 16 & 17 & 18 & 19 & 20 & 21 & 22 \\
\hline 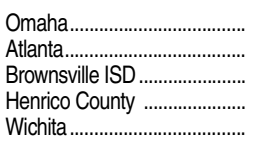 & $\begin{array}{l}\mathrm{NE} \\
\mathrm{GA} \\
\mathrm{TX} \\
\mathrm{VA} \\
\mathrm{KS}\end{array}$ & $\begin{array}{l}91 \\
92 \\
93 \\
94 \\
95\end{array}$ & $\begin{array}{l}50,340 \\
50,009 \\
49,655 \\
49,654 \\
49,389\end{array}$ & $\begin{array}{l}62,094 \\
55,895 \\
48,027 \\
53,845 \\
56,915\end{array}$ & \begin{tabular}{r|}
13,582 \\
21,876 \\
22,524 \\
7,073 \\
13,995
\end{tabular} & $\begin{array}{l}21.9 \\
39.1 \\
46.9 \\
13.1 \\
24.6\end{array}$ & $\begin{array}{l}620,026 \\
757,348 \\
504,356 \\
562,102 \\
586,367\end{array}$ & $\begin{array}{r}130,856 \\
103,765 \\
117,817 \\
45,035 \\
98,180\end{array}$ & $\begin{array}{r}21.1 \\
13.7 \\
23.4 \\
8.0 \\
16.7\end{array}$ & \begin{tabular}{r|}
2,649 \\
2,084 \\
2,362 \\
912 \\
1,990
\end{tabular} & $\begin{array}{l}19,457 \\
32,474 \\
30,156 \\
10,537 \\
27,736\end{array}$ & \begin{tabular}{r|}
18,597 \\
20,344 \\
28,518 \\
8,037 \\
16,620
\end{tabular} & $\begin{array}{r}13,306 \\
12,094 \\
7,375 \\
10,989 \\
-\end{array}$ & $\begin{array}{r}2,555 \\
5,673 \\
5,264 \\
1,380 \\
-\end{array}$ & $\begin{array}{r}1,072 \\
962 \\
1,059 \\
914 \\
0\end{array}$ & \begin{tabular}{r|}
209 \\
702 \\
115 \\
69 \\
32
\end{tabular} & \begin{tabular}{r|}
22,826 \\
34,936 \\
26,698 \\
8,045 \\
19,324
\end{tabular} & $\begin{array}{r}8,619 \\
13,550 \\
10,475 \\
3,665 \\
7,196\end{array}$ & $\begin{array}{r}1,991 \\
3,305 \\
2,662 \\
795 \\
1,742\end{array}$ & $\begin{array}{l}5,079 \\
8,490 \\
7,045 \\
1,722 \\
4,079\end{array}$ & $\begin{array}{l}7,138 \\
9,590 \\
6,516 \\
1,862 \\
6,307\end{array}$ \\
\hline 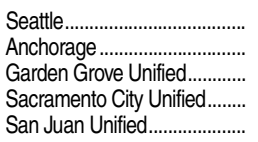 & $\begin{array}{l}\text { WA } \\
\text { AK } \\
\text { CA } \\
\text { CA } \\
\text { CA }\end{array}$ & $\begin{array}{r}96 \\
97 \\
98 \\
99 \\
100\end{array}$ & $\begin{array}{l}49,269 \\
48,765 \\
47,999 \\
47,940 \\
47,245\end{array}$ & $\begin{array}{l}61,872 \\
53,683 \\
51,249 \\
52,274 \\
49,853\end{array}$ & $\begin{array}{r}8,251 \\
6,136 \\
11,967 \\
16,142 \\
10,200\end{array}$ & $\begin{array}{l}13.3 \\
11.4 \\
23.4 \\
30.9 \\
20.5\end{array}$ & $\begin{array}{l}679,225 \\
732,488 \\
451,091 \\
512,325 \\
439,234\end{array}$ & $\begin{array}{r}68,850 \\
114,561 \\
62,943 \\
101,180 \\
56,546\end{array}$ & $\begin{array}{l}10.1 \\
15.6 \\
14.0 \\
19.7 \\
12.9\end{array}$ & $\begin{array}{l}1,442 \\
2,328 \\
1,294 \\
2,112 \\
1,200\end{array}$ & $\begin{array}{l}18,627 \\
12,476 \\
16,730 \\
34,818 \\
16,229\end{array}$ & $\begin{array}{r}9,030 \\
13,206 \\
16,636 \\
15,237 \\
9,202\end{array}$ & $\begin{array}{l}10,720 \\
12,186 \\
11,264 \\
13,047 \\
13,160\end{array}$ & $\begin{array}{r}265 \\
3,913 \\
460 \\
5,537 \\
2,210\end{array}$ & $\begin{array}{l}384 \\
974 \\
358 \\
537 \\
416\end{array}$ & $\begin{array}{r}0 \\
588 \\
82 \\
3 \\
30\end{array}$ & $\begin{array}{r}9,530 \\
13,711 \\
12,181 \\
20,829 \\
10,622\end{array}$ & $\begin{array}{l}4,043 \\
5,601 \\
5,302 \\
8,870 \\
4,729\end{array}$ & $\begin{array}{r}931 \\
901 \\
1,471 \\
2,163 \\
1,153\end{array}$ & $\begin{array}{l}2,090 \\
3,572 \\
2,855 \\
5,328 \\
2,567\end{array}$ & $\begin{array}{l}2,465 \\
3,636 \\
2,553 \\
4,467 \\
2,173\end{array}$ \\
\hline
\end{tabular}

-Not available.

1Poverty is defined based on the number of persons and related children in the family and their income. For information on poverty thresholds, see http://www.census.gov/hhes/www/poverty/data/threshld/.

2Fiscal year 2013 Department of Education funds available for spending by school districts in the 2013-14 school year.

${ }^{3}$ Federal revenue per student is based on fall enrollment collected through the "Local Education Agency (School District) Finance

NOTE: Detail may not sum to totals because of rounding. ISD $=$ independent school district.

SOURCE: US. Department of Education National Center for Education Statistics, Common Core of Data (CCD) "Local Education Agency Univere Durvey" 2011-12; "Locl Education Agency (School District) Finance Survey (F33)” 2010-11; and unp Department of Education budget data. US. Department of Commerce, Census Bureau, Small Area Income and Poverty Estimates (SAIPE) Program, 2012 Poverty Estimates for School Districts. (This table was prepared May 2014.) 
188 CHAPTER 2: Elementary and Secondary Education

Public Schools

Table 216.10. Public elementary and secondary schools, by level of school: Selected years, 1967-68 through 2011-12

\begin{tabular}{|c|c|c|c|c|c|c|c|c|c|c|c|c|c|}
\hline \multirow[b]{3}{*}{ Year } & \multirow[b]{3}{*}{$\begin{array}{r}\text { Total, all } \\
\text { public } \\
\text { schools }\end{array}$} & \multicolumn{11}{|c|}{ Schools with reported grade spans } & \multirow[b]{3}{*}{$\begin{array}{r}\text { Other } \\
\text { schools }\end{array}$} \\
\hline & & & \multicolumn{4}{|c|}{ Elementary schools } & \multicolumn{5}{|c|}{ Secondary schools } & \multirow[b]{2}{*}{$\begin{array}{r}\text { Combined } \\
\text { elementary/ } \\
\text { secondary } \\
\text { schools }^{2}\end{array}$} & \\
\hline & & Total & Total $^{3}$ & $\begin{array}{r}\text { Middle } \\
\text { schools }^{4}\end{array}$ & $\begin{array}{r}\text { One- } \\
\text { teacher } \\
\text { schools }\end{array}$ & \begin{tabular}{|r|} 
Other \\
elementary \\
schools
\end{tabular} & Total $^{5}$ & $\begin{array}{r}\text { Junior } \\
\text { high }^{6}\end{array}$ & $\begin{array}{r}\text { 3-year or 4- } \\
\text { year high } \\
\text { schools }\end{array}$ & $\begin{array}{r}5 \text {-year or 6- } \\
\text { year high } \\
\text { schools }\end{array}$ & $\begin{array}{r}\text { Other } \\
\text { secondary } \\
\text { schools }\end{array}$ & & \\
\hline 1 & 2 & 3 & 4 & 5 & 6 & 7 & 8 & 9 & 10 & 11 & 12 & 13 & 14 \\
\hline 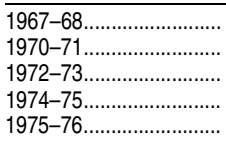 & $\begin{array}{r}- \\
- \\
- \\
88,597\end{array}$ & $\begin{array}{l}94,197 \\
89,372 \\
88,864 \\
87,456 \\
87,034\end{array}$ & $\begin{array}{l}67,186 \\
64,020 \\
62,942 \\
61,759 \\
61,704\end{array}$ & \begin{tabular}{r|}
2,080 \\
2,308 \\
3,224 \\
3,916
\end{tabular} & $\begin{array}{l}4,146 \\
1,815 \\
1,475 \\
1,247 \\
1,166\end{array}$ & $\begin{array}{l}63,040 \\
60,125 \\
59,159 \\
57,288 \\
56,622\end{array}$ & $\begin{array}{l}23,318 \\
23,572 \\
23,919 \\
23,837 \\
23,792\end{array}$ & $\begin{array}{l}7,437 \\
7,750 \\
7,878 \\
7,690 \\
7,521\end{array}$ & $\begin{array}{l}10,751 \\
11,265 \\
11,550 \\
11,480 \\
11,572\end{array}$ & $\begin{array}{l}4,650 \\
3,887 \\
3,962 \\
4,122 \\
4,113\end{array}$ & $\begin{array}{l}480 \\
670 \\
529 \\
545 \\
586\end{array}$ & $\begin{array}{l}3,693 \\
1,780 \\
2,003 \\
1,860 \\
1,538\end{array}$ & $\begin{array}{r}- \\
- \\
- \\
1,563\end{array}$ \\
\hline 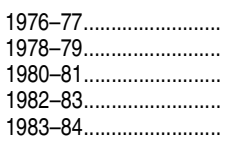 & $\begin{array}{r}- \\
- \\
85,982 \\
84,740 \\
84,178\end{array}$ & $\begin{array}{l}86,501 \\
84,816 \\
83,688 \\
82,039 \\
81,418\end{array}$ & $\begin{array}{l}61,123 \\
60,312 \\
59,326 \\
58,051 \\
57,471\end{array}$ & $\begin{array}{l}4,180 \\
5,879 \\
6,003 \\
6,875 \\
6,885\end{array}$ & $\begin{array}{r}1,111 \\
1,056 \\
921 \\
798 \\
838\end{array}$ & $\begin{array}{l}55,832 \\
53,377 \\
52,402 \\
50,378 \\
49,748\end{array}$ & $\begin{array}{l}23,857 \\
22,834 \\
22,619 \\
22,383 \\
22,336\end{array}$ & $\begin{array}{l}7,434 \\
6,282 \\
5,890 \\
5,948 \\
5,936\end{array}$ & $\begin{array}{l}11,658 \\
11,410 \\
10,758 \\
11,678 \\
11,670\end{array}$ & $\begin{array}{l}4,130 \\
4,429 \\
4,193 \\
4,067 \\
4,046\end{array}$ & $\begin{array}{r}635 \\
713 \\
1,778 \\
690 \\
684\end{array}$ & $\begin{array}{l}1,521 \\
1,670 \\
1,743 \\
1,605 \\
1,611\end{array}$ & $\begin{array}{r}- \\
2,294 \\
2,701 \\
2,760\end{array}$ \\
\hline 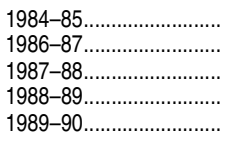 & $\begin{array}{l}84,007 \\
83,421 \\
83,248 \\
83,165 \\
83,425\end{array}$ & $\begin{array}{l}81,147 \\
82,316 \\
81,416 \\
81,579 \\
81,880\end{array}$ & $\begin{array}{l}57,231 \\
58,835 \\
57,575 \\
57,941 \\
58,419\end{array}$ & $\begin{array}{l}6,893 \\
7,483 \\
7,641 \\
7,957 \\
8,272\end{array}$ & $\begin{array}{l}825 \\
763 \\
729 \\
583 \\
630\end{array}$ & $\begin{array}{l}49,513 \\
50,589 \\
49,205 \\
49,401 \\
49,517\end{array}$ & $\begin{array}{l}22,320 \\
21,505 \\
21,662 \\
21,403 \\
21,181\end{array}$ & $\begin{array}{l}5,916 \\
5,109 \\
4,900 \\
4,687 \\
4,512\end{array}$ & $\begin{array}{l}11,671 \\
11,430 \\
11,279 \\
11,350 \\
11,492\end{array}$ & $\begin{array}{l}4,021 \\
4,196 \\
4,048 \\
3,994 \\
3,812\end{array}$ & $\begin{array}{r}712 \\
770 \\
1,435 \\
1,372 \\
1,365\end{array}$ & $\begin{array}{l}1,596 \\
1,976 \\
2,179 \\
2,235 \\
2,280\end{array}$ & $\begin{array}{l}2,860 \\
1,105^{7} \\
1,832^{7} \\
1,586^{7} \\
1,545^{7}\end{array}$ \\
\hline 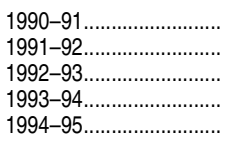 & $\begin{array}{l}84,538 \\
84,578 \\
84,497 \\
85,393 \\
86,221\end{array}$ & $\begin{array}{l}82,475 \\
82,506 \\
82,896 \\
83,431 \\
84,476\end{array}$ & $\begin{array}{l}59,015 \\
59,258 \\
59,676 \\
60,052 \\
60,808\end{array}$ & $\begin{array}{l}8,545 \\
8,829 \\
9,152 \\
9,573 \\
9,954\end{array}$ & $\begin{array}{l}617 \\
569 \\
430 \\
442 \\
458\end{array}$ & $\begin{array}{l}49,853 \\
49,860 \\
50,094 \\
50,037 \\
50,396\end{array}$ & $\begin{array}{l}21,135 \\
20,767 \\
20,671 \\
20,705 \\
20,904\end{array}$ & $\begin{array}{l}4,561 \\
4,298 \\
4,115 \\
3,970 \\
3,859\end{array}$ & $\begin{array}{l}11,537 \\
11,528 \\
11,651 \\
11,858 \\
12,058\end{array}$ & $\begin{array}{l}3,723 \\
3,699 \\
3,613 \\
3,595 \\
3,628\end{array}$ & $\begin{array}{l}1,314 \\
1,242 \\
1,292 \\
1,282 \\
1,359\end{array}$ & $\begin{array}{l}2,325 \\
2,481 \\
2,549 \\
2,674 \\
2,764\end{array}$ & $\begin{array}{l}2,063 \\
2,072 \\
1,601 \\
1,962 \\
1,745\end{array}$ \\
\hline 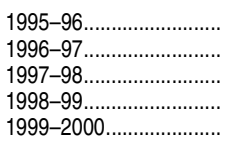 & $\begin{array}{l}87,125 \\
88,223 \\
89,508 \\
90,874 \\
92,012\end{array}$ & $\begin{array}{l}84,958 \\
86,092 \\
87,541 \\
89,259 \\
90,538\end{array}$ & $\begin{array}{l}61,165 \\
61,805 \\
62,739 \\
63,462 \\
64,131\end{array}$ & $\begin{array}{l}10,205 \\
10,499 \\
10,944 \\
11,202 \\
11,521\end{array}$ & $\begin{array}{l}474 \\
487 \\
476 \\
463 \\
423\end{array}$ & $\begin{array}{l}50,486 \\
50,819 \\
51,319 \\
51,797 \\
52,187\end{array}$ & $\begin{array}{l}20,997 \\
21,307 \\
21,682 \\
22,076 \\
22,365\end{array}$ & $\begin{array}{l}3,743 \\
3,707 \\
3,599 \\
3,607 \\
3,566\end{array}$ & $\begin{array}{l}12,168 \\
12,424 \\
12,734 \\
13,457 \\
13,914\end{array}$ & $\begin{array}{l}3,621 \\
3,614 \\
3,611 \\
3,707 \\
3,686\end{array}$ & $\begin{array}{l}1,465 \\
1,562 \\
1,738 \\
1,305 \\
1,199\end{array}$ & $\begin{array}{l}2,796 \\
2,980 \\
3,120 \\
3,721 \\
4,042\end{array}$ & $\begin{array}{l}2,167 \\
2,131 \\
1,967 \\
1,615 \\
1,474\end{array}$ \\
\hline 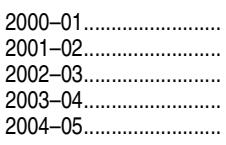 & $\begin{array}{l}93,273 \\
94,112 \\
95,615 \\
95,726 \\
96,513\end{array}$ & $\begin{array}{l}91,691 \\
92,696 \\
93,869 \\
93,977 \\
95,001\end{array}$ & $\begin{array}{l}64,601 \\
65,228 \\
65,718 \\
65,758 \\
65,984\end{array}$ & $\begin{array}{l}11,696 \\
11,983 \\
12,174 \\
12,341 \\
12,530\end{array}$ & $\begin{array}{l}411 \\
408 \\
366 \\
376 \\
338\end{array}$ & $\begin{array}{l}52,494 \\
52,837 \\
53,178 \\
53,041 \\
53,116\end{array}$ & $\begin{array}{l}21,994 \\
22,180 \\
22,599 \\
22,782 \\
23,445\end{array}$ & $\begin{array}{l}3,318 \\
3,285 \\
3,263 \\
3,251 \\
3,250\end{array}$ & $\begin{array}{l}13,793 \\
14,070 \\
14,330 \\
14,595 \\
14,854\end{array}$ & $\begin{array}{l}3,974 \\
3,917 \\
4,017 \\
3,840 \\
3,945\end{array}$ & $\begin{array}{r}909 \\
908 \\
989 \\
1,096 \\
1,396\end{array}$ & $\begin{array}{l}5,096 \\
5,288 \\
5,552 \\
5,437 \\
5,572\end{array}$ & $\begin{array}{l}1,582 \\
1,416 \\
1,746 \\
1,749 \\
1,512\end{array}$ \\
\hline 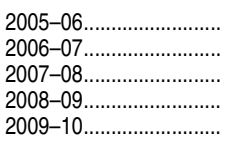 & $\begin{array}{l}97,382 \\
98,793 \\
98,916 \\
98,706 \\
98,817\end{array}$ & $\begin{array}{l}95,731 \\
96,362 \\
97,654 \\
97,119 \\
97,521\end{array}$ & $\begin{array}{l}66,026 \\
66,458 \\
67,112 \\
67,148 \\
67,140\end{array}$ & $\begin{array}{l}12,545 \\
12,773 \\
13,014 \\
13,060 \\
13,163\end{array}$ & $\begin{array}{l}326 \\
313 \\
288 \\
237 \\
217\end{array}$ & $\begin{array}{l}53,155 \\
53,372 \\
53,810 \\
53,851 \\
53,760\end{array}$ & $\begin{array}{l}23,998 \\
23,920 \\
24,643 \\
24,348 \\
24,651\end{array}$ & $\begin{array}{l}3,249 \\
3,112 \\
3,117 \\
3,037 \\
2,953\end{array}$ & $\begin{array}{l}15,103 \\
15,043 \\
16,146 \\
16,246 \\
16,706\end{array}$ & $\begin{array}{l}3,910 \\
4,048 \\
3,981 \\
3,761 \\
3,778\end{array}$ & $\begin{array}{l}1,736 \\
1,717 \\
1,399 \\
1,304 \\
1,214\end{array}$ & $\begin{array}{l}5,707 \\
5,984 \\
5,899 \\
5,623 \\
5,730\end{array}$ & $\begin{array}{l}1,651 \\
2,431 \\
1,262 \\
1,587 \\
1,296\end{array}$ \\
\hline 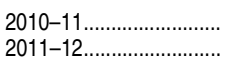 & $\begin{array}{l}98,817 \\
98,328\end{array}$ & $\begin{array}{l}97,767 \\
97,357\end{array}$ & $\begin{array}{l}67,086 \\
66,689\end{array}$ & $\begin{array}{l}13,045 \\
12,963\end{array}$ & $\begin{array}{l}224 \\
205\end{array}$ & $\begin{array}{l}53,817 \\
53,521\end{array}$ & $\begin{array}{l}24,544 \\
24,357\end{array}$ & $\begin{array}{l}2,855 \\
2,865\end{array}$ & $\begin{array}{l}16,321 \\
16,586\end{array}$ & $\begin{array}{l}4,047 \\
3,899\end{array}$ & $\begin{array}{l}1,321 \\
1,007\end{array}$ & $\begin{array}{l}6,137 \\
6,311\end{array}$ & $\begin{array}{r}1,050 \\
971\end{array}$ \\
\hline
\end{tabular}

-Not available.

${ }^{1}$ Includes special education, alternative, and other schools not reported by grade span. Includes schools beginning with grade 6 or below and ending with grade 9 or above. 3 Includes schools beginning with grade 6 or below and with no grade higher than 8 . ${ }^{4}$ Includes schools with grade spans beginning with 4,5 , or 6 and ending with 6,7 , or 8 . Includes schools with no grade lower than 7 .

${ }^{6}$ Includes schools with grades 7 and 8 or grades 7 through 9 .
${ }^{7}$ Because of revision in data collection procedures, figures not comparable to data for other years. SOURCE: U.S. Department of Education, National Center for Education Statistics, Stat State School Systems, 1967-68 and 1975-76; Statistics of Public Elementary and Secondary Day Schools, 1970-71, 1972-73, 1974-75, and 1976-77 through 1980-81; and Common Core of Data (CCD), "Public Elementary/Secondary School Universe Survey," 1982-83 through 2011-12. (This table was prepared August 2013.) 
Table 216.20. Number and enrollment of public elementary and secondary schools, by school level, type, and charter and magnet status: Selected years, 1990-91 through 2011-12

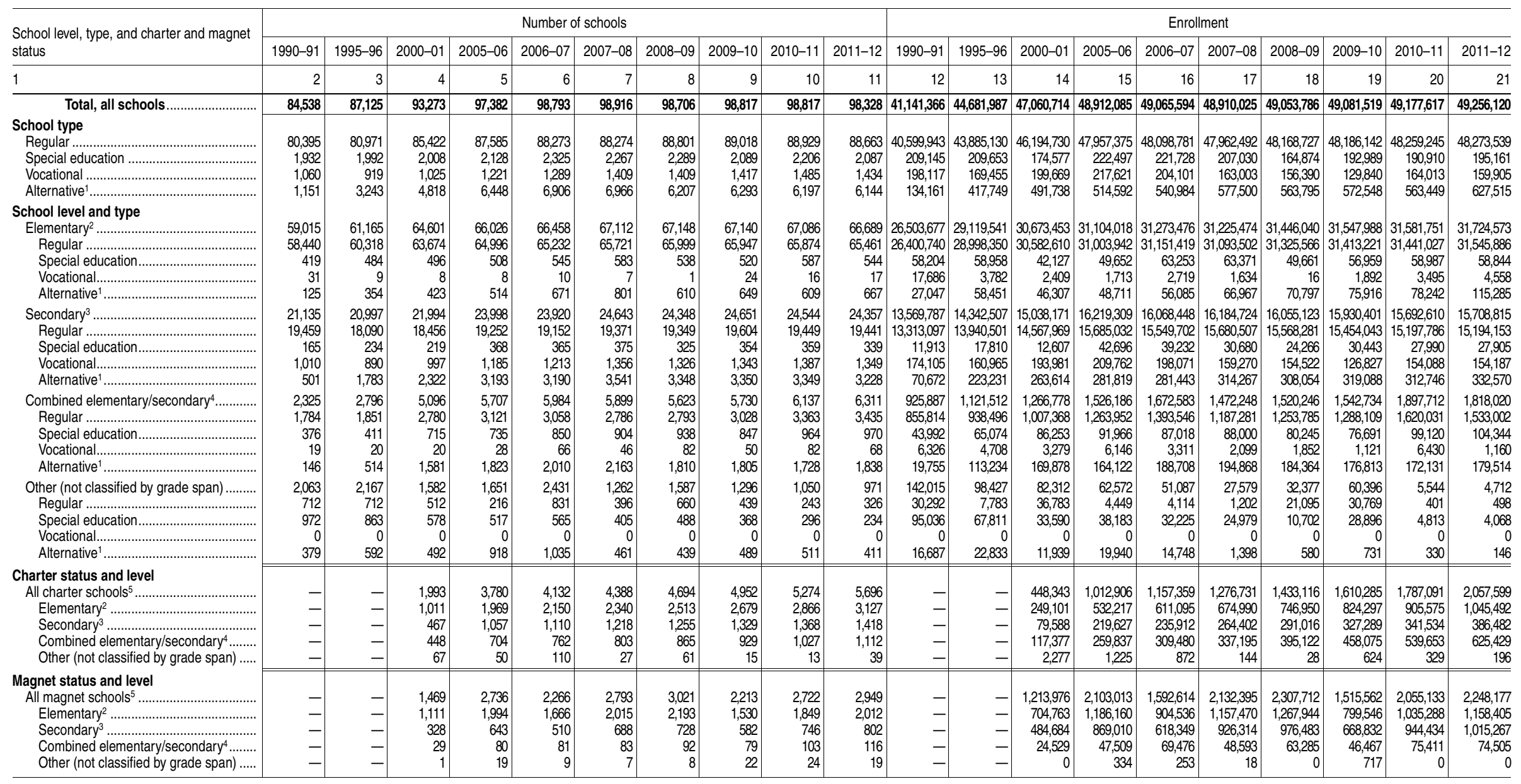

-Not available.

IIncludes schools that provide nontraditional education, address needs of students that typically cannot be met in regular schools,

serve as adjuncts to regular schools, or fall outside the categories of regular, special education, or vocational education.
Includes schools beginning with grade 6 or below and with no grade higher than 8 .

4Includes schools beginning with grade 6 or below and ending with grade 9 or above.

${ }^{5}$ Magnet and charter schools are also included under regular, special education, vocational, or alternative schools as appropriate. Includes schools with no grade lower than 7 . tary/Secondary School Universe Survey," 1990-91 through 2011-12. (This table was prepared September 2013.) 
Table 216.30. Number and percentage distribution of public elementary and secondary students and schools, by traditional or charter school status and selected characteristics: Selected years, 1999-2000 through 2011-12

\begin{tabular}{|c|c|c|c|c|c|c|c|c|c|c|c|c|}
\hline \multirow[b]{2}{*}{ Selected characteristic } & \multicolumn{3}{|c|}{ 1999-2000 } & \multicolumn{6}{|c|}{ Charter schools } & \multicolumn{3}{|c|}{ 2011-12 } \\
\hline & $\begin{array}{r}\text { Total, all } \\
\text { public } \\
\text { schools }\end{array}$ & $\begin{array}{r}\text { Traditional } \\
\text { (noncharter) } \\
\text { schools }\end{array}$ & $\begin{array}{l}\text { Charter } \\
\text { schools }\end{array}$ & $2001-02$ & $2003-04$ & $2005-06$ & $2007-08$ & $2009-10$ & $2010-11$ & $\begin{array}{r}\text { Total, all } \\
\text { public } \\
\text { schools }\end{array}$ & $\begin{array}{r}\text { Traditional } \\
\text { (noncharter) } \\
\text { schools }\end{array}$ & $\begin{array}{l}\text { Charter } \\
\text { schools }\end{array}$ \\
\hline 1 & 2 & 3 & 4 & 5 & 6 & 7 & 8 & 9 & 10 & 11 & 12 & 13 \\
\hline $\begin{array}{l}\text { Enrollment (in thousands)................................. } \\
\text { Percentage distribution of students }\end{array}$ & 46,689 & 46,350 & 340 & 571 & 789 & 1,013 & 1,277 & 1,610 & 1,787 & 49,256 & 47,199 & 2,058 \\
\hline 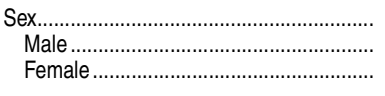 & $\begin{array}{r}100.0 \\
51.4 \\
48.6\end{array}$ & $\begin{array}{r}100.0 \\
51.4 \\
48.6\end{array}$ & $\begin{array}{r}100.0 \\
51.0 \\
49.0\end{array}$ & $\begin{array}{r}100.0 \\
50.8 \\
49.2\end{array}$ & $\begin{array}{r}100.0 \\
50.3 \\
49.7\end{array}$ & $\begin{array}{r}100.0 \\
49.9 \\
50.1\end{array}$ & $\begin{array}{r}100.0 \\
49.5 \\
50.5\end{array}$ & $\begin{array}{r}100.0 \\
49.5 \\
50.5\end{array}$ & $\begin{array}{r}100.0 \\
49.5 \\
50.5\end{array}$ & $\begin{array}{r}100.0 \\
51.4 \\
48.6\end{array}$ & $\begin{array}{r}100.0 \\
51.4 \\
48.6\end{array}$ & $\begin{array}{r}100.0 \\
49.6 \\
50.4\end{array}$ \\
\hline 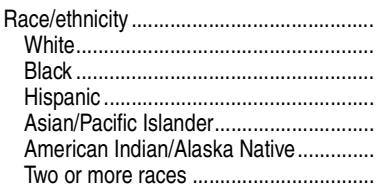 & $\begin{array}{r}100.0 \\
61.8 \\
17.1 \\
15.9 \\
4.1 \\
1.2 \\
-\end{array}$ & $\begin{array}{r}100.0 \\
61.9 \\
16.9 \\
15.9 \\
4.1 \\
1.2 \\
-\end{array}$ & $\begin{array}{r}100.0 \\
42.5 \\
33.5 \\
19.6 \\
2.8 \\
1.5 \\
-\end{array}$ & $\begin{array}{r}100.0 \\
42.6 \\
32.5 \\
20.1 \\
3.1 \\
1.7 \\
-\end{array}$ & $\begin{array}{r}100.0 \\
41.8 \\
31.9 \\
21.5 \\
3.2 \\
1.5 \\
-\end{array}$ & $\begin{array}{r}100.0 \\
40.5 \\
32.1 \\
22.4 \\
3.6 \\
1.4 \\
-\end{array}$ & $\begin{array}{r}100.0 \\
38.8 \\
31.8 \\
24.5 \\
3.8 \\
1.2 \\
-\end{array}$ & $\begin{array}{r}100.0 \\
37.3 \\
30.3 \\
26.0 \\
3.9 \\
1.0 \\
1.4\end{array}$ & $\begin{array}{r}100.0 \\
36.2 \\
28.9 \\
27.3 \\
3.7 \\
0.9 \\
2.9\end{array}$ & $\begin{array}{r}100.0 \\
51.7 \\
15.8 \\
23.7 \\
5.1 \\
1.1 \\
2.6\end{array}$ & $\begin{array}{r}100.0 \\
52.4 \\
15.2 \\
23.6 \\
5.1 \\
1.1 \\
2.6\end{array}$ & $\begin{array}{r}100.0 \\
35.6 \\
28.7 \\
28.0 \\
4.0 \\
0.9 \\
2.8\end{array}$ \\
\hline 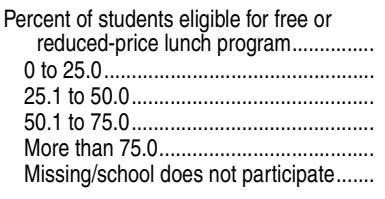 & $\begin{array}{r}100.0 \\
44.9 \\
25.4 \\
16.0 \\
12.2 \\
1.4\end{array}$ & $\begin{array}{r}100.0 \\
45.0 \\
25.5 \\
16.1 \\
12.2 \\
1.2\end{array}$ & $\begin{array}{r}100.0 \\
36.9 \\
12.7 \\
13.0 \\
14.3 \\
23.2\end{array}$ & $\begin{array}{r}100.0 \\
42.5 \\
14.3 \\
14.7 \\
15.2 \\
13.3\end{array}$ & $\begin{array}{r}100.0 \\
33.2 \\
17.1 \\
16.1 \\
18.4 \\
15.2\end{array}$ & $\begin{array}{r}100.0 \\
36.1 \\
15.9 \\
17.4 \\
22.0 \\
8.6\end{array}$ & $\begin{array}{r}100.0 \\
19.8 \\
16.5 \\
18.9 \\
21.2 \\
23.6\end{array}$ & $\begin{array}{r}100.0 \\
20.6 \\
18.8 \\
20.2 \\
30.7 \\
9.7\end{array}$ & $\begin{array}{r}100.0 \\
26.7 \\
18.9 \\
20.4 \\
30.7 \\
3.2\end{array}$ & $\begin{array}{r}100.0 \\
23.7 \\
27.6 \\
25.2 \\
18.9 \\
4.6\end{array}$ & $\begin{array}{r}100.0 \\
23.8 \\
28.0 \\
25.4 \\
18.3 \\
4.4\end{array}$ & $\begin{array}{r}100.0 \\
21.9 \\
18.4 \\
21.0 \\
30.8 \\
7.9\end{array}$ \\
\hline 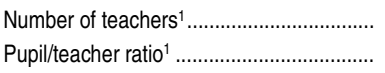 & $\begin{array}{r}2,636,277 \\
16.6 \\
\end{array}$ & $\begin{array}{r}2,622,678 \\
16.6 \\
\end{array}$ & $\begin{array}{r}13,599 \\
18.8 \\
\end{array}$ & $\begin{array}{r}23,415 \\
17.7 \\
\end{array}$ & $\begin{array}{r}36,406 \\
17.6 \\
\end{array}$ & $\begin{array}{r}49,142 \\
17.3 \\
\end{array}$ & $\begin{array}{r}69,725 \\
15.9 \\
\end{array}$ & $\begin{array}{r}84,983 \\
17.3 \\
\end{array}$ & $\begin{array}{r}91,126 \\
18.0 \\
\end{array}$ & $\begin{array}{r}3,028,283 \\
16.3 \\
\end{array}$ & $\begin{array}{r}2,920,353 \\
16.3 \\
\end{array}$ & $\begin{array}{r}107,929 \\
17.6 \\
\end{array}$ \\
\hline $\begin{array}{l}\text { Total number of schools............................. } \\
\text { Percentage distribution of schools }\end{array}$ & 92,012 & 90,488 & 1,524 & 2,348 & 2,977 & 3,780 & 4,388 & 4,952 & 5,274 & 98,328 & 92,632 & 5,696 \\
\hline 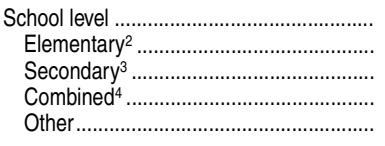 & $\begin{array}{r}100.0 \\
69.7 \\
24.3 \\
4.4 \\
1.6\end{array}$ & $\begin{array}{r}100.0 \\
70.0 \\
24.3 \\
4.2 \\
1.6\end{array}$ & $\begin{array}{r}100.0 \\
54.6 \\
25.9 \\
18.6 \\
0.9\end{array}$ & $\begin{array}{r}100.0 \\
50.6 \\
24.2 \\
21.6 \\
3.6\end{array}$ & $\begin{array}{r}100.0 \\
52.0 \\
26.2 \\
21.0 \\
0.8\end{array}$ & $\begin{array}{r}100.0 \\
52.1 \\
28.0 \\
18.6 \\
1.3\end{array}$ & $\begin{array}{r}100.0 \\
53.3 \\
27.8 \\
18.3 \\
0.6\end{array}$ & $\begin{array}{r}100.0 \\
54.1 \\
26.8 \\
18.8 \\
0.3\end{array}$ & $\begin{array}{r}100.0 \\
54.3 \\
25.9 \\
19.5 \\
0.2\end{array}$ & $\begin{array}{r}100.0 \\
67.8 \\
24.8 \\
6.4 \\
1.0\end{array}$ & $\begin{array}{r}100.0 \\
68.6 \\
24.8 \\
5.6 \\
1.0\end{array}$ & $\begin{array}{r}100.0 \\
54.9 \\
24.9 \\
19.5 \\
0.7\end{array}$ \\
\hline 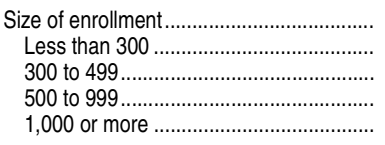 & $\begin{array}{r}100.0 \\
31.4 \\
26.4 \\
32.6 \\
9.5\end{array}$ & $\begin{array}{r}100.0 \\
30.7 \\
26.7 \\
33.0 \\
9.7\end{array}$ & $\begin{array}{r}100.0 \\
77.1 \\
12.0 \\
8.6 \\
2.4\end{array}$ & $\begin{array}{r}100.0 \\
73.6 \\
13.6 \\
9.9 \\
2.8\end{array}$ & $\begin{array}{r}100.0 \\
71.1 \\
15.6 \\
10.1 \\
3.2\end{array}$ & $\begin{array}{r}100.0 \\
69.6 \\
16.5 \\
10.9 \\
3.0\end{array}$ & $\begin{array}{r}100.0 \\
65.6 \\
19.3 \\
12.0 \\
3.1\end{array}$ & $\begin{array}{r}100.0 \\
61.5 \\
20.8 \\
14.0 \\
3.7\end{array}$ & $\begin{array}{r}100.0 \\
59.0 \\
22.3 \\
14.8 \\
3.9\end{array}$ & $\begin{array}{r}100.0 \\
30.5 \\
27.7 \\
32.8 \\
9.0\end{array}$ & $\begin{array}{r}100.0 \\
28.9 \\
28.0 \\
33.8 \\
9.3\end{array}$ & $\begin{array}{r}100.0 \\
55.8 \\
23.1 \\
17.0 \\
4.2\end{array}$ \\
\hline $\begin{array}{l}\text { Racial/ethnic concentration } \\
\text { More than } 50 \text { percent White ................... } \\
\text { More than } 50 \text { percent Black................. } \\
\text { More than } 50 \text { percent Hispanic.............. }\end{array}$ & $\begin{array}{r}70.9 \\
11.1 \\
8.8\end{array}$ & $\begin{array}{r}71.2 \\
10.8 \\
8.7\end{array}$ & $\begin{array}{l}51.1 \\
26.5 \\
11.4\end{array}$ & $\begin{array}{l}50.9 \\
23.8 \\
12.5\end{array}$ & $\begin{array}{l}48.7 \\
24.5 \\
13.6\end{array}$ & $\begin{array}{l}46.5 \\
26.4 \\
15.1\end{array}$ & $\begin{array}{l}43.2 \\
26.5 \\
17.8\end{array}$ & $\begin{array}{l}40.3 \\
25.8 \\
19.8\end{array}$ & $\begin{array}{l}38.4 \\
25.4 \\
20.8\end{array}$ & $\begin{array}{l}59.7 \\
10.3 \\
15.0\end{array}$ & $\begin{array}{r}61.1 \\
9.4 \\
14.6\end{array}$ & $\begin{array}{l}37.5 \\
25.3 \\
21.8\end{array}$ \\
\hline 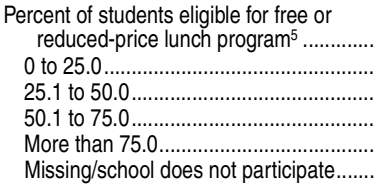 & $\begin{array}{r}100.0 \\
42.3 \\
25.6 \\
16.8 \\
11.9 \\
3.3\end{array}$ & $\begin{array}{r}100.0 \\
42.3 \\
25.9 \\
16.9 \\
11.9 \\
3.0\end{array}$ & $\begin{array}{r}100.0 \\
44.5 \\
11.1 \\
10.2 \\
12.4 \\
21.9\end{array}$ & $\begin{array}{r}100.0 \\
47.8 \\
11.7 \\
12.0 \\
13.5 \\
14.9\end{array}$ & $\begin{array}{r}100.0 \\
28.7 \\
16.0 \\
16.0 \\
19.9 \\
19.5\end{array}$ & $\begin{array}{r}100.0 \\
32.7 \\
15.2 \\
16.9 \\
22.7 \\
12.5\end{array}$ & $\begin{array}{r}100.0 \\
20.2 \\
15.5 \\
18.8 \\
22.4 \\
23.0\end{array}$ & $\begin{array}{r}100.0 \\
19.3 \\
17.2 \\
20.9 \\
32.8 \\
9.8\end{array}$ & $\begin{array}{r}100.0 \\
27.7 \\
17.4 \\
20.1 \\
33.1 \\
1.7\end{array}$ & $\begin{array}{r}100.0 \\
19.7 \\
25.8 \\
25.7 \\
20.5 \\
8.3\end{array}$ & $\begin{array}{r}100.0 \\
19.7 \\
26.3 \\
26.1 \\
19.7 \\
8.2\end{array}$ & $\begin{array}{r}100.0 \\
18.7 \\
17.9 \\
19.9 \\
33.8 \\
9.7\end{array}$ \\
\hline $\begin{array}{l}\text { Locale } \\
\text { City } \\
\text { Suburban } \\
\text { Town } \\
\text { Rural }\end{array}$ & $\begin{array}{l}- \\
- \\
- \\
-\end{array}$ & $\begin{array}{l}- \\
- \\
- \\
- \\
-\end{array}$ & $\begin{array}{l}- \\
- \\
- \\
- \\
-\end{array}$ & $\begin{array}{l}- \\
- \\
- \\
-\end{array}$ & $\begin{array}{r}100.0 \\
52.7 \\
22.0 \\
9.6 \\
15.8\end{array}$ & $\begin{array}{r}100.0 \\
52.5 \\
22.2 \\
9.4 \\
16.0\end{array}$ & $\begin{array}{r}100.0 \\
54.3 \\
22.0 \\
8.5 \\
15.2\end{array}$ & $\begin{array}{r}100.0 \\
54.8 \\
21.1 \\
8.0 \\
16.1\end{array}$ & $\begin{array}{r}100.0 \\
55.5 \\
21.3 \\
7.6 \\
15.6\end{array}$ & $\begin{array}{r}100.0 \\
26.2 \\
27.3 \\
13.6 \\
32.9\end{array}$ & $\begin{array}{r}100.0 \\
24.4 \\
27.7 \\
14.0 \\
33.9\end{array}$ & $\begin{array}{r}100.0 \\
55.4 \\
21.2 \\
7.4 \\
16.0\end{array}$ \\
\hline 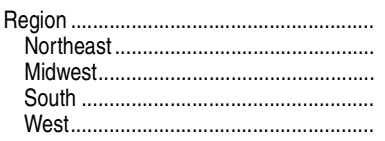 & $\begin{array}{r}100.0 \\
16.1 \\
28.9 \\
33.1 \\
21.8\end{array}$ & $\begin{array}{r}100.0 \\
16.3 \\
29.0 \\
33.2 \\
21.6\end{array}$ & $\begin{array}{r}100.0 \\
7.2 \\
24.9 \\
28.9 \\
38.9\end{array}$ & $\begin{array}{r}100.0 \\
10.1 \\
22.6 \\
28.4 \\
38.9\end{array}$ & $\begin{array}{r}100.0 \\
9.2 \\
23.7 \\
26.7 \\
40.3\end{array}$ & $\begin{array}{r}100.0 \\
9.0 \\
27.4 \\
26.5 \\
37.2\end{array}$ & $\begin{array}{r}100.0 \\
8.6 \\
26.5 \\
28.2 \\
36.6\end{array}$ & $\begin{array}{r}100.0 \\
9.1 \\
24.0 \\
29.5 \\
37.4\end{array}$ & $\begin{array}{r}100.0 \\
9.5 \\
23.1 \\
29.5 \\
37.9\end{array}$ & $\begin{array}{r}100.0 \\
15.5 \\
26.1 \\
34.9 \\
23.5\end{array}$ & $\begin{array}{r}100.0 \\
15.9 \\
26.3 \\
35.1 \\
22.7\end{array}$ & $\begin{array}{r}100.0 \\
9.7 \\
22.3 \\
30.8 \\
37.2\end{array}$ \\
\hline
\end{tabular}

-Not available.

1Data for 2010 include imputations for teachers in California and Vermont.

${ }^{2}$ Includes schools beginning with grade 6 or below and with no grade higher than 8 . Includes schools with no grade lower than 7 .

${ }^{4}$ Includes schools beginning with grade 6 or below and ending with grade 9 or above.

${ }^{5}$ The National School Lunch Program is a federally assisted meal program. To be eligible for free lunch under the program, a student must be from a household with an income at or below 130 percent of the poverty threshold; to be eligible for reduced-price lunch, a student must be from a household with an income between 130 percent and 185 percent of the poverty threshold.

NOTE: Detail may not sum to totals because of rounding. Race categories exclude persons of Hispanic ethnicity.

SOURCE: U.S. Department of Education, National Center for Education Statistics, Common Core of Data (CCD), "Public Elementary/Secondary School Universe Survey, 1999-2000 through 2011-12. (This table was prepared March 2014. ) 
Table 216.40. Number and percentage distribution of public elementary and secondary schools and enrollment, by level, type, and enrollment size of school: 2009-10, 2010-11, and 2011-12

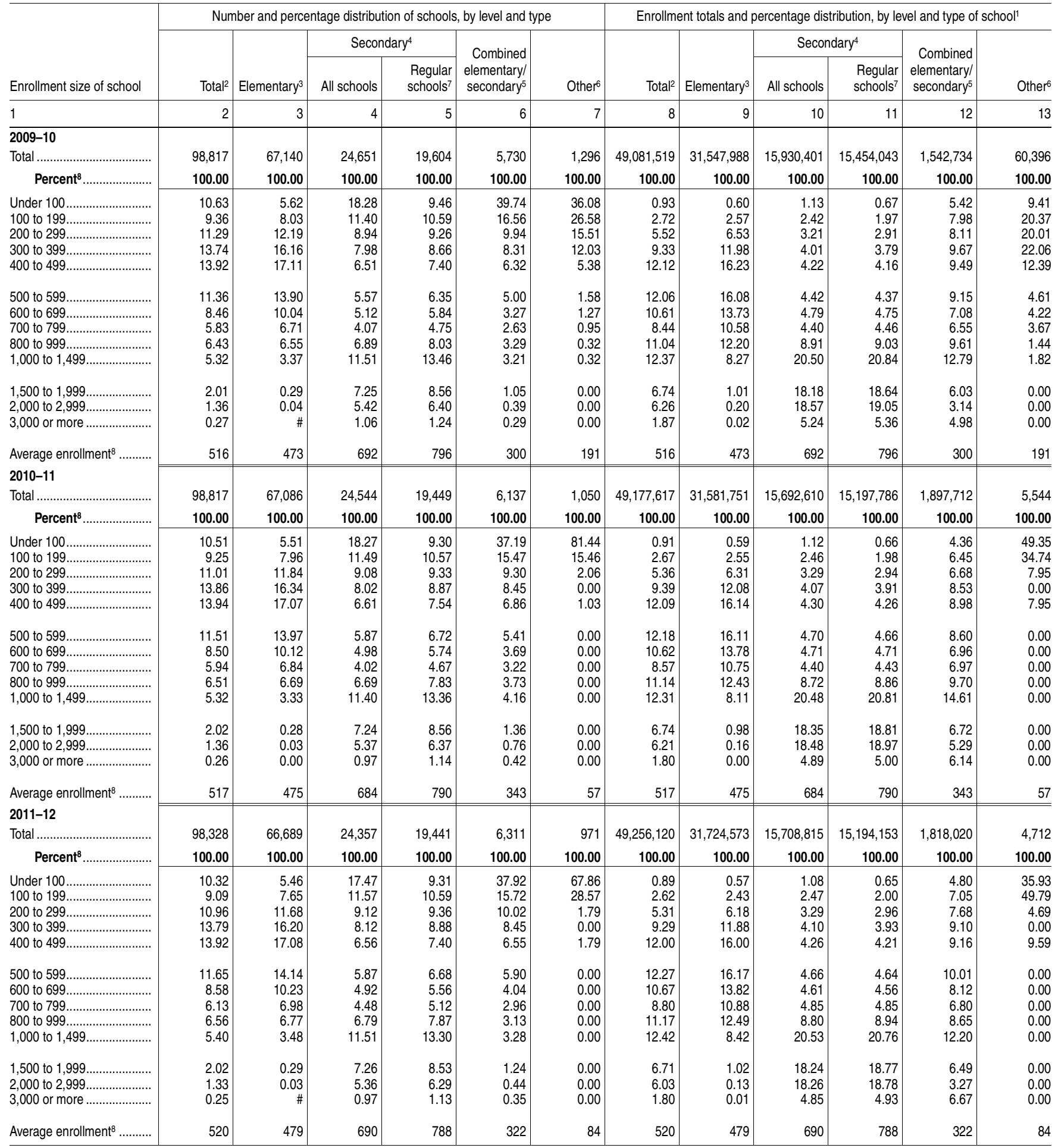

\#Rounds to zero.

Totals differ from those reported in other tables because this table represents data reported by schools rather than by states or school districts. Percentage distribution and average enrollment calculations exclude data for schools not reporting enrollment. Includes elementary, secondary, combined elementary/secondary, and other schools. ${ }^{3}$ Includes schools beginning with grade 6 or below and with no grade higher than 8 . ${ }^{4}$ Includes schools with no grade lower than 7 .

${ }^{5}$ Includes schools beginning with grade 6 or below and ending with grade 9 or above. ${ }^{6}$ Includes special education, alternative, and other schools not reported by grade span.
${ }^{7}$ Excludes special education schools, vocational schools, and alternative schools. ${ }^{8}$ Data are for schools reporting enrollments greater than zero. Enrollments greater than zero were reported for 95,178 out of 98,817 schools in $2009-10,95,111$ out of 98,817 in $2010-11$, and 94,743 out of 98,328 in 2011-12.

NOTE: Detail may not sum to totals because of rounding

SOURCE: U.S. Department of Education, National Center for Education Statistics, Common Core of Data (CCD), "Public Elementary/Secondary School Universe Survey," 2009-10, 2010-11, 2011-12. (This table was prepared August 2013.) 
192 CHAPTER 2: Elementary and Secondary Education

Public Schools

Table 216.45. Average enrollment and percentage distribution of public elementary and secondary schools, by level, type, and enrollment size: Selected years, 1982-83 through 2011-12

\begin{tabular}{|c|c|c|c|c|c|c|c|c|c|c|c|c|c|c|}
\hline \multirow[b]{3}{*}{ Year } & \multicolumn{6}{|c|}{ Average enrollment in schools, by level and type } & \multicolumn{8}{|c|}{ Percentage distribution of schools, by enrollment size } \\
\hline & \multirow[b]{2}{*}{ Total $^{1}$} & \multirow[b]{2}{*}{ Elementary ${ }^{2}$} & \multicolumn{2}{|c|}{ Secondary $^{3}$} & \multirow{2}{*}{$\begin{array}{r}\text { Combined } \\
\text { elementary/ } \\
\text { secondary }\end{array}$} & \multirow[b]{2}{*}{ Other ${ }^{5}$} & \multirow[b]{2}{*}{ Under 200} & \multirow[b]{2}{*}{200 to 299} & \multirow[b]{2}{*}{300 to 399} & \multirow[b]{2}{*}{400 to 499} & \multirow[b]{2}{*}{500 to 599} & \multirow[b]{2}{*}{600 to 699} & \multirow[b]{2}{*}{700 to 999} & \multirow[b]{2}{*}{$\begin{array}{r}1,000 \\
\text { or more }\end{array}$} \\
\hline & & & $\begin{array}{r}\text { All } \\
\text { schools }\end{array}$ & $\begin{array}{r}\text { Regular } \\
\text { schools }^{6}\end{array}$ & & & & & & & & & & \\
\hline 1 & 2 & 3 & 4 & 5 & 6 & 7 & 8 & 9 & 10 & 11 & 12 & 13 & 14 & 15 \\
\hline 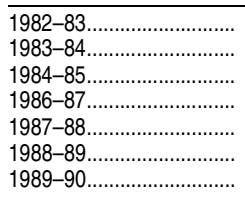 & $\begin{array}{l}478 \\
480 \\
482 \\
489 \\
490 \\
494 \\
493\end{array}$ & $\begin{array}{l}399 \\
401 \\
403 \\
416 \\
424 \\
433 \\
441\end{array}$ & $\begin{array}{l}719 \\
720 \\
721 \\
707 \\
695 \\
689 \\
669\end{array}$ & $\begin{array}{r}- \\
- \\
714 \\
711 \\
697 \\
689\end{array}$ & $\begin{array}{l}478 \\
475 \\
476 \\
426 \\
420 \\
412 \\
402\end{array}$ & $\begin{array}{l}142 \\
145 \\
146 \\
118 \\
122 \\
142 \\
142\end{array}$ & $\begin{array}{l}21.9 \\
21.7 \\
21.5 \\
21.1 \\
20.3 \\
20.0 \\
19.8\end{array}$ & $\begin{array}{l}13.8 \\
13.7 \\
13.6 \\
13.1 \\
12.9 \\
12.5 \\
12.2\end{array}$ & $\begin{array}{l}15.5 \\
15.5 \\
15.5 \\
15.0 \\
14.9 \\
14.7 \\
14.5\end{array}$ & $\begin{array}{l}13.1 \\
13.2 \\
13.2 \\
13.5 \\
13.8 \\
13.8 \\
13.7\end{array}$ & $\begin{array}{l}10.2 \\
10.2 \\
10.3 \\
10.8 \\
11.1 \\
11.4 \\
11.5\end{array}$ & $\begin{array}{l}7.1 \\
7.1 \\
7.1 \\
7.5 \\
7.8 \\
8.0 \\
8.3\end{array}$ & $\begin{array}{l}10.2 \\
10.3 \\
10.4 \\
10.7 \\
11.2 \\
11.6 \\
12.0\end{array}$ & $\begin{array}{l}8.3 \\
8.3 \\
8.4 \\
8.1 \\
8.0 \\
8.0 \\
7.9\end{array}$ \\
\hline 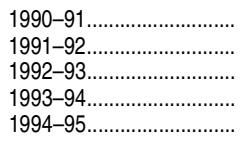 & $\begin{array}{l}497 \\
507 \\
513 \\
518 \\
520\end{array}$ & $\begin{array}{l}449 \\
458 \\
464 \\
468 \\
471\end{array}$ & $\begin{array}{l}663 \\
677 \\
688 \\
693 \\
696\end{array}$ & $\begin{array}{l}684 \\
717 \\
733 \\
748 \\
759\end{array}$ & $\begin{array}{l}398 \\
407 \\
423 \\
418 \\
412\end{array}$ & $\begin{array}{l}150 \\
152 \\
135 \\
136 \\
131\end{array}$ & $\begin{array}{l}19.7 \\
19.1 \\
18.6 \\
18.6 \\
18.6\end{array}$ & $\begin{array}{l}11.9 \\
11.7 \\
11.6 \\
11.5 \\
11.4\end{array}$ & $\begin{array}{l}14.2 \\
14.1 \\
13.9 \\
13.6 \\
13.6\end{array}$ & $\begin{array}{l}13.6 \\
13.5 \\
13.5 \\
13.5 \\
13.4\end{array}$ & $\begin{array}{l}11.7 \\
11.8 \\
11.9 \\
11.7 \\
11.8\end{array}$ & $\begin{array}{l}8.5 \\
8.6 \\
8.7 \\
8.8 \\
8.7\end{array}$ & $\begin{array}{l}12.3 \\
12.8 \\
13.1 \\
13.3 \\
13.3\end{array}$ & $\begin{array}{l}8.1 \\
8.5 \\
8.7 \\
9.0 \\
9.2\end{array}$ \\
\hline $\begin{array}{l}1995-96 \\
1996-97 \ldots \ldots \ldots \ldots \ldots \ldots \ldots \ldots \\
1997-98 \ldots \ldots \ldots \ldots \ldots \ldots \ldots \ldots \\
1998-99 \ldots \ldots \ldots \ldots \ldots \ldots \ldots \ldots \\
1999-2000\end{array}$ & $\begin{array}{l}525 \\
527 \\
525 \\
524 \\
521\end{array}$ & $\begin{array}{l}476 \\
478 \\
478 \\
478 \\
477\end{array}$ & $\begin{array}{l}703 \\
703 \\
699 \\
707 \\
706\end{array}$ & $\begin{array}{l}771 \\
777 \\
779 \\
786 \\
785\end{array}$ & $\begin{array}{l}401 \\
387 \\
374 \\
290 \\
282\end{array}$ & $\begin{array}{l}136 \\
135 \\
121 \\
135 \\
123\end{array}$ & $\begin{array}{l}18.5 \\
18.7 \\
19.3 \\
19.6 \\
20.0\end{array}$ & $\begin{array}{l}11.2 \\
11.3 \\
11.2 \\
11.2 \\
11.3\end{array}$ & $\begin{array}{l}13.5 \\
13.2 \\
13.1 \\
13.1 \\
13.3\end{array}$ & $\begin{array}{l}13.4 \\
13.2 \\
13.3 \\
13.2 \\
13.2\end{array}$ & $\begin{array}{l}11.8 \\
11.8 \\
11.6 \\
11.5 \\
11.2\end{array}$ & $\begin{array}{l}8.8 \\
8.8 \\
8.6 \\
8.5 \\
8.4\end{array}$ & $\begin{array}{l}13.4 \\
13.6 \\
13.4 \\
13.3 \\
13.1\end{array}$ & $\begin{array}{l}9.4 \\
9.5 \\
9.6 \\
9.6 \\
9.5\end{array}$ \\
\hline $\begin{array}{l}2000-01 \ldots \ldots \ldots \ldots \ldots \ldots \ldots \\
2001-02 \ldots \ldots \ldots \ldots \ldots \ldots \ldots \ldots \\
2002-03 \ldots \ldots \ldots \ldots \ldots \ldots \ldots \ldots \\
2003-04 \ldots \ldots \ldots \ldots \ldots \ldots \ldots \ldots \\
2004-05 \ldots \ldots \ldots \ldots \ldots \ldots \ldots \ldots\end{array}$ & $\begin{array}{l}519 \\
520 \\
519 \\
521 \\
521\end{array}$ & $\begin{array}{l}477 \\
477 \\
476 \\
476 \\
474\end{array}$ & $\begin{array}{l}714 \\
718 \\
720 \\
722 \\
713\end{array}$ & $\begin{array}{l}795 \\
807 \\
813 \\
816 \\
815\end{array}$ & $\begin{array}{l}274 \\
270 \\
265 \\
269 \\
298\end{array}$ & $\begin{array}{l}136 \\
138 \\
136 \\
142 \\
143\end{array}$ & $\begin{array}{l}20.4 \\
20.5 \\
20.7 \\
20.7 \\
20.7\end{array}$ & $\begin{array}{l}11.4 \\
11.5 \\
11.6 \\
11.6 \\
11.6\end{array}$ & $\begin{array}{l}13.2 \\
13.3 \\
13.4 \\
13.5 \\
13.5\end{array}$ & $\begin{array}{l}13.3 \\
13.1 \\
13.0 \\
13.2 \\
13.2\end{array}$ & $\begin{array}{l}11.0 \\
10.9 \\
10.9 \\
10.8 \\
10.8\end{array}$ & $\begin{array}{l}8.2 \\
8.1 \\
8.1 \\
8.0 \\
8.1\end{array}$ & $\begin{array}{l}12.9 \\
12.7 \\
12.4 \\
12.3 \\
12.2\end{array}$ & $\begin{array}{l}9.6 \\
9.7 \\
9.8 \\
9.9 \\
9.9\end{array}$ \\
\hline $\begin{array}{l}2005-06 \ldots \ldots \ldots \ldots \ldots \ldots \\
2006-07 \ldots \ldots \ldots \ldots \ldots \ldots \ldots \ldots \ldots \\
2007-08 \ldots \ldots \ldots \ldots \ldots \ldots \ldots \ldots \\
2008-09 \ldots \ldots \ldots \ldots \ldots \ldots \ldots \ldots \\
2009-10 \ldots \ldots \ldots \ldots \ldots \ldots \ldots . . .\end{array}$ & $\begin{array}{l}521 \\
521 \\
516 \\
517 \\
516\end{array}$ & $\begin{array}{l}473 \\
473 \\
469 \\
470 \\
473\end{array}$ & $\begin{array}{l}709 \\
711 \\
704 \\
704 \\
692\end{array}$ & $\begin{array}{l}819 \\
818 \\
816 \\
807 \\
796\end{array}$ & $\begin{array}{l}318 \\
325 \\
292 \\
308 \\
300\end{array}$ & $\begin{array}{l}128 \\
138 \\
136 \\
177 \\
191\end{array}$ & $\begin{array}{l}20.7 \\
20.3 \\
20.4 \\
20.0 \\
20.0\end{array}$ & $\begin{array}{l}11.5 \\
11.5 \\
11.5 \\
11.4 \\
11.3\end{array}$ & $\begin{array}{l}13.6 \\
13.8 \\
13.9 \\
13.8 \\
13.7\end{array}$ & $\begin{array}{l}13.2 \\
13.4 \\
13.6 \\
13.9 \\
13.9\end{array}$ & $\begin{array}{l}11.0 \\
11.0 \\
11.1 \\
11.3 \\
11.4\end{array}$ & $\begin{array}{l}8.1 \\
8.2 \\
8.1 \\
8.3 \\
8.5\end{array}$ & $\begin{array}{l}12.2 \\
12.2 \\
12.0 \\
12.2 \\
12.3\end{array}$ & $\begin{array}{l}9.8 \\
9.6 \\
9.3 \\
9.1 \\
9.0\end{array}$ \\
\hline 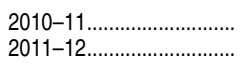 & $\begin{array}{l}517 \\
520\end{array}$ & $\begin{array}{l}475 \\
479\end{array}$ & $\begin{array}{l}684 \\
690\end{array}$ & $\begin{array}{l}790 \\
788\end{array}$ & $\begin{array}{l}343 \\
322\end{array}$ & $\begin{array}{l}57 \\
84\end{array}$ & $\begin{array}{l}19.8 \\
19.4\end{array}$ & $\begin{array}{l}11.0 \\
11.0\end{array}$ & $\begin{array}{l}13.9 \\
13.8\end{array}$ & $\begin{array}{l}13.9 \\
13.9\end{array}$ & $\begin{array}{l}11.5 \\
11.7\end{array}$ & $\begin{array}{l}8.5 \\
8.6\end{array}$ & $\begin{array}{l}12.5 \\
12.7\end{array}$ & $\begin{array}{l}9.0 \\
9.0\end{array}$ \\
\hline
\end{tabular}

-Not available

1 Includes elementary, secondary, combined elementary/secondary, and other schools. ${ }^{2}$ Includes schools beginning with grade 6 or below and with no grade higher than 8 . ${ }^{3}$ Includes schools with no grade lower than 7 .

${ }^{4}$ Includes schools beginning with grade 6 or below and ending with grade 9 or above.

Includes special education, alternative, and other schools not reported by grade span.

${ }^{6}$ Excludes special education schools, vocational schools, and alternative schools.
NOTE: Data reflect reports by schools rather than by states or school districts. Percentage distribution and average enrollment calculations include data only for schools reporting enrollments data. Enrollment data were reported for 94,743 out of 98,328 schools in 2011-12. Detail may not sum to totals because of rounding

SOURCE: U.S. Department of Education, National Center for Education Statistics, Common Core of Data (CCD), "Public Elementary/Secondary School Universe Survey," 1982-83 through 2011-12. (This table was prepared August 2013.) 
Table 216.50. Number and percentage distribution of public elementary and secondary school students, by percentage of minority enrollment in the school and student's racial/ethnic group: Selected years, fall 1995 through fall 2011

\begin{tabular}{|c|c|c|c|c|c|c|c|c|c|c|c|c|c|c|}
\hline \multirow[b]{2}{*}{ Racial/ethnic group } & \multicolumn{7}{|c|}{$\begin{array}{l}\text { Number of students in racial/ethnic group, } \\
\text { by percent minority enrollment in the school }\end{array}$} & \multicolumn{7}{|c|}{$\begin{array}{l}\text { Percentage distribution of students in racial/ethnic group, } \\
\text { by percent minority enrollment in the school }\end{array}$} \\
\hline & Total & $\begin{array}{l}\text { Less than } \\
10 \text { percent }\end{array}$ & $\begin{array}{l}10 \text { to } 24 \\
\text { percent }\end{array}$ & $\begin{array}{r}25 \text { to } 49 \\
\text { percent }\end{array}$ & $\begin{array}{r}50 \text { to } 74 \\
\text { percent }\end{array}$ & $\begin{array}{r}75 \text { to } 89 \\
\text { percent }\end{array}$ & $\begin{array}{r}90 \text { percent } \\
\text { or more }\end{array}$ & Total & $\begin{array}{r}\text { Less than } \\
10 \text { percent }\end{array}$ & $\begin{array}{c}10 \text { to } 24 \\
\text { percent }\end{array}$ & $\begin{array}{r}25 \text { to } 49 \\
\text { percent }\end{array}$ & $\begin{array}{r}50 \text { to } 74 \\
\text { percent }\end{array}$ & $\begin{array}{r}75 \text { to } 89 \\
\text { percent }\end{array}$ & $\begin{array}{l}90 \text { percent } \\
\text { or more }\end{array}$ \\
\hline 1 & 2 & 3 & 4 & 5 & 6 & 7 & 8 & 9 & 10 & 11 & 12 & 13 & 14 & 15 \\
\hline Total, $1995 \ldots \ldots . . .$. & $44,424,467$ & $14,508,573$ & $8,182,484$ & $8,261,110$ & $5,467,784$ & $2,876,302$ & $5,128,214$ & 100.0 & 32.7 & 18.4 & 18.6 & 12.3 & 6.5 & 11.5 \\
\hline White....... & $28,736,961$ & $13,939,633$ & $6,812,196$ & $5,246,785$ & $2,094,440$ & 499,884 & 144,023 & 100.0 & 48.5 & 23.7 & 18.3 & 7.3 & 1.7 & 0.5 \\
\hline Minority.. & $15,687,506$ & 568,940 & $1,370,288$ & $3,014,325$ & $3,373,344$ & $2,376,418$ & $4,984,191$ & 100.0 & 3.6 & 8.7 & 19.2 & 21.5 & 15.1 & 31.8 \\
\hline Black ....... & $7,510,678$ & 198,386 & 598,716 & $1,588,850$ & $1,622,448$ & 941,335 & $2,560,943$ & 100.0 & 2.6 & 8.0 & 21.2 & 21.6 & 12.5 & 34.1 \\
\hline Hispanic .. & $6,016,293$ & 174,140 & 415,761 & 932,949 & $1,289,184$ & $1,099,109$ & $2,105,150$ & 100.0 & 2.9 & 6.9 & 15.5 & 21.4 & 18.3 & 35.0 \\
\hline Asian/Pacific Islander & $1,656,787$ & 142,886 & 259,335 & 367,888 & 379,110 & 297,680 & 209,888 & 100.0 & 8.6 & 15.7 & 22.2 & 22.9 & 18.0 & 12.7 \\
\hline $\begin{array}{l}\text { American Indanan } \\
\text { Alaska Native. }\end{array}$ & 503,748 & 53,528 & 96,476 & 124,638 & 82,602 & 38,294 & 108,210 & 100.0 & 10.6 & 19.2 & 24.7 & 16.4 & 7.6 & 21.5 \\
\hline Total, 2000 .. & $46,120,425$ & $12,761,478$ & $8,736,252$ & $8,760,300$ & $6,013,131$ & $3,472,083$ & $6,377,181$ & 100.0 & 27.7 & 18.9 & 19.0 & 13.0 & 7.5 & 13.8 \\
\hline White................. & $28,146,613$ & $12,218,862$ & $7,271,285$ & $5,566,681$ & $2,303,106$ & 596,478 & 190,201 & 100.0 & 43.4 & 25.8 & 19.8 & 8.2 & 2.1 & 0.7 \\
\hline Minority ... & $17,973,812$ & 542,616 & $1,464,967$ & $3,193,619$ & $3,710,025$ & $2,875,605$ & $6,186,980$ & 100.0 & 3.0 & 8.2 & 17.8 & 20.6 & 16.0 & 34.4 \\
\hline Black... & $7,854,032$ & 178,185 & 561,488 & $1,485,130$ & $1,652,393$ & $1,043,907$ & $2,932,929$ & 100.0 & 2.3 & 7.1 & 18.9 & 21.0 & 13.3 & 37.3 \\
\hline Hispanic ....................... & 7,649,728 & 181,685 & 505,612 & $1,121,809$ & $1,542,982$ & $1,432,639$ & $2,865,001$ & 100.0 & 2.4 & 6.6 & 14.7 & 20.2 & 18.7 & 37.5 \\
\hline Asian/Pacific Islander & $1,924,875$ & 132,813 & 295,437 & 441,769 & 423,175 & 353,395 & 278,286 & 100.0 & 6.9 & 15.3 & 23.0 & 22.0 & 18.4 & 14.5 \\
\hline $\begin{array}{l}\text { American Indian/ } \\
\text { Alaska Native ..... }\end{array}$ & 545,177 & 49,933 & 102,430 & 144,911 & 91,475 & 45,664 & 110,764 & 100.0 & 9.2 & 18.8 & 26.6 & 16.8 & 8.4 & 20.3 \\
\hline Total, $2005 \ldots \ldots . .$. & $48,584,980$ & $10,711,307$ & $9,283,783$ & $9,865,121$ & $6,839,850$ & $4,149,802$ & $7,735,117$ & 100.0 & 22.0 & 19.1 & 20.3 & 14.1 & 8.5 & 15.9 \\
\hline White..... & $27,742,612$ & \begin{tabular}{|l|}
$10,208,608$ \\
\end{tabular} & $7,720,632$ & $6,259,485$ & $2,604,846$ & 707,603 & 241,438 & 100.0 & 36.8 & 27.8 & 22.6 & 9.4 & 2.6 & 0.9 \\
\hline Minority ............................. & $20,842,368$ & 502,699 & $1,563,151$ & $3,605,636$ & $4,235,004$ & $3,442,199$ & $7,493,679$ & 100.0 & 2.4 & 7.5 & 17.3 & 20.3 & 16.5 & 36.0 \\
\hline Black ........ & $8,366,722$ & 162,455 & 560,928 & $1,513,020$ & $1,752,207$ & $1,176,649$ & $3,201,463$ & 100.0 & 1.9 & 6.7 & 18.1 & 20.9 & 14.1 & 38.3 \\
\hline Hispanic .. & 9,638,712 & 182,039 & 581,533 & $1,388,496$ & $1,873,877$ & $1,803,567$ & $3,809,200$ & 100.0 & 1.9 & 6.0 & 14.4 & 19.4 & 18.7 & 39.5 \\
\hline Asian/Pacific Islander & 2,242,628 & 115,084 & 319,524 & 543,952 & 496,515 & 406,788 & 360,765 & 100.0 & 5.1 & 14.2 & 24.3 & 22.1 & 18.1 & 16.1 \\
\hline $\begin{array}{l}\text { American Indlan/ } \\
\text { Alaska Native..... }\end{array}$ & 594,306 & 43,121 & 101,166 & 160,168 & 112,405 & 55,195 & 122,251 & 100.0 & 7.3 & 17.0 & 27.0 & 18.9 & 9.3 & 20.6 \\
\hline Total, 2008 . & $48,566,678$ & $9,335,142$ & $9,062,421$ & $10,269,626$ & $7,178,472$ & 4,447,648 & $8,273,369$ & 100.0 & 19.2 & 18.7 & 21.1 & 14.8 & 9.2 & 17.0 \\
\hline White........ & $26,655,206$ & $8,872,938$ & $7,530,519$ & \begin{tabular}{|l|}
$6,498,016$ \\
\end{tabular} & $2,724,852$ & 761,614 & 267,267 & 100.0 & 33.3 & 28.3 & 24.4 & 10.2 & 2.9 & 1.0 \\
\hline Minority.. & $21,911,472$ & 462,204 & $1,531,902$ & $3,771,610$ & $4,453,620$ & $3,686,034$ & $8,006,102$ & 100.0 & 2.1 & 7. & 17.2 & 20.3 & 16.8 & 36.5 \\
\hline Black ... & 8,225,299 & 144,078 & 527,106 & $1,462,655$ & $1,718,729$ & $1,207,549$ & $3,165,182$ & 100.0 & 1.8 & 6.4 & 17.8 & 20.9 & 14.7 & 38.5 \\
\hline Hispanic .. & $10,439,072$ & 174,124 & 578,299 & $1,470,129$ & $1,994,543$ & $1,940,422$ & $4,281,555$ & 100.0 & 1.7 & 5.5 & 14.1 & 19.1 & 18.6 & 41.0 \\
\hline Asian/Pacific Islander & 2,419,695 & 101,577 & 315,230 & 601,718 & 548,823 & 443,063 & 409,284 & 100.0 & 4.2 & 13.0 & 24.9 & 22.7 & 18.3 & 16.9 \\
\hline $\begin{array}{l}\text { American Indian/ } \\
\text { Alaska Native ...... }\end{array}$ & 583,384 & 37,501 & 92,030 & 163,862 & 115,046 & 52,760 & 122,185 & 100.0 & 6.4 & 15.8 & 28.1 & 19.7 & 9.0 & 20.9 \\
\hline Other ${ }^{1} \ldots \ldots$ & 244,022 & 4,924 & 19,237 & 73,246 & 76,479 & 42,240 & 27,896 & 100.0 & $\begin{array}{l}0.4 \\
2.0\end{array}$ & $\begin{array}{r}7.0 \\
\end{array}$ & 30.0 & 31.3 & $\begin{array}{l}5.0 \\
17.3\end{array}$ & 11.4 \\
\hline Total, 2009 & 48,634,893 & $8,732,585$ & $9,061,653$ & $\mid 10,466,589$ & $7,419,977$ & $4,502,052$ & $8,452,037$ & 100.0 & 18.0 & 18.6 & 21.5 & 15.3 & 9.3 & 17.4 \\
\hline White........ & $26,311,473$ & $8,295,175$ & $7,532,475$ & \begin{tabular}{|l|}
$6,627,227$ \\
\end{tabular} & $2,814,575$ & 768,359 & 273,662 & 100.0 & 31.5 & 28. & 25.2 & 10.7 & 2.9 & 1.0 \\
\hline Minority. & $22,323,420$ & 437,410 & $1,529,178$ & $3,839,362$ & $4,605,402$ & $3,733,693$ & 375 & 100.0 & 2.0 & 6 & & 20.6 & 16.7 & 36.6 \\
\hline Bla & $8,166,410$ & 131,097 & 507,800 & $1,448,683$ & $1,735,281$ & $1,203,375$ & 174 & 100.0 & 1.6 & 6 & & 21.2 & 14.7 & 38.5 \\
\hline Hispani & $10,775,975$ & 165,220 & 586,701 & $1,529,688$ & $2,095,878$ & $1,981,911$ & $4,416,577$ & 100.0 & 1.5 & 5.4 & 14.2 & 19.4 & 18.4 & 41.0 \\
\hline Asian/Pacific Islander & $2,461,820$ & 94,593 & 310,703 & 614,990 & 578,595 & 441,613 & 421,326 & 100.0 & 3.8 & 12.6 & 25.0 & 23.5 & 17.9 & 17.1 \\
\hline $\begin{array}{l}\text { America } \\
\text { Alas }\end{array}$ & & & & & & & & & & & & & & \\
\hline $\begin{array}{l}\text { Alaska } \\
\text { Other'...... }\end{array}$ & $\begin{array}{l}584, \text {, } 56 \\
334,459\end{array}$ & $\begin{array}{l}34,0,9 \\
12,421\end{array}$ & $\begin{array}{l}89,843 \\
34,131\end{array}$ & $\begin{array}{r}166,648 \\
79,353\end{array}$ & $\begin{array}{r}118,637 \\
77,011\end{array}$ & $\begin{array}{l}56,413 \\
50,381\end{array}$ & $\begin{array}{r}119,136 \\
81,162\end{array}$ & $\begin{array}{l}100.0 \\
100.0\end{array}$ & $\begin{array}{l}5.8 \\
3.7\end{array}$ & $\begin{array}{l}15.4 \\
10.2\end{array}$ & $\begin{array}{l}28.5 \\
23.7\end{array}$ & $\begin{array}{l}20.3 \\
23.0\end{array}$ & $\begin{array}{r}9.6 \\
15.1\end{array}$ & $\begin{array}{l}20.4 \\
24.3\end{array}$ \\
\hline Total, 2010. & $49,212,031$ & 95,549 & 7,649 & 11,2 & & & & 0.0 & 15.0 & 18 & 22.8 & 16.1 & 9.6 & 17.8 \\
\hline White. & $25,801,021$ & $6,987,898$ & $7,614,557$ & \begin{tabular}{|l|}
$7,097,284$ \\
\end{tabular} & $3,003,599$ & 808,637 & 289,046 & 100.0 & 27.1 & 29. & 27.5 & 11.6 & 3.1 & 1.1 \\
\hline Minority. & $23,411,010$ & 407,651 & $1,563,092$ & & & $3,909,489$ & & 100.0 & 1.7 & 6 & & 20.9 & 16.7 & 36.3 \\
\hline Blac & $7,873,809$ & 95,108 & 415,807 & $1,335,674$ & $1,697,727$ & $1,236,333$ & & 100.0 & 1.2 & 5. & 17 & 21.6 & 15.7 & 39.3 \\
\hline His & $11,367,157$ & 142,927 & 583,019 & $1,654,084$ & $2,238,071$ & $2,063,492$ & $4,685,564$ & 100.0 & 1.3 & 5.1 & 6 & 19.7 & 18.2 & 41.2 \\
\hline Asi & 2,281,908 & 63,974 & 259,910 & 585,447 & 552,633 & 390,731 & 429,213 & 100.0 & 2.8 & 11.4 & 25.7 & 24.2 & 17.1 & 18.8 \\
\hline Pacific Is & 169,678 & 4,958 & 13,772 & 27,478 & 32,241 & 41,652 & 49,577 & 100.0 & 2.9 & 8.1 & 16.2 & 19.0 & 24.5 & 29.2 \\
\hline $\begin{array}{l}\text { America } \\
\text { Alas }\end{array}$ & & & & 157300 & & & & & 46 & 13.9 & & & & \\
\hline $\begin{array}{l}\text { Alaska Native ..... } \\
\text { Two or more races.... }\end{array}$ & $\begin{array}{r}501,1,20 \\
1,157,332\end{array}$ & $\begin{array}{l}24,618 \\
74,00\end{array}$ & $\begin{array}{r}7,990 \\
212,594\end{array}$ & 379,061 & $\begin{array}{l}110,181 \\
263,282\end{array}$ & $\begin{array}{r}30,410 \\
118,805\end{array}$ & & 100.0 & $\begin{array}{l}\quad .0 \\
6.4\end{array}$ & 18.4 & 32.8 & $\begin{array}{l}20.8 \\
22.7\end{array}$ & $\begin{array}{l}10.4 \\
10.3\end{array}$ & $\begin{array}{r}22.2 \\
9.4\end{array}$ \\
\hline Two or mive taves.... & & & & & & & & & & & & & & \\
\hline Total, & $49,246,537$ & $6,943,209$ & $9,090,845$ & $11,325,084$ & $8,087,862$ & 4,909,344 & $8,890,193$ & 100.0 & 14.1 & 18 & 23.0 & 16.4 & 10.0 & 18.1 \\
\hline White........... & $25,464,162$ & $6,549,257$ & $7,535,852$ & \begin{tabular}{|l|}
$7,154,879$ \\
\end{tabular} & $3,086,247$ & 842,317 & 295,610 & 100.0 & 25.7 & 29. & & 12.1 & 3.3 & 1.2 \\
\hline Minority.. & $23,782,375$ & 393,952 & $1,554,993$ & $4,170,205$ & $5,001,615$ & $4,067,027$ & $8,594,583$ & 100.0 & 1.7 & 6.5 & 17 & 21.0 & 17.1 & 36.1 \\
\hline & 7,782,146 & 85,682 & 393,118 & $1,302,027$ & $1,686,653$ & $1,255,240$ & $3,059,426$ & & 1.1 & 5. & & 21.7 & 16.1 & 39.3 \\
\hline ................... & $11,693,788$ & 141,593 & 594,874 & $1,678,320$ & $2,302,100$ & $2,161,819$ & $4,815,082$ & 100.0 & 1.2 & 5.1 & & 19.7 & 18.5 & 41.2 \\
\hline & $2,321,362$ & 58,414 & 249,943 & 587,291 & 570,921 & 415,832 & 438,961 & 100.0 & 2.5 & 10.8 & 25.3 & 24.6 & 17.9 & 18.9 \\
\hline Pacific Islander ........... & 177,871 & 5,170 & 13,635 & 27,828 & 34,546 & 42,851 & 53,841 & 100.0 & 2.9 & 7.7 & 15.6 & 19.4 & 24.1 & 30.3 \\
\hline $\begin{array}{r}\text { Amer } \\
\mathrm{A}\end{array}$ & 5 & & & & & & & 100.0 & 4. & 12 & & 20.8 & 10.7 & 23.3 \\
\hline $\begin{array}{l}\text { Alaska vative ..... } \\
\text { Two or more races... }\end{array}$ & $\begin{array}{r}54,986 \\
1,265,222\end{array}$ & $\begin{array}{l}23,215 \\
79,878\end{array}$ & $\begin{array}{r}69,953 \\
233,470\end{array}$ & $\begin{array}{l}152,088 \\
422,651\end{array}$ & $\begin{array}{l}11<, 300 \\
294,827\end{array}$ & $\begin{array}{r}50,100 \\
133,179\end{array}$ & 101,217 & 100.0 & $\begin{array}{l}4.0 \\
6.3\end{array}$ & 18.5 & 33.4 & 23.3 & 10.5 & 8.0 \\
\hline
\end{tabular}

1'ncludes data for two or more races reported by 5 states in 2008 and by 14 states in 2009 . NOTE: Data reflect racial/ethnic data reported by schools. Because some schools do not report complete racial/ethnic data, totals may differ from figures in other tables. Excludes 1995 data for Idaho and 2000 data for Tennessee because racial/ethnic data were not reported. Race categories exclude persons of Hispanic ethnicity. Detail may not sum to totals because of rounding.

SOURCE: U.S. Department of Education, National Center for Education Statistics, Common Core of Data (CCD), "Public Elementary/Secondary School Universe Survey", 1995-96 through 2011-12. (This table was prepared September 2013.) 
194 CHAPTER 2: Elementary and Secondary Education

Public Schools

Table 216.55. Number and percentage distribution of public elementary and secondary school students, by percentage of student's racial/ethnic group enrolled in the school and student's racial/ethnic group: Selected years, fall 1995 through fall 2011

\begin{tabular}{|c|c|c|c|c|c|c|c|c|c|c|c|c|c|c|}
\hline \multirow[b]{2}{*}{ Racial/ethnic group } & \multicolumn{7}{|c|}{$\begin{array}{l}\text { Number of students in each racial/ethnic group, } \\
\text { by percent of that racial/ethnic group in the school }\end{array}$} & \multicolumn{7}{|c|}{$\begin{array}{l}\text { Percentage distribution of students in each racial/ethnic group, } \\
\text { by percent of that racial/ethnic group in the school }\end{array}$} \\
\hline & Total & \begin{tabular}{|r|} 
Less than \\
10 percent \\
of group
\end{tabular} & $\begin{array}{l}10 \text { to } 24 \\
\text { percent } \\
\text { of group }\end{array}$ & $\begin{array}{r}25 \text { to } 49 \\
\text { percent } \\
\text { of group }\end{array}$ & $\begin{array}{l}50 \text { to } 74 \\
\text { percent } \\
\text { of group }\end{array}$ & $\begin{array}{r}75 \text { to } 89 \\
\text { percent } \\
\text { of group }\end{array}$ & $\begin{array}{r}90 \text { percent } \\
\text { or more } \\
\text { of group }\end{array}$ & Total & \begin{tabular}{|r|} 
Less than \\
10 percent \\
of group
\end{tabular} & $\begin{array}{l}10 \text { to } 24 \\
\text { percent } \\
\text { of group }\end{array}$ & $\begin{array}{r}25 \text { to } 49 \\
\text { percent } \\
\text { of group }\end{array}$ & $\begin{array}{l}50 \text { to } 74 \\
\text { percent } \\
\text { of group }\end{array}$ & $\begin{array}{r}75 \text { to } 89 \\
\text { percent } \\
\text { of group }\end{array}$ & $\begin{array}{l}90 \text { percent } \\
\text { or more } \\
\text { of group }\end{array}$ \\
\hline 1 & 2 & 3 & 4 & 5 & 6 & 7 & 8 & 9 & 10 & 11 & 12 & 13 & 14 & 15 \\
\hline \multicolumn{15}{|l|}{$\overline{1995}$} \\
\hline White ............. & $28,736,961$ & 143,787 & 498,649 & $2,084,689$ & $5,244,015$ & $6,813,804$ & $13,952,017$ & 100.0 & 0.5 & 1.7 & 7.3 & 18.2 & 23.7 & 48.6 \\
\hline Black ............................... & $7,510,678$ & 657,403 & $1,119,556$ & $1,873,303$ & $1,386,802$ & 811,898 & $1,661,716$ & 100.0 & 8.8 & 14.9 & 24.9 & 18.5 & 10.8 & 22.1 \\
\hline 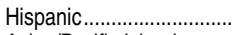 & $6,016,293$ & 646,364 & 847,792 & $1,359,649$ & $1,360,020$ & 874,878 & 927,590 & 100.0 & 10.7 & 14.1 & 22.6 & 22.6 & 14.5 & 15.4 \\
\hline Asian/Pacific Islander ...... & $1,656,787$ & 703,101 & 435,495 & 301,984 & 135,001 & 67,558 & 13,648 & 100.0 & 42.4 & 26.3 & 18.2 & 8.1 & 4.1 & 0.8 \\
\hline $\begin{array}{l}\text { American Indian/ } \\
\text { Alaska Native .................. }\end{array}$ & 503,748 & 223,244 & 75,019 & 63,070 & 39,200 & 15,084 & 88,131 & 100.0 & 44.3 & 14.9 & 12.5 & 7.8 & 3.0 & 17.5 \\
\hline \multicolumn{15}{|l|}{2000} \\
\hline White .................................. & $28,146,613$ & 189,779 & 595,137 & $2,294,232$ & $5,556,108$ & $7,279,301$ & $\mid 12,232,056$ & 100.0 & 0.7 & 2.1 & 8.2 & 19.7 & 25.9 & 43.5 \\
\hline Black........ & $7,854,032$ & 735,459 & $1,199,865$ & $1,899,982$ & $1,366,363$ & 871,399 & $1,780,964$ & 100.0 & 9.4 & 15.3 & 24.2 & 17.4 & 11.1 & 22.7 \\
\hline Hispanic... & $7,649,728$ & 738,509 & $1,054,396$ & $1,696,944$ & $1,739,038$ & $1,134,466$ & $1,286,375$ & 100.0 & 9.7 & 13.8 & 22.2 & 22.7 & 14.8 & 16.8 \\
\hline Asian/Pacific Islander ...... & $1,924,875$ & 799,220 & 524,279 & 331,576 & $\begin{array}{r}1, / 50,000 \\
171,739\end{array}$ & 81,461 & 16,600 & 100.0 & 41.5 & 27.2 & 17.2 & 8.9 & 4.2 & 0.9 \\
\hline $\begin{array}{l}\text { American Indian/ } \\
\text { Alaska Native ..................... }\end{array}$ & 545,177 & 251,983 & 81,119 & 75,831 & 39,944 & 15,363 & 80,937 & 100.0 & 46.2 & 14.9 & 13.9 & 7.3 & 2.8 & 14.8 \\
\hline \multicolumn{15}{|l|}{2005} \\
\hline White ........ & $27,742,612$ & 240,614 & 705,300 & $2,596,310$ & $6,256,109$ & $7,718,175$ & $\mid 10,226,104$ & 100.0 & 0.9 & 2.5 & 9.4 & 22.6 & 27.8 & 36.9 \\
\hline Black.... & $8,366,722$ & 849,399 & $1,396,670$ & $2,004,856$ & $1,453,759$ & 884,663 & $\begin{array}{r}1,777,375 \\
\end{array}$ & 100.0 & 10.2 & 16.7 & 24.0 & 17.4 & 10.6 & 21.2 \\
\hline Hispani & $9,638,712$ & 848,160 & $1,316,558$ & $2,071,303$ & $2,218,616$ & $1,545,322$ & $1,638,753$ & 100.0 & 8.8 & 13.7 & 21.5 & 23.0 & 16.0 & 17.0 \\
\hline Asian/Pacific Islander ....... & $2,242,628$ & 925,411 & 616,762 & 363,562 & 214,304 & 100,845 & 21,744 & 100.0 & 41.3 & 27.5 & 16.2 & 9.6 & 4.5 & 1.0 \\
\hline $\begin{array}{l}\text { American Indian/ } \\
\text { Alaska Native...... }\end{array}$ & 594,306 & 276,846 & 86,978 & 84,665 & 43,272 & 21,275 & 81,270 & 100.0 & 46.6 & 14.6 & 14.2 & 7.3 & 3.6 & 13.7 \\
\hline Mlasnc & & & & & & & & & & & & & & \\
\hline \multicolumn{15}{|l|}{2008} \\
\hline White & $26,655,206$ & 263,040 & 741,385 & $2,654,942$ & $6,427,654$ & $7,599,841$ & $8,968,344$ & 100.0 & 1.0 & 2.8 & 10.0 & 24.1 & 28.5 & 33.6 \\
\hline Black. & $8,225,299$ & 876,408 & $1,444,408$ & $1,980,487$ & $1,403,984$ & 871,014 & $1,648,998$ & 100.0 & 10.7 & 17.6 & 24.1 & 17.1 & 10.6 & 20.0 \\
\hline Hispanic.. & $10,439,072$ & 863,435 & $1,409,966$ & $2,203,867$ & $2,430,896$ & $1,713,221$ & $1,817,687$ & 100.0 & 8.3 & 13.5 & 21.1 & 23.3 & 16.4 & 17.4 \\
\hline Asian/Pacific Islander ....... & $2,419,695$ & 974,599 & 676,841 & 404,394 & 235,263 & 106,117 & $\begin{array}{r}1,02,481 \\
22,11\end{array}$ & 100.0 & $\begin{array}{r}0.0 \\
40.3\end{array}$ & 28.0 & 16.7 & $\begin{array}{r}0.0 \\
9.7\end{array}$ & $\begin{array}{r}0.4 \\
4.4\end{array}$ & 0.9 \\
\hline $\begin{array}{l}\text { American Indian/ } \\
\text { Alaska Native ..................... }\end{array}$ & 583,384 & 275,483 & 80,815 & 90,654 & 38,370 & 20,669 & 77,393 & 100.0 & 47.2 & 13.9 & 15.5 & 6.6 & 3.5 & 13.3 \\
\hline \multicolumn{15}{|l|}{2009} \\
\hline White. & $26,311.473$ & 273.285 & 766,093 & 2802,435 & $6,623,809$ & $7,537,266$ & $8.308,585$ & 100.0 & 1.0 & 2.9 & 10.7 & 25.2 & 28.6 & 31.6 \\
\hline Black... & $8,166,410$ & 885,911 & $1,469,582$ & $1,984,384$ & $1,387,212$ & 858,152 & $1,581,169$ & 100.0 & 10.8 & 18.0 & 24.3 & 17.0 & 10.5 & 19.4 \\
\hline Hispanic & $10,775,975$ & 875,979 & $1,475,714$ & $2,312,508$ & $2,557,263$ & $1,710,475$ & $1,844,036$ & 100.0 & 8.1 & 13.7 & 21.5 & 23.7 & 15.9 & 17.1 \\
\hline Asian/Pacific Islander ....... & $2,461,820$ & 990,104 & 680,770 & 422,114 & 233,733 & 109,671 & 25,428 & 100.0 & 40.2 & 27.7 & 17.1 & 9.5 & 4.5 & 1.0 \\
\hline American Indian/ & & & & & & & & & & & & & & \\
\hline Alaska Native ................. & 584,756 & 280,738 & 79,981 & 89,944 & 40,595 & 21,274 & 72,224 & 100.0 & 48.0 & 13.7 & 15.4 & 6.9 & 3.6 & 12.4 \\
\hline \multicolumn{15}{|l|}{2010} \\
\hline White & $25,801,021$ & 288,136 & 807,107 & $2,991,928$ & $7,090,581$ & $7,620,071$ & $7,003,198$ & 100.0 & 1.1 & 3.1 & 11.6 & 27.5 & 29.5 & 27.1 \\
\hline & $7,873,809$ & 904,777 & $1,453,068$ & $1,907,158$ & 1,328 & 859,843 & $1,420,799$ & 100.0 & 11.5 & 18.5 & 24 & 16.9 & 10.9 & 18.0 \\
\hline Hispani & $11,367,157$ & 896,796 & $1,603,546$ & $2,473,080$ & $2,657,108$ & $1,791,161$ & $1,945,466$ & 100.0 & 7.9 & 14.1 & 21.8 & 23.4 & 15.8 & 17.1 \\
\hline Asian. & $2,281,908$ & 944,657 & 633,149 & 431,446 & 219,381 & 43,509 & 9,766 & 100.0 & 41.4 & 27.7 & 18.9 & 9.6 & 1.9 & 0.4 \\
\hline Pacific Islander ....................... & 169,678 & 104,646 & 15,170 & 27,558 & 14,860 & 5,146 & 2,298 & 100.0 & 61.7 & 8.9 & 16.2 & 8.8 & 3.0 & 1.4 \\
\hline Alaska Native... & 561,126 & 276,859 & 76,874 & 78,978 & 38,349 & 21,156 & 68,910 & 100.0 & 49.3 & 13.7 & 14.1 & 6.8 & 3.8 & 12.3 \\
\hline Two or more races ............. & $1,157,332$ & 996,181 & 128,813 & 15,347 & 6,709 & 3,286 & 6,996 & 100.0 & 86.1 & 11.1 & 1.3 & 0.6 & 0.3 & 0.6 \\
\hline \multicolumn{15}{|l|}{2011} \\
\hline White & $25,464,162$ & 294,998 & 840,764 & $3,072,182$ & $7,153,778$ & $7,543,427$ & $6,559,013$ & 100.0 & 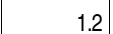 & 3.3 & 12.1 & 28.1 & 29.6 & 25.8 \\
\hline Black. & $7,782,146$ & 909,399 & $1,448,983$ & $1,912,335$ & $1,301,165$ & 864,856 & $1,345,408$ & 100.0 & 11.7 & 18.6 & 24.6 & 16.7 & 11.1 & 17.3 \\
\hline Hispanic....... & $11,693,788$ & 909,247 & $1,658,024$ & $2,543,266$ & $2,720,777$ & $1,877,108$ & $1,985,366$ & 100.0 & 7.8 & 14.2 & 21.7 & 23.3 & 16.1 & 17.0 \\
\hline Asian. & $2,321,362$ & 946,520 & 644,479 & 441,656 & 232,408 & 43,530 & (12,769 & 100.0 & 40.8 & 27.8 & 19.0 & 10.0 & 1.9 & 0.6 \\
\hline \multirow{2}{*}{\multicolumn{15}{|c|}{ American Indian/... }} \\
\hline & & & & & & & & & & & & & & \\
\hline Alaska & 541,986 & 267,993 & 72,1 & 77,142 & 36,010 & 22,095 & 66,598 & 100.0 & 49 & 13.3 & 14.2 & 6.6 & 4.1 & 12.3 \\
\hline Two or more races ............. & $1,265,222$ & $1,107,727$ & 139,250 & 8,444 & 3,484 & 5,324 & 993 & 100.0 & 87.6 & 11.0 & 0.7 & 0.3 & 0.4 & 0.1 \\
\hline
\end{tabular}

NOTE: Data reflect racial/ethnic data reported by schools. Because some schools do not report complete racial/ethnic data, totals may differ from figures in other tables. Excludes 1995 data for Idaho and 2000 data for Tennessee because racial/ethnic data were not reported. Race categories exclude persons of Hispanic ethnicity. Detail may not sum to totals because of rounding.
SOURCE: U.S. Department of Education, National Center for Education Statistics, Common Core of Data (CCD), "Public Elementary/Secondary School Universe Survey," 1995-96 through 2011-12. (This table was prepared September 2013.) 
Table 216.60. Number and percentage distribution of public school students eligible for free or reduced-price lunch, by school level, locale, and student race/ethnicity: 2011-12

\begin{tabular}{|c|c|c|c|c|c|c|c|c|c|c|c|c|}
\hline \multirow[b]{2}{*}{$\begin{array}{l}\text { School level, locale, and } \\
\text { student race/ethnicity }\end{array}$} & \multicolumn{6}{|c|}{$\begin{array}{l}\text { Number of students, by percent of students in school } \\
\text { eligible for free or reduced-price lunch }\end{array}$} & \multicolumn{6}{|c|}{$\begin{array}{l}\text { Percentage distribution of students, by percent of students } \\
\text { in school eligible for free or reduced-price lunch }\end{array}$} \\
\hline & Total $^{1}$ & $\begin{array}{r}0 \text { to } 25.0 \\
\text { percent }\end{array}$ & $\begin{array}{r}25.1 \text { to } 50.0 \\
\text { percent }\end{array}$ & $\begin{array}{r}50.1 \text { to } 75.0 \\
\text { percent }\end{array}$ & $\begin{array}{r}\text { More than } \\
75.0 \text { percent }\end{array}$ & $\begin{array}{r}\text { Missing/ } \\
\text { school } \\
\text { does not } \\
\text { participate }\end{array}$ & Total $^{1}$ & $\begin{array}{r}0 \text { to } 25.0 \\
\text { percent }\end{array}$ & $\begin{array}{r}25.1 \text { to } 50.0 \\
\text { percent }\end{array}$ & $\begin{array}{r}50.1 \text { to } 75.0 \\
\text { percent }\end{array}$ & $\begin{array}{r}\text { More than } \\
75.0 \text { percent }\end{array}$ & $\begin{array}{r}\text { Missing/ } \\
\text { school } \\
\text { does not } \\
\text { participate }\end{array}$ \\
\hline 1 & 2 & 3 & 4 & 5 & 6 & 7 & 8 & 9 & 10 & 11 & 12 & 13 \\
\hline Total $^{2}$.. & $49,246,537$ & $11,678,363$ & $13,614,098$ & $12,413,272$ & $9,285,370$ & $2,255,434$ & 100.0 & 23.7 & 27.6 & 25.2 & 18.9 & $\overline{4.6}$ \\
\hline White & $25,464,162$ & $7,804,648$ & $8,968,907$ & $6,317,536$ & $1,695,747$ & 677,324 & 100.0 & 30.6 & 35.2 & 24.8 & 6.7 & 2.7 \\
\hline Black ...................................... & $7,782,146$ & 631,431 & $1,388,051$ & $2,288,573$ & $3,305,274$ & 168,817 & 100.0 & 8.1 & 17.8 & 29.4 & 42.5 & 2.2 \\
\hline Hispanic............................ & $11,693,788$ & $2,002,762$ & $2,162,969$ & $2,848,955$ & $3,607,385$ & $1,071,717$ & 100.0 & 17.1 & 18.5 & 24.4 & 30.8 & 9.2 \\
\hline Asian & $2,321,362$ & 856,207 & 544,076 & 390,183 & 280,542 & 250,354 & 100.0 & 36.9 & 23.4 & 16.8 & 12.1 & 10.8 \\
\hline $\begin{array}{l}\text { Pacific Islander .................. } \\
\text { American Indian/ }\end{array}$ & 177,871 & 27,439 & 48,564 & 57,003 & 33,342 & 11,523 & 100.0 & 15.4 & 27.3 & 32.0 & 18.7 & 6.5 \\
\hline Alaska Native ................ & 541,986 & 57,022 & 119,280 & 172,209 & 175,497 & 17,978 & 100.0 & 10.5 & 22.0 & 31.8 & 32.4 & 3.3 \\
\hline Two or more races ............. & $1,265,222$ & 298,854 & 382,251 & 338,813 & 187,583 & 57,721 & 100.0 & 23.6 & 30.2 & 26.8 & 14.8 & 4.6 \\
\hline $\begin{array}{l}\text { School level }^{3} \\
\text { Elementary }^{4}\end{array}$ & & & & & & & & & & & & \\
\hline 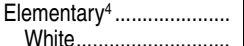 & & & $7,852,571$ & $8,276,587$ & $7,362,003$ & $1,565,409$ & 100.0 & 21.0 & 24.8 & 26.1 & $\begin{array}{r}23.2 \\
87\end{array}$ & 4.9 \\
\hline & $\begin{array}{r}15,970,296 \\
5,004,691\end{array}$ & $\begin{array}{r}4,512,750 \\
322,713\end{array}$ & $\begin{array}{r}5,158,147 \\
738,813\end{array}$ & $\begin{array}{l}4,435,042 \\
1337,712\end{array}$ & $\begin{array}{l}1,396,393 \\
2498,820\end{array}$ & $\begin{array}{l}467,964 \\
106,633\end{array}$ & $\begin{array}{l}100.0 \\
100.0\end{array}$ & $\begin{array}{r}28.3 \\
6.4\end{array}$ & $\begin{array}{l}32.3 \\
14.8\end{array}$ & $\begin{array}{l}27.8 \\
267\end{array}$ & $\begin{array}{r}8.7 \\
499\end{array}$ & $\begin{array}{l}2.9 \\
21\end{array}$ \\
\hline Hispanic ............................. & $7,912,171$ & $1,089,716$ & $1,292,413$ & $1,854,924$ & $2,918,862$ & 756,256 & 100.0 & 13.8 & 16.3 & 23.4 & 36.9 & 9.6 \\
\hline Asian ........................... & $1,486,189$ & 508,973 & 327,774 & 249,749 & 228,824 & 170,869 & 100.0 & 34.2 & 22.1 & 16.8 & 15.4 & 11.5 \\
\hline Pacific Islander.............. & 113,788 & 14,053 & 27,055 & 36,954 & 27,753 & 7,973 & 100.0 & 12.4 & 23.8 & 32.5 & 24.4 & 7.0 \\
\hline Alaska Native .......... & 337,592 & 26,465 & 61,999 & 107,791 & 129,683 & 11,654 & 100.0 & 7.8 & 18.4 & 31.9 & 38.4 & 3.5 \\
\hline Two or more races ........ & 892,475 & 185,962 & 246,370 & 254,415 & 161,668 & 44,060 & 100.0 & 20.8 & 27.6 & 28.5 & 18.1 & 4.9 \\
\hline Secondary ${ }^{5}$ & $15,707,083$ & $4,653,034$ & $5,346,143$ & $3,571,345$ & $1,522,986$ & 613,575 & 100.0 & 29.6 & 34.0 & 22.7 & 9.7 & 3.9 \\
\hline White......... & $8,525,394$ & $3,064,111$ & $3,516,648$ & $1,557,710$ & 217,404 & 169,521 & 100.0 & 35.9 & 41.2 & 18.3 & 2.6 & 2.0 \\
\hline Black ............................. & $2,397,330$ & 275,224 & 609,573 & 831,892 & 627,422 & 53,219 & 100.0 & 11.5 & 25.4 & 34.7 & 26.2 & 2.2 \\
\hline Hispanic ....................... & $3,436,091$ & 843,483 & 815,041 & 904,255 & 577,383 & 295,929 & 100.0 & 24.5 & 23.7 & 26.3 & 16.8 & 8.6 \\
\hline Asian ............................. & 785,828 & 330,292 & 204,696 & 130,925 & 45,007 & 74,908 & 100.0 & 42.0 & 26.0 & 16.7 & 5.7 & 9.5 \\
\hline Pacific Islander.............. & 56,882 & 11,998 & 20,177 & 17,837 & 3,553 & 3,317 & 100.0 & 21.1 & 35.5 & 31.4 & 6.2 & 5.8 \\
\hline Alaska Native ......... & 171,468 & 26,338 & 53,341 & 53,681 & 32,673 & 5,435 & 100.0 & 15.4 & 31.1 & 31.3 & 19.1 & 3.2 \\
\hline Two or more races ........ & 334,090 & 101,588 & 126,667 & 75,045 & 19,544 & 11,246 & 100.0 & 30.4 & 37.9 & 22.5 & 5.8 & 3.4 \\
\hline School locale & & & & & & & & & & & & \\
\hline City ..................... & $14,455,742$ & $2,214,184$ & $2,894,396$ & $3,351,632$ & $4,981,631$ & $1,013,899$ & 100.0 & 15.3 & 20.0 & 23.2 & 34.5 & 7.0 \\
\hline White.................................. & $4,298,097$ & $1,004,161$ & $1,400,675$ & $1,099,054$ & 592,086 & 202,121 & 100.0 & 23.4 & 32.6 & 25.6 & 13.8 & 4.7 \\
\hline Black ............................... & $3,587,853$ & 165,838 & 438,074 & 890,952 & $2,001,853$ & 91,136 & 100.0 & 4.6 & 12.2 & 24.8 & 55.8 & 2.5 \\
\hline Hispanic ......................... & $5,048,972$ & 712,474 & 727,342 & $1,014,983$ & $2,040,145$ & 554,028 & 100.0 & 14.1 & 14.4 & 20.1 & 40.4 & 11.0 \\
\hline Asian ............................. & 966,988 & 238,902 & 199,237 & 197,661 & 198,996 & 132,192 & 100.0 & 24.7 & 20.6 & 20.4 & 20.6 & 13.7 \\
\hline Pacific Islander.................. & 55,598 & 8,400 & 10,471 & 16,320 & 14,213 & 6,194 & 100.0 & 15.1 & 18.8 & 29.4 & 25.6 & 11.1 \\
\hline $\begin{array}{l}\text { American Indlan/ } \\
\text { Alaska Native .......... }\end{array}$ & 111,356 & 14,108 & 24,559 & 28,953 & 37,558 & 6,178 & 100.0 & 12.7 & 22.1 & 26.0 & 33.7 & 5.5 \\
\hline Two or more races ........ & 386,878 & 70,301 & 94,038 & 103,709 & 96,780 & 22,050 & 100.0 & 18.2 & 24.3 & 26.8 & 25.0 & 5.7 \\
\hline 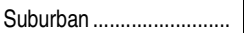 & $16,708,249$ & $5,930,996$ & $4,543,796$ & $3,246,184$ & $2,157,807$ & 829,466 & 100.0 & 35.5 & 27.2 & 19.4 & 12.9 & 5.0 \\
\hline White................................... & $8,764,170$ & $4,115,677$ & $2,737,558$ & $1,286,883$ & 353,717 & 270,335 & 100.0 & 47.0 & 31.2 & 14.7 & 4.0 & 3.1 \\
\hline Black .................................. & $2,366,886$ & 316,916 & 566,794 & 743,915 & 681,776 & 57,485 & 100.0 & 13.4 & 23.9 & 31.4 & 28.8 & 2.4 \\
\hline Hispanic ......................... & $3,970,435$ & 848,384 & 810,674 & 946,467 & 990,320 & 374,590 & 100.0 & 21.4 & 20.4 & 23.8 & 24.9 & 9.4 \\
\hline Asian ............................... & 992,871 & 470,160 & 234,197 & 129,502 & 63,749 & 95,263 & 100.0 & 47.4 & 23.6 & 13.0 & 6.4 & 9.6 \\
\hline Pacific Islander.......... & 68,843 & 13,582 & 20,979 & 19,237 & 10,849 & 4,196 & 100.0 & 19.7 & 30.5 & 27.9 & 15.8 & 6.1 \\
\hline American Indian/ & & & & & & & & & & & & \\
\hline Alaska Native .......... & 80,492 & 18,338 & 26,311 & 20,514 & 11,653 & 3,676 & 100.0 & 22.8 & 32.7 & 25.5 & 14.5 & 4.6 \\
\hline Two or more races ........ & 464,552 & 147,939 & 147,283 & 99,666 & 45,743 & 23,921 & 100.0 & 31.8 & 31.7 & 21.5 & 9.8 & 5.1 \\
\hline Town & $5,669,091$ & 641,767 & $1,913,333$ & $2,097,415$ & 874,924 & 141,652 & 100.0 & 11.3 & 33.8 & 37.0 & 15.4 & 2.5 \\
\hline White & $3,712,133$ & 482,262 & $1,525,600$ & $1,365,587$ & 275,645 & 63,039 & 100.0 & 13.0 & 41.1 & 36.8 & 7.4 & 1.7 \\
\hline Black ................................. & 591,443 & 15,662 & 83,614 & 221,313 & 266,386 & 4,468 & 100.0 & 2.6 & 14.1 & 37.4 & 45.0 & 0.8 \\
\hline Hispanic .......................... & $1,006,234$ & 110,870 & 194,674 & 365,937 & 271,329 & 63,424 & 100.0 & 11.0 & 19.3 & 36.4 & 27.0 & 6.3 \\
\hline Asian ............................... & 83,356 & 12,489 & 31,978 & 27,308 & 7,833 & 3,748 & 100.0 & 15.0 & 38.4 & 32.8 & 9.4 & 4.5 \\
\hline $\begin{array}{l}\text { Pacific Islander.............. } \\
\text { American Indian/. }\end{array}$ & 26,016 & 1,035 & 7,459 & 13,949 & 3,258 & 315 & 100.0 & 4.0 & 28.7 & 53.6 & 12.5 & 1.2 \\
\hline Alaska Native.......... & 114,719 & 7,187 & 26,677 & 47,366 & 30,166 & 3,323 & 100.0 & 6.3 & 23.3 & 41.3 & 26.3 & 2.9 \\
\hline Two or more races ........ & 135,190 & 12,262 & 43,331 & 55,955 & 20,307 & 3,335 & 100.0 & 9.1 & 32.1 & 41.4 & 15.0 & 2.5 \\
\hline Rural .... & $12,413,455$ & $2,891,416$ & $4,262,573$ & $3,718,041$ & $1,271,008$ & 270,417 & 100.0 & 23.3 & 34.3 & 30.0 & 10.2 & 2.2 \\
\hline White.................................. & $8,689,762$ & $2,202,548$ & $3,305,074$ & $2,566,012$ & 474,299 & 141,829 & 100.0 & 25.3 & 38.0 & 29.5 & 5.5 & 1.6 \\
\hline Black ................................... & $1,235,964$ & 133,015 & 299,569 & 432,393 & 355,259 & 15,728 & 100.0 & 10.8 & 24.2 & 35.0 & 28.7 & 1.3 \\
\hline Hispanic .......................... & $1,668,147$ & 331,034 & 430,279 & 521,568 & 305,591 & 79,675 & 100.0 & 19.8 & 25.8 & 31.3 & 18.3 & 4.8 \\
\hline Asian & 278,147 & 134,656 & 78,664 & 35,712 & 9,964 & 19,151 & 100.0 & 48.4 & 28.3 & 12.8 & 3.6 & 6.9 \\
\hline Pacific Islander.............. & 27,414 & 4,422 & 9,655 & 7,497 & 5,022 & 818 & 100.0 & 16.1 & 35.2 & 27.3 & 18.3 & 3.0 \\
\hline American Indian/ & & & & & & & & & & & & \\
\hline Alaska Native .......... & 235,419 & 17,389 & 41,733 & 75,376 & 96,120 & 4,801 & 100.0 & 7.4 & 17.7 & 32.0 & 40.8 & 2.0 \\
\hline Two or more races ....... & 278,602 & 68,352 & 97,599 & 79,483 & 24,753 & 8,415 & 100.0 & 24.5 & 35.0 & 28.5 & 8.9 & 3.0 \\
\hline
\end{tabular}

'Includes students enrolled in schools that did not report free or reduced-price lunch eligibility. ${ }^{2}$ Excludes 9,583 students whose race/ethnicity was not available. Includes students who attended combined elementary/secondary schools and schools not reported by grade span which are not shown separately.

${ }^{3}$ Combined elementary/secondary schools and schools not reported by grade span are not shown separately.

${ }^{4}$ Includes schools beginning with grade 6 or below and with no grade higher than 8 .

Includes schools with no grade lower than 7 .
NOTE: The National School Lunch Program is a federally assisted meal program. To be eligible for free lunch under the program, a student must be from a household with an income at or below 130 percent of the poverty threshold; to be eligible for reduced-price lunch, a student must be from a household with an income between 130 percent and 185 percent of the poverty threshold. Race categories exclude persons of Hispanic ethnicity. Detail may not sum to totals because of rounding.

SOURCE: U.S. Department of Education, National Center for Education Statistics, Common Core of Data (CCD), "Public Elementary/Secondary School Universe Survey," 2011-12. (This table was prepared March 2014.) 
Table 216.70. Public elementary and secondary schools, by level, type, and state or jurisdiction: 1990-91, 2000-01, 2010-11, and 2011-12

\begin{tabular}{|c|c|c|c|c|c|c|c|c|c|c|c|c|c|c|}
\hline \multirow[b]{3}{*}{ State or jurisdiction } & \multirow[b]{3}{*}{$\begin{array}{c}\text { Total, all } \\
\text { schools, } \\
1990-91\end{array}$} & \multirow[b]{3}{*}{$\begin{array}{l}\text { Total, all } \\
\text { schools, } \\
2000-01\end{array}$} & \multirow[b]{3}{*}{$\begin{array}{l}\text { Total, all } \\
\text { schools, } \\
\text { 2010-11 }\end{array}$} & \multicolumn{8}{|c|}{ Schools by level, 2011-12 } & \multicolumn{3}{|c|}{ Selected types of schools, 2011-12 } \\
\hline & & & & \multirow[b]{2}{*}{$\begin{array}{r}\text { Total, all } \\
\text { schools }\end{array}$} & \multirow[b]{2}{*}{$\begin{array}{r}\text { Elemen- } \\
\text { tary }\end{array}$} & \multirow[b]{2}{*}{$\begin{array}{r}\begin{array}{r}\text { Second- } \\
\text { ary }^{2}\end{array}\end{array}$} & \multicolumn{4}{|c|}{ Combined elementary/secondary ${ }^{3}$} & \multirow[b]{2}{*}{ Other ${ }^{4}$} & \multirow[b]{2}{*}{$\begin{array}{r}\text { Alter- } \\
\text { native } 5\end{array}$} & \multirow[b]{2}{*}{$\begin{array}{r}\text { Special } \\
\text { education }\end{array}$} & \multirow[b]{2}{*}{$\begin{array}{r}\text { One- } \\
\text { teacher } \\
\text { schools }\end{array}$} \\
\hline & & & & & & & Total & $\begin{array}{r}\text { Prekinder- } \\
\text { garten, } \\
\text { kindergar- } \\
\text { ten, or } 1 \mathrm{st} \\
\text { grade to } \\
\text { grade } 12 \\
\end{array}$ & $\begin{array}{r}\text { Other } \\
\text { schools } \\
\text { ending } \\
\text { with } \\
\text { grade } 12 \\
\end{array}$ & $\begin{array}{r}\text { Other } \\
\text { combined } \\
\text { schools } \\
\end{array}$ & & & & \\
\hline 1 & 2 & 3 & 4 & 5 & 6 & 7 & 8 & 9 & 10 & 11 & 12 & 13 & 14 & 15 \\
\hline United States .......... & 84,538 & 93,273 & 98,817 & 98,328 & 66,689 & 24,357 & 6,311 & 3,111 & 2,369 & 831 & 971 & 6,144 & 2,087 & 205 \\
\hline 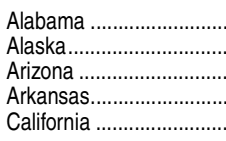 & $\begin{array}{r}1,297 \\
498 \\
1,049 \\
1,098 \\
7,913\end{array}$ & $\begin{array}{r}1,517 \\
515 \\
1,724 \\
1,138 \\
8,773\end{array}$ & $\begin{array}{r}1,600 \\
509 \\
2,265 \\
1,110 \\
10,124\end{array}$ & $\begin{array}{r}1,618 \\
511 \\
2,252 \\
1,108 \\
10,170\end{array}$ & $\begin{array}{r}712 \\
201 \\
1,323 \\
716 \\
6,925\end{array}$ & $\begin{array}{r}415 \\
82 \\
744 \\
384 \\
2,624\end{array}$ & $\begin{array}{r}459 \\
228 \\
160 \\
8 \\
570\end{array}$ & $\begin{array}{r}122 \\
212 \\
89 \\
4 \\
433\end{array}$ & $\begin{array}{r}64 \\
14 \\
49 \\
2 \\
118\end{array}$ & \begin{tabular}{r|}
273 \\
2 \\
22 \\
2 \\
19
\end{tabular} & \begin{tabular}{r|}
32 \\
0 \\
25 \\
0 \\
51
\end{tabular} & $\begin{array}{r}118 \\
65 \\
67 \\
11 \\
1,305\end{array}$ & $\begin{array}{r}42 \\
3 \\
20 \\
4 \\
146\end{array}$ & $\begin{array}{r}0 \\
8 \\
6 \\
0 \\
39\end{array}$ \\
\hline $\begin{array}{l}\text { Colorado } \\
\text { Connecticut.......... } \\
\text { Delaware.......... } \\
\text { District of Columbia } \\
\text { Florida }\end{array}$ & $\begin{array}{r}1,344 \\
985 \\
173 \\
181 \\
2,516\end{array}$ & $\begin{array}{r}1,632 \\
1,248 \\
191 \\
198 \\
3,316\end{array}$ & $\begin{array}{r}1,796 \\
1,157 \\
214 \\
228 \\
4,131\end{array}$ & $\begin{array}{r}1,813 \\
1,150 \\
221 \\
228 \\
4,212\end{array}$ & $\begin{array}{r}1,295 \\
817 \\
158 \\
170 \\
2,756\end{array}$ & $\begin{array}{r}393 \\
279 \\
39 \\
37 \\
683\end{array}$ & $\begin{array}{r}125 \\
37 \\
17 \\
13 \\
632\end{array}$ & $\begin{array}{r}49 \\
11 \\
12 \\
3 \\
244\end{array}$ & $\begin{array}{r}61 \\
18 \\
5 \\
5 \\
368\end{array}$ & $\begin{array}{r}15 \\
8 \\
0 \\
5 \\
20\end{array}$ & $\begin{array}{r}0 \\
17 \\
7 \\
8 \\
141\end{array}$ & $\begin{array}{r}87 \\
47 \\
6 \\
11 \\
413\end{array}$ & $\begin{array}{r}7 \\
48 \\
21 \\
7 \\
183\end{array}$ & $\begin{array}{l}1 \\
0 \\
0 \\
0 \\
3\end{array}$ \\
\hline 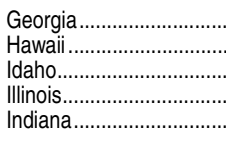 & $\begin{array}{r}1,734 \\
235 \\
582 \\
4,239 \\
1,915\end{array}$ & $\begin{array}{r}1,946 \\
261 \\
673 \\
4,342 \\
1,976\end{array}$ & $\begin{array}{r}2,449 \\
289 \\
748 \\
4,361 \\
1,936\end{array}$ & $\begin{array}{r}2,388 \\
287 \\
762 \\
4,336 \\
1,933\end{array}$ & $\begin{array}{r}1,797 \\
206 \\
448 \\
3,170 \\
1,372\end{array}$ & $\begin{array}{r}470 \\
52 \\
230 \\
989 \\
454\end{array}$ & $\begin{array}{r}55 \\
28 \\
84 \\
173 \\
107\end{array}$ & $\begin{array}{l}12 \\
22 \\
52 \\
55 \\
58\end{array}$ & $\begin{array}{r}27 \\
3 \\
23 \\
103 \\
38\end{array}$ & $\begin{array}{r}16 \\
3 \\
9 \\
15 \\
11\end{array}$ & $\begin{array}{r}66 \\
1 \\
0 \\
4 \\
0\end{array}$ & $\begin{array}{r}62 \\
1 \\
91 \\
150 \\
11\end{array}$ & $\begin{array}{r}58 \\
2 \\
15 \\
141 \\
34\end{array}$ & $\begin{array}{r}0 \\
0 \\
12\end{array}$ \\
\hline 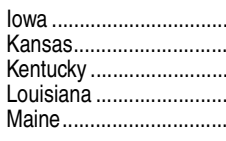 & $\begin{array}{r}1,588 \\
1,477 \\
1,400 \\
1,533 \\
747\end{array}$ & $\begin{array}{r}1,534 \\
1,430 \\
1,526 \\
1,530 \\
714\end{array}$ & $\begin{array}{r}1,436 \\
1,378 \\
1,554 \\
1,471 \\
631\end{array}$ & $\begin{array}{r}1,411 \\
1,359 \\
1,565 \\
1,437 \\
621\end{array}$ & $\begin{array}{l}980 \\
949 \\
995 \\
978 \\
448\end{array}$ & $\begin{array}{l}387 \\
365 \\
441 \\
288 \\
148\end{array}$ & $\begin{array}{r}44 \\
41 \\
116 \\
167 \\
12\end{array}$ & $\begin{array}{r}3 \\
13 \\
33 \\
100 \\
10\end{array}$ & $\begin{array}{r}41 \\
28 \\
76 \\
63 \\
2\end{array}$ & $\begin{array}{l}0 \\
0 \\
7 \\
4 \\
0\end{array}$ & \begin{tabular}{r|}
0 \\
4 \\
13 \\
4 \\
13
\end{tabular} & $\begin{array}{r}33 \\
2 \\
172 \\
266 \\
0\end{array}$ & $\begin{array}{r}6 \\
10 \\
10 \\
35 \\
3\end{array}$ & $\begin{array}{l}5 \\
0 \\
0 \\
0 \\
1\end{array}$ \\
\hline 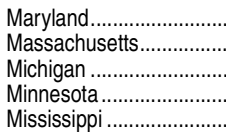 & $\begin{array}{r}1,220 \\
1,842 \\
3,313 \\
1,590 \\
972\end{array}$ & $\begin{array}{l}1,383 \\
1,905 \\
3,998 \\
2,362 \\
1,030\end{array}$ & $\begin{array}{l}1,449 \\
1,829 \\
3,877 \\
2,392 \\
1,083\end{array}$ & $\begin{array}{l}1,451 \\
1,835 \\
3,550 \\
2,392 \\
1,069\end{array}$ & $\begin{array}{r}1,129 \\
1,414 \\
2,269 \\
1,263 \\
625\end{array}$ & $\begin{array}{l}258 \\
370 \\
958 \\
849 \\
324\end{array}$ & $\begin{array}{r}46 \\
44 \\
288 \\
278 \\
109\end{array}$ & $\begin{array}{r}21 \\
14 \\
157 \\
134 \\
65\end{array}$ & $\begin{array}{r}19 \\
25 \\
111 \\
132 \\
43\end{array}$ & $\begin{array}{r}6 \\
5 \\
20 \\
12 \\
1\end{array}$ & \begin{tabular}{r|}
18 \\
7 \\
35 \\
2 \\
11
\end{tabular} & $\begin{array}{r}56 \\
19 \\
277 \\
484 \\
63\end{array}$ & $\begin{array}{r}40 \\
22 \\
197 \\
276 \\
4\end{array}$ & $\begin{array}{l}1 \\
0 \\
5\end{array}$ \\
\hline 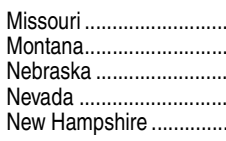 & $\begin{array}{r}2,199 \\
900 \\
1,506 \\
354 \\
439\end{array}$ & $\begin{array}{r}2,368 \\
879 \\
1,326 \\
511 \\
526\end{array}$ & $\begin{array}{r}2,410 \\
827 \\
1,096 \\
645 \\
480\end{array}$ & $\begin{array}{r}2,408 \\
826 \\
1,090 \\
649 \\
477\end{array}$ & $\begin{array}{r}1,581 \\
479 \\
718 \\
479 \\
373\end{array}$ & $\begin{array}{l}646 \\
347 \\
317 \\
129 \\
104\end{array}$ & $\begin{array}{r}161 \\
0 \\
27 \\
39 \\
0\end{array}$ & \begin{tabular}{r|}
74 \\
0 \\
17 \\
13 \\
0
\end{tabular} & $\begin{array}{r}85 \\
0 \\
9 \\
26 \\
0\end{array}$ & $\begin{array}{l}2 \\
0 \\
1 \\
0 \\
0\end{array}$ & $\begin{array}{r}20 \\
0 \\
28 \\
2 \\
0\end{array}$ & $\begin{array}{r}105 \\
4 \\
29 \\
35 \\
0\end{array}$ & \begin{tabular}{r|}
64 \\
2 \\
25 \\
12 \\
0
\end{tabular} & $\begin{array}{r}0 \\
60 \\
7 \\
11 \\
1\end{array}$ \\
\hline 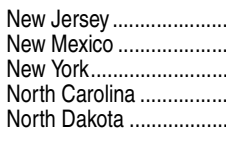 & $\begin{array}{r}2,272 \\
681 \\
4,010 \\
1,955 \\
663\end{array}$ & $\begin{array}{r}2,410 \\
765 \\
4,336 \\
2,207 \\
579\end{array}$ & $\begin{array}{r}2,607 \\
862 \\
4,757 \\
2,567 \\
516\end{array}$ & $\begin{array}{r}2,596 \\
866 \\
4,752 \\
2,577 \\
513\end{array}$ & $\begin{array}{r}1,946 \\
604 \\
3,279 \\
1,887 \\
297\end{array}$ & $\begin{array}{r}544 \\
239 \\
1,105 \\
536 \\
184\end{array}$ & $\begin{array}{r}57 \\
23 \\
278 \\
146 \\
0\end{array}$ & $\begin{array}{r}28 \\
8 \\
111 \\
77 \\
0\end{array}$ & $\begin{array}{r}19 \\
12 \\
124 \\
62 \\
0\end{array}$ & $\begin{array}{r}10 \\
3 \\
43 \\
7 \\
0\end{array}$ & $\begin{array}{r}49 \\
0 \\
90 \\
8 \\
32\end{array}$ & $\begin{array}{r}107 \\
39 \\
26 \\
88 \\
0\end{array}$ & $\begin{array}{r}69 \\
8 \\
122 \\
30 \\
33\end{array}$ & $\begin{array}{l}0 \\
0 \\
0 \\
0 \\
6\end{array}$ \\
\hline 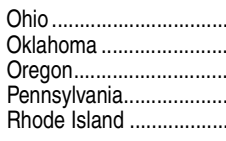 & $\begin{array}{r}3,731 \\
1,880 \\
1,199 \\
3,260 \\
309\end{array}$ & $\begin{array}{r}3,916 \\
1,821 \\
1,273 \\
3,252 \\
328\end{array}$ & $\begin{array}{r}3,758 \\
1,785 \\
1,296 \\
3,233 \\
317\end{array}$ & $\begin{array}{r}3,714 \\
1,774 \\
1,261 \\
3,181 \\
308\end{array}$ & $\begin{array}{r}2,544 \\
1,213 \\
890 \\
2,252 \\
227\end{array}$ & $\begin{array}{r}1,004 \\
554 \\
294 \\
824 \\
76\end{array}$ & $\begin{array}{r}158 \\
6 \\
77 \\
100 \\
5\end{array}$ & $\begin{array}{r}50 \\
1 \\
54 \\
47 \\
3\end{array}$ & $\begin{array}{r}69 \\
3 \\
20 \\
39 \\
1\end{array}$ & \begin{tabular}{r|}
39 \\
2 \\
3 \\
14 \\
1
\end{tabular} & $\begin{array}{l}8 \\
1 \\
0 \\
5 \\
0\end{array}$ & $\begin{array}{r}6 \\
4 \\
41 \\
12 \\
5\end{array}$ & $\begin{array}{r}57 \\
4 \\
2 \\
8 \\
2\end{array}$ & $\begin{array}{r}0 \\
0 \\
11 \\
0 \\
0\end{array}$ \\
\hline $\begin{array}{l}\text { South Carolina } \\
\text { South Dakota } \\
\text { Tennessee } \\
\text { Texas }\end{array}$ & $\begin{array}{r}1,097 \\
802 \\
1,543 \\
5,991 \\
714\end{array}$ & $\begin{array}{r}1,127 \\
769 \\
1,624 \\
7,519 \\
793\end{array}$ & $\begin{array}{r}1,214 \\
710 \\
1,784 \\
8,732 \\
1,016\end{array}$ & $\begin{array}{r}1,223 \\
704 \\
1,802 \\
8,697 \\
1,020\end{array}$ & $\begin{array}{r}907 \\
434 \\
1,295 \\
5,918 \\
630\end{array}$ & $\begin{array}{r}277 \\
246 \\
349 \\
2,113 \\
301\end{array}$ & $\begin{array}{r}31 \\
24 \\
139 \\
662 \\
89\end{array}$ & $\begin{array}{r}9 \\
10 \\
62 \\
295 \\
55\end{array}$ & $\begin{array}{r}17 \\
14 \\
47 \\
218 \\
5\end{array}$ & $\begin{array}{r}5 \\
0 \\
30 \\
149 \\
29\end{array}$ & $\begin{array}{r}8 \\
0 \\
19 \\
4 \\
0\end{array}$ & $\begin{array}{r}21 \\
37 \\
22 \\
1,032 \\
44\end{array}$ & $\begin{array}{l}10 \\
10 \\
15 \\
22 \\
85\end{array}$ & $\begin{array}{r}1 \\
13 \\
0 \\
0 \\
0\end{array}$ \\
\hline 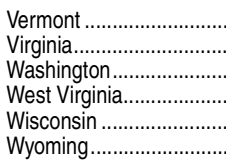 & $\begin{array}{r}397 \\
1,811 \\
1,936 \\
1,015 \\
2,018 \\
415\end{array}$ & $\begin{array}{r}393 \\
1,969 \\
2,305 \\
840 \\
2,182 \\
393\end{array}$ & $\begin{array}{r}320 \\
2,175 \\
2,338 \\
757 \\
2,238 \\
360\end{array}$ & $\begin{array}{r}320 \\
2,170 \\
2,365 \\
759 \\
2,243 \\
354\end{array}$ & $\begin{array}{r}235 \\
1,503 \\
1,517 \\
571 \\
1,553 \\
241\end{array}$ & $\begin{array}{r}69 \\
399 \\
631 \\
127 \\
583 \\
96\end{array}$ & $\begin{array}{r}16 \\
36 \\
216 \\
61 \\
103 \\
16\end{array}$ & $\begin{array}{r}11 \\
24 \\
150 \\
45 \\
32 \\
7\end{array}$ & $\begin{array}{r}5 \\
11 \\
60 \\
15 \\
67 \\
3\end{array}$ & $\begin{array}{l}0 \\
1 \\
6 \\
1 \\
4 \\
6\end{array}$ & $\begin{array}{r}0 \\
232 \\
1 \\
0 \\
4 \\
1\end{array}$ & $\begin{array}{r}1 \\
192 \\
338 \\
33 \\
87 \\
19\end{array}$ & $\begin{array}{r}0 \\
54 \\
104 \\
3 \\
11 \\
1\end{array}$ & $\begin{array}{l}1 \\
0 \\
3 \\
0 \\
7 \\
1\end{array}$ \\
\hline $\begin{array}{l}\text { Bureau of Indian } \\
\text { Education......... }\end{array}$ & \multirow[t]{2}{*}{-} & 189 & 173 & 173 & 109 & 19 & 45 & 39 & 3 & 3 & 0 & 0 & 0 & - \\
\hline $\begin{array}{l}\text { DoD, domestic and } \\
\quad \text { overseas }\end{array}$ & & 227 & 191 & 191 & 142 & 35 & 14 & 10 & 4 & 0 & 0 & 0 & 0 & 0 \\
\hline 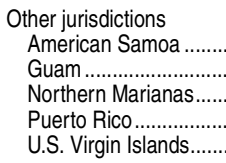 & $\begin{array}{r}30 \\
35 \\
26 \\
1,619 \\
33\end{array}$ & $\begin{array}{r}31 \\
38 \\
29 \\
1,543 \\
36\end{array}$ & $\begin{array}{r}28 \\
40 \\
30 \\
1,473 \\
32\end{array}$ & $\begin{array}{r}28 \\
40 \\
29 \\
1,464 \\
31\end{array}$ & $\begin{array}{r}22 \\
35 \\
21 \\
865 \\
22\end{array}$ & $\begin{array}{r}6 \\
5 \\
7 \\
397 \\
9\end{array}$ & $\begin{array}{r}0 \\
0 \\
0 \\
172 \\
0\end{array}$ & $\begin{array}{l}0 \\
0 \\
0 \\
2 \\
0\end{array}$ & $\begin{array}{l}0 \\
0 \\
0 \\
3 \\
0\end{array}$ & $\begin{array}{r}0 \\
0 \\
0 \\
167 \\
0\end{array}$ & $\begin{array}{r}0 \\
0 \\
1 \\
30 \\
0\end{array}$ & $\begin{array}{l}0 \\
0 \\
0 \\
9 \\
0\end{array}$ & $\begin{array}{r}0 \\
0 \\
0 \\
23 \\
0\end{array}$ & $\begin{array}{l}0 \\
0 \\
0 \\
0 \\
0\end{array}$ \\
\hline
\end{tabular}

-Not available

${ }^{1}$ Includes schools beginning with grade 6 or below and with no grade higher than 8 . ${ }^{2}$ Includes schools with no grade lower than 7.

${ }^{3}$ Includes schools beginning with grade 6 or below and ending with grade 9 or above. ${ }^{4}$ Includes schools not reported by grade span.
${ }^{5}$ Schools are also included under elementary, secondary, combined, or other as appropriate. NOTE: $\mathrm{DoD}=$ Department of Defense.

SOURCE: U.S. Department of Education, National Center for Education Statistics, Common Core of Data (CCD), "Public Elementary/Secondary School Universe Survey," 1990-91, 2000-01, 2010-11, and 2011-12. (This table was prepared August 2013.) 
Table 216.75. Public elementary schools, by grade span, average school enrollment, and state or jurisdiction: 2011-12

\begin{tabular}{|c|c|c|c|c|c|c|c|c|c|c|}
\hline \multirow[b]{2}{*}{ State or jurisdiction } & \multirow[b]{2}{*}{$\begin{array}{r}\text { Total, all } \\
\text { elementary } \\
\text { schools }\end{array}$} & \multirow[b]{2}{*}{$\begin{array}{r}\text { Total, all } \\
\text { regular } \\
\text { elementary } \\
\text { schools }^{1}\end{array}$} & \multicolumn{6}{|c|}{ Schools, by grade span } & \multicolumn{2}{|c|}{ Average school enrollment ${ }^{2}$} \\
\hline & & & $\begin{array}{r}\text { Prekinder- } \\
\text { garten, } \\
\text { kindergarten, } \\
\text { or 1st grade to } \\
\text { grades } 3 \text { or } 4\end{array}$ & \begin{tabular}{|} 
Prekinder- \\
garten, \\
kindergarten, \\
or 1st grade to \\
grade 5
\end{tabular} & $\begin{array}{r}\text { Prekinder- } \\
\text { garten, } \\
\text { kindergarten, } \\
\text { or 1st grade to } \\
\text { grade } 6\end{array}$ & \begin{tabular}{|r|} 
Prekinder- \\
garten, \\
kindergarten, \\
or 1st grade to \\
grade 8
\end{tabular} & $\begin{array}{r}\text { Grade } 4,5 \text {, or } \\
6 \text { to grade } 6, \\
7, \text { or } 8\end{array}$ & $\begin{array}{r}\text { Other grade } \\
\text { spans }\end{array}$ & $\begin{array}{r}\text { All elementary } \\
\text { schools }\end{array}$ & $\begin{array}{r}\text { Regular } \\
\text { elementary } \\
\text { schools }^{1}\end{array}$ \\
\hline 1 & 2 & 3 & 4 & 5 & 6 & 7 & 8 & 9 & 10 & 11 \\
\hline 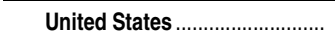 & 66,689 & 65,461 & 4,979 & 25,115 & 10,801 & 6,428 & 12,963 & 6,403 & 479 & 484 \\
\hline 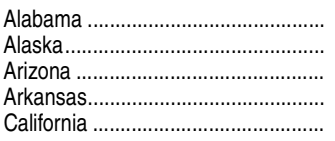 & $\begin{array}{r}712 \\
201 \\
1,323 \\
716 \\
6,925\end{array}$ & $\begin{array}{r}703 \\
192 \\
1,304 \\
713 \\
6,705\end{array}$ & \begin{tabular}{r|}
83 \\
4 \\
48 \\
128 \\
131
\end{tabular} & $\begin{array}{r}311 \\
46 \\
250 \\
142 \\
2,435\end{array}$ & $\begin{array}{r}172 \\
89 \\
344 \\
181 \\
2,170\end{array}$ & \begin{tabular}{r|r}
3 \\
28 \\
458 \\
7 \\
957
\end{tabular} & $\begin{array}{r}33 \\
23 \\
164 \\
154 \\
1,036\end{array}$ & $\begin{array}{r}110 \\
11 \\
59 \\
104 \\
196\end{array}$ & $\begin{array}{l}483 \\
325 \\
513 \\
425 \\
559\end{array}$ & $\begin{array}{l}487 \\
320 \\
515 \\
427 \\
570\end{array}$ \\
\hline 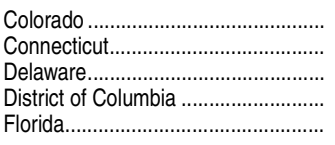 & $\begin{array}{r}1,295 \\
817 \\
158 \\
170 \\
2,756\end{array}$ & $\begin{array}{r}1,289 \\
806 \\
153 \\
164 \\
2,687\end{array}$ & $\begin{array}{l}32 \\
98 \\
15 \\
11 \\
25\end{array}$ & $\begin{array}{r}617 \\
256 \\
80 \\
63 \\
1,671\end{array}$ & \begin{tabular}{r|}
203 \\
72 \\
5 \\
11 \\
135
\end{tabular} & \begin{tabular}{r|}
115 \\
97 \\
9 \\
39 \\
216
\end{tabular} & $\begin{array}{r}242 \\
155 \\
38 \\
24 \\
577\end{array}$ & $\begin{array}{r}86 \\
139 \\
11 \\
22 \\
132\end{array}$ & $\begin{array}{l}431 \\
438 \\
558 \\
313 \\
657\end{array}$ & $\begin{array}{l}431 \\
442 \\
565 \\
313 \\
671\end{array}$ \\
\hline 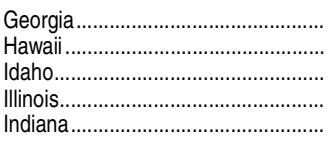 & $\begin{array}{r}1,797 \\
206 \\
448 \\
3,170 \\
1,372\end{array}$ & $\begin{array}{r}1,791 \\
206 \\
444 \\
3,133 \\
1,366\end{array}$ & \begin{tabular}{r|}
42 \\
0 \\
32 \\
295 \\
177
\end{tabular} & $\begin{array}{r}1,070 \\
82 \\
145 \\
800 \\
456\end{array}$ & $\begin{array}{r}37 \\
86 \\
140 \\
330 \\
329\end{array}$ & $\begin{array}{r}27 \\
8 \\
27 \\
709 \\
40\end{array}$ & $\begin{array}{r}466 \\
27 \\
75 \\
580 \\
259\end{array}$ & $\begin{array}{r}155 \\
3 \\
29 \\
456 \\
111\end{array}$ & $\begin{array}{l}658 \\
557 \\
386 \\
433 \\
472\end{array}$ & $\begin{array}{l}660 \\
557 \\
387 \\
437 \\
472\end{array}$ \\
\hline 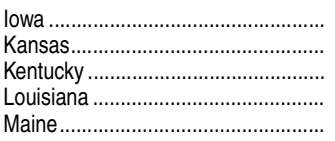 & $\begin{array}{l}980 \\
949 \\
995 \\
978 \\
448\end{array}$ & $\begin{array}{l}977 \\
945 \\
980 \\
843 \\
448\end{array}$ & $\begin{array}{r}130 \\
99 \\
25 \\
81 \\
62\end{array}$ & $\begin{array}{r}346 \\
336 \\
481 \\
341 \\
91\end{array}$ & $\begin{array}{r}141 \\
177 \\
115 \\
118 \\
57\end{array}$ & $\begin{array}{r}13 \\
66 \\
78 \\
110 \\
86\end{array}$ & $\begin{array}{r}230 \\
199 \\
202 \\
210 \\
84\end{array}$ & $\begin{array}{r}120 \\
72 \\
94 \\
118 \\
68\end{array}$ & $\begin{array}{l}325 \\
333 \\
471 \\
474 \\
263\end{array}$ & $\begin{array}{l}325 \\
335 \\
478 \\
483 \\
263\end{array}$ \\
\hline 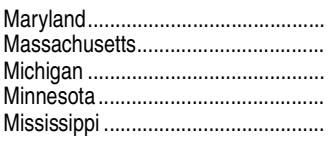 & $\begin{array}{r}1,129 \\
1,414 \\
2,269 \\
1,263 \\
625\end{array}$ & $\begin{array}{r}1,115 \\
1,402 \\
2,220 \\
1,104 \\
622\end{array}$ & $\begin{array}{r}9 \\
185 \\
229 \\
104 \\
65\end{array}$ & $\begin{array}{l}655 \\
472 \\
832 \\
355 \\
131\end{array}$ & $\begin{array}{r}96 \\
121 \\
213 \\
325 \\
103\end{array}$ & $\begin{array}{r}89 \\
107 \\
222 \\
74 \\
38\end{array}$ & $\begin{array}{l}222 \\
286 \\
483 \\
230 \\
155\end{array}$ & $\begin{array}{r}58 \\
243 \\
290 \\
175 \\
133\end{array}$ & $\begin{array}{l}515 \\
441 \\
418 \\
424 \\
510\end{array}$ & $\begin{array}{l}519 \\
442 \\
421 \\
467 \\
510\end{array}$ \\
\hline 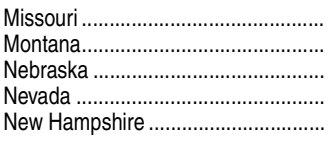 & $\begin{array}{r}1,581 \\
479 \\
718 \\
479 \\
373\end{array}$ & $\begin{array}{r}1,569 \\
476 \\
712 \\
470 \\
373\end{array}$ & $\begin{array}{r}143 \\
17 \\
50 \\
10 \\
57\end{array}$ & $\begin{array}{r}502 \\
55 \\
169 \\
260 \\
113\end{array}$ & $\begin{array}{r}296 \\
212 \\
283 \\
83 \\
36\end{array}$ & $\begin{array}{r}114 \\
112 \\
30 \\
20 \\
50\end{array}$ & $\begin{array}{r}317 \\
54 \\
99 \\
92 \\
81\end{array}$ & $\begin{array}{r}209 \\
29 \\
87 \\
14 \\
36\end{array}$ & $\begin{array}{l}379 \\
181 \\
273 \\
619 \\
337\end{array}$ & $\begin{array}{l}381 \\
182 \\
274 \\
630 \\
337\end{array}$ \\
\hline 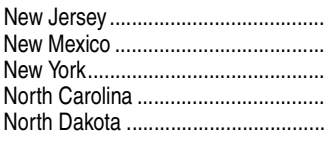 & $\begin{array}{r}1,946 \\
604 \\
3,279 \\
1,887 \\
297\end{array}$ & $\begin{array}{r}1,927 \\
593 \\
3,259 \\
1,875 \\
296\end{array}$ & $\begin{array}{r}270 \\
16 \\
292 \\
77 \\
11\end{array}$ & $\begin{array}{r}561 \\
234 \\
1,260 \\
1,089 \\
56\end{array}$ & $\begin{array}{r}153 \\
142 \\
372 \\
67 \\
126\end{array}$ & $\begin{array}{r}300 \\
21 \\
230 \\
110 \\
62\end{array}$ & $\begin{array}{r}352 \\
127 \\
730 \\
457 \\
27\end{array}$ & $\begin{array}{r}310 \\
64 \\
395 \\
87 \\
15\end{array}$ & $\begin{array}{l}461 \\
366 \\
526 \\
552 \\
204\end{array}$ & $\begin{array}{l}465 \\
371 \\
527 \\
554 \\
205\end{array}$ \\
\hline 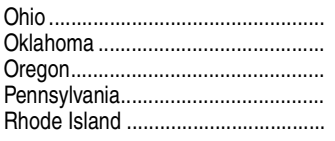 & $\begin{array}{r}2,544 \\
1,213 \\
890 \\
2,252 \\
227\end{array}$ & $\begin{array}{r}2,516 \\
1,209 \\
883 \\
2,251 \\
226\end{array}$ & $\begin{array}{r}361 \\
62 \\
31 \\
288 \\
36\end{array}$ & $\begin{array}{r}671 \\
338 \\
400 \\
705 \\
77\end{array}$ & \begin{tabular}{r|}
337 \\
138 \\
142 \\
427 \\
42
\end{tabular} & $\begin{array}{r}261 \\
292 \\
116 \\
197 \\
4\end{array}$ & $\begin{array}{r}555 \\
238 \\
174 \\
424 \\
39\end{array}$ & $\begin{array}{r}359 \\
145 \\
27 \\
211 \\
29\end{array}$ & $\begin{array}{l}429 \\
383 \\
398 \\
472 \\
399\end{array}$ & $\begin{array}{l}433 \\
384 \\
399 \\
472 \\
400\end{array}$ \\
\hline 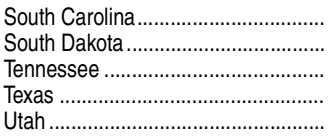 & $\begin{array}{r}907 \\
434 \\
1,295 \\
5,918 \\
630\end{array}$ & $\begin{array}{r}904 \\
430 \\
1,288 \\
5,770 \\
592\end{array}$ & $\begin{array}{r}39 \\
17 \\
96 \\
618 \\
10\end{array}$ & $\begin{array}{r}460 \\
134 \\
421 \\
2,657 \\
85\end{array}$ & $\begin{array}{r}45 \\
69 \\
196 \\
535 \\
433\end{array}$ & $\begin{array}{r}35 \\
96 \\
245 \\
130 \\
26\end{array}$ & $\begin{array}{r}228 \\
98 \\
281 \\
1,332 \\
34\end{array}$ & $\begin{array}{r}100 \\
20 \\
56 \\
646 \\
42\end{array}$ & $\begin{array}{l}550 \\
202 \\
515 \\
562 \\
543\end{array}$ & $\begin{array}{l}552 \\
204 \\
517 \\
573 \\
568\end{array}$ \\
\hline 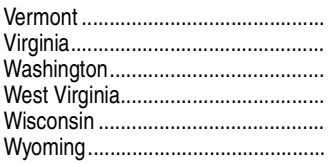 & $\begin{array}{r}235 \\
1,503 \\
1,517 \\
571 \\
1,553 \\
241\end{array}$ & $\begin{array}{r}235 \\
1,503 \\
1,435 \\
570 \\
1,547 \\
240\end{array}$ & $\begin{array}{r}12 \\
51 \\
58 \\
72 \\
150 \\
25\end{array}$ & $\begin{array}{r}25 \\
845 \\
604 \\
271 \\
603 \\
56\end{array}$ & $\begin{array}{r}106 \\
151 \\
377 \\
36 \\
144 \\
83\end{array}$ & $\begin{array}{r}64 \\
13 \\
75 \\
35 \\
154 \\
13\end{array}$ & $\begin{array}{r}17 \\
311 \\
262 \\
119 \\
317 \\
44\end{array}$ & $\begin{array}{r}11 \\
132 \\
141 \\
38 \\
185 \\
20\end{array}$ & $\begin{array}{l}220 \\
560 \\
436 \\
346 \\
367 \\
228\end{array}$ & $\begin{array}{l}220 \\
560 \\
450 \\
346 \\
368 \\
229\end{array}$ \\
\hline Bureau of Indian Education ................ & 109 & 109 & 6 & 5 & 25 & 67 & 4 & 2 & - & - \\
\hline DoD, domestic and overseas.............. & 142 & 142 & 20 & 43 & 26 & 9 & 28 & 16 & - & - \\
\hline 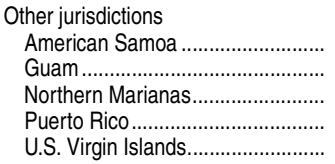 & $\begin{array}{r}22 \\
35 \\
21 \\
865 \\
22\end{array}$ & $\begin{array}{r}22 \\
35 \\
21 \\
865 \\
22\end{array}$ & $\begin{array}{r}0 \\
0 \\
0 \\
42 \\
1\end{array}$ & \begin{tabular}{r|r}
0 \\
25 \\
0 \\
1 \\
1
\end{tabular} & $\begin{array}{r}0 \\
0 \\
12 \\
793 \\
17\end{array}$ & $\begin{array}{r}22 \\
0 \\
0 \\
0 \\
1\end{array}$ & $\begin{array}{r}0 \\
8 \\
0 \\
17 \\
2\end{array}$ & $\begin{array}{r}0 \\
2 \\
9 \\
12 \\
0\end{array}$ & $\begin{array}{l}- \\
606 \\
280 \\
242 \\
397\end{array}$ & $\begin{array}{r}- \\
606 \\
280 \\
242 \\
397\end{array}$ \\
\hline
\end{tabular}

-Not available.

${ }^{2}$ Average for schools reporting enrollment data. Enrollment data were available for 66,286 out of 66,689 public elementary schools in 2011-12.
NOTE: Includes schools beginning with grade 6 or below and with no grade higher than 8 . Excludes schools not reported by grade level, such as some special education schools for the disabled. DoD = Department of Defense.

SOURCE: U.S. Department of Education, National Center for Education Statistics, Common Core of Data (CCD), "Public Elementary/Secondary School Universe Survey," 2011-12. (This table was prepared August 2013.) 
198 CHAPTER 2: Elementary and Secondary Education

Public Schools

Table 216.80. Public secondary schools, by grade span, average school enrollment, and state or jurisdiction: 2011-12

\begin{tabular}{|c|c|c|c|c|c|c|c|c|c|c|c|c|}
\hline \multirow[b]{2}{*}{ State or jurisdiction } & \multirow[b]{2}{*}{$\begin{array}{r}\text { Total, all } \\
\text { secondary } \\
\text { schools }\end{array}$} & \multirow[b]{2}{*}{$\begin{array}{r}\text { Total, all } \\
\text { regular } \\
\text { secondary } \\
\text { schools }^{1}\end{array}$} & \multicolumn{7}{|c|}{ Schools, by grade span } & \multirow[b]{2}{*}{$\begin{array}{r}\text { Vocational } \\
\text { schools }^{2}\end{array}$} & \multicolumn{2}{|c|}{ Average school enrollment ${ }^{2}$} \\
\hline & & & $\begin{array}{r}\text { Grades } \\
7 \text { to } 8 \text { and } \\
7 \text { to } 9\end{array}$ & $\begin{array}{l}\text { Grades } \\
7 \text { to } 12\end{array}$ & $\begin{array}{l}\text { Grades } \\
8 \text { to } 12\end{array}$ & $\begin{array}{l}\text { Grades } \\
9 \text { to } 12\end{array}$ & $\begin{array}{r}\text { Grades } \\
10 \text { to } 12\end{array}$ & $\begin{array}{r}\text { Other spans } \\
\text { ending with } \\
\text { grade } 12\end{array}$ & $\begin{array}{r}\text { Other grade } \\
\text { spans }\end{array}$ & & $\begin{array}{r}\text { All } \\
\text { secondary } \\
\text { schools }\end{array}$ & $\begin{array}{r}\text { Regular } \\
\text { secondary } \\
\text { schools }^{1}\end{array}$ \\
\hline 1 & 2 & 3 & 4 & 5 & 6 & 7 & 8 & 9 & 10 & 11 & 12 & 13 \\
\hline United States................ & 24,357 & 19,441 & 2,865 & 3,126 & 773 & 15,891 & 695 & 327 & 680 & 1,434 & 690 & 788 \\
\hline 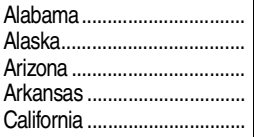 & $\begin{array}{r}415 \\
82 \\
744 \\
384 \\
2,624\end{array}$ & $\begin{array}{r}314 \\
62 \\
508 \\
349 \\
1,623\end{array}$ & $\begin{array}{r}29 \\
14 \\
80 \\
56 \\
379\end{array}$ & $\begin{array}{r}90 \\
19 \\
42 \\
129 \\
309\end{array}$ & $\begin{array}{r}245 \\
1 \\
5 \\
9 \\
14\end{array}$ & $\begin{array}{r}8 \\
47 \\
592 \\
137 \\
1,848\end{array}$ & $\begin{array}{r}30 \\
1 \\
7 \\
34 \\
46\end{array}$ & $\begin{array}{r}3 \\
0 \\
5 \\
1 \\
12\end{array}$ & $\begin{array}{r}10 \\
0 \\
13 \\
18 \\
16\end{array}$ & $\begin{array}{r}72 \\
3 \\
221 \\
26 \\
88\end{array}$ & $\begin{array}{l}712 \\
460 \\
600 \\
495 \\
873\end{array}$ & $\begin{array}{r}720 \\
559 \\
694 \\
504 \\
1,267\end{array}$ \\
\hline 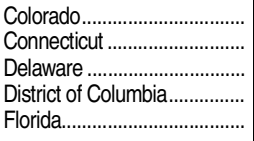 & $\begin{array}{r}393 \\
279 \\
39 \\
37 \\
683\end{array}$ & $\begin{array}{r}338 \\
204 \\
31 \\
28 \\
507\end{array}$ & \begin{tabular}{r|}
42 \\
33 \\
2 \\
0 \\
17
\end{tabular} & $\begin{array}{r}49 \\
13 \\
1 \\
3 \\
44\end{array}$ & $\begin{array}{r}3 \\
7 \\
14 \\
2 \\
34\end{array}$ & $\begin{array}{r}287 \\
185 \\
21 \\
29 \\
561\end{array}$ & $\begin{array}{r}4 \\
20 \\
0 \\
1 \\
7\end{array}$ & $\begin{array}{r}1 \\
15 \\
0 \\
0 \\
12\end{array}$ & $\begin{array}{l}7 \\
6 \\
1 \\
2 \\
8\end{array}$ & $\begin{array}{r}5 \\
16 \\
6 \\
4 \\
52\end{array}$ & $\begin{array}{r}627 \\
672 \\
974 \\
425 \\
1,199\end{array}$ & $\begin{array}{r}706 \\
852 \\
989 \\
481 \\
1,479\end{array}$ \\
\hline 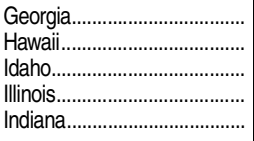 & $\begin{array}{r}470 \\
52 \\
230 \\
989 \\
454\end{array}$ & $\begin{array}{r}440 \\
51 \\
148 \\
820 \\
439\end{array}$ & $\begin{array}{r}18 \\
12 \\
40 \\
147 \\
81\end{array}$ & $\begin{array}{r}11 \\
7 \\
54 \\
71 \\
93\end{array}$ & $\begin{array}{r}7 \\
0 \\
2 \\
15 \\
4\end{array}$ & $\begin{array}{r}390 \\
33 \\
114 \\
686 \\
264\end{array}$ & $\begin{array}{r}4 \\
0 \\
17 \\
11 \\
3\end{array}$ & $\begin{array}{r}2 \\
0 \\
2 \\
32 \\
1\end{array}$ & $\begin{array}{r}38 \\
0 \\
1 \\
27 \\
8\end{array}$ & $\begin{array}{r}1 \\
0 \\
9 \\
51 \\
28\end{array}$ & $\begin{array}{r}1,020 \\
1,144 \\
437 \\
732 \\
836\end{array}$ & $\begin{array}{r}1,080 \\
1,165 \\
598 \\
818 \\
844\end{array}$ \\
\hline 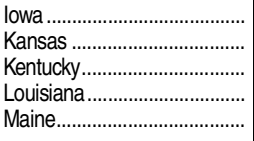 & $\begin{array}{l}387 \\
365 \\
441 \\
288 \\
148\end{array}$ & $\begin{array}{l}356 \\
359 \\
250 \\
204 \\
119\end{array}$ & $\begin{array}{l}45 \\
42 \\
28 \\
31 \\
13\end{array}$ & $\begin{array}{l}71 \\
84 \\
37 \\
48 \\
11\end{array}$ & $\begin{array}{r}0 \\
3 \\
9 \\
93 \\
0\end{array}$ & $\begin{array}{r}256 \\
231 \\
354 \\
95 \\
112\end{array}$ & $\begin{array}{r}8 \\
1 \\
4 \\
16 \\
6\end{array}$ & $\begin{array}{l}3 \\
2 \\
6 \\
0 \\
0\end{array}$ & $\begin{array}{l}4 \\
2 \\
3 \\
5 \\
6\end{array}$ & $\begin{array}{r}0 \\
1 \\
126 \\
8 \\
27\end{array}$ & $\begin{array}{l}416 \\
430 \\
649 \\
654 \\
492\end{array}$ & $\begin{array}{l}447 \\
435 \\
801 \\
745 \\
500\end{array}$ \\
\hline 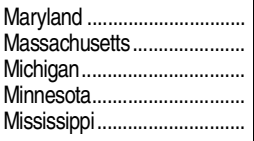 & $\begin{array}{l}258 \\
370 \\
958 \\
849 \\
324\end{array}$ & $\begin{array}{l}200 \\
317 \\
708 \\
460 \\
230\end{array}$ & $\begin{array}{l}11 \\
30 \\
73 \\
46 \\
24\end{array}$ & $\begin{array}{r}6 \\
40 \\
104 \\
285 \\
64\end{array}$ & $\begin{array}{r}2 \\
9 \\
37 \\
29 \\
3\end{array}$ & $\begin{array}{l}223 \\
284 \\
680 \\
388 \\
207\end{array}$ & $\begin{array}{r}2 \\
2 \\
29 \\
47 \\
22\end{array}$ & $\begin{array}{r}8 \\
3 \\
15 \\
46 \\
2\end{array}$ & $\begin{array}{r}6 \\
2 \\
20 \\
8 \\
2\end{array}$ & $\begin{array}{r}24 \\
39 \\
9 \\
11 \\
90\end{array}$ & $\begin{array}{r}1,064 \\
829 \\
554 \\
395 \\
644\end{array}$ & $\begin{array}{r}1,239 \\
849 \\
692 \\
610 \\
644\end{array}$ \\
\hline 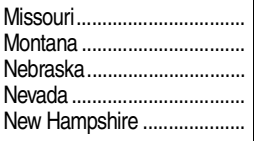 & $\begin{array}{l}646 \\
347 \\
317 \\
129 \\
104\end{array}$ & $\begin{array}{l}563 \\
344 \\
311 \\
115 \\
104\end{array}$ & $\begin{array}{r}63 \\
176 \\
28 \\
19 \\
16\end{array}$ & $\begin{array}{r}181 \\
0 \\
173 \\
8 \\
0\end{array}$ & $\begin{array}{l}1 \\
0 \\
0 \\
1 \\
0\end{array}$ & $\begin{array}{r}357 \\
171 \\
111 \\
96 \\
86\end{array}$ & $\begin{array}{r}20 \\
0 \\
1 \\
1 \\
0\end{array}$ & $\begin{array}{l}9 \\
0 \\
4 \\
4 \\
1\end{array}$ & $\begin{array}{r}15 \\
0 \\
0 \\
0 \\
1\end{array}$ & $\begin{array}{r}66 \\
0 \\
0 \\
1 \\
0\end{array}$ & $\begin{array}{r}533 \\
161 \\
359 \\
1,024 \\
636\end{array}$ & $\begin{array}{r}537 \\
162 \\
359 \\
1,128 \\
636\end{array}$ \\
\hline 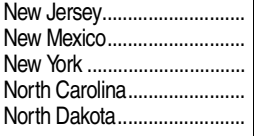 & $\begin{array}{r}544 \\
239 \\
1,105 \\
536 \\
184\end{array}$ & $\begin{array}{r}406 \\
209 \\
1,032 \\
512 \\
174\end{array}$ & $\begin{array}{l}49 \\
39 \\
71 \\
27 \\
10\end{array}$ & $\begin{array}{r}43 \\
31 \\
137 \\
10 \\
94\end{array}$ & $\begin{array}{r}18 \\
0 \\
15 \\
3 \\
0\end{array}$ & $\begin{array}{r}396 \\
152 \\
795 \\
472 \\
74\end{array}$ & $\begin{array}{r}9 \\
8 \\
27 \\
4 \\
3\end{array}$ & $\begin{array}{l}7 \\
0 \\
1 \\
6 \\
1\end{array}$ & $\begin{array}{r}22 \\
9 \\
59 \\
14 \\
2\end{array}$ & \begin{tabular}{r|r}
56 \\
1 \\
29 \\
1 \\
10
\end{tabular} & $\begin{array}{l}932 \\
479 \\
772 \\
823 \\
205\end{array}$ & $\begin{array}{r}1,036 \\
523 \\
782 \\
855 \\
205\end{array}$ \\
\hline 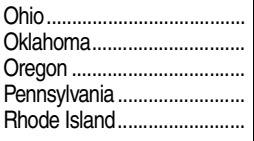 & $\begin{array}{r}1,004 \\
554 \\
294 \\
824 \\
76\end{array}$ & $\begin{array}{r}917 \\
550 \\
268 \\
728 \\
62\end{array}$ & $\begin{array}{r}132 \\
80 \\
32 \\
108 \\
13\end{array}$ & \begin{tabular}{r|}
117 \\
0 \\
50 \\
151 \\
2
\end{tabular} & $\begin{array}{r}42 \\
0 \\
3 \\
11 \\
1\end{array}$ & $\begin{array}{r}666 \\
427 \\
203 \\
469 \\
58\end{array}$ & $\begin{array}{r}18 \\
30 \\
4 \\
62 \\
0\end{array}$ & \begin{tabular}{r|}
11 \\
3 \\
2 \\
8 \\
0
\end{tabular} & $\begin{array}{r}18 \\
14 \\
0 \\
15 \\
2\end{array}$ & $\begin{array}{r}72 \\
0 \\
0 \\
87 \\
11\end{array}$ & $\begin{array}{l}592 \\
355 \\
620 \\
802 \\
740\end{array}$ & $\begin{array}{l}605 \\
356 \\
667 \\
813 \\
784\end{array}$ \\
\hline 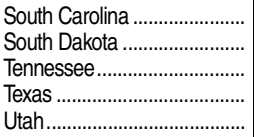 & $\begin{array}{r}277 \\
246 \\
349 \\
2,113 \\
301\end{array}$ & $\begin{array}{r}226 \\
224 \\
328 \\
1,535 \\
245\end{array}$ & $\begin{array}{r}19 \\
63 \\
11 \\
291 \\
103\end{array}$ & $\begin{array}{r}9 \\
0 \\
41 \\
161 \\
54\end{array}$ & $\begin{array}{r}2 \\
0 \\
7 \\
55 \\
7\end{array}$ & $\begin{array}{r}222 \\
180 \\
280 \\
1,277 \\
72\end{array}$ & $\begin{array}{r}13 \\
1 \\
7 \\
54 \\
51\end{array}$ & $\begin{array}{r}4 \\
1 \\
2 \\
44 \\
2\end{array}$ & $\begin{array}{r}8 \\
1 \\
1 \\
231 \\
12\end{array}$ & $\begin{array}{r}39 \\
3 \\
17 \\
0 \\
5\end{array}$ & $\begin{array}{l}898 \\
165 \\
844 \\
726 \\
781\end{array}$ & $\begin{array}{l}944 \\
175 \\
867 \\
964 \\
909\end{array}$ \\
\hline 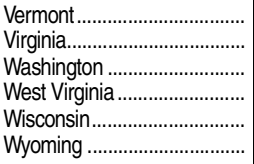 & $\begin{array}{r}69 \\
399 \\
631 \\
127 \\
583 \\
96\end{array}$ & $\begin{array}{r}53 \\
341 \\
428 \\
103 \\
518 \\
80 \\
\end{array}$ & $\begin{array}{r}8 \\
31 \\
101 \\
3 \\
60 \\
19\end{array}$ & \begin{tabular}{r|}
18 \\
8 \\
57 \\
22 \\
62 \\
12 \\
\end{tabular} & $\begin{array}{r}0 \\
29 \\
25 \\
2 \\
3 \\
1\end{array}$ & $\begin{array}{r}28 \\
320 \\
384 \\
93 \\
408 \\
62 \\
\end{array}$ & $\begin{array}{r}0 \\
4 \\
36 \\
2 \\
16 \\
2\end{array}$ & $\begin{array}{r}0 \\
1 \\
16 \\
1 \\
28 \\
0\end{array}$ & $\begin{array}{r}15 \\
6 \\
12 \\
4 \\
6 \\
0\end{array}$ & $\begin{array}{r}15 \\
50 \\
17 \\
30 \\
7 \\
0\end{array}$ & $\begin{array}{r}511 \\
1,156 \\
627 \\
607 \\
484 \\
332\end{array}$ & $\begin{array}{r}520 \\
1,183 \\
824 \\
736 \\
528 \\
388 \\
\end{array}$ \\
\hline Bureau of Indian Education.. & 19 & 19 & 1 & 5 & 0 & 13 & 0 & 0 & 0 & 0 & - & - \\
\hline DoD, domestic and overseas. & 35 & 35 & 3 & 11 & 0 & 21 & 0 & 0 & 0 & 0 & - & - \\
\hline $\begin{array}{l}\text { Other jurisdictions } \\
\text { American Samoa ............... } \\
\text { Guam............................ } \\
\text { Northern Marianas........... } \\
\text { Puerto Rico ..................... } \\
\text { U.S. Virgin Islands............ }\end{array}$ & $\begin{array}{r}6 \\
5 \\
7 \\
397 \\
9\end{array}$ & $\begin{array}{r}5 \\
5 \\
7 \\
366 \\
8\end{array}$ & $\begin{array}{r}0 \\
0 \\
2 \\
195 \\
4\end{array}$ & \begin{tabular}{r|}
0 \\
0 \\
2 \\
26 \\
0
\end{tabular} & $\begin{array}{l}0 \\
0 \\
0 \\
2 \\
0\end{array}$ & $\begin{array}{l}6 \\
5 \\
3 \\
6 \\
5\end{array}$ & $\begin{array}{r}0 \\
0 \\
0 \\
157 \\
0\end{array}$ & $\begin{array}{l}0 \\
0 \\
0 \\
1 \\
0\end{array}$ & $\begin{array}{r}0 \\
0 \\
0 \\
10 \\
0\end{array}$ & $\begin{array}{r}1 \\
0 \\
0 \\
30 \\
1\end{array}$ & $\begin{array}{r}- \\
2,004 \\
728 \\
454 \\
873\end{array}$ & $\begin{array}{r}- \\
2,004 \\
728 \\
439 \\
873\end{array}$ \\
\hline
\end{tabular}

-Not available.

${ }^{1}$ Excludes vocational, special education, and alternative schools.

${ }^{2}$ Vocational schools are also included under appropriate grade span. Includes vocational schools not classified as secondary schools.

${ }^{3}$ Average for schools reporting enrollment data. Enrollment data were available for 22,753 out of 24,357 public secondary schools in 2011-12.
NOTE: Includes schools with no grade lower than 7. Excludes schools not reported by grade level, such as some special education schools for the disabled. DoD = Department of Defense.

SOURCE: U.S. Department of Education, National Center for Education Statistics, Common Core of Data (CCD), "Public Elementary/Secondary School Universe Survey," 2011-12. (This table was prepared August 2013.) 
Table 216.90. Public elementary and secondary charter schools and enrollment, by state: Selected years, 1999-2000 through 2011-12

\begin{tabular}{|c|c|c|c|c|c|c|c|c|c|c|c|c|c|c|c|c|c|c|}
\hline \multirow[b]{2}{*}{ State } & \multicolumn{5}{|c|}{ Number of charter schools } & \multicolumn{5}{|c|}{ Charter school enrollment } & \multicolumn{4}{|c|}{$\begin{array}{l}\text { Charter schools as a percent of total public } \\
\text { schools }\end{array}$} & \multicolumn{4}{|c|}{$\begin{array}{l}\text { Charter school enrollment as a } \\
\text { percent of total public school enrollment }\end{array}$} \\
\hline & 1999-2000 & $2005-06$ & $2009-10$ & $2010-11$ & $2011-12$ & $\mid 1999-2000$ & $2005-06$ & $2009-10$ & $2010-11$ & $2011-12$ & 1999-2000 & $2005-06$ & $2010-11$ & $2011-12$ & $1999-2000$ & $2005-06$ & $2010-11$ & $2011-12$ \\
\hline 1 & 2 & 3 & 4 & 5 & 6 & 7 & 8 & 9 & 10 & 11 & 12 & 13 & 14 & 15 & 16 & 17 & 18 & 19 \\
\hline United States........ & 1,524 & 3,780 & 4,952 & 5,274 & 5,696 & 339,678 & $1,012,906$ & $1,610,285$ & $1,787,091$ & $2,057,599$ & 1.7 & 3.9 & 5.3 & 5.8 & 0.7 & 2.1 & 3.6 & 4.2 \\
\hline Alabama .. & & 0 & 0 & 0 & 0 & 0 & 0 & 0 & & 0 & 0.0 & 0.0 & 0.0 & 0.0 & 0.0 & 0.0 & 0.0 & 0.0 \\
\hline & & 23 & 25 & 27 & 27 & 2,300 & $\begin{array}{r}4,660 \\
0,57\end{array}$ & 5,196 & 5,751 & 5,922 & 3.6 & 4.6 & 5.3 & 5.3 & 1.7 & 3.5 & 4.4 & 4.5 \\
\hline & 245 & $\begin{array}{r}501 \\
19\end{array}$ & $\begin{array}{r}504 \\
38\end{array}$ & $\begin{array}{r}519 \\
40\end{array}$ & 531 & 31,176 & $\begin{array}{c}90,597 \\
4006\end{array}$ & 113,974 & $\begin{array}{r}124,467 \\
10209\end{array}$ & $\begin{array}{r}136,323 \\
11305\end{array}$ & 14.9 & $\begin{array}{l}24.1 \\
1 .\end{array}$ & $\begin{aligned} 22.9 \\
36\end{aligned}$ & $\begin{array}{r}23.6 \\
37\end{array}$ & 3.7 & 8.3 & $\begin{array}{cc}11.6 \\
21\end{array}$ & 12.6 \\
\hline $\begin{array}{l}\text { Akrkansasa....................... } \\
\text { Calfornia ................ }\end{array}$ & 238 & $\begin{array}{r}19 \\
543\end{array}$ & $\begin{array}{r}50 \\
813\end{array}$ & $\begin{array}{r}40 \\
908\end{array}$ & $\begin{array}{l}41 \\
985\end{array}$ & 104,730 & $\begin{array}{r}4,4006 \\
195,876\end{array}$ & $\begin{array}{r}\begin{array}{r}8,602 \\
316,658\end{array} \\
\end{array}$ & $\begin{array}{l}10,2099 \\
363,916\end{array}$ & $\begin{array}{r}11,13955 \\
413,124\end{array}$ & 2.8 & 5.6 & $\begin{array}{l}3.6 \\
9.0\end{array}$ & $\begin{array}{l}3.7 \\
9.7\end{array}$ & $\begin{array}{l}0.0 \\
1.8\end{array}$ & $\begin{array}{ll}0.8 \\
3.1\end{array}$ & 5.9 & $\begin{array}{l}2.4 \\
6.7\end{array}$ \\
\hline Colorado. & 69 & $\begin{array}{r}121 \\
14\end{array}$ & $\begin{array}{r}158 \\
18\end{array}$ & $\begin{array}{r}168 \\
18\end{array}$ & 178 & 17,822 & 44,254 & 66,826 & 74,685 & 83,478 & 4.3 & 7.1 & 9.4 & $\begin{array}{l}9.8 \\
9.5\end{array}$ & 2.5 & 5.7 & 8.9 & 9.8 \\
\hline & $\begin{array}{r}16 \\
1\end{array}$ & $\begin{array}{l}14 \\
13\end{array}$ & $\begin{array}{l}18 \\
18\end{array}$ & $\begin{array}{l}18 \\
19\end{array}$ & 27 & $\begin{array}{r}2,148 \\
115\end{array}$ & $\begin{array}{l}2,927 \\
6566\end{array}$ & $\begin{array}{l}5,215 \\
9173\end{array}$ & $\begin{array}{l}5,139 \\
9525\end{array}$ & $\begin{array}{r}6,0988 \\
10322\end{array}$ & $\begin{array}{l}1.5 \\
0.5\end{array}$ & $\begin{array}{l}1.3 \\
59\end{array}$ & $\begin{array}{l}1.6 \\
8.9 \\
\end{array}$ & 1.5 & 0.4 & & 0.9 & 1.1 \\
\hline mbia. & 27 & $\begin{array}{r}52 \\
52\end{array}$ & $\begin{array}{l}10 \\
99\end{array}$ & 97 & 100 & 6,432 & 17,260 & 25,813 & 26,910 & $\begin{array}{ll}10,322 & 02 \\
29\end{array}$ & 14.3 & 22.7 & & $\begin{array}{l}10.9 \\
43.9\end{array}$ & 8.3 & 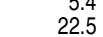 & 37.8 & $\begin{array}{r}89.0 \\
39.3\end{array}$ \\
\hline Florida..... & 113 & 342 & 412 & 458 & 519 & 17,251 & 92,335 & 137,887 & 154,703 & 180,880 & 3.5 & 9.2 & 11.1 & 12.3 & 0.7 & 3.5 & 5.9 & 6.8 \\
\hline Georgia........................................ & $\begin{array}{r}18 \\
2\end{array}$ & 58 & $\begin{array}{r}63 \\
31\end{array}$ & $\begin{array}{r}67 \\
31\end{array}$ & $\begin{array}{l}128 \\
31\end{array}$ & 11,005 & 26,440 & 37,545 & 41,981 & $\begin{array}{l}79,989 \\
0,155\end{array}$ & $\begin{array}{r}1.0 \\
0.9\end{array}$ & 2.4. & $\begin{array}{r}2.7 \\
107\end{array}$ & \begin{tabular}{r|r}
5.4 \\
108
\end{tabular} & 0.8 & 1.7 & 2.5 & 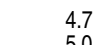 \\
\hline ........ & 8 & 26 & 36 & 40 & 45 & 915 & $\begin{array}{l}0,4,400 \\
8,003\end{array}$ & 14,529 & $\begin{array}{l}0,2090 \\
15,30\end{array}$ & 17,257 & $\begin{array}{l}0.8 \\
1.2\end{array}$ & $\begin{array}{l}9.5 \\
3.7 \\
\end{array}$ & $\begin{array}{c}10.1 \\
5.3\end{array}$ & $\begin{array}{r}10.8 \\
5.9 \\
\end{array}-2$ & 0.4 & $\begin{array}{l}3.5 \\
3.1\end{array}$ & $\begin{array}{l}4.6 \\
5.6\end{array}$ & $\begin{array}{l}5.0 \\
6.2\end{array}$ \\
\hline $\begin{array}{l}\text { hois .......................... } \\
\text { fliana. }\end{array}$ & $\begin{array}{r}17 \\
0\end{array}$ & $\begin{array}{r}29 \\
29\end{array}$ & $\begin{array}{r}39 \\
53\end{array}$ & 50 & 52 & 6,152 & $\begin{array}{c}16,968 \\
7409\end{array}$ & $\begin{array}{l}35,836 \\
18489\end{array}$ & $\begin{array}{l}43,049 \\
22472\end{array}$ & $\begin{array}{ll}49,070 \\
2820\end{array}$ & 0.4 & 0.7 & $\begin{array}{l}1.1 \\
2.1\end{array}$ & 1.2 & 0.3 & 0.8 & 2.1 & 2.4 \\
\hline lowa. & 0 & 6 & 9 & 7 & 7 & 0 & 520 & 593 & 298 & 403 & 0.0 & 0.4 & 0.5 & 0.5 & 0.0 & 0.1 & 0.1 & 0.1 \\
\hline & 0 & 26 & 35 & 25 & 17 & 0 & 1,914 & 4,684 & 4,618 & 3,122 & 0 & 1.8 & 1.8 & 1.3 & 00 & 01 & 1.0 & 0.6 \\
\hline Kentuck & 0 & 0 & $\begin{array}{c}0 \\
77\end{array}$ & $\begin{array}{r}0 \\
78\end{array}$ & 0 & 0 & $\begin{array}{r}0 \\
8315 \\
8\end{array}$ & $\begin{array}{r}0 \\
31467\end{array}$ & 0 & 0 & 0.0 & 0.0 & 0.0 & 0.0 & 0.0 & 0.0 & 0.0 & 0.0 \\
\hline 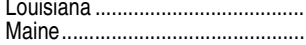 & $\begin{array}{r}16 \\
0\end{array}$ & $\begin{array}{r}26 \\
0\end{array}$ & $\begin{array}{r}77 \\
0\end{array}$ & $\begin{array}{r}78 \\
0\end{array}$ & $\begin{array}{r}99 \\
0\end{array}$ & 2,449 & & $\begin{aligned} & 31,467 \\
& 0\end{aligned}$ & 29,1999 & $\begin{aligned} 44,330 \\
0\end{aligned}$ & $\begin{array}{l}1.0 \\
0.0\end{array}$ & $\begin{array}{l}1.9 \\
0.0\end{array}$ & $\begin{array}{l}5.3 \\
0.0\end{array}$ & $\begin{array}{l}6.9 \\
0.0 \\
0.0\end{array}$ & $\begin{array}{l}0.3 \\
0.0\end{array}$ & $\begin{array}{l}1.3 \\
0.0\end{array}$ & $\begin{array}{l}4.2 \\
0.0\end{array}$ & $\begin{array}{l}6.3 \\
0.0\end{array}$ \\
\hline Maryland. & 0 & 15 & 42 & 44 & 50 & 0 & 3,363 & 11,995 & 14,492 & 17,273 & 0.0 & 1.0 & 3.0 & 3.4 & 0.0 & 0.4 & 1.7 & 2.0 \\
\hline & & 59 & $62 \mathrm{I}$ & 63 & 72 & 12,518 & 21,958 & 27,393 & & 30,595 & 2.1 & 3.1 & 3.4 & & & & & 32 \\
\hline $\begin{array}{l}\text { Michigan } \\
\text { Minneso }\end{array}$ & 193 & 264 & $\begin{array}{l}294 \\
181\end{array}$ & 300 & 306 & $\begin{array}{r}46,078 \\
7794\end{array}$ & $\begin{array}{l}91,384 \\
20603\end{array}$ & $\begin{array}{l}110,504 \\
3535 \\
\end{array}$ & $\begin{array}{l}111,344 \\
37235\end{array}$ & 118,177 & 4.9 & 6.5 & $\begin{array}{r}7.7 \\
7.4\end{array}$ & 8.6 & 2.8 & 5.3 & 7.2 & 7.7 \\
\hline Mississipp & 1 & $\begin{array}{l}101 \\
1\end{array}$ & $\begin{array}{r}01 \\
1\end{array}$ & $\begin{array}{r}110 \\
0\end{array}$ & $\begin{array}{r}1 / 4 \\
0\end{array}$ & $\begin{array}{r}, 1944 \\
347\end{array}$ & $\begin{array}{l}20,000 \\
374\end{array}$ & 政, 375 & $\begin{array}{r}3,253 \\
0\end{array}$ & $\begin{array}{l}39,143 \\
0\end{array}$ & $\begin{array}{l}2.0 \\
0.1\end{array}$ & $\begin{array}{l}0.1 \\
0.1\end{array}$ & $\begin{array}{l}. .4 \\
0.0\end{array}$ & 0.0 & 0.1 & 0.1 & 0.0 & $\begin{array}{l}4.7 \\
0.0\end{array}$ \\
\hline Missouri & 15 & 23 & 48 & 53 & 61 & 4,303 & 10,972 & 18,415 & 20,076 & 21,472 & 0.6 & 1.0 & 2.2 & 2.5 & 0.5 & 1.2 & 2.2 & 2.3 \\
\hline $\begin{array}{l}\text { Montana } \\
\text { Nebrask }\end{array}$ & $\begin{array}{l}0 \\
0\end{array}$ & $\begin{array}{l}0 \\
0\end{array}$ & $\begin{array}{l}0 \\
0\end{array}$ & $\begin{array}{l}0 \\
0\end{array}$ & $\begin{array}{l}0 \\
0\end{array}$ & $\begin{array}{l}0 \\
0\end{array}$ & $\begin{array}{l}0 \\
0\end{array}$ & $\begin{array}{l}0 \\
0\end{array}$ & $\begin{array}{l}0 \\
0\end{array}$ & $\begin{array}{l}0 \\
0\end{array}$ & $\begin{array}{l}0.0 \\
0.0\end{array}$ & $\begin{array}{l}0.0 \\
0.0\end{array}$ & $\begin{array}{l}0.0 \\
0.0\end{array}$ & $\begin{array}{l}0.0 \\
0.0\end{array}$ & $\begin{array}{l}0.0 \\
0.0\end{array}$ & $\begin{array}{l}0.0 \\
0.0\end{array}$ & 0.0 & 0.0 \\
\hline & 5 & 19 & 35 & 34 & 39 & 898 & 4,818 & 11,613 & 14,127 & 18,255 & 1.0 & 3.4 & 5.3 & 6.0 & 0.0 & 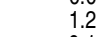 & 2 & 4.2 \\
\hline New Hampshire..... & 0 & 6 & 15 & 14 & 15 & & & & & 1,169 & 0.0 & 1.3 & 2.9 & 3.1 & 0.0 & 0.1 & 0.5 & 0.6 \\
\hline New Jersey & $\begin{array}{l}0 \\
1\end{array}$ & 54 & $\begin{array}{l}70 \\
72\end{array}$ & $\begin{array}{l}76 \\
81\end{array}$ & $\begin{array}{l}86 \\
84\end{array}$ & \begin{tabular}{c|c}
0 \\
20
\end{tabular} & $\begin{array}{l}14,937 \\
8559\end{array}$ & $\begin{array}{l}22,981 \\
13090\end{array}$ & $\begin{array}{l}24,591 \\
15200\end{array}$ & 29,007 & $\begin{array}{l}0.0 \\
0.1\end{array}$ & 2.2 & $\begin{array}{l}2.9 \\
94\end{array}$ & $\begin{array}{l}3.3 \\
9.7 \\
\end{array}$ & 0.0 & 1.1 & 1.8 & 2.1 \\
\hline $\mathrm{Ner}$ & 5 & 79 & 140 & 170 & 183 & 0 & 21,539 & 43,963 & 54,443 & 60,137 & 0.1 & 1.7 & $\begin{array}{l}3.4 \\
3.6\end{array}$ & 3.9 & - & 0.8 & 2.0 & 2.2 \\
\hline $\begin{array}{l}\text { North Carc } \\
\text { North Dak }\end{array}$ & $\begin{array}{r}82 \\
0\end{array}$ & $\begin{array}{r}99 \\
0\end{array}$ & 96 & $\begin{array}{r}99 \\
0\end{array}$ & $\begin{aligned} 100 & \end{aligned}$ & $\begin{array}{l}12,699 \\
0\end{array}$ & 27,441 & 38,973 & $\begin{array}{l}42,141 \\
0\end{array}$ & $\begin{aligned} 45,496 \\
0\end{aligned}$ & $\begin{array}{l}3.8 \\
0.0\end{array}$ & $\begin{array}{l}4.2 \\
0.0\end{array}$ & $\begin{array}{l}3.9 \\
0.0\end{array}$ & $\begin{array}{l}3.9 \\
0.0\end{array}$ & $\begin{array}{l}1.0 \\
0.0\end{array}$ & $\begin{array}{l}1.9 \\
0.0\end{array}$ & $\begin{array}{l}2.8 \\
0.0\end{array}$ & $\begin{array}{l}3.0 \\
0.0\end{array}$ \\
\hline Ohio.... & 48 & 316 & 323 & 339 & 355 & 9,809 & 68,679 & 90,989 & 96,669 & 107,089 & 1.2 & 7.9 & 9.0 & 9.6 & 0.5 & 3.7 & 5.5 & 6.2 \\
\hline & & $\begin{array}{l}14 \\
54\end{array}$ & $\begin{array}{r}18 \\
102\end{array}$ & $\begin{array}{r}18 \\
108\end{array}$ & $\begin{array}{r}21 \\
115\end{array}$ & $\begin{array}{r}0 \\
109\end{array}$ & $\begin{array}{c}81 \\
92\end{array}$ & $\left.\begin{array}{r}6,315 \\
18,34\end{array}\right]$ & 6,585 & $\begin{array}{l}9,229 \\
2,205\end{array}$ & 0.6 & 8 & $\begin{array}{l}1.0 \\
83 \\
\end{array}$ & 2 & 0 & 0.6 & 0 & $\begin{array}{l}1.4 \\
4.4\end{array}$ \\
\hline & 47 & 116 & 134 & \begin{tabular}{l|l}
145 \\
\end{tabular} & 162 & 11.413 & 55,630 & 79,167 & 90,613 & 104.967 & 1.5 & 3.6 & 4. & 3.1 & 0.6 & 1.0 & 0.1 & $\begin{array}{l}4.4 \\
6.0\end{array}$ \\
\hline Rhode Is & 2 & 11 & 12 & 16 & 18 & 446 & 2,571 & 3,233 & 3,971 & 4,662 & 0.6 & 3.3 & 5.0 & 5.8 & 0.3 & 1.7 & 2.8 & $\begin{array}{l}0.0 \\
3.3\end{array}$ \\
\hline South $C$ & 7 & 27 & 39 & 44 & 47 & 327 & 4,104 & 13,035 & 16,390 & 17,034 & 0.6 & 2.3 & 3.6 & 3.8 & $\#$ & 0.6 & 2.3 & 2.3 \\
\hline $\begin{array}{l}\text { South } \\
\text { Tunnes }\end{array}$ & 0 & 12 & 20 & 29 & 40 & & 1.685 & 4.343 & $\begin{array}{r}0.517 \\
6\end{array}$ & 9,104 & 0.0 & 0.7 & $\begin{array}{l}.0 \\
1.6\end{array}$ & 2.2 & 0.0 & 0.2 & 0.0 & .0 \\
\hline Texa & 176 & 319 & 536 & 561 & 581 & 25,687 & 70,895 & 148,392 & 164,940 & 189,654 & 2.4 & 3.7 & 6.4 & 6.7 & 0.6 & 6 & 3.3 & 3.8 \\
\hline & & 36 & 72 & 78 & 81 & & 11,439 & 33,968 & 39,862 & 44,687 & 0.8 & 3.8 & 7.7 & 7.9 & 0.1 & 2.2 & 6.8 & 7.5 \\
\hline Vermont & 0 & $\begin{array}{l}0 \\
2\end{array}$ & $\begin{array}{l}0 \\
2\end{array}$ & 0 & 0 & 0 & 0 & 100 & 0 & $\begin{array}{r}0 \\
202\end{array}$ & 0.0 & 0.0 & 0.0 & 0.0 & 0.0 & 0.0 & 0.0 & 0.0 \\
\hline $\begin{array}{l}\text { Virgnia.. } \\
\text { Washing } \\
\end{array}$ & $\begin{array}{l}0 \\
0\end{array}$ & $\begin{array}{l}3 \\
0\end{array}$ & $\begin{array}{l}0 \\
0\end{array}$ & $\begin{array}{c}4 \\
0\end{array}$ & $\begin{array}{l}4 \\
0\end{array}$ & 0 & 20 & $\begin{array}{r}r \\
0\end{array}$ & $\begin{array}{l}340 \\
0\end{array}$ & $\begin{aligned} 353 \\
0\end{aligned}$ & 0.0 & $\begin{array}{l}0.1 \\
0.0\end{array}$ & $\begin{array}{l}0.2 \\
0.0\end{array}$ & 0.0 & 0.0 & 0.0 & 0.0 & 0.0 \\
\hline $\begin{array}{l}\text { West Virginia } \\
\text { Wisconsin }\end{array}$ & $\begin{array}{r}0 \\
45\end{array}$ & $\begin{array}{r}0 \\
181\end{array}$ & 206 & 207 & 234 & $\begin{array}{r}0 \\
3,561\end{array}$ & $\begin{array}{r}27,450 \\
0\end{array}$ & 36,153 & 36,863 & 40,531 & $\begin{array}{l}0.0 \\
2.1\end{array}$ & $\begin{array}{l}0.0 \\
8.1\end{array}$ & $\begin{array}{l}0.0 \\
9.2\end{array}$ & $\begin{array}{r}0.0 \\
10.4\end{array}$ & 0.0 & 3.1 & $\begin{array}{l}0.0 \\
4.2\end{array}$ & $\begin{array}{l}0.0 \\
4.7\end{array}$ \\
\hline Wyoming.... & 0 & 3 & 3 & B & & & 238 & 269 & 258 & 306 & 0.0 & 0.8 & 0.8 & 1.1 & 0.0 & 0.3 & 0.3 & .3 \\
\hline
\end{tabular}


Table 216.95. Number and enrollment of public elementary and secondary schools that have closed, by school level, type, and charter status: Selected years, 1995-96 through 2011-12

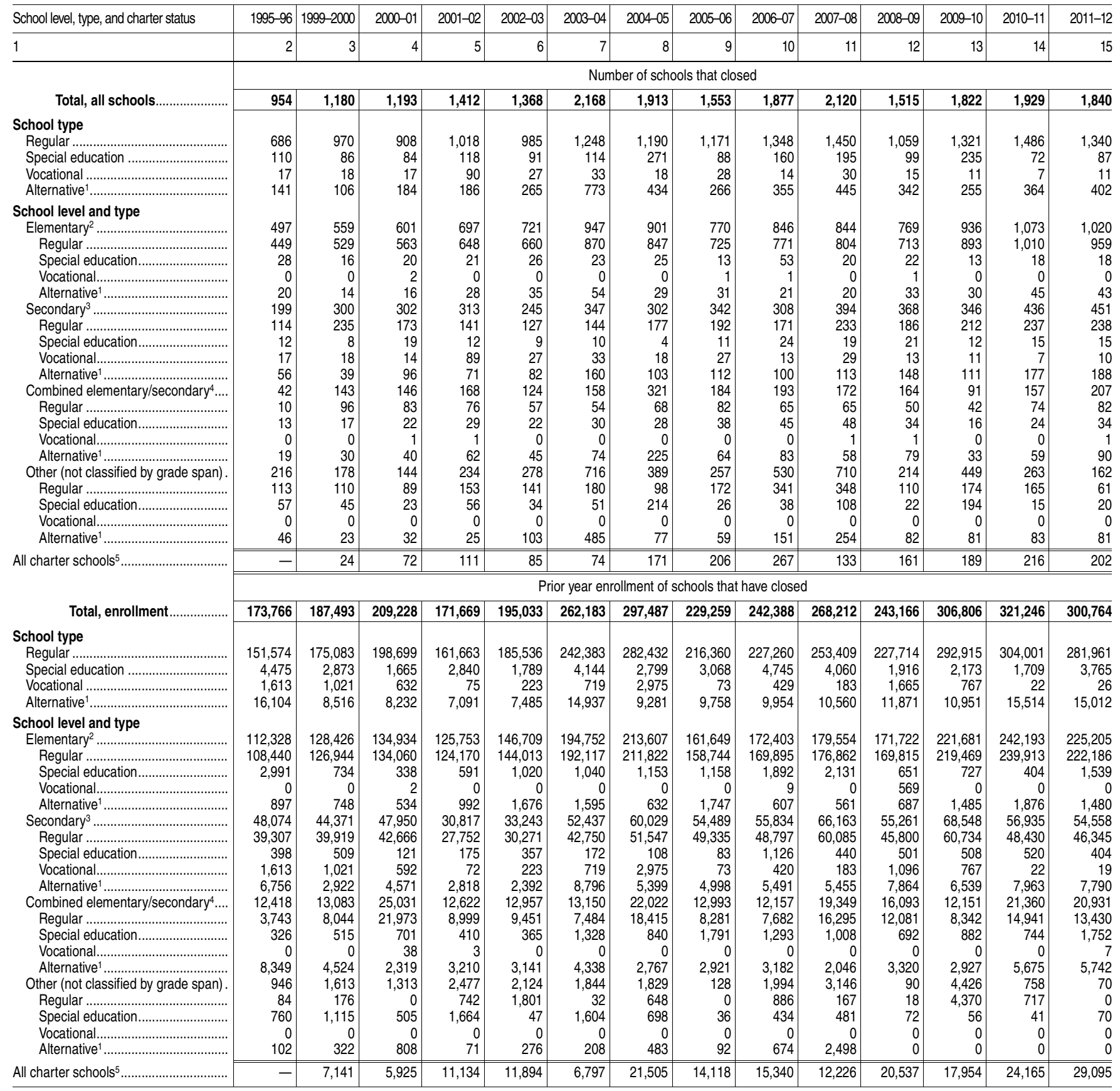

\section{-Not available.}

1 Includes schools that provide nontraditional education, address needs of students that typically cannot be met in regular schools, serve as adjuncts to regular schools, or fall outside the categories of regular, special education, or vocational education.

${ }^{2}$ Includes schools beginning with grade 6 or below and with no grade higher than 8 .

${ }^{3}$ Includes schools with no grade lower than 7 .

${ }^{4}$ Includes schools beginning with grade 6 or below and ending with grade 9 or above.

${ }^{5} \mathrm{Charter}$ schools are also included under the school level and type categories, as appropriate.
NOTE. This table indicates the school year by which the school no longer operated (generally it closed between that school year and the prior school year). The closure of a school does not necessarily mean that a building is no longer used for educational purposes. A single school may share a building with another school, or one school may be housed in several buildings. SOURCE: U.S. Department of Education, National Center for Education Statistics, Common Core of Data (CCD), "Public Elementary/Secondary School Universe Survey," 1995-96 through 2011-12. (This table was prepared September 2013.) 


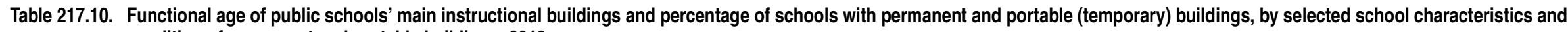
condition of permanent and portable buildings: 2012

[Standard errors appear in parentheses]

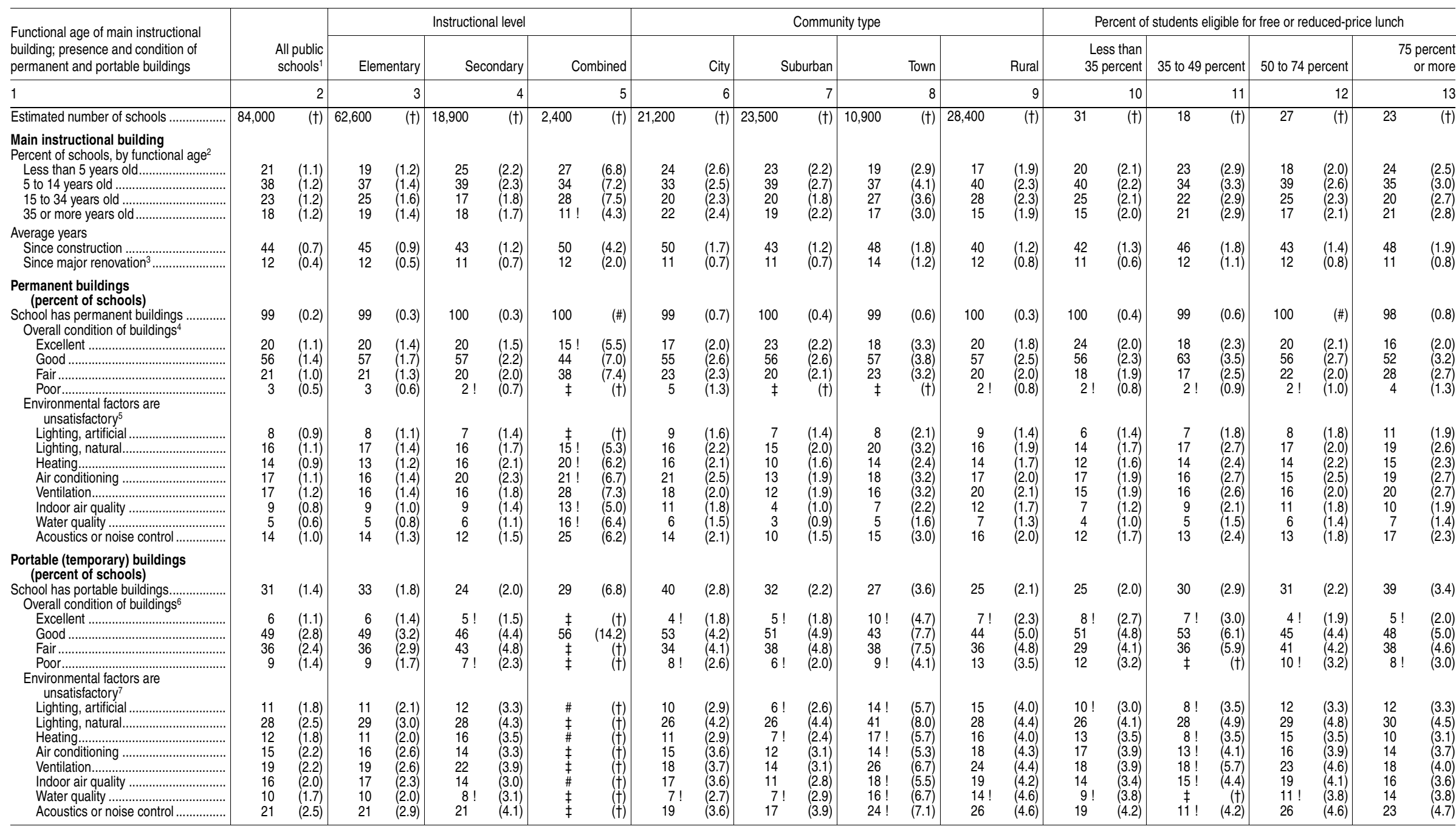

\section{†Not applicable.}

\#!Interpret data with caution. The coefficient of variation (CV) for this estimate is between 30 and 50 percent.

†Reporting standards not met. Either there are too few cases for a reliable estimate or the coefficient of variation (CV) for this †Reporting standards not met. Ë.

'Excludes special education, vocational, and alternative schools; schools without enrollment data; and schools offering only preprimary education.

${ }^{2}$ The functional age of the main instructional building is the number of years since its most recent major renovation or since its construction if no major renovation has ever occurred.
${ }^{4}$ Based on the 99 percent of public schools with permanent buildings. "Based on schools with the specified environmental factor in their permanent buildings. Includes ratings of "unsatisfactory" and very unsatistactory.

(temporary) buildings.

${ }^{7}$ Based on schools with the specified environmental factor in their portable (temporary) buildings. Includes ratings of "unsatisNOTE. Detory "very unsatisfactory."

Deducation Statistics, Fast Response Survey System (FRSS), Condition of Public School Facilities: 2012-13, FRSS 105, 2013. (This table was prepared June 2014.) 


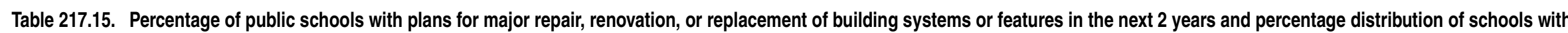
such plans, by selected school characteristics, type of system or feature, and main reason for the plans: 2012-13

[Standard errors appear in parentheses]

\begin{tabular}{|c|c|c|c|c|c|c|c|c|c|c|c|c|c|c|c|c|c|c|c|c|c|c|c|c|}
\hline \multirow{2}{*}{$\begin{array}{l}\text { Type of system or feature and main } \\
\text { reason for major repair, renovation, or } \\
\text { replacement plans }\end{array}$} & \multirow{2}{*}{\multicolumn{2}{|c|}{$\begin{array}{r}\text { All public } \\
\text { schools }\end{array}$}} & \multicolumn{6}{|c|}{ Instructional level } & \multicolumn{8}{|c|}{ Community type } & \multicolumn{8}{|c|}{ Percent of students eligible for free or reduced-priced lunch } \\
\hline & & & \multicolumn{2}{|c|}{ Elementary } & \multicolumn{2}{|c|}{ Secondary } & \multicolumn{2}{|c|}{ Combined } & \multicolumn{2}{|r|}{ City } & \multicolumn{2}{|c|}{ Suburban } & \multicolumn{2}{|r|}{ Town } & \multicolumn{2}{|r|}{ Rural } & \multicolumn{2}{|c|}{$\begin{array}{c}\text { Less than } \\
35 \text { percent }\end{array}$} & \multicolumn{2}{|c|}{35 to 49 percent } & \multicolumn{2}{|c|}{50 to 74 percent } & \multicolumn{2}{|c|}{$\begin{array}{r}75 \text { percen } \\
\text { or more }\end{array}$} \\
\hline 1 & & 2 & & 3 & & 4 & & 5 & & 6 & & 7 & & 8 & & 9 & & 10 & & 11 & & 12 & & 13 \\
\hline Roofs-percent of schools with plans & 19 & (1.1) & 17 & $(1.3)$ & 25 & (1.8) & 25 & $(6.8)$ & 19 & $\begin{array}{ll}\text { (2.1) } \\
\end{array}$ & 19 & (2.0) & 20 & $(3.0)$ & 19 & $(1.9)$ & 22 & (1.8) & 18 & (2.4) & 17 & (2.0) & 18 & $\overline{(2.3)}$ \\
\hline reas & & $(\dagger)$ & 100 & $(\dagger)$ & 100 & $(\dagger)$ & 100 & $(\dagger)$ & 100 & $(\dagger)$ & 100 & $(\dagger)$ & 100 & (†) & 100 & (†) & 100 & $(\dagger)$ & 100 & $(t)$ & 100 & $(\dagger)$ & 100 & $(\dagger)$ \\
\hline $\begin{array}{l}\text { Functional problem in existing } \\
\text { system or feature ............... }\end{array}$ & 39 & (3.1) & 38 & (3.9) & 41 & (4.4) & $31 !$ & $(14.2)$ & 35 & $(6.0)$ & 40 & $(5.6)$ & 50 & $(10.0)$ & 35 & (5.3) & 33 & $(4.5)$ & 45 & (7.5) & 40 & (5.8) & 42 & (7.1) \\
\hline Improve operational or energy & & & & & & & & & & & & & & & & & & & & & & & & \\
\hline $\begin{array}{l}\text { eeficiency ............................ } \\
\text { Replacement cycle ................ }\end{array}$ & $\begin{array}{r}9 \\
46\end{array}$ & $\begin{array}{l}(1.7) \\
(3.1)\end{array}$ & $\begin{array}{r}8 \\
47\end{array}$ & $\begin{array}{l}(2.1) \\
(4.2)\end{array}$ & $\begin{array}{r}9 \\
45\end{array}$ & $(2.6)$ & $\begin{array}{l}30 ! \\
38 !\end{array}$ & $\begin{array}{l}(15.1) \\
(12.3)\end{array}$ & $\begin{array}{c}6 ! \\
50\end{array}$ & $\begin{array}{l}(2.9) \\
(5.9)\end{array}$ & $\begin{array}{r}8 ! \\
46\end{array}$ & $\begin{array}{l}(3.0) \\
(5.3)\end{array}$ & $\begin{array}{r}\ddagger \\
36\end{array}$ & $\begin{aligned}(\dagger) \\
(9.0)\end{aligned}$ & $\begin{array}{l}13 ! \\
49\end{array}$ & $\begin{array}{l}(4.1) \\
(5.8)\end{array}$ & $\begin{array}{c}6 ! \\
55\end{array}$ & $\begin{array}{l}(2.2) \\
(5.0)\end{array}$ & $\begin{array}{r}\ddagger \\
46\end{array}$ & $\begin{aligned}(\dagger) \\
(7.6)\end{aligned}$ & $\begin{array}{r}8 ! \\
49\end{array}$ & $\begin{array}{l}(3.2) \\
(5.4)\end{array}$ & $17 !$ & $\begin{array}{l}(5.4) \\
(6.5)\end{array}$ \\
\hline 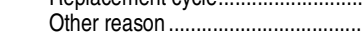 & $\begin{array}{r}40 \\
6\end{array}$ & $(1.5)$ & $7 !$ & (2.2) & $5 !$ & $(1.7)$ & $\#$ & $(t)$ & $8 !$ & (3.7) & $\neq$ & $(t)$ & $\ddagger$ & $\begin{array}{l}(t) \\
(t)\end{array}$ & $\neq$ & $\begin{array}{r}(0.0) \\
(t)\end{array}$ & $7 !$ & (2.9) & $\ddagger$ & $(t)$ & $\neq$ & $\begin{array}{r}(0.4) \\
(t)\end{array}$ & $11 !$ & (4.9) \\
\hline $\begin{array}{l}\text { Framing, floors, foundations-percent } \\
\text { of schools with plans }\end{array}$ & 7 & $(0.7)$ & 5 & $(0.9)$ & 8 & (1.4) & $22 !$ & $(6.8)$ & 7 & $(1.2)$ & 7 & (1.3) & 7 & (20) & 5 & (1.1) & 6 & (11) & 5 & (1.3) & 6 & (1.4) & 8 & (1.6) \\
\hline Percentage distribution by main & 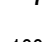 & (0.I) & 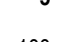 & $(0.0)$ & 更 & (1.4) & & & & & & (1.J) & & & & & & & & & 0 & (1.4) & 8 & (1.0) \\
\hline reasol & 100 & $(\dagger)$ & 100 & $(\dagger)$ & 100 & $(t)$ & 100 & $(\dagger)$ & 100 & (†) & 100 & $(\dagger)$ & 100 & $(t)$ & 100 & (†) & 100 & (t) & 100 & $(\dagger)$ & 100 & (†) & 100 & $(\dagger)$ \\
\hline runcul & 41 & $(4.9)$ & 40 & (6.2) & 42 & (7.1) & $48 !$ & (19.9) & 37 & $(9.4)$ & 38 & $(9.9)$ & 53 & $(15.6)$ & 41 & (11.6) & $27 !$ & $(8.1)$ & 58 & (12.6) & $37 !$ & $(11.3)$ & 51 & $(9.8)$ \\
\hline or energy & 16 & (3.8) & $12 !$ & (4.7) & $17 !$ & $(6.6)$ & $43 !$ & $(18.9)$ & $19 !$ & $(8.9)$ & $14 !$ & $(6.8)$ & $20 !$ & & $\ddagger$ & & $15 !$ & & \pm & & $21 !$ & & \pm & (t) \\
\hline cycle.......................... & $\begin{array}{l}10 \\
27\end{array}$ & $\begin{array}{l}(3.0) \\
(4.5)\end{array}$ & 30 & $(6.0)$ & 26 & $\begin{array}{l}(0.0) \\
(6.9)\end{array}$ & $\begin{array}{c}40 ! \\
\ddagger\end{array}$ & $(\dagger)$ & 27 & (7.5) & $23 !$ & $\left.\begin{array}{l}(0.0) \\
(9.4)\end{array}\right]$ & $\neq$ & $\begin{array}{r}r .01) \\
(\dagger)\end{array}$ & $\begin{array}{c}+ \\
32 !\end{array}$ & (10.6) & 38 & $\begin{array}{l}(0.1) \\
(9.7)\end{array}$ & $\begin{array}{l}+ \\
\ddagger\end{array}$ & $(t)$ & $33 !$ & (11.0) & $\stackrel{+}{17 !}$ & (7.5) \\
\hline Other reason & 16 & (3.9) & $19 !$ & (5.7) & $15 !$ & $(7.1)$ & $\#$ & $(\dagger)$ & $16 !$ & $(7.4)$ & $24 !$ & $(9.1)$ & $\stackrel{+}{\ddagger}$ & $(t)$ & $\ddagger$ & $(t)$ & $20 !$ & $\begin{array}{l}(8.9) \\
(8)\end{array}$ & $\ddagger$ & $(t)$ & $\ddagger$ & $(t)$ & $16 !$ & (7.5) \\
\hline $\begin{array}{l}\text { Exterior walls, finishes-percent of } \\
\text { schools with plans }\end{array}$ & 9 & $(0.7)$ & 8 & $(0.9)$ & 10 & (1.3) & $17 !$ & (6.0) & 9 & (1.5) & 8 & (1.3) & 9 & (1.9) & 8 & (1.3) & 9 & (1.3) & 9 & (1.7) & 8 & (1.3) & 10 & $(1.8)$ \\
\hline $\begin{array}{l}\text { Percentage distril } \\
\text { reason for the }\end{array}$ & 100 & $(\mathrm{t})$ & 100 & $(†)$ & 100 & (t) & 100 & $(\dagger)$ & 100 & (†) & 100 & $(t)$ & 100 & $(t)$ & 100 & (t) & 100 & (t) & 100 & (t) & 100 & (t) & 100 & $(t)$ \\
\hline Functiol & & & & & & & & & & & & & & & & & & & & & & & & \\
\hline $\begin{array}{r}\text { system } \\
\text { Improve op }\end{array}$ & 38 & (4.5) & 36 & (5.6) & 46 & (7.5) & $\ddagger$ & $(\dagger)$ & 33 & (7.1) & 39 & $(9.5)$ & 53 & $(11.8)$ & 35 & (8.9) & 38 & $(8.1)$ & $37 !$ & $(11.4)$ & 46 & $(10.5)$ & 31 & (8.8) \\
\hline efficie & 21 & (3.6) & 19 & $(4.5)$ & $23 !$ & $(7.1)$ & $\ddagger$ & (t) & $20 !$ & $(7.0)$ & $17 !$ & $(6.6)$ & $18 !$ & $(7.3)$ & $26 !$ & (8.5) & 14 ! & (5.4 & $20 !$ & $(7.7)$ & $23 !$ & $(9.3$ & $29 !$ & (8.8) \\
\hline & $? 2$ & (3.7) & 26 & (5.1) & 18 & 14 & $\ddagger$ & $(\dagger)$ & 31 & $(7.7)$ & $25 !$ & (7.7) & $\ddagger$ & & & $(8.1)$ & 32 & 10 & $18 !$ & (8.8) & $21 !$ & (7.6) & $19 !$ & $(8.0)$ \\
\hline Other & 18 & (3.9) & 20 & (5.2) & $14 !$ & $(5.9)$ & $\ddagger$ & $(t)$ & $16 !$ & $(7.3)$ & $19 !$ & $(8.1)$ & $24 !$ & $(11.5)$ & $15 !$ & (6.6) & $16 !$ & $(7.4)$ & $25 !$ & $(10.5)$ & $\ddagger$ & $(\dagger)$ & $20 !$ & (8.3) \\
\hline $\begin{array}{l}\text { Windows, doors-percent of schools } \\
\text { with plans }\end{array}$ & 15 & $(0.9)$ & 13 & (1.1) & 21 & (2.1) & $21 !$ & (6.7) & 15 & (2.1) & 14 & $(1.8)$ & 18 & (2.7) & 16 & $(1.8)$ & 15 & $(1.8)$ & 15 & (2.2) & 15 & (1.9) & 16 & $(2.2)$ \\
\hline ion by main & 100 & t) & 100 & $(t)$ & 100 & $(+)$ & 100 & t) & 100 & $(t)$ & 100 & $(t)]$ & 100 & (t) & 100 & $(+)$ & 100 & (t) & 100 & $(+)$ & 100 & (1...) & 100 & (t) \\
\hline $\begin{array}{l}\text { reason } \\
\text { Functior }\end{array}$ & 100 & 1 & 100 & (II) & 100 & 1) & 100 & (I) & 100 & (1) & 100 & $(\mathrm{t})$ & 100 & & 100 & & 100 & $(\dagger)$ & 100 & $(\dagger)$ & 100 & $(\dagger)$ & 100 & $(\dagger)$ \\
\hline $\begin{array}{l}\text { syster } \\
\text { Improve } 0\end{array}$ & 30 & (3.4) & 29 & (4.5) & 31 & $(4.8)$ & $40 !$ & (16.8) & 24 & (5.4) & 30 & $(7.0)$ & 40 & (9.6) & 31 & (6.3) & 28 & $(6.2)$ & 27 & (7.7) & 37 & (7.5) & 30 & (6.4) \\
\hline & 43 & (3.9) & 41 & (4.7) & 45 & (6.1) & 60 & $(16.8)$ & 34 & (6.7) & 36 & $(7.2)$ & 43 & (9.8) & 54 & $(7.1)$ & 39 & $(6.9$ & 52 & (9.2) & 46 & (7. & 36 & (8.0) \\
\hline Replace & 17 & $(2.6)$ & 19 & (3.4) & 14 & (3.8) & $\#$ & $(t)$ & 31 & (6.7) & 21 & (5.8) & $\ddagger$ & $(t)$ & $10 !$ & (3.9) & 20 & (4.9 & $12 !$ & (5.5) & $13 !$ & (4.4) & $22 !$ & (6.6) \\
\hline Othe & 10 & $(2.3)$ & 11 & (2.9) & $10 !$ & (3.3) & \# & $(t)$ & $11 !$ & $(5.1)$ & $13 !$ & $(4.8)$ & $14 !$ & (6.3) & $\ddagger$ & $(t)$ & $13 !$ & $(4.8)$ & $\neq$ & $(t)$ & $\ddagger$ & $(t)$ & $12 !$ & $(4.9)$ \\
\hline $\begin{array}{l}\text { Interior finishes, trim-percent of } \\
\text { schools with plans }\end{array}$ & 12 & $(0.8)$ & 11 & (1.0) & 13 & (1.5) & 25 & (6.8) & 13 & (1.7) & 13 & $(1.6)$ & 12 & (2.3) & 11 & (1.3) & 14 & (1.6) & 9 & (1.7) & 11 & (1.7) & 12 & (1.9) \\
\hline $\begin{array}{l}\text { Percentage distr } \\
\text { reason for th }\end{array}$ & 100 & $(\dagger)$ & 100 & (†) & 100 & $(\dagger)$ & 100 & $(t)$ & 100 & (†) & 100 & (†) & 100 & $(t)$ & 100 & $(t)$ & 100 & $(\dagger)$ & 100 & $(\dagger)$ & 100 & $(\dagger)$ & 100 & (†) \\
\hline $\begin{array}{l}\text { Functional problem in existing } \\
\text { system or feature .............. }\end{array}$ & 19 & $(3.1)$ & 17 & (3.7) & 27 & $(5.3)$ & $\ddagger$ & $(+)$ & 19 & (5.5) & $20 !$ & (6.1) & $32 !$ & (11.5) & $13 !$ & (5.7) & $17 !$ & (5.4) & $16 !$ & $(6.2)$ & 27 & (7.0) & $16 !$ & $(5.8)$ \\
\hline Improve operational or energy & 20 & (3?) & & (37) & 24 & (6?) & 331 & (164) & & & $17 !$ & (52) & 331 & & 191 & & 141 & & $t$ & & 20 & (57) & 31 & $(80)$ \\
\hline $\begin{array}{l}\text { efticlency.......... } \\
\text { Replacement cycle.. }\end{array}$ & $\begin{array}{l}20 \\
44\end{array}$ & $\begin{array}{l}(3.2) \\
(3.9)\end{array}$ & $\begin{array}{l}11 \\
48\end{array}$ & $\begin{array}{l}(3.7) \\
(5.1)\end{array}$ & $\begin{array}{l}24 \\
3\end{array}$ & $\begin{array}{l}(0.2) \\
(5.1)\end{array}$ & $\begin{array}{l}33 ! \\
49 !\end{array}$ & $\begin{array}{l}(16.4) \\
(15.3)\end{array}$ & 4 & $\begin{array}{l}(5.4) \\
(7.6)\end{array}$ & $\begin{array}{l}1 / ! \\
46\end{array}$ & $\begin{array}{l}(3.2) \\
(6.9)\end{array}$ & $30 !$ & $\begin{array}{l}(10.9) \\
(10.8)\end{array}$ & $\begin{array}{l}19 ! \\
47\end{array}$ & $\begin{array}{l}(6.2) \\
(7.7)\end{array}$ & $\begin{array}{l}14 ! \\
50\end{array}$ & $\begin{array}{l}(4.8) \\
(6.9)\end{array}$ & $\begin{array}{r}\mp \\
44\end{array}$ & $\left.\begin{array}{l}(T) \\
(9.0)\end{array}\right]$ & $\begin{array}{l}20 \\
39\end{array}$ & $\begin{array}{l}(5.1) \\
(7.8)\end{array}$ & $\begin{array}{l}51 \\
39\end{array}$ & $(9.0)$ \\
\hline 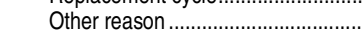 & 17 & (3.0) & 18 & $(4.0)$ & $19 !$ & (5.7) & \# & $(t)$ & $18 !$ & (6.5) & $18 !$ & (5.7) & $\ddagger$ & $(t)$ & 22 & (6.2) & $19 !$ & (5.9) & $26 !$ & (8.4) & $13 !$ & (5.8) & $14 !$ & (5.7) \\
\hline
\end{tabular}




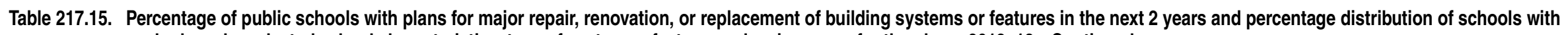
such plans, by selected school characteristics, type of system or feature, and main reason for the plans: 2012-13-Continued

[Standard errors appear in parentheses]

\begin{tabular}{|c|c|c|c|c|c|c|c|c|c|c|c|c|c|c|c|c|c|c|c|c|c|c|c|c|}
\hline \multirow{2}{*}{$\begin{array}{l}\text { Type of system or feature and main } \\
\text { reason for major repair, renovation, or } \\
\text { replacement plans }\end{array}$} & \multirow{2}{*}{\multicolumn{2}{|c|}{$\begin{array}{r}\text { All public } \\
\text { schools }\end{array}$}} & \multicolumn{6}{|c|}{ Instructional level } & \multicolumn{8}{|c|}{ Community type } & \multicolumn{8}{|c|}{ Percent of students eligible for free or reduced-priced lunch } \\
\hline & & & \multicolumn{2}{|c|}{ Elementary } & \multicolumn{2}{|c|}{ Secondary } & \multicolumn{2}{|c|}{ Combined } & & City & \multicolumn{2}{|c|}{ Suburban } & \multicolumn{2}{|r|}{ Town } & \multicolumn{2}{|r|}{ Rural } & \multicolumn{2}{|c|}{$\begin{array}{r}\text { Less than } \\
35 \text { percent }\end{array}$} & \multicolumn{2}{|c|}{35 to 49 percent } & \multicolumn{2}{|c|}{50 to 74 percent } & \multicolumn{2}{|c|}{$\begin{array}{l}75 \text { percent } \\
\text { or more }\end{array}$} \\
\hline 1 & & 2 & & 3 & & 4 & & 5 & & 6 & & 7 & & 8 & & 9 & & 10 & & 11 & & 12 & & 13 \\
\hline $\begin{array}{l}\text { Plumbing/lavatories-percent of } \\
\text { schools with plans }\end{array}$ & 13 & (1.0) & 12 & (1.2) & 17 & (1.8) & 28 & (7.2) & 15 & (2.0) & 13 & (1.9) & 16 & (2.4) & 11 & (1.5) & 13 & (1.8) & 13 & (2.0) & 13 & (1.7) & 13 & (2.2) \\
\hline $\begin{array}{l}\text { tion by main } \\
\text { lans .................. }\end{array}$ & 100 & & 100 & $(\mathrm{t})$ & 100 & $(\dagger)$ & 100 & $(t)$ & 100 & $(\dagger)$ & 100 & $(\dagger)$ & 100 & $(\dagger)$ & 100 & $(\mathrm{t})$ & 100 & $(t)$ & 100 & $(t)$ & 100 & $(\mathrm{t})$ & 100 & $(\dagger)$ \\
\hline $\begin{array}{l}\text { Functional problem in existing } \\
\text { system or feature ............. }\end{array}$ & 25 & (3.7) & 25 & (4.6) & 21 & (3.8) & $46 !$ & (16.6) & 29 & $(7.0)$ & 22 & $(6.1)$ & $26 !$ & (7.9) & 24 & $(7.2)$ & 26 & (7.4) & 29 & (8.6) & 27 & $(6.1)$ & $20 !$ & (6.5) \\
\hline 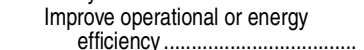 & 35 & $(3.8)$ & 32 & (4.7) & 41 & $(5.9)$ & $44 !$ & $(15.0)$ & 27 & $(6.4)$ & 33 & $(6.9)$ & & (96) & 39 & $(77)$ & 24 & $(5,7)$ & 29 & $(8.0)$ & 47 & $(7.6)$ & 42 & (7.6) \\
\hline 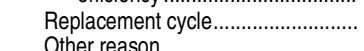 & 26 & (3.1) & 28 & $(4.4)$ & 25 & $(5.0)$ & $\neq$ & $(\dagger)$ & 34 & $(6.7)$ & 22 & $(4.8)$ & $19 !$ & $(7.7)$ & 27 & $(6.5)$ & 29 & (5.8) & $25 !$ & (7.6) & 23 & $(6.3)$ & 28 & $(7.3)$ \\
\hline$\ldots \ldots \ldots \ldots \ldots \ldots . . .$. & 13 & (2.5) & 14 & (3.5) & $13 !$ & (4.1) & \# & $(\dagger)$ & $10 !$ & (4.5) & 24 & (5.6) & $\ddagger$ & $(\dagger)$ & $10 !$ & (4.8) & 22 & (5.5) & $16 !$ & (6.6) & $\ddagger$ & $(t)$ & $10 !$ & (4.9) \\
\hline $\begin{array}{l}\text { Heating } \\
\text { with }\end{array}$ & 16 & (1.1) & 14 & (1.2) & 21 & (2.1) & 29 & (6.8) & 15 & (2.0) & 17 & (1.9) & 15 & (2.5) & 16 & (1.8) & 18 & (1.7) & 15 & (2.0) & 16 & (1.9) & 15 & (2.2) \\
\hline $\begin{array}{l}\text { Percentage distribution by main } \\
\text { reason for the plans .............. }\end{array}$ & 100 & (1.) & 100 & $(\dagger)$ & 100 & $(\dagger)$ & 100 & $(\dagger)$ & 100 & $(\dagger)$ & 100 & $(\dagger)$ & 100 & $(\dagger)$ & 100 & $(\dagger)$ & 100 & $(\dagger)$ & 100 & $(\dagger)$ & 100 & $(\dagger)$ & 100 & $(\dagger)$ \\
\hline $\begin{aligned} \text { Functi } \\
\text { sys }\end{aligned}$ & 26 & (29) & 23 & $(3.7)$ & 31 & (4.7) & $33 !$ & $(14.0)$ & 24 & $(6.1)$ & 24 & $(6.0)$ & 32 & (8.8) & 27 & $(60)$ & 23 & (5.3) & 31 & (81) & 23 & $(5.3)$ & 30 & (7) \\
\hline Impro & & & & & & & & & & & & & & & & & & & & & & (0.0) & 0 & $(1.0)$ \\
\hline e & 41 & (3.1) & 34 & (3.7) & 54 & (5.4) & 54 & (14.1) & 34 & (6.8) & 37 & (5.4) & 38 & (9.6) & 51 & $(6.8)$ & 31 & (5.0) & 38 & (8.1) & 53 & $(6.8)$ & 45 & (7.6) \\
\hline 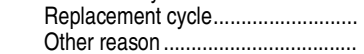 & $\begin{array}{r}27 \\
6\end{array}$ & $\begin{array}{l}(2.9) \\
(1.7)\end{array}$ & $\begin{array}{l}35 \\
8 !\end{array}$ & $\begin{array}{l}(4.0) \\
(2.7)\end{array}$ & $\begin{array}{c}13 ! \\
\ddagger\end{array}$ & $\begin{array}{r}(4.4) \\
(+)\end{array}$ & $\underset{\#}{\ddagger}$ & $\begin{array}{r}(t) \\
(t)\end{array}$ & $\begin{aligned} 35 \\
\ddagger\end{aligned}$ & $\begin{array}{r}(6.5) \\
(\dagger)\end{array}$ & $\begin{array}{l}31 \\
8 !\end{array}$ & $\begin{array}{l}(6.0) \\
(3.5)\end{array}$ & $\begin{array}{c}23 ! \\
\ddagger\end{array}$ & $\begin{array}{r}(8.4) \\
(+)\end{array}$ & $\begin{aligned} 20 \\
\ddagger\end{aligned}$ & $\left.\begin{array}{r}(5.1) \\
(\dagger)\end{array}\right]$ & $\begin{array}{c}38 \\
8 !\end{array}$ & $\begin{array}{l}(5.4) \\
(3.8)\end{array}$ & $\begin{array}{r}30 \\
\ddagger\end{array}$ & $\begin{array}{r}(7.9) \\
(+)\end{array}$ & $\begin{array}{r}20 \\
\ddagger\end{array}$ & $\begin{array}{r}(5.5) \\
(\dagger)\end{array}$ & $\begin{array}{c}17 ! \\
\ddagger\end{array}$ & $\begin{array}{r}(6.4) \\
(+)\end{array}$ \\
\hline $\begin{array}{l}\text { Air conditioning system-percent of } \\
\text { schools with plans }\end{array}$ & 16 & (1.1) & 14 & (1.3) & 22 & (2.2) & $17 !$ & (5.2) & 18 & (2.4) & 16 & (2.0) & 14 & (2.7) & 16 & (1.9) & 14 & (1.7) & 18 & (2.6) & 17 & (2.3) & 16 & (2.5) \\
\hline $\begin{array}{l}\text { Percentac } \\
\text { reaso }\end{array}$ & 100 & (t) & 100 & $(+)$ & 100 & (t) & 100 & (t) & 100 & (t) & 100 & (t) & 100 & (t) & 100 & $(t)$ & 100 & (t) & 100 & (t) & 100 & (t) & 100 & (t) \\
\hline Functio & & & & & & & & & & & & & & & & & & & & & & & & \\
\hline syst & 28 & (3.5) & 26 & (4.4) & 34 & (4.9) & $\ddagger$ & $(\mathrm{t})$ & 25 & (6.2) & 29 & (6.7) & $31 !$ & (10.4) & 30 & (6.4) & 28 & (6.0) & 31 & (7.9) & 22 & (6.2) & 34 & (7.7) \\
\hline $\begin{array}{l}\text { Improve op } \\
\text { efficien }\end{array}$ & 44 & (3.5) & 39 & (4.6) & 52 & $(5$. & $57 !$ & (19.0) & 44 & (7.4) & 43 & (5.7) & 39 & (11.1) & 46 & (7.1) & 36 & (5.9) & 44 & (8.0) & 54 & $(6.4)$ & 40 & (7.5) \\
\hline Repla & 23 & (2.8) & 29 & (3.9) & $11 !$ & (36) & $\ddagger$ & $(t)$ & 26 & $(6.0)$ & 21 & $(5.6)$ & $27 !$ & $(9.6)$ & 20 & $(5.9)$ & 31 & $(6.0)$ & $19 !$ & (6.4) & 23 & (5.9) & $16 !$ & $(5.9)$ \\
\hline Other re & 5 & (1.5) & $6 !$ & (2.2) & $4 !$ & $(1.8)$ & $\#$ & $(\mathrm{t})$ & $\ddagger$ & $(\mathrm{t})$ & $8 !$ & (3.4) & $\ddagger$ & $(t)$ & $\ddagger$ & $(t)$ & $\ddagger$ & $(\mathrm{t})$ & $\ddagger$ & $(\mathrm{t})$ & $\ddagger$ & $(t)$ & $10 !$ & (4.4) \\
\hline $\begin{array}{l}\text { Ventilation/filtration system-percent } \\
\text { of schools with plans................ } \\
\text { Percentage distribution by main }\end{array}$ & 11 & $(0.8)$ & 10 & (0.9) & 15 & (1.7) & $13 !$ & (4.3) & 11 & (1.6) & 11 & (1.6) & 11 & (2.6) & 11 & (1.5) & 13 & (1.4) & 11 & (1.9) & 11 & (1.5) & 9 & (1.7) \\
\hline $\begin{array}{r}\text { reason } \\
\text { Function }\end{array}$ & 100 & (t) & 100 & $(\dagger)$ & 100 & $(\dagger)$ & 100 & $(t)$ & 100 & $(\mathrm{t})$ & 100 & (t) & 100 & (†) & 100 & $(\dagger)$ & 100 & $(\dagger)$ & 100 & $(\dagger)$ & 100 & $(\dagger)$ & 100 & $(\dagger)$ \\
\hline $\begin{array}{l}\text { Functio } \\
\text { syst }\end{array}$ & 31 & $(4.3)$ & 30 & (5.6) & 32 & (5.6) & $\ddagger$ & $(\dagger)$ & 30 & (7.4) & 26 & $(7.5)$ & $37 !$ & (13.5) & 33 & $(7.3)$ & 27 & (6.5) & 37 & (10.8) & 26 & (7.4) & 38 & (10.7) \\
\hline $\begin{array}{l}\text { Improve op } \\
\text { efficien }\end{array}$ & 38 & (4.3) & 30 & (5.3) & 55 & (6. & $41 !$ & (19.2) & 3 & (8.4) & $3 s$ & (7.2) & $28 !$ & (10.5) & 41 & 8) | & 33 & & & .0) & & & 35 & (10.1) \\
\hline Replace & 23 & (3.4) & 29 & (5.0) & $8 !$ & (3. & $\ddagger$ & $(t)$ & $19 !$ & (5.7) & 24 & $(7.0)$ & $32 !$ & (11.6) & 22 & $(6.4)$ & 30 & (6.7) & $25 !$ & $(8.8)$ & $22 !$ & $(6.8$ & $\ddagger$ & $(t)$ \\
\hline Other $r$ & 8 & (2.4) & $10 !$ & (3.5) & $5 !$ & (2.4) & $\#$ & (†) & $\ddagger$ & $(t)$ & $11 !$ & (4.9) & $\ddagger$ & $(t)$ & $\ddagger$ & $(\dagger)$ & $\ddagger$ & $(t)$ & $\ddagger$ & $(t)$ & $\ddagger$ & $(t)$ & $18 !$ & (7.3) \\
\hline $\begin{array}{l}\text { Electrical system-percent of } \\
\text { schools with plans .................. }\end{array}$ & 9 & $(0.8)$ & 9 & $(0.9)$ & 10 & (1.4) & $17 !$ & (6.1) & 11 & (1.5) & 10 & (1.6) & 9 & (2.1) & 8 & (1.4) & 11 & (1.5) & 8 & (1.6) & 8 & (1.3) & 10 & (1.7) \\
\hline $\begin{array}{l}\text { Percentage distribution by main } \\
\text { reason for the plans ............... }\end{array}$ & 100 & $(\dagger)$ & 100 & $(\dagger)$ & 100 & $(\dagger)$ & 100 & $(\dagger)$ & 100 & $(\dagger)$ & 100 & $(\dagger)$ & 100 & (†) & 100 & $(\dagger)$ & 100 & (†) & 100 & $(\mathrm{t})$ & 100 & $(\dagger)$ & 100 & $(\dagger)$ \\
\hline $\begin{array}{l}\text { Functional problem in existing } \\
\text { system or feature ............... }\end{array}$ & 28 & (4.0) & 28 & (5.0) & 27 & (5.8) & $\ddagger$ & (†) & 31 & (8.2) & 32 & (7.6) & $25 !$ & (12.3) & $21 !$ & (8.4) & 23 & (6.2) & 46 & (12.9) & $24 !$ & (8.2) & $28 !$ & (8.3) \\
\hline rational or energy & 37 & $(4$ & 31 & & 5 & & $52 !$ & (1 & & & 35 & & $42 !$ & (13. & 45 & & 37 & & $29 !$ & 1.1 & 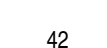 & & 38 & 4) \\
\hline Replace & 22 & (3 & 26 & (4.9) & 1 & & $\ddagger$ & $(t)$ & 33 & $(8.3)$ & $16 !$ & (5.7) & $19 !$ & $(9.2)$ & $18 !$ & & 32 & (7.0) & $\neq$ & $(\dagger)$ & $23 !$ & $(7.5)$ & 15 ! & (7.5) \\
\hline Other reason ... & 13 & (3.2) & 15 & (4.2) & $11 !$ & (5.4) & \# & (t) & $\ddagger$ & (t) & $17 !$ & $(6.2)$ & $\ddagger$ & (†) & $15 !$ & $(7.0)$ & $\ddagger$ & $(t)$ & $\ddagger$ & (†) & $\ddagger$ & (†) & $19 !$ & (7.7) \\
\hline
\end{tabular}

See notes at end of table. 


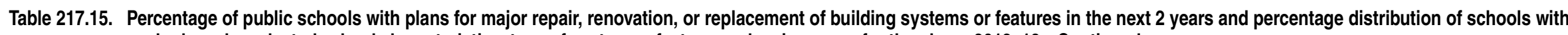
such plans, by selected school characteristics, type of system or feature, and main reason for the plans: 2012-13-Continued

[Standard errors appear in parentheses]

\begin{tabular}{|c|c|c|c|c|c|c|c|c|c|c|c|c|c|c|c|c|c|c|c|c|c|c|c|c|}
\hline \multirow{2}{*}{$\begin{array}{l}\text { Type of system or feature and main } \\
\text { reason for major repair, renovation, or } \\
\text { replacement plans }\end{array}$} & \multirow{2}{*}{\multicolumn{2}{|c|}{$\begin{array}{r}\text { All public } \\
\text { schools }\end{array}$}} & \multicolumn{6}{|c|}{ Instructional level } & \multicolumn{8}{|c|}{ Community type } & \multicolumn{8}{|c|}{ Percent of students eligible for free or reduced-priced lunch } \\
\hline & & & \multicolumn{2}{|c|}{ Elementary } & \multicolumn{2}{|c|}{ Secondary } & \multicolumn{2}{|c|}{ Combined } & & City & \multicolumn{2}{|c|}{ Suburban } & \multicolumn{2}{|r|}{ Town } & \multicolumn{2}{|r|}{ Rural } & \multicolumn{2}{|c|}{$\begin{array}{r}\text { Less than } \\
35 \text { percent }\end{array}$} & \multicolumn{2}{|c|}{35 to 49 percent } & \multicolumn{2}{|c|}{50 to 74 percent } & \multicolumn{2}{|c|}{$\begin{array}{l}75 \text { percent } \\
\text { or more }\end{array}$} \\
\hline 1 & & 2 & & 3 & & 4 & & 5 & & 6 & & 7 & & 8 & & 9 & & 10 & & 11 & & 12 & & 13 \\
\hline $\begin{array}{l}\text { Interior lighting-percent of schools } \\
\text { with plans }\end{array}$ & 13 & $(0.9)$ & 13 & (1.1) & 13 & (1.4) & $18 !$ & (6.5) & 14 & (1.9) & 14 & (1.7) & 10 & (2.3) & 12 & (1.6) & 15 & (1.6) & 10 & (1.9) & 13 & (1.7) & 12 & (2.1) \\
\hline $\begin{array}{r}\text { Percentag } \\
\text { reasor }\end{array}$ & & & 100 & $(\dagger)$ & 100 & $(†)$ & 100 & $(\dagger)$ & 100 & $(\dagger)$ & 100 & $(\dagger)$ & 100 & (†) & 100 & $(\dagger)$ & 100 & (†) & 100 & $(\dagger)$ & 100 & $(\dagger)$ & 100 & $(\dagger)$ \\
\hline $\begin{array}{l}\text { Functional problem in existing } \\
\text { system or feature ................ }\end{array}$ & 12 & $(2.6)$ & 13 & (3.4) & $11 !$ & (3.8) & $\ddagger$ & $(\dagger)$ & $12 !$ & $(4.5)$ & $12 !$ & (5.3) & $22 !$ & (9.5) & $\ddagger$ & $(\dagger)$ & $11 !$ & $(4.4)$ & $\ddagger$ & $(\dagger)$ & $13 !$ & (5.4) & $19 !$ & (6.5) \\
\hline hal or energy & 70 & (3.9) & 68 & (4.9) & 74 & (5.) & 73 & (17.7) & 66 & (72) & & (7.4) & 62 & $(112)$ & 78 & $(6.1)$ & 65 & (7.1) & 78 & (8.6) & & (5.9) & 60 & (8.4) \\
\hline Replac & 9 & $(2.0)$ & 10 & (2.6) & $6 !$ & (2.8) & $\ddagger$ & $(t)$ & $13 !$ & (5.5) & $8 !$ & (3.4) & $\ddagger$ & $(t)$ & $8 !$ & (3.5) & $13 !$ & (4.3) & $\ddagger$ & $(t)$ & $7 !$ & (3.2) & $\ddagger$ & $(t)$ \\
\hline Other re & 9 & (2.3) & $10 !$ & (2.9) & $\ddagger$ & $(t)$ & \# & $(t)$ & $\ddagger$ & $(t)$ & $13 !$ & (4.9) & $\ddagger$ & (t) & $\ddagger$ & $(t)$ & $10 !$ & (4.6) & $\ddagger$ & $(+)$ & $\ddagger$ & $(t)$ & $11 !$ & (5.4) \\
\hline $\begin{array}{l}\text { Exterior ligh } \\
\text { with plan }\end{array}$ & 10 & $(0.8)$ & 9 & $(1.0)$ & 10 & (1.3) & $18 !$ & (6.0) & 9 & (1.5) & 10 & (1.5) & 9 & (2.1) & 10 & (1.6) & 12 & (1.6) & 8 & (1.7) & 7 & (1.2) & 10 & (1.8) \\
\hline $\begin{array}{l}\text { Percentage distribution by main } \\
\text { reason for the plans ..................... }\end{array}$ & 100 & $(\dagger)$ & 100 & $(\dagger)$ & 100 & $(\mathrm{t})$ & 100 & $(\dagger)$ & 100 & (†) & 100 & (†) & 100 & (†) & 100 & (†) & 100 & (†) & 100 & $(\mathrm{t})$ & 100 & $(\mathrm{t})$ & 100 & $(\dagger)$ \\
\hline $\begin{array}{l}\text { Functic } \\
\text { sys }\end{array}$ & 19 & (3.5) & 20 & (4.6) & $19 !$ & (5.8) & $\ddagger$ & $(\dagger)$ & $12 !$ & (5.2) & $14 !$ & (6.3) & $39 !$ & (14.2) & $22 !$ & (7.2) & $13 !$ & (5.5) & $\ddagger$ & (†) & $29 !$ & (9.9) & $21 !$ & (8.1) \\
\hline $\begin{array}{l}\text { Improv } \\
\text { effi }\end{array}$ & 56 & (4) 7) & 53 & (5.9) & 62 & ( 9.9 & & (7) ? & 50 & (9?) & & & & & & & & & & & & & & \\
\hline Repla & 14 & (3.0) & 15 & (3.9) & $10 !$ & (3.9) & $\ddagger$ & $(t)$ & $27 !$ & $\begin{array}{l}(8.6) \\
(8.6)\end{array}$ & $\begin{array}{c}0 / \\
\ddagger\end{array}$ & $\begin{aligned}(8.8) \\
(\dagger)\end{aligned}$ & $\begin{aligned} & 4 / 4 \\
& \ddagger\end{aligned}$ & $\begin{array}{r}(13.9) \\
(\dagger)\end{array}$ & $\begin{array}{l}56 \\
15 !\end{array}$ & $\begin{array}{l}(8.5) \\
(6.2)\end{array}$ & $\begin{array}{l}57 \\
17 !\end{array}$ & $\begin{array}{l}(7.8) \\
(5.1)\end{array}$ & $\begin{array}{rl}66 & 0 \\
\ddagger\end{array}$ & $\begin{array}{r}(10.9) \\
(\dagger)\end{array}$ & $\begin{array}{l}48 \\
17 !\end{array}$ & $\begin{array}{r}(10.2) \\
(7.5)\end{array}$ & $\begin{array}{c}56 \\
t\end{array}$ & $\begin{aligned}(10.2) \\
(+)\end{aligned}$ \\
\hline Othe & 11 & (3.2) & $12 !$ & (3.8) & $\ddagger$ & $(t)$ & \# & $(\dagger)$ & $\ddagger$ & $(t)$ & $14 !$ & (6.1) & $\ddagger$ & $(t)$ & $\ddagger$ & $(t)$ & $13 !$ & (5.7) & $\ddagger$ & $(+)$ & $\ddagger$ & $(t)$ & $\stackrel{+}{\ddagger}$ & $(t)$ \\
\hline $\begin{array}{l}\text { Energy management system-percent } \\
\text { of schools with plans............................ }\end{array}$ & 14 & (0.9) & 13 & (1.2) & 16 & (1.9) & 34 & (7.9) & 13 & (2.0) & 14 & (1.9) & 17 & (2.9) & 15 & (1.9) & 17 & (1.9) & 12 & (2.0) & 14 & (1.9) & 14 & (2.0) \\
\hline $\begin{array}{l}\text { Percenta } \\
\text { reasc }\end{array}$ & 100 & $(\dagger) \mid$ & 100 & (†) & 100 & $(t)$ & 100 & $(\mathrm{t})$ & 100 & (†) & 100 & (t) & 100 & (†) & 100 & (†) & 100 & (†) & 100 & (t) & 100 & $(\mathrm{t})$ & 100 & (†) \\
\hline Functi & & & & & & & & & & & & & & & & & & & & & & & & \\
\hline $\begin{aligned} \text { syst } \\
\text { pprove }\end{aligned}$ & 14 & (2.4) & 13 & (3.2) & 15 & (4.1) & $\ddagger$ & $(\dagger)$ & $19 !$ & (5.9) & $\ddagger$ & $(t)$ & $21 !$ & (7.9) & $11 !$ & $(4.2)$ & 16 & (4.4) & $\ddagger$ & $(\dagger)$ & $16 !$ & (5.7) & $11 !$ & (5.2) \\
\hline effic & 65 & (3.6) & 64 & (4.5) & 66 & $(6.0)$ & 68 & (14.8) & 59 & (8.7) & 63 & (7.3) & 64 & $(10.3)$ & 71 & (5.6) & 58 & $(6.8)$ & 68 & (8.4) & 72 & (6.3) & 67 & (8.4) \\
\hline $\begin{array}{l}\text { Replace } \\
\text { Other re }\end{array}$ & $\begin{array}{r}14 \\
7\end{array}$ & $\begin{array}{r}(2.7) \\
(20)\end{array}$ & $\begin{array}{l}16 \\
7 !\end{array}$ & $(3.5)$ & $9 !$ & $(4.3)$ & 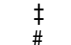 & $\left(\begin{array}{l}(\dagger) \\
(+)\end{array}\right.$ & $\begin{array}{l}13 ! \\
+\end{array}$ & $\begin{array}{r}(5.6) \\
(+)\end{array}$ & $16 !$ & $(6.2)$ & $\begin{array}{c}13 ! \\
+\end{array}$ & $\begin{array}{r}(5.1) \\
(+)\end{array}$ & $14 !$ & $\begin{array}{r}(5.0) \\
(+)\end{array}$ & $\begin{aligned} 20 \\
+\end{aligned}$ & $(5.8)$ & $\begin{array}{c}15 ! \\
t\end{array}$ & $\begin{array}{r}(6.7) \\
(+)\end{array}$ & $8 !$ & $\begin{array}{r}(3.4) \\
(+)\end{array}$ & $\neq$ & (†) \\
\hline Life safety $f$ & & & $1 !$ & & $3 !$ & & $\pi$ & & + & & $126:$ & (4.0) & $t$ & & f & (T) & $t$ & (T) & f & (T) & Ғ & (T) & $11 !$ & (3.3) \\
\hline $\begin{array}{l}\text { scho } \\
\text { Percel }\end{array}$ & 12 & $(0.8)$ & 11 & $(1.0)$ & 12 & (1.5) & $16 !$ & (5.8) & 11 & (1.6) & 13 & (1.8) & 16 & (2.7) & 10 & (1.5) & 13 & (1.8) & 12 & (2.0) & 11 & (1.8) & 9 & (1.7) \\
\hline $\begin{aligned} & \text { reasol } \\
& \text { renctio }\end{aligned}$ & 100 & (t) & 100 & $(\dagger)$ & 100 & $(t)$ & 100 & $(t)$ & 100 & $(t)$ & 100 & $(t)$ & 100 & (†) & 100 & (†) & 100 & $(\dagger)$ & 100 & (†) & 100 & $(\dagger)$ & 100 & $(\dagger)$ \\
\hline $\begin{array}{l}\text { Function } \\
\text { syste }\end{array}$ & 24 & (3.7) & 23 & (4.4) & 23 & $(5.8)$ & $\ddagger$ & $(\dagger)$ & $22 !$ & (7.5) & 30 & (7.8) & $21 !$ & (7.7) & $21 !$ & (6.6) & 26 & (6.2) & 36 & (9.4) & $20 !$ & (6.3) & $12 !$ & (4.7) \\
\hline $\begin{array}{l}\text { Improve of } \\
\text { efficier }\end{array}$ & 37 & (4.2) & 34 & (4.9) & 41 & (6.9) & $60 !$ & (22.4) & 42 & (8.3) & 33 & (7.6) & 40 & (8.5) & 35 & (8.1) & 31 & & 29 & (7.9) & 41 & (8.2) & 51 & (9.6) \\
\hline Replac & 21 & (3.0) & 22 & $(4.0)$ & 19 & $(4.9)$ & $\ddagger$ & $(t)$ & $24 !$ & $(7.5)$ & $19 !$ & (6.6) & $24 !$ & (8.7) & 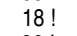 & $(6.0)$ & 23 & & $7 !$ & (6.2) & $20 !$ & (6.2) & $20 !$ & (8.6) \\
\hline Othe & 19 & (3.5) & 21 & (4.2) & $16 !$ & (5.5) & \# & (†) & $\ddagger$ & $(\dagger)$ & $19 !$ & (5.8) & $16 !$ & (6.7) & $26 !$ & (8.2) & $19 !$ & (6.0) & $19 !$ & (8.1) & $19 !$ & (6.7) & $17 !$ & (7.2) \\
\hline $\begin{array}{l}\text { Security systems-percent of } \\
\text { schools with plans }\end{array}$ & 21 & (1.2) & 20 & (1.5) & 20 & (1.9) & 32 & (7.4) & 16 & (2.1) & 19 & (2.0) & 24 & (3.1) & 24 & (2.2) & 23 & (2.2) & 19 & (2.7) & 21 & (2.2) & 17 & (2.3) \\
\hline $\begin{array}{l}\text { Percentage distribution by main } \\
\text { reason for the plans ............. }\end{array}$ & 100 & $(\dagger)$ & 100 & $(\dagger)$ & 100 & (†) & 100 & $(†)$ & 100 & $(\dagger)$ & 100 & $(\dagger)$ & 100 & (†) & 100 & $(\dagger)$ & 100 & $(\dagger)$ & 100 & $(†) \mid$ & 100 & $(†)$ & 100 & (†) \\
\hline $\begin{array}{l}\text { Functional problem in existing } \\
\text { system or feature ................... }\end{array}$ & 22 & $(2.8)$ & 22 & (3.5) & 25 & $(4.4)$ & $\ddagger$ & $(\dagger)$ & $19 !$ & (5.7) & 16 & (4.7) & 33 & (7.5) & 24 & (4.6) & 17 & (3.8) & 33 & (7.7) & 22 & (4.9) & 21 & (6.1) \\
\hline Impro & & & & & & & & & & & & & & & & & & & & & & & & \\
\hline & $\begin{array}{r}46 \\
9\end{array}$ & $\begin{array}{l}(3.0) \\
(1.8)\end{array}$ & 44 & $\begin{array}{l}(3.7) \\
(2.3)\end{array}$ & $\begin{array}{l}50 \\
10 !\end{array}$ & $\left.\begin{array}{l}(5.5) \\
(3.1)\end{array}\right]$ & $\begin{array}{r}67 \\
\#\end{array}$ & $\begin{array}{r}(12.3) \\
(t)\end{array}$ & $\begin{array}{l}43 \\
14 !\end{array}$ & (7.2) & $\begin{array}{l}53 \\
8 !\end{array}$ & (6.2) & $\begin{array}{l}51 \\
+\end{array}$ & $\begin{array}{c}(7.6) \\
(+)\end{array}$ & $\begin{array}{c}41 \\
9 !\end{array}$ & (5.3) & 48 & (5.2) & $\begin{array}{c}36 \\
+\end{array}$ & $\begin{array}{r}(7.2) \\
(+)\end{array}$ & $\begin{array}{l}48 \\
7 !\end{array}$ & (5.7) & 48 & $\begin{array}{r}(8.0) \\
(t)\end{array}$ \\
\hline $\begin{array}{l}\text { Replacement cy } \\
\text { Other reason .... }\end{array}$ & 22 & (1.0) & 25 & $(3.9)$ & 15 & (4.3) & $\begin{array}{l}\# \\
\ddagger\end{array}$ & t) & $\begin{array}{l}14 ! \\
24\end{array}$ & (6.9) & 22 & (5.5) & $9 !$ & (4.2) & 26 & $\begin{array}{l}(0.1) \\
(4.8)\end{array}$ & 21 & $\begin{array}{l}(0.0) \\
(4.7)\end{array}$ & 25 & $(6.9)$ & 22 & (4.0) & 22 & (6.6) \\
\hline
\end{tabular}

See notes at end of table. 


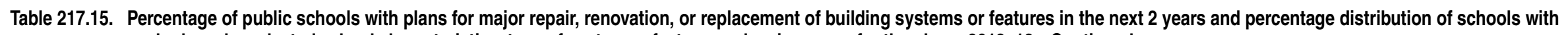
such plans, by selected school characteristics, type of system or feature, and main reason for the plans: 2012-13-Continued

[Standard errors appear in parentheses]

\begin{tabular}{|c|c|c|c|c|c|c|c|c|c|c|c|c|c|c|c|c|c|c|c|c|c|c|c|c|}
\hline \multirow{2}{*}{$\begin{array}{l}\text { Type of system or feature and main } \\
\text { reason for major repair, renovation, or } \\
\text { replacement plans }\end{array}$} & \multirow{2}{*}{\multicolumn{2}{|c|}{$\begin{array}{r}\text { All public } \\
\text { schools }\end{array}$}} & \multicolumn{6}{|c|}{ Instructional level } & \multicolumn{8}{|c|}{ Community type } & \multicolumn{8}{|c|}{ Percent of students eligible for free or reduced-priced lunch } \\
\hline & & & \multicolumn{2}{|c|}{ Elementary } & \multicolumn{2}{|c|}{ Secondary } & \multicolumn{2}{|c|}{ Combined } & & City & \multicolumn{2}{|c|}{ Suburban } & \multicolumn{2}{|r|}{ Town } & \multicolumn{2}{|r|}{ Rural } & \multicolumn{2}{|c|}{$\begin{array}{c}\text { Less than } \\
35 \text { percent }\end{array}$} & \multicolumn{2}{|c|}{35 to 49 percent } & \multicolumn{2}{|c|}{50 to 74 percent } & \multicolumn{2}{|c|}{$\begin{array}{l}75 \text { percent } \\
\text { or more }\end{array}$} \\
\hline 1 & & 2 & & 3 & & 4 & & 5 & & 6 & & 7 & & 8 & & 9 & & 10 & & 11 & & 12 & & 13 \\
\hline $\begin{array}{l}\text { Internal communication systems- } \\
\text { percent of schools with plans } \\
\text { Percentage distribution by main }\end{array}$ & 14 & (1.0) & 13 & (1.2) & 16 & (2.1) & 23 ! & (7.0) & 13 & (2.0) & 13 & $(1.7)$ & 16 & (2.6) & 14 & (1.7) & 15 & (1.8) & 12 & $(2.1)$ & 14 & $(1.8)$ & 14 & (2.5) \\
\hline $\begin{array}{l}\text { Percentage distribution by main } \\
\text { reason for the plans ............. }\end{array}$ & 100 & $(\dagger)$ & 100 & $(\dagger)$ & 100 & $(\dagger)$ & 100 & $(t)$ & 100 & $(\dagger)$ & 100 & $(\dagger)$ & 100 & $(\dagger)$ & 100 & $(\dagger)$ & 100 & $(t)$ & 100 & $(\dagger)$ & 100 & $(\dagger)$ & 100 & $(\dagger)$ \\
\hline $\begin{array}{l}\text { Functional problem in existing } \\
\text { system or feature .............. }\end{array}$ & 24 & $(3.3)$ & 21 & $(4.2)$ & 28 & (5.5) & $37 !$ & (18.4) & 24 & (6.4) & $19 !$ & $(5.9)$ & $17 !$ & (6.7) & 30 & $(6.2)$ & 21 & (5.2) & 31 & $(8.0)$ & 23 & $(6.3)$ & 24 & $(7.0)$ \\
\hline $\begin{array}{l}\text { Improve operational or energy } \\
\text { efficiency ............................. }\end{array}$ & 43 & (3.5) & 39 & (4.7) & 49 & (6.9) & 63 & (18.4) & 41 & (7.3) & 50 & $(8.1)$ & 42 & (9.1) & 39 & $(7.0)$ & 43 & (6.3) & 47 & (9.5) & 39 & $(7.5)$ & 44 & $(7.1)$ \\
\hline $\begin{array}{l}\text { Replacement cycle.......................... } \\
\text { Other reason }\end{array}$ & 21 & (3.1) & 25 & $(4.2)$ & 12 ! & (3.8) & $\#$ & $(t)$ & 21 & (6.4) & $15 !$ & $(5.2)$ & 34 & $(9.3)$ & $19 !$ & (5.7) & 25 & (6.2) & $\ddagger$ & $(t)$ & 22 & $(6.5)$ & $19 !$ & (6.3) \\
\hline $\begin{array}{l}\text { Other reason ...................... } \\
\text { Technology infrastructure-percent }\end{array}$ & 13 & (2.7) & 15 & (3.5) & $11 !$ & (4.6) & $\#$ & $(†)$ & $14 !$ & (6.2) & $16 !$ & $(5.7)$ & $\ddagger$ & $(\dagger)$ & $12 !$ & (4.8) & $12 !$ & (4.8) & $\ddagger$ & $(\mathrm{t})$ & $16 !$ & (5.3) & $13 !$ & (5.5) \\
\hline $\begin{array}{l}\text { of schools with plans ......................... } \\
\text { Percentage distribution by main }\end{array}$ & 20 & $(1.0)$ & 19 & (1.2) & 23 & (2.2) & 33 & (7.4) & 17 & (2.1) & 20 & $(2.1)$ & 23 & (2.8) & 21 & $(2.0)$ & 23 & (2.0) & 20 & $(2.6)$ & 18 & $(2.1)$ & 19 & (2.6) \\
\hline reason for the plans & 100 & $(\mathrm{t})$ & 100 & $(\dagger)$ & 100 & $(t)$ & 100 & $(\mathrm{t})$ & 100 & $(t)$ & 100 & $(\dagger)$ & 100 & $(\dagger)$ & 100 & $(\dagger)$ & 100 & $(\dagger)$ & 100 & $(t)$ & 100 & $(\dagger)$ & 100 & $(\dagger)$ \\
\hline $\begin{array}{l}\text { Functional problem in existing } \\
\text { system or feature ................ }\end{array}$ & 17 & (2.4) & 16 & (3.0) & 19 & (4.1) & $\ddagger$ & $(\mathrm{t})$ & $16 !$ & (5.0) & $11 !$ & (4.1) & $16 !$ & (5.6) & 22 & (4.7) & 14 & $(3.8)$ & $17 !$ & $(5.9)$ & 16 & $(4.6)$ & 23 & (5.3) \\
\hline $\begin{array}{l}\text { Improve operational or energy } \\
\text { efficiency }\end{array}$ & 51 & (3.3) & 46 & (4.2) & 59 & $(5.0)$ & 71 & $(14.0)$ & 53 & (6.5) & 51 & (6.5) & 65 & (7.3) & 44 & (5.3) & 44 & (4.9) & 53 & $(7.3)$ & 59 & $(6.6)$ & 51 & (6.5) \\
\hline Replacement cycle........................... & 21 & $(2.6)$ & 25 & (3.4) & 14 & (3.4) & $\ddagger$ & $(t)$ & 21 & (5.5) & 21 & $(4.5)$ & $10 !$ & $(4.6)$ & 26 & $(5.1)$ & 28 & (5.1) & $19 !$ & $(6.0)$ & 19 & $(5.4)$ & $15 !$ & $(4.8)$ \\
\hline 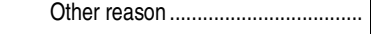 & 11 & $(2.0)$ & 13 & (2.7) & $8 !$ & (2.9) & \# & $(\dagger)$ & $9 !$ & (4.3) & 17 & (4.5) & $\ddagger$ & $(t)$ & $8 !$ & (3.6) & 13 & (3.7) & $11 !$ & (4.5) & $6 !$ & $(2.9)$ & $12 !$ & (4.8) \\
\hline
\end{tabular}

†Not applicable.

\#Rounds to zero.

haution. The coefficient of variation (CV) for this estimate is between 30 and 50 percent.

Either there are too few cases for a reliable estimate or the coefficient of variation (CV) for this timate is 50 percent or greater.
'Life safety features include sprinklers, fire alarms, and smoke detectors.

NOTE: Percentage of schools with major repair, renovation, or replacement plans is based on schools having the specified bulling system or fealure. Detail may not sum to tolals because of rounding.

(FRSS), "Condition of Public School Facilities: 2012-13," FRSS 105, 2013. (This table was prepared April 2014.) 
206 CHAPTER 2: Elementary and Secondary Education

School Facilities

Table 217.20. Percentage of public schools with enrollment under, at, or over capacity, by selected school characteristics: 1999 and 2005

[Standard errors appear in parentheses]

\begin{tabular}{|c|c|c|c|c|c|c|c|c|c|c|c|c|c|c|c|c|c|c|c|c|}
\hline \multirow[b]{2}{*}{ School enrollment versus design capacity } & \multirow{2}{*}{\multicolumn{2}{|c|}{$\begin{array}{r}\text { All public } \\
\text { schools }\end{array}$}} & \multicolumn{4}{|c|}{ Instructional level } & \multicolumn{6}{|c|}{ Size of school enrollment } & \multicolumn{8}{|c|}{ Percent of students eligible for free or reduced-price lunch } \\
\hline & & & \multicolumn{2}{|c|}{ Elementary } & \multicolumn{2}{|c|}{$\begin{array}{r}\text { Secondary/ } \\
\text { combined }\end{array}$} & \multicolumn{2}{|c|}{ Less than 350} & \multicolumn{2}{|c|}{350 to 699} & \multicolumn{2}{|c|}{700 or more } & \multicolumn{2}{|c|}{$\begin{array}{r}\text { Less than } 35 \\
\text { percent }\end{array}$} & \multicolumn{2}{|c|}{$\begin{array}{c}35 \text { to } 49 \\
\text { percent }\end{array}$} & \multicolumn{2}{|c|}{$\begin{array}{r}50 \text { to } 74 \\
\text { percent }\end{array}$} & \multicolumn{2}{|c|}{$\begin{array}{r}75 \text { percent or } \\
\text { more }\end{array}$} \\
\hline 1 & & 2 & & 3 & & 4 & & 5 & & 6 & & 7 & & 8 & & 9 & & 10 & & 11 \\
\hline 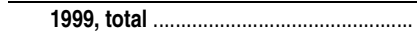 & 100 & $(\dagger)$ & 100 & $(\dagger)$ & 100 & $(t)$ & 100 & $(\dagger)$ & 100 & $(\dagger)$ & 100 & $(t)$ & 100 & $(\dagger)$ & 100 & $(\dagger)$ & 100 & $(\dagger)$ & 100 & $(t)$ \\
\hline Underenrolled by more than 25 percent ........... & 19 & $(1.5)$ & 17 & $(1.7)$ & 22 & $(2.5)$ & 39 & $(4.0)$ & 11 & $(2.0)$ & 8 & $(1.7)$ & 16 & $(2.0)$ & 18 & $(3.1)$ & 17 & $(4.1)$ & 27 & $(4.4)$ \\
\hline Underenrolled by 6 to 25 percent .. & 33 & $(1.7)$ & 31 & $(2.1)$ & 39 & $(2.9)$ & 32 & $(3.8)$ & 36 & $(2.4)$ & 31 & $(2.8)$ & 38 & $(2.6)$ & 32 & $(4.6)$ & 29 & $(4.6)$ & 25 & $(4.5)$ \\
\hline Enrollment within 5 percent of capacity . & 26 & $(1.5)$ & 28 & $(2.0)$ & 20 & $(2.2)$ & 16 & $(2.9)$ & 34 & $(2.6)$ & 25 & $(2.0)$ & 25 & $(2.2)$ & 26 & $(4.4)$ & 32 & $(4.5)$ & 23 & $(4.1)$ \\
\hline 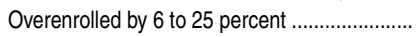 & 14 & $(1.2)$ & 15 & $(1.5)$ & 11 & $(1.8)$ & 10 & $(2.4)$ & 14 & $(2.0)$ & 20 & $(1.8)$ & 14 & $(2.1)$ & 18 & $(3.6)$ & 14 & (3.3) & 11 & $(3.0)$ \\
\hline Overenrolled by more than 25 percent. & 8 & $(0.9)$ & 8 & $(1.1)$ & 8 & $(1.6)$ & $3 !$ & $(1.3)$ & 6 & $(1.3)$ & 16 & $(2.4)$ & 6 & $(1.2)$ & 6 & $(1.8)$ & $7 !$ & $(2.4)$ & 14 & $(3.4)$ \\
\hline 2005, & 100 & $(\dagger)$ & 100 & $(\dagger)$ & 100 & $(\dagger)$ & 100 & $(t)$ & 100 & $(\dagger)$ & 100 & $(\dagger)$ & 100 & $(\dagger)$ & 100 & $(\dagger)$ & 100 & $(\dagger)$ & 100 & $(\dagger)$ \\
\hline Underenrolled by more than 25 percent ........... & 21 & $(1.4)$ & 20 & $(1.7)$ & 24 & $(2.6)$ & 41 & $(3.3)$ & 14 & $(1.7)$ & 6 & $(1.4)$ & 19 & $(2.6)$ & 25 & $(4.6)$ & 24 & $(2.7)$ & 19 & $(3.0)$ \\
\hline 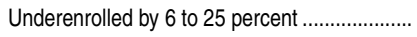 & 38 & $(1.8)$ & 39 & $(2.1)$ & 36 & $(2.6)$ & 39 & $(3.4)$ & 44 & $(2.9)$ & 29 & $(2.4)$ & 38 & $(2.7)$ & 43 & $(4.0)$ & 37 & $(2.8)$ & 36 & $(4.1)$ \\
\hline Enrollment within 5 percent of capacity ............. & 22 & $(1.5)$ & 23 & $(1.9)$ & 21 & $(1.9)$ & 14 & $(2.3)$ & 27 & $(2.5)$ & 26 & $(2.4)$ & 27 & $(2.5)$ & 19 & $(3.3)$ & 18 & $(3.1)$ & 22 & $(2.9)$ \\
\hline 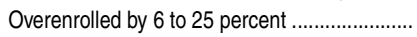 & 10 & $(1.0)$ & 10 & $(1.4)$ & 11 & $(1.2)$ & 4 & $(1.1)$ & 9 & $(1.9)$ & 20 & $(2.1)$ & 11 & $(1.8)$ & $6 !$ & $(2.0)$ & 12 & $(2.6)$ & 9 & $(1.6)$ \\
\hline Overenrolled by more than 25 percent ............. & 8 & $(1.0)$ & 8 & $(1.3)$ & 8 & $(1.0)$ & $2 !$ & $(0.9)$ & 6 & $(1.4)$ & 19 & $(2.5)$ & 5 & $(1.0)$ & $7 !$ & $(2.3)$ & 8 & $(2.2)$ & 14 & $(2.9)$ \\
\hline
\end{tabular}

†Not applicable.

!nterpret data with caution. The coefficient of variation (CV) for this estimate is between 30 and 50 percent.

${ }^{1}$ Excludes special education, vocational, and alternative schools; schools without enrollment data; and schools offering only preprimary education.
NOTE: Detail may not sum to totals because of rounding.

SOURCE: U.S. Department of Education, National Center for Education Statistics, Fast Response Survey System (FRSS), "Condition of America's Public School Facilities, 1999," FRSS 73, 1999, and "Public School Principals' Perceptions of Their School Facilities: Fall 2005," FRSS 88, 2005. (This table was prepared July 2007.) 
Table 218.10. Number and internet access of instructional computers and rooms in public schools, by selected school characteristics: Selected years, 1995 through 2008 [Standard errors appear in parentheses]

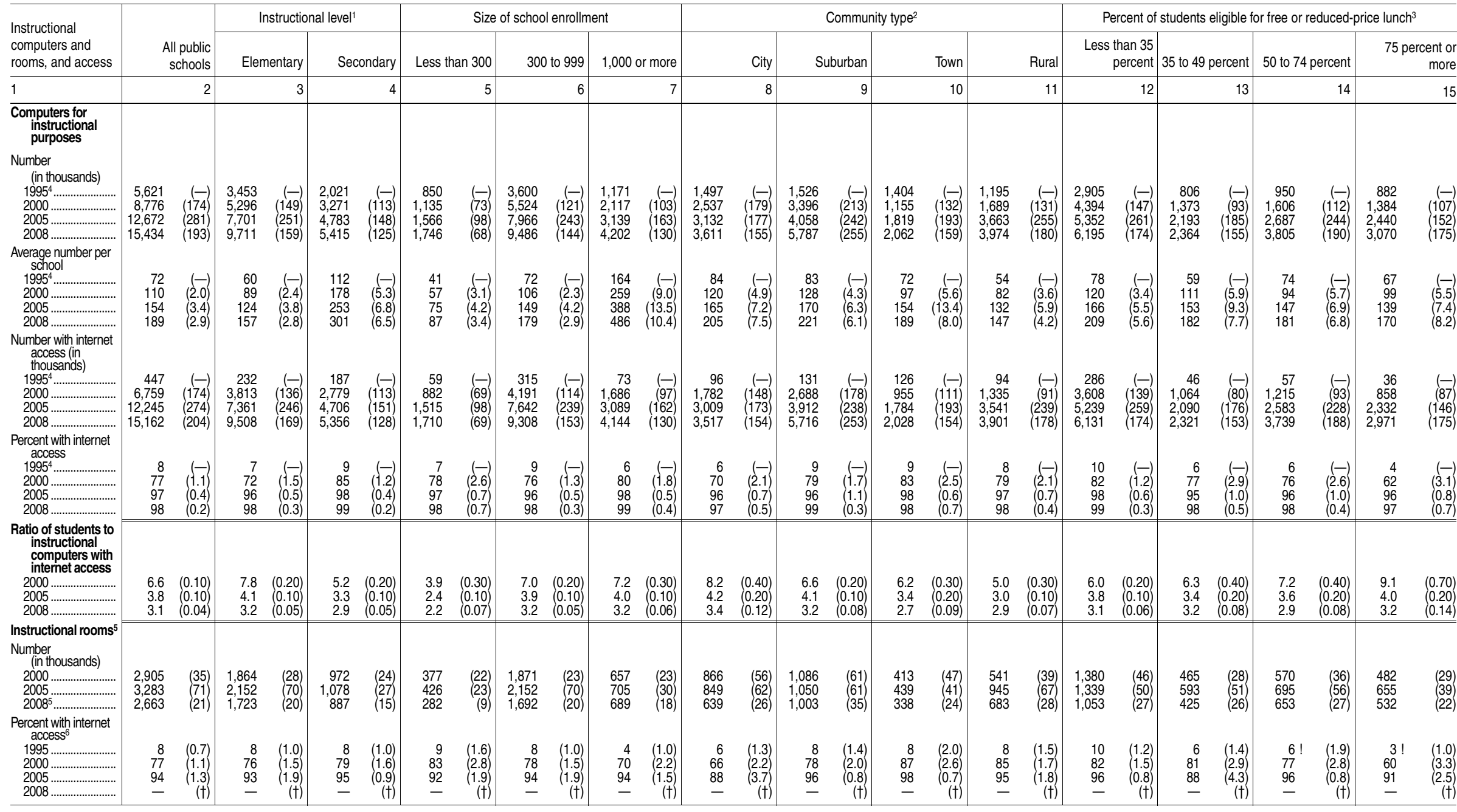

\section{-Not available}

!nterpret data with caution. The coefficient of variation (CV) for this estimate is between 30 and 50 percent. 'Data for combined schools are included in the totals and in analyses by other school characteristics, but are not shown separately. 2Due to definitional changes for community type, estimates for years prior to 2005 may not be directly comparable with estimates for later years.

${ }_{3}^{3}$ Free or reduced-price lunch information was obtained on the questionnaire and supplemented, if necessary, with data from the Common Core of Data (CCD).
5In 2008, instructional rooms included classrooms only and excluded computer labs and library/media centers. Prior to 2008

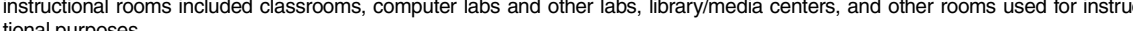
${ }^{6} \mathrm{Som}$ data differ

NOTE: Detail may not sum to totals because of rounding.

SOURCE: U.S. Department of Education, National Center for Education Statistics, Fast Response Survey System (FRSS), Internet Access in U.S. Public Schools and Classrooms: 1994-2005 and Educational Technology in U.S. Public Schools: Fall 2008; and unpublished tabulations. (This table was prepared August 2010.) 
208 CHAPTER 2: Elementary and Secondary Education

Computers and Technology

Table 218.20. Percentage of public school districts with students enrolled in technology-based distance education courses and number of enrollments in such courses, by instructional level and district characteristics: 2002-03, 2004-05, and 2009-10

[Standard errors appear in parentheses]

\begin{tabular}{|c|c|c|c|c|c|c|c|c|c|c|c|c|}
\hline \multirow[b]{2}{*}{ District characteristic } & \multirow{2}{*}{\multicolumn{2}{|c|}{$\begin{array}{r}\text { Percent of districts } \\
\text { enrolling distance } \\
\text { education students }\end{array}$}} & \multicolumn{10}{|c|}{ Number of enrollments in technology-based distance education courses, ${ }^{1}$ by instructional level } \\
\hline & & & All instruc & tional levels & & $\begin{array}{r}\text { Elementary } \\
\text { schools }\end{array}$ & & $\begin{array}{l}\text { or junior } \\
\text { ischools }\end{array}$ & & High schools & ungrac & $\begin{array}{l}\text { mbined or } \\
\text { d schools }\end{array}$ \\
\hline 1 & & 2 & & 3 & & 4 & & 5 & & 6 & & 7 \\
\hline 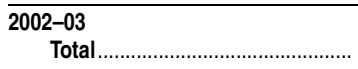 & 36 & $(1.2)$ & 317,070 & $(27,437)$ & $2,780 !$ & $(977)$ & 6,390 & $(1,067)$ & 214,140 & $(16,549)$ & 93,760 & $(22,593)$ \\
\hline 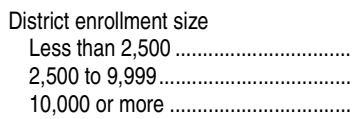 & $\begin{array}{l}37 \\
32 \\
50\end{array}$ & $\begin{array}{l}(1.5) \\
(1.8) \\
(2.1)\end{array}$ & $\begin{array}{r}116,300 \\
82,370 \\
118,390\end{array}$ & $\begin{array}{r}(21,698) \\
(6,384) \\
(15,703)\end{array}$ & $\begin{array}{r}\ddagger \\
230 ! \\
2,480 !\end{array}$ & $\begin{array}{r}(\dagger) \\
(109) \\
(968)\end{array}$ & $\begin{array}{l}1,250 ! \\
1,870 ! \\
3,270\end{array}$ & $\begin{array}{l}(450) \\
(642) \\
(723)\end{array}$ & $\begin{array}{l}72,730 \\
44,170 \\
97,240\end{array}$ & $\begin{array}{r}(6,924) \\
(5,832) \\
(13,853)\end{array}$ & $\begin{array}{r}42,240 ! \\
36,110 \\
\ddagger\end{array}$ & $\begin{array}{r}(20,502) \\
(1,210) \\
(\dagger)\end{array}$ \\
\hline 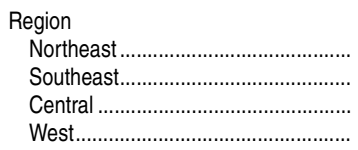 & $\begin{array}{l}21 \\
45 \\
46 \\
32\end{array}$ & $\begin{array}{l}(2.2) \\
(2.6) \\
(2.3) \\
(2.2)\end{array}$ & $\begin{array}{r}41,950 ! \\
59,240 \\
106,690 \\
109,190\end{array}$ & $\begin{array}{r}(20,821) \\
(6,251) \\
(7,726) \\
(16,010)\end{array}$ & $\begin{array}{c}100 ! \\
\ddagger \\
940 ! \\
350 !\end{array}$ & $\begin{array}{r}(49) \\
(\dagger) \\
(441) \\
(165)\end{array}$ & $\begin{array}{c}\ddagger \\
2,530 \\
1,050 ! \\
2,620\end{array}$ & $\begin{array}{r}(\dagger) \\
(632) \\
(412) \\
(782)\end{array}$ & $\begin{array}{l}17,300 \\
50,640 \\
59,110 \\
87,090\end{array}$ & $\begin{array}{r}(3,656) \\
(5,698) \\
(6,455) \\
(14,825)\end{array}$ & $\begin{array}{r}\ddagger \\
4,680 \\
45,590 \\
19,130 !\end{array}$ & $\begin{array}{r}(\dagger) \\
(1,254) \\
(2,529) \\
(8,619)\end{array}$ \\
\hline 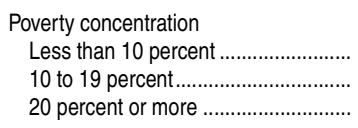 & $\begin{array}{l}33 \\
42 \\
42 \\
\end{array}$ & $\begin{array}{l}(2.1) \\
(2.1) \\
(2.5)\end{array}$ & $\begin{array}{l}75,740 \\
95,510 \\
86,110 \\
\end{array}$ & $\begin{array}{r}(11,177) \\
(7,962) \\
(13,518) \\
\end{array}$ & $\begin{array}{c}\ddagger \\
\ddagger \\
760 !\end{array}$ & $\begin{array}{r}(\dagger) \\
(\dagger) \\
(249)\end{array}$ & $\begin{array}{l}2,020 \\
1,830 \\
2,540 !\end{array}$ & $\begin{array}{l}(564) \\
(392) \\
(837)\end{array}$ & $\begin{array}{l}55,670 \\
78,680 \\
75,930 \\
\end{array}$ & $\begin{array}{r}(7,556) \\
(7,050) \\
(13,532) \\
\end{array}$ & $\begin{array}{r}17,470 ! \\
13,560 \\
6,880 \\
\end{array}$ & $\begin{array}{l}(8,591) \\
(2,446) \\
(1,557) \\
\end{array}$ \\
\hline 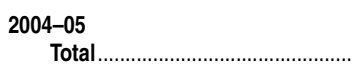 & 37 & $(1.2)$ & 506,950 & $(56,959)$ & $12,540 !$ & $(6,107)$ & 15,150 & $(3,367)$ & 309,630 & $(24,350)$ & $169,630 !$ & $(51,753)$ \\
\hline 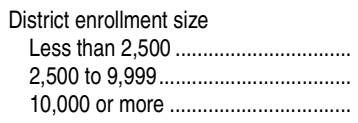 & $\begin{array}{l}37 \\
35 \\
50\end{array}$ & $\begin{array}{l}(1.6) \\
(1.6) \\
(2.5)\end{array}$ & $\begin{array}{l}210,200 \\
102,730 \\
193,440\end{array}$ & $\begin{array}{l}(54,063) \\
(13,404) \\
(16,415)\end{array}$ & $\begin{array}{c}610 ! \\
\ddagger \\
5,280 !\end{array}$ & $\begin{array}{r}(275) \\
(\dagger) \\
(2,202)\end{array}$ & $\begin{array}{r}\ddagger \\
2,570 \\
6,520\end{array}$ & $\begin{array}{r}(\dagger) \\
(731) \\
(1,101)\end{array}$ & $\begin{array}{r}103,190 \\
48,420 \\
157,440\end{array}$ & $\begin{array}{r}(17,659) \\
(5,136) \\
(16,044)\end{array}$ & $\begin{array}{r}\ddagger \\
45,080 \\
24,210\end{array}$ & $\begin{array}{r}(\dagger) \\
(9,429) \\
(5,298)\end{array}$ \\
\hline 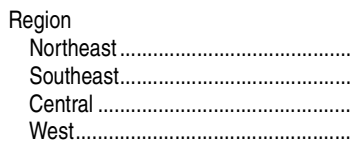 & $\begin{array}{l}22 \\
46 \\
45 \\
35\end{array}$ & $\begin{array}{l}(2.0) \\
(3.2) \\
(2.4) \\
(2.1)\end{array}$ & $\begin{array}{l}108,300 ! \\
112,830 \\
128,650 \\
157,180\end{array}$ & $\begin{array}{r}(49,777) \\
(6,341) \\
(22,055) \\
(22,608)\end{array}$ & $\begin{array}{c}570 ! \\
\ddagger \\
\ddagger \\
200 !\end{array}$ & $\begin{array}{r}(206) \\
(\dagger) \\
(\dagger) \\
(161)\end{array}$ & $\begin{array}{r}\ddagger \\
5,030 \\
2,130 ! \\
4,110 !\end{array}$ & $\begin{array}{r}(\dagger) \\
(732) \\
(953) \\
(1,732)\end{array}$ & $\begin{array}{r}16,860 \\
89,800 \\
70,450 \\
132,520\end{array}$ & $\begin{array}{r}(2,621) \\
(5,276) \\
(13,024) \\
(21,287)\end{array}$ & $\begin{array}{r}\ddagger \\
16,090 \\
46,190 ! \\
20,350 !\end{array}$ & $\begin{array}{r}(\dagger) \\
(1,913) \\
(15,067) \\
(7,587)\end{array}$ \\
\hline 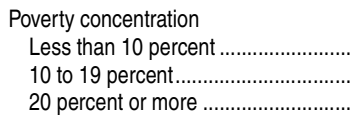 & $\begin{array}{l}35 \\
42 \\
43 \\
\end{array}$ & $\begin{array}{l}(1.9) \\
(2.2) \\
(2.7)\end{array}$ & $\begin{array}{l}112,320 \\
151,050 \\
106,610\end{array}$ & $\begin{array}{l}(16,778) \\
(12,379) \\
(14,709)\end{array}$ & $\begin{array}{l}\ddagger \\
\ddagger \\
\ddagger\end{array}$ & $\begin{array}{l}(\dagger) \\
(\dagger) \\
(t) \\
\end{array}$ & $\begin{array}{l}4,070 \\
4,800 \\
6,280 ! \\
\end{array}$ & $\begin{array}{r}(1,123) \\
(602) \\
(3,111) \\
\end{array}$ & $\begin{array}{r}80,150 \\
124,540 \\
78,590 \\
\end{array}$ & $\begin{array}{l}(10,651) \\
(10,283) \\
(13,367)\end{array}$ & $\begin{array}{r}\ddagger \\
19,700 \\
21,340\end{array}$ & $\begin{array}{r}(\dagger) \\
(5,835) \\
(2,905)\end{array}$ \\
\hline 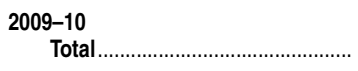 & 55 & $(1.4)$ & $1,816,390$ & $(251,054)$ & $78,040 !$ & $(25,180)$ & 154,970 & $(30,828)$ & $1,348,920$ & $(135,979)$ & $\ddagger$ & $(t)$ \\
\hline 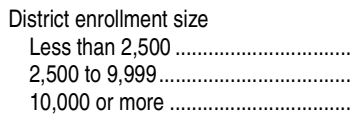 & $\begin{array}{l}51 \\
66 \\
74\end{array}$ & $\begin{array}{l}(1.8) \\
(1.5) \\
(0.8)\end{array}$ & $\begin{array}{l}509,030 ! \\
579,250 ! \\
728,110\end{array}$ & $\begin{array}{r}(167,570) \\
(185,243) \\
(27,105)\end{array}$ & $\begin{array}{r}\ddagger \\
\ddagger \\
11,540\end{array}$ & $\begin{array}{r}(\dagger) \\
(\dagger) \\
(1,862)\end{array}$ & $\begin{array}{r}\ddagger \\
23,960 ! \\
77,750\end{array}$ & $\begin{array}{r}(\dagger) \\
(9,196) \\
(4,730)\end{array}$ & $\begin{array}{l}408,030 ! \\
312,130 \\
628,760\end{array}$ & $\begin{array}{r}(123,883) \\
(50,963) \\
(23,545)\end{array}$ & $\begin{array}{r}6,570 ! \\
\ddagger \\
10,060\end{array}$ & $\begin{array}{r}2,753 \\
(\dagger) \\
2,756\end{array}$ \\
\hline 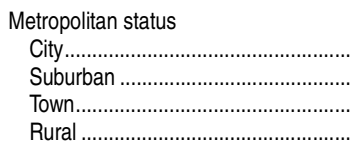 & $\begin{array}{l}37 \\
47 \\
67 \\
59\end{array}$ & $\begin{array}{l}(4.0) \\
(2.6) \\
(2.7) \\
(2.5)\end{array}$ & $\begin{array}{l}653,660 ! \\
527,250 \\
306,840 ! \\
328,640\end{array}$ & $\begin{array}{r}(201,665) \\
(34,188) \\
(145,000) \\
(36,233)\end{array}$ & $\begin{array}{c}\ddagger \\
22,900 ! \\
\ddagger \\
\ddagger\end{array}$ & $\begin{array}{r}(\dagger) \\
(11,293) \\
(\dagger) \\
(\dagger)\end{array}$ & $\begin{array}{r}40,400 ! \\
62,210 \\
\ddagger \\
15,360\end{array}$ & $\begin{array}{r}(15,671) \\
(4,106) \\
(\dagger) \\
(2,420)\end{array}$ & $\begin{array}{l}405,740 \\
434,260 \\
246,850 ! \\
262,070\end{array}$ & $\begin{array}{r}(79,507) \\
(30,904) \\
(107,079) \\
(27,077)\end{array}$ & $\begin{array}{c}\ddagger \\
7,880 \\
9,310 ! \\
\ddagger\end{array}$ & $\begin{array}{r}(\dagger) \\
2,347 \\
3,908 \\
(\dagger)\end{array}$ \\
\hline 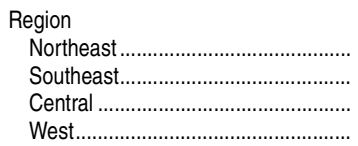 & $\begin{array}{l}39 \\
78 \\
62 \\
51\end{array}$ & $\begin{array}{l}(3.3) \\
(3.7) \\
(2.2) \\
(2.4)\end{array}$ & $\begin{array}{c}77,670 \\
518,770 \\
697,140 ! \\
522,810\end{array}$ & $\begin{array}{r}(7,358) \\
(63,187) \\
(235,103) \\
(42,673)\end{array}$ & $\begin{array}{c}\ddagger \\
12,070 ! \\
37,920 ! \\
\ddagger\end{array}$ & $\begin{array}{r}(\dagger) \\
(4,154) \\
(18,915) \\
(\dagger)\end{array}$ & $\begin{array}{r}4,970 \\
57,500 \\
\ddagger \\
41,620\end{array}$ & $\begin{array}{r}(989) \\
(9,828) \\
(\dagger) \\
(3,384)\end{array}$ & $\begin{array}{r}71,330 \\
443,770 \\
416,550 \\
417,270\end{array}$ & $\begin{array}{r}(6,651) \\
(50,079) \\
(122,633) \\
(33,400)\end{array}$ & $\begin{array}{c}\ddagger \\
5,440 ! \\
\ddagger \\
36,510 !\end{array}$ & $\begin{array}{r}(\dagger) \\
1,678 \\
(\dagger) \\
14,278\end{array}$ \\
\hline 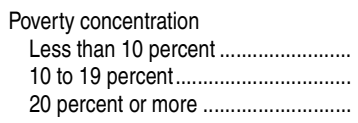 & $\begin{array}{l}54 \\
56 \\
56\end{array}$ & $\begin{array}{l}(2.5) \\
(2.1) \\
(2.4)\end{array}$ & $\begin{array}{r}287,680 \\
1,009,290 \\
519,420\end{array}$ & $\begin{array}{r}(34,577) \\
(193,646) \\
(146,507)\end{array}$ & $\begin{array}{c}\ddagger \\
23,540 ! \\
\ddagger\end{array}$ & $\begin{array}{r}(\dagger) \\
(11,116) \\
(\dagger)\end{array}$ & $\begin{array}{r}12,620 \\
97,220 \\
\ddagger\end{array}$ & $\begin{array}{r}(2,997) \\
(16,126) \\
(\dagger)\end{array}$ & $\begin{array}{l}231,890 \\
682,380 \\
434,640\end{array}$ & $\begin{array}{r}(27,672) \\
(78,795) \\
(108,046)\end{array}$ & $\begin{array}{c}\ddagger \\
\ddagger \\
5,750 !\end{array}$ & $\begin{array}{r}(\dagger) \\
(\dagger) \\
2,484\end{array}$ \\
\hline
\end{tabular}

†Not applicable.

!Interpret data with caution. The coefficient of variation (CV) for this estimate is between 30 and 50 percent.

‡Reporting standards not met. Either there are too few cases for a reliable estimate or the coefficient of variation (CV) is 50 percent or greater.

${ }^{1}$ Based on students regularly enrolled in the districts. Enrollments may include duplicated counts of students, since districts were instructed to count a student enrolled in multiple courses for each course in which he or she was enrolled.

${ }^{2}$ Combined or ungraded schools are those in which the grades offered in the school span both elementary and secondary grades or that are not divided into grade levels.
NOTE: Percentages are based on unrounded numbers. For the 2002-03 FRSS study sample, there were 3 cases for which district enrollment size was missing and 112 cases for which poverty concentration was missing. For the 2004-05 FRSS study sample, there were 7 cases for which district enrollment size was missing and 103 cases for which poverty concentration was missing. Detail may not sum to totals because of rounding or missing data.

SOURCE: U.S. Department of Education, National Center for Education Statistics, Fast Response Survey System (FRSS), Technology-Based Distance Education Courses for Public Elementary and Secondary Schools: 2002-03 and 2004-05 and "Distance Education Courses for Public Elementary and Secondary School Students: 2009-10," FRSS 98. (This table was prepared November 2011.) 
Table 219.10. High school graduates, by sex and control of school: Selected years, 1869-70 through 2023-24

\begin{tabular}{|c|c|c|c|c|c|c|c|c|c|c|}
\hline \multirow[b]{4}{*}{ School year } & \multicolumn{7}{|c|}{ High school graduates } & \multirow{4}{*}{$\begin{array}{r}\text { Averaged } \\
\text { freshman } \\
\text { graduation } \\
\text { rate for } \\
\text { public } \\
\text { schools }^{3}\end{array}$} & \multirow{4}{*}{$\begin{array}{l}\text { Population } \\
17 \text { years old }\end{array}$} & \multirow{4}{*}{$\begin{array}{r}\text { Graduates as } \\
\text { a ratio of } 17- \\
\text { year-old } \\
\text { population }\end{array}$} \\
\hline & \multirow[b]{3}{*}{ Total $^{1}$} & \multicolumn{2}{|c|}{ Sex } & \multicolumn{4}{|c|}{ Control } & & & \\
\hline & & & & \multicolumn{3}{|c|}{ Public $^{2}$} & \multirow{2}{*}{\begin{tabular}{|r|} 
Private \\
Total
\end{tabular}} & & & \\
\hline & & Males & Females & Total & Males & Females & & & & \\
\hline 1 & 2 & 3 & 4 & 5 & 6 & 7 & 8 & 9 & 10 & 11 \\
\hline 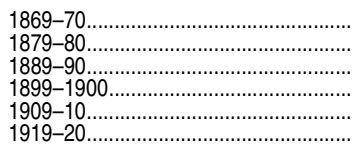 & $\begin{array}{r}16,000 \\
23,634 \\
43,731 \\
94,883 \\
156,429 \\
311,266\end{array}$ & $\begin{array}{r}7,064 \\
10,605 \\
18,549 \\
38,075 \\
63,676 \\
123,684\end{array}$ & $\begin{array}{r}8,936 \\
13,029 \\
25,182 \\
56,808 \\
92,753 \\
187,582\end{array}$ & $\begin{array}{r}- \\
21,882 \\
61,737 \\
111,363 \\
230,902\end{array}$ & $\begin{array}{l}- \\
- \\
- \\
-\end{array}$ & $\begin{array}{l}- \\
\overline{-} \\
\overline{-} \\
-\end{array}$ & 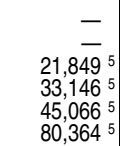 & $\begin{array}{l}- \\
- \\
- \\
- \\
-\end{array}$ & $\begin{array}{r}815,000 \\
946,026 \\
1,259,177 \\
1,489,146 \\
1,786,240 \\
1,855,173\end{array}$ & $\begin{array}{r}2.0 \\
2.5 \\
3.5 \\
6.4 \\
8.8 \\
16.8\end{array}$ \\
\hline $\begin{array}{l}1929-30 \\
1939-40 \\
1949-50 \\
1959-60 \\
1969-70\end{array}$ & $\begin{array}{r}666,904 \\
1,221,475 \\
1,199,700 \\
1,858,023 \\
2,888,639\end{array}$ & $\begin{array}{r}300,376 \\
578,718 \\
570,700 \\
895,000 \\
1,430,000\end{array}$ & $\begin{array}{r}366,528 \\
642,757 \\
629,000 \\
963,000 \\
1,459,000\end{array}$ & $\begin{array}{r}591,719 \\
1,143,246 \\
1,063,444 \\
1,627,050 \\
2,588,639\end{array}$ & $\begin{array}{r}-\overline{5} \\
505,273 \\
791,424 \\
1,285,895\end{array}$ & $\begin{array}{r}604,973 \\
558,050 \\
835,624 \\
1,302,744\end{array}$ & $\begin{array}{c}75,185^{5} \\
78,2295 \\
136,256^{5} \\
230,973 \\
300,000^{5}\end{array}$ & $\begin{array}{c}- \\
\overline{-} \\
78.7\end{array}$ & $\begin{array}{l}2,295,822 \\
2,403,074 \\
2,034,450 \\
2,672,000 \\
3,757,000\end{array}$ & $\begin{array}{l}29.0 \\
50.8 \\
59.0 \\
69.5 \\
76.9\end{array}$ \\
\hline $\begin{array}{l}1974-75 \\
1975-76 \\
1976-77 \\
1977-78 \\
1978-79\end{array}$ & $\begin{array}{l}3,132,502 \\
3,142,120 \\
3,139,536 \\
3,128,824 \\
3,101,152\end{array}$ & $\begin{array}{l}1,542,000 \\
1,552,000 \\
1,551,000 \\
1,546,000 \\
1,532,000\end{array}$ & $\begin{array}{l}1,591,000 \\
1,590,000 \\
1,589,000 \\
1,583,000 \\
1,569,000\end{array}$ & $\begin{array}{l}2,822,502 \\
2,837,129 \\
2,837,340 \\
2,824,636 \\
2,801,152\end{array}$ & $\begin{array}{r}1,391,519 \\
1,401,064 \\
- \\
-\end{array}$ & $\begin{array}{r}1,430,983 \\
1,436,065 \\
- \\
-\end{array}$ & $\begin{array}{l}310,0005 \\
304,991 \\
302,196 \\
304,188 \\
300,000^{5}\end{array}$ & $\begin{array}{l}74.9 \\
74.9 \\
74.4 \\
73.2 \\
71.9\end{array}$ & $\begin{array}{l}4,256,000 \\
4,272,000 \\
4,272,000 \\
4,286,000 \\
4,327,000\end{array}$ & $\begin{array}{l}73.6 \\
73.6 \\
73.5 \\
73.0 \\
71.7\end{array}$ \\
\hline $\begin{array}{l}1979-80 \\
1980-81 \\
1981-82 \\
1982-83 \\
1983-84 \ldots \ldots \ldots \ldots \ldots \ldots \ldots \ldots \ldots \ldots\end{array}$ & $\begin{array}{l}3,042,214 \\
3,020,285 \\
2,994,758 \\
2,887,604 \\
2,766,797\end{array}$ & $\begin{array}{r}1,503,000 \\
1,492,000 \\
1,479,000 \\
1,426,000 \\
-\end{array}$ & $\begin{array}{r}1,539,000 \\
1,528,000 \\
1,515,000 \\
1,461,000 \\
-\end{array}$ & $\begin{array}{l}2,747,678 \\
2,725,285 \\
2,704,758 \\
2,597,604 \\
2,494,797\end{array}$ & $\begin{array}{l}- \\
- \\
-\end{array}$ & $\begin{array}{l}- \\
\overline{-} \\
-\end{array}$ & $\begin{array}{l}294,536 \\
295,0005 \\
290,0005 \\
290,0005 \\
272,0005\end{array}$ & $\begin{array}{l}71.5 \\
72.2 \\
72.9 \\
73.8 \\
74.5\end{array}$ & $\begin{array}{l}4,262,000 \\
4,212,000 \\
4,134,000 \\
3,962,000 \\
3,784,000\end{array}$ & $\begin{array}{l}71.4 \\
71.7 \\
72.4 \\
72.9 \\
73.1\end{array}$ \\
\hline $\begin{array}{l}1984-85 \\
1985-86 \\
1986-87 \\
1987-88\end{array}$ & $\begin{array}{l}2,676,917 \\
2,642,616 \\
2,693,803 \\
2,773,020 \\
2,743,743\end{array}$ & $\begin{array}{l}- \\
\overline{-} \\
\overline{-} \\
-\end{array}$ & $\begin{array}{l}- \\
- \\
- \\
-\end{array}$ & $\begin{array}{l}2,413,917 \\
2,382,616 \\
2,428,803 \\
2,500,020 \\
2,458,800\end{array}$ & $\begin{array}{l}- \\
\bar{z} \\
-\end{array}$ & $\begin{array}{l}- \\
\bar{z} \\
-\end{array}$ & $\begin{array}{l}263,0005 \\
260,0005 \\
265,0005 \\
273,0005 \\
284,943\end{array}$ & $\begin{array}{l}74.2 \\
74.3 \\
74.3 \\
74.2 \\
73.4\end{array}$ & $\begin{array}{l}3,699,000 \\
3,670,000 \\
3,754,000 \\
3,849,000 \\
3,842,000\end{array}$ & $\begin{array}{l}72.4 \\
72.0 \\
71.8 \\
72.0 \\
71.4\end{array}$ \\
\hline $\begin{array}{l}1989-90^{6} \\
1990-91 \\
1991-92 \\
1992-93 \\
1993-94 \ldots \ldots \ldots \ldots\end{array}$ & $\begin{array}{l}2,574,162 \\
2,492,988 \\
2,480,399 \\
2,480,519 \\
2,463,849\end{array}$ & $\begin{array}{l}- \\
\overline{-} \\
\overline{-}\end{array}$ & $\begin{array}{l}- \\
- \\
- \\
-\end{array}$ & $\begin{array}{l}2,320,337 \\
2,234,893 \\
2,226,016 \\
2,233,241 \\
2,220,849\end{array}$ & $\begin{array}{l}- \\
\bar{z} \\
-\end{array}$ & $\begin{array}{l}z \\
\bar{z} \\
-\end{array}$ & $\begin{array}{l}253,825^{7} \\
258,095 \\
254,383^{7} \\
247,278 \\
243,000^{5}\end{array}$ & $\begin{array}{l}73.6 \\
73.7 \\
74.2 \\
73.8 \\
73.1\end{array}$ & $\begin{array}{l}3,505,000 \\
3,417,913 \\
3,398,884 \\
3,449,143 \\
3,442,521\end{array}$ & $\begin{array}{l}73.4 \\
72.9 \\
73.0 \\
71.9 \\
71.6\end{array}$ \\
\hline $\begin{array}{l}1994-95 \\
1995-96 \\
1996-97 \\
1997-98\end{array}$ & $\begin{array}{l}2,519,084 \\
2,518,109 \\
2,611,988 \\
2,704,050 \\
2,758,655\end{array}$ & $\begin{array}{l}- \\
- \\
- \\
-\end{array}$ & $\begin{array}{l}- \\
- \\
- \\
-\end{array}$ & $\begin{array}{l}2,273,541 \\
2,273,109 \\
2,358,403 \\
2,439,050 \\
2,485,630\end{array}$ & $\begin{array}{r}- \\
- \\
1,187,647 \\
1,212,924\end{array}$ & $\begin{array}{r}- \\
\overline{-} \\
1,251,403 \\
1,272,706\end{array}$ & $\begin{array}{l}245,543 \\
245,000^{5} \\
253,585 \\
265,000^{5} \\
273,025\end{array}$ & $\begin{array}{l}71.8 \\
71.0 \\
71.3 \\
71.3 \\
71.1\end{array}$ & $\begin{array}{l}3,635,803 \\
3,640,132 \\
3,792,207 \\
4,008,416 \\
3,917,885\end{array}$ & $\begin{array}{l}69.3 \\
69.2 \\
68.9 \\
67.5 \\
70.4\end{array}$ \\
\hline $\begin{array}{l}1999-2000 \\
2000-01 \\
2001-02 \\
2002-03 \\
2003-046,8\end{array}$ & $\begin{array}{l}2,832,844 \\
2,847,973 \\
2,906,534 \\
3,015,735 \\
3,054,438\end{array}$ & $\begin{array}{l}- \\
- \\
- \\
-\end{array}$ & $\begin{array}{l}- \\
- \\
- \\
-\end{array}$ & $\begin{array}{l}2,553,844 \\
2,569,200 \\
2,621,534 \\
2,719,947 \\
2,753,438\end{array}$ & $\begin{array}{l}1,241,631 \\
1,251,931 \\
1,275,813 \\
1,330,973 \\
1,347,800\end{array}$ & $\begin{array}{l}1,312,213 \\
1,317,269 \\
1,345,721 \\
1,388,974 \\
1,405,638\end{array}$ & $\begin{array}{l}279,000^{5} \\
278,773 \\
285,000^{5} \\
295,788 \\
301,000^{5}\end{array}$ & $\begin{array}{l}71.7 \\
71.7 \\
72.6 \\
73.9 \\
74.3\end{array}$ & $\begin{array}{l}4,056,639 \\
4,023,686 \\
4,023,968 \\
4,125,087 \\
4,113,074\end{array}$ & $\begin{array}{l}69.8 \\
70.8 \\
72.2 \\
73.1 \\
74.3\end{array}$ \\
\hline $\begin{array}{l}2004-05 \\
2005-06^{6} \\
2006-07 \ldots \ldots \ldots \ldots \ldots \ldots \ldots \ldots \ldots \\
2008-09^{6}\end{array}$ & $\begin{array}{l}3,106,499 \\
3,122,544 \\
3,199,650 \\
3,312,337 \\
3,347,828\end{array}$ & $\begin{array}{l}\bar{z} \\
\bar{z} \\
\overline{-}\end{array}$ & $\begin{array}{l}- \\
- \\
- \\
-\end{array}$ & $\begin{array}{l}2,799,250 \\
2,815,544 \\
2,893,045 \\
3,001,337 \\
3,039,015\end{array}$ & $\begin{array}{l}1,369,749 \\
1,376,458 \\
1,414,069 \\
1,467,180 \\
1,490,317\end{array}$ & $\begin{array}{l}1,429,501 \\
1,439,086 \\
1,478,976 \\
1,534,157 \\
1,548,698\end{array}$ & $\begin{array}{l}307,249 \\
307,0005 \\
306,605 \\
311,0005 \\
308,813\end{array}$ & $\begin{array}{l}74.7 \\
73.4 \\
73.9 \\
74.7 \\
75.5\end{array}$ & $\begin{array}{l}4,120,073 \\
4,200,554 \\
4,297,239 \\
4,436,955 \\
4,336,950\end{array}$ & $\begin{array}{l}75.4 \\
74.3 \\
74.5 \\
74.7 \\
77.2\end{array}$ \\
\hline $\begin{array}{l}2009-10 \\
2010-11 \\
2011-12 \ldots \ldots \ldots \ldots \ldots \\
2012-13^{10} \\
2013-14^{10}\end{array}$ & $\begin{array}{l}3,440,185 \\
3,449,719 \\
3,452,470 \\
3,408,600 \\
3,365,560\end{array}$ & $\begin{array}{l}\bar{z} \\
\overline{-} \\
\overline{-}\end{array}$ & $\begin{array}{l}- \\
- \\
- \\
-\end{array}$ & $\begin{array}{l}3,128,022 \\
3,143,879 \\
3,147,790 \\
3,110,150 \\
3,070,440\end{array}$ & $\begin{array}{r}1,542,684^{9} \\
- \\
- \\
-\end{array}$ & $\begin{array}{r}1,585,338^{9} \\
= \\
- \\
-\end{array}$ & $\begin{array}{l}312,163^{5} \\
305,840 \\
304,680^{5} \\
298,450 \\
295,120\end{array}$ & $\begin{array}{r}78.2 \\
79.6 \\
80.8 \\
- \\
-\end{array}$ & $\begin{array}{r}4,311,831 \\
4,366,292 \\
4,291,741 \\
- \\
-\end{array}$ & $\begin{array}{r}79.8 \\
79.0 \\
80.4 \\
-\end{array}$ \\
\hline 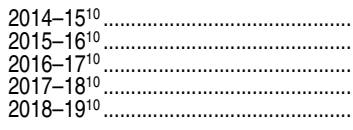 & $\begin{array}{l}3,322,780 \\
3,322,620 \\
3,328,710 \\
3,366,070 \\
3,348,610\end{array}$ & $\begin{array}{l}\bar{z} \\
\overline{-} \\
\overline{-}\end{array}$ & $\begin{array}{l}- \\
\overline{-} \\
-\end{array}$ & $\begin{array}{l}3,031,450 \\
3,047,830 \\
3,066,350 \\
3,105,970 \\
3,100,900\end{array}$ & $\begin{array}{l}- \\
- \\
-\end{array}$ & $\begin{array}{l}- \\
z \\
-\end{array}$ & $\begin{array}{l}291,320 \\
274,800 \\
262,370 \\
260,100 \\
247,710\end{array}$ & $\begin{array}{l}- \\
- \\
- \\
-\end{array}$ & $\begin{array}{l}- \\
- \\
- \\
-\end{array}$ & $\begin{array}{l}- \\
\overline{-} \\
\overline{-}\end{array}$ \\
\hline $\begin{array}{l}2019-20^{10} \\
2020-21^{10} \\
2021-22^{10} \\
2022-23^{10} \\
2023-24^{10}\end{array}$ & $\begin{array}{l}3,326,590 \\
3,352,680 \\
3,360,180 \\
3,369,380 \\
3,388,680\end{array}$ & $\begin{array}{l}\overline{-} \\
\overline{-} \\
\overline{-}\end{array}$ & $\begin{array}{l}- \\
- \\
- \\
-\end{array}$ & $\begin{array}{l}3,085,600 \\
3,115,140 \\
3,130,360 \\
3,146,530 \\
3,164,540\end{array}$ & $\begin{array}{l}- \\
- \\
-\end{array}$ & $\begin{array}{l}- \\
z \\
z\end{array}$ & $\begin{array}{l}240,980 \\
237,540 \\
229,820 \\
222,850 \\
224,140\end{array}$ & $\begin{array}{l}- \\
z \\
-\end{array}$ & $\begin{array}{l}- \\
- \\
- \\
-\end{array}$ & $\begin{array}{l}\text { - } \\
\text { - } \\
-\end{array}$ \\
\hline
\end{tabular}

\section{-Not available.}

2Data for 1929-30 and public and private schools. graduates from high schools that failed to report to the Office of Education. Includes estimates for jurisdictions not reporting counts of graduates by sex.

${ }^{3}$ The averaged freshman graduation rate provides an estimate of the percentage of students who receive a regular diploma within 4 years of entering ninth grade. The rate uses aggregate studen enrollment data to estimate the size of an incoming freshman class and aggregate counts of the number of diplomas awarded 4 years later. Averaged freshman graduation rates in this table are based on reported totals of enrollment by grade and high school graduates, rather than on details reported by race/ethnicity.

${ }^{4}$ Derived from Current Population Reports, Series P-25. For years 1869-70 through 1989-90, 17 year-old population is an estimate of the October 17-year-old population based on July data. Data for 1990-91 and later years are October resident population estimates prepared by the Census Bureau. ${ }^{5}$ Estimated.

${ }^{6}$ Includes imputations for nonreporting states.

${ }^{7}$ Projected by private schools responding to the Private School Universe Survey.

${ }^{8}$ Includes estimates for public schools in New York and Wisconsin. Without estimates for these two states, the averaged freshman graduation rate for the remaining 48 states and the District of Columbia is 75.0 percent.
Includes estimate for Connecticut, which did not report graduates by sex. ${ }^{10}$ Projected by NCES.

NOTE: Includes graduates of regular day school programs. Excludes graduates of other programs, when separately reported, and recipients of high school equivalency certificates. Some data have been revised from previously published figures. Detail may not sum to totals because of rounding. SOURCE: U.S. Department of Education, National Center for Education Statistics, Annual Report of the Commissioner of Education, 1870 through 1910; Biennial Survey of Education in the United States, 1919-20 through 1949-50; Statistics of State School Systems, 1951-52 through 1957-58; Statistics of Public Elementary and Secondary School Systems, 1958-59 through 1980-81; Statistics of Nonpublic Elementary and Secondary Schools, 1959 through 1980; Common Core of Data (CCD), "State Nonfiscal Survey of Public Elementary/Secondary Education," 1981-82 through 2009-10; "State Dropout and Completion Data File," 2005-06 through 2011-12; Public School Graduates and Dropouts From the Common Core of Data, 2007-08 and 2008-09; Private School Universe Survey (PSS), 1989 through 2011; and National High School Graduates Projection Model, 1972-73 through 2023-24. U.S. Department of Commerce, Census Bureau, Population Estimates, retrieved August 11, 2011, from http://www.census.gov/popest/ national/asrh/2009-nat-res.html and Population Estimates, retrieved April 8, 2014, from http:// www.census.gov/popest/data/national/asrh/2012/2012-nat-res.html. (This table was prepared April 2014.) 
Actual data

Projected data

Region, state, and \begin{tabular}{|r|r|r|r|r|r|r|r|r|r|r|r|r|r|r|r|r|r|r|r|r|r|r|r|r|r|r|r|r|}
$1980-81$ & $1989-90$ & $1999-2000$ & $2004-05$ & $2005-06$ & $2006-07$ & $2007-08$ & $2008-09$ & $2009-10$ & $2010-11$ & $2011-12$ & $2012-13$ & $2013-14$ & $2014-15$ & $2015-16$ & $2016-17$ & $2018-19$ & $2019-20$ & $2020-21$ & $2021-22$ & $2022-23$ & $2023-24$ & $2023-24$ \\
\hline
\end{tabular}

Region

Northeast...

Midwest......... \begin{tabular}{|l|l|l}
\hline $2,725,285$ & $2,320,337$ & \\
593,727 & 446,045 &
\end{tabular} \begin{tabular}{|l|l|}
593,727 & 446,045 \\
784,071 & 616,700 \\
868,068 & 796,385 \\
\hline
\end{tabular} \begin{tabular}{l|l|l} 
South ………………......... & 868,068 & 796,385 \\
West...................... & 479,419 & 461,207
\end{tabular} State

Alabama... Alaska...

Arizona \begin{tabular}{l|l}
44,894 & 40,485 \\
\hline & 5386
\end{tabular}

\begin{tabular}{|r|r|r|} 
California............................ & $24,52,772$ & 26,475 \\
236,291 \\
\hline
\end{tabular}

\begin{tabular}{l|r|r} 
Colorado ................... & 35,897 & 32,967 \\
\hline
\end{tabular}

\begin{tabular}{l|r|r|} 
Connecticut.................. & 38,369 & 27,878 \\
\hline Delaware & 7349 & 5550
\end{tabular}

District of Columbia ${ }^{3}$... $\quad$ 7,394

\begin{tabular}{r|r|r|} 
Florida......................... & $8,7,755$ & 88,934 \\
\hline
\end{tabular}

\begin{tabular}{l|r|r} 
Georgia ..................... & $62,963 \quad 56,605$ \\
\hline
\end{tabular}

\begin{tabular}{l|r|r} 
Hawaii ...................... & 11,472 & 10,325 \\
\hline
\end{tabular}

\begin{tabular}{l|r|r|} 
Idaho _....................... & 12,679 & 11,971 \\
\hline
\end{tabular}

\begin{tabular}{lr|r|r} 
Indiana & 136,795 & 108,119 \\
73381 & 60,012
\end{tabular}

\begin{tabular}{l|r|r|r}
\hline lowa .......................... & 42,635 & 31,796 \\
\hline
\end{tabular}

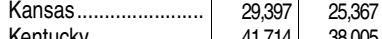

\begin{tabular}{|r|r|r|}
\hline Kentucky .................... & 41,714 & 38,005 \\
\hline Louisiana ................ & 46,199 & 36,053 \\
\hline
\end{tabular}

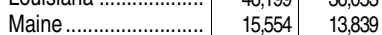

\begin{tabular}{l|r|r|} 
Maryland .................... & 54,050 & 41,566 \\
\hline
\end{tabular}

\begin{tabular}{l|r|r|} 
Massachusetts ............ & 74,831 & 55,941 \\
\cline { 1 - 2 } & 124372 &
\end{tabular}

\begin{tabular}{r|r|r} 
Michigan ..................... & 124,372 & 93,807 \\
\cline { 1 - 2 } & 64,166 & 49087
\end{tabular}

\begin{tabular}{l|r|r|} 
Minnesota .................... & 64,166 & 49,087 \\
Mississippi ............... & 28,083 & 25,182 \\
\hline
\end{tabular}

\begin{tabular}{l|r|r|}
\hline Missouri ..................... & 60,359 & 48,957 \\
\hline
\end{tabular}

\begin{tabular}{r|r|r|} 
Montana a..................... & 11,634 & 9,370 \\
Net & 17,664 \\
\hline
\end{tabular}

\begin{tabular}{r|rr} 
Nevada.............................. & 9,069 & 9,477 \\
\hline
\end{tabular}

\begin{tabular}{l|r|r} 
New Hampshire ............ & 11,552 & 10,766 \\
\hline
\end{tabular}

\begin{tabular}{|r|r|r|} 
New Jersey ................ & 93,168 & 69,824 \\
\hline
\end{tabular}

. \begin{tabular}{r|r|}
17,915 & 14,884 \\
198,455 & 143318 \\
\hline
\end{tabular} \begin{tabular}{r|r|}
198,465 & 143,318 \\
69,395 & 64,782 \\
\hline 9,928 & 7,690
\end{tabular}

\begin{tabular}{r|r|} 
North Dakota................... & 9,924 \\
7,690
\end{tabular}

\begin{tabular}{r|r|r|}
\hline Ohio .......................... & 143,503 & 114,513 \\
\hline
\end{tabular}

\begin{tabular}{l|r|r|}
\hline Oklahoma .................... & 38,875 & 35,606 \\
\hline Oregon ................... & 28,729 & 25,473 \\
\hline
\end{tabular}

Oregon...........

\begin{tabular}{l|r|r|} 
Pennsylvania................. & 144,645 & 110,527 \\
Rhode Island............. & 10,719 & 7,825
\end{tabular}

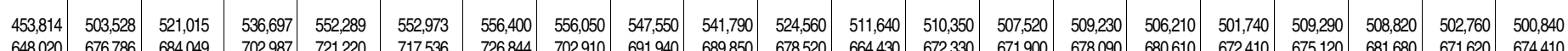

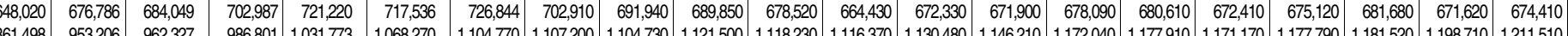

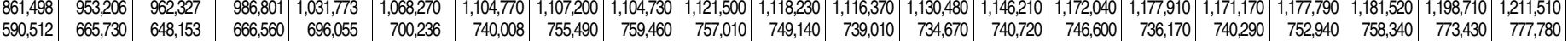

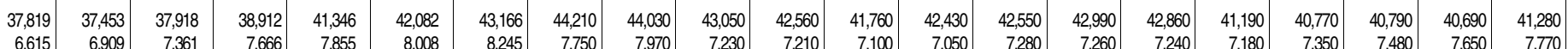

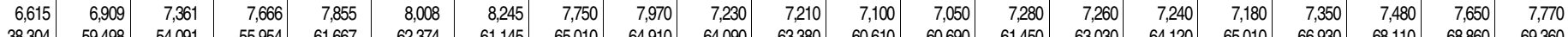

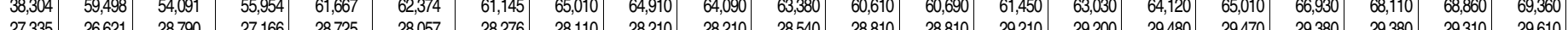

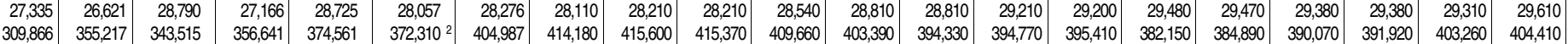

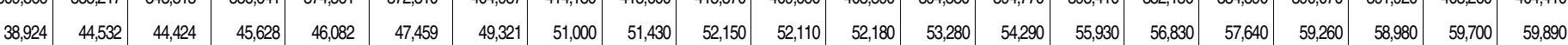

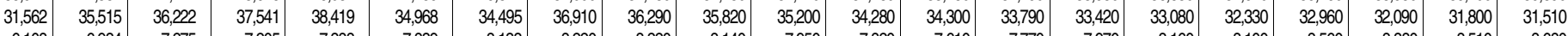
\begin{tabular}{|l|l|l|l|l|r|r|r|r|r|r|r|r|r|r|r|r|r|r|r|r|r|r|r|}
\hline $6,7,108$ & 6,934 & 7,275 & 7,205 & 7,388 & 7,839 & 8,133 & 8,220 & 8,320 & 8,140 & 7,950 & 7,820 & 7,610 & 7,770 & 7,970 & 8,160 & 8,100 & 8,560 & 8,380 & 8,510 & 8,680 \\
\hline
\end{tabular}

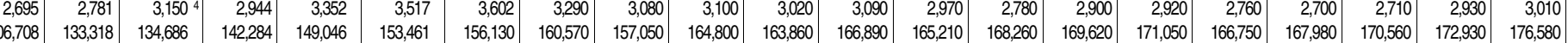

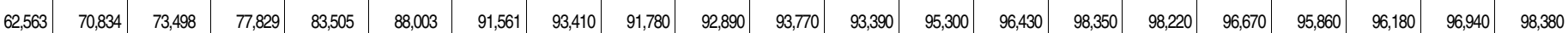

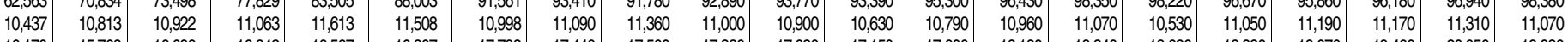

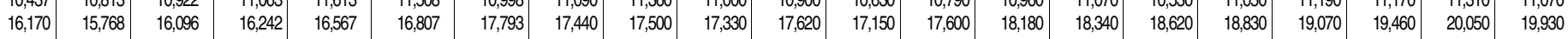

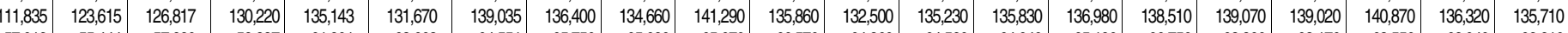

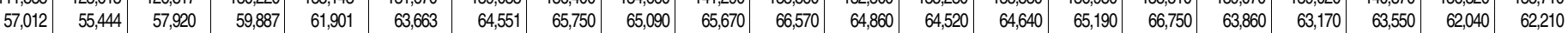

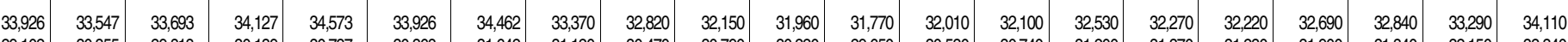

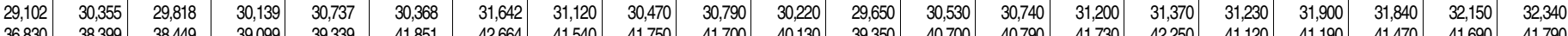

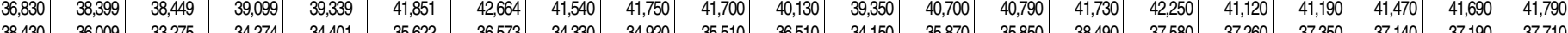

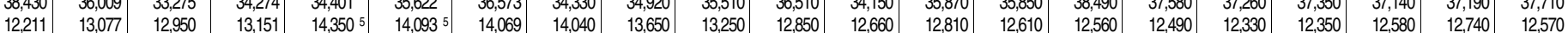

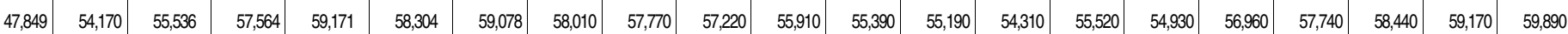

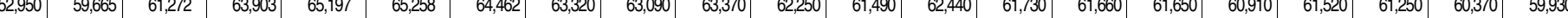
\begin{tabular}{|l|l|l|l|l|l|l|l|l|l|l|l|l|l|l|l|l|l|l|l|l|}
97,679 & 101,582 & 102,582 & $11,, 838$ & 115,183 & 112,442 & 110,682 & 107,080 & 105,580 & 102,710 & 101,970 & 98,030 & 99,420 & 97,710 & 98,110 & 97,490 & 94,460 & 93,630 & 94,170 & 91,060 & 90,480 \\
\hline
\end{tabular}

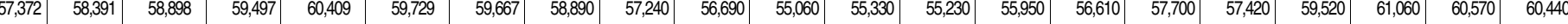

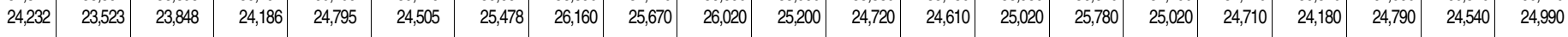

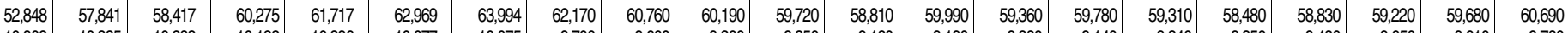
\begin{tabular}{|l|l|l|l|l|l|r|r|r|r|r|r|r|r|r|r|r|r|r|r|r|r|}
\hline 10,903 & 10,335 & 10,283 & 10,122 & 10,396 & 10,077 & 10,075 & 9,700 & 9,600 & 9,260 & 9,350 & 9,180 & 9,190 & 9,280 & 9,140 & 9,340 & 9,350 & 9,480 & 9,650 & 9,610 & 9,780 \\
\hline
\end{tabular}

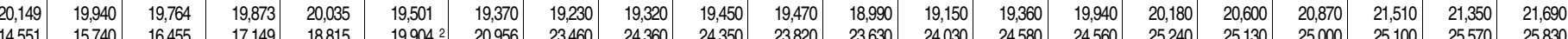

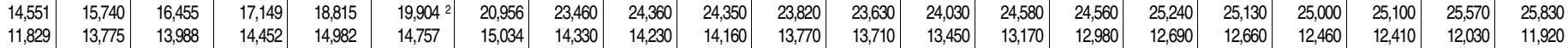

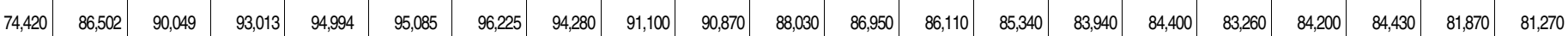

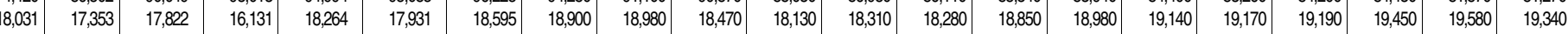

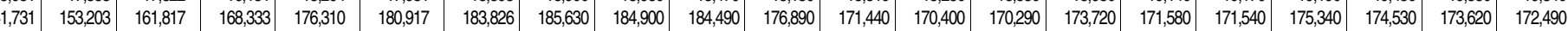

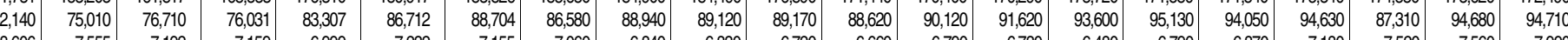
\begin{tabular}{|l|l|l|l|l|l|l|l|l|l|l|l|l|}
\hline 7,555 & 7,192 & 7,159 & 6,999 & 7,232 & 7,155 & 7,060 & 6,840 & 6,830 & 6,720 & 6,660 & 6,790 \\
\hline
\end{tabular} \begin{tabular}{|l|r|r|r|r|r|r|r|r|r|r|r|r|r|r|r|r|r|r|r|r|r|}
1111,668 & 116,702 & 117,356 & 117,658 & 120,758 & 122,203 & 123,437 & 110,360 & 109,370 & 106,100 & 103,810 & 101,340 & 102,980 & 102,710 & 103,610 & 103,130 & 101,650 & 101,170 & 101,000 & 99,610 & 100,570 \\
\hline
\end{tabular}

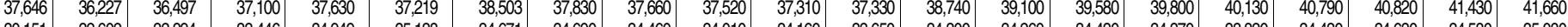

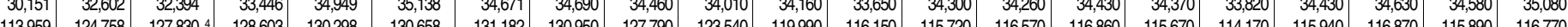

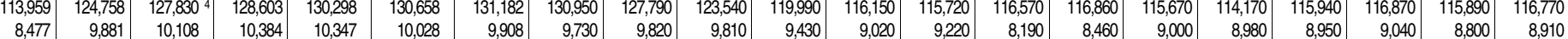


Table 219.20. Public high school graduates, by region, state, and jurisdiction: Selected years, 1980-81 through 2023-24-Continued

\begin{tabular}{|c|c|c|c|c|c|c|c|c|c|c|c|c|c|c|c|c|c|c|c|c|c|c|c|c|}
\hline \multirow[b]{2}{*}{$\begin{array}{l}\text { Region, state, and } \\
\text { jurisdiction }\end{array}$} & \multicolumn{9}{|c|}{ Actual data } & \multicolumn{15}{|c|}{ Projected data } \\
\hline & 1980-81 & $1989-90$ & 1999-2000 & $2004-05$ & $2005-06$ & 2006-07 & $2007-08$ & $2008-09$ & $2009-10$ & 2010-11 & 2011-12 & 2012-13 & 2013-14 & 2014-15 & 2015-16 & 2016-17 & 2017-18 & 2018-19 & $2019-20$ & $2020-21$ & 2021-22 & $2022-23$ & 2023-24 & 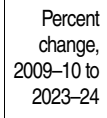 \\
\hline 1 & 2 & 3 & 4 & 5 & 6 & 7 & 8 & 9 & 10 & 11 & 12 & 13 & 14 & 15 & 16 & 17 & 18 & 19 & 20 & 21 & 22 & 23 & 24 & 25 \\
\hline $\begin{array}{l}\text { South Carolina ............. } \\
\text { South Dakota ............. }\end{array}$ & $\begin{array}{l}38,347 \\
10,385\end{array}$ & $\begin{array}{r}32,483 \\
7,650\end{array}$ & $\begin{array}{r}31,617 \\
9,278\end{array}$ & $\begin{array}{r}33,439 \\
8,585\end{array}$ & $\begin{array}{c}34,970^{4} \\
8,589\end{array}$ & $\begin{array}{r}35,108 \\
8,346\end{array}$ & $\begin{array}{r}35,303 \\
8,582\end{array}$ & \begin{tabular}{r|}
39,114 \\
8,123
\end{tabular} & $\begin{array}{r}40,438 \\
8,162\end{array}$ & $\begin{array}{r}40,050 \\
8,460\end{array}$ & $\begin{array}{r}40,050 \\
8,090\end{array}$ & $\begin{array}{r}39,830 \\
8,030\end{array}$ & $\begin{array}{r}39,420 \\
8,040\end{array}$ & $\begin{array}{r}38,580 \\
8,000\end{array}$ & $\begin{array}{r}39,680 \\
7,880\end{array}$ & $\begin{array}{r}40,250 \\
7,990\end{array}$ & $\begin{array}{r}41,410 \\
8,080\end{array}$ & $\begin{array}{r}41,760 \\
7,920\end{array}$ & $\begin{array}{r}40,980 \\
8,070\end{array}$ & $\begin{array}{r}40,850 \\
8,300\end{array}$ & $\begin{array}{r}41,490 \\
8,470\end{array}$ & $\begin{array}{r}42,100 \\
8,880\end{array}$ & $\begin{array}{r}42,780 \\
8,970\end{array}$ & $\begin{array}{l}5.8 \\
9.9\end{array}$ \\
\hline Tennessee..................... & 50,648 & 46,094 & 41,568 & 47,967 & 50,880 & 54,502 & 57,486 & 60,368 & 62,408 & 62,880 & 63,080 & 62,670 & 61,490 & 61,780 & 63,430 & 64,650 & 65,570 & 65,750 & 65,110 & 65,410 & 65,730 & 66,530 & 67,690 & 8.5 \\
\hline Texas................................ & 171,665 & 172,480 & 212,925 & 239,717 & 240,485 & 241,193 & 252,121 & 264,275 & 280,894 & 282,670 & 282,960 & 292,560 & 295,600 & 298,370 & 302,280 & 309,670 & 319,300 & 323,230 & 325,870 & 330,120 & 334,350 & 338,510 & 340,060 & 21.1 \\
\hline Utah ... & 19,886 & 21,196 & 32,501 & 30,253 & 29,050 & 28,276 & 28,167 & 30,463 & 31,481 & 30,850 & 31,620 & 31,990 & 32,350 & 33,390 & 34,850 & 36,000 & 37,100 & 37,410 & 38,020 & 39,330 & 40,120 & 40,350 & 41,720 & 32.5 \\
\hline Vermont.. & 6,424 & 6,127 & 6,675 & 7,152 & 6,779 & 7,317 & 7,392 & 7,209 & 7,199 & 6,850 & 6,670 & 6,480 & 6,140 & 5,960 & 5,900 & 5,840 & 5,630 & 5,660 & 5,560 & 5,590 & 5,620 & 5,640 & 5,480 & -23.9 \\
\hline Virginiz & 67,126 & 60,605 & 65,596 & 73,667 & 69,597 & 73,997 & 77,369 & 79,651 & 81,511 & 82,080 & 82,150 & 82,080 & 81,080 & 79,740 & 80,740 & 81,370 & 83,090 & 83,120 & 83,160 & 83,850 & 85,270 & 84,970 & 86,030 & 5.5 \\
\hline 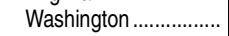 & 50,046 & 45,941 & 57,597 & 61,094 & 60,213 & 62,801 & 61,625 & 62,764 & 66,046 & 65,830 & 66,140 & 66,350 & 65,080 & 64,260 & 64,660 & 65,130 & 65,600 & 65,410 & 64,330 & 65,480 & 66,110 & 66,430 & 66,940 & 1.4 \\
\hline West Virginia................ & 23,580 & 21,854 & 19,437 & 17,137 & 16,763 & 17,407 & 17,489 & 17,690 & 17,651 & 17,260 & 17,320 & 17,100 & 16,710 & 16,590 & 16,800 & 16,570 & 16,950 & 16,650 & 16,880 & 16,450 & 16,690 & 16,600 & 16,680 & -5.5 \\
\hline Wisconsin ......................... & 67,743 & 52,038 & 58,545 & 63,229 & 63,003 & 63,968 & 65,183 & 65,410 & 64,687 & 63,020 & 61,710 & 59,890 & 59,140 & 58,500 & 58,610 & 58,780 & 59,590 & 59,180 & 58,480 & 58,850 & 59,640 & 59,120 & 59,210 & -8.5 \\
\hline Wyoming.. & 6,161 & 5,823 & 6,462 & 5,616 & 5,527 & 5,441 & 5,494 & 5,493 & 5,695 & 5,600 & 5,550 & 5,440 & 5,390 & 5,530 & 5,630 & 5,700 & 5,770 & 5,780 & 5,870 & 6,160 & 6,190 & 6,470 & 6,660 & 16.9 \\
\hline $\begin{array}{l}\text { Jurisdiction } \\
\text { Bureau of Indian } \\
\text { Education......... }\end{array}$ & - & - & - & - & - & - & - & - & - & - & - & - & - & - & - & - & - & - & - & - & - & - & - & - \\
\hline DoD, overseas........ & - & - & 2,642 & - & - & - & - & - & - & - & - & - & - & - & - & - & - & - & - & - & - & - & - & - \\
\hline DoD, domestic...... & - & - & 560 & - & - & - & - & - & - & - & - & - & - & - & - & - & - & - & - & - & - & - & - & - \\
\hline $\begin{array}{l}\text { Other jurisdictions } \\
\text { American Samoa ... }\end{array}$ & & & & & & 954 & -1 & - & - & - & -1 & - & - & -1 & - & - & -1 & -1 & - & - & -1 & -1 & & \\
\hline Guam ........................... & & $\begin{array}{r}1,033 \\
\end{array}$ & $\begin{array}{r}698 \\
1,406\end{array}$ & $\begin{array}{r}905 \\
1,179\end{array}$ & - & ${ }^{954}$ & $=$ & - & - & - & - & - & - & - & - & - & - & - & $=$ & $=$ & - & - & - & - \\
\hline Northern Marianas. & & 227 & 360 & 614 & 670 & 643 & - & - & - & - & - & - & - & - & - & - & - & - & - & - & - & - & - & - \\
\hline Puerto Rico...... & - & 29,049 & 30,856 & 29,071 & 31,896 & 31,718 & 30,016 & 29,286 & 25,514 & - & - & - & - & - & - & - & - & - & - & - & - & - & - & - \\
\hline U.S. Virgin Islands.. & - & 1,260 & 1,060 & 940 & - & 820 & 820 & 940 & 958 & - & - & - & - & - & - & - & - & - & - & - & - & - & - & - \\
\hline
\end{tabular}

-Not available.

2Estimated high school graduates from NCES 2011-312, Public School Graduates and Dropouts from the Common Core of Data: School Year 2008-09.

Peging aduded

(n) $2007-08$ and 1,169 graduates in 2008-09 from private high schools that received a majority of their

funding from public sources.
${ }_{6}^{6}$ Projected data from NCES 91-490, Projections of Education Statistics to 2002.

NOTE: Data include regular diploma recipients, but exclude students receiving a certficate of attendance and persons receiving high school equivalency certificates. $\mathrm{DoD}=$ Department of Defense. Some data have been revised from previously published figSOURCE: US Dopartment of Education National Cen

ducation Statistics, Common Core of Data (CCD), "State Nonfis2005-06 through 2009-10; Public School Graduates and Dropouts from the Common Core of Data, 2007-08 and 2008-09; and State High School Graduates Projection Model, 1980-81 through 2023-24. (This table was prepared May 2014.) 
212 CHAPTER 2: Elementary and Secondary Education

High School Completers and Dropouts

Table 219.30. Public high school graduates, by race/ethnicity: 1998-99 through 2023-24

\begin{tabular}{|c|c|c|c|c|c|c|c|c|c|c|c|c|c|c|}
\hline \multirow[b]{2}{*}{ Year } & \multicolumn{7}{|c|}{ Number of high school graduates } & \multicolumn{7}{|c|}{ Percentage distribution of graduates } \\
\hline & Total & White & Black & Hispanic & $\begin{array}{r}\text { Asian/ } \\
\text { Pacific } \\
\text { Islander }\end{array}$ & $\begin{array}{r}\text { American } \\
\text { Indian/ } \\
\text { Alaska } \\
\text { Native }\end{array}$ & $\begin{array}{r}\text { Two or } \\
\text { more races }\end{array}$ & Total & White & Black & Hispanic & $\begin{array}{r}\text { Asian/ } \\
\text { Pacific } \\
\text { Islander }\end{array}$ & $\begin{array}{r}\text { American } \\
\text { Indian/ } \\
\text { Alaska } \\
\text { Native }\end{array}$ & $\begin{array}{l}\text { Two or } \\
\text { more races }\end{array}$ \\
\hline 1 & 2 & 3 & 4 & 5 & 6 & 7 & 8 & 9 & 10 & 11 & 12 & 13 & 14 & 15 \\
\hline 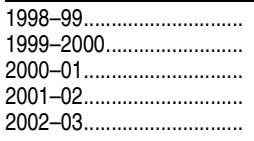 & $\begin{array}{l}2,485,630 \\
2,553,844 \\
2,569,200 \\
2,621,534 \\
2,719,947\end{array}$ & $\begin{array}{l}1,749,561 \\
1,778,370 \\
1,775,036 \\
1,796,110 \\
1,856,454\end{array}$ & $\begin{array}{l}325,708 \\
338,116 \\
339,578 \\
348,969 \\
359,920\end{array}$ & $\begin{array}{l}270,836 \\
289,139 \\
301,740 \\
317,197 \\
340,182\end{array}$ & $\begin{array}{l}115,216 \\
122,344 \\
126,465 \\
132,182 \\
135,588\end{array}$ & $\begin{array}{l}24,309 \\
25,875 \\
26,381 \\
27,076 \\
27,803\end{array}$ & $\begin{array}{l}- \\
- \\
- \\
-\end{array}$ & $\begin{array}{l}100.0 \\
100.0 \\
100.0 \\
100.0 \\
100.0\end{array}$ & $\begin{array}{l}70.4 \\
69.6 \\
69.1 \\
68.5 \\
68.3\end{array}$ & \begin{tabular}{l|}
13.1 \\
13.2 \\
13.2 \\
13.3 \\
13.2
\end{tabular} & $\begin{array}{l}10.9 \\
11.3 \\
11.7 \\
12.1 \\
12.5\end{array}$ & $\begin{array}{l}4.6 \\
4.8 \\
4.9 \\
5.0 \\
5.0\end{array}$ & $\begin{array}{l}1.0 \\
1.0 \\
1.0 \\
1.0 \\
1.0\end{array}$ & $\begin{array}{l}- \\
- \\
- \\
-\end{array}$ \\
\hline 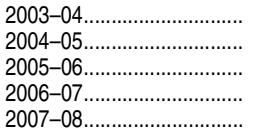 & $\begin{array}{l}2,753,438 \\
2,799,250 \\
2,815,544 \\
2,893,045 \\
3,001,337\end{array}$ & \begin{tabular}{|l|}
$1,829,177$ \\
$1,855,198$ \\
$1,838,765$ \\
$1,868,056$ \\
$1,898,367$
\end{tabular} & $\begin{array}{l}383,443 \\
385,987 \\
399,406 \\
418,113 \\
429,840\end{array}$ & $\begin{array}{l}374,492 \\
383,714 \\
396,820 \\
421,036 \\
448,887\end{array}$ & $\begin{array}{l}137,496 \\
143,729 \\
150,925 \\
154,837 \\
159,410\end{array}$ & $\begin{array}{l}28,830 \\
30,622 \\
29,628 \\
31,003 \\
32,036\end{array}$ & $\begin{array}{r}- \\
- \\
- \\
32,797\end{array}$ & $\begin{array}{l}100.0 \\
100.0 \\
100.0 \\
100.0 \\
100.0\end{array}$ & $\begin{array}{l}66.4 \\
66.3 \\
65.3 \\
64.6 \\
63.3\end{array}$ & $\begin{array}{l}13.9 \\
13.8 \\
14.2 \\
14.5 \\
14.3\end{array}$ & $\begin{array}{l}13.6 \\
13.7 \\
14.1 \\
14.6 \\
15.0\end{array}$ & $\begin{array}{l}5.0 \\
5.1 \\
5.4 \\
5.4 \\
5.3\end{array}$ & $\begin{array}{l}1.0 \\
1.1 \\
1.1 \\
1.1 \\
1.1\end{array}$ & $\begin{array}{l}- \\
- \\
\overline{1} \\
1.1^{1}\end{array}$ \\
\hline $\begin{array}{l}2008-09 \ldots \ldots \ldots \ldots \\
2009-10 \ldots \ldots \ldots \ldots \ldots \ldots \ldots \ldots \ldots \\
2010-11 \ldots \ldots \ldots \ldots \ldots \ldots \ldots \ldots \ldots \\
2011-12 \ldots \ldots \ldots \ldots \ldots \ldots \ldots \ldots \\
2012-13^{2}\end{array}$ & $\begin{array}{l}3,039,015 \\
3,128,022 \\
3,143,879 \\
3,147,790 \\
3,110,150\end{array}$ & $\begin{array}{l}1,883,382 \\
1,871,980 \\
1,835,156 \\
1,807,104 \\
1,766,390\end{array}$ & $\begin{array}{l}451,384 \\
472,261 \\
471,410 \\
467,419 \\
450,760\end{array}$ & $\begin{array}{l}481,698 \\
545,518 \\
583,907 \\
605,674 \\
626,280\end{array}$ & $\begin{array}{l}163,575 \\
167,840 \\
168,880 \\
173,762 \\
173,640\end{array}$ & $\begin{array}{l}32,213 \\
34,131 \\
32,778 \\
32,423 \\
30,240\end{array}$ & 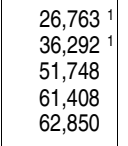 & $\begin{array}{l}100.0 \\
100.0 \\
100.0 \\
100.0 \\
100.0\end{array}$ & $\begin{array}{l}62.0 \\
59.8 \\
58.4 \\
57.4 \\
56.8\end{array}$ & $\begin{array}{l}14.9 \\
15.1 \\
15.0 \\
14.8 \\
14.5\end{array}$ & $\begin{array}{l}15.9 \\
17.4 \\
18.6 \\
19.2 \\
20.1\end{array}$ & $\begin{array}{l}5.4 \\
5.4 \\
5.4 \\
5.5 \\
5.6\end{array}$ & $\begin{array}{l}1.1 \\
1.1 \\
1.0 \\
1.0 \\
1.0\end{array}$ & $\begin{array}{l}0.9^{1} \\
1.2^{1} \\
1.6 \\
2.0 \\
2.0\end{array}$ \\
\hline $\begin{array}{l}2013-14^{2} \\
2014-15^{2} \ldots \ldots \ldots \ldots \ldots \ldots \ldots \ldots \ldots \ldots \\
2015-16^{2} \ldots \ldots \ldots \ldots \ldots \ldots \ldots \ldots \ldots \ldots \ldots \\
2016-17^{2} \ldots \ldots \ldots \ldots \ldots \ldots \ldots \ldots \\
2017-18^{2} \ldots \ldots \ldots \ldots \ldots \ldots \ldots \ldots\end{array}$ & $\begin{array}{l}3,070,440 \\
3,031,450 \\
3,047,830 \\
3,066,350 \\
3,105,970\end{array}$ & $\begin{array}{l}1,730,560 \\
1,688,980 \\
1,682,000 \\
1,677,460 \\
1,669,320\end{array}$ & $\begin{array}{l}433,110 \\
424,210 \\
428,920 \\
425,700 \\
428,510\end{array}$ & $\begin{array}{l}638,840 \\
651,690 \\
670,420 \\
692,290 \\
726,090\end{array}$ & $\begin{array}{l}173,900 \\
172,060 \\
168,750 \\
169,530 \\
178,840\end{array}$ & $\begin{array}{l}28,860 \\
27,180 \\
28,380 \\
29,020 \\
28,190\end{array}$ & $\begin{array}{l}65,170 \\
67,340 \\
69,350 \\
72,340 \\
75,020\end{array}$ & $\begin{array}{l}100.0 \\
100.0 \\
100.0 \\
100.0 \\
100.0\end{array}$ & $\begin{array}{l}56.4 \\
55.7 \\
55.2 \\
54.7 \\
53.7\end{array}$ & $\begin{array}{l}14.1 \\
14.0 \\
14.1 \\
13.9 \\
13.8\end{array}$ & $\begin{array}{l}20.8 \\
21.5 \\
22.0 \\
22.6 \\
23.4\end{array}$ & $\begin{array}{l}5.7 \\
5.7 \\
5.5 \\
5.5 \\
5.8\end{array}$ & $\begin{array}{l}0.9 \\
0.9 \\
0.9 \\
0.9 \\
0.9\end{array}$ & $\begin{array}{l}2.1 \\
2.2 \\
2.3 \\
2.4 \\
2.4\end{array}$ \\
\hline $\begin{array}{l}2018-19^{2} \\
2019-20^{2} \\
2020-21^{2} \ldots \ldots \ldots \ldots \ldots \ldots \ldots \ldots \\
2021-22^{2} \ldots \ldots \ldots \ldots \ldots \ldots \ldots \ldots \\
2022-23^{2} \ldots \ldots \ldots \ldots \ldots \ldots \ldots \\
2023-24^{2}\end{array}$ & $\begin{array}{l}3,100,900 \\
3,085,600 \\
3,115,140 \\
3,130,360 \\
3,146,530 \\
3,164,540\end{array}$ & $\begin{array}{l}1,647,840 \\
1,613,600 \\
1,614,270 \\
1,601,380 \\
1,577,570 \\
1,564,210\end{array}$ & $\begin{array}{l}419,000 \\
408,910 \\
402,510 \\
397,650 \\
398,150 \\
403,960\end{array}$ & $\begin{array}{l}752,560 \\
777,990 \\
806,220 \\
835,880 \\
876,760 \\
901,510\end{array}$ & $\begin{array}{l}176,080 \\
177,630 \\
182,550 \\
183,600 \\
179,890 \\
178,380\end{array}$ & $\begin{array}{l}27,600 \\
26,880 \\
26,170 \\
25,860 \\
25,580 \\
25,600\end{array}$ & $\begin{array}{l}77,830 \\
80,590 \\
83,420 \\
85,980 \\
88,570 \\
90,880\end{array}$ & $\begin{array}{l}100.0 \\
100.0 \\
100.0 \\
100.0 \\
100.0 \\
100.0\end{array}$ & $\begin{array}{l}53.1 \\
52.3 \\
51.8 \\
51.2 \\
50.1 \\
49.4\end{array}$ & $\begin{array}{l}13.5 \\
13.3 \\
12.9 \\
12.7 \\
12.7 \\
12.8\end{array}$ & $\begin{array}{l}24.3 \\
25.2 \\
25.9 \\
26.7 \\
27.9 \\
28.5\end{array}$ & $\begin{array}{l}5.7 \\
5.8 \\
5.9 \\
5.9 \\
5.7 \\
5.6\end{array}$ & $\begin{array}{l}0.9 \\
0.9 \\
0.8 \\
0.8 \\
0.8 \\
0.8\end{array}$ & $\begin{array}{l}2.5 \\
2.6 \\
2.7 \\
2.7 \\
2.8 \\
2.9\end{array}$ \\
\hline
\end{tabular}

-Not available.

'Data on students of two or more races were not reported by all states; therefore, the data are not comparable to figures for 2010-11 and later years.

${ }^{2}$ Projected.

NOTE: Race categories exclude persons of Hispanic ethnicity. Prior to 2007-08, data on students of two or more races were not collected separately. Some data have been revised from previously published figures. Detail may not sum to totals because of rounding.
SOURCE: U.S. Department of Education, National Center for Education Statistics, Common Core of Data (CCD), "State Nonfiscal Survey of Public Elementary/Secondary Education," 1999-2000 through 2005-06; "State Dropout and Completion Data File," 2005-06 through 2011-12; and National Public High School Graduates by Race/Ethnicity Projection Model, 1995-96 through 2023-24. (This table was prepared May 2014.) 
Table 219.35. Averaged freshman graduation rates for public secondary schools, by state or jurisdiction: Selected years, 1990-91 through 2009-10

\begin{tabular}{|c|c|c|c|c|c|c|c|c|c|c|c|c|c|c|c|}
\hline State or jurisdiction & $1990-91$ & $\mid 1995-96$ & $1997-98$ & $1998-99$ & 1999-2000 & $2000-01$ & 2001-02 & $2002-03$ & 2003-04 & $2004-05$ & $2005-06$ & $2006-07$ & $2007-08$ & $2008-09$ & $2009-10$ \\
\hline 1 & 2 & 3 & 4 & 5 & 6 & 7 & 8 & 9 & 10 & 11 & 12 & 13 & 14 & 15 & 16 \\
\hline United States ..................... & 73.7 & 71.0 & 71.3 & 71.1 & 71.7 & 71.7 & 72.6 & 73.9 & $74.3^{1}$ & 74.7 & $73.4^{2}$ & 73.9 & 74.7 & $75.5^{2}$ & 78.2 \\
\hline $\begin{array}{l}\text { Alabama } \\
\text { Alaska. } \\
\text { Arizona } \\
\text { Arkansas } \\
\text { California }\end{array}$ & $\begin{array}{l}69.8 \\
74.6 \\
76.7 \\
76.6 \\
69.6\end{array}$ & $\begin{array}{l}62.7 \\
68.3 \\
60.8 \\
74.2 \\
67.6\end{array}$ & $\begin{array}{l}64.4 \\
68.9 \\
65.6 \\
73.9 \\
69.6\end{array}$ & $\begin{array}{l}61.3 \\
70.0 \\
62.3 \\
73.7 \\
71.1\end{array}$ & $\begin{array}{l}64.1 \\
66.7 \\
63.6 \\
74.6 \\
71.7\end{array}$ & $\begin{array}{l}63.7 \\
68.0 \\
74.2 \\
73.9 \\
71.6\end{array}$ & $\begin{array}{l}62.1 \\
65.9 \\
74.7 \\
74.8 \\
72.7\end{array}$ & $\begin{array}{l}64.7 \\
68.0 \\
75.9 \\
76.6 \\
74.1\end{array}$ & $\begin{array}{l}65.0 \\
67.2 \\
66.8 \\
76.8 \\
73.9\end{array}$ & $\begin{array}{l}65.9 \\
64.1 \\
84.7 \\
75.7 \\
74.6\end{array}$ & $\begin{array}{l}66.2 \\
66.5 \\
70.5 \\
80.4 \\
69.2\end{array}$ & $\begin{array}{l}67.1 \\
69.0 \\
69.6 \\
74.4 \\
70.7\end{array}$ & $\begin{array}{l}69.0 \\
69.1 \\
70.7 \\
76.4 \\
71.2\end{array}$ & $\begin{array}{l}69.9 \\
72.6 \\
72.5 \\
74.0 \\
71.0^{3}\end{array}$ & $\begin{array}{l}71.8 \\
75.5 \\
74.7 \\
75.0 \\
78.2\end{array}$ \\
\hline 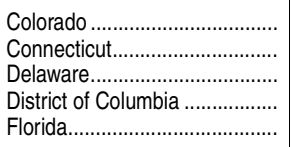 & $\begin{array}{l}76.3 \\
80.2 \\
72.5 \\
54.5 \\
65.6\end{array}$ & $\begin{array}{l}74.8 \\
76.1 \\
70.4 \\
49.7 \\
62.3\end{array}$ & $\begin{array}{l}73.9 \\
76.9 \\
74.1 \\
53.9 \\
62.1\end{array}$ & $\begin{array}{l}73.4 \\
76.0 \\
70.4 \\
52.0 \\
61.4\end{array}$ & $\begin{array}{l}74.1 \\
81.9 \\
66.8 \\
54.5 \\
61.0\end{array}$ & $\begin{array}{l}73.2 \\
77.5 \\
71.0 \\
60.2 \\
61.2\end{array}$ & $\begin{array}{l}74.7 \\
79.7 \\
69.5 \\
68.4 \\
63.4\end{array}$ & $\begin{array}{l}76.4 \\
80.9 \\
73.0 \\
59.6 \\
66.7\end{array}$ & $\begin{array}{l}78.7 \\
80.7 \\
72.9 \\
68.2 \\
66.4\end{array}$ & $\begin{array}{l}76.7 \\
80.9 \\
73.0 \\
66.3 \\
64.6\end{array}$ & $\begin{array}{l}75.5 \\
80.9 \\
76.3 \\
65.4^{4} \\
63.6\end{array}$ & $\begin{array}{l}76.6 \\
81.8 \\
71.9 \\
54.8 \\
65.0\end{array}$ & $\begin{array}{l}75.4 \\
82.2 \\
72.1 \\
56.0 \\
66.9\end{array}$ & $\begin{array}{l}77.6 \\
75.4 \\
73.7 \\
62.4 \\
68.9\end{array}$ & $\begin{array}{l}79.8 \\
75.1 \\
75.5 \\
59.9 \\
70.8\end{array}$ \\
\hline 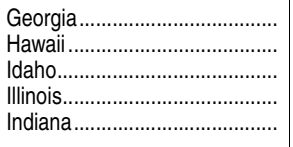 & $\begin{array}{l}70.3 \\
75.9 \\
79.6 \\
76.6 \\
76.9\end{array}$ & $\begin{array}{r}61.9 \\
74.5 \\
80.5 \\
75.2 \\
73.6\end{array}$ & $\begin{array}{l}58.2 \\
68.8 \\
79.7 \\
76.8 \\
73.8\end{array}$ & $\begin{array}{l}57.5 \\
67.5 \\
79.5 \\
76.0 \\
74.3\end{array}$ & $\begin{array}{l}59.7 \\
70.9 \\
79.4 \\
76.3 \\
71.8\end{array}$ & $\begin{array}{l}58.7 \\
68.3 \\
79.6 \\
75.6 \\
72.1\end{array}$ & $\begin{array}{l}61.1 \\
72.1 \\
79.3 \\
77.1 \\
73.1\end{array}$ & $\begin{array}{l}60.8 \\
71.3 \\
81.4 \\
75.9 \\
75.5\end{array}$ & $\begin{array}{l}61.2 \\
72.6 \\
81.5 \\
80.3 \\
73.5\end{array}$ & $\begin{array}{l}61.7 \\
75.1 \\
81.0 \\
79.4 \\
73.2\end{array}$ & $\begin{array}{l}62.4 \\
75.5 \\
80.5 \\
79.7 \\
73.3\end{array}$ & $\begin{array}{l}64.1 \\
75.4 \\
80.4 \\
79.5 \\
73.9\end{array}$ & $\begin{array}{l}65.4 \\
76.0 \\
80.1\end{array}$ & $\begin{array}{l}67.8 \\
75.3 \\
80.6 \\
77.7 \\
75.2\end{array}$ & $\begin{array}{l}69.9 \\
75.4 \\
84.0 \\
81.9 \\
77.2\end{array}$ \\
\hline $\begin{array}{l}\text { lowa } \\
\text { Kansas } \\
\text { Kentucky } \\
\text { Louisiana } \\
\text { Maine }\end{array}$ & $\begin{array}{l}84.4 \\
80.8 \\
72.9 \\
57.5 \\
80.7\end{array}$ & $\begin{array}{l}84.3 \\
77.1 \\
71.3 \\
61.7 \\
73.7\end{array}$ & $\begin{array}{l}83.9 \\
76.0 \\
70.2 \\
61.3 \\
78.5\end{array}$ & & $\begin{array}{l}83.1 \\
77.1 \\
69.7 \\
62.2 \\
75.9\end{array}$ & $\begin{array}{l}82.8 \\
76.5 \\
69.8 \\
63.7 \\
76.4\end{array}$ & $\begin{array}{l}84.1 \\
77.1 \\
69.8 \\
64.4 \\
75.6\end{array}$ & $\begin{array}{l}85.3 \\
76.9 \\
71.7 \\
64.1 \\
76.3\end{array}$ & $\begin{array}{l}85.8 \\
77.9 \\
73.0 \\
69.4 \\
77.6\end{array}$ & $\begin{array}{l}86.6 \\
79.2 \\
75.9 \\
63.9 \\
78.6\end{array}$ & $\begin{array}{l}86.9 \\
77.5 \\
77.2 \\
59.5 \\
76.3\end{array}$ & $\begin{array}{l}86.5 \\
78.8 \\
76.4 \\
61.3 \\
78.5\end{array}$ & $\begin{array}{l}86.4 \\
79.0 \\
74.4 \\
63.5 \\
79.1^{5}\end{array}$ & $\begin{array}{l}85.7 \\
80.2 \\
77.6 \\
67.3 \\
79.9^{5}\end{array}$ & $\begin{array}{l}87.9 \\
84.5 \\
79.9 \\
68.8 \\
82.8^{6}\end{array}$ \\
\hline $\begin{array}{l}\text { Maryland } \\
\text { Massachusetts. } \\
\text { Michigan } \\
\text { Minnesota } \\
\text { Mississippi }\end{array}$ & $\begin{array}{l}77.5 \\
79.1 \\
72.1 \\
90.8 \\
63.3\end{array}$ & $\begin{array}{l}78.3 \\
78.0 \\
71.4 \\
86.1 \\
59.7\end{array}$ & $\begin{array}{l}76.2 \\
78.3 \\
74.6 \\
85.0 \\
59.8\end{array}$ & $\begin{array}{l}76.6 \\
77.9 \\
73.9 \\
86.0 \\
59.2\end{array}$ & $\begin{array}{l}77.6 \\
78.0 \\
75.3 \\
84.9 \\
59.4\end{array}$ & $\begin{array}{l}78.7 \\
78.9 \\
75.4 \\
83.6 \\
59.7\end{array}$ & $\begin{array}{l}79.7 \\
77.6 \\
72.9 \\
83.9 \\
61.2\end{array}$ & $\begin{array}{l}79.2 \\
75.7 \\
74.0 \\
84.8 \\
62.7\end{array}$ & $\begin{array}{l}79.5 \\
79.3 \\
72.5 \\
84.7 \\
62.7\end{array}$ & $\begin{array}{l}79.3 \\
78.7 \\
73.0 \\
85.9 \\
63.3\end{array}$ & $\begin{array}{l}79.9 \\
79.5 \\
72.2 \\
86.2 \\
63.5\end{array}$ & $\begin{array}{l}80.0 \\
80.8 \\
77.0 \\
86.5 \\
63.5\end{array}$ & $\begin{array}{l}80.4 \\
81.5 \\
76.3\end{array}$ & $\begin{array}{l}80.1 \\
83.3 \\
75.3 \\
87.4 \\
62.0\end{array}$ & $\begin{array}{l}82.2 \\
82.6 \\
75.9 \\
88.2 \\
63.8\end{array}$ \\
\hline 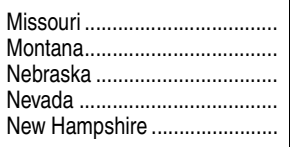 & $\begin{array}{l}76.0 \\
84.4 \\
86.7 \\
77.0 \\
78.6\end{array}$ & $\begin{array}{l}75.0 \\
83.9 \\
85.6 \\
65.8 \\
77.5\end{array}$ & $\begin{array}{l}75.2 \\
82.2 \\
85.6 \\
70.6 \\
76.7\end{array}$ & $\begin{array}{l}75.8 \\
81.3 \\
87.3 \\
71.0 \\
75.3\end{array}$ & $\begin{array}{l}76.3 \\
80.8 \\
85.7 \\
69.7 \\
76.1\end{array}$ & $\begin{array}{l}75.5 \\
80.0 \\
83.8 \\
70.0 \\
77.8\end{array}$ & $\begin{array}{l}76.8 \\
79.8 \\
83.9 \\
71.9 \\
77.8\end{array}$ & $\begin{array}{l}78.3 \\
81.0 \\
85.2 \\
72.3 \\
78.2\end{array}$ & $\begin{array}{l}80.4 \\
80.4 \\
87.6 \\
57.4 \\
78.7\end{array}$ & $\begin{array}{l}80.6 \\
81.5 \\
87.8 \\
55.8 \\
80.1\end{array}$ & $\begin{array}{l}81.0 \\
81.9 \\
87.0 \\
55.8 \\
81.1\end{array}$ & $\begin{array}{l}81.9 \\
81.5 \\
86.3 \\
54.2 \\
81.7\end{array}$ & & $\begin{array}{l}83.1 \\
82.0 \\
82.9 \\
56.3^{3} \\
84.3\end{array}$ & $\begin{array}{l}83.7 \\
81.9 \\
83.8 \\
57.8 \\
86.3\end{array}$ \\
\hline 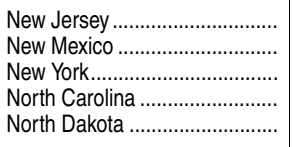 & $\begin{array}{l}81.4 \\
70.1 \\
66.1 \\
71.3 \\
87.6\end{array}$ & $\begin{array}{l}82.8 \\
63.7 \\
63.6 \\
66.5 \\
89.5\end{array}$ & $\begin{array}{l}76.3 \\
61.6 \\
63.4 \\
65.6 \\
86.7\end{array}$ & $\begin{array}{l}77.5 \\
63.3 \\
62.5 \\
65.4 \\
85.6\end{array}$ & $\begin{array}{l}83.6 \\
64.7 \\
61.8 \\
65.8 \\
86.0\end{array}$ & $\begin{array}{l}85.4 \\
65.9 \\
61.5 \\
66.5 \\
85.4\end{array}$ & $\begin{array}{l}85.8 \\
67.4 \\
60.5 \\
68.2 \\
85.0\end{array}$ & $\begin{array}{l}87.0 \\
63.1 \\
60.9 \\
70.1 \\
86.4\end{array}$ & $\begin{array}{l}86.3 \\
67.0 \\
60.9^{7} \\
71.4 \\
86.1\end{array}$ & $\begin{array}{l}85.1 \\
65.4 \\
65.3 \\
72.6 \\
86.3\end{array}$ & & $\begin{array}{l}84.4 \\
59.1 \\
68.9 \\
68.6 \\
83.1\end{array}$ & & $\begin{array}{l}85.3 \\
64.8 \\
73.5 \\
75.1 \\
87.4\end{array}$ & $\begin{array}{l}87.2 \\
67.3 \\
76.0 \\
76.9 \\
88.4\end{array}$ \\
\hline 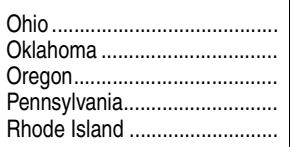 & $\begin{array}{l}77.5 \\
76.5 \\
72.7 \\
79.7 \\
75.0\end{array}$ & $\begin{array}{l}74.5 \\
75.6 \\
68.3 \\
80.0 \\
72.7\end{array}$ & $\begin{array}{l}77.0 \\
75.1 \\
69.0 \\
79.4 \\
72.5\end{array}$ & $\begin{array}{l}75.0 \\
76.4 \\
68.2 \\
79.1 \\
72.2\end{array}$ & $\begin{array}{l}75.2 \\
75.8 \\
69.6 \\
78.7 \\
72.8\end{array}$ & $\begin{array}{l}76.5 \\
75.8 \\
68.3 \\
79.0 \\
73.5\end{array}$ & $\begin{array}{l}77.5 \\
76.0 \\
71.0 \\
80.2 \\
75.7\end{array}$ & $\begin{array}{l}79.0 \\
76.0 \\
73.7 \\
81.7 \\
77.7\end{array}$ & $\begin{array}{l}81.3 \\
77.0 \\
74.2 \\
82.2 \\
75.9\end{array}$ & $\begin{array}{l}80.2 \\
76.9 \\
74.2 \\
82.5 \\
78.4\end{array}$ & $\begin{array}{l}79.2 \\
77.8 \\
73.0 \\
83.5^{4} \\
77.8\end{array}$ & $\begin{array}{l}78.7 \\
77.8 \\
73.8 \\
83.0 \\
78.4\end{array}$ & & $\begin{array}{l}79.6 \\
77.3 \\
76.5 \\
80.5 \\
75.3\end{array}$ & $\begin{array}{l}81.4 \\
78.5 \\
76.3 \\
84.1 \\
76.4\end{array}$ \\
\hline 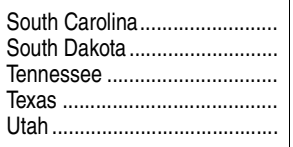 & $\begin{array}{l}66.6 \\
83.8 \\
69.8 \\
72.2 \\
77.5\end{array}$ & $\begin{array}{l}60.9 \\
84.5 \\
66.6 \\
66.1 \\
76.9\end{array}$ & $\begin{array}{l}59.3 \\
77.7 \\
58.4 \\
69.4 \\
80.7\end{array}$ & $\begin{array}{l}59.1 \\
74.2 \\
58.5 \\
69.2 \\
81.6\end{array}$ & $\begin{array}{l}58.6 \\
77.6 \\
59.5 \\
71.0 \\
82.5\end{array}$ & $\begin{array}{l}56.5 \\
77.4 \\
59.0 \\
70.8 \\
81.6\end{array}$ & $\begin{array}{l}57.9 \\
79.0 \\
59.6 \\
73.5 \\
80.5\end{array}$ & $\begin{array}{l}59.7 \\
83.0 \\
63.4 \\
75.5 \\
80.2\end{array}$ & $\begin{array}{l}60.6 \\
83.7 \\
66.1 \\
76.7 \\
83.0\end{array}$ & $\begin{array}{l}60.1 \\
82.3 \\
68.5 \\
74.0 \\
84.4\end{array}$ & $\begin{array}{l}61.0^{4} \\
84.5 \\
70.7 \\
72.5 \\
78.6\end{array}$ & $\begin{array}{l}58.9 \\
82.5 \\
72.6 \\
71.9 \\
76.6\end{array}$ & $\begin{array}{l}62.2 \\
84.4 \\
74.9 \\
73.1 \\
74.3\end{array}$ & $\begin{array}{l}66.0 \\
81.7 \\
77.4 \\
75.4 \\
79.4\end{array}$ & $\begin{array}{l}68.2 \\
81.8 \\
80.4 \\
78.9 \\
78.6\end{array}$ \\
\hline 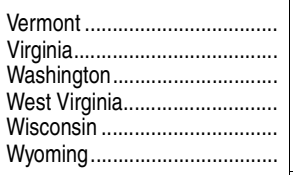 & $\begin{array}{l}79.5 \\
76.2 \\
75.7 \\
76.6 \\
85.2 \\
81.1 \\
\end{array}$ & $\begin{array}{l}85.3 \\
76.2 \\
75.5 \\
77.0 \\
83.6 \\
77.7 \\
\end{array}$ & $\begin{array}{l}83.9 \\
76.6 \\
73.3 \\
77.4 \\
83.1 \\
77.1 \\
\end{array}$ & $\begin{array}{l}81.9 \\
76.3 \\
73.2 \\
77.9 \\
82.6 \\
76.6 \\
\end{array}$ & $\begin{array}{l}81.0 \\
76.9 \\
73.7 \\
76.7 \\
82.7 \\
76.3 \\
\end{array}$ & $\begin{array}{l}80.2 \\
77.5 \\
69.2 \\
75.9 \\
83.3 \\
73.4 \\
\end{array}$ & $\begin{array}{l}82.0 \\
76.7 \\
72.2 \\
74.2 \\
84.8 \\
74.4 \\
\end{array}$ & $\begin{array}{l}83.6 \\
80.6 \\
74.2 \\
75.7 \\
85.8 \\
73.9 \\
\end{array}$ & \begin{tabular}{l|}
85.4 \\
79.3 \\
74.6 \\
76.9 \\
$85.8^{7}$ \\
76.0 \\
\end{tabular} & $\begin{array}{l}86.5 \\
79.6 \\
75.0 \\
77.3 \\
86.7 \\
76.7 \\
\end{array}$ & $\begin{array}{l}82.3 \\
74.5 \\
72.9 \\
76.9 \\
87.5 \\
76.1 \\
\end{array}$ & $\begin{array}{l}88.5 \\
75.5 \\
74.8 \\
78.2 \\
88.5 \\
75.8 \\
\end{array}$ & $\begin{array}{l}89.3 \\
77.0 \\
71.9 \\
77.3 \\
89.6 \\
76.0 \\
\end{array}$ & $\begin{array}{l}89.6 \\
78.4 \\
73.7 \\
77.0 \\
90.7 \\
75.2 \\
\end{array}$ & $\begin{array}{l}91.4 \\
81.2 \\
77.2 \\
78.3 \\
91.1 \\
80.3 \\
\end{array}$ \\
\hline 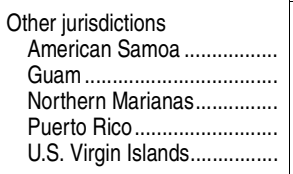 & $\begin{array}{r}85.3 \\
48.2 \\
-\overline{6} \\
60.9 \\
53.2\end{array}$ & $\begin{array}{l}79.7 \\
44.6 \\
63.3 \\
60.8 \\
54.2\end{array}$ & $\begin{array}{l}76.6 \\
39.5 \\
63.4 \\
61.9 \\
58.6\end{array}$ & $\begin{array}{l}80.4 \\
54.7 \\
63.5 \\
63.6 \\
58.6\end{array}$ & $\begin{array}{l}71.9 \\
52.9 \\
61.1 \\
64.7 \\
53.8\end{array}$ & $\begin{array}{l}77.0 \\
51.7 \\
62.7 \\
65.7 \\
57.3\end{array}$ & $\begin{array}{r}82.9 \\
- \\
65.2 \\
66.2 \\
48.7\end{array}$ & $\begin{array}{l}81.0 \\
56.3 \\
65.2 \\
67.8 \\
53.5\end{array}$ & $\begin{array}{r}80.2 \\
48.4 \\
75.3 \\
64.8 \\
-\end{array}$ & $\begin{array}{r}81.1 \\
- \\
75.4 \\
61.7 \\
-\end{array}$ & $\begin{array}{r}81.0 \\
80.3 \\
68.6 \\
-\end{array}$ & $\begin{array}{r}84.6 \\
-73.6 \\
66.7 \\
57.8\end{array}$ & $\begin{array}{r}- \\
\overline{-} \\
64.5 \\
58.3\end{array}$ & $\begin{array}{r}- \\
\overline{-} \\
67.2 \\
63.1\end{array}$ & $\begin{array}{r}- \\
\overline{-} \\
60.2 \\
65.5\end{array}$ \\
\hline
\end{tabular}

-Not available.

${ }^{1}$ Includes estimates for New York and Wisconsin. Without estimates for these two states, the averaged freshman graduation rate for the remaining 48 states and the District of Columbia is 75.0 percent.

2U.S. total includes estimates for nonreporting states.

${ }^{3}$ Estimated high school graduates from NCES 2011-312, Public School Graduates and Dropouts From the Common Core of Data: School Year 2008-09.

${ }^{4}$ Projected high school graduates from NCES 2009-062, Projections of Education Statistics to 2018.

Includes 1,161 graduates in 2007-08 and 1,169 graduates in 2008-09 from private high schools that received a majority of their funding from public sources.

${ }^{6}$ Includes 1,419 fall 2006 9th-graders who attended publicly funded private schools that were not reported in the 2006-07 Common Core of Data, but were reported in data for later years. ${ }^{7}$ Estimated high school graduates from NCES 2006-606rev, The Averaged Freshman Graduation Rate for Public High Schools From the Common Core of Data: School Years 2002-03 and 2003-04.
NOTE: The averaged freshman graduation rate provides an estimate of the percentage of students who receive a regular diploma within 4 years of entering ninth grade. The rate uses aggregate student enrollment data to estimate the size of an incoming freshman class and aggregate counts of the number of diplomas awarded 4 years later. Averaged freshman graduation rates in this table are based on reported totals of enrollment by grade and high school graduates, rather than on details reported by race/ethnicity. Some data have been revised from previously published figures.

SOURCE: U.S. Department of Education, National Center for Education Statistics, Common Core of Data (CCD), "State Nonfiscal Survey of Public Elementary/Secondary Education," 1986-87 through 2007-08; "State Dropout and Completion Data File," 2005-06 through 2009-10; The Averaged Freshman Graduation Rate for Public High Schools From the Common Core of Data: School Years 2002-03 and 2003-04; Public School Graduates and Dropouts From the Common Core of Data, 2007-08 and 2008-09; and Projections of Education Statistics to 2018. (This table was prepared October 2012.) 
Table 219.40. Public high school graduates and averaged freshman graduation rate, by race/ethnicity and state or jurisdiction: 2009-10

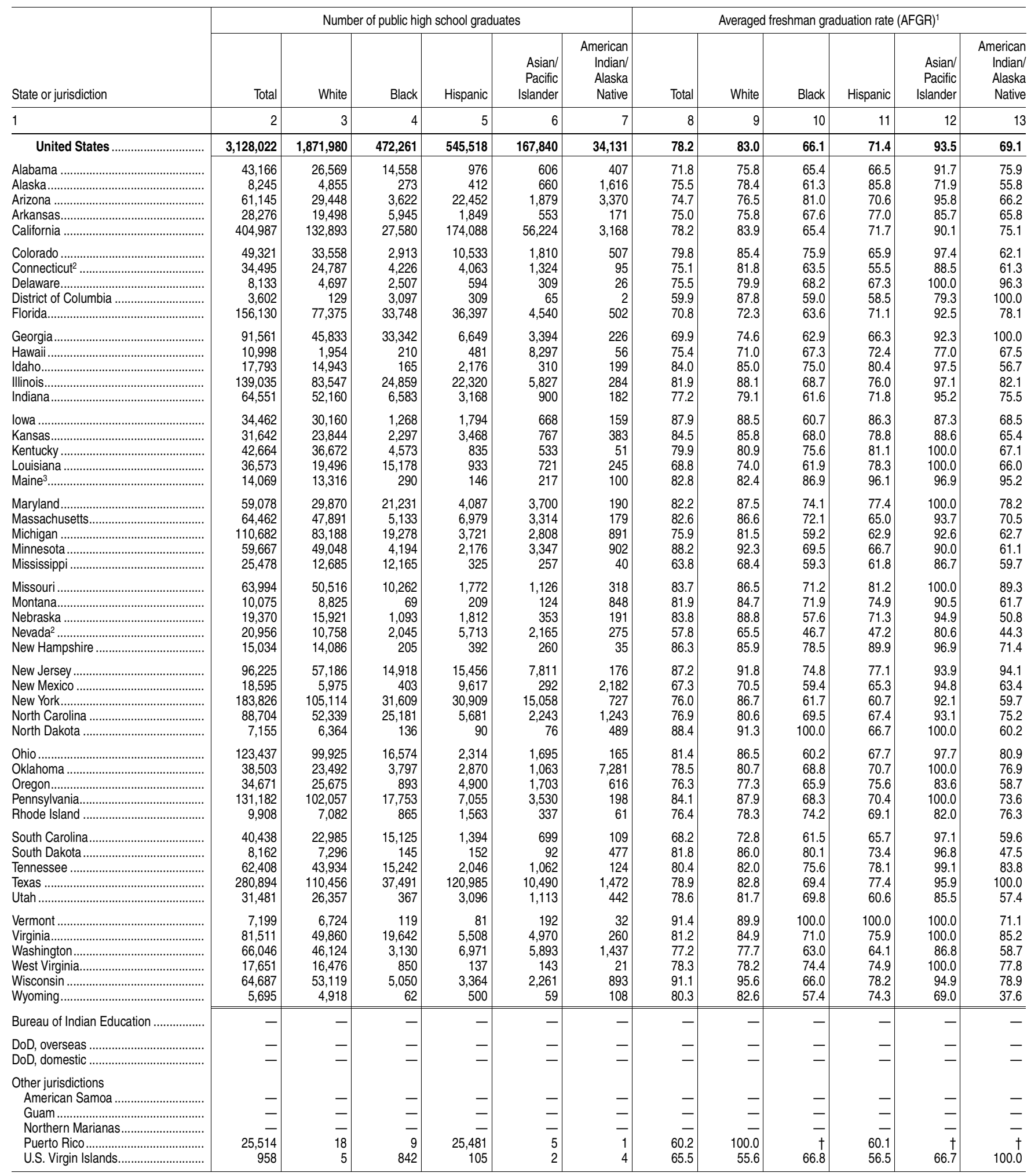

-Not available.

†Not applicable. AFGR could not be calculated because applicable enrollment was zero.

${ }^{1}$ The AFGR provides an estimate of the percentage of students who receive a regular diploma within 4 years of entering ninth grade. The rate uses aggregate student enrollment data to estimate the size of an incoming freshman class and aggregate counts of the number of diplomas awarded 4 years later.

${ }^{2} \mathrm{AFGR}$ data were imputed based on prior year rates.

3Includes 1,419 fall 2006 9th-graders who attended publicly funded private schools that were not reported in the 2006-07 Common Core of Data, but were reported in data for later years.
Of these 1,419 students, 15 were American Indian/Alaska Native, 24 were Asian/Pacific Islander, 9 were Hispanic, 20 were Black, and 1,351 were White.

NOTE: Includes only graduates for whom race/ethnicity was reported. Race categories exclude persons of Hispanic ethnicity. DoD stands for Department of Defense.

SOURCE: U.S. Department of Education, National Center for Education Statistics, Common Core of Data (CCD), "State Dropout and Completion Data File," 2009-10; and "State Nonfiscal Survey of Public Elementary/Secondary Education," 2005-06, 2006-07, and 2007-08. (This table was prepared November 2012.) 
Table 219.50. Number and percentage of 9th- to 12th-graders who dropped out of public schools, by race/ethnicity, grade, and state or jurisdiction: 2009-10

\begin{tabular}{|c|c|c|c|c|c|c|c|c|c|c|c|c|c|c|c|}
\hline \multirow[b]{3}{*}{ State or jurisdiction } & \multicolumn{7}{|c|}{$\begin{array}{l}\text { Percent of 9th- to 12th-graders who dropped out } \\
\text { (event dropout rate), by race/ethnicity }\end{array}$} & \multicolumn{8}{|c|}{$\begin{array}{l}\text { Number and percent of 9th- to 12th-graders who dropped out } \\
\text { (event dropout rate), by grade }\end{array}$} \\
\hline & \multirow[b]{2}{*}{ Total } & \multirow[b]{2}{*}{ White } & \multirow[b]{2}{*}{ Black } & \multirow[b]{2}{*}{ Hispanic } & \multirow[b]{2}{*}{$\begin{array}{r}\text { Asian/ } \\
\text { Pacific } \\
\text { Islander }\end{array}$} & \multirow[b]{2}{*}{$\begin{array}{r}\text { American } \\
\text { Indian/ } \\
\text { Alaska } \\
\text { Native }\end{array}$} & \multirow[b]{2}{*}{$\begin{array}{r}\text { Two or } \\
\text { more } \\
\text { races }\end{array}$} & \multicolumn{2}{|c|}{ Grade 9} & \multicolumn{2}{|c|}{ Grade 10} & \multicolumn{2}{|c|}{ Grade 11} & \multicolumn{2}{|c|}{ Grade 12} \\
\hline & & & & & & & & $\begin{array}{r}\text { Number } \\
\text { of } \\
\text { dropouts }\end{array}$ & $\begin{array}{r}\text { Event } \\
\text { dropout } \\
\text { rate }\end{array}$ & $\begin{array}{r}\text { Number } \\
\text { of } \\
\text { dropouts }\end{array}$ & $\begin{array}{r}\text { Event } \\
\text { dropout } \\
\text { rate }\end{array}$ & $\begin{array}{r}\text { Number } \\
\text { of } \\
\text { dropouts }\end{array}$ & $\begin{array}{r}\text { Event } \\
\text { dropout } \\
\text { rate }\end{array}$ & $\begin{array}{r}\text { Number } \\
\text { of } \\
\text { dropouts }\end{array}$ & $\begin{array}{r}\text { Event } \\
\text { dropout } \\
\text { rate }\end{array}$ \\
\hline 1 & 2 & 3 & 4 & 5 & 6 & 7 & 8 & 9 & 10 & 11 & 12 & 13 & 14 & 15 & 16 \\
\hline United States ................. & 3.4 & 2.3 & 5.5 & 5.0 & 1.9 & 6.7 & $\ddagger$ & 104,756 & 2.6 & $\begin{array}{l}113,370 \\
\end{array}$ & 3.0 & 117,536 & 3.3 & 175,806 & 5.1 \\
\hline 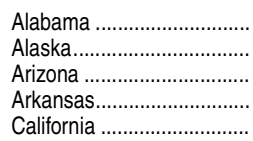 & $\begin{array}{l}1.8 \\
6.9 \\
7.8 \\
3.6 \\
4.6\end{array}$ & $\begin{array}{l}1.6 \\
5.1 \\
6.8 \\
3.1 \\
2.8\end{array}$ & $\begin{array}{l}2.0 \\
6.4 \\
8.8 \\
5.0 \\
8.4\end{array}$ & $\begin{array}{l}0.9 \\
6.1 \\
8.1 \\
4.1 \\
5.8\end{array}$ & $\begin{array}{l}1.4 \\
4.8 \\
4.9 \\
2.0 \\
2.0\end{array}$ & $\begin{array}{r}1.3 \\
11.6 \\
14.6 \\
4.9 \\
6.5\end{array}$ & $\begin{array}{l}\overline{9} \\
\overline{3.6} \\
3.1 \\
5.0\end{array}$ & $\begin{array}{r}864 \\
404 \\
4,207 \\
720 \\
13,849\end{array}$ & $\begin{array}{l}1.4 \\
4.0 \\
5.1 \\
1.9 \\
2.6\end{array}$ & $\begin{array}{r}1,128 \\
551 \\
4,594 \\
1,130 \\
15,518\end{array}$ & $\begin{array}{l}2.0 \\
5.5 \\
5.7 \\
3.2 \\
3.1\end{array}$ & $\begin{array}{r}1,048 \\
1,014 \\
5,269 \\
1,427 \\
20,625\end{array}$ & $\begin{array}{l}2.1 \\
9.3 \\
7.0 \\
4.4 \\
4.2\end{array}$ & $\begin{array}{r}862 \\
851 \\
10,795 \\
1,613 \\
42,587\end{array}$ & $\begin{array}{r}1.8 \\
8.7 \\
13.6 \\
5.3 \\
8.9\end{array}$ \\
\hline 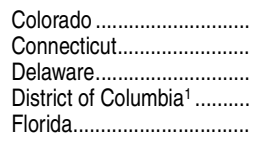 & $\begin{array}{l}5.3 \\
3.0 \\
3.9 \\
7.0 \\
2.3\end{array}$ & $\begin{array}{l}3.2 \\
1.4 \\
3.1 \\
4.9 \\
1.6\end{array}$ & $\begin{array}{l}8.6 \\
6.8 \\
4.9 \\
6.9 \\
3.5\end{array}$ & $\begin{array}{l}9.9 \\
6.9 \\
4.7 \\
8.3 \\
2.8\end{array}$ & $\begin{array}{l}2.4 \\
1.1 \\
3.2 \\
5.4 \\
0.8\end{array}$ & $\begin{array}{r}10.1 \\
3.0 \\
10.3 \\
\# \\
2.7\end{array}$ & $\begin{array}{l}- \\
- \\
- \\
-\end{array}$ & $\begin{array}{r}1,957 \\
1,316 \\
546 \\
501 \\
4,189\end{array}$ & $\begin{array}{l}3.1 \\
2.8 \\
4.7 \\
8.1 \\
1.9\end{array}$ & $\begin{array}{r}2,216 \\
1,127 \\
386 \\
262 \\
4,348\end{array}$ & $\begin{array}{l}3.7 \\
2.6 \\
3.7 \\
5.9 \\
2.2\end{array}$ & $\begin{array}{r}3,045 \\
1,452 \\
299 \\
153 \\
4,678\end{array}$ & $\begin{array}{l}5.3 \\
3.4 \\
3.4 \\
4.2 \\
2.4\end{array}$ & $\begin{array}{r}5,673 \\
1,299 \\
288 \\
133 \\
4,816\end{array}$ & $\begin{array}{l}9.7 \\
3.2 \\
3.5 \\
4.0 \\
2.8\end{array}$ \\
\hline 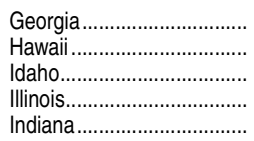 & $\begin{array}{l}3.8 \\
5.2 \\
1.4 \\
2.9 \\
1.6\end{array}$ & $\begin{array}{l}3.1 \\
6.4 \\
1.2 \\
1.8 \\
1.3\end{array}$ & $\begin{array}{l}4.6 \\
7.9 \\
1.9 \\
5.7 \\
3.1\end{array}$ & $\begin{array}{l}4.3 \\
5.9 \\
2.2 \\
3.8 \\
2.4\end{array}$ & $\begin{array}{l}1.5 \\
4.7 \\
1.2 \\
0.9 \\
1.1\end{array}$ & $\begin{array}{l}4.2 \\
9.0 \\
2.5 \\
3.0 \\
2.2\end{array}$ & $\begin{array}{l}3.4 \\
- \\
- \\
-\end{array}$ & $\begin{array}{r}5,800 \\
562 \\
211 \\
3,482 \\
373\end{array}$ & $\begin{array}{l}4.0 \\
3.7 \\
1.0 \\
2.0 \\
0.4\end{array}$ & $\begin{array}{r}5,095 \\
816 \\
235 \\
5,287 \\
945\end{array}$ & $\begin{array}{l}4.2 \\
5.7 \\
1.1 \\
3.1 \\
1.2\end{array}$ & $\begin{array}{r}4,074 \\
726 \\
301 \\
3,970 \\
1,349\end{array}$ & $\begin{array}{l}3.8 \\
5.8 \\
1.5 \\
2.7 \\
1.7\end{array}$ & $\begin{array}{r}2,800 \\
632 \\
386 \\
5,801 \\
2,346\end{array}$ & $\begin{array}{l}2.9 \\
6.0 \\
2.0 \\
4.0 \\
3.2\end{array}$ \\
\hline 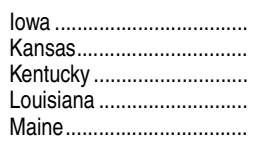 & $\begin{array}{l}3.4 \\
2.1 \\
3.2 \\
4.8 \\
4.2\end{array}$ & $\begin{array}{l}2.8 \\
1.8 \\
2.9 \\
3.2 \\
4.2\end{array}$ & $\begin{array}{l}9.1 \\
3.7 \\
5.5 \\
6.8 \\
4.9\end{array}$ & $\begin{array}{l}6.9 \\
2.9 \\
5.6 \\
3.9 \\
5.0\end{array}$ & \begin{tabular}{l|}
2.1 \\
0.7 \\
2.0 \\
2.0 \\
3.8
\end{tabular} & $\begin{array}{l}8.9 \\
4.1 \\
1.9 \\
4.8 \\
8.6\end{array}$ & $\begin{array}{l}4.9 \\
2.0 \\
- \\
- \\
-\end{array}$ & $\begin{array}{r}363 \\
442 \\
1,076 \\
3,229 \\
252\end{array}$ & $\begin{array}{l}1.0 \\
1.2 \\
2.0 \\
5.7 \\
1.7\end{array}$ & $\begin{array}{r}713 \\
661 \\
1,769 \\
1,920 \\
349\end{array}$ & $\begin{array}{l}1.9 \\
1.9 \\
3.5 \\
4.2 \\
2.3\end{array}$ & $\begin{array}{r}1,276 \\
765 \\
1,762 \\
1,663 \\
703\end{array}$ & $\begin{array}{l}3.5 \\
2.3 \\
3.8 \\
4.1 \\
4.8\end{array}$ & $\begin{array}{l}2,747 \\
1,105 \\
1,615 \\
1,892 \\
1,260\end{array}$ & $\begin{array}{l}7.1 \\
3.3 \\
3.7 \\
4.9 \\
8.3\end{array}$ \\
\hline 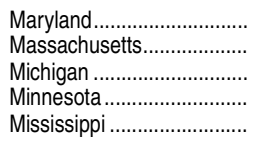 & $\begin{array}{l}2.7 \\
2.8 \\
4.3 \\
1.6 \\
7.4\end{array}$ & $\begin{array}{l}2.0 \\
1.7 \\
2.7 \\
1.0 \\
5.6\end{array}$ & $\begin{array}{l}3.4 \\
5.0 \\
9.2 \\
3.9 \\
9.3\end{array}$ & $\begin{array}{l}4.2 \\
7.3 \\
6.2 \\
4.2 \\
5.9\end{array}$ & $\begin{array}{l}0.9 \\
1.7 \\
3.1 \\
1.6 \\
2.8\end{array}$ & $\begin{array}{l}3.2 \\
3.3 \\
5.4 \\
5.7 \\
4.6\end{array}$ & $\begin{array}{c}\overline{-} \\
\overline{-} \\
\overline{\#}\end{array}$ & $\begin{array}{r}1,998 \\
2,356 \\
4,305 \\
337 \\
2,399\end{array}$ & $\begin{array}{l}2.7 \\
3.0 \\
3.1 \\
0.5 \\
6.0\end{array}$ & $\begin{array}{r}2,029 \\
2,045 \\
6,661 \\
453 \\
2,651\end{array}$ & $\begin{array}{l}3.0 \\
2.8 \\
4.9 \\
0.7 \\
7.3\end{array}$ & $\begin{array}{r}1,686 \\
1,837 \\
5,318 \\
796 \\
2,339\end{array}$ & $\begin{array}{l}2.7 \\
2.6 \\
4.2 \\
1.2 \\
7.3\end{array}$ & $\begin{array}{l}1,369 \\
1,847 \\
6,699 \\
2,752 \\
2,023\end{array}$ & $\begin{array}{l}2.2 \\
2.7 \\
5.3 \\
3.7 \\
7.0\end{array}$ \\
\hline 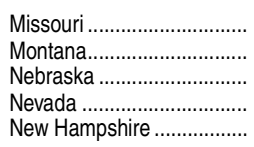 & $\begin{array}{l}3.5 \\
4.3 \\
2.2 \\
4.5 \\
1.2\end{array}$ & $\begin{array}{l}2.4 \\
3.5 \\
1.6 \\
3.4 \\
1.1\end{array}$ & $\begin{array}{l}8.4 \\
7.0 \\
4.1 \\
6.5 \\
1.6\end{array}$ & $\begin{array}{l}4.1 \\
6.2 \\
4.0 \\
5.4 \\
2.9\end{array}$ & $\begin{array}{l}1.5 \\
2.0 \\
1.8 \\
3.1 \\
1.1\end{array}$ & $\begin{array}{r}3.0 \\
10.3 \\
7.0 \\
4.7 \\
1.5\end{array}$ & $\begin{array}{l}- \\
- \\
\overline{-} \\
1.0\end{array}$ & $\begin{array}{r}2,139 \\
340 \\
186 \\
790 \\
3\end{array}$ & $\begin{array}{r}2.9 \\
2.9 \\
0.8 \\
2.3 \\
\#\end{array}$ & $\begin{array}{r}2,009 \\
435 \\
372 \\
1,389 \\
6\end{array}$ & $\begin{array}{r}2.9 \\
3.9 \\
1.7 \\
4.0 \\
\#\end{array}$ & $\begin{array}{r}2,449 \\
527 \\
538 \\
1,294 \\
90\end{array}$ & $\begin{array}{l}3.6 \\
4.9 \\
2.5 \\
4.4 \\
0.6\end{array}$ & $\begin{array}{r}3,245 \\
599 \\
825 \\
2,071 \\
667\end{array}$ & $\begin{array}{l}4.8 \\
5.7 \\
3.7 \\
8.0 \\
4.3\end{array}$ \\
\hline 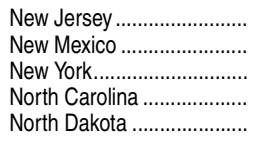 & $\begin{array}{l}1.6 \\
6.9 \\
3.6 \\
4.7 \\
2.2\end{array}$ & $\begin{array}{l}0.9 \\
5.3 \\
1.7 \\
4.0 \\
1.7\end{array}$ & $\begin{array}{l}3.5 \\
9.0 \\
6.5 \\
5.4 \\
2.6\end{array}$ & $\begin{array}{l}2.8 \\
7.2 \\
5.9 \\
6.1 \\
3.5\end{array}$ & $\begin{array}{l}0.4 \\
4.6 \\
2.4 \\
2.0 \\
0.9\end{array}$ & $\begin{array}{l}1.5 \\
8.8 \\
5.6 \\
6.1 \\
7.5\end{array}$ & $\begin{array}{l}3.4 \\
4.7 \\
- \\
- \\
-\end{array}$ & $\begin{array}{r}1,696 \\
2,229 \\
7,354 \\
6,553 \\
40\end{array}$ & $\begin{array}{l}1.6 \\
7.5 \\
3.1 \\
5.1 \\
0.5\end{array}$ & $\begin{array}{r}1,667 \\
2,075 \\
8,222 \\
5,535 \\
174\end{array}$ & $\begin{array}{l}1.6 \\
7.8 \\
3.5 \\
4.9 \\
2.3\end{array}$ & $\begin{array}{r}1,522 \\
1,484 \\
6,674 \\
4,769 \\
207\end{array}$ & $\begin{array}{l}1.5 \\
6.6 \\
3.4 \\
4.8 \\
2.7\end{array}$ & $\begin{array}{r}1,594 \\
1,021 \\
8,931 \\
3,338 \\
259\end{array}$ & $\begin{array}{l}1.6 \\
5.1 \\
4.7 \\
3.8 \\
3.4\end{array}$ \\
\hline 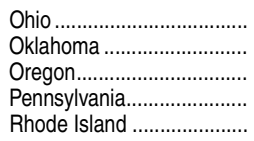 & $\begin{array}{l}4.2 \\
2.4 \\
3.4 \\
2.1 \\
4.6\end{array}$ & $\begin{array}{l}2.8 \\
2.1 \\
2.9 \\
1.5 \\
3.8\end{array}$ & $\begin{array}{l}9.4 \\
3.3 \\
6.2 \\
3.7 \\
6.6\end{array}$ & $\begin{array}{l}7.4 \\
3.5 \\
4.7 \\
5.1 \\
6.8\end{array}$ & $\begin{array}{l}1.4 \\
1.1 \\
1.4 \\
1.3 \\
4.5\end{array}$ & $\begin{array}{l}7.8 \\
2.5 \\
6.7 \\
2.2 \\
8.5\end{array}$ & $\begin{array}{l}- \\
- \\
- \\
-\end{array}$ & $\begin{array}{r}6,968 \\
949 \\
465 \\
1,643 \\
573\end{array}$ & $\begin{array}{l}4.4 \\
1.9 \\
1.0 \\
1.1 \\
4.4\end{array}$ & $\begin{array}{r}3,853 \\
1,062 \\
771 \\
3,029 \\
613\end{array}$ & $\begin{array}{l}2.8 \\
2.3 \\
1.7 \\
2.0 \\
5.0\end{array}$ & $\begin{array}{r}4,574 \\
1,188 \\
1,451 \\
3,268 \\
509\end{array}$ & $\begin{array}{l}3.7 \\
2.8 \\
3.3 \\
2.3 \\
4.7\end{array}$ & $\begin{array}{r}7,011 \\
1,086 \\
3,299 \\
4,302 \\
471\end{array}$ & $\begin{array}{l}5.9 \\
2.7 \\
7.2 \\
3.1 \\
4.4\end{array}$ \\
\hline 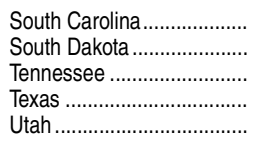 & $\begin{array}{l}3.0 \\
2.6 \\
2.7 \\
2.7 \\
2.6\end{array}$ & $\begin{array}{l}2.7 \\
1.6 \\
1.8 \\
1.2 \\
2.1\end{array}$ & $\begin{array}{l}3.3 \\
3.4 \\
4.9 \\
4.2 \\
3.8\end{array}$ & $\begin{array}{l}3.6 \\
5.2 \\
3.3 \\
3.6 \\
5.5\end{array}$ & $\begin{array}{l}1.3 \\
2.7 \\
1.2 \\
0.5 \\
2.8\end{array}$ & $\begin{array}{r}5.6 \\
10.5 \\
2.7 \\
3.6 \\
5.7\end{array}$ & $\begin{array}{l}- \\
- \\
- \\
-\end{array}$ & $\begin{array}{r}1,691 \\
184 \\
1,370 \\
6,945 \\
207\end{array}$ & $\begin{array}{l}2.7 \\
1.8 \\
1.8 \\
1.8 \\
0.5\end{array}$ & $\begin{array}{r}1,811 \\
267 \\
1,579 \\
8,253 \\
555\end{array}$ & $\begin{array}{l}3.3 \\
2.7 \\
2.1 \\
2.5 \\
1.4\end{array}$ & $\begin{array}{r}1,547 \\
258 \\
1,790 \\
6,824 \\
927\end{array}$ & $\begin{array}{l}3.2 \\
2.8 \\
2.6 \\
2.2 \\
2.3\end{array}$ & $\begin{array}{r}1,220 \\
291 \\
2,843 \\
14,048 \\
2,444\end{array}$ & $\begin{array}{l}2.7 \\
3.3 \\
4.3 \\
4.8 \\
6.1\end{array}$ \\
\hline 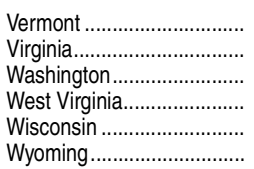 & $\begin{array}{l}2.4 \\
2.1 \\
4.2 \\
4.0 \\
2.2 \\
6.0\end{array}$ & $\begin{array}{l}2.4 \\
1.4 \\
3.6 \\
4.0 \\
1.2 \\
5.0\end{array}$ & $\begin{array}{r}1.5 \\
3.0 \\
6.1 \\
4.6 \\
7.5 \\
13.1\end{array}$ & \begin{tabular}{r|}
2.6 \\
4.6 \\
5.8 \\
4.6 \\
4.7 \\
$\#$
\end{tabular} & $\begin{array}{l}2.0 \\
1.2 \\
3.0 \\
0.5 \\
1.6 \\
1.7\end{array}$ & $\begin{array}{r}\# \\
1.6 \\
8.2 \\
3.6 \\
5.2 \\
20.8\end{array}$ & $\begin{array}{r}4.1 \\
\overline{-} \\
1.9 \\
94.9\end{array}$ & $\begin{array}{r}76 \\
1,741 \\
2,881 \\
809 \\
971 \\
215\end{array}$ & $\begin{array}{l}1.0 \\
1.7 \\
3.4 \\
3.4 \\
1.4 \\
3.2\end{array}$ & $\begin{array}{r}180 \\
1,857 \\
2,792 \\
848 \\
611 \\
516\end{array}$ & $\begin{array}{l}2.4 \\
1.9 \\
3.4 \\
4.1 \\
0.9 \\
7.3\end{array}$ & $\begin{array}{r}215 \\
1,934 \\
3,472 \\
839 \\
1,222 \\
389\end{array}$ & $\begin{array}{l}3.0 \\
2.1 \\
4.4 \\
4.4 \\
1.7 \\
6.1\end{array}$ & $\begin{array}{r}250 \\
2,467 \\
4,815 \\
798 \\
3,260 \\
460\end{array}$ & $\begin{array}{l}3.4 \\
2.8 \\
5.8 \\
4.3 \\
4.6 \\
7.5\end{array}$ \\
\hline Bureau of Indian Education. & - & - & - & - & - & - & - & - & - & - & - & - & - & - & - \\
\hline 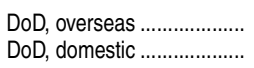 & $\begin{array}{l}- \\
-\end{array}$ & - & - & - & $\begin{array}{l}- \\
-\end{array}$ & $\begin{array}{l}- \\
-\end{array}$ & - & $\begin{array}{l}- \\
-\end{array}$ & - & - & $\begin{array}{l}- \\
-\end{array}$ & $\begin{array}{l}- \\
-\end{array}$ & $\begin{array}{l}- \\
-\end{array}$ & $\begin{array}{l}- \\
-\end{array}$ & 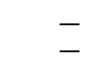 \\
\hline $\begin{array}{l}\text { Other jurisdictions } \\
\text { American Samoa ............ } \\
\text { Guam ....................... } \\
\text { Northern Marianas......... } \\
\text { Puerto Rico................. } \\
\text { U.S. Virgin Islands......... }\end{array}$ & $\begin{array}{l}- \\
\overline{-} \\
\overline{-} \\
5.5\end{array}$ & $\begin{array}{c}- \\
- \\
- \\
\overline{\#}\end{array}$ & $\begin{array}{l}\overline{-} \\
\overline{-} \\
\overline{5.3}\end{array}$ & $\begin{array}{l}- \\
- \\
- \\
7.4\end{array}$ & $\begin{array}{l}- \\
- \\
- \\
- \\
\#\end{array}$ & $\begin{array}{l}- \\
\overline{-} \\
\bar{Z} \\
\#\end{array}$ & $\begin{array}{l}- \\
- \\
- \\
-\end{array}$ & $\begin{array}{c}- \\
- \\
- \\
\overline{1} \\
122\end{array}$ & $\begin{array}{l}- \\
- \\
- \\
\overline{7} .2\end{array}$ & $\begin{array}{l}- \\
- \\
- \\
68\end{array}$ & $\begin{array}{l}- \\
- \\
- \\
5.5\end{array}$ & $\begin{array}{l}- \\
- \\
- \\
53\end{array}$ & $\begin{array}{l}- \\
\overline{-} \\
\overline{-} \\
4.7\end{array}$ & $\begin{array}{l}- \\
- \\
\overline{-} \\
38\end{array}$ & $\begin{array}{l}- \\
\overline{-} \\
\overline{3.7}\end{array}$ \\
\hline
\end{tabular}

-Not available.

\#Reporting standards not met (too few cases for a reliable estimate).

IRata were imputed based on prior year rates.

NOTE: Race categories exclude persons of Hispanic ethnicity. Event dropout rates measure the percentage of public school students in grades 9 through 12 who dropped out of school between one October and the next. Enrollment and dropout data for ungraded students were prorated into grades 9 through 12 based on the counts for graded students. DoD stands for Department of Defense.

SOURCE: U.S. Department of Education, National Center for Education Statistics, Common Core of Data (CCD), "State Dropout and Completion Data File," 2009-10. (This table was prepared November 2012.) 
216 CHAPTER 2: Elementary and Secondary Education

High School Completers and Dropouts

Table 219.60. Number of people taking the general educational development (GED) test and percentage distribution of those who passed, by age group: 1971 through 2012

\begin{tabular}{|c|c|c|c|c|c|c|c|c|}
\hline \multirow[b]{2}{*}{ Year } & \multicolumn{3}{|c|}{ Number of test takers (in thousands) } & \multicolumn{5}{|c|}{ Percentage distribution of test passers, by age group ${ }^{1}$} \\
\hline & Total $^{2}$ & $\begin{array}{c}\text { Completing } \\
\text { test battery }\end{array}$ & Passing tests ${ }^{4}$ & 16 to 18 years old & 19 to 24 years old & 25 to 29 years old & 30 to 34 years old & 35 years old or over \\
\hline 1 & 2 & 3 & 4 & 5 & 6 & 7 & 8 & 9 \\
\hline $1971^{5}$. & 377 & - & 227 & - & - & - & - & - \\
\hline $1972^{5} \ldots \ldots \ldots \ldots \ldots \ldots \ldots$ & 419 & - & 245 & - & - & - & - & - \\
\hline $1973^{5} \ldots \ldots \ldots \ldots \ldots \ldots \ldots \ldots \ldots \ldots$ & 423 & - & 249 & - & - & - & - & - \\
\hline 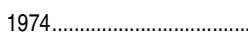 & - & - & 294 & $35^{6}$ & $27^{6}$ & 13 & 9 & 17 \\
\hline $1975 \ldots \ldots \ldots \ldots \ldots \ldots \ldots$ & - & - & 340 & $33^{6}$ & $26^{6}$ & 14 & 9 & 18 \\
\hline 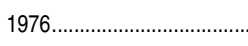 & - & - & 333 & $31^{6}$ & $28^{6}$ & 14 & 10 & 17 \\
\hline $1977 \ldots \ldots \ldots \ldots \ldots \ldots \ldots \ldots \ldots \ldots \ldots$ & - & - & 330 & $40^{6}$ & $24^{6}$ & 13 & 8 & 14 \\
\hline 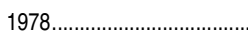 & - & - & 381 & $31^{6}$ & $27^{6}$ & 13 & 10 & 18 \\
\hline 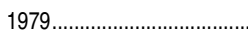 & - & - & 426 & $37^{6}$ & $28^{6}$ & 12 & 13 & 11 \\
\hline 1980 & - & - & 479 & $37^{6}$ & $27^{6}$ & 13 & 8 & 15 \\
\hline 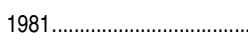 & - & - & 489 & $37^{6}$ & $27^{6}$ & 13 & 8 & 14 \\
\hline $1982 \ldots \ldots$ & - & - & 486 & $37^{6}$ & $28^{6}$ & 13 & 8 & 15 \\
\hline 1983.......................... & - & - & 465 & 346 & 296 & 14 & 8 & 15 \\
\hline $1984 \ldots$ & - & - & 427 & 326 & $28^{6}$ & 15 & 9 & 16 \\
\hline $1985 \ldots \ldots \ldots \ldots \ldots \ldots \ldots \ldots \ldots$ & - & - & 413 & $32^{6}$ & $26^{6}$ & 15 & 10 & 16 \\
\hline 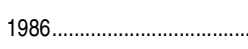 & - & - & 428 & $32^{6}$ & $26^{6}$ & 15 & 10 & 17 \\
\hline $1987 \ldots \ldots \ldots$ & - & - & 444 & $33^{6}$ & 246 & 15 & 10 & 18 \\
\hline 1988 & - & - & 410 & $35^{6}$ & 226 & 14 & 10 & 18 \\
\hline $1989 \ldots \ldots \ldots \ldots \ldots \ldots$ & 632 & 541 & 357 & 22 & 37 & 13 & - & - \\
\hline $1990 \ldots \ldots \ldots \ldots \ldots . . .$. & 714 & 615 & 410 & 22 & 39 & 13 & 10 & 15 \\
\hline 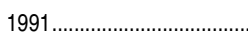 & 755 & 657 & 462 & 20 & 40 & 13 & 10 & 16 \\
\hline 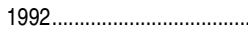 & 739 & 639 & 457 & 22 & 39 & 13 & 9 & 17 \\
\hline 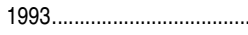 & 746 & 651 & 469 & 22 & 38 & 13 & 10 & 16 \\
\hline 1994................................. & 774 & 668 & 491 & 25 & 37 & 13 & 10 & 15 \\
\hline 1995 & 787 & 682 & 504 & 27 & 36 & 13 & 9 & 15 \\
\hline $1996 \ldots \ldots \ldots \ldots . . . . .$. & 824 & 716 & 488 & 27 & 37 & 13 & 9 & 14 \\
\hline 1997.................... & 785 & 681 & 460 & 31 & 36 & 12 & 8 & 13 \\
\hline 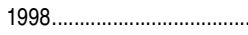 & 776 & 673 & 481 & 32 & 36 & 11 & 7 & 13 \\
\hline 1999......................... & 808 & 702 & 498 & 32 & 37 & 11 & 7 & 13 \\
\hline 2000 & 811 & 699 & 487 & 33 & 37 & 11 & 7 & 13 \\
\hline $2001^{7} \ldots \ldots \ldots \ldots \ldots$ & 1,016 & 928 & 648 & 29 & 38 & 11 & 8 & 14 \\
\hline $2002^{7}$ & 557 & 467 & 330 & 38 & 36 & 10 & 6 & 11 \\
\hline $2003 \ldots \ldots$ & 657 & 552 & 387 & 35 & 37 & 10 & 7 & 11 \\
\hline 2004 & 666 & 570 & 406 & 35 & 38 & 11 & 6 & 10 \\
\hline 2005 & 681 & 588 & 424 & 34 & 37 & 12 & 7 & 11 \\
\hline $2006 \ldots$ & 676 & 580 & 398 & 35 & 36 & 12 & 6 & 11 \\
\hline 2007 & 692 & 600 & 429 & 35 & 35 & 12 & 7 & 11 \\
\hline 2008 & 737 & 642 & 469 & 34 & 35 & 13 & 7 & 11 \\
\hline 2009 & 748 & 645 & 448 & 31 & 36 & 13 & 8 & 12 \\
\hline $2010 \ldots$ & 720 & 623 & 452 & 27 & 37 & 14 & 9 & 14 \\
\hline $2011 \ldots \ldots \ldots \ldots$ & 691 & 602 & 434 & 27 & 37 & 13 & 9 & 14 \\
\hline $2012 \ldots$ & 674 & 581 & 401 & 26 & 37 & 14 & 9 & 13 \\
\hline
\end{tabular}

-Not available.

${ }^{1}$ Age data for 1988 and prior years are for all test takers and may not be comparable to data for later years. For 1989 and later years, age data are only for test passers. The less than 1 percent of people who failed to report their date of birth-245 of the 401,388 test passers in 2012 - were excluded from the calculation.

${ }^{2}$ All people taking the GED tests (one or more subtests).

${ }^{3}$ People completing the entire GED battery of five tests.

${ }^{4}$ Data for 2002 and later years are for people passing the GED tests (i.e., earning both a passing total score on the test battery and a passing score on each individual test). Data for 2001 and prior years are for high school equivalency credentials issued by the states to GED test passers. In order to receive high school equivalency credentials in some states, GED test passers must meet additional state requirements (e.g., complete an approved course in civics or government).
Includes other jurisdictions, such as Puerto Rico, Guam, and American Samoa. ${ }^{6}$ For 1988 and prior years, 19-year-olds are included with the 16- to 18-year-olds instead of the 19- to 24-year-olds.

${ }^{7} \mathrm{~A}$ revised GED test was introduced in 2002. In 2001, test takers were required to successfully complete all five components of the GED or else begin the five-part series again with the new test that was introduced in 2002

NOTE: Data are for the United States only and exclude other jurisdictions, except where NOTE: Data are for the United States only and exclude
noted. Detail may not sum to totals because of rounding.

SOURCE: American Council on Education, General Educational Development Testing Service, the GED annual Statistical Report, 1971 through 1992; Who Took the GED? 1993 through 2001; Who Passed the GED Tests? 2002 through 2005; and GED Testing Program Statistical Report, 2006 through 2012, retrieved July 15, 2013, from http://www.gedtesting service.com/educators/historical-testing-data. (This table was prepared July 2013.) 
Table 219.70. Percentage of high school dropouts among persons 16 through 24 years old (status dropout rate), by sex and race/ethnicity: Selected years, 1960 through 2012

[Standard errors appear in parentheses]

\begin{tabular}{|c|c|c|c|c|c|c|c|c|c|c|c|c|c|c|c|c|c|c|c|c|c|c|c|c|}
\hline \multirow[b]{2}{*}{ Year } & \multicolumn{8}{|c|}{ Total status dropout rate } & \multicolumn{8}{|c|}{ Male status dropout rate } & \multicolumn{8}{|c|}{ Female status dropout rate } \\
\hline & & races $^{1}$ & & White & & Black & & ispanic & & races $^{1}$ & & White & & Black & & Hispanic & & | races $^{1}$ & & White & & Black & & -ispanic \\
\hline 1 & & 2 & & 3 & & 4 & & 5 & & 6 & & 7 & & 8 & & 9 & & 10 & & 11 & & 12 & & 13 \\
\hline $60^{2}$ & 2 & $(-)$ & - & $(\dagger)$ & - & $(t)$ & - & $(\dagger)$ & 7.8 & $(-)$ & - & $(\dagger)$ & - & $(\dagger)$ & - & $(\dagger)$ & 6.7 & $(-)$ & - & $(t)$ & - & (t) & - & $(†)$ \\
\hline & & $(-)$ & 15.4 & $(-)$ & 28.6 & $(-)$ & - & $(\dagger)$ & .5 & $(-)$ & 4.7 & $(-)$ & 0.6 & $(-)$ & - & $(\dagger)$ & 7.3 & $(-)$ & 6.1 & $(-)$ & 6.9 & $(-)$ & - & (†) \\
\hline & & $(-)$ & 14.7 & $(-)$ & 27.4 & $(-)$ & - & $(\dagger)$ & 5.8 & $(-)$ & 4 & $(-)$ & 81 & $(-)$ & - & (†) & 6.5 & $(-)$ & 5.0 & $(-)$ & 7.6 & $(-)$ & - & (†) \\
\hline & 15.2 & & 13.6 & $(-)$ & 26.7 & $(-)$ & - & $(\dagger)$ & 14.3 & $(-)$ & 2.6 & $(-)$ & 26.9 & $(-)$ & - & $(†)$ & 16.0 & $(-)$ & 4.6 & $(-)$ & 3.7 & $(-)$ & - & (†) \\
\hline & 0 & $(0.29)$ & 13.2 & $(0.30)$ & 27.9 & $(1.22)$ & - & & 1.2 & $(0.42)$ & 2.2 & $(0.42)$ & 9.4 & $(1.02)$ & - & $(\dagger)$ & 15.7 & (0.41) & 4.1 & (0.42) & 3.6 & $(1.00)$ & - & \\
\hline & .7 & $(0.28)$ & 13.4 & $(0.29)$ & 24.0 & $(1.14)$ & - & $(\dagger)$ & 4.2 & $(0.41)$ & 2.6 & $(0.41)$ & 5.5 & (1.70) & - & $(\dagger)$ & 15.2 & $(0.40)$ & 4.2 & $(0.42)$ & 2.6 & $(1.54)$ & - & 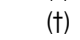 \\
\hline & 6 & $(0.28)$ & 12.3 & $(0.29)$ & .3 & $(1.07)$ & 34.3 & (2.22) & 4.1 & $(0.40)$ & 1.6 & $(0.40)$ & 2.3 & (1.59) & 33.7 & $(3.23)$ & 5.1 & $(0.39)$ & 2.8 & $(0.41)$ & 0.5 & $(1.44)$ & 4.8 & $(3.05)$ \\
\hline & .1 & $(0.27)$ & 11.6 & $(0.28)$ & .2 & $(1.06)$ & .5 & (2.24) & 3.7 & $(0.38)$ & 1.5 & $(0.39)$ & 1.5 & (1.53) & 0.4 & $(3.16)$ & 14.5 & $(0.38)$ & .8 & $(0.39)$ & 2.8 & $(1.47)$ & 6.4 & $(3.16)$ \\
\hline & .3 & $(0.27)$ & 11.9 & $(0.28)$ & 21.2 & $(1.05)$ & 33.0 & (2.08) & 14.2 & $(0.39)$ & 12.0 & $(0.40)$ & 20.1 & (1.51) & 3.8 & $(2.99)$ & 14.3 & $(0.38)$ & 1.8 & $(0.39)$ & 2.1 & $(1.45)$ & 2.2 & $(2.90)$ \\
\hline & & 27) & & & & & 2 & & 3 & () & .0 & & & 5) & .7 & & .5 & & & & & & 6 & \\
\hline & & $(0.27)$ & 12 & & .5 & & 4 & & 17 & & 1 & $(0$. & 2 & (1.49) & .3 & & 1.2 & 37) & & (0. & & & & 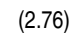 \\
\hline & 1 & $(0.27)$ & 11.9 & & 9.8 & $(0.99)$ & .0 & (2. & .5 & (0. & 2.6 & $(0$. & 1.5 & (1. & 1.6 & $(2.89)$ & 3.8 & $(0.37)$ & & $(0$. & 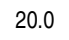 & & 3 & (2) \\
\hline & .2 & $(0.27)$ & 11.9 & (0. & 20.2 & $(1.00)$ & 33.3 & (2. & 1.6 & $(0.38)$ & 12.2 & $(0.40)$ & 2.5 & (1.52) & 3.6 & $(2.88)$ & 3.9 & $(0.37)$ & 6 & $(0.3$ & 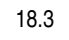 & 1 & 3.1 & $(2.7$ \\
\hline & 4.6 & $(0.27)$ & 12.0 & $(0.28)$ & 21.1 & $(1.01)$ & 33.8 & (1.98) & 5.0 & $(0.39)$ & 12.6 & $(0.40$ & 22.4 & $(1.52$ & 33.0 & $(2.83)$ & 14.2 & $(0.37)$ & 1.5 & 10.38 & 0.0 & (1.3 & 4.5 & $(2.77)$ \\
\hline & .1 & $(0.26)$ & 111. & 10. & .1 & $(0$. & 2 & 1. & .1 & & 12.3 & & 8 & & 7.2 & & 3.1 & & & & & & & \\
\hline & 9 & $(0.26)$ & 11.3 & & .4 & & 2 & ( & 5.1 & & 2.5 & & 9 & & 5.0 & & .8 & & & & & & & \\
\hline & & $(0.27)$ & 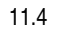 & & 4 & & & & .5 & & 2.0 & & & & 1.5 & & 3.3 & & & & & & & \\
\hline & 3.7 & $(0.27)$ & 11.1 & & .0 & & 6 & & .9 & & 2 & & 9 & (1. & 3 & & .5 & & & & & & 1 & \\
\hline & 13. & $(0.27)$ & 11.0 & $(0.2$ & 15.5 & $(0.9$ & 29.8 & (1. & 4.0 & $(0.4$ & 11.9 & $(0$. & 8 & (1.3 & 30.6 & $(2.78)$ & 12.3 & $(0.37)$ & .1 & $(0.3$ & 4.3 & (1.2 & 9.0 & 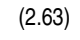 \\
\hline & 6 & $(0.27)$ & 0.4 & & 2 & (0. & 6 & (1. & 4 & 10 & .1 & & 1 & (1. & 9.9 & 6) & .8 & & & & 4.3 & & 2 & \\
\hline & 2 & $(0.27)$ & 7 & & 2 & & 1 & & 1 & & .3 & & 0 & & 2.8 & 66) & 1.4 & & 1 & & .5 & & 2 & \\
\hline & 6 & $(0.28)$ & 4 & & 1 & & 6 & & 2 & & .8 & & 0 & & .1 & & 2.1 & & .0 & & & & & \\
\hline & .9 & $(0.30)$ & 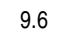 & & .5 & & 8 & & .5 & & .3 & & 0 & & 0 & & 2.2 & & 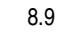 & & 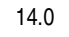 & & & \\
\hline & 12.6 & $(0.31)$ & 9.4 & $(0.32)$ & 13.9 & $(0.98)$ & 33.0 & (2.19) & 3.6 & $(0.45)$ & 10.3 & $(0.47)$ & 4.9 & $(1.46$ & 34.4 & $(3.08)$ & 11.7 & $(0.4$ & .5 & $(0.4$ & 3.0 & (1.3 & .6 & (3.11) \\
\hline & & $(0$. & & & & & & & & & & & & & 3 & & 1.8 & & 7 & & & & & \\
\hline & .5 & $(0.30)$ & 8.9 & & 6 & $(0.9$ & 3 & (1 & 0 & 6 & 9 & (0. & 1.5 & (1.37) & 9.2 & $(2.74)$ & 1.9 & $(0.41)$ & 9 & $(0.43)$ & 7 & & 1 & \\
\hline & .0 & $(0.28)$ & 7.7 & $(0.29)$ & 3.7 & $(0.95)$ & 9.4 & $(1.86)$ & .3 & (0. & 3.0 & $(0.42)$ & 2.5 & (1.32) & 2.1 & $(2.67)$ & 10.7 & $(0.39)$ & 4 & $(0.40)$ & 4.8 & & 6 & \\
\hline & 0 & $(0.28)$ & 7.9 & (0. & 3.6 & $(0.94)$ & 7.5 & (1.7) & .2 & (0. & 8.2 & $(0.42)$ & 2.6 & & 8.1 & (2.54) & 10.9 & $(0.40)$ & 6 & $(0.41)$ & 4 & & .9 & \\
\hline & 11.4 & $(0.26)$ & 7.7 & (0. & 12.6 & $(0.75)$ & 30.0 & (1.1 & 12.3 & $(0.3 \varepsilon$ & 8.0 & $(0.38$ & 4.1 & (1.1 & 31.6 & $(1.60)$ & 10.6 & $(0.36)$ & 7.5 & $(0.37)$ & 1.3 & $(0.9$ & 3.1 & $(1.66)$ \\
\hline & & $(0.2$ & & & & & & & & & & & & & 0 & & .7 & & & & & & & \\
\hline & 1 & $(0.27)$ & 7.3 & & 0 & & .4 & & .4 & & 3 & & .5 & & .3 & & 0.9 & & s & & 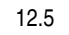 & & & \\
\hline & 0 & $(0.27)$ & 7.6 & $(0.2$ & 3.4 & $(0.8$ & 3 & & .9 & (0. & 8.5 & $(0$. & 3.3 & (1. & 7.0 & $(1.55)$ & 10.1 & (0. & 7 & (0. & .5 & & 4 & \\
\hline & 1.8 & $(0.27)$ & 7.7 & $(0.28)$ & 13.8 & $(0.81)$ & 29.5 & (1.1 & 3.3 & $(0.4 C$ & 8.6 & $(0.41)$ & 5.5 & (1.24) & 33.5 & $(1.59)$ & 10.3 & $(0.36)$ & 9 & $(0.37)$ & 2.2 & (1 & 50 & (1.56) \\
\hline ..... & 11.2 & $(0.26)$ & 7.3 & $(0.27)$ & 12.6 & $(0.77)$ & 28.6 & (1.11 & 11.9 & $(0.38$ & 7.7 & $(0.39)$ & 12.1 & (1.10 & 31.0 & $(1.58)$ & 10.5 & $(0.36)$ & 6.9 & $(0.37)$ & 13.0 & $(1.08)$ & 6.0 & (1.54) \\
\hline & & 10. & & & & & & & & & 0 & & & & 8 & & 9 & & & & & & & \\
\hline & .7 & $(0.25)$ & 7.3 & & 9 & & .0 & (1. & .2 & (u. & 7.9 & & 0 & (1. & 1.6 & 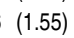 & 3 & & 7 & & 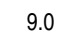 & & 1 & \\
\hline & .5 & $(0.2$ & 6.5 & & .3 & & 7 & & 1.8 & & 6.7 & & 2.8 & & 9.6 & & 9.2 & & 3 & $(0$ & 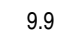 & & 2 & \\
\hline & 9.9 & $(0.23)$ & 6.3 & & .9 & & 23.5 & & 1.3 & & 7.1 & & 2.5 & (1. & 6.7 & $(1.2$ & 8.4 & & 6 & $(0.3$ & 9.5 & & .1 & 11. \\
\hline & 10.3 & $(0.23)$ & 6.8 & $(0.24)$ & 11.8 & $(0.70)$ & 23.8 & $(0.89)$ & 11.6 & $(0.34$ & 7.1 & $(0.35)$ & 13.5 & $(1.08)$ & 28.5 & $(1.30$ & 9.0 & $(0.31)$ & 6.4 & $(0.34)$ & 10.2 & $(0.92)$ & 18.5 & $(1.18)$ \\
\hline & & & & & & & & & & & & & .0 & & & & & & & & & & & \\
\hline & & $(0.2$ & & & 17 & & & & 10 & & & & 17 & & .7 & & & & 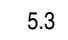 & & .7 & & & \\
\hline & & $(0.2$ & & (0. & 0 & & & & & & 0 & & 0 & & 4.7 & & 7 & & ; & & & & & \\
\hline & & $(0.2$ & & & & & & & & & 5.4 & & 7 & $(0$. & 19.9 & & 5 & & 2 & $(0$. & 1.1 & & 7 & \\
\hline & (1) & $(0.20)$ & 5.2 & $(0.2$ & 3 & $(0.61)$ & 17.6 & $(0.76$ & 9.1 & $(0.3$ & 6 & $(0.33)$ & 10.6 & $(0.93$ & 19.0 & $(1.10$ & 7.0 & $(0.2$ & 1 & $(0.2$ & 8.1 & $(0.80)$ & 16.1 & $(1.06)$ \\
\hline & & & & & & & & & & & & & & & 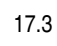 & & & & & & & & & \\
\hline & & $(0.2$ & 5.0 & & 3 & $(0.6$ & 13 & $(0$ & & (0. & 4 & $(0$. & 3 & $(0.9$ & 14.6 & & .5 & & 6 & $(0.3$ & 4 & & 2.4 & \\
\hline 16 & 6 & $(0.25)$ & 4.3 & $(0.31)$ & 5 & $(0.76)$ & 12.7 & $(0.72)$ & 7.3 & $(0.36)$ & 4.8 & $(0.40)$ & 3.1 & (1.15) & 13.9 & $(1.04$ & 5.9 & $(0.33$ & 3.8 & $(0.37)$ & 7.0 & $(1.01)$ & 11.3 & $(1.00)$ \\
\hline
\end{tabular}

\section{-Not available.}

†Not applicable.

Includes other racial/ethnic categories not separately shown

2Based on the April 1960 decennial census.

${ }^{3}$ For 1967 through 1971, White and Black include persons of Hispanic ethnicity.

${ }^{4}$ Because of changes in data collection procedures, data may not be comparable with figures for years prior to 1992 .

${ }^{5}$ White and Black exclude persons identifying themselves as two or more races.

${ }^{6}$ Beginning in 2010, standard errors were computed using replicate weights, which produced more precise values than the methodology used in prior years.
NOTE: "Status" dropouts are 16- to 24-year-olds who are not enrolled in school and who have not completed a high school program, regardless of when they left school. People who have received GED credentials are counted as high school completers. All data except for 1960 are based on October counts. Data are based on sample surveys of the civilian noninstitutionalized population, which excludes persons in prisons, persons in the military, and other persons not living in households. Race categories exclude persons of Hispanic ethnicity except where otherwise noted.

SOURCE: U.S. Department of Commerce, Census Bureau, Current Population Survey (CPS), October, 1967 through 2012. (This table was prepared May 2013.) 


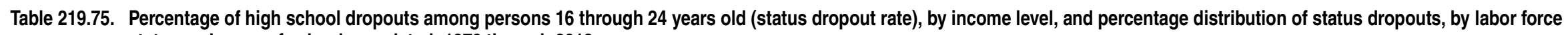
status and years of school completed: 1970 through 2012

[Standard errors appear in parentheses]

\begin{tabular}{|c|c|c|c|c|c|c|c|c|c|c|c|c|c|c|c|c|c|c|c|c|c|c|c|c|c|c|c|c|}
\hline \multirow{3}{*}{ Year } & \multicolumn{10}{|c|}{ Status dropout rate, by family income quartile } & \multicolumn{8}{|c|}{ Percentage distribution of status dropouts, by labor force status } & \multicolumn{10}{|c|}{ Percentage distribution of status dropouts, by years of school completed } \\
\hline & \multicolumn{2}{|c|}{$\begin{array}{r}\text { Status } \\
\text { dropout rate }\end{array}$} & \multicolumn{2}{|c|}{ Lowest quartile } & \multicolumn{2}{|c|}{$\begin{array}{r}\text { Middle } \\
\text { low quartile }\end{array}$} & \multicolumn{2}{|c|}{$\begin{array}{r}\text { Middle } \\
\text { high quartile }\end{array}$} & \multicolumn{2}{|c|}{ Highest quartile } & \multicolumn{2}{|r|}{ Total } & \multicolumn{2}{|c|}{ Employed ${ }^{1}$} & \multicolumn{2}{|c|}{ Unemployed } & \multicolumn{2}{|c|}{$\begin{array}{r}\text { Not in } \\
\text { labor force }\end{array}$} & \multicolumn{2}{|r|}{ Total } & \multicolumn{2}{|c|}{$\begin{array}{r}\text { Less than } \\
9 \text { years }\end{array}$} & \multicolumn{2}{|r|}{9 years } & \multicolumn{2}{|r|}{10 years } & \multicolumn{2}{|c|}{11 or 12 years } \\
\hline & & 2 & & 3 & & 4 & & 5 & & 6 & & 7 & & 8 & & 9 & & 10 & & 11 & & 12 & & 13 & & 14 & & $\overline{15}$ \\
\hline $\begin{array}{l}1970 \ldots \ldots \ldots \ldots \ldots \ldots . . . \\
1971 \ldots \ldots \ldots \ldots \ldots \ldots . . . \\
1972 \ldots \ldots \ldots \ldots \ldots \ldots \ldots . . \\
1973 \ldots \ldots \ldots \ldots \ldots \ldots . . . \\
1974 \ldots \ldots \ldots \ldots \ldots \ldots . . .\end{array}$ & $\begin{array}{l}15.0 \\
14.7 \\
14.6 \\
14.1 \\
14.3\end{array}$ & $\begin{array}{l}(0.29) \\
(0.28) \\
(0.28) \\
(0.27) \\
(0.27)\end{array}$ & $\begin{array}{l}28.0 \\
28.8 \\
27.6 \\
28.0\end{array}$ & $\begin{array}{r}(0.92) \\
(0.90) \\
(0.85) \\
(0.85) \\
(\dagger)\end{array}$ & $\begin{array}{l}21.2 \\
20.7 \\
20.8 \\
19.6\end{array}$ & $\begin{array}{r}(0.65) \\
(0.63) \\
(0.62) \\
(0.60) \\
(\dagger)\end{array}$ & $\begin{array}{r}11.7 \\
10.9 \\
10.2 \\
9.9\end{array}$ & \begin{tabular}{r|}
$(0.50)$ \\
$(0.49$ \\
$(0.46)$ \\
$(0.45)$ \\
$(\dagger)$
\end{tabular} & $\begin{array}{l}5.2 \\
5.1 \\
5.4 \\
4.9 \\
-\end{array}$ & \begin{tabular}{r|}
$(0.34)$ \\
$(0.32)$ \\
$(0.33)$ \\
$(0.31)$ \\
$(\dagger)$
\end{tabular} & $\begin{array}{l}100.0 \\
100.0 \\
100.0 \\
100.0 \\
100.0\end{array}$ & $\begin{array}{l}(\dagger) \\
(\dagger) \\
(\dagger) \\
(\dagger) \\
(t)\end{array}$ & $\begin{array}{l}49.8 \\
49.5 \\
51.2 \\
53.2 \\
51.8\end{array}$ & $\begin{array}{l}(1.06) \\
(1.05) \\
(1.03) \\
(1.04) \\
(1.02)\end{array}$ & $\begin{array}{r}10.3 \\
10.9 \\
10.2 \\
9.2 \\
12.3\end{array}$ & \begin{tabular}{l|}
$(0.65)$ \\
$(0.65)$ \\
$(0.63)$ \\
$(0.60)$ \\
$(0.67)$
\end{tabular} & $\begin{array}{l}39.9 \\
39.6 \\
38.6 \\
37.5 \\
35.9\end{array}$ & $\begin{array}{l}(1.04) \\
(1.02) \\
(1.01) \\
(1.01) \\
(0.98)\end{array}$ & $\begin{array}{l}100.0 \\
100.0 \\
100.0 \\
100.0 \\
100.0\end{array}$ & $\begin{array}{l}(+) \\
(+) \\
(\dagger) \\
(\dagger) \\
(\dagger)\end{array}$ & $\begin{array}{l}28.5 \\
27.9 \\
27.5 \\
26.5 \\
25.4\end{array}$ & $\begin{array}{l}(0.96) \\
(0.94) \\
(0.92) \\
(0.92) \\
(0.89)\end{array}$ & $\begin{array}{l}20.6 \\
21.7 \\
20.8 \\
20.9 \\
20.1\end{array}$ & \begin{tabular}{l|}
$(0.86)$ \\
$(0.86)$ \\
$(0.84)$ \\
$(0.84)$ \\
$(0.82)$
\end{tabular} & $\begin{array}{l}26.8 \\
27.8 \\
29.0 \\
27.4 \\
28.7\end{array}$ & \begin{tabular}{l|}
$(0.94)$ \\
$(0.94)$ \\
$(0.94)$ \\
$(0.93)$ \\
$(0.93)$
\end{tabular} & $\begin{array}{l}24.0 \\
22.7 \\
22.7 \\
25.3 \\
25.8\end{array}$ & $\begin{array}{l}(0.91) \\
(0.88) \\
(0.87) \\
(0.90) \\
(0.90)\end{array}$ \\
\hline 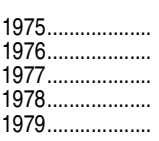 & $\begin{array}{l}13.9 \\
14.1 \\
14.1 \\
14.2 \\
14.6\end{array}$ & $\begin{array}{l}(0.27) \\
(0.27) \\
(0.27) \\
(0.27) \\
(0.27)\end{array}$ & $\begin{array}{l}28.8 \\
28.1 \\
28.5 \\
28.2 \\
28.1\end{array}$ & $\begin{array}{l}(0.82) \\
(0.79) \\
(0.80) \\
(0.80) \\
(0.79)\end{array}$ & $\begin{array}{l}18.0 \\
19.2 \\
19.0 \\
18.9 \\
18.5\end{array}$ & $\begin{array}{l}(0.58) \\
(0.60) \\
(0.60) \\
(0.60) \\
(0.60)\end{array}$ & $\begin{array}{l}10.2 \\
10.1 \\
10.4 \\
10.5 \\
11.5\end{array}$ & $\begin{array}{l}(0.45) \\
(0.45) \\
(0.46) \\
(0.46) \\
(0.47)\end{array}$ & $\begin{array}{l}5.0 \\
4.9 \\
4.5 \\
5.5 \\
5.6\end{array}$ & $\begin{array}{l}(0.30) \\
(0.29) \\
(0.29) \\
(0.31) \\
(0.32)\end{array}$ & $\begin{array}{l}100.0 \\
100.0 \\
100.0 \\
100.0 \\
100.0\end{array}$ & $\begin{array}{l}(t) \\
(\dagger) \\
(\dagger) \\
(\dagger) \\
(t)\end{array}$ & $\begin{array}{l}46.0 \\
48.8 \\
52.9 \\
54.3 \\
54.0\end{array}$ & $\begin{array}{l}(1.02) \\
(1.01) \\
(1.02) \\
(1.01) \\
(0.99)\end{array}$ & $\begin{array}{l}15.6 \\
16.0 \\
13.6 \\
12.4 \\
12.7\end{array}$ & $\begin{array}{l}(0.74) \\
(0.74) \\
(0.70) \\
(0.67) \\
(0.66)\end{array}$ & $\begin{array}{l}38.4 \\
35.2 \\
33.6 \\
33.3 \\
33.3\end{array}$ & $\begin{array}{l}(1.00) \\
(0.97) \\
(0.96) \\
(0.95) \\
(0.94)\end{array}$ & $\begin{array}{l}100.0 \\
100.0 \\
100.0 \\
100.0 \\
100.0\end{array}$ & $\begin{array}{c}(+) \\
(+) \\
(+) \\
(+) \\
(t)\end{array}$ & $\begin{array}{l}23.5 \\
24.3 \\
24.3 \\
22.9 \\
22.6\end{array}$ & $\begin{array}{l}(0.87) \\
(0.87) \\
(0.87) \\
(0.85) \\
(0.83)\end{array}$ & $\begin{array}{l}21.1 \\
20.1 \\
21.7 \\
20.2 \\
21.0\end{array}$ & $\begin{array}{l}(0.84) \\
(0.81) \\
(0.84) \\
(0.81) \\
(0.81)\end{array}$ & $\begin{array}{l}27.5 \\
27.8 \\
27.3 \\
28.2 \\
28.6\end{array}$ & $\begin{array}{l}(0.92) \\
(0.91) \\
(0.91) \\
(0.91) \\
(0.90)\end{array}$ & $\begin{array}{l}27.9 \\
27.8 \\
26.6 \\
28.8 \\
27.8\end{array}$ & $\begin{array}{l}(0.92) \\
(0.91) \\
(0.90) \\
(0.91) \\
(0.89)\end{array}$ \\
\hline 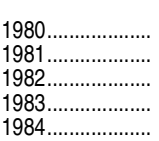 & $\begin{array}{l}14.1 \\
13.9 \\
13.9 \\
13.7 \\
13.1\end{array}$ & $\begin{array}{l}(0.26) \\
(0.26) \\
(0.27) \\
(0.27) \\
(0.27)\end{array}$ & $\begin{array}{l}27.0 \\
26.4 \\
27.2 \\
26.5 \\
25.9\end{array}$ & $\begin{array}{l}(0.77) \\
(0.75) \\
(0.78) \\
(0.77) \\
(0.76)\end{array}$ & $\begin{array}{l}18.1 \\
17.8 \\
18.3 \\
17.8 \\
16.5\end{array}$ & $\begin{array}{l}(0.60) \\
(0.57) \\
(0.63) \\
(0.62) \\
(0.61)\end{array}$ & $\begin{array}{r}10.7 \\
11.1 \\
10.2 \\
10.5 \\
9.9\end{array}$ & $\begin{array}{l}(0.46) \\
(0.47) \\
(0.48) \\
(0.50) \\
(0.48)\end{array}$ & $\begin{array}{l}5.7 \\
5.2 \\
4.4 \\
4.1 \\
3.8\end{array}$ & $\begin{array}{l}(0.32) \\
(0.30) \\
(0.29) \\
(0.29) \\
(0.29)\end{array}$ & $\begin{array}{l}100.0 \\
100.0 \\
100.0 \\
100.0 \\
100.0\end{array}$ & $\begin{array}{l}(t) \\
(\dagger) \\
(\dagger) \\
(t) \\
(t)\end{array}$ & $\begin{array}{l}50.4 \\
49.8 \\
45.2 \\
48.4 \\
49.7\end{array}$ & $\begin{array}{l}(1.01) \\
(1.01) \\
(1.06) \\
(1.08) \\
(1.11)\end{array}$ & $\begin{array}{l}17.0 \\
18.3 \\
21.1 \\
18.2 \\
17.3\end{array}$ & $\begin{array}{l}(0.76) \\
(0.78) \\
(0.87) \\
(0.83) \\
(0.84)\end{array}$ & $\begin{array}{l}32.6 \\
31.9 \\
33.7 \\
33.4 \\
32.9\end{array}$ & $\begin{array}{l}(0.95) \\
(0.94) \\
(1.01) \\
(1.02) \\
(1.05)\end{array}$ & $\begin{array}{l}100.0 \\
100.0 \\
100.0 \\
100.0 \\
100.0\end{array}$ & $\begin{array}{l}(\dagger) \\
(\dagger) \\
(\dagger) \\
(\dagger) \\
(t)\end{array}$ & $\begin{array}{l}23.6 \\
24.3 \\
22.9 \\
23.0 \\
23.6\end{array}$ & $\begin{array}{l}(0.86) \\
(0.86) \\
(0.90) \\
(0.91) \\
(0.95)\end{array}$ & $\begin{array}{l}19.7 \\
18.6 \\
20.8 \\
19.3 \\
21.4\end{array}$ & $\begin{array}{l}(0.80) \\
(0.78) \\
(0.87) \\
(0.85) \\
(0.91)\end{array}$ & $\begin{array}{l}29.8 \\
30.2 \\
28.8 \\
28.8 \\
27.5\end{array}$ & $\begin{array}{l}(0.93) \\
(0.92) \\
(0.96) \\
(0.98) \\
(1.00)\end{array} \mid$ & $\begin{array}{l}27.0 \\
26.9 \\
27.6 \\
28.8 \\
27.5\end{array}$ & $\begin{array}{l}(0.90) \\
(0.89) \\
(0.95) \\
(0.98) \\
(0.99)\end{array}$ \\
\hline $\begin{array}{l}5 \ldots \ldots \ldots \ldots \ldots . . \\
6 \ldots \ldots \ldots \ldots \ldots . . . \\
7 \ldots \ldots \ldots \ldots \ldots \ldots . . .\end{array}$ & $\begin{array}{l}12.6 \\
12.2 \\
12.6 \\
12.9 \\
12.6\end{array}$ & $\begin{array}{l}(0.27) \\
(0.27) \\
(0.28) \\
(0.30) \\
(0.31)\end{array}$ & $\begin{array}{l}27.1 \\
25.4 \\
25.5 \\
27.2 \\
25.0\end{array}$ & $\begin{array}{l}(0.78) \\
(0.75) \\
(0.76) \\
(0.85) \\
(0.84)\end{array}$ & $\begin{array}{l}14.7 \\
14.8 \\
16.6 \\
15.4 \\
16.2\end{array}$ & $\begin{array}{l}(0.60) \\
(0.63) \\
(0.68) \\
(0.71)\end{array}$ & $\begin{array}{l}8.3 \\
8.0 \\
8.0 \\
8.2 \\
8.7\end{array}$ & $\begin{array}{l}(0.46) \\
(0.45) \\
(0.46) \\
(0.51) \\
(0.52)\end{array}$ & $\begin{array}{l}4.0 \\
3.4 \\
3.6 \\
3.4 \\
3.3\end{array}$ & $\begin{array}{l}(0.28) \\
(0.30) \\
(0.31)\end{array}$ & 100.0 & $\begin{array}{l}(t) \\
(\dagger) \\
(t) \\
(t) \\
(t)\end{array}$ & $\begin{array}{l}50.1 \\
51.1 \\
52.4 \\
52.9 \\
53.2\end{array}$ & $\begin{array}{l}(1.15) \\
(1.18) \\
(1.16) \\
(1.27) \\
(1.30)\end{array}$ & $\begin{array}{r}17.5 \\
16.4 \\
13.6 \\
13.8\end{array}$ & $\begin{array}{r}(0.88) \\
(0.87) \\
(0.80) \\
(t) \\
(0.90)\end{array}$ & $\begin{array}{r}32.4 \\
32.5 \\
34.0 \\
\overline{3} .0\end{array}$ & $\begin{array}{r}(1.08) \\
(1.10) \\
(1.10) \\
(\dagger) \\
(1.22)\end{array}$ & & $\begin{array}{l}(t) \\
(\dagger) \\
(\dagger) \\
(\dagger) \\
(t)\end{array}$ & $\begin{array}{l}23.9 \\
25.4 \\
25.9 \\
28.9 \\
29.4\end{array}$ & & $\begin{array}{l}21.0 \\
21.5 \\
20.7 \\
19.3 \\
20.8\end{array}$ & $\begin{array}{l}(0.94) \\
(1.00) \\
(1.05)\end{array}$ & $\begin{array}{l}27.9 \\
25.7 \\
26.0 \\
25.1 \\
24.9\end{array}$ & $\begin{array}{l}(1.03) \\
(1.03) \\
(1.02) \\
(1.10) \\
(1.12)\end{array}$ & $\begin{array}{l}27.2 \\
27.4 \\
27.5 \\
26.8 \\
25.0\end{array}$ & $\begin{array}{l}(1.03) \\
(1.05) \\
(1.04) \\
(1.12) \\
(1.13)\end{array}$ \\
\hline 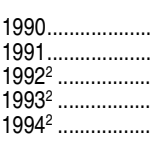 & $\begin{array}{l}12.1 \\
12.5 \\
11.0 \\
11.0 \\
11.4\end{array}$ & $\begin{array}{l}(0.29) \\
(0.30) \\
(0.28) \\
(0.28) \\
(0.26)\end{array}$ & $\begin{array}{l}24.3 \\
25.9 \\
23.4 \\
22.9 \\
20.7\end{array}$ & $\begin{array}{l}(0.82) \\
(0.83) \\
(0.79) \\
(0.77) \\
(0.71)\end{array}$ & $\begin{array}{l}15.1 \\
15.5 \\
12.9 \\
12.7 \\
13.7\end{array}$ & $\begin{array}{l}(0.62) \\
(0.62) \\
(0.58)\end{array}$ & $\begin{array}{l}8.7 \\
7.7 \\
7.3 \\
6.6 \\
8.7\end{array}$ & $\begin{array}{l}(0.48) \\
(0.46) \\
(0.45)\end{array}$ & $\begin{array}{l}2.9 \\
3.0 \\
2.4 \\
2.9 \\
4.9\end{array}$ & $\begin{array}{l}(0.26) \\
(0.29) \\
(0.33)\end{array}$ & $\begin{array}{l}100.0 \\
100.0\end{array}$ & $\begin{array}{l}(t) \\
(t) \\
(t) \\
(t) \\
(t)\end{array}$ & $\begin{array}{l}52.5 \\
47.5 \\
47.6 \\
48.7 \\
49.5\end{array}$ & $\begin{array}{l}(1.29) \\
(1.28) \\
(1.36) \\
(1.37) \\
(1.21)\end{array}$ & $\begin{array}{l}13.3 \\
15.8 \\
15.0 \\
12.8 \\
13.0\end{array}$ & $\begin{array}{l}(0.88) \\
(0.93) \\
(0.97) \\
(0.91) \\
(0.81)\end{array}$ & $\begin{array}{l}34.2 \\
36.7 \\
37.4 \\
38.5 \\
37.5\end{array}$ & & $\begin{array}{l}100.0 \\
100.0 \\
100.0 \\
100.0 \\
100.0\end{array}$ & $\begin{array}{l}(t) \\
(+) \\
(\dagger) \\
(\dagger) \\
(t)\end{array}$ & $\begin{array}{l}21.6 \\
20.5 \\
23.9\end{array}$ & & $\begin{array}{l}20.9 \\
20.5 \\
17.5 \\
16.6 \\
16.2\end{array}$ & & $\begin{array}{l}24.4 \\
26.1 \\
24.4 \\
24.1 \\
20.3\end{array}$ & $\begin{array}{l}(1.11) \\
(1.12) \\
(1.17) \\
(1.17) \\
(0.97)\end{array}$ & $\begin{array}{l}26.1 \\
24.9 \\
36.5 \\
38.8 \\
39.6\end{array}$ & $\begin{array}{l}(1.14) \\
(1.10) \\
(1.31) \\
(1.33) \\
(1.18)\end{array}$ \\
\hline 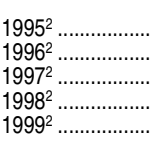 & $\begin{array}{l}12.0 \\
11.1 \\
11.0 \\
11.8 \\
11.2\end{array}$ & $\begin{array}{l}(0.27) \\
(0.27) \\
(0.27) \\
(0.27) \\
(0.26)\end{array}$ & $\begin{array}{l}23.2 \\
22.0 \\
21.8 \\
22.3 \\
21.0\end{array}$ & $\begin{array}{l}(0.69) \\
(0.72) \\
(0.71) \\
(0.71) \\
(0.70)\end{array}$ & $\begin{array}{l}13.8 \\
13.6 \\
13.5 \\
14.9 \\
14.3\end{array}$ & $\begin{array}{l}(0.59) \\
(0.60) \\
(0.59) \\
(0.62) \\
(0.60)\end{array}$ & $\begin{array}{l}8.3 \\
7.0 \\
6.2 \\
7.7 \\
7.4\end{array}$ & $\begin{array}{l}(0.46) \\
(0.45) \\
(0.42) \\
(0.45) \\
(0.44)\end{array}$ & & \begin{tabular}{l|}
$(0.29)$ \\
$(0.28)$ \\
$(0.29)$ \\
$(0.29)$ \\
$(0.30)$
\end{tabular} & $\begin{array}{l}100.0 \\
100.0\end{array}$ & $\begin{array}{l}(\dagger) \\
(\dagger) \\
(\dagger) \\
(\dagger) \\
(\dagger)\end{array}$ & $\begin{array}{l}48.9 \\
47.3 \\
53.3 \\
55.1 \\
55.6\end{array}$ & $\begin{array}{l}(1.19) \\
(1.28) \\
(1.28) \\
(1.22) \\
(1.24)\end{array}$ & $\begin{array}{l}14.2 \\
15.0 \\
13.2 \\
10.3 \\
10.0\end{array}$ & $\begin{array}{l}(0.83) \\
(0.91) \\
(0.86) \\
(0.74) \\
(0.75)\end{array}$ & $\begin{array}{l}37.0 \\
37.7 \\
33.5 \\
34.6 \\
34.4\end{array}$ & $\begin{array}{l}(1.14) \\
(1.24) \\
(1.21) \\
(1.17) \\
(1.18)\end{array}$ & $\begin{array}{l}100.0 \\
100.0\end{array}$ & $\begin{array}{c}(+) \\
(+) \\
(+) \\
(t) \\
(t)\end{array}$ & 22.2 & & $\begin{array}{l}17.0 \\
17.7 \\
15.7 \\
14.9 \\
16.3\end{array}$ & $\begin{array}{l}(0.87) \\
(0.92)\end{array}$ & $\begin{array}{l}22.5 \\
22.6 \\
22.3 \\
21.4 \\
22.5\end{array}$ & $\begin{array}{l}(0.99) \\
(1.07) \\
(1.06) \\
(1.01) \\
(1.04)\end{array} \mid$ & $\begin{array}{l}38.3 \\
39.4 \\
42.1 \\
42.6 \\
39.0\end{array}$ & $\begin{array}{l}(1.15) \\
(1.25) \\
(1.26) \\
(1.21) \\
(1.21)\end{array}$ \\
\hline 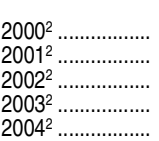 & $\begin{array}{r}10.9 \\
10.7 \\
10.5 \\
9.9 \\
10.3\end{array}$ & $\begin{array}{l}(0.26) \\
(0.25) \\
(0.24) \\
(0.23) \\
(0.23)\end{array}$ & $\begin{array}{l}20.7 \\
19.3 \\
18.8 \\
19.5 \\
18.0\end{array}$ & $\begin{array}{l}(0.70) \\
(0.68) \\
(0.62) \\
(0.64) \\
(0.60)\end{array}$ & $\begin{array}{l}12.8 \\
13.4 \\
12.3 \\
10.8 \\
12.7\end{array}$ & $\begin{array}{l}(0.56) \\
(0.57) \\
(0.53) \\
(0.49) \\
(0.52)\end{array}$ & $\begin{array}{l}8.3 \\
9.0 \\
8.4 \\
7.3 \\
8.2\end{array}$ & $\begin{array}{l}(0.46) \\
(0.47) \\
(0.43) \\
(0.40) \\
(0.42)\end{array}$ & $\begin{array}{l}3.5 \\
3.2 \\
3.8 \\
3.4 \\
3.7\end{array}$ & $\begin{array}{l}(0.29) \\
(0.27) \\
(0.28) \\
(0.26) \\
(0.27)\end{array}$ & $\begin{array}{l}100.0 \\
100.0 \\
100.0\end{array}$ & $\begin{array}{l}(\dagger) \\
(\dagger) \\
(\dagger) \\
(\dagger) \\
(\dagger)\end{array}$ & $\begin{array}{l}56.9 \\
58.3 \\
57.4 \\
53.5 \\
53.0\end{array}$ & $\begin{array}{l}(1.24) \\
(1.24) \\
(1.18) \\
(1.22) \\
(1.19)\end{array}$ & $\begin{array}{l}12.3 \\
14.8 \\
13.3 \\
13.7 \\
14.3\end{array}$ & $\begin{array}{l}(0.82) \\
(0.89) \\
(0.81) \\
(0.84) \\
(0.83)\end{array}$ & $\begin{array}{l}30.8 \\
26.9 \\
29.2 \\
32.9 \\
32.7\end{array}$ & $\begin{array}{l}(1.16) \\
(1.11) \\
(1.09) \\
(1.15) \\
(1.12)\end{array}$ & $\begin{array}{l}100.0 \\
100.0 \\
100.0 \\
100.0 \\
100.0\end{array}$ & $\begin{array}{c}(t) \\
(t) \\
(t) \\
(t) \\
(t)\end{array}$ & $\begin{array}{l}21.5 \\
18.4 \\
22.8 \\
21.2 \\
21.4\end{array}$ & $\begin{array}{l}(1.03) \\
(0.97) \\
(1.00) \\
(1.00) \\
(0.97)\end{array}$ & $\begin{array}{l}15.3 \\
16.8 \\
17.1 \\
18.2 \\
15.9\end{array}$ & $\begin{array}{l}(0.94) \\
(0.90) \\
(0.94) \\
(0.87)\end{array}$ & $\begin{array}{l}23.1 \\
23.8 \\
21.3 \\
20.7 \\
22.5\end{array}$ & $\begin{array}{l}(1.06) \\
(1.07) \\
(0.98) \\
(0.99) \\
(0.99)\end{array}$ & $\begin{array}{l}40.0 \\
40.9 \\
38.9 \\
40.0 \\
40.3\end{array}$ & $\begin{array}{l}(1.23) \\
(1.23) \\
(1.17) \\
(1.20) \\
(1.17)\end{array}$ \\
\hline 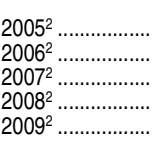 & $\begin{array}{l}9.4 \\
9.3 \\
8.7 \\
8.0 \\
8.1\end{array}$ & $\begin{array}{l}(0.22) \\
(0.22) \\
(0.21) \\
(0.20) \\
(0.20)\end{array}$ & $\begin{array}{l}17.9 \\
16.5 \\
16.7 \\
16.4 \\
15.8\end{array}$ & $\begin{array}{l}(0.60) \\
(0.58) \\
(0.59) \\
(0.58) \\
(0.57)\end{array}$ & $\begin{array}{r}11.5 \\
12.1 \\
10.5 \\
9.4 \\
9.7\end{array}$ & $\begin{array}{l}(0.51) \\
(0.48) \\
(0.45) \\
(0.45)\end{array}$ & $\begin{array}{l}7.1 \\
6.3 \\
6.4 \\
5.4 \\
5.4\end{array}$ & $\begin{array}{l}(0.37) \\
(0.36) \\
(0.34) \\
(0.34)\end{array}$ & $\begin{array}{l}3.8 \\
3.2 \\
2.2 \\
2.5\end{array}$ & $\begin{array}{l}(0.25) \\
(0.21) \\
(0.22)\end{array}$ & $\begin{array}{l}100.0 \\
100.0 \\
100.0 \\
100.0\end{array}$ & 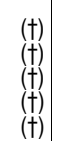 & $\begin{array}{l}56.4 \\
55.5 \\
46.8 \\
43.2\end{array}$ & $\begin{array}{l}(1.27) \\
(1.33) \\
(1.31)\end{array}$ & $\begin{array}{l}11.7 \\
11.2 \\
16.3 \\
19.9\end{array}$ & $\begin{array}{l}(0.80) \\
(0.98) \\
(1.06)\end{array}$ & $\begin{array}{l}32.0 \\
33.3 \\
36.9 \\
36.9\end{array}$ & $\begin{array}{l}(1.10) \\
(1.28) \\
(1.28)\end{array}$ & $\begin{array}{l}100.0 \\
100.0 \\
100.0 \\
100.0\end{array}$ & $(\dagger)$ & $\begin{array}{l}18.9 \\
22.1 \\
21.2 \\
18.4 \\
17.7\end{array}$ & $\begin{array}{l}(1.04) \\
(1.03) \\
(1.01)\end{array}$ & $\begin{array}{l}13.4 \\
16.9 \\
15.2 \\
13.6\end{array}$ & $\begin{array}{l}(0.00) \\
(0.96) \\
(0.96) \\
(0.91)\end{array}$ & $\begin{array}{l}22.9 \\
23.8 \\
24.4\end{array}$ & $\begin{array}{l}(1.01) \\
(1.07) \\
(1.13) \\
(1.14)\end{array}$ & $\begin{array}{l}42.9 \\
43.9 \\
39.0 \\
42.6 \\
44.3\end{array}$ & $\begin{array}{l}(1.24) \\
(1.32) \\
(1.32)\end{array}$ \\
\hline $\begin{array}{l}2011^{2,3} \ldots \ldots \ldots \ldots . . . \\
2011^{2,3} \ldots \ldots \ldots \ldots . . . \\
2012^{2,3} \ldots \ldots \ldots \ldots \ldots . . .\end{array}$ & $\begin{array}{l}7.4 \\
7.1 \\
6.6\end{array}$ & $\begin{array}{l}(0.27) \\
(0.26) \\
(0.25)\end{array}$ & $\begin{array}{l}13.0 \\
13.0 \\
11.8\end{array}$ & $\begin{array}{l}(0.73) \\
(0.70)\end{array}$ & $\begin{array}{l}8.9 \\
9.0 \\
8.7\end{array}$ & $\begin{array}{c}(0.53) \\
(0.65)\end{array}$ & $\begin{array}{l}5.1 \\
4.8 \\
4.1\end{array}$ & $\begin{array}{l}(0.45) \\
(0.44)\end{array}$ & $\begin{array}{l}2.3 \\
1.9\end{array}$ & $\begin{array}{l}(0.32) \\
(0.31)\end{array}$ & $\begin{array}{l}100.0 \\
100.0\end{array}$ & $\begin{array}{l}(t) \\
(\dagger) \\
(t)\end{array}$ & $\begin{array}{l}45.8 \\
49.8 \\
44.8\end{array}$ & $\begin{array}{l}(1.77) \\
(2.07)\end{array}$ & $\begin{array}{l}16.0 \\
18.1\end{array}$ & $\begin{array}{l}(1.33) \\
(1.49)\end{array}$ & $\begin{array}{l}34.2 \\
37.1\end{array}$ & $\begin{array}{l}(1.69) \\
(1.83)\end{array}$ & $\begin{array}{l}100.0 \\
100.0\end{array}$ & $(\dagger)$ & $\begin{array}{l}18.1 \\
18.3\end{array}$ & $\left(\begin{array}{l}1.726 \\
(1.76)\end{array}\right.$ & $\begin{array}{l}12.9 \\
10.2\end{array}$ & $(1.21)$ & 21.9 & & $\begin{array}{l}45.2 \\
47.7 \\
49.6\end{array}$ & $\begin{array}{l}(1.87) \\
(2.20)\end{array}$ \\
\hline
\end{tabular}

\section{-Not available.}

IIncludes persons who were employed but not at work during the survey week
Inticable

2Because of changes in data colleclion procedurs, dala may not be comparable with figures for years prior to 1992

which produced more precise values than the meth-

odology used in prior years.
NOTE: "Status" dropouts are 16- to 24-year-olds who are not enrolled in school and who have not completed a high school program, regardless of when they left school. People who have received GED credentials are counted as high school completers. Data are based on sample surveys of the civilian noninstitutionalized population, which excludes persons in prisons, persons in
the military, and other persons not living in households. Detail may not sum to totals because of rounding. SOURCE: U.S. Department of Commerce, Census Bureau, Current Population Survey (CPS), October, 1970 through 2012. (This table was prepared May 2013.) 


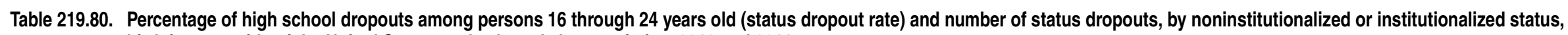
birth in or outside of the United States, and selected characteristics: 2010 and 2011

[Standard errors appear in parentheses]

\begin{tabular}{|c|c|c|c|c|c|c|c|c|c|c|c|c|c|c|c|c|c|c|c|}
\hline \multirow[b]{4}{*}{ Selected characteristic } & \multicolumn{4}{|c|}{ Total status dropout rate } & \multicolumn{14}{|c|}{2011} & \\
\hline & \multirow{3}{*}{\multicolumn{2}{|c|}{2010}} & \multirow{3}{*}{\multicolumn{2}{|c|}{2011}} & \multicolumn{10}{|c|}{ Noninstitutionalized population ${ }^{1}$} & \multicolumn{4}{|c|}{ Institutionalized population ${ }^{2}$} & \\
\hline & & & & & \multirow{2}{*}{\multicolumn{2}{|c|}{$\begin{array}{r}\text { Number of status } \\
\text { dropouts }\end{array}$}} & \multirow{2}{*}{\multicolumn{2}{|c|}{$\begin{array}{r}\text { Percentage } \\
\text { distribution } \\
\text { of status dropouts }\end{array}$}} & \multicolumn{6}{|c|}{ Status dropout rate } & \multirow{2}{*}{\multicolumn{2}{|c|}{$\begin{array}{r}\text { Number of } \\
\text { status dropouts }\end{array}$}} & \multirow{2}{*}{\multicolumn{2}{|c|}{ Status dropout rate }} & \\
\hline & & & & & & & & & \multicolumn{2}{|c|}{$\begin{array}{c}\text { Total for noninstitu- } \\
\text { tionalized population }\end{array}$} & \multicolumn{2}{|c|}{$\begin{array}{c}\text { For those born in } \\
\text { the United States }\end{array}$} & \multicolumn{2}{|c|}{$\begin{array}{l}\text { For those born outside } \\
\text { of the United States }\end{array}$} & & & & & \\
\hline 1 & & 2 & & 3 & & 4 & & 5 & & 6 & & 7 & & 8 & & 9 & & 10 & \\
\hline 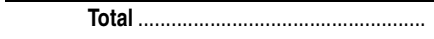 & 8.3 & $(0.08)$ & 7.7 & $(0.06)$ & $2,866,410$ & $(25,305)$ & 100.0 & (t) & 7.3 & $(0.06)$ & 6.2 & $(0.06)$ & 16.1 & (0.26) & 177,100 & $(3,724)$ & 35.4 & $(0.56)$ & \\
\hline 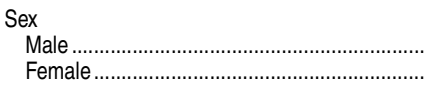 & $\begin{array}{r}10.0 \\
6.6\end{array}$ & $\begin{array}{l}(0.10) \\
(0.08)\end{array}$ & $\begin{array}{l}9.0 \\
6.2\end{array}$ & $\begin{array}{l}(0.09) \\
(0.07)\end{array}$ & $\begin{array}{l}1,671,090 \\
1,195,320\end{array}$ & $\begin{array}{l}(16,867) \\
(14,261)\end{array}$ & $\begin{array}{l}58.3 \\
41.7\end{array}$ & $\begin{array}{l}(0.32) \\
(0.32)\end{array}$ & $\begin{array}{l}8.4 \\
6.2\end{array}$ & $\begin{array}{l}(0.08) \\
(0.07)\end{array}$ & $\begin{array}{l}7.0 \\
5.4\end{array}$ & $\begin{array}{l}(0.08) \\
(0.08)\end{array}$ & $\begin{array}{l}18.8 \\
12.9\end{array}$ & $\begin{array}{l}(0.43) \\
(0.34)\end{array}$ & $\begin{array}{r}165,050 \\
12,050\end{array}$ & $\begin{array}{l}(3,550) \\
(1,165)\end{array}$ & $\begin{array}{l}37.1 \\
21.9\end{array}$ & $\begin{array}{l}(0.59) \\
(1.95)\end{array}$ & \\
\hline 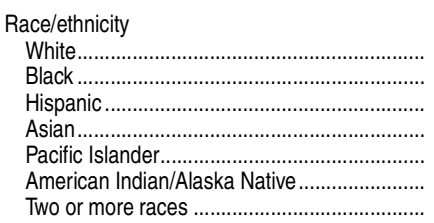 & $\begin{array}{r}5.3 \\
10.3 \\
16.7 \\
2.8 \\
4.8 \\
15.4 \\
6.1\end{array}$ & $\begin{array}{l}(0.07) \\
(0.17) \\
(0.26) \\
(0.16) \\
(0.95) \\
(0.80) \\
(0.30)\end{array}$ & $\begin{array}{r}5.1 \\
9.6 \\
14.5 \\
2.7 \\
8.8 \\
13.1 \\
6.0\end{array}$ & $\begin{array}{l}(0.07) \\
(0.18) \\
(0.19) \\
(0.14) \\
(1.62) \\
(0.75) \\
(0.33)\end{array}$ & $\begin{array}{r}1,085,210 \\
477,010 \\
1,143,830 \\
49,700 \\
6,810 \\
38,810 \\
58,300\end{array}$ & $\begin{array}{r}(15,090) \\
(9,745) \\
(16,263) \\
(2,690) \\
(1,254) \\
(2,239) \\
(3,251)\end{array}$ & $\begin{array}{r}37.9 \\
16.6 \\
39.9 \\
1.7 \\
0.2 \\
1.4 \\
2.0\end{array}$ & $\begin{array}{l}(0.40) \\
(0.32) \\
(0.39) \\
(0.10) \\
(0.04) \\
(0.08) \\
(0.11)\end{array}$ & $\begin{array}{r}4.9 \\
8.5 \\
14.1 \\
2.7 \\
8.8 \\
12.6 \\
5.7\end{array}$ & $\begin{array}{l}(0.07) \\
(0.17) \\
(0.19) \\
(0.14) \\
(1.64) \\
(0.68) \\
(0.33)\end{array}$ & $\begin{array}{r}4.9 \\
8.8 \\
9.2 \\
1.7 \\
5.0 \\
12.5 \\
5.6\end{array}$ & $\begin{array}{l}(0.07) \\
(0.18) \\
(0.18) \\
(0.17) \\
(1.11) \\
(0.67) \\
(0.38)\end{array}$ & $\begin{array}{c}4.3 \\
5.2 \\
27.9 \\
3.6 \\
24.0 \\
18.4 ! \\
6.5\end{array}$ & $\begin{array}{l}(0.32) \\
(0.58) \\
(0.47) \\
(0.25) \\
(5.28) \\
(8.79) \\
(1.53)\end{array}$ & $\begin{array}{r}43,300 \\
81,270 \\
45,160 \\
\ddagger \\
\ddagger \\
2,780 \\
3,550\end{array}$ & $\begin{array}{r}(1,628) \\
(2,590) \\
(1,779) \\
(\dagger) \\
(+) \\
(782) \\
(595)\end{array}$ & $\begin{array}{r}26.9 \\
40.1 \\
40.6 \\
23.2 \\
\ddagger \\
33.3 \\
30.5\end{array}$ & $\begin{array}{r}(0.83) \\
(1.04) \\
(1.22) \\
(6.25) \\
(\dagger) \\
(6.83) \\
(5.11)\end{array}$ & \\
\hline $\begin{array}{l}\text { Race/ethnicity by sex } \\
\text { Male }\end{array}$ & & & & & & & & & & & & & & & & & & & \\
\hline White ....................... & 6.1 & $(0.09)$ & 5.8 & $(0.10)$ & 619,080 & $(11,427)$ & 37.0 & $(0.51)$ & 5.5 & $(0.10)$ & 5.5 & $(0.10)$ & 3.9 & $(0.43)$ & 38,840 & $(1,426)$ & 28.5 & $(0.86)$ & \\
\hline 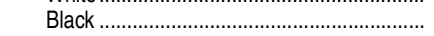 & 12.7 & $(0.26)$ & 11.8 & $(0.25)$ & 271,010 & $(6,709)$ & 16.2 & $(0.41)$ & 9.8 & $(0.24)$ & 10.2 & $(0.25)$ & 5.0 & $(0.72)$ & 77,540 & $(2,577)$ & 41.4 & (1.11) & \\
\hline 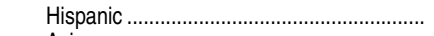 & 20.2 & $(0.34)$ & 17.0 & $(0.27)$ & 688,710 & $(12,064)$ & 41.2 & $(0.54)$ & 16.4 & $(0.28)$ & 10.1 & $(0.24)$ & 32.2 & $(0.71)$ & 42,590 & $(1,652)$ & 42.2 & (1.34) & \\
\hline 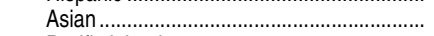 & 3.4 & $(0.25)$ & 3.1 & $(0.19)$ & 28,350 & $(1,899)$ & 1.7 & $(0.12)$ & 3.0 & $(0.19)$ & 1.9 & $(0.23)$ & 4.0 & $(0.38)$ & $\ddagger$ & $(t)$ & 26.0 & $(7.06)$ & \\
\hline Pacific Islander...... & 4.9 & (1.05) & 9.2 & $(2.10)$ & 3,610 & $(870)$ & 0.2 & $(0.05)$ & 9.1 & $(2.11)$ & 4.5 & $(1.25)$ & $29.3 !$ & (8.83) & $\ddagger$ & $(+)$ & $\ddagger$ & $(t)$ & \\
\hline American Indian/Alaska Native .................... & 17.6 & (1.34) & 14.8 & (1.11) & 22,100 & $(1,649)$ & 1.3 & $(0.10)$ & 14.2 & $(1.00)$ & 14.3 & $(1.00)$ & $\neq$ & $(t)$ & $1,820 !$ & (644) & 31.5 & (8.26) & \\
\hline $\begin{array}{l}\text { Two or more races............................................ } \\
\text { Female }\end{array}$ & 7.3 & $(0.49)$ & 7.4 & (0.57) & 34,630 & $(2,801)$ & 2.1 & $(0.17)$ & 6.9 & $(0.56)$ & 6.7 & $(0.61)$ & 8.9 & (2.61) & 3,230 & (581) & 32.4 & $(5.21)$ & \\
\hline 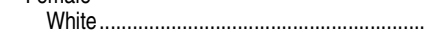 & & $(0.09)$ & 4.3 & $(0.08)$ & 466,140 & $(8,663)$ & 39.0 & $(0.61)$ & 4.3 & $(0.08)$ & 4.3 & $(0.09)$ & 4.8 & (0.52) & 4,460 & (683) & 17.9 & (2.48) & \\
\hline Black ........………………………… & 7.8 & $(0.23)$ & 7.3 & $(0.22)$ & 206,000 & $(6,510)$ & 17.2 & $(0.49)$ & 7.2 & $(0.22)$ & 7.4 & $(0.23)$ & 5.4 & $(0.72)$ & 3,730 & (586) & 24.5 & (3.25) & \\
\hline 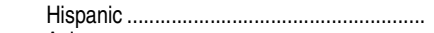 & 12.8 & $(0.27)$ & 11.7 & $(0.23)$ & 455,110 & $(9,545)$ & 38.1 & $(0.60)$ & 11.7 & $(0.24)$ & 8.2 & $(0.23)$ & 22.6 & $(0.60)$ & 2,580 & (536) & 25.2 & $(4.26)$ & \\
\hline ................. & 2.3 & $(0.20)$ & 2.4 & $(0.18)$ & 21,350 & $(1,697)$ & 1.8 & $(0.14)$ & 2.4 & $(0.18)$ & 1.6 & $(0.22)$ & 3.1 & $(0.29)$ & $\ddagger$ & $(t)$ & $\ddagger$ & $(t)$ & $\Omega$ \\
\hline Pacific Islander ........ & $4.8 !$ & (1.60) & 8.4 & (2.11) & & & 0.3 & $(0.07)$ & 8.5 & $(2.11)$ & $5.5 !$ & $(1.91)$ & 19.3 & $(5.60)$ & $\ddagger$ & $(\dagger)$ & $\ddagger$ & $(t)$ & $\stackrel{T}{D}$ \\
\hline lan/Alaska Native ..................... & 13.2 & $(1.15)$ & 11.4 & $(0.86)$ & $16,710^{+}$ & $(1,365)$ & 1.4 & $(0.11)$ & 10.9 & $(0.86)$ & 10.7 & $(0.81)$ & $\ddagger$ & $(t)$ & $\ddagger$ & $(t)$ & $37.2 !$ & $(12.96)$ & D \\
\hline Two or more races....................................... & 4.9 & $(0.41)$ & 4.6 & $(0.41)$ & 23,670 & $(2,112)$ & 2.0 & $(0.18)$ & 4.6 & $(0.41)$ & 4.6 & $(0.45)$ & $4.2 !$ & $(1.46)$ & $\stackrel{+}{\ddagger}$ & $(+)$ & $19.0 !$ & $(9.26)$ & 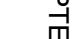 \\
\hline Age & & & & & & & & & & & & & & & & & & & \\
\hline $16 \ldots \ldots \ldots$ & 2.5 & $(0.09)$ & 2.2 & $(0.09)$ & 88,030 & $(3,885)$ & 3.1 & $(0.13)$ & 2.1 & $(0.09)$ & 2.0 & $(0.10)$ & 3.5 & $(0.44)$ & 2,760 & (589) & 8.9 & (1.83) & بִ \\
\hline 17 & 4.0 & $(0.12)$ & 3.8 & $(0.11)$ & 153,870 & $(4,516)$ & 5.4 & $(0.15)$ & 3.6 & $(0.11)$ & 3.4 & $(0.11)$ & 6.5 & $(0.52)$ & 7,660 & (665) & 19.4 & (1.58) & \\
\hline 18 & 6.7 & $(0.14)$ & 6.2 & $(0.15)$ & 276,460 & $(7,584)$ & 9.6 & $(0.25)$ & 5.9 & $(0.15)$ & 5.5 & $(0.14)$ & 10.0 & $(0.76)$ & 14,660 & $(1,246)$ & 36.3 & (2.23) & $\frac{\overline{0}}{7} \frac{1}{\bar{D}}$ \\
\hline 19 & 8.9 & $(0.19)$ & 7.7 & $(0.15)$ & 315,110 & $(6,262)$ & 11.0 & $(0.21)$ & 7.3 & $(0.15)$ & 6.8 & $(0.16)$ & 11.8 & $(0.66)$ & 20,320 & $(1,450)$ & 42.6 & (2.54) & 了学 \\
\hline $20-24 \ldots \ldots$ & 10.6 & $(0.10)$ & 9.8 & $(0.10)$ & $2,032,940$ & $(21,006)$ & 70.9 & $(0.36)$ & 9.3 & $(0.09)$ & 7.7 & $(0.10)$ & 20.1 & $(0.35)$ & 131,680 & $(3,026)$ & 38.6 & $(0.65)$ & 垔 \\
\hline Region & & & & & & & & & & & & & & & & & & & \\
\hline 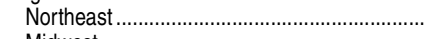 & 6.3 & $(0.13)$ & 6.1 & $(0.13)$ & 399,510 & $(8,950)$ & 13.9 & $(0.29)$ & 5.8 & $(0.13)$ & 5.1 & (0.12) & 11.1 & (0.51) & 21,600 & $(1,532)$ & 29.5 & (1.78) & \\
\hline 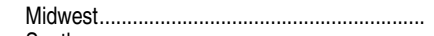 & 7.2 & $(0.12)$ & 6.8 & $(0.12)$ & 544,490 & $(10,471)$ & 19.0 & $(0.34)$ & 6.5 & $(0.12)$ & 5.9 & $(0.13)$ & 14.4 & $(0.83)$ & 32,790 & $(1,568)$ & 32.3 & (1.36) & 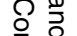 \\
\hline 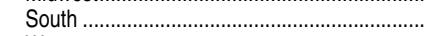 & 9.6 & $(0.13)$ & 8.7 & $(0.11)$ & $1,191,580$ & $(15,844)$ & 41.6 & $(0.40)$ & 8.2 & $(0.11)$ & 7.0 & $(0.10)$ & 18.6 & $(0.45)$ & 87,200 & $(3,053)$ & 39.6 & $(0.98)$ & \\
\hline 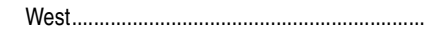 & 8.9 & $(0.14)$ & 8.0 & (0.12) & 730,840 & $(11,601)$ & 25.5 & $(0.33)$ & 7.8 & $(0.12)$ & 6.2 & $(0.12)$ & 17.1 & $(0.45)$ & 35,510 & $(1,677)$ & 33.8 & (1.22) & $\frac{\overrightarrow{0}}{\Phi} \mathbb{\infty}$ \\
\hline $\begin{array}{l}\text { †Not applicable. } \\
\text { !nterpret data with caution. The coefficient of } v \\
\text { fReporting standards not met. Either there are } \\
\text { percent or greater. } \\
\text { 'Persons living in households as well as persor } \\
\text { ters include college and university housing, } \\
\text { ters for the homeless. } \\
\text { 2Persons living in institutionalized group quar } \\
\text { other health care facilities. }\end{array}$ & $\begin{array}{l}n \text { (CV) } \\
\text { w cas } \\
\text { in no } \\
\text { uarter } \\
\text { cludin }\end{array}$ & $\begin{array}{l}\text { is estin } \\
\text { a relia } \\
\text { tutional } \\
\text { lities fo } \\
\text { It and }\end{array}$ & troup & $\begin{array}{l}30 \text { an } \\
\text { he co } \\
\text { ters. } N \\
\text { eligiou }\end{array}$ & $\begin{array}{l}\text { dd } 50 \text { perc } \\
\text { efficient c } \\
\text { Noninstitut } \\
\text { us groups, } \\
\text { facilities, }\end{array}$ & $\begin{array}{l}\text { ariation (c } \\
\text { alized gro } \\
\text { d tempor } \\
\text { sing facili }\end{array}$ & $\begin{array}{l}50 \\
\text { har- } \\
\text { hel- } \\
\text { and }\end{array}$ & $\begin{array}{l}\text { 3Unite } \\
\text { NOTE } \\
\text { progra } \\
\text { receiv } \\
\text { catego } \\
\text { the Cu } \\
\text { SOUR } \\
\text { was pr }\end{array}$ & $\begin{array}{l}\text { d States refe } \\
\text { : "Status" dr } \\
\text { am, regardles } \\
\text { ed GED cre } \\
\text { ories exclude } \\
\text { urrent Popula } \\
\text { RCE: U.S. De } \\
\text { repared Jun }\end{array}$ & $\begin{array}{l}\text { s to the } 5 \\
\text { pouts are } \\
\text { s of when } \\
\text { entials are } \\
\text { persons o } \\
\text { ion Surve } \\
\text { vartment o } \\
2013 \text {.) }\end{array}$ & $\begin{array}{l}\text { tes and } \\
\text { to } 24-\text {-ye } \\
\text { left sch } \\
\text { unted as } \\
\text { spanic et } \\
\text { PS) beca } \\
\text { mmerce }\end{array}$ & $\begin{array}{l}\text { e District o } \\
\text {-olds who } \\
\text { ol and whe } \\
\text { igh school } \\
\text { nicity. Stat } \\
\text { se of differ } \\
\text { Census Bu }\end{array}$ & $\begin{array}{l}\text { of Columbia. } \\
\text { o are not enro } \\
\text { ether they eve } \\
\text { ol completers. } \\
\text { atus dropout re } \\
\text { erences in sur } \\
\text { Bureau, Americ }\end{array}$ & $\begin{array}{l}\text { ed in scho } \\
\text { rattended } \\
\text { Detail may } \\
\text { tes in this } \\
\text { ey design } \\
\text { an Commu }\end{array}$ & $\begin{array}{l}\text { ool and who } \\
\text { i school in th } \\
\text { y not sum to } \\
\text { table may di } \\
\text { and target p } \\
\text { unity Survey }\end{array}$ & $\begin{array}{l}\text { ave not co } \\
\text { United St } \\
\text { tals beca } \\
\text { er from th } \\
\text { ulations. } \\
\text { CS), } 201\end{array}$ & $\begin{array}{l}\text { leted a } \\
\text { s. People } \\
\text { of roun } \\
\text { in table }\end{array}$ & $\begin{array}{l}\text { school } \\
\text { ho have } \\
\text { g. Race } \\
\text { ased on } \\
\text { is table }\end{array}$ & 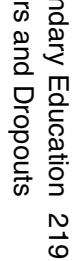 \\
\hline
\end{tabular}


Table 219.90. Number and percentage distribution of 14- through 21-year-old students served under Individuals with Disabilities Education Act, Part B, who exited school, by exit reason, age, and type of disability: 2009-10 and 2010-11

\begin{tabular}{|c|c|c|c|c|c|c|c|c|}
\hline \multirow[b]{2}{*}{ Year, age, and type of disability } & \multicolumn{6}{|c|}{ Exiting school } & \multirow[b]{2}{*}{$\begin{array}{r}\text { Transferred to } \\
\text { regular } \\
\text { education }{ }^{3}\end{array}$} & \multirow[b]{2}{*}{$\begin{array}{r}\text { Moved, known to } \\
\text { be continuing }\end{array}$} \\
\hline & Total & $\begin{array}{r}\text { Graduated } \\
\text { with diploma }\end{array}$ & $\begin{array}{r}\text { Received a } \\
\text { certificate of } \\
\text { attendance }\end{array}$ & $\begin{array}{r}\text { Reached } \\
\text { maximum age }{ }^{1}\end{array}$ & $\begin{array}{r}\text { Dropped } \\
\text { out }^{2}\end{array}$ & Died & & \\
\hline 1 & 2 & 3 & 4 & 5 & 6 & 7 & 8 & 9 \\
\hline 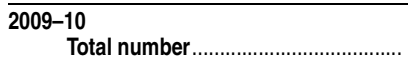 & 408,642 & 255,800 & 59,973 & 5,071 & 86,244 & 1,554 & 66,782 & 199,833 \\
\hline Percentage distribution of total .......................... & 100.0 & 62.6 & 14.7 & 1.2 & 21.1 & 0.4 & $\dagger$ & $\dagger$ \\
\hline Number by age & $\begin{array}{r}3,226 \\
6,741 \\
19,878 \\
149,616 \\
153,432 \\
46,315 \\
17,908 \\
11,526\end{array}$ & $\begin{array}{r}5 \\
44 \\
3,243 \\
108,083 \\
107,004 \\
26,623 \\
7,766 \\
3,032\end{array}$ & $\begin{array}{r}5 \\
26 \\
823 \\
16,664 \\
23,524 \\
9,703 \\
5,299 \\
3,929\end{array}$ & $\begin{array}{r}\dagger \\
\dagger \\
\dagger \\
\dagger \\
8 \\
65 \\
1,354 \\
3,644\end{array}$ & $\begin{array}{r}3,024 \\
6,445 \\
15,504 \\
24,542 \\
22,670 \\
9,796 \\
3,392 \\
871\end{array}$ & $\begin{array}{r}192 \\
226 \\
308 \\
327 \\
226 \\
128 \\
97 \\
50\end{array}$ & $\begin{array}{r}16,898 \\
15,247 \\
14,785 \\
12,141 \\
5,715 \\
1,369 \\
430 \\
197\end{array}$ & $\begin{array}{r}38,790 \\
43,303 \\
44,988 \\
39,687 \\
22,826 \\
7,119 \\
2,401 \\
719\end{array}$ \\
\hline 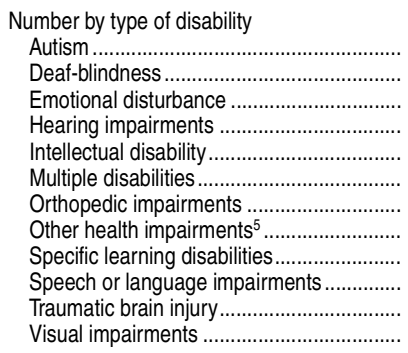 & $\begin{array}{r}12,295 \\
90 \\
45,659 \\
4,768 \\
41,709 \\
8,919 \\
3,762 \\
49,743 \\
227,048 \\
10,357 \\
2,480 \\
1,812\end{array}$ & $\begin{array}{r}8,145 \\
54 \\
22,806 \\
3,421 \\
16,966 \\
4,245 \\
2,361 \\
34,400 \\
153,017 \\
7,287 \\
1,687 \\
1,411\end{array}$ & $\begin{array}{r}2,730 \\
17 \\
4,706 \\
793 \\
14,389 \\
2,511 \\
691 \\
5,383 \\
26,899 \\
1,256 \\
397 \\
201\end{array}$ & $\begin{array}{r}567 \\
5 \\
365 \\
52 \\
2,101 \\
626 \\
151 \\
200 \\
871 \\
37 \\
66 \\
30\end{array}$ & $\begin{array}{r}816 \\
12 \\
17,654 \\
488 \\
7,987 \\
1,238 \\
467 \\
9,515 \\
45,846 \\
1,760 \\
309 \\
152\end{array}$ & $\begin{array}{r}37 \\
2 \\
128 \\
14 \\
266 \\
299 \\
92 \\
245 \\
415 \\
17 \\
21 \\
18\end{array}$ & $\begin{array}{r}1,820 \\
8 \\
7,084 \\
660 \\
1,854 \\
286 \\
432 \\
9,890 \\
33,983 \\
10,321 \\
229 \\
215 \\
\end{array}$ & $\begin{array}{r}3,852 \\
35 \\
40,578 \\
1,649 \\
16,521 \\
3,826 \\
1,282 \\
24,428 \\
100,786 \\
5,564 \\
798 \\
514\end{array}$ \\
\hline $\begin{array}{l}\text { 2010-11 } \\
\quad \text { Total number } \ldots \ldots \ldots \ldots \ldots \ldots \ldots \ldots \ldots \ldots \ldots \ldots . . . \ldots \ldots \ldots \ldots \ldots\end{array}$ & 402,038 & 255,512 & 58,938 & 5,245 & 80,839 & 1,504 & 61,102 & 181,554 \\
\hline Percentage distribution of total ......................... & 100.0 & 63.6 & 14.7 & 1.3 & 20.1 & 0.4 & $\dagger$ & $t$ \\
\hline Number by age & $\begin{array}{r}3,023 \\
6,051 \\
18,118 \\
145,037 \\
152,198 \\
47,013 \\
18,595 \\
12,003\end{array}$ & $\begin{array}{r}1 \\
35 \\
3,429 \\
105,110 \\
107,659 \\
28,176 \\
7,845 \\
3,257\end{array}$ & $\begin{array}{r}4 \\
29 \\
658 \\
16,384 \\
23,017 \\
9,102 \\
5,659 \\
4,085\end{array}$ & $\begin{array}{r}\dagger \\
\dagger \\
\dagger \\
\dagger \\
0 \\
29 \\
1,548 \\
3,668\end{array}$ & $\begin{array}{r}2,808 \\
5,735 \\
13,743 \\
23,225 \\
21,323 \\
9,589 \\
3,458 \\
958\end{array}$ & $\begin{array}{r}210 \\
252 \\
288 \\
318 \\
199 \\
117 \\
85 \\
35\end{array}$ & $\begin{array}{r}15,836 \\
13,769 \\
13,386 \\
10,996 \\
5,160 \\
1,346 \\
441 \\
168\end{array}$ & $\begin{array}{r}35,708 \\
38,361 \\
40,515 \\
35,885 \\
21,103 \\
6,899 \\
2,251 \\
832\end{array}$ \\
\hline 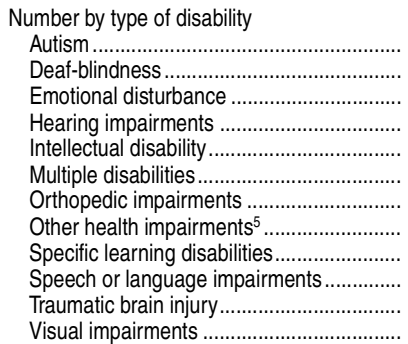 & $\begin{array}{r}14,162 \\
93 \\
42,889 \\
4,707 \\
40,439 \\
8,523 \\
3,605 \\
52,682 \\
220,902 \\
9,795 \\
2,536 \\
1,705\end{array}$ & $\begin{array}{r}9,179 \\
48 \\
22,423 \\
3,439 \\
16,137 \\
4,019 \\
2,243 \\
36,883 \\
150,974 \\
7,111 \\
1,717 \\
1,339\end{array}$ & $\begin{array}{r}3,366 \\
21 \\
4,160 \\
737 \\
14,446 \\
2,456 \\
673 \\
5,598 \\
25,806 \\
1,060 \\
431 \\
184\end{array}$ & $\begin{array}{r}685 \\
8 \\
308 \\
42 \\
2,122 \\
665 \\
172 \\
238 \\
861 \\
45 \\
73 \\
26\end{array}$ & $\begin{array}{r}892 \\
14 \\
15,866 \\
479 \\
7,480 \\
1,116 \\
416 \\
9,683 \\
42,894 \\
1,564 \\
289 \\
146\end{array}$ & $\begin{array}{r}40 \\
2 \\
132 \\
10 \\
254 \\
267 \\
101 \\
280 \\
367 \\
15 \\
26 \\
10\end{array}$ & $\begin{array}{r}1,366 \\
6 \\
6,207 \\
620 \\
1,556 \\
267 \\
458 \\
9,806 \\
31,676 \\
8,776 \\
178 \\
186\end{array}$ & $\begin{array}{r}4,297 \\
35 \\
34,844 \\
1,469 \\
15,383 \\
3,133 \\
1,141 \\
23,862 \\
91,302 \\
4,899 \\
706 \\
483\end{array}$ \\
\hline
\end{tabular}

†Not applicable.

'Students may exit special education services due to maximum age beginning at age 18 depending on state law or practice or order of any court.

2"Dropped out" is defined as the total who were enrolled at some point in the reporting year, were not enrolled at the end of the reporting year, and did not exit for any of the other reasons described. Includes students previously categorized as "moved, not known to continue."

3"Transferred to regular education" was previously labeled "no longer receives special education."

4"Moved, known to be continuing" is the total number of students who moved out of the administrative area or transferred to another district and are known to be continuing in an educational program.
${ }^{5}$ Other health impairments include having limited strength, vitality, or alertness due to chronic or acute health problems such as a heart condition, tuberculosis, rheumatic fever, nephritis, asthma, sickle cell anemia, hemophilia, epilepsy, lead poisoning, leukemia, or diabetes.

NOTE: Data are for the 50 states, the District of Columbia, and the Bureau of Indian Education schools. Detail may not sum to totals because of rounding.

SOURCE: U.S. Department of Education, Office of Special Education Programs, Individuals with Disabilities Education Act (IDEA) database. Retrieved June 6, 2013, from http://tadnet.public.tadnet.org/ pages/712. (This table was prepared June 2013.) 
Table 220.10. Percentage of children demonstrating specific cognitive and motor skills at about 9 months of age, by child's age and selected characteristics: 2001-02 [Standard errors appear in parentheses]

\begin{tabular}{|c|c|c|c|c|c|c|c|c|c|c|c|c|c|c|c|c|c|c|c|c|c|c|c|c|c|c|}
\hline \multirow[b]{3}{*}{ Age and selected characteristic } & \multirow{3}{*}{\multicolumn{2}{|c|}{$\begin{array}{l}\text { Number of } \\
\text { children (in } \\
\text { thousands) }\end{array}$}} & \multirow{3}{*}{\multicolumn{2}{|c|}{$\begin{array}{r}\text { Percentage } \\
\text { distribution of } \\
\text { children }\end{array}$}} & \multicolumn{22}{|c|}{ Percent of children who demonstrate skills ${ }^{1}$} \\
\hline & & & & & \multicolumn{10}{|c|}{ Specific cognitive skills } & \multicolumn{12}{|c|}{ Specific motor skills } \\
\hline & & & & & \multicolumn{2}{|c|}{$\begin{array}{r}\text { Explores } \\
\text { objects }^{2}\end{array}$} & \multicolumn{2}{|c|}{$\begin{array}{r}\text { Explores } \\
\text { purposefully }\end{array}$} & \multicolumn{2}{|c|}{$\begin{array}{r}\text { Jabbers } \\
\text { expressively } \\
\end{array}$} & \multicolumn{2}{|c|}{$\begin{array}{r}\text { Early problem } \\
\text { solving }^{5} \\
\end{array}$} & \multicolumn{2}{|c|}{$\begin{array}{r}\text { Names } \\
\text { objects }^{6}\end{array}$} & \multicolumn{2}{|c|}{$\begin{array}{r}\text { Eye-hand } \\
\text { coordination }^{7}\end{array}$} & \multicolumn{2}{|r|}{ Sitting ${ }^{8}$} & \multicolumn{2}{|c|}{ Prewalking ${ }^{9}$} & \multicolumn{2}{|r|}{$\begin{array}{l}\text { Stands } \\
\text { alone }{ }^{10}\end{array}$} & \multicolumn{2}{|c|}{$\begin{array}{r}\text { Skillful } \\
\text { walking' }\end{array}$} & \multicolumn{2}{|c|}{ Balance $^{12}$} \\
\hline 1 & & 2 & & 3 & & 4 & & 5 & & 6 & & 7 & & 8 & & 9 & & 10 & & 11 & & 12 & & 13 & & 14 \\
\hline 8 through 10 months & 32 & 39.1) & 100.0 & $(t)$ & 3.6 & $(0.06)$ & 3.2 & $(0.54)$ & 9.6 & $(0.57)$ & .7 & $(0.13)$ & 0.6 & $0.03)$ & 9.1 & $(0.26)$ & 6.8 & $(0.24)$ & 64.7 & $(0.60)$ & 8.6 & $(0.50)$ & 8.4 & $(0.21)$ & 1.7 & $(0.09)$ \\
\hline 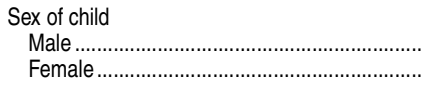 & & $\begin{array}{l}(23.0) \\
(22.0)\end{array}$ & $\begin{array}{l}50.7 \\
49.3\end{array}$ & $\begin{array}{l}(0.38) \\
(0.38)\end{array}$ & $\begin{array}{l}98.6 \\
98.7\end{array}$ & $\begin{array}{l}(0.06) \\
(0.09)\end{array}$ & $\begin{array}{l}82.7 \\
83.8\end{array}$ & & $\begin{array}{l}28.8 \\
30.4\end{array}$ & $\begin{array}{l}(0.56) \\
(0.71)\end{array}$ & $\begin{array}{l}3.5 \\
3.9\end{array}$ & & $\begin{array}{l}6 \\
7\end{array}$ & $\begin{array}{l}(0.03) \\
(0.05)\end{array}$ & $\begin{array}{l}89.3 \\
88.9\end{array}$ & $\left.\begin{array}{l}(0.30) \\
(0.36)\end{array}\right]$ & 80 & $\begin{array}{l}(0.27) \\
(0.33)\end{array}$ & $\begin{array}{l}65.1 \\
64.4\end{array}$ & $\begin{array}{l}(0.69) \\
(0.78)\end{array}$ & $\begin{array}{l}18.5 \\
18.7\end{array}$ & $\left.\begin{array}{l}(0.55) \\
(0.67)\end{array}\right]$ & $\begin{array}{l}8.3 \\
8.4\end{array}$ & $\begin{array}{l}(0.23) \\
(0.29)\end{array}$ & $\begin{array}{l}1.7 \\
1.8\end{array}$ & $\begin{array}{l}(0.10) \\
(0.14)\end{array}$ \\
\hline 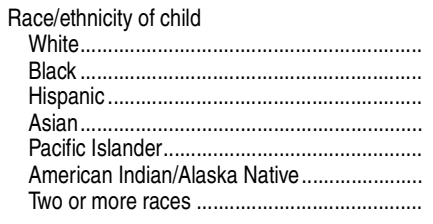 & $\begin{array}{r}1,569 \\
381 \\
717 \\
79 \\
6 \\
10 \\
115\end{array}$ & $\begin{array}{r}(29.2) \\
(11.1) \\
(18.5) \\
(3.1) \\
(1.5) \\
(1.1) \\
(9.8)\end{array}$ & $\begin{array}{r}54.5 \\
13.3 \\
24.9 \\
2.7 \\
0.2 \\
0.4 \\
4.0\end{array}$ & $\begin{array}{l}(0.63) \\
(0.38) \\
(0.54) \\
(0.10) \\
(0.05) \\
(0.04) \\
(0.33)\end{array}$ & $\begin{array}{l}98.8 \\
98.1 \\
98.5 \\
98.8 \\
98.9 \\
98.4 \\
98.6\end{array}$ & $\begin{array}{l}(0.07) \\
(0.16) \\
(0.13) \\
(0.13) \\
(0.23) \\
(0.30) \\
(0.14)\end{array}$ & $\begin{array}{l}84.0 \\
80.8 \\
82.9 \\
83.3 \\
81.8 \\
80.3 \\
83.0\end{array}$ & $\begin{array}{l}(0.69) \\
(0.92) \\
(0.82) \\
(0.96) \\
(3.58) \\
(2.72) \\
(1.24)\end{array}$ & $\begin{array}{l}30.4 \\
27.8 \\
29.0 \\
28.2 \\
23.8 \\
27.2 \\
29.8\end{array}$ & $\begin{array}{l}(0.72) \\
(0.99) \\
(0.84) \\
(0.92) \\
(3.22) \\
(2.49) \\
(1.51)\end{array}$ & $\begin{array}{l}3.9 \\
3.3 \\
3.4 \\
3.1 \\
2.0 \\
3.4 \\
3.9\end{array}$ & $\begin{array}{l}(0.17) \\
(0.25) \\
(0.21) \\
(0.20) \\
(0.47) \\
(0.70) \\
(0.55)\end{array}$ & $\begin{array}{l}0.7 \\
0.6 \\
0.6 \\
0.5 \\
0.3 \\
0.6 \\
0.8\end{array}$ & $\begin{array}{l}(0.04) \\
(0.07) \\
(0.05) \\
(0.04) \\
(0.07) \\
(0.18) \\
(0.21)\end{array}$ & $\begin{array}{l}88.8 \\
91.0 \\
88.4 \\
89.5 \\
95.4 \\
90.2 \\
90.0\end{array}$ & $\begin{array}{l}(0.37) \\
(0.33) \\
(0.47) \\
(0.53) \\
(0.97) \\
(0.99) \\
(0.94)\end{array}$ & $\begin{array}{l}86.5 \\
88.6 \\
86.1 \\
87.1 \\
93.0 \\
87.8 \\
87.8\end{array}$ & $\begin{array}{l}(0.33) \\
(0.32) \\
(0.43) \\
(0.49) \\
(1.13) \\
(0.91) \\
(0.87)\end{array}$ & $\begin{array}{l}63.8 \\
69.7 \\
63.4 \\
65.2 \\
79.9 \\
66.8 \\
67.7\end{array}$ & $\begin{array}{l}(0.81) \\
(0.94) \\
(1.00) \\
(1.21) \\
(3.81) \\
(2.15) \\
(2.20)\end{array}$ & $\begin{array}{l}18.0 \\
22.8 \\
17.0 \\
18.2 \\
34.8 \\
19.6 \\
22.1\end{array}$ & $\begin{array}{l}(0.66) \\
(1.15) \\
(0.77) \\
(1.00) \\
(8.69) \\
(2.08) \\
(2.03)\end{array}$ & $\begin{array}{r}8.1 \\
10.4 \\
7.8 \\
8.2 \\
15.1 \\
8.4 \\
9.6\end{array}$ & $\begin{array}{l}(0.27) \\
(0.58) \\
(0.32) \\
(0.39) \\
(3.90) \\
(0.80) \\
(0.79)\end{array}$ & $\begin{array}{l}1.6 \\
2.6 \\
1.6 \\
1.6 \\
3.9 ! \\
1.5 \\
2.0\end{array}$ & $\begin{array}{l}(0.10) \\
(0.35) \\
(0.15) \\
(0.14) \\
(1.67) \\
(0.29) \\
(0.30)\end{array}$ \\
\hline 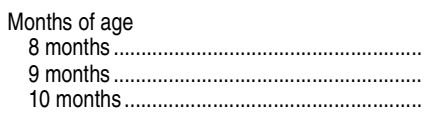 & $\begin{array}{r}642 \\
1,389 \\
851\end{array}$ & $\begin{array}{l}(32.8) \\
(28.2) \\
(24.2)\end{array}$ & $\begin{array}{l}29.5 \\
22.3 \\
48.2\end{array}$ & $\begin{array}{l}(0.90) \\
0.99) \\
(0.76)\end{array}$ & $\begin{array}{l}97.5 \\
98.7 \\
99.3\end{array}$ & $\begin{array}{l}(0.14) \\
(0.06) \\
(0.07)\end{array}$ & $\begin{array}{l}67.9 \\
84.5 \\
92.7\end{array}$ & & $\begin{array}{l}15.7 \\
27.5 \\
43.5\end{array}$ & & $\begin{array}{l}1.1 \\
2.7 \\
7.1\end{array}$ & & $\begin{array}{l}0.1 \\
0.4 \\
1.4\end{array}$ & $\begin{array}{l}(0.02) \\
(0.02) \\
(0.08)\end{array}$ & $\begin{array}{l}84.0 \\
89.1 \\
92.8\end{array}$ & $\begin{array}{l}(0.52) \\
(0.32) \\
(0.26)\end{array}$ & $\begin{array}{l}82.0 \\
86.7 \\
90.5\end{array}$ & $\begin{array}{l}(0.46) \\
(0.30) \\
(0.25)\end{array}$ & $\begin{array}{l}52.7 \\
64.2 \\
74.6\end{array}$ & $\begin{array}{l}(1.08) \\
(0.74) \\
(0.63)\end{array}$ & $\begin{array}{r}8.8 \\
16.1 \\
30.1\end{array}$ & $\begin{array}{l}(0.63) \\
(0.55) \\
(0.85)\end{array}$ & $\begin{array}{r}4.5 \\
7.2 \\
13.3\end{array}$ & $\begin{array}{l}(0.22) \\
(0.21) \\
(0.42)\end{array}$ & $\begin{array}{l}0.5 \\
1.2 \\
3.6\end{array}$ & $\begin{array}{l}(0.05) \\
(0.07) \\
(0.25)\end{array}$ \\
\hline $\begin{array}{l}\text { Primary type of nonparental care arrangement }{ }^{13} \\
\text { No regular nonparental arrangement............. } \\
\text { Home-based care }\end{array}$ & 1,459 & (28.0) & 50.7 & $(0.90)$ & 98.5 & $(0.09)$ & 82.4 & $(0.59)$ & 28.7 & (0.55) & 3.4 & $(0.14)$ & 0.6 & $(0.04)$ & 88.2 & $(0.34)$ & 86.0 & $(0.30)$ & 63.1 & $(0.70)$ & 17.7 & $(0.52)$ & 8.0 & $(0.22)$ & 1.6 & $(0.10)$ \\
\hline & & & & & & .36) & & & & & & & & & 86.8 & 28 & 84.6 & (2.55) & 61.8 & (5.09) & 14.4 & (2) & & $(0.94)$ & & 19) \\
\hline 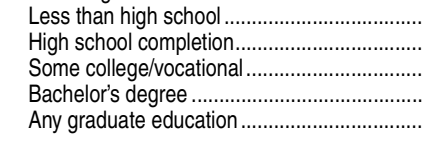 & $\begin{array}{l}388 \\
702 \\
847 \\
497 \\
446\end{array}$ & $\begin{array}{l}(12.4) \\
(19.8) \\
(24.8) \\
(16.2) \\
(15.7)\end{array}$ & $\begin{array}{l}13.5 \\
24.4 \\
29.4 \\
17.3 \\
15.5\end{array}$ & $\begin{array}{l}(0.42) \\
(0.60) \\
(0.68) \\
(0.54) \\
(0.52)\end{array}$ & $\begin{array}{l}98.4 \\
98.4 \\
98.7 \\
98.8 \\
98.8\end{array}$ & $\begin{array}{l}(0.11) \\
(0.13) \\
(0.08) \\
(0.07) \\
(0.11)\end{array}$ & $\begin{array}{l}80.0 \\
82.6 \\
84.4 \\
83.9 \\
84.0\end{array}$ & $\begin{array}{l}(0.87) \\
(0.89) \\
(0.60) \\
(0.60) \\
(0.94)\end{array}$ & $\begin{array}{l}30.2 \\
30.4\end{array}$ & $\begin{array}{l}(0.79) \\
(0.81) \\
(0.69) \\
(0.71) \\
(0.88)\end{array}$ & $\begin{array}{l}2.8 \\
3.6 \\
3.9 \\
3.8 \\
3.8\end{array}$ & $\begin{array}{l}(0.20) \\
(0.21) \\
(0.20) \\
(0.20) \\
(0.22)\end{array}$ & $\begin{array}{l}0.5 \\
0.7 \\
0.7 \\
0.7 \\
0.7\end{array}$ & $\begin{array}{l}(0.06) \\
(0.06) \\
(0.05) \\
(0.05) \\
(0.06)\end{array}$ & $\begin{array}{l}88.9 \\
89.6 \\
90.0 \\
88.4 \\
87.5\end{array}$ & $\begin{array}{l}(0.62) \\
(0.45) \\
(0.35) \\
(0.46) \\
(0.58)\end{array}$ & $\begin{array}{l}86.5 \\
87.3 \\
87.7 \\
86.1 \\
85.4\end{array}$ & $\begin{array}{l}(0.58) \\
(0.42) \\
(0.33) \\
(0.41) \\
(0.52)\end{array}$ & $\begin{array}{l}62.5 \\
60.5\end{array}$ & (1.23) & $\begin{array}{l}17.3 \\
20.6 \\
20.8 \\
16.3 \\
15.2\end{array}$ & $\begin{array}{l}(0.96) \\
(0.84) \\
(0.82) \\
(0.85) \\
(0.91)\end{array}$ & $\begin{array}{l}8.0 \\
9.1 \\
9.3 \\
7.4 \\
7.0\end{array}$ & $\begin{array}{l}(0.42) \\
(0.36) \\
(0.35) \\
(0.34) \\
(0.40)\end{array}$ & $\begin{array}{l}1.7 \\
1.9 \\
2.0 \\
1.4 \\
1.4\end{array}$ & $\begin{array}{l}(0.12) \\
(0.18)\end{array}$ \\
\hline $\begin{array}{l}\text { Poverty status }{ }^{18} \\
\text { Below poverty threshold................. } \\
\text { At or above poverty threshold .......... }\end{array}$ & $\begin{array}{r}682 \\
2,200\end{array}$ & $\begin{array}{l}(23.0) \\
(37.2)\end{array}$ & $\begin{array}{l}23.7 \\
76.3\end{array}$ & $\begin{array}{l}(0.74) \\
(0.74)\end{array}$ & $\begin{array}{l}98.3 \\
98.7\end{array}$ & $\begin{array}{l}(0.14) \\
(0.07)\end{array}$ & $\begin{array}{l}80.9 \\
84.0\end{array}$ & $\begin{array}{l}(0.75) \\
(0.58)\end{array}$ & $\begin{array}{l}27.1 \\
30.4\end{array}$ & $\begin{array}{l}(0.79) \\
(0.63)\end{array}$ & $\begin{array}{l}3.1 \\
3.8\end{array}$ & $\begin{array}{l}(0.21) \\
(0.15)\end{array}$ & $\begin{array}{l}0.5 \\
0.7\end{array}$ & $\begin{array}{l}(0.05) \\
(0.04)\end{array}$ & $\begin{array}{l}89.1 \\
89.1\end{array}$ & $\begin{array}{l}(0.47) \\
(0.27)\end{array}$ & $\begin{array}{l}86.8 \\
86.8\end{array}$ & $\left.\begin{array}{l}(0.43) \\
(0.25)\end{array}\right]$ & $\begin{array}{l}65.5 \\
64.5\end{array}$ & $(0.66)$ & $\begin{array}{l}19.2 \\
18.4\end{array}$ & $\left.\begin{array}{l}(0.86) \\
(0.56)\end{array}\right]$ & $\begin{array}{l}8.7 \\
8.3\end{array}$ & $\left.\begin{array}{l}(0.42) \\
(0.23)\end{array}\right]$ & $\begin{array}{l}1.9 \\
1.7\end{array}$ & $\begin{array}{l}(0.24) \\
(0.10)\end{array}$ \\
\hline 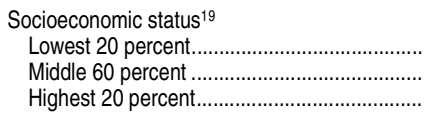 & $\begin{array}{r}557 \\
1,719 \\
606 \\
\end{array}$ & $\begin{array}{l}(16.8) \\
(38.2) \\
(18.4)\end{array}$ & $\begin{array}{l}19.3 \\
59.7 \\
21.0\end{array}$ & $\begin{array}{l}(0.58) \\
(0.83) \\
(0.63)\end{array}$ & $\begin{array}{l}98.3 \\
98.6 \\
98.8\end{array}$ & $\begin{array}{l}(0.13) \\
(0.08) \\
(0.09)\end{array}$ & $\begin{array}{l}80.7 \\
83.5 \\
84.8 \\
\end{array}$ & $\begin{array}{l}(0.72) \\
(0.63) \\
(0.73)\end{array}$ & $\begin{array}{l}26.8 \\
30.2 \\
30.5 \\
\end{array}$ & $\begin{array}{l}(0.69) \\
(0.67) \\
(0.79)\end{array}$ & $\begin{array}{l}3.0 \\
3.8 \\
3.8\end{array}$ & $\begin{array}{l}(0.17) \\
(0.18) \\
(0.18)\end{array}$ & $\begin{array}{l}0.5 \\
0.7 \\
0.6 \\
\end{array}$ & $\begin{array}{l}(0.04) \\
(0.05) \\
(0.04)\end{array}$ & $\begin{array}{l}89.1 \\
89.5 \\
88.0 \\
\end{array}$ & $\begin{array}{l}(0.30) \\
(0.45)\end{array}$ & $\begin{array}{l}86.7 \\
87.2 \\
85.8 \\
\end{array}$ & $\begin{array}{l}(0.28) \\
(0.40)\end{array}$ & $\begin{array}{l}65.4 \\
65.6 \\
61.5 \\
\end{array}$ & $\begin{array}{l}(0.73) \\
(0.96)\end{array}$ & $\begin{array}{l}18.8 \\
19.6 \\
15.6 \\
\end{array}$ & $\begin{array}{l}(0.67) \\
(0.66)\end{array}$ & $\begin{array}{l}8.5 \\
8.8 \\
7.1 \\
\end{array}$ & $\begin{array}{l}(0.28) \\
(0.28)\end{array}$ & $\begin{array}{l}1.8 \\
1.9 \\
1.3 \\
\end{array}$ & $\begin{array}{l}(0.11) \\
(0.13) \\
\end{array}$ \\
\hline
\end{tabular}

See notes at end of table. 
Table 220.10. Percentage of children demonstrating specific cognitive and motor skills at about 9 months of age, by child's age and selected characteristics: 2001-02-Continued

[Standard errors appear in parentheses]

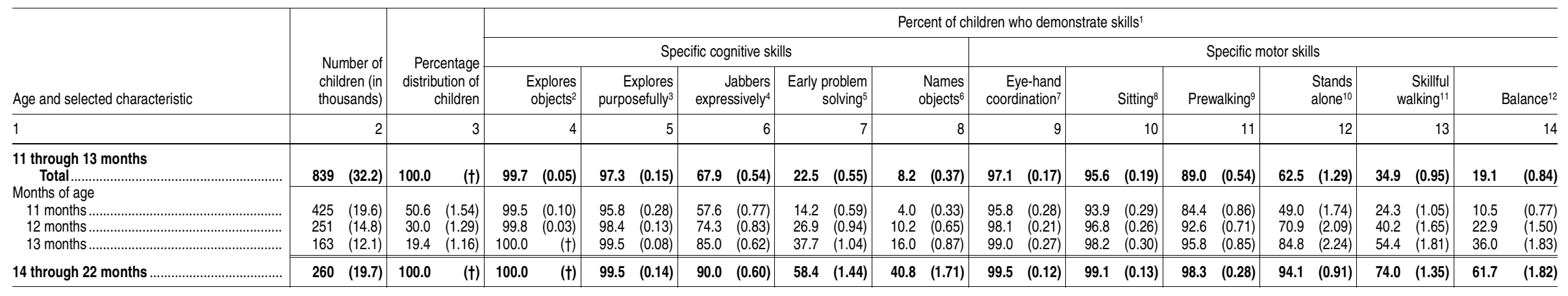

†Not applicable.

!Interpret data with caution. The coefficient of variation (CV) for this estimate is between 30 and 50 percent.

Based on assessments collected using the Bayley Short Form Research Edition (BSF-R), a shortened field method of administering

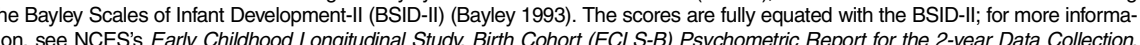
The proficiency probabilities indicate mastery of a specific skill or ability within cognitive or physical domains. Ability to explore objects, for example, reaching for and holding objects. The child may have no specific purpose except to play or

discover.
${ }^{3} \mathrm{Ability}$ to explore objects with a purpose, such as to explore a bell to understand the source of the sound.

${ }^{4}$ Measures proficiency in communication through diverse nonverbal sounds and gestures, such as vowel and vowel-consonant "Measures proficiency in early communication skills, such as saying simple words like "mama" and "dada."

"Measures proficiency in being able to use visual tracking to guide hand movements to pick up a small object.

Measures proficiency in ability to engage in various prewalking types of mobility, with and without support, such as shifting weight rom one toot to he olher.

help and to stand independently.

${ }^{12}$ Measures proficiency in ability to maintain balance while changing positio

${ }^{15}$ are provided in the child's home or in another private home by a relative (excluding parents).

${ }^{16} \mathrm{Care}$ provided in places such as early learning centers, nursery schools, and preschools.

${ }^{17}$ Children who spent an equal amount of time in each of two or more types of arrangements.

${ }^{18}$ Poverty status based on Census Bureau guidelines from 2002, which identify a dollar amount determined to meet a household's needs, given its size and composition. In 2002, a family of four was considered to live below the poverty threshold if its income was less than or equal to $\$ 18,332$.

(SES) was measured by a composite score based on parental education and occupations, and family

NOTE: Estimates weighted by W1C0. This table is based on a survey that sampled children born in 2001 and was designed to collect information about them for the first time when the children were about 9 months of age (i.e., 8 to 10 months). As shown in the table, some children were older than this at the time data were collected, although only 6.5 percent were over 13 months of age. Race categories exclude persons of Hispanic ethnicity. Detail may not sum to totals because of rounding and survey item nonresponse. Some data have been revised from previously published igures.

Study, Birth Cohor "Measures proficiency in being able to walk independently. 
Table 220.20. Percentage of children demonstrating specific cognitive skills, motor skills, and secure emotional attachment to parents at about 2 years of age, by selected characteristics: 2003-04

[Standard errors appear in parentheses]

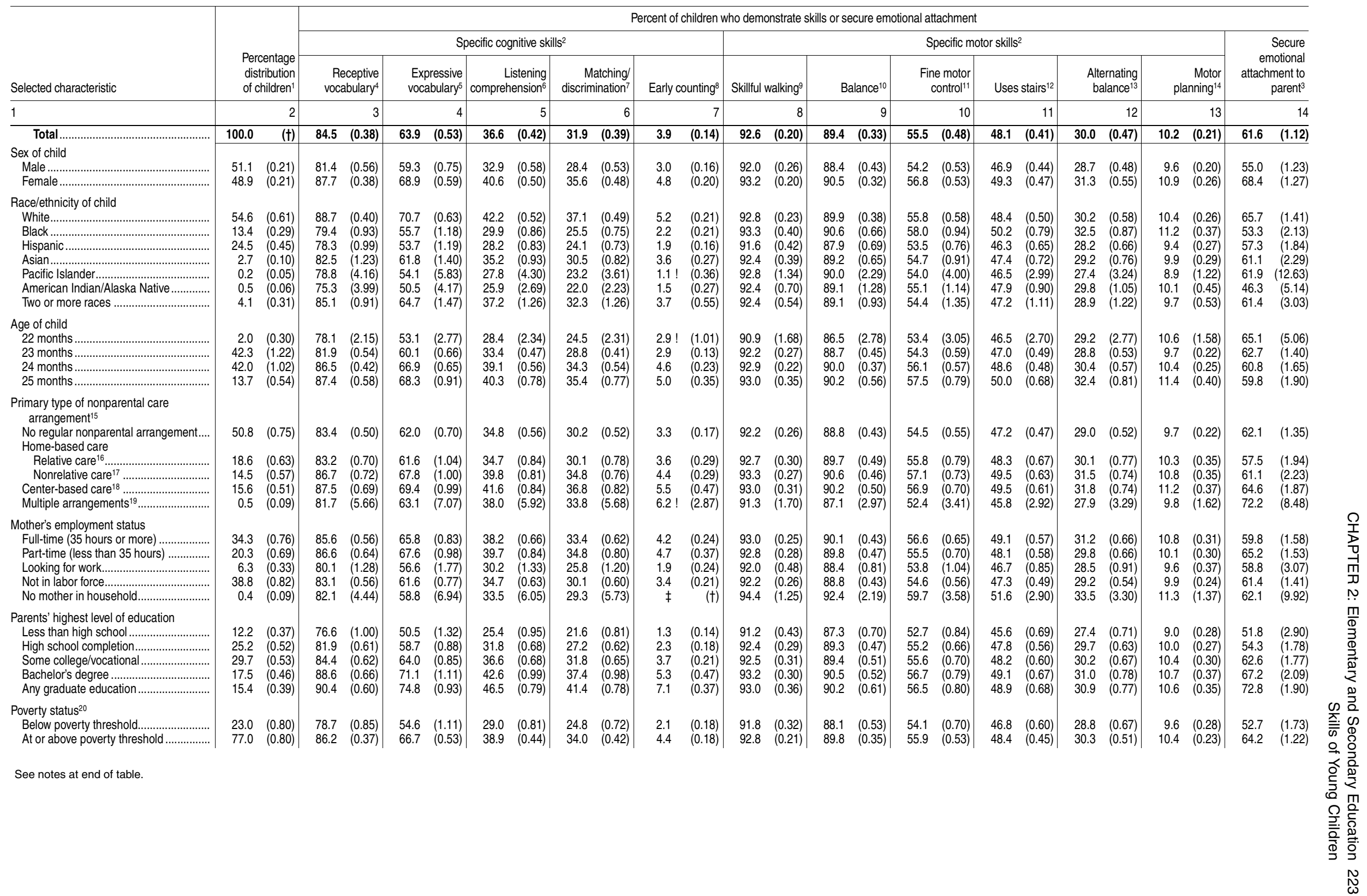


Table 220.20. Percentage of children demonstrating specific cognitive skills, motor skills, and secure emotional attachment to parents at about 2 years of age, by selected characteristics: 2003-04-Continued

[Standard errors appear in parentheses]

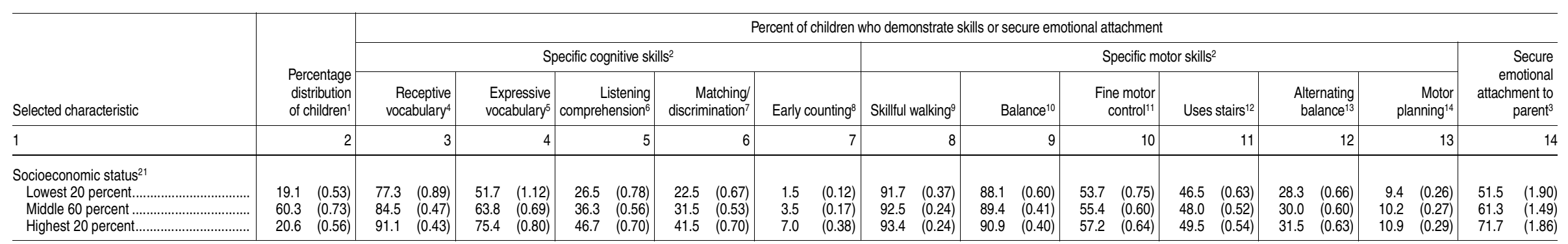

†Not applicable.

Interpret data with caution. The coefficient of variation (CV) for this estimate is between 30 and 50 percent.

Theporting standards not met. The coefficient of variation (CV) for this estimate is 50 percent or greater.
'Weighted distribution of Early Childhood Longitudinal Study, Birth Cohort survey population between 22 and 25 months of age.

2Based on assessments collected using the Bayley Short Form Research Edition (BSF-R), a shortened field method of administering

the Bayley Scales of Infant Development-II (BSID-II) (Bayley 1993). The scores are fully equated with the BSID-II; for more information, see NCES's Early Childhood Longitudinal Study, Birth Cohort (ECLS-B) Psychometric Report for the 2-year Data Collection. The proficiency probabilities indicate mastery of a specific skill or ability within cognitive or physical domains.

${ }^{3}$ Attachment was measured by trained observers using the Toddler Attachment Sort-45 ltem (TAS-45) assessment. The formation of secure attachments in early childhood is an indicator that the child is able to use the parent as a secure base from which to explore ${ }_{4}^{4} \mathrm{Ability}$ to recognize and understand spoken words or to indicate a named object by pointing.

${ }^{5}$ Verbal expressiveness using gestures, words, and sentences.

${ }^{6}$ Ability to understand actions depicted by a story, in pictures, or by verbal instructions.

"Ability to match objects by their properties (e.g., color) or differentiate one object from another.

Abilty to maintain balance wher

${ }^{12}$ Ability to walk up and down stairs, with or without alternating feet.

13Ability to maintain balance when changing position or when in motion, such as jumping.

${ }^{17}$ Care provided in the child's home or in another private home by a person unrelated to thents).

${ }^{18}$ Care provided in places such as early learning centers, nursery schools, and preschools.

20poverty status based on Census Bureau guidelines from 2002, which identify a dollar amount determined to meet a household's needs, given

income.

NOTE: Estimates weighted by W2R0. Estimates pertain to sample of children born in 2001 and assessed between 22 months and 25 months of age. Children younger than 22 months (less than 1 percent of the survey population) and children older than 25 month (approximately 9 percent of he survey population) are excluded fom this table. Race calegones exclude persons or Hispanic elhnicity. Detail may not sum to totals SOURCE. US. Depar

9-month-Kindergarten 2007 Restricted-Use Data File and Electronic Codebook. (This table was prepared December 2010.) 
Table 220.30. Children's reading, language, mathematics, color knowledge, and fine motor skills at about 4 years of age, by child's age and selected characteristics: 2005-06

[Standard errors appear in parentheses]

\begin{tabular}{|c|c|c|c|c|c|c|c|c|c|c|c|c|c|c|}
\hline \multirow{2}{*}{$\frac{\text { Age and selected characteristic }}{1}$} & \multicolumn{2}{|c|}{$\begin{array}{r}\text { Number } \\
\text { of children } \\
\text { (in thousands) } \\
\end{array}$} & \multicolumn{2}{|c|}{$\begin{array}{r}\text { Percentage } \\
\text { distribution } \\
\text { of children }\end{array}$} & \multicolumn{2}{|c|}{$\begin{array}{r}\text { Average } \\
\text { early reading } \\
\text { scale score }^{1} \\
\end{array}$} & \multicolumn{2}{|c|}{$\begin{array}{r}\text { Expressive } \\
\text { vocabulary (telling } \\
\text { stories) } \text { score }^{2}\end{array}$} & \multicolumn{2}{|c|}{$\begin{array}{r}\text { Average } \\
\text { mathematics } \\
\text { scale score }^{3} \\
\end{array}$} & \multicolumn{2}{|c|}{$\begin{array}{r}\text { Color } \\
\text { knowledge- } \\
\text { percent scoring } \\
10 \text { out of } 10^{4} \\
\end{array}$} & \multicolumn{2}{|c|}{ Fine motor score ${ }^{5}$} \\
\hline & & 2 & & 3 & & 4 & & 5 & & 6 & & 7 & & 8 \\
\hline $\begin{array}{l}\text { Less than } 48 \text { months } \\
\text { Total ............................... }\end{array}$ & 645 & $(22.3)$ & 100.0 & $(t)$ & 21.5 & $(0.32)$ & 2.1 & $(0.04)$ & 24.5 & $(0.31)$ & 49.0 & $(1.89)$ & 2.5 & $(0.05)$ \\
\hline 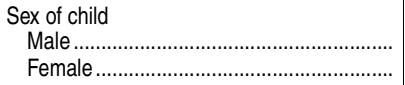 & $\begin{array}{l}324 \\
321\end{array}$ & $\begin{array}{l}(15.8) \\
(16.3)\end{array}$ & $\begin{array}{l}50.3 \\
49.7\end{array}$ & $\begin{array}{l}(1.79) \\
(1.79)\end{array}$ & $\begin{array}{l}20.7 \\
22.4\end{array}$ & $\begin{array}{l}(0.48) \\
(0.43)\end{array}$ & $\begin{array}{l}1.9 \\
2.2\end{array}$ & $\begin{array}{l}(0.05) \\
(0.06)\end{array}$ & $\begin{array}{l}23.5 \\
25.5\end{array}$ & $\begin{array}{l}(0.44) \\
(0.45)\end{array}$ & $\begin{array}{l}41.8 \\
56.1\end{array}$ & $\begin{array}{l}(3.03) \\
(2.40)\end{array}$ & $\begin{array}{l}2.3 \\
2.8\end{array}$ & $\begin{array}{l}(0.07) \\
(0.06)\end{array}$ \\
\hline 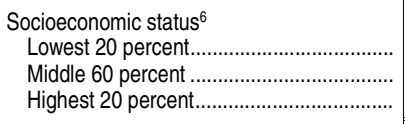 & $\begin{array}{l}121 \\
380 \\
144 \\
\end{array}$ & $\begin{array}{l}(11.3) \\
(16.7) \\
(10.7) \\
\end{array}$ & $\begin{array}{l}18.7 \\
58.9 \\
22.4 \\
\end{array}$ & $\begin{array}{l}(1.50) \\
(1.67) \\
(1.59) \\
\end{array}$ & $\begin{array}{l}16.7 \\
21.0 \\
26.3 \\
\end{array}$ & $\begin{array}{l}(0.35) \\
(0.39) \\
(0.67) \\
\end{array}$ & $\begin{array}{l}1.8 \\
2.1 \\
2.2 \\
\end{array}$ & $\begin{array}{l}(0.09) \\
(0.04) \\
(0.07) \\
\end{array}$ & $\begin{array}{l}19.1 \\
24.2 \\
29.2 \\
\end{array}$ & $\begin{array}{l}(0.52) \\
(0.39) \\
(0.64) \\
\end{array}$ & $\begin{array}{l}16.2 \\
50.9 \\
67.8 \\
\end{array}$ & $\begin{array}{l}(3.65) \\
(2.57) \\
(2.97) \\
\end{array}$ & $\begin{array}{l}2.0 \\
2.6 \\
2.9 \\
\end{array}$ & $\begin{array}{l}(0.10) \\
(0.06) \\
(0.09) \\
\end{array}$ \\
\hline $\begin{array}{l}48 \text { through } 57 \text { months } \\
\text { Total............................... }\end{array}$ & 2,939 & (23.2) & 100.0 & $(t)$ & 25.5 & $(0.22)$ & 2.4 & $(0.02)$ & 29.7 & $(0.20)$ & 63.6 & $(0.84)$ & 3.4 & $(0.02)$ \\
\hline $\begin{array}{l}\text { Sex of child } \\
\text { Male } \\
\text { Female }\end{array}$ & $\begin{array}{l}1,516 \\
1,423\end{array}$ & $\begin{array}{l}(18.2) \\
(18.4)\end{array}$ & $\begin{array}{l}51.6 \\
48.4\end{array}$ & $\begin{array}{l}(0.48) \\
(0.48)\end{array}$ & $\begin{array}{l}24.6 \\
26.4\end{array}$ & $\begin{array}{l}(0.26) \\
(0.29)\end{array}$ & $\begin{array}{l}2.3 \\
2.6\end{array}$ & $\begin{array}{l}(0.03) \\
(0.02)\end{array}$ & $\begin{array}{l}29.2 \\
30.3\end{array}$ & $\begin{array}{l}(0.25) \\
(0.24)\end{array}$ & $\begin{array}{l}61.2 \\
66.1\end{array}$ & $\begin{array}{l}(1.12) \\
(1.29)\end{array}$ & $\begin{array}{l}3.1 \\
3.7\end{array}$ & $\begin{array}{l}(0.04) \\
(0.04)\end{array}$ \\
\hline 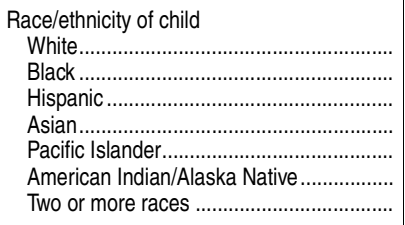 & $\begin{array}{r}1,604 \\
391 \\
729 \\
74 \\
4 \\
15 \\
115\end{array}$ & $\begin{array}{r}(22.9) \\
(11.5) \\
(18.1) \\
(3.6) \\
(0.7) \\
(1.5) \\
(9.0)\end{array}$ & $\begin{array}{r}54.7 \\
13.3 \\
24.9 \\
2.5 \\
0.1 \\
0.5 \\
3.9\end{array}$ & $\begin{array}{l}(0.69) \\
(0.37) \\
(0.56) \\
(0.12) \\
(0.03) \\
(0.05) \\
(0.31)\end{array}$ & $\begin{array}{l}27.4 \\
22.9 \\
21.2 \\
30.5 \\
22.2 \\
20.1 \\
27.3\end{array}$ & $\begin{array}{l}(0.30) \\
(0.46) \\
(0.36) \\
(0.56) \\
(2.24) \\
(0.89) \\
(0.89)\end{array}$ & $\begin{array}{l}2.6 \\
2.4 \\
2.1 \\
2.1 \\
2.1 \\
2.1 \\
2.5\end{array}$ & $\begin{array}{l}(0.03) \\
(0.04) \\
(0.04) \\
(0.05) \\
(0.18) \\
(0.09) \\
(0.06)\end{array}$ & $\begin{array}{l}31.6 \\
26.9 \\
26.2 \\
34.7 \\
26.3 \\
23.2 \\
30.2\end{array}$ & $\begin{array}{l}(0.28) \\
(0.44) \\
(0.34) \\
(0.42) \\
(3.41) \\
(0.98) \\
(0.82)\end{array}$ & $\begin{array}{l}71.0 \\
55.3 \\
50.2 \\
70.7 \\
39.0 \\
44.1 \\
62.7\end{array}$ & $\begin{array}{l}(1.11) \\
(2.44) \\
(1.79) \\
(2.37) \\
(9.21) \\
(3.83) \\
(3.04)\end{array}$ & $\begin{array}{l}3.5 \\
3.2 \\
3.3 \\
4.5 \\
3.0 \\
3.0 \\
3.5\end{array}$ & $\begin{array}{l}(0.03) \\
(0.06) \\
(0.06) \\
(0.09) \\
(0.34) \\
(0.18) \\
(0.12)\end{array}$ \\
\hline $\begin{array}{l}\text { Primary type of nonparental care } \\
\quad \text { arrangement } \\
\text { No regular nonparental arrangement......... } \\
\text { Home-based care ................................... }\end{array}$ & 535 & (20.8) & 18.2 & $(0.69)$ & 22.9 & $(0.41)$ & 2.3 & $(0.04)$ & 26.9 & $(0.41)$ & 51.6 & (2.04) & 3.1 & $(0.05)$ \\
\hline 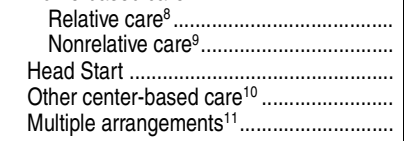 & $\begin{array}{r}384 \\
220 \\
386 \\
1,358 \\
52\end{array}$ & $\begin{array}{r}(18.8) \\
(11.8) \\
(22.3) \\
(26.2) \\
(6.8)\end{array}$ & $\begin{array}{r}13.1 \\
7.5 \\
13.2 \\
46.3 \\
1.8\end{array}$ & $\begin{array}{l}(0.65) \\
(0.40) \\
(0.73) \\
(0.83) \\
(0.23)\end{array}$ & $\begin{array}{l}23.0 \\
25.1 \\
22.2 \\
28.0 \\
24.6\end{array}$ & $\begin{array}{l}(0.44) \\
(0.51) \\
(0.35) \\
(0.32) \\
(0.93)\end{array}$ & $\begin{array}{l}2.3 \\
2.5 \\
2.3 \\
2.6 \\
2.5\end{array}$ & $\begin{array}{l}(0.05) \\
(0.07) \\
(0.05) \\
(0.03) \\
(0.10)\end{array}$ & $\begin{array}{l}27.3 \\
30.2 \\
26.8 \\
32.2 \\
29.3\end{array}$ & $\begin{array}{l}(0.42) \\
(0.58) \\
(0.40) \\
(0.27) \\
(0.92)\end{array}$ & $\begin{array}{l}53.4 \\
63.8 \\
52.8 \\
73.5 \\
67.1\end{array}$ & $\begin{array}{l}(2.58) \\
(2.72) \\
(2.55) \\
(1.19) \\
(5.44)\end{array}$ & $\begin{array}{l}3.2 \\
3.3 \\
3.2 \\
3.6 \\
3.2\end{array}$ & $\begin{array}{l}(0.07) \\
(0.09) \\
(0.07) \\
(0.04) \\
(0.23)\end{array}$ \\
\hline $\begin{array}{l}\text { Mother's employment status } \\
\text { Full-time ( } 35 \text { hours or more) ..................... } \\
\text { Part-time (less than } 35 \text { hours) .................. } \\
\text { Looking for work...................................... } \\
\text { Not in labor force................................... } \\
\text { No mother in household........................... }\end{array}$ & $\begin{array}{r}1,149 \\
573 \\
163 \\
1,010 \\
22\end{array}$ & $\begin{array}{r}(26.5) \\
(17.7) \\
(9.9) \\
(27.1) \\
(4.0)\end{array}$ & $\begin{array}{r}39.4 \\
19.6 \\
5.6 \\
34.6 \\
0.8\end{array}$ & $\begin{array}{l}(0.85) \\
(0.60) \\
(0.34) \\
(0.88) \\
(0.14)\end{array}$ & $\begin{array}{l}25.6 \\
26.3 \\
21.7 \\
25.5 \\
21.6\end{array}$ & $\begin{array}{l}(0.30) \\
(0.35) \\
(0.57) \\
(0.39) \\
(1.35)\end{array}$ & $\begin{array}{l}2.5 \\
2.5 \\
2.2 \\
2.4 \\
2.3\end{array}$ & $\begin{array}{l}(0.03) \\
(0.04) \\
(0.07) \\
(0.03) \\
(0.24)\end{array}$ & $\begin{array}{l}30.3 \\
30.6 \\
25.8 \\
29.3 \\
26.3\end{array}$ & $\begin{array}{l}(0.24) \\
(0.35) \\
(0.74) \\
(0.35) \\
(1.25)\end{array}$ & $\begin{array}{l}67.5 \\
63.5 \\
47.1 \\
62.1 \\
57.3\end{array}$ & $\begin{array}{l}(1.09) \\
(2.06) \\
(3.83) \\
(1.42) \\
(8.79)\end{array}$ & $\begin{array}{l}3.5 \\
3.5 \\
3.0 \\
3.3 \\
3.0\end{array}$ & $\begin{array}{l}(0.05) \\
(0.05) \\
(0.11) \\
(0.04) \\
(0.21)\end{array}$ \\
\hline $\begin{array}{l}\text { Parents' highest level of education } \\
\text { Less than high school ................................ } \\
\text { High school completion........................... } \\
\text { Some college/vocational ........................... } \\
\text { Bachelor's degree } \\
\text { Any graduate education }\end{array}$ & $\begin{array}{l}292 \\
672 \\
998 \\
498 \\
475\end{array}$ & $\begin{array}{l}(11.9) \\
(24.1) \\
(23.5) \\
(17.6) \\
(14.6)\end{array}$ & $\begin{array}{r}9.9 \\
22.9 \\
34.0 \\
17.0 \\
16.2\end{array}$ & $\begin{array}{l}(0.41) \\
(0.79) \\
(0.76) \\
(0.57) \\
(0.49)\end{array}$ & $\begin{array}{l}18.7 \\
21.6 \\
24.3 \\
28.8 \\
33.0\end{array}$ & $\begin{array}{l}(0.41) \\
(0.28) \\
(0.30) \\
(0.40) \\
(0.43)\end{array}$ & $\begin{array}{l}1.9 \\
2.3 \\
2.5 \\
2.7 \\
2.7\end{array}$ & $\begin{array}{l}(0.06) \\
(0.03) \\
(0.03) \\
(0.04) \\
(0.04)\end{array}$ & $\begin{array}{l}23.6 \\
25.9 \\
28.9 \\
33.2 \\
36.2\end{array}$ & $\begin{array}{l}(0.47) \\
(0.30) \\
(0.28) \\
(0.28) \\
(0.33)\end{array}$ & $\begin{array}{l}37.3 \\
52.0 \\
63.4 \\
75.6 \\
81.0\end{array}$ & $\begin{array}{l}(2.74) \\
(1.64) \\
(1.29) \\
(1.69) \\
(1.48)\end{array}$ & $\begin{array}{l}3.1 \\
3.1 \\
3.4 \\
3.7 \\
3.9\end{array}$ & $\begin{array}{l}(0.09) \\
(0.04) \\
(0.04) \\
(0.08) \\
(0.05)\end{array}$ \\
\hline 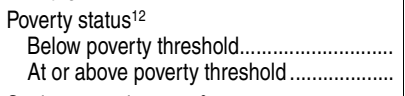 & $\begin{array}{r}732 \\
2,207\end{array}$ & $\begin{array}{l}(21.0) \\
(28.4)\end{array}$ & $\begin{array}{l}24.9 \\
75.1\end{array}$ & $\begin{array}{l}(0.71) \\
(0.71)\end{array}$ & $\begin{array}{l}20.5 \\
27.0\end{array}$ & $\begin{array}{l}(0.26) \\
(0.24)\end{array}$ & $\begin{array}{l}2.1 \\
2.5\end{array}$ & $\begin{array}{l}(0.03) \\
(0.02)\end{array}$ & $\begin{array}{l}24.6 \\
31.3\end{array}$ & $\begin{array}{l}(0.28) \\
(0.21)\end{array}$ & $\begin{array}{l}46.9 \\
68.8\end{array}$ & $\begin{array}{l}(1.76) \\
(0.91)\end{array}$ & $\begin{array}{l}3.1 \\
3.5\end{array}$ & $\begin{array}{l}(0.05) \\
(0.03)\end{array}$ \\
\hline $\begin{array}{l}\text { Socioeconomic status }^{6} \\
\text { Lowest } 20 \text { percent.......... } \\
\text { Middle } 60 \text { percent .......... } \\
\text { Highest } 20 \text { percent......... }\end{array}$ & $\begin{array}{r}576 \\
1,768 \\
594 \\
\end{array}$ & $\begin{array}{l}(17.2) \\
(27.3) \\
(20.4) \\
\end{array}$ & $\begin{array}{l}19.6 \\
60.2 \\
20.2 \\
\end{array}$ & $\begin{array}{l}(0.57) \\
(0.77) \\
(0.68) \\
\end{array}$ & $\begin{array}{l}19.3 \\
24.7 \\
32.7 \\
\end{array}$ & $\begin{array}{l}(0.31) \\
(0.22) \\
(0.43) \\
\end{array}$ & $\begin{array}{l}2.0 \\
2.5 \\
2.8 \\
\end{array}$ & $\begin{array}{l}(0.04) \\
(0.03) \\
(0.03) \\
\end{array}$ & $\begin{array}{l}23.6 \\
29.3 \\
36.2 \\
\end{array}$ & $\begin{array}{l}(0.35) \\
(0.23) \\
(0.33) \\
\end{array}$ & $\begin{array}{l}43.1 \\
63.5 \\
81.6 \\
\end{array}$ & $\begin{array}{l}(2.15) \\
(1.07) \\
(1.51) \\
\end{array}$ & $\begin{array}{l}3.0 \\
3.4 \\
3.9 \\
\end{array}$ & $\begin{array}{l}(0.06) \\
(0.03) \\
(0.05) \\
\end{array}$ \\
\hline 58 months or more & 356 & (16.4) & 100.0 & (t) & 29.7 & $(0.58)$ & 2.6 & $(0.04)$ & 34.5 & $(0.44)$ & 71.1 & $(2.09)$ & 4.1 & $(0.07)$ \\
\hline 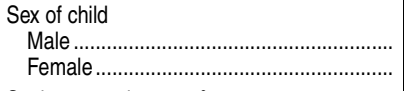 & $\begin{array}{l}179 \\
177\end{array}$ & $\begin{array}{l}(12.1) \\
(10.5)\end{array}$ & $\begin{array}{l}50.3 \\
49.7\end{array}$ & $\begin{array}{l}(2.21) \\
(2.21)\end{array}$ & $\begin{array}{l}29.0 \\
30.4\end{array}$ & $\begin{array}{l}(0.77) \\
(0.76)\end{array}$ & $\begin{array}{l}2.6 \\
2.7\end{array}$ & $\begin{array}{l}(0.06) \\
(0.06)\end{array}$ & $\begin{array}{l}34.2 \\
34.8\end{array}$ & $\begin{array}{l}(0.64) \\
(0.51)\end{array}$ & $\begin{array}{l}66.5 \\
75.9\end{array}$ & $\begin{array}{l}(3.05) \\
(2.49)\end{array}$ & $\begin{array}{l}3.7 \\
4.4\end{array}$ & $\begin{array}{l}(0.10) \\
(0.10)\end{array}$ \\
\hline 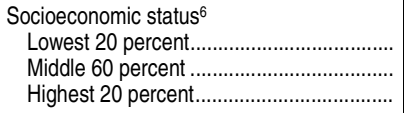 & $\begin{array}{r}91 \\
215 \\
50\end{array}$ & $\begin{array}{r}(8.0) \\
(14.7) \\
(6.9)\end{array}$ & $\begin{array}{l}25.5 \\
60.5 \\
14.0\end{array}$ & $\begin{array}{l}(2.26) \\
(2.47) \\
(1.84)\end{array}$ & $\begin{array}{l}22.3 \\
30.0 \\
40.3\end{array}$ & $\begin{array}{l}(0.91) \\
(0.75) \\
(2.31)\end{array}$ & $\begin{array}{l}2.1 \\
2.7 \\
2.9\end{array}$ & $\begin{array}{l}(0.11) \\
(0.05) \\
(0.10)\end{array}$ & $\begin{array}{l}28.4 \\
34.9 \\
42.8\end{array}$ & $\begin{array}{l}(0.97) \\
(0.54) \\
(1.15)\end{array}$ & $\begin{array}{l}47.4 \\
76.0 \\
88.5\end{array}$ & $\begin{array}{l}(5.25) \\
(2.63) \\
(2.89)\end{array}$ & $\begin{array}{l}3.6 \\
4.1 \\
4.7\end{array}$ & $\begin{array}{l}(0.14) \\
(0.10) \\
(0.18)\end{array}$ \\
\hline
\end{tabular}

\section{†Not applicable.}

${ }^{1}$ Reflects performance on language and literacy items (e.g., conventions of print, letter recognition understanding of letter-sound relationships, phonological awareness, sight word recognition, and understanding words in the context of simple sentences). Potential score ranges from 0 to 85 Verbal expressiveness using gestures, words, and sentences. Potential score ranges from 0 to 5 . ${ }^{3}$ Includes number sense, geometry, counting, operations, and patterns. Potential score ranges from 0 to 71.

${ }^{4}$ Percentage of children who scored 10 on a test with a potential score range of 0 to 10 . These children were able to name the colors of five pictured objects ( 2 points per correct answer).

${ }^{5}$ Measures the ability to use fine motor skills in drawing basic forms and shapes. Potential score ranges from 0 to 7 .

${ }^{6}$ Socioeconomic status (SES) was measured by a composite score based on parental education and occupations, and family income.

The type of nonparental care in which the child spent the most hours.

Care provided in the child's home or in another private home by a relative (excluding parents).

${ }^{9}$ Care provided in the child's home or in another private home by a person unrelated to the child.
${ }^{10}$ Care provided in places such as early learning centers, nursery schools, and preschools, excluding Head Start.

${ }^{11}$ Children who spent an equal amount of time in each of two or more types of arrangements. ${ }^{12}$ Poverty status based on Census Bureau guidelines from 2005, which identify a dollar amount determined to meet a household's needs, given its size and composition. In 2005, a family of four was considered to live below the poverty threshold if its income was less than or equal to $\$ 19,971$. NOTE: Estimates weighted by W3R0. Estimates pertain to a sample of children who were born in 2001. This table was designed to present data collected when the children were about 4 years of age (i.e., 48 to 57 months old). As shown in the table, some children were younger or older than this at the time data were collected, although 75 percent were within the target age range. Race categories exclude persons of Hispanic ethnicity. Detail may not sum to totals because of rounding categories exclude persons of Hispanic ethnicity. Detail may not sum to totals because of rounding
and survey item nonresponse. Some data have been revised from previously published figures. SOURCE: U.S. Department of Education, National Center for Education Statistics, Early Childhood Longitudinal Study, Birth Cohort (ECLS-B), Longitudinal 9-Month-Kindergarten 2007 Restricted-Use Data File. (This table was prepared December 2010. 


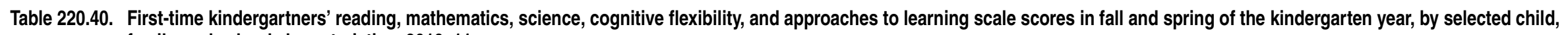
family, and school characteristics: 2010-11

[Standard errors appear in parentheses]

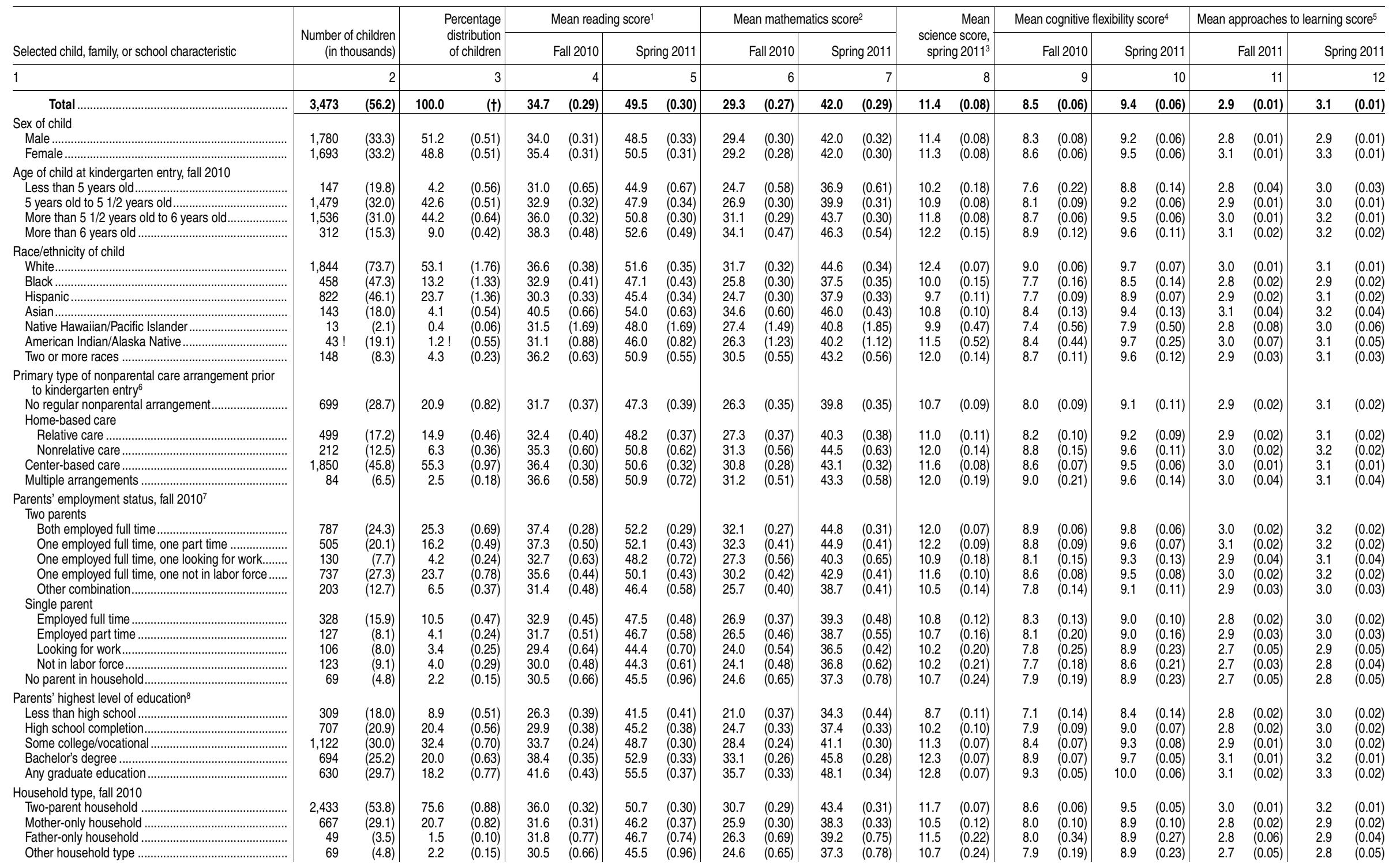

See notes at end of table. 


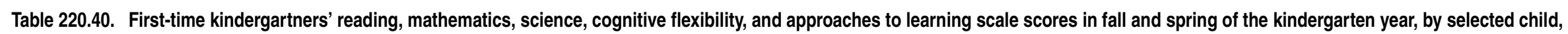
family, and school characteristics: 2010-11-Continued

[Standard errors appear in parentheses]

\begin{tabular}{|c|c|c|c|c|c|c|c|c|c|c|c|c|c|c|c|c|c|c|c|c|c|c|}
\hline \multirow[b]{2}{*}{ Selected child, family, or school characteristic } & \multirow{2}{*}{\multicolumn{2}{|c|}{$\begin{array}{r}\text { Number of children } \\
\text { (in thousands) }\end{array}$}} & \multirow{2}{*}{\multicolumn{2}{|c|}{$\begin{array}{r}\text { Percentage } \\
\text { distribution } \\
\text { of children }\end{array}$}} & \multicolumn{4}{|c|}{ Mean reading score ${ }^{1}$} & \multicolumn{4}{|c|}{ Mean mathematics score ${ }^{2}$} & \multirow{2}{*}{\multicolumn{2}{|c|}{$\begin{array}{r}\text { Mean } \\
\text { science score, } \\
\text { spring 2011 } \\
\end{array}$}} & \multicolumn{4}{|c|}{ Mean cognitive flexibility score ${ }^{4}$} & \multicolumn{4}{|c|}{ Mean approaches to learning score ${ }^{5}$} \\
\hline & & & & & & all 2010 & Spri & hg 2011 & & Fall 2010 & & hg 2011 & & & & Fall 2010 & & $\lg 2011$ & & Fall 2011 & & hg 2011 \\
\hline 1 & & 2 & & 3 & & 4 & & 5 & & 6 & & 7 & & 8 & & 9 & & 10 & & 11 & & 12 \\
\hline $\begin{array}{l}\text { Primary home language } \\
\text { English .................................... } \\
\text { Non-English ........................ } \\
\text { Primary language not identified ..... }\end{array}$ & $\begin{array}{r}2,910 \\
514 \\
39\end{array}$ & $\begin{array}{r}(63.1) \\
(23.6) \\
(4.7)\end{array}$ & $\begin{array}{r}84.0 \\
14.8 \\
1.1\end{array}$ & $\begin{array}{l}(0.79) \\
(0.73) \\
(0.14)\end{array}$ & $\begin{array}{l}35.6 \\
29.4 \\
31.3\end{array}$ & $\begin{array}{l}(0.29) \\
(0.49) \\
(1.07)\end{array}$ & $\begin{array}{l}50.5 \\
44.2 \\
46.8\end{array}$ & $\begin{array}{l}(0.32) \\
(0.49) \\
(1.23)\end{array}$ & $\begin{array}{l}30.2 \\
24.1 \\
25.8\end{array}$ & $\begin{array}{l}(0.26) \\
(0.46) \\
(0.95)\end{array}$ & $\begin{array}{l}42.9 \\
37.3 \\
38.3\end{array}$ & $\begin{array}{l}(0.30) \\
(0.46) \\
(0.83)\end{array}$ & $\begin{array}{r}11.8 \\
8.8 \\
9.6\end{array}$ & $\begin{array}{l}(0.07) \\
(0.11) \\
(0.27)\end{array}$ & $\begin{array}{l}8.7 \\
7.3 \\
7.5\end{array}$ & $\begin{array}{l}(0.06) \\
(0.13) \\
(0.27)\end{array}$ & $\begin{array}{l}9.5 \\
8.6 \\
8.9\end{array}$ & $\begin{array}{l}(0.06) \\
(0.08) \\
(0.23)\end{array}$ & $\begin{array}{l}2.9 \\
2.9 \\
2.8\end{array}$ & $\begin{array}{l}(0.01) \\
(0.02) \\
(0.05)\end{array}$ & $\begin{array}{l}3.1 \\
3.1 \\
3.0\end{array}$ & $\begin{array}{l}(0.01) \\
(0.02) \\
(0.06)\end{array}$ \\
\hline 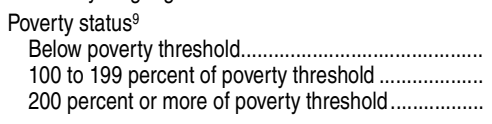 & $\begin{array}{r}707 \\
636 \\
1,519\end{array}$ & $\begin{array}{l}(31.9) \\
(17.6) \\
(49.2)\end{array}$ & $\begin{array}{l}24.7 \\
22.2 \\
53.1\end{array}$ & $\begin{array}{l}(1.06) \\
(0.52) \\
(1.33)\end{array}$ & $\begin{array}{l}29.6 \\
33.4 \\
38.6\end{array}$ & $\begin{array}{l}(0.32) \\
(0.31) \\
(0.34)\end{array}$ & $\begin{array}{l}44.4 \\
48.4 \\
53.1\end{array}$ & $\begin{array}{l}(0.34) \\
(0.40) \\
(0.32)\end{array}$ & $\begin{array}{l}24.1 \\
27.9 \\
33.3\end{array}$ & $\begin{array}{l}(0.33) \\
(0.33) \\
(0.27)\end{array}$ & $\begin{array}{l}36.8 \\
40.6 \\
45.9\end{array}$ & $\begin{array}{l}(0.35) \\
(0.39) \\
(0.30)\end{array}$ & $\begin{array}{r}9.8 \\
11.1 \\
12.5\end{array}$ & $\begin{array}{l}(0.12) \\
(0.09) \\
(0.06)\end{array}$ & $\begin{array}{l}7.7 \\
8.3 \\
9.0\end{array}$ & $\begin{array}{l}(0.10) \\
(0.09) \\
(0.05)\end{array}$ & $\begin{array}{l}8.7 \\
9.3 \\
9.8\end{array}$ & $\begin{array}{l}(0.08) \\
(0.07) \\
(0.06)\end{array}$ & $\begin{array}{l}2.8 \\
2.9 \\
3.1\end{array}$ & $\begin{array}{l}(0.01) \\
(0.02) \\
(0.01)\end{array}$ & $\begin{array}{l}2.9 \\
3.1 \\
3.2\end{array}$ & $\begin{array}{l}(0.02) \\
(0.02) \\
(0.01)\end{array}$ \\
\hline 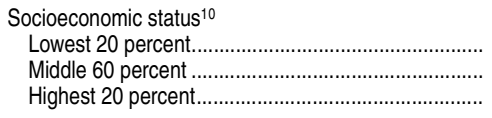 & $\begin{array}{r}645 \\
2,102 \\
715\end{array}$ & $\begin{array}{l}(27.1) \\
(43.9) \\
(32.6)\end{array}$ & $\begin{array}{l}18.6 \\
60.7 \\
20.6\end{array}$ & $\begin{array}{l}(0.76) \\
(0.74) \\
(0.87)\end{array}$ & $\begin{array}{l}27.8 \\
34.4 \\
41.7\end{array}$ & $\begin{array}{l}(0.34) \\
(0.25) \\
(0.43)\end{array}$ & $\begin{array}{l}42.8 \\
49.4 \\
55.6\end{array}$ & $\begin{array}{l}(0.36) \\
(0.29) \\
(0.38)\end{array}$ & $\begin{array}{l}22.3 \\
29.1 \\
35.9\end{array}$ & $\begin{array}{l}(0.33) \\
(0.24) \\
(0.30)\end{array}$ & $\begin{array}{l}35.3 \\
41.9 \\
48.3\end{array}$ & $\begin{array}{l}(0.39) \\
(0.27) \\
(0.31)\end{array}$ & $\begin{array}{r}9.3 \\
11.4 \\
12.9\end{array}$ & $\begin{array}{l}(0.12) \\
(0.06) \\
(0.06)\end{array}$ & $\begin{array}{l}7.4 \\
8.5 \\
9.3\end{array}$ & $\begin{array}{l}(0.11) \\
(0.07) \\
(0.05)\end{array}$ & $\begin{array}{r}8.6 \\
9.3 \\
10.1\end{array}$ & $\begin{array}{l}(0.10) \\
(0.07) \\
(0.05)\end{array}$ & $\begin{array}{l}2.8 \\
2.9 \\
3.1\end{array}$ & $\begin{array}{l}(0.02) \\
(0.01) \\
(0.02)\end{array}$ & $\begin{array}{l}3.0 \\
3.1 \\
3.3\end{array}$ & $\begin{array}{l}(0.02) \\
(0.01) \\
(0.02)\end{array}$ \\
\hline 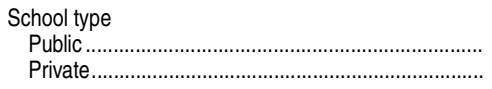 & $\begin{array}{r}3,074 \\
399\end{array}$ & $\begin{array}{r}(53.6) \\
(8.1)\end{array}$ & $\begin{array}{l}88.5 \\
11.5\end{array}$ & $\begin{array}{l}(0.23) \\
(0.23)\end{array}$ & $\begin{array}{l}34.3 \\
37.9\end{array}$ & $\begin{array}{l}(0.32) \\
(0.58)\end{array}$ & $\begin{array}{l}49.1 \\
52.1\end{array}$ & $\begin{array}{l}(0.34) \\
(0.63)\end{array}$ & $\begin{array}{l}28.8 \\
32.9\end{array}$ & $\begin{array}{l}(0.30) \\
(0.45)\end{array}$ & 45.8 & $(0.57)$ & $\begin{array}{l}11.2 \\
12.3\end{array}$ & $(0.11)$ & $\begin{array}{l}8.4 \\
8.7\end{array}$ & $\begin{array}{l}(0.07) \\
(0.11)\end{array}$ & $\begin{array}{l}9.3 \\
9.7\end{array}$ & $\begin{array}{l}(0.06) \\
(0.07)\end{array}$ & $\begin{array}{l}2.9 \\
3.1\end{array}$ & $\begin{array}{l}(0.01) \\
(0.02)\end{array}$ & $\begin{array}{l}3.1 \\
3.2\end{array}$ & $\begin{array}{l}(0.01) \\
(0.02)\end{array}$ \\
\hline
\end{tabular}

†Not applicable.

with caution. The coefficient of variation (CV) for this estimate is between 30 and 50 percent.

TReflects performance on questions measuring basic skills (print familiarity, letter recognition, beginning and ending sounds,

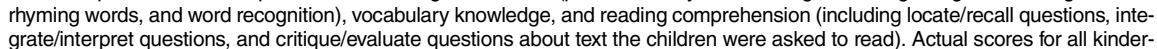
gartners range from 6 to 83 .

'Reflects performance on questions on number sense, properties, and operations; measurement; geometry and spatial sense; data analysis, statistics, and probability (measured with a set of simple questions assessing children's ability to read a graph); and prealgebra skils such, as ide ping

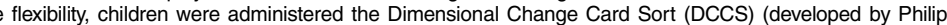
Zelazo in 2006). Children were asked to sort a series of cards into one of two trays according to different rules (e.g., by color, by shape). Actual scores for all kindergartners range from 0 to 12.

'The approaches to learning scale is based on teachers' reports on how students rate in seven areas: attentiveness, task persistence, eageness to learn, learning independence, lexibilty, organization, and ability to follow classroom rules. Actual scores
${ }^{6}$ The type of nonparental care in which the child spent the most hours. "Multiple arrangements" refers to children who spent an ngements.

than 35 hours per week are defined as employ per week are defined as employed full time, while those who reported working less 'Parents' highest level of education is the highest level of education achieved by either of the parents or guardians in a two-paren household, by the only parent in a single-parent household, or by any guardian in a household with no parents.

SPoverty status is based on preliminary U.S. Census income thresholds for 2010, which identify incomes determined to meet household needs, given family size and composition. For example, a family of three with one child was below the poverty threst 10Socin income was less than

(a) of data collection.

NOTE: Estimates weighted by W1_2P0. Estimates pertain to a sample of children who were enrolled in kindergarten for the first time in the 2010-11 school year. Two parents may refer to two biological parents, two adoptive parents, or one biological/adoptive parent and one other parenupartner. Single parent reters to one biological or adoplive parent only. In households without parents,

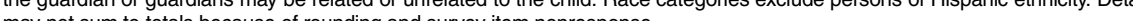
SOURCE: US. Dep because or rounding and survey liem nontesponse.

ten Class of 2010-11 (ECLS-K-2011), Preliminary Resticted-Use Data 
Table 220.50. Number and percentage distribution of kindergartners, by fall 2010 kindergarten entry status and selected child, family, and school characteristics: 2010-11

[Standard errors appear in parentheses]

\begin{tabular}{|c|c|c|c|c|c|c|c|c|c|c|c|c|c|c|}
\hline \multirow[b]{2}{*}{ Selected child, family, or school characteristic } & \multicolumn{4}{|c|}{ All kindergartners' } & \multicolumn{10}{|c|}{ Percentage distribution of kindergartners, by entry status ${ }^{2}$} \\
\hline & \multicolumn{2}{|c|}{$\begin{array}{r}\text { Number } \\
\text { (in thousands) }\end{array}$} & \multicolumn{2}{|c|}{$\begin{array}{r}\text { Percentage } \\
\text { distribution, } \\
\text { by selected } \\
\text { characteristics }\end{array}$} & \multicolumn{2}{|r|}{ Total' } & \multicolumn{2}{|c|}{$\begin{array}{r}\text { Early } \\
\text { kindergarten } \\
\text { entrants }\end{array}$} & \multicolumn{2}{|c|}{$\begin{array}{r}\text { On-time } \\
\text { kindergarten } \\
\text { entrants }\end{array}$} & \multicolumn{2}{|c|}{$\begin{array}{r}\text { Delayed } \\
\text { kindergarten } \\
\text { entrants }\end{array}$} & \multicolumn{2}{|c|}{$\begin{array}{l}\text { Kindergarten } \\
\text { repeaters }\end{array}$} \\
\hline 1 & & 2 & & 3 & & 4 & & 5 & & 6 & & 7 & & 8 \\
\hline Total... & 4,054 & (5.7) & 100.0 & $(+)$ & 100.0 & $(\dagger)$ & 1.5 & $(0.17)$ & 86.6 & $(0.91)$ & 5.9 & $(0.41)$ & 6.0 & $(0.87)$ \\
\hline $\begin{array}{l}\text { Sex of child } \\
\text { Male } \\
\text { Female....... }\end{array}$ & $\begin{array}{l}2,097 \\
1,957\end{array}$ & $\left(\begin{array}{l}(18.9) \\
19.7\end{array}\right)$ & $\begin{array}{l}51.7 \\
48.3\end{array}$ & $(0.47)$ & $\begin{array}{l}100.0 \\
100.0\end{array}$ & $(\dagger)$ & $\begin{array}{l}1.1 \\
1.9\end{array}$ & $\begin{array}{l}(0.16) \\
(0.24)\end{array}$ & $\begin{array}{l}85.0 \\
88.3\end{array}$ & $\left(\begin{array}{l}1.03) \\
(0.96)\end{array}\right.$ & $\begin{array}{l}6.8 \\
4.9\end{array}$ & $\left.\begin{array}{l}(0.63) \\
(0.35)\end{array}\right)$ & $\begin{array}{l}7.1 \\
4.9\end{array}$ & $\left(\begin{array}{l}0.90) \\
(0.90)\end{array}\right.$ \\
\hline 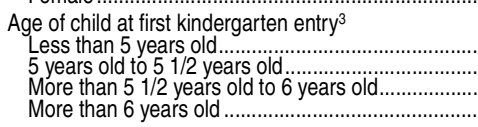 & $\begin{array}{r}234 \\
1,557 \\
1,572 \\
315\end{array}$ & $\begin{array}{l}(33.2) \\
31.0 \\
31.6 \\
(15.7)\end{array}$ & $\begin{array}{r}6.4 \\
42.3 \\
42.7 \\
8.6\end{array}$ & 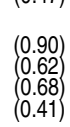 & $\begin{array}{l}100.0 \\
100.0 \\
100.0 \\
100.0\end{array}$ & $(+)$ & $\begin{array}{r}12.3 \\
1.0 \\
0.5 \\
\neq\end{array}$ & $\left.\begin{array}{r}2.57) \\
0.18 \\
0.11 \\
(\dagger)\end{array}\right)$ & $\begin{array}{l}47.2 \\
92.3 \\
92.3 \\
60.4\end{array}$ & $\begin{array}{l}(7.36) \\
0.56 \\
(0.49 \\
(3.20)\end{array}$ & $\begin{array}{r}1.2 \\
1.3 \\
48.7 \\
38.3\end{array}$ & $\begin{array}{l}(0.32 \\
0.18 \\
0.48 \\
(3.14)\end{array}$ & $\begin{array}{l}39.3 \\
5.4 \\
2.5 \\
1.1 !\end{array}$ & $\begin{array}{l}(8.87) \\
(0.42 \\
0.29 \\
(0.47)\end{array}$ \\
\hline 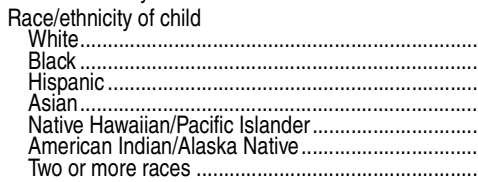 & $\begin{array}{r}2,078 \\
548 \\
1,003 \\
186 \\
17 \\
50 ! \\
168\end{array}$ & $\begin{array}{r}(70.5) \\
52.0 \\
54.0 \\
28.3 \\
(3.2) \\
(21.4) \\
(9.0)\end{array}$ & $\begin{array}{r}51.3 \\
13.5 \\
24.8 \\
4.6 \\
0.4 \\
1.2 \\
4.1\end{array}$ & $\left.\begin{array}{l}1.75 \\
1.28 \\
1.33 \\
0.70 \\
0.08 \\
0.53 \\
0.22\end{array}\right)$ & $\begin{array}{l}100.0 \\
100.0 \\
100.0 \\
100.0 \\
100.0 \\
100.0 \\
100.0\end{array}$ & $\left(\begin{array}{l}+ \\
) \\
(f) \\
f \\
f \\
f\end{array}\right)$ & $\begin{array}{l}1.0 \\
1.8 ! \\
1.7 \\
5.1 ! \\
\# \\
1.5 !\end{array}$ & $\begin{array}{r}(0.17) \\
0.64 \\
0.32 \\
(1.55) \\
(+1) \\
(0.49)\end{array}$ & $\begin{array}{l}86.5 \\
85.4 \\
88.3 \\
84.0 \\
90.3 \\
81.5 \\
86.4\end{array}$ & $\begin{array}{l}(0.75) \\
3.29 \\
(0.93 \\
2.27 \\
(4.38) \\
2.00 \\
1.85\end{array}$ & $\begin{array}{l}7.4 \\
3.1 \\
3.7 \\
6.1 \\
7.9 \\
6.6\end{array}$ & $\begin{array}{l}(0.64) \\
0.40 \\
0.40 \\
1.15 \\
(15 \\
(1.85 \\
1.28\end{array}$ & $\begin{array}{l}5.1 \\
9.7 ! \\
6.3 \\
4.8 ! \\
8.7 \\
5.5\end{array}$ & $\begin{array}{l}(0.59) \\
3.26 \\
(0.84) \\
(1.70) \\
(\dagger) \\
(2.36 \\
(1.20)\end{array}$ \\
\hline $\begin{array}{l}\text { Primary type of nonparental care arrang } \\
\text { kindergarten entry }\end{array}$ & & & & & & & & & & & & & & \\
\hline $\begin{array}{l}\text { Nor regul } \\
\text { Home-b }\end{array}$ & 815 & (29.3) & 21.5 & $(0.75)$ & 100.0 & $(\mathrm{t})$ & 1.3 & $(0.25)$ & 85.1 & $(1.21)$ & 5.6 & (0.55) & 8.1 & $(1.12)$ \\
\hline 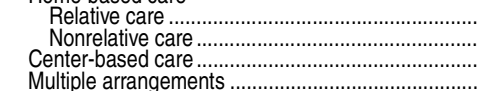 & $\begin{array}{r}560 \\
225 \\
2,103 \\
90\end{array}$ & $\left.\begin{array}{r}(17.3) \\
12.7 \\
33.3 \\
(6.5)\end{array}\right)$ & $\begin{array}{r}14.8 \\
5.9 \\
55.4 \\
2.4\end{array}$ & $\left.\begin{array}{l}(0.44) \\
0.33 \\
0.90 \\
0.17\end{array}\right)$ & $\begin{array}{l}100.0 \\
100.0 \\
100.0 \\
100.0\end{array}$ & $(f)$ & $\begin{array}{l}1.6 \\
0.9 ! \\
1.7 \\
0.7 !\end{array}$ & $\left.\begin{array}{l}0.31 \\
0.35 \\
0.25 \\
0.34\end{array}\right)$ & $\begin{array}{l}87.3 \\
87.9 \\
87.0 \\
86.6\end{array}$ & $\left.\begin{array}{l}(1.06) \\
1.46 \\
1.02 \\
1.87\end{array}\right)$ & $\begin{array}{l}4.7 \\
7.4 \\
6.2 \\
5.9\end{array}$ & $\left.\begin{array}{l}0.51 \\
1.26 \\
0.53 \\
1.51\end{array}\right)$ & $\begin{array}{l}6.5 \\
3.8 \\
5.1 \\
6.7\end{array}$ & 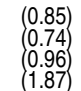 \\
\hline Parents' employment status, fall $2010^{5}$ & & & & & & & & & & & & & & \\
\hline 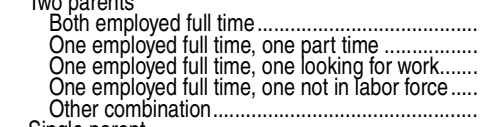 & $\begin{array}{l}824 \\
524 \\
141 \\
779 \\
220\end{array}$ & $\begin{array}{l}(24.5) \\
20.1 \\
(8.0) \\
(28.2) \\
(12.5)\end{array}$ & $\begin{array}{r}25.0 \\
15.9 \\
4.3 \\
23.6 \\
6.7\end{array}$ & $\begin{array}{l}0.68 \\
0.51 \\
0.23 \\
0.81 \\
0.35\end{array}$ & $\begin{array}{l}100.0 \\
100.0 \\
100.0 \\
100.0 \\
100.0\end{array}$ & $(f)$ & $\begin{array}{l}1.8 \\
1.5 \\
2.4 ! \\
1.1 \\
1.7\end{array}$ & $\left.\begin{array}{l}(0.25) \\
0.35 \\
0.87 \\
0.22 \\
0.46\end{array}\right)$ & $\begin{array}{l}87.3 \\
88.1 \\
86.8 \\
86.8 \\
84.8\end{array}$ & $\begin{array}{l}(0.97) \\
0.77 \\
2.08 \\
(1.11 \\
(1.56)\end{array}$ & $\begin{array}{l}6.4 \\
6.8 \\
3.5 ! \\
6.7 \\
5.8\end{array}$ & $\left.\begin{array}{l}(0.75) \\
0.59 \\
1.31 \\
0.64 \\
1.05\end{array}\right)$ & $\begin{array}{l}4.5 \\
3.5 \\
7.3 \\
5.4 \\
7.7\end{array}$ & $\begin{array}{l}(0.59) \\
(0.65) \\
1.51 \\
0.90 \\
(1.41)\end{array}$ \\
\hline $\begin{array}{l}\text { Single parent } \\
\text { Employed full time.... } \\
\text { Employed part time. } \\
\text { Looking for work...... } \\
\text { Not in labor force.... } \\
\text { No parent in household }\end{array}$ & $\begin{array}{r}348 \\
135 \\
116 \\
137 \\
79\end{array}$ & $\left.\begin{array}{r}(17.0) \\
8.3 \\
8.9 \\
(10.1) \\
(5.6)\end{array}\right)$ & $\begin{array}{r}10.5 \\
4.1 \\
3.5 \\
4.1 \\
2.4\end{array}$ & 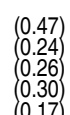 & $\begin{array}{l}100.0 \\
100.0 \\
100.0 \\
100.0 \\
100.0\end{array}$ & $(f)$ & $\begin{array}{c}1.6 \\
1.0 ! \\
\stackrel{f}{\mid}\end{array}$ & $\left.\begin{array}{r}(0.41 \\
0.45 \\
(+5) \\
(+)\end{array}\right)$ & $\begin{array}{l}88.4 \\
87.6 \\
84.3 \\
83.0 \\
82.2\end{array}$ & $\left.\begin{array}{l}1.49 \\
2.03 \\
2.53 \\
2.42 \\
2.26\end{array}\right)$ & $\begin{array}{l}4.1 \\
5.5 \\
6.1 \\
5.7 \\
3.8 !\end{array}$ & $\left.\begin{array}{l}(0.53) \\
1.16 \\
1.48 \\
11.14 \\
1.52\end{array}\right)$ & $\begin{array}{r}5.9 \\
5.8 \\
8.8 \\
9.9 \\
12.1\end{array}$ & $\left.\begin{array}{l}1.46 \\
1.51 \\
2.31 \\
2.02 \\
2.28\end{array}\right)$ \\
\hline 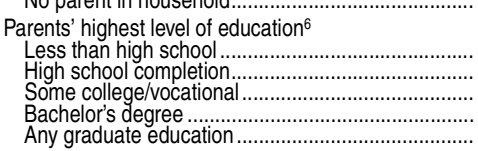 & $\begin{array}{r}388 \\
852 \\
1,292 \\
792 \\
711\end{array}$ & $\begin{array}{l}(0.0) \\
(18.6) \\
23.0 \\
27.3 \\
24.6 \\
29.2\end{array}$ & $\begin{array}{r}2.4 \\
9.6 \\
21.1 \\
32.0 \\
19.6 \\
17.6\end{array}$ & $\begin{array}{l}(0.46) \\
0.56 \\
0.67 \\
0.60 \\
0.73\end{array}$ & $\begin{array}{l}100.0 \\
100.0 \\
100.0 \\
100.0 \\
100.0 \\
100.0\end{array}$ & $\left(\begin{array}{l}(1) \\
(+) \\
(t) \\
+)\end{array}\right.$ & $\begin{array}{r}+ \\
2.0 \\
1.1 \\
1.0 \\
1.8 \\
2.2\end{array}$ & $\left.\begin{array}{r}(1) \\
(0.50) \\
0.26 \\
0.18 \\
0.34 \\
0.44\end{array}\right)$ & $\begin{array}{l}0<.4 \\
82.7 \\
86.3 \\
88.4 \\
85.3 \\
87.0\end{array}$ & $\left.\begin{array}{l}(2.20) \\
(1.48) \\
1(1.20) \\
(1.93 \\
0.75)\end{array}\right)$ & $\begin{array}{l}3.8 ! \\
4.7 \\
4.4 \\
4.8 \\
8.4 \\
7.4\end{array}$ & $\begin{array}{l}(1.52) \\
(0.85) \\
0.53 \\
0.55 \\
0.67 \\
0.64\end{array}$ & $\begin{array}{l}12.1 \\
10.7 \\
8.1 \\
5.9 \\
4.5 \\
3.4\end{array}$ & $\left.\begin{array}{l}1.58 \\
(1.15 \\
1.09 \\
0.79 \\
0.60\end{array}\right)$ \\
\hline $\begin{array}{l}\text { Household type, fall } 2010 \\
\text { Two-parent housenold..... } \\
\text { Mother-only household... } \\
\text { Father-only householdl... } \\
\text { Other household type .... }\end{array}$ & $\begin{array}{r}2,563 \\
719 \\
51 \\
79\end{array}$ & 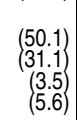 & $\begin{array}{r}75.1 \\
21.1 \\
1.5 \\
2.3\end{array}$ & $\begin{array}{l}(0.92) \\
0.84 \\
0.10 \\
0.17\end{array}$ & $\begin{array}{l}100.0 \\
100.0 \\
100.0 \\
1000\end{array}$ & $(f)$ & $\begin{array}{r}1.5 \\
1.2 \\
\stackrel{\#}{F}\end{array}$ & 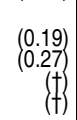 & $\begin{array}{l}87.1 \\
86.8 \\
83.5 \\
82.2\end{array}$ & $\begin{array}{l}(0.75) \\
\left(\begin{array}{l}1.59 \\
(2.75) \\
2.26\end{array}\right)\end{array}$ & $\begin{array}{l}6.3 \\
4.6 \\
9.7 ! \\
3.8 !\end{array}$ & $\left.\begin{array}{l}0.50 \\
0.48 \\
2.96 \\
1.52\end{array}\right)$ & $\begin{array}{l}5.1 \\
7.3 \\
4.6 ! \\
12.1\end{array}$ & $\left.\begin{array}{l}(0.65) \\
(1.57 \\
2.04 \\
2.28\end{array}\right)$ \\
\hline 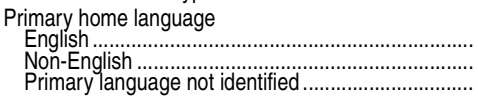 & $\begin{array}{r}3,338 \\
663 \\
42\end{array}$ & $\left.\begin{array}{r}(36.8) \\
33.7 \\
(4.9\end{array}\right)$ & $\begin{array}{r}82.6 \\
16.4 \\
1.0\end{array}$ & 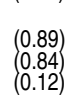 & $\begin{array}{l}100.0 \\
100.0 \\
100.0\end{array}$ & $(f)$ & $\begin{array}{l}1.3 \\
2.6 \\
1.9 !\end{array}$ & $\begin{array}{l}\left(\begin{array}{l}0.17 \\
0.67 \\
0.89\end{array}\right) \\
0\end{array}$ & $\begin{array}{l}86.8 \\
85.1 \\
90.6\end{array}$ & $\begin{array}{l}(0.90) \\
\left(\begin{array}{l}1.64 \\
2.55\end{array}\right)\end{array}$ & $\begin{array}{c}6.3 \\
4.0 \\
\neq\end{array}$ & $\begin{array}{l}0.45 \\
0.53 \\
(\dagger)\end{array}$ & $\begin{array}{l}5.7 \\
8.3 \\
5.6 !\end{array}$ & $\left.\begin{array}{l}(0.84) \\
(1.56) \\
2.18\end{array}\right)$ \\
\hline 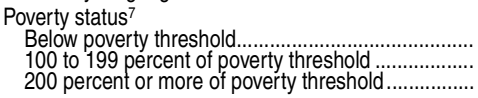 & $\begin{array}{r}893 \\
762 \\
1,736\end{array}$ & $\left.\begin{array}{l}(35.8) \\
(8.1 \\
44.5\end{array}\right)$ & $\begin{array}{l}26.3 \\
22.5 \\
51.2\end{array}$ & 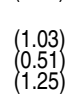 & $\begin{array}{l}100.0 \\
100.0 \\
100.0\end{array}$ & $(\ddagger)$ & $\begin{array}{l}1.2 \\
0.9 \\
1.8\end{array}$ & $\begin{array}{l}\left(\begin{array}{l}0.30 \\
0.20 \\
0.26\end{array}\right) \\
0\end{array}$ & $\begin{array}{l}84.5 \\
87.1 \\
87.2\end{array}$ & $\left.\begin{array}{l}(1.64) \\
1.31 \\
0.64\end{array}\right)$ & $\begin{array}{l}4.4 \\
5.7 \\
7.3\end{array}$ & $\left.\begin{array}{l}0.53 \\
0.64 \\
0.57\end{array}\right)$ & $\begin{array}{l}9.9 \\
6.3 \\
3.8\end{array}$ & $\begin{array}{l}1.63 \\
(1.07 \\
(0.52)\end{array}$ \\
\hline $\begin{array}{l}\text { Socioeconomic status } \\
\text { Lowest } 20 \text { percent..... } \\
\text { Middle } 0 \text { percent.... } \\
\text { Highest } 20 \text { percent.... }\end{array}$ & $\begin{array}{r}799 \\
2,429 \\
808\end{array}$ & $\left.\begin{array}{l}(29.9) \\
30.6 \\
33.5\end{array}\right)$ & $\begin{array}{l}19.8 \\
60.2 \\
20.0\end{array}$ & $\left.\begin{array}{l}(0.75) \\
(0.73) \\
0.83\end{array}\right)$ & $\begin{array}{l}100.0 \\
100.0 \\
100.0\end{array}$ & $(\ddagger)$ & $\begin{array}{l}1.5 \\
1.2 \\
2.4\end{array}$ & $\left.\begin{array}{l}(0.33) \\
0.16 \\
0.47\end{array}\right)$ & $\begin{array}{l}84.1 \\
87.1 \\
87.2\end{array}$ & $\begin{array}{l}\left(\begin{array}{l}1.46 \\
1.01 \\
0.70\end{array}\right) \\
\left(\begin{array}{ll}0 \\
0\end{array}\right)\end{array}$ & $\begin{array}{l}4.3 \\
5.9 \\
7.2\end{array}$ & $\left(\begin{array}{l}0.51 \\
0.52 \\
0.61)\end{array} \mid\right.$ & $\begin{array}{r}10.1 \\
5.7 \\
3.2\end{array}$ & $\begin{array}{l}(1.55) \\
(0.88) \\
(0.59)\end{array}$ \\
\hline $\begin{array}{l}\text { School type } \\
\text { Public..... } \\
\text { Private.... }\end{array}$ & $\begin{array}{r}3,329 \\
432\end{array}$ & $\left.\begin{array}{r}(48.4) \\
(5.1)\end{array}\right) \quad r(r)$ & $\begin{array}{l}88.5 \\
11.5\end{array}$ & $\begin{array}{l}(0.18) \\
(0.18)\end{array}$ & $\begin{array}{l}100.0 \\
100.0\end{array}$ & $(\dagger)$ & $\begin{array}{l}0.8 \\
6.8\end{array}$ & $\left(\begin{array}{l}0.11 \\
1.12\end{array}\right) \quad r(1)$ & $\begin{array}{l}87.8 \\
78.0\end{array}$ & $\left(\begin{array}{l}0.86) \\
(1.87)\end{array}\right.$ & $\begin{array}{l}5.6 \\
7.8\end{array}$ & $(0.92)$ & 7.5 & $(2.18)$ \\
\hline
\end{tabular}

†Not applicable.

\section{\#Rounds to zero.}

!Interpret data with caution. The coefficient of variation (CV) for this estimate is between 30 and 50 percent.

¥Reporting standards not met. Either there are too few cases for a reliable estimate or the coefficient of variation (CV) is 50 percent or greater.

${ }^{1}$ Includes students with missing kindergarten entry status information.

${ }^{2} \mathrm{~A}$ child who enrolled in kindergarten for the first time in $2010-11$ is classified as an early, on-time, or delayed kindergarten entrant depending on whether the parent reported enrolling the child early, enrolling the child when he or she was old enough, or waiting until the child was older relative to school guidelines about when children can start school based on their birth date. A child is classified as a kindergarten repeater if the parent reported that 2010-11 was the child's second (or third or more) year of kindergarten.

${ }^{3}$ Most of the children first entered kindergarten in 2010-11, but the children who were repeating kindergarten in 2010-11-that is, the "Kindergarten repeaters" shown in column 8-had first entered kindergarten in an earlier school year.

${ }^{4}$ The type of nonparental care in which the child spent the most hours. "Multiple arrangements" refers to children who spent an equal amount of time in each of two or more arrangements.

${ }^{5}$ Parents who reported working at least 35 hours per week are defined as employed full time while those who reported working less than 35 hours per week are defined as employed part time. Those neither employed nor looking for work are not in the labor force.
'Parents' highest level of education is the highest level of education achieved by either of the parents or guardians in a two-parent household, by the only parent in a single-parent household, or by any guardian in a household with no parents.

${ }^{7}$ Poverty status is based on preliminary U.S. Census income thresholds for 2010, which identify incomes determined to meet household needs, given family size and composition. For example, a family of three with one child was below the poverty threshold if its income was less than $\$ 17,552$ in 2010 .

${ }^{8}$ Socioeconomic status (SES) was measured by a composite score based on parental education and occupations and household income at the time of data collection.

NOTE: Estimates weighted by W1_2PO. Estimates pertain to a sample of children who were enrolled in kindergarten in the 2010-11 school year. Two parents may refer to two biological parents, two adoptive parents, or one biological/adoptive parent and one other parent/partner. Single parent refers to one biological or adoptive parent only. In households without parents, the guardian or guardians may be related or unrelated to the child. Race categories exclude persons of Hispanic ethnicity. Detail may not sum to totals because of rounding and survey item nonresponse.

SOURCE: U.S. Department of Education, National Center for Education Statistics, Early Childhood Longitudinal Study, Kindergarten Class of 2010-11 (ECLS-K:2011), Preliminary Restricted-Use Data File. (This table was prepared January 2013.) 
Table 220.60. Kindergartners' reading, mathematics, science, cognitive flexibility, and approaches to learning scale scores in fall and spring of the kindergarten year, by fall 2010 kindergarten entry status: 2010-11

[Standard errors appear in parentheses]

\begin{tabular}{|c|c|c|c|c|c|c|c|c|c|c|}
\hline \multirow[b]{2}{*}{ Type and time of assessment } & \multirow{2}{*}{\multicolumn{2}{|c|}{ Overall mean score ${ }^{1}$}} & \multicolumn{8}{|c|}{ Mean score by fall 2010 kindergarten entry status ${ }^{2}$} \\
\hline & & & \multicolumn{2}{|c|}{ Early kindergarten entrants } & \multicolumn{2}{|c|}{$\begin{array}{r}\text { On-time } \\
\text { kindergarten entrants }\end{array}$} & \multicolumn{2}{|c|}{$\begin{array}{r}\text { Delayed } \\
\text { kindergarten entrants }\end{array}$} & \multicolumn{2}{|c|}{ Kindergarten repeaters } \\
\hline 1 & & 2 & & 3 & & 4 & & 5 & & 6 \\
\hline $\begin{array}{l}\text { Reading scale score } \\
\text { Fall } 2010 \\
\text { Spring } 2011\end{array}$ & $\begin{array}{l}34.8 \\
49.4\end{array}$ & $\begin{array}{l}(0.28) \\
(0.29)\end{array}$ & $\begin{array}{l}34.0 \\
47.8\end{array}$ & $\begin{array}{l}(1.04) \\
(1.47)\end{array}$ & $\begin{array}{l}34.8 \\
49.6\end{array}$ & $\begin{array}{l}(0.30) \\
(0.30)\end{array}$ & $\begin{array}{l}36.5 \\
50.7\end{array}$ & $\begin{array}{l}(0.61) \\
(0.55)\end{array}$ & $\begin{array}{l}36.7 \\
47.9\end{array}$ & $\begin{array}{l}(0.67) \\
(0.65)\end{array}$ \\
\hline 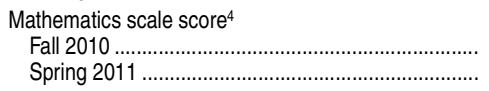 & $\begin{array}{l}29.3 \\
42.0\end{array}$ & $\begin{array}{l}(0.27) \\
(0.28)\end{array}$ & $\begin{array}{l}27.0 \\
40.1\end{array}$ & $\begin{array}{l}(0.94) \\
(1.14)\end{array}$ & $\begin{array}{l}29.3 \\
42.0\end{array}$ & $\begin{array}{l}(0.29) \\
(0.31)\end{array}$ & $\begin{array}{l}32.8 \\
44.8\end{array}$ & $\begin{array}{l}(0.55) \\
(0.61)\end{array}$ & $\begin{array}{l}29.9 \\
40.9\end{array}$ & $\begin{array}{l}(0.57) \\
(0.62)\end{array}$ \\
\hline $\begin{array}{l}\text { Science scale score }^{5} \\
\text { Spring } 2011\end{array}$ & 11.3 & $(0.07)$ & 10.7 & $(0.28)$ & 11.4 & $(0.08)$ & 12.1 & $(0.13)$ & 11.0 & $(0.19)$ \\
\hline 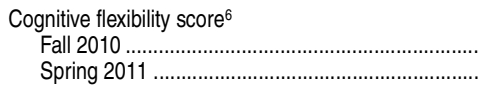 & $\begin{array}{l}8.4 \\
9.3\end{array}$ & $\begin{array}{l}(0.06) \\
(0.06)\end{array}$ & $\begin{array}{l}7.9 \\
9.0\end{array}$ & $\begin{array}{l}(0.34) \\
(0.23)\end{array}$ & $\begin{array}{l}8.5 \\
9.4\end{array}$ & $\begin{array}{l}(0.06) \\
(0.06)\end{array}$ & $\begin{array}{l}8.8 \\
9.6\end{array}$ & $\begin{array}{l}(0.17) \\
(0.10)\end{array}$ & $\begin{array}{l}8.0 \\
9.0\end{array}$ & $\begin{array}{l}(0.20) \\
(0.15)\end{array}$ \\
\hline 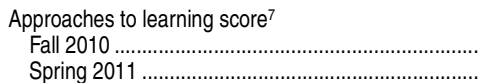 & $\begin{array}{l}2.9 \\
3.1\end{array}$ & $\begin{array}{l}(0.01) \\
(0.01)\end{array}$ & $\begin{array}{l}3.0 \\
3.1\end{array}$ & $\begin{array}{l}(0.07) \\
(0.06)\end{array}$ & $\begin{array}{l}2.9 \\
3.1\end{array}$ & $\begin{array}{l}(0.01) \\
(0.01)\end{array}$ & $\begin{array}{l}3.0 \\
3.1\end{array}$ & $\begin{array}{l}(0.02) \\
(0.02)\end{array}$ & $\begin{array}{l}2.8 \\
2.9\end{array}$ & $\begin{array}{l}(0.05) \\
(0.04)\end{array}$ \\
\hline
\end{tabular}

1 Includes students with missing kindergarten entry status information.

${ }^{2} \mathrm{~A}$ child who enrolled in kindergarten for the first time in $2010-11$ is classified as an early, ontime, or delayed kindergarten entrant depending on whether the parent reported enrolling the child early, enrolling the child when he or she was old enough, or waiting until the child was older relative to school guidelines about when children can start school based on their birth date. A child is classified as a kindergarten repeater if the parent reported that 2010-11 was the child's second (or third or more) year of kindergarten.

${ }^{3}$ Reflects performance on questions measuring basic skills (print familiarity, letter recognition, beginning and ending sounds, rhyming words, and word recognition), vocabulary knowledge, and reading comprehension (including locate/recall questions, integrate/interpret questions, and critique/evaluate questions about text the children were asked to read). Actual scores for all kindergartners range from 6 to 83 .

${ }^{4}$ Reflects performance on questions on number sense, properties, and operations; measurement; geometry and spatial sense; data analysis, statistics, and probability (measured with a set of simple questions assessing children's ability to read a graph); and prealgebra skills such as identification of patterns. Actual scores for all kindergartners range from 5 to 75 .
${ }^{5}$ Science was assessed only in the spring of kindergarten. Reflects performance on questions on physical sciences, life sciences, environmental sciences, and scientific inquiry Actual scores for all kindergartners range from 4 to 18.

${ }^{6}$ To measure cognitive flexibility, children were administered the Dimensional Change Card Sort (DCCS) (developed by Philip Zelazo in 2006). Children were asked to sort a series of cards into one of two trays according to different rules (e.g., by color, by shape). Actual scores for all kindergartners range from 0 to 12 .

${ }^{7}$ The approaches to learning scale is based on teachers' reports on how students rate in seven areas: attentiveness, task persistence, eagerness to learn, learning independence, flexibility, organization, and ability to follow classroom rules. Actual scores for all kindergartners range from 1 to 4 , with higher scores indicating that a child exhibits positive learning behaviors more often.

NOTE: Estimates weighted by W1_2P0. Estimates pertain to a sample of children who were enrolled in kindergarten in the 2010-11 school year.

SOURCE: U.S. Department of Education, National Center for Education Statistics, Early Childhood Longitudinal Study, Kindergarten Class of 2010-11 (ECLS-K:2011), Preliminary

Restricted-Use Data File. (This table was prepared May 2013.) 


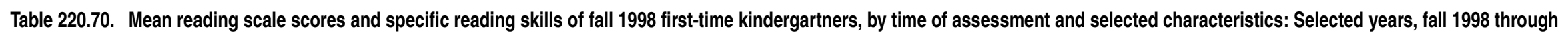
spring 2007

[Standard errors appear in parentheses]

\begin{tabular}{|c|c|c|c|c|c|c|c|c|c|c|c|c|c|c|c|c|c|c|c|c|}
\hline \multirow[b]{3}{*}{ Selected characteristic } & \multicolumn{12}{|c|}{ Mean reading scale score } & \multicolumn{8}{|c|}{ Percentage of children with specific reading skills, eighth grade, spring 2007} \\
\hline & \multicolumn{4}{|c|}{ Kindergarten } & \multirow{2}{*}{\multicolumn{2}{|c|}{$\begin{array}{l}\text { First grade, } \\
\text { spring } 2000\end{array}$}} & \multirow{2}{*}{\multicolumn{2}{|c|}{$\begin{array}{l}\text { Third grade, } \\
\text { spring } 2002\end{array}$}} & \multirow{2}{*}{\multicolumn{2}{|c|}{$\begin{array}{l}\text { Fifth grade, } \\
\text { spring } 2004\end{array}$}} & \multirow{2}{*}{\multicolumn{2}{|c|}{$\begin{array}{r}\text { Eighth grade, } \\
\text { spring } 2007\end{array}$}} & \multirow{2}{*}{\multicolumn{2}{|c|}{$\begin{array}{r}\text { Deriving meaning } \\
\text { from text }\end{array}$}} & \multirow{2}{*}{\multicolumn{2}{|c|}{$\begin{array}{r}\text { Interpreting } \\
\text { beyond text }\end{array}$}} & \multirow{2}{*}{\multicolumn{2}{|c|}{$\begin{array}{r}\text { Evaluating } \\
\text { nonfiction }\end{array}$}} & \multirow{2}{*}{\multicolumn{2}{|c|}{$\begin{array}{r}\text { Evaluating } \\
\text { complex syntax }\end{array}$}} \\
\hline & & all 1998 & & 1999 & & & & & & & & & & & & & & & & \\
\hline 1 & & 2 & & 3 & & 4 & & 5 & & 6 & & 7 & & 8 & & 9 & & 10 & & 11 \\
\hline Total & 36 & $(0.2)$ & 47 & $(0.3)$ & 79 & $(0.6)$ & 128 & $(0.8)$ & 151 & $(0.7)$ & 169 & $(0.8)$ & 83 & $(0.8)$ & 66 & $(0.8)$ & 29 & $(0.9)$ & 6 & $(0.3)$ \\
\hline 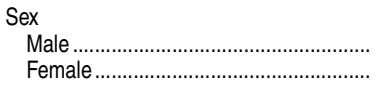 & $\begin{array}{l}35 \\
36\end{array}$ & $\begin{array}{l}(0.3) \\
(0.3)\end{array}$ & $\begin{array}{l}46 \\
48\end{array}$ & $\begin{array}{l}(0.4) \\
(0.5)\end{array}$ & $\begin{array}{l}77 \\
81\end{array}$ & $\begin{array}{l}(0.9) \\
(0.8)\end{array}$ & $\begin{array}{l}126 \\
131\end{array}$ & $\begin{array}{l}(1.0) \\
(1.0)\end{array}$ & $\begin{array}{l}149 \\
153\end{array}$ & $\begin{array}{l}(1.0) \\
(0.9)\end{array}$ & $\begin{array}{l}166 \\
172\end{array}$ & $\begin{array}{l}(1.2) \\
(0.9)\end{array}$ & $\begin{array}{l}80 \\
85\end{array}$ & $\begin{array}{l}(1.1) \\
(0.8)\end{array}$ & $\begin{array}{l}63 \\
69\end{array}$ & $\begin{array}{l}(1.2) \\
(1.0)\end{array}$ & $\begin{array}{l}26 \\
31\end{array}$ & $\begin{array}{l}(1.3) \\
(1.2)\end{array}$ & $\begin{array}{l}5 \\
7\end{array}$ & $\begin{array}{l}(0.4) \\
(0.4)\end{array}$ \\
\hline 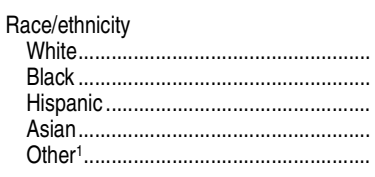 & $\begin{array}{l}37 \\
32 \\
33 \\
41 \\
34\end{array}$ & $\begin{array}{l}(0.3) \\
(0.5) \\
(0.5) \\
(1.3) \\
(1.4)\end{array}$ & $\begin{array}{l}48 \\
42 \\
44 \\
53 \\
46\end{array}$ & $\begin{array}{l}(0.4) \\
(0.8) \\
(0.8) \\
(1.7) \\
(1.7)\end{array}$ & $\begin{array}{l}83 \\
70 \\
72 \\
90 \\
76\end{array}$ & $\begin{array}{l}(0.8) \\
(1.3) \\
(1.1) \\
(2.0) \\
(2.4)\end{array}$ & $\begin{array}{l}135 \\
114 \\
118 \\
135 \\
125\end{array}$ & $\begin{array}{l}(0.9) \\
(2.0) \\
(1.3) \\
(2.3) \\
(3.9)\end{array}$ & $\begin{array}{l}158 \\
135 \\
142 \\
157 \\
150\end{array}$ & $\begin{array}{l}(0.8) \\
(1.9) \\
(1.1) \\
(1.8) \\
(4.3)\end{array}$ & $\begin{array}{l}176 \\
149 \\
160 \\
178 \\
167\end{array}$ & $\begin{array}{l}(0.8) \\
(2.4) \\
(1.3) \\
(2.0) \\
(3.8)\end{array}$ & $\begin{array}{l}89 \\
66 \\
76 \\
89 \\
82\end{array}$ & $\begin{array}{l}(0.7) \\
(2.6) \\
(1.3) \\
(1.6) \\
(3.3)\end{array}$ & $\begin{array}{l}74 \\
45 \\
57 \\
75 \\
64\end{array}$ & $\begin{array}{l}(0.8) \\
(2.4) \\
(1.4) \\
(2.2) \\
(4.1)\end{array}$ & $\begin{array}{l}36 \\
10 \\
18 \\
41 \\
25\end{array}$ & $\begin{array}{l}(1.1) \\
(1.6) \\
(1.4) \\
(3.3) \\
(3.6)\end{array}$ & $\begin{array}{r}8 \\
2 \\
3 \\
10 \\
5\end{array}$ & $\begin{array}{l}(0.4) \\
(0.3) \\
(0.3) \\
(1.2) \\
(0.8)\end{array}$ \\
\hline 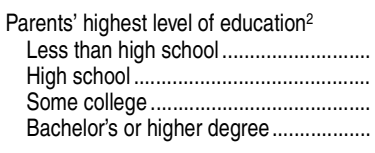 & $\begin{array}{l}30 \\
32 \\
35 \\
40\end{array}$ & $\begin{array}{l}(0.5) \\
(0.3) \\
(0.4) \\
(0.5)\end{array}$ & $\begin{array}{l}39 \\
42 \\
46 \\
52\end{array}$ & $\begin{array}{l}(0.7) \\
(0.5) \\
(0.4) \\
(0.7)\end{array}$ & $\begin{array}{l}64 \\
71 \\
78 \\
89\end{array}$ & $\begin{array}{l}(1.5) \\
(1.0) \\
(0.8) \\
(1.1)\end{array}$ & $\begin{array}{l}103 \\
118 \\
128 \\
143\end{array}$ & $\begin{array}{l}(1.7) \\
(1.2) \\
(1.1) \\
(0.8)\end{array}$ & $\begin{array}{l}128 \\
140 \\
151 \\
165\end{array}$ & $\begin{array}{l}(1.8) \\
(1.2) \\
(1.0) \\
(0.8)\end{array}$ & $\begin{array}{l}141 \\
159 \\
169 \\
183\end{array}$ & $\begin{array}{l}(2.2) \\
(1.3) \\
(1.1) \\
(0.8)\end{array}$ & $\begin{array}{l}58 \\
75 \\
84 \\
93\end{array}$ & $\begin{array}{l}(2.5) \\
(1.3) \\
(1.1) \\
(0.6)\end{array}$ & $\begin{array}{l}37 \\
55 \\
66 \\
81\end{array}$ & $\begin{array}{l}(2.1) \\
(1.4) \\
(1.2) \\
(0.8)\end{array}$ & $\begin{array}{r}5 \\
16 \\
25 \\
49\end{array}$ & $\begin{array}{l}(0.7) \\
(1.3) \\
(1.1) \\
(1.3)\end{array}$ & $\begin{array}{r}1 \\
3 \\
4 \\
12\end{array}$ & $\begin{array}{l}(0.1) \\
(0.3) \\
(0.3) \\
(0.6)\end{array}$ \\
\hline 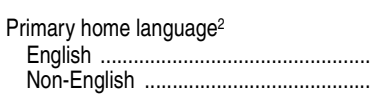 & $\begin{array}{l}36 \\
33\end{array}$ & $\begin{array}{l}(0.2) \\
(0.6)\end{array}$ & $\begin{array}{l}47 \\
44\end{array}$ & $\begin{array}{l}(0.3) \\
(0.8)\end{array}$ & $\begin{array}{l}80 \\
70\end{array}$ & $\begin{array}{l}(0.7) \\
(1.1)\end{array}$ & $\begin{array}{l}130 \\
113\end{array}$ & $\begin{array}{l}(0.8) \\
(1.3)\end{array}$ & $\begin{array}{l}152 \\
138\end{array}$ & $\begin{array}{l}(0.7) \\
(1.4)\end{array}$ & $\begin{array}{l}170 \\
157\end{array}$ & $\begin{array}{l}(0.9) \\
(1.6)\end{array}$ & $\begin{array}{l}84 \\
73\end{array}$ & $\begin{array}{l}(0.8) \\
(1.6)\end{array}$ & $\begin{array}{l}67 \\
54\end{array}$ & $\begin{array}{l}(0.9) \\
(1.6)\end{array}$ & $\begin{array}{l}30 \\
17\end{array}$ & $\begin{array}{l}(0.9) \\
(1.4)\end{array}$ & $\begin{array}{l}6 \\
4\end{array}$ & $\begin{array}{l}(0.3) \\
(0.5)\end{array}$ \\
\hline 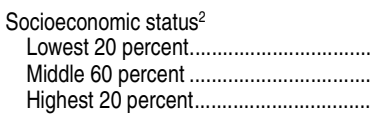 & $\begin{array}{l}30 \\
35 \\
41\end{array}$ & $\begin{array}{l}(0.3) \\
(0.3) \\
(0.6)\end{array}$ & $\begin{array}{l}39 \\
46 \\
54\end{array}$ & $\begin{array}{l}(0.5) \\
(0.3) \\
(0.8)\end{array}$ & $\begin{array}{l}64 \\
78 \\
92\end{array}$ & $\begin{array}{l}(1.1) \\
(0.7) \\
(1.4)\end{array}$ & $\begin{array}{l}105 \\
128 \\
145\end{array}$ & $\begin{array}{l}(1.3) \\
(0.8) \\
(0.9)\end{array}$ & $\begin{array}{l}129 \\
151 \\
167\end{array}$ & $\begin{array}{l}(1.3) \\
(0.7) \\
(0.9)\end{array}$ & $\begin{array}{l}145 \\
169 \\
186\end{array}$ & $\begin{array}{l}(1.5) \\
(0.8) \\
(0.8)\end{array}$ & $\begin{array}{l}62 \\
84 \\
95\end{array}$ & $\begin{array}{l}(1.7) \\
(0.8) \\
(0.6)\end{array}$ & $\begin{array}{l}41 \\
66 \\
84\end{array}$ & $\begin{array}{l}(1.5) \\
(0.9) \\
(0.9)\end{array}$ & $\begin{array}{r}8 \\
26 \\
52\end{array}$ & $\begin{array}{l}(0.9) \\
(0.9) \\
(1.5)\end{array}$ & $\begin{array}{r}1 \\
5 \\
14\end{array}$ & $\begin{array}{l}(0.2) \\
(0.3) \\
(0.8)\end{array}$ \\
\hline 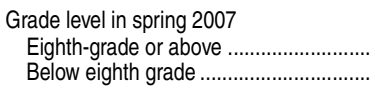 & $\begin{array}{l}36 \\
30\end{array}$ & $\begin{array}{l}(0.2) \\
(0.5)\end{array}$ & $\begin{array}{l}48 \\
37\end{array}$ & $\begin{array}{l}(0.4) \\
(0.6)\end{array}$ & $\begin{array}{l}82 \\
57\end{array}$ & $\begin{array}{l}(0.6) \\
(1.4)\end{array}$ & $\begin{array}{l}133 \\
100\end{array}$ & $\begin{array}{l}(0.7) \\
(1.9)\end{array}$ & $\begin{array}{l}155 \\
126\end{array}$ & $\begin{array}{l}(0.7) \\
(2.2)\end{array}$ & $\begin{array}{l}173 \\
143\end{array}$ & $\begin{array}{l}(0.9) \\
(2.5)\end{array}$ & $\begin{array}{l}86 \\
58\end{array}$ & $\begin{array}{l}(0.8) \\
(2.7)\end{array}$ & $\begin{array}{l}70 \\
39\end{array}$ & $\begin{array}{l}(0.9) \\
(2.5)\end{array}$ & $\begin{array}{r}32 \\
9\end{array}$ & $\begin{array}{l}(1.0) \\
(2.0)\end{array}$ & $\begin{array}{l}7 \\
2 !\end{array}$ & $\begin{array}{l}(0.3) \\
(0.7)\end{array}$ \\
\hline $\begin{array}{l}\text { School type across all waves of the study } \\
\text { Public school all years } \\
\text { Private school all years.................................................. } \\
\text { Change in school type during study..... }\end{array}$ & $\begin{array}{l}35 \\
39 \\
38\end{array}$ & $\begin{array}{l}(0.3) \\
(0.6) \\
(0.8)\end{array}$ & $\begin{array}{l}46 \\
52 \\
51\end{array}$ & $\begin{array}{l}(0.4) \\
(0.9) \\
(1.1)\end{array}$ & $\begin{array}{l}77 \\
88 \\
84\end{array}$ & $\begin{array}{l}(0.6) \\
(1.5) \\
(1.9)\end{array}$ & $\begin{array}{l}126 \\
140 \\
134\end{array}$ & $\begin{array}{l}(0.9) \\
(1.4) \\
(1.8)\end{array}$ & $\begin{array}{l}149 \\
163 \\
158\end{array}$ & $\begin{array}{l}(0.8) \\
(1.0) \\
(1.4)\end{array}$ & $\begin{array}{l}166 \\
184 \\
177\end{array}$ & $\begin{array}{l}(0.9) \\
(1.2) \\
(1.8)\end{array}$ & $\begin{array}{l}80 \\
94 \\
89\end{array}$ & $\begin{array}{l}(0.9) \\
(0.7) \\
(1.4)\end{array}$ & $\begin{array}{l}63 \\
81 \\
74\end{array}$ & $\begin{array}{l}(1.0) \\
(1.4) \\
(1.9)\end{array}$ & $\begin{array}{l}25 \\
47 \\
38\end{array}$ & $\begin{array}{l}(1.0) \\
(2.5) \\
(2.7)\end{array}$ & $\begin{array}{r}5 \\
10 \\
9\end{array}$ & $\begin{array}{l}(0.2) \\
(0.8) \\
(1.1)\end{array}$ \\
\hline
\end{tabular}

!Interpret data with caution. The coefficient of variation (CV) for this estimate is between 30 and 50 percent. 1Includes persons of all other races and two or more races.

NOTE: Reading scale ranges from 0

9. Estimates for each assessment round include all children assessed in English in not administered the English battery because of nonpassing scores on the fall 1998, 8 percent of the kindergarten sample was proficiency assessment. By spring of first grade, this percentage had decreased to 2 percent. In the third grade and subsequent years, the OLDS was not administered and all children were assessed in English. Most of the children were in first grade in
1999-2000, but 5 percent were in kindergarten or other grades (e.g., second grade, ungraded classrooms); most were in third grade in 2001-02, but 11 percent were in second grade or other grades (e.g., fourth grade, ungraded classrooms); most were in fifth grade in 2003-04, but 14 percent were in fourth grade or other grades (e.g., sixth grade, ungraded classrooms); most were Data were calculated using $\mathrm{C} 1$ 1 7 FCO weight. Estimates differ from previously published figures because the data were recalibrated to represent the kindergarten through eighth-grade reading assessment item pool. Race categories exclude persons of Hispanic ethnicity.

SOURCE: U.S. Department of Education, National Center for Education Statistics, Early Childhood Longitudinal Study, Kindergarten Class of 1998-99 (ECLS-K), Longitudinal Kindergarten-Eighth Grade Full Sample Public-Use Data File, fall 1998, spring 


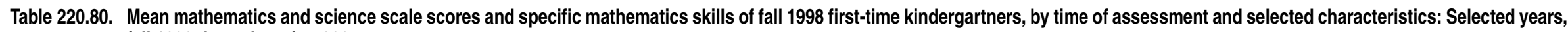
fall 1998 through spring 2007

[Standard errors appear in parentheses]

\begin{tabular}{|c|c|c|c|c|c|c|c|c|c|c|c|c|c|c|c|c|c|c|c|c|c|c|c|c|}
\hline \multirow[b]{4}{*}{ Selected characteristic } & \multicolumn{18}{|c|}{ Mathematics } & \multirow{2}{*}{\multicolumn{6}{|c|}{$\begin{array}{c}\text { Science } \\
\text { Mean scale score }\end{array}$}} \\
\hline & \multicolumn{12}{|c|}{ Mean scale score } & \multicolumn{6}{|c|}{$\begin{array}{l}\text { Percentage of children with specific skills, } \\
\text { eighth grade, spring } 2007\end{array}$} & & & & & & \\
\hline & \multicolumn{4}{|c|}{ Kindergarten } & \multirow{2}{*}{\multicolumn{2}{|c|}{$\begin{array}{c}\text { First grade, } \\
\text { spring } 2000\end{array}$}} & \multirow{2}{*}{\multicolumn{2}{|c|}{$\begin{array}{l}\text { Third grade, } \\
\text { spring } 2002\end{array}$}} & \multirow{2}{*}{\multicolumn{2}{|c|}{$\begin{array}{r}\text { Fitth grade, } \\
\text { spring } 2004\end{array}$}} & \multirow{2}{*}{\multicolumn{2}{|c|}{$\begin{array}{r}\text { Eighth grade, } \\
\text { spring } 2007\end{array}$}} & \multirow{2}{*}{\multicolumn{2}{|c|}{$\begin{array}{r}\text { Rate and } \\
\text { measurement }\end{array}$}} & \multirow{2}{*}{\multicolumn{2}{|c|}{ Fractions }} & \multirow{2}{*}{\multicolumn{2}{|c|}{ Area and volume }} & \multirow{2}{*}{\multicolumn{2}{|c|}{$\begin{array}{l}\text { Third grade, } \\
\text { spring } 2002\end{array}$}} & \multirow{2}{*}{\multicolumn{2}{|c|}{$\begin{array}{r}\text { Fitth grade, } \\
\text { spring } 2004\end{array}$}} & \multirow{2}{*}{\multicolumn{2}{|c|}{$\begin{array}{l}\text { Eighth grade } \\
\text { spring } 2007\end{array}$}} \\
\hline & & || 1998 & Sprin & $g 1999$ & & & & & & & & & & & & & & & & & & & & \\
\hline 1 & & 2 & & 3 & & 4 & & 5 & & 6 & & 7 & & 8 & & 9 & & 10 & & 11 & & 12 & & 13 \\
\hline Total.. & 26 & $(0.2)$ & 37 & $(0.3)$ & 62 & $(0.4)$ & 100 & (0.7) & 124 & $(0.7)$ & 140 & $(0.6)$ & 68 & $(0.9)$ & 38 & $(1.0)$ & 16 & $(0.8)$ & 51 & $(0.4)$ & 65 & $(0.4)$ & 84 & $(0.5)$ \\
\hline 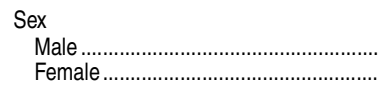 & $\begin{array}{l}26 \\
26\end{array}$ & $\begin{array}{l}(0.3) \\
(0.3)\end{array}$ & $\begin{array}{l}37 \\
37\end{array}$ & $\begin{array}{l}(0.4) \\
(0.4)\end{array}$ & $\begin{array}{l}63 \\
61\end{array}$ & $\begin{array}{l}(0.6) \\
(0.5)\end{array}$ & $\begin{array}{r}103 \\
97\end{array}$ & $\begin{array}{l}(0.8) \\
(0.9)\end{array}$ & $\begin{array}{l}126 \\
121\end{array}$ & $\begin{array}{l}(0.9) \\
(1.0)\end{array}$ & $\begin{array}{l}141 \\
139\end{array}$ & $\begin{array}{l}(0.8) \\
(0.8)\end{array}$ & $\begin{array}{l}70 \\
65\end{array}$ & $\begin{array}{l}(1.3) \\
(1.3)\end{array}$ & $\begin{array}{l}40 \\
35\end{array}$ & $\begin{array}{l}(1.3) \\
(1.4)\end{array}$ & $\begin{array}{l}18 \\
14\end{array}$ & $\begin{array}{l}(1.0) \\
(1.0)\end{array}$ & $\begin{array}{l}53 \\
49\end{array}$ & $\begin{array}{l}(0.6) \\
(0.6)\end{array}$ & $\begin{array}{l}67 \\
63\end{array}$ & $\begin{array}{l}(0.6) \\
(0.6)\end{array}$ & $\begin{array}{l}85 \\
82\end{array}$ & $\begin{array}{l}(0.7) \\
(0.6)\end{array}$ \\
\hline 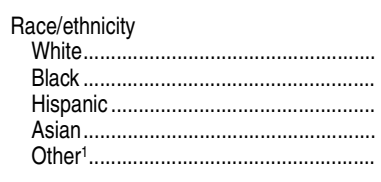 & $\begin{array}{l}29 \\
22 \\
22 \\
30 \\
25\end{array}$ & $\begin{array}{l}(0.3) \\
(0.4) \\
(0.4) \\
(1.0) \\
(1.0)\end{array}$ & $\begin{array}{l}40 \\
31 \\
32 \\
40 \\
36\end{array}$ & $\begin{array}{l}(0.4) \\
(0.6) \\
(0.5) \\
(1.2) \\
(1.3)\end{array}$ & $\begin{array}{l}67 \\
52 \\
57 \\
65 \\
60\end{array}$ & $\begin{array}{l}(0.6) \\
(0.8) \\
(0.9) \\
(1.7) \\
(2.1)\end{array}$ & $\begin{array}{r}106 \\
84 \\
93 \\
107 \\
97\end{array}$ & $\begin{array}{l}(0.8) \\
(1.8) \\
(1.1) \\
(2.7) \\
(3.3)\end{array}$ & $\begin{array}{l}130 \\
105 \\
119 \\
135 \\
122\end{array}$ & $\begin{array}{l}(0.8) \\
(1.8) \\
(1.1) \\
(2.4) \\
(3.6)\end{array}$ & $\begin{array}{l}146 \\
123 \\
136 \\
150 \\
138\end{array}$ & $\begin{array}{l}(0.6) \\
(1.6) \\
(1.0) \\
(2.3) \\
(3.2)\end{array}$ & $\begin{array}{l}77 \\
40 \\
62 \\
81 \\
65\end{array}$ & $\begin{array}{l}(1.0) \\
(2.3) \\
(1.7) \\
(3.1) \\
(5.2)\end{array}$ & $\begin{array}{l}46 \\
13 \\
29 \\
59 \\
34\end{array}$ & $\begin{array}{l}(1.3) \\
(1.8) \\
(2.1) \\
(3.8) \\
(4.7)\end{array}$ & $\begin{array}{r}21 \\
4 \\
10 \\
38 \\
15\end{array}$ & $\begin{array}{l}(1.1) \\
(1.2) \\
(1.1) \\
(3.7) \\
(3.2)\end{array}$ & $\begin{array}{l}56 \\
40 \\
44 \\
53 \\
49\end{array}$ & $\begin{array}{l}(0.5) \\
(1.1) \\
(0.7) \\
(1.5) \\
(2.0)\end{array}$ & $\begin{array}{l}70 \\
52 \\
60 \\
67 \\
63\end{array}$ & $\begin{array}{l}(0.4) \\
(1.1) \\
(0.7) \\
(1.6) \\
(2.2)\end{array}$ & $\begin{array}{l}89 \\
69 \\
78 \\
89 \\
82\end{array}$ & $\begin{array}{l}(0.5) \\
(1.3) \\
(0.8) \\
(1.1) \\
(2.6)\end{array}$ \\
\hline 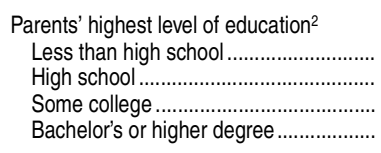 & $\begin{array}{l}20 \\
23 \\
26 \\
31\end{array}$ & $\begin{array}{l}(0.4) \\
(0.3) \\
(0.3) \\
(0.3)\end{array}$ & $\begin{array}{l}28 \\
33 \\
37 \\
42\end{array}$ & $\begin{array}{l}(0.6) \\
(0.5) \\
(0.4) \\
(0.4)\end{array}$ & $\begin{array}{l}49 \\
56 \\
62 \\
70\end{array}$ & $\begin{array}{l}(1.1) \\
(0.7) \\
(0.6) \\
(0.6)\end{array}$ & $\begin{array}{r}81 \\
91 \\
100 \\
111\end{array}$ & $\begin{array}{l}(1.4) \\
(1.0) \\
(1.0) \\
(0.9)\end{array}$ & $\begin{array}{l}105 \\
114 \\
124 \\
136\end{array}$ & $\begin{array}{l}(1.9) \\
(1.0) \\
(0.9) \\
(0.8)\end{array}$ & $\begin{array}{l}122 \\
131 \\
141 \\
152\end{array}$ & $\begin{array}{l}(2.1) \\
(0.8) \\
(0.8) \\
(0.7)\end{array}$ & $\begin{array}{l}41 \\
53 \\
70 \\
85\end{array}$ & $\begin{array}{l}(2.9) \\
(1.4) \\
(1.3) \\
(1.2)\end{array}$ & $\begin{array}{l}14 \\
21 \\
35 \\
59\end{array}$ & $\begin{array}{l}(1.9) \\
(1.2) \\
(1.5) \\
(1.5)\end{array}$ & $\begin{array}{r}3 \\
7 \\
13 \\
30\end{array}$ & $\begin{array}{l}(0.8) \\
(0.7) \\
(1.0) \\
(1.4)\end{array}$ & $\begin{array}{l}37 \\
45 \\
51 \\
59\end{array}$ & $\begin{array}{l}(0.9) \\
(0.6) \\
(0.6) \\
(0.6)\end{array}$ & $\begin{array}{l}50 \\
59 \\
65 \\
73\end{array}$ & $\begin{array}{l}(1.0) \\
(0.7) \\
(0.6) \\
(0.5)\end{array}$ & $\begin{array}{l}68 \\
77 \\
84 \\
92\end{array}$ & $\begin{array}{l}(1.2) \\
(0.7) \\
(0.6) \\
(0.4)\end{array}$ \\
\hline 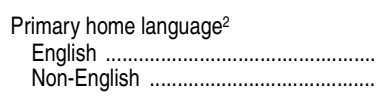 & $\begin{array}{l}27 \\
21\end{array}$ & $\begin{array}{l}(0.2) \\
(0.4)\end{array}$ & $\begin{array}{l}38 \\
30\end{array}$ & $\begin{array}{l}(0.3) \\
(0.6)\end{array}$ & $\begin{array}{l}63 \\
55\end{array}$ & $\begin{array}{l}(0.4) \\
(0.8)\end{array}$ & $\begin{array}{r}101 \\
91\end{array}$ & $\begin{array}{l}(0.7) \\
(1.1)\end{array}$ & $\begin{array}{l}125 \\
117\end{array}$ & $\begin{array}{l}(0.8) \\
(1.2)\end{array}$ & $\begin{array}{l}141 \\
135\end{array}$ & $\begin{array}{l}(0.6) \\
(1.1)\end{array}$ & $\begin{array}{l}69 \\
58\end{array}$ & $\begin{array}{l}(0.9) \\
(1.7)\end{array}$ & $\begin{array}{l}38 \\
30\end{array}$ & $\begin{array}{l}(1.0) \\
(1.9)\end{array}$ & $\begin{array}{l}16 \\
13\end{array}$ & $\begin{array}{l}(0.8) \\
(1.2)\end{array}$ & $\begin{array}{l}52 \\
41\end{array}$ & $\begin{array}{l}(0.4) \\
(0.8)\end{array}$ & $\begin{array}{l}66 \\
57\end{array}$ & $\begin{array}{l}(0.5) \\
(0.8)\end{array}$ & $\begin{array}{l}84 \\
77\end{array}$ & $\begin{array}{l}(0.5) \\
(0.9)\end{array}$ \\
\hline 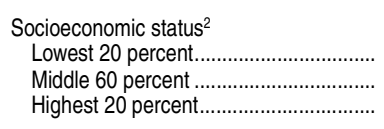 & $\begin{array}{l}20 \\
26 \\
32\end{array}$ & $\begin{array}{l}(0.3) \\
(0.2) \\
(0.4)\end{array}$ & $\begin{array}{l}28 \\
37 \\
43\end{array}$ & $\begin{array}{l}(0.4) \\
(0.3) \\
(0.5)\end{array}$ & $\begin{array}{l}50 \\
62 \\
72\end{array}$ & $\begin{array}{l}(0.8) \\
(0.4) \\
(0.7)\end{array}$ & $\begin{array}{r}83 \\
99 \\
115\end{array}$ & $\begin{array}{l}(1.1) \\
(0.7) \\
(0.9)\end{array}$ & $\begin{array}{l}105 \\
123 \\
139\end{array}$ & $\begin{array}{l}(1.3) \\
(0.7) \\
(0.9)\end{array}$ & $\begin{array}{l}123 \\
140 \\
154\end{array}$ & $\begin{array}{l}(1.2) \\
(0.6) \\
(0.7)\end{array}$ & $\begin{array}{l}42 \\
67 \\
88\end{array}$ & $\begin{array}{l}(1.8) \\
(0.9) \\
(1.0)\end{array}$ & $\begin{array}{l}14 \\
35 \\
63\end{array}$ & $\begin{array}{l}(1.1) \\
(1.0) \\
(1.8)\end{array}$ & $\begin{array}{r}4 \\
13 \\
33\end{array}$ & $\begin{array}{l}(0.5) \\
(0.8) \\
(1.8)\end{array}$ & $\begin{array}{l}38 \\
51 \\
60\end{array}$ & $\begin{array}{l}(0.8) \\
(0.4) \\
(0.6)\end{array}$ & $\begin{array}{l}51 \\
65 \\
75\end{array}$ & $\begin{array}{l}(0.9) \\
(0.4) \\
(0.6)\end{array}$ & $\begin{array}{l}70 \\
84 \\
94\end{array}$ & $\begin{array}{l}(0.9) \\
(0.5) \\
(0.5)\end{array}$ \\
\hline 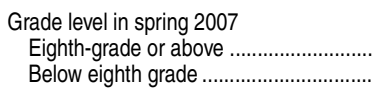 & $\begin{array}{l}27 \\
20\end{array}$ & $\begin{array}{l}(0.2) \\
(0.4)\end{array}$ & $\begin{array}{l}38 \\
27\end{array}$ & $\begin{array}{l}(0.3) \\
(0.6)\end{array}$ & $\begin{array}{l}65 \\
47\end{array}$ & $\begin{array}{l}(0.4) \\
(1.2)\end{array}$ & $\begin{array}{r}103 \\
79\end{array}$ & $\begin{array}{l}(0.7) \\
(1.6)\end{array}$ & $\begin{array}{l}127 \\
103\end{array}$ & $\begin{array}{l}(0.8) \\
(1.9)\end{array}$ & $\begin{array}{l}143 \\
121\end{array}$ & $\begin{array}{l}(0.6) \\
(1.8)\end{array}$ & $\begin{array}{l}73 \\
37\end{array}$ & $\begin{array}{l}(1.0) \\
(2.5)\end{array}$ & $\begin{array}{l}41 \\
14\end{array}$ & $\begin{array}{l}(1.1) \\
(2.5)\end{array}$ & $\begin{array}{r}18 \\
5\end{array}$ & $\begin{array}{l}(0.8) \\
(1.5)\end{array}$ & $\begin{array}{l}53 \\
40\end{array}$ & $\begin{array}{l}(0.4) \\
(1.1)\end{array}$ & $\begin{array}{l}67 \\
53\end{array}$ & $\begin{array}{l}(0.4) \\
(1.3)\end{array}$ & $\begin{array}{l}86 \\
69\end{array}$ & $\begin{array}{l}(0.5) \\
(1.4)\end{array}$ \\
\hline $\begin{array}{l}\text { School type across all waves of the study } \\
\text { Public school all years ....................... } \\
\text { Private school all years................... } \\
\text { Change in school type during study..... }\end{array}$ & $\begin{array}{l}26 \\
31 \\
28\end{array}$ & $\begin{array}{l}(0.2) \\
(0.6) \\
(0.7)\end{array}$ & $\begin{array}{l}36 \\
43 \\
39\end{array}$ & $\begin{array}{l}(0.4) \\
(0.8) \\
(0.8)\end{array}$ & $\begin{array}{l}61 \\
69 \\
66\end{array}$ & $\begin{array}{l}(0.5) \\
(1.0) \\
(1.1)\end{array}$ & $\begin{array}{r}99 \\
107 \\
103\end{array}$ & $\begin{array}{l}(0.9) \\
(1.7) \\
(1.5)\end{array}$ & $\begin{array}{l}122 \\
133 \\
128\end{array}$ & $\begin{array}{l}(0.9) \\
(1.5) \\
(1.6)\end{array}$ & $\begin{array}{l}139 \\
149 \\
144\end{array}$ & $\begin{array}{l}(0.7) \\
(1.3) \\
(1.3)\end{array}$ & $\begin{array}{l}66 \\
82 \\
73\end{array}$ & $\left.\begin{array}{l}(1.1) \\
(2.4) \\
(2.0)\end{array}\right]$ & $\begin{array}{l}35 \\
50 \\
44\end{array}$ & $\begin{array}{l}(1.2) \\
(3.0) \\
(2.6)\end{array}$ & $\begin{array}{l}15 \\
22 \\
20\end{array}$ & $\left.\begin{array}{l}(0.8) \\
(1.9) \\
(2.1)\end{array}\right]$ & $\begin{array}{l}50 \\
56 \\
55\end{array}$ & $\left.\begin{array}{l}(0.5) \\
(1.0) \\
(1.0)\end{array}\right]$ & $\begin{array}{l}64 \\
71 \\
69\end{array}$ & $\begin{array}{l}(0.5) \\
(0.9) \\
(1.0)\end{array}$ & $\begin{array}{l}82 \\
90 \\
88\end{array}$ & $\begin{array}{l}(0.6) \\
(0.8) \\
(0.9)\end{array}$ \\
\hline
\end{tabular}

IIncludes persons of all other races and two or more races.

2Status during kindergarten year.
NOTE: Mathematics scale ranges from 0 to 172 , and science scale ranges from 0 to 108 . Estimates for each assessment round include all children assessed in that round, including children assessed in Spanish. In kindergarten and first grade, the mathematics assessment was administered in Spanish for Spanish-speaking children who did not pass the English OLDS (Oral Language Development Scale). All assessments were administered in English in third grade through eighth grade. Most of the classrooms); most were in third grade in 2001-02, but 11 percent were in second grade or other grades (e.g., fourth grade, ungraded classrooms); most were in fifth grade in 2003-04, but 14 percent were in fourth grade or other grades (e.g., sixth grade, ungraded classrooms); most were in eighth grade in 2006-07, but 14 percent were in seventh grade or other grades (e.g., ninth grade or ungraded classrooms). Data were calculated using C1_7FCO weight. Estimates differ from previously published figure the third-grade through eighth-grade science assessment item pool. Race categories exclude persons of Hispanic ethnicity.

(a) 1009 , sping 2000, sping 2002, sping 2004, and sping 2007. (This table was prepad September 2000) 
Table 221.10. Average National Assessment of Educational Progress (NAEP) reading scale score, by grade and selected student and school characteristics: Selected years, 1992 through 2013

[Standard errors appear in parentheses]

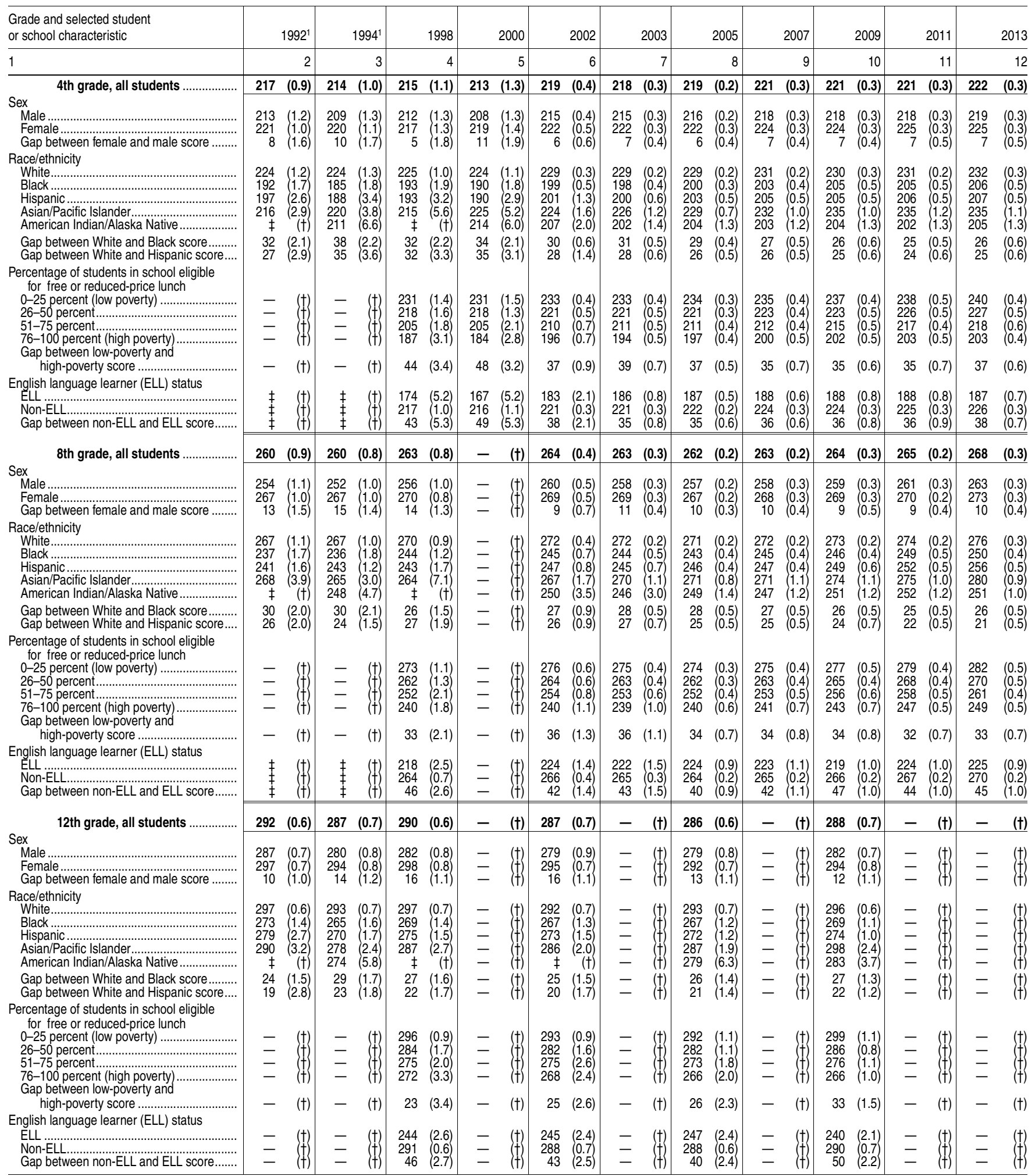

-Not available.

†Not applicable.

fReporting standards not met (too few cases for a reliable estimate).

${ }^{1}$ Accommodations were not permitted for this assessment.

NOTE: Scale ranges from 0 to 500 . Includes public and private schools. For 1998 and later years, includes students tested with accommodations ( 1 to 10 percent of all students, depending on grade level and year); excludes only those students with disabilities and English language learners who were unable to be tested even with accommodations (2 to 6 percent of all students). Race categories exclude persons of Hispanic ethnicity. Totals include other racial/ethnic groups not shown separately. Grade 12 results for the 2013 NAEP Reading Assessment were not yet available at the time this table was created. SOURCE: U.S. Department of Education, National Center for Education Statistics, National Assessment of Educational Progress (NAEP), 1992, 1994, 1998, 2000, 2002, 2003, 2005, 2007, 2009, 2011, and 2013 Reading Assessments, retrieved November 14, 2013, from the Main NAEP Data Explorer (http://nces.ed.gov/nationsreportcard/naepdata/). (This table was prepared November 2013.) 
Table 221.20. Percentage of students at or above selected National Assessment of Educational Progress (NAEP) reading achievement levels, by grade and selected student characteristics: Selected years, 1998 through 2013

[Standard errors appear in parentheses]

\begin{tabular}{|c|c|c|c|c|c|c|c|c|c|c|c|c|c|c|c|c|c|c|c|c|c|c|c|c|c|c|c|c|c|c|c|c|}
\hline \multirow[b]{2}{*}{$\begin{array}{l}\text { Grade and selected } \\
\text { student characteristic }\end{array}$} & \multicolumn{4}{|c|}{1998} & \multicolumn{4}{|c|}{2000} & \multicolumn{4}{|c|}{2003} & \multicolumn{4}{|c|}{2005} & \multicolumn{4}{|c|}{2007} & \multicolumn{4}{|c|}{2009} & \multicolumn{4}{|c|}{2011} & \multicolumn{4}{|c|}{2013} \\
\hline & or a & & & & & & $\begin{array}{l}\text { Ato } \\
\text { Prc }\end{array}$ & & At or & $\begin{array}{l}\text { above } \\
\text { Basic }\end{array}$ & & & & & & & At or a & & $\begin{array}{l}\text { At or a } \\
\text { Profic }\end{array}$ & & & & & & 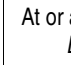 & & & & At or a & & & \\
\hline & & 2 & & 3 & & 4 & & 5 & & 6 & & 7 & & 8 & & 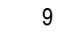 & & 10 & & 11 & & 12 & & 13 & & 14 & & 15 & & 16 & & \\
\hline II students. & 60 & $(1.2)$ & 29 & $(0.9)$ & 59 & (1.4) & 29 & (1.1) & 63 & $\begin{array}{l}(0.3) \\
\end{array}$ & 31 & $(0.3)$ & 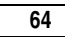 & $\begin{array}{l}(0.3) \\
\end{array}$ & 3 & $(0.2)$ & 67 & $(0.3)$ & 33 & $(0.3)$ & 67 & $(0.3)$ & 33 & $(0.4)$ & 67 & $(0.3)$ & 34 & $(0.4)$ & 68 & $(0.3)$ & 35 & \\
\hline $\begin{array}{l}\text { Sex } \\
\text { Male } \\
\text { Female }\end{array}$ & & $\begin{array}{l}(1.3) \\
(1.5)\end{array}$ & $\begin{array}{l}27 \\
32\end{array}$ & $\begin{array}{l}(1.1) \\
(1.2)\end{array}$ & & $\begin{array}{l}(1.4) \\
(1.6)\end{array}$ & & & 60 & .4) & & & & $\begin{array}{l}(0.4) \\
(0.3)\end{array}$ & 29 & $\begin{array}{l}(0.3) \\
(0.3)\end{array}$ & & $\begin{array}{l}(0.4) \\
(0.3)\end{array}$ & & $\begin{array}{l}(0.3) \\
(0.4)\end{array}$ & 64 & & & 4) & & & $\begin{array}{l}31 \\
37\end{array}$ & $\begin{array}{l}(0.4) \\
(0.5)\end{array}$ & 65 & $\begin{array}{l}(0.3) \\
(0.4)\end{array}$ & 32 & \\
\hline 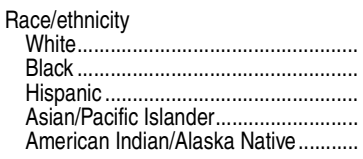 & $\begin{array}{r}70 \\
36 \\
37 \\
58 \\
\ddagger\end{array}$ & $\begin{array}{r}(1.3) \\
(1.8) \\
(3.2) \\
(6.1) \\
(\dagger)\end{array}$ & $\begin{array}{r}37 \\
10 \\
13 \\
30 \\
\ddagger\end{array}$ & $\begin{array}{r}(1.2) \\
(1.1) \\
(1.7) \\
(4.5) \\
(\dagger)\end{array}$ & $\begin{array}{l}70 \\
35 \\
37 \\
70 \\
63\end{array}$ & $\begin{array}{r}(1.2) \\
(1.6) \\
(3.0) \\
(5.0) \\
(10.9)\end{array}$ & $\begin{array}{l}10 \\
13 \\
41 \\
28\end{array}$ & $\begin{array}{l}(1.2) \\
(1.0) \\
(1.8) \\
(5.7) \\
(8.9)\end{array}$ & $\begin{array}{l}40 \\
44 \\
70 \\
47\end{array}$ & $\begin{array}{l}(0.3) \\
(0.5) \\
(0.7) \\
(1.5) \\
(2.0)\end{array}$ & $\begin{array}{l}41 \\
13\end{array}$ & $\begin{array}{l}(0.4) \\
(0.4) \\
(0.5) \\
(1.4) \\
(1.5)\end{array}$ & $\begin{array}{l}76 \\
42 \\
46 \\
73 \\
48\end{array}$ & $\begin{array}{l}(0.3) \\
(0.5) \\
(0.7) \\
(0.9) \\
(1.5)\end{array}$ & $\begin{array}{l}41 \\
13 \\
16 \\
42\end{array}$ & $\begin{array}{l}(0.3) \\
(0.3) \\
(0.5) \\
(0.9) \\
(1.0)\end{array}$ & $\begin{array}{l}78 \\
46 \\
50 \\
77 \\
49\end{array}$ & $\begin{array}{l}(0.3) \\
(0.6) \\
(0.6) \\
(1.0) \\
(1.4)\end{array}$ & $\begin{array}{l}43 \\
14 \\
17 \\
46 \\
18\end{array}$ & $\begin{array}{l}(0.4) \\
(0.4) \\
(0.6) \\
(1.4) \\
(1.1)\end{array}$ & $\begin{array}{l}78 \\
48 \\
49 \\
80 \\
50\end{array}$ & $\begin{array}{l}(0.3) \\
(0.8) \\
(0.7) \\
(1.0) \\
(1.7)\end{array}$ & $\begin{array}{l}42 \\
16 \\
17 \\
49 \\
20\end{array}$ & $\begin{array}{l}(0.5) \\
(1.3) \\
(1.4)\end{array}$ & $\begin{array}{l}78 \\
49 \\
51 \\
80 \\
47\end{array}$ & $\begin{array}{l}(0.3) \\
(0.6) \\
(0.8) \\
(1.2) \\
(1.7)\end{array}$ & $\begin{array}{l}44 \\
17 \\
18 \\
49 \\
18\end{array}$ & $\begin{array}{l}(0.4) \\
(0.5) \\
(0.5) \\
(1.7) \\
(1.4)\end{array}$ & $\begin{array}{l}79 \\
50 \\
53 \\
50 \\
51\end{array}$ & $\begin{array}{l}(0.3) \\
(0.6) \\
(0.6) \\
(1.0) \\
(1.6)\end{array}$ & $\begin{array}{l}46 \\
18 \\
20 \\
51 \\
21\end{array}$ & 10 \\
\hline r reduced-price lunch & $\begin{array}{l}39 \\
73 \\
69 \\
\end{array}$ & $\begin{array}{l}(1.8) \\
(0.9) \\
(3.0) \\
\end{array}$ & $\begin{array}{l}13 \\
40 \\
37 \\
\end{array}$ & $\begin{array}{l}(1.0) \\
(1.2) \\
(3.8) \\
\end{array}$ & $\begin{array}{l}38 \\
73 \\
71 \\
\end{array}$ & $\begin{array}{l}(1.8) \\
(1.4) \\
(2.4) \\
\end{array}$ & $\begin{array}{l}13 \\
39 \\
40 \\
\end{array}$ & $\begin{array}{l}(1.1) \\
(1.5) \\
(2.4) \\
\end{array}$ & $\begin{array}{l}45 \\
76 \\
76 \\
\end{array}$ & $\begin{array}{l}(0.4) \\
(0.3) \\
(0.9) \\
\end{array}$ & $\begin{array}{l}15 \\
42\end{array}$ & & $\begin{array}{l}46 \\
77 \\
77 \\
\end{array}$ & $\begin{array}{l}(0.4) \\
(0.2) \\
(1.1) \\
\end{array}$ & $\begin{array}{l}16 \\
42 \\
45 \\
\end{array}$ & $\begin{array}{l}(0.3) \\
(0.3) \\
(1.4) \\
\end{array}$ & $\begin{array}{l}50 \\
79 \\
80 \\
\end{array}$ & $\begin{array}{l}(0.4) \\
(0.3) \\
(1.3) \\
\end{array}$ & $\begin{array}{l}17 \\
44 \\
46 \\
\end{array}$ & $\begin{array}{l}(0.3) \\
(0.4) \\
(1.8) \\
\end{array}$ & $\begin{array}{l}51 \\
80 \\
81 \\
\end{array}$ & $\begin{array}{l}(0.4) \\
(0.3) \\
(1.9) \\
\end{array}$ & 50 & .3) & $\begin{array}{l}52 \\
82 \\
82 \\
\end{array}$ & $\begin{array}{l}(0.4) \\
(0.3) \\
(1.0) \\
\end{array}$ & $\begin{array}{l}18 \\
48 \\
48 \\
\end{array}$ & $\begin{array}{l}(0.3) \\
(0.5) \\
(1.3) \\
\end{array}$ & $\begin{array}{l}53 \\
83\end{array}$ & & $\begin{array}{l}20 \\
51 \\
51\end{array}$ & \\
\hline 8th $\mathrm{gr}$ & 73 & $(0.8)$ & 32 & (1.1) & - & (t) & - & $(t)$ & 7 & $(0.3)$ & 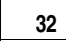 & 10 & 73 & $(0.2)$ & 31 & $(0.2)$ & 74 & $(0.2$ & 31 & $(0.2)$ & 75 & $(0$. & 32 & $(0$. & 76 & $(0.3$ & 34 & $(0.3)$ & 78 & $(0$ & 36 & \\
\hline $\begin{array}{l}\text { Sex } \\
\text { Male.. } \\
\text { Femal }\end{array}$ & & $\begin{array}{l}(1.2) \\
(0.9)\end{array}$ & $\begin{array}{l}26 \\
39\end{array}$ & & $\overline{-}$ & $\begin{array}{l}(t) \\
(t)\end{array}$ & $\overline{-}$ & $\begin{array}{l}(\dagger) \\
(t)\end{array}$ & $\begin{array}{l}69 \\
79\end{array}$ & $\begin{array}{l}(0.3) \\
(0.3)\end{array}$ & $\begin{array}{l}27 \\
38\end{array}$ & & $\begin{array}{l}68 \\
78\end{array}$ & $\begin{array}{l}(0.3) \\
(0.2)\end{array}$ & $\begin{array}{l}26 \\
36\end{array}$ & $\begin{array}{l}(0.3) \\
(0.3)\end{array}$ & & $\begin{array}{l}(0.4) \\
(0.3)\end{array}$ & 6 & $\begin{array}{l}(0.3) \\
(0.3)\end{array}$ & $\begin{array}{l}71 \\
79\end{array}$ & $\begin{array}{l}(0.4) \\
(0.4)\end{array}$ & $\begin{array}{l}28 \\
37\end{array}$ & $\begin{array}{l}(0.4) \\
(0.5)\end{array}$ & 80 & $\begin{array}{l}(0.4) \\
(0.3)\end{array}$ & $\begin{array}{l}29 \\
38\end{array}$ & $\begin{array}{l}(0.3) \\
(0.4)\end{array}$ & $\begin{array}{l}74 \\
82\end{array}$ & $\begin{array}{l}(0.4) \\
(0.3)\end{array}$ & $4 c$ & \\
\hline 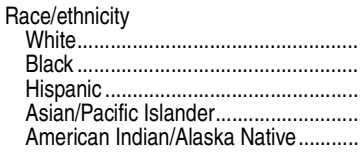 & $\begin{array}{r}81 \\
53 \\
53 \\
75 \\
\ddagger\end{array}$ & $\begin{array}{r}(0.9) \\
(1.8) \\
(2.4) \\
(8.8) \\
(\dagger)\end{array}$ & $\begin{array}{r}39 \\
13 \\
14 \\
33 \\
\ddagger\end{array}$ & $\begin{array}{r}(1.0) \\
(5.6) \\
(+)\end{array}$ & $\begin{array}{l}z \\
= \\
- \\
-\end{array}$ & $\begin{array}{l}(\dagger) \\
(\dagger) \\
(\dagger) \\
(\dagger) \\
(\dagger)\end{array}$ & $\begin{array}{l}\bar{z} \\
\bar{z}\end{array}$ & $\begin{array}{l}(+) \\
(+) \\
(+) \\
(t) \\
(t)\end{array}$ & 57 & $\begin{array}{l}(0.6) \\
(0.9) \\
(1.2) \\
(3.3)\end{array}$ & 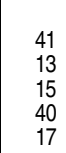 & & $\begin{array}{l}82 \\
52 \\
56 \\
80 \\
59\end{array}$ & $\begin{array}{l}(0.2) \\
(0.6) \\
(0.6) \\
(0.8) \\
(2.1)\end{array}$ & 17 & $\begin{array}{l}(0.3) \\
(0.4) \\
(0.4) \\
(1.2) \\
(1.7)\end{array}$ & & $\begin{array}{l}(0.6) \\
(0.5) \\
(1.1) \\
(1.9)\end{array}$ & $\begin{array}{l}41 \\
18\end{array}$ & $\begin{array}{l}(0.3) \\
(0.4) \\
(0.4) \\
(1.1) \\
(1.3)\end{array}$ & $\begin{array}{l}4 \\
7 \\
1 \\
3 \\
2\end{array}$ & $\begin{array}{l}(0.2) \\
(0.6) \\
(0.8) \\
(1.1) \\
(2.0)\end{array}$ & $\begin{array}{l}17 \\
45 \\
21\end{array}$ & & $\begin{array}{l}85 \\
59 \\
64 \\
83 \\
63\end{array}$ & $\begin{array}{l}(0.2) \\
(0.7) \\
(0.8) \\
(1.0) \\
(1.4)\end{array}$ & $\begin{array}{l}43 \\
15 \\
19 \\
47 \\
22\end{array}$ & $\begin{array}{l}(0.4) \\
(0.5) \\
(0.5) \\
(1.4) \\
(1.7)\end{array}$ & $\begin{array}{l}86 \\
61 \\
68 \\
66 \\
62\end{array}$ & $\begin{array}{l}(0.2) \\
(0.6) \\
(0.7) \\
(0.7) \\
(1.8)\end{array}$ & 19 & \\
\hline $\begin{array}{l}\text { Not eligible. } \\
\text { Unknown.... }\end{array}$ & $\begin{array}{l}56 \\
80 \\
80 \\
\end{array}$ & $\begin{array}{l}(1.3) \\
(1.0) \\
(1.9) \\
\end{array}$ & $\begin{array}{l}14 \\
38 \\
43 \\
\end{array}$ & $\begin{array}{l}1 \\
1.5 \\
(2.5 \\
\end{array}$ & $\begin{array}{l}\overline{-} \\
\overline{-}\end{array}$ & $\begin{array}{l}(\dagger) \\
(\dagger) \\
(\dagger) \\
\end{array}$ & $\begin{array}{l}\overline{-} \\
- \\
\end{array}$ & $\begin{array}{l}(+) \\
(+) \\
(t) \\
+\end{array}$ & 81 & $\begin{array}{l}(0.3) \\
(0.9) \\
\end{array}$ & 42 & $\begin{array}{l}(0.4) \\
(1.2) \\
\end{array}$ & 84 & $\begin{array}{l}(0.4) \\
(0.3) \\
(1.0) \\
\end{array}$ & 45 & $\begin{array}{l}(0.2) \\
(1.3) \\
\end{array}$ & 86 & $\begin{array}{l}(0.3) \\
(1.0) \\
\end{array}$ & 18 & $\begin{array}{l}0 . \\
(1 . \\
\end{array}$ & 9 & & 51 & & $\begin{array}{l}63 \\
86 \\
90 \\
\end{array}$ & $\begin{array}{l}(0.5) \\
(0.3) \\
(0.8) \\
\end{array}$ & $\begin{array}{l}18 \\
45 \\
54 \\
\end{array}$ & $\begin{array}{l}(0.3) \\
(0.4) \\
(1.4) \\
\end{array}$ & $\begin{array}{l}66 \\
87 \\
92 \\
\end{array}$ & $\begin{array}{l}(0.3) \\
(0.9) \\
\end{array}$ & 59 & \\
\hline 12 & 76 & $(0$ & 40 & $(0$. & - & $(t)$ & - & t) & - & $(t)$ & - & ( & 73 & $(0.8)$ & 3 & 10 & - & (t) & - & (t) & 4 & $(0.6$ & 38 & $(0.8$ & - & (†) & - & (t) & - & (t) & & \\
\hline $\begin{array}{l}\text { Sex } \\
\text { Male. } \\
\text { Femal }\end{array}$ & $\begin{array}{l}70 \\
83\end{array}$ & $\begin{array}{l}(0.9) \\
(0.8)\end{array}$ & $\begin{array}{l}32 \\
48\end{array}$ & & - & $\begin{array}{l}(\dagger) \\
(\dagger)\end{array}$ & 7 & $\begin{array}{l}(t) \\
(t)\end{array}$ & - & $(t)$ & - & ( & 3 & & & & - & $\begin{array}{l}(t) \\
(t)\end{array}$ & $\overline{-}$ & t) & & & & & $\overline{-}$ & $\begin{array}{l}(\dagger) \\
(\dagger)\end{array}$ & - & (†) & - & (†) & - & \\
\hline & $\begin{array}{r}82 \\
57 \\
62 \\
74 \\
\ddagger\end{array}$ & $\begin{array}{r}(0.7) \\
(1.9) \\
(2.5) \\
(3.1) \\
(\dagger)\end{array}$ & $\begin{array}{r}47 \\
17 \\
24 \\
38 \\
\ddagger\end{array}$ & $\begin{array}{r}(0.9) \\
(1.4) \\
(1.5) \\
(2.9) \\
(\dagger)\end{array}$ & $\overline{-}$ & $\begin{array}{l}(\dagger) \\
(\dagger) \\
(\dagger) \\
(\dagger) \\
(\dagger)\end{array}$ & $\begin{array}{l}- \\
\overline{-} \\
\overline{-} \\
-\end{array}$ & $\begin{array}{l}(+) \\
(+) \\
(\dagger) \\
(t) \\
(t)\end{array}$ & $\begin{array}{l}- \\
\overline{-} \\
\overline{-} \\
-\end{array}$ & $(t)$ & $\begin{array}{l}- \\
- \\
- \\
-\end{array}$ & (t) & $\begin{array}{l}79 \\
54 \\
60 \\
74 \\
67\end{array}$ & $\begin{array}{r}(0.8) \\
(1.5) \\
(1.9) \\
(2.3) \\
(10.1)\end{array}$ & $\begin{array}{l}43 \\
16\end{array}$ & $\begin{array}{l}(0.9) \\
(1.2) \\
(1.3) \\
(2.3) \\
(8.6)\end{array}$ & $\begin{array}{l}z \\
z \\
z \\
-\end{array}$ & $\begin{array}{l}(t) \\
(t) \\
(t) \\
(t) \\
(t)\end{array}$ & $\begin{array}{l}- \\
= \\
- \\
-\end{array}$ & $\begin{array}{l}(t) \\
(\dagger)\end{array}$ & $\begin{array}{l}81 \\
57 \\
61 \\
81 \\
70\end{array}$ & $\begin{array}{l}(0.5) \\
(1.3) \\
(1.1) \\
(1.5) \\
(6.4)\end{array}$ & $\begin{array}{l}46 \\
17 \\
22 \\
49 \\
29\end{array}$ & $\begin{array}{l}(1.2) \\
(1.3) \\
(2.9) \\
(5.5)\end{array}$ & $\begin{array}{l}- \\
\bar{z} \\
-\end{array}$ & $\begin{array}{l}(+) \\
(+) \\
(+) \\
(+) \\
(t)\end{array}$ & $\begin{array}{l}- \\
- \\
- \\
-\end{array}$ & $\begin{array}{l}\text { (T) } \\
(\dagger)\end{array}$ & $\begin{array}{l}= \\
\overline{-} \\
\overline{-}\end{array}$ & $\begin{array}{c}(+) \\
(t) \\
(t)\end{array}$ & $\begin{array}{l}- \\
\overline{-} \\
\overline{-}\end{array}$ & \\
\hline 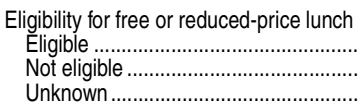 & $\begin{array}{l}56 \\
79 \\
81\end{array}$ & $\begin{array}{l}(1.6) \\
(0.6) \\
(1.6)\end{array}$ & $\begin{array}{l}43 \\
45\end{array}$ & $\begin{array}{l}(0.8) \\
(2.0)\end{array}$ & - & $\begin{array}{l}(t) \\
(t)\end{array}$ & $\begin{array}{l}\bar{z} \\
\bar{z}\end{array}$ & $(\dagger)$ & $\begin{array}{l}\bar{z} \\
\overline{-}\end{array}$ & (T) & - & (II) & $\begin{array}{l}59 \\
76 \\
80\end{array}$ & $\begin{array}{l}(0.8) \\
(2.0)\end{array}$ & 46 & $\begin{array}{l}(0.8) \\
(2.1)\end{array}$ & $\begin{array}{l}\bar{z} \\
-\end{array}$ & $(t)$ & $\begin{array}{l}\bar{z} \\
\overline{-}\end{array}$ & (T) & $\begin{array}{l}61 \\
79 \\
81\end{array}$ & & 48 & & - & $\begin{array}{l}(\dagger) \\
(+)\end{array}$ & $\begin{array}{l}\bar{z} \\
\overline{-}\end{array}$ & $(†)$ & $\begin{array}{l}- \\
-\end{array}$ & $\begin{array}{l}(\dot{\dagger}) \\
(\dagger)\end{array}$ & - & \\
\hline
\end{tabular}

\section{-Not available.}

fReporting standards not met (too few cases for a reliable estimate)

Basic denotes partial mastery of the knowledge and skills that are fundamental for proficient work at a given grade. 2Proficient represents solid academic performance. Students reaching this level have demonstrated competency over challen

NOTE: Includes public and private schools. Includes students tested with accommodations (1 to 11 percent of all students, depending on grade level and year); excludes only those students with disabilities and English language learners who were unable to be tested even with accommodations ( 2 to 6 percent of all students). Race categories exclude persons of Hispan (a) SOURCE: U.S. Department of Education, National Center for Education Statistics, National Assessment of Educational Progress (NAEP), 1998, 2000, 2003, 2005, 2007, 2009, 2011, and 2013 Reading Assessments, retrieved November 13, 2013, from
the Main NAEP Data Explorer (http://nces.ed. gov/nationsreportcard/naepdata). (This table was prepared November 2013.) 


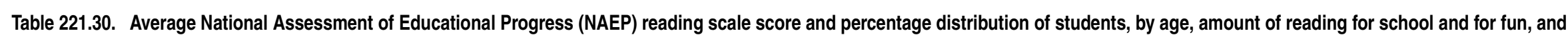
time spent on homework and watching TV/video: Selected years, 1984 through 2012

[Standard errors appear in parentheses]

\begin{tabular}{|c|c|c|c|c|c|c|c|c|c|c|c|c|c|c|c|c|c|c|c|c|c|c|c|c|c|c|c|c|c|c|}
\hline \multirow{2}{*}{$\begin{array}{l}\text { Amount of reading for school and } \\
\text { for fun, time spent on homework } \\
\text { and watching TV/video }\end{array}$} & \multicolumn{10}{|c|}{ 9-year-olds } & \multicolumn{10}{|c|}{ 13-year-olds } & \multicolumn{10}{|c|}{ 17-year-olds } \\
\hline & & 1984 & & 1994 & & 1999 & & 2008 & & 2012 & & 1984 & & 1994 & & 1999 & & 2008 & & 2012 & & 1984 & & 1994 & & 1999 & & 2008 & & 2012 \\
\hline \multirow[t]{2}{*}{1} & & 2 & & 3 & & 4 & & 5 & & 6 & & 7 & & - & & 9 & & 10 & & 11 & & 12 & & 13 & & 14 & & 15 & & 16 \\
\hline & \multicolumn{30}{|c|}{ Average scale score ${ }^{1}$} \\
\hline 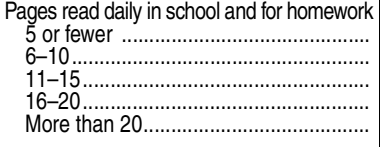 & $\begin{array}{l}208 \\
215 \\
220 \\
215 \\
215\end{array}$ & $\left(\begin{array}{l}0.9 \\
1.0 \\
1.4 \\
1.4 \\
1.6\end{array}\right)$ & $\begin{array}{l}203 \\
214 \\
217 \\
209 \\
217\end{array}$ & $\left.\begin{array}{l}2.3 .3 \\
1.7 \\
2.3 \\
2.9 \\
2.4 \\
2.4\end{array}\right)$ & $\begin{array}{l}202 \\
212 \\
221 \\
214 \\
217\end{array}$ & $\left.\begin{array}{l}1.8 \\
1.7 \\
2.4 \\
2.0 \\
2.1\end{array}\right)$ & $\begin{array}{l}210 \\
219 \\
224 \\
225 \\
226\end{array}$ & $\left(\begin{array}{r}1.1 \\
1.3 \\
1.4 \\
1.5 \\
1.2\end{array}\right)$ & $\begin{array}{l}207 \\
219 \\
225 \\
226 \\
227\end{array}$ & $\left(\begin{array}{l}1.1 \\
1.5 \\
1.3 \\
1.2 \\
1.0\end{array}\right)$ & $\begin{array}{l}250 \\
261 \\
264 \\
263 \\
261\end{array}$ & $\left(\begin{array}{l}0.8 \\
0.6 \\
1.0 \\
1.1 \\
(1.5) \\
\end{array}\right.$ & $\begin{array}{l}249 \\
261 \\
266 \\
263 \\
261\end{array}$ & $\left(\begin{array}{l}1.7 \\
1.4 \\
1.8 \\
2.3 \\
2.0\end{array}\right)$ & $\begin{array}{l}249 \\
262 \\
263 \\
264 \\
265\end{array}$ & $\left(\begin{array}{l}2.0 \\
1.7 \\
2.1 \\
2.6 \\
2.0\end{array}\right)$ & $\begin{array}{l}50 \\
58 \\
63 \\
67 \\
67\end{array}$ & $\begin{array}{r}1.2 \\
1.2 \\
1.1 \\
1.6 \\
(1.4)\end{array}$ & $\begin{array}{l}251 \\
261 \\
266 \\
268 \\
271\end{array}$ & $\left.\begin{array}{l}(1.8) \\
1.5 \\
1.8 \\
1.8 \\
1.3\end{array}\right)$ & $\begin{array}{l}273 \\
287 \\
294 \\
296 \\
300\end{array}$ & $\left.\begin{array}{l}(0.8) \\
0.9 \\
0.9 \\
1.1 \\
1.2\end{array}\right)$ & $\begin{array}{l}271 \\
284 \\
288 \\
298 \\
304\end{array}$ & $\left.\begin{array}{l}1.9 \\
2.1 \\
1.9 \\
2.8 \\
(2.2)\end{array}\right)$ & $\begin{array}{l}273 \\
285 \\
292 \\
292 \\
302\end{array}$ & $\begin{array}{l}(2.7) \\
1.7 \\
2.1 \\
2.9 \\
(1.9)\end{array} \mid$ & $\begin{array}{l}271 \\
284 \\
290 \\
296 \\
303\end{array}$ & $\begin{array}{r}1.3 \\
1.4 \\
1.6 \\
1.5 \\
(1.3)\end{array}$ & $\begin{array}{l}274 \\
283 \\
289 \\
297 \\
301\end{array}$ & $\left.\begin{array}{l}(1.1) \\
1.2 \\
1.5 \\
1.5 \\
1.5\end{array}\right)$ \\
\hline $\begin{array}{l}\text { Frequency of reading for fun } \\
\text { Almost every day.............. }\end{array}$ & $\begin{array}{l}214 \\
212 \\
204 \\
197 \\
198\end{array}$ & $\left.\begin{array}{l}(1.1) \\
1.7 \\
3.3 \\
4.2 \\
2.7\end{array}\right)$ & $\begin{array}{r}215 \\
214 \\
213 \\
\ddagger \\
193\end{array}$ & $\begin{array}{r}(2.3) \\
3.1 \\
(5.8) \\
(+) \\
(3.9)\end{array}$ & $\begin{array}{r}215 \\
215 \\
211 \\
\ddagger \\
195\end{array}$ & $\begin{array}{r}(2.4) \\
2.6 \\
(4.2) \\
(\dagger) \\
(3.3)\end{array}$ & $\begin{array}{l}225 \\
225 \\
221 \\
212 \\
211\end{array}$ & $\begin{array}{l}1.2 \\
1.3 \\
1.7 \\
2.0 \\
(1.2)\end{array}$ & $\begin{array}{l}226 \\
226 \\
219 \\
211 \\
208\end{array}$ & $\left.\begin{array}{l}(0.9) \\
0.9 \\
2.0 \\
1.9 \\
1.9\end{array}\right)$ & $\begin{array}{l}264 \\
255 \\
255 \\
252 \\
239\end{array}$ & $\begin{array}{r}(1.4) \\
1.4 \\
2.1 \\
(3.6) \\
(2.5)\end{array}$ & $\begin{array}{l}272 \\
255 \\
255 \\
252 \\
237\end{array}$ & $\left.\begin{array}{l}(3.2 .2 \\
3.1 \\
5.7 \\
5.4 \\
5.1\end{array}\right)$ & $\begin{array}{l}272 \\
263 \\
260 \\
253 \\
242\end{array}$ & $\left.\begin{array}{l}(3.2) \\
3.2 \\
3.7 \\
4.4 \\
5.3\end{array}\right)$ & $\begin{array}{l}274 \\
264 \\
261 \\
254 \\
247\end{array}$ & $\left.\begin{array}{l}(1.4) \\
(1.1) \\
1.3 \\
1.3 \\
0.9\end{array}\right)$ & $\begin{array}{l}276 \\
267 \\
264 \\
258 \\
249\end{array}$ & $\left.\begin{array}{r}1.4 \\
1.4 \\
1.7 \\
1.6 \\
1.3\end{array}\right)$ & $\begin{array}{l}297 \\
290 \\
290 \\
279 \\
269\end{array}$ & $\left.\begin{array}{l}(1.5) \\
1.7 \\
1.8 \\
2.7 \\
2.4\end{array}\right)$ & $\begin{array}{l}302 \\
286 \\
286 \\
281 \\
258\end{array}$ & $\begin{array}{l}(4.2) \\
(4.1) \\
4.5 \\
(8.2) \\
(5.2)\end{array}$ & $\begin{array}{l}301 \\
289 \\
286 \\
283 \\
262\end{array}$ & $\left(\begin{array}{l}4.9 \\
29\end{array}\right)$ & 2887 & $\left.\begin{array}{l}1.3 \\
1.7 \\
1.3 \\
1.5 \\
1.1\end{array}\right)$ & $\begin{array}{l}302 \\
294 \\
288 \\
288 \\
272\end{array}$ & $\left.\begin{array}{l}1.3 \\
1.4 \\
1.5 \\
1.3 \\
1.4\end{array}\right)$ \\
\hline \multirow[t]{2}{*}{ 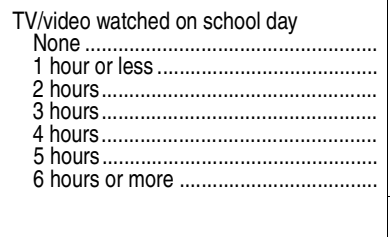 } & $\begin{array}{l}212 \\
217 \\
222 \\
220 \\
219 \\
214 \\
199 \\
\end{array}$ & $\begin{array}{l}(3.4) \\
(.5) \\
1.1 \\
1.2 \\
1.0 \\
(1.4) \\
0.8)\end{array}$ & $\begin{array}{l}212 \\
216 \\
219 \\
218 \\
212 \\
209 \\
192 \\
\end{array}$ & $\left.\begin{array}{l}(4.8) \\
1.8 \\
2.1 \\
2.2 \\
1.8 \\
(2.7) \\
2.7\end{array}\right)$ & $\begin{array}{l}221 \\
218 \\
221 \\
218 \\
214 \\
208 \\
191 \\
\end{array}$ & 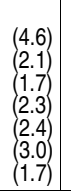 & $\begin{array}{l}223 \\
225 \\
229 \\
227 \\
223 \\
219 \\
205 \\
\end{array}$ & $\left.\begin{array}{l}(3.0) \\
1.2 \\
1.1 \\
1.3 \\
1.4 \\
2.2 \\
(1.2)\end{array}\right)$ & $\begin{array}{l}222 \\
229 \\
227 \\
226 \\
224 \\
213 \\
205 \\
\end{array}$ & $\left.\begin{array}{l}3.1 \\
1.2 \\
1.1 \\
1.4 \\
1.4 \\
2.1 \\
(1.2)\end{array}\right)$ & $\begin{array}{l}264 \\
269 \\
268 \\
264 \\
262 \\
257 \\
245 \\
\end{array}$ & $\left.\begin{array}{l}(2.7) \\
1.1 \\
0.8 \\
0.7 \\
0.9 \\
1.0 \\
1.0\end{array}\right)$ & $\begin{array}{l}270 \\
270 \\
268 \\
262 \\
254 \\
250 \\
234 \\
\end{array}$ & $\begin{array}{l}(5.1 \\
1.5 \\
1.4 \\
1.4 \\
2.2 \\
(2.0) \\
(3.1)\end{array}$ & $\begin{array}{l}265 \\
270 \\
268 \\
263 \\
254 \\
253 \\
238 \\
\end{array}$ & $\left.\begin{array}{l}(6.0) \\
1.6 \\
1.6 \\
1.5 \\
(2.4 \\
3.2 \\
(1.8)\end{array}\right)$ & $\begin{array}{l}267 \\
266 \\
266 \\
262 \\
255 \\
255 \\
238 \\
\end{array}$ & $\left.\begin{array}{l}(3.0) \\
1.2 \\
1.1 \\
1.3 \\
1.5 \\
2.6 \\
1.4\end{array}\right)$ & $\begin{array}{l}276 \\
269 \\
266 \\
261 \\
259 \\
255 \\
241 \\
\end{array}$ & $\left.\begin{array}{l}(3.5) \\
1.2 \\
1.5 \\
1.5 \\
1.5\end{array}\right)$ & $\begin{array}{l}300 \\
300 \\
295 \\
288 \\
284 \\
277 \\
269 \\
\end{array}$ & $\left.\begin{array}{l}1.6 \\
1.2 \\
0.9 \\
1.0 \\
1.0 \\
1.5 \\
1.5\end{array}\right)$ & $\begin{array}{l}308 \\
299 \\
292 \\
284 \\
276 \\
269 \\
256 \\
\end{array}$ & $\left.\begin{array}{l}(3.4) \\
2.0 \\
1.8 \\
2.0 \\
4.1 \\
4.0 \\
(3.7)\end{array}\right)$ & $\begin{array}{l}300 \\
298 \\
292 \\
282 \\
273\end{array}$ & $\left.\begin{array}{l}(2.8) \\
2.0 \\
2.1 \\
2.3 \\
2.2 \\
3.2 \\
(5.2)\end{array}\right)$ & $\begin{array}{l}276 \\
273 \\
256 \\
\end{array}$ & $\begin{array}{l}(2.4) \\
1.2 \\
1.1 \\
1.3 \\
(2.3) \\
2.4 \\
(2.3)\end{array}$ & $\begin{array}{l}292 \\
292 \\
290 \\
284 \\
277 \\
275 \\
261 \\
\end{array}$ & $\begin{array}{l}2.5) \\
1.3 \\
1.3 \\
1.2 \\
2.1 \\
3.9 \\
2.6 \\
\end{array}$ \\
\hline & \multicolumn{30}{|c|}{ Percentage distribution } \\
\hline $\begin{array}{l}5 \text { or few } \\
6-10 \ldots \\
11-15 \\
16-20 \\
\text { More th }\end{array}$ & $\begin{array}{l}36 \\
25 \\
14 \\
13 \\
13\end{array}$ & $\begin{array}{l}(0.8) \\
0.4 \\
0.4 \\
0.4 \\
0.5)\end{array}$ & $\begin{array}{l}28 \\
26 \\
14 \\
14 \\
17\end{array}$ & $\left.\begin{array}{l}1.4 \\
0.6 \\
0.5 \\
0.9 \\
1.0\end{array}\right)$ & $\begin{array}{l}28 \\
24 \\
15 \\
14 \\
19\end{array}$ & $\left.\begin{array}{l}1.4 \\
0.9 \\
0.7 \\
0.7 \\
1.0\end{array}\right)$ & $\begin{array}{l}25 \\
20 \\
14 \\
14 \\
28\end{array}$ & $\begin{array}{l}(0.9) \\
0.5 \\
0.5 \\
0.6 \\
0.8)\end{array}$ & $\begin{array}{l}22 \\
17 \\
12 \\
15 \\
34\end{array}$ & $\begin{array}{l}(0.7) \\
0.6 \\
0.4 \\
0.6 \\
(1.1)\end{array}$ & $\begin{array}{l}27 \\
34 \\
18 \\
11 \\
11\end{array}$ & $\begin{array}{l}(0.7) \\
0.5 \\
0.4 \\
0.2 \\
0.5)\end{array}$ & 14 & $\left.\begin{array}{l}(0.9) \\
0.9 \\
0.6 \\
0.5 \\
0.8\end{array}\right)$ & $\begin{array}{l}23 \\
31 \\
18 \\
13 \\
16\end{array}$ & $\left(\begin{array}{l}1.0 \\
1.1 \\
0.8 \\
0.7 \\
1.0\end{array}\right)$ & $\begin{array}{l}26 \\
24 \\
17 \\
13 \\
22\end{array}$ & $\left.\begin{array}{l}(0.8) \\
0.6 \\
0.5 \\
0.4 \\
0.9\end{array}\right)$ & $\begin{array}{l}23 \\
22 \\
17 \\
14 \\
24\end{array}$ & $\begin{array}{l}0.8 \\
0.8 \\
0.5 \\
0.5 \\
1.1\end{array}$ & $\begin{array}{l}21 \\
26 \\
18 \\
14 \\
21\end{array}$ & $\left.\begin{array}{l}(0.8) \\
0.6 \\
0.3 \\
0.5 \\
0.9\end{array}\right)$ & $\begin{array}{l}21 \\
25\end{array}$ & $\left(\begin{array}{l}1.2 \\
0.9 \\
0.6 \\
0.6 \\
(1.5)\end{array}\right)$ & $\begin{array}{l}23 \\
24 \\
17 \\
14 \\
22\end{array}$ & & $\begin{array}{l}30 \\
23\end{array}$ & $\begin{array}{l}(0.9) \\
0.5 \\
0.5 \\
0.4 \\
0.7)\end{array}$ & $\begin{array}{l}29 \\
22 \\
15 \\
12 \\
22\end{array}$ & $\begin{array}{l}0.7) \\
0.6 \\
0.4 \\
0.5 \\
0.7)\end{array}$ \\
\hline $\begin{array}{r}\text { Frequenc } \\
\text { Almost } \\
\text { Once o } \\
\text { Once o } \\
\text { A few ti } \\
\text { Never }\end{array}$ & $\begin{array}{r}53 \\
28 \\
7 \\
3 \\
9\end{array}$ & $\left.\begin{array}{l}1.0 \\
0.8 \\
0.6 \\
0.3 \\
0.5\end{array}\right)$ & $\begin{array}{r}58 \\
25 \\
5 \\
3 \\
9\end{array}$ & $\left.\begin{array}{l}1.6 \\
1.5 \\
0.6 \\
0.6 \\
0.8\end{array}\right)$ & $\begin{array}{r}54 \\
25 \\
6 \\
4 \\
10\end{array}$ & $\begin{array}{l}1.7 \\
1.5 \\
0.6 \\
0.7 \\
0.8\end{array} \mid$ & $\begin{array}{r}48 \\
23 \\
8 \\
8 \\
14\end{array}$ & $\begin{array}{l}(0.7) \\
0.6 \\
0.3 \\
0.4 \\
0.6)\end{array}$ & $\begin{array}{r}53 \\
23 \\
7 \\
7 \\
11\end{array}$ & $\begin{array}{l}(0.8) \\
0.6 \\
0.4 \\
0.3 \\
0.4)\end{array}$ & $\begin{array}{r}35 \\
35 \\
14 \\
7 \\
8\end{array}$ & $\begin{array}{l}1.0 \\
1.2 \\
0.8 \\
0.5 \\
0.6)\end{array}$ & $\begin{array}{l}32 \\
32 \\
14\end{array}$ & $\left(\begin{array}{l}1.8 \\
2.1 \\
1.7 \\
1.2 \\
1.7\end{array}\right)$ & $\begin{array}{c}28 \\
36 \\
17 \\
10 \\
9\end{array}$ & $\left(\begin{array}{l}1.6 \\
1.6 \\
1.1 \\
1.4\end{array}\right)$ & $\begin{array}{l}26 \\
25 \\
13 \\
12 \\
24\end{array}$ & $\begin{array}{l}0.6 \\
0.4 \\
0.4 \\
0.7)\end{array}$ & $\begin{array}{l}27 \\
26 \\
14 \\
11 \\
22\end{array}$ & (c & $\begin{array}{r}31 \\
33 \\
17 \\
10 \\
9\end{array}$ & $\left.\begin{array}{l}1.1 \\
0.5 \\
0.5 \\
0.6\end{array}\right)$ & $\begin{array}{l}30 \\
31\end{array}$ & $\left(\begin{array}{l}1.9 \\
1.5 \\
(1.5 \\
1.4\end{array}\right)$ & $\begin{array}{l}25 \\
28 \\
19 \\
12 \\
16\end{array}$ & $\left(\begin{array}{l}2.7 \\
1.7 \\
1.4 \\
2.4\end{array}\right)$ & $\begin{array}{l}20 \\
22 \\
17 \\
16 \\
24\end{array}$ & $\left.\begin{array}{l}0.6 \\
0.5 \\
0.5 \\
0.5 \\
0.6\end{array}\right)$ & $\begin{array}{l}19 \\
21 \\
16 \\
18 \\
27\end{array}$ & $\begin{array}{l}(0.6) \\
0.6 \\
0.4 \\
0.6 \\
0.6)\end{array}$ \\
\hline $\begin{array}{c}\text { Time s } \\
\text { No h } \\
\text { Didn } \\
\text { Less } \\
\text { 1 to } \\
\text { More }\end{array}$ & $\begin{array}{r}35 \\
4 \\
41 \\
13 \\
6\end{array}$ & $\left.\begin{array}{l}1.3 \\
0.3 \\
1.0 \\
0.4 \\
0.2)\end{array}\right)$ & $\begin{array}{r}32 \\
4 \\
48 \\
11 \\
4\end{array}$ & $\left.\begin{array}{l}(2.1) \\
0.4 \\
1.7 \\
0.7 \\
0.4\end{array}\right)$ & $\begin{array}{r}26 \\
4 \\
53 \\
12 \\
5\end{array}$ & $\left.\begin{array}{l}(1.6) \\
0.3 \\
1.4 \\
0.7 \\
0.5\end{array}\right)$ & $\begin{array}{r}18 \\
5 \\
60 \\
12 \\
5\end{array}$ & $\left.\begin{array}{l}1.3 \\
0.3 \\
1.2 \\
0.5 \\
0.3\end{array}\right)$ & $\begin{array}{r}22 \\
4 \\
57 \\
12 \\
5\end{array}$ & $\begin{array}{l}(1.6) \\
0.4 \\
1.3 \\
0.6 \\
0.3)\end{array}$ & $\begin{array}{r}22 \\
4 \\
36 \\
29 \\
9\end{array}$ & $\begin{array}{l}0.7) \\
0.2 \\
0.6 \\
0.5 \\
0.3)\end{array}$ & $\begin{array}{r}23 \\
6 \\
34 \\
28 \\
9\end{array}$ & $\begin{array}{l}1.4 \\
0.6 \\
1.0 \\
1.0 \\
0.7)\end{array}$ & $\begin{array}{r}24 \\
5 \\
37 \\
26 \\
8\end{array}$ & $\left(\begin{array}{c}1.2 \\
(0.4) \\
1.4 \\
(1.0) \\
0.8)\end{array}\right.$ & $\begin{array}{r}23 \\
7 \\
43 \\
21 \\
6\end{array}$ & $\left.\begin{array}{l}1.2 \\
0.3 \\
1.2 \\
0.7 \\
0.4\end{array}\right)$ & $\begin{array}{r}21 \\
5 \\
44 \\
23 \\
7\end{array}$ & $(0.3)$ & $\begin{array}{l}22 \\
11 \\
26 \\
27 \\
13\end{array}$ & $\left.\begin{array}{l}(0.9) \\
0.3 \\
0.4 \\
0.5 \\
0.5\end{array}\right)$ & $\begin{array}{l}23 \\
11 \\
27\end{array}$ & $\left.\begin{array}{l}(1.4) \\
0.6 \\
(0.9 \\
1.2 \\
0.9\end{array}\right)$ & $\begin{array}{l}26 \\
13 \\
26 \\
23 \\
12\end{array}$ & $\left.\begin{array}{l}1.0 \\
0.7 \\
1.0 \\
0.8 \\
0.9\end{array}\right)$ & $\begin{array}{l}28 \\
12 \\
27 \\
22 \\
10\end{array}$ & $\left.\begin{array}{l}0.8 \\
0.4 \\
0.5 \\
0.5 \\
0.5\end{array}\right)$ & $\begin{array}{l}27 \\
11 \\
26 \\
23 \\
13\end{array}$ & $\begin{array}{l}0.9) \\
0.4 \\
0.8 \\
0.6 \\
0.7)\end{array}$ \\
\hline 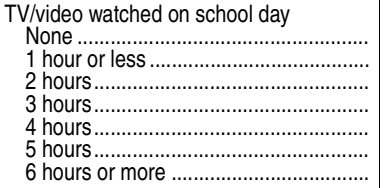 & $\begin{array}{r}3 \\
14 \\
16 \\
15 \\
12 \\
9 \\
30\end{array}$ & $\begin{array}{l}(0.2) \\
0.3 \\
0.4 \\
0.3 \\
0.2 \\
0.3 \\
0.7)\end{array}$ & $\begin{array}{r}23 \\
23 \\
23 \\
16 \\
11 \\
6 \\
20\end{array}$ & $\begin{array}{l}(0.2) \\
1.0 \\
0.7 \\
0.5 \\
0.5 \\
0.4 \\
0.8\end{array}$ & $\begin{array}{r}4 \\
24 \\
21 \\
14 \\
9 \\
6 \\
62 \\
22\end{array}$ & $\left(\begin{array}{l}0.8) \\
0.9 \\
0.9 \\
0.6 \\
0.4 \\
0.4 \\
1.2\end{array}\right)$ & $\begin{array}{r}4 \\
24 \\
18 \\
13 \\
9 \\
6 \\
26\end{array}$ & $\left.\begin{array}{l}(0.3) \\
0.6 \\
0.5 \\
0.4 \\
0.4 \\
0.3 \\
0.8\end{array}\right)$ & $\begin{array}{r}6 \\
27 \\
18 \\
12 \\
8 \\
6 \\
23\end{array}$ & $\begin{array}{l}(0.3) \\
0.7 \\
0.5 \\
0.5 \\
0.4 \\
0.3 \\
0.8)\end{array}$ & $\begin{array}{r}2 \\
12 \\
23 \\
23 \\
17 \\
10 \\
13\end{array}$ & $\left.\begin{array}{l}(0.2) \\
0.4 \\
0.5 \\
0.4 \\
0.4 \\
0.3 \\
0.4\end{array}\right)$ & $\begin{array}{r}3 \\
20 \\
27 \\
22 \\
12 \\
7 \\
10\end{array}$ & $\left.\begin{array}{l}(0.3) \\
1.0 \\
0.7) \\
0.8 \\
0.7 \\
0.4 \\
0.9\end{array}\right)$ & $\begin{array}{r}4 \\
22 \\
29 \\
20 \\
11 \\
5 \\
9\end{array}$ & $\begin{array}{l}(0.6) \\
0.8 \\
0.8 \\
0.9 \\
0.6 \\
0.3 \\
0.6)\end{array}$ & $\begin{array}{r}5 \\
25 \\
25 \\
18 \\
10 \\
5 \\
13\end{array}$ & $\begin{array}{l}0.3 \\
0.7 \\
0.5 \\
0.5 \\
0.4 \\
0.3 \\
0.4)\end{array}$ & $\begin{array}{r}6 \\
29 \\
27 \\
15 \\
8 \\
4 \\
10\end{array}$ & $\left.\begin{array}{l}0.6 \\
0.7 \\
0.5 \\
0.3\end{array}\right)$ & $\begin{array}{r}5 \\
25 \\
26 \\
20 \\
12 \\
6 \\
6\end{array}$ & $\left.\begin{array}{l}(0.3) \\
0.5 \\
0.3 \\
0.3 \\
0.3 \\
0.2 \\
0.2)\end{array}\right)$ & $\begin{array}{r}6 \\
31 \\
26 \\
18 \\
9 \\
5 \\
5\end{array}$ & $\left.\begin{array}{l}(0.8) \\
0.9 \\
0.8 \\
0.8 \\
0.6 \\
0.5 \\
0.4\end{array}\right)$ & $\begin{array}{r}34 \\
26 \\
17 \\
8 \\
4 \\
5\end{array}$ & $\left.\begin{array}{l}0.3 \\
0.9 \\
0.9 \\
0.7 \\
0.5 \\
0.4 \\
0.6\end{array}\right)$ & $\begin{array}{r}6 \\
33 \\
27 \\
16 \\
8 \\
4 \\
6\end{array}$ & $\left.\begin{array}{l}(0.3) \\
0.6 \\
0.6 \\
0.5 \\
0.4 \\
0.2 \\
0.4)\end{array}\right)$ & $\begin{array}{r}10 \\
34 \\
25 \\
16 \\
8 \\
3 \\
5\end{array}$ & $\begin{array}{l}0.3 \\
0.6 \\
0.5 \\
0.6 \\
0.3 \\
0.2 \\
0.3)\end{array}$ \\
\hline
\end{tabular}

\section{†Not applicable.}

Scale ranges from 0 to 500 . Students scoring 150 (or higher) are able to follow brief written directions and carry out simple, discrete reading tasks. Students scoring 200 are able to understand, combine ideas, and make inferences based on short uncomplicated passages about speciific or sequentially related information. Students scoring 250 are able to search for speciifi information, interrelate ideas, and make generalizations about literature, science, and social studies materials. Students scoring 300 are able to find,
understand, summmarize, and explain relatively complicated literary and informational material. NOTE: Includes public and private schools. For 1984, 1994, and 1999, accommodations were not permitted. For 2008 and later years, includes students tested with accommodations; excludes only those students with disabilities and English language learnyear). Detail may not sum to totals because of rounding.

SOURCE: U.S. Department of Education, National Center for Education Statistics, National Assessment of Educational Progress (NAEP), NAEP Trends in Academic Progress, 1996 and 1999; and 2008 and 2012 NAEP Long-Term Trend Reading Assessments, retrieved June 24, 2009, and July 02, 2013, from the Long-Term Trend NAEP Data Explorer (http://nces.ed.gov/
nationsreportcard/naepdata/). (This table was prepared July 2013.) 
Table 221.40. Average National Assessment of Educational Progress (NAEP) reading scale score of 4th-grade public school students and percentage attaining reading achievement levels, by state: Selected years, 1992 through 2013

[Standard errors appear in parentheses]

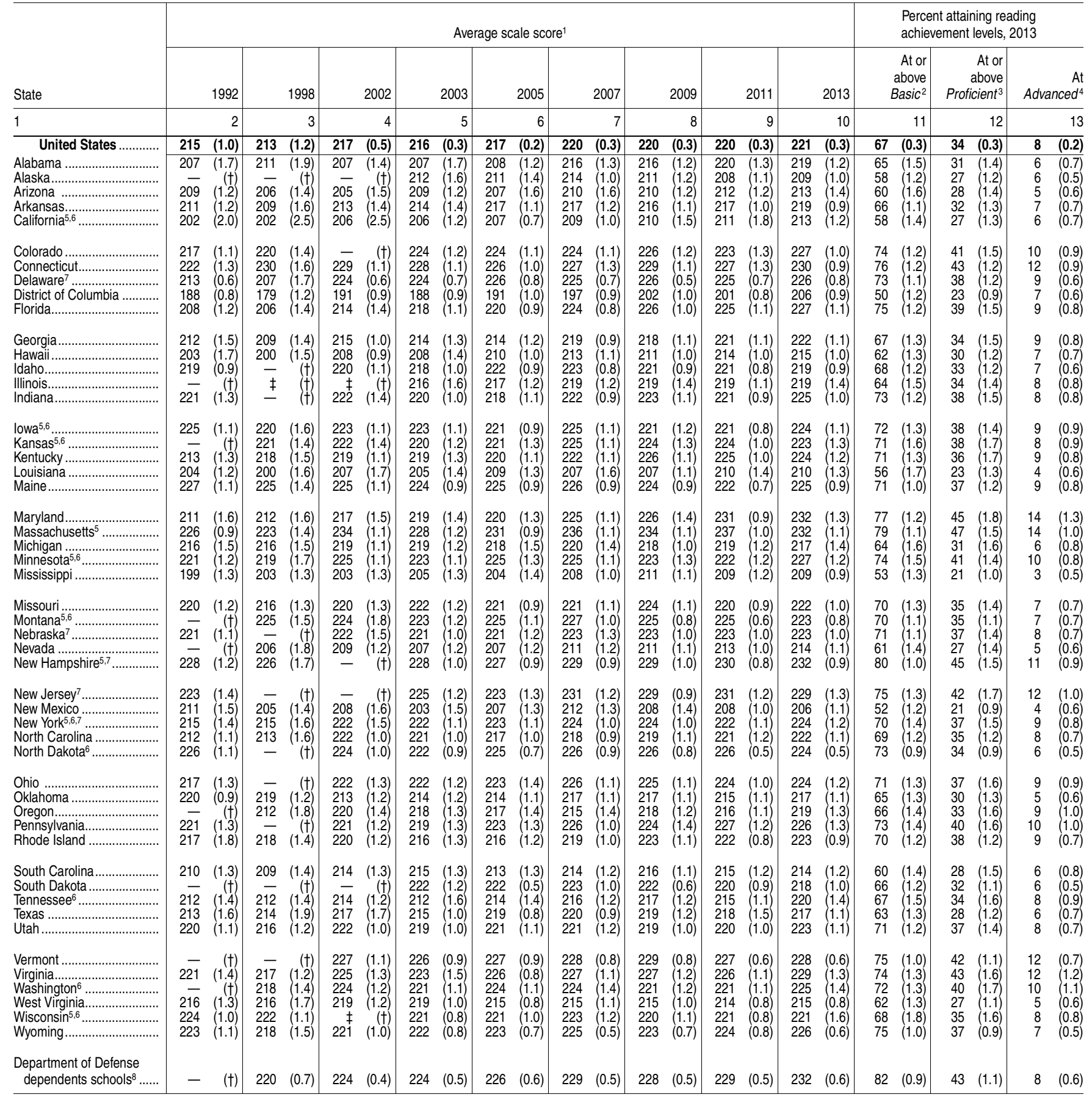

-Not available.

†Not applicable.

†Reporting standards not met. Participation rates fell below the required standards for reporting

Scale ranges from 0 to 500 .

${ }^{2}$ Basic denotes partial mastery of the knowledge and skills that are fundamental for proficient work at the 4th-grade level.

${ }^{3}$ Proficient represents solid academic performance for 4 th-graders. Students reaching this level have demonstrated competency over challenging subject matter.

${ }^{4}$ Advanced signifies superior performance.

${ }^{5}$ Did not satisfy one or more of the guidelines for school participation in 1998. Data are subject to appreciable nonresponse bias.

${ }^{6}$ Did not satisfy one or more of the guidelines for school participation in 2002. Data are subject to appreciable nonresponse bias.

${ }^{7}$ Did not satisfy one or more of the guidelines for school participation in 1992. Data are subject to appreciable nonresponse bias.
${ }^{8}$ Prior to 2005, NAEP divided the Department of Defense (DoD) schools into two jurisdictions, domestic and overseas. In 2005, NAEP began combining the DoD domestic and overseas schools into a single jurisdiction. Data shown in this table for years prior to 2005 were recalculated for comparability.

NOTE: With the exception of 1992, includes public school students who were tested with accommodations; excludes only those students with disabilities (SD) and English language learners (ELL) who were unable to be tested even with accommodations. SD and ELL populations, accommodation rates, and exclusion rates vary from state to state. Race categories exclude persons of Hispanic ethnicity.

SOURCE: U.S. Department of Education, National Center for Education Statistics, National Assessment of Educational Progress (NAEP), 1992, 1998, 2002, 2003, 2005, 2007, 2009, 2011, and 2013 Reading Assessments, retrieved November 8, 2013, from the Main NAEP Data Explorer (http://nces.ed.gov/nationsreportcard/naepdata/). (This table was prepared November 2013.) 
Table 221.50. Average National Assessment of Educational Progress (NAEP) reading scale score and percentage of 4th-grade public school students, by race/ethnicity and state: 2013

[Standard errors appear in parentheses]

\begin{tabular}{|c|c|c|c|c|c|c|c|c|c|c|c|c|c|c|c|c|c|c|c|c|c|c|c|c|}
\hline \multirow[b]{2}{*}{ State } & \multicolumn{12}{|c|}{ Average scale score ${ }^{1}$} & \multicolumn{12}{|c|}{ Percent of students } \\
\hline & \multirow{2}{*}{\multicolumn{2}{|c|}{ White }} & \multirow{2}{*}{\multicolumn{2}{|c|}{ Black }} & \multicolumn{2}{|c|}{ Hispanic } & \multicolumn{2}{|r|}{ Asian } & \multicolumn{2}{|c|}{$\begin{array}{l}\text { Pacific } \\
\text { Islander }\end{array}$} & \multicolumn{2}{|c|}{$\begin{array}{c}\text { American } \\
\text { Indian/ } \\
\text { Alaska } \\
\text { Native }\end{array}$} & & White & & Black & & panic & & Asian & & $\begin{array}{l}\text { Pacific } \\
\text { ander }\end{array}$ & & $\begin{array}{l}\text { rican } \\
\text { dian/ } \\
\text { laska } \\
\text { lative }\end{array}$ \\
\hline 1 & & & & & & 4 & & 5 & & 6 & & 7 & & 8 & & 9 & & 10 & & 11 & & 12 & & 13 \\
\hline United States & 231 & $(0.3)$ & 205 & $(0.5)$ & 207 & $(0.5)$ & 237 & (1.1) & 210 & (2.5) & 206 & (1.5) & 51 & $(0.4)$ & 15 & $(0.3)$ & 25 & (0.4) & 5 & $(0.2)$ & \# & (t) & 1 & (\#) \\
\hline Alabama. & 227 & (1.3) & 202 & (1.8) & 206 & (4.1) & $\ddagger$ & (†) & $\ddagger$ & $(\dagger)$ & & $(\dagger)$ & 60 & (1.6) & 30 & $(1.8)$ & 7 & $(0.9)$ & 2 & $(0.2)$ & & & 1 & $(0.3)$ \\
\hline Alaskz & 28 & $(1.1)$ & 203 & (4.3) & 213 & (2.9) & 207 & (2.9) & 197 & (5.1) & 173 & (2.1) & 47 & $(1.0)$ & 4 & $(0.3)$ & 7 & $(0.4)$ & 8 & $(0.5)$ & 3 & (0.3) & 24 & (1.0) \\
\hline 701 & 228 & $(1.4)$ & 206 & (4.0) & 202 & (1.7) & 219 & (8.8) & $\ddagger$ & $(\dagger)$ & 186 & (3.9) & 41 & (1.5) & 5 & $(0.4)$ & 45 & & 3 & $(0.5)$ & \# & $(t)$ & - & $(0.6)$ \\
\hline kan & 226 & $(1.0)$ & 200 & (2.4) & 211 & (2.8) & $\ddagger$ & $(t)$ & $\ddagger$ & $(t)$ & $\ddagger$ & $(\dagger)$ & 64 & (1.3) & 21 & (1.4) & 11 & $(0.9)$ & 2 & $(0.3)$ & \# & $(t)$ & 1 & $(0.2)$ \\
\hline California .... & 232 & $(1.6)$ & 202 & (2.6) & 201 & (1.5) & 229 & (2.8) & $\ddagger$ & $(t)$ & $\ddagger$ & $(\dagger)$ & 26 & (1.7) & 6 & $(0.7)$ & 54 & (1.8) & 11 & (1.3) & 1 & $(0.1)$ & 1 & $(0.2)$ \\
\hline lor & 237 & (1.2) & 203 & (4.5) & 210 & (1.6) & 230 & $(5.0)$ & $\ddagger$ & $(†)$ & $\ddagger$ & $(\dagger)$ & 57 & (1.1) & 5 & $(0.5)$ & 31 & $(1.2)$ & . & $(0.4)$ & \# & $(\dagger)$ & 1 & $(0.2)$ \\
\hline $\mathrm{nn}$ & 238 & $(1.0)$ & 208 & (2.6) & 209 & (2.2) & 246 & (3.2) & $\ddagger$ & $(\dagger)$ & $\ddagger$ & $(\dagger)$ & 61 & (1.3) & 11 & $(0.7)$ & 0 & 1 & 5 & $(0.4)$ & $\#$ & $(+)$ & 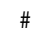 & $(t)$ \\
\hline la & 235 & $(0.9)$ & 213 & $(1.3)$ & 216 & (1.8) & 249 & (3.6) & $\ddagger$ & $(t)$ & $\ddagger$ & $(\dagger)$ & 7 & (1.0) & 1 & $(0.8)$ & 5 & & & $(0.3)$ & \# & $(t)$ & & $0.2)$ \\
\hline tric & 259 & $(2.3)$ & 197 & $(1.0)$ & 208 & (2.1) & $\ddagger$ & $(t)$ & $\ddagger$ & $(\dagger)$ & $\ddagger$ & $(\dagger)$ & 10 & $(0.3)$ & 73 & $(0.5)$ & 14 & $(0.4)$ & 2 & $(0.2)$ & \# & $(t)$ & \# & (†) \\
\hline Florida... & 236 & $(1.4)$ & 212 & (1.6) & 225 & (1.5) & 248 & (2.9) & $\ddagger$ & $(t)$ & $\ddagger$ & $(\dagger)$ & 40 & (1.7) & 22 & $(1.3)$ & 31 & (1.6) & 3 & $(0.3)$ & $\#$ & $(\dagger)$ & $\#$ & $(\dagger)$ \\
\hline oro & 3 & (1.5) & 209 & (1.7) & 213 & (2.0) & 0 & (3.5) & $\ddagger$ & $(\dagger)$ & $\ddagger$ & $(\dagger)$ & 44 & (1.4) & 34 & (1. & 15 & (1) & 4 & $(0.4)$ & $\#$ & $(\dagger)$ & \# & $(t)$ \\
\hline & 31 & (1.9) & 223 & (6.4) & 211 & (3.2) & 218 & (1.7) & 203 & (1.5) & $\ddagger$ & $(t)$ & 15 & 10 & 2 & $(0.3)$ & 6 & ( & 36 & (1.1) & 33 & (1.1) & & $(0.1)$ \\
\hline h & 24 & $(1.0)$ & $\ddagger$ & $(t)$ & 198 & (1.9) & $\ddagger$ & $(t)$ & $\ddagger$ & $(t)$ & $\ddagger$ & $(\dagger)$ & 8 & & 1 & $(0.2)$ & 16 & & 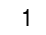 & $(0.2)$ & \# & $(t)$ & 1 & $(0.3)$ \\
\hline noi & 231 & (1.8) & 199 & (2.7) & 204 & (1.6) & 242 & (3.4) & $\ddagger$ & $(\dagger)$ & $\ddagger$ & $(\dagger)$ & 48 & (1.6) & 17 & $(1.2)$ & 27 & (1.5) & 5 & $(0.6)$ & \# & $(\dagger)$ & \# & (†) \\
\hline Indiana...... & 229 & $(1.1)$ & 207 & (3.0) & 215 & (2.3) & 236 & (7.3) & $\ddagger$ & $(\mathrm{t})$ & $\ddagger$ & $(\dagger)$ & 74 & (1.6) & 10 & $(1.6)$ & 9 & $(0.9)$ & 2 & $(0.4)$ & $\#$ & $(t)$ & $\#$ & $(\dagger)$ \\
\hline owa & 27 & (1.3) & 200 & (3.8) & 210 & (2.7) & 4 & .3) & $\ddagger$ & $(†)$ & $\ddagger$ & $(\dagger)$ & D & (1 & 5 & $(0.5$ & 8 & (( & 3 & 10. & \# & $(t)$ & \# & $(\dagger)$ \\
\hline ssa & 230 & (1.2) & 200 & (3.9) & 208 & (2.1) & 228 & (5.6) & $\ddagger$ & $(\dagger)$ & $\ddagger$ & $(t)$ & 67 & (1. & 7 & $(0.8)$ & 17 & (1 & 3 & (0. & \# & $(t)$ & 1 & $(0.2)$ \\
\hline & 27 & $(1.3)$ & 204 & (2.3) & 220 & (3.1) & 243 & (4.9) & $\ddagger$ & $(t)$ & $\ddagger$ & $(t)$ & D & & 11 & $(0.8)$ & 5 & & 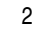 & (0. & \# & t) & $\pi$ & $(t)$ \\
\hline & 223 & $(1.3)$ & 198 & (1.5) & 212 & (3.4) & $\ddagger$ & $(t)$ & $\ddagger$ & $(t)$ & $\ddagger$ & $(t)$ & 44 & (2. & 48 & $(1.8)$ & 4 & (0 & 1 & $(0.2)$ & \# & (I) & 1 & $(0.3)$ \\
\hline Maine.. & 226 & $(0.9)$ & 192 & $(5.0)$ & $\ddagger$ & $(t)$ & $\ddagger$ & $(†)$ & $\ddagger$ & $(\mathrm{t})$ & $\ddagger$ & $(\dagger)$ & 92 & $(0.4)$ & 3 & $(0.3)$ & 2 & $(0.2)$ & 2 & $(0.2)$ & $\#$ & $(t)$ & 1 & $(0.2)$ \\
\hline & 14 & $(1.6)$ & 214 & $(1.3)$ & 224 & (2.7) & 5 & 3) & $\ddagger$ & $(\dagger)$ & $\ddagger$ & $(\dagger)$ & 3 & $(1$ & 34 & $(1$. & 12 & 10.9 & 6 & (1) & \# & dt & \# & (†) \\
\hline M & 241 & $(1.2)$ & 209 & $(3.3)$ & 208 & (2.5) & 239 & (3.3) & $\ddagger$ & $(\dagger)$ & $\ddagger$ & $(t)$ & 64 & (1) & 7 & $(1.0)$ & 18 & (1 & 7 & (0. & \# & $(t)$ & \# & †) \\
\hline & 4 & $(1.8)$ & 196 & (2.3) & 9 & (3.1) & 8 & 4) & $\ddagger$ & $(t)$ & $\ddagger$ & $(\dagger)$ & 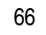 & & 18 & (2. & 9 & & 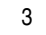 & (0 & \# & & r & $(0.3)$ \\
\hline & 233 & $(1.0)$ & 208 & (3.2) & 207 & (3.1) & 223 & (5.6) & $\ddagger$ & $(t)$ & $\ddagger$ & $(\uparrow)$ & 72 & & 9 & (1.2 & 7 & & 7 & (1.0 & \# & $(t)$ & 1 & $(0.2)$ \\
\hline Missis & 222 & $(1.0)$ & 197 & (1.5) & 206 & (3.0) & $\ddagger$ & $(t)$ & $\ddagger$ & $(t)$ & $\ddagger$ & $(\dagger)$ & 44 & $(1.3)$ & 52 & $(1.3)$ & 3 & $(0.4$ & 1 & $(0.2)$ & $\#$ & $(t)$ & $\#$ & $(t)$ \\
\hline & 8 & $(1.0)$ & 200 & (2.0) & 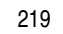 & (4. & $\ddagger$ & (†) & + & $(\dagger)$ & $\ddagger$ & & & & 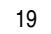 & & & & & & \# & & & 1) \\
\hline & 228 & $(0.8)$ & $\ddagger$ & $(\dagger)$ & 214 & $(4.2)$ & $\ddagger$ & $(\dagger)$ & $\ddagger$ & $(t)$ & 198 & (2.4) & 79 & (1 & 1 & $(0.2)$ & 4 & $(0$ & 1 & (0. & \# & (†) & 13 & $(0.9)$ \\
\hline & 29 & $(1.1)$ & 202 & (3.1) & 207 & (2.1) & 32 & (6.1) & $t$ & $(t)$ & $\ddagger$ & $(+)$ & 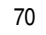 & & 6 & & 17 & & 2 & & \# & & 1 & $(0.3)$ \\
\hline & 226 & $(1.2)$ & 201 & (2.6) & 202 & $(1.5)$ & 227 & (3.2) & $\ddagger$ & $(t)$ & $\ddagger$ & $(t)$ & 36 & (1 & 10 & $(0.8)$ & 41 & (1 & 5 & $(0.5$ & 1 & $(0.2)$ & 1 & $(0.1)$ \\
\hline New Hampshire...... & 233 & $(0.9)$ & 215 & $(5.0)$ & 209 & (4.1) & 237 & (4.4) & $\ddagger$ & $(\dagger)$ & $\ddagger$ & $(\dagger)$ & 89 & $(0.8$ & 2 & $(0.2)$ & 4 & $(0.5$ & 4 & $(0.4)$ & $\#$ & $(\mathrm{t})$ & $\#$ & $(t)$ \\
\hline & 38 & $(1.3)$ & 211 & $(2.2$ & 216 & (2. & 250 & (2.4) & $\ddagger$ & $(\dagger)$ & $\ddagger$ & $(t)$ & 3 & & 17 & (1. & 21 & & & & $\pi$ & & & $(\dagger)$ \\
\hline & 25 & $(1.8)$ & 210 & $(5.8)$ & 201 & $(1.2)$ & $\ddagger$ & $(t)$ & $\ddagger$ & $(\dagger)$ & 187 & (3.4) & 24 & & 2 & $(0.2)$ & 3 & & 1 & $(0$ & \# & $(\dagger$ & 9 & (1.1) \\
\hline & 33 & (13) & 211 & (2.2) & 210 & (1.8) & 37 & (2.4) & \pm & (t) & $\ddagger$ & $(t)$ & & & 18 & (1 & 2 & & 9 & & \# & & $\#$ & $(t)$ \\
\hline & 232 & $(1.2)$ & 210 & (1.5) & 210 & (2.2) & 238 & $(4.1)$ & $\ddagger$ & $(\dagger)$ & 206 & (7.3) & 49 & & 26 & (1.2 & 16 & & 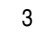 & $(0.3)$ & \# & & 2 & $(0.8)$ \\
\hline North Dakota .... & 227 & $(0.5)$ & 211 & (4.4) & 217 & (4.2) & $\ddagger$ & $(t)$ & $\ddagger$ & $(t)$ & 201 & $(2.1)$ & 84 & $(0.4)$ & 3 & $(0.2)$ & 2 & $(0.2)$ & 1 & $(0.1)$ & $\#$ & $(\dagger)$ & 9 & $(0.3)$ \\
\hline & & (1. & 195 & (2. & 2 & (2. & 244 & $(5.6$ & t & $(†)$ & \pm & & 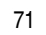 & & 17 & & 4 & & & & $\pi$ & & & (†) \\
\hline & 223 & $(1.3)$ & 201 & (2.5) & 204 & (2.0) & 228 & & $\ddagger$ & $(\dagger)$ & 217 & (2.4) & 52 & & 11 & $(0.8)$ & 14 & & 2 & (0 & \# & $(\dagger)$ & 15 & $(0.8)$ \\
\hline & 5 & & 200 & $(4.0)$ & 199 & (2.0) & 234 & (6) & $t$ & $(t)$ & $\ddagger$ & $(t)$ & & & 3 & & 21 & & & & 1 & (0.1) & 2 & $(0.4)$ \\
\hline & 233 & $(1.2)$ & 208 & $(3.0)$ & 208 & (3.6) & 236 & (3.4) & $\ddagger$ & 11 & $\ddagger$ & $(\dagger)$ & 69 & & 16 & $(1.4)$ & 8 & & 4 & $(0$ & \# & $(t)$ & $\#$ & $(t)$ \\
\hline Rhode $|s|$ & 233 & $(0.9)$ & 205 & (2.8) & 201 & (1.8) & 224 & (4.9) & $\ddagger$ & $(t)$ & $\ddagger$ & $(\dagger)$ & 63 & $(1.2$ & 9 & $(0.4)$ & 22 & (1.1 & 3 & $(0.3)$ & $\#$ & $(\dagger)$ & 1 & $(0.1)$ \\
\hline & 24 & (1.7) & 197 & $(1 . \varepsilon$ & 21 & (3.) & $\ddagger$ & & $\ddagger$ & $(\dagger)$ & $\ddagger$ & & 3 & & 35 & (1 & 7 & & 1 & & $\pi$ & $(\dagger$ & $\#$ & $(\dagger)$ \\
\hline & 225 & $(0.8)$ & 202 & $(6.1)$ & 207 & (4.) & $\ddagger$ & & $\ddagger$ & $(\dagger)$ & 191 & (2.5) & 76 & & 3 & & 4 & & 2 & & \# & $(\dagger)$ & 14 & (1.2) \\
\hline & 77 & (13) & 201 & (2.7) & 203 & (3.6) & 240 & (5.4) & 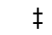 & ( & $\ddagger$ & $(t)$ & 7 & & 1 & (1 & 8 & & 2 & & \# & & $\#$ & (†) \\
\hline & 233 & $(1.6)$ & 209 & (2.1) & 206 & $(1.2)$ & 252 & (4.5) & $\ddagger$ & $(\dagger)$ & $\ddagger$ & (T) & 30 & & 14 & $(1.0$ & 50 & & 4 & & \# & & $\#$ & 7 \\
\hline Utah. & 229 & $(0.9)$ & $\ddagger$ & $(t)$ & 196 & (2.0) & $\ddagger$ & $(t)$ & $\ddagger$ & $(t)$ & $\ddagger$ & $(t)$ & 77 & $(1.3)$ & 1 & $(0.2)$ & 16 & (1.1) & 1 & $(0.2)$ & 1 & (0.2) & 1 & $(0.3)$ \\
\hline & 9 & 10 & $\ddagger$ & $(t)$ & $\ddagger$ & & t & & $\ddagger$ & $(\dagger)$ & $\ddagger$ & $(t$ & 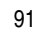 & & 2 & & 1 & & 2 & & \# & & \# & (†) \\
\hline & 236 & $(1.3)$ & 211 & (2.2) & 211 & (3.4) & 248 & $(4.0)$ & $\ddagger$ & $(\dagger)$ & $\ddagger$ & 11 & 54 & & 20 & $(1.1)$ & 12 & & 9 & (1 & \# & & $\#$ & $(\dagger)$ \\
\hline & 232 & $(1.4)$ & 211 & (3.9) & 205 & (2.6) & 243 & (3.9) & $\ddagger$ & $(\dagger)$ & & & 8 & (1 & 4 & $(0.5)$ & 21 & & 8 & & 1 & $(0.2)$ & & $(0.4)$ \\
\hline & 215 & $(0.8)$ & 203 & (3.5) & $\ddagger$ & $(t)$ & $\ddagger$ & , & $t$ & $(+t)$ & $t$ & & 2 & & 5 & & 1 & & 1 & & \# & & & 1 \\
\hline & 228 & $(1.1)$ & 193 & (3.0) & 201 & (3.5) & 223 & (3.9) & $\ddagger$ & $(t)$ & 211 & (6.6) & 71 & (1.7) & 10 & $(0.9)$ & 12 & (1.1) & 4 & $(0.4)$ & \# & (II) & 2 & $(0.7)$ \\
\hline Wyoming & 229 & $(0.6)$ & $\ddagger$ & $(\dagger)$ & 215 & (1.6) & $\ddagger$ & $(t)$ & $\ddagger$ & $(t)$ & 199 & (2.7) & 79 & $(0.4)$ & 1 & $(0.1)$ & 13 & $(0.3)$ & 1 & $(0.2)$ & $\#$ & $(\mathrm{t})$ & 4 & $(0.2)$ \\
\hline $\begin{array}{l}\text { Department of Defens } \\
\text { dependents scho }\end{array}$ & 236 & $(0.9)$ & 222 & $(1.6)$ & 228 & (1.5) & 235 & (2.5) & $\ddagger$ & $(\dagger)$ & $\ddagger$ & & 47 & (0.5) & 15 & $(0.4)$ & 19 & $(0.5)$ & 6 & $(0.3)$ & 1 & $(0.2)$ & \# & \\
\hline
\end{tabular}

†Not applicable.

\#Rounds to zero.

Reporting standards not met (too few cases for a reliable estimate).

Scale ranges from 0 to 500 .

NOTE: Includes public school students who were tested with accommodations; excludes only

those students with disabilities (SD) and English language learners (ELL) who were unable to

be tested even with accommodations. SD and ELL populations, accommodation rates, and exclusion rates vary from state to state. Race/ethnicity based on school records. Race categories exclude persons of Hispanic ethnicity. Detail may not sum to totals because of rounding and because table does not include students classified as "Two or more races."

SOURCE: U.S. Department of Education, National Center for Education Statistics, National Assessment of Educational Progress (NAEP), 2013 Reading Assessment, retrieved November 15,2013 , from the Main NAEP Data Explorer (http://nces.ed.gov/nationsreportcard/naepdata). (This table was prepared November 2013.) 
Table 221.60. Average National Assessment of Educational Progress (NAEP) reading scale score of 8th-grade public school students and percentage attaining reading achievement levels, by locale and state: Selected years, 2003 through 2013

[Standard errors appear in parentheses]

\begin{tabular}{|c|c|c|c|c|c|c|c|c|c|c|c|c|c|c|c|c|c|c|c|c|c|c|c|c|}
\hline \multirow[b]{2}{*}{ State } & \multicolumn{12}{|c|}{ Average scale score ${ }^{1}$} & \multicolumn{4}{|c|}{$\begin{array}{l}\text { Percent attaining reading } \\
\text { achievement levels, } 2013\end{array}$} & \multicolumn{8}{|c|}{ Average scale score ${ }^{1}$ by school locale, 2013} \\
\hline & \multicolumn{2}{|r|}{2003} & \multicolumn{2}{|r|}{2005} & \multicolumn{2}{|r|}{2007} & \multicolumn{2}{|r|}{2009} & & 2011 & & 2013 & $\begin{array}{l}\text { At or a } \\
B\end{array}$ & $\begin{array}{l}\text { above } \\
\text { 3asic } \\
\text { P }^{2}\end{array}$ & $\begin{array}{l}\text { At or a } \\
\text { Profic }\end{array}$ & $\begin{array}{l}\text { above } \\
\text { icient } \\
\end{array}$ & & City & & irb & & own & & Rur \\
\hline 1 & & 2 & & 3 & & 4 & & 5 & & 6 & & 7 & & 8 & & 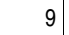 & & 10 & & 11 & & 12 & & 13 \\
\hline United & 61 & $(0.2)$ & 60 & $(0.2)$ & 261 & (0.2) & 62 & (0.3) & 264 & $(0.2)$ & 266 & $(0.2)$ & 77 & $(0.3)$ & 34 & $(0.3)$ & 260 & $(0.6)$ & 270 & $(0.4)$ & 263 & $(0.6)$ & 268 & $\overline{0.5)}$ \\
\hline bama & 33 & (1.5) & 52 & 4) & 52 & $(1.0)$ & 255 & (1.1) & 8 & (1.5) & 57 & (1.2) & 68 & (1.3) & 25 & (1.5) & 250 & (3.5) & 261 & (3.4) & 259 & (1.8) & 259 & 1.4) \\
\hline & & & 59 & & 259 & (1) & 259 & $(0.9)$ & 1 & $(0.9)$ & 1 & $(0.8)$ & 1 & (11) & 1 & & $\ddagger$ & $(\dagger)$ & $t$ & $(\dagger)$ & $\ddagger$ & $(+)$ & $\ddagger$ & (t) \\
\hline & 5 & 4) & 255 & 0) & 255 & ( & 258 & $(1.2)$ & 0 & (1.2) & 0 & 1) & 72 & 3) & 8 & $(1.5)$ & 259 & $(1.5)$ & 66 & (2.3) & 51 & $3.4)$ & 61 & \\
\hline & 258 & (1.3) & 258 & (1.1) & 258 & $(1.0)$ & 258 & $(1.2)$ & 259 & $(0.9)$ & 2 & $(1.1)$ & 73 & (1.2) & 30 & $(1.5)$ & 265 & $(1.5)$ & 261 & (2.5) & 260 & $(2.0)$ & 61 & \\
\hline lifforni & 251 & (1.3) & 250 & $(0.6)$ & 251 & $(0.8)$ & 253 & (1.2) & 255 & $(1.0)$ & 62 & $(1.2)$ & 72 & $(1.2)$ & 29 & (1.4) & 261 & $(2.0)$ & 263 & $(1.9)$ & 254 & (3.4) & 66 & .1) \\
\hline rolarado & 268 & .2) & 265 & (1.1) & 266 & $(1.0)$ & 266 & $(0.8)$ & 1 & (1.4) & 1 & (1.1) & 81 & (1.1) & 40 & $(1.5)$ & 264 & $(2.5)$ & 274 & (2.1) & 68 & 3.0) & 78 & 1.9) \\
\hline & 267 & $(1.1)$ & 264 & (13) & 267 & $(1.6$ & & $(0.9)$ & & $(0,9)$ & 4 & (1) & 3 & & 5 & $(1.3)$ & 61 & $(2.7)$ & 278 & $(1.1)$ & 32 & & 33 & 1.9) \\
\hline & 265 & $(0.7)$ & 266 & $(0.6)$ & 265 & $(0.6)$ & 265 & $(0.7)$ & 6 & $(0.6)$ & 6 & & 7 & & 3 & $(1.0)$ & 63 & $(2.2)$ & 64 & $(1.0)$ & 68 & (1.7) & 69 & .1) \\
\hline & 239 & (08) & 238 & (0.9) & 241 & $(0.7$ & & $(0$. & & $(09)$ & 8 & & 7 & & & & 48 & $(0.9)$ & $\ddagger$ & $(t)$ & $\ddagger$ & $(t)$ & $\ddagger$ & \\
\hline orida & 257 & (1.3) & 256 & (1.2) & 260 & (1.2) & 264 & (1.2) & 262 & $(1.0)$ & 66 & (1.1) & 77 & (1.2) & 33 & $(1.5)$ & 265 & $(3.0)$ & 266 & $(1.3)$ & 263 & (2.3) & 267 & 6) \\
\hline orai & 258 & .1) & 257 & .3) & 259 & $(1.0$ & 0 & $(1.0)$ & 2 & (1 & 5 & (1.2) & 75 & (1.4) & 32 & $(1.5)$ & 255 & (2.6) & 270 & (1.9) & 264 & (3.0) & 62 & 2.1) \\
\hline & 251 & 14 & 249 & (0.9) & 251 & $(0.8$ & & $(0.6)$ & & $(0.7)$ & 0 & .8) & & & & $(1.1)$ & 64 & $(1.5)$ & 61 & $(1.5)$ & 57 & .5) & 66 & .0) \\
\hline & 264 & (1) & 264 & (11) & 265 & (ng) & 5 & $(0.9)$ & & & 0 & & 82 & & & & 73 & (2. & 71 & $(1.5)$ & 88 & & 99 & (1.5) \\
\hline & 266 & $(1.0)$ & 264 & .0) & 263 & $(1.0)$ & 265 & $(1.2)$ & 6 & $(0.8)$ & 7 & $(1.0)$ & 77 & 10. & 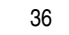 & $(1.4)^{\prime}$ & 259 & $(2.5)$ & 269 & $(1.5)$ & 68 & 1.5) & 76 & (2.8) \\
\hline Indiar & 265 & $(1.0)$ & 261 & $(1.1)$ & 264 & (1.1) & 266 & $(1.0)$ & 265 & $(1.0)$ & 267 & $(1.2)$ & 79 & $(1.2)$ & 35 & $(1.7)$ & 261 & $(2.5)$ & 269 & (2.6) & 267 & (2.2) & 271 & (1.6) \\
\hline & 268 & $(0.8)$ & 267 & (0) & 267 & $(0.9)$ & & $(0.9)$ & 265 & (1.0) & 9 & $(0.8)$ & & & & & & (2.0) & 281 & & 267 & & 270 & (1.0) \\
\hline & 0 & & 267 & & 267 & $(0$ & 2 & (1. & 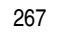 & & 7 & & & & & & 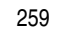 & & 5 & & & & & \\
\hline & 266 & (1.3) & 264 & 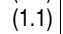 & 262 & (1.0 & 267 & $(0$. & & & 0 & & 0 & & & & 266 & (1. & 44 & & 9 & 7) & 0 & \\
\hline & 253 & (1.6) & 253 & ( & 253 & (1. & 253 & (1. & 5 & (1. & 77 & (1 & 68 & & 4 & (1 & 253 & (2. & 263 & & 54 & & 59 & 8) \\
\hline & 268 & $(1.0)$ & 270 & (1.C & 270 & $(0.8$ & 268 & $(0.7$ & 270 & $(0.8$ & 69 & $(0.8$ & 79 & (1 & 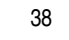 & (1. & 267 & $(2.6$ & 276 & (2 3) & 269 & (1.7) & 68 & (1) \\
\hline & 262 & (1.4) & 261 & (1.2) & 265 & (1. & 267 & (1. & & (1. & 4 & & & & & & 69 & & 274 & (1. & & & 78 & \\
\hline & 273 & & 274 & & 273 & i & 4 & (1. & & & 7 & & & & & & & (2 & & & & & & \\
\hline & 264 & (1 & 261 & & 30 & (1 & & (1. & & & 6 & & & & 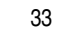 & & & (2 & & $(1.2)$ & 268 & $(z$ & 6 & 3) \\
\hline & 268 & (1 & 268 & ( & 268 & 10. & 270 & (1. & & (1 & 1 & & 82 & & & & & (2. & 4 & $(1.8)$ & 70 & ( & 2 & 9) \\
\hline ssissipp & 255 & (1.4) & 251 & (1.3) & 250 & (1.1) & 251 & $(1.0)$ & 254 & $(1.2)$ & 53 & $(1.0)$ & 64 & (1.3) & 0 & $(1.3)$ & 249 & $(4.8)$ & 258 & (2.2) & 245 & $(2.1)$ & 57 & (1. \\
\hline & 267 & $(1.0)$ & ; & (1.0) & 263 & ( & 267 & (1) & 267 & (1.1) & 267 & (1.1) & 78 & (1. & 36 & (1.4) & 257 & ( & 272 & (1.8) & 263 & (2.6) & 871 & 1.4) \\
\hline & & $i$ & 9 & & 27 & & & $(0$. & & & & & & & & & 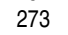 & & & & & & 2 & \\
\hline & & & 267 & & & $(0$ & & $(0$ & & & & & & & & & & & & & & & & \\
\hline & 252 & $(0.8$ & 253 & (v. & 252 & $(0.8$ & 254 & 0. & & 0. & 2 & (u & & & & & ? & (1 & & & & & 66 & (1.6) \\
\hline & 271 & $(0.9)$ & 270 & (1.2 & 270 & $(0.5$ & 271 & $(1.0)$ & 272 & $(0.7)$ & 274 & $(0.8)$ & 84 & (0.8 & . & $(1.3)$ & 260 & $(2.0)$ & 277 & (1.8) & 273 & $(1.5)$ & 278 & (1.2) \\
\hline & & & & & & & & & & & & & & & & & & & & & & & & \\
\hline & & & & & & & & & & & & & & & & & & & & & & & & \\
\hline & 5 & & 265 & & 4 & & & (1 & & & & & & & & & & & & & & & & \\
\hline & & & 258 & & 259 & & & (1. & & & & & & & & & & & & & & & & 5) \\
\hline . & 270 & $(0.8)$ & 270 & $(0.0)$ & 268 & $(0.7$ & 269 & $(0.6)$ & 269 & (0. & 268 & $(0.6)$ & 1 & (1. & 34 & $(0.9)$ & 268 & $(1.2)$ & 270 & $(2.0)$ & 268 & $(1.2)$ & 267 & $(0.8)$ \\
\hline & 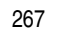 & (1.3 & $y$ & (1. & 268 & (1 & 26 & (1) & & & & & & & & & & & & & & & & \\
\hline & & & & & & & & & & & & & & & & & & & & & & & & \\
\hline & 264 & $(1$ & 263 & & 2 & & & (1 & & & & & & & & & & & & & & & & \\
\hline & 264 & (1. & 267 & & 26 & (1. & 271 & $(0$. & & (1. & & (1 & & & & & 46 & (2 & & & 3 & & 75 & $.5)$ \\
\hline & 261 & $(0.7$ & 261 & $(0$. & 258 & $(0$. & 260 & $(0.6$ & 265 & $(0.7$ & 267 & $(0.6$ & 7 & (0. & 36 & $(1.2)$ & 257 & (1. & 268 & (1. & 279 & (4 & 278 & (1.3) \\
\hline & 258 & (13) & 257 & (11) & 257 & $(0.9)$ & 257 & 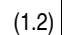 & 260 & $(0.9)$ & 261 & $(1.0$ & & & 29 & & 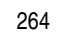 & 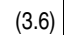 & 262 & (1.9) & 258 & & & \\
\hline & & & & & 270 & & ) & & & & & & & & & & & & & & & & 8 & \\
\hline & 258 & & 259 & & 259 & & & (1 & & & & & & & & & & & & & & & & \\
\hline & 259 & & 25 & & 261 & & & (1 & & & & & & & & & & & & & & & & \\
\hline & 264 & $(0.8$ & 262 & (0 & 262 & (1) & 266 & $(0.8$ & 267 & $(0.8$ & 0 & (0. & & (1 & 39 & (1. & 272 & $(3.1)$ & 271 & $(1.0)$ & 265 & $(2.0)$ & 270 & (2.2) \\
\hline & & & & & & & & & & & & & & & & & & & & & & & & \\
\hline & & & & & & & & & & & & & & & & & & & & & & & & \\
\hline & 264 & $(0$. & 265 & & 265 & 10 & 2 & (1. & 3 & (1 & & & & & & & 270 & & 275 & & 0 & & 0 & .0) \\
\hline & & & & & 255 & & & & & & & & & & & & & & & & & & & \\
\hline & 266 & $(1.3$ & 266 & (1.1 & 264 & (1. & 266 & $(1.0)$ & 267 & 10. & 268 & $(0.9$ & 78 & (0. & 6 & (1. & 257 & $(2.0)$ & 273 & (2.3) & 272 & (1.6) & 269 & (1.6) \\
\hline & 267 & $(0.5)$ & 268 & $(0.7$ & 266 & $(0.7$ & 268 & $(1.0)$ & 270 & (1.0 & 271 & $(0.6$ & 84 & $(0.7$ & 38 & $(1.0$ & 272 & (1.1 & t & & 272 & $(1.0)$ & 268 & (1.2) \\
\hline & & & & & & & & & & & & & & & 5 & & 266 & & & & & & 75 & \\
\hline & & & & & & & & & & & & & & & & & & & & & & & & \\
\hline
\end{tabular}

†Not applicable.

†Reporting standards not met. Either there are too few cases for a reliable estimate or item response rates fell below the required standards for reporting.

'Scale ranges from 0 to 500 .

${ }^{2}$ Basic denotes partial mastery of the knowledge and skills that are fundamental for proficient work at the 8th-grade level.

${ }_{3}^{3}$ Proficient represents solid academic performance for 8th-graders. Students reaching this level have demonstrated competency over challenging subject matter.

${ }^{4}$ Did not satisfy one or more of the guidelines for school participation in 2003. Data are subject to appreciable nonresponse bias.

${ }^{5}$ Prior to 2005, NAEP divided the Department of Defense (DoD) schools into two jurisdictions, domestic and overseas. In 2005, NAEP began combining the DoD domestic and overseas schools into a single jurisdiction. Data shown in this table for 2003 were recalculated for comparability.

NOTE: Includes public school students who were tested with accommodations; excludes only those students with disabilities (SD) and English language learners (ELL) who were unable to be tested even with accommodations. SD and ELL populations, accommodation rates, and exclusion rates vary from state to state.

SOURCE: U.S. Department of Education, National Center for Education Statistics, National Assessment of Educational Progress (NAEP), 2003, 2005, 2007, 2009, 2011, and 2013 Reading Assessments, retrieved November 8, 2013, from the Main NAEP Data Explorer (http://nces.ed.gov/nationsreportcard/naepdata/). (This table was prepared November 2013.) 
Table 221.70. Average National Assessment of Educational Progress (NAEP) reading scale scores of 4th- and 8th-graders in public schools and percentage scoring at or above selected reading achievement levels, by English language learner (ELL) status and state: 2013

[Standard errors appear in parentheses]

\begin{tabular}{|c|c|c|c|c|c|c|c|c|c|c|c|c|c|c|c|c|c|c|c|c|c|c|c|}
\hline \multirow[b]{4}{*}{ State } & \multicolumn{11}{|c|}{ 4th-graders } & \multicolumn{12}{|c|}{ 8th-graders } \\
\hline & \multicolumn{5}{|c|}{ English language learners } & \multicolumn{6}{|c|}{ Not English language learners } & \multicolumn{7}{|c|}{ English language learners } & \multicolumn{5}{|c|}{ Not English language learners } \\
\hline & \multirow{2}{*}{\multicolumn{2}{|c|}{$\begin{array}{r}\text { Percent } \\
\text { of all } \\
\text { students } \\
\text { assessed }\end{array}$}} & & Perc & & & & & Perc & cent & & & & & & Perc & & & & & Perc & & \\
\hline & & & $\begin{array}{r}\text { Average } \\
\text { scale } \\
\text { score }^{1}\end{array}$ & $\begin{array}{r}\text { At or } \\
\text { above } \\
\text { Basic }^{2}\end{array}$ & $\begin{array}{r}\text { At or } \\
\text { above } \\
\text { Proficient }\end{array}$ & & $\begin{array}{c}\text { erage } \\
\text { scale } \\
\text { core }\end{array}$ & & $\begin{array}{r}\text { At or } \\
\text { above } \\
\text { Basic }\end{array}$ & Profic & $\begin{array}{l}\text { At or } \\
\text { above } \\
\text { icient }\end{array}$ & & $\begin{array}{l}\text { of all } \\
\text { tudents } \\
\text { sessed }\end{array}$ & $\begin{array}{r}\text { Average } \\
\text { scale } \\
\text { score }^{1}\end{array}$ & & \begin{tabular}{|} 
At or \\
above \\
Basic
\end{tabular} & $\begin{array}{r}a \\
\text { Profic }\end{array}$ & $\begin{array}{l}\text { At or } \\
\text { bove } \\
\text { ient }\end{array}$ & $\begin{array}{r}\text { Average } \\
\text { scale } \\
\text { score }^{1}\end{array}$ & & \begin{tabular}{|l} 
At or \\
above \\
asic
\end{tabular} & & $\begin{array}{l}\text { At or } \\
\text { above } \\
\text { icient }{ }^{3}\end{array}$ \\
\hline 1 & & 2 & 3 & 4 & 5 & & 6 & & 7 & & 8 & & 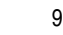 & 10 & & 11 & & 12 & 13 & & 14 & & 15 \\
\hline United Sta & & $(0.3)$ & $187(0.7)$ & $31(0.8)$ & $7(0.4)$ & 225 & (0.3) & & (0.3) & & $(0.4)$ & & $(0.1)$ & $25(0.9)$ & 30 & (1.4) & & (0.4) & $68(0.2)$ & 79( & (0.3) & & $(0.3)$ \\
\hline 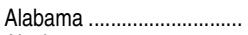 & & $(0.5)$ & $\neq(\dagger)$ & & & 9 & (1.2) & & $(1.5)$ & & & & $1(0.2)$ & & $\ddagger$ & $(\dagger)$ & $\ddagger$ & $(t)$ & $58(1.2)$ & & & 25 & 15 \\
\hline & & $(0.9)$ & $154(3.0)$ & $10(2.3)$ & $1(0.6)$ & 218 & (1.0) & & (1.3) & 2 & (1.3) & 11 & $1(0.7)$ & $14 \quad(2.5)$ & 16 & $(2.9)$ & 1 & (†) & 57( & $B($ & & 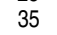 & \\
\hline & & $(0.9)$ & $159(4.4)$ & $8(2.4)$ & & 217 & (1.2) & & (1.5) & 30 & (1.4) & & $1(0.2)$ & $\ddagger \quad(t)$ & $\ddagger$ & $(t)$ & $\ddagger$ & $\left(\begin{array}{l}(t) \\
(\dagger)\end{array}\right.$ & $51(1$ & 3( & (1.3) & 28 & \\
\hline & & $(0.8)$ & $202(2.8)$ & $47(3.8)$ & 17 (2.6) & & (1.0) & & (1.2) & 33 & (1.4) & & $6(0.5)$ & $45 \quad(3.2)$ & 55 & $(4.7)$ & & (3.8) & & 74( & (1.2) & 31 & \\
\hline aliforni & & & $182(1.8)$ & $26(1.8)$ & $5(0.8)$ & 223 & $(1.1)$ & & $(1.4)$ & 34 & (1.5) & 12 & $2(0.9)$ & $220(2.2)$ & 23 & (3.5) & & (1.0) & $267(1.2)$ & 79 & (1.1) & 33 & (1.4) \\
\hline & 4 & (1.1) & $2(2.3)$ & $37(2.9)$ & $8(1.6)$ & 2 & (1.0) & & (1.2) & 6 & (1.7) & & $8(0.8)$ & $32(2.5)$ & 37 & 4.4) & & (1.5) & $4(1-2)$ & & & 13 & 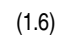 \\
\hline & & (0.4) & $181(4.0)$ & $25(5.1)$ & 4( & 2 & ( & & (1.2) & 5 & & & & $222(5.7)$ & 27 & & & & 610 & & & 47 & \\
\hline & & $(0.2)$ & $184(5.5)$ & 24 (6.7) & 4 & 227 & (0.7) & & (1.1) & 9 & (1 & & $1(0.2)$ & $\neq \quad(t)$ & $\ddagger$ & $(t)$ & $\ddagger$ & t) & 7 & & & 34 & \\
\hline & 6 & $(0.3)$ & $182(3.7)$ & $23(4.8)$ & $5(2.6)$ & 207 & $(0.9)$ & & (1.2) & 4 & $(0$ & & $5(0.4)$ & $218(3.9)$ & 25 & (5.4) & & $\begin{array}{lll}(t) \\
(\dagger)\end{array}$ & $49(0.9)$ & 59( & (1.3) & 18 & \\
\hline Florid & & $(0.8)$ & $199(2.4)$ & $\begin{array}{ll}41 & (3.7)\end{array}$ & $10(1.9)$ & 230 & $(1.0)$ & & (1.1) & 42 & (1.5) & & $4(0.3)$ & 226 (3.3) & 30 & $(4.8)$ & & (1.4) & 268 (1.1) & 79 & (1.2) & 35 & $(1.5)$ \\
\hline & & $(0.6)$ & $189(4.5)$ & $29(5.9)$ & $8(3.5)$ & 3 & $(1$ & & & 5 & & & $2(0.4)$ & 0( & 21 & & & & 65 & & & 2 & \\
\hline & & $(0.6)$ & $166(3.5)$ & $14(2.9)$ & 31 & 219 & $(1$ & & ( & & & 10 & & $4(2.4)$ & 9 & & & & & & & & \\
\hline & & $(0.5)$ & $170(4.2)$ & 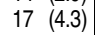 & $3(1$ & 222 & 10 & & ( & 4 & $(1$. & & $3(0.4)$ & $22(3.8)$ & 21 & & 2 & & 72 & 84( & & 9 & \\
\hline & & $(0.7)$ & $174(2.8)$ & 18 (3.1) & $3(1.7)$ & 222 & (1.4) & 68 & (1.6) & 36 & $(1.5$ & & $5(0.5)$ & $219(3.8)$ & 23 & & 1 & 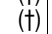 & $69(1.0)$ & 80 & (1.0) & 38 & \\
\hline & & $(0.8)$ & $203(3.5)$ & $\begin{array}{ll}48 & (5.0)\end{array}$ & $13(3.1)$ & 227 & (1.1) & & (1.2) & 39 & (1.6) & & $3(0.4)$ & 236 (4.6) & 40 & $(6.0)$ & & (2.3) & 268 (1.1) & & (1.3) & 36 & $(1.8)$ \\
\hline & & $(0.8)$ & $195(5.2)$ & $41 \quad(6.4)$ & $11 \quad(2.8)$ & 225 & $(1.2)$ & 3 & & 9 & $(1$ & & $2(0.3)$ & $6(3.9)$ & 27 & (6.9) & 2 & & $70(0$ & & & 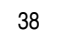 & \\
\hline & & (1) & 00 & & 7 & 226 & & & & 1 & & & $\begin{array}{ll}8 & (1.3) \\
\end{array}$ & $5(24)$ & 5 & & 13 & (2.3) & 9 & & & & \\
\hline & & $(0.3)$ & $197(6.0)$ & 41 & 11 & 225 & $(1.2)$ & 72 & & 7 & $(1$ & & $1(0.2)$ & $237(4.5)$ & 43 & & 5 & t) & $0(0$ & & & 8 & \\
\hline & & (0.3) & $202 \quad(4.7)$ & $\begin{array}{ll}47 & (7.8)\end{array}$ & $10(5.2)$ & 211 & $(1$ & 57 & $(1$ & 3 & $(1$ & & $1(0$ & $\neq \quad(t)$ & $\ddagger$ & $(t$ & $\ddagger$ & & $58(1$ & 68 & (1.4) & 4 & 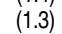 \\
\hline & & $(0.3)$ & $190(6.5)$ & $35(8.0)$ & $9(4.9)$ & 226 & $(0.9)$ & 72 & (1.0) & 38 & $(1$. & & $2(0$ & $\begin{array}{lll}t & (t+1)\end{array}$ & $\ddagger$ & $(t)$ & $t$ & & $270(0.8)$ & 79 & (1.0) & 39 & 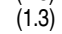 \\
\hline & 4 & )) & $207(5.0)$ & $51(7.1)$ & $18(4$ & 233 & 1 & 78 & ( & 6 & $(1$ & & $1(0$ & & $\ddagger$ & & & & 274 & & & 13 & \\
\hline & & & $192(4.3)$ & 40 & & 237 & & & & 1 & & & & $24 \quad(3.0)$ & 28 & & & & & & & & \\
\hline & & (1.6) & $194 \quad(4.3)$ & $\begin{array}{ll}39 & (5.8)\end{array}$ & 9 & 219 & $(1$ & 6 & $(1$ & 2 & & & $3(0.7)$ & $232(5.3)$ & 41 & & 8 & & 1 & & & 4 & \\
\hline & & $(0.9)$ & $188 \quad(2.9)$ & $\begin{array}{ll}33 & (4.7)\end{array}$ & $8(1$. & 230 & $(1$ & & & 44 & $(1$ & & $5(0)$ & 231 & 40 & & 6 & (2) & $73(1$ & & & & \\
\hline ISS & & $(0.3)$ & $\neq \quad(t)$ & $\ddagger(t)$ & $\ddagger$ & 209 & $(1.0)$ & 54 & (1.3) & 21 & $(1.0$ & & $1(0$ & $\neq \quad(t)$ & $\ddagger$ & $(t)$ & & $(t)$ & $253(1.0)$ & 64 & $(1.3$ & 20 & \\
\hline & & $(0$ & $(4.0)$ & 37 & $6(3$ & 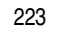 & $(1$ & & ( & & & & 1( & $\ddagger$ & $\ddagger$ & & + & & 267 & & & & \\
\hline & & $(0.5)$ & 174 (4.3) & $16(4.6)$ & 2( & 225 & $(0$ & tit & $(1$ & 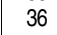 & & & & $\ddagger$ & $\ddagger$ & $(\dagger$ & $\ddagger$ & & 2 & & & & \\
\hline & & $(0.6)$ & 190 & 34 & 7 & 226 & & 7 & & 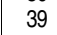 & & & & & $\ddagger$ & & & & & & & 7 & \\
\hline & 22 & (1.2) & $185(1.6)$ & $\begin{array}{ll}30 & (2.5)\end{array}$ & $6(1$ & 222 & & 71 & $(1$ & 33 & $(1$ & & $7(0.4)$ & 217 (2.5) & 21 & & & (1.4) & 265 & $76 i$ & & 3 & \\
\hline lew $F$ & & $(0.4)$ & $196(5.7)$ & $\begin{array}{ll}34 & (7.3)\end{array}$ & $10(4.6)$ & 233 & $(0.9)$ & 81 & (1.0) & 45 & $(1.5$ & & $2(0.2)$ & $\begin{array}{l}\ddagger \\
(t)\end{array}$ & $\ddagger$ & $(t)$ & $\ddagger$ & $(t)$ & $275(0.8)$ & 85 & $(0.8$ & 44 & \\
\hline & & $(0.5)$ & $1 \varepsilon$ & 33 & 9 & & & & & & & & 1 & & $\ddagger$ & & & & & & & & \\
\hline & & & 168 & 16 & & & & & & & & 13 & & $224 \quad(1.7)$ & 29 & & & & & & & & \\
\hline & & $(0.5)$ & $182(2$ & 25 & & 7 & & & & ) & & & & $\begin{array}{ll}5 & (2.7)\end{array}$ & 20 & & 1 & & & & & & \\
\hline & & $(0.7)$ & $183(3.4)$ & $23(3.8)$ & $4(1$. & 225 & & 72 & $(1$ & 37 & (1. & & $4(0)$ & $232(3.6)$ & 41 & & & (3 & & & & & \\
\hline North & 2 & $(0.2)$ & $\neq(t)$ & $\neq(t)$ & $\ddagger$ & 225 & $(0.5)$ & 74 & $(0.9)$ & 34 & $(0.9$ & & $2(0.2)$ & $\neq \quad(t)$ & $\ddagger$ & $(t)$ & $\ddagger$ & & $269(0.6)$ & 82( & $(1$. & 35 & 10 \\
\hline & & $(0.5)$ & & & 19 & & & & & & & & & & & & & & & & & & \\
\hline & & & 1 & & & & & & & & & & & 2 & & & 6 & & & & & & \\
\hline & 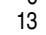 & (0.9) & $183(2$. & 2 & 6( & 225 & & & ( & & & & ( & $(4.5)$ & & & 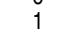 & & & & & & \\
\hline & 2 & $(0.3)$ & $181 \quad(7.4)$ & $\begin{array}{ll}27 & (6.9)\end{array}$ & $5(2$ & 227 & $(1$ & 74 & $(1$ & 41 & $(1$. & & $2(0.4)$ & $222(5.2)$ & 26 & & & (1. & $2 t$ & & & & \\
\hline she & & $(0.5)$ & $168(3.5)$ & $17(3.4)$ & $4(2$. & 226 & $(0.9)$ & 73 & (1.1) & 40 & $(1$. & & $4(0.3)$ & $216(3.5)$ & 20 & (4.4) & 3 & (2.0) & $269(0.6)$ & 79 & 10 & 37 & \\
\hline & & $(0$. & 206 & $54(5$ & 18( & & & & & & & & & $242(4.3)$ & 54 & & 10 & & & & & & \\
\hline & & & & & & & & & & & & & & & $t$ & & t & & & & & & \\
\hline & & $(0.4)$ & $174(5.4)$ & $19(4.6)$ & & 221 & & & $(1$ & 5 & & & $1(0.2)$ & & + & & & & 266 & & & & \\
\hline & 22 & $(1.6)$ & $194(1.4)$ & $36(2$. & $9(1$. & 223 & & & $(1$ & 34 & $(1$ & & $7(0.7)$ & $227 \quad(2.6)$ & 32 & & 2 & (1.3) & 26 & & & & \\
\hline & & $(0.6)$ & 159 (3.6) & $9(2.9)$ & $2(1.3)$ & 226 & $(1.0)$ & 74 & (1.2) & 39 & $(1.4$ & & $3(0.4)$ & $220(3.3)$ & 21 & $(5.1)$ & 3 & (1.9) & $272(0.9)$ & $83 i$ & (1.0) & 40 & (1. \\
\hline & & & & & & 229 & & & & & & & & & $\ddagger$ & & & & & & & & \\
\hline & & & 186 & 28 & & & & & & 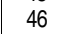 & & & & (3.6) & $T^{\top}$ & & & & & & & & \\
\hline & & $(0.8)$ & $179(2.9)$ & $20(3$ & $3(1.4)$ & 229 & & & $(1$ & 3 & $(1$ & & $5(0.6)$ & $222(4.7)$ & 26 & I & 3 & $(2$ & 8 & & & & \\
\hline & & $(0.3)$ & 10 & $\ddagger$ & & 215 & & & & & & & 1 & -17 & $\ddagger$ & & 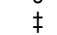 & & 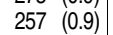 & & & & \\
\hline & & $(0.8)$ & $190(2.8)$ & $34(4$ & 9( & 223 & & & $(1$ & 37 & & & $5(0.4)$ & $242(2.9)$ & 51 & $(4.3)$ & 9 & (2.7) & $269(1.0)$ & & & & \\
\hline Wy & & $(0.2)$ & $196(3.9)$ & $37(6.8)$ & $9(4.4)$ & 227 & $(0.5)$ & 76 & $(1.0)$ & 38 & $(1.0)$ & & $2(0.2)$ & $\ddagger \quad(t)$ & $\ddagger$ & $(t)$ & $\ddagger$ & $(t)$ & $272(0.6)$ & 85 & $(0.8)$ & 38 & $(1.0)$ \\
\hline dependents school & 5 & $(0.3)$ & $216(2.5)$ & $63(4.7)$ & $20(4.0)$ & 233 & $(0.6)$ & 83 & $(0.9)$ & 44 & (1.1) & & $3(0.3)$ & $244(3.7)$ & 52 & (7.4) & 6 & (3.8) & $278(0.7)$ & 91( & $(0.8)$ & 46 & $(1.2$ \\
\hline
\end{tabular}

†Not applicable.

\#Rounds to zero.

†Reporting standards not met (too few cases for a reliable estimate).

${ }^{1}$ Scale ranges from 0 to 500 .

${ }^{2}$ Basic denotes partial mastery of the knowledge and skills that are fundamental for proficient work at a given grade.

${ }^{3}$ Proficient represents solid academic performance. Students reaching this level have demonstrated competency over challenging subject matter.
NOTE: The results for English language learners are based on students who were assessed and cannot be generalized to the total population of such students. Although testing accommodations were permitted, some English language learners did not have a sufficient level of English proficiency to participate in the 2013 Reading Assessment.

SOURCE: U.S. Department of Education, National Center for Education Statistics, National Assessment of Educational Progress (NAEP), 2013 Reading Assessment, retrieved November 8, 2013, from the Main NAEP Data Explorer (http://nces.ed.gov/nationsreport card/naepdata). (This table was prepared November 2013.) 
Table 221.75. Average National Assessment of Educational Progress (NAEP) reading scale score and standard deviation, by selected student characteristics, percentile, and grade: Selected years, 1992 through 2013

[Standard errors appear in parentheses]

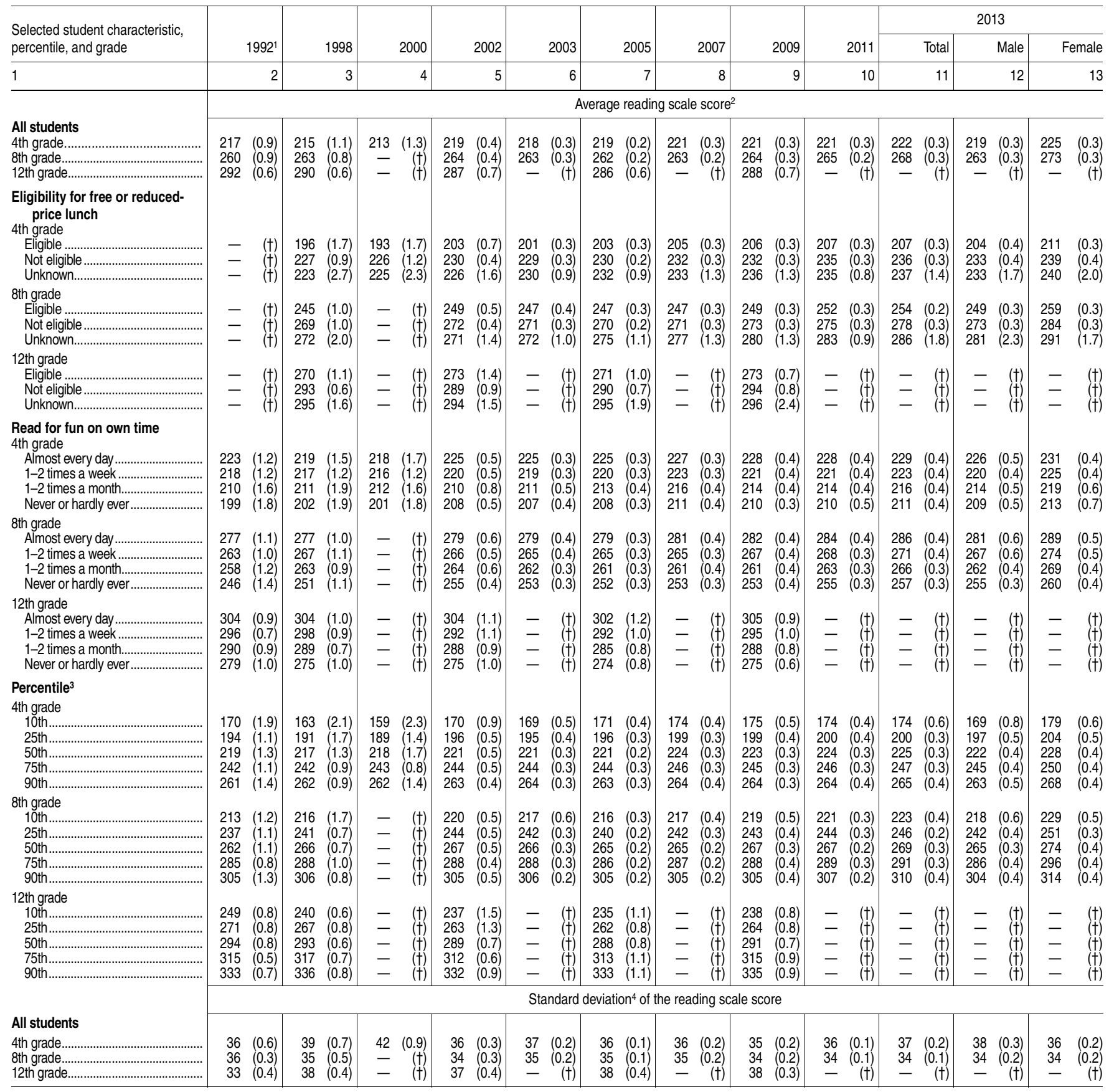

\section{-Not available.}

†Not applicable.

${ }^{1}$ Accommodations were not permitted for this assessment.

2Scale ranges from 0 to 500 .

The percentile represents a specific point on the percentage distribution of all students ranked by their reading score from low to high. For example, 10 percent of students scored at or below the 10th percentile score, while 90 percent of students scored above it.

${ }^{4}$ The standard deviation provides an indication of how much the test scores varied. The lower the standard deviation, the closer the scores were clustered around the average score. About two-thirds of the student scores can be expected to fall within the range of one standard deviation above and one standard deviation below the average score. For example, the average score for all 4th-graders in 2013 was 222, and the standard deviation was 37 . This means that we would expect about two-thirds of the students to have scores between 259 (one standard deviation above the average) and 185 (one standard deviation below). Standard errors also must be taken into account when making comparisons of these ranges.

NOTE: Includes public and private schools. For 1998 and later years, includes students tested with accommodations ( 1 to 11 percent of all students, depending on grade level and year); excludes only those students with disabilities and English language learners who were unable to be tested even with accommodations ( 2 to 6 percent of all students). On the student questionnaire, the format of the question about reading for fun on your own time changed slightly beginning with the 2002 assessment year. In 1992 through 2000, reading for fun was one of several activities included in the same question ("How often do you do each of the following?"), and the response options were listed in order from most frequent to least frequent (that is, "Almost every day" was listed first, and "Never or hardly ever" was listed last); in 2002 through 2011, reading for fun was the only activity in the question, and the order of the response options was reversed. Grade 12 results for the 2013 NAEP Reading Assessment were not yet available at the time this table was created.

SOURCE: U.S. Department of Education, National Center for Education Statistics, National Assessment of Educational Progress (NAEP), 1992, 1998, 2000, 2002, 2003, 2005, 2007, 2009, 2011, and 2013 Reading Assessments, retrieved November 19, 2013, from the Main NAEP Data Explorer (http://nces.ed.gov/nationsreportcard/naepdata/). (This table was prepared November 2013.) 
240 CHAPTER 2: Elementary and Secondary Education

Reading Achievement

Table 221.80. Average National Assessment of Educational Progress (NAEP) reading scale scores of 4th- and 8th-grade public school students and percentage attaining reading achievement levels, by race/ethnicity and jurisdiction or specific urban district: 2009, 2011, and 2013

[Standard errors appear in parentheses]

\begin{tabular}{|c|c|c|c|c|c|c|c|c|c|c|c|c|c|c|c|c|c|c|c|c|c|c|c|c|c|c|}
\hline \multirow[b]{3}{*}{$\begin{array}{l}\text { Grade level and jurisdiction } \\
\text { or specific urban district }\end{array}$} & \multicolumn{22}{|c|}{ Average reading scale score ${ }^{1}$} & \multirow{2}{*}{\multicolumn{4}{|c|}{$\begin{array}{c}\text { Percent of students } \\
2013\end{array}$}} \\
\hline & \multicolumn{2}{|c|}{2009} & \multicolumn{10}{|c|}{2011} & \multicolumn{10}{|c|}{2013} & & & & \\
\hline & & $\begin{array}{r}\text { All } \\
\text { dents }\end{array}$ & stud & $\begin{array}{r}\text { All } \\
\text { ents }^{2}\end{array}$ & & White & & Black & & panic & & Asian & stud & $\begin{array}{r}\text { All } \\
\text { ents }^{2}\end{array}$ & & White & & Black & His & nic & & Asian & $\mathrm{Ba}$ & $\begin{array}{l}\text { ove } \\
\text { sic }^{3} \\
\end{array}$ & & $\begin{array}{l}\text { ove } \\
\text { ent }{ }^{4}\end{array}$ \\
\hline 1 & & 2 & & 3 & & 4 & & 5 & & 6 & & 7 & & 8 & & 9 & & 10 & & 11 & & 12 & & 13 & & 14 \\
\hline \multicolumn{27}{|l|}{ 4th grade } \\
\hline United Stat & 220 & $(0.3)$ & 220 & $(0.3)$ & 230 & $(0.3)$ & 205 & $(0.4)$ & 205 & $(0.5)$ & 236 & (1.3) & 221 & $(0.3)$ & 231 & $(0.3)$ & 205 & $(0.5)$ & 207 & (0.5) & 237 & $(1.1)$ & 77 & (0.3) & 34 & $(0.3)$ \\
\hline All large cities & 210 & $(0.7)$ & 211 & $(0.7)$ & 232 & $(0.9)$ & 202 & $(0.7)$ & 203 & $(0.8)$ & 225 & (2.5) & 212 & $(0.7)$ & 235 & $(1.0)$ & 202 & $(0.8)$ & 204 & $(0.8)$ & 229 & $(2.5)$ & 7 & ).8) & 6 & $(0.7)$ \\
\hline \multicolumn{27}{|l|}{ Selected urban districts ..... } \\
\hline & - & $(\dagger)$ & 209 & (1.6) & 231 & (2.5) & $\ddagger$ & $(\dagger)$ & 201 & (1.7) & $\ddagger$ & $(t)$ & 207 & (1.5) & 232 & (2.4) & $\ddagger$ & $(\dagger)$ & 199 & (1.7) & $\ddagger$ & $(\dagger)$ & 54 & (1.7) & 24 & (1.5) \\
\hline Atlant & 209 & $(1.5)$ & 212 & $(1.4)$ & 251 & (1.9) & 203 & $(1.6)$ & 215 & (3.4) & $\ddagger$ & $(t)$ & 214 & (1.3) & 252 & (1.9) & 204 & (1.4) & 208 & & $\ddagger$ & $(t)$ & 57 & .6) & 27 & \\
\hline 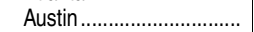 & 220 & (1.8) & 224 & (2.3) & 249 & (3.3) & 215 & (4.5) & 210 & (2.6) & $\ddagger$ & $(t)$ & 221 & (1.6) & 250 & (2.2) & 206 & (5.4) & 208 & (2.1) & $\ddagger$ & $(t)$ & 5 & 7) & 6 & 1) \\
\hline$\ldots$ & 202 & $(1.7)$ & 200 & (1.7) & 221 & (3.3) & 198 & $(1.7)$ & $\ddagger$ & $(t)$ & $\ddagger$ & $(t)$ & 204 & (1.6) & 233 & (5.2) & 201 & $(1.7)$ & $\ddagger$ & $(t)$ & $\ddagger$ & $(t)$ & 5 & (2.2) & 4 & 4) \\
\hline Bostor & 215 & (1.2) & 217 & $(0.8)$ & 241 & (2.5) & 211 & $(1.7)$ & 214 & (1.1) & 226 & (3.8) & 214 & (1.1) & 237 & (2.2) & 205 & (1.9) & 210 & (1.7) & 234 & (3.3) & 1 & (1.4) & 26 & 3) \\
\hline Charlotte & 225 & (1.6) & 224 & (1.2) & 244 & (1.5) & 211 & (1.9) & 212 & (2.6) & 233 & (5.3) & 226 & (1.6) & 245 & (1.8) & 215 & (2.0) & 212 & (2.9) & 238 & (4.9) & 72 & (1.8) & 40 & (1.9) \\
\hline & 202 & (1.5) & 203 & & 229 & (2.4) & 197 & (1.9) & 201 & (1.5) & 228 & (4.2) & 206 & (1.6) & 23 & (4.1) & 198 & (2.5) & 203 & (1.6) & 235 & (4.7) & 51 & .6) & 0 & \\
\hline Cle & 194 & (2.0) & 193 & (0. & 209 & (2.6) & 187 & (1.1) & 196 & (3.3) & $\ddagger$ & $(t)$ & 190 & (1.9) & 206 & (3.7) & 185 & (2.2) & 191 & (4.1) & $\ddagger$ & $(t)$ & 3 & 2) & 9 & \\
\hline $\mathrm{Dc}$ & - & $(t)$ & 204 & $(1.6$ & 237 & (6.9) & 204 & $(2.0)$ & 200 & (1.4) & $\ddagger$ & $(t)$ & 205 & (1.4) & 231 & (4.9) & 201 & (2.1) & 204 & $(1.8)$ & $\ddagger$ & $(t)$ & 9 & (2.1) & 16 & 5) \\
\hline Detro & 187 & (1.9) & 191 & (2. & $\ddagger$ & $(t)$ & 190 & $(2.5)$ & 199 & (5.5) & $\ddagger$ & $(t)$ & 190 & (2.2) & $t$ & $(t)$ & 188 & (2.6) & 199 & (3.4) & $\ddagger$ & $(\dagger)$ & 0 & (2.7) & 7 & 3) \\
\hline District of Columbia & 203 & (1.2) & 201 & $(1.0)$ & 255 & (3.0) & 191 & (1.3) & 204 & (3.3) & $\ddagger$ & (†) & 206 & (1.2) & 260 & (2.6) & 192 & (1.4) & 211 & (2.6) & $\ddagger$ & $(†)$ & 49 & (1.4) & 25 & (1.0) \\
\hline $\mathrm{Fr}$ & 197 & $(1.7)$ & 194 & (2. & 216 & (3.9) & 191 & (4.3) & 190 & (2.5) & 195 & (3.0) & 196 & (1.7) & 218 & (2.9) & 187 & (3.0) & 192 & & 199 & (3.0) & 9 & $.9)$ & 3 & \\
\hline Hillsbc & - & $(t)$ & 231 & (1. & 242 & (1.8) & 218 & $(2.5)$ & 223 & (2.1) & $\ddagger$ & $(t)$ & 228 & (1.3) & 237 & $(1.8)$ & 214 & (3.1) & 223 & (1.6) & 247 & $(4.0)$ & 5 & .4) & 0 & \\
\hline ....... & 211 & $(1.7)$ & 213 & (1. & 243 & (3.0) & 207 & $(1.7)$ & 209 & (1.6) & 245 & (6.3) & 208 & (1 & 23 & (3.3) & 202 & (2.7) & 20 & & 245 & (4.7) & & 6) & 9 & \\
\hline Jeffers & 219 & (1.8) & 223 & $(1.3$ & 230 & (1.4) & 208 & (2.1) & 221 & (3.9) & 256 & (5.7) & 221 & $(1.2)$ & 23 & $(1.7)$ & 203 & $(1.9)$ & 221 & (3.5) & $\ddagger$ & $(t)$ & 6 & (1.6) & 33 & (1.6) \\
\hline Los Angeles & 197 & (1.1) & 201 & (1.2) & 225 & (3.7) & 196 & (4.2) & 196 & (1.1) & 226 & (4.2) & 205 & (1.6) & 237 & (3.4) & 204 & (2.9) & 199 & (1.3) & 222 & $(4.3)$ & 50 & (1.9) & 19 & (1.7) \\
\hline & 221 & (1.2) & 221 & & 240 & & 210 & (2.1) & 222 & (1.8) & $\ddagger$ & $(t)$ & 223 & (1.5) & 25 & (2.8) & 209 & (2.2) & 225 & (1) & $\ddagger$ & $(t)$ & 0 & .7) & 5 & \\
\hline. & 196 & $(2.0)$ & 195 & (1. & 216 & (3.9) & 187 & $(2.0)$ & 198 & (2.7) & 206 & (3.3) & 199 & (1.9) & 223 & (3.8) & 190 & (2.3) & 200 & (2.6) & 201 & (8.2) & & 1) & 5 & B) \\
\hline & 217 & (1.4) & 216 & & 2 & & 2 & (1.7) & 2 & $(1$ & 230 & & 216 & & & (3.1) & 210 & (1.8) & 20 & & 233 & (3.2) & & 6) & 8 & \\
\hline & 195 & (1.8) & 19 & (1. & 21 & & 19 & (1.9) & 15 & (3.5) & 212 & 5 & 200 & & 2 & (3.2) & 196 & $(2$. & 19 & (3 & 215 & (4.9) & & .2) & 4 & 7) \\
\hline San Diego. & 213 & (2.1) & 215 & & & & 205 & (3.0) & 201 & & 225 & (3.3) & 218 & (1.6) & 240 & (2.2) & 205 & (4.0) & 204 & (2 & 229 & (3.9) & 84 & (2.0) & 3 & 8) \\
\hline \multicolumn{27}{|l|}{ 8th grade } \\
\hline & 262 & $(0.3)$ & 264 & & & & 248 & $(0.5)$ & 251 & (0.5) & 277 & 1) & 26 & & & (0.2) & 250 & $(0.4)$ & 255 & & 280 & $(1.0)$ & & .3) & 34 & $(0.3)$ \\
\hline All large cities .. & 252 & $(0.5)$ & 255 & & & $(1.0)$ & 245 & $(0.8)$ & 249 & $(0.8)$ & 271 & (1.5) & 258 & $(0.8)$ & 276 & $(1.0)$ & 246 & $(0.9)$ & 253 & $(0.7)$ & 273 & $(2.8)$ & 68 & $(0.7)$ & 6 & $(0.9)$ \\
\hline & & & & & & & & & & & & & & & & & & & & & & & & & & \\
\hline & - & $(\dagger)$ & 254 & (1.2) & 271 & (2.2) & $\ddagger$ & $(t)$ & 248 & (1.6) & $\ddagger$ & $(\mathrm{t})$ & 256 & $(1.0)$ & 27 & (2.6) & $\ddagger$ & $(t)$ & 250 & (1. & $\ddagger$ & (†) & 36 & (1.5) & 3 & (1.4) \\
\hline & 250 & (1.5) & 253 & & & & 249 & (1.2) & & $(t)$ & $\ddagger$ & (†) & 255 & & & (2.8) & 249 & (1.2) & 254 & (4.5) & $\ddagger$ & $(\dagger)$ & $\beta$ & .5) & 2 & \\
\hline & 261 & (2.0) & 261 & & 285 & (1.8) & 246 & $(3.6)$ & 251 & (2.2) & $\ddagger$ & $(\mathrm{t})$ & 261 & (1.4) & 286 & (2.9) & 245 & $(3.5)$ & 251 & (1.6) & $\ddagger$ & $(t)$ & 0 & (1.5) & 1 & .1) \\
\hline & 245 & (1.7) & 246 & (1. & 267 & (3.7) & 242 & $(1.7)$ & $\ddagger$ & $(t)$ & $\ddagger$ & $(t)$ & 252 & (1.5) & 275 & (5.6) & 249 & $(1.5)$ & $\ddagger$ & $(t)$ & $\ddagger$ & $(t)$ & 1 & (2.7) & 6 & (1.8) \\
\hline Boston & 257 & (1.5) & 255 & (1. & 281 & (4.3) & 246 & $(2.0)$ & 245 & (2.3) & 280 & (3.4) & 257 & $(1.0)$ & 281 & (2.8) & 247 & $(1.8)$ & 250 & (1.5) & 278 & $(3.5)$ & 66 & $(1.5)$ & 28 & (1.3) \\
\hline $\mathrm{Cl}$ & 259 & (1.0) & 265 & & 28 & (1. & 253 & $(1.6)$ & 256 & $(2$. & 264 & (5.3) & 266 & (1.2) & 286 & (2.0) & 253 & $(1.8)$ & 259 & & $t$ & (11) & 76 & .3) & 6 & 7) \\
\hline & 249 & (1.6) & & & 271 & (3.5) & 245 & (1.9) & 255 & (1.3) & 262 & $(13.1)$ & 253 & $(1.0)$ & 279 & (2.6) & 244 & (1.6) & 255 & (1.6) & 278 & $(4.3)$ & 4 & 1.5) & 1 & 3) \\
\hline 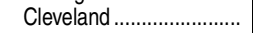 & 242 & (1.6) & 240 & & 260 & (3.1) & 234 & (2.2) & 241 & (3.8) & $\ddagger$ & $(t)$ & 239 & (1.6) & 250 & (3.2) & 235 & $(1.8)$ & 241 & (3.6) & $\ddagger$ & $(t)$ & 9 & (2.0) & 1 & .5) \\
\hline & & $(t)$ & 248 & (1. & 276 & (4.1) & 244 & $(2.8)$ & 246 & (1.1) & $\ddagger$ & $(t)$ & 251 & (1.3) & + & $(t)$ & 244 & $(2.4)$ & 253 & (1. & $t$ & $(t)$ & & (2.0) & 15 & (1.4) \\
\hline & 232 & (2.4) & 237 & (1. & & & 235 & $(1.1)$ & 244 & (4.2) & $\begin{array}{l}\ddagger \\
\ddagger\end{array}$ & $(t)$ & 239 & (1.6) & & $(t)$ & 239 & (1.6) & 242 & (4.7) & $\begin{array}{l}+ \\
\ddagger\end{array}$ & $(t)$ & 46 & (2.1) & 9 & (1.6) \\
\hline Columbia & 240 & (1.5) & 237 & (1. & 290 & (3.4) & 231 & $(1.2)$ & 232 & (3.8) & $\ddagger$ & (t) & 245 & (1.3) & 301 & (4.0) & 237 & (1.4) & 247 & (3.6) & $\ddagger$ & $(\dagger)$ & 53 & (1.8) & 18 & 1) \\
\hline & 240 & (2.4) & 238 & (1. & 257 & (3.2) & 230 & (3.5) & 234 & (2.2) & 241 & (3.4) & 245 & (1.4) & 2 & (3.4) & 236 & (3.3) & 241 & (1.6) & 247 & (3.1) & 4 & (2.3) & 3 & .5) \\
\hline & & & 264 & (1. & & & 247 & (2.4) & 258 & (2.3) & $\ddagger$ & $\left(t^{\prime}\right)$ & 267 & (1.2) & 277 & $(1.6)$ & 252 & (2.3) & 263 & (1.8) & $\ddagger$ & $(t)$ & 7 & (1.6) & 5 & 6) \\
\hline & 252 & (1.2) & 252 & $(0.9)$ & 283 & (2.2) & 247 & (2.4) & 249 & (1.3) & $\ddagger$ & $(t)$ & 252 & $(1.2)$ & 284 & (3.2) & 245 & (2.2) & 250 & (1.4) & 284 & (5.6) & 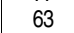 & (1.7) & 19 & (1.3) \\
\hline & 259 & $(1.0)$ & 260 & & 269 & (1.7) & 245 & (1.7) & $\ddagger$ & $(t)$ & $\ddagger$ & $(t)$ & 261 & $(1.0)$ & 271 & (1.6) & 243 & (1.4) & 258 & (4.5) & $\ddagger$ & $(t)$ & 69 & (1.3) & 29 & (1.5) \\
\hline Los Ar & 244 & $(1.1)$ & 246 & (1.1) & 273 & (3.6) & 242 & (3.3) & 241 & (1.2) & 269 & (4.5) & 250 & (1.4) & 276 & (3.2) & 240 & (3.8) & 245 & (1.1) & 272 & (3.1) & 60 & (1.6) & 19 & (1.5) \\
\hline & 261 & (1.4) & 260 & (1. & 275 & (2.4) & 246 & $(1.8)$ & 262 & (1.5) & $\ddagger$ & $(t)$ & 259 & $(1.0)$ & 278 & (2.8) & 245 & (2.0) & 261 & (1.1) & $\ddagger$ & $(t)$ & 71 & (1.3) & 27 & (1.5) \\
\hline & 241 & (2.0) & 238 & (1.6) & 255 & (3.0) & 232 & $(2.0)$ & 243 & (2.9) & 248 & (5.5) & 242 & (1.4) & 262 & (3.3) & 232 & (1.7) & 253 & (2.5) & $\ddagger$ & $(t)$ & 51 & (2.0) & 13 & (1.4) \\
\hline & 252 & (1.4) & 254 & (1. & 271 & (3.6) & 248 & (2.3) & 246 & (2.4) & 273 & (3.3) & 256 & (1.2) & 274 & (4.0) & 253 & (2.0) & 249 & (2.0) & $271^{\top}$ & (3.1) & 67 & (1.2) & 25 & (1.6) \\
\hline & 247 & $(2.5)$ & 247 & (1.5 & 264 & (3.8) & 244 & (1.9) & 239 & (3.0) & 258 & (4.7) & 249 & $(1.8)$ & 26 & (3.1) & 244 & (2.4) & 243 & (3.3) & 265 & $(5.4)$ & 58 & (2.2) & 16 & (2.0) \\
\hline 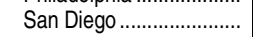 & 254 & (2.8) & 256 & (2.1) & 275 & (2.6) & 238 & $(4.8)$ & 245 & (3.2) & 268 & (4.2) & 260 & (1.5) & 281 & (2.4) & 244 & (3.7) & 247 & (2.1) & 266 & (3.6) & 70 & $(1.8)$ & 29 & (2.3) \\
\hline
\end{tabular}

-Not available.

†Not applicable.

†Reporting standards not met (too few cases for a reliable estimate).

'Scale ranges from 0 to 500 .

2Includes data for students of two or more races, which are not separately shown.

${ }^{3}$ Basic denotes partial mastery of prerequisite knowledge and skills that are fundamental for proficient work at a given grade.
${ }^{4}$ Proficient represents solid academic performance. Students reaching this level have demonstrated competency over challenging subject matter.

NOTE: Race categories exclude persons of Hispanic ethnicity. Totals include racial/ethnic groups not shown separately.

SOURCE: U.S. Department of Education, National Center for Education Statistics, National Assessment of Educational Progress (NAEP), 2009, 2011, and 2013 Reading Assessments, retrieved December 30, 2013, from the Main NAEP Data Explorer (http:// nces.ed.gov/nationsreportcard/naepdata/). (This table was prepared December 2013.) 
Table 221.85. Average National Assessment of Educational Progress (NAEP) reading scale score, by age and selected student characteristics: Selected years, 1971 through 2012

[Standard errors appear in parentheses]

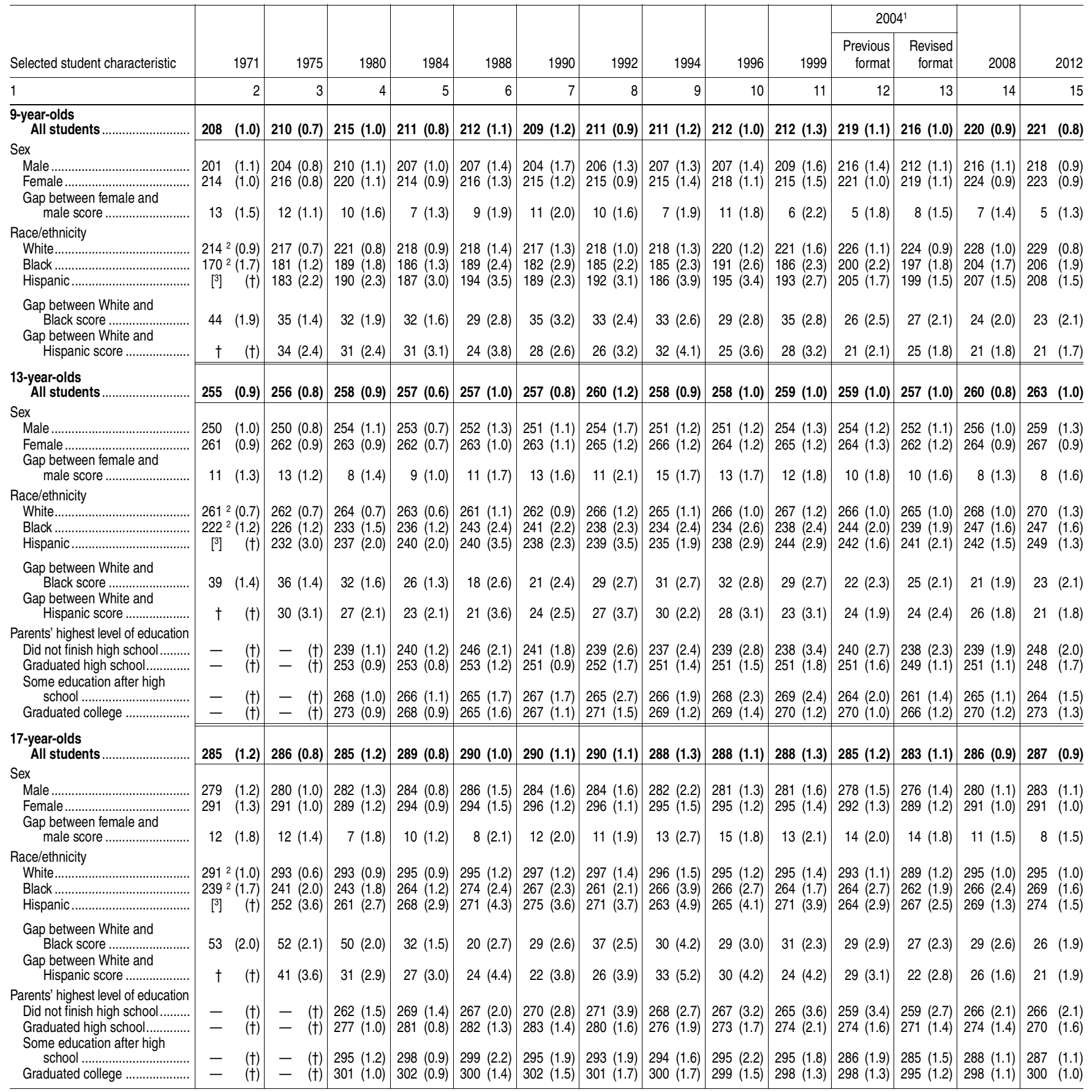

-Not available.

†Not applicable.

${ }^{1}$ In 2004, two assessments were conducted-one using the same format that was used in previous assessments, and one using a revised assessment format that provides accommodations for students with disabilities and for English language learners. The 2004 data in column 12 are for the format that was used in previous assessment years, while the 2004 data in column 13 are for the revised format. In subsequent years, only the revised format was used. 2Data for 1971 include persons of Hispanic ethnicity.

${ }^{3}$ Test scores of Hispanics were not tabulated separately.

NOTE: Scale ranges from 0 to 500 . Students scoring 150 (or higher) are able to follow brief written directions and carry out simple, discrete reading tasks. Students scoring 200 are able to understand, combine ideas, and make inferences based on short uncomplicated passages about specific or sequentially related information. Students scoring 250 are able to search for specific information, interrelate ideas, and make generalizations about literature, science, and social studies materials. Students scoring 300 are able to find, understand, summarize, and explain relatively complicated literary and informational material. Includes public and private schools. For assessment years prior to 2004, accommodations were not permitted. For 2004 (revised format) and later years, includes students tested with accommodations; excludes only those students with disabilities and English language learners who were unable to be tested even with accommodations ( 2 to 5 percent of all students, depending on age and assessment year). Race categories exclude persons of Hispanic ethnicity, except where noted. Totals include other racial/ethnic groups not shown separately.

SOURCE: U.S. Department of Education, National Center for Education Statistics, National Assessment of Educational Progress (NAEP), NAEP 2012 Trends in Academic Progress; and 2012 NAEP Long-Term Trend Reading Assessment, retrieved June 27, 2013, from Long-Term Trend NAEP Data Explorer (http://nces.ed.gov/nationsreportcard/naepdata/). (This table was prepared June 2013.) 
Table 221.90. Percentage of students at or above selected National Assessment of Educational Progress (NAEP) reading score levels, by age, sex, and race/ethnicity: Selected years, 1971 through 2012

[Standard errors appear in parentheses]

\begin{tabular}{|c|c|c|c|c|c|c|c|c|c|c|c|c|c|c|c|c|c|c|c|c|c|c|c|c|c|c|}
\hline $\begin{array}{l}\text { Age, sex, race/ethnicity, } \\
\text { and score level }\end{array}$ & & 1971 & & 1975 & & 1980 & & 1984 & & 1988 & & 1990 & & 1992 & & 1994 & & 1996 & & 1999 & & 2004 & & 2008 & & 2012 \\
\hline 1 & & 2 & & 3 & & 4 & & 5 & & 6 & & 7 & & 8 & & 9 & & 10 & & 11 & & 12 & & 13 & & 14 \\
\hline \multicolumn{27}{|l|}{ 9-year-olds } \\
\hline 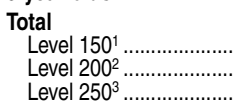 & $\begin{array}{l}91 \\
59 \\
16\end{array}$ & $\begin{array}{l}(0.5) \\
1.0 \\
0.6)\end{array}$ & $\begin{array}{l}93 \\
62 \\
15\end{array}$ & $\begin{array}{l}(0.4) \\
0.8) \\
0.6)\end{array}$ & $\begin{array}{l}95 \\
68 \\
18\end{array}$ & $\left.\begin{array}{l}(0.4) \\
1.0 \\
0.8\end{array}\right)$ & $\begin{array}{l}92 \\
62 \\
17\end{array}$ & $\begin{array}{l}(0.4) \\
0.8) \\
0.7)\end{array}$ & $\begin{array}{l}93 \\
63 \\
17\end{array}$ & $\left.\begin{array}{l}(0.7) \\
1.3 \\
1.1\end{array}\right)$ & $\begin{array}{l}90 \\
59 \\
18\end{array}$ & $\left(\begin{array}{l}0.9) \\
1.3 \\
1.0\end{array}\right)$ & $\begin{array}{l}92 \\
62 \\
16\end{array}$ & $\left(\begin{array}{l}0.4) \\
1.1 \\
0.8)\end{array}\right.$ & $\begin{array}{l}92 \\
63 \\
17\end{array}$ & $\left.\begin{array}{l}(0.7) \\
1.4 \\
1.2\end{array}\right)$ & $\begin{array}{l}93 \\
64 \\
17\end{array}$ & $\left(\begin{array}{l}0.6) \\
1.3 \\
0.8)\end{array}\right)$ & $\begin{array}{l}93 \\
64 \\
16\end{array}$ & $\left(\begin{array}{l}0.7) \\
1.4 \\
1.0\end{array}\right)$ & $\begin{array}{l}94 \\
69 \\
19\end{array}$ & $\left(\begin{array}{l}0.5 \\
1.0 \\
0.7\end{array}\right)$ & $\begin{array}{l}96 \\
73 \\
21\end{array}$ & $\left.\begin{array}{l}(0.4) \\
0.9 \\
0.8\end{array}\right)$ & $\begin{array}{l}96 \\
74 \\
22\end{array}$ & $\begin{array}{l}(0.4) \\
0.9 \\
0.7\end{array}$ \\
\hline 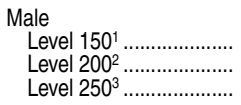 & $\begin{array}{l}88 \\
53 \\
12\end{array}$ & $\begin{array}{l}(0.7) \\
1.2 \\
0.6)\end{array}$ & $\begin{array}{l}91 \\
56 \\
12\end{array}$ & $\left.\begin{array}{l}(0.5) \\
1.0 \\
0.6)\end{array}\right)$ & $\begin{array}{l}93 \\
63 \\
15\end{array}$ & $\left.\begin{array}{l}(0.5) \\
1.1 \\
0.9\end{array}\right)$ & $\begin{array}{l}90 \\
58 \\
16\end{array}$ & $\left(\begin{array}{l}0.5) \\
1.0 \\
0.8)\end{array}\right)$ & $\begin{array}{l}90 \\
58 \\
16\end{array}$ & $\left.\begin{array}{l}(0.9) \\
1.8 \\
1.4\end{array}\right)$ & $\begin{array}{l}88 \\
54 \\
16\end{array}$ & $\left(\begin{array}{l}1.4 \\
1.9 \\
1.2\end{array}\right)$ & $\begin{array}{l}90 \\
57 \\
14\end{array}$ & $\left(\begin{array}{l}0.8) \\
1.6 \\
1.0\end{array}\right)$ & $\begin{array}{l}90 \\
59 \\
15\end{array}$ & $\left(\begin{array}{l}1.0 \\
1.5 \\
1.2\end{array}\right)$ & $\begin{array}{l}92 \\
58 \\
14\end{array}$ & $\left.\begin{array}{l}(0.8) \\
2.0 \\
1.3\end{array}\right)$ & $\begin{array}{l}91 \\
61 \\
15\end{array}$ & $\left(\begin{array}{l}1.1) \\
1.8 \\
1.3\end{array}\right)$ & $\begin{array}{l}92 \\
64 \\
17\end{array}$ & $\left.\begin{array}{l}(0.6) \\
1.3 \\
0.8\end{array}\right)$ & $\begin{array}{l}94 \\
70 \\
19\end{array}$ & $\left(\begin{array}{l}0.6 \\
1.2 \\
1.0\end{array}\right)$ & $\begin{array}{l}94 \\
71 \\
21\end{array}$ & $\left.\begin{array}{l}(0.6 \\
1.0 \\
0.8\end{array}\right)$ \\
\hline 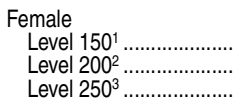 & $\begin{array}{l}93 \\
65 \\
19\end{array}$ & $\begin{array}{l}(0.5) \\
1.1 \\
0.8)\end{array}$ & $\begin{array}{l}95 \\
68 \\
18\end{array}$ & $\begin{array}{l}(0.3) \\
0.8 \\
0.8)\end{array}$ & $\begin{array}{l}96 \\
73 \\
21\end{array}$ & $\left.\begin{array}{l}(0.4) \\
1.0 \\
1.0\end{array}\right)$ & $\begin{array}{l}94 \\
65 \\
18\end{array}$ & $\begin{array}{l}(0.5) \\
1.0 \\
0.8)\end{array}$ & $\begin{array}{l}95 \\
67 \\
19\end{array}$ & $\left(\begin{array}{l}1.0 \\
1.4 \\
1.2\end{array}\right)$ & $\begin{array}{l}92 \\
64 \\
21\end{array}$ & $\left(\begin{array}{l}1.1 \\
1.2 \\
(1.2)\end{array}\right)$ & $\begin{array}{l}94 \\
67 \\
18\end{array}$ & $\left(\begin{array}{l}0.6 \\
1.2 \\
1.1\end{array}\right)$ & $\begin{array}{l}94 \\
67 \\
18\end{array}$ & $\left.\begin{array}{l}(0.8) \\
1.9 \\
1.5\end{array}\right)$ & $\begin{array}{l}95 \\
70 \\
19\end{array}$ & $\left(\begin{array}{l}0.6) \\
1.6 \\
1.3\end{array}\right)$ & $\begin{array}{l}95 \\
67 \\
17\end{array}$ & $\left(\begin{array}{l}0.8) \\
1.6 \\
1.3\end{array}\right)$ & $\begin{array}{l}96 \\
73 \\
20\end{array}$ & $\left(\begin{array}{l}0.5 \\
1.2 \\
1.0\end{array}\right)$ & $\begin{array}{l}97 \\
77 \\
22\end{array}$ & $\left(\begin{array}{l}0.4) \\
1.1 \\
1.0\end{array}\right)$ & $\begin{array}{l}97 \\
77 \\
23\end{array}$ & $\left.\begin{array}{l}(0.4) \\
1.1 \\
0.9\end{array}\right)$ \\
\hline 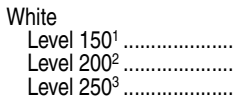 & $\begin{array}{l}94^{5} \\
65^{5} \\
18^{5}\end{array}$ & $\begin{array}{l}(0.4) \\
1.0 \\
0.7)\end{array}$ & $\begin{array}{l}96 \\
69 \\
17\end{array}$ & $\begin{array}{l}(0.3) \\
0.8) \\
0.7)\end{array}$ & $\begin{array}{l}97 \\
74 \\
21\end{array}$ & $\left.\begin{array}{l}(0.2) \\
0.7 \\
0.9\end{array}\right)$ & $\begin{array}{l}95 \\
69 \\
21\end{array}$ & $\begin{array}{l}(0.3) \\
0.9 \\
0.8)\end{array}$ & $\begin{array}{l}95 \\
68 \\
20\end{array}$ & $\left.\begin{array}{l}(0.7) \\
1.6 \\
1.5\end{array}\right)$ & $\begin{array}{l}94 \\
66 \\
23\end{array}$ & $\begin{array}{l}(0.9) \\
(1.4) \\
(1.2)\end{array}$ & $\begin{array}{l}96 \\
69 \\
20\end{array}$ & $\left(\begin{array}{l}0.5) \\
1.2 \\
1.0\end{array}\right)$ & $\begin{array}{l}96 \\
70 \\
20\end{array}$ & $\left.\begin{array}{l}(0.5) \\
1.5 \\
1.5\end{array}\right)$ & $\begin{array}{l}96 \\
71 \\
20\end{array}$ & $\left(\begin{array}{l}0.6 \\
1.5 \\
1.1\end{array}\right)$ & $\begin{array}{l}97 \\
73 \\
20\end{array}$ & $\left.\begin{array}{l}(0.4) \\
1.6 \\
1.4\end{array}\right)$ & $\begin{array}{l}97 \\
77 \\
24\end{array}$ & $\left(\begin{array}{l}0.4) \\
1.0 \\
0.8\end{array}\right)$ & $\begin{array}{l}98 \\
81 \\
27\end{array}$ & $\left(\begin{array}{l}0.4) \\
1.0 \\
(1.1)\end{array}\right.$ & $\begin{array}{l}98 \\
82 \\
28\end{array}$ & $\begin{array}{l}(0.4) \\
0.8 \\
0.8\end{array}$ \\
\hline 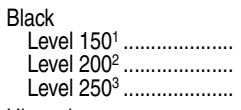 & $\begin{array}{r}70^{5} \\
22^{5} \\
2^{5}\end{array}$ & $\left.\begin{array}{l}1.7 \\
1.5 \\
0.5\end{array}\right)$ & $\begin{array}{r}81 \\
32 \\
2\end{array}$ & $\left(\begin{array}{l}1.1 \\
1.5 \\
0.3)\end{array}\right.$ & $\begin{array}{r}85 \\
41 \\
4\end{array}$ & $\left.\begin{array}{l}1.4 \\
1.9 \\
0.6\end{array}\right)$ & $\begin{array}{r}81 \\
37 \\
5\end{array}$ & $\left(\begin{array}{l}1.2 \\
1.5 \\
0.6)\end{array}\right)$ & $\begin{array}{r}83 \\
39 \\
6\end{array}$ & $\begin{array}{l}(2.4) \\
(2.9) \\
1.2)\end{array}$ & $\begin{array}{r}77 \\
34 \\
5\end{array}$ & $\left.\begin{array}{l}(2.7) \\
(.4) \\
(1.5)\end{array}\right)$ & $\begin{array}{r}80 \\
37 \\
5\end{array}$ & $\begin{array}{l}(2.2) \\
2.2 \\
0.8)\end{array}$ & $\begin{array}{r}79 \\
38 \\
4\end{array}$ & $\left.\begin{array}{l}(2.4) \\
2.8 \\
1.5\end{array}\right)$ & $\begin{array}{r}84 \\
42 \\
6\end{array}$ & $\left(\begin{array}{l}1.9 \\
3.2 \\
1.1\end{array}\right)$ & $\begin{array}{r}82 \\
36 \\
4\end{array}$ & $\left.\begin{array}{l}(2.5) \\
(3.0) \\
1.1\end{array}\right)$ & $\begin{array}{r}88 \\
50 \\
7\end{array}$ & $\left.\begin{array}{l}(1.7) \\
2.3 \\
0.8\end{array}\right)$ & $\begin{array}{r}91 \\
58 \\
9\end{array}$ & $\left.\begin{array}{l}(1.1) \\
2.3 \\
(0.9)\end{array}\right)$ & $\begin{array}{l}94 \\
61 \\
10\end{array}$ & $\left.\begin{array}{l}(1.0) \\
2.1 \\
1.1\end{array}\right)$ \\
\hline 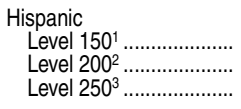 & $\begin{array}{l}6 \\
6 \\
6 \\
66 \\
6\end{array}$ & $\begin{array}{c}(t) \\
+ \\
(t)\end{array}$ & $\begin{array}{r}81 \\
35 \\
3 \\
\end{array}$ & $\left.\begin{array}{l}(2.5) \\
3.0 \\
0.5\end{array}\right)$ & $\begin{array}{r}84 \\
42 \\
5 \\
\end{array}$ & $\left.\begin{array}{l}1.8 \\
2.6 \\
1.4\end{array}\right)$ & $\begin{array}{r}82 \\
40 \\
4 \\
\end{array}$ & $\begin{array}{l}(3.0) \\
2.7 \\
0.7) \\
\end{array}$ & $\begin{array}{r}86 \\
46 \\
9 \\
\end{array}$ & $\begin{array}{l}(3.5) \\
(3.3) \\
(2.3) \\
\end{array}$ & $\begin{array}{r}84 \\
41 \\
6 \\
\end{array}$ & $\begin{array}{l}1.8) \\
2.7 \\
(2.0) \\
\end{array}$ & $\begin{array}{r}83 \\
43 \\
7 \\
\end{array}$ & $\left.\begin{array}{l}(2.6) \\
3.5 \\
2.3\end{array}\right)$ & $\begin{array}{r}80 \\
37 \\
6 \\
\end{array}$ & $\begin{array}{l}(4.6) \\
4.6 \\
(1.6) \\
\end{array}$ & $\begin{array}{r}86 \\
48 \\
7 \\
\end{array}$ & $\begin{array}{l}(2.4) \\
3.8 \\
(3.2) \\
\end{array}$ & $\begin{array}{r}87 \\
44 \\
6 \\
\end{array}$ & $\begin{array}{l}(3.3) \\
(3.4) \\
(1.7) \\
\end{array}$ & $\begin{array}{r}89 \\
53 \\
7 \\
\end{array}$ & $\left.\begin{array}{l}(1.3) \\
1.7 \\
0.8\end{array}\right)$ & $\begin{array}{l}93 \\
62 \\
10 \\
\end{array}$ & $\begin{array}{l}(0.8) \\
1.7 \\
(1.2) \\
\end{array}$ & $\begin{array}{l}92 \\
63 \\
11 \\
\end{array}$ & $\begin{array}{l}1.1 \\
1.8 \\
1.0\end{array}$ \\
\hline $\begin{array}{l}\text { 13-year-olds } \\
\text { Total }\end{array}$ & & & & & & & & & & & & & & & & & & & & & & & & & & \\
\hline $\begin{array}{l}\text { Level } 200^{2} \ldots \ldots \ldots \ldots \ldots \ldots \\
\text { Level } 250^{3} \ldots \ldots \ldots \ldots \ldots \ldots . . \\
\text { Level } 300^{4} \ldots \ldots \ldots \ldots \ldots \ldots \ldots . .\end{array}$ & $\begin{array}{l}93 \\
58 \\
10\end{array}$ & $\begin{array}{l}(0.5) \\
(1.1) \\
0.5)\end{array}$ & $\begin{array}{l}93 \\
59 \\
10\end{array}$ & $\begin{array}{l}(0.4) \\
(1.0) \\
0.5)\end{array}$ & $\begin{array}{l}95 \\
61 \\
11\end{array}$ & $\left.\begin{array}{l}(0.4) \\
(1.1) \\
0.5\end{array}\right)$ & $\begin{array}{l}94 \\
59 \\
11\end{array}$ & $\begin{array}{l}(0.3) \\
(0.8) \\
(0.4)\end{array}$ & $\begin{array}{l}95 \\
59 \\
11\end{array}$ & $\begin{array}{l}(0.6) \\
(1.3) \\
0.8)\end{array}$ & $\begin{array}{l}94 \\
59 \\
11\end{array}$ & $\begin{array}{l}(0.6) \\
(1.0) \\
(0.6)\end{array}$ & $\begin{array}{l}93 \\
62 \\
15\end{array}$ & $\begin{array}{l}(0.7) \\
(1.4) \\
(0.9)\end{array}$ & $\begin{array}{l}92 \\
60 \\
14\end{array}$ & $\begin{array}{l}(0.6) \\
(1.2) \\
0.8)\end{array}$ & $\begin{array}{l}92 \\
60 \\
14\end{array}$ & $\left.\begin{array}{l}(0.7) \\
(1.3) \\
1.0\end{array}\right)$ & $\begin{array}{l}93 \\
61 \\
15\end{array}$ & $\begin{array}{l}(0.7) \\
(1.5) \\
1.1)\end{array}$ & $\begin{array}{l}92 \\
59 \\
12\end{array}$ & $\begin{array}{l}(0.6) \\
(1.1) \\
0.8)\end{array}$ & $\begin{array}{l}94 \\
63 \\
13\end{array}$ & $\begin{array}{l}(0.4) \\
(0.8) \\
0.5)\end{array}$ & $\begin{array}{l}94 \\
66 \\
15\end{array}$ & $\left.\begin{array}{l}(0.4) \\
(1.3 \\
1.0\end{array}\right)$ \\
\hline 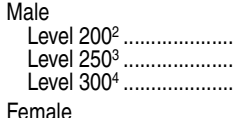 & $\begin{array}{r}91 \\
52 \\
7\end{array}$ & $\begin{array}{l}(0.7) \\
(1.2) \\
0.5)\end{array}$ & $\begin{array}{r}91 \\
52 \\
7\end{array}$ & $\begin{array}{l}(0.5) \\
(1.1) \\
0.4)\end{array}$ & $\begin{array}{r}93 \\
56 \\
9\end{array}$ & $\begin{array}{l}(0.6) \\
(1.2) \\
0.7)\end{array}$ & $\begin{array}{r}92 \\
54 \\
9\end{array}$ & $\begin{array}{l}(0.4) \\
(0.9) \\
0.5)\end{array}$ & $\begin{array}{r}93 \\
52 \\
9\end{array}$ & $\begin{array}{l}(1.0) \\
(1.9) \\
0.9)\end{array}$ & $\begin{array}{r}91 \\
52 \\
8\end{array}$ & $\begin{array}{l}(0.9) \\
(1.5) \\
(0.8)\end{array}$ & $\begin{array}{l}90 \\
55 \\
13\end{array}$ & $\begin{array}{l}(1.1) \\
(2.0) \\
(1.1)\end{array}$ & $\begin{array}{l}89 \\
53 \\
10\end{array}$ & $\begin{array}{l}(1.1) \\
(1.9) \\
0.7)\end{array}$ & $\begin{array}{l}89 \\
53 \\
10\end{array}$ & $\begin{array}{l}(1.2) \\
(1.6) \\
(1.0)\end{array}$ & $\begin{array}{l}91 \\
55 \\
11\end{array}$ & $\begin{array}{l}(0.9) \\
(1.9) \\
(1.1)\end{array}$ & $\begin{array}{l}89 \\
55 \\
11\end{array}$ & $\left.\begin{array}{l}(0.8) \\
(1.3) \\
0.9\end{array}\right)$ & $\begin{array}{l}92 \\
59 \\
11\end{array}$ & $\begin{array}{l}(0.6) \\
(1.2) \\
(0.7)\end{array}$ & $\begin{array}{l}93 \\
62 \\
13\end{array}$ & $\begin{array}{l}(0.7) \\
(1.6) \\
1.1\end{array}$ \\
\hline $\begin{array}{l}\text { Level } 200^{2} \ldots \ldots \ldots \ldots \ldots \ldots \\
\text { Level } 250^{3} \ldots \ldots \ldots \ldots \ldots \ldots . . . \\
\text { Level } 300^{4} \ldots \ldots \ldots \ldots \ldots \ldots\end{array}$ & $\begin{array}{l}95 \\
64 \\
12\end{array}$ & $\begin{array}{l}(0.4) \\
(1.1) \\
0.6)\end{array}$ & $\begin{array}{l}95 \\
65 \\
13\end{array}$ & $\begin{array}{l}(0.4) \\
(1.2) \\
0.7)\end{array}$ & $\begin{array}{l}96 \\
65 \\
13\end{array}$ & $\begin{array}{l}(0.4) \\
(1.1) \\
0.6)\end{array}$ & $\begin{array}{l}96 \\
64 \\
13\end{array}$ & $\begin{array}{l}(0.3) \\
(0.8) \\
0.6)\end{array}$ & $\begin{array}{l}97 \\
65 \\
13\end{array}$ & $\begin{array}{l}(0.6) \\
(1.4) \\
0.9)\end{array}$ & $\begin{array}{l}96 \\
65 \\
14\end{array}$ & $\begin{array}{l}(0.6) \\
(1.5) \\
(0.9)\end{array}$ & $\begin{array}{l}95 \\
68 \\
18\end{array}$ & $\left.\begin{array}{l}(0.7) \\
(1.4) \\
1.1\end{array}\right)$ & $\begin{array}{l}95 \\
68 \\
18\end{array}$ & $\begin{array}{l}(0.6) \\
(1.7) \\
1.1)\end{array}$ & $\begin{array}{l}95 \\
66 \\
17\end{array}$ & $\begin{array}{l}(0.6) \\
(1.6) \\
1.3)\end{array}$ & $\begin{array}{l}96 \\
66 \\
18\end{array}$ & $\begin{array}{l}(0.7) \\
(1.9) \\
1.7)\end{array}$ & $\begin{array}{l}95 \\
65 \\
14\end{array}$ & $\left.\begin{array}{l}(0.6) \\
(1.3) \\
1.0\end{array}\right)$ & $\begin{array}{l}96 \\
66 \\
16\end{array}$ & $\begin{array}{l}(0.5) \\
(1.0) \\
0.9)\end{array}$ & $\begin{array}{l}96 \\
69 \\
17\end{array}$ & $\left.\begin{array}{l}(0.4) \\
(1.4) \\
1.1\end{array}\right)$ \\
\hline 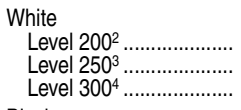 & $\begin{array}{l}96^{5} \\
64^{5} \\
11^{5}\end{array}$ & $\begin{array}{l}(0.3) \\
(0.9) \\
0.5)\end{array}$ & $\begin{array}{l}96 \\
65 \\
12\end{array}$ & $\begin{array}{l}(0.2) \\
(0.9) \\
0.5)\end{array}$ & $\begin{array}{l}97 \\
68 \\
14\end{array}$ & $\begin{array}{l}(0.2) \\
(0.8) \\
0.6)\end{array}$ & $\begin{array}{l}96 \\
65 \\
13\end{array}$ & $\begin{array}{l}(0.2) \\
(0.8) \\
(0.6)\end{array}$ & $\begin{array}{l}96 \\
64 \\
12\end{array}$ & $\begin{array}{l}(0.6) \\
(1.5) \\
0.9)\end{array}$ & $\begin{array}{l}96 \\
65 \\
13\end{array}$ & $\begin{array}{l}(0.6) \\
(1.2) \\
(0.9)\end{array}$ & $\begin{array}{l}96 \\
68 \\
18\end{array}$ & $\begin{array}{l}(0.6) \\
(1.4) \\
(1.1)\end{array}$ & $\begin{array}{l}95 \\
68 \\
17\end{array}$ & $\begin{array}{l}(0.7) \\
(1.3) \\
1.0)\end{array}$ & $\begin{array}{l}95 \\
69 \\
17\end{array}$ & $\begin{array}{l}(0.5) \\
(1.4) \\
(1.3)\end{array}$ & $\begin{array}{l}96 \\
69 \\
18\end{array}$ & $\begin{array}{l}(0.6) \\
(1.7) \\
1.4)\end{array}$ & $\begin{array}{l}95 \\
68 \\
16\end{array}$ & $\begin{array}{l}(0.5) \\
(1.1) \\
0.9)\end{array}$ & $\begin{array}{l}96 \\
72 \\
18\end{array}$ & $\begin{array}{l}(0.4) \\
(1.2) \\
(0.8)\end{array}$ & $\begin{array}{l}96 \\
74 \\
19\end{array}$ & $\begin{array}{l}(0.6) \\
(1.8) \\
1.0\end{array}$ \\
\hline 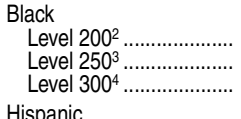 & $\begin{array}{r}74^{5} \\
21^{5} \\
1^{5}\end{array}$ & $\begin{array}{l}(1.7) \\
(1.2) \\
0.2)\end{array}$ & $\begin{array}{r}77 \\
25 \\
2\end{array}$ & $\begin{array}{l}(1.3) \\
(1.6) \\
0.3)\end{array}$ & $\begin{array}{r}84 \\
30 \\
2\end{array}$ & $\begin{array}{l}(1.7) \\
(2.0) \\
0.5)\end{array}$ & $\begin{array}{r}85 \\
35 \\
3\end{array}$ & $\begin{array}{l}(1.2) \\
(1.3) \\
0.6)\end{array}$ & $\begin{array}{r}91 \\
40 \\
5\end{array}$ & $\begin{array}{l}(2.2) \\
(2.3) \\
(1.2)\end{array}$ & $\begin{array}{r}88 \\
42 \\
5\end{array}$ & $\begin{array}{l}(2.3) \\
(3.5) \\
(0.8)\end{array}$ & $\begin{array}{r}82 \\
38 \\
6\end{array}$ & $\begin{array}{l}(2.7) \\
(2.7) \\
1.4)\end{array}$ & $\begin{array}{r}81 \\
36 \\
4\end{array}$ & $\begin{array}{l}(2.3) \\
(3.5) \\
1.2\end{array}$ & $\begin{array}{r}82 \\
34 \\
3\end{array}$ & $\begin{array}{l}(3.2) \\
(3.9) \\
0.9)\end{array}$ & $\begin{array}{r}85 \\
38 \\
5\end{array}$ & $\begin{array}{l}(2.3) \\
(2.7) \\
1.4)\end{array}$ & $\begin{array}{r}86 \\
40 \\
4\end{array}$ & $\begin{array}{l}(1.5) \\
(2.3) \\
0.7)\end{array}$ & $\begin{array}{r}91 \\
48 \\
6\end{array}$ & $\begin{array}{l}(1.1) \\
(2.3) \\
(0.8)\end{array}$ & $\begin{array}{r}90 \\
48 \\
6\end{array}$ & $\begin{array}{l}(1.3) \\
(2.5) \\
(0.9)\end{array}$ \\
\hline 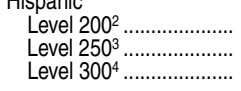 & $\begin{array}{l}{[6]} \\
{[6]} \\
66]\end{array}$ & $\begin{array}{l}(t) \\
(t) \\
(t)\end{array}$ & $\begin{array}{r}81 \\
32 \\
2 \\
\end{array}$ & $\begin{array}{l}(2.3) \\
(3.6) \\
1.0\end{array}$ & $\begin{array}{r}87 \\
35 \\
2 \\
\end{array}$ & $\begin{array}{l}(2.4) \\
(2.6) \\
0.6)\end{array}$ & $\begin{array}{r}86 \\
39 \\
4 \\
\end{array}$ & $\begin{array}{l}(1.7) \\
(2.3) \\
1.0) \\
\end{array}$ & $\begin{array}{r}87 \\
38 \\
4 \\
\end{array}$ & $\begin{array}{l}(2.6) \\
(4.4) \\
1.9) \\
\end{array}$ & $\begin{array}{r}86 \\
37 \\
4 \\
\end{array}$ & $\begin{array}{l}(2.4) \\
(2.9) \\
(1.2)\end{array}$ & $\begin{array}{r}83 \\
41 \\
6 \\
\end{array}$ & $\begin{array}{l}(3.5) \\
(5.1) \\
(1.9)\end{array}$ & $\begin{array}{r}82 \\
34 \\
4 \\
\end{array}$ & $\begin{array}{l}(2.7) \\
(3.9) \\
1.8\end{array}$ & $\begin{array}{r}85 \\
38 \\
5 \\
\end{array}$ & $\begin{array}{l}(3.2) \\
(3.7) \\
1.7)\end{array}$ & $\begin{array}{r}89 \\
43 \\
6 \\
\end{array}$ & $\begin{array}{l}(2.8) \\
(3.8) \\
1.8)\end{array}$ & $\begin{array}{r}85 \\
44 \\
5 \\
\end{array}$ & $\begin{array}{l}(1.9) \\
(2.3) \\
1.2\end{array}$ & $\begin{array}{r}87 \\
44 \\
5 \\
\end{array}$ & $\begin{array}{l}(1.3) \\
(1.8) \\
(0.6)\end{array}$ & $\begin{array}{r}91 \\
51 \\
6 \\
\end{array}$ & $\begin{array}{l}(1.2) \\
(1.7) \\
(0.5) \\
\end{array}$ \\
\hline $\begin{array}{l}\text { 17-year-old } \\
\text { Total }\end{array}$ & & & & & & & & & & & & & & & & & & & & & & & & & & \\
\hline 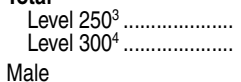 & $\begin{array}{l}79 \\
39\end{array}$ & $\left(\begin{array}{l}0.9 \\
1.0\end{array}\right)$ & $\begin{array}{l}80 \\
39\end{array}$ & $\begin{array}{l}(0.7) \\
0.8)\end{array}$ & $\begin{array}{l}81 \\
38\end{array}$ & $\left(\begin{array}{l}0.9 \\
1.1\end{array}\right)$ & $\begin{array}{l}83 \\
40\end{array}$ & $\left(\begin{array}{l}0.6) \\
1.0\end{array}\right)$ & $\begin{array}{l}86 \\
41\end{array}$ & $\left(\begin{array}{l}0.8) \\
1.5\end{array}\right)$ & $\begin{array}{l}84 \\
41\end{array}$ & $\left(\begin{array}{l}1.0 \\
1.0\end{array}\right)$ & $\begin{array}{l}83 \\
43\end{array}$ & $\left(\begin{array}{l}0.8) \\
1.1\end{array}\right)$ & $\begin{array}{l}81 \\
41\end{array}$ & $\left(\begin{array}{l}1.0 \\
1.2\end{array}\right)$ & $\begin{array}{l}82 \\
39\end{array}$ & $\left(\begin{array}{l}0.8) \\
1.4\end{array}\right)$ & $\begin{array}{l}82 \\
40\end{array}$ & $\left(\begin{array}{l}1.0 \\
1.4\end{array}\right)$ & $\begin{array}{l}79 \\
36\end{array}$ & $\left(\begin{array}{l}0.9) \\
1.2\end{array}\right)$ & $\begin{array}{l}80 \\
39\end{array}$ & $\left.\begin{array}{l}(0.6) \\
0.8\end{array}\right)$ & $\begin{array}{l}82 \\
39\end{array}$ & $\left.\begin{array}{l}0.6 \\
0.9\end{array}\right)$ \\
\hline Level $250^{3} \ldots \ldots \ldots \ldots \ldots \ldots$ & $\begin{array}{l}74 \\
34\end{array}$ & $\left(\begin{array}{l}1.0 \\
1.1\end{array}\right)$ & $\begin{array}{l}76 \\
34\end{array}$ & $\left(\begin{array}{l}0.8) \\
1.0\end{array}\right)$ & $\begin{array}{l}78 \\
35\end{array}$ & $\left(\begin{array}{l}1.0 \\
1.3\end{array}\right)$ & $\begin{array}{l}80 \\
36\end{array}$ & $\left(\begin{array}{l}0.7) \\
1.0\end{array}\right)$ & $\begin{array}{l}83 \\
37\end{array}$ & $\left(\begin{array}{l}1.4) \\
2.3\end{array}\right)$ & $\begin{array}{l}80 \\
36\end{array}$ & $\left(\begin{array}{l}1.4) \\
1.5\end{array}\right)$ & $\begin{array}{l}78 \\
38\end{array}$ & $\left(\begin{array}{l}1.2 \\
1.6\end{array}\right)$ & $\begin{array}{l}76 \\
36\end{array}$ & $\left(\begin{array}{l}1.5 \\
1.9\end{array}\right)$ & $\begin{array}{l}77 \\
34\end{array}$ & $\left(\begin{array}{l}1.2) \\
1.9\end{array}\right)$ & $\begin{array}{l}77 \\
34\end{array}$ & $\left(\begin{array}{l}1.5 \\
1.7\end{array}\right)$ & $\begin{array}{l}73 \\
32\end{array}$ & $\left(\begin{array}{l}1.2 \\
1.2\end{array}\right)$ & $\begin{array}{l}76 \\
35\end{array}$ & $\left(\begin{array}{l}0.8) \\
0.9\end{array}\right)$ & $\begin{array}{l}79 \\
36\end{array}$ & $\left.\begin{array}{l}(0.8) \\
1.2\end{array}\right)$ \\
\hline $\begin{array}{l}\text { Cemale } \\
\text { Level } 250^{3} \ldots . \\
\text { Level } 300^{4} \ldots\end{array}$ & $\begin{array}{l}83 \\
44\end{array}$ & $\begin{array}{l}(1.0) \\
(1.2)\end{array}$ & $\begin{array}{l}84 \\
44\end{array}$ & $\begin{array}{l}(0.9) \\
(0.9)\end{array}$ & $\begin{array}{l}84 \\
41\end{array}$ & $\begin{array}{l}(1.0) \\
(1.2)\end{array}$ & $\begin{array}{l}87 \\
45\end{array}$ & $\begin{array}{l}(0.6) \\
(1.1)\end{array}$ & $\begin{array}{l}88 \\
44\end{array}$ & $\begin{array}{l}(1.1) \\
(2.0)\end{array}$ & $\begin{array}{l}89 \\
47\end{array}$ & $\begin{array}{l}(1.0) \\
(1.3)\end{array}$ & $\begin{array}{l}87 \\
48\end{array}$ & $\begin{array}{l}(1.1) \\
(1.5)\end{array}$ & $\begin{array}{l}86 \\
46\end{array}$ & $\begin{array}{l}(1.2) \\
(1.5)\end{array}$ & $\begin{array}{l}87 \\
45\end{array}$ & $\begin{array}{l}(1.0) \\
(1.7)\end{array}$ & $\begin{array}{l}87 \\
45\end{array}$ & $\begin{array}{l}(1.0) \\
(1.8)\end{array}$ & $\begin{array}{l}84 \\
41\end{array}$ & $\begin{array}{l}(0.9) \\
(1.6)\end{array}$ & $\begin{array}{l}84 \\
43\end{array}$ & $\begin{array}{l}(0.8) \\
(1.0)\end{array}$ & $\begin{array}{l}85 \\
42\end{array}$ & $\begin{array}{l}(0.7) \\
(1.1)\end{array}$ \\
\hline $\begin{array}{l}\text { White } \\
\quad \text { Level } 250^{3} \ldots \ldots \ldots \\
\text { Level } 300^{4} \ldots \ldots . .\end{array}$ & $\begin{array}{l}84^{5} \\
43^{5}\end{array}$ & $\begin{array}{l}(0.7) \\
0.9)\end{array}$ & $\begin{array}{l}86 \\
44\end{array}$ & $\begin{array}{l}(0.6) \\
0.8)\end{array}$ & $\begin{array}{l}87 \\
43\end{array}$ & $\left(\begin{array}{l}0.6 \\
(1.1)\end{array}\right)$ & $\begin{array}{l}88 \\
47\end{array}$ & $\left(\begin{array}{c}0.5) \\
(1.1)\end{array}\right.$ & $\begin{array}{l}89 \\
45\end{array}$ & $\begin{array}{l}(0.9) \\
1.6)\end{array}$ & $\begin{array}{l}88 \\
48\end{array}$ & $\left(\begin{array}{l}1.1) \\
(1.2)\end{array}\right.$ & $\begin{array}{l}88 \\
50\end{array}$ & $\left(\begin{array}{l}0.9 \\
1.4\end{array}\right)$ & $\begin{array}{l}86 \\
48\end{array}$ & $\left(\begin{array}{l}1.1 \\
1.4\end{array}\right)$ & $\begin{array}{l}87 \\
46\end{array}$ & $\left(\begin{array}{l}0.8) \\
1.5\end{array}\right)$ & $\begin{array}{l}87 \\
46\end{array}$ & $\left(\begin{array}{l}1.3 \\
1.5\end{array}\right)$ & $\begin{array}{l}83 \\
42\end{array}$ & $\left(\begin{array}{l}0.9 \\
1.3\end{array}\right)$ & $\begin{array}{l}87 \\
47\end{array}$ & $\left(\begin{array}{l}0.6) \\
(1.0)\end{array}\right.$ & $\begin{array}{l}87 \\
47\end{array}$ & $\begin{array}{l}(0.6) \\
(1.3)\end{array}$ \\
\hline 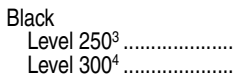 & $\begin{array}{r}40^{5} \\
8^{5}\end{array}$ & $\left(\begin{array}{l}1.6) \\
0.9\end{array}\right)$ & $\begin{array}{r}43 \\
8\end{array}$ & $\left(\begin{array}{l}1.6 \\
0.7)\end{array}\right.$ & $\begin{array}{r}44 \\
7\end{array}$ & $\begin{array}{l}(2.0) \\
0.8)\end{array}$ & $\begin{array}{l}65 \\
16\end{array}$ & $\left(\begin{array}{l}1.5) \\
1.0\end{array}\right)$ & $\begin{array}{l}76 \\
25\end{array}$ & $\begin{array}{l}(2.4) \\
3.1)\end{array}$ & $\begin{array}{l}69 \\
20\end{array}$ & $\begin{array}{l}(2.8) \\
(1.8)\end{array}$ & $\begin{array}{l}61 \\
17\end{array}$ & $\left(\begin{array}{l}2.3 \\
2.5\end{array}\right)$ & $\begin{array}{l}66 \\
22\end{array}$ & $\left.\begin{array}{l}(4.1) \\
3.7\end{array}\right)$ & $\begin{array}{l}68 \\
18\end{array}$ & $\left(\begin{array}{l}4.0 \\
(2.2)\end{array}\right)$ & $\begin{array}{l}66 \\
17\end{array}$ & $\left(\begin{array}{l}2.5) \\
1.7)\end{array}\right.$ & $\begin{array}{l}64 \\
16\end{array}$ & $\left(\begin{array}{l}2.2 \\
1.8\end{array}\right)$ & $\begin{array}{l}67 \\
21\end{array}$ & $\left(\begin{array}{l}2.4 \\
(1.5)\end{array}\right)$ & $\begin{array}{l}70 \\
22\end{array}$ & $\left(\begin{array}{l}1.4 \\
1.5\end{array}\right)$ \\
\hline 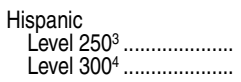 & {$\left[\begin{array}{l}6 \\
6 \\
6\end{array}\right]$} & $\left(\begin{array}{l}(t) \\
(t)\end{array}\right.$ & $\begin{array}{l}53 \\
13\end{array}$ & $\left(\begin{array}{l}4.1 \\
2.7\end{array}\right)$ & $\begin{array}{l}62 \\
17\end{array}$ & $\left.\begin{array}{l}(3.1) \\
2.1\end{array}\right)$ & $\begin{array}{l}68 \\
21\end{array}$ & $\begin{array}{l}(2.4) \\
(3.0)\end{array}$ & $\begin{array}{l}71 \\
23\end{array}$ & $\begin{array}{l}(4.8) \\
(3.7)\end{array}$ & $\begin{array}{l}75 \\
27\end{array}$ & $\begin{array}{l}(4.7) \\
(3.3)\end{array}$ & $\begin{array}{l}69 \\
27\end{array}$ & $\left.\begin{array}{l}(4.0) \\
(3.2)\end{array}\right)$ & $\begin{array}{l}63 \\
20\end{array}$ & $\begin{array}{l}(4.4) \\
(3.0)\end{array}$ & $\begin{array}{l}65 \\
20\end{array}$ & $\begin{array}{l}(4.2) \\
(4.8)\end{array}$ & $\begin{array}{l}68 \\
24\end{array}$ & $\begin{array}{l}(4.3) \\
(3.8)\end{array}$ & $\begin{array}{l}67 \\
23\end{array}$ & $\left(\begin{array}{l}2.4 \\
2.1\end{array}\right)$ & $\begin{array}{l}70 \\
22\end{array}$ & $\begin{array}{l}(1.5) \\
(1.0)\end{array}$ & $\begin{array}{l}74 \\
26\end{array}$ & $\left(\begin{array}{l}1.3 \\
1.3\end{array}\right)$ \\
\hline
\end{tabular}

†Not applicable

Students scoring 150 (or higher) are able to follow brief written directions and carry out simple, discrete reading tasks.

${ }^{2}$ Students scoring 200 (or higher) are able to understand, combine ideas, and make inferences based on short uncomplicated passages about specific or sequentially related information.

${ }^{3}$ Students scoring 250 (or higher) are able to search for specific information, interrelate ideas, and make generalizations about literature, science, and social studies materials.

${ }^{4}$ Students scoring 300 (or higher) are able to find, understand, summarize, and explain relatively complicated literary and informational material.

${ }^{5}$ Data for 1971 include persons of Hispanic ethnicity.

${ }^{6}$ Test scores of Hispanics were not tabulated separately.
NOTE: The NAEP reading scores have been evaluated at certain performance levels, as outlined in footnotes 1 through 4 . Scale ranges from 0 to 500 . Includes public and private schools. For assessment years prior to 2004, accommodations were not permitted. For 2004 and later years, includes students tested with accommodations; excludes only those students with disabilities and English language learners who were unable to be tested even with accommodations (2 to 5 percent of all students, depending on age and assessment year). Race categories exclude persons of Hispanic ethnicity, except where noted. Totals include other racial/ethnic groups not shown separately.

SOURCE: U.S. Department of Education, National Center for Education Statistics, National Assessment of Educational Progress (NAEP), NAEP 1999 Trends in Academic Progress; and 2004, 2008, and 2012 Long-Term Trend Reading Assessments, retrieved May 12, 2009, and July 15, 2013, from the Long-Term Trend NAEP Data Explorer (http://nces.ed.gov/nations reportcard/naepdata/). (This table was prepared July 2013.) 
Table 222.10. Average National Assessment of Educational Progress (NAEP) mathematics scale score, by grade and selected student and school characteristics: Selected years, 1990 through 2013

[Standard errors appear in parentheses]

\begin{tabular}{|c|c|c|c|c|c|c|c|c|c|c|c|c|c|c|c|}
\hline Grade and selected student or school characteristic & $1990^{1}$ & $1992^{1}$ & & 1996 & 2000 & 2003 & 2005 & & 2007 & & 2009 & & 2011 & & 2013 \\
\hline 1 & 2 & 3 & & 4 & 5 & 6 & 7 & & 8 & & $y$ & & 10 & & 11 \\
\hline 4th grade & $13(0.9)$ & $20(0.7)$ & 224( & $(1.0)$ & $226(0.9)$ & $235(0.2)$ & $238(0.1)$ & 240 & $(0.2)$ & 240 & $(0.2)$ & 241 & $(0.2)$ & 242 & $\overline{(0.2)}$ \\
\hline 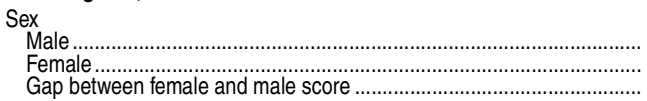 & $\begin{array}{rr}214 & (1.2) \\
213 & (1.1) \\
-1 & (1.7)\end{array}$ & $\begin{array}{rr}221 & (0.8) \\
219 & (1.0) \\
-2 & (1.2)\end{array}$ & $\left.\begin{array}{r}224 \\
223 \\
\#\end{array}\right\}$ & $\left.\begin{array}{r}1.1 \\
1.1 \\
(\dagger\end{array}\right)$ & 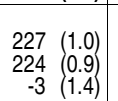 & $\begin{array}{rr}236 & (0.3) \\
233 & (0.2) \\
-3 & (0.3)\end{array}$ & $\begin{array}{rr}239 & (0.2) \\
237 & (0.2) \\
-3 & (0.2)\end{array}$ & $\left.\begin{array}{r}241 \\
239 \\
-2\end{array}\right\}$ & $\left.\begin{array}{l}(0.2) \\
0.2 \\
0.3\end{array}\right)$ & $\left.\begin{array}{r}241 \\
239 \\
-2\end{array}\right\}$ & $\left.\begin{array}{l}0.3 \\
0.3 \\
0.4\end{array}\right)$ & $\begin{array}{r}241 \\
240 \\
-1\end{array}$ & $\left(\begin{array}{l}0.2 \\
0.2 \\
0.3\end{array}\right)$ & $\begin{array}{r}242 \\
241 \\
-1\end{array}$ & $\begin{array}{l}0.3) \\
(0.2) \\
(0.4)\end{array}$ \\
\hline 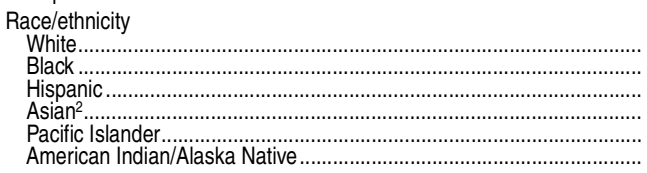 & $\begin{array}{rr}220 & (1.0) \\
188 & (1.8) \\
200 & (2.2) \\
225 & (4.1) \\
{\left[{ }^{2}\right]} & (\dagger) \\
f & (\dagger)\end{array}$ & $\begin{array}{rr}227 & (0.8) \\
193 & 1.4 \\
202 & 1.5 \\
231 & (2.1) \\
{\left[{ }^{2}\right]} & (\dagger) \\
f & (\dagger)\end{array}$ & $\left.\begin{array}{r}232 \\
198 \\
207 \\
229 \\
{\left[{ }^{2]}\right.} \\
217\end{array}\right\}$ & $\begin{array}{r}(1.0) \\
1.6 \\
1.9 \\
4.2 \\
(\dagger) \\
(5.6)\end{array}$ & $\begin{array}{rr}234 & (0.8) \\
203 & 1.2 \\
208 & (1.5) \\
\ddagger & (†) \\
{\left[\begin{array}{ll}\ddagger \\
{[2]}\end{array}\right.} & (\dagger) \\
208 & (3.5)\end{array}$ & \begin{tabular}{rr|}
243 & $(0.2)$ \\
216 & 0.4 \\
222 & $0.4)$ \\
246 & $(1.1)$ \\
{$[2]$} & $(t)$ \\
223 & $(1.0)$
\end{tabular} & \begin{tabular}{rr|}
246 & $(0.1)$ \\
220 & $0.3)$ \\
226 & $0.3)$ \\
251 & $(0.7)$ \\
{$[2]$} & $(\dagger)$ \\
226 & $(0.9)$
\end{tabular} & $\left.\begin{array}{r}248 \\
222 \\
227 \\
253 \\
\left.{ }^{2}\right] \\
228\end{array}\right\}$ & $\begin{array}{r}(0.2) \\
0.3) \\
0.3 \\
0.8) \\
(\dagger) \\
(0.7)\end{array}$ & $\left.\begin{array}{r}248 \\
222 \\
227 \\
255 \\
{\left[{ }^{2}\right]} \\
225\end{array}\right\}$ & $\begin{array}{r}(0.2) \\
0.3) \\
0.4) \\
1.0 \\
(\dagger) \\
(0.9)\end{array}$ & $\begin{array}{l}249 \\
224 \\
229 \\
257 \\
236 \\
225\end{array}$ & $\begin{array}{l}(0.2) \\
0.4 \\
0.3 \\
1.0 \\
2.1 \\
(0.9)\end{array}$ & $\begin{array}{l}250 \\
224 \\
231 \\
259 \\
236 \\
227\end{array}$ & $\left.\begin{array}{l}0.2 \\
0.3 \\
0.4 \\
0.8 \\
2.0 \\
1.1\end{array}\right)$ \\
\hline ore & $\begin{array}{ll}32 & (2.0) \\
20 & (2.4)\end{array}$ & $\begin{array}{l}35 \\
25\end{array}(1.6)$ & $\left.\begin{array}{l}34 \\
25\end{array}\right\}$ & $\left(\begin{array}{l}1.8) \\
2.1\end{array}\right)$ & $\begin{array}{ll}31 & (1.5) \\
27 & (1.7)\end{array}$ & $\begin{array}{ll}27 & (0.4) \\
22 & (0.5)\end{array}$ & $\begin{array}{ll}26 & (0.3) \\
20 & (0.3)\end{array}$ & $\left.\begin{array}{l}26 \\
21\end{array}\right\}$ & $\left.\begin{array}{l}(0.4) \\
0.4\end{array}\right)$ & $\begin{array}{l}26 \\
21\end{array}$ & $\left(\begin{array}{l}0.4) \\
0.5\end{array}\right)$ & $\begin{array}{l}25 \\
20\end{array}$ & $\left(\begin{array}{l}0.4) \\
0.4\end{array}\right)$ & $\begin{array}{l}26 \\
19\end{array}$ & $\left.\begin{array}{l}0.4 \\
0.5\end{array}\right)$ \\
\hline ligible for free or reduced-price lunch & $\begin{array}{ll}- & (t) \\
- & (t) \\
- & (t) \\
- & (t)\end{array}$ & $\begin{array}{ll}- & (t) \\
- & (t) \\
- & (t) \\
- & (\dagger)\end{array}$ & $\begin{array}{l}- \\
z \\
-\end{array}$ & $\left.\begin{array}{c}(t) \\
+ \\
(t) \\
+ \\
(t)\end{array}\right)$ & $\begin{array}{rr}239 & (1.2) \\
227 & (1.2) \\
216 & (1.5) \\
205 & (1.2) \\
34 & (1.7)\end{array}$ & $\begin{array}{rr}247 & (0.3) \\
237 & 0.3) \\
229 & 0.4 \\
216 & 0.5 \\
31 & (0.6)\end{array}$ & $\begin{array}{rr}250 & (0.3) \\
240 & 0.3 \\
232 & 0.3 \\
220 & 0.3 \\
30 & (0.4)\end{array}$ & $\left.\begin{array}{r}252 \\
242 \\
234 \\
222 \\
30\end{array}\right\}$ & $\left.\begin{array}{l}(0.3) \\
0.3 \\
0.3 \\
0.4 \\
0.5\end{array}\right)$ & $\left.\begin{array}{r}254 \\
242 \\
234 \\
223 \\
31\end{array}\right\}$ & $\left.\begin{array}{l}(0.4) \\
0.4 \\
0.4 \\
0.4 \\
0.6\end{array}\right)$ & $\begin{array}{r}255 \\
245 \\
237 \\
226 \\
29\end{array}$ & $\begin{array}{l}(0.4) \\
0.4 \\
0.3 \\
0.3 \\
0.6)\end{array}$ & $\begin{array}{r}257 \\
246 \\
238 \\
226 \\
31\end{array}$ & $\begin{array}{l}0.4) \\
0.4 \\
0.5 \\
0.5 \\
0.6)\end{array}$ \\
\hline 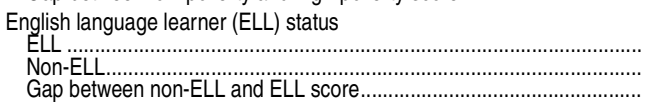 & $\begin{array}{ll}- & (t) \\
- & (t) \\
- & (t)\end{array}$ & $\begin{array}{ll}- & (\dagger) \\
- & (\dagger) \\
- & (\dagger)\end{array}$ & $\left.\begin{array}{r}201 \\
225 \\
24\end{array}\right\}$ & $\begin{array}{l}3.6 \\
0.9 \\
(3.7)\end{array}$ & $\begin{array}{rr}199 & (2.0) \\
227 & 0.8 \\
28 & (2.1) \\
\end{array}$ & $\begin{array}{rr}214 & (0.6) \\
237 & 0.2 \\
23 & (0.6) \\
\end{array}$ & $\begin{array}{rr}216 & (0.5) \\
240 & 0.1 \\
24 & (0.5) \\
\end{array}$ & $\left.\begin{array}{r}217 \\
242 \\
25\end{array}\right\}$ & $\left.\begin{array}{l}(0.5) \\
0.2 \\
0.5\end{array}\right)$ & $\begin{array}{r}218 \\
242 \\
24 \\
\end{array}$ & $\left.\begin{array}{l}(0.6) \\
0.2 \\
0.7\end{array}\right)$ & $\begin{array}{r}219 \\
243 \\
24 \\
\end{array}$ & $\begin{array}{l}(0.5) \\
0.2 \\
(0.5)\end{array}$ & $\begin{array}{r}219 \\
244 \\
25 \\
\end{array}$ & $\begin{array}{l}0.6 \\
0.2 \\
0.6)\end{array}$ \\
\hline $8 \mathrm{t}$ & $263(1.3)$ & $268(0.9)$ & 270( & $(0.9)$ & $273(0.8)$ & $278(0.3)$ & $279(0.2)$ & 281( & (0.3) & 283 & (0.3) & 284 & $(0.2)$ & 285 & $(0.3)$ \\
\hline (1) & $\begin{array}{rr}263 & (1.6) \\
262 & 1.3 \\
-1 & (2.1)\end{array}$ & $\begin{array}{rr}268 & (1.1) \\
269 & (1.0) \\
1 & (1.5)\end{array}$ & $\left.\begin{array}{r}271 \\
269 \\
-2\end{array}\right\}$ & $\left(\begin{array}{l}1.1 \\
1.1 \\
1.5\end{array}\right)$ & $\begin{array}{rr}274 & (0.9) \\
272 & (0.9) \\
-2 & (1.3)\end{array}$ & $\begin{array}{rr}278 & (0.3) \\
277 & 0.3 \\
-2 & (0.4)\end{array}$ & $\begin{array}{rr}280 & (0.2) \\
278 & (0.2) \\
-2 & (0.3)\end{array}$ & $\left.\begin{array}{r}282 \\
280 \\
-2\end{array}\right\}$ & $\left.\begin{array}{l}0.3) \\
0.3 \\
0.4\end{array}\right)$ & $\left.\begin{array}{r}284 \\
282 \\
-2\end{array}\right\}$ & $\left.\begin{array}{l}0.3 \\
0.4 \\
0.5\end{array}\right)$ & $\begin{array}{r}284 \\
283 \\
-1\end{array}$ & $\left.\begin{array}{l}(0.3) \\
0.2 \\
0.4\end{array}\right)$ & $\begin{array}{r}285 \\
284 \\
-1\end{array}$ & $\left.\begin{array}{l}0.3 \\
0.3 \\
0.4\end{array}\right)$ \\
\hline $\begin{array}{l}\text { Black........ } \\
\text { Hispanic... } \\
\text { Asiann2...... } \\
\text { Pacific Isla } \\
\text { American }\end{array}$ & $\begin{array}{rr}270 & (1.3) \\
237 & (2.7) \\
246 & 4.3) \\
275 & (5.0) \\
{\left[{ }^{2}\right]} & (\dagger) \\
f & (\dagger)\end{array}$ & $\begin{array}{rr}277 & (1.0) \\
237 & (1.3) \\
249 & 1.2 \\
290 & (5.9) \\
{\left[{ }^{2}\right]} & (\dagger) \\
f & (\dagger)\end{array}$ & $\left.\begin{array}{r}281 \\
240 \\
251 \\
\ddagger \\
{\left[^{2}\right]} \\
f\end{array}\right\}$ & $\begin{array}{r}(1.1) \\
1.9 \\
1.7 \\
(\dagger \\
+ \\
(\dagger)\end{array}$ & \begin{tabular}{rr|}
284 & $(0.8)$ \\
244 & 1.2 \\
253 & 1.3 \\
288 & $(3.5)$ \\
{$\left[{ }^{2}\right]$} & $(\dagger)$ \\
259 & $(7.5)$
\end{tabular} & $\begin{array}{rr}288 & (0.3) \\
252 & 0.5 \\
259 & 0.6) \\
291 & (1.3) \\
{\left[{ }^{2}\right]} & (t) \\
263 & (1.8)\end{array}$ & \begin{tabular}{cc|}
289 & $(0.2)$ \\
255 & $0.4)$ \\
262 & $0.4)$ \\
295 & 0.9 \\
{$\left[^{2}\right]$} & $(\dagger)$ \\
264 & $(0.9)$
\end{tabular} & $\left.\begin{array}{l}291 \\
260 \\
265 \\
297 \\
{\left[^{2}\right]} \\
264\end{array}\right\}$ & $\begin{array}{r}(0.3) \\
0.4 \\
0.4) \\
0.9 \\
(\dagger) \\
(1.2)\end{array}$ & $\left.\begin{array}{r}293 \\
261 \\
266 \\
301 \\
{\left[^{2}\right]} \\
266\end{array}\right\}$ & $\begin{array}{r}(0.3) \\
0.5 \\
0.6 \\
1.2 \\
(\dagger) \\
(1.1)\end{array}$ & $\begin{array}{l}293 \\
262 \\
270 \\
305 \\
269 \\
265\end{array}$ & $\left.\begin{array}{l}(0.2) \\
0.5 \\
0.5 \\
1.1 \\
2.4 \\
0.9\end{array}\right)$ & $\begin{array}{l}294 \\
263 \\
272 \\
309 \\
275 \\
269\end{array}$ & $\left.\begin{array}{l}0.3 \\
0.4 \\
0.5 \\
1.1 \\
2.3 \\
1.2\end{array}\right)$ \\
\hline & $\begin{array}{ll}33 & (3.0) \\
24 & (4.5)\end{array}$ & $\begin{array}{ll}40 & (1.7) \\
28 & (1.5)\end{array}$ & $\left.\begin{array}{l}41 \\
30\end{array}\right\}$ & $\begin{array}{l}(2.2) \\
(2.0)\end{array}$ & $\begin{array}{ll}40 & (1.5) \\
31 & (1.6)\end{array}$ & $\begin{array}{ll}35 & (0.6) \\
29 & (0.7)\end{array}$ & $\begin{array}{ll}34 & (0.4) \\
27 & (0.5)\end{array}$ & $\left.\begin{array}{l}32 \\
26\end{array}\right\}$ & $\left.\begin{array}{l}0.5) \\
0.5\end{array}\right)$ & $\begin{array}{l}32 \\
26\end{array}$ & $\begin{array}{l}(0.5) \\
0.6)\end{array}$ & $\begin{array}{l}31 \\
23\end{array}$ & $\left(\begin{array}{l}0.5 \\
0.5\end{array}\right)$ & $\begin{array}{l}31 \\
22\end{array}$ & $\begin{array}{l}0.5 \\
(0.5)\end{array}$ \\
\hline $\begin{array}{l}\text { Percenta } \\
0-25 p \\
26-50 \\
51-75 \\
76-10 \\
\text { Gap b }\end{array}$ & $\begin{array}{lc}- & (t) \\
- & (t) \\
- & (t) \\
- & (\dagger)\end{array}$ & $\begin{array}{ll}- & (t) \\
- & (t) \\
- & (t) \\
- & (t)\end{array}$ & $\begin{array}{l}- \\
\overline{-} \\
\overline{-}\end{array}$ & 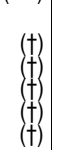 & $\begin{array}{rr}287 & (1.1) \\
270 & (1.4) \\
260 & (1.8) \\
246 & (2.2) \\
41 & (2.4)\end{array}$ & $\begin{array}{rr}291 & (0.4) \\
278 & 0.4 \\
266 & 0.7 \\
251 & 0.7 \\
40 & (0.8)\end{array}$ & $\begin{array}{rr}293 & (0.4) \\
280 & 0.3 \\
268 & 0.4 \\
254 & 0.6 \\
38 & (0.7)\end{array}$ & $\left.\begin{array}{r}296 \\
282 \\
271 \\
259 \\
37\end{array}\right\}$ & $\left.\begin{array}{l}0.4 \\
0.4 \\
0.6 \\
0.7 \\
0.8\end{array}\right)$ & $\left.\begin{array}{r}298 \\
284 \\
274 \\
260 \\
38\end{array}\right\}$ & $\left.\begin{array}{l}0.5 \\
0.5 \\
0.7 \\
0.7 \\
0.8\end{array}\right)$ & $\begin{array}{r}300 \\
287 \\
276 \\
264 \\
36\end{array}$ & $\left.\begin{array}{l}(0.5) \\
0.5 \\
0.7 \\
0.7 \\
0.9\end{array}\right)$ & $\begin{array}{r}301 \\
289 \\
277 \\
265 \\
36\end{array}$ & $\left.\begin{array}{l}0.5 \\
0.5 \\
0.4 \\
0.6 \\
0.8\end{array}\right)$ \\
\hline $\begin{array}{l}\text { ELL } \\
\text { Non-ELL............ } \\
\text { Gap between }\end{array}$ & $\begin{array}{ll}- & (t) \\
- & (t) \\
- & (t)\end{array}$ & $\begin{array}{ll}- & (t) \\
- & (\dagger) \\
- & (\dagger)\end{array}$ & $\left.\begin{array}{r}226 \\
272 \\
46\end{array}\right\}$ & $\begin{array}{l}3.2 \\
1.0 \\
(3.4)\end{array}$ & $\begin{array}{rr}234 & (2.7) \\
274 & (0.8) \\
40 & (2.8) \\
\end{array}$ & $\begin{array}{rr}242 & (1.0) \\
279 & (0.3) \\
38 & (1.0) \\
\end{array}$ & $\begin{array}{rr}244 & (0.8) \\
281 & (0.2) \\
37 & (0.8) \\
\end{array}$ & $\left.\begin{array}{r}246 \\
283 \\
38\end{array}\right\}$ & $\left.\begin{array}{l}0.8) \\
0.3 \\
0.8\end{array}\right)$ & $\left.\begin{array}{r}243 \\
285 \\
42\end{array}\right\}$ & $\left.\begin{array}{l}0.9 \\
0.3 \\
0.9\end{array}\right)$ & $\begin{array}{r}244 \\
286 \\
42 \\
\end{array}$ & $(1.0)$ & $\begin{array}{r}246 \\
287 \\
41 \\
\end{array}$ & $\left.\begin{array}{l}0.8 \\
0.3 \\
0.8\end{array}\right)$ \\
\hline 12th grade, & {$\left[\begin{array}{ll}3 \\
{[}\end{array} \quad(t)\right.$} & $(t)$ & [3] & $(t)$ & [3] & $(t)$ & $150(0.6)$ & 一 & $(t)$ & 153 & $(0.7$ & 一 & $(t)$ & - & $(\dagger)$ \\
\hline $\begin{array}{l}\text { Male ................. } \\
\text { Female........ } \\
\text { Gap between }\end{array}$ & {$\left[\begin{array}{ll}3 \\
3 \\
3 \\
3\end{array}\right] \quad\left(\begin{array}{l}t \\
+ \\
+t\end{array}\right)$} & 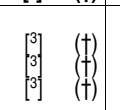 & {$\left[\begin{array}{l}3 \\
3 \\
3 \\
3\end{array}\right]$} & $\left(\begin{array}{l}(t) \\
+ \\
(\dagger)\end{array}\right.$ & {$\left[\begin{array}{ll}3 \\
3 \\
3 \\
3\end{array}\right] \quad\left(\begin{array}{l}t \\
3\end{array}\right)$} & $\begin{array}{ll}\bar{z} & (t) \\
\overline{-} & (\dagger)\end{array}$ & $\begin{array}{rr}151 & (0.7) \\
149 & 0.7) \\
-3 & (1.0)\end{array}$ & - & $\left(\begin{array}{c}+ \\
+ \\
+\end{array}\right)$ & $\left.\begin{array}{r}155 \\
152 \\
-3\end{array}\right\}$ & $\left(\begin{array}{l}0.9 \\
0.7 \\
1.1\end{array}\right)$ & z & $\left(\begin{array}{l}+ \\
+ \\
+\end{array}\right)$ & $\begin{array}{l}- \\
-\end{array}$ & $\left(\begin{array}{l}(t) \\
+ \\
+\end{array}\right)$ \\
\hline 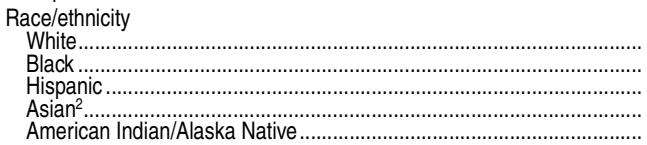 & 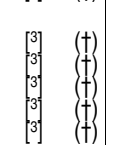 & {$\left[\begin{array}{l}3 \\
3 \\
3 \\
3 \\
3 \\
3 \\
3 \\
3\end{array}\right]$} & {$\left[\begin{array}{l}3 \\
3 \\
3 \\
3 \\
3 \\
3 \\
3\end{array}\right]$} & 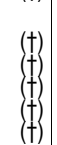 & 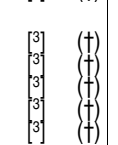 & $\begin{array}{ll}- & (t) \\
- & (t) \\
- & (t) \\
- & (\dagger)\end{array}$ & $\begin{array}{ll}157 & (0.6) \\
127 & (1.1) \\
133 & (1.3) \\
163 & (2.0) \\
134 & (4.1)\end{array}$ & $\begin{array}{l}- \\
\overline{-} \\
-\end{array}$ & $\left.\begin{array}{c}(t \\
+ \\
+ \\
+ \\
+\end{array}\right)$ & $\left.\begin{array}{l}161 \\
131 \\
138 \\
175 \\
144\end{array}\right\}$ & $\left.\begin{array}{l}(0.6) \\
0.8 \\
0.8 \\
2.7 \\
2.8\end{array}\right)$ & $\begin{array}{l}- \\
- \\
-\end{array}$ & $\left.\begin{array}{l}(t \\
+ \\
+ \\
+ \\
(t)\end{array}\right)$ & $\begin{array}{l}- \\
- \\
-\end{array}$ & $\left(\begin{array}{l}+ \\
+ \\
+ \\
+ \\
+\end{array}\right)$ \\
\hline$y^{2}$ & {$\left[\begin{array}{ll}{[3} & (t) \\
{[3}\end{array}\right] \quad(t)$} & $\left(\begin{array}{l}t \\
(t)\end{array}\right.$ & {$\left[\begin{array}{l}3 \\
3 \\
3\end{array}\right]$} & $\left(\begin{array}{l}t \\
(t)\end{array}\right.$ & $\left(\begin{array}{l}t \\
(t\end{array}\right)$ & $\begin{array}{ll}- & (t) \\
- & (t)\end{array}$ & $\begin{array}{ll}31 & (1.2) \\
24 & (1.4)\end{array}$ & - & $\left(\begin{array}{l}t \\
(t)\end{array}\right.$ & $\begin{array}{l}30 \\
23\end{array}$ & $\left(\begin{array}{l}1.0 \\
1.0\end{array}\right)$ & - & $(t)$ & - & $\left(\begin{array}{l}t \\
\dagger\end{array}\right)$ \\
\hline 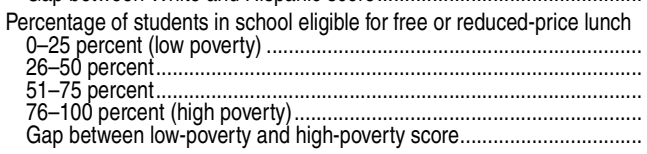 & 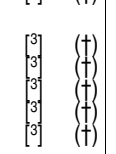 & $\left.\begin{array}{l}3 \\
3 \\
3 \\
3 \\
3 \\
3 \\
3 \\
3\end{array}\right]$ & {$\left[\begin{array}{l}3 \\
3 \\
3 \\
3 \\
3 \\
3 \\
3\end{array}\right]$} & $\left.\begin{array}{l}(t) \\
+ \\
+ \\
+ \\
(t)\end{array}\right)$ & 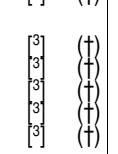 & $\begin{array}{ll}- & (t) \\
- & (t) \\
- & (t) \\
- & (t)\end{array}$ & $\begin{array}{rr}158 & (1.0) \\
147 & 1.0 \\
136 & (1.3) \\
122 & 2.7 \\
36 & (2.8)\end{array}$ & $\begin{array}{l}- \\
\overline{-} \\
-\end{array}$ & $\left.\begin{array}{c}(t \\
+ \\
+ \\
+ \\
+ \\
+\end{array}\right)$ & $\left.\begin{array}{r}166 \\
150 \\
140 \\
130 \\
36\end{array}\right\}$ & $\left(\begin{array}{l}1.3 \\
0.7 \\
1.2 \\
1.7 \\
2.1\end{array}\right)$ & $\begin{array}{l}- \\
- \\
- \\
-\end{array}$ & $\left(\begin{array}{l}(t) \\
(t) \\
(t) \\
(t) \\
(t)\end{array}\right.$ & $\begin{array}{l}- \\
- \\
- \\
-\end{array}$ & (It) \\
\hline
\end{tabular}

-Not available

†Not applicable.

\#Rounds to zero.

†Reporting standards not met (too few cases for a reliable estimate).

${ }^{1}$ Accommodations were not permitted for this assessment.

${ }^{2}$ For assessment years prior to 2011, Pacific Islander students are included with Asian students.

${ }^{3}$ Because of major changes to the framework and content of the grade 12 assessment, scores from 2005 and later assessment years cannot be compared with scores from earlie assessment years. Therefore, this table does not include scores from the earlier grade 12 assessment years (1990, 1992, 1996, and 2000). For data pertaining to comparisons between earlier years, see the Digest of Education Statistics 2009, table 138 (http:/l nces.ed.gov/programs/digest/d09/tables/dt09 138.asp).

NOTE: For the grade 4 and grade 8 assessments, scale ranges from 0 to 500 . For the grade 12 assessment, scale ranges from 0 to 300 . Includes public and private schools. For 1996 and later years, includes students tested with accommodations ( 1 to 12 percent of all students, depending on grade level and year); excludes only those students with disabilities and English language learners who were unable to be tested even with accommodations (1 to 4 percent of all students). Race categories exclude persons of Hispanic ethnicity. Totals include other racial/ethnic groups not shown separately. Gaps are computed based on unrounded scores. Grade 12 results for the 2013 NAEP Mathematics Assessment were not yet available at the time this table was created.

SOURCE: U.S. Department of Education, National Center for Education Statistics, National Assessment of Educational Progress (NAEP), 1990, 1992, 1996, 2000, 2003, 2005, 2007, 2009, 2011, and 2013 Mathematics Assessments, retrieved November 9, 2013, from the Main NAEP Data Explorer (http://nces.ed.gov/nationsreportcard/naepdata/). (This table was prepared November 2013.) 


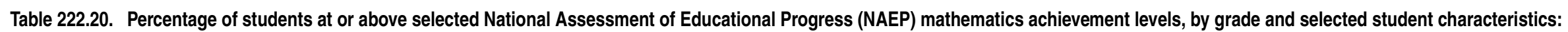
Selected years, 1996 through 2013

[Standard errors appear in parentheses]

\begin{tabular}{|c|c|c|c|c|c|c|c|c|c|c|c|c|c|c|c|c|c|c|c|c|c|c|c|c|c|c|c|c|c|c|c|c|}
\hline \multirow[b]{2}{*}{$\begin{array}{l}\text { Grade and selected student } \\
\text { characteristic }\end{array}$} & \multicolumn{4}{|c|}{1996} & \multicolumn{4}{|c|}{2000} & \multicolumn{4}{|c|}{2003} & \multicolumn{4}{|c|}{2005} & \multicolumn{4}{|c|}{2007} & \multicolumn{4}{|c|}{2009} & \multicolumn{4}{|c|}{2011} & \multicolumn{4}{|c|}{2013} \\
\hline & & & & & $\begin{array}{r}\mathrm{rab} \\
B c\end{array}$ & $\begin{array}{l}\text { above } \\
\text { Basic }\end{array}$ & & & At or a & $\begin{array}{l}\text { above } \\
\text { Basic }\end{array}$ & & & At or a & $\begin{array}{l}\text { above } \\
\text { Basic }^{1}\end{array}$ & $\begin{array}{l}\text { At or a } \\
\text { Profic }\end{array}$ & & $\begin{array}{c}\text { At or a } \\
B\end{array}$ & $\begin{array}{l}\text { above } \\
\text { Basic }\end{array}$ & & & At or a & $\begin{array}{l}\text { above } \\
\text { Basic }^{1}\end{array}$ & Profic & & $B$ & $\begin{array}{l}\text { above } \\
\text { Basic }\end{array}$ & & & $B$ & \begin{tabular}{l|} 
above \\
Basic $^{1}$
\end{tabular} & & \\
\hline 1 & & 2 & & 3 & & 4 & & 5 & & 6 & & 7 & & 8 & & 9 & & 10 & & 11 & & 12 & & 13 & & 14 & & 15 & & 16 & & 17 \\
\hline 4th $\mathrm{gr}$ & & $\begin{array}{l}(1.3) \\
\end{array}$ & & (1.1) & 7 & $(1.3)$ & 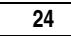 & $(1.0)$ & 77 & $(0.3)$ & 32 & $(0.3)$ & 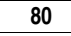 & $(0.2)$ & 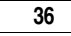 & $(0.2)$ & 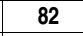 & $(0.2)$ & 39 & $(0.3)$ & 2 & $(0.3)$ & 99 & $(0.3)$ & 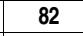 & $(0.2)$ & 40 & $(0.3)$ & 33 & $(0.2)$ & 42 & $(0.3)$ \\
\hline 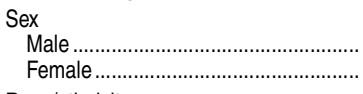 & & $\begin{array}{l}(1.5) \\
(1.4)\end{array}$ & $\begin{array}{l}2 \\
2\end{array}$ & $\begin{array}{l}(1.2) \\
(1.4)\end{array}$ & $\begin{array}{l}67 \\
64\end{array}$ & $\begin{array}{l}(1.4) \\
(1.5)\end{array}$ & 26 & $\begin{array}{l}(1.2) \\
(1.1)\end{array}$ & $\begin{array}{l}78 \\
76\end{array}$ & $\begin{array}{l}(0.4) \\
(0.3)\end{array}$ & & & $\begin{array}{l}1 \\
0\end{array}$ & & $\begin{array}{l}38 \\
34\end{array}$ & $\begin{array}{l}(0.2) \\
(0.3)\end{array}$ & & $\begin{array}{l}(0.2) \\
(0.2)\end{array}$ & $\begin{array}{l}41 \\
37\end{array}$ & $\begin{array}{l}(0.3) \\
(0.4)\end{array}$ & $\begin{array}{l}82 \\
82\end{array}$ & $\begin{array}{l}(0.3) \\
(0.3)\end{array}$ & $\begin{array}{l}41 \\
37\end{array}$ & $\begin{array}{l}(0.4) \\
(0.4)\end{array}$ & 83 & & 42 & $\begin{array}{l}(0.4) \\
(0.4)\end{array}$ & 82 & $\begin{array}{l}(0.3) \\
(0.2)\end{array}$ & 43 & $\begin{array}{l}0.4) \\
0.4)\end{array}$ \\
\hline 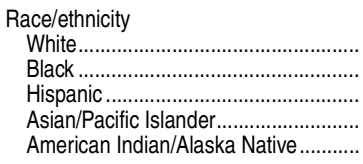 & $\begin{array}{l}10 \\
27 \\
40 \\
67 \\
57\end{array}$ & $\begin{array}{l}(1.2) \\
(2.0) \\
(2.7) \\
(5.7) \\
(7.5)\end{array}$ & $\begin{array}{r}3 \\
3 \\
7 \\
27 \\
\ddagger\end{array}$ & $\begin{array}{r}(1.3) \\
(0.6) \\
(1.4) \\
(5.0) \\
(\dagger)\end{array}$ & $\begin{array}{r}78 \\
36 \\
42 \\
\ddagger \\
40\end{array}$ & $\begin{array}{r}(1.4) \\
(1.9) \\
(2.6) \\
(\dagger) \\
(6.1)\end{array}$ & $\begin{array}{l}5 \\
7 \\
\ddagger \\
8\end{array}$ & $\begin{array}{r}(1.2) \\
(0.8) \\
(1.0) \\
(+) \\
(4.5)\end{array}$ & $\begin{array}{l}87 \\
54 \\
62 \\
87 \\
64\end{array}$ & $\begin{array}{l}(0.2) \\
(0.6) \\
(0.7) \\
(0.8) \\
(1.7)\end{array}$ & & $\begin{array}{l}(0.3) \\
(0.3) \\
(0.5) \\
(1.9) \\
(1.2)\end{array}$ & $\begin{array}{l}60 \\
68 \\
90 \\
68\end{array}$ & $\begin{array}{l}(0.2) \\
(0.5) \\
(0.5) \\
(0.5) \\
(1.5)\end{array}$ & $\begin{array}{l}47 \\
13 \\
19 \\
55 \\
21\end{array}$ & $\begin{array}{l}(0.3) \\
(1.3) \\
(1.2)\end{array}$ & $\begin{array}{l}70 \\
91 \\
70\end{array}$ & $\begin{array}{l}(0.2) \\
(0.6) \\
(0.5) \\
(0.7) \\
(1.2)\end{array}$ & $\begin{array}{l}51 \\
15 \\
22 \\
25 \\
25\end{array}$ & $\begin{array}{l}(0.4) \\
(0.4) \\
(0.4) \\
(1.3) \\
(1.1)\end{array}$ & $\begin{array}{l}91 \\
64 \\
71 \\
92 \\
66\end{array}$ & $\begin{array}{l}(0.2) \\
(0.6) \\
(0.7) \\
(0.6) \\
(1.6)\end{array}$ & $\begin{array}{l}1 \\
6 \\
2 \\
2 \\
01\end{array}$ & $\begin{array}{l}(0.4) \\
(0.5) \\
(0.4) \\
(1.5) \\
(1.2)\end{array}$ & 66 & $\begin{array}{l}(0.2) \\
(0.6) \\
(0.5) \\
(0.6) \\
(1.2)\end{array}$ & 2 & $\begin{array}{l}(0.4) \\
(0.5) \\
(0.5) \\
(1.6) \\
(1.2)\end{array}$ & $\begin{array}{l}66 \\
71 \\
61 \\
68\end{array}$ & $\begin{array}{l}(0.2) \\
(0.6) \\
(0.7) \\
(0.6) \\
(1.7)\end{array}$ & $\begin{array}{l}26 \\
64 \\
23\end{array}$ & $\begin{array}{l}1.2) \\
1.4)\end{array}$ \\
\hline & $\begin{array}{l}40 \\
76 \\
72 \\
\end{array}$ & $\begin{array}{l}(1.8) \\
(1.2) \\
(3.0) \\
\end{array}$ & $\begin{array}{r}8 \\
27 \\
28 \\
\end{array}$ & $\begin{array}{l}(0.9) \\
(1.2) \\
(4.1) \\
\end{array}$ & $\begin{array}{l}43 \\
78 \\
80 \\
\end{array}$ & $\begin{array}{l}(1.5) \\
(1.6) \\
(2.2) \\
\end{array}$ & ह & $\begin{array}{l}(0.8) \\
(1.6) \\
(2.2) \\
\end{array}$ & & $\begin{array}{l}(0.5) \\
(0.3) \\
(0.9) \\
\end{array}$ & & & & & $\begin{array}{l}19 \\
49 \\
45 \\
\end{array}$ & & & $\begin{array}{l}(0.4) \\
(0.2) \\
(0.9) \\
\end{array}$ & & $\begin{array}{l}(0.3) \\
(0.4) \\
(1.5) \\
\end{array}$ & & $\begin{array}{l}(0.4) \\
(0.3) \\
(1.3) \\
\end{array}$ & $\begin{array}{l}22 \\
54 \\
47 \\
\end{array}$ & & & & & $\begin{array}{l}(0.4) \\
(1.4)\end{array}$ & 90 & $\begin{array}{l}(0.2) \\
(1.0) \\
\end{array}$ & 52 & \\
\hline 8th 9 & & (1.0) & & $(1.0)$ & & $(0.9)$ & & (0.8) & & $(0.3)$ & & (0.3) & & $(0.2$ & & $(0.2$ & 71 & $(0.3$ & & $(0.3$ & & $(0.5$ & & (0.) & 73 & (0. & & $(0.2)$ & 74 & $(0.3$ & & \\
\hline & & $\begin{array}{l}(1.2) \\
(1.2)\end{array}$ & & $\begin{array}{l}(1.2) \\
(1.2)\end{array}$ & & $\begin{array}{l}(1.1) \\
(1.1)\end{array}$ & & $\begin{array}{l}(1.0) \\
(0.9)\end{array}$ & $\begin{array}{l}69 \\
67\end{array}$ & $\begin{array}{l}(0.4) \\
(0.4)\end{array}$ & & $\begin{array}{l}(0.4) \\
(0.3)\end{array}$ & & & & $\left.\begin{array}{l}(0.3) \\
(0.3)\end{array}\right]$ & & & & $\begin{array}{l}(0.4) \\
(0.3)\end{array}$ & & $\begin{array}{l}(0.3) \\
(0.4)\end{array}$ & $\begin{array}{l}36 \\
32\end{array}$ & $\begin{array}{l}(0.4) \\
(0.4)\end{array}$ & & $\begin{array}{l}(0.4) \\
(0.2)\end{array}$ & & $\begin{array}{l}(0.3) \\
(0.3)\end{array}$ & & $\left.\begin{array}{l}(0.3) \\
(0.4)\end{array}\right]$ & & \\
\hline 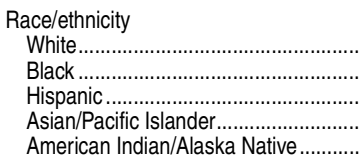 & $\begin{array}{r}25 \\
39 \\
\ddagger \\
\ddagger\end{array}$ & $\begin{array}{r}(1.3) \\
(1.8) \\
(2.0) \\
(\dagger) \\
(\dagger)\end{array}$ & $\begin{array}{r}30 \\
4 \\
8 \\
\ddagger \\
\ddagger\end{array}$ & $\begin{array}{r}(1.3) \\
(0.8) \\
(1.1) \\
(\dagger) \\
(\dagger)\end{array}$ & $\begin{array}{l}76 \\
31 \\
41 \\
75 \\
47\end{array}$ & $\begin{array}{r}(0.9) \\
(1.5) \\
(1.9) \\
(2.8) \\
(10.4)\end{array}$ & $\begin{array}{r}5 \\
8 \\
41 \\
\ddagger\end{array}$ & $\begin{array}{r}(1.0) \\
(0.6) \\
(1.0) \\
(4.4) \\
(\dagger)\end{array}$ & $\begin{array}{l}39 \\
48 \\
78 \\
52\end{array}$ & $\begin{array}{l}(0.0) \\
(0.8) \\
(1.1) \\
(2.7)\end{array}$ & 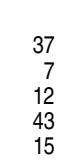 & $\begin{array}{l}(1.3) \\
(1.7)\end{array}$ & 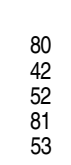 & & 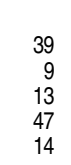 & & 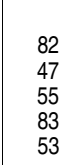 & $\begin{array}{l}(0.7) \\
(0.7) \\
(0.8) \\
(1.8)\end{array}$ & & $\begin{array}{l}(0.3) \\
(0.3) \\
(0.4) \\
(1.1) \\
(1.2)\end{array}$ & & $\begin{array}{l}(0 . \\
0 . \\
0 . \\
(0 . \\
(1 . \\
(1 .\end{array}$ & $\begin{array}{l}4 \\
2 \\
7 \\
4 \\
8\end{array}$ & & $\begin{array}{l}1 \\
6 \\
5\end{array}$ & & $\begin{array}{l}0 \\
5 \\
7\end{array}$ & $\begin{array}{l}(0.3) \\
(0.4) \\
(0.6) \\
(1.2) \\
(1.2)\end{array}$ & $\begin{array}{l}52 \\
62 \\
87 \\
59\end{array}$ & $\begin{array}{l}(0.7) \\
(0.6) \\
(0.8) \\
(1.7)\end{array}$ & -1 & \\
\hline & $\begin{array}{l}38 \\
69 \\
70 \\
\end{array}$ & $\begin{array}{l}(2.1) \\
(1.5) \\
(2.6) \\
\end{array}$ & $\begin{array}{r}8 \\
28 \\
30 \\
\end{array}$ & $\begin{array}{l}(1.2) \\
(1.3) \\
(2.6) \\
\end{array}$ & $\begin{array}{l}41 \\
74 \\
67 \\
\end{array}$ & $\begin{array}{l}(1.3) \\
(1.1 \\
(2.0) \\
\end{array}$ & $\begin{array}{r}9 \\
34 \\
29 \\
\end{array}$ & $\begin{array}{l}(0.8) \\
(1.3) \\
(1.5) \\
\end{array}$ & $\begin{array}{l}48 \\
79 \\
75 \\
\end{array}$ & $\begin{array}{l}(0.5) \\
(0.3) \\
(1.1) \\
\end{array}$ & 36 & $\begin{array}{l}(0.4) \\
(0.4) \\
(1.2) \\
\end{array}$ & $\begin{array}{l}51 \\
79 \\
79 \\
\end{array}$ & $\begin{array}{l}(0.4 \\
(0.2 \\
(1 . \\
\end{array}$ & & $\begin{array}{l}(0.3) \\
(1.4) \\
\end{array}$ & $\begin{array}{l}55 \\
81 \\
81 \\
\end{array}$ & $\begin{array}{l}(0.5) \\
(0.3) \\
(1.7) \\
\end{array}$ & $\begin{array}{l}15 \\
42 \\
43 \\
\end{array}$ & $\begin{array}{l}(0.3) \\
(0.4) \\
(1.7) \\
\end{array}$ & & $\begin{array}{l}(0.5) \\
(0.3) \\
(1.3) \\
\end{array}$ & $\begin{array}{l}17 \\
45 \\
48 \\
\end{array}$ & & $\begin{array}{l}59 \\
84 \\
85 \\
\end{array}$ & $\begin{array}{l}(0.4) \\
(0.2) \\
(0.9) \\
\end{array}$ & $\begin{array}{l}19 \\
47 \\
48 \\
\end{array}$ & $\begin{array}{l}(0.3) \\
(0.4) \\
(1.5) \\
\end{array}$ & $\begin{array}{l}86 \\
84 \\
\end{array}$ & $\begin{array}{l}(0.4) \\
(0.3) \\
(1.3) \\
\end{array}$ & 50 & \\
\hline 12th grade, all students ......... & [3] & $(t)$ & {[]} & $(\dagger$ & II & $(\dagger$ & {$\left[{ }^{3}\right]$} & (T) & - & $(t)$ & - & I & - & ( & & $(0.7)$ & - & $(\dagger$ & - & $(t)$ & 4 & $(0$ & 26 & 1 & - & $(t)$ & - & $(\dagger)$ & - & $(t)$ & - & $(t)$ \\
\hline 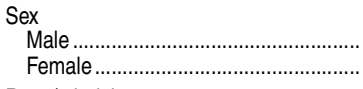 & $\left.\begin{array}{l}{[3]} \\
{[3]}\end{array}\right]$ & $\begin{array}{l}(\dagger) \\
(\dagger)\end{array}$ & $\begin{array}{l}{[3]} \\
{[3]}\end{array}$ & $(t)$ & {$\left[\begin{array}{l}{[3]} \\
{[3]}\end{array}\right]$} & $\begin{array}{l}(t) \\
(\dagger)\end{array}$ & $l^{3}$ & $\begin{array}{l}(t) \\
(\dagger)\end{array}$ & - & $\begin{array}{l}(t) \\
(\dagger)\end{array}$ & - & $\begin{array}{l}(+) \\
(+)\end{array}$ & & & & & $\overline{-}$ & $\begin{array}{l}(t) \\
(\dagger)\end{array}$ & - & & & $\begin{array}{l}(0 \\
(0\end{array}$ & & & $\overline{-}$ & $\begin{array}{l}(t) \\
(\dagger)\end{array}$ & - & $\begin{array}{l}(t) \\
(\dagger)\end{array}$ & $\overline{-}$ & $\begin{array}{l}(t) \\
(\dagger)\end{array}$ & $\begin{array}{l}- \\
-\end{array}$ & (11) \\
\hline $\begin{array}{c}\text { Race/ } \\
\text { Whi } \\
\text { Blac } \\
\text { His } \\
\text { Asi } \\
\text { Am }\end{array}$ & $\begin{array}{l}{[3]} \\
{[3]} \\
{[3]} \\
{[3]} \\
{[3]}\end{array}$ & $\begin{array}{c}(\dagger) \\
(\dagger) \\
(\dagger) \\
(\dagger) \\
(t)\end{array}$ & $\begin{array}{l}{[3]} \\
{[3]} \\
{[3]} \\
{[3]} \\
{[3]}\end{array}$ & $\begin{array}{c}(\dagger) \\
(\dagger) \\
(\dagger) \\
(\dagger) \\
(\dagger)\end{array}$ & $\begin{array}{l}{[3]} \\
{[3]} \\
{[3]} \\
{[3]} \\
{[3]}\end{array}$ & $\begin{array}{c}(\dagger) \\
(\dagger) \\
(\dagger) \\
(\dagger) \\
(\dagger)\end{array}$ & $\begin{array}{l}{[3]} \\
{[3]} \\
{[3]} \\
{[3]} \\
{[3]} \\
{[3]}\end{array}$ & $\begin{array}{c}(t) \\
(t) \\
(t) \\
(t) \\
(t)\end{array}$ & $\begin{array}{l}- \\
\overline{-} \\
\overline{-}\end{array}$ & $\begin{array}{l}(+) \\
(+) \\
(t) \\
(t)\end{array}$ & $\begin{array}{l}- \\
\overline{-} \\
- \\
-\end{array}$ & $\begin{array}{l}(t) \\
(t) \\
(t) \\
(t) \\
(t)\end{array}$ & $\begin{array}{l}70 \\
30 \\
40 \\
73 \\
42\end{array}$ & $\begin{array}{l}(0.8) \\
(1.7) \\
(2.1) \\
(2.6) \\
(8.6)\end{array}$ & $\begin{array}{r}29 \\
6 \\
8 \\
36 \\
6\end{array}$ & $\begin{array}{l}(0.8) \\
(1.0) \\
(3.0) \\
(2.9)\end{array}$ & $\begin{array}{l}- \\
\overline{-} \\
\overline{-}\end{array}$ & $\begin{array}{l}(t) \\
(t) \\
(t) \\
(t) \\
(t)\end{array}$ & $\begin{array}{l}- \\
\overline{-} \\
\overline{-}\end{array}$ & (T) & $\begin{array}{l}75 \\
37 \\
45 \\
84 \\
56\end{array}$ & & $\begin{array}{r}33 \\
6 \\
11 \\
52 \\
12\end{array}$ & $\begin{array}{l}(0.8) \\
(0.6) \\
(0.8) \\
(3.4) \\
(3.3)\end{array}$ & $\begin{array}{l}\overline{-} \\
\overline{-} \\
\overline{-}\end{array}$ & $\begin{array}{l}(t) \\
(t) \\
(t) \\
(t) \\
(t)\end{array}$ & $\begin{array}{l}\overline{-} \\
\overline{-} \\
\overline{-}\end{array}$ & $\left(\begin{array}{l}(t) \\
t+1\end{array}\right.$ & $\begin{array}{l}- \\
- \\
- \\
-\end{array}$ & $\left.\begin{array}{l}(+) \\
(+) \\
(+)\end{array}\right)$ & $\begin{array}{l}\overline{-} \\
\bar{z} \\
\overline{-}\end{array}$ & $(+)$ \\
\hline $\begin{array}{l}\text { Eligibility for fr } \\
\text { Eligible ....... } \\
\text { Not eligible } \\
\text { Unknown... }\end{array}$ & $\begin{array}{l}{[3]} \\
{[3]} \\
{[3]}\end{array}$ & $\begin{array}{l}(\dagger) \\
(\dagger) \\
(\dagger)\end{array}$ & $\begin{array}{l}{[3]} \\
{[3]} \\
{[3]}\end{array}$ & $(t)$ & $\begin{array}{l}{[3]} \\
{[3]} \\
{[3]}\end{array}$ & $\begin{array}{l}(t) \\
(\dagger) \\
(t)\end{array}$ & $\begin{array}{l}{[3} \\
{[3]} \\
{[3]}\end{array}$ & $\begin{array}{l}(t) \\
(t)\end{array}$ & $\begin{array}{l}- \\
-\end{array}$ & $\begin{array}{l}(t) \\
(t) \\
(t)\end{array}$ & $\begin{array}{l}- \\
-\end{array}$ & $\begin{array}{l}(t) \\
(t)\end{array}$ & $\begin{array}{l}39 \\
66 \\
75 \\
\end{array}$ & $\begin{array}{l}(1.6 \\
(0.9 \\
(2.7\end{array}$ & $\begin{array}{r}8 \\
27 \\
35\end{array}$ & $\begin{array}{l}(0.9) \\
(2.3)\end{array}$ & $\begin{array}{l}- \\
-\end{array}$ & $\begin{array}{l}(t) \\
(t)\end{array}$ & $\begin{array}{l}- \\
-\end{array}$ & $\begin{array}{l}(+) \\
(t)\end{array}$ & $\begin{array}{l}72 \\
71\end{array}$ & $\begin{array}{l}(0.7) \\
(3.3)\end{array}$ & $\begin{array}{l}32 \\
32\end{array}$ & $\begin{array}{l}(1.1) \\
(3.0)\end{array}$ & $\begin{array}{l}- \\
\overline{-}\end{array}$ & $\begin{array}{c}(t) \\
(+)\end{array}$ & $\begin{array}{l}- \\
-\end{array}$ & $\begin{array}{l}(\dagger) \\
(t)\end{array}$ & $\begin{array}{l}- \\
-\end{array}$ & $\left.\begin{array}{l}(t) \\
(t)\end{array}\right]$ & $\begin{array}{l}- \\
-\end{array}$ & $\begin{array}{l}\text { (1) } \\
(+) \\
(+)\end{array}$ \\
\hline
\end{tabular}

\section{-Not available.}

†Not applicable.

in mastery of the knowledge and skills that are fundamental for proficient work.

Proficient represents solid academic performance. Students reaching this level have demonstrated competency over challenging subject matter.

years cannot be compared with results from earlier assessment years. Therefore, this table excludes grade 12 results from 1996 and 2000 .
NOTE: Includes public and private schools. Includes students tested with accommodations ( 1 to 12 percent of all students, depending on grade level and year), excludes only those students with disabilities and English language learners who were unable to be tested even with accommodations ( 1 to 4 percent of all students). Race categories exclude persons of Hispanic ethnicity. Totals include other racial/ethnic groups not shown separately. Grade 12 results for the 2013 NAEP Mathematics Assessment were no
yet available at the time this table was created. SOURCE: U.S. Department of Education, National Center for Education Statistics, National Assessment of Educational Progress (NAEP), 1996, 2000, 2003, 2005, 2007, 2009, 2011, and 2013 Mathematics Assessments, retrieved November 11, 2013, from the Main NAEP Data Explorer (http://nces.ed.gov/nationsreportcard/naepdata). (This table was prepared November 2013.) 


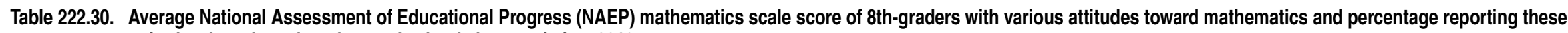
attitudes, by selected student and school characteristics: 2013

[Standard errors appear in parentheses]

\begin{tabular}{|c|c|c|c|c|c|c|c|c|c|c|c|c|c|c|c|c|c|c|c|c|c|c|c|c|}
\hline \multirow[b]{2}{*}{$\begin{array}{l}\text { Student or school } \\
\text { characteristic }\end{array}$} & \multicolumn{8}{|c|}{ Math work is engaging and interesting } & \multicolumn{8}{|c|}{ Math work is challenging } & \multicolumn{8}{|c|}{ Math work is too easy } \\
\hline & \multicolumn{2}{|c|}{$\begin{array}{r}\text { Never or } \\
\text { hardly ever }\end{array}$} & \multicolumn{2}{|c|}{ Sometimes } & \multicolumn{2}{|r|}{ Often } & \multicolumn{2}{|c|}{$\begin{array}{r}\text { Always/ } \\
\text { almost always }\end{array}$} & \multicolumn{2}{|c|}{$\begin{array}{r}\text { Never or } \\
\text { hardly ever }\end{array}$} & \multicolumn{2}{|c|}{ Sometimes } & \multicolumn{2}{|r|}{ Often } & \multicolumn{2}{|c|}{$\begin{array}{r}\text { Always/ } \\
\text { almost always }\end{array}$} & \multicolumn{2}{|c|}{$\begin{array}{r}\text { Never or } \\
\text { hardly ever }\end{array}$} & \multicolumn{2}{|c|}{ Sometimes } & \multicolumn{2}{|r|}{ Often } & \multicolumn{2}{|c|}{$\begin{array}{r}\text { Always } \\
\text { almost always }\end{array}$} \\
\hline 1 & & 2 & & 3 & & 4 & & 5 & & 6 & & 7 & & 8 & & 9 & & 10 & & 11 & & 12 & & \\
\hline & \multicolumn{24}{|c|}{ Average scale score ${ }^{1}$} \\
\hline All students .................. & 280 & $(0.4)$ & 284 & $(0.4)$ & 289 & $(0.3)$ & 287 & $(0.6)$ & 295 & $(0.6)$ & 286 & $(0.3)$ & 284 & $(0.3)$ & 275 & $(0.5)$ & 285 & $(0.5)$ & 283 & $(0.3)$ & 287 & $(0.3)$ & 290 & 0.7 \\
\hline 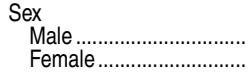 & $\begin{array}{l}281 \\
279\end{array}$ & $\left(\begin{array}{l}0.5 \\
0.5\end{array}\right)$ & $\begin{array}{l}285 \\
284\end{array}$ & $\left(\begin{array}{l}0.4 \\
0.4\end{array}\right)$ & $\begin{array}{l}290 \\
289\end{array}$ & $\left(\begin{array}{l}0.4) \\
0.4\end{array}\right)$ & $\begin{array}{l}287 \\
288\end{array}$ & $\left(\begin{array}{l}0.8) \\
0.7\end{array}\right)$ & $\begin{array}{l}297 \\
293\end{array}$ & $\left(\begin{array}{l}0.9 \\
0.7\end{array}\right)$ & $\begin{array}{l}287 \\
285\end{array}$ & $\left.\begin{array}{l}(0.4) \\
0.3\end{array}\right)$ & $\begin{array}{l}284 \\
284\end{array}$ & $\left.\begin{array}{l}(0.4) \\
0.5\end{array}\right)$ & $\begin{array}{l}274 \\
277\end{array}$ & $\left(\begin{array}{l}0.7) \\
0.7\end{array}\right)$ & $\begin{array}{l}284 \\
286\end{array}$ & $\left(\begin{array}{l}0.7) \\
0.6\end{array}\right)$ & $\begin{array}{l}284 \\
283\end{array}$ & $\left(\begin{array}{l}0.4) \\
0.4\end{array}\right)$ & $\begin{array}{l}289 \\
286\end{array}$ & $\left.\begin{array}{l}(0.5) \\
0.5\end{array}\right)$ & $\begin{array}{l}292 \\
288\end{array}$ & (1 \\
\hline 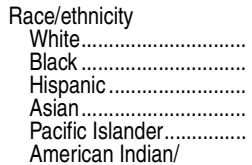 & $\begin{array}{l}286 \\
260 \\
268 \\
303 \\
269\end{array}$ & $\left.\begin{array}{l}0.4 \\
0.8 \\
0.9 \\
2.0 \\
4.7\end{array}\right)$ & $\begin{array}{l}294 \\
263 \\
271 \\
306 \\
278\end{array}$ & $\left.\begin{array}{l}0.4 \\
0.6 \\
0.7 \\
1.8 \\
4.1\end{array}\right)$ & $\begin{array}{l}300 \\
267 \\
275 \\
314 \\
273\end{array}$ & $\left.\begin{array}{l}(0.4) \\
0.8 \\
0.6 \\
1.4 \\
5.4\end{array}\right)$ & $\begin{array}{l}300 \\
266 \\
275 \\
311 \\
277\end{array}$ & $\left.\begin{array}{l}(0.7) \\
1.0 \\
1.2 \\
2.1 \\
4.6\end{array}\right)$ & $\begin{array}{l}303 \\
273 \\
279 \\
324 \\
289\end{array}$ & $\left.\begin{array}{l}(0.5) \\
1.4 \\
1.6 \\
1.8 \\
7.0\end{array}\right)$ & $\begin{array}{l}295 \\
265 \\
273 \\
310 \\
278\end{array}$ & $\begin{array}{l}(0.3) \\
0.5 \\
0.5 \\
1.2 \\
(3.0)\end{array}$ & $\begin{array}{l}294 \\
263 \\
271 \\
303 \\
271\end{array}$ & $\left.\begin{array}{l}(0.4) \\
0.7 \\
0.8 \\
(1.9 \\
4.4\end{array}\right)$ & $\begin{array}{l}286 \\
255 \\
264 \\
296 \\
265\end{array}$ & $\left.\begin{array}{l}0.7) \\
0.9 \\
0.9 \\
3.6 \\
3.6\end{array}\right)$ & $\begin{array}{l}292 \\
264 \\
272 \\
311 \\
277\end{array}$ & $\left(\begin{array}{l}0.5 \\
1.0 \\
1.4 \\
2.7 \\
7.5\end{array}\right)$ & $\begin{array}{l}293 \\
262 \\
270 \\
307 \\
274\end{array}$ & $\left.\begin{array}{l}(0.3) \\
0.5 \\
0.6 \\
1.6 \\
2.7\end{array}\right)$ & $\begin{array}{l}297 \\
266 \\
275 \\
310 \\
275\end{array}$ & $\begin{array}{l}(0.4) \\
0.7 \\
0.7 \\
1.6 \\
(5.3)\end{array}$ & $\begin{array}{l}299 \\
269 \\
277 \\
316 \\
283\end{array}$ & $\begin{array}{l}1.4 \\
1.7 \\
2.2 \\
(5.7)\end{array}$ \\
\hline $\begin{array}{l}\text { Alaska Native............ } \\
\text { Two or more races ........ }\end{array}$ & $\begin{array}{l}270 \\
281\end{array}$ & $\left(\begin{array}{l}2.8 \\
(1.9\end{array}\right)$ & $\begin{array}{l}269 \\
285\end{array}$ & $\left(\begin{array}{l}2.2 \\
(1.3)\end{array}\right)$ & $\begin{array}{l}272 \\
290\end{array}$ & $\begin{array}{l}(2.2) \\
(2.2)\end{array}$ & $\begin{array}{l}271 \\
302\end{array}$ & $\left(\begin{array}{l}3.9 \\
5.4\end{array}\right)$ & $\begin{array}{l}281 \\
299\end{array}$ & $\left(\begin{array}{l}4.0 \\
(3.1\end{array}\right)$ & $\begin{array}{l}270 \\
290\end{array}$ & $\left(\begin{array}{l}2.2 \\
(1.7)\end{array}\right)$ & $\begin{array}{l}271 \\
285\end{array}$ & $\left(\begin{array}{l}2.4 \\
(1.5\end{array}\right)$ & $\begin{array}{l}262 \\
277\end{array}$ & $\left.\begin{array}{l}(3.7) \\
(3.6\end{array}\right)$ & $\begin{array}{l}268 \\
286\end{array}$ & $\left(\begin{array}{l}2.9 \\
2.5\end{array}\right)$ & $\begin{array}{l}268 \\
285\end{array}$ & $\left(\begin{array}{l}1.8 \\
1.3\end{array}\right)$ & $\begin{array}{l}277 \\
293\end{array}$ & $\begin{array}{l}2.6 \\
(3.0)\end{array}$ & $\begin{array}{l}276 \\
299\end{array}$ & $\begin{array}{l}\left(\begin{array}{l}5 \\
2\end{array}\right. \\
2\end{array}$ \\
\hline \multicolumn{25}{|l|}{$\begin{array}{l}\text { Eligibility for free or } \\
\text { reduced-pricelunch }\end{array}$} \\
\hline 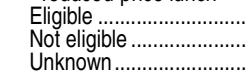 & $\begin{array}{l}267 \\
289 \\
284\end{array}$ & $\left.\begin{array}{l}0.5 \\
0.5 \\
(1.8\end{array}\right)$ & $\begin{array}{l}270 \\
297 \\
297\end{array}$ & $\begin{array}{l}0.4 \\
0.4 \\
(2.4)\end{array}$ & $\begin{array}{l}274 \\
303 \\
306\end{array}$ & $\begin{array}{l}(0.4) \\
0.4 \\
(2.6)\end{array}$ & $\begin{array}{l}272 \\
303 \\
305\end{array}$ & $\left.\begin{array}{l}0.6 \\
0.6 \\
4.1\end{array}\right)$ & $\begin{array}{l}280 \\
306 \\
308\end{array}$ & $\begin{array}{l}(0.9) \\
0.6 \\
(3.7)\end{array}$ & $\begin{array}{l}272 \\
298 \\
299\end{array}$ & $\begin{array}{l}0.3 \\
0.4 \\
(2.5)\end{array}$ & $\begin{array}{l}269 \\
296 \\
295\end{array}$ & $\left.\begin{array}{l}0.4) \\
0.4 \\
(2.4)\end{array}\right)$ & $\begin{array}{l}260 \\
289 \\
292\end{array}$ & $\left.\begin{array}{l}0.6 \\
0.8 \\
(3.8\end{array}\right)$ & $\begin{array}{l}268 \\
296 \\
296\end{array}$ & $\left.\begin{array}{l}0.7 \\
0.5 \\
(3.3)\end{array}\right)$ & $\begin{array}{l}269 \\
296 \\
297\end{array}$ & $\left(\begin{array}{l}0.3) \\
0.4 \\
(2.2)\end{array}\right)$ & $\begin{array}{l}274 \\
300 \\
304\end{array}$ & $\begin{array}{l}(0.4) \\
(0.5) \\
(2.6)\end{array}$ & $\begin{array}{l}277 \\
304 \\
302\end{array}$ & $\left(\begin{array}{l}1.0 \\
(5.2)\end{array}\right)$ \\
\hline 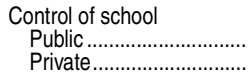 & $\begin{array}{l}279 \\
284 \\
\end{array}$ & $\left(\begin{array}{l}0.4 \\
1.5\end{array}\right)$ & $\begin{array}{l}283 \\
295 \\
\end{array}$ & $\left.\begin{array}{l}0.3 \\
2.1\end{array}\right)$ & $\begin{array}{l}288 \\
303\end{array}$ & $\left.\begin{array}{l}(0.3) \\
(2.1)\end{array}\right)$ & $\begin{array}{l}286 \\
303\end{array}$ & $\begin{array}{l}(0.5) \\
(3.4)\end{array}$ & $\begin{array}{l}294 \\
307\end{array}$ & $\left.\begin{array}{l}(0.6) \\
4.0\end{array}\right)$ & $\begin{array}{l}285 \\
298 \\
\end{array}$ & $\left.\begin{array}{l}(0.3) \\
1.8\end{array}\right)$ & $\begin{array}{l}283 \\
292 \\
\end{array}$ & $\left(\begin{array}{l}0.3) \\
1.8\end{array}\right)$ & $\begin{array}{l}274 \\
292\end{array}$ & $\left.\begin{array}{l}0.4) \\
2.7\end{array}\right)$ & $\begin{array}{l}284 \\
295\end{array}$ & $\begin{array}{l}0.5 \\
(2.4)\end{array}$ & $\begin{array}{l}282 \\
294 \\
\end{array}$ & $\begin{array}{l}(0.3) \\
(1.9)\end{array}$ & $\begin{array}{l}286 \\
303\end{array}$ & $\begin{array}{l}(0.4) \\
(2.2)\end{array}$ & $\begin{array}{l}290 \\
301 \\
\end{array}$ & $(4$ \\
\hline & \multicolumn{24}{|c|}{ Percent of students } \\
\hline All students ............... & 22 & $(0.2)$ & 35 & $(0.2)$ & 28 & $(0.2)$ & 15 & $(0.2)$ & 12 & $(0.2)$ & 45 & $(0.3)$ & 32 & $(0.2)$ & 11 & $(0.1)$ & 17 & $(0.2)$ & 55 & $(0.2)$ & 21 & (0.2) & 7 & $(0.1$ \\
\hline 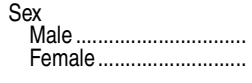 & $\begin{array}{l}21 \\
22\end{array}$ & $\left.\begin{array}{l}(0.3) \\
0.3\end{array}\right)$ & $\begin{array}{l}33 \\
37\end{array}$ & $\left(\begin{array}{l}0.3 \\
0.2\end{array}\right)$ & $\begin{array}{l}29 \\
27\end{array}$ & $\left.\begin{array}{l}(0.3) \\
0.3\end{array}\right)$ & $\begin{array}{l}16 \\
14\end{array}$ & $\left(\begin{array}{l}0.3) \\
0.2)\end{array}\right.$ & $\begin{array}{l}12 \\
11\end{array}$ & $\left.\begin{array}{l}(0.2) \\
0.2\end{array}\right)$ & $\begin{array}{l}45 \\
45\end{array}$ & $\left.\begin{array}{l}(0.3) \\
0.4\end{array}\right)$ & $\begin{array}{l}33 \\
32\end{array}$ & $\left.\begin{array}{l}0.3 \\
0.3\end{array}\right)$ & $\begin{array}{l}10 \\
12\end{array}$ & $\left.\begin{array}{l}(0.2) \\
0.2\end{array}\right)$ & $\begin{array}{l}15 \\
20\end{array}$ & $\left(\begin{array}{l}0.2 \\
0.3\end{array}\right)$ & $\begin{array}{l}54 \\
55\end{array}$ & $\left(\begin{array}{l}0.3) \\
0.3)\end{array}\right.$ & $\begin{array}{l}23 \\
19\end{array}$ & $\begin{array}{l}(0.2) \\
(0.2)\end{array}$ & $\begin{array}{l}8 \\
6\end{array}$ & \\
\hline 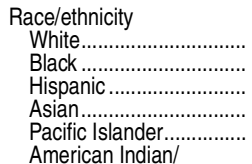 & $\begin{array}{l}25 \\
18 \\
19 \\
14 \\
15\end{array}$ & $\left.\begin{array}{l}0.3 \\
0.5 \\
0.5 \\
0.8 \\
1.9\end{array}\right)$ & $\begin{array}{l}36 \\
33 \\
36 \\
37 \\
36\end{array}$ & $\left.\begin{array}{l}0.3 \\
0.4 \\
0.5 \\
1.0 \\
2.7\end{array}\right)$ & $\begin{array}{l}27 \\
27 \\
30 \\
31 \\
28\end{array}$ & $\left.\begin{array}{l}(0.2) \\
0.4 \\
0.5 \\
0.9 \\
3.1\end{array}\right)$ & $\begin{array}{l}12 \\
21 \\
16 \\
18 \\
21\end{array}$ & $\left.\begin{array}{l}(0.2) \\
0.5 \\
0.4 \\
0.8 \\
2.4\end{array}\right)$ & $\begin{array}{l}12 \\
11 \\
10 \\
14 \\
11\end{array}$ & $\left.\begin{array}{l}(0.2) \\
0.3 \\
0.4 \\
0.8 \\
2.5\end{array}\right)$ & $\begin{array}{l}45 \\
44 \\
46 \\
50 \\
46\end{array}$ & $\begin{array}{l}0.3 \\
0.5 \\
0.6 \\
1.2 \\
(3.0)\end{array}$ & $\begin{array}{l}32 \\
32 \\
33 \\
28 \\
33\end{array}$ & $\left.\begin{array}{l}(0.3) \\
0.5 \\
0.5 \\
1.1 \\
2.9\end{array}\right)$ & $\begin{array}{l}11 \\
14 \\
11 \\
8 \\
11\end{array}$ & $\left.\begin{array}{l}0.2 \\
0.4 \\
0.3 \\
0.6 \\
1.7\end{array}\right)$ & $\begin{array}{r}20 \\
15 \\
13 \\
9 \\
9\end{array}$ & $\left.\begin{array}{l}(0.3) \\
0.4 \\
0.4 \\
0.8 \\
1.5\end{array}\right)$ & $\begin{array}{l}54 \\
54 \\
56 \\
52 \\
57\end{array}$ & $\begin{array}{l}(0.3) \\
0.5 \\
0.5 \\
1.2 \\
(3.2)\end{array}$ & $\begin{array}{l}19 \\
22 \\
23 \\
27 \\
28\end{array}$ & $\begin{array}{l}(0.2) \\
0.5 \\
0.4 \\
0.9 \\
(3.1)\end{array}$ & $\begin{array}{r}6 \\
8 \\
8 \\
12 \\
7\end{array}$ & $\begin{array}{l}0.1 \\
0.3 \\
0.2 \\
0.7\end{array}$ \\
\hline $\begin{array}{l}\text { Alaska Native ............. } \\
\text { Two or more races ......... }\end{array}$ & $\begin{array}{l}20 \\
22\end{array}$ & $\left(\begin{array}{l}1.4 \\
1.0\end{array}\right)$ & $\begin{array}{l}36 \\
37\end{array}$ & $\left(\begin{array}{l}1.5 \\
(1.3\end{array}\right)$ & $\begin{array}{l}28 \\
28\end{array}$ & $\left(\begin{array}{l}1.4) \\
(1.3)\end{array}\right.$ & $\begin{array}{l}16 \\
14\end{array}$ & $\left(\begin{array}{l}1.3 \\
1.1\end{array}\right)$ & $\begin{array}{l}11 \\
13\end{array}$ & $\left.\begin{array}{l}(1.3) \\
0.9\end{array}\right)$ & $\begin{array}{l}44 \\
44\end{array}$ & $\left(\begin{array}{l}1.7) \\
1.5\end{array}\right)$ & $\begin{array}{l}32 \\
32\end{array}$ & $\left(\begin{array}{l}1.6 \\
1.2\end{array}\right)$ & $\begin{array}{l}13 \\
12\end{array}$ & $\left(\begin{array}{l}1.0 \\
0.8)\end{array}\right)$ & $\begin{array}{l}16 \\
18\end{array}$ & $\left(\begin{array}{l}1.2 \\
0.9\end{array}\right)$ & $\begin{array}{l}57 \\
52\end{array}$ & $\left(\begin{array}{l}1.8) \\
1.1\end{array}\right)$ & $\begin{array}{l}21 \\
22\end{array}$ & $\begin{array}{l}1.2 \\
(0.9)\end{array}$ & $\begin{array}{l}7 \\
8\end{array}$ & \\
\hline 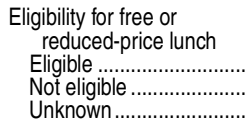 & $\begin{array}{l}20 \\
23 \\
22\end{array}$ & $\begin{array}{l}(0.3) \\
0.3 \\
(1.3)\end{array}$ & $\begin{array}{l}35 \\
36 \\
33\end{array}$ & $\left.\begin{array}{l}0.3 \\
0.2 \\
(1.1)\end{array}\right)$ & $\begin{array}{l}28 \\
28 \\
28\end{array}$ & $\begin{array}{l}(0.3) \\
0.3 \\
(1.3)\end{array}$ & $\begin{array}{l}16 \\
13 \\
16\end{array}$ & $\left.\begin{array}{l}0.3 \\
0.2 \\
1.1\end{array}\right)$ & $\begin{array}{l}11 \\
12 \\
11\end{array}$ & $\begin{array}{l}(0.2) \\
(0.2) \\
(0.8)\end{array}$ & $\begin{array}{l}45 \\
45 \\
45\end{array}$ & $\begin{array}{l}(0.3) \\
0.3 \\
(1.5)\end{array}$ & $\begin{array}{l}32 \\
32 \\
33\end{array}$ & $\left(\begin{array}{l}0.3 \\
0.3 \\
(1.2)\end{array}\right)$ & $\begin{array}{l}12 \\
10 \\
11\end{array}$ & $\left.\begin{array}{l}(0.2) \\
(0.2) \\
0.8\end{array}\right)$ & $\begin{array}{l}14 \\
19 \\
23\end{array}$ & $\left.\begin{array}{l}(0.2) \\
0.3 \\
(1.2)\end{array}\right)$ & $\begin{array}{l}55 \\
54 \\
56\end{array}$ & $\left.\begin{array}{l}(0.3) \\
0.3 \\
1.3\end{array}\right)$ & $\begin{array}{l}23 \\
20 \\
16\end{array}$ & $\begin{array}{l}(0.3) \\
0.2 \\
(0.7)\end{array}$ & $\begin{array}{l}8 \\
7 \\
5\end{array}$ & $\hat{l}_{0}^{0}$ \\
\hline 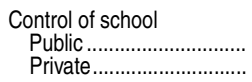 & $\begin{array}{l}22 \\
23\end{array}$ & $\left(\begin{array}{l}0.2) \\
0.9\end{array}\right)$ & $\begin{array}{l}36 \\
34\end{array}$ & $\left(\begin{array}{l}0.2 \\
1.0\end{array}\right)$ & $\begin{array}{l}28 \\
28\end{array}$ & $\left.\begin{array}{l}(0.2) \\
(1.0)\end{array}\right)$ & $\begin{array}{l}15 \\
15\end{array}$ & $\left(\begin{array}{l}0.2 \\
0.9\end{array}\right)$ & $\begin{array}{l}12 \\
10\end{array}$ & $\left(\begin{array}{l}0.2 \\
(0.6)\end{array}\right)$ & $\begin{array}{l}45 \\
43\end{array}$ & $\left(\begin{array}{l}0.2) \\
1.3\end{array}\right)$ & $\begin{array}{l}32 \\
35\end{array}$ & $\left(\begin{array}{l}0.2 \\
1.1\end{array}\right)$ & $\begin{array}{l}11 \\
12\end{array}$ & $\left(\begin{array}{l}0.1 \\
0.7\end{array}\right)$ & $\begin{array}{l}17 \\
24\end{array}$ & $\left(\begin{array}{l}0.2 \\
1.0\end{array}\right)$ & $\begin{array}{l}54 \\
57\end{array}$ & $\left(\begin{array}{l}0.2 \\
(1.1)\end{array}\right)$ & $\begin{array}{l}21 \\
15\end{array}$ & $\left(\begin{array}{l}0.2 \\
(0.7)\end{array}\right)$ & $\begin{array}{l}8 \\
5\end{array}$ & \\
\hline
\end{tabular}

'Scale ranges from 0 to 500 .

NOTE: Includes public and private schools. Includes students tested with accommodations (12 percent of all 8th-grade students); excludes only those students with disabilities and English language learners who were unable to be tested even with accommodations (1 percent of all 8th-grade students). Race categories exclude persons of Hispanic ethnicity. Detail may not

SOURCE: U.S. Department of Education, National Center for Education Statistics, National Assessment of Educational Progress (NAEP), 2011 Mathematics Assessment, retrieved November 15, 2013, from the Main NAEP Data Explorer (http://nces.ed.gov/ nationsreportcard/naepdata). (This table was prepared November 2013.) 
246 CHAPTER 2: Elementary and Secondary Education

Mathematics Achievement

Table 222.40. Average National Assessment of Educational Progress (NAEP) mathematics scale score of high school graduates at grade 12, by highest mathematics course taken in high school and selected student and school characteristics: 2009

[Standard errors appear in parentheses]

\begin{tabular}{|c|c|c|c|c|c|c|c|c|c|c|c|c|c|c|}
\hline Selected student or school characteristic & \multicolumn{2}{|c|}{ Algebra I or below ${ }^{1}$} & \multicolumn{2}{|c|}{ Geometry } & \multicolumn{2}{|c|}{$\begin{array}{r}\text { Algebra II/ } \\
\text { trigonometry }\end{array}$} & \multicolumn{2}{|c|}{$\begin{array}{r}\text { Analysis/ } \\
\text { precalculus }\end{array}$} & \multicolumn{2}{|c|}{$\begin{array}{r}\text { Statistics/ } \\
\text { probability }\end{array}$} & \multicolumn{2}{|c|}{$\begin{array}{r}\text { Advanced } \\
\text { mathematics, other } \\
\end{array}$} & \multicolumn{2}{|c|}{ Calculus } \\
\hline 1 & & 2 & & 3 & & 4 & & 5 & & 6 & & 7 & & 8 \\
\hline 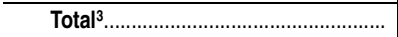 & 114 & $(1.1)$ & 127 & $(1.0)$ & 143 & $(0.6)$ & 166 & $(0.9)$ & 164 & $(1.8)$ & 154 & (1.3) & 193 & $(1.2)$ \\
\hline 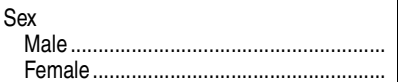 & $\begin{array}{l}117 \\
111\end{array}$ & $\begin{array}{l}(1.7) \\
(1.6)\end{array}$ & $\begin{array}{l}128 \\
126\end{array}$ & $\begin{array}{l}(1.2) \\
(1.1)\end{array}$ & $\begin{array}{l}145 \\
142\end{array}$ & $\begin{array}{l}(0.8) \\
(0.8)\end{array}$ & $\begin{array}{l}169 \\
163\end{array}$ & $\begin{array}{l}(1.0) \\
(1.0)\end{array}$ & $\begin{array}{l}165 \\
162\end{array}$ & $\begin{array}{l}(2.2) \\
(2.0)\end{array}$ & $\begin{array}{l}156 \\
153\end{array}$ & $\begin{array}{l}(1.5) \\
(1.4)\end{array}$ & $\begin{array}{l}197 \\
190\end{array}$ & $\begin{array}{l}(1.4) \\
(1.2)\end{array}$ \\
\hline 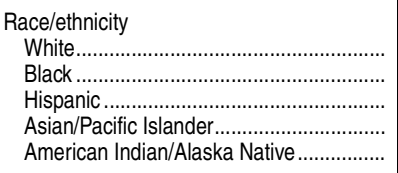 & $\begin{array}{r}117 \\
104 \\
109 \\
\ddagger \\
\ddagger\end{array}$ & $\begin{array}{r}(1.6) \\
(2.8) \\
(2.2) \\
(\dagger) \\
(\dagger)\end{array}$ & $\begin{array}{r}133 \\
114 \\
122 \\
129 \\
\ddagger\end{array}$ & $\begin{array}{r}(1.3) \\
(1.8) \\
(1.0) \\
(3.9) \\
(\dagger)\end{array}$ & $\begin{array}{l}150 \\
129 \\
136 \\
149 \\
143\end{array}$ & $\begin{array}{l}(0.8) \\
(0.9) \\
(0.8) \\
(4.1) \\
(3.8)\end{array}$ & $\begin{array}{r}172 \\
147 \\
155 \\
170 \\
\ddagger\end{array}$ & $\begin{array}{r}(0.9) \\
(1.6) \\
(1.6) \\
(2.3) \\
(\dagger)\end{array}$ & $\begin{array}{r}169 \\
139 \\
154 \\
176 \\
\ddagger\end{array}$ & $\begin{array}{r}(1.5) \\
(4.0) \\
(3.2) \\
(4.1) \\
(\dagger)\end{array}$ & $\begin{array}{r}160 \\
138 \\
142 \\
164 \\
\ddagger\end{array}$ & $\begin{array}{r}(1.3) \\
(2.1) \\
(2.3) \\
(2.9) \\
(\dagger)\end{array}$ & $\begin{array}{r}194 \\
170 \\
179 \\
203 \\
\ddagger\end{array}$ & $\begin{array}{r}(1.1) \\
(2.7) \\
(2.5) \\
(1.8) \\
(\dagger)\end{array}$ \\
\hline $\begin{array}{l}\text { Student with disabilities (SD) status } \\
\text { SD }^{4} \ldots \ldots \ldots \ldots \ldots \ldots \\
\text { Non-SD }\end{array}$ & $\begin{array}{l}103 \\
122\end{array}$ & $\begin{array}{l}(1.7) \\
(1.2)\end{array}$ & $\begin{array}{l}114 \\
129\end{array}$ & $\begin{array}{l}(2.5) \\
(0.9)\end{array}$ & $\begin{array}{l}126 \\
144\end{array}$ & $\begin{array}{l}(2.1) \\
(0.6)\end{array}$ & $\begin{array}{l}166 \\
166\end{array}$ & $\begin{array}{l}(5.0) \\
(0.9)\end{array}$ & $\begin{array}{l}136 \\
164\end{array}$ & $\begin{array}{l}(6.3) \\
(1.7)\end{array}$ & $\begin{array}{l}134 \\
156\end{array}$ & $\begin{array}{l}(3.5) \\
(1.3)\end{array}$ & $\begin{array}{l}197 \\
193\end{array}$ & $\begin{array}{l}(3.7) \\
(1.2)\end{array}$ \\
\hline 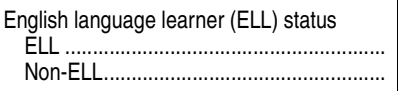 & $\begin{array}{l}104 \\
114\end{array}$ & $\begin{array}{l}(4.5) \\
(1.2)\end{array}$ & $\begin{array}{l}113 \\
128\end{array}$ & $\begin{array}{l}(2.8) \\
(1.0)\end{array}$ & $\begin{array}{l}121 \\
144\end{array}$ & $\begin{array}{l}(2.1) \\
(0.6)\end{array}$ & $\begin{array}{l}144 \\
166\end{array}$ & $\begin{array}{l}(6.1) \\
(0.9)\end{array}$ & $\begin{array}{r}\ddagger \\
164\end{array}$ & $\begin{array}{r}(\dagger) \\
(1.8)\end{array}$ & $\begin{array}{l}129 \\
155\end{array}$ & $\begin{array}{l}(4.8) \\
(1.3)\end{array}$ & $\begin{array}{r}\ddagger \\
193\end{array}$ & $\begin{array}{r}(\dagger) \\
(1.2)\end{array}$ \\
\hline 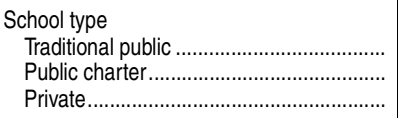 & $\begin{array}{r}114 \\
\ddagger \\
\ddagger\end{array}$ & $\begin{array}{r}(1.2) \\
(\dagger) \\
(\dagger)\end{array}$ & $\begin{array}{r}127 \\
\ddagger \\
123\end{array}$ & $\begin{array}{r}(1.0) \\
(\dagger) \\
(3.3)\end{array}$ & $\begin{array}{l}143 \\
137 \\
146\end{array}$ & $\begin{array}{r}(0.7) \\
(10.3) \\
(3.3)\end{array}$ & $\begin{array}{l}166 \\
141 \\
169\end{array}$ & $\begin{array}{l}(0.9) \\
(6.8) \\
(2.7)\end{array}$ & $\begin{array}{l}164 \\
132 \\
168\end{array}$ & $\begin{array}{l}(1.8) \\
(1.6) \\
(3.9)\end{array}$ & $\begin{array}{r}155 \\
\ddagger \\
146\end{array}$ & $\begin{array}{r}(1.4) \\
(\dagger) \\
(4.0)\end{array}$ & $\begin{array}{r}193 \\
\ddagger \\
193\end{array}$ & $\begin{array}{r}(1.3) \\
(\dagger) \\
(3.3)\end{array}$ \\
\hline 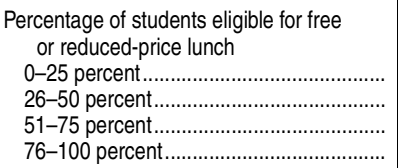 & $\begin{array}{l}116 \\
115 \\
111 \\
107\end{array}$ & $\begin{array}{l}(3.0) \\
(1.5) \\
(3.0) \\
(5.4)\end{array}$ & $\begin{array}{l}134 \\
127 \\
123 \\
115\end{array}$ & $\begin{array}{l}(2.0) \\
(1.4) \\
(1.8) \\
(3.1)\end{array}$ & $\begin{array}{l}151 \\
144 \\
136 \\
126\end{array}$ & $\begin{array}{l}(1.3) \\
(1.0) \\
(1.1) \\
(2.0)\end{array}$ & $\begin{array}{l}173 \\
165 \\
156 \\
144\end{array}$ & $\begin{array}{l}(1.5) \\
(1.1) \\
(1.3) \\
(3.7)\end{array}$ & $\begin{array}{l}173 \\
162 \\
149 \\
137\end{array}$ & $\begin{array}{l}(1.5) \\
(2.9) \\
(3.6) \\
(4.1)\end{array}$ & $\begin{array}{l}162 \\
154 \\
146 \\
131\end{array}$ & $\begin{array}{l}(1.9) \\
(1.7) \\
(3.7) \\
(2.6)\end{array}$ & $\begin{array}{l}199 \\
189 \\
179 \\
163\end{array}$ & $\begin{array}{l}(1.6) \\
(1.0) \\
(2.8) \\
(3.9)\end{array}$ \\
\hline 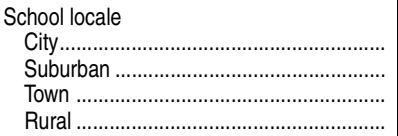 & $\begin{array}{l}110 \\
112 \\
114 \\
117\end{array}$ & $\begin{array}{l}(2.6) \\
(2.3) \\
(2.5) \\
(2.0)\end{array}$ & $\begin{array}{l}125 \\
127 \\
129 \\
129\end{array}$ & $\begin{array}{l}(1.7) \\
(1.9) \\
(1.9) \\
(1.4)\end{array}$ & $\begin{array}{l}140 \\
144 \\
144 \\
145\end{array}$ & $\begin{array}{l}(1.8) \\
(1.0) \\
(1.6) \\
(1.3)\end{array}$ & $\begin{array}{l}163 \\
169 \\
166 \\
165\end{array}$ & $\begin{array}{l}(2.1) \\
(1.4) \\
(1.6) \\
(1.9)\end{array}$ & $\begin{array}{l}163 \\
167 \\
164 \\
157\end{array}$ & $\begin{array}{l}(3.3) \\
(2.4) \\
(3.1) \\
(4.9)\end{array}$ & $\begin{array}{l}151 \\
157 \\
152 \\
155\end{array}$ & $\begin{array}{l}(3.0) \\
(2.0) \\
(3.8) \\
(2.1)\end{array}$ & $\begin{array}{l}195 \\
195 \\
191 \\
187\end{array}$ & $\begin{array}{l}(2.3) \\
(2.0) \\
(2.1) \\
(2.0)\end{array}$ \\
\hline
\end{tabular}

†Not applicable.

‡Reporting standards not met (too few cases for a reliable estimate).

1 Includes basic math, general math, applied math, prealgebra, and algebra I.

${ }^{2}$ Includes courses such as actuarial sciences, pure mathematics, discrete math, and advanced functions and modeling.

Includes other racial/ethnic groups not shown separately, as well as students for whom information on race/ethnicity or sex was missing.

${ }^{4} \mathrm{SD}$ estimates include both students with an Individualized Education Plan (IEP) and students with a plan under Section 504 of the Rehabilitation Act (a "504 plan"). IEPs are only for students who require specialized instruction, whereas 504 plans apply to students who require accommodations but may not require specialized instruction.
NOTE: Scale ranges from 0 to 300 . Includes students tested with accommodations (6 percent of all 12th-graders); excludes only those students with disabilities and English language learners who were unable to be tested even with accommodations ( 3 percent of all 12th-graders). For a transcript to be included in the analyses, it had to meet three requirements: (1) the graduate receive ments. (1) the gaduate received transcript contained 16 or more Carnegie credits, and (3) the graduate's transcript contained more than 0 Carnegie credits in English courses. Race categories exclude persons of Hispanic ethnicity.

SOURCE: U.S. Department of Education, National Center for Education Statistics, National Assessment of Educational Progress (NAEP), 2009 Mathematics Assessment; and 2009 High School Transcript Study (HSTS). (This table was prepared September 2012.) 
Table 222.50. Average National Assessment of Educational Progress (NAEP) mathematics scale score of 4th-grade public school students and percentage attaining mathematics achievement levels, by state: Selected years, 1992 through 2013

[Standard errors appear in parentheses]

\begin{tabular}{|c|c|c|c|c|c|c|c|c|c|c|c|c|c|c|c|c|c|c|c|c|c|c|}
\hline \multirow[b]{2}{*}{ State } & \multicolumn{16}{|c|}{ Average scale score ${ }^{1}$} & \multicolumn{6}{|c|}{$\begin{array}{l}\text { Percent attaining mathematics achievement } \\
\text { levels, } 2013\end{array}$} \\
\hline & & 1992 & & 2000 & & 2003 & & 2005 & & 2007 & & 2009 & & 2011 & & 2013 & At or & $\begin{array}{l}\text { above } \\
\text { Basic }^{2}\end{array}$ & & \begin{tabular}{l|} 
above \\
icient $^{3}$
\end{tabular} & Adva & $\begin{array}{r}\text { At } \\
\text { ceed }\end{array}$ \\
\hline 1 & & 2 & & 3 & & 4 & & 5 & & 6 & & 7 & & 8 & & 9 & & 10 & & 11 & & 12 \\
\hline United States .............. & 219 & $(0.8)$ & 224 & $(1.0)$ & 234 & $(0.2)$ & 237 & $(0.2)$ & 239 & $(0.2)$ & 239 & $(0.2)$ & 240 & $(0.2)$ & 241 & (0.2) & 82 & (0.2) & 41 & $(0.3)$ & 8 & $(0.2)$ \\
\hline 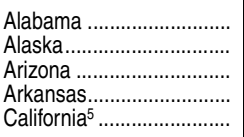 & $\begin{array}{l}208 \\
215 \\
210 \\
208\end{array}$ & $\begin{array}{r}(1.6) \\
(\dagger) \\
(1.1) \\
(0.9) \\
(1.6)\end{array}$ & $\begin{array}{r}217 \\
219 \\
216 \\
213\end{array}$ & \begin{tabular}{r|}
$(1.2)$ \\
$(\dagger)$ \\
$(1.3)$ \\
$(1.1)$ \\
$(1.6)$
\end{tabular} & $\begin{array}{l}223 \\
233 \\
229 \\
229 \\
227\end{array}$ & $\begin{array}{l}(1.2) \\
(0.8) \\
(1.1) \\
(0.9) \\
(0.9)\end{array}$ & $\begin{array}{l}225 \\
236 \\
230 \\
236 \\
230\end{array}$ & $\begin{array}{l}(0.9) \\
(1.0) \\
(1.1) \\
(0.9) \\
(0.6)\end{array}$ & $\begin{array}{l}229 \\
237 \\
232 \\
238 \\
230\end{array}$ & $\begin{array}{l}(1.3) \\
(1.0) \\
(1.0) \\
(1.1) \\
(0.7)\end{array}$ & $\begin{array}{l}228 \\
237 \\
230 \\
238 \\
232\end{array}$ & $\begin{array}{l}(1.1) \\
(0.9) \\
(1.1) \\
(0.9) \\
(1.2)\end{array}$ & $\begin{array}{l}231 \\
236 \\
235 \\
238 \\
234\end{array}$ & $\begin{array}{l}(1.0) \\
(0.9) \\
(1.1) \\
(0.8) \\
(1.4)\end{array}$ & $\begin{array}{l}233 \\
236 \\
240 \\
240 \\
234\end{array}$ & $\begin{array}{l}(1.0) \\
(0.8) \\
(1.2) \\
(0.9) \\
(1.2)\end{array}$ & $\begin{array}{l}75 \\
77 \\
82 \\
83 \\
74\end{array}$ & $\begin{array}{l}(1.4) \\
(1.1) \\
(1.1) \\
(1.0) \\
(1.5)\end{array}$ & $\begin{array}{l}30 \\
37 \\
40 \\
39 \\
33\end{array}$ & $\begin{array}{l}(1.6) \\
(1.1) \\
(1.8) \\
(1.4) \\
(1.7)\end{array}$ & $\begin{array}{l}3 \\
6 \\
7 \\
5 \\
5\end{array}$ & $\begin{array}{l}(0.5) \\
(0.6) \\
(1.0) \\
(0.6) \\
(0.7)\end{array}$ \\
\hline 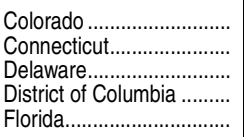 & $\begin{array}{l}221 \\
227 \\
218 \\
193 \\
214\end{array}$ & $\begin{array}{l}(1.0) \\
(1.1) \\
(0.8) \\
(0.5) \\
(1.5)\end{array}$ & $\begin{array}{r}\overline{234} \\
\overline{192} \\
-\end{array}$ & $\begin{array}{r}(\dagger) \\
(1.1) \\
(\dagger) \\
(1.1) \\
(\dagger)\end{array}$ & $\begin{array}{l}235 \\
241 \\
236 \\
205 \\
234\end{array}$ & $\begin{array}{l}(1.0) \\
(0.8) \\
(0.5) \\
(0.7) \\
(1.1)\end{array}$ & $\begin{array}{l}239 \\
242 \\
240 \\
211 \\
239\end{array}$ & $\begin{array}{l}(1.1) \\
(0.8) \\
(0.5) \\
(0.8) \\
(0.7)\end{array}$ & $\begin{array}{l}240 \\
243 \\
242 \\
214 \\
242\end{array}$ & $\begin{array}{l}(1.0) \\
(1.1) \\
(0.4) \\
(0.8) \\
(0.8)\end{array}$ & $\begin{array}{l}243 \\
245 \\
239 \\
219 \\
242\end{array}$ & $\begin{array}{l}(1.0) \\
(1.0) \\
(0.5) \\
(0.7) \\
(1.0)\end{array}$ & $\begin{array}{l}244 \\
242 \\
240 \\
222 \\
240\end{array}$ & $\begin{array}{l}(0.9) \\
(1.3) \\
(0.6) \\
(0.7) \\
(0.8)\end{array}$ & $\begin{array}{l}247 \\
243 \\
243 \\
229 \\
242\end{array}$ & $\begin{array}{l}(0.8) \\
(0.9) \\
(0.7) \\
(0.7) \\
(0.8)\end{array}$ & $\begin{array}{l}87 \\
83 \\
86 \\
66 \\
84\end{array}$ & $\begin{array}{l}(1.0) \\
(1.1) \\
(0.9) \\
(1.3) \\
(0.9)\end{array}$ & $\begin{array}{l}50 \\
45 \\
42 \\
28 \\
41\end{array}$ & $\begin{array}{l}(1.3) \\
(1.3) \\
(1.1) \\
(1.0) \\
(1.3)\end{array}$ & $\begin{array}{r}11 \\
9 \\
7 \\
6 \\
6\end{array}$ & $\begin{array}{l}(0.9) \\
(0.9) \\
(0.6) \\
(0.7) \\
(0.7)\end{array}$ \\
\hline 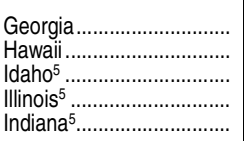 & $\begin{array}{r}216 \\
214 \\
222 \\
-221\end{array}$ & $\begin{array}{r}(1.2) \\
(1.3) \\
(1.0) \\
(\dagger) \\
(1.0)\end{array}$ & $\begin{array}{l}219 \\
216 \\
224 \\
223 \\
233\end{array}$ & $\begin{array}{l}(1.1) \\
(1.0) \\
(1.4) \\
(1.9) \\
(1.1)\end{array}$ & $\begin{array}{l}230 \\
227 \\
235 \\
233 \\
238\end{array}$ & $\begin{array}{l}(1.0) \\
(1.0) \\
(0.7) \\
(1.1) \\
(0.9)\end{array}$ & $\begin{array}{l}234 \\
230 \\
242 \\
233 \\
240\end{array}$ & $\begin{array}{l}(1.0) \\
(0.8) \\
(0.7) \\
(1.0) \\
(0.9)\end{array}$ & $\begin{array}{l}235 \\
234 \\
241 \\
237 \\
245\end{array}$ & $\begin{array}{l}(0.8) \\
(0.8) \\
(0.7) \\
(1.1) \\
(0.8)\end{array}$ & $\begin{array}{l}236 \\
236 \\
241 \\
238 \\
243\end{array}$ & $\begin{array}{l}(0.9) \\
(1.1) \\
(0.8) \\
(1.0) \\
(0.9)\end{array}$ & $\begin{array}{l}238 \\
239 \\
240 \\
239 \\
244\end{array}$ & $\begin{array}{l}(0.7) \\
(0.7) \\
(0.6) \\
(1.1) \\
(1.0)\end{array}$ & $\begin{array}{l}240 \\
243 \\
241 \\
239 \\
249\end{array}$ & $\begin{array}{l}(1.0) \\
(0.8) \\
(0.9) \\
(1.2) \\
(0.9)\end{array}$ & $\begin{array}{l}81 \\
83 \\
83 \\
79 \\
90\end{array}$ & $\begin{array}{l}(1.2) \\
(0.8) \\
(1.0) \\
(1.0) \\
(0.8)\end{array}$ & $\begin{array}{l}39 \\
46 \\
40 \\
39 \\
52\end{array}$ & $\begin{array}{l}(1.5) \\
(1.3) \\
(1.5) \\
(1.7) \\
(1.5)\end{array}$ & $\begin{array}{r}7 \\
9 \\
6 \\
8 \\
10\end{array}$ & $\begin{array}{l}(0.7) \\
(0.7) \\
(0.8) \\
(1.0) \\
(1.0)\end{array}$ \\
\hline 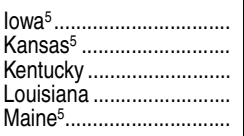 & $\begin{array}{l}230 \\
215 \\
204 \\
232\end{array}$ & $\begin{array}{r}(1.0) \\
(\dagger) \\
(1.0) \\
(1.5) \\
(1.0)\end{array}$ & $\begin{array}{l}231 \\
232 \\
219 \\
218 \\
230\end{array}$ & $\begin{array}{l}(1.2) \\
(1.6) \\
(1.4) \\
(1.4) \\
(1.0)\end{array}$ & $\begin{array}{l}238 \\
242 \\
229 \\
226 \\
238\end{array}$ & $\begin{array}{l}(0.7) \\
(1.0) \\
(1.1) \\
(1.0) \\
(0.7)\end{array}$ & $\begin{array}{l}240 \\
246 \\
232 \\
230 \\
241\end{array}$ & $\begin{array}{l}(0.7) \\
(1.0) \\
(0.9) \\
(0.9) \\
(0.8)\end{array}$ & $\begin{array}{l}243 \\
248 \\
235 \\
230 \\
242\end{array}$ & $\begin{array}{l}(0.8) \\
(0.9) \\
(0.9) \\
(1.0) \\
(0.8)\end{array}$ & $\begin{array}{l}243 \\
245 \\
239 \\
229 \\
244\end{array}$ & $\begin{array}{l}(0.8) \\
(1.0) \\
(1.1) \\
(1.0) \\
(0.8)\end{array}$ & $\begin{array}{l}243 \\
246 \\
241 \\
231 \\
244\end{array}$ & $\begin{array}{l}(0.8) \\
(0.9) \\
(0.8) \\
(1.0) \\
(0.7)\end{array}$ & $\begin{array}{l}246 \\
246 \\
241 \\
231 \\
246\end{array}$ & $\begin{array}{l}(0.9) \\
(0.8) \\
(0.9) \\
(1.2) \\
(0.7)\end{array}$ & $\begin{array}{l}87 \\
89 \\
84 \\
75 \\
88\end{array}$ & $\begin{array}{l}(0.9) \\
(0.9) \\
(0.9) \\
(1.4) \\
(0.8)\end{array}$ & $\begin{array}{l}48 \\
48 \\
41 \\
26 \\
47\end{array}$ & $\begin{array}{l}(1.6) \\
(1.4) \\
(1.4) \\
(1.8) \\
(1.4)\end{array}$ & $\begin{array}{l}9 \\
8 \\
6 \\
3 \\
9\end{array}$ & $\begin{array}{l}(0.9) \\
(0.7) \\
(0.7) \\
(0.6) \\
(0.7)\end{array}$ \\
\hline 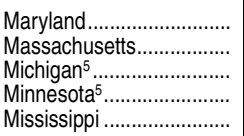 & $\begin{array}{l}217 \\
227 \\
220 \\
228 \\
202\end{array}$ & $\begin{array}{l}(1.3) \\
(1.2) \\
(1.7) \\
(0.9) \\
(1.1)\end{array}$ & $\begin{array}{l}222 \\
233 \\
229 \\
234 \\
211\end{array}$ & $\begin{array}{l}(1.2) \\
(1.2) \\
(1.6) \\
(1.3) \\
(1.1)\end{array}$ & $\begin{array}{l}233 \\
242 \\
236 \\
242 \\
223\end{array}$ & $\begin{array}{l}(1.3) \\
(0.8) \\
(0.9) \\
(0.9) \\
(1.0)\end{array}$ & $\begin{array}{l}238 \\
247 \\
238 \\
246 \\
227\end{array}$ & $\begin{array}{l}(1.0) \\
(0.8) \\
(1.2) \\
(1.0) \\
(0.9)\end{array}$ & $\begin{array}{l}240 \\
252 \\
238 \\
247 \\
228\end{array}$ & $\begin{array}{l}(0.9) \\
(0.8) \\
(1.3) \\
(1.0) \\
(1.0)\end{array}$ & $\begin{array}{l}244 \\
252 \\
236 \\
249 \\
227\end{array}$ & $\begin{array}{l}(0.9) \\
(0.9) \\
(1.0) \\
(1.1) \\
(1.0)\end{array}$ & $\begin{array}{l}247 \\
253 \\
236 \\
249 \\
230\end{array}$ & $\begin{array}{l}(0.9) \\
(0.8) \\
(1.1) \\
(0.9) \\
(0.9)\end{array}$ & $\begin{array}{l}245 \\
253 \\
237 \\
253 \\
231\end{array}$ & $\begin{array}{l}(1.3) \\
(1.0) \\
(1.1) \\
(1.1) \\
(0.7)\end{array}$ & $\begin{array}{l}82 \\
90 \\
77 \\
90 \\
74\end{array}$ & $\begin{array}{l}(1.1) \\
(0.8) \\
(1.2) \\
(1.0) \\
(1.2)\end{array}$ & $\begin{array}{l}47 \\
58 \\
37 \\
59 \\
26\end{array}$ & $\begin{array}{l}(1.7) \\
(1.5) \\
(1.7) \\
(1.7) \\
(1.2)\end{array}$ & $\begin{array}{r}13 \\
16 \\
7 \\
16 \\
2\end{array}$ & $\begin{array}{l}(1.5) \\
(1.1) \\
(0.8) \\
(1.1) \\
(0.4)\end{array}$ \\
\hline 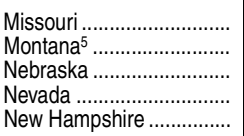 & $\begin{array}{r}222 \\
\frac{-}{225} \\
\frac{-}{230}\end{array}$ & $\begin{array}{r}(1.2) \\
(\dagger) \\
(1.2) \\
(\dagger) \\
(1.2)\end{array}$ & $\begin{array}{r}228 \\
228 \\
225 \\
220 \\
-\end{array}$ & $\begin{array}{r}(1.2) \\
(1.7) \\
(1.8) \\
(1.0) \\
(\dagger)\end{array}$ & $\begin{array}{l}235 \\
236 \\
236 \\
228 \\
243\end{array}$ & $\begin{array}{l}(0.9) \\
(0.8) \\
(0.8) \\
(0.8) \\
(0.9)\end{array}$ & $\begin{array}{l}235 \\
241 \\
238 \\
230 \\
246\end{array}$ & $\begin{array}{l}(0.9) \\
(0.8) \\
(0.9) \\
(0.8) \\
(0.9)\end{array}$ & $\begin{array}{l}239 \\
244 \\
238 \\
232 \\
249\end{array}$ & $\begin{array}{l}(0.9) \\
(0.8) \\
(1.1) \\
(0.9) \\
(0.8)\end{array}$ & $\begin{array}{l}241 \\
244 \\
239 \\
235 \\
251\end{array}$ & $\begin{array}{l}(1.2) \\
(0.7) \\
(1.0) \\
(0.9) \\
(0.8)\end{array}$ & $\begin{array}{l}240 \\
244 \\
240 \\
237 \\
252\end{array}$ & $\begin{array}{l}(0.9) \\
(0.6) \\
(1.0) \\
(0.8) \\
(0.6)\end{array}$ & $\begin{array}{l}240 \\
244 \\
243 \\
236 \\
253\end{array}$ & $\begin{array}{l}(0.8) \\
(0.6) \\
(1.0) \\
(0.8) \\
(0.8)\end{array}$ & $\begin{array}{l}83 \\
86 \\
84 \\
80 \\
93\end{array}$ & $\begin{array}{l}(1.1) \\
(0.9) \\
(1.1) \\
(1.1) \\
(0.8)\end{array}$ & $\begin{array}{l}39 \\
45 \\
45 \\
34 \\
59\end{array}$ & $\begin{array}{l}(1.3) \\
(1.2) \\
(1.5) \\
(1.2) \\
(1.2)\end{array}$ & $\begin{array}{r}5 \\
7 \\
8 \\
4 \\
12\end{array}$ & $\begin{array}{l}(0.7) \\
(0.6) \\
(0.7) \\
(0.5) \\
(0.8)\end{array}$ \\
\hline 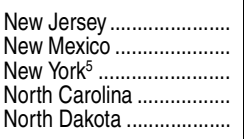 & $\begin{array}{l}227 \\
213 \\
218 \\
213 \\
229\end{array}$ & $\begin{array}{l}(1.5) \\
(1.4) \\
(1.2) \\
(1.1) \\
(0.8)\end{array}$ & $\begin{array}{l}-\overline{213} \\
225 \\
230 \\
230\end{array}$ & $\begin{array}{r}(\dagger) \\
(1.5) \\
(1.4) \\
(1.1) \\
(1.2)\end{array}$ & $\begin{array}{l}239 \\
223 \\
236 \\
242 \\
238\end{array}$ & $\begin{array}{l}(1.1) \\
(1.1) \\
(0.9) \\
(0.8) \\
(0.7)\end{array}$ & $\begin{array}{l}244 \\
224 \\
238 \\
241 \\
243\end{array}$ & $\begin{array}{l}(1.1) \\
(0.8) \\
(0.9) \\
(0.9) \\
(0.5)\end{array}$ & $\begin{array}{l}249 \\
228 \\
243 \\
242 \\
245\end{array}$ & $\begin{array}{l}(1.1) \\
(0.9) \\
(0.8) \\
(0.8) \\
(0.5)\end{array}$ & $\begin{array}{l}247 \\
230 \\
241 \\
244 \\
245\end{array}$ & $\begin{array}{l}(1.0) \\
(1.0) \\
(0.7) \\
(0.8) \\
(0.6)\end{array}$ & $\begin{array}{l}248 \\
233 \\
238 \\
245 \\
245\end{array}$ & $\begin{array}{l}(0.9) \\
(0.8) \\
(0.8) \\
(0.7) \\
(0.4)\end{array}$ & $\begin{array}{l}247 \\
233 \\
240 \\
245 \\
246\end{array}$ & $\begin{array}{l}(1.1) \\
(0.7) \\
(1.0) \\
(0.9) \\
(0.5)\end{array}$ & $\begin{array}{l}87 \\
74 \\
82 \\
87 \\
89\end{array}$ & $\begin{array}{l}(0.9) \\
(1.0) \\
(1.2) \\
(0.9) \\
(0.6)\end{array}$ & $\begin{array}{l}49 \\
31 \\
40 \\
45 \\
48\end{array}$ & $\begin{array}{l}(1.7) \\
(1.0) \\
(1.5) \\
(1.4) \\
(1.0)\end{array}$ & $\begin{array}{r}10 \\
4 \\
7 \\
8 \\
7\end{array}$ & $\begin{array}{l}(1.1) \\
(0.4) \\
(0.6) \\
(0.8) \\
(0.6)\end{array}$ \\
\hline 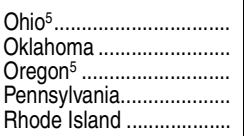 & $\begin{array}{r}219 \\
220 \\
-\overline{224} \\
215\end{array}$ & $\begin{array}{r}(1.2) \\
(1.0) \\
(\dagger) \\
(1.3) \\
(1.5)\end{array}$ & $\begin{array}{r}230 \\
224 \\
224 \\
-224\end{array}$ & $\begin{array}{r}(1.5) \\
(1.0) \\
(1.8) \\
(t) \\
(1.1)\end{array}$ & $\begin{array}{l}238 \\
229 \\
236 \\
236 \\
230\end{array}$ & $\begin{array}{l}(1.0) \\
(1.0) \\
(0.9) \\
(1.1) \\
(1.0)\end{array}$ & $\begin{array}{l}242 \\
234 \\
238 \\
241 \\
233\end{array}$ & $\begin{array}{l}(1.0) \\
(1.0) \\
(0.8) \\
(1.2) \\
(0.9)\end{array}$ & $\begin{array}{l}245 \\
237 \\
236 \\
244 \\
236\end{array}$ & $\begin{array}{l}(1.0) \\
(0.8) \\
(1.0) \\
(0.8) \\
(0.9)\end{array}$ & $\begin{array}{l}244 \\
237 \\
238 \\
244 \\
239\end{array}$ & $\begin{array}{l}(1.1) \\
(0.9) \\
(0.9) \\
(1.1) \\
(0.8)\end{array}$ & $\begin{array}{l}244 \\
237 \\
237 \\
246 \\
242\end{array}$ & $\begin{array}{l}(0.8) \\
(0.8) \\
(0.9) \\
(1.1) \\
(0.7)\end{array}$ & $\begin{array}{l}246 \\
239 \\
240 \\
244 \\
241\end{array}$ & $\begin{array}{l}(1.1) \\
(0.7) \\
(1.3) \\
(1.0) \\
(0.8)\end{array}$ & $\begin{array}{l}86 \\
83 \\
81 \\
85 \\
83\end{array}$ & $\begin{array}{l}(0.9) \\
(1.0) \\
(1.2) \\
(1.0) \\
(1.0)\end{array}$ & $\begin{array}{l}48 \\
36 \\
40 \\
44 \\
42\end{array}$ & $\begin{array}{l}(1.7) \\
(1.3) \\
(2.0) \\
(1.7) \\
(1.2)\end{array}$ & $\begin{array}{r}10 \\
5 \\
8 \\
8 \\
7\end{array}$ & $\begin{array}{l}(1.0) \\
(0.6) \\
(0.9) \\
(0.8) \\
(0.6)\end{array}$ \\
\hline 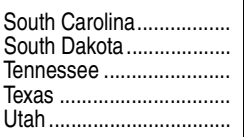 & $\begin{array}{l}212 \\
211 \\
218 \\
224\end{array}$ & $\begin{array}{r}(1.1) \\
(\dagger) \\
(1.4) \\
(1.2) \\
(1.0)\end{array}$ & $\begin{array}{r}220 \\
220 \\
231 \\
227\end{array}$ & $\begin{array}{r}(1.4) \\
(t) \\
(1.4) \\
(1.1) \\
(1.3)\end{array}$ & $\begin{array}{l}236 \\
237 \\
228 \\
237 \\
235\end{array}$ & $\begin{array}{l}(0.9) \\
(0.7) \\
(1.0) \\
(0.9) \\
(0.8)\end{array}$ & $\begin{array}{l}238 \\
242 \\
232 \\
242 \\
239\end{array}$ & $\begin{array}{l}(0.9) \\
(0.5) \\
(1.2) \\
(0.6) \\
(0.8)\end{array}$ & $\begin{array}{l}237 \\
241 \\
233 \\
242 \\
239\end{array}$ & $\begin{array}{l}(0.8) \\
(0.7) \\
(0.9) \\
(0.7) \\
(0.9)\end{array}$ & $\begin{array}{l}236 \\
242 \\
232 \\
240 \\
240\end{array}$ & $\begin{array}{l}(0.9) \\
(0.5) \\
(1.1) \\
(0.7) \\
(1.0)\end{array}$ & $\begin{array}{l}237 \\
241 \\
233 \\
241 \\
243\end{array}$ & $\begin{array}{l}(1.0) \\
(0.6) \\
(0.9) \\
(1.1) \\
(0.8)\end{array}$ & $\begin{array}{l}237 \\
241 \\
240 \\
242 \\
243\end{array}$ & $\begin{array}{l}(1.0) \\
(0.5) \\
(0.9) \\
(0.9) \\
(0.9)\end{array}$ & $\begin{array}{l}79 \\
84 \\
80 \\
84 \\
83\end{array}$ & $\begin{array}{l}(1.3) \\
(1.0) \\
(1.2) \\
(1.0) \\
(1.0)\end{array}$ & $\begin{array}{l}35 \\
40 \\
40 \\
41 \\
44\end{array}$ & $\begin{array}{l}(1.5) \\
(1.1) \\
(1.4) \\
(1.5) \\
(1.4)\end{array}$ & $\begin{array}{l}5 \\
5 \\
7 \\
7 \\
8\end{array}$ & $\begin{array}{l}(0.7) \\
(0.6) \\
(0.9) \\
(0.9) \\
(0.9)\end{array}$ \\
\hline 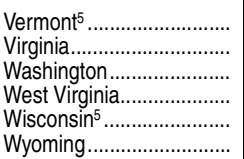 & $\begin{array}{l}-\overline{2} \\
-\overline{1} \\
215 \\
229 \\
225\end{array}$ & $\begin{array}{r}(t) \\
(1.3) \\
(t) \\
(1.1) \\
(1.1) \\
(0.9)\end{array}$ & $\begin{array}{r}232 \\
230 \\
\frac{-}{223} \\
\frac{2}{229}\end{array}$ & $\begin{array}{r}(1.6) \\
(1.0) \\
(t) \\
(1.3) \\
(+) \\
(1.1)\end{array}$ & $\begin{array}{l}242 \\
239 \\
238 \\
231 \\
237 \\
241\end{array}$ & $\begin{array}{l}(0.8) \\
(1.1) \\
(1.0) \\
(0.8) \\
(0.9) \\
(0.6)\end{array}$ & $\begin{array}{l}244 \\
241 \\
242 \\
231 \\
241 \\
243\end{array}$ & $\begin{array}{l}(0.5) \\
(0.9) \\
(0.9) \\
(0.7) \\
(0.9) \\
(0.6)\end{array}$ & $\begin{array}{l}246 \\
244 \\
243 \\
236 \\
244 \\
244\end{array}$ & $\begin{array}{l}(0.5) \\
(0.9) \\
(1.0) \\
(0.9) \\
(0.9) \\
(0.5)\end{array}$ & $\begin{array}{l}248 \\
243 \\
242 \\
233 \\
244 \\
242\end{array}$ & $\begin{array}{l}(0.4) \\
(1.0) \\
(0.8) \\
(0.8) \\
(0.9) \\
(0.6)\end{array}$ & $\begin{array}{l}247 \\
245 \\
243 \\
235 \\
245 \\
244\end{array}$ & $\begin{array}{l}(0.5) \\
(0.8) \\
(0.9) \\
(0.7) \\
(0.8) \\
(0.4)\end{array}$ & $\begin{array}{l}248 \\
246 \\
246 \\
237 \\
245 \\
247\end{array}$ & $\begin{array}{l}(0.6) \\
(1.1) \\
(1.1) \\
(0.8) \\
(1.0) \\
(0.4)\end{array}$ & $\begin{array}{l}87 \\
88 \\
86 \\
81 \\
85 \\
90\end{array}$ & $\begin{array}{l}(0.7) \\
(0.9) \\
(0.8) \\
(1.0) \\
(1.1) \\
(0.7)\end{array}$ & $\begin{array}{l}52 \\
47 \\
48 \\
35 \\
47 \\
48\end{array}$ & $\begin{array}{l}(1.1) \\
(1.7) \\
(1.6) \\
(1.2) \\
(1.6) \\
(0.9)\end{array}$ & $\begin{array}{r}11 \\
9 \\
10 \\
4 \\
9 \\
7\end{array}$ & $\begin{array}{l}(0.7) \\
(1.2) \\
(1.2) \\
(0.5) \\
(0.8) \\
(0.5)\end{array}$ \\
\hline $\begin{array}{l}\text { Department of Defense } \\
\text { dependents schools }{ }^{6} .\end{array}$ & - & $(\dagger)$ & 227 & $(0.6)$ & 237 & $(0.4)$ & 239 & $(0.5)$ & 240 & $(0.4)$ & 240 & $(0.5)$ & 241 & $(0.4)$ & 245 & $(0.4)$ & 89 & $(0.6)$ & 45 & $(0.8)$ & 6 & $(0.6)$ \\
\hline
\end{tabular}

-Not available.

†Not applicable.

1Scale ranges from 0 to 500 .

${ }^{2}$ Basic denotes partial mastery of the knowledge and skills that are fundamental for proficient work at the 4 th-grade level.

${ }^{3}$ Proficient represents solid academic performance for 4 th-graders. Students reaching this level have demonstrated competency over challenging subject matter.

${ }^{4}$ Advanced signifies superior performance.

${ }^{5} \mathrm{Did}$ not meet one or more of the guidelines for school participation in 2000. Data are subject to appreciable nonresponse bias.

${ }^{6}$ Prior to 2005, NAEP divided the Department of Defense (DoD) schools into two jurisdictions, domestic and overseas. In 2005, NAEP began combining the DoD domestic and overseas schools into a single jurisdiction. Data shown in this table for years prior to 2005 were recalculated for comparability.

NOTE: With the exception of 1992, includes public school students who were tested with accommodations; excludes only those students with disabilities (SD) and English language learners (ELL) who were unable to be tested even with accommodations. SD and ELL populations, accommodation rates, and exclusion rates vary from state to state. Detail may not sum to totals because of rounding.

SOURCE: U.S. Department of Education, National Center for Education Statistics, National Assessment of Educational Progress (NAEP), 1992, 2000, 2003, 2005, 2007, 2009, 2011, and 2013 Mathematics Assessments, retrieved November 21, 2013, from the Main NAEP Data Explorer (http://nces.ed.gov/nationsreportcard/naepdata/). (This table was prepared November 2013.) 
Table 222.60. Average National Assessment of Educational Progress (NAEP) mathematics scale score of 8th-grade public school students and percentage attaining mathematics achievement levels, by state: Selected years, 1990 through 2013

[Standard errors appear in parentheses]

\begin{tabular}{|c|c|c|c|c|c|c|c|c|c|c|c|c|c|c|c|c|c|c|c|c|c|c|c|c|}
\hline \multirow[b]{2}{*}{ State } & \multicolumn{18}{|c|}{ Average scale score ${ }^{1}$} & \multicolumn{6}{|c|}{$\begin{array}{l}\text { Percent attaining mathematics } \\
\text { achievement levels, } 2013\end{array}$} \\
\hline & & $1990^{2}$ & & $1996^{3}$ & & 2000 & & 2003 & & 2005 & & 007 & & 2009 & & 2011 & & 2013 & & & & & dvan & \\
\hline 1 & & 2 & & 3 & & 4 & & 5 & & 6 & & 7 & & 8 & & 9 & & 10 & & 11 & & 12 & & 13 \\
\hline Unitec & 2 & 1.4) & 71 & (1.2) & 2 & $(0.9)$ & 6 & $(0.3)$ & 78 & D.2) & 280 & (0.3) & 32 & $(0.3)$ & 83 & $(0.2)$ & 84 & $(0.2)$ & 73 & $(0.3)$ & 34 & $(0.3)$ & 8 & (0.2) \\
\hline 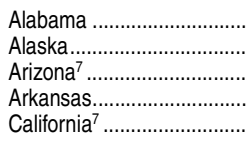 & $\begin{array}{r}253 \\
- \\
260 \\
256 \\
256\end{array}$ & $\begin{array}{r}(1.1) \\
(\dagger) \\
(1.3) \\
(0.9) \\
(1.3)\end{array}$ & $\begin{array}{l}257 \\
278 \\
268 \\
262 \\
263\end{array}$ & $\begin{array}{l}(2.1) \\
(1.8) \\
(1.6) \\
(1.5) \\
(1.9)\end{array}$ & $\begin{array}{r}264 \\
-269 \\
257 \\
260\end{array}$ & $\begin{array}{r}(1.8) \\
(\dagger) \\
(1.8) \\
(1.5) \\
(2.1)\end{array}$ & $\begin{array}{l}2 \\
9 \\
1 \\
6 \\
7\end{array}$ & $\begin{array}{l}(1.5) \\
(0.9) \\
(1.2) \\
(1.2) \\
(1.2)\end{array}$ & $\begin{array}{l}262 \\
279 \\
274 \\
272 \\
269\end{array}$ & $\begin{array}{l}(1.5) \\
(0.8) \\
(1.1) \\
(1.2) \\
(0.7)\end{array}$ & $\begin{array}{l}266 \\
283 \\
276 \\
274 \\
270\end{array}$ & $\begin{array}{l}(1.5) \\
(1.1) \\
(1.2) \\
(1.1) \\
(0.8)\end{array}$ & $\begin{array}{l}269 \\
283 \\
277 \\
276 \\
270\end{array}$ & $\begin{array}{l}(1.2) \\
(1.0) \\
(1.4) \\
(1.1) \\
(1.3)\end{array}$ & $\begin{array}{l}699 \\
879 \\
79 \\
79 \\
73\end{array}$ & $\begin{array}{l}(1.4) \\
(0.8) \\
(1.2) \\
(1.0) \\
(1.2)\end{array}$ & $\begin{array}{l}269 \\
282 \\
280 \\
278 \\
276\end{array}$ & $\begin{array}{l}(1.3) \\
(0.9) \\
(1.2) \\
(1.1) \\
(1.2)\end{array}$ & $\begin{array}{l}60 \\
72 \\
69 \\
69 \\
65\end{array}$ & $\begin{array}{l}(1.5) \\
(1.1) \\
(1.3) \\
(1.4) \\
(1.3)\end{array}$ & $\begin{array}{l}31 \\
28 \\
28\end{array}$ & $\begin{array}{l}(1.6) \\
(1.1) \\
(1.3) \\
(1.3) \\
(1.3)\end{array}$ & 5 & $\begin{array}{l}(0.6) \\
(0.7) \\
(0.9) \\
(0.6) \\
(0.7)\end{array}$ \\
\hline 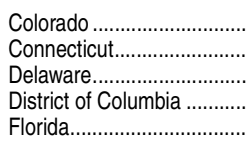 & $\begin{array}{l}267 \\
270 \\
261 \\
231 \\
255\end{array}$ & $\begin{array}{l}(0.9) \\
(1.0) \\
(0.9) \\
(0.9) \\
(1.2)\end{array}$ & $\begin{array}{l}276 \\
280 \\
267 \\
233 \\
264\end{array}$ & $\begin{array}{l}(1.1) \\
(1.1) \\
(0.9) \\
(1.3) \\
(1.8)\end{array}$ & $\begin{array}{r}-\overline{281} \\
-\overline{2} \\
-\end{array}$ & $\begin{array}{r}(t) \\
(1.3) \\
(\dagger) \\
(1.1) \\
(\dagger)\end{array}$ & $\begin{array}{l}83 \\
84 \\
77 \\
43 \\
71\end{array}$ & $\begin{array}{l}(1.1) \\
(1.2) \\
(0.7) \\
(0.8) \\
(1.5)\end{array}$ & $\begin{array}{l}281 \\
281 \\
281 \\
245 \\
274\end{array}$ & $\begin{array}{l}(1.2) \\
(1.4) \\
(0.6) \\
(0.9) \\
(1.1)\end{array}$ & $\begin{array}{l}286 \\
282 \\
283 \\
248 \\
277\end{array}$ & & $\begin{array}{l}37 \\
39 \\
34 \\
4 \\
9\end{array}$ & & & $\begin{array}{l}(1.1) \\
(1.1) \\
(0.7) \\
(0.7) \\
(0.8)\end{array}$ & $\begin{array}{l}90 \\
85 \\
82 \\
65 \\
81\end{array}$ & $\begin{array}{l}(1.2) \\
(1.1) \\
(0.7) \\
(0.9) \\
(0.8)\end{array}$ & 0 & & 42 & & 12 & $\begin{array}{l}(0.9) \\
(0.8) \\
(0.6) \\
(0.5) \\
(0.6)\end{array}$ \\
\hline & $\begin{array}{l}259 \\
251 \\
271 \\
261 \\
267\end{array}$ & $\begin{array}{l}(1.3) \\
(0.8) \\
(0.8) \\
(1.7) \\
(1.2)\end{array}$ & $\begin{array}{r}262 \\
262 \\
- \\
- \\
276\end{array}$ & $\begin{array}{r}(1.6) \\
(1.0) \\
(\dagger) \\
(\dagger) \\
(1.4)\end{array}$ & $\begin{array}{l}265 \\
262 \\
277 \\
275 \\
281\end{array}$ & $\begin{array}{l}(1.2) \\
(1.4) \\
(1.0) \\
(1.7) \\
(1.4)\end{array}$ & $\begin{array}{l}270 \\
266 \\
280 \\
277 \\
281\end{array}$ & $\begin{array}{l}(1.2) \\
(0.8) \\
(0.9) \\
(1.2) \\
(1.1)\end{array}$ & $\begin{array}{l}272 \\
266 \\
281 \\
278 \\
282\end{array}$ & & $\begin{array}{l}275 \\
269 \\
284 \\
280 \\
285\end{array}$ & & $\begin{array}{l}278 \\
274 \\
287 \\
282 \\
287\end{array}$ & & & $\begin{array}{l}(1.0) \\
(0.7) \\
(0.8) \\
(1.1) \\
(1.0)\end{array}$ & $\begin{array}{l}279 \\
281 \\
286 \\
285 \\
288\end{array}$ & $\begin{array}{l}(1.2) \\
(0.8) \\
(0.7) \\
(1.0) \\
(1.1)\end{array}$ & $\begin{array}{l}74 \\
77\end{array}$ & $\begin{array}{l}(1.0) \\
(1.1)\end{array}$ & $\begin{array}{l}36 \\
38\end{array}$ & & $\begin{array}{r}7 \\
9 \\
10\end{array}$ & $\begin{array}{l}(0.8) \\
(0.6) \\
(0.8) \\
(0.9) \\
(0.9)\end{array}$ \\
\hline & $\begin{array}{l}7 \\
66\end{array}$ & $\begin{array}{r}(1.1) \\
(\dagger) \\
(1.2) \\
(1.2) \\
(\dagger)\end{array}$ & $\begin{array}{r}284 \\
267 \\
252 \\
284\end{array}$ & $\begin{array}{r}(1.3) \\
(\dagger) \\
(1.1) \\
(1.6) \\
(1.3)\end{array}$ & $\begin{array}{r}- \\
283 \\
270 \\
259 \\
281\end{array}$ & $\begin{array}{r}(\dagger) \\
(1.7) \\
(1.3) \\
(1.5) \\
(1.1)\end{array}$ & $\begin{array}{l}284 \\
284 \\
274 \\
266 \\
282\end{array}$ & & 281 & $(0.8)$ & $\begin{array}{l}285 \\
290 \\
279 \\
272 \\
286\end{array}$ & & $\begin{array}{l}284 \\
289 \\
279 \\
272 \\
286\end{array}$ & & & & & $\begin{array}{l}(0.9) \\
(1.0) \\
(0.9) \\
(0.9) \\
(0.7)\end{array}$ & & & 40 & & 10 & $\begin{array}{l}0.8) \\
0.6) \\
0.4) \\
0.7)\end{array}$ \\
\hline & $\begin{array}{l}261 \\
264 \\
275\end{array}$ & $\begin{array}{r}(1.4) \\
(t) \\
(1.2) \\
(0.9) \\
(t)\end{array}$ & $\begin{array}{l}270 \\
278 \\
277 \\
284 \\
250\end{array}$ & $\begin{array}{l}(2.1) \\
(1.7) \\
(1.8) \\
(1.3) \\
(1.2)\end{array}$ & & $\left.\begin{array}{l}(1.9) \\
(1.4) \\
(1.1)\end{array}\right]$ & & & & & & & $\begin{array}{l}288 \\
299 \\
278 \\
294 \\
265\end{array}$ & & & & & $\begin{array}{l}(1.1) \\
(0.9) \\
(1.3) \\
(1.0) \\
(0.9)\end{array}$ & & & 21 & & $\begin{array}{r}7 \\
14 \\
3\end{array}$ & $\begin{array}{l}(1.2) \\
(0.7) \\
(1.0) \\
(0.4)\end{array}$ \\
\hline & $\frac{276}{273}$ & $\begin{array}{r}(\dagger) \\
(0.9) \\
(1.0) \\
(\dagger) \\
(0.9)\end{array}$ & $\begin{array}{r}273 \\
283 \\
283 \\
- \\
-\end{array}$ & $\begin{array}{r}(1.4) \\
(1.3) \\
(1.0) \\
(\dagger) \\
(\dagger)\end{array}$ & $\begin{array}{r}280 \\
265 \\
-\end{array}$ & $\begin{array}{r}(0.8) \\
(t)\end{array}$ & & & & & & & & & & & & & & & & & 3 & $\begin{array}{l}(0.7) \\
0.7) \\
(0.5) \\
(1.0)\end{array}$ \\
\hline & $\begin{array}{l}250 \\
281\end{array}$ & $\begin{array}{l}(1.1) \\
(0.7) \\
(1.4) \\
(1.1) \\
(1.2)\end{array}$ & $\begin{array}{l}-\overline{262} \\
270 \\
268 \\
284\end{array}$ & $\begin{array}{r}(\dagger) \\
(1.2) \\
(1.7) \\
(1.4) \\
(0.9)\end{array}$ & $\begin{array}{l}-\overline{259} \\
271 \\
276 \\
282\end{array}$ & $\begin{array}{l}(1.3) \\
(1.1)\end{array}$ & & & & & $\begin{array}{l}289 \\
268 \\
280 \\
284 \\
292\end{array}$ & & & & & & & & & & 41 & & $\begin{array}{r}16 \\
4 \\
8 \\
9 \\
8\end{array}$ & $\begin{array}{l}(0.4) \\
(0.7) \\
(0.8) \\
(0.6)\end{array}$ \\
\hline & 260 & $\begin{array}{l}(1.0) \\
(1.3) \\
(1.0) \\
(1.6) \\
(0.6)\end{array}$ & $\begin{array}{r}- \\
2 \overline{6} \\
\overline{269}\end{array}$ & $\begin{array}{r}(1.5) \\
(t) \\
(0.9)\end{array}$ & $\begin{array}{r}281 \\
270 \\
280 \\
- \\
269\end{array}$ & $\begin{array}{r}(1.5) \\
(\dagger) \\
(1.3)\end{array}$ & $\begin{array}{l}282 \\
272 \\
281 \\
279 \\
272\end{array}$ & & & & $\begin{array}{l}275 \\
284 \\
286 \\
275\end{array}$ & $\begin{array}{l}(1.1) \\
(1.1) \\
(0.7)\end{array}$ & $\begin{array}{l}276 \\
285 \\
288 \\
278\end{array}$ & & & $\begin{array}{l}(1.2) \\
(0.5)\end{array}$ & $\begin{array}{l}276 \\
284 \\
290 \\
284\end{array}$ & $\begin{array}{l}(1.0) \\
(1.1) \\
(1.0) \\
(0.6)\end{array}$ & & & 30 & & $\begin{array}{r}11 \\
4 \\
8 \\
10 \\
8\end{array}$ & $(0.6)$ \\
\hline & . & $\begin{array}{r}(t) \\
(t) \\
(1.4) \\
(t)\end{array}$ & $\begin{array}{r}261 \\
-263 \\
270 \\
277\end{array}$ & $\begin{array}{r}(\dagger) \\
(1.4) \\
(1.4) \\
(1.0)\end{array}$ & 274 & $\begin{array}{r}(1.5) \\
(\dagger) \\
(1.5) \\
(1.6) \\
(1.2)\end{array}$ & $\begin{array}{l}285 \\
268 \\
277 \\
281\end{array}$ & $\begin{array}{l}(1.8) \\
(1.1) \\
(1.0)\end{array}$ & $\begin{array}{l}271 \\
281 \\
279\end{array}$ & & $\begin{array}{l}288 \\
274 \\
286 \\
281\end{array}$ & & $\begin{array}{l}291 \\
275 \\
287 \\
284\end{array}$ & & $\begin{array}{l}291 \\
274 \\
290 \\
283\end{array}$ & & $\begin{array}{l}280 \\
287 \\
278 \\
288 \\
284\end{array}$ & $\begin{array}{l}(1.1) \\
(0.7) \\
(1.3) \\
(1.0) \\
(0.9)\end{array}$ & 75 & & 36 & & $\begin{array}{l}8 \\
7 \\
5 \\
8\end{array}$ & $(0.7)$ \\
\hline & $\begin{array}{l}256 \\
274 \\
272\end{array}$ & $\begin{array}{r}(\dagger) \\
(1.5) \\
(\dagger) \\
(1.0) \\
(1.3) \\
(0.7)\end{array}$ & $\begin{array}{l}279 \\
270 \\
276 \\
265 \\
283 \\
275\end{array}$ & $\begin{array}{l}(1.0) \\
(1.5) \\
(0.9)\end{array}$ & $\begin{array}{r}281 \\
275 \\
- \\
266 \\
- \\
276\end{array}$ & $\begin{array}{r}(1.5) \\
(1.3) \\
(\dagger) \\
(1.2) \\
(\dagger) \\
(1.0)\end{array}$ & $\begin{array}{l}286 \\
282 \\
281 \\
271 \\
284 \\
284\end{array}$ & (0.7) & $\begin{array}{l}284 \\
285 \\
269 \\
285 \\
282\end{array}$ & $\begin{array}{l}(1.0) \\
(1.2) \\
(0.8)\end{array}$ & $\begin{array}{l}291 \\
288 \\
285 \\
270 \\
286 \\
287\end{array}$ & $\begin{array}{l}(1.1) \\
(1.0) \\
(1.0) \\
(1.1) \\
(0.7)\end{array}$ & $\begin{array}{l}293 \\
286 \\
289 \\
270 \\
288 \\
286\end{array}$ & $\begin{array}{l}(1.0) \\
(0.9) \\
(0.6)\end{array}$ & $\begin{array}{l}273 \\
273 \\
289 \\
288\end{array}$ & $\left.\begin{array}{l}(1.0) \\
(0.7) \\
(1.0) \\
(0.6)\end{array}\right]$ & $\begin{array}{l}295 \\
288 \\
290 \\
274 \\
289 \\
288\end{array}$ & $\left.\begin{array}{l}(0.7) \\
(1.2) \\
(1.0) \\
(0.9) \\
(0.9) \\
(0.5)\end{array}\right]$ & 81 & $\begin{array}{l}(0.9) \\
(0.8)\end{array}$ & $\begin{array}{l}24 \\
40 \\
38\end{array}$ & $\begin{array}{l}(1.2) \\
(1.1)\end{array}$ & $\begin{array}{r}14 \\
10 \\
12 \\
3 \\
11 \\
7\end{array}$ & $\begin{array}{l}(0.7) \\
(0.5)\end{array}$ \\
\hline dependents schools ${ }^{8}$ & - & $(t)$ & 274 & $(0.9)$ & 27 & (1.1) & 285 & (0.7) & 284 & $(0.7)$ & 285 & $(0.8)$ & 287 & $(0.9)$ & 288 & $(0.8)$ & 290 & $(0.8)$ & 83 & (0.9) & 40 & (1.2) & 8 & (0.7) \\
\hline
\end{tabular}

-Not available.

†Not applicable.

iScale ranges from 0 to 500

${ }^{2}$ Accommodations were not permitted for this assessment.

${ }^{3}$ The 1996 data in this table do not include students who were tested with accommodations. Data for students tested with accommodations are not available at the state level for 1996. ${ }^{4}$ Basic denotes partial mastery of the knowledge and skills that are fundamental for proficient work at the 8th-grade level.

${ }^{5}$ Proficient represents solid academic performance for 8th-graders. Students reaching this level have demonstrated competency over challenging subject matter.

${ }^{6}$ Advanced signifies superior performance.

${ }^{7}$ Did not meet one or more of the guidelines for school participation in 2000. Data are subject to appreciable nonresponse bias.
${ }^{8}$ Prior to 2005, NAEP divided the Department of Defense (DoD) schools into two jurisdictions, domestic and overseas. In 2005, NAEP began combining the DoD domestic and overseas schools into a single jurisdiction. Data shown in this table for years prior to 2005 were recalculated for comparability.

NOTE: For 2000 and later years, includes public school students who were tested with accommodations; excludes only those students with disabilities (SD) and English language learners (ELL) who were unable to be tested even with accommodations. SD and ELL populations, accommodation rates, and exclusion rates vary from state to state. Detail may not sum to totals because of rounding.

SOURCE: U.S. Department of Education, National Center for Education Statistics, National Assessment of Educational Progress (NAEP), 1990, 1996, 2000, 2003, 2005, 2007, 2009, 2011, and 2013 Mathematics Assessments, retrieved November 7, 2013, from the Main NAEP Data Explorer (http://nces.ed.gov/nationsreportcard/naepdata/). (This table was prepared November 2013.) 
Table 222.70. Average National Assessment of Educational Progress (NAEP) mathematics scale score of 8th-grade public school students, by race/ethnicity, highest level of parental education, and state: 2013

[Standard errors appear in parentheses]

\begin{tabular}{|c|c|c|c|c|c|c|c|c|c|c|c|c|c|c|c|c|c|c|c|c|}
\hline \multirow[b]{2}{*}{ State } & \multicolumn{12}{|c|}{ Race/ethnicity $^{1}$} & \multicolumn{8}{|c|}{ Highest level of education attained by parents 2} \\
\hline & & White & & Black & & spanic & & Asian & Pacific & ander & $\begin{array}{r}\mathrm{Ar} \\
\text { Alaska }\end{array}$ & $\begin{array}{l}\text { erican } \\
\text { ndian/ } \\
\text { Native }\end{array}$ & & & & & $\begin{array}{r}\text { educe } \\
\text { hi }\end{array}$ & $\begin{array}{l}\text { Some } \\
\text { nafter } \\
\text { school }\end{array}$ & & \\
\hline 1 & & 2 & & 3 & & 4 & & 5 & & 6 & & 7 & & 8 & & 9 & & 10 & & 11 \\
\hline United States ............. & 293 & $(0.3)$ & 263 & $(0.4)$ & 271 & $(0.4)$ & 308 & (1.1) & 274 & (2.3) & 270 & (1.3) & 267 & $(0.5)$ & 270 & $(0.4)$ & 285 & (0.4) & 295 & $(0.3)$ \\
\hline Alabama . & 280 & (1.6) & 250 & $(1.4)$ & 257 & (3.5) & $\ddagger$ & $(\dagger)$ & $\ddagger$ & $(\dagger)$ & $\ddagger$ & $(\dagger)$ & 252 & (2.7) & 253 & (2.0) & 274 & (1.6) & 279 & (2.0) \\
\hline aska...... & 294 & $(1.0)$ & 2 & $(3.9)$ & & & 278 & (2.5) & 257 & (4.7) & 262 & (2.3) & $\ddagger$ & $(\dagger)$ & $\ddagger$ & $(\dagger)$ & $\ddagger$ & $(\dagger)$ & & $(t)$ \\
\hline izona ...... & 294 & (1.6) & 266 & $(4.0)$ & 269 & (1.3) & 306 & (4.3) & $\ddagger$ & $(t)$ & 259 & (3.4) & 267 & (2.3) & 268 & (2.1) & 283 & (2.0) & 294 & 1.8) \\
\hline rkansas.... & 286 & (1.2) & 255 & (1.7) & 274 & 4) & $\ddagger$ & $(\dagger)$ & $\ddagger$ & $(t)$ & $\ddagger$ & (t) & 267 & .4) & 266 & (1.9) & 281 & $.5)$ & 88 & .4) \\
\hline California .. & 291 & (1.6) & 258 & (3.0) & 263 & (1.1) & 307 & (2.8) & $\ddagger$ & $(t)$ & $\ddagger$ & $(\mathrm{t})$ & 260 & (1.7) & 266 & (1.8) & 279 & (2.1) & 292 & (1.7) \\
\hline plorac & 300 & (1.3) & 260 & (3.8) & 273 & 3) & 308 & (5.4) & $\ddagger$ & $(\dagger)$ & $\ddagger$ & (†) & 65 & 4) & 271 & (2.3) & 293 & (1.8) & 302 & (1.3) \\
\hline onnecticl & 297 & $(1.0)$ & 260 & $(2.6)$ & 258 & & & (3.6) & $\ddagger$ & $(t)$ & $t$ & $(t)$ & & & 77 & (2.0) & & & 96 & 2) \\
\hline elaware........ & 293 & $(0.9)$ & 264 & $(1.1)$ & 276 & (2.0) & 312 & (4.8) & $\ddagger$ & $(t)$ & $\ddagger$ & $(t)$ & 88 & 7) & 71 & (1.7) & 282 & ) & 92 & 1) \\
\hline istrict & 317 & (3.5) & 261 & $(1.0)$ & 265 & (2.7) & $\ddagger$ & $(t)$ & $\ddagger$ & $(t)$ & $\ddagger$ & $(\dagger)$ & 57 & & 53 & (2.1) & 71 & & 77 & .7) \\
\hline Florida & 291 & (1.2) & 264 & $(1.7)$ & 274 & $(1.0)$ & 310 & (4.7) & $\ddagger$ & $(t)$ & $\ddagger$ & $(\mathrm{t})$ & 266 & (2.3) & 269 & (1.5) & 286 & (1.3) & 290 & (1.0) \\
\hline teoraia & 292 & (1. & 262 & $(1.4)$ & 276 & (2.8) & 310 & (6.6) & $\ddagger$ & $(†)$ & $\ddagger$ & $(\dagger)$ & 7 & (2.4) & 267 & (1.6) & 81 & (1 & 39 & (1.5) \\
\hline .......... & 290 & (2.3) & $\ddagger$ & $(t)$ & 280 & (3. & 291 & (1.3) & 267 & (1.3) & $\ddagger$ & $(t)$ & & & 70 & (1.4) & 87 & & & \\
\hline aho......... & 291 & $(0.8)$ & $\ddagger$ & $(t)$ & 268 & (1.6) & $\ddagger$ & $(t)$ & $\ddagger$ & $(t)$ & $\ddagger$ & $(t)$ & 268 & (2.2) & 70 & (2.0) & 288 & ) & 6 & 1) \\
\hline nois & 296 & (1.3) & 260 & $(1.3)$ & 272 & (1 & 313 & (6.2) & $\ddagger$ & $(t)$ & $\ddagger$ & $(\dagger)$ & 267 & (2.3) & 72 & (2.0) & 285 & & 97 & 1.2) \\
\hline Indiana.... & 293 & $(1.1)$ & 265 & $(2.4)$ & 278 & (2.4) & $\ddagger$ & $(t)$ & $\ddagger$ & $(t)$ & $\ddagger$ & $(t)$ & 272 & (2.9) & 276 & (1.9) & 290 & (1. & 298 & $(1.5)$ \\
\hline & 289 & $(1.0$ & 255 & (3.1) & 265 & 8 & 301 & (4.7) & $\ddagger$ & $(t)$ & $\ddagger$ & $(t)$ & 261 & 14 & 272 & (1.9) & 37 & & 294 & \\
\hline$\ldots . .$. & 295 & (1.1) & 268 & (3.2) & 216 & & 2 & (7.1) & $\ddagger$ & (†) & $\ddagger$ & $(\dagger)$ & 08 & & & (2.0) & 81 & & 0 & \\
\hline ky & 283 & $(1.0)$ & 260 & $(1.6)$ & 269 & (3) & 313 & (7.1) & $\ddagger$ & (†) & $\ddagger$ & $(t)$ & 262 & 8 & 70 & (1.4) & 81 & & 1 & .2) \\
\hline -ouis & 285 & $(0.8$ & 259 & $(1.1)$ & 277 & (3. & $\ddagger$ & $(\dagger)$ & $\ddagger$ & (†) & $\ddagger$ & $(\dagger)$ & 66 & & 65 & (1.5) & 79 & & 79 & .3) \\
\hline Maine & 290 & $(0.8$ & 262 & $(4.9)$ & $\ddagger$ & $(t)$ & $\ddagger$ & $(t)$ & $\ddagger$ & $(t)$ & $\ddagger$ & $(t)$ & 270 & (3.5 & 275 & (1.9) & 285 & $(1$ & 98 & $(0.9)$ \\
\hline & 99 & (1. & 268 & (1.4) & 280 & (2.3) & 319 & (4.1) & $\ddagger$ & (†) & $\ddagger$ & (†) & 269 & & 272 & (1) & 8 & & 297 & 4) \\
\hline husetts & 307 & $(1.0)$ & 277 & $(1.8)$ & 271 & $(2$ & 4 & (3.5) & $\ddagger$ & $(\dagger)$ & $\ddagger$ & $(\dagger)$ & 7 & (2) & 00 & (2.2) & 98 & & 1 & 2) \\
\hline & 87 & $(1.2)$ & 251 & $(2.2)$ & 261 & (2 & 310 & (7.7) & $\ddagger$ & (†) & $\ddagger$ & $(t)$ & 30 & 3 & 264 & (2.2) & 279 & & 291 & 6) \\
\hline & 301 & $(1$ & 260 & (3.5) & 273 & & 291 & (3.1) & $\ddagger$ & $(t)$ & $\ddagger$ & $(\dagger)$ & 9 & & 74 & (2.3) & 93 & & 05 & .2) \\
\hline Mississipp & 285 & $(1.1)$ & 255 & $(1.1)$ & 279 & (3.7) & $\ddagger$ & $(t)$ & $\ddagger$ & $(\dagger)$ & $\ddagger$ & $(t)$ & 265 & (2.3) & 259 & (1.5) & 278 & $(2$. & 279 & (1.3) \\
\hline issouri & 288 & $(0$ & 260 & $(3.1)$ & 276 & (2.9) & $\ddagger$ & $(\dagger)$ & $\ddagger$ & $(\dagger$ & $\ddagger$ & $(t)$ & 265 & (2.7) & 269 & (1.7) & 289 & $(1.8$ & 92 & 3) \\
\hline Monta & 93 & (c & $\ddagger$ & $(\dagger)$ & 2 & & $\ddagger$ & $(t)$ & $\ddagger$ & †) & 263 & (2.2) & 8 & & 19 & (1.6) & 290 & & & 1) \\
\hline & 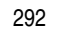 & $(0$ & 250 & $(4.2)$ & 267 & & 02 & (4.9) & $\ddagger$ & t) & $\ddagger$ & $(t)$ & 7 & & 72 & (1.9) & 287 & & 95 & .0) \\
\hline & 2 & & 263 & (2.2) & 268 & & 3 & & $\ddagger$ & $(\dagger)$ & $\ddagger$ & $(\dagger)$ & 65 & & & & 88 & & 39 & .2) \\
\hline New Hampshire ... & 297 & $(0.8)$ & $\ddagger$ & $(t)$ & 270 & (3.7) & 313 & $(6.4)$ & $\ddagger$ & $(\dagger)$ & $\ddagger$ & $(t)$ & 274 & (3.2) & 282 & (1.6) & 293 & $(1.6$ & 304 & (1.0) \\
\hline & 303 & $(1$ & 274 & (2.6) & 283 & & 323 & $(3$ & \pm & $(t)$ & $\ddagger$ & $(t)$ & 279 & & & (2.1) & 292 & & & 2) \\
\hline & & & & & & & t & $(\dagger)$ & $\ddagger$ & & 260 & (2.3) & & & & & & & & \\
\hline & 94 & $(1$ & & $(1$ & 5 & & 305 & (2.4) & $\ddagger$ & & $\ddagger$ & $(t)$ & 5 & & & & 2 & & & 1) \\
\hline & & $(1$ & 268 & $(1.6)$ & 279 & (2. & 301 & (6.4) & $t$ & $(\dagger)$ & $\ddagger$ & (t) & & & & & 9 & & & 3) \\
\hline North Dakota & 294 & $(0.6)$ & 272 & $(4.1)$ & $\ddagger$ & $(t)$ & $\ddagger$ & $(t)$ & $\ddagger$ & 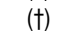 & 265 & (2.4) & 270 & (3.2) & 274 & $(1.8)$ & 290 & (1. & 297 & $(0.6)$ \\
\hline & & & & & & & & & & & $t$ & & & & & & & & & \\
\hline & & & 256 & $(3$ & & & & & $\ddagger$ & & 275 & (1.9) & & & & & & & & \\
\hline & 290 & & $\ddagger$ & t t & 2 & & 3 & (5.6) & $\ddagger$ & & $\ddagger$ & $(t)$ & & & & & 36 & & & 6) \\
\hline & 297 & (1. & 262 & $(2.1)$ & 264 & $(2$ & 307 & (4.4) & $\ddagger$ & (II) & $\ddagger$ & $(\uparrow)$ & 09 & & & & 290 & & 99 & .4) \\
\hline Rhode Island .. & 294 & $(0.7)$ & 263 & $(2.8)$ & 263 & $(1$. & 285 & $(4.9)$ & $\ddagger$ & $(\dagger)$ & $\ddagger$ & $(t)$ & 264 & (2.5) & 269 & (1.9) & 284 & $(1.9$ & 297 & $(0.9)$ \\
\hline & & & & & & & + & $(t)$ & & & + & $(\dagger)$ & & & & & & & & \\
\hline & & & & & & & $\ddagger$ & it & & & 260 & (1.7) & & & & & & & & \\
\hline & 284 & (1) & 25 & (2) & 270 & & $\ddagger$ & $(t)$ & $\ddagger$ & & $\ddagger$ & $(t)$ & 1 & & & & 82 & & & .5) \\
\hline & 300 & $(1.5$ & 273 & $(2.0)$ & 281 & $(1$ & 321 & (3.7) & $\ddagger$ & $(t)$ & $\ddagger$ & $(t)$ & 277 & (1.5) & 278 & (1.5) & 289 & & 99 & .3) \\
\hline Utah ............................. & 291 & $(0.9)$ & $\ddagger$ & $(t)$ & 258 & (1.9) & $\ddagger$ & $(t)$ & $\ddagger$ & $(t)$ & $\ddagger$ & $(t)$ & 258 & (3.1) & 264 & (2.1) & 284 & (1. & 297 & $(0.8)$ \\
\hline & & & & & $\ddagger$ & & $\ddagger$ & 1 & t & ( & $t$ & $(\dagger)$ & & & & & 5 & & & \\
\hline & & & & (1. & 279 & $(2$ & & (3.5) & $\ddagger$ & & $\ddagger$ & $(t)$ & & & & & 34 & & & 6) \\
\hline & & & 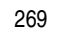 & & 273 & & 10 & & $\ddagger$ & & $\ddagger$ & $(\dagger)$ & & & & & & & & \\
\hline 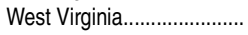 & 275 & $(0.9)$ & 264 & $(2.9)$ & $\ddagger$ & $(\dagger$ & $\ddagger$ & $(\dagger)$ & $\ddagger$ & (I) & $\ddagger$ & $(t)$ & 259 & (2.5) & 5 & (1.4) & 79 & & 34 & .3) \\
\hline & 296 & $(0$ & 252 & $(2.3)$ & 273 & te & 290 & (3.4) & $\ddagger$ & $(\dagger)$ & 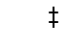 & & 205 & & 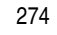 & & 288 & & 298 & 1.0) \\
\hline Wyon & 290 & $(0.6)$ & $\ddagger$ & $(\dagger)$ & 278 & $(1$ & $\ddagger$ & $(t)$ & i & (t) & 269 & (3.4) & 272 & (2.6) & 275 & (1.3) & 291 & (1.3) & 296 & $(0.8)$ \\
\hline dependents schools..... & 296 & $(1.1)$ & 276 & $(1.8)$ & 283 & (1.7) & 301 & (2.4) & $F$ & †) & $F$ & (I) & $\mp$ & $(\dagger)$ & 278 & (2.0) & 288 & (1.7) & 295 & $(0.8)$ \\
\hline
\end{tabular}

†Not applicable.

†Reporting standards not met. Either there are too few cases for a reliable estimate or item response rates fell below the required standards for reporting.

${ }^{1}$ Data for students of two or more races are not separately shown.

"Excludes students who responded "I don't know" to the question about educational level of parents.

NOTE: Scale ranges from 0 to 500 . Includes public school students who were tested with accommodations; excludes only those students with disabilities (SD) and English language learners (ELL) who were unable to be tested even with accommodations. SD and ELL populations, accommodation rates, and exclusion rates vary from state to state. Detail may not sum to totals because of rounding.

SOURCE: U.S. Department of Education, National Center for Education Statistics, National Assessment of Educational Progress (NAEP), 2013 Mathematics Assessment, retrieved November 11, 2013, from the Main NAEP Data Explorer (http://nces.ed.gov/nationsreport card/naepdata/). (This table was prepared November 2013.) 
Table 222.80. Average National Assessment of Educational Progress (NAEP) mathematics scale scores of 4th- and 8th-grade public school students and percentage attaining achievement levels, by race/ethnicity and jurisdiction or specific urban district: 2009, 2011, and 2013 [Standard errors appear in parentheses]

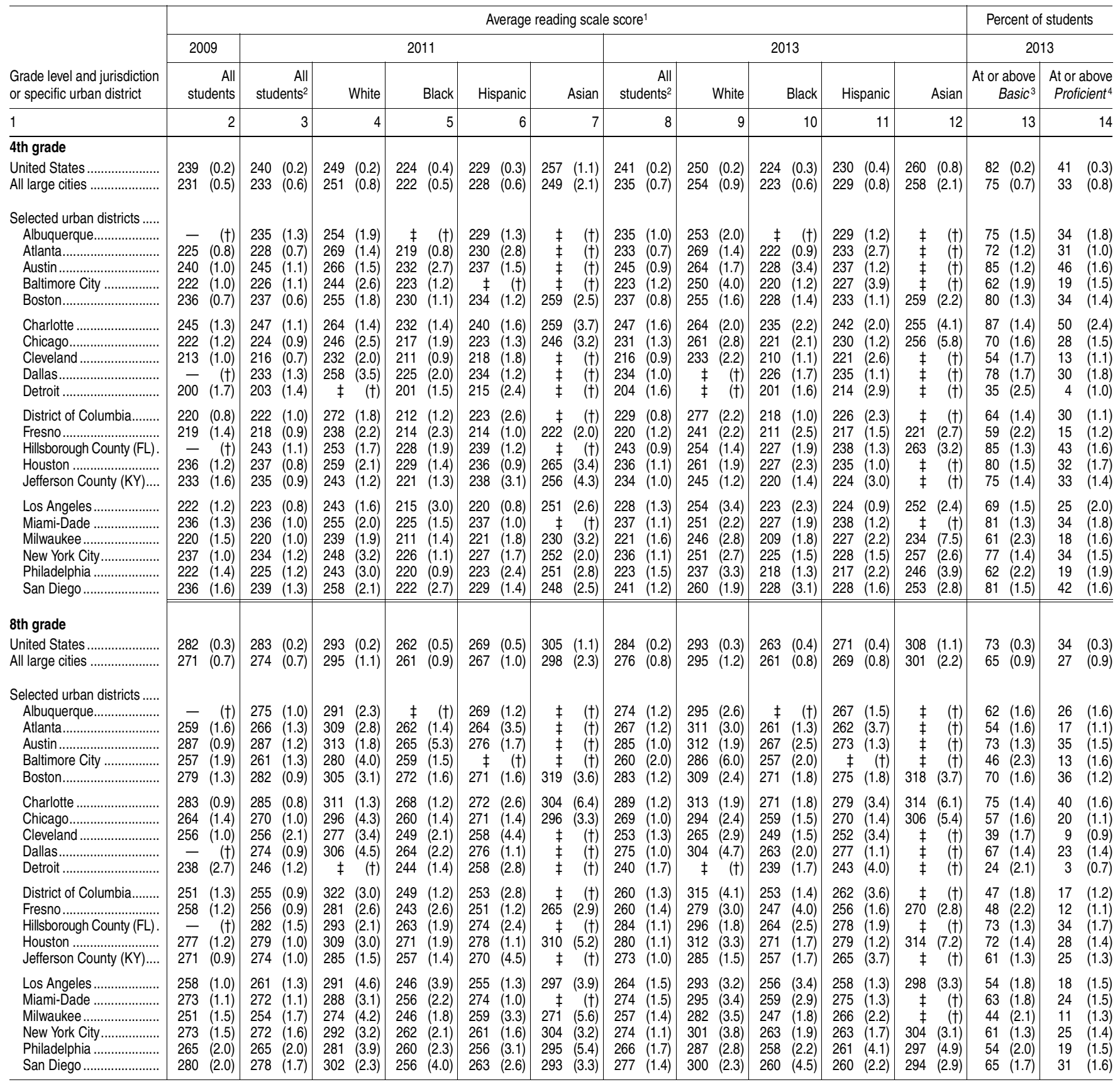

—Not available.

†Reporting standards not met (too few cases for a reliable estimate).

1Scale ranges from 0 to 500 .

Includes data for students of two or more races, which are not separately shown.

${ }^{3}$ Basic denotes partial mastery of the knowledge and skills that are fundamental for proficient work at a given grade.
${ }^{4}$ Proficient represents solid academic performance. Students reaching this level have demonstrated competency over challenging subject matter.

NOTE: Race categories exclude persons of Hispanic ethnicity. Totals include racial/ethnic groups not shown separately.

SOURCE: U.S. Department of Education, National Center for Education Statistics, National Assessment of Educational Progress (NAEP), 2009, 2011, and 2013 Mathematics Assessments, retrieved December 30, 2013, from the Main NAEP Data Explorer (http://nces.ed.gov/ nationsreportcard/naepdata/). (This table was prepared December 2013.) 
Table 222.85. Average National Assessment of Educational Progress (NAEP) mathematics scale score, by age and selected student characteristics: Selected years, 1973 through 2012

[Standard errors appear in parentheses]

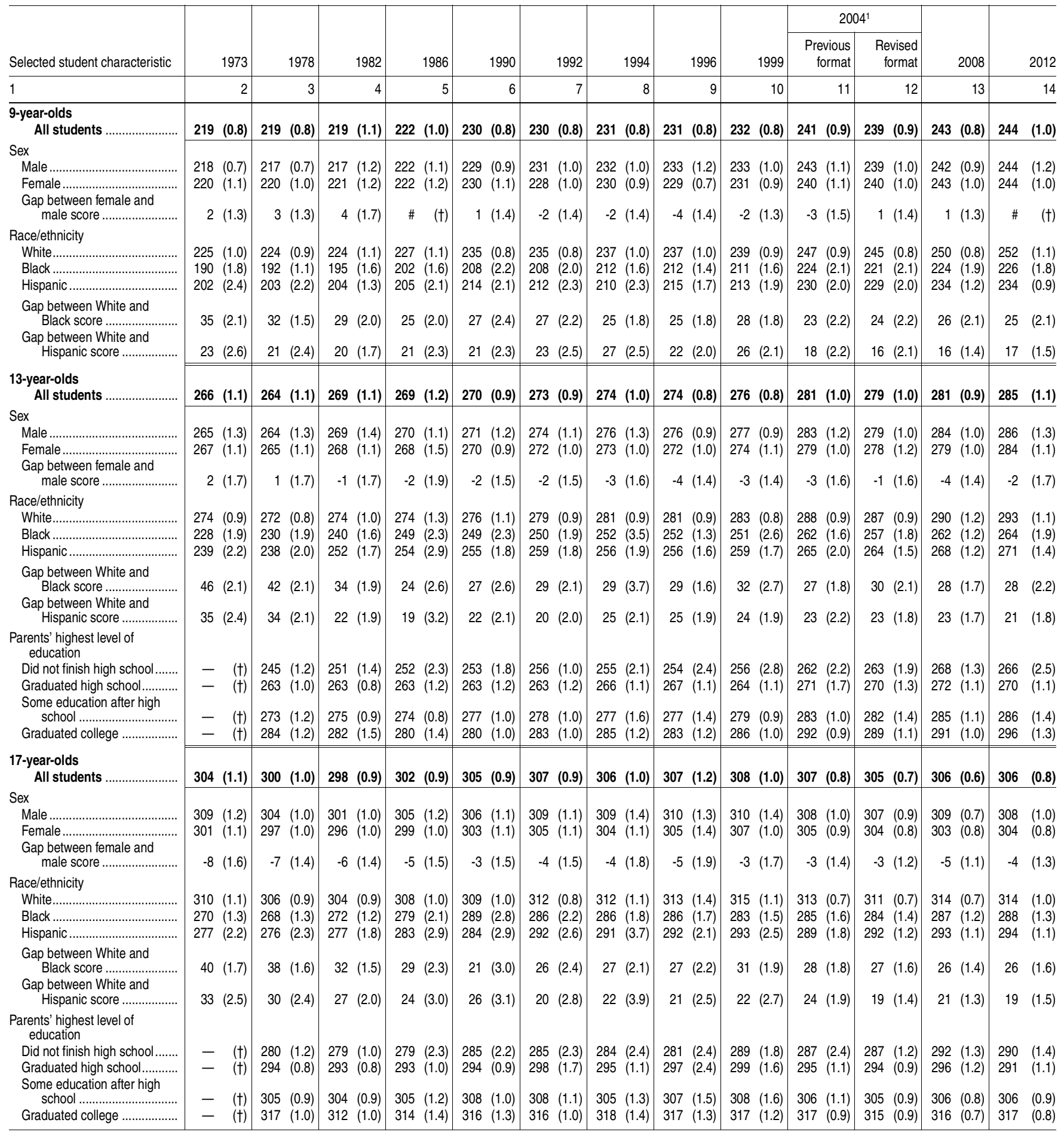

-Not available.

†Not applicable.

\#Rounds to zero.

${ }^{1}$ In 2004, two assessments were conducted-one using the same format that was used in previous assessments, and one using a revised assessment format that provides accommodations for students with disabilities and for English language learners. The 2004 data in column 11 are for the format that was used in previous assessment years, while the 2004 data in column 12 are for the revised format. In subsequent years, only the revised format was used.

NOTE: Scale ranges from 0 to 500. Students scoring 150 (or higher) know some basic addition and subtraction facts. Students scoring 200 have a considerable understanding of twodigit numbers and know some basic multiplication and division facts. Students scoring 250 lyze simple logical relations. Students scoring 300 can perform reasoning and problem solving involving fractions, decimals, percents, elementary geometry, and simple algebra. Students scoring 350 can perform reasoning and problem solving involving geometry, algebra, and beginning statistics and probability. Includes public and private schools. For assessment years prior to 2004, accommodations were not permitted. For 2004 (revised format) and later years, includes students tested with accommodations; excludes only those students with disabilities and English language learners who were unable to be tested even with accommodations ( 1 to 4 percent of all students, depending on age and assessment year). Race categories exclude persons of Hispanic ethnicity. Totals include other racial/ethnic groups not shown separately. SOURCE: U.S. Department of Education, National Center for Education Statistics, National Assessment of Educational Progress (NAEP), NAEP 2012 Trends in Academic Progress; and 2012 NAEP Long-Term Trend Mathematics Assessment, retrieved August 29, 2013, from Long-Term Trend NAEP Data Explorer (http://nces.ed.gov/nationsreportcard/naepdata/). (This table was prepared August 2013.) 
Table 222.90. Percentage of students at or above selected National Assessment of Educational Progress (NAEP) mathematics score levels, by age, sex, and race/ethnicity: Selected years, 1978 through 2012

[Standard errors appear in parentheses]

\begin{tabular}{|c|c|c|c|c|c|c|c|c|c|c|c|c|c|c|c|c|c|c|}
\hline \multirow{2}{*}{$\begin{array}{l}\text { Sex, race/ } \\
\text { ethnicity, and year }\end{array}$} & \multicolumn{6}{|c|}{ 9-year-olds } & \multicolumn{6}{|c|}{ 13-year-olds } & \multicolumn{6}{|c|}{ 17-year-olds } \\
\hline & \multicolumn{2}{|c|}{ Level $150^{1}$} & \multicolumn{2}{|c|}{ Level $200^{2}$} & \multicolumn{2}{|c|}{ Level $250^{3}$} & \multicolumn{2}{|c|}{ Level $200^{2}$} & \multicolumn{2}{|c|}{ Level $250^{3}$} & \multicolumn{2}{|c|}{ Level $300^{4}$} & \multicolumn{2}{|c|}{ Level $250^{3}$} & \multicolumn{2}{|c|}{ Level $300^{4}$} & \multicolumn{2}{|c|}{ Level $350^{5}$} \\
\hline 1 & & 2 & & 3 & & 4 & & 5 & & 6 & & 7 & & 8 & & 9 & & 10 \\
\hline 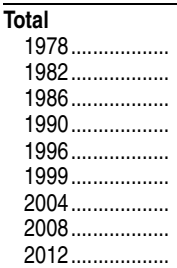 & $\begin{array}{l}96.7 \\
97.1 \\
97.9 \\
99.1 \\
99.1 \\
98.9 \\
98.7 \\
99.0 \\
98.7\end{array}$ & $\begin{array}{l}(0.25) \\
(0.35) \\
(0.29) \\
(0.21) \\
(0.18) \\
(0.17) \\
(0.19) \\
(0.18) \\
(0.21)\end{array}$ & $\begin{array}{l}70.4 \\
71.4 \\
74.1 \\
81.5 \\
81.5 \\
82.5 \\
87.0 \\
89.1 \\
88.7\end{array}$ & $\begin{array}{l}(0.92) \\
(1.18) \\
(1.24) \\
(0.96) \\
(0.76) \\
(0.84) \\
(0.77) \\
(0.69) \\
(0.69)\end{array}$ & $\begin{array}{l}19.6 \\
18.8 \\
20.7 \\
27.7 \\
29.7 \\
30.9 \\
40.9 \\
44.5 \\
46.7\end{array}$ & $\begin{array}{l}(0.73) \\
(0.96) \\
(0.88) \\
(0.86) \\
(1.02) \\
(1.07) \\
(0.89) \\
(1.01) \\
(1.28)\end{array}$ & $\begin{array}{l}94.6 \\
97.7 \\
98.6 \\
98.5 \\
98.8 \\
98.7 \\
98.1 \\
98.2 \\
98.5\end{array}$ & $\begin{array}{l}(0.46) \\
(0.37) \\
(0.25) \\
(0.21) \\
(0.20) \\
(0.25) \\
(0.19) \\
(0.19) \\
(0.21)\end{array}$ & $\begin{array}{l}64.9 \\
71.4 \\
73.3 \\
74.7 \\
78.6 \\
78.8 \\
81.1 \\
83.4 \\
84.7\end{array}$ & $\begin{array}{l}(1.18) \\
(1.18) \\
(1.59) \\
(1.03) \\
(0.87) \\
(1.02) \\
(0.98) \\
(0.63) \\
(0.71)\end{array}$ & $\begin{array}{l}18.0 \\
17.4 \\
15.8 \\
17.3 \\
20.6 \\
23.2 \\
27.8 \\
30.0 \\
34.0\end{array}$ & $\begin{array}{l}(0.73) \\
(0.95) \\
(1.01) \\
(0.99) \\
(1.24) \\
(0.95) \\
(1.09) \\
(1.08) \\
(1.38)\end{array}$ & $\begin{array}{l}92.0 \\
93.0 \\
95.6 \\
96.0 \\
96.8 \\
96.8 \\
95.8 \\
96.0 \\
95.7\end{array}$ & $\begin{array}{l}(0.50) \\
(0.50) \\
(0.48) \\
(0.52) \\
(0.42) \\
(0.45) \\
(0.40) \\
(0.37) \\
(0.31)\end{array}$ & $\begin{array}{l}51.5 \\
48.5 \\
51.7 \\
56.1 \\
60.1 \\
60.7 \\
58.3 \\
59.4 \\
59.7\end{array}$ & $\begin{array}{l}(1.14) \\
(1.28) \\
(1.43) \\
(1.43) \\
(1.72) \\
(1.63) \\
(1.12) \\
(0.87) \\
(1.22)\end{array}$ & $\begin{array}{l}7.3 \\
5.5 \\
6.5 \\
7.2 \\
7.4 \\
8.4 \\
6.1 \\
6.2 \\
7.0\end{array}$ & $\begin{array}{l}(0.44) \\
(0.43) \\
(0.52) \\
(0.63) \\
(0.77) \\
(0.83) \\
(0.47) \\
(0.40) \\
(0.51)\end{array}$ \\
\hline 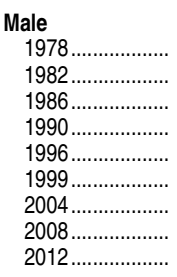 & $\begin{array}{l}96.2 \\
96.5 \\
98.0 \\
99.0 \\
99.1 \\
98.8 \\
98.3 \\
99.0 \\
98.6\end{array}$ & $\begin{array}{l}(0.48) \\
(0.55) \\
(0.51) \\
(0.26) \\
(0.20) \\
(0.28) \\
(0.27) \\
(0.27) \\
(0.24)\end{array}$ & $\begin{array}{l}68.9 \\
68.8 \\
74.0 \\
80.6 \\
82.5 \\
82.6 \\
86.1 \\
88.4 \\
88.0\end{array}$ & $\begin{array}{l}(0.98) \\
(1.29) \\
(1.45) \\
(1.05) \\
(1.10) \\
(0.92) \\
(0.89) \\
(0.87) \\
(0.79)\end{array}$ & $\begin{array}{l}19.2 \\
18.1 \\
20.9 \\
27.5 \\
32.7 \\
32.4 \\
40.7 \\
44.4 \\
47.0\end{array}$ & $\begin{array}{l}(0.64) \\
(1.06) \\
(1.10) \\
(0.96) \\
(1.74) \\
(1.25) \\
(1.03) \\
(1.18) \\
(1.47)\end{array}$ & $\begin{array}{l}93.9 \\
97.5 \\
98.5 \\
98.2 \\
98.7 \\
98.5 \\
97.7 \\
98.2 \\
98.2\end{array}$ & $\begin{array}{l}(0.49) \\
(0.55) \\
(0.32) \\
(0.34) \\
(0.25) \\
(0.27) \\
(0.29) \\
(0.28) \\
(0.27)\end{array}$ & $\begin{array}{l}63.9 \\
71.3 \\
73.8 \\
75.1 \\
79.8 \\
79.3 \\
80.5 \\
84.3 \\
84.7\end{array}$ & $\begin{array}{l}(1.32) \\
(1.44) \\
(1.76) \\
(1.75) \\
(1.43) \\
(1.12) \\
(1.08) \\
(0.75) \\
(0.84)\end{array}$ & $\begin{array}{l}18.4 \\
18.9 \\
17.6 \\
19.0 \\
23.0 \\
25.4 \\
29.9 \\
33.4 \\
35.7\end{array}$ & $\begin{array}{l}(0.85) \\
(1.18) \\
(1.12) \\
(1.24) \\
(1.64) \\
(1.19) \\
(1.27) \\
(1.29) \\
(1.55)\end{array}$ & $\begin{array}{l}93.0 \\
93.9 \\
96.1 \\
95.8 \\
97.0 \\
96.5 \\
95.6 \\
96.2 \\
95.5\end{array}$ & $\begin{array}{l}(0.52) \\
(0.58) \\
(0.63) \\
(0.77) \\
(0.66) \\
(0.81) \\
(0.45) \\
(0.47) \\
(0.43)\end{array}$ & $\begin{array}{l}55.1 \\
51.9 \\
54.6 \\
57.6 \\
62.7 \\
63.1 \\
60.8 \\
62.9 \\
61.5\end{array}$ & $\begin{array}{l}(1.21) \\
(1.51) \\
(1.78) \\
(1.42) \\
(1.77) \\
(2.12) \\
(1.31) \\
(0.96) \\
(1.33)\end{array}$ & $\begin{array}{l}9.5 \\
6.9 \\
8.4 \\
8.8 \\
9.5 \\
9.8 \\
7.3 \\
7.6 \\
9.0\end{array}$ & $\begin{array}{l}(0.57) \\
(0.70) \\
(0.91) \\
(0.76) \\
(1.32) \\
(1.09) \\
(0.68) \\
(0.61) \\
(0.75)\end{array}$ \\
\hline 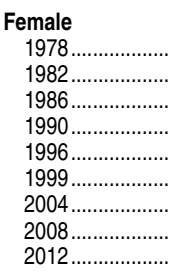 & $\begin{array}{l}97.2 \\
97.6 \\
97.8 \\
99.1 \\
99.1 \\
99.0 \\
99.0 \\
99.0 \\
98.8\end{array}$ & $\begin{array}{l}(0.27) \\
(0.33) \\
(0.38) \\
(0.26) \\
(0.36) \\
(0.19) \\
(0.22) \\
(0.21) \\
(0.29)\end{array}$ & $\begin{array}{l}72.0 \\
74.0 \\
74.3 \\
82.3 \\
80.7 \\
82.5 \\
87.8 \\
89.9 \\
89.4\end{array}$ & $\begin{array}{l}(1.05) \\
(1.30) \\
(1.32) \\
(1.26) \\
(0.93) \\
(1.15) \\
(0.96) \\
(0.78) \\
(0.80)\end{array}$ & $\begin{array}{l}19.9 \\
19.6 \\
20.6 \\
27.9 \\
26.7 \\
29.4 \\
41.1 \\
44.6 \\
46.5\end{array}$ & $\begin{array}{l}(1.00) \\
(1.11) \\
(1.28) \\
(1.31) \\
(1.07) \\
(1.36) \\
(1.13) \\
(1.18) \\
(1.34)\end{array}$ & $\begin{array}{l}95.2 \\
98.0 \\
98.6 \\
98.9 \\
98.8 \\
99.0 \\
98.4 \\
98.2 \\
98.8\end{array}$ & $\begin{array}{l}(0.49) \\
(0.27) \\
(0.31) \\
(0.18) \\
(0.27) \\
(0.40) \\
(0.25) \\
(0.25) \\
(0.23)\end{array}$ & $\begin{array}{l}65.9 \\
71.4 \\
72.7 \\
74.4 \\
77.4 \\
78.4 \\
81.7 \\
82.5 \\
84.7\end{array}$ & $\begin{array}{l}(1.17) \\
(1.29) \\
(1.95) \\
(1.32) \\
(1.09) \\
(1.22) \\
(1.10) \\
(0.86) \\
(0.91)\end{array}$ & $\begin{array}{l}17.5 \\
15.9 \\
14.1 \\
15.7 \\
18.4 \\
21.0 \\
25.7 \\
26.7 \\
32.2\end{array}$ & $\begin{array}{l}(0.75) \\
(1.00) \\
(1.31) \\
(1.00) \\
(1.48) \\
(1.38) \\
(1.24) \\
(1.13) \\
(1.42)\end{array}$ & $\begin{array}{l}91.0 \\
92.1 \\
95.1 \\
96.2 \\
96.7 \\
97.2 \\
95.9 \\
95.7 \\
96.0\end{array}$ & $\begin{array}{l}(0.57) \\
(0.56) \\
(0.65) \\
(0.84) \\
(0.57) \\
(0.40) \\
(0.58) \\
(0.43) \\
(0.37)\end{array}$ & $\begin{array}{l}48.2 \\
45.3 \\
48.9 \\
54.7 \\
57.6 \\
58.5 \\
55.9 \\
55.8 \\
57.9\end{array}$ & $\begin{array}{l}(1.29) \\
(1.37) \\
(1.73) \\
(1.84) \\
(2.21) \\
(1.89) \\
(1.18) \\
(1.25) \\
(1.45)\end{array}$ & $\begin{array}{l}5.2 \\
4.1 \\
4.7 \\
5.6 \\
5.3 \\
7.1 \\
4.9 \\
4.6 \\
5.1\end{array}$ & $\begin{array}{l}(0.66) \\
(0.42) \\
(0.59) \\
(0.79) \\
(0.80) \\
(1.06) \\
(0.48) \\
(0.34) \\
(0.60)\end{array}$ \\
\hline 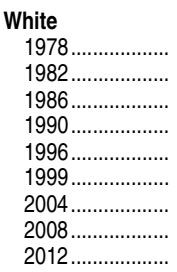 & $\begin{array}{l}98.3 \\
98.5 \\
98.8 \\
99.6 \\
99.6 \\
99.6 \\
99.2 \\
99.6 \\
99.4\end{array}$ & $\begin{array}{l}(0.19) \\
(0.25) \\
(0.24) \\
(0.16) \\
(0.15) \\
(0.12) \\
(0.18) \\
(0.12) \\
(0.18)\end{array}$ & $\begin{array}{l}76.3 \\
76.8 \\
79.6 \\
86.9 \\
86.6 \\
88.6 \\
91.9 \\
94.0 \\
93.2\end{array}$ & $\begin{array}{l}(1.00) \\
(1.22) \\
(1.33) \\
(0.86) \\
(0.80) \\
(0.78) \\
(0.61) \\
(0.52) \\
(0.58)\end{array}$ & $\begin{array}{l}22.9 \\
21.8 \\
24.6 \\
32.7 \\
35.7 \\
37.1 \\
47.2 \\
52.9 \\
55.9\end{array}$ & $\begin{array}{l}(0.87) \\
(1.13) \\
(1.03) \\
(1.04) \\
(1.38) \\
(1.35) \\
(0.97) \\
(1.29) \\
(1.54)\end{array}$ & $\begin{array}{l}97.6 \\
99.1 \\
99.3 \\
99.4 \\
99.6 \\
99.4 \\
99.1 \\
98.9 \\
99.2\end{array}$ & $\begin{array}{l}(0.27) \\
(0.14) \\
(0.27) \\
(0.14) \\
(0.16) \\
(0.29) \\
(0.16) \\
(0.17) \\
(0.15)\end{array}$ & $\begin{array}{l}72.9 \\
78.3 \\
78.9 \\
82.0 \\
86.4 \\
86.7 \\
89.3 \\
90.4 \\
91.6\end{array}$ & $\begin{array}{l}(0.85) \\
(0.94) \\
(1.69) \\
(1.01) \\
(1.02) \\
(0.92) \\
(0.82) \\
(0.83) \\
(0.57)\end{array}$ & $\begin{array}{l}21.4 \\
20.5 \\
18.6 \\
21.0 \\
25.4 \\
29.0 \\
35.1 \\
39.2 \\
41.4\end{array}$ & $\begin{array}{l}(0.73) \\
(1.00) \\
(1.17) \\
(1.23) \\
(1.50) \\
(1.26) \\
(1.21) \\
(1.60) \\
(1.65)\end{array}$ & $\begin{array}{l}95.6 \\
96.2 \\
98.0 \\
97.6 \\
98.7 \\
98.7 \\
97.5 \\
98.2 \\
97.9\end{array}$ & $\begin{array}{l}(0.30) \\
(0.33) \\
(0.36) \\
(0.28) \\
(0.37) \\
(0.40) \\
(0.28) \\
(0.26) \\
(0.33)\end{array}$ & $\begin{array}{l}57.6 \\
54.7 \\
59.1 \\
63.2 \\
68.7 \\
69.9 \\
66.8 \\
70.5 \\
70.3\end{array}$ & $\begin{array}{l}(1.14) \\
(1.41) \\
(1.69) \\
(1.59) \\
(2.18) \\
(1.96) \\
(1.08) \\
(1.09) \\
(1.56)\end{array}$ & $\begin{array}{r}8.5 \\
6.4 \\
7.9 \\
8.3 \\
9.2 \\
10.4 \\
7.6 \\
8.1 \\
9.1\end{array}$ & $\begin{array}{l}(0.48) \\
(0.54) \\
(0.68) \\
(0.73) \\
(1.02) \\
(1.07) \\
(0.63) \\
(0.55) \\
(0.71)\end{array}$ \\
\hline 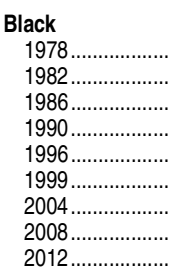 & $\begin{array}{l}88.4 \\
90.2 \\
93.9 \\
96.9 \\
97.3 \\
96.4 \\
97.1 \\
96.9 \\
97.5\end{array}$ & $\begin{array}{l}(1.01) \\
(0.97) \\
(1.37) \\
(0.88) \\
(0.84) \\
(0.64) \\
(0.65) \\
(0.86) \\
(0.66)\end{array}$ & $\begin{array}{l}42.0 \\
46.1 \\
53.4 \\
60.0 \\
65.3 \\
63.3 \\
74.3 \\
75.6 \\
77.2\end{array}$ & $\begin{array}{l}(1.44) \\
(2.35) \\
(2.47) \\
(2.76) \\
(2.38) \\
(2.11) \\
(2.61) \\
(2.31) \\
(1.56)\end{array}$ & $\begin{array}{r}4.1 \\
4.4 \\
5.6 \\
9.4 \\
10.0 \\
12.3 \\
22.0 \\
24.6 \\
26.3\end{array}$ & $\begin{array}{l}(0.64) \\
(0.81) \\
(0.92) \\
(1.72) \\
(1.24) \\
(1.48) \\
(1.72) \\
(1.67) \\
(2.01)\end{array}$ & $\begin{array}{l}79.7 \\
90.2 \\
95.4 \\
95.4 \\
96.2 \\
96.5 \\
95.3 \\
96.6 \\
96.7\end{array}$ & $\begin{array}{l}(1.48) \\
(1.60) \\
(0.95) \\
(1.10) \\
(1.27) \\
(1.06) \\
(0.78) \\
(0.68) \\
(0.66)\end{array}$ & $\begin{array}{l}28.7 \\
37.9 \\
49.0 \\
48.7 \\
53.7 \\
50.8 \\
61.5 \\
67.6 \\
67.3\end{array}$ & $\begin{array}{l}(2.06) \\
(2.51) \\
(3.70) \\
(3.56) \\
(2.56) \\
(4.01) \\
(2.47) \\
(1.69) \\
(2.10)\end{array}$ & $\begin{array}{r}2.3 \\
2.9 \\
4.0 \\
3.9 \\
4.8 \\
4.4 \\
9.7 \\
10.2 \\
14.2\end{array}$ & $\begin{array}{l}(0.48) \\
(0.96) \\
(1.42) \\
(1.61) \\
(1.08) \\
(1.37) \\
(1.35) \\
(1.17) \\
(1.61)\end{array}$ & $\begin{array}{l}70.7 \\
76.4 \\
85.6 \\
92.4 \\
90.6 \\
88.6 \\
89.1 \\
90.6 \\
89.8\end{array}$ & $\begin{array}{l}(1.73) \\
(1.47) \\
(2.53) \\
(2.20) \\
(1.33) \\
(1.95) \\
(1.63) \\
(1.42) \\
(1.03)\end{array}$ & $\begin{array}{l}16.8 \\
17.1 \\
20.8 \\
32.8 \\
31.2 \\
26.6 \\
29.4 \\
31.8 \\
33.8\end{array}$ & $\begin{array}{l}(1.57) \\
(1.51) \\
(2.83) \\
(4.49) \\
(2.51) \\
(2.70) \\
(2.07) \\
(1.60) \\
(2.04)\end{array}$ & $\begin{array}{l}0.5 \\
0.5 \\
0.2 \\
2.0 \\
0.9 \\
1.0 \\
0.4 \\
0.8 \\
1.1\end{array}$ & $\begin{array}{r}(-) \\
(-) \\
(-) \\
(1.04) \\
(-) \\
(-) \\
(-) \\
(0.23) \\
(0.32)\end{array}$ \\
\hline $\begin{array}{l}\text { Hispanic } \\
1978 \ldots \ldots \ldots \ldots \\
1982 \ldots \ldots \ldots \ldots \ldots \\
1986 \ldots \ldots \ldots \ldots \ldots \\
1990 \ldots \ldots \ldots \ldots \\
1996 \ldots \ldots \ldots \ldots \\
1999 \ldots \ldots \ldots \ldots \\
2004 \ldots \ldots \ldots \ldots \\
2008 \ldots \ldots \ldots \ldots \\
2012 \ldots \ldots \ldots \ldots \ldots\end{array}$ & $\begin{array}{l}93.0 \\
94.3 \\
96.4 \\
98.0 \\
98.1 \\
98.1 \\
98.0 \\
98.9 \\
98.3\end{array}$ & $\begin{array}{l}(1.20) \\
(1.19) \\
(1.29) \\
(0.76) \\
(0.73) \\
(0.71) \\
(0.46) \\
(0.28) \\
(0.40)\end{array}$ & $\begin{array}{l}54.2 \\
55.7 \\
57.6 \\
68.4 \\
67.1 \\
67.5 \\
80.5 \\
85.1 \\
84.7\end{array}$ & $\begin{array}{l}(2.80) \\
(2.26) \\
(2.95) \\
(3.03) \\
(2.14) \\
(2.47) \\
(2.03) \\
(1.25) \\
(1.00)\end{array}$ & $\begin{array}{r}9.2 \\
7.8 \\
7.3 \\
11.3 \\
13.8 \\
10.5 \\
30.2 \\
33.5 \\
34.6\end{array}$ & $\begin{array}{l}(2.49) \\
(1.74) \\
(2.81) \\
(3.49) \\
(2.26) \\
(1.63) \\
(2.17) \\
(1.46) \\
(1.22)\end{array}$ & $\begin{array}{l}86.4 \\
95.9 \\
96.9 \\
96.8 \\
96.2 \\
97.2 \\
96.4 \\
97.0 \\
97.3\end{array}$ & $\begin{array}{l}(0.94) \\
(0.95) \\
(1.43) \\
(1.06) \\
(0.78) \\
(0.60) \\
(0.66) \\
(0.44) \\
(0.54)\end{array}$ & $\begin{array}{l}36.0 \\
52.2 \\
56.0 \\
56.7 \\
58.3 \\
62.9 \\
68.5 \\
73.3 \\
76.4\end{array}$ & $\begin{array}{l}(2.92) \\
(2.48) \\
(5.01) \\
(3.32) \\
(2.28) \\
(2.50) \\
(1.86) \\
(1.71) \\
(1.94)\end{array}$ & $\begin{array}{r}4.0 \\
6.3 \\
5.5 \\
6.4 \\
6.7 \\
8.2 \\
13.7 \\
14.4 \\
18.5\end{array}$ & $\begin{array}{l}(0.95) \\
(0.97) \\
(1.15) \\
(1.70) \\
(1.17) \\
(1.37) \\
(1.44) \\
(1.09) \\
(1.45)\end{array}$ & $\begin{array}{l}78.3 \\
81.4 \\
89.3 \\
85.8 \\
92.2 \\
93.6 \\
92.3 \\
92.2 \\
92.9\end{array}$ & $\begin{array}{l}(2.29) \\
(1.86) \\
(2.52) \\
(4.18) \\
(2.24) \\
(2.21) \\
(1.05) \\
(1.10) \\
(0.59)\end{array}$ & $\begin{array}{l}23.4 \\
21.6 \\
26.5 \\
30.1 \\
40.1 \\
37.7 \\
38.1 \\
41.1 \\
43.3\end{array}$ & $\begin{array}{l}(2.67) \\
(2.16) \\
(4.48) \\
(3.09) \\
(3.47) \\
(4.15) \\
(2.12) \\
(1.69) \\
(1.91)\end{array}$ & $\begin{array}{l}1.4 \\
0.7 \\
1.1 \\
1.9 \\
1.8 \\
3.1 \\
1.9 \\
1.5 \\
2.4\end{array}$ & $\begin{array}{r}(0.58) \\
(0.36) \\
(-) \\
(0.78) \\
(-) \\
(1.12) \\
(0.60) \\
(0.41) \\
(0.44)\end{array}$ \\
\hline
\end{tabular}

-Not available.

Students scoring 150 (or higher) know some basic addition and subtraction facts. 2Students scoring 200 (or higher) have a considerable understanding of two-digit numbers and know some basic multiplication and division facts.

${ }^{3}$ Students scoring 250 (or higher) have an initial understanding of the four basic operations and are developing an ability to analyze simple logical relations.

${ }^{4}$ Students scoring 300 (or higher) can perform reasoning and problem solving involving fractions, decimals, percents, elementary geometry, and simple algebra.

${ }^{5}$ Students scoring 350 (or above) can perform reasoning and problem solving involving geometry, algebra, and beginning statistics and probability.

NOTE: The NAEP mathematics scores have been evaluated at certain performance levels, as outlined in footnotes 1 through 5 . Scale ranges from 0 to 500 . Includes public and pri- vate schools. For assessment years prior to 2004, accommodations were not permitted For 2004 and later years, includes students tested with accommodations; excludes only those students with disabilities and English language learners who were unable to be tested even with accommodations ( 1 to 4 percent of all students, depending on age and assessment year). Race categories exclude persons of Hispanic ethnicity. Totals include other racial/ethnic groups not shown separately.

SOURCE: U.S. Department of Education, National Center for Education Statistics, National Assessment of Educational Progress (NAEP), NAEP Trends in Academic Progress, 1996 and 1999; and 2004, 2008, and 2012 Long-Term Trend Mathematics Assessments, retrieved May 4, 2009, and July 20, 2013, from the Long-Term Trend NAEP Data Explorer (http://nces.ed.gov/nationsreportcard/naepdata/). (This table was prepared July 2013.) 
Table 222.95. National Assessment of Educational Progress (NAEP) mathematics performance of 17-year-olds, by highest mathematics course taken, sex, and race/ethnicity: Selected years, 1978 through 2012

[Standard errors appear in parentheses]

\begin{tabular}{|c|c|c|c|c|c|c|c|c|c|c|c|c|c|c|c|c|c|c|c|c|c|c|}
\hline \multirow[b]{2}{*}{$\begin{array}{l}\text { Year, sex, } \\
\text { and race/ethnicity }\end{array}$} & \multirow{2}{*}{\multicolumn{2}{|c|}{$\begin{array}{r}\text { Percent } \\
\text { of students }\end{array}$}} & \multicolumn{12}{|c|}{ Average scale score by highest mathematics course taken } & \multicolumn{8}{|c|}{ Percent of students at or above score levels } \\
\hline & & & All st & dents & $\begin{array}{r}\text { Prealge } \\
\text { mathe }\end{array}$ & $\begin{array}{l}\text { bra or } \\
\text { eneral } \\
\text { matics }\end{array}$ & \multicolumn{2}{|c|}{ Algebra I } & \multicolumn{2}{|c|}{ Geometry } & \multicolumn{2}{|c|}{ Algebra II } & \multicolumn{2}{|c|}{$\begin{array}{r}\text { Precalculus } \\
\text { or calculus }\end{array}$} & \multicolumn{2}{|c|}{200} & \multicolumn{2}{|r|}{250} & \multicolumn{2}{|r|}{300} & \multicolumn{2}{|r|}{350} \\
\hline 1 & & 2 & & 3 & & 4 & & 5 & & 6 & & 7 & & 8 & & 9 & & 10 & & 11 & & 12 \\
\hline $\begin{array}{l}1978 \text { All students ............. } \\
\quad \text {. }\end{array}$ & 100 & $(\dagger)$ & 300 & $(1.0)$ & 267 & $(0.8)$ & 286 & $(0.7)$ & 307 & $(0.7)$ & 321 & $(0.7)$ & 334 & $(1.4)$ & 100 & $(\dagger)$ & 92 & $(0.5)$ & 52 & (1.1) & 7 & $(0.4)$ \\
\hline 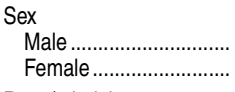 & $\begin{array}{l}49 \\
51\end{array}$ & $\begin{array}{l}(0.5) \\
(0.5)\end{array}$ & $\begin{array}{l}304 \\
297\end{array}$ & $\begin{array}{l}(1.0) \\
(1.0)\end{array}$ & $\begin{array}{l}269 \\
264\end{array}$ & $\begin{array}{l}(1.0) \\
(0.9)\end{array}$ & $\begin{array}{l}289 \\
284\end{array}$ & $\begin{array}{l}(0.9) \\
(1.0)\end{array}$ & $\begin{array}{l}310 \\
304\end{array}$ & $\begin{array}{l}(1.0) \\
(0.8)\end{array}$ & $\begin{array}{l}325 \\
318\end{array}$ & $\begin{array}{l}(0.8) \\
(0.9)\end{array}$ & $\begin{array}{l}337 \\
329\end{array}$ & $\begin{array}{l}(2.0) \\
(1.8)\end{array}$ & $\begin{array}{l}100 \\
100\end{array}$ & $\begin{array}{l}(\dagger) \\
(\dagger)\end{array}$ & $\begin{array}{l}93 \\
91\end{array}$ & $\begin{array}{l}(0.5) \\
(0.6)\end{array}$ & $\begin{array}{l}55 \\
48\end{array}$ & $\begin{array}{l}(1.2) \\
(1.3)\end{array}$ & $\begin{array}{r}10 \\
5\end{array}$ & $\begin{array}{l}(0.6) \\
(0.7)\end{array}$ \\
\hline 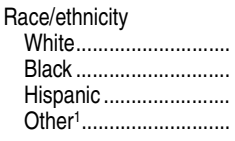 & $\begin{array}{r}83 \\
12 \\
4 \\
1\end{array}$ & $\begin{array}{l}(1.3) \\
(1.1) \\
(0.5) \\
(0.1)\end{array}$ & $\begin{array}{l}306 \\
268 \\
276 \\
313\end{array}$ & $\begin{array}{l}(0.9) \\
(1.3) \\
(2.3) \\
(3.3)\end{array}$ & $\begin{array}{r}272 \\
247 \\
256 \\
\ddagger\end{array}$ & $\begin{array}{r}(0.6) \\
(1.6) \\
(2.3) \\
(\dagger) \\
\end{array}$ & $\begin{array}{r}291 \\
264 \\
273 \\
\ddagger\end{array}$ & $\begin{array}{r}(0.6) \\
(1.5) \\
(2.8) \\
(\dagger)\end{array}$ & $\begin{array}{r}310 \\
281 \\
294 \\
\ddagger\end{array}$ & $\begin{array}{r}(0.6) \\
(1.9) \\
(4.4) \\
(\dagger) \\
\end{array}$ & $\begin{array}{l}325 \\
292 \\
303 \\
323 \\
\end{array}$ & $\begin{array}{l}(0.6) \\
(1.4) \\
(2.9) \\
(2.9)\end{array}$ & $\begin{array}{r}338 \\
297 \\
\ddagger \\
\ddagger\end{array}$ & $\begin{array}{r}(1.1) \\
(6.5) \\
(t) \\
(t)\end{array}$ & $\begin{array}{r}100 \\
99 \\
99 \\
100\end{array}$ & $\begin{array}{r}(t) \\
(0.3) \\
(0.4) \\
(t)\end{array}$ & $\begin{array}{l}96 \\
71 \\
78 \\
94\end{array}$ & $\begin{array}{l}(0.3) \\
(1.7) \\
(2.3) \\
(2.6)\end{array}$ & $\begin{array}{l}58 \\
17 \\
23 \\
65\end{array}$ & $\begin{array}{l}(1.1) \\
(1.6) \\
(2.7) \\
(4.9)\end{array}$ & $\begin{array}{r}8 \\
\# \\
1 \\
15 \\
\end{array}$ & $\begin{array}{r}(0.5) \\
(\dagger) \\
(0.6) \\
(3.2)\end{array}$ \\
\hline 1990 All students .................. & 100 & $(t)$ & 305 & $(0.9)$ & 273 & (1.1) & 288 & (1.2) & 299 & (1.5) & 319 & $(1.0)$ & 344 & (2.7) & 100 & $(t)$ & 96 & $(0.5)$ & 56 & (1.4) & 7 & $(0.6)$ \\
\hline 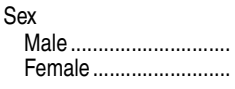 & $\begin{array}{l}49 \\
51\end{array}$ & $\begin{array}{l}(0.9) \\
(0.9)\end{array}$ & $\begin{array}{l}306 \\
303\end{array}$ & $\begin{array}{l}(1.1) \\
(1.1)\end{array}$ & $\begin{array}{l}274 \\
271\end{array}$ & $\begin{array}{l}(1.7) \\
(1.8)\end{array}$ & $\begin{array}{l}291 \\
285\end{array}$ & $\begin{array}{l}(1.6) \\
(1.8)\end{array}$ & $\begin{array}{l}302 \\
296\end{array}$ & $\begin{array}{l}(1.6) \\
(1.8)\end{array}$ & $\begin{array}{l}323 \\
316\end{array}$ & $\begin{array}{l}(1.2) \\
(1.1)\end{array}$ & $\begin{array}{l}347 \\
340\end{array}$ & $\begin{array}{l}(2.4) \\
(4.0)\end{array}$ & $\begin{array}{l}100 \\
100\end{array}$ & $\begin{array}{l}(\dagger) \\
(\dagger)\end{array}$ & $\begin{array}{l}96 \\
96\end{array}$ & $\begin{array}{l}(0.8) \\
(0.8)\end{array}$ & $\begin{array}{l}58 \\
55\end{array}$ & $\begin{array}{l}(1.4) \\
(1.8)\end{array}$ & $\begin{array}{l}9 \\
6\end{array}$ & $\begin{array}{l}(0.8) \\
(0.8)\end{array}$ \\
\hline 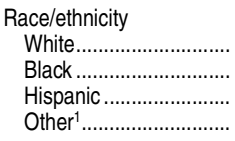 & $\begin{array}{r}73 \\
16 \\
7 \\
4\end{array}$ & $\begin{array}{l}(0.5) \\
(0.3) \\
(0.4) \\
(0.5)\end{array}$ & $\begin{array}{l}309 \\
289 \\
284 \\
312\end{array}$ & $\begin{array}{l}(1.0) \\
(2.8) \\
(2.9) \\
(5.2)\end{array}$ & $\begin{array}{r}277 \\
264 \\
\ddagger \\
\ddagger\end{array}$ & $\begin{array}{r}(1.1) \\
(2.2) \\
(\dagger) \\
(\dagger)\end{array}$ & $\begin{array}{r}292 \\
278 \\
\ddagger \\
\ddagger\end{array}$ & $\begin{array}{r}(1.6) \\
(4.0) \\
(\dagger) \\
(\dagger)\end{array}$ & $\begin{array}{r}304 \\
285 \\
\ddagger \\
\ddagger\end{array}$ & $\begin{array}{r}(1.3) \\
(3.5) \\
(\dagger) \\
(\dagger)\end{array}$ & $\begin{array}{l}323 \\
302 \\
306 \\
321\end{array}$ & $\begin{array}{l}(0.9) \\
(3.2) \\
(3.3) \\
(3.8)\end{array}$ & $\begin{array}{r}347 \\
\ddagger \\
\ddagger \\
\ddagger\end{array}$ & $\begin{array}{r}(2.8) \\
(\dagger) \\
(\dagger) \\
(t)\end{array}$ & $\begin{array}{l}100 \\
100 \\
100 \\
100\end{array}$ & $\begin{array}{l}(t) \\
(t) \\
(t) \\
(t)\end{array}$ & $\begin{array}{l}98 \\
92 \\
86 \\
98\end{array}$ & $\begin{array}{r}(0.3) \\
(2.2) \\
(4.2) \\
(\ddagger)\end{array}$ & $\begin{array}{l}63 \\
33 \\
30 \\
62\end{array}$ & $\begin{array}{l}(1.6) \\
(4.5) \\
(3.1) \\
(7.0)\end{array}$ & $\begin{array}{r}8 \\
2 \\
2 \\
16\end{array}$ & $\begin{array}{l}(0.7) \\
(1.0) \\
(0.8) \\
(4.3)\end{array}$ \\
\hline 1996 All students ............... & 100 & $(t)$ & 307 & (1.2) & 269 & (1.9) & 283 & (1.3) & 298 & (1.3) & 316 & (1.3) & 339 & (1.7) & 100 & $(t)$ & 97 & $(0.4)$ & 60 & (1.7) & 7 & $(0.8)$ \\
\hline 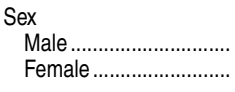 & $\begin{array}{l}50 \\
50\end{array}$ & $\begin{array}{l}(1.2) \\
(1.2)\end{array}$ & $\begin{array}{l}310 \\
305\end{array}$ & $\begin{array}{l}(1.3) \\
(1.4)\end{array}$ & $\begin{array}{l}272 \\
265\end{array}$ & $\begin{array}{l}(2.5) \\
(2.2)\end{array}$ & $\begin{array}{l}286 \\
278\end{array}$ & $\begin{array}{l}(1.5) \\
(2.2)\end{array}$ & $\begin{array}{l}302 \\
294\end{array}$ & $\begin{array}{l}(1.7) \\
(1.5)\end{array}$ & $\begin{array}{l}320 \\
313\end{array}$ & $\begin{array}{l}(1.7) \\
(1.4)\end{array}$ & $\begin{array}{l}342 \\
335\end{array}$ & $\begin{array}{l}(2.3) \\
(2.2)\end{array}$ & $\begin{array}{l}100 \\
100\end{array}$ & $\begin{array}{l}(\dagger) \\
(t)\end{array}$ & $\begin{array}{l}97 \\
97\end{array}$ & $\begin{array}{l}(0.7) \\
(0.6)\end{array}$ & $\begin{array}{l}63 \\
58\end{array}$ & $\begin{array}{l}(1.8) \\
(2.2)\end{array}$ & $\begin{array}{l}9 \\
5\end{array}$ & $\begin{array}{l}(1.3) \\
(0.8)\end{array}$ \\
\hline 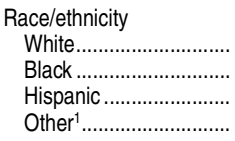 & $\begin{array}{r}71 \\
15 \\
9 \\
4\end{array}$ & $\begin{array}{l}(0.6) \\
(0.3) \\
(0.7) \\
(0.7)\end{array}$ & $\begin{array}{l}313 \\
286 \\
292 \\
312\end{array}$ & $\begin{array}{l}(1.4) \\
(1.7) \\
(2.1) \\
(5.7)\end{array}$ & $\begin{array}{r}273 \\
\ddagger \\
\ddagger \\
\ddagger\end{array}$ & $\begin{array}{r}(2.3) \\
(\dagger) \\
(\dagger) \\
(\dagger)\end{array}$ & $\begin{array}{r}287 \\
272 \\
\ddagger \\
\ddagger\end{array}$ & $\begin{array}{r}(2.0) \\
(2.4) \\
(\dagger) \\
(\dagger)\end{array}$ & $\begin{array}{r}304 \\
280 \\
\ddagger \\
\ddagger\end{array}$ & $\begin{array}{r}(1.6) \\
(3.0) \\
(\dagger) \\
(\dagger)\end{array}$ & $\begin{array}{r}320 \\
299 \\
306 \\
\ddagger\end{array}$ & $\begin{array}{r}(1.4) \\
(2.2) \\
(2.8) \\
(\dagger)\end{array}$ & $\begin{array}{r}342 \\
\ddagger \\
\ddagger \\
\ddagger\end{array}$ & $\begin{array}{r}(1.9) \\
(t) \\
(t) \\
(t)\end{array}$ & $\begin{array}{l}100 \\
100 \\
100 \\
100\end{array}$ & $\begin{array}{l}(t) \\
(t) \\
(t) \\
(t)\end{array}$ & $\begin{array}{l}99 \\
91 \\
92 \\
97\end{array}$ & $\begin{array}{l}(0.4) \\
(1.3) \\
(2.2) \\
(1.2)\end{array}$ & $\begin{array}{l}69 \\
31 \\
40 \\
64\end{array}$ & $\begin{array}{l}(2.2) \\
(2.5) \\
(3.5) \\
(7.2)\end{array}$ & $\begin{array}{r}9 \\
1 \\
2 \\
14\end{array}$ & $\begin{array}{r}(1.0) \\
(-) \\
(-) \\
(5.0)\end{array}$ \\
\hline 1999 All students ............. & 100 & $(t)$ & 308 & $(1.0)$ & 278 & $(2.8)$ & 285 & (1.7) & 298 & (1.2) & 315 & $(0.8)$ & 341 & (1.4) & 100 & $(t)$ & 97 & $(0.5)$ & 61 & (1.6) & 8 & $(0.8)$ \\
\hline 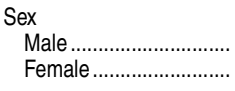 & $\begin{array}{l}48 \\
52\end{array}$ & $\begin{array}{l}(1.0) \\
(1.0)\end{array}$ & $\begin{array}{l}310 \\
307\end{array}$ & $\begin{array}{l}(1.4) \\
(1.0)\end{array}$ & $\begin{array}{l}281 \\
274\end{array}$ & $\begin{array}{l}(3.2) \\
(3.2)\end{array}$ & $\begin{array}{l}288 \\
282\end{array}$ & $\begin{array}{l}(2.6) \\
(2.5)\end{array}$ & $\begin{array}{l}301 \\
295\end{array}$ & $\begin{array}{l}(1.8) \\
(1.3)\end{array}$ & $\begin{array}{l}317 \\
314\end{array}$ & $\begin{array}{l}(1.3) \\
(1.1)\end{array}$ & $\begin{array}{l}343 \\
340\end{array}$ & $\begin{array}{l}(1.9) \\
(2.0)\end{array}$ & $\begin{array}{l}100 \\
100\end{array}$ & $\begin{array}{l}(\dagger) \\
(\dagger)\end{array}$ & $\begin{array}{l}96 \\
97\end{array}$ & $\begin{array}{l}(0.8) \\
(0.4)\end{array}$ & $\begin{array}{l}63 \\
58\end{array}$ & $\begin{array}{l}(2.1) \\
(1.9)\end{array}$ & $\begin{array}{r}10 \\
7\end{array}$ & $\begin{array}{l}(1.1) \\
(1.1)\end{array}$ \\
\hline 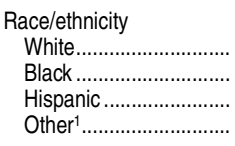 & $\begin{array}{r}72 \\
15 \\
10 \\
4\end{array}$ & $\begin{array}{l}(0.5) \\
(0.4) \\
(0.5) \\
(0.2) \\
\end{array}$ & $\begin{array}{l}315 \\
283 \\
293 \\
320\end{array}$ & $\begin{array}{l}(1.1) \\
(1.5) \\
(2.5) \\
(4.0)\end{array}$ & $\begin{array}{r}282 \\
\ddagger \\
\ddagger \\
\ddagger\end{array}$ & $\begin{array}{r}(3.4) \\
(\dagger) \\
(\dagger) \\
(\dagger) \\
\end{array}$ & $\begin{array}{r}290 \\
267 \\
\ddagger \\
\ddagger\end{array}$ & $\begin{array}{r}(2.2) \\
(2.9) \\
(\dagger) \\
(\dagger) \\
\end{array}$ & $\begin{array}{r}303 \\
281 \\
\ddagger \\
\ddagger\end{array}$ & $\begin{array}{r}(1.5) \\
(2.5) \\
(\dagger) \\
(t) \\
\end{array}$ & $\begin{array}{l}320 \\
293 \\
308 \\
320 \\
\end{array}$ & $\begin{array}{l}(0.9) \\
(1.4) \\
(3.0) \\
(4.4)\end{array}$ & $\begin{array}{r}343 \\
\ddagger \\
\ddagger \\
\ddagger\end{array}$ & $\begin{array}{r}(1.5) \\
(t) \\
(t) \\
(t)\end{array}$ & $\begin{array}{l}100 \\
100 \\
100 \\
100 \\
\end{array}$ & $\begin{array}{l}(t) \\
(t) \\
(t) \\
(t) \\
\end{array}$ & $\begin{array}{r}99 \\
89 \\
94 \\
100 \\
\end{array}$ & $\begin{array}{r}(0.4) \\
(2.0) \\
(2.2) \\
(t)\end{array}$ & $\begin{array}{l}70 \\
27 \\
38 \\
76 \\
\end{array}$ & $\begin{array}{l}(2.0) \\
(2.7) \\
(4.1) \\
(6.3) \\
\end{array}$ & $\begin{array}{r}10 \\
1 \\
3 \\
14 \\
\end{array}$ & $\begin{array}{r}(1.1) \\
(-) \\
(1.1) \\
(4.1)\end{array}$ \\
\hline 2008 All students .............. & 100 & $(t)$ & 306 & $(0.6)$ & 270 & (1.9) & 280 & (1.1) & 295 & $(0.8)$ & 307 & $(0.7)$ & 333 & $(0.8)$ & - & (t) & 96 & $(0.4)$ & 59 & $(0.9)$ & 6 & $(0.4)$ \\
\hline $\begin{array}{l}\text { Sex } \\
\quad \text { Male } \\
\text { Female }\end{array}$ & $\begin{array}{l}50 \\
50\end{array}$ & $\begin{array}{l}(0.5) \\
(0.5)\end{array}$ & $\begin{array}{l}309 \\
303\end{array}$ & $\begin{array}{l}(0.7) \\
(0.8)\end{array}$ & $\begin{array}{l}273 \\
267\end{array}$ & $\begin{array}{l}(2.9) \\
(2.8)\end{array}$ & $\begin{array}{l}283 \\
276\end{array}$ & $\begin{array}{l}(1.5) \\
(1.6)\end{array}$ & $\begin{array}{l}300 \\
289\end{array}$ & $\begin{array}{l}(0.8) \\
(1.0)\end{array}$ & $\begin{array}{l}310 \\
303\end{array}$ & $\begin{array}{l}(0.8) \\
(0.8)\end{array}$ & $\begin{array}{l}336 \\
331\end{array}$ & $\begin{array}{l}(1.1) \\
(0.9)\end{array}$ & $\begin{array}{l}- \\
-\end{array}$ & $\begin{array}{l}(\dagger) \\
(\dagger) \\
(\dagger)\end{array}$ & $\begin{array}{l}96 \\
96\end{array}$ & $\begin{array}{l}(0.5) \\
(0.4)\end{array}$ & $\begin{array}{l}63 \\
56\end{array}$ & $\begin{array}{l}(1.0) \\
(1.3)\end{array}$ & $\begin{array}{l}8 \\
5\end{array}$ & $\begin{array}{l}(0.6) \\
(0.3)\end{array}$ \\
\hline 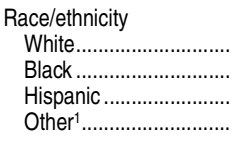 & $\begin{array}{r}59 \\
14 \\
19 \\
7\end{array}$ & $\begin{array}{l}(1.5) \\
(1.4) \\
(1.2) \\
(0.5)\end{array}$ & $\begin{array}{l}314 \\
287 \\
293 \\
316\end{array}$ & $\begin{array}{l}(0.7) \\
(1.2) \\
(1.1) \\
(1.8)\end{array}$ & $\begin{array}{r}275 \\
\ddagger \\
261 \\
\ddagger\end{array}$ & $\begin{array}{r}(2.3) \\
(t) \\
(3.2) \\
(t)\end{array}$ & $\begin{array}{r}287 \\
266 \\
274 \\
\ddagger\end{array}$ & $\begin{array}{r}(1.3) \\
(2.6) \\
(2.3) \\
(\mathrm{t})\end{array}$ & $\begin{array}{l}301 \\
282 \\
289 \\
297\end{array}$ & $\begin{array}{l}(0.9) \\
(1.6) \\
(1.3) \\
(2.8)\end{array}$ & $\begin{array}{l}314 \\
291 \\
296 \\
311\end{array}$ & $\begin{array}{l}(0.8) \\
(1.5) \\
(1.2) \\
(1.9)\end{array}$ & $\begin{array}{l}337 \\
312 \\
320 \\
340\end{array}$ & $\begin{array}{l}(0.8) \\
(2.6) \\
(1.9) \\
(2.2)\end{array}$ & $\begin{array}{l}- \\
- \\
- \\
-\end{array}$ & $\begin{array}{l}(\dagger) \\
(\dagger) \\
(\dagger) \\
(\dagger) \\
(t)\end{array}$ & $\begin{array}{l}98 \\
91 \\
92 \\
98\end{array}$ & $\begin{array}{l}(0.3) \\
(1.4) \\
(1.1) \\
(0.7)\end{array}$ & $\begin{array}{l}71 \\
32 \\
41 \\
71\end{array}$ & $\begin{array}{l}(1.1) \\
(1.6) \\
(1.7) \\
(2.2)\end{array}$ & $\begin{array}{r}8 \\
1 \\
1 \\
13 \\
\end{array}$ & $\begin{array}{l}(0.5) \\
(0.2) \\
(0.4) \\
(1.8)\end{array}$ \\
\hline 2012 All students ............. & 100 & $(t)$ & 306 & $(0.8)$ & 263 & (3.6) & 272 & (1.5) & 290 & $(1.3)$ & 305 & $(1.0)$ & 334 & $(0.8)$ & - & $(t)$ & 96 & $(0.3)$ & 60 & $(1.2)$ & 7 & $(0.5)$ \\
\hline 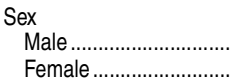 & $\begin{array}{l}49 \\
51\end{array}$ & $\begin{array}{l}(0.5) \\
(0.5)\end{array}$ & $\begin{array}{l}308 \\
304\end{array}$ & $\begin{array}{l}(1.0) \\
(0.8)\end{array}$ & $\begin{array}{r}266 \\
\ddagger\end{array}$ & $\begin{array}{r}(4.4) \\
(\dagger)\end{array}$ & $\begin{array}{l}276 \\
267\end{array}$ & $\begin{array}{l}(1.7) \\
(2.0)\end{array}$ & $\begin{array}{l}293 \\
287\end{array}$ & $\begin{array}{l}(1.6) \\
(1.3)\end{array}$ & $\begin{array}{l}308 \\
302\end{array}$ & $\begin{array}{l}(1.1) \\
(1.1)\end{array}$ & $\begin{array}{l}337 \\
331\end{array}$ & $\begin{array}{l}(1.2) \\
(1.0)\end{array}$ & - & $\begin{array}{l}(t) \\
(t)\end{array}$ & $\begin{array}{l}95 \\
96\end{array}$ & $\begin{array}{l}(0.4) \\
(0.4)\end{array}$ & $\begin{array}{l}62 \\
58\end{array}$ & $\begin{array}{l}(1.3) \\
(1.4)\end{array}$ & $\begin{array}{l}9 \\
5\end{array}$ & $\begin{array}{l}(0.8) \\
(0.6)\end{array}$ \\
\hline 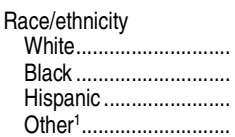 & $\begin{array}{r}56 \\
13 \\
22 \\
8\end{array}$ & $\begin{array}{l}(1.6) \\
(1.2) \\
(1.5) \\
(0.8)\end{array}$ & $\begin{array}{l}314 \\
288 \\
294 \\
318\end{array}$ & $\begin{array}{l}(1.0) \\
(1.3) \\
(1.1) \\
(2.4)\end{array}$ & $\begin{array}{r}268 \\
\ddagger \\
\ddagger \\
\ddagger\end{array}$ & $\begin{array}{r}(5.2) \\
(\dagger) \\
(\dagger) \\
(\dagger)\end{array}$ & $\begin{array}{r}278 \\
260 \\
269 \\
\ddagger\end{array}$ & $\begin{array}{r}(2.1) \\
(2.7) \\
(2.5) \\
(\dagger)\end{array}$ & $\begin{array}{l}298 \\
280 \\
284 \\
293\end{array}$ & $\begin{array}{l}(1.8) \\
(1.6) \\
(1.4) \\
(3.7)\end{array}$ & $\begin{array}{l}311 \\
290 \\
296 \\
308\end{array}$ & $\begin{array}{l}(1.2) \\
(1.0) \\
(1.0) \\
(2.4)\end{array}$ & $\begin{array}{l}337 \\
317 \\
324 \\
338\end{array}$ & $\begin{array}{l}(0.8) \\
(2.5) \\
(2.0) \\
(2.1)\end{array}$ & $\begin{array}{l}- \\
- \\
-\end{array}$ & $\begin{array}{l}(t) \\
(t) \\
(t) \\
(t)\end{array}$ & $\begin{array}{l}98 \\
90 \\
93 \\
98\end{array}$ & $\begin{array}{l}(0.3) \\
(1.0) \\
(0.6) \\
(0.8)\end{array}$ & $\begin{array}{l}70 \\
34 \\
43 \\
73\end{array}$ & $\begin{array}{l}(1.6) \\
(2.0) \\
(1.9) \\
(3.0)\end{array}$ & $\begin{array}{r}9 \\
1 \\
2 \\
14\end{array}$ & $\begin{array}{l}(0.7) \\
(0.3) \\
(0.4) \\
(2.3)\end{array}$ \\
\hline
\end{tabular}

-Not available.

†Not applicable.

\#Rounds to zero.

†Reporting standards not met (too few cases for a reliable estimate)

${ }^{1}$ Includes Asians/Pacific Islanders and American Indians/Alaska Natives.

NOTE: Scale ranges from 0 to 500 . Students scoring 200 (or higher) have a considerable understanding of two-digit numbers and know some basic multiplication and division facts. Students scoring 250 have an initial understanding of the four basic operations and are developing an ability to analyze simple logical relations. Students scoring 300 can perform reasoning and problem solving involving fractions, decimals, percents, elementary geometry, and simple algebra. Students scoring 350 can perform reasoning and problem solving involving geometry, alge- bra, and beginning statistics and probability. Includes public and private schools. For assessment years prior to 2004, accommodations were not permitted. For 2004 and later years, includes students tested with accommodations; excludes only those students with disabilities and English language learners who were unable to be tested even with accommodations ( 1 to 4 percent of all students, depending on age and assessment year). Race categories exclude persons of Hispanic ethnicity. Detail may not sum to totals because of rounding. SOURCE: U.S. Department of Education, National Center for Education Statistics, National Assessment of Educational Progress (NAEP), NAEP Trends in Academic Progress, 1996 and 1999; and 2004, 2008, and 2012 Long-Term Trend Mathematics Assessments, retrieved June 4, 2009, and August 12, 2013, from the Long-Term Trend NAEP Data Explorer (http:// nces.ed.gov/nationsreportcard/naepdata/). (This table was prepared August 2013.) 


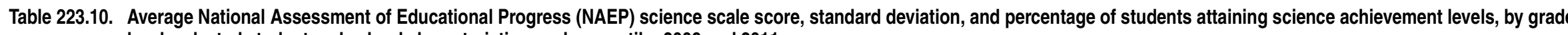
level, selected student and school characteristics, and percentile: 2009 and 2011

[Standard errors appear in parentheses]

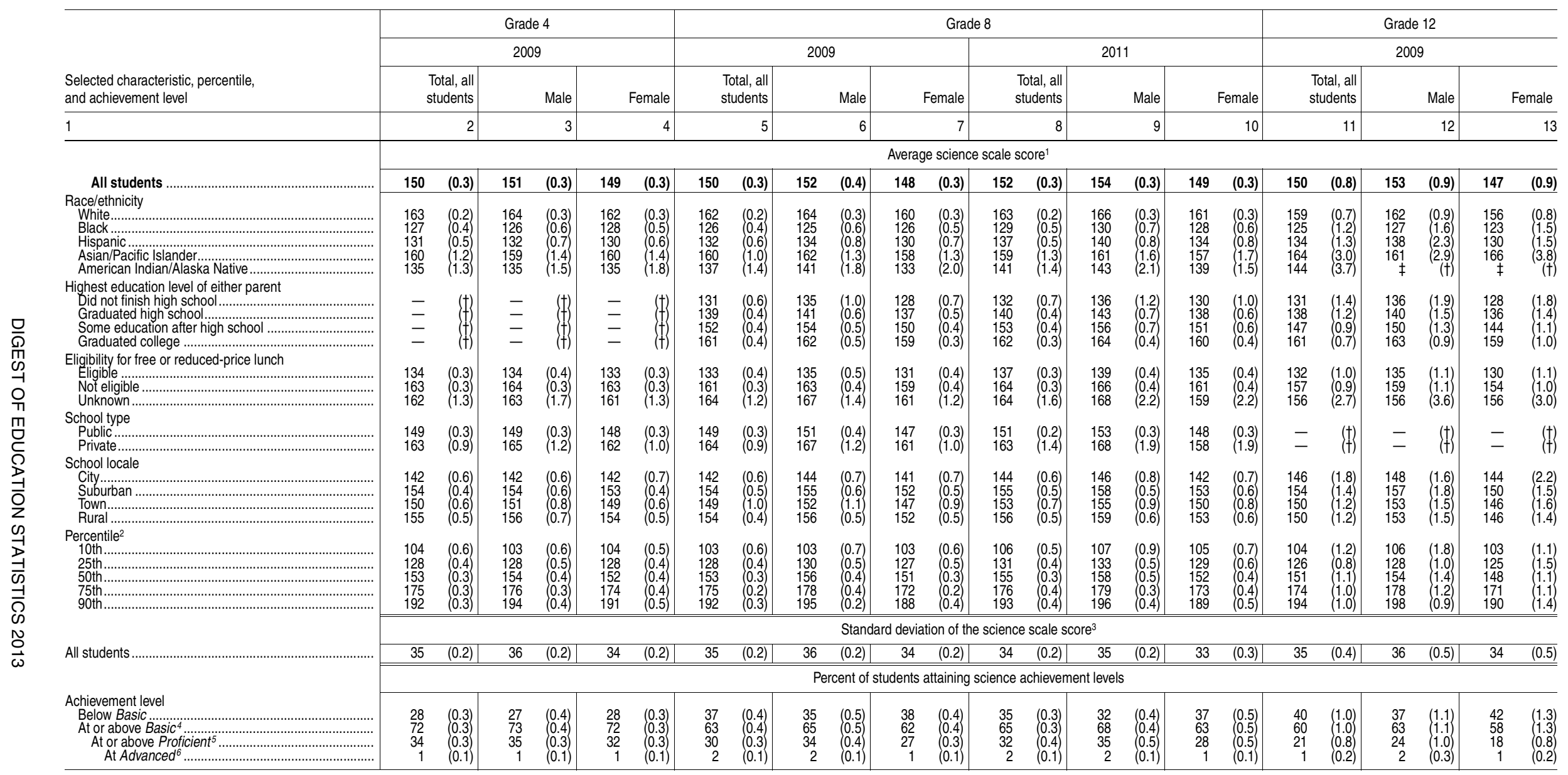

\section{-Not available.}

†Not applicable.

(too few cases for a reliable estimate).

Scale ranges from 0 to 300 for all three grades, but scores cannot be compared across grades. For example, the average score The percentile 4 hepresents a specific deint on the percentage distribution score of 159 tor White 12 th-graders.

high. For example, 10 percent of students scored at or below the 10th percentile score, while 90 percent of students low to

${ }^{3}$ The standard deviation provides an indication of how much the test scores varied. The lower the standard deviation, the closer the scores were clustered around the average score. About two-thirds of the student scores can be expected to fall within the range of one standard deviation above and one standard deviation below the average score. For example, the average score for have also must be taken into account when making comparisons of these ranges. For a discussion of standard errors, see Appendix A Guide to Sources.

ing of the knowledge and skills that are fundamental for proficient work

${ }^{5}$ Proficient represents solid academic performance. Students reaching this level have demonstrated competency over challenging subject matter. learners who were unable to be tested even with accommodations ( 2 to 3 percent of all students). Race categories exclude per-

SOURCE: U.S. Department of Education, National Center for Education Statistics, National Assessment of Educational Progress (NAEP), 2011 Science Assessment, retrieved August 1, 2012, from the Main NAEP Data Explorer (http://nces.ed.gov 
Table 223.20. Average National Assessment of Educational Progress (NAEP) science scale scores of 8th-grade public school students, by race/ ethnicity and state: 2009 and 2011

[Standard errors appear in parentheses]

\begin{tabular}{|c|c|c|c|c|c|c|c|c|c|c|c|c|c|c|c|c|c|c|c|c|}
\hline \multirow[b]{3}{*}{ State } & \multicolumn{10}{|c|}{2009} & \multicolumn{10}{|c|}{2011} \\
\hline & \multirow{2}{*}{\multicolumn{2}{|c|}{$\begin{array}{l}\text { Total, all } \\
\text { students }\end{array}$}} & \multicolumn{8}{|c|}{ Race/ethnicity } & & & \multicolumn{8}{|c|}{ Race/ethnicity } \\
\hline & & & & White & & Black & & spanic & & & & & & White & & Black & & spanic & & \\
\hline 1 & & 2 & & 3 & & 4 & & 5 & & 6 & & 7 & & 8 & & 9 & & 10 & & 11 \\
\hline United States. & 149 & $(0.3)$ & 161 & $(0.2)$ & 125 & $(0.4)$ & 131 & $(0.6)$ & 159 & $(1.0)$ & 151 & $(0.2)$ & 163 & $(0.2)$ & 128 & $(0.5)$ & 136 & $(0.5)$ & 159 & (1.2) \\
\hline labama . & 139 & (1.1) & 152 & (1.1) & 115 & (1.8) & 129 & (3.5) & $\ddagger$ & $(\dagger)$ & 140 & (1.4) & 152 & (1.3) & 118 & (1.4) & 136 & (3.6) & $\ddagger$ & $(t)$ \\
\hline aska..... & - & $(\dagger)$ & - & $(\dagger)$ & - & $(\dagger)$ & - & $(t)$ & - & $(\dagger)$ & 153 & $(0.7)$ & 166 & $(0.9)$ & 133 & (3.2) & 147 & (2.7) & 145 & (2.2) \\
\hline izona ...... & 141 & (1.3) & 157 & (1.3) & 126 & (3.2) & 127 & (1.5) & 159 & (5.5) & 144 & (1.3) & 158 & (1.3) & 128 & (2.9) & 132 & (1.6) & $\ddagger$ & $(\dagger)$ \\
\hline$\ldots$ & 144 & (1.3) & 154 & $(0.9)$ & 111 & (2.1) & 134 & (3.0) & $\ddagger$ & $(t)$ & 148 & (1.1) & 158 & $(1.0)$ & 119 & (2.1) & 38 & (2.1) & $\ddagger$ & $(\dagger)$ \\
\hline Salifornia ........................................ & 137 & (1.4) & 157 & $(2.0)$ & 122 & $(2.8)$ & 122 & (1.3) & 154 & (2.2) & 140 & (1.3) & 159 & (1.6) & 124 & (3.4) & 128 & (1.4) & 157 & $(2.8)$ \\
\hline lorac & 56 & $(1.0)$ & 166 & $(1.0)$ & 135 & (3.7) & 137 & $(1.6)$ & 161 & (3.7) & 161 & (1.3) & 171 & (1.4) & 149 & (3.7) & 141 & (1.8) & 162 & 4.5) \\
\hline onnecticut. & 155 & $(0.9)$ & 164 & $(0.8)$ & 126 & $(2.3)$ & 128 & $(1.8)$ & 169 & (3.5) & 155 & (1.1) & 165 & $(1.0)$ & 128 & (2.3) & 129 & (2.5) & 70 & 4.2) \\
\hline elaware.......... & 148 & $(0.6)$ & 159 & $(0.9)$ & 133 & $(1.0)$ & 141 & (2.2) & 160 & (4.3) & 150 & $(0.6)$ & 161 & $(0.8)$ & 134 & $(1.3)$ & 139 & (2.0) & 168 & (3.3) \\
\hline stric & - & $(\dagger)$ & - & $(\dagger)$ & - & $(t)$ & - & $(t)$ & - & $(\dagger)$ & 112 & $(1.0)$ & 174 & (3.3) & 107 & (1.1) & 116 & (2.6) & $\ddagger$ & $(\dagger)$ \\
\hline Florida. & 146 & $(1.0)$ & 158 & (1.4) & 126 & (1.4) & 139 & (1.2) & 163 & (4.1) & 148 & (1.1) & 161 & (1.1) & 127 & (2.0) & 144 & (1.5) & 161 & (4.5) \\
\hline .. & 47 & (1.0) & 161 & (1.2) & 129 & (1.3) & 137 & (2.2) & 172 & (2.7) & 151 & (1.4) & 166 & (1.6) & 133 & (1.8) & 143 & (3.1) & 168 & 3.9) \\
\hline$\ldots$ & 139 & $(0.7)$ & 15 & (1.5) & 133 & $(5.0)$ & 14 & (4.3) & 136 & $(1.0)$ & 14 & $(0.7)$ & & .8) & $\ddagger$ & (†) & 44 & .3) & 139 & $0.9)$ \\
\hline ho.... & 158 & $(0.9)$ & 162 & $(0.9)$ & $\ddagger$ & $(t)$ & 137 & (1.4) & $\ddagger$ & (†) & 159 & $(0.7)$ & 163 & $(0.7)$ & $\ddagger$ & (t) & 139 & (1.8) & $\ddagger$ & $(\dagger)$ \\
\hline$\ldots \ldots \ldots \ldots$ & 48 & (1.4) & 162 & (1.2) & 118 & (1.5) & 131 & (1.5) & 167 & (3.2) & 147 & (1.0) & 161 & (1.1) & 120 & (1.9) & 135 & (1.2) & 163 & (4.4) \\
\hline$\ldots \ldots \ldots \ldots$ & 152 & (1.2) & 159 & $(1.0)$ & 126 & (3.9) & 135 & (3.5) & $\ddagger$ & (†) & 153 & $(0.9)$ & 160 & (1.0) & 125 & (2.7) & 136 & (3.7) & $\ddagger$ & (†) \\
\hline wa & 156 & $(0.9)$ & 160 & $(0.8)$ & 127 & (3.5) & 133 & (3.2) & $\ddagger$ & (†) & 157 & $(0.8)$ & 161 & $(0.8)$ & 128 & (3.7 & 143 & (3.1) & $\ddagger$ & $(\dagger)$ \\
\hline & - & $(t)$ & - & $(t)$ & - & $(t)$ & - & (t) & - & (†) & 15 & $(0.8)$ & 163 & I & 129 & & 134 & (2.1) & 156 & (5.2) \\
\hline$\ldots$ & 156 & $(0.8)$ & 159 & $(0.9)$ & 137 & (1.8) & 145 & (3.5) & $\ddagger$ & $(t)$ & 15 & $(0.8)$ & 16 & $(0.9)$ & 135 & (1.7 & 49 & (3.0) & $\ddagger$ & $(\dagger)$ \\
\hline$\ldots$ & 139 & (1.7) & 155 & (1.5) & 120 & (1.9) & $\ddagger$ & $(t)$ & $\ddagger$ & (†) & 143 & (1.7) & 56 & (1.6) & 125 & (2.1) & 142 & $(5.2)$ & $\ddagger$ & $(t)$ \\
\hline Maine. & 158 & $(0.8)$ & 159 & $(0.8)$ & 126 & (4.5) & $\ddagger$ & ( & $\ddagger$ & (†) & 160 & $(0.5)$ & 160 & $(0.6)$ & $\ddagger$ & (†) & $\ddagger$ & $(\dagger)$ & $\ddagger$ & $(\dagger)$ \\
\hline onte & 48 & (1.1) & 164 & (1.2) & 127 & (1.5) & 136 & (2.8) & 169 & (2.5) & 152 & (1.2 & 167 & $(1.2)$ & 31 & (1.8) & 142 & 2.2 & 64 & 4.3) \\
\hline . & 160 & (1.1) & 16 & (1.1) & 1 & (2.6) & 131 & (2.7) & 168 & (4.1) & 161 & (1.1) & 169 & & 133 & & 30 & (2. & 70 & 4.1) \\
\hline ................. & 53 & $(1$. & 52 & I & 121 & (2. & 139 & (3.4) & $\ddagger$ & $(t)$ & To & (1.0) & & $0)$ & 24 & $(2.8)$ & 46 & (3.3) & 166 & $6.9)$ \\
\hline .……........ & 159 & $(1.0)$ & 166 & $(0.9)$ & 128 & (2.8) & 132 & (3.7) & 141 & (3.0) & 16 & $(1.0)$ & 168 & $(1.0)$ & 129 & $(2.5)$ & 137 & $(4.0)$ & 149 & (3.9) \\
\hline Mississipp & 132 & (1.2) & 150 & (1.2) & 114 & (1.1) & $\ddagger$ & $(\dagger)$ & $\ddagger$ & (†) & 137 & (1.3) & 156 & (1.1) & 119 & (1.4) & $\ddagger$ & & $\ddagger$ & $(\dagger)$ \\
\hline & & (1. & & (0 & 129 & (2.5) & 15 & (3.8) & 167 & (4.7) & & (1. & & (0. & 13 & (3. & $\ddagger$ & & $\ddagger$ & $(†)$ \\
\hline$\ldots$ & 62 & $(0.7)$ & 166 & $(0.7)$ & $\ddagger$ & $(t)$ & 155 & (3.3) & $\ddagger$ & $(\dagger)$ & 163 & $(0$ & & & $\ddagger$ & ) & $\ddagger$ & f & $\ddagger$ & $(\dagger)$ \\
\hline & - & $(t)$ & - & $(t)$ & - & $(t)$ & - & $(t)$ & - & $(t)$ & 1 & & & & 126 & & 35 & (1.9) & $\ddagger$ & $(\dagger)$ \\
\hline$\ldots \ldots \ldots \ldots \ldots . .$. & 141 & $(0.7)$ & 153 & $(0.9)$ & 127 & (2.4) & 129 & $(1.0)$ & 148 & (2.4) & 144 & $(0.8)$ & 157 & (1.3) & 123 & (3.3) & 133 & (1.1) & 154 & (2.6) \\
\hline New Hamps & 160 & $(0.8)$ & 161 & $(0.8)$ & $\ddagger$ & $(t)$ & 131 & $(4.2)$ & $\ddagger$ & $(t)$ & 162 & $(0.7)$ & 164 & $(0.6)$ & $\ddagger$ & $(+)$ & 137 & $(4.3)$ & $\ddagger$ & (t) \\
\hline & & $(1.5$ & & $(1.0$ & 127 & la & & $(2.7)$ & 174 & (2.6) & 155 & & 166 & $(1.2$ & 131 & (2.5) & 1 & $(1.9$ & 173 & (2.8) \\
\hline & 14 & 1 & & & $\ddagger$ & ( & & (1 & $t$ & $(\dagger)$ & & & & & 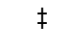 & & & $(0.8)$ & $\ddagger$ & $(t)$ \\
\hline & & $(1$ & & & 123 & $(1.8)$ & & $(1$ & 161 & $(2.3)$ & & & & & 130 & & 9 & (1.7) & 154 & (2.6) \\
\hline & & $(1$ & & & 121 & $(1$ & 102 & (2.3) & 165 & (7.1) & & & & & 125 & (1.8) & 138 & (2.4) & 160 & $(6.5)$ \\
\hline North Dakota. & 162 & $(0.5)$ & 166 & $(0.6)$ & $\ddagger$ & $(t)$ & $\ddagger$ & $(\dagger)$ & $\ddagger$ & $(\dagger)$ & 164 & $(0.7)$ & 168 & $(0.8)$ & $\ddagger$ & (II) & + & (I) & $\ddagger$ & $(\dagger)$ \\
\hline & 158 & $(1.0$ & & & & & & $(4.6$ & $\ddagger$ & 1 & & & & & & & & & $\ddagger$ & $(\dagger)$ \\
\hline 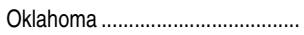 & & (C & & & 12 & & & & $\ddagger$ & $t$ & & & & (1. & 126 & (3.6) & 35 & D) & $\ddagger$ & $(\dagger)$ \\
\hline .. & 54 & & & & & & & 8) & 160 & $(3$ & 1 & & 1 & & $\ddagger$ & $(\dagger)$ & 35 & 4) & 159 & 4.3) \\
\hline & 154 & $(1$ & & $(0$ & 12 & $(2$ & 16 & (4.4) & 159 & & 15 & (1.3) & & & 120 & (2.3) & 118 & (4.8) & 63 & 4.9) \\
\hline Rhode Island .. & 146 & $(0.6)$ & 155 & $(0.8)$ & 125 & (2.6) & 119 & $(1.9)$ & 146 & $(5.3)$ & 149 & $(0.7)$ & 161 & $(0.7)$ & 122 & (3.4) & 120 & (1.9) & 151 & (4.6) \\
\hline & & & & & & & & & + & & & & & & 28 & & & & $\ddagger$ & $(\dagger)$ \\
\hline & & & & & & & & & $\ddagger$ & 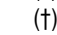 & & & & & $\ddagger$ & & 51 & $(4$. & $\ddagger$ & $(\dagger)$ \\
\hline & 148 & (1) & & & 1 & & & & $\ddagger$ & & & & 1 & & 121 & (1.6) & 37 & 1) & $\ddagger$ & $(\dagger)$ \\
\hline$\ldots \ldots \ldots \ldots . .$. & 150 & (1.2) & 1 & (1.4) & 133 & (2.5) & & (1.5) & 170 & (3.6) & 3 & $(1.0)$ & 167 & (1.2) & 137 & (2.3) & 146 & $(1.3)$ & 172 & (4.3) \\
\hline Utah & 158 & $(1.0)$ & 164 & (1.1) & $\ddagger$ & $(\dagger)$ & 129 & (1.7) & 147 & (3.9) & 161 & $(0.8)$ & 167 & $(0.8)$ & $\ddagger$ & $(t)$ & 137 & $(2.0)$ & 153 & (4.7) \\
\hline & - & ( & - & ( & - & ( & - & & - & & & & & & $\ddagger$ & & $\ddagger$ & & $\ddagger$ & $(\dagger)$ \\
\hline & 156 & (1. & 16 & & 135 & $(2$ & 144 & (2.2) & 168 & & 1 & & & & 8 & (1.7) & 145 & $(2.8)$ & 72 & 2.4) \\
\hline & & $(1$ & & & & & 132 & (2.3) & 157 & $(3$ & & & & & כ0 & & 141 & (2.5) & 156 & 2.8) \\
\hline & & $(0$ & & & 127 & & + & & $t$ & & & & & & 6 & & $t$ & $(t)$ & \pm & $(\dagger)$ \\
\hline rviour & 157 & $(0.9$ & 165 & $(0.8$ & 120 & (1.5) & 134 & (3.9) & 152 & (3.5) & 159 & $(1.0)$ & 166 & $(0.9)$ & 121 & (3.1) & 140 & $(4.8)$ & 149 & $(4.7)$ \\
\hline Wyoming ............. & 158 & $(0.7)$ & 162 & $(0.7)$ & $\ddagger$ & $(t)$ & 137 & (1.8) & $\ddagger$ & $(\dagger)$ & 160 & $(0.5)$ & 164 & $(0.6)$ & $\ddagger$ & $(t)$ & 143 & $(2.0)$ & $\ddagger$ & $(\dagger)$ \\
\hline $\begin{array}{l}\text { epartment of Defense } \\
\text { dependents schools................ }\end{array}$ & 162 & $(0.7)$ & 170 & 1.0) & 144 & (1.4) & 155 & $2.0)$ & 160 & (2.3) & 161 & $(0.8)$ & 169 & (1.1) & 143 & (2.2) & 158 & (2.5) & 155 & (3.2) \\
\hline
\end{tabular}

-Not available.

†Not applicable.

fReporting standards not met (too few cases for a reliable estimate).

NOTE: Scale ranges from 0 to 300 . Includes students tested with accommodations (10 percent of all students in 2009 and 9 percent of all students in 2011); excludes only those students with disabilities and English language learners who were unable to be tested even with accommodations ( 2 percent of all students in both years). Race categories exclude persons of Hispanic ethnicity. Totals include other racial/ethnic groups not shown separately.

SOURCE: U.S. Department of Education, National Center for Education Statistics, National Assessment of Educational Progress (NAEP), 2009 and 2011 Science Assessment, retrieved August 12, 2012, from the Main NAEP Data Explorer (http://nces.ed.gov/nations reportcard/naepdata/). (This table was prepared August 2012.) 


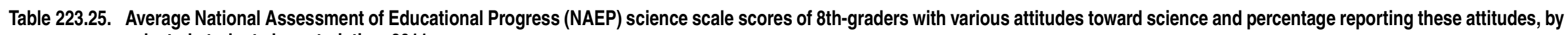
selected student characteristics: 2011

[Standard errors appear in parentheses]

\begin{tabular}{|c|c|c|c|c|c|c|c|c|c|c|c|c|c|c|c|c|c|c|c|c|c|c|c|c|}
\hline \multirow[b]{2}{*}{ Student characteristic } & \multicolumn{8}{|c|}{ Take science only because it will help in future } & \multicolumn{8}{|c|}{ Like science } & \multicolumn{8}{|c|}{ Take science only because required } \\
\hline & \multicolumn{2}{|c|}{\begin{tabular}{|l|} 
Strongly disagree \\
\end{tabular}} & \multicolumn{2}{|c|}{ Disagree } & \multirow{2}{*}{\multicolumn{2}{|c|}{\begin{tabular}{r|} 
Agree \\
4 \\
\end{tabular}}} & \multicolumn{2}{|c|}{ Strongly agree } & \multicolumn{2}{|c|}{ Strongly disagree } & \multicolumn{2}{|c|}{ Disagree } & \multirow{2}{*}{\multicolumn{2}{|c|}{\begin{tabular}{r|} 
Agree \\
8
\end{tabular}}} & \multicolumn{2}{|c|}{ Strongly agree } & \multicolumn{2}{|c|}{ Strongly disagree } & \multicolumn{2}{|r|}{ Disagree } & & Agree & Stron & $y$ agree \\
\hline 1 & & 2 & & 3 & & & & 5 & & 6 & & 7 & & & & 9 & & 10 & & 11 & & 12 & & 13 \\
\hline & & & & & & & & & & & & erage sc & e score & & & & & & & & & & & \\
\hline All students .. & 154 & $(0.5)$ & 161 & (0.4) & 150 & $(0.3)$ & 143 & $(0.5)$ & 136 & $(0.6)$ & 144 & (0.5) & 155 & $(0.3)$ & 166 & $(0.5)$ & 164 & (0.5) & 160 & (0.4) & 146 & (0.3) & 138 & $(0.5)$ \\
\hline 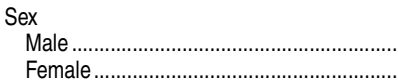 & $\begin{array}{l}156 \\
152\end{array}$ & $\left.\begin{array}{l}(0.7) \\
(0.9)\end{array}\right]$ & $\begin{array}{l}163 \\
158\end{array}$ & $\begin{array}{l}(0.4) \\
(0.5)\end{array}$ & $\begin{array}{l}153 \\
148\end{array}$ & $\begin{array}{l}(0.4) \\
(0.5)\end{array}$ & $\begin{array}{l}145 \\
141\end{array}$ & $\begin{array}{l}(0.7) \\
(0.6)\end{array}$ & $\begin{array}{l}136 \\
136\end{array}$ & $\begin{array}{l}(0.9) \\
(0.8)\end{array}$ & $\begin{array}{l}146 \\
144\end{array}$ & $\begin{array}{l}(0.7) \\
(0.6)\end{array}$ & $\begin{array}{l}157 \\
153\end{array}$ & $\begin{array}{l}(0.4) \\
(0.5)\end{array}$ & $\begin{array}{l}168 \\
162\end{array}$ & $\begin{array}{l}(0.7) \\
(0.7)\end{array}$ & $\begin{array}{l}166 \\
161\end{array}$ & $\begin{array}{l}(0.6) \\
(0.7)\end{array}$ & $\begin{array}{l}162 \\
158\end{array}$ & $\begin{array}{l}(0.5) \\
(0.6)\end{array}$ & $\begin{array}{l}148 \\
144\end{array}$ & $\begin{array}{l}(0.5) \\
(0.5)\end{array}$ & $\begin{array}{l}140 \\
137\end{array}$ & $\begin{array}{l}(0.7) \\
(0.6)\end{array}$ \\
\hline Race/ethnicity & & & & & & & & & & & & & & & & & & & & & & & & \\
\hline W & 164 & $(0.6)$ & 169 & $(0.4)$ & 161 & $(0.3)$ & 158 & $(0.6)$ & 148 & $(0.6)$ & 156 & (0.5) & 165 & $(0.3)$ & 175 & $(0.5)$ & 174 & (0.5) & 170 & $(0.4)$ & 157 & $(0.4)$ & 150 & $(0.6)$ \\
\hline Black. & 132 & $(1.3)$ & 137 & $(1.3)$ & 130 & $(0.8)$ & 123 & $(0.9)$ & 120 & (1.1) & 124 & $(0.8)$ & 131 & (0.6) & 141 & (1.2) & 139 & (1.6) & 137 & $(0.7)$ & 126 & (0.7) & 121 & $(0.8)$ \\
\hline Hispan & 140 & $(1.6)$ & 145 & $(1.0)$ & 135 & $(0.7)$ & 132 & $(1.0)$ & 124 & (1.3) & 129 & (1.1) & 140 & $(0.6)$ & 151 & (1.3) & 149 & (1.1) & 144 & $(0.9)$ & 132 & & 129 & $(0.9)$ \\
\hline 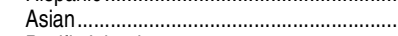 & 165 & $(2.8)$ & 170 & $(1.9)$ & 159 & $(2.1)$ & 156 & (2.0) & 140 & (3.3) & 151 & $(2.2)$ & 162 & $(1.7)$ & 177 & $(2.1)$ & 176 & (2.4) & 167 & (2 2 & 15 & (2 $2 x-x)$ & 144 & (2.3) \\
\hline 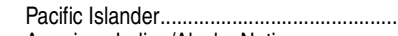 & 143 & $(6.5)$ & 146 & $(3.9)$ & 139 & (2.2) & 137 & (5.1) & 117 & $(5.3)$ & 130 & $(3.4)$ & 147 & $(3.1)$ & 153 & (3.6) & 150 & (4.8) & 150 & (3.4) & 134 & 3) & 126 & (3.4) \\
\hline laska Native. & 140 & $(4.4)$ & 151 & $(2.2)$ & 141 & (1.9) & 134 & (2.2) & 126 & (3.2) & 138 & (2.3) & 146 & (2.2) & 150 & (3.1) & 149 & 3) & 150 & o) & 140 & 7) & 132 & (3.2) \\
\hline s... & 158 & $(5.0)$ & 161 & (1.8) & 153 & (1.6) & 155 & (4.2) & 139 & $(4.6)$ & 147 & $(2.3)$ & 159 & $(1.2)$ & 170 & (3.6) & 167 & (3.9) & 163 & (1.7) & 152 & (2.2) & 139 & (2.6) \\
\hline free or reduced-price lunch & & & & & & & & & & & & & & & & & & & & & & & & \\
\hline & 140 & $(0.7)$ & 146 & $(0.5)$ & 136 & $(0.4)$ & 130 & $(0.6)$ & 125 & $(0.7)$ & 131 & (0.7) & 140 & $(0.4)$ & 149 & $(0.6)$ & 147 & $(0.5)$ & 145 & $(0.5)$ & 133 & $(0.5)$ & 128 & $(0.6)$ \\
\hline & 16 & $(0.7)$ & 170 & 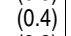 & 162 & $(0$. & 15 & 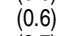 & & $(0.6)$ & 156 & $x_{0}$ & 166 & $(0$ & $17+2-3$ & $(0.5)$ & 175 & & 170 & & 150 & & 150 & (0.5) \\
\hline Unknov & 168 & (3.9) & 170 & $(2.3)$ & 161 & (2.4) & 154 & (3.7) & 147 & (5.4) & 156 & (2.6) & 166 & (1.9) & 177 & (3.4) & 174 & (3.1) & 170 & (2.5) & 157 & (2.4) & 147 & (5.1) \\
\hline level of education & & & & & & & & & & & & & & & & & & & & & & & & \\
\hline & 134 & (1.9) & 142 & (1.3) & 130 & (1.4) & 128 & (1.5) & 125 & (1.8) & 126 & (1.6) & 136 & $(0.9)$ & 144 & (1.8) & 140 & (1.6) & 140 & (1.3) & 128 & (1.2) & 129 & (1.5) \\
\hline Gradu & 143 & $(1$. & 148 & $(0.9)$ & 139 & $(0.6)$ & 132 & (1.1) & 129 & $(1.0)$ & 135 & $(0.8)$ & 3 & $(0.6)$ & 153 & & 151 & & 148 & & 136 & & 132 & (0.7) \\
\hline Some & 156 & (1.3) & 160 & $(0.8)$ & 152 & $(0.6)$ & 145 & $(0.9)$ & 140 & (1.3) & 146 & $(0.9)$ & 156 & $(0.5)$ & 165 & $(1.0)$ & 164 & (0 & 160 & $(0$ & 149 & & 141 & $(0.9)$ \\
\hline Graduated college . & 165 & $(0.8)$ & 170 & $(0.4)$ & 161 & $(0.4)$ & 153 & $(0.7)$ & 145 & $(0.9)$ & 155 & $(0.6)$ & 164 & $(0.4)$ & 174 & $(0.5)$ & 173 & $(0.6)$ & 169 & $(0.4)$ & 156 & $(0.5)$ & 146 & $(0.8)$ \\
\hline & & & & & & & & & & & & ercent of & dents & & & & & & & & & & & \\
\hline All students. & 12 & (0.2) & 32 & (0.3) & 39 & (0.2) & 18 & $(0.2)$ & 12 & $(0.2)$ & 19 & $(0.3)$ & 50 & $(0.3)$ & 19 & $(0.3)$ & 18 & $(0.2)$ & 34 & $(0.3)$ & 30 & $(0.2)$ & 17 & $(0.2)$ \\
\hline Sex & & & & & & & & & & & & & & & & & & & & & & & & \\
\hline & 14 & $(0$. & 33 & $(0$. & 36 & (0.4) & 16 & $(0$. & 11 & 10 & 16 & 10 & 51 & $(0$. & 22 & $(0$ & 21 & $(0.3)$ & 35 & $(0.4)$ & 27 & & 17 & 2) \\
\hline Female & 10 & $(0.2)$ & 30 & $(0.4)$ & 41 & $(0.4)$ & 19 & $(0.3)$ & 12 & $(0.3)$ & 23 & $(0.4)$ & 49 & $(0.4)$ & 16 & $(0.3)$ & 15 & $(0.2)$ & 34 & $(0.4)$ & 33 & $(0.4)$ & 18 & $(0.3)$ \\
\hline Race/ethnicity & & & & & & & & & & & & & & & & & & & & & & & & \\
\hline & 13 & $(0.2)$ & 36 & $(0.4)$ & 37 & $(0.4)$ & 13 & $(0.2)$ & 10 & $(0.2)$ & 19 & $(0.3)$ & 50 & $(0.4)$ & 20 & $(0.3)$ & 20 & $(0.2)$ & 37 & $(0.4)$ & 28 & $(0.3)$ & 16 & $(0.2)$ \\
\hline & 12 & $(0$. & 22 & $(0$ & 37 & $(0.7)$ & 29 & $(0.6)$ & 16 & $(0.5)$ & 20 & & 46 & $(0$ & 19 & & 17 & & 28 & & 30 & & 25 & \\
\hline & 11 & 10 & 27 & 10 & 42 & 10 & 20 & $(0.6)$ & 13 & & 21 & & 50 & (0.6) & 16 & & 15 & & 33 & & 35 & & 18 & (0.5) \\
\hline & 9 & 0. & 26 & $(1$ & 42 & (1.7) & 22 & (1.1) & 8 & & 16 & & 57 & (1.4) & 19 & & 19 & & 37 & & 30 & & 14 & $(0.8)$ \\
\hline Pacifi & 11 & $(2$. & 26 & $(3$ & 39 & (3.7) & 23 & $(3$ & 15 & & 21 & $(3$ & 50 & (4.3) & 15 & & 14 & & 37 & & 30 & & 18 & (2.9) \\
\hline laska Native..... & 10 & $(1.2$ & 27 & $(1.8$ & 44 & (2.0) & 18 & (1.1) & 14 & $(1.3)$ & 19 & $(1.2)$ & 52 & (1.6) & 15 & (1.3) & 14 & $(1$ & 29 & & 37 & & 19 & (1.5) \\
\hline Two 0 & 13 & (1.4) & 33 & $(2.0)$ & 36 & (1.9) & 18 & (1.7) & 14 & $(1.8)$ & 18 & $(1.0)$ & 47 & (2.0) & 21 & (1.8) & 20 & (2.4) & 34 & (1.9) & 28 & (1.7) & 19 & (1.5) \\
\hline Eligibility & & & & & & & & & & & & & & & & & & & & & & & & \\
\hline & & & & & & & 21 & $(0.3)$ & 14 & & 20 & $(0.3)$ & 49 & $(0.3)$ & 17 & $(0.3)$ & 16 & & 31 & $(0$ & 32 & & 21 & $(0.3)$ \\
\hline & 12 & $(0.2$ & 35 & 0. & 38 & $(0.3)$ & 15 & $(0.3)$ & 10 & $(0$ & 18 & 10 & 51 & 10 & 20 & $(0.3)$ & 20 & & 37 & & 28 & & 15 & (0.2) \\
\hline & 12 & $(1.9)$ & 38 & $(2.9)$ & 35 & (2.7) & 15 & $(1.6)$ & 10 & (1.2) & 20 & (2.1) & 48 & (2.5) & 22 & (2.1) & 22 & (2.1) & 36 & (2.5) & 30 & (2.4) & 12 & (1.4) \\
\hline Paren & & & & & & & & & & & & & & & & & & & & & & & & \\
\hline & 12 & $(0.6)$ & 27 & $(1$. & 40 & (1.0) & 20 & 10 & 16 & $(0.7)$ & 23 & $(0.9)$ & 45 & (1.1) & 15 & $(0.7)$ & 14 & (0. & 29 & $(0$. & 34 & $(1$ & 23 & $(0.9)$ \\
\hline 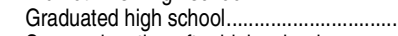 & 12 & $(0.4)$ & 31 & $(0.6)$ & 39 & $(0.6)$ & 18 & $(0.5)$ & 13 & $(0.4)$ & 21 & $(0$ & 50 & $(0.6)$ & 16 & $(0.6)$ & 15 & & 32 & & 32 & & 20 & $(0.4)$ \\
\hline igh school ................... & 12 & $(0.3$ & 31 & $(0.5)$ & 39 & $(0.5)$ & 17 & $(0.4)$ & 12 & $(0.4)$ & 20 & $(0.5)$ & 50 & $(0.6)$ & 18 & $(0.5)$ & 18 & 10. & 35 & 10 & 29 & $(0.5)$ & 18 & (0.5) \\
\hline Graduated college ...................................... & 12 & $(0.3)$ & 33 & $(0.4)$ & 38 & $(0.4)$ & 17 & $(0.3)$ & 10 & $(0.3)$ & 18 & $(0.4)$ & 51 & $(0.5)$ & 22 & $(0.3)$ & 21 & $(0.3)$ & 37 & $(0.5)$ & 28 & $(0.4)$ & 15 & $(0.3)$ \\
\hline
\end{tabular}

'Scale ranges from 0 to 300 .
NOTE: Includes public and private schools. Includes students tested with accommodations (11 percent of all 8th-graders); excludes only those students with disabilities and English language learners who were unable to be tested even with accom-
modations ( 2 percent of all 8 th-graders). Detail may not sum to totals because of rounding. Race categories exclude persons of Hispanic ethnicity.
SOURCE: U.S. Department of Education, National Center for Education Statistics, National Assessment of Educational Prosress (NAEP), 2011 Science Assessment, retrieved November 22, 2013, from the Main NAEP Data Explorer (http:/l nces.ed.gov/nationsreportcard/naepdata). (This table was prepared November 2013.) 


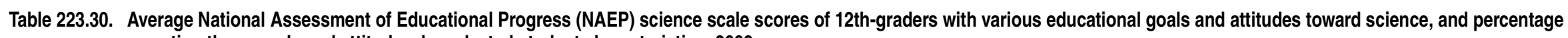
reporting these goals and attitudes, by selected student characteristics: 2009

[Standard errors appear in parentheses]

\begin{tabular}{|c|c|c|c|c|c|c|c|c|c|c|c|c|c|c|c|c|c|c|c|c|c|c|c|c|}
\hline \multirow[b]{2}{*}{ Student characteristic } & \multicolumn{8}{|c|}{ Educational goals ${ }^{1}$} & \multicolumn{8}{|c|}{ Like science } & \multicolumn{8}{|c|}{ Take science only because required } \\
\hline & \multicolumn{2}{|c|}{$\begin{array}{r}\text { Graduate } \\
\text { high school }\end{array}$} & \multicolumn{2}{|c|}{$\begin{array}{l}\text { Some education } \\
\text { after high school }\end{array}$} & \multicolumn{2}{|c|}{$\begin{array}{r}\text { Graduate } \\
\text { college }\end{array}$} & \multicolumn{2}{|c|}{$\begin{array}{r}\text { Go to } \\
\text { graduate school }\end{array}$} & \multicolumn{2}{|c|}{$\begin{array}{l}\text { Strongly } \\
\text { disagree }\end{array}$} & \multicolumn{2}{|c|}{ Disagree } & \multicolumn{2}{|r|}{ Agree } & \multicolumn{2}{|c|}{$\begin{array}{r}\text { Strongly } \\
\text { agree }\end{array}$} & \multicolumn{2}{|c|}{$\begin{array}{l}\text { Strongly } \\
\text { disagree }\end{array}$} & \multicolumn{2}{|c|}{ Disagree } & & Agree & \multicolumn{2}{|c|}{$\begin{array}{r}\text { Strongly } \\
\text { agree }\end{array}$} \\
\hline \multirow[b]{3}{*}{ All students. } & & 2 & & 3 & & 4 & & 5 & & 6 & & 7 & & 8 & & 9 & & 10 & & 11 & & 12 & & 13 \\
\hline & \multicolumn{24}{|c|}{ Average scale score ${ }^{2}$} \\
\hline & 114 & (1.9) & 131 & $(1.3)$ & 148 & $(0.6)$ & 171 & $(1.0)$ & 132 & (1.3) & 141 & $(0.9)$ & 153 & $(0.9)$ & 172 & (1.1) & 169 & (1.1) & 159 & $(0.9)$ & 142 & (0.9) & 134 & $(1.0)$ \\
\hline 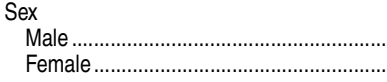 & $\begin{array}{l}121 \\
103\end{array}$ & $\begin{array}{l}(2.6) \\
(2.6)\end{array}$ & $\begin{array}{l}134 \\
127\end{array}$ & $\begin{array}{l}(1.8) \\
(1.9)\end{array}$ & $\begin{array}{l}152 \\
143\end{array}$ & $\begin{array}{l}(0.8) \\
(0.8)\end{array}$ & $\begin{array}{l}177 \\
166\end{array}$ & $\begin{array}{l}(1.3) \\
(1.2)\end{array}$ & $\begin{array}{l}130 \\
133\end{array}$ & $\begin{array}{l}(1.7) \\
(1.8)\end{array}$ & $\begin{array}{l}141 \\
141\end{array}$ & $\begin{array}{l}(1.4) \\
(1.1)\end{array}$ & $\begin{array}{l}155 \\
150\end{array}$ & $\begin{array}{l}(1.2) \\
(0.9)\end{array}$ & $\begin{array}{l}175 \\
169\end{array}$ & $\begin{array}{l}(1.3) \\
(1.8)\end{array}$ & $\begin{array}{l}172 \\
165\end{array}$ & $\begin{array}{l}(1.4) \\
(1.8)\end{array}$ & $\begin{array}{l}162 \\
156\end{array}$ & $\begin{array}{l}(1.2) \\
(0.9)\end{array}$ & $\begin{array}{l}143 \\
140\end{array}$ & $\begin{array}{l}(1.2) \\
(1.2)\end{array}$ & $\begin{array}{l}134 \\
134\end{array}$ & $\begin{array}{l}(1.3) \\
(1.4)\end{array}$ \\
\hline Race/ethnicity & & & & & & & & & & & & & & & & & & & & & & & & \\
\hline White................. & 127 & (2.1) & 140 & (1.6) & 156 & $(0.7)$ & 178 & $(1.0)$ & 140 & $(1.6)$ & 150 & (1.1) & 161 & $(0.9)$ & 180 & (1.0) & 176 & (1.1) & 167 & $(0.8)$ & 151 & $(1.0)$ & 143 & (1.4) \\
\hline 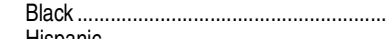 & 89 & (3.6) & 107 & (3.2) & 124 & $(1.1)$ & 144 & $(1.8)$ & 113 & $(2.0)$ & 120 & $(2.0)$ & 128 & $(1.5)$ & 142 & (2.4) & 140 & (2.6) & 135 & $(2.3)$ & 121 & $(1.6)$ & 115 & (1.7) \\
\hline 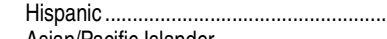 & 106 & (3.7) & 122 & (2.7) & 136 & (1.2) & 154 & (2.3) & 123 & (2.6) & 127 & (1.5) & 135 & (1.8) & 157 & (2.4) & 152 & (2.9) & 143 & (1.7) & 128 & (1.6) & 125 & (2.3) \\
\hline icific Islander................................ & $\ddagger$ & $(t)$ & $\ddagger$ & $(t)$ & 154 & $(2.9)$ & 181 & (3.4) & 141 & $(5.2)$ & 149 & (3.8) & 166 & $(2.9)$ & 188 & (4.5) & 181 & (4.2) & 171 & (3.3) & 154 & (3.2) & 141 & (4.5) \\
\hline American Indian/Alaska Native .................. & $\ddagger$ & (t) & $\ddagger$ & (t) & $\ddagger$ & $(\mathrm{t})$ & $\ddagger$ & $(t)$ & $\ddagger$ & $(t)$ & $\ddagger$ & $(\mathrm{t})$ & $\ddagger$ & $(t)$ & $\ddagger$ & $(t)$ & $\ddagger$ & $(t)$ & $\ddagger$ & $(\mathrm{t})$ & $\ddagger$ & $(\mathrm{t})$ & $\ddagger$ & $(t)$ \\
\hline Eligibility for free or reduced-price lunch & & & & & & & & & & & & & & & & & & & & & & & & \\
\hline 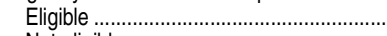 & 105 & (2.9) & 120 & (2.0) & 134 & $(0.8)$ & 151 & $(2.0)$ & 120 & (1.8) & 125 & (1.4) & 135 & $(1.1)$ & 152 & (2.0) & 147 & (2.7) & 142 & (1.4) & 127 & (1.1) & 121 & (1.6) \\
\hline Not el & 122 & (2.0) & 138 & (1.8) & 153 & $(0.8)$ & 176 & $(1.0)$ & 137 & $(1.5)$ & 148 & (1.1) & 159 & $(1.1)$ & 179 & (1.3) & 175 & (1.2) & 165 & $(1.0)$ & 148 & (1.1) & 140 & (1.4) \\
\hline Unknown ............................................. & $\ddagger$ & $(t)$ & $\ddagger$ & $(t)$ & 151 & $(2.4)$ & 169 & (3.5) & 139 & $(3.1)$ & 146 & (3.6) & 158 & $(2.9)$ & 177 & (3.8) & 175 & (3.6) & 164 & (3.3) & 149 & (2.6) & 138 & (3.3) \\
\hline Parents' highest level of education & & & & & & & & & & & & & & & & & & & & & & & & \\
\hline Did not finish high school...... & 112 & (3.7) & 124 & (2.8) & 134 & (1.5) & 145 & (3.1) & 119 & $(2.7)$ & 125 & (2.5) & 134 & $(2.0)$ & 153 & (3.5) & 147 & (3.1) & 138 & (2.5) & 127 & (2.3) & 121 & (2.2) \\
\hline $\mathrm{Gr}$ & 109 & $(2.8)$ & 129 & (2.7) & 141 & (1.3) & 158 & (2.1) & 124 & $(2.2)$ & 132 & $(1.5)$ & 141 & $(1.3)$ & 158 & (2.7) & 149 & (2.7) & 149 & (1.6) & 133 & (1.8) & 126 & (1.9) \\
\hline Some education after high school ............ & 126 & $(4.0)$ & 135 & (2.2) & 146 & $(0.9)$ & 162 & (2.1) & 133 & $(1.5)$ & 138 & $(1.2)$ & 149 & $(1.2)$ & 168 & (1.7) & 164 & (2.3) & 156 & (1.3) & 140 & (1.1) & 133 & (1.7) \\
\hline Graduated college ....................................... & 120 & (3.9) & 140 & (2.4) & 155 & $(0.8)$ & 177 & $(0.9)$ & 141 & (1.7) & 151 & (1.3) & 163 & $(1.0)$ & 181 & $(1.3)$ & 180 & (1.3) & 168 & $(1.0)$ & 152 & $(1.0)$ & 143 & (1.2) \\
\hline & & & & & & & & & & & & cent of & dents & & & & & & & & & & & \\
\hline All students & 5 & (0.3) & 7 & (0.3) & 59 & $(0.7)$ & 26 & $(0.8)$ & 14 & (0.4) & 21 & $(0.4)$ & 48 & $(0.5)$ & 16 & (0.3) & 15 & $(0.4)$ & 34 & $(0.5)$ & 31 & $(0.4)$ & 19 & $(0.4)$ \\
\hline & & & & & & & & & & & & & & & & & & & & & & & & \\
\hline 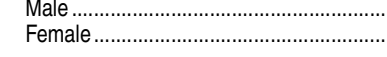 & $\begin{array}{l}6 \\
4\end{array}$ & $\begin{array}{l}(0.4) \\
(0.3)\end{array}$ & $\begin{array}{l}9 \\
6\end{array}$ & $\begin{array}{l}(0.4) \\
(0.4)\end{array}$ & $\begin{array}{l}59 \\
58\end{array}$ & $\begin{array}{l}(0.8) \\
(0.9)\end{array}$ & $\begin{array}{l}22 \\
31\end{array}$ & $\begin{array}{l}(0.8) \\
(1.0)\end{array}$ & $\begin{array}{l}12 \\
16\end{array}$ & $\left.\begin{array}{l}(0.5) \\
(0.5)\end{array}\right]$ & $\begin{array}{l}18 \\
25\end{array}$ & $\begin{array}{l}(0.5) \\
(0.6)\end{array}$ & $\begin{array}{l}52 \\
45\end{array}$ & $\begin{array}{l}(0.7) \\
(0.7)\end{array}$ & $\begin{array}{l}18 \\
14\end{array}$ & $\begin{array}{l}(0.5) \\
(0.5)\end{array}$ & $\begin{array}{l}17 \\
14\end{array}$ & $\begin{array}{l}(0.5) \\
(0.6)\end{array}$ & $\begin{array}{l}37 \\
31\end{array}$ & $(0.6)$ & $\begin{array}{l}29 \\
33\end{array}$ & $\begin{array}{l}(0.7) \\
(0.6)\end{array}$ & $\begin{array}{l}17 \\
21\end{array}$ & $\begin{array}{l}(0.5) \\
(0.6)\end{array}$ \\
\hline Race/ethnicity & & & & & & & & & & & & & & & & & & & & & & & & \\
\hline White... & 4 & (0.3) & 7 & $(0.3)$ & 60 & $(0.7)$ & 26 & $(0.8)$ & 13 & $(0.5)$ & 21 & (0.5) & 49 & $(0.7)$ & 17 & (0.5) & 17 & $(0.5)$ & 36 & $(0.6)$ & 29 & $(0.6)$ & 18 & $(0.5)$ \\
\hline ․․․․………....... & 6 & $(0.8)$ & 6 & $(0.6)$ & 60 & (1.3) & 25 & (1.4) & 20 & $(1.0)$ & 23 & $(0.9)$ & 43 & $(1.3)$ & 14 & $(0.9)$ & 11 & $(0.8)$ & 28 & $(1.2)$ & 33 & $(1.0)$ & 28 & (1.1) \\
\hline 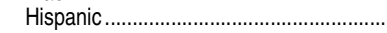 & 7 & $(0.7)$ & 12 & $(0.8)$ & 59 & (1.4) & 18 & (1.1) & 13 & $(0.7)$ & 24 & $(0.9)$ & 49 & $(1.1)$ & 14 & $(0.9)$ & 12 & $(0.8)$ & 31 & (1.1) & 38 & $(1.0)$ & 19 & (0.9) \\
\hline sific Islander........... & 3 & $(0.8)$ & 2 & $(0.5)$ & 42 & $(2.6)$ & 50 & $(2.8)$ & 9 & $(1.0)$ & 18 & (1.7) & 55 & $(1.5)$ & 18 & (1.5) & 19 & $(1.6)$ & 40 & (1.3) & 28 & $(1.9)$ & 13 & (1.1) \\
\hline American Indian/Alaska Native .................. & $\ddagger$ & $(t)$ & $\ddagger$ & $(t)$ & $\ddagger$ & $(t)$ & $\ddagger$ & $(t)$ & $\ddagger$ & $(t)$ & $\ddagger$ & $(t)$ & $\ddagger$ & $(t)$ & $\ddagger$ & $(t)$ & $\ddagger$ & $(+)$ & $\ddagger$ & $(\dagger)$ & $\ddagger$ & $(\dagger)$ & $\ddagger$ & $(\dagger)$ \\
\hline $\begin{array}{l}\text { Eligibility for free or reduced-price lunch } \\
\text { Flinible }\end{array}$ & & & & & & & & & & & & & & & & & 13 & & 30 & & 34 & & & \\
\hline 年 & $\begin{array}{l}8 \\
4\end{array}$ & $\begin{array}{r}(0.5) \\
(0.3)\end{array}$ & $\begin{array}{r}10 \\
7\end{array}$ & $\begin{array}{l}(0.6) \\
(0.4)\end{array}$ & $\begin{array}{l}60 \\
59\end{array}$ & $\begin{array}{l}(1.2) \\
(0.8)\end{array}$ & $\begin{array}{l}18 \\
29\end{array}$ & $\begin{array}{l}(1.1) \\
(0.9)\end{array}$ & $\begin{array}{l}16 \\
13\end{array}$ & $\begin{array}{l}(0.7) \\
(0.4)\end{array}$ & $\begin{array}{l}23 \\
21\end{array}$ & $\left.\begin{array}{l}(0.9) \\
(0.5)\end{array}\right]$ & $\begin{array}{l}47 \\
49\end{array}$ & $\begin{array}{l}(1.0) \\
(0.6)\end{array}$ & $\begin{array}{l}14 \\
17\end{array}$ & $(0.4)$ & $\begin{array}{l}13 \\
16\end{array}$ & $(0.5)$ & 35 & $(0.6)$ & $\begin{array}{l}34 \\
30\end{array}$ & $(0.6)$ & $\begin{array}{l}22 \\
18\end{array}$ & $\begin{array}{l}(0.8) \\
(0.5)\end{array}$ \\
\hline 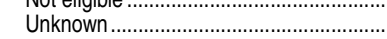 & 2 & $(0.7)$ & 4 & (1.0) & 56 & $(2.4)$ & 35 & $(2.7)$ & 13 & $(1.2)$ & 21 & $(1.3)$ & 48 & $(1.9)$ & 18 & (1.6) & 16 & (1.6) & 36 & (2.3) & 29 & $(1.8)$ & 19 & $(1.6)$ \\
\hline Parents' highest level of education & & & & & & & & & & & & & & & & & & & & & & & & \\
\hline Did not & 11 & (1.1) & 13 & $(1.0)$ & 53 & (2.2) & 16 & (1.8) & 19 & $(1.4)$ & 22 & (1.4) & 47 & $(1.7)$ & 13 & $(1$. & 13 & (1.2) & 30 & (1.6) & 35 & (1.7) & 23 & (1.3) \\
\hline 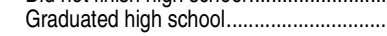 & 10 & $(0.6)$ & 12 & $(0.8)$ & 62 & $(1.4)$ & 13 & (1.0) & 16 & $(0.8)$ & 25 & $(1.0)$ & 46 & $(1.2)$ & 12 & $(0$ & 12 & (0.7) & 31 & $(1.3)$ & 35 & (1.1) & 22 & $(1.1)$ \\
\hline Some education after high school ........... & 4 & $(0.4)$ & 9 & $(0.5)$ & 65 & $(1.0)$ & 20 & (1.1) & 15 & $(0.8)$ & 22 & $(1.0)$ & 48 & $(1.2)$ & 15 & $(0.8)$ & 14 & $(0.9)$ & 33 & (1.0) & 32 & $(0.9)$ & 21 & (0.8) \\
\hline 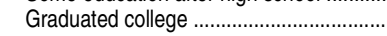 & 2 & $(0.2)$ & 4 & $(0.3)$ & 56 & $(0.8)$ & 37 & $(0.9)$ & 12 & $(0.6)$ & 19 & $(0.6)$ & 50 & $(0.7)$ & 19 & $(0.5)$ & 18 & $(0.4)$ & 37 & $(0.7)$ & 28 & $(0.6)$ & 17 & $(0.6)$ \\
\hline
\end{tabular}

†Not applicable.

The eductiandards not met (too few cases for a reliable estimate).

reported that they would not finish high school and ${ }^{2}$ Scale ranges from 0 to 300 .
NOTE: Includes students tested with accommodations (7 percent of all 12th-graders); excludes only those students with SOURCE. US. categories exclude persons of Hispanic ethnicity

ress (NAEP), 2009 Science Assessment, retrieved May 26, 2011, from the Main NAtional Assessment of Educational Pro nationsreportcard/naepdata/). (This table was prepared May 2011.) 


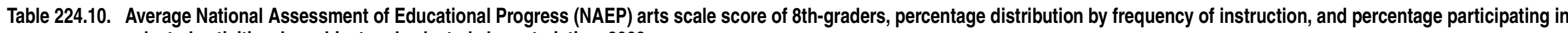
selected activities, by subject and selected characteristics: 2008

[Standard errors appear in parentheses]

\begin{tabular}{|c|c|c|c|c|c|c|c|c|c|c|c|c|c|c|c|c|c|c|c|c|c|c|c|c|c|c|c|c|}
\hline \multirow[b]{3}{*}{ Selected characteristic } & \multicolumn{6}{|c|}{ Average score } & \multicolumn{16}{|c|}{ Percentage distribution of students by school-reported frequency of instruction } & \multicolumn{6}{|c|}{$\begin{array}{l}\text { Percent of students reporting } \\
\text { participation in musical activities in school }\end{array}$} \\
\hline & \multirow{2}{*}{\multicolumn{2}{|c|}{$\begin{array}{r}\text { Music, }{ }^{1} \\
\text { responding } \\
\text { scale score } \\
(0 \text { to } 300)\end{array}$}} & \multicolumn{4}{|c|}{ Visual arts ${ }^{2}$} & \multicolumn{8}{|c|}{ Music } & \multicolumn{8}{|c|}{ Visual arts } & \multirow{2}{*}{\multicolumn{2}{|c|}{ Play in band }} & \multirow{2}{*}{\multicolumn{2}{|c|}{$\begin{array}{r}\text { Play in } \\
\text { orchestra }\end{array}$}} & \multirow{2}{*}{\multicolumn{2}{|c|}{$\begin{array}{r}\text { Sing in } \\
\text { chorus or choir }\end{array}$}} \\
\hline & & & \multicolumn{2}{|c|}{$\begin{array}{r}\text { Responding } \\
\text { scale score } \\
(0 \text { to } 300)\end{array}$} & \multicolumn{2}{|c|}{$\begin{array}{r}\text { Creating } \\
\text { task score } \\
(0 \text { to } 100)\end{array}$} & \multicolumn{2}{|c|}{$\begin{array}{r}\text { Subject } \\
\text { not offered }\end{array}$} & \multicolumn{2}{|c|}{$\begin{array}{r}\text { Less than } \\
\text { once a week }\end{array}$} & \multicolumn{2}{|c|}{$\begin{array}{r}\text { Once or } \\
\text { twice a week }\end{array}$} & \multicolumn{2}{|c|}{$\begin{array}{c}\text { At least } 3 \text { or } 4 \\
\text { times a week }\end{array}$} & \multicolumn{2}{|c|}{$\begin{array}{r}\text { Subject } \\
\text { not offered }\end{array}$} & \multicolumn{2}{|c|}{$\begin{array}{r}\text { Less than } \\
\text { once a week }\end{array}$} & \multicolumn{2}{|c|}{$\begin{array}{r}\text { Once or } \\
\text { twice a week }\end{array}$} & \multicolumn{2}{|c|}{$\begin{array}{c}\text { At least } 3 \text { or } 4 \\
\text { times a week }\end{array}$} & & & & & & \\
\hline 1 & & 2 & & 3 & & 4 & & 5 & & 6 & & 7 & & 8 & & 9 & & 10 & & 11 & & 12 & & 13 & & 14 & & 15 \\
\hline 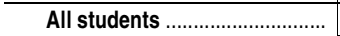 & 150 & (1.2) & 150 & (1.2) & 52 & (0.6) & 8 & (2.0) & 8 & (2.0) & 27 & (3.1) & 57 & (3.2) & 14 & (2.4) & 10 & (2.5) & 30 & (3.5) & 47 & (3.9) & 16 & $(0.9)$ & 5 & $(0.5)$ & 17 & $(1.2)$ \\
\hline 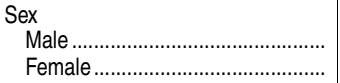 & $\left.\begin{array}{l}145 \\
155\end{array}\right\}$ & $\begin{array}{l}(1.3) \\
(1.4)\end{array}$ & $\begin{array}{l}145 \\
155\end{array}$ & $\begin{array}{l}(1.4) \\
(1.2)\end{array}$ & $\begin{array}{l}49 \\
54\end{array}$ & $\begin{array}{l}(0.7) \\
(0.7)\end{array}$ & $\begin{array}{l}9 \\
8\end{array}$ & $\begin{array}{l}(2.1) \\
(2.0)\end{array}$ & $\begin{array}{l}8 \\
7\end{array}$ & $\begin{array}{l}(2.1) \\
(1.9)\end{array}$ & $\begin{array}{l}27 \\
28\end{array}$ & $\begin{array}{l}(3.1) \\
(3.2)\end{array}$ & $\begin{array}{l}56 \\
57\end{array}$ & $\begin{array}{l}(3.2) \\
(3.2)\end{array} \mid$ & $\begin{array}{l}14 \\
13\end{array}$ & $\begin{array}{l}(2.6) \\
(2.3)\end{array}$ & $\begin{array}{l}10 \\
10\end{array}$ & $\begin{array}{l}(2.5) \\
(2.5)\end{array}$ & $\begin{array}{l}30 \\
29\end{array}$ & $\begin{array}{l}(3.6) \\
(3.3)\end{array}$ & $\begin{array}{l}46 \\
48\end{array}$ & $\begin{array}{l}(4.1) \\
(3.8)\end{array}$ & $\begin{array}{l}18 \\
14\end{array}$ & $\left.\begin{array}{l}(1.0) \\
(1.0)\end{array}\right]$ & $\begin{array}{l}3 \\
6\end{array}$ & $\begin{array}{l}(0.5) \\
(0.6)\end{array}$ & $\begin{array}{r}9 \\
26\end{array}$ & $\begin{array}{l}(1.2) \\
(1.8)\end{array}$ \\
\hline 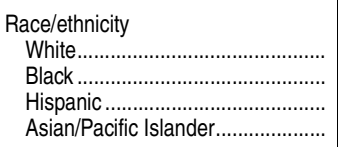 & $\begin{array}{l}161 \\
130 \\
129 \\
159\end{array}$ & $\begin{array}{l}(1.3) \\
(2.0) \\
(1.9) \\
(4.7)\end{array}$ & $\begin{array}{l}160 \\
129 \\
134 \\
156\end{array}$ & $\begin{array}{l}(1.2) \\
(2.4) \\
(1.9) \\
(4.2)\end{array}$ & $\begin{array}{l}55 \\
43 \\
46 \\
54\end{array}$ & $\begin{array}{l}(0.5) \\
(1.5) \\
(1.1) \\
(2.0)\end{array}$ & $\begin{array}{r}6 \\
10 \\
14 \\
7\end{array}$ & $\begin{array}{l}(2.5) \\
(2.9) \\
(4.3) \\
(4.1)\end{array}$ & $\begin{array}{l}8 \\
8 \\
6 \\
8\end{array}$ & $\begin{array}{l}(2.5) \\
(4.5) \\
(2.3) \\
(3.4)\end{array}$ & $\begin{array}{l}29 \\
26 \\
21 \\
25\end{array}$ & $\begin{array}{l}(4.0) \\
(5.5) \\
(4.1) \\
(6.6)\end{array}$ & $\begin{array}{l}57 \\
56 \\
59 \\
60\end{array}$ & $\left.\begin{array}{l}(3.6) \\
(7.0) \\
(4.5) \\
(8.7)\end{array}\right]$ & $\begin{array}{r}11 \\
18 \\
17 \\
5\end{array}$ & $\left.\begin{array}{l}(2.6) \\
(4.9) \\
(4.5) \\
(2.5)\end{array}\right]$ & $\begin{array}{r}11 \\
10 \\
5 \\
11\end{array}$ & $\begin{array}{l}(3.4) \\
(4.9) \\
(2.0) \\
(4.6)\end{array}$ & $\begin{array}{l}34 \\
24 \\
23 \\
29\end{array}$ & $\begin{array}{l}(4.4) \\
(4.5) \\
(4.7) \\
(6.0)\end{array}$ & $\begin{array}{l}44 \\
49 \\
56 \\
54\end{array}$ & $\begin{array}{l}(4.6) \\
(5.7) \\
(6.0) \\
(8.4)\end{array}$ & $\begin{array}{r}19 \\
13 \\
8 \\
21\end{array}$ & $\left.\begin{array}{l}(1.2) \\
(1.2) \\
(1.2) \\
(3.5)\end{array}\right]$ & $\begin{array}{l}5 \\
4 \\
3 \\
6\end{array}$ & $\begin{array}{l}(0.6) \\
(2.1)\end{array}$ & $\begin{array}{l}19 \\
21 \\
10 \\
16\end{array}$ & $\begin{array}{l}(1.6) \\
(1.9) \\
(1.6) \\
(2.9)\end{array}$ \\
\hline Free or rec & & & & & & & & & & & & & & & & & & & & & & & & & & & & \\
\hline $\begin{array}{l}\text { Eligible } \\
\text { Not eliai }\end{array}$ & $\begin{array}{l}132 \\
161\end{array}$ & $\begin{array}{l}(1.3) \\
(1.4)\end{array}$ & $\begin{array}{l}132 \\
161\end{array}$ & $\begin{array}{l}(1.4) \\
(1.2)\end{array} \mid$ & $\begin{array}{l}46 \\
55\end{array}$ & $\begin{array}{l}(1.0) \\
(0.6)\end{array}$ & $\begin{array}{r}10 \\
8\end{array}$ & $\begin{array}{l}(2.1) \\
(2.6)\end{array}$ & $\begin{array}{l}6 \\
8\end{array}$ & $\begin{array}{l}(2.1) \\
(2.6)\end{array}$ & $\begin{array}{l}26 \\
26\end{array}$ & $\begin{array}{l}(3.4) \\
(4.0)\end{array}$ & $\begin{array}{l}58 \\
59\end{array}$ & $(3.9)$ & $\begin{array}{l}18 \\
10\end{array}$ & (3.4) & $\begin{array}{r}9 \\
10\end{array}$ & $\begin{array}{l}(3.2) \\
(3.2)\end{array}$ & $\begin{array}{l}26 \\
30\end{array}$ & (3.7) & 47 & $(4.7)$ & $\begin{array}{l}12 \\
19\end{array}$ & (1.2) & 3 & (0.6) & 15 & (1.4) \\
\hline Unknown & 156 & (5.6) & 156 & $\begin{array}{l}(1.2) \\
(5.9)\end{array}$ & 57 & (2.6) & 4 & (2.0) & 19 & $\begin{array}{l}(2.0) \\
(8.7)\end{array}$ & $\begin{array}{l}20 \\
54\end{array}$ & (11.5) & 23 & (10.5) & 16 & $\begin{array}{r}(2.4) \\
(10.3)\end{array}$ & $\begin{array}{l}10 \\
13\end{array}$ & $\begin{array}{l}(3.2) \\
(8.4)\end{array}$ & $\begin{array}{l}30 \\
47\end{array}$ & (13.6) & $\begin{array}{l}50 \\
24\end{array}$ & $\begin{array}{r}(4.6) \\
(10.6)\end{array}$ & $\begin{array}{l}19 \\
14\end{array}$ & $\begin{array}{l}(1.0) \\
(6.3)\end{array}$ & 5 & (2.3) & $\begin{array}{l}19 \\
13\end{array}$ & $\begin{array}{l}(1.6) \\
(2.0)\end{array}$ \\
\hline Control of school & & & & & & & & & & & & & & & & & & & & & & & & & & & & \\
\hline Public. & 149 & (1.3) & 149 & (1.2) & 51 & $(0.7)$ & 8 & (2.1) & 7 & (2.1) & 24 & (3.2) & 61 & (3.5) & 13 & $(2.4$ & 10 & 7) & 26 & $(3.5$ & 51 & $(4$. & 17 & $(0$. & 5 & $(0.5)$ & 18 & (1.3) \\
\hline Private.. & 163 & $(2.8)$ & 159 & (5.2) & 60 & (1.3) & 10 & (6.0) & 15 & (6.9) & 71 & (8.8) & 3 & $(\mathrm{t})$ & 17 & (8.2) & 10 & (6.1) & 70 & (10.2) & 3 & $(0.9)$ & 9 & (1.9) & 1 & $(0.4)$ & 13 & (2.1) \\
\hline $\begin{array}{l}\text { School location } \\
\text { City }\end{array}$ & & & & & & & & & & & & & & & & & & & & & & & & & & & & \\
\hline urba & 155 & (1.9) & 155 & $(1$ & 54 & 10 & 3 & $\begin{array}{l}(4.2) \\
(2.2)\end{array}$ & 7 & $\begin{array}{l}(3.8) \\
(3.5)\end{array}$ & $\begin{array}{l}24 \\
32\end{array}$ & (5.6) & 57 & $\begin{array}{l}5 \\
(6\end{array}$ & 10 & (3.1) & 10 & (4.6) & $\begin{array}{l}24 \\
33\end{array}$ & $\begin{array}{l}(4.9) \\
(6.4)\end{array}$ & 46 & $\begin{array}{l}10 \\
6\end{array}$ & $\begin{array}{l}14 \\
14\end{array}$ & $\left(\begin{array}{l}1.0) \\
(1.5)\end{array}\right.$ & $\begin{array}{l}4 \\
6\end{array}$ & $\left.\begin{array}{l}(0.6) \\
(1.0)\end{array}\right]$ & $\begin{array}{l}13 \\
16\end{array}$ & $\begin{array}{l}(1.3) \\
(1.6)\end{array}$ \\
\hline & 156 & (3.5) & 149 & (2.8) & 50 & (1.2) & 4 & $(1.0)$ & \# & $(t)$ & 18 & (9.0) & 78 & (9.0) & 16 & (8.4) & $\#$ & $(t)$ & 23 & (9.2) & 60 & (10.5 & 23 & (3.0) & 4 & (1.3) & 23 & (3.4) \\
\hline Rural. & 150 & (2.6) & 151 & (3.0) & 52 & $(1.5)$ & 13 & $(5.0)$ & 8 & $(4.8)$ & 29 & (5.7) & 50 & $(7.7)$ & 20 & $(7.3)$ & 17 & (6.8) & 35 & (7.8) & 28 & $(6.7)$ & 18 & $(2.5)$ & 3 & $(1.0)$ & 21 & (3.4) \\
\hline Region & & & & & & & & & & & & & & & & & & & & & & & & & & & & \\
\hline Northea & 154 & (3.1) & 160 & (2.3) & 52 & $(0.9)$ & 10 & (5.3) & 13 & (5.8) & 40 & (9.0) & 37 & (8.6) & 5 & (3.3) & 5 & $(\dagger)$ & 50 & (6.2) & 39 & (9.3) & 16 & (2.7) & 6 & $(0.9)$ & 17 & (2.6) \\
\hline Midwe & 158 & (2.9) & 155 & $(2.3$ & 53 & $(1$ & 12 & 6. & $\#$ & 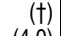 & 25 & (7.2) & 63 & $(5$. & 9 & (2. & 15 & (7.7) & 26 & (6.7) & 50 & & 22 & & 6 & & 24 & (1) \\
\hline & 147 & $(1.9)$ & 147 & $(2.2$ & 51 & $(1.0$ & 6 & $(1.8)$ & 10 & $(4.0)$ & 25 & (3.9) & 59 & $(5$. & 19 & $(5.3$ & 9 & (3.8) & 26 & (5.0) & 46 & & 16 & (1. & & & 16 & (v) \\
\hline West.... & 144 & (2.0) & 143 & $(2.1)$ & 51 & $(1.1)$ & 8 & (3.7) & 8 & (3.5) & 24 & (6.9) & 60 & $(5.4)$ & 15 & $(4.9)$ & 9 & $(4.0)$ & 25 & (9.0) & 51 & (8.2) & 9 & $(1.2)$ & 3 & $(0.6)$ & 12 & (1.7) \\
\hline Frequen & & & & & & & & & & & & & & & & & & & & & & & & & & & & \\
\hline & 139 & $(6.3)$ & 138 & (4.2) & - & (t) & $\dagger$ & (t) & $\dagger$ & (†) & $\dagger$ & (t) & $\dagger$ & (†) & $\dagger$ & $(t)$ & $\dagger$ & $(\dagger)$ & $\dagger$ & (†) & $\dagger$ & $(\dagger$ & 17 & $(4.0)$ & 4 & (1.5) & 11 & (2.1) \\
\hline Le & 149 & (6.4) & 154 & (5.3) & - & (t) & $t$ & $(t)$ & $\dagger$ & (t) & $\dagger$ & (t) & $\dagger$ & $(t)$ & $\dagger$ & it & $\dagger$ & $(t)$ & $\dagger$ & (I) & $\dagger$ & & 11 & & 4 & (1 & 10 & 0) \\
\hline & 152 & $(2.8)$ & 154 & (2.) & - & (†) & $\dagger$ & (†) & $\dagger$ & (t) & $\dagger$ & (†) & $\dagger$ & (I) & $\dagger$ & (†) & $\dagger$ & (†) & $\dagger$ & (t) & $\dagger$ & 11 & 12 & (1. & 3 & $(0.8)$ & 17 & (2.2) \\
\hline At least 3 or 4 times a week.......... & 149 & $(1.8)$ & 149 & (1.8) & - & $(\dagger)$ & $\dagger$ & $(\dagger)$ & $\dagger$ & $(\dagger)$ & $\dagger$ & $(+)$ & $\dagger$ & $(\dagger)$ & $t$ & $(t)$ & $\dagger$ & $(+)$ & $\dagger$ & $(\dagger)$ & $\dagger$ & $(\dagger)$ & 17 & (1.4) & 5 & $(0.7)$ & 20 & (1.6) \\
\hline
\end{tabular}

\section{-Not available.}

†Not applicable.

Students were asked to analyze and describe aspects of music they heard, critique instrumental and vocal performances, and demonstrate their knowledge of standard musical notation and music's role in society.

'The visual arts assessment measured students' ability to respond to and create visual arts. Responding questions asked students
NOTE: Excludes students unable to be tested due to limited proficiency in English or due to a disability (if the accommodations provided were not sufficient to enable the test to properly reflect the students' music or visual arts proficiency). Detail may not sum to totals because of rounding.
racial/ethnic groups not shown separately.

SOURCE: U.S. Department of Education, National Center for Education Statistics, National Assessment of Educational Progress (NAEP), 2008 Arts Assessment, retrieved June 30, 2009, from the Main NAEP Data Explorer (http://nces.ed.gov/ 
Table 224.20. Average National Assessment of Educational Progress (NAEP) civics scale score and percentage of students attaining civics achievement levels, by grade level and selected student characteristics: 1998, 2006, and 2010

[Standard errors appear in parentheses]

\begin{tabular}{|c|c|c|c|c|c|c|c|c|c|c|c|c|c|c|c|c|c|c|}
\hline \multirow[b]{3}{*}{ Selected student characteristic } & & & & & & & \multicolumn{12}{|c|}{ Percent of students attaining achievement levels } \\
\hline & \multicolumn{6}{|c|}{ Average scale score ${ }^{1}$} & \multicolumn{4}{|c|}{ At or above Basic $^{2}$} & \multicolumn{4}{|c|}{ At or above Proficient ${ }^{3}$} & \multicolumn{4}{|c|}{ At Advanced $^{4}$} \\
\hline & & 1998 & & 2006 & & 2010 & & 1998 & & 2010 & & 1998 & & 2010 & & 1998 & & 2010 \\
\hline 1 & & 2 & & 3 & & 4 & & 5 & & 6 & & 7 & & 8 & & 9 & & 10 \\
\hline 4th-graders $\ldots \ldots \ldots \ldots \ldots \ldots \ldots \ldots \ldots \ldots \ldots$ & 150 & $(0.7)$ & 154 & $(1.0)$ & 157 & $(0.8)$ & 69 & $(1.0)$ & 77 & $(1.0)$ & 23 & $(0.9)$ & 27 & $(0.9)$ & 2 & (0.3) & 2 & $(0.2)$ \\
\hline 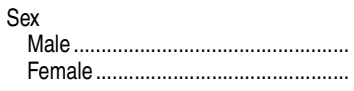 & $\begin{array}{l}149 \\
151\end{array}$ & $\begin{array}{l}(1.0) \\
(0.9)\end{array}$ & $\begin{array}{l}153 \\
155\end{array}$ & $\begin{array}{l}(1.1) \\
(1.1)\end{array}$ & $\begin{array}{l}153 \\
160\end{array}$ & $\begin{array}{l}(1.0) \\
(0.8)\end{array}$ & $\begin{array}{l}68 \\
70\end{array}$ & $\begin{array}{l}(1.2) \\
(1.0)\end{array}$ & $\begin{array}{l}73 \\
81\end{array}$ & $\begin{array}{l}(1.3) \\
(1.0)\end{array}$ & $\begin{array}{l}22 \\
23\end{array}$ & $\begin{array}{l}(1.2) \\
(1.2)\end{array}$ & $\begin{array}{l}24 \\
30\end{array}$ & $\begin{array}{l}(1.0) \\
(1.2)\end{array}$ & $\begin{array}{l}2 \\
1\end{array}$ & $\begin{array}{l}(0.4) \\
(0.4)\end{array}$ & $\begin{array}{l}1 \\
2\end{array}$ & $\begin{array}{l}(0.3) \\
(0.3)\end{array}$ \\
\hline 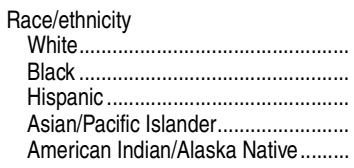 & $\begin{array}{r}158 \\
130 \\
123 \\
147 \\
\ddagger\end{array}$ & $\begin{array}{r}(0.9) \\
(1.1) \\
(2.2) \\
(4.0) \\
(\dagger)\end{array}$ & $\begin{array}{l}164 \\
140 \\
138 \\
154 \\
124\end{array}$ & $\begin{array}{l}(0.9) \\
(1.5) \\
(1.3) \\
(3.8) \\
(7.6)\end{array}$ & $\begin{array}{l}167 \\
143 \\
140 \\
164 \\
143\end{array}$ & $\begin{array}{l}(0.8) \\
(1.2) \\
(1.6) \\
(2.0) \\
(7.0)\end{array}$ & $\begin{array}{r}78 \\
45 \\
40 \\
66 \\
\ddagger\end{array}$ & $\begin{array}{r}(1.3) \\
(1.7) \\
(2.8) \\
(5.5) \\
(\dagger)\end{array}$ & $\begin{array}{l}87 \\
62 \\
58 \\
82 \\
63\end{array}$ & $\begin{array}{r}(0.9) \\
(2.2) \\
(2.3) \\
(2.3) \\
(10.9)\end{array}$ & $\begin{array}{r}29 \\
7 \\
6 \\
20 \\
\ddagger\end{array}$ & $\begin{array}{r}(1.2) \\
(1.1) \\
(1.1) \\
(3.5) \\
(\dagger)\end{array}$ & $\begin{array}{l}37 \\
12 \\
10 \\
37 \\
12\end{array}$ & $\begin{array}{l}(1.3) \\
(1.1) \\
(1.2) \\
(4.4) \\
(7.4)\end{array}$ & $\begin{array}{l}2 \\
1 \\
\# \\
2 \\
\ddagger\end{array}$ & $\begin{array}{r}(0.4) \\
(0.3) \\
(\dagger) \\
(0.9) \\
(\dagger)\end{array}$ & $\begin{array}{l}2 \\
\# \\
\# \\
3 \\
\#\end{array}$ & $\begin{array}{r}(0.3) \\
(\dagger) \\
(\dagger) \\
(1.4) \\
(\dagger)\end{array}$ \\
\hline 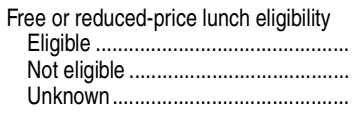 & $\begin{array}{l}132 \\
160 \\
154 \\
\end{array}$ & $\begin{array}{l}(0.9) \\
(1.1) \\
(2.2) \\
\end{array}$ & $\begin{array}{l}139 \\
166 \\
167 \\
\end{array}$ & $\begin{array}{l}(1.1) \\
(0.8) \\
(2.1) \\
\end{array}$ & $\begin{array}{l}143 \\
169 \\
171 \\
\end{array}$ & $\begin{array}{l}(0.9) \\
(0.8) \\
(2.7) \\
\end{array}$ & $\begin{array}{l}49 \\
80 \\
72 \\
\end{array}$ & $\begin{array}{l}(1.3) \\
(1.4) \\
(3.1) \\
\end{array}$ & $\begin{array}{l}62 \\
90 \\
89 \\
\end{array}$ & $\begin{array}{l}(1.3) \\
(0.9) \\
(2.9) \\
\end{array}$ & $\begin{array}{r}9 \\
30 \\
27 \\
\end{array}$ & $\begin{array}{l}(0.9) \\
(1.3) \\
(2.5) \\
\end{array}$ & $\begin{array}{l}11 \\
40 \\
44 \\
\end{array}$ & $\begin{array}{l}(0.9) \\
(1.4) \\
(3.4) \\
\end{array}$ & $\begin{array}{l}\# \\
2 \\
2 \\
\end{array}$ & $\begin{array}{r}(\dagger) \\
(0.5) \\
(0.9) \\
\end{array}$ & $\begin{array}{l}\# \\
3 \\
5 \\
\end{array}$ & $\begin{array}{r}(\dagger) \\
(0.4) \\
(1.4) \\
\end{array}$ \\
\hline 8th-graders & 150 & $(0.7)$ & 150 & $(0.8)$ & 151 & $(0.8)$ & 70 & $(0.9)$ & 72 & $(1.0)$ & 22 & $(0.8)$ & 22 & $(0.8)$ & 2 & $(0.2)$ & 1 & $(0.1)$ \\
\hline 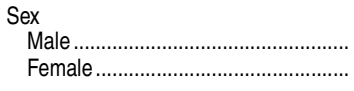 & $\begin{array}{l}148 \\
152\end{array}$ & $\begin{array}{l}(0.9) \\
(0.8)\end{array}$ & $\begin{array}{l}149 \\
151\end{array}$ & $\begin{array}{l}(1.0) \\
(0.8)\end{array}$ & $\begin{array}{l}150 \\
152\end{array}$ & $\begin{array}{l}(0.9) \\
(0.8)\end{array}$ & $\begin{array}{l}67 \\
73\end{array}$ & $\begin{array}{l}(1.1) \\
(1.2)\end{array}$ & $\begin{array}{l}70 \\
74\end{array}$ & $\begin{array}{l}(1.1) \\
(1.1)\end{array}$ & $\begin{array}{l}22 \\
22\end{array}$ & $\begin{array}{l}(1.0) \\
(1.1)\end{array}$ & $\begin{array}{l}22 \\
22\end{array}$ & $\begin{array}{l}(0.9) \\
(0.9)\end{array}$ & $\begin{array}{l}2 \\
1\end{array}$ & $\begin{array}{l}(0.3) \\
(0.3)\end{array}$ & $\begin{array}{l}1 \\
1\end{array}$ & $\begin{array}{l}(0.2) \\
(0.2)\end{array}$ \\
\hline 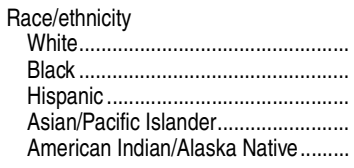 & $\begin{array}{r}158 \\
131 \\
127 \\
151 \\
\ddagger\end{array}$ & $\begin{array}{r}(0.9) \\
(1.2) \\
(1.3) \\
(8.9) \\
(\dagger)\end{array}$ & $\begin{array}{l}161 \\
133 \\
131 \\
154 \\
127\end{array}$ & $\begin{array}{l}(0.8) \\
(1.5) \\
(1.1) \\
(3.2) \\
(7.3)\end{array}$ & $\begin{array}{l}160 \\
135 \\
137 \\
158 \\
136\end{array}$ & $\begin{array}{r}(0.8) \\
(1.6) \\
(1.1) \\
(2.5) \\
(12.6)\end{array}$ & $\begin{array}{r}78 \\
49 \\
44 \\
69 \\
\ddagger\end{array}$ & $\begin{array}{r}(1.1) \\
(1.7) \\
(2.3) \\
(9.5) \\
(\dagger)\end{array}$ & $\begin{array}{l}82 \\
53 \\
56 \\
78 \\
56\end{array}$ & $\begin{array}{r}(1.0) \\
(2.3) \\
(1.4) \\
(2.5) \\
(18.0)\end{array}$ & $\begin{array}{r}28 \\
7 \\
7 \\
25 \\
\ddagger\end{array}$ & $\begin{array}{r}(1.0) \\
(1.0) \\
(1.0) \\
(5.8) \\
(\dagger)\end{array}$ & $\begin{array}{r}29 \\
9 \\
11 \\
30 \\
11\end{array}$ & $\begin{array}{l}(1.0) \\
(1.1) \\
(0.9) \\
(3.1) \\
(6.0)\end{array}$ & $\begin{array}{l}2 \\
\# \\
\# \\
3 \\
\ddagger\end{array}$ & $\begin{array}{r}(0.3) \\
(t) \\
(t) \\
(1.3) \\
(t)\end{array}$ & $\begin{array}{l}2 \\
\# \\
\# \\
2 \\
1\end{array}$ & $\begin{array}{r}(0.2) \\
(\dagger) \\
(\dagger) \\
(0.8) \\
(\dagger)\end{array}$ \\
\hline 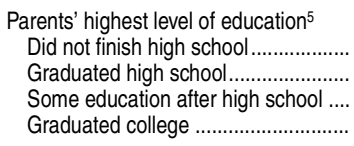 & $\begin{array}{l}123 \\
144 \\
143 \\
160\end{array}$ & $\begin{array}{l}(3.2) \\
(1.2) \\
(1.0) \\
(0.8)\end{array}$ & $\begin{array}{l}129 \\
140 \\
153 \\
162\end{array}$ & $\begin{array}{l}(1.6) \\
(1.3) \\
(1.0) \\
(0.9)\end{array}$ & $\begin{array}{l}134 \\
139 \\
155 \\
162\end{array}$ & $\begin{array}{l}(1.3) \\
(1.1) \\
(1.1) \\
(0.8)\end{array}$ & $\begin{array}{l}40 \\
65 \\
64 \\
80\end{array}$ & $\begin{array}{l}(3.8) \\
(2.0) \\
(1.5) \\
(1.0)\end{array}$ & $\begin{array}{l}52 \\
60 \\
78 \\
83\end{array}$ & $\begin{array}{l}(2.1) \\
(1.8) \\
(1.5) \\
(1.0)\end{array}$ & $\begin{array}{r}4 \\
14 \\
15 \\
32\end{array}$ & $\begin{array}{l}(1.2) \\
(1.4) \\
(1.2) \\
(1.2)\end{array}$ & $\begin{array}{r}6 \\
10 \\
22 \\
32\end{array}$ & $\begin{array}{l}(1.2) \\
(0.7) \\
(1.3) \\
(1.2)\end{array}$ & $\begin{array}{l}\# \\
\# \\
1 \\
3\end{array}$ & $\begin{array}{r}(\dagger) \\
(\dagger) \\
(0.2) \\
(0.4)\end{array}$ & $\begin{array}{l}\# \\
\# \\
1 \\
2\end{array}$ & $\begin{array}{r}(\dagger) \\
(\dagger) \\
(0.4) \\
(0.3)\end{array}$ \\
\hline 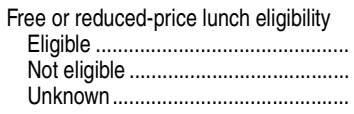 & $\begin{array}{l}131 \\
157 \\
156 \\
\end{array}$ & $\begin{array}{l}(1.1) \\
(1.0) \\
(2.2)\end{array}$ & $\begin{array}{l}132 \\
160 \\
171\end{array}$ & $\begin{array}{l}(1.0) \\
(0.8) \\
(2.4)\end{array}$ & $\begin{array}{l}136 \\
163 \\
166 \\
\end{array}$ & $\begin{array}{l}(0.9) \\
(0.7) \\
(2.3) \\
\end{array}$ & $\begin{array}{l}48 \\
78 \\
76 \\
\end{array}$ & $\begin{array}{l}(1.6) \\
(1.2) \\
(2.7)\end{array}$ & $\begin{array}{l}54 \\
85 \\
88 \\
\end{array}$ & $\begin{array}{l}(1.4) \\
(0.8) \\
(2.5)\end{array}$ & $\begin{array}{r}8 \\
27 \\
29 \\
\end{array}$ & $\begin{array}{l}(0.8) \\
(1.2) \\
(2.1)\end{array}$ & $\begin{array}{r}9 \\
31 \\
35 \\
\end{array}$ & $\begin{array}{l}(0.6) \\
(1.0) \\
(3.5)\end{array}$ & $\begin{array}{l}\# \\
2 \\
3 \\
\end{array}$ & $\begin{array}{l}(0.2) \\
(0.3) \\
(0.6) \\
\end{array}$ & $\begin{array}{l}\# \\
2 \\
3 \\
\end{array}$ & $\begin{array}{r}(\dagger) \\
(0.3) \\
(0.9) \\
\end{array}$ \\
\hline 12th-graders & 150 & $(0.8)$ & 151 & $(0.9)$ & 148 & $(0.8)$ & 65 & $(0.9)$ & 64 & $(1.0)$ & 26 & $(0.9)$ & 24 & $(0.9)$ & 4 & $(0.4)$ & 4 & $(0.3)$ \\
\hline $\begin{array}{l}\text { Sex } \\
\text { Male } \\
\text { Female }\end{array}$ & $\begin{array}{l}148 \\
152\end{array}$ & $\begin{array}{l}(1.1) \\
(0.8)\end{array}$ & $\begin{array}{l}150 \\
152\end{array}$ & $\begin{array}{l}(1.1) \\
(1.0)\end{array}$ & $\begin{array}{l}148 \\
148\end{array}$ & $\begin{array}{l}(0.9) \\
(0.9)\end{array}$ & $\begin{array}{l}62 \\
68\end{array}$ & $\begin{array}{l}(1.2) \\
(1.2)\end{array}$ & $\begin{array}{l}63 \\
64\end{array}$ & $\begin{array}{l}(1.0) \\
(1.3)\end{array}$ & $\begin{array}{l}27 \\
26\end{array}$ & $\begin{array}{l}(1.2) \\
(1.1)\end{array}$ & $\begin{array}{l}25 \\
22\end{array}$ & $\begin{array}{l}(0.9) \\
(1.1)\end{array}$ & $\begin{array}{l}5 \\
3\end{array}$ & $\begin{array}{l}(0.6) \\
(0.4)\end{array}$ & $\begin{array}{l}5 \\
3\end{array}$ & $\begin{array}{l}(0.5) \\
(0.4)\end{array}$ \\
\hline 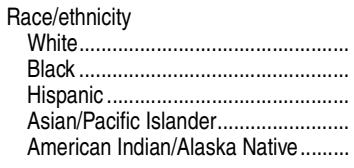 & $\begin{array}{r}157 \\
130 \\
132 \\
149 \\
\ddagger\end{array}$ & $\begin{array}{r}(1.0) \\
(1.6) \\
(1.1) \\
(5.2) \\
(\dagger)\end{array}$ & $\begin{array}{l}158 \\
131 \\
134 \\
155 \\
131\end{array}$ & $\begin{array}{l}(1.0) \\
(1.4) \\
(1.1) \\
(3.1) \\
(3.5)\end{array}$ & $\begin{array}{l}156 \\
127 \\
137 \\
153 \\
134\end{array}$ & $\begin{array}{r}(0.9) \\
(1.6) \\
(1.4) \\
(2.6) \\
(14.6)\end{array}$ & $\begin{array}{r}73 \\
41 \\
45 \\
63 \\
\ddagger\end{array}$ & $\begin{array}{r}(1.1) \\
(2.0) \\
(1.9) \\
(4.8) \\
(\dagger)\end{array}$ & $\begin{array}{l}73 \\
38 \\
50 \\
70 \\
47\end{array}$ & $\begin{array}{r}(1.0) \\
(1.9) \\
(1.8) \\
(3.1) \\
(17.3)\end{array}$ & $\begin{array}{r}32 \\
9 \\
10 \\
27 \\
\ddagger\end{array}$ & $\begin{array}{r}(1.3) \\
(1.3) \\
(1.2) \\
(6.6) \\
(\dagger)\end{array}$ & $\begin{array}{r}30 \\
8 \\
13 \\
29 \\
16\end{array}$ & $\begin{array}{l}(1.1) \\
(0.9) \\
(1.4) \\
(2.8) \\
(9.0)\end{array}$ & $\begin{array}{l}5 \\
1 \\
1 \\
5 \\
\ddagger\end{array}$ & $\begin{array}{r}(0.6) \\
(0.3) \\
(0.3) \\
(2.3) \\
(\dagger)\end{array}$ & $\begin{array}{l}5 \\
1 \\
2 \\
5 \\
1\end{array}$ & $\begin{array}{r}(0.4) \\
(0.2) \\
(0.4) \\
(1.4) \\
(\dagger)\end{array}$ \\
\hline 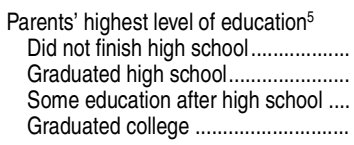 & $\begin{array}{l}124 \\
140 \\
145 \\
160\end{array}$ & $\begin{array}{l}(2.1) \\
(1.2) \\
(1.1) \\
(0.9)\end{array}$ & $\begin{array}{l}126 \\
138 \\
150 \\
162\end{array}$ & $\begin{array}{l}(1.8) \\
(1.0) \\
(0.9) \\
(1.1)\end{array}$ & $\begin{array}{l}128 \\
137 \\
147 \\
158\end{array}$ & $\begin{array}{l}(1.4) \\
(1.2) \\
(1.1) \\
(0.9)\end{array}$ & $\begin{array}{l}38 \\
54 \\
60 \\
75\end{array}$ & $\begin{array}{l}(2.6) \\
(1.8) \\
(1.3) \\
(1.0)\end{array}$ & $\begin{array}{l}40 \\
51 \\
63 \\
75\end{array}$ & $\begin{array}{l}(2.3) \\
(1.7) \\
(1.5) \\
(1.0)\end{array}$ & $\begin{array}{r}6 \\
14 \\
20 \\
36\end{array}$ & $\begin{array}{l}(1.6) \\
(1.4) \\
(1.4) \\
(1.3)\end{array}$ & $\begin{array}{r}8 \\
13 \\
20 \\
33\end{array}$ & $\begin{array}{l}(1.2) \\
(1.1) \\
(1.4) \\
(1.2)\end{array}$ & $\begin{array}{l}\# \\
\# \\
2 \\
7\end{array}$ & $\begin{array}{r}(\dagger) \\
(\dagger) \\
(0.4) \\
(0.8)\end{array}$ & $\begin{array}{l}\# \\
1 \\
3 \\
6\end{array}$ & $\begin{array}{r}(\dagger) \\
(0.4) \\
(0.6) \\
(0.5)\end{array}$ \\
\hline 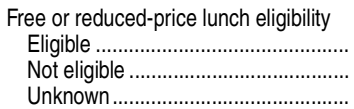 & $\begin{array}{l}130 \\
153 \\
153\end{array}$ & $\begin{array}{l}(1.4) \\
(1.0) \\
(1.3)\end{array}$ & $\begin{array}{l}133 \\
156 \\
160\end{array}$ & $\begin{array}{l}(1.0) \\
(1.0) \\
(2.4)\end{array}$ & $\begin{array}{l}132 \\
155 \\
159\end{array}$ & $\begin{array}{l}(1.0) \\
(0.9) \\
(3.3)\end{array}$ & $\begin{array}{l}42 \\
69 \\
68\end{array}$ & $\begin{array}{l}(2.1) \\
(1.1) \\
(1.6)\end{array}$ & $\begin{array}{l}44 \\
72 \\
75\end{array}$ & $\begin{array}{l}(1.4) \\
(1.0) \\
(3.3)\end{array}$ & $\begin{array}{l}10 \\
29 \\
29\end{array}$ & $\begin{array}{l}(1.7) \\
(1.3) \\
(1.5)\end{array}$ & $\begin{array}{l}11 \\
29 \\
35\end{array}$ & $\begin{array}{l}(0.8) \\
(1.2) \\
(3.7)\end{array}$ & $\begin{array}{l}1 \\
5 \\
5\end{array}$ & $\begin{array}{l}(0.4) \\
(0.5) \\
(0.7)\end{array}$ & $\begin{array}{l}1 \\
5 \\
7\end{array}$ & $\begin{array}{l}(0.2) \\
(0.4) \\
(1.6)\end{array}$ \\
\hline
\end{tabular}

†Not applicable.

\#Rounds to zero.

†Reporting standards not met (too few cases for a reliable estimate)

'Scale ranges from 0 to 300 for all three grades, but scores cannot be compared across grades. For example, the average score of 167 for White 4th-graders in 2010 does not denote higher performance than the score of 160 for White 8th-graders.

${ }^{2}$ Basic denotes partial mastery of the knowledge and skills that are fundamental for proficient work at a given grade.

${ }^{3}$ Proficient represents solid academic performance. Students reaching this level have demonstrated competency over challenging subject matter.

${ }^{4}$ Advanced signifies superior performance for a given grade.
5These data are based on students' responses to questions about their parents' education level. Because the wording of the questions was different in 1998 than in the later assesssment years, data from 1998 are not directly comparable to data from 2006 and 2010. NOTE: Includes students tested with accommodations (1 to 13 percent of all students, depending on grade level and year); excludes only those students with disabilities and English language learners who were unable to be tested even with accommodations ( 1 to 5 percent of all students). Race categories exclude persons of Hispanic ethnicity.

SOURCE: U.S. Department of Education, National Center for Education Statistics, National Assessment of Educational Progress (NAEP), 1998, 2006, and 2010 Civics Assessments, retrieved May 25, 2011, from the Main NAEP Data Explorer (http://nces.ed.gov/nations reportcard/naepdata/). (This table was prepared May 2011.) 
Table 224.30. Average National Assessment of Educational Progress (NAEP) economics scale score of 12th-graders, percentage attaining economics achievement levels, and percentage with different levels of economics coursework, by selected characteristics: 2006 and 2012

[Standard errors appear in parentheses]

\begin{tabular}{|c|c|c|c|c|c|c|c|c|c|c|c|c|c|c|c|c|c|c|}
\hline \multirow[b]{2}{*}{ Selected characteristic } & \multirow{2}{*}{\multicolumn{2}{|c|}{$\begin{array}{r}\text { Average } \\
\text { scale score }^{1}\end{array}$}} & \multicolumn{6}{|c|}{ Percent of students attaining achievement levels } & \multicolumn{10}{|c|}{ Percentage distribution of students by highest level of economics coursework taken } \\
\hline & & & \multicolumn{2}{|c|}{$\begin{array}{r}\text { At or above } \\
\text { Basic }^{2}\end{array}$} & \multicolumn{2}{|c|}{$\begin{array}{r}\text { At or above } \\
\text { Proficient }^{3}\end{array}$} & \multicolumn{2}{|c|}{ At Advanced ${ }^{4}$} & \multicolumn{2}{|c|}{$\begin{array}{r}\text { No economics } \\
\text { courses }\end{array}$} & \multicolumn{2}{|c|}{$\begin{array}{r}\text { Combined } \\
\text { course }\end{array}$} & \multicolumn{2}{|c|}{$\begin{array}{r}\text { Consumer } \\
\text { economics/ } \\
\text { business }\end{array}$} & \multicolumn{2}{|c|}{$\begin{array}{r}\text { General } \\
\text { economics }\end{array}$} & \multicolumn{2}{|c|}{$\begin{array}{r}\text { Advanced } \\
\text { economics }\end{array}$} \\
\hline 1 & & 2 & & 3 & & 4 & & 5 & & 6 & & 7 & & 8 & & 9 & & 10 \\
\hline $\begin{array}{l}2006 \\
\quad \text { All students ........... }\end{array}$ & 150 & (0.9) & 79 & $(0.8)$ & 42 & (1.1) & 3 & (0.3) & 13 & (0.9) & 12 & (0.7) & 11 & $(0.7)$ & 49 & (1.4) & 16 & (0.7) \\
\hline 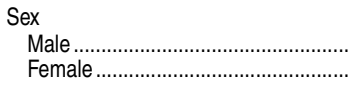 & $\begin{array}{l}152 \\
148\end{array}$ & $\begin{array}{l}(1.0) \\
(0.9)\end{array}$ & $\begin{array}{l}79 \\
79\end{array}$ & $\begin{array}{l}(0.8) \\
(0.9)\end{array}$ & $\begin{array}{l}45 \\
38\end{array}$ & $\begin{array}{l}(1.3) \\
(1.3)\end{array}$ & $\begin{array}{l}4 \\
2\end{array}$ & $\begin{array}{l}(0.5) \\
(0.3)\end{array}$ & $\begin{array}{l}13 \\
12\end{array}$ & $\begin{array}{l}(1.0) \\
(0.9)\end{array}$ & $\begin{array}{l}10 \\
13\end{array}$ & $\begin{array}{l}(0.6) \\
(0.9)\end{array}$ & $\begin{array}{l}10 \\
11\end{array}$ & $\begin{array}{l}(0.7) \\
(0.8)\end{array}$ & $\begin{array}{l}50 \\
48\end{array}$ & $\begin{array}{l}(1.4) \\
(1.6)\end{array}$ & $\begin{array}{l}16 \\
15\end{array}$ & $\begin{array}{l}(0.8) \\
(0.8)\end{array}$ \\
\hline 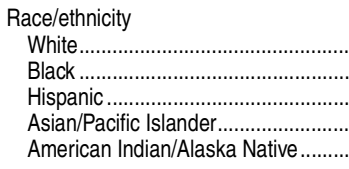 & $\begin{array}{l}158 \\
127 \\
133 \\
153 \\
137\end{array}$ & $\begin{array}{l}(0.8) \\
(1.2) \\
(1.2) \\
(3.5) \\
(4.1)\end{array}$ & $\begin{array}{l}87 \\
57 \\
64 \\
80 \\
72\end{array}$ & $\begin{array}{l}(0.7) \\
(1.9) \\
(1.6) \\
(4.0) \\
(5.6)\end{array}$ & $\begin{array}{l}51 \\
16 \\
21 \\
44 \\
26\end{array}$ & $\begin{array}{l}(1.2) \\
(1.3) \\
(1.2) \\
(4.5) \\
(4.8)\end{array}$ & $\begin{array}{l}4 \\
\# \\
\# \\
4 \\
2\end{array}$ & $\begin{array}{r}(0.4) \\
(t) \\
(t) \\
(1.4) \\
(t)\end{array}$ & $\begin{array}{r}15 \\
8 \\
8 \\
13 \\
11\end{array}$ & $\begin{array}{l}(1.1) \\
(0.8) \\
(1.7) \\
(1.8) \\
(3.9)\end{array}$ & $\begin{array}{l}12 \\
11 \\
13 \\
10 \\
10\end{array}$ & $\begin{array}{l}(0.8) \\
(0.9) \\
(1.1) \\
(1.8) \\
(2.7)\end{array}$ & $\begin{array}{r}11 \\
11 \\
7 \\
10 \\
17\end{array}$ & $\begin{array}{l}(0.8) \\
(1.2) \\
(0.9) \\
(1.4) \\
(3.2)\end{array}$ & $\begin{array}{l}49 \\
49 \\
55 \\
45 \\
41\end{array}$ & $\begin{array}{l}(1.6) \\
(1.7) \\
(2.6) \\
(4.1) \\
(4.9)\end{array}$ & $\begin{array}{l}13 \\
21 \\
18 \\
22 \\
13\end{array}$ & $\begin{array}{l}(0.9) \\
(1.1) \\
(1.2) \\
(1.9) \\
(3.1)\end{array}$ \\
\hline 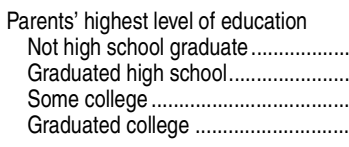 & $\begin{array}{l}129 \\
138 \\
150 \\
160\end{array}$ & $\begin{array}{l}(1.4) \\
(1.2) \\
(0.8) \\
(0.9)\end{array}$ & $\begin{array}{l}59 \\
69 \\
82 \\
87\end{array}$ & $\begin{array}{l}(2.1) \\
(1.5) \\
(1.1) \\
(0.8)\end{array}$ & $\begin{array}{l}17 \\
27 \\
39 \\
54\end{array}$ & $\begin{array}{l}(1.7) \\
(1.4) \\
(1.4) \\
(1.3)\end{array}$ & $\begin{array}{l}\# \\
1 \\
1 \\
5\end{array}$ & $\begin{array}{r}(\dagger) \\
(0.3) \\
(0.4) \\
(0.6)\end{array}$ & $\begin{array}{l}10 \\
11 \\
11 \\
14\end{array}$ & $\begin{array}{l}(1.7) \\
(1.2) \\
(1.0) \\
(1.0)\end{array}$ & $\begin{array}{l}13 \\
12 \\
13\end{array}$ & $\begin{array}{l}(1.4) \\
(1.0) \\
(0.9) \\
(0.8)\end{array}$ & $\begin{array}{l}10 \\
12 \\
12 \\
10\end{array}$ & $\begin{array}{l}(1.4) \\
(1.0) \\
(1.0) \\
(0.7)\end{array}$ & $\begin{array}{l}53 \\
52 \\
51 \\
47\end{array}$ & $\begin{array}{l}(3.2) \\
(1.7) \\
(1.9) \\
(1.5)\end{array}$ & $\begin{array}{l}14 \\
13 \\
14 \\
17\end{array}$ & $\begin{array}{l}(1.3) \\
(0.9) \\
(1.0) \\
(1.0)\end{array}$ \\
\hline 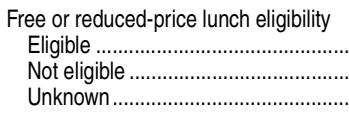 & $\begin{array}{l}132 \\
155 \\
157\end{array}$ & $\begin{array}{l}(0.9) \\
(0.9) \\
(1.9)\end{array}$ & $\begin{array}{l}62 \\
84 \\
86\end{array}$ & $\begin{array}{l}(1.1) \\
(0.8) \\
(1.7)\end{array}$ & $\begin{array}{l}20 \\
48 \\
50\end{array}$ & $\begin{array}{l}(1.1) \\
(1.2) \\
(2.8)\end{array}$ & $\begin{array}{l}1 \\
4 \\
4\end{array}$ & $\begin{array}{l}(0.2) \\
(0.4) \\
(1.1)\end{array}$ & $\begin{array}{r}9 \\
13 \\
16\end{array}$ & $\begin{array}{l}(0.7) \\
(1.1) \\
(3.0)\end{array}$ & $\begin{array}{l}13 \\
12 \\
12\end{array}$ & $\begin{array}{l}(1.1) \\
(0.8) \\
(1.6)\end{array}$ & $\begin{array}{r}10 \\
12 \\
7\end{array}$ & $(0.9)$ & $\begin{array}{l}50 \\
48 \\
54\end{array}$ & $\begin{array}{l}(1.6) \\
(1.6) \\
(3.1)\end{array}$ & $\begin{array}{l}18 \\
16 \\
11\end{array}$ & $\begin{array}{l}(0.8) \\
(0.9) \\
(1.4)\end{array}$ \\
\hline 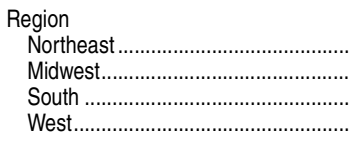 & $\begin{array}{r}153 \\
153 \\
147 \\
\ddagger \\
\end{array}$ & $\begin{array}{r}(2.0) \\
(1.5) \\
(1.4) \\
(\dagger) \\
\end{array}$ & $\begin{array}{r}81 \\
83 \\
77 \\
\ddagger \\
\end{array}$ & $\begin{array}{r}(1.7) \\
(1.4) \\
(1.4) \\
(\dagger) \\
\end{array}$ & $\begin{array}{r}46 \\
45 \\
37 \\
\ddagger \\
\end{array}$ & $\begin{array}{r}(2.6) \\
(2.0) \\
(1.7) \\
(\dagger) \\
\end{array}$ & $\begin{array}{l}4 \\
3 \\
2 \\
\ddagger \\
\end{array}$ & $\begin{array}{r}(0.9) \\
(0.6) \\
(0.5) \\
(\dagger) \\
\end{array}$ & $\begin{array}{r}26 \\
12 \\
6 \\
\ddagger \\
\end{array}$ & $\begin{array}{r}(2.6) \\
(2.2) \\
(1.1) \\
(\dagger) \\
\end{array}$ & $\begin{array}{r}7 \\
12 \\
14 \\
\ddagger \\
\end{array}$ & $\begin{array}{r}(1.1) \\
(1.6) \\
(1.2) \\
(\dagger) \\
\end{array}$ & $\begin{array}{r}11 \\
15 \\
9 \\
\ddagger \\
\end{array}$ & $\begin{array}{r}(1.3) \\
(1.5) \\
(1.3) \\
(\dagger) \\
\end{array}$ & $\begin{array}{r}43 \\
51 \\
49 \\
\ddagger \\
\end{array}$ & $\begin{array}{r}(3.2) \\
(2.6) \\
(2.0) \\
(\dagger) \\
\end{array}$ & $\begin{array}{r}13 \\
10 \\
22 \\
\ddagger \\
\end{array}$ & $\begin{array}{r}(1.4) \\
(1.0) \\
(1.5) \\
(\dagger) \\
\end{array}$ \\
\hline 2012 All stu & 152 & $(0.8)$ & 82 & $(0.8)$ & 42 & $(1.1)$ & 3 & $(0.3)$ & 9 & $(1.0)$ & 9 & $(0.8)$ & 10 & $(1.2)$ & 54 & (2.0) & 18 & $(0.9)$ \\
\hline $\begin{array}{l}\text { Sex } \\
\text { Male..... } \\
\text { Female. }\end{array}$ & $\begin{array}{l}155 \\
149\end{array}$ & $\begin{array}{l}(0.9) \\
(0.9)\end{array}$ & $\begin{array}{l}83 \\
80\end{array}$ & $\begin{array}{l}(1.0) \\
(1.0)\end{array}$ & $\begin{array}{l}47 \\
37\end{array}$ & $\begin{array}{l}(1.3) \\
(1.3)\end{array}$ & $\begin{array}{l}4 \\
2\end{array}$ & $\begin{array}{l}(0.4) \\
(0.2)\end{array}$ & $\begin{array}{r}8 \\
10\end{array}$ & $\begin{array}{l}(0.9) \\
(1.2)\end{array}$ & $\begin{array}{l}9 \\
9\end{array}$ & $\begin{array}{l}(0.8) \\
(0.9)\end{array}$ & $\begin{array}{l}10 \\
10\end{array}$ & $\begin{array}{l}(1.2) \\
(1.3)\end{array}$ & $\begin{array}{l}54 \\
53\end{array}$ & $\begin{array}{l}(2.0) \\
(2.2)\end{array}$ & $\begin{array}{l}18 \\
18\end{array}$ & $\begin{array}{l}(1.0) \\
(1.1)\end{array}$ \\
\hline 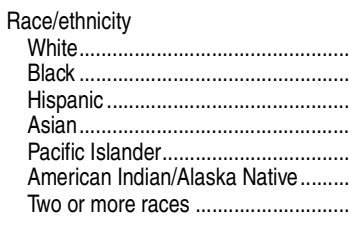 & $\begin{array}{r}160 \\
131 \\
138 \\
160 \\
\ddagger \\
136 \\
154\end{array}$ & $\begin{array}{r}(1.0) \\
(1.4) \\
(1.4) \\
(1.9) \\
(+) \\
(4.7) \\
(3.4)\end{array}$ & $\begin{array}{r}89 \\
61 \\
71 \\
86 \\
\ddagger \\
72 \\
87\end{array}$ & $\begin{array}{r}(0.9) \\
(2.1) \\
(2.0) \\
(1.9) \\
(\dagger) \\
(7.8) \\
(3.0)\end{array}$ & $\begin{array}{r}53 \\
16 \\
25 \\
53 \\
\ddagger \\
20 \\
42\end{array}$ & $\begin{array}{r}(1.6) \\
(1.3) \\
(1.4) \\
(2.4) \\
(\dagger) \\
(5.6) \\
(5.2)\end{array}$ & $\begin{array}{l}4 \\
1 \\
1 \\
6 \\
\ddagger \\
2 \\
3\end{array}$ & $\begin{array}{r}(0.4) \\
(0.2) \\
(0.3) \\
(1.3) \\
(\dagger) \\
(\dagger) \\
(1.8)\end{array}$ & $\begin{array}{r}10 \\
6 \\
5 \\
10 \\
\ddagger \\
4 \\
10\end{array}$ & $\begin{aligned}(1.4) \\
(1.2) \\
(1.1) \\
(1.5) \\
(\dagger) \\
(2.7) \\
(2.9)\end{aligned}$ & $\begin{array}{l}9 \\
\ddagger\end{array}$ & $\begin{array}{r}(1.0) \\
(1.2) \\
(+) \\
(2.9) \\
(1.4)\end{array}$ & $\begin{array}{r}11 \\
9 \\
7 \\
7 \\
\ddagger \\
19 \\
7\end{array}$ & $\begin{array}{r}(1.2) \\
(1.2) \\
(\dagger) \\
(9.9) \\
(1.8)\end{array}$ & $\begin{array}{r}45 \\
\ddagger \\
54 \\
57\end{array}$ & $\begin{array}{r}(2.4) \\
(2.9) \\
(2.9) \\
(2.7) \\
(t) \\
(8.0) \\
(4.5)\end{array}$ & $\begin{array}{r}15 \\
23 \\
21 \\
29 \\
\ddagger \\
16 \\
20\end{array}$ & $\begin{array}{r}(1.1) \\
(1.4) \\
(2.0) \\
(2.6) \\
(\dagger) \\
(4.6) \\
(2.8)\end{array}$ \\
\hline 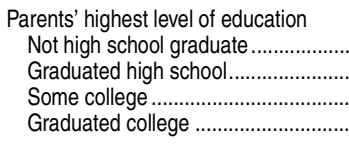 & $\begin{array}{l}134 \\
139 \\
150 \\
161\end{array}$ & $\begin{array}{l}(1.5) \\
(1.1) \\
(0.8) \\
(0.9)\end{array}$ & $\begin{array}{l}66 \\
71 \\
84 \\
89\end{array}$ & $\begin{array}{l}(2.1) \\
(1.7) \\
(1.0) \\
(1.0)\end{array}$ & $\begin{array}{l}21 \\
27 \\
38 \\
55\end{array}$ & $\begin{array}{l}(1.9) \\
(1.6) \\
(1.2) \\
(1.4)\end{array}$ & $\begin{array}{l}\# \\
1 \\
1 \\
5\end{array}$ & $\begin{array}{r}(\dagger) \\
(0.2) \\
(0.3) \\
(0.5)\end{array}$ & $\begin{array}{r}4 \\
7 \\
8 \\
10\end{array}$ & $\begin{array}{l}(0.7) \\
(1.2) \\
(1.2) \\
(1.4)\end{array}$ & $\begin{array}{r}10 \\
9 \\
9 \\
9\end{array}$ & $(1.0$ & $\begin{array}{l}10 \\
11 \\
10 \\
10\end{array}$ & $\begin{array}{l}(1.2) \\
(1.5) \\
(1.3)\end{array}$ & 59 & $\begin{array}{l}(2.4) \\
(2.3) \\
(2.3) \\
(2.3)\end{array}$ & $\begin{array}{l}17 \\
16 \\
16 \\
20\end{array}$ & $\begin{array}{l}(1.5) \\
(1.0) \\
(1.6) \\
(1.2)\end{array}$ \\
\hline 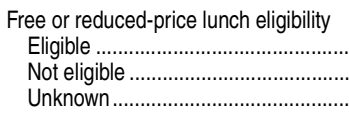 & $\begin{array}{l}138 \\
159 \\
164\end{array}$ & $\begin{array}{l}(0.9) \\
(0.9) \\
(3.3)\end{array}$ & $\begin{array}{l}70 \\
88 \\
90\end{array}$ & $\begin{array}{l}(1.3) \\
(0.8) \\
(2.3)\end{array}$ & $\begin{array}{l}25 \\
52 \\
59\end{array}$ & $\begin{array}{l}(1.1) \\
(1.4) \\
(4.2)\end{array}$ & $\begin{array}{l}\# \\
4 \\
5\end{array}$ & $\begin{array}{r}(\dagger) \\
(0.4) \\
(1.4)\end{array}$ & $\begin{array}{r}7 \\
10 \\
13\end{array}$ & $\begin{array}{l}(0.9) \\
(1.3) \\
(4.7)\end{array}$ & $\begin{array}{l}9 \\
9 \\
8\end{array}$ & $\begin{array}{l}(1.1) \\
(1.8)\end{array}$ & $\begin{array}{r}10 \\
11 \\
6\end{array}$ & $\begin{array}{l}(1.4) \\
(1.6)\end{array}$ & $\begin{array}{l}57 \\
51 \\
58\end{array}$ & $\begin{array}{l}(2.1) \\
(2.3) \\
(5.0)\end{array}$ & $\begin{array}{l}18 \\
19 \\
15\end{array}$ & $\begin{array}{l}(1.3) \\
(1.1) \\
(1.9)\end{array}$ \\
\hline 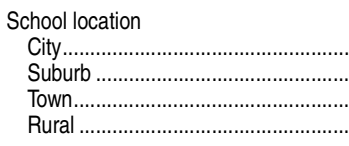 & $\begin{array}{l}147 \\
156 \\
149 \\
152\end{array}$ & $\begin{array}{l}(1.8) \\
(0.9) \\
(2.7) \\
(1.5)\end{array}$ & $\begin{array}{l}77 \\
85 \\
81 \\
83\end{array}$ & $\begin{array}{l}(1.9) \\
(1.0) \\
(2.4) \\
(1.5)\end{array}$ & $\begin{array}{l}37 \\
48 \\
39 \\
42\end{array}$ & $\begin{array}{l}(2.3) \\
(1.1) \\
(3.8) \\
(2.5)\end{array}$ & $\begin{array}{l}3 \\
4 \\
2 \\
2\end{array}$ & $\begin{array}{l}(0.5) \\
(0.4) \\
(0.6) \\
(0.6)\end{array}$ & $\begin{array}{r}8 \\
12 \\
9 \\
5\end{array}$ & $\begin{array}{l}(1.5) \\
(1.8) \\
(2.8) \\
(1.2)\end{array}$ & $\begin{array}{r}9 \\
10 \\
8 \\
9\end{array}$ & $\begin{array}{l}(1.1) \\
(1.2) \\
(1.4)\end{array}$ & $\begin{array}{r}8 \\
11 \\
10 \\
12\end{array}$ & $\begin{array}{l}(1.6) \\
(2.4) \\
(2.8)\end{array}$ & $\begin{array}{l}54 \\
50 \\
57 \\
57\end{array}$ & $\begin{array}{l}(2.1) \\
(3.5) \\
(4.0)\end{array}$ & $\begin{array}{l}22 \\
17 \\
16 \\
17\end{array}$ & $\begin{array}{l}(1.8) \\
(1.5) \\
(3.8) \\
(2.1)\end{array}$ \\
\hline $\begin{array}{l}\text { Region } \\
\text { Northeast ....... } \\
\text { Midwest......... } \\
\text { South ............ } \\
\text { West............. }\end{array}$ & $\begin{array}{l}154 \\
157 \\
149 \\
148\end{array}$ & $\begin{array}{l}(1.7) \\
(1.6) \\
(1.8) \\
(1.1)\end{array}$ & $\begin{array}{l}84 \\
86 \\
79 \\
79\end{array}$ & $\begin{array}{l}(1.8) \\
(1.1) \\
(1.7) \\
(1.4)\end{array}$ & $\begin{array}{l}46 \\
50 \\
38 \\
40\end{array}$ & $\left.\begin{array}{l}(2.0) \\
(2.2) \\
(2.7) \\
(1.5)\end{array}\right]$ & $\begin{array}{l}3 \\
4 \\
2 \\
2\end{array}$ & $\begin{array}{l}(0.7) \\
(0.5) \\
(0.3)\end{array}$ & $\begin{array}{r}27 \\
5 \\
3 \\
7\end{array}$ & $\begin{array}{l}(1.2) \\
(1.5) \\
(1.2)\end{array}$ & $\begin{array}{r}9 \\
9 \\
8 \\
11\end{array}$ & $\begin{array}{l}(2.3) \\
(1.2) \\
(1.1)\end{array}$ & $\begin{array}{r}11 \\
18 \\
5 \\
9\end{array}$ & $\begin{array}{l}(3.4) \\
(0.9) \\
(3.1)\end{array}$ & $\begin{array}{l}39 \\
57 \\
55 \\
60\end{array}$ & $\begin{array}{l}(5.5) \\
(4.3) \\
(3.6) \\
(3.0)\end{array}$ & $\begin{array}{l}14 \\
11 \\
29 \\
13\end{array}$ & $\begin{array}{l}(2.2) \\
(1.0) \\
(2.0) \\
(1.0)\end{array}$ \\
\hline
\end{tabular}

†Not applicable.

\#Rounds to zero.

†Reporting standards not met. Either there are too few cases for a reliable estimate or item response rates fell below the required standards for reporting.

'Scale ranges from 0 to 300 .

${ }^{2}$ Basic denotes partial mastery of the knowledge and skills that are fundamental for proficient work at a given grade.

${ }^{3}$ Proficient represents solid academic performance. Students reaching this level have demonstrated competency over challenging subject matter.

${ }^{4}$ Advanced signifies superior performance for a given grade.
${ }^{5}$ Advanced economics includes Advanced Placement, International Baccalaureate, and honors courses.

NOTE: Includes public and private schools. Includes students tested with accommodations; excludes only those students with disabilities and English language learners who were unable to be tested even with accommodations ( 3 percent of all students in both assessment years). Detail may not sum to totals because of rounding. Race categories exclude persons of Hispanic ethnicity. Totals include other racial/ethnic groups not shown separately. SOURCE: U.S. Department of Education, National Center for Education Statistics, National Assessment of Educational Progress (NAEP), 2006 and 2012 Economics Assessment, retrieved May 08, 2013, from the NAEP Data Explorer (http://nces.ed.gov/nationsreportcard/ naepdata/). (This table was prepared May 2013.) 
Table 224.40. Average National Assessment of Educational Progress (NAEP) geography scale score, standard deviation, and percentage of students attaining geography achievement levels, by grade level, selected student characteristics, and percentile: 1994, 2001, and 2010

[Standard errors appear in parentheses]

\begin{tabular}{|c|c|c|c|c|c|c|c|c|c|c|c|c|c|c|c|c|c|c|}
\hline \multirow[b]{2}{*}{ Selected student characteristic } & \multicolumn{6}{|c|}{ 4th-graders } & \multicolumn{6}{|c|}{ 8th-graders } & \multicolumn{6}{|c|}{ 12th-graders } \\
\hline & & $1994^{1}$ & & 2001 & & 2010 & & $1994^{1}$ & & 2001 & & 2010 & & $1994^{1}$ & & 2001 & & 2010 \\
\hline \multirow[t]{2}{*}{1} & & 2 & & 3 & & 4 & & 5 & & 6 & & 7 & & 8 & & 9 & & 10 \\
\hline & \multicolumn{18}{|c|}{ Average geography scale score ${ }^{2}$} \\
\hline All students & 206 & (1.2) & 208 & (0.9) & 213 & $(0.8)$ & 260 & $(0.7)$ & 260 & $(1.0)$ & 261 & $(0.7)$ & 285 & $(0.7)$ & 284 & $(0.8)$ & 282 & $(0.6)$ \\
\hline \multicolumn{19}{|l|}{ Sex } \\
\hline Male .......... & 208 & (1.4) & 210 & (1.0) & 215 & (0.9) & 262 & $(0.9)$ & 262 & (1.2) & 263 & $(0.8)$ & 288 & $(0.8)$ & 287 & $(1.0)$ & 285 & $(0.6)$ \\
\hline Female .......... & 203 & (1.4) & 206 & (1.3) & 211 & $(0.9)$ & 258 & $(0.8)$ & 258 & $(1.0)$ & 259 & $(0.8)$ & 281 & $(0.9)$ & 281 & $(0.8)$ & 280 & $(0.8)$ \\
\hline \multicolumn{19}{|l|}{ Race/ethnicity } \\
\hline White.... & 218 & (1.5) & 219 & (1.1) & 224 & (0.9) & 269 & (0.8) & 269 & (1.4) & 272 & $(0.6)$ & 290 & (0.8) & 291 & $(0.8)$ & 290 & $(0.5)$ \\
\hline Black ...... & 166 & (2.4) & 180 & (1.8) & 192 & (1.3) & 229 & (1.7) & 233 & (1.6) & 241 & (1.1) & 258 & (1.4) & 258 & $(1.5)$ & 261 & (1.2) \\
\hline 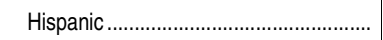 & 177 & (3.3) & 185 & (2.5) & 197 & (1.2) & 238 & (2.0) & 237 & (2.0) & 244 & (1.0) & 269 & (1.7) & 268 & $(1.6)$ & 270 & (1.2) \\
\hline Asian/Pacific Islander..................... & 211 & $(4.0)$ & 214 & (3.5) & 224 & (3.3) & 262 & (5.3) & 264 & (2.7) & 268 & (2.7) & 283 & (3.1) & 284 & $(5.0)$ & 285 & (1.7) \\
\hline American Indian/Alaska Native........ & $\ddagger$ & $(\dagger)$ & $\ddagger$ & $(†)$ & 201 & (3.5) & 251 & (5.5) & 261 & (5.3) & 250 & (3.9) & $\ddagger$ & (†) & $\ddagger$ & $(\dagger)$ & 277 & (2.5) \\
\hline \multicolumn{19}{|l|}{ Parents' highest level of education } \\
\hline Did not finish high school ...................... & - & $(t)$ & - & $(\dagger)$ & - & ( t) & 238 & (1.7) & 236 & (1.8) & 243 & (1.3) & 263 & (1.2) & 266 & (1.7) & 263 & (1.2) \\
\hline Graduated high school.......................... & - & $(\dagger)$ & - & $(\dagger)$ & - & $(\dagger)$ & 250 & (1.2) & 251 & (1.2) & 251 & (1.1) & 274 & (1.1) & 275 & $(0.9)$ & 274 & $(0.8)$ \\
\hline Some education after high school ........ & - & $(\dagger)$ & - & $(\dagger)$ & - & ( t) & 265 & (1.0) & 264 & (1.1) & 262 & $(1.0)$ & 286 & (1.0) & 284 & $(0.9)$ & 280 & $(0.7)$ \\
\hline Graduated college .... & - & $(\dagger)$ & - & $(\mathrm{t})$ & - & $(\mathrm{t})$ & 272 & $(1.0)$ & 273 & $(1.0)$ & 272 & $(0.7)$ & 294 & (0.9) & 293 & $(1.0)$ & 291 & $(0.7)$ \\
\hline \multicolumn{19}{|l|}{ Eligibility for free or reduced-price lunch } \\
\hline Eligibl & - & $(\dagger)$ & 185 & (1.4) & 197 & (0.7) & - & $(\dagger)$ & 239 & (1.3) & 246 & (0.9) & - & (†) & 268 & $(1.7)$ & 269 & $(0.8)$ \\
\hline Not eligible... & - & $(\dagger)$ & 221 & (1.1) & 227 & $(0.8)$ & - & $(\dagger)$ & 269 & (1.2) & 272 & $(0.7)$ & - & $(\dagger)$ & 287 & $(1.0)$ & 288 & $(0.5)$ \\
\hline Unknown.. & - & $(\dagger)$ & 219 & (2.8) & 227 & (3.7) & - & $(t)$ & 265 & (2.3) & 276 & (2.6) & - & $(t)$ & 288 & $(1.6)$ & 289 & (2.2) \\
\hline \multicolumn{19}{|l|}{ Percentile ${ }^{3}$} \\
\hline 10th.. & 146 & (1.9) & 159 & (2.6) & 169 & (1.8) & 213 & (1.3) & 213 & (1.2) & 220 & $(1.2)$ & 244 & $(0.9)$ & 246 & $(1.1)$ & 247 & (0.8) \\
\hline 25th... & 179 & (1.5) & 184 & (1.4) & 192 & (1.2) & 237 & (1.0) & 238 & (1.3) & 241 & $(0.7)$ & 265 & (1.1) & 266 & (1.2) & 265 & $(0.8)$ \\
\hline 50 th .... & 211 & (1.1) & 211 & (1.0) & 216 & (1.1) & 263 & (1.1) & 264 & (1.2) & 263 & $(0.9)$ & 287 & $(0.9)$ & 286 & $(0.9)$ & 284 & $(0.7)$ \\
\hline 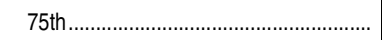 & 237 & (1.3) & 235 & (1.4) & 236 & (0.7) & 285 & $(0.9)$ & 285 & (1.1) & 284 & $(0.9)$ & 306 & $(1.0)$ & 304 & $(0.9)$ & 301 & $(0.7)$ \\
\hline \multirow[t]{2}{*}{ 90th } & 257 & $(2.0)$ & 254 & $(1.3)$ & 253 & $(0.9)$ & 302 & $(1.9)$ & 302 & $(1.1)$ & 300 & $(0.7)$ & 321 & $(1.0)$ & 319 & $(1.3)$ & 315 & $(0.7)$ \\
\hline & \multicolumn{18}{|c|}{ Standard deviation of the geography scale score ${ }^{4}$} \\
\hline \multirow[t]{2}{*}{ 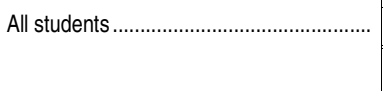 } & 44 & $(0.8)$ & 37 & $(0.8)$ & 33 & $(0.4)$ & 35 & $(0.4)$ & 35 & $(0.5)$ & 31 & $(0.3)$ & 30 & $(0.4)$ & 28 & $(0.4)$ & 26 & $(0.3)$ \\
\hline & \multicolumn{18}{|c|}{ Percent of students achieving geography achievement levels } \\
\hline \multicolumn{19}{|l|}{ Achievement level } \\
\hline Below Basic.. & 30 & $(1.1)$ & 27 & $(1.0)$ & 21 & $(0.9)$ & 29 & $(1.0)$ & 28 & $(1.2)$ & 26 & $(0.9)$ & 30 & (0.9) & 29 & $(1.0)$ & 30 & $(0.9)$ \\
\hline 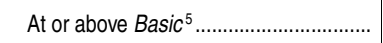 & 70 & $(1.1)$ & 73 & $(1.0)$ & 79 & $(0.9)$ & 71 & $(1.0)$ & 72 & (1.2) & 74 & $(0.9)$ & 70 & $(0.9)$ & 71 & $(1.0)$ & 70 & (0.9) \\
\hline \multicolumn{19}{|l|}{ At or above Basic by sex } \\
\hline Male... & 71 & (1.3) & 74 & (0.9) & 80 & (1.0) & 72 & (1.3) & 73 & (1.5) & 75 & $(1.0)$ & 73 & (1.1) & 74 & $(1.3)$ & 73 & $(1.0)$ \\
\hline Female ... & 68 & (1.4) & 71 & (1.5) & 78 & (1.1) & 69 & (1.1) & 71 & (1.1) & 73 & (1.1) & 67 & (1.2) & 68 & (1.2) & 66 & $(1.2)$ \\
\hline At or $a b$ & & & & & & & & & & & & & & & & & & \\
\hline White.. & 81 & (1.3) & 84 & (1.1) & 89 & (1.0) & 81 & $(0.9)$ & 82 & (1.5) & 86 & $(0.7)$ & 78 & $(0.9)$ & 81 & $(0.9)$ & 81 & $(0.8)$ \\
\hline Black..... & 33 & (2.4) & 43 & (2.5) & 57 & (2.1) & 34 & (3.0) & 39 & (2.4) & 49 & (1.7) & 33 & (2.3) & 33 & (2.0) & 36 & (1.8) \\
\hline Hispanic... & 44 & (3.1) & 50 & (3.1) & 64 & (1.7) & 49 & (3.8) & 45 & (2.5) & 55 & (1.5) & 48 & (3.0) & 48 & (2.9) & 52 & (2.0) \\
\hline Asian/Pacific & 72 & (4.4) & 77 & (4.2) & 87 & (3.2) & 72 & (6.7) & 77 & (3.6) & 80 & (3.3) & 67 & (3.8) & 70 & $(6.2)$ & 73 & (2.7) \\
\hline American Indian/Alaska Native ..... & $\ddagger$ & $(\dagger)$ & $\ddagger$ & $(\dagger)$ & 68 & (6.4) & 62 & (7.7) & 74 & (4.8) & 62 & (7.2) & $\ddagger$ & (†) & $\ddagger$ & $(\dagger)$ & 62 & (5.1) \\
\hline 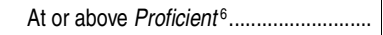 & 22 & (1.2) & 20 & (0.9) & 21 & (0.8) & 28 & (1.0) & 29 & (1.3) & 27 & $(0.8)$ & 27 & (1.2) & 24 & $(1.2)$ & 20 & $(0.8)$ \\
\hline At Advanced ${ }^{7} \ldots \ldots \ldots$ & 3 & $(0.4)$ & 2 & $(0.3)$ & 2 & $(0.2)$ & 4 & $(0.4)$ & 4 & $(0.5)$ & 3 & $(0.2)$ & 2 & $(0.5)$ & 1 & $(0.3)$ & 1 & $(0.1)$ \\
\hline
\end{tabular}

-Not available.

†Not applicable.

†Reporting standards not met (too few cases for a reliable estimate).

${ }^{1}$ Accommodations were not permitted for this assessment.

2Scale ranges from 0 to 500 .

The percentile represents a specific point on the percentage distribution of all students ranked by their geography score from low to high. For example, 10 percent of students scored at or below the 10th percentile score, while 90 percent of students scored above it.

${ }^{4}$ The standard deviation provides an indication of how much the test scores varied. The lower the standard deviation, the closer the scores were clustered around the average score About tion above and one standard deviation below the average score. For example, the average score for all 4th-graders in 2010 was 213 , and the standard deviation was 33 . This mean that we would expect about two-thirds of the students to have scores between 246 (one standard deviation above the average) and 180 (one standard deviation below). Standard errors also must be taken into account when making comparisons of these ranges. For a discussion of standard errors, see Appendix A: Guide to Sources.

${ }^{5}$ Basic denotes partial mastery of the knowledge and skills that are fundamental for proficient work.

${ }^{6}$ Proficient represents solid academic performance. Students reaching this level have demonstrated competency over challenging subject matter.

7 Advanced signifies superior performance.
NOTE: For 2001 and later years, includes students tested with accommodations ( 3 to 13 percent of all students, depending on grade level and year); excludes only those students with disabilities and English language learners who were unable to be tested even with accommodations ( 1 to 4 percent of all students). Race categories exclude persons of Hispanic ethnicity. Detail may not sum to totals because of rounding.

SOURCE: U.S. Department of Education, National Center for Education Statistics, National Assessment of Educational Progress (NAEP), 1994, 2001, and 2010 Geography Assessments, retrieved July 22, 2011, from the Main NAEP Data Explorer (http://nces.ed.gov/nation reportcard/naepdata). (This table was prepared July 2011.) 


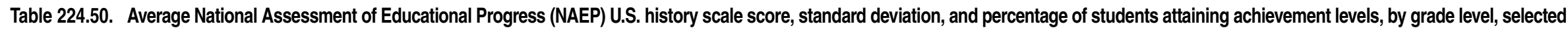
characteristics, and percentile: Selected years, 1994 through 2010

[Standard errors appear in parentheses]

\begin{tabular}{|c|c|c|c|c|c|c|c|c|c|c|c|c|c|c|c|c|c|c|c|c|c|c|c|c|}
\hline \multirow[b]{2}{*}{ Selected characteristic } & \multicolumn{8}{|c|}{ 4th-graders } & \multicolumn{8}{|c|}{ 8th-graders } & \multicolumn{8}{|c|}{ 12th-graders } \\
\hline & \multicolumn{2}{|r|}{$1994^{1}$} & \multicolumn{2}{|c|}{2001} & \multicolumn{2}{|r|}{2006} & \multicolumn{2}{|r|}{2010} & \multicolumn{2}{|r|}{$1994^{1}$} & \multicolumn{2}{|r|}{2001} & \multirow{2}{*}{\multicolumn{2}{|c|}{2006}} & \multicolumn{2}{|r|}{2010} & \multicolumn{2}{|r|}{19941} & \multicolumn{2}{|r|}{2001} & \multicolumn{2}{|r|}{2006} & \multicolumn{2}{|r|}{201} \\
\hline \multirow[t]{2}{*}{1} & & 2 & & 3 & & 4 & & 5 & & 6 & & 7 & & & & 9 & & 10 & & 11 & & 12 & & \\
\hline & \multicolumn{24}{|c|}{ Average U.S. history scale score ${ }^{2}$} \\
\hline All students & 205 & $(1.0)$ & 208 & $(0.9)$ & 211 & (1.1) & 214 & (0.8) & 259 & (0.6) & 260 & $(0.8)$ & 263 & $(0.8)$ & 266 & (0.8) & 286 & $(0.8)$ & 287 & $(0.9)$ & 290 & (0.7) & 288 & (0. \\
\hline 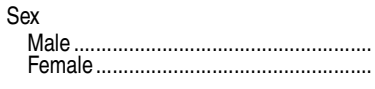 & $\begin{array}{l}203 \\
206\end{array}$ & $\left(\begin{array}{l}1.5 \\
1.1\end{array}\right)$ & $\begin{array}{l}207 \\
209\end{array}$ & $\left(\begin{array}{l}1.1 \\
1.2\end{array}\right)$ & $\begin{array}{l}211 \\
211\end{array}$ & $\left(\begin{array}{l}1.2 \\
1.1\end{array}\right)$ & $\begin{array}{l}215 \\
213\end{array}$ & $\left(\begin{array}{l}1.0) \\
0.9\end{array}\right)$ & $\begin{array}{l}259 \\
259\end{array}$ & $\left(\begin{array}{l}0.8) \\
0.7)\end{array}\right.$ & $\begin{array}{l}261 \\
260\end{array}$ & $\left(\begin{array}{l}0.9 \\
0.9\end{array}\right)$ & $\begin{array}{l}264 \\
261\end{array}$ & $\left(\begin{array}{l}0.9 \\
0.8\end{array}\right)$ & $\begin{array}{l}268 \\
263\end{array}$ & $\left(\begin{array}{l}0.8) \\
(0.8)\end{array}\right.$ & $\begin{array}{l}288 \\
285\end{array}$ & $\left(\begin{array}{l}0.8 \\
0.9\end{array}\right)$ & $\begin{array}{l}288 \\
286\end{array}$ & $\left(\begin{array}{l}1.1 \\
0.9\end{array}\right)$ & $\begin{array}{l}292 \\
288\end{array}$ & $\begin{array}{l}(0.9) \\
(0.8)\end{array}$ & $\begin{array}{l}290 \\
286\end{array}$ & \\
\hline 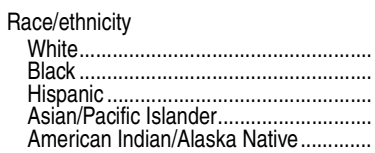 & $\begin{array}{r}214 \\
176 \\
175 \\
204 \\
\ddagger\end{array}$ & $\begin{array}{r}(1.3) \\
1.6 \\
2.6 \\
3.6 \\
(\dagger)\end{array}$ & $\begin{array}{r}217 \\
186 \\
184 \\
216 \\
\ddagger\end{array}$ & $\begin{array}{r}1.3 \\
2.0 \\
2.6 \\
3.7 \\
(\dagger)\end{array}$ & $\begin{array}{l}223 \\
191 \\
194 \\
214 \\
190\end{array}$ & $\left.\begin{array}{l}1.1 \\
1.9 \\
1.9 \\
5.1 \\
5.9\end{array}\right)$ & $\begin{array}{l}224 \\
198 \\
198 \\
221 \\
193\end{array}$ & $\left(\begin{array}{l}1.1 \\
1.9 \\
1.2 \\
(2.4) \\
6.2\end{array}\right)$ & $\begin{array}{l}266 \\
238 \\
243 \\
261 \\
245\end{array}$ & $\begin{array}{l}(0.8) \\
1.6 \\
1.4 \\
5.0 \\
(3.4)\end{array}$ & $\begin{array}{l}268 \\
240 \\
240 \\
264 \\
255\end{array}$ & $\begin{array}{l}(0.9) \\
1.9 \\
2.0 \\
2.8 \\
(4.4)\end{array}$ & $\begin{array}{l}273 \\
244 \\
248 \\
270 \\
244\end{array}$ & $\left.\begin{array}{l}(0.6) \\
1.2 \\
1.2 \\
(3.0 \\
6.3\end{array}\right)$ & $\begin{array}{l}274 \\
250 \\
252 \\
275 \\
259\end{array}$ & $\left.\begin{array}{l}(0.7) \\
1.1 \\
1.0 \\
1.8 \\
5.0\end{array}\right)$ & $\begin{array}{l}292 \\
265 \\
267 \\
283 \\
272\end{array}$ & $\left.\begin{array}{l}(0.8) \\
(1.5 \\
1.7 \\
3.5 \\
(3.0)\end{array}\right)$ & $\begin{array}{l}292 \\
267 \\
271 \\
294 \\
283\end{array}$ & $\left(\begin{array}{l}1.0 \\
1.4 \\
1.9 \\
6.0 \\
(4.2)\end{array}\right)$ & $\begin{array}{l}297 \\
270 \\
275 \\
296 \\
278\end{array}$ & $\left.\begin{array}{l}(0.8) \\
1.3 \\
1.0 \\
2.6 \\
4.1\end{array}\right)$ & $\begin{array}{l}296 \\
268 \\
275 \\
293 \\
278\end{array}$ & $(1.3)$ \\
\hline 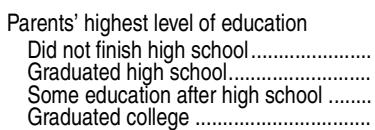 & $\begin{array}{l}\bar{z} \\
\bar{z}\end{array}$ & $\begin{array}{l}(t) \\
(t) \\
(t) \\
(t)\end{array}$ & $\begin{array}{l}\bar{z} \\
\bar{z}\end{array}$ & 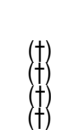 & $\begin{array}{l}\bar{z} \\
\bar{z}\end{array}$ & $\left(\begin{array}{c}+ \\
+ \\
+ \\
+ \\
+\end{array}\right)$ & $\begin{array}{l}- \\
z \\
z\end{array}$ & 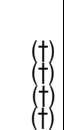 & $\begin{array}{l}241 \\
251 \\
264 \\
270\end{array}$ & $\left.\begin{array}{l}1.3 \\
0.8 \\
0.8 \\
0.8\end{array}\right)$ & $\begin{array}{l}241 \\
251 \\
264 \\
273\end{array}$ & $\left.\begin{array}{l}2.8 \\
1.0 \\
1.0 \\
0.9\end{array}\right)$ & $\begin{array}{l}244 \\
252 \\
265 \\
274\end{array}$ & $\left.\begin{array}{l}(1.2) \\
1.3 \\
0.9 \\
0.8\end{array}\right)$ & $\begin{array}{l}249 \\
255 \\
267 \\
276\end{array}$ & $\begin{array}{l}(0.9) \\
0.9 \\
0.9 \\
0.8)\end{array}$ & $\begin{array}{l}263 \\
276 \\
287 \\
296\end{array}$ & $\left(\begin{array}{l}1.4 \\
1.1 \\
1.2 \\
0.9\end{array}\right)$ & $\begin{array}{l}266 \\
274 \\
286 \\
298\end{array}$ & $\left(\begin{array}{l}1.6 \\
1.1 \\
0.8 \\
(1.2)\end{array}\right)$ & $\begin{array}{l}268 \\
278 \\
290 \\
300\end{array}$ & $\left(\begin{array}{l}1.3 \\
1.0 \\
0.8 \\
0.8\end{array}\right)$ & $\begin{array}{l}268 \\
277 \\
286 \\
298\end{array}$ & $(1.7)$ \\
\hline 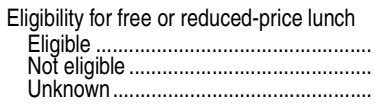 & $\bar{z}$ & $\begin{array}{c}\left(\begin{array}{c}t \\
+ \\
+\end{array}\right) \\
\end{array}$ & $\begin{array}{l}188 \\
219 \\
217\end{array}$ & $\left(\begin{array}{l}1.4 \\
1.4 \\
(2.8\end{array}\right)$ & $\begin{array}{l}195 \\
224 \\
227\end{array}$ & $\left(\begin{array}{l}1.1 \\
1.0 \\
3.9\end{array}\right)$ & $\begin{array}{l}199 \\
227 \\
225\end{array}$ & $\left.\begin{array}{l}0.9 \\
0.8 \\
6.1\end{array}\right)$ & $\bar{z}$ & 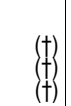 & $\begin{array}{l}242 \\
267 \\
266\end{array}$ & $\left(\begin{array}{l}1.3 \\
1.1 \\
(2.0\end{array}\right)$ & $\begin{array}{l}247 \\
273 \\
281\end{array}$ & $\left.\begin{array}{l}1.1 \\
0.7 \\
2.7\end{array}\right)$ & $\begin{array}{l}253 \\
275 \\
278\end{array}$ & $\left(\begin{array}{l}0.7) \\
0.8 \\
(2.0)\end{array}\right)$ & $\bar{z}$ & $\left.\begin{array}{c}(t) \\
(t \\
+\end{array}\right)$ & $\begin{array}{l}269 \\
289 \\
294\end{array}$ & $\left(\begin{array}{l}1.4 \\
1.2 \\
(2.1)\end{array}\right)$ & $\begin{array}{l}273 \\
295 \\
300\end{array}$ & $\left(\begin{array}{l}1.0 \\
0.8 \\
2.4\end{array}\right)$ & $\begin{array}{l}273 \\
294 \\
300\end{array}$ & \\
\hline \multirow[t]{3}{*}{ 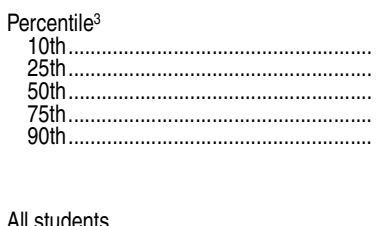 } & $\begin{array}{l}147 \\
180 \\
210 \\
234 \\
253\end{array}$ & $\left.\begin{array}{l}(2.1 \\
1.5 \\
0.9 \\
(1.2 \\
1.4\end{array}\right)$ & $\begin{array}{l}157 \\
184 \\
211 \\
234 \\
254 \\
\end{array}$ & $\left(\begin{array}{l}1.4 \\
1.4 \\
1.1 \\
1.0 \\
1.4\end{array}\right)$ & $\begin{array}{l}165 \\
189 \\
213 \\
235 \\
254 \\
\end{array}$ & $\begin{array}{l}(2.3) \\
1.3 \\
1.0 \\
1.1 \\
1.0 \\
\end{array}$ & $\begin{array}{l}169 \\
192 \\
216 \\
238 \\
256\end{array}$ & $\begin{array}{l}1.4 \\
1.6 \\
0.6 \\
0.9 \\
1.4\end{array}$ & $\begin{array}{l}217 \\
239 \\
261 \\
282 \\
299 \\
\end{array}$ & $\left.\begin{array}{l}(1.1) \\
0.9 \\
1.1 \\
0.7 \\
0.6\end{array}\right)$ & $\begin{array}{l}216 \\
239 \\
262 \\
284 \\
302 \\
\end{array}$ & $\begin{array}{l}(1.3) \\
0.9 \\
1.1 \\
1.0 \\
0.7 \\
\end{array}$ & $\begin{array}{l}221 \\
243 \\
265 \\
285 \\
302 \\
\end{array}$ & $\begin{array}{l}(1.4) \\
0.9 \\
0.7 \\
0.7 \\
1.0\end{array}$ & $\begin{array}{l}227 \\
246 \\
267 \\
286 \\
302 \\
\end{array}$ & $\begin{array}{l}1.2 \\
0.9 \\
0.9 \\
0.7 \\
(1.1) \\
\end{array}$ & $\begin{array}{l}243 \\
265 \\
288 \\
309 \\
326 \\
\end{array}$ & $\left.\begin{array}{l}(1.2 \\
1.2 \\
0.8 \\
0.9 \\
1.0\end{array}\right)$ & $\begin{array}{l}244 \\
266 \\
288 \\
309 \\
326 \\
\end{array}$ & $\left.\begin{array}{l}(1.2 \\
1.1 \\
1.1 \\
1.0 \\
1.5\end{array}\right)$ & $\begin{array}{l}249 \\
270 \\
291 \\
312 \\
329 \\
\end{array}$ & $\left.\begin{array}{l}(1.3) \\
1.0 \\
0.9 \\
0.7) \\
0.9\end{array}\right)$ & $\begin{array}{l}246 \\
267 \\
290 \\
311 \\
328 \\
\end{array}$ & (1. \\
\hline & \multicolumn{24}{|c|}{ Standard deviation of the U.S. history scale score ${ }^{4}$} \\
\hline & 41 & $(0.7)$ & 38 & $(0.7)$ & 34 & $(0.5)$ & 34 & $(0.7)$ & 32 & $(0.3)$ & 33 & $(0.4)$ & 32 & $(0.4)$ & 29 & $(0.3)$ & 32 & $(0.4)$ & 32 & $(0.6)$ & 31 & $(0.3)$ & 32 & $(0$ \\
\hline tts & \multicolumn{24}{|c|}{ Percent of students achieving U.S. history achievement levels } \\
\hline $\begin{array}{l}\text { Achievement level } \\
\text { Below Basic ........ } \\
\text { At or above Basic } \\
\text { At or above Basic }\end{array}$ & $\begin{array}{l}36 \\
64\end{array}$ & $\left(\begin{array}{l}1.1 \\
(1.1)\end{array}\right)$ & $\begin{array}{l}34 \\
66\end{array}$ & $\left(\begin{array}{l}1.2 \\
(1.2)\end{array}\right)$ & $\begin{array}{l}30 \\
70\end{array}$ & $\left(\begin{array}{l}1.3 \\
1.3\end{array}\right)$ & $\begin{array}{l}27 \\
73\end{array}$ & $\left(\begin{array}{l}0.8) \\
(0.8)\end{array}\right.$ & $\begin{array}{l}39 \\
61\end{array}$ & $(0.9)$ & $\begin{array}{l}38 \\
62\end{array}$ & $\left(\begin{array}{l}1.0 \\
1.0\end{array}\right)$ & $\begin{array}{l}35 \\
65\end{array}$ & $\left(\begin{array}{l}1.0 \\
1.0\end{array}\right)$ & $\begin{array}{l}31 \\
69\end{array}$ & $\left(\begin{array}{l}1.0 \\
1.0\end{array}\right)$ & $\begin{array}{l}57 \\
43\end{array}$ & $\left(\begin{array}{l}1.1 \\
1.1\end{array}\right)$ & $\begin{array}{l}57 \\
43\end{array}$ & $\left(\begin{array}{l}1.2 \\
(1.2)\end{array}\right.$ & $\begin{array}{l}53 \\
47\end{array}$ & $\left(\begin{array}{l}1.1 \\
1.1\end{array}\right)$ & $\begin{array}{l}55 \\
45\end{array}$ & \\
\hline 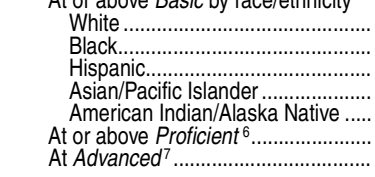 & $\begin{array}{r}73 \\
35 \\
36 \\
62 \\
\pm \\
17 \\
2\end{array}$ & $\begin{array}{l}(1.3) \\
1.5 \\
3.2 \\
(4.3) \\
(+) \\
(1.0) \\
(0.3)\end{array}$ & $\begin{array}{r}76 \\
41 \\
40 \\
74 \\
\ddagger \\
18 \\
2\end{array}$ & $\begin{array}{r}(1.5) \\
2.3 \\
2.8 \\
4.5 \\
(\dagger \\
(0.9) \\
0.3\end{array}$ & $\begin{array}{r}84 \\
46 \\
49 \\
71 \\
41 \\
18 \\
2\end{array}$ & $\begin{array}{l}(1.2) \\
2.5 \\
2.7 \\
4.8 \\
7.7 \\
1.0 \\
0.3)\end{array}$ & $\begin{array}{r}83 \\
54 \\
56 \\
82 \\
49 \\
20 \\
2\end{array}$ & $\left.\begin{array}{l}(1.0) \\
2.6 \\
1.6 \\
3.1 \\
5.4 \\
0.7 \\
0.3\end{array}\right)$ & $\begin{array}{r}70 \\
32 \\
41 \\
60 \\
42 \\
14 \\
1\end{array}$ & $\begin{array}{l}(1.1) \\
2.4 \\
(2.2) \\
6.9 \\
6.2 \\
(0.6) \\
(0.1)\end{array}$ & $\begin{array}{r}71 \\
35 \\
36 \\
65 \\
57 \\
16 \\
1\end{array}$ & $\begin{array}{l}(1.1) \\
2.1 \\
2.6 \\
3.0 \\
6.5 \\
0.7 \\
0.2\end{array}$ & $\begin{array}{r}79 \\
40 \\
46 \\
75 \\
43 \\
17 \\
1\end{array}$ & $\begin{array}{l}(0.8) \\
1.7 \\
2.2 \\
4.4 \\
6.1 \\
0.8 \\
0.1 \\
0.1\end{array}$ & $\begin{array}{r}80 \\
48 \\
52 \\
78 \\
61 \\
17 \\
1\end{array}$ & $\begin{array}{l}(0.9) \\
2.1 \\
1.7 \\
2.1 \\
6.3 \\
0.8 \\
0.1 \\
0.1\end{array}$ & $\begin{array}{r}50 \\
17 \\
22 \\
40 \\
21 \\
11 \\
1\end{array}$ & $\begin{array}{l}(1.2) \\
1.5 \\
2.4 \\
4.7 \\
6.3 \\
0.7 \\
0.2)\end{array}$ & $\begin{array}{r}49 \\
19 \\
24 \\
51 \\
37 \\
11 \\
1\end{array}$ & $\begin{array}{l}(1.3) \\
1.5 \\
2.3 \\
6.7 \\
7.8 \\
0.9 \\
(0.3)\end{array}$ & $\begin{array}{r}56 \\
20 \\
27 \\
54 \\
32 \\
13 \\
1\end{array}$ & $\left(\begin{array}{c}1.3 \\
1.6 \\
1.4 \\
3.5 \\
(7.3) \\
0.7) \\
(0.2)\end{array}\right.$ & $\begin{array}{r}55 \\
20 \\
28 \\
50 \\
29 \\
12 \\
1\end{array}$ & \\
\hline
\end{tabular}

-Not available.

Reporting standards not met (too few cases for a reliable estimate).

Accommodations were not permitted for this assessment.

Scale ranges from 0 to 500

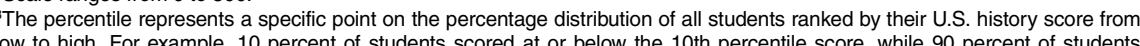
sconts at or below the $10^{\text {th }}$ percentile score, while 90 percent of students ${ }^{4}$ The standard deviation provides an indication of how much the test scores varied. The lower the standard deviation, the closer the scores were clustered around the average score. About two-thirds of the student scores can be expected to fall within the range of one standard deviation above and one standard deviation below the average score. For example, the average score for all 4th-graders in 2010 was 214 , and the standard deviation was 34 . This means that we would expect about two-thirds of the dard errors also must be taken into account when making comparisons of these ranges. For a discussion of standard errors, see ${ }^{5}$ Basic denotes partial mastery of the knowledge and skills that are fundamental for proficient work. ${ }_{6}^{6}$ Proficient represents solid academic performance. Students reaching this level have demonstrated competency over challenging subject matter.

NOTE: For 2001 and later years, includes students tested with accommodations ( 3 to 13 percent of all students, depending on grade level and year): excludes only those students with disabilites and English language parners who were unable to be tested even with accommodations (2 to 3 percent of all students). Race categories exclude persons of Hispanic ethnicity.

SOURCE: U.S. Department of Education, National Center for Education Statistics, National Assessment of Educational Progress (NAEP), 1994, 2001, 2006, and 2010 U.S. History Assessments, retrieved June 27, 2010, from the Main NAEP Data Explorer (http://nces.ed.gov/nationsreportcard/naepdata)). (This table was prepared June 2011. 
Table 224.60. Average National Assessment of Educational Progress (NAEP) writing scale score of 8th- and 12th-graders, standard deviation, and percentage of students attaining writing achievement levels, by selected student and school characteristics and percentile: 2011

[Standard errors appear in parentheses]

\begin{tabular}{|c|c|c|c|c|c|c|c|c|c|c|c|c|c|c|c|c|}
\hline \multirow[b]{3}{*}{ Selected student or school characteristic } & \multicolumn{8}{|c|}{ 8th-graders } & \multicolumn{8}{|c|}{ 12th-graders } \\
\hline & \multirow{2}{*}{\multicolumn{2}{|c|}{$\begin{array}{l}\text { Total, all } \\
\text { students }\end{array}$}} & \multicolumn{6}{|c|}{ Eligibility for free or reduced-price lunch } & \multirow{2}{*}{\multicolumn{2}{|c|}{$\begin{array}{l}\text { Total, all } \\
\text { students }\end{array}$}} & \multicolumn{6}{|c|}{ Eligibility for free or reduced-price lunch } \\
\hline & & & \multicolumn{2}{|c|}{ Eligible } & \multicolumn{2}{|c|}{ Not eligible } & \multicolumn{2}{|c|}{ Unknown } & & & \multicolumn{2}{|r|}{ Eligible } & \multicolumn{2}{|c|}{ Not eligible } & \multicolumn{2}{|c|}{ Unknown } \\
\hline \multirow[t]{2}{*}{1} & & 2 & & 3 & & 4 & & 5 & & 6 & & 7 & & 8 & & 9 \\
\hline & & & & & & & Aver & e writin & cale sc & & & & & & & \\
\hline All students ......................... & 150 & (0.7) & 134 & $(0.6)$ & 161 & $(0.8)$ & 163 & (2.2) & 150 & $(0.5)$ & 133 & (0.7) & 157 & (0.6) & 167 & (1.7) \\
\hline $\begin{array}{l}\text { Sex } \\
\quad \text { Male........ }\end{array}$ & 140 & $(0.7)$ & 125 & $(0.7)$ & 151 & $(0.9)$ & 154 & (2.6) & 143 & $(0.6)$ & 126 & $(0.8)$ & 150 & $(0.6)$ & 162 & (1.9) \\
\hline Female..... & 160 & $(0.7)$ & 144 & $(0.6)$ & 171 & $(0.8)$ & 171 & (2.5) & 157 & $(0.6)$ & 140 & $(0.7)$ & 165 & $(0.6)$ & 173 & (1.9) \\
\hline Race/ethnicity & & & & & & & & & & & & & & & & \\
\hline White. & 158 & $(0.8)$ & 142 & $(0.8)$ & 163 & $(0.9)$ & 166 & (2.3) & 159 & $(0.7)$ & 144 & $(1.0)$ & 161 & $(0.7)$ & 172 & (1.6) \\
\hline Black... & 132 & (1.1) & 127 & $(1.1)$ & 145 & (1.4) & 140 & (4.6) & 130 & $(1.0)$ & 124 & (1.1) & 140 & $(1.2)$ & 148 & (3.6) \\
\hline Hispan & 136 & (0.7) & 130 & $(0.8)$ & 150 & $(1.0)$ & 150 & (5.4) & 134 & $(0.7)$ & 128 & $(0.8)$ & 142 & $(1.0)$ & 149 & (3.6) \\
\hline Asian/Pacific Islander........ & 163 & (2.4) & 146 & $(2.8)$ & 171 & (2.4) & 175 & (4.0) & 158 & (1.6) & 146 & (2.3) & 163 & (2.0) & 162 & $(4.9)$ \\
\hline Asian & 165 & $(2.0)$ & 148 & $(2.7)$ & 172 & (2.2) & 175 & $(4.0)$ & 158 & $(1.5)$ & 146 & (2.5) & 164 & $(1.7)$ & 162 & $(5.0)$ \\
\hline IPacific Islander .. & 141 & (6.3) & $\ddagger$ & $(\dagger)$ & $\ddagger$ & $(\dagger)$ & $\ddagger$ & $(t)$ & 144 & $(6.0)$ & $\ddagger$ & $(t)$ & $\ddagger$ & $(t)$ & $\ddagger$ & $(t)$ \\
\hline laska Native...... & 145 & (4.0) & 139 & $(4.3)$ & $\ddagger$ & $(\dagger)$ & $\ddagger$ & $(t)$ & 145 & (3.5) & 135 & (4.4) & 153 & (4.4) & $\ddagger$ & $(\dagger)$ \\
\hline Two or more & 155 & (1.9) & 141 & $(2.3)$ & 165 & (2.5) & $\ddagger$ & $(\mathrm{t})$ & 158 & $(2.3)$ & 137 & $(4.2)$ & 163 & $(2.8)$ & $\ddagger$ & $(\dagger)$ \\
\hline Parents' highes & & & & & & & & & & & & & & & & \\
\hline Did $n$ & 133 & $(1.0)$ & 131 & $(1.0)$ & 142 & $(2.0)$ & $\ddagger$ & $(t)$ & 129 & $(0.9)$ & 127 & $(1.0)$ & 135 & (1.6) & $\ddagger$ & $(\dagger)$ \\
\hline Gradua & 138 & $(0.8)$ & 131 & $(0.8)$ & 149 & (1.3) & 146 & (4.4) & 138 & $(0.7)$ & 131 & $(1.0)$ & 145 & & 153 & (3.5) \\
\hline igh school & 150 & (0.9) & 143 & $(0.9)$ & 158 & (1.2) & 155 & (3.8) & 149 & $(0$ & 140 & & 15 & & 158 & (2.2) \\
\hline ...………… & & $(0.8)$ & 141 & $(0.8)$ & 166 & $(0.9)$ & 167 & (2.3) & 160 & $(0.7)$ & 139 & $(1.1)$ & 164 & $(0.7)$ & 173 & (1.5) \\
\hline Student's attitud & & & & & & & & & & & & & & & & \\
\hline $\begin{array}{c}\text { Agreed or } \\
\text { of } \mathrm{my}\end{array}$ & 157 & $(0.8)$ & 141 & $(0.8)$ & 170 & $(0.9)$ & 172 & $(2.5)$ & 157 & $(0.6)$ & 139 & $(0.8)$ & 165 & $(0.6)$ & 175 & $(2.0)$ \\
\hline Uses a & & & & & & & & & & & & & & & & \\
\hline assignme & 157 & (0.9) & 140 & $(0.7)$ & 168 & (1.2) & 169 & (2.9) & 154 & $(0.6)$ & 136 & $(0.8)$ & 161 & $(0.7)$ & 167 & (1.4) \\
\hline School locale & & & & & & & & & & & & & & & & \\
\hline City.. & 144 & (1.2) & 130 & $(1.0)$ & 160 & (1.4) & 164 & (4.3) & 146 & (1.0) & 131 & $(0.8)$ & 156 & (1.2) & 168 & (2.5) \\
\hline Suburb & 155 & (1.3) & 137 & $(1.0)$ & 165 & (1.3) & 164 & (4.4) & 154 & $(0.9)$ & 135 & (1.1) & 160 & (0) & 167 & (2.1) \\
\hline & 148 & (1.1) & 137 & (1.3) & 156 & (1. & 157 & (3.8) & 149 & (2.0) & 134 & (3.1) & 156 & $(1$ & $\ddagger$ & $(t)$ \\
\hline Rural ... & 150 & (1.4) & 137 & $(1.5)$ & 158 & (1.3) & 158 & (5.3) & 149 & $(1.1)$ & 135 & (1.5) & 154 & (1.0) & 164 & (5.4) \\
\hline Percentile ${ }^{2}$ & & & & & & & & & & & & & & & & \\
\hline 10th & 104 & (1.0) & 92 & (1.1) & 119 & (1. & 121 & (3.8) & 104 & $(0.9)$ & 90 & $(0.9)$ & 114 & $(1$. & 126 & (4.6) \\
\hline 2 & 127 & $(0.8)$ & 113 & 10 & 140 & & 142 & & 127 & $(0.8)$ & 111 & 9) & 136 & & 149 & (2.3) \\
\hline & 151 & $(0.8)$ & 135 & $(0$. & 163 & $(0$. & 163 & (2.6) & 152 & $(0.7)$ & 135 & (1.1) & & & 170 & (2.2) \\
\hline 75th. & 175 & $(0.7)$ & 157 & $(0.8$ & 184 & $(1.1$ & 185 & (2.6) & 175 & $(0.6)$ & 156 & (0.6) & 180 & $(0$ & 189 & (1.7) \\
\hline 90th....... & 194 & $(0.9)$ & 176 & $(0.9)$ & 201 & (1.4) & 203 & (3.5) & 194 & $(0.7)$ & 176 & $(0.8)$ & 198 & $(0.8)$ & 205 & (3.2) \\
\hline & & & & & & & rd dev & tion of $\mathrm{t}$ & writing & cale sc & & & & & & \\
\hline 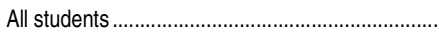 & 35 & $(0.3)$ & 33 & $(0.3)$ & 32 & $(0.3)$ & 32 & $(1.1)$ & 35 & $(0.3)$ & 33 & $(0.3)$ & 33 & $(0.3)$ & 31 & $(0.9)$ \\
\hline & & & & & & ercer & udent & attair & riting a & hiever & levels & & & & & \\
\hline Achieveme & & & & & & & & & & & & & & & & \\
\hline Below & 20 & (0.6) & 32 & $(0.8)$ & 10 & $(0.6)$ & 10 & (1.6) & 21 & (0.6) & 36 & $(0.9)$ & 14 & $(0$. & 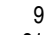 & (1.3) \\
\hline At or above Basic.. & 80 & $(0.6)$ & 68 & $(0.8)$ & 90 & $(0.6)$ & 90 & (1.6) & 79 & $(0.6)$ & 64 & $(0.9)$ & 86 & $(0.5)$ & 91 & (1.3) \\
\hline $\begin{array}{l}\text { At } \\
\text { W }\end{array}$ & 87 & & 76 & & 91 & & 4 & & 87 & & 76 & & 88 & & 95 & \\
\hline Black. & 65 & (1.7) & 59 & $(1$. & 79 & $(2$ & 74 & $(6.4)$ & 61 & $(1$ & 54 & $(1$ & 71 & & 82 & (3.9) \\
\hline $\mathrm{H}$ & 69 & $(0.9)$ & 63 & $(1$. & 82 & $(1$ & 80 & $(5.4)$ & 65 & 10 & 59 & $(1.1)$ & 74 & & 79 & (4.7) \\
\hline Asian & 88 & (2.3) & 76 & $(3$. & 93 & $(1$. & 96 & (2.1) & 85 & & 78 & (2.7) & 89 & & 83 & (4.4) \\
\hline Asian & 89 & (1.9) & 79 & (3.0) & 94 & (1.7) & 95 & (2.2) & 85 & (1.4) & 78 & (2.9) & 89 & (1.3) & 83 & (4.4) \\
\hline Pacific Island & 70 & (7.3) & $\ddagger$ & $(\dagger)$ & $\ddagger$ & $(t)$ & $\ddagger$ & $(t)$ & 78 & (5.0) & $\neq$ & & $\ddagger$ & $(t)$ & $\ddagger$ & $(t)$ \\
\hline Amer & 78 & (4.7) & 74 & $(6$. & $\ddagger$ & & $\ddagger$ & $(\dagger)$ & 76 & $(4$ & 66 & (7.2) & 84 & & $\ddagger$ & $(t)$ \\
\hline & 87 & (1.7) & 79 & (3.9) & 92 & (1.9) & $\neq$ & $\left(\begin{array}{l}W \\
(t)\end{array}\right.$ & 86 & (2.7) & 70 & (7.1) & 90 & (3.1) & $\ddagger$ & $(t)$ \\
\hline At or & 27 & (0.7) & 12 & $(0$. & 37 & (1.0) & 39 & (2.9) & 27 & $(0.6)$ & 12 & $(0.5)$ & 33 & $(0.7)$ & 46 & (2.3) \\
\hline At Advanced 6 & 3 & $(0.2)$ & 1 & $(0.1)$ & 5 & $(0.4)$ & 5 & $(1.2)$ & 3 & $(0.2)$ & 1 & $(0.1)$ & 4 & $(0.3)$ & 7 & $(1.2)$ \\
\hline
\end{tabular}

\section{†Not applicable.}

tReporting standards not met (too few cases for a reliable estimate).

${ }^{1}$ Scale ranges from 0 to 300

The percentile represents a specific point on the percentage distribution of all students ranked by their writing score from low to high. For example, 10 percent of students scored at or below the 10 th percentile score, while 90 percent of students scored above it.

${ }^{3}$ The standard deviation provides an indication of how much the test scores varied. The lower the standard deviation, the closer the scores were clustered around the average score. About twothirds of the student scores can be expected to fall within the range of one standard deviation the average score. For exa 12th-graders was 150 and the standard deviation was 35 . This means that we would expect about two-thirds of the students to have scores between 185 (one standard deviation above the average) and 115 (one standard deviation below). Standard errors also must be taken into account when making comparisons of these ranges.

${ }^{4}$ Basic denotes partial mastery of the knowledge and skills that are fundamental for proficient work.
${ }^{5}$ Proficient represents solid academic performance. Students reaching this level have demonstrated competency over challenging subject matter.

${ }^{6}$ Advanced signifies superior performance.

NOTE: Writing scores from 2011 cannot be compared with writing scores from earlier assessment years. The 2011 writing assessment was developed under a new framework and is NAEP's first computer-based writing assessment. Includes public and private schools. Includes students tested with accommodations ( 8 percent of all 8 th-graders and 7 percent of all 12th-graders); excludes only those students with disabilities and English language learners who were unable to be tested even with accommodations ( 2 percent of all students at both grades). Race categories exclude persons of Hispanic ethnicity. Detail may not sum to totals because of rounding.

SOURCE: U.S. Department of Education, National Center for Education Statistics, National Assessment of Educational Progress (NAEP), 2011 Writing Assessment, retrieved October 1, 2012, from the Main NAEP Data Explorer (http://nces.ed.gov/nationsreportcard/naepdata). (This table was prepared October 2012.) 


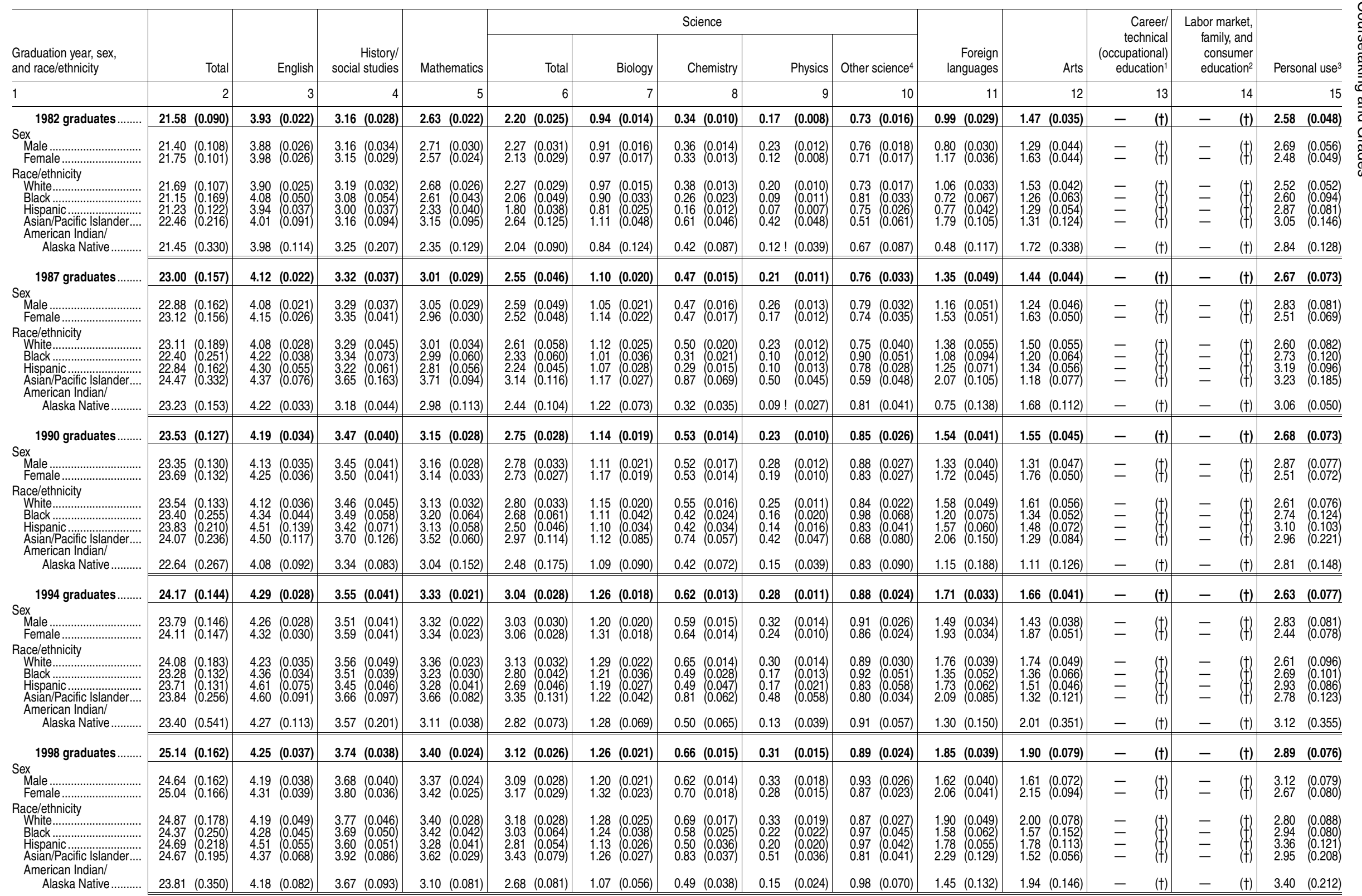


Table 225.10. Average number of Carnegie units earned by public high school graduates in various subject fields, by sex and race/ethnicity: Selected years, 1982 through 2009-Continued [Standard errors appear in parentheses]

\begin{tabular}{|c|c|c|c|c|c|c|c|c|c|c|c|c|c|c|c|c|c|}
\hline \multirow[b]{2}{*}{$\begin{array}{l}\text { Graduation year, sex, } \\
\text { and race/ethnicity }\end{array}$} & \multirow[b]{2}{*}{ Total } & \multirow[b]{2}{*}{ English } & \multirow[b]{2}{*}{$\begin{array}{r}\text { History/ } \\
\text { social studies }\end{array}$} & \multirow[b]{2}{*}{ Mathematics } & \multicolumn{6}{|c|}{ Science } & \multirow[b]{2}{*}{$\begin{array}{r}\text { Foreign } \\
\text { languages }\end{array}$} & \multirow[b]{2}{*}{ Arts } & \multirow{2}{*}{$\begin{array}{r}\text { Career/ } \\
\text { technical } \\
\text { (occupational) } \\
\text { education } 1\end{array}$} & \multirow{2}{*}{\begin{tabular}{r|} 
Labor market, \\
family, and \\
consumer \\
education ${ }^{2}$
\end{tabular}} & \multirow{2}{*}{\multicolumn{2}{|c|}{ Personal use ${ }^{3}$}} & \\
\hline & & & & & Total & Biology & Chemistry & & Physics & Other science ${ }^{4}$ & & & & & & & \\
\hline 1 & 2 & 3 & 4 & 5 & 6 & 7 & 8 & & 9 & 10 & 11 & 12 & 13 & 14 & & $\overline{15}$ & \\
\hline 2000 graduates ........ & $26.15(0.204)$ & $4.26(0.037)$ & $3.89(0.036)$ & $3.62(0.029)$ & $3.20(0.038)$ & $1.28(0.028)$ & $0.71(0.020)$ & 0.37 & $(0.018)$ & $0.84(0.030)$ & $2.01(0.045)$ & $2.03(0.054)$ & $2.86(0.105)$ & $1.35(0.044)$ & 3.49 & $(0.071)$ & \\
\hline 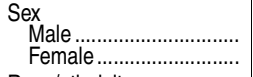 & $\begin{array}{ll}26.01 & (0.210) \\
26.26 & (0.204)\end{array}$ & $\begin{array}{ll}4.18 & (0.036) \\
4.34 & (0.040)\end{array}$ & $\begin{array}{ll}3.83 & (0.036) \\
3.95 & (0.038)\end{array}$ & $\begin{array}{ll}3.60 & (0.032) \\
3.64 & (0.028)\end{array}$ & $\begin{array}{ll}3.15 & (0.039) \\
3.24 & (0.041)\end{array}$ & $\begin{array}{l}1.20(0.030) \\
1.36(0.030)\end{array}$ & $\begin{array}{ll}0.67 & (0.020) \\
0.74 & (0.022)\end{array}$ & $\begin{array}{l}0.42 \\
0.33\end{array}$ & $\begin{array}{l}(0.020) \\
(0.018)\end{array}$ & $\begin{array}{ll}0.87 & (0.029) \\
0.81 & (0.031)\end{array}$ & $\begin{array}{ll}1.77 & (0.045) \\
2.25 & (0.050)\end{array}$ & $\begin{array}{ll}1.75 & (0.051) \\
2.29 & (0.065)\end{array}$ & $\begin{array}{ll}3.24 & (0.133) \\
2.48 & (0.086)\end{array}$ & $\begin{array}{ll}1.35 & (0.049) \\
1.34 & (0.047)\end{array}$ & $\begin{array}{l}3.76 \\
3.22\end{array}$ & $\begin{array}{l}(0.079) \\
(0.068)\end{array}$ & \\
\hline 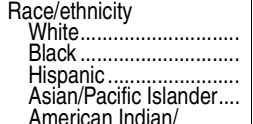 & $\begin{array}{ll}26.31 & (0.256) \\
25.85 & (0.233 \\
25.59 & 0.358 \\
26.23 & (0.332)\end{array}$ & $\begin{array}{ll}4.26 & (0.037) \\
4.36 & (0.078 \\
4.29 & (0.125) \\
4.12 & (0.060)\end{array}$ & $\begin{array}{ll}3.93 & (0.042) \\
3.81 & (0.068) \\
3.84 & (0.076) \\
3.80 & (0.055)\end{array}$ & $\begin{array}{ll}3.63 & (0.032) \\
3.57 & (0.046 \\
3.48 & (0.069) \\
4.01 & (0.108)\end{array}$ & $\begin{array}{ll}3.24 & (0.038) \\
3.12 & (0.059) \\
2.86 & (0.19 \\
3.70 & (0.162)\end{array}$ & $\begin{array}{ll}1.30 & (0.034) \\
1.25 & (0.041) \\
1.18 & (0.068) \\
1.35 & (0.066)\end{array}$ & 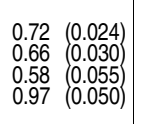 & $\begin{array}{l}0.39 \\
0.30 \\
0.25 \\
0.67\end{array}$ & 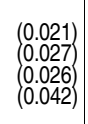 & $\begin{array}{ll}0.83 & (0.033) \\
0.91 & (0.043 \\
0.84 & (0.044) \\
0.71 & (0.086)\end{array}$ & $\begin{array}{ll}1.98 & (0.054) \\
1.71 & (0.070 \\
2.22 & (0.063) \\
2.90 & (0.089)\end{array}$ & $\begin{array}{ll}2.11 & (0.068) \\
1.94 & (0.134 \\
1.76 & (0.062) \\
1.78 & (0.085)\end{array}$ & $\begin{array}{ll}2.97 & (0.136) \\
2.74 & 0.143 \\
2.64 & (152) \\
1.99 & (0.149)\end{array}$ & $\begin{array}{ll}1.37 & (0.055) \\
1.54 & (0.075) \\
1.20 & (0.082) \\
0.81 & (0.050)\end{array}$ & $\begin{array}{l}3.37 \\
3.60 \\
3.95 \\
3.52\end{array}$ & $\begin{array}{l}(0.080) \\
0.134 \\
0.173 \\
0.221)\end{array}$ & \\
\hline Alaska Native .......... & $25.24 \quad(0.342)$ & $4.08(0.069)$ & $3.82(0.102)$ & $3.35(0.117)$ & $2.88(0.086)$ & $1.25(0.080)$ & $0.45(0.045)$ & 0.19 & $(0.042)$ & $0.98(0.038)$ & $1.41 \quad(0.105)$ & $1.99(0.220)$ & $3.23(0.380)$ & $1.60(0.151)$ & 3.60 & $(0.365)$ & \\
\hline 2005 graduates ........ & $26.88 \quad(0.102)$ & $4.33(0.022)$ & $4.08(0.027)$ & $3.80(0.018)$ & $3.35(0.019)$ & $1.28(0.016)$ & $0.75(0.011)$ & 0.37 & $(0.012)$ & $0.95(0.019)$ & $2.07(0.022)$ & $2.06(0.035)$ & $2.64(0.045)$ & $1.38(0.030)$ & 3.83 & $(0.047)$ & \\
\hline 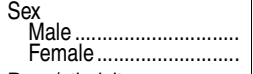 & $\begin{array}{ll}26.70 & (0.107) \\
27.05 & (0.104)\end{array}$ & $\begin{array}{ll}4.26 & (0.024) \\
4.39 & (0.022)\end{array}$ & $\begin{array}{ll}4.01 & (0.030) \\
4.16 & (0.028)\end{array}$ & $\begin{array}{ll}3.78 & (0.021) \\
3.83 & (0.018)\end{array}$ & $\begin{array}{ll}3.29 & (0.023) \\
3.41 & (0.019)\end{array}$ & $\begin{array}{l}1.19(0.016) \\
1.37 \\
(0.017)\end{array}$ & $\begin{array}{ll}0.71 & (0.012) \\
0.79 & (0.012)\end{array}$ & $\begin{array}{l}0.41 \\
0.33\end{array}$ & $\begin{array}{l}0.014) \\
0.012)\end{array}$ & $\begin{array}{ll}0.98 & (0.019) \\
0.92 & (0.020)\end{array}$ & $\begin{array}{ll}1.87 & (0.025) \\
2.25 & (0.023)\end{array}$ & $\begin{array}{ll}1.71 & (0.035) \\
2.38 & (0.045)\end{array}$ & $\begin{array}{ll}3.01 & (0.050) \\
2.29 & (0.049)\end{array}$ & $\begin{array}{ll}1.36 & (0.032) \\
1.41 & (0.033)\end{array}$ & $\begin{array}{l}4.17 \\
3.52\end{array}$ & $\left(\begin{array}{l}0.055) \\
0.050)\end{array}\right.$ & \\
\hline 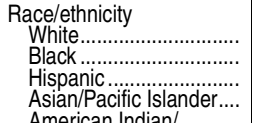 & $\begin{array}{ll}27.06 & (0.127) \\
26.76 & 0.151 \\
26.18 & 0.147 \\
26.58 & (0.183)\end{array}$ & $\begin{array}{ll}4.30 & (0.030 \\
4.50 & (0.028 \\
4.33 & (0.026 \\
4.28 & (0.043)\end{array}$ & $\begin{array}{l}4.12(0.030) \\
4.10 \\
3.80(0.054) \\
4.02(0.052) \\
4.028)\end{array}$ & $\begin{array}{ll}3.80 & (0.022) \\
3.86 & 0.036 \\
3.64 & (0.034 \\
4.08 & (0.051)\end{array}$ & $\begin{array}{ll}3.44 & (0.021) \\
3.22 & 0.035 \\
2.93 & (0.036 \\
3.65 & (0.057)\end{array}$ & $\begin{array}{ll}1.31 & (0.018) \\
1.27 & 0.025) \\
1.11 & (0.021 \\
1.31 & (0.035)\end{array}$ & $\begin{array}{l}0.77(0.014) \\
0.69 \\
0.64(0.017) \\
0.98 \\
0.0228 \\
(0.028)\end{array}$ & $\begin{array}{l}0.39 \\
0.28 \\
0.25 \\
0.59\end{array}$ & $\left.\begin{array}{l}(0.012 \\
0.025 \\
0.017 \\
0.036)\end{array}\right)$ & $\begin{array}{ll}0.96 & (0.021) \\
0.99 & (0.037 \\
0.94 & (0.031 \\
0.77 & (0.061)\end{array}$ & $\begin{array}{ll}2.03 & (0.025) \\
1.77 & (0.041) \\
2.39 & (0.047 \\
2.70 & (0.066)\end{array}$ & $\begin{array}{ll}2.17 & (0.043) \\
1.77 & 0.056 \\
1.78 & (0.055) \\
1.80 & (0.076)\end{array}$ & $\begin{array}{ll}2.75 & (0.059) \\
2.58 & (0.074) \\
2.41 & (0.06) \\
1.94 & (0.116)\end{array}$ & $\begin{array}{ll}1.39 & (0.036) \\
1.56 & (0.065) \\
1.30 & (0.046 \\
0.98 & (0.052)\end{array}$ & $\begin{array}{l}3.64 \\
4.32 \\
4.44 \\
3.53\end{array}$ & $\left.\begin{array}{l}(0.059) \\
0.096 \\
0.100 \\
0.122\end{array}\right)$ & \\
\hline Alaska Native.......... & $26.66(0.454)$ & $4.42(0.136)$ & $4.15(0.151)$ & $3.60(0.175)$ & $3.00(0.075)$ & $1.27(0.061)$ & $0.52(0.053)$ & 0.17 & $(0.036)$ & $1.04(0.063)$ & $1.55(0.125)$ & $2.45(0.179)$ & $2.45(0.208)$ & $1.70(0.184)$ & 4.24 & $(0.294)$ & \\
\hline 2009 graduates ......... & $27.15(0.100)$ & $4.37(0.013)$ & $4.19(0.027)$ & $3.91(0.017)$ & $3.47(0.022)$ & $1.35(0.014)$ & $0.78(0.011)$ & 0.42 & $(0.013)$ & $0.92(0.017)$ & $2.21(0.027)$ & $2.12(0.036)$ & $2.47(0.059)$ & $1.11(0.030)$ & 3.86 & $(0.059)$ & \\
\hline $\begin{array}{l}\text { Sex } \\
\text { Male } \\
\text { Female ................................................. }\end{array}$ & $\begin{array}{ll}26.98 & (0.111) \\
27.31 & (0.095)\end{array}$ & $\begin{array}{ll}4.30 & (0.015) \\
4.42 & (0.014)\end{array}$ & $\begin{array}{ll}4.13 & (0.028) \\
4.25 & (0.027)\end{array}$ & $\begin{array}{ll}3.88 & (0.018) \\
3.93 & (0.018)\end{array}$ & $\begin{array}{ll}3.46 & (0.027) \\
3.49 & (0.020)\end{array}$ & $\begin{array}{l}1.27(0.014) \\
1.43(0.015)\end{array}$ & $\begin{array}{ll}0.74 & (0.012) \\
0.82 & (0.011)\end{array}$ & $\begin{array}{l}0.48 \\
0.37\end{array}$ & $\left(\begin{array}{l}0.017) \\
(0.012)\end{array}\right)$ & $\begin{array}{ll}0.96 & (0.017) \\
0.88 & (0.019)\end{array}$ & $\begin{array}{ll}2.01 & (0.028) \\
2.40 & (0.028)\end{array}$ & $\begin{array}{ll}1.76 & (0.034) \\
2.46 & (0.046)\end{array}$ & $\begin{array}{ll}2.77 & (0.068) \\
2.19 & (0.055)\end{array}$ & $\begin{array}{ll}1.13 & (0.036) \\
1.10 & (0.028)\end{array}$ & $\begin{array}{l}4.18 \\
3.57\end{array}$ & $\left(\begin{array}{l}0.070) \\
0.060)\end{array}\right.$ & \\
\hline 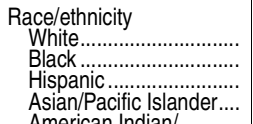 & $\begin{array}{ll}27.30 & (0.151) \\
27.42 & 0.141 \\
26.47 & 0.194) \\
26.94 & (0.190)\end{array}$ & $\begin{array}{ll}4.32 & (0.016) \\
4.56 & (0.039 \\
4.43 & (0.024) \\
4.19 & (0.039)\end{array}$ & $\begin{array}{ll}4.23 & (0.037) \\
4.26 & (0.036) \\
4.04 & (0.040 \\
4.13 & (0.083)\end{array}$ & $\begin{array}{ll}3.91 & (0.021) \\
4.02 & 0.035 \\
3.70 & (0.029 \\
4.16 & (0.052)\end{array}$ & $\begin{array}{ll}3.55 & (0.026) \\
3.31 & 0.027 \\
3.13 & (0.028 \\
4.06 & (0.091)\end{array}$ & $\begin{array}{l}1.37 \\
1.33 \\
1.2015 \\
1.24 \\
1.56 \\
0.019 \\
(0.077)\end{array}$ & $\begin{array}{ll}0.80 & (0.013) \\
0.68 & (0.022 \\
0.70 & (0.015 \\
1.08 & (0.035)\end{array}$ & $\begin{array}{l}0.44 \\
0.30 \\
0.32 \\
0.75\end{array}$ & $\begin{array}{l}(0.016) \\
0.019 \\
0.015 \\
(0.033)\end{array}$ & $\begin{array}{ll}0.94 & (0.022) \\
1.00 & 0.028 \\
0.87 & 0.024 \\
0.68 & (0.063)\end{array}$ & $\begin{array}{ll}2.19 & (0.032) \\
1.87 & 0.044 \\
2.34 & (0.034 \\
2.98 & (0.090)\end{array}$ & $\begin{array}{l}2.26 \\
1.87 \\
1.042 \\
1.85 \\
1.099 \\
(0.046 \\
(0.065)\end{array}$ & $\begin{array}{ll}2.55 & (0.071) \\
2.72 & 0.127 \\
2.31 & (0.101) \\
1.63 & (0.074)\end{array}$ & $\begin{array}{l}1.16(0.040) \\
1.21(0.052) \\
1.04(0.040 \\
0.62(0.054)\end{array}$ & $\begin{array}{l}3.70 \\
4.29 \\
4.26 \\
3.47\end{array}$ & $\left.\begin{array}{l}(0.075) \\
0.102 \\
0.095 \\
0.100\end{array}\right)$ & \\
\hline Alaska Native........... & $26.17(0.409)$ & $4.39(0.085)$ & $4.11(0.083)$ & $3.76(0.125)$ & $3.20(0.070)$ & $1.38(0.062)$ & $0.50(0.051)$ & 0.24 & $(0.046)$ & $1.09(0.066)$ & $1.56(0.097)$ & $2.19(0.157)$ & $2.35(0.188)$ & $1.20(0.117)$ & 4.54 & $(0.370)$ & 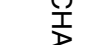 \\
\hline $\begin{array}{l}\text {-Not available. } \\
\text { +Not applicable. } \\
\text { !Interpret data with caution. } \\
\text { IIncludes occupational edu } \\
\text { sciences; construction and } \\
\text { and personal, public, and I } \\
\text { sciences education courses } \\
\text { 2Includes general labor mar } \\
\text { 3Includes general skills, per } \\
\text { not included in other acade } \\
\text { tional) education column an }\end{array}$ & $\begin{array}{l}\text { The coefficient o } \\
\text { ation in agricultu } \\
\text { architecture; ens } \\
\text { gal services. Do } \\
\text { ket preparation c } \\
\text { sonal health and } \\
\text { mic subject field } \\
\text { d the Labor mark }\end{array}$ & $\begin{array}{l}\text { variation (CV) fo } \\
\text { e; business and } \\
\text { ineering technol } \\
\text { s not include ge } \\
\text { urses and famil) } \\
\text { hysical educatio } \\
\text { Some persona } \\
\text { t, family, and co }\end{array}$ & $\begin{array}{l}\text { narketing; comm } \\
\text { gies; health scie } \\
\text { neral labor marke } \\
\text { and consumer s } \\
\text { n, religion, militar } \\
\text {-use courses are } \\
\text { ssumer education }\end{array}$ & $\begin{array}{l}\text { ications and d } \\
\text { ces; manufact } \\
\text { preparation co } \\
\text { snces educatic } \\
\text { ciences, spec } \\
\text { laso included i } \\
\text { olumn. }\end{array}$ & $\begin{array}{l}0 \text { percent. } \\
\text { sign; computer a } \\
\text { ing; repair and } \\
\text { rses and family } \\
\text { courses. } \\
\text { leducation, and } \\
\text { the Career/tech }\end{array}$ & $\begin{array}{l}\text { information } \\
\text { nsportation; } \\
\text { d consumer } \\
\text { her courses } \\
\text { :al (occupa- }\end{array}$ & $\begin{array}{l}\text { differ sligh } \\
\text { Race cate } \\
\text { may not S } \\
\text { SOURCE } \\
\text { of } 1980 \text { S } \\
\text { High Sche }\end{array}$ & $\begin{array}{l}\text { ly from } \\
\text { gories } \mathrm{e} \\
\text { m to tot } \\
\text { U.S. De } \\
\text { phomo } \\
\text { ol Trans }\end{array}$ & $\begin{array}{l}\text { figures a } \\
\text { exclude p } \\
\text { tals becal } \\
\text { epartmen } \\
\text { ores (HS\& } \\
\text { script Stuc }\end{array}$ & $\begin{array}{l}\text { pepearing in othe } \\
\text { ersons of Hispar } \\
\text { use of rounding. } \\
\text { t of Education, N } \\
\text { kB-So: } 80 / 82 \text { ), "Hi } \\
\text { dy (HSTS). (This }\end{array}$ & $\begin{array}{l}\text { biology, chemi } \\
\text { asurement tha } \\
\text { NCES reports } \\
\text { ethnicity. Tota } \\
\text { ional Center fo } \\
\text { I School Trans } \\
\text { ble was prepar }\end{array}$ & $\begin{array}{l}y \text {, and physics. } \\
\text { epresents one } \\
\text { cause of differe } \\
\text { include other r } \\
\text { ducation Statis } \\
\text { ipt Study"; and } \\
\text { September } 20\end{array}$ & $\begin{array}{l}\text { redit for the comp } \\
\text { nces in taxonom } \\
\text { acial/ethnic group } \\
\text { tics, High School } \\
\text { 1987, 1990, 199 } \\
\text { 11.) }\end{array}$ & $\begin{array}{l}\text { etion of a 1-yea } \\
\text { s and case exc } \\
\text { not separately } \\
\text { nd Beyond Lono } \\
1998,2000,20\end{array}$ & in. & $\begin{array}{l}\text { Data } \\
\text { Diteria. } \\
\text { Detail } \\
\text { Study } \\
2009\end{array}$ & 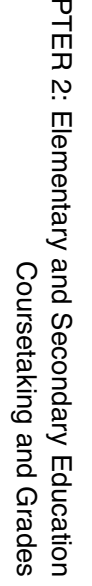 \\
\hline
\end{tabular}


Table 225.20. Average number of Carnegie units earned by public high school graduates in career/technical education courses in various occupational fields, by sex and race/ethnicity, and percentage distribution of students, by units earned: Selected years, 2000 through 2009

[Standard errors appear in parentheses]

\begin{tabular}{|c|c|c|c|c|c|c|c|c|c|c|c|c|c|c|c|c|c|c|c|c|c|c|}
\hline \multirow{2}{*}{$\begin{array}{l}\text { Graduation year, sex, } \\
\text { and race/ethnicity } \\
1\end{array}$} & \multicolumn{2}{|c|}{$\begin{array}{r}\text { Total, all } \\
\text { occupational } \\
\text { education } \\
\text { courses }^{1} \\
\end{array}$} & \multicolumn{2}{|r|}{ Agriculture } & \multicolumn{2}{|c|}{$\begin{array}{r}\text { Business and } \\
\text { marketing }\end{array}$} & \multicolumn{2}{|c|}{$\begin{array}{r}\text { Communications } \\
\text { and design }\end{array}$} & \multicolumn{2}{|c|}{$\begin{array}{r}\text { Computer and } \\
\text { information sciences }\end{array}$} & \multicolumn{2}{|c|}{$\begin{array}{r}\text { Construction and } \\
\text { architecture }\end{array}$} & \multicolumn{2}{|c|}{$\begin{array}{r}\text { Engineering } \\
\text { technologies }\end{array}$} & \multicolumn{2}{|c|}{ Health sciences } & \multicolumn{2}{|c|}{ Manufacturing } & \multicolumn{2}{|c|}{$\begin{array}{r}\text { Repair and } \\
\text { transportation }\end{array}$} & \multicolumn{2}{|c|}{$\begin{array}{r}\text { Personal, public, } \\
\text { and legal } \\
\text { services }\end{array}$} \\
\hline & & 2 & & 3 & & 4 & & 5 & & 6 & & 7 & & 8 & & 9 & & 10 & & 11 & & 12 \\
\hline 2000 graduates & & & & & & & & & & & & & & & & & & & & & & \\
\hline $\begin{array}{l}\text { Average units earned, } \\
\text { all students }{ }^{2}\end{array}$ & 2.86 & $(0.105)$ & 0.25 & $(0.029)$ & 0.82 & $(0.041)$ & 0.30 & $(0.016)$ & 0.27 & $(0.021)$ & 0.14 & 0.018) & 0.20 & $(0.020)$ & 0.15 & $(0.019)$ & 0.24 & $(0.021)$ & 0.18 & $(0.015)$ & 0.32 & $(0.018)$ \\
\hline 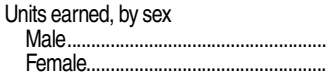 & $\begin{array}{l}3.24 \\
2.48\end{array}$ & $\begin{array}{l}(0.133) \\
(0.086)\end{array}$ & $\begin{array}{l}0.34 \\
0.16\end{array}$ & $\begin{array}{l}(0.041) \\
(0.022)\end{array}$ & $\begin{array}{l}0.71 \\
0.91\end{array}$ & $\left.\begin{array}{l}(0.043) \\
(0.042)\end{array}\right)$ & $\begin{array}{l}0.28 \\
0.32\end{array}$ & $\begin{array}{l}(0.018) \\
(0.017)\end{array}$ & $\begin{array}{l}0.33 \\
0.21\end{array}$ & $\begin{array}{l}(0.026) \\
(0.020)\end{array}$ & $\begin{array}{l}0.25 \\
0.02\end{array}$ & $0.035)$ & $\begin{array}{l}0.34 \\
0.06\end{array}$ & $\begin{array}{l}(0.034) \\
(0.008)\end{array}$ & $\begin{array}{l}0.07 \\
0.22\end{array}$ & $\begin{array}{l}(0.013) \\
(0.026)\end{array}$ & $\begin{array}{l}0.40 \\
0.10\end{array}$ & $0.035)$ & $\begin{array}{l}0.33 \\
0.03\end{array}$ & $0.028)$ & $\begin{array}{l}0.18 \\
0.46\end{array}$ & $\begin{array}{l}(0.015) \\
(0.027)\end{array}$ \\
\hline 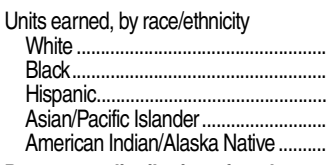 & $\begin{array}{l}2.97 \\
2.74 \\
2.64 \\
1.99 \\
3.23 \\
\end{array}$ & $\begin{array}{l}(0.136) \\
(0.143) \\
(0.152) \\
(0.149) \\
(0.380)\end{array}$ & $\begin{array}{l}0.31 \\
0.11 \\
0.13 \\
0.06 \\
0.37 ! \\
\end{array}$ & $\begin{array}{l}(0.038) \\
(0.027) \\
(0.020) \\
(0.014) \\
(0.131)\end{array}$ & $\begin{array}{l}0.79 \\
0.98 \\
0.86 \\
0.54 \\
0.80\end{array}$ & $\begin{array}{l}(0.049) \\
(0.068) \\
(0.083) \\
(0.065) \\
(0.088)\end{array}$ & $\begin{array}{l}0.31 \\
0.29 \\
0.29 \\
0.25 \\
0.24 \\
\end{array}$ & $\begin{array}{l}(0.019) \\
(0.026) \\
(0.024) \\
(0.035) \\
(0.050)\end{array}$ & $\begin{array}{l}0.26 \\
0.24 \\
0.26 \\
0.45 \\
0.32 \\
\end{array}$ & $\begin{array}{l}(0.023) \\
(0.024) \\
(0.021) \\
(0.098) \\
(0.072)\end{array}$ & $\begin{array}{l}0.16 \\
0.08 \\
0.09 \\
0.02 ! \\
0.08 ! \\
\end{array}$ & $\begin{array}{l}(0.027) \\
(0.017) \\
(0.018) \\
(0.007) \\
(0.029)\end{array}$ & $\begin{array}{l}0.22 \\
0.15 \\
0.14 \\
0.17 \\
0.20 ! \\
\end{array}$ & $\begin{array}{l}(0.025) \\
(0.029) \\
(0.019) \\
(0.033) \\
(0.067)\end{array}$ & $\begin{array}{l}0.13 \\
0.17 \\
0.24 ! \\
0.15 \\
0.11 \\
\end{array}$ & $\begin{array}{l}(0.019) \\
(0.022) \\
(0.100) \\
(0.037) \\
(0.030)\end{array}$ & $\begin{array}{l}0.27 \\
0.17 \\
0.17 \\
0.12 \\
0.49 ! \\
\end{array}$ & $\begin{array}{l}(0.027) \\
(0.023) \\
(0.027) \\
(0.030) \\
(0.160)\end{array}$ & $\begin{array}{r}0.20 \\
0.11 \\
0.15 \\
0.07 \\
\ddagger \\
\end{array}$ & $\begin{array}{r}(0.021) \\
(0.016) \\
(0.017) \\
(0.018) \\
(\dagger)\end{array}$ & $\begin{array}{l}0.31 \\
0.44 \\
0.31 \\
0.16 \\
0.41\end{array}$ & $\begin{array}{l}(0.020) \\
(0.050) \\
(0.029) \\
(0.022) \\
(0.121) \\
\end{array}$ \\
\hline 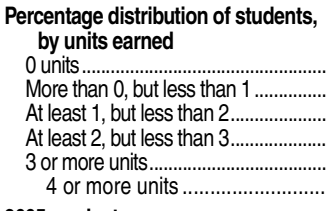 & $\begin{array}{r}11.1 \\
7.9 \\
22.1 \\
17.0 \\
41.8 \\
28.9 \\
\end{array}$ & $\begin{array}{l}(0.79) \\
(0.57) \\
(0.77) \\
(0.56) \\
(1.53) \\
(1.48) \\
\end{array}$ & $\begin{array}{r}88.3 \\
2.3 \\
4.5 \\
1.7 \\
3.3 \\
2.1 \\
\end{array}$ & $\begin{array}{l}(0.86) \\
(0.37) \\
(0.37) \\
(0.18) \\
(0.44) \\
(0.37) \\
\end{array}$ & $\begin{array}{r}49.0 \\
12.1 \\
22.7 \\
8.1 \\
8.1 \\
4.0 \\
\end{array}$ & $\begin{array}{l}(1.83) \\
(1.18) \\
(0.91) \\
(0.50) \\
(0.63) \\
(0.47) \\
\end{array}$ & $\begin{array}{r}74.5 \\
8.9 \\
12.1 \\
3.0 \\
1.6 \\
0.8 \\
\end{array}$ & $\begin{array}{l}(1.29) \\
(0.72) \\
(0.72) \\
(0.25) \\
(0.20) \\
(0.13) \\
\end{array}$ & $\begin{array}{r}75.7 \\
8.7 \\
11.9 \\
2.5 \\
1.1 \\
0.6 \\
\end{array}$ & $\begin{array}{l}(1.61) \\
(1.22) \\
(0.94) \\
(0.39) \\
(0.20) \\
(0.15) \\
\end{array}$ & $\begin{array}{r}93.1 \\
1.8 \\
3.0 \\
0.7 \\
1.4 \\
1.0 \\
\end{array}$ & $\begin{array}{l}(0.51) \\
(0.26) \\
(0.33) \\
(0.11) \\
(0.21) \\
(0.20) \\
\end{array}$ & $\begin{array}{r}85.8 \\
3.4 \\
7.5 \\
2.1 \\
1.3 \\
0.6 \\
\end{array}$ & $\begin{array}{l}(1.10) \\
(0.44) \\
(0.67) \\
(0.23) \\
(0.18) \\
(0.13) \\
\end{array}$ & $\begin{array}{r}89.4 \\
5.6 \\
2.3 \\
0.8 \\
1.9 \\
1.1 ! \\
\end{array}$ & $\begin{array}{l}(1.28) \\
(1.22) \\
(0.32) \\
(0.13) \\
(0.39) \\
(0.37) \\
\end{array}$ & $\begin{array}{r}83.6 \\
5.4 \\
7.0 \\
2.1 \\
1.9 \\
1.2 \\
\end{array}$ & $\begin{array}{l}(0.98) \\
(0.53) \\
(0.61) \\
(0.27) \\
(0.26) \\
(0.20) \\
\end{array}$ & $\begin{array}{r}90.7 \\
2.7 \\
3.5 \\
0.9 \\
2.1 \\
1.4 \\
\end{array}$ & $\begin{array}{l}(0.61) \\
(0.43) \\
(0.38) \\
(0.11) \\
(0.21) \\
(0.18) \\
\end{array}$ & $\begin{array}{r}74.5 \\
11.8 \\
8.6 \\
2.5 \\
2.6 \\
1.5 \\
\end{array}$ & $\begin{array}{l}(1.34) \\
(1.01) \\
(0.64) \\
(0.29) \\
(0.22) \\
(0.19) \\
\end{array}$ \\
\hline 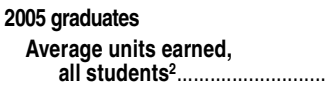 & 64 & $(0.045)$ & 23 & .013) & 64 & $(0.020)$ & 0.36 & $(0.012)$ & 0.24 & .011) & 0.12 & .007) & 0.15 & .008) & 0.16 & 0.010) & 0.21 & .011) & 0.18 & $(0.011)$ & 0.35 & $(0.013)$ \\
\hline 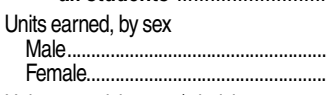 & $\begin{array}{l}3.01 \\
2.29\end{array}$ & $\begin{array}{l}(0.050) \\
(0.049)\end{array}$ & $\begin{array}{l}0.32 \\
0.15\end{array}$ & $\begin{array}{l}(0.020) \\
(0.011)\end{array}$ & $\begin{array}{l}0.62 \\
0.66\end{array}$ & $\begin{array}{l}(0.022) \\
(0.023)\end{array}$ & $\begin{array}{l}0.34 \\
0.38\end{array}$ & $\begin{array}{l}(0.014) \\
(0.014)\end{array}$ & $\begin{array}{l}0.33 \\
0.15\end{array}$ & .015) & 0.03 & $\begin{array}{l}.014) \\
.003)\end{array}$ & $\begin{array}{l}0.26 \\
0.05\end{array}$ & .014) & $\begin{array}{l}0.07 \\
0.25\end{array}$ & $\begin{array}{l}(0.007) \\
(0.016)\end{array}$ & $\begin{array}{l}0.33 \\
0.10\end{array}$ & $\begin{array}{l}(0.019) \\
(0.008)\end{array}$ & $\begin{array}{l}0.33 \\
0.03\end{array}$ & $\begin{array}{l}(0.019) \\
(0.005)\end{array}$ & $\begin{array}{l}0.20 \\
0.49\end{array}$ & $\begin{array}{l}(0.011) \\
(0.018)\end{array}$ \\
\hline 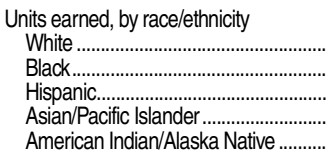 & $\begin{array}{l}2.75 \\
2.58 \\
2.41 \\
1.94 \\
2.45 \\
\end{array}$ & $\begin{array}{l}(0.059) \\
(0.074) \\
(0.086) \\
(0.116) \\
(0.208)\end{array}$ & $\begin{array}{l}0.28 \\
0.10 \\
0.14 \\
0.06 ! \\
0.46\end{array}$ & $\begin{array}{l}(0.017) \\
(0.018) \\
(0.019) \\
(0.019) \\
(0.127)\end{array}$ & $\begin{array}{l}0.63 \\
0.80 \\
0.63 \\
0.49 \\
0.46 \\
\end{array}$ & $\begin{array}{l}(0.024) \\
(0.041) \\
(0.033) \\
(0.045) \\
(0.080)\end{array}$ & $\begin{array}{l}0.39 \\
0.28 \\
0.30 \\
0.32 \\
0.33 \\
\end{array}$ & $\begin{array}{l}(0.015) \\
(0.019) \\
(0.016) \\
(0.040) \\
(0.056)\end{array}$ & $\begin{array}{l}0.24 \\
0.23 \\
0.21 \\
0.36 \\
0.24 ! \\
\end{array}$ & $\begin{array}{l}(0.013) \\
(0.021) \\
(0.015) \\
(0.032) \\
(0.076) \\
\end{array}$ & $\begin{array}{l}0.13 \\
0.11 \\
0.10 \\
0.04 \\
0.09 ! \\
\end{array}$ & $\begin{array}{l}(0.010) \\
(0.012) \\
(0.014) \\
(0.010) \\
(0.038)\end{array}$ & $\begin{array}{l}0.17 \\
0.11 \\
0.12 \\
0.13 \\
0.02 ! \\
\end{array}$ & $\begin{array}{l}(0.010) \\
(0.015) \\
(0.019) \\
(0.021) \\
(0.009)\end{array}$ & $\begin{array}{l}0.15 \\
0.25 \\
0.16 \\
0.10 \\
0.10 \\
\end{array}$ & $\begin{array}{l}(0.012) \\
(0.023) \\
(0.019) \\
(0.022) \\
(0.029)\end{array}$ & $\begin{array}{l}0.25 \\
0.11 \\
0.17 \\
0.13 \\
0.24 \\
\end{array}$ & $\begin{array}{l}(0.015) \\
(0.013) \\
(0.022) \\
(0.024) \\
(0.055)\end{array}$ & $\begin{array}{l}0.19 \\
0.13 \\
0.19 \\
0.09 \\
0.21 ! \\
\end{array}$ & $\begin{array}{l}(0.014) \\
(0.023) \\
(0.020) \\
(0.018) \\
(0.069)\end{array}$ & $\begin{array}{l}0.33 \\
0.45 \\
0.39 \\
0.21 \\
0.31 \\
\end{array}$ & $\begin{array}{l}(0.015) \\
(0.030) \\
(0.030) \\
(0.020) \\
(0.057) \\
\end{array}$ \\
\hline 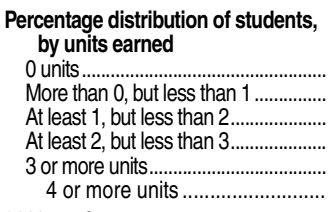 & $\begin{array}{r}13.0 \\
8.2 \\
22.0 \\
17.3 \\
39.5 \\
26.5 \\
\end{array}$ & $\begin{array}{l}(0.45) \\
(0.35) \\
(0.41) \\
(0.34) \\
(0.76) \\
(0.67) \\
\end{array}$ & $\begin{array}{r}88.4 \\
2.0 \\
4.8 \\
1.8 \\
3.0 \\
1.9 \\
\end{array}$ & $\begin{array}{l}(0.54) \\
(0.20) \\
(0.28) \\
(0.12) \\
(0.21) \\
(0.16) \\
\end{array}$ & $\begin{array}{r}55.8 \\
11.5 \\
20.7 \\
6.5 \\
5.4 \\
2.7 \\
\end{array}$ & $\begin{array}{l}(1.05) \\
(0.62) \\
(0.65) \\
(0.29) \\
(0.32) \\
(0.20) \\
\end{array}$ & $\begin{array}{r}69.8 \\
10.6 \\
14.2 \\
3.4 \\
2.1 \\
0.9 \\
\end{array}$ & $\begin{array}{l}(0.79) \\
(0.50) \\
(0.59) \\
(0.16) \\
(0.17) \\
(0.09) \\
\end{array}$ & $\begin{array}{r}80.5 \\
6.3 \\
9.5 \\
2.3 \\
1.4 \\
0.6 \\
\end{array}$ & $\begin{array}{l}(0.91) \\
(0.36) \\
(0.62) \\
(0.19) \\
(0.12) \\
(0.09) \\
\end{array}$ & $\begin{array}{r}93.3 \\
1.6 \\
2.9 \\
0.9 \\
1.2 \\
0.8 \\
\end{array}$ & $\begin{array}{l}(0.33) \\
(0.17) \\
(0.20) \\
(0.11) \\
(0.12) \\
(0.09) \\
\end{array}$ & $\begin{array}{r}88.2 \\
3.7 \\
5.7 \\
1.4 \\
1.0 \\
0.5 \\
\end{array}$ & $\begin{array}{l}(0.53) \\
(0.34) \\
(0.28) \\
(0.12) \\
(0.13) \\
(0.08) \\
\end{array}$ & $\begin{array}{r}90.4 \\
3.3 \\
2.9 \\
1.1 \\
2.2 \\
1.1 \\
\end{array}$ & $\begin{array}{l}(0.67) \\
(0.52) \\
(0.21) \\
(0.11) \\
(0.19) \\
(0.13) \\
\end{array}$ & $\begin{array}{r}83.6 \\
6.2 \\
6.4 \\
2.0 \\
1.8 \\
0.8 \\
\end{array}$ & $\begin{array}{l}(0.82) \\
(0.48) \\
(0.35) \\
(0.18) \\
(0.16) \\
(0.11) \\
\end{array}$ & $\begin{array}{r}91.2 \\
2.6 \\
2.8 \\
1.1 \\
2.3 \\
1.5 \\
\end{array}$ & $\begin{array}{l}(0.38) \\
(0.26) \\
(0.17) \\
(0.12) \\
(0.20) \\
(0.16) \\
\end{array}$ & $\begin{array}{r}74.9 \\
9.7 \\
9.6 \\
2.7 \\
3.0 \\
1.7 \\
\end{array}$ & $\begin{array}{l}(0.85) \\
(0.61) \\
(0.47) \\
(0.20) \\
(0.20) \\
(0.15) \\
\end{array}$ \\
\hline $\begin{array}{l}2009 \text { graduates } \\
\text { Average units earned, } \\
\text { all students }{ }^{2} \text {................ }\end{array}$ & 47 & $(0.059)$ & . & $(0.013)$ & 51 & $(0.017)$ & 36 & $(0.011)$ & 0.23 & $(0.010)$ & 0.11 & .009) & 0.14 & .008) & 0.20 & $(0.015)$ & 0.17 & $(0.010)$ & 0.17 & $(0.015)$ & 0.37 & $(0.020)$ \\
\hline 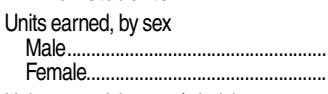 & $\begin{array}{l}2.77 \\
2.19\end{array}$ & $\begin{array}{l}(0.068) \\
(0.055)\end{array}$ & $\begin{array}{l}0.27 \\
0.14\end{array}$ & $\begin{array}{l}(0.020) \\
(0.009)\end{array}$ & $\begin{array}{l}0.52 \\
0.50\end{array}$ & $\begin{array}{l}(0.020) \\
(0.018)\end{array}$ & $\begin{array}{l}0.35 \\
0.38\end{array}$ & $\begin{array}{l}(0.012) \\
(0.013)\end{array}$ & 0.16 & $\begin{array}{l}(0.013) \\
(0.009)\end{array}$ & $\begin{array}{l}0.20 \\
0.03\end{array}$ & $(0.004)$ & $\begin{array}{l}0.24 \\
0.05\end{array}$ & $\begin{array}{l}(0.013) \\
(0.005)\end{array}$ & 0.31 & $\begin{array}{l}(0.010) \\
(0.021)\end{array}$ & $\begin{array}{l}0.26 \\
0.09\end{array}$ & $\begin{array}{l}(0.017) \\
(0.007)\end{array}$ & $\begin{array}{l}0.32 \\
0.03\end{array}$ & $\begin{array}{l}(0.027) \\
(0.005)\end{array}$ & $\begin{array}{l}0.22 \\
0.51\end{array}$ & $\begin{array}{l}(0.013) \\
(0.028)\end{array}$ \\
\hline 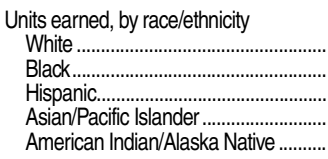 & $\begin{array}{l}2.55 \\
2.72 \\
2.31 \\
1.63 \\
2.35 \\
\end{array}$ & $\begin{array}{l}(0.071) \\
(0.127) \\
(0.101) \\
(0.074) \\
(0.188)\end{array}$ & $\begin{array}{l}0.27 \\
0.09 \\
0.14 \\
0.03 \\
0.17 !\end{array}$ & $\begin{array}{l}(0.020) \\
(0.010) \\
(0.018) \\
(0.009) \\
(0.069)\end{array}$ & $\begin{array}{l}0.50 \\
0.69 \\
0.43 \\
0.42 \\
0.43 \\
\end{array}$ & $\begin{array}{l}(0.022) \\
(0.035) \\
(0.027) \\
(0.054) \\
(0.065)\end{array}$ & $\begin{array}{l}0.38 \\
0.34 \\
0.34 \\
0.26 \\
0.44\end{array}$ & $\begin{array}{l}(0.013) \\
(0.026) \\
(0.015) \\
(0.026) \\
(0.065)\end{array}$ & $\begin{array}{l}0.22 \\
0.26 \\
0.23 \\
0.27 \\
0.24 !\end{array}$ & $\begin{array}{l}(0.026) \\
(0.025) \\
(0.024) \\
(0.079) \\
\end{array}$ & $\begin{array}{r}0.10 \\
0.08 \\
0.04 \\
\ddagger\end{array}$ & $\begin{array}{r}(0.021) \\
(0.011) \\
(0.009) \\
(\dagger)\end{array}$ & $\begin{array}{l}0.10 \\
0.10 \\
0.13 \\
0.07 !\end{array}$ & $\begin{array}{l}(0.015) \\
(0.009) \\
(0.034) \\
(0.028)\end{array}$ & $\begin{array}{l}0.16 \\
0.31 \\
0.24 \\
0.20 \\
0.12 ! \\
\end{array}$ & $\begin{array}{l}(0.044) \\
(0.031) \\
(0.048) \\
(0.050)\end{array}$ & $\begin{array}{l}0.12 \\
0.13 \\
0.08 \\
0.30\end{array}$ & $\left.\begin{array}{l}(0.015) \\
(0.013) \\
(0.012) \\
(0.071)\end{array}\right]$ & $\begin{array}{l}0.19 ! \\
0.20 \\
0.07 \\
0.19 !\end{array}$ & $\left.\begin{array}{l}(0.056) \\
(0.026) \\
(0.015) \\
(0.068)\end{array}\right]$ & $\begin{array}{l}0.35 \\
0.52 \\
0.43 \\
0.14 \\
0.26\end{array}$ & $\begin{array}{l}(0.020) \\
(0.037) \\
(0.044) \\
(0.020) \\
(0.057) \\
\end{array}$ \\
\hline
\end{tabular}


Table 225.20. Average number of Carnegie units earned by public high school graduates in career/technical education courses in various occupational fields, by sex and race/ethnicity, and percentage distribution of students, by units earned: Selected years, 2000 through 2009-Continued

Standard errors appear in parentheses]

\begin{tabular}{|c|c|c|c|c|c|c|c|c|c|c|c|c|c|c|c|c|c|c|c|c|c|c|}
\hline \multirow{2}{*}{$\begin{array}{l}\text { Graduation year, sex, } \\
\text { and race/ethnicity } \\
1\end{array}$} & \multicolumn{2}{|c|}{$\begin{array}{r}\text { Total, all } \\
\text { occupational } \\
\text { education } \\
\text { courses }^{1}\end{array}$} & \multicolumn{2}{|c|}{ Agriculture } & \multicolumn{2}{|c|}{$\begin{array}{r}\text { Business an } \\
\text { marketin }\end{array}$} & \multicolumn{2}{|c|}{$\begin{array}{r}\text { Communications } \\
\text { and design }\end{array}$} & \multicolumn{2}{|c|}{$\begin{array}{r}\text { Computer and } \\
\text { information sciences }\end{array}$} & \multicolumn{2}{|c|}{$\begin{array}{r}\text { Construction and } \\
\text { architecture }\end{array}$} & \multicolumn{2}{|c|}{$\begin{array}{r}\text { Engineering } \\
\text { technologies }\end{array}$} & \multicolumn{2}{|c|}{ Health sciences } & \multicolumn{2}{|c|}{ Manufacturing } & \multicolumn{2}{|c|}{$\begin{array}{r}\text { Repair and } \\
\text { transportation }\end{array}$} & \multicolumn{2}{|c|}{$\begin{array}{r}\text { Personal, public, } \\
\text { and lega } \\
\text { services }\end{array}$} \\
\hline & & 2 & & 3 & & 4 & & 5 & & 6 & & 7 & & 8 & & 9 & & 10 & & 11 & & 12 \\
\hline 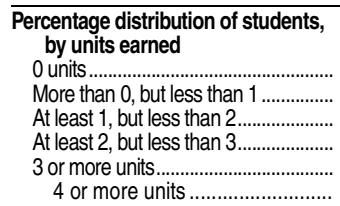 & $\begin{array}{r}15.0 \\
8.7 \\
23.0 \\
17.0 \\
36.2 \\
23.8\end{array}$ & $\begin{array}{l}(0.61) \\
(0.33) \\
(0.59) \\
(0.33) \\
(1.02) \\
(0.89)\end{array}$ & $\begin{array}{r}89.3 \\
2.1 \\
4.3 \\
1.7 \\
2.7 \\
1.6\end{array}$ & $\begin{array}{l}(0.58) \\
(0.26) \\
(0.32) \\
(0.15) \\
(0.24) \\
(0.15)\end{array}$ & $\begin{array}{r}63.4 \\
10.1 \\
17.0 \\
5.4 \\
4.1 \\
1.8\end{array}$ & $\begin{array}{l}(1.04 \\
(0.51 \\
(0.60 \\
(0.35 \\
(0.23 \\
(0.16)\end{array}$ & $\begin{array}{r}70.2 \\
10.2 \\
13.8 \\
3.6 \\
2.2 \\
1.0\end{array}$ & $\begin{array}{l}(0.91) \\
(0.55) \\
(0.53) \\
(0.20) \\
(0.13) \\
(0.07)\end{array}$ & $\begin{array}{r}78.5 \\
8.3 \\
10.1 \\
2.1 \\
1.1 \\
0.4\end{array}$ & $\begin{array}{l}(0.89) \\
(0.64) \\
(0.50) \\
(0.16) \\
(0.14) \\
(0.07)\end{array}$ & $\begin{array}{r}93.3 \\
1.7 \\
2.9 \\
1.0 \\
1.1 \\
0.7\end{array}$ & $\begin{array}{l}(0.43) \\
(0.18) \\
(0.23) \\
(0.17) \\
(0.11) \\
(0.08)\end{array} \mid$ & $\begin{array}{r}88.8 \\
2.8 \\
6.1 \\
1.3 \\
0.9 \\
0.4\end{array}$ & $\begin{array}{l}(0.62) \\
(0.24) \\
(0.51) \\
(0.12) \\
(0.09) \\
(0.05)\end{array}$ & $\begin{array}{r}89.6 \\
2.3 \\
4.1 \\
1.4 \\
2.6 \\
1.7\end{array}$ & $\begin{array}{l}(0.64) \\
(0.28) \\
(0.44) \\
(0.13) \\
(0.25) \\
(0.19)\end{array}$ & $\begin{array}{r}87.1 \\
4.5 \\
5.6 \\
1.6 \\
1.3 \\
0.6\end{array}$ & $\begin{array}{l}(0.52) \\
(0.30) \\
(0.31) \\
(0.12) \\
(0.15) \\
(0.09)\end{array}$ & $\begin{array}{r}92.0 \\
2.0 \\
2.8 \\
1.1 \\
2.1 \\
1.5\end{array}$ & $\begin{array}{l}(0.43) \\
(0.21) \\
(0.20) \\
(0.10) \\
(0.24) \\
(0.21)\end{array}$ & $\begin{array}{r}74.6 \\
9.2 \\
10.2 \\
2.9 \\
3.2 \\
1.9\end{array}$ & $\begin{array}{l}(0.73) \\
(0.40) \\
(0.45) \\
(0.22) \\
(0.24) \\
(0.19)\end{array}$ \\
\hline
\end{tabular}

†Not applicable.

!Interpret data with caution. The coefficient of variation (CV) for this estimate is between 30 and 50 percent.

fReporting standards not met. The coeficient of variation (CV) for this eslimate is 50 percent or greater.

tion courses and family and consumer sciences education courses.

ס
NOTE: The Carnegie unit is a standard of measurement that represents one credit for the completion of a 1-year course. Data may differ from figures appearing in other NCES reports because of differences in course taxonomies and/or inclusion criteria. of 16 or more Carnegie credits with credits in English making up sord or horts diploma and whose transcripts reflected a tota panic ethnicity. Totals include other racialethnic groups not separately shown. Detail may not sum to totals because of rounding. SOURCE: U.S. Department of Education, National Center for Education Statistics, 2000, 2005, and 2009 High School Transcript Study (HSTS). (This table was prepared September 2011.) 


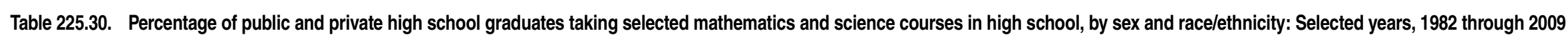
[Standard errors appear in parentheses]

\begin{tabular}{|c|c|c|c|c|c|c|c|c|c|c|c|c|c|c|c|c|c|c|c|c|c|c|c|c|c|c|c|c|}
\hline \multirow[b]{3}{*}{ Course (Carnegie units) } & \multirow{3}{*}{\multicolumn{2}{|c|}{1982}} & \multirow{3}{*}{\multicolumn{2}{|c|}{1990}} & \multirow{3}{*}{\multicolumn{2}{|c|}{1994}} & \multirow{3}{*}{\multicolumn{2}{|c|}{1998}} & \multirow{3}{*}{\multicolumn{2}{|c|}{2000}} & \multirow{3}{*}{\multicolumn{2}{|c|}{2005}} & \multicolumn{16}{|c|}{2009} \\
\hline & & & & & & & & & & & & & \multirow{2}{*}{\multicolumn{2}{|c|}{ Total }} & \multicolumn{4}{|c|}{ Sex } & \multicolumn{10}{|c|}{ Race/ethnicity } \\
\hline & & & & & & & & & & & & & & & & Male & & Female & & White & & Black & & Hispanic & $\begin{array}{l}\text { Asian } \\
\text { I }\end{array}$ & $\begin{array}{l}\text { n/Pacific } \\
\text { Islander }\end{array}$ & $\begin{array}{r}\text { Americar } \\
\text { Alask }\end{array}$ & $\begin{array}{l}\text { Indian/ } \\
\text { Native }\end{array}$ \\
\hline 1 & & 2 & & 3 & & 4 & & 5 & & 6 & & 7 & & 8 & & 9 & & 10 & & 11 & & 12 & & 13 & & 14 & & 15 \\
\hline \multicolumn{29}{|l|}{ Mathematics' 1} \\
\hline Any mathematics ( $\geq$ & 98.5 & $(0.21)$ & 99.6 & $(0.07)$ & 99.5 & $(0.07)$ & 99.9 & $(0.05)$ & 99.8 & $(0.05)$ & 99.9 & $(0.02)$ & 100.0 & $(\dagger)$ & 100.0 & $(\dagger)$ & 100.0 & $(\dagger)$ & 100.0 & $(†)$ & 100.0 & $(\dagger)$ & 100.0 & $(\dagger)$ & 100.0 & $(\dagger)$ & 100.0 & $(\dagger)$ \\
\hline Algebra $I(\geq 1.0)^{2}$.. & 55.2 & $(1.01)$ & 64.5 & (1.55) & 66.9 & (1.33) & 63.4 & (1.44) & 66.5 & (1.75) & 68.4 & $(0.99)$ & 68.9 & $(0.94)$ & 68.5 & $(0.98)$ & 69.3 & $(1.01)$ & 67.0 & $(1.09)$ & 77.2 & $(1.26)$ & 75.4 & $(1.60)$ & 53.3 & $(3.52)$ & 74.8 & $(5.85)$ \\
\hline Geometry $(\geq 1.0)$. & 47.1 & $(0.99)$ & 64.1 & (1.33) & 70.6 & (1.25) & 75.3 & $(1.06)$ & 78.3 & $(1.08)$ & 83.8 & $(0.63)$ & 88.3 & $(0.53)$ & 86.6 & $(0.75)$ & 89.9 & $(0.54)$ & 88.8 & $(0.73)$ & 88.4 & $(1.07)$ & 87.0 & $(0.96)$ & 86.1 & $(1.47)$ & 81.6 & $(4.09)$ \\
\hline Algebra & 39.9 & $(0.93)$ & 48.8 & (1.39) & 61.5 & $(1.38)$ & 61.7 & (1.77) & 67.6 & (1.43) & 70.3 & $(1.01)$ & 75.5 & $(0.92)$ & 73.5 & $(1.09)$ & 77.6 & $(0.91)$ & 77.1 & $(1.09)$ & 70.5 & $(1.68)$ & 71.1 & $(1.83)$ & 82.8 & $(2.57)$ & 66.3 & (4.12) \\
\hline Trigon & 8.1 & $(0.54)$ & 18.2 & (1.28) & 11.8 & (1.16) & 8.9 & $(1.06)$ & 7.9 & (1.33) & 8.4 & $(0.88)$ & 6.1 & $(0.77)$ & 5.8 & $(0.78)$ & 6.4 & $(0.81)$ & 7.1 & (1.01) & 3.2 & $(0.55)$ & 3.6 & $(0.69)$ & 8.5 & $(1.96)$ & 6.5 & $(1.84)$ \\
\hline Analysis/prec & 6.2 & $(0.46)$ & 13.4 & $(0.95)$ & 17.4 & $(0.87)$ & 23.2 & (1.44) & 26.6 & (1.40) & 29.4 & $(0.98)$ & 35.3 & $(0.84)$ & 33.8 & (1.02) & 36.6 & $(0.89)$ & 37.9 & $(0.98)$ & 22.7 & $(1.29)$ & 26.5 & $(1.36)$ & 60.5 & $(2.88)$ & 18.5 & (2.98) \\
\hline Statistic & 1.0 & $(0.16)$ & 1.0 & $(0.21)$ & 2.0 & $(0.33)$ & 3.7 & $(0.54)$ & 5.7 & $(0.85)$ & 7.7 & $(0.53)$ & 10.8 & (0.49) & 10.7 & (0.51) & 10.9 & $(0.58)$ & 11.6 & $(0.64)$ & 7.9 & $(1.04)$ & 7.5 & $(0.77)$ & 17.6 & (1.69) & $5.9 !$ & (2.07) \\
\hline Calculus ( & 5.0 & $(0.43)$ & 6.5 & (0.46) & 9.4 & (0.56) & 11.0 & $(0.85)$ & 11.6 & (0.72) & 13.6 & (0.53) & 15.9 & $(0.66)$ & 16.1 & $(0.75)$ & 15.7 & $(0.69)$ & 17.5 & $(0.69)$ & 6.1 & $(0.59)$ & 8.6 & $(0.64)$ & 42.2 & (3.11) & 6.3 & $(1.60)$ \\
\hline AP/honors calculus $(\geq 1.0)^{4} \ldots$ & 1.6 & $(0.26)$ & 4.2 & $(0.44)$ & 7.0 & $(0.54)$ & 6.8 & (0.49) & 7.8 & $(0.58)$ & 9.2 & $(0.44)$ & 11.0 & $(0.55)$ & 11.3 & $(0.65)$ & 10.7 & $(0.54)$ & 11.5 & $(0.52)$ & 4.0 & $(0.37)$ & 6.3 & $(0.46)$ & 34.8 & $(2.77)$ & 4.9 & (1.44) \\
\hline \multicolumn{29}{|l|}{ Science ${ }^{1}$} \\
\hline Any science & 96.4 & $(0.39)$ & 99.4 & $(0.13)$ & 99.5 & $(0.09)$ & 99.5 & $(0.10)$ & 99.4 & $(0.12)$ & 99.7 & $(0.05)$ & 99.9 & $(0.02)$ & 99.8 & $(0.04)$ & 99.9 & $(0.02)$ & 99.9 & $(0.03)$ & 99.9 & $(0.04)$ & 99.8 & $(0.06)$ & 100.0 & $(\dagger)$ & 100.0 & $(\dagger)$ \\
\hline Biolc & 77.4 & $(0.87)$ & 91.3 & $(0.98)$ & 93.7 & (0.98) & 92.9 & $(0.68)$ & 91.1 & (1.01) & 92.5 & $(0.60)$ & 95.6 & (0.40) & 94.9 & $(0.45)$ & 96.2 & $(0.43)$ & 95.6 & $(0.51)$ & 96.3 & $(0.56)$ & 94.8 & $(0.67)$ & 95.8 & $(0.95)$ & 94.5 & $(1.64)$ \\
\hline $\mathrm{AP} / \mathrm{ho}$ & 10.0 & $(0.64)$ & 5.0 & (0.76) & 12.0 & $(0.93)$ & 16.3 & (1.32) & 16.3 & (1.45) & 16.0 & $(0.83)$ & 22.4 & (0.78) & 19.7 & $(0.76)$ & 25.0 & $(0.89)$ & 24.2 & $(0.88)$ & 14.1 & $(0.80)$ & 16.1 & $(0.88)$ & 39.7 & $(3.58)$ & 15.4 & (3.38) \\
\hline Chemistry $(\geq 1.0)$. & 32.1 & $(0.84)$ & 49.2 & (1.22) & 56.1 & (1.01) & 60.5 & (1.29) & 61.8 & (1.48) & 66.4 & $(0.94)$ & 70.4 & $(0.75)$ & 67.4 & $(0.95)$ & 73.4 & $(0.76)$ & 71.5 & $(0.87)$ & 65.3 & $(1.80)$ & 65.7 & $(1.41)$ & 84.8 & (1.72) & 44.5 & (4.78) \\
\hline AP/honors chemistry $(\geq 1.0)^{4}$. & 3.0 & $(0.33)$ & 3.5 & $(0.47)$ & 3.9 & $(0.53)$ & 4.8 & $(0.50)$ & 5.7 & $(0.84)$ & 7.6 & $(0.53)$ & 5.9 & $(0.43)$ & 6.1 & $(0.52)$ & 5.8 & $(0.39)$ & 6.5 & $(0.47)$ & 2.5 & $(0.46)$ & 2.6 & $(0.35)$ & 17.0 & $(2.36)$ & $3.4 !$ & (1.39) \\
\hline Physics $(\geq 1.0) \ldots \ldots \ldots$ & 15.0 & $(0.62)$ & 21.3 & $(0.84)$ & 24.8 & $(0.86)$ & 28.8 & (1.49) & 31.3 & (1.16) & 32.9 & $(0.91)$ & 36.1 & $(1.01)$ & 39.2 & $(1.29)$ & 33.0 & $(0.92)$ & 37.6 & $(1.24)$ & 26.9 & (1.72) & 28.6 & $(1.33)$ & 61.1 & $(2.35)$ & 19.8 & $(3.89)$ \\
\hline AP/honors physi & 1.2 & $(0.17)$ & 2.0 & $(0.38)$ & 2.7 & $(0.34)$ & 3.0 & $(0.37)$ & 3.9 & $(0.60)$ & 5.3 & $(0.33)$ & 5.7 & $(0.46)$ & 7.7 & $(0.63)$ & 3.7 & $(0.38)$ & 6.1 & $(0.54)$ & 2.5 & $(0.39)$ & 3.4 & $(0.39)$ & 15.1 & $(2.51)$ & $\ddagger$ & $(\dagger)$ \\
\hline Engin & 1.2 & $(0.21)$ & 0.1 & $(0.04)$ & 4.5 & $(0.80$ & 6.7 & (1.76) & 4.1 & $(0.98$ & 4.8 & $(0.56)$ & 8.2 & $(0.93)$ & 9.0 & $(1.02)$ & 7.4 & $(0.93)$ & 8.2 & (1.18) & 10.1 & $(1.75)$ & 7.1 & $(1.06)$ & 6.4 & $(1.17)$ & $9.0 !$ & (3.15) \\
\hline Astron & 1.2 & $(0.24)$ & 1.2 & $(0.31)$ & 1.7 & (0.50) & 1.9 & $(0.46)$ & 2.8 & (0.59) & 2.8 & $(0.37)$ & 3.3 & $(0.40)$ & 3.9 & $(0.51)$ & 2.7 & $(0.33)$ & 4.0 & $(0.57)$ & 1.8 & $(0.38)$ & 2.0 & $(0.36)$ & 1.9 & $(0.43)$ & $5.3 !$ & (2.51) \\
\hline Geology & 13.6 & $(1.04)$ & 25.3 & (2.47) & 23.1 & $(2.44)$ & 20.9 & $(2.35)$ & 18.5 & $(1.92)$ & 24.7 & $(1.43)$ & 27.7 & $(1.70)$ & 28.9 & $(1.88)$ & 26.5 & $(1.66)$ & 28.2 & $(2.04)$ & 30.1 & $(2.57)$ & 27.1 & $(2.15)$ & 19.1 & $(2.38)$ & 26.0 & $(5.25)$ \\
\hline Biology and chemistry $(\geq 2.0)^{5} \ldots$ & 29.3 & $(0.83)$ & 47.8 & $(1.23)$ & 53.8 & $(1.18)$ & 59.1 & $(1.22)$ & 59.2 & $(1.50)$ & 64.3 & $(0.97)$ & 68.3 & $(0.77)$ & 65.0 & $(0.91)$ & 71.4 & $(0.84)$ & 68.9 & $(0.93)$ & 64.3 & $(1.74)$ & 64.2 & $(1.45)$ & 82.7 & $(1.93)$ & 43.9 & $(4.77)$ \\
\hline $\begin{array}{c}\text { Biology, chemistry, and } \\
\text { physics }(\geq 3.0)^{5} \ldots \ldots\end{array}$ & 11.2 & $(0.51)$ & 18.7 & $(0.71)$ & 21.4 & $(0.83)$ & 25.6 & $(1.34)$ & 25.0 & $(1.10)$ & 27.4 & $(0.89)$ & 30.1 & $(0.87)$ & 31.9 & $(1.08)$ & 28.3 & $(0.85)$ & 31.4 & $(1.04)$ & 21.9 & $(1.48)$ & 22.7 & $(1.19)$ & 54.4 & $(2.77)$ & 13.6 & (2.87) \\
\hline
\end{tabular}

†Not applicable.

!nterpret data with caution. The coefficient of variation (CV) for this estimate is between 30 and 50 percent. †Reporting standards not met. The coefficient of variation (CV) for this estimate is 50 percent or greater.

For each course category, percentages include only students who earned at least the number of credits shown in parentheses. Excludes prealgebra.

ors courses.

${ }_{5}^{5}$ ercentages include only students who earned at least one credit in each of the indicated courses.
NOTE: For a transcript to be included in the analyses, it had to meet three requirements: (1) the student graduated with either a standard or honors diploma, (2) the student's transcript contained 16 or more Carnegie units, and (3) the student's transcript contained more than 0 Carnegle units in English courses. The Carnegie unit is a standard of measurement that represents one credit for the completion of a 1-year course $(0.5=$ one semester; $1.0=$ one academic year). Data differ slightly from figures teria. Race categories exclude persons of Hispanic ethnicity. Totals include other racial/ethnic groups not separately shown. Some data have been revised from previously published figures. SOURCE: U.S. Department of Education, National Center for Education Statistics, High School and Beyond Longitudinal Study
of 1980 Sophomores (HS\&B-So:80/82), "High School Transcript Study"; and 1990, 1994, 1998, 2000, 2005, and 2009 High School Transcript Study (HSTS). (This table was prepared October 2012.) 


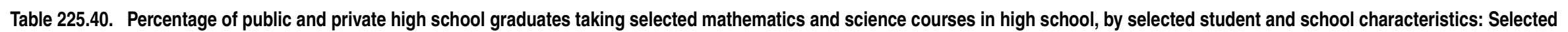
years, 1990 through 2009

[Standard errors appear in parentheses]

\begin{tabular}{|c|c|c|c|c|c|c|c|c|c|c|c|c|c|c|c|c|c|c|c|c|c|c|}
\hline \multirow[b]{2}{*}{$\begin{array}{l}\text { Year and student or } \\
\text { school characteristic }\end{array}$} & \multicolumn{12}{|c|}{ Mathematics } & \multicolumn{10}{|c|}{ Science } \\
\hline & & ebra 1,2 $^{1,2}$ & & ometry ${ }^{1}$ & & $\begin{array}{l}\text { bra II/ } \\
\text { netry }\end{array}$ & & $\begin{array}{l}\text { alysis/ } \\
\text { culus }\end{array}$ & & atistics/ & & alculus' ${ }^{1}$ & & Biology ${ }^{1}$ & & mistry $^{1}$ & & Physics ${ }^{1}$ & & $\begin{array}{l}y \text { and } \\
\text { histry }{ }^{4}\end{array}$ & $\begin{array}{r}\text { Biology } \\
a\end{array}$ & $\begin{array}{l}\text { emistry, } \\
\text { ohysics }\end{array}$ \\
\hline 1 & & 2 & & 3 & & 4 & & 5 & & 6 & & 7 & & 8 & & 9 & & 10 & & 11 & & 12 \\
\hline $\begin{array}{l}1990 \\
\text { Total }^{6} . .\end{array}$ & 64.5 & (1.55) & 64.1 & $(1.33)$ & 53.6 & (1.32) & 13.4 & $(0.95)$ & 1.0 & $(0.21)$ & 6.5 & $(0.46)$ & 91.3 & $(0.98)$ & 49.2 & (1.22) & 21.3 & (0.84) & 47.8 & (1.23) & 18.7 & $(0.71)$ \\
\hline 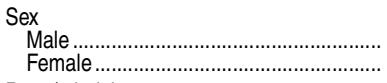 & $\begin{array}{l}62.0 \\
66.7\end{array}$ & $\left(\begin{array}{l}1.57) \\
1.69\end{array}\right)$ & $\begin{array}{l}63.0 \\
65.0\end{array}$ & $\left(\begin{array}{l}1.57) \\
1.31\end{array}\right)$ & $\begin{array}{l}51.8 \\
55.2\end{array}$ & $\left(\begin{array}{l}1.44) \\
1.45\end{array}\right)$ & $\begin{array}{l}14.1 \\
12.8\end{array}$ & $\begin{array}{l}(1.14) \\
(0.94)\end{array}$ & $\begin{array}{l}1.2 \\
0.8\end{array}$ & $\left(\begin{array}{l}0.27) \\
0.20)\end{array}\right.$ & $\begin{array}{l}7.6 \\
5.6\end{array}$ & $\left(\begin{array}{l}0.64) \\
0.37\end{array}\right)$ & $\begin{array}{l}90.0 \\
92.5\end{array}$ & $\left(\begin{array}{l}1.099 \\
0.94\end{array}\right)$ & $\begin{array}{l}48.1 \\
50.2\end{array}$ & $\left(\begin{array}{l}1.40) \\
1.29\end{array}\right)$ & $\begin{array}{l}25.1 \\
17.7\end{array}$ & $(0.95)$ & $\begin{array}{l}46.6 \\
48.9\end{array}$ & $\left(\begin{array}{l}1.40 \\
1.30\end{array}\right)$ & $\begin{array}{l}21.8 \\
16.0\end{array}$ & $\begin{array}{l}(0.82) \\
0.76)\end{array}$ \\
\hline 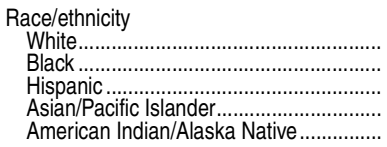 & $\begin{array}{l}64.6 \\
65.1 \\
64.8 \\
63.5 \\
61.7\end{array}$ & $\begin{array}{l}(1.83) \\
2.42 \\
2.75 \\
3.01 \\
(8.40)\end{array}$ & $\begin{array}{l}66.4 \\
56.3 \\
54.1 \\
71.5 \\
55.7\end{array}$ & $\left.\begin{array}{l}1.43 \\
2.58 \\
2.89 \\
2.90 \\
2.85\end{array}\right)$ & $\begin{array}{l}56.9 \\
43.9 \\
39.9 \\
69.3 \\
53.9\end{array}$ & $\left.\begin{array}{l}(1.53) \\
2.77 \\
2.80 \\
5.51 \\
4.80\end{array}\right)$ & $\begin{array}{r}14.9 \\
6.2 \\
7.1 \\
25.2 \\
\ddagger\end{array}$ & $\begin{array}{r}(1.04) \\
0.96 \\
0.82 \\
6.54 \\
(\dagger)\end{array}$ & $\begin{array}{c}1.0 \\
1.1 ! \\
\ddagger \\
\ddagger \\
\ddagger\end{array}$ & $\left.\begin{array}{r}(0.22) \\
0.44 \\
(t) \\
+ \\
(t)\end{array}\right)$ & $\begin{array}{r}6.9 \\
2.8 \\
3.8 \\
18.4 \\
\ddagger\end{array}$ & $\left.\begin{array}{r}(0.53) \\
0.55 \\
0.67 \\
3.23 \\
(\dagger)\end{array}\right)$ & $\begin{array}{l}91.5 \\
91.3 \\
90.2 \\
90.2 \\
90.5\end{array}$ & $\left.\begin{array}{l}(1.06) \\
(2.19 \\
1.40 \\
2.73 \\
4.37\end{array}\right)$ & $\begin{array}{l}51.8 \\
40.3 \\
38.3 \\
63.5 \\
35.5\end{array}$ & $\left.\begin{array}{l}(1.33) \\
2.19 \\
2.90 \\
4.01 \\
(4.50)\end{array}\right)$ & $\begin{array}{r}22.8 \\
14.5 \\
12.7 \\
38.0 \\
\ddagger\end{array}$ & $\begin{array}{r}(0.91) \\
1.85 \\
1.33 \\
3.36 \\
(\dagger)\end{array}$ & $\begin{array}{l}50.5 \\
39.5 \\
36.4 \\
60.0 \\
34.2\end{array}$ & $\left.\begin{array}{l}(1.35) \\
2.24 \\
2.70 \\
3.45 \\
(4.46)\end{array}\right)$ & $\begin{array}{r}20.5 \\
12.0 \\
10.0 \\
33.4 \\
\ddagger\end{array}$ & $\left.\begin{array}{r}(0.82) \\
1.23 \\
1.21 \\
2.56 \\
(\dagger\end{array}\right)$ \\
\hline $\begin{array}{c}\text { Student with disabilities (SD) status } \\
\text { SD } \\
\text { Non-SD }\end{array}$ & $\begin{array}{l}20.6 \\
65.4\end{array}$ & $\begin{array}{l}3.09) \\
(1.59)\end{array}$ & $\begin{array}{l}11.8 \\
65.1\end{array}$ & $\begin{array}{l}(2.42) \\
(1.32)\end{array}$ & $\begin{array}{r}8.3 \\
54.5\end{array}$ & $\left(\begin{array}{l}2.04) \\
(1.35)\end{array}\right.$ & $\begin{array}{r}\ddagger \\
13.6\end{array}$ & 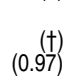 & $\begin{array}{r}\ddagger \\
1.0\end{array}$ & $\begin{array}{c}(t) \\
(0.21)\end{array}$ & 6.7 & $\begin{array}{r}(t) \\
(0.47)\end{array}$ & $\begin{array}{l}65.0 \\
91.8\end{array}$ & $\left.\begin{array}{l}(4.73) \\
0.92)\end{array}\right)$ & $\begin{array}{r}7.7 \\
50.0\end{array}$ & $\left(\begin{array}{l}1.53 \\
1.24\end{array}\right)$ & 21.6 & $\begin{array}{c}(t) \\
(0.84)\end{array}$ & $\begin{array}{r}\ddagger \\
48.6\end{array}$ & $\begin{array}{r}(t) \\
(1.23)\end{array}$ & $19.1^{\ddagger}$ & $\begin{array}{l}\left(\begin{array}{l}(\dagger) \\
(0.71\end{array}\right)\end{array}$ \\
\hline 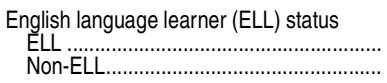 & $\begin{array}{l}57.7 \\
64.5\end{array}$ & $\begin{array}{l}(5.79) \\
(1.56)\end{array}$ & $\begin{array}{l}42.2 \\
64.2\end{array}$ & $\begin{array}{l}(6.30) \\
(1.34)\end{array}$ & $\begin{array}{l}37.1 \\
53.7\end{array}$ & $\left.\begin{array}{l}(6.64) \\
(1.34)\end{array}\right)$ & $\begin{array}{r}\stackrel{\ddagger}{\ddagger} \\
13.4\end{array}$ & $\begin{array}{r}\left(\begin{array}{l}(t) \\
(0.95)\end{array}\right. \\
\text { (a) }\end{array}$ & $\begin{array}{r}\ddagger \\
1.0\end{array}$ & $\begin{array}{r}\left(\begin{array}{l}(t) \\
0.21\end{array}\right)\end{array}$ & $\begin{array}{r}\ddagger \\
6.6\end{array}$ & $\begin{array}{r}\left(\begin{array}{l}(t) \\
(0.47)\end{array}\right.\end{array}$ & $\begin{array}{l}70.5 \\
91.4\end{array}$ & $\left(\begin{array}{l}4.66) \\
(0.98)\end{array}\right)$ & 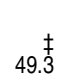 & $\begin{array}{r}(t) \\
(1.23)\end{array}$ & $21.3^{\ddagger}$ & $\begin{array}{r}(t) \\
(0.84)\end{array}$ & $\begin{array}{r}\ddagger \\
48.0\end{array}$ & $\begin{array}{r}\left(\begin{array}{l}(\dagger) \\
(1.23)\end{array}\right.\end{array}$ & 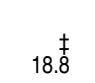 & $\begin{array}{r}(t) \\
(0.71)\end{array}$ \\
\hline $\begin{array}{l}\text { School type } \\
\text { Traditional public ................................................ } \\
\text { Public charter }\end{array}$ & 62.9 & $\begin{array}{r}(1.66) \\
(+)\end{array}$ & 61.9 & $\begin{array}{r}(1.41) \\
(t)\end{array}$ & 51.4 & $\begin{array}{c}(1.32) \\
(\dagger)\end{array}$ & 12.2 & (1.11) & 0.8 & $\begin{array}{r}(0.20) \\
(t)\end{array}$ & 6.2 & $\begin{array}{r}(0.48) \\
(t)\end{array}$ & 90.7 & $\begin{array}{c}(1.08) \\
(+)\end{array}$ & 47.4 & $(1.32)$ & 20.2 & $\begin{array}{c}(0.86) \\
(t)\end{array}$ & 46.0 & $\begin{array}{r}(1.33) \\
(+)\end{array}$ & 17.8 & $\left.\begin{array}{r}(0.71) \\
(t)\end{array}\right)$ \\
\hline Private.... & $79 . \overline{9}$ & (2.22) & $85 . \overline{5}$ & (1.98) & $75 . \overline{5}$ & (3.55) & $25 . \overline{3}$ & (3.44) & $2 . \overline{6} !$ & $(1.03)$ & $9 . \overline{7}$ & (1.33) & $97 . \overline{2}$ & $(0.55)$ & 66.7 & (2.71) & $31 . \overline{4}$ & (2.30) & 65.2 & (2.67) & $28 . \overline{2}$ & (2.07) \\
\hline 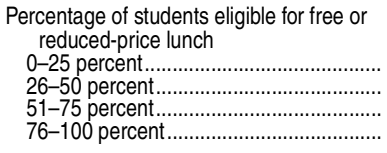 & $\begin{array}{l}64.9 \\
60.6 \\
74.2 \\
96.0 \\
\end{array}$ & $\begin{array}{l}2.16 \\
3.97 \\
7.31 \\
4.01\end{array}$ & $\begin{array}{l}67.4 \\
45.4 \\
56.0 \\
89.4 \\
\end{array}$ & $\begin{array}{r}(1.67) \\
(2.90) \\
(14.72) \\
(0.92) \\
\end{array}$ & $\begin{array}{l}57.8 \\
44.6 \\
40.1 \\
78.7 \\
\end{array}$ & $\begin{array}{l}2.05) \\
2.74 \\
5.12 \\
(2.96\end{array}$ & $\begin{array}{r}15.3 \\
5.5 \\
5.6 \\
\ddagger \\
\end{array}$ & $\begin{array}{r}(1.38) \\
1.43 \\
1.54 \\
(\dagger)\end{array}$ & $\begin{array}{r}1.1 \\
\ddagger \\
\# \\
\# \\
\# \\
\end{array}$ & 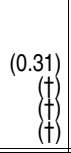 & $\begin{array}{r}7.5 \\
3.8 \\
\ddagger \\
\# \\
\end{array}$ & $\begin{array}{r}(0.70) \\
0.89 \\
(+) \\
(+)\end{array}$ & $\begin{array}{l}92.4 \\
88.8 \\
93.6 \\
99.0 \\
\end{array}$ & $\begin{array}{l}1.09) \\
4.60 \\
2.87 \\
(0.99) \\
\end{array}$ & $\begin{array}{r}54.0 \\
36.5 \\
33.5 \\
\ddagger \\
\end{array}$ & $\begin{array}{r}(1.60) \\
3.08 \\
4.28 \\
(\dagger)\end{array}$ & $\begin{array}{r}22.8 \\
15.3 \\
12.7 \\
\ddagger \\
\end{array}$ & $\begin{array}{r}1.27) \\
2.08 \\
3.12 \\
(\dagger)\end{array}$ & $\begin{array}{r}52.8 \\
35.5 \\
33.0 \\
\ddagger \\
\end{array}$ & $\begin{array}{r}1.59 \\
(3.33 \\
(4.42 \\
(\dagger) \\
\end{array}$ & $\begin{array}{r}21.0 \\
12.8 \\
11.7 \\
\ddagger \\
\end{array}$ & $\begin{array}{r}1.12 \\
1.71 \\
(2.83) \\
(\dagger) \\
\end{array}$ \\
\hline $\begin{array}{l}2000 \\
\quad \text { Total }^{6} \ldots\end{array}$ & 66.5 & (1.75) & 78.3 & $(1.08)$ & 68.3 & (1.45) & 26.6 & (1.40) & 5.7 & $(0.85)$ & 11.6 & $(0.72)$ & 91.1 & (1.01) & 61.8 & (1.48) & 31.3 & (1.16) & 59.2 & (1.50) & 25.0 & (1.10) \\
\hline 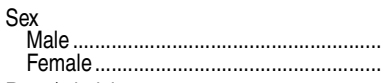 & $\begin{array}{l}65.0 \\
68.0\end{array}$ & $\left(\begin{array}{l}1.72 \\
1.87\end{array}\right)$ & $\begin{array}{l}74.8 \\
81.4\end{array}$ & $\left(\begin{array}{l}1.31 \\
1.01\end{array}\right)$ & $\begin{array}{l}65.2 \\
71.1\end{array}$ & $\left(\begin{array}{l}1.46 \\
1.69\end{array}\right)$ & $\begin{array}{l}25.3 \\
27.8\end{array}$ & $\left(\begin{array}{l}1.39 \\
1.61\end{array}\right)$ & $\begin{array}{l}5.8 \\
5.6\end{array}$ & $\left(\begin{array}{l}0.97) \\
0.85)\end{array}\right.$ & $\begin{array}{l}12.1 \\
11.1\end{array}$ & $\left(\begin{array}{l}0.79 \\
0.77\end{array}\right)$ & $\begin{array}{l}88.9 \\
93.2\end{array}$ & $\left(\begin{array}{l}1.32 \\
0.82\end{array}\right)$ & $\begin{array}{l}57.7 \\
65.5\end{array}$ & $\left(\begin{array}{l}1.42 \\
1.75\end{array}\right)$ & $\begin{array}{l}34.1 \\
28.9\end{array}$ & $\left(\begin{array}{l}1.29 \\
1.22)\end{array}\right)$ & $\begin{array}{l}54.3 \\
63.6\end{array}$ & $\left(\begin{array}{l}1.49 \\
1.76\end{array}\right)$ & $\begin{array}{l}26.3 \\
23.9\end{array}$ & $\left(\begin{array}{l}1.23 \\
1.14\end{array}\right)$ \\
\hline 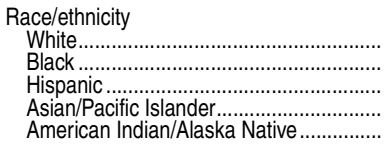 & $\begin{array}{l}65.1 \\
70.1 \\
73.2 \\
58.1 \\
68.7\end{array}$ & $\begin{array}{l}(2.08) \\
3.20 \\
2.43 \\
3.28 \\
(5.80)\end{array}$ & $\begin{array}{l}79.2 \\
77.8 \\
72.6 \\
81.3 \\
65.0\end{array}$ & $\left.\begin{array}{l}(1.21) \\
1.93 \\
3.30 \\
2.03 \\
6.18\end{array}\right)$ & $\begin{array}{l}69.6 \\
64.7 \\
60.0 \\
81.3 \\
60.3\end{array}$ & $\left.\begin{array}{l}(1.57) \\
2.32 \\
5.06 \\
2.00 \\
5.51\end{array}\right)$ & $\begin{array}{r}28.1 \\
16.1 \\
19.3 \\
48.7 \\
\ddagger\end{array}$ & $\left.\begin{array}{r}(1.74) \\
1.52 \\
2.95 \\
2.79 \\
(\dagger)\end{array}\right)$ & $\begin{array}{r}6.1 \\
3.7 ! \\
2.3 \\
11.4 \\
\ddagger\end{array}$ & 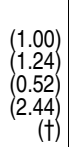 & $\begin{array}{r}12.5 \\
4.6 \\
5.6 \\
30.4 \\
\ddagger\end{array}$ & $\left.\begin{array}{r}(0.77) \\
0.55 \\
0.86 \\
5.02 \\
(\dagger)\end{array}\right)$ & $\begin{array}{l}91.7 \\
92.4 \\
87.8 \\
87.8 \\
88.4\end{array}$ & $\begin{array}{l}(1.15) \\
(1.09) \\
2.69 \\
(3.20) \\
(2.88)\end{array}$ & $\begin{array}{l}62.9 \\
59.5 \\
52.0 \\
75.1 \\
43.6\end{array}$ & $\begin{array}{l}(1.66) \\
2.38 \\
4.13 \\
2.89 \\
(4.03)\end{array}$ & $\begin{array}{r}32.3 \\
25.1 \\
23.1 \\
53.8 \\
\ddagger\end{array}$ & 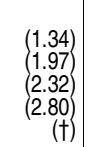 & $\begin{array}{l}60.1 \\
57.8 \\
50.3 \\
70.6 \\
39.4\end{array}$ & $\left.\begin{array}{l}(1.72) \\
2.31 \\
4.30 \\
3.03 \\
(3.81)\end{array}\right)$ & $\begin{array}{r}25.6 \\
20.0 \\
17.7 \\
47.0 \\
\ddagger\end{array}$ & $\left.\begin{array}{r}(1.20) \\
1.76 \\
2.19 \\
2.70 \\
(\dagger\end{array}\right)$ \\
\hline $\begin{array}{l}\text { Student with disabilities (SD) status } \\
\text { SDD } \\
\text { Non-SD }\end{array}$ & $\begin{array}{l}45.2 \\
67.3\end{array}$ & $\left(\begin{array}{l}2.96) \\
(1.77)\end{array}\right.$ & $\begin{array}{l}36.1 \\
79.9\end{array}$ & $\begin{array}{l}(2.90) \\
(1.08)\end{array}$ & $\begin{array}{l}22.9 \\
70.1\end{array}$ & $\left(\begin{array}{l}2.88) \\
(1.46)\end{array}\right.$ & $\begin{array}{l}6.7 \text { ! } \\
27.4\end{array}$ & $\left(\begin{array}{l}2.23 \\
1.43\end{array}\right)$ & $\begin{array}{r}\stackrel{\ddagger}{\ddagger} \\
5.9\end{array}$ & $\begin{array}{c}(t) \\
(0.87)\end{array}$ & 11.9 & 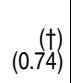 & $\begin{array}{l}72.0 \\
91.9\end{array}$ & $\left(\begin{array}{l}2.71 \\
1.02)\end{array}\right)$ & $\begin{array}{l}21.2 \\
63.4\end{array}$ & $\left(\begin{array}{l}2.88) \\
1.47)\end{array}\right.$ & $\begin{array}{l}13.6 \\
32.0\end{array}$ & $\left(\begin{array}{l}2.63 \\
1.18\end{array}\right)$ & $\begin{array}{l}19.9 \\
60.7\end{array}$ & $\left(\begin{array}{l}2.84 \\
1.51\end{array}\right)$ & $\begin{array}{r}7.9 ! \\
25.7\end{array}$ & $\left(\begin{array}{l}2.45 \\
1.11\end{array}\right)$ \\
\hline 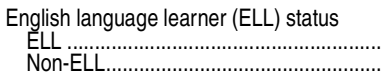 & $\begin{array}{l}62.3 \\
66.5\end{array}$ & $\left(\begin{array}{l}5.71 \\
1.75\end{array}\right)$ & $\begin{array}{l}57.8 \\
78.5\end{array}$ & $\left.\begin{array}{l}(4.11) \\
1.07\end{array}\right)$ & $\begin{array}{l}45.8 \\
68.6\end{array}$ & $\left(\begin{array}{l}4.82 \\
(1.44)\end{array}\right)$ & $\begin{array}{l}15.0 \\
26.7\end{array}$ & $\left(\begin{array}{l}2.20 \\
1.41\end{array}\right)$ & 5.7 & $\begin{array}{r}\left(\begin{array}{l}(t) \\
(0.86)\end{array}\right)\end{array}$ & $11.6^{+}$ & $\begin{array}{r}(t) \\
(0.73)\end{array}$ & $\begin{array}{l}73.4 \\
91.3\end{array}$ & $\left(\begin{array}{l}7.02) \\
(0.98)\end{array}\right)$ & $\begin{array}{l}34.9 \\
62.1\end{array}$ & (1.47) & $\begin{array}{l}20.8 \\
31.4\end{array}$ & $\left(\begin{array}{l}4.16 \\
1.18\end{array}\right)$ & $\begin{array}{l}31.3 \\
59.5\end{array}$ & $\left(\begin{array}{l}4.97) \\
1.50\end{array}\right)$ & $\begin{array}{l}11.2 \\
25.2\end{array}$ & $\left(\begin{array}{l}2.53 \\
1.11\end{array}\right)$ \\
\hline 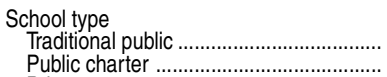 & 65.3 & $\left.\begin{array}{c}(1.76) \\
(\dagger\end{array}\right)$ & 77.0 & $\begin{array}{r}(1.20) \\
(\dagger)\end{array}$ & 67.1 & $\left.\begin{array}{r}(1.57) \\
(\dagger\end{array}\right)$ & 24.1 & $\left.\begin{array}{r}(1.43 \\
(t)\end{array}\right)$ & 5.5 & $\begin{array}{r}(0.85) \\
(t)\end{array}$ & 10.9 & $\left.\begin{array}{r}(0.71) \\
(t\end{array}\right)$ & 90.5 & $\left.\begin{array}{r}(1.11) \\
(t)\end{array}\right)$ & 59.5 & $\begin{array}{c}(1.42) \\
(\dagger)\end{array}$ & 30.0 & $\begin{array}{c}(1.22) \\
(\dagger)\end{array}$ & 56.8 & $\begin{array}{r}(1.44) \\
(t)\end{array}$ & 23.5 & $\left.\begin{array}{c}(1.10) \\
(\dagger\end{array}\right)$ \\
\hline 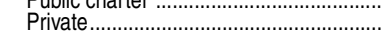 & $79 . \overline{1}$ & $(3.29)$ & $92 . \overline{3}$ & $(2.52)$ & $81 . \overline{9}$ & $(6.49)$ & $53 . \overline{8}$ & $(5.88)$ & $\overline{7.8} !$ & $(3.33)$ & $18 . \overline{2}$ & $(3.99)$ & $98 . \overline{2}$ & $(0.53)$ & $86 . \overline{6}$ & $(3.88)$ & $45 . \overline{1}$ & (7.62) & $85 . \overline{4}$ & $(3.87)$ & $41 . \overline{5}$ & $(7.38)$ \\
\hline 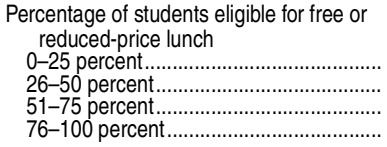 & $\begin{array}{l}66.8 \\
64.8 \\
72.7 \\
81.7\end{array}$ & $\left.\begin{array}{l}(2.64) \\
3.65 \\
3.97 \\
3.87\end{array}\right)$ & $\begin{array}{l}80.3 \\
72.5 \\
77.5 \\
83.1\end{array}$ & $\begin{array}{l}(1.47) \\
2.90 \\
3.48 \\
(5.61)\end{array}$ & $\begin{array}{l}68.1 \\
67.2 \\
66.7 \\
68.1\end{array}$ & $\left.\begin{array}{l}2.36 \\
1.86 \\
5.53 \\
9.69\end{array}\right)$ & $\begin{array}{l}29.6 \\
19.1 \\
18.0 \\
23.9\end{array}$ & $\begin{array}{l}2.41 \\
2.12 \\
2.97 \\
(4.40)\end{array}$ & $\begin{array}{c}6.5 \\
3.5 \\
3.4 ! \\
\ddagger\end{array}$ & $\left(\begin{array}{c}1.53 \\
1.00 \\
1.62 \\
(\dagger)\end{array}\right)$ & $\begin{array}{r}13.4 \\
8.8 \\
4.8 \\
5.4\end{array}$ & $\left.\begin{array}{l}(1.32) \\
1.09 \\
1.11 \\
1.05\end{array}\right)$ & $\begin{array}{l}91.4 \\
93.4 \\
90.8 \\
91.4\end{array}$ & $\left.\begin{array}{l}1.53 \\
1.49 \\
(3.02 \\
(5.08)\end{array}\right)$ & $\begin{array}{l}65.2 \\
56.0 \\
58.9 \\
60.8\end{array}$ & $\left.\begin{array}{l}2.51 \\
2.10 \\
3.11 \\
(9.48)\end{array}\right)$ & $\begin{array}{l}34.5 \\
26.3 \\
22.5 \\
35.0\end{array}$ & $\left.\begin{array}{l}2.05 \\
2.50 \\
1.75 \\
6.03\end{array}\right)$ & $\begin{array}{l}61.9 \\
55.0 \\
57.4 \\
59.5\end{array}$ & $\begin{array}{l}2.59 \\
2.15 \\
3.47 \\
(9.38)\end{array}$ & $\begin{array}{l}28.6 \\
19.1 \\
17.5 \\
26.1\end{array}$ & $\left.\begin{array}{l}(1.83 \\
1.19 \\
1.85 \\
5.80\end{array}\right)$ \\
\hline
\end{tabular}

See notes at end of table. 


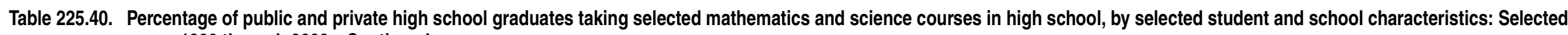
years, 1990 through 2009-Continued

[Standard errors appear in parentheses]

\begin{tabular}{|c|c|c|c|c|c|c|c|c|c|c|c|c|c|c|c|c|c|c|c|c|c|c|}
\hline \multirow[b]{2}{*}{$\begin{array}{l}\text { Year and student or } \\
\text { school characteristic }\end{array}$} & \multicolumn{12}{|c|}{ Mathematics } & \multicolumn{10}{|c|}{ Science } \\
\hline & \multicolumn{2}{|c|}{ Algebra $\left.\right|^{1,2}$} & \multicolumn{2}{|c|}{ Geometry ${ }^{1}$} & \multicolumn{2}{|c|}{$\begin{array}{r}\text { Algebra II/ } \\
\text { trigonometry }\end{array}$} & \multicolumn{2}{|c|}{$\begin{array}{r}\text { Analysis/ } \\
\text { precalculus }^{3}\end{array}$} & \multicolumn{2}{|c|}{$\begin{array}{r}\text { Statistics/ } \\
\text { probability }^{3}\end{array}$} & \multicolumn{2}{|c|}{ Calculus $^{1}$} & \multicolumn{2}{|r|}{ Biology ${ }^{1}$} & \multicolumn{2}{|c|}{ Chemistry $^{1}$} & \multicolumn{2}{|r|}{ Physics $^{1}$} & \multicolumn{2}{|c|}{$\begin{array}{r}\text { Biology and } \\
\text { chemistry }\end{array}$} & \multicolumn{2}{|c|}{$\begin{array}{r}\text { Biology, chemistry, } \\
\text { and physics }\end{array}$} \\
\hline 1 & & 2 & & 3 & & 4 & & 5 & & 6 & & 7 & & 8 & & 9 & & 10 & & 11 & & 12 \\
\hline $\begin{array}{l}2005 \\
\quad \text { Total }^{6} \ldots\end{array}$ & 68.4 & (0.99) & 83.8 & $(0.63)$ & 71.3 & $(0.97)$ & 29.4 & $(0.98)$ & 7.7 & (0.53) & 13.6 & (0.53) & 92.5 & $(0.60)$ & 66.4 & $(0.94)$ & 32.9 & $(0.91)$ & 64.3 & $(0.97)$ & 27.4 & $(0.89)$ \\
\hline 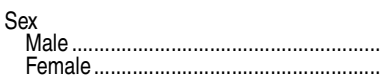 & $\begin{array}{l}66.8 \\
69.8\end{array}$ & $\left(\begin{array}{l}1.04) \\
(1.06)\end{array}\right)$ & $\begin{array}{l}81.9 \\
85.6\end{array}$ & $\left(\begin{array}{l}0.70) \\
(0.66)\end{array}\right)$ & $\begin{array}{l}68.0 \\
74.4\end{array}$ & $\left(\begin{array}{l}1.09 \\
0.98\end{array}\right)$ & $\begin{array}{l}28.0 \\
30.8\end{array}$ & $\left(\begin{array}{l}1.02 \\
1.05\end{array}\right)$ & 7.7 & $(0.57)$ & $\begin{array}{l}14.0 \\
13.2\end{array}$ & $(0.62)$ & $\begin{array}{l}91.0 \\
93.9\end{array}$ & $\begin{array}{l}0.68) \\
(0.58)\end{array}$ & $\begin{array}{l}62.7 \\
70.0\end{array}$ & $\left(\begin{array}{l}1.08) \\
0.99\end{array}\right)$ & $\begin{array}{l}34.9 \\
31.0\end{array}$ & $\left(\begin{array}{l}0.90 \\
1.09\end{array}\right)$ & $\begin{array}{l}60.3 \\
68.0\end{array}$ & $\left(\begin{array}{l}1.08) \\
(1.03)\end{array}\right)$ & $\begin{array}{l}28.2 \\
26.5\end{array}$ & $\left(\begin{array}{l}0.86) \\
(1.10)\end{array}\right)$ \\
\hline 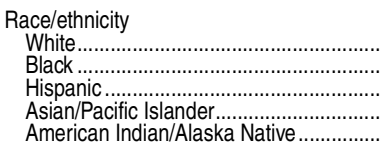 & $\begin{array}{l}66.8 \\
75.4 \\
70.2 \\
65.4 \\
70.1\end{array}$ & $\left.\begin{array}{l}(1.17) \\
1.60 \\
1.79 \\
2.71 \\
4.82\end{array}\right)$ & $\begin{array}{l}83.9 \\
85.0 \\
81.0 \\
87.1 \\
73.8\end{array}$ & $\begin{array}{l}(0.79) \\
1.04 \\
1.16 \\
1.29 \\
(3.36)\end{array}$ & $\begin{array}{l}72.4 \\
69.3 \\
63.1 \\
79.5 \\
67.2\end{array}$ & $\left.\begin{array}{l}(1.17 \\
(1.63) \\
1.55 \\
(2.94) \\
3.54\end{array}\right)$ & $\begin{array}{l}32.0 \\
17.9 \\
20.4 \\
48.8 \\
15.8\end{array}$ & $\left(\begin{array}{l}1.18 \\
1.61 \\
1.42 \\
2.84 \\
3.07\end{array}\right)$ & $\begin{array}{r}8.5 \\
5.8 \\
3.4 \\
12.9 \\
\ddagger\end{array}$ & $\begin{array}{r}(0.65) \\
0.83 \\
0.48 \\
1.21 \\
(\dagger)\end{array} \mid$ & $\begin{array}{r}15.3 \\
5.5 \\
6.4 \\
30.0 \\
\ddagger\end{array}$ & $\begin{array}{r}(0.61) \\
0.53 \\
0.63 \\
1.63 \\
(\dagger)\end{array}$ & $\begin{array}{l}92.8 \\
93.7 \\
89.2 \\
92.4 \\
91.5\end{array}$ & $\left(\begin{array}{c}0.67) \\
(0.60) \\
(1.22 \\
(1.92) \\
(1.92)\end{array}\right)$ & $\begin{array}{l}67.4 \\
63.6 \\
59.3 \\
79.7 \\
48.9\end{array}$ & $\left(\begin{array}{l}1.06 \\
1.61 \\
2.09 \\
1.60) \\
(4.70)\end{array}\right.$ & $\begin{array}{l}34.8 \\
25.8 \\
23.4 \\
50.3 \\
18.1\end{array}$ & $\begin{array}{l}(0.87) \\
2.31 \\
1.66 \\
2.35 \\
(3.82) \\
\end{array}$ & $\begin{array}{l}65.3 \\
62.0 \\
57.2 \\
75.5 \\
47.6\end{array}$ & $\left.\begin{array}{l}1.10 \\
1.60 \\
2.28 \\
2.16 \\
4.69\end{array}\right)$ & $\begin{array}{r}29.0 \\
21.3 \\
18.8 \\
42.9 \\
\ddagger\end{array}$ & $\begin{array}{r}(0.85) \\
2.25 \\
1.63 \\
(2.49 \\
(\dagger)\end{array}$ \\
\hline $\begin{array}{l}\text { Student with } \\
\text { SD? } \\
\text { Non-SD....... }\end{array}$ & $\begin{array}{l}49.5 \\
69.9\end{array}$ & $\left(\begin{array}{l}2.05 \\
1.04\end{array}\right)$ & $\begin{array}{l}47.8 \\
87.0\end{array}$ & $\left(\begin{array}{l}1.83) \\
0.68\end{array}\right)$ & $\begin{array}{l}27.9 \\
75.2\end{array}$ & $\left(\begin{array}{l}1.67) \\
0.98\end{array}\right)$ & $\begin{array}{r}6.0 \\
31.6\end{array}$ & $\left(\begin{array}{l}0.71) \\
(1.07)\end{array}\right)$ & $\begin{array}{l}2.2 \\
8.3\end{array}$ & $\begin{array}{l}(0.46) \\
0.56)\end{array}$ & $\begin{array}{r}2.0 \\
14.7\end{array}$ & $\left(\begin{array}{c}0.54) \\
0.56)\end{array}\right.$ & $\begin{array}{l}71.6 \\
94.4\end{array}$ & $\left(\begin{array}{l}1.58) \\
0.57\end{array}\right)$ & $\begin{array}{l}26.6 \\
69.9\end{array}$ & $\begin{array}{l}(1.88) \\
0.92)\end{array}$ & $\begin{array}{l}13.2 \\
34.5\end{array}$ & $\left.\begin{array}{l}(1.27) \\
0.94)\end{array}\right)$ & $\begin{array}{l}24.8 \\
67.8\end{array}$ & $\begin{array}{l}(1.75) \\
(0.96)\end{array}$ & $\begin{array}{r}6.6 \\
29.0\end{array}$ & $\left.\begin{array}{l}(11) \\
(0.94)\end{array}\right)$ \\
\hline 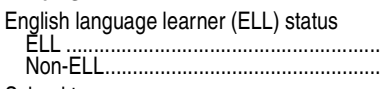 & $\begin{array}{l}63.7 \\
68.4\end{array}$ & $\left(\begin{array}{l}2.75) \\
1.00\end{array}\right)$ & $\begin{array}{l}70.1 \\
84.3\end{array}$ & $\left.\begin{array}{r}(2.10) \\
0.67\end{array}\right)$ & $\begin{array}{l}48.0 \\
72.0\end{array}$ & $\left(\begin{array}{l}2.97) \\
1.00\end{array}\right)$ & $\begin{array}{l}13.8 \\
30.0\end{array}$ & $\left(\begin{array}{l}1.85) \\
1.02\end{array}\right)$ & $\begin{array}{l}3.9 \\
7.9\end{array}$ & $\begin{array}{l}(0.88) \\
(0.54)\end{array}$ & $\begin{array}{r}6.1 \\
13.8\end{array}$ & $\left(\begin{array}{l}1.79) \\
0.54)\end{array}\right)$ & $\begin{array}{l}81.4 \\
92.9\end{array}$ & $\left(\begin{array}{l}1.96) \\
(0.62)\end{array}\right.$ & $\begin{array}{l}46.1 \\
67.0\end{array}$ & $\left.\begin{array}{l}(2.61) \\
(0.97)\end{array}\right)$ & $\begin{array}{l}20.2 \\
33.2\end{array}$ & $\begin{array}{l}(2.40) \\
(0.93)\end{array}$ & $\begin{array}{l}43.0 \\
64.9\end{array}$ & $\left(\begin{array}{l}2.85) \\
(1.01)\end{array}\right.$ & $\begin{array}{l}13.0 \\
13.8 \\
27.6\end{array}$ & $\left(\begin{array}{l}2.02) \\
(0.91)\end{array}\right)$ \\
\hline 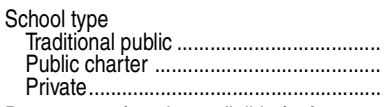 & $\begin{array}{l}67.6 \\
84.5 \\
74.4\end{array}$ & $\left(\begin{array}{l}1.09 \\
5.72 \\
3.27)\end{array}\right)$ & $\begin{array}{l}83.0 \\
78.1 \\
91.2\end{array}$ & $\left(\begin{array}{l}0.71 \\
7.06 \\
(1.41)\end{array}\right)$ & $\begin{array}{l}69.3 \\
69.3 \\
89.6\end{array}$ & $\left.\begin{array}{r}(1.07) \\
(11.47 \\
(1.88)\end{array}\right)$ & $\begin{aligned} 27.6 \\
\ddagger \\
45.3\end{aligned}$ & $\begin{array}{r}(0.92) \\
(+) \\
(3.93)\end{array}$ & $\begin{aligned} & 7.7 \\
& \ddagger \\
& 8.3\end{aligned}$ & $\begin{array}{c}(0.55) \\
(+) \\
(1.84)\end{array}$ & $\begin{array}{r}12.5 \\
\ddagger \\
23.9\end{array}$ & $\begin{array}{r}(0.53) \\
(t \\
(2.45)\end{array}$ & $\begin{array}{l}92.1 \\
91.6 \\
96.1\end{array}$ & $\left.\begin{array}{l}(0.59) \\
(2.47 \\
(2.31\end{array}\right)$ & $\begin{array}{l}64.2 \\
72.2 \\
86.8\end{array}$ & $\left.\begin{array}{r}(0.87) \\
(11.52) \\
(2.79)\end{array}\right)$ & $\begin{array}{l}30.6 \\
36.7 ! \\
53.8\end{array}$ & $\begin{array}{r}(0.94) \\
(13.63) \\
(2.46)\end{array}$ & $\begin{array}{l}62.0 \\
67.0 \\
85.1\end{array}$ & $\begin{array}{r}(0.85) \\
(10.91 \\
(3.10)\end{array}$ & $\begin{array}{l}24.8 \\
33.9 ! \\
49.9\end{array}$ & $\begin{aligned}(0.86) \\
(13.67) \\
(2.72)\end{aligned}$ \\
\hline 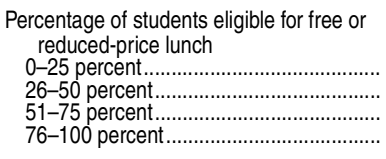 & $\begin{array}{l}65.4 \\
69.5 \\
74.3 \\
75.1 \\
\end{array}$ & $\begin{array}{l}(1.85) \\
1.93 \\
(2.78 \\
(3.73) \\
\end{array}$ & $\begin{array}{l}82.2 \\
84.2 \\
82.2 \\
88.2 \\
\end{array}$ & $\begin{array}{l}1.41 \\
1.04 \\
(1.99 \\
(1.61) \\
\end{array}$ & $\begin{array}{l}70.9 \\
69.8 \\
66.3 \\
69.4 \\
\end{array}$ & $\begin{array}{l}1.73 \\
1.37 \\
2.80 \\
(3.05) \\
\end{array}$ & $\begin{array}{l}34.0 \\
23.4 \\
19.2 \\
18.2 \\
\end{array}$ & $\left.\begin{array}{l}1.64) \\
1.30 \\
2.26 \\
2.90\end{array}\right)$ & $\begin{array}{c}10.2 \\
6.7 \\
3.3 \\
2.8 ! \\
\end{array}$ & $\begin{array}{l}(0.97) \\
0.93 \\
0.91 \\
(0.87) \\
\end{array}$ & $\begin{array}{r}15.7 \\
10.8 \\
6.9 \\
4.9 \\
\end{array}$ & $\begin{array}{l}(0.92) \\
0.58 \\
(0.86 \\
0.90) \\
\end{array}$ & $\begin{array}{l}92.8 \\
93.0 \\
86.7 \\
90.2 \\
\end{array}$ & $\left.\begin{array}{l}1.01 \\
0.97 \\
2.05 \\
3.04\end{array}\right)$ & $\begin{array}{l}68.4 \\
61.0 \\
57.0 \\
67.6 \\
\end{array}$ & $\begin{array}{l}(1.34) \\
1.60 \\
2.80 \\
(3.04) \\
\end{array}$ & $\begin{array}{l}35.3 \\
26.9 \\
20.9 \\
21.2 \\
\end{array}$ & $\begin{array}{l}(1.40) \\
1.44 \\
2.38 \\
(3.16) \\
\end{array}$ & $\begin{array}{l}65.9 \\
59.1 \\
54.1 \\
64.1 \\
\end{array}$ & $\begin{array}{l}1.39 \\
1.72 \\
2.90 \\
(3.60)\end{array}$ & $\begin{array}{l}28.7 \\
21.8 \\
16.1 \\
17.8 \\
\end{array}$ & $\begin{array}{l}\left(\begin{array}{l}1.32 \\
1.42 \\
(2.06 \\
(2.80\end{array}\right) \\
\end{array}$ \\
\hline${ }^{2009}$ & 68.9 & $(0.94)$ & 88.3 & $(0.53)$ & 75.8 & $(0.92)$ & 5.3 & $(0.84)$ & 10.8 & (0.49) & 15.9 & $(0.66)$ & 95.6 & $(0.40)$ & 70.4 & $(0.75)$ & 6.1 & (1.01) & 68.3 & o.77) & 30.1 & $(0.87)$ \\
\hline $\begin{array}{l}\text { Sex } \\
\text { Male } \ldots \ldots \ldots \ldots \ldots . . . . . \\
\text { Female ............. }\end{array}$ & $\begin{array}{l}68.5 \\
69.3\end{array}$ & $\left(\begin{array}{l}0.98 \\
1.01\end{array}\right)$ & $\begin{array}{l}86.6 \\
89.9\end{array}$ & $\left(\begin{array}{l}0.75 \\
0.54\end{array}\right)$ & $\begin{array}{l}73.8 \\
77.8\end{array}$ & $\left(\begin{array}{l}1.099 \\
0.91\end{array}\right)$ & $\begin{array}{l}33.8 \\
36.6\end{array}$ & $\left(\begin{array}{l}1.02 \\
0.89\end{array}\right)$ & $\begin{array}{l}10.7 \\
10.9\end{array}$ & $.51)$ & $\begin{array}{l}16.1 \\
15.7\end{array}$ & $\begin{array}{l}.75) \\
.69)\end{array}$ & $\begin{array}{l}94.9 \\
96.2\end{array}$ & $\left(\begin{array}{l}0.45) \\
(0.43)\end{array}\right.$ & $\begin{array}{l}67.4 \\
73.4\end{array}$ & $(0.95)$ & 3.0 & $\left(\begin{array}{l}1.29) \\
0.92)\end{array}\right.$ & $\begin{array}{l}65.0 \\
71.4\end{array}$ & $0.94)$ & $\begin{array}{l}31.9 \\
28.3\end{array}$ & $\begin{array}{l}1.08) \\
(0.85)\end{array}$ \\
\hline 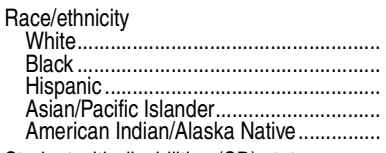 & $\begin{array}{l}67.0 \\
77.2 \\
75.4 \\
53.3 \\
74.8\end{array}$ & $\left.\begin{array}{l}(1.09) \\
1.26 \\
1.60 \\
3.52 \\
(5.85)\end{array}\right)$ & $\begin{array}{l}88.8 \\
88.4 \\
87.0 \\
86.1 \\
81.6\end{array}$ & $\left.\begin{array}{l}(0.73 \\
1.07 \\
0.96 \\
1.47 \\
4.09\end{array}\right)$ & $\begin{array}{l}77.4 \\
70.6 \\
71.4 \\
83.0 \\
66.6\end{array}$ & $\left.\begin{array}{l}(1.08) \\
1.69 \\
1.81 \\
(2.59 \\
4.12\end{array}\right)$ & $\begin{array}{l}37.9 \\
22.7 \\
26.5 \\
60.5 \\
18.5\end{array}$ & $\left.\begin{array}{l}(0.98) \\
1.29 \\
1.36 \\
2.88 \\
2.98\end{array}\right)$ & $\begin{array}{r}11.6 \\
7.9 \\
7.5 \\
17.6 \\
\ddagger\end{array}$ & $\left.\begin{array}{r}(0.64) \\
1.04 \\
0.77 \\
1.69 \\
(\dagger)\end{array}\right)$ & $\begin{array}{r}17.5 \\
6.1 \\
8.6 \\
42.2 \\
\ddagger\end{array}$ & $\left.\begin{array}{r}(0.69) \\
0.59 \\
0.64 \\
3.11 \\
(\dagger)\end{array}\right)$ & $\begin{array}{l}95.6 \\
96.3 \\
94.8 \\
95.8 \\
94.5\end{array}$ & $\left.\begin{array}{l}(0.51) \\
0.56 \\
0.67 \\
0.95 \\
(1.64)\end{array}\right)$ & $\begin{array}{l}71.5 \\
65.3 \\
65.7 \\
84.8 \\
44.5\end{array}$ & $\left.\begin{array}{l}(0.87) \\
1.80 \\
1.41 \\
1.72 \\
4.78)\end{array}\right)$ & & $\begin{array}{l}(1.24) \\
1.72 \\
1.33 \\
2.35 \\
(3.89)\end{array}$ & $\begin{array}{l}68.9 \\
64.3 \\
64.2 \\
82.7 \\
43.9\end{array}$ & $\left.\begin{array}{l}(0.93) \\
1.74 \\
1.45 \\
1.93 \\
4.77)\end{array}\right)$ & $\begin{array}{l}31.4 \\
21.9 \\
22.7 \\
54.4 \\
13.6\end{array}$ & $\left.\begin{array}{l}(1.04) \\
1.48 \\
1.19 \\
2.77 \\
2.87\end{array}\right)$ \\
\hline $\begin{array}{l}\text { Student with disabilities (SD) status } \\
\text { SDD } \\
\text { Non-SD }\end{array}$ & $\begin{array}{l}56.0 \\
70.1\end{array}$ & $\left(\begin{array}{l}1.63) \\
0.97)\end{array}\right)$ & $\begin{array}{l}61.1 \\
90.7\end{array}$ & $\left(\begin{array}{l}1.82 \\
0.53\end{array}\right)$ & $\begin{array}{l}39.5 \\
79.1\end{array}$ & $(0.93)$ & 37.6 & $(0.90)$ & $\begin{array}{r}3.9 \\
11.4\end{array}$ & $\left(\begin{array}{l}0.57) \\
0.53)\end{array}\right.$ & $\begin{array}{r}3.0 \\
17.1\end{array}$ & $(0.71)$ & 96.8 & $\left(\begin{array}{l}1.30) \\
0.41\end{array}\right)$ & 73.6 & $\left(\begin{array}{l}1.69) \\
(0.75)\end{array}\right.$ & 37.6 & $\left(\begin{array}{l}1.67) \\
1.06)\end{array}\right.$ & $\begin{array}{l}33.8 \\
71.4\end{array}$ & $(0.79)$ & $\begin{array}{l}12.0 \\
31.7\end{array}$ & $\begin{array}{l}(1.51) \\
(0.94)\end{array}$ \\
\hline 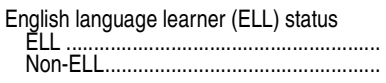 & $\begin{array}{l}73.3 \\
68.8\end{array}$ & $\left(\begin{array}{l}2.33) \\
0.95)\end{array}\right)$ & $\begin{array}{l}76.2 \\
88.5\end{array}$ & $\left(\begin{array}{l}1.99 \\
0.54\end{array}\right)$ & $\begin{array}{l}58.1 \\
76.2\end{array}$ & $\left.\begin{array}{l}(2.54) \\
(0.93)\end{array}\right)$ & $\begin{array}{l}19.4 \\
35.6\end{array}$ & $\left(\begin{array}{l}2.36 \\
0.86\end{array}\right)$ & $\begin{array}{r}4.4 \\
10.9\end{array}$ & $\left(\begin{array}{l}1.03) \\
0.50)\end{array}\right.$ & $\begin{array}{r}4.7 \\
16.2\end{array}$ & $\left(\begin{array}{l}0.87) \\
0.67)\end{array}\right.$ & $\begin{array}{l}86.9 \\
95.7\end{array}$ & $\left(\begin{array}{l}2.12 \\
(0.41)\end{array}\right)$ & $\begin{array}{l}47.4 \\
70.9\end{array}$ & $\left(\begin{array}{l}2.99) \\
0.77)\end{array}\right)$ & $\begin{array}{l}23.2 \\
36.3\end{array}$ & $\left(\begin{array}{l}2.41 \\
1.02\end{array}\right)$ & $\begin{array}{l}43.8 \\
68.7\end{array}$ & $\left.\begin{array}{l}3.03) \\
0.79\end{array}\right)$ & $\begin{array}{l}15.4 \\
30.3\end{array}$ & $\begin{array}{l}(2.02) \\
(0.89)\end{array}$ \\
\hline $\begin{array}{l}\text { School type } \\
\text { Traditional public... } \\
\text { Public charter ....... } \\
\text { Private......................... }\end{array}$ & $\begin{array}{l}68.2 \\
79.0 \\
74.7\end{array}$ & $\left(\begin{array}{l}0.99 \\
4.21 \\
2.95\end{array}\right)$ & $\begin{array}{l}88.1 \\
86.9 \\
90.0\end{array}$ & $\left.\begin{array}{l}0.53 \\
(.57) \\
3.98\end{array}\right)$ & $\begin{array}{l}74.9 \\
77.8 \\
84.6\end{array}$ & $\left.\begin{array}{l}(0.96) \\
6.64 \\
(4.01)\end{array}\right)$ & $\begin{array}{l}34.0 \\
34.1 \\
47.5\end{array}$ & $\left.\begin{array}{l}(0.97) \\
(9.95) \\
(3.76)\end{array}\right)$ & $\begin{array}{r}10.7 \\
1 . \\
12.5\end{array}$ & $\begin{array}{r}(0.51) \\
(t) \\
(1.86)\end{array}$ & $\begin{aligned} 15.4 \\
\neq \\
23.3\end{aligned}$ & $\begin{array}{l}(0.73) \\
(t) \\
(2.05)\end{array}$ & $\begin{array}{l}95.3 \\
94.0 \\
98.6\end{array}$ & $\left.\begin{array}{l}(0.44) \\
1.92 \\
0.28\end{array}\right)$ & $\begin{array}{l}68.9 \\
56.8 \\
87.4\end{array}$ & $\left.\begin{array}{r}(0.75) \\
(11.13 \\
(1.87)\end{array}\right)$ & $\begin{array}{l}40.0 \\
49.5\end{array}$ & $\begin{array}{l}(1.03) \\
7.36 \\
(3.73)\end{array}$ & $\begin{array}{l}66.9 \\
55.7 \\
83.3\end{array}$ & $\left.\begin{array}{r}(0.78) \\
(10.77) \\
(2.67)\end{array}\right)$ & $\begin{array}{l}28.8 \\
23.2 ! \\
43.9\end{array}$ & $\begin{array}{l}(0.83) \\
(7.52) \\
(3.77)\end{array}$ \\
\hline 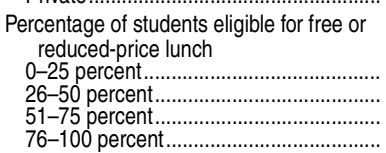 & $\begin{array}{l}61.3 \\
70.9 \\
75.8 \\
80.1\end{array}$ & $\left(\begin{array}{l}1.72 \\
1.82 \\
1.85 \\
3.75\end{array}\right)$ & $\begin{array}{l}89.7 \\
88.4 \\
87.4 \\
88.8\end{array}$ & $\left.\begin{array}{l}(0.82) \\
0.87 \\
1.45 \\
2.26\end{array}\right)$ & $\begin{array}{l}80.1 \\
74.7 \\
69.3 \\
70.7\end{array}$ & $\left.\begin{array}{l}1.75 \\
1.38 \\
3.35 \\
4.02\end{array}\right)$ & $\begin{array}{l}43.1 \\
29.7 \\
25.4 \\
25.5\end{array}$ & $\left(\begin{array}{l}1.88) \\
1.44 \\
1.52 \\
2.80\end{array}\right)$ & $\begin{array}{r}14.8 \\
8.6 \\
7.5 \\
5.1\end{array}$ & $\left(\begin{array}{l}1.03) \\
0.80 \\
1.14 \\
1.08)\end{array}\right)$ & $\begin{array}{r}22.6 \\
11.8 \\
9.8 \\
7.5\end{array}$ & $\left.\begin{array}{l}1.37) \\
0.76 \\
1.05 \\
1.34\end{array}\right)$ & $\begin{array}{l}96.4 \\
94.5 \\
95.6 \\
95.6\end{array}$ & $\left.\begin{array}{l}(1.03) \\
(0.98 \\
0.72 \\
(1.42)\end{array}\right)$ & $\begin{array}{l}76.3 \\
64.0 \\
65.6 \\
69.4\end{array}$ & $\left(\begin{array}{l}1.58) \\
1.52 \\
2.03 \\
3.68\end{array}\right)$ & $\begin{array}{l}46.5 \\
27.6 \\
29.4 \\
26.6\end{array}$ & $\left(\begin{array}{l}2.02 \\
1.79 \\
2.56 \\
3.07)\end{array}\right)$ & $\begin{array}{l}74.9 \\
61.6 \\
64.2 \\
68.2\end{array}$ & $\left.\begin{array}{l}1.70) \\
1.59 \\
1.97 \\
3.69\end{array}\right)$ & $\begin{array}{l}40.4 \\
22.2 \\
22.7 \\
22.8\end{array}$ & $\left.\begin{array}{l}2.07) \\
1.54 \\
2.12 \\
2.97\end{array}\right)$ \\
\hline
\end{tabular}

See notes at end of table. 


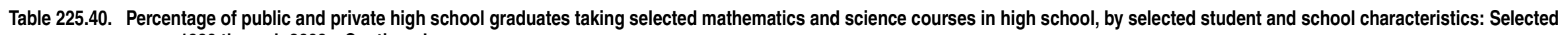
years, 1990 through 2009-Continued

[Standard errors appear in parentheses]

\begin{tabular}{|c|c|c|c|c|c|c|c|c|c|c|c|c|c|c|c|c|c|c|c|c|c|c|}
\hline \multirow[b]{2}{*}{$\begin{array}{l}\text { Year and student or } \\
\text { school characteristic }\end{array}$} & \multicolumn{12}{|c|}{ Mathematics } & \multicolumn{10}{|c|}{ Science } \\
\hline & & ebra $\left.\right|^{1,2}$ & & ometry ${ }^{1}$ & ${ }_{\text {trigo }}^{A}$ & $\begin{array}{l}\text { ebra III } \\
\text { ometry }\end{array}$ & & $\begin{array}{l}\text { nnalysis/ } \\
\text { alculus }\end{array}$ & & $\begin{array}{l}\text { atistics/ } \\
\text { pability } \\
3\end{array}$ & & 'alculus ${ }^{1}$ & & Biology ${ }^{1}$ & & emistry ${ }^{1}$ & & Physics ${ }^{1}$ & & $\begin{array}{l}\text { gyy and } \\
\text { emistry }\end{array}$ & $\begin{array}{r}\text { Biology } \\
a\end{array}$ & $\begin{array}{l}\text { nemistry } \\
\text { physics }\end{array}$ \\
\hline 1 & & 2 & & 3 & & 4 & & 5 & & 6 & & 7 & & 8 & & 9 & & 10 & & 11 & & 12 \\
\hline 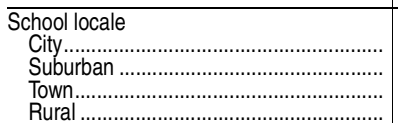 & $\begin{array}{l}72.5 \\
62.8 \\
76.9 \\
70.2\end{array}$ & $\left.\begin{array}{l}1.85 \\
1.62 \\
2.25 \\
2.19\end{array}\right)$ & $\begin{array}{l}89.1 \\
89.4 \\
86.4 \\
86.3\end{array}$ & $\left.\begin{array}{l}(0.911 \\
1.27 \\
1.08 \\
0.95\end{array}\right)$ & $\begin{array}{l}74.9 \\
78.7 \\
71.4 \\
74.5\end{array}$ & $\left.\begin{array}{l}(2.06 \\
1.79 \\
3.00 \\
1.38\end{array}\right)$ & $\begin{array}{l}36.7 \\
39.0 \\
30.1 \\
30.0\end{array}$ & $\left.\begin{array}{l}(1.98) \\
1.71 \\
2.40 \\
1.35\end{array}\right)$ & $\begin{array}{r}10.6 \\
13.1 \\
8.4 \\
8.6\end{array}$ & $\begin{array}{l}0.91) \\
0.97 \\
1.25 \\
(1.12)\end{array}$ & $\begin{array}{l}15.5 \\
19.5 \\
10.7 \\
13.5\end{array}$ & $\left.\begin{array}{c}(1.42 \\
(1.12 \\
1.02 \\
0.87\end{array}\right)$ & $\begin{array}{l}96.4 \\
97.1 \\
92.2 \\
93.7\end{array}$ & $\left.\begin{array}{l}(0.53) \\
0.30 \\
2.23 \\
1.66\end{array}\right)$ & $\begin{array}{l}74.0 \\
76.7 \\
62.3 \\
59.6\end{array}$ & $\begin{array}{l}(1.59) \\
1.14 \\
(1.84) \\
(1.82)\end{array}$ & $\begin{array}{l}38.8 \\
43.8 \\
24.0 \\
26.0\end{array}$ & $\left.\begin{array}{l}(1.99) \\
1.42 \\
(2.45) \\
1.95)\end{array}\right)$ & $\begin{array}{l}70.8 \\
75.4 \\
60.4 \\
57.2\end{array}$ & $\left(\begin{array}{l}1.977 \\
1.04 \\
1.87 \\
1.77\end{array}\right)$ & $\begin{array}{l}31.6 \\
38.6 \\
18.9 \\
19.7\end{array}$ & $\left(\begin{array}{l}1.97 \\
1.21 \\
1.94 \\
1.41\end{array}\right)$ \\
\hline
\end{tabular}

\section{-Not available.}

Not applicable.

Interpret data with caution. The coefficient of variation (CV) for this estimate is between 30 and 50 percent. ₹Reporting standards not met (too few cases for a reliable estimate)

Percentages are for students who earned at least one Carnegie credit.

2Excludes prealgebra.
3Percentages are for students who earned at least one-half of a Carnegie credit in a course that includes a focus on at least

Percentages are for students who

${ }^{6}$ Includes other racial/ethnic groups not shown separately, as well as students for whom information on race/ethnicity or sex

(IEP) and students with a plan under Section 504 of the Rehabilitation Act (a "504 plan"). IEPs are only for students who require specialized instruction, whereas 504 plans apply to students who require accommodations but may not require specialized instruction.

NOTE: For a transcript to be included in the analyses, it had to meet three requirements: (1) the graduate received either a standard or honors diploma, (2) the graduate's transcript contained 16 or more Carnegie credits, and (3) the graduate's transcript contained more than 0 Carnegle credits in English courses. Race calegories exclude persons of Hispanic ethnicity. Transcript Study (HSTS). (This table was prepared September 2012.) 
272 CHAPTER 2: Elementary and Secondary Education

Coursetaking and Grades

Table 225.50. Percentage of public and private high school graduates earning minimum credits in selected combinations of academic courses, by sex and race/ethnicity: Selected years, 1982 through 2009

[Standard errors appear in parentheses]

\begin{tabular}{|c|c|c|c|c|c|c|c|c|c|c|c|c|c|c|c|c|}
\hline \multirow[b]{2}{*}{$\begin{array}{l}\text { Year of graduation and } \\
\text { course combination taken }\end{array}$} & & & \multicolumn{4}{|c|}{ Sex } & \multicolumn{10}{|c|}{ Race/ethnicity } \\
\hline & \multicolumn{2}{|c|}{ All students ${ }^{2}$} & \multicolumn{2}{|r|}{ Male } & \multicolumn{2}{|r|}{ Female } & \multicolumn{2}{|r|}{ White } & \multicolumn{2}{|r|}{ Black } & \multicolumn{2}{|r|}{ Hispanic } & \multicolumn{2}{|c|}{$\begin{array}{r}\text { Asian/Pacific } \\
\text { Islander }\end{array}$} & \multicolumn{2}{|c|}{$\begin{array}{r}\text { American Indian/ } \\
\text { Alaska Native }\end{array}$} \\
\hline 1 & & 2 & & 3 & & 4 & & 5 & & 6 & & 7 & & 8 & & 9 \\
\hline 1982 graduates & & & & & & & & & & & & & & & & \\
\hline 4 Eng, 3 SS, 3 Sci, 3 Math, and $2 \mathrm{FL}^{3}$.. & 9.5 & $(0.57)$ & 9.1 & $(0.70)$ & 9.9 & $(0.71)$ & 10.9 & $(0.69)$ & 5.2 & $(1.02)$ & 3.9 & $(0.57)$ & 17.0 & $(2.49)$ & $\ddagger$ & $(\dagger)$ \\
\hline 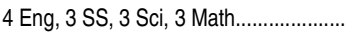 & 14.3 & $(0.66)$ & 15.2 & $(0.86)$ & 13.4 & $(0.79)$ & 15.9 & $(0.79)$ & 11.0 & $(1.39)$ & 6.7 & $(0.79)$ & 21.1 & $(2.65)$ & $8.1 !$ & $(3.02)$ \\
\hline $\begin{array}{l}4 \text { Eng, } 3 \text { SS, } 2 \text { Sci, } 2 \text { Math.................... } \\
1987 \text { graduates }\end{array}$ & 31.5 & $(1.07)$ & 31.7 & $(1.26)$ & 31.3 & $(1.22)$ & 32.4 & $(1.21)$ & 30.8 & $(2.32)$ & 25.6 & $(1.76)$ & 32.0 & $(3.40)$ & 23.6 & $(5.39)$ \\
\hline 4 Eng, 3 SS, 3 Sci, 3 Math, and $2 \mathrm{FL}^{3}$.. & 18.1 & $(0.91)$ & 18.0 & $(1.13)$ & 18.3 & $(1.01)$ & 19.0 & $(1.10)$ & 12.7 & $(1.15)$ & 10.8 & $(1.70)$ & 35.7 & $(4.49)$ & 4.9 & $(1.40)$ \\
\hline 4 Eng, 3 SS, 3 Sci, 3 Math..................... & 24.8 & $(1.03)$ & 25.9 & $(1.27)$ & 23.7 & $(1.07)$ & 26.1 & $(1.21)$ & 19.6 & $(1.99)$ & 14.5 & (1.69) & 39.8 & (4.51) & 24.3 & (3.69) \\
\hline $\begin{array}{l}4 \text { Eng, } 3 \text { SS, } 2 \text { Sci, } 2 \text { Math.................... } \\
1990 \text { graduates }\end{array}$ & 48.1 & $(1.74)$ & 48.0 & $(2.22)$ & 48.4 & $(1.56)$ & 48.1 & $(2.15)$ & 48.3 & $(2.63)$ & 43.9 & (1.92) & 57.9 & $(4.82)$ & 61.8 & $(5.56)$ \\
\hline 4 Eng, 3 SS, 3 Sci, 3 Math, and $2 \mathrm{FL}^{3}$.. & 29.9 & $(1.26)$ & 28.8 & $(1.38)$ & 31.0 & $(1.36)$ & 31.7 & $(1.46)$ & 22.9 & $(2.27)$ & 25.4 & $(2.41)$ & 42.6 & $(2.95)$ & $9.9 !$ & $(3.70)$ \\
\hline 4 Eng, 3 SS, 3 Sci, 3 Math..................... & 38.2 & $(1.50)$ & 38.5 & $(1.69)$ & 37.9 & $(1.54)$ & 39.2 & $(1.63)$ & 39.0 & $(3.57)$ & 29.8 & $(2.51)$ & 47.4 & $(3.04)$ & 19.2 & $(4.70)$ \\
\hline $\begin{array}{l}4 \text { Eng, } 3 \text { SS, } 2 \text { Sci, } 2 \text { Math.................... } \\
1994 \text { graduates }\end{array}$ & 65.5 & $(1.96)$ & 64.3 & $(2.09)$ & 66.4 & $(1.98)$ & 64.9 & $(2.28)$ & 71.3 & $(3.00)$ & 63.7 & $(3.01)$ & 69.1 & $(3.90)$ & 46.3 & (6.39) \\
\hline 4 Eng, 3 SS, 3 Sci, 3 Math, and $2 \mathrm{FL}^{3}$.. & 39.0 & $(1.12)$ & 35.0 & $(1.11)$ & 42.7 & (1.33) & 41.6 & (1.32) & 29.6 & $(1.52)$ & 35.6 & (2.94) & 50.1 & (2.39) & 22.5 & (4.31) \\
\hline 4 Eng, 3 SS, 3 Sci, 3 Math..................... & 49.3 & $(1.45)$ & 47.0 & $(1.45)$ & 51.5 & (1.58) & 52.4 & $(1.67)$ & 43.7 & $(2.39)$ & 40.3 & (3.25) & 54.9 & $(2.46)$ & 46.0 & (3.30) \\
\hline $\begin{array}{l}4 \text { Eng, } 3 \text { SS, } 2 \text { Sci, } 2 \text { Math.................... } \\
1998 \text { graduates }\end{array}$ & 73.9 & $(1.50)$ & 71.2 & $(1.63)$ & 76.4 & $(1.46)$ & 75.1 & $(1.69)$ & 74.5 & $(2.32)$ & 74.7 & $(2.61)$ & 72.3 & $(3.62)$ & 76.3 & $(3.60)$ \\
\hline 4 Eng, 3 SS, 3 Sci, 3 Math, and $2 \mathrm{FL}^{3}$.. & 44.2 & $(1.92)$ & 40.5 & $(2.19)$ & 48.2 & $(2.05)$ & 46.2 & $(2.16)$ & 40.0 & $(3.41)$ & 32.0 & $(2.94)$ & 57.8 & $(4.51)$ & 28.3 & $(4.53)$ \\
\hline 4 Eng, 3 SS, 3 Sci, 3 Math.................... & 55.0 & $(2.44)$ & 52.9 & $(2.64)$ & 57.8 & $(2.48)$ & 56.8 & $(2.69)$ & 55.6 & $(4.39)$ & 40.0 & $(3.28)$ & 66.1 & $(5.69)$ & 40.0 & $(4.73)$ \\
\hline $\begin{array}{l}4 \text { Eng, } 3 \text { SS, } 2 \text { Sci, } 2 \text { Math.................... } \\
2000 \text { graduates }\end{array}$ & 74.5 & $(2.18)$ & 72.8 & $(2.34)$ & 77.0 & $(2.14)$ & 74.7 & (2.64) & 76.0 & $(3.21)$ & 70.1 & $(2.57)$ & 79.5 & $(4.76)$ & 76.4 & $(5.21)$ \\
\hline 4 Eng, 3 SS, 3 Sci, 3 Math, and $2 \mathrm{FL}^{3}$.. & 47.8 & $(1.53)$ & 41.5 & $(1.68)$ & 53.4 & $(1.65)$ & 48.9 & $(1.60)$ & 45.6 & $(2.27)$ & 40.3 & $(5.47)$ & 58.2 & $(3.48)$ & 26.8 & (3.63) \\
\hline 4 Eng, 3 SS, 3 Sci, 3 Math..................... & 58.6 & $(1.64)$ & 54.4 & $(1.70)$ & 62.3 & $(1.75)$ & 59.2 & $(1.74)$ & 64.1 & $(2.51)$ & 48.3 & $(5.74)$ & 62.7 & $(3.44)$ & 42.5 & $(5.84)$ \\
\hline $\begin{array}{l}4 \text { Eng, } 3 \text { SS, } 2 \text { Sci, } 2 \text { Math.................... } \\
2005 \text { graduates }\end{array}$ & 78.2 & $(1.60)$ & 74.9 & $(1.88)$ & 81.2 & $(1.43)$ & 78.3 & $(1.85)$ & 82.5 & $(2.26)$ & 75.4 & $(3.16)$ & 75.0 & $(3.27)$ & 72.6 & $(4.48)$ \\
\hline 4 Eng, 3 SS, 3 Sci, 3 Math, and $2 \mathrm{FL}^{3}$.. & 54.7 & $(0.96)$ & 49.0 & $(1.14)$ & 60.1 & $(0.94)$ & 55.5 & (1.19) & 54.3 & $(1.87)$ & 46.3 & $(2.08)$ & 66.7 & $(2.10)$ & 38.1 & (3.37) \\
\hline 4 Eng, 3 SS, 3 Sci, 3 Math..................... & 67.4 & $(1.02)$ & 63.5 & $(1.22)$ & 71.0 & $(0.94)$ & 68.5 & $(1.29)$ & 72.3 & $(1.76)$ & 53.5 & $(2.20)$ & 72.2 & $(2.05)$ & 60.9 & $(3.40)$ \\
\hline $\begin{array}{l}4 \text { Eng, } 3 \text { SS, } 2 \text { Sci, } 2 \text { Math.................... } \\
2009 \text { graduates }\end{array}$ & 83.0 & $(1.02)$ & 80.3 & $(1.19)$ & 85.4 & $(0.94)$ & 82.1 & $(1.34)$ & 89.7 & $(0.91)$ & 79.6 & $(1.38)$ & 85.0 & $(1.68)$ & 81.0 & $(3.10)$ \\
\hline 4 Eng, 3 SS, 3 Sci, 3 Math, and $2 \mathrm{FL}^{3}$.. & 61.8 & $(0.84)$ & 57.4 & $(1.06)$ & 66.0 & $(0.82)$ & 62.4 & $(0.94)$ & 58.4 & $(1.71)$ & 58.4 & $(1.65)$ & 73.1 & $(2.28)$ & 43.0 & $(3.44)$ \\
\hline 4 Eng, 3 SS, 3 Sci, 3 Math.................... & 74.3 & $(0.81)$ & 72.1 & $(0.96)$ & 76.4 & $(0.77)$ & 75.0 & $(1.04)$ & 78.1 & $(1.20)$ & 67.2 & $(1.49)$ & 76.9 & $(2.08)$ & 64.7 & $(4.23)$ \\
\hline 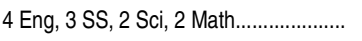 & 87.7 & $(0.74)$ & 86.2 & $(0.82)$ & 89.1 & $(0.73)$ & 86.8 & $(0.97)$ & 92.0 & $(0.63)$ & 88.0 & $(0.87)$ & 86.1 & (1.52) & 86.6 & (2.99) \\
\hline
\end{tabular}

†Not applicable.

!Interpret data with caution. The coefficient of variation (CV) for this estimate is between 30 and 50 percent.

¥Reporting standards not met. The coefficient of variation (CV) for this estimate is 50 percent or greater.

${ }^{1}$ Eng = English; $\mathrm{SS}=$ social studies; $\mathrm{Sci}=$ science; and $\mathrm{FL}=$ foreign language

2Totals include other racial/ethnic groups not separately shown.

In 1983, the National Commission on Excellence in Education recommended that all college-bound high school students take these courses plus 0.5 credits of computer science as a minimum.
NOTE: Data differ slightly from figures appearing in other NCES reports because of differences in taxonomies and case exclusion criteria. Race categories exclude persons of Hispanic ethnicity.

SOURCE: U.S. Department of Education, National Center for Education Statistics, High School and Beyond Longitudinal Study of 1980 Sophomores (HS\&B-So:80/82), "High School Transcript Study"; and 1987, 1990, 1994, 1998, 2000, 2005, and 2009 High School Transcript Study (HSTS). (This table was prepared October 2011.) 
Table 225.60. Number and percentage of public high school graduates taking dual credit, Advanced Placement (AP), and International Baccalaureate (IB) courses in high school and average credits earned, by selected student and school characteristics: 2000, 2005, and 2009

[Standard errors appear in parentheses]

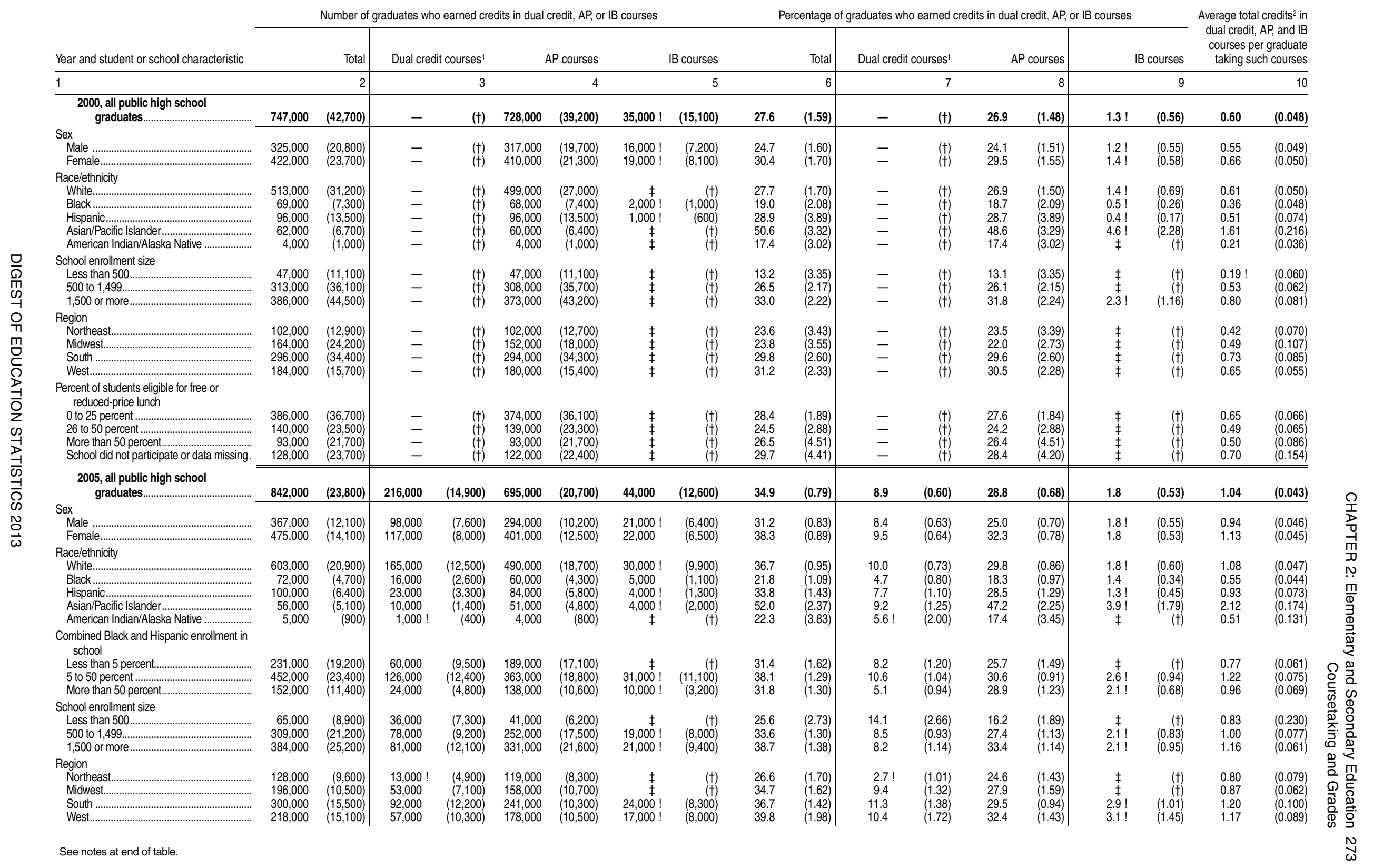


Table 225.60. Number and percentage of public high school graduates taking dual credit, Advanced Placement (AP), and International Baccalaureate (IB) courses in high school and average credits earned, by selected student and school characteristics: 2000, 2005, and 2009-Continued

[Standard errors appear in parentheses]

\begin{tabular}{|c|c|c|c|c|c|c|c|c|c|c|c|c|c|c|c|c|c|c|}
\hline \multirow[b]{2}{*}{ Year and student or school characteristic } & \multicolumn{8}{|c|}{ Number of graduates who earned credits in dual credit, AP, or IB courses } & \multicolumn{8}{|c|}{ Percentage of graduates who earned credits in dual credit, AP, or IB courses } & \multirow{2}{*}{\multicolumn{2}{|c|}{$\begin{array}{r}\text { Average total credits }{ }^{2} \text { in } \\
\text { dual credit, AP, and IB } \\
\text { courses per graduate } \\
\text { taking such courses }\end{array}$}} \\
\hline & & Total & \multicolumn{2}{|c|}{ Dual credit courses ${ }^{1}$} & \multicolumn{2}{|c|}{ AP courses } & \multicolumn{2}{|r|}{ IB courses } & & Total & \multicolumn{2}{|c|}{ Dual credit courses ${ }^{1}$} & \multicolumn{2}{|c|}{ AP courses } & \multicolumn{2}{|c|}{ IB courses } & & \\
\hline 1 & & 2 & & 3 & & 4 & & 5 & & 6 & & 7 & & 8 & & 9 & & 10 \\
\hline 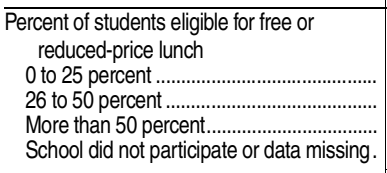 & $\begin{array}{l}410,000 \\
223,000 \\
103,000 \\
105,000 \\
\end{array}$ & $\begin{array}{l}(26,700) \\
(19,400) \\
(10,100) \\
(13,900) \\
\end{array}$ & $\begin{array}{r}102,000 \\
67,000 \\
22,000 \\
25,000 \\
\end{array}$ & $\begin{array}{r}(14,800) \\
(10,700) \\
(4,900) \\
(5,500) \\
\end{array}$ & $\begin{array}{r}344,000 \\
174,000 \\
89,000 \\
88,000 \\
\end{array}$ & $\begin{array}{r}(23,200) \\
(13,900) \\
(8,700) \\
(12,300) \\
\end{array}$ & $\begin{array}{r}22,000 ! \\
13,000 ! \\
6,000 ! \\
\ddagger \\
\end{array}$ & $\begin{array}{r}(10,500) \\
(4,300) \\
(2,500) \\
(\dagger) \\
\end{array}$ & $\begin{array}{l}39.3 \\
32.0 \\
28.3 \\
34.4 \\
\end{array}$ & $\begin{array}{l}(1.36) \\
(1.55) \\
(1.83) \\
(2.39) \\
\end{array}$ & $\begin{array}{l}9.8 \\
9.6 \\
5.9 \\
8.2 \\
\end{array}$ & $\begin{array}{l}(1.32) \\
(1.31) \\
(1.32) \\
(1.72) \\
\end{array}$ & $\begin{array}{l}32.9 \\
24.9 \\
24.5 \\
28.8 \\
\end{array}$ & $\begin{array}{l}(1.27) \\
(1.16) \\
(1.46) \\
(2.04) \\
\end{array}$ & $\begin{array}{r}2.1 ! \\
1.9 ! \\
1.6 ! \\
\ddagger \\
\end{array}$ & $\begin{array}{r}(1.00) \\
(0.62) \\
(0.69) \\
(\dagger) \\
\end{array}$ & $\begin{array}{l}1.24 \\
0.91 \\
0.77 \\
0.94 \\
\end{array}$ & $\begin{array}{l}(0.083) \\
(0.058) \\
(0.066) \\
(0.092) \\
\end{array}$ \\
\hline $\begin{array}{l}\text { 2009, all public high school } \\
\text { graduates... }\end{array}$ & $1,104,000$ & $(36,400)$ & 249,000 & $(20,700)$ & 968,000 & $(33,900)$ & 50,000 & $(10,500)$ & 41.4 & $(1.00)$ & 9.3 & (0.76) & 36.3 & $(0.94)$ & 1.9 & (0.40) & 1.39 & $(0.051)$ \\
\hline 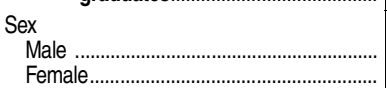 & $\begin{array}{l}477,000 \\
628,000\end{array}$ & $\begin{array}{l}(17,900) \\
(20,100)\end{array}$ & $\begin{array}{l}110,000 \\
139,000\end{array}$ & $\begin{array}{l}(10,800) \\
(10,700)\end{array}$ & $\begin{array}{l}413,000 \\
554,000\end{array}$ & $\begin{array}{l}(16,200) \\
(19,100)\end{array}$ & $\begin{array}{l}21,000 \\
29,000\end{array}$ & $\begin{array}{l}(4,900) \\
(5,800)\end{array}$ & $\begin{array}{l}36.8 \\
45.8\end{array}$ & $\begin{array}{l}(1.05) \\
(1.07)\end{array}$ & $\begin{array}{r}8.5 \\
10.1\end{array}$ & $\begin{array}{l}(0.80) \\
(0.78)\end{array}$ & $\begin{array}{l}31.9 \\
40.4\end{array}$ & $\left.\begin{array}{l}(0.98) \\
(1.01)\end{array}\right)$ & $\begin{array}{l}1.7 \\
2.1\end{array}$ & $\begin{array}{l}(0.38) \\
(0.43)\end{array}$ & $\begin{array}{l}1.24 \\
1.53\end{array}$ & $\begin{array}{l}(0.057) \\
(0.049)\end{array}$ \\
\hline \multicolumn{19}{|l|}{ Race/ethnicity } \\
\hline White.............. & 702,000 & $(25,700)$ & 160,000 & $(16,300)$ & 617,000 & $(23,700)$ & 29,000 & $(7,100)$ & 42.5 & $(1.04)$ & 9.7 & $(1.00)$ & 37.3 & $(0.95)$ & 1.8 & $(0.43)$ & 1.41 & $(0.049)$ \\
\hline 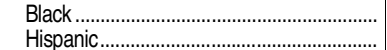 & $\begin{array}{l}106,000 \\
170,000\end{array}$ & $\begin{array}{l}(6,600) \\
(9,300)\end{array}$ & $\begin{array}{l}25,000 \\
46,000\end{array}$ & $\begin{array}{r}(3,700) \\
(5,900)\end{array}$ & $\begin{array}{r}86,000 \\
144,000\end{array}$ & $\left.\begin{array}{l}(5,100) \\
(7,800)\end{array}\right]$ & $\begin{array}{l}7,000 \\
7,000\end{array}$ & $\left.\begin{array}{l}(1,700) \\
(2,000)\end{array}\right]$ & $\begin{array}{l}27.3 \\
39.8\end{array}$ & $\begin{array}{l}(1.50) \\
(1.45)\end{array}$ & $\begin{array}{r}6.4 \\
10.8\end{array}$ & $\begin{array}{l}(0.99) \\
(1.18)\end{array}$ & $\begin{array}{l}22.2 \\
33.8\end{array}$ & $\left(\begin{array}{l}1.00) \\
(1.30)\end{array}\right.$ & $\begin{array}{l}1.7 \\
1.6\end{array}$ & $\begin{array}{l}(0.44) \\
(0.47)\end{array}$ & $\begin{array}{l}0.75 \\
1.17\end{array}$ & $\begin{array}{l}(0.054) \\
(0.059)\end{array}$ \\
\hline Asian/Pacific Islander ................................. & 115,000 & $(14,800)$ & 15,000 & $(2,300)$ & 111,000 & $(14,800)$ & 7,000 & $(1,900)$ & 69.1 & $\begin{array}{l}1.45) \\
(2.36)\end{array}$ & $\begin{array}{r}10.8 \\
9.2\end{array}$ & $(1.46)$ & 66.3 & (1.50) & $4.1 !$ & $\left(\begin{array}{ll}(.23) \\
(1.23)\end{array}\right.$ & 3.25 & $(0.263)$ \\
\hline American Indian/Alaska Native ................... & 4,000 & (900) & 1,000 ! & (400) & 3,000 & (900) & $\neq$ & $(t)$ & 25.0 & $(3.97)$ & $7.0 !$ & $(2.20)$ & 20.3 & (3.74) & $\ddagger$ & $(t)$ & 0.79 & $(0.187)$ \\
\hline \multicolumn{19}{|l|}{$\begin{array}{l}\text { Combined Black and Hispanic enrollment in } \\
\text { school }\end{array}$} \\
\hline Less than 5 percent......................................... & 239,000 & $(28,100)$ & 45,000 & $(13,300)$ & 209,000 & $(25,500)$ & & (†) & 35.9 & $(2.27)$ & 6.8 & (1.92) & 31.5 & (2.13) & $\ddagger$ & $(t)$ & 1.01 & $(0.102)$ \\
\hline 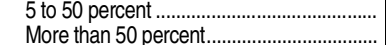 & $\begin{array}{l}601,000 \\
265,000\end{array}$ & $\begin{array}{l}(38,100) \\
(17,900)\end{array}$ & $\begin{array}{r}132,000 \\
72,000\end{array}$ & $\begin{array}{l}(15,000) \\
(10800)\end{array}$ & $\begin{array}{l}533,000 \\
225,000\end{array}$ & $\begin{array}{l}(35,200) \\
(15,900)\end{array}$ & $\begin{array}{l}32,000 \\
13,000\end{array}$ & $\begin{array}{l}(8,400) \\
(3,600)\end{array}$ & $\begin{array}{l}45.4 \\
39.0\end{array}$ & $\begin{array}{l}(1.36) \\
(1.55)\end{array}$ & $\begin{array}{l}10.0 \\
106\end{array}$ & $(0.96)$ & $\begin{array}{l}40.3 \\
331\end{array}$ & $(1.34)$ & 2.5 & $(0.62)$ & 1.64 & $(0.092)$ \\
\hline \multicolumn{19}{|l|}{ School enrollment size } \\
\hline Less than $500 \ldots \ldots \ldots \ldots . . . . .$. & 93,000 & $(12,500)$ & 46,000 & $(9,400)$ & 61,000 & $(9,000)$ & + & (†) & 28.2 & (3.13) & 13.9 & (2.77) & 18.3 & (2.19) & $\ddagger$ & (†) & 0.90 & $(0.199)$ \\
\hline $\begin{array}{l}500 \text { to } 1,499 \ldots \\
1,500 \text { or more }\end{array}$ & $\begin{array}{l}355,000 \\
551,000\end{array}$ & $(28,300)$ & $\begin{array}{r}71,000 \\
111000\end{array}$ & $(11,500)$ & 314,000 & $(27,900)$ & $\begin{array}{r}6,000 ! \\
35000\end{array}$ & $(2,100)$ & 36.8 & $(1.50)$ & 7.4 & $(1.11)$ & 32.5 & $(1.73)$ & $0.7 !$ & $(0.21)$ & $1.13 !$ & $(0.100)$ \\
\hline \multicolumn{19}{|l|}{ School locale } \\
\hline City................... & 354,000 & $(27,500)$ & 81,000 & $(10,200)$ & 311,000 & $(24,300)$ & 28,000 & $(8,100)$ & 48.1 & (2.03) & 11.0 & (1.26) & 42.3 & (1.78) & 3.8 & $(1.05)$ & 1.72 & $(0.105)$ \\
\hline Suburb. & 434,000 & $(26,300)$ & 81,000 & $(14,800)$ & 396,000 & $(25,300)$ & 13,000 & $(3,200)$ & 44.4 & (1.52) & 8.3 & (1.51) & 40.6 & (1.51) & 1.4 & $(0.33)$ & 1.60 & $(0.102)$ \\
\hline & 120,000 & $(14,800)$ & 31,000 & $(6,900)$ & 101,000 & $(13,700)$ & $t$ & $(t)$ & 35.8 & (2.05) & 9.4 & $(1.88)$ & 30.3 & $(2.06)$ & $\ddagger$ & $(t)$ & 0.99 & $(0.073)$ \\
\hline Rural. & 197,000 & $(17,100)$ & 56,000 & $(8,000)$ & 159,000 & $(16,700)$ & $\ddagger$ & (†) & 31.7 & (2.02) & 9.0 & (1.47) & 25.7 & (1.77) & $\ddagger$ & $(\mathrm{t})$ & 0.89 & $(0.064)$ \\
\hline \multicolumn{19}{|l|}{ Region } \\
\hline Northeast.. & 220,000 & $(17,600)$ & 46,000 & $(13,500)$ & 198,000 & $(15,900)$ & $5,000 !$ & $(1,800)$ & 40.9 & (2.54) & 8.5 & (2.52) & 37.0 & $(2.20)$ & $0.9 !$ & $(0.34)$ & $1.28 !$ & $(0.120)$ \\
\hline Midwest.... & 224,000 & $(13,500)$ & 40,000 & $(8,000)$ & 194,000 & $(12,500)$ & 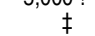 & $(1,000)$ & 35.4 & $(2.00)$ & 6.4 & $(1.30)$ & 30.6 & (1.86) & $\ddagger$ & $\begin{array}{r}(t) .04) \\
(t)\end{array}$ & 0.98 & $(0.078)$ \\
\hline & 385,000 & $(17,100)$ & 128,000 & $(12,400)$ & 320,000 & $(16,800)$ & 16,000 & $(4,500)$ & 43.8 & $(1.24)$ & 14.5 & $(1.37)$ & 36.4 & $(1.30)$ & $1.9^{\top}$ & $(0.53)$ & & $(0.084)$ \\
\hline West... & 275,000 & $(25,800)$ & 35,000 & $(7,200)$ & 255,000 & $(25,200)$ & $17,000 !$ & $(5,800)$ & 44.7 & $(2.34)$ & 5.7 & $(1.14)$ & 41.4 & (2.41) & $2.8 !$ & $(0.92)$ & $1.54 !$ & $(0.165)$ \\
\hline \multicolumn{19}{|l|}{$\begin{array}{l}\text { Percent of students eligible for free or } \\
\text { reduced-price lunch }\end{array}$} \\
\hline 0 to 25 percent & 481,000 & $(39,800)$ & 91,000 & $(16,000)$ & 442,000 & $(37,100)$ & $14,000 !$ & $(6,400)$ & 48.8 & $(1.83)$ & 9.3 & (1.56) & 44.9 & (1.72) & $1.5 !$ & $(0.63)$ & $1.75 !$ & $(0.108)$ \\
\hline 26 to 50 percent ............ & 311,000 & $(24,700)$ & 77,000 & $(11,900)$ & 261,000 & $(21,600)$ & $18,000 !$ & $(5,700)$ & 37.1 & $(1.41)$ & 9.2 & $(1.25)$ & 31.3 & $(1.40)$ & $2.1 !$ & $(0.69)$ & $1.17 !$ & $(0.058)$ \\
\hline More than 50 percent. & 193,000 & $(16,100)$ & 51,000 & $(8,400)$ & 160,000 & $(12,900)$ & $16,000 !$ & $(5,900)$ & 34.4 & $(1.92)$ & 9.1 & $(1.33)$ & 28.6 & (1.64) & $2.8 !$ & $(1.02)$ & $1.05 !$ & $(0.083)$ \\
\hline School did not participate or data missing. & 120,000 & $(17,500)$ & 30,000 & $(7,600)$ & 104,000 & $(16,000)$ & $\ddagger$ & $(t)$ & 42.1 & $(2.84)$ & 10.4 & $(2.50)$ & 36.5 & (2.42) & $\ddagger$ & $(t)$ & 1.44 & $(0.214)$ \\
\hline
\end{tabular}

\section{†Not applicable.}

HNot applicable.

†Reporting standards not met. Either there are too few cases for a reliable estimate or the coefficient of variation (CV) is 50 percent

or greater.
'Dual credit courses are those in which high school students can earn both high school and postsecondary credits for the same course. For 2009, includes some courses for which college credits were conditional upon the student meeting additional require-
ments. For example, one school offered a consumer economics course for which the student earned college credits only if the student later attended that college and took an advanced consumer economics course there. If the student did not attend that college and take the advanced course, then no college credits would be earned for the course (only high school credits would be earned). In 2009 , such conditional college credit courses made up an unweighted 15 percent of the dual credit courses in the sample.
${ }^{2}$ Credits are shown in Carnegie units. The Carnegie unit is a standard unit of measurement that represents one credit for the completion of a 1-year course.

NOTE: For a transcript to be included in the analyses, it had to meet three requirements: (1) the graduate graduated with either a standard or honors diploma, (2) the graduate's transcript contained 16 or more Carnegie credits, and (3) the graduate's transcript contained more than 0 Carnegie credits in English courses. Race categories exclude persons of Hispanic ethnicity. Totals include in each column, regardless of the number of courses taken. Students are counted only once in the total columns even if they earned credits in more than one category-e.g., a student may take both AP courses and dual credit courses, or a single course may fall into both the AP and the dual credit categories. Detail may not sum to totals because of rounding.
SOURCE: U.S. Department of Education, National Center for Education Statistics, 2000, 2005, and 2009 High School Transcript Study (HSTS). (This table was prepared November 2012.) 
Table 225.70. Number and percentage of high school graduates who took foreign language courses in high school and average number of credits earned, by language and number of credits: 2000, 2005, and 2009

[Standard errors appear in parentheses]

\begin{tabular}{|c|c|c|c|c|c|c|c|c|c|c|c|c|c|c|c|c|c|c|}
\hline \multirow[b]{2}{*}{$\begin{array}{l}\text { Language and } \\
\text { number of credits }\end{array}$} & \multicolumn{6}{|c|}{2000} & \multicolumn{6}{|c|}{2005} & \multicolumn{6}{|c|}{2009} \\
\hline & \multicolumn{2}{|c|}{$\begin{array}{r}\text { Number of } \\
\text { graduates } \\
\text { (in thousands) }\end{array}$} & \multicolumn{2}{|c|}{$\begin{array}{l}\text { Percent of } \\
\text { graduates }\end{array}$} & \multicolumn{2}{|c|}{ Average credits ${ }^{1}$} & \multicolumn{2}{|c|}{$\begin{array}{r}\text { Number of } \\
\text { graduates } \\
\text { (in thousands) }\end{array}$} & \multicolumn{2}{|c|}{$\begin{array}{l}\text { Percent of } \\
\text { graduates }\end{array}$} & \multicolumn{2}{|c|}{ Average credits ${ }^{1}$} & \multicolumn{2}{|c|}{$\begin{array}{r}\text { Number of } \\
\text { graduates } \\
\text { (in thousands) }\end{array}$} & \multicolumn{2}{|c|}{$\begin{array}{l}\text { Percent of } \\
\text { graduates }\end{array}$} & \multicolumn{2}{|c|}{ Average credits ${ }^{1}$} \\
\hline 1 & & 2 & & 3 & & 4 & & 5 & & 6 & & 7 & & 8 & & 9 & & 10 \\
\hline $\begin{array}{c}\text { All foreign languages } \\
\text { Any credit .......... }\end{array}$ & 2,487 & (33.8) & 84.0 & $(0.92)$ & 2.5 & $(0.03)$ & 2,295 & $(51.1)$ & 85.7 & $(0.49)$ & 2.5 & $(0.02)$ & 2,599 & $(52.7)$ & 88.5 & $(0.45)$ & 2.6 & $(0.02)$ \\
\hline $\begin{array}{l}\text { Spanish } \\
\text { Any credit..................... } \\
2 \text { or more credits....... } \\
3 \text { or more credits ........ }\end{array}$ & $\begin{array}{r}1,780 \\
1,369 \\
554\end{array}$ & $\begin{array}{l}(31.9) \\
(32.2) \\
(26.3)\end{array}$ & $\begin{array}{l}60.1 \\
46.2 \\
18.7\end{array}$ & $\begin{array}{l}(0.90) \\
(1.04) \\
(0.90)\end{array}$ & $\begin{array}{l}2.2 \\
2.6 \\
3.4\end{array}$ & $\begin{array}{l}(0.03) \\
(0.03) \\
(0.03)\end{array}$ & $\begin{array}{r}1,705 \\
1,344 \\
531\end{array}$ & $\begin{array}{l}(42.2) \\
(35.9) \\
(20.1)\end{array}$ & $\begin{array}{l}63.7 \\
50.2 \\
19.8\end{array}$ & $\begin{array}{l}(0.66) \\
(0.67) \\
(0.57)\end{array}$ & $\begin{array}{l}2.2 \\
2.6 \\
3.4\end{array}$ & $\begin{array}{l}(0.02) \\
(0.01) \\
(0.01)\end{array}$ & $\begin{array}{r}2,032 \\
1,638 \\
721\end{array}$ & $\begin{array}{l}(45.0) \\
(39.2) \\
(30.2)\end{array}$ & $\begin{array}{l}69.2 \\
55.8 \\
24.5\end{array}$ & $\begin{array}{l}(0.70) \\
(0.73) \\
(0.78)\end{array}$ & $\begin{array}{l}2.3 \\
2.6 \\
3.4\end{array}$ & $\begin{array}{l}(0.02) \\
(0.02) \\
(0.02)\end{array}$ \\
\hline $\begin{array}{l}\text { French } \\
\text { Any credit..................... } \\
2 \text { or more credits....... } \\
3 \text { or more credits ......... }\end{array}$ & $\begin{array}{l}528 \\
398 \\
190\end{array}$ & $\begin{array}{l}(21.5) \\
(17.8) \\
(12.1)\end{array}$ & $\begin{array}{r}17.8 \\
13.4 \\
6.4\end{array}$ & $\begin{array}{l}(0.73) \\
(0.61) \\
(0.42)\end{array}$ & $\begin{array}{l}2.3 \\
2.7 \\
3.5\end{array}$ & $\begin{array}{l}(0.05) \\
(0.04) \\
(0.04)\end{array}$ & $\begin{array}{l}414 \\
309 \\
143\end{array}$ & $\begin{array}{r}(14.1) \\
(11.1) \\
(7.2)\end{array}$ & $\begin{array}{r}15.5 \\
11.5 \\
5.4\end{array}$ & $\begin{array}{l}(0.49) \\
(0.38) \\
(0.25)\end{array}$ & $\begin{array}{l}2.3 \\
2.7 \\
3.5\end{array}$ & $\begin{array}{l}(0.03) \\
(0.03) \\
(0.03)\end{array}$ & $\begin{array}{l}411 \\
314 \\
167\end{array}$ & $\begin{array}{l}(16.1) \\
(14.1) \\
(10.6)\end{array}$ & $\begin{array}{r}14.0 \\
10.7 \\
5.7\end{array}$ & $\begin{array}{l}(0.47) \\
(0.42) \\
(0.32)\end{array}$ & $\begin{array}{l}2.4 \\
2.8 \\
3.5\end{array}$ & $\begin{array}{l}(0.04) \\
(0.03) \\
(0.03)\end{array}$ \\
\hline $\begin{array}{l}\text { German } \\
\text { Any credit.................... } \\
2 \text { or more credits........ } \\
\quad 3 \text { or more credits ........ }\end{array}$ & $\begin{array}{r}142 \\
104 \\
55\end{array}$ & $\begin{array}{r}(17.2) \\
(14.6) \\
(8.6)\end{array}$ & $\begin{array}{l}4.8 \\
3.5 \\
1.8\end{array}$ & $\begin{array}{l}(0.57) \\
(0.49) \\
(0.29)\end{array}$ & $\begin{array}{l}2.3 \\
2.8 \\
3.5\end{array}$ & $\begin{array}{l}(0.08) \\
(0.07) \\
(0.06)\end{array}$ & $\begin{array}{r}139 \\
102 \\
53\end{array}$ & $\begin{array}{r}(10.0) \\
(8.2) \\
(4.7)\end{array}$ & $\begin{array}{l}5.2 \\
3.8 \\
2.0\end{array}$ & $\begin{array}{l}(0.36) \\
(0.29) \\
(0.17)\end{array}$ & $\begin{array}{l}2.3 \\
2.8 \\
3.5\end{array}$ & $\begin{array}{l}(0.04) \\
(0.04) \\
(0.04)\end{array}$ & $\begin{array}{r}122 \\
91 \\
46\end{array}$ & $\begin{array}{l}(8.6) \\
(7.8) \\
(5.3)\end{array}$ & $\begin{array}{l}4.2 \\
3.1 \\
1.6\end{array}$ & $\begin{array}{l}(0.29) \\
(0.27) \\
(0.18)\end{array}$ & $\begin{array}{l}2.3 \\
2.8 \\
3.5\end{array}$ & $\begin{array}{l}(0.06) \\
(0.05) \\
(0.03)\end{array}$ \\
\hline $\begin{array}{l}\text { Latin } \\
\quad \text { Any credit....................... } \\
\text { Italian }\end{array}$ & 120 & $(15.3)$ & 4.0 & $(0.52)$ & 2.1 & $(0.08)$ & 106 & $(10.4)$ & 4.0 & $(0.36)$ & 2.1 & $(0.05)$ & 108 & $(10.6)$ & 3.7 & $0.35)$ & 2.2 & $(0.07)$ \\
\hline $\begin{array}{l}\text { Any credit...................... } \\
\text { Japanese } \\
\text { Any credit......................... }\end{array}$ & 29 & (5.5) & 1.0 & $(0.19)$ & 2.2 & $(0.20)$ & 29 & $(5.3)$ & 1.1 & $(0.20)$ & 2.4 & $(0.16)$ & 36 & (7.0) & 1.2 & $(0.23)$ & 2.3 & $(0.18)$ \\
\hline $\begin{array}{l}\text { Any credit ......................... } \\
\text { Chinese }\end{array}$ & 36 & (7.3) & 1.2 & $(0.25)$ & 2.3 & $(0.15)$ & 30 & (4.4) & 1.1 & $(0.16)$ & 2.1 & $(0.12)$ & 28 & (4.3) & 1.0 & $(0.15)$ & 2.5 & (0.12) \\
\hline $\begin{array}{l}\text { Any credit..................... } \\
\text { Arabic } \\
\quad \text { Any credit............................... }\end{array}$ & 12 & $(t)$ & 0.4 & $(0.10)$ & 2.4 & $(0.20)$ & 8 & $(2.1)$ & 0.3 & $(0.08)$ & 2.1 & $(0.23)$ & $\begin{array}{l}20 \\
\ddagger\end{array}$ & $(4.1)$ & $\begin{array}{r}0.7 \\
\ddagger\end{array}$ & $(0.14)$ & 2.8 & $(0.36)$ \\
\hline $\begin{array}{l}\text { Russian } \\
\quad \text { Any credit .......................... }\end{array}$ & 10 & $(2.7)$ & 0.3 & $(0.09)$ & 1.9 & $(0.24)$ & 5 & (1.3) & 0.2 & $(0.05)$ & 1.5 & $(0.17)$ & $3 !$ & (1.3) & $0.1 !$ & $(0.04)$ & 2.4 & $(0.14)$ \\
\hline $\begin{array}{l}\text { Other foreign languages } \\
\text { Any credit........................ }\end{array}$ & 106 & $(12.0)$ & 3.6 & $(0.40)$ & 2.5 & $(0.17)$ & 89 & $(5.9)$ & 3.3 & $(0.23)$ & 2.8 & $(0.10)$ & 105 & $(10.6)$ & 3.6 & $(0.37)$ & 2.5 & $(0.18)$ \\
\hline $\begin{array}{c}\text { AP/B/honors foreign languages } \\
\text { Any credit........................... }\end{array}$ & 183 & $(23.9)$ & 6.2 & $(0.81)$ & 1.2 & $(0.04)$ & 157 & $(10.3)$ & 5.9 & $(0.38)$ & 1.2 & $(0.02)$ & 233 & $(15.9)$ & 7.9 & $(0.52)$ & 1.2 & $(0.02)$ \\
\hline
\end{tabular}

†Not applicable.

!Interpret data with caution. The coefficient of variation (CV) for this estimate is between 30 and 50 percent.

†Reporting standards not met. Either there are too few cases for a reliable estimate or the coefficient of variation (CV) is 50 percent or greater.

Average credits earned are shown only for those graduates who earned any credit in the specified language while in high school. For these students, however, credits earned include both courses taken in high school and courses taken prior to entering high school. Credits are shown in Carnegie units. The Carnegie unit is a standard unit of measurement that represents one credit for the completion of a 1-year course.

NOTE: For a transcript to be included in the analyses, it had to meet three requirements: (1) the graduate received either a standard or honors diploma, (2) the graduate's transcrip contained 16 or more Carnegie credits, and (3) the graduate's transcript contained more than 0 Carnegie credits in English courses.

SOURCE: U.S. Department of Education, National Center for Education Statistics, 2000, 2005, and 2009 High School Transcript Study (HSTS). (This table was prepared April 2014.) 


\begin{tabular}{|c|c|c|c|c|c|c|c|c|c|c|c|c|c|c|c|c|c|c|c|c|c|c|c|c|}
\hline \multirow[b]{3}{*}{ Selected child or school characteristic } & \multicolumn{24}{|c|}{ Distribution of children, by parental reports of average grades in all subjects } \\
\hline & \multicolumn{8}{|c|}{1996} & \multicolumn{8}{|c|}{2003} & \multicolumn{8}{|c|}{2007} \\
\hline & \multicolumn{2}{|c|}{ Mostly A's } & \multicolumn{2}{|c|}{ Mostly B's } & \multicolumn{2}{|c|}{ Mostly C's } & \multicolumn{2}{|c|}{ Mostly D's or F's } & \multicolumn{2}{|c|}{ Mostly A's } & \multicolumn{2}{|c|}{ Mostly B's } & \multicolumn{2}{|c|}{ Mostly C's } & \multicolumn{2}{|c|}{ Mostly D's or F's } & \multicolumn{2}{|c|}{ Mostly A's } & \multicolumn{2}{|c|}{ Mostly B's } & \multicolumn{2}{|c|}{ Mostly C's } & Mostly D & sor F's \\
\hline 1 & & 2 & & 3 & & 4 & & 5 & & 6 & & 7 & & 8 & & 9 & & 10 & & 11 & & 12 & & 13 \\
\hline All students. & 39.5 & $(0.53)$ & 37.8 & $(0.56)$ & 18.5 & $(0.41)$ & 4.2 & $(0.22)$ & 43.6 & $(0.62)$ & 37.0 & (0.58) & 15.9 & (0.52) & 3.6 & (0.24) & 47.2 & (0.75) & 35.0 & (0.80) & 14.1 & (0.72) & 3.8 & $(0.36)$ \\
\hline 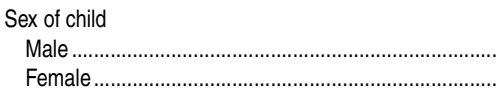 & $\begin{array}{l}32.5 \\
46.9\end{array}$ & $\begin{array}{l}(0.68) \\
(0.79)\end{array}$ & $\begin{array}{l}38.3 \\
37.2\end{array}$ & $\begin{array}{l}(0.82) \\
(0.77)\end{array}$ & $\begin{array}{l}23.5 \\
13.2\end{array}$ & $\begin{array}{l}(0.62) \\
(0.60)\end{array}$ & $\begin{array}{l}5.7 \\
2.7\end{array}$ & $\begin{array}{l}(0.36) \\
(0.27)\end{array}$ & $\begin{array}{l}36.4 \\
51.0\end{array}$ & $\begin{array}{l}(0.72) \\
(0.84)\end{array}$ & $\begin{array}{l}38.6 \\
35.3\end{array}$ & $\begin{array}{l}(0.86) \\
(0.76)\end{array}$ & $\begin{array}{l}19.8 \\
11.9\end{array}$ & $\begin{array}{l}(0.74) \\
(0.61)\end{array}$ & $\begin{array}{l}5.2 \\
1.9\end{array}$ & $\left.\begin{array}{l}(0.40) \\
(0.24)\end{array}\right]$ & $\begin{array}{l}40.3 \\
54.7\end{array}$ & $\begin{array}{l}(1.01) \\
(0.99)\end{array}$ & $\begin{array}{l}37.1 \\
32.7\end{array}$ & $\begin{array}{l}(1.17) \\
(0.97)\end{array}$ & $\begin{array}{l}17.0 \\
11.0\end{array}$ & $\begin{array}{l}(1.25) \\
(0.62)\end{array}$ & $\begin{array}{l}5.7 \\
1.7\end{array}$ & $\begin{array}{l}(0.64) \\
(0.24)\end{array}$ \\
\hline Race/ethnicity of child & & & & & & & & & & & & & & & & & & & & & & & & \\
\hline White.. & 43.7 & (0.66) & 36.1 & $(0.60)$ & 16.5 & (0.48) & 3.7 & $(0.27)$ & 47.8 & $(0.86)$ & 35.2 & (0.75) & 14.0 & (0.63) & 3.1 & $(0.25)$ & 53.9 & $(0.97)$ & 32.2 & (0.91) & 11.7 & $(0.68)$ & 2.1 & $(0.27)$ \\
\hline Black.... & 27.0 & (1.40) & 41.0 & (1.48) & 26.2 & (1.51) & 5.8 & $(0.67)$ & 34.5 & (1.75) & 39.5 & (1.65) & 20.9 & (1.33) & 5.0 & $(0.82)$ & 28.3 & (2.04) & 40.5 & (2.75) & 24.9 & (2.89) & 6.3 & $(1.41)$ \\
\hline Hispanic.. & 31.7 & (1.41) & 43.8 & (1.50) & 19.6 & (1.17) & 4.9 & $(0.71)$ & 34.9 & (1.14) & 42.3 & $(1.24)$ & 18.6 & $(1.03)$ & 4.2 & $(0.48)$ & 40.8 & (1.68) & 39.2 & (1.66) & 14.1 & $(1.24)$ & 6.0 & $(1.15)$ \\
\hline Asian/Pacific Islander.... & 55.5 & (3.46) & 35.0 & (3.35) & 8.3 & (1.93) & $\ddagger$ & $(t)$ & 62.0 & (3.47) & 25.5 & (2.76) & 11.3 & $(3.06)$ & $\ddagger$ & $(t)$ & - & $(t)$ & - & $(t)$ & - & $(\dagger)$ & - & $(t)$ \\
\hline Asian. & - & $(t)$ & - & $(t)$ & - & $(t)$ & - & $(\dagger)$ & - & $(t)$ & - & $(\dagger)$ & - & $(t)$ & - & $(\dagger)$ & 74.5 & $(3.67)$ & 20.7 & $(3.60)$ & $3.2 !$ & (1.10) & $\ddagger$ & $(t)$ \\
\hline Pacific & - & $(t)$ & - & (†) & - & $(t)$ & - & $(\mathrm{t})$ & - & $(\dagger)$ & - & $(t)$ & - & $(\dagger)$ & - & $(\dagger)$ & $\ddagger$ & $(t)$ & 70.5 & $(18.20)$ & $\ddagger$ & $(\dagger)$ & $\ddagger$ & $(t)$ \\
\hline American Indian/Alaska Native ............... & 30.2 & (3.90) & 31.9 & (4.78) & 29.3 & (4.92) & $8.7 !$ & (3.82) & 29.5 & (6.53) & 53.3 & (6.42) & 12.1 ! & (4.90) & $5.1 !$ & (2.54) & 39.7 & (9.13) & 29.2 & (8.22) & $19.9 !$ & (6.67) & $\ddagger$ & $(t)$ \\
\hline Other ....................... & 40.7 & (2.98) & 33.3 & (3.35) & 20.1 & (2.85) & $5.8 !$ & (1.96) & 41.4 & (4.34) & 36.2 & (3.91) & 18.8 & (2.81) & $3.5 !$ & $(1.38)$ & $\ddagger$ & $(\dagger)$ & $50.2 !$ & $(21.33)$ & $\ddagger$ & $(\dagger)$ & $\ddagger$ & $(\dagger)$ \\
\hline Two or more races ..................... & - & $(t)$ & - & $(t)$ & - & $(\dagger)$ & - & $(\dagger)$ & - & $(t)$ & - & $(t)$ & - & $(t)$ & - & $(\dagger)$ & 44.3 & $(3.92)$ & 38.2 & $(4.13)$ & 11.3 & $(2.25)$ & 6.2 & $(1.77)$ \\
\hline Highest education level of parents & & & & & & & & & & & & & & & & & & & & & & & & \\
\hline Less & 28.7 & $(1.87)$ & 39.2 & $(1.89)$ & 24.0 & (1.68) & 8.1 & $(1.04)$ & 27.8 & (2.17) & 41.6 & (2.05) & 22.7 & (2.27) & 7.8 & (1.46) & 26.8 & (3.18) & 41.9 & $(4.27)$ & 22.0 & (2.55) & 9.3 & $(2.02)$ \\
\hline Hig & 30.5 & $(0.90)$ & 40.5 & $(1.09)$ & 23.1 & $(0.91)$ & 5.9 & $(0.52)$ & 32.1 & $(1.20)$ & 41.4 & $(1.23)$ & 21.7 & (1.12) & 4.8 & $(0.57)$ & 32.9 & (1.70) & 39.8 & (1.64) & 21.9 & (2.02) & 5.4 & $(0.82)$ \\
\hline ical or some college. & 35.2 & $(1.25)$ & 41.3 & $(1.20)$ & 19.4 & $(0.82)$ & 4.1 & $(0.52)$ & 39.8 & $(1.34)$ & 38.3 & (1.36) & 17.2 & $(0.95)$ & 4.7 & $(0.58)$ & 40.7 & $(1.65)$ & 38.6 & (2.03) & 16.6 & (1.43) & 4.0 & $(0.78)$ \\
\hline Associ & 41.5 & $(1.83)$ & 36.9 & $(1.88)$ & 18.0 & (1.53) & 3.5 & $(0.68)$ & 46.7 & (2.13) & 34.5 & (1.94) & 16.4 & (1.51) & 2.4 & $(0.57)$ & 40.3 & $(2.27)$ & 38.4 & (2.00) & 15.7 & (1.76) & $5.5 !$ & $(2.10)$ \\
\hline Bachelo & 52.7 & (1.32) & 32.9 & (1.16) & 12.5 & $(0.92)$ & 1.9 & $(0.31)$ & 53.0 & $(1.26)$ & 34.2 & $(1.29)$ & 11.1 & $(0.85)$ & 1.7 & $(0.28)$ & 58.9 & $(1.62)$ & 32.2 & (1.52) & 7.3 & $(0.85)$ & 1.6 & $(0.38)$ \\
\hline 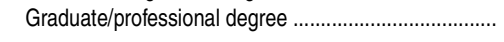 & 59.1 & $(1.40)$ & 30.4 & $(1.26)$ & 9.5 & $(0.99)$ & 1.0 & $(0.24)$ & 61.9 & $(1.71)$ & 30.5 & $(1.75)$ & 6.7 & $(0.67)$ & 0.9 & $(0.24)$ & 68.2 & $(1.59)$ & 24.1 & $(1.37)$ & 6.6 & $(1.33)$ & $1.2 !$ & $(0.38)$ \\
\hline Family income (in current dollars) & & & & & & & & & & & & & & & & & & & & & & & & \\
\hline$\$ 5$, & 28.9 & (2.50) & 38.8 & (2.39) & 23.3 & (2.35) & 8.9 & $(1.67)$ & 31.8 & $(4.43)$ & 38.9 & $(4.27)$ & 21.0 & (3.53) & $8.3 !$ & $(3.25)$ & 22.9 & (4.72) & 31.0 & (5.89) & 32.6 & $(7.04)$ & 13.6 & $(3.93)$ \\
\hline$\$ 5,001$ & 26.6 & (1.97) & 41.9 & (2.30) & 24.6 & $(2.3$ & 9 & $(1.15)$ & 31.6 & (2.90) & 40.1 & (3.70) & 24.9 & (2.70) & 3.4 & $(0.98)$ & 26.4 & (4.16) & 51.1 & (5.45) & 17.2 & (3.65) & $5.3 !$ & (1.97) \\
\hline $0 \ldots \ldots \ldots \ldots \ldots \ldots \ldots$ & 27.6 & $(2.00)$ & 40.0 & (2.33) & 26.1 & (1.95) & 6.3 & $(1.10)$ & 33.4 & (3.49) & 35.1 & (2.85) & 23.9 & (2.67) & 7.5 & (1.44) & 34.7 & $(3.80)$ & 38.9 & $(4.35)$ & 21.1 & $(3.21)$ & 5.3 & $(1.44)$ \\
\hline & 32.7 & (2.34) & 38.4 & (1.99) & 21.6 & (1.81) & & (1.35) & 34.6 & (2.28) & 41.1 & (2.41) & 18.8 & $(2.00)$ & 5.4 & $(1.26)$ & 30.0 & (4.45) & 35.7 & $(4.69)$ & 29.5 & (7.46) & 4.8 & (1.45) \\
\hline$\$ 20,00$ & 34.4 & (1.92) & 40.8 & (2.19) & 20.6 & (1.77) & 4.2 & $(0.88)$ & 33.5 & (2.51) & 42.1 & (2.93) & 19.8 & (1.99) & 4.7 & $(0.96)$ & 32.3 & (3.13) & 39.8 & (3.38) & 20.2 & (3.49) & 7.7 & (1.85) \\
\hline$\$ 2$ & 33.0 & (1.88) & 42.0 & (2.05) & 19.8 & (1.41) & 5.2 & $(0.76)$ & 34.5 & (2.67) & 42.6 & (3.13) & 17.9 & (1.92) & 5.0 & $(1.21)$ & 38.5 & $(4.05)$ & 39.2 & $(4.27)$ & 16.2 & (2.91) & $6.1 !$ & $(2.01)$ \\
\hline & 40.0 & (1.88) & 38.0 & (1.66) & 18.1 & $(1.44$ & ? & $(0.69)$ & 35.1 & (2.76) & 43.1 & (2.57) & 16.9 & (1.84) & 5.0 & (1.09) & 44.2 & (3.61) & 32.7 & (3.44) & 18.7 & (3.83) & $4.4 !$ & (1.67) \\
\hline & 40.4 & (1.70) & 37.3 & (1.69) & 19.4 & (1.22) & 2.8 & $(0.65)$ & 39.6 & (3.20) & 37.8 & (2.79) & 19.1 & (1.78) & 3.6 & $(0.93)$ & 37.6 & (3.35) & 36.4 & (3.56) & 19.8 & $(2.89)$ & 1 & (1.75) \\
\hline$\$ 4$ & 43.2 & (1.49) & 36.0 & (1.51) & 16.8 & (1.09) & 4.0 & $(0.57)$ & 43.9 & (2.06) & 35.8 & (1.95) & 15.8 & (1.51) & 4.4 & $(0.7$ & 37.9 & (2.57) & 39.4 & (2.92) & 15.9 & (1.76) & $6.9 !$ & $(2.57)$ \\
\hline$\$ 50$ & 50.2 & $(1.05)$ & 32.7 & $(1.04)$ & 14.9 & $(0.86)$ & 2.2 & $(0.34)$ & 48.0 & (1.29) & 35.0 & $(1.22)$ & 14.0 & $(0.81)$ & 3.0 & $(0.45)$ & 53.0 & (1.50) & 33.8 & (1.42) & 11.0 & $(0.97)$ & 2.2 & $(0.42)$ \\
\hline Over $\$ 75,000$ & 51.0 & (1.58) & 36.8 & (1.55) & 10.9 & $(0.93)$ & 1.3 & $(0.31)$ & 54.0 & (1.19) & 33.8 & (1.18) & 11.0 & $(0.78)$ & 1.2 & $(0.19)$ & 59.4 & (1.13) & 31.3 & $(1.09)$ & 8.0 & $(0.70)$ & 1.3 & $(0.25)$ \\
\hline Child at & 38.2 & (0.54) & 37.9 & (0.56) & 19.3 & (0.44) & 4.6 & $(0.23)$ & 41.8 & $(0.64)$ & 37.5 & (0.62) & 16.8 & $(0.57)$ & 3.8 & $(0.26)$ & 45.5 & $(0.80)$ & 35.5 & $(0.84)$ & 14.9 & $(0.77)$ & 4.1 & $(0.39)$ \\
\hline & 43.2 & $(0.75)$ & 36.6 & $(0.69)$ & 16.3 & $(0.55)$ & 3.9 & $(0.26)$ & 46.1 & $(0.80)$ & 35.9 & $(0.84)$ & 14.6 & (0.74) & 3.4 & $(0.3$ & 50.0 & $(0.99)$ & 33.1 & $(1.00)$ & 13.4 & (1.12) & 3.5 & $(0.43)$ \\
\hline Secondary (grades 9 to 12) & 29.6 & $(0.89)$ & 40.2 & $(1.00)$ & 24.5 & $(0.89)$ & 5.7 & $(0.46)$ & 34.6 & $(0.96)$ & 40.2 & $(0.97)$ & 20.6 & $(0.94)$ & 4.6 & $(0.46)$ & 38.6 & (1.36) & 39.1 & (1.27) & 17.2 & $(1.08)$ & 5.2 & $(0.71)$ \\
\hline Child a & 50.6 & $(1.64)$ & 36.3 & $(1.58)$ & 11.9 & 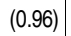 & $1.3 !$ & $(0.40)$ & 57.6 & $(1.7-7)$ & 33.0 & $(1.6$ & 8.1 & $(0.91)$ & $1.3 !$ & $(0.4$ & 60.6 & $(2.7)$ & 30.8 & (2.85) & 7.8 & (1.73) & $0.9 !$ & $(0.35)$ \\
\hline Eler & 55.5 & (2.02) & 35.5 & $(1.90)$ & 7.5 & $(0.86)$ & $1.4 !$ & $(0.57)$ & 61.6 & $(2$. & 30.3 & (2.28) & 7.3 & $(1.03)$ & $0.8 !$ & $(0.28)$ & 66.1 & (3.73) & 26.6 & $(4.05)$ & 6.6 & (1.66) & $\ddagger$ & $(\dagger)$ \\
\hline Secondary (grades 9 to 12 ).. & 40.9 & (2.89) & 37.7 & (2.39) & 20.4 & (2.29) & $1.0 !$ & $(0.44)$ & 48.8 & (3.22) & 38.9 & (2.94) & 10.0 & (1.77) & $\ddagger$ & $(t)$ & 51.2 & (3.91) & 37.8 & (3.43) & $9.8 !$ & (3.87) & $\ddagger$ & $(t)$ \\
\hline
\end{tabular}

\section{-Not available}

!Interpret data with caution. The coefficient of variation (CV) for this estimate is between 30 and 50 percent.

†Reporting standards not met. Either there are too few cases for a reliable estimate or the coefficient of variation (CV) is 50 percent or greater
NOTE: Includes children enrolled in kindergarten through grade 12. Excludes children whose programs have no classes with lettered grades. Race categories exclude persons of Hispanic ethnicity. Detail may not sum to totals because of rounding. Some deara have been revised from previously published figures. Civic Involvement Survey and Parent and Family Involvement in Education Survey of the National Household Education Surveys
Program (PFI/CI-NHES:1996 and PFI-NHES:2003 and 2007). (This table was prepared August 2009.) 


\section{Table 226.10. SAT mean scores of college-bound seniors, by race/ethnicity: Selected years, 1986-87 through 2012-13}

\begin{tabular}{|c|c|c|c|c|c|c|c|c|c|c|c|c|c|c|c|c|c|c|c|c|}
\hline \multirow[b]{2}{*}{ Race/ethnicity } & \multirow[b]{2}{*}{$1986-87$} & \multirow[b]{2}{*}{ 1990-91 } & \multirow[b]{2}{*}{ 1996-97 } & \multirow[b]{2}{*}{$2000-01$} & \multirow[b]{2}{*}{ 2001-02 } & \multirow[b]{2}{*}{$2002-03$} & \multirow[b]{2}{*}{$2003-04$} & \multirow[b]{2}{*}{$2004-05$} & \multirow[b]{2}{*}{$2005-06$} & \multirow[b]{2}{*}{$2006-07$} & \multirow[b]{2}{*}{$2007-08$} & \multirow[b]{2}{*}{$2008-09$} & \multirow[b]{2}{*}{$2009-10$} & \multirow[b]{2}{*}{ 2010-11 } & \multirow[b]{2}{*}{ 2011-12 } & \multirow[b]{2}{*}{ 2012-13 } & \multicolumn{4}{|c|}{ Score change } \\
\hline & & & & & & & & & & & & & & & & & $\begin{array}{r}1990-91 \\
\text { to } \\
2002-03 \\
\end{array}$ & \begin{tabular}{|r|}
$2002-03$ \\
to \\
$2012-13$ \\
\end{tabular} & $\begin{array}{r}2007-08 \\
\text { to } \\
2012-13 \\
\end{array}$ & $\begin{array}{r}2011-12 \\
\text { to } \\
2012-13 \\
\end{array}$ \\
\hline 1 & 2 & 3 & 4 & 5 & 6 & 7 & 8 & 9 & 10 & 11 & 12 & 13 & 14 & 15 & 16 & 17 & 18 & 19 & 20 & 21 \\
\hline $\begin{array}{l}\text { SAT-Critical reading } \\
\text { All students }\end{array}$ & 507 & 499 & 505 & 506 & 504 & 507 & 508 & 508 & 503 & 502 & 502 & 501 & 501 & 497 & 496 & 496 & 8 & -11 & -6 & 0 \\
\hline 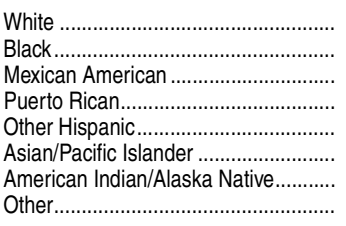 & $\begin{array}{l}524 \\
428 \\
457 \\
436 \\
464 \\
479 \\
471 \\
480 \\
\end{array}$ & $\begin{array}{l}518 \\
427 \\
454 \\
436 \\
458 \\
485 \\
470 \\
486 \\
\end{array}$ & $\begin{array}{l}526 \\
434 \\
451 \\
454 \\
466 \\
496 \\
475 \\
512 \\
\end{array}$ & $\begin{array}{l}529 \\
433 \\
451 \\
457 \\
460 \\
501 \\
481 \\
503 \\
\end{array}$ & $\begin{array}{l}527 \\
430 \\
446 \\
455 \\
458 \\
501 \\
479 \\
502 \\
\end{array}$ & $\begin{array}{l}529 \\
431 \\
448 \\
456 \\
457 \\
508 \\
480 \\
501 \\
\end{array}$ & $\begin{array}{l}528 \\
430 \\
451 \\
457 \\
461 \\
507 \\
483 \\
494 \\
\end{array}$ & $\begin{array}{l}532 \\
433 \\
453 \\
460 \\
463 \\
511 \\
489 \\
495 \\
\end{array}$ & $\begin{array}{l}527 \\
434 \\
454 \\
459 \\
458 \\
510 \\
487 \\
494 \\
\end{array}$ & $\begin{array}{l}527 \\
433 \\
455 \\
459 \\
459 \\
514 \\
487 \\
497 \\
\end{array}$ & $\begin{array}{l}528 \\
430 \\
454 \\
456 \\
455 \\
513 \\
485 \\
496 \\
\end{array}$ & $\begin{array}{l}528 \\
429 \\
453 \\
452 \\
455 \\
516 \\
486 \\
494 \\
\end{array}$ & $\begin{array}{l}528 \\
429 \\
454 \\
454 \\
454 \\
519 \\
485 \\
494 \\
\end{array}$ & $\begin{array}{l}528 \\
428 \\
451 \\
452 \\
451 \\
517 \\
484 \\
493 \\
\end{array}$ & $\begin{array}{l}527 \\
428 \\
448 \\
452 \\
447 \\
518 \\
482 \\
491 \\
\end{array}$ & $\begin{array}{l}527 \\
431 \\
449 \\
456 \\
450 \\
521 \\
480 \\
492 \\
\end{array}$ & \begin{tabular}{r|}
11 \\
4 \\
-6 \\
20 \\
-1 \\
23 \\
10 \\
15 \\
\end{tabular} & \begin{tabular}{r|}
-2 \\
0 \\
1 \\
0 \\
-7 \\
13 \\
0 \\
-9 \\
\end{tabular} & \begin{tabular}{r|}
-1 \\
1 \\
-5 \\
0 \\
-5 \\
8 \\
-5 \\
-4 \\
\end{tabular} & $\begin{array}{r}0 \\
3 \\
1 \\
4 \\
3 \\
3 \\
-2 \\
1 \\
\end{array}$ \\
\hline $\begin{array}{l}\text { SAT-Mathematics } \\
\text { All students }\end{array}$ & 501 & 500 & 511 & 514 & 516 & 519 & 518 & 520 & 518 & 515 & 515 & 515 & 516 & 514 & 514 & 514 & 19 & -5 & -1 & 0 \\
\hline 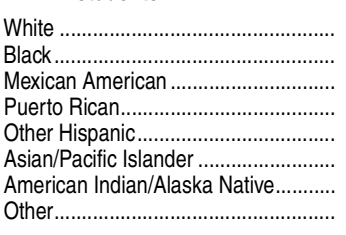 & $\begin{array}{l}514 \\
411 \\
455 \\
432 \\
462 \\
541 \\
463 \\
482 \\
\end{array}$ & $\begin{array}{l}513 \\
419 \\
459 \\
439 \\
462 \\
548 \\
468 \\
492 \\
\end{array}$ & \begin{tabular}{l|}
526 \\
423 \\
458 \\
447 \\
468 \\
560 \\
475 \\
514 \\
\end{tabular} & \begin{tabular}{l|}
531 \\
426 \\
458 \\
451 \\
465 \\
566 \\
479 \\
512 \\
\end{tabular} & \begin{tabular}{l|}
533 \\
427 \\
457 \\
451 \\
464 \\
569 \\
483 \\
514 \\
\end{tabular} & $\begin{array}{l}534 \\
426 \\
457 \\
453 \\
464 \\
575 \\
482 \\
513 \\
\end{array}$ & \begin{tabular}{l|}
531 \\
427 \\
458 \\
452 \\
465 \\
577 \\
488 \\
508 \\
\end{tabular} & $\begin{array}{l}536 \\
431 \\
463 \\
457 \\
469 \\
580 \\
493 \\
513 \\
\end{array}$ & $\begin{array}{l}536 \\
429 \\
465 \\
456 \\
463 \\
578 \\
494 \\
513 \\
\end{array}$ & \begin{tabular}{l|}
534 \\
429 \\
466 \\
454 \\
463 \\
578 \\
494 \\
512 \\
\end{tabular} & $\begin{array}{l}537 \\
426 \\
463 \\
453 \\
461 \\
581 \\
491 \\
512 \\
\end{array}$ & $\begin{array}{l}536 \\
426 \\
463 \\
450 \\
461 \\
587 \\
493 \\
514 \\
\end{array}$ & $\begin{array}{l}536 \\
428 \\
467 \\
452 \\
462 \\
591 \\
492 \\
514 \\
\end{array}$ & \begin{tabular}{l|}
535 \\
427 \\
466 \\
452 \\
462 \\
595 \\
488 \\
517 \\
\end{tabular} & \begin{tabular}{l|}
536 \\
428 \\
465 \\
452 \\
461 \\
595 \\
489 \\
516 \\
\end{tabular} & $\begin{array}{l}534 \\
429 \\
464 \\
453 \\
461 \\
597 \\
486 \\
519 \\
\end{array}$ & \begin{tabular}{r|}
21 \\
7 \\
-2 \\
14 \\
2 \\
27 \\
14 \\
21 \\
\end{tabular} & $\begin{array}{r}0 \\
0 \\
3 \\
7 \\
0 \\
-3 \\
22 \\
4 \\
6 \\
\end{array}$ & $\begin{array}{r}-1 \\
-3 \\
3 \\
1 \\
0 \\
0 \\
16 \\
-5 \\
7 \\
\end{array}$ & $\begin{array}{r}-2 \\
1 \\
-1 \\
1 \\
0 \\
2 \\
-3 \\
3 \\
\end{array}$ \\
\hline 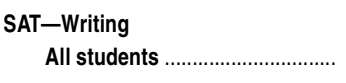 & $t$ & $t$ & $t$ & $t$ & $t$ & $t$ & $t$ & $t$ & 497 & 494 & 494 & 493 & 492 & 489 & 488 & 488 & $t$ & $t$ & -6 & 0 \\
\hline White & $t$ & $t$ & $\dagger$ & t & $t$ & $\dagger$ & $\dagger$ & t & 519 & 518 & 518 & 517 & 516 & 516 & 515 & 515 & $t$ & $\dagger$ & -3 & 0 \\
\hline 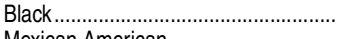 & $\dagger$ & $\dagger$ & $t$ & $t$ & $\dagger$ & $t$ & $\dagger$ & $\dagger$ & 428 & 42 & 424 & 421 & 420 & 417 & 417 & 418 & $t$ & $t$ & -6 & 1 \\
\hline Mexican American ................... & $\dagger$ & $\dagger$ & $\dagger$ & $\dagger$ & $\dagger$ & $\dagger$ & $\dagger$ & $\dagger$ & 452 & 45 & 447 & 446 & 448 & 445 & 443 & 442 & $\dagger$ & + & -5 & -1 \\
\hline$\ldots \ldots \ldots \ldots \ldots \ldots \ldots \ldots$ & $\dagger$ & $\dagger$ & $\dagger$ & $\dagger$ & $\dagger$ & $\dagger$ & $\dagger$ & $\dagger$ & 44 & 447 & 445 & 443 & 443 & 442 & 442 & 445 & $\dagger$ & & 0 & 3 \\
\hline Other Hispanic................. & $\dagger$ & $t$ & $\dagger$ & $t$ & $\dagger$ & $t$ & $\dagger$ & $\dagger$ & 450 & 450 & 448 & 448 & 447 & 444 & 44 & 443 & 1 & & -5 & 1 \\
\hline Asian/Pacific Islander ....................... & $t$ & $t$ & $t$ & $t$ & $\begin{array}{l}\dagger \\
+\end{array}$ & $\begin{array}{l}\dagger \\
t\end{array}$ & $\begin{array}{l}\dagger \\
t\end{array}$ & $\begin{array}{l}\dagger \\
+\end{array}$ & 512 & 513 & 516 & 520 & 526 & 528 & 528 & 527 & $\dagger$ & 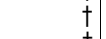 & 11 & -1 \\
\hline $\begin{array}{l}\text { American Indian/Alaska Native........... } \\
\text { Other. }\end{array}$ & $\begin{array}{l}\dagger \\
\dagger\end{array}$ & $\begin{array}{c}\dagger \\
t\end{array}$ & $\begin{array}{l}\dagger \\
\dagger\end{array}$ & $\begin{array}{l}\dagger \\
\dagger\end{array}$ & $\begin{array}{l}\dagger \\
t\end{array}$ & $\begin{array}{l}\dagger \\
t\end{array}$ & $\begin{array}{l}\dagger \\
t\end{array}$ & $t$ & $\begin{array}{l}474 \\
493\end{array}$ & $\begin{array}{l}473 \\
493\end{array}$ & $\begin{array}{l}470 \\
494\end{array}$ & $\begin{array}{l}469 \\
493\end{array}$ & $\begin{array}{l}467 \\
492\end{array}$ & $\begin{array}{l}465 \\
492\end{array}$ & $\begin{array}{l}462 \\
491\end{array}$ & $\begin{array}{l}461 \\
490\end{array}$ & $\begin{array}{l}t \\
t\end{array}$ & $t$ & $\begin{array}{l}-9 \\
-4\end{array}$ & $\begin{array}{l}-1 \\
-1\end{array}$ \\
\hline
\end{tabular}

†Not applicable.

NOTE: Data for 2009-10 and earlier years are for seniors who took the SAT any time during their high school years through March of their senior year. Data for $2010-11$ onwards are for seniors who took the SAT any time during their high school years through
June of their senior year. If a student took a test more than once, the most recent score was used. The SAT was formerly known as the Scholastic Assessment Test and the Scholastic Aptitude Test. Possible scores on each part of the SAT range from 200 to 800. The critical reading section was formerly known as the verbal section. The writing section was introduced in March 2005. SOURCE: College Entrance Examination Board, College-Bound Seniors: Total Group Profile [National] Report, selected years, 1986-87 through 2012-13, retrieved September 26, 2013, from http
TotalGroup-2013.pdf. (This table was prepared September 2013.) 
Table 226.20. SAT mean scores of college-bound seniors, by sex: 1966-67 through 2012-13

\begin{tabular}{|c|c|c|c|c|c|c|c|c|c|c|c|c|c|c|c|}
\hline \multirow[b]{3}{*}{ School year } & \multicolumn{9}{|c|}{ SAT ${ }^{1}$} & \multicolumn{6}{|c|}{ Scholastic Aptitude Test (old scale) } \\
\hline & \multicolumn{3}{|c|}{ Critical reading score } & \multicolumn{3}{|c|}{ Mathematics score } & \multicolumn{3}{|c|}{ Writing score ${ }^{2}$} & \multicolumn{3}{|c|}{ Verbal score } & \multicolumn{3}{|c|}{ Mathematics score } \\
\hline & Total & Male & Female & Total & Male & Female & Total & Male & Female & Total & Male & Female & Total & Male & Female \\
\hline 1 & 2 & 3 & 4 & 5 & 6 & 7 & 8 & 9 & 10 & 11 & 12 & 13 & 14 & 15 & 16 \\
\hline $1966-67 \ldots$ & 543 & 540 & 545 & 516 & 535 & 495 & $\dagger$ & $\dagger$ & $\dagger$ & 466 & 463 & 468 & 492 & 514 & 467 \\
\hline $1967-68 \ldots$ & 543 & 541 & 543 & 516 & 533 & 497 & $t$ & $\dagger$ & $\dagger$ & 466 & 464 & 466 & 492 & 512 & 470 \\
\hline $1968-69 \ldots$ & 540 & 536 & 543 & 517 & 534 & 498 & $\dagger$ & $\dagger$ & $\dagger$ & 463 & 459 & 466 & 493 & 513 & 470 \\
\hline $1969-70 \ldots . .$. & 537 & 536 & 538 & 512 & 531 & 493 & $\dagger$ & $\dagger$ & $\dagger$ & 460 & 459 & 461 & 488 & 509 & 465 \\
\hline $1970-71 \ldots \ldots$. & 532 & 531 & 534 & 513 & 529 & 494 & $\dagger$ & $\dagger$ & $\dagger$ & 455 & 454 & 457 & 488 & 507 & 466 \\
\hline $1971-72 \ldots .$. & 530 & 531 & 529 & 509 & 527 & 489 & $\dagger$ & $\dagger$ & $\dagger$ & 453 & 454 & 452 & 484 & 505 & 461 \\
\hline $1972-73 \ldots . .$. & 523 & 523 & 521 & 506 & 525 & 489 & $\dagger$ & $\dagger$ & $\dagger$ & 445 & 446 & 443 & 481 & 502 & 460 \\
\hline $1973-74 \ldots$. & 521 & 524 & 520 & 505 & 524 & 488 & $t$ & $t$ & $\dagger$ & 444 & 447 & 442 & 480 & 501 & 459 \\
\hline $1974-75 \ldots$. & 512 & 515 & 509 & 498 & 518 & 479 & $t$ & $t$ & $\dagger$ & 434 & 437 & 431 & 472 & 495 & 449 \\
\hline $1975-76 \ldots \ldots$ & 509 & 511 & 508 & 497 & 520 & 475 & $\dagger$ & $\dagger$ & $\dagger$ & 431 & 433 & 430 & 472 & 497 & 446 \\
\hline $1976-77 \ldots$ & 507 & 509 & 505 & 496 & 520 & 474 & $\dagger$ & $\dagger$ & $\dagger$ & 429 & 431 & 427 & 470 & 497 & 445 \\
\hline $1977-78 \ldots$. & 507 & 511 & 503 & 494 & 517 & 474 & $\dagger$ & $\dagger$ & $\dagger$ & 429 & 433 & 425 & 468 & 494 & 444 \\
\hline $1978-79 \ldots . .$. & 505 & 509 & 501 & 493 & 516 & 473 & $\dagger$ & $\dagger$ & $\dagger$ & 427 & 431 & 423 & 467 & 493 & 443 \\
\hline 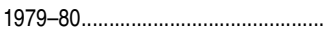 & 502 & 506 & 498 & 492 & 515 & 473 & $t$ & $\dagger$ & $\dagger$ & 424 & 428 & 420 & 466 & 491 & 443 \\
\hline$\ldots$ & 502 & 508 & 496 & 492 & 516 & 473 & $\dagger$ & $\dagger$ & $\dagger$ & 424 & 430 & 418 & 466 & 492 & 443 \\
\hline $1981-82 \ldots$ & 504 & 509 & 499 & 493 & 516 & 473 & $\dagger$ & $\dagger$ & $\dagger$ & 426 & 431 & 421 & 467 & 493 & 443 \\
\hline $1982-83 \ldots$ & 503 & 508 & 498 & 494 & 516 & 474 & $\dagger$ & $\dagger$ & $\dagger$ & 425 & 430 & 420 & 468 & 493 & 445 \\
\hline $1983-84 \ldots$. & 504 & 511 & 498 & 497 & 518 & 478 & $\dagger$ & $\dagger$ & $\dagger$ & 426 & 433 & 420 & 471 & 495 & 449 \\
\hline $1984-85 \ldots . .$. & 509 & 514 & 503 & 500 & 522 & 480 & $\dagger$ & $\dagger$ & $\dagger$ & 431 & 437 & 425 & 475 & 499 & 452 \\
\hline $1985-86 \ldots . .$. & 509 & 515 & 504 & 500 & 523 & 479 & $\dagger$ & $\dagger$ & $\dagger$ & 431 & 437 & 426 & 475 & 501 & 451 \\
\hline $1986-87 \ldots$. & 507 & 512 & 502 & 501 & 523 & 481 & $t$ & $t$ & $t$ & 430 & 435 & 425 & 476 & 500 & 453 \\
\hline $1987-88 \ldots . .$. & 505 & 512 & 499 & 501 & 521 & 483 & $\dagger$ & $\dagger$ & $\dagger$ & 428 & 435 & 422 & 476 & 498 & 455 \\
\hline $1988-89 \ldots . .$. & 504 & 510 & 498 & 502 & 523 & 482 & $\dagger$ & $\dagger$ & $\dagger$ & 427 & 434 & 421 & 476 & 500 & 454 \\
\hline $1989-90 \ldots$. & 500 & 505 & 496 & 501 & 521 & 483 & $\dagger$ & $\dagger$ & $\dagger$ & 424 & 429 & 419 & 476 & 499 & 455 \\
\hline $1990-91 \ldots$. & 499 & 503 & 495 & 500 & 520 & 482 & $\dagger$ & $\dagger$ & $\dagger$ & 422 & 426 & 418 & 474 & 497 & 453 \\
\hline $1991-92 \ldots$. & 500 & 504 & 496 & 501 & 521 & 484 & $t$ & $\dagger$ & $\dagger$ & 423 & 428 & 419 & 476 & 499 & 456 \\
\hline $1992-93 \ldots$. & 500 & 504 & 497 & 503 & 524 & 484 & $\dagger$ & $\dagger$ & $\dagger$ & 424 & 428 & 420 & 478 & 502 & 457 \\
\hline $1993-94 \ldots$. & 499 & 501 & 497 & 504 & 523 & 487 & $\dagger$ & $\dagger$ & $\dagger$ & 423 & 425 & 421 & 479 & 501 & 460 \\
\hline $1994-95 \ldots$. & 504 & 505 & 502 & 506 & 525 & 490 & $t$ & $\dagger$ & $\dagger$ & 428 & 429 & 426 & 482 & 503 & 463 \\
\hline $1995-96 \ldots . .$. & 505 & 507 & 503 & 508 & 527 & 492 & $\dagger$ & $\dagger$ & $\dagger$ & - & - & - & - & - & - \\
\hline $1996-97 \ldots .$. & 505 & 507 & 503 & 511 & 530 & 494 & $\dagger$ & $\dagger$ & $\dagger$ & - & - & - & - & - & - \\
\hline $1997-98 \ldots . .$. & 505 & 509 & 502 & 512 & 531 & 496 & $t$ & $t$ & $t$ & - & - & - & - & - & - \\
\hline $1998-99 \ldots \ldots$ & 505 & 509 & 502 & 511 & 531 & 495 & $t$ & $t$ & $t$ & - & - & - & - & - & - \\
\hline $1999-2000 \ldots$. & 505 & 507 & 504 & 514 & 533 & 498 & $t$ & $\dagger$ & $\dagger$ & $t$ & $\dagger$ & $\dagger$ & $\dagger$ & $\dagger$ & $\dagger$ \\
\hline $2000-01 \ldots . .$. & 506 & 509 & 502 & 514 & 533 & 498 & $\dagger$ & $\dagger$ & $\dagger$ & $\dagger$ & $\dagger$ & $\dagger$ & $\dagger$ & $\dagger$ & $\dagger$ \\
\hline $2001-02 \ldots$ & 504 & 507 & 502 & 516 & 534 & 500 & $\dagger$ & $\dagger$ & $\dagger$ & $\dagger$ & $\dagger$ & $\dagger$ & $\dagger$ & $\dagger$ & $\dagger$ \\
\hline $2002-03 \ldots .$. & 507 & 512 & 503 & 519 & 537 & 503 & $\dagger$ & $\dagger$ & $\dagger$ & $\dagger$ & $\dagger$ & $\dagger$ & $\dagger$ & $\dagger$ & $\dagger$ \\
\hline 2003-04 & 508 & 512 & 504 & 518 & 537 & 501 & $\dagger$ & $\dagger$ & $\dagger$ & $\dagger$ & $\dagger$ & $\dagger$ & $\dagger$ & $\dagger$ & $\dagger$ \\
\hline $2004-05 \ldots \ldots \ldots$ & 508 & 513 & 505 & 520 & 538 & 504 & $\dagger$ & $\dagger$ & $\dagger$ & $\dagger$ & $\dagger$ & $\dagger$ & $\dagger$ & $\dagger$ & $\dagger$ \\
\hline $2005-06 \ldots . .$. & 503 & 505 & 502 & 518 & 536 & 502 & 497 & 491 & 502 & $\dagger$ & $\dagger$ & $\dagger$ & $\dagger$ & $\dagger$ & $\dagger$ \\
\hline $2006-07 \ldots . .$. & 502 & 504 & 502 & 515 & 533 & 499 & 494 & 489 & 500 & $\dagger$ & $\dagger$ & $\dagger$ & $\dagger$ & $\dagger$ & $\dagger$ \\
\hline $2007-08 \ldots .$. & 502 & 504 & 500 & 515 & 533 & 500 & 494 & 488 & 501 & $\dagger$ & $\dagger$ & $\dagger$ & $\dagger$ & $\dagger$ & $\dagger$ \\
\hline $2008-09$ & 501 & 503 & 498 & 515 & 534 & 499 & 493 & 486 & 499 & $\dagger$ & $\dagger$ & $\dagger$ & $\dagger$ & $\dagger$ & $\dagger$ \\
\hline $2009-10$ & 501 & 503 & 498 & 516 & 534 & 500 & 492 & 486 & 498 & $\dagger$ & $\dagger$ & $\dagger$ & $\dagger$ & $\dagger$ & $\dagger$ \\
\hline $2010-11 \ldots \ldots \ldots \ldots \ldots \ldots \ldots \ldots \ldots$ & 497 & 500 & 495 & 514 & 531 & 500 & 489 & 482 & 496 & $\dagger$ & $\dagger$ & $\dagger$ & $\dagger$ & $\dagger$ & $\dagger$ \\
\hline 2011 & 496 & 498 & 493 & 514 & 532 & 499 & 488 & 481 & 494 & $\dagger$ & $\dagger$ & $\dagger$ & $\dagger$ & $\dagger$ & $\dagger$ \\
\hline (1)................... & 496 & 499 & 494 & 514 & 531 & 499 & 488 & 482 & 493 & $\dagger$ & $\dagger$ & $\dagger$ & $\dagger$ & $\dagger$ & $\dagger$ \\
\hline
\end{tabular}

\section{-Not available.}

†Not applicable.

'Data for $1966-67$ to $1985-86$ were converted to the recentered scale by using a formula applied to the original mean and standard deviation. For 1986-87 to 1994-95, individual student scores were converted to the recentered scale and then the mean was recomputed. For 1995-96 to 1998-99, nearly all students received scores on the recentered scale; any score on the original scale was converted to the recentered scale prior to recomputing the mean. From 1999-2000 on, all scores have been reported on the recentered scale.

${ }^{2}$ Writing data are based on students who took the SAT writing section, which was introduced in March 2005.

NOTE: Data for 1966-67 through 1970-71 are estimates derived from the test scores of al participants. Data for 1971-72 through 2009-10 are for seniors who took the SAT any time during their high school years through March of their senior year. Data for 2010-11 onwards are for seniors who took the SAT any time during their high school years through June of their senior year. If a student took a test more than once, the most recent score was used. The SAT was formerly known as the Scholastic Assessment Test and the Scholastic Aptitude Test. Possible scores on each part of the SAT range from 200 to 800 . The critical reading section was formerly known as the verbal section.

SOURCE: College Entrance Examination Board, College-Bound Seniors: Total Group Profile [National] Report, selected years, 1966-67 through 2012-13, retrieved September 26, 2013, from http://media.collegeboard.com/digitalServices/pdf/research/2013/TotalGroup-2013.pdf. (This table was prepared September 2013.) 
Table 226.30. SAT mean scores and percentage distribution of college-bound seniors, by selected student characteristics: Selected years, 1995-96 through 2012-13

\begin{tabular}{|c|c|c|c|c|c|c|c|c|c|c|c|c|c|c|c|c|c|c|c|}
\hline \multirow[b]{2}{*}{ Selected student characteristic } & \multicolumn{3}{|c|}{ 1995-96 } & \multicolumn{3}{|c|}{ 2000-01 } & \multicolumn{4}{|c|}{ 2005-06 } & \multicolumn{4}{|c|}{$2010-11$} & \multicolumn{4}{|c|}{$2012-13$} & \\
\hline & $\begin{array}{r}\text { Critical } \\
\text { reading } \\
\text { score }^{1}\end{array}$ & $\begin{array}{r}\text { Mathe- } \\
\text { matics } \\
\text { score }\end{array}$ & $\begin{array}{r}\text { Percentage } \\
\text { distribution }\end{array}$ & $\begin{array}{r}\text { Critical } \\
\text { reading } \\
\text { score }^{1}\end{array}$ & $\begin{array}{r}\text { Mathe- } \\
\text { matics } \\
\text { score }\end{array}$ & $\begin{array}{c}\text { Percentage } \\
\text { distribution }\end{array}$ & $\begin{array}{r}\text { Critical } \\
\text { reading } \\
\text { score }^{1}\end{array}$ & $\begin{array}{r}\text { Mathe- } \\
\text { matics } \\
\text { score }\end{array}$ & $\begin{array}{c}\text { Writing } \\
\text { score }^{2}\end{array}$ & $\begin{array}{c}\text { Percentage } \\
\text { distribution }\end{array}$ & $\begin{array}{r}\text { Critical } \\
\text { reading } \\
\text { score }^{1}\end{array}$ & $\begin{array}{c}\text { Mathe- } \\
\text { matics } \\
\text { score }\end{array}$ & $\begin{array}{l}\text { Writing } \\
\text { score }^{2}\end{array}$ & $\begin{array}{r}\text { Percentage } \\
\text { distribution }\end{array}$ & $\begin{array}{r}\text { Critical } \\
\text { reading } \\
\text { score }^{1}\end{array}$ & $\begin{array}{r}\text { Mathe- } \\
\text { matics } \\
\text { score }\end{array}$ & $\begin{array}{c}\text { Writing } \\
\text { score }^{2}\end{array}$ & $\begin{array}{l}\text { Percentage } \\
\text { distribution }\end{array}$ & \\
\hline 1 & 2 & 3 & 4 & 5 & 6 & 7 & 8 & 9 & 10 & 11 & 12 & 13 & 14 & 15 & 16 & 17 & 18 & 19 & \\
\hline All students & 505 & 508 & 100 & 506 & 514 & 100 & 503 & 518 & 497 & 100 & 497 & 514 & 489 & 100 & 496 & 514 & 488 & 100 & \\
\hline High school rank & & & & & & & & & & & & & & & & & & & \\
\hline Top decile.......... & 591 & 606 & 22 & 588 & 607 & 24 & 580 & 604 & 577 & 31 & 575 & 606 & 572 & 35 & 572 & 606 & 569 & 36 & \\
\hline Second decile ................................................ & 530 & 539 & 22 & 526 & 540 & 23 & 516 & 537 & 511 & 25 & 510 & 535 & 503 & 27 & 508 & 534 & 499 & 27 & \\
\hline Second quintile ........................................... & 494 & 496 & 28 & 490 & 497 & 26 & 484 & 498 & 476 & 20 & 482 & 498 & 470 & 18 & 481 & 497 & 468 & 18 & \\
\hline Third quintile ................................................... & 455 & 448 & 24 & 454 & 452 & 22 & - & - & - & - & - & - & - & - & - & - & - & - & \\
\hline Fourth quintile ............................................. & 429 & 418 & 4 & 423 & 417 & 4 & - & - & - & - & - & - & - & - & - & - & - & - & \\
\hline 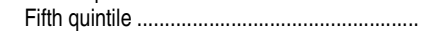 & 411 & 401 & 1 & 407 & 401 & 1 & - & - & - & - & - & - & - & - & - & - & - & - & \\
\hline Bottom three quintiles ${ }^{3}$........................................ & - & - & - & - & - & - & 443 & 449 & 435 & 23 & 438 & 448 & 426 & 20 & 436 & 445 & 423 & 20 & \\
\hline High school grade point average & & & & & & & & & & & & & & & & & & & \\
\hline$A+(97-100) \ldots$ & 617 & 632 & 6 & 609 & 626 & 7 & 602 & 621 & 599 & 7 & 596 & 620 & 595 & 6 & 592 & 619 & 590 & 7 & \\
\hline A (93-96) & 573 & 583 & 14 & 566 & 581 & 17 & 563 & 582 & 559 & 18 & 560 & 583 & 556 & 19 & 557 & 580 & 553 & 21 & \\
\hline A- $(90-92), \ldots \ldots \ldots \ldots$ & 545 & 554 & 15 & 540 & 552 & 17 & 534 & 552 & 529 & 18 & 528 & 548 & 521 & 19 & 522 & 543 & 515 & 20 & \\
\hline B (80-89) & 486 & 485 & 49 & 482 & 486 & 47 & 479 & 489 & 471 & 46 & 469 & 480 & 458 & 45 & 465 & 476 & 454 & 44 & \\
\hline $\mathrm{C}(70-79)$ & 432 & 426 & 15 & 428 & 425 & 12 & 426 & 428 & 414 & 11 & 416 & 421 & 401 & 10 & 411 & 417 & 398 & 9 & \\
\hline$D, E$, or $F($ below 70) & 414 & 408 & \# & 403 & 404 & \# & 406 & 413 & 389 & $\#$ & 409 & 425 & 398 & \# & 399 & 417 & 389 & \# & \\
\hline High school type & & & & & & & & & & & & & & & & & & & \\
\hline Public ................ & 502 & 506 & 83 & 502 & 510 & 83 & 500 & 514 & 492 & 83 & 494 & 506 & 483 & 84 & 491 & 503 & 480 & 84 & \\
\hline Private, religiously affiliated ………………....... & 525 & 510 & 12 & 530 & 523 & 12 & 531 & 529 & 528 & 11 & 531 & 533 & 528 & 10 & 531 & 536 & 528 & 9 & \\
\hline Private, independent ............................................ & 547 & 556 & 5 & 549 & 567 & 5 & 544 & 573 & 550 & 5 & 541 & 579 & 550 & 6 & 536 & 581 & 545 & 6 & \\
\hline Intended college major ${ }^{4}$ & & & & & & & & & & & & & & & & & & & \\
\hline Agriculture and related sciences.......................... & 491 & 484 & 2 & 487 & 484 & 1 & 481 & 485 & 469 & 1 & 475 & 484 & 461 & 1 & 469 & 478 & 457 & 1 & \\
\hline Architecture/environmental design................... & 492 & 519 & 3 & 493 & 521 & 2 & 488 & 528 & 485 & 3 & 490 & 534 & 485 & 2 & 487 & 530 & 482 & 2 & \\
\hline Area, ethnic, cultural and gender studies....... & $t$ & $t$ & $t$ & $t$ & $\dagger$ & $\dagger$ & $t$ & $\dagger$ & $t$ & $\dagger$ & 545 & 513 & 531 & \# & 539 & 509 & 525 & \# & \\
\hline 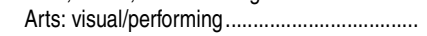 & 520 & 497 & 6 & 518 & 501 & 8 & 516 & 502 & 507 & 9 & 508 & 497 & 499 & 8 & 504 & 494 & 492 & 7 & \\
\hline Biological sciences …………………................. & 546 & 545 & 6 & 545 & 549 & 5 & 540 & 554 & 532 & 6 & 540 & 557 & 533 & 6 & 537 & 552 & 529 & 7 & \\
\hline Business and commerce ...................................... & 483 & 500 & 13 & 489 & 511 & 14 & 486 & 511 & 481 & 15 & 488 & 522 & 484 & 11 & 490 & 522 & 485 & 11 & Q \\
\hline Communications and journalism...................... & 527 & 497 & 4 & 527 & 506 & 4 & 522 & 504 & 520 & 4 & 519 & 502 & 516 & 3 & 515 & 498 & 511 & 3 & $\frac{5}{2}$ \\
\hline Computer or information sciences .................. & 497 & 522 & 3 & 501 & 533 & 7 & 503 & 534 & 482 & 4 & 511 & 539 & 485 & 2 & 518 & 547 & 493 & 3 & 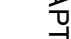 \\
\hline Construction trades.......................................... & $t$ & $\dagger$ & $\dagger$ & $\dagger$ & $\dagger$ & $\dagger$ & $t$ & $t$ & $\dagger$ & $t$ & 422 & 451 & 399 & \# & 421 & 452 & 401 & \# & m \\
\hline Education & 487 & 477 & 8 & 483 & 481 & 9 & 480 & 484 & 478 & 8 & 480 & 487 & 476 & 6 & 481 & 485 & 476 & 4 & 崖 \\
\hline Engineering........................................................ & 525 & 569 & 8 & 523 & 572 & 9 & 519 & 577 & 506 & 8 & 528 & 584 & 513 & 8 & 527 & 580 & 512 & 10 & بִ \\
\hline Engineering technologies/technicians ............ & $t$ & $t$ & $\dagger$ & $t$ & $\dagger$ & $t$ & $t$ & $t$ & $t$ & $t$ & 464 & 511 & 447 & 2 & 471 & 524 & 458 & 1 & $\underline{m}$ \\
\hline English language and literature/letters............ & 605 & 545 & 1 & 606 & 549 & 1 & 597 & 541 & 584 & 2 & 584 & 529 & 570 & 1 & 578 & 524 & 563 & 1 & \\
\hline 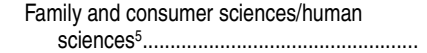 & 458 & 452 & $\#$ & 459 & 458 & $\#$ & 462 & 466 & 461 & $\#$ & 456 & 461 & 452 & $\#$ & 448 & 452 & 445 & \# & $\stackrel{\mathbb{\Phi}}{ٍ}$ \\
\hline Foreign languages, literatures, and linguistics. & 556 & 534 & \# & 557 & 540 & 1 & 572 & 549 & 563 & 1 & 567 & 542 & 557 & 1 & 562 & $\begin{array}{l}452 \\
539\end{array}$ & $\begin{array}{l}440 \\
551\end{array}$ & 1 & ब्ञ \\
\hline 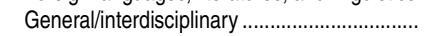 & 576 & 553 & \# & 554 & 539 & \# & 542 & 532 & 532 & \# & $t$ & $\dagger$ & $\dagger$ & $\dagger$ & t & $t$ & t & $\dagger$ & \\
\hline Health and allied services.............................. & 500 & 505 & 19 & 494 & 502 & 15 & 485 & 498 & 483 & 18 & 487 & 502 & 484 & 19 & 484 & 497 & 479 & 19 & \\
\hline History. & $t$ & $t$ & $t$ & $t$ & $\dagger$ & $\dagger$ & $\dagger$ & $\dagger$ & $t$ & $t$ & 542 & 510 & 511 & 1 & 540 & 509 & 511 & 1 & \\
\hline Legal professions and studies .......................... & $\dagger$ & $\dagger$ & $\dagger$ & $\dagger$ & $\dagger$ & $\dagger$ & $\dagger$ & $\dagger$ & $\dagger$ & $\dagger$ & 512 & 507 & 500 & 3 & 516 & 509 & 503 & 3 & $\stackrel{0}{\infty}$ \\
\hline $\begin{array}{l}\text { Liberal arts and sciences, general studies, } \\
\text { and humanities }\end{array}$ & $\dagger$ & $\dagger$ & $\dagger$ & $\dagger$ & $\dagger$ & $\dagger$ & $\dagger$ & $\dagger$ & $\dagger$ & $\dagger$ & 552 & 532 & 541 & 1 & 547 & 530 & 536 & 1 & $\stackrel{D}{>}$ \\
\hline Library and archival sciences ............................... & 554 & 512 & $\#$ & 574 & 504 & $\#$ & 579 & 509 & 542 & $\#$ & 564 & 505 & 516 & \# & 563 & 509 & 520 & \# & 尝. \\
\hline Mathematics & 552 & 628 & 1 & 549 & 625 & 1 & 539 & 624 & 537 & 1 & 518 & 603 & 519 & 1 & 523 & 604 & 522 & 1 & $\begin{array}{l}\bar{c} \cdot< \\
\underline{0} . \\
\underline{0}\end{array}$ \\
\hline Mechanic and repair technologies/technician ... & $t$ & $t$ & $\dagger$ & $t$ & $\dagger$ & $\dagger$ & $t$ & $\dagger$ & $t$ & $\dagger$ & 421 & 451 & 400 & \# & 416 & 444 & 397 & \# & 을 \\
\hline Military sciences ............................................ & 503 & 505 & \# & 507 & 511 & \# & 510 & 521 & 487 & 1 & 467 & 471 & 433 & \# & 486 & 496 & 460 & 1 & 5 \\
\hline Multi/interdisciplinary studies ........................... & $t$ & $t$ & $\dagger$ & $t$ & $\dagger$ & $\dagger$ & $t$ & $t$ & $t$ & $\dagger$ & 582 & 580 & 570 & \# & 587 & 594 & 576 & \# & 等 \\
\hline Natural resources and conservation .............. & $\dagger$ & $\dagger$ & $\dagger$ & $\dagger$ & $\dagger$ & $\dagger$ & $\dagger$ & $\dagger$ & $\dagger$ & $\dagger$ & 525 & 524 & 506 & 1 & 518 & 519 & 500 & 1 & \\
\hline
\end{tabular}


Table 226.30. SAT mean scores and percentage distribution of college-bound seniors, by selected student characteristics: Selected years, 1995-96 through 2012-13-Continued

\begin{tabular}{|c|c|c|c|c|c|c|c|c|c|c|c|c|c|c|c|c|c|c|}
\hline \multirow[b]{2}{*}{ Selected student characteristic } & \multicolumn{3}{|c|}{$1995-96$} & \multicolumn{3}{|c|}{$2000-01$} & \multicolumn{4}{|c|}{$2005-06$} & \multicolumn{4}{|c|}{$2010-11$} & \multicolumn{4}{|c|}{$2012-13$} \\
\hline & $\begin{array}{r}\text { Critical } \\
\text { reading } \\
\text { score }^{1}\end{array}$ & $\begin{array}{c}\text { Mathe- } \\
\text { matics } \\
\text { score }\end{array}$ & $\begin{array}{l}\text { Percentage } \\
\text { distribution }\end{array}$ & $\begin{array}{r}\text { Critical } \\
\text { reading } \\
\text { score }^{1}\end{array}$ & $\begin{array}{r}\text { Mathe- } \\
\text { matics } \\
\text { score }\end{array}$ & $\begin{array}{l}\text { Percentage } \\
\text { distribution }\end{array}$ & $\begin{array}{r}\text { Critical } \\
\text { reading } \\
\text { score }^{1}\end{array}$ & $\begin{array}{c}\text { Mathe- } \\
\text { matics } \\
\text { score }\end{array}$ & $\begin{array}{c}\text { Writing } \\
\text { score }^{2}\end{array}$ & $\begin{array}{l}\text { Percentage } \\
\text { distribution }\end{array}$ & $\begin{array}{r}\text { Critical } \\
\text { reading } \\
\text { score }^{1}\end{array}$ & $\begin{array}{c}\text { Mathe- } \\
\text { matics } \\
\text { score }\end{array}$ & $\begin{array}{c}\text { Writing } \\
\text { score }^{2}\end{array}$ & $\begin{array}{c}\text { Percentage } \\
\text { distribution }\end{array}$ & $\begin{array}{r}\text { Critical } \\
\text { reading } \\
\text { score }^{1}\end{array}$ & $\begin{array}{c}\text { Mathe- } \\
\text { matics } \\
\text { score }\end{array}$ & $\begin{array}{c}\text { Writing } \\
\text { score }^{2}\end{array}$ & $\begin{array}{l}\text { Percentage } \\
\text { distribution }\end{array}$ \\
\hline 1 & 2 & 3 & 4 & 5 & 6 & 7 & 8 & 9 & 10 & 11 & 12 & 13 & 14 & 15 & 16 & 17 & 18 & 19 \\
\hline Parks, recreation, leisure, and fitness studies... & $t$ & $t$ & $t$ & $t$ & $t$ & $t$ & $t$ & $t$ & $t$ & $t$ & 444 & 468 & 435 & 1 & 438 & 461 & 429 & 1 \\
\hline Personal and culinary services ........................... & $\dagger$ & $t$ & $t$ & $\dagger$ & $t$ & $\dagger$ & $\dagger$ & $t$ & $t$ & $\dagger$ & 457 & 456 & 440 & \# & 448 & 449 & 433 & \# \\
\hline Philosophy/religious studies................................. & 560 & 536 & $\#$ & 561 & 539 & 1 & 557 & 537 & 535 & 1 & 557 & 535 & 530 & $\#$ & 546 & 530 & 527 & \# \\
\hline 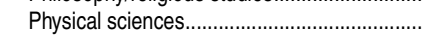 & 575 & 595 & 1 & 568 & 588 & 1 & 557 & 589 & 542 & 2 & 553 & 582 & 537 & 1 & 554 & 582 & 537 & 2 \\
\hline 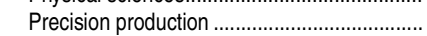 & t & t & $t$ & t & t & $\dagger$ & t & $\dagger$ & t & $\dagger$ & 436 & 468 & 422 & \# & 442 & 476 & 427 & \# \\
\hline 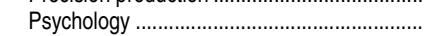 & $t$ & $\dagger$ & $t$ & $\dagger$ & $t$ & $\dagger$ & $\dagger$ & $t$ & $t$ & $\dagger$ & 505 & 494 & 497 & 5 & 502 & 490 & 492 & 5 \\
\hline Public affairs and services & 458 & 448 & $\begin{array}{cccccc}1 \\
3\end{array}$ & 461 & 455 & $\begin{array}{ccccccc}1 \\
2\end{array}$ & 462 & 461 & 454 & $\begin{array}{ccc}1 \\
3\end{array}$ & 467 & 459 & 462 & \# & 462 & 454 & 457 & \# \\
\hline Security and protective services ....................... & $t$ & $\dagger$ & $\dagger$ & $\dagger$ & t & $\dagger$ & $\dagger$ & $\dagger$ & $t$ & $t$ & 445 & 454 & 432 & 2 & 445 & 453 & 433 & 3 \\
\hline Social sciences and history ....................................... & 532 & 509 & 11 & 531 & 512 & 10 & 539 & 519 & 525 & $\begin{array}{cccc}1 \\
9\end{array}$ & t & $t$ & t & $\dagger$ & t & t & t & $\dagger$ \\
\hline 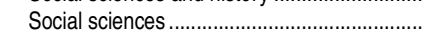 & t & $t$ & $t$ & $t$ & $t$ & $t$ & $t$ & $t$ & $t$ & $t$ & 573 & 558 & 559 & 2 & 565 & 553 & 551 & 2 \\
\hline Technical and vocational .................................... & 435 & 441 & 1 & 444 & 451 & 1 & 437 & 454 & 421 & 1 & t & $t$ & $\dagger$ & $\dagger$ & $\dagger$ & t & $t$ & $\dagger$ \\
\hline Theology and religious vocations..................... & t & $\dagger$ & $\dagger$ & $t$ & $t$ & $\dagger$ & $t$ & $t$ & $t$ & $t$ & 539 & 522 & 513 & $\#$ & 527 & 509 & 507 & \# \\
\hline Transportation and materials moving .................. & $t$ & $t$ & $t$ & $t$ & $t$ & $t$ & $t$ & $t$ & t & $t$ & 465 & 496 & 446 & \# & 451 & 486 & 438 & \# \\
\hline 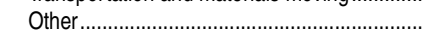 & $t$ & $t$ & $t$ & $\dagger$ & $t$ & $\dagger$ & $t$ & $t$ & $t$ & $\dagger$ & 453 & 462 & 443 & 2 & 450 & 460 & 440 & 2 \\
\hline 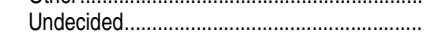 & 500 & 507 & 7 & 515 & 524 & 7 & 512 & 530 & 502 & 3 & 530 & 545 & 522 & 8 & 533 & 547 & 524 & 7 \\
\hline \multicolumn{19}{|l|}{ Degree-level goal } \\
\hline Certificate program & 434 & 439 & 1 & 443 & 455 & 1 & 443 & 462 & 435 & 1 & 445 & 464 & 434 & 1 & 440 & 459 & 430 & 1 \\
\hline 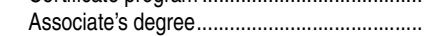 & 422 & 415 & 2 & 419 & 416 & 2 & 416 & 420 & 409 & 1 & 412 & 416 & 400 & 1 & 409 & 414 & 397 & 1 \\
\hline 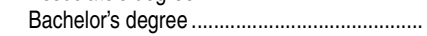 & 476 & 476 & 23 & 478 & 483 & 25 & 477 & 487 & 469 & 25 & 478 & 490 & 467 & 30 & 478 & 489 & 466 & 30 \\
\hline Master's degree ...................................... & 514 & 518 & 29 & 516 & 526 & 31 & 512 & 525 & 505 & 30 & 506 & 524 & 499 & 29 & 506 & 524 & 499 & 30 \\
\hline Doctor's or related degree....................................... & 548 & 552 & 24 & 547 & 554 & 21 & 539 & 553 & 532 & 20 & 534 & 550 & 527 & 21 & 533 & 548 & 525 & 21 \\
\hline Other .............. & 430 & 438 & 1 & 438 & 449 & 1 & 439 & 456 & 436 & 1 & 425 & 451 & 423 & 1 & 412 & 445 & 411 & 1 \\
\hline 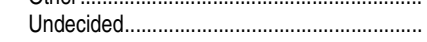 & 502 & 503 & 20 & 511 & 517 & 19 & 515 & 528 & 508 & 22 & 509 & 522 & 499 & 16 & 504 & 520 & 495 & 15 \\
\hline \multicolumn{19}{|l|}{ Family income } \\
\hline Less than $\$ 20,000$ & - & - & - & - & - & - & - & - & - & - & 434 & 460 & 429 & 13 & 435 & 462 & 429 & 14 \\
\hline 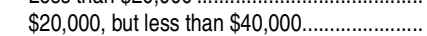 & - & - & - & - & - & - & - & - & - & - & 464 & 480 & 454 & 16 & 465 & 482 & 455 & 16 \\
\hline$\$ 40,000$, but less than $\$ 60,000 \ldots \ldots \ldots \ldots \ldots \ldots \ldots$ & - & - & - & - & - & - & - & - & - & - & 487 & 499 & 475 & 15 & 487 & 500 & 474 & 14 \\
\hline 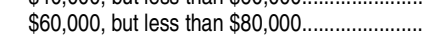 & - & - & - & - & - & - & - & - & - & - & 502 & 512 & 489 & 14 & 500 & 511 & 486 & 13 \\
\hline$\$ 80,000$, but less than $\$ 100,000 \ldots \ldots \ldots \ldots \ldots \ldots$ & - & - & - & - & - & - & - & - & - & - & 515 & 527 & 503 & 12 & 512 & 524 & 499 & 11 \\
\hline 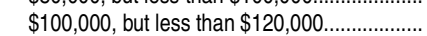 & - & - & - & - & - & - & - & - & - & - & 526 & 539 & 515 & 10 & 522 & 536 & 511 & 10 \\
\hline$\$ 120,000$, but less than $\$ 140,000 \ldots \ldots \ldots \ldots \ldots \ldots$ & - & - & - & - & - & - & - & - & - & - & 530 & 544 & 520 & 5 & 526 & 540 & 515 & 5 \\
\hline 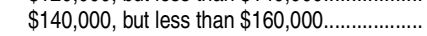 & - & - & - & - & - & - & - & - & - & - & 538 & 552 & 529 & 4 & 533 & 548 & 523 & 4 \\
\hline$\$ 160,000$, but less than $\$ 200,000 \ldots \ldots \ldots \ldots \ldots . .$. & - & - & - & - & - & - & - & - & - & - & 543 & 557 & 536 & 5 & 539 & 555 & 531 & 5 \\
\hline More than $\$ 200,000$ & - & - & - & - & - & - & - & - & - & - & 568 & 586 & 567 & 7 & 565 & 586 & 563 & 8 \\
\hline \multicolumn{19}{|l|}{ Highest level of parental education } \\
\hline No high school diploma ................. & 414 & 439 & 4 & 411 & 438 & 4 & 418 & 445 & 418 & 4 & 421 & 449 & 418 & 6 & 423 & 451 & 420 & 6 \\
\hline 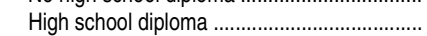 & 475 & 474 & 35 & 472 & 476 & 32 & 467 & 478 & 460 & 31 & 463 & 476 & 452 & 31 & 464 & 477 & 453 & 29 \\
\hline 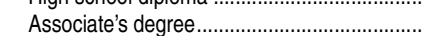 & 489 & 487 & 8 & 489 & 491 & 9 & 484 & 493 & 474 & 8 & 480 & 489 & 466 & 8 & 480 & 488 & 466 & 8 \\
\hline 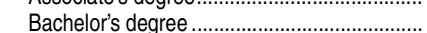 & 525 & 529 & 28 & 525 & 533 & 29 & 522 & 536 & 514 & 30 & 522 & 538 & 514 & 31 & 523 & 540 & 513 & 31 \\
\hline Graduate degree & 556 & 558 & 25 & 559 & 567 & 26 & 558 & 571 & 552 & 27 & 559 & 574 & 554 & 25 & 560 & 576 & 553 & 25 \\
\hline
\end{tabular}

\section{-Not available.}

†Not applicable.
\#Rounds to zero.

1Prior to 2006, the critical reading section was known as the verbal section.

Writing data are based on students who took the SAT wrting section, which was introduced in March 2005

Beginning in 2005-06, the College Board has reported third, fourth, and fith quintiles as the bottom three quintiles instead of report-

ing them separately as in previous years.

the list of majors and changes in subspecialties within majors. NOTE: Prior to 2010-11, data are for seniors who took the SAT any time during their high school years through March of their senior year. If a student took a test more than once, the most recent score was used. The SAT was formerly known as the Scholastic
Assessment Test and the Scholastic Aptitude Test. Possible scores on each part of the SAT range from 200 to 800 . Detail may not

sum to totals because of rounding.
SOURCE: College Entrance Examination Board, College-Bound Seniors: Total Group Profile [National] Report, selected years, 1995-96 through 2012-13, retrieved September 26, 2013, from hitp://research.collegeboard.org/programs/sat/data/cb-seniors-2013 
Table 226.40. Mean SAT scores of college-bound seniors and percentage of graduates taking SAT, by state: Selected years, 1995-96 through 2012-13

\begin{tabular}{|c|c|c|c|c|c|c|c|c|c|c|c|c|c|c|c|c|c|c|}
\hline \multirow[b]{2}{*}{ State } & \multicolumn{2}{|c|}{$1995-96$} & \multicolumn{2}{|c|}{$2000-01$} & \multicolumn{3}{|c|}{$2005-06$} & \multicolumn{3}{|c|}{$2010-11$} & \multicolumn{3}{|c|}{$2011-12$} & \multicolumn{3}{|c|}{$2012-13$} & \multirow{2}{*}{$\begin{array}{r}\text { Percent } \\
\text { of } \\
\text { graduates } \\
\text { taking } \\
\text { SAT, } \\
2011-12^{1}\end{array}$} & \multirow{2}{*}{$\begin{array}{r}\text { Percent } \\
\text { of } \\
\text { graduates } \\
\text { taking } \\
\text { SAT } \\
2012-13\end{array}$} \\
\hline & $\begin{array}{c}\text { Critical } \\
\text { reading }\end{array}$ & $\begin{array}{l}\text { Mathe- } \\
\text { matics }\end{array}$ & $\begin{array}{l}\text { Critical } \\
\text { reading }\end{array}$ & $\begin{array}{l}\text { Mathe- } \\
\text { matics }\end{array}$ & $\begin{array}{c}\text { Critical } \\
\text { reading }\end{array}$ & $\begin{array}{c}\text { Mathe- } \\
\text { matics }\end{array}$ & Writing 2 & $\begin{array}{r}\text { Critical } \\
\text { reading }\end{array}$ & $\begin{array}{c}\text { Mathe- } \\
\text { matics }\end{array}$ & Writing ${ }^{2}$ & $\begin{array}{c}\text { Critical } \\
\text { reading }\end{array}$ & $\begin{array}{c}\text { Mathe- } \\
\text { matics }\end{array}$ & Writing $^{2}$ & $\begin{array}{c}\text { Critical } \\
\text { reading }\end{array}$ & $\begin{array}{c}\text { Mathe- } \\
\text { matics }\end{array}$ & Writing $^{2}$ & & \\
\hline 1 & 2 & 3 & 4 & 5 & 6 & 7 & 8 & 9 & 10 & 11 & 12 & 13 & 14 & 15 & 16 & 17 & 18 & 19 \\
\hline United States .... & 505 & 508 & 506 & 514 & 503 & 518 & 497 & 497 & 514 & 489 & 496 & 514 & 488 & 496 & 514 & 488 & 48 & 49 \\
\hline 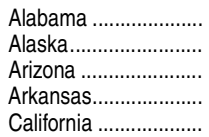 & $\begin{array}{l}565 \\
521 \\
525 \\
566 \\
495\end{array}$ & $\begin{array}{l}558 \\
513 \\
521 \\
550 \\
511\end{array}$ & $\begin{array}{l}559 \\
514 \\
523 \\
562 \\
498\end{array}$ & $\begin{array}{l}554 \\
510 \\
525 \\
550 \\
517\end{array}$ & $\begin{array}{l}565 \\
517 \\
521 \\
574 \\
501\end{array}$ & $\begin{array}{l}561 \\
517 \\
528 \\
568 \\
518\end{array}$ & $\begin{array}{l}565 \\
493 \\
507 \\
567 \\
501\end{array}$ & $\begin{array}{l}546 \\
515 \\
517 \\
568 \\
499\end{array}$ & $\begin{array}{l}541 \\
511 \\
523 \\
570 \\
515\end{array}$ & $\begin{array}{l}536 \\
487 \\
499 \\
554 \\
499\end{array}$ & $\begin{array}{l}538 \\
512 \\
517 \\
565 \\
495\end{array}$ & $\begin{array}{l}531 \\
507 \\
525 \\
566 \\
512\end{array}$ & $\begin{array}{l}527 \\
485 \\
499 \\
549 \\
496\end{array}$ & $\begin{array}{l}544 \\
508 \\
521 \\
572 \\
498\end{array}$ & $\begin{array}{l}534 \\
505 \\
528 \\
570 \\
512\end{array}$ & $\begin{array}{l}530 \\
482 \\
502 \\
555 \\
495\end{array}$ & $\begin{array}{r}8 \\
54 \\
27 \\
4 \\
55\end{array}$ & $\begin{array}{r}7 \\
52 \\
35 \\
4 \\
57\end{array}$ \\
\hline 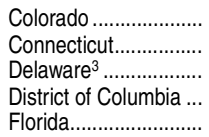 & $\begin{array}{l}536 \\
507 \\
508 \\
489 \\
498\end{array}$ & $\begin{array}{l}538 \\
504 \\
495 \\
473 \\
496\end{array}$ & $\begin{array}{l}539 \\
509 \\
501 \\
482 \\
498\end{array}$ & $\begin{array}{l}542 \\
510 \\
499 \\
474 \\
499\end{array}$ & $\begin{array}{l}558 \\
512 \\
495 \\
487 \\
496\end{array}$ & $\begin{array}{l}564 \\
516 \\
500 \\
472 \\
497\end{array}$ & $\begin{array}{l}548 \\
511 \\
484 \\
482 \\
480\end{array}$ & $\begin{array}{l}570 \\
509 \\
489 \\
469 \\
487\end{array}$ & $\begin{array}{l}573 \\
513 \\
490 \\
457 \\
489\end{array}$ & $\begin{array}{l}556 \\
513 \\
476 \\
459 \\
471\end{array}$ & $\begin{array}{l}575 \\
506 \\
456 \\
466 \\
492\end{array}$ & $\begin{array}{l}581 \\
512 \\
462 \\
460 \\
492\end{array}$ & $\begin{array}{l}562 \\
510 \\
444 \\
456 \\
476\end{array}$ & $\begin{array}{l}578 \\
508 \\
451 \\
473 \\
492\end{array}$ & $\begin{array}{l}581 \\
512 \\
457 \\
466 \\
490\end{array}$ & $\begin{array}{l}562 \\
512 \\
443 \\
461 \\
475\end{array}$ & $\begin{array}{r}17 \\
88 \\
100 \\
83 \\
66\end{array}$ & $\begin{array}{r}14 \\
85 \\
100 \\
91 \\
67\end{array}$ \\
\hline 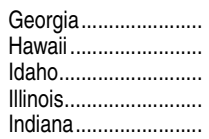 & $\begin{array}{l}484 \\
485 \\
543 \\
564 \\
494\end{array}$ & $\begin{array}{l}477 \\
510 \\
536 \\
575 \\
494\end{array}$ & $\begin{array}{l}491 \\
486 \\
543 \\
576 \\
499\end{array}$ & $\begin{array}{l}489 \\
515 \\
542 \\
589 \\
501\end{array}$ & $\begin{array}{l}494 \\
482 \\
543 \\
591 \\
498\end{array}$ & $\begin{array}{l}496 \\
509 \\
545 \\
609 \\
509\end{array}$ & $\begin{array}{l}487 \\
472 \\
525 \\
586 \\
486\end{array}$ & $\begin{array}{l}485 \\
479 \\
542 \\
599 \\
493\end{array}$ & $\begin{array}{l}487 \\
500 \\
539 \\
617 \\
501\end{array}$ & $\begin{array}{l}473 \\
469 \\
517 \\
591 \\
475\end{array}$ & $\begin{array}{l}488 \\
478 \\
547 \\
596 \\
493\end{array}$ & $\begin{array}{l}489 \\
500 \\
541 \\
615 \\
501\end{array}$ & $\begin{array}{l}475 \\
467 \\
525 \\
587 \\
476\end{array}$ & $\begin{array}{l}490 \\
481 \\
454 \\
600 \\
493\end{array}$ & $\begin{array}{l}487 \\
504 \\
459 \\
617 \\
500\end{array}$ & $\begin{array}{l}475 \\
468 \\
451 \\
590 \\
477\end{array}$ & $\begin{array}{r}81 \\
66 \\
20 \\
5 \\
69\end{array}$ & $\begin{array}{r}75 \\
64 \\
99 \\
5 \\
70\end{array}$ \\
\hline 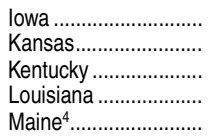 & $\begin{array}{l}590 \\
579 \\
549 \\
559 \\
504\end{array}$ & $\begin{array}{l}600 \\
571 \\
544 \\
550 \\
498\end{array}$ & $\begin{array}{l}593 \\
577 \\
550 \\
564 \\
506\end{array}$ & $\begin{array}{l}603 \\
580 \\
550 \\
562 \\
500\end{array}$ & $\begin{array}{l}602 \\
582 \\
562 \\
570 \\
501\end{array}$ & $\begin{array}{l}613 \\
590 \\
562 \\
571 \\
501\end{array}$ & $\begin{array}{l}591 \\
566 \\
555 \\
571 \\
491\end{array}$ & $\begin{array}{l}596 \\
580 \\
576 \\
555 \\
469\end{array}$ & $\begin{array}{l}606 \\
591 \\
572 \\
550 \\
469\end{array}$ & $\begin{array}{l}575 \\
563 \\
563 \\
546 \\
453\end{array}$ & $\begin{array}{l}603 \\
584 \\
579 \\
542 \\
470\end{array}$ & $\begin{array}{l}606 \\
594 \\
575 \\
536 \\
472\end{array}$ & $\begin{array}{l}580 \\
561 \\
566 \\
529 \\
452\end{array}$ & $\begin{array}{l}592 \\
589 \\
585 \\
556 \\
462\end{array}$ & $\begin{array}{l}601 \\
595 \\
584 \\
553 \\
467\end{array}$ & $\begin{array}{l}570 \\
568 \\
572 \\
546 \\
451\end{array}$ & $\begin{array}{r}3 \\
6 \\
6 \\
9 \\
93\end{array}$ & $\begin{array}{r}3 \\
6 \\
5 \\
5 \\
95\end{array}$ \\
\hline $\begin{array}{l}\text { Maryland................ } \\
\text { Massachusetts........... } \\
\text { Michigan .................... } \\
\text { Minnesota................. } \\
\text { Mississippi ................. }\end{array}$ & $\begin{array}{l}507 \\
507 \\
557 \\
582 \\
569\end{array}$ & $\begin{array}{l}504 \\
504 \\
565 \\
593 \\
557\end{array}$ & $\begin{array}{l}508 \\
511 \\
561 \\
580 \\
566\end{array}$ & $\begin{array}{l}510 \\
515 \\
572 \\
589 \\
551\end{array}$ & $\begin{array}{l}503 \\
513 \\
568 \\
591 \\
556\end{array}$ & $\begin{array}{l}509 \\
524 \\
583 \\
600 \\
541\end{array}$ & $\begin{array}{l}499 \\
510 \\
555 \\
574 \\
562\end{array}$ & $\begin{array}{l}499 \\
513 \\
583 \\
593 \\
564\end{array}$ & $\begin{array}{l}502 \\
527 \\
604 \\
608 \\
543\end{array}$ & $\begin{array}{l}491 \\
509 \\
573 \\
577 \\
553\end{array}$ & $\begin{array}{l}497 \\
513 \\
586 \\
592 \\
561\end{array}$ & $\begin{array}{l}502 \\
530 \\
603 \\
606 \\
544\end{array}$ & $\begin{array}{l}488 \\
508 \\
574 \\
573 \\
551\end{array}$ & $\begin{array}{l}497 \\
515 \\
590 \\
595 \\
568\end{array}$ & $\begin{array}{l}500 \\
529 \\
610 \\
608 \\
547\end{array}$ & $\begin{array}{l}486 \\
509 \\
582 \\
577 \\
558\end{array}$ & $\begin{array}{r}74 \\
89 \\
4 \\
7 \\
4\end{array}$ & $\begin{array}{r}73 \\
83 \\
4 \\
6 \\
3\end{array}$ \\
\hline $\begin{array}{l}\text { Missouri ..................... } \\
\text { Montana.................... } \\
\text { Nebraska ................. } \\
\text { Nevada ................... } \\
\text { New Hampshire ......... }\end{array}$ & $\begin{array}{l}570 \\
546 \\
567 \\
508 \\
520\end{array}$ & $\begin{array}{l}569 \\
547 \\
568 \\
507 \\
514\end{array}$ & $\begin{array}{l}577 \\
539 \\
562 \\
509 \\
520\end{array}$ & $\begin{array}{l}577 \\
539 \\
568 \\
515 \\
516\end{array}$ & $\begin{array}{l}587 \\
538 \\
576 \\
498 \\
520\end{array}$ & $\begin{array}{l}591 \\
545 \\
583 \\
508 \\
524\end{array}$ & $\begin{array}{l}582 \\
524 \\
566 \\
481 \\
509\end{array}$ & $\begin{array}{l}592 \\
539 \\
585 \\
494 \\
523\end{array}$ & $\begin{array}{l}593 \\
537 \\
591 \\
496 \\
525\end{array}$ & $\begin{array}{l}579 \\
516 \\
569 \\
470 \\
511\end{array}$ & $\begin{array}{l}589 \\
536 \\
576 \\
491 \\
521\end{array}$ & $\begin{array}{l}592 \\
536 \\
585 \\
493 \\
525\end{array}$ & $\begin{array}{l}575 \\
511 \\
562 \\
466 \\
510\end{array}$ & $\begin{array}{l}596 \\
539 \\
584 \\
492 \\
524\end{array}$ & $\begin{array}{l}595 \\
540 \\
583 \\
494 \\
528\end{array}$ & $\begin{array}{l}582 \\
516 \\
567 \\
468 \\
515\end{array}$ & $\begin{array}{r}5 \\
28 \\
5 \\
49 \\
75\end{array}$ & $\begin{array}{r}4 \\
25 \\
4 \\
48 \\
70\end{array}$ \\
\hline $\begin{array}{l}\text { New Jersey ................. } \\
\text { New Mexico ............... } \\
\text { New York................. } \\
\text { North Carolina ........... } \\
\text { North Dakota ............. }\end{array}$ & $\begin{array}{l}498 \\
554 \\
497 \\
490 \\
596\end{array}$ & $\begin{array}{l}505 \\
548 \\
499 \\
486 \\
599\end{array}$ & $\begin{array}{l}499 \\
551 \\
495 \\
493 \\
592\end{array}$ & $\begin{array}{l}513 \\
542 \\
505 \\
499 \\
599\end{array}$ & $\begin{array}{l}496 \\
557 \\
493 \\
495 \\
610\end{array}$ & $\begin{array}{l}515 \\
549 \\
510 \\
513 \\
617\end{array}$ & $\begin{array}{l}496 \\
543 \\
483 \\
485 \\
588\end{array}$ & $\begin{array}{l}495 \\
548 \\
485 \\
493 \\
586\end{array}$ & $\begin{array}{l}516 \\
541 \\
499 \\
508 \\
612\end{array}$ & $\begin{array}{l}497 \\
529 \\
476 \\
474 \\
561\end{array}$ & $\begin{array}{l}495 \\
550 \\
483 \\
491 \\
588\end{array}$ & $\begin{array}{l}517 \\
546 \\
500 \\
506 \\
610\end{array}$ & $\begin{array}{l}499 \\
529 \\
475 \\
472 \\
568\end{array}$ & $\begin{array}{l}499 \\
550 \\
485 \\
495 \\
609\end{array}$ & $\begin{array}{l}522 \\
545 \\
501 \\
506 \\
609\end{array}$ & $\begin{array}{l}500 \\
531 \\
477 \\
478 \\
581\end{array}$ & $\begin{array}{r}78 \\
13 \\
90 \\
68 \\
3\end{array}$ & $\begin{array}{r}78 \\
12 \\
76 \\
62 \\
2\end{array}$ \\
\hline 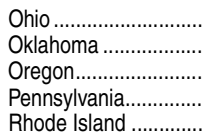 & $\begin{array}{l}536 \\
566 \\
523 \\
498 \\
501\end{array}$ & $\begin{array}{l}535 \\
557 \\
521 \\
492 \\
491\end{array}$ & $\begin{array}{l}534 \\
567 \\
526 \\
500 \\
501\end{array}$ & $\begin{array}{l}539 \\
561 \\
526 \\
499 \\
499\end{array}$ & $\begin{array}{l}535 \\
576 \\
523 \\
493 \\
495\end{array}$ & $\begin{array}{l}544 \\
574 \\
529 \\
500 \\
502\end{array}$ & $\begin{array}{l}521 \\
563 \\
503 \\
483 \\
490\end{array}$ & $\begin{array}{l}539 \\
571 \\
520 \\
493 \\
495\end{array}$ & $\begin{array}{l}545 \\
565 \\
521 \\
501 \\
493\end{array}$ & $\begin{array}{l}522 \\
547 \\
499 \\
479 \\
489\end{array}$ & $\begin{array}{l}543 \\
568 \\
521 \\
491 \\
490\end{array}$ & $\begin{array}{l}552 \\
566 \\
523 \\
501 \\
491\end{array}$ & $\begin{array}{l}525 \\
546 \\
498 \\
480 \\
485\end{array}$ & $\begin{array}{l}548 \\
571 \\
520 \\
494 \\
491\end{array}$ & $\begin{array}{l}556 \\
569 \\
520 \\
504 \\
490\end{array}$ & $\begin{array}{l}531 \\
549 \\
499 \\
482 \\
487\end{array}$ & $\begin{array}{r}19 \\
5 \\
57 \\
74 \\
69\end{array}$ & $\begin{array}{r}17 \\
5 \\
49 \\
71 \\
72\end{array}$ \\
\hline $\begin{array}{l}\text { South Carolina ............ } \\
\text { South Dakota ............. } \\
\text { Tennessee ................. } \\
\text { Texas ......................... } \\
\text { Utah }\end{array}$ & $\begin{array}{l}480 \\
574 \\
563 \\
495 \\
583\end{array}$ & $\begin{array}{l}474 \\
566 \\
552 \\
500 \\
575\end{array}$ & $\begin{array}{l}486 \\
577 \\
562 \\
493 \\
575\end{array}$ & $\begin{array}{l}488 \\
582 \\
553 \\
499 \\
570\end{array}$ & $\begin{array}{l}487 \\
590 \\
573 \\
491 \\
560\end{array}$ & $\begin{array}{l}498 \\
604 \\
569 \\
506 \\
557\end{array}$ & $\begin{array}{l}480 \\
578 \\
572 \\
487 \\
550\end{array}$ & $\begin{array}{l}482 \\
584 \\
575 \\
479 \\
563\end{array}$ & $\begin{array}{l}490 \\
591 \\
568 \\
502 \\
559\end{array}$ & $\begin{array}{l}464 \\
562 \\
567 \\
465 \\
545\end{array}$ & $\begin{array}{l}481 \\
589 \\
576 \\
474 \\
568\end{array}$ & $\begin{array}{l}488 \\
610 \\
570 \\
499 \\
566\end{array}$ & $\begin{array}{l}462 \\
570 \\
566 \\
461 \\
548\end{array}$ & $\begin{array}{l}484 \\
592 \\
574 \\
477 \\
569\end{array}$ & $\begin{array}{l}487 \\
601 \\
569 \\
499 \\
566\end{array}$ & $\begin{array}{l}465 \\
567 \\
566 \\
461 \\
549\end{array}$ & $\begin{array}{r}73 \\
3 \\
10 \\
62 \\
6\end{array}$ & $\begin{array}{r}64 \\
3 \\
8 \\
59 \\
6\end{array}$ \\
\hline 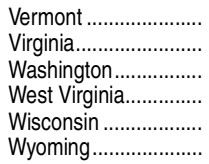 & $\begin{array}{l}506 \\
507 \\
519 \\
526 \\
577 \\
544\end{array}$ & $\begin{array}{l}500 \\
496 \\
519 \\
506 \\
586 \\
544\end{array}$ & $\begin{array}{l}511 \\
510 \\
527 \\
527 \\
584 \\
547\end{array}$ & $\begin{array}{l}506 \\
501 \\
527 \\
512 \\
596 \\
545\end{array}$ & $\begin{array}{l}513 \\
512 \\
527 \\
519 \\
588 \\
548\end{array}$ & $\begin{array}{l}519 \\
513 \\
532 \\
510 \\
600 \\
555\end{array}$ & $\begin{array}{l}502 \\
500 \\
511 \\
515 \\
577 \\
537\end{array}$ & $\begin{array}{l}515 \\
512 \\
523 \\
514 \\
590 \\
572\end{array}$ & $\begin{array}{l}518 \\
509 \\
529 \\
501 \\
602 \\
569\end{array}$ & $\begin{array}{l}505 \\
495 \\
508 \\
497 \\
575 \\
551\end{array}$ & $\begin{array}{l}519 \\
510 \\
519 \\
516 \\
594 \\
567\end{array}$ & $\begin{array}{l}523 \\
512 \\
530 \\
502 \\
605 \\
579\end{array}$ & $\begin{array}{l}505 \\
495 \\
503 \\
497 \\
577 \\
549\end{array}$ & $\begin{array}{l}516 \\
516 \\
515 \\
514 \\
591 \\
581\end{array}$ & $\begin{array}{l}519 \\
514 \\
523 \\
501 \\
604 \\
588\end{array}$ & $\begin{array}{l}505 \\
498 \\
499 \\
498 \\
576 \\
588\end{array}$ & $\begin{array}{r}69 \\
72 \\
58 \\
17 \\
4 \\
5\end{array}$ & $\begin{array}{r}61 \\
71 \\
60 \\
15 \\
4 \\
4\end{array}$ \\
\hline
\end{tabular}

${ }^{1}$ Participation rate is based on the projection of high school graduates by the Western Interstate Commission for Higher Education (WICHE), and the number of seniors who took the SAT in each state.

${ }^{2}$ Writing data are based on students who took the SAT writing section, which was introduced in March 2005.

${ }^{3}$ Beginning with the spring SAT administration in 2011, the SAT tests were administered to all high school juniors attending Delaware public high schools.

${ }^{4}$ Beginning with the spring SAT administration in 2006, all Maine high school juniors, including all students in their third year of high school, are required to take SAT tests in critical reading, writing, and mathematics.

NOTE: Data for 2005-06 and earlier years are for seniors who took the SAT any time during their high school years through March of their senior year. Data for 2010-11 onwards are for seniors who took the SAT any time during their high school years through June of their senior year. If a student took a test more than once, the most recent score was used. The SAT was formerly known as the Scholastic Assessment Test and the Scholastic Aptitude Test. Possible scores on each part of the SAT range from 200 to 800 . The critical reading section was formerly known as the verbal section.

SOURCE: College Entrance Examination Board, College-Bound Seniors Tables and Related Items, selected years, selected years, 1995-96 through 2012-13, retrieved January 08,2013 , from http://research.collegeboard.org/programs/sat/data/cb-seniors-2013 and http://www.commonwealthfoundation.org/policyblog/detail/sat-scores-by-state-2013. (This table was prepared January 2013.) 
282 CHAPTER 2: Elementary and Secondary Education

College Admission Tests

Table 226.50. ACT score averages and standard deviations, by sex and race/ethnicity, and percentage of ACT test takers, by selected composite score ranges and planned fields of postsecondary study: Selected years, 1995 through 2013

\begin{tabular}{|c|c|c|c|c|c|c|c|c|c|c|c|c|c|}
\hline $\begin{array}{l}\text { Score type and test-taker } \\
\text { characteristic }\end{array}$ & 1995 & 2000 & 2003 & 2004 & 2005 & 2006 & 2007 & 2008 & 2009 & 2010 & 2011 & 2012 & 2013 \\
\hline 1 & 2 & 3 & 4 & 5 & 6 & 7 & 8 & 9 & 10 & 11 & 12 & 13 & 14 \\
\hline $\begin{array}{l}\text { Total test takers } \\
\text { Number (in thousands) ... }\end{array}$ & 945 & 1,065 & 1,175 & 1,171 & 1,186 & 1,206 & 1,301 & 1,422 & 1,480 & 1,569 & 1,623 & 1,666 & 1,799 \\
\hline Percent of graduates ....... & 37.5 & 37.6 & 39.0 & 38.4 & 38.2 & 38.6 & 40.6 & 42.9 & 44.2 & 45.6 & 47.1 & 48.3 & 52.8 \\
\hline & \multicolumn{13}{|c|}{ Average test score ${ }^{1}$} \\
\hline $\begin{array}{l}\text { Composite score, total ... } \\
\text { Sex }\end{array}$ & 20.8 & 21.0 & 20.8 & 20.9 & 20.9 & 21.1 & 21.2 & 21.1 & 21.1 & 21.0 & 21.1 & 21.1 & 20.9 \\
\hline Male & $\begin{array}{l}21.0 \\
20.7\end{array}$ & $\begin{array}{l}21.2 \\
20.9\end{array}$ & $\begin{array}{l}21.0 \\
20.8\end{array}$ & $\begin{array}{l}21.0 \\
20.9\end{array}$ & $\begin{array}{l}21.1 \\
20.9\end{array}$ & $\begin{array}{l}21.2 \\
21.0\end{array}$ & $\begin{array}{l}21.2 \\
21.0\end{array}$ & $\begin{array}{l}21.2 \\
21.0\end{array}$ & $\begin{array}{l}21.3 \\
20.9\end{array}$ & $\begin{array}{l}21.2 \\
20.9\end{array}$ & $\begin{array}{l}21.2 \\
21.0\end{array}$ & $\begin{array}{l}21.2 \\
21.0\end{array}$ & $\begin{array}{l}20.9 \\
20.9\end{array}$ \\
\hline \multicolumn{14}{|l|}{ Race/ethnicity } \\
\hline & - & $\begin{array}{l}22.7 \\
17.8\end{array}$ & $\begin{array}{l}21.7 \\
16.9\end{array}$ & $\begin{array}{l}21.8 \\
17.1\end{array}$ & $\begin{array}{l}21.9 \\
17.0\end{array}$ & $\begin{array}{l}22.0 \\
17.1\end{array}$ & $\begin{array}{l}22.1 \\
17.0\end{array}$ & $\begin{array}{l}22.1 \\
16.9\end{array}$ & $\begin{array}{l}22.2 \\
16.9\end{array}$ & $\begin{array}{l}22.3 \\
16.9\end{array}$ & $\begin{array}{l}22.4 \\
17.0\end{array}$ & $\begin{array}{l}22.4 \\
17.0\end{array}$ & $\begin{array}{l}22.2 \\
16.9\end{array}$ \\
\hline Hispanic ............................... & - & - & 18.5 & 18.5 & 18.6 & 18.6 & 18.7 & 18.7 & 18.7 & 18.6 & 18.7 & 18.9 & 18.8 \\
\hline $\begin{array}{c}\text { Asian/Pacific Islander......... } \\
\text { Asian }\end{array}$ & - & 22.4 & 21.8 & 21.9 & 22.1 & 22.3 & 22.6 & 22.9 & 23.2 & 23.4 & $2 \overline{6}$ & $2 \overline{6}$ & \\
\hline $\begin{array}{c}\text { Native Hawaiian/Pacific } \\
\text { Islander ............................... }\end{array}$ & - & - & - & - & - & - & - & - & - & - & $\begin{array}{l}20.0 \\
19.5\end{array}$ & $\begin{array}{l}20.0 \\
19.8\end{array}$ & $\begin{array}{ll}20.5 \\
19.5\end{array}$ \\
\hline $\begin{array}{c}\text { American Indian/Alaska } \\
\text { Native............................ } \\
\text { Two or more races .............. }\end{array}$ & $\overline{-}$ & $\stackrel{20.4}{-}$ & $\begin{array}{r}18.7 \\
-\end{array}$ & $\begin{array}{r}18.8 \\
-\end{array}$ & $\begin{array}{r}18.7 \\
-\end{array}$ & $\begin{array}{r}18.8 \\
-\end{array}$ & $\begin{array}{r}18.9 \\
-\end{array}$ & $\begin{array}{r}19.0 \\
-\end{array}$ & $\begin{array}{r}18.9 \\
-\end{array}$ & $\begin{array}{r}19.0 \\
-\end{array}$ & $\begin{array}{l}18.6 \\
21.1\end{array}$ & $\begin{array}{l}18.4 \\
21.4\end{array}$ & $\begin{array}{l}18.0 \\
21.1\end{array}$ \\
\hline $\begin{array}{l}\text { Subject-area scores } \\
\text { English ................................. } \\
\text { Male ........................... } \\
\text { Female ....................... }\end{array}$ & $\begin{array}{l}20.2 \\
19.8 \\
20.6\end{array}$ & $\begin{array}{l}20.5 \\
20.0 \\
20.9\end{array}$ & $\begin{array}{l}20.3 \\
19.8 \\
20.7\end{array}$ & $\begin{array}{l}20.4 \\
19.9 \\
20.8\end{array}$ & $\begin{array}{l}20.4 \\
20.0 \\
20.8\end{array}$ & $\begin{array}{l}20.6 \\
20.1 \\
21.0\end{array}$ & $\begin{array}{l}20.7 \\
20.2 \\
21.0\end{array}$ & $\begin{array}{l}20.6 \\
20.1 \\
21.0\end{array}$ & $\begin{array}{l}20.6 \\
20.2 \\
20.9\end{array}$ & $\begin{array}{l}20.5 \\
20.1 \\
20.8\end{array}$ & $\begin{array}{l}20.6 \\
20.2 \\
20.9\end{array}$ & $\begin{array}{l}20.5 \\
20.2 \\
20.9\end{array}$ & $\begin{array}{l}20.2 \\
19.8 \\
20.6\end{array}$ \\
\hline 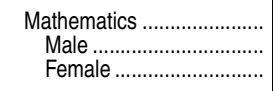 & $\begin{array}{l}20.2 \\
20.9 \\
19.7\end{array}$ & $\begin{array}{l}20.7 \\
21.4 \\
20.2\end{array}$ & $\begin{array}{l}20.6 \\
21.2 \\
20.1\end{array}$ & $\begin{array}{l}20.7 \\
21.3 \\
20.2\end{array}$ & $\begin{array}{l}20.7 \\
21.3 \\
20.2\end{array}$ & $\begin{array}{l}20.8 \\
21.5 \\
20.3\end{array}$ & $\begin{array}{l}21.0 \\
21.6 \\
20.4\end{array}$ & $\begin{array}{l}21.0 \\
21.6 \\
20.4\end{array}$ & $\begin{array}{l}21.0 \\
21.6 \\
20.4\end{array}$ & $\begin{array}{l}21.0 \\
21.6 \\
20.5\end{array}$ & $\begin{array}{l}21.1 \\
21.6 \\
20.6\end{array}$ & $\begin{array}{l}21.1 \\
21.7 \\
20.6\end{array}$ & $\begin{array}{l}20.9 \\
21.4 \\
20.5\end{array}$ \\
\hline 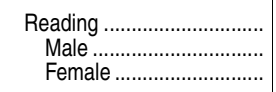 & $\begin{array}{l}21.3 \\
21.1 \\
21.4\end{array}$ & $\begin{array}{l}21.4 \\
21.2 \\
21.5\end{array}$ & $\begin{array}{l}21.2 \\
21.0 \\
21.4\end{array}$ & $\begin{array}{l}21.3 \\
21.1 \\
21.5\end{array}$ & $\begin{array}{l}21.3 \\
21.0 \\
21.5\end{array}$ & $\begin{array}{l}21.4 \\
21.1 \\
21.6\end{array}$ & $\begin{array}{l}21.5 \\
21.2 \\
21.6\end{array}$ & $\begin{array}{l}21.4 \\
21.2 \\
21.5\end{array}$ & $\begin{array}{l}21.4 \\
21.3 \\
21.4\end{array}$ & $\begin{array}{l}21.3 \\
21.1 \\
21.4\end{array}$ & $\begin{array}{l}21.3 \\
21.1 \\
21.4\end{array}$ & $\begin{array}{l}21.3 \\
21.2 \\
21.4\end{array}$ & $\begin{array}{l}21.1 \\
20.9 \\
21.4\end{array}$ \\
\hline 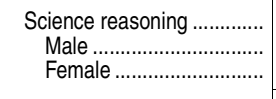 & $\begin{array}{l}21.0 \\
21.6 \\
20.5\end{array}$ & $\begin{array}{l}21.0 \\
21.6 \\
20.6\end{array}$ & $\begin{array}{l}20.8 \\
21.3 \\
20.4\end{array}$ & $\begin{array}{l}20.9 \\
21.3 \\
20.5\end{array}$ & $\begin{array}{l}20.9 \\
21.4 \\
20.5\end{array}$ & $\begin{array}{l}20.9 \\
21.4 \\
20.5\end{array}$ & $\begin{array}{l}21.0 \\
21.4 \\
20.5\end{array}$ & $\begin{array}{l}20.8 \\
21.3 \\
20.4\end{array}$ & $\begin{array}{l}20.9 \\
21.4 \\
20.4\end{array}$ & \begin{tabular}{l|}
20.9 \\
21.4 \\
20.5
\end{tabular} & $\begin{array}{l}20.9 \\
21.4 \\
20.5\end{array}$ & $\begin{array}{l}20.9 \\
21.4 \\
20.5\end{array}$ & $\begin{array}{l}20.7 \\
21.2 \\
20.4 \\
\end{array}$ \\
\hline 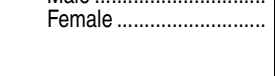 & \multicolumn{13}{|c|}{ Standard deviation ${ }^{2}$} \\
\hline Composite score, total ... & - & 4.7 & 4.8 & 4.8 & - & 4.8 & 5.0 & 5.0 & 5.1 & 5.2 & 5.2 & 5.3 & $\overline{5.4}$ \\
\hline 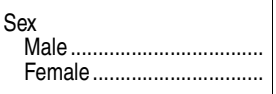 & $\overline{-}$ & $\begin{array}{l}4.9 \\
4.6\end{array}$ & $\begin{array}{l}5.0 \\
4.7\end{array}$ & $\begin{array}{l}5.0 \\
4.7\end{array}$ & $\begin{array}{l}5.0 \\
4.7\end{array}$ & - & - & - & - & - & - & - & - \\
\hline 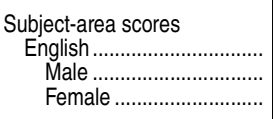 & $\begin{array}{l}- \\
- \\
-\end{array}$ & $\begin{array}{l}5.5 \\
5.6 \\
5.5\end{array}$ & $\begin{array}{l}5.8 \\
5.8 \\
5.8\end{array}$ & $\begin{array}{l}5.9 \\
5.9 \\
5.8\end{array}$ & $\begin{array}{l}-\overline{6.0} \\
5.9\end{array}$ & $\begin{array}{c}5.9 \\
- \\
-\end{array}$ & $\begin{array}{c}6.0 \\
- \\
-\end{array}$ & $\begin{array}{c}6.1 \\
- \\
-\end{array}$ & $\begin{array}{c}6.3 \\
- \\
-\end{array}$ & $\begin{array}{c}6.4 \\
- \\
-\end{array}$ & $\begin{array}{c}6.5 \\
- \\
-\end{array}$ & $\begin{array}{l}6.5 \\
- \\
-\end{array}$ & $\frac{6.5}{-}$ \\
\hline $\begin{array}{c}\text { Mathematics ...................... } \\
\text { Male ............................. } \\
\text { Female ........................ }\end{array}$ & $\begin{array}{l}- \\
-\end{array}$ & $\begin{array}{l}5.0 \\
5.2 \\
4.8\end{array}$ & $\begin{array}{l}5.1 \\
4.8 \\
5.3\end{array}$ & $\begin{array}{l}5.0 \\
5.3 \\
4.8\end{array}$ & $\begin{array}{l}-\overline{5} \\
4.8\end{array}$ & $\begin{array}{c}5.0 \\
- \\
-\end{array}$ & $\begin{array}{c}5.1 \\
- \\
-\end{array}$ & $\begin{array}{c}5.2 \\
- \\
-\end{array}$ & $\begin{array}{c}5.3 \\
- \\
-\end{array}$ & $\begin{array}{c}5.3 \\
- \\
-\end{array}$ & $\begin{array}{c}5.3 \\
- \\
-\end{array}$ & $\begin{array}{c}5.3 \\
- \\
-\end{array}$ & $\begin{array}{l}5.3 \\
- \\
-\end{array}$ \\
\hline 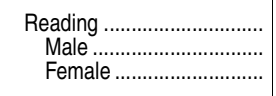 & $\begin{array}{l}- \\
-\end{array}$ & $\begin{array}{l}6.1 \\
6.1 \\
6.0\end{array}$ & $\begin{array}{l}6.1 \\
5.3 \\
4.8\end{array}$ & $\begin{array}{l}6.0 \\
6.1 \\
5.9\end{array}$ & $\begin{array}{l}- \\
6.1 \\
6.0\end{array}$ & $\begin{array}{c}6.0 \\
- \\
-\end{array}$ & $\begin{array}{c}6.1 \\
- \\
-\end{array}$ & $\begin{array}{l}6.1 \\
- \\
-\end{array}$ & $\begin{array}{c}6.2 \\
- \\
-\end{array}$ & $\begin{array}{c}6.2 \\
- \\
-\end{array}$ & $\begin{array}{c}6.2 \\
- \\
-\end{array}$ & $\begin{array}{c}6.2 \\
- \\
-\end{array}$ & $\frac{6.3}{-}$ \\
\hline 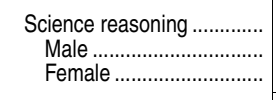 & $\begin{array}{l}- \\
- \\
\end{array}$ & $\begin{array}{l}4.5 \\
4.8 \\
4.3\end{array}$ & $\begin{array}{l}4.6 \\
4.9 \\
4.3\end{array}$ & $\begin{array}{l}4.6 \\
4.9 \\
4.3\end{array}$ & $\begin{array}{l}-\overline{9} \\
4.3\end{array}$ & $\begin{array}{c}4.6 \\
- \\
-\end{array}$ & $\begin{array}{l}4.9 \\
- \\
-\end{array}$ & $\begin{array}{l}4.9 \\
- \\
-\end{array}$ & $\begin{array}{r}5.0 \\
- \\
-\end{array}$ & $\begin{array}{c}5.1 \\
- \\
-\end{array}$ & $\begin{array}{l}5.1 \\
- \\
-\end{array}$ & $\begin{array}{c}5.2 \\
- \\
-\end{array}$ & $\begin{array}{r}5.3 \\
- \\
-\end{array}$ \\
\hline 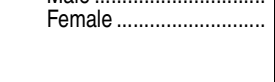 & \multicolumn{13}{|c|}{ Percent of ACT test takers } \\
\hline 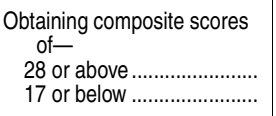 & $\overline{-}$ & $\begin{array}{l}10 \\
25\end{array}$ & $\begin{array}{l}10 \\
27\end{array}$ & $\begin{array}{l}10 \\
26\end{array}$ & $\begin{array}{l}10 \\
26\end{array}$ & $\begin{array}{l}11 \\
25\end{array}$ & $\begin{array}{l}11 \\
25\end{array}$ & $\begin{array}{l}12 \\
26\end{array}$ & $\begin{array}{l}12 \\
27\end{array}$ & $\begin{array}{l}12 \\
28\end{array}$ & $\begin{array}{l}13 \\
28\end{array}$ & $\begin{array}{l}13 \\
28\end{array}$ & $\begin{array}{l}13 \\
30\end{array}$ \\
\hline 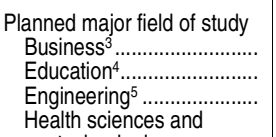 & $\begin{array}{r}13 \\
8 \\
8\end{array}$ & $\begin{array}{r}11 \\
9 \\
8\end{array}$ & $\begin{array}{r}10 \\
7 \\
7\end{array}$ & $\begin{array}{l}9 \\
7 \\
6\end{array}$ & $\begin{array}{l}9 \\
6 \\
6\end{array}$ & $\begin{array}{l}9 \\
6 \\
6\end{array}$ & $\begin{array}{l}8 \\
5 \\
5\end{array}$ & $\begin{array}{r}11 \\
6 \\
7\end{array}$ & $\begin{array}{r}12 \\
7 \\
8\end{array}$ & $\begin{array}{r}11 \\
7 \\
8\end{array}$ & $\begin{array}{r}10 \\
6 \\
8\end{array}$ & $\begin{array}{l}9 \\
6 \\
8\end{array}$ & $\begin{array}{l}9 \\
5 \\
9\end{array}$ \\
\hline 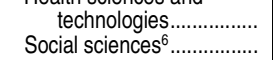 & $\overline{9}$ & $\begin{array}{r}17 \\
9\end{array}$ & $\begin{array}{r}16 \\
8\end{array}$ & $\begin{array}{r}17 \\
7\end{array}$ & $\begin{array}{r}16 \\
7\end{array}$ & $\begin{array}{r}15 \\
6\end{array}$ & $\begin{array}{r}14 \\
5\end{array}$ & $\begin{array}{r}17 \\
6\end{array}$ & $\begin{array}{r}19 \\
7\end{array}$ & $\begin{array}{r}20 \\
7\end{array}$ & $\begin{array}{r}19 \\
8\end{array}$ & $\begin{array}{r}19 \\
9\end{array}$ & $\begin{array}{r}19 \\
8\end{array}$ \\
\hline
\end{tabular}

-Not available.

${ }^{1}$ Minimum score is 1 and maximum score is 36

${ }^{2}$ Standard deviations not available for racial/ethnic groups.

${ }^{3}$ For years prior to 2011, includes business and management, business and office, and marketing and distribution.

${ }^{4}$ For years prior to 2011 , includes education and teacher education.

${ }^{5}$ Includes engineering and engineering-related technologies.

Includes social sciences and philosophy, religion, and theology. For 2011 and later years, also includes law.
NOTE: Data are for high school graduates who took the ACT during their sophomore, junior or senior year. If a student took a test more than once, the most recent score was used. Race categories exclude persons of Hispanic ethnicity. Some data have been revised from previously published figures.

SOURCE: ACT, High School Profile Report, selected years, 1995 through 2013. U.S. Department of Education, National Center for Education Statistics, Common Core of Data (CCD), "State Nonfiscal Survey of Public Elementary/Secondary Education" 1995-96 through 2005-06; "State Dropout and Completion Data File," 2005-06 through 2010-11; Private School Universe Survey (PSS), 1995 through 2011; and Projections of Education Statistics to 2023. (This table was prepared November 2013.) 
Table 227.10. Percentage of 9th-grade students participating in various school-sponsored and non-school-sponsored activities, by sex and race/ethnicity: 2009

[Standard errors appear in parentheses]

\begin{tabular}{|c|c|c|c|c|c|c|c|c|c|c|c|c|c|c|c|c|c|c|c|c|c|c|}
\hline \multirow[b]{2}{*}{ Sex and race/ethnicity } & \multicolumn{6}{|c|}{ School-sponsored activities } & \multicolumn{16}{|c|}{ Non-school-sponsored activities } \\
\hline & \multicolumn{2}{|c|}{ Math-related ${ }^{1}$} & \multicolumn{2}{|c|}{ Science-related ${ }^{1}$} & \multicolumn{2}{|c|}{$\begin{array}{r}\text { At least one of } \\
\text { the math- or } \\
\text { science-related } \\
\text { activities }\end{array}$} & \multicolumn{2}{|c|}{$\begin{array}{l}\text { Music, dance, } \\
\text { art, or theater }\end{array}$} & \multicolumn{2}{|c|}{$\begin{array}{r}\text { Organized } \\
\text { sports }\end{array}$} & \multicolumn{2}{|c|}{$\begin{array}{l}\text { Religious } \\
\text { youth group } \\
\text { or instruction }\end{array}$} & \multicolumn{2}{|c|}{$\begin{array}{l}\text { Scouting or } \\
\text { other group or } \\
\text { club activity }\end{array}$} & \multicolumn{2}{|c|}{$\begin{array}{l}\text { Academic } \\
\text { instruction }{ }^{2}\end{array}$} & \multicolumn{2}{|c|}{$\begin{array}{r}\text { Math or } \\
\text { science camp }\end{array}$} & \multicolumn{2}{|c|}{ Another camp } & \multicolumn{2}{|c|}{$\begin{array}{r}\text { At least one } \\
\text { of the non- } \\
\text { school- } \\
\text { sponsored } \\
\text { activities }\end{array}$} \\
\hline 1 & & 2 & & 3 & & 4 & & 5 & & 6 & & 7 & & 8 & & 9 & & 10 & & 11 & & 12 \\
\hline Total $\ldots \ldots \ldots \ldots \ldots \ldots \ldots \ldots \ldots \ldots \ldots$ & 9.8 & $(0.39)$ & 6.4 & $(0.36)$ & 13.4 & $(0.50)$ & 34.6 & $(0.91)$ & 54.9 & $(0.81)$ & 51.4 & $(0.93)$ & 22.8 & $(0.64)$ & 17.7 & $(0.62)$ & 4.1 & $(0.31)$ & 23.8 & $(0.76)$ & 85.7 & $(0.60)$ \\
\hline 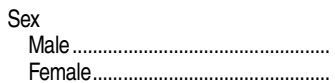 & $\begin{array}{r}8.9 \\
10.7\end{array}$ & $\begin{array}{l}(0.44) \\
(0.55)\end{array}$ & $\begin{array}{l}6.3 \\
6.5\end{array}$ & $\begin{array}{l}(0.59) \\
(0.45)\end{array}$ & $\begin{array}{l}12.6 \\
14.2\end{array}$ & $\begin{array}{l}(0.69) \\
(0.67)\end{array}$ & $\begin{array}{l}27.9 \\
41.3\end{array}$ & $\begin{array}{l}(0.93) \\
(1.20)\end{array} \mid$ & $\begin{array}{l}59.8 \\
50.0\end{array}$ & $\begin{array}{l}(0.93) \\
(1.10)\end{array}$ & $\begin{array}{l}49.5 \\
53.4\end{array}$ & $\begin{array}{l}(1.10) \\
(1.12)\end{array}$ & $\begin{array}{l}21.6 \\
24.1\end{array}$ & $\begin{array}{l}(0.87) \\
(0.88)\end{array}$ & $\begin{array}{l}17.5 \\
17.9\end{array}$ & $\begin{array}{l}(0.80) \\
(0.80)\end{array}$ & $\begin{array}{l}4.1 \\
4.0\end{array}$ & $\begin{array}{l}(0.51) \\
(0.40)\end{array}$ & $\begin{array}{l}23.2 \\
24.4\end{array}$ & $\begin{array}{l}(0.92) \\
(0.91)\end{array}$ & $\begin{array}{l}86.1 \\
85.4\end{array}$ & $\begin{array}{l}(0.79) \\
(0.75)\end{array}$ \\
\hline Race/ethnicity & & & & & & & & & & & & & & & & & & & & & & \\
\hline White............. & 8.3 & $(0.35)$ & 6.4 & $(0.43)$ & 12.2 & $(0.46)$ & 36.8 & $(0.78)$ & 60.5 & $(0.87)$ & 56.7 & $(1.04)$ & 24.0 & $(0.83)$ & 13.2 & $(0.65)$ & 2.7 & $(0.26)$ & 30.6 & $(0.92)$ & 89.7 & $(0.47)$ \\
\hline Black. & 12.5 & $(1.54)$ & 5.4 & $(0.77)$ & 15.3 & $(1.71)$ & 33.8 & $(2.90)$ & 49.1 & $(2.39)$ & 52.3 & (2.31) & 26.3 & (2.02) & 32.8 & (2.55) & 7.4 & $(1.24)$ & 14.8 & $(1.79)$ & 84.9 & (1.72) \\
\hline Hispanic.. & 10.5 & (0.92) & 5.5 & $(0.72)$ & 13.4 & $(1.07)$ & 27.5 & $(1.47)$ & 46.9 & $(2.46)$ & 39.1 & (2.36) & 16.6 & $(1.27)$ & 18.6 & (1.20) & 3.6 & $(0.77)$ & 14.5 & $(1.66)$ & 76.9 & $(2.28)$ \\
\hline Asian....... & 17.3 & $(2.25)$ & 13.0 & $(1.93)$ & 22.3 & $(2.48)$ & 44.4 & (3.43) & 38.5 & $(2.87)$ & 38.8 & (3.31) & 25.8 & $(2.28)$ & 31.1 & (3.49) & 15.0 & $(2.06)$ & 16.2 & $(2.14)$ & 82.1 & $(2.76)$ \\
\hline Native Hawaiian/Pacific Islander....... & $\ddagger$ & $(t)$ & $\ddagger$ & $(t)$ & $\ddagger$ & $(t)$ & $\ddagger$ & $(t)$ & $\ddagger$ & $(t)$ & $\ddagger$ & $(t)$ & $\ddagger$ & $(t)$ & $\ddagger$ & $(t)$ & $\ddagger$ & $(t)$ & $\ddagger$ & $(t)$ & $\ddagger$ & $(t)$ \\
\hline American Indian/Alaska Native ......... & $9.1 !$ & $(2.95)$ & $\ddagger$ & $(t)$ & $12.8 !$ & $(3.87)$ & $20.0 !$ & $(6.56)$ & $48.8^{+}$ & $(6.60)$ & 42.3 & $(6.00)$ & 31.6 & $(6.00)$ & 16.8 & $(4.36)$ & $\ddagger$ & $(t)$ & $19.1 !$ & $(8.31)$ & 78.9 & $(5.22)$ \\
\hline 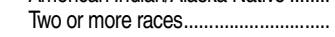 & 10.5 & $(1.19)$ & $7.6^{+}$ & (1.02) & 14.2 & $(1.41)$ & 36.4 & $(2.49)$ & 55.8 & $(2.46)$ & 53.6 & (2.47) & 24.9 & $(2.13)$ & 15.4 & (1.57) & 3.4 & $(0.81)$ & 21.2 & $(1.60)$ & 86.8 & $(1.53)$ \\
\hline $\begin{array}{l}\text { Race/ethnicity by sex } \\
\text { Male }\end{array}$ & & & & & & & & & & & & & & & & & & & & & & \\
\hline White........................ & 7.6 & $(0.45)$ & 6.1 & $(0.61)$ & 11.5 & $(0.73)$ & 29.1 & $(0.95)$ & 63.3 & $(1.06)$ & 54.5 & (1.19) & 23.2 & $(1.1$ & 14.2 & $(0.93)$ & 2.8 & $(0.36)$ & 29.6 & (1.22) & 89.0 & $(0.61)$ \\
\hline Black...... & 12.2 & $(1.74)$ & 5.8 & $(1.10)$ & 15.4 & $(1.92)$ & 27.4 & $(2.88)$ & 58.2 & (3.15) & 49.0 & (3.03) & 21.0 & $(2.85)$ & 31.1 & $(3.11)$ & 7.5 & $(2.01)$ & 14.6 & $(2.46)$ & 87.3 & $(1.95)$ \\
\hline Hispanic.. & 9.2 & (1.22) & 5.5 & (1.15) & 12 & $(1.50)$ & 22.4 & $(2.04)$ & 54.4 & $(2.86)$ & 37.1 & (2.92) & 15.3 & $(1.69)$ & 16.9 & (1.83) & 2.9 ! & $(0.88)$ & 13.1 & (2.11) & 78.4 & $(2.70)$ \\
\hline sir & 18.4 & (2.96) & 11.5 & (2.38) & 22.8 & $(3.23)$ & 36.9 & $(4.02)$ & 42.9 & $(3.89)$ & 32.8 & (5.50) & 26.1 & $(3.78)$ & 31.0 & $(4.54)$ & 18.4 & (3.34) & 20.3 & (3.47) & 78.9 & (3.87) $19-1$ \\
\hline Native Hawaiian/Pacific Islander .. & $\ddagger$ & $(t)$ & $\ddagger$ & $(t)$ & $\ddagger$ & $(t)$ & $\ddagger$ & $(t)$ & $\ddagger$ & $(\dagger)$ & $\ddagger$ & $(\dagger)$ & $\ddagger$ & $(\dagger)$ & $\ddagger$ & $(t)$ & $\ddagger$ & $(t)$ & $\ddagger$ & $(\dagger)$ & $\ddagger$ & $(t)$ \\
\hline American Indian/Alaska Native .... & $10.9 !$ & $(4.96)$ & 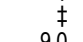 & $(+)$ & $\ddagger$ & $(\dagger)$ & $18.8 !$ & $(9.40)$ & 49.9 & $(9.31)$ & 38.2 & $(9.74)$ & 31.3 & $(8.35)$ & $\ddagger$ & $(t)$ & $\ddagger$ & $(t)$ & $\ddagger$ & $(t)$ & 78.4 & $(6.67)$ \\
\hline $\begin{array}{l}\text { Two or more races............................ } \\
\text { Female }\end{array}$ & 8.3 & (1.37) & 9.0 & (1.85) & 13.4 & $(2.04)$ & 29.9 & (2.96) & 59.2 & (3.78) & 56.9 & (3.48) & 26.2 & $(2.99)$ & 16.0 & (2.30) & $3.4 !$ & (1.22) & 20.4 & $(2.28)$ & 88.6 & (1.82) \\
\hline White. & 9.0 & $(0.56)$ & 6.7 & $(0.61)$ & 13.0 & $(0.71)$ & 44.9 & $(1.16)$ & 57.5 & $(1.13)$ & 59.0 & $(1.17)$ & 24.8 & $(1.04)$ & 12.1 & & 2.7 & $(0,34)$ & 317 & & 90.4 & \\
\hline Black.. & 12.8 & $(2.14)$ & 5.0 & $(1.09)$ & 15.2 & $(2.38)$ & 39.0 & $(4.64)$ & 41.8 & $(3.87)$ & 55.0 & (3.33) & 30.5 & $(2.59)$ & 34.2 & $(3.75)$ & 7.3 & $\begin{array}{l}(0.54) \\
(1.53)\end{array}$ & $\begin{array}{l}3.1 \\
14.9\end{array}$ & $\begin{array}{l}(2.58) \\
(2.5)\end{array}$ & $\begin{array}{l}90.4 \\
83.0\end{array}$ & $(2.66)$ \\
\hline Hispan & 11.9 & $(1.16)$ & 5.5 & $(0.76)$ & 14.6 & $(1.28)$ & 32. & $(2.06)$ & 39.0 & (3.27) & 41.1 & (2.95) & 17.9 & $(1.83)$ & 20.3 & $(1.85)$ & 4.4 & $(1.12)$ & 16.0 & $(2.15)$ & 75.4 & $(2.71)$ \\
\hline Asian. & 16.1 & (2.49) & 14.6 & (2.92) & 21.8 & $(3.16)$ & 51.8 & $(4.88)$ & 34.2 & (3.19) & 44.8 & (3.24) & 25.6 & (3.53) & 31.2 & (3.72) & 11.7 & $(3.07)$ & 12.2 & $(2.55)$ & 85.3 & $(3.16)$ \\
\hline Native Hawaiian/Pacific Islander .. & $\ddagger$ & $(t)$ & $\ddagger$ & $(t)$ & $\ddagger$ & $(t)$ & $\ddagger$ & $(t)$ & $\ddagger$ & $(\dagger)$ & $\ddagger$ & $(t)$ & $\neq$ & $(\dagger)$ & $\ddagger$ & $(t)$ & $\ddagger$ & $(t)$ & $\ddagger$ & $(t)$ & $\ddagger$ & $(t)$ \\
\hline American Indian/Alaska Native & $\ddagger$ & $(t)$ & $\ddagger$ & $(\dagger)$ & $\ddagger$ & $(\dagger)$ & $21.4 !$ & $(8.36)$ & $47.4^{+}$ & (9.63) & $47.0^{+}$ & (11.74) & $32.0^{+}$ & (8.98) & $\ddagger$ & $(\dagger)$ & $T$ & (II) & & & $79.5^{\top}$ & 44) \\
\hline Two or more races...... & 12.7 & $(1.71)$ & 6.3 & $(1.00)$ & 15.0 & $(1.73)$ & 42.4 & (3.39) & 52.5 & (4.18) & 50.4 & (3.62) & 23.7 & $(2.95)$ & 14.8 & $(2.05)$ & $3.4 !$ & (1.19) & 22.0 & (2.24) & 85.1 & $(2.47)$ \\
\hline
\end{tabular}

†Not applicable.

The

NOTE: Data on school-sponsored activities are based on student responses and are weighted by W1STUDENT. Studen percent or greater.
IStudents could indicate that they participated in clubs, competitions, camps, study groups, or tutoring programs.

${ }^{2}$ Academic instruction outside of school such as from a Saturday academy, learning center, personal tutor, or summer school these students was 8 th grade, or the fall of 2008. Data on non-school-sponsored activities are based on parent responses and are weighted by W1 PARENT. Parent reports about non-school-sponsored activities refer to the last 12 months. Race categories exclude persons of Hispanic ethnicity.

SOURCE: U.S. Department of Education, National Center for Education Statistics, High School Longitudinal Study of 2009, program. 
Table 227.20. Percentage of high school seniors who say they engage in various activities, by selected student and school characteristics: 1992 and 2004

[Standard errors appear in parentheses]

\begin{tabular}{|c|c|c|c|c|c|c|c|c|c|c|c|c|c|c|}
\hline \multirow[b]{2}{*}{ Activity } & \multirow[b]{2}{*}{ Total } & \multicolumn{2}{|c|}{ Sex } & \multicolumn{5}{|c|}{ Race/ethnicity } & \multicolumn{3}{|c|}{ Socioeconomic status ${ }^{1}$} & \multicolumn{3}{|c|}{ Control of school attended } \\
\hline & & Male & Female & White & Black & Hispanic & $\begin{array}{r}\text { Asian/ } \\
\text { Pacific } \\
\text { Islander }\end{array}$ & $\begin{array}{r}\text { American } \\
\text { Indian/Alaska } \\
\text { Native }\end{array}$ & Low & Middle & High & Public & Catholic & $\begin{array}{l}\text { Other } \\
\text { private }\end{array}$ \\
\hline 1 & 2 & 3 & 4 & 5 & 6 & 7 & 8 & 9 & 10 & 11 & 12 & 13 & 14 & 15 \\
\hline
\end{tabular}

1992

At least once a week

Use personal computer

Work on hobbies.

Perform community service...

Visiting with friends at a local hangout.

Talk on phone with friends.

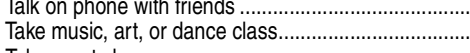

Take sports lessons....

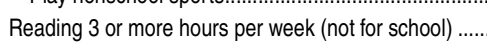

Plays video/computer games 3 or more hours per day

on weekdays........

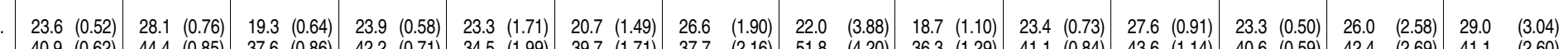
$\begin{array}{llllllllllllllllllllllllllll}40.9 & (0.62) & 44.4 & (0.85) & 37.6(0.86) & 42.2 & (0.71) & 34.5 & (1.99) & 39.7 & (1.71) & 37.7 & (2.16) & 51.8 & (4.20) & 36.3 & (1.29) & 41.1 & (0.84) & 43.6 & (1.14) & 40.6 & (0.59) & 42.4 & (2.69) & 41.1 & (2.60)\end{array}$

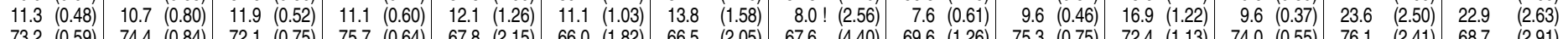

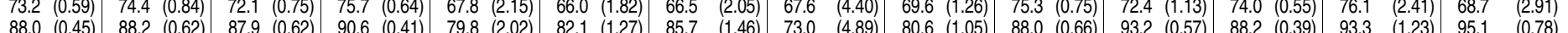

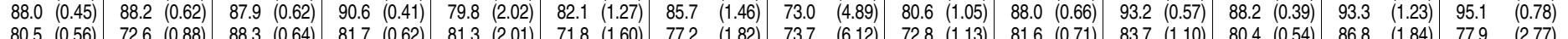

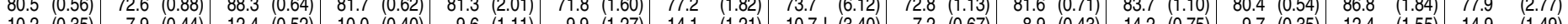

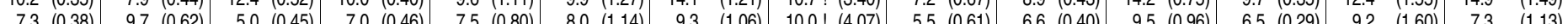

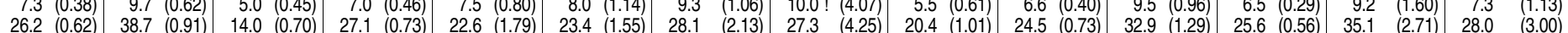

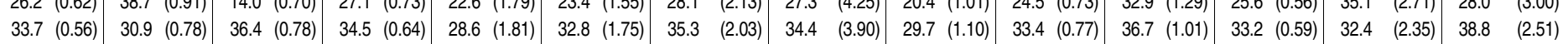

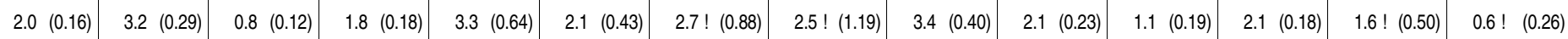
2004

At least once a week

Use personal computer at home

Work on hobbies

Perform community service..........

Driving or riding around

Visiting with friends at a local hangout.

Talk on phone with friends.

Take music, art, or language class.

Play nonschool sports.

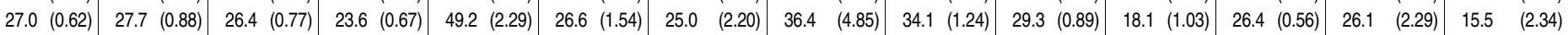

Play

Plays video/computer games 3 or more hours per day

on weekdays..

Watches television/DVDs 3 or more hours per day on

Hours of homework per week

Less than 1 hour..

1 to 3 hours

4 to 6 hours........

7 to 12 hours....................
More than 12 hours.

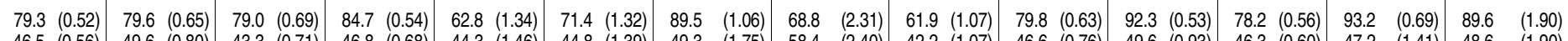

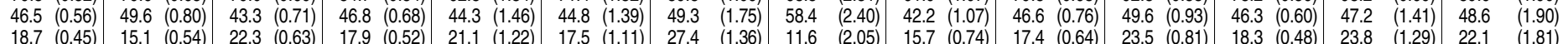

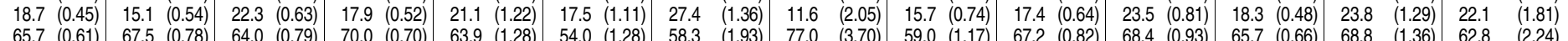

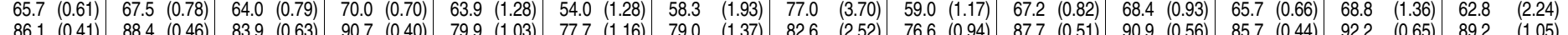

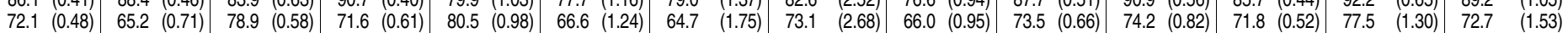

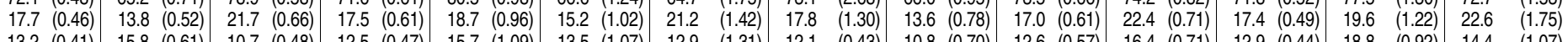

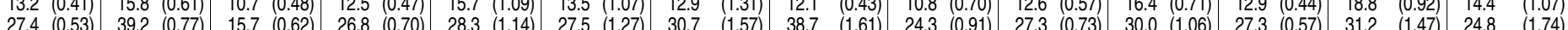

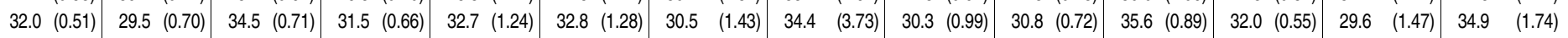

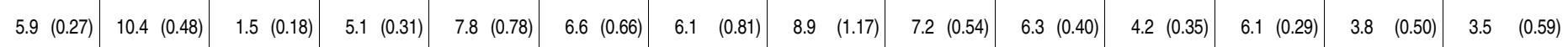

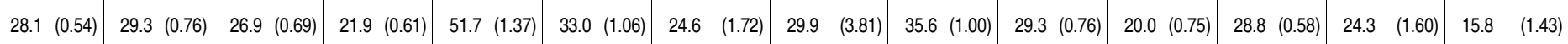

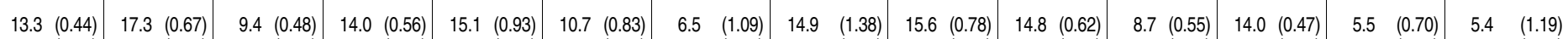

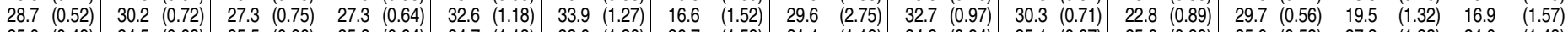

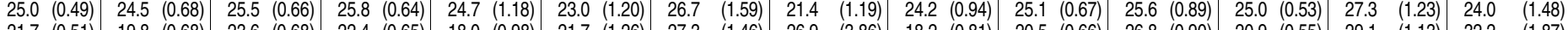

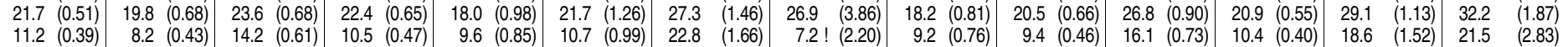

!Interpret data with caution. The coefficient of variation (CV) for this estimate is between 30 and 50 percent. "Socioeconomic status (SES) was measured by a composite score on parental education and occupations, and family income. The "low" SES group is the lowest quartile; the "middle" SES group is the middle two quartiles; and the "high" SES group is the

${ }^{2}$ Question does not specify where computer is used. 
Table 227.30. Percentage of high school seniors who participate in various school-sponsored extracurricular activities, by selected student characteristics: 1992 and 2004

[Standard errors appear in parentheses]

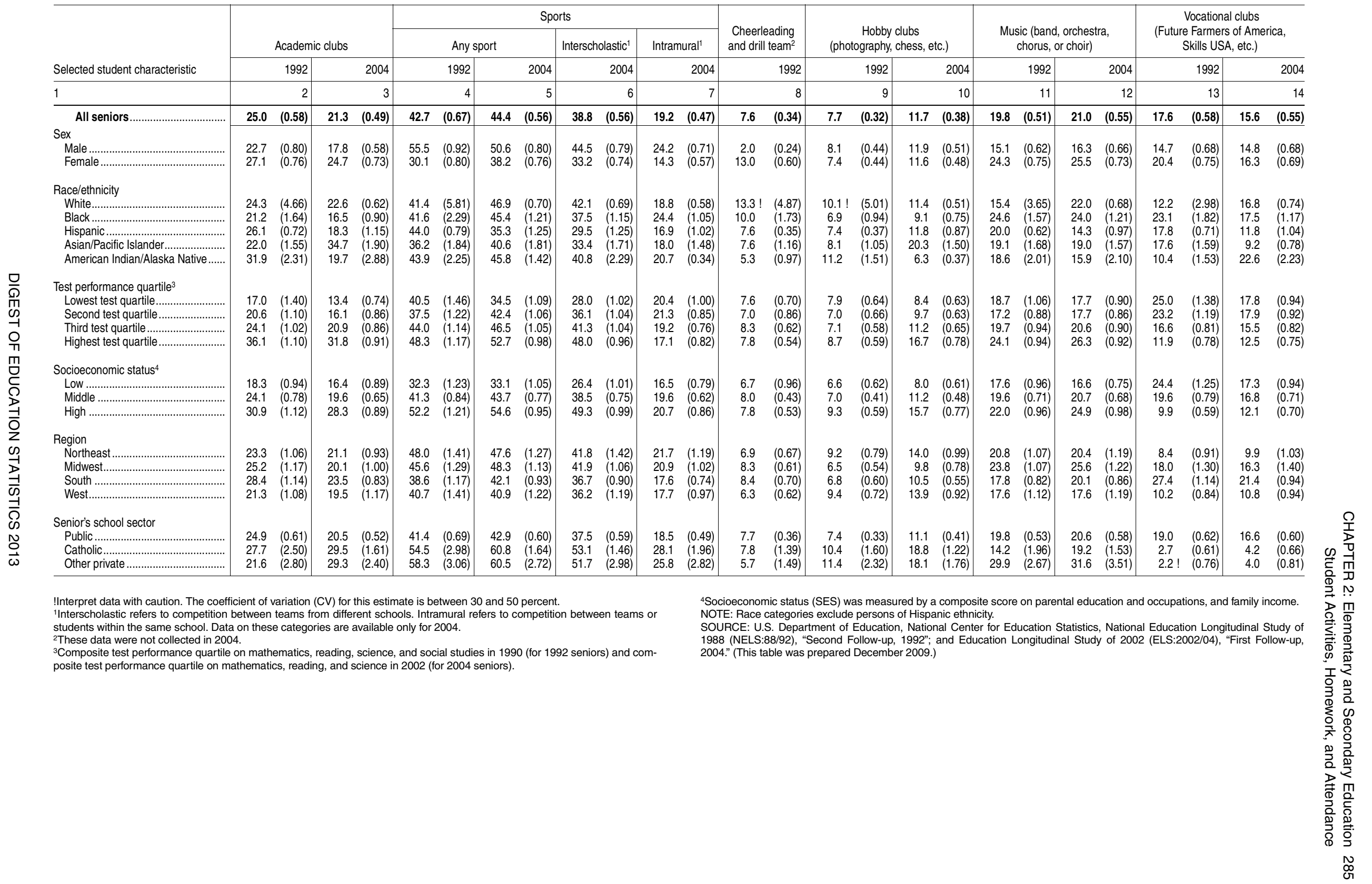




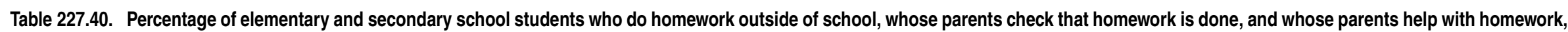
by frequency and selected student and school characteristics: 2003 and 2007

[Standard errors appear in parentheses]

\begin{tabular}{|c|c|c|c|c|c|c|c|c|c|c|c|c|c|c|c|c|c|c|c|c|c|c|c|c|}
\hline \multirow{3}{*}{$\begin{array}{l}\text { Year and selected student } \\
\text { or school characteristic }\end{array}$} & \multirow{2}{*}{\multicolumn{2}{|c|}{$\begin{array}{r}\text { Percent of } \\
\text { students who } \\
\text { do homework } \\
\text { outside of school }\end{array}$}} & \multirow{2}{*}{\multicolumn{2}{|c|}{$\begin{array}{r}\text { Average hours } \\
\text { per week spent } \\
\text { by students who } \\
\text { do homework } \\
\text { outside of school }\end{array}$}} & \multicolumn{8}{|c|}{$\begin{array}{l}\text { Distribution of students who do homework outside } \\
\text { of school by how frequently they do homework }\end{array}$} & \multirow{2}{*}{\multicolumn{2}{|c|}{$\begin{array}{r}\text { Percent of } \\
\text { students whose } \\
\text { parents } \\
\text { check that } \\
\text { homework } \\
\text { is done }\end{array}$}} & \multicolumn{10}{|c|}{ Distribution of students by how frequently their parents ${ }^{1}$ help with homework } \\
\hline & & & & & \multicolumn{2}{|c|}{$\begin{array}{r}\text { Less than } \\
\text { once a week }\end{array}$} & \multicolumn{2}{|c|}{$\begin{array}{r}1 \text { to } 2 \text { days } \\
\text { per week }\end{array}$} & \multicolumn{2}{|c|}{$\begin{array}{r}3 \text { to } 4 \text { days } \\
\text { per week }\end{array}$} & \multicolumn{2}{|c|}{$\begin{array}{r}5 \text { or more } \\
\text { days a week }\end{array}$} & & & \multicolumn{2}{|c|}{ No help given } & \multicolumn{2}{|c|}{$\begin{array}{r}\text { Less than } \\
\text { once a week }\end{array}$} & \multicolumn{2}{|c|}{$\begin{array}{r}1 \text { to } 2 \text { days } \\
\text { per week }\end{array}$} & \multicolumn{2}{|c|}{$\begin{array}{r}3 \text { to } 4 \text { days } \\
\text { per week }\end{array}$} & \multicolumn{2}{|c|}{$\begin{array}{r}5 \text { or more } \\
\text { days per week }\end{array}$} \\
\hline & & 2 & & 3 & & 4 & & 5 & & 6 & & 7 & & 8 & & 9 & & 10 & & 11 & & 12 & & 13 \\
\hline 2003 All students... & 95.6 & $(0.23)$ & 9.1 & (0.19) & 2.9 & (0.16) & 15.1 & $(0.45)$ & 43.9 & (0.61) & 38.2 & $(0.57)$ & 85.2 & (0.33) & - & $(t)$ & - & $(\mathrm{t})$ & - & $(t)$ & - & ( & - & (†) \\
\hline $\begin{array}{l}\text { All elementary school students } \\
\text { (kindergarten through grade 8).. }\end{array}$ & 96.2 & $(0.26)$ & 9.2 & (0.24) & 2.3 & (0.18) & 12.9 & (0.43) & 46.5 & (0.75) & 38.3 & (0.73) & 94.6 & (0.29) & - & $(t)$ & - & $(\mathrm{t})$ & - & $(\dagger)$ & - & $(t)$ & - & $(\dagger)$ \\
\hline 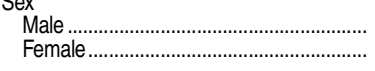 & $\begin{array}{l}95.8 \\
96.7\end{array}$ & $\left(\begin{array}{l}0.41) \\
0.32\end{array}\right)$ & $\begin{array}{l}9.6 \\
8.7\end{array}$ & $\begin{array}{l}(0.36) \\
(0.32)\end{array}$ & $\begin{array}{l}2.7 \\
2.0\end{array}$ & $\begin{array}{l}(0.26) \\
(0.23)\end{array}$ & $\begin{array}{l}13.5 \\
12.3\end{array}$ & $\begin{array}{l}(0.58) \\
0.61)\end{array}$ & $\begin{array}{l}47.4 \\
45.5\end{array}$ & $\left(\begin{array}{l}0.95) \\
1.08)\end{array}\right.$ & $\begin{array}{l}36.4 \\
40.3\end{array}$ & $\left(\begin{array}{l}0.93) \\
(1.09)\end{array}\right)$ & $\begin{array}{l}95.6 \\
93.4\end{array}$ & $\begin{array}{l}(0.38) \\
(0.52)\end{array}$ & - & $\left(\begin{array}{l}+ \\
(\dagger\end{array}\right)$ & $\overline{-}$ & $\left(\begin{array}{l}-1 \\
(+)\end{array}\right)$ & $\overline{-}$ & $\left(\begin{array}{l}+ \\
\dagger\end{array}\right)$ & $\overline{-}$ & $\left(\begin{array}{l}+ \\
(\dagger\end{array}\right)$ & $\overline{-}$ & $\left(\begin{array}{l}-1 \\
(t)\end{array}\right.$ \\
\hline 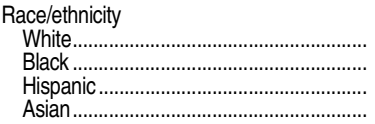 & $\begin{array}{l}95.9 \\
97.8 \\
96.3 \\
95.1\end{array}$ & $\begin{array}{l}(0.37) \\
0.51) \\
(0.50) \\
(1.62)\end{array}$ & $\begin{array}{r}9.4 \\
8.0 \\
8.8 \\
11.1\end{array}$ & $\begin{array}{l}(0.30) \\
0.44) \\
(0.57) \\
(1.44)\end{array}$ & $\begin{array}{r}2.8 \\
1.4 \\
1.5 \\
\ddagger\end{array}$ & $\left.\begin{array}{r}(0.27) \\
0.35) \\
(0.34) \\
(t)\end{array}\right]$ & $\begin{array}{r}14.9 \\
8.1 \\
11.8 \\
6.9\end{array}$ & $\left.\begin{array}{l}(0.64) \\
1.02 \\
(0.87) \\
(1.74)\end{array}\right)$ & $\begin{array}{l}47.5 \\
47.6 \\
41.8 \\
41.1\end{array}$ & $\left.\begin{array}{l}(0.97) \\
1.66) \\
(1.37) \\
(4.96)\end{array}\right)$ & $\begin{array}{l}34.7 \\
42.9 \\
44.9 \\
51.2\end{array}$ & $\left.\begin{array}{l}(1.05) \\
1.61 \\
1.51 \\
5.30\end{array}\right)$ & $\begin{array}{l}93.1 \\
98.0 \\
96.4 \\
96.6\end{array}$ & $\left.\begin{array}{l}(0.44) \\
0.79 \\
0.45 \\
(1.18)\end{array}\right)$ & $\begin{array}{l}z \\
z \\
z\end{array}$ & 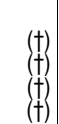 & $\begin{array}{l}\bar{z} \\
\bar{z}\end{array}$ & $\left.\begin{array}{c}(+) \\
+ \\
+ \\
+ \\
+\end{array}\right)$ & $\begin{array}{l}\bar{z} \\
\bar{z}\end{array}$ & 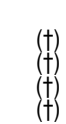 & $\begin{array}{l}\bar{z} \\
\bar{z}\end{array}$ & 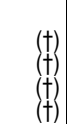 & $\begin{array}{l}\bar{z} \\
\bar{z}\end{array}$ & $\begin{array}{l}(+) \\
+ \\
(+) \\
(+)\end{array}$ \\
\hline 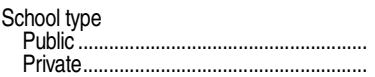 & $\begin{array}{l}96.4 \\
94.6\end{array}$ & $\begin{array}{l}(0.25) \\
(0.87)\end{array}$ & $\begin{array}{l}9.1 \\
9.6\end{array}$ & $\left.\begin{array}{l}(0.24) \\
(0.58)\end{array}\right]$ & $\begin{array}{l}2.5 \\
1.3\end{array}$ & $\left.\begin{array}{l}(0.20) \\
(0.31)\end{array}\right]$ & $\begin{array}{r}13.5 \\
8.0\end{array}$ & $\begin{array}{l}(0.47) \\
(0.92)\end{array}$ & $\begin{array}{l}47.1 \\
41.8\end{array}$ & $\begin{array}{l}(0.75) \\
(1.90)\end{array}$ & $\begin{array}{l}36.9 \\
49.0\end{array}$ & $\left.\begin{array}{l}(0.73) \\
(1.81)\end{array}\right)$ & $\begin{array}{l}95.0 \\
91.4\end{array}$ & $\begin{array}{l}(0.28) \\
(1.16)\end{array}$ & - & 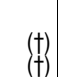 & $z$ & $\left(\begin{array}{l}(t) \\
(+)\end{array}\right.$ & - & $\begin{array}{c}(\dagger) \\
(\dagger)\end{array}$ & $\overline{-}$ & $\begin{array}{c}(\dagger) \\
(\dagger)\end{array}$ & - & $\begin{array}{c}(\dagger) \\
(\dagger)\end{array}$ \\
\hline 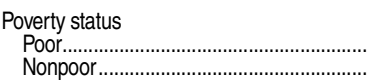 & $\begin{array}{l}95.7 \\
96.3\end{array}$ & $\begin{array}{l}(0.71) \\
(0.28)\end{array}$ & $\begin{array}{l}9.6 \\
9.1\end{array}$ & $\begin{array}{l}(0.63) \\
(0.25)\end{array}$ & $\begin{array}{l}1.3 \\
2.6\end{array}$ & $\begin{array}{l}(0.34) \\
(0.21)\end{array}$ & $\begin{array}{l}14.3 \\
12.6\end{array}$ & $\begin{array}{l}(1.33) \\
(0.45)\end{array}$ & $\begin{array}{l}42.4 \\
47.4\end{array}$ & $\begin{array}{l}(1.87) \\
(0.77)\end{array}$ & $\begin{array}{l}42.0 \\
37.5\end{array}$ & $\begin{array}{l}(1.75) \\
(0.78)\end{array}$ & $\begin{array}{l}96.9 \\
94.0\end{array}$ & $\begin{array}{l}(0.77) \\
(0.31)\end{array}$ & $\overline{-}$ & $\begin{array}{l}(t) \\
(\dagger)\end{array}$ & - & $\left(\begin{array}{l}(+) \\
(\dagger)\end{array}\right.$ & $\overline{-}$ & $\left(\begin{array}{l}(t) \\
(\dagger)\end{array}\right.$ & $\overline{-}$ & $\begin{array}{l}(\dagger) \\
(\dagger)\end{array}$ & - & $\begin{array}{l}(\dagger) \\
(\dagger)\end{array}$ \\
\hline $\begin{array}{l}\text { All secondary school students } \\
\text { (grades } 9 \text { through 12).......... }\end{array}$ & 94.2 & $(0.52)$ & 8.8 & $(0.25)$ & 4.1 & $(0.40)$ & 20.3 & $(0.94)$ & 37.6 & $(1.01)$ & 38.0 & $(1.04)$ & 62.8 & $(0.86)$ & - & $(t)$ & - & $(t)$ & - & $(t)$ & - & (t) & - & (t) \\
\hline 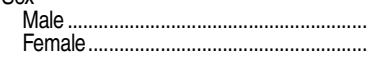 & $\begin{array}{l}91.3 \\
97.2\end{array}$ & $\begin{array}{l}(0.81) \\
(0.56)\end{array}$ & $\begin{array}{l}9.0 \\
8.5\end{array}$ & $\begin{array}{l}(0.42) \\
(0.27)\end{array}$ & $\begin{array}{l}6.2 \\
2.1\end{array}$ & $\begin{array}{l}(0.72) \\
(0.35)\end{array}$ & $\begin{array}{l}23.6 \\
17.0\end{array}$ & $\begin{array}{l}(1.30) \\
(1.23)\end{array}$ & $\begin{array}{l}38.1 \\
37.1\end{array}$ & $\begin{array}{l}(1.45) \\
(1.35)\end{array}$ & $\begin{array}{l}32.1 \\
43.8\end{array}$ & $\begin{array}{l}(1.15) \\
(1.53)\end{array}$ & $\begin{array}{l}66.6 \\
59.0\end{array}$ & $\begin{array}{l}(1.14) \\
(1.47)\end{array}$ & - & $\begin{array}{l}(t) \\
(t)\end{array}$ & - & $\begin{array}{l}(\dagger) \\
(\dagger)\end{array}$ & - & $\left(\begin{array}{l}(\dagger) \\
(\dagger)\end{array}\right.$ & - & $\begin{array}{l}(\dagger) \\
(\dagger)\end{array}$ & 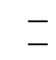 & $\begin{array}{l}(\dagger) \\
(\dagger)\end{array}$ \\
\hline $\begin{array}{l}\text { Race/ethnicity } \\
\text { White.............. } \\
\text { Black ............. } \\
\text { Hispanic......... } \\
\text { Asian.............. }\end{array}$ & $\begin{array}{r}94.2 \\
95.3 \\
92.2 \\
100.0\end{array}$ & $\begin{array}{r}(0.64) \\
(1.05) \\
1.20 \\
(\dagger)\end{array}$ & $\begin{array}{r}8.8 \\
9.3 \\
8.1 \\
10.4\end{array}$ & $\begin{array}{l}(0.33) \\
(0.78) \\
0.45) \\
(1.48)\end{array}$ & $\begin{array}{r}4.4 \\
3.4 \\
4.2 \\
\ddagger\end{array}$ & $\left.\begin{array}{r}(0.49) \\
(0.82) \\
(1.15) \\
(\dagger)\end{array}\right]$ & $\begin{array}{l}20.2 \\
21.2 \\
20.9 \\
6.7 !\end{array}$ & $\begin{array}{l}(1.21) \\
(2.48) \\
(2.20) \\
(2.65)\end{array}$ & 36.3 & $\begin{array}{l}(1.20) \\
(2.56) \\
(2.39) \\
(5.65)\end{array}$ & $\begin{array}{l}39.0 \\
32.6 \\
34.8 \\
59.0\end{array}$ & $\begin{array}{l}(1.32) \\
(2.49) \\
(2.45) \\
(5.76)\end{array}$ & $\begin{array}{l}55.4 \\
80.0 \\
78.6 \\
52.6\end{array}$ & $\begin{array}{l}(1.12) \\
(2.13) \\
(1.68) \\
(4.94)\end{array}$ & $\begin{array}{l}- \\
\overline{-} \\
\overline{-}\end{array}$ & 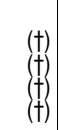 & $\begin{array}{l}\bar{z} \\
\overline{-}\end{array}$ & 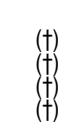 & $\begin{array}{l}\bar{z} \\
\overline{-}\end{array}$ & 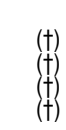 & $\begin{array}{l}\bar{z} \\
\overline{-}\end{array}$ & 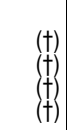 & $\begin{array}{l}\bar{z} \\
\overline{-}\end{array}$ & $\begin{array}{l}(+) \\
(+) \\
(\dagger) \\
(\dagger)\end{array}$ \\
\hline 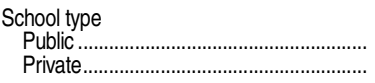 & $\begin{array}{l}93.9 \\
96.6\end{array}$ & $\left.\begin{array}{l}(0.58) \\
1.06\end{array}\right)$ & $\begin{array}{l}8.7 \\
9.9\end{array}$ & $(0.27)$ & $\begin{array}{r}4.6 \\
\neq\end{array}$ & $\begin{array}{r}(0.44) \\
(t)\end{array}$ & $\begin{array}{r}21.7 \\
7.1\end{array}$ & $\left(\begin{array}{l}1.03) \\
1.90)\end{array}\right.$ & $\begin{array}{l}38.7 \\
26.9\end{array}$ & $\left(\begin{array}{l}1.06) \\
2.88)\end{array}\right.$ & $\begin{array}{l}35.0 \\
65.9\end{array}$ & $\left.\begin{array}{l}(1.02) \\
(2.92)\end{array}\right)$ & $\begin{array}{l}64.3 \\
49.4\end{array}$ & $\begin{array}{l}(0.92) \\
3.51)\end{array}$ & - & $\left(\begin{array}{l}(t) \\
(t)\end{array}\right.$ & - & $\left(\begin{array}{l}+ \\
+\end{array}\right)$ & - & $\left(\begin{array}{l}+ \\
+\end{array}\right)$ & - & $\left(\begin{array}{l}+ \\
\dagger\end{array}\right)$ & 二 & $\left(\begin{array}{l}+ \\
(\dagger)\end{array}\right.$ \\
\hline 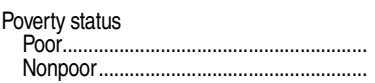 & $\begin{array}{l}90.1 \\
95.0\end{array}$ & $\left(\begin{array}{l}1.53 \\
0.55\end{array}\right)$ & $\begin{array}{l}8.6 \\
8.8\end{array}$ & $\begin{array}{l}(0.74) \\
(0.28)\end{array}$ & $\begin{array}{l}4.3 \\
4.1\end{array}$ & $\left(\begin{array}{l}0.97) \\
0.43\end{array}\right)$ & $\begin{array}{l}23.2 \\
19.8\end{array}$ & $\begin{array}{l}3.33) \\
0.94)\end{array}$ & $\begin{array}{l}42.3 \\
36.7\end{array}$ & $\left.\begin{array}{l}3.16 \\
1.11)\end{array}\right)$ & $\begin{array}{l}30.2 \\
39.4\end{array}$ & $\left(\begin{array}{l}2.83) \\
1.05\end{array}\right)$ & $\begin{array}{l}75.3 \\
60.5\end{array}$ & $\begin{array}{l}(2.94) \\
(0.91)\end{array}$ & - & $\left(\begin{array}{c}t \\
(t\end{array}\right)$ & - & $\left(\begin{array}{l}+ \\
+\end{array}\right)$ & 二 & $\left(\begin{array}{l}+ \\
(+)\end{array}\right)$ & $\overline{-}$ & $\left(\begin{array}{l}(\dagger \\
\dagger\end{array}\right)$ & - & $\left(\begin{array}{l}+ \\
(\dagger)\end{array}\right.$ \\
\hline 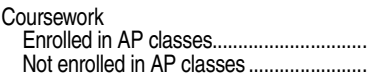 & $\begin{array}{l}98.0 \\
91.5 \\
\end{array}$ & $\begin{array}{l}(0.47) \\
0.80\end{array}$ & $\begin{array}{l}9.6 \\
8.2 \\
\end{array}$ & $\begin{array}{l}(0.38) \\
(0.34)\end{array}$ & $\begin{array}{l}2.2 \\
5.6 \\
\end{array}$ & $\begin{array}{l}(0.46) \\
(0.67)\end{array}$ & $\begin{array}{l}13.4 \\
25.4 \\
\end{array}$ & $\left.\begin{array}{l}1.10 \\
1.35\end{array}\right)$ & $\begin{array}{l}31.9 \\
41.8 \\
\end{array}$ & $\begin{array}{l}1.44) \\
(1.43)\end{array}$ & $\begin{array}{l}52.5 \\
27.3 \\
\end{array}$ & $\begin{array}{l}1.66) \\
(1.30)\end{array}$ & $\begin{array}{l}53.4 \\
69.7 \\
\end{array}$ & $\begin{array}{l}1.32 \\
(1.10)\end{array}$ & - & $\left(\begin{array}{l}(t \\
t\end{array}\right)$ & - & $\left(\begin{array}{l}(+) \\
(+)\end{array}\right.$ & - & $\left(\begin{array}{l}(t) \\
(t)\end{array}\right.$ & - & $\begin{array}{l}\left(\begin{array}{l}0 \\
(\dagger\end{array}\right) \\
\end{array}$ & - & $\left(\begin{array}{l}t \\
(t) \\
\end{array}\right.$ \\
\hline 2007 All students...... & 94.4 & $(0.30)$ & 5.4 & $(0.06)$ & 3.1 & $(0.34)$ & 13.1 & $(0.47)$ & 43.6 & $(0.62)$ & 40.2 & $(0.60)$ & 85.4 & $(0.46)$ & 10.2 & (0.41) & 20.3 & $(0.51)$ & 31.7 & $(0.64)$ & 25.3 & $(0.59)$ & 12.4 & $(0.41)$ \\
\hline $\begin{array}{l}\text { All elementary school students } \\
\text { (kindergarten through grade 8)... }\end{array}$ & 95.0 & $(0.37)$ & 4.7 & $(0.07)$ & 2.1 & $(0.23)$ & 12.3 & $(0.56)$ & 46.2 & $(0.73)$ & 39.4 & $(0.68)$ & 95.0 & $(0.34)$ & 4.3 & $(0.34)$ & 13.1 & $(0.52)$ & 32.6 & $(0.77)$ & 32.9 & $(0.76)$ & 17.0 & $(0.56)$ \\
\hline
\end{tabular}




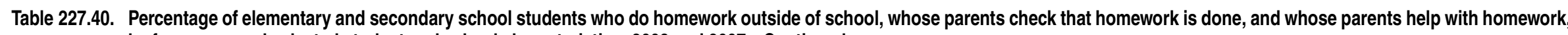
by frequency and selected student and school characteristics: 2003 and 2007-Continued

[Standard errors appear in parentheses]

\begin{tabular}{|c|c|c|c|c|c|c|c|c|c|c|c|c|c|c|c|c|c|c|c|c|c|c|c|c|c|}
\hline \multirow[b]{2}{*}{$\begin{array}{l}\text { Year and selected student } \\
\text { or school characteristic } \\
\end{array}$} & \multirow{2}{*}{\multicolumn{2}{|c|}{$\begin{array}{r}\text { Percent of } \\
\text { students who } \\
\text { do homework } \\
\text { outside of school }\end{array}$}} & \multirow{2}{*}{\multicolumn{2}{|c|}{$\begin{array}{r}\text { Average hours } \\
\text { per week spent } \\
\text { by students who } \\
\text { do homework } \\
\text { outside of school }\end{array}$}} & \multicolumn{8}{|c|}{$\begin{array}{l}\text { Distribution of students who do homework outside } \\
\text { of school by how frequently they do homework }\end{array}$} & \multirow{2}{*}{\multicolumn{2}{|c|}{$\begin{array}{r}\text { Percent of } \\
\text { students whose } \\
\text { parents } \\
\text { check that } \\
\text { homework } \\
\text { is done }\end{array}$}} & \multicolumn{10}{|c|}{ Distribution of students by how frequently their parents ${ }^{1}$ help with homework } & \\
\hline & & & & & \multicolumn{2}{|c|}{$\begin{array}{r}\text { Less than } \\
\text { once a week }\end{array}$} & \multicolumn{2}{|c|}{$\begin{array}{r}1 \text { to } 2 \text { days } \\
\text { per week }\end{array}$} & \multicolumn{2}{|c|}{$\begin{array}{r}3 \text { to } 4 \text { days } \\
\text { per week }\end{array}$} & \multicolumn{2}{|c|}{$\begin{array}{r}5 \text { or more } \\
\text { days a week }\end{array}$} & & & \multicolumn{2}{|c|}{ No help given } & \multicolumn{2}{|c|}{$\begin{array}{r}\text { Less than } \\
\text { once a week }\end{array}$} & \multicolumn{2}{|c|}{$\begin{array}{r}1 \text { to } 2 \text { days } \\
\text { per week }\end{array}$} & \multicolumn{2}{|c|}{$\begin{array}{r}3 \text { to } 4 \text { days } \\
\text { per week }\end{array}$} & \multicolumn{2}{|c|}{$\begin{array}{r}5 \text { or more } \\
\text { days per week }\end{array}$} & \\
\hline 1 & & 2 & & 3 & & 4 & & 5 & & 6 & & 7 & & 8 & & 9 & & 10 & & 11 & & 12 & & 13 & \\
\hline 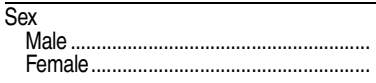 & $\begin{array}{l}94.6 \\
95.4\end{array}$ & $\left(\begin{array}{l}0.51 \\
0.53\end{array}\right)$ & $\begin{array}{l}4.6 \\
4.9\end{array}$ & $\left(\begin{array}{l}0.09 \\
0.10\end{array}\right)$ & $\begin{array}{l}2.1 \\
2.1\end{array}$ & $\left(\begin{array}{l}0.31) \\
0.31)\end{array}\right.$ & $\begin{array}{l}12.4 \\
12.2\end{array}$ & $\left(\begin{array}{l}0.71) \\
0.96)\end{array}\right)$ & $\begin{array}{l}47.9 \\
44.4\end{array}$ & $\left(\begin{array}{l}1.19 \\
1.13\end{array}\right)$ & $\begin{array}{l}37.6 \\
41.3\end{array}$ & $\left(\begin{array}{l}1.09 \\
1.08\end{array}\right)$ & $\begin{array}{l}95.3 \\
94.6\end{array}$ & $\left(\begin{array}{l}0.47) \\
(0.48)\end{array}\right)$ & $\begin{array}{l}4.3 \\
4.3\end{array}$ & $\left(\begin{array}{l}0.39 \\
0.56)\end{array}\right)$ & $\begin{array}{l}12.9 \\
13.4\end{array}$ & $\left(\begin{array}{l}0.63) \\
(0.76)\end{array}\right.$ & $\begin{array}{l}32.3 \\
32.9\end{array}$ & $\left(\begin{array}{l}1.02 \\
1.17\end{array}\right)$ & $\begin{array}{l}32.7 \\
33.2\end{array}$ & $\left(\begin{array}{l}1.28) \\
1.17\end{array}\right)$ & $\begin{array}{l}17.8 \\
16.1\end{array}$ & $\left(\begin{array}{l}0.85 \\
(0.79\end{array}\right)$ & \\
\hline 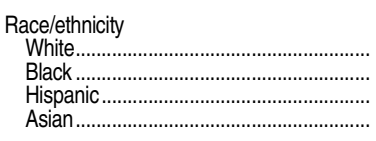 & $\begin{array}{l}94.7 \\
95.5 \\
94.8 \\
97.7\end{array}$ & $\left.\begin{array}{l}0.48 \\
1.07 \\
0.85) \\
(0.97)\end{array}\right)$ & $\begin{array}{l}4.4 \\
5.6 \\
4.7 \\
5.7\end{array}$ & $\begin{array}{l}(0.07) \\
0.27 \\
0.111 \\
(0.39)\end{array} \mid$ & $\begin{array}{l}2.7 \\
1.3 ! \\
1.3 \\
\ddagger\end{array}$ & $\begin{array}{r}(0.36) \\
0.53 \\
0.33) \\
(\dagger)\end{array} \mid$ & $\begin{array}{c}13.7 \\
7.0 \\
13.5 \\
5.1 !\end{array}$ & $\begin{array}{l}(0.74) \\
(1.199 \\
1.39) \\
(1.53)\end{array}$ & $\begin{array}{l}48.3 \\
44.4 \\
40.7 \\
39.1\end{array}$ & $\left(\begin{array}{l}1.05 \\
(3.40 \\
1.94) \\
(4.31)\end{array}\right)$ & $\begin{array}{l}35.3 \\
47.2 \\
44.4 \\
54.8\end{array}$ & $\left.\begin{array}{l}(0.99) \\
3.11 \\
1.74 \\
(4.48)\end{array}\right)$ & $\begin{array}{l}94.0 \\
98.1 \\
96.1 \\
88.5\end{array}$ & $\begin{array}{l}(0.42) \\
(0.63) \\
(3.40) \\
(3.44)\end{array}$ & $\begin{array}{l}3.8 \\
3.5 \\
7.1 \\
3.1 !\end{array}$ & $\begin{array}{l}(0.37) \\
1.03 \\
(0.95) \\
(1.36)\end{array} \mid$ & $\begin{array}{r}15.7 \\
7.4 \\
10.3 \\
12.8\end{array}$ & $\left.\begin{array}{l}(0.74) \\
(1.14 \\
(0.91) \\
(2.84)\end{array}\right)$ & $\begin{array}{l}34.9 \\
25.2 \\
30.1 \\
37.5\end{array}$ & $\begin{array}{l}(0.94) \\
(2.22) \\
(1.79) \\
(4.52)\end{array}$ & $\begin{array}{l}31.3 \\
38.3 \\
34.0 \\
30.7\end{array}$ & $\left.\begin{array}{l}(0.92 \\
(3.36 \\
(1.78) \\
(4.22)\end{array}\right)$ & $\begin{array}{l}14.3 \\
25.5 \\
18.6 \\
15.9\end{array}$ & $\begin{array}{l}(0.63) \\
(2.38) \\
(1.52) \\
(2.56)\end{array}$ & \\
\hline 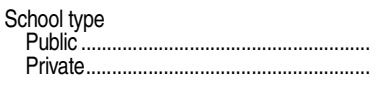 & $\begin{array}{l}95.1 \\
94.0\end{array}$ & $\left(\begin{array}{l}0.38 \\
(1.01)\end{array}\right)$ & $\begin{array}{l}4.7 \\
4.8\end{array}$ & $\left(\begin{array}{l}0.08 \\
0.19\end{array}\right)$ & $\begin{array}{l}2.0 \\
2.7\end{array}$ & $\left(\begin{array}{l}0.25) \\
0.63)\end{array}\right.$ & $\begin{array}{l}12.4 \\
11.4\end{array}$ & $\left(\begin{array}{l}0.62 \\
1.96\end{array}\right)$ & $\begin{array}{l}46.1 \\
46.7\end{array}$ & $\left(\begin{array}{l}0.76 \\
(2.64)\end{array}\right)$ & $\begin{array}{l}39.4 \\
39.2\end{array}$ & $\left.\begin{array}{l}(0.73) \\
(2.46)\end{array}\right)$ & $\begin{array}{l}95.4 \\
91.5\end{array}$ & $\left(\begin{array}{l}0.36 \\
1.19\end{array}\right)$ & $\begin{array}{l}4.4 \\
3.6\end{array}$ & $\left(\begin{array}{l}0.38) \\
0.85\end{array}\right)$ & $\begin{array}{l}13.1 \\
13.6\end{array}$ & $\left(\begin{array}{l}0.55) \\
(1.48)\end{array}\right)$ & $\begin{array}{l}32.4 \\
34.3\end{array}$ & $\left(\begin{array}{l}0.86 \\
2.10\end{array}\right)$ & $\begin{array}{l}32.9 \\
33.5\end{array}$ & $\left(\begin{array}{l}0.81 \\
(2.36)\end{array}\right)$ & $\begin{array}{l}17.2 \\
15.2\end{array}$ & $\left(\begin{array}{l}0.64) \\
(1.68)\end{array}\right.$ & \\
\hline 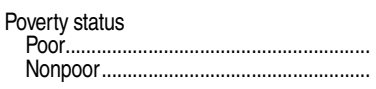 & $\begin{array}{l}94.2 \\
95.2\end{array}$ & $\begin{array}{l}(0.99) \\
(0.36)\end{array}$ & $\begin{array}{l}4.7 \\
4.8\end{array}$ & $\left.\begin{array}{l}(0.20) \\
(0.08)\end{array}\right]$ & $\begin{array}{l}2.9 \\
1.9\end{array}$ & $\begin{array}{l}(0.72) \\
(0.22)\end{array}$ & $\begin{array}{l}16.3 \\
11.3\end{array}$ & $\begin{array}{l}(2.18) \\
(0.58)\end{array}$ & $\begin{array}{l}39.0 \\
48.0\end{array}$ & $\begin{array}{l}(2.53) \\
(0.80)\end{array}$ & $\begin{array}{l}41.7 \\
38.8\end{array}$ & $\begin{array}{l}(2.21) \\
(0.75)\end{array}$ & $\begin{array}{l}97.9 \\
94.2\end{array}$ & $\begin{array}{l}(0.55) \\
(0.40)\end{array}$ & $\begin{array}{l}6.1 \\
3.9\end{array}$ & $\begin{array}{l}(1.01) \\
(0.33)\end{array}$ & $\begin{array}{r}8.8 \\
14.2\end{array}$ & $\begin{array}{l}(1.29) \\
(0.56)\end{array}$ & $\begin{array}{l}28.5 \\
33.7\end{array}$ & $\begin{array}{l}(2.44) \\
(0.80)\end{array}$ & $\begin{array}{l}35.2 \\
32.4\end{array}$ & $\begin{array}{l}(2.41) \\
(0.72)\end{array}$ & $\begin{array}{l}21.3 \\
15.9\end{array}$ & $\begin{array}{l}(1.90) \\
(0.58)\end{array}$ & \\
\hline 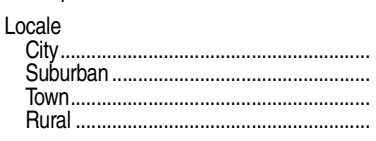 & $\begin{array}{l}95.2 \\
95.4 \\
93.0 \\
95.0\end{array}$ & $\begin{array}{l}(0.65) \\
(0.51) \\
(1.50) \\
0.85)\end{array} \mid$ & $\begin{array}{l}5.1 \\
4.9 \\
4.1 \\
4.2\end{array}$ & $\left.\begin{array}{l}(0.13) \\
0.11 \\
(0.14 \\
0.15\end{array}\right)$ & $\begin{array}{l}1.5 \\
1.9 \\
2.7 \\
3.2\end{array}$ & $\begin{array}{l}(0.31) \\
(0.37) \\
0.79 \\
0.69)\end{array}$ & $\begin{array}{r}9.1 \\
9.3 \\
18.8 \\
19.5\end{array}$ & $\left.\begin{array}{l}(0.91) \\
(0.71) \\
(1.98 \\
1.79\end{array}\right)$ & $\begin{array}{l}43.4 \\
46.1 \\
46.4 \\
50.6\end{array}$ & $\left.\begin{array}{l}(1.58) \\
(1.24) \\
(2.29 \\
(1.90)\end{array}\right)$ & $\begin{array}{l}46.0 \\
42.7 \\
32.2 \\
26.8\end{array}$ & $\left.\begin{array}{l}(1.43) \\
(1.19 \\
2.08 \\
1.63\end{array}\right)$ & $\begin{array}{l}95.4 \\
93.5 \\
96.0 \\
96.3\end{array}$ & $\begin{array}{l}(0.54) \\
(0.67) \\
(1.04) \\
0.72)\end{array}$ & $\begin{array}{l}4.8 \\
4.4 \\
3.2 \\
4.1\end{array}$ & $\begin{array}{l}(0.67) \\
(0.55) \\
0.80 \\
0.94)\end{array}$ & $\begin{array}{l}11.3 \\
14.5 \\
14.2 \\
13.1\end{array}$ & $\begin{array}{l}(1.02) \\
(0.85) \\
(1.62) \\
(1.30)\end{array}$ & $\begin{array}{l}29.1 \\
33.1 \\
35.7 \\
35.5\end{array}$ & $\begin{array}{l}(1.39) \\
(1.05) \\
(2.68) \\
(2.29)\end{array}$ & $\begin{array}{l}36.0 \\
30.8 \\
31.1 \\
32.8\end{array}$ & $\begin{array}{l}(1.41) \\
(1.14) \\
(2.31 \\
(2.23)\end{array}$ & $\begin{array}{l}18.7 \\
17.1 \\
15.7 \\
14.6\end{array}$ & $\begin{array}{l}(1.15) \\
(0.91) \\
(1.62) \\
(1.37)\end{array}$ & \\
\hline $\begin{array}{l}\text { All secondary school students } \\
\text { (grades } 9 \text { through 12)............. }\end{array}$ & 93.0 & (0.55) & 6.8 & $(0.11)$ & 5.4 & (0.85) & 14.8 & (0.96) & 38.0 & (1.15) & 41.9 & (1.18) & 64.6 & (1.21) & 23.1 & $(1.08)$ & 35.9 & (1.26) & 29.7 & (1.19) & 8.8 & $(0.81)$ & 2.5 & $(0.34)$ & \\
\hline 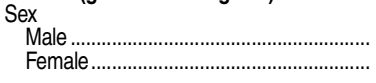 & $\begin{array}{l}91.2 \\
94.9\end{array}$ & $\left.\begin{array}{l}(0.80) \\
(0.79)\end{array}\right]$ & $\begin{array}{l}6.0 \\
7.5\end{array}$ & $\left.\begin{array}{l}(0.19) \\
(0.16)\end{array}\right]$ & $\begin{array}{l}7.4 \\
3.3\end{array}$ & $\begin{array}{l}(1.53) \\
(0.72)\end{array}$ & $\begin{array}{l}18.3 \\
11.2\end{array}$ & $\left.\begin{array}{l}(1.59) \\
(1.10)\end{array}\right)$ & $\begin{array}{l}38.2 \\
37.7\end{array}$ & $\left.\begin{array}{l}(1.78) \\
(1.79)\end{array}\right)$ & $\begin{array}{l}36.0 \\
47.9\end{array}$ & $\begin{array}{l}(1.64) \\
(1.85)\end{array}$ & $\begin{array}{l}67.8 \\
61.4\end{array}$ & $\begin{array}{l}(1.88) \\
(1.78)\end{array}$ & $\begin{array}{l}24.1 \\
22.0\end{array}$ & $\begin{array}{l}(1.56) \\
(1.32)\end{array}$ & $\begin{array}{l}36.9 \\
35.0\end{array}$ & $\begin{array}{l}(1.97) \\
(1.44)\end{array}$ & $\begin{array}{l}29.1 \\
30.4\end{array}$ & $\left.\begin{array}{l}(1.84) \\
(1.35)\end{array}\right)$ & $\begin{array}{l}8.2 \\
9.3\end{array}$ & $\left.\begin{array}{l}(1.11) \\
(1.11)\end{array}\right)$ & $\begin{array}{l}1.8 \\
3.3\end{array}$ & $\begin{array}{l}(0.41) \\
(0.60)\end{array}$ & \\
\hline 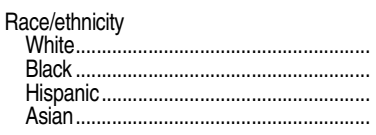 & $\begin{array}{l}94.5 \\
91.8 \\
90.7 \\
93.6\end{array}$ & $\left.\begin{array}{l}(0.52) \\
(1.98) \\
(2.11 \\
(5.45)\end{array}\right)$ & $\begin{array}{r}6.8 \\
6.3 \\
6.4 \\
10.3\end{array}$ & $\begin{array}{l}(0.13) \\
0.38) \\
(.34) \\
(1.37)\end{array}$ & $\begin{array}{r}4.2 \\
\ddagger \\
5.9 \\
\#\end{array}$ & $\begin{array}{r}(0.58) \\
(t) \\
(1.29) \\
(t)\end{array}$ & $\begin{array}{l}12.9 \\
20.1 \\
17.7 \\
13.8 !\end{array}$ & $\left.\begin{array}{l}(0.91) \\
(3.86) \\
3.55 \\
5.51)\end{array}\right]$ & $\begin{array}{l}38.6 \\
41.0 \\
36.6 \\
18.5 !\end{array}$ & $\left.\begin{array}{l}(1.51) \\
(4.72) \\
(2.93 \\
(6.12)\end{array}\right)$ & $\begin{array}{l}44.3 \\
29.7 \\
39.9 \\
67.7\end{array}$ & $\left.\begin{array}{l}(1.42) \\
(3.43 \\
3.03 \\
(7.18)\end{array}\right)$ & $\begin{array}{l}57.2 \\
83.1 \\
75.6 \\
59.0\end{array}$ & $\begin{array}{l}(1.54) \\
(2.84) \\
(271) \\
(7.69)\end{array}$ & $\begin{array}{l}22.5 \\
19.5 \\
26.2 \\
26.4\end{array}$ & $\begin{array}{l}(1.28) \\
(2.97) \\
(2.94) \\
(7.58)\end{array}$ & $\begin{array}{l}41.1 \\
26.5 \\
25.8 \\
36.1\end{array}$ & $\begin{array}{l}(1.36) \\
(4.77) \\
(2.38 \\
(7.55)\end{array}$ & $\begin{array}{l}27.7 \\
34.4 \\
33.8 \\
26.8\end{array}$ & $\begin{array}{l}(1.43) \\
(4.03) \\
(3.49 \\
(7.61)\end{array}$ & $\begin{array}{c}6.3 \\
16.7 \\
11.0 \\
7.6 !\end{array}$ & $\begin{array}{l}(0.66) \\
(4.45) \\
(.76 \\
(3.11)\end{array}$ & $\begin{array}{l}2.3 \\
2.9 ! \\
3.3 ! \\
\neq\end{array}$ & $\left.\begin{array}{r}(0.42) \\
(1.13 \\
1.00 \\
(+)\end{array}\right)$ & $\stackrel{O}{\frac{T}{D}}$ \\
\hline 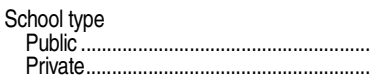 & $\begin{array}{l}92.3 \\
98.5\end{array}$ & $\left.\begin{array}{l}(0.60) \\
(0.54)\end{array}\right]$ & $\begin{array}{l}6.5 \\
9.3\end{array}$ & $\begin{array}{l}(0.11) \\
(0.39)\end{array}$ & $\begin{array}{l}5.9 \\
0.8 !\end{array}$ & $\begin{array}{l}(0.96) \\
(0.35)\end{array}$ & $\begin{array}{r}15.9 \\
5.9\end{array}$ & $\left.\begin{array}{l}(1.06) \\
(1.34)\end{array}\right)$ & $\begin{array}{l}39.7 \\
24.0\end{array}$ & $\begin{array}{l}(1.26) \\
(2.72)\end{array}$ & $\begin{array}{l}38.5 \\
69.4\end{array}$ & $\begin{array}{l}(1.17) \\
(2.89)\end{array}$ & $\begin{array}{l}66.1 \\
53.1\end{array}$ & $\begin{array}{l}(1.24) \\
(3.98)\end{array}$ & $\begin{array}{l}22.8 \\
25.0\end{array}$ & $\begin{array}{l}(1.16) \\
(2.64)\end{array}$ & $\begin{array}{l}35.4 \\
40.1\end{array}$ & $\begin{array}{l}(1.29) \\
(3.68)\end{array}$ & $\begin{array}{l}30.0 \\
27.5\end{array}$ & $\begin{array}{l}(1.26) \\
(4.07)\end{array}$ & $\begin{array}{l}9.1 \\
6.1\end{array}$ & $\begin{array}{l}(0.87) \\
(1.36)\end{array}$ & $\begin{array}{l}2.7 \\
1.4 !\end{array}$ & $\begin{array}{l}(0.37) \\
(0.61)\end{array}$ & 高罗 \\
\hline 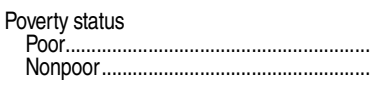 & $\begin{array}{l}89.5 \\
93.7\end{array}$ & $\begin{array}{l}(2.21) \\
(0.58)\end{array}$ & $\begin{array}{l}5.5 \\
7.0\end{array}$ & $\begin{array}{l}(0.32) \\
(0.12)\end{array}$ & $\begin{array}{r}\ddagger \\
4.8\end{array}$ & $\begin{array}{r}(t) \\
(0.53)\end{array}$ & $\begin{array}{l}19.2 \\
13.9\end{array}$ & $\left.\begin{array}{l}(3.62) \\
(0.91)\end{array}\right)$ & $\begin{array}{l}38.7 \\
37.8\end{array}$ & $\begin{array}{l}(4.32) \\
(1.27)\end{array}$ & $\begin{array}{l}33.7 \\
43.6\end{array}$ & $\begin{array}{l}(3.69) \\
(1.37)\end{array}$ & $\begin{array}{l}81.0 \\
61.4\end{array}$ & $\begin{array}{l}(3.03) \\
(1.30)\end{array}$ & $\begin{array}{l}24.2 \\
22.8\end{array}$ & $\begin{array}{l}(3.80) \\
(1.05)\end{array}$ & $\begin{array}{l}24.0 \\
38.3\end{array}$ & $\begin{array}{l}(4.21) \\
(1.19)\end{array}$ & $\begin{array}{l}36.1 \\
28.5\end{array}$ & $\begin{array}{l}(3.76) \\
(1.24)\end{array}$ & $\begin{array}{r}14.0 \\
7.7\end{array}$ & $\begin{array}{l}(3.21) \\
(0.66)\end{array}$ & $\begin{array}{l}1.7 ! \\
2.7\end{array}$ & $\begin{array}{l}(0.63) \\
(0.38)\end{array}$ & \\
\hline $\begin{array}{l}\text { Coursework } \\
\text { Enrolled in AP classes..................... } \\
\text { Not enrolled in AP classes .............. }\end{array}$ & $\begin{array}{l}96.9 \\
90.6\end{array}$ & $\left(\begin{array}{l}0.59 \\
0.81)\end{array}\right.$ & $\begin{array}{l}8.5 \\
5.7\end{array}$ & $\left(\begin{array}{l}0.22) \\
(0.13)\end{array}\right.$ & $\begin{array}{l}2.4 \\
7.3\end{array}$ & $\left(\begin{array}{l}0.70) \\
(1.31)\end{array}\right.$ & $\begin{array}{r}7.5 \\
19.5\end{array}$ & $\left(\begin{array}{l}0.93) \\
1.40\end{array}\right)$ & $\begin{array}{l}31.9 \\
41.9\end{array}$ & $\left(\begin{array}{l}1.81 \\
1.56\end{array}\right)$ & $\begin{array}{l}58.2 \\
31.2\end{array}$ & $\left(\begin{array}{l}1.97) \\
(1.42)\end{array}\right)$ & $\begin{array}{l}56.3 \\
70.1\end{array}$ & $\left(\begin{array}{l}2.06 \\
1.46\end{array}\right)$ & $\begin{array}{l}27.4 \\
20.2\end{array}$ & $\left(\begin{array}{l}1.90 \\
(1.14)\end{array}\right)$ & $\begin{array}{l}36.3 \\
35.7\end{array}$ & $\left(\begin{array}{l}1.69) \\
(1.70)\end{array}\right)$ & $\begin{array}{l}28.3 \\
30.7\end{array}$ & $\left(\begin{array}{l}1.74) \\
1.59\end{array}\right)$ & $\begin{array}{r}6.0 \\
10.5\end{array}$ & $\begin{array}{l}(0.99) \\
(1.23)\end{array}$ & $\begin{array}{l}1.9 \\
2.9\end{array}$ & $\left.\begin{array}{l}(0.43) \\
0.51\end{array}\right)$ & 崩 \\
\hline 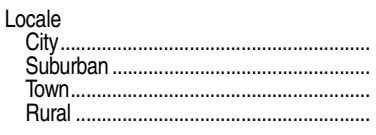 & $\begin{array}{l}92.8 \\
93.6 \\
89.7 \\
93.9\end{array}$ & $\begin{array}{l}(1.01) \\
0.95) \\
(2.16) \\
(1.23)\end{array}$ & $\begin{array}{l}6.8 \\
7.5 \\
6.4 \\
5.6\end{array}$ & $\begin{array}{l}(0.22) \\
0.17) \\
(0.27) \\
0.29)\end{array}$ & $\begin{array}{l}6.3 ! \\
4.8 \\
5.4 \\
5.1\end{array}$ & $\begin{array}{l}(2.46) \\
0.86 \\
(1.48) \\
(1.20)\end{array}$ & $\begin{array}{l}14.1 \\
11.4 \\
13.2 \\
22.7\end{array}$ & $\left.\begin{array}{l}(1.90) \\
1.27 \\
(1.74) \\
(2.76)\end{array}\right)$ & $\begin{array}{l}35.9 \\
36.5 \\
45.9 \\
39.6\end{array}$ & $\begin{array}{l}(2.32) \\
1.71) \\
(3.46 \\
(3.04)\end{array}$ & $\begin{array}{l}43.7 \\
47.4 \\
35.5 \\
32.6\end{array}$ & $\begin{array}{l}(2.53) \\
2.07 \\
(3.17) \\
(2.79)\end{array}$ & $\begin{array}{l}71.5 \\
58.9 \\
64.8 \\
65.5\end{array}$ & $\begin{array}{l}(1.89) \\
(2.00) \\
(3.12 \\
(2.94)\end{array}$ & $\begin{array}{l}22.6 \\
23.6 \\
24.3 \\
22.1\end{array}$ & $\left.\begin{array}{l}(1.88) \\
(1.74) \\
(2.81) \\
(2.69)\end{array}\right)$ & $\begin{array}{l}33.4 \\
39.1 \\
34.4 \\
34.4\end{array}$ & $\left.\begin{array}{l}(2.64) \\
1.79) \\
(2.96) \\
(2.71)\end{array}\right)$ & $\begin{array}{l}29.3 \\
27.8 \\
27.9 \\
34.8\end{array}$ & $\left.\begin{array}{l}(2.00) \\
1.68 \\
(3.41 \\
(3.43)\end{array}\right)$ & $\begin{array}{r}12.0 \\
7.5 \\
9.3 \\
6.2\end{array}$ & $\left.\begin{array}{l}(1.80) \\
1.01 \\
(1.80 \\
(1.53)\end{array}\right)$ & $\begin{array}{l}2.7 \\
2.0 \\
4.2 ! \\
2.5 !\end{array}$ & $\begin{array}{l}(0.55) \\
0.47) \\
(1.54) \\
(0.88)\end{array}$ & 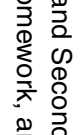 \\
\hline $\begin{array}{l}\text { - Not available. } \\
\text { †Not applicable. } \\
\text { !Interpret data with caution. The coefficien } \\
\text { fReporting standards not met. Either ther } \\
\text { cent or greater. } \\
\text { 'Refers to one or more parent or other ho } \\
\text { NOTE: Includes children enrolled in kinde } \\
\text { ent most knowledgeable about the studen }\end{array}$ & ent & ew cases & $c$ cor & able est & 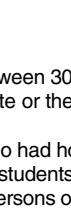 & & $n$ & & 50 & & $\begin{array}{l}\text { nic grou } \\
\text { SOURC } \\
\text { Survey c }\end{array}$ & f th & & & ducation & Surveys $\mathrm{P}$ & to & PF & 2003 an & nd 200 & IS & & ther ra & $\begin{array}{l}\text { loo7, for } \\
\text { as non- } \\
\text { cial//eth- } \\
\text { ducation } \\
\text { e 2008.) }\end{array}$ & 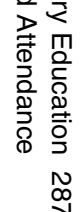 \\
\hline
\end{tabular}




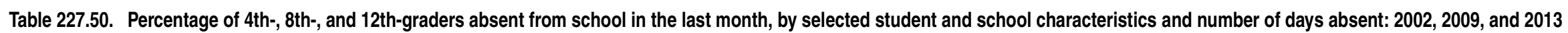

[Standard errors appear in parentheses]

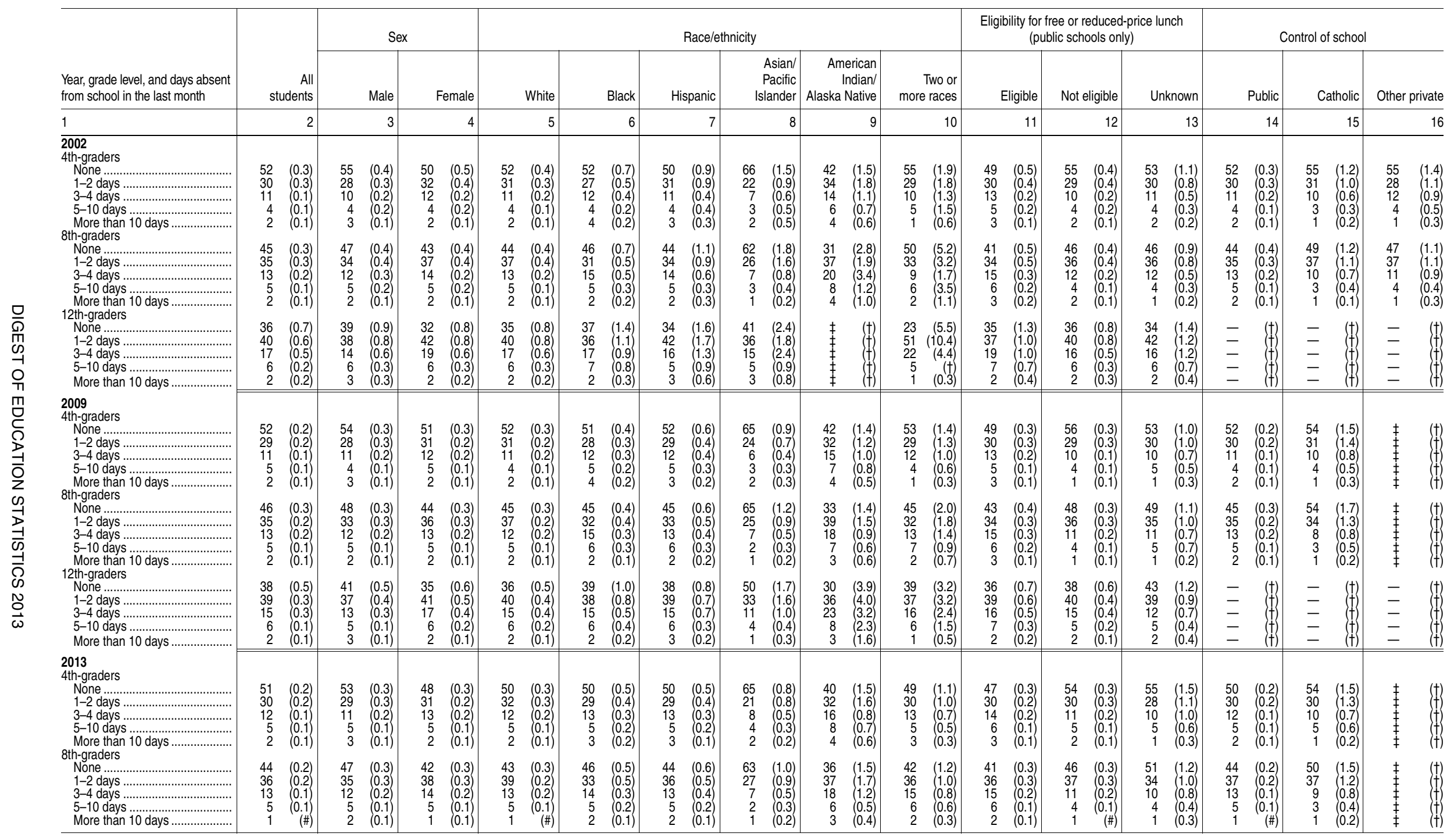

\section{-Not available} †Not applicable.
\#Rounds to zero.

\#Reporting standards not met (too few cases for a reliable estimate).

NOTE: Includes public and private schools unless otherwise noted. Race categories exclude persons of Hispanic ethnicity Prior to 2011, students in the "two or more races" category were categorized as "unclassified." Detail may not sum to totals because of rounding. Grade 12 results for the 2013 National Assessment of Educational Progress (NAEP) Reading Assessment were not yet available at the time this table was created.

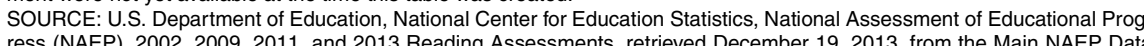
Explorer (http://nces.ed.gov/nationsreportcard/naepdata). (This table was prepared December 2013.) 
Table 228.10. School-associated violent deaths of all persons, homicides and suicides of youth ages 5-18 at school, and total homicides and suicides of youth ages 5-18, by type of violent death: 1992-93 to 2010-11

\begin{tabular}{|c|c|c|c|c|c|c|c|c|c|}
\hline \multirow[b]{2}{*}{ Year } & \multicolumn{5}{|c|}{$\begin{array}{l}\text { School-associated violent deaths }{ }^{1} \text { of all persons } \\
\text { (includes students, staff, and other nonstudents) }\end{array}$} & \multicolumn{2}{|c|}{ Homicides of youth ages $5-18$} & \multicolumn{2}{|c|}{ Suicides of youth ages 5-18 } \\
\hline & Total & Homicides & Suicides & $\begin{array}{r}\text { Legal } \\
\text { interventions }\end{array}$ & $\begin{array}{r}\text { Unintentional } \\
\text { firearm-related } \\
\text { deaths }\end{array}$ & $\begin{array}{r}\text { Homicides at } \\
\text { school }^{2}\end{array}$ & Total homicides & $\begin{array}{r}\text { Suicides at } \\
\text { school }^{2}\end{array}$ & Total suicides ${ }^{3}$ \\
\hline 1 & 2 & 3 & 4 & 5 & 6 & 7 & 8 & 9 & 10 \\
\hline 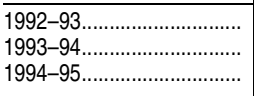 & $\begin{array}{l}57 \\
48 \\
48\end{array}$ & $\begin{array}{l}47 \\
38 \\
39\end{array}$ & $\begin{array}{r}10 \\
10 \\
8\end{array}$ & $\begin{array}{l}0 \\
0 \\
0\end{array}$ & $\begin{array}{l}0 \\
0 \\
1\end{array}$ & $\begin{array}{l}34 \\
29 \\
28\end{array}$ & $\begin{array}{l}2,721 \\
2,932 \\
2,696\end{array}$ & $\begin{array}{l}6 \\
7 \\
7\end{array}$ & $\begin{array}{l}1,680 \\
1,723 \\
1,767\end{array}$ \\
\hline $\begin{array}{l}1995-96 \ldots \ldots \ldots \ldots \ldots \\
1996-97 \ldots \ldots \ldots \ldots \ldots \ldots \ldots \ldots . . . \\
1997-98 \ldots \ldots \ldots \ldots \ldots \ldots \ldots \ldots \ldots \ldots \\
1998-99 \ldots \ldots \ldots \ldots \ldots \ldots \ldots \ldots . . .\end{array}$ & $\begin{array}{l}53 \\
48 \\
57 \\
47 \\
374\end{array}$ & $\begin{array}{l}46 \\
45 \\
47 \\
38 \\
26\end{array}$ & \begin{tabular}{c|}
6 \\
2 \\
9 \\
6 \\
$11^{4}$
\end{tabular} & $\begin{array}{l}1 \\
1 \\
1 \\
2 \\
0^{4}\end{array}$ & $\begin{array}{l}0 \\
0 \\
0 \\
1 \\
04\end{array}$ & $\begin{array}{l}32 \\
28 \\
34 \\
33 \\
14\end{array}$ & $\begin{array}{l}2,545 \\
2,221 \\
2,100 \\
1,777 \\
1,567\end{array}$ & $\begin{array}{l}6 \\
1 \\
6 \\
4 \\
8^{4}\end{array}$ & $\begin{array}{l}1,725 \\
1,633 \\
1,626 \\
1,597 \\
1,415\end{array}$ \\
\hline $\begin{array}{l}2000-01 \ldots \ldots \ldots \ldots \ldots \ldots \ldots \\
2001-02 \ldots \ldots \ldots \ldots \ldots \ldots \ldots \ldots \ldots \\
2002-03 \ldots \ldots \ldots \ldots \ldots \ldots \ldots \ldots \\
2003-04 \ldots \ldots \ldots \ldots \ldots \ldots \ldots \ldots \\
2004-05 \ldots \ldots \ldots \ldots \ldots \ldots \ldots \ldots . . .\end{array}$ & $\begin{array}{l}34 \\
36 \\
36 \\
45 \\
52\end{array}$ & $\begin{array}{ll}26 & 4 \\
27 & 4 \\
25 & 4 \\
37 & 4 \\
40 & 4\end{array}$ & $\begin{array}{r}74 \\
84 \\
11^{4} \\
74 \\
10^{4}\end{array}$ & $\begin{array}{ll}1 & 4 \\
1 & 4 \\
0 & 4 \\
1 & 4 \\
2 & 4\end{array}$ & $\begin{array}{ll}0 & 4 \\
0 & 4 \\
0 & 4 \\
0 & 4 \\
0 & 4\end{array}$ & $\begin{array}{l}14^{4} \\
16^{4} \\
18^{4} \\
23^{4} \\
22\end{array}$ & $\begin{array}{l}1,509 \\
1,498 \\
1,553 \\
1,474 \\
1,554\end{array}$ & $\begin{array}{r}6^{4} \\
5^{4} \\
10^{4} \\
5^{4} \\
8^{4}\end{array}$ & $\begin{array}{l}1,493 \\
1,400 \\
1,331 \\
1,285 \\
1,471\end{array}$ \\
\hline 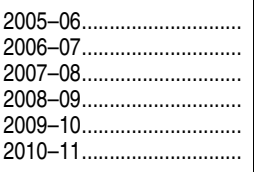 & 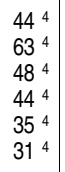 & $\begin{array}{ll}37 & 4 \\
48 & 4 \\
39 & 4 \\
29 & 4 \\
27 & 4 \\
25^{4} & \end{array}$ & $\begin{array}{r}6^{4} \\
13^{4} \\
77^{4} \\
15^{4} \\
5^{4} \\
6^{4}\end{array}$ & 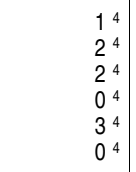 & $\begin{array}{ll}0 & 4 \\
0 & 4 \\
0 & 4 \\
0 & 4 \\
0 & 4 \\
0 & 4\end{array}$ & $\begin{array}{ll}21 & 4 \\
32 & 4 \\
21 & 4 \\
17 & 4 \\
19 & 4 \\
11 & 4\end{array}$ & $\begin{array}{l}1,697 \\
1,801 \\
1,744 \\
1,605 \\
1,410 \\
1,336\end{array}$ & $\begin{array}{l}34 \\
9 \\
5^{4} \\
7^{4} \\
2 \\
3^{4}\end{array}$ & $\begin{array}{l}1,408 \\
1,296 \\
1,231 \\
1,344 \\
1,467 \\
1,456\end{array}$ \\
\hline
\end{tabular}

${ }^{1}$ A school-associated violent death is defined as "a homicide, suicide, or legal intervention (involving a law enforcement officer), in which the fatal injury occurred on the campus of a functioning elementary or secondary school in the United States," while the victim was on the way to or from regular sessions at school, or while the victim was attending or traveling to or from an official school-sponsored event.

2"At school" includes on school property, on the way to or from regular sessions at school, and while attending or traveling to or from a school-sponsored event.

${ }^{3}$ Total youth suicides are reported for calendar years 1992 through 2010 (instead of school years 1992-93 through 2010-11)

${ }^{4}$ Data from 1999-2000 onward are subject to change until interviews with school and law enforcement officials have been completed. The details learned during the interviews can occasionally change the classification of a case.
NOTE: Unless otherwise noted, data are reported for the school year, defined as July 1 through June 30 . Some data have been revised from previously published figures. SOURCE: Centers for Disease Control and Prevention (CDC), 1992-2011 School-Associated Violent Deaths Study (SAVD) (partially funded by the U.S. Department of Education, Office of Safe and Healthy Students), previously unpublished tabulation (August 2012); CDC, National Center for Injury Prevention and Control, Web-based Injury Statistics Query and Reporting System Fatal (WISQARS'M Fatal), 1999-2010, retrieved August 2013 from http://www.cdc.gov/ injury/wisqars/index.html; and Federal Bureau of Investigation and Bureau of Justice Statistics, injury/wisqars/index.html; and Federal Bureau of Investigation and Bureau of Justice Statistics,
Supplementary Homicide Reports (SHR), preliminary data (August 2013). (This table was prepared November 2013.) 
Table 228.20. Number of nonfatal victimizations against students ages 12-18 and rate of victimization per 1,000 students, by type of victimization, location, and year: 1992 through 2012

[Standard errors appear in parentheses]

\begin{tabular}{|c|c|c|c|c|c|c|c|c|c|c|c|c|c|c|c|c|}
\hline \multirow[b]{3}{*}{ Location and year } & \multicolumn{8}{|c|}{ Number of nonfatal victimizations } & \multicolumn{8}{|c|}{ Rate of victimization per 1,000 students } \\
\hline & & \multirow[b]{2}{*}{ Total } & & \multirow[b]{2}{*}{ Theft } & \multicolumn{4}{|c|}{ Violent } & & \multirow[b]{2}{*}{ Total } & & \multirow[b]{2}{*}{ Theft } & \multicolumn{4}{|c|}{ Violent } \\
\hline & & & & & & All violent & \multicolumn{2}{|c|}{ Serious violent ${ }^{1}$} & & & & & & All violent & \multicolumn{2}{|c|}{ Serious violent ${ }^{1}$} \\
\hline 1 & & 2 & & 3 & & 4 & & 5 & & 6 & & 7 & & 8 & & 9 \\
\hline 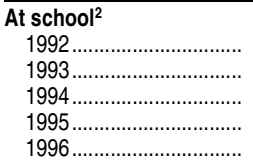 & $\begin{array}{l}4,281,200 \\
4,692,800 \\
4,721,000 \\
4,400,700 \\
4,130,400\end{array}$ & $\begin{array}{l}(196,220) \\
(183,610) \\
(144,790) \\
(138,690) \\
(136,300)\end{array}$ & $\begin{array}{l}2,679,400 \\
2,477,100 \\
2,474,100 \\
2,468,400 \\
2,205,200\end{array}$ & $\begin{array}{r}(147,660) \\
(124,600) \\
(97,820) \\
(97,690) \\
(93,280)\end{array}$ & $\begin{array}{l}1,601,800 \\
2,215,700 \\
2,246,900 \\
1,932,200 \\
1,925,300\end{array}$ & $\begin{array}{r}(121,630) \\
(131,600) \\
(104,300) \\
(94,940) \\
(96,780)\end{array}$ & $\begin{array}{l}197,600 \\
535,500 \\
459,100 \\
294,500 \\
371,900\end{array}$ & $\begin{array}{l}(35,430) \\
(55,610) \\
(39,920) \\
(30,880) \\
(36,090)\end{array}$ & $\begin{array}{l}181.5 \\
193.5 \\
187.7 \\
172.2 \\
158.4\end{array}$ & $\begin{array}{l}(7.09) \\
(6.39) \\
(4.88) \\
(4.66) \\
(4.54)\end{array}$ & $\begin{array}{r}113.6 \\
102.1 \\
98.4 \\
96.6 \\
84.5\end{array}$ & $\begin{array}{l}(5.64) \\
(4.67) \\
(3.55) \\
(3.49) \\
(3.30)\end{array}$ & $\begin{array}{l}67.9 \\
91.4 \\
89.3 \\
75.6 \\
73.8\end{array}$ & $\begin{array}{l}(4.77) \\
(4.91) \\
(3.76) \\
(3.41) \\
(3.41)\end{array}$ & $\begin{array}{r}8.4 \\
22.1 \\
18.3 \\
11.5 \\
14.3\end{array}$ & $\begin{array}{l}(1.48) \\
(2.22) \\
(1.55) \\
(1.19) \\
(1.35)\end{array}$ \\
\hline $\begin{array}{l}1997 \\
1998 \ldots 9 . \\
1999 \ldots \\
2000 \\
2001\end{array}$ & $\begin{array}{l}3,610,900 \\
3,247,300 \\
3,152,400 \\
2,301,000 \\
2,521,300\end{array}$ & $\begin{array}{l}(152,370) \\
(135,860) \\
(135,080) \\
(114,960) \\
(128,980)\end{array}$ & $\begin{array}{l}1,975,000 \\
1,635,100 \\
1,752,200 \\
1,331,500 \\
1,348,500\end{array}$ & $\begin{array}{r}(101,170) \\
(87,360) \\
(92,620) \\
(80,140) \\
(84,740)\end{array}$ & $\begin{array}{r}1,635,900 \\
1,612,200 \\
1,400,200 \\
969,500 \\
1,172,700\end{array}$ & $\begin{array}{r}(97,350) \\
(106,090) \\
(88,150) \\
(73,270) \\
(84,450)\end{array}$ & $\begin{array}{l}376,200 \\
314,500 \\
281,100 \\
214,200 \\
259,400\end{array}$ & $\begin{array}{l}(39,950) \\
(37,870) \\
(33,540) \\
(29,750) \\
(33,440)\end{array}$ & $\begin{array}{r}136.6 \\
121.3 \\
117.0 \\
84.9 \\
92.3\end{array}$ & $\begin{array}{l}(4.57) \\
(4.33) \\
(4.29) \\
(3.72) \\
(4.04)\end{array}$ & $\begin{array}{l}74.7 \\
61.1 \\
65.1 \\
49.1 \\
49.4\end{array}$ & $\begin{array}{l}(3.31) \\
(2.98) \\
(3.12) \\
(2.71) \\
(2.82)\end{array}$ & $\begin{array}{l}61.9 \\
60.2 \\
52.0 \\
35.8 \\
42.9\end{array}$ & $\begin{array}{l}(3.32) \\
(3.59) \\
(3.11) \\
(2.57) \\
(2.85)\end{array}$ & $\begin{array}{r}14.2 \\
11.7 \\
10.4 \\
7.9 \\
9.5\end{array}$ & $\begin{array}{l}(1.47) \\
(1.38) \\
(1.23) \\
(1.08) \\
(1.20)\end{array}$ \\
\hline 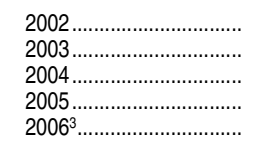 & $\begin{array}{l}2,082,600 \\
2,308,800 \\
1,762,200 \\
1,678,600 \\
1,799,900\end{array}$ & $\begin{array}{l}(89,740) \\
(95,740) \\
(84,830) \\
(88,690) \\
(90,050)\end{array}$ & $\begin{array}{r}1,088,800 \\
1,270,500 \\
1,065,400 \\
875,900 \\
859,000\end{array}$ & $\begin{array}{l}(64,030) \\
(70,290) \\
(65,540) \\
(62,420) \\
(62,380)\end{array}$ & $\begin{array}{r}993,800 \\
1,038,300 \\
696,800 \\
802,600 \\
940,900\end{array}$ & $\begin{array}{l}(72,340) \\
(76,800) \\
(60,570) \\
(72,930) \\
(78,400)\end{array}$ & $\begin{array}{l}173,500 \\
188,400 \\
107,300 \\
140,300 \\
249,900\end{array}$ & $\begin{array}{l}(26,110) \\
(28,300) \\
(21,230) \\
(27,020) \\
(36,900)\end{array}$ & $\begin{array}{l}75.4 \\
87.4 \\
67.2 \\
63.2 \\
67.5\end{array}$ & $\begin{array}{l}(3.45) \\
(3.85) \\
(3.38) \\
(3.52) \\
(3.56)\end{array}$ & $\begin{array}{l}39.4 \\
48.1 \\
40.6 \\
33.0 \\
32.2\end{array}$ & $\begin{array}{l}(2.40) \\
(2.76) \\
(2.57) \\
(2.42) \\
(2.40)\end{array}$ & $\begin{array}{l}36.0 \\
39.3 \\
26.6 \\
30.2 \\
35.3\end{array}$ & $\begin{array}{l}(2.53) \\
(2.80) \\
(2.25) \\
(2.67) \\
(2.85)\end{array}$ & $\begin{array}{l}6.3 \\
7.1 \\
4.1 \\
5.3 \\
9.4\end{array}$ & $\begin{array}{l}(0.94) \\
(1.06) \\
(0.81) \\
(1.01) \\
(1.37)\end{array}$ \\
\hline 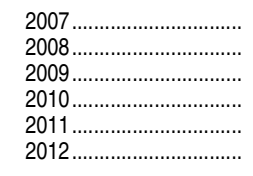 & $\begin{array}{r}1,801,200 \\
1,435,500 \\
1,322,800 \\
892,000 \\
1,246,200 \\
1,364,900 \\
\end{array}$ & $\begin{array}{l}(83,670) \\
(98,840) \\
(87,660) \\
(64,960) \\
(92,180) \\
(82,050) \\
\end{array}$ & $\begin{array}{l}896,700 \\
648,000 \\
594,500 \\
469,800 \\
647,700 \\
615,600 \\
\end{array}$ & $\begin{array}{l}(58,960) \\
(61,170) \\
(54,480) \\
(45,300) \\
(61,500) \\
(51,440) \\
\end{array}$ & $\begin{array}{l}904,400 \\
787,500 \\
728,300 \\
422,300 \\
598,600 \\
749,200 \\
\end{array}$ & $\begin{array}{r}(75,270) \\
(108,480) \\
(111,550) \\
(73,310) \\
(84,090) \\
(90,250) \\
\end{array}$ & $\begin{array}{r}116,100 \\
128,700 \\
233,700 \\
155,000 \\
89,500 \\
89,000 \\
\end{array}$ & $\begin{array}{l}(22,340) \\
(34,370) \\
(51,610) \\
(36,500) \\
(23,360) \\
(23,850) \\
\end{array}$ & $\begin{array}{l}67.8 \\
54.3 \\
51.0 \\
34.9 \\
49.3 \\
52.4 \\
\end{array}$ & $\begin{array}{l}(3.39) \\
(3.56) \\
(3.23) \\
(2.47) \\
(3.47) \\
(3.01) \\
\end{array}$ & $\begin{array}{l}33.7 \\
24.5 \\
22.9 \\
18.4 \\
25.6 \\
23.6 \\
\end{array}$ & $\begin{array}{l}(2.31) \\
(2.26) \\
(2.05) \\
(1.75) \\
(2.36) \\
(1.93) \\
\end{array}$ & $\begin{array}{l}34.0 \\
29.8 \\
28.1 \\
16.5 \\
23.7 \\
28.8 \\
\end{array}$ & $\begin{array}{l}(2.73) \\
(3.91) \\
(4.08) \\
(2.75) \\
(3.16) \\
(3.31) \\
\end{array}$ & $\begin{array}{l}4.4 \\
4.9 \\
9.0 \\
6.1 \\
3.5 \\
3.4 \\
\end{array}$ & $\begin{array}{l}(0.83) \\
(1.28) \\
(1.94) \\
(1.40) \\
(0.91) \\
(0.91) \\
\end{array}$ \\
\hline 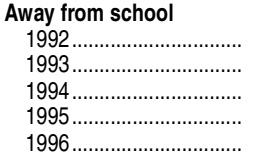 & $\begin{array}{l}4,084,100 \\
3,835,900 \\
4,147,100 \\
3,626,600 \\
3,483,200\end{array}$ & $\begin{array}{l}(190,660) \\
(162,330) \\
(133,750) \\
(123,250) \\
(122,860)\end{array}$ & $\begin{array}{l}1,857,600 \\
1,731,100 \\
1,713,900 \\
1,604,800 \\
1,572,700\end{array}$ & $\begin{array}{r}(118,610) \\
(100,630) \\
(78,590) \\
(75,590) \\
(76,310)\end{array}$ & $\begin{array}{l}2,226,500 \\
2,104,800 \\
2,433,200 \\
2,021,800 \\
1,910,600\end{array}$ & $\begin{array}{r}(149,210) \\
(127,450) \\
(109,630) \\
(97,650) \\
(96,320)\end{array}$ & $\begin{array}{r}1,025,100 \\
1,004,300 \\
1,074,900 \\
829,700 \\
870,000\end{array}$ & $\begin{array}{l}(92,600) \\
(80,900) \\
(66,230) \\
(56,660) \\
(59,560)\end{array}$ & $\begin{array}{l}173.1 \\
158.2 \\
164.9 \\
141.9 \\
133.5\end{array}$ & $\begin{array}{l}(6.94) \\
(5.81) \\
(4.59) \\
(4.24) \\
(4.17)\end{array}$ & $\begin{array}{l}78.7 \\
71.4 \\
68.1 \\
62.8 \\
60.3\end{array}$ & $\begin{array}{l}(4.66) \\
(3.87) \\
(2.92) \\
(2.78) \\
(2.75)\end{array}$ & $\begin{array}{l}94.4 \\
86.8 \\
96.7 \\
79.1 \\
73.3\end{array}$ & $\begin{array}{l}(5.70) \\
(4.77) \\
(3.92) \\
(3.49) \\
(3.39)\end{array}$ & $\begin{array}{l}43.5 \\
41.4 \\
42.7 \\
32.5 \\
33.4\end{array}$ & $\begin{array}{l}(3.72) \\
(3.17) \\
(2.50) \\
(2.12) \\
(2.19)\end{array}$ \\
\hline $\begin{array}{l}1997 \ldots \\
1998 \ldots 9 \\
1999 \ldots \\
2000 \\
2001\end{array}$ & $\begin{array}{l}3,717,600 \\
3,047,800 \\
2,713,800 \\
2,303,600 \\
1,780,300\end{array}$ & $\begin{array}{l}(155,480) \\
(130,340) \\
(122,530) \\
(115,050) \\
(101,940)\end{array}$ & $\begin{array}{r}1,710,700 \\
1,408,000 \\
1,129,200 \\
1,228,900 \\
961,400\end{array}$ & $\begin{array}{l}(92,020) \\
(79,510) \\
(70,410) \\
(76,060) \\
(67,910)\end{array}$ & $\begin{array}{r}2,006,900 \\
1,639,800 \\
1,584,500 \\
1,074,800 \\
819,000\end{array}$ & $\begin{array}{r}(110,940) \\
(107,280) \\
(95,150) \\
(78,100) \\
(67,260)\end{array}$ & $\begin{array}{l}853,300 \\
684,900 \\
675,400 \\
402,100 \\
314,800\end{array}$ & $\begin{array}{l}(64,970) \\
(61,210) \\
(56,470) \\
(43,010) \\
(37,510)\end{array}$ & $\begin{array}{r}140.7 \\
113.8 \\
100.8 \\
85.0 \\
65.2\end{array}$ & $\begin{array}{l}(4.64) \\
(4.19) \\
(3.96) \\
(3.72) \\
(3.31)\end{array}$ & $\begin{array}{l}64.7 \\
52.6 \\
41.9 \\
45.3 \\
35.2\end{array}$ & $\begin{array}{l}(3.06) \\
(2.74) \\
(2.44) \\
(2.59) \\
(2.31)\end{array}$ & $\begin{array}{l}75.9 \\
61.3 \\
58.8 \\
39.6 \\
30.0\end{array}$ & $\begin{array}{l}(3.71) \\
(3.63) \\
(3.34) \\
(2.73) \\
(2.32)\end{array}$ & $\begin{array}{l}32.3 \\
25.6 \\
25.1 \\
14.8 \\
11.5\end{array}$ & $\begin{array}{l}(2.31) \\
(2.17) \\
(2.04) \\
(1.55) \\
(1.34)\end{array}$ \\
\hline 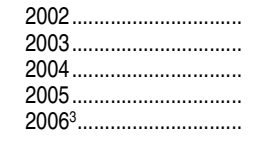 & $\begin{array}{l}1,619,500 \\
1,824,100 \\
1,371,800 \\
1,429,000 \\
1,413,100\end{array}$ & $\begin{array}{l}(78,980) \\
(85,020) \\
(74,730) \\
(81,470) \\
(80,130)\end{array}$ & $\begin{array}{l}820,100 \\
780,900 \\
718,000 \\
637,700 \\
714,200\end{array}$ & $\begin{array}{l}(54,930) \\
(53,930) \\
(53,190) \\
(52,320) \\
(56,730)\end{array}$ & $\begin{array}{r}799,400 \\
1,043,200 \\
653,700 \\
791,300 \\
698,900\end{array}$ & $\begin{array}{l}(63,490) \\
(77,020) \\
(58,380) \\
(72,320) \\
(66,010)\end{array}$ & $\begin{array}{l}341,200 \\
412,800 \\
272,500 \\
257,100 \\
263,600\end{array}$ & $\begin{array}{l}(38,460) \\
(44,430) \\
(35,500) \\
(37,890) \\
(38,020)\end{array}$ & $\begin{array}{l}58.6 \\
69.1 \\
52.3 \\
53.8 \\
53.0\end{array}$ & $\begin{array}{l}(3.00) \\
(3.38) \\
(2.95) \\
(3.21) \\
(3.13)\end{array}$ & $\begin{array}{l}29.7 \\
29.6 \\
27.4 \\
24.0 \\
26.8\end{array}$ & $\begin{array}{l}(2.04) \\
(2.09) \\
(2.07) \\
(2.02) \\
(2.17)\end{array}$ & $\begin{array}{l}28.9 \\
39.5 \\
24.9 \\
29.8 \\
26.2\end{array}$ & $\begin{array}{l}(2.24) \\
(2.81) \\
(2.18) \\
(2.65) \\
(2.42)\end{array}$ & $\begin{array}{r}12.4 \\
15.6 \\
10.4 \\
9.7 \\
9.9\end{array}$ & $\begin{array}{l}(1.37) \\
(1.65) \\
(1.34) \\
(1.41) \\
(1.41)\end{array}$ \\
\hline 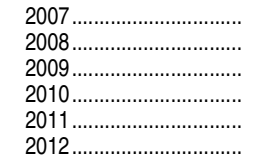 & $\begin{array}{r}1,371,700 \\
1,132,600 \\
857,200 \\
689,900 \\
966,100 \\
991,200\end{array}$ & $\left.\begin{array}{l}(73,270) \\
(85,570) \\
(67,630) \\
(56,180) \\
(78,690) \\
(67,920)\end{array}\right]$ & $\begin{array}{l}614,300 \\
498,500 \\
484,200 \\
378,800 \\
541,900 \\
470,800\end{array}$ & $\begin{array}{l}(48,300) \\
(52,350) \\
(48,320) \\
(40,200) \\
(55,160) \\
(44,070)\end{array}$ & $\begin{array}{l}757,400 \\
634,100 \\
372,900 \\
311,200 \\
424,300 \\
520,400\end{array}$ & $\begin{array}{l}(67,520) \\
(94,160) \\
(70,660) \\
(59,190) \\
(66,350) \\
(71,280)\end{array}$ & $\begin{array}{l}337,700 \\
258,600 \\
176,800 \\
167,300 \\
137,600 \\
169,900\end{array}$ & $\left.\begin{array}{l}(41,520) \\
(52,980) \\
(42,890) \\
(38,460) \\
(31,000) \\
(35,260)\end{array}\right]$ & $\begin{array}{l}51.6 \\
42.8 \\
33.1 \\
27.0 \\
38.2 \\
38.0\end{array}$ & $\begin{array}{l}(2.92) \\
(3.11) \\
(2.53) \\
(2.15) \\
(2.99) \\
(2.52)\end{array}$ & $\begin{array}{l}23.1 \\
18.9 \\
18.7 \\
14.8 \\
21.4 \\
18.1\end{array}$ & $\left.\begin{array}{l}(1.87) \\
(1.94) \\
(1.83) \\
(1.55) \\
(2.13) \\
(1.66)\end{array}\right)$ & $\begin{array}{l}28.5 \\
24.0 \\
14.4 \\
12.2 \\
16.8 \\
20.0\end{array}$ & $\begin{array}{l}(2.46) \\
(3.42) \\
(2.63) \\
(2.24) \\
(2.52) \\
(2.64)\end{array}$ & $\begin{array}{r}12.7 \\
9.8 \\
6.8 \\
6.5 \\
5.4 \\
6.5\end{array}$ & $\begin{array}{l}(1.54) \\
(1.96) \\
(1.62) \\
(1.47) \\
(1.20) \\
(1.33)\end{array}$ \\
\hline
\end{tabular}

'Serious violent victimization is also included in all violent victimization.

2"At school" includes inside the school building on school property, or on the way to and from school.

${ }^{3}$ Due to methodological differences, use caution when comparing 2006 estimates to other years.

NOTE: "Serious violent victimization" includes the crimes of rape, sexual assault, robbery, and aggravated assault. "All violent victimization" includes serious violent crimes as well as simple assault. "Theft" includes attempted and completed purse-snatching, completed pickpocketing, and all attempted and completed thefts, with the exception of motor vehicle thefts. Theft does not
include robbery, which involves the threat or use of force and is classified as a violent crime. "Total victimization" includes theft

and violent crimes. Data in this table are from the National Crime Victimization Survey (NCVS); due to differences in time covercompared with data in tables that are based on the SCS. Detail may not sum to totals because of rounding Some data have been revised from previously published figures. SOURCE: U.S. Department of Justice, Bureas 2012. (This table was prepared August 2013). 


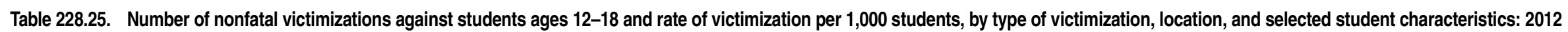

[Standard errors appear in parentheses]

\begin{tabular}{|c|c|c|c|c|c|c|c|c|c|c|c|c|c|c|c|c|}
\hline \multirow{3}{*}{$\begin{array}{l}\text { Location and student } \\
\text { characteristic }\end{array}$} & \multicolumn{8}{|c|}{ Number of nonfatal victimizations } & \multicolumn{8}{|c|}{ Rate of victimization per 1,000 students } \\
\hline & \multirow{2}{*}{\multicolumn{2}{|c|}{ Total }} & & \multirow[b]{2}{*}{ Theft } & \multicolumn{4}{|c|}{ Violent } & \multirow{2}{*}{\multicolumn{2}{|c|}{ Total }} & & \multirow[b]{2}{*}{ Theft } & \multicolumn{4}{|c|}{ Violent } \\
\hline & & & & & & All violent & & Is violent ${ }^{1}$ & & & & & & All violent & & violen \\
\hline 1 & & 2 & & 3 & & 4 & & 5 & & 6 & & 7 & & 8 & & \\
\hline $\begin{array}{l}\text { At school } \\
\text { Total }\end{array}$ & $1,364,900$ & $(82,050)$ & 615,600 & $(51,440)$ & 749,200 & $(90,250)$ & 89,000 & $(23,850)$ & 52.4 & $(3.01)$ & 23.6 & (1.93) & 28.8 & (3.31) & 3.4 & (0. \\
\hline 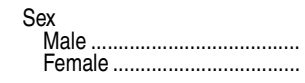 & $\begin{array}{l}802,800 \\
562,000\end{array}$ & $\left(\begin{array}{l}60,030) \\
48,800)\end{array}\right.$ & $\begin{array}{l}345,600 \\
270,000\end{array}$ & $\begin{array}{l}36,940) \\
(32,130)\end{array}$ & $\begin{array}{l}457,200 \\
292,000\end{array}$ & $\left.\begin{array}{l}65,600) \\
49,360\end{array}\right)$ & $\begin{array}{l}69,800 ! \\
19,300 !\end{array}$ & $\begin{array}{r}(20,640) \\
(9,890)\end{array}$ & $\begin{array}{l}59.8 \\
44.5\end{array}$ & $\left(\begin{array}{l}4.24) \\
3.71\end{array}\right)$ & $\begin{array}{l}25.7 \\
21.4\end{array}$ & $\begin{array}{l}(2.68) \\
(2.49)\end{array}$ & $\begin{array}{l}34.1 \\
23.1\end{array}$ & $\begin{array}{l}(4.63) \\
(3.76)\end{array}$ & $\begin{array}{l}5.2 ! \\
1.5 !\end{array}$ & $\left(\begin{array}{l}1 . \\
0 .\end{array}\right.$ \\
\hline 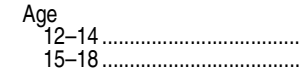 & $\begin{array}{l}807,200 \\
557,700\end{array}$ & $\left(\begin{array}{l}60,220) \\
48,580)\end{array}\right)$ & $\begin{array}{l}278,500 \\
337,200\end{array}$ & $\begin{array}{l}(32,690) \\
(36,430)\end{array}$ & $\begin{array}{l}528,700 \\
220,500\end{array}$ & $\left(\begin{array}{l}72,020) \\
(41,410)\end{array}\right)$ & $\begin{array}{l}69,800 ! \\
19,200 !\end{array}$ & $\begin{array}{r}(20,650) \\
(9,870)\end{array}$ & $\begin{array}{l}64.7 \\
41.1\end{array}$ & $\left.\begin{array}{l}(4.56) \\
3.44\end{array}\right)$ & $\begin{array}{l}22.3 \\
24.8\end{array}$ & $\begin{array}{l}(2.56) \\
(2.62)\end{array}$ & $\begin{array}{l}42.4 \\
16.2\end{array}$ & $\begin{array}{l}(5.42) \\
(2.96)\end{array}$ & $\begin{array}{l}5.6 ! \\
1.4 !\end{array}$ & \\
\hline 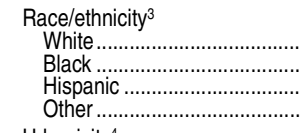 & $\begin{array}{r}756,400 \\
223,100 \\
294,400 \\
91,000\end{array}$ & $\begin{array}{l}(57,970) \\
28,870) \\
33,740) \\
(17,620)\end{array}$ & $\begin{array}{r}306,900 \\
134,400 \\
125,900 \\
48,400\end{array}$ & $\begin{array}{l}(34,540) \\
21,800 \\
21,030 \\
(12,550)\end{array}$ & $\begin{array}{r}449,500 \\
88,700 \\
168,500 \\
42,600\end{array}$ & $\begin{array}{l}(64,890) \\
23,800 \\
35,080 \\
(15,480)\end{array}$ & $\begin{array}{r}20,400 ! \\
\ddagger \\
63,800 ! \\
4,900 !\end{array}$ & $\begin{array}{r}(10,200) \\
(\dagger) \\
\left(\begin{array}{r}19,580 \\
(4,690)\end{array}\right)\end{array}$ & $\begin{array}{l}53.3 \\
55.2 \\
50.7 \\
45.4\end{array}$ & $\begin{array}{l}3.89) \\
6.81 \\
5.55 \\
8.47\end{array}$ & $\begin{array}{l}21.6 \\
33.3 \\
21.7 \\
24.1\end{array}$ & $\left.\begin{array}{l}(2.38) \\
5.24 \\
3.55 \\
6.13\end{array}\right)$ & $\begin{array}{l}31.7 \\
21.9 \\
29.0 \\
21.2\end{array}$ & $\begin{array}{l}(<. .00) \\
4.35) \\
5.70 \\
5.78 \\
7.50)\end{array}$ & $\begin{array}{r}1.4 ! \\
11.0 ! \\
2.4 !\end{array}$ & (3. \\
\hline 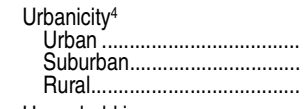 & $\begin{array}{l}480,000 \\
758,900 \\
125,900\end{array}$ & $\begin{array}{l}(44,560) \\
(58,090) \\
(21,040)\end{array} \mid$ & $\begin{array}{r}187,300 \\
363,700 \\
64,600\end{array}$ & $\left.\begin{array}{l}(26,190) \\
38,030 \\
(14,640)\end{array}\right)$ & $\begin{array}{r}292,700 \\
395,200 \\
61,400\end{array}$ & $\begin{array}{l}(49,430) \\
59,770 \\
19,140)\end{array}$ & $\begin{array}{r}69,800 ! \\
16,800 ! \\
2,500 !\end{array}$ & $\begin{array}{r}(20,640) \\
(9,140) \\
(3,300)\end{array}$ & $\begin{array}{l}62.4 \\
53.7 \\
29.7\end{array}$ & $\begin{array}{l}(5.48) \\
3.92 \\
(4.83)\end{array}$ & $\begin{array}{l}24.4 \\
25.8 \\
15.2\end{array}$ & $\left.\begin{array}{l}3.32 \\
2.63 \\
3.41\end{array}\right)$ & $\begin{array}{l}38.0 \\
28.0 \\
14.5\end{array}$ & $\left.\begin{array}{l}(6.07) \\
4.04 \\
4.41\end{array}\right)$ & $\begin{array}{l}2.4 ! \\
9.1 ! \\
1.2 ! \\
0.6 !\end{array}$ & 0. \\
\hline 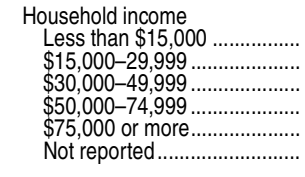 & $\begin{array}{l}202,000 \\
206,400 \\
265,000 \\
193,900 \\
344,600 \\
152,900 \\
\end{array}$ & $\begin{array}{l}(27,320) \\
27,640 \\
31,000 \\
26,700) \\
36,880 \\
(23,400) \\
\end{array}$ & $\begin{array}{r}52,700 \\
59,000 \\
129,100 \\
100,800 \\
213,400 \\
60,600 \\
\end{array}$ & $\begin{array}{l}(13,130) \\
13,940 \\
21,330 \\
18,630 \\
28,160) \\
(14,150)\end{array}$ & $\begin{array}{r}149,300 \\
147,500 \\
135,900 \\
93,100 \\
131,300 \\
92,200 \\
\end{array}$ & $\begin{array}{l}32,580) \\
32,330 \\
30,760 \\
24,490 \\
30,120 \\
(24,360)\end{array}$ & $\begin{array}{r}3,800 ! \\
5,900 ! \\
15,800 ! \\
46,800 ! \\
\vdots \\
16,800 ! \\
\end{array}$ & $\begin{array}{r}(4,080) \\
5,170) \\
(8,850) \\
(16,350) \\
(t) \\
(9,150) \\
\end{array}$ & $\begin{array}{l}90.9 \\
63.3 \\
62.3 \\
54.4 \\
47.9 \\
27.4 \\
\end{array}$ & $\left.\begin{array}{r}(11.44) \\
(8.04 \\
7.09 \\
7.16 \\
4.91 \\
4.10\end{array}\right)$ & $\begin{array}{l}23.7 \\
18.1 \\
30.4 \\
28.3 \\
29.7 \\
10.9 \\
\end{array}$ & $\begin{array}{l}5.79 \\
4.21 \\
4.88 \\
5.10 \\
3.81 \\
2.51)\end{array}$ & $\begin{array}{l}67.2 \\
45.2 \\
32.0 \\
26.1 \\
18.3 \\
16.6 \\
\end{array}$ & $\begin{array}{r}(13.55) \\
(9.34) \\
6.91 \\
6.62 \\
4.06 \\
(4.25)\end{array}$ & $\begin{array}{r}1.7 ! \\
1.8 ! \\
3.7 ! \\
13.1 ! \\
\overline{3.0 !}\end{array}$ & $\begin{array}{r}1.58 \\
2.07 \\
4.49 \\
(\dagger \\
(1.63) \\
\end{array}$ \\
\hline $\begin{array}{l}\text { Away from school } \\
\text { Total........................ }\end{array}$ & 991,200 & $(67,920)$ & 470,800 & $(44,070)$ & 520,400 & $(71,280)$ & 169,900 & $(35,260)$ & 38.0 & (2.52) & 18.1 & (1.66) & 20.0 & (2.64) & 6.5 & \\
\hline 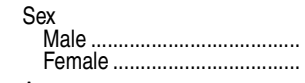 & $\begin{array}{l}598,700 \\
392,500\end{array}$ & $\left.\begin{array}{l}(50,610) \\
39,710)\end{array}\right)$ & $\begin{array}{l}275,500 \\
195,300\end{array}$ & $\begin{array}{l}(32,490) \\
26,810)\end{array}$ & $\begin{array}{l}323,300 \\
197,100\end{array}$ & $\left(\begin{array}{l}52,630) \\
(38,640)\end{array}\right)$ & $\begin{array}{r}117,800 \\
52,100\end{array}$ & $\left(\begin{array}{l}28,220) \\
(17,400)\end{array}\right)$ & $\begin{array}{l}44.6 \\
31.1\end{array}$ & $\left.\begin{array}{l}3.62 \\
(3.05)\end{array}\right)$ & $\begin{array}{l}20.5 \\
15.5\end{array}$ & $(2.37)$ & $\begin{array}{l}24.1 \\
15.6\end{array}$ & $\left(\begin{array}{l}3.76) \\
(2.97)\end{array}\right)$ & $\begin{array}{l}8.8 \\
4.1\end{array}$ & \\
\hline 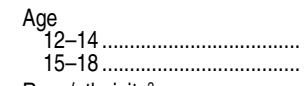 & $\begin{array}{l}460,200 \\
531,000\end{array}$ & $\left(\begin{array}{l}43,490) \\
47,220\end{array}\right)$ & $\begin{array}{l}225,800 \\
245,000\end{array}$ & $\left(\begin{array}{l}29,070) \\
(30,420)\end{array}\right)$ & $\begin{array}{l}234,300 \\
286,100\end{array}$ & $\begin{array}{l}43,010) \\
(48,730)\end{array}$ & $\begin{array}{l}78,500 \\
91,500\end{array}$ & $\begin{array}{l}(22,130) \\
(24,240)\end{array}$ & $\begin{array}{l}36.9 \\
39.1\end{array}$ & $\begin{array}{l}3.37) \\
(3.35)\end{array}$ & $\begin{array}{l}18.1 \\
18.1\end{array}$ & $\begin{array}{l}(2.29) \\
(2.20)\end{array}$ & $\begin{array}{l}18.8 \\
21.1\end{array}$ & $\begin{array}{l}3.33) \\
(3.46)\end{array}$ & $\begin{array}{l}6.3 \\
6.7\end{array}$ & $(1.7$ \\
\hline 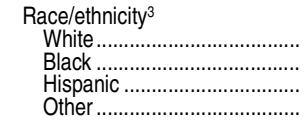 & $\begin{array}{r}568,200 \\
158,200 \\
188,100 \\
76,800\end{array}$ & $\left.\begin{array}{l}(49,100) \\
23,850 \\
26,250 \\
(16,070)\end{array}\right)$ & $\begin{array}{r}249,000 \\
86,000 \\
104,200 \\
31,600\end{array}$ & $\left.\begin{array}{l}(30,700) \\
17,090 \\
18,970 \\
10,010)\end{array}\right)$ & $\begin{array}{l}319,200 \\
72,200 \\
83,800 \\
45,200 !\end{array}$ & $\begin{array}{l}(52,210) \\
21,060 \\
23,020) \\
16,020)\end{array}$ & $\begin{array}{l}98,100 \\
32,600 ! \\
26,400 ! \\
12,900 !\end{array}$ & $\begin{array}{r}25,280) \\
13,280) \\
11,780) \\
(7,900)\end{array} \mid$ & $\begin{array}{l}40.0 \\
39.1 \\
32.4 \\
38.3\end{array}$ & $\begin{array}{l}3.33 \\
5.70 \\
4.39 \\
(7.77)\end{array}$ & $\begin{array}{l}17.5 \\
21.3 \\
17.9 \\
15.7\end{array}$ & $\left.\begin{array}{l}(2.12 \\
4.15 \\
3.21 \\
(4.92)\end{array}\right)$ & $\begin{array}{l}22.5 \\
17.9 \\
14.4 \\
22.5 !\end{array}$ & $\begin{array}{l}3.54) \\
5.07 \\
3.87 \\
(7.75)\end{array}$ & $\begin{array}{l}6.9 \\
8.1 ! \\
4.5 ! \\
6.4 !\end{array}$ & $\begin{array}{l}1 . \\
3 . \\
2 . \\
3 . \\
3 .\end{array}$ \\
\hline 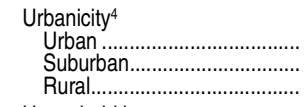 & $\begin{array}{l}257,800 \\
590,800 \\
142,600\end{array}$ & $\left.\begin{array}{l}(31,300) \\
(50,220) \\
(22,520)\end{array}\right)$ & $\begin{array}{r}132,700 \\
277,900 \\
60,200\end{array}$ & $\left.\begin{array}{l}(21,650) \\
32,650) \\
(14,100)\end{array}\right)$ & $\begin{array}{r}125,100 \\
312,900 \\
82,400\end{array}$ & $\left.\begin{array}{l}(29,250) \\
51,560 \\
(22,790\end{array}\right)$ & $\begin{array}{l}54,400 \\
88,300 \\
27,200 !\end{array}$ & $\left.\begin{array}{l}(17,850) \\
23,730) \\
(11,990)\end{array}\right)$ & $\begin{array}{l}33.5 \\
41.8 \\
33.7\end{array}$ & $\left.\begin{array}{l}3.94) \\
3.42 \\
(5.16)\end{array}\right)$ & $\begin{array}{l}17.3 \\
19.7 \\
14.2\end{array}$ & $\left.\begin{array}{l}(2.77) \\
(2.27) \\
3.28\end{array}\right)$ & $\begin{array}{l}16.3 \\
22.2 \\
19.5\end{array}$ & $\left.\begin{array}{l}3.69) \\
3.51 \\
5.22\end{array}\right)$ & $\begin{array}{l}7.1 \\
6.3 \\
6.4 !\end{array}$ & \\
\hline 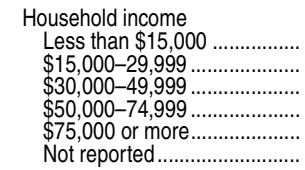 & $\begin{array}{l}158,900 \\
142,500 \\
201,200 \\
152,500 \\
180,000 \\
156,100\end{array}$ & $\begin{array}{l}(23,910) \\
22,520) \\
27,250) \\
23,370 \\
25,610) \\
23,680)\end{array}$ & $\begin{array}{r}66,400 \\
63,300 \\
86,800 \\
81,500 \\
111,500 \\
61,400\end{array}$ & $\begin{array}{c}14,860) \\
14,480 \\
17,180 \\
16,600 \\
19,680) \\
14,240)\end{array}$ & $\begin{array}{r}92,500 \\
79,200 \\
114,400 \\
71,000 \\
68,500 \\
94,800\end{array}$ & $\left.\begin{array}{l}24,410) \\
22,260 \\
27,710 \\
20,850) \\
20,420 \\
(24,760)\end{array}\right)$ & $\begin{array}{l}53,400 ! \\
25,200 ! \\
39,000 \\
17,500 ! \\
18,700 ! \\
16,100 !\end{array}$ & $\begin{array}{r}(17,640) \\
11,490) \\
14,720) \\
(9,370) \\
(9,730) \\
8,940)\end{array}$ & $\begin{array}{l}71.5 \\
43.7 \\
47.3 \\
42.8 \\
25.0 \\
28.0\end{array}$ & $\left.\begin{array}{r}(10.16) \\
6.65 \\
6.15 \\
6.32 \\
3.48 \\
(4.14\end{array}\right)$ & $\begin{array}{l}29.9 \\
19.4 \\
20.4 \\
22.9 \\
15.5 \\
11.0\end{array}$ & $\begin{array}{l}(6.52) \\
4.36 \\
3.97 \\
4.57 \\
2.70 \\
2.53)\end{array}$ & $\begin{array}{r}41.6 \\
24.3 \\
26.9 \\
19.9 \\
9.5 \\
17.0\end{array}$ & $\left.\begin{array}{r}(10.42 \\
6.59 \\
6.26 \\
5.68 \\
2.79 \\
4.32\end{array}\right)$ & $\begin{array}{r}24.0 ! \\
7.7 ! \\
9.2 ! \\
4.9 ! \\
2.6 ! \\
2.9 !\end{array}$ & $\begin{array}{l}7.68) \\
3.48 \\
3.41 \\
2.61 \\
1.35 \\
(.60)\end{array}$ \\
\hline
\end{tabular}

\section{- Not available.}

IInterpret data with caution. Estimate based on 10 or fewer sample cases, or the coefficient of variation is greater than 50 percent †Reporting standards not met. There are too few cases for a reliable estimate.

${ }^{2}$ "At school" includes inside the school building, on school property, or on the way to and from school.

${ }^{3}$ Race categories exclude persons of Hispanic ethnicity. "Other" includes Asians, Pacific Islanders, American Indians/Alaska Natives, and persons of two or more races.

Refers to the Standard Metropolitan Statistical Area (MSA) status of the respondent's household as defined in 2000 by the U.S. Census Bureau. Categories include "central city of an MSA (Urban)," "in MSA but not in central city (Suburban)," and "not MSA (Rural)."
NOTE: "Serious violent victimization" includes the crimes of rape, sexual assault, robbery, and aggravated assault. "All violent victimization" includes serious violent crimes as well as simple assault. "Theff" includes attempted and completed purse-snatching, completed pickpocketing, and all attempted and completed thefts, with the exception of motor vehicle thefts. Theft does not include robbery,
which involves the threat or use of force and is classified as a violent crime. "Total victimization" includes theft and violent crimes. Data in this table are from the National Crime Victimization Survey (NCVS); due to differences in time coverage and administration between the NCVS and the School Crime Supplement (SCS) to the NCVS, data in this table cannot be compared with data in tables that are based on the SCS. Detail may not sum to totals because of rounding and missing data on student characteristics. The population size for students ages 12-18 was 26,052,400 in 2012.

SOURCE: U.S. Department of Justice, Bureau of Justice Statistics, National Crime Victimization Survey (NCVS), 2012. (This table was prepared August 2013.) 
292 CHAPTER 2: Elementary and Secondary Education

School Crime Victims

Table 228.30. Percentage of students ages 12-18 who reported criminal victimization at school during the previous 6 months, by type of victimization and selected student and school characteristics: Selected years, 1995 through 2011

[Standard errors appear in parentheses]

\begin{tabular}{|c|c|c|c|c|c|c|c|c|c|c|c|c|c|c|c|c|}
\hline $\begin{array}{l}\text { Type of victimization and } \\
\text { student or school characteristic }\end{array}$ & & 1995 & & 1999 & & 2001 & & 2003 & & 2005 & & 2007 & & 2009 & & 2011 \\
\hline 1 & & 2 & & 3 & & 4 & & 5 & & 6 & & 7 & & 8 & & 9 \\
\hline 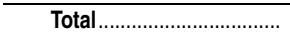 & 9.5 & $(0.35)$ & 7.6 & $(0.35)$ & 5.5 & $(0.31)$ & 5.1 & $(0.24)$ & 4.3 & $(0.31)$ & 4.3 & $(0.30)$ & 3.9 & $(0.28)$ & 3.5 & $\overline{(0.28)}$ \\
\hline 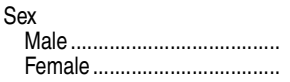 & $\begin{array}{r}10.0 \\
9.0\end{array}$ & $\begin{array}{l}(0.46) \\
(0.47)\end{array}$ & $\begin{array}{l}7.8 \\
7.3\end{array}$ & $\begin{array}{l}(0.46) \\
(0.46)\end{array}$ & $\begin{array}{l}6.1 \\
4.9\end{array}$ & $\begin{array}{l}(0.41) \\
(0.39)\end{array}$ & $\begin{array}{l}5.4 \\
4.8\end{array}$ & $\begin{array}{l}(0.33) \\
(0.36)\end{array}$ & $\begin{array}{l}4.6 \\
3.9\end{array}$ & $\begin{array}{l}(0.42) \\
(0.38)\end{array}$ & $\begin{array}{l}4.5 \\
4.0\end{array}$ & $\begin{array}{l}(0.43) \\
(0.39)\end{array}$ & $\begin{array}{l}4.6 \\
3.2\end{array}$ & $\begin{array}{l}(0.40) \\
(0.35)\end{array}$ & $\begin{array}{l}3.7 \\
3.4\end{array}$ & $\begin{array}{l}(0.35) \\
(0.38)\end{array}$ \\
\hline 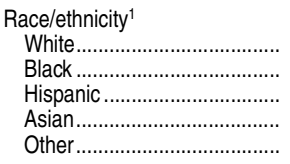 & $\begin{array}{r}9.8 \\
10.2 \\
7.6 \\
- \\
8.8\end{array}$ & $\begin{array}{r}(0.37) \\
(1.04) \\
(0.90) \\
(\dagger) \\
(1.54)\end{array}$ & $\begin{array}{l}7.5 \\
9.9 \\
5.7 \\
- \\
6.4\end{array}$ & $\begin{array}{r}(0.44) \\
(0.85) \\
(0.77) \\
(\dagger) \\
(1.28)\end{array}$ & $\begin{array}{r}5.8 \\
6.1 \\
4.6 \\
- \\
3.1\end{array}$ & $\begin{array}{r}(0.39) \\
(0.78) \\
(0.64) \\
(\dagger) \\
(0.91)\end{array}$ & $\begin{array}{l}5.4 \\
5.3 \\
3.9 \\
- \\
5.0\end{array}$ & $\begin{array}{r}(0.31) \\
(0.80) \\
(0.50) \\
(\dagger) \\
(1.08)\end{array}$ & $\begin{array}{l}4.7 \\
3.8 \\
3.9 \\
1.5 ! \\
4.3 !\end{array}$ & $\begin{array}{l}(0.35) \\
(0.80) \\
(0.70) \\
(0.68) \\
(2.00)\end{array}$ & $\begin{array}{l}4.3 \\
4.3 \\
3.6 \\
3.6 ! \\
8.1\end{array}$ & $\begin{array}{l}(0.38) \\
(0.83) \\
(0.54) \\
(1.38) \\
(2.01)\end{array}$ & $\begin{array}{r}3.9 \\
4.4 \\
3.9 \\
\ddagger \\
\ddagger\end{array}$ & $\begin{array}{r}(0.37) \\
(0.74) \\
(0.75) \\
(\dagger) \\
(\dagger)\end{array}$ & $\begin{array}{l}3.6 \\
4.6 \\
2.9 \\
2.5 ! \\
3.7 !\end{array}$ & $\begin{array}{l}(0.35) \\
(0.89) \\
(0.47) \\
(1.23) \\
(1.37)\end{array}$ \\
\hline 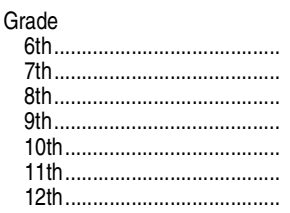 & $\begin{array}{r}9.6 \\
11.2 \\
10.5 \\
11.9 \\
9.1 \\
7.3 \\
6.1\end{array}$ & $\begin{array}{l}(0.97) \\
(0.81) \\
(0.78) \\
(0.88) \\
(0.76) \\
(0.74) \\
(0.74)\end{array}$ & $\begin{array}{l}8.0 \\
8.2 \\
7.6 \\
8.9 \\
8.0 \\
7.2 \\
4.8\end{array}$ & $\begin{array}{l}(1.24) \\
(0.81) \\
(0.84) \\
(0.79) \\
(0.82) \\
(0.88) \\
(0.81)\end{array}$ & $\begin{array}{l}5.9 \\
5.8 \\
4.3 \\
7.9 \\
6.5 \\
4.8 \\
2.9\end{array}$ & $\begin{array}{l}(0.90) \\
(0.66) \\
(0.61) \\
(0.81) \\
(0.77) \\
(0.62) \\
(0.52)\end{array}$ & $\begin{array}{l}3.8 \\
6.3 \\
5.2 \\
6.3 \\
4.8 \\
5.1 \\
3.6\end{array}$ & $\begin{array}{l}(0.77) \\
(0.74) \\
(0.65) \\
(0.70) \\
(0.63) \\
(0.68) \\
(0.71)\end{array}$ & $\begin{array}{l}4.6 \\
5.4 \\
3.6 \\
4.7 \\
4.3 \\
3.6 \\
3.8\end{array}$ & $\begin{array}{l}(0.83) \\
(0.71) \\
(0.63) \\
(0.69) \\
(0.71) \\
(0.51) \\
(0.85)\end{array}$ & $\begin{array}{l}4.1 \\
4.7 \\
4.4 \\
5.3 \\
4.4 \\
4.0 \\
2.7\end{array}$ & $\begin{array}{l}(0.87) \\
(0.69) \\
(0.63) \\
(0.75) \\
(0.67) \\
(0.75) \\
(0.70)\end{array}$ & $\begin{array}{l}3.7 \\
3.4 \\
3.8 \\
5.3 \\
4.2 \\
4.7 \\
2.0\end{array}$ & $\begin{array}{l}(0.91) \\
(0.70) \\
(0.78) \\
(0.85) \\
(0.79) \\
(0.88) \\
(0.52)\end{array}$ & $\begin{array}{l}3.8 \\
3.1 \\
3.8 \\
5.1 \\
3.0 \\
3.1 \\
2.9\end{array}$ & $\begin{array}{l}(0.85) \\
(0.61) \\
(0.67) \\
(0.83) \\
(0.58) \\
(0.65) \\
(0.68)\end{array}$ \\
\hline 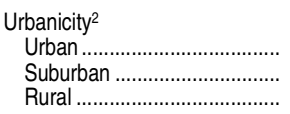 & $\begin{array}{r}9.3 \\
10.3 \\
8.3\end{array}$ & $\begin{array}{l}(0.64) \\
(0.49) \\
(0.79)\end{array}$ & $\begin{array}{l}8.4 \\
7.6 \\
6.4\end{array}$ & $\begin{array}{l}(0.69) \\
(0.43) \\
(0.96)\end{array}$ & $\begin{array}{l}5.9 \\
5.7 \\
4.7\end{array}$ & $\begin{array}{l}(0.58) \\
(0.40) \\
(0.93)\end{array}$ & $\begin{array}{l}6.1 \\
4.8 \\
4.7\end{array}$ & $\begin{array}{l}(0.58) \\
(0.33) \\
(0.75)\end{array}$ & $\begin{array}{l}5.3 \\
4.2 \\
2.8\end{array}$ & $\begin{array}{l}(0.65) \\
(0.34) \\
(0.69)\end{array}$ & $\begin{array}{l}4.5 \\
4.1 \\
4.4\end{array}$ & $\begin{array}{l}(0.58) \\
(0.38) \\
(0.55)\end{array}$ & $\begin{array}{l}4.2 \\
4.0 \\
3.1\end{array}$ & $\begin{array}{l}(0.56) \\
(0.36) \\
(0.66)\end{array}$ & $\begin{array}{l}4.3 \\
3.3 \\
2.8\end{array}$ & $\begin{array}{l}(0.56) \\
(0.34) \\
(0.57)\end{array}$ \\
\hline 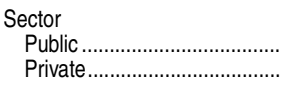 & $\begin{array}{l}9.8 \\
6.6 \\
\end{array}$ & $\begin{array}{l}(0.38) \\
(0.90) \\
\end{array}$ & $\begin{array}{l}7.9 \\
4.5 \\
\end{array}$ & $\begin{array}{l}(0.37) \\
(0.80) \\
\end{array}$ & $\begin{array}{l}5.7 \\
3.4 \\
\end{array}$ & $\begin{array}{l}(0.34) \\
(0.72) \\
\end{array}$ & $\begin{array}{l}5.2 \\
4.9 \\
\end{array}$ & $\begin{array}{l}(0.26) \\
(0.79) \\
\end{array}$ & $\begin{array}{l}4.4 \\
2.7 \\
\end{array}$ & $\begin{array}{l}(0.32) \\
(0.77) \\
\end{array}$ & $\begin{array}{l}4.6 \\
1.1 ! \\
\end{array}$ & $\begin{array}{l}(0.32) \\
(0.50) \\
\end{array}$ & $\begin{array}{l}4.1 \\
1.8 ! \\
\end{array}$ & $\begin{array}{l}(0.30) \\
(0.76) \\
\end{array}$ & $\begin{array}{l}3.7 \\
1.9 ! \\
\end{array}$ & $\begin{array}{l}(0.29) \\
(0.68) \\
\end{array}$ \\
\hline$\ldots \ldots \ldots \ldots \ldots$ & 7.1 & $(0.29)$ & 5.7 & $(0.32)$ & 4.2 & $(0.24)$ & 4.0 & $(0.21)$ & 3.1 & $(0.27)$ & 3.0 & $(0.23)$ & 2.8 & $(0.23)$ & 2.6 & $(0.23)$ \\
\hline 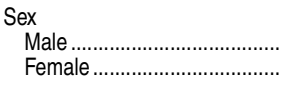 & $\begin{array}{l}7.1 \\
7.1\end{array}$ & $\begin{array}{l}(0.38) \\
(0.41)\end{array}$ & $\begin{array}{l}5.7 \\
5.7\end{array}$ & $\begin{array}{l}(0.41) \\
(0.43)\end{array}$ & $\begin{array}{l}4.5 \\
3.8\end{array}$ & $\begin{array}{l}(0.34) \\
(0.33)\end{array}$ & $\begin{array}{l}4.0 \\
4.1\end{array}$ & $\begin{array}{l}(0.27) \\
(0.32)\end{array}$ & $\begin{array}{l}3.1 \\
3.2\end{array}$ & $\begin{array}{l}(0.34) \\
(0.36)\end{array}$ & $\begin{array}{l}3.0 \\
3.0\end{array}$ & $\begin{array}{l}(0.34) \\
(0.33)\end{array}$ & $\begin{array}{l}3.4 \\
2.1\end{array}$ & $\begin{array}{l}(0.36) \\
(0.28)\end{array}$ & $\begin{array}{l}2.6 \\
2.6\end{array}$ & $\begin{array}{l}(0.29) \\
(0.33)\end{array}$ \\
\hline 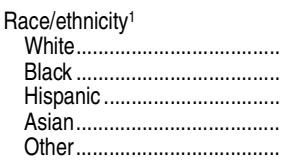 & $\begin{array}{l}7.4 \\
7.1 \\
5.8 \\
- \\
6.5\end{array}$ & $\begin{array}{r}(0.32) \\
(0.85) \\
(0.78) \\
(\dagger) \\
(1.40)\end{array}$ & $\begin{array}{r}5.8 \\
7.4 \\
3.9 \\
-\overline{4.4}\end{array}$ & $\begin{array}{r}(0.43) \\
(0.77) \\
(0.61) \\
(\dagger) \\
(0.98)\end{array}$ & $\begin{array}{l}4.2 \\
5.0 \\
3.7 \\
-\overline{2.9}\end{array}$ & $\begin{array}{r}(0.30) \\
(0.68) \\
(0.69) \\
(\dagger) \\
(0.87)\end{array}$ & $\begin{array}{r}4.3 \\
4.0 \\
3.0 \\
\overline{4.4}\end{array}$ & $\begin{array}{r}(0.28) \\
(0.66) \\
(0.41) \\
(t) \\
(1.04)\end{array}$ & $\begin{array}{r}3.4 \\
2.7 \\
3.1 \\
\ddagger \\
\ddagger\end{array}$ & $\begin{array}{r}(0.32) \\
(0.65) \\
(0.64) \\
(\dagger) \\
(\dagger)\end{array}$ & $\begin{array}{l}3.1 \\
3.0 \\
2.2 \\
3.2 ! \\
4.5 !\end{array}$ & $\begin{array}{l}(0.29) \\
(0.70) \\
(0.47) \\
(1.32) \\
(1.57)\end{array}$ & $\begin{array}{r}2.9 \\
2.5 \\
3.0 \\
\ddagger \\
\ddagger\end{array}$ & $\begin{array}{r}(0.31) \\
(0.61) \\
(0.63) \\
(\dagger) \\
(\dagger)\end{array}$ & $\begin{array}{l}2.5 \\
3.7 \\
2.0 \\
2.5 ! \\
2.8 !\end{array}$ & $\begin{array}{l}(0.28) \\
(0.78) \\
(0.41) \\
(1.23) \\
(1.21)\end{array}$ \\
\hline 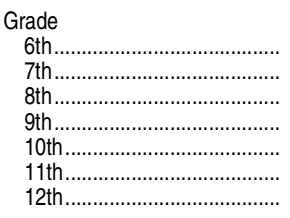 & $\begin{array}{l}5.4 \\
8.1 \\
7.9 \\
9.1 \\
7.7 \\
5.5 \\
4.6\end{array}$ & $\begin{array}{l}(0.66) \\
(0.71) \\
(0.72) \\
(0.77) \\
(0.72) \\
(0.66) \\
(0.67)\end{array}$ & $\begin{array}{l}5.2 \\
6.0 \\
5.9 \\
6.5 \\
6.5 \\
5.5 \\
4.0\end{array}$ & $\begin{array}{l}(0.97) \\
(0.73) \\
(0.81) \\
(0.71) \\
(0.73) \\
(0.67) \\
(0.71)\end{array}$ & $\begin{array}{l}4.0 \\
3.4 \\
3.3 \\
6.2 \\
5.7 \\
3.8 \\
2.3\end{array}$ & $\begin{array}{l}(0.70) \\
(0.51) \\
(0.50) \\
(0.76) \\
(0.72) \\
(0.57) \\
(0.45)\end{array}$ & $\begin{array}{l}2.2 \\
4.8 \\
4.1 \\
5.3 \\
3.7 \\
4.1 \\
3.1\end{array}$ & $\begin{array}{l}(0.63) \\
(0.67) \\
(0.56) \\
(0.62) \\
(0.59) \\
(0.64) \\
(0.68)\end{array}$ & $\begin{array}{l}2.8 \\
2.9 \\
2.4 \\
3.7 \\
3.8 \\
2.8 \\
3.5\end{array}$ & $\begin{array}{l}(0.75) \\
(0.50) \\
(0.53) \\
(0.61) \\
(0.66) \\
(0.45) \\
(0.85)\end{array}$ & $\begin{array}{l}2.7 \\
2.7 \\
2.5 \\
4.6 \\
3.6 \\
2.6 \\
1.9\end{array}$ & $\begin{array}{l}(0.77) \\
(0.54) \\
(0.54) \\
(0.70) \\
(0.63) \\
(0.61) \\
(0.55)\end{array}$ & $\begin{array}{l}1.3 ! \\
2.1 \\
2.0 \\
4.9 \\
3.5 \\
3.3 \\
1.5\end{array}$ & $\begin{array}{l}(0.52) \\
(0.57) \\
(0.55) \\
(0.80) \\
(0.72) \\
(0.74) \\
(0.44)\end{array}$ & $\begin{array}{l}2.7 \\
1.9 \\
2.0 \\
4.4 \\
2.1 \\
2.7 \\
2.4\end{array}$ & $\begin{array}{l}(0.70) \\
(0.44) \\
(0.48) \\
(0.78) \\
(0.50) \\
(0.58) \\
(0.62)\end{array}$ \\
\hline $\begin{array}{l}\text { Urbanicity }^{2} \\
\text { Urban }\end{array}$ & $\begin{array}{l}6.6 \\
7.6 \\
6.8\end{array}$ & $\begin{array}{l}(0.51) \\
(0.40) \\
(0.66)\end{array}$ & $\begin{array}{l}6.9 \\
5.4 \\
5.0\end{array}$ & $\begin{array}{l}(0.59) \\
(0.36) \\
(0.95)\end{array}$ & $\begin{array}{l}4.5 \\
4.3 \\
3.4\end{array}$ & $\begin{array}{l}(0.52) \\
(0.32) \\
(0.65)\end{array}$ & $\begin{array}{l}4.5 \\
3.8 \\
3.9\end{array}$ & $\begin{array}{l}(0.47) \\
(0.27) \\
(0.66)\end{array}$ & $\begin{array}{l}3.6 \\
3.2 \\
2.2 !\end{array}$ & $\begin{array}{l}(0.51) \\
(0.31) \\
(0.68)\end{array}$ & $\begin{array}{l}2.8 \\
3.0 \\
3.2\end{array}$ & $\begin{array}{l}(0.48) \\
(0.31) \\
(0.46)\end{array}$ & $\begin{array}{l}2.9 \\
2.8 \\
2.3\end{array}$ & $\begin{array}{l}(0.45) \\
(0.32) \\
(0.59)\end{array}$ & $\begin{array}{l}3.0 \\
2.5 \\
2.0\end{array}$ & $\begin{array}{l}(0.45) \\
(0.30) \\
(0.47)\end{array}$ \\
\hline 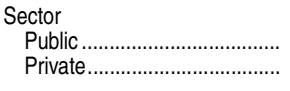 & $\begin{array}{l}7.3 \\
5.2 \\
\end{array}$ & $\begin{array}{l}(0.32) \\
(0.74) \\
\end{array}$ & $\begin{array}{l}5.9 \\
4.3 \\
\end{array}$ & $\begin{array}{l}(0.34) \\
(0.78) \\
\end{array}$ & $\begin{array}{l}4.4 \\
2.5 \\
\end{array}$ & $\begin{array}{l}(0.26) \\
(0.67) \\
\end{array}$ & $\begin{array}{l}4.0 \\
4.0 \\
\end{array}$ & $\begin{array}{l}(0.22) \\
(0.77) \\
\end{array}$ & $\begin{array}{l}3.3 \\
1.3 ! \\
\end{array}$ & $\begin{array}{l}(0.28) \\
(0.48) \\
\end{array}$ & $\begin{array}{l}3.2 \\
1.1 ! \\
\end{array}$ & $\begin{array}{l}(0.25) \\
(0.50) \\
\end{array}$ & $\begin{array}{r}2.9 \\
\ddagger \\
\end{array}$ & $\begin{array}{r}(0.25) \\
(\dagger) \\
\end{array}$ & $\begin{array}{l}2.7 \\
1.2 ! \\
\end{array}$ & $\begin{array}{l}(0.24) \\
(0.52) \\
\end{array}$ \\
\hline 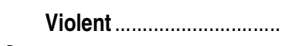 & 3.0 & $(0.21)$ & 2.3 & $(0.18)$ & 1.8 & $(0.19)$ & 1.3 & $(0.15)$ & 1.2 & $(0.15)$ & 1.6 & $(0.18)$ & 1.4 & $(0.17)$ & 1.1 & $(0.15)$ \\
\hline 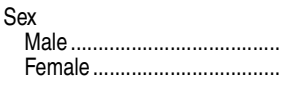 & $\begin{array}{l}3.5 \\
2.4\end{array}$ & $\begin{array}{l}(0.27) \\
(0.25)\end{array}$ & $\begin{array}{l}2.5 \\
2.0\end{array}$ & $\begin{array}{l}(0.26) \\
(0.22)\end{array}$ & $\begin{array}{l}2.1 \\
1.5\end{array}$ & $\begin{array}{l}(0.26) \\
(0.24)\end{array}$ & $\begin{array}{l}1.8 \\
0.9\end{array}$ & $\begin{array}{l}(0.24) \\
(0.16)\end{array}$ & $\begin{array}{l}1.6 \\
0.8\end{array}$ & $\begin{array}{l}(0.25) \\
(0.15)\end{array}$ & $\begin{array}{l}1.7 \\
1.4\end{array}$ & $\begin{array}{l}(0.26) \\
(0.23)\end{array}$ & $\begin{array}{l}1.6 \\
1.1\end{array}$ & $\begin{array}{l}(0.25) \\
(0.21)\end{array}$ & $\begin{array}{l}1.2 \\
0.9\end{array}$ & $\begin{array}{l}(0.21) \\
(0.17)\end{array}$ \\
\hline 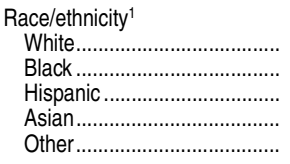 & $\begin{array}{l}3.0 \\
3.4 \\
2.7 \\
-\overline{2.5 !}\end{array}$ & $\begin{array}{r}(0.23) \\
(0.61) \\
(0.43) \\
(\dagger) \\
(0.87)\end{array}$ & $\begin{array}{l}2.1 \\
3.5 \\
1.9 \\
-\overline{2.2 !}\end{array}$ & $\begin{array}{r}(0.22) \\
(0.55) \\
(0.38) \\
(\dagger) \\
(0.81)\end{array}$ & $\begin{array}{l}2.0 \\
1.3 ! \\
1.5 \\
\frac{7}{\ddagger}\end{array}$ & $\begin{array}{r}(0.24) \\
(0.40) \\
(0.41) \\
(\dagger) \\
(\dagger)\end{array}$ & $\begin{array}{l}1.4 \\
1.6 \\
1.1 \\
- \\
\ddagger\end{array}$ & $\begin{array}{r}(0.18) \\
(0.41) \\
(0.28) \\
(\dagger) \\
(\dagger)\end{array}$ & $\begin{array}{l}1.3 \\
1.3 ! \\
0.9 \\
\ddagger \\
\ddagger\end{array}$ & $\begin{array}{r}(0.20) \\
(0.46) \\
(0.24) \\
(\dagger) \\
(\dagger)\end{array}$ & $\begin{array}{l}1.5 \\
1.6 ! \\
1.4 \\
\ddagger \\
4.5 !\end{array}$ & $\begin{array}{r}(0.22) \\
(0.50) \\
(0.42) \\
(\dagger) \\
(1.50)\end{array}$ & $\begin{array}{l}1.2 \\
2.3 \\
1.3 ! \\
\# \\
\ddagger\end{array}$ & $\begin{array}{r}(0.21) \\
(0.62) \\
(0.40) \\
(\dagger) \\
(\dagger)\end{array}$ & $\begin{array}{l}1.2 \\
1.1 ! \\
1.0 \\
\# \\
\ddagger\end{array}$ & $\begin{array}{r}(0.17) \\
(0.42) \\
(0.28) \\
\dagger \\
\dagger\end{array}$ \\
\hline 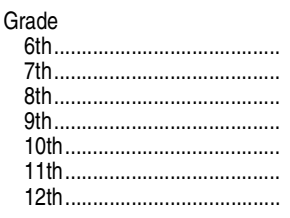 & $\begin{array}{l}5.1 \\
3.8 \\
3.1 \\
3.4 \\
2.1 \\
1.9 \\
1.9\end{array}$ & $\begin{array}{l}(0.73) \\
(0.54) \\
(0.44) \\
(0.50) \\
(0.36) \\
(0.40) \\
(0.41)\end{array}$ & $\begin{array}{l}3.8 \\
2.6 \\
2.4 \\
3.2 \\
1.7 \\
1.8 ! \\
0.8 !\end{array}$ & $\begin{array}{l}(0.76) \\
(0.43) \\
(0.44) \\
(0.47) \\
(0.39) \\
(0.58) \\
(0.31)\end{array}$ & $\begin{array}{l}2.6 \\
2.6 \\
1.3 \\
2.4 \\
1.2 \\
1.6 \\
0.9 !\end{array}$ & $\begin{array}{l}(0.66) \\
(0.47) \\
(0.34) \\
(0.46) \\
(0.31) \\
(0.39) \\
(0.31)\end{array}$ & $\begin{array}{l}1.9 \\
1.7 \\
1.5 \\
1.5 \\
1.4 \\
1.0 ! \\
0.5 !\end{array}$ & $\begin{array}{l}(0.53) \\
(0.43) \\
(0.35) \\
(0.31) \\
(0.36) \\
(0.33) \\
(0.26)\end{array}$ & $\begin{array}{c}1.9 \\
2.6 \\
1.4 \\
1.0 \\
0.5 ! \\
0.7 ! \\
\ddagger\end{array}$ & $\begin{array}{r}(0.55) \\
(0.53) \\
(0.39) \\
(0.29) \\
(0.24) \\
(0.31) \\
(t)\end{array}$ & $\begin{array}{l}1.5 ! \\
2.4 \\
2.1 \\
1.2 ! \\
1.2 ! \\
1.5 ! \\
0.8 !\end{array}$ & $\begin{array}{l}(0.54) \\
(0.50) \\
(0.47) \\
(0.37) \\
(0.39) \\
(0.46) \\
(0.35)\end{array}$ & $\begin{array}{c}2.6 ! \\
1.2 ! \\
2.0 \\
0.9 ! \\
1.0 ! \\
1.5 ! \\
\ddagger\end{array}$ & $\begin{array}{r}(0.83) \\
(0.42) \\
(0.60) \\
(0.37) \\
(0.37) \\
(0.51) \\
(t)\end{array}$ & $\begin{array}{l}1.3 ! \\
1.2 ! \\
2.1 \\
1.1 ! \\
0.9 ! \\
\ddagger \\
\ddagger\end{array}$ & $\begin{array}{r}(0.49) \\
(0.41) \\
(0.50) \\
(0.35) \\
(0.34) \\
\dagger \\
\dagger\end{array}$ \\
\hline 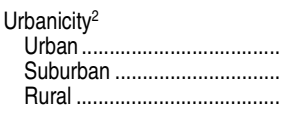 & $\begin{array}{l}3.3 \\
3.5 \\
1.8\end{array}$ & $\begin{array}{l}(0.40) \\
(0.30) \\
(0.31)\end{array}$ & $\begin{array}{l}2.3 \\
2.4 \\
1.9\end{array}$ & $\begin{array}{l}(0.38) \\
(0.26) \\
(0.50)\end{array}$ & $\begin{array}{l}1.7 \\
1.7 \\
2.0 !\end{array}$ & $\begin{array}{l}(0.29) \\
(0.20) \\
(0.64)\end{array}$ & $\begin{array}{l}1.8 \\
1.2 \\
0.9 !\end{array}$ & $\begin{array}{l}(0.32) \\
(0.19) \\
(0.31)\end{array}$ & $\begin{array}{l}1.8 \\
1.1 \\
0.6 !\end{array}$ & $\begin{array}{l}(0.34) \\
(0.18) \\
(0.26)\end{array}$ & $\begin{array}{l}2.0 \\
1.3 \\
1.7\end{array}$ & $\begin{array}{l}(0.35) \\
(0.23) \\
(0.36)\end{array}$ & $\begin{array}{l}1.8 \\
1.3 \\
0.8 !\end{array}$ & $\begin{array}{l}(0.41) \\
(0.23) \\
(0.32)\end{array}$ & $\begin{array}{l}1.4 \\
0.9 \\
1.0 !\end{array}$ & $\begin{array}{l}(0.31) \\
(0.16) \\
(0.31)\end{array}$ \\
\hline 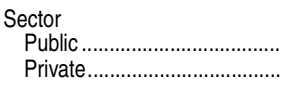 & $\begin{array}{l}3.1 \\
1.7\end{array}$ & $\begin{array}{l}(0.22) \\
(0.45)\end{array}$ & $\begin{array}{r}2.5 \\
\ddagger\end{array}$ & $\begin{array}{r}(0.20) \\
(t)\end{array}$ & $\begin{array}{l}1.9 \\
1.0 !\end{array}$ & $\begin{array}{l}(0.20) \\
(0.32)\end{array}$ & $\begin{array}{l}1.4 \\
0.9 !\end{array}$ & $\begin{array}{l}(0.15) \\
(0.39)\end{array}$ & $\begin{array}{l}1.2 \\
1.4 !\end{array}$ & $\begin{array}{l}(0.15) \\
(0.60)\end{array}$ & $\begin{array}{r}1.7 \\
\ddagger\end{array}$ & $\begin{array}{r}(0.20) \\
(t)\end{array}$ & $\begin{array}{r}1.4 \\
\ddagger\end{array}$ & $\begin{array}{r}(0.19) \\
(t)\end{array}$ & $\begin{array}{r}1.1 \\
\ddagger\end{array}$ & $\begin{array}{r}(0.15) \\
\dagger\end{array}$ \\
\hline
\end{tabular}

See notes at end of table. 
Table 228.30. Percentage of students ages 12-18 who reported criminal victimization at school during the previous 6 months, by type of victimization and selected student and school characteristics: Selected years, 1995 through 2011-Continued

[Standard errors appear in parentheses]

\begin{tabular}{|c|c|c|c|c|c|c|c|c|c|c|c|c|c|c|c|c|}
\hline $\begin{array}{l}\text { Type of victimization and } \\
\text { student or school characteristic }\end{array}$ & & 1995 & & 1999 & & 2001 & & 2003 & & 2005 & & 2007 & & 2009 & & 2011 \\
\hline 1 & & 2 & & 3 & & 4 & & 5 & & 6 & & 7 & & 8 & & 9 \\
\hline Serious violent ${ }^{3} \ldots \ldots \ldots \ldots \ldots$ & 0.7 & $(0.09)$ & 0.5 & $(0.09)$ & 0.4 & $(0.08)$ & 0.2 & $(0.06)$ & 0.3 & $(0.07)$ & 0.4 & $(0.08)$ & 0.3 & $(0.09)$ & $0.1 !$ & $(0.05)$ \\
\hline 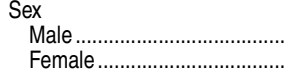 & $\begin{array}{l}0.9 \\
0.4\end{array}$ & $\begin{array}{l}(0.14) \\
(0.10)\end{array}$ & $\begin{array}{l}0.6 \\
0.5\end{array}$ & $\begin{array}{l}(0.12) \\
(0.12)\end{array}$ & $\begin{array}{l}0.5 \\
0.4 !\end{array}$ & $\begin{array}{l}(0.11) \\
(0.12)\end{array}$ & $\begin{array}{c}0.3 ! \\
\ddagger\end{array}$ & $\begin{array}{r}(0.10) \\
(\dagger)\end{array}$ & $\begin{array}{l}0.3 ! \\
0.3\end{array}$ & $\begin{array}{l}(0.10) \\
(0.07)\end{array}$ & $\begin{array}{l}0.5 ! \\
0.2 !\end{array}$ & $\begin{array}{l}(0.14) \\
(0.08)\end{array}$ & $\begin{array}{r}0.6 \\
\ddagger\end{array}$ & $\begin{array}{r}(0.16) \\
(\dagger)\end{array}$ & $\begin{array}{l}0.2 ! \\
\ddagger\end{array}$ & $\begin{array}{r}(0.08) \\
\dagger\end{array}$ \\
\hline 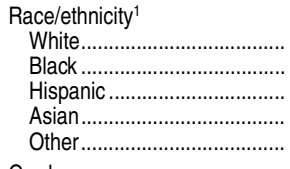 & $\begin{array}{l}0.6 \\
1.0 ! \\
0.9 ! \\
- \\
\ddagger\end{array}$ & $\begin{array}{r}(0.09) \\
(0.31) \\
(0.30) \\
(\dagger) \\
(\dagger)\end{array}$ & $\begin{array}{l}0.4 \\
1.2 \\
0.6 ! \\
\frac{\#}{\#}\end{array}$ & $\begin{array}{r}(0.09) \\
(0.33) \\
(0.22) \\
(\dagger) \\
(\dagger)\end{array}$ & $\begin{array}{l}0.4 \\
0.5 ! \\
0.8 ! \\
- \\
\#\end{array}$ & $\begin{array}{r}(0.08) \\
(0.25) \\
(0.33) \\
(t) \\
(t)\end{array}$ & $\begin{array}{l}0.2 ! \\
\ddagger \\
0.4 ! \\
- \\
\ddagger\end{array}$ & $\begin{array}{r}(0.06) \\
(\dagger) \\
(0.18) \\
(\dagger) \\
(\dagger)\end{array}$ & $\begin{array}{l}0.3 ! \\
\ddagger \\
0.4 ! \\
\ddagger \\
\ddagger\end{array}$ & $\begin{array}{r}(0.09) \\
(\dagger) \\
(0.16) \\
(\dagger) \\
(\dagger)\end{array}$ & $\begin{array}{l}0.2 ! \\
\ddagger \\
0.8 ! \\
\ddagger \\
\ddagger\end{array}$ & $\begin{array}{r}(0.08) \\
(\dagger) \\
(0.32) \\
(\dagger) \\
(\dagger)\end{array}$ & $\begin{array}{c}0.3 ! \\
\ddagger \\
\ddagger \\
\# \\
\#\end{array}$ & $\begin{array}{r}(0.10) \\
(t) \\
(t) \\
(t) \\
(t)\end{array}$ & $\begin{array}{c}0.2 ! \\
\ddagger \\
\ddagger \\
\# \\
\#\end{array}$ & $\begin{array}{r}(0.07) \\
\dagger \\
\dagger \\
\dagger \\
\dagger\end{array}$ \\
\hline $\begin{array}{l}\text { Grade } \\
\text { 6th } \\
\text { 7th } \\
\text { 8th } \\
\text { 9th } \\
\text { 10th } \\
\text { 11th }\end{array}$ & $\begin{array}{l}1.5 \\
0.9 \\
0.8 ! \\
0.7 \\
0.4 ! \\
0.4 ! \\
\quad \ddagger\end{array}$ & $\begin{array}{r}(0.42) \\
(0.24) \\
(0.23) \\
(0.21) \\
(0.17) \\
(0.16) \\
(\dagger)\end{array}$ & $\begin{array}{l}1.3 ! \\
0.9 ! \\
0.5 ! \\
0.6 ! \\
\ddagger \\
\ddagger \\
\ddagger\end{array}$ & $\begin{array}{r}(0.40) \\
(0.27) \\
(0.22) \\
(0.18) \\
(\dagger) \\
(\dagger) \\
(\dagger)\end{array}$ & $\begin{array}{l}\ddagger \\
0.6 ! \\
0.3 ! \\
0.8 ! \\
0.4 ! \\
\ddagger \\
\ddagger\end{array}$ & $\begin{array}{r}(\dagger) \\
(0.24) \\
(0.14) \\
(0.31) \\
(0.18) \\
(\dagger) \\
(\dagger)\end{array}$ & $\begin{array}{c}\# \\
\ddagger \\
0.3 ! \\
0.6 ! \\
\# \\
\ddagger \\
\#\end{array}$ & $\begin{array}{r}(\dagger) \\
(\dagger) \\
(0.15) \\
(0.21) \\
(\dagger) \\
(\dagger) \\
(t)\end{array}$ & $\begin{array}{l}\ddagger \\
\ddagger \\
\ddagger \\
\ddagger \\
\ddagger \\
\ddagger \\
\ddagger\end{array}$ & \begin{tabular}{r|}
$(\dagger)$ \\
$(\dagger)$ \\
$(\dagger)$ \\
$(\dagger)$ \\
$(\dagger)$ \\
$(t)$ \\
$(t)$
\end{tabular} & $\begin{array}{l}\ddagger \\
0.4 ! \\
\ddagger \\
\ddagger \\
\ddagger \\
0.6 ! \\
\ddagger\end{array}$ & $\begin{array}{r}(\dagger) \\
(0.20) \\
(\dagger) \\
(\dagger) \\
(\dagger) \\
(0.27) \\
(\dagger)\end{array}$ & $\begin{array}{l}\ddagger \\
\ddagger \\
\ddagger \\
\ddagger \\
\ddagger \\
\ddagger \\
\ddagger\end{array}$ & $\begin{array}{r}(t) \\
(t) \\
(t) \\
(t) \\
(t) \\
(t) \\
(t)\end{array}$ & $\begin{array}{c}\ddagger \\
0.5 ! \\
\# \\
\ddagger \\
\# \\
\# \\
\#\end{array}$ & $\begin{array}{r}\dagger \\
(0.23) \\
\dagger \\
\dagger \\
\dagger \\
\dagger \\
\dagger\end{array}$ \\
\hline $\begin{array}{l}\text { Urbanicity }^{2} \\
\text { Urban } \\
\text { Suburban } \\
\text { Rural }\end{array}$ & $\begin{array}{l}1.3 \\
0.6 \\
0.3 !\end{array}$ & $\begin{array}{l}(0.24) \\
(0.12) \\
(0.10)\end{array}$ & $\begin{array}{l}0.7 \\
0.5 \\
0.4 !\end{array}$ & $\begin{array}{l}(0.19) \\
(0.11) \\
(0.18)\end{array}$ & $\begin{array}{l}0.5 \\
0.4 \\
0.5 !\end{array}$ & $\begin{array}{l}(0.15) \\
(0.09) \\
(0.24)\end{array}$ & $\begin{array}{l}0.4 ! \\
0.1 ! \\
\ddagger\end{array}$ & $\begin{array}{r}(0.14) \\
(0.05) \\
(\dagger)\end{array}$ & $\begin{array}{l}0.4 ! \\
0.3 ! \\
\ddagger\end{array}$ & $\begin{array}{r}(0.17) \\
(0.08) \\
(\dagger)\end{array}$ & $\begin{array}{l}0.7 ! \\
0.2 ! \\
\ddagger\end{array}$ & $\begin{array}{r}(0.23) \\
(0.09) \\
(\dagger)\end{array}$ & $\begin{array}{l}0.6 ! \\
0.3 ! \\
\ddagger\end{array}$ & $\begin{array}{r}(0.22) \\
(0.11) \\
(\dagger)\end{array}$ & $\begin{array}{l}\ddagger \\
\ddagger \\
\ddagger\end{array}$ & $\begin{array}{l}\dagger \\
\dagger \\
\dagger\end{array}$ \\
\hline 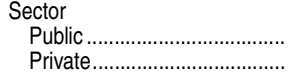 & $\begin{array}{r}0.7 \\
\ddagger\end{array}$ & $\begin{array}{r}(0.10) \\
(t)\end{array}$ & $\begin{array}{r}0.6 \\
\#\end{array}$ & $\begin{array}{r}(0.10) \\
(t)\end{array}$ & $\begin{array}{r}0.5 \\
\#\end{array}$ & $\begin{array}{r}(0.09) \\
(t)\end{array}$ & $\begin{array}{r}0.2 \\
\#\end{array}$ & $\begin{array}{r}(0.06) \\
(t)\end{array}$ & $\begin{array}{r}0.3 \\
\ddagger\end{array}$ & $\begin{array}{r}(0.06) \\
(\dagger)\end{array}$ & $\begin{array}{r}0.4 \\
\ddagger\end{array}$ & $\begin{array}{r}(0.09) \\
(\dagger)\end{array}$ & $\begin{array}{r}0.4 \\
\ddagger\end{array}$ & $\begin{array}{r}(0.10) \\
(t)\end{array}$ & $\begin{array}{c}0.1 ! \\
\#\end{array}$ & $\begin{array}{r}(0.06) \\
\dagger\end{array}$ \\
\hline
\end{tabular}

-Not available.

$†$ Not applicable.

!Interpret data with caution. The coefficient of variation (CV) for this estimate is between 30 and 50 percent.

†Reporting standards not met. Either there are too few cases for a reliable estimate or the coefficient of variation (CV) is 50 percent or greater.

'Race categories exclude persons of Hispanic ethnicity. "Other" includes American Indians/ Alaska Natives, Asians (prior to 2005), Pacific Islanders, and, from 2003 onward, persons reporting that they are of two or more races. Due to changes in racial/ethnic categories, comparisons of race/ethnicity across years should be made with caution.

${ }^{2}$ Refers to the Standard Metropolitan Statistical Area (MSA) status of the respondent's household as defined in 2000 by the U.S. Census Bureau. Categories include "central city of an MSA (Urban)," "in MSA but not in central city (Suburban)," and "not MSA (Rural)."
${ }^{3}$ Serious violent victimization is also included in violent victimization.

NOTE: "Total victimization" includes theft and violent victimization. A single student could report more than one type of victimization. In the total victimization rows, students who reported both theft and violent victimization are counted only once. "Theft" includes attempted and completed purse-snatching, completed pickpocketing, and all attempted and completed thefts, with the exception of motor vehicle thefts. Theft does not include robbery, which involves the threat or use of force and is classified as a violent crime. "Serious violent victimization" includes the crimes of rape, sexual assault, robbery, and aggravated assault. "Violent victimization" includes the serious violent crimes as well as simple assault. "At school" includes the school building, on school property, on a school bus, and, from 2001 onward, going to and from school.

SOURCE: U.S. Department of Justice, Bureau of Justice Statistics, School Crime Supplement (SCS) to the National Crime Victimization Survey, selected years, 1995 through 2011. (This table was prepared September 2013.) 


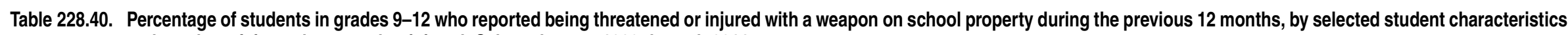
and number of times threatened or injured: Selected years, 1993 through 2011

[Standard errors appear in parentheses]

\begin{tabular}{|c|c|c|c|c|c|c|c|c|c|c|c|c|c|c|c|c|c|c|c|c|c|c|c|c|c|c|c|c|}
\hline \multirow[b]{2}{*}{ Number of times and year } & \multirow{2}{*}{\multicolumn{2}{|c|}{ Total }} & \multicolumn{4}{|c|}{ Sex } & \multicolumn{14}{|c|}{ Race/ethnicity ${ }^{1}$} & \multicolumn{8}{|c|}{ Grade } \\
\hline & & & & Male & & Female & & White & & Black & & Hispanic & & Asian $^{2}$ & \begin{tabular}{|c|} 
America \\
Alas
\end{tabular} & $\begin{array}{l}\text { Indian/ } \\
\text { a Native }\end{array}$ & Pacific I & slander ${ }^{2}$ & & $\begin{array}{l}\text { Two or } \\
\text { e races }\end{array}$ & & th grade & & th grade & & $h$ grade & & th grade \\
\hline 1 & & 2 & & 3 & & 4 & & 5 & & 6 & & 7 & & 8 & & 9 & & 10 & & 11 & & 12 & & 13 & & 14 & & 15 \\
\hline \multicolumn{29}{|l|}{ At least once } \\
\hline 1993 & & $(0.44)$ & 9.2 & $(0.64)$ & & $(0.40)$ & 6.3 & $(0.58)$ & 11.2 & $(0.95)$ & 8.6 & $(0.83)$ & - & (†) & 11.7 & $(2.50)$ & - & $(\dagger)$ & - & $(t)$ & 9.4 & $(0.92)$ & 7.3 & (0.59) & 7.3 & $(0.64)$ & & $(0.62)$ \\
\hline 1995. & 8.4 & $(0.52)$ & 10.9 & $(0.57)$ & 5.8 & (0.68) & 7.0 & $(0.53)$ & 11.0 & (1.61) & 12.4 & (1.44) & - & $(+)$ & 11.4 ! & (4.22) & - & $(\dagger)$ & - & $(t)$ & 9.6 & $(0.96)$ & 9.6 & (1.03) & 7.7 & $(0.64)$ & 6.7 & $(0.57)$ \\
\hline 1997 & 7.4 & $(0.45)$ & 10.2 & $(0.71)$ & 4.0 & $(0.32)$ & 6.2 & $(0.56)$ & 9.9 & $(0.91)$ & 9.0 & $(0.63)$ & - & $(+)$ & 12.5 ! & (5.15) & - & $\left(\begin{array}{l}1 \\
(\dagger)\end{array}\right.$ & - & $(t)$ & 10.1 & (1.02) & 7.9 & (1.14) & 5.9 & $(0.70)$ & 5.8 & $(0.80)$ \\
\hline $1999 \ldots$ & 7.7 & $(0.42)$ & 9.5 & $(0.80)$ & 5.8 & (0.64) & 6.6 & $(0.35)$ & 7.6 & $(0.85)$ & 9.8 & (1.09) & 7.7 & $(1.05)$ & 13.2 ! & (5.45) & 15.6 & $(4.46)$ & 9.3 & (1.22) & 10.5 & $(0.95)$ & 8.2 & $(0.92)$ & 6.1 & $(0.46)$ & 5.1 & $(0.79)$ \\
\hline $2001 \ldots \ldots \ldots \ldots \ldots \ldots \ldots \ldots$ & 8.9 & $(0.55)$ & 11.5 & $(0.66)$ & 6.5 & $(0.52)$ & 8.5 & $(0.66)$ & 9.3 & $(0.71)$ & 8.9 & $(1.05)$ & 11.3 & $(2.73)$ & 15.2 ! & $(4.57)$ & 24.8 & $(7.16)$ & 10.3 & $(2.33)$ & 12.7 & $(0.89)$ & 9.1 & $(0.75)$ & 6.9 & $(0.65)$ & 5.3 & $(0.52)$ \\
\hline $2003 \ldots$ & 9.2 & $(0.75)$ & 11.6 & $(0.96)$ & 6.5 & $(0.61)$ & 7.8 & $(0.77)$ & 10.9 & $(0.80)$ & 9.4 & (1.23) & 11.5 & $(2.66)$ & 22.1 & $(4.79)$ & 16.3 & $(4.31)$ & 18.7 & $(3.11)$ & 12.1 & $(1.25)$ & 9.2 & (1.02) & 7.3 & $(0.69)$ & 6.3 & $(0.92)$ \\
\hline 2005 & 7.9 & $(0.35)$ & 9.7 & $(0.42)$ & 6.1 & $(0.41)$ & 7.2 & $(0.46)$ & 8.1 & $(0.69)$ & 9.8 & $(0.86)$ & 4.6 & $(1.10)$ & 9.8 & $(2.67)$ & $14.5 !$ & (4.93) & 10.7 & $(2.33)$ & 10.5 & $(0.63)$ & 8.8 & $(0.72)$ & 5.5 & $(0.43)$ & 5.8 & $(0.52)$ \\
\hline 20 & 7.8 & $(0.44)$ & 10.2 & $(0.59)$ & 5.4 & $(0.41)$ & 6.9 & $(0.52)$ & 9.7 & $(0.86)$ & 8.7 & $(0.60)$ & $7.6 !$ & $(2.29)$ & 5.9 & $(1.24)$ & $8.1 !$ & $(2.45)$ & 13.3 & $(2.25)$ & 9.2 & $(0.69)$ & 8.4 & $(0.51)$ & 6.8 & $(0.57)$ & 6.3 & $(0.64)$ \\
\hline & 7.7 & $(0.37)$ & 9.6 & $(0.59)$ & 5.5 & $(0.37)$ & 6.4 & $(0.43)$ & 9.4 & $(0.80)$ & 9.1 & $(0.61)$ & 5.5 & $(0.91)$ & 16.5 & $(2.68)$ & 12.5 & $(3.11)$ & 9.2 & $(1.50)$ & 8.7 & $(0.53)$ & 8.4 & $(0.72)$ & 7.9 & $(0.60)$ & 5.2 & $(0.53)$ \\
\hline ……...... & 7.4 & $(0.31)$ & 9.5 & $(0.39)$ & 5.2 & $(0.37)$ & 6.1 & $(0.35)$ & 8.9 & $(0.64)$ & 9.2 & $(0.81)$ & 7.0 & $(0.99)$ & 8.2 & (1.52) & 11.3 & $(3.23)$ & 9.9 & $(1.35)$ & 8.3 & $(0.63)$ & 7.7 & $(0.58)$ & 7.3 & $(0.61)$ & 5.9 & $(0.45)$ \\
\hline \multicolumn{29}{|l|}{ Number of times, 2011} \\
\hline 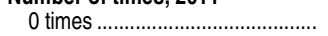 & & & & $(0.39)$ & & $(0.37)$ & & & & $(0.64)$ & & $(0.81)$ & & $(0.99)$ & 91.8 & $(1.52)$ & 88.7 & $(3.23)$ & 90.1 & $(1.35)$ & 91.7 & (0.63) & 92.3 & (0.58) & 92.7 & $(0.61)$ & 94.1 & $(0.45)$ \\
\hline 1 tim & 3.1 & $(0.17)$ & 3.6 & $(0.26)$ & 2.5 & $(0.22)$ & 2.9 & $(0.25)$ & 3.6 & $(0.40)$ & 3.1 & $(0.32)$ & $2.7 !$ & $(0.88)$ & 3.7 & $(0.92)$ & $2.5 !$ & $(1.10)$ & 3.9 & $(1.08)$ & 4.1 & $(0.53)$ & 2.5 & $(0.36)$ & 3.0 & $(0.33)$ & 2.5 & $(0.28)$ \\
\hline 2 or 3 & 1.9 & $(0.15)$ & 2.6 & $(0.25)$ & 1.3 & $(0.18)$ & 1.5 & $(0.17)$ & 2.3 & $(0.35)$ & 2.8 & $(0.35)$ & $2.0 !$ & $(0.64)$ & 2.8 & $(0.60)$ & $\ddagger$ & $(t)$ & 2.3 & $(0.67)$ & 2.1 & $(0.24)$ & 2.5 & (0.33) & 1.8 & $(0.29)$ & 1.3 & $(0.21)$ \\
\hline 4 to 11 & 1.4 & $(0.13)$ & 1.8 & $(0.20)$ & 1.0 & $(0.15)$ & 1.1 & $(0.15)$ & 1.9 & $(0.39)$ & 1.9 & $(0.37)$ & $\ddagger$ & $(t)$ & $\ddagger$ & $(t)$ & $\ddagger$ & $(\dagger)$ & $0.8 !$ & $(0.34)$ & 1.2 & $(0.24)$ & 1.7 & $(0.24)$ & 1.3 & $(0.24)$ & 1.2 & $(0.22)$ \\
\hline 12 or more times ......................... & 1.0 & $(0.12)$ & 1.5 & $(0.19)$ & 0.4 & $(0.09)$ & 0.7 & $(0.10)$ & 1.1 & $(0.23)$ & 1.4 & $(0.32)$ & + & $(+)$ & $\ddagger$ & $(+)$ & $\ddagger$ & $(\dagger)$ & $2.8 !$ & $(0.96)$ & 0.9 & $(0.20)$ & 0.9 & $(0.22)$ & 1.2 & $(0.24)$ & 0.8 & $(0.21)$ \\
\hline
\end{tabular}

\section{-Not available.}

!Interpret data with caution. The coefficient of variation (CV) for this estimate is between 30 and 50 percent. ‡Reporting standards not met. Either there are too few cases for a reliable estimate or the coefficient of variation (CV) is 50 percent or greater.

Race categories exclude persons of Hispanic ethnicity.
2Before 1999, Asian students and Pacific Islander students were not categorized separately, and students were not given the option of choosing two or more races. Because the response categories changed in 1999, caution should be used in comparing NOTE: "On school property" was not defined for survey respondents. "Weapon" was defined as a gun, knife, or club for survey respondents. Detail may not sum to totals because of rounding. SOURCE: Centers for Disease Control and Prevention, Division of Adolescent and School Health, Youth Risk Behavior Surveil-
lance System (YRBSS), 1993 through 2011. (This table was prepared September 2013.) 
Table 228.50. Percentage of public school students in grades 9-12 who reported being threatened or injured with a weapon on school property at least one time during the previous 12 months, by state: Selected years, 2003 through 2011

[Standard errors appear in parentheses]

\begin{tabular}{|c|c|c|c|c|c|c|c|c|c|c|}
\hline State & & 2003 & & 2005 & & 2007 & & 2009 & & 2011 \\
\hline 1 & & 2 & & 3 & & 4 & & 5 & & 6 \\
\hline United States $^{1}$................ & 9.2 & $(0.75)$ & 7.9 & $(0.35)$ & 7.8 & $(0.44)$ & 7.7 & $(0.37)$ & 7.4 & $\overline{(0.31)}$ \\
\hline 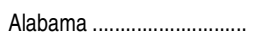 & 7.2 & $(0.91)$ & 10.6 & $(0.86)$ & - & $(\dagger)$ & 10.4 & $(1.56)$ & 7.6 & $(1.20)$ \\
\hline 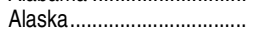 & 8.1 & $(1.01)$ & - & $(\dagger)$ & 7.7 & $(0.88)$ & 7.3 & $(0.90)$ & 5.6 & $(0.70)$ \\
\hline 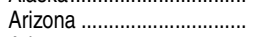 & 9.7 & $(1.10)$ & 10.7 & $(0.55)$ & 11.2 & $(0.79)$ & 9.3 & $(0.92)$ & 10.4 & $(0.74)$ \\
\hline 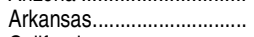 & - & $(t)$ & 9.6 & $(1.06)$ & 9.1 & $(1.03)$ & 11.9 & $(1.38)$ & 6.3 & $(0.85)$ \\
\hline 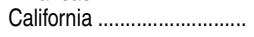 & - & $(\dagger)$ & - & $(t)$ & - & $(t)$ & - & $(t)$ & - & $(\mathrm{t})$ \\
\hline 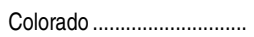 & - & $(\dagger)$ & 7.6 & $(0.75)$ & - & $(\dagger)$ & 8.0 & $(0.74)$ & 6.7 & $(0.80)$ \\
\hline 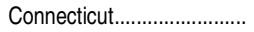 & - & $(t)$ & 9.1 & $(0.91)$ & 7.7 & $(0.59)$ & 7.0 & $(0.62)$ & 6.8 & $(0.71)$ \\
\hline 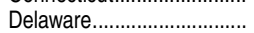 & 7.7 & $(0.60)$ & 6.2 & $(0.63)$ & 5.6 & $(0.50)$ & 7.8 & $(0.63)$ & 6.4 & $(0.62)$ \\
\hline District of Columbia ............. & 12.7 & $(1.42)$ & 12.1 & $(0.78)$ & 11.3 & $(0.98)$ & - & $(t)$ & 8.7 & $(0.92)$ \\
\hline 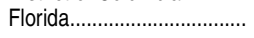 & 8.4 & $(0.44)$ & 7.9 & $(0.45)$ & 8.6 & $(0.57)$ & 8.2 & $(0.39)$ & 7.2 & $(0.31)$ \\
\hline 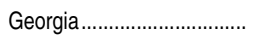 & 8.2 & $(0.75)$ & 8.3 & $(2.08)$ & 8.1 & $(0.81)$ & 8.2 & $(0.83)$ & 11.7 & (2.08) \\
\hline 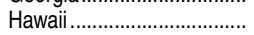 & - & $(t)$ & 6.8 & $(0.87)$ & 6.4 & $(1.10)$ & 7.7 & $(1.03)$ & 6.3 & $(0.62)$ \\
\hline 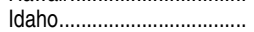 & 9.4 & $(0.82)$ & 8.3 & $(0.59)$ & 10.2 & $(1.07)$ & 7.9 & $(0.62)$ & 7.3 & (0.99) \\
\hline 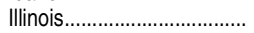 & - & $(t)$ & - & $(t)$ & 7.8 & $(0.69)$ & 8.8 & $(0.86)$ & 7.6 & $(0.48)$ \\
\hline 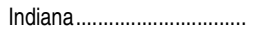 & 6.7 & $(0.91)$ & 8.8 & $(0.96)$ & 9.6 & $(0.68)$ & 6.5 & $(0.66)$ & 6.8 & $(1.14)$ \\
\hline lowa & - & $(\dagger)$ & 7.8 & $(1.02)$ & 7.1 & $(0.86)$ & - & $(\dagger)$ & 6.3 & $(0.85)$ \\
\hline 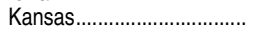 & - & $(t)$ & 7.4 & $(0.82)$ & 8.6 & $(1.12)$ & 6.2 & $(0.62)$ & 5.6 & $(0.68)$ \\
\hline 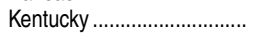 & 5.2 & $(0.72)$ & 8.0 & $(0.75)$ & 8.3 & $(0.53)$ & 7.9 & $(1.00)$ & 7.4 & $(0.98)$ \\
\hline 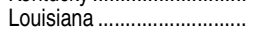 & - & $(t)$ & - & $(\dagger)$ & - & $(t)$ & 9.5 & $(1.29)$ & 8.7 & (1.18) \\
\hline 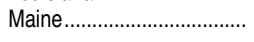 & 8.5 & $(0.78)$ & 7.1 & $(0.68)$ & 6.8 & $(0.84)$ & 7.7 & $(0.32)$ & 6.8 & $(0.26)$ \\
\hline 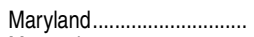 & - & $(t)$ & 11.7 & $(1.30)$ & 9.6 & $(0.86)$ & 9.1 & $(0.75)$ & 8.4 & $(0.67)$ \\
\hline Massachusetts......................... & 6.3 & $(0.54)$ & 5.4 & $(0.44)$ & 5.3 & $(0.47)$ & 7.0 & $(0.58)$ & 6.8 & $(0.67)$ \\
\hline 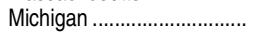 & 9.7 & $(0.57)$ & 8.6 & $(0.81)$ & 8.1 & $(0.77)$ & 9.4 & $(0.63)$ & 6.8 & $(0.50)$ \\
\hline Minnesota ............................. & - & $(\dagger)$ & - & $(\dagger)$ & - & $(\dagger)$ & - & $(\dagger)$ & - & $(\dagger)$ \\
\hline 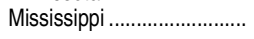 & 6.6 & $(0.82)$ & - & $(\dagger)$ & 8.3 & $(0.59)$ & 8.0 & $(0.69)$ & 7.5 & $(0.63)$ \\
\hline 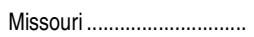 & 7.5 & $(0.93)$ & 9.1 & (1.19) & 9.3 & $(1.03)$ & 7.8 & $(0.76)$ & - & $(\dagger)$ \\
\hline 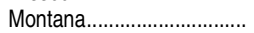 & 7.1 & $(0.46)$ & 8.0 & $(0.64)$ & 7.0 & $(0.51)$ & 7.4 & $(0.99)$ & 7.5 & (0.53) \\
\hline 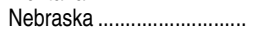 & 8.8 & $(0.80)$ & 9.7 & $(0.68)$ & - & $(t)$ & - & $(t)$ & 6.4 & $(0.54)$ \\
\hline 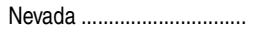 & 6.0 & $(0.65)$ & 8.1 & $(0.96)$ & 7.8 & $(0.70)$ & 10.7 & $(0.84)$ & - & $(\dagger)$ \\
\hline New Hampshire ....................... & 7.5 & $(0.98)$ & 8.6 & $(0.91)$ & 7.3 & $(0.69)$ & - & $(t)$ & - & $(t)$ \\
\hline 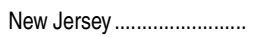 & - & $(\dagger)$ & 8.0 & $(1.07)$ & - & $(t)$ & 6.6 & $(0.75)$ & 5.7 & $(0.51)$ \\
\hline 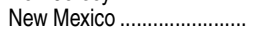 & - & $(t)$ & 10.4 & $(0.96)$ & 10.1 & $(0.68)$ & - & $(t)$ & - & $(t)$ \\
\hline 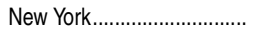 & 7.2 & $(0.44)$ & 7.2 & $(0.47)$ & 7.3 & $(0.57)$ & 7.5 & $(0.55)$ & 7.3 & $(0.60)$ \\
\hline North Carolina ....................... & 7.2 & $(0.74)$ & 7.9 & $(0.92)$ & 6.6 & $(0.62)$ & 6.8 & $(0.61)$ & 9.1 & $(0.95)$ \\
\hline North Dakota .......................... & 5.9 & $(0.89)$ & 6.6 & $(0.58)$ & 5.2 & $(0.59)$ & - & $(t)$ & - & $(t)$ \\
\hline 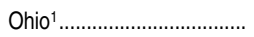 & 7.7 & $(1.30)$ & 8.2 & $(0.67)$ & 8.3 & $(0.77)$ & - & $(\dagger)$ & - & $(\dagger)$ \\
\hline 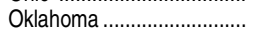 & 7.4 & $(1.10)$ & 6.0 & $(0.65)$ & 7.0 & $(0.72)$ & 5.8 & $(0.66)$ & 5.7 & $(0.88)$ \\
\hline 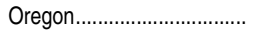 & - & $(t)$ & - & $(\dagger)$ & - & $(t)$ & - & $(t)$ & - & $(\dagger)$ \\
\hline Pennsylvania....................... & - & $(\dagger)$ & - & $(\dagger)$ & - & $(\dagger)$ & 5.6 & $(0.73)$ & - & $(\dagger)$ \\
\hline Rhode Island ......................... & 8.2 & $(0.84)$ & 8.7 & $(0.87)$ & 8.3 & $(0.42)$ & 6.5 & $(0.65)$ & - & $(t)$ \\
\hline 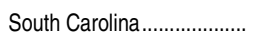 & - & $(\dagger)$ & 10.1 & $(0.93)$ & 9.8 & $(0.85)$ & 8.8 & $(1.48)$ & 9.2 & (0.92) \\
\hline 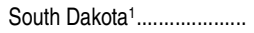 & 6.5 & $(0.71)$ & 8.1 & $(1.04)$ & 5.9 & $(0.87)$ & 6.8 & $(0.87)$ & 6.1 & $(0.77)$ \\
\hline Tennessee .......................... & 8.4 & $(1.17)$ & 7.4 & $(0.79)$ & 7.3 & $(0.76)$ & 7.0 & $(0.71)$ & 5.8 & $(0.52)$ \\
\hline 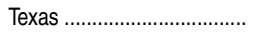 & - & $(t)$ & 9.3 & $(0.84)$ & 8.7 & $(0.52)$ & 7.2 & $(0.52)$ & 6.8 & $(0.40)$ \\
\hline 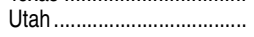 & 7.3 & $(1.44)$ & 9.8 & $(1.32)$ & 11.4 & $(1.92)$ & 7.7 & $(0.88)$ & 7.0 & $(0.98)$ \\
\hline 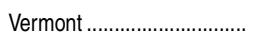 & 7.3 & $(0.20)$ & 6.3 & $(0.46)$ & 6.2 & $(0.56)$ & 6.0 & $(0.30)$ & 5.5 & $(0.37)$ \\
\hline 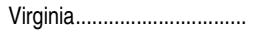 & - & $(\dagger)$ & - & $(\dagger)$ & - & $(t)$ & - & $(\dagger)$ & 7.0 & $(0.86)$ \\
\hline 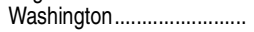 & - & $(\dagger)$ & - & $(\dagger)$ & - & $(\mathrm{t})$ & - & $(t)$ & - & $(t)$ \\
\hline 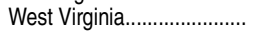 & 8.5 & $(1.26)$ & 8.0 & $(0.78)$ & 9.7 & $(0.77)$ & 9.2 & $(0.77)$ & 6.6 & $(0.93)$ \\
\hline 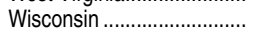 & 5.5 & $(0.70)$ & 7.6 & $(0.73)$ & 5.6 & $(0.66)$ & 6.7 & $(0.75)$ & 5.1 & (0.48) \\
\hline 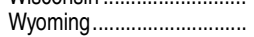 & 9.7 & $(1.00)$ & 7.8 & $(0.67)$ & 8.3 & $(0.67)$ & 9.4 & $(0.58)$ & 7.3 & $(0.58)$ \\
\hline
\end{tabular}

-Not available.

†Not applicable.

'Data include both public and private schools.

NOTE: "On school property" was not defined for survey respondents. "Weapon" was defined as a gun, knife, or club for survey respondents. State-level data include public schools only, with the exception of data for Ohio and South Dakota. Data for the United States total, Ohio, and South Dakota include both public and private schools.

SOURCE: Centers for Disease Control and Prevention, Division of Adolescent and School Health, Youth Risk Behavior Surveillance System (YRBSS), 2003 through 2011. (This table was prepared September 2013.) 


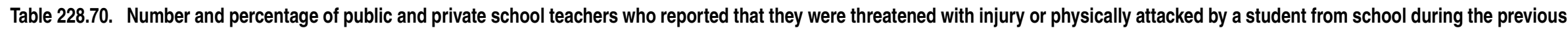
12 months, by selected teacher and school characteristics: Selected years, 1993-94 through 2011-12

[Standard errors appear in parentheses]

\begin{tabular}{|c|c|c|c|c|c|c|c|c|c|c|c|c|c|c|c|c|c|c|c|c|c|c|}
\hline \multirow[b]{2}{*}{ Year } & \multirow{2}{*}{\multicolumn{2}{|c|}{ Total }} & \multicolumn{4}{|c|}{ Sex } & \multicolumn{8}{|c|}{ Race/ethnicity } & \multicolumn{4}{|c|}{ Instructional level ${ }^{1}$} & \multicolumn{4}{|c|}{ Control of school } \\
\hline & & & & Male & & Female & & White & & Black & & Hispanic & & Other ${ }^{2}$ & & Elementary & & econdary & & Public $^{3}$ & & Private \\
\hline \multirow[t]{2}{*}{1} & & 2 & & 3 & & 4 & & 5 & & 6 & & 7 & & 8 & & 9 & & 10 & & 11 & & 12 \\
\hline & \multicolumn{22}{|c|}{ Number of teachers } \\
\hline 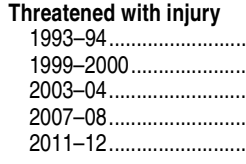 & $\begin{array}{l}342,700 \\
304,900 \\
252,800 \\
289,900 \\
352,900\end{array}$ & $\begin{array}{r}(7,140) \\
(7,090) \\
(8,750) \\
(10,660) \\
(17,080)\end{array}$ & $\begin{array}{r}115,900 \\
95,100 \\
78,400 \\
88,300 \\
84,500\end{array}$ & $\begin{array}{l}(3,870) \\
(3,610) \\
(3,930) \\
(5,970) \\
(5,220)\end{array}$ & $\begin{array}{l}226,800 \\
209,800 \\
174,400 \\
201,600 \\
268,400\end{array}$ & $\begin{array}{r}(5,570) \\
(5,490) \\
(7,260) \\
(8,140) \\
(15,450)\end{array}$ & $\begin{array}{l}295,700 \\
252,500 \\
198,900 \\
234,700 \\
279,900\end{array}$ & $\begin{array}{r}(6,320) \\
(5,670) \\
(6,980) \\
(8,850) \\
(13,300)\end{array}$ & $\begin{array}{l}23,900 \\
28,300 \\
32,500 \\
28,700 \\
34,200\end{array}$ & $\begin{array}{l}(1,380) \\
(2,150) \\
(3,050) \\
(3,080) \\
(4,380)\end{array}$ & $\begin{array}{l}15,900 \\
17,200 \\
12,400 \\
17,900 \\
27,100\end{array}$ & $\begin{array}{l}(1,850) \\
(1,980) \\
(1,810) \\
(3,230) \\
(4,660)\end{array}$ & $\begin{array}{r}7,300 \\
7,000 \\
9,000 \\
8,600 \\
11,800\end{array}$ & $\begin{array}{r}(680) \\
(850) \\
(1,250) \\
(1,630) \\
(2,200)\end{array}$ & $\begin{array}{l}135,200 \\
148,100 \\
113,600 \\
130,000 \\
189,800\end{array}$ & $\begin{array}{r}(4,520) \\
(5,560) \\
(7,240) \\
(7,720) \\
(13,430)\end{array}$ & $\begin{array}{l}207,500 \\
156,900 \\
139,200 \\
160,000 \\
163,200\end{array}$ & $\begin{array}{l}(5,380) \\
(4,360) \\
(5,280) \\
(7,220) \\
(7,520)\end{array}$ & $\begin{array}{l}326,800 \\
287,400 \\
242,100 \\
276,600 \\
338,400\end{array}$ & $\begin{array}{r}(7,040) \\
(7,060) \\
(7,840) \\
(10,570) \\
(17,290)\end{array} \mid$ & $\begin{array}{l}15,900 \\
17,500 \\
10,700 \\
13,300 \\
14,500\end{array}$ & $\begin{array}{l}(1,130) \\
(1,700) \\
(1,780) \\
(1,460) \\
(1,450)\end{array}$ \\
\hline $\begin{array}{l}\text { Physically attacked } \\
1993-94 \ldots \\
1999-2000 \\
2003-04 \ldots \ldots \\
2007-08 \ldots \ldots\end{array}$ & $\begin{array}{l}121,100 \\
134,800 \\
129,200 \\
156,000 \\
209,800 \\
\end{array}$ & $\begin{array}{r}(3,950) \\
(4,820) \\
(7,810) \\
(8,090) \\
(11,880) \\
\end{array}$ & $\begin{array}{l}30,800 \\
30,600 \\
23,600 \\
34,900 \\
32,500 \\
\end{array}$ & $\begin{array}{l}(1,770) \\
(1,990) \\
(2,610) \\
(4,760) \\
(3,330) \\
\end{array}$ & $\begin{array}{r}90,300 \\
104,200 \\
105,700 \\
121,100 \\
177,300 \\
\end{array}$ & $\begin{array}{r}(3,900) \\
(4,390) \\
(6,460) \\
(6,120) \\
(11,310) \\
\end{array}$ & $\begin{array}{l}104,300 \\
111,700 \\
102,200 \\
132,300 \\
171,300 \\
\end{array}$ & $\begin{array}{r}(4,020) \\
(3,810) \\
(5,920) \\
(6,860) \\
(10,950) \\
\end{array}$ & $\begin{array}{r}7,700 \\
11,600 \\
15,100 \\
12,300 \\
18,800 \\
\end{array}$ & $\begin{array}{r}(860) \\
(1,540) \\
(2,300) \\
(2,350) \\
(3,580)\end{array}$ & $\begin{array}{r}6,200 \\
8,800 \\
7,000 \\
8,200 \\
11,800 \\
\end{array}$ & $\begin{array}{l}(1,290) \\
(1,660) \\
(1,860) \\
(2,040) \\
(2,890)\end{array}$ & $\begin{array}{l}2,800 \\
2,600 \\
5,000 \\
3,200 ! \\
7,900 \\
\end{array}$ & $\begin{array}{r}(450) \\
(460) \\
(1,110) \\
(1,250) \\
(1,990) \\
\end{array}$ & $\begin{array}{r}77,300 \\
102,200 \\
89,800 \\
114,700 \\
160,700 \\
\end{array}$ & $\begin{array}{r}(3,240) \\
(4,360) \\
(6,680) \\
(7,220) \\
(10,210) \\
\end{array}$ & $\begin{array}{l}43,800 \\
32,600 \\
39,400 \\
41,300 \\
49,100 \\
\end{array}$ & $\begin{array}{l}(1,980) \\
(2,270) \\
(3,410) \\
(3,220) \\
(4,310)\end{array}$ & $\begin{array}{l}112,400 \\
125,000 \\
121,400 \\
146,400 \\
197,400 \\
\end{array}$ & $\begin{array}{r}(3,730) \\
(4,630) \\
(7,180) \\
(8,200) \\
(11,730) \\
\end{array}$ & $\begin{array}{r}8,700 \\
9,800 \\
7,800 \\
9,600 \\
12,400 \\
\end{array}$ & $\begin{array}{r}(860) \\
(1,070) \\
(1,450) \\
(1,170) \\
(1,490) \\
\end{array}$ \\
\hline $2011-12 \ldots \ldots \ldots \ldots$ & \multicolumn{22}{|c|}{ Percent of teachers } \\
\hline 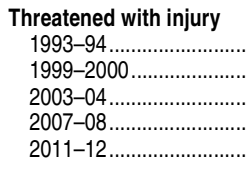 & $\begin{array}{r}11.7 \\
8.8 \\
6.8 \\
7.4 \\
9.2\end{array}$ & $\begin{array}{l}(0.23) \\
(0.20) \\
(0.24) \\
(0.26) \\
(0.42)\end{array}$ & $\begin{array}{r}14.7 \\
11.0 \\
8.5 \\
9.3 \\
9.2\end{array}$ & $\begin{array}{l}(0.40) \\
(0.38) \\
(0.39) \\
(0.59) \\
(0.49)\end{array}$ & $\begin{array}{r}10.5 \\
8.1 \\
6.2 \\
6.8 \\
9.2\end{array}$ & $\begin{array}{l}(0.25) \\
(0.20) \\
(0.27) \\
(0.27) \\
(0.50)\end{array}$ & $\begin{array}{r}11.5 \\
8.6 \\
6.4 \\
7.2 \\
8.8\end{array}$ & $\begin{array}{l}(0.24) \\
(0.19) \\
(0.24) \\
(0.26) \\
(0.40)\end{array}$ & $\begin{array}{l}11.9 \\
11.6 \\
11.8 \\
11.1 \\
13.8\end{array}$ & $\begin{array}{l}(0.61) \\
(0.84) \\
(0.96) \\
(0.93) \\
(1.72)\end{array}$ & $\begin{array}{r}13.1 \\
9.1 \\
5.5 \\
6.7 \\
9.4\end{array}$ & $\begin{array}{l}(1.32) \\
(1.01) \\
(0.82) \\
(1.19) \\
(1.54)\end{array}$ & $\begin{array}{r}13.4 \\
8.3 \\
8.7 \\
7.6 \\
9.1\end{array}$ & $\begin{array}{l}(1.08) \\
(0.98) \\
(1.25) \\
(1.36) \\
(1.54)\end{array}$ & $\begin{array}{l}8.7 \\
8.0 \\
5.7 \\
6.6 \\
9.6\end{array}$ & $\begin{array}{l}(0.30) \\
(0.29) \\
(0.37) \\
(0.38) \\
(0.67)\end{array}$ & $\begin{array}{r}15.0 \\
9.9 \\
8.0 \\
8.4 \\
8.7\end{array}$ & $\begin{array}{l}(0.28) \\
(0.26) \\
(0.27) \\
(0.36) \\
(0.34)\end{array}$ & $\begin{array}{r}12.8 \\
9.6 \\
7.4 \\
8.1 \\
10.0\end{array}$ & $\begin{array}{l}(0.26) \\
(0.22) \\
(0.24) \\
(0.30) \\
(0.48)\end{array}$ & $\begin{array}{l}4.2 \\
3.9 \\
2.3 \\
2.7 \\
3.1\end{array}$ & $\begin{array}{l}(0.29) \\
(0.35) \\
(0.40) \\
(0.30) \\
(0.32)\end{array}$ \\
\hline 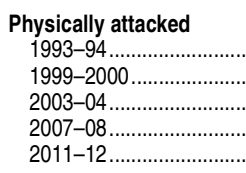 & $\begin{array}{l}4.1 \\
3.9 \\
3.5 \\
4.0 \\
5.4\end{array}$ & $\begin{array}{l}(0.13) \\
(0.14) \\
(0.21) \\
(0.21) \\
(0.30)\end{array}$ & $\begin{array}{l}3.9 \\
3.5 \\
2.6 \\
3.7 \\
3.5\end{array}$ & $\begin{array}{l}(0.21) \\
(0.22) \\
(0.27) \\
(0.49) \\
(0.35)\end{array}$ & $\begin{array}{l}4.2 \\
4.0 \\
3.8 \\
4.1 \\
6.0\end{array}$ & $\begin{array}{l}(0.17) \\
(0.24) \\
(0.21) \\
(0.37)\end{array}$ & $\begin{array}{l}4.1 \\
3.8 \\
3.3 \\
4.1 \\
5.4\end{array}$ & $\begin{array}{l}(0.13) \\
(0.20) \\
(0.22) \\
(0.33)\end{array}$ & $\begin{array}{l}3.9 \\
4.8 \\
5.5 \\
4.7 \\
7.6\end{array}$ & $\left.\begin{array}{l}(0.59) \\
(0.78) \\
(0.89) \\
(1.41)\end{array}\right]$ & $\begin{array}{l}5.2 \\
4.6 \\
3.1 \\
3.1 \\
4.1\end{array}$ & $\begin{array}{l}(0.99) \\
(0.83) \\
(0.85) \\
(0.73) \\
(0.96)\end{array}$ & $\begin{array}{l}5.2 \\
3.1 \\
4.8 \\
2.8 ! \\
6.1\end{array}$ & $\begin{array}{l}(0.76) \\
(0.54) \\
(1.10) \\
(0.97) \\
(1.43)\end{array}$ & $\begin{array}{l}5.0 \\
5.5 \\
4.5 \\
5.8 \\
8.2\end{array}$ & $\begin{array}{l}(0.23) \\
(0.35) \\
(0.38) \\
(0.50)\end{array}$ & $\begin{array}{l}3.2 \\
2.1 \\
2.3 \\
2.2 \\
2.6\end{array}$ & $\begin{array}{l}(0.14) \\
(0.19) \\
(0.16) \\
(0.21)\end{array}$ & $\begin{array}{l}4.4 \\
4.2 \\
3.7 \\
4.3 \\
5.8\end{array}$ & $\begin{array}{l}(0.15) \\
(0.22) \\
(0.24) \\
(0.33)\end{array}$ & $\begin{array}{l}2.3 \\
2.2 \\
1.7 \\
2.0 \\
2.7\end{array}$ & $\begin{array}{l}(0.23) \\
(0.22) \\
(0.32) \\
(0.24) \\
(0.33)\end{array}$ \\
\hline
\end{tabular}

!Interpret data with caution. The coefficient of variation (CV) for this estimate is between 30 and 50 percent.

Teachers were classified as elementary or secondary on the basis of the grades they taught, rather than on the level of the teaching multiple grades, with a preponderance of grades taught being kindergarten through grade 6 . In general, secondary teachers include those teaching any of grades 7 through 12 and those teaching multiple grades, with a preponderance of grades taught being grades 7 through 12 and usually with no grade taught being lower than grade 5 . 2Includes American Indians/Alaska Natives, Asians, and Pacific Islanders; for 2003-04 and later years, also includes persons of

two or more races.
IIncludes traditional public and public charter schools.

NOTE: Teachers who taught only prekindergarten students are excluded. Instructional level divides teachers into elementary or secondary based on a combination of the grades taught, main teaching assignment, and the structure of the teachers' class(es),
Please see the glossary for a more detailed definition. Race categories exclude persons of Hispanic ethnicity. Please see the glossary for a more detailed definition. Detail may not sum to totals because of rounding. Some data have been revised from previously published figures. SOURCE: U.S. Department of Education, National Center for Education Statistics, Schools and Staffing Survey (SASS), "Public School Teacher Data File" and “Private School Teacher Data File," 1993-94, 1999-2000, 2003-C
"Charter School Teacher Data File," 1999-2000. (This table was prepared October 2013.) 
Table 228.80. Percentage of public school teachers who reported that they were threatened with injury or physically attacked by a student from school during the previous 12 months, by state: Selected years, 1993-94 through 2011-12

[Standard errors appear in parentheses]

\begin{tabular}{|c|c|c|c|c|c|c|c|c|c|c|c|c|c|c|c|c|c|c|c|c|}
\hline \multirow{3}{*}{$\frac{\text { State }}{1}$} & \multicolumn{10}{|c|}{ Threatened with injury } & \multicolumn{10}{|c|}{ Physically attacked } \\
\hline & \multicolumn{2}{|c|}{ 1993-94 } & \multicolumn{2}{|c|}{$1999-2000$} & \multicolumn{2}{|c|}{ 2003-04 } & \multicolumn{2}{|c|}{$2007-08$} & \multicolumn{2}{|c|}{$2011-12$} & \multicolumn{2}{|c|}{ 1993-94 } & \multicolumn{2}{|c|}{$1999-2000$} & \multicolumn{2}{|c|}{ 2003-04 } & \multicolumn{2}{|c|}{$2007-08$} & \multicolumn{2}{|c|}{$2011-12$} \\
\hline & & 2 & & 3 & & 4 & & 5 & & 6 & & 7 & & 8 & & 9 & & 10 & & 11 \\
\hline United States ..................... & 12.8 & $(0.26)$ & 9.6 & $(0.22)$ & 7.4 & $(0.24)$ & 8.1 & $(0.30)$ & 10.0 & $(0.48)$ & 4.4 & $(0.14)$ & 4.2 & $(0.15)$ & 3.7 & $(0.22)$ & 4.3 & $(0.24)$ & 5.8 & $(0.33)$ \\
\hline 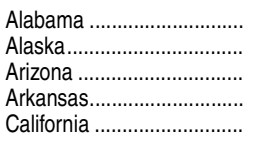 & $\begin{array}{r}13.3 \\
13.7 \\
13.0 \\
13.8 \\
7.4\end{array}$ & $\begin{array}{l}(1.29) \\
(0.92) \\
(1.07) \\
(1.38) \\
(0.91)\end{array}$ & $\begin{array}{r}8.8 \\
10.9 \\
9.5 \\
10.1 \\
5.8\end{array}$ & $\begin{array}{l}(0.99) \\
(0.80) \\
(1.16) \\
(1.18) \\
(0.70)\end{array}$ & $\begin{array}{l}6.1 \\
8.9 \\
6.8 \\
4.8 \\
6.0\end{array}$ & $\begin{array}{l}(0.88) \\
(1.25) \\
(0.98) \\
(0.81) \\
(1.00)\end{array}$ & $\begin{array}{l}6.8 \\
7.8 \\
6.4 \\
5.9 \\
8.5\end{array}$ & $\begin{array}{l}(1.41) \\
(1.24) \\
(1.04) \\
(1.18) \\
(1.31)\end{array}$ & $\begin{array}{r}7.6 \\
12.3 \\
9.1 \\
7.8 \\
7.7\end{array}$ & $\begin{array}{l}(1.92) \\
(2.82) \\
(2.08) \\
(1.48) \\
(1.17)\end{array}$ & $\begin{array}{l}3.2 \\
6.5 \\
3.6 \\
3.0 \\
20\end{array}$ & $\begin{array}{l}(0.84) \\
(0.48) \\
(0.67) \\
(0.67) \\
(0.61)\end{array}$ & $\begin{array}{l}3.8 \\
5.2 \\
4.5 \\
2.5 \\
2.5\end{array}$ & $\begin{array}{l}(0.57) \\
(0.51) \\
(0.95) \\
(0.59) \\
(0.46)\end{array}$ & $\begin{array}{l}2.7 \\
6.0 \\
2.6 \\
2.7 \\
2.0\end{array}$ & $\begin{array}{l}(0.75) \\
(0.94) \\
(0.58) \\
(0.72) \\
(0.53)\end{array}$ & $\begin{array}{l}3.2 ! \\
6.7 \\
4.9 \\
4.1 \\
3.6\end{array}$ & $\begin{array}{l}(1.12) \\
(1.50) \\
(1.29) \\
(1.07) \\
(0.78)\end{array}$ & $\begin{array}{l}3.1 ! \\
5.1 ! \\
4.7 ! \\
5.2 ! \\
4.4\end{array}$ & $\begin{array}{l}(0.94) \\
(1.78) \\
(1.43) \\
(1.80) \\
(0.95)\end{array}$ \\
\hline 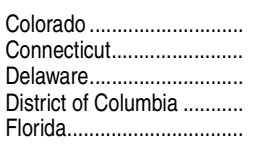 & $\begin{array}{l}13.1 \\
11.8 \\
18.7 \\
24.0 \\
20.1\end{array}$ & $\begin{array}{l}(1.29) \\
(0.86) \\
(1.56) \\
(1.80) \\
(1.65)\end{array}$ & $\begin{array}{r}6.6 \\
9.1 \\
11.4 \\
22.3 \\
12.2\end{array}$ & $\begin{array}{l}(0.97) \\
(0.88) \\
(1.37) \\
(1.30) \\
(1.07)\end{array}$ & $\begin{array}{r}3.8 \\
6.9 \\
7.7 \\
17.3 \\
11.2\end{array}$ & $\begin{array}{l}(0.82) \\
(1.28) \\
(1.35) \\
(2.63) \\
(1.26)\end{array}$ & $\begin{array}{r}6.8 \\
7.2 \\
11.7 \\
16.9 \\
11.4\end{array}$ & $\begin{array}{l}(1.64) \\
(1.39) \\
(1.93) \\
(3.06) \\
(2.11)\end{array}$ & $\begin{array}{c}7.3 \\
7.5 ! \\
15.8 \\
\ddagger \\
\ddagger\end{array}$ & $\begin{array}{r}(1.69) \\
(3.03) \\
(3.49) \\
(\dagger) \\
(\dagger)\end{array}$ & $\begin{array}{l}4.9 \\
3.5 \\
7.2\end{array}$ & $\begin{array}{l}(0.82) \\
(0.46) \\
(1.10) \\
(1.34) \\
(0.78)\end{array}$ & $\begin{array}{l}3.1 \\
4.1 \\
5.3 \\
9.1 \\
6.7\end{array}$ & $\begin{array}{l}(0.60) \\
(0.55) \\
(0.92) \\
(0.83) \\
(0.91)\end{array}$ & $\begin{array}{l}1.5 ! \\
2.8 \\
3.2 ! \\
5.2 \\
6.5\end{array}$ & $\begin{array}{l}(0.45) \\
(0.70) \\
(1.00) \\
(1.24) \\
(1.58)\end{array}$ & $\begin{array}{l}4.7 \\
3.3 ! \\
5.4 \\
7.3 \\
4.0\end{array}$ & & $\begin{array}{l}3.6 ! \\
6.2 ! \\
9.8 \\
\ddagger \\
\ddagger\end{array}$ & $\begin{array}{r}(1.26) \\
(2.91) \\
(2.80) \\
(\dagger) \\
(\dagger)\end{array}$ \\
\hline 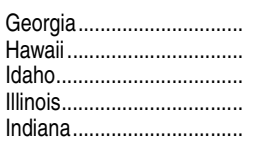 & $\begin{array}{r}14.0 \\
9.9 \\
9.7 \\
10.9 \\
13.8\end{array}$ & $\begin{array}{l}(1.29) \\
(1.48) \\
(1.02) \\
(0.76) \\
(1.28)\end{array}$ & $\begin{array}{l}9.5 \\
9.4 \\
7.8 \\
8.2 \\
7.6\end{array}$ & $\begin{array}{l}(1.42) \\
(0.99) \\
(0.44) \\
(0.89) \\
(1.12)\end{array}$ & $\begin{array}{l}6.4 \\
9.0 \\
5.4 \\
7.9 \\
7.2\end{array}$ & $\begin{array}{l}(1.21) \\
(1.33) \\
(0.98) \\
(1.60) \\
(1.18)\end{array}$ & $\begin{array}{r}5.8 \\
8.0 \\
5.9 \\
8.1 \\
10.2\end{array}$ & $\begin{array}{l}(1.18) \\
(1.84) \\
(1.24) \\
(1.42) \\
(1.78)\end{array}$ & $\begin{array}{r}9.5 ! \\
\ddagger \\
6.7 \\
7.3 \\
11.2\end{array}$ & $\begin{array}{r}(2.98) \\
(\dagger) \\
(1.42) \\
(1.41) \\
(2.87)\end{array}$ & $\begin{array}{l}3.4 \\
2.9 \\
4.2 \\
4.5\end{array}$ & $\begin{array}{l}(0.66) \\
(0.57) \\
(0.76) \\
(0.50) \\
(0.66)\end{array}$ & $\begin{array}{l}3.6 \\
3.2 \\
4.3 \\
2.7 \\
3.0\end{array}$ & $\begin{array}{l}(0.84) \\
(0.57) \\
(0.39) \\
(0.39) \\
(0.75)\end{array}$ & $\begin{array}{l}4.6 \\
5.7 \\
2.5 ! \\
2.3 ! \\
4.1 !\end{array}$ & $\begin{array}{l}(1.30) \\
(1.18) \\
(0.75) \\
(0.77) \\
(1.28)\end{array}$ & $\begin{array}{l}4.0 \\
4.5 \\
2.9 ! \\
3.9 \\
4.7\end{array}$ & $\begin{array}{l}(1.04) \\
(1.30) \\
(0.87) \\
(0.90) \\
(0.93)\end{array}$ & $\begin{array}{l}6.3 ! \\
\ddagger \\
3.6 ! \\
4.1 \\
6.4\end{array}$ & $\begin{array}{r}(2.60) \\
(\dagger) \\
(1.34) \\
(1.11) \\
(1.88)\end{array}$ \\
\hline 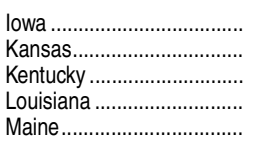 & $\begin{array}{r}9.4 \\
10.9 \\
14.0 \\
17.0 \\
9.0\end{array}$ & $\begin{array}{l}(1.19) \\
(0.91) \\
(1.33) \\
(1.17) \\
(1.11)\end{array}$ & $\begin{array}{r}10.7 \\
6.0 \\
12.6 \\
13.4 \\
11.7\end{array}$ & $\begin{array}{l}(0.93) \\
(0.78) \\
(1.22) \\
(2.31) \\
(1.13)\end{array}$ & $\begin{array}{l}4.9 \\
3.9 \\
7.8 \\
9.8 \\
5.2\end{array}$ & $\begin{array}{l}(1.13) \\
(0.81) \\
(1.46) \\
(1.42) \\
(1.09)\end{array}$ & $\begin{array}{r}7.2 \\
5.7 \\
9.8 \\
10.3 \\
9.5\end{array}$ & $\begin{array}{l}(1.32) \\
(1.07) \\
(1.86) \\
(2.35) \\
(1.49)\end{array}$ & $\begin{array}{r}11.7 \\
7.2 \\
10.6 \\
18.3 \\
9.1\end{array}$ & $\begin{array}{l}(2.43) \\
(1.66) \\
(1.48) \\
(2.95) \\
(1.98)\end{array}$ & 4.3 & $\begin{array}{l}(0.88) \\
(0.61) \\
(0.72) \\
(0.82) \\
(0.62)\end{array}$ & $\begin{array}{l}3.9 \\
2.9 \\
4.5 \\
5.0 \\
6.3\end{array}$ & $\begin{array}{l}(0.73) \\
(0.55) \\
(0.62) \\
(1.31) \\
(0.96)\end{array}$ & $\begin{array}{l}2.4 \\
3.3 \\
2.7 \\
2.7 \\
3.3 !\end{array}$ & & $\begin{array}{l}3.4 \\
5.0 \\
5.8 \\
4.0 ! \\
5.2\end{array}$ & & $\begin{array}{l}7.6 \\
5.5 ! \\
7.0 \\
7.2 ! \\
5.2\end{array}$ & $\begin{array}{l}(2.11) \\
(1.77) \\
(1.25) \\
(2.27) \\
(1.55)\end{array}$ \\
\hline 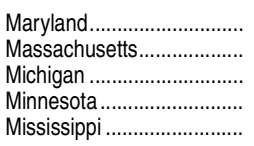 & $\begin{array}{r}19.8 \\
10.8 \\
10.7 \\
9.6 \\
13.4\end{array}$ & $\begin{array}{l}(2.15) \\
(0.83) \\
(1.54) \\
(1.13) \\
(1.48)\end{array}$ & $\begin{array}{r}10.7 \\
11.3 \\
8.0 \\
9.5 \\
11.1\end{array}$ & $\begin{array}{l}(1.31) \\
(1.48) \\
(0.93) \\
(1.11) \\
(0.99)\end{array}$ & $\begin{array}{r}13.5 \\
6.4 \\
9.2 \\
8.1 \\
5.5\end{array}$ & $\begin{array}{l}(2.24) \\
(1.23) \\
(1.55) \\
(1.17) \\
(0.92)\end{array}$ & $\begin{array}{r}12.6 \\
9.7 \\
6.0 \\
7.3 \\
10.7\end{array}$ & $\begin{array}{l}(2.47) \\
(1.98) \\
(1.15) \\
(1.16) \\
(1.59)\end{array}$ & $\begin{array}{r}\ddagger \\
6.2 \\
11.8 \\
11.4 \\
7.7\end{array}$ & $\begin{array}{r}(\dagger) \\
(1.69) \\
(1.62) \\
(1.49) \\
(1.42)\end{array}$ & 86 & $\begin{array}{l}(1.34) \\
(0.64) \\
(1.13) \\
(0.85) \\
(0.78)\end{array}$ & $\begin{array}{l}4.6 \\
4.3 \\
3.8 \\
4.4 \\
3.7\end{array}$ & $\begin{array}{l}(0.93) \\
(0.67) \\
(0.91) \\
(1.04) \\
(0.58)\end{array}$ & $\begin{array}{l}6.5 \\
3.8 \\
5.4 \\
3.6 \\
0.9 !\end{array}$ & & $\begin{array}{l}8.4 \\
4.1 \\
3.5 ! \\
6.5 \\
2.9\end{array}$ & $\begin{array}{l}(1.57) \\
(0.93) \\
(1.32) \\
(1.38) \\
(0.83)\end{array}$ & $\begin{array}{l}\ddagger \\
5.3 \\
9.0 \\
6.5 \\
3.1 !\end{array}$ & $\begin{array}{r}(\dagger) \\
(1.51) \\
(2.00) \\
(1.27) \\
(1.14)\end{array}$ \\
\hline 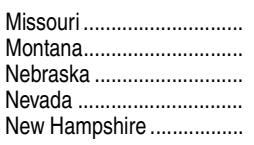 & $\begin{array}{r}12.6 \\
7.7 \\
10.4 \\
13.2 \\
11.1\end{array}$ & $\begin{array}{l}(1.11) \\
(0.58) \\
(0.61) \\
(1.22) \\
(1.30)\end{array}$ & $\begin{array}{r}11.3 \\
8.3 \\
9.9 \\
11.6 \\
8.8\end{array}$ & $\begin{array}{l}(1.73) \\
(0.97) \\
(0.70) \\
(1.34) \\
(1.43)\end{array}$ & $\begin{array}{l}8.3 \\
6.0 \\
7.5 \\
7.3 \\
5.8\end{array}$ & $\begin{array}{l}(1.27) \\
(0.78) \\
(1.12) \\
(1.89) \\
(1.37)\end{array}$ & $\begin{array}{l}8.7 \\
6.3 \\
7.2 \\
9.2 \\
6.5\end{array}$ & $\begin{array}{l}(1.17) \\
(1.25) \\
(1.27) \\
(2.21) \\
(1.47)\end{array}$ & $\begin{array}{r}12.3 \\
7.6 \\
8.0 \\
9.1 \\
5.6 !\end{array}$ & $\begin{array}{l}(2.25) \\
(2.24) \\
(1.46) \\
(2.65) \\
(2.11)\end{array}$ & 3.6 & $\begin{array}{l}(0.73) \\
(0.48) \\
(0.64) \\
(0.86) \\
(0.70)\end{array}$ & $\begin{array}{l}5.6 \\
2.7 \\
3.8 \\
8.1 \\
4.2\end{array}$ & $\begin{array}{l}(1.41) \\
(0.38) \\
(0.57) \\
(1.07) \\
(1.09)\end{array}$ & $\begin{array}{l}5.5 \\
1.9 \\
4.1 \\
4.1 ! \\
2.8 !\end{array}$ & $\begin{array}{l}(1.43) \\
(0.47) \\
(0.89) \\
(1.28) \\
(0.91)\end{array}$ & $\begin{array}{l}5.3 \\
4.0 \\
4.2 \\
3.7 ! \\
2.2 !\end{array}$ & $\begin{array}{l}(1.15) \\
(0.81) \\
(1.11) \\
(1.41) \\
(0.91)\end{array}$ & $\begin{array}{l}7.5 \\
4.2 ! \\
5.8 \\
4.7 ! \\
\ddagger\end{array}$ & $\begin{array}{r}(1.73) \\
(1.37) \\
(1.36) \\
(2.25) \\
(\dagger)\end{array}$ \\
\hline 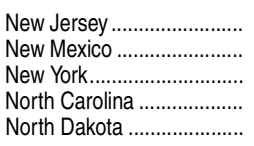 & $\begin{array}{r}7.9 \\
12.8 \\
16.2 \\
17.1 \\
5.5\end{array}$ & $\begin{array}{l}(0.87) \\
(1.27) \\
(1.32) \\
(1.32) \\
(0.62)\end{array}$ & $\begin{array}{r}7.5 \\
10.2 \\
11.5 \\
12.8 \\
5.7\end{array}$ & $\begin{array}{l}(0.80) \\
(1.75) \\
(1.06) \\
(1.63) \\
(0.57)\end{array}$ & $\begin{array}{r}4.3 \\
7.8 \\
10.4 \\
8.7 \\
5.0\end{array}$ & $\begin{array}{l}(1.20) \\
(1.25) \\
(1.62) \\
(1.44) \\
(0.95)\end{array}$ & $\begin{array}{r}4.6 \\
12.8 \\
10.5 \\
9.6 \\
2.5\end{array}$ & $\begin{array}{l}(1.26) \\
(1.85) \\
(1.85) \\
(1.71) \\
(0.70)\end{array}$ & $\begin{array}{r}6.9 \\
10.0 \\
11.9 \\
13.4 \\
6.1\end{array}$ & $\begin{array}{l}(1.08) \\
(2.76) \\
(1.86) \\
(2.79) \\
(1.48)\end{array}$ & 2.9 & $\begin{array}{l}(0.45) \\
(0.72) \\
(0.97) \\
(0.95) \\
(0.66)\end{array}$ & $\begin{array}{l}6.8 \\
5.2 \\
5.5 \\
2.1\end{array}$ & $\begin{array}{l}(0.78) \\
(1.77) \\
(0.79) \\
(1.23) \\
(0.37)\end{array}$ & $\begin{array}{l}2.0 ! \\
5.9 \\
6.5 \\
4.4 \\
2.1\end{array}$ & $\begin{array}{l}(0.67) \\
(0.97) \\
(1.12) \\
(0.95) \\
(0.49)\end{array}$ & $\begin{array}{l}2.2 ! \\
4.5 \\
6.4 \\
5.9 ! \\
1.6 !\end{array}$ & $\begin{array}{l}(0.82) \\
(1.33) \\
(1.56) \\
(1.84) \\
(0.50)\end{array}$ & $\begin{array}{l}3.6 \\
9.9 ! \\
7.0 \\
6.3 \\
3.3 !\end{array}$ & $\begin{array}{l}(0.97) \\
(3.17) \\
(1.48) \\
(1.58) \\
(1.06)\end{array}$ \\
\hline 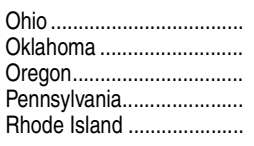 & $\begin{array}{l}15.2 \\
11.0 \\
11.5 \\
11.0 \\
13.4\end{array}$ & $\begin{array}{l}(1.48) \\
(1.21) \\
(1.00) \\
(1.75) \\
(1.78)\end{array}$ & $\begin{array}{r}9.6 \\
8.5 \\
6.9 \\
9.5 \\
10.2\end{array}$ & $\begin{array}{l}(1.35) \\
(1.17) \\
(1.33) \\
(1.28) \\
(0.64)\end{array}$ & $\begin{array}{l}6.2 \\
6.0 \\
5.5 \\
9.5 \\
4.6 !\end{array}$ & $\begin{array}{l}(1.14) \\
(0.79) \\
(1.11) \\
(1.29) \\
(1.39)\end{array}$ & $\begin{array}{l}8.7 \\
7.4 \\
6.3 \\
4.6 \\
8.6\end{array}$ & $\begin{array}{l}(1.59) \\
(0.87) \\
(1.30) \\
(1.04) \\
(2.13)\end{array}$ & $\begin{array}{r}9.9 \\
9.6 \\
5.3 \\
10.1 \\
\ddagger\end{array}$ & $\begin{array}{r}(1.20) \\
(2.12) \\
(1.56) \\
(1.54) \\
(\dagger)\end{array}$ & 4.6 & $\begin{array}{l}(0.69) \\
(0.81) \\
(0.64) \\
(1.02) \\
(0.91)\end{array}$ & $\begin{array}{l}2.9 \\
4.5 \\
3.0 \\
4.5 \\
4.8\end{array}$ & $\begin{array}{l}(0.83) \\
(1.12) \\
(0.60) \\
(0.97) \\
(0.59)\end{array}$ & $\begin{array}{l}2.5 ! \\
3.0 \\
1.4 ! \\
5.0 \\
2.4 !\end{array}$ & $\begin{array}{l}(0.83) \\
(0.53) \\
(0.55) \\
(0.82) \\
(0.92)\end{array}$ & $\begin{array}{l}2.2 ! \\
3.2 \\
3.9 ! \\
3.8 \\
\ddagger\end{array}$ & $\begin{array}{r}(0.70) \\
(0.63) \\
(1.18) \\
(0.90) \\
(\mathrm{t})\end{array}$ & $\begin{array}{l}3.9 \\
6.2 \\
3.4 ! \\
4.4 \\
\ddagger\end{array}$ & $\begin{array}{r}(0.88) \\
(1.66) \\
(1.27) \\
(0.99) \\
(\dagger)\end{array}$ \\
\hline 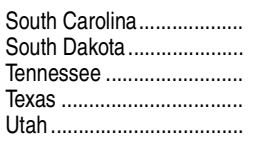 & $\begin{array}{r}15.2 \\
6.5 \\
12.4 \\
12.6 \\
11.1\end{array}$ & $\begin{array}{l}(1.62) \\
(0.83) \\
(1.45) \\
(1.15) \\
(0.87)\end{array}$ & $\begin{array}{r}11.5 \\
7.7 \\
13.3 \\
8.9 \\
8.0\end{array}$ & $\begin{array}{l}(1.10) \\
(0.91) \\
(1.65) \\
(0.89) \\
(1.15)\end{array}$ & $\begin{array}{l}8.5 \\
4.7 \\
6.5 \\
7.6 \\
5.2\end{array}$ & $\begin{array}{l}(1.30) \\
(1.23) \\
(1.24) \\
(1.13) \\
(0.82)\end{array}$ & $\begin{array}{l}8.5 \\
6.9 \\
7.7 \\
7.6 \\
5.7\end{array}$ & $\begin{array}{l}(1.46) \\
(1.88) \\
(1.26) \\
(1.31) \\
(1.18)\end{array}$ & $\begin{array}{r}13.1 \\
10.0 \\
9.4 \\
10.0 \\
7.2\end{array}$ & $\begin{array}{l}(2.70) \\
(2.28) \\
(2.11) \\
(1.81) \\
(1.96)\end{array}$ & 1.2 & $\begin{array}{l}(0.92) \\
(0.46) \\
(0.91) \\
(0.65) \\
(0.72)\end{array}$ & $\begin{array}{l}5.3 \\
3.9 \\
2.6 \\
4.8 \\
2.6\end{array}$ & $\begin{array}{l}(0.94) \\
(0.50) \\
(0.67) \\
(0.75) \\
(0.58)\end{array}$ & $\begin{array}{l}3.1 \\
2.9 \\
3.7 \\
3.9 \\
4.1\end{array}$ & $\begin{array}{l}(0.82) \\
(0.79) \\
(1.02) \\
(0.92) \\
(0.90)\end{array}$ & $\begin{array}{l}2.9 ! \\
4.3 \\
4.1 \\
4.2 \\
3.8 !\end{array}$ & $\begin{array}{l}(1.18) \\
(0.88) \\
(1.11) \\
(1.18) \\
(1.26)\end{array}$ & $\begin{array}{l}\ddagger \\
5.2 ! \\
3.2 ! \\
5.7 \\
5.4\end{array}$ & $\begin{array}{r}(\dagger) \\
(1.66) \\
(1.04) \\
(1.30) \\
(1.53)\end{array}$ \\
\hline 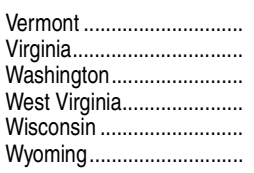 & $\begin{array}{r}12.4 \\
14.9 \\
13.0 \\
11.7 \\
13.7 \\
9.0\end{array}$ & $\begin{array}{l}(1.28) \\
(1.37) \\
(1.33) \\
(0.86) \\
(1.82) \\
(0.79)\end{array}$ & $\begin{array}{r}9.9 \\
12.1 \\
10.0 \\
10.0 \\
10.1 \\
6.7\end{array}$ & $\begin{array}{l}(1.46) \\
(1.19) \\
(0.98) \\
(1.19) \\
(0.99) \\
(0.96)\end{array}$ & $\begin{array}{l}4.9 \\
6.5 \\
6.7 \\
7.4 \\
4.7 \\
3.8 !\end{array}$ & $\begin{array}{l}(1.18) \\
(1.11) \\
(1.29) \\
(1.13) \\
(0.99) \\
(1.31)\end{array}$ & $\begin{array}{l}7.6 \\
8.1 \\
7.0 \\
8.1 \\
8.8 \\
5.1\end{array}$ & $\begin{array}{l}(1.82) \\
(1.38) \\
(1.34) \\
(1.67) \\
(1.51) \\
(1.00)\end{array}$ & $\begin{array}{r}8.7 \\
9.9 \\
7.4 \\
9.4 \\
13.7 \\
10.9\end{array}$ & $\begin{array}{l}(1.86) \\
(1.58) \\
(1.36) \\
(2.08) \\
(2.37) \\
(3.10)\end{array}$ & 2.7 & $\begin{array}{l}(1.38) \\
(1.23) \\
(0.74) \\
(0.67) \\
(0.77) \\
(0.49)\end{array}$ & $\begin{array}{l}5.3 \\
4.9 \\
5.0 \\
3.4 \\
4.4 \\
2.6\end{array}$ & $\begin{array}{l}(0.94) \\
(0.76) \\
(0.61) \\
(0.67) \\
(0.79) \\
(0.47)\end{array}$ & $\begin{array}{l}1.8 ! \\
2.9 ! \\
4.1 \\
3.4 \\
2.5 \\
2.5 !\end{array}$ & $\begin{array}{l}(0.90) \\
(0.88) \\
(0.85) \\
(0.82) \\
(0.71) \\
(1.04)\end{array}$ & $\begin{array}{l}4.2 \\
6.0 \\
4.4 \\
4.0 \\
6.5 \\
3.0\end{array}$ & $\begin{array}{l}(1.22) \\
(1.32) \\
(1.28) \\
(1.07) \\
(1.29) \\
(0.86)\end{array}$ & $\begin{array}{c}5.3 \\
6.5 \\
6.8 \\
4.3 ! \\
11.3 \\
\ddagger\end{array}$ & $\begin{array}{r}(1.29) \\
(1.68) \\
(1.80) \\
(1.72) \\
(2.56) \\
(\dagger)\end{array}$ \\
\hline
\end{tabular}

†Not applicable.

!Interpret data with caution. The coefficient of variation (CV) for this estimate is between 30 and 50 percent.

†Reporting standards not met. Data may be suppressed because the response rate is unde 50 percent, there are too few cases for a reliable estimate, or the coefficient of variation (CV) is 50 percent or greater.
NOTE: Teachers who taught only prekindergarten students are excluded. Includes traditional public and public charter schools. Detail may not sum to totals because of rounding. Some data have been revised from previously published figures.

SOURCE: U.S. Department of Education, National Center for Education Statistics, Schools and Staffing Survey (SASS), "Public School Teacher Data File," 1993-94, 1999-2000, 2003-04, 2007-08, and 2011-12; and "Charter School Teacher Data File," 1999-2000. (This table was prepared October 2013.) 


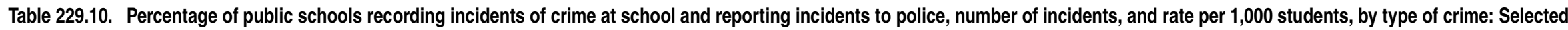
years, 1999-2000 through 2009-10

[Standard errors appear in parentheses]

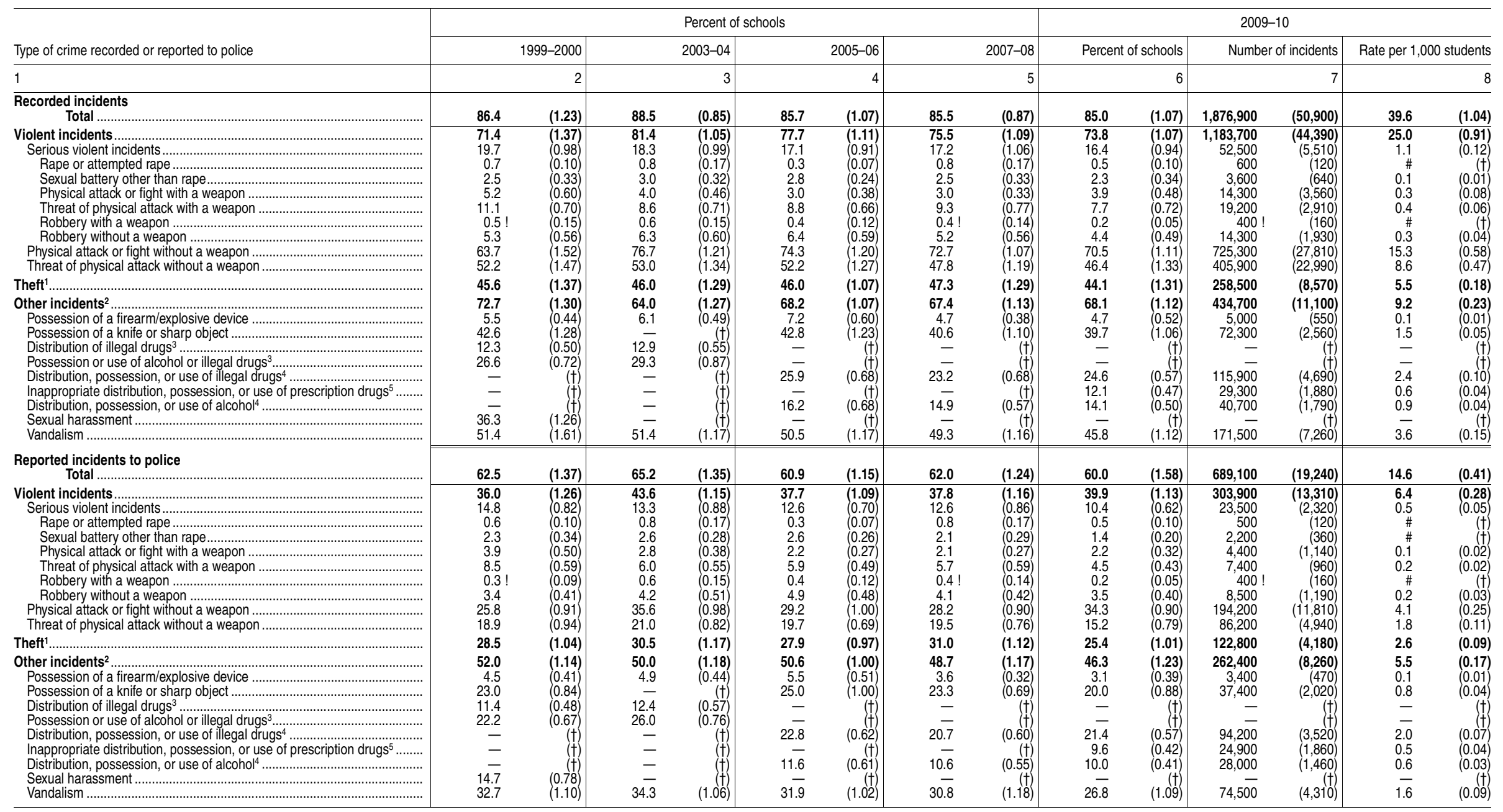

\section{-Not available.}

†Not applicable.

!nterpret data with caution. The coefficient of variation (CV) for this estimate is between 30 and 50 percent.

'Theffllarceny (taking things worth over $\$ 10$ without personal confrontation) was defined for respondents as "the unlawful taking of another person's property without personal confrontation, threat, violence, or bodily harm." This includes pocket picking, stealing a purse or back-
pack (if left unattended or no force was used to take it from owner), theft from a building, theft from a motor vehicle or motor vehicle parts or accessories, theft of a bicycle, theft from a vending machine, and all other types of thefts.

"Caution should be used when making direct comparisons of "Other incidents" between years because the survey questions about alcohol and drugs changed, as oultined in footholes 3,4 , and 5 .

(1999-2000 and

4The survey items "Distribution, possession, or use of illegal drugs" and "Distribution, possession, or use of alcohol" appear only on the questionnaires for $2005-06$ and later years.

NOTE- Responses were provided by the principat the survey item "Inappropriate distribution, possession, or use of prescription druggs." school" was defined to include activities that happen in school buildings, on school grounds, on school buses, and at places that hold school-sponsored events or activties. Respondents were instructed to include incidents that occurred before, during, and after normal school hours or when school activities or events were in session. Detail may not sum to totals because of rounding and because schools that recorded or reported more than one type of crime incident were counted only once in the total percentage of schools recording or reporting incidents.

2009-10 Sch. Department of Education, National Center for Education Statistics, 1999-2000, 2003-04, 2005-06, 2007-08, and

2003-04 questionnaires. Different alcohol- and drug-related survey items were used on the questionnaires for later years. 
Table 229.20. Number and percentage of public schools recording at least one crime incident that occurred at school, and number and rate of incidents, by school characteristics and type of incident: 1999-2000 and 2009-10

[Standard errors appear in parentheses]

\begin{tabular}{|c|c|c|c|c|c|c|c|c|c|c|c|c|c|c|c|c|c|c|c|c|c|c|c|c|}
\hline \multirow[b]{3}{*}{ Type of incident } & \multirow{3}{*}{\multicolumn{2}{|c|}{$\begin{array}{l}\text { All public } \\
\text { schools, } \\
1999-2000\end{array}$}} & \multicolumn{22}{|c|}{$2009-10$} \\
\hline & & & \multirow{2}{*}{\multicolumn{2}{|c|}{$\begin{array}{l}\text { All public } \\
\text { schools }\end{array}$}} & \multicolumn{6}{|c|}{ Instruction level of school } & \multicolumn{8}{|c|}{ Locale } & \multicolumn{6}{|c|}{$\begin{array}{l}\text { Percent of students eligible for } \\
\text { free or reduced-price lunch }\end{array}$} \\
\hline & & & & & & Primary & & Middle & & High & & City & & uburban & & Town & & Rural & & 0 to 20 & & 21 to 50 & & or more \\
\hline 1 & & 2 & & 3 & & 4 & & 5 & & 6 & & 7 & & 8 & & 9 & & 10 & & 11 & & 12 & & 13 \\
\hline \multicolumn{25}{|l|}{ Number of public schools (in thousands) } \\
\hline 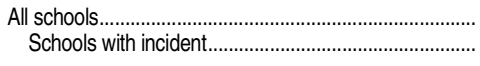 & $\begin{array}{l}82 \\
71 \\
\end{array}$ & $\begin{array}{r}(\#) \\
(1.0) \\
\end{array}$ & $\begin{array}{l}83 \\
70 \\
\end{array}$ & $\begin{array}{l}(0.5) \\
(1.0) \\
\end{array}$ & $\begin{array}{l}49 \\
38 \\
\end{array}$ & $\begin{array}{l}(0.3) \\
(0.9) \\
\end{array}$ & $\begin{array}{l}15 \\
15 \\
\end{array}$ & $\begin{array}{l}(0.1) \\
(0.1) \\
\end{array}$ & $\begin{array}{l}12 \\
12 \\
\end{array}$ & $\begin{array}{l}(0.1) \\
(0.1) \\
\end{array}$ & $\begin{array}{l}22 \\
19 \\
\end{array}$ & $\begin{array}{l}(0.2) \\
(0.4) \\
\end{array}$ & $\begin{array}{l}24 \\
20 \\
\end{array}$ & $\begin{array}{l}(0.2) \\
(0.6) \\
\end{array}$ & $\begin{array}{l}12 \\
11 \\
\end{array}$ & $\begin{array}{l}(0.1) \\
(0.3) \\
\end{array}$ & $\begin{array}{l}25 \\
21 \\
\end{array}$ & $\begin{array}{l}(0.3) \\
(0.5) \\
\end{array}$ & $\begin{array}{l}14 \\
10 \\
\end{array}$ & $\begin{array}{l}(0.7) \\
(0.7) \\
\end{array}$ & $\begin{array}{l}26 \\
23 \\
\end{array}$ & $\begin{array}{l}(1.2) \\
(1.1) \\
\end{array}$ & $\begin{array}{l}43 \\
38 \\
\end{array}$ & $\begin{array}{l}(1.1) \\
(1.2) \\
\end{array}$ \\
\hline Percent of schools with incident.. & 86.4 & (1.23) & 85.0 & $(1.07)$ & 77.9 & (1.69) & 96.2 & $(0.66)$ & 98.3 & $(0.49)$ & 86.9 & (1.71) & 84.3 & $(2.07)$ & 89.4 & (2.63) & 82.1 & (2.04) & 73.0 & (3.28) & 85.8 & (1.78) & 88.4 & $(1.30)$ \\
\hline Viole & & 37) & 738 & 071 & 644 & $(163)$ & & 101 & 09 & 211 & 100 & 112 & 20 & 201 & 2 & 210 & 0 & 101 & 17 & 101 & & (20) & & \\
\hline & 19 & & & & & $(1.4 c)>2$ & 18.9 & 40) & 27.0 & (1.35) & 21.1 & 2.1. & 10.5 & 80) & 15.0 & & & 11) & 0.5 & 41) & .4 & & 19 & \\
\hline & 0.7 & $(0.10)$ & 0.5 & (0.10) & - & $(\dagger)$ & $1.3 !$ & $(0.42)$ & 2.0 & $(0.4 \quad-3$ & $0.7 !$ & $(0.2-2)$ & $0.6 !$ & $(0.2$ & $0.6 !$ & $(0.2$ & $0.3 !$ & ( & 0.4 ! & $(0.20)$ & 0.6 & $(0.17)$ & 0.5 & 15) \\
\hline & 2.5 & $(0.33)$ & 2.3 & $(0.34)$ & $1.0 !$ & $(0.38)$ & 3.2 & 05 & 5.1 & $(0$. & 3.2 & $107+2$ & 1.6 & & $2.7 !$ & 10 & $1.9 !$ & & 1.4 & & & & & \\
\hline & 5.2 & $(0.60)$ & 3.9 & $(0.48)$ & 3.0 & $(0.68)$ & 3.9 & $(0.75)$ & 7.1 & $(1$. & 5.5 & $(1.1$ & 4.6 & ) & $4.1 !$ & $(1$ & 1.8 & $(0$. & 2.3 ! & 7) & 3.6 & $(0$ & 4.6 & 73) \\
\hline Threa & 11.1 & $(0.70)$ & 7.7 & (0.72) & 6.8 & (1.11) & 10.3 & 04) & 10.0 & & 10.2 & (1.69) & 7.7 & & 6.3 & (1.57) & 6.2 & 1 & 4.7 & $(1.06)$ & 5.9 & $(0.72)$ & 9.7 & 1.32) \\
\hline & $0.5 !$ & $(0.15)$ & 0.2 & $(0.05)$ & - & & $0.5 !$ & $(0$ & 1.0 & $(0.30)$ & $0.6 !$ & $(0.19)$ & $0.2 !$ & 0 & $\ddagger$ & $(\dagger)$ & t & & $\ddagger$ & & $0.2 !$ & & $0.3 !$ & 09) \\
\hline & 5.3 & $(0.56)$ & 4.4 & & 2.7 & $(0.66)$ & 5.5 & & 10.6 & & 6.5 & & 3.4 & & $3.0^{+}$ & & 4.3 & & + & & 4.5 & & . & 1) \\
\hline Physical & 63.7 & $(1.52$ & 70.5 & $(1$ & 60.3 & $(1$. & 88.8 & $(1.1$ & 88.4 & $(1$ & 71.7 & $(2.0$ & 69.9 & (2) & 76.8 & $(2$ & 67.2 & & 57.9 & & 70.4 & & 74.6 & (3) \\
\hline Threat of attack without weapon.......... & 52.2 & (1.47) & 46.4 & (1.33) & 38.0 & (1.94) & 61.5 & $(1.73)$ & 61.9 & (1.58) & 48.6 & (2.43) & 46.3 & (2.44) & 56.2 & (3.86) & 40.0 & (2.15) & 34.7 & .84) & 47.7 & (2.21) & 49.4 & (1.97) \\
\hline Theft/larceny $1 \ldots$ & 45.6 & (1.37) & 44.1 & (1.31) & 25.7 & $(1.82)$ & 65.2 & $(1.48)$ & 82.6 & (1.35) & 47.6 & (2.70) & 43.1 & (1.97) & 46.2 & (3.22) & 41.1 & (2.51) & 38.0 & (2.26) & 48.8 & (2.50) & 43.1 & (1.98) \\
\hline Other incidents ${ }^{2}$. & - & (†) & 68.1 & (1.12) & 57.3 & (1.72) & 81.9 & $(1.25)$ & 92.2 & (1.10) & 73.5 & .39) & 66.1 & (2.23) & 74.1 & (2.97) & 62.6 & 2.62) & 54.8 & .31) & 67.3 & (2.10) & 72.9 & 1.79) \\
\hline ses & 5.5 & $(0.44)$ & $\begin{array}{r}4.7 \\
397\end{array}$ & $(0.52)$ & $\begin{array}{r}3.5 \\
33.5\end{array}$ & $\begin{array}{l}(0.81) \\
(1.51)\end{array}$ & $\begin{array}{r}5.8 \\
515\end{array}$ & (c) & $\begin{array}{r}9.4 \\
552\end{array}$ & & $\begin{array}{r}6.0 \\
411\end{array}$ & 9) & $\begin{array}{r}4.9 \\
387\end{array}$ & 89) & $3.8 !$ & & $\begin{array}{r}3.8 \\
34.7\end{array}$ & & 3.1 & 64) & 3.3 & $(0.58)$ & 6.0 & 93) \\
\hline Distribution, pos & $\begin{array}{r}42.6 \\
-\end{array}$ & $\begin{array}{r}(1.28) \\
(\dagger)\end{array}$ & $\begin{array}{l}39.7 \\
24.6\end{array}$ & $\begin{array}{l}(1.06) \\
(0.57)\end{array}$ & $\begin{array}{r}33.5 \\
3.5\end{array}$ & & $\begin{array}{l}51.5 \\
44.7\end{array}$ & $\begin{array}{l}(1.94) \\
(1.17)\end{array}$ & $\begin{array}{l}55.2 \\
77.2\end{array}$ & $\begin{array}{l}(1.51) \\
(1.51)\end{array}$ & $\begin{array}{l}41.1 \\
27.8\end{array}$ & & $\begin{array}{l}38.7 \\
22.4\end{array}$ & $\begin{array}{l}(1.75) \\
(0.83)\end{array}$ & $\begin{array}{l}49.8 \\
25.5\end{array}$ & $\left.\begin{array}{l}(3.16) \\
(1.42)\end{array}\right]$ & $\begin{array}{l}34.7 \\
23.4\end{array}$ & & $\begin{array}{l}26.7 \\
20.3\end{array}$ & $\begin{array}{l}(2.20) \\
(1.39)\end{array}$ & $\begin{array}{l}38.0 \\
27.9\end{array}$ & $\begin{array}{l}(1.96) \\
(1.67)\end{array}$ & $\begin{array}{l}44.8 \\
23.8\end{array}$ & $\begin{array}{l}(1.72) \\
(0.96)\end{array}$ \\
\hline Inapprol & & & & & & & & & & & & & & & & & & & & & & & & \\
\hline & - & t) & 12.1 & $(0.47)$ & $1.5 !$ & $(0.48)$ & 18.8 & $(1.13)$ & 43.0 & $(1.64)$ & 10.3 & $(0.92)$ & 12.1 & $(0.79)$ & 12.3 & $(1.12$ & 13.5 & $(1.18$ & 13.1 & (1.20) & 15.2 & $(0.98)$ & 9.8 & $(0.76)$ \\
\hline Distribut & - & & 14 & & 2.1 & & 19.7 & & 6 & & & & 15 & & 12 & & & & & & & & & \\
\hline Vandalism...... & 51.4 & (1.61) & 45.8 & (1.12) & 37.9 & (1.69) & 55.5 & $(1.38)$ & 62.5 & $(1.86)$ & 56.9 & (2.11) & 47.2 & (2.44) & 44.7 & (3.54) & 35.7 & $(2.25)$ & 38.5 & (2.96) & 47.0 & (2.27) & 47.5 & (1.92) \\
\hline Number of incidents (in thousands)..... & 2,259 & (117.0) & 1,877 & (50.9) & 626 & $(39.6$ & 548 & $(23.6$ & 590 & (18.2) & 642 & (32.5) & 585 & (37.5) & 255 & $(23.1$ & 395 & $(19$ & 211 & (15.1) & 560 & (25.6) & 1,106 & (51.1) \\
\hline Violent incider & 1,466 & (103.7) & 1,184 & (44.4) & 482 & $(3$ & 3 & (1 & 264 & (12. & 396 & (27.4) & 371 & $(33$ & 166 & $(21$ & 250 & $(15$ & 110 & (10 & 322 & (20.5) & 752 & (43.2) \\
\hline & & $(7,0)$ & 50 & $(5$ & 20 & & . & & 14 & $(1$ & 17 & (2.8) & 16 & & 6 & (1. & 13 & & 6 & $(1.4)$ & 13 & & 33 & $(5.4)$ \\
\hline & & 1) & 1 & 10 & - & & \# & & \# & & $\#$ & & \# & & \# & 1. & $\#$ & & \# & $(t)$ & $\#$ & $(t)$ & \# & (i) \\
\hline & & & 4 & $(0.6)$ & $1 !$ & $(0$ & 1 & 10 & 1 & & 1 & $(0.4)$ & 1 & $(0$ & $\#$ & & $1 !$ & 10. & $\#$ & & 1 ! & & 2 & \\
\hline & 12 & (2.5) & 14 & (3.6) & $8 !$ & $(2)$. & $2 !$ & $(0.7$ & 3 & 10 & $3 !$ & (1.0) & $5 !$ & $(2)$. & $3 !$ & (1. & $\ddagger$ & & 1 ! & 10 & 3 & $(0.9)$ & $10 !$ & (3.6) \\
\hline & 21 & (1.9) & 19 & (2.9) & 8 & (19) & 8 & $(1.9)$ & 3 & & 7 & $(1.8)$ & 7 & (1. & $2 !$ & $(1$. & 3 & & $2 !$ & & 5 & (1.3) & 12 & (2.7) \\
\hline & & & \# & & - & & \# & & \# & & \# & & \# & & \# & & - & & & & \# & & \# & $(\dagger)$ \\
\hline Rob & 20 & .2) & 14 & ) & $6 !$ & (1.9) & $\begin{array}{l}\pi \\
3\end{array}$ & $(0.6$ & $\begin{array}{l}\pi \\
6\end{array}$ & 8) & 6 & $(0.9)$ & $\begin{array}{l}\pi \\
3\end{array}$ & $(0$. & 1 ! & $(0.3)$ & $5 !$ & $(1$ & $3 !$ & & 4 & (1.2) & $\begin{array}{l}\pi \\
8\end{array}$ & (1.4) \\
\hline Physical & 807 & (59.6) & 725 & $(27.8)$ & 295 & (24.0) & 239 & (12. & 157 & $(10$ & 249 & (19. & 232 & (17. & 93 & (15. & 152 & (10 & 60 & & r & & & $(270$ \\
\hline $\mathrm{Th}$ & 599 & $1527-7$ & 406 & $(23$. & 10,2 & (21. & 123 & $(8.8$ & 94 & $(5.4)$ & 130 & (10.7) & 123 & $(17.0$ & 67 & $(9.4)$ & 86 & & 36 & (4.6) & 115 & (11.7) & 255 & $0.8)$ \\
\hline Theft/larceny ${ }^{1} \ldots$ & 218 & $(9.2)$ & 259 & (8.6) & 42 & (5.7) & 69 & $(4.8$ & 125 & $(5.1)$ & 85 & $(7.0)$ & 81 & $(4.0)$ & 33 & (3.3) & 59 & (4.6) & 41 & (3.3) & 96 & (5.7) & 121 & (8.4) \\
\hline Other incidents ${ }^{2}$ & - & & 435 & (11.1) & 102 & (6.4) & 104 & (4 & 200 & & 160 & & 133 & & 55 & (4 & 86 & & 60 & (4.1) & 142 & (7.2) & 233 & (11.7) \\
\hline & 0 & $(2.2)$ & 5 & & 2 & & 1 & & 2 & & 2 & (03) & 2 & & 1 ! & 0. & 1 & & 1 & & 1 & & 3 & (0.5) \\
\hline & 86 & 140 & 72 & & 29 & & 18 & & 22 & & 21 & & 22 & (1 & 12 & & 17 & & 7 & & 22 & & 44 & .0) \\
\hline $\begin{array}{l}\text { Distribution, po } \\
\text { Inappropriate }\end{array}$ & & & 116 & 7) & & & 25 & $(1.6$ & 79 & (3.6) & 44 & $(4.0)$ & 36 & (2.0) & 15 & (1.5) & 20 & (1.5) & 17 & (1.4) & 42 & (2.6) & 56 & (4.4) \\
\hline & & & 29 & $(1$ & $1 !$ & & 6 & $(0.6$ & 1 & & 7 & $(0.9)$ & 10 & & 5 & & 8 & & 5 & & 13 & & 11 & \\
\hline Distribut & & & 41 & (1.8) & 1 & & 7 & & 29 & (1) & 14 & (1.3) & 14 & & & (U. & 8 & & 9 & & 16 & (1.3) & 15 & (1.3) \\
\hline andalism.. & os $>$ & 3.6) & 172 & 7.3) & 66 & (5.8) & 46 & (3.1 & 49 & $(4.5)$ & 72 & (5.7) & 49 & (3.6) & 18 & (1.8) & 32 & (3.5) & 21 & (2.6) & 47 & (3.4) & 103 & (6.9) \\
\hline
\end{tabular}

See notes at end of table. 
[Standard errors appear in parentheses]

\begin{tabular}{|c|c|c|c|c|c|c|c|c|c|c|c|c|c|c|c|c|c|c|c|c|c|c|c|c|}
\hline \multirow[b]{3}{*}{ Type of incident } & \multirow{3}{*}{\multicolumn{2}{|c|}{$\begin{array}{r}\text { All public } \\
\text { schools, } \\
1999-2000\end{array}$}} & \multicolumn{22}{|c|}{$2009-10$} \\
\hline & & & \multirow{2}{*}{\multicolumn{2}{|c|}{$\begin{array}{r}\text { All public } \\
\text { schools }\end{array}$}} & \multicolumn{6}{|c|}{ Instruction level of school } & \multicolumn{8}{|c|}{ Locale } & \multicolumn{6}{|c|}{$\begin{array}{l}\text { Percent of students eligible for } \\
\text { free or reduced-price lunch }\end{array}$} \\
\hline & & & & & \multicolumn{2}{|c|}{ Primary } & \multicolumn{2}{|r|}{ Middle } & \multicolumn{2}{|r|}{ High } & \multicolumn{2}{|c|}{ City } & \multicolumn{2}{|c|}{ Suburban } & \multicolumn{2}{|r|}{ Town } & \multicolumn{2}{|r|}{ Rural } & \multicolumn{2}{|r|}{0 to 20} & \multicolumn{2}{|r|}{21 to 50} & \multicolumn{2}{|c|}{51 or more } \\
\hline 1 & & 2 & & 3 & & 4 & & 5 & & 6 & & 7 & & 8 & & 9 & & 10 & & 11 & & 12 & & 13 \\
\hline Number of incidents per 100,000 students. & 4,849 & $(252.4)$ & 3,965 & (103.7) & 2,766 & (172.3) & 5,840 & $(249.6)$ & 4,773 & (149.9) & 4,672 & $(250.7)$ & 3,527 & (210.5) & 4,320 & (350.6) & 3,554 & $(184.8)$ & 2,220 & (131.3) & 3,613 & (149.4) & 4,950 & $(200.9)$ \\
\hline \multirow{2}{*}{ 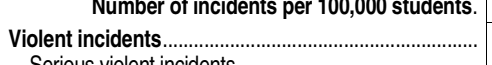 } & 3,147 & (223.8) & 2,500 & (90.9) & 2,131 & (163.6) & 3,997 & (203.9) & 2,141 & (105.3) & 2,885 & (210.8) & 2,236 & (192.4) & 2,820 & (335.6) & 2,250 & $(149.0)$ & 1,153 & (93.1) & 2,081 & (127.4) & 3,364 & $(177.9)$ \\
\hline & 130 & $(15.2)$ & 111 & & 97 & (16.8) & 145 & (25.2) & 110 & & 126 & $(21.3)$ & 98 & (18.4) & 107 & $(23.2)$ & 113 & $(26.4)$ & 62 & (14.3) & 86 & (13.2) & 149 & (24.4) \\
\hline Rape or attempt & 1 & $\begin{aligned} &(0.2) \\
&\end{aligned}$ & 1 & $(0.3)$ & - & $(t)$ & $3 !$ & $(1.0)$ & 3 & $(0.6)$ & 1 ! & $(0.5)$ & $1 !$ & $\begin{array}{ll}! & (0.5) \\
\end{array}$ & $2 !$ & $(0.9)$ & 1 ! & $(0.3)$ & $1 !$ & $(0.4)$ & $1 !$ & $\begin{array}{l}(0.3) \\
1\end{array}$ & 2 & $(0.5)$ \\
\hline Sexual battery other than r $r$ & 9 & (2.4) & 8 & $(1.3)$ & $4 !$ & $(2.0)$ & 10 & (2.4) & 11 & (1.8) & 11 & (2.7) & 4 & (1.2) & 8 & (2.5) & $8 !$ & $(3.5)$ & 3 & $(0.8)$ & 8 & (2.9) & 9 & (1.8) \\
\hline Physical attack or fight wit & 26 & (5.4) & 30 & (7.5) & 34 ! & $(13.0)$ & $19 !$ & (7.4) & 23 & (5.5) & 22 ! & (7.5) & $32 !$ & ! (12.7) & $43 !$ & (16.7) & $\ddagger$ & $(t)$ & $9 !$ & (3.1) & 21 & (6.1) & $46 !$ & (16.0) \\
\hline Threat & 45 & 4.1) & 41 & (6.1) & 34 & $(8.4)$ & 81 & (20.4) & 26 & (4.8) & 49 & (13.2) & 40 & $(9.2)$ & $38 !$ & $(17.9)$ & 31 & $(7.6)$ & 22 ! & (7.7) & 30 & (8.3) & 56 & (12.3) \\
\hline Robbery with weapon & $\ddagger$ & $(t)$ & $1 !$ & $(0.3)$ & - & $(t)$ & $\ddagger$ & $(t)$ & $\ddagger$ & $(t)$ & $2 !$ & $\begin{aligned} &(1.2) \\
& \text { (1) }\end{aligned}$ & \# & $(t)$ & $\#$ & $(t)$ & - & $(t)$ & $\#$ & $(t)$ & $\#$ & $(t)$ & $2 !$ & $(0.7)$ \\
\hline Robbery without weapon ... & 43 & (6.8) & 30 & (4.1) & 25 ! & (8.2) & 31 & (6.2) & 45 & (6.5) & 40 & (6.6) & 19 & (4.3) & 15 ! & (4.6) & $43 !$ & $(14.3)$ & 28 ! & (9.6) & 25 & (7.6) & 35 & (6.3) \\
\hline Physical attack or fight without w & 1,732 & $(128.8)$ & 1,532 & $(57.9)$ & 1,305 & $(106.9)$ & 2,545 & (132.7) & 1,271 & (85.0) & 1,814 & (148.1) & 1,398 & (104.3) & 1,571 & $(242.2)$ & 1,364 & $(100.3)$ & 713 & (49.9) & 1,251 & (89.8) & 2,076 & (117.2) \\
\hline Threat of attack without weapon. & 1,285 & (113.2) & 857 & (47.4) & 730 & (94.0) & 1,307 & (94.3) & 760 & (45.4) & 945 & (81.4) & 741 & (100.8) & 1,142 & (154.3) & 773 & $\begin{array}{l}(64.6) \\
(6)\end{array}$ & 378 & (44.0) & 744 & (73.4) & 1,139 & (86.5) \\
\hline 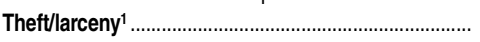 & 468 & $(20.2)$ & 546 & (18.5) & 185 & (24.8) & 736 & (50.7) & 1,012 & $(43.5)$ & 622 & (53.0) & 488 & (21.6) & 565 & (52.2) & 528 & (40.7) & 436 & $(34.0)$ & 619 & $(37.3)$ & 542 & (36.2) \\
\hline \multirow{6}{*}{ 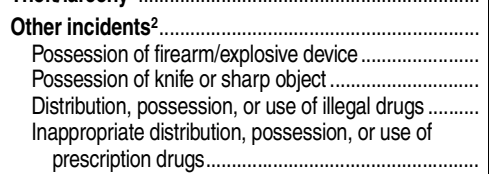 } & - & $(t)$ & 918 & (23.2) & 450 & (27.9) & 1,108 & (47.1) & 1,620 & $(60.8)$ & 1,166 & (62.6) & 803 & (32.2) & 935 & (65.7) & 776 & (42.2) & 631 & (41.1) & 914 & (37.1) & 1,044 & (46.9) \\
\hline & 18 & $(4.8)$ & 11 & $(1.2)$ & 8 & $(1.9)$ & 15 & (2.8) & 13 & $(1.9)$ & 13 & (2.2) & 10 & $\begin{array}{r}(1.8) \\
\end{array}$ & $10 !$ & (3.5) & 9 & (2.4) & 6 & $(1.1)$ & 7 & $(1.2)$ & 15 & (2.3) \\
\hline & 184 & (8.7) & 153 & (5.2) & 126 & $(7.3)$ & 193 & (9.8) & 175 & (12.5) & 156 & (9.7) & 131 & (10.9) & 208 & (15.1) & 151 & (10.1) & 72 & (5.4) & 140 & (6.6) & 196 & (11.2) \\
\hline & r & $(t)$ & 245 & $(9.8)$ & 14 & (3.4) & 262 & (17.4) & 637 & $(28.9)$ & 321 & (27.1) & 220 & (10.4) & 250 & (25.6) & 184 & (13.5) & 183 & (13.8) & 273 & (15.8) & 251 & (18.4) \\
\hline & & & & & & & & & & & & & & & & & & & & & & & & \\
\hline & $=$ & $\left(\begin{array}{l}+ \\
(+)\end{array}\right.$ & $\begin{array}{l}62 \\
86\end{array}$ & $\left.\begin{array}{l}(4.0) \\
(3.9)\end{array}\right]$ & $4 !$ & $\begin{array}{r}(1.3) \\
(1.3)\end{array}$ & 68 & $\begin{array}{l}(6.5) \\
(6.9)\end{array}$ & $\begin{array}{l}157 \\
238\end{array}$ & $\begin{array}{l}(12.4) \\
(1137)\end{array}$ & $\begin{array}{r}48 \\
100\end{array}$ & (6.4) & $\begin{array}{l}60 \\
85\end{array}$ & $(7.2)$ & $\begin{array}{l}84 \\
82\end{array}$ & (15.3) & $\begin{array}{l}70 \\
72\end{array}$ & (8.3) & 55 & $(6.2$ & $\begin{array}{r}83 \\
105\end{array}$ & $(9.3)$ & 50 & $\begin{array}{l}(4.8) \\
(57)\end{array}$ \\
\hline 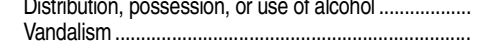 & $4 \overline{53}$ & $\begin{aligned} &(\dagger)(0) \\
&(28.6)\end{aligned}$ & $\begin{array}{r}86 \\
362\end{array}$ & $\begin{array}{r}(3.9) \\
(15.3)\end{array}$ & $\begin{array}{r}5 \\
293\end{array}$ & $\begin{aligned}(1.3) \\
(25.6)\end{aligned}$ & 492 & $\begin{aligned}(6.9) \\
(32.4)\end{aligned}$ & $\begin{array}{l}238 \\
400\end{array}$ & $\begin{array}{l}(13 .) \\
(35.4)\end{array}$ & $\begin{array}{l}100 \\
527\end{array}$ & $\begin{array}{l}(9.9) \\
(40.4)\end{array}$ & $\begin{array}{r}85 \\
297\end{array}$ & $\begin{aligned}(0.2) \\
(20.5)\end{aligned}$ & $\begin{array}{r}82 \\
301\end{array}$ & $\begin{array}{l}(14.4) \\
(30.3)\end{array}$ & 289 & $(32.3)$ & 221 & (27.0) & 305 & $(18.2)$ & 462 & $(29.6)$ \\
\hline
\end{tabular}

\section{-Not available.}

†Not applicable.

NOTE: "At school" was defined to include activities that happen in school buildings, on school grounds, on school buses, and

Interpret data with caution. The coefficient of variation (CV) for this estimate is 30 percent or greater. at places holding school-sponsored events or activities. Includes incidents that occurred before, during, or after normal schoo is not higher than grade 3 and the highest grade is not higher than grade 8 . Middle schools are defined as schools in which the lowest grade is not lower than grade 4 and the highest grade is not higher than grade 9 . High schools are defined schools in which the lowest grade is not lower than grade 9 and the highest grade is not higher than grade 12. All public schools also includes schools with other combinations of grades (including K-12 schools), which are not shown separately. pack (if left unattended or if no force was used to take it from owner), theft from a building, theft from a motor vehicle or of motor vehicle parts or accessories, theft of bicycles, theft from vending machines, and all other types of thefts. ${ }^{2}$ This table shows only the "Other incidents" that were included on the 2009-10 questionnaire. In 1999-2000, most of the
"Other incidents" differed from those shown in this table. Detail may not sum to totals because of rounding.

SOURCE: U.S. Department of Education, National Center for Education Statistics, 1999-2000 and 2009-10 School Survey 
Table 229.30. Percentage of public schools recording incidents of crime at school, number of incidents, and rate per 1,000 students, by type of crime and selected school characteristics: 2009-10 [Standard errors appear in parentheses]

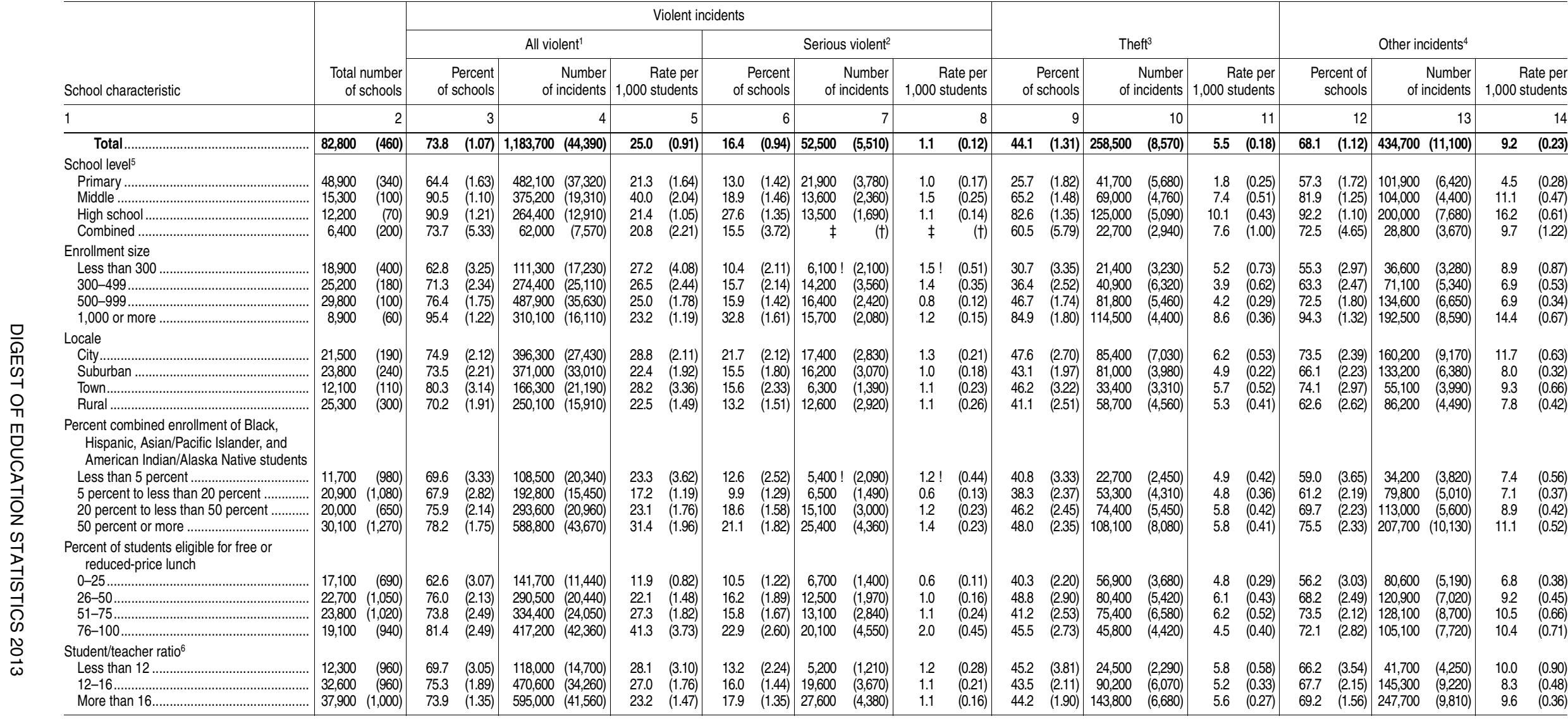

\section{†Not applicable.}

IInterpret data with caution. The coefficient of variation (CV) for this estimate is between 30 and 50 percent.

†Reporting standards not met. Either there are too few cases for a reliable estimate or the coefficient of variation (CV) is 50 percent or greater.

All violent incidents include serious violent incidents (see footnote 2) as well as physical attack or fight without a weapon and threat

attack with a weapon, attack with a weapon, and robbery with or without a weapon

antherceny (taking things worth over $\$ 10$ without personal confrontation) was defined for respondents as "the unlawful taking of another person's property without personal confrontation, threat, violence, or bodily harm." This includes pocket picking, stealing a
purse or backpack (if left unattended or no force was used to take it from owner) theft from a building, theft from a motor vehicle or motor vehicle parts or accessories, theft of a bicycle, theft from a vending machine, and all other types of thefts

4"Other incidents" include possession of a firearm or explosive device; possession of a knife or sharp object; distribution, possession, or use of illegal drugs or alcohol; inappropriate distribution, possession, or use of prescription drugs; and vandalism.
5Primary schools are defined as schools in which the lowest grade is not higher than grade 3 and the highest grade is not higher than grade 8. Middle schools are defined as schools in which the lowest grade is not lower than grade 4 and the highest grade is not is not higher than grade 12. Combined schools include all other combinations of grades, including K-12 schools.

'Studentteacher ratio was calculated by dividing the total number of students enrolled in the school by the total number of full-timeequivalent (FTE) teachers. Information regarding the total number of FTE teachers was obtained from the Common Core of Data (CCD), the sampling frame for SSOCS.

"At chol" " hold school-sponsored events or activities that happen in school buildings, on school grounds, on school buses, and at places tha normal school hours or when school activities or events were in session. Detail may not sum to totals because of rounding. SOURCE: U.S. Department of Education, National Center for Education Statistics, 2009-10 School Survey on Crime and Safety (SSOCS), 2010. (This table was prepared September 2013.) 
Table 229.40. Percentage of public schools reporting incidents of crime at school to the police, number of incidents, and rate per 1,000 students, by type of crime and selected school characteristics: 2009--10

[Standard errors appear in parentheses]

\begin{tabular}{|c|c|c|c|c|c|c|c|c|c|c|c|c|c|c|c|c|c|c|c|c|c|c|c|c|c|c|}
\hline \multirow[b]{3}{*}{ School characteristic } & \multicolumn{14}{|c|}{ Violent incidents } & \multirow{2}{*}{\multicolumn{6}{|c|}{ Theft $^{3}$}} & \multirow{2}{*}{\multicolumn{6}{|c|}{ Other incidents ${ }^{4}$}} \\
\hline & \multirow{2}{*}{\multicolumn{2}{|c|}{$\begin{array}{r}\text { Total number } \\
\text { of schools }\end{array}$}} & \multicolumn{6}{|c|}{ All violent ${ }^{1}$} & \multicolumn{6}{|c|}{ Serious violent ${ }^{2}$} & & & & & & & & & & & & \\
\hline & & & \multicolumn{2}{|c|}{$\begin{array}{r}\text { Percent } \\
\text { of schools }\end{array}$} & \multicolumn{2}{|c|}{$\begin{array}{r}\text { Number } \\
\text { of incidents }\end{array}$} & \multicolumn{2}{|c|}{$\begin{array}{r}\text { Rate per } \\
1,000 \text { students } \\
\end{array}$} & \multicolumn{2}{|c|}{$\begin{array}{r}\text { Percent } \\
\text { of schools }\end{array}$} & \multicolumn{2}{|c|}{$\begin{array}{r}\text { Number } \\
\text { of incidents }\end{array}$} & \multicolumn{2}{|c|}{$\begin{array}{r}\text { Rate per } \\
1,000 \text { students }\end{array}$} & \multicolumn{2}{|c|}{$\begin{array}{r}\text { Percent } \\
\text { of schools }\end{array}$} & \multicolumn{2}{|c|}{$\begin{array}{r}\text { Number } \\
\text { of incidents }\end{array}$} & \multicolumn{2}{|c|}{$\begin{array}{r}\text { Rate per } \\
1,000 \text { students }\end{array}$} & \multicolumn{2}{|c|}{$\begin{array}{r}\text { Percent } \\
\text { of schools }\end{array}$} & \multicolumn{2}{|c|}{$\begin{array}{r}\text { Number } \\
\text { of incidents }\end{array}$} & \multicolumn{2}{|c|}{$\begin{array}{r}\text { Rate per } \\
1,000 \text { students } \\
\end{array}$} \\
\hline 1 & & 2 & & 3 & & 4 & & 5 & & 6 & & 7 & & 8 & & 9 & & 10 & & 11 & & 12 & & 13 & & 14 \\
\hline Total ........ & 82,800 & (460) & 39.9 & (1.13) & 303,900 & $(13,310)$ & 6.4 & $(0.28)$ & 10.4 & (0.62) & 23,500 & $(2,320)$ & 0.5 & $(0.05)$ & 25.4 & (1.01) & 122,800 & $(4,180)$ & 2.6 & $(0.09)$ & 46.3 & (1.23) & 262,400 & $(8,260)$ & 5.5 & $(0.17)$ \\
\hline 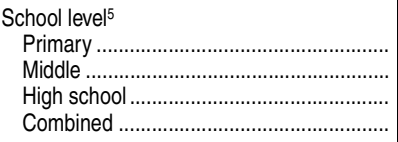 & $\begin{array}{r}48,900 \\
15,300 \\
12,200 \\
6,400\end{array}$ & $\begin{array}{r}(340) \\
(100) \\
(70) \\
(200)\end{array}$ & $\begin{array}{l}21.1 \\
65.9 \\
76.6 \\
51.0\end{array}$ & $\left.\begin{array}{l}(1.60) \\
(1.53) \\
(1.61) \\
(5.72)\end{array}\right]$ & $\begin{array}{r}35,300 \\
100,100 \\
146,200 \\
22,300\end{array}$ & $\begin{array}{r}(5,400) \\
(6,140) \\
(10,520) \\
(3,820)\end{array}$ & $\begin{array}{r}1.6 \\
10.7 \\
11.8 \\
7.5\end{array}$ & $\begin{array}{l}(0.23) \\
(0.64) \\
(0.84) \\
(1.20)\end{array}$ & $\begin{array}{r}5.5 \\
15.5 \\
24.9 \\
8.4\end{array}$ & $\left.\begin{array}{l}(0.84) \\
(1.25) \\
(1.16) \\
(2.41)\end{array}\right]$ & $\begin{array}{c}6,100 \\
6,300 \\
10,200 \\
1,000 !\end{array}$ & $\begin{array}{r}(1,450) \\
(850) \\
(1,120) \\
(400)\end{array}$ & $\begin{array}{l}0.3 \\
0.7 \\
0.8 \\
0.3 !\end{array}$ & $\begin{array}{l}(0.06) \\
(0.09) \\
(0.09) \\
(0.13)\end{array}$ & $\begin{array}{r}9.3 \\
41.1 \\
64.1 \\
36.9\end{array}$ & $\left.\begin{array}{l}(1.18) \\
(1.81) \\
(1.59) \\
(5.41)\end{array}\right]$ & $\begin{array}{r}9,500 \\
27,100 \\
73,800 \\
12,500\end{array}$ & $\begin{array}{l}(1,950) \\
(2,110) \\
(3,370) \\
(2,420)\end{array}$ & $\begin{array}{l}0.4 \\
2.9 \\
6.0 \\
4.2\end{array}$ & $\left.\begin{array}{l}(0.09) \\
(0.23) \\
(0.31) \\
(0.84)\end{array}\right]$ & $\begin{array}{l}30.3 \\
65.4 \\
83.6 \\
52.0\end{array}$ & $\begin{array}{l}(1.78) \\
(1.32) \\
(1.32) \\
(4.86)\end{array}$ & $\begin{array}{r}40,100 \\
60,300 \\
146,200 \\
15,900\end{array}$ & $\begin{array}{l}(3,810) \\
(2,600) \\
(5,850) \\
(2,350)\end{array}$ & $\begin{array}{r}1.8 \\
6.4 \\
11.8 \\
5.3\end{array}$ & $\begin{array}{l}(0.17) \\
(0.29) \\
(0.50) \\
(0.82)\end{array}$ \\
\hline \multicolumn{27}{|l|}{ Enrollment size } \\
\hline Lescth & 18,900 & (400) & 22.6 & $(2.54)$ & 14,800 & $(2,740)$ & 3.6 & $(0.67)$ & $4.7 !$ & $(1.44)$ & 1,400 & (380) & 0.3 & $(0.09)$ & 14.6 & (2.73) & 7,800 & $(2,210)$ & 1.9 & $(0.53)$ & 30.1 & (2.59) & 16,000 & $(2,590)$ & 3.9 & $(0.66)$ \\
\hline $300-45$ & 25,200 & (180) & 31.4 & $(2.29)$ & 36,800 & $(4,240)$ & 3.6 & $(0.42)$ & 7.1 & (1.32) & 3,700 & (860) & 0.4 & $(0.08)$ & 17.1 & $(1.91)$ & 12,800 & $(1,780)$ & 1.2 & $(0.17)$ & 40.2 & $(2.58)$ & 33,100 & $(2,720)$ & 3.2 & $(0.27)$ \\
\hline & 29,800 & (100) & 45.6 & (1.79) & 93,400 & $(6,070)$ & 4.8 & $(0.31)$ & 10.6 & $(1.04)$ & 7,900 & $(1,440)$ & 0.4 & $(0.07)$ & 26.4 & (1.40) & 31,000 & $(2,410)$ & 1.6 & $(0.12)$ & 48.9 & $(2.08)$ & 74,300 & $(4,010)$ & 3.8 & $(0.20)$ \\
\hline 1,000 or $r$ & 8,900 & $(60)$ & 81.1 & (1.67) & 159,000 & $(12,100)$ & 11.9 & $(0.90)$ & 31.1 & (1.67) & 10,600 & $(1,100)$ & 0.8 & $(0.08)$ & 68.4 & (1.70) & 71,200 & $(3,640)$ & 5.3 & $(0.29)$ & 89.0 & $(1.72)$ & 139,000 & $(5,870)$ & 10.4 & $(0.46)$ \\
\hline Locale & & & & & & & & & & & & & & & & & & & & & & & & & & \\
\hline City... & 21,500 & (190) & 42.5 & (2.01) & 94,100 & $(4,900)$ & 6.8 & $(0.35)$ & 14.0 & (1.45) & 9,200 & $(1,460)$ & 0.7 & $(0.11)$ & 23.7 & (1.65) & 37,000 & $(3,420)$ & 2.7 & $(0.24)$ & 50.6 & $(1.85)$ & 91,000 & $(4,370)$ & 6.6 & $(0.31)$ \\
\hline Subur & 23,800 & (240) & 39.9 & (1.80) & 107,600 & $(12,150)$ & 6.5 & (0.72) & 10.0 & $(1.11)$ & 7,300 & $(1,280)$ & 04 & 100 & 26.3 & $(1.46)$ & 39,900 & $(2,430)$ & 21 & $(014)$ & 47.5 & $(2.11)$ & 85,700 & $(5,410)$ & 5 & $(0.28)$ \\
\hline Town... & 12,100 & (110) & 43.1 & $(3.06)$ & 39,100 & $(3,510)$ & 6.6 & $(0.56)$ & 9.9 & (1.91) & 2,100 & (350) & 0.4 & $(0.06)$ & 26.9 & (2.33) & 16,400 & $(1,720)$ & 2.8 & $(0.27)$ & 48.1 & (3.27) & 35,900 & $(3,090)$ & 6.1 & $(0.52)$ \\
\hline ………............... & 25,300 & $(300)$ & 36.0 & (1.93) & 63,200 & $(5,590)$ & 5.7 & $(0.52)$ & 8.1 & (1.22) & 4,900 & $(1,110)$ & 0.4 & $(0.10)$ & 25.3 & (2.00) & 29,500 & $(2,930)$ & 2.7 & $(0.27)$ & 40.8 & $(1.89)$ & 49,800 & $(2,620)$ & 4.5 & $(0.26)$ \\
\hline $\begin{array}{l}\text { Percent combined enrollment of Black, } \\
\text { Hispanic, Asian/Pacific Islander, and } \\
\text { American Indian/Alaska Native students }\end{array}$ & & & & & & & & & & & & & & & & & & & & & & & & & & \\
\hline Less than 5 percent. & 11,700 & (980) & 36.5 & $(3.00)$ & 20,000 & $(2,360)$ & 4.3 & $(0.42)$ & 7.1 & (1.64) & 1,400 & (400) & 0.3 & $(0.09)$ & 23.5 & (2.54) & 10,200 & $(1,490)$ & 2.2 & (0.32) & 38.5 & $(3.20)$ & 20,200 & $(2,820)$ & 4.3 & $(0.49)$ \\
\hline 5 perce & 20,900 & $(1,080)$ & 35.8 & (1.72) & 48,800 & $(3,620)$ & 4.4 & & 6.5 & $(0.80)$ & 3,200 & 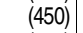 & 0. & & 24.8 & (1.66) & 30,100 & $(2,970)$ & 2.7 & & 40.1 & $(2.31)$ & 53,200 & & 4.7 & $(0.32)$ \\
\hline $20 \mathrm{p}$ & 20,000 & $(650)$ & 41.7 & $(2.20)$ & 75,000 & $(5,870)$ & 5.9 & $(0.50)$ & 10.3 & $(1.16)$ & 5,000 & (710) & 0. & $(0.0$ & 26.8 & $(1.71)$ & 34,900 & $(2,900)$ & 2.7 & 10.2 & 46.3 & $(2.29)$ & 65,500 & $(4,240)$ & 5.1 & $(0.33)$ \\
\hline 50 percent or more & 30,100 & $(1,270)$ & 42.8 & (2.36) & 160,200 & $(13,150)$ & 8.5 & $(0.67)$ & 14.5 & (1.27) & 14,100 & $(2,310)$ & 0.7 & $(0.12)$ & 25.7 & (1.78) & 47,500 & $(3,470)$ & 2.5 & $(0.19)$ & 53.7 & $(2.25)$ & 123,500 & $(6,250)$ & 6.6 & $(0.34)$ \\
\hline $\begin{array}{l}\text { Percent of students eligible for free or } \\
\text { reduced-price lunch }\end{array}$ & & & & & & & & & & & & & & & & & & & & & & & & & & \\
\hline $0-25$ & 17,100 & (690) & 33.8 & (1.98) & 42,200 & $(3,270)$ & 3.6 & $(0.25)$ & 7.4 & $(0.76)$ & 3,600 & (560) & 0.3 & $(0.04)$ & 26.8 & (1.72) & 30,500 & $(2,420)$ & 2.6 & $(0.2$ & 40.6 & $(2.55)$ & 54,200 & $(3, c$ & 4.6 & $(0.31)$ \\
\hline $26-5$ & 22,700 & $(1,050)$ & 42.7 & (1.92) & 76,100 & $(4,170)$ & 5.8 & $(0.3$ & 10.7 & $(1.31)$ & & 6 & 0.4 & $(0$. & 31.2 & (1.83) & 43,300 & $(3,740)$ & 3.3 & & 48.0 & (2.92) & 76,900 & & 5.9 & \\
\hline $51-7$ & 23,800 & $(1,020)$ & 40.3 & $(2.50)$ & 87,200 & $(6,600)$ & 7.1 & $(0.51)$ & 8.8 & (1.01) & 5,400 & $(1,160)$ & 0.4 & $(0.09)$ & 22.9 & (1.95) & 31,200 & $(3,220)$ & 2.6 & $(0.25)$ & 47.5 & $(2.55)$ & 72,300 & $(5,400)$ & 5.9 & $(0.40)$ \\
\hline $76-100$. & 19,100 & (940) & 41.4 & (2.91) & 98,400 & $(13,140)$ & 9.8 & $(1.28)$ & 14.7 & (1.92) & 9,500 & $(2,230)$ & 0.9 & $(0.22)$ & 20.3 & (1.88) & 17,800 & $(2,030)$ & 1.8 & $(0.19)$ & 48.0 & $(2.76)$ & 59,000 & $(4,970)$ & 5.8 & $(0.49)$ \\
\hline Studentt & & & & & & & & & & & & & & & & & & & & & & & & & & \\
\hline Less $\mathrm{t}$ & 12,300 & (960) & 36.8 & (3.46) & 29,000 & $(3,330)$ & 6.9 & $(0.74)$ & 8.7 & (1.85) & 2,20 & (450) & 0.5 & $(0.11)$ & 24.8 & (3.36) & 11,400 & $(1,470)$ & 2.7 & $(0.38)$ & 46.4 & (3.51) & 22,100 & $(2$, & 5.3 & $(0.65)$ \\
\hline & 32,600 & (960) & 41.5 & (1.96) & 128,500 & $(13,4$ & 7.4 & & 10.0 & (1.10) & 7,900 & $(9$ & 0. & & 25.8 & (1.43) & 42,100 & $(3,2$ & 2.4 & & 45.6 & (1.77) & 88,900 & & 5.1 & $(0.33)$ \\
\hline 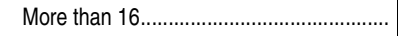 & $37,900(1$ & $(1,000)$ & 39.4 & (1.76) & 146,400 & $(8,760)$ & 5.7 & $(0.33)$ & 11.3 & $(0.83)$ & 13,400 & $(2,210)$ & 0.5 & $(0.08)$ & 25.3 & (1.55) & 69,300 & $(3,600)$ & 2.7 & $(0.15)$ & 46.9 & $(1.67)$ & 151,500 & $(6,510)$ & 5.9 & $(0.26)$ \\
\hline
\end{tabular}

!Interpret data with caution. The coefficient of variation (CV) for this estimate is between 30 and 50 percent.

${ }^{1}$ All violent incidents include serious violent incidents (see footnote 2) as well as physical attack or fight without a weapon and ${ }^{2}$ Serious violent incidents include reapon. attack with a weapon, and robbery with or without a weapon. Theflarceny (taking things worth over $\$ 10$ without personal confrontation) was defined for respondents as "the unlawful taking of another person's property without personal confrontation, threat, violence, or bodily harm." This includes pocket picking, stealing a motor vackpack (it left unattended or no force was used to take it from owner), thet from a building, theft from a motor vehicle or 4"Other incident"' include possession of a firearm or explosive device; possession of a knife or sharp object; disto

sion, or use of illegal drugs or alcohol: inappropriate distribution, possession, or use of prescription drugs: and vandalis pos 5 Primary schools are defined as schols in which the lowest grade is not higher than grade 3 and the highest grade is no

than grade 8. Middle schools are defined as schools in which the lowest grade is not lower than grade 4 and the highest grade is not higher than grade 9 . High schools are defined as schools in which the lowest grade is not lower than grade 9 and the highest grade is not higher than grade 12 . Combined schools include all other combinations of grades, including $\mathrm{K}-12$ schools.
$6 \mathrm{~S}$ tudent/teacher ratio was calculated by dividing the total number of students enrolled in the school by the total num

time-equivalent (FTE) teachers. Information regarding the total number of FTE teachers was obtained from the Common of fullData (CCD), the sampling frame for SSOCS.

NOTE: Responses were provided by the principal or the person most knowledgeable about crime and safety issues at the school. "At school" was defined to include activities that happen in school buildings, on school grounds, on school buses, and at places that hold school-sponsored events or activities. Respondents were instructed to include incidents that occurred before, during, or SOURCE: U.S. Department of Education, National Center for Education Statistics, 2009-10 School Survey on Crime and Safety (SSOCS), 2010. (This table was prepared September 2013.) 
Table 229.50. Percentage distribution of public schools, by number of violent incidents of crime at school recorded and reported to the police and selected school characteristics: $2009-10$

[Standard errors appear in parentheses]

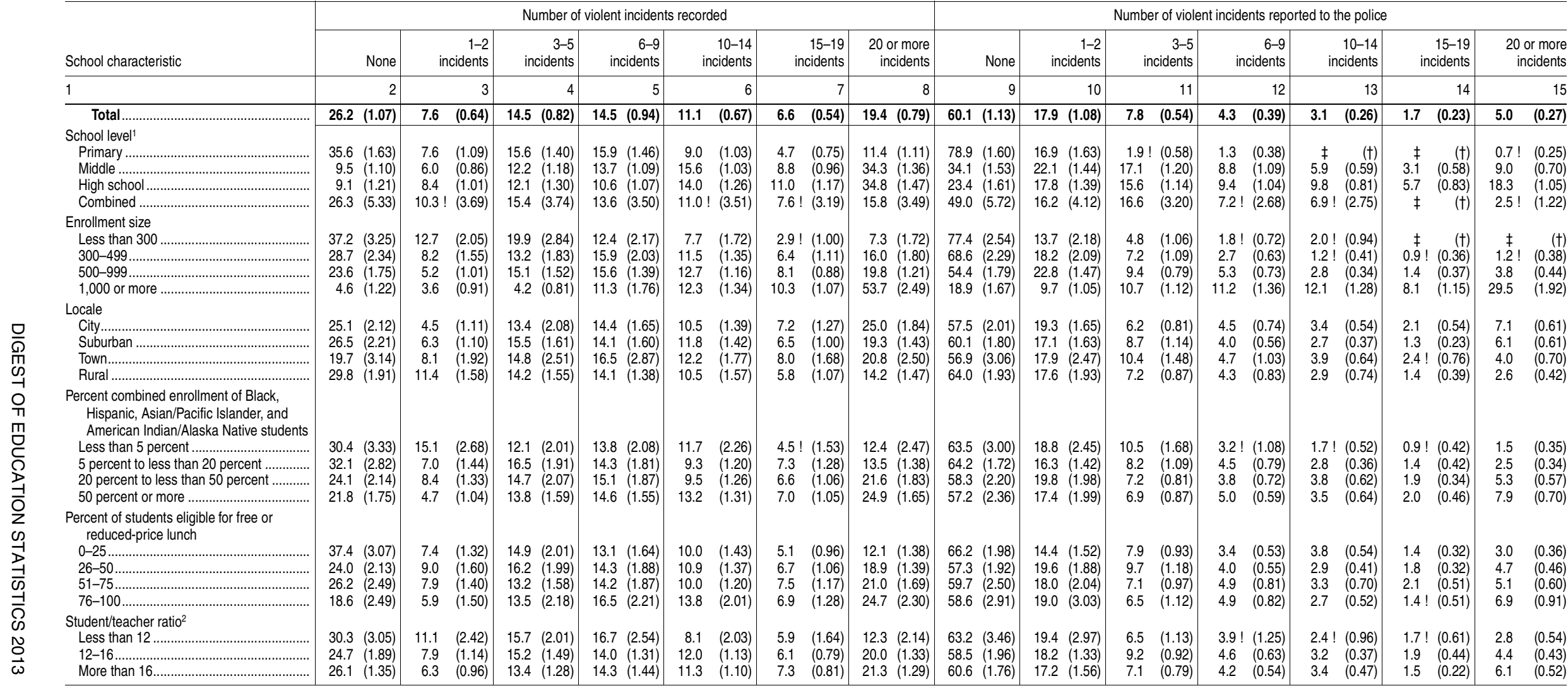

†Not applicable.

!Interpret data with caution. The coefficient of variation (CV) for this estimate is between 30 and 50 percent

†Reporting standards not met. Either there are too few cases for a reliable estimate or the coefficient of variation (CV) is 50 percent or greater.
iPrimary schools

than grade 8 . Middl defined as schools in which the lowest grade is not higher than grade 3 and the highest grade is not higher not higher than grade 9 . High schools are defined as schools in which the lowest grade is not lower than grade 9 and the highest grade is not higher than grade 12. Combined schools include all other combinations of grades, including K-12 schools. ${ }^{2}$ Studentteacher ratio was calculated by dividing the total number of students enrolled in the school by the total number of full-
time-equivalent (FTE) teachers. Information regarding the total number of FTE teachers was obtained from the Common Core of
Data (CCD), the sampling frame for SSOCS.

NOTE: Violent incidents include rape, sexual battery other than rape, physical attack or fight with or without a weapon, threat of physical attack with or without a weapon, and robbery with or without a weapon. Responses were provided by the principal or happen in school buildings, on school grounds, on school buses, and at places that hold schoolsponsored events or activities. Respondents were instructed to include incidents that occurred before, during, or after normal school hours or when schoo activities or events were in session. Detail may not sum to totals because of rounding SOURCE: U.S. Department of Education, National Center for Education Statistics, 2009-10 School Survey on Crime and Safety (SSOCS), 2010. (This table was prepared September 2013.) 


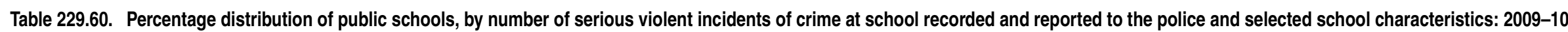
[Standard errors appear in parentheses]

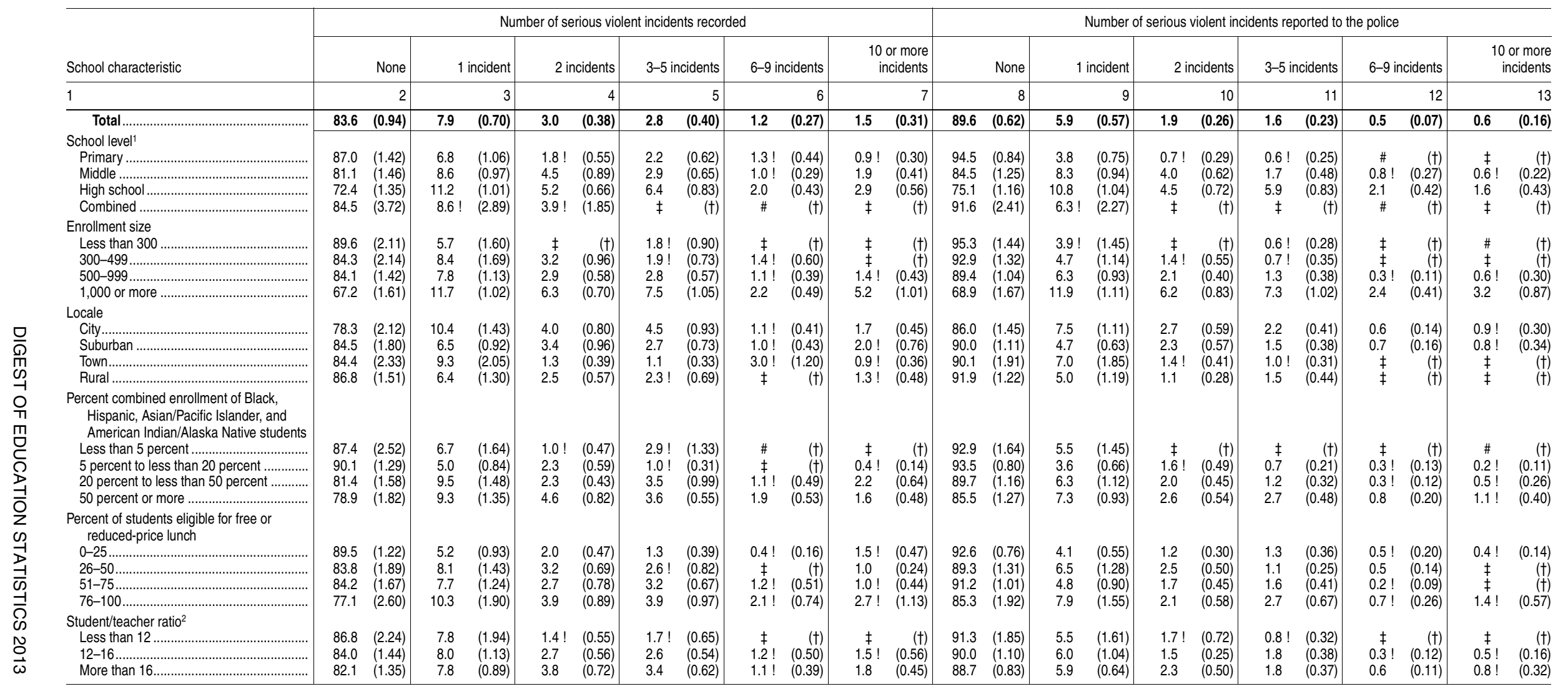

\section{†Not applicable.}

\#Rounds to zero.
IInterpret data with caution. The coefficient of variation (CV) for this estimate is between 30 and 50 percent.

†Reporting standards not met. Either there are too few cases for a reliable estimate or the coefficient of variation (CV) is 50 per-

cent or greater.
1Primary schools are defined as schools in which the lowest grade is not higher than grade 3 and the highest grade is not higher
than grade 8 . Middle schools are defined as schools in which the lowest grade is not lower than grade 4 and the highest grade is not higher than grade 9 . High schools are defined as schools in which the lowest grade is not lower than grade 9 and the highest

grade is not higher than grade 12 . Combined schools include all other combinations of grades, including $\mathrm{K}-12 \mathrm{schools}$.
${ }^{2}$ Student/teacher ratio was calculated by dividing the total number of students enrolled in the school by the total number of full- time-equivalent (FTE) teachers. Information regarding the total number of FTE teachers was obtained from the Common Core of

Data (CCD), the sampling frame for SSOCS.
NOTE: Serious violent incidents include rape, sexual battery other than rape, physical attack or fight with a weapon, threat of physical attack with a weapon, and robbery with or without a weapon. Responses were provided by the principal or the person
most knowledgeable about crime and safety issues at the school. "At school" was defined to include activities that happen in school buildings, on school grounds, on school buses, and at places that hold school-sponsored events or activities. Respondents were instructed to include incidents that occurred before, during, or after normal school hours or when school activities or

SOURCE: U.S. Department of Education, National Center for Education Statistics, 2009-10 School Survey on Crime and Safety (SSOCS), 2010. (This table prepared September 2013.) 


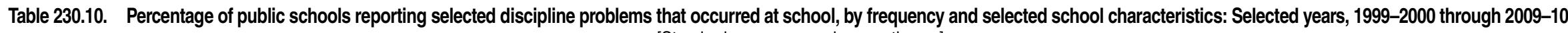
[Standard errors appear in parentheses]

\begin{tabular}{|c|c|c|c|c|c|c|c|c|c|c|c|c|c|c|c|c|c|c|}
\hline \multirow[b]{2}{*}{ Year and school characteristic } & \multicolumn{14}{|c|}{ Happens at least once a week ${ }^{1}$} & \multicolumn{4}{|c|}{ Happens at all² } \\
\hline & \multicolumn{2}{|c|}{$\begin{array}{r}\text { Student racial// } \\
\text { ethnic tensions }{ }^{3}\end{array}$} & \multicolumn{2}{|c|}{ Student bullying } & \multicolumn{2}{|c|}{$\begin{array}{r}\text { Student } \\
\text { sexual harassment } \\
\text { of other students }\end{array}$} & \multicolumn{2}{|c|}{$\begin{array}{r}\text { Student } \\
\text { harassment of other } \\
\text { students based on } \\
\text { sexual orientation } \\
\text { or gender identity }\end{array}$} & \multicolumn{2}{|c|}{$\begin{array}{r}\text { Student verbal } \\
\text { abuse of teachers }\end{array}$} & \multicolumn{2}{|c|}{$\begin{array}{r}\text { Widespread } \\
\text { disorder in classrooms }\end{array}$} & \multicolumn{2}{|c|}{$\begin{array}{r}\text { Student acts of } \\
\text { disrespect for teachers } \\
\text { other than verbal } \\
\text { abuse }\end{array}$} & \multicolumn{2}{|c|}{ Gang activities } & \multicolumn{2}{|c|}{$\begin{array}{r}\text { Cult or extremist group } \\
\text { activities }\end{array}$} \\
\hline 1 & & 2 & & 3 & & 4 & & 5 & & 6 & & 7 & & 8 & & 9 & & \\
\hline 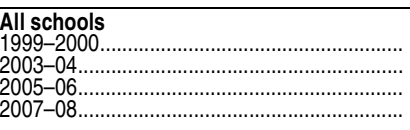 & $\begin{array}{l}3.4 \\
2.1 \\
2.8 \\
3.7 \\
\end{array}$ & $\begin{array}{l}0.41 \\
0.28 \\
0.31 \\
0.49\end{array}$ & $\begin{array}{l}29.3 \\
26.8 \\
24.5 \\
25.3 \\
\end{array}$ & $\left.\begin{array}{l}(1.21) \\
1.09 \\
1.14 \\
1.11\end{array}\right)$ & $\begin{array}{l}\overline{4} .0 \\
3.5 \\
3.0 \\
\end{array}$ & $\begin{array}{r}\left(\begin{array}{c}(t) \\
(0.40 \\
0.40 \\
0.39\end{array}\right. \\
\end{array}$ & $\begin{array}{l}\bar{z} \\
\bar{z}\end{array}$ & $\begin{array}{l}(+) \\
(+) \\
(\dagger) \\
\end{array}$ & $\begin{array}{r}12.5 \\
10.7 \\
9.5 \\
6.0 \\
\end{array}$ & $\begin{array}{l}(0.69) \\
0.80 \\
0.61 \\
0.48) \\
\end{array}$ & $\begin{array}{l}3.1 \\
2.8 \\
2.3 \\
4.0 \\
\end{array}$ & $\begin{array}{l}0.44) \\
0.39 \\
0.24 \\
(0.45) \\
\end{array}$ & $\frac{\bar{z}}{10.5}$ & $\begin{array}{r}\left(\begin{array}{r}+ \\
+ \\
+ \\
(0.71\end{array}\right) \\
\end{array}$ & $\begin{array}{l}18.7 \\
16.7 \\
16.9 \\
19.8 \\
\end{array}$ & $\begin{array}{l}(0.85) \\
0.78 \\
0.76 \\
0.88)\end{array}$ & $\begin{array}{l}6.7 \\
3.4 \\
3.7 \\
2.6 \\
\end{array}$ & $\left.\begin{array}{l}0.35 \\
0.41 \\
0.36\end{array}\right)$ \\
\hline 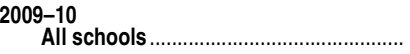 & 2.8 & (0.39) & 23.1 & (1.12) & 3.2 & $(0.55)$ & 2.5 & (0.41) & 4.8 & $(0.49)$ & 2.5 & $(0.37)$ & 8.6 & $(0.67)$ & 16.4 & $(0.84)$ & 1.7 & \\
\hline 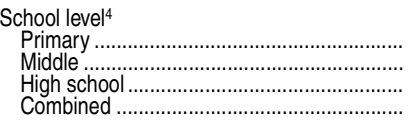 & $\begin{array}{r}2.1 \\
5.4 \\
3.3 \\
\ddagger\end{array}$ & $\left.\begin{array}{r}(0.62) \\
0.81 \\
0.56 \\
(\dagger\end{array}\right)$ & $\begin{array}{l}19.6 \\
38.6 \\
19.8 \\
18.6\end{array}$ & $\left(\begin{array}{l}1.75) \\
1.60 \\
1.41 \\
4.38\end{array}\right)$ & $\begin{array}{l}1.8 ! \\
6.1 \\
3.2 \\
7.5 !\end{array}$ & $\left.\begin{array}{l}(0.70) \\
0.89 \\
0.58 \\
2.92\end{array}\right)$ & $\begin{array}{l}0.8 ! \\
6.2 ! \\
3.1 \\
6.0 !\end{array}$ & $\begin{array}{l}(0.35) \\
0.92 \\
(0.55) \\
(2.74)\end{array}$ & $\begin{array}{r}3.4 \\
6.8 \\
8.6 \\
\ddagger\end{array}$ & $\left.\begin{array}{c}(0.67) \\
0.83 \\
1.00 \\
(\dagger\end{array}\right)$ & $\begin{array}{l}1.9 ! \\
4.1 \\
4.4 \\
\#\end{array}$ & $\left.\begin{array}{r}(0.60) \\
0.67 \\
0.80 \\
(\dagger\end{array}\right)$ & $\begin{array}{c}6.1 \\
13.7 \\
14.3 \\
4.4 !\end{array}$ & $\left.\begin{array}{l}(0.92) \\
1.15 \\
1.27 \\
2.05\end{array}\right)$ & $\begin{array}{r}7.5 \\
29.2 \\
38.4 \\
11.1\end{array}$ & $\left.\begin{array}{l}1.11 \\
1.48 \\
1.50 \\
2.89\end{array}\right)$ & $\begin{array}{l}1.4 ! \\
1.4 \\
3.9 \\
\ddagger\end{array}$ & \\
\hline 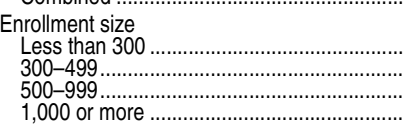 & $\begin{array}{r}+ \\
\ddagger \\
2.5 \\
3.0 \\
5.5\end{array}$ & 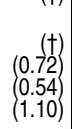 & $\begin{array}{l}16.5 \\
24.0 \\
25.3 \\
27.0\end{array}$ & $\begin{array}{r}(2.48) \\
2.19 \\
1.55 \\
(2.12)\end{array}$ & $\begin{array}{l}4.5 ! \\
2.4 ! \\
2.6 \\
4.7\end{array}$ & $\left(\begin{array}{l}1.38) \\
0.75 \\
0.55 \\
(1.01)\end{array}\right)$ & $\begin{array}{l}4.3 ! \\
1.0 \\
2.4 \\
3.8\end{array}$ & $\left.\begin{array}{l}(1.33) \\
0.28 \\
0.48 \\
0.82\end{array}\right)$ & $\begin{array}{r}\ddagger \\
5.2 \\
4.3 \\
11.2\end{array}$ & $\begin{array}{r}(t) \\
1.03 \\
0.64 \\
1.37)\end{array}$ & $\begin{array}{r}\ddagger \\
2.4 \\
2.6 \\
4.3\end{array}$ & $\begin{array}{r}(\dagger) \\
(0.70 \\
0.60 \\
0.96)\end{array}$ & $\begin{array}{r}3.3 ! \\
9.5 \\
8.3 \\
18.2\end{array}$ & $\left(\begin{array}{l}1.09) \\
(1.57) \\
(1.00) \\
1.64\end{array}\right.$ & $\begin{array}{r}6.5 \\
11.9 \\
16.4 \\
49.8\end{array}$ & $\left(\begin{array}{l}1.34) \\
1.49 \\
1.24 \\
1.72\end{array}\right)$ & 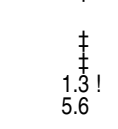 & \\
\hline 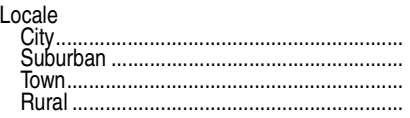 & $\begin{array}{l}5.3 \\
2.7 \\
1.0 ! \\
1.6 !\end{array}$ & $\left(\begin{array}{l}1.14 \\
0.61 \\
0.36 \\
0.63\end{array}\right)$ & $\begin{array}{l}27.0 \\
19.9 \\
26.2 \\
21.2\end{array}$ & $\left.\begin{array}{l}(2.08) \\
1.96 \\
2.71 \\
2.11\end{array}\right)$ & $\begin{array}{l}3.6 ! \\
2.6 \\
2.9 ! \\
3.6\end{array}$ & $\left.\begin{array}{l}1.16 \\
0.69 \\
0.99 \\
1.01\end{array}\right)$ & $\begin{array}{l}2.9 ! \\
2.0 \\
2.0 \\
2.9\end{array}$ & $\left.\begin{array}{l}1.06 \\
0.42 \\
0.56 \\
0.69\end{array}\right)$ & $\begin{array}{l}9.1 \\
4.7 \\
3.3 ! \\
1.9 !\end{array}$ & $\left.\begin{array}{l}1.38 \\
0.92 \\
1.24 \\
0.58)\end{array}\right)$ & $\begin{array}{l}4.5 \\
3.0 \\
0.6 ! \\
1.3 !\end{array}$ & $\left.\begin{array}{l}0.85 \\
0.77 \\
0.26 \\
0.62\end{array}\right)$ & $\begin{array}{r}11.7 \\
8.1 \\
11.6 \\
5.0\end{array}$ & $\left.\begin{array}{l}(1.46) \\
1.10 \\
(2.16 \\
0.93)\end{array}\right)$ & $\begin{array}{r}28.3 \\
14.6 \\
13.9 \\
9.1\end{array}$ & $\left.\begin{array}{l}2.10 \\
1.16 \\
1.56 \\
1.13\end{array}\right)$ & $\begin{array}{l}2.5 \\
1.2 ! \\
1.7 ! \\
1.6 !\end{array}$ & \\
\hline 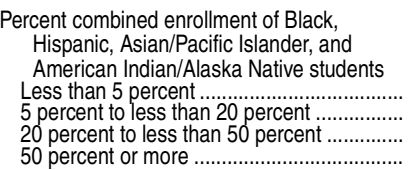 & $\begin{array}{l}\ddagger \\
1.5 \\
3.2 \\
4.3\end{array}$ & 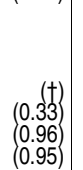 & $\begin{array}{l}22.0 \\
21.3 \\
22.3 \\
25.2\end{array}$ & $\left.\begin{array}{l}(3.36 \\
1.66 \\
1.70 \\
2.35\end{array}\right)$ & $\begin{array}{l}4.5 ! \\
1.8 ! \\
2.6 \\
4.1 !\end{array}$ & $\left.\begin{array}{l}1.91 \\
0.58 \\
0.45 \\
1.25\end{array}\right)$ & $\begin{array}{l}2.7 ! \\
1.9 \\
2.6 \\
2.9 !\end{array}$ & $\left.\begin{array}{l}1.19 \\
0.46 \\
0.47 \\
0.87\end{array}\right)$ & $\begin{array}{r}\ddagger \\
1.8 \\
4.5 \\
8.5\end{array}$ & 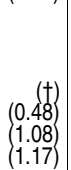 & $\begin{array}{l}\ddagger \\
0.5 ! \\
1.1 ! \\
5.7\end{array}$ & $\begin{array}{l}(+) \\
(0.16 \\
0.48 \\
0.94)\end{array}$ & $\begin{array}{r}3.6 ! \\
6.1 \\
9.6 \\
11.7\end{array}$ & $\left(\begin{array}{l}1.18 \\
1.22 \\
(1.122 \\
(1.22)\end{array}\right)$ & $\begin{array}{r}1.5 \\
5.8 \\
16.9 \\
29.1\end{array}$ & $\left.\begin{array}{l}(0.39) \\
0.80 \\
1.40 \\
1.88\end{array}\right)$ & $\begin{array}{l}0.4 ! \\
1.8 ! \\
1.4 \\
2.4\end{array}$ & $\begin{array}{l}0.19 \\
0.75 \\
0.23 \\
0.64\end{array}$ \\
\hline $\begin{array}{c}\text { Percent of students eligible for free or } \\
\text { reduced-price lunch } \\
0-25\end{array}$ & $\begin{array}{l}1.9 \\
2.6 ! \\
2.4 ! \\
4.3\end{array}$ & $\left.\begin{array}{l}(0.40) \\
0.85 \\
0.83 \\
1.16\end{array}\right)$ & $\begin{array}{l}19.7 \\
21.9 \\
24.1 \\
26.1\end{array}$ & $\left.\begin{array}{l}1.99 \\
1.58 \\
2.24 \\
3.07\end{array}\right)$ & $\begin{array}{l}2.6 \\
3.2 \\
3.2 ! \\
3.9 !\end{array}$ & $\left.\begin{array}{l}(0.74) \\
0.80 \\
0.98 \\
(1.47)\end{array}\right)$ & $\begin{array}{l}2.1 \\
3.0 \\
2.7 ! \\
2.1 !\end{array}$ & $\left.\begin{array}{l}(0.55) \\
0.67 \\
0.86 \\
0.87\end{array}\right)$ & $\begin{array}{l}1.5 \\
2.3 \\
5.6 \\
9.6\end{array}$ & $\left.\begin{array}{l}(0.28) \\
0.52 \\
0.95 \\
(1.64)\end{array}\right)$ & $\begin{array}{l}0.7 ! \\
1.3 ! \\
1.0 ! \\
7.5\end{array}$ & $\left.\begin{array}{l}0.21 \\
0.43 \\
(0.37 \\
1.38\end{array}\right)$ & $\begin{array}{r}3.6 \\
6.9 \\
10.7 \\
12.5\end{array}$ & $\left.\begin{array}{l}(0.60) \\
0.91 \\
(1.42 \\
(1.49)\end{array}\right)$ & $\begin{array}{r}7.9 \\
13.2 \\
17.4 \\
26.5\end{array}$ & $\left(\begin{array}{l}0.91 \\
1.33 \\
1.46 \\
2.19\end{array}\right)$ & $\begin{array}{l}1.4 \\
1.9 ! \\
1.3 ! \\
2.3 !\end{array}$ & \\
\hline 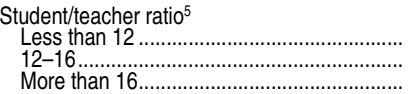 & $\begin{array}{l}1.6 ! \\
3.1 \\
2.9\end{array}$ & $\left(\begin{array}{l}0.69) \\
0.81 \\
0.61\end{array}\right)$ & $\begin{array}{l}19.6 \\
21.8 \\
25.3\end{array}$ & $\left(\begin{array}{l}2.85 \\
1.73 \\
1.57\end{array}\right)$ & $\begin{array}{l}4.2 ! \\
2.4 \\
3.6\end{array}$ & $\left.\begin{array}{l}1.46 \\
0.66 \\
0.87)\end{array}\right)$ & $\begin{array}{l}3.6 ! \\
2.2 \\
2.5\end{array}$ & $\left(\begin{array}{l}1.38 \\
0.52 \\
0.60\end{array}\right)$ & $\begin{array}{l}4.3 \\
4.8 \\
4.9\end{array}$ & $\left.\begin{array}{l}1.23 \\
0.73 \\
0.83\end{array}\right)$ & $\begin{array}{l}2.5 ! \\
3.0 \\
2.1\end{array}$ & $\left.\begin{array}{l}(0.82) \\
0.74 \\
0.54\end{array}\right)$ & $\begin{array}{l}7.0 \\
9.0 \\
8.8\end{array}$ & $\left(\begin{array}{l}1.42 \\
1.27 \\
0.91\end{array}\right)$ & $\begin{array}{l}12.3 \\
16.0 \\
18.1\end{array}$ & $\left(\begin{array}{l}1.77) \\
1.54 \\
1.08\end{array}\right)$ & 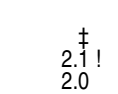 & 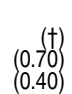 \\
\hline 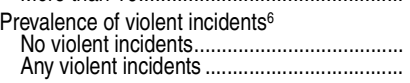 & 3.5 & $\begin{array}{r}(+) \\
(0.50)\end{array}$ & $\begin{array}{r}7.6 \\
28.5\end{array}$ & $\left(\begin{array}{l}1.53 \\
1.36\end{array}\right)$ & 4.1 & 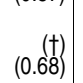 & $3.2^{+}$ & 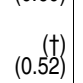 & $6.4^{+}$ & $(0.63)$ & $3.0^{+}$ & $\begin{array}{r}(+t) \\
(0.46)\end{array}$ & $0.8 !$ & $\left(\begin{array}{l}0.39 \\
0.87)\end{array}\right.$ & $21.6 !$ & $\left(\begin{array}{l}0.67) \\
(1.04)\end{array}\right)$ & $2.1^{\ddagger}$ & $\left.\begin{array}{rl}(+) \\
(0.39\end{array}\right)$ \\
\hline
\end{tabular}

\section{-Not available.}

†Not applicable.
\#Rounds to zero.

\#Rounds to zero.
!Interpret data with caution. The coefficient of variation (CV) for this estimate is between 30 and 50 percent.

theporting standards not met. Either there are too few cases for a reliable estimate or the coefficient of variation (CV) is 50 percent or greater.

${ }^{2}$ Includes schools that reported the activity happens at all at their school during the school year. In the 1999-2000 survey administration, the questionnaire specified "undesirable" gang activities and "undesirable" cult or extremist group activities. "Prior to the 2007-08 survey administration, the questionnaire wording was "student racial tensions."

${ }^{4}$ Primary schools are defined as schools in which the lowest grade is not higher than grade 3 and the highest grade is not higher than grade 8. Middle schools are defined as schools in which the lowest grade is not lower than grade 4 and the highand the highest grade is not higher than grade 12 . Combined schools include all other combinations of grades, including $\mathrm{K}-12$ schools.
${ }^{5}$ Student/teacher ratio was calculated by dividing the total number of students enrolled in the school by the total number of full-time-equivalent (FTE) teachers. linformation regarding the total number of FTE teachers was obtained from the Common Core of Data (CCD), the sampling frame for SSOCS.

${ }^{6}$ "Violent incidents" include rape or attempted rape, sexual battery other than rape, physical attack or fight with or without a NOTE: R

school "At school" was defined for respondents to include activites that hapen in school buldings, on scty issues at the school "Asses, and at places that hold school-sponsored enents or activites. Re those times that were during normal school hours or when school activities or events were in session, unless the survey spec-

SOURCE: U.S. Department of Education, National Center for Education Statistics, 1999-2000, 2003-04, 2005-06, 2007-08, and 2009-10 School Survey on Crime and Safety (SSOCS), 2000, 2004, 2006, 2008, and 2010. (This table was prepare 


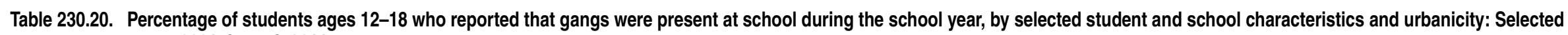
years, 2001 through 2011

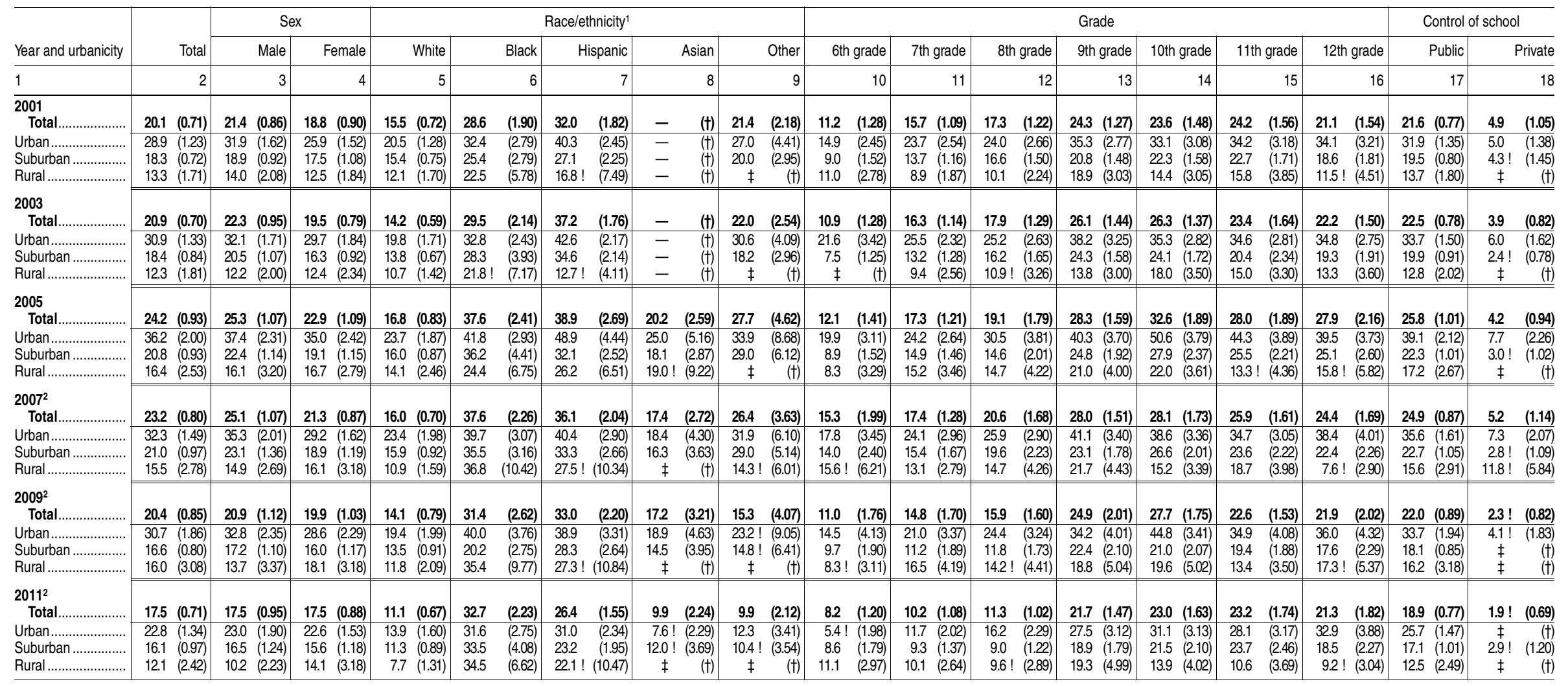

\section{-Not available.}

IInterpret data with caution. The coefficient of variation (CV) for this estimate is between 30 and 50 percent. ₹Reporting standards not met. Either there are too few cases for a reliable estimate or the coefficient of variation (CV) is 50 percent or greater.

'Race categories exclude persons of Hispanic ethnicity. "Other" includes American Indians/Alaska Natives, Asians (prior to 2005), Pacific Islanders, and, from 2003 onward, persons reporting that they are of two or more races. Due to changes in racial/
${ }^{2}$ Starting in 2007, the reference period was the school year, whereas in prior survey years the reference period was the previous 6 months. Cognitive testing showed that estimates from 2007 onward are comparable to previous years.

NOTE: Urbanicity refers to the Standard Metropolitan Statistical Area (MSA) status of the respondent's household as defined in 2000 by the U.S. Census Bureau. Categories include "central city of an MSA (Urban)," "in MSA but not in central city (Suburban)," and "not MSA (Rural)." All gangs, whether or not they are involved in violent or illegal activity, are included. "At school .

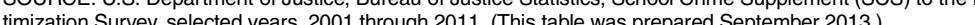




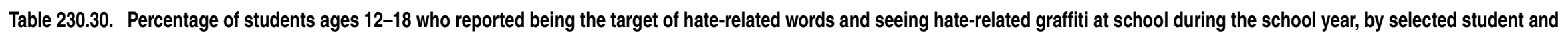
school characteristics: Selected years, 1999 through 2011

[Standard errors appear in parentheses]

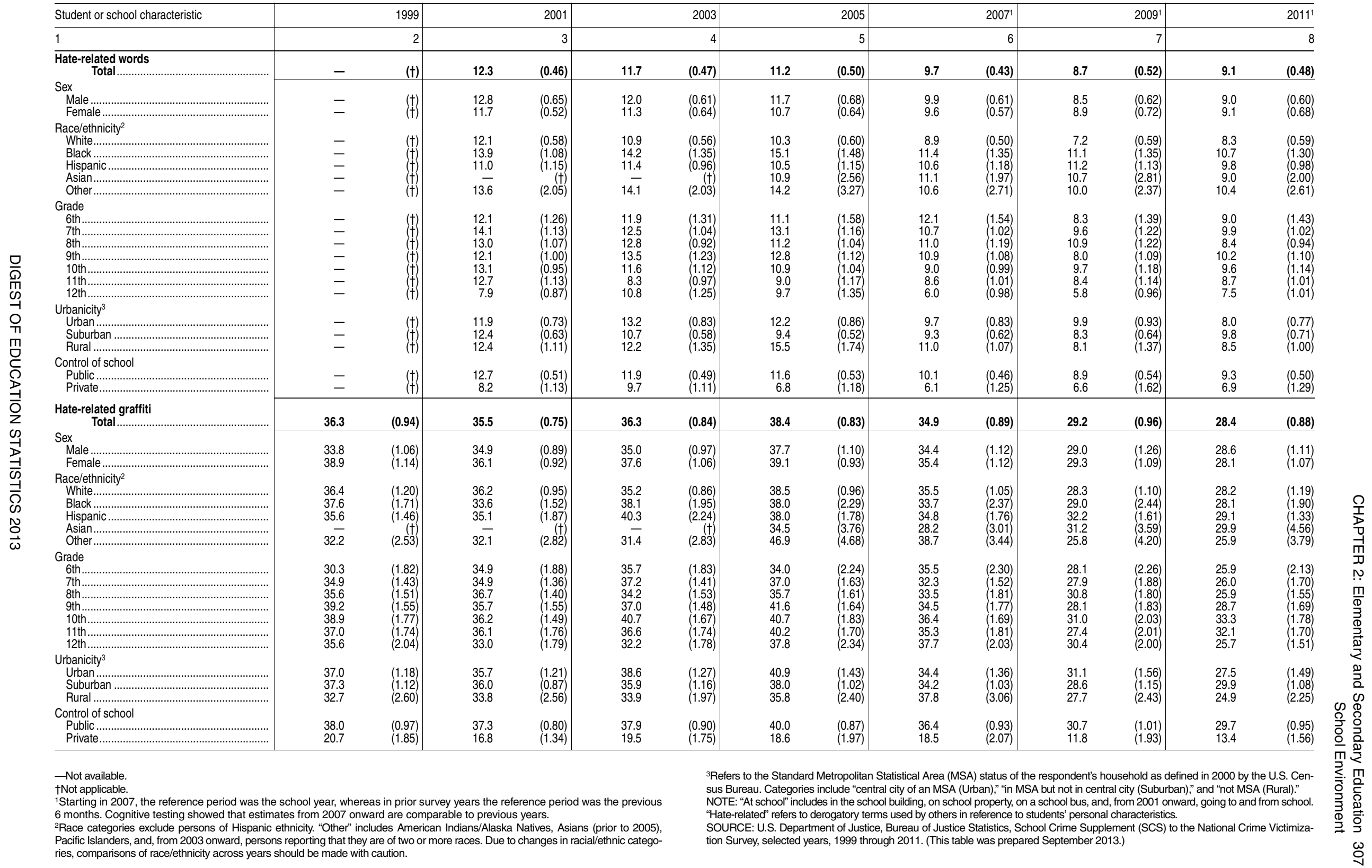


308 CHAPTER 2: Elementary and Secondary Education

School Environment

Table 230.35. Percentage of students ages 12-18 who reported being the target of hate-related words at school, by type of hate-related word and selected student and school characteristics: 2011

[Standard errors appear in parentheses]

\begin{tabular}{|c|c|c|c|c|c|c|c|c|c|c|c|c|c|c|}
\hline \multirow[b]{2}{*}{ Student or school characteristic } & \multirow{2}{*}{\multicolumn{2}{|c|}{ Total $^{1}$}} & \multicolumn{12}{|c|}{ Hate-related words related to student's characteristic } \\
\hline & & & & Race & & Ethnicity & & Religion & & isability & & Gender & Sexual 0 & entation \\
\hline 1 & & 2 & & 3 & & 4 & & 5 & & 6 & & 7 & & 8 \\
\hline 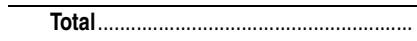 & 9.1 & $(0.48)$ & 4.5 & $(0.31)$ & 2.8 & $(0.25)$ & 1.4 & $(0.17)$ & 1.2 & $(0.14)$ & 1.4 & $(0.18)$ & 1.3 & $(0.18)$ \\
\hline 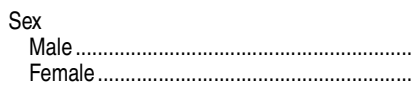 & $\begin{array}{l}9.0 \\
9.1\end{array}$ & $\begin{array}{l}(0.60) \\
(0.68)\end{array}$ & $\begin{array}{l}5.1 \\
3.8\end{array}$ & $\begin{array}{r}(0.47) \\
(0.38)\end{array}$ & $\begin{array}{l}3.0 \\
2.5\end{array}$ & $\begin{array}{l}(0.36) \\
(0.31)\end{array}$ & $\begin{array}{l}1.5 \\
1.3\end{array}$ & $\begin{array}{l}(0.24) \\
(0.24)\end{array}$ & $\begin{array}{l}1.3 \\
1.1\end{array}$ & $\begin{array}{l}(0.21) \\
(0.19)\end{array}$ & $\begin{array}{l}0.7 \\
2.2\end{array}$ & $\begin{array}{l}(0.16) \\
(0.31)\end{array}$ & $\begin{array}{l}1.3 \\
1.4\end{array}$ & $\begin{array}{l}(0.22) \\
(0.25)\end{array}$ \\
\hline 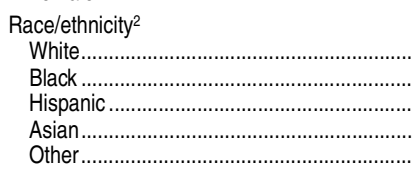 & $\begin{array}{r}8.3 \\
10.7 \\
9.8 \\
9.0 \\
10.4\end{array}$ & $\begin{array}{l}(0.59) \\
(1.30) \\
(0.98) \\
(2.00) \\
(2.61)\end{array}$ & $\begin{array}{l}2.5 \\
7.1 \\
6.8 \\
6.8 \\
8.1\end{array}$ & $\begin{array}{l}(0.29) \\
(1.08) \\
(0.82) \\
(1.79) \\
(2.24)\end{array}$ & $\begin{array}{l}1.4 \\
1.8 ! \\
6.7 \\
3.8 ! \\
3.5 !\end{array}$ & $\begin{array}{l}(0.22) \\
(0.57) \\
(0.81) \\
(1.31) \\
(1.34)\end{array}$ & $\begin{array}{l}1.7 \\
\ddagger \\
0.8 ! \\
3.4 ! \\
3.0 !\end{array}$ & $\begin{array}{r}(0.23) \\
(\dagger) \\
(0.24) \\
(1.41) \\
(1.23)\end{array}$ & $\begin{array}{c}1.5 \\
0.7 ! \\
0.8 ! \\
\ddagger \\
1.8 !\end{array}$ & $\begin{array}{r}(0.20) \\
(0.30) \\
(0.25) \\
(\dagger) \\
(0.88)\end{array}$ & $\begin{array}{l}1.7 \\
1.3 ! \\
1.0 \\
\ddagger \\
\ddagger\end{array}$ & $\begin{array}{r}(0.26) \\
(0.50) \\
(0.29) \\
(\dagger) \\
(t)\end{array}$ & $\begin{array}{l}1.7 \\
1.0 ! \\
0.8 \\
\ddagger \\
\ddagger\end{array}$ & $\begin{array}{r}(0.28) \\
(0.37) \\
(0.24) \\
(\dagger) \\
(\dagger)\end{array}$ \\
\hline $\begin{array}{l}\text { Grade } \\
\text { 6th } \\
\text { 7th } \\
\text { 8th } \\
\text { 9th } \\
\text { 10th } \\
\text { 11th } \\
\text { 12th }\end{array}$ & $\begin{array}{r}9.0 \\
9.9 \\
8.4 \\
10.2 \\
9.6 \\
8.7 \\
7.5\end{array}$ & $\begin{array}{l}(1.43) \\
(1.02) \\
(0.94) \\
(1.10) \\
(1.14) \\
(1.01) \\
(1.01)\end{array}$ & $\begin{array}{l}5.3 \\
4.3 \\
4.2 \\
5.5 \\
4.4 \\
4.8 \\
3.0\end{array}$ & $\begin{array}{l}(1.11) \\
(0.62) \\
(0.75) \\
(0.87) \\
(0.72) \\
(0.71) \\
(0.65)\end{array}$ & $\begin{array}{l}3.4 \\
2.1 \\
3.0 \\
3.2 \\
3.1 \\
2.6 \\
2.2\end{array}$ & $\begin{array}{l}(0.90) \\
(0.39) \\
(0.61) \\
(0.60) \\
(0.70) \\
(0.62) \\
(0.56)\end{array}$ & $\begin{array}{l}1.6 ! \\
1.0 ! \\
1.3 \\
1.7 \\
1.6 \\
1.5 \\
1.4 !\end{array}$ & $\begin{array}{l}(0.60) \\
(0.31) \\
(0.38) \\
(0.38) \\
(0.42) \\
(0.43) \\
(0.44)\end{array}$ & $\begin{array}{l}1.9 ! \\
2.0 \\
0.9 ! \\
1.1 ! \\
0.8 ! \\
0.8 ! \\
1.1 !\end{array}$ & $\begin{array}{l}(0.71) \\
(0.40) \\
(0.31) \\
(0.41) \\
(0.27) \\
(0.31) \\
(0.40)\end{array}$ & $\begin{array}{l}\ddagger \\
2.0 \\
0.9 ! \\
1.3 \text { ! } \\
1.7 \\
1.7 \\
1.5 \text { ! }\end{array}$ & $\begin{array}{r}(\dagger) \\
(0.55) \\
(0.31) \\
(0.45) \\
(0.42) \\
(0.46) \\
(0.50)\end{array}$ & $\begin{array}{l}\ddagger \\
1.1 ! \\
1.4 \\
1.3 ! \\
1.6 \\
1.1 ! \\
1.8\end{array}$ & $\begin{array}{r}(t) \\
(0.44) \\
(0.40) \\
(0.41) \\
(0.45) \\
(0.35) \\
(0.51)\end{array}$ \\
\hline 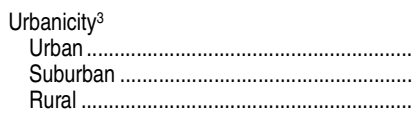 & $\begin{array}{l}8.0 \\
9.8 \\
8.5\end{array}$ & $\begin{array}{l}(0.77) \\
(0.71) \\
(1.00)\end{array}$ & $\begin{array}{l}4.2 \\
5.0 \\
3.0\end{array}$ & $\begin{array}{l}(0.55) \\
(0.48) \\
(0.59)\end{array}$ & $\begin{array}{l}2.3 \\
3.3 \\
1.9\end{array}$ & $\begin{array}{l}(0.42) \\
(0.38) \\
(0.40)\end{array}$ & $\begin{array}{l}1.3 \\
1.7 \\
0.9 !\end{array}$ & $\begin{array}{l}(0.29) \\
(0.23) \\
(0.32)\end{array}$ & $\begin{array}{l}1.1 \\
1.0 \\
2.2\end{array}$ & $\begin{array}{l}(0.28) \\
(0.18) \\
(0.49)\end{array}$ & $\begin{array}{l}1.1 \\
1.7 \\
1.2\end{array}$ & $\begin{array}{l}(0.28) \\
(0.27) \\
(0.32)\end{array}$ & $\begin{array}{l}1.3 \\
1.4 \\
1.2 !\end{array}$ & $\begin{array}{l}(0.29) \\
(0.25) \\
(0.45)\end{array}$ \\
\hline 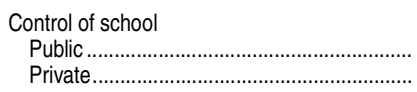 & $\begin{array}{l}9.3 \\
6.9\end{array}$ & $\begin{array}{l}(0.50) \\
(1.29)\end{array}$ & $\begin{array}{l}4.6 \\
2.5 !\end{array}$ & $\begin{array}{l}(0.33) \\
(0.80)\end{array}$ & $\begin{array}{l}2.9 \\
1.3 !\end{array}$ & $\begin{array}{l}(0.27) \\
(0.62)\end{array}$ & $\begin{array}{r}1.6 \\
\ddagger\end{array}$ & $\begin{array}{r}(0.19) \\
(\dagger)\end{array}$ & $\begin{array}{r}1.2 \\
\ddagger\end{array}$ & $\begin{array}{r}(0.16) \\
(\dagger)\end{array}$ & $\begin{array}{l}1.4 \\
1.5 !\end{array}$ & $\begin{array}{l}(0.19) \\
(0.59)\end{array}$ & $\begin{array}{l}1.3 \\
2.0 !\end{array}$ & $\begin{array}{l}(0.18) \\
(0.71)\end{array}$ \\
\hline
\end{tabular}

†Not applicable.

!Interpret data with caution. The coefficient of variation (CV) for this estimate is between 30 and 50 percent.

‡Reporting standards not met. Either there are too few cases for a reliable estimate or the coefficient of variation (CV) is 50 percent or greater.

${ }^{1}$ Students who indicated that they had been called a hate-related word were asked to choose the specific characteristics that the hate-related word or words targeted. Students were allowed to choose more than one characteristic. If a student chose more than one characteristic, he or she is counted only once in the total percentage of students who reported being called a hate-related word; therefore, the total is less than the sum of the students' individual characteristics.

${ }^{2}$ Race categories exclude persons of Hispanic ethnicity. "Other" includes American Indians/
Alaska Natives, Pacific Islanders, and persons reporting that they are of two or more races. ${ }^{3}$ Refers to the Standard Metropolitan Statistical Area (MSA) status of the respondent's household as defined in 2000 by the U.S. Census Bureau. Categories include "central city of an MSA (Urban)," "in MSA but not in central city (Suburban)," "and not MSA (Rural)," NOTE: "At school" includes in the school building, on school property, on a school bus, or going to and from school. "Hate-related" refers to derogatory terms used by others in reference to students' personal characteristics. Detail may not sum to totals because of rounding and because students may have reported being targets of hate-related words related to more than one student characteristic.

SOURCE: U.S. Department of Justice, Bureau of Justice Statistics, School Crime Supplement (SCS) to the National Crime Victimization Survey, 2011. (This table was prepared September 2013.) 


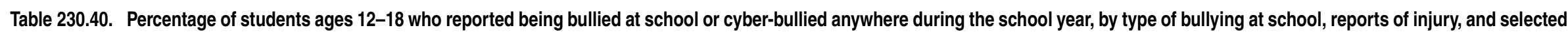
student and school characteristics: 2011

[Standard errors appear in parentheses]

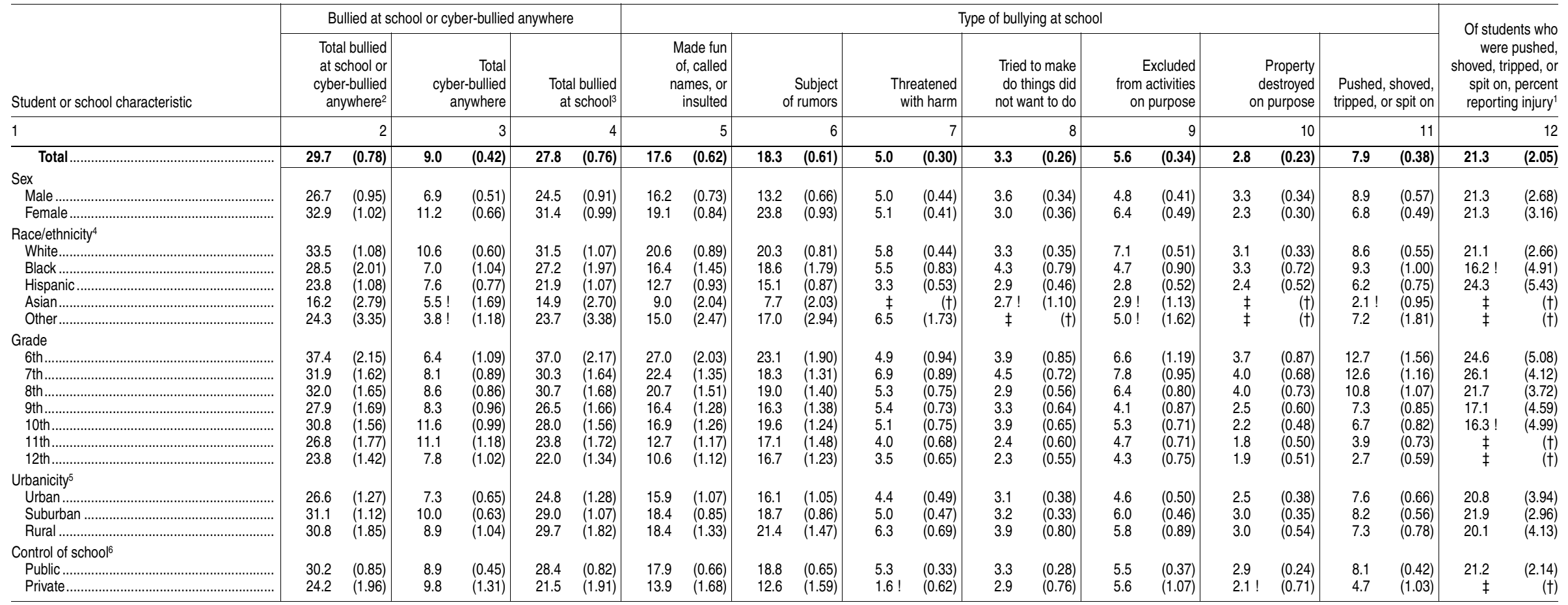

†Not applicable.

!Interpret data with caution. The coefficient of variation (CV) for this estimate is between 30 and 50 percent.

†Reporting standards not met. Either there are too few cases for a reliable estimate or the coefficient of variation (CV) is 50 per-

cent or greater.
1 Only students who reported that they were pushed, shoved, tripped, or spit on were asked if they suffered injuries as a result of the incident.

reported that they were both bullied at school and cyber-bullied anywhere were counted only once in the total for ied at school or cyber-bullied anywhere.

Students who reported experiencing more than one type of bullying at school were counted only once in the total for students bullied at school.

Race categories exclude persons of Hispanic ethnicity. "Other" includes American Indians/Alaska Natives, Pacific Islanders, and persons reporting that they are of two or more races.
${ }^{5}$ Refers to the Standard Metropolitan Statistical Area (MSA) status of the respondent's household as defined in 2000 by the U.S. Census Bureau. Categories include "central city of an MSA (Urban)," "in MSA but not in central city (Suburban)," and "not MSA (Rural)." These data by metropolitan status were based on the location of households and differ from those published in Student Reports of Bullying and Cyber-Bullying: Results from the 2011 School Crime Supplement to the National Cim
Survey, which were based on the urban-centric measure of the location of the school that the child attended.

Survey, which were based on the urban-centric measure of the localion of the school that the child altended. school name to the Common Core of Data's Public Elementary/Sen hos School Universe Survey or the Private Schoor Sur vey, as reported in Student Reports of Bullying and Cyber-Bullying: Results from the 2011 School Crime Supplement to the National Crime Victimization Survey. NOTE: "At school" includes the school building, on school property, on a school bus, or going to a

SO not sum to totals because students could have experienced more than one type of bullying. timization Survey, 2011. (This table was prepared September 2013, 
310 CHAPTER 2: Elementary and Secondary Education

School Environment

Table 230.45. Percentage of students ages 12-18 who reported being bullied at school during the school year, by type of bullying and selected student and school characteristics: Selected years, 2005 through 2009

[Standard errors appear in parentheses]

\begin{tabular}{|c|c|c|c|c|c|c|c|c|c|c|c|c|c|}
\hline \multirow[b]{2}{*}{ Year and student or school characteristic } & \multirow[b]{2}{*}{$\begin{array}{r}\text { Total bullied } \\
\text { at school }\end{array}$} & \multicolumn{12}{|c|}{ Type of bullying at school } \\
\hline & & $\begin{array}{r}\text { Made fun of, } \\
\text { called names, } \\
\text { or insulted }\end{array}$ & $\begin{array}{r}\text { Subject of } \\
\text { rumors }\end{array}$ & & & & & $\begin{array}{r}\text { Exclud } \\
\text { actii }\end{array}$ & $\begin{array}{l}\text { led from } \\
\text { vities on } \\
\text { purpose }\end{array}$ & & \begin{tabular}{|l|} 
Property \\
royed on \\
purpose
\end{tabular} & & \\
\hline 1 & 2 & 3 & 4 & & 5 & & 6 & & 7 & & 8 & & 9 \\
\hline $\begin{array}{l}5 \\
\text { Total... }\end{array}$ & $28.1 \quad(0.70)$ & $\begin{array}{ll}18.7 & (0.58)\end{array}$ & $14.7 \quad(0.53)$ & 4.8 & $(0.31)$ & 3.5 & $(0.27)$ & 4.6 & $(0.30)$ & 3.4 & $(0.29)$ & 9.0 & (0.45) \\
\hline $\begin{array}{l}\text { Male....... } \\
\text { Memale:. }\end{array}$ & $\begin{array}{ll}27.1 & (0.90) \\
29.2 & (0.84)\end{array}$ & $\begin{array}{ll}18.5 & (0.73) \\
19.0 & (0.79)\end{array} \mid$ & $\begin{array}{ll}11.0 & (0.64) \\
18.5 & (0.74)\end{array}$ & $\begin{array}{l}5.2 \\
4.4\end{array}$ & $\begin{array}{l}(0.51) \\
(0.37)\end{array}$ & $\begin{array}{l}3.9 \\
3.1\end{array}$ & $\begin{array}{l}(0.39) \\
(0.32)\end{array}$ & $\begin{array}{l}4.1 \\
5.2\end{array}$ & $\left(\begin{array}{l}0.40) \\
(0.40)\end{array}\right.$ & $\begin{array}{l}3.5 \\
3.3\end{array}$ & $(0.41)$ & $\begin{aligned} 10.9 \\
7.1\end{aligned}$ & $\left(\begin{array}{l}0.70) \\
(0.50)\end{array}\right.$ \\
\hline 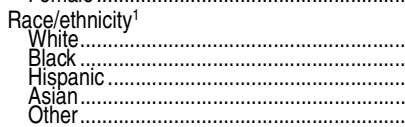 & $\begin{array}{ll}30.0 & (0.84) \\
28.5 & (2.21) \\
22.3 & (1.28 \\
24.6 & (2.06)\end{array}$ & $\begin{array}{cc}20.1 & (0.72) \\
18.5 & (1.72) \\
14.7 & (1.11 \\
16.3 & (1.82\end{array}$ & $\left.\begin{array}{cc}15.8 & (0.66) \\
14.2 & (1.36 \\
12.4 & 1.00 \\
11.6 & (1.71)\end{array}\right)$ & $\begin{array}{l}5.9 \\
4.6 \\
2.1\end{array}$ & $\begin{array}{l}(0.47) \\
0.76 \\
0.64 \\
(0.59) \\
(0.59\end{array}$ & $\begin{array}{l}3.6 \\
4.7 \\
2.6 \\
2.1 !\end{array}$ & $\begin{array}{l}(0.35 \\
1.00 \\
0.55 \\
(0.74)\end{array}$ & $\begin{array}{l}5.3 \\
4.5 \\
3.0 \\
2.5 !\end{array}$ & $\begin{array}{l}(0.36) \\
(0.913 \\
(0.53) \\
(0.79\end{array}$ & $\begin{array}{l}3.4 \\
4.6 \\
2.7 \\
2.5 !\end{array}$ & $\begin{array}{l}(0.35) \\
(0.89 \\
(0.49 \\
(0.77)\end{array}$ & $\begin{array}{l}9.7 \\
\frac{8.9}{7.6} \\
6.8\end{array}$ & $\begin{array}{l}(0.62) \\
(1.14) \\
(0.94) \\
(1.19)\end{array}$ \\
\hline 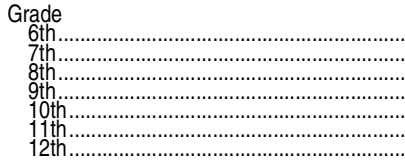 & $\begin{array}{ll}36.6 & (1.99) \\
35.0 & (1.72) \\
30.4 & (1.50) \\
28.1 & (1.57) \\
24.9 & (1.43 \\
23.0 & (1.58) \\
19.9 & (1.75)\end{array}$ & $\begin{array}{ll}26.3 & (2.05) \\
25.2 & (1.57) \\
20.4 & (1.30 \\
18.9 & (1.33 \\
15.5 & (1.14 \\
14.7 & (1.32 \\
11.3 & (1.52)\end{array}$ & $\begin{array}{ll}16.4 & (1.60) \\
18.9 & (1.27 \\
14.3 & (1.10) \\
13.8 & (1.23 \\
13.6 & (1.19 \\
13.4 & (1.29) \\
12.5 & (1.54)\end{array}$ & $\begin{array}{l}4.3 \\
4.3 \\
3.9 \\
3.2\end{array}$ & $\begin{array}{l}(1.18) \\
0.80 \\
0.64 \\
0.67 \\
0.82 \\
0.61 \\
(0.71)\end{array}$ & $\begin{array}{l}4.4 \\
4.7 \\
3.8 \\
3.2 \\
3.6 \\
2.8 \\
1.8\end{array}$ & $\begin{array}{l}(0.92) \\
0.83 \\
0.71 \\
0.58 \\
0.64 \\
0.59 \\
0.51 \\
0.51\end{array}$ & $\begin{array}{l}7.4 \\
7.1 \\
5.4 \\
3.8 \\
3.6 \\
3.3 \\
2.2 !\end{array}$ & $\begin{array}{l}(1.19 \\
(0.85 \\
0.68 \\
0.63 \\
0.63 \\
0.61 \\
0.72)\end{array}$ & $\begin{array}{l}3.9 \\
4.6 \\
4.5 \\
2.7 \\
2.9 \\
2.4\end{array}$ & $\begin{array}{l}0.91 \\
(0.79 \\
0.75 \\
0.53 \\
0.64 \\
0.56 \\
0.63\end{array}$ & $\begin{array}{r}15.1 \\
15.4 \\
11.3 \\
8.2 \\
6.8 \\
4.2 \\
2.9\end{array}$ & $\begin{array}{l}(1.75) \\
(1.25) \\
(0.91) \\
0.78 \\
0.69 \\
(0.66)\end{array}$ \\
\hline 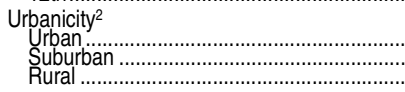 & $\begin{array}{ll}26.0 & (1.29) \\
28.9 & (0.81) \\
29.0 & (1.96)\end{array}$ & $\begin{array}{ll}17.7 & (0.95) \\
18.9 & (0.75) \\
19.8 & (1.76)\end{array}$ & $\begin{array}{ll}13.3 & (1.07) \\
14.6 & (0.64) \\
17.2 & (1.32)\end{array}$ & $\begin{array}{l}5.5 \\
4.4 \\
5.0\end{array}$ & $\begin{array}{l}(0.49) \\
(0.42) \\
(1.10)\end{array}$ & $\begin{array}{l}4.1 \\
3.1 \\
3.7\end{array}$ & $\begin{array}{l}(0.53 \\
0.33 \\
(0.74)\end{array}$ & $\begin{array}{l}4.9 \\
4.5 \\
4.5\end{array}$ & $\left.\begin{array}{l}(0.63) \\
(0.373) \\
(0.88\end{array}\right)$ & $\begin{array}{l}3.9 \\
3.0 \\
3.8\end{array}$ & $\begin{array}{l}(0.58) \\
(0.32 \\
(0.87)\end{array}$ & $\begin{array}{l}8.5 \\
9.0 \\
9.9\end{array}$ & $\begin{array}{l}\left(\begin{array}{l}0.73) \\
(0.56) \\
(1.23)\end{array}\right. \\
\text { (1) }\end{array}$ \\
\hline 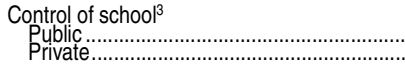 & $\begin{array}{ll}28.6 & (0.74) \\
22.7 & (2.09) \\
\end{array}$ & $\begin{array}{cc}19.0 & (0.61) \\
15.3 & (1.67)\end{array}$ & $\begin{array}{ll}14.9 & (0.55) \\
12.4 & (1.66)\end{array}$ & $\begin{array}{l}5.1 \\
0.9\end{array}$ & $\begin{array}{l}(0.33) \\
(0.40)\end{array}$ & $\begin{array}{l}3.5 \\
3.0 !\end{array}$ & $\begin{array}{l}(0.27) \\
(0.90)\end{array}$ & $\begin{array}{l}4.5 \\
6.2 \\
\end{array}$ & $\left.\begin{array}{l}(0.30) \\
(1.06)\end{array}\right)$ & $\begin{array}{l}3.5 \\
2.0 !\end{array}$ & $\begin{array}{l}(0.31) \\
(0.70)\end{array}$ & $\begin{array}{l}9.3 \\
5.5\end{array}$ & $\begin{array}{l}(0.48) \\
(1.03)\end{array}$ \\
\hline${ }^{007}$ Total.. & $31.7 \quad(0.74)$ & $21.0 \quad(0.62)$ & $\begin{array}{ll}18.1 & (0.61)\end{array}$ & 5.8 & $(0.35)$ & 4.1 & $(0.27)$ & 5.2 & $(0.30)$ & 4.2 & $(0.28)$ & 11.0 & $(0.42)$ \\
\hline 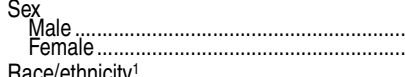 & $\begin{array}{ll}30.3 & (0.96) \\
33.2 & (0.99)\end{array}$ & $\begin{array}{ll}20.3 & (0.83) \\
21.7 & (0.89)\end{array}$ & $\begin{array}{ll}13.5 & (0.73) \\
22.8 & (0.91)\end{array}$ & $\begin{array}{l}6.0 \\
5.6\end{array}$ & $\begin{array}{l}(0.50) \\
(0.45)\end{array}$ & $\begin{array}{l}4.8 \\
3.4\end{array}$ & $\left(\begin{array}{l}(0.43) \\
(0.32)\end{array}\right.$ & $\begin{array}{l}4.6 \\
5.8\end{array}$ & $\left(\begin{array}{l}0.40 \\
(0.43)\end{array}\right.$ & $\begin{array}{l}4.0 \\
4.4\end{array}$ & $(0.35)$ & $\begin{array}{l}12.2 \\
9.7\end{array}$ & $\begin{array}{l}(0.58) \\
(0.59)\end{array}$ \\
\hline 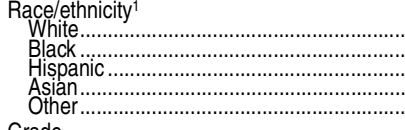 & $\begin{array}{ll}34.1 & (0.97) \\
30.4 & (2.18 \\
27.3 & 1.53 \\
18.1 & (2.60 \\
34.1 & (3.03)\end{array}$ & $\begin{array}{ll}23.5 & (0.84) \\
19.5 & (1.71) \\
16.1 & (.25 \\
10.6 & (2.19 \\
20.1 & (3.12)\end{array}$ & $\begin{array}{cc}20.3 & (0.84) \\
15.7 & (1.51) \\
14.4 & (1.27 \\
8.2 & 1.93 \\
20.8 & (2.98)\end{array}$ & $\begin{array}{l}6.3 \\
5.8 \\
4.9 \\
7.7\end{array}$ & $\begin{array}{l}(0.47) \\
0.89 \\
0.75 \\
(2.01)\end{array}$ & $\begin{array}{l}4.8 \\
3.2 \\
3.0 \\
3.7 !\end{array}$ & $\left.\begin{array}{l}(0.36) \\
0.69 \\
0.71 \\
(1.23)\end{array}\right)$ & $\begin{array}{l}6.1 \\
3.7 \\
4.0 \\
7.7\end{array}$ & $\begin{array}{l}(0.44) \\
0.72 \\
(0.60) \\
(2.08)\end{array}$ & $\begin{array}{l}4.2 \\
5.6 \\
31.6 \\
3.4 ! \\
3.4 !\end{array}$ & $\begin{array}{l}(0.35) \\
(0.96 \\
(0.67) \\
(1.30)\end{array}$ & $\begin{array}{r}11.5 \\
11.3 \\
9.9 \\
3.8 \\
14.4\end{array}$ & $\begin{array}{l}(0.56) \\
(1.42) \\
(1.05) \\
(2.25) \\
(2.73)\end{array}$ \\
\hline 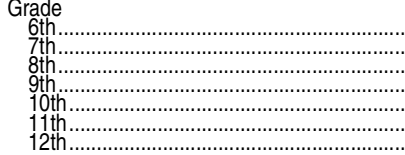 & $\begin{array}{ll}42.7 & (2.23) \\
35.6 & (1.78 \\
36.9 & (1.84 \\
30.6 & (1.72 \\
27.7 & (1.44 \\
28.5 & (1.48) \\
23.0 & (1.60)\end{array}$ & $\begin{array}{lc}31.2 & (2.00) \\
27.6 & (1.58) \\
25.1 & (1.65) \\
20.3 & (1.39) \\
17.7 & (1.22) \\
15.3 & (1.25) \\
12.1 & (1.36)\end{array}$ & $\begin{array}{ll}21.3 & (1.84) \\
20.2 & (1.33 \\
19.7 & (14) \\
18.1 & (1.45) \\
15.0 & (1.13 \\
18.7 & (1.40 \\
14.1 & (1.38)\end{array}$ & $\begin{array}{l}7.0 \\
7.4 \\
6.9 \\
4.6 \\
5.8 \\
4.9 \\
4.3\end{array}$ & $\begin{array}{l}1.13) \\
0.92 \\
0.84 \\
0.77 \\
0.81 \\
0.80 \\
0.83\end{array}$ & $\begin{array}{l}5.4 \\
4.1 \\
3.6 \\
5.1 \\
4.6 \\
4.2 \\
2.1\end{array}$ & $\begin{array}{l}(0.98) \\
0.64 \\
0.64 \\
0.67 \\
0.68 \\
0.73 \\
0.53)\end{array}$ & $\begin{array}{l}7.4 \\
7.7 \\
5.4 \\
4.5 \\
4.6 \\
3.9 \\
3.5\end{array}$ & $\begin{array}{l}(1.20) \\
(0.92 \\
0.77 \\
0.69 \\
0.74 \\
(0.68) \\
(0.75)\end{array}$ & $\begin{array}{l}5.2 \\
6.0 \\
4.6 \\
3.5 \\
3.4 \\
4.4 \\
2.4\end{array}$ & $\begin{array}{l}(0.98) \\
(0.81 \\
0.79 \\
0.63 \\
0.59 \\
0.78 \\
0.61)\end{array}$ & $\begin{array}{r}17.6 \\
15.8 \\
14.2 \\
11.4 \\
8.6 \\
6.5 \\
4.1\end{array}$ & $\begin{array}{l}(1.56) \\
(1.28) \\
(1.13) \\
(0.89 \\
0.92 \\
0.81\end{array}$ \\
\hline 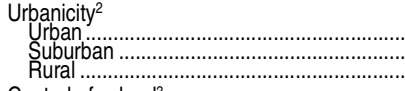 & $\begin{array}{ll}30.7 & (1.36) \\
31.2 & (1.07) \\
35.2 & (1.73)\end{array}$ & $\begin{array}{ll}20.0 & (1.09) \\
211.1 & (0.84) \\
22.1 & (1.43)\end{array} \mid$ & $\begin{array}{ll}15.5 & (1.02) \\
117.4 & (0.87) \\
24.1 & (1.42)\end{array}$ & $\begin{array}{l}5.7 \\
7.0\end{array}$ & $\begin{array}{l}(0.54) \\
0.48 \\
(0.78)\end{array}$ & $\begin{array}{l}3.6 \\
4.1 \\
5.1\end{array}$ & $\left.\begin{array}{l}(0.46) \\
0.37 \\
(0.69)\end{array}\right]$ & $\begin{array}{l}4.9 \\
5.0 \\
6.3\end{array}$ & $\begin{array}{l}(0.57) \\
(0.42) \\
(0.79)\end{array}$ & $\begin{array}{l}4.2 \\
4.0 \\
4.9\end{array}$ & $\begin{array}{l}(0.59) \\
(0.38) \\
0.63)\end{array}$ & $\begin{array}{r}9.2 \\
11.2 \\
13.1\end{array}$ & $\begin{array}{l}(0.76) \\
(0.60) \\
(0.98)\end{array}$ \\
\hline 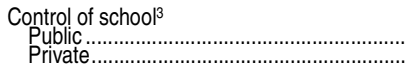 & $\begin{array}{rr}32.0 & (0.76) \\
29.1 & (2.10) \\
\end{array}$ & $\begin{array}{ll}21.1 & (0.65) \\
20.1 & (1.79) \\
\end{array}$ & $\begin{array}{cc}18.3 & (0.64) \\
16.0 & (1.76) \\
\end{array}$ & $\begin{array}{l}6.2 \\
1.3 \\
\end{array}$ & $\begin{array}{l}(0.38) \\
(0.50)\end{array}$ & $\begin{array}{l}4.2 \\
3.6 \\
\end{array}$ & $\begin{array}{l}(0.28) \\
(0.92) \\
\end{array}$ & $\begin{array}{r}5.2 \\
5.9 \\
\end{array}$ & $\begin{array}{l}(0.32) \\
(1.11) \\
\end{array}$ & $\begin{array}{l}4.1 \\
5.0 \\
\end{array}$ & $\begin{array}{l}(0.28) \\
(1.11)\end{array}$ & $\begin{array}{l}11.4 \\
6.5 \\
\end{array}$ & $\begin{array}{l}(0.45) \\
(1.14) \\
\end{array}$ \\
\hline $20099_{\text {Total... }}$ & $28.0 \quad(0.83)$ & $\begin{array}{ll}18.8 & (0.65) \\
\end{array}$ & $16.5 \quad(0.66)$ & 5.7 & $(0.34)$ & 3.6 & $(0.28)$ & 4.7 & $(0.34)$ & 3.3 & $(0.28)$ & 9.0 & (0.48) \\
\hline 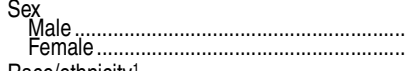 & $\begin{array}{ll}26.6 & (1.04) \\
29.5 & (1.08)\end{array}$ & $\begin{array}{ll}18.4 & (0.89 \\
19.2 & (0.95)\end{array}$ & $\begin{array}{ll}12.8 & (0.79) \\
20.3 & (0.92)\end{array}$ & $\begin{array}{l}5.6 \\
5.8\end{array}$ & $\begin{array}{l}(0.50) \\
(0.50)\end{array}$ & $\begin{array}{l}4.0 \\
3.2\end{array}$ & $\left(\begin{array}{l}0.43) \\
(0.37)\end{array}\right.$ & $\begin{array}{l}3.8 \\
5.7\end{array}$ & $\begin{array}{l}(0.39) \\
(0.52)\end{array}$ & $\begin{array}{l}3.4 \\
3.2\end{array}$ & $\begin{array}{l}(0.40) \\
(0.39)\end{array}$ & 10.1 & $\begin{array}{l}(0.65) \\
(0.64)\end{array}$ \\
\hline 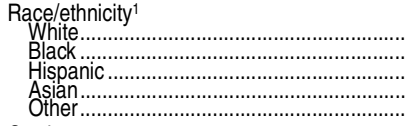 & $\begin{array}{ll}29.3 & (1.03) \\
29.1 & (2.29) \\
25.5 & (1.71 \\
17.3 & (3.01 \\
26.7 & (4.61)\end{array}$ & $\begin{array}{rc}20.5 & (0.89) \\
18.4 & (1.78) \\
15.8 & (1.34 \\
9.6 & (2.38) \\
17.4 & (3.83)\end{array}$ & $\begin{array}{cc}17.4 & (0.86) \\
17.7 & 1.60 \\
14.8 & 1.44 \\
8.1 & (2.114 \\
12.9 & 3.21)\end{array}$ & $\begin{array}{l}5.4 \\
7.8 \\
5.8 \\
9.7 !\end{array}$ & $\begin{array}{l}(0.40) \\
1.20 \\
0.87 \\
(3.01)\end{array}$ & $\begin{array}{l}3.7 \\
4.8 \\
2.7 \\
4.5 !\end{array}$ & $\left.\begin{array}{l}(0.38) \\
0.92 \\
(0.59) \\
(1.97)\end{array}\right)$ & $\begin{array}{l}5.2 \\
4.6 \\
3.6 \\
3.4 ! \\
4.5 !\end{array}$ & $\begin{array}{l}(0.44) \\
(0.977 \\
(0.68 \\
(1.41) \\
(1.85)\end{array}$ & $\begin{array}{l}3.3 \\
4.6 \\
2.6 \\
3.8 !\end{array}$ & $\begin{array}{l}(0.32) \\
(0.99 \\
0.55 \\
(1.67)\end{array}$ & $\begin{array}{l}9.1 \\
9.9 \\
9.1 \\
7.5 \\
7.1\end{array}$ & $\begin{array}{l}(0.61) \\
(1.55) \\
(1.975) \\
(2.39)\end{array}$ \\
\hline 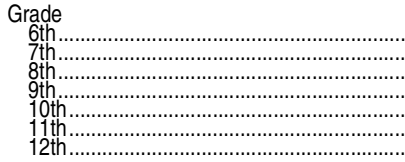 & $\begin{array}{ll}39.4 & (2.60) \\
33.1 & (1.87 \\
31.7 & (1.85 \\
28.0 & (1.90 \\
26.6 & (1.71 \\
21.1 & (1.69) \\
20.4 & (1.63)\end{array}$ & $\begin{array}{ll}30.6 & (2.32) \\
23.6 & (1.76 \\
22.8 & (1.64) \\
19.2 & (1.66) \\
15.0 & (1.41 \\
13.9 & (1.42 \\
11.1 & (1.20)\end{array}$ & $\begin{array}{ll}21.4 & (2.20) \\
17.3 & (1.58) \\
18.1 & (1.50) \\
16.6 & (1.53 \\
17.0 & (1.32) \\
13.9 & (1.42 \\
13.1 & (1.32)\end{array}$ & $\begin{array}{l}9.3 \\
.8 .8 \\
.1\end{array}$ & $\begin{array}{l}(1.34) \\
1.00 \\
0.94 \\
1.00 \\
0.91 \\
0.84 \\
0.57)\end{array}$ & $\begin{array}{l}4.2 ! \\
4.6 ! \\
5.4 \\
4.0 \\
2.5 \\
1.5 !\end{array}$ & $\begin{array}{l}1.27) \\
0.82 \\
0.91 \\
0.74 \\
0.63 \\
0.63 \\
0.52\end{array}$ & $\begin{array}{l}6.6 \\
5.6 \\
6.9 \\
4.5 \\
4.0 \\
3.6 \\
2.6\end{array}$ & $\begin{array}{l}(1.31) \\
(0.95 \\
(1.54 \\
0.78 \\
0.76 \\
0.76 \\
0.64)\end{array}$ & $\begin{array}{l}4.0 \\
4.6 \\
6.1 \\
2.9 \\
2.9 \\
1.5 ! \\
1.3 !\end{array}$ & $\begin{array}{l}1.00) \\
0.85 \\
0.92 \\
0.71 \\
0.63 \\
(0.49 \\
0.46)\end{array}$ & $\begin{array}{r}14.5 \\
13.1 \\
12.8 \\
9.7 \\
7.3 \\
4.4 \\
3.0\end{array}$ & $\begin{array}{l}1.89 \\
(1.34) \\
1.29 \\
1.24 \\
(03) \\
0.84 \\
(0.65)\end{array}$ \\
\hline 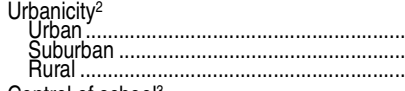 & $\left.\begin{array}{ll}27.4 & (1.25) \\
27.5 & (1.06) \\
30.7 & (1.99\end{array}\right)$ & $\begin{array}{ll}17.0 & (1.00 \\
19.3 & (0.87) \\
20.2 & (1.60)\end{array}$ & $\begin{array}{ll}16.5 & (1.01) \\
15.5 & 0.97) \\
19.9 & (1.56)\end{array}$ & 6.1 & $\begin{array}{l}(0.67) \\
0.44 \\
(0.79)\end{array}$ & $\begin{array}{l}4.2 \\
3.2 \\
4.1\end{array}$ & $\begin{array}{l}\left(\begin{array}{l}0.59 \\
0.33 \\
(0.80\end{array}\right) \\
\end{array}$ & $\begin{array}{l}4.0 \\
5.0 \\
5.2\end{array}$ & $\begin{array}{l}(0.57) \\
(0.46 \\
(0.85)\end{array} \mid$ & $\begin{array}{l}4.2 \\
2.9 \\
3.3\end{array}$ & $\left.\begin{array}{l}(0.63) \\
(0.34 \\
0.64\end{array}\right)$ & $\begin{array}{l}9.0 \\
8.9 \\
9.5\end{array}$ & $\begin{array}{l}(0.98) \\
(0.56) \\
(1.27)\end{array}$ \\
\hline 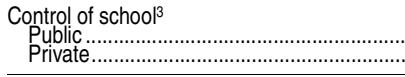 & $\begin{array}{cc}28.8 & (0.88) \\
18.9 & (2.16) \\
\end{array}$ & $\begin{array}{ll}19.3 & (0.68) \\
13.3 & (1.87)\end{array}$ & $\begin{array}{ll}16.9 & (0.69) \\
11.6 & (1.75)\end{array}$ & $\begin{array}{l}5.9 \\
4.4 \\
\end{array}$ & $\begin{array}{l}(0.37) \\
(1.12) \\
\end{array}$ & $\begin{array}{l}3.8 \\
1.9 !\end{array}$ & $(0.76)$ & $\begin{array}{l}4.7 \\
4.9 \\
\end{array}$ & $\begin{array}{l}(0.36) \\
(1.16)\end{array}$ & $\begin{array}{l}3.4 ! \\
1.8 !\end{array}$ & $\begin{array}{l}(0.29) \\
(0.68)\end{array}$ & $\begin{array}{l}9.4 \\
4.5 \\
\end{array}$ & $\begin{array}{l}(0.52) \\
(1.14) \\
\end{array}$ \\
\hline
\end{tabular}

-Not available.

†Not applicable.

!Interpret data with caution. The coefficient of variation (CV) for this estimate is between 30 and 50 percent.

¥Reporting standards not met. Either there are too few cases for a reliable estimate or the coefficient of variation (CV) is 50 percent or greater.

${ }^{1}$ Race categories exclude persons of Hispanic ethnicity. "Other" includes American Indians/ Alaska Natives, Pacific Islanders, and persons reporting that they are of two or more races. ${ }^{2}$ Refers to the Standard Metropolitan Statistical Area (MSA) status of the respondent's household as defined in 2000 by the U.S. Census Bureau. Categories include "central city of an MSA (Urban)," "in MSA but not in central city (Suburban)," and "not MSA (Rural)." These data by metropolitan status were based on the location of households and differ from those published in Student Reports of Bullying and Cyber-Bullying: Results from the 2011 School
Crime Supplement to the National Crime Victimization Survey, which were based on the urban-centric measure of the location of the school that the child attended.

${ }^{3}$ Control of school as reported by the respondent. These data differ from those based on a matching of the respondent-reported school name to the Common Core of Data's Public Elementary/Secondary School Universe Survey or the Private School Survey, as reported in Student Reports of Bullying and Cyber-Bullying: Results from the 2011 School Crime Supplement to the National Crime Victimization Survey.

NOTE: "At school" includes the school building, on school property, on a school bus, or going to and from school. Bullying types do not sum to totals because students could have experienced more than one type of bullying.

SOURCE: U.S. Department of Justice, Bureau of Justice Statistics, School Crime Supplement (SCS) to the National Crime Victimization Survey, selected years, 2005 through 2009. (This table was prepared September 2013.) 
Table 230.50. Percentage of students ages 12-18 who reported being bullied at school during the school year and, among bullied students, percentage who reported being bullied in various locations, by selected student and school characteristics: 2011

[Standard errors appear in parentheses]

\begin{tabular}{|c|c|c|c|c|c|c|c|c|c|c|c|c|c|c|c|c|}
\hline \multirow[b]{2}{*}{ Student or school characteristic } & \multirow{2}{*}{\multicolumn{2}{|c|}{ Total }} & \multicolumn{14}{|c|}{ Among students who were bullied, percent by location } \\
\hline & & & Inside cla & ssroom & & $\begin{array}{l}\text { allway } \\
\text { airwell }\end{array}$ & $\begin{array}{r}\text { In ba } \\
\text { or locke }\end{array}$ & $\begin{array}{l}\text { hroom } \\
\text { r room }\end{array}$ & & afeteria & $\begin{array}{l}\text { Somewhe } \\
\text { in school }\end{array}$ & $\begin{array}{l}\text { ere else } \\
\text { building }\end{array}$ & $\begin{array}{r}\text { Out } \\
\text { school g }\end{array}$ & $\begin{array}{l}\text { side on } \\
\text { grounds }\end{array}$ & On sc & nool bus \\
\hline 1 & & 2 & & 3 & & 4 & & 5 & & 6 & & 7 & & 8 & & 9 \\
\hline 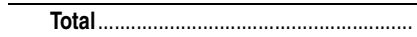 & 27.8 & $(0.76)$ & 32.8 & $(1.27)$ & 45.6 & $(1.32)$ & 11.0 & $(0.94)$ & 8.6 & $(0.72)$ & 1.9 & $(0.40)$ & 22.1 & (1.14) & 7.4 & $(0.78)$ \\
\hline 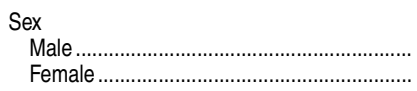 & $\begin{array}{l}24.5 \\
31.4\end{array}$ & $\begin{array}{l}(0.91) \\
(0.99)\end{array}$ & $\begin{array}{l}30.8 \\
34.4\end{array}$ & $\begin{array}{l}(1.66) \\
(1.69)\end{array}$ & $\begin{array}{l}44.0 \\
46.9\end{array}$ & $\begin{array}{l}(2.13) \\
(1.79)\end{array}$ & $\begin{array}{r}13.2 \\
9.2\end{array}$ & $\begin{array}{l}(1.30) \\
(1.33)\end{array}$ & $\begin{array}{l}8.1 \\
9.0\end{array}$ & $\begin{array}{l}(1.03) \\
(0.95)\end{array}$ & $\begin{array}{l}1.7 ! \\
2.0\end{array}$ & $\begin{array}{l}(0.59) \\
(0.56)\end{array}$ & $\begin{array}{l}23.1 \\
21.3\end{array}$ & $\begin{array}{l}(1.76) \\
(1.49)\end{array}$ & $\begin{array}{l}8.2 \\
6.8\end{array}$ & $\begin{array}{l}(1.22) \\
(0.95)\end{array}$ \\
\hline $\begin{array}{l}\text { Race/ethnicity } \\
\text { White. } \\
\text { Black } \\
\text { Hispanic } \\
\text { Asian } \\
\text { Other }\end{array}$ & $\begin{array}{l}31.5 \\
27.2 \\
21.9 \\
14.9 \\
23.7\end{array}$ & $\begin{array}{l}(1.07) \\
(1.97) \\
(1.07) \\
(2.70) \\
(3.38)\end{array}$ & $\begin{array}{l}34.2 \\
34.1 \\
28.2 \\
19.3 ! \\
30.2\end{array}$ & $\begin{array}{l}(1.70) \\
(3.52) \\
(2.54) \\
(6.88) \\
(6.57)\end{array}$ & $\begin{array}{l}46.5 \\
39.1 \\
47.6 \\
44.4 \\
47.1\end{array}$ & $\begin{array}{l}(1.59) \\
(3.80) \\
(2.94) \\
(9.13) \\
(6.74)\end{array}$ & $\begin{array}{r}10.9 \\
9.8 \\
13.3 \\
\ddagger \\
10.0 !\end{array}$ & $\begin{array}{r}(1.14) \\
(2.30) \\
(2.23) \\
(\dagger) \\
(4.05)\end{array}$ & $\begin{array}{r}7.7 \\
12.5 \\
8.9 \\
\ddagger \\
8.9 !\end{array}$ & $\begin{array}{r}(0.92) \\
(2.08) \\
(1.69) \\
(\dagger) \\
(3.11)\end{array}$ & $\begin{array}{r}2.3 \\
\ddagger \\
\ddagger \\
\# \\
\#\end{array}$ & $\begin{array}{r}(0.59) \\
(\dagger) \\
(\dagger) \\
(\dagger) \\
(\dagger)\end{array}$ & $\begin{array}{l}22.1 \\
19.5 \\
21.5 \\
30.3 \\
32.1\end{array}$ & $\begin{array}{l}(1.30) \\
(2.82) \\
(2.90) \\
(7.54) \\
(7.33)\end{array}$ & $\begin{array}{r}8.0 \\
8.3 \\
6.0 \\
\ddagger \\
\ddagger\end{array}$ & $\begin{array}{r}(0.89) \\
(1.80) \\
(1.55) \\
(\dagger) \\
(\dagger)\end{array}$ \\
\hline 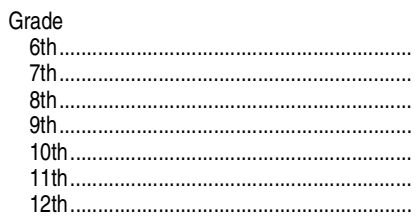 & $\begin{array}{l}37.0 \\
30.3 \\
30.7 \\
26.5 \\
28.0 \\
23.8 \\
22.0\end{array}$ & $\begin{array}{l}(2.17) \\
(1.64) \\
(1.68) \\
(1.66) \\
(1.56) \\
(1.72) \\
(1.34)\end{array}$ & $\begin{array}{l}33.5 \\
32.8 \\
36.2 \\
37.0 \\
27.6 \\
28.6 \\
33.1\end{array}$ & $\begin{array}{l}(3.17) \\
(2.90) \\
(2.89) \\
(3.61) \\
(2.71) \\
(3.24) \\
(3.75)\end{array}$ & $\begin{array}{l}36.5 \\
48.2 \\
44.2 \\
45.5 \\
50.5 \\
48.8 \\
42.9\end{array}$ & $\begin{array}{l}(3.47) \\
(3.62) \\
(3.42) \\
(3.02) \\
(2.79) \\
(3.85) \\
(3.83)\end{array}$ & $\begin{array}{r}13.2 \\
13.5 \\
10.9 \\
9.6 \\
10.3 \\
9.8 \\
9.3\end{array}$ & $\begin{array}{l}(2.44) \\
(2.53) \\
(1.87) \\
(1.77) \\
(2.08) \\
(2.15) \\
(2.32)\end{array}$ & $\begin{array}{r}7.7 \\
12.2 \\
7.7 \\
9.2 \\
9.0 \\
6.8 \\
6.3 !\end{array}$ & $\begin{array}{l}(2.02) \\
(2.20) \\
(1.58) \\
(1.89) \\
(1.93) \\
(1.99) \\
(1.92)\end{array}$ & $\begin{array}{c}\# \\
\ddagger \\
1.7 ! \\
\ddagger \\
3.1 ! \\
\ddagger \\
4.2 !\end{array}$ & $\begin{array}{r}(\dagger) \\
(\dagger) \\
(0.78) \\
(\dagger) \\
(1.27) \\
(\dagger) \\
(1.30)\end{array}$ & $\begin{array}{l}26.7 \\
21.5 \\
23.1 \\
15.4 \\
20.3 \\
26.2 \\
23.4\end{array}$ & $\begin{array}{l}(3.63) \\
(2.89) \\
(2.58) \\
(2.53) \\
(2.62) \\
(3.24) \\
(3.25)\end{array}$ & $\begin{array}{c}12.5 \\
9.9 \\
7.3 \\
6.4 \\
7.2 \\
4.7 ! \\
3.3 !\end{array}$ & $\begin{array}{l}(2.54) \\
(2.38) \\
(1.48) \\
(1.57) \\
(1.67) \\
(1.59) \\
(1.32)\end{array}$ \\
\hline $\begin{array}{l}\text { Urbanicity } \\
\text { Urban } \\
\text { Suburban } \\
\text { Rural }\end{array}$ & $\begin{array}{l}24.8 \\
29.0 \\
29.7\end{array}$ & $\begin{array}{l}(1.28) \\
(1.07) \\
(1.82)\end{array}$ & $\begin{array}{l}35.0 \\
31.1 \\
34.6\end{array}$ & $\begin{array}{l}(2.34) \\
(1.68) \\
(3.41)\end{array}$ & $\begin{array}{l}45.3 \\
44.3 \\
50.2\end{array}$ & $\begin{array}{l}(2.87) \\
(1.64) \\
(2.99)\end{array}$ & $\begin{array}{l}11.7 \\
10.5 \\
11.5\end{array}$ & $\begin{array}{l}(1.70) \\
(1.19) \\
(1.93)\end{array}$ & $\begin{array}{r}10.2 \\
8.0 \\
7.9\end{array}$ & $\begin{array}{l}(1.57) \\
(0.87) \\
(1.71)\end{array}$ & $\begin{array}{l}\ddagger \\
2.4 \\
1.9 !\end{array}$ & $\begin{array}{r}(\dagger) \\
(0.60) \\
(0.90)\end{array}$ & $\begin{array}{l}24.5 \\
22.0 \\
18.6\end{array}$ & $\begin{array}{l}(2.39) \\
(1.31) \\
(2.41)\end{array}$ & $\begin{array}{l}5.0 \\
8.7 \\
7.1\end{array}$ & $\begin{array}{l}(1.07) \\
(1.19) \\
(1.57)\end{array}$ \\
\hline 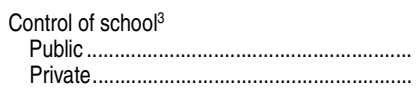 & $\begin{array}{l}28.4 \\
21.5\end{array}$ & $\begin{array}{l}(0.82) \\
(1.91)\end{array}$ & $\begin{array}{l}33.0 \\
28.4\end{array}$ & $\begin{array}{l}(1.28) \\
(4.41)\end{array}$ & $\begin{array}{l}45.9 \\
40.9\end{array}$ & $\begin{array}{l}(1.37) \\
(5.24)\end{array}$ & $\begin{array}{l}10.8 \\
14.5\end{array}$ & $\begin{array}{l}(0.94) \\
(3.62)\end{array}$ & $\begin{array}{l}8.6 \\
9.2 !\end{array}$ & $\begin{array}{l}(0.72) \\
(2.95)\end{array}$ & $\begin{array}{r}1.9 \\
\ddagger\end{array}$ & $\begin{array}{r}(0.42) \\
(\dagger)\end{array}$ & $\begin{array}{l}21.5 \\
31.0\end{array}$ & $\begin{array}{l}(1.12) \\
(5.09)\end{array}$ & $\begin{array}{r}7.8 \\
\ddagger\end{array}$ & $\begin{array}{r}(0.83) \\
(t)\end{array}$ \\
\hline
\end{tabular}

†Not applicable.

\#Rounds to zero.

!Interpret data with caution. The coefficient of variation (CV) for this estimate is between 30 and 50 percent.

‡Reporting standards not met. Either there are too few cases for a reliable estimate or the coefficient of variation (CV) is 50 percent or greater.

${ }^{1}$ Race categories exclude persons of Hispanic ethnicity. "Other" includes American Indians/ Alaska Natives, Pacific Islanders, and persons reporting that they are of two or more races. ${ }^{2}$ Refers to the Standard Metropolitan Statistical Area (MSA) status of the respondent's household as defined in 2000 by the U.S. Census Bureau. Categories include "central city of an MSA (Urban)" "in MSA but not in central city (Suburban)" and "not MSA (Rural)" These data by metropolitan status were based on the location of households and differ from those lished in Student Reports of Bullying and Cyber-Bullying: Results from the 2011 School
Crime Supplement to the National Crime Victimization Survey, which were based on the urban-centric measure of the location of the school that the child attended.

${ }^{3}$ Control of school as reported by the respondent. These data differ from those based on a matching of the respondent-reported school name to the Common Core of Data's Public Elementary/Secondary School Universe Survey or the Private School Survey, as reported in Student Reports of Bullying and Cyber-Bullying: Results from the 2011 School Crime Supplement to the National Crime Victimization Survey.

NOTE: "At school" includes the school building, on school property, on a school bus, or going to and from school. Location totals may sum to more than 100 percent because students could have been bullied in more than one location.

SOURCE: U.S. Department of Justice, Bureau of Justice Statistics, School Crime Supplement (SCS) to the National Crime Victimization Survey, 2011. (This table was prepared September 2013.) 
312 CHAPTER 2: Elementary and Secondary Education

School Environment

Table 230.55. Percentage of students ages 12-18 who reported being cyber-bullied anywhere during the school year, by type of cyber-bullying and selected student and school characteristics: 2011

[Standard errors appear in parentheses]

\begin{tabular}{|c|c|c|c|c|c|c|c|c|c|c|c|c|c|c|c|c|}
\hline \multirow[b]{2}{*}{ Student or school characteristic } & \multirow{2}{*}{\multicolumn{2}{|c|}{$\begin{array}{l}\text { Total cyber- } \\
\text { bullying }\end{array}$}} & \multicolumn{14}{|c|}{ Type of cyber-bullying } \\
\hline & & & $\begin{array}{l}\text { info } \\
\text { on }\end{array}$ & $\begin{array}{l}\text { Hurtful } \\
\text { rmation } \\
\text { Internet }\end{array}$ & $\begin{array}{r}\text { info } \\
\text { purposely } \\
\text { on }\end{array}$ & $\begin{array}{l}\text { Private } \\
\text { rmation } \\
\text { shared } \\
\text { Internet }\end{array}$ & $\begin{array}{r}\text { Su } \\
\text { harassing } \\
\text { me }\end{array}$ & $\begin{array}{r}\text { bject of } \\
\text { instant } \\
\text { ssages }\end{array}$ & $\begin{array}{r}\text { Su } \\
\text { harass } \\
\text { me }\end{array}$ & $\begin{array}{l}\text { bject of } \\
\text { ing text } \\
\text { ssages }\end{array}$ & & $\begin{array}{l}\text { abject of } \\
\text { arassing } \\
\text { e-mails }\end{array}$ & $\begin{array}{r}\text { Su } \\
\text { hara } \\
\text { while }\end{array}$ & $\begin{array}{l}\text { ibject of } \\
\text { issment } \\
\text { gaming }\end{array}$ & & $\begin{array}{r}\text { Excluded } \\
\text { online }\end{array}$ \\
\hline 1 & & 2 & & 3 & & 4 & & 5 & & 6 & & 7 & & 8 & & 9 \\
\hline 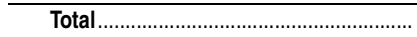 & 9.0 & $(0.42)$ & 3.6 & $(0.23)$ & 1.1 & $(0.15)$ & 2.7 & $(0.26)$ & 4.4 & $(0.31)$ & 1.9 & $(0.18)$ & 1.5 & $(0.17)$ & 1.2 & $(0.14)$ \\
\hline $\begin{array}{l}\text { Sex } \\
\quad \text { Male } \\
\text { Female }\end{array}$ & $\begin{array}{r}6.9 \\
11.2\end{array}$ & $\begin{array}{l}(0.51) \\
(0.66)\end{array}$ & $\begin{array}{l}1.7 \\
5.7\end{array}$ & $\begin{array}{l}(0.24) \\
(0.44)\end{array}$ & $\begin{array}{l}0.7 \\
1.5\end{array}$ & $\begin{array}{l}(0.16) \\
(0.26)\end{array}$ & $\begin{array}{l}1.5 \\
4.0\end{array}$ & $\begin{array}{l}(0.27) \\
(0.44)\end{array}$ & $\begin{array}{l}2.4 \\
6.5\end{array}$ & $\begin{array}{l}(0.32) \\
(0.52)\end{array}$ & $\begin{array}{l}1.1 \\
2.7\end{array}$ & $\begin{array}{l}(0.20) \\
(0.31)\end{array}$ & $\begin{array}{l}2.7 \\
0.2 !\end{array}$ & $\begin{array}{l}(0.32) \\
(0.08)\end{array}$ & $\begin{array}{l}1.0 \\
1.4\end{array}$ & $\begin{array}{l}(0.21) \\
(0.21)\end{array}$ \\
\hline 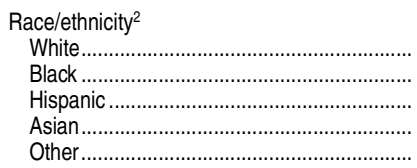 & $\begin{array}{l}10.6 \\
7.0 \\
7.6 \\
5.5 ! \\
3.8 !\end{array}$ & $\begin{array}{l}(0.60) \\
(1.04) \\
(0.77) \\
(1.69) \\
(1.18)\end{array}$ & $\begin{array}{r}4.2 \\
3.8 \\
2.5 \\
\ddagger \\
\ddagger\end{array}$ & $\begin{array}{r}(0.30) \\
(0.72) \\
(0.45) \\
(\dagger) \\
(\dagger)\end{array}$ & $\begin{array}{l}1.2 \\
1.3 ! \\
0.9 ! \\
\ddagger \\
\#\end{array}$ & $\begin{array}{r}(0.20) \\
(0.43) \\
(0.30) \\
(\dagger) \\
(\dagger)\end{array}$ & $\begin{array}{r}3.3 \\
1.8 \\
2.3 \\
\ddagger \\
\ddagger\end{array}$ & $\begin{array}{r}(0.36) \\
(0.50) \\
(0.47) \\
(\dagger) \\
(\dagger)\end{array}$ & $\begin{array}{l}5.5 \\
2.9 \\
3.3 \\
2.4 ! \\
\ddagger\end{array}$ & $\begin{array}{r}(0.48) \\
(0.66) \\
(0.49) \\
(1.06) \\
(\dagger)\end{array}$ & $\begin{array}{r}2.2 \\
1.6 \\
1.5 \\
\# \\
\ddagger\end{array}$ & $\begin{array}{r}(0.26) \\
(0.48) \\
(0.36) \\
(\dagger) \\
(\dagger)\end{array}$ & $\begin{array}{r}1.6 \\
\ddagger \\
2.0 \\
\ddagger \\
\#\end{array}$ & $\begin{array}{r}(0.23) \\
(\dagger) \\
(0.44) \\
(\dagger) \\
(t)\end{array}$ & $\begin{array}{r}1.4 \\
\ddagger \\
1.4 \\
\ddagger \\
\ddagger\end{array}$ & $\begin{array}{r}(0.20) \\
(\dagger) \\
(0.38) \\
(\dagger) \\
(\dagger)\end{array}$ \\
\hline $\begin{array}{l}\text { Grade } \\
\text { 6th } \\
\text { 7th } \\
\text { 8th } \\
9 \text { th } \\
\text { 10th } \\
11 \text { th } \\
\text { 12th }\end{array}$ & $\begin{array}{r}6.4 \\
8.1 \\
8.6 \\
8.3 \\
11.6 \\
11.1 \\
7.8\end{array}$ & $\begin{array}{l}(1.09) \\
(0.89) \\
(0.86) \\
(0.96) \\
(0.99) \\
(1.18) \\
(1.02)\end{array}$ & $\begin{array}{l}1.6 ! \\
3.3 \\
3.4 \\
3.7 \\
4.8 \\
4.7 \\
3.0\end{array}$ & $\begin{array}{l}(0.53) \\
(0.57) \\
(0.57) \\
(0.66) \\
(0.57) \\
(0.78) \\
(0.64)\end{array}$ & $\begin{array}{l}\ddagger \\
0.6 ! \\
0.9 ! \\
1.5 \\
1.5 \\
1.1 ! \\
1.2 !\end{array}$ & $\begin{array}{r}(\dagger) \\
(0.25) \\
(0.31) \\
(0.41) \\
(0.40) \\
(0.38) \\
(0.41)\end{array}$ & $\begin{array}{l}1.2 ! \\
3.0 \\
3.0 \\
3.2 \\
3.6 \\
2.7 \\
1.5 !\end{array}$ & $\begin{array}{l}(0.50) \\
(0.54) \\
(0.53) \\
(0.57) \\
(0.65) \\
(0.64) \\
(0.47)\end{array}$ & $\begin{array}{l}2.1 ! \\
3.7 \\
3.6 \\
4.2 \\
6.6 \\
5.8 \\
3.9\end{array}$ & $\begin{array}{l}(0.65) \\
(0.63) \\
(0.60) \\
(0.62) \\
(0.81) \\
(0.79) \\
(0.72)\end{array}$ & $\begin{array}{l}1.4 \text { ! } \\
1.9 \\
1.7 \\
1.6 \\
2.7 \\
2.9 \\
0.7 !\end{array}$ & $\begin{array}{l}(0.51) \\
(0.43) \\
(0.39) \\
(0.42) \\
(0.49) \\
(0.68) \\
(0.31)\end{array}$ & $\begin{array}{l}1.5 ! \\
1.7 \\
1.5 \\
0.9 ! \\
1.8 \\
1.7 \\
1.3 !\end{array}$ & $\begin{array}{l}(0.52) \\
(0.50) \\
(0.42) \\
(0.42) \\
(0.40) \\
(0.52) \\
(0.41)\end{array}$ & $\begin{array}{l}1.2 \text { ! } \\
1.1 ! \\
1.3 \\
1.9 \\
1.4 \\
0.6 ! \\
0.7 !\end{array}$ & $\begin{array}{l}(0.47) \\
(0.36) \\
(0.35) \\
(0.52) \\
(0.41) \\
(0.26) \\
(0.29)\end{array}$ \\
\hline $\begin{array}{l}\text { Urbanicity } \\
\quad \text { Urban } \\
\text { Suburban } \\
\text { Rural }\end{array}$ & $\begin{array}{r}7.3 \\
10.0 \\
8.9\end{array}$ & $\begin{array}{l}(0.65) \\
(0.63) \\
(1.04)\end{array}$ & $\begin{array}{l}3.3 \\
3.7 \\
4.0\end{array}$ & $\begin{array}{l}(0.43) \\
(0.34) \\
(0.55)\end{array}$ & $\begin{array}{l}1.2 \\
1.0 \\
1.1 !\end{array}$ & $\begin{array}{l}(0.27) \\
(0.19) \\
(0.39)\end{array}$ & $\begin{array}{l}1.9 \\
2.9 \\
3.5\end{array}$ & $\begin{array}{l}(0.36) \\
(0.33) \\
(0.80)\end{array}$ & $\begin{array}{l}3.4 \\
4.9 \\
4.9\end{array}$ & $\begin{array}{l}(0.50) \\
(0.42) \\
(0.89)\end{array}$ & $\begin{array}{l}1.5 \\
2.0 \\
2.2\end{array}$ & $\begin{array}{l}(0.29) \\
(0.25) \\
(0.46)\end{array}$ & $\begin{array}{r}1.1 \\
1.9 \\
\ddagger\end{array}$ & $\begin{array}{r}(0.26) \\
(0.27) \\
(\dagger)\end{array}$ & $\begin{array}{l}1.0 \\
1.2 \\
1.2 !\end{array}$ & $\begin{array}{l}(0.25) \\
(0.21) \\
(0.37)\end{array}$ \\
\hline 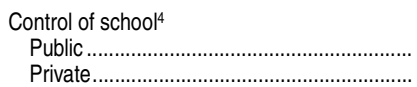 & $\begin{array}{l}8.9 \\
9.8\end{array}$ & $\begin{array}{l}(0.45) \\
(1.31)\end{array}$ & $\begin{array}{l}3.5 \\
4.8\end{array}$ & $\begin{array}{l}(0.24) \\
(1.01)\end{array}$ & $\begin{array}{l}1.1 \\
1.3 !\end{array}$ & $\begin{array}{l}(0.16) \\
(0.58)\end{array}$ & $\begin{array}{l}2.7 \\
2.7\end{array}$ & $\begin{array}{l}(0.26) \\
(0.78)\end{array}$ & $\begin{array}{l}4.5 \\
3.2\end{array}$ & $\begin{array}{l}(0.33) \\
(0.91)\end{array}$ & $\begin{array}{r}2.0 \\
\ddagger\end{array}$ & $\begin{array}{r}(0.19) \\
(\dagger)\end{array}$ & $\begin{array}{l}1.4 \\
1.8 !\end{array}$ & $\begin{array}{l}(0.18) \\
(0.55)\end{array}$ & $\begin{array}{l}1.1 \\
1.6 !\end{array}$ & $\begin{array}{l}(0.15) \\
(0.65)\end{array}$ \\
\hline
\end{tabular}

†Not applicable.

\#Rounds to zero.

!Interpret data with caution. The coefficient of variation (CV) for this estimate is between 30 and 50 percent.

†Reporting standards not met. Either there are too few cases for a reliable estimate or the coefficient of variation (CV) is 50 percent or greater.

1 Includes all students who responded that another student had posted hurtful information about them on the Internet; purposely shared private information about them on the Internet; threatened or insulted them through instant messaging; threatened or insulted them through text messaging; threatened or insulted them through e-mail; threatened or insulted them while gaming; or excluded them online. Students could report more than one of these types of cyber-bullying. A student who reported more than one type is counted only once under total cyber-bullying.

${ }^{2}$ Race categories exclude persons of Hispanic ethnicity. "Other" includes American Indians/ Alaska Natives, Pacific Islanders, and persons reporting that they are of two or more races.

${ }^{3}$ Refers to the Standard Metropolitan Statistical Area (MSA) status of the respondent's house- hold as defined in 2000 by the U.S. Census Bureau. Categories include "central city of an MSA (Urban)," "in MSA but not in central city (Suburban)," and "not MSA (Rural)." These data by metropolitan status were based on the location of households and differ from those published in Student Reports of Bullying and Cyber-Bullying: Results from the 2011 School Crime Supplement to the National Crime Victimization Survey, which were based on the urban-centric measure of the location of the school that the child attended.

${ }^{4} \mathrm{Control}$ of school as reported by the respondent. These data differ from those based on a matching of the respondent-reported school name to the Common Core of Data's Public Elementary/Secondary School Universe Survey or the Private School Survey, as reported in Student Reports of Bullying and Cyber-Bullying: Results from the 2011 School Crime Supplement to the National Crime Victimization Survey.

NOTE: Detail may not sum to totals because of rounding and because students could have experienced more than one type of cyber-bullying.

SOURCE: U.S. Department of Justice, Bureau of Justice Statistics, School Crime Supplement (SCS) to the National Crime Victimization Survey, 2011. (This table was prepared September 2013.) 


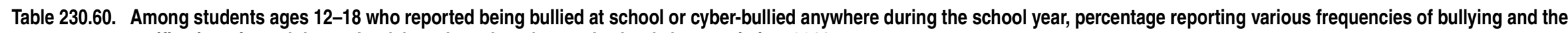
notification of an adult at school, by selected student and school characteristics: 2011

[Standard errors appear in parentheses]

\begin{tabular}{|c|c|c|c|c|c|c|c|c|c|c|c|c|c|c|c|c|c|c|c|c|}
\hline \multirow[b]{3}{*}{ Student or school characteristic } & \multicolumn{10}{|c|}{ Students who reported being bullied at school } & \multicolumn{10}{|c|}{ Students who reported being cyber-bullied anywhere ${ }^{1}$} \\
\hline & \multicolumn{8}{|c|}{ Percentage distribution, by frequency of bullying } & \multirow{2}{*}{\multicolumn{2}{|c|}{$\begin{array}{r}\text { Percent } \\
\text { indicating adult at } \\
\text { school notified } \\
\end{array}$}} & \multicolumn{8}{|c|}{ Percentage distribution, by frequency of cyber-bullying } & \multirow{2}{*}{\multicolumn{2}{|c|}{$\begin{array}{r}\text { Percent } \\
\text { indicating adult at } \\
\text { school notified }{ }^{2}\end{array}$}} \\
\hline & \multicolumn{2}{|c|}{$\begin{array}{r}\text { Once or twice } \\
\text { in the school year }\end{array}$} & \multicolumn{2}{|c|}{$\begin{array}{r}\text { Once or } \\
\text { twice a month }\end{array}$} & \multicolumn{2}{|c|}{$\begin{array}{r}\text { Once or } \\
\text { twice a week }\end{array}$} & \multicolumn{2}{|c|}{ Almost every day } & & & \multicolumn{2}{|c|}{$\begin{array}{r}\text { Once or twice } \\
\text { in the school year }\end{array}$} & \multicolumn{2}{|c|}{$\begin{array}{r}\text { Once or } \\
\text { twice a month }\end{array}$} & \multicolumn{2}{|c|}{$\begin{array}{r}\text { Once or } \\
\text { twice a week }\end{array}$} & \multicolumn{2}{|c|}{ Almost every day } & & \\
\hline 1 & & 2 & & 3 & & 4 & & 5 & & 6 & & 7 & & 8 & & 9 & & 10 & & 11 \\
\hline Total .......................................................... & 64.5 & (1.33) & 18.5 & $(0.98)$ & 9.2 & (0.82) & 7.8 & $(0.75)$ & 39.5 & $(1.38)$ & 71.9 & $(2.01)$ & 19.6 & (1.78) & 5.3 & $(0.94)$ & 3.1 & $(0.85)$ & 26.1 & $(2.04)$ \\
\hline 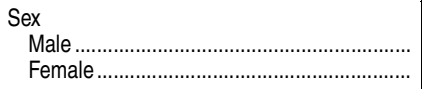 & $\begin{array}{l}62.4 \\
66.2\end{array}$ & $\begin{array}{l}(2.00) \\
(1.69)\end{array}$ & $\begin{array}{l}19.4 \\
17.7\end{array}$ & $\begin{array}{l}(1.58) \\
(1.16)\end{array}$ & $\begin{array}{r}10.0 \\
8.6\end{array}$ & $\begin{array}{l}(1.09) \\
(1.08)\end{array}$ & $\begin{array}{l}8.2 \\
7.5\end{array}$ & $\begin{array}{l}(1.13) \\
(1.02)\end{array}$ & $\begin{array}{l}39.4 \\
39.7\end{array}$ & $\begin{array}{l}(1.90) \\
(1.79)\end{array}$ & $\begin{array}{l}60.5 \\
79.2\end{array}$ & $\begin{array}{l}(3.95) \\
(2.29)\end{array}$ & $\begin{array}{l}25.7 \\
15.7\end{array}$ & $\begin{array}{l}(3.53) \\
(2.10)\end{array}$ & $\begin{array}{l}9.0 \\
3.0\end{array}$ & $\begin{array}{l}(1.99) \\
(0.83)\end{array}$ & $\begin{array}{l}4.8 ! \\
2.1 !\end{array}$ & $\begin{array}{l}(1.84) \\
(0.86)\end{array}$ & $\begin{array}{l}16.5 \\
32.5\end{array}$ & $\begin{array}{l}(2.92) \\
(2.81)\end{array}$ \\
\hline \multicolumn{21}{|l|}{ Race/ethnicity ${ }^{3}$} \\
\hline Wit & 62.6 & (1.62) & 20.5 & (1.24) & 10.0 & $(1.03)$ & 7.0 & $(0.80)$ & 38.5 & (1.78) & 69.6 & (2.48) & 20.4 & $(2.08)$ & 6.5 & $(1.30)$ & $3.6 !$ & $(1.20)$ & 24.8 & (2.40) \\
\hline Black... & 68.3 & (3.31) & 12.9 & (2.42) & 7.5 & (2.07) & 11.3 & (2.35) & 46.4 & $(3.30)$ & 82.2 & $(5.91)$ & 15.4 & (5.77) & $\ddagger$ & $(t)$ & \# & $(t)$ & 36.2 & (6.64) \\
\hline Hispanic. & 65.9 & (2.68) & 16.1 & (2.17) & 8.6 & $(1.83)$ & 9.5 & $(2.02)$ & 39.0 & $(2.97)$ & 71.5 & $(4.70)$ & 20.3 & $(4.13)$ & $4.1 !$ & $(1.38)$ & 4.1 ! & $(1.94)$ & 24.8 & (4.82) \\
\hline Asian & 66.5 & $(9.22)$ & $16.6 !$ & $(6.69)$ & $16.8 !$ & (6.72) & \# & $(t)$ & $24.4 !$ & $(7.34)$ & $\ddagger$ & $(t)$ & $\ddagger$ & $(t)$ & \# & $(t)$ & $\#$ & $(t)$ & $\ddagger$ & \\
\hline 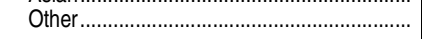 & 77.7 & (5.52) & 18.4 & $(5.27)$ & $\#$ & $(t)$ & $\ddagger$ & $(t)$ & 42.3 & $(7.42)$ & $\ddagger$ & $(t)$ & $\ddagger$ & $(\dagger)$ & \# & $(t)$ & \# & $(t)$ & $\ddagger$ & \\
\hline \multicolumn{21}{|l|}{ Grade } \\
\hline 6th.... & 64.6 & (3.15) & 15.2 & (2.53) & 15.3 & (2.66) & 4.9 ! & (1.59) & 57.9 & (3.72) & 61.2 & $(8.52)$ & 32.3 & $(8.18)$ & $\ddagger$ & $(\dagger)$ & $\ddagger$ & $(\dagger)$ & 43.7 & \\
\hline 7th...... & 57.0 & $(3.07)$ & 21.2 & $(2.62$ & 8.2 & $(1.68)$ & 13.6 & (2.29) & 51.5 & (3.42) & 72.2 & $(5.24)$ & 19.0 & $(4.50)$ & $\ddagger$ & (†) & $\ddagger$ & $(t)$ & 27.6 & $(5.6$ \\
\hline 8th.... & 60.4 & $(3.06)$ & 22.5 & $(2$. & 9.3 & (2.04) & 7.8 & $(1.48)$ & 3 & $(2.60)$ & 74. & $(5.24)$ & 14 & $(4.10)$ & $6.6 !$ & (2.92) & $\ddagger$ & $(t)$ & 35.2 & (5.15) \\
\hline & 69.5 & (2.99) & 13.6 & (2.33) & 10.6 & (2.06) & 6.3 & $(1.63)$ & 42.9 & (3.30) & 71.7 & $(5.22)$ & 17 & (4.44) & $8.5 !$ & (3.26) & $\ddagger$ & $(\dagger)$ & 31.2 & (5.78) \\
\hline 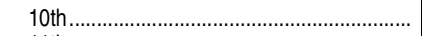 & 61.3 & $(3.54)$ & 20.1 & $(2.95)$ & 10.5 & (2.34) & 8.1 & $(2.14)$ & 26 & $(2.40)$ & 72.4 & $(4.59)$ & 20 & $(4.23)$ & 4.1 & $(1.21)$ & $\ddagger$ & $(t)$ & 24.6 & $(4.3$ \\
\hline$\ldots$ & 68.3 & (3.61) & 21.1 & $(3.05)$ & $5.8 !$ & (1.78) & $4.9 !$ & $(1.56)$ & 29.7 & (3.54) & 77.1 & $(5.22)$ & 20 & $(5.02)$ & $\ddagger$ & $(t)$ & $\#$ & $(t)$ & 13.6 & $(3.8$ \\
\hline 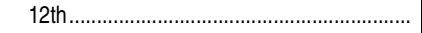 & 75.2 & (3.58) & 13.5 & (2.70) & $4.4 !$ & (1.74) & $7.0 !$ & (2.18) & 28.2 & $(3.66)$ & 65.4 & $(6.52)$ & 20.5 & $(5.41)$ & $\ddagger$ & $(t)$ & $7.6 !$ & $(3.73)$ & 19.6 & (5.14) \\
\hline \multicolumn{21}{|l|}{ Urbanicity $^{4}$} \\
\hline Urban. & 65.9 & $(2.68)$ & 18.2 & (2.08) & 7.6 & $(1.43$ & 8.3 & (1.46) & 42.8 & (2.33) & 76.1 & $(4.1$ & 16.1 & (3.76) & $6.2 !$ & (2.30) & $\ddagger$ & $(t)$ & 32.0 & \\
\hline Suburb & 64.1 & $(1.75)$ & 18.9 & $(1.30)$ & 10.6 & $(1.17)$ & 6.3 & $(0.86)$ & 37.4 & $(1.81)$ & 72.8 & $(2.77)$ & 17.8 & $(2.23)$ & 5.2 & $(1.35)$ & $4.2 !$ & $(1.29)$ & 22.4 & (2.73) \\
\hline 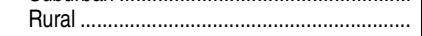 & 63.4 & (3.39) & 17.7 & (2.33) & 7.0 & $(1.92)$ & 11.8 & $(1.96)$ & 41.4 & $(2.96)$ & 62.3 & $(4.93)$ & 32.2 & $(4.93)$ & $\ddagger$ & $(t)$ & $\ddagger$ & $(t)$ & 31.5 & $(4.53)$ \\
\hline \multicolumn{21}{|l|}{ Control of school $\left.\right|^{5}$} \\
\hline Public. & 64.6 & $(1.34)$ & 18.3 & $(0.97)$ & 9.3 & $(0.86)$ & 7.7 & $(0.7)$ & 39.3 & $(1$. & 72.0 & $(2.03)$ & 19 & $(1.81)$ & 5.6 & $(1.02)$ & 2.5 & $(0.68)$ & 25.6 & $(2.04)$ \\
\hline 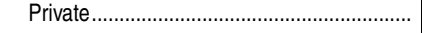 & 62.8 & (5.03) & 19.9 & $(4.06)$ & $8.6 !$ & (2.74) & $8.7 !$ & (3.06) & 43.1 & $(4.80)$ & 71.0 & $(7.10)$ & 16.3 & $(6.43)$ & $\ddagger$ & $(t)$ & $\ddagger$ & $(t)$ & 32.6 & (7.41) \\
\hline
\end{tabular}

\section{†Not applicable.}

\#Rounds to zero.

!nterprel data with caution. The coefficient of variation (CV) for this estimate is between 30 and 50 percent.

eporting standards not met. Either there are too few cases for a reliable estimate or the coefficient of variation (CV) is 50 percent or greater.
IStudents who

ing: posted hurtful information cyber-bullied are those who responded that another student had done one or more of the followthreatened or insulted them through instant messaging; threatened or insulted them through text messaging; threatened or insulted them through e-mail; threatened or insulted them while gaming; or excluded them online.

${ }^{2}$ Teacher or other adult at school notified.

ethnicity. "Other" includes American Indians/Alaska Natives, Pacific Islanders, and persons reporting that they are of two or more races.
"Refers to the Standard Metropolitan Statistical Area (MSA) status of the respondent's household as defined in 2000 by the U.S. Census Bureau. Categories include "central city of an MSA (Urban)," "in MSA but not in central city (Suburban)," and "not MSA (Rural). These data by metropollan stalus were based on the localion ol households and alter from Survey which wing based on the urban

school name to the Common Core of Data's Public Elementary/Secondary School Universe Survey or the Private School Survey, as reported in Student Reports of Bullying and Cyber-Bullying: Results from the 2011 School Crime Supplement to the

National Crime Victimization Survey.
NOTE: "At school" includes the school building, on school property, on a school bus, or going to and from school. Detail may no sum to tolals because of rounding.

(S) the National Crime Victimization Survey, 2011. (This table was prepared September 2013.) 
314 CHAPTER 2: Elementary and Secondary Education

School Environment

Table 230.65. Percentage of public schools reporting selected types of cyber-bullying problems occurring at school or away from school at least once a week, by selected school characteristics: 2009-10

[Standard errors appear in parentheses]

\begin{tabular}{|c|c|c|c|c|c|c|}
\hline School characteristic & \multicolumn{2}{|c|}{ Cyber-bullying among students } & \multicolumn{2}{|c|}{ School environment is affected by cyber-bullying } & \multicolumn{2}{|c|}{ Staff resources are used to deal with cyber-bullying } \\
\hline 1 & & 2 & & 3 & & 4 \\
\hline 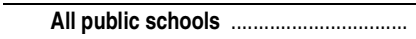 & 7.9 & $(0.49)$ & 4.4 & $(0.34)$ & 3.8 & $(0.39)$ \\
\hline 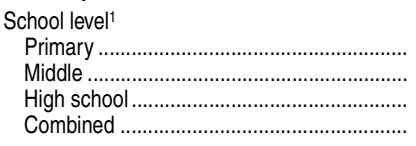 & $\begin{array}{r}1.5 \\
18.6 \\
17.6 \\
12.6\end{array}$ & $\begin{array}{l}(0.43) \\
(1.48) \\
(1.11) \\
(3.34)\end{array}$ & $\begin{array}{l}0.9 ! \\
9.8 \\
9.9 \\
7.4 !\end{array}$ & $\begin{array}{l}(0.38) \\
(1.07) \\
(0.85) \\
(2.64)\end{array}$ & $\begin{array}{c}0.9 ! \\
8.5 \\
8.6 \\
\ddagger\end{array}$ & $\begin{array}{r}(0.34) \\
(1.01) \\
(0.81) \\
(\dagger)\end{array}$ \\
\hline 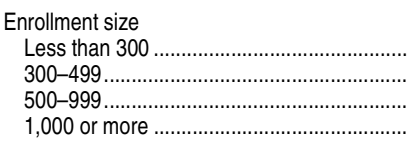 & $\begin{array}{r}4.8 \\
4.6 \\
9.3 \\
19.2\end{array}$ & $\begin{array}{l}(1.21) \\
(0.74) \\
(0.63) \\
(1.42)\end{array}$ & $\begin{array}{r}3.2 ! \\
2.8 \\
4.6 \\
10.7\end{array}$ & $\begin{array}{l}(1.05) \\
(0.57) \\
(0.57) \\
(1.26)\end{array}$ & $\begin{array}{l}2.9 ! \\
2.7 \\
3.7 \\
9.4\end{array}$ & $\begin{array}{l}(0.89) \\
(0.64) \\
(0.58) \\
(0.96)\end{array}$ \\
\hline 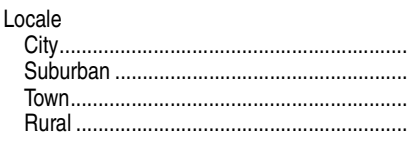 & $\begin{array}{l}5.7 \\
8.5 \\
9.6 \\
8.4\end{array}$ & $\begin{array}{l}(0.62) \\
(0.85) \\
(1.45) \\
(1.07)\end{array}$ & $\begin{array}{l}3.8 \\
4.0 \\
5.8 \\
4.5\end{array}$ & $\begin{array}{l}(0.57) \\
(0.48) \\
(1.15) \\
(0.89)\end{array}$ & $\begin{array}{l}3.6 \\
3.7 \\
4.1 \\
4.0\end{array}$ & $\begin{array}{l}(0.70) \\
(0.46) \\
(1.06) \\
(0.82)\end{array}$ \\
\hline 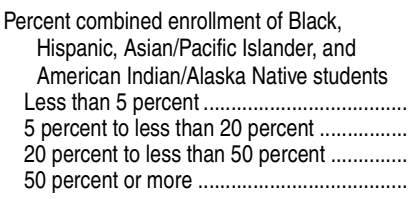 & $\begin{array}{r}12.8 \\
10.1 \\
6.7 \\
5.3\end{array}$ & $\begin{array}{l}(2.05) \\
(0.90) \\
(0.77) \\
(0.60)\end{array}$ & $\begin{array}{l}7.7 \\
5.1 \\
3.6 \\
3.1\end{array}$ & $\begin{array}{l}(1.66) \\
(0.59) \\
(0.67) \\
(0.41)\end{array}$ & $\begin{array}{l}4.7 \\
4.7 \\
3.9 \\
2.8\end{array}$ & $\begin{array}{l}(1.32) \\
(0.72) \\
(0.74) \\
(0.54)\end{array}$ \\
\hline $\begin{array}{l}\text { Percent of students eligible for free or } \\
\text { reduced-price lunch } \\
0-25\end{array}$ & $\begin{array}{r}10.8 \\
9.7 \\
6.8 \\
4.5\end{array}$ & $\begin{array}{l}(1.08) \\
(1.14) \\
(0.83) \\
(0.96)\end{array}$ & $\begin{array}{l}5.0 \\
4.3 \\
4.9 \\
3.3\end{array}$ & $\begin{array}{l}(0.62) \\
(0.55) \\
(0.78) \\
(0.91)\end{array}$ & $\begin{array}{l}4.9 \\
3.4 \\
4.1 \\
3.0\end{array}$ & $\begin{array}{l}(0.72) \\
(0.48) \\
(0.78) \\
(0.73)\end{array}$ \\
\hline 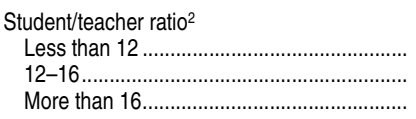 & $\begin{array}{l}6.8 \\
7.4 \\
8.7\end{array}$ & $\begin{array}{l}(1.36) \\
(0.71) \\
(0.75)\end{array}$ & $\begin{array}{l}4.1 \\
4.0 \\
4.8\end{array}$ & $\begin{array}{l}(1.20) \\
(0.48) \\
(0.60)\end{array}$ & $\begin{array}{l}3.5 \\
3.8 \\
3.9\end{array}$ & $\begin{array}{l}(1.02) \\
(0.66) \\
(0.56)\end{array}$ \\
\hline 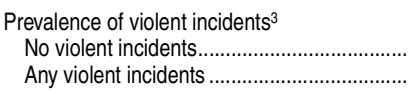 & $\begin{array}{l}2.4 ! \\
9.9\end{array}$ & $\begin{array}{l}(0.90) \\
(0.53)\end{array}$ & $\begin{array}{r}\ddagger \\
5.6\end{array}$ & $\begin{array}{r}(\dagger) \\
(0.40)\end{array}$ & $\underset{5}{\ddagger}$ & $\begin{array}{r}(\dagger) \\
(0.53)\end{array}$ \\
\hline
\end{tabular}

†Not applicable.

!nterpret data with caution. The coefficient of variation (CV) for this estimate is between 30 and 50 percent.

fReporting standards not met. Either there are too few cases for a reliable estimate or the coefficient of variation (CV) is 50 percent or greater.

1Primary schools are defined as schools in which the lowest grade is not higher than grade 3 and the highest grade is not higher than grade 8 . Middle schools are defined as schools in which the lowest grade is not lower than grade 4 and the highest grade is not higher than grade 9 . High schools are defined as schools in which the lowest grade is not lower than grade 9 and the highest grade is not higher than grade 12. Combined schools include all other combinations of grades, including $\mathrm{K}-12$ schools.

${ }^{2}$ Student/teacher ratio was calculated by dividing the total number of students enrolled in the school by the total number of full-time-equivalent (FTE) teachers. Information regarding the total number of FTE teachers was obtained from the Common Core of Data (CCD), the sampling frame for SSOCS.

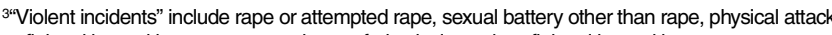
or fight with or without a weapon, threat of physical attack or fight with or without a weapon, and robbery with or without a weapon. "At school" was defined for respondents to include activities that happen in school buildings, on school grounds, on school buses, and at places that hold school-sponsored events or activities. Respondents were instructed to respond only for those times that were during normal school hours or when school activities and events were in session. NOTE: Includes schools reporting that cyber-bullying happens either "daily" or "at least once a week." "Cyber-bullying" was defined for respondents as occurring "when willful and repeated harm is inflicted through the use of computers, cell phones, or other electronic devices." Responses were provided by the principal or the person most knowledgeable about crime and safety issues at the school. Respondents were instructed to include cyber-bullying "problems that can occur anywhere (both at your school and away from school)."

SOURCE: U.S. Department of Education, National Center for Education Statistics, 2009-10 School Survey on Crime and Safety (SSOCS), 2010. (This table was prepared September 2013.) 
Table 230.70. Percentage of students ages 12-18 who reported being afraid of attack or harm, by location and selected student and school characteristics: Selected years, 1995 through 2011

[Standard errors appear in parentheses]

\begin{tabular}{|c|c|c|c|c|c|c|c|c|c|c|c|c|c|c|c|c|}
\hline Student or school characteristic & & 1995 & & 1999 & & 2001 & & 2003 & & 2005 & & $2007^{1}$ & & $2009^{1}$ & & $2011^{1}$ \\
\hline 1 & & 2 & & 3 & & 4 & & 5 & & 6 & & 7 & & 8 & & 9 \\
\hline \multicolumn{17}{|l|}{ At school } \\
\hline 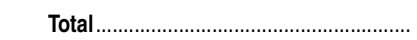 & 11.8 & $(0.39)$ & 7.3 & $(0.37)$ & 6.4 & $(0.31)$ & 6.1 & $(0.31)$ & 6.4 & $(0.39)$ & 5.3 & $(0.33)$ & 4.2 & $(0.33)$ & 3.7 & $(0.28)$ \\
\hline \multicolumn{17}{|l|}{ Sex } \\
\hline Male.... & 10.8 & $(0.51)$ & 6.5 & $(0.44)$ & 6.4 & $(0.38)$ & 5.3 & $(0.34)$ & 6.1 & $(0.56)$ & 4.6 & $(0.42)$ & 3.7 & $(0.38)$ & 3.7 & $(0.41)$ \\
\hline 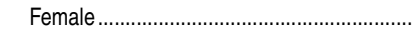 & 12.8 & $(0.58)$ & 8.2 & $(0.53)$ & 6.4 & $(0.43)$ & 6.9 & $(0.48)$ & 6.7 & $(0.47)$ & 6.0 & $(0.45)$ & 4.8 & $(0.51)$ & 3.8 & $(0.36)$ \\
\hline \multicolumn{17}{|l|}{ Race/ethnicity² } \\
\hline White................... & 8.1 & $(0.36)$ & 5.0 & $(0.32)$ & 4.9 & $(0.35)$ & 4.1 & $(0.35)$ & 4.6 & $(0.39)$ & 4.2 & $(0.37)$ & 3.3 & $(0.35)$ & 3.0 & $(0.31)$ \\
\hline Black ... & 20.3 & $(1.31)$ & 13.5 & $(1.27)$ & 8.9 & $(0.87)$ & 10.7 & $(1.22)$ & 9.2 & $(1.19)$ & 8.6 & $(1.18)$ & 7.0 & $(1.12)$ & 4.9 & (1.03) \\
\hline (2) & 20.9 & $(1.27)$ & 11.7 & $(1.20)$ & 10.6 & $(1.07)$ & 9.5 & $(0.65)$ & 10.3 & $(1.16)$ & 7.1 & $(0.88)$ & 4.9 & $(0.89)$ & 4.8 & $(0.59)$ \\
\hline 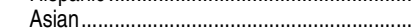 & - & $(t)$ & - & $(t)$ & - & $(t)$ & - & $(t)$ & $6.2 !$ & $(2.09)$ & $2.3 !$ & $(1.05)$ & $5.9 !$ & $(2.25)$ & $4.2 !$ & (1.52) \\
\hline Other & 13.5 & $(1.58)$ & 6.7 & $(1.09)$ & 6.4 & $(1.11)$ & 5.0 & $(1.31)$ & 5.7 & $(1.63)$ & $3.3 !$ & $(1.09)$ & $\ddagger$ & $(\dagger)$ & $4.1 !$ & (1.31) \\
\hline \multicolumn{17}{|l|}{ Grade } \\
\hline 6th... & 14.3 & $(1.13)$ & 10.9 & $(1.37)$ & 10.6 & $(1.26)$ & 10.0 & $(1.35)$ & 9.5 & $(1.14)$ & 9.9 & $(1.33)$ & 6.4 & $(1.20)$ & 5.6 & (1.08) \\
\hline 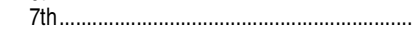 & 15.3 & $(1.02)$ & 9.5 & $(0.79)$ & 9.2 & $(0.95)$ & 8.2 & $(0.86)$ & 9.1 & $(1.04)$ & 6.7 & $(0.86)$ & 6.2 & $(1.06)$ & 4.5 & $(0.69)$ \\
\hline 8th & 13.0 & $(0.84)$ & 8.1 & $(0.74)$ & 7.6 & $(0.69)$ & 6.3 & $(0.68)$ & 7.1 & $(0.95)$ & 4.6 & $(0.71)$ & 3.5 & $(0.75)$ & 4.6 & $(0.71)$ \\
\hline 9th & 11.6 & $(0.82)$ & 7.1 & $(0.74)$ & 5.5 & $(0.63)$ & 6.3 & $(0.61)$ & 5.9 & $(0.71)$ & 5.5 & $(0.87)$ & 4.6 & $(0.75)$ & 4.2 & $(0.66)$ \\
\hline 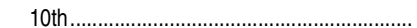 & 11.0 & $(0.82)$ & 7.1 & $(0.77)$ & 5.0 & $(0.71)$ & 4.4 & $(0.67)$ & 5.5 & $(0.89)$ & 5.2 & $(0.87)$ & 4.6 & $(0.79)$ & 3.9 & $(0.63)$ \\
\hline 11th & 8.9 & $(0.80)$ & 4.8 & $(0.68)$ & 4.8 & $(0.65)$ & 4.7 & $(0.66)$ & 4.6 & $(0.73)$ & 3.1 & $(0.63)$ & 3.3 & $(0.74)$ & 1.8 & $(0.48)$ \\
\hline 12th & 7.8 & $(0.94)$ & 4.8 & $(0.88)$ & 2.9 & $(0.55)$ & 3.7 & $(0.53)$ & 3.3 & $(0.69)$ & 3.1 & $(0.65)$ & $1.9 !$ & $(0.57)$ & 2.2 & $(0.57)$ \\
\hline \multicolumn{17}{|l|}{ Urbanicity ${ }^{3}$} \\
\hline Urban ..... & 18.4 & $(0.84)$ & 11.6 & $(0.81)$ & 9.7 & $(0.59)$ & 9.5 & $(0.68)$ & 10.5 & $(0.92)$ & 7.1 & $(0.81)$ & 6.9 & $(0.84)$ & 5.2 & $(0.60)$ \\
\hline Suburban & 9.8 & $(0.49)$ & 6.2 & $(0.42)$ & 4.8 & $(0.33)$ & 4.8 & $(0.30)$ & 4.7 & $(0.41)$ & 4.4 & $(0.41)$ & 3.0 & $(0.33)$ & 3.1 & $(0.39)$ \\
\hline Rural & 8.6 & $(0.80)$ & 4.8 & $(0.70)$ & 6.0 & $(0.97)$ & 4.7 & $(0.93)$ & 5.1 & $(0.97)$ & 4.9 & $(0.59)$ & 3.9 & $(0.63)$ & 3.0 & $(0.63)$ \\
\hline \multicolumn{17}{|l|}{ Control of school } \\
\hline Public ................ & 12.2 & $(0.43)$ & 7.7 & $(0.38)$ & 6.6 & $(0.33)$ & 6.4 & $(0.34)$ & 6.6 & $(0.42)$ & 5.5 & $(0.34)$ & 4.4 & $(0.35)$ & 3.9 & $(0.30)$ \\
\hline Private & 7.3 & $(1.01)$ & 3.6 & $(0.81)$ & 4.6 & $(0.92)$ & 3.0 & $(0.73)$ & 3.8 & $(0.82)$ & $2.5 !$ & $(0.89)$ & $1.9 !$ & $(0.74)$ & $1.5 !$ & $(0.64)$ \\
\hline \multicolumn{17}{|l|}{ Away from school } \\
\hline Total & - & $(\dagger)$ & 5.7 & $(0.32)$ & 4.6 & $(0.28)$ & 5.4 & $(0.29)$ & 5.2 & $(0.33)$ & 3.5 & $(0.29)$ & 3.3 & $(0.32)$ & 2.4 & $(0.23)$ \\
\hline \multicolumn{17}{|l|}{ Sex } \\
\hline 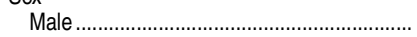 & - & $(\dagger)$ & 4.1 & $(0.34)$ & 3.7 & $(0.31)$ & 4.0 & $(0.30)$ & 4.6 & $(0.42)$ & 2.4 & $(0.31)$ & 2.5 & $(0.34)$ & 2.0 & $(0.27)$ \\
\hline Female & - & $(\dagger)$ & 7.4 & $(0.49)$ & 5.6 & $(0.42)$ & 6.8 & $(0.48)$ & 5.8 & $(0.48)$ & 4.5 & $(0.40)$ & 4.1 & $(0.51)$ & 2.7 & $(0.30)$ \\
\hline \multicolumn{17}{|l|}{ Race/ethnicity² } \\
\hline White................... & - & $(\dagger)$ & 4.3 & $(0.32)$ & 3.7 & $(0.29)$ & 3.8 & $(0.31)$ & 4.2 & $(0.40)$ & 2.5 & $(0.28)$ & 2.2 & $(0.28)$ & 1.6 & $(0.24)$ \\
\hline 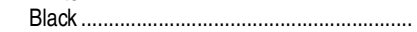 & - & $(\dagger)$ & 8.7 & $(1.00)$ & 6.3 & $(0.87)$ & 10.0 & $(1.13)$ & 7.3 & $(0.96)$ & 4.9 & $(0.73)$ & $\begin{array}{l}2.2 \\
5.7\end{array}$ & $(1.10)$ & 3.5 & $(0.86)$ \\
\hline Hispanic.. & - & $(t)$ & 8.9 & $(1.03)$ & 6.5 & $(0.75)$ & 7.4 & $(0.80)$ & 6.2 & $(0.84)$ & 5.9 & $(0.80)$ & 3.9 & $(0.70)$ & 3.3 & $(0.50)$ \\
\hline Asian & - & $(\dagger)$ & - & $(t)$ & - & $(\dagger)$ & - & $(\dagger)$ & $7.4 !$ & $(2.89)$ & $\ddagger$ & $(t)$ & $7.1 !$ & $(2.50)$ & $3.2 !$ & $(1.15)$ \\
\hline Other & - & $(\dagger)$ & 5.4 & $(1.04)$ & 6.6 & $(1.32)$ & 3.9 & $(1.02)$ & $3.1 !$ & $(1.28)$ & $\stackrel{+}{\ddagger}$ & $(\dagger)$ & $4.0 !$ & $(1.79)$ & $2.5 !$ & $(1.05)$ \\
\hline \multicolumn{17}{|l|}{ Grade } \\
\hline 6th & - & $(\dagger)$ & 7.8 & $(1.11)$ & 6.3 & $(1.15)$ & 6.8 & $(1.01)$ & 5.6 & $(0.99)$ & 5.9 & $(1.20)$ & 3.3 & $(0.89)$ & 3.0 & $(0.86)$ \\
\hline 7th & - & $(\dagger)$ & 6.1 & $(0.72)$ & 5.5 & $(0.80)$ & 6.7 & $(0.80)$ & 7.5 & $(0.89)$ & 3.0 & $(0.55)$ & 4.0 & $(0.78)$ & 2.7 & $(0.58)$ \\
\hline (1) & - & $(\dagger)$ & 5.5 & $(0.66)$ & 4.4 & $(0.61)$ & 5.3 & $(0.71)$ & 5.0 & $(0.72)$ & 3.6 & $(0.65)$ & 3.3 & $(0.72)$ & 2.1 & $(0.43)$ \\
\hline (2) & - & $(\dagger)$ & 4.6 & $(0.63)$ & 4.5 & $(0.62)$ & 4.3 & $(0.55)$ & 3.8 & $(0.61)$ & 4.0 & $(0.75)$ & 2.6 & $(0.62)$ & 3.5 & $(0.65)$ \\
\hline (1) & - & $(\dagger)$ & 4.8 & $(0.63)$ & 4.2 & $(0.63)$ & 5.3 & $(0.67)$ & 4.7 & $(0.66)$ & 3.0 & $(0.60)$ & 5.5 & $(0.96)$ & 1.7 & $(0.46)$ \\
\hline 11 th & - & $(\dagger)$ & 5.9 & $(0.72)$ & 4.7 & $(0.62)$ & 4.7 & $(0.69)$ & 4.2 & $(0.74)$ & 2.3 & $(0.56)$ & 2.2 & $(0.56)$ & 2.9 & $(0.70)$ \\
\hline 12th & - & $(t)$ & 6.1 & $(0.86)$ & 3.3 & $(0.62)$ & 4.9 & $(0.72)$ & 5.4 & $(0.98)$ & 3.2 & $(0.61)$ & 2.1 & $(0.63)$ & $1.0 !$ & $(0.37)$ \\
\hline \multicolumn{17}{|l|}{ Urbanicity $^{3}$} \\
\hline Urban ...... & - & $(t)$ & 9.1 & $(0.82)$ & 7.4 & $(0.68)$ & 8.1 & $(0.60)$ & 6.7 & $(0.61)$ & 5.3 & $(0.67)$ & 5.8 & $(0.87)$ & 3.4 & $(0.42)$ \\
\hline Suburban & - & $(\dagger)$ & 5.0 & $(0.31)$ & 3.8 & $(0.33)$ & 4.4 & $(0.34)$ & 4.6 & $(0.43)$ & 2.7 & $(0.36)$ & 2.5 & $(0.33)$ & 2.2 & $(0.30)$ \\
\hline Rural & - & $(\dagger)$ & 3.0 & $(0.71)$ & 3.0 & $(0.59)$ & 4.0 & $(0.69)$ & 4.7 & $(0.98)$ & 2.8 & $(0.54)$ & 1.9 & $(0.48)$ & $1.0 !$ & $(0.35)$ \\
\hline \multicolumn{17}{|l|}{ Control of school } \\
\hline Public .................. & - & $(\dagger)$ & 5.8 & $(0.32)$ & 4.6 & $(0.30)$ & 5.4 & $(0.31)$ & 5.2 & $(0.34)$ & 3.6 & $(0.30)$ & 3.5 & $(0.33)$ & 2.4 & $(0.23)$ \\
\hline Private........................................................... & - & $(\dagger)$ & 5.0 & $(0.92)$ & 5.1 & (1.08) & 4.7 & $(0.89)$ & 4.9 & $(1.41)$ & $2.1 !$ & $(0.72)$ & $1.8 !$ & $(0.71)$ & $1.6 !$ & $(0.68)$ \\
\hline
\end{tabular}

-Not available.

!Interpret data with caution. The coefficient of variation (CV) for this estimate is between 30 and 50 percent.

¥Reporting standards not met. Either there are too few cases for a reliable estimate or the coefficient of variation $(\mathrm{CV})$ is 50 percent or greater.

${ }^{1}$ Starting in 2007, the reference period was the school year, whereas in prior survey years the reference period was the previous 6 months. Cognitive testing showed that estimates from 2007 onward are comparable to previous years.

'Race categories exclude persons of Hispanic ethnicity. "Other" includes American Indians/ Alaska Natives, Asians (prior to 2005), Pacific Islanders, and, from 2003 onward, persons reporting that they are of two or more races. Due to changes in racial/ethnic categories, comparisons of race/ethnicity across years should be made with caution.
${ }^{3}$ Refers to the Standard Metropolitan Statistical Area (MSA) status of the respondent's household as defined in 2000 by the U.S. Census Bureau. Categories include "central city of an MSA (Urban)," "in MSA but not in central city (Suburban)," and "not MSA (Rural)."

NOTE: "At school" includes the school building, on school property, on a school bus, and from 2001 onward, going to and from school. Students were asked if they "never," "almost never," "sometimes," or "most of the time" feared that someone would attack or harm them at school or away from school. Students responding "sometimes" or "most of the time" were considered fearful. For the 2001 survey only, the wording was changed from "attack or harm" to "attack or threaten to attack."

SOURCE: U.S. Department of Justice, Bureau of Justice Statistics, School Crime Supplement (SCS) to the National Crime Victimization Survey, selected years, 1995 through 2011. (This table was prepared September 2013.) 
316 CHAPTER 2: Elementary and Secondary Education

School Environment

Table 230.80. Percentage of students ages 12-18 who reported avoiding one or more places in school or avoiding school activities or classes because of fear of attack or harm, by selected student and school characteristics: Selected years, 1995 through 2011

[Standard errors appear in parentheses]

\begin{tabular}{|c|c|c|c|c|c|c|c|c|c|c|c|c|c|c|c|c|}
\hline \multirow{2}{*}{$\begin{array}{l}\text { Type of avoidance and } \\
\text { student or school characteristic } \\
1\end{array}$} & \multicolumn{2}{|r|}{1995} & \multicolumn{2}{|r|}{1999} & \multicolumn{2}{|r|}{2001} & \multicolumn{2}{|r|}{2003} & \multicolumn{2}{|r|}{2005} & \multicolumn{2}{|r|}{$2007^{1}$} & \multicolumn{2}{|r|}{$2009^{1}$} & \multicolumn{2}{|r|}{$2011^{1}$} \\
\hline & & 2 & & 3 & & 4 & & 5 & & 6 & & 7 & & 8 & & 9 \\
\hline 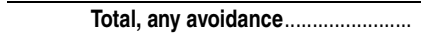 & - & $(t)$ & 6.9 & $(0.34)$ & 6.1 & $(0.32)$ & 5.0 & $(0.30)$ & 5.5 & $(0.32)$ & 7.2 & $(0.36)$ & 5.0 & $(0.35)$ & 5.5 & $(0.34)$ \\
\hline \multicolumn{17}{|l|}{ Avoided one or more places in school } \\
\hline 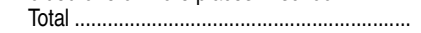 & 8.7 & $(0.29)$ & 4.6 & $(0.29)$ & 4.7 & $(0.27)$ & 4.0 & $(0.27)$ & 4.5 & $(0.28)$ & 5.8 & $(0.31)$ & 4.0 & $(0.32)$ & 4.7 & $(0.30)$ \\
\hline 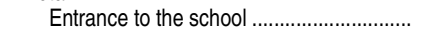 & 2.1 & $(0.15)$ & 1.1 & $(0.14)$ & 1.2 & $(0.11)$ & 1.2 & $(0.11)$ & 1.0 & $(0.14)$ & 1.5 & $(0.15)$ & 0.9 & $(0.15)$ & 0.9 & $(0.13)$ \\
\hline 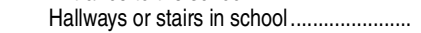 & 4.2 & $(0.21)$ & 2.1 & $(0.17)$ & 2.1 & $(0.18)$ & 1.7 & $(0.17)$ & 2.1 & $(0.21)$ & 2.6 & $(0.21)$ & 2.2 & $(0.23)$ & 2.5 & $(0.21)$ \\
\hline Parts of the school cafeteria.......................... & 2.5 & $(0.18)$ & 1.3 & $(0.15)$ & 1.4 & $(0.16)$ & 1.2 & $(0.13)$ & 1.8 & $(0.16)$ & 1.9 & $(0.19)$ & 1.1 & $(0.17)$ & 1.8 & $(0.18)$ \\
\hline 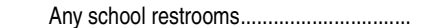 & 4.4 & $(0.22)$ & 2.1 & $(0.19)$ & 2.2 & $(0.19)$ & 2.0 & $(0.16)$ & 2.1 & $(0.20)$ & 2.6 & $(0.24)$ & 1.4 & $(0.19)$ & 1.7 & $(0.19)$ \\
\hline Other places inside the school building.... & 2.5 & $(0.18)$ & 1.4 & $(0.17)$ & 1.4 & $(0.14)$ & 1.2 & $(0.14)$ & 1.4 & $(0.18)$ & 1.5 & $(0.17)$ & 1.0 & $(0.16)$ & 1.1 & $(0.15)$ \\
\hline \multicolumn{17}{|l|}{ Sex } \\
\hline Male ... & 8.8 & $(0.43)$ & 4.6 & $(0.35)$ & 4.7 & $(0.40)$ & 3.9 & $(0.34)$ & 4.9 & $(0.46)$ & 6.1 & $(0.47)$ & 3.9 & $(0.45)$ & 3.9 & $(0.42)$ \\
\hline Female .............. & 8.5 & $(0.46)$ & 4.6 & $(0.39)$ & 4.6 & $(0.35)$ & 4.1 & $(0.37)$ & 4.1 & $(0.40)$ & 5.5 & $(0.41)$ & 4.0 & $(0.42)$ & 5.5 & $(0.40)$ \\
\hline \multicolumn{17}{|l|}{ Race/ethnicity ${ }^{2}$} \\
\hline White .................. & 7.1 & $(0.32)$ & 3.8 & $(0.27)$ & 3.9 & $(0.30)$ & 3.0 & $(0.27)$ & 3.6 & $(0.30)$ & 5.3 & $(0.36)$ & 3.3 & $(0.38)$ & 4.4 & $(0.38)$ \\
\hline Black .............. & 12.1 & (1.01) & 6.7 & $(0.90)$ & 6.6 & $(0.75)$ & 5.1 & $(0.79)$ & 7.2 & $(0.98)$ & 8.3 & $(1.02)$ & 6.1 & $(1.04)$ & 4.5 & $(0.80)$ \\
\hline 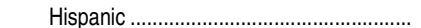 & 12.9 & $(0.97)$ & 6.2 & $(0.73)$ & 5.5 & $(0.71)$ & 6.3 & $(0.70)$ & 6.0 & $(0.80)$ & 6.8 & $(0.82)$ & 4.8 & $(0.86)$ & 6.0 & $(0.68)$ \\
\hline Asian & - & $(\dagger)$ & - & $(\dagger)$ & - & $(\dagger)$ & - & $(t)$ & $2.5 !$ & $(0.87)$ & $\ddagger$ & $(\dagger)$ & $3.7 !$ & $(1.53)$ & 2.7 & $(1.06)$ \\
\hline \multirow{2}{*}{\multicolumn{17}{|c|}{ Grade }} \\
\hline & & & & & & & & & & & & & & & & \\
\hline 6 th ... & 11.6 & $(0.99)$ & 5.9 & $(0.92)$ & 6.8 & $(0.93)$ & 5.6 & $(0.94)$ & 7.9 & $(1.27)$ & 7.8 & $(1.20)$ & 7.1 & $(1.13)$ & 6.9 & $(0.99)$ \\
\hline 7th & 11.8 & $(0.89)$ & 6.1 & $(0.72)$ & 6.2 & $(0.79)$ & 5.7 & $(0.73)$ & 5.8 & $(0.93)$ & 7.5 & $(0.86)$ & 5.5 & $(0.86)$ & 5.1 & $(0.76)$ \\
\hline 8th & 8.8 & $(0.77)$ & 5.5 & $(0.70)$ & 5.2 & $(0.62)$ & 4.7 & $(0.63)$ & 4.5 & $(0.67)$ & 5.9 & $(0.84)$ & 4.8 & $(0.93)$ & 5.2 & $(0.75)$ \\
\hline 9th & 9.5 & $(0.71)$ & 5.3 & $(0.63)$ & 5.0 & $(0.61)$ & 5.1 & $(0.62)$ & 5.2 & $(0.78)$ & 6.7 & $(0.81)$ & 4.5 & $(0.89)$ & 3.7 & $(0.67)$ \\
\hline 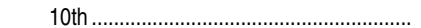 & 7.8 & $(0.75)$ & 4.7 & $(0.61)$ & 4.2 & $(0.64)$ & 3.1 & $(0.54)$ & 4.2 & $(0.65)$ & 5.5 & $(0.80)$ & 4.2 & $(0.88)$ & 5.4 & $(0.72)$ \\
\hline 11th & 6.9 & $(0.64)$ & 2.5 & $(0.46)$ & 2.8 & $(0.43)$ & 2.5 & $(0.53)$ & 3.3 & $(0.58)$ & 4.2 & $(0.70)$ & $1.2 !$ & $(0.44)$ & 3.6 & $(0.65)$ \\
\hline 12th .................. & 4.1 & $(0.74)$ & 2.4 & $(0.51)$ & 3.0 & $(0.64)$ & $1.2 !$ & $(0.41)$ & $1.3 !$ & $(0.41)$ & 3.2 & $(0.71)$ & $1.6 !$ & $(0.50)$ & 3.7 & $(0.71)$ \\
\hline \multicolumn{17}{|l|}{ Urbanicity ${ }^{3}$} \\
\hline Urban ....... & 11.7 & $(0.73)$ & 5.8 & $(0.48)$ & 6.0 & $(0.52)$ & 5.7 & $(0.59)$ & 6.3 & $(0.67)$ & 6.1 & $(0.65)$ & 5.5 & $(0.69)$ & 5.3 & $(0.61)$ \\
\hline Suburban....... & 7.9 & $(0.40)$ & 4.7 & $(0.38)$ & 4.3 & $(0.38)$ & 3.5 & $(0.30)$ & 3.8 & $(0.36)$ & 5.2 & $(0.38)$ & 3.1 & $(0.38)$ & 4.6 & $(0.36)$ \\
\hline Rural.................... & 7.0 & $(0.65)$ & 3.0 & $(0.56)$ & 3.9 & $(0.70)$ & 2.8 & $(0.53)$ & 4.2 & $(0.74)$ & 6.9 & $(0.69)$ & 4.3 & $(0.80)$ & 3.5 & $(0.54)$ \\
\hline \multicolumn{17}{|l|}{ School control } \\
\hline 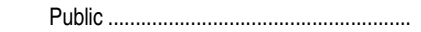 & 9.3 & $(0.33)$ & 5.0 & $(0.31)$ & 4.9 & $(0.29)$ & 4.2 & $(0.29)$ & 4.8 & $(0.30)$ & 6.2 & $(0.35)$ & 4.2 & $(0.34)$ & 4.9 & $(0.32)$ \\
\hline Private & 2.2 & $(0.47)$ & 1.6 & $(0.45)$ & $2.0 !$ & $(0.69)$ & $1.5 !$ & $(0.49)$ & $1.4 !$ & $(0.55)$ & $1.4 !$ & $(0.54)$ & $1.8 !$ & $(0.73)$ & $2.1 !$ & $(0.70)$ \\
\hline \multicolumn{17}{|l|}{ Avoided school activities or classes } \\
\hline Total & - & $(\dagger)$ & 3.2 & $(0.22)$ & 2.3 & $(0.18)$ & 1.9 & $(0.18)$ & 2.1 & $(0.23)$ & 2.6 & $(0.23)$ & 2.1 & $(0.25)$ & 2.0 & $(0.20)$ \\
\hline 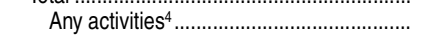 & 1.7 & $(0.15)$ & 0.8 & $(0.10)$ & 1.1 & $(0.12)$ & 1.0 & $(0.11)$ & 1.0 & $(0.16)$ & 1.8 & $(0.20)$ & 1.3 & $(0.20)$ & 1.2 & $(0.16)$ \\
\hline 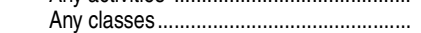 & - & $(\dagger)$ & 0.6 & $(0.09)$ & 0.6 & $(0.09)$ & 0.6 & $(0.10)$ & 0.7 & $(0.13)$ & 0.7 & $(0.12)$ & 0.6 & $(0.13)$ & 0.7 & $(0.10)$ \\
\hline 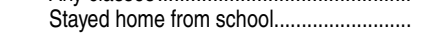 & - & $(\dagger)$ & 2.3 & $(0.19)$ & 1.1 & $(0.13)$ & 0.8 & $(0.11)$ & 0.7 & $(0.11)$ & 0.8 & $(0.13)$ & 0.6 & $(0.14)$ & 0.8 & $(0.12)$ \\
\hline
\end{tabular}

-Not available.

†Not applicable.

!Interpret data with caution. The coefficient of variation (CV) for this estimate is between 30 and 50 percent.

$\ddagger$ Reporting standards not met. Either there are too few cases for a reliable estimate or the coefficient of variation (CV) is 50 percent or greater.

'Starting in 2007, the reference period was the school year, whereas in prior survey years the reference period was the previous 6 months. Cognitive testing showed that estimates from 2007 onward are comparable to previous years.

"Race categories exclude persons of Hispanic ethnicity. "Other" includes American Indians/ Alaska Natives, Asians (prior to 2005), Pacific Islanders, and, from 2003 onward, persons reporting that they are of two or more races. Due to changes in racial/ethnic categories, comparisons of race/ethnicity across years should be made with caution.
${ }^{3}$ Refers to the Standard Metropolitan Statistical Area (MSA) status of the respondent's house hold as defined in 2000 by the U.S. Census Bureau. Categories include "central city of an MSA (Urban)," "in MSA but not in central city (Suburban)," and "not MSA (Rural)."

"Before 2007, students were asked whether they avoided "any extracurricular activities." Starting in 2007, the survey wording was changed to "any activities."

NOTE: Students were asked whether they avoided places or activities because they thought that someone might attack or harm them. For the 2001 survey only, the wording was changed from "attack or harm" to "attack or threaten to attack." Detail may not sum to totals because of rounding and because a student who reported more than one type of avoidance was counted only once in the totals.

SOURCE: U.S. Department of Justice, Bureau of Justice Statistics, School Crime Supplement (SCS) to the National Crime Victimization Survey, selected years, 1995 through 2011. (This table was prepared September 2013.) 


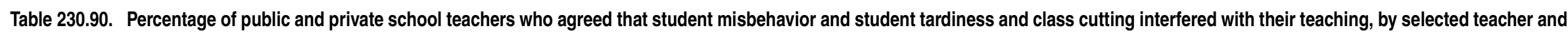
school characteristics: Selected years, 1987-88 through 2011-12

[Standard errors appear in parentheses]

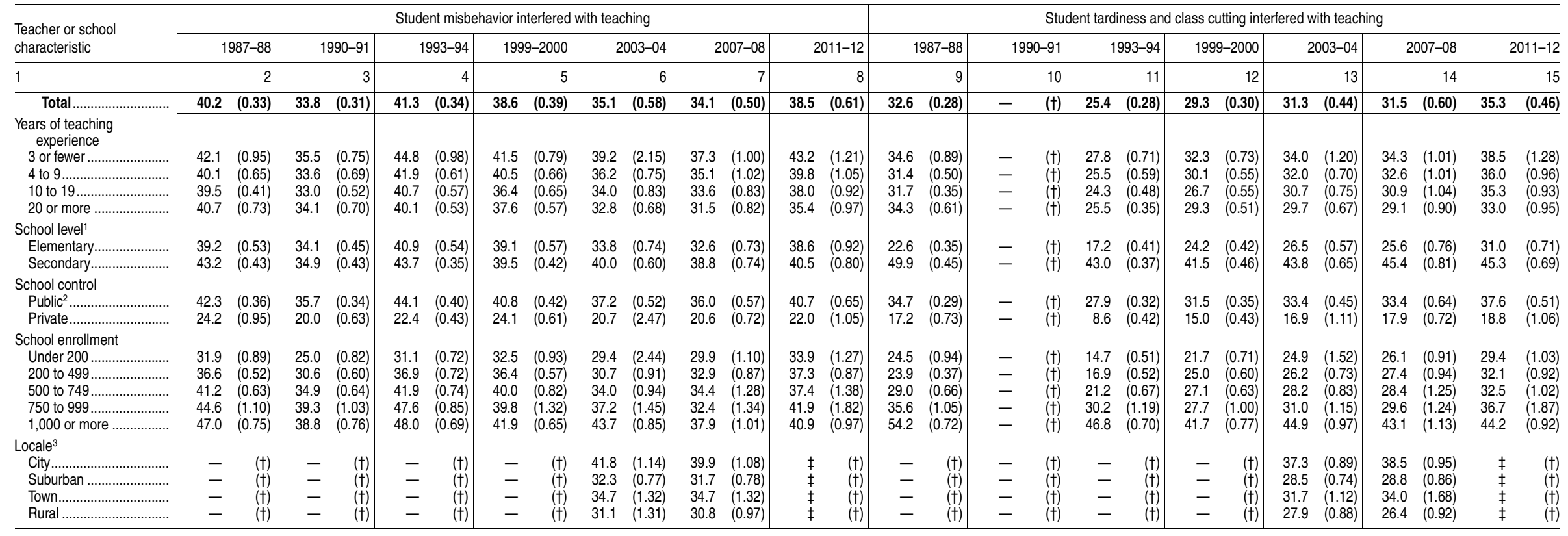

\section{-Not available.}

‡Reporting standards not met. Data may be suppressed because the response rate is under 50 percent, there are too few cases tor a reliable estimate, or the coefficient of variation (CV) is 50 percent or greater.

'Elementary schools are those with any of grades kindergarten through grade 6 and none of grades 9 through 12. Secondary schools have any of grades 7 through 12 and none of grades kindergarten through grade 6. Combined elementary/secondary 2Includes traditional public and public charter schools.
${ }^{3}$ Substantial improvements in geocoding technology and changes in the Office of Management and Budget's definition of metropolitan and nonm
are not possible.

NOTE: Teachers who taught only prekindergarten students are excluded. Includes both teachers who "strongly" agreed and those who "somewhat" agreed that student misbehavior or student tardiness and class cutting interfered with their teaching. Some data have been revised from previously published figures.

School 2007-08, and 2011-12; and "Charter School Teacher Data File" 1999-2000. (This table was prepared October 2013) 


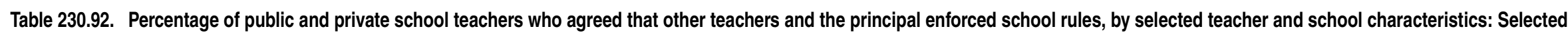
years, 1987-88 through 2011-12

[Standard errors appear in parentheses]

\begin{tabular}{|c|c|c|c|c|c|c|c|c|c|c|c|c|c|c|c|c|c|c|c|c|c|c|c|c|c|c|c|c|}
\hline \multirow{2}{*}{$\begin{array}{l}\text { Teacher or school } \\
\text { characteristic }\end{array}$} & \multicolumn{14}{|c|}{ Other teachers enforced school rules 1} & \multicolumn{14}{|c|}{ Principal enforced school rules ${ }^{2}$} \\
\hline & \multicolumn{2}{|c|}{$1987-88$} & \multicolumn{2}{|c|}{$1990-91$} & \multicolumn{2}{|c|}{$1993-94$} & \multicolumn{2}{|c|}{$1999-2000$} & \multicolumn{2}{|c|}{ 2003-04 } & \multicolumn{2}{|c|}{$2007-08$} & \multicolumn{2}{|c|}{$2011-12$} & \multicolumn{2}{|c|}{$1987-88$} & \multicolumn{2}{|c|}{$1990-91$} & \multicolumn{2}{|c|}{ 1993-94 } & \multicolumn{2}{|c|}{$1999-2000$} & \multicolumn{2}{|c|}{$2003-04$} & \multicolumn{2}{|c|}{$2007-08$} & \multicolumn{2}{|c|}{$2011-12$} \\
\hline 1 & & 2 & & 3 & & 4 & & 5 & & 6 & & 7 & & 8 & & 9 & & 10 & & 11 & & 12 & & 13 & & 14 & & 15 \\
\hline Total ........ & 1 & $\begin{array}{l}(0.30) \\
\end{array}$ & 73.4 & $\begin{array}{l}(0.34) \\
\end{array}$ & 8 & $\begin{array}{l}(0.36) \\
\end{array}$ & 4 & $(0.35)$ & 4 & $(0.41)$ & 1.8 & $(0.47)$ & 8 & $(0.48)$ & 3.7 & $\begin{array}{l}(0.22) \\
\end{array}$ & 7.4 & $(0.26)$ & 81.8 & $\begin{array}{l}(0.31) \\
\end{array}$ & 83.0 & $(0.28)$ & 87.8 & $(0.30)$ & 88.5 & $\begin{array}{l}0.34) \\
\end{array}$ & 84.4 & $(0.41)$ \\
\hline 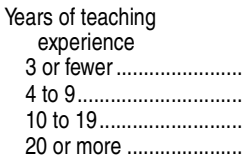 & $\begin{array}{l}68.6 \\
65.3 \\
64.3 \\
64.9\end{array}$ & $\begin{array}{l}(0.93) \\
(0.71) \\
(0.49) \\
(0.58)\end{array}$ & $\begin{array}{l}76.1 \\
72.7 \\
72.9 \\
73.5\end{array}$ & $\begin{array}{l}(0.88) \\
(0.69) \\
(0.48) \\
(0.57)\end{array}$ & $\begin{array}{l}68.8 \\
63.0 \\
63.1 \\
63.1\end{array}$ & $\begin{array}{l}(0.92) \\
(0.78) \\
(0.55) \\
(0.58)\end{array}$ & $\begin{array}{l}69.4 \\
61.6 \\
64.6 \\
63.6\end{array}$ & $\begin{array}{l}(0.71) \\
(0.62) \\
(0.65) \\
(0.59)\end{array}$ & $\begin{array}{l}76.6 \\
70.6 \\
71.4 \\
72.5\end{array}$ & $\begin{array}{l}(0.91) \\
(0.70) \\
(0.76) \\
(0.64)\end{array}$ & $\begin{array}{l}73.6 \\
69.5 \\
71.0 \\
73.8\end{array}$ & $\begin{array}{l}(1.07) \\
(0.88) \\
(0.73) \\
(0.80)\end{array}$ & $\begin{array}{l}70.2 \\
66.6 \\
68.3 \\
71.1\end{array}$ & $\begin{array}{l}(1.27) \\
(0.88) \\
(0.86) \\
(0.84)\end{array}$ & $\begin{array}{l}85.0 \\
84.1 \\
83.9 \\
82.8\end{array}$ & $\begin{array}{l}(0.52) \\
(0.45) \\
(0.35) \\
(0.56)\end{array}$ & $\begin{array}{l}88.1 \\
87.4 \\
87.5 \\
86.9\end{array}$ & $\begin{array}{l}(0.49) \\
(0.55) \\
(0.43) \\
(0.41)\end{array}$ & $\begin{array}{l}85.1 \\
80.7 \\
82.4 \\
80.6\end{array}$ & & $\begin{array}{l}84.5 \\
82.7 \\
83.1 \\
82.4\end{array}$ & & $\begin{array}{l}88.6 \\
86.9 \\
87.8 \\
88.3\end{array}$ & $\begin{array}{l}(0.66) \\
(0.57) \\
(0.53) \\
(0.43)\end{array}$ & $\begin{array}{l}89.9 \\
88.2 \\
87.2 \\
89.4\end{array}$ & $\begin{array}{l}(0.68) \\
(0.61) \\
(0.62) \\
(0.55)\end{array}$ & $\begin{array}{l}86.6 \\
84.6 \\
82.3 \\
85.9\end{array}$ & $\begin{array}{l}(1.15) \\
(0.72) \\
(0.74) \\
(0.79)\end{array}$ \\
\hline 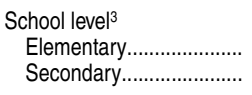 & $\begin{array}{l}74.2 \\
49.9\end{array}$ & $\begin{array}{l}(0.41) \\
(0.60)\end{array}$ & $\begin{array}{l}80.5 \\
60.2\end{array}$ & $\begin{array}{l}(0.52) \\
(0.43)\end{array}$ & $\begin{array}{l}72.2 \\
47.0\end{array}$ & $\begin{array}{l}(0.48) \\
(0.34)\end{array}$ & $\begin{array}{l}72.2 \\
47.2\end{array}$ & $(0.2$ & $\begin{array}{l}79.5 \\
55.7\end{array}$ & $\begin{array}{l}(0.54) \\
(0.55)\end{array}$ & .4 & $\begin{array}{l}(0.61) \\
(0.64)\end{array}$ & $\begin{array}{l}5.6 \\
4.4\end{array}$ & $\begin{array}{l}(0.71) \\
(0.69)\end{array}$ & $\begin{array}{l}85.1 \\
81.5\end{array}$ & $\begin{array}{l}.36) \\
.37)\end{array}$ & $\begin{array}{l}88.0 \\
85.8\end{array}$ & $\begin{array}{l}41) \\
37)\end{array}$ & $\begin{array}{l}82.8 \\
79.0\end{array}$ & & $\begin{array}{l}84.2 \\
80.0\end{array}$ & & $\begin{array}{l}88.3 \\
86.2\end{array}$ & 5) & $\begin{array}{l}9.5 \\
6.3\end{array}$ & $\begin{array}{l}(0.44) \\
(0.48)\end{array}$ & 5.0 & $\begin{array}{l}.60) \\
.56)\end{array}$ \\
\hline $\begin{array}{l}\text { School control } \\
\text { Public } \ldots . \ldots \ldots \ldots . . . . \\
\text { Private............... }\end{array}$ & $\begin{array}{l}63.8 \\
75.4\end{array}$ & $\begin{array}{l}(0.31) \\
(0.98)\end{array}$ & $\begin{array}{l}71.9 \\
84.3\end{array}$ & $\begin{array}{l}(0.36) \\
(0.61)\end{array}$ & $\begin{array}{l}61.8 \\
77.6\end{array}$ & $\begin{array}{l}(0.42) \\
(0.50)\end{array}$ & $\begin{array}{l}62.6 \\
75.9\end{array}$ & $\begin{array}{l}(0.39) \\
(0.51)\end{array}$ & $\begin{array}{l}71.1 \\
81.0\end{array}$ & $\begin{array}{l}(0.46) \\
(1.52)\end{array}$ & $\begin{array}{l}70.6 \\
80.1\end{array}$ & $\begin{array}{l}(0.55) \\
(0.81)\end{array}$ & $\begin{array}{l}67.6 \\
77.4\end{array}$ & $\begin{array}{l}(0.51) \\
(1.49)\end{array}$ & $\begin{array}{l}83.1 \\
88.6\end{array}$ & $\begin{array}{l}(0.22) \\
(0.57)\end{array}$ & $\begin{array}{l}86.7 \\
92.0\end{array}$ & $\begin{array}{l}(0.29) \\
(0.42)\end{array}$ & $\begin{array}{l}80.8 \\
88.4\end{array}$ & & $\begin{array}{l}82.2 \\
88.3\end{array}$ & $(0.09)$ & $\begin{array}{l}87.2 \\
92.2\end{array}$ & $(0.15)$ & $\begin{array}{l}88.0 \\
92.2\end{array}$ & $\left.\begin{array}{l}(0.37) \\
(0.57)\end{array}\right]$ & $\begin{array}{l}83.7 \\
89.4\end{array}$ & $\begin{array}{l}(0.43) \\
(0.98)\end{array}$ \\
\hline $\begin{array}{l}500 \text { to } \\
750 \text { to } \\
1,000\end{array}$ & $\begin{array}{l}76.1 \\
72.6 \\
66.6 \\
59.8 \\
48.1\end{array}$ & $\begin{array}{l}(0.90) \\
(0.42) \\
(0.74) \\
(1.00) \\
(0.89)\end{array}$ & $\begin{array}{l}83.7 \\
79.4 \\
75.8 \\
68.5 \\
57.5\end{array}$ & $\begin{array}{l}(0.60) \\
(0.55) \\
(0.74) \\
(1.01) \\
(0.67)\end{array}$ & $\begin{array}{l}76.5 \\
71.2 \\
66.8 \\
58.6 \\
45.8\end{array}$ & $\begin{array}{l}(0.04) \\
(0.65) \\
(1.10) \\
(0.77)\end{array}$ & $\begin{array}{l}75.4 \\
71.6 \\
67.7 \\
63.0 \\
47.3\end{array}$ & $\begin{array}{l}(0.58) \\
(0.66) \\
(0.97) \\
(0.75)\end{array}$ & $\begin{array}{l}84.0 \\
78.9 \\
75.8 \\
69.4 \\
56.3\end{array}$ & $\begin{array}{l}(1.54) \\
(0.62) \\
(0.68) \\
(1.32) \\
(0.88)\end{array}$ & $\begin{array}{l}78.6 \\
74.1 \\
71.7 \\
57.1\end{array}$ & $\begin{array}{l}(0.85) \\
(0.71) \\
(1.04) \\
(1.50) \\
(1.17)\end{array}$ & $\begin{array}{l}78.7 \\
74.2 \\
72.2 \\
66.0 \\
55.4\end{array}$ & $\begin{array}{l}(1.00) \\
(1.06) \\
(1.33) \\
(1.04)\end{array}$ & $\begin{array}{l}86.6 \\
84.6 \\
84.4 \\
83.0 \\
80.7\end{array}$ & $\begin{array}{l}(0.54) \\
(0.38) \\
(0.55) \\
(0.80) \\
(0.62)\end{array}$ & $\begin{array}{l}89.3 \\
88.1 \\
88.5 \\
85.7 \\
84.9\end{array}$ & $\begin{array}{l}(0.42) \\
(0.53) \\
(0.81) \\
(0.66)\end{array}$ & $\begin{array}{l}85.2 \\
83.5 \\
82.3 \\
79.6 \\
78.0\end{array}$ & $\begin{array}{l}(0.61) \\
(0.47) \\
(0.76) \\
(0.87) \\
(0.58)\end{array}$ & $\begin{array}{l}84.2 \\
83.5 \\
82.5 \\
79.4\end{array}$ & $\begin{array}{l}(0.55) \\
(0.83) \\
(0.57)\end{array}$ & $\begin{array}{l}89.3 \\
87.7 \\
86.0 \\
85.8\end{array}$ & $\begin{array}{l}(0.48) \\
(0.66) \\
(1.14) \\
(0.63)\end{array}$ & $\begin{array}{l}90.8 \\
89.4 \\
88.6 \\
88.4 \\
86.5\end{array}$ & $\begin{array}{l}(0.60) \\
(0.60) \\
(0.68) \\
(0.89) \\
(0.73)\end{array}$ & $\begin{array}{l}88.7 \\
84.7 \\
85.2 \\
82.7 \\
82.3\end{array}$ & $\begin{array}{l}(1.30) \\
(0.81)\end{array}$ \\
\hline 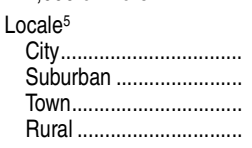 & $\begin{array}{l}- \\
\overline{-} \\
-\end{array}$ & $\begin{array}{l}(t) \\
(+) \\
(t) \\
(t)\end{array}$ & $\begin{array}{l}- \\
\overline{-} \\
-\end{array}$ & $\begin{array}{l}(t) \\
(t) \\
(t)\end{array}$ & $\begin{array}{l}- \\
\overline{-} \\
-\end{array}$ & $\begin{array}{l}(t) \\
(t) \\
(t)\end{array}$ & $\begin{array}{l}- \\
- \\
-\end{array}$ & $\begin{array}{l}(T) \\
(t) \\
(t)\end{array}$ & $\begin{array}{l}73.5 \\
72.4 \\
74.3\end{array}$ & $\begin{array}{l}(0.86) \\
(0.70) \\
(1.03) \\
(0.74)\end{array}$ & $\begin{array}{l}72.6 \\
71.7 \\
73.6\end{array}$ & $\begin{array}{l}(0.98) \\
(0.76) \\
(1.32) \\
(0.81)\end{array}$ & $\begin{array}{l}\ddagger \\
\ddagger \\
\ddagger \\
\ddagger\end{array}$ & $\begin{array}{l}(\dagger) \\
(\dagger)\end{array}$ & $\begin{array}{l}- \\
\overline{-} \\
-\end{array}$ & $\begin{array}{l}(t) \\
(t)\end{array}$ & $\begin{array}{l}- \\
= \\
-\end{array}$ & $\begin{array}{c}(t) \\
(t)\end{array}$ & $\begin{array}{l}- \\
\overline{-} \\
-\end{array}$ & (I) & $\begin{array}{l}- \\
\overline{-} \\
-\end{array}$ & (II) & $\begin{array}{l}89.1 \\
88.9 \\
88.5\end{array}$ & & $\begin{array}{l}89.7 \\
87.5 \\
89.5\end{array}$ & $\begin{array}{l}(0.53) \\
(1.26) \\
(0.58)\end{array}$ & & (†) \\
\hline
\end{tabular}

\section{-Not available.}

fReporting standards not met. Data may be suppressed because the response rate is under 50 percent, there are too few cases

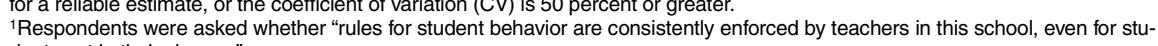
dents not in their classes."

ether their "principal enforces school rules for student conduct and backs me up when I need it." ${ }^{3}$ Elementary schools are those with any of grades kindergarten through grade 6 and none of grades 9 through 12 . Secondary
schools have any of grades 7 through 12 and none of grades kindergarten through grade 6 . Combined elementary/secondary schools are included in totals but are not shown separately.

${ }^{4}$ Includes traditional public and public charter schools.

${ }^{5}$ Substantial improvements in geocoding technology and changes in the Office of Management and Budget's definition of metropolitan and nonmetropolitan areas allow for more precision in describing an area as of 2003-04. Comparisons with earlier years

are not possible.
NOTE: Teachers who taught only prekindergarten students are excluded. Includes both teachers who "strongly" agreed and those who "somewhat" agreed that rules were enforced by other teachers and the principal. Some data have been revised from SOURCE: US Ded figures.

School Teacher Data File" of Education, National Center for Education Statistics, Schools and Staffing Survey (SASS), "Public 2007-08, and 2011-12; and "Charter School Teacher Data File," 1999-2000. (This table was prepared October 2013.) 
Table 230.95. Percentage of public school teachers who agreed that student misbehavior and student tardiness and class cutting interfered with their teaching and that other teachers and the principal enforced school rules, by state: 2011-12

[Standard errors appear in parentheses]

\begin{tabular}{|c|c|c|c|c|c|c|c|c|}
\hline \multirow[b]{2}{*}{ State } & \multicolumn{4}{|c|}{ Interfered with teaching } & \multicolumn{4}{|c|}{ Enforced school rules } \\
\hline & \multicolumn{2}{|c|}{ Student misbehavior } & \multicolumn{2}{|c|}{ Student tardiness and class cutting } & \multicolumn{2}{|c|}{ Other teachers ${ }^{1}$} & \multicolumn{2}{|r|}{ Principal $^{2}$} \\
\hline 1 & & 2 & & 3 & & 4 & & 5 \\
\hline United States .................... & 40.7 & $(0.65)$ & 37.6 & $(0.51)$ & 67.6 & $(0.51)$ & 83.7 & $(0.43)$ \\
\hline 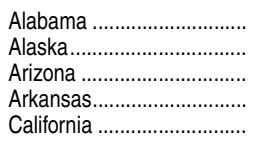 & $\begin{array}{l}40.9 \\
35.8 \\
41.3 \\
39.5 \\
38.9\end{array}$ & $\begin{array}{l}(3.36) \\
(5.73) \\
(2.56) \\
(3.56) \\
(2.47)\end{array}$ & $\begin{array}{l}38.6 \\
56.8 \\
44.5 \\
38.5 \\
39.7\end{array}$ & $\begin{array}{l}(2.82) \\
(6.73) \\
(2.67) \\
(3.80) \\
(2.36)\end{array}$ & $\begin{array}{l}71.8 \\
72.2 \\
67.9 \\
74.0 \\
69.7\end{array}$ & $\begin{array}{l}(2.84) \\
(4.41) \\
(2.72) \\
(2.60) \\
(1.83)\end{array}$ & $\begin{array}{l}86.8 \\
83.2 \\
83.4 \\
90.0 \\
83.0\end{array}$ & $\begin{array}{l}(2.26) \\
(5.16) \\
(2.06) \\
(2.16) \\
(1.63)\end{array}$ \\
\hline 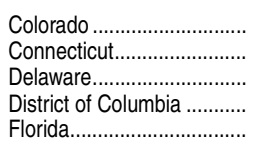 & $\begin{array}{r}45.5 \\
37.2 \\
46.7 \\
\ddagger \\
\ddagger\end{array}$ & $\begin{array}{r}(3.54) \\
(2.35) \\
(4.47) \\
(\dagger) \\
(\dagger)\end{array}$ & $\begin{array}{r}47.6 \\
28.6 \\
35.2 \\
\ddagger \\
\ddagger\end{array}$ & $\begin{array}{r}(4.02) \\
(3.81) \\
(4.58) \\
(\dagger) \\
(\dagger)\end{array}$ & $\begin{array}{r}61.7 \\
61.7 \\
68.7 \\
\ddagger \\
\ddagger\end{array}$ & $\begin{array}{r}(3.39) \\
(3.91) \\
(3.58) \\
(\dagger) \\
(\dagger)\end{array}$ & $\begin{array}{r}80.6 \\
80.7 \\
82.9 \\
\ddagger \\
\ddagger\end{array}$ & $\begin{array}{r}(3.28) \\
(2.98) \\
(3.32) \\
(\dagger) \\
(\dagger)\end{array}$ \\
\hline 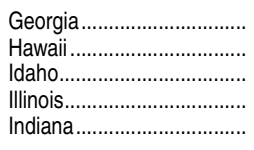 & $\begin{array}{r}38.2 \\
\ddagger \\
34.6 \\
40.0 \\
38.8\end{array}$ & $\begin{array}{r}(3.56) \\
(\dagger) \\
(3.54) \\
(2.96) \\
(3.33)\end{array}$ & $\begin{array}{r}32.1 \\
\ddagger \\
36.1 \\
33.9 \\
41.0\end{array}$ & $\begin{array}{r}(3.36) \\
(\dagger) \\
(3.08) \\
(3.07) \\
(2.95)\end{array}$ & $\begin{array}{r}71.9 \\
\ddagger \\
74.7 \\
66.0 \\
68.4\end{array}$ & $\begin{array}{r}(2.64) \\
(\dagger) \\
(2.48) \\
(3.18) \\
(2.47)\end{array}$ & $\begin{array}{r}85.5 \\
\ddagger \\
87.9 \\
83.6 \\
81.8\end{array}$ & $\begin{array}{r}(2.29) \\
(\dagger) \\
(2.18) \\
(2.31) \\
(2.99)\end{array}$ \\
\hline 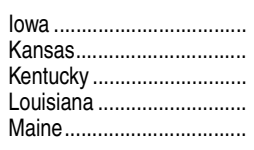 & $\begin{array}{l}37.9 \\
32.0 \\
42.8 \\
55.1 \\
39.1\end{array}$ & $\begin{array}{l}(3.12) \\
(3.57) \\
(3.06) \\
(3.92) \\
(3.00)\end{array}$ & $\begin{array}{l}34.6 \\
24.9 \\
32.8 \\
36.1 \\
39.2\end{array}$ & $\begin{array}{l}(3.18) \\
(2.34) \\
(2.92) \\
(3.60) \\
(3.02)\end{array}$ & $\begin{array}{l}68.5 \\
70.9 \\
67.4 \\
62.5 \\
62.9\end{array}$ & $\begin{array}{l}(2.77) \\
(3.29) \\
(2.80) \\
(3.19) \\
(2.90)\end{array}$ & $\begin{array}{l}81.8 \\
91.8 \\
86.9 \\
82.1 \\
83.2\end{array}$ & $\begin{array}{l}(2.40) \\
(1.61) \\
(2.47) \\
(3.89) \\
(3.06)\end{array}$ \\
\hline 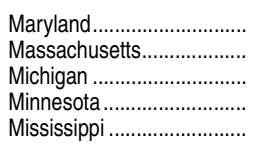 & $\begin{array}{r}\ddagger \\
37.2 \\
46.6 \\
43.7 \\
37.4\end{array}$ & $\begin{array}{r}(\dagger) \\
(3.07) \\
(2.87) \\
(2.49) \\
(3.30)\end{array}$ & $\begin{array}{r}\ddagger \\
32.0 \\
40.9 \\
37.3 \\
35.6\end{array}$ & $\begin{array}{r}(\dagger) \\
(2.74) \\
(2.63) \\
(2.50) \\
(3.40)\end{array}$ & $\begin{array}{r}\ddagger \\
66.6 \\
67.6 \\
68.7 \\
72.4\end{array}$ & $\begin{array}{r}(t) \\
(3.04) \\
(2.12) \\
(1.88) \\
(2.96)\end{array}$ & $\begin{array}{r}\ddagger \\
83.1 \\
84.4 \\
84.5 \\
84.5\end{array}$ & $\begin{array}{r}(\dagger) \\
(2.80) \\
(2.08) \\
(1.84) \\
(2.51)\end{array}$ \\
\hline 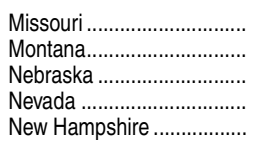 & $\begin{array}{l}33.2 \\
41.3 \\
38.2 \\
45.5 \\
38.3\end{array}$ & $\begin{array}{l}(2.10) \\
(3.43) \\
(3.01) \\
(3.77) \\
(4.36)\end{array}$ & $\begin{array}{l}33.6 \\
45.3 \\
33.6 \\
42.3 \\
30.9\end{array}$ & $\begin{array}{l}(2.87) \\
(4.08) \\
(2.81) \\
(4.86) \\
(3.11)\end{array}$ & $\begin{array}{l}68.9 \\
66.5 \\
70.9 \\
65.5 \\
62.0\end{array}$ & $\begin{array}{l}(2.17) \\
(3.65) \\
(2.73) \\
(3.42) \\
(3.93)\end{array}$ & $\begin{array}{l}86.6 \\
83.1 \\
86.7 \\
79.3 \\
83.2\end{array}$ & $\begin{array}{l}(1.76) \\
(2.97) \\
(1.66) \\
(3.22) \\
(2.66)\end{array}$ \\
\hline $\begin{array}{l}\text { New Jersey ...................... } \\
\text { New Mexico ...................... } \\
\text { New York...................... } \\
\text { North Carolina .................. } \\
\text { North Dakota .................... }\end{array}$ & $\begin{array}{l}35.9 \\
39.0 \\
40.3 \\
41.9 \\
34.6\end{array}$ & $\begin{array}{l}(2.36) \\
(4.55) \\
(2.91) \\
(3.13) \\
(3.26)\end{array}$ & $\begin{array}{l}29.9 \\
54.5 \\
45.3 \\
37.0 \\
33.5\end{array}$ & $\begin{array}{l}(2.29) \\
(5.87) \\
(3.06) \\
(2.94) \\
(3.52)\end{array}$ & $\begin{array}{l}66.8 \\
64.2 \\
65.9 \\
69.0 \\
70.4\end{array}$ & $\begin{array}{l}(2.06) \\
(3.80) \\
(2.47) \\
(2.58) \\
(2.77)\end{array}$ & $\begin{array}{l}84.4 \\
78.7 \\
80.7 \\
84.0 \\
86.7\end{array}$ & $\begin{array}{l}(1.70) \\
(4.23) \\
(2.46) \\
(2.34) \\
(2.45)\end{array}$ \\
\hline 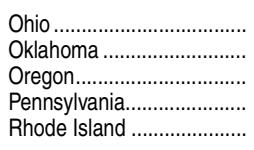 & $\begin{array}{r}41.8 \\
40.1 \\
33.1 \\
40.0 \\
\ddagger\end{array}$ & $\begin{array}{r}(1.95) \\
(2.74) \\
(3.24) \\
(2.64) \\
(\dagger)\end{array}$ & $\begin{array}{r}38.8 \\
40.8 \\
35.6 \\
33.4 \\
\ddagger\end{array}$ & $\begin{array}{r}(1.96) \\
(2.87) \\
(3.73) \\
(2.55) \\
(\dagger)\end{array}$ & $\begin{array}{r}66.4 \\
72.5 \\
77.3 \\
65.2 \\
\ddagger\end{array}$ & $\begin{array}{r}(1.73) \\
(2.47) \\
(2.90) \\
(2.18) \\
(\dagger)\end{array}$ & $\begin{array}{r}84.7 \\
86.5 \\
88.1 \\
82.5 \\
\ddagger\end{array}$ & $\begin{array}{r}(1.55) \\
(2.12) \\
(1.77) \\
(1.88) \\
(\dagger)\end{array}$ \\
\hline $\begin{array}{l}\text { South Carolina................ } \\
\text { South Dakota ................... } \\
\text { Tennessee ...................... } \\
\text { Texas }\end{array}$ & $\begin{array}{l}40.9 \\
40.1 \\
41.5 \\
45.6 \\
39.7\end{array}$ & $\begin{array}{l}(3.22) \\
(3.10) \\
(3.56) \\
(2.29) \\
(3.67)\end{array}$ & $\begin{array}{l}33.7 \\
37.2 \\
40.0 \\
35.1 \\
45.1\end{array}$ & $\begin{array}{l}(3.40) \\
(3.92) \\
(3.56) \\
(2.13) \\
(4.30)\end{array}$ & $\begin{array}{l}71.8 \\
73.2 \\
71.4 \\
65.8 \\
75.8\end{array}$ & $\begin{array}{l}(3.23) \\
(2.91) \\
(3.14) \\
(2.56) \\
(3.56)\end{array}$ & $\begin{array}{l}86.8 \\
84.8 \\
88.7 \\
81.8 \\
89.9\end{array}$ & $\begin{array}{l}(2.15) \\
(2.53) \\
(2.14) \\
(1.99) \\
(2.27)\end{array}$ \\
\hline 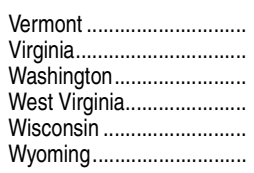 & $\begin{array}{l}39.9 \\
40.8 \\
39.2 \\
43.9 \\
42.7 \\
30.7\end{array}$ & $\begin{array}{l}(2.61) \\
(3.46) \\
(2.89) \\
(3.87) \\
(2.70) \\
(4.76)\end{array}$ & $\begin{array}{l}36.2 \\
35.6 \\
39.5 \\
42.4 \\
34.2 \\
40.0\end{array}$ & $\begin{array}{l}(2.62) \\
(3.06) \\
(3.16) \\
(4.09) \\
(3.07) \\
(4.78)\end{array}$ & $\begin{array}{l}59.2 \\
64.9 \\
73.1 \\
73.4 \\
69.5 \\
73.9\end{array}$ & $\begin{array}{l}(2.59) \\
(2.87) \\
(2.60) \\
(2.90) \\
(2.87) \\
(3.55)\end{array}$ & $\begin{array}{l}80.5 \\
82.5 \\
85.6 \\
90.4 \\
85.8 \\
89.1\end{array}$ & $\begin{array}{l}(2.28) \\
(2.52 \\
(2.18) \\
(2.58) \\
(1.70) \\
(3.41)\end{array}$ \\
\hline
\end{tabular}

†Not applicable.

†Reporting standards not met. Data may be suppressed because the response rate is under 50 percent, there are too few cases for a reliable estimate, or the coefficient of variation (CV) is 50 percent or greater.

${ }^{1}$ Respondents were asked whether "rules for student behavior are consistently enforced by teachers in this school, even for students not in their classes."

${ }^{2}$ Respondents were asked whether their "principal enforces school rules for student conduct and backs me up when I need it."

NOTE: Teachers who taught only prekindergarten students are excluded. Includes traditional public and public charter school teachers. Includes both teachers who "strongly" agreed and those who "somewhat" agreed.

SOURCE: U.S. Department of Education, National Center for Education Statistics, Schools and Staffing Survey (SASS), "Public School Teacher Data File," 2011-12. (This table was prepared July 2013.) 


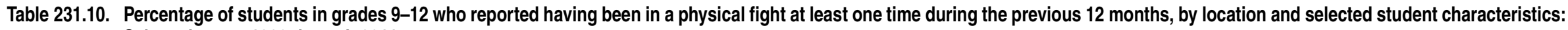
Selected years, 1993 through 2011

[Standard errors appear in parentheses]

\begin{tabular}{|c|c|c|c|c|c|c|c|c|c|c|c|c|c|c|c|c|c|c|c|c|}
\hline Location and student characteristic & & 1993 & & 1995 & & 1997 & & 1999 & & 2001 & & 2003 & & 2005 & & 2007 & & 2009 & & 2011 \\
\hline 1 & & 2 & & 3 & & 4 & & 5 & & 6 & & 7 & & 8 & & 9 & & 10 & & 11 \\
\hline $\begin{array}{l}\text { Anywhere (including on school property) } \\
\text { Total }\end{array}$ & 41.8 & $(0.99)$ & 38.7 & (1.14) & 36.6 & $(1.01)$ & 35.7 & $(1.17)$ & 33.2 & $(0.71)$ & 33.0 & $(0.99)$ & 35.9 & $(0.77)$ & 35.5 & $(0.77)$ & 31.5 & $(0.70)$ & 32.8 & $(0.65)$ \\
\hline 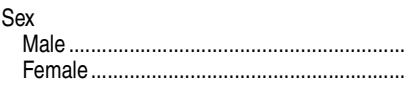 & $\begin{array}{l}51.2 \\
31.7\end{array}$ & $\begin{array}{l}(1.05) \\
(1.19)\end{array}$ & $\begin{array}{l}46.1 \\
30.6\end{array}$ & $\begin{array}{l}(1.09) \\
(1.49)\end{array}$ & $\begin{array}{l}45.5 \\
26.0\end{array}$ & $\begin{array}{l}(1.07) \\
(1.26)\end{array}$ & $\begin{array}{l}44.0 \\
27.3\end{array}$ & $\begin{array}{l}(1.27) \\
(1.70)\end{array}$ & $\begin{array}{l}43.1 \\
23.9\end{array}$ & $\begin{array}{l}(0.84) \\
(0.95)\end{array}$ & $\begin{array}{l}40.5 \\
25.1\end{array}$ & $\begin{array}{l}(1.32) \\
(0.85)\end{array}$ & $\begin{array}{l}43.4 \\
28.1\end{array}$ & $\begin{array}{l}(1.01) \\
(0.94)\end{array}$ & $\begin{array}{l}44.4 \\
26.5\end{array}$ & $\begin{array}{l}(0.89) \\
(0.99)\end{array}$ & $\begin{array}{l}39.3 \\
22.9\end{array}$ & $\begin{array}{l}(1.20) \\
(0.74)\end{array}$ & $\begin{array}{l}40.7 \\
24.4\end{array}$ & $\begin{array}{l}(0.74) \\
(0.92)\end{array}$ \\
\hline 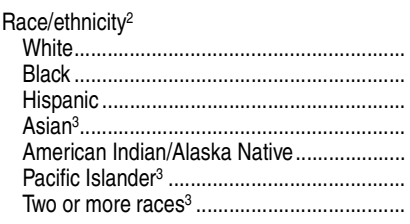 & $\begin{array}{r}40.3 \\
49.5 \\
43.2 \\
-\overline{-} \\
49.8 \\
- \\
-\end{array}$ & $\begin{array}{r}(1.13) \\
(1.82) \\
(1.58) \\
(\dagger) \\
(4.79) \\
(\dagger) \\
(\dagger)\end{array}$ & $\begin{array}{r}36.0 \\
41.6 \\
47.9 \\
-\overline{-} \\
47.2 \\
- \\
-\end{array}$ & $\begin{array}{r}(1.06) \\
(1.99) \\
(2.69) \\
(t) \\
(6.44) \\
(\dagger) \\
(\dagger)\end{array}$ & $\begin{array}{r}33.7 \\
43.0 \\
40.7 \\
-\overline{-} \\
54.7 \\
- \\
-\end{array}$ & $\begin{array}{r}(1.29) \\
(1.92) \\
(1.68) \\
(\dagger) \\
(5.75) \\
(\dagger) \\
(\dagger)\end{array}$ & $\begin{array}{l}33.1 \\
41.4 \\
39.9 \\
22.7 \\
48.7 \\
50.7 \\
40.2\end{array}$ & $\begin{array}{l}(1.45) \\
(3.12) \\
(1.65) \\
(2.71) \\
(6.78) \\
(3.42) \\
(2.76)\end{array}$ & $\begin{array}{l}32.2 \\
36.5 \\
35.8 \\
22.3 \\
49.2 \\
51.7 \\
39.6\end{array}$ & $\begin{array}{l}(0.95) \\
(1.60) \\
(0.91) \\
(2.73) \\
(6.58) \\
(6.25) \\
(2.85)\end{array}$ & $\begin{array}{l}30.5 \\
39.7 \\
36.1 \\
25.9 \\
46.6 \\
30.0 \\
38.2\end{array}$ & $\begin{array}{l}(1.11) \\
(1.23) \\
(0.98) \\
(2.99) \\
(6.53) \\
(5.21) \\
(3.64)\end{array}$ & $\begin{array}{l}33.1 \\
43.1 \\
41.0 \\
21.6 \\
44.2 \\
34.4 \\
46.9\end{array}$ & $\begin{array}{l}(0.88) \\
(1.74) \\
(1.64) \\
(2.43) \\
(3.40) \\
(5.58) \\
(4.16)\end{array}$ & $\begin{array}{l}31.7 \\
44.7 \\
40.4 \\
24.3 \\
36.0 \\
42.6 \\
47.8\end{array}$ & $\begin{array}{l}(0.96) \\
(1.33) \\
(1.25) \\
(3.50) \\
(1.49) \\
(7.74) \\
(3.30)\end{array}$ & $\begin{array}{l}27.8 \\
41.1 \\
36.2 \\
18.9 \\
42.4 \\
32.6 \\
34.2\end{array}$ & $\begin{array}{l}(0.88) \\
(1.71) \\
(0.95) \\
(1.72) \\
(5.23) \\
(3.50) \\
(3.51)\end{array}$ & $\begin{array}{l}29.4 \\
39.1 \\
36.8 \\
18.4 \\
42.4 \\
43.0 \\
45.0\end{array}$ & $\begin{array}{l}(0.74) \\
(1.52) \\
(1.44) \\
(1.87) \\
(2.12) \\
(5.14) \\
(2.60)\end{array}$ \\
\hline $\begin{array}{l}\text { Grade } \\
\text { 9th } \\
\text { 10th } \\
11 \text { th } \\
12 \text { th }\end{array}$ & $\begin{array}{l}50.4 \\
42.2 \\
40.5 \\
34.8\end{array}$ & $\begin{array}{l}(1.54) \\
(1.45) \\
(1.52) \\
(1.56)\end{array}$ & $\begin{array}{l}47.3 \\
40.4 \\
36.9 \\
31.0\end{array}$ & $\begin{array}{l}(2.22) \\
(1.49) \\
(1.48) \\
(1.71)\end{array}$ & $\begin{array}{l}44.8 \\
40.2 \\
34.2 \\
28.8\end{array}$ & $\begin{array}{l}(1.98) \\
(1.91) \\
(1.72) \\
(1.36)\end{array}$ & $\begin{array}{l}41.1 \\
37.7 \\
31.3 \\
30.4\end{array}$ & $\begin{array}{l}(1.96) \\
(2.11) \\
(1.55) \\
(1.91)\end{array}$ & $\begin{array}{l}39.5 \\
34.7 \\
29.1 \\
26.5\end{array}$ & $\begin{array}{l}(1.27) \\
(1.37) \\
(1.10) \\
(1.01)\end{array}$ & $\begin{array}{l}38.6 \\
33.5 \\
30.9 \\
26.5\end{array}$ & $\begin{array}{l}(1.38) \\
(1.20) \\
(1.38) \\
(1.08)\end{array}$ & $\begin{array}{l}43.5 \\
36.6 \\
31.6 \\
29.1\end{array}$ & $\begin{array}{l}(1.15) \\
(1.09) \\
(1.44) \\
(1.26)\end{array}$ & $\begin{array}{l}40.9 \\
36.2 \\
34.8 \\
28.0\end{array}$ & $\begin{array}{l}(1.16) \\
(1.34) \\
(1.36) \\
(1.42)\end{array}$ & $\begin{array}{l}37.0 \\
33.5 \\
28.6 \\
24.9\end{array}$ & $\begin{array}{l}(1.21) \\
(1.19) \\
(0.93) \\
(0.99)\end{array}$ & $\begin{array}{l}37.7 \\
35.3 \\
29.7 \\
26.9\end{array}$ & $\begin{array}{l}(1.11) \\
(1.35) \\
(1.14) \\
(0.95)\end{array}$ \\
\hline $\begin{array}{l}\text { Urbanicity } \\
\text { Urban } \\
\text { Suburban } \\
\text { Rural }\end{array}$ & $\begin{array}{l}- \\
- \\
-\end{array}$ & $\begin{array}{l}(t) \\
(\dagger) \\
(t)\end{array}$ & $\begin{array}{l}- \\
- \\
-\end{array}$ & $\begin{array}{l}(+) \\
(t) \\
(\dagger)\end{array}$ & $\begin{array}{l}38.2 \\
36.7 \\
32.9\end{array}$ & $\begin{array}{l}(2.00) \\
(1.59) \\
(2.91)\end{array}$ & $\begin{array}{l}37.0 \\
35.0 \\
36.6\end{array}$ & $\begin{array}{l}(2.66) \\
(1.56) \\
(2.14)\end{array}$ & $\begin{array}{l}36.8 \\
31.3 \\
33.8\end{array}$ & $\begin{array}{l}(1.53) \\
(0.80) \\
(2.58)\end{array}$ & $\begin{array}{l}35.5 \\
33.1 \\
29.7\end{array}$ & $\begin{array}{l}(2.17) \\
(1.23) \\
(1.61)\end{array}$ & $\begin{array}{l}- \\
\overline{-} \\
-\end{array}$ & $\begin{array}{l}(+) \\
(+) \\
(t)\end{array}$ & $\begin{array}{l}- \\
- \\
-\end{array}$ & $\begin{array}{l}(t) \\
(\dagger) \\
(\dagger)\end{array}$ & $\begin{array}{l}- \\
- \\
-\end{array}$ & $\begin{array}{l}(t) \\
(t) \\
(t)\end{array}$ & $\begin{array}{l}- \\
- \\
-\end{array}$ & $\begin{array}{l}(\dagger) \\
(\dagger) \\
(\dagger)\end{array}$ \\
\hline $\begin{array}{l}\text { On school property } \\
\text { Total }\end{array}$ & 16.2 & $(0.59)$ & 15.5 & $(0.79)$ & 14.8 & $(0.64)$ & 14.2 & $(0.62)$ & 12.5 & $(0.49)$ & 12.8 & $(0.76)$ & 13.6 & $(0.56)$ & 12.4 & $(0.48)$ & 11.1 & $(0.54)$ & 12.0 & $(0.39)$ \\
\hline 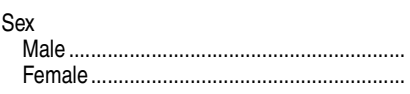 & $\begin{array}{r}23.5 \\
8.6\end{array}$ & $\begin{array}{l}(0.71) \\
(0.73)\end{array}$ & $\begin{array}{r}21.0 \\
9.5\end{array}$ & $\begin{array}{l}(0.90) \\
(1.03)\end{array}$ & $\begin{array}{r}20.0 \\
8.6\end{array}$ & $\begin{array}{l}(1.04) \\
(0.78)\end{array}$ & $\begin{array}{r}18.5 \\
9.8\end{array}$ & $\left.\begin{array}{l}(0.66) \\
(0.95)\end{array}\right]$ & $\begin{array}{r}18.0 \\
7.2\end{array}$ & $\begin{array}{l}(0.74) \\
(0.47)\end{array}$ & $\begin{array}{r}17.1 \\
8.0\end{array}$ & $\begin{array}{l}(0.92) \\
(0.70)\end{array}$ & $\begin{array}{r}18.2 \\
8.8\end{array}$ & $\begin{array}{l}(0.93) \\
(0.52)\end{array}$ & $\begin{array}{r}16.3 \\
8.5\end{array}$ & $\begin{array}{l}(0.60) \\
(0.62)\end{array}$ & $\begin{array}{r}15.1 \\
6.7\end{array}$ & $\begin{array}{l}(1.05) \\
(0.42)\end{array}$ & $\begin{array}{r}16.0 \\
7.8\end{array}$ & $\begin{array}{l}(0.58) \\
(0.43)\end{array}$ \\
\hline 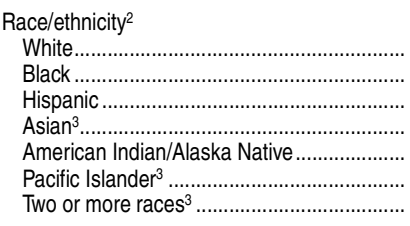 & $\begin{array}{r}15.0 \\
22.0 \\
17.9 \\
- \\
18.6 \\
- \\
-\end{array}$ & $\begin{array}{r}(0.68) \\
(1.39) \\
(1.75) \\
(\dagger) \\
(2.74) \\
(\dagger) \\
(\dagger)\end{array}$ & $\begin{array}{r}12.9 \\
20.3 \\
21.1 \\
-\overline{3} \\
31.4 \\
-\end{array}$ & $\begin{array}{r}(0.62) \\
(1.25) \\
(1.68) \\
(t) \\
(5.58) \\
(\dagger) \\
(\dagger)\end{array}$ & $\begin{array}{r}13.3 \\
20.7 \\
19.0 \\
\overline{1} \\
18.9 \\
- \\
-\end{array}$ & $\begin{array}{r}(0.84) \\
(1.20) \\
(1.50) \\
(t) \\
(5.55) \\
(\dagger) \\
(\dagger)\end{array}$ & $\begin{array}{l}12.3 \\
18.7 \\
15.7 \\
10.4 \\
16.2 ! \\
25.3 \\
16.9\end{array}$ & $\begin{array}{l}(0.86) \\
(1.51) \\
(0.91) \\
(0.95) \\
(5.23) \\
(4.60) \\
(2.40)\end{array}$ & $\begin{array}{l}11.2 \\
16.8 \\
14.1 \\
10.8 \\
18.2 \\
29.1 \\
14.7\end{array}$ & $\begin{array}{l}(0.60) \\
(1.26) \\
(0.89) \\
(1.92) \\
(4.41) \\
(7.63) \\
(1.97)\end{array}$ & $\begin{array}{l}10.0 \\
17.1 \\
16.7 \\
13.1 \\
24.2 \\
22.2 \\
20.2\end{array}$ & $\begin{array}{l}(0.73) \\
(1.30) \\
(1.14) \\
(2.26) \\
(5.03) \\
(4.82) \\
(3.83)\end{array}$ & $\begin{array}{r}11.6 \\
16.9 \\
18.3 \\
5.9 \\
22.0 \\
24.5 \\
15.8\end{array}$ & $\begin{array}{l}(0.66) \\
(1.39) \\
(1.62) \\
(1.53) \\
(3.16) \\
(5.60) \\
(2.61)\end{array}$ & $\begin{array}{r}10.2 \\
17.6 \\
15.5 \\
8.5 \\
15.0 \\
9.6 ! \\
19.6\end{array}$ & $\begin{array}{l}(0.56) \\
(1.10) \\
(0.81) \\
(1.99) \\
(1.12) \\
(3.47) \\
(2.39)\end{array}$ & $\begin{array}{r}8.6 \\
17.4 \\
13.5 \\
7.7 \\
20.7 \\
14.8 \\
12.4\end{array}$ & $\begin{array}{l}(0.58) \\
(0.99) \\
(0.82) \\
(1.09) \\
(3.73) \\
(2.37) \\
(2.19)\end{array}$ & $\begin{array}{r}9.9 \\
16.4 \\
14.4 \\
6.2 \\
12.0 \\
20.9 \\
16.6\end{array}$ & $\begin{array}{l}(0.51) \\
(0.89) \\
(0.79) \\
(1.06) \\
(1.77) \\
(4.41) \\
(1.41)\end{array}$ \\
\hline $\begin{array}{l}\text { Grade } \\
\text { 9th } \\
\text { 10th } \\
11 \text { th } \\
\text { 12th }\end{array}$ & $\begin{array}{l}23.1 \\
17.2 \\
13.8 \\
11.4\end{array}$ & $\begin{array}{l}(1.55) \\
(1.07) \\
(1.27) \\
(0.66)\end{array}$ & $\begin{array}{l}21.6 \\
16.5 \\
13.6 \\
10.6\end{array}$ & $\begin{array}{l}(1.79) \\
(1.57) \\
(1.00) \\
(0.73)\end{array}$ & $\begin{array}{r}21.3 \\
17.0 \\
12.5 \\
9.5\end{array}$ & $\begin{array}{l}(1.29) \\
(1.67) \\
(0.87) \\
(0.73)\end{array}$ & $\begin{array}{r}18.6 \\
17.2 \\
10.8 \\
8.1\end{array}$ & $\begin{array}{l}(1.02) \\
(1.23) \\
(1.01) \\
(1.00)\end{array}$ & $\begin{array}{r}17.3 \\
13.5 \\
9.4 \\
7.5\end{array}$ & $\begin{array}{l}(0.77) \\
(0.88) \\
(0.71) \\
(0.56)\end{array}$ & $\begin{array}{r}18.0 \\
12.8 \\
10.4 \\
7.3\end{array}$ & $\begin{array}{l}(1.24) \\
(0.89) \\
(0.89) \\
(0.70)\end{array}$ & $\begin{array}{r}18.9 \\
14.4 \\
10.4 \\
8.5\end{array}$ & $\begin{array}{l}(0.93) \\
(1.08) \\
(0.75) \\
(0.70)\end{array}$ & $\begin{array}{r}17.0 \\
11.7 \\
11.0 \\
8.6\end{array}$ & $\begin{array}{l}(0.67) \\
(0.86) \\
(0.73) \\
(0.62)\end{array}$ & $\begin{array}{r}14.9 \\
12.1 \\
9.5 \\
6.6\end{array}$ & $\begin{array}{l}(0.98) \\
(0.83) \\
(0.63) \\
(0.59)\end{array}$ & $\begin{array}{r}16.2 \\
12.8 \\
9.2 \\
8.8\end{array}$ & $\begin{array}{l}(0.77) \\
(0.86) \\
(0.55) \\
(0.69)\end{array}$ \\
\hline 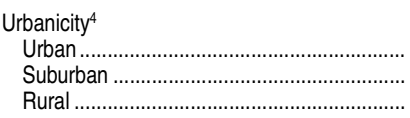 & $\begin{array}{l}- \\
-\end{array}$ & $\begin{array}{l}(t) \\
(t) \\
(t)\end{array}$ & $\begin{array}{l}- \\
-\end{array}$ & $\begin{array}{c}(t) \\
(t) \\
(t)\end{array}$ & $\begin{array}{l}15.8 \\
14.2 \\
14.7\end{array}$ & $\begin{array}{c}(1.50) \\
(0.95) \\
(2.09)\end{array}$ & $\begin{array}{l}14.4 \\
13.7 \\
16.3\end{array}$ & $\begin{array}{l}(0.86) \\
(2.33)\end{array}$ & $\begin{array}{l}14.8 \\
11.0 \\
13.8\end{array}$ & $\begin{array}{l}(0.75) \\
(1.10)\end{array}$ & $\begin{array}{l}12.8 \\
10.0\end{array}$ & $\begin{array}{l}(1.31) \\
(1.23) \\
(1.36)\end{array}$ & $\begin{array}{l}- \\
-\end{array}$ & $\begin{array}{c}(t) \\
(t) \\
(t)\end{array}$ & $\begin{array}{l}- \\
-\end{array}$ & $\begin{array}{l}(t) \\
(t) \\
(t)\end{array}$ & $\begin{array}{l}- \\
-\end{array}$ & $\begin{array}{c}(t) \\
(t) \\
(t)\end{array}$ & $\begin{array}{l}- \\
-\end{array}$ & $\begin{array}{l}(+) \\
(+) \\
(+)\end{array}$ \\
\hline
\end{tabular}

\section{-Not available.}

IInterpret data with caution. The coefficient of variation (CV) for this estimate is between 30 and 50 percent.

"The term "anywhere" is not used in the Youth Risk Behavior Survey (YRBS) questionnaire; students were simply asked how many times in the past 12 months they had been in a physical fight.

${ }_{3}^{3}$ Before 1999, Asian students and Pacific Islander students were not categorized separately, and students were not given the option of choosing two or more races. Because the response categories changed in 1999, caution should be used in comparing data on race The

sus Bureau. Cas IIn the question asking students about physical fights at school, "in MSA but not in central city (Suburban)," and "not MSA (Ru

2Race categories exclude persons of Hispanic ethnicity.

SOURCE: Centers for Disease Control and Prevention, Division of Adolescent and School Health, Youth Risk Behavior Surveillance System (YRBSS), 1993 through 2011. (This table was prepared September 2013.) 
Table 231.20. Percentage distribution of students in grades 9-12, by number of times they reported having been in a physical fight anywhere or on school property during the previous 12 months and selected student characteristics: 2011

[Standard errors appear in parentheses]

\begin{tabular}{|c|c|c|c|c|c|c|c|c|c|c|c|c|c|c|c|c|}
\hline \multirow[b]{2}{*}{ Student characteristic } & \multicolumn{8}{|c|}{ Anywhere (including on school property) ${ }^{1}$} & \multicolumn{8}{|c|}{ On school property² } \\
\hline & & 0 times & 1 to & 3 times & 4 to 1 & 1 times & 12 or more & times & & 0 times & 1 to & 3 times & 4 to 1 & 1 times & 12 or mo & e times \\
\hline 1 & & 2 & & 3 & & 4 & & 5 & & 6 & & 7 & & 8 & & 9 \\
\hline 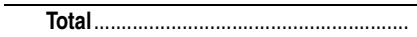 & 67.2 & $(0.65)$ & 24.3 & $(0.54)$ & 5.6 & $(0.28)$ & 2.9 & $(0.23)$ & 88.0 & $(0.39)$ & 10.1 & $(0.37)$ & 1.2 & $(0.12)$ & 0.7 & $(0.08)$ \\
\hline 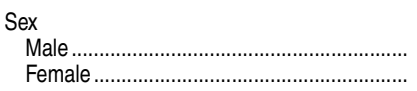 & $\begin{array}{l}59.3 \\
75.6\end{array}$ & $\begin{array}{l}(0.74) \\
(0.92)\end{array}$ & $\begin{array}{l}28.8 \\
19.6\end{array}$ & $\begin{array}{l}(0.65) \\
(0.81)\end{array}$ & $\begin{array}{l}7.4 \\
3.6\end{array}$ & $\begin{array}{l}(0.43) \\
(0.25)\end{array}$ & $\begin{array}{l}4.5 \\
1.2\end{array}$ & $\begin{array}{l}(0.37) \\
(0.16)\end{array}$ & $\begin{array}{l}84.0 \\
92.2\end{array}$ & $\begin{array}{l}(0.58) \\
(0.43)\end{array}$ & $\begin{array}{r}13.0 \\
7.1\end{array}$ & $\begin{array}{l}(0.54) \\
(0.42)\end{array}$ & $\begin{array}{l}1.9 \\
0.5\end{array}$ & $\begin{array}{l}(0.20) \\
(0.10)\end{array}$ & $\begin{array}{l}1.1 \\
0.2\end{array}$ & $\begin{array}{l}(0.15) \\
(0.04)\end{array}$ \\
\hline 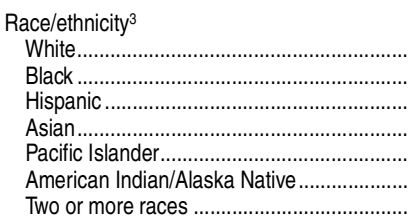 & $\begin{array}{l}70.6 \\
60.9 \\
63.2 \\
81.6 \\
57.0 \\
57.6 \\
55.0\end{array}$ & $\begin{array}{l}(0.74) \\
(1.52) \\
(1.44) \\
(1.87) \\
(5.14) \\
(2.12) \\
(2.60)\end{array}$ & $\begin{array}{l}22.8 \\
27.0 \\
26.4 \\
13.0 \\
24.6 \\
28.2 \\
33.1\end{array}$ & $\begin{array}{l}(0.72) \\
(0.84) \\
(1.24) \\
(1.96) \\
(4.54) \\
(1.99) \\
(1.87)\end{array}$ & $\begin{array}{r}4.3 \\
8.8 \\
6.7 \\
2.7 ! \\
14.0 \\
10.6 \\
5.5\end{array}$ & $\begin{array}{l}(0.29) \\
(0.83) \\
(0.46) \\
(0.89) \\
(4.08) \\
(0.97) \\
(0.98)\end{array}$ & $\begin{array}{l}2.2 \\
3.2 \\
3.8 \\
2.6 \\
4.4 ! \\
3.5 \\
6.4\end{array}$ & $\begin{array}{l}(0.27) \\
(0.45) \\
(0.45) \\
(0.70) \\
(2.06) \\
(0.64) \\
(1.85)\end{array}$ & $\begin{array}{l}90.1 \\
83.6 \\
85.6 \\
93.8 \\
79.1 \\
88.0 \\
83.4\end{array}$ & $\begin{array}{l}(0.51) \\
(0.89) \\
(0.79) \\
(1.06) \\
(4.41) \\
(1.77) \\
(1.41)\end{array}$ & $\begin{array}{r}8.5 \\
13.6 \\
12.0 \\
4.2 \\
16.7 \\
10.3 \\
13.9\end{array}$ & $\begin{array}{l}(0.48) \\
(0.69) \\
(0.75) \\
(0.96) \\
(3.89) \\
(1.92) \\
(1.35)\end{array}$ & $\begin{array}{l}1.0 \\
2.0 \\
1.3 \\
1.2 ! \\
\ddagger \\
\ddagger \\
1.2 !\end{array}$ & $\begin{array}{r}(0.19) \\
(0.38) \\
(0.21) \\
(0.50) \\
(\dagger) \\
(\dagger) \\
(0.43)\end{array}$ & $\begin{array}{r}0.4 \\
0.8 \\
1.1 \\
\ddagger \\
\ddagger \\
\ddagger \\
\ddagger\end{array}$ & $\begin{array}{r}(0.07) \\
(0.21) \\
(0.26) \\
(\dagger) \\
(\dagger) \\
(\dagger) \\
(\dagger)\end{array}$ \\
\hline 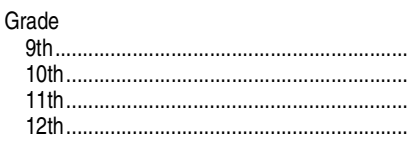 & $\begin{array}{l}62.3 \\
64.7 \\
70.3 \\
73.1\end{array}$ & $\begin{array}{l}(1.11) \\
(1.35) \\
(1.14) \\
(0.95)\end{array}$ & $\begin{array}{l}27.1 \\
26.6 \\
22.1 \\
20.7\end{array}$ & $\begin{array}{l}(0.93) \\
(1.01) \\
(1.02) \\
(0.84)\end{array}$ & $\begin{array}{l}7.1 \\
5.8 \\
4.7 \\
4.4\end{array}$ & $\begin{array}{l}(0.39) \\
(0.58) \\
(0.42) \\
(0.49)\end{array}$ & $\begin{array}{l}3.5 \\
2.9 \\
2.9 \\
1.8\end{array}$ & $\begin{array}{l}(0.39) \\
(0.53) \\
(0.35) \\
(0.36)\end{array}$ & $\begin{array}{l}83.8 \\
87.2 \\
90.8 \\
91.2\end{array}$ & $\begin{array}{l}(0.77) \\
(0.86) \\
(0.55) \\
(0.69)\end{array}$ & $\begin{array}{r}13.6 \\
10.9 \\
7.9 \\
7.4\end{array}$ & $\begin{array}{l}(0.77) \\
(0.75) \\
(0.53) \\
(0.68)\end{array}$ & $\begin{array}{l}1.8 \\
1.3 \\
0.6 \\
1.0\end{array}$ & $\begin{array}{l}(0.22) \\
(0.28) \\
(0.13) \\
(0.23)\end{array}$ & $\begin{array}{l}0.8 \\
0.5 \\
0.7 \\
0.4 !\end{array}$ & $\begin{array}{l}(0.17) \\
(0.14) \\
(0.15) \\
(0.14)\end{array}$ \\
\hline
\end{tabular}

†Not applicable.

!nterpret data with caution. The coefficient of variation (CV) for this estimate is between 30 and 50 percent.

†Reporting standards not met. Either there are too few cases for a reliable estimate or the coefficient of variation (CV) is 50 percent or greater.

"The term "anywhere" is not used in the Youth Risk Behavior Survey (YRBS) questionnaire; students were simply asked how many times in the past 12 months they had been in a physical fight.
2In the question asking students about physical fights at school, "on school property" was not defined for respondents.

${ }^{3}$ Race categories exclude persons of Hispanic ethnicity.

NOTE: Detail may not sum to totals because of rounding.

SOURCE: Centers for Disease Control and Prevention, Division of Adolescent and School Health, Youth Risk Behavior Surveillance System (YRBSS), 2011. (This table was prepared September 2013.) 
322 CHAPTER 2: Elementary and Secondary Education

Fights and Weapons

Table 231.30. Percentage of public school students in grades 9-12 who reported having been in a physical fight at least one time during the previous 12 months, by location and state: Selected years, 2003 through 2011

[Standard errors appear in parentheses]

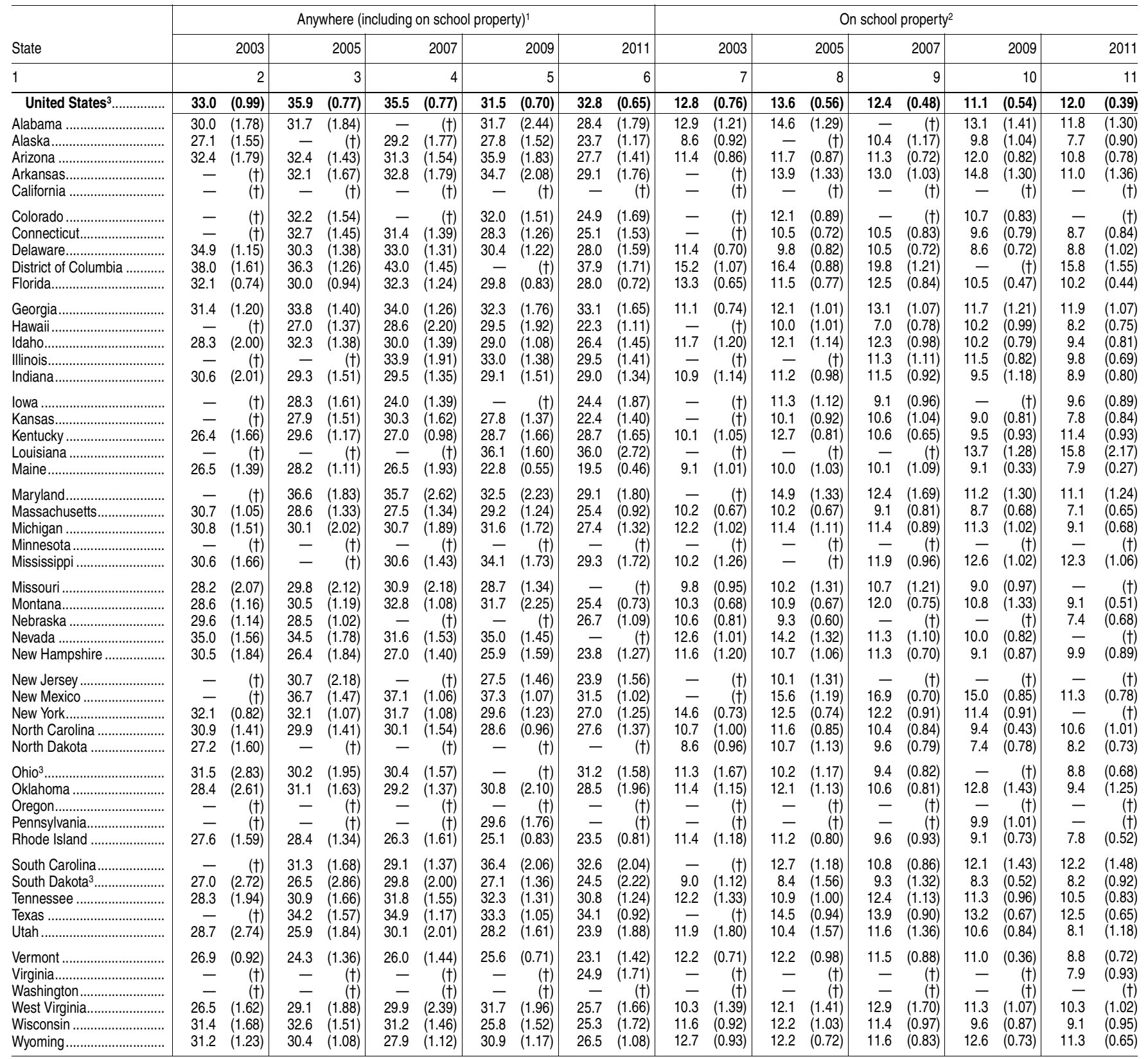

-Not available.

†Not applicable.

"The term "anywhere" is not used in the Youth Risk Behavior Survey (YRBS) questionnaire; students were simply asked how many times in the past 12 months they had been in a physical fight 'In the question asking students about physical fights at school, "on school property" was not defined for survey respondents.

${ }^{3}$ ata include both public and private schools.
NOTE: State-level data include public schools only, with the exception of data for Ohio and South Dakota. Data for the United States total, Ohio, and South Dakota include both public and private schools.

SOURCE: Centers for Disease Control and Prevention, Division of Adolescent and School Health, Youth Risk Behavior Surveillance System (YRBSS), 2003 through 2011. (This table was prepared September 2013.) 


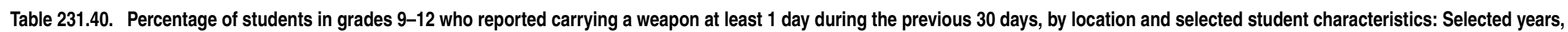
1993 through 2011

[Standard errors appear in parentheses]

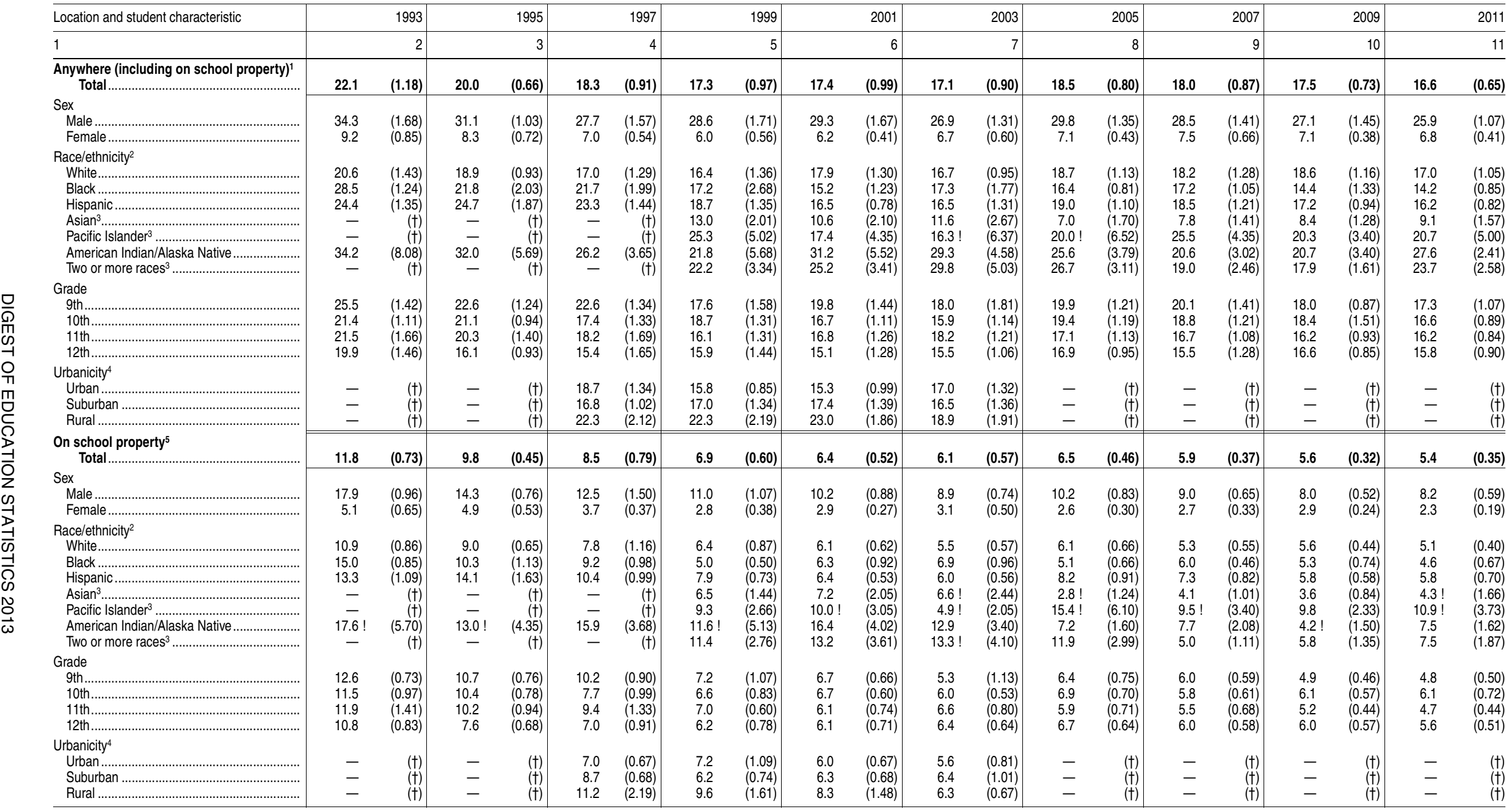

\section{Not available.}

!Interpret data with caution. The coefficient of variation (CV) for this estimate is between 30 and 50 percent.

"The term "anywhere" is not used in the Youth Risk Behavior Survey (YRBS) questionnaire; students were simply asked how many days they carried a weapon during the past 30 days.
${ }^{2}$ Race categories exclude persons of Hispanic ethnicity.

2Race categories exclude persons of Hispanic ethnicity.
3Before 1999, Asian students and Pacific Islander students were not categorized separately and students were not given the option of

from 1993, 1995, and 1997 with data from later years.

列 sus Bureau. Categories include "central city of an MSA (Urban)," "in MSA but not in central city (Suburban)," and "not MSA (Rural): NOTE: Respondents were ants about carrying a weapon at school, "on school property",

SOURCE: Centers for Disease Control and Prevention, Division of Adolescent and School Health, Youth Risk Behavior Surveillance

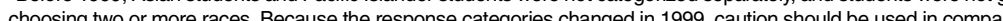
stem (YRBSS) 1993 through 2011. (This table was prepared September 2013.) 
324 CHAPTER 2: Elementary and Secondary Education

Fights and Weapons

Table 231.50. Percentage distribution of students in grades 9-12, by number of days they reported carrying a weapon anywhere or on school property during the previous 30 days and selected student characteristics: 2011

[Standard errors appear in parentheses]

\begin{tabular}{|c|c|c|c|c|c|c|c|c|c|c|c|c|c|c|c|c|}
\hline \multirow[b]{2}{*}{ Student characteristic } & \multicolumn{8}{|c|}{ Anywhere (including on school property) ${ }^{1}$} & \multicolumn{8}{|c|}{ On school property ${ }^{2}$} \\
\hline & & 0 days & & 1 day & 2 tc & 5 days & 6 or $\mathrm{mc}$ & re days & & 0 days & & 1 day & & 5 days & 6 or mo & re days \\
\hline 1 & & 2 & & 3 & & 4 & & 5 & & 6 & & 7 & & 8 & & 9 \\
\hline 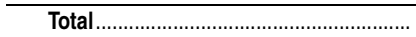 & 83.4 & $(0.65)$ & 3.5 & $(0.18)$ & 5.6 & $(0.27)$ & 7.5 & $(0.45)$ & 94.6 & $(0.35)$ & 1.6 & $(0.16)$ & 1.4 & $(0.12)$ & 2.4 & $(0.23)$ \\
\hline 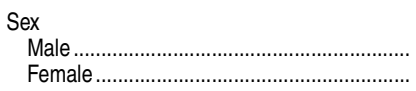 & $\begin{array}{l}74.1 \\
93.2\end{array}$ & $\begin{array}{l}(1.07) \\
(0.41)\end{array}$ & $\begin{array}{l}4.8 \\
2.1\end{array}$ & $\begin{array}{l}(0.23) \\
(0.27)\end{array}$ & $\begin{array}{l}8.5 \\
2.6\end{array}$ & $\begin{array}{l}(0.46) \\
(0.21)\end{array}$ & $\begin{array}{r}12.6 \\
2.2\end{array}$ & $\begin{array}{l}(0.82) \\
(0.19)\end{array}$ & $\begin{array}{l}91.8 \\
97.7\end{array}$ & $\begin{array}{l}(0.59) \\
(0.19)\end{array}$ & $\begin{array}{l}2.5 \\
0.7\end{array}$ & $\begin{array}{l}(0.26) \\
(0.12)\end{array}$ & $\begin{array}{l}2.1 \\
0.6\end{array}$ & $\begin{array}{l}(0.21) \\
(0.09)\end{array}$ & $\begin{array}{l}3.7 \\
1.0\end{array}$ & $\begin{array}{l}(0.39) \\
(0.13)\end{array}$ \\
\hline 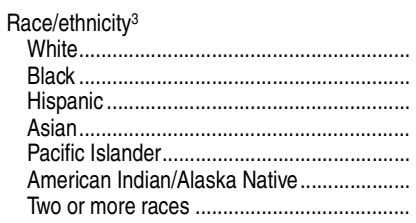 & $\begin{array}{l}83.0 \\
85.8 \\
83.8 \\
90.9 \\
79.3 \\
72.4 \\
76.3\end{array}$ & $\begin{array}{l}(1.05) \\
(0.85) \\
(0.82) \\
(1.57) \\
(5.00) \\
(2.41) \\
(2.58)\end{array}$ & $\begin{array}{l}3.2 \\
3.1 \\
4.4 \\
1.9 \\
3.0 ! \\
5.3 \\
5.6\end{array}$ & $\begin{array}{l}(0.21) \\
(0.41) \\
(0.44) \\
(0.54) \\
(1.37) \\
(0.91) \\
(1.18)\end{array}$ & $\begin{array}{r}5.9 \\
5.2 \\
5.2 \\
1.8 ! \\
7.6 ! \\
12.1 \\
7.1\end{array}$ & $\begin{array}{l}(0.48) \\
(0.46) \\
(0.50) \\
(0.78) \\
(2.75) \\
(1.52) \\
(1.32)\end{array}$ & $\begin{array}{c}8.0 \\
6.0 \\
6.7 \\
5.4 \\
10.1 ! \\
10.2 \\
10.9\end{array}$ & $\begin{array}{l}(0.68) \\
(0.56) \\
(0.48) \\
(1.57) \\
(3.53) \\
(1.23) \\
(1.92)\end{array}$ & $\begin{array}{l}94.9 \\
95.4 \\
94.2 \\
95.7 \\
89.1 \\
92.5 \\
92.5\end{array}$ & $\begin{array}{l}(0.40) \\
(0.67) \\
(0.70) \\
(1.66) \\
(3.73) \\
(1.62) \\
(1.87)\end{array}$ & $\begin{array}{c}1.6 \\
1.7 \\
1.4 \\
\ddagger \\
6.5 ! \\
2.7 \\
1.6 !\end{array}$ & $\begin{array}{r}(0.21) \\
(0.46) \\
(0.20) \\
(\dagger) \\
(2.63) \\
(0.68) \\
(0.52)\end{array}$ & $\begin{array}{c}1.3 \\
1.2 \\
2.0 \\
\ddagger \\
\ddagger \\
3.2 ! \\
1.2 !\end{array}$ & $\begin{array}{r}(0.16) \\
(0.26) \\
(0.32) \\
(\dagger) \\
(\dagger) \\
(1.23) \\
(0.42)\end{array}$ & $\begin{array}{r}2.3 \\
1.6 \\
2.4 \\
\ddagger \\
4.4 ! \\
1.6 \\
4.7 !\end{array}$ & $\begin{array}{r}(0.33) \\
(0.34) \\
(0.46) \\
(\dagger) \\
(1.89) \\
(0.48) \\
(1.81)\end{array}$ \\
\hline 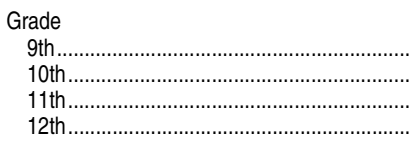 & $\begin{array}{l}82.7 \\
83.4 \\
83.8 \\
84.2\end{array}$ & $\begin{array}{l}(1.07) \\
(0.89) \\
(0.84) \\
(0.90)\end{array}$ & $\begin{array}{l}4.3 \\
3.2 \\
3.3 \\
3.0\end{array}$ & $\begin{array}{l}(0.47) \\
(0.36) \\
(0.32) \\
(0.36)\end{array}$ & $\begin{array}{l}6.5 \\
5.7 \\
5.5 \\
4.6\end{array}$ & $\begin{array}{l}(0.46) \\
(0.50) \\
(0.46) \\
(0.40)\end{array}$ & $\begin{array}{l}6.5 \\
7.7 \\
7.5 \\
8.1\end{array}$ & $\begin{array}{l}(0.58) \\
(0.62) \\
(0.46) \\
(0.84)\end{array}$ & $\begin{array}{l}95.2 \\
93.9 \\
95.3 \\
94.4\end{array}$ & $\begin{array}{l}(0.50) \\
(0.72) \\
(0.44) \\
(0.51)\end{array}$ & $\begin{array}{l}1.8 \\
1.9 \\
1.3 \\
1.4\end{array}$ & $\begin{array}{l}(0.28) \\
(0.41) \\
(0.26) \\
(0.31)\end{array}$ & $\begin{array}{l}1.3 \\
1.7 \\
1.2 \\
1.3\end{array}$ & $\begin{array}{l}(0.19) \\
(0.25) \\
(0.23) \\
(0.24)\end{array}$ & $\begin{array}{l}1.8 \\
2.4 \\
2.2 \\
2.9\end{array}$ & $\begin{array}{l}(0.31) \\
(0.39) \\
(0.33) \\
(0.40)\end{array}$ \\
\hline
\end{tabular}

†Not applicable.

!nterpret data with caution. The coefficient of variation (CV) for this estimate is between 30 and 50 percent.

†Reporting standards not met. Either there are too few cases for a reliable estimate or the coefficient of variation $(\mathrm{CV})$ is 50 percent or greater.

'The term "anywhere" is not used in the Youth Risk Behavior Survey (YRBS) questionnaire; students were simply asked how many days they carried a weapon during the past 30 days.
2In the question asking students about carrying a weapon at school, "on school property" was not defined for survey respondents.

${ }^{3}$ Race categories exclude persons of Hispanic ethnicity.

NOTE: Respondents were asked about carrying "a weapon such as a gun, knife, or club." Detail may not sum to totals because of rounding.

SOURCE: Centers for Disease Control and Prevention, Division of Adolescent and School Health, Youth Risk Behavior Surveillance System (YRBSS), 2011. (This table was prepared September 2013.) 
Table 231.60. Percentage of public school students in grades 9-12 who reported carrying a weapon at least 1 day during the previous 30 days, by location and state: Selected years, 2003 through 2011

[Standard errors appear in parentheses]

\begin{tabular}{|c|c|c|c|c|c|c|c|c|c|c|c|c|c|c|c|c|c|c|c|c|}
\hline \multirow[b]{2}{*}{ State } & \multicolumn{10}{|c|}{ Anywhere (including on school property) $)^{1}$} & \multicolumn{10}{|c|}{ On school property ${ }^{2}$} \\
\hline & & 2003 & & 2005 & & 2007 & & 2009 & & 2011 & & 2003 & & 2005 & & 2007 & & 2009 & & 2011 \\
\hline 1 & & 2 & & 3 & & 4 & & 5 & & 6 & & 7 & & 8 & & 9 & & 10 & & 11 \\
\hline United States ${ }^{3} \ldots \ldots \ldots \ldots \ldots$ & 17.1 & $(0.90)$ & 18.5 & $(0.80)$ & 18.0 & $(0.87)$ & 17.5 & $(0.73)$ & 16.6 & $(0.65)$ & 6.1 & $(0.57)$ & 6.5 & $(0.46)$ & 5.9 & $(0.37)$ & 5.6 & $(0.32)$ & 5.4 & $(0.35)$ \\
\hline 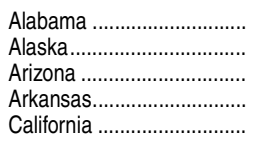 & $\begin{array}{r}19.9 \\
18.4 \\
18.4 \\
- \\
-\end{array}$ & $\begin{array}{r}(1.44) \\
(1.14) \\
(0.82) \\
(\dagger) \\
(\dagger)\end{array}$ & $\begin{array}{r}21.0 \\
-\overline{2} \\
25.9 \\
-\end{array}$ & $\begin{array}{r}(1.72) \\
(\dagger) \\
(0.84) \\
(1.15) \\
(\dagger)\end{array}$ & $\begin{array}{r}- \\
24.4 \\
20.5 \\
20.7 \\
-\end{array}$ & $\begin{array}{r}(\dagger) \\
(1.61) \\
(0.91) \\
(1.36) \\
(\dagger)\end{array}$ & $\begin{array}{r}22.9 \\
20.0 \\
19.9 \\
22.9 \\
-\end{array}$ & $\begin{array}{r}(2.27) \\
(1.30) \\
(1.25) \\
(1.82) \\
(\dagger)\end{array}$ & $\begin{array}{r}21.5 \\
19.0 \\
17.5 \\
21.1 \\
-\end{array}$ & $\begin{array}{r}(1.54) \\
(1.19) \\
(1.17) \\
(1.76) \\
(\dagger)\end{array}$ & $\begin{array}{l}7.3 \\
7.1 \\
5.8 \\
- \\
-\end{array}$ & $\begin{array}{r}(1.35) \\
(0.81) \\
(0.68) \\
(\dagger) \\
(\dagger)\end{array}$ & $\begin{array}{r}8.4 \\
- \\
7.4 \\
10.5 \\
-\end{array}$ & $\begin{array}{r}(1.44) \\
(\dagger) \\
(0.53) \\
(1.10) \\
(\dagger)\end{array}$ & $\begin{array}{l}-\overline{8.4} \\
7.0 \\
6.8 \\
-\end{array}$ & $\begin{array}{r}(\dagger) \\
(1.07) \\
(0.75) \\
(0.85) \\
(\dagger)\end{array}$ & $\begin{array}{l}8.7 \\
7.8 \\
6.5 \\
8.4 \\
-\end{array}$ & $\begin{array}{r}(1.42) \\
(0.83) \\
(0.64) \\
(1.02) \\
(\dagger)\end{array}$ & $\begin{array}{l}8.2 \\
5.7 \\
5.7 \\
6.5 \\
-\end{array}$ & $\begin{array}{r}(1.02) \\
(0.72) \\
(0.59) \\
(0.95) \\
(\dagger)\end{array}$ \\
\hline 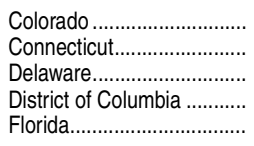 & $\begin{array}{r}- \\
16.0 \\
25.0 \\
17.2\end{array}$ & $\begin{array}{r}(t) \\
(t) \\
(0.88) \\
(1.40) \\
(0.76)\end{array}$ & $\begin{array}{l}17.0 \\
16.3 \\
16.6 \\
17.2 \\
15.2\end{array}$ & $\begin{array}{l}(1.57) \\
(1.30) \\
(1.04) \\
(1.11) \\
(0.68)\end{array}$ & $\begin{array}{r}- \\
17.2 \\
17.1 \\
21.3 \\
18.0\end{array}$ & $\begin{array}{r}(\dagger) \\
(1.72) \\
(1.00) \\
(1.45) \\
(0.93)\end{array}$ & $\begin{array}{r}16.7 \\
12.4 \\
18.5 \\
- \\
17.3\end{array}$ & $\begin{array}{r}(1.27) \\
(0.89) \\
(0.92) \\
(\dagger) \\
(0.60)\end{array}$ & $\begin{array}{r}15.5 \\
- \\
13.5 \\
18.9 \\
15.6\end{array}$ & $\begin{array}{r}(1.31) \\
(t) \\
(0.88) \\
(1.34) \\
(0.76)\end{array}$ & $\begin{array}{r}- \\
5.0 \\
10.6 \\
5.3\end{array}$ & $\begin{array}{r}(\dagger) \\
(\dagger) \\
(0.47) \\
(0.96) \\
(0.38)\end{array}$ & $\begin{array}{l}5.4 \\
6.4 \\
5.7 \\
6.7 \\
4.7\end{array}$ & $\begin{array}{l}(0.81) \\
(0.83) \\
(0.54) \\
(0.60) \\
(0.41)\end{array}$ & $\begin{array}{l}- \\
5.5 \\
5.4 \\
7.4 \\
5.6\end{array}$ & $\begin{array}{r}(\dagger) \\
(1.03) \\
(0.55) \\
(0.76) \\
(0.41)\end{array}$ & $\begin{array}{r}5.5 \\
3.9 \\
5.1 \\
\overline{4.7}\end{array}$ & $\begin{array}{r}(0.90) \\
(0.45) \\
(0.59) \\
(\dagger) \\
(0.35)\end{array}$ & $\begin{array}{l}5.5 \\
6.6 \\
5.2 \\
5.5 \\
-\end{array}$ & $\begin{array}{r}(0.69) \\
(0.67) \\
(0.57) \\
(0.88) \\
(\dagger)\end{array}$ \\
\hline 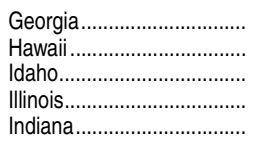 & $\begin{array}{r}18.7 \\
- \\
- \\
17.8\end{array}$ & $\begin{array}{r}(1.17) \\
(\dagger) \\
(\dagger) \\
(\dagger) \\
(1.93)\end{array}$ & $\begin{array}{r}22.1 \\
13.3 \\
23.9 \\
- \\
19.2\end{array}$ & $\begin{array}{r}(1.99) \\
(1.03) \\
(1.45) \\
(\dagger) \\
(1.25)\end{array}$ & $\begin{array}{l}19.5 \\
14.8 \\
23.6 \\
14.3 \\
20.9\end{array}$ & $\begin{array}{l}(0.96) \\
(1.56) \\
(1.35) \\
(1.01) \\
(0.80)\end{array}$ & $\begin{array}{l}18.8 \\
15.9 \\
21.8 \\
16.0 \\
18.1\end{array}$ & $\begin{array}{l}(1.11) \\
(2.06) \\
(1.15) \\
(1.04) \\
(1.58)\end{array}$ & $\begin{array}{l}22.8 \\
13.9 \\
22.8 \\
12.6 \\
17.0\end{array}$ & $\begin{array}{l}(2.25) \\
(0.81) \\
(1.30) \\
(0.91) \\
(1.46)\end{array}$ & $\frac{5.0}{-}$ & $\begin{array}{r}(0.52) \\
(\dagger) \\
(0.90) \\
(\dagger) \\
(0.91)\end{array}$ & $\begin{array}{r}7.5 \\
4.9 \\
- \\
- \\
5.8\end{array}$ & $\begin{array}{r}(1.50) \\
(0.72) \\
(\dagger) \\
(\dagger) \\
(0.71)\end{array}$ & $\begin{array}{l}5.3 \\
3.7 \\
8.9 \\
3.7 \\
6.9\end{array}$ & $\begin{array}{l}(0.48) \\
(0.92) \\
(0.96) \\
(0.67) \\
(0.64)\end{array}$ & $\begin{array}{l}6.0 \\
4.7 \\
6.7 \\
4.8 \\
5.7\end{array}$ & $\begin{array}{l}(0.90) \\
(0.63) \\
(0.59) \\
(0.59) \\
(0.80)\end{array}$ & $\begin{array}{l}8.6 \\
4.2 \\
6.3 \\
3.9 \\
3.7\end{array}$ & $\begin{array}{l}(1.80) \\
(0.45) \\
(0.78) \\
(0.53) \\
(0.46)\end{array}$ \\
\hline 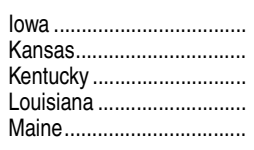 & $\begin{array}{r}- \\
18.5 \\
16.5\end{array}$ & $\begin{array}{r}(\dagger) \\
(\dagger) \\
(1.20) \\
(\dagger) \\
(1.20)\end{array}$ & $\begin{array}{r}15.7 \\
16.2 \\
23.1 \\
-\overline{18.3}\end{array}$ & $\begin{array}{r}(1.49) \\
(1.37) \\
(1.49) \\
(\dagger) \\
(2.00)\end{array}$ & $\begin{array}{r}12.8 \\
18.4 \\
24.4 \\
- \\
15.0\end{array}$ & $\begin{array}{r}(1.13) \\
(1.19) \\
(1.08) \\
(\dagger) \\
(1.47)\end{array}$ & $\begin{array}{r}- \\
16.0 \\
21.7 \\
19.6 \\
-\end{array}$ & $\begin{array}{r}(\dagger) \\
(1.26) \\
(1.72) \\
(1.73) \\
(\dagger)\end{array}$ & $\begin{array}{r}15.8 \\
- \\
22.8 \\
22.2 \\
-\end{array}$ & $\begin{array}{r}(1.26) \\
(\dagger) \\
(1.72) \\
(0.98) \\
(\dagger)\end{array}$ & $\begin{array}{l}- \\
\frac{7.4}{6.6}\end{array}$ & $\begin{array}{r}(\dagger) \\
(\dagger) \\
(0.86) \\
(\dagger) \\
(0.91)\end{array}$ & $\begin{array}{r}4.3 \\
4.9 \\
6.8 \\
- \\
5.9\end{array}$ & $\begin{array}{r}(0.70) \\
(0.85) \\
(0.72) \\
(\dagger) \\
(1.03)\end{array}$ & $\begin{array}{r}4.4 \\
5.7 \\
8.0 \\
-\overline{4.9}\end{array}$ & $\begin{array}{r}(0.61) \\
(0.75) \\
(0.59) \\
(\dagger) \\
(0.70)\end{array}$ & $\begin{array}{l}-\overline{5} \\
6.5 \\
5.8 \\
-\end{array}$ & $\begin{array}{r}(\dagger) \\
(0.65) \\
(0.77) \\
(1.12) \\
(\dagger)\end{array}$ & $\begin{array}{l}4.5 \\
5.2 \\
7.4 \\
4.2 \\
8.0\end{array}$ & $\begin{array}{l}(0.76) \\
(0.72) \\
(1.25) \\
(1.01) \\
(0.45)\end{array}$ \\
\hline 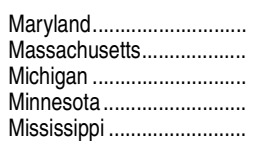 & $\begin{array}{r}-\overline{13.5} \\
15.2 \\
\overline{-} \\
20.0\end{array}$ & $\begin{array}{r}(\dagger) \\
(0.89) \\
(0.89) \\
(\dagger) \\
(1.78)\end{array}$ & $\begin{array}{r}19.1 \\
15.2 \\
15.8 \\
- \\
-\end{array}$ & $\begin{array}{r}(1.59) \\
(0.88) \\
(1.49) \\
(\dagger) \\
(\dagger)\end{array}$ & $\begin{array}{r}19.3 \\
14.9 \\
17.9 \\
-\overline{17.3}\end{array}$ & $\begin{array}{r}(1.51) \\
(0.88) \\
(1.30) \\
(\dagger) \\
(1.33)\end{array}$ & $\begin{array}{r}16.6 \\
12.8 \\
16.6 \\
- \\
17.2\end{array}$ & $\begin{array}{r}(1.19) \\
(1.00) \\
(0.69) \\
(\dagger) \\
(1.02)\end{array}$ & $\begin{array}{r}15.9 \\
12.3 \\
15.7 \\
- \\
18.0\end{array}$ & $\begin{array}{r}(1.10) \\
(0.95) \\
(0.94) \\
(\dagger) \\
(1.39)\end{array}$ & $\begin{array}{l}- \\
5.0 \\
5.1 \\
- \\
5.2\end{array}$ & $\begin{array}{r}(\dagger) \\
(0.50) \\
(0.66) \\
(\dagger) \\
(0.78)\end{array}$ & $\begin{array}{r}6.9 \\
5.8 \\
4.7 \\
- \\
-\end{array}$ & $\begin{array}{r}(0.88) \\
(0.59) \\
(0.54) \\
(\dagger) \\
(\dagger)\end{array}$ & $\begin{array}{l}5.9 \\
5.0 \\
5.0 \\
- \\
4.8\end{array}$ & $\begin{array}{r}(0.81) \\
(0.48) \\
(0.66) \\
(\dagger) \\
(0.60)\end{array}$ & $\begin{array}{r}4.6 \\
4.4 \\
5.4 \\
- \\
4.5\end{array}$ & $\begin{array}{r}(0.58) \\
(0.58) \\
(0.33) \\
(\dagger) \\
(0.48)\end{array}$ & $\begin{array}{l}5.3 \\
3.7 \\
3.5 \\
\overline{4.2}\end{array}$ & $\begin{array}{r}(0.55) \\
(0.46) \\
(0.37) \\
(\dagger) \\
(0.76)\end{array}$ \\
\hline 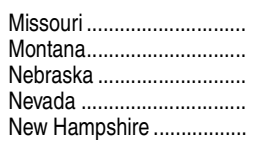 & $\begin{array}{l}16.8 \\
19.4 \\
16.0 \\
14.9 \\
15.1\end{array}$ & $\begin{array}{l}(1.87) \\
(0.88) \\
(1.06) \\
(1.09) \\
(1.59)\end{array}$ & $\begin{array}{l}19.4 \\
21.4 \\
17.9 \\
18.4 \\
16.2\end{array}$ & $\begin{array}{l}(1.79) \\
(1.20) \\
(0.89) \\
(1.32) \\
(1.26)\end{array}$ & $\begin{array}{r}18.6 \\
22.1 \\
- \\
14.5 \\
18.1\end{array}$ & $\begin{array}{r}(1.48) \\
(0.76) \\
(\dagger) \\
(1.08) \\
(1.46)\end{array}$ & $\begin{array}{r}16.0 \\
23.0 \\
- \\
19.1 \\
-\end{array}$ & $\begin{array}{r}(1.44) \\
(1.07) \\
(\dagger) \\
(1.08) \\
(\dagger)\end{array}$ & $\begin{array}{r}-\overline{23.5} \\
18.6 \\
\overline{1} \\
14.5\end{array}$ & $\begin{array}{r}(\dagger) \\
(0.96) \\
(0.90) \\
(\dagger) \\
(1.04)\end{array}$ & $\begin{array}{l}5.5 \\
7.2 \\
5.0 \\
6.3 \\
5.8\end{array}$ & $\begin{array}{l}(1.04) \\
(0.56) \\
(0.53) \\
(0.67) \\
(1.00)\end{array}$ & $\begin{array}{r}7.3 \\
10.2 \\
4.8 \\
6.8 \\
6.5\end{array}$ & $\begin{array}{l}(0.99) \\
(0.89) \\
(0.48) \\
(0.91) \\
(0.93)\end{array}$ & $\begin{array}{r}4.6 \\
9.7 \\
- \\
4.7 \\
5.8\end{array}$ & $\begin{array}{r}(0.83) \\
(0.57) \\
(\dagger) \\
(0.61) \\
(0.61)\end{array}$ & $\begin{array}{r}5.3 \\
7.9 \\
- \\
6.2 \\
8.8\end{array}$ & $\begin{array}{r}(1.02) \\
(0.67) \\
(t) \\
(0.62) \\
(1.00)\end{array}$ & $\begin{array}{l}\overline{-} \\
9.3 \\
3.8 \\
- \\
-\end{array}$ & $\begin{array}{r}(\dagger) \\
(0.69) \\
(0.45) \\
(\dagger) \\
(\dagger)\end{array}$ \\
\hline 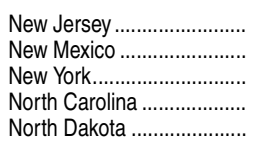 & $\begin{array}{r}- \\
13.5 \\
19.2 \\
-\end{array}$ & $\begin{array}{r}(\dagger) \\
(\dagger) \\
(1.01) \\
(1.49) \\
(\dagger)\end{array}$ & $\begin{array}{r}10.5 \\
24.5 \\
14.3 \\
21.5 \\
-\end{array}$ & $\begin{array}{r}(0.95) \\
(1.44) \\
(0.74) \\
(1.35) \\
(\dagger)\end{array}$ & $\begin{array}{r}- \\
27.5 \\
14.2 \\
21.2 \\
-\end{array}$ & $\begin{array}{r}(\dagger) \\
(1.20) \\
(0.76) \\
(1.19) \\
(\dagger)\end{array}$ & $\begin{array}{r}9.6 \\
27.4 \\
13.9 \\
19.6 \\
-\end{array}$ & $\begin{array}{r}(0.81) \\
(0.90) \\
(0.98) \\
(0.95) \\
(\dagger)\end{array}$ & $\begin{array}{r}9.6 \\
22.8 \\
12.6 \\
20.8 \\
-\end{array}$ & $\begin{array}{r}(1.17) \\
(0.93) \\
(0.76) \\
(1.24) \\
(\dagger)\end{array}$ & $\begin{array}{l}- \\
- \\
5.2 \\
6.3 \\
5.7\end{array}$ & $\begin{array}{r}(\dagger) \\
(\dagger) \\
(0.51) \\
(0.79) \\
(0.98)\end{array}$ & $\begin{array}{l}3.1 \\
8.0 \\
5.2 \\
6.4 \\
6.0\end{array}$ & $\begin{array}{l}(0.53) \\
(0.29) \\
(0.42) \\
(0.77) \\
(0.74)\end{array}$ & $\begin{array}{l}- \\
9.3 \\
4.7 \\
6.8 \\
5.0\end{array}$ & $\begin{array}{r}(\dagger) \\
(0.66) \\
(0.41) \\
(0.94) \\
(0.57)\end{array}$ & $\begin{array}{l}3.1 \\
8.1 \\
4.8 \\
4.7 \\
5.4\end{array}$ & $\begin{array}{l}(0.45) \\
(0.59) \\
(0.64) \\
(0.57) \\
(0.64)\end{array}$ & $\begin{array}{l}-\overline{5} \\
6.2 \\
6.1 \\
5.7\end{array}$ & $\begin{array}{r}(\dagger) \\
(0.51) \\
(0.32) \\
(0.64) \\
(0.73)\end{array}$ \\
\hline 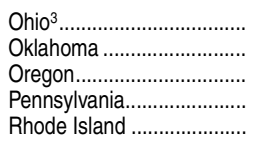 & $\begin{array}{r}12.5 \\
21.8 \\
- \\
12 . \overline{3}\end{array}$ & $\begin{array}{r}(1.40) \\
(1.72) \\
(\dagger) \\
(\dagger) \\
(1.01)\end{array}$ & $\begin{array}{r}15.2 \\
18.9 \\
- \\
- \\
12.4\end{array}$ & $\begin{array}{r}(1.27) \\
(1.38) \\
(\dagger) \\
(\dagger) \\
(0.90)\end{array}$ & $\begin{array}{r}16.6 \\
22.3 \\
- \\
12.0\end{array}$ & $\begin{array}{r}(1.42) \\
(1.65) \\
(\dagger) \\
(\dagger) \\
(0.74)\end{array}$ & $\begin{array}{r}19.0 \\
\overline{-} \\
14.8 \\
10.4\end{array}$ & $\begin{array}{r}(\dagger) \\
(1.44) \\
(\dagger) \\
(1.28) \\
(0.50)\end{array}$ & $\begin{array}{r}16.4 \\
19.4 \\
- \\
- \\
11.2\end{array}$ & $\begin{array}{r}(1.37) \\
(1.86) \\
(\dagger) \\
(\dagger) \\
(0.82)\end{array}$ & $\begin{array}{r}3.6 \\
8.0 \\
- \\
-9\end{array}$ & $\begin{array}{r}(0.75) \\
(1.01) \\
(\dagger) \\
(\dagger) \\
(0.85)\end{array}$ & $\begin{array}{r}4.4 \\
7.0 \\
- \\
- \\
4.9\end{array}$ & $\begin{array}{r}(0.63) \\
(0.77) \\
(\dagger) \\
(\dagger) \\
(0.41)\end{array}$ & $\begin{array}{r}4.1 \\
9.0 \\
- \\
4.9\end{array}$ & $\begin{array}{r}(0.51) \\
(1.43) \\
(\dagger) \\
(\dagger) \\
(0.63)\end{array}$ & $\begin{array}{r}\overline{5.6} \\
\overline{3.3} \\
4.0\end{array}$ & $\begin{array}{r}(\dagger) \\
(0.79) \\
(\dagger) \\
(0.47) \\
(0.33)\end{array}$ & $\begin{array}{l}\overline{6} .1 \\
-\overline{4} \\
\overline{4.0}\end{array}$ & $\begin{array}{r}(\dagger) \\
(1.14) \\
(\dagger) \\
(\dagger) \\
(0.39)\end{array}$ \\
\hline 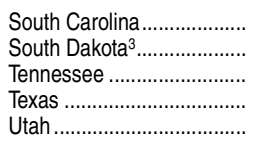 & $\begin{array}{r}- \\
21 . \overline{3} \\
\overline{15.3}\end{array}$ & $\begin{array}{r}(\dagger) \\
(\dagger) \\
(2.06) \\
(\dagger) \\
(1.80)\end{array}$ & $\begin{array}{r}20.5 \\
-\overline{24.1} \\
19.3 \\
17.7\end{array}$ & $\begin{array}{r}(1.42) \\
(\dagger) \\
(1.58) \\
(0.93) \\
(1.70)\end{array}$ & $\begin{array}{r}19.8 \\
- \\
22.6 \\
18.8 \\
17.1\end{array}$ & $\begin{array}{r}(1.69) \\
(\dagger) \\
(1.41) \\
(0.71) \\
(1.38)\end{array}$ & $\begin{array}{r}20.4 \\
- \\
20.5 \\
18.2 \\
16.0\end{array}$ & $\begin{array}{r}(2.22) \\
(\dagger) \\
(1.64) \\
(0.89) \\
(1.40)\end{array}$ & $\begin{array}{r}23.4 \\
- \\
21.1 \\
17.6 \\
16.8\end{array}$ & $\begin{array}{r}(1.86) \\
(\dagger) \\
(1.34) \\
(0.73) \\
(1.48)\end{array}$ & $\begin{array}{l}- \\
7.1 \\
5.4 \\
- \\
5.6\end{array}$ & $\begin{array}{r}(\dagger) \\
(0.73) \\
(0.80) \\
(\dagger) \\
(1.24)\end{array}$ & $\begin{array}{l}6.7 \\
8.3 \\
8.1 \\
7.9 \\
7.0\end{array}$ & $\begin{array}{l}(0.82) \\
(0.72) \\
(0.92) \\
(0.63) \\
(1.03)\end{array}$ & $\begin{array}{l}4.8 \\
6.3 \\
5.6 \\
6.8 \\
7.5\end{array}$ & $\begin{array}{l}(0.79) \\
(0.80) \\
(0.70) \\
(0.55) \\
(1.00)\end{array}$ & $\begin{array}{l}4.6 \\
9.2 \\
5.1 \\
6.4 \\
4.6\end{array}$ & $\begin{array}{l}(0.67) \\
(0.76) \\
(0.70) \\
(0.76) \\
(0.63)\end{array}$ & $\begin{array}{l}6.3 \\
5.7 \\
5.2 \\
4.9 \\
5.9\end{array}$ & $\begin{array}{l}(0.89) \\
(0.52) \\
(0.80) \\
(0.45) \\
(1.01)\end{array}$ \\
\hline 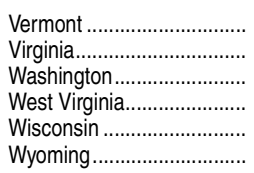 & $\begin{array}{r}- \\
- \\
20.7 \\
13.2 \\
24.6\end{array}$ & $\begin{array}{r}(\dagger) \\
(\dagger) \\
(\dagger) \\
(1.37) \\
(0.81) \\
(1.49)\end{array}$ & $\begin{array}{r}- \\
- \\
22.3 \\
15.8 \\
28.0\end{array}$ & $\begin{array}{r}(\dagger) \\
(\dagger) \\
(\dagger) \\
(1.32) \\
(1.19) \\
(1.17)\end{array}$ & $\begin{array}{r}- \\
- \\
21.3 \\
12.7 \\
26.8\end{array}$ & $\begin{array}{r}(\dagger) \\
(\dagger) \\
(\dagger) \\
(1.52) \\
(0.76) \\
(1.28)\end{array}$ & $\begin{array}{r}- \\
- \\
24.4 \\
10.9 \\
26.0\end{array}$ & $\begin{array}{r}(\dagger) \\
(\dagger) \\
(\dagger) \\
(1.05) \\
(0.81) \\
(1.04)\end{array}$ & $\begin{array}{r}-\overline{2} \\
-\overline{4} \\
20.7 \\
10.4 \\
27.1\end{array}$ & $\begin{array}{r}(\dagger) \\
(1.26) \\
(\dagger) \\
(1.64) \\
(0.66) \\
(1.19)\end{array}$ & $\begin{array}{r}8.3 \\
- \\
6.6 \\
3.2 \\
10.1\end{array}$ & $\begin{array}{r}(0.31) \\
(\dagger) \\
(\dagger) \\
(1.25) \\
(0.43) \\
(0.91)\end{array}$ & $\begin{array}{r}9.1 \\
- \\
- \\
8.5 \\
3.9 \\
10.0\end{array}$ & $\begin{array}{r}(0.90) \\
(\dagger) \\
(\dagger) \\
(1.00) \\
(0.54) \\
(0.71)\end{array}$ & $\begin{array}{r}9.6 \\
- \\
6.9 \\
3.6 \\
11.4\end{array}$ & $\begin{array}{r}(1.05) \\
(\dagger) \\
(\dagger) \\
(0.89) \\
(0.49) \\
(0.76)\end{array}$ & $\begin{array}{r}9.0 \\
- \\
- \\
6.5 \\
3.4 \\
11.5\end{array}$ & $\begin{array}{r}(0.61) \\
(\dagger) \\
(\dagger) \\
(0.72) \\
(0.50) \\
(0.81)\end{array}$ & $\begin{array}{r}9.1 \\
5.7 \\
- \\
5.5 \\
3.1 \\
10.5\end{array}$ & $\begin{array}{r}(0.73) \\
(0.64) \\
(\dagger) \\
(0.75) \\
(0.41) \\
(0.71)\end{array}$ \\
\hline
\end{tabular}

-Not available.

†Not applicable.

"The term "anywhere" is not used in the Youth Risk Behavior Survey (YRBS) questionnaire students were simply asked how many days they carried a weapon during the past 30 days. 'In the question asking students about carrying a weapon at school, "on school property" was not defined for survey respondents.

3Data include both public and private schools.
NOTE: Respondents were asked about carrying "a weapon such as a gun, knife, or club." State-level data include public schools only, with the exception of data for Ohio and South Dakota. Data for the United States total, Ohio, and South Dakota include both public and private schools.

SOURCE: Centers for Disease Control and Prevention, Division of Adolescent and School Health, Youth Risk Behavior Surveillance System (YRBSS), 2003 through 2011. (This table was prepared September 2013.) 
326 CHAPTER 2: Elementary and Secondary Education

Fights and Weapons

Table 231.70. Percentage of students ages 12-18 who reported having access to a loaded gun, without adult permission, at school or away from school during the school year, by selected student and school characteristics: 2007, 2009, and 2011

[Standard errors appear in parentheses]

\begin{tabular}{|c|c|c|c|c|c|c|}
\hline Student or school characteristic & & 2007 & & 2009 & & 2011 \\
\hline 1 & & 2 & & 3 & & 4 \\
\hline 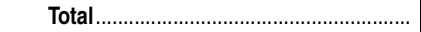 & 6.7 & $(0.40)$ & 5.5 & $(0.47)$ & 4.7 & $(0.43)$ \\
\hline $\begin{array}{l}\text { Sex } \\
\quad \text { Male } \\
\text { Female }\end{array}$ & $\begin{array}{l}8.4 \\
5.0\end{array}$ & $\begin{array}{l}(0.56) \\
(0.47)\end{array}$ & $\begin{array}{l}7.6 \\
3.4\end{array}$ & $\begin{array}{l}(0.72) \\
(0.44)\end{array}$ & $\begin{array}{l}5.6 \\
3.6\end{array}$ & $\begin{array}{l}(0.59) \\
(0.44)\end{array}$ \\
\hline 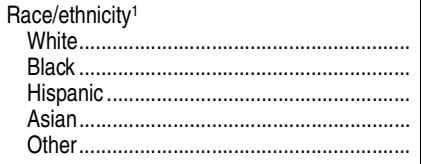 & $\begin{array}{r}7.7 \\
6.2 \\
4.8 \\
\ddagger \\
9.3\end{array}$ & $\begin{array}{r}(0.55) \\
(0.98) \\
(0.79) \\
(\dagger) \\
(2.30)\end{array}$ & $\begin{array}{l}6.4 \\
3.9 \\
4.9 \\
\ddagger \\
5.4 !\end{array}$ & $\begin{array}{r}(0.60) \\
(0.92) \\
(0.90) \\
(\dagger) \\
(2.40)\end{array}$ & $\begin{array}{r}5.3 \\
4.1 \\
4.1 \\
\ddagger \\
\ddagger\end{array}$ & $\begin{array}{r}(0.50) \\
(0.86) \\
(0.89) \\
(\dagger) \\
(\dagger)\end{array}$ \\
\hline $\begin{array}{l}\text { Grade } \\
\text { 6th } \\
\text { 8th } \\
\text { 9th } \\
\text { 10th } \\
\text { 11th } \\
\text { 12th }\end{array}$ & $\begin{array}{r}2.4 \\
2.6 \\
3.2 \\
6.8 \\
9.2 \\
9.9 \\
12.3\end{array}$ & $\begin{array}{l}(0.64) \\
(0.56) \\
(0.63) \\
(0.98) \\
(1.13) \\
(1.00) \\
(1.33)\end{array}$ & $\begin{array}{l}0.8 ! \\
3.6 \\
3.2 \\
4.4 \\
7.3 \\
7.6 \\
9.8\end{array}$ & $\begin{array}{l}(0.40) \\
(0.84) \\
(0.63) \\
(0.80) \\
(1.02) \\
(1.16) \\
(1.44)\end{array}$ & $\begin{array}{l}2.0 ! \\
3.0 \\
2.9 \\
4.0 \\
5.3 \\
6.4 \\
8.2\end{array}$ & $\begin{array}{l}(0.89) \\
(0.63) \\
(0.60) \\
(0.75) \\
(0.70) \\
(1.06) \\
(1.06)\end{array}$ \\
\hline 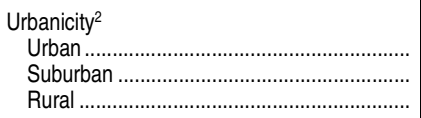 & $\begin{array}{l}5.8 \\
6.4 \\
9.1\end{array}$ & $\begin{array}{l}(0.67) \\
(0.59) \\
(1.04)\end{array}$ & $\begin{array}{l}4.7 \\
5.5 \\
7.1\end{array}$ & $\begin{array}{l}(0.72) \\
(0.57) \\
(1.39)\end{array}$ & $\begin{array}{l}4.1 \\
4.9 \\
4.9\end{array}$ & $\begin{array}{l}(0.61) \\
(0.55) \\
(0.92)\end{array}$ \\
\hline $\begin{array}{l}\text { Control of school } \\
\text { Public } \\
\text { Private }\end{array}$ & $\begin{array}{l}6.9 \\
4.5\end{array}$ & $\begin{array}{l}(0.44) \\
(0.88)\end{array}$ & $\begin{array}{l}5.8 \\
2.3 !\end{array}$ & $\begin{array}{l}(0.49) \\
(0.83)\end{array}$ & $\begin{array}{l}4.8 \\
3.2 !\end{array}$ & $\begin{array}{l}(0.42) \\
(0.98)\end{array}$ \\
\hline
\end{tabular}

†Not applicable.

!nterpret data with caution. The coefficient of variation (CV) for this estimate is between 30 and 50 percent.

†Reporting standards not met. Either there are too few cases for a reliable estimate or the coefficient of variation (CV) is 50 percent or greater.

${ }^{1}$ Race categories exclude persons of Hispanic ethnicity.
${ }^{2}$ Refers to the Standard Metropolitan Statistical Area (MSA) status of the respondent's household as defined in 2000 by the U.S. Census Bureau. Categories include "central city of an MSA (Urban)," "in MSA but not in central city (Suburban)," and "not MSA (Rural)."

SOURCE: U.S. Department of Justice, Bureau of Justice Statistics, School Crime Supplement (SCS) to the National Crime Victimization Survey, 2007, 2009, and 2011. (This table was prepared September 2013.) 


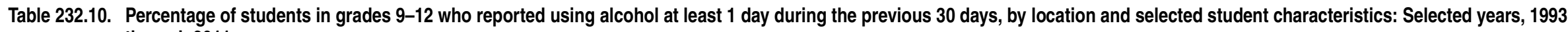
through 2011

[Standard errors appear in parentheses]

\begin{tabular}{|c|c|c|c|c|c|c|c|c|c|c|c|c|c|c|c|c|c|c|c|c|}
\hline Location and student characteristic & & 1993 & & 1995 & & 1997 & & 1999 & & 2001 & & 2003 & & 2005 & & 2007 & & 2009 & & 2011 \\
\hline 1 & & 2 & & 3 & & 4 & & 5 & & 6 & & 7 & & 8 & & 9 & & 10 & & 1 \\
\hline $\begin{array}{l}\text { Anywhere (including on school property) } \\
\text { Total }\end{array}$ & 48.0 & $(1.06)$ & 51.6 & (1.19) & 50.8 & (1.43) & 50.0 & (1.30) & 47.1 & (1.11) & 44.9 & (1.21) & 43.3 & (1.38) & 44.7 & (1.15) & 41.8 & $(0.80)$ & 38.7 & \\
\hline 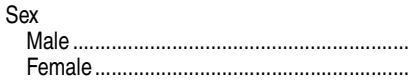 & $\begin{array}{l}50.1 \\
45.9\end{array}$ & $\begin{array}{l}(1.23) \\
(1.32)\end{array}$ & $\begin{array}{l}53.2 \\
49.9\end{array}$ & $\begin{array}{l}(1.33) \\
(1.79)\end{array}$ & $\begin{array}{l}53.3 \\
47.8\end{array}$ & $\begin{array}{l}(1.22) \\
(1.99)\end{array}$ & $\begin{array}{l}52.3 \\
47.7\end{array}$ & $\begin{array}{l}(1.47) \\
(1.45)\end{array}$ & $\begin{array}{l}49.2 \\
45.0\end{array}$ & $\begin{array}{l}(1.42) \\
(1.11)\end{array}$ & $\begin{array}{l}43.8 \\
45.8\end{array}$ & $\begin{array}{l}(1.31) \\
(1.29)\end{array}$ & $\begin{array}{l}43.8 \\
42.8\end{array}$ & $\begin{array}{l}(1.40) \\
(1.56)\end{array}$ & $\begin{array}{l}44.7 \\
44.6\end{array}$ & $\begin{array}{l}(1.39) \\
(1.42)\end{array}$ & $\begin{array}{l}40.8 \\
42.9\end{array}$ & $\begin{array}{l}(1.11) \\
(0.85)\end{array}$ & $\begin{array}{l}39.5 \\
37.9\end{array}$ & \\
\hline 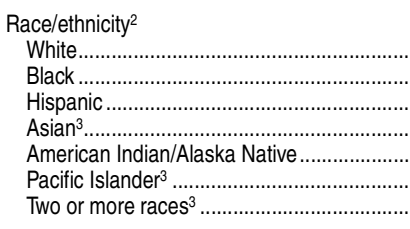 & $\begin{array}{r}49.9 \\
42.5 \\
50.8 \\
- \\
45.3 \\
- \\
-\end{array}$ & $\begin{array}{r}(1.26) \\
(1.82) \\
(2.82) \\
(\dagger) \\
(7.18) \\
(\dagger) \\
(\dagger)\end{array}$ & $\begin{array}{r}54.1 \\
42.0 \\
54.7 \\
- \\
51.4 \\
- \\
-\end{array}$ & $\begin{array}{r}(1.77) \\
(2.24) \\
(2.56) \\
(\dagger) \\
(7.18) \\
(\dagger) \\
(\dagger)\end{array}$ & $\begin{array}{r}54.0 \\
36.9 \\
53.9 \\
- \\
57.6 \\
- \\
-\end{array}$ & $\begin{array}{r}(1.51) \\
(1.46) \\
(1.96) \\
(+) \\
(3.79) \\
(\dagger) \\
(\dagger)\end{array}$ & $\begin{array}{l}52.5 \\
39.9 \\
52.8 \\
25.7 \\
49.4 \\
60.8 \\
51.1\end{array}$ & $\begin{array}{l}(1.62) \\
(4.07) \\
(2.41) \\
(2.24) \\
(6.43) \\
(5.11) \\
(3.98)\end{array}$ & $\begin{array}{l}50.4 \\
32.7 \\
49.2 \\
28.4 \\
51.4 \\
52.3 \\
45.4\end{array}$ & $\begin{array}{l}(1.12) \\
(2.33) \\
(1.52) \\
(3.22) \\
(3.97) \\
(8.54) \\
(4.11)\end{array}$ & $\begin{array}{l}47.1 \\
37.4 \\
45.6 \\
27.5 \\
51.9 \\
40.0 \\
47.1\end{array}$ & $\begin{array}{l}(1.51) \\
(1.67) \\
(1.39) \\
(3.47) \\
(5.29) \\
(7.04) \\
(3.59)\end{array}$ & $\begin{array}{l}46.4 \\
31.2 \\
46.8 \\
21.5 \\
57.4 \\
38.7 \\
39.0\end{array}$ & $\begin{array}{l}(1.84) \\
(1.05) \\
(1.39) \\
(1.98) \\
(4.13) \\
(8.43) \\
(3.59)\end{array}$ & $\begin{array}{l}47.3 \\
34.5 \\
47.6 \\
25.4 \\
34.5 \\
48.8 \\
46.2\end{array}$ & $\begin{array}{l}(1.67) \\
(1.65) \\
(1.80) \\
(2.17) \\
(1.77) \\
(6.58) \\
(2.89)\end{array}$ & $\begin{array}{l}44.7 \\
33.4 \\
42.9 \\
18.3 \\
42.8 \\
34.8 \\
44.3\end{array}$ & $\begin{array}{l}(1.16) \\
(1.45) \\
(1.43) \\
(1.60) \\
(5.43) \\
(4.36) \\
(2.42)\end{array}$ & $\begin{array}{l}40.3 \\
30.5 \\
42.3 \\
25.6 \\
44.9 \\
38.4 \\
36.9\end{array}$ & \\
\hline 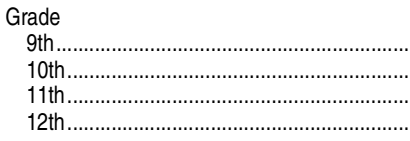 & $\begin{array}{l}40.5 \\
44.0 \\
49.7 \\
56.4\end{array}$ & $\begin{array}{l}(1.79) \\
(2.00) \\
(1.73) \\
(1.35)\end{array}$ & $\begin{array}{l}45.6 \\
49.5 \\
53.7 \\
56.5\end{array}$ & $\begin{array}{l}(1.87) \\
(2.38) \\
(1.51) \\
(1.64)\end{array}$ & $\begin{array}{l}44.2 \\
47.2 \\
53.2 \\
57.3\end{array}$ & $\begin{array}{l}(3.12) \\
(2.19) \\
(1.49) \\
(2.50)\end{array}$ & $\begin{array}{l}40.6 \\
49.7 \\
50.9 \\
61.7\end{array}$ & $\begin{array}{l}(2.17) \\
(1.89) \\
(1.98) \\
(2.25)\end{array}$ & $\begin{array}{l}45.2 \\
49.3 \\
55.2\end{array}$ & $\begin{array}{l}(1.82) \\
(1.29) \\
(1.70) \\
(1.53)\end{array}$ & $\begin{array}{l}47.0 \\
55.9\end{array}$ & $\begin{array}{l}(1.43) \\
(1.66) \\
(2.08) \\
(1.65)\end{array}$ & $\begin{array}{l}36.2 \\
42.0 \\
46.0 \\
50.8\end{array}$ & $\begin{array}{l}(1.23) \\
(1.95) \\
(1.98) \\
(2.12)\end{array}$ & $\begin{array}{l}35.7 \\
41.8 \\
49.0 \\
54.9\end{array}$ & $\begin{array}{l}(1.15) \\
(1.68) \\
(1.83) \\
(2.09)\end{array}$ & $\begin{array}{l}31.5 \\
40.6 \\
45.7 \\
51.7\end{array}$ & $\begin{array}{l}(1.28) \\
(1.42) \\
(2.05) \\
(1.37)\end{array}$ & $\begin{array}{l}29.8 \\
35.7 \\
42.7 \\
48.4\end{array}$ & $\begin{array}{l}1 . \\
(1 . \\
(1 . \\
(1 .\end{array}$ \\
\hline $\begin{array}{l}\text { Urbanicity } \\
\text { Urban } \\
\text { Suburban } \\
\text { Rural }\end{array}$ & $\begin{array}{l}- \\
- \\
\end{array}$ & $\begin{array}{c}(t) \\
(t) \\
(t) \\
\end{array}$ & $\begin{array}{l}- \\
- \\
\end{array}$ & $\begin{array}{c}(t) \\
(t) \\
(t)\end{array}$ & $\begin{array}{l}48.9 \\
50.5 \\
55.4 \\
\end{array}$ & $\begin{array}{l}(2.07) \\
(2.11) \\
(5.36)\end{array}$ & $\begin{array}{l}46.5 \\
51.4 \\
52.2 \\
\end{array}$ & $\begin{array}{l}(2.75) \\
(1.32) \\
(4.51)\end{array}$ & $\begin{array}{l}45.2 \\
47.6 \\
50.2 \\
\end{array}$ & $\begin{array}{l}(1.97) \\
(1.26) \\
(1.91)\end{array}$ & $\begin{array}{l}41.5 \\
46.5 \\
45.3 \\
\end{array}$ & $\begin{array}{l}(1.48) \\
(2.10) \\
(2.35)\end{array}$ & $\begin{array}{l}- \\
- \\
\end{array}$ & $\begin{array}{l}(t) \\
(t) \\
(t)\end{array}$ & $\begin{array}{l}- \\
-\end{array}$ & $\begin{array}{l}(\dagger) \\
(\dagger) \\
(\dagger)\end{array}$ & $\begin{array}{l}- \\
- \\
\end{array}$ & $\begin{array}{l}(t) \\
(t) \\
(t)\end{array}$ & $\begin{array}{l}- \\
-\end{array}$ & \\
\hline $\begin{array}{l}\text { On school property } \\
\text { Total }\end{array}$ & 5.2 & $(0.39)$ & 6.3 & $(0.45)$ & 5.6 & $(0.34)$ & 4.9 & $(0.39)$ & 4.9 & $(0.28)$ & 5.2 & $(0.46)$ & 4.3 & $(0.30)$ & 4.1 & $(0.32)$ & 4.5 & $(0.29)$ & 5.1 & \\
\hline 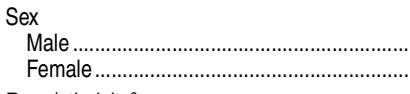 & $\begin{array}{l}6.2 \\
4.2\end{array}$ & $\begin{array}{l}(0.39) \\
(0.54)\end{array}$ & $\begin{array}{l}7.2 \\
5.3\end{array}$ & $\begin{array}{l}(0.50) \\
(0.70)\end{array}$ & $\begin{array}{l}7.2 \\
3.6\end{array}$ & $\begin{array}{l}(0.66) \\
(0.37)\end{array}$ & $\begin{array}{l}6.1 \\
3.6\end{array}$ & $\begin{array}{l}(0.54) \\
(0.39)\end{array}$ & $\begin{array}{l}6.1 \\
3.8\end{array}$ & $\begin{array}{l}(0.43) \\
(0.39)\end{array}$ & $\begin{array}{l}6.0 \\
4.2\end{array}$ & $\left.\begin{array}{l}(0.61) \\
(0.41)\end{array}\right)$ & $\begin{array}{l}5.3 \\
3.3\end{array}$ & $\begin{array}{l}(0.39) \\
(0.32)\end{array}$ & $\begin{array}{l}4.6 \\
3.6\end{array}$ & $\begin{array}{l}(0.35) \\
(0.37)\end{array}$ & $\begin{array}{l}5.3 \\
3.6\end{array}$ & $\begin{array}{l}(0.41) \\
(0.34)\end{array}$ & $\begin{array}{l}5.4 \\
4.7\end{array}$ & \\
\hline 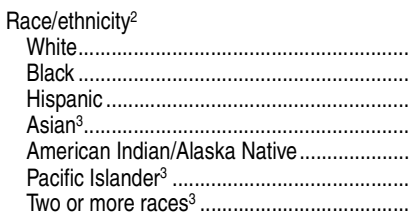 & $\begin{array}{l}4.6 \\
6.9 \\
6.8 \\
- \\
6.7 ! \\
-\end{array}$ & $\begin{array}{r}(0.44) \\
(0.98) \\
(0.84) \\
(\dagger) \\
(3.06) \\
(\dagger) \\
(\dagger)\end{array}$ & $\begin{array}{l}5.6 \\
7.6 \\
9.6 \\
- \\
8.1 ! \\
- \\
-\end{array}$ & $\begin{array}{r}(0.62) \\
(0.87) \\
(1.73) \\
(t) \\
(3.30) \\
(\dagger) \\
(\dagger)\end{array}$ & $\begin{array}{l}4.8 \\
5.6 \\
8.2 \\
- \\
8.6 ! \\
- \\
-\end{array}$ & $\begin{array}{r}(0.42) \\
(0.72) \\
(0.96) \\
(+) \\
(4.15) \\
(\dagger) \\
(\dagger)\end{array}$ & $\begin{array}{r}4.8 \\
4.3 \\
7.0 \\
2.0 \\
\ddagger \\
6.7 \\
5.2\end{array}$ & 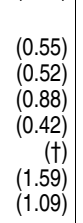 & $\begin{array}{c}4.2 \\
5.3 \\
7.0 \\
6.8 \\
8.2 \\
12.4 \\
7.0 !\end{array}$ & $\begin{array}{l}(0.26) \\
(0.65) \\
(0.71) \\
(1.42) \\
(1.69) \\
(3.50) \\
(2.36)\end{array}$ & $\begin{array}{c}3.9 \\
5.8 \\
7.6 \\
5.6 \\
7.1 ! \\
8.5 ! \\
13.3\end{array}$ & $\begin{array}{l}(0.45) \\
(0.80) \\
(1.08) \\
(1.55) \\
(2.61) \\
(3.29) \\
(2.93)\end{array}$ & $\begin{array}{c}3.8 \\
3.2 \\
7.7 \\
1.3 ! \\
6.2 ! \\
\neq \\
3.5\end{array}$ & $\begin{array}{r}(0.38) \\
(0.45) \\
(1.04) \\
(0.62) \\
(2.05) \\
(t) \\
(1.02)\end{array}$ & $\begin{array}{r}3.2 \\
3.4 \\
7.5 \\
4.4 \\
5.0 \\
\ddagger \\
5.4\end{array}$ & $\begin{array}{r}(0.35) \\
(0.63) \\
(0.86) \\
(1.17) \\
(0.89) \\
(\dagger) \\
(1.25)\end{array}$ & $\begin{array}{c}3.3 \\
5.4 \\
6.9 \\
2.9 \\
4.3 ! \\
10.0 \\
6.7\end{array}$ & $\begin{array}{l}(0.27) \\
(0.59) \\
(0.70) \\
(0.65) \\
(1.58) \\
(2.34) \\
(1.37)\end{array}$ & $\begin{array}{c}4.0 \\
5.1 \\
7.3 \\
3.5 ! \\
20.9 \\
8.3 ! \\
5.8\end{array}$ & $\begin{array}{l}(0 . \\
(0 . \\
1\end{array}$ \\
\hline 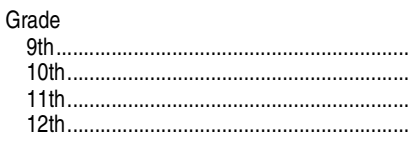 & $\begin{array}{l}5.2 \\
4.7 \\
5.2 \\
5.5\end{array}$ & $\begin{array}{l}(0.38) \\
(0.43) \\
(0.80) \\
(0.64)\end{array}$ & $\begin{array}{l}7.5 \\
5.9 \\
5.7 \\
6.2\end{array}$ & $\begin{array}{l}(0.90) \\
(0.88) \\
(0.86) \\
(0.58)\end{array}$ & $\begin{array}{l}5.9 \\
4.6 \\
6.0 \\
5.9\end{array}$ & $\begin{array}{l}(0.83) \\
(0.71) \\
(0.86) \\
(0.66)\end{array}$ & $\begin{array}{l}4.4 \\
5.0 \\
4.7 \\
5.0\end{array}$ & $\begin{array}{l}(0.67) \\
(0.57) \\
(0.89)\end{array}$ & $\begin{array}{l}5.3 \\
5.1 \\
4.7 \\
4.3\end{array}$ & $\begin{array}{l}(0.45) \\
(0.45) \\
(0.44)\end{array}$ & $\begin{array}{l}5.6 \\
5.0 \\
4.5\end{array}$ & $\begin{array}{l}(0.60) \\
(0.57) \\
(0.68)\end{array}$ & $\begin{array}{l}3.7 \\
4.5 \\
4.0 \\
4.8\end{array}$ & $\begin{array}{l}(0.45) \\
(0.47) \\
(0.57)\end{array}$ & $\begin{array}{l}3.4 \\
4.1 \\
4.2 \\
4.8\end{array}$ & $\begin{array}{l}(0.43) \\
(0.50) \\
(0.54) \\
(0.55)\end{array}$ & $\begin{array}{l}4.4 \\
4.8 \\
4.6 \\
4.1\end{array}$ & $\begin{array}{l}(0.37) \\
(0.46) \\
(0.44) \\
(0.44)\end{array}$ & $\begin{array}{l}5.4 \\
4.4 \\
5.2 \\
5.1\end{array}$ & \\
\hline 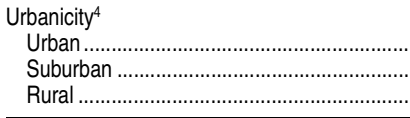 & $\begin{array}{l}- \\
- \\
-\end{array}$ & $\begin{array}{l}(+) \\
(t) \\
(\dagger)\end{array}$ & $\begin{array}{l}- \\
-\end{array}$ & $\begin{array}{l}(t) \\
(+) \\
(t)\end{array}$ & $\begin{array}{l}6.4 \\
5.2 \\
5.3\end{array}$ & $\begin{array}{l}(0.85) \\
(0.43) \\
(0.55)\end{array}$ & $\begin{array}{l}5.0 \\
4.6 \\
5.6\end{array}$ & $\begin{array}{l}(0.60) \\
(0.61) \\
(0.67)\end{array}$ & $\begin{array}{l}5.4 \\
4.9 \\
4.0\end{array}$ & $\begin{array}{l}(0.61) \\
(0.37) \\
(0.83)\end{array}$ & $\begin{array}{l}6.1 \\
4.8 \\
4.7\end{array}$ & $\begin{array}{l}(0.94) \\
(0.54) \\
(0.49)\end{array}$ & $\begin{array}{l}- \\
- \\
-\end{array}$ & $\begin{array}{l}(+) \\
(+) \\
(\dagger)\end{array}$ & $\begin{array}{l}- \\
- \\
-\end{array}$ & $\begin{array}{l}(\dagger) \\
(\dagger) \\
(\dagger)\end{array}$ & $\begin{array}{l}- \\
\overline{-}\end{array}$ & $\begin{array}{l}(+) \\
(+) \\
(\dagger)\end{array}$ & $\begin{array}{l}- \\
- \\
-\end{array}$ & \\
\hline
\end{tabular}

\section{-Not available.}

INot applicable.

fReporting standards not met. The coefficient of variation (CV) for this estimate is 50 percent or greater.

"The term "anywhere" is not used in the Youth Risk Behavior Survey (YRBS) questionnaire; students were simply asked how many days during the previous 30 days they had at least one drink of alcohol.

${ }^{3}$ Before 1999, Asian students and Pacific Islander students were not categorized separately, and students were not given the option of choosing two or more races. Because the response categories changed in 1999, caution should be used in comparin data on tace

respondent's household as defined in 2000 by the U.S. (Rural):

${ }^{2}$ Race categories exclude persons of Hispanic ethnicity.

SOURCE: Centers for Disease Control and Prevention, Division of Adolescent and School Health, Youth Risk Behavior Surve lance System (YRBSS), 1993 through 2011. (This table was prepared September 2013.) 
328 CHAPTER 2: Elementary and Secondary Education

Alcohol, Illicit Drugs, and Cigarettes

Table 232.20. Percentage distribution of students in grades 9-12, by number of days they reported using alcohol anywhere or on school property during the previous 30 days and selected student characteristics: 2011

[Standard errors appear in parentheses]

\begin{tabular}{|c|c|c|c|c|c|c|c|c|c|c|c|c|c|c|c|c|}
\hline \multirow[b]{2}{*}{ Student characteristic } & \multicolumn{8}{|c|}{ Anywhere (including on school property) ${ }^{1}$} & \multicolumn{8}{|c|}{ On school property ${ }^{2}$} \\
\hline & & 0 days & 10 & 2 days & 3 to & 29 days & All & 30 days & & 0 days & & 2 days & 3 to & 29 days & & 30 days \\
\hline 1 & & 2 & & 3 & & 4 & & 5 & & 6 & & 7 & & 8 & & 9 \\
\hline 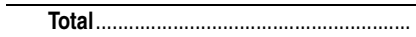 & 61.3 & $(0.75)$ & 19.4 & $(0.62)$ & 18.3 & $(0.47)$ & 0.9 & $(0.11)$ & 94.9 & $(0.33)$ & 3.3 & $(0.23)$ & 1.3 & $(0.15)$ & 0.5 & $(0.07)$ \\
\hline 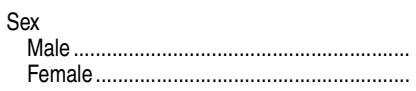 & $\begin{array}{l}60.5 \\
62.1\end{array}$ & $\begin{array}{l}(0.93) \\
(0.91)\end{array}$ & $\begin{array}{l}18.5 \\
20.5\end{array}$ & $\begin{array}{l}(0.68) \\
(0.74)\end{array}$ & $\begin{array}{l}19.5 \\
17.1\end{array}$ & $\begin{array}{r}(0.65) \\
(0.63)\end{array}$ & $\begin{array}{l}1.5 \\
0.3\end{array}$ & $\begin{array}{l}(0.19) \\
(0.08)\end{array}$ & $\begin{array}{l}94.6 \\
95.3\end{array}$ & $\begin{array}{l}(0.43) \\
(0.35)\end{array}$ & $\begin{array}{l}3.1 \\
3.4\end{array}$ & $\begin{array}{l}(0.26) \\
(0.29)\end{array}$ & $\begin{array}{l}1.5 \\
1.1\end{array}$ & $\begin{array}{l}(0.21) \\
(0.16)\end{array}$ & $\begin{array}{l}0.8 \\
0.1 !\end{array}$ & $\begin{array}{l}(0.14) \\
(0.04)\end{array}$ \\
\hline 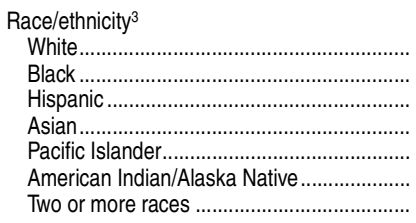 & $\begin{array}{l}59.7 \\
69.5 \\
57.7 \\
74.4 \\
61.6 \\
55.1 \\
63.1\end{array}$ & $\begin{array}{l}(0.97) \\
(1.40) \\
(1.38) \\
(2.90) \\
(6.40) \\
(2.26) \\
(3.08)\end{array}$ & $\begin{array}{l}19.5 \\
17.5 \\
21.5 \\
16.7 \\
15.6 \\
23.8 \\
19.6\end{array}$ & $\begin{array}{l}(0.83) \\
(1.06) \\
(0.75) \\
(2.86) \\
(3.98) \\
(2.23) \\
(2.94)\end{array}$ & $\begin{array}{r}20.1 \\
12.1 \\
19.4 \\
7.3 \\
21.9 \\
20.1 \\
15.0\end{array}$ & $\begin{array}{l}(0.62) \\
(0.97) \\
(0.94) \\
(1.42) \\
(4.87) \\
(1.51) \\
(1.88)\end{array}$ & $\begin{array}{l}0.7 \\
0.9 \\
1.4 \\
1.6 ! \\
\ddagger \\
\ddagger \\
2.3 !\end{array}$ & $\begin{array}{r}(0.13) \\
(0.21) \\
(0.25) \\
(0.73) \\
(\dagger) \\
(\dagger) \\
(0.96)\end{array}$ & $\begin{array}{l}96.0 \\
94.9 \\
92.7 \\
96.5 \\
91.7 \\
79.1 \\
94.2\end{array}$ & $\begin{array}{l}(0.38) \\
(0.50) \\
(0.68) \\
(1.21) \\
(3.61) \\
(4.15) \\
(1.32)\end{array}$ & $\begin{array}{c}2.8 \\
3.2 \\
4.3 \\
2.2 ! \\
3.6 ! \\
15.0 \\
3.3\end{array}$ & $\begin{array}{l}(0.29) \\
(0.41) \\
(0.31) \\
(0.96) \\
(1.62) \\
(3.14) \\
(0.86)\end{array}$ & $\begin{array}{r}0.9 \\
1.4 \\
2.2 \\
\ddagger \\
\ddagger \\
5.3 \\
\ddagger\end{array}$ & $\begin{array}{r}(0.12) \\
(0.28) \\
(0.45) \\
(\dagger) \\
(t) \\
(0.96) \\
(t)\end{array}$ & $\begin{array}{c}0.3 \\
0.5 ! \\
0.7 \\
\ddagger \\
\ddagger \\
\ddagger \\
1.6 !\end{array}$ & $\begin{array}{r}(0.06) \\
(0.18) \\
(0.17) \\
(\dagger) \\
(\dagger) \\
(\dagger) \\
(0.74)\end{array}$ \\
\hline 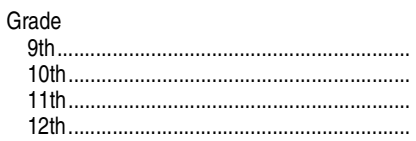 & $\begin{array}{l}70.2 \\
64.3 \\
57.3 \\
51.6\end{array}$ & $\begin{array}{l}(1.35) \\
(1.37) \\
(1.28) \\
(1.29)\end{array}$ & $\begin{array}{l}17.8 \\
19.2 \\
21.1 \\
20.1\end{array}$ & $\begin{array}{l}(0.99) \\
(1.11) \\
(0.87) \\
(0.93)\end{array}$ & $\begin{array}{l}11.2 \\
15.8 \\
20.6 \\
27.1\end{array}$ & $\begin{array}{l}(0.95) \\
(0.66) \\
(1.31) \\
(1.25)\end{array}$ & $\begin{array}{l}0.7 \\
0.6 \\
1.1 \\
1.1\end{array}$ & $\begin{array}{l}(0.18) \\
(0.15) \\
(0.21) \\
(0.24)\end{array}$ & $\begin{array}{l}94.6 \\
95.6 \\
94.8 \\
94.9\end{array}$ & $\begin{array}{l}(0.56) \\
(0.51) \\
(0.56) \\
(0.48)\end{array}$ & $\begin{array}{l}3.7 \\
2.8 \\
3.2 \\
3.5\end{array}$ & $\begin{array}{l}(0.41) \\
(0.40) \\
(0.39) \\
(0.38)\end{array}$ & $\begin{array}{l}1.4 \\
1.2 \\
1.3 \\
1.3\end{array}$ & $\begin{array}{l}(0.31) \\
(0.24) \\
(0.26) \\
(0.26)\end{array}$ & $\begin{array}{l}0.4 \\
0.4 \\
0.7 \\
0.3 !\end{array}$ & $\begin{array}{l}(0.09) \\
(0.11) \\
(0.16) \\
(0.10)\end{array}$ \\
\hline
\end{tabular}

†Not applicable.

!nterpret data with caution. The coefficient of variation (CV) for this estimate is between 30 and 50 percent.

¥Reporting standards not met. Either there are too few cases for a reliable estimate or the coefficient of variation (CV) is 50 percent or greater.

"The term "anywhere" is not used in the Youth Risk Behavior Survey (YRBS) questionnaire; students were simply asked how many days during the previous 30 days they had at least one drink of alcohol.
2In the question about drinking alcohol at school, "on school property" was not defined for survey respondents.

${ }^{3}$ Race categories exclude persons of Hispanic ethnicity.

NOTE: Detail may not sum to totals because of rounding.

SOURCE: Centers for Disease Control and Prevention, Division of Adolescent and School Health, Youth Risk Behavior Surveillance System (YRBSS), 2011. (This table was prepared September 2013.) 
Table 232.30. Percentage of public school students in grades 9-12 who reported using alcohol at least 1 day during the previous 30 days, by location and state: Selected years, 2003 through 2011

[Standard errors appear in parentheses]

\begin{tabular}{|c|c|c|c|c|c|c|c|c|c|c|c|c|c|c|c|c|c|c|c|c|}
\hline \multirow[b]{2}{*}{ State } & \multicolumn{10}{|c|}{ Anywhere (including on school property) ${ }^{1}$} & \multicolumn{10}{|c|}{ On school property ${ }^{2}$} \\
\hline & & 2003 & & 2005 & & 2007 & & 2009 & & 2011 & & 2003 & & 2005 & & 2007 & & 2009 & & 2011 \\
\hline 1 & & 2 & & 3 & & 4 & & 5 & & 6 & & 7 & & 8 & & 9 & & 10 & & 11 \\
\hline United States ${ }^{3} \ldots \ldots \ldots \ldots \ldots$ & 44.9 & $(1.21)$ & 43.3 & $(1.38)$ & 44.7 & $(1.15)$ & 41.8 & $(0.80)$ & 38.7 & $(0.75)$ & 5.2 & $(0.46)$ & 4.3 & $(0.30)$ & 4.1 & $(0.32)$ & 4.5 & $(0.29)$ & 5.1 & $(0.33)$ \\
\hline 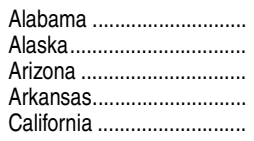 & $\begin{array}{r}40.2 \\
38.7 \\
51.8 \\
- \\
-\end{array}$ & $\begin{array}{r}(2.04) \\
(2.05) \\
(1.93) \\
(\dagger) \\
(\dagger)\end{array}$ & $\begin{array}{r}39.4 \\
- \\
47.1 \\
43.1 \\
-\end{array}$ & $\begin{array}{r}(2.55) \\
(\dagger) \\
(1.73) \\
(1.99) \\
(\dagger)\end{array}$ & $\begin{array}{r}39.7 \\
45.6 \\
42.2 \\
-\end{array}$ & $\begin{array}{r}(\dagger) \\
(2.11) \\
(1.73) \\
(1.75) \\
(\dagger)\end{array}$ & $\begin{array}{r}39.5 \\
33.2 \\
44.5 \\
39.7 \\
-\end{array}$ & $\begin{array}{r}(2.22) \\
(1.66) \\
(1.67) \\
(1.91) \\
(\dagger)\end{array}$ & $\begin{array}{r}35.6 \\
28.6 \\
43.8 \\
33.9 \\
-\end{array}$ & $\begin{array}{r}(1.99) \\
(1.95) \\
(1.47) \\
(1.81) \\
(\dagger)\end{array}$ & $\begin{array}{l}4.1 \\
4.9 \\
7.1 \\
- \\
-\end{array}$ & $\begin{array}{r}(0.82) \\
(0.81) \\
(0.67) \\
(\dagger) \\
(\dagger)\end{array}$ & $\begin{array}{r}4.5 \\
- \\
7.5 \\
5.2 \\
-\end{array}$ & $\begin{array}{r}(0.59) \\
(\dagger) \\
(0.88) \\
(0.62) \\
(\dagger)\end{array}$ & $\begin{array}{l}- \\
4.1 \\
6.0 \\
5.1 \\
-\end{array}$ & $\begin{array}{r}(\dagger) \\
(0.58) \\
(0.54) \\
(0.65) \\
(\dagger)\end{array}$ & $\begin{array}{r}5.4 \\
3.0 \\
5.9 \\
6.1 \\
-\end{array}$ & $\begin{array}{r}(0.76) \\
(0.48) \\
(0.61) \\
(0.89) \\
(\dagger)\end{array}$ & $\begin{array}{r}5.7 \\
3.4 \\
6.2 \\
4.2 \\
-\end{array}$ & $\begin{array}{r}(1.08) \\
(0.52) \\
(0.55) \\
(0.68) \\
(\dagger)\end{array}$ \\
\hline 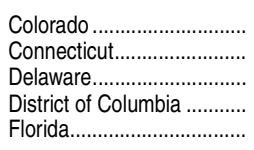 & $\begin{array}{r}- \\
45.4 \\
33.8 \\
42.7\end{array}$ & $\begin{array}{r}(\dagger) \\
(\dagger) \\
(1.30) \\
(1.72) \\
(1.10)\end{array}$ & $\begin{array}{l}47.4 \\
45.3 \\
43.1 \\
23.1 \\
39.7\end{array}$ & $\begin{array}{l}(4.42) \\
(2.16) \\
(1.16) \\
(1.40) \\
(1.43)\end{array}$ & $\begin{array}{r}- \\
46.0 \\
45.2 \\
32.6 \\
42.3\end{array}$ & $\begin{array}{r}(\dagger) \\
(2.13) \\
(1.40) \\
(1.47) \\
(1.30)\end{array}$ & $\begin{array}{r}40.8 \\
43.5 \\
43.7 \\
-\overline{40.5}\end{array}$ & $\begin{array}{r}(2.44) \\
(2.22) \\
(1.65) \\
(\dagger) \\
(1.03)\end{array}$ & $\begin{array}{l}36.4 \\
41.5 \\
40.4 \\
32.8 \\
37.0\end{array}$ & $\begin{array}{l}(2.29) \\
(1.90) \\
(1.55) \\
(1.89) \\
(0.98)\end{array}$ & $\begin{array}{l}- \\
-\overline{4} \\
4.9 \\
5.1\end{array}$ & $\begin{array}{r}(\dagger) \\
(t) \\
(0.44) \\
(0.64) \\
(0.36)\end{array}$ & $\begin{array}{l}5.9 \\
6.6 \\
5.5 \\
4.6 \\
4.5\end{array}$ & $\begin{array}{l}(1.08) \\
(0.71) \\
(0.66) \\
(0.55) \\
(0.30)\end{array}$ & $\begin{array}{l}- \\
5.6 \\
4.5 \\
6.1 \\
5.3\end{array}$ & $\begin{array}{r}(\dagger) \\
(0.99) \\
(0.48) \\
(0.92) \\
(0.31)\end{array}$ & $\begin{array}{r}4.1 \\
5.0 \\
5.0 \\
- \\
4.9\end{array}$ & $\begin{array}{r}(0.61) \\
(0.47) \\
(0.73) \\
(\dagger) \\
(0.26)\end{array}$ & $\begin{array}{l}5.3 \\
4.6 \\
5.0 \\
6.8 \\
5.1\end{array}$ & $\begin{array}{l}(0.87) \\
(0.61) \\
(0.50) \\
(0.91) \\
(0.29)\end{array}$ \\
\hline 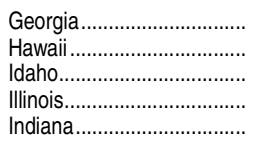 & $\begin{array}{r}37.7 \\
\overline{-} \\
34.8 \\
\overline{4} . \overline{9}\end{array}$ & $\begin{array}{r}(1.41) \\
(\dagger) \\
(2.44) \\
(\dagger) \\
(1.57)\end{array}$ & $\begin{array}{r}39.9 \\
34.8 \\
39.8 \\
- \\
41.4\end{array}$ & $\begin{array}{r}(2.12) \\
(2.05) \\
(2.62) \\
(\dagger) \\
(2.12)\end{array}$ & $\begin{array}{l}37.7 \\
29.1 \\
42.5 \\
43.7 \\
43.9\end{array}$ & $\begin{array}{l}(1.52) \\
(2.93) \\
(2.73) \\
(2.72) \\
(2.24)\end{array}$ & $\begin{array}{l}34.3 \\
37.8 \\
34.2 \\
39.8 \\
38.5\end{array}$ & $\begin{array}{l}(1.65) \\
(3.02) \\
(1.97) \\
(1.91) \\
(2.13)\end{array}$ & $\begin{array}{l}34.6 \\
29.1 \\
36.2 \\
37.8 \\
33.5\end{array}$ & $\begin{array}{l}(1.93) \\
(1.64) \\
(2.28) \\
(1.87) \\
(1.65)\end{array}$ & $\begin{array}{l}3.7 \\
\frac{-}{3.8} \\
\frac{-}{3.9}\end{array}$ & $\begin{array}{r}(0.55) \\
(t) \\
(0.56) \\
(\dagger) \\
(0.57)\end{array}$ & $\begin{array}{r}4.3 \\
8.8 \\
4.3 \\
- \\
3.4\end{array}$ & $\begin{array}{r}(0.67) \\
(0.93) \\
(0.69) \\
(\dagger) \\
(0.64)\end{array}$ & $\begin{array}{l}4.4 \\
6.0 \\
6.2 \\
5.5 \\
4.1\end{array}$ & $\begin{array}{l}(0.58) \\
(0.93) \\
(0.81) \\
(0.75) \\
(0.47)\end{array}$ & $\begin{array}{l}4.2 \\
7.9 \\
3.5 \\
4.4 \\
3.5\end{array}$ & $\begin{array}{l}(0.48) \\
(1.31) \\
(0.53) \\
(0.64) \\
(0.52)\end{array}$ & $\begin{array}{l}5.4 \\
5.0 \\
4.1 \\
3.3 \\
2.0\end{array}$ & $\begin{array}{l}(0.80) \\
(0.42) \\
(0.50) \\
(0.40) \\
(0.36)\end{array}$ \\
\hline 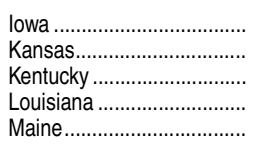 & $\begin{array}{r}- \\
45.1 \\
\overline{-} \\
42.2\end{array}$ & $\begin{array}{r}(\dagger) \\
(\dagger) \\
(1.87) \\
(\dagger) \\
(1.78)\end{array}$ & $\begin{array}{r}43.8 \\
43.9 \\
37.4 \\
-\overline{43.0}\end{array}$ & $\begin{array}{r}(2.56) \\
(1.74) \\
(1.77) \\
(\dagger) \\
(2.15)\end{array}$ & $\begin{array}{r}41.0 \\
42.4 \\
40.6 \\
- \\
39.3\end{array}$ & $\begin{array}{r}(2.36) \\
(1.69) \\
(1.25) \\
(\dagger) \\
(2.29)\end{array}$ & $\begin{array}{r}- \\
38.7 \\
37.8 \\
47.5 \\
32.2\end{array}$ & $\begin{array}{r}(\dagger) \\
(1.93) \\
(1.30) \\
(2.80) \\
(0.66)\end{array}$ & $\begin{array}{l}37.1 \\
32.6 \\
34.6 \\
44.4 \\
28.7\end{array}$ & $\begin{array}{l}(2.58) \\
(1.53) \\
(1.56) \\
(2.00) \\
(0.69)\end{array}$ & $\begin{array}{l}- \\
\overline{4.8} \\
\overline{3.7}\end{array}$ & $\begin{array}{r}(\dagger) \\
(\dagger) \\
(0.69) \\
(\dagger) \\
(0.48)\end{array}$ & $\begin{array}{l}4.6 \\
5.1 \\
3.5 \\
- \\
3.9\end{array}$ & $\begin{array}{r}(0.89) \\
(0.74) \\
(0.37) \\
(\dagger) \\
(0.44)\end{array}$ & $\begin{array}{r}3.4 \\
4.8 \\
4.7 \\
- \\
5.6\end{array}$ & $\begin{array}{r}(0.78) \\
(0.66) \\
(0.47) \\
(\dagger) \\
(0.89)\end{array}$ & $\begin{array}{l}- \\
3.2 \\
5.2 \\
5.6 \\
4.0\end{array}$ & $\begin{array}{r}(\dagger) \\
(0.55) \\
(0.87) \\
(1.33) \\
(0.23)\end{array}$ & $\begin{array}{l}2.3 \\
2.9 \\
4.1 \\
6.0 \\
3.1\end{array}$ & $\begin{array}{l}(0.41) \\
(0.45) \\
(0.53) \\
(1.36) \\
(0.21)\end{array}$ \\
\hline 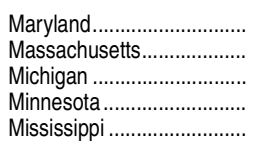 & $\begin{array}{r}-\overline{7} \\
45.7 \\
\overline{-} \\
41.8\end{array}$ & $\begin{array}{r}(\dagger) \\
(1.19) \\
(1.40) \\
(\dagger) \\
(1.74)\end{array}$ & $\begin{array}{r}39.8 \\
47.8 \\
38.1 \\
- \\
-\end{array}$ & $\begin{array}{r}(2.17) \\
(1.36) \\
(1.73) \\
(\dagger) \\
(\dagger)\end{array}$ & $\begin{array}{r}42.9 \\
46.2 \\
42.8 \\
- \\
40.6\end{array}$ & $\begin{array}{r}(3.13) \\
(1.57) \\
(1.70) \\
(\dagger) \\
(1.57)\end{array}$ & $\begin{array}{r}37.0 \\
43.6 \\
37.0 \\
-\overline{39.2}\end{array}$ & $\begin{array}{r}(1.44) \\
(1.28) \\
(1.28) \\
(\dagger) \\
(1.43)\end{array}$ & $\begin{array}{r}34.8 \\
40.1 \\
30.6 \\
- \\
36.2\end{array}$ & $\begin{array}{r}(1.98) \\
(1.54) \\
(1.64) \\
(\dagger) \\
(2.07)\end{array}$ & $\begin{array}{l}-\overline{5.3} \\
4.6 \\
\overline{4.9}\end{array}$ & $\begin{array}{r}(\dagger) \\
(0.50) \\
(0.33) \\
(\dagger) \\
(0.70)\end{array}$ & $\begin{array}{l}3.2 \\
4.2 \\
3.6 \\
- \\
-\end{array}$ & $\begin{array}{r}(0.42) \\
(0.32) \\
(0.46) \\
(\dagger) \\
(\dagger)\end{array}$ & $\begin{array}{l}6.2 \\
4.7 \\
3.6 \\
- \\
5.1\end{array}$ & $\begin{array}{r}(1.10) \\
(0.45) \\
(0.51) \\
(\dagger) \\
(0.71)\end{array}$ & $\begin{array}{r}4.8 \\
3.8 \\
3.7 \\
- \\
4.3\end{array}$ & $\begin{array}{r}(0.67) \\
(0.48) \\
(0.40) \\
(\dagger) \\
(0.45)\end{array}$ & $\begin{array}{r}5.4 \\
3.6 \\
2.7 \\
- \\
4.6\end{array}$ & $\begin{array}{r}(0.63) \\
(0.44) \\
(0.37) \\
(\dagger) \\
(0.67)\end{array}$ \\
\hline 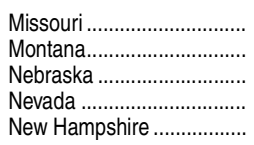 & $\begin{array}{l}49.2 \\
49.5 \\
46.5 \\
43.4 \\
47.1\end{array}$ & $\begin{array}{l}(2.16) \\
(1.68) \\
(1.29) \\
(1.51) \\
(2.70)\end{array}$ & $\begin{array}{l}40.8 \\
48.6 \\
42.9 \\
41.4 \\
44.0\end{array}$ & $\begin{array}{l}(2.04) \\
(1.50) \\
(1.27) \\
(1.73) \\
(2.31)\end{array}$ & $\begin{array}{r}44.4 \\
46.5 \\
- \\
37.0 \\
44.8\end{array}$ & $\begin{array}{r}(2.35) \\
(1.39) \\
(\dagger) \\
(1.52) \\
(1.83)\end{array}$ & $\begin{array}{r}39.3 \\
42.8 \\
- \\
38.6 \\
39.3\end{array}$ & $\begin{array}{r}(2.71) \\
(1.81) \\
(\dagger) \\
(1.66) \\
(2.18)\end{array}$ & $\begin{array}{r}- \\
38.3 \\
26.6 \\
- \\
38.4\end{array}$ & $\begin{array}{r}(\dagger) \\
(1.08) \\
(1.24) \\
(\dagger) \\
(1.83)\end{array}$ & $\begin{array}{l}2.6 \\
6.7 \\
4.6 \\
7.4 \\
4.0\end{array}$ & $\begin{array}{l}(0.58) \\
(0.70) \\
(0.61) \\
(0.74) \\
(0.79)\end{array}$ & $\begin{array}{r}3.3 \\
6.4 \\
3.6 \\
6.8 \\
-\end{array}$ & $\begin{array}{r}(0.57) \\
(0.73) \\
(0.42) \\
(0.92) \\
(\dagger)\end{array}$ & $\begin{array}{r}3.4 \\
5.7 \\
-\overline{4} \\
5.4\end{array}$ & $\begin{array}{r}(0.74) \\
(0.47) \\
(\dagger) \\
(0.58) \\
(0.73)\end{array}$ & $\begin{array}{r}3.0 \\
5.1 \\
- \\
4.4 \\
4.3\end{array}$ & $\begin{array}{r}(0.55) \\
(0.69) \\
(\dagger) \\
(0.52) \\
(0.68)\end{array}$ & $\begin{array}{l}- \\
3.5 \\
3.0 \\
- \\
5.6\end{array}$ & $\begin{array}{r}(\dagger) \\
(0.35) \\
(0.41) \\
(\dagger) \\
(0.70)\end{array}$ \\
\hline 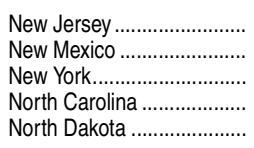 & $\begin{array}{r}- \\
44.2 \\
39.4 \\
54.2\end{array}$ & $\begin{array}{r}(\dagger) \\
(\dagger) \\
(1.53) \\
(2.68) \\
(1.74)\end{array}$ & $\begin{array}{l}46.5 \\
42.3 \\
43.4 \\
42.3 \\
49.0\end{array}$ & $\begin{array}{l}(2.65) \\
(1.93) \\
(1.47) \\
(2.16) \\
(1.89)\end{array}$ & $\begin{array}{r}- \\
43.2 \\
43.7 \\
37.7 \\
46.1\end{array}$ & $\begin{array}{r}(\dagger) \\
(1.07) \\
(1.41) \\
(1.36) \\
(1.82)\end{array}$ & $\begin{array}{l}45.2 \\
40.5 \\
41.4 \\
35.0 \\
43.3\end{array}$ & $\begin{array}{l}(2.21) \\
(1.41) \\
(1.38) \\
(2.43) \\
(1.79)\end{array}$ & $\begin{array}{l}42.9 \\
36.9 \\
38.4 \\
34.3 \\
38.8\end{array}$ & $\begin{array}{l}(2.46) \\
(1.40) \\
(1.96) \\
(1.41) \\
(1.67)\end{array}$ & $\begin{array}{l}- \\
5.2 \\
3.6 \\
5.1\end{array}$ & $\begin{array}{r}(\dagger) \\
(\dagger) \\
(0.39) \\
(0.47) \\
(0.79)\end{array}$ & $\begin{array}{l}3.7 \\
7.6 \\
4.1 \\
5.4 \\
3.6\end{array}$ & $\begin{array}{l}(0.42) \\
(0.87) \\
(0.45) \\
(0.74) \\
(0.52)\end{array}$ & $\begin{array}{l}-\overline{8.7} \\
5.1 \\
4.7 \\
4.4\end{array}$ & $\begin{array}{r}(\dagger) \\
(1.35) \\
(0.58) \\
(0.65) \\
(0.65)\end{array}$ & $\begin{array}{l}-\overline{8.0} \\
\overline{4} \\
4.1\end{array}$ & $\begin{array}{r}(\dagger) \\
(0.90) \\
(\dagger) \\
(0.57) \\
(0.53)\end{array}$ & $\begin{array}{l}-\overline{6.4} \\
- \\
5.5 \\
3.1\end{array}$ & $\begin{array}{r}(\dagger) \\
(0.54) \\
(\dagger) \\
(0.77) \\
(0.51)\end{array}$ \\
\hline 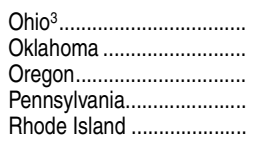 & $\begin{array}{r}42.2 \\
47.8 \\
- \\
-\overline{4} \\
4\end{array}$ & $\begin{array}{r}(2.40) \\
(1.41) \\
(\dagger) \\
(\dagger) \\
(1.92)\end{array}$ & $\begin{array}{r}42.4 \\
40.5 \\
- \\
-\overline{4} \\
42.7\end{array}$ & $\begin{array}{r}(1.96) \\
(1.62) \\
(\dagger) \\
(\dagger) \\
(1.15)\end{array}$ & $\begin{array}{r}45.7 \\
43.1 \\
- \\
-\end{array}$ & $\begin{array}{r}(1.70) \\
(1.88) \\
(\dagger) \\
(\dagger) \\
(1.76)\end{array}$ & $\begin{array}{r}-\overline{39.0} \\
\overline{-} \\
38.4 \\
34.0\end{array}$ & $\begin{array}{r}(\dagger) \\
(1.97) \\
(\dagger) \\
(2.10) \\
(2.01)\end{array}$ & $\begin{array}{r}38.0 \\
38.3 \\
- \\
-\end{array}$ & $\begin{array}{r}(2.94) \\
(1.75) \\
(\dagger) \\
(\dagger) \\
(1.25)\end{array}$ & $\begin{array}{r}3.9 \\
3.2 \\
- \\
- \\
4.6\end{array}$ & $\begin{array}{r}(0.69) \\
(0.64) \\
(\dagger) \\
(\dagger) \\
(0.73)\end{array}$ & $\begin{array}{r}3.2 \\
3.8 \\
- \\
- \\
5.3\end{array}$ & $\begin{array}{r}(0.59) \\
(0.49) \\
(\dagger) \\
(\dagger) \\
(0.66)\end{array}$ & $\begin{array}{l}3.2 \\
5.0 \\
- \\
\overline{4.8}\end{array}$ & $\begin{array}{r}(0.50) \\
(0.59) \\
(\dagger) \\
(\dagger) \\
(0.54)\end{array}$ & $\begin{array}{l}-\overline{3.9} \\
-\overline{2.8} \\
3.2\end{array}$ & $\begin{array}{r}(t) \\
(0.55) \\
(t) \\
(0.50) \\
(0.50)\end{array}$ & $\begin{array}{l}- \\
2.6 \\
- \\
-\end{array}$ & $\begin{array}{r}(t) \\
(0.65) \\
(\dagger) \\
(\dagger) \\
(t)\end{array}$ \\
\hline $\begin{array}{l}\text { South Carolina............... } \\
\text { South Dakota }{ }^{3} \ldots \ldots \ldots \ldots \ldots \ldots \ldots . . . . . . . . . \\
\text { Tennessee ..................... } \\
\text { Texas }\end{array}$ & $\begin{array}{r}-\overline{2} \\
40.1 \\
-\overline{1} \\
21.3\end{array}$ & $\begin{array}{r}(\dagger) \\
(2.58) \\
(2.04) \\
(\dagger) \\
(2.19)\end{array}$ & $\begin{array}{l}43.2 \\
46.6 \\
41.8 \\
47.3 \\
15.8\end{array}$ & $\begin{array}{l}(1.64) \\
(2.12) \\
(1.90) \\
(1.93) \\
(1.92)\end{array}$ & $\begin{array}{l}36.8 \\
44.5 \\
36.7 \\
48.3 \\
17.0\end{array}$ & $\begin{array}{l}(2.31) \\
(1.80) \\
(1.90) \\
(1.64) \\
(1.88)\end{array}$ & $\begin{array}{l}35.2 \\
40.1 \\
33.5 \\
44.8 \\
18.2\end{array}$ & $\begin{array}{l}(2.80) \\
(1.54) \\
(1.71) \\
(1.25) \\
(2.72)\end{array}$ & $\begin{array}{l}39.7 \\
39.3 \\
33.3 \\
39.7 \\
15.1\end{array}$ & $\begin{array}{l}(1.72) \\
(2.14) \\
(1.39) \\
(1.15) \\
(1.54)\end{array}$ & $\begin{array}{l}- \\
5.4 \\
4.2 \\
- \\
3.8\end{array}$ & $\begin{array}{r}(t) \\
(1.13) \\
(0.48) \\
(\dagger) \\
(0.74)\end{array}$ & $\begin{array}{l}6.0 \\
4.0 \\
3.7 \\
5.7 \\
2.1\end{array}$ & $\begin{array}{l}(0.96) \\
(0.70) \\
(0.66) \\
(0.56) \\
(0.39)\end{array}$ & $\begin{array}{l}4.7 \\
3.6 \\
4.1 \\
4.9 \\
4.7 !\end{array}$ & $\begin{array}{l}(0.73) \\
(0.92) \\
(0.54) \\
(0.57) \\
(1.69)\end{array}$ & $\begin{array}{l}3.6 \\
- \\
3.0 \\
4.7 \\
2.7\end{array}$ & $\begin{array}{r}(0.79) \\
(\dagger) \\
(0.38) \\
(0.36) \\
(0.45)\end{array}$ & $\begin{array}{l}5.9 \\
- \\
3.2 \\
3.9 \\
2.7\end{array}$ & $\begin{array}{r}(0.90) \\
(\dagger) \\
(0.34) \\
(0.35) \\
(0.54)\end{array}$ \\
\hline 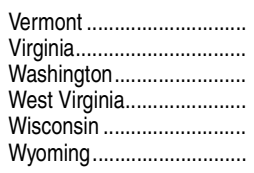 & $\begin{array}{r}43.5 \\
- \\
44.4 \\
47.3 \\
49.0\end{array}$ & $\begin{array}{r}(1.48) \\
(\dagger) \\
(\dagger) \\
(1.81) \\
(1.63) \\
(2.16)\end{array}$ & $\begin{array}{r}41.8 \\
- \\
41.5 \\
49.2 \\
45.4\end{array}$ & $\begin{array}{r}(1.53) \\
(\dagger) \\
(\dagger) \\
(1.41) \\
(1.51) \\
(1.47)\end{array}$ & $\begin{array}{r}42.6 \\
- \\
43.5 \\
48.9 \\
42.4\end{array}$ & $\begin{array}{r}(1.04) \\
(\dagger) \\
(\dagger) \\
(1.45) \\
(1.56) \\
(1.22)\end{array}$ & $\begin{array}{r}39.0 \\
- \\
40.4 \\
41.3 \\
41.7\end{array}$ & $\begin{array}{r}(1.57) \\
(\dagger) \\
(\dagger) \\
(1.10) \\
(1.83) \\
(1.36)\end{array}$ & $\begin{array}{r}35.3 \\
30.5 \\
-\overline{-} \\
34.3 \\
39.2 \\
36.1\end{array}$ & $\begin{array}{r}(1.10) \\
(2.49) \\
(\dagger) \\
(2.40) \\
(1.35) \\
(1.34)\end{array}$ & $\begin{array}{r}5.3 \\
- \\
4.1 \\
- \\
6.2\end{array}$ & $\begin{array}{r}(0.60) \\
(\dagger) \\
(\dagger) \\
(0.84) \\
(\dagger) \\
(0.75)\end{array}$ & $\begin{array}{c}4.8 \\
- \\
6.4 \\
- \\
6.2\end{array}$ & $\begin{array}{r}(0.54) \\
(\dagger) \\
(\dagger) \\
(1.08) \\
(\dagger) \\
(0.56)\end{array}$ & $\begin{array}{c}4.6 \\
- \\
5.5 \\
- \\
6.9\end{array}$ & $\begin{array}{r}(0.40) \\
(\dagger) \\
(\dagger) \\
(0.89) \\
(\dagger) \\
(0.63)\end{array}$ & $\begin{array}{c}3.3 \\
- \\
5.7 \\
- \\
6.4\end{array}$ & $\begin{array}{r}(0.28) \\
(\dagger) \\
(\dagger) \\
(0.61) \\
(\dagger) \\
(0.50)\end{array}$ & $\begin{array}{r}3.3 \\
3.3 \\
- \\
4.2 \\
5.1\end{array}$ & $\begin{array}{r}(0.50) \\
(0.59) \\
(\dagger) \\
(0.67) \\
(\dagger) \\
(0.48)\end{array}$ \\
\hline
\end{tabular}

-Not available.

†Not applicable.

!Interpret data with caution. The coefficient of variation (CV) for this estimate is between 30 and 50 percent.

"The term "anywhere" is not used in the Youth Risk Behavior Survey (YRBS) questionnaire; students were simply asked how many days during the previous 30 days they had at least one drink of alcohol.

'In the question about drinking alcohol at school, "on school property" was not defined for survey respondents.

${ }^{3}$ Data include both public and private schools.

NOTE: State-level data include public schools only, with the exception of data for Ohio and South Dakota. Data for the United States total, Ohio, and South Dakota include both public and private schools.

SOURCE: Centers for Disease Control and Prevention, Division of Adolescent and School Health, Youth Risk Behavior Surveillance System (YRBSS), 2003 through 2011 (This table was prepared September 2013.) 


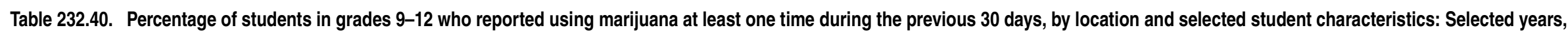
1993 through 2011

[Standard errors appear in parentheses]

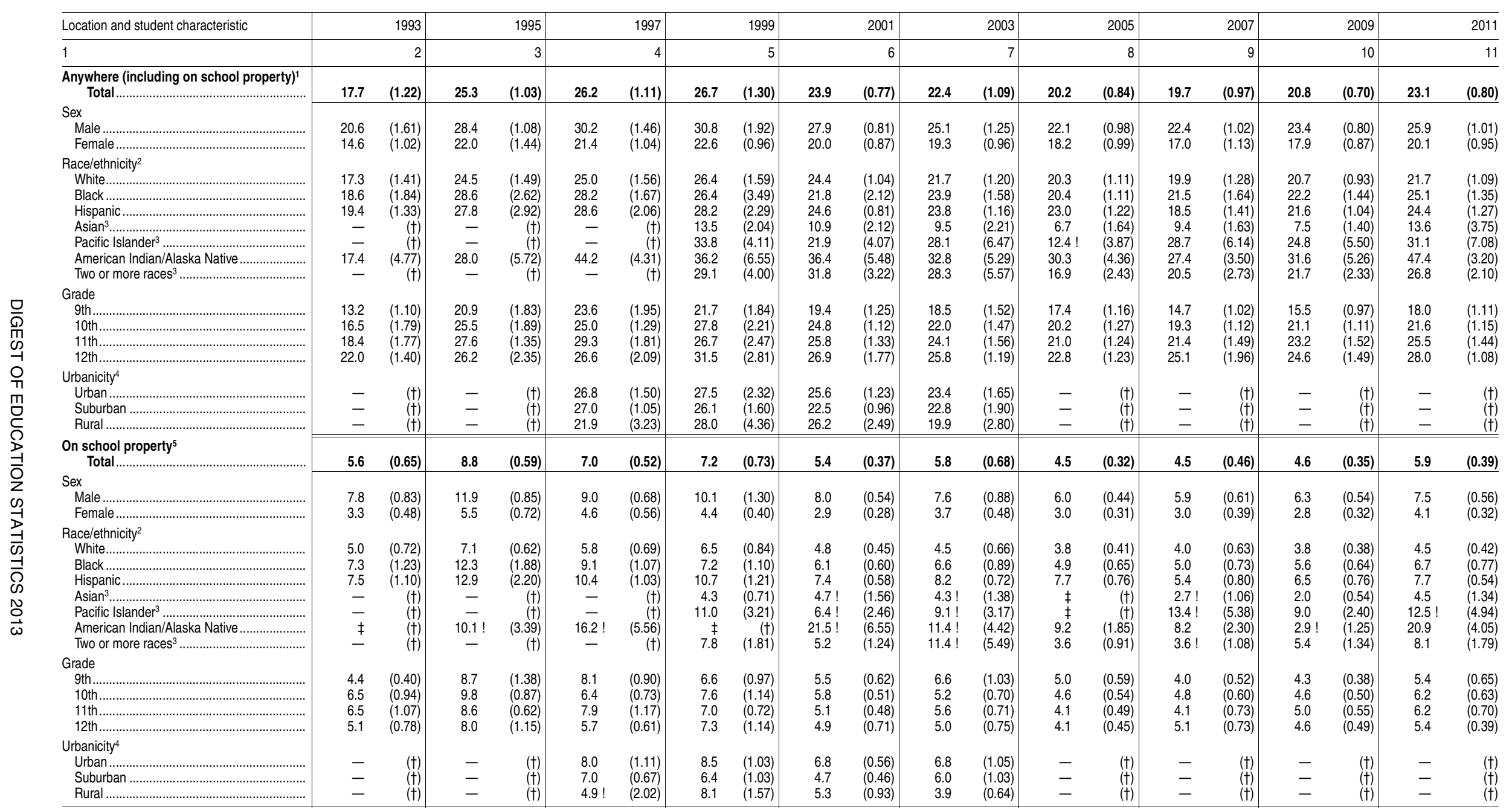

\section{-Not available.}

!nterpret data with caution. The coefficient of variation (CV) for this estimate is between 30 and 50 percent

fReporting standards not met. The coefficient of variation (CV) for this estimate is 50 percent or greater.

"The term "anywhere" is not used in the Youth Risk Behavior Survey (YRBS) questionnaire; students were simply asked how many

times during the previous 30 days they had used marijuana.
2Race categories exclude persons of Hispanic ethnicity. 3Before 1999, Asian students and Paciic Islander students were not categorized separately, and students were not given the option of from 1993, 1995, and 1997 with data from later years.
4Refers to the Standard Metropolitan Statistical Area (MSA) status of the respondent's household as defined in 2000 by the U.S. Census Bureau. Categories include "central city of an MSA (Urban)," "in MSA but not in central city (Suburban)," and "not MSA (Rural)." In the question about using marijuana at school, "on school property" was not defined for survey respondents. System (YRBSS) 1093 through 2011. (This lable was pepared 
Table 232.50. Percentage distribution of students in grades 9-12, by number of times they reported using marijuana anywhere or on school property during the previous 30 days and selected student characteristics: 2011

[Standard errors appear in parentheses]

\begin{tabular}{|c|c|c|c|c|c|c|c|c|c|c|c|c|c|c|c|c|}
\hline \multirow[b]{2}{*}{ Student characteristic } & \multicolumn{8}{|c|}{ Anywhere (including on school property) ${ }^{1}$} & \multicolumn{8}{|c|}{ On school property ${ }^{2}$} \\
\hline & & 0 times & 1 or & 2 times & 3 to 3 & 9 times & 40 or mo & e times & & 0 times & 1 or & 2 times & 3 to 3 & 9 times & 40 or mo & e times \\
\hline 1 & & 2 & & 3 & & 4 & & 5 & & 6 & & 7 & & 8 & & 9 \\
\hline 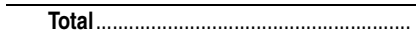 & 76.9 & $(0.80)$ & 7.4 & $(0.30)$ & 10.9 & $(0.42)$ & 4.8 & $(0.30)$ & 94.1 & $(0.39)$ & 2.8 & $(0.22)$ & 2.3 & $(0.21)$ & 0.7 & $(0.09)$ \\
\hline 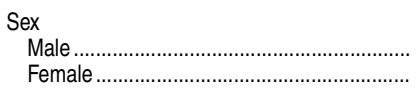 & $\begin{array}{l}74.1 \\
79.9\end{array}$ & $\begin{array}{l}(1.01) \\
(0.95)\end{array}$ & $\begin{array}{l}7.1 \\
7.7\end{array}$ & $\begin{array}{l}(0.40) \\
(0.48)\end{array}$ & $\begin{array}{r}11.8 \\
9.9\end{array}$ & $\begin{array}{l}(0.57) \\
(0.56)\end{array}$ & $\begin{array}{l}7.0 \\
2.4\end{array}$ & $\begin{array}{l}(0.47) \\
(0.26)\end{array}$ & $\begin{array}{l}92.5 \\
95.9\end{array}$ & $\begin{array}{l}(0.56) \\
(0.32)\end{array}$ & $\begin{array}{l}3.1 \\
2.5\end{array}$ & $\begin{array}{l}(0.28) \\
(0.21)\end{array}$ & $\begin{array}{l}3.2 \\
1.4\end{array}$ & $\begin{array}{l}(0.31) \\
(0.19)\end{array}$ & $\begin{array}{l}1.2 \\
0.2\end{array}$ & $\begin{array}{l}(0.17) \\
(0.04)\end{array}$ \\
\hline 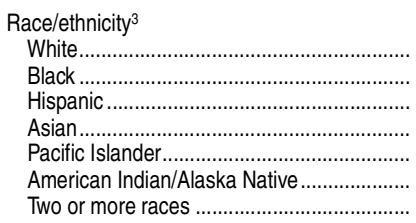 & $\begin{array}{l}78.3 \\
74.9 \\
75.6 \\
86.4 \\
68.9 \\
52.6 \\
73.2\end{array}$ & $\begin{array}{l}(1.09) \\
(1.35) \\
(1.27) \\
(3.75) \\
(7.08) \\
(3.20) \\
(2.10)\end{array}$ & $\begin{array}{r}6.9 \\
7.9 \\
8.3 \\
\ddagger \\
11.3 \\
10.5 \\
7.2\end{array}$ & $\begin{array}{r}(0.42) \\
(0.69) \\
(0.59) \\
(\dagger) \\
(3.34) \\
(2.82) \\
(1.20)\end{array}$ & $\begin{array}{r}10.2 \\
12.5 \\
11.5 \\
5.5 \\
13.2 ! \\
23.6 \\
12.9\end{array}$ & $\begin{array}{l}(0.59) \\
(0.81) \\
(0.67) \\
(0.96) \\
(5.20) \\
(2.57) \\
(1.44)\end{array}$ & $\begin{array}{r}4.6 \\
4.7 \\
4.7 \\
3.2 ! \\
6.6 ! \\
13.2 \\
6.7\end{array}$ & $\begin{array}{l}(0.44) \\
(0.63) \\
(0.46) \\
(1.34) \\
(2.27) \\
(1.81) \\
(1.33)\end{array}$ & $\begin{array}{l}95.5 \\
93.3 \\
92.3 \\
95.5 \\
87.5 \\
79.1 \\
91.9\end{array}$ & $\begin{array}{l}(0.42) \\
(0.77) \\
(0.54) \\
(1.34) \\
(4.94) \\
(4.05) \\
(1.79)\end{array}$ & $\begin{array}{l}2.2 \\
3.2 \\
3.6 \\
2.4 ! \\
5.6 ! \\
8.6 \\
3.7\end{array}$ & $\begin{array}{l}(0.26) \\
(0.43) \\
(0.26) \\
(1.15) \\
(2.24) \\
(2.18) \\
(0.98)\end{array}$ & $\begin{array}{c}1.9 \\
2.8 \\
3.1 \\
\ddagger \\
\ddagger \\
9.8 \\
2.4 !\end{array}$ & $\begin{array}{r}(0.23) \\
(0.52) \\
(0.40) \\
(\dagger) \\
(\dagger) \\
(1.79) \\
(0.86)\end{array}$ & $\begin{array}{l}0.4 \\
0.7 \\
1.0 \\
1.5 ! \\
\ddagger \\
2.5 \\
2.0 !\end{array}$ & $\begin{array}{r}(0.09) \\
(0.18) \\
(0.21) \\
(0.70) \\
(\dagger) \\
(0.67) \\
(0.69)\end{array}$ \\
\hline 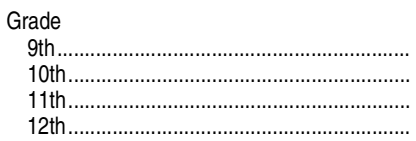 & $\begin{array}{l}82.0 \\
78.4 \\
74.5 \\
72.0\end{array}$ & $\begin{array}{l}(1.11) \\
(1.15) \\
(1.44) \\
(1.08)\end{array}$ & $\begin{array}{l}6.2 \\
7.4 \\
8.0 \\
8.3\end{array}$ & $\begin{array}{l}(0.47) \\
(0.60) \\
(0.59) \\
(0.59)\end{array}$ & $\begin{array}{r}8.2 \\
10.0 \\
12.9 \\
13.0\end{array}$ & $\begin{array}{l}(0.63) \\
(0.65) \\
(0.82) \\
(0.69)\end{array}$ & $\begin{array}{l}3.6 \\
4.3 \\
4.5 \\
6.7\end{array}$ & $\begin{array}{l}(0.42) \\
(0.50) \\
(0.50) \\
(0.53)\end{array}$ & $\begin{array}{l}94.6 \\
93.8 \\
93.8 \\
94.6\end{array}$ & $\begin{array}{l}(0.65) \\
(0.63) \\
(0.70) \\
(0.39)\end{array}$ & $\begin{array}{l}2.7 \\
3.2 \\
3.2 \\
2.2\end{array}$ & $\begin{array}{l}(0.41) \\
(0.38) \\
(0.47) \\
(0.30)\end{array}$ & $\begin{array}{l}2.2 \\
2.3 \\
2.3 \\
2.4\end{array}$ & $\begin{array}{l}(0.33) \\
(0.40) \\
(0.35) \\
(0.30)\end{array}$ & $\begin{array}{l}0.5 \\
0.7 \\
0.7 \\
0.8\end{array}$ & $\begin{array}{l}(0.11) \\
(0.16) \\
(0.16) \\
(0.18)\end{array}$ \\
\hline
\end{tabular}

†Not applicable.

!nterpret data with caution. The coefficient of variation (CV) for this estimate is between 30 and 50 percent.

‡Reporting standards not met. Either there are too few cases for a reliable estimate or the coefficient of variation (CV) is 50 percent or greater.

"The term "anywhere" is not used in the Youth Risk Behavior Survey (YRBS) questionnaire; students were simply asked how many times during the previous 30 days they had used marijuana.
2In the question about using marijuana at school, "on school property" was not defined for survey respondents.

${ }^{3}$ Race categories exclude persons of Hispanic ethnicity.

NOTE: Detail may not sum to totals because of rounding.

SOURCE: Centers for Disease Control and Prevention, Division of Adolescent and School Health, Youth Risk Behavior Surveillance System (YRBSS), 2011. (This table was prepared September 2013.) 
Table 232.60. Percentage of public school students in grades $9-12$ who reported using marijuana at least one time during the previous 30 days, by location and state: Selected years, 2003 through 2011

[Standard errors appear in parentheses]

\begin{tabular}{|c|c|c|c|c|c|c|c|c|c|c|c|c|c|c|c|c|c|c|c|c|}
\hline \multirow[b]{2}{*}{ State } & \multicolumn{10}{|c|}{ Anywhere (including on school property) ${ }^{1}$} & \multicolumn{10}{|c|}{ On school property ${ }^{2}$} \\
\hline & & 2003 & & 2005 & & 2007 & & 2009 & & 2011 & & 2003 & & 2005 & & 2007 & & 2009 & & 2011 \\
\hline 1 & & 2 & & 3 & & 4 & & 0 & & 6 & & 7 & & 8 & & 9 & & 10 & & 11 \\
\hline United States ${ }^{3} \ldots \ldots \ldots \ldots \ldots$ & 22.4 & $(1.09)$ & 20.2 & $(0.84)$ & 19.7 & $(0.97)$ & 20.8 & $(0.70)$ & 23.1 & $(0.80)$ & 5.8 & $(0.68)$ & 4.5 & $(0.32)$ & 4.5 & $(0.46)$ & 4.6 & $(0.35)$ & 5.9 & $0.39)$ \\
\hline 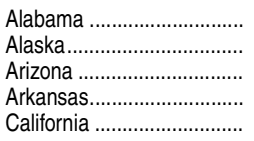 & $\begin{array}{r}17.7 \\
23.9 \\
25.6 \\
- \\
-\end{array}$ & $\begin{array}{r}(1.38) \\
(1.29) \\
(1.08) \\
(\dagger) \\
(\dagger)\end{array}$ & $\begin{array}{r}18.5 \\
-\overline{-} \\
20.0 \\
18.9 \\
-\end{array}$ & $\begin{array}{r}(1.49) \\
(\dagger) \\
(1.08) \\
(1.70) \\
(\dagger)\end{array}$ & $\begin{array}{r}-\overline{2} \\
20.5 \\
22.0 \\
16.4 \\
-\end{array}$ & $\begin{array}{r}(\dagger) \\
(1.47) \\
(1.38) \\
(1.08) \\
(\dagger)\end{array}$ & $\begin{array}{r}16.2 \\
22.7 \\
23.7 \\
17.8 \\
-\end{array}$ & $\begin{array}{r}(1.28) \\
(1.65) \\
(1.90) \\
(1.24) \\
(\dagger)\end{array}$ & $\begin{array}{r}20.8 \\
21.2 \\
22.9 \\
16.8 \\
-\end{array}$ & $\begin{array}{r}(1.62) \\
(1.68) \\
(1.59) \\
(1.72) \\
(\dagger)\end{array}$ & $\begin{array}{l}2.6 \\
6.5 \\
6.5 \\
- \\
-\end{array}$ & $\begin{array}{r}(0.54) \\
(0.80) \\
(0.52) \\
(\dagger) \\
(\dagger)\end{array}$ & $\begin{array}{l}3.5 \\
- \\
5.1 \\
4.1 \\
-\end{array}$ & $\begin{array}{r}(0.80) \\
(\dagger) \\
(0.63) \\
(0.61) \\
(\dagger)\end{array}$ & $\begin{array}{l}5.9 \\
6.1 \\
2.8 \\
-\end{array}$ & $\begin{array}{r}(\dagger) \\
(0.70) \\
(0.68) \\
(0.50) \\
(\dagger)\end{array}$ & $\begin{array}{r}4.6 \\
5.9 \\
6.4 \\
4.5 \\
-\end{array}$ & $\begin{array}{r}(0.81) \\
(0.69) \\
(0.74) \\
(1.02) \\
(\dagger)\end{array}$ & $\begin{array}{l}4.0 \\
4.3 \\
5.6 \\
3.9 \\
-\end{array}$ & $\begin{array}{r}(0.68) \\
(0.59) \\
(0.75) \\
(0.78) \\
(\dagger)\end{array}$ \\
\hline 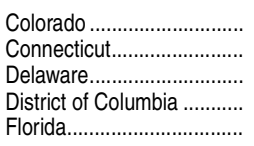 & $\begin{array}{r}\overline{-} \\
27.3 \\
23.5 \\
21.4\end{array}$ & $\begin{array}{r}(\dagger) \\
(\dagger) \\
(1.13) \\
(1.23) \\
(0.89)\end{array}$ & $\begin{array}{l}22.7 \\
23.1 \\
22.8 \\
14.5 \\
16.8\end{array}$ & $\begin{array}{l}(2.99) \\
(1.37) \\
(1.12) \\
(1.08) \\
(0.86)\end{array}$ & $\begin{array}{r}- \\
23.2 \\
25.1 \\
20.8 \\
18.9\end{array}$ & $\begin{array}{r}(\dagger) \\
(1.35) \\
(1.03) \\
(1.33) \\
(0.88)\end{array}$ & $\begin{array}{r}24.8 \\
21.8 \\
25.8 \\
- \\
21.4\end{array}$ & $\begin{array}{r}(2.22) \\
(1.52) \\
(1.30) \\
(\dagger) \\
(0.72)\end{array}$ & $\begin{array}{l}22.0 \\
24.2 \\
27.6 \\
26.1 \\
22.5\end{array}$ & $\begin{array}{l}(1.16) \\
(1.44) \\
(1.37) \\
(1.29) \\
(0.86)\end{array}$ & $\begin{array}{l}\overline{-} \\
6.0 \\
7.5 \\
4.9\end{array}$ & $\begin{array}{r}(\dagger) \\
(t) \\
(0.54) \\
(0.88) \\
(0.41)\end{array}$ & $\begin{array}{l}6.0 \\
5.1 \\
5.6 \\
4.8 \\
4.0\end{array}$ & $\begin{array}{l}(0.88) \\
(0.49) \\
(0.57) \\
(0.62) \\
(0.31)\end{array}$ & $\begin{array}{l}- \\
5.9 \\
5.4 \\
5.8 \\
4.7\end{array}$ & $\begin{array}{r}(\dagger) \\
(0.77) \\
(0.53) \\
(0.66) \\
(0.40)\end{array}$ & $\begin{array}{l}6.1 \\
6.2 \\
5.6 \\
- \\
5.2\end{array}$ & $\begin{array}{r}(0.89) \\
(0.76) \\
(0.71) \\
(\dagger) \\
(0.39)\end{array}$ & $\begin{array}{l}6.0 \\
5.2 \\
6.1 \\
7.9 \\
6.3\end{array}$ & $\begin{array}{l}(0.77) \\
(0.68) \\
(0.65) \\
(0.91) \\
(0.39)\end{array}$ \\
\hline 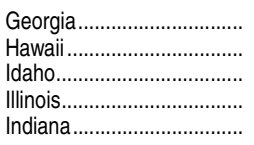 & $\begin{array}{r}19.5 \\
\overline{14.7} \\
22 . \overline{1}\end{array}$ & $\begin{array}{r}(0.94) \\
(\dagger) \\
(1.56) \\
(\dagger) \\
(1.19)\end{array}$ & $\begin{array}{r}18.9 \\
17.2 \\
17.1 \\
\overline{18.9}\end{array}$ & $\begin{array}{r}(1.59) \\
(1.73) \\
(1.32) \\
(\dagger) \\
(1.38)\end{array}$ & $\begin{array}{l}19.6 \\
15.7 \\
17.9 \\
20.3 \\
18.9\end{array}$ & $\begin{array}{l}(0.96) \\
(1.78) \\
(1.73) \\
(1.38) \\
(1.19)\end{array}$ & $\begin{array}{l}18.3 \\
22.1 \\
13.7 \\
21.0 \\
20.9\end{array}$ & $\begin{array}{l}(1.02) \\
(2.03) \\
(1.07) \\
(1.53) \\
(1.83)\end{array}$ & $\begin{array}{l}21.2 \\
22.0 \\
18.8 \\
23.1 \\
20.0\end{array}$ & $\begin{array}{l}(1.23) \\
(1.32) \\
(1.76) \\
(1.59) \\
(1.13)\end{array}$ & $\begin{array}{l}3.2 \\
\frac{-}{2.7} \\
\overline{3.8}\end{array}$ & $\begin{array}{r}(0.45) \\
(\dagger) \\
(0.55) \\
(\dagger) \\
(0.67)\end{array}$ & $\begin{array}{l}3.3 \\
7.2 \\
3.9 \\
- \\
3.4\end{array}$ & $\begin{array}{r}(0.58) \\
(1.14) \\
(0.61) \\
(\dagger) \\
(0.57)\end{array}$ & $\begin{array}{l}3.6 \\
5.7 \\
4.7 \\
4.2 \\
4.1\end{array}$ & $\begin{array}{l}(0.58) \\
(0.85) \\
(0.80) \\
(0.76) \\
(0.45)\end{array}$ & $\begin{array}{l}3.4 \\
8.3 \\
3.0 \\
5.0 \\
4.4\end{array}$ & $\begin{array}{l}(0.62) \\
(1.86) \\
(0.44) \\
(0.77) \\
(0.62)\end{array}$ & $\begin{array}{l}5.6 \\
7.6 \\
4.9 \\
4.7 \\
3.3\end{array}$ & $\begin{array}{l}(0.70) \\
(0.67) \\
(0.73) \\
(0.50) \\
(0.66)\end{array}$ \\
\hline 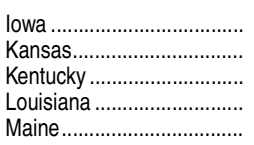 & $\begin{array}{r}\overline{-} \\
21.1 \\
\overline{2} \\
26.4\end{array}$ & $\begin{array}{r}(\dagger) \\
(\dagger) \\
(1.09) \\
(\dagger) \\
(1.69)\end{array}$ & $\begin{array}{r}15.6 \\
15.6 \\
15.8 \\
- \\
22.2\end{array}$ & $\begin{array}{r}(1.74) \\
(1.46) \\
(1.19) \\
(\dagger) \\
(2.13)\end{array}$ & $\begin{array}{r}11.5 \\
15.3 \\
16.4 \\
-\overline{2} \\
22.0\end{array}$ & $\begin{array}{r}(1.53) \\
(0.93) \\
(1.07) \\
(\dagger) \\
(1.55)\end{array}$ & $\begin{array}{r}-\overline{14.7} \\
16.1 \\
16.3 \\
20.5\end{array}$ & $\begin{array}{r}(\dagger) \\
(1.19) \\
(1.15) \\
(1.29) \\
(0.57)\end{array}$ & $\begin{array}{l}14.6 \\
16.8 \\
19.2 \\
16.8 \\
21.2\end{array}$ & $\begin{array}{l}(1.99) \\
(0.87) \\
(1.47) \\
(1.02) \\
(0.72)\end{array}$ & $\begin{array}{l}\overline{-} \\
\frac{\overline{4}}{6} \\
6.3\end{array}$ & $\begin{array}{r}(\dagger) \\
(\dagger) \\
(0.55) \\
(\dagger) \\
(0.76)\end{array}$ & $\begin{array}{r}2.7 \\
3.2 \\
3.2 \\
- \\
4.6\end{array}$ & $\begin{array}{r}(0.64) \\
(0.51) \\
(0.45) \\
(\dagger) \\
(0.72)\end{array}$ & $\begin{array}{l}2.5 \\
3.8 \\
3.9 \\
- \\
5.2\end{array}$ & $\begin{array}{r}(0.66) \\
(0.53) \\
(0.44) \\
(\dagger) \\
(0.65)\end{array}$ & $\begin{array}{l}-\overline{2.7} \\
3.1 \\
3.6 \\
-\end{array}$ & $\begin{array}{r}(\dagger) \\
(0.35) \\
(0.54) \\
(0.89) \\
(\dagger)\end{array}$ & $\begin{array}{l}3.4 \\
2.9 \\
4.2 \\
4.1 \\
-\end{array}$ & $\begin{array}{r}(0.88) \\
(0.53) \\
(0.65) \\
(0.59) \\
(\dagger)\end{array}$ \\
\hline 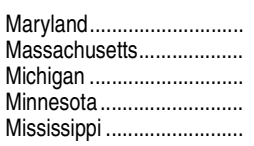 & $\begin{array}{r}-\overline{2} \\
24.0 \\
\overline{2} \\
20.6\end{array}$ & $\begin{array}{r}(\dagger) \\
(1.39) \\
(1.96) \\
(\dagger) \\
(1.57)\end{array}$ & $\begin{array}{r}18.5 \\
26.2 \\
18.8 \\
- \\
-\end{array}$ & $\begin{array}{r}(2.25) \\
(1.22) \\
(1.29) \\
(\dagger) \\
(\dagger)\end{array}$ & $\begin{array}{r}19.4 \\
24.6 \\
18.0 \\
- \\
16.7\end{array}$ & $\begin{array}{r}(1.91) \\
(1.43) \\
(1.10) \\
(\dagger) \\
(1.02)\end{array}$ & $\begin{array}{r}21.9 \\
27.1 \\
20.7 \\
-\overline{17.7}\end{array}$ & $\begin{array}{r}(1.57) \\
(1.24) \\
(0.91) \\
(\dagger) \\
(1.21)\end{array}$ & $\begin{array}{r}23.2 \\
27.9 \\
18.6 \\
- \\
17.5\end{array}$ & $\begin{array}{r}(1.51) \\
(1.31) \\
(1.15) \\
(\dagger) \\
(1.18)\end{array}$ & $\begin{array}{r}-\overline{6.3} \\
7.0 \\
\overline{4.4}\end{array}$ & $\begin{array}{r}(\dagger) \\
(0.44) \\
(1.20) \\
(\dagger) \\
(0.90)\end{array}$ & $\begin{array}{l}3.7 \\
5.3 \\
3.7 \\
- \\
-\end{array}$ & $\begin{array}{r}(0.82) \\
(0.54) \\
(0.50) \\
(\dagger) \\
(\dagger)\end{array}$ & $\begin{array}{r}4.7 \\
4.8 \\
4.0 \\
- \\
2.7\end{array}$ & $\begin{array}{r}(1.13) \\
(0.44) \\
(0.57) \\
(\dagger) \\
(0.35)\end{array}$ & $\begin{array}{r}5.0 \\
5.9 \\
4.8 \\
- \\
2.5\end{array}$ & $\begin{array}{r}(0.65) \\
(0.79) \\
(0.59) \\
(\dagger) \\
(0.46)\end{array}$ & $\begin{array}{l}5.7 \\
6.3 \\
3.3 \\
- \\
3.2\end{array}$ & $\begin{array}{r}(0.70) \\
(0.51) \\
(0.44) \\
(\dagger) \\
(0.58)\end{array}$ \\
\hline 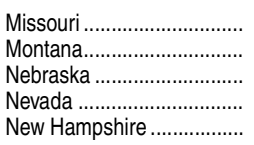 & $\begin{array}{l}21.8 \\
23.1 \\
18.3 \\
22.3 \\
30.6\end{array}$ & $\begin{array}{l}(1.37) \\
(1.45) \\
(1.23) \\
(1.31) \\
(2.51)\end{array}$ & $\begin{array}{l}18.1 \\
22.3 \\
17.5 \\
17.3 \\
25.9\end{array}$ & $\begin{array}{l}(2.23) \\
(1.43) \\
(1.05) \\
(1.34) \\
(1.69)\end{array}$ & $\begin{array}{r}19.0 \\
21.0 \\
- \\
15.5 \\
22.9\end{array}$ & $\begin{array}{r}(1.23) \\
(1.44) \\
(\dagger) \\
(1.07) \\
(1.39)\end{array}$ & $\begin{array}{r}20.6 \\
23.1 \\
-\overline{-} \\
20.0 \\
25.6\end{array}$ & $\begin{array}{r}(2.02) \\
(1.58) \\
(\dagger) \\
(1.36) \\
(1.86)\end{array}$ & $\begin{array}{r}-\overline{2} \\
21.2 \\
12.7 \\
-\overline{28.4}\end{array}$ & $\begin{array}{r}(\dagger) \\
(1.50) \\
(1.06) \\
(\dagger) \\
(1.82)\end{array}$ & $\begin{array}{l}3.0 \\
6.4 \\
3.9 \\
5.3 \\
6.6\end{array}$ & $\begin{array}{l}(0.58) \\
(0.70) \\
(0.51) \\
(0.69) \\
(0.86)\end{array}$ & $\begin{array}{l}4.0 \\
6.1 \\
3.1 \\
5.7 \\
-\end{array}$ & $\begin{array}{r}(0.82) \\
(0.70) \\
(0.41) \\
(0.81) \\
(\dagger)\end{array}$ & $\begin{array}{r}3.6 \\
5.0 \\
- \\
3.6 \\
4.7\end{array}$ & $\begin{array}{r}(0.63) \\
(0.49) \\
(\dagger) \\
(0.55) \\
(0.64)\end{array}$ & $\begin{array}{r}3.4 \\
5.8 \\
- \\
4.9 \\
6.8\end{array}$ & $\begin{array}{r}(0.48) \\
(0.67) \\
(\dagger) \\
(0.53) \\
(0.78)\end{array}$ & $\begin{array}{l}-\overline{5.5} \\
2.7 \\
- \\
7.3\end{array}$ & $\begin{array}{r}(\dagger) \\
(0.59) \\
(0.43) \\
(\dagger) \\
(0.87)\end{array}$ \\
\hline 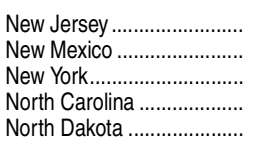 & $\begin{array}{r}- \\
20.7 \\
24.3 \\
20.6\end{array}$ & $\begin{array}{r}(\dagger) \\
(\dagger) \\
(1.05) \\
(1.99) \\
(1.58)\end{array}$ & $\begin{array}{l}19.9 \\
26.2 \\
18.3 \\
21.4 \\
15.5\end{array}$ & $\begin{array}{l}(2.18) \\
(2.00) \\
(1.13) \\
(1.61) \\
(1.62)\end{array}$ & $\begin{array}{r}- \\
25.0 \\
18.6 \\
19.1 \\
14.8\end{array}$ & $\begin{array}{r}(\dagger) \\
(2.07) \\
(0.78) \\
(1.27) \\
(1.18)\end{array}$ & $\begin{array}{l}20.3 \\
28.0 \\
20.9 \\
19.8 \\
16.9\end{array}$ & $\begin{array}{l}(1.53) \\
(1.52) \\
(1.32) \\
(1.67) \\
(1.55)\end{array}$ & $\begin{array}{l}21.1 \\
27.6 \\
20.6 \\
24.2 \\
15.3\end{array}$ & $\begin{array}{l}(1.33) \\
(1.58) \\
(1.07) \\
(1.25) \\
(1.52)\end{array}$ & $\begin{array}{l}-\overline{-} \\
4.5 \\
3.5 \\
6.3\end{array}$ & $\begin{array}{r}(\dagger) \\
(\dagger) \\
(0.41) \\
(0.71) \\
(0.98)\end{array}$ & $\begin{array}{l}3.4 \\
8.4 \\
3.6 \\
4.1 \\
4.0\end{array}$ & $\begin{array}{l}(0.67) \\
(0.98) \\
(0.41) \\
(0.65) \\
(0.71)\end{array}$ & $\begin{array}{l}7.9 \\
4.1 \\
4.3 \\
2.7\end{array}$ & $\begin{array}{r}(\dagger) \\
(0.86) \\
(0.44) \\
(0.54) \\
(0.43)\end{array}$ & $\begin{array}{l}\overline{9.7} \\
\overline{-} \\
3.0\end{array}$ & $\begin{array}{r}(\dagger) \\
(1.06) \\
(\dagger) \\
(0.63) \\
(0.59)\end{array}$ & $\begin{array}{l}\overline{9.7} \\
\overline{5.2} \\
3.4\end{array}$ & $\begin{array}{r}(\dagger) \\
(0.84) \\
(\dagger) \\
(0.91) \\
(0.45)\end{array}$ \\
\hline 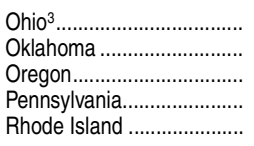 & $\begin{array}{r}21.4 \\
22.0 \\
- \\
-\overline{2} \\
27.6\end{array}$ & $\begin{array}{r}(2.33) \\
(2.20) \\
(t) \\
(\dagger) \\
(1.11)\end{array}$ & $\begin{array}{r}20.9 \\
18.7 \\
- \\
25.0\end{array}$ & $\begin{array}{r}(1.79) \\
(1.12) \\
(\dagger) \\
(\dagger) \\
(1.16)\end{array}$ & $\begin{array}{r}17.7 \\
15.9 \\
- \\
- \\
23.2\end{array}$ & $\begin{array}{r}(1.50) \\
(1.37) \\
(\dagger) \\
(\dagger) \\
(1.85)\end{array}$ & $\begin{array}{r}17.2 \\
- \\
19.3 \\
26.3\end{array}$ & $\begin{array}{r}(\dagger) \\
(2.04) \\
(\dagger) \\
(1.43) \\
(1.33)\end{array}$ & $\begin{array}{r}23.6 \\
19.1 \\
- \\
26.3\end{array}$ & $\begin{array}{r}(1.95) \\
(1.90) \\
(\dagger) \\
(\dagger) \\
(1.35)\end{array}$ & $\frac{4.3}{-}$ & $\begin{array}{r}(0.96) \\
(0.70) \\
(\dagger) \\
(\dagger) \\
(0.70)\end{array}$ & $\begin{array}{l}4.3 \\
3.0 \\
- \\
7.2\end{array}$ & $\begin{array}{r}(0.62) \\
(0.38) \\
(\dagger) \\
(\dagger) \\
(0.65)\end{array}$ & $\begin{array}{l}3.7 \\
2.6 \\
- \\
- \\
6.5\end{array}$ & $\begin{array}{r}(0.67) \\
(0.40) \\
(\dagger) \\
(\dagger) \\
(0.93)\end{array}$ & $\begin{array}{l}-\overline{2.9} \\
- \\
3.5 \\
5.1\end{array}$ & $\begin{array}{r}(t) \\
(0.70) \\
(t) \\
(0.58) \\
(0.60)\end{array}$ & $\begin{array}{l}- \\
2.4 \\
- \\
-\end{array}$ & $\begin{array}{r}(\dagger) \\
(0.58) \\
(\dagger) \\
(\dagger) \\
(\dagger)\end{array}$ \\
\hline 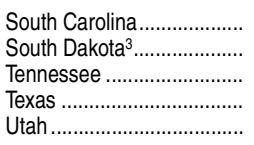 & $\begin{array}{r}-\overline{5} \\
21.5 \\
23.6 \\
11 . \overline{4}\end{array}$ & $\begin{array}{r}(\dagger) \\
(3.35) \\
(2.10) \\
(\dagger) \\
(1.28)\end{array}$ & $\begin{array}{r}19.0 \\
16.8 \\
19.5 \\
21.7 \\
7.6\end{array}$ & $\begin{array}{l}(1.24) \\
(1.87) \\
(1.38) \\
(0.99) \\
(1.18)\end{array}$ & $\begin{array}{r}18.6 \\
17.7 \\
19.4 \\
19.3 \\
8.7\end{array}$ & $\begin{array}{l}(1.44) \\
(3.72) \\
(1.29) \\
(1.01) \\
(2.00)\end{array}$ & $\begin{array}{l}20.4 \\
15.2 \\
20.1 \\
19.5 \\
10.0\end{array}$ & $\begin{array}{l}(1.56) \\
(1.36) \\
(1.31) \\
(0.71) \\
(1.53)\end{array}$ & $\begin{array}{r}24.1 \\
17.8 \\
20.6 \\
20.8 \\
9.6\end{array}$ & $\begin{array}{l}(1.99) \\
(3.57) \\
(0.96) \\
(1.30) \\
(1.26)\end{array}$ & $\begin{array}{l}\overline{-} \\
4.5 ! \\
\overline{4} \overline{7}\end{array}$ & $\begin{array}{r}(\dagger) \\
(1.50) \\
(0.86) \\
(\dagger) \\
(0.59)\end{array}$ & $\begin{array}{l}4.6 \\
2.9 \\
3.5 \\
3.8 \\
1.7\end{array}$ & $\begin{array}{l}(0.64) \\
(0.73) \\
(0.67) \\
(0.52) \\
(0.42)\end{array}$ & $\begin{array}{l}3.3 \\
5.0 ! \\
4.1 \\
3.6 \\
3.8 !\end{array}$ & $\begin{array}{l}(0.52) \\
(2.41) \\
(0.60) \\
(0.30) \\
(1.24)\end{array}$ & $\begin{array}{l}3.7 \\
2.9 \\
3.8 \\
4.6 \\
2.5\end{array}$ & $\begin{array}{l}(0.63) \\
(0.49) \\
(0.65) \\
(0.51) \\
(0.48)\end{array}$ & $\begin{array}{l}5.2 \\
- \\
3.6 \\
4.8 \\
4.0\end{array}$ & $\begin{array}{r}(0.75) \\
(\dagger) \\
(0.40) \\
(0.47) \\
(0.72)\end{array}$ \\
\hline 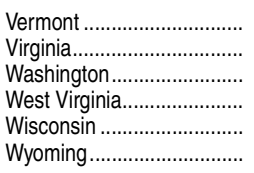 & $\begin{array}{r}28.2 \\
- \\
23.1 \\
21.8 \\
20.4\end{array}$ & $\begin{array}{r}(1.58) \\
(\dagger) \\
(\dagger) \\
(2.13) \\
(1.18) \\
(1.56)\end{array}$ & $\begin{array}{r}25.3 \\
- \\
19.6 \\
15.9 \\
17.8\end{array}$ & $\begin{array}{r}(1.59) \\
(\dagger) \\
(\dagger) \\
(1.70) \\
(1.07) \\
(1.05)\end{array}$ & $\begin{array}{r}24.1 \\
- \\
23.5 \\
20.3 \\
14.4\end{array}$ & $\begin{array}{r}(0.88) \\
(\dagger) \\
(\dagger) \\
(1.05) \\
(1.30) \\
(0.79)\end{array}$ & $\begin{array}{r}24.6 \\
- \\
20.3 \\
18.9 \\
16.9\end{array}$ & $\begin{array}{r}(1.14) \\
(\dagger) \\
(\dagger) \\
(1.73) \\
(1.64) \\
(0.91)\end{array}$ & $\begin{array}{r}24.4 \\
18.0 \\
- \\
19.7 \\
21.6 \\
18.5\end{array}$ & $\begin{array}{r}(1.43) \\
(1.79) \\
(\dagger) \\
(1.61) \\
(1.78) \\
(1.23)\end{array}$ & $\begin{array}{l}8.0 \\
\overline{-} \\
4.5 \\
\overline{5.1}\end{array}$ & $\begin{array}{r}(0.44) \\
(t) \\
(t) \\
(0.72) \\
(t) \\
(0.66)\end{array}$ & $\begin{array}{l}7.0 \\
\overline{-} \\
\overline{4.9} \\
\overline{4.0}\end{array}$ & $\begin{array}{r}(0.80) \\
(\dagger) \\
(\dagger) \\
(0.85) \\
(t) \\
(0.43)\end{array}$ & $\begin{array}{r}6.3 \\
\overline{-} \\
\overline{5.8} \\
\overline{4} \\
4.7\end{array}$ & $\begin{array}{r}(0.63) \\
(t) \\
(t) \\
(0.97) \\
(t) \\
(0.52)\end{array}$ & $\begin{array}{c}6.3 \\
\overline{-} \\
3.9 \\
- \\
5.3\end{array}$ & $\begin{array}{r}(0.57) \\
(\dagger) \\
(\dagger) \\
(0.37) \\
(\dagger) \\
(0.45)\end{array}$ & $\begin{array}{c}6.0 \\
3.5 \\
-\overline{3.0} \\
- \\
4.7\end{array}$ & $\begin{array}{r}(0.84) \\
(0.70) \\
(\dagger) \\
(0.45) \\
(\dagger) \\
(0.44)\end{array}$ \\
\hline
\end{tabular}

-Not available.

†Not applicable.

!Interpret data with caution. The coefficient of variation (CV) for this estimate is between 30 and 50 percent.

${ }^{1}$ The term "anywhere" is not used in the Youth Risk Behavior Survey (YRBS) questionnaire; students were simply asked how many times during the previous 30 days they had used marijuana.

'In the question about using marijuana at school, "on school property" was not defined for survey respondents.

${ }^{3}$ Data include both public and private schools.

NOTE: State-level data include public schools only, with the exception of data for Ohio and South Dakota. Data for the United States total, Ohio, and South Dakota include both public and private schools.

SOURCE: Centers for Disease Control and Prevention, Division of Adolescent and School Health, Youth Risk Behavior Surveillance System (YRBSS), 2003 through 2011. (This table was prepared September 2013.) 
Table 232.70. Percentage of students in grades 9-12 who reported that illegal drugs were made available to them on school property during the previous 12 months, by selected student characteristics: Selected years, 1993 through 2011

[Standard errors appear in parentheses]

\begin{tabular}{|c|c|c|c|c|c|c|c|c|c|c|c|c|c|c|c|c|c|c|c|c|}
\hline Student characteristic & & 1993 & & 1995 & & 1997 & & 1999 & & 2001 & & 2003 & & 2005 & & 2007 & & 2009 & & 2011 \\
\hline 1 & & 2 & & 3 & & 4 & & 5 & & 6 & & 7 & & 8 & & 9 & & 10 & & 11 \\
\hline Total $\ldots$ & 24.0 & (1.33) & 32.1 & (1.55) & 31.7 & $(0.90)$ & 30.2 & $(1.23)$ & 28.5 & (1.01) & 28.7 & $(1.95)$ & 25.4 & $(1.05)$ & 22.3 & (1.04) & 22.7 & $(1.04)$ & 25.6 & $(0.99)$ \\
\hline 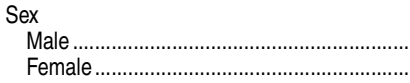 & $\begin{array}{l}28.5 \\
19.1\end{array}$ & $\begin{array}{l}(1.50) \\
(1.31)\end{array}$ & $\begin{array}{l}38.8 \\
24.8\end{array}$ & $\begin{array}{l}(1.73) \\
(1.43)\end{array}$ & $\begin{array}{l}37.4 \\
24.7\end{array}$ & $\begin{array}{l}(1.19) \\
(1.22)\end{array}$ & $\begin{array}{l}34.7 \\
25.7\end{array}$ & $\begin{array}{l}(1.69) \\
(1.26)\end{array}$ & $\begin{array}{l}34.6 \\
22.7\end{array}$ & $\begin{array}{l}(1.20) \\
(1.03)\end{array}$ & $\begin{array}{l}31.9 \\
25.0\end{array}$ & $\begin{array}{l}(2.07) \\
(1.92)\end{array}$ & $\begin{array}{l}28.8 \\
21.8\end{array}$ & $\begin{array}{l}(1.23) \\
(1.03)\end{array}$ & $\begin{array}{l}25.7 \\
18.7\end{array}$ & $\begin{array}{l}(1.15) \\
(1.16)\end{array}$ & $\begin{array}{l}25.9 \\
19.3\end{array}$ & $\begin{array}{l}(1.36) \\
(1.01)\end{array}$ & $\begin{array}{l}29.2 \\
21.7\end{array}$ & $\begin{array}{l}(1.10) \\
(1.17)\end{array}$ \\
\hline 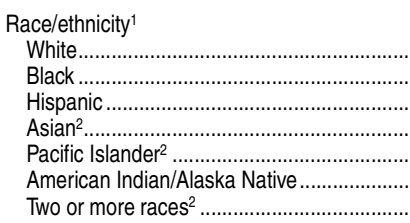 & $\begin{array}{r}24.1 \\
17.5 \\
34.1 \\
- \\
-\overline{2} \\
-\end{array}$ & $\begin{array}{r}(1.69) \\
(1.49) \\
(1.58) \\
(\dagger) \\
(\dagger) \\
(4.55) \\
(\dagger)\end{array}$ & $\begin{array}{r}31.7 \\
28.5 \\
40.7 \\
- \\
- \\
22.8 \\
-\end{array}$ & $\begin{array}{r}(2.24) \\
(1.98) \\
(2.45) \\
(\dagger) \\
(\dagger) \\
(4.78) \\
(\dagger)\end{array}$ & $\begin{array}{r}31.0 \\
25.4 \\
41.1 \\
- \\
- \\
30.1 \\
-\end{array}$ & $\begin{array}{r}(1.36) \\
(1.69) \\
(2.04) \\
(\dagger) \\
(\dagger) \\
(4.54) \\
(\dagger)\end{array}$ & $\begin{array}{l}28.8 \\
25.3 \\
36.9 \\
25.7 \\
46.9 \\
30.6 \\
36.0\end{array}$ & $\begin{array}{l}(1.50) \\
(2.03) \\
(2.10) \\
(2.65) \\
(4.33) \\
(5.90) \\
(2.72)\end{array}$ & $\begin{array}{l}28.3 \\
21.9 \\
34.2 \\
25.7 \\
50.2 \\
34.5 \\
34.5\end{array}$ & $\begin{array}{l}(1.31) \\
(1.72) \\
(1.17) \\
(2.92) \\
(5.73) \\
(5.15) \\
(3.22)\end{array}$ & $\begin{array}{l}27.5 \\
23.1 \\
36.5 \\
22.5 \\
34.7 \\
31.3 \\
36.6\end{array}$ & $\begin{array}{l}(2.68) \\
(1.42) \\
(1.91) \\
(3.71) \\
(6.19) \\
(5.64) \\
(3.99)\end{array}$ & $\begin{array}{l}23.6 \\
23.9 \\
33.5 \\
15.9 \\
41.3 \\
24.4 \\
31.6\end{array}$ & $\begin{array}{l}(1.32) \\
(2.22) \\
(1.18) \\
(2.68) \\
(5.75) \\
(3.57) \\
(3.13)\end{array}$ & $\begin{array}{l}20.8 \\
19.2 \\
29.1 \\
21.0 \\
38.5 \\
25.1 \\
24.6\end{array}$ & $\begin{array}{l}(1.23) \\
(1.36) \\
(1.94) \\
(2.78) \\
(5.45) \\
(2.04) \\
(3.55)\end{array}$ & $\begin{array}{l}19.8 \\
22.2 \\
31.2 \\
18.3 \\
27.6 \\
34.0 \\
26.9\end{array}$ & $\begin{array}{l}(1.13) \\
(1.42) \\
(1.53) \\
(2.03) \\
(5.10) \\
(4.81) \\
(2.62)\end{array}$ & $\begin{array}{l}22.7 \\
22.8 \\
33.2 \\
23.3 \\
38.9 \\
40.5 \\
33.3\end{array}$ & $\begin{array}{l}(0.96) \\
(1.82) \\
(1.70) \\
(2.46) \\
(5.01) \\
(2.80) \\
(2.79)\end{array}$ \\
\hline $\begin{array}{l}\text { Grade } \\
\text { 9th } \\
\text { 10th } \\
\text { 11th } \\
\text { 12th }\end{array}$ & $\begin{array}{l}21.8 \\
23.7 \\
27.5 \\
23.0\end{array}$ & $\begin{array}{l}(1.24) \\
(1.86) \\
(1.61) \\
(1.82)\end{array}$ & $\begin{array}{l}31.1 \\
35.0 \\
32.8 \\
29.1\end{array}$ & $\begin{array}{l}(1.69) \\
(1.54) \\
(1.88) \\
(2.63)\end{array}$ & $\begin{array}{l}31.4 \\
33.4 \\
33.2 \\
29.0\end{array}$ & $\begin{array}{l}(2.33) \\
(1.71) \\
(1.42) \\
(1.80)\end{array}$ & $\begin{array}{l}27.6 \\
32.1 \\
31.1 \\
30.5\end{array}$ & $\begin{array}{l}(2.51) \\
(1.94) \\
(2.16) \\
(1.11)\end{array}$ & $\begin{array}{l}29.0 \\
29.0 \\
28.7 \\
26.9\end{array}$ & $\begin{array}{l}(1.59) \\
(1.39) \\
(1.39) \\
(1.30)\end{array}$ & $\begin{array}{l}29.5 \\
29.2 \\
29.9 \\
24.9\end{array}$ & $\begin{array}{l}(2.39) \\
(2.02) \\
(2.33) \\
(2.24)\end{array}$ & $\begin{array}{l}24.0 \\
27.5 \\
24.9 \\
24.9\end{array}$ & $\begin{array}{l}(1.21) \\
(1.68) \\
(1.03) \\
(1.40)\end{array}$ & $\begin{array}{l}21.2 \\
25.3 \\
22.8 \\
19.6\end{array}$ & $\begin{array}{l}(1.23) \\
(1.29) \\
(1.42) \\
(1.26)\end{array}$ & $\begin{array}{l}22.0 \\
23.7 \\
24.3 \\
20.6\end{array}$ & $\begin{array}{l}(1.32) \\
(1.11) \\
(1.44) \\
(1.21)\end{array}$ & $\begin{array}{l}23.7 \\
27.8 \\
27.0 \\
23.8\end{array}$ & $\begin{array}{l}(1.22) \\
(1.21) \\
(1.51) \\
(1.13)\end{array}$ \\
\hline 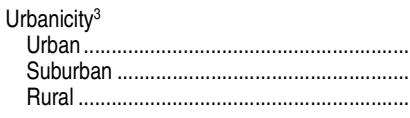 & $\begin{array}{l}- \\
-\end{array}$ & $\begin{array}{l}(\dagger) \\
(\dagger) \\
(\dagger)\end{array}$ & $\begin{array}{l}- \\
-\end{array}$ & $\begin{array}{l}(\dagger) \\
(\dagger) \\
(\dagger)\end{array}$ & $\begin{array}{l}31.2 \\
34.2 \\
22.7\end{array}$ & $\begin{array}{l}(1.11) \\
(0.94) \\
(1.91)\end{array}$ & $\begin{array}{l}30.3 \\
29.7 \\
32.1\end{array}$ & $\begin{array}{l}(1.50) \\
(1.87) \\
(5.76)\end{array}$ & $\begin{array}{l}32.0 \\
26.6 \\
28.2\end{array}$ & $\begin{array}{l}(1.36) \\
(1.34) \\
(3.10)\end{array}$ & $\begin{array}{l}31.1 \\
28.4 \\
26.2\end{array}$ & $\begin{array}{l}(2.12) \\
(2.16) \\
(5.08)\end{array}$ & $\begin{array}{l}- \\
-\end{array}$ & $\begin{array}{l}(t) \\
(t) \\
(t)\end{array}$ & $\begin{array}{l}- \\
-\end{array}$ & $\begin{array}{l}(t) \\
(t) \\
(t)\end{array}$ & $\begin{array}{l}- \\
-\end{array}$ & $\begin{array}{l}(\dagger) \\
(\dagger) \\
(t)\end{array}$ & $\begin{array}{l}- \\
-\end{array}$ & $\begin{array}{l}(t) \\
(t) \\
(t)\end{array}$ \\
\hline
\end{tabular}

\section{-Not available.}

'Race categories exclude persons of Hispanic ethnicity.

2Before 1999, Asian students and Pacific Islander students were not categorized separately, and students were not given the option of

${ }^{3}$ Refers to the Standard Metropolitan Statistical Area (MSA) status of the respondent's household as defined in 2000 by the U.S. Cen-

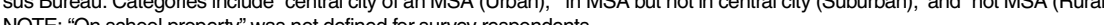

choosing two or more races. Because the response categories changed in 1999, caution should be used in comparing data on race

vey respondents.

System (YRBSS), 1993 through 2011. (This table was prepared September 2013.)

from 1993, 1995, and 1997 with data from later years. 
334 CHAPTER 2: Elementary and Secondary Education

Alcohol, Illicit Drugs, and Cigarettes

Table 232.80. Percentage of public school students in grades 9-12 who reported that illegal drugs were made available to them on school property during the previous 12 months, by state: Selected years, 2003 through 2011

[Standard errors appear in parentheses]

\begin{tabular}{|c|c|c|c|c|c|c|c|c|c|c|}
\hline State & & 2003 & & 2005 & & 2007 & & 2009 & & 2011 \\
\hline 1 & & 2 & & 3 & & 4 & & 5 & & 6 \\
\hline United States ${ }^{1} \ldots \ldots \ldots \ldots \ldots$ & 28.7 & $(1.95)$ & 25.4 & $(1.05)$ & 22.3 & $(1.04)$ & 22.7 & $(1.04)$ & 25.6 & $(0.99)$ \\
\hline 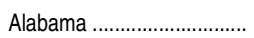 & 26.0 & $(1.78)$ & 26.2 & $(1.90)$ & - & $(\dagger)$ & 27.6 & $(1.30)$ & 20.3 & (1.32) \\
\hline 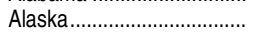 & 28.4 & $(1.24)$ & - & $(\dagger)$ & 25.1 & $(1.36)$ & 24.8 & $(1.25)$ & 23.2 & $(0.98)$ \\
\hline 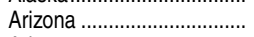 & 28.6 & $(1.23)$ & 38.7 & $(1.18)$ & 37.1 & $(1.45)$ & 34.6 & $(1.43)$ & 34.6 & (1.55) \\
\hline 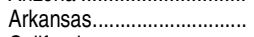 & - & $(t)$ & 29.2 & $(1.35)$ & 28.1 & $(1.28)$ & 31.4 & $(1.56)$ & 26.1 & (1.30) \\
\hline 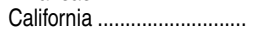 & - & $(\dagger)$ & - & $(\mathrm{t})$ & - & $(t)$ & - & $(\mathrm{t})$ & - & $(\mathrm{t})$ \\
\hline 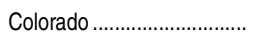 & - & $(\dagger)$ & 21.2 & $(1.81)$ & - & $(\dagger)$ & 22.7 & $(1.52)$ & 17.2 & (1.28) \\
\hline 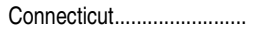 & - & $(t)$ & 31.5 & $(0.90)$ & 30.5 & $(1.52)$ & 28.9 & $(1.25)$ & 27.8 & (1.43) \\
\hline 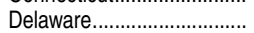 & 27.9 & $(0.90)$ & 26.1 & $(1.05)$ & 22.9 & $(0.99)$ & 20.9 & $(0.87)$ & 23.1 & $(1.20)$ \\
\hline District of Columbia ............. & 30.2 & $(1.46)$ & 20.3 & (1.18) & 25.7 & $(1.20)$ & - & $(t)$ & 22.6 & (1.53) \\
\hline 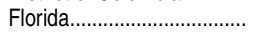 & 25.7 & $(0.81)$ & 23.2 & $(0.85)$ & 19.0 & $(0.80)$ & 21.8 & $(0.72)$ & 22.9 & $(0.84)$ \\
\hline 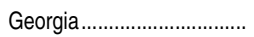 & 33.3 & $(1.00)$ & 30.7 & $(1.25)$ & 32.0 & $(1.23)$ & 32.9 & (1.22) & 32.1 & (1.34) \\
\hline 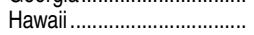 & - & $(t)$ & 32.7 & $(1.74)$ & 36.2 & $(2.46)$ & 36.1 & $(1.51)$ & 31.7 & (1.48) \\
\hline 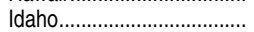 & 19.6 & $(1.26)$ & 24.8 & $(1.52)$ & 25.1 & $(1.63)$ & 22.7 & (1.39) & 24.4 & $(1.56)$ \\
\hline 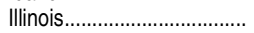 & - & $(t)$ & - & $(\dagger)$ & 21.2 & (1.18) & 27.5 & (1.97) & 27.3 & (1.46) \\
\hline 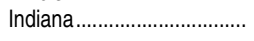 & 28.3 & $(1.55)$ & 28.9 & (1.33) & 20.5 & $(1.02)$ & 25.5 & $(1.24)$ & 28.3 & (1.33) \\
\hline lowa & - & $(\dagger)$ & 15.5 & $(1.37)$ & 10.1 & $(1.08)$ & - & $(\dagger)$ & 11.9 & $(1.16)$ \\
\hline 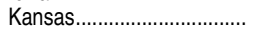 & - & $(\dagger)$ & 16.7 & $(1.27)$ & 15.0 & $(1.24)$ & 15.1 & $(0.78)$ & 24.9 & (1.19) \\
\hline 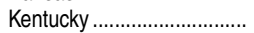 & 30.4 & $(1.51)$ & 19.8 & $(1.23)$ & 27.0 & $(1.11)$ & 25.6 & (1.49) & 24.4 & (1.40) \\
\hline 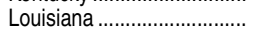 & - & $(t)$ & - & $(t)$ & - & $(t)$ & 22.8 & (1.66) & 25.1 & (1.82) \\
\hline 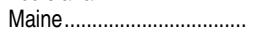 & 32.6 & $(1.73)$ & 33.5 & $(1.89)$ & 29.1 & $(1.67)$ & 21.2 & $(0.51)$ & 21.7 & $(0.80)$ \\
\hline 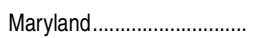 & - & $(\dagger)$ & 28.9 & $(2.04)$ & 27.4 & $(1.46)$ & 29.3 & $(1.35)$ & 30.4 & (1.99) \\
\hline 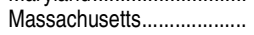 & 31.9 & $(1.08)$ & 29.9 & $(1.09)$ & 27.3 & $(1.06)$ & 26.1 & (1.34) & 27.1 & (1.04) \\
\hline 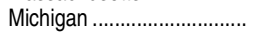 & 31.3 & $(1.50)$ & 28.8 & $(1.37)$ & 29.1 & $(1.07)$ & 29.5 & $(0.90)$ & 25.4 & $(0.90)$ \\
\hline Minnesota ............................. & - & $(\dagger)$ & - & $(\dagger)$ & - & $(\dagger)$ & - & $(\dagger)$ & - & $(\dagger)$ \\
\hline Mississippi ............................... & 22.3 & $(1.31)$ & - & $(\dagger)$ & 15.6 & $(1.53)$ & 18.0 & $(1.07)$ & 15.9 & $(0.89)$ \\
\hline Missouri ......... & 21.6 & $(2.09)$ & 18.2 & (1.92) & 17.8 & (1.49) & 17.3 & (1.32) & - & $(\dagger)$ \\
\hline 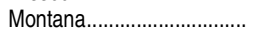 & 26.9 & $(1.23)$ & 25.3 & $(1.09)$ & 24.9 & $(0.83)$ & 20.7 & $(1.10)$ & 25.2 & (0.93) \\
\hline 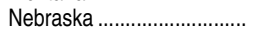 & 23.3 & $(1.04)$ & 22.0 & $(0.82)$ & - & $(t)$ & - & $(t)$ & 20.3 & (1.01) \\
\hline 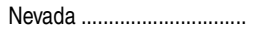 & 34.5 & $(1.30)$ & 32.6 & $(1.53)$ & 28.8 & $(1.39)$ & 35.6 & (1.30) & - & $(\dagger)$ \\
\hline New Hampshire ...................... & 28.2 & $(1.87)$ & 26.9 & $(1.40)$ & 22.5 & $(1.25)$ & 22.1 & (1.44) & 23.2 & (1.44) \\
\hline 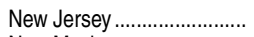 & - & $(\dagger)$ & 32.6 & $(1.32)$ & - & $(t)$ & 32.2 & $(1.38)$ & 27.3 & (1.41) \\
\hline 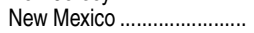 & - & $(t)$ & 33.5 & $(1.37)$ & 31.3 & $(1.39)$ & 30.9 & (1.54) & 34.5 & (1.24) \\
\hline 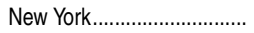 & 23.0 & $(0.97)$ & 23.7 & $(0.76)$ & 26.6 & $(1.09)$ & 24.0 & $(1.05)$ & - & $(\dagger)$ \\
\hline 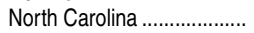 & 31.9 & $(1.74)$ & 27.4 & $(1.66)$ & 28.5 & $(1.37)$ & 30.2 & (1.51) & 29.8 & (1.87) \\
\hline North Dakota ........................... & 21.3 & $(1.07)$ & 19.6 & $(1.10)$ & 18.7 & $(1.05)$ & 19.5 & $(1.16)$ & 20.8 & (1.03) \\
\hline 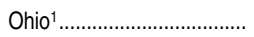 & 31.1 & $(1.68)$ & 30.9 & $(1.88)$ & 26.7 & $(1.26)$ & - & $(t)$ & 24.3 & (1.70) \\
\hline 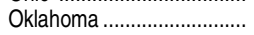 & 22.2 & $(1.23)$ & 18.4 & $(1.49)$ & 19.1 & $(1.12)$ & 16.8 & $(1.50)$ & 17.2 & (1.36) \\
\hline 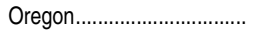 & - & $(\dagger)$ & - & $(\dagger)$ & - & $(t)$ & - & $(t)$ & - & $(\dagger)$ \\
\hline Pennsylvania........................ & - & $(\dagger)$ & - & $(\dagger)$ & - & $(\dagger)$ & 16.1 & $(1.07)$ & - & $(t)$ \\
\hline Rhode Island ........................ & 26.0 & $(1.26)$ & 24.1 & $(1.11)$ & 25.3 & $(1.33)$ & 25.2 & (1.52) & 22.4 & $(0.95)$ \\
\hline 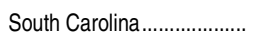 & - & $(\dagger)$ & 29.1 & $(1.45)$ & 26.6 & $(1.58)$ & 27.6 & $(1.74)$ & 29.3 & (1.83) \\
\hline 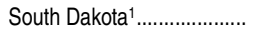 & 22.1 & $(1.25)$ & 20.9 & $(2.30)$ & 21.1 & (1.98) & 17.7 & $(0.64)$ & 16.0 & (1.81) \\
\hline Tennessee .......................... & 24.3 & $(2.25)$ & 26.6 & $(1.21)$ & 21.6 & $(1.35)$ & 18.8 & $(1.06)$ & 16.6 & $(0.88)$ \\
\hline 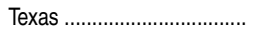 & - & $(t)$ & 30.7 & $(1.73)$ & 26.5 & $(0.83)$ & 25.9 & (1.25) & 29.4 & (1.34) \\
\hline Utah & 24.7 & $(2.04)$ & 20.6 & $(1.36)$ & 23.2 & $(1.83)$ & 19.7 & $(1.52)$ & 21.4 & (1.55) \\
\hline 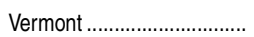 & 29.4 & $(1.67)$ & 23.1 & $(1.59)$ & 22.0 & $(0.99)$ & 21.1 & $(1.21)$ & 17.6 & (1.51) \\
\hline 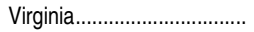 & - & $(t)$ & - & $(t)$ & - & $(\dagger)$ & - & $(t)$ & 24.0 & (1.67) \\
\hline 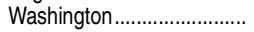 & - & $(\dagger)$ & - & $(\dagger)$ & - & $(\dagger)$ & - & $(t)$ & - & $(\dagger)$ \\
\hline 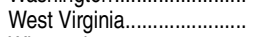 & 26.5 & $(2.06)$ & 24.8 & $(1.36)$ & 28.6 & $(2.76)$ & 28.0 & (1.27) & 17.3 & (1.04) \\
\hline 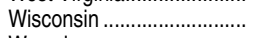 & 26.3 & $(1.18)$ & 21.7 & $(1.18)$ & 22.7 & $(1.34)$ & 20.5 & $(1.03)$ & 20.9 & (1.29) \\
\hline 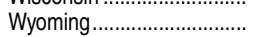 & 18.1 & $(0.99)$ & 22.7 & $(0.97)$ & 24.7 & $(1.08)$ & 23.7 & $(0.93)$ & 25.2 & $(0.97)$ \\
\hline
\end{tabular}

- Not available.

†Not applicable.

${ }^{1}$ Data include both public and private schools.

NOTE: "On school property" was not defined for survey respondents. State-level data include

public schools only, with the exception of data for Ohio and South Dakota. Data for the United
States total, Ohio, and South Dakota include both public and private schools.

SOURCE: Centers for Disease Control and Prevention, Division of Adolescent and School Health, Youth Risk Behavior Surveillance System (YRBSS), 2003 through 2011. (This table was prepared September 2013.) 
Table 232.90. Percentage of high school seniors reporting use of alcohol and illicit drugs, by frequency of use and substance used: Selected years, 1975 through 2012

[Standard errors appear in parentheses]

\begin{tabular}{|c|c|c|c|c|c|c|c|c|c|c|c|c|c|c|c|c|c|c|c|c|c|c|c|c|c|c|c|c|}
\hline \multirow{2}{*}{$\begin{array}{l}\text { Frequency of use } \\
\text { and substance used } \\
1\end{array}$} & \multicolumn{2}{|c|}{ Class of 1975} & \multicolumn{2}{|c|}{ Class of 1980} & \multicolumn{2}{|c|}{ Class of 1985} & \multicolumn{2}{|c|}{ Class of 1990} & \multicolumn{2}{|c|}{ Class of 1995} & \multicolumn{2}{|c|}{ Class of 2000} & \multicolumn{2}{|c|}{ Class of 2005} & \multicolumn{2}{|c|}{ Class of 2006} & \multicolumn{2}{|c|}{ Class of 2007} & \multicolumn{2}{|c|}{ Class of 2008} & \multicolumn{2}{|c|}{ Class of 2009} & \multicolumn{2}{|c|}{ Class of 2010} & \multicolumn{2}{|c|}{ Class of 2011} & \multicolumn{2}{|c|}{ Class of 2012} \\
\hline & & 2 & & 3 & & 4 & & 5 & & 6 & & 7 & & 8 & & 9 & & 10 & & 11 & & 12 & & 13 & & 14 & & 15 \\
\hline \multicolumn{29}{|l|}{ Ever used } \\
\hline Alcohol' 1 .......... & 90.4 & $(0.69)$ & 93.2 & $(0.46)$ & 92.2 & $(0.48)$ & 89.5 & $(0.57)$ & 80.7 & $(0.73)$ & 80.3 & $(0.80)$ & 75.1 & $(0.81)$ & 72.7 & $(0.85)$ & 72.2 & $(0.83)$ & 71.9 & $(0.85)$ & 72.3 & $(0.85)$ & 71.0 & $(0.84)$ & 70.0 & $(0.88)$ & 69.4 & $(0.90)$ \\
\hline $\begin{array}{c}\text { Any illicit drug........... } \\
\text { Marijuana only..... } \\
\text { Any illicit drug } \\
\text { other than } \\
\text { marijuana }{ }^{2} . . . . .\end{array}$ & $\begin{array}{l}55.2 \\
19.0\end{array}$ & $\begin{array}{l}(1.68) \\
(1.32)\end{array}$ & $\begin{array}{l}65.4 \\
26.7\end{array}$ & $\begin{array}{l}(1.23) \\
(1.15)\end{array}$ & $\begin{array}{l}60.6 \\
20.9\end{array}$ & $\begin{array}{l}(1.26) \\
(1.05)\end{array}$ & $\begin{array}{l}47.9 \\
18.5\end{array}$ & $\begin{array}{l}(1.33) \\
(1.03)\end{array}$ & $\begin{array}{l}48.4 \\
20.3\end{array}$ & $\begin{array}{l}(1.32) \\
(1.06)\end{array}$ & $\begin{array}{l}54.0 \\
25.0\end{array}$ & $\begin{array}{l}(1.44) \\
(1.25)\end{array}$ & $\begin{array}{l}50.4 \\
23.0\end{array}$ & $\begin{array}{l}(1.35) \\
(1.14)\end{array}$ & $\begin{array}{l}48.2 \\
21.3\end{array}$ & $\begin{array}{l}(1.37) \\
(1.12)\end{array}$ & $\begin{array}{l}46.8 \\
21.3\end{array}$ & $\begin{array}{l}(1.33) \\
(1.09)\end{array}$ & $\begin{array}{l}47.4 \\
22.5\end{array}$ & $\begin{array}{l}(1.35) \\
(1.13)\end{array}$ & $\begin{array}{l}46.7 \\
22.7\end{array}$ & $\begin{array}{l}(1.36) \\
(1.15)\end{array}$ & $\begin{array}{l}48.2 \\
23.5\end{array}$ & $\begin{array}{l}(1.33) \\
(1.13)\end{array}$ & $\begin{array}{l}49.9 \\
25.0\end{array}$ & $\begin{array}{l}(1.38) \\
(1.19)\end{array}$ & $\begin{array}{l}49.1 \\
25.0\end{array}$ & $\begin{array}{l}(1.40) \\
(1.21)\end{array}$ \\
\hline \multirow{2}{*}{\multicolumn{29}{|c|}{$\begin{array}{l}\text { Selected drugs } \\
\text { Cocaine ............ }\end{array}$}} \\
\hline & & & & & & $(0.74)$ & & $(0.59)$ & & $(0.48)$ & 8.6 & $(0.62)$ & & & 8.5 & $(0.58)$ & 7.8 & $(0.54)$ & & $(0.53)$ & & $(0.49)$ & 5.5 & $(0.46)$ & & $(0.47)$ & 4.9 & $(0.46)$ \\
\hline & 2.2 & $(0.21)$ & 1.1 & & 1.2 & & 1.3 & $(0.13)$ & 1.6 & & 2.4 & & 1.5 & & 1.4 & $(0.14)$ & 1.5 & $(0.14)$ & 1.3 & $(0.13)$ & 1.2 & $(0.13)$ & 1.6 & $(0.14)$ & 1.4 & $(0.14)$ & 1.1 & $(0.13)$ \\
\hline LSD & 11.3 & $(0.81)$ & 9.3 & $(0.57)$ & 7.5 & $(0.52)$ & 8.7 & $(0.57)$ & 11.7 & $(0.64)$ & 11.1 & $(0.69)$ & 3.5 & $(0.38)$ & 3.3 & $(0.37)$ & 3.4 & $(0.37)$ & 4.0 & $(0.40)$ & 3.1 & $(0.36)$ & 4.0 & $(0.40)$ & 4.0 & $(0.41)$ & 3.8 & $(0.41)$ \\
\hline Mariju & 47.3 & (1.68) & 60.3 & (1.27) & 54.2 & (1.83) & 40.7 & (1.30) & 41.7 & (1.30) & 48.8 & (1.45) & 44.8 & (1.34) & 42.3 & (1.36) & 41.8 & (1.31) & 42.6 & $(1.34)$ & 42.0 & (1.35) & 43.8 & (1.32) & 45.5 & $(1.37)$ & 45.2 & (1.39) \\
\hline PCP.... & - & (†) & 9.6 & $(0.33)$ & 4.9 & $(0.24)$ & 2.8 & $(0.19)$ & 2.7 & $(0.18)$ & 3.4 & $(0.23)$ & 2.4 & $(0.18)$ & 2.2 & $(0.17)$ & 2.1 & $(0.17)$ & 1.8 & $(0.16)$ & 1.7 & $(0.15)$ & 1.8 & $(0.15)$ & 2.3 & $(0.18)$ & 1.6 & $(0.15)$ \\
\hline \multicolumn{29}{|l|}{$\begin{array}{l}\text { Used during past } \\
12 \text { months }\end{array}$} \\
\hline Alcohol'........ & 84.8 & $(0.84)$ & 87.9 & (0.59) & 85.6 & $(0.63)$ & 80.6 & $(0.73)$ & 73.7 & $(0.81)$ & 73.2 & $(0.89)$ & 68.6 & $(0.87)$ & 66.5 & $(0.90)$ & 66.4 & $(0.88)$ & 65.5 & $(0.90)$ & 66.2 & $(0.90)$ & 65.2 & $(0.88)$ & 63.5 & $(0.92)$ & 63.5 & $(0.94)$ \\
\hline Any illicit drug & 45.0 & (1.64) & 53.1 & (1.26) & 46.3 & (1.26) & 32.5 & (1.21) & 39.0 & $(1.26)$ & 40.9 & (1.39) & 38.4 & $(1.28)$ & 36.5 & $(1.29)$ & 35.9 & $(1.25)$ & 36.6 & (1.27) & 36.5 & (1.29) & 38.3 & $(1.26)$ & 40.0 & (1.32) & 39.7 & (1.34) \\
\hline $\begin{array}{l}\text { Marijuana only...... } \\
\text { Any illicit drug } \\
\text { other than }\end{array}$ & 18.8 & (1.29) & 22.7 & $(1.06)$ & 18.9 & $(0.99)$ & 14.6 & $(0.91)$ & 19.6 & (1.02) & 20.5 & (1.14) & 18.8 & $(1.03)$ & 17.3 & (1.01) & 17.4 & $(0.99)$ & 18.3 & $(1.02)$ & 19.5 & $(1.06)$ & 21.0 & $(1.06)$ & 22.4 & (1.12) & 22.7 & (1.14) \\
\hline marijuana ${ }^{2} . . . . .$. & 26.2 & (1.15) & 30.4 & $(0.92)$ & 27.4 & $(0.89)$ & 17.9 & $(0.79)$ & 19.4 & $(0.81)$ & 20.4 & $(0.90)$ & 19.7 & $(0.83)$ & 19.2 & $(0.84)$ & 18.5 & $(0.80)$ & 18.3 & $(0.81)$ & 17.0 & $(0.79)$ & 17.3 & $(0.78)$ & 17.6 & $(0.81)$ & 17.0 & $(0.81)$ \\
\hline Selected & & & & & & & & & & & & & & & & & & & & & & & & & & & & \\
\hline ". & 5.6 & $(0.52)$ & 12.3 & $(0.58)$ & 13.1 & $(0.59)$ & 5.3 & $(0.40)$ & 4.0 & $(0.35)$ & 5.0 & $(0.43)$ & 5.1 & $(0.40)$ & 5.7 & $(0.43)$ & 5.2 & $(0.40)$ & 4.4 & $(0.38)$ & 3.4 & $(0.34)$ & 2.9 & $(0.30)$ & 2.9 & $(0.31)$ & 2.7 & $(0.31)$ \\
\hline & 1.0 & $(0.13)$ & 0.5 & & 0.6 & $(0.07)$ & 0.5 & $(0.07)$ & 1.1 & $(0$. & 1.5 & $(0.13)$ & 0.8 & $(0.09)$ & 08 & & 09 & & 0.7 & $(0$ & 0.7 & & 0.9 & & 0.8 & & 6 & $(0.08)$ \\
\hline & 7.2 & $(0.59)$ & 6.5 & & 4 & (0.) & 5 & 10 & 8.4 & & 6.6 & & 1.8 & & 1.7 & & 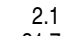 & & 2.7 & & 1.9 & & & & .7 & & 2.4 & $0.29)$ \\
\hline ashish. & 40.0 & $(1.61)$ & 48.8 & $(1.27)$ & 40.6 & (1.24) & 27.0 & (1.15) & 34.7 & (1.23) & 36.5 & (1.36) & 33.6 & (1.24) & 31.5 & (1.24) & 31.7 & $(1.21)$ & 32.4 & $(1.24)$ & 32.8 & $(1.25)$ & 34.8 & $(1.24)$ & 36.4 & $(1.29)$ & 36.4 & (1.31) \\
\hline PCP & - & $(t)$ & 4.4 & $(0.20)$ & 2.9 & $(0.16)$ & 1.2 & $(0.11)$ & 1.8 & $(0.13)$ & 2.3 & $(0.16)$ & 1.3 & $(0.11)$ & 0.7 & $(0.09)$ & 0.9 & $(0.09)$ & 1.1 & $(0.11)$ & 1.0 & $(0.10)$ & 1.0 & $(0.10)$ & 1.3 & $(0.12)$ & 0.9 & $(0.10)$ \\
\hline $\begin{array}{l}\text { Used during past } \\
30 \text { days }\end{array}$ & & & & & & & & & & & & & & & & & & & & & & & & & & & & \\
\hline Alcohol $^{1} \ldots \ldots \ldots \ldots \ldots$ & 68.2 & $(1.10)$ & 72.0 & $(0.81)$ & 65.9 & $(0.85)$ & 57.1 & $(0.92)$ & 51.3 & $(0.92)$ & 50.0 & $(1.01)$ & 47.0 & $(0.94)$ & 45.3 & $(0.95)$ & 44.4 & $(0.92)$ & 43.1 & $(0.93)$ & 43.5 & $(0.95)$ & 41.2 & $(0.91)$ & 40.0 & $(0.94)$ & 41.5 & $(0.96)$ \\
\hline Any illicit drug........ & 30.7 & $(1.35)$ & 37.2 & $(1.0$ & 29.7 & $(1.03)$ & 17.2 & $(0.87)$ & 23.8 & $(0.98)$ & 24.9 & $(1.09)$ & 23.1 & $(0.99)$ & 21.5 & $(0.98)$ & 21.9 & $(0.96)$ & 22.3 & $(0.98)$ & 23.3 & $(1.01)$ & 23.8 & $(0.99)$ & 25.2 & $(1.04)$ & 25.2 & $(1.06)$ \\
\hline Marijuana only....... & 15.3 & $(1.06)$ & 18.8 & $(0.88)$ & 14.8 & $(0.80)$ & 9.2 & $(0.67)$ & 13.8 & $(0.79)$ & 14.5 & $(0.89)$ & 12.8 & $(0.78)$ & 11.7 & $(0.77)$ & 12.4 & $(0.76)$ & 13.0 & $(0.79)$ & 14.7 & $(0.84)$ & 15.2 & $(0.83)$ & 16.3 & $(0.89)$ & 16.8 & $(0.91)$ \\
\hline & & & & & & & & & & & & & & & & & & & & & & & & & & & & \\
\hline $1 a^{2} \ldots \ldots$ & 15.4 & $(0.80)$ & 18.4 & $(0.66)$ & 14.9 & $(0.60)$ & 8.0 & $(0.47)$ & 10.0 & $(0.52)$ & 10.4 & $(0.58)$ & 10.3 & $(0.54)$ & 9.8 & $(0.54)$ & 9.5 & $(0.51)$ & 9.3 & $(0.52)$ & 8.6 & $(0.50)$ & 8.6 & $(0.49)$ & 8.9 & $(0.51)$ & 8.4 & $(0.51)$ \\
\hline Sel & & & & & & & & & & & & & & & & & & & & & & & & & & & & \\
\hline & & $(0.25)$ & 5.2 & $(0.3$ & 6.7 & $(0.35)$ & 1.9 & $(0.20)$ & 1.8 & $(0.1$ & 2.1 & $(0.23)$ & 2.3 & $(0.22)$ & 2.5 & $(0.23)$ & 2.0 & $(0.20)$ & 1.9 & $(0.2$ & 1.3 & $(0$. & 1.3 & $(0$ & 1.1 & $(0$. & 1.1 & $(0.16)$ \\
\hline & 0.4 & $(0.08)$ & 0.2 & & 0.3 & & 0.2 & & 0.6 & $(0$. & 0.7 & $(0$. & 0.5 & & 0.4 & & 0.4 & $(0$. & 0.4 & $(0$. & 0.4 & $(0.06)$ & 0.4 & & 0.4 & & 0.3 & $(0.06)$ \\
\hline LSD .......................... & 2.3 & $(0.28)$ & 2.3 & $(0.2$ & 1.6 & $(0.18)$ & 1.9 & $(0.20)$ & 4.0 & 0.2 & 1.6 & $(0.20)$ & 0.7 & $(0.12)$ & 0.6 & $(0.12)$ & 0.6 & $(0.11)$ & 1.1 & $(0.15)$ & 0.5 & $(0.11)$ & 0.8 & $(0.13)$ & 0.8 & $(0.13)$ & 0.8 & $(0.14)$ \\
\hline Marijuana/hashish. & 27.1 & $(1.30)$ & 33.7 & $(1.0$ & 25.7 & $(0.98)$ & 14.0 & $(0.80)$ & 21.2 & $(0.9$ & 21.6 & $(1.04)$ & 19.8 & $(0.94)$ & 18.3 & $(0$. & 18.8 & $(0.8$ & 19.4 & $(0$. & 20.6 & (o. & 21.4 & $(0.95)$ & 22.6 & $(1.00)$ & 22.9 & $(1.02)$ \\
\hline PCP... & - & $(t)$ & 1.4 & $(0.11)$ & 1.6 & $(0.12)$ & 0.4 & $(0.06)$ & 0.6 & $(0.08)$ & 0.9 & $(0.10)$ & 0.7 & $(0.08)$ & 0.4 & $(0.06)$ & 0.5 & $(0.07)$ & 0.6 & $(0.08)$ & 0.5 & $(0.07)$ & 0.8 & $(0.09)$ & 0.8 & $(0.09)$ & 0.5 & $(0.07)$ \\
\hline
\end{tabular}

-Not available.

'Survey question changed in 1993; later data are not comparable to figures for earlier years.

${ }^{2}$ Other illicit drugs include any use of LSD or other hallucinogens, crack or other cocaine, or heroin, or any use of other narcotics, amphetamines, barbiturates, or tranquilizers not under a doctor's orders.
NOTE: Detail may not sum to totals because of rounding. Standard errors were calculated from formulas to perform trend analysis over an interval greater than 1 year (for example, a comparison between 1975 and 1990). A revised questionnaire was used responses for some types of drug abuse. April 15, 2013, from http://monitoringthefuture.org/data/12data.html. (This table was prepared April 2013.) 


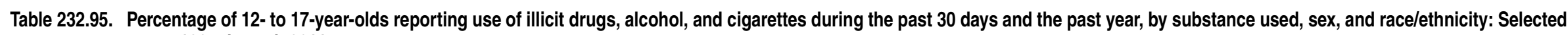
years, 1985 through 2011

[Standard errors appear in parentheses]

\begin{tabular}{|c|c|c|c|c|c|c|c|c|c|c|c|c|c|c|c|c|c|c|c|c|}
\hline \multirow[b]{3}{*}{ Year, sex, and race/ethnicity } & \multicolumn{10}{|c|}{ Percent reporting use during past 30 days } & \multicolumn{10}{|c|}{ Percent reporting use during past year } \\
\hline & \multicolumn{6}{|c|}{ Illicit drugs } & \multirow{2}{*}{\multicolumn{2}{|c|}{ Alcohol }} & \multirow{2}{*}{\multicolumn{2}{|c|}{ Cigarettes }} & \multicolumn{6}{|c|}{ Illicit drugs } & \multirow{2}{*}{\multicolumn{2}{|c|}{ Alcohol }} & \multirow{2}{*}{\multicolumn{2}{|c|}{ Cigarettes }} \\
\hline & & Any ${ }^{1}$ & & arijuana & & Cocaine & & & & & & Any ${ }^{1}$ & & Marijuana & & Cocaine & & & & \\
\hline 1 & & 2 & & 3 & & 4 & & 5 & & 6 & & 7 & & 8 & & 9 & & 10 & & 11 \\
\hline 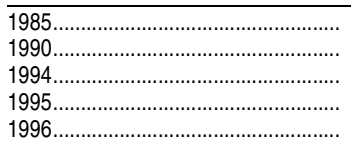 & $\begin{array}{r}13.2 \\
7.1 \\
8.2 \\
10.9 \\
9.0\end{array}$ & $\begin{array}{l}(-) \\
(-) \\
(-) \\
(-) \\
(-)\end{array}$ & $\begin{array}{r}10.2 \\
4.4 \\
6.0 \\
8.2 \\
7.1\end{array}$ & \begin{tabular}{l|}
$(-)$ \\
$(-)$ \\
$(-)$ \\
$(-)$ \\
$(-)$
\end{tabular} & $\begin{array}{l}1.5 \\
0.6 \\
0.3 \\
0.8 \\
0.6\end{array}$ & $\begin{array}{l}(-) \\
(-) \\
(-) \\
(-) \\
(-)\end{array}$ & $\begin{array}{l}41.2 \\
32.5 \\
21.6 \\
21.1 \\
18.8\end{array}$ & $\begin{array}{l}(-) \\
(-) \\
(-) \\
(-) \\
(-)\end{array}$ & $\begin{array}{l}29.4 \\
22.4 \\
18.9 \\
20.2 \\
18.3\end{array}$ & $\begin{array}{l}(-) \\
(-) \\
(-) \\
(-) \\
(-)\end{array}$ & $\begin{array}{l}20.7 \\
14.1 \\
15.5 \\
18.0 \\
16.7\end{array}$ & $\begin{array}{l}(-) \\
(-) \\
(-) \\
(-) \\
(-)\end{array}$ & $\begin{array}{r}16.7 \\
9.6 \\
11.4 \\
14.2 \\
13.0\end{array}$ & $\begin{array}{l}(-) \\
(-) \\
(-) \\
(-) \\
(-)\end{array}$ & $\begin{array}{l}3.4 \\
1.9 \\
1.1 \\
1.7 \\
1.4\end{array}$ & \begin{tabular}{l|}
$(-)$ \\
$(-)$ \\
$(-)$ \\
$(-)$ \\
$(-)$
\end{tabular} & $\begin{array}{l}52.7 \\
41.8 \\
36.2 \\
35.1 \\
32.7\end{array}$ & \begin{tabular}{l|}
$(-)$ \\
$(-)$ \\
$(-)$ \\
$(-)$ \\
$(-)$
\end{tabular} & $\begin{array}{l}29.9 \\
26.2 \\
24.5 \\
26.6 \\
24.2\end{array}$ & $\begin{array}{l}(-) \\
(-) \\
(-) \\
(-) \\
(-)\end{array}$ \\
\hline 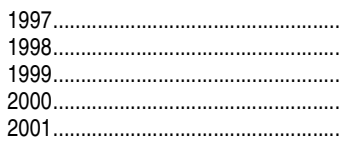 & $\begin{array}{r}11.4 \\
9.9 \\
9.8 \\
9.7 \\
10.8\end{array}$ & $\begin{array}{r}(-) \\
(-) \\
(0.23) \\
(0.24) \\
(0.26)\end{array}$ & $\begin{array}{l}9.4 \\
8.3 \\
7.2 \\
7.2 \\
8.0\end{array}$ & $\begin{array}{r}(-) \\
(-) \\
(0.20) \\
(0.21) \\
(0.24)\end{array}$ & $\begin{array}{l}1.0 \\
0.8 \\
0.5 \\
0.6 \\
0.4\end{array}$ & $\begin{array}{r}(-) \\
(-) \\
(0.06) \\
(0.07) \\
(0.06)\end{array}$ & $\begin{array}{l}20.5 \\
19.1 \\
16.5 \\
16.4 \\
17.3\end{array}$ & $\begin{array}{r}(-) \\
(-) \\
(0.30) \\
(0.29) \\
(0.33)\end{array}$ & $\begin{array}{l}19.9 \\
18.2 \\
14.9 \\
13.4 \\
13.0\end{array}$ & \begin{tabular}{r|}
$(-)$ \\
$(-)$ \\
$(0.31)$ \\
$(0.28)$ \\
$(0.28)$
\end{tabular} & $\begin{array}{l}18.8 \\
16.4 \\
19.8 \\
18.6 \\
20.8\end{array}$ & $\begin{array}{r}(-) \\
(-) \\
(0.32) \\
(0.31) \\
(0.36)\end{array}$ & $\begin{array}{l}15.8 \\
14.1 \\
14.2 \\
13.4 \\
15.2\end{array}$ & $\begin{array}{r}(-) \\
(-) \\
(0.29) \\
(0.27) \\
(0.32)\end{array}$ & $\begin{array}{l}2.2 \\
1.7 \\
1.6 \\
1.7 \\
1.5\end{array}$ & $\begin{array}{r}(-) \\
(-) \\
(0.10) \\
(0.12) \\
(0.10)\end{array}$ & $\begin{array}{l}34.0 \\
31.8 \\
34.1 \\
33.0 \\
33.9\end{array}$ & $\begin{array}{r}(-) \\
(-) \\
(0.41) \\
(0.39) \\
(0.39)\end{array}$ & $\begin{array}{l}26.4 \\
23.8 \\
23.4 \\
20.8 \\
20.0\end{array}$ & $\begin{array}{r}(-) \\
(-) \\
(0.37) \\
(0.34) \\
(0.35)\end{array}$ \\
\hline $\begin{array}{l}2002 \\
2003 \\
2004 \\
2005\end{array}$ & $\begin{array}{r}11.6 \\
11.2 \\
10.6 \\
9.9 \\
9.8\end{array}$ & $\begin{array}{l}(0.29) \\
(0.27) \\
(0.27) \\
(0.25) \\
(0.27)\end{array}$ & $\begin{array}{l}8.2 \\
7.9 \\
7.6 \\
6.8 \\
6.7\end{array}$ & $\begin{array}{l}(0.24) \\
(0.24) \\
(0.23) \\
(0.22) \\
(0.21)\end{array}$ & $\begin{array}{l}0.6 \\
0.6 \\
0.5 \\
0.6 \\
0.4\end{array}$ & $\begin{array}{l}(0.07) \\
(0.06) \\
(0.06) \\
(0.06) \\
(0.05)\end{array}$ & $\begin{array}{l}17.6 \\
17.7 \\
17.6 \\
16.5 \\
16.6\end{array}$ & $\begin{array}{l}(0.32) \\
(0.33) \\
(0.32) \\
(0.32) \\
(0.32)\end{array}$ & $\begin{array}{l}13.0 \\
12.2 \\
11.9 \\
10.8 \\
10.4\end{array}$ & $\begin{array}{l}(0.30) \\
(0.29) \\
(0.30) \\
(0.28) \\
(0.26)\end{array}$ & $\begin{array}{l}22.2 \\
21.8 \\
21.0 \\
19.9 \\
19.6\end{array}$ & $\begin{array}{l}(0.38) \\
(0.36) \\
(0.34) \\
(0.35) \\
(0.37)\end{array}$ & $\begin{array}{l}15.8 \\
15.0 \\
14.5 \\
13.3 \\
13.2\end{array}$ & $\begin{array}{l}(0.32) \\
(0.31) \\
(0.31) \\
(0.30) \\
(0.31)\end{array}$ & $\begin{array}{l}2.1 \\
1.8 \\
1.6 \\
1.7 \\
1.6\end{array}$ & $\begin{array}{l}(0.13) \\
(0.11) \\
(0.11) \\
(0.11) \\
(0.11)\end{array}$ & $\begin{array}{l}34.6 \\
34.3 \\
33.9 \\
33.3 \\
32.9\end{array}$ & $\begin{array}{l}(0.42) \\
(0.42) \\
(0.41) \\
(0.41) \\
(0.42)\end{array}$ & $\begin{array}{l}20.3 \\
19.0 \\
18.4 \\
17.3 \\
17.0\end{array}$ & $\begin{array}{l}(0.35) \\
(0.36) \\
(0.35) \\
(0.36) \\
(0.35)\end{array}$ \\
\hline $\begin{array}{l}2007 \\
2008 \ldots \\
2009 \ldots \ldots\end{array}$ & $\begin{array}{r}9.5 \\
9.3 \\
10.0\end{array}$ & $\begin{array}{l}(0.27) \\
(0.24) \\
(0.27)\end{array}$ & $\begin{array}{l}6.7 \\
6.7 \\
7.3\end{array}$ & $\begin{array}{l}(0.22) \\
(0.22) \\
(0.24)\end{array}$ & $\begin{array}{l}0.4 \\
0.4 \\
0.3\end{array}$ & $\begin{array}{l}(0.05) \\
(0.05) \\
(0.05)\end{array}$ & $\begin{array}{l}15.9 \\
14.6 \\
14.7\end{array}$ & $\begin{array}{l}(0.34) \\
(0.31) \\
(0.32)\end{array}$ & $\begin{array}{l}9.8 \\
9.1 \\
8.9\end{array}$ & $\begin{array}{l}(0.26) \\
(0.24) \\
(0.26)\end{array}$ & $\begin{array}{l}18.7 \\
19.0 \\
19.5\end{array}$ & $\begin{array}{l}(0.35) \\
(0.35) \\
(0.36)\end{array}$ & $\begin{array}{l}12.5 \\
13.0 \\
13.6\end{array}$ & $\begin{array}{l}(0.30) \\
(0.29) \\
(0.31)\end{array}$ & $\begin{array}{l}1.5 \\
1.2 \\
1.0\end{array}$ & $\begin{array}{l}(0.11) \\
(0.10) \\
(0.09)\end{array}$ & $\begin{array}{l}31.8 \\
30.8 \\
30.3\end{array}$ & $\begin{array}{l}(0.42) \\
(0.40) \\
(0.42)\end{array}$ & $\begin{array}{l}15.7 \\
15.0 \\
15.0\end{array}$ & $\begin{array}{l}(0.34) \\
(0.31) \\
(0.33)\end{array}$ \\
\hline $\begin{array}{l}2010^{2} \ldots \ldots \ldots \ldots \ldots \ldots \ldots \ldots \ldots \\
\text { Sex }\end{array}$ & 10.1 & $(0.29)$ & 7.4 & $(0.25)$ & 0.2 & $(0.05)$ & 13.6 & $(0.33)$ & 8.4 & $(0.26)$ & 19.5 & (0.38) & 14.0 & $(0.34)$ & 1.0 & $(0.09)$ & 28.7 & $(0.43)$ & 14.2 & $(0.34)$ \\
\hline 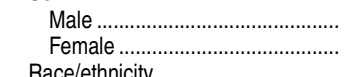 & $\begin{array}{r}10.4 \\
9.8\end{array}$ & $\begin{array}{l}(0.42) \\
(0.41)\end{array}$ & $\begin{array}{l}8.4 \\
6.4\end{array}$ & $\begin{array}{l}(0.37) \\
(0.34)\end{array}$ & $\begin{array}{l}0.3 \\
0.2\end{array}$ & $\begin{array}{l}(0.07) \\
(0.05)\end{array}$ & $\begin{array}{l}13.7 \\
13.5\end{array}$ & $\begin{array}{l}(0.46) \\
(0.45)\end{array}$ & $\begin{array}{l}8.6 \\
8.2\end{array}$ & $\begin{array}{l}(0.36) \\
(0.34)\end{array}$ & $\begin{array}{l}19.4 \\
19.5\end{array}$ & $\begin{array}{l}(0.53) \\
(0.54)\end{array}$ & $\begin{array}{l}14.9 \\
13.1\end{array}$ & $\begin{array}{l}(0.49) \\
(0.45)\end{array}$ & $\begin{array}{l}0.9 \\
1.0\end{array}$ & $\begin{array}{l}(0.13) \\
(0.14)\end{array}$ & $\begin{array}{l}27.8 \\
29.6\end{array}$ & $\begin{array}{l}(0.58) \\
(0.61)\end{array}$ & $\begin{array}{l}14.4 \\
14.0\end{array}$ & $\begin{array}{l}(0.46) \\
(0.46)\end{array}$ \\
\hline 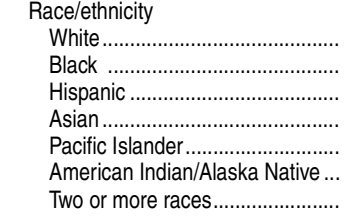 & $\begin{array}{r}9.7 \\
10.8 \\
11.8 \\
4.0 \\
4.6 ! \\
12.7 \\
13.4\end{array}$ & $\begin{array}{l}(0.35) \\
(0.66) \\
(0.76) \\
(1.00) \\
(1.55) \\
(2.54) \\
(1.91)\end{array}$ & $\begin{array}{l}7.5 \\
7.5 \\
8.0 \\
2.6 ! \\
1.8 ! \\
9.1 \\
8.2\end{array}$ & $\begin{array}{l}(0.31) \\
(0.57) \\
(0.62) \\
(0.81) \\
(0.65) \\
(2.13) \\
(1.35)\end{array}$ & $\begin{array}{c}0.2 ! \\
\ddagger \\
0.5 ! \\
\# \\
\ddagger \\
\ddagger \\
\ddagger\end{array}$ & $\begin{array}{r}(0.06) \\
(+) \\
(0.16) \\
(\dagger) \\
(\dagger) \\
(t) \\
(\dagger)\end{array}$ & $\begin{array}{r}15.0 \\
10.8 \\
13.9 \\
4.9 \\
\neq \\
11.1 \\
13.0\end{array}$ & $\begin{array}{r}(0.44) \\
(0.75) \\
(0.76) \\
(1.08) \\
(\dagger) \\
(2.18) \\
(1.52)\end{array}$ & $\begin{array}{c}9.8 \\
4.4 \\
7.9 \\
3.6 \\
3.1 ! \\
14.9 \\
9.1\end{array}$ & $\begin{array}{l}(0.35) \\
(0.48) \\
(0.58) \\
(1.04) \\
(1.26) \\
(2.88) \\
(1.47)\end{array}$ & $\begin{array}{c}19.1 \\
19.4 \\
22.3 \\
9.4 \\
8.2 ! \\
28.3 \\
23.0\end{array}$ & $\begin{array}{l}(0.47) \\
(0.90) \\
(0.98) \\
(1.51) \\
(2.81) \\
(3.58) \\
(2.31)\end{array}$ & $\begin{array}{r}14.1 \\
13.6 \\
15.7 \\
5.9 \\
5.1 ! \\
19.7 \\
15.4\end{array}$ & $\begin{array}{l}(0.41) \\
(0.77) \\
(0.88) \\
(1.27) \\
(2.24) \\
(3.20) \\
(1.82)\end{array}$ & $\begin{array}{l}1.1 \\
0.1 ! \\
1.4 \\
\ddagger \\
\ddagger \\
\ddagger \\
0.8 !\end{array}$ & $\begin{array}{r}(0.12) \\
(0.04) \\
(0.26) \\
(t) \\
(+) \\
(t) \\
(0.30)\end{array}$ & $\begin{array}{r}30.2 \\
23.7 \\
30.2 \\
17.5 \\
\ddagger \\
27.1 \\
32.1\end{array}$ & $\begin{array}{r}(0.54) \\
(0.95) \\
(1.07) \\
(1.90) \\
(+) \\
(3.36) \\
(2.50)\end{array}$ & $\begin{array}{r}16.2 \\
8.3 \\
14.0 \\
6.8 \\
6.1 ! \\
22.7 \\
16.1\end{array}$ & $\begin{array}{l}(0.44) \\
(0.66) \\
(0.78) \\
(1.40) \\
(1.88) \\
(3.44) \\
(1.93)\end{array}$ \\
\hline $\begin{array}{l}2011 \ldots . \\
\text { Sex }\end{array}$ & 10.1 & $(0.27)$ & 7.9 & $(0.24)$ & 0.3 & $(0.05)$ & 13.3 & $(0.31)$ & 7.8 & $(0.24)$ & 19.0 & $(0.37)$ & 14.2 & (0.33) & 0.9 & $(0.08)$ & 27.8 & $(0.43)$ & 13.2 & $(0.31)$ \\
\hline $\begin{array}{l}\text { Male ............................................. } \\
\text { Female ............................... } \\
\text { Race/ethnicity }\end{array}$ & $\begin{array}{r}10.8 \\
9.3\end{array}$ & $\begin{array}{l}(0.39) \\
(0.36)\end{array}$ & $\begin{array}{l}9.0 \\
6.7\end{array}$ & $\begin{array}{l}(0.36) \\
(0.31)\end{array}$ & $\begin{array}{l}0.2 \\
0.4\end{array}$ & $\begin{array}{l}(0.04) \\
(0.08)\end{array}$ & $\begin{array}{l}13.3 \\
13.3\end{array}$ & $\begin{array}{l}(0.42) \\
(0.43)\end{array}$ & $\begin{array}{l}8.2 \\
7.3\end{array}$ & $\begin{array}{l}(0.36) \\
(0.33)\end{array}$ & $\begin{array}{l}19.1 \\
18.8\end{array}$ & $\begin{array}{l}(0.53) \\
(0.50)\end{array}$ & $\begin{array}{l}15.1 \\
13.3\end{array}$ & $\begin{array}{l}(0.46) \\
(0.45)\end{array}$ & $\begin{array}{l}0.9 \\
0.9\end{array}$ & $\begin{array}{l}(0.11) \\
(0.12)\end{array}$ & $\begin{array}{l}27.0 \\
28.6\end{array}$ & $\begin{array}{l}(0.58) \\
(0.59)\end{array}$ & $\begin{array}{l}13.7 \\
12.6\end{array}$ & $\begin{array}{l}(0.43) \\
(0.42)\end{array}$ \\
\hline 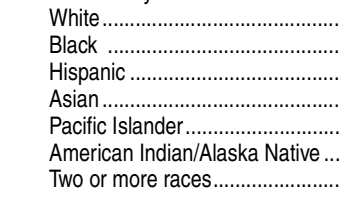 & $\begin{array}{r}9.8 \\
11.1 \\
10.3 \\
5.0 \\
\ddagger \\
16.3 \\
16.6\end{array}$ & $\begin{array}{r}(0.33) \\
(0.81) \\
(0.66) \\
(1.13) \\
(\dagger) \\
(3.16) \\
(2.05)\end{array}$ & $\begin{array}{r}7.9 \\
8.2 \\
7.7 \\
3.7 \\
\ddagger \\
10.4 \\
13.8\end{array}$ & $\begin{array}{r}(0.30) \\
(0.72) \\
(0.60) \\
(1.01) \\
(+) \\
(2.22) \\
(1.99)\end{array}$ & $\begin{array}{c}0.3 \\
\# \\
0.4 ! \\
\ddagger \\
\ddagger \\
\ddagger \\
\ddagger\end{array}$ & $\begin{array}{r}(0.06) \\
(t) \\
(0.13) \\
(\dagger) \\
(\dagger) \\
(\dagger) \\
(\dagger)\end{array}$ & $\begin{array}{r}14.6 \\
10.5 \\
12.6 \\
7.4 \\
\ddagger \\
15.2 \\
17.5\end{array}$ & $\begin{array}{r}(0.42) \\
(0.78) \\
(0.68) \\
(1.24) \\
(\dagger) \\
(2.60) \\
(2.11)\end{array}$ & $\begin{array}{r}9.3 \\
4.9 \\
6.1 \\
3.3 \\
\ddagger \\
12.3 \\
10.7\end{array}$ & $\begin{array}{r}(0.33) \\
(0.51) \\
(0.54) \\
(0.94) \\
(\dagger) \\
(2.55) \\
(1.77)\end{array}$ & $\begin{array}{r}18.6 \\
19.8 \\
19.7 \\
9.4 \\
\ddagger \\
28.5 \\
29.5\end{array}$ & $\begin{array}{r}(0.45) \\
(0.97) \\
(0.84) \\
(1.46) \\
(t) \\
(3.75) \\
(2.53)\end{array}$ & $\begin{array}{r}14.3 \\
14.2 \\
14.2 \\
6.6 \\
\ddagger \\
18.9 \\
24.8\end{array}$ & $\begin{array}{r}(0.41) \\
(0.87) \\
(0.77) \\
(1.28) \\
(\dagger) \\
(2.85) \\
(2.52)\end{array}$ & $\begin{array}{l}0.9 \\
0.1 ! \\
1.5 \\
\ddagger \\
\ddagger \\
\ddagger \\
1.7 !\end{array}$ & $\begin{array}{r}(0.10) \\
(0.04) \\
(0.23) \\
(t) \\
(t) \\
(t) \\
(0.69)\end{array}$ & $\begin{array}{r}29.8 \\
23.7 \\
26.9 \\
17.1 \\
\ddagger \\
29.0 \\
33.2\end{array}$ & $\begin{array}{r}(0.53) \\
(1.06) \\
(0.94) \\
(1.82) \\
(\dagger) \\
(3.43) \\
(2.61)\end{array}$ & $\begin{array}{r}15.2 \\
9.0 \\
11.1 \\
6.5 \\
\ddagger \\
20.2 \\
19.9\end{array}$ & $\begin{array}{r}(0.41) \\
(0.65) \\
(0.69) \\
(1.22) \\
(t) \\
(3.04) \\
(2.24)\end{array}$ \\
\hline
\end{tabular}

-Not available.

\#Rounds to zero.

!lnterpret data with caution. The coefficient of variation (CV) for this estimate is between 30 and 50 percent.

theporting standards not met (too few cases for a reliable estimate).

the heroin, hallucinogens, and inhalants, as well as 2Some data have been revised from previously published figures.
NOTE: Marijuana includes hashish usage. Data for 1999 and later years were gathered using Computer Assisted Interviewing (CAI) and may not be directly comparable to previous years. Because of survey improvements in 2002, the 2002 data constitute a new baseline for tracking trends. Valid trend comparisons can be made for 1985 through 1998, 1999 through 2001, and 2002 through 2011. Race categories exclude persons of Hispanic ethnicity.

SOURCE: U.S. Department of Health and Human Services, Substance Abuse and Mental Health Services Administration, Use and Health 2002 through 2011. Retrieved May 20, 2013, from http//mww samhsa gov/data/NSDUH aspx. (This table was prepared May 2013.)

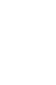




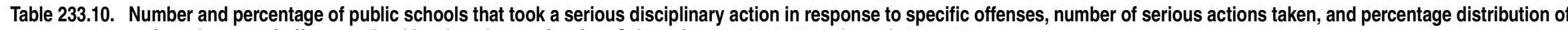
actions, by type of offense, school level, and type of action: Selected years, 1999-2000 through 2009-10

[Standard errors appear in parentheses]

\begin{tabular}{|c|c|c|c|c|c|c|c|c|c|c|c|c|c|c|}
\hline \multirow{2}{*}{$\frac{\text { Year, school level, and type of serious disciplinary action }}{1}$} & \multirow{2}{*}{\multicolumn{2}{|c|}{\begin{tabular}{r|} 
Total \\
2
\end{tabular}}} & \multicolumn{2}{|c|}{ Physical attacks or fights } & \multicolumn{2}{|c|}{ Insubordination } & \multicolumn{2}{|c|}{$\begin{array}{r}\text { Distribution, possession, } \\
\text { or use of alcohol }\end{array}$} & \multicolumn{2}{|c|}{$\begin{array}{r}\text { Distribution, possession, } \\
\text { or use of illegal drugs }\end{array}$} & \multicolumn{2}{|c|}{$\begin{array}{r}\text { Use or possession of a } \\
\text { firearm or explosive device }\end{array}$} & \multicolumn{2}{|c|}{$\begin{array}{r}\text { Use or possession } \\
\text { of a weapon other than a } \\
\text { firearm or explosive device }\end{array}$} \\
\hline & & & & 3 & & 4 & & 5 & & 6 & & 7 & & 8 \\
\hline $\begin{array}{l}\text { Number of schools taking at least one action } \\
2009-10\end{array}$ & 32,300 & (940) & 24,000 & (770) & - & (†) & 7,600 & (320) & 16,100 & (400) & 2,500 & (340) & 11,200 & (650) \\
\hline 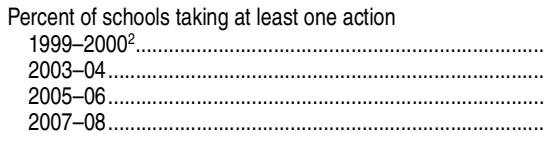 & $\begin{array}{l}45 . \overline{7} \\
48.0 \\
46.4\end{array}$ & 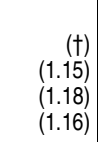 & $\begin{array}{l}35.4 \\
32.0 \\
31.5 \\
31.5\end{array}$ & $\begin{array}{l}(1.02) \\
(0.94) \\
(1.02) \\
(0.89)\end{array}$ & $\begin{array}{l}18.3 \\
21.6 \\
21.2 \\
21.4\end{array}$ & $\begin{array}{l}(0.79) \\
(0.85) \\
(0.85) \\
(0.95)\end{array}$ & $\begin{array}{r}\overline{9.2} \\
10.2 \\
9.8\end{array}$ & $\begin{array}{r}(\dagger) \\
(0.50) \\
(0.47) \\
(0.48)\end{array}$ & $\begin{array}{l}21.2 \\
20.8 \\
19.3\end{array}$ & $\begin{array}{r}(\dagger) \\
(0.58) \\
(0.61) \\
(0.53)\end{array}$ & $\begin{array}{l}\overline{-} \\
4.9 \\
2.8\end{array}$ & $\begin{array}{r}(\dagger) \\
(0.40) \\
(0.35) \\
(0.26)\end{array}$ & $\begin{array}{l}16.8 \\
19.3 \\
15.3\end{array}$ & 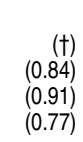 \\
\hline 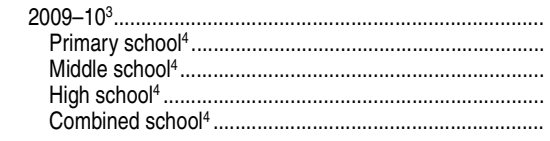 & $\begin{array}{l}39.1 \\
18.1 \\
67.0 \\
82.7 \\
49.2\end{array}$ & $\begin{array}{l}(1.14) \\
(1.51) \\
(1.68) \\
(1.57) \\
(5.31)\end{array}$ & $\begin{array}{l}29.0 \\
13.2 \\
49.7 \\
62.6 \\
35.6\end{array}$ & $\begin{array}{l}(0.94) \\
(1.26) \\
(1.87) \\
(1.63) \\
(4.26)\end{array}$ & $\begin{array}{l}- \\
- \\
- \\
- \\
-\end{array}$ & $\begin{array}{l}(+) \\
(+) \\
(+) \\
(t) \\
(\dagger)\end{array}$ & $\begin{array}{r}9.2 \\
1.0 ! \\
13.6 \\
36.1 \\
9.9\end{array}$ & $\begin{array}{l}(0.39) \\
(0.33) \\
(1.17) \\
(1.47) \\
(2.54)\end{array}$ & $\begin{array}{r}19.5 \\
2.0 \\
36.9 \\
66.1 \\
22.7\end{array}$ & $\begin{array}{l}(0.48) \\
(0.47) \\
(1.19) \\
(1.39) \\
(3.57)\end{array}$ & $\begin{array}{l}3.0 \\
1.7 ! \\
4.1 \\
7.3 \\
\ddagger\end{array}$ & $\begin{array}{r}(0.41) \\
(0.57) \\
(0.65) \\
(1.05) \\
(\dagger)\end{array}$ & $\begin{array}{r}13.5 \\
6.4 \\
25.1 \\
28.9 \\
10.9\end{array}$ & $\begin{array}{l}(0.78) \\
(0.93) \\
(1.70) \\
(1.39) \\
(2.72)\end{array}$ \\
\hline 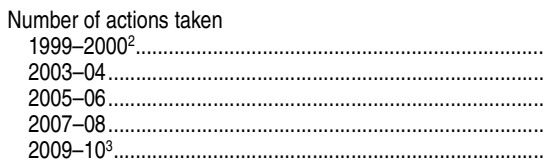 & $\begin{array}{l}- \\
655,700 \\
830,700 \\
767,900 \\
433,800\end{array}$ & 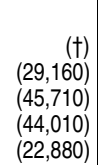 & $\begin{array}{l}332,500 \\
273,500 \\
323,900 \\
271,800 \\
265,100\end{array}$ & $\begin{array}{l}(27,420) \\
(14,450) \\
(16,690) \\
(15,180) \\
(22,170)\end{array}$ & $\begin{array}{r}253,500 \\
220,400 \\
309,000 \\
327,100 \\
-\end{array}$ & $\begin{array}{r}(27,720) \\
(16,990) \\
(33,840) \\
(38,470) \\
(\dagger)\end{array}$ & $\begin{array}{l}-\overline{2} \\
25,500 \\
30,100 \\
28,400 \\
28,700\end{array}$ & $\begin{array}{r}(\dagger) \\
(1,600) \\
(1,880) \\
(1,470) \\
(1,920)\end{array}$ & $\begin{array}{r}-\overline{9} \\
91,100 \\
106,800 \\
98,700 \\
105,400\end{array}$ & $\begin{array}{r}(\dagger) \\
(3,410) \\
(4,950) \\
(5,780) \\
(4,070)\end{array}$ & $\begin{array}{r}-\overline{-} \\
9,900 ! \\
14,300 \\
5,200 \\
5,800\end{array}$ & $\begin{array}{r}(\dagger) \\
(4,300) \\
(2,690) \\
(910) \\
(1,360)\end{array}$ & $\begin{array}{r}-\overline{3} \\
46,400 \\
36,800 \\
28,800\end{array}$ & $\begin{array}{r}(\dagger) \\
(1,470) \\
(2,040) \\
(2,630) \\
(1,580)\end{array}$ \\
\hline 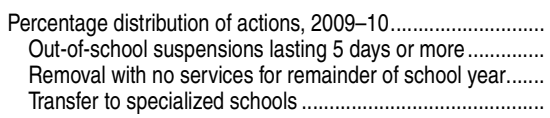 & $\begin{array}{r}100.0 \\
73.9 \\
6.1 \\
20.0\end{array}$ & $\begin{array}{r}(\dagger) \\
(1.79) \\
(0.86) \\
(1.36)\end{array}$ & $\begin{array}{r}100.0 \\
81.2 \\
5.0 \\
13.9\end{array}$ & $\begin{array}{r}(\dagger) \\
(2.18) \\
(1.22) \\
(1.57)\end{array}$ & $\begin{array}{l}- \\
- \\
- \\
-\end{array}$ & $\begin{array}{l}(t) \\
(+) \\
(+) \\
(\dagger)\end{array}$ & $\begin{array}{r}100.0 \\
74.3 \\
4.0 \\
21.7\end{array}$ & $\begin{array}{r}(\dagger) \\
(2.23) \\
(0.92) \\
(2.27)\end{array}$ & $\begin{array}{r}100.0 \\
59.6 \\
8.0 \\
32.4\end{array}$ & $\begin{array}{r}(\dagger) \\
(1.70) \\
(0.94) \\
(1.57)\end{array}$ & $\begin{array}{r}100.0 \\
55.5 \\
22.2 \\
22.3 !\end{array}$ & $\begin{array}{r}(t) \\
(9.64) \\
(4.96) \\
(7.91)\end{array}$ & $\begin{array}{r}100.0 \\
62.2 \\
8.8 \\
29.0\end{array}$ & $\begin{array}{r}(\dagger) \\
(2.44) \\
(1.31) \\
(2.32)\end{array}$ \\
\hline
\end{tabular}

\section{-Not available.}

†Not applicable.
!Interpret data with caution. The coefficient of variation (CV) for this estimate is between 30 and 50 percent.

Interpret data with caution. The coefficient of variation (CV) for this estimate is between 30 and 50 percent.
†Reporting standards not met. Either there are too few cases for a reliable estimate or the coefficient of variation (CV) is 50 percent or greater.

"Prior to 2005-06, the questionnaire wording was simply "a weapon other than a firearm" (instead of "a weapon other osive device").

2In the 1999-2000 questionnaire, only two items are the same as in questionnaires for later years-the item on physical attacks or fights and the item on insubordination. There are no comparable 1999-2000 data for serious disciplinary actions taken in response to the other specific offenses listed in this table, nor for total actions taken in response to all the listed offenses.

${ }^{3}$ Totals for 2009-10 are not comparable to totals for other years, because the 2009-10 questionnaire did not include an iterimary schools are defin

not higher than grade 8. Middle schools are defined as schools in which the lowest grade is not lower than grade 4 and the highest grade is not higher than grade 9 . High schools are defined as schools in which the lowest grade is not lowe than grade 9 and he highest grade is not higher than grade 12. Combined schools include all other combinations of grades, including $\mathrm{K}-12$ schools.

actions include out-of-school suspensions lasting 5 or more days, but less than the remainto specialized schools formovals with no continuing services for at least the remainder of the school year; and transfers edgeable about crime and safety issues at the school. Respondents were instructed to respond only for those times that were during normal school hours or when school activities or events were in session, unless the survey specified otherwise. Detail may not sum to totals because of rounding and because schools that reported serious disciplinary actions response to more than one type of offense were counted only once in the total number or percentage of schools. 2007-08, and 2009-10 School Survey on Crime and Safety (SSOCS), 2000, 2004, 2006, 2008, and 2010, (This tab 
Table 233.30. Number of students suspended and expelled from public elementary and secondary schools, by sex, race/ethnicity, and state: 2006

[Standard errors appear in parentheses]

\begin{tabular}{|c|c|c|c|c|c|c|c|c|c|c|c|c|c|c|c|c|}
\hline \multirow[b]{3}{*}{ State } & \multicolumn{16}{|c|}{ Students suspended ${ }^{1}$} \\
\hline & \multirow{3}{*}{\multicolumn{2}{|c|}{\begin{tabular}{r|} 
Total \\
2
\end{tabular}}} & \multicolumn{4}{|c|}{ Sex } & \multicolumn{10}{|c|}{ Race/ethnicity } \\
\hline & & & \multicolumn{2}{|r|}{ Male } & \multicolumn{2}{|r|}{ Female } & \multicolumn{2}{|r|}{ White } & \multicolumn{2}{|r|}{ Black } & \multicolumn{2}{|r|}{ Hispanic } & \multicolumn{2}{|c|}{ Asian/Pacific Islander } & \multicolumn{2}{|c|}{$\begin{array}{c}\text { American Indian/ } / \\
\text { Alaska Native }\end{array}$} \\
\hline 1 & & & & 3 & & 4 & & 5 & & 6 & & 7 & & 8 & & 9 \\
\hline United States ............................... & $3,328,750$ & $(20,038)$ & $2,272,290$ & $(13,667)$ & $1,056,470$ & $(6,842)$ & $1,302,410$ & $(9,493)$ & $1,244,820$ & $(11,267)$ & 670,700 & $(6,889)$ & 63,220 & (836) & 47,610 & $(2,861)$ \\
\hline 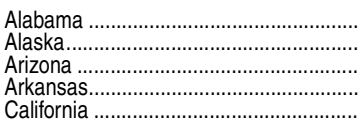 & $\begin{array}{r}75,090 \\
8,060 \\
56,000 \\
34,920 \\
474,590\end{array}$ & 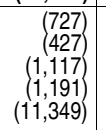 & $\begin{array}{r}50,580 \\
5,660 \\
40,900 \\
24,870 \\
340,090\end{array}$ & $\begin{array}{r}(485) \\
306 \\
(800) \\
(910) \\
(8,199)\end{array}$ & $\begin{array}{r}24,510 \\
2,390 \\
15,110 \\
10,050 \\
134,500\end{array}$ & $\begin{array}{r}(256) \\
124 \\
347 \\
(318) \\
(3,481)\end{array}$ & $\begin{array}{r}25,730 \\
3,470 \\
19,130 \\
16,340 \\
115,320\end{array}$ & $\begin{array}{r}(380) \\
(72) \\
(291) \\
(757) \\
(3,178)\end{array}$ & $\begin{array}{r}47,810 \\
620 \\
5,960 \\
16,310 \\
84,860\end{array}$ & $\begin{array}{r}(690) \\
(5) \\
(118) \\
(819) \\
(4,117)\end{array}$ & $\begin{array}{r}960 \\
380 \\
25,010 \\
1,870 \\
242,110\end{array}$ & 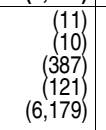 & $\begin{array}{r}260 \\
460 \\
660 \\
260 \\
24,690\end{array}$ & $\begin{array}{r}(\#) \\
(33) \\
(9) \\
(23) \\
(770)\end{array}$ & $\begin{array}{r}330 \\
3,120 \\
5,250 \\
150 \\
7,600\end{array}$ & $\begin{array}{r}(26) \\
(402) \\
(973) \\
(19) \\
(1,531)\end{array}$ \\
\hline 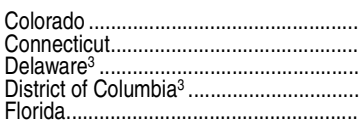 & $\begin{array}{r}47,650 \\
36,370 \\
12,150 \\
210 \\
291,820\end{array}$ & $\begin{array}{r}(463) \\
(2,749) \\
(\dagger) \\
(\dagger) \\
(3,692)\end{array}$ & $\begin{array}{r}33,580 \\
24,240 \\
7,890 \\
120 \\
192,470\end{array}$ & $\begin{array}{r}(353) \\
(1,770) \\
(t) \\
(†) \\
(2,270)\end{array}$ & $\begin{array}{r}14,070 \\
12,130 \\
4,260 \\
80 \\
99,350\end{array}$ & $\begin{array}{r}(142) \\
999 \\
(t) \\
(t) \\
(1,454)\end{array}$ & $\begin{array}{r}22,380 \\
14,430 \\
3,890 \\
10 \\
105,550\end{array}$ & $\begin{array}{r}(339) \\
(1,304) \\
(+) \\
(t) \\
(1,744)\end{array}$ & $\begin{array}{r}6,030 \\
12,700 \\
7,110 \\
190 \\
129,630\end{array}$ & $\begin{array}{r}(12) \\
(1,536) \\
(t) \\
(t) \\
(2,599)\end{array}$ & $\begin{array}{r}17,600 \\
8,620 \\
1,020 \\
10 \\
54,170\end{array}$ & $\begin{array}{r}(185) \\
890 \\
(+) \\
(+) \\
(534)\end{array}$ & $\begin{array}{r}850 \\
510 \\
110 \\
0 \\
1,890\end{array}$ & $\begin{array}{r}(7) \\
(43) \\
(+) \\
(1) \\
(18)\end{array}$ & $\begin{array}{r}790 \\
100 \\
20 \\
0 \\
580\end{array}$ & $\begin{array}{r}(72) \\
17 \\
(+) \\
(+) \\
(49)\end{array}$ \\
\hline 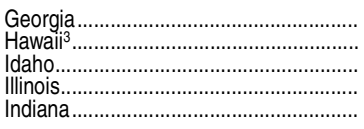 & $\begin{array}{r}143,560 \\
9,770 \\
9,100 \\
130,650 \\
77,460\end{array}$ & $\begin{array}{r}(2,598) \\
(\dagger \\
(434) \\
(2,807) \\
(2,737)\end{array}$ & $\begin{array}{r}95,080 \\
6,640 \\
6,980 \\
86,950 \\
53,300\end{array}$ & $\begin{array}{r}(1,757) \\
(\dagger) \\
(326) \\
(1,987) \\
(1,860)\end{array}$ & $\begin{array}{r}48,470 \\
3,120 \\
2,120 \\
43,700 \\
24,170\end{array}$ & $\begin{array}{r}(877) \\
(t) \\
(115) \\
892 \\
(945)\end{array}$ & $\begin{array}{r}37,670 \\
1,290 \\
6,850 \\
41,270 \\
49,720\end{array}$ & $\begin{array}{r}(1,334) \\
(\dagger \\
(385) \\
(1,742) \\
(2,094)\end{array}$ & $\begin{array}{r}96,980 \\
290 \\
90 \\
63,590 \\
22,420\end{array}$ & $\begin{array}{r}(1,684) \\
(t \\
(5 \\
(1,940) \\
(1,266)\end{array}$ & $\begin{array}{r}7,800 \\
310 \\
1,750 \\
24,430 \\
4,850\end{array}$ & $\begin{array}{r}(297) \\
(+) \\
(85) \\
(637) \\
(557)\end{array}$ & $\begin{array}{r}1,010 \\
7,810 \\
70 \\
1,330 \\
310\end{array}$ & $\begin{array}{r}(22) \\
(+) \\
(3 \\
40 \\
(30)\end{array}$ & $\begin{array}{l}90 \\
70 \\
350 ! \\
130 \\
160\end{array}$ & 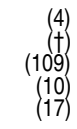 \\
\hline 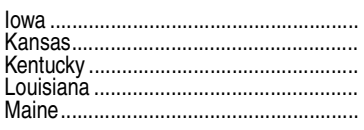 & $\begin{array}{r}14,190 \\
24,300 \\
43,420 \\
67,780 \\
8,540\end{array}$ & $\begin{array}{r}(440) \\
(701) \\
(2,319) \\
2,535) \\
(440)\end{array}$ & $\begin{array}{r}9,860 \\
17,160 \\
29,840 \\
44,370 \\
6,340\end{array}$ & $\left.\begin{array}{r}(294) \\
(531) \\
(1,636) \\
1,636) \\
(345)\end{array}\right)$ & $\begin{array}{r}4,330 \\
7,4140 \\
13,580 \\
23,40 \\
2,200\end{array}$ & $\left.\begin{array}{l}(167) \\
197 \\
734 \\
911 \\
114\end{array}\right)$ & $\begin{array}{r}10,000 \\
13,680 \\
32,800 \\
23,370 \\
7,880\end{array}$ & $\left.\begin{array}{r}(397) \\
(621) \\
(1,780) \\
1,721) \\
(421)\end{array}\right)$ & $\begin{array}{r}2,960 \\
5,920 \\
9,870 \\
43,040 \\
420\end{array}$ & $\left.\begin{array}{r}(64) \\
67) \\
(1,002 \\
(1,536) \\
(16)\end{array}\right)$ & $\begin{array}{r}930 \\
3,950 \\
620 \\
730 \\
110\end{array}$ & $\left.\begin{array}{l}37 \\
71 \\
46 \\
21 \\
22\end{array}\right)$ & $\begin{array}{r}160 \\
350 \\
90 \\
230 \\
80\end{array}$ & $\begin{array}{c}(16) \\
(8) \\
(11) \\
(12) \\
(4)\end{array}$ & $\begin{array}{r}140 \\
400 \\
40 \\
410 \\
50\end{array}$ & $\begin{array}{r}(6) \\
(32) \\
(9) \\
(107) \\
(8)\end{array}$ \\
\hline 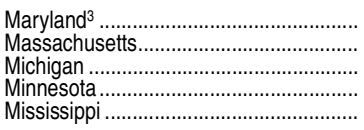 & $\begin{array}{r}60,550 \\
49,930 \\
131,750 \\
30,780 \\
51,940\end{array}$ & $\begin{array}{r}(\dagger) \\
(2,490) \\
(5,404) \\
(674) \\
(1,756)\end{array}$ & $\begin{array}{l}38,780 \\
32,960 \\
89,450 \\
21,360 \\
34,420\end{array}$ & $\begin{array}{r}(t) \\
(1,580) \\
(3,547) \\
(476) \\
(1,154)\end{array}$ & $\begin{array}{r}21,770 \\
16,970 \\
42,310 \\
9,420 \\
17,520\end{array}$ & $\begin{array}{r}(t) \\
(944) \\
(2,039) \\
(234) \\
(623)\end{array}$ & $\begin{array}{l}23,600 \\
28,040 \\
71,480 \\
15,760 \\
13,050\end{array}$ & $\begin{array}{r}(\dagger) \\
\left(\begin{array}{r}1,627 \\
2,916 \\
(541) \\
(565)\end{array}\right)\end{array}$ & $\begin{array}{r}26,450 \\
7,650 \\
52,580 \\
9,910 \\
38,250\end{array}$ & $\begin{array}{r}(\dagger) \\
(311) \\
(4,227) \\
(1,495)\end{array}$ & $\begin{array}{r}9,220 \\
12,780 \\
5,650 \\
2,440 \\
380\end{array}$ & $\begin{array}{r}(\dagger) \\
(1,231) \\
(528) \\
110 \\
(34)\end{array}$ & $\begin{array}{r}1,000 \\
1,230 \\
980 \\
1,130 \\
120\end{array}$ & $\begin{array}{r}(\dagger) \\
(100) \\
136 \\
(17) \\
(18)\end{array}$ & $\begin{array}{r}290 \\
230 \\
1,060 \\
1,540 \\
130\end{array}$ & $\begin{array}{r}(+) \\
(27) \\
(133) \\
194 \\
(35)\end{array}$ \\
\hline 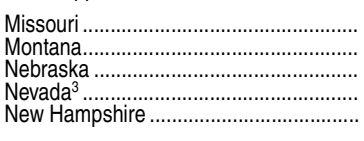 & $\begin{array}{r}67,820 \\
6,500 \\
10,600 \\
31,600 \\
10,170\end{array}$ & $\begin{array}{r}(2,020) \\
(232) \\
(185) \\
(\dagger) \\
(498)\end{array}$ & $\begin{array}{r}47,010 \\
4,600 \\
7,240 \\
20,690 \\
6,770\end{array}$ & $\begin{array}{r}(1,408) \\
(163) \\
(142) \\
(\dagger) \\
(399)\end{array}$ & $\begin{array}{r}20,810 \\
1,900 \\
3,360 \\
10,930 \\
3,400\end{array}$ & $\begin{array}{r}(643) \\
(78 \\
49 \\
(+) \\
(111)\end{array}$ & $\begin{array}{r}32,790 \\
4,490 \\
5,620 \\
9,700 \\
9,080\end{array}$ & $\left.\begin{array}{r}(1,174) \\
(177) \\
121 \\
(+) \\
(489)\end{array}\right)$ & $\begin{array}{r}32,560 \\
70 \\
2,820 \\
7,360 \\
310\end{array}$ & $\left.\begin{array}{r}(1,551) \\
(3 \\
5 \\
+ \\
(8)\end{array}\right)$ & $\begin{array}{r}1,780 \\
120 \\
1,770 \\
12,850 \\
670\end{array}$ & $\begin{array}{r}(63) \\
(6 \\
(71) \\
(7) \\
(7)\end{array}$ & $\begin{array}{r}450 \\
40 \\
100 \\
1,270 \\
80\end{array}$ & $\left.\begin{array}{c}(13) \\
(2 \\
2 \\
(t \\
(6)\end{array}\right)$ & $\begin{array}{r}240 \\
1,780 \\
280 \\
440 \\
30\end{array}$ & $\begin{array}{r}(15) \\
(157) \\
(25) \\
(+) \\
(2)\end{array}$ \\
\hline 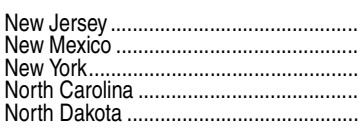 & $\begin{array}{r}79,030 \\
17,140 \\
106,670 \\
149,780 \\
2,140\end{array}$ & $\begin{array}{r}(3,559) \\
(572) \\
(3,845) \\
6,774) \\
(153)\end{array}$ & $\begin{array}{r}53,730 \\
11,560 \\
72,970 \\
101,920 \\
1,460\end{array}$ & $\begin{array}{r}(2,347) \\
(387) \\
(2,437) \\
(4,535) \\
(100)\end{array}$ & $\begin{array}{r}25,300 \\
5,570 \\
33,700 \\
47,860 \\
670\end{array}$ & $\begin{array}{r}(1,260) \\
(196) \\
(1,456) \\
(2,350) \\
(59)\end{array}$ & $\begin{array}{r}28,260 \\
3,970 \\
49,950 \\
50,630 \\
1,260\end{array}$ & $\left.\begin{array}{r}(2,252) \\
(171) \\
(1,918 \\
(2,234) \\
(71)\end{array}\right)$ & $\begin{array}{r}30,520 \\
590 \\
38,640 \\
85,000 \\
100\end{array}$ & $\begin{array}{r}(1,609) \\
(15) \\
(2,377) \\
(4,561) \\
(2)\end{array}$ & $\begin{array}{r}18,700 \\
9,510 \\
16,040 \\
9,250 \\
50\end{array}$ & $\begin{array}{r}(1,170) \\
(497 \\
857 \\
(392) \\
(3)\end{array}$ & $\begin{array}{r}1,490 \\
110 \\
1,360 \\
790 \\
20\end{array}$ & $\begin{array}{r}(104) \\
(3) \\
(88) \\
43 \\
(1)\end{array}$ & $\begin{array}{r}70 \\
2,960 \\
680 \\
4,100 \\
720\end{array}$ & $\begin{array}{r}(12) \\
(79) \\
(124) \\
(1,947) \\
(135)\end{array}$ \\
\hline 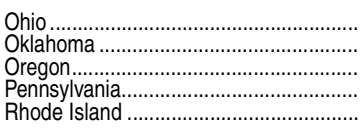 & $\begin{array}{r}109,370 \\
31,160 \\
27,470 \\
114,040 \\
12,250\end{array}$ & $\begin{array}{r}(4,049) \\
(966) \\
(1,028) \\
6,402 \\
(1,071)\end{array}$ & $\begin{array}{r}73,860 \\
21,830 \\
20,140 \\
74,950 \\
8,040\end{array}$ & $\begin{array}{r}(2,696) \\
(706) \\
(732) \\
(4,013) \\
(776)\end{array}$ & $\begin{array}{r}35,500 \\
9,330 \\
7,330 \\
39,900 \\
4,210\end{array}$ & $\begin{array}{r}(1,442) \\
(286) \\
(322) \\
(2,435) \\
(309)\end{array}$ & $\begin{array}{r}62,880 \\
14,940 \\
19,520 \\
53,090 \\
6,920\end{array}$ & $\begin{array}{r}(2,712) \\
(627) \\
(773) \\
(2,856) \\
(847)\end{array}$ & $\begin{array}{r}43,030 \\
8,210 \\
1,620 \\
52,730 \\
1,930\end{array}$ & $\begin{array}{r}(2,880) \\
(403) \\
(44) \\
(4,090) \\
(200)\end{array}$ & $\begin{array}{l}2,810 \\
3,150 \\
4,870 \\
6,950 \\
2,950\end{array}$ & $\left.\begin{array}{l}(357) \\
(78) \\
(339) \\
568 \\
143\end{array}\right)$ & $\begin{array}{r}570 \\
200 \\
590 \\
1,190 \\
340\end{array}$ & $\begin{array}{r}(56) \\
(7) \\
(21) \\
(202) \\
(30)\end{array}$ & $\begin{array}{r}90 \\
4,660 \\
880 \\
90 \\
120\end{array}$ & $\begin{array}{r}(10) \\
(233 \\
(73 \\
16 \\
24)\end{array}$ \\
\hline 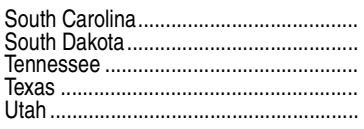 & $\begin{array}{r}83,830 \\
3,100 \\
73,380 \\
253,530 \\
16,350\end{array}$ & $\begin{array}{r}(2,289) \\
(161) \\
(2,200) \\
(2,298) \\
(119)\end{array}$ & $\begin{array}{r}54,320 \\
2,180 \\
49,860 \\
173,460 \\
11,740\end{array}$ & $\begin{array}{r}(1,547) \\
(112) \\
(1,562) \\
(1,671) \\
(97)\end{array}$ & $\begin{array}{r}29,520 \\
910 \\
23,520 \\
80,070 \\
4,610\end{array}$ & $\begin{array}{r}(828) \\
(52 \\
666) \\
693 \\
(50)\end{array}$ & $\begin{array}{r}25,750 \\
1,850 \\
39,350 \\
46,910 \\
10,020\end{array}$ & $\begin{array}{r}(1,067) \\
(87) \\
(1,655) \\
(824) \\
(98)\end{array}$ & $\begin{array}{r}55,540 \\
170 \\
31,280 \\
82,270 \\
540\end{array}$ & $\begin{array}{r}(1,753) \\
(3) \\
(924) \\
(1,276) \\
(2)\end{array}$ & $\begin{array}{r}2,120 \\
110 \\
2,290 \\
121,480 \\
4,640\end{array}$ & $\begin{array}{r}(302) \\
(1 \\
(64) \\
(1,411) \\
(20)\end{array}$ & $\begin{array}{r}240 \\
40 \\
400 \\
2,410 \\
660\end{array}$ & $\begin{array}{r}(21) \\
(2) \\
(6) \\
(16 \\
(5)\end{array}$ & $\begin{array}{r}180 ! \\
930 \\
70 \\
460 \\
490\end{array}$ & $\begin{array}{r}(77) \\
(138) \\
(7) \\
(12) \\
(4)\end{array}$ \\
\hline 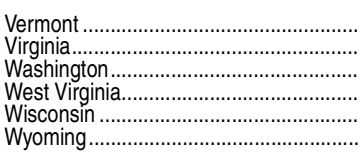 & $\begin{array}{r}3,430 \\
91,810 \\
59,920 \\
30,750 \\
43,680 \\
2,680\end{array}$ & $\begin{array}{r}(136) \\
(2,805) \\
1,326 \\
(2,986) \\
1,126) \\
(400)\end{array}$ & $\begin{array}{r}2,420 \\
61,580 \\
44,470 \\
21,430 \\
28,210 \\
1,970\end{array}$ & $\begin{array}{r}(99) \\
(1,867) \\
1,011 \\
(2,033) \\
(721) \\
288)\end{array}$ & $\begin{array}{r}1,010 \\
30,230 \\
15,450 \\
9,330 \\
15,460 \\
710\end{array}$ & $\left.\begin{array}{r}(44) \\
(991) \\
335 \\
962 \\
449 \\
119\end{array}\right)$ & $\begin{array}{r}3,260 \\
35,200 \\
36,360 \\
27,270 \\
18,480 \\
2,200\end{array}$ & $\left.\begin{array}{r}(129) \\
(1,080 \\
1,082 \\
2,482 \\
(724) \\
(346)\end{array}\right)$ & $\begin{array}{r}100 \\
49,590 \\
7,060 \\
3,090 \\
18,010 \\
40\end{array}$ & $\begin{array}{r}(8) \\
(2,284) \\
(37) \\
(548) \\
(399) \\
(5)\end{array}$ & $\begin{array}{r}30 \\
5,490 \\
10,280 \\
310 \\
4,650 \\
250\end{array}$ & $\left.\begin{array}{r}(4) \\
(165) \\
390 \\
(73 \\
65 \\
43\end{array}\right)$ & $\begin{array}{r}30 \\
1,370 \\
3,180 \\
50 \\
660 \\
20\end{array}$ & $\begin{array}{r}(3) \\
(38 \\
33 \\
11 \\
16 \\
(3)\end{array}$ & $\begin{array}{r}20 \\
170 \\
3,040 \\
30 \\
1,880 ! \\
160\end{array}$ & $\begin{array}{r}(2) \\
(13) \\
(370) \\
(8) \\
(751) \\
(46)\end{array}$ \\
\hline
\end{tabular}

See notes at end of table. 
Table 233.30. Number of students suspended and expelled from public elementary and secondary schools, by sex, race/ethnicity, and state: 2006—Continued

[Standard errors appear in parentheses]

\begin{tabular}{|c|c|c|c|c|c|c|c|c|c|c|c|c|c|c|c|c|}
\hline \multirow[b]{3}{*}{$\underline{\text { State }}$} & \multicolumn{16}{|c|}{ Students expelled² } \\
\hline & & \multirow[b]{2}{*}{ Total } & \multicolumn{4}{|c|}{ Sex } & \multicolumn{10}{|c|}{ Race/ethnicity } \\
\hline & & & \multirow{2}{*}{\multicolumn{2}{|c|}{\begin{tabular}{r|} 
Male \\
11
\end{tabular}}} & \multicolumn{2}{|r|}{ Female } & \multirow{2}{*}{\multicolumn{2}{|c|}{$\begin{array}{r}\text { White } \\
13\end{array}$}} & \multirow{2}{*}{\multicolumn{2}{|c|}{$\begin{array}{r}\text { Black } \\
14\end{array}$}} & \multicolumn{2}{|r|}{ Hispanic } & \multicolumn{2}{|c|}{ Asian/Pacific Islander } & \multicolumn{2}{|c|}{$\begin{array}{c}\text { American Indian } \\
\text { Alaska Native }\end{array}$} \\
\hline 1 & & 10 & & & & 12 & & & & & & 15 & & 16 & & 17 \\
\hline United States .................................... & 102,080 & $(1,329)$ & 76,360 & (976) & 25,720 & (398) & 38,030 & (612) & 38,640 & (935) & 22,140 & (388) & 1,720 & (44) & 1,550 & $(69)$ \\
\hline 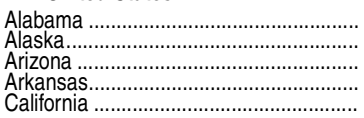 & $\begin{array}{r}1,300 \\
180 \\
660 \\
500 \\
19,460\end{array}$ & $\begin{array}{r}(21) \\
(4) \\
(41) \\
(63) \\
(608)\end{array}$ & $\begin{array}{r}900 \\
140 \\
530 \\
360 \\
15,600\end{array}$ & $\begin{array}{r}(21) \\
(2) \\
(36) \\
(29) \\
(477)\end{array}$ & $\begin{array}{r}400 \\
50 \\
130 \\
130 \\
3,870\end{array}$ & $\begin{array}{r}(5) \\
(6) \\
(19 \\
(152)\end{array}$ & $\begin{array}{r}390 \\
100 \\
260 \\
310 \\
5,350\end{array}$ & $\begin{array}{r}(8) \\
3 \\
(32 \\
32 \\
(230)\end{array}$ & $\begin{array}{r}870 \\
30 \\
60 \\
150 \\
3,010\end{array}$ & 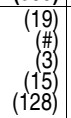 & $\begin{array}{r}40 \\
10 \\
300 \\
30 ! \\
9,960\end{array}$ & $\begin{array}{r}(\#) \\
(16) \\
(9) \\
(360)\end{array}$ & $\begin{array}{r}\# \\
10 \\
10 \\
10 \\
860\end{array}$ & $\begin{array}{c}(+) \\
\#) \\
(\#) \\
(40)\end{array}$ & $\begin{array}{r}\# \\
40 \\
40 \\
\# \\
280\end{array}$ & $\begin{aligned}(t) \\
2 \\
5 \\
+ \\
(37)\end{aligned}$ \\
\hline 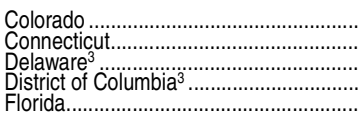 & $\begin{array}{r}2,210 \\
1,330 \\
230 \\
130 \\
1,120\end{array}$ & $\begin{array}{r}(62) \\
(135) \\
(7+) \\
(71)\end{array}$ & $\begin{array}{r}1,760 \\
970 \\
170 \\
70 \\
860\end{array}$ & $\begin{array}{r}(43) \\
87 \\
(+) \\
(60)\end{array}$ & $\begin{array}{r}450 \\
360 \\
50 \\
60 \\
270\end{array}$ & $\begin{array}{r}(25) \\
(56) \\
(+4) \\
(12)\end{array}$ & $\begin{array}{r}1,000 \\
470 \\
100 \\
\# \\
530\end{array}$ & $\begin{array}{c}(32) \\
(54) \\
(+) \\
(39)\end{array}$ & $\begin{array}{l}260 \\
490 \\
110 \\
120 \\
420\end{array}$ & 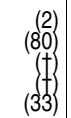 & $\begin{array}{r}860 \\
340 \\
10 \\
10 \\
160\end{array}$ & $\begin{array}{r}(47) \\
53 \\
(+5) \\
(9)\end{array}$ & $\begin{array}{r}30 \\
20 \\
\# \\
\# \\
\# \\
\#\end{array}$ & $\left.\begin{array}{l}(1 \\
4 \\
+ \\
(+) \\
(7)\end{array}\right)$ & $\begin{array}{r}60 \\
\# \\
0 \\
0 \\
10\end{array}$ & $\begin{array}{c}(12) \\
(+1) \\
(1) \\
(1)\end{array}$ \\
\hline 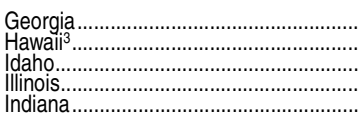 & $\begin{array}{r}3,660 \\
0 \\
230 \\
2,760 \\
6,620\end{array}$ & $\left.\begin{array}{r}(170) \\
(1) \\
(13) \\
(1325)\end{array}\right)$ & $\begin{array}{r}2,740 \\
0 \\
190 \\
2,040 \\
4,560\end{array}$ & $\begin{array}{r}(131) \\
(+9 \\
(80) \\
(272)\end{array}$ & $\begin{array}{r}930 \\
0 \\
40 \\
730 \\
2,060\end{array}$ & $\begin{array}{r}(46) \\
(+) \\
(5) \\
(137) \\
(137)\end{array}$ & $\begin{array}{r}1,390 \\
0 \\
140 \\
890 \\
4,510\end{array}$ & $\begin{array}{r}(93) \\
\left(\begin{array}{l}(9) \\
(116 \\
309\end{array}\right)\end{array}$ & $\begin{array}{r}2,100 \\
0 \\
\# \\
1,390 \\
1,610\end{array}$ & $\begin{array}{c}(92) \\
(+f) \\
(31) \\
(119)\end{array}$ & $\begin{array}{r}150 \\
0 \\
70 \\
460 \\
460\end{array}$ & $\left.\begin{array}{r}(15) \\
(6) \\
(14 \\
(45)\end{array}\right)$ & $\begin{array}{r}20 \\
0 \\
\# \\
20 \\
30\end{array}$ & $\left.\begin{array}{l}(2 \\
+ \\
+ \\
4 \\
6 \\
6\end{array}\right)$ & $\begin{array}{r}\# \\
0 \\
20 \\
\# \\
20\end{array}$ & $\left(\begin{array}{l}+ \\
+ \\
4 \\
+ \\
4\end{array}\right)$ \\
\hline 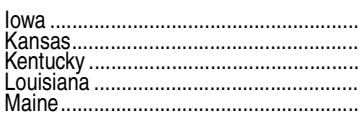 & $\begin{array}{r}200 \\
850 \\
540 \\
5,800 \\
160\end{array}$ & $\begin{array}{r}(39) \\
(63) \\
(110) \\
212 \\
(21)\end{array}$ & $\begin{array}{r}160 \\
630 \\
370 \\
4,120 \\
130\end{array}$ & $\begin{array}{r}(31) \\
35 \\
(72 \\
(159) \\
(14)\end{array}$ & $\begin{array}{c}40 \\
220 \\
170 ! \\
1,680 \\
40 !\end{array}$ & $\begin{array}{c}(8) \\
(30) \\
45 \\
56 \\
10)\end{array}$ & $\begin{array}{r}160 \\
430 \\
400 \\
1,500 \\
160\end{array}$ & $\begin{array}{r}(34) \\
58 \\
67 \\
(113) \\
(21)\end{array}$ & $\begin{array}{r}20 \\
280 \\
7,180 \\
\#\end{array}$ & $\begin{array}{r}(3) \\
7 \\
+ \\
(157) \\
(\dagger)\end{array}$ & $\begin{array}{r}20 ! \\
110 \\
\# \\
70 \\
\#\end{array}$ & $\left.\begin{array}{l}(6) \\
6 \\
+ \\
3 \\
+ \\
+\end{array}\right)$ & $\begin{array}{r}\# \\
20 \\
\# \\
20 \\
\#\end{array}$ & $\left.\begin{array}{c}(t) \\
(2) \\
(t \\
1 \\
(t)\end{array}\right)$ & $\begin{array}{c}\# \\
10 ! \\
\# \\
20 \\
\#\end{array}$ & $\left(\begin{array}{c}+ \\
6 \\
+ \\
4 \\
+ \\
+\end{array}\right)$ \\
\hline 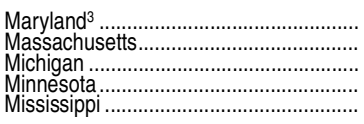 & $\begin{array}{r}1,560 \\
530 \\
2,140 \\
250 \\
1,490\end{array}$ & $\begin{array}{r}(+5) \\
(35) \\
(149 \\
(73)\end{array}$ & $\begin{array}{r}1,190 \\
410 \\
1,610 \\
200 \\
1,090\end{array}$ & $\left.\begin{array}{r}(t) \\
(27) \\
(113 \\
15 \\
(64)\end{array}\right)$ & $\begin{array}{r}360 \\
120 \\
530 \\
50 \\
400\end{array}$ & 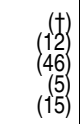 & $\begin{array}{r}340 \\
200 \\
1,030 \\
150 \\
290\end{array}$ & 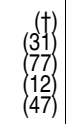 & $\begin{array}{r}1,010 \\
180 \\
950 \\
50 \\
1,190\end{array}$ & $\begin{array}{r}(+1) \\
(108) \\
(1) \\
(45)\end{array}$ & $\begin{array}{l}200 \\
140 \\
110 \\
20 \\
10\end{array}$ & $\begin{array}{r}(+1) \\
(7) \\
(3) \\
(\#)\end{array}$ & $\begin{array}{r}20 \\
10 \\
30 \\
10 \\
\#\end{array}$ & $\left.\begin{array}{l}(t) \\
(2 \\
5 \\
1 \\
+ \\
+\end{array}\right)$ & $\begin{array}{c}\# \\
\# \\
20 ! \\
20 ! \\
\#\end{array}$ & 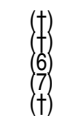 \\
\hline 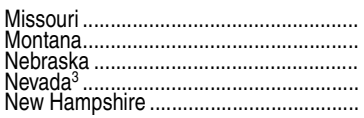 & $\begin{array}{r}280 \\
100 \\
650 \\
1,520 \\
120 !\end{array}$ & $\begin{array}{c}(36) \\
10 \\
(11) \\
(+) \\
(38)\end{array}$ & $\begin{array}{r}220 \\
90 \\
480 \\
1,190 \\
80 !\end{array}$ & $\begin{array}{r}(26) \\
(9 \\
(9 \\
(+) \\
(22)\end{array}$ & $\begin{array}{c}60 \\
20 \\
170 \\
340 \\
40 !\end{array}$ & $\begin{array}{r}(15) \\
(3) \\
2 \\
(17) \\
(17)\end{array}$ & $\begin{array}{l}210 \\
60 \\
290 \\
490 \\
100 !\end{array}$ & $\begin{array}{r}(35) \\
(8) \\
7 \\
(4 \\
(36)\end{array}$ & $\begin{array}{r}60 \\
\# \\
210 \\
410 \\
10\end{array}$ & $\begin{array}{c}(4) \\
(+5 \\
(+) \\
(2)\end{array}$ & $\begin{array}{r}10 \\
\# \\
110 \\
530 \\
\#\end{array}$ & $\begin{array}{c}(\#) \\
+ \\
4 \\
+ \\
+ \\
(+)\end{array}$ & $\begin{array}{r}\# \\
\# \\
10 \\
70 \\
\#\end{array}$ & $\begin{array}{l}(+) \\
(\#) \\
(+) \\
(\dagger)\end{array}$ & $\begin{array}{r}\# \\
40 \\
30 \\
20 \\
\#\end{array}$ & $\left(\begin{array}{l}+ \\
7 \\
4 \\
1 \\
+ \\
+\end{array}\right)$ \\
\hline 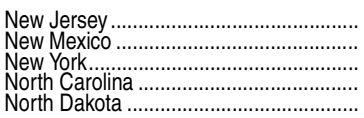 & $\begin{array}{c}270 ! \\
240 \\
890 \\
1,970 ! \\
20\end{array}$ & $\begin{array}{r}(118) \\
(16) \\
(180) \\
830 \\
(6)\end{array}$ & $\begin{array}{c}250 ! \\
200 \\
700 \\
1,480 ! \\
20\end{array}$ & $\left.\begin{array}{r}(118) \\
(14) \\
(143 \\
572 \\
(4)\end{array}\right)$ & $\begin{array}{r}20 ! \\
50 \\
190 \\
\vdots \\
\#\end{array}$ & $\begin{array}{c}(5) \\
(3) \\
(41) \\
(†) \\
(†)\end{array}$ & $\begin{array}{r}100 ! \\
40 \\
580 \\
300 \\
10\end{array}$ & $\begin{array}{r}(49) \\
(3 \\
(144) \\
(52) \\
(2)\end{array}$ & $\begin{array}{r}70 ! \\
10 \\
240 ! \\
1,580 ! \\
\#\end{array}$ & $\begin{array}{r}(23) \\
(\#) \\
(75) \\
(821) \\
(\dagger)\end{array}$ & $\begin{array}{c}80 ! \\
110 \\
60 ! \\
60 \\
\#\end{array}$ & $\left.\begin{array}{r}(39) \\
10 \\
11 \\
9 \\
+\end{array}\right)$ & $\begin{array}{r}\ddagger \\
10 \\
10 \\
10 \\
\#\end{array}$ & $\begin{array}{l}(t \\
(\#) \\
3 \\
1 \\
1 \\
(t)\end{array}$ & $\begin{array}{r}\# \\
80 \\
\ddagger \\
30 \\
10 !\end{array}$ & 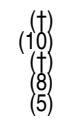 \\
\hline 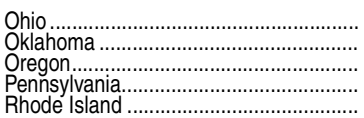 & $\begin{array}{r}8,150 \\
2,200 \\
1,890 \\
2,750 \\
\#\end{array}$ & $\left.\begin{array}{r}(319) \\
(73) \\
(140) \\
122 \\
(\dagger)\end{array}\right)$ & $\begin{array}{r}5,450 \\
1,550 \\
1,490 \\
1,890 \\
\#\end{array}$ & $\left.\begin{array}{r}(223) \\
(55 \\
(124) \\
(93 \\
(\dagger\end{array}\right)$ & $\begin{array}{r}2,700 \\
650 \\
400 \\
860 \\
\#\end{array}$ & $\left.\begin{array}{r}(115) \\
23 \\
24 \\
40 \\
(\dagger\end{array}\right)$ & $\begin{array}{r}2,810 \\
1,070 \\
1,320 \\
1,110 \\
\#\end{array}$ & $\begin{array}{r}(214) \\
(47) \\
(105) \\
(88) \\
(\dagger)\end{array}$ & $\begin{array}{r}4,970 \\
640 \\
110 \\
1,440 \\
\#\end{array}$ & $\begin{array}{r}(194) \\
22 \\
17 \\
61 \\
(\dagger)\end{array}$ & $\begin{array}{l}340 \\
130 \\
360 \\
160 \\
\#\end{array}$ & $\left.\begin{array}{r}(27) \\
(7 \\
(12 \\
11 \\
(+)\end{array}\right)$ & $\begin{array}{r}30 \\
20 \\
50 \\
30 \\
\#\end{array}$ & $\left.\begin{array}{l}(4 \\
4 \\
8 \\
6 \\
(\dagger\end{array}\right)$ & $\begin{array}{r}10 \\
330 \\
60 \\
\# \\
\#\end{array}$ & $\left.\begin{array}{r}(1) \\
(22 \\
(9 \\
+ \\
+\end{array}\right)$ \\
\hline 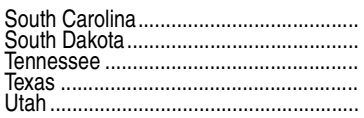 & $\begin{array}{r}5,130 \\
120 ! \\
3,200 \\
11,990 \\
250\end{array}$ & $\begin{array}{r}(271) \\
52 \\
(77) \\
(232 \\
(5)\end{array}$ & $\begin{array}{l}3,730 \\
90 ! \\
2,440 \\
9,010 \\
190\end{array}$ & $\begin{array}{r}(201) \\
39 \\
(60) \\
(190) \\
(5)\end{array}$ & $\begin{array}{r}1,400 \\
30 ! \\
760 \\
2,980 \\
60\end{array}$ & $\begin{array}{c}(81) \\
13 \\
21 \\
50 \\
(\#) \\
(\#)\end{array}$ & $\begin{array}{r}1,390 \\
\neq \\
1,350 \\
2,630 \\
160\end{array}$ & $\begin{array}{r}(97) \\
(7) \\
(70) \\
(5)\end{array}$ & $\begin{array}{r}3,650 \\
\# \\
1,700 \\
3,760 \\
20\end{array}$ & $\begin{array}{r}(224) \\
(+4) \\
(90) \\
(\#)\end{array}$ & $\begin{array}{r}70 \\
10 \\
120 \\
5,450 \\
40\end{array}$ & $\begin{array}{r}(10) \\
3 \\
(2) \\
(91) \\
(1)\end{array}$ & $\begin{array}{r}20 \\
\# \\
30 \\
120 \\
10\end{array}$ & 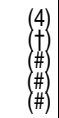 & $\begin{array}{l}10 \\
80 ! \\
10 \\
30 \\
10\end{array}$ & $\begin{array}{c}(3) \\
(29) \\
(\#) \\
(\#) \\
(1)\end{array}$ \\
\hline 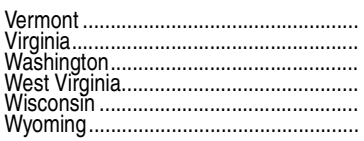 & $\begin{array}{r}40 ! \\
1,150 \\
3,470 \\
210 \\
1,470 \\
100\end{array}$ & $\begin{array}{r}(16) \\
(174) \\
(34) \\
(65) \\
(16)\end{array}$ & $\begin{array}{r}40 \\
980 \\
2,770 \\
140 \\
1,030 \\
90\end{array}$ & $\begin{array}{r}(14) \\
(163) \\
104 \\
22 \\
50 \\
(12)\end{array}$ & $\begin{array}{c}10 ! \\
170 \\
700 \\
60 \\
440 \\
10 !\end{array}$ & $\begin{array}{r}(2) \\
(18) \\
35 \\
14 \\
26 \\
(4)\end{array}$ & $\begin{array}{r}40 ! \\
580 \\
2,140 \\
190 \\
830 \\
90\end{array}$ & $\left.\begin{array}{r}(16) \\
(162) \\
101 \\
(30 \\
60 \\
16\end{array}\right)$ & $\begin{array}{c}\# \\
440 \\
280 \\
10 ! \\
430 \\
\#\end{array}$ & $\begin{array}{r}(t) \\
(45 \\
(6) \\
(5 \\
(10) \\
(\dagger)\end{array}$ & $\begin{array}{r}\# \\
90 \\
720 \\
\# \\
140 \\
10\end{array}$ & $\begin{array}{r}(t) \\
(5) \\
(40) \\
(1) \\
(12) \\
(\#)\end{array}$ & $\begin{array}{r}\# \\
40 \\
140 \\
\# \\
20 \\
\#\end{array}$ & 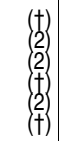 & $\begin{array}{r}\# \\
\# \\
190 \\
\# \\
40 \text { ! } \\
\#\end{array}$ & $\begin{array}{r}(t) \\
(34) \\
(+) \\
(13) \\
(\dagger)\end{array}$ \\
\hline
\end{tabular}

TNot applicable.
\#Rounds to zero.

!nterpret data with caution. The coefficient of variation (CV) for this estimate is between 30 and 50 percent. fReporting standards not met. The coefficient of variation $(\mathrm{CV})$ for this estimate is 50 percent or greater ${ }^{1} A$ student is counted only once, even if suspended more than once during the same school year.

${ }^{2 A}$ student is counted only once, even if expelled more than once during the same school year.
${ }^{3}$ Data are based on universe counts of schools and school districts; therefore, these figures do not have standard errors.
NOTE: Suspension is excluding a student from school for disciplinary reasons for 1 school day or longer. Expulsion is the exclusion of a student from school for disciplinary reasons that results in the student's removal from school attendance rolls or th Hispanic ethnicity. Detail may not sum to totals because of rounding. SOURCE: U.S. Department of Education, Office for Civil Rights, July 2008.) 
[Standard errors appear in parentheses]

\begin{tabular}{|c|c|c|c|c|c|c|c|c|c|c|c|c|c|c|c|c|c|c|c|c|c|c|c|c|c|c|c|c|}
\hline \multirow[b]{3}{*}{ State } & \multicolumn{12}{|c|}{ Percent suspended ${ }^{1}$} & \multicolumn{16}{|c|}{ Percent expelled ${ }^{2}$} \\
\hline & \multirow{2}{*}{\multicolumn{2}{|c|}{ Total }} & \multicolumn{3}{|c|}{ Sex } & \multicolumn{7}{|c|}{ Race/ethnicity } & \multicolumn{6}{|c|}{ Sex } & \multicolumn{10}{|c|}{ Race/ethnicity } \\
\hline & & & & Male & Female & White & & Black & Hispanic & \begin{tabular}{r|} 
Asian/ \\
Pacific \\
Islander
\end{tabular} & $\begin{array}{r}\text { Ame } \\
\text { Indian/A| } \\
\mathrm{N}\end{array}$ & \begin{tabular}{|l|} 
erican \\
Alaska \\
Native
\end{tabular} & \multicolumn{2}{|r|}{ Total } & \multicolumn{2}{|r|}{ Male } & \multicolumn{2}{|r|}{ Female } & \multicolumn{2}{|r|}{ White } & \multicolumn{2}{|r|}{ Black } & \multicolumn{2}{|c|}{ Hispanic } & \multicolumn{2}{|c|}{$\begin{array}{r}\text { Asian/Pacific } \\
\text { Islander }\end{array}$} & \multicolumn{2}{|c|}{$\begin{array}{r}\text { American } \\
\text { Indian/Alaska } \\
\text { Native }\end{array}$} \\
\hline 1 & & 2 & & 3 & 4 & 5 & & 6 & 7 & 8 & & & & 10 & & 11 & & 12 & & 13 & & 14 & & 15 & & 16 & & 17 \\
\hline 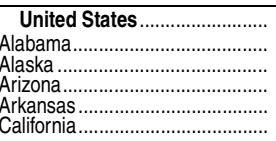 & $\begin{array}{rl}6.9 & 0 . \\
10.1 & 0 . \\
5.9 & 0 . \\
5.9 & 0 . \\
7.3 & 0 . \\
7.5 & 0 .\end{array}$ & \begin{tabular}{l|}
$0.04)$ \\
0.11 \\
0.35 \\
0.14 \\
0.30 \\
$0.18)$
\end{tabular} & $\left.\begin{array}{r}9.1 \\
13.3 \\
8.0 \\
8.4 \\
10.2 \\
10.5\end{array}\right\}$ & \begin{tabular}{l|}
$(0.06)$ \\
$(0.15$ \\
0.47 \\
0.19 \\
0.43 \\
$(0.25)$
\end{tabular} & \begin{tabular}{ll|}
4.5 & $(0.03)$ \\
6.8 & $(0.08)$ \\
3.6 & $(0.21)$ \\
3.3 & $(0.09)$ \\
4.3 & $(0.17)$ \\
4.4 & $(0.12)$
\end{tabular} & \begin{tabular}{ll|}
4.8 & $(0.04)$ \\
5.8 & $(0.10)$ \\
4.6 & $(0.13)$ \\
4.5 & 0.10 \\
5.0 & 0.28 \\
6.0 & $(0.18)$
\end{tabular} & $\left.\begin{array}{l}15.0 \\
18.3 \\
10.0 \\
11.8 \\
15.9 \\
17.1\end{array}\right\}$ & \begin{tabular}{l|}
$(0.14)$ \\
0.32 \\
0.10 \\
0.27 \\
0.96 \\
$0.82)$
\end{tabular} & $\begin{array}{ll}6.8 & (0.07) \\
4.3 & (0.10) \\
5.9 & 0.29 \\
6.4 & 0.14 \\
4.9 & (0.48) \\
7.9 & (0.22)\end{array}$ & $\begin{array}{ll}2.7 & (0.04) \\
3.2 & (0.14) \\
4.6 & (0.50) \\
2.6 & (0.05 \\
3.5 & (0.35) \\
3.3 & (0.13)\end{array}$ & $\begin{array}{r}7.9 \\
4.8 \\
8.2 \\
10.0 \\
4.7 \\
12.2\end{array}$ & \begin{tabular}{l|}
$(0.49)$ \\
0.49 \\
1.18 \\
2.19 \\
0.63 \\
2.33
\end{tabular} & $\left.\begin{array}{l}0.21 \\
0.18 \\
0.13 \\
0.07 \\
0.10 \\
0.31\end{array}\right\}$ & $\begin{array}{l}(0.003) \\
(0.003 \\
0.005 \\
0.004 \\
0.009 \\
(0.010)\end{array}$ & $\begin{array}{l}\mathbf{0 . 3 1} \\
0.24 \\
0.20 \\
0.11 \\
0.15 \\
0.48\end{array}$ & \begin{tabular}{l|}
$(0.004)$ \\
$(0.006$ \\
0.007 \\
0.008 \\
0.012 \\
$0.015)$
\end{tabular} & $\begin{array}{l}0.11 \\
0.11 \\
0.07 \\
0.03 \\
0.06 \\
0.13\end{array}$ & $\begin{array}{l}(0.002) \\
(0.002 \\
0.060 \\
0.001 \\
0.008 \\
0.005\end{array}$ & $\begin{array}{l}0.14 \\
0.09 \\
0.13 \\
0.06 \\
0.10 \\
0.28\end{array}$ & $\begin{array}{l}(0.002) \\
(0.002) \\
0.004 \\
0.008 \\
0.010 \\
(0.013)\end{array}$ & $\left.\begin{array}{l}0.47 \\
0.33 \\
0.45 \\
0.12 \\
0.14 \\
0.61\end{array}\right\}$ & $\begin{array}{l}(0.011) \\
(0.009 \\
0.003 \\
0.060 \\
0.0616 \\
0.030\end{array}$ & $\begin{array}{l}0.22 \\
0.16 \\
0.16 \\
0.08 \\
0.09 \\
0.32\end{array}$ & $\begin{array}{l}(0.004) \\
(0.003 \\
0.006 \\
0.004 \\
0.025) \\
0.013\end{array}$ & $\begin{array}{l}\mathbf{0 . 0 7} \\
\# \\
0.13 \\
0.03 \\
0.07 ! \\
0.11\end{array}$ & \begin{tabular}{r|}
$(0.002)$ \\
$(\dagger)$ \\
$(0.011)$ \\
$(\#)$ \\
$!(0.031)$ \\
$0.006)$
\end{tabular} & \begin{tabular}{|l|}
0.26 \\
0.01 \\
0.10 \\
0.08 \\
0.03 \\
0.46
\end{tabular} & $\begin{array}{l}(0.013) \\
(0.001) \\
0.009 \\
0.015 \\
0.002 \\
0.068)\end{array}$ \\
\hline 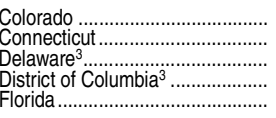 & $\begin{array}{rr}6.0 & 0 . \\
6.8 & 0 . \\
10.9 \\
0.4 \\
10.5 \\
10 .\end{array}$ & $\begin{array}{r}0.09 \\
0.52 \\
(+) \\
0.14 \\
0.14)\end{array}$ & $\begin{array}{r}8.3 \\
8.9 \\
13.8 \\
0.4 \\
13.4\end{array}$ & $\begin{array}{r}(0.13) \\
(0.65) \\
(+) \\
(0.17)\end{array}$ & $\begin{array}{rr}3.7 & (0.06) \\
4.7 & (0.39) \\
7.9 & (f) \\
0.3 & (t) \\
7.3 & (0.11)\end{array}$ & $\begin{array}{lr}4.5 & (0.09) \\
4.0 & (0.37) \\
6.4 & (t) \\
0.2 & (\dagger) \\
7.9 & (0.16)\end{array}$ & $\begin{array}{r}13.2 \\
17.2 \\
20.1 \\
0.4 \\
19.3\end{array}$ & $\begin{array}{r}(0.05) \\
(2.39 \\
(+) \\
(0.34)\end{array}$ & $\begin{array}{rr}8.1 & (0.14) \\
11.4 & (1.39 \\
9.2 & (\dagger) \\
0.2 & (+) \\
7.7 & (0.08)\end{array}$ & $\begin{array}{lr}3.2 & (0.03) \\
2.4 & (0.22) \\
3.3 & (7) \\
0.0 & (7) \\
2.9 & (0.03)\end{array}$ & $\begin{array}{l}8.7 \\
5.2 \\
5.5 \\
0.0 \\
7.2\end{array}$ & $\begin{array}{r}(0.89) \\
0.95 \\
(f) \\
(0.59)\end{array}$ & $\begin{array}{l}0.28 \\
0.25 \\
0.20 \\
0.22 \\
0.04\end{array}$ & $\begin{array}{r}(0.008 \\
0.026 \\
\left(\begin{array}{r}+ \\
+ \\
(0.003\end{array}\right)\end{array}$ & $\begin{array}{l}0.43 \\
0.36 \\
0.30 \\
0.25 \\
0.06\end{array}$ & $\begin{array}{r}(0.012 \\
0.034 \\
\left(\begin{array}{l}0 \\
( \\
0.004\end{array}\right) \\
\mid\end{array}$ & $\begin{array}{l}0.12 \\
0.14 \\
0.10 \\
0.20 \\
0.02\end{array}$ & 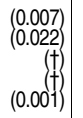 & $\begin{array}{l}0.20 \\
0.13 \\
0.17 \\
0.03 \\
0.04\end{array}$ & $\begin{array}{r}(0.007) \\
0.016 \\
(t) \\
\left(\begin{array}{c}0 \\
(0.003)\end{array}\right)\end{array}$ & $\begin{array}{l}0.56 \\
0.66 \\
0.32 \\
0.25 \\
0.06\end{array}$ & 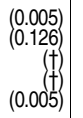 & $\begin{array}{l}0.40 \\
0.45 \\
0.06 \\
0.17 \\
0.02\end{array}$ & 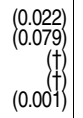 & $\begin{array}{l}0.12 \\
0.10 \\
0.06 \\
0.10 \\
0.01\end{array}$ & $\begin{array}{r}(0.003 \\
0.017 \\
(+) \\
(+) \\
\#)\end{array}$ & $\begin{array}{l}0.60 \\
0.15 ! \\
0.00 \\
0.00 \\
0.06\end{array}$ & 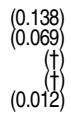 \\
\hline 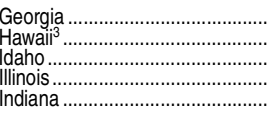 & $\begin{array}{ll}8.8 & 0 . \\
5.5 & \\
3.6 & 0 . \\
6.4 & 0 . \\
7.4 & 0 .\end{array}$ & \begin{tabular}{l|}
0.23 \\
$(\dagger$ \\
0.18 \\
0.15 \\
$0.28)$
\end{tabular} & $\left.\begin{array}{r}11.4 \\
7.2 \\
5.3 \\
8.4 \\
9.9\end{array}\right\}$ & $\begin{array}{l}(0.29) \\
(t) \\
(0.26) \\
0.20 \\
(0.37)\end{array}$ & $\begin{array}{ll}6.1 & (0.16) \\
3.6 & (t) \\
1.7 & (0.10) \\
4.4 & 0.10 \\
4.7 & (0.20)\end{array}$ & $\begin{array}{ll}4.8 & (0.21) \\
4.9 & (\dagger) \\
3.3 & (0.19) \\
3.8 & 0.17) \\
6.0 & (0.27)\end{array}$ & $\left.\begin{array}{r}15.0 \\
7.0 \\
3.5 \\
14.5 \\
17.3\end{array}\right\}$ & $\left.\begin{array}{r}(0.36) \\
(+) \\
(0.21) \\
0.53 \\
1.18\end{array}\right)$ & $\begin{array}{ll}5.4 & (0.27) \\
5.7 & (\dagger) \\
5.1 & (0.29) \\
6.0 & 0.19 \\
7.4 & (0.87)\end{array}$ & $\begin{array}{ll}2.1 & (0.07) \\
5.5 & (t) \\
1.6 & (0.07 \\
1.7 & (0.08 \\
1.8 & (0.24)\end{array}$ & $\begin{array}{l}3.7 \\
6.0 \\
8.6 ! \\
2.9 \\
6.1\end{array}$ & $\begin{array}{l}(0.21) \\
(t) \\
2.90 \\
0.41 \\
0.70)\end{array}$ & $\begin{array}{l}0.23 \\
0.00 \\
0.09 \\
0.14 \\
0.63\end{array}$ & $\left.\begin{array}{r}(0.011) \\
(t \\
(0.005 \\
0.007 \\
0.039\end{array}\right)$ & $\begin{array}{l}0.33 \\
0.00 \\
0.14 \\
0.20 \\
0.85\end{array}$ & $\begin{array}{r}(0.017) \\
(t) \\
(0.008 \\
0.008 \\
0.053)\end{array} \mid$ & $\begin{array}{l}0.12 \\
0.00 \\
0.03 \\
0.07 \\
0.40\end{array}$ & \begin{tabular}{r|}
$(0.006)$ \\
$(1)$ \\
$(0.004$ \\
0.006 \\
0.028
\end{tabular} \mid & $\begin{array}{l}0.18 \\
0.00 \\
0.07 \\
0.08 \\
0.54\end{array}$ & $\begin{array}{r}(0.013) \\
(\dagger \\
(0.005) \\
0.011 \\
0.039)\end{array} \mid$ & $\left.\begin{array}{r}0.32 \\
0.00 \\
\# \\
0.32 \\
1.24\end{array}\right\}$ & 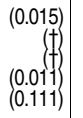 & $\begin{array}{l}0.11 \\
0.00 \\
0.20 \\
0.11 \\
0.70\end{array}$ & $\left.\begin{array}{r}(0.011) \\
(+) \\
(0.018 \\
0.004 \\
0.077\end{array}\right)$ & $\begin{array}{r}0.04 \\
0.00 \\
\# \\
0.03 \\
0.19\end{array}$ & $\begin{array}{r}(0.005) \\
(\dagger) \\
(0.005 \\
0.038)\end{array}$ & $\begin{array}{l}0.08 ! \\
0.00 \\
0.37 \\
0.07 \\
0.60\end{array}$ & $\begin{array}{l}(0.035) \\
(\dagger) \\
(0.111) \\
0.008) \\
0.168)\end{array}$ \\
\hline 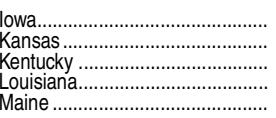 & $\begin{array}{rl}3.0 & 0 . \\
5.1 & 0 . \\
6.6 & 0 . \\
10.3 & 0 . \\
4.6 & 0 .\end{array}$ & $\begin{array}{l}0.11 \\
0.18 \\
0.36 \\
0.41 \\
0.28)\end{array}$ & $\left.\begin{array}{r}4.0 \\
6.9 \\
8.7 \\
13.2 \\
6.6\end{array}\right\}$ & $\begin{array}{l}(0.14) \\
0.26 \\
0.48 \\
0.51 \\
(0.41)\end{array}$ & $\begin{array}{ll}1.9 & (0.08) \\
3.1 & 0.11 \\
4.3 & 0.24 \\
7.3 & 0.31 \\
2.4 & (0.15)\end{array}$ & $\begin{array}{ll}2.4 & (0.11) \\
3.8 & 0.20) \\
5.8 & (0.33) \\
7.1 & 0.56 \\
4.5 & (0.28)\end{array}$ & $\left.\begin{array}{r}11.4 \\
14.6 \\
13.3 \\
14.6 \\
9.0\end{array}\right\}$ & $\left.\begin{array}{l}0.31) \\
0.27 \\
1.27 \\
0.48 \\
0.38\end{array}\right)$ & $\begin{array}{ll}3.2 & (0.27) \\
6.6 & 0.22 \\
4.0 & 0.33 \\
4.7 & 0.16 \\
5.7 & (1.11)\end{array}$ & $\begin{array}{ll}1.6 & (0.18) \\
2.9 & (0.10) \\
1.5 & 0.19 \\
2.6 & (0.14) \\
2.9 & (0.18)\end{array}$ & $\begin{array}{l}5.2 \\
5.8 \\
3.8 \\
6.8 ! \\
6.4\end{array}$ & $\begin{array}{l}(0.25) \\
0.59 \\
0.89 \\
2.24 \\
(1.13)\end{array}$ & $\begin{array}{l}0.04 \\
0.18 \\
0.08 \\
0.89 \\
0.09\end{array}$ & $\begin{array}{l}(0.008) \\
0.014 \\
0.017 \\
0.037 \\
0.012\end{array}$ & $\begin{array}{l}0.07 \\
0.25 \\
0.11 \\
1.23 \\
0.13\end{array}$ & $\begin{array}{l}(0.013) \\
0.015 \\
0.021 \\
0.045 \\
0.015)\end{array}$ & $\begin{array}{l}0.01 \\
0.10 \\
0.05 \\
0.52 \\
0.04\end{array}$ & $\begin{array}{l}(0.004) \\
0.013 \\
0.014 \\
0.021 \\
0.011)\end{array}$ & $\begin{array}{l}0.04 \\
0.12 \\
0.07 \\
0.45 \\
0.09\end{array}$ & $\begin{array}{l}(0.008) \\
0.017) \\
0.012 \\
0.039 \\
(0.012)\end{array}$ & $\left.\begin{array}{r}0.07 \\
0.68 \\
\ddagger \\
1.42 \\
0.09\end{array}\right\}$ & $\begin{array}{l}(0.012) \\
0.019 \\
(0.7) \\
(0.056) \\
0.022)\end{array}$ & $\begin{array}{l}0.06 ! \\
0.19 \\
0.7 \\
0.47 \\
0.05\end{array}$ & $\begin{array}{l}(0.022) \\
(0.011 \\
(0.020 \\
(0.002)\end{array}$ & $\begin{array}{l}0.01 \\
0.12 \\
0.03 ! \\
0.17 \\
\ddagger\end{array}$ & $\begin{array}{r}(0.001 \\
0.013 \\
0.013 \\
0.011 \\
(\dagger)\end{array} \mid$ & $\begin{array}{c}\ddagger \\
0.20 ! \\
\# \\
0.39 \\
\#\end{array}$ & $\begin{array}{r}(\dagger) \\
(0.090 \\
(\dagger) \\
(0.109 \\
(\dagger)\end{array}$ \\
\hline setts & $\begin{array}{rl}7.1 & \\
5.6 & 0 . \\
8.2 & 0 . \\
3.7 & 0 . \\
10.2 & 0 .\end{array}$ & \begin{tabular}{l|}
$0 .(\dagger)$ \\
0.28 \\
0.10 \\
0.33 \\
0.10 \\
\end{tabular} & $\left.\begin{array}{r}8.9 \\
7.1 \\
10.8 \\
5.0 \\
13.3\end{array}\right\}$ & $\begin{array}{r}(t) \\
(0.35) \\
0.43 \\
0.14 \\
0.41)\end{array}$ & $\begin{array}{lr}5.2 & (t) \\
3.9 & (0.22) \\
5.4 & 0.27) \\
2.4 & 0.07 \\
7.0 & (0.24)\end{array}$ & $\begin{array}{lc}5.8 & (t) \\
4.2 & (0.25) \\
6.1 & 0.27) \\
2.4 & 0.09 \\
5.5 & (0.26)\end{array}$ & $\left.\begin{array}{r}8.2 \\
10.3 \\
17.8 \\
14.4 \\
14.8\end{array}\right\}$ & $\left.\begin{array}{l}(0.50) \\
1.48 \\
0.33 \\
0.55\end{array}\right)$ & $\begin{array}{rr}12.9 & (\dagger) \\
12.0 & (1.18 \\
7.4 & 0.83 \\
5.4 & 0.28 \\
4.3 & (0.44)\end{array}$ & $\begin{array}{ll}2.2 & (t) \\
2.5 & (0.25) \\
2.2 & 0.34 \\
2.5 & (0.5) \\
3.0 & (0.47)\end{array}$ & $\begin{array}{r}8.5 \\
5.0 \\
6.8 \\
10.0 \\
12.7\end{array}$ & $\left.\begin{array}{r}(t) \\
(0.63 \\
1.08 \\
1.43 \\
3.08\end{array}\right)$ & $\begin{array}{l}0.18 \\
0.06 \\
0.13 \\
0.03 \\
0.29\end{array}$ & 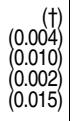 & $\begin{array}{l}0.27 \\
0.09 \\
0.19 \\
0.05 \\
0.42\end{array}$ & 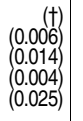 & $\begin{array}{l}0.09 \\
0.03 \\
0.07 \\
0.01 \\
0.16\end{array}$ & 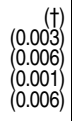 & $\begin{array}{l}0.08 \\
0.03 \\
0.09 \\
0.02 \\
0.12\end{array}$ & $\begin{array}{r}(t) \\
(0.005) \\
0.007 \\
0.002 \\
0.020)\end{array}$ & $\begin{array}{l}0.31 \\
0.24 \\
0.32 \\
0.08 \\
0.46\end{array}$ & $\begin{array}{l}\left(\begin{array}{r}(t) \\
0.013 \\
0.040 \\
0.002 \\
0.019\end{array} \mid\right. \\
\end{array}$ & $\begin{array}{l}0.27 \\
0.13 \\
0.15 \\
0.04 \\
0.07\end{array}$ & $\begin{array}{r}(t) \\
0.009 \\
(0.023) \\
0.007 \\
0.007)\end{array}$ & $\begin{array}{l}0.03 \\
0.02 \\
0.06 \\
0.01 \\
0.08\end{array}$ & $\begin{array}{l}\left(\begin{array}{r}(t) \\
0.003 \\
0.012 \\
0.002 \\
0.013\end{array}\right) \\
\end{array}$ & $\begin{array}{l}0.09 \\
0.04 \\
0.12 ! \\
0.14 ! \\
0.09\end{array}$ & 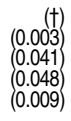 \\
\hline 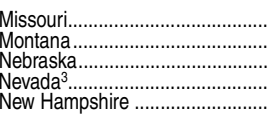 & $\begin{array}{ll}7.3 & 0 . \\
4.5 & 0 . \\
3.7 & 0 . \\
7.4 & \\
5.6 & (0 .\end{array}$ & $\begin{array}{l}0.24) \\
0.18 \\
0.08 \\
(\dagger) \\
0.32)\end{array}$ & $\left.\begin{array}{l}9.8 \\
6.1 \\
4.9 \\
9.5 \\
7.2\end{array}\right\}$ & $\begin{array}{c}(0.32) \\
(0.24) \\
0.11 \\
(+) \\
(0.46)\end{array}$ & $\begin{array}{cc}4.6 & (0.16) \\
2.7 & 0.12 \\
2.4 & (0.05) \\
5.2 & (\dagger) \\
3.9 & (0.18)\end{array}$ & $\begin{array}{cc}4.6 & (0.19) \\
3.7 & 0.17) \\
2.6 & (0.06) \\
5.1 & (\dagger) \\
5.4 & (0.33)\end{array}$ & $\left.\begin{array}{r}20.2 \\
4.9 \\
12.6 \\
15.5 \\
8.7\end{array}\right\}$ & $\begin{array}{l}1.07) \\
0.27 \\
0.05 \\
(+) \\
(0.32)\end{array}$ & \begin{tabular}{rr|}
5.4 & $(0.32)$ \\
3.5 & 0.19 \\
5.0 & $(0.30)$ \\
8.5 & $(\dagger)$ \\
12.1 & $(0.23)$
\end{tabular} & $\begin{array}{ll}2.9 & (0.10) \\
2.3 & (0.16 \\
1.9 & (0.04) \\
3.9 & (1) \\
2.2 & (0.19)\end{array}$ & $\begin{array}{l}7.0 \\
9.6 \\
6.7 \\
6.6 \\
4.8\end{array}$ & $\begin{array}{c}(0.51) \\
1.05 \\
0.89 \\
+ \\
(0.45)\end{array}$ & \begin{tabular}{|l|}
0.03 \\
0.07 \\
0.23 \\
0.36 \\
$0.06 !$
\end{tabular} & $\begin{array}{r}(0.004) \\
0.007 \\
0.005 \\
(+) \\
(0.021)\end{array}$ & $\begin{array}{l}0.05 \\
0.12 \\
0.32 \\
0.55 \\
0.08\end{array}$ & $\begin{array}{r}(0.005) \\
0.013 \\
(0.008 \\
+ \\
(0.024)\end{array}$ & $\begin{array}{l}0.01 \\
0.02 \\
0.12 \\
0.16 \\
0.04 !\end{array}$ & $\begin{array}{r}(0.003) \\
0.05 \\
(0.002 \\
\left(\begin{array}{l}0 \\
(0.020\end{array}\right)\end{array}$ & $\begin{array}{l}0.03 \\
0.05 \\
0.13 \\
0.26 \\
0.06 !\end{array}$ & $\begin{array}{r}(0.005) \\
0.007 \\
0.004 \\
(t \\
(0.021)\end{array}$ & $\begin{array}{l}0.04 \\
\# \\
0.92 \\
0.86 \\
0.28\end{array}$ & $\begin{array}{c}(0.003) \\
(t) \\
(0.004 \\
(t) \\
(0.065)\end{array}$ & $\begin{array}{l}0.02 \\
\# \\
0.32 \\
0.35 \\
0.07\end{array}$ & $\begin{array}{c}(0.001) \\
(t) \\
(0.018 \\
(t) \\
(0.001)\end{array}$ & $\begin{array}{l}0.01 \\
\# \\
0.13 \\
0.22 \\
0.03\end{array}$ & 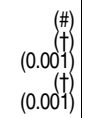 & $\begin{array}{r}\# \\
0.24 \\
0.76 \\
0.36 \\
0.17\end{array}$ & 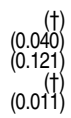 \\
\hline 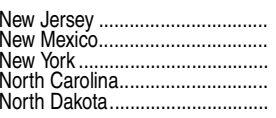 & $\begin{array}{rl}5.7 & 0 . \\
5.3 & 0 . \\
3.8 & 0 . \\
10.8 & 0 . \\
2.2 & 0 .\end{array}$ & $\begin{array}{l}0.26 \\
0.20 \\
0.14 \\
0.52 \\
0.17)\end{array}$ & $\left.\begin{array}{r}7.5 \\
6.9 \\
5.1 \\
14.3 \\
2.9\end{array}\right\}$ & $\begin{array}{l}(0.33) \\
0.26 \\
0.17 \\
0.66 \\
0.21)\end{array}$ & $\begin{array}{ll}3.7 & (0.19) \\
3.5 & 0.14 \\
2.5 & 0.11 \\
7.0 & 0.37 \\
1.4 & (0.13)\end{array}$ & $\begin{array}{ll}3.7 & (0.30) \\
4.0 & (0.19 \\
3.4 & 0.14 \\
6.5 & 0.33 \\
1.5 & (0.10)\end{array}$ & $\left.\begin{array}{r}12.4 \\
7.0 \\
7.3 \\
20.0 \\
5.0\end{array}\right\}$ & $\left.\begin{array}{l}(0.79) \\
0.21 \\
0.45 \\
1.06 \\
0.16\end{array}\right)$ & $\begin{array}{ll}6.9 & (0.51) \\
5.4 & 0.31 \\
2.8 & 0.15 \\
7.2 & 0.40 \\
3.1 & (0.35)\end{array}$ & $\begin{array}{ll}1.4 & (0.13) \\
2.5 & (0.12 \\
0.7 & 0.05 \\
2.7 & (0.19 \\
2.0 & (0.12)\end{array}$ & $\begin{array}{r}3.7 \\
8.3 \\
4.5 \\
\neq \\
\quad \neq\end{array}$ & $\begin{array}{c}(0.70) \\
0.47 \\
0.97 \\
(+) \\
(1.80)\end{array}$ & \begin{tabular}{|l|}
$0.02 !$ \\
0.07 \\
0.03 \\
$0.14 !$ \\
0.02
\end{tabular} & $\begin{array}{l}(0.008) \\
0.005 \\
0.006 \\
0.060 \\
0.006)\end{array}$ & $\begin{array}{l}0.03 ! \\
0.12 \\
0.05 \\
0.21 ! \\
0.05\end{array}$ & $\begin{array}{l}(0.016 \\
0.009 \\
0.018 \\
0.018 \\
0.008\end{array} \mid$ & $\begin{array}{r}\# \\
0.03 \\
0.01 \\
\neq \\
\#\end{array}$ & 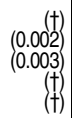 & $\begin{array}{l}0.01 ! \\
0.03 \\
0.04 \\
0.04 \\
0.01\end{array}$ & $\left.\begin{array}{l}(0.006) \\
0.003 \\
0.010 \\
0.007 \\
0.002\end{array}\right)$ & $\left.\begin{array}{c}0.03 ! \\
0.13 \\
0.04 ! \\
\ddagger \\
0.05\end{array}\right\}$ & 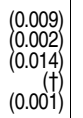 & $\begin{array}{l}0.03 ! \\
0.06 \\
0.01 \\
0.05 \\
\#\end{array}$ & $\begin{array}{r}(0.015) \\
0.006 \\
0.002 \\
0.007 \\
(\dagger)\end{array}$ & $\begin{array}{r}\# \\
0.17 \\
\# \\
0.03 \\
\#\end{array}$ & $\begin{array}{r}(\dagger) \\
(0.006 \\
(\dagger) \\
(0.004) \\
(t)\end{array}$ & $\begin{array}{c}\# \\
0.22 \\
\ddagger \\
\ddagger \\
0.12 !\end{array}$ & 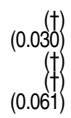 \\
\hline 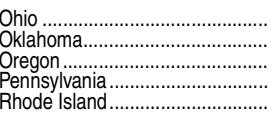 & $\begin{array}{ll}6.2 & 0 . \\
4.9 & 0 . \\
4.9 & 0 . \\
6.8 & 0 . \\
8.4 & 0 .\end{array}$ & $\begin{array}{l}0.24 \\
0.18 \\
.074 \\
0.74\end{array}$ & $\left.\begin{array}{r}8.2 \\
6.7 \\
7.1 \\
8.7 \\
10.7\end{array}\right\}$ & $\begin{array}{l}(0.30) \\
0.24 \\
0.26 \\
0.45 \\
(1.00)\end{array}$ & $\begin{array}{ll}4.2 & (0.17) \\
3.0 & 0.11 \\
2.7 & 0.15 \\
4.8 & 0.29) \\
5.9 & (0.47)\end{array}$ & $\begin{array}{ll}4.6 & (0.21) \\
3.9 & 0.18 \\
4.8 & 0.19 \\
4.2 & 0.23 \\
6.7 & (0.83)\end{array}$ & $\left.\begin{array}{r}14.6 \\
12.1 \\
8.8 \\
18.9 \\
14.6\end{array}\right\}$ & $\begin{array}{l}(0.99) \\
0.60 \\
0.24 \\
1.41 \\
2.07)\end{array}$ & \begin{tabular}{rr|}
6.0 & $(0.83)$ \\
5.3 & 0.18 \\
5.5 & 0.37 \\
8.7 & 0.79 \\
12.6 & $(0.65)$
\end{tabular} & $\begin{array}{ll}2.1 & (0.24) \\
1.8 & (0.07 \\
2.1 & 0.08 \\
2.7 & (0.46 \\
7.2 & (0.73)\end{array}$ & $\begin{array}{r}3.7 \\
4.0 \\
7.2 \\
3.4 \\
11.8\end{array}$ & $\begin{array}{l}(0.45) \\
0.24 \\
0.57 \\
0.64) \\
(2.92)\end{array}$ & $\begin{array}{l}0.47 \\
0.34 \\
0.34 \\
0.16 \\
\#\end{array}$ & $\begin{array}{r}(0.020) \\
0.013 \\
0.025 \\
0.008 \\
(\dagger)\end{array}$ & $\begin{array}{l}0.61 \\
0.47 \\
0.52 \\
0.22 \\
\#\end{array}$ & $\begin{array}{r}(0.026) \\
0.019 \\
0.044 \\
0.0114 \\
(\dagger)\end{array} \mid$ & $\begin{array}{l}0.32 \\
0.21 \\
0.15 \\
0.10 \\
\#\end{array}$ & $\begin{array}{r}(0.014) \\
0.008 \\
0.010 \\
0.005 \\
(\dagger)\end{array}$ & $\begin{array}{l}0.20 \\
0.28 \\
0.32 \\
0.09 \\
\#\end{array}$ & $\left.\begin{array}{r}(0.016 \\
0.014 \\
0.026 \\
0.007 \\
(\dagger)\end{array}\right)$ & $\left.\begin{array}{l}1.69 \\
0.94 \\
0.58 \\
0.52 \\
\#\end{array}\right\}$ & $\begin{array}{r}(0.091) \\
0.039 \\
0.093 \\
0.031 \\
(\dagger)\end{array} \mid$ & $\begin{array}{l}0.72 \\
0.23 \\
0.41 \\
0.21 \\
\#\end{array}$ & 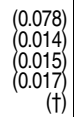 & $\begin{array}{l}0.09 \\
0.16 \\
0.18 \\
0.06 \\
\#\end{array}$ & $\begin{array}{r}(0.014) \\
0.039 \\
0.028 \\
0.013 \\
(\dagger)\end{array}$ & $\begin{array}{l}0.21 \\
0.29 \\
0.47 \\
0.04 \\
\#\end{array}$ & $\begin{array}{r}(0.038) \\
0.021 \\
0.070 \\
0.002 \\
(\dagger)\end{array}$ \\
\hline 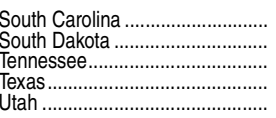 & $\begin{array}{rl}11.9 & 0 . \\
2.7 & 0 . \\
7.2 & 0 . \\
5.6 & 0 . \\
3.2 & 0 .\end{array}$ & \begin{tabular}{l|}
$0.44)$ \\
0.26 \\
.06 \\
.04
\end{tabular} & $\left.\begin{array}{r}15.1 \\
3.7 \\
9.6 \\
7.4 \\
4.5\end{array}\right\}$ & $\begin{array}{l}(0.56) \\
(0.22) \\
0.35 \\
0.08 \\
(0.05)\end{array}$ & $\begin{array}{ll}8.6 & (0.33) \\
1.6 & 0.11 \\
4.8 & 0.17 \\
3.6 & 0.04 \\
1.9 & (0.03)\end{array}$ & $\begin{array}{ll}6.9 & (0.36) \\
1.9 & 0.12 \\
5.5 & (0.27) \\
2.9 & 0.06 \\
2.4 & (0.03)\end{array}$ & $\left.\begin{array}{r}19.2 \\
7.1 \\
12.8 \\
12.7 \\
7.8\end{array}\right\}$ & $\begin{array}{l}(0.89) \\
0.24 \\
0.38 \\
0.24 \\
(0.04)\end{array}$ & $\begin{array}{ll}6.5 & (1.05) \\
4.3 & 0.16 \\
5.4 & 0.22 \\
5.7 & 0.08 \\
6.7 & (0.07)\end{array}$ & $\begin{array}{ll}2.9 & (0.31) \\
3.0 & (0.19 \\
2.7 & 0.15 \\
1.6 & 0.01 \\
4.2 & (0.04)\end{array}$ & $\begin{array}{l}9.6 ! \\
6.8 \\
3.4 \\
3.1 \\
6.9\end{array}$ & $\left.\begin{array}{l}(4.26) \\
1.19 \\
0.36 \\
0.10 \\
0.09\end{array}\right)$ & $\begin{array}{l}0.73 \\
0.11 ! \\
0.32 \\
0.26 \\
0.05\end{array}$ & $\begin{array}{l}(0.043 \\
0.045 \\
0.010 \\
0.005 \\
0.001)\end{array}$ & $\begin{array}{l}1.03 \\
0.16 ! \\
0.47 \\
0.39 \\
0.07\end{array}$ & $\left.\begin{array}{l}(0.063) \\
0.066 \\
0.016 \\
0.080 \\
0.002\end{array}\right)$ & $\begin{array}{l}0.40 \\
0.05 ! \\
0.15 \\
0.13 \\
0.02\end{array}$ & $\begin{array}{r}(0.026) \\
0.024 \\
0.006 \\
0.002 \\
(\#)\end{array}$ & $\begin{array}{l}0.37 \\
\neq \\
0.19 \\
0.16 \\
0.04\end{array}$ & $\begin{array}{r}(0.029) \\
(t) \\
(0.011) \\
0.007 \\
0.001)\end{array}$ & $\left.\begin{array}{l}1.26 \\
0.08 ! \\
0.70 \\
0.58 \\
0.22\end{array}\right\}$ & $\begin{array}{l}(0.091 \\
0.038 \\
0.011 \\
0.016 \\
0.001)\end{array}$ & $\begin{array}{l}0.20 \\
\ddagger \\
0.29 \\
0.26 \\
0.06\end{array}$ & $\left.\begin{array}{l}(0.035) \\
(+) \\
(0.011 \\
0.005 \\
0.002\end{array}\right)$ & $\begin{array}{l}0.19 \\
\# \\
0.17 \\
0.08 \\
0.09\end{array}$ & $\begin{array}{r}(0.047) \\
(+1) \\
(0.009 \\
(\#) \\
(\#)\end{array}$ & $\begin{array}{l}0.42 ! \\
0.55 ! \\
0.29 \\
0.20 \\
0.19\end{array}$ & $\begin{array}{l}(0.169) \\
0.221 \\
0.014 \\
0.004 \\
0.020)\end{array}$ \\
\hline 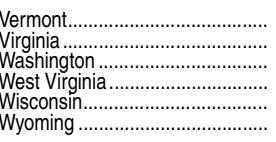 & $\begin{array}{rl}4.0 & 0 . \\
7.2 & 0 . \\
5.9 & 0 . \\
10.2 & 1 . \\
5.0 & 0 . \\
2.8 & 0 .\end{array}$ & $\begin{array}{l}0.18 \\
.04 \\
.15 \\
.116 \\
.034) \\
\end{array}$ & $\left.\begin{array}{r}5.5 \\
9.4 \\
8.6 \\
13.8 \\
6.3 \\
4.0\end{array}\right\}$ & $\left(\begin{array}{l}0.251 \\
0.31 \\
0.21 \\
1.31 \\
0.20 \\
(0.33)\end{array}\right.$ & \begin{tabular}{rr|}
2.4 & $(0.12)$ \\
4.9 & $(0.18$ \\
3.2 & $(0.08$ \\
6.4 & 0.70 \\
3.6 & $(0.13$ \\
$\ddagger$ & $(\dagger)$
\end{tabular} & $\begin{array}{ll}4.0 & (0.18) \\
4.7 & 0.17 \\
5.3 & 0.17 \\
9.7 & 0.91 \\
2.7 & 0.12 \\
2.7 & 0.34)\end{array}$ & $\left.\begin{array}{r}5.8 \\
13.9 \\
12.0 \\
21.5 \\
19.7 \\
3.2\end{array}\right\}$ & $\begin{array}{l}(0.50) \\
0.73 \\
0.09 \\
4.03 \\
0.60 \\
0.26)\end{array}$ & \begin{tabular}{rr|}
4.1 & $(0.55)$ \\
5.6 & $(0.21$ \\
7.2 & 0.39 \\
11.2 & 3.07 \\
7.5 & $(0.18$ \\
3.1 & $(0.43)$
\end{tabular} & $\begin{array}{ll}1.8 & (0.23) \\
2.1 & (0.06 \\
3.7 & (0.05 \\
2.4 & (0.54) \\
2.1 & 0.07 \\
1.7 & (0.26)\end{array}$ & $\begin{array}{c}5.7 \\
4.0 \\
11.3 \\
8.2 \\
13.5 ! \\
6.4\end{array}$ & $\begin{array}{l}(0.77) \\
0.34 \\
1.36 \\
1.98 \\
5(.23) \\
1.37\end{array} \mid$ & $\begin{array}{l}0.05 ! \\
0.09 \\
0.34 \\
0.07 \\
0.17 \\
0.11\end{array}$ & $\begin{array}{l}(0.019 \\
0.014 \\
0.014 \\
0.012 \\
0.008 \\
0.018\end{array}$ & $\begin{array}{l}0.08 ! \\
0.15 \\
0.53 \\
0.09 \\
0.23 \\
0.18\end{array}$ & $\begin{array}{l}(0.031) \\
0.025 \\
0.021 \\
0.015 \\
0.012 \\
0.027)\end{array} \mid$ & $\begin{array}{l}0.02 ! \\
0.03 \\
0.14 \\
0.04 \\
0.10 \\
0.03 !\end{array}$ & $\left.\begin{array}{l}(0.006) \\
0.003 \\
0.007 \\
0.010 \\
0.006 \\
0.010\end{array}\right)$ & $\begin{array}{l}0.05 ! \\
0.08 \\
0.31 \\
0.07 \\
0.12 \\
0.11\end{array}$ & $\begin{array}{l}(0.020) \\
0.022 \\
0.016 \\
0.011 \\
0.009 \\
0.021)\end{array}$ & $\left.\begin{array}{l}0.12 \\
0.48 \\
0.09 ! \\
0.47 \\
0.23\end{array}\right\}$ & $\begin{array}{r}\left(\begin{array}{r}(t) \\
0.013 \\
0.010 \\
0.034 \\
0.016 \\
0.006\end{array}\right) \\
\end{array}$ & $\begin{array}{r}\ddagger \\
0.09 \\
0.50 \\
\neq \\
0.22 \\
0.09\end{array}$ & 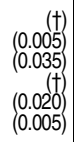 & $\begin{array}{r}\# \\
0.06 \\
0.16 \\
\# \\
0.06 \\
0.10\end{array}$ & $\begin{array}{r}(\dagger) \\
(0.003 \\
(0.002 \\
(\dagger) \\
(0.008 \\
0.007)\end{array}$ & $\begin{array}{c}\# \\
0.10 ! \\
0.69 \\
\# \\
0.30 ! \\
\#\end{array}$ & 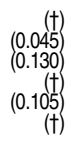 \\
\hline
\end{tabular}

†Not applicable.
\#Rounds to zero.

\#Rounds to zero.
!Interpret data with caution. The coefficient of variation (CV) for this estimate is between 30 and 50 percent. fReporting standards not met. The coefficient of variation (CV) for this estimate is 50 percent or grealer. 2A student is counted only once, even if expelled more than once during the same school year. ${ }^{3}$ Data are based on universe counts of schools and school districts; therefore, these figures do not have standard errors.
NOTE: Suspension is excluding a student from school for disciplinary reasons for 1 school day or longer. Expulsion is the exclusion of a student from school for disciplinary reasons that results in the student's removal from school attendance rolls or that meets the criteria for expulsion as defined by the appropriate state or local school authority. Race categories exclude persons of
Hispanic ethnicity. SOURCE: U.S. D May 2008.) 
Table 233.50. Percentage of public and private schools with various safety and security measures, by school level: 2003-04, 2007-08, and 2011-12

[Standard errors appear in parentheses]

\begin{tabular}{|c|c|c|c|c|c|c|c|c|c|c|c|c|c|c|c|c|c|c|}
\hline \multirow{3}{*}{ School control and school safety and security measure } & \multicolumn{6}{|c|}{ Total $^{1}$} & \multicolumn{6}{|c|}{ Elementary schools ${ }^{2}$} & \multicolumn{6}{|c|}{ Secondary schools ${ }^{3}$} \\
\hline & \multicolumn{2}{|c|}{$2003-04$} & \multicolumn{2}{|c|}{$2007-08$} & \multicolumn{2}{|r|}{ 2011-12 } & \multicolumn{2}{|r|}{$2003-04$} & \multicolumn{2}{|r|}{$2007-08$} & \multicolumn{2}{|r|}{ 2011-12 } & \multicolumn{2}{|c|}{$2003-04$} & \multicolumn{2}{|c|}{$2007-08$} & \multicolumn{2}{|c|}{$2011-12$} \\
\hline & & 2 & & 3 & & 4 & & 5 & & 6 & & 7 & & 8 & & 9 & & 10 \\
\hline \multicolumn{19}{|l|}{ Public schools } \\
\hline 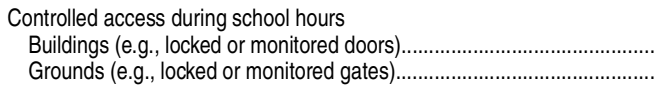 & $\begin{array}{l}81.5 \\
39.4\end{array}$ & $\begin{array}{l}(0.60) \\
(0.83)\end{array}$ & $\begin{array}{l}88.8 \\
44.9\end{array}$ & $\begin{array}{l}(0.63) \\
(1.12)\end{array}$ & $\begin{array}{l}88.2 \\
44.1\end{array}$ & $\begin{array}{l}(0.56) \\
(0.72)\end{array}$ & $\begin{array}{l}84.7 \\
39.0\end{array}$ & $\begin{array}{l}(0.65) \\
(1.03)\end{array}$ & $\begin{array}{l}92.1 \\
45.7\end{array}$ & $\begin{array}{l}(0.71) \\
(1.61)\end{array}$ & $\begin{array}{l}90.4 \\
45.4\end{array}$ & $\begin{array}{l}(0.67) \\
(0.94)\end{array}$ & $\begin{array}{l}75.0 \\
41.4\end{array}$ & $\begin{array}{l}(1.33) \\
(1.38)\end{array}$ & $\begin{array}{l}82.1 \\
43.3\end{array}$ & $\begin{array}{l}(1.42) \\
(1.53)\end{array}$ & $\begin{array}{l}83.9 \\
39.6\end{array}$ & $\begin{array}{l}(1.04) \\
(1.13)\end{array}$ \\
\hline 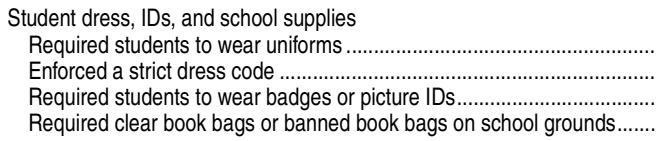 & $\begin{array}{r}13.5 \\
49.3 \\
6.1 \\
6.0\end{array}$ & $\begin{array}{l}(0.53) \\
(0.70) \\
(0.31) \\
(0.31)\end{array}$ & $\begin{array}{r}16.5 \\
54.0 \\
7.5 \\
6.8\end{array}$ & $\begin{array}{l}(0.83) \\
(0.99) \\
(0.53) \\
(0.43)\end{array}$ & $\begin{array}{r}19.3 \\
49.1 \\
7.4 \\
5.7\end{array}$ & $\begin{array}{l}(0.54) \\
(0.68) \\
(0.33) \\
(0.28)\end{array}$ & $\begin{array}{r}14.7 \\
45.2 \\
3.5 \\
3.3\end{array}$ & $\begin{array}{l}(0.67) \\
(0.94) \\
(0.35) \\
(0.32)\end{array}$ & $\begin{array}{r}17.5 \\
50.0 \\
4.1 \\
4.7\end{array}$ & $\begin{array}{l}(1.05) \\
(1.38) \\
(0.57) \\
(0.54)\end{array}$ & $\begin{array}{r}20.3 \\
44.6 \\
4.6 \\
3.2\end{array}$ & $\begin{array}{l}(0.76) \\
(0.94) \\
(0.32) \\
(0.28)\end{array}$ & $\begin{array}{r}8.8 \\
59.7 \\
14.1 \\
11.3\end{array}$ & $\begin{array}{l}(1.11) \\
(1.33) \\
(0.74) \\
(0.74)\end{array}$ & $\begin{array}{l}12.1 \\
64.4 \\
16.8 \\
10.5\end{array}$ & $\begin{array}{l}(1.19) \\
(1.87) \\
(1.15) \\
(1.07)\end{array}$ & $\begin{array}{r}12.2 \\
58.3 \\
14.3 \\
9.3\end{array}$ & $\begin{array}{l}(0.69) \\
(1.02) \\
(1.02) \\
(0.72)\end{array}$ \\
\hline 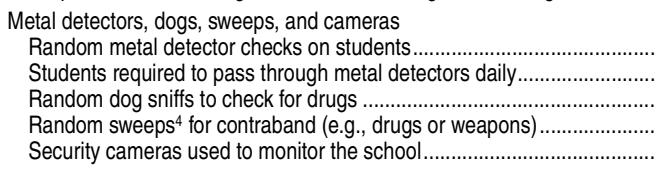 & $\begin{array}{r}5.7 \\
2.0 \\
23.6 \\
12.8 \\
32.5\end{array}$ & $\begin{array}{l}(0.32) \\
(0.21) \\
(0.59) \\
(0.48) \\
(0.68)\end{array}$ & $\begin{array}{r}5.9 \\
2.3 \\
25.0 \\
14.8 \\
51.8\end{array}$ & $\begin{array}{l}(0.45) \\
(0.31) \\
(0.68) \\
(0.76) \\
(0.94)\end{array}$ & $\begin{array}{r}5.0 \\
2.7 \\
24.0 \\
12.1 \\
64.3\end{array}$ & $\begin{array}{l}(0.32) \\
(0.33) \\
(0.40) \\
(0.44) \\
(0.75)\end{array}$ & $\begin{array}{c}3.4 \\
0.8 ! \\
10.8 \\
5.6 \\
26.3\end{array}$ & $\begin{array}{l}(0.33) \\
(0.23) \\
(0.62) \\
(0.44) \\
(0.77)\end{array}$ & $\begin{array}{r}3.0 \\
0.3 ! \\
13.2 \\
7.6 \\
46.1\end{array}$ & $\begin{array}{l}(0.48) \\
(0.14) \\
(0.83) \\
(0.84) \\
(1.29)\end{array}$ & $\begin{array}{r}2.6 \\
0.8 \\
10.6 \\
5.0 \\
57.7\end{array}$ & $\begin{array}{l}(0.28) \\
(0.16) \\
(0.39) \\
(0.39) \\
(0.97)\end{array}$ & $\begin{array}{r}10.2 \\
3.7 \\
56.5 \\
28.2 \\
51.1\end{array}$ & $\begin{array}{l}(0.64) \\
(0.38) \\
(1.59) \\
(1.33) \\
(1.55)\end{array}$ & $\begin{array}{r}11.9 \\
5.2 \\
54.6 \\
30.5 \\
68.7\end{array}$ & $\begin{array}{l}(1.05) \\
(1.03) \\
(1.59) \\
(1.59) \\
(1.77)\end{array}$ & $\begin{array}{r}7.9 \\
4.6 \\
57.3 \\
26.1 \\
81.2\end{array}$ & $\begin{array}{l}(0.63) \\
(0.65) \\
(1.28) \\
(1.16) \\
(1.07)\end{array}$ \\
\hline 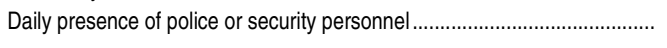 & 24.8 & $(0.59)$ & 27.2 & $(0.99)$ & 28.1 & $(0.51)$ & 15.5 & $(0.62)$ & 16.2 & $(1.14)$ & 17.1 & $(0.57)$ & 53.9 & $(1.61)$ & 58.3 & $(1.93)$ & 57.6 & (1.44) \\
\hline $\begin{array}{l}\text { Private schools } \\
\text { Controlled access }\end{array}$ & & & & & & & & & & & & & & & & & & \\
\hline 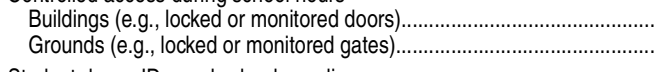 & $\begin{array}{l}73.5 \\
40.2\end{array}$ & $\begin{array}{l}(1.02) \\
(1.08)\end{array}$ & $\begin{array}{l}81.5 \\
42.4\end{array}$ & $\begin{array}{l}(1.15) \\
(1.22)\end{array}$ & $\begin{array}{l}80.1 \\
42.1\end{array}$ & $\begin{array}{l}(1.50) \\
(1.43)\end{array}$ & $\begin{array}{l}79.5 \\
44.9\end{array}$ & $\begin{array}{l}(1.19) \\
(1.32)\end{array}$ & $\begin{array}{l}84.1 \\
45.6\end{array}$ & $\begin{array}{l}(1.35) \\
(1.50)\end{array}$ & $\begin{array}{l}82.0 \\
44.0\end{array}$ & $\begin{array}{l}(2.22) \\
(1.99)\end{array}$ & $\begin{array}{l}62.9 \\
32.2\end{array}$ & $\begin{array}{l}(3.65) \\
(3.80)\end{array}$ & $\begin{array}{l}76.9 \\
34.7\end{array}$ & $\begin{array}{l}(2.83) \\
(3.37)\end{array}$ & $\begin{array}{l}71.5 \\
34.0\end{array}$ & $\begin{array}{l}(3.50) \\
(4.67)\end{array}$ \\
\hline 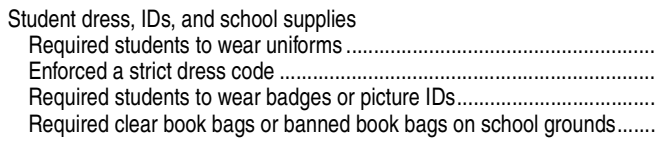 & $\begin{array}{r}55.5 \\
73.7 \\
2.2 \\
2.3\end{array}$ & $\begin{array}{l}(1.06) \\
(1.00) \\
(0.30) \\
(0.35)\end{array}$ & $\begin{array}{r}55.4 \\
76.3 \\
2.9 \\
3.2\end{array}$ & $\begin{array}{l}(1.19) \\
(1.08) \\
(0.42) \\
(0.43)\end{array}$ & $\begin{array}{r}56.9 \\
71.3 \\
2.7 \\
1.7\end{array}$ & $\begin{array}{l}(1.77) \\
(1.49) \\
(0.48) \\
(0.33)\end{array}$ & $\begin{array}{r}60.6 \\
74.1 \\
1.0 \\
1.0\end{array}$ & $\begin{array}{l}(1.27) \\
(1.32) \\
(0.27) \\
(0.30)\end{array}$ & $\begin{array}{r}62.2 \\
75.9 \\
1.6 \\
1.7\end{array}$ & $\begin{array}{l}(1.68) \\
(1.48) \\
(0.38) \\
(0.46)\end{array}$ & $\begin{array}{c}60.0 \\
71.2 \\
1.4 \\
0.9 !\end{array}$ & $\begin{array}{l}(2.21) \\
(2.12) \\
(0.40) \\
(0.30)\end{array}$ & $\begin{array}{r}44.9 \\
70.0 \\
9.8 \\
9.4\end{array}$ & $\begin{array}{l}(3.53) \\
(3.78) \\
(2.10) \\
(2.59)\end{array}$ & $\begin{array}{r}42.8 \\
75.3 \\
6.2 \\
7.5\end{array}$ & $\begin{array}{l}(3.22) \\
(3.36) \\
(1.27) \\
(2.11)\end{array}$ & $\begin{array}{r}49.2 \\
70.8 \\
8.2 \\
5.2\end{array}$ & $\begin{array}{l}(4.55) \\
(3.13) \\
(1.91) \\
(1.47)\end{array}$ \\
\hline 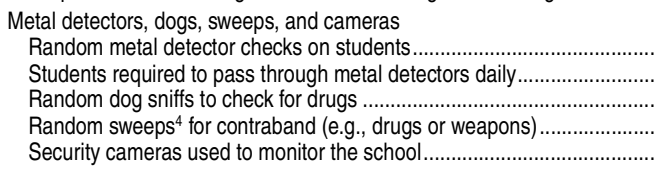 & $\begin{array}{r}0.7 \\
0.8 \\
3.4 \\
7.7 \\
19.4\end{array}$ & $\begin{array}{l}(0.20) \\
(0.21) \\
(0.35) \\
(0.61) \\
(0.79)\end{array}$ & $\begin{array}{l}1.1 \\
0.6 ! \\
3.9 \\
8.8 \\
32.9\end{array}$ & $\begin{array}{l}(0.24) \\
(0.19) \\
(0.43) \\
(0.69) \\
(1.21)\end{array}$ & $\begin{array}{r}1.2 ! \\
0.4 ! \\
4.1 \\
7.5 \\
40.6\end{array}$ & $\begin{array}{c}(0.42) \\
(0.16) \\
(0.45) \\
(0.93) \\
(1.51)\end{array}$ & $\begin{array}{r}\ddagger \\
\neq \\
\ddagger \\
2.4 \\
19.9\end{array}$ & $\begin{array}{r}(\dagger) \\
(\dagger) \\
(\dagger) \\
(0.52) \\
(0.97)\end{array}$ & $\begin{array}{r}\ddagger \\
\ddagger \\
0.4 ! \\
2.1 \\
31.4\end{array}$ & $\begin{array}{r}(t) \\
(\dagger) \\
(0.20) \\
(0.42) \\
(1.65)\end{array}$ & $\begin{array}{r}\ddagger \\
\neq \\
\ddagger \\
1.5 ! \\
39.8\end{array}$ & 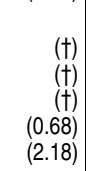 & $\begin{array}{r}\ddagger \\
\ddagger \\
15.0 \\
23.3 \\
24.3\end{array}$ & $\begin{array}{r}(\dagger) \\
(\dagger) \\
(2.04) \\
(3.75) \\
(3.11)\end{array}$ & $\begin{array}{r}\ddagger \\
\ddagger \\
17.0 \\
26.0 \\
43.1\end{array}$ & $\begin{array}{r}(\dagger) \\
(\dagger) \\
(2.32) \\
(3.64) \\
(3.64)\end{array}$ & $\begin{array}{r}\ddagger \\
\ddagger \\
16.3 \\
20.4 \\
52.0\end{array}$ & $\begin{array}{r}(\dagger) \\
(\dagger) \\
(2.36) \\
(2.95) \\
(5.46)\end{array}$ \\
\hline 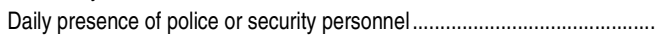 & 5.9 & (0.50) & 6.4 & (0.54) & 7.2 & $(0.77)$ & 3.1 & $(0.50)$ & 4.3 & $(0.61)$ & 3.9 & $(0.80)$ & 16.2 & (2.99) & 11.8 & (2.46) & 19.2 & (4.77) \\
\hline
\end{tabular}

†Not applicable.

!nterpret data with caution. The coefficient of variation (CV) for this estimate is between 30 and 50 percent.

fReporting standards not met. Either there are too few cases for a reliable estimate or the coefficient of variation (CV) is 50 percent or greater.

Elementary schools are those with any of grades kindergarten through grade 6 and none of grades 9 through 12 .
${ }^{3}$ Secondary schools have any of grades 7 through 12 and none of grades kindergarten through grade 6 . "Does not include random dog snifts.

SOU. Re

(SASS), "Public (This table was prepared August 2013.) 


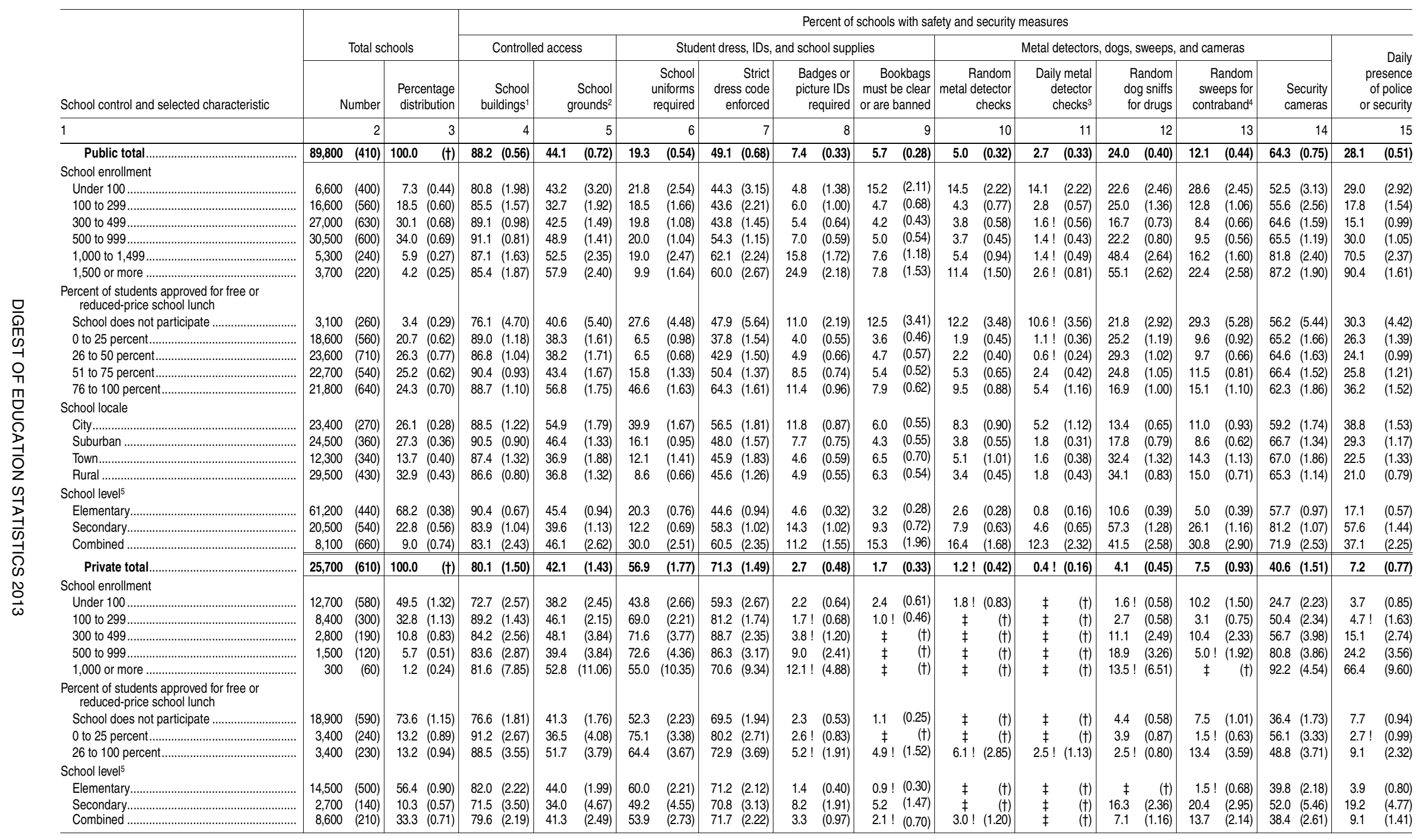

\section{†Not applicable.}

!Interpret data with caution. The coefficient of variation (CV) for this estimate is between 30 and 50 percent

₹Reporting standards not met. Either there are too few cases for a reliable estimate or the coefficient of variation (CV) is 50 percent or greater.
1 Access to build

${ }^{2}$ Access to grounds is controlled during school hours (e.g., by locked or monitored doors). .

4Examples of contraband include drugs and weapons. The "sweeps" category does not include dog sniffs. ${ }^{5}$ Elementary schools have grade 6 or below, with no grade higher than 8; secondary schools have no grade lower than 7; and combined schools have grades lower than 7 and higher than 8.

NOTE: Responses were provided by the principal. Detail may not sum to totals because of rounding. School Principal Data File" and "Private School Principal Data File," 2011-12. (This table was prepared October 2013.) 


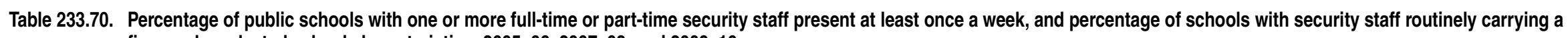
firearm, by selected school characteristics: 2005-06, 2007-08, and 2009-10

[Standard errors appear in parentheses]

\begin{tabular}{|c|c|c|c|c|c|c|c|c|c|c|c|c|c|c|c|c|c|c|c|c|c|c|c|c|}
\hline \multirow[b]{3}{*}{ School characteristic } & \multicolumn{18}{|c|}{ Percent with one or more security guards, security personnel, School Resource Officers (SROs), or sworn law enforcement officers who are not SROs' } & \multirow{2}{*}{\multicolumn{6}{|c|}{$\begin{array}{l}\text { Percent with security guards, security personnel, or sworn } \\
\text { law enforcement officers routinely carrying a firearm }{ }^{2}\end{array}$}} \\
\hline & \multicolumn{6}{|c|}{ Total } & \multicolumn{6}{|c|}{ Full-time } & \multicolumn{6}{|c|}{ Part-time only } & & & & & & \\
\hline & \multicolumn{2}{|c|}{$2005-06$} & \multicolumn{2}{|c|}{$2007-08$} & \multicolumn{2}{|c|}{ 2009-10 } & \multicolumn{2}{|r|}{$2005-06$} & \multicolumn{2}{|c|}{$2007-08$} & \multicolumn{2}{|c|}{$2009-10$} & \multicolumn{2}{|c|}{$2005-06$} & \multicolumn{2}{|c|}{$2007-08$} & \multicolumn{2}{|r|}{ 2009-10 } & \multicolumn{2}{|c|}{$2005-06$} & \multicolumn{2}{|c|}{$2007-08$} & \multicolumn{2}{|r|}{$2009-10$} \\
\hline 1 & & 2 & & 3 & & 4 & & 5 & & 6 & & 7 & & 8 & & 9 & & 10 & & 11 & & 12 & & 13 \\
\hline \multicolumn{25}{|l|}{ All public schools .............................................. } \\
\hline School level ${ }^{3}$ & & & & & & & & & & & & & & & & & & & & & & & & \\
\hline hool & 26.2 & $(1.87)$ & 33.1 & $2.04)$ & 27.7 & 1.50) & 12.5 & (1.32) & 17.8 & (1.37) & 15.7 & $(1.43)$ & 13.7 & $(1.59)$ & 15.3 & $(1.31)$ & 12.1 & $(0.89)$ & 15.7 & $(1.55)$ & 20.1 & (1.68) & 12.5 & $(1.25)$ \\
\hline Middle s & 63.7 & $(1.30)$ & 65.5 & $(1.59)$ & 66.4 & $(1.45)$ & 44.5 & (1.17) & 44.9 & (1.55) & 45.8 & (1.39) & 19.2 & (1.18) & 20.7 & $(1.17)$ & 20.6 & (1.32) & 51.8 & $(1.32)$ & 54.2 & (1.92) & 51.0 & $(1.84)$ \\
\hline High & 75.2 & (1.66) & 79.6 & (1.47) & 76.4 & (1.45) & 64.0 & (1.53) & 66.1 & (1.48) & 62.0 & (1.56) & 11.2 & (1.14) & 13.5 & $(1.42)$ & 14.5 & (1.50) & 64.0 & $(1.71)$ & 67.5 & (1.51) & 63.3 & $(1.75)$ \\
\hline Combined school.... & 43.5 & $(5.25)$ & 39.9 & (5.59) & 36.6 & $(4.89)$ & 26.8 & (4.44) & 26.2 & $(4.79)$ & 24.0 & (4.49) & 16.7 & (4.13) & $13.6 !$ & $(4.15)$ & 12.7 & (3.56) & 32.4 & $(4.50)$ & 32.1 & $(4.89)$ & 24.6 & $(4.26)$ \\
\hline \multicolumn{25}{|l|}{ Enrollment size } \\
\hline Less than 300 & 22.7 & (2.65) & 27.6 & $(2.55)$ & 25.6 & .91) & 10.8 & (1.58) & 15.1 & $(2.09)$ & 15.1 & 2.29) & 11.9 & $(2.07)$ & 12.5 & $(2.07)$ & 10.5 & (2.20) & 16.2 & (2.17) & 16.1 & (2.39) & 13.5 & (2.16) \\
\hline $300-499 \ldots \ldots . . .$. & 29.8 & $(2.29)$ & 36.1 & $(2.66)$ & 33.5 & $(2.26)$ & 16.7 & (1.93) & 19.4 & $(1.84)$ & 18.0 & $(1.96)$ & 13.0 & (1.64) & 16.8 & $(2.05)$ & 15.5 & (1.76) & 20.5 & $(1.83)$ & 26.7 & (2.37) & 19.8 & $(1.84)$ \\
\hline $500-999 \ldots$ & 50.5 & $(1.90)$ & 52.7 & (1.99) & 47.3 & $(1.60)$ & 31.0 & (1.27) & 34.0 & $(1.52)$ & 31.2 & $(1.34)$ & 19.5 & (1.62) & 18.8 & $(1.53)$ & 16.1 & (1.08) & 36.9 & $(1.67)$ & 39.5 & (1.98) & 30.3 & (1.42) \\
\hline 1,000 or more & 86.9 & $(1.39)$ & 90.6 & (1.59) & 90.0 & $(1.37)$ & 77.3 & (1.61) & 79.5 & $(1.65)$ & 79.3 & (1.82) & 9.7 & $(1.40)$ & 11.1 & $(1.83)$ & 10.7 & (1.50) & 70.3 & (1.67) & 73.5 & $(1.62)$ & 74.6 & $(1.75)$ \\
\hline \multicolumn{25}{|l|}{ Locale } \\
\hline & 49.1 & $(2.57)$ & 57.3 & $(3.05)$ & 50.9 & $(2.51)$ & 37.7 & (2.04) & 45.3 & (2.24) & 39.7 & $(2$. & 11.4 & (1.59) & 12.0 & $(1.97)$ & 11.2 & (1.69) & 30.5 & (1.73) & 33.1 & (2.32) & 27.6 & (1.98) \\
\hline Suburb ...……………..... & 42.7 & (1.67) & 45.4 & $(2.08)$ & 45.4 & $(1.90)$ & & $(1.41)$ & & $(1.64)$ & 31.3 & $(1$. & 150 & (1. & 15.4 & & 14.1 & & 32.2 & & 33.7 & & 29.6 & (1.45) \\
\hline ................. & 44.4 & (3.86) & 51.1 & (3.50) & 39.0 & (3.11) & 26.3 & (2.88) & 26.9 & (2.32) & 21.2 & $(2.1$ & 18.1 & $(2.90)$ & 24.2 & $(2.75)$ & 17.8 & (2.39) & 38.1 & (3.62) & 45.0 & (3.54) & 31.6 & $(2.81)$ \\
\hline Rural .. & 33.8 & $(1.87)$ & 36.0 & $(1.98)$ & 35.2 & $(2.20)$ & 18.6 & (1.39) & 20.2 & (1.67) & 20.5 & $(1.83)$ & 15.2 & $(1.87)$ & 15.7 & $(1.70)$ & 14.7 & (1.51) & 27.1 & (1.84) & 30.5 & (2.05) & 25.3 & (1.78) \\
\hline \multicolumn{25}{|l|}{$\begin{array}{l}\text { Percent combined enrollment of Black, } \\
\text { Hispanic, Asian/Pacific Islander, and } \\
\text { American Indian/Alaska Native students }\end{array}$} \\
\hline Less than 5 percent & 28.3 & $(1.96)$ & 35.6 & $(3.2$ & 30.4 & $(2.69)$ & 12.4 & $(1.60)$ & 16.9 & $(2.7$ & 13.6 & $(2$. & 16.0 & $(1.8$ & 18.7 & $(2$. & 16.8 & (2.51) & 22.9 & $(2$. & 27.1 & (2.95) & 21.9 & (2.25) \\
\hline & 38.9 & $(2.5$ & 42.9 & $(2$. & & $(2$. & & $(1)$. & 001 & (1. & & $(2)$. & 15.0 & (1. & 19.9 & (1. & 16.6 & & 30.2 & $(2)$. & 37.7 & & 27.6 & (2.08) \\
\hline 20 percent to less th & 41.6 & $(2.32)$ & 44.7 & $(2.76)$ & 41.9 & $(1.93)$ & $2 \varepsilon$ & (1.94) & 29 & $(2$. & 27.8 & (1.69) & 13.3 & $(1.75)$ & 15.5 & $(1$. & 14.1 & (1.50) & 35.3 & (1.97) & 38.4 & $(2.65)$ & 30.5 & $(1.89)$ \\
\hline 50 percent or more & 51.3 & $(2.46)$ & 55.4 & $(2.71)$ & 52.5 & $(2.04)$ & 37.3 & $(1.91)$ & 43.8 & (2.16) & 41.3 & $(2.09)$ & 14.0 & $(1.81)$ & 11.6 & $(1.68)$ & 11.2 & $(1.33)$ & 31.3 & (1.84) & 31.8 & $(2.07)$ & 29.1 & (1.53) \\
\hline $\begin{array}{l}\text { Percent of students eligible for free or reduced- } \\
\text { price lunch }\end{array}$ & & & & & & & & & & & & & & & & & & & & & & & & \\
\hline $0-25$ perc & 37.9 & (2.14) & 46.5 & (1) & 39.2 & $(2.44)$ & 24.9 & $(1.70)$ & 29.7 & $(2.01)$ & 27.9 & (2. & 13.0 & $(1$. & 16.8 & $(1$. & 11.3 & (1.21) & 30.3 & (1.95) & 34.8 & (2.12) & 27.2 & (1.93) \\
\hline & 42.1 & $(2.08)$ & 40.8 & $(2.52)$ & 40.0 & $(1.68)$ & 26.4 & (1.63) & 24.2 & (2.01) & 21.5 & $(1.52)$ & 15.7 & $(2.01)$ & 16.6 & $(1.65)$ & 18.5 & (1.37) & 33.8 & (1.78) & 35.2 & (2.02) & 30.3 & (1.59) \\
\hline & 39.3 & $(2.2$ & 46.1 & $(2.8$ & 42.3 & $(2.6$ & 25.7 & (1.85) & 29.7 & $(2.34)$ & 29.0 & $(2$. & 13.7 & $(1.9$ & 16 & $(2.3)-3$ & 13.3 & (1.45) & 31 & $(2.05)$ & 35.8 & (2.77) & 27.4 & (2.07) \\
\hline 76-100 percent .. & 49.8 & $(2.73)$ & 55.0 & (3.68) & 49.8 & $(2.76)$ & 33.0 & (2.49) & 42.1 & $(3.17)$ & 37.6 & $(2.66)$ & 16.8 & $(2.07)$ & 12.9 & $(2.17)$ & 12.2 & (1.84) & 25.6 & (2.17) & 29.7 & (2.68) & 26.8 & (2.32) \\
\hline
\end{tabular}

!Interpret data with caution. The coefficient of variation (CV) for this estimate is between 30 and 50 percent.

"Security guards" and "security personnel" do not include law enforcement. School Resource Officers include all career law enforce-

higher than grade 9. High schools are defined as schools in which the lowest grade is not lower than grade 9 and the highest grade ment officers with arrest authority who have specialized training and are assigned to work in collaboration with school organizations. 2The survey item about carrying firearms did not include the term "School Resource Officer" in the question text. 3Primary schools are defined as schools in which the lowest grade is not higher than grade 3 and the highest grade is not higher
than grade 8 . Middle schools are defined as schools in which the lowest grade is not lower than grade 4 and the highest grade is not is not higher than grade 12. Combined schools include all other combinations of grades, including $\mathrm{K}-12$ schools. NOTE: Responses were provided by the principal or the person most knowledgeable about crime and safety issues at the school. SOURCE: U.S. Department of Education, National Center for Education Statistics, 2005-06, 2007-08, and 2009-10 School Survey on Crime and Safety (SSOCS), 2006, 2008, and 2010. (This table was prepared September 2013.) 
344 CHAPTER 2: Elementary and Secondary Education

Discipline, Safety, and Security Measures

Table 233.80. Percentage of students ages 12-18 who reported various security measures at school: Selected years, 1999 through 2011

[Standard errors appear in parentheses]

\begin{tabular}{|c|c|c|c|c|c|c|c|c|c|c|c|c|c|c|}
\hline Security measure & & 1999 & & 2001 & & 2003 & & 2005 & & 2007 & & 2009 & & 2011 \\
\hline 1 & & 2 & & 3 & & 4 & & 5 & & 6 & & 7 & & 8 \\
\hline Total, at least one of the listed security measures ........................... & - & $(t)$ & 99.4 & $(0.09)$ & 99.3 & (0.12) & 99.6 & $(0.10)$ & 99.8 & $(0.06)$ & 99.3 & $(0.10)$ & 99.6 & $(0.08)$ \\
\hline Metal detectors & 9.0 & $(0.51)$ & 8.7 & $(0.61)$ & 10.1 & $(0.84)$ & 10.7 & $(0.74)$ & 10.1 & $(0.51)$ & 10.6 & $(0.76)$ & 11.2 & $(0.64)$ \\
\hline Locker checks..... & 53.3 & $(0.83)$ & 53.5 & $(0.92)$ & 53.0 & $(0.91)$ & 53.2 & $(0.90)$ & 53.6 & $(0.95)$ & 53.8 & (1.17) & 53.0 & (0.99) \\
\hline One or more security cameras to monitor the school.... & - & $(\dagger)$ & 38.5 & (1.13) & 47.9 & $(1.16)$ & 57.9 & (1.35) & 66.0 & $(0.99)$ & 70.0 & (1.05) & 76.7 & $(0.83)$ \\
\hline Security guards and/or assigned police officers.... & 54.1 & $(1.36)$ & 63.6 & $(1.25)$ & 69.6 & $(0.91)$ & 68.3 & (1.13) & 68.8 & $(0.98)$ & 68.1 & $(1.05)$ & 69.8 & (1.01) \\
\hline Other school staff or other adults supervising the hallway .. & 85.4 & $(0.54)$ & 88.3 & $(0.45)$ & 90.6 & $(0.39)$ & 90.1 & $(0.42)$ & 90.0 & $(0.50)$ & 90.6 & $(0.46)$ & 88.9 & $(0.46)$ \\
\hline A requirement that students wear badges or picture identification... & - & $(\dagger)$ & 21.2 & (0.99) & 22.5 & $(1.11)$ & 24.9 & $(1.20)$ & 24.3 & $(1.00)$ & 23.4 & (1.14) & 24.8 & (1.02) \\
\hline 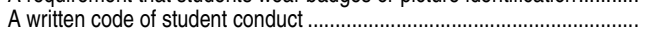 & - & $(\dagger)$ & 95.1 & $(0.34)$ & 95.3 & $(0.37)$ & 95.5 & $(0.36)$ & 95.9 & $(0.29)$ & 95.6 & (0.39) & 95.7 & $(0.30)$ \\
\hline 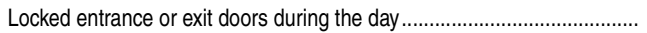 & 38.1 & $(0.97)$ & 48.8 & $(1.12)$ & 52.8 & $(1.16)$ & 54.3 & $(1.06)$ & 60.9 & $(1.07)$ & 64.3 & (1.27) & 64.5 & (1.02) \\
\hline 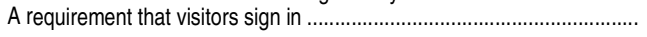 & 87.1 & $(0.62)$ & 90.2 & $(0.58)$ & 91.7 & $(0.48)$ & 93.0 & $(0.49)$ & 94.3 & $(0.38)$ & 94.3 & (0.52) & 94.9 & (0.37) \\
\hline
\end{tabular}

-Not available.

†Not applicable.

NOTE: "At school" includes the school building, on school property, on a school bus, and,

from 2001 onward, going to and from school.
SOURCE: U.S. Department of Justice, Bureau of Justice Statistics, School Crime Supplement (SCS) to the National Crime Victimization Survey, selected years, 1999 through 2011 (This table was prepared September 2013.) 
Table 234.10. Age range for compulsory school attendance and special education services, and policies on year-round schools and kindergarten programs, by state: Selected years, 2000 through 2014

\begin{tabular}{|c|c|c|c|c|c|c|c|c|c|c|c|c|c|}
\hline \multirow[b]{3}{*}{ State } & \multicolumn{7}{|c|}{ Compulsory attendance } & \multirow{3}{*}{$\begin{array}{r}\text { Compulsory } \\
\text { special } \\
\text { education } \\
\text { services, } 2004^{1}\end{array}$} & \multicolumn{2}{|c|}{$\begin{array}{c}\text { Year-round } \\
\text { schools, } 2008\end{array}$} & \multicolumn{3}{|c|}{ Kindergarten programs, 2014} \\
\hline & \multirow[b]{2}{*}{2000} & \multirow[b]{2}{*}{2002} & \multirow[b]{2}{*}{2004} & \multirow[b]{2}{*}{2006} & \multirow[b]{2}{*}{2008} & \multirow[b]{2}{*}{2010} & \multirow[b]{2}{*}{2013} & & \multirow{2}{*}{$\begin{array}{r}\text { Has policy } \\
\text { on year- } \\
\text { round } \\
\text { schools }\end{array}$} & \multirow{2}{*}{$\begin{array}{r}\text { Has } \\
\text { districts } \\
\text { with year- } \\
\text { round } \\
\text { schools }\end{array}$} & \multicolumn{2}{|c|}{$\begin{array}{l}\text { School districts } \\
\text { required to offer }\end{array}$} & \multirow[b]{2}{*}{$\begin{array}{r}\text { Attendance } \\
\text { required }\end{array}$} \\
\hline & & & & & & & & & & & Program & $\begin{array}{c}\text { Full-day } \\
\text { program }\end{array}$ & \\
\hline 1 & 2 & 3 & 4 & 5 & 6 & 7 & 8 & 9 & 10 & 11 & 12 & 13 & 14 \\
\hline 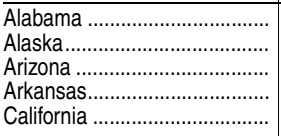 & $\begin{array}{l}7 \text { to } 16 \\
7 \text { to } 16 \\
6 \text { to } 16^{2} \\
5 \text { to } 17^{2,3} \\
6 \text { to } 18^{2}\end{array}$ & $\begin{array}{l}7 \text { to } 16 \\
7 \text { to } 16 \\
6 \text { to } 16^{2} \\
5 \text { to } 17^{2,3} \\
6 \text { to } 18\end{array}$ & $\begin{array}{l}7 \text { to } 16^{2} \\
7 \text { to } 16^{2} \\
6 \text { to } 16^{2} \\
5 \text { to } 17^{2,3} \\
6 \text { to } 18\end{array}$ & $\begin{array}{l}7 \text { to } 16 \\
7 \text { to } 16 \\
6 \text { to } 16^{2} \\
5 \text { to } 17^{2,3} \\
6 \text { to } 18\end{array}$ & $\begin{array}{l}7 \text { to } 16 \\
7 \text { to } 16 \\
6 \text { to } 16^{2} \\
5 \text { to } 17^{2,3} \\
6 \text { to } 18\end{array}$ & $\begin{array}{l}7 \text { to } 17 \\
7 \text { to } 16 \\
6 \text { to } 16^{2} \\
5 \text { to } 17^{2,3} \\
6 \text { to } 18\end{array}$ & $\begin{array}{l}6 \text { to } 17 \\
7 \text { to } 16 \\
6 \text { to } 16^{2} \\
5 \text { to } 17 \\
6 \text { to } 18\end{array}$ & $\begin{array}{c}6 \text { to } 21 \\
3 \text { to } 22 \\
3 \text { to } 21 \\
5 \text { to } 21 \\
\text { Birth to } 214\end{array}$ & $\begin{array}{l}\bar{x} \\
x\end{array}$ & $\begin{array}{l}\text { Yes } \\
\text { Yes } \\
\text { Yes } \\
\text { Yes }\end{array}$ & \begin{tabular}{l|}
$x$ \\
$X$ \\
$X$ \\
$X$
\end{tabular} & $\mathrm{X}$ & $X$ \\
\hline 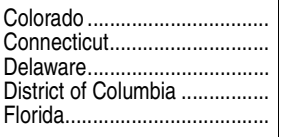 & $\begin{array}{l}7 \text { to } \overline{16} \\
5 \text { to } \frac{16}{-} \\
6 \text { to } \overline{16}\end{array}$ & $\begin{array}{l}7 \text { to } \overline{18^{2}} \\
5 \text { to } 16^{2} \\
5 \text { to } 18^{5} \\
6 \text { to } 16^{5}\end{array}$ & $\begin{array}{l}7 \text { to } 16 \\
7 \text { to } 18^{2} \\
5 \text { to } 16^{2} \\
5 \text { to } 18^{2} \\
6 \text { to } 16^{5}\end{array}$ & $\begin{array}{l}7 \text { to } 16 \\
5 \text { to } 18^{3} \\
5 \text { to } 16 \\
5 \text { to } 18 \\
6 \text { to } 16^{5}\end{array}$ & $\begin{array}{l}6 \text { to } 17 \\
5 \text { to } 18^{3} \\
5 \text { to } 16 \\
5 \text { to } 18 \\
6 \text { to } 16^{5}\end{array}$ & $\begin{array}{l}6 \text { to } 17 \\
5 \text { to } 18^{3} \\
5 \text { to } 16 \\
5 \text { to } 18 \\
6 \text { to } 16^{5}\end{array}$ & $\begin{array}{l}6 \text { to } 17 \\
5 \text { to } 18 \\
5 \text { to } 16 \\
5 \text { to } 18 \\
6 \text { to } 16\end{array}$ & $\begin{array}{r}3 \text { to } 21 \\
3 \text { to } 21 \\
\text { Birth to } 20 \\
3 \text { to } \overline{21}\end{array}$ & $\bar{x}$ & $\begin{array}{l}\text { Yes } \\
\frac{-}{\text { Yes }} \\
\text { Yes }\end{array}$ & $\begin{array}{l}x \\
x \\
x \\
X \\
x \\
X\end{array}$ & $\begin{array}{l}X \\
X\end{array}$ & $\begin{array}{l}X \\
X \\
X\end{array}$ \\
\hline 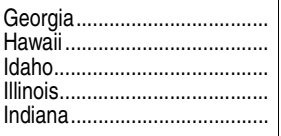 & $\begin{array}{l}6 \text { to } 16 \\
6 \text { to } 18 \\
7 \text { to } 16 \\
7 \text { to } 16 \\
7 \text { to } 16\end{array}$ & $\begin{array}{l}6 \text { to } 16 \\
6 \text { to } 18 \\
7 \text { to } 16 \\
7 \text { to } 16 \\
7 \text { to } 16\end{array}$ & $\begin{array}{l}6 \text { to } 16 \\
6 \text { to } 18 \\
7 \text { to } 16 \\
7 \text { to } 17 \\
7 \text { to } 16\end{array}$ & $\begin{array}{l}6 \text { to } 16 \\
6 \text { to } 18 \\
7 \text { to } 16 \\
7 \text { to } 17 \\
7 \text { to } 18^{2}\end{array}$ & $\begin{array}{l}6 \text { to } 16 \\
6 \text { to } 18 \\
7 \text { to } 16 \\
7 \text { to } 17 \\
7 \text { to } 18^{2}\end{array}$ & $\begin{array}{l}6 \text { to } 16 \\
6 \text { to } 18 \\
7 \text { to } 16 \\
7 \text { to } 17 \\
7 \text { to } 18^{2}\end{array}$ & $\begin{array}{l}6 \text { to } 16 \\
6 \text { to } 18 \\
7 \text { to } 16 \\
7 \text { to } 17 \\
7 \text { to } 16\end{array}$ & $\begin{array}{l}\text { Birth to } 21^{6} \\
\text { Birth to } 19 \\
3 \text { to } 21 \\
3 \text { to } 21 \\
3 \text { to } 22\end{array}$ & $X$ & $\begin{array}{r}\text { Yes } \\
(7) \\
\text { Yes } \\
\text { Yes } \\
\text { Yes }\end{array}$ & $\begin{array}{l}x \\
x \\
X \\
X\end{array}$ & & \\
\hline 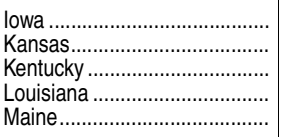 & $\begin{array}{l}6 \text { to } 16^{2} \\
7 \text { to } 18^{2} \\
6 \text { to } 16^{2} \\
7 \text { to } 17 \\
7 \text { to } 17\end{array}$ & $\begin{array}{l}6 \text { to } 16^{2} \\
7 \text { to } 18^{2} \\
6 \text { to } 16^{2} \\
7 \text { to } 17 \\
7 \text { to } 17\end{array}$ & $\begin{array}{l}6 \text { to } 16^{2} \\
7 \text { to } 18^{2} \\
6 \text { to } 16^{2} \\
7 \text { to } 17^{2} \\
7 \text { to } 17^{2}\end{array}$ & $\begin{array}{l}6 \text { to } 16 \\
7 \text { to } 18^{2} \\
6 \text { to } 16^{2} \\
7 \text { to } 18^{2} \\
7 \text { to } 17^{2}\end{array}$ & $\begin{array}{l}6 \text { to } 16 \\
7 \text { to } 18^{2} \\
6 \text { to } 16 \\
7 \text { to } 18^{2} \\
7 \text { to } 17^{2}\end{array}$ & $\begin{array}{l}6 \text { to } 16 \\
7 \text { to } 18^{2} \\
6 \text { to } 16 \\
7 \text { to } 18^{2} \\
7 \text { to } 17^{2}\end{array}$ & $\begin{array}{l}6 \text { to } 16 \\
7 \text { to } 18 \\
6 \text { to } 16 \\
7 \text { to } 18 \\
7 \text { to } 17\end{array}$ & $\begin{array}{l}\text { Birth to } 21 \\
3 \text { to } 21^{8} \\
\text { Birth to } 21 \\
3 \text { to } 21^{9} \\
5 \text { to } 19^{9,10}\end{array}$ & $x$ & $\begin{array}{l}\text { Yes } \\
\text { Yes } \\
\text { Yes } \\
-\end{array}$ & $\begin{array}{l}x \\
x \\
X \\
X \\
x \\
x\end{array}$ & $x$ & $x$ \\
\hline 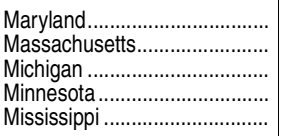 & $\begin{array}{l}5 \text { to } 16 \\
6 \text { to } 16 \\
6 \text { to } 16 \\
7 \text { to } 18^{2} \\
6 \text { to } 17\end{array}$ & $\begin{array}{l}5 \text { to } 16 \\
6 \text { to } 16 \\
6 \text { to } 16 \\
7 \text { to } 16 \\
6 \text { to } 17\end{array}$ & $\begin{array}{l}5 \text { to } 16 \\
6 \text { to } 16 \\
6 \text { to } 16 \\
7 \text { to } 16 \\
6 \text { to } 16\end{array}$ & $\begin{array}{l}5 \text { to } 16 \\
6 \text { to } 16^{2} \\
6 \text { to } 16 \\
7 \text { to } 16^{2} \\
6 \text { to } 16\end{array}$ & $\begin{array}{l}5 \text { to } 16 \\
6 \text { to } 16^{2} \\
6 \text { to } 16^{2} \\
7 \text { to } 16^{2} \\
6 \text { to } 17\end{array}$ & $\begin{array}{l}5 \text { to } 16^{3} \\
6 \text { to } 16^{2} \\
6 \text { to } 18^{2} \\
7 \text { to } 16^{2} \\
6 \text { to } 17\end{array}$ & $\begin{array}{l}5 \text { to } 16 \\
6 \text { to } 16 \\
6 \text { to } 16 \\
7 \text { to } 16 \\
6 \text { to } 17\end{array}$ & $\begin{array}{l}\text { Birth to } 21 \\
3 \text { to } 21^{6} \\
\text { Birth to } 25 \\
\text { Birth to } 21 \\
\text { Birth to } 20\end{array}$ & $\begin{array}{r}X \\
\left({ }^{11}\right) \\
X \\
X\end{array}$ & $\begin{array}{l}\overline{-} \\
\text { Yes } \\
\text { Yes } \\
-\end{array}$ & $\begin{array}{l}x \\
X \\
X \\
X \\
X \\
X\end{array}$ & $x$ & $x$ \\
\hline 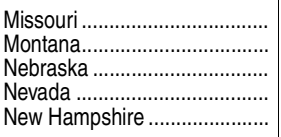 & $\begin{array}{l}7 \text { to } 16 \\
7 \text { to } 16^{2} \\
7 \text { to } 16 \\
7 \text { to } 17 \\
6 \text { to } 16\end{array}$ & $\begin{array}{l}7 \text { to } 16 \\
7 \text { to } 16^{2} \\
7 \text { to } 16 \\
7 \text { to } 17 \\
6 \text { to } 16\end{array}$ & $\begin{array}{l}7 \text { to } 16 \\
7 \text { to } 16^{2} \\
7 \text { to } 16 \\
7 \text { to } 17 \\
6 \text { to } 16\end{array}$ & $\begin{array}{l}7 \text { to } 16 \\
7 \text { to } 16^{2} \\
6 \text { to } 18 \\
7 \text { to } 17 \\
6 \text { to } 16\end{array}$ & $\begin{array}{l}7 \text { to } 16 \\
7 \text { to } 16^{2} \\
6 \text { to } 18^{2} \\
7 \text { to } 18^{2} \\
6 \text { to } 16\end{array}$ & $\begin{array}{l}7 \text { to } 17 \\
7 \text { to } 16^{2} \\
6 \text { to } 18^{2} \\
7 \text { to } 18^{2} \\
6 \text { to } 18\end{array}$ & $\begin{array}{l}7 \text { to } 16 \\
7 \text { to } 16 \\
6 \text { to } 18 \\
7 \text { to } 18 \\
6 \text { to } 18\end{array}$ & $\begin{array}{l}\text { Birth to } 20 \\
3 \text { to } 18^{9} \\
\text { Birth to } 20 \\
\text { Birth to } 21^{4} \\
3 \text { to } 21^{4}\end{array}$ & & $\begin{array}{l}\text { Yes }{ }^{12} \\
\text { Yes } \\
\text { Yes } \\
-\end{array}$ & $\begin{array}{l}x \\
x \\
X \\
X \\
X \\
x\end{array}$ & 13 & $X$ \\
\hline 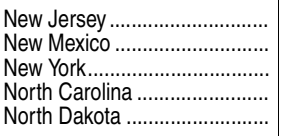 & $\begin{array}{l}6 \text { to } 16 \\
5 \text { to } 18 \\
6 \text { to } 16^{2} \\
7 \text { to } 16 \\
7 \text { to } 16\end{array}$ & $\begin{array}{l}6 \text { to } 16 \\
5 \text { to } 18 \\
6 \text { to } 16 \\
7 \text { to } 16 \\
7 \text { to } 16\end{array}$ & $\begin{array}{l}6 \text { to } 16 \\
5 \text { to } 18^{2} \\
6 \text { to } 16 \\
7 \text { to } 16 \\
7 \text { to } 16\end{array}$ & $\begin{array}{l}6 \text { to } 16 \\
5 \text { to } 18^{2} \\
6 \text { to } 16^{15} \\
7 \text { to } 16 \\
7 \text { to } 16\end{array}$ & $\begin{array}{l}6 \text { to } 16 \\
5 \text { to } 18^{2} \\
6 \text { to } 16^{15} \\
7 \text { to } 16 \\
7 \text { to } 16\end{array}$ & $\begin{array}{l}6 \text { to } 16 \\
5 \text { to } 18^{2} \\
6 \text { to } 16^{15} \\
7 \text { to } 16 \\
7 \text { to } 16\end{array}$ & $\begin{array}{l}6 \text { to } 16 \\
5 \text { to } 18 \\
6 \text { to } 16 \\
7 \text { to } 16 \\
7 \text { to } 16\end{array}$ & $\begin{array}{r}5 \text { to } 21 \\
3 \text { to } 21 \\
\text { Birth to } 20 \\
5 \text { to } 20 \\
3 \text { to } 21\end{array}$ & $\begin{array}{l}x \\
x\end{array}$ & $\begin{array}{l}- \\
\text { Yes } \\
\text { Yes } \\
\text { No }\end{array}$ & $\begin{array}{l}x \\
x \\
X\end{array}$ & $x$ & $X$ \\
\hline 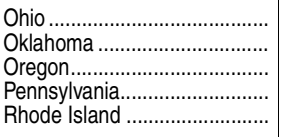 & $\begin{array}{l}6 \text { to } 18 \\
5 \text { to } 18 \\
7 \text { to } 18 \\
8 \text { to } 17 \\
6 \text { to } 16\end{array}$ & $\begin{array}{l}6 \text { to } 18 \\
5 \text { to } 18 \\
7 \text { to } 18 \\
8 \text { to } 17 \\
6 \text { to } 16\end{array}$ & $\begin{array}{l}6 \text { to } 18 \\
5 \text { to } 18 \\
7 \text { to } 18^{2} \\
8 \text { to } 17^{2} \\
6 \text { to } 16\end{array}$ & $\begin{array}{l}6 \text { to } 18 \\
5 \text { to } 18 \\
7 \text { to } 18 \\
8 \text { to } 172 \\
6 \text { to } 16\end{array}$ & $\begin{array}{l}6 \text { to } 18 \\
5 \text { to } 18 \\
7 \text { to } 18 \\
8 \text { to } 172 \\
6 \text { to } 16\end{array}$ & $\begin{array}{l}6 \text { to } 18 \\
5 \text { to } 18 \\
7 \text { to } 18^{2} \\
8 \text { to } 17^{2} \\
6 \text { to } 16\end{array}$ & $\begin{array}{l}6 \text { to } 18 \\
5 \text { to } 18 \\
7 \text { to } 18 \\
8 \text { to } 17 \\
6 \text { to } 16^{2}\end{array}$ & $\begin{array}{c}3 \text { to } 21 \\
\text { Birth to } 21^{9} \\
3 \text { to } 20 \\
6 \text { to } 21 \\
3 \text { to } 21\end{array}$ & $X^{12}$ & $\begin{array}{l}- \\
\text { Yes } \\
\text { Yes } \\
-12 \\
-\end{array}$ & $\begin{array}{l}x \\
X \\
X \\
X\end{array}$ & $X$ & $\begin{array}{l}X \\
X\end{array}$ \\
\hline 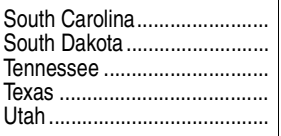 & $\begin{array}{l}5 \text { to } 16 \\
6 \text { to } 16 \\
6 \text { to } 17 \\
6 \text { to } 18 \\
6 \text { to } 18\end{array}$ & $\begin{array}{l}5 \text { to } 16 \\
6 \text { to } 16 \\
6 \text { to } 17 \\
6 \text { to } 18 \\
6 \text { to } 18\end{array}$ & $\begin{array}{l}5 \text { to } 16 \\
6 \text { to } 16 \\
6 \text { to } 17 \\
6 \text { to } 18 \\
6 \text { to } 18\end{array}$ & $\begin{array}{l}5 \text { to } 17^{3} \\
6 \text { to } 16^{3} \\
6 \text { to } 17^{3} \\
6 \text { to } 18 \\
6 \text { to } 18\end{array}$ & $\begin{array}{l}5 \text { to } 17^{3} \\
6 \text { to } 16 \\
6 \text { to } 17^{3} \\
6 \text { to } 18 \\
6 \text { to } 18\end{array}$ & $\begin{array}{l}5 \text { to } 17^{3} \\
6 \text { to } 18^{2} \\
6 \text { to } 17^{3} \\
6 \text { to } 18^{3} \\
6 \text { to } 18\end{array}$ & $\begin{array}{l}5 \text { to } 17 \\
6 \text { to } 18^{2} \\
6 \text { to } 17 \\
6 \text { to } 18 \\
6 \text { to } 18\end{array}$ & $\begin{array}{c}3 \text { to } 211^{16} \\
\text { Birth to } 21 \\
3 \text { to } 21^{4} \\
3 \text { to } 21 \\
3 \text { to } 22\end{array}$ & $\begin{array}{l}X \\
X \\
X\end{array}$ & $\begin{array}{l}- \\
\text { Yes } \\
\text { Yes } \\
\text { Yes }\end{array}$ & $\begin{array}{l}x \\
x \\
x \\
x \\
x \\
x\end{array}$ & $\begin{array}{l}x \\
X\end{array}$ & $\begin{array}{l}X \\
X^{17} \\
X\end{array}$ \\
\hline 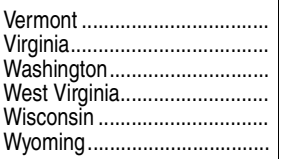 & $\begin{array}{l}7 \text { to } 16 \\
5 \text { to } 18 \\
8 \text { to } 17^{2} \\
6 \text { to } 16 \\
6 \text { to } 18 \\
6 \text { to } 16^{2}\end{array}$ & $\begin{array}{l}6 \text { to } 16 \\
5 \text { to } 18 \\
8 \text { to } 17^{2} \\
6 \text { to } 16 \\
6 \text { to } 18 \\
6 \text { to } 16^{2}\end{array}$ & $\begin{array}{l}6 \text { to } 16 \\
5 \text { to } 18 \\
8 \text { to } 16^{2} \\
6 \text { to } 16 \\
6 \text { to } 18 \\
7 \text { to } 16^{2}\end{array}$ & $\begin{array}{l}6 \text { to } 16^{2} \\
5 \text { to } 18^{2} \\
8 \text { to } 18 \\
6 \text { to } 16 \\
6 \text { to } 18 \\
7 \text { to } 16^{2}\end{array}$ & $\begin{array}{l}6 \text { to } 16^{2} \\
5 \text { to } 18^{2} \\
8 \text { to } 18 \\
6 \text { to } 16 \\
6 \text { to } 18 \\
7 \text { to } 16^{2}\end{array}$ & $\begin{array}{l}6 \text { to } 16^{2} \\
5 \text { to } 18^{2,3} \\
8 \text { to } 18 \\
6 \text { to } 17 \\
6 \text { to } 18 \\
7 \text { to } 16^{2}\end{array}$ & $\begin{array}{l}6 \text { to } 16^{2} \\
5 \text { to } 18 \\
8 \text { to } 18 \\
6 \text { to } 16 \\
6 \text { to } 18 \\
7 \text { to } 16\end{array}$ & $\begin{array}{l}3 \text { to } 21 \\
2 \text { to } 21 \\
3 \text { to } 2116 \\
5 \text { to } 211^{19} \\
3 \text { to } 21 \\
3 \text { to } 21\end{array}$ & $\begin{array}{l}x \\
x\end{array}$ & $\begin{array}{l}-^{12} \\
\text { Yes } \\
\text { Yes } \\
\text { Yes } \\
\text { Yes } \\
-\end{array}$ & $\begin{array}{l}x \\
x \\
X \\
x \\
X \\
x \\
x\end{array}$ & $\begin{array}{l}18 \\
X \\
20\end{array}$ & $\begin{array}{l}x \\
x\end{array}$ \\
\hline
\end{tabular}

\section{-Not available.}

$X$ Denotes that the state has a policy. A blank denotes that the state does not have a policy. ${ }^{1}$ Most states have a provision whereby education is provided up to a certain age or completion of secondary school, whichever comes first.

2Child may be exempted from compulsory attendance if he/she meets state requirements for early withdrawal with or without meeting conditions for a diploma or equivalency.

${ }^{3}$ Parent/guardian may delay child's entry until a later age per state law/regulation.

${ }^{4}$ Student may continue in the program if 22nd birthday falls before the end of the school year. ${ }^{5}$ Attendance is compulsory until age 18 for Manatee County students, unless they earn a high school diploma prior to reaching their 18 th birthday.

${ }^{6}$ Through age 21 or until child graduates with a high school or special education diploma or equivalent.

Some districts operate on a multitrack system; the schools are open year-round, but different cohorts start and end at different times.

${ }^{8}$ To be determined by rules and regulations adopted by the state board.

${ }^{9} \mathrm{C}$ ildren from birth through age 2 are eligible for additional services.

${ }^{10}$ Must be age 5 before October 15 , and not age 20 before start of school year.

${ }_{11}^{1}$ Policies about year-round schools are decided locally.

${ }^{12}$ State did not participate in 2008 online survey. Data are from 2006

${ }^{13}$ In certain school districts in Nevada, the lowest performing schools with the highest num

bers of limited English proficient students will start offering full-day kindergarten programs.

${ }^{14}$ The Abbott District is required to offer full-day kindergarten.
${ }^{15} \mathrm{New}$ York City and Buffalo require school attendance until age 17 unless employed; Syracuse requires kindergarten attendance at age 5 .

${ }^{16}$ Student may complete school year if 21 st birthday occurs while attending school. ${ }^{17} \mathrm{All}$ children must attend kindergarten before age 7 .

${ }^{18}$ Full-day kindergarten is being phased in beginning in the 2012-13 school year, beginning with the highest poverty schools. Statewide implementation will be achieved by 2017-18. ${ }^{19}$ Severely handicapped children may begin receiving services at age 3 .

${ }^{20}$ Statute requires one full-day program per district.

NOTE: The Education of the Handicapped Act (EHA) Amendments of 1986 make it mandatory for all states receiving EHA funds to serve all 3- to 18-year-old disabled children

SOURCE: Council of Chief State School Officers, Key State Education Policies on PK-12 Education, 2000, 2002, 2004, and 2008; Education Commission of the States (ECS), ECS StateNotes, Compulsory School Age Requirements, retrieved August 9, 2010, from http:// www.ecs.org/clearinghouse/86/62/8662.pdf; ECS StateNotes, Special Education: State Special Education Definitions, Ages Served, retrieved August 9, 2010, from http://www.ecs.org/ clearinghouse/52/29/5229.pdf; ECS StateNotes, Compulsory School Age Requirements, retrieved April 18, 2014, from http://www.ecs.org/clearinghouse/01/07/03/10703.pdf; ECS StateNotes, District Must Offer Kindergarten, retrieved April 18, 2014, from http:// StateNotes, District Must Offer Kindergarten, retrieved April 18, 2014, from hittp://
ecs.force.com/mbdata/mbquestRT?rep=Kq1416; ECS StateNotes, Child Must Attend Kinderecs.force.com/mbdata/mbquestRT?rep=Kq1416; ECS StateNotes, Child Must Attend Kinderand supplemental information retrieved from various state websites. (This table was prepared April 2014.) 
Table 234.20. Minimum amount of instructional time per year and policy on textbook selection, by state: Selected years, 2000 through 2013

\begin{tabular}{|c|c|c|c|c|c|c|c|c|c|c|c|}
\hline \multirow[b]{3}{*}{ State } & \multicolumn{5}{|c|}{ Minimum amount of instructional time per year } & \multicolumn{5}{|c|}{ State policy on textbook selection, 2008} & $\stackrel{\mathscr{O}}{\stackrel{O}{\perp}}$ \\
\hline & \multicolumn{4}{|c|}{ In days } & In hours & \multicolumn{3}{|c|}{ State recommends or selects textbooks } & \multirow[b]{2}{*}{ Local decision } & \multirow[b]{2}{*}{$\begin{array}{r}\text { State } \\
\text { standards used }\end{array}$} & \\
\hline & 2000 & 2006 & 2011 & 2013 & 2013 & Recommends & Selects & $\begin{array}{r}\text { Either } \\
\text { recommends } \\
\text { or selects }\end{array}$ & & & 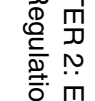 \\
\hline 1 & 2 & 3 & 4 & 5 & 6 & 7 & 8 & 9 & 10 & $\overline{11}$ & \\
\hline $\begin{array}{l}\text { Alabama ................. } \\
\text { Alaska.................. } \\
\text { Arizona ................ } \\
\text { Arkansas.............. } \\
\text { California ............... }\end{array}$ & $\begin{array}{r}175 \\
180 \\
178 \\
175\end{array}$ & $\begin{array}{l}175 \\
180 \\
180 \\
178 \\
180\end{array}$ & \begin{tabular}{r|}
180 \\
$170^{1}$ \\
$180^{2}$ \\
$1788^{1}$ \\
$180 / 175^{4}$
\end{tabular} & $\begin{array}{r}180 \\
1701 \\
180^{2} \\
178{ }^{1} \\
180 / 175^{4}\end{array}$ & $\begin{array}{r}740(\mathrm{~K}-3) ; 900(4-12) \\
356(\mathrm{~K}) ; 712(1-3) ; 890(4-6) ; 1,000(7-8) ; 720^{3}(9-12) \\
\dagger \\
600 \text { (K); } 840(1-3) ; 900(4-8) ; 1,080(9-12)\end{array}$ & $\begin{array}{l}x \\
x\end{array}$ & & $\mathrm{x}$ & $\begin{array}{l}x \\
x\end{array}$ & $\bar{x}$ & 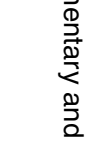 \\
\hline $\begin{array}{l}\text { Colorado ................. } \\
\text { Connecticut............ } \\
\text { Delaware............. } \\
\text { District of Columbia.. } \\
\text { Florida.................. }\end{array}$ & 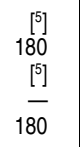 & $\begin{array}{r}160 \\
180 \\
\dagger \\
180 \\
180\end{array}$ & $\begin{array}{r}160 \\
180 \\
\dagger \\
178 \\
180\end{array}$ & $\begin{array}{r}160 \\
180 \\
\dagger \\
180 \\
180\end{array}$ & $\begin{array}{r}435 / 870(\mathrm{~K}) ; 968(1-5) ; 1,056(6-12) \\
450 / 900(\mathrm{~K}) ; 900(1-12) \\
1,060^{6}(\mathrm{~K}) ; 1,060(1-11) ; 1,032(12) \\
+ \\
720^{7}(\mathrm{~K}-3) ; 900^{7}(4-12)\end{array}$ & $x$ & & & $\begin{array}{l}x \\
x \\
x\end{array}$ & $x$ & 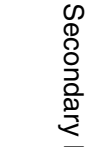 \\
\hline $\begin{array}{l}\text { Georgia.................. } \\
\text { Hawaii .................. } \\
\text { Idaho................. } \\
\text { Illinois.................. } \\
\text { Indiana................ }\end{array}$ & $\begin{array}{l}-\overline{184} \\
180 \\
180^{12} \\
180\end{array}$ & $\begin{array}{r}180 \\
179 \\
+ \\
176 \\
180\end{array}$ & \begin{tabular}{c|}
180 \\
$180^{8}$ \\
$\dagger$ \\
176 \\
180
\end{tabular} & $\begin{array}{c}180 \\
180^{8} \\
\dagger \\
176 \\
180\end{array}$ & $\begin{array}{r}810(\mathrm{~K}-3) ; 900(4-5) ; 990(6-12) \\
915(\mathrm{~K}-6) 8,9990(7-12)^{8,9} \\
450^{10}(\mathrm{~K}) ; 810^{10}(1-3) ; 900^{10}(4-8) ; 990^{10,11}(9-12) \\
\dagger \\
\dagger\end{array}$ & $\begin{array}{l}x \\
X \\
X \\
X\end{array}$ & & & $x$ & $\begin{array}{l}x \\
x \\
x \\
x\end{array}$ & 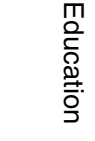 \\
\hline $\begin{array}{l}\text { lowa ..................... } \\
\text { Kansas................ } \\
\text { Kentucky .............. } \\
\text { Louisiana ............. } \\
\text { Maine.................. }\end{array}$ & $\begin{array}{l}180 \\
186 \\
175 \\
175 \\
175\end{array}$ & $\begin{array}{r}180 \\
186(\mathrm{~K}-11) ; 181(12) \\
175 \\
177 \\
175\end{array}$ & $\begin{array}{r}180 \\
186(\mathrm{~K}-11) ; 181(12) \\
175 \\
177 \\
175\end{array}$ & $\begin{array}{r}180 \\
186(\mathrm{~K}-11) ; 181(12) \\
175^{1} \\
177^{1} \\
175^{1}\end{array}$ & 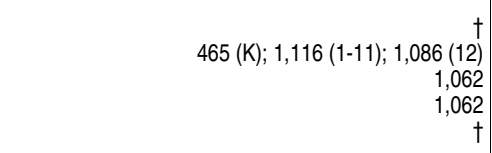 & $\mathrm{x}$ & & $x$ & $\begin{array}{l}x \\
x\end{array}$ & $x$ & \\
\hline $\begin{array}{l}\text { Maryland............... } \\
\text { Massachusetts....... } \\
\text { Michigan ............... } \\
\text { Minnesota............. } \\
\text { Mississippi .............. }\end{array}$ & $\begin{array}{r}180 \\
180 \\
180 \\
{ }^{[5]} \\
180\end{array}$ & $\begin{array}{r}180 \\
180 \\
\dagger \\
+[5] \\
180\end{array}$ & $\begin{array}{r}180 \\
180 \\
165 \\
\dagger \\
180\end{array}$ & $\begin{array}{r}180 \\
180 \\
170 \\
\dagger \\
180\end{array}$ & $\begin{array}{r}1,080 \\
425(\mathrm{~K}) ; 900(1-5) ; 990(6-12) \\
1,098 \\
425(\mathrm{~K}) ; 935(1-6) ; 1,020(7-12) \\
\dagger\end{array}$ & & $\mathrm{x}$ & & $\begin{array}{l}x \\
x \\
x \\
x\end{array}$ & & \\
\hline $\begin{array}{l}\text { Missouri .................. } \\
\text { Montana................ } \\
\text { Nebraska .............. } \\
\text { Nevada ............... } \\
\text { New Hampshire ...... }\end{array}$ & $\begin{array}{r}174 \\
180 \\
{\left[{ }^{5}\right]} \\
180 \\
180\end{array}$ & $\begin{array}{r}174 \\
90(\mathrm{~K}) ; 180(\mathrm{~K}-12) \\
\dagger \\
180 \\
180\end{array}$ & $\begin{array}{c}174 / 142^{13} \\
\dagger \\
\dagger \\
180 \\
180\end{array}$ & $\begin{array}{c}174 / 1422^{13} \\
\dagger \\
\dagger \\
180 \\
180\end{array}$ & $\begin{array}{r}1,044 \\
360 / 720^{1}(\mathrm{~K}) ; 720^{1}(1-3) ; 1,080^{1,11}(4-12) \\
400(\mathrm{~K}) ; 1,032(1-8) ; 1,080(9-12) \\
+ \\
450 \text { (K); } 945(1-5) ; 990(6-12)\end{array}$ & - & - & - & $\begin{array}{l}-\bar{x} \\
\mathrm{x} \\
\mathrm{x}\end{array}$ & - & \\
\hline $\begin{array}{l}\text { New Jersey ............. } \\
\text { New Mexico ........... } \\
\text { New York.............. } \\
\text { North Carolina ....... } \\
\text { North Dakota .......... }\end{array}$ & $\begin{array}{r}180 \\
180 \\
-\overline{180} \\
173\end{array}$ & $\begin{array}{l}180 \\
180 \\
180 \\
180 \\
173\end{array}$ & $\begin{array}{l}180 \\
180 \\
180 \\
180 \\
175^{1}\end{array}$ & $\begin{array}{l}180 \\
180 \\
190 \\
185 \\
175\end{array}$ & $\begin{array}{r}450 / 990^{14}(\mathrm{~K}) ; 990^{14}(1-6) ; 1,080(7-12) \\
\dagger \\
\dagger \\
1,025 \\
951.5(\mathrm{~K}-8) ; 1,038(9-12)\end{array}$ & & $\begin{array}{l}x \\
x\end{array}$ & & $\begin{array}{l}x \\
x \\
x\end{array}$ & $x$ & \\
\hline $\begin{array}{l}\text { Ohio ....................... } \\
\text { Oklahoma .............. } \\
\text { Oregon................ } \\
\text { Pennsylvania......... } \\
\text { Rhode Island .......... }\end{array}$ & $\begin{array}{r}182 \\
180 \\
{\left[{ }^{5}\right]} \\
180 \\
180\end{array}$ & $\begin{array}{r}182 \\
180 \\
\dagger \\
180 \\
180\end{array}$ & $\begin{array}{c}182{ }^{10} \\
180^{10} \\
\dagger \\
180 \\
180\end{array}$ & $\begin{array}{c}182^{10} \\
180^{10} \\
\dagger \\
180 \\
180\end{array}$ & $\begin{array}{r}900^{10}(1-6) ; 1,080^{10}(7-12) \\
405(\mathrm{~K}) ; 810(1-3) ; 900(4-8) ; 990^{11}(9-12) \\
450(\mathrm{~K}) ; 900(1-8) ; 990(9-12) \\
\end{array}$ & - & $\begin{array}{l}x \\
-\end{array}$ & $\frac{x}{-}$ & $\bar{x}$ & $\begin{array}{l}x \\
x \\
-\end{array}$ & \\
\hline 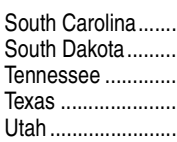 & $\begin{array}{r}180 \\
\overline{180} \\
187 \\
180\end{array}$ & $\begin{array}{r}180 \\
\dagger \\
180 \\
180 \\
180\end{array}$ & $\begin{array}{c}180^{1} \\
\dagger \\
180^{1} \\
180 \\
180\end{array}$ & $\begin{array}{c}180^{1} \\
\dagger \\
180^{1} \\
180 \\
180\end{array}$ & $\begin{array}{r}437.5(\mathrm{~K}) ; 875(1-3) ; 962.5^{11}(4-12) \\
\dagger \\
4 \\
450(\mathrm{~K}) ; 810(1) ; 990(2-12)\end{array}$ & & $\mathrm{x}$ & $\begin{array}{l}X \\
X\end{array}$ & $\mathrm{x}$ & $\begin{array}{l}x \\
x\end{array}$ & \\
\hline
\end{tabular}

See notes at end of table. 
Table 234.20. Minimum amount of instructional time per year and policy on textbook selection, by state: Selected years, 2000 through 2013-Continued

\begin{tabular}{|c|c|c|c|c|c|c|c|c|c|c|}
\hline \multirow[b]{3}{*}{ State } & \multicolumn{5}{|c|}{ Minimum amount of instructional time per year } & \multicolumn{5}{|c|}{ State policy on textbook selection, 2008} \\
\hline & \multicolumn{4}{|c|}{ In days } & In hours & \multicolumn{3}{|c|}{ State recommends or selects textbooks } & \multirow[b]{2}{*}{ Local decision } & \multirow[b]{2}{*}{$\begin{array}{l}\text { State } \\
\text { standards used }\end{array}$} \\
\hline & 2000 & 2006 & 2011 & 2013 & 2013 & Recommends & Selects & $\begin{array}{r}\text { Either } \\
\text { recommends } \\
\text { or selects }\end{array}$ & & \\
\hline 1 & 2 & 3 & 4 & 5 & 6 & 7 & 8 & 9 & 10 & 11 \\
\hline $\begin{array}{l}\text { Vermont .................. } \\
\text { Virginia................ } \\
\text { Washington ........... } \\
\text { West Virginia.......... } \\
\text { Wisconsin .............. } \\
\text { Wyoming .............. }\end{array}$ & \begin{tabular}{l|}
175 \\
180 \\
180 \\
180 \\
180 \\
175
\end{tabular} & $\begin{array}{l}175 \\
180 \\
180 \\
180 \\
180 \\
175\end{array}$ & $\begin{array}{l}175 \\
180 \\
180 \\
180 \\
180 \\
180\end{array}$ & $\begin{array}{l}175 \\
180 \\
180 \\
180 \\
180 \\
175\end{array}$ & $\begin{array}{r}540(\mathrm{~K}) ; 990(1-12) \\
450 \text { (K); } 1,000(1-6) ; 1,080(7-12) \\
\dagger \\
437 \text { (K); } 1,050(1-6) ; 1,137(7-12) \\
450 \text { (K); } 900 \text { (Elementary); 1,050 (Middle/Jr. High); } 1,100 \text { (Secondary) }\end{array}$ & $\bar{x}$ & - & - & $\begin{array}{l}\bar{x} \\
x \\
x \\
x\end{array}$ & $\begin{array}{l}\bar{x} \\
x\end{array}$ \\
\hline
\end{tabular}

\section{-Not available.}

$\mathrm{X}$ Denotes that the state has a policy. A blank denotes that the state does not have a policy.

or parent-teacher conferences.

tes of instruction per year.

$\bar{\Omega}$ 3Students must enroll in at least 4 subjects that meet at least 720 hours.

C) ${ }^{4}$ Through 2014-15, charter schools and districts are allowed to shorten the 180-day instructional year to 175 days without fiscal

penalty.
${ }^{5}$ No statewide policy; varies by district.

1,060-hour requirement for kindergarten waived if district shows inability to implement full-day program

.

For the 2014-15 and 2015-16 school years.

${ }^{10}$ Includes time for in-service or staff development or parent-teacher conferences.

11"Instructional time for graduating seniors may be reduced.

${ }^{13} 174$ days required for a 5-day week: 142 days required for a 4-day week.

${ }^{14}$ Teachers may use 33 hours of the full-day kindergarten program and 22 hours of the grades 1 through 5 programs for home NOTE: Minimum number of instructional days refers to the actual number of days that pupils have contact with a teacher. Some states allow for different types of school calendars by setting instructional time in both days and hours, while others use only days or only hours. For states in which the number of days or hours varies by grade, the relevant grade(s) appear in parentheses. cation Commission of the States. StateNotes, Number of Instructional Days/Hours in the School Year (March 2013 revisuretrieved May 1, 2014, from http://www.ecs.org/clearinghouse/01/06/68/10668.pdf; and supplemental information retrieved from various state websites. (This table was prepared May 2014.) 
Table 234.30. Course credit requirements and exit exam requirements for a standard high school diploma and the use of other high school completion credentials, by state: 2013

\begin{tabular}{|c|c|c|c|c|c|c|c|c|c|c|c|c|}
\hline \multirow[b]{3}{*}{ State } & \multicolumn{6}{|c|}{ Course credits (in Carnegie units) } & \multicolumn{4}{|c|}{ High school exit exams } & \multicolumn{2}{|c|}{$\begin{array}{l}\text { Other completion } \\
\text { credentials }\end{array}$} \\
\hline & \multirow[b]{2}{*}{$\begin{array}{r}\text { Total } \\
\text { required } \\
\text { credits } \\
\text { for standard } \\
\text { diploma, } \\
\text { all courses }\end{array}$} & \multicolumn{5}{|c|}{ Required credits in selected subject areas } & \multirow[b]{2}{*}{$\begin{array}{r}\text { Exit exam } \\
\text { required for } \\
\text { standard } \\
\text { diploma }\end{array}$} & \multicolumn{3}{|c|}{ Characteristics of required exams } & \multirow[b]{2}{*}{$\begin{array}{r}\text { Advanced } \\
\text { recognition } \\
\text { for exceeding } \\
\text { standard } \\
\text { requirements }\end{array}$} & \multirow[b]{2}{*}{$\begin{array}{r}\text { Alternative } \\
\text { credential for } \\
\text { not meeting } \\
\text { all standard } \\
\text { requirements }\end{array}$} \\
\hline & & $\begin{array}{r}\text { English/ } \\
\text { language } \\
\text { arts }\end{array}$ & $\begin{array}{r}\text { Social } \\
\text { studies }\end{array}$ & Science & Mathematics & Other credits & & $\begin{array}{r}\text { Subjects } \\
\text { tested }^{1}\end{array}$ & $\begin{array}{r}\text { Exam based } \\
\text { on standards } \\
\text { for } 10 \text { th } \\
\text { grade or } \\
\text { higher }\end{array}$ & $\begin{array}{r}\text { Appeals } \\
\text { or alternative } \\
\text { route to } \\
\text { standard } \\
\text { diploma if } \\
\text { exam failed }\end{array}$ & & \\
\hline 1 & 2 & 3 & 4 & 5 & 6 & 7 & 8 & 9 & 10 & 11 & 12 & 13 \\
\hline 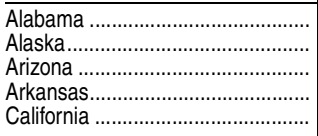 & $\begin{array}{l}24.0 \\
21.0 \\
22.0 \\
22.0 \\
13.0\end{array}$ & $\begin{array}{l}4.0 \\
4.0 \\
4.0 \\
4.0 \\
3.0\end{array}$ & $\begin{array}{l}4.0 \\
3.0 \\
3.0 \\
3.0 \\
3.0\end{array}$ & $\begin{array}{l}4.0 \\
2.0 \\
3.0 \\
3.0 \\
2.0\end{array}$ & $\begin{array}{l}4.0 \\
2.0 \\
4.0 \\
4.0 \\
2.0\end{array}$ & \begin{tabular}{r|}
8.0 \\
10.0 \\
8.0 \\
8.0 \\
3.0
\end{tabular} & $\begin{array}{l}\text { Yes } \\
\text { Yes } \\
\text { Yes } \\
\text { Yes } \\
\text { Yes }\end{array}$ & $\begin{array}{r}\text { EMSH } \\
\text { EM } \\
\text { EM } \\
M \\
\text { EM }\end{array}$ & \begin{tabular}{l|} 
Yes \\
Yes \\
Yes \\
No \\
Yes
\end{tabular} & \begin{tabular}{l|} 
Yes \\
Yes \\
Yes \\
Yes \\
Yes
\end{tabular} & \begin{tabular}{l|} 
Yes \\
No \\
Yes \\
Yes \\
Yes
\end{tabular} & $\begin{array}{l}\text { Yes } \\
\text { Yes } \\
\text { No } \\
\text { No } \\
\text { Yes }\end{array}$ \\
\hline 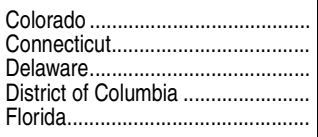 & $\begin{array}{l}20.0 \\
22.0 \\
24.0 \\
24.0\end{array}$ & $\begin{array}{l}-\overline{4.0} \\
4.0 \\
4.0 \\
4.0\end{array}$ & $\begin{array}{l}0.5 \\
3.0 \\
3.0 \\
4.0 \\
3.0\end{array}$ & $\begin{array}{l}-\overline{2} .0 \\
3.0 \\
4.0 \\
3.0\end{array}$ & $\begin{array}{l}- \\
3.0 \\
4.0 \\
4.0 \\
4.0\end{array}$ & $\begin{array}{r}-\overline{8.0} \\
8.0 \\
8.0 \\
10.0\end{array}$ & $\begin{array}{l}\text { No } \\
\text { No }{ }^{3} \\
\text { No } \\
\text { No } \\
\text { Yes }\end{array}$ & $\begin{array}{r}t \\
t \\
t \\
t \\
\text { EM }\end{array}$ & $\begin{array}{r}t \\
t \\
t \\
\dagger \\
Y e s\end{array}$ & $\begin{array}{r}t \\
t \\
t \\
\dagger \\
\text { Yes }\end{array}$ & $\begin{array}{l}\text { No } \\
\text { No } \\
\text { No } \\
\text { No } \\
\text { No }\end{array}$ & $\begin{array}{l}\text { No } \\
\text { No } \\
\text { Yes } \\
\text { Yes } \\
\text { Yes }\end{array}$ \\
\hline 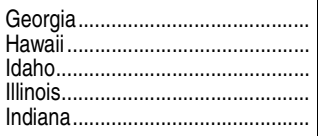 & $\begin{array}{l}23.0 \\
24.0 \\
23.0 \\
16.0 \\
20.0\end{array}$ & $\begin{array}{l}4.0 \\
4.0 \\
4.5 \\
4.0 \\
4.0\end{array}$ & $\begin{array}{l}3.0 \\
4.0 \\
2.5 \\
2.0 \\
3.0\end{array}$ & $\begin{array}{l}4.0 \\
3.0 \\
3.0 \\
2.0 \\
3.0\end{array}$ & $\begin{array}{l}4.0 \\
3.0 \\
3.0 \\
3.0 \\
3.0\end{array}$ & $\begin{array}{r}8.0 \\
10.0 \\
10.0 \\
5.0 \\
7.0\end{array}$ & $\begin{array}{l}\text { Yes } \\
\text { No } \\
\text { Yes } \\
\text { No } \\
\text { Yes }\end{array}$ & $\begin{array}{r}\text { EMSH } \\
\dagger \\
\text { EM } \\
\dagger \\
\text { EM }\end{array}$ & \begin{tabular}{r|r} 
Yes \\
$\dagger$ \\
Yes \\
$\dagger$ \\
Yes
\end{tabular} & $\begin{array}{r}\text { Yes } \\
\dagger \\
\text { Yes } \\
\dagger \\
\text { Yes }\end{array}$ & $\begin{array}{l}\text { No } \\
\text { Yes } \\
\text { No } \\
\text { No } \\
\text { Yes }\end{array}$ & $\begin{array}{l}\text { Yes } \\
\text { Yes } \\
\text { No } \\
\text { No } \\
\text { Yes }\end{array}$ \\
\hline 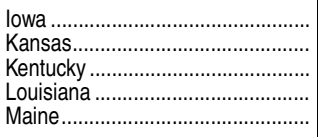 & $\begin{array}{l}14.0 \\
21.0 \\
22.0 \\
24.0 \\
16.0\end{array}$ & $\begin{array}{l}4.0 \\
4.0 \\
4.0 \\
4.0 \\
4.0\end{array}$ & $\begin{array}{l}3.0 \\
3.0 \\
3.0 \\
4.0 \\
2.0\end{array}$ & $\begin{array}{l}3.0 \\
3.0 \\
3.0 \\
4.0 \\
2.0\end{array}$ & $\begin{array}{l}3.0 \\
3.0 \\
3.0 \\
4.0 \\
2.0\end{array}$ & $\begin{array}{l}1.0 \\
8.0 \\
9.0 \\
8.0 \\
6.0\end{array}$ & $\begin{array}{l}\text { No } \\
\text { No } \\
\text { No } \\
\text { Yes } \\
\text { No }\end{array}$ & $\begin{array}{c}t \\
t \\
\text { EMSH }^{4} \\
+\end{array}$ & $\begin{array}{r}t \\
t \\
\dagger \\
\text { Yes } \\
+\end{array}$ & $\begin{array}{r}t \\
\dagger \\
\dagger \\
\text { Yes } \\
\dagger\end{array}$ & $\begin{array}{l}\text { Yes } \\
\text { No } \\
\text { Yes } \\
\text { Yes } \\
\text { No }\end{array}$ & $\begin{array}{l}\text { No } \\
\text { No } \\
\text { Yes } \\
\text { Yes } \\
\text { Yes }\end{array}$ \\
\hline 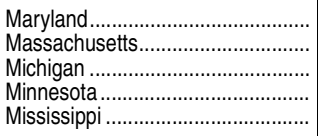 & $\begin{array}{r}21.0 \\
16.0 \\
21.5 \\
24.0\end{array}$ & $\begin{array}{l}4.0 \\
-\overline{4} \\
4.0 \\
4.0\end{array}$ & $\begin{array}{l}3.0 \\
- \\
3.0 \\
3.5 \\
4.0\end{array}$ & $\begin{array}{l}3.0 \\
- \\
3.0 \\
3.0 \\
4.0\end{array}$ & $\begin{array}{l}3.0 \\
4.0 \\
3.0 \\
4.0\end{array}$ & $\begin{array}{l}8.0 \\
- \\
2.0 \\
8.0 \\
8.0\end{array}$ & $\begin{array}{l}\text { Yes } \\
\text { Yes } \\
\text { No } \\
\text { Yes } \\
\text { Yes }\end{array}$ & $\begin{array}{c}\text { EMS } \\
\text { EMS } \\
\begin{array}{c}\dagger \\
\text { EM }^{5}\end{array} \\
\text { EMSH }\end{array}$ & \begin{tabular}{r|} 
Yes \\
Yes \\
$\dagger$ \\
Yes \\
Yes
\end{tabular} & $\begin{array}{r}\text { Yes } \\
\text { Yes } \\
\dagger \\
\text { Yes } \\
\text { Yes }\end{array}$ & $\begin{array}{l}\text { Yes } \\
\text { No } \\
\text { No } \\
\text { No } \\
\text { No }\end{array}$ & $\begin{array}{l}\text { Yes } \\
\text { No } \\
\text { No } \\
\text { No } \\
\text { Yes }\end{array}$ \\
\hline 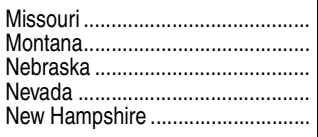 & $\begin{array}{l}24.0 \\
20.0^{6} \\
200.0^{6} \\
22.5^{2} \\
20.0\end{array}$ & $\begin{array}{r}4.0 \\
4.0 \\
-\overline{4} \\
4.0\end{array}$ & $\begin{array}{l}3.0 \\
2.0 \\
-\overline{2.0} \\
2.5\end{array}$ & $\begin{array}{l}3.0 \\
2.0 \\
- \\
2.0 \\
2.0\end{array}$ & $\begin{array}{r}3.0 \\
2.0 \\
-\overline{3} \\
3.0 \\
3.0\end{array}$ & $\begin{array}{r}11.0 \\
10.0 \\
-\overline{11.5} \\
8.5\end{array}$ & $\begin{array}{l}\text { No } \\
\text { No } \\
\text { No } \\
\text { Yes } \\
\text { No }\end{array}$ & 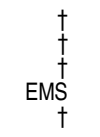 & $\begin{array}{r}t \\
t \\
t \\
\text { Yes } \\
+\end{array}$ & $\begin{array}{r}t \\
\dagger \\
\dagger \\
\text { Yes } \\
\dagger\end{array}$ & $\begin{array}{l}\text { No } \\
\text { No } \\
\text { No } \\
\text { Yes } \\
\text { Yes }\end{array}$ & $\begin{array}{l}\text { No } \\
\text { No } \\
\text { No } \\
\text { Yes } \\
\text { Yes }\end{array}$ \\
\hline 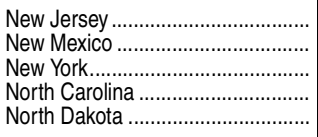 & $\begin{array}{l}24.0 \\
24.0 \\
22.0 \\
21.0 \\
22.0\end{array}$ & $\begin{array}{l}4.0 \\
4.0 \\
4.0 \\
4.0 \\
4.0\end{array}$ & $\begin{array}{l}3.0 \\
3.5 \\
4.0 \\
3.0 \\
3.0\end{array}$ & $\begin{array}{l}3.0 \\
3.0 \\
3.0 \\
3.0 \\
3.0\end{array}$ & $\begin{array}{l}3.0 \\
4.0 \\
3.0 \\
4.0 \\
3.0\end{array}$ & $\begin{array}{r}11.0 \\
9.5 \\
8.0 \\
7.0 \\
9.0\end{array}$ & $\begin{array}{l}\text { Yes } \\
\text { Yes } \\
\text { Yes } \\
\text { No } \\
\text { No }\end{array}$ & $\begin{array}{r}\text { EM } \\
\text { EMSH } \\
\text { EMSH } \\
\dagger \\
\dagger\end{array}$ & $\begin{array}{r}\text { Yes } \\
\text { Yes } \\
\text { Yes } \\
\dagger \\
\dagger\end{array}$ & $\begin{array}{r}\text { Yes } \\
\text { Yes } \\
\text { Yes } \\
\dagger \\
\dagger\end{array}$ & $\begin{array}{l}\text { No } \\
\text { No } \\
\text { Yes } \\
\text { Yes } \\
\text { No }\end{array}$ & $\begin{array}{l}\text { No } \\
\text { Yes } \\
\text { Yes } \\
\text { Yes } \\
\text { No }\end{array}$ \\
\hline 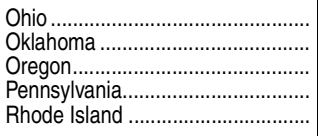 & $\begin{array}{r}20.0 \\
23.0 \\
24.0 \\
20.0\end{array}$ & $\begin{array}{r}4.0 \\
4.0 \\
4.0 \\
-\overline{4.0}\end{array}$ & $\begin{array}{l}3.0 \\
3.0 \\
3.0 \\
-\overline{3} .0\end{array}$ & $\begin{array}{l}3.0 \\
3.0 \\
3.0 \\
-\overline{3} .0\end{array}$ & $\begin{array}{l}3.0 \\
3.0 \\
3.0 \\
-\overline{4.0}\end{array}$ & $\begin{array}{r}7.0 \\
10.0 \\
11.0 \\
-\overline{6.0}\end{array}$ & $\begin{array}{l}\text { Yes } \\
\text { Yes } \\
\text { No } \\
\text { No } \\
\text { No }{ }^{8}\end{array}$ & $\begin{array}{c}\text { EMSH } \\
\text { EMSH }^{7} \\
+ \\
+ \\
+\end{array}$ & $\begin{array}{r}\text { Yes } \\
\text { Yes } \\
+ \\
+ \\
+\end{array}$ & $\begin{array}{r}\text { Yes } \\
\text { Yes } \\
\dagger \\
t \\
\dagger\end{array}$ & $\begin{array}{l}\text { Yes } \\
\text { Yes } \\
\text { No } \\
\text { No } \\
\text { No }\end{array}$ & $\begin{array}{l}\text { No } \\
\text { No } \\
\text { Yes } \\
\text { No } \\
\text { No }\end{array}$ \\
\hline 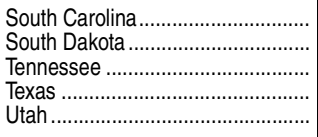 & $\begin{array}{l}24.0 \\
22.0 \\
22.0 \\
26.0 \\
24.0\end{array}$ & $\begin{array}{l}4.0 \\
4.0 \\
4.0 \\
4.0 \\
4.0\end{array}$ & $\begin{array}{l}3.0 \\
3.0 \\
3.0 \\
4.0 \\
3.0\end{array}$ & $\begin{array}{l}3.0 \\
3.0 \\
3.0 \\
4.0 \\
3.0\end{array}$ & $\begin{array}{l}4.0 \\
3.0 \\
4.0 \\
4.0 \\
3.0\end{array}$ & $\begin{array}{r}10.0 \\
9.0 \\
8.0 \\
10.0 \\
11.0\end{array}$ & $\begin{array}{l}\text { Yes } \\
\text { No } \\
\text { No } \\
\text { Yes } \\
\text { No }\end{array}$ & $\begin{array}{r}\text { EM } \\
\dagger \\
+ \\
\text { EMSH } \\
\dagger\end{array}$ & \begin{tabular}{r|r} 
Yes \\
$t$ \\
$\dagger$ \\
Yes \\
+
\end{tabular} & $\begin{array}{r}\text { No } \\
\dagger \\
\text { No } \\
\text { Yes } \\
\dagger\end{array}$ & $\begin{array}{l}\text { Yes } \\
\text { Yes } \\
\text { Yes } \\
\text { Yes } \\
\text { No }\end{array}$ & $\begin{array}{l}\text { Yes } \\
\text { No } \\
\text { Yes } \\
\text { Yes } \\
\text { Yes }\end{array}$ \\
\hline 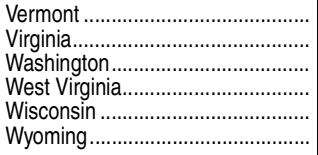 & $\begin{array}{l}20.0 \\
22.0 \\
20.0 \\
24.0 \\
13.0 \\
13.0\end{array}$ & $\begin{array}{l}4.0 \\
4.0 \\
3.0 \\
4.0 \\
4.0 \\
4.0\end{array}$ & $\begin{array}{l}3.0 \\
3.0 \\
2.5 \\
4.0 \\
3.0 \\
3.0\end{array}$ & $\begin{array}{l}3.0 \\
3.0 \\
2.0 \\
3.0 \\
2.0 \\
3.0\end{array}$ & $\begin{array}{l}3.0 \\
3.0 \\
3.0 \\
4.0 \\
2.0 \\
3.0\end{array}$ & $\begin{array}{l}7.0 \\
9.0 \\
9.5 \\
9.0 \\
2.0 \\
0.0\end{array}$ & $\begin{array}{l}\text { No } \\
\text { Yes } \\
\text { Yes } \\
\text { No } \\
\text { No } \\
\text { No }\end{array}$ & $\begin{array}{c}\mathrm{EMSH}^{\dagger} \\
\mathrm{EM}^{9} \\
\dagger \\
\dagger \\
\dagger\end{array}$ & $\begin{array}{r}t \\
\text { Yes } \\
\text { Yes } \\
t \\
t \\
t\end{array}$ & $\begin{array}{r}\dagger \\
\text { Yes } \\
\text { Yes } \\
\dagger \\
\dagger \\
\dagger\end{array}$ & $\begin{array}{r}\text { No } \\
\text { Yes } \\
\text { No } \\
\text { Yes } \\
\text { No } \\
\text { Yes }\end{array}$ & $\begin{array}{l}\text { No } \\
\text { Yes } \\
\text { No } \\
\text { Yes } \\
\text { Yes } \\
\text { No }\end{array}$ \\
\hline
\end{tabular}

-Not available.

†Not applicable.

Exit exam subjects tested: $\mathrm{E}=$ English (including writing), $\mathrm{M}=$ Mathematics, $\mathrm{S}=$ Science and $\mathrm{H}=$ History/social studies.

${ }^{2} \mathrm{~A}$ certificate of attendance is an example of an alternative credential for students who do not meet all requirements for a standard diploma. Depending on an individual state's policies, alternative credentials may be offered to students with disabilities, students who fail exit exams, or other students who do not meet all requirements.

${ }^{3}$ Requirement takes effect for class of 2020 .

${ }^{4}$ Students must pass either the science or social studies components of the Graduation Exit Examination (GEE) to receive a standard diploma.

${ }^{5}$ Students can graduate by passing statewide reading and writing assessments and either passing mathematics assessments or meeting other requirements.
${ }^{6}$ Expressed in semester credits instead of Carnegie units.

7 To receive the standard diploma, students must pass tests in algebra 1, English 2, and two of the following five subjects: algebra 2, biology 1, English 3, geometry, and U.S. history. ${ }^{8}$ Requirement takes effect for class of 2014.

${ }^{9}$ To receive the standard diploma, students must earn at least six verified credits by passing end-of-course assessments. One of those credits may be earned by passing a studentselected test in computer science, technology, career and technical education, or other areas. NOTE: Local school districts frequently have other graduation requirements in addition to state requirements. The Carnegie unit is a standard of measurement that represents one credit for the completion of a 1 -year course.

SOURCE: Editorial Projects in Education Research Center, custom table, retrieved August 27, 2013, from Education Counts database (http://www.edcounts.org/createtable/step1.php). (This table was prepared August 2013.) 
Table 234.40. States that use criterion-referenced tests (CRTs) aligned to state standards, by subject area and level: 2006-07

\begin{tabular}{|c|c|c|c|c|c|c|c|}
\hline \multirow[b]{2}{*}{ State } & \multicolumn{2}{|c|}{ Aligned to state standards } & \multirow{2}{*}{$\begin{array}{r}\text { Off-the-shelf/ } \\
\text { norm-referenced } \\
\text { test (NRT) }\end{array}$} & \multicolumn{4}{|c|}{ CRTs, ${ }^{2}$ by subject area and level } \\
\hline & $\mathrm{CRT}^{2}$ & $\begin{array}{r}\text { Augmented or } \\
\text { hybrid test }^{3}\end{array}$ & & $\begin{array}{r}\text { English/ } \\
\text { language arts }\end{array}$ & Mathematics & Science & $\begin{array}{r}\text { Social studies/ } \\
\text { history }\end{array}$ \\
\hline 1 & 2 & 3 & 4 & 5 & 6 & 7 & 8 \\
\hline Alabama & $x$ & & $\mathrm{x}$ & ES, MS, HS & ES, MS, HS & HS & HS \\
\hline 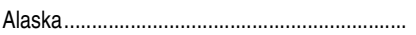 & $x$ & & $\mathrm{x}$ & ES, MS, HS & $\mathrm{ES}, \mathrm{MS}, \mathrm{HS}$ & & \\
\hline Arizona & $\mathrm{x}$ & $\mathrm{x}$ & $\mathrm{x}$ & $\mathrm{ES}, \mathrm{MS}, \mathrm{HS}$ & ES, MS, HS & & \\
\hline 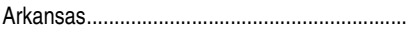 & $\mathrm{x}$ & & $\mathrm{x}$ & ES, MS, HS & $\mathrm{ES}, \mathrm{MS}, \mathrm{HS}$ & ES, MS & \\
\hline California & $x$ & & $\mathrm{x}$ & $\mathrm{ES}, \mathrm{MS}, \mathrm{HS}$ & $\mathrm{ES}, \mathrm{MS}, \mathrm{HS}$ & ES, MS, HS & MS, HS \\
\hline 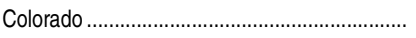 & $\mathrm{x}$ & & $\mathrm{x}$ & ES, MS, HS & ES, MS, HS & ES, MS, HS & \\
\hline 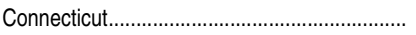 & $\mathrm{x}$ & & & ES, MS, HS & $E S, M S, H S$ & HS & \\
\hline Delaware.......... & & $\mathrm{x}$ & & $\mathrm{ES}, \mathrm{MS}, \mathrm{HS}$ & $\mathrm{ES}, \mathrm{MS}, \mathrm{HS}$ & ES, MS, HS & ES, MS, HS \\
\hline District of Columbia .......................... & $\mathrm{x}$ & & & ES, MS, HS & $\mathrm{ES}, \mathrm{MS}, \mathrm{HS}$ & & \\
\hline Florida & $\mathrm{x}$ & & $\mathrm{x}$ & ES, MS, HS & ES, MS, HS & ES, MS, HS & \\
\hline$\ldots$ & $x$ & & $\mathrm{x}$ & $\mathrm{ES}, \mathrm{MS}, \mathrm{HS}$ & ES, MS, HS & ES, MS, HS & ES, MS, HS \\
\hline 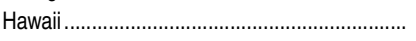 & & $\mathrm{x}$ & & $\mathrm{ES}, \mathrm{MS}, \mathrm{HS}$ & ES, MS, HS & & \\
\hline Idaho & $x$ & & & $\mathrm{ES}, \mathrm{MS}, \mathrm{HS}$ & ES, MS, HS & & \\
\hline 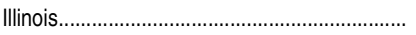 & $\mathrm{x}$ & $\mathrm{x}$ & & ES, MS, HS & ES, MS, HS & HS & \\
\hline Indiana & $\mathrm{x}$ & & & $\mathrm{ES}, \mathrm{MS}, \mathrm{HS}$ & $\mathrm{ES}, \mathrm{MS}, \mathrm{HS}$ & ES, MS & \\
\hline lowa ... & & & $x$ & ES, MS, HS & ES, MS, HS & $\mathrm{ES}, \mathrm{MS}, \mathrm{HS}$ & \\
\hline$\ldots \ldots \ldots \ldots \ldots \ldots \ldots \ldots \ldots$ & $\mathrm{x}$ & & & ES, MS, HS & ES, MS, HS & & \\
\hline 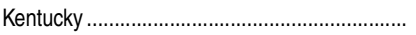 & $\mathrm{x}$ & & $\mathrm{x}$ & ES, MS, HS & ES, MS, HS & ES, MS, HS & ES, MS, HS \\
\hline Louisiana & $\mathrm{x}$ & $\mathrm{x}$ & & ES, MS, HS & ES, MS, HS & ES, MS, HS & ES, MS, HS \\
\hline Maine & $x$ & & $\mathrm{x}$ & $\mathrm{ES}, \mathrm{MS}, \mathrm{HS}$ & ES, MS, HS & $\mathrm{ES}, \mathrm{MS}$ & \\
\hline Maryland ..................................... & $x$ & $\mathrm{x}$ & & ES, MS, HS & ES, MS, HS & HS & HS \\
\hline Massachusetts............................... & $\mathrm{x}$ & & & ES, MS, HS & ES, MS, HS & ES, MS, HS & \\
\hline Michigan ................................... & $\mathrm{x}$ & & $\mathrm{x}$ & ES, MS, HS & ES, MS, HS & ES, MS, HS & MS, HS \\
\hline Minnesota .................................... & $\mathrm{x}$ & & & ES, MS, HS & ES, MS, HS & & \\
\hline 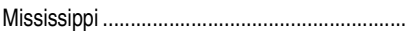 & $x$ & & $\mathrm{x}$ & $\mathrm{ES}, \mathrm{MS}, \mathrm{HS}$ & $\mathrm{ES}, \mathrm{MS}, \mathrm{HS}$ & ES, MS, HS & HS \\
\hline 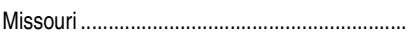 & & $\mathrm{x}$ & & $\mathrm{ES}, \mathrm{MS}, \mathrm{HS}$ & ES, MS, HS & & \\
\hline Montana & $x$ & & $\mathrm{x}$ & ES, MS, HS & $\mathrm{ES}, \mathrm{MS}, \mathrm{HS}$ & & \\
\hline Nebraska ........................................... & $\mathrm{x}$ & & & ES, MS, HS & & & \\
\hline 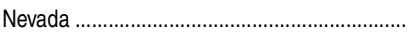 & $x$ & & $\mathrm{x}$ & $\mathrm{ES}, \mathrm{MS}, \mathrm{HS}$ & ES, MS, HS & & \\
\hline New Hampshire .................................. & $x$ & & & ES, MS & ES, MS & & \\
\hline 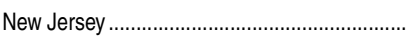 & $x$ & & & $\mathrm{ES}, \mathrm{MS}, \mathrm{HS}$ & ES, MS, HS & ES, MS & \\
\hline New Mexico ................................. & $\mathrm{x}$ & & $\mathrm{x}$ & ES, MS, HS & ES, MS, HS & ES, MS, HS & \\
\hline New York........... & $\mathrm{x}$ & & & ES, MS, HS & ES, MS, HS & ES, MS, HS & ES, MS, HS \\
\hline North Carolina .......................... & $\mathrm{x}$ & & & ES, MS, HS & $E S, M S, H S$ & HS & HS \\
\hline North Dakota .................................................... & $\mathrm{x}$ & & & $\mathrm{ES}, \mathrm{MS}, \mathrm{HS}$ & $\mathrm{ES}, \mathrm{MS}, \mathrm{HS}$ & $\mathrm{ES}, \mathrm{MS}, \mathrm{HS}$ & \\
\hline Ohio ................................................ & $\mathrm{x}$ & & & $\mathrm{ES}, \mathrm{MS}, \mathrm{HS}$ & $E S, M S, H S$ & ES, MS, HS & ES, MS, HS \\
\hline 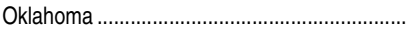 & $\mathrm{x}$ & & & ES, MS, HS & $\mathrm{ES}, \mathrm{MS}, \mathrm{HS}$ & ES, MS, HS & ES, MS, HS \\
\hline Oregon & $\mathrm{x}$ & & & ES, MS, HS & ES, MS, HS & MS, HS & \\
\hline 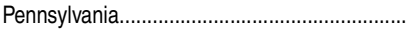 & $\mathrm{x}$ & & & ES, MS, HS & ES, MS, HS & & \\
\hline Rhode Island & $x$ & $\mathrm{x}$ & & $\mathrm{ES}, \mathrm{MS}, \mathrm{HS}$ & $\mathrm{ES}, \mathrm{MS}, \mathrm{HS}$ & & \\
\hline 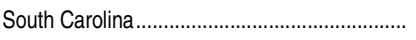 & $x$ & & & ES, MS, HS & $E S, M S, H S$ & ES, MS, HS & ES, MS, HS \\
\hline South Dakota.... & & $\mathrm{x}$ & $\mathrm{x}$ & ES, MS, HS & $E S, M S, H S$ & ES, MS, HS & \\
\hline Tennessee ........................................ & $\mathrm{x}$ & & & $\mathrm{ES}, \mathrm{MS}, \mathrm{HS}$ & ES, MS, HS & ES, MS, HS & ES, MS, HS \\
\hline 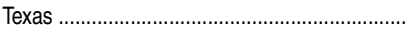 & $\mathrm{x}$ & & & $\mathrm{ES}, \mathrm{MS}, \mathrm{HS}$ & $\mathrm{ES}, \mathrm{MS}, \mathrm{HS}$ & ES, MS, HS & MS, HS \\
\hline Utah & $x$ & & $\mathrm{x}$ & ES, MS, HS & ES, MS, HS & ES, MS, HS & \\
\hline Vermont & $x$ & & & ES, MS & $\mathrm{ES}, \mathrm{MS}$ & & \\
\hline Virginia. & $x$ & & & $\mathrm{ES}, \mathrm{MS}, \mathrm{HS}$ & ES, MS, HS & $\mathrm{ES}, \mathrm{MS}, \mathrm{HS}$ & $\mathrm{ES}, \mathrm{MS}, \mathrm{HS}$ \\
\hline Washington & $\mathrm{x}$ & & & ES, MS, HS & $\mathrm{ES}, \mathrm{MS}, \mathrm{HS}$ & ES, MS, HS & \\
\hline West Virginia................................................... & $\mathrm{x}$ & & $\mathrm{x}$ & ES, MS, HS & ES, MS, HS & ES, MS, HS & ES, MS \\
\hline Wisconsin & & $\mathrm{x}$ & & ES, MS, HS & ES, MS, HS & ES, MS, HS & ES, MS, HS \\
\hline Wyoming & $\mathrm{x}$ & & & ES, MS, HS & $E S, M S, H S$ & & \\
\hline
\end{tabular}

$\mathrm{X}$ State has a test. A blank denotes that the state does not have this type of test. 1Off-the-shelf/norm-referenced tests (NRTs) are commercially developed tests that have not been modified to reflect state content standards.

${ }^{2}$ Criterion-referenced tests (CRTs) are custom-developed and explicitly designed to measure state content standards.
${ }^{3}$ Augmented or hybrid tests incorporate elements of both NRTs and CRTs. These tests include NRTs that have been augmented or modified to reflect state standards. NOTE: $\mathrm{ES}$ = elementary school, $\mathrm{MS}=$ middle school, and HS = high school. SOURCE: Quality Counts 2007, Cradle to Career, Education Week, 2007. (This table was prepared September 2008.) 
Table 234.50. Required testing for initial certification of elementary and secondary school teachers, by type of assessment and state: 2012 and 2013

\begin{tabular}{|c|c|c|c|c|c|c|c|c|}
\hline \multirow[b]{2}{*}{ State } & \multicolumn{4}{|c|}{ Assessment for certification, 2012} & \multicolumn{4}{|c|}{ Assessment for certification, 2013} \\
\hline & $\begin{array}{r}\text { Basic } \\
\text { skills exam }\end{array}$ & $\begin{array}{r}\text { Subject- } \\
\text { matter exam }\end{array}$ & $\begin{array}{c}\text { Knowledge of } \\
\text { teaching exam }\end{array}$ & $\begin{array}{r}\text { Assessment } \\
\text { of teaching } \\
\text { performance }\end{array}$ & $\begin{array}{r}\text { Basic } \\
\text { skills exam }\end{array}$ & $\begin{array}{r}\text { Subject- } \\
\text { matter exam }\end{array}$ & $\begin{array}{c}\text { Knowledge of } \\
\text { teaching exam }\end{array}$ & $\begin{array}{r}\text { Assessment } \\
\text { of teaching } \\
\text { performance }\end{array}$ \\
\hline 1 & 2 & 3 & 4 & 5 & 6 & 7 & 8 & 9 \\
\hline 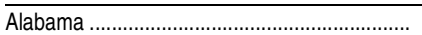 & $\mathrm{x}$ & $\mathrm{x}$ & $x$ & $\mathrm{x}$ & $\mathrm{X}$ & $\mathrm{X}$ & $\mathrm{x}$ & $\bar{x}$ \\
\hline Alaska & $x$ & & & & $x$ & & & \\
\hline Arizona & & $\mathrm{x}$ & $\mathrm{x}$ & & & $\mathrm{x}$ & $\mathrm{x}$ & \\
\hline 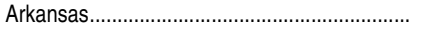 & $\mathrm{x}$ & $\mathrm{x}$ & $\mathrm{x}$ & $\mathrm{x}$ & $\mathrm{x}$ & $\mathrm{x}$ & $\mathrm{X}$ & $\mathrm{x}$ \\
\hline 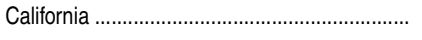 & $\mathrm{x}$ & - & & $x$ & $x$ & - & & $\mathrm{X}$ \\
\hline Colorado & & $x$ & & & & $x$ & & \\
\hline 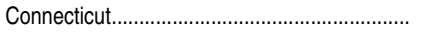 & $\mathrm{x}$ & $\mathrm{x}$ & $\mathrm{x}$ & $\mathrm{x}$ & $\mathrm{x}$ & $\mathrm{x}$ & - & - \\
\hline 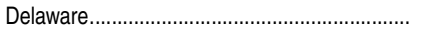 & $\mathrm{x}$ & $\mathrm{x}$ & & & $x$ & $\mathrm{x}$ & & \\
\hline District of Columbia .......................................... & $\mathrm{x}$ & $\mathrm{x}$ & $x$ & & $x$ & $\mathrm{x}$ & $\mathrm{X}$ & \\
\hline Florida & $\mathrm{x}$ & & & $\mathrm{x}$ & $\mathrm{x}$ & & & $\mathrm{x}$ \\
\hline Georgia & $x$ & $x$ & & & $x$ & $x$ & & \\
\hline 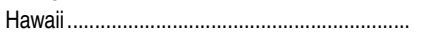 & $x$ & $\mathrm{x}$ & & - & $x$ & $x$ & & - \\
\hline Idaho & & $\mathrm{x}$ & & $\mathrm{x}$ & & $\mathrm{x}$ & & $\mathrm{x}$ \\
\hline 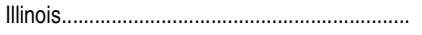 & $\mathrm{x}$ & $\mathrm{x}$ & $x$ & & $x$ & $\mathrm{x}$ & $x$ & \\
\hline Indiana & $\mathrm{x}$ & $\mathrm{x}$ & & $x$ & $x$ & $x$ & & $x$ \\
\hline lowa & & & & & & & & \\
\hline Kansas & & $\mathrm{x}$ & $\mathrm{x}$ & & & $\mathrm{x}$ & $\mathrm{x}$ & \\
\hline Kentucky & $\mathrm{x}$ & $\mathrm{x}$ & $\mathrm{x}$ & $\mathrm{x}$ & $\mathrm{x}$ & $\mathrm{x}$ & $\mathrm{x}$ & $\mathrm{x}$ \\
\hline 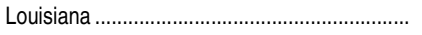 & $\mathrm{x}$ & $\mathrm{x}$ & $\mathrm{x}$ & $\mathrm{x}$ & $\mathrm{x}$ & $\mathrm{x}$ & $x$ & $\mathrm{x}$ \\
\hline Maine & - & - & - & - & - & - & - & - \\
\hline Maryland ................ & $x$ & $x$ & $x$ & $x$ & $x$ & $x$ & $x$ & $x$ \\
\hline Massachusetts................................................ & $\mathrm{x}$ & $\mathrm{x}$ & & $\mathrm{x}$ & $x$ & $\mathrm{x}$ & & $\mathrm{x}$ \\
\hline 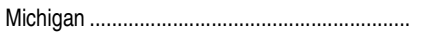 & $\mathrm{x}$ & $\mathrm{x}$ & & $\mathrm{x}$ & $x$ & $x$ & & $x$ \\
\hline Minnesota & $\mathrm{x}$ & $\mathrm{x}$ & $x$ & & $x$ & $x$ & $x$ & \\
\hline Mississippi .................................................... & - & - & - & - & - & - & - & - \\
\hline Missouri .............................................. & $x$ & $\mathrm{x}$ & & $x$ & $x$ & $x$ & & $x$ \\
\hline 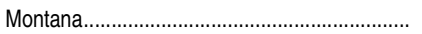 & & & & & & & & \\
\hline Nebraska & $\mathrm{x}$ & & & & $\mathrm{x}$ & & & \\
\hline 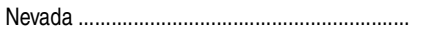 & - & $\mathrm{x}$ & - & - & - & $\mathrm{x}$ & - & - \\
\hline 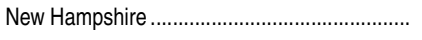 & $\mathrm{x}$ & $\mathrm{x}$ & & & $x$ & $x$ & & \\
\hline New Jersey ........................ & - & - & - & - & - & - & - & - \\
\hline New Mexico .......................... & $\mathrm{x}$ & $\mathrm{x}$ & $x$ & $\mathrm{x}$ & $\mathrm{x}$ & $\mathrm{x}$ & $\mathrm{X}$ & $\mathrm{x}$ \\
\hline New York & & $\mathrm{x}$ & $\mathrm{x}$ & & & $\mathrm{x}$ & $\mathrm{X}$ & \\
\hline 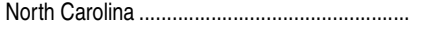 & - & - & - & - & - & - & - & - \\
\hline North Dakota ....................................................... & - & $\mathrm{x}$ & - & - & - & $x$ & - & - \\
\hline Ohio & & $x$ & $x$ & $x$ & & $x$ & $\mathrm{x}$ & $\mathrm{x}$ \\
\hline Oklahoma & - & - & - & - & - & - & - & - \\
\hline Oregon & $\mathrm{x}$ & $\mathrm{x}$ & & $\mathrm{x}$ & $\mathrm{x}$ & $\mathrm{x}$ & & $\mathrm{x}$ \\
\hline 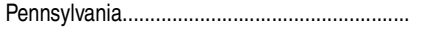 & $\mathrm{X}$ & $\mathrm{x}$ & $\mathrm{x}$ & $\mathrm{x}$ & $\mathrm{x}$ & $\mathrm{x}$ & $\mathrm{X}$ & $\mathrm{x}$ \\
\hline Rhode Island ................................................. & & & $x$ & $\mathrm{x}$ & & & $\mathrm{x}$ & $\mathrm{X}$ \\
\hline South Carolina & & $\mathrm{x}$ & $x$ & & & $\mathrm{x}$ & $\mathrm{x}$ & \\
\hline South Dakota ............................................. & $\mathrm{x}$ & $\mathrm{x}$ & $\mathrm{x}$ & $\mathrm{x}$ & $\mathrm{x}$ & $\mathrm{x}$ & $\mathrm{x}$ & $x$ \\
\hline 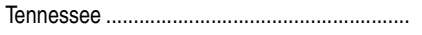 & $\mathrm{x}$ & $\mathrm{x}$ & $x$ & & $\mathrm{x}$ & $\mathrm{x}$ & $x$ & \\
\hline 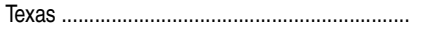 & $\mathrm{x}$ & $\mathrm{x}$ & $\mathrm{x}$ & $\mathrm{x}$ & $\mathrm{x}$ & $\mathrm{x}$ & $\mathrm{x}$ & $\mathrm{x}$ \\
\hline ............... & & $\mathrm{x}$ & & $x$ & & $\mathrm{x}$ & & $\mathrm{x}$ \\
\hline Vermont & $\mathrm{x}$ & $\mathrm{x}$ & & & $x$ & $x$ & & \\
\hline Virginia & $\mathrm{x}$ & $\mathrm{x}$ & $x$ & & $x$ & $\mathrm{x}$ & $\mathrm{x}$ & \\
\hline Washington ……………………………..... & $\mathrm{x}$ & $\mathrm{x}$ & & $\mathrm{x}$ & $\mathrm{x}$ & $\mathrm{x}$ & & $x$ \\
\hline 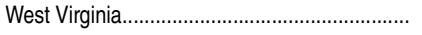 & $\mathrm{x}$ & $\mathrm{x}$ & $x$ & $\mathrm{x}$ & $\mathrm{x}$ & $\mathrm{x}$ & $x$ & $\mathrm{x}$ \\
\hline Wisconsin & $\mathrm{X}$ & $\mathrm{X}$ & & & $\mathrm{x}$ & $\mathrm{x}$ & & \\
\hline Wyoming & - & & - & - & - & & - & - \\
\hline
\end{tabular}

-Not available.

$\mathrm{X}$ Denotes that the state requires testing. A blank denotes that the state does not require testing.
SOURCE: National Association of State Directors of Teacher Education and Certification (NASDTEC), NASDTEC Knowledgebase, retrieved August 8, 2013, from https://www.nasdtec.info/. (This table was prepared August 2013.) 
Table 235.10. Revenues for public elementary and secondary schools, by source of funds: Selected years, 1919-20 through 2010-11

\begin{tabular}{|c|c|c|c|c|c|c|c|c|c|c|c|c|c|c|c|}
\hline \multirow[b]{3}{*}{ School year } & \multicolumn{7}{|c|}{ Revenues (in thousands) } & \multicolumn{7}{|c|}{ Revenues per pupil } & \\
\hline & \multirow[b]{2}{*}{ Total } & \multirow[b]{2}{*}{ Federal } & \multirow[b]{2}{*}{ State } & \multicolumn{4}{|c|}{ Local (including intermediate sources below the state level) } & \multirow[b]{2}{*}{ Total } & \multirow[b]{2}{*}{ Federal } & \multirow[b]{2}{*}{ State } & \multicolumn{4}{|c|}{ Local (including intermediate sources below the state level) } & \\
\hline & & & & Total & Property taxes & $\begin{array}{r}\text { Other } \\
\text { public revenue }\end{array}$ & Private $^{1}$ & & & & Total & Property taxes & \begin{tabular}{|r|} 
Other \\
public revenue
\end{tabular} & Private $^{1}$ & \\
\hline 1 & 2 & 3 & 4 & 5 & 6 & 7 & 8 & 9 & 10 & 11 & 12 & 13 & 14 & 15 & \\
\hline & \multicolumn{14}{|c|}{ Current dollars } & \\
\hline $\begin{array}{l}1919-20 \\
1929-30 \\
1939-40 \\
1949-50 \ldots \\
1959-60 \\
1969-70 \ldots \\
1979-80\end{array}$ & $\begin{array}{r}\$ 970,121 \\
2,088,557 \\
2,260,527 \\
5,437,044 \\
14,746,618 \\
40,266,922 \\
96,881,164\end{array}$ & $\begin{array}{r}\$ 2,475 \\
7,334 \\
39,810 \\
155,848 \\
651,639 \\
3,219,557 \\
9,503,537\end{array}$ & $\begin{array}{r}\$ 160,085 \\
353,670 \\
684,354 \\
2,165,689 \\
5,768,047 \\
16,062,776 \\
45,348,814\end{array}$ & \begin{tabular}{r|}
$\$ 807,561$ \\
$1,727,553$ \\
$1,536,363$ \\
$3,115,507$ \\
$8,326,932$ \\
$20,984,589$ \\
$42,028,813$
\end{tabular} & $\begin{array}{l}- \\
- \\
- \\
- \\
- \\
- \\
-\end{array}$ & $\begin{array}{l}- \\
- \\
- \\
- \\
- \\
- \\
-\end{array}$ & $\begin{array}{l}- \\
- \\
- \\
- \\
- \\
- \\
-\end{array}$ & \begin{tabular}{r|}
45 \\
81 \\
89 \\
217 \\
419 \\
884 \\
2,326
\end{tabular} & \begin{tabular}{r|}
$\#$ \\
$\#$ \\
$\$ 2$ \\
6 \\
19 \\
71 \\
228
\end{tabular} & $\begin{array}{r}7 \\
14 \\
27 \\
86 \\
164 \\
353 \\
1,089\end{array}$ & $\begin{array}{r}\$ 37 \\
67 \\
60 \\
124 \\
237 \\
461 \\
1,009\end{array}$ & $\begin{array}{l}- \\
- \\
- \\
- \\
- \\
- \\
-\end{array}$ & $\begin{array}{l}- \\
- \\
- \\
- \\
- \\
- \\
-\end{array}$ & $\begin{array}{l}- \\
- \\
- \\
- \\
- \\
-\end{array}$ & \\
\hline 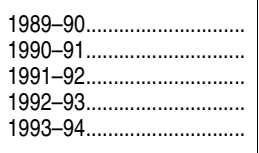 & $\begin{array}{l}208,547,573 \\
223,340,537 \\
234,581,384 \\
247,626,168 \\
260,159,468\end{array}$ & $\begin{array}{l}12,700,784 \\
13,776,066 \\
15,493,330 \\
17,261,252 \\
18,341,483\end{array}$ & $\begin{array}{r}98,238,633 \\
105,324,533 \\
108,783,449 \\
113,403,436 \\
117,474,209\end{array}$ & $\begin{array}{r}97,608,157 \\
104,239,939 \\
110,304,605 \\
116,961,481 \\
124,343,776\end{array}$ & $\begin{array}{r}\$ 74,867,627 \\
80,373,547 \\
85,874,700 \\
87,143,955 \\
97,762,990\end{array}$ & $\begin{array}{r}\$ 17,084,494 \\
17,951,451 \\
18,213,748 \\
23,116,567 \\
19,661,128\end{array}$ & $\begin{array}{r}\$ 5,656,036 \\
5,914,941 \\
6,216,157 \\
6,700,958 \\
6,919,657\end{array}$ & $\begin{array}{l}5,144 \\
5,419 \\
5,579 \\
5,783 \\
5,986\end{array}$ & $\begin{array}{l}313 \\
334 \\
368 \\
403 \\
422\end{array}$ & $\begin{array}{l}2,423 \\
2,555 \\
2,587 \\
2,648 \\
2,703\end{array}$ & $\begin{array}{l}2,408 \\
2,529 \\
2,623 \\
2,731 \\
2,861\end{array}$ & $\begin{array}{r}\$ 1,847 \\
1,950 \\
2,042 \\
2,035 \\
2,249\end{array}$ & $\begin{array}{r}\$ 421 \\
436 \\
433 \\
540 \\
452\end{array}$ & $\begin{array}{r}\$ 140 \\
144 \\
148 \\
156 \\
159\end{array}$ & \\
\hline $\begin{array}{l}1994-95 \ldots \ldots \ldots \ldots \ldots \ldots \ldots \ldots \ldots . . \\
1995-96 \ldots \ldots \ldots \ldots \ldots \ldots \ldots \ldots \ldots . \\
1996-97 \ldots \ldots \ldots \ldots \ldots \ldots \ldots \ldots \ldots . . \\
1997-98 \ldots \ldots \ldots \ldots \ldots \ldots \ldots \ldots \ldots \\
1998-99 \ldots \ldots \ldots \ldots \ldots \ldots \ldots \ldots . .\end{array}$ & $\begin{array}{l}273,149,449 \\
287,702,844 \\
305,065,192 \\
325,925,708 \\
347,377,993\end{array}$ & $\begin{array}{l}18,582,157 \\
19,104,019 \\
20,081,287 \\
22,201,965 \\
24,521,817\end{array}$ & $\begin{array}{l}127,729,576 \\
136,670,754 \\
146,435,584 \\
157,645,372 \\
169,298,232\end{array}$ & $\begin{array}{l}126,837,717 \\
131,928,071 \\
138,548,321 \\
146,078,370 \\
153,557,944\end{array}$ & \begin{tabular}{r|}
$97,978,129$ \\
$101,785,858$ \\
$106,545,881$ \\
$111,184,150$ \\
$119,483,487$
\end{tabular} & $\begin{array}{l}21,560,162 \\
22,522,345 \\
24,288,693 \\
26,676,244 \\
25,348,879\end{array}$ & $\begin{array}{l}7,299,425 \\
7,619,869 \\
7,713,747 \\
8,217,977 \\
8,725,578\end{array}$ & $\begin{array}{l}6,192 \\
6,416 \\
6,688 \\
7,066 \\
7,464\end{array}$ & $\begin{array}{l}421 \\
426 \\
440 \\
481 \\
527\end{array}$ & $\begin{array}{l}2,896 \\
3,048 \\
3,211 \\
3,418 \\
3,638\end{array}$ & $\begin{array}{l}2,875 \\
2,942 \\
3,038 \\
3,167 \\
3,300\end{array}$ & $\begin{array}{l}2,221 \\
2,270 \\
2,336 \\
2,410 \\
2,567\end{array}$ & $\begin{array}{l}489 \\
502 \\
533 \\
578 \\
545\end{array}$ & $\begin{array}{l}165 \\
170 \\
169 \\
178 \\
187\end{array}$ & \\
\hline $\begin{array}{l}1999-2000 \\
2000-01 \\
2001-02 \\
2002-03 \\
2003-04 \ldots \ldots\end{array}$ & $\begin{array}{l}372,943,802 \\
401,356,120 \\
419,501,976 \\
440,111,653 \\
462,026,099\end{array}$ & $\begin{array}{l}27,097,866 \\
29,100,183 \\
33,144,633 \\
37,515,909 \\
41,923,435\end{array}$ & $\begin{array}{l}184,613,352 \\
199,583,097 \\
206,541,793 \\
214,277,407 \\
217,384,191\end{array}$ & \begin{tabular}{l|}
$161,232,584$ \\
$172,672,840$ \\
$179,815,551$ \\
$188,318,337$ \\
$202,718,474$
\end{tabular} & $\begin{array}{l}124,735,516 \\
132,575,925 \\
141,095,685 \\
148,511,786 \\
160,602,055\end{array}$ & $\begin{array}{l}27,628,923 \\
30,889,273 \\
28,924,825 \\
29,579,240 \\
31,651,489\end{array}$ & $\begin{array}{r}8,868,145 \\
9,207,643 \\
9,795,041 \\
10,227,310 \\
10,464,930\end{array}$ & $\begin{array}{l}7,959 \\
8,503 \\
8,800 \\
9,134 \\
9,518\end{array}$ & $\begin{array}{l}578 \\
616 \\
695 \\
779 \\
864\end{array}$ & $\begin{array}{l}3,940 \\
4,228 \\
4,333 \\
4,447 \\
4,478\end{array}$ & $\begin{array}{l}3,441 \\
3,658 \\
3,772 \\
3,908 \\
4,176\end{array}$ & $\begin{array}{l}2,662 \\
2,809 \\
2,960 \\
3,082 \\
3,309\end{array}$ & $\begin{array}{l}590 \\
654 \\
607 \\
614 \\
652\end{array}$ & $\begin{array}{l}189 \\
195 \\
205 \\
212 \\
216\end{array}$ & \\
\hline $\begin{array}{l}2004-05 \ldots \ldots \ldots \ldots \ldots \ldots \ldots \ldots . \\
2005-06 \ldots \ldots \ldots \ldots \ldots \ldots \ldots \ldots . \\
2006-07 \ldots \ldots \ldots \ldots \ldots \ldots \ldots \ldots \\
2007-08 \ldots \ldots \ldots \ldots \ldots \ldots \ldots \ldots \\
2008-09 \ldots \ldots \ldots \ldots \ldots \ldots \ldots \ldots \\
.\end{array}$ & $\begin{array}{l}487,753,525 \\
520,621,788 \\
555,710,762 \\
584,683,686 \\
592,422,033\end{array}$ & $\begin{array}{l}44,809,532 \\
47,553,778 \\
47,150,608 \\
47,788,467 \\
56,670,261\end{array}$ & $\begin{array}{l}228,553,579 \\
242,151,076 \\
263,608,741 \\
282,622,523 \\
276,525,603\end{array}$ & $\begin{array}{l}214,390,414 \\
230,916,934 \\
244,951,413 \\
254,272,697 \\
259,226,169\end{array}$ & \begin{tabular}{l|}
$167,909,883$ \\
$178,279,408$ \\
$188,287,298$ \\
$196,521,569$ \\
$205,821,844$
\end{tabular} & $\begin{array}{l}35,433,486 \\
41,111,066 \\
44,806,422 \\
45,314,965 \\
41,195,313\end{array}$ & $\begin{array}{l}11,047,044 \\
11,526,460 \\
11,857,694 \\
12,436,163 \\
12,209,012\end{array}$ & $\begin{array}{r}9,996 \\
10,600 \\
11,281 \\
11,879 \\
12,032\end{array}$ & $\begin{array}{r}918 \\
968 \\
957 \\
971 \\
1,151\end{array}$ & $\begin{array}{l}4,684 \\
4,930 \\
5,351 \\
5,742 \\
5,616\end{array}$ & $\begin{array}{l}4,394 \\
4,702 \\
4,972 \\
5,166 \\
5,265\end{array}$ & $\begin{array}{l}3,441 \\
3,630 \\
3,822 \\
3,993 \\
4,180\end{array}$ & $\begin{array}{l}726 \\
837 \\
910 \\
921 \\
837\end{array}$ & $\begin{array}{l}226 \\
235 \\
241 \\
253 \\
248\end{array}$ & \\
\hline \multirow[t]{2}{*}{$\begin{array}{l}2009-10^{2} \\
2010-11 \ldots \ldots \ldots \ldots \ldots \ldots \ldots \ldots \ldots \\
.\end{array}$} & $\begin{array}{l}596,390,664 \\
604,293,209 \\
\end{array}$ & $\begin{array}{l}75,997,858 \\
75,541,475 \\
\end{array}$ & $\begin{array}{l}258,863,973 \\
266,786,402 \\
\end{array}$ & $\begin{array}{l}261,528,833 \\
261,965,331 \\
\end{array}$ & $\begin{array}{l}210,837,095 \\
211,651,391 \\
\end{array}$ & $\begin{array}{l}38,771,186 \\
38,478,546 \\
\end{array}$ & $\begin{array}{l}11,920,551 \\
11,835,394 \\
\end{array}$ & $\begin{array}{l}12,089 \\
12,217 \\
\end{array}$ & $\begin{array}{l}1,540 \\
1,527 \\
\end{array}$ & $\begin{array}{l}5,247 \\
5,394 \\
\end{array}$ & $\begin{array}{l}5,301 \\
5,296 \\
\end{array}$ & $\begin{array}{l}4,274 \\
4,279 \\
\end{array}$ & $\begin{array}{l}786 \\
778 \\
\end{array}$ & $\begin{array}{l}242 \\
239 \\
\end{array}$ & 告 \\
\hline & \multicolumn{14}{|c|}{ Constant 2012-13 dollars ${ }^{3}$} & \\
\hline 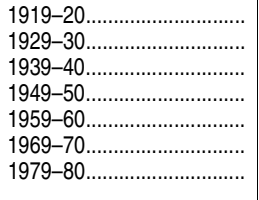 & $\begin{array}{r}\$ 11,776,652 \\
28,228,769 \\
37,422,357 \\
53,112,824 \\
116,109,981 \\
246,613,711 \\
288,712,932\end{array}$ & \begin{tabular}{r|}
$\$ 30,045$ \\
99,126 \\
659,043 \\
$1,522,432$ \\
$5,130,789$ \\
$19,718,093$ \\
$28,321,233$ \\
\end{tabular} & $\begin{array}{r}\$ 1,943,330 \\
4,780,175 \\
11,329,278 \\
21,155,955 \\
45,415,690 \\
98,376,052 \\
135,142,772\end{array}$ & \begin{tabular}{|r|}
$\$ 9,803,277$ \\
$23,349,468$ \\
$25,434,036$ \\
$30,434,437$ \\
$65,563,502$ \\
$128,519,567$ \\
$125,248,927$
\end{tabular} & $\begin{array}{l}- \\
- \\
- \\
- \\
- \\
- \\
-\end{array}$ & $\begin{array}{l}- \\
- \\
- \\
- \\
- \\
-\end{array}$ & $\begin{array}{l}- \\
- \\
- \\
- \\
- \\
-\end{array}$ & \begin{tabular}{r|}
$\$ 546$ \\
1,099 \\
1,471 \\
2,115 \\
3,300 \\
5,414 \\
6,932
\end{tabular} & $\begin{array}{r}1 \\
4 \\
26 \\
61 \\
146 \\
433 \\
680\end{array}$ & $\begin{array}{r}\$ 90 \\
186 \\
445 \\
842 \\
1,291 \\
2,160 \\
3,245\end{array}$ & $\begin{array}{r}\$ 454 \\
909 \\
1,000 \\
1,212 \\
1,864 \\
2,821 \\
3,007\end{array}$ & $\begin{array}{l}- \\
- \\
- \\
- \\
- \\
- \\
-\end{array}$ & $\begin{array}{l}- \\
- \\
- \\
- \\
- \\
- \\
-\end{array}$ & $\begin{array}{l}\overline{-} \\
\overline{-} \\
\overline{-} \\
\overline{-} \\
-\end{array}$ & 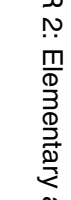 \\
\hline 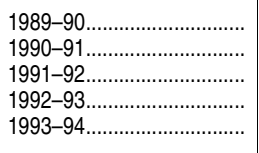 & $\begin{array}{l}379,979,509 \\
385,838,094 \\
392,675,333 \\
401,956,213 \\
411,637,588\end{array}$ & $\begin{array}{l}23,141,183 \\
23,799,222 \\
25,934,916 \\
28,019,120 \\
29,020,831\end{array}$ & $\begin{array}{l}178,993,535 \\
181,956,296 \\
182,097,046 \\
184,080,770 \\
185,873,689\end{array}$ & \begin{tabular}{l|}
$177,844,791$ \\
$180,082,576$ \\
$184,643,371$ \\
$189,856,323$ \\
$196,743,068$
\end{tabular} & $\begin{array}{r}\$ 136,410,910 \\
138,851,533 \\
143,749,158 \\
141,455,382 \\
154,685,592\end{array}$ & $\begin{array}{r}\$ 31,128,426 \\
31,012,524 \\
30,488,734 \\
37,523,691 \\
31,108,841\end{array}$ & \begin{tabular}{r|}
$\$ 10,305,455$ \\
$10,218,519$ \\
$10,405,478$ \\
$10,877,250$ \\
$10,948,635$
\end{tabular} & $\begin{array}{l}9,372 \\
9,361 \\
9,339 \\
9,386 \\
9,471\end{array}$ & $\begin{array}{l}571 \\
577 \\
617 \\
654 \\
668\end{array}$ & $\begin{array}{l}4,415 \\
4,415 \\
4,331 \\
4,299 \\
4,276\end{array}$ & $\begin{array}{l}4,387 \\
4,369 \\
4,391 \\
4,433 \\
4,526\end{array}$ & $\begin{array}{r}\$ 3,365 \\
3,369 \\
3,419 \\
3,303 \\
3,559\end{array}$ & $\begin{array}{r}\$ 768 \\
752 \\
725 \\
876 \\
716\end{array}$ & $\begin{array}{r}\$ 254 \\
248 \\
247 \\
254 \\
252\end{array}$ & 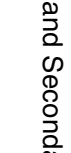 \\
\hline 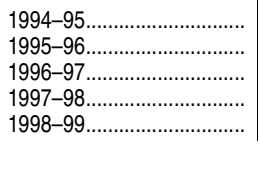 & $\begin{array}{l}420,148,339 \\
430,813,128 \\
444,140,271 \\
466,196,562 \\
488,426,016\end{array}$ & $\begin{array}{l}28,582,384 \\
28,606,816 \\
29,236,073 \\
31,757,176 \\
34,478,562\end{array}$ & $\begin{array}{l}196,468,890 \\
204,654,059 \\
213,193,579 \\
225,492,279 \\
238,039,434\end{array}$ & $\begin{array}{l}195,097,065 \\
197,552,253 \\
201,710,620 \\
208,947,107 \\
215,908,021\end{array}$ & $\begin{array}{l}150,706,319 \\
152,416,581 \\
155,118,702 \\
159,035,225 \\
167,998,102\end{array}$ & $\begin{array}{l}33,163,041 \\
33,725,498 \\
35,361,578 \\
38,157,079 \\
35,641,441\end{array}$ & $\begin{array}{l}11,227,705 \\
11,410,174 \\
11,230,340 \\
11,754,803 \\
12,268,478\end{array}$ & $\begin{array}{r}9,525 \\
9,608 \\
9,738 \\
10,107 \\
10,495\end{array}$ & $\begin{array}{l}648 \\
638 \\
641 \\
688 \\
741\end{array}$ & $\begin{array}{l}4,454 \\
4,564 \\
4,674 \\
4,889 \\
5,115\end{array}$ & $\begin{array}{l}4,423 \\
4,406 \\
4,422 \\
4,530 \\
4,639\end{array}$ & $\begin{array}{l}3,416 \\
3,399 \\
3,401 \\
3,448 \\
3,610\end{array}$ & $\begin{array}{l}752 \\
752 \\
775 \\
827 \\
766\end{array}$ & $\begin{array}{l}255 \\
254 \\
246 \\
255 \\
264\end{array}$ & 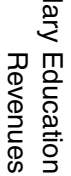 \\
\hline
\end{tabular}




\begin{tabular}{|c|c|c|c|c|c|c|c|c|c|c|c|c|c|c|}
\hline \multirow[b]{3}{*}{ School year } & \multicolumn{7}{|c|}{ Revenues (in thousands) } & \multicolumn{7}{|c|}{ Revenues per pupil } \\
\hline & \multirow[b]{2}{*}{ Total } & \multirow[b]{2}{*}{ Federal } & \multirow[b]{2}{*}{ State } & \multicolumn{4}{|c|}{ Local (including intermediate sources below the state level) } & \multirow[b]{2}{*}{ Total } & \multirow[b]{2}{*}{ Federal } & \multirow[b]{2}{*}{ State } & \multicolumn{4}{|c|}{ Local (including intermediate sources below the state level) } \\
\hline & & & & Total & Property taxes & $\begin{array}{r}\text { Other } \\
\text { public revenue }\end{array}$ & Private $^{1}$ & & & & Total & Property taxes & $\begin{array}{r}\text { Other } \\
\text { public revenue }\end{array}$ & Private $^{1}$ \\
\hline 1 & 2 & 3 & 4 & 5 & 6 & 7 & 8 & 9 & 10 & 11 & 12 & 13 & 14 & 15 \\
\hline 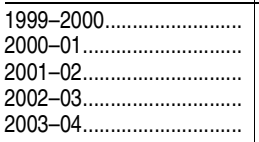 & $\begin{array}{l}509,659,608 \\
530,318,581 \\
544,651,955 \\
559,122,670 \\
574,396,869\end{array}$ & $\begin{array}{l}37,031,552 \\
38,450,560 \\
43,032,668 \\
47,660,622 \\
52,119,761\end{array}$ & $\begin{array}{l}252,289,938 \\
263,712,498 \\
268,159,383 \\
272,220,367 \\
270,254,859\end{array}$ & $\begin{array}{l}220,338,118 \\
228,155,523 \\
233,459,904 \\
239,241,680 \\
252,022,249\end{array}$ & \begin{tabular}{l|}
$170,461,753$ \\
$175,174,796$ \\
$183,188,746$ \\
$188,671,002$ \\
$199,662,568$
\end{tabular} & $\begin{array}{l}37,757,286 \\
40,814,515 \\
37,553,965 \\
37,577,791 \\
39,349,544\end{array}$ & $\begin{array}{l}12,119,079 \\
12,166,213 \\
12,717,194 \\
12,992,887 \\
13,010,137\end{array}$ & $\begin{array}{l}10,877 \\
11,235 \\
11,425 \\
11,604 \\
11,833\end{array}$ & $\begin{array}{r}790 \\
815 \\
903 \\
989 \\
1,074\end{array}$ & $\begin{array}{l}5,384 \\
5,587 \\
5,625 \\
5,650 \\
5,568\end{array}$ & $\begin{array}{l}4,702 \\
4,833 \\
4,897 \\
4,965 \\
5,192\end{array}$ & $\begin{array}{l}3,638 \\
3,711 \\
3,843 \\
3,916 \\
4,113\end{array}$ & $\begin{array}{l}806 \\
865 \\
788 \\
780 \\
811\end{array}$ & $\begin{array}{l}259 \\
258 \\
267 \\
270 \\
268\end{array}$ \\
\hline 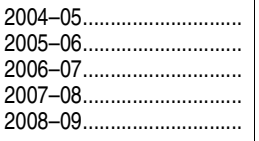 & $\begin{array}{l}588,666,994 \\
605,285,096 \\
629,793,552 \\
638,953,529 \\
638,494,825\end{array}$ & $\begin{array}{l}54,080,373 \\
55,286,954 \\
53,436,340 \\
52,224,151 \\
61,077,520\end{array}$ & $\begin{array}{l}275,840,033 \\
281,529,588 \\
298,750,891 \\
308,855,305 \\
298,031,060\end{array}$ & $\begin{array}{l}258,746,589 \\
268,468,554 \\
277,606,322 \\
277,874,073 \\
279,386,245\end{array}$ & $\begin{array}{l}202,649,497 \\
207,271,134 \\
213,388,212 \\
214,762,534 \\
221,828,655\end{array}$ & $\begin{array}{l}42,764,476 \\
47,796,531 \\
50,779,645 \\
49,521,061 \\
44,399,081\end{array}$ & $\begin{array}{l}13,332,616 \\
13,400,889 \\
13,438,464 \\
13,590,477 \\
13,158,509\end{array}$ & $\begin{array}{l}12,064 \\
12,324 \\
12,784 \\
12,981 \\
12,968\end{array}$ & $\begin{array}{l}1,108 \\
1,126 \\
1,085 \\
1,061 \\
1,241\end{array}$ & $\begin{array}{l}5,653 \\
5,732 \\
6,064 \\
6,275 \\
6,053\end{array}$ & $\begin{array}{l}5,303 \\
5,466 \\
5,635 \\
5,645 \\
5,674\end{array}$ & $\begin{array}{l}4,153 \\
4,220 \\
4,332 \\
4,363 \\
4,505\end{array}$ & $\begin{array}{r}876 \\
973 \\
1,031 \\
1,006 \\
902\end{array}$ & $\begin{array}{l}273 \\
273 \\
273 \\
276 \\
267\end{array}$ \\
\hline $\begin{array}{l}2009-10^{2} \ldots \ldots \ldots \ldots \ldots \ldots \ldots \ldots \ldots \\
2010-111 \ldots \ldots \ldots \ldots \ldots \ldots \ldots \ldots \ldots . . .\end{array}$ & $\begin{array}{l}636,612,328 \\
632,350,353\end{array}$ & $\begin{array}{l}81,123,291 \\
79,048,842\end{array}$ & $\begin{array}{l}276,322,227 \\
279,173,211 \\
\end{array}$ & $\begin{array}{l}279,166,810 \\
274,128,299 \\
\end{array}$ & $\begin{array}{l}225,056,330 \\
221,478,298 \\
\end{array}$ & $\begin{array}{l}41,385,985 \\
40,265,093 \\
\end{array}$ & $\begin{array}{l}12,724,494 \\
12,384,908 \\
\end{array}$ & $\begin{array}{l}12,904 \\
12,784\end{array}$ & $\begin{array}{l}1,644 \\
1,598\end{array}$ & $\begin{array}{l}5,601 \\
5,644\end{array}$ & $\begin{array}{l}5,659 \\
5,542\end{array}$ & $\begin{array}{l}4,562 \\
4,478\end{array}$ & $\begin{array}{l}839 \\
814\end{array}$ & $\begin{array}{l}258 \\
250 \\
\end{array}$ \\
\hline & \multicolumn{14}{|c|}{ Percentage distribution } \\
\hline 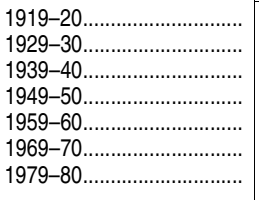 & $\begin{array}{l}100.0 \\
100.0 \\
100.0 \\
100.0 \\
100.0 \\
100.0 \\
100.0\end{array}$ & \begin{tabular}{l|}
0.3 \\
0.4 \\
1.8 \\
2.9 \\
4.4 \\
8.0 \\
9.8
\end{tabular} & \begin{tabular}{l|}
16.5 \\
16.9 \\
30.3 \\
39.8 \\
39.1 \\
39.9 \\
46.8
\end{tabular} & $\begin{array}{l}83.2 \\
82.7 \\
68.0 \\
57.3 \\
56.5 \\
52.1 \\
43.4\end{array}$ & $\begin{array}{l}- \\
- \\
- \\
- \\
- \\
- \\
-\end{array}$ & $\begin{array}{l}- \\
- \\
- \\
- \\
- \\
-\end{array}$ & $\begin{array}{l}- \\
- \\
- \\
- \\
- \\
- \\
-\end{array}$ & $\begin{array}{l}\mid 100.0 \\
100.0 \\
100.0 \\
100.0 \\
100.0 \\
100.0 \\
100.0\end{array}$ & $\begin{array}{l}0.3 \\
0.4 \\
1.8 \\
2.9 \\
4.4 \\
8.0 \\
9.8\end{array}$ & \begin{tabular}{l|}
16.5 \\
16.9 \\
30.3 \\
39.8 \\
39.1 \\
39.9 \\
46.8
\end{tabular} & $\begin{array}{l}83.2 \\
82.7 \\
68.0 \\
57.3 \\
56.5 \\
52.1 \\
43.4\end{array}$ & $\begin{array}{l}- \\
- \\
- \\
- \\
- \\
- \\
-\end{array}$ & $\begin{array}{l}- \\
- \\
- \\
- \\
- \\
- \\
-\end{array}$ & $\begin{array}{l}- \\
- \\
- \\
- \\
- \\
-\end{array}$ \\
\hline 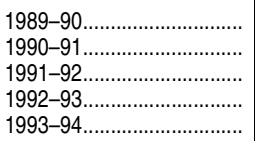 & $\begin{array}{l}100.0 \\
100.0 \\
100.0 \\
100.0 \\
100.0\end{array}$ & $\begin{array}{l}6.1 \\
6.2 \\
6.6 \\
7.0 \\
7.1\end{array}$ & $\begin{array}{l}47.1 \\
47.2 \\
46.4 \\
45.8 \\
45.2\end{array}$ & $\begin{array}{l}46.8 \\
46.7 \\
47.0 \\
47.2 \\
47.8\end{array}$ & $\begin{array}{l}35.9 \\
36.0 \\
36.6 \\
35.2 \\
37.6\end{array}$ & $\begin{array}{l}8.2 \\
8.0 \\
7.8 \\
9.3 \\
7.6\end{array}$ & $\begin{array}{l}2.7 \\
2.6 \\
2.6 \\
2.7 \\
2.7\end{array}$ & $\begin{array}{l}100.0 \\
100.0 \\
100.0 \\
100.0 \\
100.0\end{array}$ & $\begin{array}{l}6.1 \\
6.2 \\
6.6 \\
7.0 \\
7.1\end{array}$ & $\begin{array}{l}47.1 \\
47.2 \\
46.4 \\
45.8 \\
45.2\end{array}$ & $\begin{array}{l}46.8 \\
46.7 \\
47.0 \\
47.2 \\
47.8\end{array}$ & $\begin{array}{l}35.9 \\
36.0 \\
36.6 \\
35.2 \\
37.6\end{array}$ & $\begin{array}{l}8.2 \\
8.0 \\
7.8 \\
9.3 \\
7.6\end{array}$ & $\begin{array}{l}2.7 \\
2.6 \\
2.6 \\
2.7 \\
2.7\end{array}$ \\
\hline $\begin{array}{c}1994-95 \ldots \ldots \ldots \ldots \ldots \ldots \ldots \ldots . . \\
1995-96 \ldots \ldots \ldots \ldots \ldots \ldots \ldots \ldots \ldots . . \\
1996-97 \ldots \ldots \ldots \ldots \ldots \ldots \ldots \ldots \ldots . . \\
1997-98 \ldots \ldots \ldots \ldots \ldots \ldots \ldots \ldots \ldots . . \\
1998-99 \ldots \ldots \ldots \ldots \ldots \ldots \ldots \ldots . .\end{array}$ & $\begin{array}{l}100.0 \\
100.0 \\
100.0 \\
100.0 \\
100.0\end{array}$ & $\begin{array}{l}6.8 \\
6.6 \\
6.6 \\
6.8 \\
7.1\end{array}$ & $\begin{array}{l}46.8 \\
47.5 \\
48.0 \\
48.4 \\
48.7\end{array}$ & $\begin{array}{l}46.4 \\
45.9 \\
45.4 \\
44.8 \\
44.2\end{array}$ & $\begin{array}{l}35.9 \\
35.4 \\
34.9 \\
34.1 \\
34.4\end{array}$ & $\begin{array}{l}7.9 \\
7.8 \\
8.0 \\
8.2 \\
7.3\end{array}$ & $\begin{array}{l}2.7 \\
2.6 \\
2.5 \\
2.5 \\
2.5\end{array}$ & $\begin{array}{l}100.0 \\
100.0 \\
100.0 \\
100.0 \\
100.0\end{array}$ & $\begin{array}{l}6.8 \\
6.6 \\
6.6 \\
6.8 \\
7.1\end{array}$ & $\begin{array}{l}46.8 \\
47.5 \\
48.0 \\
48.4 \\
48.7\end{array}$ & $\begin{array}{l}46.4 \\
45.9 \\
45.4 \\
44.8 \\
44.2\end{array}$ & $\begin{array}{l}35.9 \\
35.4 \\
34.9 \\
34.1 \\
34.4\end{array}$ & $\begin{array}{l}7.9 \\
7.8 \\
8.0 \\
8.2 \\
7.3\end{array}$ & $\begin{array}{l}2.7 \\
2.6 \\
2.5 \\
2.5 \\
2.5\end{array}$ \\
\hline 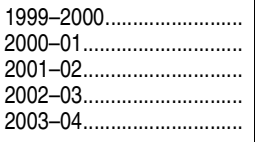 & $\begin{array}{l}100.0 \\
100.0 \\
100.0 \\
100.0 \\
100.0\end{array}$ & $\begin{array}{l}7.3 \\
7.3 \\
7.9 \\
8.5 \\
9.1\end{array}$ & $\begin{array}{l}49.5 \\
49.7 \\
49.2 \\
48.7 \\
47.1\end{array}$ & $\begin{array}{l}43.2 \\
43.0 \\
42.9 \\
42.8 \\
43.9\end{array}$ & $\begin{array}{l}33.4 \\
33.0 \\
33.6 \\
33.7 \\
34.8\end{array}$ & $\begin{array}{l}7.4 \\
7.7 \\
6.9 \\
6.7 \\
6.9\end{array}$ & $\begin{array}{l}2.4 \\
2.3 \\
2.3 \\
2.3 \\
2.3\end{array}$ & $\begin{array}{l}100.0 \\
100.0 \\
100.0 \\
100.0 \\
100.0\end{array}$ & $\begin{array}{l}7.3 \\
7.3 \\
7.9 \\
8.5 \\
9.1\end{array}$ & $\begin{array}{l}49.5 \\
49.7 \\
49.2 \\
48.7 \\
47.1\end{array}$ & $\begin{array}{l}43.2 \\
43.0 \\
42.9 \\
42.8 \\
43.9\end{array}$ & $\begin{array}{l}33.4 \\
33.0 \\
33.6 \\
33.7 \\
34.8\end{array}$ & $\begin{array}{l}7.4 \\
7.7 \\
6.9 \\
6.7 \\
6.9\end{array}$ & $\begin{array}{l}2.4 \\
2.3 \\
2.3 \\
2.3 \\
2.3\end{array}$ \\
\hline $\begin{array}{l}2004-05 \ldots \ldots \ldots \ldots \ldots \ldots \ldots \ldots . . \\
2005-06 \ldots \ldots \ldots \ldots \ldots \ldots \ldots \ldots \\
2006-07 \ldots \ldots \ldots \ldots \ldots \ldots \ldots \ldots . \\
2007-08 \ldots \ldots \ldots \ldots \ldots \ldots \ldots \ldots . \\
2008-09 \ldots \ldots \ldots \ldots \ldots \ldots \ldots . . \\
.\end{array}$ & $\begin{array}{l}100.0 \\
100.0 \\
100.0 \\
100.0 \\
100.0\end{array}$ & $\begin{array}{l}9.2 \\
9.1 \\
8.5 \\
8.2 \\
9.6\end{array}$ & $\begin{array}{l}46.9 \\
46.5 \\
47.4 \\
48.3 \\
46.7\end{array}$ & $\begin{array}{l}44.0 \\
44.4 \\
44.1 \\
43.5 \\
43.8\end{array}$ & $\begin{array}{l}34.4 \\
34.2 \\
33.9 \\
33.6 \\
34.7\end{array}$ & $\begin{array}{l}7.3 \\
7.9 \\
8.1 \\
7.8 \\
7.0\end{array}$ & $\begin{array}{l}2.3 \\
2.2 \\
2.1 \\
2.1 \\
2.1\end{array}$ & $\begin{array}{l}100.0 \\
100.0 \\
100.0 \\
100.0 \\
100.0\end{array}$ & $\begin{array}{l}9.2 \\
9.1 \\
8.5 \\
8.2 \\
9.6\end{array}$ & $\begin{array}{l}46.9 \\
46.5 \\
47.4 \\
48.3 \\
46.7\end{array}$ & $\begin{array}{l}44.0 \\
44.4 \\
44.1 \\
43.5 \\
43.8\end{array}$ & $\begin{array}{l}34.4 \\
34.2 \\
33.9 \\
33.6 \\
34.7\end{array}$ & $\begin{array}{l}7.3 \\
7.9 \\
8.1 \\
7.8 \\
7.0\end{array}$ & $\begin{array}{l}2.3 \\
2.2 \\
2.1 \\
2.1 \\
2.1\end{array}$ \\
\hline $\begin{array}{l}2009-10^{2} \ldots \ldots \ldots \ldots \ldots \ldots \ldots \\
2010-11 \ldots \ldots \ldots \ldots \ldots \ldots \ldots \ldots\end{array}$ & $\begin{array}{l}100.0 \\
100.0\end{array}$ & $\begin{array}{l}12.7 \\
12.5\end{array}$ & $\begin{array}{l}43.4 \\
44.1\end{array}$ & $\begin{array}{l}43.9 \\
43.4\end{array}$ & $\begin{array}{l}35.4 \\
35.0\end{array}$ & $\begin{array}{l}6.5 \\
6.4\end{array}$ & $\begin{array}{l}2.0 \\
2.0\end{array}$ & $\begin{array}{l}100.0 \\
100.0\end{array}$ & $\begin{array}{l}12.7 \\
12.5\end{array}$ & $\begin{array}{l}43.4 \\
44.1\end{array}$ & $\begin{array}{l}43.9 \\
43.4\end{array}$ & $\begin{array}{l}35.4 \\
35.0\end{array}$ & $\begin{array}{l}6.5 \\
6.4\end{array}$ & $\begin{array}{l}2.0 \\
2.0\end{array}$ \\
\hline
\end{tabular}

-Not available. \#Rounds to zero.

Includes revenues from gifts, and tuition and fees from patrons.

adjusted to a school-year basis.
NOTE: Beginning in 1989-90, revenues for state education agencies were excluded and new survey collection procedures were initiated; data may not be entirely comparable with figures for earlier years. Detail may not sum to totals because of rounding.

SOURCE: U.S. Department of Education, National Center for Education Statistics, Biennial Survey of Education in the United Public Elementary and Secondary Eduction, 1979-80; and Common Core of Data (CCD) "National Public Eduction Financial Survey," 1989-90 through 2010-11. (This table was prepared July 2013.) 
Table 235.20. Revenues for public elementary and secondary schools, by source of funds and state or jurisdiction: 2010-11

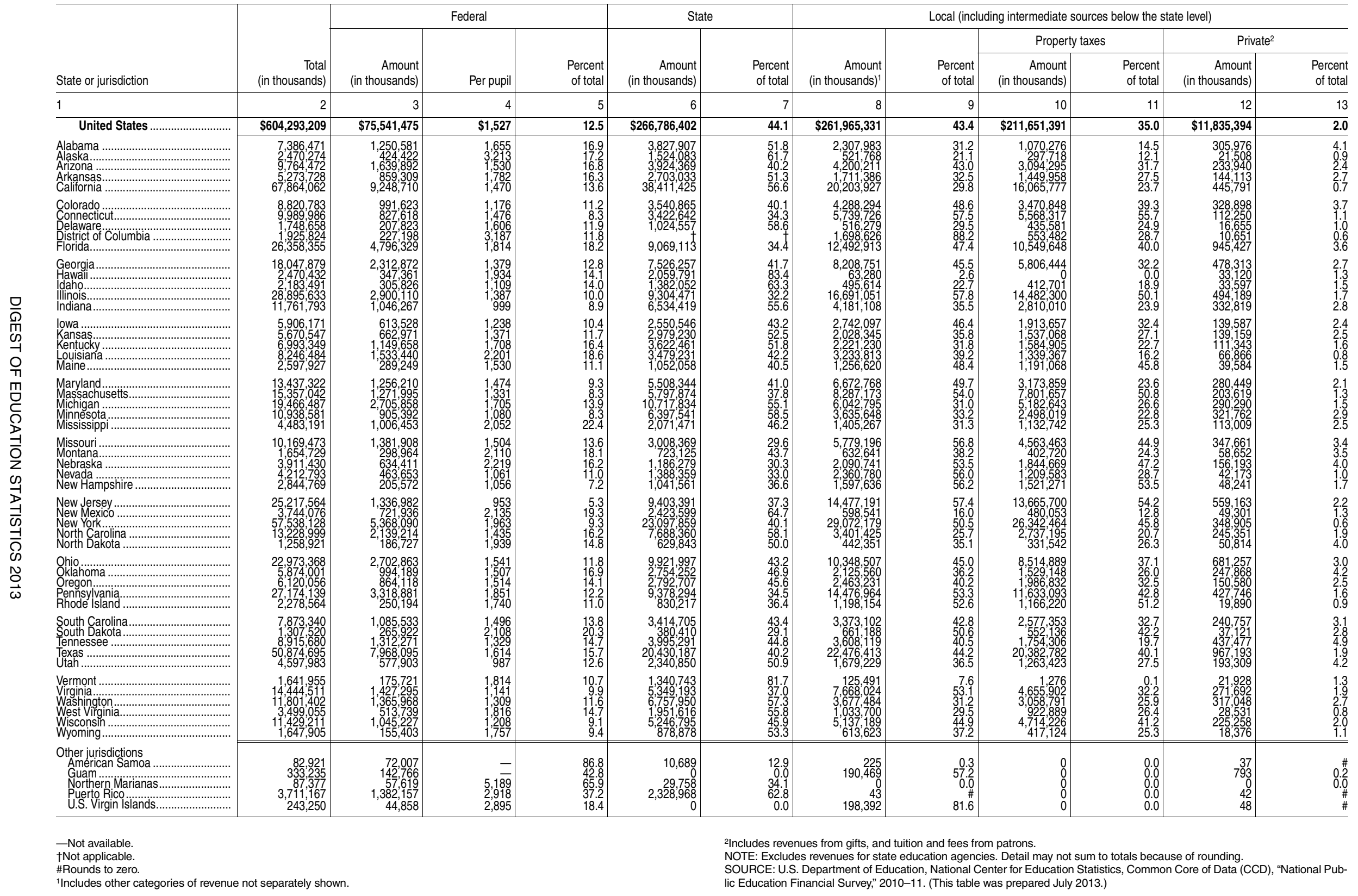


Table 235.30. Revenues for public elementary and secondary schools, by source of funds and state or jurisdiction: 2009-10

\begin{tabular}{|c|c|c|c|c|c|c|c|c|c|c|c|c|}
\hline \multirow[b]{3}{*}{ State or jurisdiction } & \multirow[b]{3}{*}{$\begin{array}{r}\text { Total } \\
\text { (in thousands) }\end{array}$} & \multicolumn{3}{|c|}{ Federal } & \multicolumn{2}{|c|}{ State } & \multicolumn{6}{|c|}{ Local (including intermediate sources below the state level) } \\
\hline & & \multirow[b]{2}{*}{$\begin{array}{r}\text { Amount } \\
\text { (in thousands) }\end{array}$} & \multirow[b]{2}{*}{ Per pupil } & \multirow[b]{2}{*}{$\begin{array}{r}\text { Percent } \\
\text { of total }\end{array}$} & \multirow[b]{2}{*}{$\begin{array}{r}\text { Amount } \\
\text { (in thousands) }\end{array}$} & \multirow[b]{2}{*}{$\begin{array}{r}\text { Percent } \\
\text { of total }\end{array}$} & \multirow[b]{2}{*}{$\begin{array}{r}\text { Amount } \\
\text { (in thousands) }\end{array}$} & \multirow[b]{2}{*}{$\begin{array}{r}\text { Percent } \\
\text { of total }\end{array}$} & \multicolumn{2}{|c|}{ Property taxes } & \multicolumn{2}{|c|}{ Private $^{2}$} \\
\hline & & & & & & & & & $\begin{array}{r}\text { Amount } \\
\text { (in thousands) }\end{array}$ & $\begin{array}{r}\text { Percent } \\
\text { of total }\end{array}$ & $\begin{array}{r}\text { Amount } \\
\text { (in thousands) }\end{array}$ & $\begin{array}{r}\text { Percent } \\
\text { of total }\end{array}$ \\
\hline 1 & 2 & 3 & 4 & 5 & 6 & 7 & 8 & 9 & 10 & 11 & 12 & 13 \\
\hline 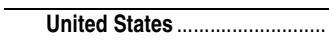 & $\$ 596,390,664$ & $\$ 75,997,858$ & $\$ 1,540$ & 12.7 & $\$ 258,863,973$ & 43.4 & $\$ 261,528,833$ & 43.9 & $\$ 210,837,095$ & 35.4 & $\$ 11,920,551$ & $\overline{2.0}$ \\
\hline 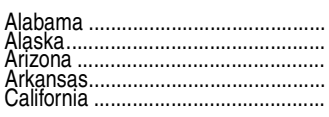 & $\begin{array}{r}7,239,691 \\
2,338,215 \\
10,069,959 \\
5,160,401 \\
64,130,242\end{array}$ & $\begin{array}{l}1,168,016 \\
369,729 \\
1,893,298 \\
819,459 \\
8,855,246\end{array}$ & $\begin{array}{l}1,560 \\
2,808 \\
1,757 \\
1,705 \\
1,414\end{array}$ & $\begin{array}{l}16.1 \\
15.8 \\
18.8 \\
15.9 \\
13.8\end{array}$ & $\begin{array}{r}3,800,153 \\
1,461,906 \\
3,896,117 \\
2,686,231 \\
34,743,249\end{array}$ & $\begin{array}{l}52.5 \\
62.5 \\
38.7 \\
52.1 \\
54.2\end{array}$ & $\begin{array}{r}2,271,522 \\
506,580 \\
4,280,545 \\
1,654,711 \\
20,531,747\end{array}$ & $\begin{array}{l}31.4 \\
21.7 \\
42.5 \\
32.1 \\
32.0\end{array}$ & $\begin{array}{r}1,066,022 \\
264,899 \\
3,236,621 \\
1,404,473 \\
16,379,989\end{array}$ & $\begin{array}{l}14.7 \\
11.3 \\
32.1 \\
27.2 \\
25.5\end{array}$ & $\begin{array}{l}315,061 \\
22,533 \\
228,786 \\
141,642 \\
476,595\end{array}$ & $\begin{array}{l}4.4 \\
1.0 \\
2.3 \\
2.7 \\
0.7\end{array}$ \\
\hline 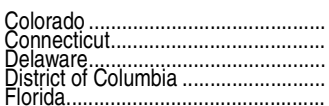 & $\begin{array}{r}8,852,609 \\
9,895,487 \\
1,784,101 \\
1,720,917 \\
26,056,857\end{array}$ & $\begin{array}{r}730,363 \\
854,645 \\
218,204 \\
156,202 \\
4,200,101\end{array}$ & $\begin{array}{r}877 \\
1,515 \\
1,721 \\
2,250 \\
1,594\end{array}$ & $\begin{array}{r}8.3 \\
8.6 \\
12.2 \\
9.1 \\
16.1\end{array}$ & $\begin{array}{l}3,860,026 \\
3,463,790 \\
1,046,317 \\
8,216,579\end{array}$ & $\begin{array}{r}43.6 \\
35.0 \\
58.6 \\
\vdots 1.5\end{array}$ & $\begin{array}{r}4,262,220 \\
5,577,052 \\
519,580 \\
1,564,715 \\
13,640,177\end{array}$ & $\begin{array}{l}48.1 \\
56.4 \\
29.1 \\
90.9 \\
52.3\end{array}$ & $\begin{array}{r}3,453,889 \\
5,410,541 \\
439,793 \\
600,285 \\
11,545,456\end{array}$ & $\begin{array}{l}39.0 \\
54.7 \\
24.7 \\
34.9 \\
44.3\end{array}$ & $\begin{array}{r}320,211 \\
119,437 \\
17,112 \\
11,538 \\
1,045,943\end{array}$ & $\begin{array}{l}3.6 \\
1.2 \\
1.0 \\
0.7 \\
4.0\end{array}$ \\
\hline 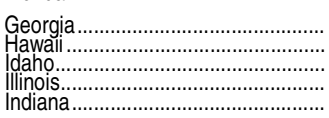 & $\begin{array}{r}17,835,791 \\
2,489,462 \\
2,222,539 \\
28,263,059 \\
13,641,695\end{array}$ & $\begin{array}{r}2,645,785 \\
382,399 \\
462,867 \\
3,508,917 \\
1,513,137\end{array}$ & $\begin{array}{l}1,587 \\
2,122 \\
1,675 \\
1,668 \\
1,446\end{array}$ & $\begin{array}{l}14.8 \\
15.4 \\
20.8 \\
12.4 \\
11.1\end{array}$ & $\begin{array}{l}6,764,686 \\
2,057,144 \\
1,284,139 \\
8,021,17 \\
6,441,408\end{array}$ & $\begin{array}{l}37.9 \\
82.6 \\
57.8 \\
28.4 \\
47.2\end{array}$ & $\begin{array}{r}8,425,320 \\
49,799 \\
475,533 \\
16,732,925 \\
5,687,150\end{array}$ & $\begin{array}{r}47.2 \\
2.0 \\
21.4 \\
59.2 \\
41.7\end{array}$ & $\begin{array}{r}6,028,115 \\
0 \\
395,012 \\
14,652,216 \\
4,242,737\end{array}$ & $\begin{array}{r}33.8 \\
0.0 \\
17.8 \\
51.8 \\
31.1\end{array}$ & $\begin{array}{r}459,224 \\
28,276 \\
34,792 \\
494,, 60 \\
332,598\end{array}$ & $\begin{array}{l}2.6 \\
1.1 \\
1.6 \\
1.7 \\
2.4\end{array}$ \\
\hline 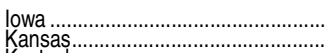 & $\begin{array}{l}5,541,140 \\
5,487,071\end{array}$ & $\begin{array}{r}743,561 \\
641,619\end{array}$ & $\begin{array}{l}1,512 \\
1,352\end{array}$ & $\begin{array}{l}13.4 \\
11.7\end{array}$ & $\begin{array}{l}2,217,893 \\
2,893,517\end{array}$ & $\begin{array}{l}40.0 \\
52.7\end{array}$ & $\begin{array}{l}2,579,686 \\
1,951,936\end{array}$ & $\begin{array}{l}46.6 \\
35.6\end{array}$ & $\begin{array}{l}1,775,152 \\
1,532,464\end{array}$ & $\begin{array}{l}32.0 \\
27.9\end{array}$ & $\begin{array}{l}143,962 \\
117,068\end{array}$ & $\begin{array}{l}2.6 \\
2.1\end{array}$ \\
\hline 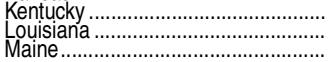 & $\begin{array}{l}6,873,286 \\
8,215,973 \\
2,639,779\end{array}$ & $\begin{array}{l}1,139,931 \\
1,572,272 \\
315,277\end{array}$ & $\begin{array}{l}1,676 \\
2,276 \\
1,666\end{array}$ & $\begin{array}{l}16.6 \\
19.1 \\
11.9\end{array}$ & $\begin{array}{l}3,582,406 \\
3,53,026 \\
1,079,330\end{array}$ & $\begin{array}{l}52.1 \\
43.0 \\
40.9\end{array}$ & $\begin{array}{l}2,150,950 \\
3,10,675 \\
1,245,173\end{array}$ & $\begin{array}{l}31.3 \\
37.9 \\
47.2\end{array}$ & $\begin{array}{l}1,529,687 \\
1,302,572 \\
1,176,557\end{array}$ & $\begin{array}{l}\overline{2} 2.3 \\
15.9 \\
44.6\end{array}$ & $\begin{array}{r}114,275 \\
68,158 \\
40,480\end{array}$ & $\begin{array}{l}1.7 \\
0.8 \\
15\end{array}$ \\
\hline 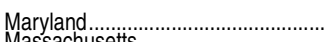 & $13,352,511$ & $1,039,305$ & 1,225 & 7.8 & $5,544,364$ & 41.5 & $6,768,842$ & 50.7 & $3,223,729$ & 24.1 & 288,940 & 2.2 \\
\hline 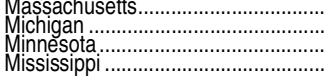 & $\begin{array}{r}14,859,331 \\
19,401,180 \\
10,639,251 \\
4,443,683\end{array}$ & $\begin{array}{l}1,155,524 \\
2,5759 \\
1,326,127 \\
945,971\end{array}$ & $\begin{array}{l}1,228 \\
1,562 \\
1,584 \\
1,921\end{array}$ & $\begin{array}{r}73.9 \\
13.3 \\
21.3\end{array}$ & $\begin{array}{r}5,765,516 \\
10,516,655 \\
6,309,625 \\
2,109,083\end{array}$ & $\begin{array}{l}38.8 \\
54.2 \\
59.3 \\
47.5\end{array}$ & 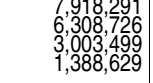 & $\begin{array}{l}53.3 \\
32.5 \\
28.2 \\
31.2\end{array}$ & $\begin{array}{l}7,428,777 \\
5,46,855 \\
1,918,305 \\
1,101,206\end{array}$ & $\begin{array}{l}50.0 \\
28.2 \\
18.0 \\
24.8\end{array}$ & $\begin{array}{l}225,, 281 \\
30024 \\
320,535 \\
113,622\end{array}$ & $\begin{array}{l}1.5 \\
3.5 \\
2.6\end{array}$ \\
\hline 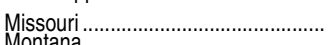 & $10,157,112$ & $\begin{array}{l}1,515,939 \\
259,304\end{array}$ & 1,651 & 14.9 & $2,971,265$ & 29.3 & $5,669,907$ & 55.8 & $4,444,319$ & 43.8 & 349,604 & 3.4 \\
\hline 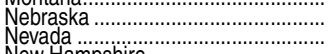 & $\begin{array}{l}3,69,930 \\
4,310,014 \\
4,3014\end{array}$ & $\begin{array}{l}469,503 \\
367,140 \\
351,270\end{array}$ & $\begin{array}{l}1,657 \\
1,656 \\
1850\end{array}$ & $\begin{array}{r}12.7 \\
8.5 \\
1.5\end{array}$ & $\begin{array}{l}1,220,466 \\
1,40,630\end{array}$ & $\begin{array}{l}33.0 \\
32.6 \\
32.6\end{array}$ & $\begin{array}{l}2,003,961 \\
2,53,244 \\
2,56,240\end{array}$ & $\begin{array}{l}54.3 \\
58.8\end{array}$ & $\begin{array}{l}1,702,545 \\
1,428,542 \\
1,428,812\end{array}$ & $\begin{array}{l}4.3 \\
33.2 \\
33.2\end{array}$ & $\begin{array}{r}150,369 \\
43,417 \\
43\end{array}$ & $\begin{array}{l}3.1 \\
1.0\end{array}$ \\
\hline Tew Hampsnire ............. & $\begin{array}{r}2,810,018 \\
25,547,376\end{array}$ & $\begin{array}{r}351,279 \\
2.422 .449\end{array}$ & $\begin{array}{l}1,182 \\
1,735\end{array}$ & $\begin{array}{r}2.5 \\
9.5\end{array}$ & $\begin{array}{r}902,020 \\
9,214,018\end{array}$ & $\begin{array}{l}32.1 \\
36.1\end{array}$ & $\begin{array}{r}1,556, / 19 \\
13,910,909\end{array}$ & $\begin{array}{l}55.4 \\
54.5\end{array}$ & $\begin{array}{r}1,482,599 \\
13,091,624\end{array}$ & $\begin{array}{l}52.8 \\
51.2\end{array}$ & $\begin{array}{r}48,388 \\
544,032\end{array}$ & $\begin{array}{l}1.7 \\
21\end{array}$ \\
\hline 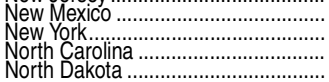 & $\begin{array}{r}5,, 760,801 \\
13,056,375 \\
1,256,048\end{array}$ & $\begin{array}{l}5,7,122,369 \\
1,91,491 \\
277,989\end{array}$ & $\begin{array}{l}2,360 \\
1,852 \\
1,343 \\
2,924\end{array}$ & $\begin{array}{l}21.0 \\
9.0 \\
15.3 \\
22.1\end{array}$ & $\begin{array}{r}2,384,730 \\
23,438,008 \\
7,602,930 \\
552,862\end{array}$ & $\begin{array}{l}63.4 \\
41.0 \\
58.2 \\
44.0\end{array}$ & $\begin{array}{r}28,586,762 \\
3,462,703 \\
425,346 \\
42,197\end{array}$ & $\begin{array}{l}15.6 \\
50.0 \\
26.5 \\
33.9\end{array}$ & $\begin{array}{r}25,359,714 \\
25,626 \\
2,734,835 \\
318,596\end{array}$ & $\begin{array}{r}12.2 \\
44.3 \\
20.9 \\
25.4\end{array}$ & $\begin{array}{r}50,553 \\
350,624 \\
260,556 \\
49,289\end{array}$ & $\begin{array}{l}1.3 \\
0.6 \\
2.0 \\
3.9\end{array}$ \\
\hline $\begin{array}{l}\text { Ohio } \\
\text { Oklahoma }\end{array}$ & $\begin{array}{r}22,729,890 \\
5,699,758\end{array}$ & $\begin{array}{l}2,452,032 \\
978,847\end{array}$ & $\begin{array}{l}1,390 \\
1,495\end{array}$ & $\begin{array}{l}10.8 \\
17.2\end{array}$ & $\begin{array}{r}10,017,540 \\
2,726,116\end{array}$ & $\begin{array}{l}44.1 \\
47.8\end{array}$ & $\begin{array}{r}10,260,318 \\
1,994,795\end{array}$ & $\begin{array}{l}45.1 \\
35.0\end{array}$ & $\begin{array}{l}8,374,127 \\
1,472,521\end{array}$ & $\begin{array}{l}36.8 \\
25.8\end{array}$ & $\begin{array}{l}684,267 \\
250\end{array}$ & $\begin{array}{l}3.0 \\
4.4\end{array}$ \\
\hline 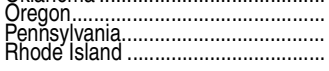 & $\begin{array}{r}6,211,294 \\
26,408,846 \\
2,262,193\end{array}$ & $\begin{array}{r}820,955 \\
2,887,079 \\
259,486\end{array}$ & $\begin{array}{l}1,409 \\
1,617 \\
1,788\end{array}$ & $\begin{array}{l}13.2 \\
10.9 \\
11.5\end{array}$ & & $\begin{array}{l}47.4 \\
35.8 \\
34.9\end{array}$ & $\begin{array}{r}1,444,352 \\
14,065,265 \\
1,212,447\end{array}$ & $\begin{array}{l}39.4 \\
53.3 \\
53.6\end{array}$ & $\begin{array}{r}1,958,001 \\
11,258,861 \\
1,179,194\end{array}$ & $\begin{array}{l}31.5 \\
42.6 \\
52.1\end{array}$ & $\begin{array}{r}150,287 \\
393,, 956 \\
21,334\end{array}$ & $\begin{array}{l}2.4 \\
1.5 \\
0.9\end{array}$ \\
\hline 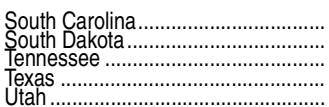 & $\begin{array}{r}7,837,314 \\
1,300,147 \\
8,528,4074 \\
50,045,607 \\
4,464,562\end{array}$ & $\begin{array}{l}1,092,174 \\
1,533,761 \\
1,158,247 \\
7,786,692 \\
560,352\end{array}$ & $\begin{array}{l}1,510 \\
2,051 \\
1,191 \\
1,606 \\
995\end{array}$ & $\begin{array}{l}13.9 \\
19.5 \\
13.6 \\
15.6 \\
12.6\end{array}$ & $\begin{array}{r}3,431,142 \\
404,402 \\
3,842,346 \\
19,714,162 \\
2,283,683\end{array}$ & $\begin{array}{l}43.8 \\
31.1 \\
45.1 \\
39.4 \\
59.2\end{array}$ & $\begin{array}{r}3,313,999 \\
641,985 \\
3,, 527,454 \\
22,543,753 \\
1,620,527\end{array}$ & $\begin{array}{l}42.3 \\
49.4 \\
41.4 \\
45.0 \\
36.3\end{array}$ & $\begin{array}{r}2,559,866 \\
535,294 \\
1,718,271 \\
20,441,180 \\
1,215,476\end{array}$ & $\begin{array}{l}32.7 \\
41.2 \\
20.1 \\
40.8 \\
27.2\end{array}$ & $\begin{array}{l}242,710 \\
36,414 \\
420,647 \\
951,295 \\
187,945\end{array}$ & $\begin{array}{l}3.1 \\
2.8 \\
4.9 \\
4.2\end{array}$ \\
\hline 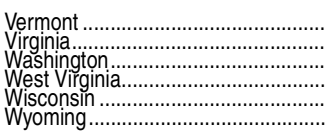 & $\begin{array}{r}1,638,396 \\
14,692,849 \\
11,817,488 \\
3,432,220 \\
11,104,749 \\
1,708,365 \\
\end{array}$ & $\begin{array}{r}174,139 \\
1,527,093 \\
1,401,295 \\
536,424 \\
1,163,103 \\
124,360 \\
\end{array}$ & $\begin{array}{l}1,904 \\
1,226 \\
1,353 \\
1,898 \\
1,343 \\
1,419 \\
\end{array}$ & $\begin{array}{r}10.6 \\
10.4 \\
11.9 \\
15.6 \\
10.5 \\
7.3 \\
\end{array}$ & $\begin{array}{l}1,337,034 \\
5,485,997 \\
6,931,627 \\
1,899,967 \\
4,975,033 \\
880,, 853 \\
\end{array}$ & $\begin{array}{l}81.6 \\
37.3 \\
58.7 \\
55.4 \\
44.8 \\
51.6\end{array}$ & $\begin{array}{r}127,223 \\
7,679,759 \\
3,48,756 \\
9,96,506 \\
4,966,614 \\
703,152 \\
\end{array}$ & $\begin{array}{r}7.8 \\
52.3 \\
29.5 \\
29.0 \\
44.7 \\
41.2 \\
\end{array}$ & $\begin{array}{r}1,808 \\
4,299,233 \\
2,888,260 \\
896,121 \\
4,562,148 \\
458,790 \\
\end{array}$ & $\begin{array}{r}0.1 \\
29.3 \\
24.4 \\
26.1 \\
41.1 \\
26.9 \\
\end{array}$ & $\begin{array}{r}24,793 \\
275,539 \\
312,865 \\
28,, 102 \\
232,262 \\
17,935 \\
\end{array}$ & $\begin{array}{l}1.5 \\
1.9 \\
2.6 \\
0.8 \\
2.1 \\
1.0\end{array}$ \\
\hline 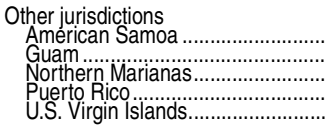 & $\begin{array}{r}75,691 \\
252,926 \\
72,628 \\
4,345,726 \\
266,086\end{array}$ & $\begin{array}{r}64,364 \\
50,166 \\
41,148 \\
1,617,604 \\
89,574\end{array}$ & $\begin{array}{r}- \\
3, \overline{54} \\
3,279 \\
5,782\end{array}$ & $\begin{array}{l}85.0 \\
19.8 \\
56.7 \\
37.2 \\
33.7\end{array}$ & $\begin{array}{r}11,051 \\
31 \\
2,20 \\
2,725,019 \\
0\end{array}$ & $\begin{array}{r}14.6 \\
0.0 \\
43.0 \\
62.7 \\
0.0\end{array}$ & $\begin{array}{r}277 \\
202,760 \\
260 \\
3,103 \\
176,513\end{array}$ & $\begin{array}{r}0.4 \\
80.2 \\
0.4 \\
0.1 \\
66.3\end{array}$ & $\begin{array}{l}0 \\
0 \\
0 \\
0 \\
0\end{array}$ & $\begin{array}{l}0.0 \\
0.0 \\
0.0 \\
0.0 \\
0.0\end{array}$ & $\begin{array}{r}84 \\
865 \\
0 \\
3,100 \\
142\end{array}$ & $\begin{array}{l}0.1 \\
0.3 \\
0.0 \\
0.1 \\
0.1\end{array}$ \\
\hline
\end{tabular}

\section{-Not available.}

TNot applicable.
IIncludes other categories of revenue not separately shown

2Includes revenues from gifts, and tuition and fees from patrons.
NOTE: Excludes revenues for state education agencies. Some data have been revised from previously published figures. Detail may not sum to totals because of rounding. lic Education Financial Survey," 2009-10. (This table was prepared July 2013.) 
Table 235.40. Public elementary and secondary revenues and expenditures, by type of locale: 2010-11

\begin{tabular}{|c|c|c|c|c|c|c|c|c|c|c|c|c|c|}
\hline Selected characteristic & Total & City, large ${ }^{1}$ & $\begin{array}{r}\text { City, } \\
\text { midsize }\end{array}$ & $\begin{array}{r}\text { City, } \\
\text { small }^{3}\end{array}$ & $\begin{array}{r}\text { Suburban, } \\
\text { large }^{4}\end{array}$ & $\begin{array}{r}\text { Suburban, } \\
\text { midsize }^{5}\end{array}$ & $\begin{array}{r}\text { Suburban, } \\
\text { small }^{6}\end{array}$ & $\begin{array}{r}\text { Town, } \\
\text { fringe }^{7}\end{array}$ & $\begin{array}{r}\text { Town, } \\
\text { distant }^{8}\end{array}$ & $\begin{array}{r}\text { Town, } \\
\text { remote }^{9}\end{array}$ & $\begin{array}{r}\text { Rural, } \\
\text { fringe }^{10}\end{array}$ & $\begin{array}{r}\text { Rural, } \\
\text { distant }^{11}\end{array}$ & $\begin{array}{r}\text { Rural, } \\
\text { remote }^{12}\end{array}$ \\
\hline 1 & 2 & 3 & 4 & 5 & 6 & 7 & 8 & 9 & 10 & 11 & 12 & 13 & 14 \\
\hline \multicolumn{14}{|l|}{ Revenues, 2010-11 } \\
\hline Total revenue (in millions of dollars).... & $\$ 618,593$ & $\$ 110,099$ & $\$ 41,108$ & $\$ 46,720$ & $\$ 205,993$ & $\$ 18,494$ & $\$ 10,945$ & $\$ 10,099$ & $\$ 34,990$ & $\$ 21,917$ & $\$ 65,304$ & $\$ 37,936$ & $\$ 14,900$ \\
\hline 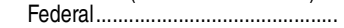 & 74,944 & 18,093 & 6,015 & 5,927 & 18,961 & 1,995 & 1,143 & 951 & 4,449 & 3,258 & 7,322 & 4,552 & 2,249 \\
\hline Title I... & 17,114 & 5,900 & 1,467 & 1,351 & 3,508 & 348 & 210 & 175 & 945 & 701 & 1,161 & 871 & 476 \\
\hline Child Nutrition Act ....................... & 12,479 & 2,662 & 1,019 & 1,015 & 3,208 & 337 & 199 & 176 & 829 & 537 & 1,303 & 858 & 336 \\
\hline Children with disabilities (IDEA).. & 13,976 & 2,472 & 1,040 & 1,269 & 4,562 & 435 & 253 & 191 & 809 & 516 & 1,476 & 705 & 240 \\
\hline Impact aid ................................. & 1,152 & 106 & 88 & 53 & 187 & 21 & 9 & 26 & 41 & 94 & 162 & 100 & 264 \\
\hline 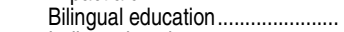 & 372 & 110 & 36 & 37 & 112 & 9 & 6 & 7 & 13 & 8 & 23 & 6 & 4 \\
\hline Indian education............................. & 104 & 12 & 4 & 5 & 7 & 1 & 1 & 1 & 9 & 14 & 13 & 10 & 27 \\
\hline \multicolumn{14}{|l|}{ Math, science, and professional } \\
\hline 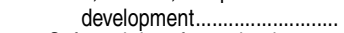 & 1,827 & 417 & 175 & 160 & 389 & 50 & 30 & 25 & 123 & 105 & 166 & 119 & 68 \\
\hline $\begin{array}{l}\text { Safe and drug-free schools......... } \\
\text { Vocational and technical }\end{array}$ & 178 & 40 & 14 & 17 & 37 & 2 & 4 & 2 & 17 & 10 & 17 & 12 & 8 \\
\hline 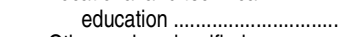 & 608 & 127 & 49 & 50 & 159 & 15 & 11 & 5 & 37 & 35 & 72 & 32 & 14 \\
\hline Other and unclassified .. & 27,134 & 6,246 & 2,123 & 1,971 & 6,792 & 778 & 419 & 344 & 1,626 & 1,238 & 2,928 & 1,839 & 811 \\
\hline State (in millions of dollars)...... & 267,762 & 47,204 & 18,731 & 21,559 & 78,789 & 8,291 & 5,038 & 4,713 & 17,057 & 10,525 & 29,366 & 19,468 & 6,993 \\
\hline Special education programs......... & 16,877 & 3,492 & 1,163 & 1,333 & 6,001 & 532 & 281 & 278 & 833 & 522 & 1,382 & 775 & 283 \\
\hline Compensatory and basic skills ... & 4,650 & 927 & 382 & 451 & 1,593 & 173 & 87 & 67 & 202 & 123 & 316 & 225 & 102 \\
\hline Bilingual education ........................... & 732 & 62 & 28 & & 475 & 39 & 3 & 2 & & 8 & & & \\
\hline Gifted and talented ....... & 484 & & & & 324 & 21 & 1 & 1 & & 6 & 38 & 13 & 5 \\
\hline Vocational education ........................ & 856 & 39 & 46 & 57 & 248 & 30 & 12 & & & 66 & 162 & 83 & 36 \\
\hline 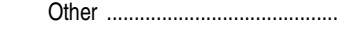 & 244,163 & 42,666 & 17,083 & 19,665 & 70,147 & 7,496 & 4,654 & 4,357 & 15,919 & 9,799 & 27,425 & 18,364 & 6,565 \\
\hline Local (in millions of dollars) ${ }^{13} \ldots \ldots \ldots . .$. & 275,887 & 44,803 & 16,362 & 19,234 & 108,242 & 8,208 & 4,763 & 4,435 & 13,484 & 8,134 & 28,616 & 13,916 & 5,658 \\
\hline 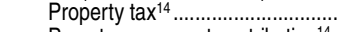 & 170,188 & 21,471 & 9,704 & 11,847 & 71,857 & 4,604 & 3,204 & 2,987 & 8,993 & 5,677 & 17,064 & 8,893 & 3,883 \\
\hline Parent government contribution ${ }^{14}$.. & 46,985 & 14,179 & 2,832 & 2,521 & 17,434 & 1,904 & 531 & 415 & 762 & 247 & 4,518 & 1,334 & 309 \\
\hline Private (fees from individuals) ..... & 13,527 & 1,156 & 716 & 900 & 5,180 & 429 & 251 & 271 & 854 & 511 & 1,889 & 999 & 368 \\
\hline 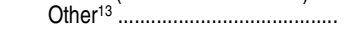 & 45,187 & 7,996 & 3,111 & 3,966 & 13,772 & 1,272 & 776 & 763 & 2,876 & 1,700 & 5,146 & 2,690 & 1,099 \\
\hline Total revenue (percentage distribution). & 100.0 & 100.0 & 100.0 & 100.0 & 100.0 & 100.0 & 100.0 & 100.0 & 100.0 & 100.0 & 100.0 & 100.0 & 100.0 \\
\hline 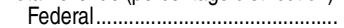 & 12.1 & 16.4 & 14.6 & 12.7 & 9.2 & 10.8 & 10.4 & 9.4 & 12.7 & 14.9 & 11.2 & 12.0 & 15.1 \\
\hline State .... & 43.3 & 42.9 & 45.6 & 46.1 & 38.2 & 44.8 & 46.0 & 46.7 & 48.7 & 48.0 & 45.0 & 51.3 & 46.9 \\
\hline Local ................................. & 44.6 & 40.7 & 39.8 & 41.2 & 52.5 & 44.4 & 43.5 & 43.9 & 38.5 & 37.1 & 43.8 & 36.7 & 38.0 \\
\hline \multicolumn{14}{|l|}{ Expenditures, 2010-11 } \\
\hline \multicolumn{14}{|l|}{ Total expenditures } \\
\hline (in millions of dollars)... & $\$ 616,991$ & $\$ 112,924$ & $\$ 40,993$ & $\$ 46,498$ & $\$ 203,479$ & $\$ 18,559$ & $\$ 10,920$ & $\$ 10,019$ & $\$ 34,693$ & $\$ 21,881$ & $\$ 64,558$ & $\$ 37,577$ & $\$ 14,771$ \\
\hline Current expenditures for schools .... & 519,324 & 91,564 & 34,447 & 39,316 & 173,702 & 15,588 & 9,190 & 8,423 & 29,632 & 18,549 & 54,200 & 32,126 & 12,510 \\
\hline 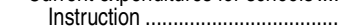 & 316,518 & 56,947 & 20,613 & 23,871 & 106,541 & 9,515 & 5,560 & 5,147 & 17,923 & 11,215 & 32,599 & 19,188 & 7,369 \\
\hline Support services, students .......... & 29,009 & 4,476 & 2,065 & 2,391 & 10,485 & 890 & 532 & 467 & 1,555 & 1,035 & 3,084 & 1,500 & 520 \\
\hline \multicolumn{14}{|l|}{ Support services, instructional } \\
\hline staff ...................... & 24,619 & 4,613 & 1,937 & 2,087 & 7,998 & 739 & 420 & 336 & 1,361 & 815 & 2,486 & 1,322 & 486 \\
\hline Administration .... & 38,626 & 6,010 & 2,543 & 2,790 & 12,669 & 1,153 & 693 & 656 & 2,354 & 1,543 & 4,206 & 2,798 & 1,202 \\
\hline Operation and maintenance......... & 49,656 & 8,973 & 3,220 & 3,638 & 16,684 & 1,492 & 874 & 787 & 2,776 & 1,788 & 5,091 & 3,052 & 1,277 \\
\hline Transportation ................................ & 22,834 & 3,602 & 1,317 & 1,418 & 7,755 & 643 & 412 & 413 & 1,328 & 725 & 2,690 & 1,851 & 676 \\
\hline Food service & 19,989 & 3,354 & 1,395 & 1,529 & 5,794 & 581 & 355 & 326 & 1,335 & 859 & 2,339 & 1,521 & 600 \\
\hline Other .............................. & 18,072 & 3,587 & 1,357 & 1,593 & 5,775 & 573 & 343 & 290 & 999 & 570 & 1,705 & 895 & 380 \\
\hline Other current expenditures ............... & 21,243 & 3,446 & 1,438 & 1,615 & 6,285 & 664 & 379 & 338 & 1,392 & 891 & 2,526 & 1,594 & 649 \\
\hline Interest on school debt & 17,894 & 3,422 & 1,157 & 1,211 & 6,157 & 530 & 339 & 325 & 861 & 487 & 2,293 & 891 & 219 \\
\hline Capital outlay ..................... & 52,984 & 11,617 & 3,666 & 3,799 & 15,068 & 1,605 & 1,016 & 912 & 2,933 & 2,155 & 5,593 & 3,231 & 1,386 \\
\hline \multicolumn{14}{|l|}{ Current expenditures } \\
\hline (percentage distribution) ................ & 100.0 & 100.0 & 100.0 & 100.0 & 100.0 & 100.0 & 100.0 & 100.0 & 100.0 & 100.0 & 100.0 & 100.0 & 100.0 \\
\hline Instruction .............................. & 60.9 & 62.2 & 59.8 & 60.7 & 61.3 & 61.0 & 60.5 & 61.1 & 60.5 & 60.5 & 60.1 & 59.7 & 58.9 \\
\hline Support services...................... & 10.3 & 9.9 & 11.6 & 11.4 & 10.6 & 10.5 & 10.4 & 9.5 & 9.8 & 10.0 & 10.3 & 8.8 & 8.0 \\
\hline Administration .......................... & 7.4 & 6.6 & 7.4 & 7.1 & 7.3 & 7.4 & 7.5 & 7.8 & 7.9 & 8.3 & 7.8 & 8.7 & 9.6 \\
\hline Operation and maintenance.... & 9.6 & 9.8 & 9.3 & 9.3 & 9.6 & 9.6 & 9.5 & 9.3 & 9.4 & 9.6 & 9.4 & 9.5 & 10.2 \\
\hline Transportation ..................................... & 4.4 & 3.9 & 3.8 & 3.6 & 4.5 & 4.1 & 4.5 & 4.9 & 4.5 & 3.9 & 5.0 & 5.8 & 5.4 \\
\hline Food service and other ....................... & 7.3 & 7.6 & 8.0 & 7.9 & 6.7 & 7.4 & 7.6 & 7.3 & 7.9 & 7.7 & 7.5 & 7.5 & 7.8 \\
\hline \multirow{2}{*}{\multicolumn{14}{|c|}{$\begin{array}{l}\text { Current expenditure per student } \\
\text { (in dollars) }\end{array}$}} \\
\hline & $\$ 10,532$ & $\$ 11,592$ & $\$ 10,051$ & $\$ 10,499$ & $\$ 10,851$ & $\$ 10,196$ & $\$ 9,881$ & $\$ 10,030$ & $\$ 9,851$ & $\$ 9,641$ & $\$ 9,571$ & $\$ 9,945$ & $\$ 11,311$ \\
\hline 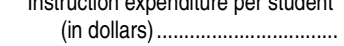 & 6,419 & 7,210 & 6,015 & 6,374 & 6,656 & 6,224 & 5,978 & 6,129 & 5,958 & 5,829 & 5,757 & 5,940 & 6,663 \\
\hline
\end{tabular}

'Located inside an urbanized area and inside a principal city with a population of at least 250,000

${ }^{2}$ Located inside an urbanized area and inside a principal city with a population of at least 100,000 , but less than 250,000 .

${ }^{3}$ Located inside an urbanized area and inside a principal city with a population less than 100,000 .

${ }^{4}$ Located inside an urbanized area and outside a principal city with a population of 250,000 or more.

${ }^{5}$ Located inside an urbanized area and outside a principal city with a population of at leas 100,000 , but less than 250,000 .

${ }^{6}$ Located inside an urbanized area and outside a principal city with a population less than 100,000 .

${ }^{7}$ Located inside an urban cluster that is 10 miles or less from an urbanized area.

${ }^{8}$ Located inside an urban cluster that is more than 10 but less than or equal to 35 miles from an urbanized area.

פLocated inside an urban cluster that is more than 35 miles from an urbanized area.
${ }^{10}$ Located outside any urbanized area or urban cluster, but 5 miles or less from an urbanized area or 2.5 miles or less from an urban cluster.

${ }^{11}$ Located outside any urbanized area or urban cluster and more than 5 miles but less than or equal to 25 miles from an urbanized area, or more than 2.5 miles but less than or equal to 10 miles from an urban cluster.

${ }^{12}$ Located outside any urbanized area or urban cluster, more than 25 miles from an urbanized area, and more than 10 miles from an urban cluster.

${ }^{13}$ Includes tuition and fee revenues from other in-state school systems, which are excluded from state data reported through the "National Public Education Financial Survey." ${ }^{14}$ Property tax and parent government contributions are determined on the basis of independence or dependence of the local school system and are mutually exclusive.

NOTE: Detail may not sum to totals because of rounding.

SOURCE: U.S. Department of Education, National Center for Education Statistics, Common Core of Data (CCD), "Local Education Agency (School District) Finance Survey (F-33)," 2010-11. (This table was prepared May 2014.) 
356 CHAPTER 2: Elementary and Secondary Education

Expenditures

Table 236.10. Summary of expenditures for public elementary and secondary education and other related programs, by purpose: Selected years, 1919-20 through 2010-11

\begin{tabular}{|c|c|c|c|c|c|c|c|c|c|c|c|}
\hline \multirow[b]{2}{*}{ School year } & \multirow[b]{2}{*}{$\begin{array}{r}\text { Total } \\
\text { expenditures }\end{array}$} & \multicolumn{7}{|c|}{ Current expenditures for public elementary and secondary education } & \multirow{2}{*}{$\begin{array}{r}\text { Current } \\
\text { expenditures } \\
\text { for other } \\
\text { programs }{ }^{2}\end{array}$} & \multirow[b]{2}{*}{ Capital outlay ${ }^{3}$} & \multirow[b]{2}{*}{$\begin{array}{l}\text { Interest on } \\
\text { school debt }\end{array}$} \\
\hline & & Total & Administration & Instruction & $\begin{array}{r}\text { Plant } \\
\text { operation }\end{array}$ & $\begin{array}{r}\text { Plant } \\
\text { maintenance }\end{array}$ & $\begin{array}{r}\text { Fixed } \\
\text { charges }\end{array}$ & $\begin{array}{r}\text { Other school } \\
\text { services }\end{array}$ & & & \\
\hline 1 & 2 & 3 & 4 & 5 & 6 & 7 & 8 & 9 & 10 & 11 & 12 \\
\hline & \multicolumn{11}{|c|}{ Amounts in thousands of current dollars } \\
\hline $\begin{array}{l}1919-20 \ldots \ldots \ldots \ldots \ldots \\
1929-30 \ldots \ldots \ldots \ldots \ldots . . . \\
1939-40 \ldots \ldots \ldots \ldots \ldots . . . . . . \\
1949-50 \ldots \ldots \ldots \ldots \ldots . . . \\
1959-60 \ldots \ldots \ldots \ldots \ldots . . .\end{array}$ & $\begin{array}{r}\$ 1,036,151 \\
2,316,790 \\
2,344,049 \\
5,837,643 \\
15,613,254\end{array}$ & \begin{tabular}{r|}
861,120 \\
$1,843,552$ \\
$1,941,799$ \\
$4,687,274$ \\
$12,329,388$
\end{tabular} & $\begin{array}{r}\$ 36,752 \\
78,680 \\
91,571 \\
220,050 \\
528,408\end{array}$ & $\begin{array}{l}\$ 632,556 \\
1,317,727 \\
1,403,285 \\
3,112,340 \\
8,350,738\end{array}$ & $\begin{array}{r}\$ 115,707 \\
216,072 \\
194,365 \\
427,587 \\
1,085,036\end{array}$ & $\begin{array}{r}\$ 30,432 \\
78,810 \\
73,321 \\
214,164 \\
422,586\end{array}$ & \begin{tabular}{r|}
$\$ 9,286$ \\
50,270 \\
50,116 \\
261,469 \\
909,323
\end{tabular} & $\begin{array}{r}\$ 36,387 \\
101,993 \\
129,141 \\
451,663 \\
1,033,297\end{array}$ & \begin{tabular}{r|}
$\$ 3,277$ \\
9,825 \\
13,367 \\
35,614 \\
132,566
\end{tabular} & \begin{tabular}{r|}
$\$ 153,543$ \\
370,878 \\
257,974 \\
$1,014,176$ \\
$2,661,786$
\end{tabular} & $\begin{array}{r}\$ 18,212 \\
92,536 \\
130,909 \\
100,578 \\
489,514\end{array}$ \\
\hline $\begin{array}{l}1969-70 \ldots \ldots \ldots \ldots . . . \\
1979-80 \ldots \ldots \ldots \ldots \ldots . . . \\
1989-90 \ldots \ldots \ldots \ldots \ldots . . . \\
1999-2000 \ldots \ldots \ldots \ldots . . . \\
2000-01 \ldots \ldots \ldots \ldots \ldots . . .\end{array}$ & $\begin{array}{r}40,683,429 \\
95,961,561 \\
212,769,564 \\
381,838,155 \\
410,811,185\end{array}$ & $\begin{array}{r}34,217,773 \\
86,984,142 \\
188,229,359 \\
323,888,508 \\
348,360,841\end{array}$ & 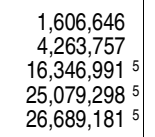 & \begin{tabular}{|c|}
$23,270,158$ \\
$53,257,937$ \\
$113,550,405^{5}$ \\
$199,968,138$ \\
$214,333,003^{5}$
\end{tabular} & $\begin{array}{c}2,537,257 \\
9,744,785 \\
20,261,415 \\
31,190,295 \\
34,034,158\end{array}$ & $\begin{array}{r}974,941 \\
\left({ }^{4}\right) \\
\left(\left(^{4}\right)\right. \\
\left({ }^{4}\right) \\
(4)\end{array}$ & $\begin{array}{r}3,266,920 \\
11,793,934 \\
- \\
-\end{array}$ & $\begin{array}{c}2,561,856 \\
7,923,729 \\
38,070,5485 \\
67,650,7765 \\
73,304,4988^{5}\end{array}$ & $\begin{array}{r}635,803 \\
597,585 \\
2,982,543 \\
5,457,015 \\
6,063,700\end{array}$ & $\begin{array}{r}4,659,072 \\
6,506,167 \\
17,781,342 \\
43,357,186 \\
46,220,704\end{array}$ & $\begin{array}{r}1,170,782 \\
1,873,666 \\
3,776,321 \\
9,135,445 \\
10,165,940\end{array}$ \\
\hline 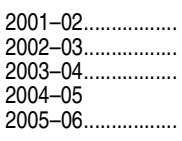 & $\begin{array}{l}435,364,404 \\
454,906,912 \\
474,241,531 \\
499,568,736 \\
528,268,772\end{array}$ & $\begin{array}{l}368,378,006 \\
387,593,617 \\
403,390,369 \\
425,047,565 \\
449,131,342\end{array}$ & 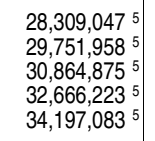 & $\begin{array}{l}226,668,386 \\
237,731,734 \\
247,444,620 \\
260,046,266 \\
273,760,798\end{array}$ & 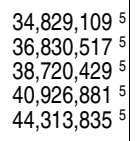 & $\begin{array}{l}(4) \\
(4) \\
(4) \\
(4) \\
(4)\end{array}$ & $\begin{array}{l}- \\
- \\
- \\
-\end{array}$ & $\begin{array}{l}78,571,4645 \\
83,279,4085 \\
86,360,4445 \\
91,408,1955 \\
96,859,6265\end{array}$ & $\begin{array}{l}6,530,554 \\
6,873,762 \\
6,927,551 \\
7,691,468 \\
7,415,575\end{array}$ & $\begin{array}{l}49,960,542 \\
48,940,374 \\
50,842,973 \\
53,528,382 \\
57,375,299\end{array}$ & $\begin{array}{l}10,495,301 \\
11,499,160 \\
13,080,638 \\
13,301,322 \\
14,346,556\end{array}$ \\
\hline $\begin{array}{l}2006-07 \ldots \ldots \ldots \ldots \ldots \\
2007-08 \ldots \ldots \ldots \ldots \ldots . . . \\
2008-09 \ldots \ldots \ldots \ldots \ldots . . . . . \\
2009-10^{6} \ldots \ldots \ldots \ldots \ldots . . . \\
2010-11 \ldots \ldots \ldots \ldots \ldots . .\end{array}$ & $\begin{array}{l}562,194,807 \\
597,313,726 \\
610,326,007 \\
607,018,292 \\
604,214,912 \\
\end{array}$ & $\begin{array}{l}476,814,206 \\
506,884,219 \\
518,922,842 \\
524,715,242 \\
527,166,106 \\
\end{array}$ & 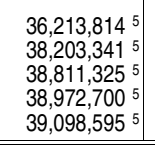 & 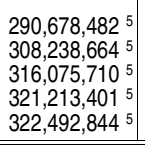 & $\begin{array}{l}46,828,916^{5} \\
49,362,6611^{5} \\
50,559,027 \\
50,023,919 \\
50,182,060^{5}\end{array}$ & $\begin{array}{l}(4) \\
\left({ }^{4}\right) \\
\left({ }^{4}\right) \\
(4) \\
(4) \\
\end{array}$ & $\begin{array}{l}- \\
- \\
- \\
-\end{array}$ & $\begin{array}{l}103,092,995 \\
111,079,554 \\
5 \\
113,476,779 \\
114,505,223 \\
115,392,607 \\
5\end{array}$ & $\begin{array}{l}7,804,253 \\
8,307,720 \\
8,463,793 \\
8,355,761 \\
8,187,042 \\
\end{array}$ & $\begin{array}{l}62,863,465 \\
66,426,299 \\
65,890,367 \\
56,714,992 \\
50,927,540 \\
\end{array}$ & $\begin{array}{l}14,712,882 \\
15,695,488 \\
17,049,004 \\
17,232,297 \\
17,934,224 \\
\end{array}$ \\
\hline & \multicolumn{11}{|c|}{ Amounts in thousands of constant 2012-13 dollars ${ }^{7}$} \\
\hline 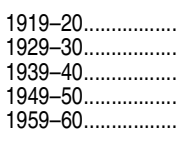 & \begin{tabular}{r|}
$12,578,214$ \\
$31,313,548$ \\
$38,805,039$ \\
$57,026,153$ \\
$122,933,585$
\end{tabular} & \begin{tabular}{r|}
$10,453,449$ \\
$24,917,301$ \\
$32,145,909$ \\
$45,788,540$ \\
$97,077,513$
\end{tabular} & $\begin{array}{l}\$ 446,146 \\
1,063,433 \\
1,515,931 \\
2,149,601 \\
4,160,509\end{array}$ & \begin{tabular}{l|}
$\$ 7,678,828$ \\
$17,810,293$ \\
$23,230,969$ \\
$30,403,500$ \\
$65,750,942$
\end{tabular} & $\begin{array}{r}1,404,609 \\
2,920,412 \\
3,217,655 \\
4,176,967 \\
8,543,214\end{array}$ & \begin{tabular}{r|}
$\$ 369,425$ \\
$1,065,190$ \\
$1,213,808$ \\
$2,092,103$ \\
$3,327,302$
\end{tabular} & \begin{tabular}{r|}
112,726 \\
679,445 \\
829,656 \\
$2,554,211$ \\
$7,159,708$
\end{tabular} & $\begin{array}{r}\$ 441,715 \\
1,378,529 \\
2,137,891 \\
4,412,158 \\
8,135,838\end{array}$ & \begin{tabular}{r|}
39,781 \\
132,794 \\
221,287 \\
347,902 \\
$1,043,781$
\end{tabular} & \begin{tabular}{r|}
$1,863,914$ \\
$5,012,757$ \\
$4,270,683$ \\
$9,907,176$ \\
$20,958,020$
\end{tabular} & $\begin{array}{r}\$ 221,082 \\
1,250,709 \\
2,167,160 \\
982,516 \\
3,854,271\end{array}$ \\
\hline $\begin{array}{l}1969-70 \ldots \ldots \ldots \ldots . . . \\
1979-80 \ldots \ldots \ldots \ldots \ldots \\
1989-90 \ldots \ldots \ldots \ldots \ldots . . . . . . \\
1999-2000 \ldots \ldots \ldots \ldots . . . \\
2000-01 \ldots \ldots \ldots \ldots \ldots . . . .\end{array}$ & $\begin{array}{l}249,164,597 \\
285,972,448 \\
387,672,094 \\
521,814,502 \\
542,811,718\end{array}$ & $\begin{array}{l}209,565,887 \\
259,219,085 \\
342,959,155 \\
442,621,353 \\
460,295,029\end{array}$ & $\begin{array}{c}9,839,861 \\
12,706,307 \\
29,784,675 \\
34,273,0065 \\
35,264,863\end{array}$ & $\begin{array}{l}142,517,474 \\
158,712,535 \\
206,892,013 \\
273,273,5675 \\
283,201,7975\end{array}$ & $\begin{array}{l}15,539,364 \\
29,040,170 \\
36,916,865 \\
42,624,206 \\
4 \\
44,969,905^{5}\end{array}$ & 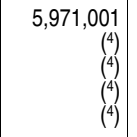 & $\begin{array}{r}20,008,166 \\
35,146,783 \\
- \\
-\end{array}$ & $\begin{array}{l}15,690,020 \\
23,613,290 \\
69,365,603 \\
92,450,573 \\
9 \\
96,858,464\end{array}$ & $\begin{array}{l}3,893,959 \\
1,780,847 \\
5,434,277 \\
7,457,478 \\
8,012,069\end{array}$ & $\begin{array}{l}28,534,365 \\
19,388,852 \\
32,398,102 \\
59,251,304 \\
61,072,193\end{array}$ & $\begin{array}{r}7,170,424 \\
5,583,661 \\
6,880,562 \\
12,484,368 \\
13,432,427\end{array}$ \\
\hline 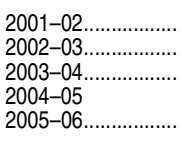 & $\begin{array}{l}565,246,620 \\
577,918,729 \\
589,583,253 \\
602,926,707 \\
614,175,630\end{array}$ & $\begin{array}{l}478,276,177 \\
492,403,181 \\
501,500,164 \\
512,987,523 \\
522,168,903\end{array}$ & $\begin{array}{l}36,754,482 \\
37,797,214 \\
38,371,615 \\
39,424,681 \\
39 \\
39,758,199\end{array}$ & $\begin{array}{l}294,290,341 \\
302,017,002 \\
307,626,377 \\
313,848,380 \\
318,279,671\end{array}$ & $\begin{array}{l}45,219,6735 \\
46,789,8925 \\
48,137,7425 \\
49,394,4235 \\
51,520,1335\end{array}$ & $\begin{array}{l}(4) \\
(4) \\
(4) \\
(4) \\
(4)\end{array}$ & $\begin{array}{l}- \\
- \\
- \\
-\end{array}$ & $\begin{array}{l}102,011,680 \\
105,799,073 \\
107,364,430 \\
110,320,0395 \\
112,610,900^{5}\end{array}$ & $\begin{array}{l}8,478,814 \\
8,732,502 \\
8,612,422 \\
9,282,789 \\
8,621,493\end{array}$ & $\begin{array}{l}64,865,265 \\
62,174,388 \\
63,208,647 \\
64,603,104 \\
66,705,647\end{array}$ & $\begin{array}{l}13,626,363 \\
14,608,658 \\
16,262,020 \\
16,053,290 \\
16,679,587\end{array}$ \\
\hline \multirow[t]{2}{*}{$\begin{array}{l}2006-07 \ldots \ldots \ldots \ldots \ldots \\
2007-08 \ldots \ldots \ldots \ldots \ldots . . . \\
2008-09 \ldots \ldots \ldots \ldots \ldots . . . . . . . . \\
2009-10^{6} \ldots \ldots \ldots \ldots \ldots . . . \\
2010-11 \ldots \ldots \ldots \ldots \ldots . . .\end{array}$} & $\begin{array}{l}637,141,997 \\
652,755,879 \\
657,791,195 \\
647,956,702 \\
632,268,421 \\
\end{array}$ & $\begin{array}{l}540,379,156 \\
553,932,782 \\
559,279,585 \\
560,102,986 \\
551,642,262 \\
\end{array}$ & 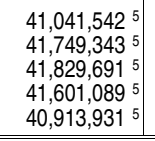 & $\begin{array}{l}329,429,347 \\
336,849,115 \\
340,656,987 \\
342,876,613 \\
337,466,085 \\
5\end{array}$ & $\begin{array}{l}53,071,7625 \\
53,944,4615 \\
54,491,0145 \\
53,397,6225 \\
52,511,9975 \\
\end{array}$ & $\begin{array}{l}(4) \\
(4) \\
(4) \\
(4) \\
(4) \\
(4)\end{array}$ & $\begin{array}{l}- \\
- \\
- \\
-\end{array}$ & $\begin{array}{l}116,836,505 \\
121,389,864 \\
5 \\
122,301,893 \\
122,227,6625 \\
120,750,2495 \\
\end{array}$ & $\begin{array}{l}8,844,652 \\
9,078,835 \\
9,122,024 \\
8,919,289 \\
8,567,164 \\
\end{array}$ & $\begin{array}{l}71,243,905 \\
72,591,931 \\
71,014,676 \\
60,539,953 \\
53,292,089 \\
\end{array}$ & $\begin{array}{l}16,674,283 \\
17,152,330 \\
18,374,909 \\
18,394,474 \\
18,766,905 \\
\end{array}$ \\
\hline & \multicolumn{11}{|c|}{ Percentage distribution } \\
\hline $\begin{array}{l}1919-20 \ldots \ldots \ldots \ldots \ldots \\
1929-30 \ldots \ldots \ldots \ldots \ldots \\
1939-40 \ldots \ldots \ldots \ldots \ldots . . . \\
1949-50 \ldots \ldots \ldots \ldots \ldots . . . . . \\
1959-60 \ldots \ldots \ldots \ldots \ldots . . .\end{array}$ & $\begin{array}{l}100.0 \\
100.0 \\
100.0 \\
100.0 \\
100.0\end{array}$ & $\begin{array}{l}83.1 \\
79.6 \\
82.8 \\
80.3 \\
79.0\end{array}$ & $\begin{array}{l}3.5 \\
3.4 \\
3.9 \\
3.8 \\
3.4\end{array}$ & $\begin{array}{l}61.0 \\
56.9 \\
59.9 \\
53.3 \\
53.5\end{array}$ & $\begin{array}{r}11.2 \\
9.3 \\
8.3 \\
7.3 \\
6.9\end{array}$ & \begin{tabular}{l|}
2.9 \\
3.4 \\
3.1 \\
3.7 \\
2.7
\end{tabular} & \begin{tabular}{l|}
0.9 \\
2.2 \\
2.1 \\
4.5 \\
5.8
\end{tabular} & $\begin{array}{l}3.5 \\
4.4 \\
5.5 \\
7.7 \\
6.6\end{array}$ & $\begin{array}{l}0.3 \\
0.4 \\
0.6 \\
0.6 \\
0.8\end{array}$ & $\begin{array}{l}14.8 \\
16.0 \\
11.0 \\
17.4 \\
17.0\end{array}$ & $\begin{array}{l}1.8 \\
4.0 \\
5.6 \\
1.7 \\
3.1\end{array}$ \\
\hline $\begin{array}{l}1969-70 \ldots \ldots \ldots \ldots \\
1979-80 \ldots \ldots \ldots \ldots \ldots \\
1989-90 \ldots \ldots \ldots \ldots \ldots \ldots \\
1999-2000 \ldots \ldots \ldots \ldots . . . . . . \\
2000-01 \ldots \ldots \ldots \ldots \ldots . . . .\end{array}$ & $\begin{array}{l}100.0 \\
100.0 \\
100.0 \\
100.0 \\
100.0\end{array}$ & $\begin{array}{l}84.1 \\
90.6 \\
88.5 \\
84.8 \\
84.8\end{array}$ & $\begin{array}{l}3.9 \\
4.4 \\
7.7^{5} \\
6.6 \\
6.5^{5}\end{array}$ & $\begin{array}{l}57.2 \\
55.5 \\
53.4^{5} \\
52.4^{5} \\
52.2^{5}\end{array}$ & \begin{tabular}{r|}
6.2 \\
10.2 \\
$9.5^{5}$ \\
$8.2^{5}$ \\
$8.3^{5}$
\end{tabular} & $\begin{array}{r}2.4 \\
(4) \\
(4) \\
(4) \\
(4)\end{array}$ & $\begin{array}{r}8.0 \\
12.3 \\
- \\
- \\
-\end{array}$ & \begin{tabular}{r|}
6.3 \\
8.3 \\
$17.9^{5}$ \\
$17.7^{5}$ \\
$17.8^{5}$
\end{tabular} & $\begin{array}{l}1.6 \\
0.6 \\
1.4 \\
1.4 \\
1.5\end{array}$ & $\begin{array}{r}11.5 \\
6.8 \\
8.4 \\
11.4 \\
11.3\end{array}$ & $\begin{array}{l}2.9 \\
2.0 \\
1.8 \\
2.4 \\
2.5\end{array}$ \\
\hline 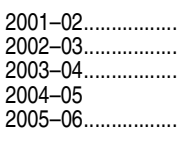 & $\begin{array}{l}100.0 \\
100.0 \\
100.0 \\
100.0 \\
100.0\end{array}$ & $\begin{array}{l}84.6 \\
85.2 \\
85.1 \\
85.1 \\
85.0\end{array}$ & $\begin{array}{ll}6.5 & 5 \\
6.5 & 5 \\
6.5 & 5 \\
6.5 & 5 \\
6.5 & 5\end{array}$ & $\begin{array}{l}52.1^{5} \\
52.3^{5} \\
52.2^{5} \\
52.1^{5} \\
51.8^{5}\end{array}$ & $\begin{array}{l}8.0^{5} \\
8.1^{5} \\
8.2^{5} \\
8.2^{5} \\
8.4^{5}\end{array}$ & $\begin{array}{l}(4) \\
\left({ }^{4}\right) \\
\left({ }^{4}\right) \\
\left({ }^{4}\right) \\
(4)\end{array}$ & $\begin{array}{l}- \\
- \\
- \\
-\end{array}$ & $\begin{array}{l}18.0^{5} \\
18.3^{5} \\
18.2^{5} \\
18.3^{5} \\
18.3^{5}\end{array}$ & $\begin{array}{l}1.5 \\
1.5 \\
1.5 \\
1.5 \\
1.4\end{array}$ & $\begin{array}{l}11.5 \\
10.8 \\
10.7 \\
10.7 \\
10.9\end{array}$ & $\begin{array}{l}2.4 \\
2.5 \\
2.8 \\
2.7 \\
2.7\end{array}$ \\
\hline $\begin{array}{l}2006-07 \ldots \ldots \ldots \ldots . . . \\
2007-08 \ldots \ldots \ldots \ldots \ldots \\
2008-09 \ldots \ldots \ldots \ldots \ldots . . . . . \\
2009-10^{6} \ldots \ldots \ldots \ldots \ldots . . \\
2010-11 \ldots \ldots \ldots \ldots \ldots . . .\end{array}$ & $\begin{array}{l}100.0 \\
100.0 \\
100.0 \\
100.0 \\
100.0\end{array}$ & $\begin{array}{l}84.8 \\
84.9 \\
85.0 \\
86.4 \\
87.2\end{array}$ & $\begin{array}{l}6.4 \\
6.4 \\
6.4 \\
6.4 \\
6.4 \\
6.5^{5}\end{array}$ & $\begin{array}{l}51.7^{5} \\
51.6^{5} \\
51.8^{5} \\
52.9^{5} \\
53.4^{5}\end{array}$ & $\begin{array}{l}8.3^{5} \\
8.3^{5} \\
8.3^{5} \\
8.2^{5} \\
8.3^{5}\end{array}$ & $\begin{array}{l}\left({ }^{4}\right) \\
\left({ }^{4}\right) \\
\left({ }^{4}\right) \\
\left({ }^{4}\right) \\
(4)\end{array}$ & $\begin{array}{l}- \\
- \\
-\end{array}$ & $\begin{array}{l}18.3^{5} \\
18.6^{5} \\
18.6 \\
18.9^{5} \\
19.1^{5}\end{array}$ & $\begin{array}{l}1.4 \\
1.4 \\
1.4 \\
1.4 \\
1.4\end{array}$ & $\begin{array}{r}11.2 \\
11.1 \\
10.8 \\
9.3 \\
8.4\end{array}$ & $\begin{array}{l}2.6 \\
2.6 \\
2.8 \\
2.8 \\
3.0\end{array}$ \\
\hline
\end{tabular}

\section{-Not available}

${ }^{1}$ Prior to 1959-60, items included under "other school services" were listed under "auxiliary services," a more comprehensive classification that also included community services.

Includes expenditures for summer schools, adult education, community colleges, and community services.

${ }^{3}$ Prior to $1969-70$, excludes capital outlay by state and local school housing authorities. ${ }^{4}$ Plant operation also includes plant maintenance.

5 Data not comparable to figures prior to $1989-90$.

${ }^{6}$ Data have been revised from previously published figures.

${ }^{7}$ Constant dollars based on the Consumer Price Index, prepared by the Bureau of Labor Statistics, U.S. Department of Labor, adjusted to a school-year basis.
NOTE: Beginning in 1959-60, includes Alaska and Hawaii. Beginning in 1989-90, state administration expenditures were excluded from both "total" and "current" expenditures. Beginning in 1989-90, extensive changes were made in the data collection procedures. Detail may not sum to totals because of rounding.

SOURCE: U.S. Department of Education, National Center for Education Statistics, Biennial Survey of Education in the United States, 1919-20 through 1949-50; Statistics of State School Systems, 1959-60 and 1969-70; Revenues and Expenditures for Public Elementary and Secondary Education, 1979-80; and Common Core of Data (CCD), "National Public Education Financial Survey," 1989-90 through 2010-11. (This table was prepared July 2013.) 
Table 236.15. Current expenditures and current expenditures per pupil in public elementary and secondary schools: 1989-90 through 2023-24

\begin{tabular}{|c|c|c|c|c|c|c|c|c|c|}
\hline \multirow[b]{3}{*}{ School year } & \multicolumn{3}{|c|}{ Current expenditures in unadjusted dollars ${ }^{1}$} & \multicolumn{6}{|c|}{ Current expenditures in constant 2012-13 dollars² } \\
\hline & \multirow[b]{2}{*}{ Total, in billions } & \multirow[b]{2}{*}{$\begin{array}{r}\text { Per pupil in } \\
\text { fall enrollment }\end{array}$} & \multirow{2}{*}{$\begin{array}{r}\text { Per pupil in } \\
\text { average daily } \\
\text { attendance } \\
(A D A)\end{array}$} & \multicolumn{2}{|c|}{ Total current expenditures } & \multicolumn{2}{|c|}{ Per pupil in fall enrollment } & \multicolumn{2}{|c|}{$\begin{array}{l}\text { Per pupil in average } \\
\text { daily attendance (ADA) }\end{array}$} \\
\hline & & & & In billions & $\begin{array}{r}\text { Annual } \\
\text { percentage } \\
\text { change }\end{array}$ & Per pupil enrolled & $\begin{array}{r}\text { Annual } \\
\text { percentage } \\
\text { change }\end{array}$ & Per pupil in ADA & $\begin{array}{r}\text { Annual } \\
\text { percentage } \\
\text { change }\end{array}$ \\
\hline 1 & 2 & 3 & 4 & 5 & 6 & 7 & 8 & 9 & 10 \\
\hline 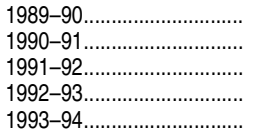 & $\begin{array}{r}\$ 188.2 \\
202.0 \\
211.2 \\
220.9 \\
231.5\end{array}$ & $\begin{array}{r}\$ 4,643 \\
4,902 \\
5,023 \\
5,160 \\
5,327\end{array}$ & $\begin{array}{r}\$ 4,980 \\
5,258 \\
5,421 \\
5,584 \\
5,767\end{array}$ & $\begin{array}{r}\$ 343.0 \\
349.0 \\
353.6 \\
358.7 \\
366.4\end{array}$ & $\begin{array}{l}3.8 \\
1.8 \\
1.3 \\
1.4 \\
2.1\end{array}$ & $\begin{array}{r}\$ 8,459 \\
8,468 \\
8,409 \\
8,375 \\
8,429\end{array}$ & $\begin{array}{r}2.9 \\
0.1 \\
-0.7 \\
-0.4 \\
0.6\end{array}$ & $\begin{array}{r}\$ 9,073 \\
9,083 \\
9,075 \\
9,064 \\
9,126\end{array}$ & $\begin{array}{r}2.3 \\
0.1 \\
-0.1 \\
-0.1 \\
0.7\end{array}$ \\
\hline 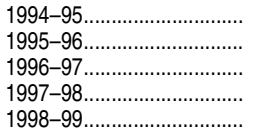 & $\begin{array}{l}243.9 \\
255.1 \\
270.2 \\
285.5 \\
302.9\end{array}$ & $\begin{array}{l}5,529 \\
5,689 \\
5,923 \\
6,189 \\
6,508\end{array}$ & $\begin{array}{l}5,989 \\
6,147 \\
6,393 \\
6,676 \\
7,013\end{array}$ & $\begin{array}{l}375.1 \\
382.0 \\
393.3 \\
408.4 \\
425.9\end{array}$ & $\begin{array}{l}2.4 \\
1.8 \\
3.0 \\
3.8 \\
4.3\end{array}$ & $\begin{array}{l}8,504 \\
8,519 \\
8,624 \\
8,853 \\
9,151\end{array}$ & $\begin{array}{l}0.9 \\
0.2 \\
1.2 \\
2.7 \\
3.4\end{array}$ & $\begin{array}{l}9,212 \\
9,205 \\
9,307 \\
9,549 \\
9,861\end{array}$ & $\begin{array}{r}0.9 \\
-0.1 \\
1.1 \\
2.6 \\
3.3\end{array}$ \\
\hline $\begin{array}{l}1999-2000 \ldots \ldots \ldots \ldots \ldots \ldots \\
2000-01 \ldots \ldots \ldots \ldots \ldots \ldots \ldots \ldots \ldots \\
2001-02 \ldots \ldots \ldots \ldots \ldots \ldots \ldots \ldots \ldots \\
2002-03 \ldots \ldots \ldots \ldots \ldots \ldots \ldots \ldots \ldots \ldots \\
2003-04 \ldots \ldots \ldots \ldots \ldots \ldots \ldots \ldots . . .\end{array}$ & $\begin{array}{l}323.9 \\
348.4 \\
368.4 \\
387.6 \\
403.4\end{array}$ & $\begin{array}{l}6,912 \\
7,380 \\
7,727 \\
8,044 \\
8,310\end{array}$ & $\begin{array}{l}7,394 \\
7,904 \\
8,259 \\
8,610 \\
8,900\end{array}$ & $\begin{array}{l}442.6 \\
460.3 \\
478.3 \\
492.4 \\
501.5\end{array}$ & $\begin{array}{l}3.9 \\
4.0 \\
3.9 \\
3.0 \\
1.8\end{array}$ & $\begin{array}{r}9,446 \\
9,751 \\
10,033 \\
10,219 \\
10,332\end{array}$ & $\begin{array}{l}3.2 \\
3.2 \\
2.9 \\
1.9 \\
1.1\end{array}$ & $\begin{array}{l}10,104 \\
10,443 \\
10,723 \\
10,938 \\
11,064\end{array}$ & $\begin{array}{l}2.5 \\
3.4 \\
2.7 \\
2.0 \\
1.2\end{array}$ \\
\hline $\begin{array}{l}2004-05 \ldots \ldots \ldots \ldots \ldots \ldots \ldots \\
2005-06 \ldots \ldots \ldots \ldots \ldots \ldots \ldots \ldots \ldots \\
2006-07 \ldots \ldots \ldots \ldots \ldots \ldots \ldots \ldots \ldots \\
2007-08 \ldots \ldots \ldots \ldots \ldots \ldots \ldots \ldots \ldots \\
2008-09 \ldots \ldots \ldots \ldots \ldots \ldots \ldots \ldots\end{array}$ & $\begin{array}{l}425.0 \\
449.1 \\
476.8 \\
506.9 \\
518.9\end{array}$ & $\begin{array}{r}8,711 \\
9,145 \\
9,679 \\
10,298 \\
10,540\end{array}$ & $\begin{array}{r}9,316 \\
9,778 \\
10,336 \\
10,982 \\
11,239\end{array}$ & $\begin{array}{l}513.0 \\
522.2 \\
540.4 \\
553.9 \\
559.3\end{array}$ & $\begin{array}{l}2.3 \\
1.8 \\
3.5 \\
2.5 \\
1.0\end{array}$ & $\begin{array}{l}10,513 \\
10,632 \\
10,969 \\
11,254 \\
11,359\end{array}$ & $\begin{array}{l}1.8 \\
1.1 \\
3.2 \\
2.6 \\
0.9\end{array}$ & $\begin{array}{l}11,243 \\
11,368 \\
11,714 \\
12,001 \\
12,113\end{array}$ & $\begin{array}{l}1.6 \\
1.1 \\
3.0 \\
2.5 \\
0.9\end{array}$ \\
\hline 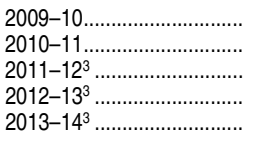 & $\begin{array}{l}524.7 \\
527.2 \\
527.5 \\
542.2 \\
556.6\end{array}$ & $\begin{array}{l}10,636 \\
10,658 \\
10,650 \\
10,920 \\
11,190\end{array}$ & $\begin{array}{l}11,427 \\
11,418 \\
11,400 \\
11,680 \\
11,970\end{array}$ & $\begin{array}{l}560.1 \\
551.6 \\
536.3 \\
542.2 \\
548.4\end{array}$ & $\begin{array}{r}0.1 \\
-1.5 \\
-2.8 \\
1.1 \\
1.1\end{array}$ & $\begin{array}{l}11,353 \\
11,153 \\
10,830 \\
10,920 \\
11,020\end{array}$ & $\begin{array}{r}-0.1 \\
-1.8 \\
-2.9 \\
0.8 \\
0.9\end{array}$ & $\begin{array}{l}12,198 \\
11,948 \\
11,590 \\
11,680 \\
11,790\end{array}$ & $\begin{array}{r}0.7 \\
-2.0 \\
-3.0 \\
0.8 \\
0.9\end{array}$ \\
\hline $\begin{array}{l}2014-15^{3} \ldots \ldots \ldots \ldots \ldots \ldots \ldots \ldots \\
2015-16^{3} \ldots \ldots \ldots \ldots \ldots \ldots \ldots \ldots \\
2016-17^{3} \ldots \ldots \ldots \ldots \ldots \ldots \ldots \ldots \\
2017-18^{3} \ldots \ldots \ldots \ldots \ldots \ldots \ldots \ldots \\
2018-19^{3} \ldots \ldots \ldots \ldots \ldots \ldots \ldots \ldots\end{array}$ & $\begin{array}{r}576.8 \\
- \\
- \\
- \\
-\end{array}$ & $\begin{array}{r}11,590 \\
- \\
- \\
- \\
-\end{array}$ & $\begin{array}{r}12,400 \\
- \\
- \\
- \\
-\end{array}$ & $\begin{array}{l}558.8 \\
570.0 \\
582.8 \\
598.3 \\
610.7\end{array}$ & $\begin{array}{l}1.9 \\
2.0 \\
2.2 \\
2.7 \\
2.1\end{array}$ & $\begin{array}{l}11,230 \\
11,440 \\
11,670 \\
11,900 \\
12,080\end{array}$ & $\begin{array}{l}1.9 \\
1.8 \\
2.0 \\
2.0 \\
1.5\end{array}$ & $\begin{array}{l}12,020 \\
12,240 \\
12,480 \\
12,730 \\
12,930\end{array}$ & $\begin{array}{l}1.9 \\
1.8 \\
2.0 \\
2.0 \\
1.5\end{array}$ \\
\hline 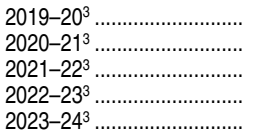 & $\begin{array}{l}- \\
- \\
- \\
-\end{array}$ & $\begin{array}{l}- \\
- \\
- \\
-\end{array}$ & $\begin{array}{l}- \\
- \\
- \\
-\end{array}$ & $\begin{array}{l}622.4 \\
633.0 \\
643.2 \\
654.2 \\
662.9\end{array}$ & $\begin{array}{l}1.9 \\
1.7 \\
1.6 \\
1.7 \\
1.3\end{array}$ & $\begin{array}{l}12,240 \\
12,370 \\
12,490 \\
12,630 \\
12,720\end{array}$ & $\begin{array}{l}1.3 \\
1.0 \\
1.0 \\
1.1 \\
0.7\end{array}$ & $\begin{array}{l}13,100 \\
13,240 \\
13,370 \\
13,510 \\
13,610\end{array}$ & $\begin{array}{l}1.3 \\
1.0 \\
1.0 \\
1.1 \\
0.7\end{array}$ \\
\hline
\end{tabular}

-Not available.

'Unadjusted (or "current") dollars have not been adjusted to compensate for inflation.

${ }^{2}$ Constant dollars based on the Consumer Price Index, prepared by the Bureau of Labor Statistics, U.S. Department of Labor, adjusted to a school-year basis.

${ }^{3}$ Projected.

NOTE: Current expenditures include instruction, support services, food services, and enterprise operations. Some data have been revised from previously published figures.
SOURCE: U.S. Department of Education, National Center for Education Statistics, Common Core of Data (CCD), "National Public Education Financial Survey," 1989-90 through 2010-11; National Elementary and Secondary Enrollment Projection Model, 1972 through 2023; and Public Elementary and Secondary Education Current Expenditure Projection Model, 1973-74 through 2023-24. (This table was prepared May 2014.) 
Table 236.20. Total expenditures for public elementary and secondary education and other related programs, by function and subfunction: Selected years, 1990-91 through 2010-11

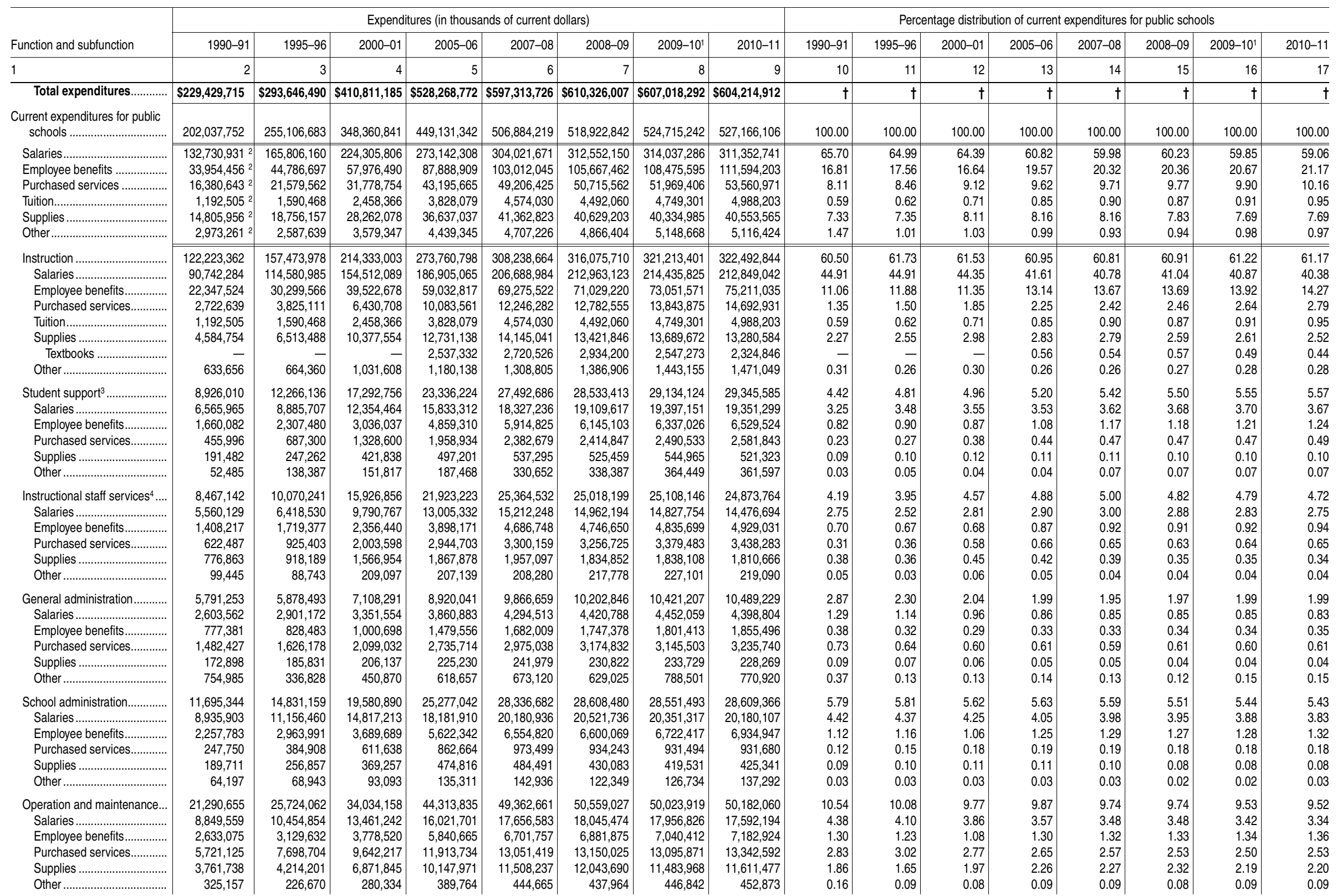

See notes at end of table. 


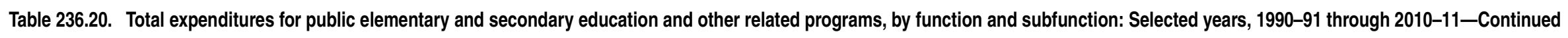

\begin{tabular}{|c|c|c|c|c|c|c|c|c|c|c|c|c|c|c|c|c|}
\hline \multirow[b]{2}{*}{ Function and subfunction } & \multicolumn{8}{|c|}{ Expenditures (in thousands of current dollars) } & \multicolumn{8}{|c|}{ Percentage distribution of current expenditures for public schools } \\
\hline & $1990-91$ & $1995-96$ & $2000-01$ & $2005-06$ & $2007-08$ & $2008-09$ & $2009-10^{1}$ & $2010-11$ & $1990-91$ & $1995-96$ & $2000-01$ & $2005-06$ & $2007-08$ & $2008-09$ & $2009-10^{1}$ & $2010-11$ \\
\hline 1 & 2 & 3 & 4 & 5 & 6 & 7 & 8 & 9 & 10 & 11 & 12 & 13 & 14 & 15 & 16 & 17 \\
\hline $\begin{array}{c}\text { Student transportation ............ } \\
\text { Salaries ......................... } \\
\text { Employee benefits............. } \\
\text { Purchased services............ } \\
\text { Supplies ............................ } \\
\text { Other ............................... }\end{array}$ & $\begin{array}{r}8,678,954 \\
3,285,127 \\
892,985 \\
3,345,232 \\
961,447 \\
194,163\end{array}$ & \begin{tabular}{r|}
$10,396,426$ \\
$3,933,969$ \\
$1,207,961$ \\
$4,257,805$ \\
836,450 \\
160,239
\end{tabular} & $\begin{array}{r}14,052,654 \\
5,406,092 \\
1,592,127 \\
5,767,462 \\
1,159,350 \\
127,623\end{array}$ & $\begin{array}{r}18,850,234 \\
6,701,455 \\
2,535,296 \\
7,547,730 \\
1,867,495 \\
198,259\end{array}$ & $\begin{array}{r}21,536,978 \\
7,507,100 \\
2,867,686 \\
8,556,631 \\
2,427,117 \\
178,444\end{array}$ & \begin{tabular}{r|}
$21,679,876$ \\
$7,591,289$ \\
$2,933,989$ \\
$9,001,837$ \\
$1,983,454$ \\
169,307
\end{tabular} & $\begin{array}{r}21,819,304 \\
7,633,213 \\
3,048,962 \\
8,982,432 \\
1,967,717 \\
186,979\end{array}$ & $\begin{array}{r}22,345,048 \\
7,550,253 \\
3,133,600 \\
9,152,708 \\
2,319,491 \\
188,997\end{array}$ & $\begin{array}{l}4.30 \\
1.63 \\
0.44 \\
1.66 \\
0.48 \\
0.10\end{array}$ & $\begin{array}{l}4.08 \\
1.54 \\
0.47 \\
1.67 \\
0.33 \\
0.06\end{array}$ & $\begin{array}{l}4.03 \\
1.55 \\
0.46 \\
1.66 \\
0.33 \\
0.04\end{array}$ & $\begin{array}{l}4.20 \\
1.49 \\
0.56 \\
1.68 \\
0.42 \\
0.04\end{array}$ & $\begin{array}{l}4.25 \\
1.48 \\
0.57 \\
1.69 \\
0.48 \\
0.04\end{array}$ & $\begin{array}{l}4.18 \\
1.46 \\
0.57 \\
1.73 \\
0.38 \\
0.03\end{array}$ & $\begin{array}{l}4.16 \\
1.45 \\
0.58 \\
1.71 \\
0.38 \\
0.04\end{array}$ & $\begin{array}{l}4.24 \\
1.43 \\
0.59 \\
1.74 \\
0.44 \\
0.04\end{array}$ \\
\hline 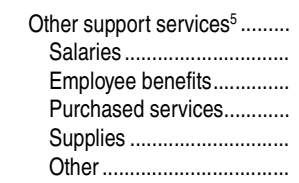 & $\begin{array}{r}5,587,837 \\
2,900,394 \\
980,859 \\
798,922 \\
294,527 \\
613,135\end{array}$ & $\begin{array}{r}7,039,408 \\
3,450,836 \\
1,182,229 \\
1,362,961 \\
398,534 \\
644,849\end{array}$ & $\begin{array}{r}11,439,134 \\
5,521,381 \\
1,594,540 \\
2,783,176 \\
626,889 \\
913,148\end{array}$ & $\begin{array}{r}14,463,815 \\
6,577,129 \\
2,483,366 \\
3,455,292 \\
793,997 \\
1,154,031\end{array}$ & $\begin{array}{r}16,310,815 \\
7,517,159 \\
2,982,979 \\
3,778,311 \\
988,542 \\
1,043,824\end{array}$ & \begin{tabular}{r|}
$17,187,109$ \\
$8,091,102$ \\
$3,148,252$ \\
$3,928,346$ \\
884,381 \\
$1,135,027$
\end{tabular} & $\begin{array}{r}17,189,474 \\
8,162,557 \\
3,136,979 \\
3,915,823 \\
852,467 \\
1,121,648\end{array}$ & $\begin{array}{r}17,172,420 \\
8,134,057 \\
3,227,910 \\
3,875,454 \\
875,929 \\
1,059,070\end{array}$ & $\begin{array}{l}2.77 \\
1.44 \\
0.49 \\
0.40 \\
0.15 \\
0.30\end{array}$ & $\begin{array}{l}2.76 \\
1.35 \\
0.46 \\
0.53 \\
0.16 \\
0.25\end{array}$ & $\begin{array}{l}3.28 \\
1.58 \\
0.46 \\
0.80 \\
0.18 \\
0.26\end{array}$ & $\begin{array}{l}3.22 \\
1.46 \\
0.55 \\
0.77 \\
0.18 \\
0.26\end{array}$ & $\begin{array}{l}3.22 \\
1.48 \\
0.59 \\
0.75 \\
0.20 \\
0.21\end{array}$ & $\begin{array}{l}3.31 \\
1.56 \\
0.61 \\
0.76 \\
0.17 \\
0.22\end{array}$ & $\begin{array}{l}3.28 \\
1.56 \\
0.60 \\
0.75 \\
0.16 \\
0.21\end{array}$ & $\begin{array}{l}3.26 \\
1.54 \\
0.61 \\
0.74 \\
0.17 \\
0.20\end{array}$ \\
\hline 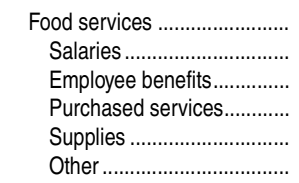 & $\begin{array}{r}8,430,490 \\
- \\
- \\
- \\
-\end{array}$ & $\begin{array}{r}10,648,844 \\
3,844,285 \\
1,103,433 \\
627,902 \\
4,916,299 \\
156,924\end{array}$ & $\begin{array}{r}13,816,635 \\
4,966,092 \\
1,381,923 \\
923,091 \\
6,420,201 \\
125,327\end{array}$ & $\begin{array}{r}17,263,582 \\
5,841,522 \\
2,061,344 \\
1,464,511 \\
7,727,182 \\
169,023\end{array}$ & $\begin{array}{r}19,190,249 \\
6,332,680 \\
2,264,203 \\
1,699,764 \\
8,727,170 \\
166,431\end{array}$ & $\begin{array}{r}19,794,945 \\
6,505,821 \\
2,343,119 \\
1,815,966 \\
8,908,841 \\
221,198\end{array}$ & $\begin{array}{r}19,996,995 \\
6,483,443 \\
2,409,983 \\
1,926,821 \\
8,943,177 \\
233,573\end{array}$ & $\begin{array}{r}20,394,757 \\
6,482,085 \\
2,492,673 \\
2,058,018 \\
9,118,875 \\
243,105\end{array}$ & $\begin{array}{r}4.17 \\
\dagger \\
\dagger \\
\dagger \\
\dagger \\
\dagger\end{array}$ & $\begin{array}{l}4.17 \\
1.51 \\
0.43 \\
0.25 \\
1.93 \\
0.06\end{array}$ & $\begin{array}{l}3.97 \\
1.43 \\
0.40 \\
0.26 \\
1.84 \\
0.04\end{array}$ & $\begin{array}{l}3.84 \\
1.30 \\
0.46 \\
0.33 \\
1.72 \\
0.04\end{array}$ & $\begin{array}{l}3.79 \\
1.25 \\
0.45 \\
0.34 \\
1.72 \\
0.03\end{array}$ & $\begin{array}{l}3.81 \\
1.25 \\
0.45 \\
0.35 \\
1.72 \\
0.04\end{array}$ & $\begin{array}{l}3.81 \\
1.24 \\
0.46 \\
0.37 \\
1.70 \\
0.04\end{array}$ & $\begin{array}{l}3.87 \\
1.23 \\
0.47 \\
0.39 \\
1.73 \\
0.05\end{array}$ \\
\hline $\begin{array}{c}\text { Enterprise operations }{ }^{6} . . . . . . . . . . \\
\text { Salaries ........................... } \\
\text { Employee benefits.............. } \\
\text { Purchased services............ } \\
\text { Supplies ............................ } \\
\text { Other ................................. }\end{array}$ & $\begin{array}{r}946,705 \\
- \\
- \\
- \\
- \\
-\end{array}$ & $\begin{array}{r}777,937 \\
179,360 \\
44,545 \\
183,288 \\
269,046 \\
101,697 \\
\end{array}$ & $\begin{array}{r}776,463 \\
124,913 \\
23,837 \\
189,230 \\
242,052 \\
196,430 \\
\end{array}$ & $\begin{array}{r}1,022,549 \\
213,999 \\
76,042 \\
228,823 \\
304,129 \\
199,556 \\
\end{array}$ & $\begin{array}{r}1,184,293 \\
304,233 \\
81,496 \\
242,643 \\
345,854 \\
210,068 \\
\end{array}$ & $\begin{array}{r}1,263,238 \\
341,007 \\
91,807 \\
256,186 \\
365,775 \\
208,463 \\
\end{array}$ & $\begin{array}{r}1,257,180 \\
337,140 \\
91,133 \\
257,570 \\
361,651 \\
209,686 \\
\end{array}$ & $\begin{array}{r}1,261,032 \\
338,208 \\
97,063 \\
251,720 \\
361,612 \\
212,430 \\
\end{array}$ & $\begin{array}{r}0.47 \\
\dagger \\
\dagger \\
\dagger \\
\dagger \\
\dagger \\
\end{array}$ & $\begin{array}{l}0.30 \\
0.07 \\
0.02 \\
0.07 \\
0.11 \\
0.04 \\
\end{array}$ & $\begin{array}{l}0.22 \\
0.04 \\
0.01 \\
0.05 \\
0.07 \\
0.06\end{array}$ & $\begin{array}{l}0.23 \\
0.05 \\
0.02 \\
0.05 \\
0.07 \\
0.04 \\
\end{array}$ & $\begin{array}{l}0.23 \\
0.06 \\
0.02 \\
0.05 \\
0.07 \\
0.04 \\
\end{array}$ & $\begin{array}{l}0.24 \\
0.07 \\
0.02 \\
0.05 \\
0.07 \\
0.04 \\
\end{array}$ & $\begin{array}{l}0.24 \\
0.06 \\
0.02 \\
0.05 \\
0.07 \\
0.04 \\
\end{array}$ & $\begin{array}{l}0.24 \\
0.06 \\
0.02 \\
0.05 \\
0.07 \\
0.04\end{array}$ \\
\hline 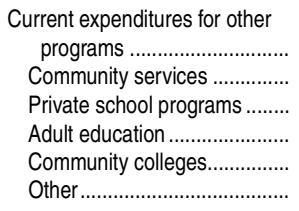 & $\begin{array}{r}3,295,717 \\
964,370 \\
527,609 \\
1,365,523 \\
5,356 \\
432,858\end{array}$ & $\begin{array}{r}4,724,659 \\
1,728,669 \\
781,148 \\
1,500,438 \\
7,746 \\
706,657\end{array}$ & $\begin{array}{r}6,063,700 \\
2,426,189 \\
1,026,695 \\
1,838,265 \\
351 \\
772,200\end{array}$ & $\begin{array}{r}7,415,575 \\
3,015,207 \\
1,389,204 \\
2,001,459 \\
0 \\
1,009,704\end{array}$ & \begin{tabular}{r|}
$8,307,720$ \\
$3,289,736$ \\
$1,564,201$ \\
$2,148,351$ \\
32,694 \\
$1,272,738$
\end{tabular} & $\begin{array}{r}8,463,793 \\
3,364,620 \\
1,541,922 \\
2,187,628 \\
33,303 \\
1,336,321\end{array}$ & $\begin{array}{r}8,355,761 \\
3,398,025 \\
1,423,681 \\
2,084,477 \\
33,274 \\
1,416,305\end{array}$ & $\begin{array}{r}8,187,042 \\
3,295,371 \\
1,427,539 \\
2,013,156 \\
34,045 \\
1,416,931\end{array}$ & $\begin{array}{l}\dagger \\
\dagger \\
\dagger \\
\dagger \\
\dagger \\
\dagger\end{array}$ & $\begin{array}{l}\dagger \\
\dagger \\
\dagger \\
\dagger \\
\dagger \\
\dagger\end{array}$ & $\begin{array}{l}\dagger \\
\dagger \\
\dagger \\
\dagger \\
\dagger \\
\dagger\end{array}$ & $\begin{array}{l}\dagger \\
\dagger \\
\dagger \\
\dagger \\
\dagger \\
\dagger\end{array}$ & $\begin{array}{l}\dagger \\
\dagger \\
\dagger \\
\dagger \\
\dagger \\
\dagger\end{array}$ & $\begin{array}{l}\dagger \\
\dagger \\
\dagger \\
\dagger \\
\dagger \\
\dagger\end{array}$ & $\begin{array}{l}\dagger \\
\dagger \\
\dagger \\
\dagger \\
\dagger \\
\dagger\end{array}$ & $\begin{array}{l}\dagger \\
+ \\
\dagger \\
\dagger \\
\dagger\end{array}$ \\
\hline $\begin{array}{l}\text { Capital outlay } \\
\text { Public schools ................................ } \\
\text { Other current expenditures .... }\end{array}$ & $\begin{array}{r}19,771,478 \\
19,655,496 \\
115,982\end{array}$ & $\begin{array}{r}27,555,667 \\
27,457,489 \\
98,179\end{array}$ & $\begin{array}{r}46,220,704 \\
46,078,494 \\
142,210\end{array}$ & $\begin{array}{r}57,375,299 \\
57,281,425 \\
93,874\end{array}$ & $\begin{array}{r}66,426,299 \\
66,331,738 \\
94,561\end{array}$ & $\begin{array}{r}65,890,367 \\
65,799,088 \\
91,279\end{array}$ & $\begin{array}{r}56,714,992 \\
56,621,337 \\
93,655\end{array}$ & $\begin{array}{r}50,927,540 \\
50,847,585 \\
79,955\end{array}$ & $\begin{array}{l}\dagger \\
\dagger \\
\dagger\end{array}$ & $\begin{array}{l}\dagger \\
\dagger \\
\dagger\end{array}$ & $\begin{array}{l}\dagger \\
\dagger \\
\dagger\end{array}$ & $\begin{array}{l}\dagger \\
\dagger \\
\dagger\end{array}$ & $\begin{array}{l}\dagger \\
\dagger \\
\dagger\end{array}$ & $\begin{array}{l}\dagger \\
\dagger \\
\dagger\end{array}$ & $\begin{array}{l}\dagger \\
\dagger \\
\dagger\end{array}$ & $\begin{array}{l}\dagger \\
\dagger \\
\dagger\end{array}$ \\
\hline Interest on school debt .............. & $4,324,768$ & $6,259,480$ & $10,165,940$ & $14,346,556$ & $15,695,488$ & $17,049,004$ & $17,232,297$ & $17,934,224$ & $\dagger$ & $\dagger$ & $\dagger$ & $\dagger$ & $\dagger$ & $\dagger$ & $\dagger$ & $\dagger$ \\
\hline
\end{tabular}

†Not applicable.

'Data have been revised from previously published figures.

Includes estimated data for subfunctions of food services and enterprise operations.

Includes expenditures for guidance, health, attendance, and speech pathology services.
4 Includes expenditures for curriculum development, staft training, libraries, and media and computer centers.

Includes business support services concerned with paying, transporting, exchanging, and maintaining goods and services for

local education agencies; central support services, including planning, research, evaluation, information, staft, and data process-

ing services; and other support services.
IIncludes expenditures for operations funded by sales of products or services (e.g., school bookstore or computer time). Includes very small amounts for direct program support made by state education agencies for local school districts. ${ }^{7}$ Includes expenditures for property and for buildings and alterations completed by school district staff or contractors.

NOTE: Excludes expenditures for state education agencies. Detail may not sum to totals because of rounding. "
SOURCE: U.S. Department of Education, National Center for Education Statistics, Common Core of Data (CCD), "National PubSOURCE: U.S. Department of Education, National Center for Education Statistics, Common Core
lic Education Financial Survey" 1990-91 through 2010-11. (This table was prepared July 2013.) 
Table 236.25. Current expenditures for public elementary and secondary education, by state or jurisdiction: Selected years, 1969-70 through 2010-11

[In thousands of current dollars]

\begin{tabular}{|c|c|c|c|c|c|c|c|c|c|c|c|c|c|c|c|c|}
\hline State or jurisdiction & $1969-70$ & $1979-80$ & $1989-90$ & $1995-96$ & 1999-2000 & $2000-01$ & 2001-02 & 2002-03 & 2003-04 & 2004-05 & 2005-06 & $2006-07$ & $2007-08$ & 2008-09 & $2009-10^{1}$ & $2010-11$ \\
\hline 1 & 2 & 3 & 4 & 5 & 6 & 7 & 8 & 9 & 10 & 11 & 12 & 13 & 14 & 15 & 16 & 17 \\
\hline United States ............ & $\$ 34,217,773$ & $\$ 86,984,142$ & $\$ 188,229,359$ & $\$ 255,106,683$ & $\$ 323,888,508$ & $\$ 348,360,841$ & $\$ 368,378,006$ & $\$ 387,593,617$ & $\$ 403,390,369$ & $\$ 425,047,565$ & $\$ 449,131,342$ & $\$ 476,814,206$ & $\$ 506,884,219$ & $\$ 518,922,842$ & $\$ 524,715,242$ & $\$ 527,166,106$ \\
\hline Alabama . & 422,730 & $1,146,713$ & $2,275,233$ & $3,240,364$ & $4,176,082$ & $4,354,794$ & $4,444,390$ & $4,657,643$ & $4,812,479$ & $5,164,406$ & $5,699,076$ & $6,245,031$ & $6,832,439$ & $6,683,843$ & $6,670,517$ & $6,592,925$ \\
\hline ....... & 81,374 & 377,947 & 828,051 & $1,045,022$ & $1,183,499$ & $1,229,036$ & $1,284,854$ & $1,326,226$ & $1,354,846$ & $1,442,269$ & $1,529,645$ & $1,634,316$ & $1,918,375$ & $2,007,319$ & $2,084,019$ & $2,201,270$ \\
\hline Arizona ……....................... & 281,941 & 949,753 & $2,258,660$ & $3,327,969$ & $4,288,739$ & $4,846,105$ & $5,395,814$ & $5,892,227$ & $6,071,785$ & $6,579,957$ & $7,130,341$ & $7,815,720$ & $8,403,221$ & $8,726,755$ & $8,482,552$ & $8,340,211$ \\
\hline Arkansas.............................. & 235,083 & 666,949 & $1,404,545$ & $1,994,748$ & $2,380,331$ & $2,505,179$ & $2,822,877$ & $2,923,401$ & $3,109,644$ & $3,546,999$ & $3,808,011$ & $3,997,701$ & $4,156,368$ & $4,240,839$ & $4,459,910$ & $4,578,136$ \\
\hline California .... & $3,831,595$ & $9,172,158$ & $21,485,782$ & $27,334,639$ & $38,129,479$ & $42,908,787$ & $46,265,544$ & $47,983,402$ & $49,215,866$ & $50,918,654$ & $53,436,103$ & $57,352,599$ & $61,570,555$ & $60,080,929$ & $58,248,662$ & $57,526,835$ \\
\hline Colorado. & 369,218 & $1,243,049$ & $2,451,833$ & $3,360,529$ & $4,401,010$ & $4,758,173$ & $5,151,003$ & $5,551,506$ & $5,666,191$ & $5,994,440$ & $6,368,289$ & $6,579,053$ & $7,338,766$ & $7,187,267$ & $7,429,302$ & $7,409,462$ \\
\hline Connecticut......................... & 588,710 & $1,227,892$ & $3,444,520$ & $4,366,123$ & $5,402,836$ & $5,693,207$ & $6,031,062$ & $6,302,988$ & $6,600,767$ & $7,080,396$ & $7,517,025$ & $7,855,459$ & $8,336,789$ & $8,708,294$ & $8,853,337$ & $9,094,036$ \\
\hline Delaware............................... & 108,747 & 269,108 & 520,953 & 726,241 & 937,630 & $1,027,224$ & $1,072,875$ & $1,127,745$ & $1,201,631$ & $1,299,349$ & $1,405,465$ & $1,437,707$ & $1,489,594$ & $1,518,786$ & $1,549,812$ & $1,613,304$ \\
\hline Columbia ........... & 141,138 & 298,448 & 639,983 & 679,106 & 780,192 & 830,299 & 912,432 & 902,318 & $1,011,536$ & $1,067,500$ & $1,057,166$ & $1,130,006$ & $1,282,437$ & $1,352,905$ & $1,451,870$ & $1,482,202$ \\
\hline Florida.... & 961,273 & $2,766,468$ & $8,228,531$ & $11,480,359$ & $13,885,988$ & $15,023,514$ & $15,535,864$ & $16,355,123$ & $17,578,884$ & $19,042,877$ & $20,897,327$ & $22,887,024$ & $24,224,114$ & $23,328,028$ & $23,349,314$ & $23,870,090$ \\
\hline Georgia & 599,371 & $1,608,028$ & $4,505,962$ & $6,629,646$ & $9,158,624$ & $10,011,343$ & $10,853,496$ & $11,630,576$ & $11,788,616$ & $12,528,856$ & $13,739,263$ & $14,828,715$ & $16,030,039$ & $15,976,945$ & $15,730,409$ & $15,527,907$ \\
\hline & 141,324 & 351,889 & 700,012 & $1,040,682$ & $1,213,695$ & $1,215,968$ & $1,348,381$ & $1,489,092$ & $1,566,792$ & $1,648,086$ & $1,805,521$ & $2,045,198$ & $2,122,779$ & & & $2,141,561$ \\
\hline Idaho.... & 103,107 & 313,927 & 627,794 & $1,019,594$ & $1,302,817$ & $1,403,190$ & $1,481,803$ & $1,511,862$ & $1,555,006$ & $1,618,215$ & $1,694,827$ & $1,777,491$ & $1,891,505$ & $1,957,740$ & $1,961,857$ & $1,881,746$ \\
\hline ........ & $1,896,067$ & $4,579,355$ & $8,125,493$ & $10,727,091$ & $14,462,773$ & $15,634,490$ & $16,480,787$ & $17,271,301$ & $18,081,827$ & $18,658,428$ & $19,244,908$ & $20,326,591$ & $21,874,484$ & $23,495,271$ & $24,695,773$ & $24,554,467$ \\
\hline Indiana. & 809,105 & $1,851,292$ & $4,074,578$ & $5,493,653$ & $7,110,930$ & $7,548,487$ & $7,704,547$ & $8,088,684$ & $8,524,980$ & $9,108,931$ & $9,241,986$ & $9,497,077$ & $9,281,709$ & $9,680,895$ & $9,921,243$ & $9,687,949$ \\
\hline lowa.. & 527,086 & $1,186,659$ & $2,004,742$ & $2,753,425$ & $3,264,336$ & $3,430,885$ & $3,565,796$ & $3,652,022$ & $3,669,797$ & $3,808,200$ & $4,039,389$ & $4,231,932$ & $4,499,236$ & 463 & $4,794,308$ & $4,855,871$ \\
\hline Kansas. & 362,593 & 830,133 & $1,848,302$ & $2,488,077$ & $2,971,814$ & $3,264,698$ & $3,450,923$ & $3,510,675$ & $3,658,421$ & 153 & $4,039,417$ & $4,339,477$ & $4,633,517$ & 603 & 676 & $4,741,372$ \\
\hline Kentuck & 353,265 & $1,054,459$ & $2,134,011$ & $3,171,495$ & $3,837,794$ & $4,047,392$ & $4,268,608$ & $4,401,627$ & $4,553,382$ & $4,812,591$ & & $5,424,621$ & $5,822,550$ & $5,886,890$ & 6,0 & $6,211,453$ \\
\hline Louisiana & 503,217 & $1,303,902$ & $2,838,283$ & $3,545,832$ & $4,391,189$ & $4,485,878$ & $4,802,565$ & $5,056,583$ & $5,290,964$ & $5,554,766$ & $5,554,278$ & $6,040,368$ & $6,814,455$ & $7,276,651$ & $7,393,452$ & $7,522,098$ \\
\hline Maine...... & 155,907 & 385,492 & $1,048,195$ & $1,313,759$ & $1,604,438$ & $1,704,422$ & $1,812,798$ & $1,909,268$ & $1,969,497$ & $2,056,266$ & $2,119,408$ & $2,258,764$ & $2,308,071$ & $2,350,447$ & $2,370,085$ & $2,377,878$ \\
\hline ruland & 721,794 & $1,783,056$ & $3,894,644$ & $5,311,207$ & $6,545,135$ & $7,044,881$ & 723 & ,055 & 154 & 86 & 13 & 03 & 76 & 365 & 77 & 719 \\
\hline & 907,341 & 734 & 0,390 & $6,435,458$ & & 387 & & & & & & 447 & & & & \\
\hline iga & $1,799,945$ & $4,642,847$ & $8,025,621$ & $11,137,877$ & 13,994,294 & $14,243,597$ & $14,975,150$ & $15,674,698$ & $15,983,044$ & $16,353,921$ & $16,681,981$ & $17,013,259$ & $17,053,521$ & 7,584 & 515 & $16,786,444$ \\
\hline & 781,243 & $1,786,768$ & $3,474,398$ & $4,844,879$ & $6,140,442$ & $6,531,198$ & $6,586,559$ & 7,403 & $7,084,005$ & & & & ;,264 & & & $8,944,867$ \\
\hline MVISS & 262,760 & 756,018 & $1,472,710$ & $2,000,321$ & $2,510,376$ & $2,576,457$ & $2,642,116$ & $2,853,531$ & $3,059,569$ & $3,243,888$ & $3,550,261$ & 3,692,358 & $3,898,401$ & $3,967,232$ & $3,990,876$ & $3,887,981$ \\
\hline sol & 42,030 & $1,504,988$ & $3,288,738$ & $4,531,192$ & $5,655,531$ & 76,169 & 885 & 57 & 154 & 07 & 185 & 705 & 341 & 224 & 448 & $8,691,887$ \\
\hline & 7,176 & & & 92 & 4,770 & & & & & & & & & & & \\
\hline Nebraska ................................ & 231,612 & 581,615 & $1,233,431$ & $1,648,104$ & $1,926,500$ & $2,067,290$ & $2,206,946$ & $2,304,223$ & $2,413,404$ & $2,512,914$ & 2,67 & $2,825,608$ & 2,97 & $3,053,575$ & 646 & $3,298,536$ \\
\hline Al & 87,273 & 281,901 & 712,898 & $1,296,629$ & & & 9,000 & & & & & & & & & $3,676,997$ \\
\hline New Hampshire.... & 101,370 & 295,400 & 821,671 & $1,114,540$ & $1,418,503$ & $1,518,792$ & $1,641,378$ & $1,781,594$ & $1,900,240$ & $2,021,144$ & $2,139,113$ & $2,246,692$ & $2,399,330$ & $2,490,623$ & $2,576,956$ & $2,637,911$ \\
\hline th & $1,343,564$ & $3,638,533$ & $8,119,336$ & $11,208,558$ & $13,327,645$ & $14,773,650$ & $15,822,609$ & $17,185,966$ & $18,416,695$ & $19,669,576$ & $20,869,993$ & $22,448,262$ & $24,357,079$ & $23,446,911$ & $24,261,392$ & $23,639,281$ \\
\hline ........ & 183,736 & & & 17 & & 93 & & & & & & & & & & 463 \\
\hline New Yorl & $4,111,839$ & $8,760,500$ & $18,090,978$ & $23,522,461$ & $28,433,240$ & $30,884,292$ & $32,218,975$ & $34,546,965$ & $36,205,111$ & $38,866,853$ & $41,149,457$ & $43,679,908$ & $46,443,426$ & 5,363 & $50,251,461$ & $51,509,285$ \\
\hline Nort & 676,193 & $1,880,862$ & $4,342,826$ & $5,582,994$ & $7,713,293$ & $8,201,901$ & $8,543,290$ & $8,766,968$ & $8,994,620$ & $9,835,550$ & 6,056 & $11,248,336$ & $11,482,912$ & $12,598,382$ & 200,362 & $12,322,555$ \\
\hline North Dakota ........................ & 97,895 & 228,483 & 459,391 & 557,043 & 638,946 & 668,814 & 711,437 & 716,007 & 749,697 & 832,157 & 857,774 & 838,221 & 886,317 & 928,528 & $1,000,095$ & $1,049,772$ \\
\hline & $1,639,805$ & $3,836,576$ & 99437 & $10,408,022$ & $12,974,575$ & $13,893,495$ & $14,774,065$ & $15,868,494$ & $16,662,985$ & $17,167,866$ & $17,829,599$ & $18,251,361$ & $18,892,374$ & $19,387,318$ & $19,801,670$ & $19,988,921$ \\
\hline OK & 339,105 & 5,844 & 5,332 & $2,804,088$ & 2,581 & $3,750,542$ & $3,875,547$ & $3,804,570$ & 3,308 & $4,161,024$ & $4,406,002$ & $4,750,536$ & $4,932,913$ & $5,082,062$ & $5,192,124$ & $5,036,031$ \\
\hline & 403,844 & $1,126,812$ & $2,297,944$ & $3,056,801$ & 6,287 & $4,112,069$ & $4,214,512$ & $4,150,747$ & 485 & & & $5,039,632$ & $5,409,630$ & $5,529,831$ & $5,401,667$ & $5,430,888$ \\
\hline Pen & $1,912,644$ & $4,584,320$ & $9,496,788$ & $12,374,073$ & $14,120,112$ & $14,895,316$ & $15,550,975$ & $16,344,439$ & $17,680,332$ & $18,711,100$ & $19,631,006$ & $20,404,304$ & $21,157,430$ & $21,831,816$ & $22,733,518$ & $23,485,203$ \\
\hline Rhode Island ......................... & 145,443 & 362,046 & 801,908 & $1,094,185$ & $1,393,143$ & $1,465,703$ & $1,533,455$ & $1,647,587$ & $1,765,585$ & $1,825,900$ & $1,934,429$ & $2,039,633$ & $2,134,609$ & $2,139,317$ & $2,136,582$ & $2,149,366$ \\
\hline South Carolina... & 367,689 & 997,984 & $2,322,618$ & $3,085,495$ & $4,087,355$ & $4,492,161$ & $4,744,809$ & $4,888,250$ & $5,017,833$ & $5,312,739$ & $5,696,629$ & $6,023,043$ & $6,453,817$ & $6,626,763$ & 6,566 & $6,461,884$ \\
\hline South $D$ & 109,375 & 238,332 & 447,074 & 610,640 & 737,998 & 796,133 & 819,296 & 851,429 & 887,328 & 916,563 & 948,671 & 977,006 & & 054 & 861 & $1,126,503$ \\
\hline Tenness & 473,226 & $1,319,303$ & $2,790,808$ & $3,728,486$ & $4,931,734$ & $5,170,379$ & $5,501,029$ & $5,674,773$ & $6,056,657$ & $6,446,691$ & $6,681,445$ & $6,975,099$ & $7,540,306$ & $7,768,063$ & $7,894,661$ & $8,377,599$ \\
\hline 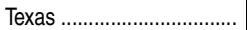 & $1,518,181$ & $4,997,689$ & $12,763,954$ & $18,801,462$ & $25,098,703$ & $26,546,557$ & $28,191,128$ & $30,399,603$ & $30,974,890$ & $31,919,107$ & $33,851,773$ & $36,105,784$ & $39,033,235$ & $40,688,181$ & $42,621,886$ & $42,864,291$ \\
\hline Utah & 179,981 & 518,251 & $1,130,135$ & $1,719,782$ & $2,102,655$ & $2,250,339$ & $2,374,702$ & $2,366,897$ & $2,475,550$ & $2,627,022$ & $2,778,236$ & $2,987,810$ & $3,444,936$ & $3,638,775$ & $3,635,085$ & $3,704,133$ \\
\hline
\end{tabular}

See notes at end of table. 
Table 236.25. Current expenditures for public elementary and secondary education, by state or jurisdiction: Selected years, 1969-70 through 2010-11-Continued

[n thousands of current dollars]

\begin{tabular}{|c|c|c|c|c|c|c|c|c|c|c|c|c|c|c|c|c|}
\hline State or jurisdiction & 1969-70 & $1979-80$ & $1989-90$ & $1995-96$ & $1999-2000$ & $2000-01$ & $2001-02$ & $2002-03$ & $2003-04$ & $2004-05$ & $2005-06$ & $2006-07$ & $2007-08$ & $2008-09$ & $2009-10^{1}$ & $2010-11$ \\
\hline 1 & 2 & 3 & 4 & 5 & 6 & 7 & 8 & 9 & 10 & 11 & 12 & 13 & 14 & 15 & 16 & 17 \\
\hline Vermont. & 78,921 & 189,811 & 546,901 & 684,864 & 70,198 & 934,031 & 2,149 & 045,213 & $1,111,029$ & $1,177,478$ & $1,237,442$ & $1,300,149$ & $1,356,165$ & $, 413,329$ & $1,432,683$ & $1,424,507$ \\
\hline Virgini & 704,677 & 1,881 & & 5,969 & & 55 & & & & 10,7 & 11,4 & 12,4 & & 290 & & $12,968,457$ \\
\hline Washington ................... & 699,984 & $1,825,782$ & $3,550,819$ & $5,394,507$ & $6,399,885$ & 782,136 & $7,103,817$ & 359,566 & $7,549,235$ & $7,870,979$ & $8,239,716$ & $8,752,007$ & $9,331,539$ & $9,940,325$ & $9,832,913$ & $10,040,312$ \\
\hline West & 249,404 & 678 & & $1,806,004$ & & & & & & & & & & & & $3,388,294$ \\
\hline Wiscon & 777,288 & $1,908,523$ & $3,929,920$ & $5,670,826$ & $6,852,178$ & $7,249,081$ & $7,592,176$ & $7,934,755$ & $8,131,276$ & $8,435,359$ & 195 & 660 & & ,228 & $9,966,244$ & $10,333,016$ \\
\hline Wyoming............. & 69,584 & 226,067 & 509,084 & 581,817 & 33,918 & 704,695 & 761,830 & 791,732 & 814,092 & 863,423 & 965,350 & $1,124,564$ & $1,191,736$ & $1,268,407$ & $1,334,655$ & $1,398,444$ \\
\hline Other jurisdictions & -1 & - & & 30382 & 395 & 40642 & 46192 & 47566 & & 58163 & & & & 65436 & & \\
\hline 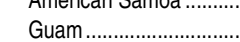 & 16,652 & - & $\begin{array}{r}21,000 \\
101,130\end{array}$ & $\begin{array}{r}30,002 \\
-\end{array}$ & - & $\begin{aligned}, 042 \\
-\end{aligned}$ & - & $\begin{array}{r}7,000 \\
-\end{array}$ & $\begin{array}{r}30,519 \\
182,506\end{array}$ & $\begin{array}{r}00,100 \\
-\end{array}$ & $\begin{array}{r}50,039 \\
210,119\end{array}$ & $\begin{array}{r}51,090 \\
219,881\end{array}$ & $\begin{array}{r}0,105 \\
229,243\end{array}$ & $\begin{array}{r}0,430 \\
235,711\end{array}$ & $\begin{array}{r}17,305 \\
235,639\end{array}$ & $\begin{array}{r}15,300 \\
266,952\end{array}$ \\
\hline Northern Marianas......... & - & - & 20,476 & 44,037 & 49,832 & 49,151 & 46,508 & 50,843 & 47,681 & 58,400 & 57,694 & 55,048 & 51,241 & 62,787 & 62,210 & 84,657 \\
\hline Puerto & - & - & $1,045,407$ & $1,667,640$ & $2,086,414$ & $2,257,837$ & $2,152,724$ & $2,541,385$ & $2,425,372$ & $2,865,945$ & $3,082,295$ & $3,268,200$ & $3,433,229$ & $3,502,757$ & $3,464,044$ & $3,519,547$ \\
\hline U.S. Virgin Islands.......... & - & - & 128,065 & 122,286 & 135,174 & 125,252 & 107,343 & 125,405 & 128,250 & 137,793 & 146,872 & 157,446 & 196,533 & 201,326 & 220,234 & 212,112 \\
\hline
\end{tabular}

$\frac{\overline{0}}{\mathrm{D}}$
-Not available.

NOTE: Current expenditures include instruction, support services, food services, and enterprise operations. Beginning in 1989-90, expenditures for state administration are excluded. Data are not adjusted for changes in the purchasing power of the dollar due to inflation. Detail may not sum to totals because of rounding.
SOURCE: U.S. Department of Education, National Center for Education Statistics, Statistics of State School Systems, 1969-70, Revenues and Expenditures for Public Elementary and Secondary Education, 1979-80; and Common Core of Data (CCD), "National Public Education Financial Survey," 1989-90 through 2010-11. (This table was prepared July 2013.) 
Table 236.30. Total expenditures for public elementary and secondary education and other related programs, by function and state or jurisdiction: 2010-11

[In thousands of current dollars]

\begin{tabular}{|c|c|c|c|c|c|c|c|c|c|c|c|c|c|c|c|c|}
\hline \multirow[b]{4}{*}{ State or jurisdiction } & \multicolumn{16}{|c|}{ Total expenditures } \\
\hline & \multirow[b]{3}{*}{ Total } & \multicolumn{12}{|c|}{ Current expenditures for elementary and secondary programs } & \multirow{3}{*}{$\begin{array}{r}\text { Current } \\
\text { expenditures } \\
\text { for other } \\
\text { programs } \\
\end{array}$} & \multirow[b]{3}{*}{$\begin{array}{l}\text { Capital } \\
\text { outlay }\end{array}$} & \multirow[b]{3}{*}{$\begin{array}{l}\text { Interest on } \\
\text { school debt }\end{array}$} \\
\hline & & \multirow{2}{*}{$\begin{array}{r}\text { Elementary/ } \\
\text { secondary } \\
\text { current } \\
\text { expenditures, } \\
\text { total }\end{array}$} & \multirow[b]{2}{*}{ Instruction } & \multicolumn{8}{|c|}{ Support services } & \multirow[b]{2}{*}{$\begin{array}{r}\text { Food } \\
\text { services }\end{array}$} & \multirow[b]{2}{*}{$\begin{array}{r}\text { Enterprise } \\
\text { operations }^{3}\end{array}$} & & & \\
\hline & & & & Total & $\begin{array}{r}\text { Student } \\
\text { support }\end{array}$ & $\begin{array}{r}\text { Instructional } \\
\text { staff }\end{array}$ & $\begin{array}{r}\text { General } \\
\text { administration }\end{array}$ & $\begin{array}{r}\text { School } \\
\text { administration }\end{array}$ & $\begin{array}{r}\text { Operation and } \\
\text { maintenance }\end{array}$ & $\begin{array}{r}\text { Student } \\
\text { transportation }\end{array}$ & $\begin{array}{r}\text { Other support } \\
\text { services }\end{array}$ & & & & & \\
\hline 1 & 2 & 3 & 4 & 5 & 6 & 7 & 8 & 8 & 10 & 11 & 12 & 13 & 14 & 15 & 16 & 17 \\
\hline United States..... & $\$ 604,214,912$ & $\$ 527,166,106$ & $\$ 322,492,844$ & $\$ 183,017,473$ & $\$ 29,345,585$ & $\$ 24,873,764$ & \begin{tabular}{|l|}
$\$ 10,489,229$ \\
\end{tabular} & $\$ 28,609,366$ & $\$ 50,182,060$ & $\$ 22,345,048$ & $\$ 17,172,420$ & $\$ 20,394,757$ & $\$ 1,261,032$ & $\$ 8,187,042$ & $\$ 50,927,540$ & $\$ 17,934,224$ \\
\hline 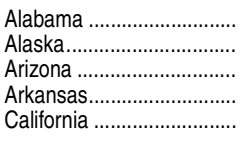 & $\begin{array}{r}7,410,192 \\
2,430,593 \\
9,889,232 \\
5,392,058 \\
67,570,728\end{array}$ & $\begin{array}{r}6,592,925 \\
2,201,270 \\
8,340,211 \\
4,578,136 \\
57,526,835\end{array}$ & $\begin{array}{r}3,846,419 \\
1,218,685 \\
4,506,883 \\
2,615,474 \\
34,679,610\end{array}$ & \begin{tabular}{r|}
$2,301,718$ \\
913,896 \\
$3,394,014$ \\
$1,702,516$ \\
$20,417,014$
\end{tabular} & $\begin{array}{r}382,417 \\
180,052 \\
1,087,247 \\
233,099 \\
3,004,958\end{array}$ & $\begin{array}{r}297,721 \\
154,044 \\
195,308 \\
392,196 \\
3,499,992\end{array}$ & $\begin{array}{r}158,287 \\
30,576 \\
126,897 \\
112,986 \\
555,828\end{array}$ & $\begin{array}{r}407,947 \\
133,786 \\
392,530 \\
231,473 \\
3,811,666\end{array}$ & $\begin{array}{r}594,180 \\
269,143 \\
937,481 \\
435,105 \\
5,695,223\end{array}$ & $\begin{array}{r}330,019 \\
64,056 \\
323,522 \\
172,141 \\
1,386,604\end{array}$ & $\begin{array}{r}131,147 \\
82,239 \\
331,029 \\
125,517 \\
2,462,742\end{array}$ & $\begin{array}{r}444,788 \\
60,491 \\
393,701 \\
254,728 \\
2,287,136\end{array}$ & $\begin{array}{r}0 \\
8,198 \\
45,613 \\
5,418 \\
143,075\end{array}$ & $\begin{array}{r}116,732 \\
8,633 \\
47,020 \\
30,556 \\
938,345\end{array}$ & $\begin{array}{r}565,985 \\
181,341 \\
864,847 \\
676,234 \\
6,763,699\end{array}$ & $\begin{array}{r}134,550 \\
39,349 \\
637,155 \\
126,132 \\
2,341,849\end{array}$ \\
\hline 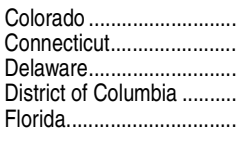 & $\begin{array}{r}8,743,142 \\
9,944,121 \\
1,855,007 \\
2,063,029 \\
27,433,536\end{array}$ & $\begin{array}{r}7,409,462 \\
9,094,036 \\
1,613,304 \\
1,482,202 \\
23,870,090\end{array}$ & $\begin{array}{r}4,250,693 \\
5,768,873 \\
1,018,491 \\
754,464 \\
14,566,298\end{array}$ & $\begin{array}{r}2,868,302 \\
3,031,013 \\
536,283 \\
670,690 \\
8,237,108\end{array}$ & $\begin{array}{r}361,218 \\
555,702 \\
75,881 \\
86,134 \\
1,066,264\end{array}$ & $\begin{array}{r}420,592 \\
281,253 \\
21,042 \\
114,951 \\
1,541,508\end{array}$ & $\begin{array}{r}159,259 \\
178,833 \\
22,133 \\
61,731 \\
253,657\end{array}$ & $\begin{array}{r}495,909 \\
515,530 \\
88,755 \\
110,235 \\
1,343,045\end{array}$ & $\begin{array}{r}695,046 \\
842,535 \\
160,882 \\
165,485 \\
2,471,262\end{array}$ & $\begin{array}{r}217,522 \\
449,853 \\
94,237 \\
100,107 \\
959,102\end{array}$ & $\begin{array}{r}518,757 \\
207,308 \\
73,355 \\
32,047 \\
602,272\end{array}$ & $\begin{array}{r}254,581 \\
219,101 \\
58,529 \\
54,224 \\
1,066,684\end{array}$ & $\begin{array}{r}35,885 \\
75,049 \\
0 \\
2,824 \\
0\end{array}$ & $\begin{array}{r}58,479 \\
145,124 \\
28,277 \\
37,802 \\
570,458\end{array}$ & $\begin{array}{r}835,266 \\
563,519 \\
189,766 \\
391,652 \\
2,217,064\end{array}$ & $\begin{array}{r}439,936 \\
141,441 \\
23,660 \\
151,373 \\
775,923\end{array}$ \\
\hline 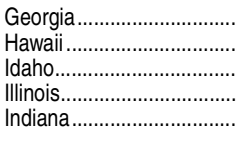 & \begin{tabular}{r|}
$17,178,095$ \\
$2,342,924$ \\
$2,107,272$ \\
$27,621,033$ \\
$11,037,564$
\end{tabular} & $\begin{array}{r}15,527,907 \\
2,141,561 \\
1,881,746 \\
24,554,467 \\
9,687,949\end{array}$ & $\begin{array}{r}9,668,819 \\
1,242,693 \\
1,148,131 \\
14,690,696 \\
5,702,356\end{array}$ & $\begin{array}{r}5,009,451 \\
782,875 \\
637,447 \\
9,118,001 \\
3,1555,487\end{array}$ & $\begin{array}{r}733,717 \\
201,020 \\
106,724 \\
1,658,199 \\
456,293\end{array}$ & $\begin{array}{r}777,196 \\
71,439 \\
75,237 \\
1,059,076 \\
367,778\end{array}$ & $\begin{array}{r}234,176 \\
10,796 \\
42,676 \\
999,732 \\
251,190\end{array}$ & $\begin{array}{r}932,355 \\
137,151 \\
105,642 \\
1,249,947 \\
558,236\end{array}$ & $\begin{array}{r}1,156,798 \\
251,208 \\
171,558 \\
2,21,843 \\
1,097,726\end{array}$ & $\begin{array}{r}658,161 \\
66,436 \\
91,532 \\
1,152,373 \\
582,621\end{array}$ & $\begin{array}{r}517,049 \\
44,825 \\
44,077 \\
786,830 \\
241,642\end{array}$ & $\begin{array}{r}806,569 \\
115,993 \\
95,780 \\
745,770 \\
430,106\end{array}$ & $\begin{array}{r}43,067 \\
0 \\
389 \\
0 \\
0\end{array}$ & $\begin{array}{r}26,993 \\
17,627 \\
4,151 \\
151,196 \\
139,215\end{array}$ & $\begin{array}{r}1,367,894 \\
85,475 \\
160,083 \\
2,093,497 \\
871,863\end{array}$ & $\begin{array}{r}255,301 \\
98,261 \\
61,292 \\
821,873 \\
338,537\end{array}$ \\
\hline 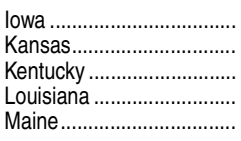 & $\begin{array}{l}5,859,335 \\
5,824,926 \\
7,200,059 \\
8,502,295 \\
2,630,548\end{array}$ & $\begin{array}{l}4,855,871 \\
4,741,372 \\
6,211,453 \\
7,522,098 \\
2,377,878\end{array}$ & $\begin{array}{l}2,994,346 \\
2,873,575 \\
3,641,680 \\
4,380,197 \\
1,442,329\end{array}$ & $\begin{array}{r}1,640,916 \\
1,651,762 \\
2,197,751 \\
2,743,272 \\
859,075\end{array}$ & $\begin{array}{l}273,995 \\
275,382 \\
279,805 \\
369,620 \\
155,421\end{array}$ & $\begin{array}{l}231,275 \\
202,415 \\
337,676 \\
410,213 \\
124,072\end{array}$ & $\begin{array}{r}125,472 \\
139,658 \\
137,247 \\
177,276 \\
76,259\end{array}$ & $\begin{array}{l}274,596 \\
271,235 \\
345,210 \\
437,419 \\
127,845\end{array}$ & $\begin{array}{l}412,748 \\
443,398 \\
576,020 \\
700,509 \\
232,893\end{array}$ & $\begin{array}{l}177,495 \\
191,568 \\
376,894 \\
435,310 \\
114,101\end{array}$ & $\begin{array}{r}145,336 \\
128,107 \\
144,898 \\
212,926 \\
28,484\end{array}$ & $\begin{array}{r}215,791 \\
216,035 \\
356,658 \\
398,537 \\
76,393\end{array}$ & $\begin{array}{r}4,817 \\
0 \\
15,365 \\
92 \\
80\end{array}$ & $\begin{array}{r}30,310 \\
4,295 \\
83,981 \\
45,343 \\
28,301\end{array}$ & $\begin{array}{l}871,157 \\
869,746 \\
747,269 \\
812,767 \\
172,590\end{array}$ & $\begin{array}{r}101,997 \\
209,512 \\
157,355 \\
122,086 \\
51,778\end{array}$ \\
\hline 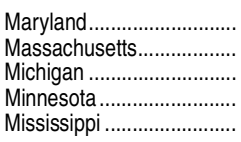 & $\begin{array}{r}13,251,725 \\
14,715,706 \\
19,444,952 \\
10,816,918 \\
4,268,801\end{array}$ & $\begin{array}{r}12,035,719 \\
13,649,965 \\
16,786,444 \\
8,944,867 \\
3,887,981\end{array}$ & $\begin{array}{l}7,424,153 \\
8,867,542 \\
9,672,947 \\
5,888,594 \\
2,247,757\end{array}$ & $\begin{array}{l}4,149,496 \\
4,419,333 \\
6,535,509 \\
2,649,197 \\
1,399,692\end{array}$ & $\begin{array}{r}528,145 \\
953,027 \\
1,269,121 \\
236,405 \\
187,586\end{array}$ & $\begin{array}{l}668,989 \\
611,858 \\
889,719 \\
377,320 \\
197,923\end{array}$ & $\begin{array}{r}92,610 \\
182,474 \\
343,162 \\
269,575 \\
115,358\end{array}$ & $\begin{array}{l}833,866 \\
554,090 \\
914,817 \\
357,613 \\
224,147\end{array}$ & $\begin{array}{r}1,070,409 \\
1,239,104 \\
1,572,870 \\
646,876 \\
400,360\end{array}$ & $\begin{array}{l}612,124 \\
559,868 \\
706,467 \\
498,338 \\
186,606\end{array}$ & $\begin{array}{r}343,352 \\
318,911 \\
839,353 \\
263,070 \\
87,713\end{array}$ & $\begin{array}{l}311,684 \\
363,090 \\
577,989 \\
381,430 \\
240,263\end{array}$ & $\begin{array}{r}150,386 \\
0 \\
0 \\
25,646 \\
269\end{array}$ & $\begin{array}{r}28,220 \\
55,711 \\
332,187 \\
417,151 \\
28,526\end{array}$ & $\begin{array}{r}1,022,082 \\
758,688 \\
1,434,833 \\
1,052,205 \\
281,036\end{array}$ & $\begin{array}{r}165,704 \\
251,343 \\
891,488 \\
402,695 \\
71,258\end{array}$ \\
\hline 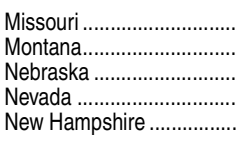 & $\begin{array}{r}10,072,167 \\
1,653,315 \\
3,739,179 \\
4,244,029 \\
2,896,807\end{array}$ & $\begin{array}{l}8,691,887 \\
1,518,818 \\
3,298,536 \\
3,676,997 \\
2,637,911\end{array}$ & $\begin{array}{r}5,208,082 \\
909,036 \\
2,185,379 \\
2,190,166 \\
1,712,141\end{array}$ & $\begin{array}{r}3,090,488 \\
543,485 \\
892,158 \\
1,364,559 \\
855,470\end{array}$ & $\begin{array}{r}406,335 \\
93,752 \\
119,384 \\
187,908 \\
190,003\end{array}$ & $\begin{array}{r}389,078 \\
57,707 \\
101,175 \\
194,601 \\
81,626\end{array}$ & $\begin{array}{r}274,499 \\
43,611 \\
102,258 \\
45,813 \\
85,942\end{array}$ & $\begin{array}{r}496,717 \\
81,039 \\
125,196 \\
261,636 \\
140,018\end{array}$ & $\begin{array}{l}871,391 \\
158,869 \\
282,923 \\
386,890 \\
217,962\end{array}$ & $\begin{array}{r}444,318 \\
72,215 \\
93,628 \\
152,658 \\
111,866\end{array}$ & $\begin{array}{r}208,149 \\
36,291 \\
67,594 \\
135,054 \\
28,052\end{array}$ & $\begin{array}{r}393,317 \\
62,689 \\
135,430 \\
122,068 \\
70,300\end{array}$ & $\begin{array}{r}0 \\
3,607 \\
85,569 \\
204 \\
0\end{array}$ & $\begin{array}{r}198,591 \\
11,231 \\
2,629 \\
25,308 \\
7,823\end{array}$ & $\begin{array}{l}854,963 \\
107,204 \\
356,643 \\
297,155 \\
206,275\end{array}$ & $\begin{array}{r}326,725 \\
16,062 \\
81,372 \\
244,570 \\
44,799\end{array}$ \\
\hline 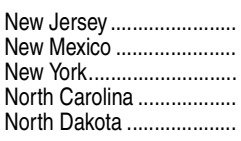 & $\begin{array}{r}25,308,865 \\
3,641,735 \\
57,350,534 \\
13,277,669 \\
1,198,926\end{array}$ & $\begin{array}{r}23,639,281 \\
3,127,463 \\
51,509,285 \\
12,322,555 \\
1,049,772\end{array}$ & $\begin{array}{r}14,209,004 \\
1,793,031 \\
35,992,426 \\
7,702,399 \\
607,522\end{array}$ & $\begin{array}{r}8,659,183 \\
1,191,752 \\
14,485,533 \\
3,955,217 \\
356,906\end{array}$ & $\begin{array}{r}2,290,750 \\
325,026 \\
1,708,221 \\
581,125 \\
47,023\end{array}$ & $\begin{array}{r}732,617 \\
88,261 \\
1,330,084 \\
451,273 \\
35,583\end{array}$ & $\begin{array}{r}483,063 \\
70,665 \\
984,671 \\
198,490 \\
48,894\end{array}$ & $\begin{array}{r}1,117,966 \\
187,111 \\
1,965,608 \\
767,107 \\
51,693\end{array}$ & $\begin{array}{r}2,345,908 \\
322,521 \\
4,561,407 \\
1,057,753 \\
102,037\end{array}$ & $\begin{array}{r}1,169,718 \\
103,320 \\
2,686,652 \\
526,541 \\
44,942\end{array}$ & $\begin{array}{r}519,162 \\
94,849 \\
1,248,890 \\
372,928 \\
26,734\end{array}$ & $\begin{array}{r}510,851 \\
140,845 \\
1,031,327 \\
664,939 \\
54,145\end{array}$ & $\begin{array}{r}260,243 \\
1,836 \\
0 \\
0 \\
31,199\end{array}$ & $\begin{array}{r}146,882 \\
3,862 \\
2,165,740 \\
67,080 \\
8,143\end{array}$ & $\begin{array}{r}855,532 \\
510,320 \\
2,513,775 \\
878,592 \\
123,406\end{array}$ & $\begin{array}{r}667,171 \\
90 \\
1,161,734 \\
9,442 \\
17,605\end{array}$ \\
\hline 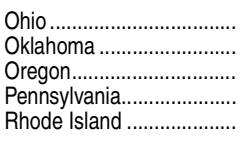 & $\begin{array}{r}23,500,247 \\
5,618,816 \\
6,201,702 \\
27,393,554 \\
2,316,164\end{array}$ & $\begin{array}{r}19,988,921 \\
5,036,031 \\
5,430,888 \\
23,485,203 \\
2,149,366\end{array}$ & $\begin{array}{r}11,372,653 \\
2,862,054 \\
3,165,170 \\
14,382,313 \\
1,324,326\end{array}$ & $\begin{array}{r}7,956,671 \\
1,829,693 \\
2,067,274 \\
8,213,549 \\
771,429\end{array}$ & $\begin{array}{r}1,268,590 \\
341,623 \\
387,583 \\
1,215,179 \\
225,594\end{array}$ & $\begin{array}{r}1,335,790 \\
205,512 \\
219,223 \\
866,873 \\
78,607\end{array}$ & $\begin{array}{r}598,776 \\
165,478 \\
71,446 \\
692,759 \\
29,670\end{array}$ & $\begin{array}{r}1,130,956 \\
266,368 \\
340,070 \\
1,028,872 \\
102,131\end{array}$ & $\begin{array}{r}1,782,173 \\
531,204 \\
447,946 \\
2,327,779 \\
176,137\end{array}$ & $\begin{array}{r}949,390 \\
165,215 \\
249,061 \\
1,188,411 \\
82,675\end{array}$ & $\begin{array}{r}890,996 \\
154,292 \\
351,945 \\
893,677 \\
76,616\end{array}$ & $\begin{array}{r}658,520 \\
295,573 \\
195,412 \\
786,566 \\
52,553\end{array}$ & $\begin{array}{r}1,077 \\
48,711 \\
3,032 \\
102,775 \\
1,057\end{array}$ & $\begin{array}{r}436,310 \\
13,899 \\
25,737 \\
569,951 \\
69,475\end{array}$ & $\begin{array}{r}2,535,352 \\
508,086 \\
461,338 \\
2,271,818 \\
47,874\end{array}$ & $\begin{array}{r}539,664 \\
60,800 \\
283,739 \\
1,066,582 \\
49,449\end{array}$ \\
\hline 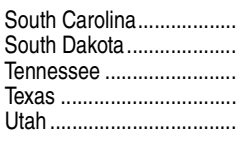 & $\begin{array}{r}7,919,837 \\
1,347,213 \\
9,294,028 \\
52,711,794 \\
4,642,830\end{array}$ & $\begin{array}{r}6,461,884 \\
1,126,503 \\
8,377,599 \\
42,864,291 \\
3,704,133\end{array}$ & $\begin{array}{r}3,688,634 \\
666,180 \\
5,325,040 \\
25,719,093 \\
2,382,888\end{array}$ & $\begin{array}{r}2,419,435 \\
396,459 \\
2,647,827 \\
14,811,471 \\
1,104,285\end{array}$ & $\begin{array}{r}474,538 \\
62,504 \\
342,363 \\
2,081,440 \\
143,615\end{array}$ & $\begin{array}{r}396,370 \\
46,946 \\
512,100 \\
2,224,154 \\
147,035\end{array}$ & $\begin{array}{r}71,970 \\
37,112 \\
169,585 \\
626,347 \\
42,186\end{array}$ & $\begin{array}{r}389,412 \\
55,538 \\
465,391 \\
2,377,519 \\
225,694\end{array}$ & $\begin{array}{r}629,655 \\
115,533 \\
718,289 \\
4,675,412 \\
335,661\end{array}$ & $\begin{array}{r}256,128 \\
40,275 \\
293,094 \\
1,211,190 \\
115,410\end{array}$ & $\begin{array}{r}201,362 \\
38,550 \\
147,006 \\
1,615,409 \\
94,685\end{array}$ & $\begin{array}{r}335,226 \\
57,729 \\
404,732 \\
2,333,728 \\
200,910\end{array}$ & $\begin{array}{r}18,589 \\
6,135 \\
0 \\
0 \\
16,050\end{array}$ & $\begin{array}{r}65,127 \\
2,947 \\
84,493 \\
337,583 \\
103,832\end{array}$ & $\begin{array}{r}985,481 \\
190,229 \\
641,341 \\
6,556,136 \\
701,431\end{array}$ & $\begin{array}{r}407,345 \\
27,535 \\
190,595 \\
2,953,783 \\
133,434\end{array}$ \\
\hline
\end{tabular}


Table 236.30. Total expenditures for public elementary and secondary education and other related programs, by function and state or jurisdiction: 2010-11-Continued [In thousands of current dollars]

\begin{tabular}{|c|c|c|c|c|c|c|c|c|c|c|c|c|c|c|c|c|}
\hline \multirow[b]{4}{*}{ State or jurisdiction } & \multicolumn{16}{|c|}{ Total expenditures } \\
\hline & \multirow[b]{3}{*}{ Total } & \multicolumn{12}{|c|}{ Current expenditures for elementary and secondary programs } & \multirow{3}{*}{$\begin{array}{r}\text { Current } \\
\text { expenditures } \\
\text { for other } \\
\text { programs } \\
1\end{array}$} & \multirow[b]{3}{*}{$\begin{array}{l}\text { Capital } \\
\text { outlay }\end{array}$} & \multirow[b]{3}{*}{$\begin{array}{l}\text { Interest on } \\
\text { school debt }\end{array}$} \\
\hline & & \multirow{2}{*}{$\begin{array}{r}\text { Elementary/ } \\
\text { secondary } \\
\text { current } \\
\text { expenditures, } \\
\text { total }\end{array}$} & \multirow[b]{2}{*}{ Instruction } & \multicolumn{8}{|c|}{ Support services } & \multirow[b]{2}{*}{$\begin{array}{r}\text { Food } \\
\text { services }\end{array}$} & \multirow[b]{2}{*}{$\begin{array}{c}\text { Enterprise } \\
\text { operations }\end{array}$} & & & \\
\hline & & & & Total & $\begin{array}{r}\text { Student } \\
\text { support }\end{array}$ & $\begin{array}{r}\text { Instructional } \\
\text { staff }\end{array}$ & $\begin{array}{r}\text { General } \\
\text { administration }\end{array}$ & $\begin{array}{r}\text { School } \\
\text { administration }\end{array}$ & $\begin{array}{r}\text { Operation and } \\
\text { maintenance }\end{array}$ & $\begin{array}{r}\text { Student } \\
\text { transportation }\end{array}$ & $\begin{array}{r}\text { Other support } \\
\text { services }\end{array}$ & & & & & \\
\hline 1 & 2 & 3 & 4 & 5 & 6 & 7 & 8 & 9 & 10 & 11 & 12 & 13 & 14 & 15 & 16 & 17 \\
\hline 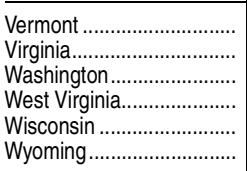 & \begin{tabular}{r|}
$1,515,638$ \\
$14,291,767$ \\
$12,025,483$ \\
$3,515,624$ \\
$11,359,841$ \\
$1,643,359$ \\
\end{tabular} & \begin{tabular}{r|}
$1,424,507$ \\
$12,968,477$ \\
$10,040,312$ \\
$3,388,294$ \\
$10,333,016$ \\
$1,398,444$ \\
\end{tabular} & $\begin{array}{r}876,070 \\
7,861,182 \\
6,067,366 \\
2,029,616 \\
6,322,480 \\
826,891\end{array}$ & $\begin{array}{r}507,645 \\
4,602,565 \\
3,516,776 \\
1,178,712 \\
3,648,765 \\
528,345 \\
\end{array}$ & \begin{tabular}{r|}
111,637 \\
627,158 \\
671,779 \\
153,000 \\
490,843 \\
81,181 \\
\end{tabular} & \begin{tabular}{r|}
63,719 \\
862,346 \\
402,544 \\
133,942 \\
504,489 \\
91,318 \\
\end{tabular} & \begin{tabular}{r|}
31,782 \\
199,556 \\
192,069 \\
66,053 \\
270,163 \\
28,523 \\
\end{tabular} & \begin{tabular}{r|}
95,207 \\
750,559 \\
572,454 \\
180,907 \\
504,803 \\
74,347 \\
\end{tabular} & $\begin{array}{r}122,930 \\
1,263,117 \\
896,173 \\
337,813 \\
928,720 \\
135,194 \\
\end{array}$ & $\begin{array}{r}48,791 \\
695,293 \\
408,823 \\
248,745 \\
415,340 \\
64,292 \\
\end{array}$ & $\begin{array}{r}33,579 \\
204,535 \\
372,934 \\
58,252 \\
534,406 \\
53,490 \\
\end{array}$ & $\begin{array}{r}40,024 \\
502,837 \\
335,166 \\
179,966 \\
361,656 \\
42,193 \\
\end{array}$ & $\begin{array}{r}769 \\
1,873 \\
121,004 \\
0 \\
115 \\
1,015 \\
\end{array}$ & $\begin{array}{r}13,106 \\
74,580 \\
57,362 \\
46,185 \\
265,689 \\
8,844 \\
\end{array}$ & $\begin{array}{r}63,945 \\
1,075,075 \\
1,514,773 \\
65,730 \\
539,098 \\
234,410 \\
\end{array}$ & $\begin{array}{r}14,079 \\
173,655 \\
413,036 \\
15,415 \\
222,038 \\
1,660 \\
\end{array}$ \\
\hline 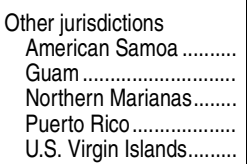 & $\begin{array}{r}84,478 \\
342,273 \\
2,405,388 \\
3,664,247 \\
215,278\end{array}$ & $\begin{array}{r}75,355 \\
266,952 \\
84,657 \\
3,519,547 \\
212,112\end{array}$ & $\begin{array}{r}32,770 \\
149,292 \\
36,014 \\
1,460,167 \\
108,061\end{array}$ & $\begin{array}{r}22,938 \\
105,475 \\
40,089 \\
1,779,736 \\
91,752\end{array}$ & $\begin{array}{r}535 \\
27,736 \\
11,416 \\
235,775 \\
15,828\end{array}$ & $\begin{array}{r}7,983 \\
5,319 \\
4,848 \\
289,143 \\
5,922\end{array}$ & $\begin{array}{r}2,089 \\
2,225 \\
3,141 \\
331,065 \\
7,504\end{array}$ & $\begin{array}{r}5,338 \\
16,482 \\
4,384 \\
144,192 \\
11,060\end{array}$ & $\begin{array}{r}4,803 \\
35,068 \\
8,492 \\
401,622 \\
14,151\end{array}$ & $\begin{array}{r}1,014 \\
7,616 \\
2,089 \\
72,901 \\
15,088\end{array}$ & $\begin{array}{r}1,176 \\
11,029 \\
5,719 \\
305,037 \\
22,199\end{array}$ & $\begin{array}{r}19,647 \\
12,186 \\
8,554 \\
279,644 \\
11,596\end{array}$ & $\begin{array}{r}0 \\
0 \\
0 \\
0 \\
703\end{array}$ & $\begin{array}{r}2,084 \\
0 \\
2,319,587 \\
82,528 \\
3,071\end{array}$ & $\begin{array}{r}7,039 \\
72,196 \\
1,145 \\
62,172 \\
94\end{array}$ & $\begin{array}{r}0 \\
3,124 \\
0 \\
0 \\
0\end{array}$ \\
\hline
\end{tabular}

'Includes expenditures for adult education, community colleges, private school programs funded by local and state education agencies, and community services.

4 Includes expenditures for guidance, health, attendance, and speech pathology services.

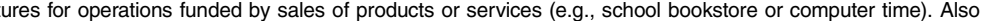

Includes expenditures for curriculum development, staff training, libraries, and media and computer centers.

SOURCE: U.S. Department of Education, National Center for Education Statistics, Common Core of Data (CCD), "National Pub- 
Table 236.40. Total expenditures for public elementary and secondary education and other related programs, by function and state or jurisdiction: 2009-10

[In thousands of current dollars]

\begin{tabular}{|c|c|c|c|c|c|c|c|c|c|c|c|c|c|c|c|c|}
\hline \multirow[b]{4}{*}{ State or jurisdiction } & \multicolumn{16}{|c|}{ Total expenditures } \\
\hline & \multicolumn{13}{|c|}{ Current expenditures for elementary and secondary programs } & \multirow[b]{3}{*}{$\begin{array}{r}\text { Current } \\
\text { expenditures } \\
\text { for other } \\
\text { programs }\end{array}$} & \multirow[b]{3}{*}{$\begin{array}{l}\text { Capital } \\
\text { outlay }\end{array}$} & \multirow[b]{3}{*}{$\begin{array}{l}\text { Interest on } \\
\text { school debt }\end{array}$} \\
\hline & & \multirow{2}{*}{$\begin{array}{r}\text { Elementary/ } \\
\text { secondary } \\
\text { current } \\
\text { expenditures, } \\
\text { total }\end{array}$} & \multirow[b]{2}{*}{ Instruction } & \multicolumn{8}{|c|}{ Support services } & \multirow[b]{2}{*}{$\begin{array}{r}\text { Food } \\
\text { services }\end{array}$} & \multirow[b]{2}{*}{$\begin{array}{c}\text { Enterprise } \\
\text { operations }^{3}\end{array}$} & & & \\
\hline & Total & & & Total & $\begin{array}{r}\text { Student } \\
\text { support }^{4}\end{array}$ & $\begin{array}{r}\text { Instructional } \\
\text { staff }\end{array}$ & $\begin{array}{r}\text { General } \\
\text { administration }\end{array}$ & $\begin{array}{r}\text { School } \\
\text { administration }\end{array}$ & $\begin{array}{r}\text { Operation } \\
\text { and } \\
\text { maintenance }\end{array}$ & $\begin{array}{r}\text { Student } \\
\text { transportation }\end{array}$ & $\begin{array}{r}\text { Other } \\
\text { support } \\
\text { services }\end{array}$ & & & & & \\
\hline 1 & 2 & 3 & 4 & 5 & 6 & 7 & 8 & 9 & 10 & 11 & 12 & 13 & 14 & 15 & 16 & 17 \\
\hline United States ............ & $\$ 607,018,292$ & $\$ 524,715,242$ & $\$ 321,213,401$ & $\$ 182,247,666$ & $\$ 29,134,124$ & $\$ 25,108,146$ & $\$ 10,421,207$ & $\$ 28,551,493$ & $\$ 50,023,919$ & $\$ 21,819,304$ & $\$ 17,189,474$ & $\$ 19,996,995$ & $\$ 1,257,180$ & $\$ 8,355,761$ & $\$ 56,714,992$ & $\$ 17,232,297$ \\
\hline 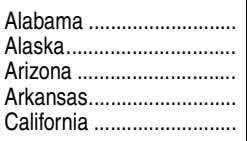 & $\begin{array}{r}7,646,087 \\
2,363,392 \\
9,974,741 \\
5,275,687 \\
68,479,096\end{array}$ & $\begin{array}{r}6,670,517 \\
2,084,019 \\
8,482,552 \\
4,459,910 \\
58,248,662\end{array}$ & $\begin{array}{r}3,902,381 \\
1,155,587 \\
4,683,211 \\
2,572,811 \\
35,056,436\end{array}$ & $\begin{array}{r}2,324,021 \\
861,776 \\
3,358,498 \\
1,640,086 \\
20,823,219 \\
\end{array}$ & $\begin{array}{r}382,558 \\
177,944 \\
993,110 \\
223,016 \\
3,005,113\end{array}$ & $\begin{array}{r}308,327 \\
130,048 \\
207,989 \\
386,858 \\
3,553,254\end{array}$ & $\begin{array}{r}161,202 \\
29,942 \\
126,843 \\
108,803 \\
544,599\end{array}$ & $\begin{array}{r}413,164 \\
126,087 \\
406,808 \\
226,313 \\
3,906,521\end{array}$ & $\begin{array}{r}597,251 \\
258,027 \\
955,815 \\
417,690 \\
5,876,868\end{array}$ & $\begin{array}{r}323,407 \\
61,986 \\
322,795 \\
159,502 \\
1,402,700\end{array}$ & $\begin{array}{r}138,112 \\
77,744 \\
345,138 \\
117,904 \\
2,534,164\end{array}$ & $\begin{array}{r}444,115 \\
57,689 \\
395,149 \\
242,520 \\
2,229,166\end{array}$ & $\begin{array}{r}0 \\
8,967 \\
45,695 \\
4,492 \\
139,841\end{array}$ & $\begin{array}{r}113,797 \\
7,912 \\
47,738 \\
29,508 \\
1,072,757\end{array}$ & $\begin{array}{r}731,677 \\
231,689 \\
846,449 \\
664,273 \\
7,077,190\end{array}$ & $\begin{array}{r}130,096 \\
39,772 \\
598,001 \\
121,996 \\
2,080,487\end{array}$ \\
\hline 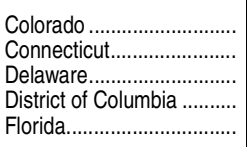 & $\begin{array}{r}8,970,879 \\
9,931,276 \\
1,816,880 \\
1,969,851 \\
27,637,538\end{array}$ & $\begin{array}{r}7,429,302 \\
8,853,337 \\
1,549,812 \\
1,451,870 \\
23,349,314\end{array}$ & $\begin{array}{r}4,269,477 \\
5,618,936 \\
952,560 \\
723,156 \\
14,111,697\end{array}$ & $\begin{array}{r}2,872,622 \\
2,938,402 \\
537,447 \\
678,806 \\
8,209,985\end{array}$ & $\begin{array}{r}362,441 \\
539,157 \\
78,770 \\
102,645 \\
1,068,011\end{array}$ & $\begin{array}{r}424,490 \\
269,545 \\
16,825 \\
98,510 \\
1,556,045\end{array}$ & $\begin{array}{r}123,864 \\
178,778 \\
18,813 \\
49,050 \\
249,468\end{array}$ & $\begin{array}{r}502,348 \\
500,854 \\
87,822 \\
94,998 \\
1,316,997\end{array}$ & $\begin{array}{r}705,620 \\
814,614 \\
159,536 \\
156,157 \\
2,486,252\end{array}$ & $\begin{array}{r}215,818 \\
431,233 \\
95,685 \\
101,755 \\
934,992\end{array}$ & $\begin{array}{r}538,041 \\
204,221 \\
79,995 \\
75,692 \\
598,221\end{array}$ & $\begin{array}{r}248,684 \\
220,824 \\
59,805 \\
45,595 \\
1,027,632\end{array}$ & $\begin{array}{r}38,519 \\
75,175 \\
0 \\
4,313 \\
0\end{array}$ & $\begin{array}{r}52,867 \\
146,050 \\
21,013 \\
25,558 \\
537,883\end{array}$ & $\begin{array}{r}1,017,841 \\
783,973 \\
196,727 \\
358,315 \\
2,940,511\end{array}$ & $\begin{array}{r}470,869 \\
147,916 \\
49,327 \\
134,109 \\
809,829\end{array}$ \\
\hline 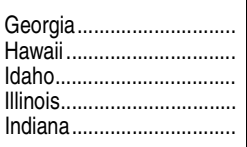 & $\begin{array}{r}17,851,273 \\
2,360,379 \\
2,275,076 \\
28,198,147 \\
11,351,074\end{array}$ & $\begin{array}{r}15,730,409 \\
2,136,144 \\
1,961,857 \\
24,695,773 \\
9,921,243\end{array}$ & $\begin{array}{r}9,838,312 \\
1,277,749 \\
1,199,775 \\
14,782,525 \\
5,834,548\end{array}$ & $\begin{array}{r}5,055,843 \\
749,520 \\
664,570 \\
9,170,079 \\
3,666,744\end{array}$ & $\begin{array}{r}764,719 \\
210,993 \\
112,049 \\
1,614,534 \\
464,829\end{array}$ & $\begin{array}{r}815,234 \\
72,141 \\
79,138 \\
1,151,798 \\
388,705\end{array}$ & $\begin{array}{r}221,860 \\
9,364 \\
47,181 \\
1,009,188 \\
313,058\end{array}$ & $\begin{array}{r}927,752 \\
132,438 \\
109,102 \\
1,254,159 \\
566,372\end{array}$ & $\begin{array}{r}1,159,510 \\
223,752 \\
179,071 \\
2,156,745 \\
1,112,746\end{array}$ & $\begin{array}{r}644,926 \\
41,423 \\
93,822 \\
1,168,000 \\
571,147\end{array}$ & $\begin{array}{r}521,841 \\
59,408 \\
44,206 \\
815,654 \\
249,887\end{array}$ & $\begin{array}{r}792,772 \\
108,876 \\
97,096 \\
743,169 \\
419,951\end{array}$ & $\begin{array}{r}43,482 \\
0 \\
417 \\
0 \\
0\end{array}$ & $\begin{array}{r}33,018 \\
21,475 \\
3,903 \\
218,628 \\
146,116\end{array}$ & $\begin{array}{r}1,812,290 \\
113,201 \\
249,386 \\
2,518,863 \\
952,504\end{array}$ & $\begin{array}{r}275,556 \\
89,558 \\
59,930 \\
764,884 \\
331,211\end{array}$ \\
\hline $\begin{array}{l}\text { lowa } \\
\text { Kansas... } \\
\text { Kentucky } \\
\text { Louisiana } \\
\text { Maine }\end{array}$ & $\begin{array}{l}5,728,512 \\
6,053,538 \\
7,097,739 \\
8,358,506 \\
2,616,386\end{array}$ & $\begin{array}{l}4,794,308 \\
4,731,676 \\
6,091,814 \\
7,393,452 \\
2,370,085\end{array}$ & $\begin{array}{l}2,954,930 \\
2,880,088 \\
3,614,078 \\
4,328,354 \\
1,428,312\end{array}$ & $\begin{array}{r}1,620,379 \\
1,636,845 \\
2,116,644 \\
2,675,351 \\
864,641\end{array}$ & $\begin{array}{l}275,660 \\
274,052 \\
270,367 \\
356,776 \\
151,467\end{array}$ & $\begin{array}{l}221,666 \\
212,488 \\
324,904 \\
416,533 \\
124,712\end{array}$ & $\begin{array}{r}124,636 \\
143,178 \\
131,947 \\
170,651 \\
89,125\end{array}$ & $\begin{array}{l}278,371 \\
270,308 \\
340,495 \\
415,937 \\
126,790\end{array}$ & $\begin{array}{l}410,123 \\
435,769 \\
548,858 \\
691,338 \\
234,941\end{array}$ & $\begin{array}{l}167,111 \\
178,153 \\
355,546 \\
407,862 \\
109,911\end{array}$ & $\begin{array}{r}142,811 \\
122,898 \\
144,526 \\
216,255 \\
27,694\end{array}$ & $\begin{array}{r}214,049 \\
214,743 \\
346,282 \\
389,434 \\
77,071\end{array}$ & $\begin{array}{r}4,950 \\
0 \\
14,810 \\
313 \\
61\end{array}$ & $\begin{array}{r}27,759 \\
4,713 \\
85,885 \\
52,208 \\
27,756\end{array}$ & $\begin{array}{r}816,779 \\
1,119,957 \\
759,083 \\
793,340 \\
168,449\end{array}$ & $\begin{array}{r}89,666 \\
197,192 \\
160,957 \\
119,506 \\
50,096\end{array}$ \\
\hline 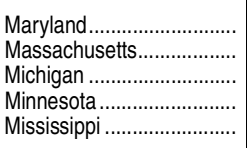 & $\begin{array}{r}13,206,361 \\
14,401,441 \\
19,792,568 \\
10,737,802 \\
4,384,125\end{array}$ & $\begin{array}{r}11,883,677 \\
13,356,373 \\
17,227,515 \\
8,927,288 \\
3,990,876\end{array}$ & $\begin{array}{l}7,386,467 \\
8,643,167 \\
9,913,891 \\
5,906,921 \\
2,346,594\end{array}$ & $\begin{array}{l}4,038,811 \\
4,357,295 \\
6,743,083 \\
2,623,877 \\
1,406,044\end{array}$ & $\begin{array}{r}540,462 \\
929,218 \\
1,309,087 \\
234,716 \\
192,446\end{array}$ & $\begin{array}{l}626,266 \\
605,338 \\
878,948 \\
390,926 \\
194,095\end{array}$ & $\begin{array}{r}85,404 \\
189,429 \\
359,693 \\
262,256 \\
116,890\end{array}$ & $\begin{array}{l}805,593 \\
552,590 \\
951,096 \\
361,043 \\
233,926\end{array}$ & $\begin{array}{r}1,077,694 \\
1,212,985 \\
1,674,023 \\
636,415 \\
400,186\end{array}$ & $\begin{array}{l}587,105 \\
549,997 \\
724,611 \\
486,051 \\
180,065\end{array}$ & $\begin{array}{r}316,288 \\
317,739 \\
845,626 \\
252,469 \\
88,436\end{array}$ & $\begin{array}{l}302,434 \\
355,911 \\
570,541 \\
372,386 \\
237,967\end{array}$ & $\begin{array}{r}155,964 \\
0 \\
0 \\
24,104 \\
271\end{array}$ & $\begin{array}{r}27,254 \\
56,806 \\
351,828 \\
416,027 \\
29,801\end{array}$ & $\begin{array}{r}1,144,040 \\
727,992 \\
1,373,001 \\
984,573 \\
291,069\end{array}$ & $\begin{array}{r}151,390 \\
260,270 \\
840,224 \\
409,914 \\
72,378\end{array}$ \\
\hline 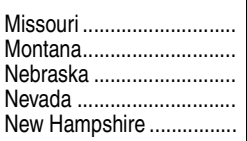 & $\begin{array}{r}10,402,883 \\
1,640,014 \\
3,674,796 \\
4,257,268 \\
2,760,682\end{array}$ & $\begin{array}{l}8,923,448 \\
1,498,252 \\
3,213,646 \\
3,592,994 \\
2,576,956\end{array}$ & $\begin{array}{r}5,378,592 \\
901,788 \\
2,128,741 \\
2,139,830 \\
1,671,301\end{array}$ & $\begin{array}{r}3,149,432 \\
533,627 \\
872,977 \\
1,336,098 \\
837,088\end{array}$ & $\begin{array}{r}416,186 \\
88,330 \\
123,135 \\
187,286 \\
183,457\end{array}$ & $\begin{array}{r}406,663 \\
58,364 \\
100,208 \\
180,484 \\
80,065\end{array}$ & $\begin{array}{r}276,796 \\
42,623 \\
98,503 \\
43,028 \\
86,240\end{array}$ & $\begin{array}{r}505,535 \\
80,016 \\
122,596 \\
263,446 \\
136,757\end{array}$ & $\begin{array}{l}889,460 \\
159,249 \\
279,823 \\
379,073 \\
215,400\end{array}$ & $\begin{array}{r}452,663 \\
69,635 \\
84,244 \\
149,462 \\
108,222\end{array}$ & $\begin{array}{r}202,130 \\
35,411 \\
64,468 \\
133,319 \\
26,947\end{array}$ & $\begin{array}{r}395,423 \\
60,528 \\
129,497 \\
117,065 \\
68,568\end{array}$ & $\begin{array}{r}0 \\
2,309 \\
82,431 \\
0 \\
0\end{array}$ & $\begin{array}{r}209,724 \\
10,567 \\
2,936 \\
23,528 \\
7,821\end{array}$ & $\begin{array}{l}943,183 \\
115,639 \\
384,443 \\
381,734 \\
131,284\end{array}$ & $\begin{array}{r}326,529 \\
15,556 \\
73,771 \\
259,011 \\
44,621\end{array}$ \\
\hline 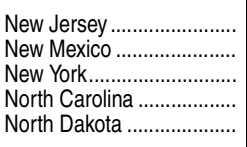 & $\begin{array}{r}26,157,669 \\
3,792,958 \\
56,690,809 \\
13,297,984 \\
1,159,215\end{array}$ & $\begin{array}{r}24,261,392 \\
3,217,328 \\
50,251,461 \\
12,200,362 \\
1,000,095\end{array}$ & $\begin{array}{r}14,541,885 \\
1,847,604 \\
35,061,778 \\
7,641,089 \\
578,011\end{array}$ & $\begin{array}{r}8,941,204 \\
1,233,314 \\
14,151,143 \\
3,896,502 \\
339,223\end{array}$ & $\begin{array}{r}2,320,206 \\
341,902 \\
1,668,771 \\
566,392 \\
43,760\end{array}$ & $\begin{array}{r}806,439 \\
104,281 \\
1,321,472 \\
473,907 \\
34,285\end{array}$ & $\begin{array}{r}499,536 \\
72,947 \\
942,694 \\
197,512 \\
46,360\end{array}$ & $\begin{array}{r}1,138,539 \\
191,270 \\
1,967,299 \\
753,948 \\
48,767\end{array}$ & $\begin{array}{r}2,402,071 \\
323,053 \\
4,372,240 \\
1,036,894 \\
99,088\end{array}$ & $\begin{array}{r}1,237,887 \\
104,407 \\
2,606,769 \\
501,214 \\
42,250\end{array}$ & $\begin{array}{r}536,526 \\
95,454 \\
1,271,899 \\
366,635 \\
24,713\end{array}$ & $\begin{array}{r}510,303 \\
134,831 \\
1,038,540 \\
662,771 \\
52,600\end{array}$ & $\begin{array}{r}268,000 \\
1,580 \\
0 \\
0 \\
30,261\end{array}$ & $\begin{array}{r}177,598 \\
4,288 \\
2,177,552 \\
67,088 \\
6,226\end{array}$ & $\begin{array}{r}1,091,477 \\
571,227 \\
3,085,854 \\
1,022,714 \\
140,282\end{array}$ & $\begin{array}{r}627,202 \\
114 \\
1,175,942 \\
7,819 \\
12,612\end{array}$ \\
\hline 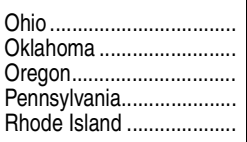 & $\begin{array}{r}23,262,091 \\
5,664,915 \\
6,288,121 \\
26,520,058 \\
2,286,061\end{array}$ & $\begin{array}{r}19,801,670 \\
5,192,124 \\
5,401,667 \\
22,733,518 \\
2,136,582\end{array}$ & $\begin{array}{r}11,321,779 \\
2,989,502 \\
3,157,351 \\
13,889,978 \\
1,294,924\end{array}$ & $\begin{array}{r}7,828,971 \\
1,849,065 \\
2,048,895 \\
7,976,627 \\
791,356\end{array}$ & $\begin{array}{r}1,231,856 \\
352,223 \\
388,122 \\
1,169,785 \\
248,278\end{array}$ & $\begin{array}{r}1,309,048 \\
198,733 \\
218,636 \\
869,650 \\
77,905\end{array}$ & $\begin{array}{r}583,207 \\
163,070 \\
71,583 \\
680,902 \\
29,022\end{array}$ & $\begin{array}{r}1,123,377 \\
273,301 \\
336,196 \\
986,932 \\
106,806\end{array}$ & $\begin{array}{r}1,795,464 \\
558,406 \\
438,798 \\
2,301,592 \\
177,245\end{array}$ & $\begin{array}{r}921,536 \\
159,175 \\
242,450 \\
1,136,499 \\
83,895\end{array}$ & $\begin{array}{r}864,483 \\
144,157 \\
353,111 \\
831,268 \\
68,206\end{array}$ & $\begin{array}{r}648,764 \\
307,510 \\
192,220 \\
768,862 \\
50,292\end{array}$ & $\begin{array}{r}2,155 \\
46,048 \\
3,201 \\
98,052 \\
9\end{array}$ & $\begin{array}{r}423,021 \\
13,868 \\
23,440 \\
563,076 \\
62,343\end{array}$ & $\begin{array}{r}2,510,832 \\
393,436 \\
573,747 \\
2,250,685 \\
41,726\end{array}$ & $\begin{array}{r}526,568 \\
65,487 \\
289,267 \\
972,779 \\
45,410\end{array}$ \\
\hline 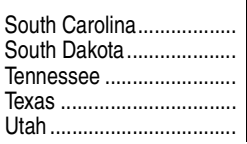 & $\begin{array}{r}8,215,180 \\
1,289,355 \\
8,759,495 \\
53,838,221 \\
4,564,279\end{array}$ & $\begin{array}{r}6,566,165 \\
1,115,861 \\
7,894,661 \\
42,621,886 \\
3,635,085\end{array}$ & $\begin{array}{r}3,784,450 \\
666,468 \\
4,970,275 \\
25,747,871 \\
2,340,227\end{array}$ & \begin{tabular}{|r|}
$2,430,708$ \\
387,939 \\
$2,531,294$ \\
$14,616,776$ \\
$1,086,469$
\end{tabular} & $\begin{array}{r}480,587 \\
61,498 \\
321,711 \\
2,058,007 \\
140,093\end{array}$ & $\begin{array}{r}418,805 \\
45,242 \\
486,954 \\
2,252,663 \\
147,674\end{array}$ & $\begin{array}{r}73,338 \\
37,397 \\
155,977 \\
617,841 \\
45,462\end{array}$ & $\begin{array}{r}387,926 \\
52,998 \\
451,096 \\
2,313,777 \\
221,322\end{array}$ & $\begin{array}{r}618,827 \\
113,403 \\
694,860 \\
4,663,558 \\
331,055\end{array}$ & $\begin{array}{r}246,949 \\
37,809 \\
279,665 \\
1,160,097 \\
110,653\end{array}$ & $\begin{array}{r}204,277 \\
39,593 \\
141,031 \\
1,550,833 \\
90,210\end{array}$ & $\begin{array}{r}332,045 \\
55,733 \\
393,091 \\
2,257,239 \\
192,764\end{array}$ & $\begin{array}{r}18,962 \\
5,721 \\
0 \\
0 \\
15,625\end{array}$ & $\begin{array}{r}70,481 \\
2,987 \\
83,795 \\
327,847 \\
103,763\end{array}$ & $\begin{array}{r}1,200,466 \\
147,831 \\
606,630 \\
8,055,551 \\
697,755\end{array}$ & $\begin{array}{r}378,068 \\
22,676 \\
174,410 \\
2,832,938 \\
127,675\end{array}$ \\
\hline
\end{tabular}


Table 236.40. Total expenditures for public elementary and secondary education and other related programs, by function and state or jurisdiction: 2009-10-Continued

[In thousands of current dollars]

\begin{tabular}{|c|c|c|c|c|c|c|c|c|c|c|c|c|c|c|c|c|}
\hline \multirow[b]{4}{*}{ State or jurisdiction } & \multicolumn{16}{|c|}{ Total expenditures } \\
\hline & \multirow[b]{3}{*}{ Total } & \multicolumn{12}{|c|}{ Current expenditures for elementary and secondary programs } & \multirow{3}{*}{$\begin{array}{r}\text { Current } \\
\text { expenditures } \\
\text { for other } \\
\text { programs } \\
\end{array}$} & \multirow[b]{3}{*}{$\begin{array}{l}\text { Capital } \\
\text { outlay }\end{array}$} & \multirow[b]{3}{*}{$\begin{array}{l}\text { Interest on } \\
\text { school debt }\end{array}$} \\
\hline & & \multirow{2}{*}{$\begin{array}{r}\text { Elementary/ } \\
\text { secondary } \\
\text { current } \\
\text { expenditures, } \\
\text { total }\end{array}$} & \multirow[b]{2}{*}{ Instruction } & \multicolumn{8}{|c|}{ Support services } & \multirow[b]{2}{*}{$\begin{array}{r}\text { Food } \\
\text { services }\end{array}$} & \multirow[b]{2}{*}{$\begin{array}{r}\text { Enterprise } \\
\text { operations }^{3}\end{array}$} & & & \\
\hline & & & & Total & $\begin{array}{r}\text { Student } \\
\text { support }{ }^{4}\end{array}$ & $\begin{array}{r}\text { Instructional } \\
\text { staff }\end{array}$ & $\begin{array}{r}\text { General } \\
\text { administration }\end{array}$ & $\begin{array}{r}\text { School } \\
\text { administration }\end{array}$ & $\begin{array}{r}\text { Operation } \\
\text { and } \\
\text { maintenance }\end{array}$ & $\begin{array}{r}\text { Student } \\
\text { transportation }\end{array}$ & $\begin{array}{r}\text { Other } \\
\text { support } \\
\text { services }\end{array}$ & & & & & \\
\hline 1 & 2 & 3 & 4 & 5 & 6 & 7 & 8 & 9 & 10 & 11 & 12 & 13 & 14 & 15 & 16 & 17 \\
\hline 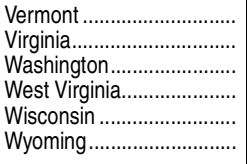 & $\begin{array}{r}1,524,207 \\
14,548,960 \\
11,797,716 \\
3,447,770 \\
11,013,618 \\
1,685,613 \\
\end{array}$ & $\begin{array}{r}1,432,683 \\
13,193,633 \\
9,832,913 \\
3,328,177 \\
9,966,244 \\
1,334,655 \\
\end{array}$ & $\begin{array}{r}881,073 \\
8,049,182 \\
5,932,836 \\
2,007,943 \\
6,118,246 \\
788,716 \\
\end{array}$ & $\begin{array}{r}512,731 \\
4,654,450 \\
3,456,003 \\
1,146,313 \\
3,500,036 \\
504,837 \\
\end{array}$ & $\begin{array}{r}112,672 \\
642,427 \\
658,555 \\
146,615 \\
471,102 \\
77,033 \\
\end{array}$ & $\begin{array}{r}66,119 \\
880,781 \\
414,040 \\
129,451 \\
484,575 \\
86,920 \\
\end{array}$ & $\begin{array}{r}34,935 \\
208,524 \\
188,219 \\
72,863 \\
260,167 \\
27,235 \\
\end{array}$ & $\begin{array}{r}98,999 \\
776,274 \\
564,547 \\
173,385 \\
495,898 \\
72,602 \\
\end{array}$ & $\begin{array}{r}120,248 \\
1,260,203 \\
872,213 \\
332,644 \\
877,065 \\
130,000 \\
\end{array}$ & $\begin{array}{r}46,362 \\
673,845 \\
390,841 \\
234,586 \\
361,461 \\
61,125 \\
\end{array}$ & $\begin{array}{r}33,395 \\
212,396 \\
367,588 \\
56,769 \\
549,767 \\
49,921 \\
\end{array}$ & $\begin{array}{r}37,978 \\
488,588 \\
326,067 \\
173,920 \\
347,830 \\
40,106 \\
\end{array}$ & $\begin{array}{r}901 \\
1,413 \\
118,007 \\
0 \\
133 \\
996 \\
\end{array}$ & $\begin{array}{r}11,351 \\
75,524 \\
36,158 \\
43,024 \\
261,305 \\
8,190 \\
\end{array}$ & $\begin{array}{r}65,110 \\
1,126,998 \\
1,509,632 \\
62,733 \\
590,171 \\
340,679 \\
\end{array}$ & $\begin{array}{r}15,064 \\
152,806 \\
419,013 \\
13,836 \\
195,898 \\
2,090 \\
\end{array}$ \\
\hline 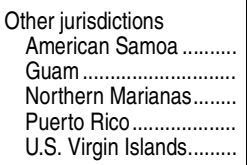 & $\begin{array}{r}76,796 \\
242,990 \\
66,240 \\
3,921,181 \\
226,080\end{array}$ & $\begin{array}{r}70,305 \\
235,639 \\
62,210 \\
3,464,044 \\
220,234\end{array}$ & $\begin{array}{r}32,396 \\
132,599 \\
30,164 \\
1,742,259 \\
119,422\end{array}$ & $\begin{array}{r}20,165 \\
88,662 \\
24,106 \\
1,407,566 \\
90,489\end{array}$ & $\begin{array}{r}1,919 \\
26,356 \\
6,131 \\
227,571 \\
16,227\end{array}$ & $\begin{array}{r}6,418 \\
4,578 \\
3,151 \\
169,006 \\
6,737\end{array}$ & $\begin{array}{r}1,067 \\
2,263 \\
2,140 \\
126,506 \\
5,828\end{array}$ & $\begin{array}{r}5,920 \\
14,695 \\
5,397 \\
176,859 \\
11,423\end{array}$ & $\begin{array}{r}2,239 \\
30,174 \\
2,931 \\
455,091 \\
14,700\end{array}$ & $\begin{array}{r}1,185 \\
7,542 \\
1,625 \\
97,337 \\
14,616\end{array}$ & $\begin{array}{r}1,417 \\
3,054 \\
2,731 \\
155,195 \\
20,959\end{array}$ & $\begin{array}{r}17,744 \\
14,378 \\
457 \\
314,219 \\
10,323\end{array}$ & $\begin{array}{r}0 \\
0 \\
7,483 \\
0 \\
0\end{array}$ & $\begin{array}{r}2,084 \\
0 \\
2,534 \\
71,026 \\
3,261 \\
\end{array}$ & $\begin{array}{r}4,407 \\
4,171 \\
1,496 \\
381,015 \\
2,585\end{array}$ & $\begin{array}{r}0 \\
3,181 \\
0 \\
5,096 \\
0\end{array}$ \\
\hline
\end{tabular}

IIncludes expenditures for adult education, community colleges, private school programs funded by local and state education

5Includes expenditures for curriculum development, staff training, libraries, and media and computer centers.

IIncludes expenditures for property and for buildings and alterations completed by school district staff or contractors. includes small amounts for direct program support made by state education agencies for local school districts.

SOURCE: U.S. Department of Education, National Center for Education Statistics, Common Core of Data (CCD), "National Public Education Financial Survey," 2009-10. (This table was prepared July 2013.) 
366 CHAPTER 2: Elementary and Secondary Education Expenditures

Table 236.50. Expenditures for instruction in public elementary and secondary schools, by subfunction and state or jurisdiction: 2009-10 and 2010-11

[In thousands of current dollars]

\begin{tabular}{|c|c|c|c|c|c|c|c|c|c|c|c|c|}
\hline \multirow[b]{2}{*}{ State or jurisdiction } & \multicolumn{6}{|c|}{$2009-10^{1}$} & \multicolumn{6}{|c|}{$2010-11$} \\
\hline & Total & Salaries & $\begin{array}{r}\text { Employee } \\
\text { benefits }\end{array}$ & $\begin{array}{r}\text { Purchased } \\
\text { services }^{2}\end{array}$ & Supplies & $\begin{array}{l}\text { Tuition } \\
\text { and other }\end{array}$ & Total & Salaries & $\begin{array}{r}\text { Employee } \\
\text { benefits }\end{array}$ & $\begin{array}{r}\text { Purchased } \\
\text { services }^{2}\end{array}$ & Supplies & $\begin{array}{l}\text { Tuition } \\
\text { and other }\end{array}$ \\
\hline 1 & 2 & 3 & 4 & 5 & 6 & 7 & 8 & 9 & 10 & 11 & 12 & 13 \\
\hline United States ....... & $\$ \$ 321,213,401$ & $\$ 214,435,825$ & $\$ 73,051,571$ & $\$ 13,843,875$ & $\$ 13,689,672$ & $\$ 6,192,457$ & $\$ 322,492,844$ & $\$ 212,849,042$ & $\$ 75,211,035$ & $\$ 14,692,931$ & $\$ 13,280,584$ & $\$ 6,459,252$ \\
\hline 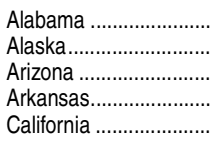 & \begin{tabular}{r|}
$3,902,381$ \\
$1,155,587$ \\
$4,683,211$ \\
$2,572,811$ \\
$35,056,436$
\end{tabular} & $\begin{array}{r}2,527,834 \\
641,431 \\
3,360,288 \\
1,757,604 \\
23,503,106\end{array}$ & $\begin{array}{r}998,530 \\
384,228 \\
859,499 \\
479,524 \\
7,756,666\end{array}$ & $\begin{array}{r}104,085 \\
59,289 \\
206,464 \\
90,422 \\
1,679,025\end{array}$ & $\begin{array}{r}258,191 \\
59,981 \\
110,184 \\
214,753 \\
1,365,473\end{array}$ & $\begin{array}{r}13,742 \\
10,658 \\
146,776 \\
30,508 \\
752,165\end{array}$ & $\begin{array}{r}3,846,419 \\
1,218,685 \\
4,506,883 \\
2,615,474 \\
34,679,610\end{array}$ & $\begin{array}{r}2,500,993 \\
666,919 \\
3,256,513 \\
1,798,852 \\
22,874,871\end{array}$ & $\begin{array}{r}983,940 \\
413,655 \\
770,957 \\
492,291 \\
7,843,569\end{array}$ & $\begin{array}{r}112,088 \\
61,055 \\
225,929 \\
98,070 \\
1,741,303\end{array}$ & $\begin{array}{r}235,134 \\
67,196 \\
99,765 \\
196,051 \\
1,461,634\end{array}$ & $\begin{array}{r}14,264 \\
9,860 \\
153,720 \\
30,210 \\
758,232\end{array}$ \\
\hline 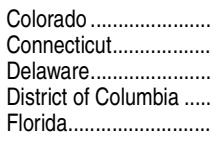 & $\begin{array}{r}4,269,477 \\
5,618,936 \\
952,560 \\
723,156 \\
14,111,697\end{array}$ & $\begin{array}{r}3,059,053 \\
3,544,681 \\
607,857 \\
458,470 \\
8,699,435\end{array}$ & $\begin{array}{r}724,108 \\
1,371,505 \\
265,700 \\
60,640 \\
2,680,150\end{array}$ & $\begin{array}{r}110,502 \\
204,106 \\
14,029 \\
13,030 \\
2,129,009\end{array}$ & $\begin{array}{r}274,122 \\
126,809 \\
48,807 \\
18,708 \\
502,706\end{array}$ & $\begin{array}{r}101,691 \\
371,835 \\
16,167 \\
172,308 \\
100,397\end{array}$ & $\begin{array}{r}4,250,693 \\
5,768,873 \\
1,018,491 \\
754,464 \\
14,566,298\end{array}$ & $\begin{array}{r}3,018,418 \\
3,601,405 \\
643,671 \\
451,341 \\
8,826,445\end{array}$ & $\begin{array}{r}743,335 \\
1,448,012 \\
281,665 \\
79,700 \\
2,860,946\end{array}$ & $\begin{array}{r}112,520 \\
199,225 \\
24,378 \\
52,967 \\
2,196,960\end{array}$ & $\begin{array}{r}271,478 \\
115,141 \\
54,010 \\
18,961 \\
582,507\end{array}$ & $\begin{array}{r}104,942 \\
405,089 \\
14,767 \\
151,496 \\
99,440\end{array}$ \\
\hline 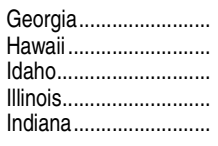 & $\begin{array}{r}9,838,312 \\
1,277,749 \\
1,199,775 \\
14,782,525 \\
5,834,548\end{array}$ & $\begin{array}{r}6,863,150 \\
783,726 \\
829,549 \\
9,541,184 \\
3,808,314\end{array}$ & $\begin{array}{r}2,243,363 \\
268,859 \\
273,217 \\
3,894,222 \\
1,729,415\end{array}$ & $\begin{array}{r}192,239 \\
103,098 \\
44,791 \\
590,515 \\
100,161\end{array}$ & $\begin{array}{r}500,742 \\
102,865 \\
50,620 \\
438,190 \\
188,548\end{array}$ & $\begin{array}{r}38,818 \\
19,201 \\
1,597 \\
318,414 \\
8,110\end{array}$ & $\begin{array}{r}9,668,819 \\
1,242,693 \\
1,148,131 \\
14,690,696 \\
5,702,356\end{array}$ & $\begin{array}{r}6,661,760 \\
829,260 \\
801,451 \\
9,447,166 \\
3,668,624\end{array}$ & $\begin{array}{r}2,226,686 \\
263,734 \\
265,057 \\
3,839,639 \\
1,771,180\end{array}$ & $\begin{array}{r}224,261 \\
68,519 \\
40,803 \\
678,624 \\
93,399\end{array}$ & $\begin{array}{r}505,759 \\
64,916 \\
39,309 \\
397,632 \\
159,286\end{array}$ & $\begin{array}{r}50,354 \\
16,264 \\
1,511 \\
327,634 \\
9,867\end{array}$ \\
\hline 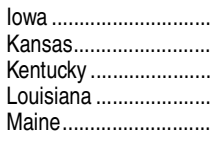 & $\begin{array}{l}2,954,930 \\
2,880,088 \\
3,614,078 \\
4,328,354 \\
1,428,312\end{array}$ & $\begin{array}{r}2,111,224 \\
2,109,134 \\
2,557,262 \\
2,912,229 \\
912,900\end{array}$ & $\begin{array}{r}645,635 \\
551,743 \\
845,438 \\
1,008,889 \\
375,762\end{array}$ & $\begin{array}{r}76,451 \\
82,012 \\
68,008 \\
106,206 \\
29,712\end{array}$ & $\begin{array}{r}92,624 \\
116,484 \\
130,797 \\
285,880 \\
37,688\end{array}$ & $\begin{array}{l}28,996 \\
20,716 \\
12,573 \\
15,149 \\
72,250\end{array}$ & $\begin{array}{l}2,994,346 \\
2,873,575 \\
3,641,680 \\
4,380,197 \\
1,442,329\end{array}$ & $\begin{array}{r}2,111,774 \\
2,075,510 \\
2,580,067 \\
2,869,599 \\
914,977\end{array}$ & $\begin{array}{r}670,350 \\
543,674 \\
866,875 \\
1,146,439 \\
387,202\end{array}$ & $\begin{array}{r}82,724 \\
90,862 \\
67,417 \\
102,961 \\
31,789\end{array}$ & $\begin{array}{r}99,366 \\
138,936 \\
116,696 \\
250,343 \\
37,564\end{array}$ & $\begin{array}{l}30,132 \\
24,593 \\
10,625 \\
10,856 \\
70,797\end{array}$ \\
\hline 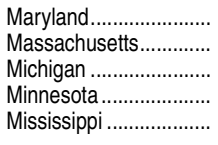 & $\begin{array}{l}7,386,467 \\
8,643,167 \\
9,913,891 \\
5,906,921 \\
2,346,594\end{array}$ & $\begin{array}{l}4,768,639 \\
5,536,313 \\
6,046,627 \\
3,962,598 \\
1,651,702\end{array}$ & $\begin{array}{r}1,925,146 \\
2,146,152 \\
2,857,136 \\
1,349,709 \\
498,594\end{array}$ & $\begin{array}{r}203,855 \\
54,298 \\
693,935 \\
330,105 \\
55,878\end{array}$ & $\begin{array}{l}214,323 \\
258,212 \\
298,548 \\
188,968 \\
125,499\end{array}$ & $\begin{array}{r}274,504 \\
648,192 \\
17,644 \\
75,540 \\
14,921\end{array}$ & $\begin{array}{l}7,424,153 \\
8,867,542 \\
9,672,947 \\
5,888,594 \\
2,247,757\end{array}$ & $\begin{array}{l}4,708,564 \\
5,644,823 \\
5,711,512 \\
4,026,985 \\
1,569,391\end{array}$ & $\begin{array}{r}2,025,230 \\
2,247,971 \\
2,916,048 \\
1,258,416 \\
475,160\end{array}$ & $\begin{array}{r}227,255 \\
57,083 \\
732,872 \\
337,946 \\
62,080\end{array}$ & $\begin{array}{l}206,217 \\
261,104 \\
293,849 \\
188,447 \\
126,656\end{array}$ & $\begin{array}{r}256,886 \\
656,561 \\
18,666 \\
76,800 \\
14,469\end{array}$ \\
\hline 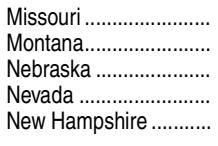 & $\begin{array}{r}5,378,592 \\
901,788 \\
2,128,741 \\
2,139,830 \\
1,671,301\end{array}$ & $\begin{array}{r}3,773,167 \\
595,725 \\
1,375,800 \\
1,428,342 \\
1,029,385\end{array}$ & $\begin{array}{r}1,030,092 \\
172,492 \\
468,113 \\
515,923 \\
415,873\end{array}$ & $\begin{array}{r}172,347 \\
60,481 \\
125,093 \\
36,767 \\
44,849\end{array}$ & $\begin{array}{r}371,570 \\
69,385 \\
124,864 \\
154,696 \\
42,510\end{array}$ & $\begin{array}{r}31,417 \\
3,704 \\
34,872 \\
4,103 \\
138,684 \\
\end{array}$ & $\begin{array}{r}5,208,082 \\
909,036 \\
2,185,379 \\
2,190,166 \\
1,712,141\end{array}$ & $\begin{array}{r}3,632,510 \\
601,939 \\
1,425,176 \\
1,439,113 \\
1,045,326\end{array}$ & $\begin{array}{r}1,030,137 \\
177,068 \\
482,026 \\
536,624 \\
440,816\end{array}$ & $\begin{array}{r}171,191 \\
60,063 \\
134,001 \\
56,334 \\
44,965\end{array}$ & $\begin{array}{r}343,008 \\
65,466 \\
114,881 \\
155,303 \\
42,637\end{array}$ & $\begin{array}{r}31,236 \\
4,500 \\
29,295 \\
2,791 \\
138,398\end{array}$ \\
\hline $\begin{array}{l}\text { New Jersey ................... } \\
\text { New Mexico ................. } \\
\text { New York................... } \\
\text { North Carolina ............. } \\
\text { North Dakota ............... }\end{array}$ & $\begin{array}{r}14,541,885 \\
1,847,604 \\
35,061,778 \\
7,641,089 \\
578,011\end{array}$ & $\begin{array}{r}9,318,554 \\
1,267,212 \\
22,419,307 \\
5,495,033 \\
405,129\end{array}$ & $\begin{array}{r}3,594,863 \\
390,637 \\
9,503,554 \\
1,445,007 \\
122,536\end{array}$ & $\begin{array}{r}464,905 \\
74,630 \\
1,819,078 \\
274,235 \\
18,016\end{array}$ & $\begin{array}{r}419,575 \\
114,882 \\
762,178 \\
426,814 \\
28,160\end{array}$ & $\begin{array}{r}743,988 \\
243 \\
557,661 \\
0 \\
4,170\end{array}$ & $\begin{array}{r}14,209,004 \\
1,793,031 \\
35,992,426 \\
7,702,399 \\
607,522\end{array}$ & $\begin{array}{r}9,006,686 \\
1,227,588 \\
22,145,426 \\
5,450,501 \\
426,980\end{array}$ & $\begin{array}{r}3,647,162 \\
387,735 \\
10,225,654 \\
1,566,742 \\
131,943\end{array}$ & $\begin{array}{r}470,068 \\
71,269 \\
2,139,734 \\
267,061 \\
17,890\end{array}$ & $\begin{array}{r}377,576 \\
106,129 \\
715,000 \\
418,096 \\
27,023\end{array}$ & $\begin{array}{r}707,513 \\
310 \\
766,612 \\
0 \\
3,686\end{array}$ \\
\hline 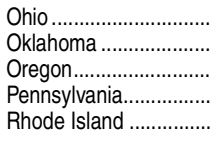 & $\begin{array}{r}11,321,779 \\
2,989,502 \\
3,157,351 \\
13,889,978 \\
1,294,924\end{array}$ & $\begin{array}{r}7,436,422 \\
2,091,724 \\
1,936,211 \\
9,078,091 \\
834,178\end{array}$ & $\begin{array}{r}2,515,056 \\
624,222 \\
901,639 \\
3,176,889 \\
352,977\end{array}$ & $\begin{array}{r}559,152 \\
44,298 \\
120,958 \\
771,406 \\
9,175\end{array}$ & $\begin{array}{r}445,040 \\
219,922 \\
161,440 \\
579,651 \\
23,156\end{array}$ & $\begin{array}{r}366,109 \\
9,336 \\
37,103 \\
283,941 \\
75,438\end{array}$ & $\begin{array}{r}11,372,653 \\
2,862,054 \\
3,165,170 \\
14,382,313 \\
1,324,326\end{array}$ & $\begin{array}{r}7,419,242 \\
2,017,034 \\
1,927,067 \\
9,318,410 \\
861,668\end{array}$ & $\begin{array}{r}2,578,234 \\
613,229 \\
920,550 \\
3,381,178 \\
347,020\end{array}$ & $\begin{array}{r}578,882 \\
47,986 \\
120,586 \\
810,393 \\
10,339\end{array}$ & $\begin{array}{r}412,847 \\
174,222 \\
158,327 \\
569,513 \\
25,252\end{array}$ & $\begin{array}{r}383,447 \\
9,583 \\
38,641 \\
302,818 \\
80,047\end{array}$ \\
\hline 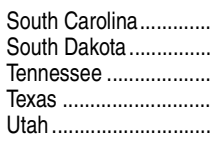 & $\begin{array}{r}3,784,450 \\
666,468 \\
4,970,275 \\
25,747,871 \\
2,340,227\end{array}$ & $\begin{array}{r}2,651,844 \\
444,367 \\
3,400,112 \\
19,686,185 \\
1,489,881\end{array}$ & $\begin{array}{r}785,027 \\
126,560 \\
1,008,551 \\
3,015,717 \\
614,804\end{array}$ & $\begin{array}{r}129,937 \\
34,217 \\
97,974 \\
856,632 \\
60,241\end{array}$ & $\begin{array}{r}193,770 \\
52,129 \\
446,717 \\
1,892,724 \\
165,582\end{array}$ & $\begin{array}{r}23,871 \\
9,196 \\
16,922 \\
296,613 \\
9,718\end{array}$ & $\begin{array}{r}3,688,634 \\
666,180 \\
5,325,040 \\
25,719,093 \\
2,382,888\end{array}$ & $\begin{array}{r}2,569,308 \\
449,743 \\
3,467,350 \\
19,881,407 \\
1,503,172\end{array}$ & $\begin{array}{r}796,285 \\
130,050 \\
1,132,546 \\
3,074,615 \\
632,253\end{array}$ & $\begin{array}{r}128,228 \\
32,994 \\
110,668 \\
865,178 \\
73,759\end{array}$ & $\begin{array}{r}171,226 \\
44,733 \\
599,449 \\
1,602,088 \\
165,709\end{array}$ & $\begin{array}{r}23,588 \\
8,660 \\
15,027 \\
295,805 \\
7,994\end{array}$ \\
\hline 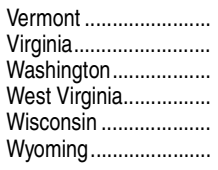 & $\begin{array}{r}881,073 \\
8,049,182 \\
5,932,836 \\
2,007,943 \\
6,118,246 \\
788,716 \\
\end{array}$ & $\begin{array}{r}572,577 \\
5,674,422 \\
4,053,728 \\
1,115,154 \\
3,781,965 \\
527,000 \\
\end{array}$ & $\begin{array}{r}170,142 \\
1,850,325 \\
1,262,584 \\
719,971 \\
1,882,004 \\
192,182 \\
\end{array}$ & $\begin{array}{r}47,958 \\
186,658 \\
330,377 \\
35,872 \\
100,692 \\
26,703 \\
\end{array}$ & $\begin{array}{r}24,141 \\
327,674 \\
234,887 \\
134,208 \\
223,661 \\
40,613 \\
\end{array}$ & $\begin{array}{r}66,256 \\
10,102 \\
51,259 \\
2,738 \\
129,923 \\
2,218 \\
\end{array}$ & $\begin{array}{r}876,070 \\
7,861,182 \\
6,067,366 \\
2,029,616 \\
6,322,480 \\
826,891 \\
\end{array}$ & $\begin{array}{r}566,647 \\
5,573,464 \\
4,120,582 \\
1,116,785 \\
3,855,317 \\
539,711 \\
\end{array}$ & $\begin{array}{r}173,695 \\
1,732,130 \\
1,294,236 \\
747,810 \\
1,997,077 \\
212,491 \\
\end{array}$ & $\begin{array}{r}47,370 \\
191,019 \\
349,878 \\
38,357 \\
103,837 \\
27,788 \\
\end{array}$ & $\begin{array}{r}22,856 \\
353,681 \\
249,485 \\
122,536 \\
211,031 \\
44,554 \\
\end{array}$ & $\begin{array}{r}65,501 \\
10,888 \\
53,185 \\
4,128 \\
155,218 \\
2,346 \\
\end{array}$ \\
\hline $\begin{array}{l}\text { Other jurisdictions } \\
\text { American Samoa ...... } \\
\text { Guam ...................... } \\
\text { Northern Marianas... } \\
\text { Puerto Rico ............. } \\
\text { U.S. Virgin Islands.... }\end{array}$ & $\begin{array}{r}32,396 \\
132,599 \\
30,164 \\
1,742,259 \\
119,422\end{array}$ & $\begin{array}{r}20,546 \\
98,610 \\
24,103 \\
1,303,413 \\
82,258\end{array}$ & $\begin{array}{r}3,460 \\
30,114 \\
4,160 \\
223,457 \\
31,258\end{array}$ & $\begin{array}{r}1,523 \\
2,479 \\
599 \\
27,319 \\
1,550\end{array}$ & $\begin{array}{r}2,864 \\
1,396 \\
1,292 \\
51,736 \\
4,355\end{array}$ & $\begin{array}{r}4,004 \\
0 \\
10 \\
136,333 \\
0\end{array}$ & $\begin{array}{r}32,770 \\
149,292 \\
36,014 \\
1,460,167 \\
108,061\end{array}$ & $\begin{array}{r}20,734 \\
102,505 \\
27,206 \\
1,029,741 \\
75,314\end{array}$ & $\begin{array}{r}3,593 \\
40,305 \\
6,469 \\
238,718 \\
28,392\end{array}$ & $\begin{array}{r}1,599 \\
5,134 \\
563 \\
165,297 \\
1,784\end{array}$ & $\begin{array}{r}2,670 \\
1,348 \\
75 \\
24,310 \\
2,571\end{array}$ & $\begin{array}{r}4,174 \\
0 \\
1,702 \\
2,101 \\
0\end{array}$ \\
\hline
\end{tabular}

'Data have been revised from previously published figures.

Includes purchased professional services of teachers or others who provide instruction for students.

NOTE: Excludes expenditures for state education agencies. Detail may not sum to totals because of rounding.
SOURCE: U.S. Department of Education, National Center for Education Statistics, Common Core of Data (CCD), "National Public Education Financial Survey," 2009-10 and 2010-11. (This table was prepared July 2013.) 


\section{Table 236.55. Total and current expenditures per pupil in public elementary and secondary schools: Selected years, 1919-20 through 2010-11}

\begin{tabular}{|c|c|c|c|c|c|c|c|c|c|}
\hline \multirow[b]{3}{*}{ School year } & \multicolumn{4}{|c|}{ Expenditure per pupil in average daily attendance } & \multicolumn{5}{|c|}{ Expenditure per pupil in fall enrollment ${ }^{1}$} \\
\hline & \multicolumn{2}{|c|}{ Unadjusted dollars ${ }^{2}$} & \multicolumn{2}{|c|}{ Constant 2012-13 dollars ${ }^{3}$} & \multicolumn{2}{|c|}{ Unadjusted dollars $^{2}$} & \multicolumn{3}{|c|}{ Constant 2012-13 dollars ${ }^{3}$} \\
\hline & $\begin{array}{r}\text { Total } \\
\text { expenditure }\end{array}$ & $\begin{array}{r}\text { Current } \\
\text { expenditure }\end{array}$ & $\begin{array}{r}\text { Total } \\
\text { expenditure }{ }^{4}\end{array}$ & $\begin{array}{r}\text { Current } \\
\text { expenditure }\end{array}$ & $\begin{array}{r}\text { Total } \\
\text { expenditure }\end{array}$ & $\begin{array}{r}\text { Current } \\
\text { expenditure }\end{array}$ & $\begin{array}{r}\text { Total } \\
\text { expenditure }\end{array}$ & $\begin{array}{r}\text { Current } \\
\text { expenditure }\end{array}$ & $\begin{array}{r}\text { Annual percent } \\
\text { change in } \\
\text { current } \\
\text { expenditure }\end{array}$ \\
\hline 1 & 2 & 3 & 4 & 5 & 6 & 7 & 8 & 9 & 10 \\
\hline 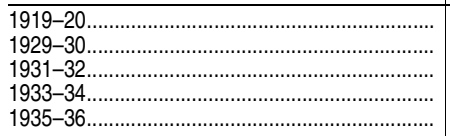 & $\begin{array}{r}\$ 64 \\
108 \\
97 \\
76 \\
88\end{array}$ & $\begin{array}{r}\$ 53 \\
87 \\
81 \\
67 \\
74\end{array}$ & $\begin{array}{l}\$ 776 \\
1,466 \\
1,555 \\
1,332 \\
1,481\end{array}$ & $\begin{array}{l}\$ 647 \\
1,172 \\
1,301 \\
1,179 \\
1,251\end{array}$ & $\begin{array}{r}\$ 48 \\
90 \\
82 \\
65 \\
74\end{array}$ & $\begin{array}{r}\$ 40 \\
72 \\
69 \\
57 \\
63\end{array}$ & $\begin{array}{l}\$ 581 \\
1,214 \\
1,316 \\
1,131 \\
1,252\end{array}$ & $\begin{array}{r}\$ 484 \\
970 \\
1,102 \\
1,002 \\
1,058\end{array}$ & $\begin{array}{l}- \\
- \\
- \\
-\end{array}$ \\
\hline 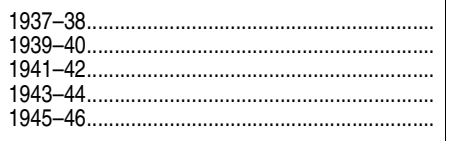 & $\begin{array}{l}100 \\
106 \\
110 \\
125 \\
146\end{array}$ & $\begin{array}{r}84 \\
88 \\
98 \\
117 \\
136\end{array}$ & $\begin{array}{l}1,610 \\
1,750 \\
1,633 \\
1,655 \\
1,850\end{array}$ & $\begin{array}{l}1,354 \\
1,458 \\
1,459 \\
1,553 \\
1,730\end{array}$ & $\begin{array}{r}86 \\
92 \\
94 \\
105 \\
124\end{array}$ & $\begin{array}{r}72 \\
76 \\
84 \\
99 \\
116\end{array}$ & $\begin{array}{l}1,382 \\
1,517 \\
1,398 \\
1,395 \\
1,576\end{array}$ & $\begin{array}{l}1,163 \\
1,264 \\
1,249 \\
1,309 \\
1,474\end{array}$ & $\begin{array}{l}- \\
\overline{-} \\
\overline{-}\end{array}$ \\
\hline 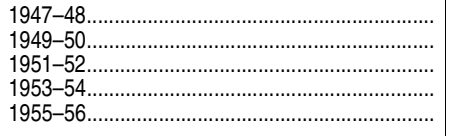 & $\begin{array}{l}205 \\
260 \\
314 \\
351 \\
387\end{array}$ & $\begin{array}{l}181 \\
210 \\
246 \\
265 \\
294\end{array}$ & $\begin{array}{l}2,034 \\
2,543 \\
2,768 \\
3,019 \\
3,331\end{array}$ & $\begin{array}{l}1,802 \\
2,055 \\
2,166 \\
2,278 \\
2,532\end{array}$ & $\begin{array}{l}179 \\
231 \\
275 \\
312 \\
354\end{array}$ & $\begin{array}{l}158 \\
187 \\
215 \\
236 \\
269\end{array}$ & $\begin{array}{l}1,776 \\
2,257 \\
2,424 \\
2,685 \\
3,045\end{array}$ & $\begin{array}{l}1,574 \\
1,823 \\
1,896 \\
2,026 \\
2,315\end{array}$ & $\begin{array}{l}- \\
\overline{-} \\
\overline{-}\end{array}$ \\
\hline 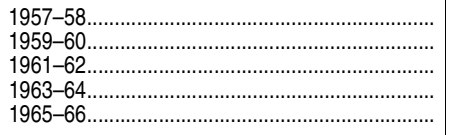 & $\begin{array}{l}447 \\
471 \\
517 \\
559 \\
654\end{array}$ & $\begin{array}{l}341 \\
375 \\
419 \\
460 \\
538\end{array}$ & $\begin{array}{l}3,625 \\
3,709 \\
3,980 \\
4,191 \\
4,741\end{array}$ & $\begin{array}{l}2,764 \\
2,954 \\
3,225 \\
3,453 \\
3,899\end{array}$ & $\begin{array}{l}408 \\
440 \\
485 \\
520 \\
607\end{array}$ & $\begin{array}{l}311 \\
350 \\
393 \\
428 \\
499\end{array}$ & $\begin{array}{l}3,306 \\
3,465 \\
3,735 \\
3,901 \\
4,401\end{array}$ & $\begin{array}{l}2,520 \\
2,759 \\
3,026 \\
3,214 \\
3,620\end{array}$ & $\begin{array}{l}- \\
\overline{-} \\
-\end{array}$ \\
\hline 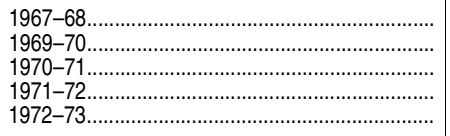 & $\begin{array}{r}786 \\
955 \\
1,049 \\
1,128 \\
1,211\end{array}$ & $\begin{array}{r}658 \\
816 \\
911 \\
990 \\
1,077\end{array}$ & $\begin{array}{l}5,350 \\
5,849 \\
6,112 \\
6,341 \\
6,543\end{array}$ & $\begin{array}{l}4,478 \\
4,997 \\
5,306 \\
5,564 \\
5,820\end{array}$ & $\begin{array}{r}732 \\
879 \\
970 \\
1,034 \\
1,117\end{array}$ & $\begin{array}{l}612 \\
751 \\
842 \\
908 \\
993\end{array}$ & $\begin{array}{l}4,977 \\
5,385 \\
5,650 \\
5,815 \\
6,035\end{array}$ & $\begin{array}{l}4,166 \\
4,601 \\
4,905 \\
5,103 \\
5,368\end{array}$ & $\begin{array}{l}\overline{-} \\
6 . \overline{6} \\
4.0 \\
5.2\end{array}$ \\
\hline 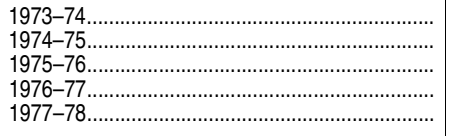 & $\begin{array}{l}1,364 \\
1,545 \\
1,697 \\
1,816 \\
2,002\end{array}$ & $\begin{array}{l}1,207 \\
1,365 \\
1,504 \\
1,638 \\
1,823\end{array}$ & $\begin{array}{l}6,768 \\
6,900 \\
7,081 \\
7,159 \\
7,396\end{array}$ & $\begin{array}{l}5,990 \\
6,095 \\
6,273 \\
6,455 \\
6,733\end{array}$ & $\begin{array}{l}1,244 \\
1,423 \\
1,563 \\
1,674 \\
1,842\end{array}$ & $\begin{array}{l}1,101 \\
1,257 \\
1,385 \\
1,509 \\
1,677\end{array}$ & $\begin{array}{l}6,171 \\
6,357 \\
6,520 \\
6,597 \\
6,803\end{array}$ & $\begin{array}{l}5,462 \\
5,615 \\
5,776 \\
5,948 \\
6,193\end{array}$ & $\begin{array}{l}1.7 \\
2.8 \\
2.9 \\
3.0 \\
4.1\end{array}$ \\
\hline 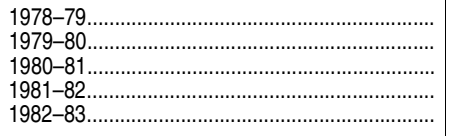 & $\begin{array}{l}2,210 \\
2,491 \\
2,7425 \\
2,973^{5} \\
3,203^{5}\end{array}$ & $\begin{array}{l}2,020 \\
2,272 \\
2,502 \\
2,726 \\
2,955\end{array}$ & $\begin{array}{l}7,464 \\
7,422 \\
7,324 \\
7,310^{5} \\
7,551^{5}\end{array}$ & $\begin{array}{l}6,824 \\
6,770 \\
6,681 \\
6,701 \\
6,966\end{array}$ & $\begin{array}{l}2,029 \\
2,290 \\
2,5295 \\
2,7545 \\
2,966^{5}\end{array}$ & $\begin{array}{l}1,855 \\
2,088 \\
2,307 \\
2,525 \\
2,736\end{array}$ & $\begin{array}{l}6,854 \\
6,823 \\
6,7555 \\
6,7715 \\
6,9925\end{array}$ & $\begin{array}{l}6,267 \\
6,224 \\
6,162 \\
6,207 \\
6,450\end{array}$ & $\begin{array}{r}1.2 \\
-0.7 \\
-1.0 \\
0.7 \\
3.9\end{array}$ \\
\hline 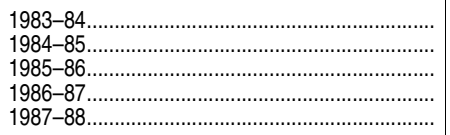 & $\begin{array}{l}3,4715 \\
3,7225 \\
4,022^{5} \\
4,3085 \\
4,6545\end{array}$ & $\begin{array}{l}3,173 \\
3,470 \\
3,756 \\
3,970 \\
4,240\end{array}$ & $\begin{array}{l}7,8905 \\
8,1415 \\
8,5465 \\
8,9605 \\
9,2955\end{array}$ & $\begin{array}{l}7,213 \\
7,591 \\
7,985 \\
8,258 \\
8,468\end{array}$ & $\begin{array}{l}3,2165 \\
3,4565 \\
3,7245 \\
3,9955 \\
4,310^{5}\end{array}$ & $\begin{array}{l}2,940 \\
3,222 \\
3,479 \\
3,682 \\
3,927\end{array}$ & $\begin{array}{l}7,3095 \\
7,5595 \\
7,9185 \\
8,3095 \\
8,6085\end{array}$ & $\begin{array}{l}6,682 \\
7,048 \\
7,397 \\
7,658 \\
7,842\end{array}$ & $\begin{array}{l}3.6 \\
5.5 \\
5.0 \\
3.5 \\
2.4\end{array}$ \\
\hline 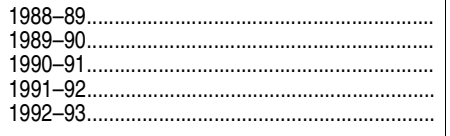 & $\begin{array}{l}5,108 \\
5,547 \\
5,882 \\
6,072 \\
6,279\end{array}$ & $\begin{array}{l}4,645 \\
4,980 \\
5,258 \\
5,421 \\
5,584\end{array}$ & $\begin{array}{r}9,751 \\
10,107 \\
10,161 \\
10,164 \\
10,193\end{array}$ & $\begin{array}{l}8,867 \\
9,073 \\
9,083 \\
9,075 \\
9,064\end{array}$ & $\begin{array}{l}4,737 \\
5,172 \\
5,484 \\
5,626 \\
5,802\end{array}$ & $\begin{array}{l}4,307 \\
4,643 \\
4,902 \\
5,023 \\
5,160\end{array}$ & $\begin{array}{l}9,042 \\
9,423 \\
9,473 \\
9,418 \\
9,419\end{array}$ & $\begin{array}{l}8,222 \\
8,459 \\
8,468 \\
8,409 \\
8,375\end{array}$ & $\begin{array}{r}4.8 \\
2.9 \\
0.1 \\
-0.7 \\
-0.4\end{array}$ \\
\hline 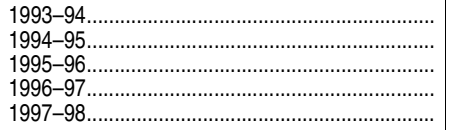 & $\begin{array}{l}6,489 \\
6,723 \\
6,959 \\
7,297 \\
7,701\end{array}$ & $\begin{array}{l}5,767 \\
5,989 \\
6,147 \\
6,393 \\
6,676\end{array}$ & $\begin{array}{l}10,267 \\
10,341 \\
10,421 \\
10,624 \\
11,015\end{array}$ & $\begin{array}{l}9,126 \\
9,212 \\
9,205 \\
9,307 \\
9,549\end{array}$ & $\begin{array}{l}5,994 \\
6,206 \\
6,441 \\
6,761 \\
7,139\end{array}$ & $\begin{array}{l}5,327 \\
5,529 \\
5,689 \\
5,923 \\
6,189\end{array}$ & $\begin{array}{r}9,483 \\
9,546 \\
9,645 \\
9,844 \\
10,212\end{array}$ & $\begin{array}{l}8,429 \\
8,504 \\
8,519 \\
8,624 \\
8,853\end{array}$ & $\begin{array}{l}0.6 \\
0.9 \\
0.2 \\
1.2 \\
2.7\end{array}$ \\
\hline 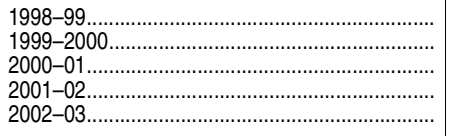 & $\begin{array}{l}8,115 \\
8,589 \\
9,180 \\
9,611 \\
9,950\end{array}$ & $\begin{array}{l}7,013 \\
7,394 \\
7,904 \\
8,259 \\
8,610\end{array}$ & $\begin{array}{l}11,411 \\
11,738 \\
12,129 \\
12,479 \\
12,641\end{array}$ & $\begin{array}{r}9,861 \\
10,104 \\
10,443 \\
10,723 \\
10,938\end{array}$ & $\begin{array}{l}7,531 \\
8,030 \\
8,572 \\
8,993 \\
9,296\end{array}$ & $\begin{array}{l}6,508 \\
6,912 \\
7,380 \\
7,727 \\
8,044\end{array}$ & $\begin{array}{l}10,589 \\
10,973 \\
11,326 \\
11,676 \\
11,810\end{array}$ & $\begin{array}{r}9,151 \\
9,446 \\
9,751 \\
10,033 \\
10,219\end{array}$ & $\begin{array}{l}3.4 \\
3.2 \\
3.2 \\
2.9 \\
1.9\end{array}$ \\
\hline 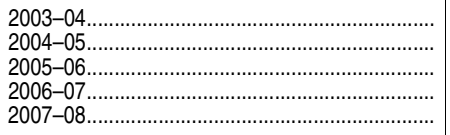 & $\begin{array}{l}10,308 \\
10,779 \\
11,338 \\
12,015 \\
12,759\end{array}$ & $\begin{array}{r}8,900 \\
9,316 \\
9,778 \\
10,336 \\
10,982\end{array}$ & $\begin{array}{l}12,815 \\
13,009 \\
13,181 \\
13,617 \\
13,943\end{array}$ & $\begin{array}{l}11,064 \\
11,243 \\
11,368 \\
11,714 \\
12,001\end{array}$ & $\begin{array}{r}9,625 \\
10,078 \\
10,603 \\
11,252 \\
11,965\end{array}$ & $\begin{array}{r}8,310 \\
8,711 \\
9,145 \\
9,679 \\
10,298\end{array}$ & $\begin{array}{l}11,966 \\
12,164 \\
12,328 \\
12,752 \\
13,075\end{array}$ & $\begin{array}{r}10,332 \\
10,513 \\
10,632 \\
10,969 \\
11,254\end{array}$ & $\begin{array}{l}1.1 \\
1.8 \\
1.1 \\
3.2 \\
2.6\end{array}$ \\
\hline $\begin{array}{l}2008-09 \\
2009-10^{6} \\
2010-11 \ldots \ldots \ldots \ldots \ldots\end{array}$ & $\begin{array}{l}13,033 \\
13,035 \\
12,908\end{array}$ & $\begin{array}{l}11,239 \\
11,427 \\
11,418\end{array}$ & $\begin{array}{l}14,046 \\
13,914 \\
13,507\end{array}$ & $\begin{array}{l}12,113 \\
12,198 \\
11,948\end{array}$ & $\begin{array}{l}12,222 \\
12,133 \\
12,048\end{array}$ & $\begin{array}{l}10,540 \\
10,636 \\
10,658\end{array}$ & $\begin{array}{l}13,173 \\
12,951 \\
12,608\end{array}$ & $\begin{array}{l}11,359 \\
11,353 \\
11,153\end{array}$ & $\begin{array}{r}0.9 \\
-0.1 \\
-1.8\end{array}$ \\
\hline
\end{tabular}

-Not available.

${ }^{1}$ Data for 1919-20 to 1953-54 are based on school-year enrollment.

2Unadjusted (or "current") dollars have not been adjusted to compensate for inflation.

${ }^{3}$ Constant dollars based on the Consumer Price Index, prepared by the Bureau of Labor Statistics, U.S. Department of Labor, adjusted to a school-year basis.

${ }^{4}$ Excludes "Other current expenditures," such as community services, private school programs, adult education, and other programs not allocable to expenditures per student at pub-

lic schools.

${ }^{6}$ Revised from previously published figures.
NOTE: Beginning in 1980-81, state administration expenditures are excluded from both "total" and "current" expenditures. Current expenditures include instruction, support services, food services, and enterprise operations. Total expenditures include current expenditures, capital outlay, and interest on debt. Beginning in 1988-89, extensive changes were made in the data collection procedures.

SOURCE: U.S. Department of Education, National Center for Education Statistics, Biennial Survey of Education in the United States, 1919-20 through 1955-56; Statistics of State School Systems, 1957-58 through 1969-70; Revenues and Expenditures for Public Elementary and Secondary Education, 1970-71 through 1986-87; and Common Core of Data (CCD), "National Public Education Financial Survey," 1987-88 through 2010-11. (This table was prepared July 2013.) 
Table 236.60. Total and current expenditures per pupil in fall enrollment in public elementary and secondary schools, by function and subfunction: Selected years, 1990-91 through 2010-11

\begin{tabular}{|c|c|c|c|c|c|c|c|c|c|c|c|c|c|c|c|c|c|c|}
\hline \multirow[b]{2}{*}{ Function and subfunction } & \multicolumn{9}{|c|}{ Expenditures per pupil in current dollars } & \multicolumn{9}{|c|}{ Expenditures per pupil in constant 2012-13 dollars 1} \\
\hline & $1990-91$ & $1995-96$ & 1999-2000 & $2000-01$ & $2005-06$ & $2007-08$ & $2008-09$ & $2009-10^{2}$ & 2010-11 & $1990-91$ & $1995-96$ & $|1999-2000|$ & $2000-01$ & $2005-06$ & $2007-08$ & $2008-09$ & $2009-10^{2}$ & $2010-11$ \\
\hline 1 & 2 & 3 & 4 & 5 & 6 & 7 & 8 & 9 & 10 & 11 & 12 & 13 & 14 & 15 & 16 & 17 & 18 & 19 \\
\hline Total expenditures ....................... & $\$ 5,484$ & $\$ 6,441$ & $\$ 8,030$ & $\$ 8,572$ & $\$ 10,603$ & $\$ 11,965$ & $\$ 12,222$ & $\$ 12,133$ & $\$ 12,048$ & $\$ 9,473$ & $\$ 9,645$ & $\$ 10,973$ & $\$ 11,326$ & $\$ 12,328$ & $\$ 13,075$ & $\$ 13,173$ & $\$ 12,951$ & $\$ 12,608$ \\
\hline Current expenditures for public schools... & 4,902 & 5,689 & 6,912 & 7,380 & 9,145 & 10,298 & 10,540 & 10,636 & 10,658 & 8,468 & 8,519 & 9,446 & 9,751 & 10,632 & 11,254 & 11,359 & 11,353 & 11,153 \\
\hline 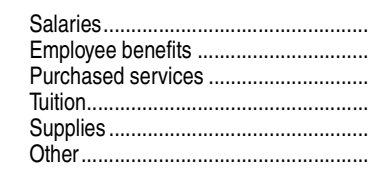 & $\begin{array}{r}3,220^{3} \\
824^{3} \\
397^{3} \\
29^{3} \\
359^{3} \\
72^{3} \\
\end{array}$ & $\begin{array}{r}3,698 \\
999 \\
481 \\
35 \\
418 \\
58 \\
\end{array}$ & $\begin{array}{r}4,485 \\
1,138 \\
620 \\
48 \\
553 \\
69 \\
\end{array}$ & $\begin{array}{r}4,752 \\
1,228 \\
673 \\
52 \\
599 \\
76 \\
\end{array}$ & $\begin{array}{r}5,561 \\
1,790 \\
880 \\
78 \\
746 \\
90 \\
\end{array}$ & $\begin{array}{r}6,177 \\
2,093 \\
1,000 \\
93 \\
840 \\
96 \\
\end{array}$ & $\begin{array}{r}6,348 \\
2,146 \\
1,030 \\
91 \\
825 \\
99 \\
\end{array}$ & $\begin{array}{r}6,366 \\
2,199 \\
1,053 \\
96 \\
818 \\
104 \\
\end{array}$ & $\begin{array}{r}6,295 \\
2,256 \\
1,083 \\
101 \\
820 \\
103 \\
\end{array}$ & $\begin{array}{r}5,563^{3} \\
1,423^{3} \\
687^{3} \\
50^{3} \\
621^{3} \\
125^{3} \\
\end{array}$ & $\begin{array}{r}5,537 \\
1,496 \\
721 \\
53 \\
626 \\
86 \\
\end{array}$ & $\begin{array}{r}6,129 \\
1,555 \\
847 \\
65 \\
755 \\
94 \\
\end{array}$ & $\begin{array}{r}6,279 \\
1,623 \\
890 \\
69 \\
791 \\
100 \\
\end{array}$ & $\begin{array}{r}6,466 \\
2,081 \\
1,023 \\
91 \\
867 \\
105 \\
\end{array}$ & $\begin{array}{r}6,750 \\
2,287 \\
1,093 \\
102 \\
918 \\
105 \\
\end{array}$ & $\begin{array}{r}6,842 \\
2,313 \\
1,110 \\
98 \\
889 \\
107 \\
\end{array}$ & $\begin{array}{r}6,795 \\
2,347 \\
1,124 \\
103 \\
873 \\
111 \\
\end{array}$ & $\begin{array}{r}6,587 \\
2,361 \\
1,133 \\
106 \\
858 \\
108 \\
\end{array}$ \\
\hline 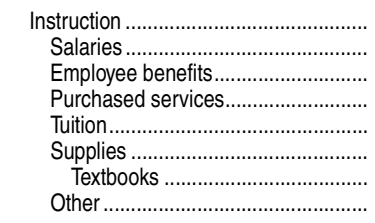 & $\begin{array}{r}2,965 \\
2,202 \\
542 \\
66 \\
29 \\
111 \\
- \\
15\end{array}$ & $\begin{array}{r}3,512 \\
2,555 \\
676 \\
85 \\
35 \\
145 \\
-15 \\
15\end{array}$ & $\begin{array}{r}4,268 \\
3,096 \\
773 \\
125 \\
48 \\
208 \\
-19\end{array}$ & $\begin{array}{r}4,541 \\
3,273 \\
837 \\
136 \\
52 \\
220 \\
- \\
22\end{array}$ & $\begin{array}{r}5,574 \\
3,806 \\
1,202 \\
205 \\
78 \\
259 \\
52 \\
24\end{array}$ & $\begin{array}{r}6,262 \\
4,199 \\
1,407 \\
249 \\
93 \\
287 \\
55 \\
27\end{array}$ & $\begin{array}{r}6,420 \\
4,325 \\
1,443 \\
260 \\
91 \\
273 \\
60 \\
28\end{array}$ & $\begin{array}{r}6,511 \\
4,347 \\
1,481 \\
281 \\
96 \\
277 \\
52 \\
29\end{array}$ & $\begin{array}{r}6,520 \\
4,303 \\
1,521 \\
297 \\
101 \\
268 \\
47 \\
30\end{array}$ & $\begin{array}{r}5,123 \\
3,803 \\
937 \\
114 \\
50 \\
192 \\
- \\
27\end{array}$ & $\begin{array}{r}5,259 \\
3,826 \\
1,012 \\
128 \\
53 \\
218 \\
22\end{array}$ & $\begin{array}{r}5,832 \\
4,231 \\
1,056 \\
170 \\
65 \\
284 \\
-26\end{array}$ & $\begin{array}{r}6,000 \\
4,325 \\
1,106 \\
180 \\
69 \\
290 \\
- \\
29\end{array}$ & $\begin{array}{r}6,481 \\
4,424 \\
1,397 \\
239 \\
91 \\
301 \\
60 \\
28\end{array}$ & $\begin{array}{r}6,844 \\
4,589 \\
1,538 \\
272 \\
102 \\
314 \\
60 \\
29\end{array}$ & $\begin{array}{r}6,919 \\
4,662 \\
1,555 \\
280 \\
98 \\
294 \\
64 \\
30\end{array}$ & $\begin{array}{r}6,950 \\
4,640 \\
1,581 \\
300 \\
103 \\
296 \\
55 \\
31\end{array}$ & $\begin{array}{r}6,823 \\
4,503 \\
1,591 \\
311 \\
106 \\
281 \\
49 \\
31\end{array}$ \\
\hline 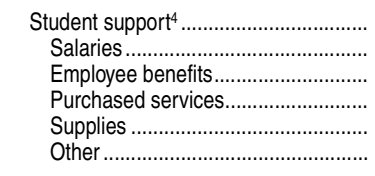 & $\begin{array}{r}217 \\
159 \\
40 \\
11 \\
5 \\
1\end{array}$ & $\begin{array}{r}274 \\
198 \\
51 \\
15 \\
6 \\
3\end{array}$ & $\begin{array}{r}342 \\
245 \\
61 \\
25 \\
8 \\
3\end{array}$ & $\begin{array}{r}366 \\
262 \\
64 \\
28 \\
9 \\
3\end{array}$ & $\begin{array}{r}475 \\
322 \\
99 \\
40 \\
10 \\
4\end{array}$ & $\begin{array}{r}559 \\
372 \\
120 \\
48 \\
11 \\
7\end{array}$ & $\begin{array}{r}580 \\
388 \\
125 \\
49 \\
11 \\
7\end{array}$ & $\begin{array}{r}591 \\
393 \\
128 \\
50 \\
11 \\
7\end{array}$ & $\begin{array}{r}593 \\
391 \\
132 \\
52 \\
11 \\
7\end{array}$ & $\begin{array}{r}374 \\
275 \\
70 \\
19 \\
8 \\
2\end{array}$ & $\begin{array}{r}410 \\
297 \\
77 \\
23 \\
8 \\
5\end{array}$ & $\begin{array}{r}468 \\
335 \\
83 \\
34 \\
11 \\
4\end{array}$ & $\begin{array}{r}484 \\
346 \\
85 \\
37 \\
12 \\
4\end{array}$ & $\begin{array}{r}552 \\
375 \\
115 \\
46 \\
12 \\
4\end{array}$ & $\begin{array}{r}610 \\
407 \\
131 \\
53 \\
12 \\
7\end{array}$ & $\begin{array}{r}625 \\
418 \\
135 \\
53 \\
12 \\
7\end{array}$ & $\begin{array}{r}630 \\
420 \\
137 \\
54 \\
12 \\
8\end{array}$ & $\begin{array}{r}621 \\
409 \\
138 \\
55 \\
11 \\
8\end{array}$ \\
\hline 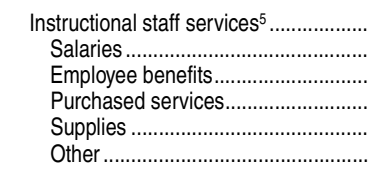 & $\begin{array}{r}205 \\
135 \\
34 \\
15 \\
19 \\
2\end{array}$ & $\begin{array}{r}225 \\
143 \\
38 \\
21 \\
20 \\
2\end{array}$ & $\begin{array}{r}312 \\
191 \\
46 \\
38 \\
32 \\
5\end{array}$ & $\begin{array}{r}337 \\
207 \\
50 \\
42 \\
33 \\
4\end{array}$ & $\begin{array}{r}446 \\
265 \\
79 \\
60 \\
38 \\
4\end{array}$ & $\begin{array}{r}515 \\
309 \\
95 \\
67 \\
40 \\
4\end{array}$ & $\begin{array}{r}508 \\
304 \\
96 \\
66 \\
37 \\
4\end{array}$ & $\begin{array}{r}509 \\
301 \\
98 \\
69 \\
37 \\
5\end{array}$ & $\begin{array}{r}503 \\
293 \\
100 \\
70 \\
37 \\
4\end{array}$ & $\begin{array}{r}355 \\
233 \\
59 \\
26 \\
33 \\
4\end{array}$ & $\begin{array}{r}336 \\
214 \\
57 \\
31 \\
31 \\
3\end{array}$ & $\begin{array}{r}427 \\
262 \\
63 \\
52 \\
43 \\
7\end{array}$ & $\begin{array}{r}446 \\
274 \\
66 \\
56 \\
44 \\
6\end{array}$ & $\begin{array}{r}519 \\
308 \\
92 \\
70 \\
44 \\
5\end{array}$ & $\begin{array}{r}563 \\
338 \\
104 \\
73 \\
43 \\
5\end{array}$ & $\begin{array}{r}548 \\
328 \\
104 \\
71 \\
40 \\
5\end{array}$ & $\begin{array}{r}543 \\
321 \\
105 \\
73 \\
40 \\
5\end{array}$ & $\begin{array}{r}526 \\
306 \\
104 \\
73 \\
38 \\
5\end{array}$ \\
\hline 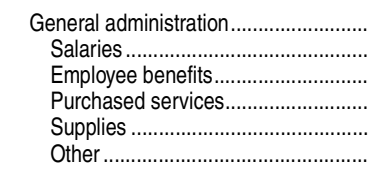 & $\begin{array}{r}141 \\
63 \\
19 \\
36 \\
4 \\
18\end{array}$ & $\begin{array}{r}131 \\
65 \\
18 \\
36 \\
4 \\
8\end{array}$ & $\begin{array}{r}143 \\
68 \\
20 \\
41 \\
4 \\
9\end{array}$ & $\begin{array}{r}151 \\
71 \\
21 \\
44 \\
4 \\
10\end{array}$ & $\begin{array}{r}182 \\
79 \\
30 \\
56 \\
5 \\
13\end{array}$ & $\begin{array}{r}200 \\
87 \\
34 \\
60 \\
5 \\
14\end{array}$ & $\begin{array}{r}207 \\
90 \\
35 \\
64 \\
5 \\
13\end{array}$ & $\begin{array}{r}211 \\
90 \\
37 \\
64 \\
5 \\
16\end{array}$ & $\begin{array}{r}212 \\
89 \\
38 \\
65 \\
5 \\
16\end{array}$ & $\begin{array}{r}243 \\
109 \\
33 \\
62 \\
7 \\
32\end{array}$ & \begin{tabular}{r|}
196 \\
97 \\
28 \\
54 \\
6 \\
11
\end{tabular} & $\begin{array}{r}195 \\
93 \\
27 \\
57 \\
6 \\
13\end{array}$ & $\begin{array}{r}199 \\
94 \\
28 \\
59 \\
6 \\
13\end{array}$ & $\begin{array}{r}211 \\
91 \\
35 \\
65 \\
5 \\
15\end{array}$ & $\begin{array}{r}219 \\
95 \\
37 \\
66 \\
5 \\
15\end{array}$ & $\begin{array}{r}223 \\
97 \\
38 \\
69 \\
5 \\
14\end{array}$ & $\begin{array}{r}225 \\
96 \\
39 \\
68 \\
5 \\
17\end{array}$ & $\begin{array}{r}222 \\
93 \\
39 \\
68 \\
5 \\
16\end{array}$ \\
\hline 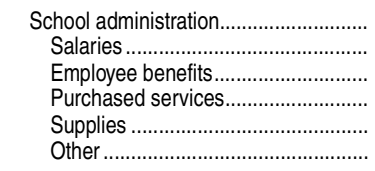 & $\begin{array}{r}284 \\
217 \\
55 \\
6 \\
5 \\
2\end{array}$ & $\begin{array}{r}331 \\
249 \\
66 \\
9 \\
6 \\
2\end{array}$ & $\begin{array}{r}392 \\
297 \\
74 \\
12 \\
7 \\
2\end{array}$ & $\begin{array}{r}415 \\
314 \\
78 \\
13 \\
8 \\
2\end{array}$ & $\begin{array}{r}515 \\
370 \\
114 \\
18 \\
10 \\
3\end{array}$ & $\begin{array}{r}576 \\
410 \\
133 \\
20 \\
10 \\
3\end{array}$ & $\begin{array}{r}581 \\
417 \\
134 \\
19 \\
9 \\
2\end{array}$ & $\begin{array}{r}579 \\
413 \\
136 \\
19 \\
9 \\
3\end{array}$ & $\begin{array}{r}578 \\
408 \\
140 \\
19 \\
9 \\
3\end{array}$ & $\begin{array}{r}490 \\
375 \\
95 \\
10 \\
8 \\
3\end{array}$ & $\begin{array}{r}495 \\
373 \\
99 \\
13 \\
9 \\
2\end{array}$ & $\begin{array}{r}536 \\
406 \\
101 \\
17 \\
10 \\
3\end{array}$ & $\begin{array}{r}548 \\
415 \\
103 \\
17 \\
10 \\
3\end{array}$ & $\begin{array}{r}598 \\
430 \\
133 \\
20 \\
11 \\
3\end{array}$ & $\begin{array}{r}629 \\
448 \\
146 \\
22 \\
11 \\
3\end{array}$ & $\begin{array}{r}626 \\
449 \\
144 \\
20 \\
9 \\
3\end{array}$ & $\begin{array}{r}618 \\
440 \\
145 \\
20 \\
9 \\
3\end{array}$ & $\begin{array}{r}605 \\
427 \\
147 \\
20 \\
9 \\
3\end{array}$ \\
\hline 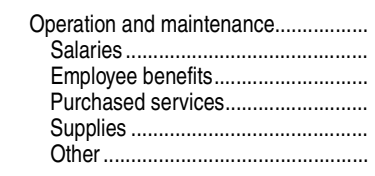 & $\begin{array}{r}517 \\
215 \\
64 \\
139 \\
91 \\
8\end{array}$ & $\begin{array}{r}574 \\
233 \\
70 \\
172 \\
94 \\
5\end{array}$ & $\begin{array}{r}666 \\
272 \\
75 \\
189 \\
124 \\
5\end{array}$ & $\begin{array}{r}721 \\
285 \\
80 \\
204 \\
146 \\
6\end{array}$ & $\begin{array}{r}902 \\
326 \\
119 \\
243 \\
207 \\
8\end{array}$ & $\begin{array}{r}1,003 \\
359 \\
136 \\
265 \\
234 \\
9\end{array}$ & $\begin{array}{r}1,027 \\
367 \\
140 \\
267 \\
245 \\
9\end{array}$ & $\begin{array}{r}1,014 \\
364 \\
143 \\
265 \\
233 \\
9\end{array}$ & $\begin{array}{r}1,015 \\
356 \\
145 \\
270 \\
235 \\
9\end{array}$ & $\begin{array}{r}892 \\
371 \\
110 \\
240 \\
158 \\
14\end{array}$ & $\begin{array}{r}859 \\
349 \\
105 \\
257 \\
141 \\
8\end{array}$ & $\begin{array}{r}910 \\
372 \\
103 \\
259 \\
169 \\
7\end{array}$ & $\begin{array}{r}953 \\
377 \\
106 \\
270 \\
192 \\
8\end{array}$ & $\begin{array}{r}1,049 \\
379 \\
138 \\
282 \\
240 \\
9\end{array}$ & $\begin{array}{r}1,096 \\
392 \\
149 \\
290 \\
256 \\
10\end{array}$ & $\begin{array}{r}1,107 \\
395 \\
151 \\
288 \\
264 \\
10\end{array}$ & $\begin{array}{r}1,082 \\
389 \\
152 \\
283 \\
248 \\
10\end{array}$ & $\begin{array}{r}1,062 \\
372 \\
152 \\
282 \\
246 \\
10\end{array}$ \\
\hline 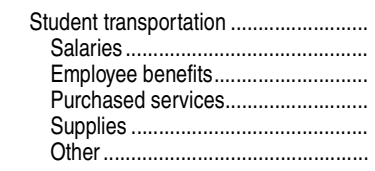 & $\begin{array}{r}211 \\
80 \\
22 \\
81 \\
23 \\
5\end{array}$ & $\begin{array}{r}232 \\
88 \\
27 \\
95 \\
19 \\
4\end{array}$ & $\begin{array}{r}278 \\
108 \\
31 \\
114 \\
22 \\
2\end{array}$ & $\begin{array}{r}298 \\
115 \\
34 \\
122 \\
25 \\
3\end{array}$ & $\begin{array}{r}384 \\
136 \\
52 \\
154 \\
38 \\
4\end{array}$ & $\begin{array}{r}438 \\
153 \\
58 \\
174 \\
49 \\
4\end{array}$ & $\begin{array}{r}440 \\
154 \\
60 \\
183 \\
40 \\
3\end{array}$ & $\begin{array}{r}442 \\
155 \\
62 \\
182 \\
40 \\
4\end{array}$ & $\begin{array}{r}452 \\
153 \\
63 \\
185 \\
47 \\
4\end{array}$ & $\begin{array}{r}364 \\
138 \\
37 \\
140 \\
40 \\
8\end{array}$ & $\begin{array}{r}347 \\
131 \\
40 \\
142 \\
28 \\
5\end{array}$ & $\begin{array}{r}379 \\
148 \\
43 \\
155 \\
30 \\
3\end{array}$ & $\begin{array}{r}393 \\
151 \\
45 \\
161 \\
32 \\
4\end{array}$ & $\begin{array}{r}446 \\
159 \\
60 \\
179 \\
44 \\
5\end{array}$ & $\begin{array}{r}478 \\
167 \\
64 \\
190 \\
54 \\
4\end{array}$ & $\begin{array}{r}475 \\
166 \\
64 \\
197 \\
43 \\
4\end{array}$ & $\begin{array}{r}472 \\
165 \\
66 \\
194 \\
43 \\
4\end{array}$ & $\begin{array}{r}473 \\
160 \\
66 \\
194 \\
49 \\
4\end{array}$ \\
\hline
\end{tabular}




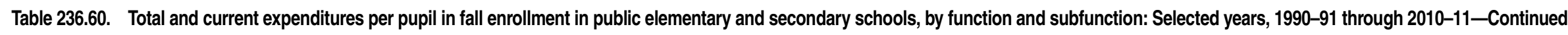

\begin{tabular}{|c|c|c|c|c|c|c|c|c|c|c|c|c|c|c|c|c|c|c|}
\hline \multirow[b]{2}{*}{ Function and subfunction } & \multicolumn{9}{|c|}{ Expenditures per pupil in current dollars } & \multicolumn{9}{|c|}{ Expenditures per pupil in constant 2012-13 dollars 1} \\
\hline & $1990-91$ & $1995-96$ & $1999-2000$ & $2000-01$ & $2005-06$ & $2007-08$ & $2008-09$ & $2009-10^{2}$ & $2010-11$ & $1990-91$ & $1995-96$ & $1999-2000$ & $2000-01$ & $2005-06$ & $2007-08$ & $2008-09$ & $2009-10^{2}$ & $2010-11$ \\
\hline 1 & 2 & 3 & 4 & 5 & 6 & 7 & 8 & 9 & 10 & 11 & 12 & 13 & 14 & 15 & 16 & 17 & 18 & 19 \\
\hline 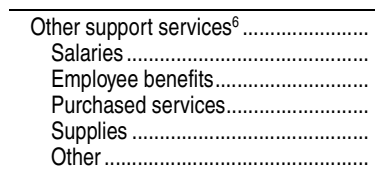 & \begin{tabular}{r|}
136 \\
70 \\
24 \\
19 \\
7 \\
15
\end{tabular} & \begin{tabular}{r|}
157 \\
77 \\
26 \\
30 \\
9 \\
14
\end{tabular} & \begin{tabular}{r|}
217 \\
105 \\
31 \\
53 \\
12 \\
17
\end{tabular} & \begin{tabular}{r|}
242 \\
117 \\
34 \\
59 \\
13 \\
19
\end{tabular} & \begin{tabular}{r|}
294 \\
134 \\
51 \\
70 \\
16 \\
23
\end{tabular} & $\begin{array}{r}331 \\
153 \\
61 \\
77 \\
20 \\
21\end{array}$ & $\begin{array}{r}349 \\
164 \\
64 \\
80 \\
18 \\
23\end{array}$ & \begin{tabular}{r|}
348 \\
165 \\
64 \\
79 \\
17 \\
23
\end{tabular} & $\begin{array}{r}347 \\
164 \\
65 \\
78 \\
18 \\
21\end{array}$ & \begin{tabular}{r|}
234 \\
122 \\
41 \\
33 \\
12 \\
26
\end{tabular} & \begin{tabular}{r|}
235 \\
115 \\
39 \\
46 \\
13 \\
22
\end{tabular} & $\begin{array}{r}297 \\
144 \\
42 \\
72 \\
17 \\
23\end{array}$ & $\begin{array}{r}320 \\
155 \\
45 \\
78 \\
18 \\
26\end{array}$ & \begin{tabular}{r|}
342 \\
156 \\
59 \\
82 \\
19 \\
27
\end{tabular} & \begin{tabular}{r|}
362 \\
167 \\
66 \\
84 \\
22 \\
23
\end{tabular} & \begin{tabular}{r|}
376 \\
177 \\
69 \\
86 \\
19 \\
25
\end{tabular} & \begin{tabular}{r|}
372 \\
177 \\
68 \\
85 \\
18 \\
24 \\
\end{tabular} & $\begin{array}{r}363 \\
172 \\
68 \\
82 \\
19 \\
22\end{array}$ \\
\hline 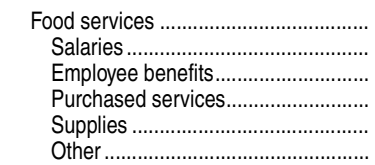 & $\begin{array}{l}205 \\
- \\
- \\
- \\
-\end{array}$ & $\begin{array}{r}237 \\
86 \\
25 \\
14 \\
110 \\
3\end{array}$ & $\begin{array}{r}276 \\
98 \\
27 \\
19 \\
129 \\
3\end{array}$ & $\begin{array}{r}293 \\
105 \\
29 \\
20 \\
136 \\
3\end{array}$ & $\begin{array}{r}352 \\
119 \\
42 \\
30 \\
157 \\
3\end{array}$ & $\begin{array}{r}390 \\
129 \\
46 \\
35 \\
177 \\
3\end{array}$ & $\begin{array}{r}402 \\
132 \\
48 \\
37 \\
181 \\
4\end{array}$ & $\begin{array}{r}405 \\
131 \\
49 \\
39 \\
181 \\
5\end{array}$ & $\begin{array}{r}412 \\
131 \\
50 \\
42 \\
184 \\
5\end{array}$ & $\begin{array}{l}353 \\
- \\
- \\
- \\
-\end{array}$ & $\begin{array}{r}356 \\
128 \\
37 \\
21 \\
164 \\
5\end{array}$ & $\begin{array}{r}378 \\
134 \\
37 \\
26 \\
176 \\
4\end{array}$ & $\begin{array}{r}387 \\
139 \\
39 \\
26 \\
180 \\
4\end{array}$ & $\begin{array}{r}409 \\
138 \\
49 \\
35 \\
183 \\
4\end{array}$ & $\begin{array}{r}426 \\
141 \\
50 \\
38 \\
194 \\
4\end{array}$ & $\begin{array}{r}433 \\
142 \\
51 \\
40 \\
195 \\
5\end{array}$ & $\begin{array}{r}433 \\
140 \\
52 \\
42 \\
194 \\
5\end{array}$ & $\begin{array}{r}431 \\
137 \\
53 \\
44 \\
193 \\
5\end{array}$ \\
\hline 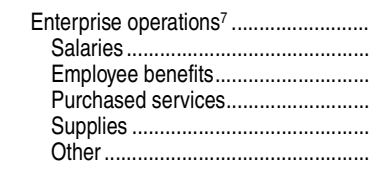 & $\begin{array}{l}23 \\
- \\
- \\
- \\
- \\
\end{array}$ & $\begin{array}{r}17 \\
4 \\
1 \\
4 \\
6 \\
2 \\
\end{array}$ & \begin{tabular}{r|}
17 \\
4 \\
1 \\
4 \\
6 \\
3 \\
\end{tabular} & $\begin{array}{r}16 \\
3 \\
1 \\
4 \\
5 \\
4 \\
\end{array}$ & $\begin{array}{r}21 \\
4 \\
2 \\
5 \\
6 \\
4 \\
\end{array}$ & $\begin{array}{r}24 \\
6 \\
2 \\
5 \\
7 \\
4 \\
\end{array}$ & $\begin{array}{r}26 \\
7 \\
2 \\
5 \\
7 \\
4 \\
\end{array}$ & \begin{tabular}{r|}
25 \\
7 \\
2 \\
5 \\
7 \\
4 \\
\end{tabular} & \begin{tabular}{r|}
25 \\
7 \\
2 \\
5 \\
7 \\
4 \\
\end{tabular} & $\begin{array}{l}40 \\
- \\
- \\
- \\
-\end{array}$ & $\begin{array}{r}26 \\
6 \\
1 \\
6 \\
9 \\
3 \\
\end{array}$ & $\begin{array}{r}24 \\
5 \\
1 \\
5 \\
8 \\
4 \\
\end{array}$ & $\begin{array}{r}22 \\
3 \\
1 \\
5 \\
7 \\
5 \\
\end{array}$ & \begin{tabular}{r|}
24 \\
5 \\
2 \\
5 \\
7 \\
5 \\
\end{tabular} & $\begin{array}{r}26 \\
7 \\
2 \\
5 \\
8 \\
5 \\
\end{array}$ & $\begin{array}{r}28 \\
7 \\
2 \\
6 \\
8 \\
5 \\
\end{array}$ & $\begin{array}{r}27 \\
7 \\
2 \\
6 \\
8 \\
5 \\
\end{array}$ & $\begin{array}{r}27 \\
7 \\
2 \\
5 \\
8 \\
4 \\
\end{array}$ \\
\hline Capital outlay ${ }^{8} \ldots \ldots \ldots \ldots \ldots$ & 477 & 612 & 923 & 976 & 1,166 & 1,348 & 1,336 & 1,148 & 1,028 & 824 & 917 & 1,261 & 1,290 & 1,356 & 1,473 & 1,440 & 1,225 & 1,076 \\
\hline Interest on school debt .............................. & 105 & 140 & 195 & 215 & 292 & 319 & 346 & 349 & 363 & 181 & 209 & 266 & 285 & 340 & 348 & 373 & 373 & 379 \\
\hline
\end{tabular}

\section{-Not available.}

Constant dollars based on the Consumer Price Index, prepared by the Bureau of Labor Statistics, U.S. Department of Labor, adjusted to a school-year basis.

d enterprise operations

Includes expenditures for curriculum development, staff training, libraries, and media and computer centers.

Includes business support services concerned with paying, transporting, exchanging, and maintaining goods and services for local education agencies; central support services, including planning, research, evaluation, information, staff, and data

processing services;
Includes expenditures for operations funded by sales of products or services (e.g., school bookstore or computer time). Includes very small amounts for direct program support made by state education agencies for local school districts.

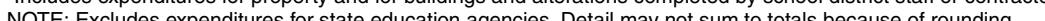

SOURCE: U.S. Department of Education, National Center for Education Statistics, Common Core of Data (CCD), "National Public Education Financial Survey," 1990-91 through 2010-11. (This table was prepared July 2013.) 
370 CHAPTER 2: Elementary and Secondary Education Expenditures

Table 236.65. Current expenditure per pupil in fall enrollment in public elementary and secondary schools, by state or jurisdiction: Selected years, 1969-70 through 2010-11

\begin{tabular}{|c|c|c|c|c|c|c|c|c|c|c|c|c|c|c|}
\hline \multirow[b]{2}{*}{ State or jurisdiction } & \multicolumn{14}{|c|}{ Unadjusted dollars ${ }^{1}$} \\
\hline & $1969-70$ & $1979-80$ & $1989-90$ & 1999-2000 & $2001-02$ & $2002-03$ & 2003-04 & $2004-05$ & $2005-06$ & $2006-07$ & $2007-08$ & $2008-09$ & $2009-10$ & $2010-11$ \\
\hline 1 & 2 & 3 & 4 & 5 & 6 & 7 & 8 & 9 & 10 & 11 & 12 & 13 & 14 & 15 \\
\hline United States ................... & $\$ 751$ & $\$ 2,088$ & $\$ 4,643$ & $\$ 6,912$ & $\$ 7,727$ & $\$ 8,044$ & $\$ 8,310$ & $\$ 8,711$ & $\$ 9,145$ & $\$ 9,679$ & $\$ 10,298$ & $\$ 10,540$ & $\$ 10,636$ & $\$ 10,658$ \\
\hline 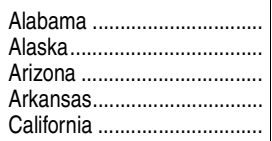 & $\begin{array}{r}512 \\
1,059 \\
674 \\
511 \\
833\end{array}$ & $\begin{array}{l}1,520 \\
4,267 \\
1,865 \\
1,472 \\
2,227\end{array}$ & $\begin{array}{l}3,144 \\
7,577 \\
3,717 \\
3,229 \\
4,502\end{array}$ & $\begin{array}{l}5,638 \\
8,806 \\
5,030 \\
5,277 \\
6,314\end{array}$ & $\begin{array}{l}6,029 \\
9,564 \\
5,851 \\
6,276 \\
7,405\end{array}$ & $\begin{array}{l}6,300 \\
9,870 \\
6,283 \\
6,482 \\
7,552\end{array}$ & $\begin{array}{r}6,581 \\
10,116 \\
5,999 \\
6,842 \\
7,673\end{array}$ & $\begin{array}{r}7,073 \\
10,847 \\
6,307 \\
7,659 \\
7,905\end{array}$ & $\begin{array}{r}7,683 \\
11,476 \\
6,515 \\
8,030 \\
8,301\end{array}$ & $\begin{array}{r}8,398 \\
12,324 \\
7,316 \\
8,391 \\
8,952\end{array}$ & $\begin{array}{r}9,197 \\
14,641 \\
7,727 \\
8,677 \\
9,706\end{array}$ & $\begin{array}{r}8,964 \\
15,363 \\
8,022 \\
8,854 \\
9,503\end{array}$ & $\begin{array}{r}8,907 \\
15,829 \\
7,870 \\
9,281 \\
9,300\end{array}$ & $\begin{array}{r}8,726 \\
16,663 \\
7,782 \\
9,496 \\
9,146\end{array}$ \\
\hline 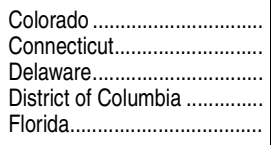 & $\begin{array}{l}686 \\
911 \\
833 \\
947 \\
683\end{array}$ & $\begin{array}{l}2,258 \\
2,167 \\
2,587 \\
2,811 \\
1,834\end{array}$ & $\begin{array}{l}4,357 \\
7,463 \\
5,326 \\
7,872 \\
4,597\end{array}$ & $\begin{array}{r}6,215 \\
9,753 \\
8,310 \\
10,107 \\
5,831\end{array}$ & $\begin{array}{r}6,941 \\
10,577 \\
9,285 \\
12,102 \\
6,213\end{array}$ & $\begin{array}{r}7,384 \\
11,057 \\
9,693 \\
11,847 \\
6,439\end{array}$ & $\begin{array}{r}7,478 \\
11,436 \\
10,212 \\
12,959 \\
6,793\end{array}$ & $\begin{array}{r}7,826 \\
12,263 \\
10,911 \\
13,915 \\
7,215\end{array}$ & $\begin{array}{r}8,166 \\
13,072 \\
11,621 \\
13,752 \\
7,812\end{array}$ & $\begin{array}{r}8,286 \\
13,659 \\
11,760 \\
15,511 \\
8,567\end{array}$ & $\begin{array}{r}9,152 \\
14,610 \\
12,153 \\
16,353 \\
9,084\end{array}$ & $\begin{array}{r}8,782 \\
15,353 \\
12,109 \\
19,698 \\
8,867\end{array}$ & $\begin{array}{r}8,926 \\
15,698 \\
12,222 \\
20,910 \\
8,863\end{array}$ & $\begin{array}{r}8,786 \\
16,224 \\
12,467 \\
20,793 \\
9,030\end{array}$ \\
\hline 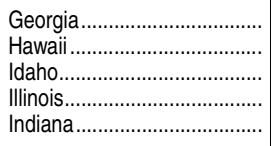 & $\begin{array}{l}539 \\
792 \\
573 \\
816 \\
661\end{array}$ & $\begin{array}{l}1,491 \\
2,086 \\
1,548 \\
2,241 \\
1,708\end{array}$ & $\begin{array}{l}4,000 \\
4,130 \\
2,921 \\
4,521 \\
4,270\end{array}$ & $\begin{array}{l}6,437 \\
6,530 \\
5,315 \\
7,133 \\
7,192\end{array}$ & $\begin{array}{l}7,380 \\
7,306 \\
6,011 \\
7,956 \\
7,734\end{array}$ & $\begin{array}{l}7,774 \\
8,100 \\
6,081 \\
8,287 \\
8,057\end{array}$ & $\begin{array}{l}7,742 \\
8,533 \\
6,168 \\
8,606 \\
8,431\end{array}$ & $\begin{array}{l}8,065 \\
8,997 \\
6,319 \\
8,896 \\
8,919\end{array}$ & $\begin{array}{l}8,595 \\
9,876 \\
6,469 \\
9,113 \\
8,929\end{array}$ & $\begin{array}{r}9,102 \\
11,316 \\
6,648 \\
9,596 \\
9,080\end{array}$ & $\begin{array}{r}9,718 \\
11,800 \\
6,951 \\
10,353 \\
8,867\end{array}$ & $\begin{array}{r}9,649 \\
12,400 \\
7,118 \\
11,097 \\
9,254\end{array}$ & $\begin{array}{r}9,432 \\
11,855 \\
7,100 \\
11,739 \\
9,479\end{array}$ & $\begin{array}{r}9,259 \\
11,924 \\
6,821 \\
11,742 \\
9,251\end{array}$ \\
\hline 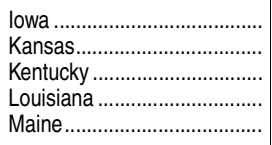 & $\begin{array}{l}798 \\
699 \\
502 \\
589 \\
649\end{array}$ & $\begin{array}{l}2,164 \\
1,963 \\
1,557 \\
1,629 \\
1,692\end{array}$ & $\begin{array}{l}4,190 \\
4,290 \\
3,384 \\
3,625 \\
4,903\end{array}$ & $\begin{array}{l}6,564 \\
6,294 \\
5,921 \\
5,804 \\
7,667\end{array}$ & $\begin{array}{l}7,338 \\
7,339 \\
6,523 \\
6,567 \\
8,818\end{array}$ & $\begin{array}{l}7,574 \\
7,454 \\
6,661 \\
6,922 \\
9,344\end{array}$ & $\begin{array}{l}7,626 \\
7,776 \\
6,864 \\
7,271 \\
9,746\end{array}$ & $\begin{array}{r}7,962 \\
7,926 \\
7,132 \\
7,669 \\
10,342\end{array}$ & $\begin{array}{r}8,355 \\
8,640 \\
7,668 \\
8,486 \\
10,841\end{array}$ & $\begin{array}{r}8,791 \\
9,243 \\
7,941 \\
8,937 \\
11,644\end{array}$ & $\begin{array}{r}9,520 \\
9,894 \\
8,740 \\
10,006 \\
11,761\end{array}$ & $\begin{array}{r}9,704 \\
10,204 \\
8,786 \\
10,625 \\
12,183\end{array}$ & $\begin{array}{r}9,748 \\
9,972 \\
8,957 \\
10,701 \\
12,525\end{array}$ & $\begin{array}{r}9,795 \\
9,802 \\
9,228 \\
10,799 \\
12,576\end{array}$ \\
\hline 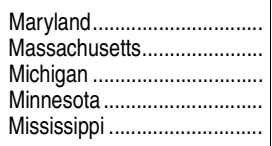 & $\begin{array}{l}809 \\
791 \\
841 \\
855 \\
457\end{array}$ & $\begin{array}{l}2,293 \\
2,548 \\
2,495 \\
2,296 \\
1,568\end{array}$ & $\begin{array}{l}5,573 \\
5,766 \\
5,090 \\
4,698 \\
2,934\end{array}$ & $\begin{array}{l}7,731 \\
8,816 \\
8,110 \\
7,190 \\
5,014\end{array}$ & $\begin{array}{r}8,692 \\
10,232 \\
8,653 \\
7,736 \\
5,354\end{array}$ & $\begin{array}{r}9,153 \\
10,460 \\
8,781 \\
8,109 \\
5,792\end{array}$ & $\begin{array}{r}9,433 \\
11,015 \\
9,094 \\
8,405 \\
6,199\end{array}$ & $\begin{array}{r}10,031 \\
11,642 \\
9,338 \\
8,718 \\
6,548\end{array}$ & $\begin{array}{r}10,909 \\
12,087 \\
9,575 \\
9,159 \\
7,173\end{array}$ & $\begin{array}{r}11,989 \\
12,784 \\
9,876 \\
9,589 \\
7,459\end{array}$ & $\begin{array}{r}13,257 \\
13,690 \\
10,075 \\
10,060 \\
7,890\end{array}$ & $\begin{array}{r}13,737 \\
14,534 \\
10,373 \\
10,983 \\
8,064\end{array}$ & $\begin{array}{r}14,007 \\
13,956 \\
10,447 \\
10,665 \\
8,104\end{array}$ & $\begin{array}{r}14,123 \\
14,285 \\
10,577 \\
10,674 \\
7,926\end{array}$ \\
\hline 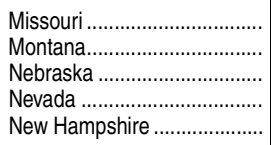 & $\begin{array}{l}596 \\
728 \\
700 \\
706 \\
666\end{array}$ & $\begin{array}{l}1,724 \\
2,264 \\
2,025 \\
1,908 \\
1,732\end{array}$ & $\begin{array}{l}4,071 \\
4,240 \\
4,553 \\
3,816 \\
4,786\end{array}$ & $\begin{array}{l}6,187 \\
6,314 \\
6,683 \\
5,760 \\
6,860\end{array}$ & $\begin{array}{l}7,136 \\
7,062 \\
7,741 \\
6,079 \\
7,935\end{array}$ & $\begin{array}{l}7,495 \\
7,496 \\
8,074 \\
6,092 \\
8,579\end{array}$ & $\begin{array}{l}7,542 \\
7,825 \\
8,452 \\
6,410 \\
9,161\end{array}$ & $\begin{array}{l}7,858 \\
8,133 \\
8,794 \\
6,804 \\
9,771\end{array}$ & $\begin{array}{r}8,273 \\
8,626 \\
9,324 \\
7,177 \\
10,396\end{array}$ & $\begin{array}{r}8,848 \\
9,191 \\
10,068 \\
7,796 \\
11,036\end{array}$ & $\begin{array}{r}9,532 \\
9,786 \\
10,565 \\
8,187 \\
11,951\end{array}$ & $\begin{array}{r}9,617 \\
10,120 \\
10,846 \\
8,321 \\
12,583\end{array}$ & $\begin{array}{r}9,721 \\
10,565 \\
11,339 \\
8,376 \\
13,072\end{array}$ & $\begin{array}{r}9,461 \\
10,719 \\
11,540 \\
8,411 \\
13,548\end{array}$ \\
\hline 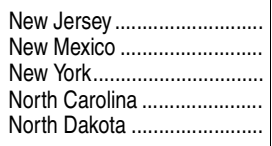 & $\begin{array}{r}924 \\
665 \\
1,194 \\
570 \\
662\end{array}$ & $\begin{array}{l}2,825 \\
1,870 \\
2,950 \\
1,635 \\
1,941\end{array}$ & $\begin{array}{l}7,546 \\
3,446 \\
7,051 \\
4,018 \\
3,899\end{array}$ & $\begin{array}{r}10,337 \\
5,825 \\
9,846 \\
6,045 \\
5,667\end{array}$ & $\begin{array}{r}11,793 \\
6,882 \\
11,218 \\
6,495 \\
6,709\end{array}$ & $\begin{array}{r}12,568 \\
7,125 \\
11,961 \\
6,562 \\
6,870\end{array}$ & $\begin{array}{r}13,338 \\
7,572 \\
12,638 \\
6,613 \\
7,333\end{array}$ & $\begin{array}{r}14,117 \\
7,834 \\
13,703 \\
7,098 \\
8,279\end{array}$ & $\begin{array}{r}14,954 \\
8,354 \\
14,615 \\
7,396 \\
8,728\end{array}$ & $\begin{array}{r}16,163 \\
8,849 \\
15,546 \\
7,878 \\
8,671\end{array}$ & $\begin{array}{r}17,620 \\
9,291 \\
16,794 \\
7,798 \\
9,324\end{array}$ & $\begin{array}{r}16,973 \\
9,648 \\
17,746 \\
8,463 \\
9,802\end{array}$ & $\begin{array}{r}17,379 \\
9,621 \\
18,167 \\
8,225 \\
10,519\end{array}$ & $\begin{array}{r}16,855 \\
9,250 \\
18,834 \\
8,267 \\
10,898\end{array}$ \\
\hline 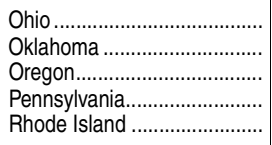 & $\begin{array}{l}677 \\
554 \\
843 \\
815 \\
807\end{array}$ & $\begin{array}{l}1,894 \\
1,810 \\
2,412 \\
2,328 \\
2,340\end{array}$ & $\begin{array}{l}4,531 \\
3,293 \\
4,864 \\
5,737 \\
5,908\end{array}$ & $\begin{array}{l}7,065 \\
5,395 \\
7,149 \\
7,772 \\
8,904\end{array}$ & $\begin{array}{l}8,069 \\
6,229 \\
7,642 \\
8,537 \\
9,703\end{array}$ & $\begin{array}{r}8,632 \\
6,092 \\
7,491 \\
8,997 \\
10,349\end{array}$ & $\begin{array}{r}9,029 \\
6,154 \\
7,618 \\
9,708 \\
11,078\end{array}$ & $\begin{array}{r}9,330 \\
6,610 \\
8,069 \\
10,235 \\
11,667\end{array}$ & $\begin{array}{r}9,692 \\
6,941 \\
8,645 \\
10,723 \\
12,609\end{array}$ & $\begin{array}{r}9,937 \\
7,430 \\
8,958 \\
10,905 \\
13,453\end{array}$ & $\begin{array}{r}10,340 \\
7,683 \\
9,565 \\
11,741 \\
14,459\end{array}$ & $\begin{array}{r}10,669 \\
7,878 \\
9,611 \\
12,299 \\
14,719\end{array}$ & $\begin{array}{r}11,224 \\
7,929 \\
9,268 \\
12,729 \\
14,723\end{array}$ & $\begin{array}{r}11,395 \\
7,631 \\
9,516 \\
13,096 \\
14,948\end{array}$ \\
\hline 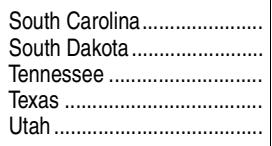 & $\begin{array}{l}567 \\
656 \\
531 \\
551 \\
595\end{array}$ & $\begin{array}{l}1,597 \\
1,781 \\
1,523 \\
1,740 \\
1,556\end{array}$ & $\begin{array}{l}3,769 \\
3,511 \\
3,405 \\
3,835 \\
2,577\end{array}$ & $\begin{array}{l}6,130 \\
5,632 \\
5,383 \\
6,288 \\
4,378\end{array}$ & $\begin{array}{l}7,017 \\
6,424 \\
5,948 \\
6,771 \\
4,899\end{array}$ & $\begin{array}{l}7,040 \\
6,547 \\
6,118 \\
7,136 \\
4,838\end{array}$ & $\begin{array}{l}7,177 \\
7,068 \\
6,466 \\
7,151 \\
4,991\end{array}$ & $\begin{array}{l}7,549 \\
7,464 \\
6,850 \\
7,246 \\
5,216\end{array}$ & $\begin{array}{l}8,120 \\
7,775 \\
7,004 \\
7,480 \\
5,464\end{array}$ & $\begin{array}{l}8,507 \\
8,064 \\
7,129 \\
7,850 \\
5,709\end{array}$ & $\begin{array}{l}9,060 \\
8,535 \\
7,820 \\
8,350 \\
5,978\end{array}$ & $\begin{array}{l}9,228 \\
8,543 \\
7,992 \\
8,562 \\
6,612\end{array}$ & $\begin{array}{l}9,080 \\
9,020 \\
8,117 \\
8,788 \\
6,452\end{array}$ & $\begin{array}{l}8,903 \\
8,931 \\
8,484 \\
8,685 \\
6,326\end{array}$ \\
\hline 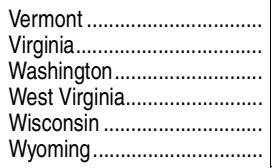 & $\begin{array}{l}790 \\
654 \\
853 \\
621 \\
793 \\
805\end{array}$ & $\begin{array}{l}1,930 \\
1,824 \\
2,387 \\
1,749 \\
2,225 \\
2,369\end{array}$ & $\begin{array}{l}5,770 \\
4,690 \\
4,382 \\
4,020 \\
5,020 \\
5,239\end{array}$ & $\begin{array}{l}8,323 \\
6,841 \\
6,376 \\
7,152 \\
7,806 \\
7,425\end{array}$ & $\begin{array}{l}9,806 \\
7,496 \\
7,039 \\
7,844 \\
8,634 \\
8,645\end{array}$ & $\begin{array}{r}10,454 \\
7,822 \\
7,252 \\
8,319 \\
9,004 \\
8,985\end{array}$ & $\begin{array}{r}11,211 \\
8,219 \\
7,391 \\
8,588 \\
9,240 \\
9,308\end{array}$ & $\begin{array}{r}11,972 \\
8,886 \\
7,717 \\
9,024 \\
9,755 \\
10,190\end{array}$ & $\begin{array}{r}12,805 \\
9,452 \\
7,984 \\
9,440 \\
9,993 \\
11,437\end{array}$ & $\begin{array}{r}13,629 \\
10,214 \\
8,524 \\
9,727 \\
10,372 \\
13,266\end{array}$ & $\begin{array}{r}14,421 \\
10,664 \\
9,058 \\
10,059 \\
10,791 \\
13,856\end{array}$ & $\begin{array}{r}15,096 \\
10,928 \\
9,585 \\
10,606 \\
11,183 \\
14,628\end{array}$ & $\begin{array}{r}15,666 \\
10,594 \\
9,497 \\
11,774 \\
11,507 \\
15,232\end{array}$ & $\begin{array}{r}14,707 \\
10,363 \\
9,619 \\
11,978 \\
11,946 \\
15,815\end{array}$ \\
\hline $\begin{array}{l}\text { Other jurisdictions } \\
\text { American Samoa ............... } \\
\text { Guam ........................... } \\
\text { Northern Marianas............ } \\
\text { Puerto Rico .................... } \\
\text { U.S. Virgin Islands............. }\end{array}$ & $\begin{array}{c}-\overline{766} \\
- \\
- \\
-\end{array}$ & $\begin{array}{l}- \\
- \\
- \\
-\end{array}$ & $\begin{array}{l}1,781 \\
3,817 \\
3,356 \\
1,605 \\
6,043\end{array}$ & $\begin{array}{r}2,739 \\
- \\
5,120 \\
3,404 \\
6,478\end{array}$ & $\begin{array}{r}2,906 \\
- \\
4,438 \\
3,563 \\
5,716\end{array}$ & $\begin{array}{r}2,976 \\
- \\
4,519 \\
4,260 \\
6,840\end{array}$ & $\begin{array}{l}3,493 \\
5,781 \\
4,241 \\
4,147 \\
7,239\end{array}$ & $\begin{array}{r}3,607 \\
- \\
5,034 \\
4,979 \\
8,387\end{array}$ & $\begin{array}{l}3,561 \\
6,781 \\
4,924 \\
5,470 \\
8,768\end{array}$ & $\begin{array}{r}3,481 \\
- \\
4,707 \\
6,006 \\
9,669\end{array}$ & $\begin{array}{r}- \\
- \\
4,535 \\
6,520 \\
12,358\end{array}$ & $\begin{array}{r}- \\
- \\
5,753 \\
6,955 \\
12,768\end{array}$ & $\begin{array}{r}- \\
- \\
5,676 \\
7,021 \\
14,215\end{array}$ & $\begin{array}{r}- \\
8,443 \\
7,623 \\
7,429 \\
13,689\end{array}$ \\
\hline
\end{tabular}

See notes at end of table. 
Table 236.65. Current expenditure per pupil in fall enrollment in public elementary and secondary schools, by state or jurisdiction: Selected years, 1969-70 through 2010-11-Continued

\begin{tabular}{|c|c|c|c|c|c|c|c|c|c|c|c|c|c|c|}
\hline \multirow[b]{2}{*}{ State or jurisdiction } & \multicolumn{14}{|c|}{ Constant 2012-13 dollars 2} \\
\hline & $1969-70$ & $1979-80$ & $1989-90$ & 1999-2000 & $2001-02$ & $2002-03$ & $2003-04$ & $2004-05$ & $2005-06$ & $2006-07$ & $2007-08$ & 2008-09 & $2009-10$ & $2010-11$ \\
\hline 1 & 16 & 17 & 18 & 19 & 20 & 21 & 22 & 23 & 24 & 25 & 26 & 27 & 28 & 29 \\
\hline United States .. & $\$ 4,601$ & $\$ 6,224$ & $\$ 8,459$ & $\$ 9,446$ & $\$ 10,033$ & $\$ 10,219$ & $\$ 10,332$ & $\$ 10,513$ & $\$ 10,632$ & $\$ 10,969$ & $\$ 11,254$ & $\$ 11,359$ & $\$ 11,353$ & $\$ 11,153$ \\
\hline 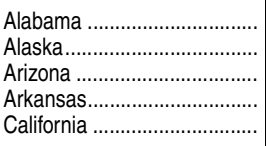 & $\begin{array}{l}3,133 \\
6,487 \\
4,130 \\
3,129 \\
5,104\end{array}$ & $\begin{array}{r}4,531 \\
12,716 \\
5,558 \\
4,386 \\
6,635\end{array}$ & $\begin{array}{r}5,728 \\
13,806 \\
6,773 \\
5,884 \\
8,204\end{array}$ & $\begin{array}{r}7,705 \\
12,035 \\
6,874 \\
7,212 \\
8,629\end{array}$ & $\begin{array}{r}7,827 \\
12,417 \\
7,597 \\
8,148 \\
9,614\end{array}$ & $\begin{array}{r}8,003 \\
12,539 \\
7,982 \\
8,235 \\
9,594\end{array}$ & $\begin{array}{r}8,182 \\
12,576 \\
7,459 \\
8,506 \\
9,540\end{array}$ & $\begin{array}{r}8,537 \\
13,091 \\
7,612 \\
9,244 \\
9,540\end{array}$ & $\begin{array}{r}8,933 \\
13,342 \\
7,574 \\
9,336 \\
9,651\end{array}$ & $\begin{array}{r}9,518 \\
13,967 \\
8,292 \\
9,510 \\
10,145\end{array}$ & $\begin{array}{r}10,050 \\
16,000 \\
8,445 \\
9,482 \\
10,607\end{array}$ & $\begin{array}{r}9,661 \\
16,557 \\
8,646 \\
9,543 \\
10,242\end{array}$ & $\begin{array}{r}9,508 \\
16,896 \\
8,401 \\
9,907 \\
9,927\end{array}$ & $\begin{array}{r}9,131 \\
17,437 \\
8,143 \\
9,937 \\
9,571\end{array}$ \\
\hline 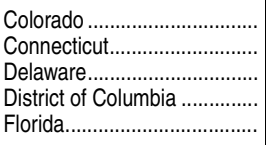 & $\begin{array}{l}4,202 \\
5,578 \\
5,105 \\
5,799 \\
4,181\end{array}$ & $\begin{array}{l}6,729 \\
6,458 \\
7,709 \\
8,378 \\
5,466\end{array}$ & $\begin{array}{r}7,938 \\
13,597 \\
9,705 \\
14,343 \\
8,376\end{array}$ & $\begin{array}{r}8,494 \\
13,328 \\
11,356 \\
13,812 \\
7,969\end{array}$ & $\begin{array}{r}9,011 \\
13,732 \\
12,054 \\
15,713 \\
8,067\end{array}$ & $\begin{array}{r}9,380 \\
14,047 \\
12,315 \\
15,050 \\
8,180\end{array}$ & $\begin{array}{r}9,297 \\
14,217 \\
12,696 \\
16,111 \\
8,446\end{array}$ & $\begin{array}{r}9,445 \\
14,800 \\
13,168 \\
16,794 \\
8,708\end{array}$ & $\begin{array}{r}9,494 \\
15,197 \\
13,511 \\
15,988 \\
9,082\end{array}$ & $\begin{array}{r}9,390 \\
15,480 \\
13,328 \\
17,579 \\
9,709\end{array}$ & $\begin{array}{r}10,002 \\
15,966 \\
13,281 \\
17,871 \\
9,927\end{array}$ & $\begin{array}{r}9,465 \\
16,547 \\
13,050 \\
21,230 \\
9,556\end{array}$ & $\begin{array}{r}9,527 \\
16,757 \\
13,047 \\
22,321 \\
9,461\end{array}$ & $\begin{array}{r}9,194 \\
16,977 \\
13,046 \\
21,758 \\
9,450\end{array}$ \\
\hline 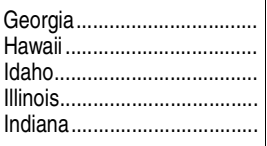 & $\begin{array}{l}3,300 \\
4,850 \\
3,511 \\
4,996 \\
4,049\end{array}$ & $\begin{array}{l}4,443 \\
6,218 \\
4,614 \\
6,679 \\
5,090\end{array}$ & $\begin{array}{l}7,288 \\
7,525 \\
5,322 \\
8,237 \\
7,781\end{array}$ & $\begin{array}{l}8,797 \\
8,924 \\
7,263 \\
9,748 \\
9,829\end{array}$ & $\begin{array}{r}9,582 \\
9,486 \\
7,804 \\
10,330 \\
10,042\end{array}$ & $\begin{array}{r}9,877 \\
10,291 \\
7,726 \\
10,528 \\
10,236\end{array}$ & $\begin{array}{r}9,625 \\
10,609 \\
7,668 \\
10,700 \\
10,482\end{array}$ & $\begin{array}{r}9,734 \\
10,858 \\
7,626 \\
10,736 \\
10,764\end{array}$ & $\begin{array}{r}9,993 \\
11,482 \\
7,521 \\
10,595 \\
10,381\end{array}$ & $\begin{array}{r}10,315 \\
12,825 \\
7,534 \\
10,875 \\
10,290\end{array}$ & $\begin{array}{r}10,620 \\
12,895 \\
7,596 \\
11,314 \\
9,690\end{array}$ & $\begin{array}{r}10,400 \\
13,364 \\
7,671 \\
11,960 \\
9,974\end{array}$ & $\begin{array}{r}10,069 \\
12,654 \\
7,579 \\
12,530 \\
10,118\end{array}$ & $\begin{array}{r}9,689 \\
12,478 \\
7,138 \\
12,287 \\
9,681\end{array}$ \\
\hline 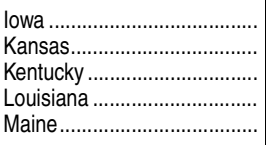 & $\begin{array}{l}4,888 \\
4,280 \\
3,074 \\
3,610 \\
3,976\end{array}$ & $\begin{array}{l}6,449 \\
5,849 \\
4,641 \\
4,855 \\
5,042\end{array}$ & $\begin{array}{l}7,634 \\
7,816 \\
6,165 \\
6,604 \\
8,934\end{array}$ & $\begin{array}{r}8,970 \\
8,601 \\
8,091 \\
7,932 \\
10,478\end{array}$ & $\begin{array}{r}9,527 \\
9,529 \\
8,469 \\
8,526 \\
11,448\end{array}$ & $\begin{array}{r}9,621 \\
9,470 \\
8,463 \\
8,794 \\
11,870\end{array}$ & $\begin{array}{r}9,481 \\
9,667 \\
8,533 \\
9,039 \\
12,116\end{array}$ & $\begin{array}{r}9,609 \\
9,565 \\
8,607 \\
9,256 \\
12,482\end{array}$ & $\begin{array}{r}9,713 \\
10,045 \\
8,916 \\
9,866 \\
12,604\end{array}$ & $\begin{array}{r}9,963 \\
10,475 \\
8,999 \\
10,129 \\
13,196\end{array}$ & $\begin{array}{r}10,403 \\
10,813 \\
9,551 \\
10,935 \\
12,853\end{array}$ & $\begin{array}{r}10,459 \\
10,997 \\
9,469 \\
11,451 \\
13,130\end{array}$ & $\begin{array}{r}10,405 \\
10,645 \\
9,561 \\
11,423 \\
13,370\end{array}$ & $\begin{array}{r}10,249 \\
10,257 \\
9,656 \\
11,300 \\
13,160\end{array}$ \\
\hline 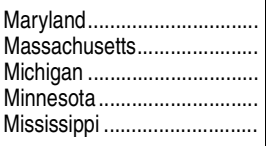 & $\begin{array}{l}4,956 \\
4,842 \\
5,154 \\
5,235 \\
2,797\end{array}$ & $\begin{array}{l}6,832 \\
7,592 \\
7,437 \\
6,844 \\
4,674\end{array}$ & $\begin{array}{r}10,155 \\
10,506 \\
9,274 \\
8,560 \\
5,345\end{array}$ & $\begin{array}{r}10,565 \\
12,048 \\
11,083 \\
9,826 \\
6,851\end{array}$ & $\begin{array}{r}11,285 \\
13,285 \\
11,234 \\
10,044 \\
6,951\end{array}$ & $\begin{array}{r}11,628 \\
13,288 \\
11,155 \\
10,302 \\
7,359\end{array}$ & $\begin{array}{r}11,727 \\
13,694 \\
11,305 \\
10,449 \\
7,707\end{array}$ & $\begin{array}{r}12,107 \\
14,051 \\
11,270 \\
10,522 \\
7,903\end{array}$ & $\begin{array}{r}12,683 \\
14,052 \\
11,132 \\
10,648 \\
8,339\end{array}$ & $\begin{array}{r}13,587 \\
14,488 \\
11,193 \\
10,868 \\
8,453\end{array}$ & $\begin{array}{r}14,487 \\
14,961 \\
11,010 \\
10,994 \\
8,622\end{array}$ & $\begin{array}{r}14,805 \\
15,665 \\
11,179 \\
11,837 \\
8,691\end{array}$ & $\begin{array}{r}14,952 \\
14,897 \\
11,151 \\
11,384 \\
8,650\end{array}$ & $\begin{array}{r}14,779 \\
14,948 \\
11,068 \\
11,169 \\
8,294\end{array}$ \\
\hline 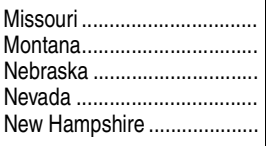 & $\begin{array}{l}3,650 \\
4,456 \\
4,286 \\
4,322 \\
4,079\end{array}$ & $\begin{array}{l}5,138 \\
6,746 \\
6,033 \\
5,686 \\
5,162\end{array}$ & $\begin{array}{l}7,417 \\
7,725 \\
8,295 \\
6,952 \\
8,720\end{array}$ & $\begin{array}{l}8,455 \\
8,628 \\
9,133 \\
7,871 \\
9,375\end{array}$ & $\begin{array}{r}9,264 \\
9,168 \\
10,050 \\
7,892 \\
10,303\end{array}$ & $\begin{array}{r}9,521 \\
9,522 \\
10,257 \\
7,740 \\
10,899\end{array}$ & $\begin{array}{r}9,376 \\
9,728 \\
10,508 \\
7,970 \\
11,390\end{array}$ & $\begin{array}{r}9,484 \\
9,816 \\
10,613 \\
8,212 \\
11,793\end{array}$ & $\begin{array}{r}9,619 \\
10,029 \\
10,840 \\
8,344 \\
12,086\end{array}$ & $\begin{array}{r}10,027 \\
10,417 \\
11,410 \\
8,835 \\
12,508\end{array}$ & $\begin{array}{r}10,417 \\
10,695 \\
11,545 \\
8,946 \\
13,060\end{array}$ & $\begin{array}{r}10,365 \\
10,907 \\
11,689 \\
8,968 \\
13,562\end{array}$ & $\begin{array}{r}10,376 \\
11,278 \\
12,104 \\
8,941 \\
13,953\end{array}$ & $\begin{array}{r}9,900 \\
11,217 \\
12,075 \\
8,802 \\
14,177\end{array}$ \\
\hline 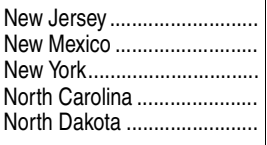 & $\begin{array}{l}5,658 \\
4,073 \\
7,315 \\
3,493 \\
4,057\end{array}$ & $\begin{array}{l}8,420 \\
5,574 \\
8,793 \\
4,874 \\
5,786\end{array}$ & $\begin{array}{r}13,749 \\
6,278 \\
12,847 \\
7,322 \\
7,104\end{array}$ & $\begin{array}{r}14,127 \\
7,961 \\
13,455 \\
8,261 \\
7,744\end{array}$ & $\begin{array}{r}15,312 \\
8,936 \\
14,564 \\
8,433 \\
8,710\end{array}$ & $\begin{array}{r}15,967 \\
9,051 \\
15,196 \\
8,337 \\
8,727\end{array}$ & $\begin{array}{r}16,582 \\
9,413 \\
15,712 \\
8,221 \\
9,117\end{array}$ & $\begin{array}{r}17,037 \\
9,455 \\
16,538 \\
8,566 \\
9,992\end{array}$ & $\begin{array}{r}17,386 \\
9,712 \\
16,992 \\
8,599 \\
10,147\end{array}$ & $\begin{array}{r}18,318 \\
10,029 \\
17,619 \\
8,928 \\
9,827\end{array}$ & $\begin{array}{r}19,256 \\
10,153 \\
18,353 \\
8,522 \\
10,189\end{array}$ & $\begin{array}{r}18,293 \\
10,398 \\
19,126 \\
9,121 \\
10,564\end{array}$ & $\begin{array}{r}18,551 \\
10,269 \\
19,392 \\
8,779 \\
11,229\end{array}$ & $\begin{array}{r}17,637 \\
9,679 \\
19,708 \\
8,651 \\
11,404\end{array}$ \\
\hline 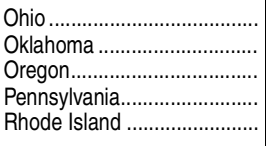 & $\begin{array}{l}4,143 \\
3,391 \\
5,164 \\
4,993 \\
4,941\end{array}$ & $\begin{array}{l}5,645 \\
5,393 \\
7,189 \\
6,939 \\
6,974\end{array}$ & $\begin{array}{r}8,255 \\
6,000 \\
8,863 \\
10,453 \\
10,765\end{array}$ & $\begin{array}{r}9,654 \\
7,372 \\
9,769 \\
10,622 \\
12,169\end{array}$ & $\begin{array}{r}10,476 \\
8,088 \\
9,922 \\
11,084 \\
12,597\end{array}$ & $\begin{array}{r}10,966 \\
7,739 \\
9,517 \\
11,429 \\
13,147\end{array}$ & $\begin{array}{r}11,225 \\
7,651 \\
9,471 \\
12,070 \\
13,773\end{array}$ & $\begin{array}{r}11,261 \\
7,978 \\
9,738 \\
12,353 \\
14,081\end{array}$ & $\begin{array}{r}11,268 \\
8,070 \\
10,051 \\
12,467 \\
14,659\end{array}$ & $\begin{array}{r}11,262 \\
8,420 \\
10,152 \\
12,359 \\
15,246\end{array}$ & $\begin{array}{r}11,299 \\
8,396 \\
10,452 \\
12,831 \\
15,801\end{array}$ & $\begin{array}{r}11,499 \\
8,491 \\
10,358 \\
13,256 \\
15,864\end{array}$ & $\begin{array}{r}11,980 \\
8,464 \\
9,893 \\
13,587 \\
15,716\end{array}$ & $\begin{array}{r}11,924 \\
7,986 \\
9,958 \\
13,704 \\
15,642\end{array}$ \\
\hline 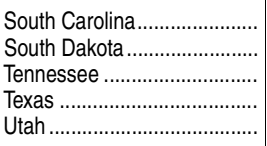 & $\begin{array}{l}3,474 \\
4,019 \\
3,251 \\
3,375 \\
3,645\end{array}$ & $\begin{array}{l}4,760 \\
5,307 \\
4,539 \\
5,184 \\
4,637\end{array}$ & $\begin{array}{l}6,868 \\
6,397 \\
6,204 \\
6,987 \\
4,695\end{array}$ & $\begin{array}{l}8,377 \\
7,697 \\
7,356 \\
8,593 \\
5,983\end{array}$ & $\begin{array}{l}9,110 \\
8,340 \\
7,722 \\
8,791 \\
6,361\end{array}$ & $\begin{array}{l}8,943 \\
8,317 \\
7,772 \\
9,066 \\
6,146\end{array}$ & $\begin{array}{l}8,922 \\
8,787 \\
8,039 \\
8,890 \\
6,205\end{array}$ & $\begin{array}{l}9,111 \\
9,008 \\
8,268 \\
8,745 \\
6,296\end{array}$ & $\begin{array}{l}9,441 \\
9,040 \\
8,143 \\
8,697 \\
6,353\end{array}$ & $\begin{array}{l}9,641 \\
9,139 \\
8,080 \\
8,896 \\
6,470\end{array}$ & $\begin{array}{l}9,901 \\
9,327 \\
8,546 \\
9,125 \\
6,533\end{array}$ & $\begin{array}{l}9,946 \\
9,207 \\
8,614 \\
9,228 \\
7,127\end{array}$ & $\begin{array}{l}9,692 \\
9,628 \\
8,665 \\
9,380 \\
6,888\end{array}$ & $\begin{array}{l}9,316 \\
9,346 \\
8,878 \\
9,088 \\
6,620\end{array}$ \\
\hline 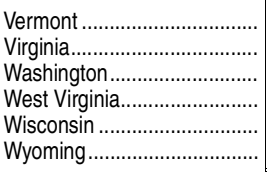 & $\begin{array}{l}4,836 \\
4,008 \\
5,225 \\
3,806 \\
4,857 \\
4,930 \\
\end{array}$ & $\begin{array}{l}5,752 \\
5,436 \\
7,113 \\
5,211 \\
6,630 \\
7,060 \\
\end{array}$ & $\begin{array}{r}10,514 \\
8,545 \\
7,985 \\
7,324 \\
9,146 \\
9,546 \\
\end{array}$ & $\begin{array}{r}11,373 \\
9,349 \\
8,714 \\
9,773 \\
10,668 \\
10,147 \\
\end{array}$ & $\begin{array}{r}12,731 \\
9,732 \\
9,139 \\
10,184 \\
11,209 \\
11,224 \\
\end{array}$ & $\begin{array}{r}13,281 \\
9,937 \\
9,213 \\
10,569 \\
11,439 \\
11,415 \\
\end{array}$ & $\begin{array}{r}13,937 \\
10,218 \\
9,189 \\
10,677 \\
11,487 \\
11,572 \\
\end{array}$ & $\begin{array}{r}14,449 \\
10,724 \\
9,313 \\
10,891 \\
11,773 \\
12,298 \\
\end{array}$ & $\begin{array}{r}14,887 \\
10,989 \\
9,283 \\
10,976 \\
11,618 \\
13,296 \\
\end{array}$ & $\begin{array}{r}15,445 \\
11,576 \\
9,660 \\
11,023 \\
11,755 \\
15,035 \\
\end{array}$ & $\begin{array}{r}15,760 \\
11,654 \\
9,898 \\
10,992 \\
11,793 \\
15,142 \\
\end{array}$ & $\begin{array}{l}16,270 \\
11,778 \\
10,331 \\
11,431 \\
12,053 \\
15,766 \\
\end{array}$ & $\begin{array}{l}16,723 \\
11,309 \\
10,138 \\
12,568 \\
12,283 \\
16,259 \\
\end{array}$ & $\begin{array}{l}15,390 \\
10,844 \\
10,066 \\
12,534 \\
12,501 \\
16,549 \\
\end{array}$ \\
\hline $\begin{array}{l}\text { Other jurisdictions } \\
\text { American Samoa ................ } \\
\text { Guam .............................. } \\
\text { Northern Marianas............ } \\
\text { Puerto Rico } \\
\text { U.S. Virgin Islands.................. }\end{array}$ & $\begin{array}{r}-694 \\
- \\
- \\
-\end{array}$ & $\begin{array}{l}- \\
- \\
- \\
-\end{array}$ & $\begin{array}{r}3,246 \\
6,955 \\
6,115 \\
2,925 \\
11,010\end{array}$ & $\begin{array}{r}3,743 \\
- \\
6,998 \\
4,651 \\
8,853\end{array}$ & $\begin{array}{r}3,773 \\
- \\
5,762 \\
4,626 \\
7,421\end{array}$ & $\begin{array}{r}3,781 \\
- \\
5,741 \\
5,413 \\
8,690\end{array}$ & $\begin{array}{l}4,343 \\
7,187 \\
5,272 \\
5,155 \\
9,000\end{array}$ & $\begin{array}{r}4,353 \\
- \\
6,076 \\
6,009 \\
10,122\end{array}$ & $\begin{array}{r}4,140 \\
7,884 \\
5,724 \\
6,360 \\
10,194\end{array}$ & $\begin{array}{r}3,945 \\
- \\
5,334 \\
6,807 \\
10,958\end{array}$ & $\begin{array}{r}- \\
- \\
4,956 \\
7,125 \\
13,505\end{array}$ & $\begin{array}{r}- \\
- \\
6,201 \\
7,496 \\
13,761\end{array}$ & $\begin{array}{r}- \\
- \\
6,058 \\
7,494 \\
15,174\end{array}$ & $\begin{array}{r}- \\
8,835 \\
7,977 \\
7,774 \\
14,325\end{array}$ \\
\hline
\end{tabular}

-Not available.

'Unadjusted (or "current") dollars have not been adjusted to compensate for inflation. ${ }^{2}$ Constant dollars based on the Consumer Price Index (CPI), prepared by the Bureau of Labor Statistics, U.S. Department of Labor, adjusted to a school-year basis. The CPI does not account for differences in inflation rates from state to state.

NOTE: Current expenditures include instruction, support services, food services, and enterprise operations. Expenditures for state administration are excluded in all years except
1969-70 and 1979-80. Beginning in 1989-90, extensive changes were made in the data collection procedures. Some data have been revised from previously published figures. SOURCE: U.S. Department of Education, National Center for Education Statistics, Statistics of State School Systems, 1969-70; Revenues and Expenditures for Public Elementary and Secondary Schools, 1979-80; and Common Core of Data (CCD), "National Public Education Financial Survey," 1989-90 through 2010-11. (This table was prepared July 2013.) 
Table 236.70. Current expenditure per pupil in average daily attendance in public elementary and secondary schools, by state or jurisdiction: Selected years, 1969-70 through 2010-11

\begin{tabular}{|c|c|c|c|c|c|c|c|c|c|c|c|c|c|c|}
\hline \multirow[b]{2}{*}{ State or jurisdiction } & \multicolumn{14}{|c|}{ Unadjusted dollars } \\
\hline & $1969-70$ & $1979-80$ & $1989-90$ & $1999-2000$ & $2001-02$ & $2002-03$ & 2003-04 & $2004-05$ & $2005-06$ & $2006-07$ & $2007-08$ & $2008-09$ & $2009-10$ & $2010-11$ \\
\hline 1 & 2 & 3 & 4 & 5 & 6 & 7 & 8 & 9 & 10 & 11 & 12 & 13 & 14 & 15 \\
\hline United States ................. & $\$ 816$ & $\$ 2,272$ & $\$ 4,980$ & $\$ 7,394$ & $\$ 8,259$ & $\$ 8,610$ & $\$ 8,900$ & $\$ 9,316$ & $\$ 9,778$ & $\$ 10,336$ & $\$ 10,982$ & $\$ 11,239$ & $\$ 11,427$ & $\$ 11,418$ \\
\hline 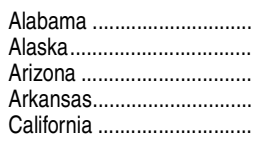 & $\begin{array}{r}544 \\
1,123 \\
720 \\
568 \\
867\end{array}$ & $\begin{array}{l}1,612 \\
4,728 \\
1,971 \\
1,574 \\
2,268\end{array}$ & $\begin{array}{l}3,327 \\
8,431 \\
4,053 \\
3,485 \\
4,391\end{array}$ & $\begin{array}{l}5,758 \\
9,668 \\
5,478 \\
5,628 \\
6,401\end{array}$ & $\begin{array}{r}6,327 \\
10,419 \\
6,470 \\
6,676 \\
7,439\end{array}$ & $\begin{array}{r}6,642 \\
10,770 \\
6,784 \\
6,981 \\
7,601\end{array}$ & $\begin{array}{r}6,812 \\
11,074 \\
6,908 \\
7,307 \\
7,708\end{array}$ & $\begin{array}{r}7,309 \\
11,851 \\
7,218 \\
8,243 \\
7,989\end{array}$ & $\begin{array}{r}7,980 \\
12,537 \\
7,637 \\
8,748 \\
8,416\end{array}$ & $\begin{array}{r}8,743 \\
13,508 \\
8,038 \\
9,152 \\
9,029\end{array}$ & $\begin{array}{r}9,345 \\
16,002 \\
8,630 \\
9,460 \\
9,673\end{array}$ & $\begin{array}{r}9,385 \\
16,822 \\
8,732 \\
9,651 \\
9,439\end{array}$ & $\begin{array}{r}9,554 \\
17,350 \\
8,756 \\
10,237 \\
9,680\end{array}$ & $\begin{array}{r}9,296 \\
18,352 \\
8,646 \\
10,332 \\
9,540\end{array}$ \\
\hline 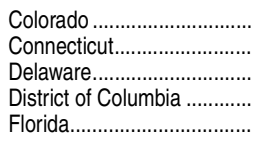 & $\begin{array}{r}738 \\
951 \\
900 \\
1,018 \\
732\end{array}$ & $\begin{array}{l}2,421 \\
2,420 \\
2,861 \\
3,259 \\
1,889\end{array}$ & $\begin{array}{l}4,720 \\
7,837 \\
5,799 \\
8,955 \\
4,997\end{array}$ & $\begin{array}{r}6,702 \\
10,122 \\
8,809 \\
11,935 \\
6,383\end{array}$ & $\begin{array}{r}7,284 \\
11,022 \\
9,959 \\
14,557 \\
6,679\end{array}$ & $\begin{array}{r}7,826 \\
11,302 \\
10,257 \\
14,735 \\
6,922\end{array}$ & $\begin{array}{r}8,416 \\
11,755 \\
11,049 \\
15,414 \\
7,269\end{array}$ & $\begin{array}{r}8,558 \\
12,655 \\
11,770 \\
15,074 \\
7,731\end{array}$ & $\begin{array}{r}8,938 \\
13,461 \\
12,330 \\
17,877 \\
8,376\end{array}$ & $\begin{array}{r}9,110 \\
14,143 \\
12,612 \\
18,285 \\
9,055\end{array}$ & $\begin{array}{r}9,977 \\
15,063 \\
12,789 \\
20,807 \\
9,711\end{array}$ & $\begin{array}{r}9,611 \\
15,840 \\
12,753 \\
19,766 \\
9,452\end{array}$ & $\begin{array}{r}9,747 \\
16,133 \\
12,928 \\
21,283 \\
9,363\end{array}$ & $\begin{array}{r}9,709 \\
16,932 \\
13,228 \\
21,304 \\
9,394\end{array}$ \\
\hline 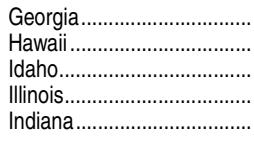 & $\begin{array}{l}588 \\
841 \\
603 \\
909 \\
728\end{array}$ & $\begin{array}{l}1,625 \\
2,322 \\
1,659 \\
2,587 \\
1,882\end{array}$ & $\begin{array}{l}4,275 \\
4,448 \\
3,078 \\
5,118 \\
4,606\end{array}$ & $\begin{array}{l}6,903 \\
7,090 \\
5,644 \\
8,084 \\
7,652\end{array}$ & $\begin{array}{l}7,870 \\
7,919 \\
6,391 \\
8,967 \\
8,268\end{array}$ & $\begin{array}{l}8,308 \\
8,770 \\
6,454 \\
9,309 \\
8,582\end{array}$ & $\begin{array}{l}8,278 \\
9,341 \\
6,559 \\
9,710 \\
9,033\end{array}$ & $\begin{array}{r}8,577 \\
9,705 \\
6,698 \\
10,020 \\
9,640\end{array}$ & $\begin{array}{r}9,164 \\
10,747 \\
6,861 \\
10,282 \\
9,558\end{array}$ & $\begin{array}{r}9,615 \\
12,364 \\
7,074 \\
10,816 \\
9,727\end{array}$ & $\begin{array}{r}10,263 \\
12,774 \\
7,402 \\
11,624 \\
9,569\end{array}$ & $\begin{array}{r}10,178 \\
13,397 \\
7,567 \\
12,489 \\
9,946\end{array}$ & $\begin{array}{r}9,855 \\
12,887 \\
7,481 \\
13,083 \\
10,160\end{array}$ & $\begin{array}{r}9,577 \\
12,603 \\
7,155 \\
13,180 \\
9,924\end{array}$ \\
\hline 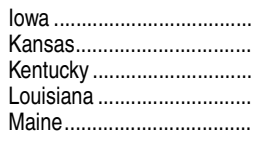 & $\begin{array}{l}844 \\
771 \\
545 \\
648 \\
692\end{array}$ & $\begin{array}{l}2,326 \\
2,173 \\
1,701 \\
1,792 \\
1,824\end{array}$ & $\begin{array}{l}4,453 \\
4,752 \\
3,745 \\
3,903 \\
5,373\end{array}$ & $\begin{array}{l}6,925 \\
6,962 \\
6,784 \\
6,256 \\
8,247\end{array}$ & $\begin{array}{l}7,714 \\
8,342 \\
7,536 \\
7,061 \\
9,517\end{array}$ & $\begin{array}{r}7,943 \\
8,373 \\
7,728 \\
7,492 \\
10,114\end{array}$ & $\begin{array}{r}8,017 \\
8,804 \\
7,976 \\
7,846 \\
10,504\end{array}$ & $\begin{array}{r}8,341 \\
9,037 \\
8,379 \\
8,288 \\
11,153\end{array}$ & $\begin{array}{r}8,460 \\
9,905 \\
8,975 \\
8,568 \\
11,760\end{array}$ & $\begin{array}{r}8,789 \\
10,280 \\
9,303 \\
9,650 \\
12,628\end{array}$ & $\begin{array}{r}9,128 \\
11,065 \\
9,940 \\
10,797 \\
13,177\end{array}$ & $\begin{array}{l}10,482 \\
11,485 \\
10,054 \\
11,410 \\
13,558\end{array}$ & $\begin{array}{l}10,524 \\
10,859 \\
10,376 \\
11,492 \\
14,090\end{array}$ & $\begin{array}{l}10,924 \\
10,909 \\
10,469 \\
11,500 \\
14,406\end{array}$ \\
\hline 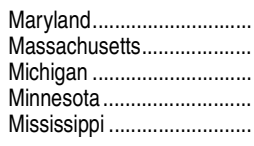 & $\begin{array}{l}918 \\
859 \\
904 \\
904 \\
501\end{array}$ & $\begin{array}{l}2,598 \\
2,819 \\
2,640 \\
2,387 \\
1,664\end{array}$ & $\begin{array}{l}6,275 \\
6,237 \\
5,546 \\
4,971 \\
3,094\end{array}$ & $\begin{array}{l}8,273 \\
9,375 \\
8,886 \\
7,499 \\
5,356\end{array}$ & $\begin{array}{r}9,266 \\
10,808 \\
9,428 \\
8,050 \\
5,719\end{array}$ & $\begin{array}{r}9,801 \\
11,161 \\
9,847 \\
8,440 \\
6,186\end{array}$ & $\begin{array}{r}10,140 \\
11,583 \\
10,049 \\
8,934 \\
6,601\end{array}$ & $\begin{array}{r}10,790 \\
12,208 \\
10,328 \\
9,273 \\
6,994\end{array}$ & $\begin{array}{r}11,719 \\
12,629 \\
10,598 \\
9,761 \\
7,699\end{array}$ & $\begin{array}{r}12,836 \\
13,263 \\
10,932 \\
10,185 \\
7,988\end{array}$ & $\begin{array}{r}14,122 \\
14,373 \\
11,155 \\
10,663 \\
8,448\end{array}$ & $\begin{array}{r}14,612 \\
15,249 \\
11,493 \\
11,602 \\
8,610\end{array}$ & $\begin{array}{r}14,937 \\
14,632 \\
11,661 \\
11,366 \\
8,670\end{array}$ & $\begin{array}{r}15,064 \\
14,991 \\
11,560 \\
11,368 \\
8,436\end{array}$ \\
\hline 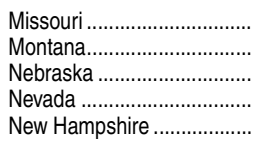 & $\begin{array}{l}709 \\
782 \\
736 \\
769 \\
723\end{array}$ & $\begin{array}{l}1,936 \\
2,476 \\
2,150 \\
2,088 \\
1,916\end{array}$ & $\begin{array}{l}4,507 \\
4,736 \\
4,842 \\
4,117 \\
5,304\end{array}$ & $\begin{array}{l}6,764 \\
6,990 \\
7,360 \\
6,148 \\
7,082\end{array}$ & $\begin{array}{l}7,700 \\
7,861 \\
8,238 \\
6,477 \\
8,230\end{array}$ & $\begin{array}{l}8,002 \\
8,391 \\
8,550 \\
6,496 \\
8,900\end{array}$ & $\begin{array}{l}8,022 \\
8,771 \\
9,270 \\
6,780 \\
9,391\end{array}$ & $\begin{array}{r}8,360 \\
9,108 \\
9,638 \\
7,198 \\
10,043\end{array}$ & $\begin{array}{r}8,834 \\
9,653 \\
10,170 \\
7,720 \\
10,698\end{array}$ & $\begin{array}{r}9,266 \\
10,244 \\
10,711 \\
8,372 \\
11,347\end{array}$ & $\begin{array}{r}10,007 \\
10,541 \\
11,217 \\
8,891 \\
12,280\end{array}$ & $\begin{array}{r}10,341 \\
10,881 \\
11,457 \\
8,865 \\
12,912\end{array}$ & $\begin{array}{r}10,468 \\
11,463 \\
11,920 \\
8,869 \\
13,424\end{array}$ & $\begin{array}{r}10,348 \\
11,599 \\
12,151 \\
9,035 \\
13,964\end{array}$ \\
\hline 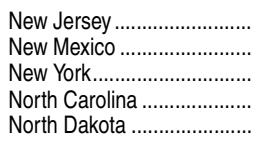 & $\begin{array}{r}1,016 \\
707 \\
1,327 \\
612 \\
690\end{array}$ & $\begin{array}{l}3,191 \\
2,034 \\
3,462 \\
1,754 \\
1,920\end{array}$ & $\begin{array}{l}8,139 \\
3,515 \\
8,062 \\
4,290 \\
4,189\end{array}$ & $\begin{array}{r}10,903 \\
5,835 \\
10,957 \\
6,505 \\
6,078\end{array}$ & $\begin{array}{r}12,197 \\
6,886 \\
12,343 \\
6,970 \\
7,112\end{array}$ & $\begin{array}{r}13,093 \\
7,126 \\
13,211 \\
7,057 \\
7,315\end{array}$ & $\begin{array}{r}13,776 \\
7,653 \\
13,926 \\
7,114 \\
7,791\end{array}$ & $\begin{array}{r}14,666 \\
7,933 \\
15,054 \\
7,628 \\
8,776\end{array}$ & $\begin{array}{r}15,362 \\
8,426 \\
16,095 \\
7,940 \\
9,239\end{array}$ & $\begin{array}{r}16,650 \\
8,876 \\
17,182 \\
8,373 \\
9,203\end{array}$ & $\begin{array}{r}18,174 \\
9,377 \\
18,423 \\
8,415 \\
9,637\end{array}$ & $\begin{array}{r}17,466 \\
9,727 \\
19,373 \\
9,167 \\
10,113\end{array}$ & $\begin{array}{r}18,060 \\
9,716 \\
19,965 \\
8,930 \\
10,976\end{array}$ & $\begin{array}{r}17,654 \\
9,356 \\
20,491 \\
8,492 \\
11,356\end{array}$ \\
\hline 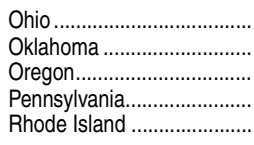 & $\begin{array}{l}730 \\
604 \\
925 \\
882 \\
891\end{array}$ & $\begin{array}{l}2,075 \\
1,926 \\
2,692 \\
2,535 \\
2,601\end{array}$ & $\begin{array}{l}5,045 \\
3,508 \\
5,474 \\
6,228 \\
6,368\end{array}$ & $\begin{array}{l}7,816 \\
5,770 \\
8,129 \\
8,380 \\
9,646\end{array}$ & $\begin{array}{r}8,928 \\
6,672 \\
8,725 \\
9,196 \\
10,552\end{array}$ & $\begin{array}{r}9,427 \\
6,540 \\
8,514 \\
9,648 \\
11,377\end{array}$ & $\begin{array}{r}9,799 \\
6,599 \\
8,640 \\
10,393 \\
12,279\end{array}$ & $\begin{array}{r}9,984 \\
7,086 \\
8,799 \\
11,014 \\
12,685\end{array}$ & $\begin{array}{r}10,306 \\
7,449 \\
9,294 \\
11,530 \\
13,917\end{array}$ & $\begin{array}{r}10,792 \\
7,968 \\
9,762 \\
11,995 \\
14,674\end{array}$ & $\begin{array}{r}11,374 \\
8,270 \\
10,487 \\
12,493 \\
15,843\end{array}$ & $\begin{array}{r}11,905 \\
8,423 \\
10,673 \\
12,989 \\
16,211\end{array}$ & $\begin{array}{r}12,307 \\
8,511 \\
10,476 \\
13,678 \\
16,243\end{array}$ & $\begin{array}{r}12,484 \\
8,165 \\
10,497 \\
14,072 \\
16,346\end{array}$ \\
\hline 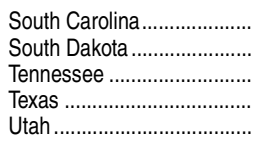 & $\begin{array}{l}613 \\
690 \\
566 \\
624 \\
626\end{array}$ & $\begin{array}{l}1,752 \\
1,908 \\
1,635 \\
1,916 \\
1,657\end{array}$ & $\begin{array}{l}4,082 \\
3,731 \\
3,664 \\
4,150 \\
2,764\end{array}$ & $\begin{array}{l}6,545 \\
6,037 \\
5,837 \\
6,771 \\
4,692\end{array}$ & $\begin{array}{l}7,549 \\
6,890 \\
6,476 \\
7,302 \\
5,294\end{array}$ & $\begin{array}{l}7,759 \\
7,192 \\
6,674 \\
7,714 \\
5,247\end{array}$ & $\begin{array}{l}7,893 \\
7,607 \\
7,047 \\
7,711 \\
5,427\end{array}$ & $\begin{array}{l}8,302 \\
7,960 \\
7,426 \\
7,814 \\
5,654\end{array}$ & $\begin{array}{l}8,795 \\
8,273 \\
7,580 \\
8,085 \\
5,809\end{array}$ & $\begin{array}{l}9,226 \\
8,506 \\
7,843 \\
8,484 \\
6,116\end{array}$ & $\begin{array}{l}9,823 \\
9,047 \\
8,459 \\
9,029 \\
6,841\end{array}$ & $\begin{array}{r}10,007 \\
9,457 \\
8,676 \\
9,260 \\
7,081\end{array}$ & $\begin{array}{l}9,887 \\
9,683 \\
8,810 \\
9,528 \\
6,877\end{array}$ & $\begin{array}{l}9,730 \\
9,431 \\
9,315 \\
9,418 \\
6,851\end{array}$ \\
\hline 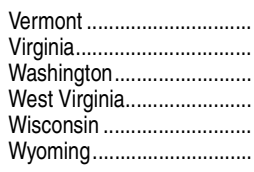 & $\begin{array}{l}807 \\
708 \\
915 \\
670 \\
883 \\
856 \\
\end{array}$ & $\begin{array}{l}1,997 \\
1,970 \\
2,568 \\
1,920 \\
2,477 \\
2,527 \\
\end{array}$ & $\begin{array}{l}6,227 \\
4,672 \\
4,702 \\
4,360 \\
5,524 \\
5,577 \\
\end{array}$ & $\begin{array}{l}8,799 \\
6,491 \\
6,914 \\
7,637 \\
8,299 \\
7,944 \\
\end{array}$ & $\begin{array}{r}10,229 \\
7,928 \\
7,626 \\
8,451 \\
9,237 \\
9,321 \\
\end{array}$ & $\begin{array}{r}10,903 \\
8,300 \\
7,882 \\
9,025 \\
9,538 \\
9,906 \\
\end{array}$ & $\begin{array}{r}11,675 \\
8,761 \\
8,051 \\
9,076 \\
9,834 \\
10,351 \\
\end{array}$ & $\begin{array}{r}12,579 \\
9,441 \\
8,362 \\
9,321 \\
10,141 \\
11,087 \\
\end{array}$ & $\begin{array}{r}13,377 \\
10,046 \\
8,702 \\
9,756 \\
10,484 \\
12,415 \\
\end{array}$ & $\begin{array}{r}14,219 \\
10,913 \\
9,233 \\
10,080 \\
10,813 \\
14,219 \\
\end{array}$ & $\begin{array}{r}15,089 \\
11,410 \\
9,846 \\
10,605 \\
11,370 \\
14,936 \\
\end{array}$ & $\begin{array}{l}16,073 \\
11,696 \\
10,423 \\
11,122 \\
11,773 \\
15,658 \\
\end{array}$ & $\begin{array}{l}16,586 \\
11,383 \\
10,242 \\
12,378 \\
12,194 \\
16,535 \\
\end{array}$ & $\begin{array}{l}16,661 \\
11,123 \\
10,402 \\
12,505 \\
12,515 \\
17,126 \\
\end{array}$ \\
\hline 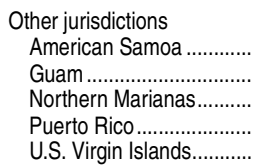 & $\begin{array}{r}8 \overline{8} \\
- \\
- \\
-\end{array}$ & $\begin{array}{l}- \\
- \\
- \\
-\end{array}$ & $\begin{array}{l}1,908 \\
4,234 \\
3,007 \\
1,750 \\
6,767\end{array}$ & $\begin{array}{r}2,807 \\
- \\
5,720 \\
3,859 \\
7,238\end{array}$ & $\begin{array}{r}2,983 \\
- \\
4,934 \\
4,013 \\
6,248\end{array}$ & $\begin{array}{r}3,121 \\
- \\
5,221 \\
4,743 \\
7,747\end{array}$ & $\begin{array}{l}3,671 \\
6,449 \\
4,746 \\
4,534 \\
8,077\end{array}$ & $\begin{array}{r}3,801 \\
- \\
5,669 \\
5,304 \\
8,698\end{array}$ & $\begin{array}{l}3,842 \\
7,095 \\
5,307 \\
5,897 \\
9,637\end{array}$ & $\begin{array}{r}3,909 \\
7,450 \\
5,356 \\
6,152 \\
10,548\end{array}$ & $\begin{array}{r}4,309 \\
8,084 \\
5,162 \\
6,937 \\
12,358\end{array}$ & $\begin{array}{r}4,468 \\
8,264 \\
6,397 \\
7,329 \\
12,768\end{array}$ & $\begin{array}{r}4,881 \\
8,393 \\
6,284 \\
7,426 \\
14,215\end{array}$ & $\begin{array}{r}4,877 \\
9,280 \\
8,495 \\
8,560 \\
13,470\end{array}$ \\
\hline
\end{tabular}

See notes at end of table. 
Table 236.70. Current expenditure per pupil in average daily attendance in public elementary and secondary schools, by state or jurisdiction: Selected years, 1969-70 through 2010-11-Continued

\begin{tabular}{|c|c|c|c|c|c|c|c|c|c|c|c|c|c|c|}
\hline \multirow[b]{2}{*}{ State or jurisdiction } & \multicolumn{14}{|c|}{ Constant $2012-13$ dollars ${ }^{1}$} \\
\hline & $1969-70$ & $1979-80$ & $1989-90$ & $1999-2000$ & $2001-02$ & $2002-03$ & $2003-04$ & $2004-05$ & $2005-06$ & $2006-07$ & $2007-08$ & $2008-09$ & $2009-10$ & $2010-11$ \\
\hline 1 & 16 & 17 & 18 & 19 & 20 & 21 & 22 & 23 & 24 & 25 & 26 & 27 & 28 & 29 \\
\hline United States ............... & $\$ 4,997$ & $\$ 6,770$ & $\$ 9,073$ & $\$ 10,104$ & $\$ 10,723$ & $\$ 10,938$ & $\$ 11,064$ & $\$ 11,243$ & $\$ 11,368$ & $\$ 11,714$ & $\$ 12,001$ & $\$ 12,113$ & $\$ 12,198$ & $\$ 11,948$ \\
\hline 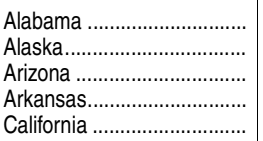 & $\begin{array}{l}3,332 \\
6,875 \\
4,410 \\
3,476 \\
5,311\end{array}$ & $\begin{array}{r}4,803 \\
14,089 \\
5,873 \\
4,692 \\
6,758\end{array}$ & $\begin{array}{r}6,062 \\
15,362 \\
7,385 \\
6,350 \\
8,000\end{array}$ & $\begin{array}{r}7,869 \\
13,212 \\
7,487 \\
7,691 \\
8,747\end{array}$ & $\begin{array}{r}8,215 \\
13,528 \\
8,400 \\
8,668 \\
9,659\end{array}$ & $\begin{array}{r}8,438 \\
13,682 \\
8,618 \\
8,869 \\
9,657\end{array}$ & $\begin{array}{r}8,469 \\
13,768 \\
8,589 \\
9,084 \\
9,583\end{array}$ & $\begin{array}{r}8,821 \\
14,303 \\
8,711 \\
9,949 \\
9,641\end{array}$ & $\begin{array}{r}9,277 \\
14,576 \\
8,879 \\
10,171 \\
9,785\end{array}$ & $\begin{array}{r}9,908 \\
15,309 \\
9,109 \\
10,372 \\
10,233\end{array}$ & $\begin{array}{r}10,212 \\
17,488 \\
9,431 \\
10,338 \\
10,571\end{array}$ & $\begin{array}{r}10,115 \\
18,130 \\
9,411 \\
10,401 \\
10,173\end{array}$ & $\begin{array}{r}10,198 \\
18,520 \\
9,347 \\
10,927 \\
10,333\end{array}$ & $\begin{array}{r}9,728 \\
19,204 \\
9,047 \\
10,811 \\
9,983\end{array}$ \\
\hline 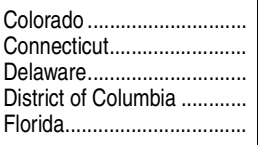 & $\begin{array}{l}4,519 \\
5,826 \\
5,513 \\
6,237 \\
4,485\end{array}$ & $\begin{array}{l}7,214 \\
7,212 \\
8,526 \\
9,712 \\
5,630\end{array}$ & $\begin{array}{r}8,601 \\
14,279 \\
10,566 \\
16,316 \\
9,105\end{array}$ & $\begin{array}{r}9,158 \\
13,832 \\
12,038 \\
16,310 \\
8,723\end{array}$ & $\begin{array}{r}9,457 \\
14,310 \\
12,930 \\
18,899 \\
8,671\end{array}$ & $\begin{array}{r}9,942 \\
14,358 \\
13,031 \\
18,720 \\
8,794\end{array}$ & $\begin{array}{r}10,463 \\
14,614 \\
13,737 \\
19,163 \\
9,037\end{array}$ & $\begin{array}{r}10,328 \\
15,274 \\
14,205 \\
18,193 \\
9,330\end{array}$ & $\begin{array}{r}10,392 \\
15,650 \\
14,335 \\
20,784 \\
9,739\end{array}$ & $\begin{array}{l}10,325 \\
16,029 \\
14,294 \\
20,723 \\
10,263\end{array}$ & $\begin{array}{l}10,903 \\
16,462 \\
13,976 \\
22,738 \\
10,613\end{array}$ & $\begin{array}{l}10,358 \\
17,072 \\
13,745 \\
21,303 \\
10,187\end{array}$ & $\begin{array}{r}10,405 \\
17,221 \\
13,800 \\
22,718 \\
9,995\end{array}$ & $\begin{array}{r}10,160 \\
17,718 \\
13,842 \\
22,293 \\
9,830\end{array}$ \\
\hline 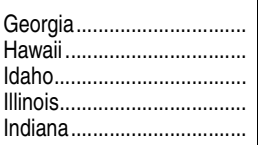 & $\begin{array}{l}3,601 \\
5,148 \\
3,695 \\
5,570 \\
4,459\end{array}$ & $\begin{array}{l}4,843 \\
6,919 \\
4,945 \\
7,708 \\
5,610\end{array}$ & $\begin{array}{l}7,789 \\
8,105 \\
5,608 \\
9,325 \\
8,393\end{array}$ & $\begin{array}{r}9,434 \\
9,689 \\
7,713 \\
11,047 \\
10,457\end{array}$ & $\begin{array}{r}10,217 \\
10,282 \\
8,298 \\
11,643 \\
10,734\end{array}$ & $\begin{array}{r}10,554 \\
11,141 \\
8,200 \\
11,826 \\
10,903\end{array}$ & $\begin{array}{r}10,292 \\
11,612 \\
8,154 \\
12,071 \\
11,230\end{array}$ & $\begin{array}{r}10,351 \\
11,712 \\
8,084 \\
12,094 \\
11,634\end{array}$ & $\begin{array}{r}10,654 \\
12,494 \\
7,977 \\
11,955 \\
11,112\end{array}$ & $\begin{array}{r}10,896 \\
14,012 \\
8,017 \\
12,258 \\
11,024\end{array}$ & $\begin{array}{r}11,216 \\
13,960 \\
8,090 \\
12,703 \\
10,457\end{array}$ & $\begin{array}{r}10,969 \\
14,439 \\
8,156 \\
13,460 \\
10,720\end{array}$ & $\begin{array}{r}10,520 \\
13,756 \\
7,986 \\
13,966 \\
10,845\end{array}$ & $\begin{array}{r}10,022 \\
13,188 \\
7,487 \\
13,792 \\
10,385\end{array}$ \\
\hline 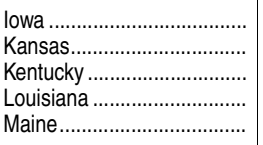 & $\begin{array}{l}5,170 \\
4,722 \\
3,339 \\
3,969 \\
4,241\end{array}$ & $\begin{array}{l}6,933 \\
6,476 \\
5,069 \\
5,340 \\
5,434\end{array}$ & $\begin{array}{l}8,113 \\
8,658 \\
6,824 \\
7,112 \\
9,790\end{array}$ & $\begin{array}{r}9,464 \\
9,514 \\
9,271 \\
8,549 \\
11,270\end{array}$ & $\begin{array}{r}10,015 \\
10,831 \\
9,784 \\
9,168 \\
12,356\end{array}$ & $\begin{array}{r}10,091 \\
10,637 \\
9,818 \\
9,518 \\
12,849\end{array}$ & $\begin{array}{r}9,966 \\
10,946 \\
9,915 \\
9,755 \\
13,059\end{array}$ & $\begin{array}{l}10,067 \\
10,906 \\
10,112 \\
10,002 \\
13,460\end{array}$ & $\begin{array}{r}9,835 \\
11,516 \\
10,434 \\
9,962 \\
13,672\end{array}$ & $\begin{array}{r}9,960 \\
11,650 \\
10,543 \\
10,937 \\
14,311\end{array}$ & $\begin{array}{r}9,975 \\
12,092 \\
10,863 \\
11,799 \\
14,400\end{array}$ & $\begin{array}{l}11,297 \\
12,379 \\
10,835 \\
12,297 \\
14,613\end{array}$ & $\begin{array}{l}11,233 \\
11,591 \\
11,076 \\
12,267 \\
15,040\end{array}$ & $\begin{array}{l}11,431 \\
11,415 \\
10,955 \\
12,034 \\
15,074\end{array}$ \\
\hline 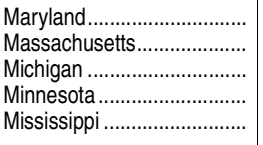 & $\begin{array}{l}5,624 \\
5,261 \\
5,536 \\
5,534 \\
3,067\end{array}$ & $\begin{array}{l}7,742 \\
8,402 \\
7,868 \\
7,113 \\
4,958\end{array}$ & $\begin{array}{r}11,434 \\
11,364 \\
10,106 \\
9,056 \\
5,637\end{array}$ & $\begin{array}{r}11,306 \\
12,812 \\
12,143 \\
10,248 \\
7,319\end{array}$ & $\begin{array}{r}12,030 \\
14,033 \\
12,241 \\
10,452 \\
7,426\end{array}$ & $\begin{array}{r}12,452 \\
14,179 \\
12,509 \\
10,722 \\
7,859\end{array}$ & $\begin{array}{r}12,606 \\
14,400 \\
12,493 \\
11,107 \\
8,207\end{array}$ & $\begin{array}{r}13,022 \\
14,734 \\
12,464 \\
11,191 \\
8,441\end{array}$ & $\begin{array}{r}13,625 \\
14,683 \\
12,322 \\
11,348 \\
8,951\end{array}$ & $\begin{array}{r}14,547 \\
15,031 \\
12,389 \\
11,543 \\
9,053\end{array}$ & $\begin{array}{r}15,433 \\
15,707 \\
12,190 \\
11,653 \\
9,232\end{array}$ & $\begin{array}{r}15,748 \\
16,435 \\
12,387 \\
12,504 \\
9,279\end{array}$ & $\begin{array}{r}15,945 \\
15,619 \\
12,448 \\
12,132 \\
9,254\end{array}$ & $\begin{array}{r}15,764 \\
15,687 \\
12,097 \\
11,896 \\
8,827\end{array}$ \\
\hline 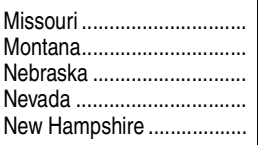 & $\begin{array}{l}4,339 \\
4,788 \\
4,510 \\
4,713 \\
4,428\end{array}$ & $\begin{array}{l}5,770 \\
7,380 \\
6,407 \\
6,223 \\
5,709\end{array}$ & $\begin{array}{l}8,212 \\
8,630 \\
8,822 \\
7,502 \\
9,664\end{array}$ & $\begin{array}{r}9,244 \\
9,552 \\
10,058 \\
8,401 \\
9,679\end{array}$ & $\begin{array}{r}9,997 \\
10,206 \\
10,695 \\
8,410 \\
10,686\end{array}$ & $\begin{array}{r}10,166 \\
10,660 \\
10,862 \\
8,253 \\
11,306\end{array}$ & $\begin{array}{r}9,973 \\
10,904 \\
11,524 \\
8,429 \\
11,675\end{array}$ & $\begin{array}{r}10,089 \\
10,993 \\
11,632 \\
8,687 \\
12,121\end{array}$ & $\begin{array}{r}10,271 \\
11,223 \\
11,823 \\
8,975 \\
12,438\end{array}$ & $\begin{array}{r}10,501 \\
11,609 \\
12,139 \\
9,488 \\
12,859\end{array}$ & $\begin{array}{r}10,935 \\
11,519 \\
12,258 \\
9,716 \\
13,420\end{array}$ & $\begin{array}{r}11,146 \\
11,727 \\
12,347 \\
9,554 \\
13,916\end{array}$ & $\begin{array}{r}11,174 \\
12,236 \\
12,724 \\
9,468 \\
14,329\end{array}$ & $\begin{array}{r}10,828 \\
12,137 \\
12,715 \\
9,455 \\
14,612\end{array}$ \\
\hline 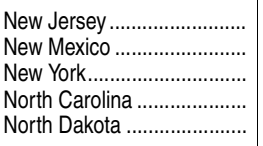 & $\begin{array}{l}6,224 \\
4,330 \\
8,126 \\
3,750 \\
4,223\end{array}$ & $\begin{array}{r}9,511 \\
6,061 \\
10,318 \\
5,228 \\
5,722\end{array}$ & $\begin{array}{r}14,830 \\
6,404 \\
14,688 \\
7,817 \\
7,633\end{array}$ & $\begin{array}{r}14,899 \\
7,974 \\
14,973 \\
8,890 \\
8,306\end{array}$ & $\begin{array}{r}15,836 \\
8,941 \\
16,025 \\
9,050 \\
9,234\end{array}$ & $\begin{array}{r}16,633 \\
9,053 \\
16,784 \\
8,966 \\
9,293\end{array}$ & $\begin{array}{r}17,126 \\
9,514 \\
17,312 \\
8,845 \\
9,685\end{array}$ & $\begin{array}{r}17,700 \\
9,574 \\
18,169 \\
9,206 \\
10,592\end{array}$ & $\begin{array}{r}17,860 \\
9,796 \\
18,712 \\
9,232 \\
10,741\end{array}$ & $\begin{array}{r}18,869 \\
10,059 \\
19,472 \\
9,490 \\
10,430\end{array}$ & $\begin{array}{r}19,861 \\
10,247 \\
20,133 \\
9,196 \\
10,531\end{array}$ & $\begin{array}{r}18,825 \\
10,484 \\
20,879 \\
9,880 \\
10,899\end{array}$ & $\begin{array}{r}19,278 \\
10,371 \\
21,312 \\
9,533 \\
11,717\end{array}$ & $\begin{array}{r}18,474 \\
9,790 \\
21,442 \\
8,886 \\
11,884\end{array}$ \\
\hline 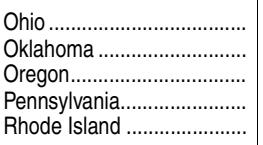 & $\begin{array}{l}4,471 \\
3,702 \\
5,663 \\
5,400 \\
5,458\end{array}$ & $\begin{array}{l}6,183 \\
5,741 \\
8,022 \\
7,554 \\
7,751\end{array}$ & $\begin{array}{r}9,191 \\
6,391 \\
9,974 \\
11,348 \\
11,602\end{array}$ & $\begin{array}{r}10,682 \\
7,885 \\
11,109 \\
11,452 \\
13,183\end{array}$ & $\begin{array}{r}11,591 \\
8,662 \\
11,328 \\
11,939 \\
13,699\end{array}$ & $\begin{array}{r}11,976 \\
8,308 \\
10,816 \\
12,256 \\
14,454\end{array}$ & $\begin{array}{r}12,182 \\
8,204 \\
10,741 \\
12,921 \\
15,265\end{array}$ & $\begin{array}{r}12,049 \\
8,552 \\
10,620 \\
13,293 \\
15,310\end{array}$ & $\begin{array}{r}11,982 \\
8,660 \\
10,805 \\
13,405 \\
16,180\end{array}$ & $\begin{array}{r}12,231 \\
9,031 \\
11,063 \\
13,594 \\
16,631\end{array}$ & $\begin{array}{r}12,430 \\
9,038 \\
11,461 \\
13,652 \\
17,313\end{array}$ & $\begin{array}{r}12,831 \\
9,078 \\
11,503 \\
13,999 \\
17,472\end{array}$ & $\begin{array}{r}13,137 \\
9,085 \\
11,182 \\
14,601 \\
17,339\end{array}$ & $\begin{array}{r}13,063 \\
8,544 \\
10,984 \\
14,725 \\
17,105\end{array}$ \\
\hline 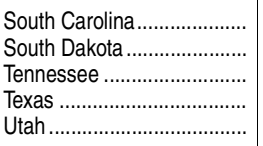 & $\begin{array}{l}3,751 \\
4,225 \\
3,467 \\
3,823 \\
3,835\end{array}$ & $\begin{array}{l}5,221 \\
5,685 \\
4,874 \\
5,709 \\
4,937\end{array}$ & $\begin{array}{l}7,437 \\
6,798 \\
6,675 \\
7,562 \\
5,036\end{array}$ & $\begin{array}{l}8,945 \\
8,250 \\
7,977 \\
9,254 \\
6,413\end{array}$ & $\begin{array}{l}9,801 \\
8,945 \\
8,408 \\
9,481 \\
6,873\end{array}$ & $\begin{array}{l}9,857 \\
9,137 \\
8,478 \\
9,800 \\
6,666\end{array}$ & $\begin{array}{l}9,812 \\
9,457 \\
8,760 \\
9,587 \\
6,746\end{array}$ & $\begin{array}{r}10,019 \\
9,607 \\
8,962 \\
9,431 \\
6,824\end{array}$ & $\begin{array}{r}10,225 \\
9,618 \\
8,813 \\
9,400 \\
6,754\end{array}$ & $\begin{array}{r}10,456 \\
9,640 \\
8,889 \\
9,615 \\
6,931\end{array}$ & $\begin{array}{r}10,735 \\
9,887 \\
9,244 \\
9,867 \\
7,476\end{array}$ & $\begin{array}{r}10,785 \\
10,192 \\
9,351 \\
9,980 \\
7,632\end{array}$ & $\begin{array}{r}10,554 \\
10,336 \\
9,404 \\
10,171 \\
7,340\end{array}$ & $\begin{array}{r}10,182 \\
9,869 \\
9,747 \\
9,856 \\
7,169\end{array}$ \\
\hline 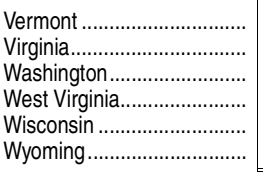 & $\begin{array}{l}4,944 \\
4,335 \\
5,606 \\
4,103 \\
5,406 \\
5,242 \\
\end{array}$ & $\begin{array}{l}5,951 \\
5,871 \\
7,653 \\
5,723 \\
7,381 \\
7,530 \\
\end{array}$ & $\begin{array}{r}11,345 \\
8,512 \\
8,568 \\
7,945 \\
10,064 \\
10,162 \\
\end{array}$ & $\begin{array}{r}12,025 \\
8,871 \\
9,448 \\
10,436 \\
11,341 \\
10,856 \\
\end{array}$ & $\begin{array}{r}13,280 \\
10,294 \\
9,901 \\
10,972 \\
11,993 \\
12,102 \\
\end{array}$ & $\begin{array}{l}13,851 \\
10,544 \\
10,014 \\
11,466 \\
12,117 \\
12,585 \\
\end{array}$ & $\begin{array}{l}14,515 \\
10,891 \\
10,009 \\
11,284 \\
12,226 \\
12,868 \\
\end{array}$ & $\begin{array}{l}15,181 \\
11,394 \\
10,092 \\
11,249 \\
12,239 \\
13,381 \\
\end{array}$ & $\begin{array}{l}15,552 \\
11,680 \\
10,118 \\
11,343 \\
12,188 \\
14,434 \\
\end{array}$ & $\begin{array}{l}16,115 \\
12,367 \\
10,464 \\
11,424 \\
12,255 \\
16,114 \\
\end{array}$ & $\begin{array}{l}16,489 \\
12,470 \\
10,759 \\
11,589 \\
12,425 \\
16,323 \\
\end{array}$ & $\begin{array}{l}17,323 \\
12,606 \\
11,233 \\
11,987 \\
12,689 \\
16,876 \\
\end{array}$ & $\begin{array}{l}17,705 \\
12,150 \\
10,932 \\
13,213 \\
13,017 \\
17,650 \\
\end{array}$ & $\begin{array}{l}17,434 \\
11,640 \\
10,885 \\
13,085 \\
13,097 \\
17,922 \\
\end{array}$ \\
\hline $\begin{array}{l}\text { Other jurisdictions } \\
\text { American Samoa ............. } \\
\text { Guam ...................... } \\
\text { Northern Marianas.......... } \\
\text { Puerto Rico ................... } \\
\text { U.S. Virgin Islands........... }\end{array}$ & $\begin{array}{r}- \\
5,020 \\
- \\
- \\
-\end{array}$ & $\begin{array}{l}- \\
- \\
- \\
-\end{array}$ & $\begin{array}{r}3,476 \\
7,715 \\
5,479 \\
3,188 \\
12,330\end{array}$ & $\begin{array}{r}3,836 \\
- \\
7,817 \\
5,274 \\
9,891\end{array}$ & $\begin{array}{r}3,872 \\
- \\
6,406 \\
5,210 \\
8,112\end{array}$ & $\begin{array}{r}3,964 \\
- \\
6,632 \\
6,025 \\
9,842\end{array}$ & $\begin{array}{r}4,564 \\
8,017 \\
5,900 \\
5,637 \\
10,042\end{array}$ & $\begin{array}{r}4,587 \\
- \\
6,842 \\
6,401 \\
10,498\end{array}$ & $\begin{array}{r}4,467 \\
8,248 \\
6,170 \\
6,856 \\
11,204\end{array}$ & $\begin{array}{r}4,430 \\
8,443 \\
6,070 \\
6,972 \\
11,954\end{array}$ & $\begin{array}{r}4,709 \\
8,834 \\
5,641 \\
7,581 \\
13,505\end{array}$ & $\begin{array}{r}4,815 \\
8,907 \\
6,894 \\
7,899 \\
13,761\end{array}$ & $\begin{array}{r}5,210 \\
8,959 \\
6,708 \\
7,927 \\
15,174\end{array}$ & $\begin{array}{r}5,103 \\
9,711 \\
8,890 \\
8,957 \\
14,095\end{array}$ \\
\hline
\end{tabular}

-Not available.

${ }^{1}$ Constant dollars based on the Consumer Price Index (CPI), prepared by the Bureau of Labor Statistics, U.S. Department of Labor, adjusted to a school-year basis. The CPI does not account for differences in inflation rates from state to state.

NOTE: Current expenditures include instruction, support services, food services, and enterprise operations. Expenditures for state administration are excluded in all years except 1969-70 and 1979-80. Beginning in 1989-90, extensive changes were made in the data col- lection procedures. There are discrepancies in average daily attendance reporting practices from state to state. Some data have been revised from previously published figures. SOURCE: U.S. Department of Education, National Center for Education Statistics, Statistics of State School Systems, 1969-70; Revenues and Expenditures for Public Elementary and Secondary Education, 1979-80; and Common Core of Data (CCD), "National Public Education Financial Survey," 1989-90 through 2010-11. (This table was prepared July 2013.) 
Table 236.75. Total and current expenditures per pupil in fall enrollment in public elementary and secondary education, by function and state or jurisdiction: 2010-11

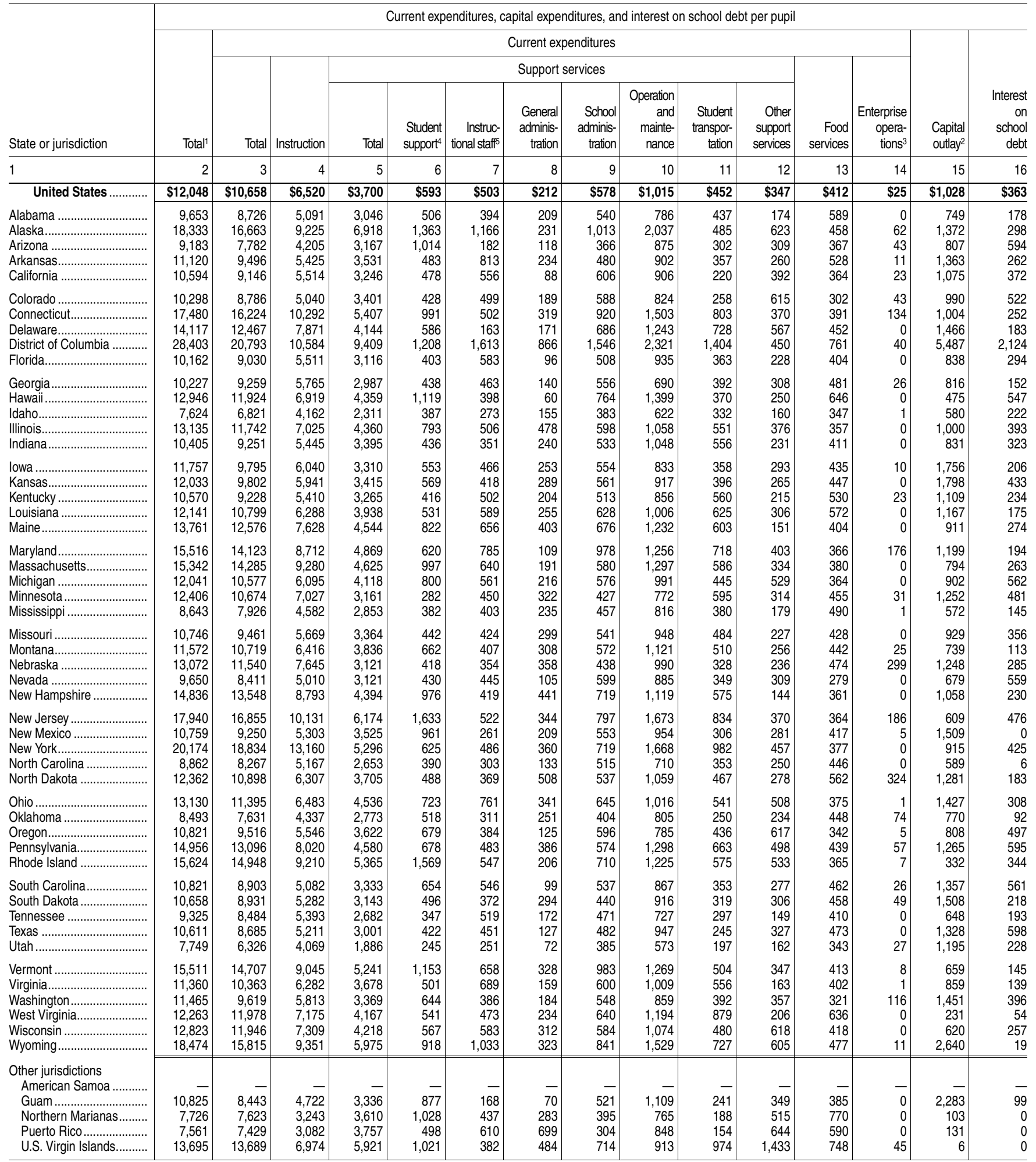

-Not available.

'Excludes "Other current expenditures," such as community services, private school programs, adult education, and other programs not allocable to expenditures per pupil in public schools.

${ }^{2}$ Includes expenditures for property and for buildings and alterations completed by school district staff or contractors.

Includes expenditures for operations funded by sales of products or services (e.g., school bookstore or computer time). Includes very small amounts for direct program support made by state education agencies for local school districts.
${ }^{4}$ Includes expenditures for guidance, health, attendance, and speech pathology services. ${ }^{5}$ Includes expenditures for curriculum development, staff training, libraries, and media and computer centers.

NOTE: Excludes expenditures for state education agencies. "0" indicates none or less than $\$ 0.50$. Detail may not sum to totals because of rounding.

SOURCE: U.S. Department of Education, National Center for Education Statistics, Common Core of Data (CCD), "National Public Education Financial Survey," 2010-11. (This table was prepared July 2013.) 
Table 236.80. Total and current expenditures per pupil in fall enrollment in public elementary and secondary education, by function and state or jurisdiction: 2009-10

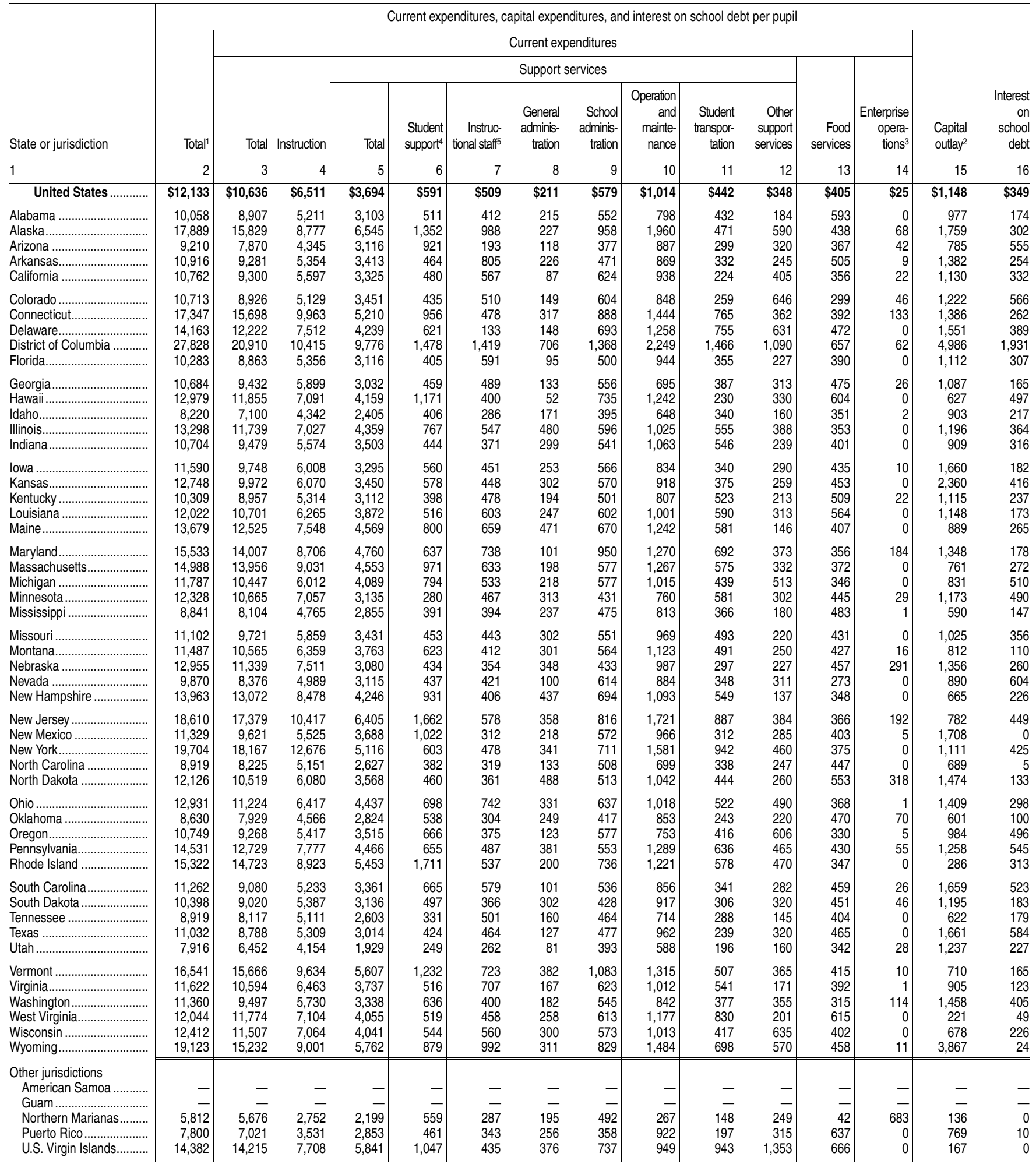

\section{-Not available.}

'Excludes "Other current expenditures," such as community services, private school programs, adult education, and other programs not allocable to expenditures per pupil in public schools.

${ }^{2}$ Includes expenditures for property and for buildings and alterations completed by school district staff or contractors. Excludes capital outlay related to "Other current expenditures."

${ }^{3}$ Includes expenditures for operations funded by sales of products or services (e.g., school bookstore or computer time).

${ }^{4}$ Includes expenditures for guidance, health, attendance, and speech pathology services.
Includes expenditures for curriculum development, staff training, libraries, and media and computer centers.

NOTE: Excludes expenditures for state education agencies. "0" indicates none or less than $\$ 0.50$. Some data have been revised from previously published figures. Detail may not sum to totals because of rounding.

SOURCE: U.S. Department of Education, National Center for Education Statistics, Common Core of Data (CCD), "National Public Education Financial Survey," 2009-10. (This table was prepared July 2013.) 
Table 236.90. Students transported at public expense and current expenditures for transportation: Selected years, 1929-30 through 2010-11

\begin{tabular}{|c|c|c|c|c|c|c|c|}
\hline \multirow[b]{2}{*}{ School year } & \multirow[b]{2}{*}{$\begin{array}{r}\text { Average daily } \\
\text { attendance, all } \\
\text { students }\end{array}$} & \multicolumn{2}{|c|}{$\begin{array}{l}\text { Students transported } \\
\text { at public expense }\end{array}$} & \multicolumn{2}{|c|}{$\begin{array}{l}\text { Expenditures for transportation } \\
\quad \text { (in unadjusted dollars) }^{1}\end{array}$} & \multicolumn{2}{|c|}{$\begin{array}{l}\text { Expenditures for transportation } \\
\text { (in constant 2012-13 dollars) }^{2}\end{array}$} \\
\hline & & Number & $\begin{array}{r}\text { Percent } \\
\text { of total }\end{array}$ & (in thousands) & $\begin{array}{r}\text { Average } \\
\text { per student } \\
\text { transported }\end{array}$ & (in thousands) & $\begin{array}{r}\text { Average } \\
\text { per student } \\
\text { transported }\end{array}$ \\
\hline 1 & 2 & 3 & 4 & 5 & 6 & 7 & 8 \\
\hline 1929-30 1931 & \begin{tabular}{l|}
$21,265,000$ \\
$22,245,000$ \\
$22,458,000$ \\
$22,299,000$ \\
$22,298,000$
\end{tabular} & $\begin{array}{l}1,902,826 \\
2,419,173 \\
2,794,724 \\
3,250,658 \\
3,769,242\end{array}$ & \begin{tabular}{r|}
8.9 \\
10.9 \\
12.4 \\
14.6 \\
16.9
\end{tabular} & $\begin{array}{r}\$ 54,823 \\
58,078 \\
53,908 \\
62,653 \\
75,637\end{array}$ & $\begin{array}{r}\$ 29 \\
24 \\
19 \\
19 \\
20\end{array}$ & $\begin{array}{r}\$ 740,983 \\
931,987 \\
941,831 \\
1,054,788 \\
1,221,555\end{array}$ & $\begin{array}{r}\$ 389 \\
385 \\
337 \\
324 \\
324\end{array}$ \\
\hline $\begin{array}{l}1939-40 \\
1941-42 \\
1943-44 \\
1945-46 \\
1947-48\end{array}$ & $\begin{array}{l}22,042,000 \\
21,031,000 \\
19,603,000 \\
19,849,000 \\
20,910,000\end{array}$ & $\begin{array}{l}4,144,161 \\
4,503,081 \\
4,512,412 \\
5,056,966 \\
5,854,041\end{array}$ & $\begin{array}{l}18.8 \\
21.4 \\
23.0 \\
25.5 \\
28.0\end{array}$ & $\begin{array}{r}83,283 \\
92,922 \\
107,754 \\
129,756 \\
176,265\end{array}$ & $\begin{array}{l}20 \\
21 \\
24 \\
26 \\
30\end{array}$ & $\begin{array}{l}1,378,725 \\
1,378,764 \\
1,430,652 \\
1,645,615 \\
1,750,183\end{array}$ & $\begin{array}{l}333 \\
306 \\
317 \\
325 \\
299\end{array}$ \\
\hline $\begin{array}{l}1949-50 \\
1951-52 \\
1953-54 \ldots \\
1955-56\end{array}$ & $\begin{array}{l}22,284,000 \\
23,257,000 \\
25,643,871 \\
27,740,149 \\
29,722,275\end{array}$ & $\begin{array}{r}6,947,384 \\
7,697,130 \\
8,411,719 \\
9,695,819 \\
10,861,689\end{array}$ & $\begin{array}{l}31.2 \\
33.1 \\
32.8 \\
35.0 \\
36.5\end{array}$ & $\begin{array}{l}214,504 \\
268,827 \\
307,437 \\
353,972 \\
416,491\end{array}$ & $\begin{array}{l}31 \\
35 \\
37 \\
37 \\
38\end{array}$ & $\begin{array}{l}2,095,424 \\
2,366,308 \\
2,644,882 \\
3,046,242 \\
3,374,047\end{array}$ & $\begin{array}{l}302 \\
307 \\
314 \\
314 \\
311\end{array}$ \\
\hline $\begin{array}{l}1959-60 \\
1961-62 \\
1963-64 \ldots \\
1965-66\end{array}$ & $\begin{array}{l}32,477,440 \\
34,682,340 \\
37,405,058 \\
39,154,497 \\
40,827,965\end{array}$ & $\begin{array}{l}12,225,142 \\
13,222,667 \\
14,475,778 \\
15,536,567 \\
17,130,873\end{array}$ & $\begin{array}{l}37.6 \\
38.1 \\
38.7 \\
39.7 \\
42.0\end{array}$ & $\begin{array}{l}486,338 \\
576,361 \\
673,845 \\
787,358 \\
981,006\end{array}$ & $\begin{array}{l}40 \\
44 \\
47 \\
51 \\
57\end{array}$ & $\begin{array}{l}3,829,264 \\
4,436,166 \\
5,054,646 \\
5,708,814 \\
6,673,656\end{array}$ & $\begin{array}{l}313 \\
335 \\
349 \\
367 \\
390\end{array}$ \\
\hline $\begin{array}{l}1969-70 \\
1971-72 \\
1973-74 \ldots \\
1975-76\end{array}$ & $\begin{array}{l}41,934,376 \\
42,254,272 \\
41,438,054 \\
41,269,720 \\
40,079,590\end{array}$ & $\begin{array}{l}18,198,577 \\
19,474,355 \\
21,347,039 \\
21,772,483 \\
21,800,0004\end{array}$ & $\begin{array}{l}43.4 \\
46.1 \\
51.5 \\
52.8 \\
54.4\end{array}$ & $\begin{array}{l}1,218,557 \\
1,507,830 \\
1,858,141 \\
2,377,313 \\
2,731,041\end{array}$ & $\begin{array}{c}67 \\
77 \\
87 \\
109 \\
125\end{array}$ & $\begin{array}{r}7,463,020 \\
8,477,266 \\
9,220,046 \\
9,917,345 \\
10,087,842\end{array}$ & $\begin{array}{l}410 \\
435 \\
432 \\
455 \\
463\end{array}$ \\
\hline $\begin{array}{l}1979-80 \\
1980-81 \\
1981-82 \\
1982-83\end{array}$ & $\begin{array}{l}38,288,911 \\
37,703,744 \\
37,094,652 \\
36,635,868 \\
36,362,978\end{array}$ & \begin{tabular}{l|}
$21,713,515$ \\
$22,272,000^{4}$ \\
$22,246,000^{4}$ \\
$22,199,000^{4}$ \\
$22,031,000^{4}$
\end{tabular} & $\begin{array}{l}56.7 \\
59.1 \\
60.0 \\
60.6 \\
60.6\end{array}$ & \begin{tabular}{l|}
$3,833,145$ \\
$4,408,0004$ \\
$4,793,000^{4}$ \\
$5,000,000^{4}$ \\
$5,284,000^{4}$
\end{tabular} & \begin{tabular}{l|}
177 \\
198 \\
215 \\
225 \\
22 \\
240 \\
24
\end{tabular} & $\begin{array}{l}11,423,052 \\
11,772,5794 \\
11,782,9533^{4} \\
11,785,634^{4} \\
12,010,4934\end{array}$ & $\begin{array}{l}526 \\
529 \\
530 \\
531^{4} \\
545^{4}\end{array}$ \\
\hline $\begin{array}{l}1984-85 \\
1985-86 \\
1986-87 \\
1987-88 \ldots \ldots \ldots \ldots\end{array}$ & $\begin{array}{l}36,404,261 \\
36,523,103 \\
36,863,867 \\
37,050,707 \\
37,268,072\end{array}$ & $\begin{array}{l}22,320,0004 \\
22,041,000^{4} \\
22,397,000^{4} \\
22,158,000^{4} \\
22,635,000^{4}\end{array}$ & $\begin{array}{l}61.3 \\
60.3 \\
60.8 \\
59.8 \\
60.7\end{array}$ & $\begin{array}{l}5,722,0004 \\
6,123,0004 \\
6,551,000^{4} \\
6,888,000^{4} \\
7,550,000^{4}\end{array}$ & $\begin{array}{l}2564 \\
278 \\
292 \\
29 \\
311 \\
334 \\
334\end{array}$ & $\begin{array}{l}12,516,155^{4} \\
13,017,895 \\
13,625,336 \\
13,756,259 \\
14,412,730 \\
14\end{array}$ & $\begin{array}{l}561^{4} \\
591^{4} \\
608^{4} \\
621^{4} \\
637^{4}\end{array}$ \\
\hline $\begin{array}{l}1989-90 \\
1990-91 \\
1991-92 \\
1992-93 \\
1993-94\end{array}$ & $\begin{array}{l}37,799,296 \\
38,426,543 \\
38,960,783 \\
39,570,462 \\
40,146,393\end{array}$ & $\begin{array}{l}22,459,000^{4} \\
22,000,000^{4} \\
23,165,000^{4} \\
23,439,000^{4} \\
23,858,000^{4}\end{array}$ & $\begin{array}{l}59.4 \\
57.3 \\
59.5 \\
59.2 \\
59.4\end{array}$ & $\begin{array}{l}8,030,990 \\
8,678,954 \\
8,769,754 \\
9,252,300 \\
9,627,155\end{array}$ & $\begin{array}{l}3584 \\
394 \\
379 \\
395 \\
395 \\
404\end{array}$ & $\begin{array}{l}14,632,689 \\
14,993,567 \\
14,680,048 \\
15,018,686 \\
15,232,576\end{array}$ & $\begin{array}{l}652^{4} \\
682^{4} \\
634^{4} \\
641^{4} \\
638^{4}\end{array}$ \\
\hline $\begin{array}{l}1994-95 \\
1995-96 \\
1996-97 \\
1997-98 \ldots \ldots \ldots \ldots\end{array}$ & $\begin{array}{l}40,720,763 \\
41,501,596 \\
42,262,004 \\
42,765,774 \\
43,186,715\end{array}$ & $\begin{array}{l}23,693,000^{4} \\
24,155,000^{4} \\
24,090,000^{4} \\
24,342,000^{4} \\
24,898,000^{4}\end{array}$ & $\begin{array}{l}58.2 \\
58.2 \\
57.0 \\
56.9 \\
57.7\end{array}$ & $\begin{array}{r}9,889,034 \\
10,396,426 \\
10,989,809 \\
11,465,658 \\
12,224,454\end{array}$ & $\begin{array}{l}4177^{4} \\
4304 \\
456 \\
471 \\
47 \\
491\end{array}$ & $\begin{array}{l}15,210,944 \\
15,567,857 \\
15,999,914 \\
16,400,211 \\
17,188,025\end{array}$ & $\begin{array}{l}642^{4} \\
644^{4} \\
664^{4} \\
674^{4} \\
690^{4}\end{array}$ \\
\hline $\begin{array}{l}1999-2000 \\
2000-01 \\
2001-02 \\
2002-03 \ldots \ldots \ldots \ldots \ldots \ldots \\
2003\end{array}$ & $\begin{array}{l}43,806,726 \\
44,075,930 \\
44,604,592 \\
45,017,360 \\
45,325,731\end{array}$ & $\begin{array}{l}24,951,000^{4} \\
24,471,000^{4} \\
24,529,000^{5} \\
24,621,000^{5} \\
25,159,000^{5}\end{array}$ & $\begin{array}{l}57.0 \\
55.5 \\
55.0 \\
54.7 \\
55.5\end{array}$ & $\begin{array}{l}13,007,625 \\
14,052,654 \\
14,799,365 \\
15,648,821 \\
16,348,784\end{array}$ & $\begin{array}{l}521^{4} \\
5744^{4} \\
603 \\
636^{5} \\
650^{5}\end{array}$ & $\begin{array}{l}17,776,033 \\
18,568,008 \\
19,214,459 \\
19,880,433 \\
20,325,021\end{array}$ & $\begin{array}{l}712^{4} \\
759^{4} \\
783^{5} \\
807^{5} \\
808^{5}\end{array}$ \\
\hline $2004-05$ & $\begin{array}{l}45,625,458 \\
45,931,617 \\
46,132,663 \\
46,155,880 \\
46,173,477\end{array}$ & $\begin{array}{c}25,318,000^{5} \\
25,252,000^{5} \\
25,285,000^{5} \\
25,221,000^{5} \\
-\end{array}$ & $\begin{array}{r}55.5 \\
55.0 \\
54.8 \\
54.6 \\
-\end{array}$ & $\begin{array}{l}17,459,659 \\
18,850,234 \\
19,979,068 \\
21,536,978 \\
21,679,876\end{array}$ & $\begin{array}{l}690^{5} \\
746^{5} \\
790^{5} \\
854^{4} \\
860^{4}\end{array}$ & $\begin{array}{l}21,071,964 \\
21,915,651 \\
22,642,513 \\
23,536,022 \\
23,365,924\end{array}$ & $\begin{array}{l}832^{5} \\
868^{5} \\
895^{5} \\
933^{4} \\
927^{4}\end{array}$ \\
\hline 2009-10 $2010-11$ & $\begin{array}{l}45,919,206 \\
46,168,400\end{array}$ & - & - & $\begin{array}{l}21,819,304 \\
22,345,048\end{array}$ & $\begin{array}{l}870^{4} \\
8864\end{array}$ & $\begin{array}{l}23,290,837 \\
23,382,522\end{array}$ & $\begin{array}{l}929^{4} \\
928^{4}\end{array}$ \\
\hline
\end{tabular}

-Not available

"Unadjusted (or "current") dollars have not been adjusted to compensate for inflation. ${ }^{2}$ Constant dollars based on the Consumer Price Index, prepared by the Bureau of Labor Statistics, U.S. Department of Labor, adjusted to a school-year basis.

${ }^{3}$ Excludes capital outlay for years through $1979-80$, and $1989-90$ to the latest year. From 1980-81 to 1988-89 total transportation figures include capital outlay.

${ }^{4}$ Estimate based on data appearing in January issues of School Bus Fleet.

${ }^{5}$ Estimate based on data reported by School Transportation News.

NOTE: Some data have been revised from previously published figures.
SOURCE: U.S. Department of Education, National Center for Education Statistics, Statistics of State School Systems, 1929-30 through 1975-76; Revenues and Expenditures for Public Elementary and Secondary Education, 1977-78 and 1979-80; Common Core of Data (CCD), "National Public Education Financial Survey," 1987-88 through 2010-11; Bobit Publishing Co., School Bus Fleet, "School Transportation: 2000-2001 School Year" and "2010 Fact Book"; School Transportation News, "K-12 Enrollment/Transportation Data," 2001-02 through 2007-08; and unpublished data. (This table was prepared July 2013.) 


\section{CHAPTER 3 Postsecondary Education}

Postsecondary education includes academic, career and technical, and continuing professional education programs after high school. American colleges and universities and career/technical institutions offer a diverse array of postsecondary educational experiences. For example, a community college normally offers the first 2 years of a standard college curriculum as well as a selection of terminal career and technical education programs. A university typically offers a full undergraduate course of study leading to a bachelor's degree, as well as programs leading to advanced degrees. A specialized career/technical institution offers training programs of varying lengths that are designed to prepare students for specific careers.

This chapter provides an overview of the latest statistics on postsecondary education, including data on various types of postsecondary institutions and programs. However, to maintain comparability over time, most of the data in the Digest are for degree-granting institutions, which are defined as postsecondary institutions that grant an associate's or higher degree and whose students are eligible to participate in the Title IV federal financial aid programs. ${ }^{1}$ Degree-granting institutions include almost all 2- and 4-year colleges and universities; they exclude institutions offering only career and technical programs of less than 2 years' duration and continuing education programs. The degreegranting institution classification currently used by the National Center for Education Statistics (NCES) includes approximately the same set of institutions as the higher education institution classification that was used by NCES prior to $1996-97 .^{2}$ This chapter highlights historical data that enable the reader to observe long-range trends in college education in America.

\footnotetext{
${ }^{1}$ Title IV programs, which are administered by the U.S. Department of Education, provide financial aid to postsecondary students.

${ }^{2}$ Included in the current degree-granting classification are some institutions (primarily 2-year colleges) that were not previously designated as higher education institutions. Excluded from the current degree-granting classification are a few institutions that were previously designated as higher education institutions even though they did not award an associate's or higher degree. The former higher education classification was defined as including institutions that were accredited by an agency or association that was recognized by the U.S. Department of Education, or recognized directly by the Secretary of Education. The former institutions of higher education offered courses that led to an associate's or higher degree, or were accepted for credit towards a degree.
}

Other chapters provide related information on postsecondary education. Data on price indexes and on the number of degrees held by the general population are shown in chapter 1. Chapter 4 contains tabulations on federal funding for postsecondary education. Information on employment outcomes for college graduates is shown in chapter 5. Chapter 7 contains data on college libraries. Further information on survey methodologies is presented in Appendix A: Guide to Sources and in the publications cited in the table source notes. For information on adults' participation in nonpostsecondary education, such as General Educational Development (GED) or English as a Second Language (ESL) classes, see chapter 5 .

\section{Enrollment}

Enrollment in degree-granting institutions increased by 15 percent between 1992 and 2002 (table 303.10 and figure 12). Between 2002 and 2012, enrollment increased 24 percent, from 16.6 million to 20.6 million. Much of the growth between 2002 and 2012 was in full-time enrollment; the number of full-time students rose 28 percent, while the number of part-time students rose 19 percent. During the same time period, the number of females rose 25 percent, while the number of males rose 24 percent. Enrollment increases can be affected both by population growth and by rising rates of enrollment. Between 2002 and 2012, the number of 18- to 24year-olds increased from 28.5 million to 31.4 million, an increase of 10 percent (table 101.10), and the percentage of 18- to 24-year-olds enrolled in college rose from 37 percent in 2002 to 41 percent in 2012 (table 302.60). In addition to enrollment in accredited 2-year colleges, 4-year colleges, and universities, about 504,000 students attended non-degreegranting, Title IV eligible, postsecondary institutions in fall 2012 (table 303.20). These institutions are postsecondary institutions that do not award associate's or higher degrees; they include, for example, institutions that offer only career and technical programs of less than 2 years' duration.

Like enrollment in degree-granting institutions for the United States as a whole, the number of students enrolled in degree-granting institutions located within individual states has generally increased (table 304.10 and figure 13). From 2007 to 2012, when U.S. enrollment in degree-granting institutions increased by 13 percent overall, all 50 states experienced enrollment increases, with only the District of 
Columbia having a decrease (22 percent). However, enrollment increases varied from state to state. The largest increase was in Iowa (41 percent), followed by West Virginia (39 percent) and Idaho (37 percent). Three other states had increases of 25 percent or more. Thirty states had increases of between 10 percent and 25 percent, and 14 states had increases of less than 10 percent.

In recent years, the percentage increase in the number of students age 25 and over who enrolled in degree-granting institutions has been similar to the percentage increase in the number of younger students, but the rate of increase is expected to be higher for students age 25 and over than for younger students in the coming years (table 303.40 and figure 14). Between 2000 and 2012, the enrollment of students under age 25 and the enrollment of those age 25 and over both increased by 35 percent. From 2012 to 2023, however, NCES projects the rate of increase for students under age 25 to be 12 percent, compared with 20 percent for students age 25 and over.

Enrollment trends have differed at the undergraduate and postbaccalaureate levels. Undergraduate enrollment increased 47 percent between 1970 and 1983, when it reached 10.8 million (table 303.70). Undergraduate enrollment dipped to 10.6 million in 1984 and 1985, but then increased each year from 1985 to 1992, rising 18 percent before stabilizing between 1992 and 1998. Between 2002 and 2012, undergraduate enrollment rose 24 percent overall, from 14.3 million to 17.7 million; however, undergraduate enrollment in 2012 was lower than in 2010 (18.1 million). Postbaccalaureate enrollment increased 34 percent between 1970 and 1984, with most of this increase occurring in the early 1970s (table 303.80). Postbaccalaureate enrollment increased from 1985 to 2012, rising a total of 76 percent. During the last decade of this period, between 2002 and 2012, postbaccalaureate enrollment rose 24 percent, from 2.4 million to 2.9 million.

Since 1988, the number of females in postbaccalaureate programs has exceeded the number of males. Between 2002 and 2012, the number of full-time male postbaccalaureate students increased by 28 percent, compared with a 42 percent increase in the number of full-time female postbaccalaureate students. Among part-time postbaccalaureate students, the number of males increased by 8 percent and the number of females increased by 13 percent.

Eleven percent of undergraduates in both 2007-08 and 2011-12 reported having a disability (table 311.10). In 2011-12, some 44 percent of undergraduates with disabilities were male and 56 percent were female, about the same percentages as for undergraduates without disabilities. There were some differences in characteristics such as race/ethnicity, age, dependency status, and veteran status between undergraduates reporting disabilities and those without disabilities in 2011-12. For example, Black students made up a larger percentage of undergraduates reporting disabilities than of undergraduates without disabilities (18 percent vs. 16 percent). Undergraduates age 30 and over made up a larger percentage of those reporting disabilities than of those not reporting disabilities (36 percent vs. 24 percent). A larger percentage of undergraduates who had dependents reported disabilities than of those not reporting disabilities (33 percent vs. 27 percent). Also, veterans made up a larger percentage of undergraduates with disabilities than of undergraduates without disabilities ( 7 percent vs. 3 percent).

The percentage of American college students who are Hispanic, Asian/Pacific Islander, Black, and American Indian/ Alaska Native has been increasing (table 306.10). From 1976 to 2012, the percentage of Hispanic students rose from 4 percent to 15 percent, the percentage of Asian/Pacific Islander students rose from 2 percent to 6 percent, the percentage of Black students rose from 10 percent to 15 percent, and the percentage of American Indian/Alaska Native students rose from 0.7 to 0.9 percent. During the same period, the percentage of White students fell from 84 percent to 60 percent.

Of 20.6 million students enrolled in fall 2012, some 14 percent took at least one distance education course as part of their program that included a mix of in-person and distance education classes (table 311.15). In addition, about 13 percent of students took their college program exclusively through distance education classes. The remaining 74 percent of students took no distance education classes. About 8 percent of students at public institutions took their coursework exclusively through distance education courses, in comparison to 12 percent of students at private nonprofit institutions and 51 percent of students at private for-profit institutions.

Despite the sizable numbers of small degree-granting colleges, most students attend larger colleges and universities. In fall 2012, some 43 percent of institutions had fewer than 1,000 students; however, these campuses enrolled 4 percent of all college students (table 317.40). While 12 percent of campuses enrolled 10,000 or more students, they accounted for 60 percent of total college enrollment.

In 2012, the five postsecondary institutions with the highest enrollment were University of Phoenix, Online Campus, with 256,400 students; Ivy Tech Community College, with 100,300 students; Ashford University, with 77,700 students; Liberty University, with 74,400 students; and Arizona State University, with 73,400 students (table 312.10).

\section{Faculty, Staff, and Salaries}

Approximately 3.8 million people were employed in colleges and universities in fall 2011, including 2.9 million professional and 0.9 million nonprofessional staff (table 314.20). In fall 2011, there were 1.5 million faculty members in degree-granting institutions, including 0.8 million full-time and 0.8 million part-time faculty. From 1991 to 2011, the proportion of staff classified as professionalsincluding executive, administrative, and managerial professionals; faculty; graduate assistants; and other professionals_rose from 63 percent to 76 percent (table 314.20). The proportion of staff who were executive, administrative, and managerial professionals was 6 percent in 1991 and 6 percent in 2011. The proportion of staff who were faculty rose from 33 percent in 1991 to 40 percent in 2011. 
The proportion of other professionals not engaged in teaching rose from 17 percent in 1991 to 21 percent in 2011. The proportion of nonprofessional staff-including technical and paraprofessional, clerical and secretarial, skilled crafts, and service and maintenance staff-declined from 37 percent to 24 percent. The full-time-equivalent (FTE) student/ FTE staff ratio at colleges and universities increased from 4.9 in 1991 to 5.4 in 2011 (table 314.10 and figure 15). The FTE student/FTE faculty ratio was lower in 2011 (15.6) than in 1991 (16.4).

Colleges and universities differ in their practices of employing part-time and full-time staff. In fall 2011, some 47 percent of the employees at public 2-year colleges were employed full time, compared with 67 percent at public 4year colleges and universities, 70 percent at private nonprofit 4-year colleges and universities, and 61 percent at private nonprofit 2-year colleges (table 314.30). A higher percentage of the faculty at public 4-year colleges and universities were employed full time (66 percent) than at private nonprofit 4-year colleges and universities (56 percent), private for-profit 4-year colleges and universities (14 percent), private nonprofit 2-year colleges (43 percent), private for-profit 2-year colleges (40 percent), or public 2 -year colleges ( 30 percent). In general, the number of full-time staff has been growing at a slower rate than the number of part-time staff (table 314.20). Between 2001 and 2011, the number of full-time staff increased by 19 percent, compared to an increase of 35 percent in the number of part-time staff. Most of the increase in the part-time staff was due to the increase in the number of part-time faculty (54 percent) and graduate assistants (36 percent) during this time period.

In fall 2011, some 7 percent of college and university faculty were Black (based on a faculty count that excludes persons whose race/ethnicity was unknown), 7 percent were Asian, 5 percent were Hispanic, 1 percent were American Indian/Alaska Native, 1 percent were of two or more races, and less than 1 percent were Pacific Islander (table 314.40). About 80 percent of all faculty with known race/ethnicity were White; 42 percent were White males and 38 percent were White females. Staff who were Black, Hispanic, Asian, Pacific Islander, American Indian/Alaska Native, or of two or more races made up about 20 percent of executive, administrative, and managerial staff in 2011 and about 34 percent of nonprofessional staff. The proportion of total staff made up of Blacks, Hispanics, Asians, Pacific Islanders, American Indians/Alaska Natives, and persons of two or more races was similar at public 4-year colleges (26 percent), private 4 -year colleges ( 24 percent), and public 2-year colleges ( 24 percent), but the proportion at private 2-year colleges (37 percent) was higher.

On average, full-time faculty and instructional staff spent 58 percent of their time teaching in 2003 (table 315.30). Research and scholarship accounted for 20 percent of their time, and 22 percent was spent on other activities (administration, professional growth, etc.).
Faculty salaries generally lost purchasing power during the 1970s. In constant 2012-13 dollars, average salaries for faculty on 9 -month contracts declined by 16 percent during the period from $1970-71(\$ 74,000)$ to $1980-81$ $(\$ 62,200)$ (table 316.10$)$. During the 1980 s, average salaries rose and recouped most of the losses. Between 1990-91 and 2012-13, there was a further increase in average faculty salaries, resulting in an average salary in 2012-13 $(\$ 77,300)$ that was about 4 percent higher than the average salary in 1970-71. The average salary for males was higher than the average salary for females in all years for which data are available. The average salary in constant 2012-13 dollars for males in 2002-03 and $2012-13$ was about the same $(\$ 84,000)$. Also, for females, the average salary in $2012-13(\$ 69,100)$ was similar to the salary in 2002-03 (\$68,700). In 2012-13, average salaries were about 22 percent higher for males than for females $(\$ 84,000$ versus $\$ 69,100)$.

The percentage of faculty with tenure has declined. Of those faculty at institutions with tenure systems, about 49 percent of full-time instructional faculty had tenure in 2011-12, compared with 56 percent in 1993-94 (table 316.80). Also, the percentage of institutions with tenure systems in 2011-12 (45 percent) was lower than in 1993-94 (63 percent). Part of this change was due to the expansion in the number of for-profit institutions (table $317.10)$, relatively few of which have tenure systems (1.3 percent in 2011-12) (table 316.80). At institutions with tenure systems, there were differences between males and females in the percentage of full-time instructional faculty having tenure. Fifty-four percent of males had tenure in 2011-12, compared with 41 percent of females. In 2011-12, about 51 percent of full-time instructional faculty had tenure at public institutions with tenure systems, compared with 44 percent at private nonprofit institutions with tenure systems and 31 percent at private for-profit institutions with tenure systems.

\section{Degrees}

During the 2012-13 academic year, 4,726 accredited institutions offered degrees at the associate's degree level or above (table 317.10). These included 1,623 public institutions, 1,652 private nonprofit institutions, and 1,451 private for-profit institutions. Of the 4,726 institutions, 3,026 were 4-year institutions that awarded degrees at the bachelor's or higher level, and 1,700 were 2-year institutions that offered associate's degrees as their highest award. Institutions awarding various degrees in 2011-12 numbered 2,968 for associate's degrees, 2,533 for bachelor's degrees, 1,881 for master's degrees, and 885 for doctor's degrees (table 318.60).

Growing numbers of people are completing college degrees. Between 2001-02 and 2011-12, the number of associate's, bachelor's, master's, and doctor's degrees that were conferred rose (table 318.10). The doctor's degree total includes most degrees formerly classified as first-professional, 
such as M.D. (medical), D.D.S. (dental), and J.D. (law) degrees. During this period, the number of associate's degrees increased by 71 percent, the number of bachelor's degrees increased by 39 percent, the number of master's degrees increased by 55 percent, and the number of doctor's degrees increased by 42 percent. Since the mid-1980s, more females than males have earned associate's, bachelor's, and master's degrees. Beginning in 2005-06, the number of females earning doctor's degrees has exceeded the number of males. Also, the number of associate's, master's, and doctor's degrees awarded to females has increased at a faster rate than the number awarded to males. Between 2001-02 and 2011-12, the number of associate's degrees awarded to females increased by 75 percent, while the number awarded to males increased by 65 percent. The number of females earning master's degrees rose 59 percent during this period, while the number of males earning master's degrees rose 49 percent. The number of females earning doctor's degrees increased 54 percent, while the number of males earning doctor's degrees increased 32 percent. Between 2001-02 and 2011-12, the number of bachelor's degrees awarded to males increased 39 percent and the number awarded to females increased by 38 percent. In addition to degrees awarded at the associate's and higher levels, 988,000 certificates were awarded by postsecondary institutions participating in federal Title IV financial aid programs in 2011-12 (table 320.20).

Of the 1,791,000 bachelor's degrees conferred in 2011-12, the greatest numbers of degrees were conferred in the fields of business $(367,000)$, social sciences and history $(179,000)$, health professions and related programs $(163,000)$, psychology $(109,000)$, and education $(106,000)$ (table 322.10). At the master's degree level, the greatest numbers of degrees were conferred in the fields of business $(192,000)$ and education $(178,000)$ (table 323.10). At the doctor's degree level, the greatest numbers of degrees were conferred in the fields of health professions and related programs $(62,100)$, legal professions and studies $(46,800)$, education $(10,000)$, engineering $(8,700)$, biological and biomedical sciences $(7,900)$, psychology $(5,900)$, and physical sciences and science technologies $(5,400)$ (table 324.10).

In recent years, the numbers of bachelor's degrees conferred have followed patterns that differed significantly by field of study. While the number of degrees conferred increased by 39 percent overall between 2001-02 and 2011-12, there was substantial variation among the different fields of study, as well as shifts in the patterns of change during this time period (table 322.10 and figure 16). For example, the number of bachelor's degrees conferred in agriculture and natural resources was 1 percent lower in 2006-07 than in 2001-02, but then rose 34 percent between 2006-07 and 2011-12. Also, the number of degrees conferred in computer and information sciences was 16 percent lower in 2006-07 than in 2001-02, but the number in 2011-12 was 12 percent higher than in 2006-07. In contrast, the number of bachelor's degrees conferred in the combined fields of engineering and engineering technologies increased
10 percent between 2001-02 and 2006-07, and then increased a further 20 percent between 2006-07 and 2011-12. In some other major fields, the number of bachelor's degrees also increased by somewhat higher percentages in the second half of the 10-year period than in the first half. For example, the number of degrees conferred in physical sciences and science technologies increased by 19 percent between 2001-02 and 2006-07 and then by 25 percent between 2006-07 and 2011-12. The number of degrees conferred in health professions and related programs increased by 40 percent between 2001-02 and 2006-07 and then by 61 percent between 2006-07 and 2011-12. Also, the number of degrees conferred in public administration and social services increased by 19 percent between 2001-02 and 2006-07 and then by 28 percent between 2006-07 and 2011-12. Other fields with sizable numbers of degrees (over 5,000 in 2011-12) that showed increases of 30 percent or more between 2006-07 and 2011-12 included parks, recreation, leisure, and fitness studies (42 percent); multi/interdisciplinary studies (42 percent); and homeland security, law enforcement, and firefighting (37 percent).

Among first-time students who were seeking a bachelor's degree or its equivalent and attending a 4-year institution full time in 2006, 39 percent completed a bachelor's degree or its equivalent at that institution within 4 years, while 55 percent did so within 5 years, and 59 percent did so within 6 years (table 326.10). These graduation rates were calculated as the total number of completers within the specified time to degree attainment divided by the cohort of students who first enrolled at that institution in 2006. Graduation rates were higher at private nonprofit institutions than at public or private for-profit institutions. For example, the 6-year graduation rate for the 2006 cohort at private nonprofit institutions was 66 percent, compared with 57 percent at public institutions and 32 percent at private for-profit institutions. Graduation rates also varied by race/ethnicity. At 4-year institutions overall, the 6-year graduation rate for Asians in the 2006 cohort was 71 percent, compared with 67 percent for students of two or more races, 63 percent for Whites, 52 percent for Hispanics, 49 percent for Pacific Islanders, 40 percent for Blacks, and 40 percent for American Indians/ Alaska Natives.

\section{Finances and Financial Aid}

For the 2012-13 academic year, annual current dollar prices for undergraduate tuition, room, and board were estimated to be $\$ 15,022$ at public institutions, $\$ 39,173$ at private nonprofit institutions, and $\$ 23,158$ at private for-profit institutions (table 330.10). Between 2002-03 and 2012-13, prices for undergraduate tuition, room, and board at public institutions rose 39 percent, and prices at private nonprofit institutions rose 27 percent, after adjustment for inflation. The price for undergraduate tuition, room, and board at private for-profit institutions decreased 7 percent between 2002-03 and 2012-13, after adjustment for inflation. 
In 2011-12, about 84 percent of full-time undergraduate students received financial aid (grants, loans, work-study, or aid of multiple types) (table 331.10). About 73 percent of full-time undergraduates received federal financial aid in 2011-12, and 57 percent received aid from nonfederal sources. (Some students receive aid from both federal and nonfederal sources.) Section 484(r) of the Higher Education Act of 1965, as amended, suspends a student's eligibility for Title IV federal financial aid if the student is convicted of certain drug-related offenses that were committed while the student was receiving Title IV aid. About 0.01 percent of postsecondary students had their eligibility to receive aid suspended for 2009-10 (table C).

Table C. Postsecondary students denied access to Title IV financial aid because eligibility was suspended due to a drug-related conviction: 2009-10

\begin{tabular}{|c|c|c|}
\hline Suspension status & $\begin{array}{r}\text { Number of } \\
\text { applications }\end{array}$ & $\begin{array}{l}\text { Percentage } \\
\text { distribution }\end{array}$ \\
\hline Total & $19,490,666$ & 100.00 \\
\hline No suspension of eligibility... & $19,478,370$ & 99.98 \\
\hline $\begin{array}{l}\text { Suspension of eligibility } \\
\text { For part of award year (suspension ends during year)... } \\
\text { For full award year }\end{array}$ & 666 & \# \\
\hline $\begin{array}{l}\text { Due to conviction } \\
\text { Due to failure to report conviction status on aid } \\
\text { application form. }\end{array}$ & 1,751 & 0.01 \\
\hline
\end{tabular}

\#Rounds to zero.

NOTE: It is not possible to determine whether a student who lost eligibility due to a drug conviction otherwise would have received Title IV aid, since there are other reasons why an applicant may not receive aid. Detail may not sum to totals because of rounding.

SOURCE: U.S. Department of Education, Federal Student Aid, Free Application for Federal Student Aid (FAFSA), unpublished data.

In 2011-12, total revenue was $\$ 317$ billion at public institutions, \$162 billion at private nonprofit institutions, and \$27 billion at private for-profit institutions (tables 333.10, 333.40, and 333.55 and figures 17,18 , and 19). The category of student tuition and fees typically accounts for a significant percentage of total revenue and was the largest single revenue source at both private nonprofit and for-profit institutions in 2011-12 (39 and 89 percent, respectively). At public institu- tions, the share of revenue from tuition and fees (21 percent) was higher than that from state appropriations (19 percent) in 2011-12. Tuition and fees constituted the largest revenue category for private nonprofit 2- and 4-year institutions, private for-profit 2- and 4-year institutions, and public 4-year institutions. For public 2-year institutions, tuition and fees constituted the fourth largest revenue category.

In 2011-12, average total expenditures per full-timeequivalent (FTE) student at public degree-granting colleges were \$27,900 (table 334.10). The 2011-12 total expenditures per FTE student were about 1 percent higher than in 2005-06, after adjustment for inflation. In 2011-12, public 4-year colleges had average total expenditures per FTE student of $\$ 37,400$, compared with $\$ 12,800$ at public 2 -year colleges. At private nonprofit colleges, total expenditures per FTE student rose 5 percent between 2005-06 and 2011-12, after adjustment for inflation (table 334.30). In 2011-12, total expenditures per FTE student at private nonprofit colleges were $\$ 48,200$; they averaged $\$ 48,500$ at 4 -year colleges and $\$ 18,000$ at 2-year colleges (table 334.40). The expenditures per FTE student at private for-profit institutions were $\$ 14,300$ in 2011-12, which was about 10 percent higher than in 2005-06, after adjustment for inflation (tables 334.50 and 334.60). The difference between average expenditures per FTE student at private for-profit 4-year colleges $(\$ 14,100)$ and private for-profit 2 -year colleges $(\$ 15,000)$ was relatively small compared to the differences between 2-year and 4-year public and private nonprofit colleges.

At the end of fiscal year 2012, the market value of the endowment funds of colleges and universities was $\$ 425$ billion, reflecting an increase of 1 percent compared to the beginning of the fiscal year, when the total was $\$ 421$ billion (table 333.90). At the end of fiscal year 2012, the 120 colleges with the largest endowments accounted for $\$ 316$ billion, or about three-fourths of the national total. The five colleges with the largest endowments in 2012 were Harvard University ( $\$ 31$ billion), Yale University ( $\$ 19$ billion), Princeton University ( $\$ 17$ billion), the University of Texas System ( $\$ 17$ billion), and Stanford University ( $\$ 17$ billion). 
Figure 12. Enrollment, degrees conferred, and expenditures in degree-granting postsecondary institutions: 1960-61 through 2012-13

\section{Fall enrollment, in millions}

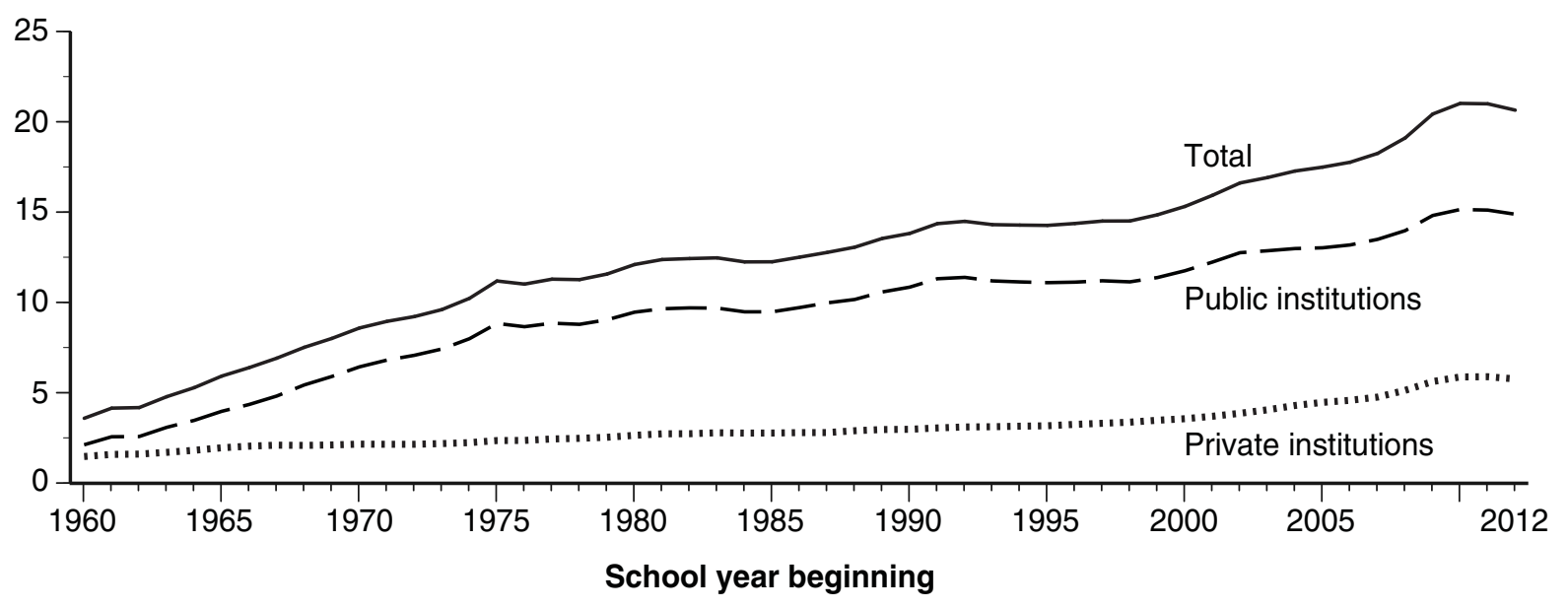

\section{Degrees, in millions}

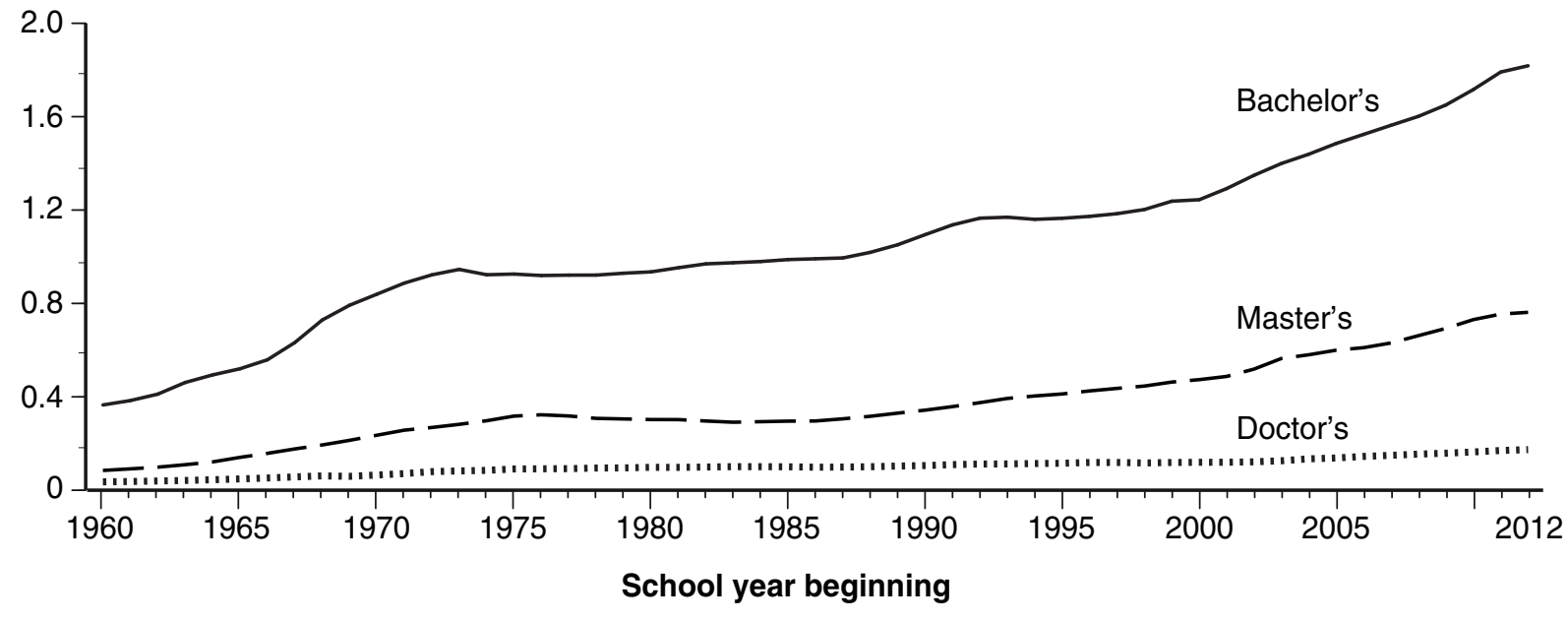

Total expenditures, in billions of constant 2012-13 dollars

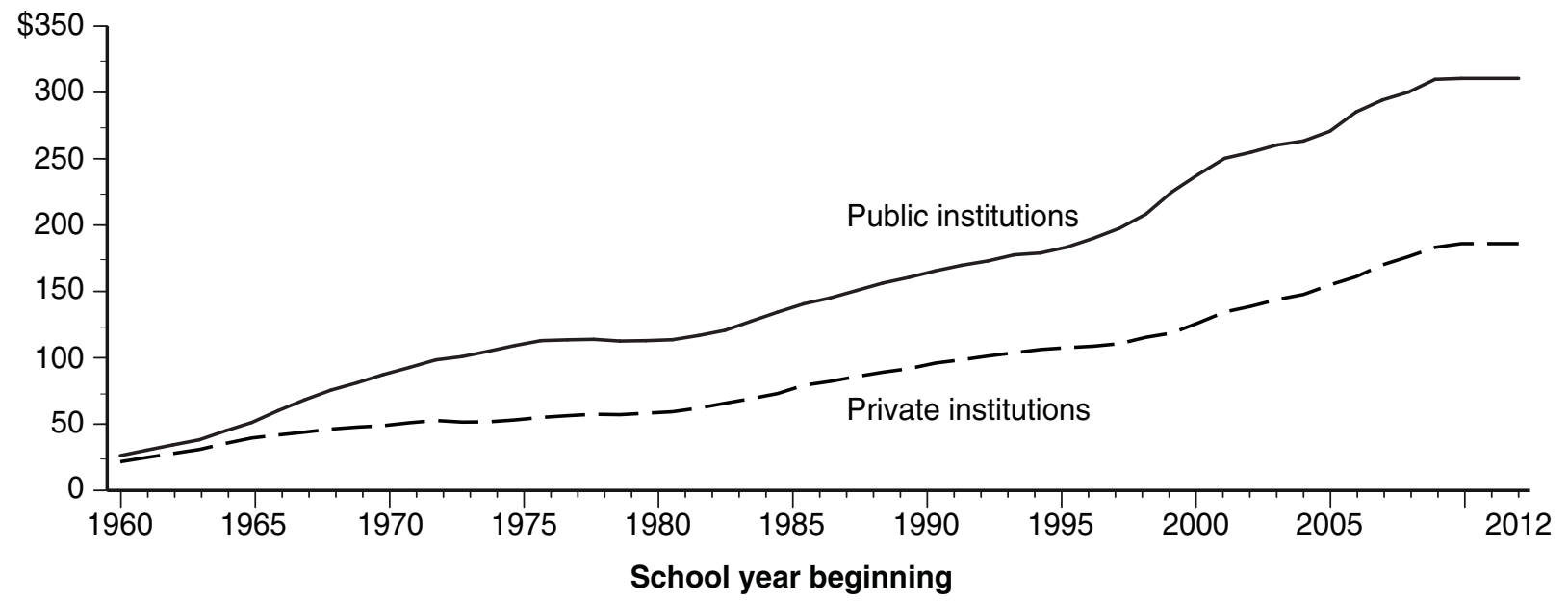

NOTE: Expenditure data for school year 2012 (2012-13) are estimated. Degree data for school year 2012 are projected. Doctor's degrees include Ph.D., Ed.D., and comparable degrees at the doctoral level, as well as such degrees as M.D., D.D.S., and law degrees that were formerly classified as first-professional degrees.

SOURCE: U.S. Department of Education, National Center for Education Statistics, Opening Fall Enrollment in Higher Education, 1960 through 1965 ; Financial Statistics of Higher Education, 1959-60 through 1964-65; Earned Degrees Conferred, 1959-60 through 1964-65; Degrees Conferred Projection Model, 1980-81 through 2023-24; Higher Education General Information Survey (HEGIS), "Fall Enrollment in Institutions of Higher Education," "Degrees and Other Formal Awards Conferred," and "Financial Statistics of Institutions of Higher Education" surveys, 1965-66 through 1985-86; Integrated Postsecondary Education Data System (IPEDS), "Fall Enrollment Survey" (IPEDS-EF:86-99), "Completions Survey" (IPEDS-C:87-99), and "Finance

Survey" (IPEDS-F:FY87-99); IPEDS Fall 2000 through Fall 2012, Completions component; and IPEDS Spring 2001 through Spring 2013, Enrollment and Finance components. 
Figure 13. Percentage change in total enrollment in degree-granting postsecondary institutions, by state: Fall 2007 to fall 2012

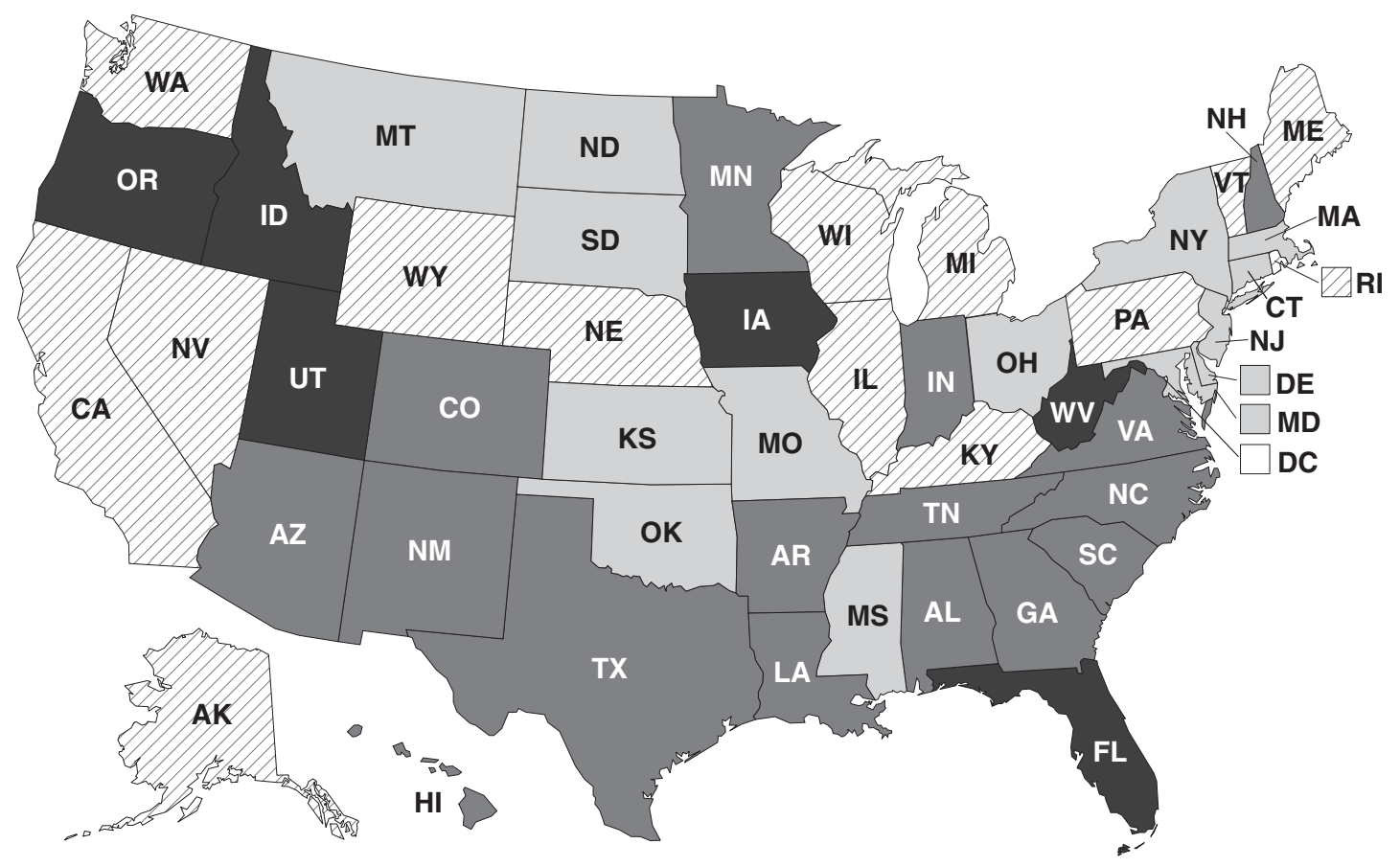

Percent change

Increase of 25 percent or more (6 states)

Increase of 15 percent, but less than 25 percent (16 states)

Increase of 10 percent, but less than 15 percent (14 states)

SOURCE: U.S. Department of Education, National Center for Education Statistics, Integrated Postsecondary Education Data System (IPEDS), Spring 2008 and Spring 2013 , Enrollment component.

Figure 14. Enrollment in degree-granting postsecondary institutions, by age: Fall 1970 through fall 2023

\section{Enrollment, in millions}

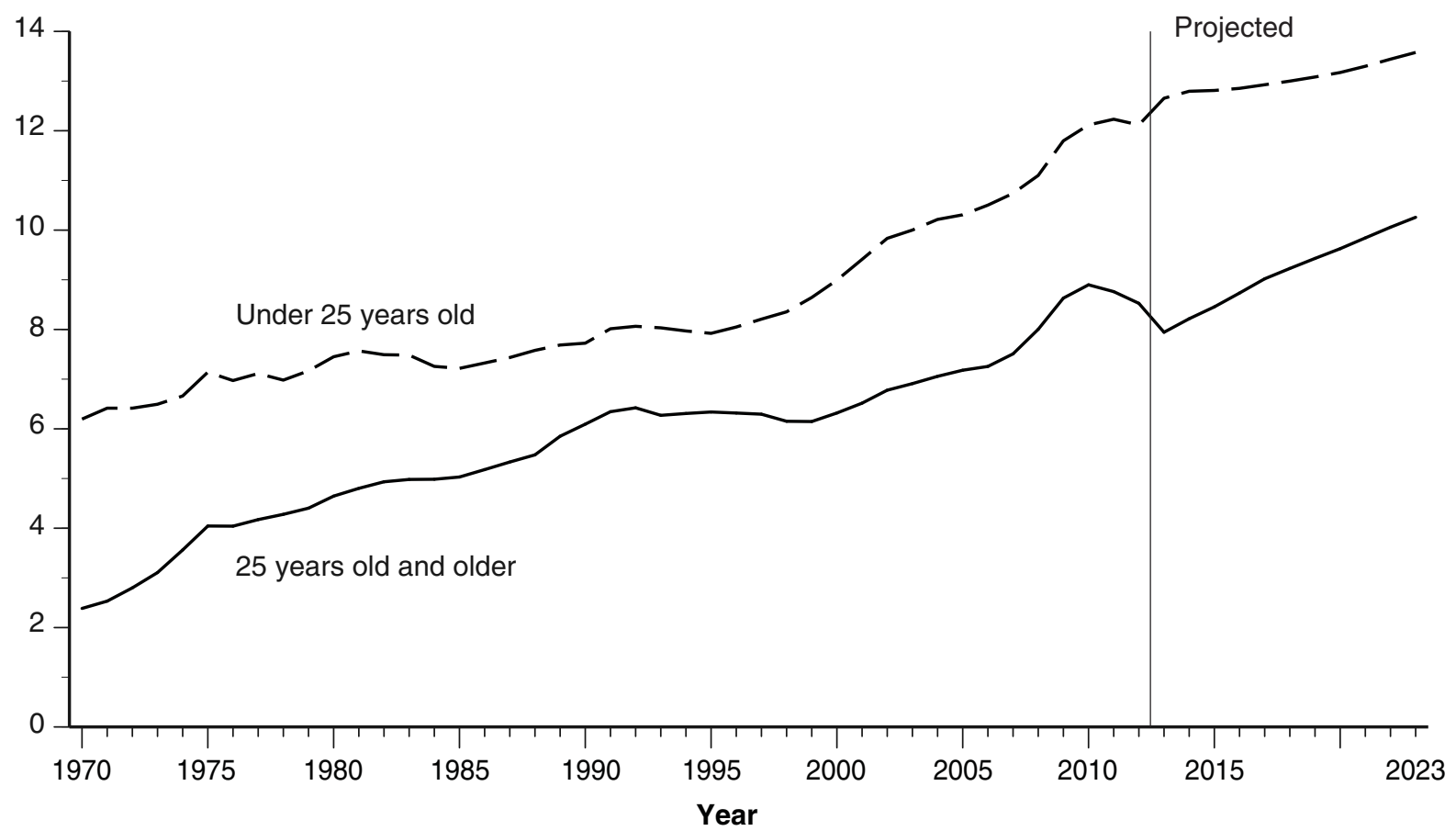

SOURCE: U.S. Department of Education, National Center for Education Statistics, Higher Education General Information Survey (HEGIS), "Fall Enrollment in Institutions of Higher Education" surveys, 1970 through 1985; Integrated Postsecondary Education Data System (IPEDS), "Fall Enrollment Survey" (IPEDS-EF:86-99); IPEDS Spring 2001 through Spring 2012, Enrollment component; and Enrollment in Degree-Granting Institutions Projection Model, 1980 through 2023. U.S. Department of Commerce, Census Bureau, Current Population Survey (CPS), October, selected years, 1970 through 2012. 
Figure 15. Ratio of full-time-equivalent (FTE) students to total FTE staff and to FTE faculty in degree-granting institutions, by control of institution: 1991, 2001, and 2011

\section{FTE students per \\ FTE staff member}

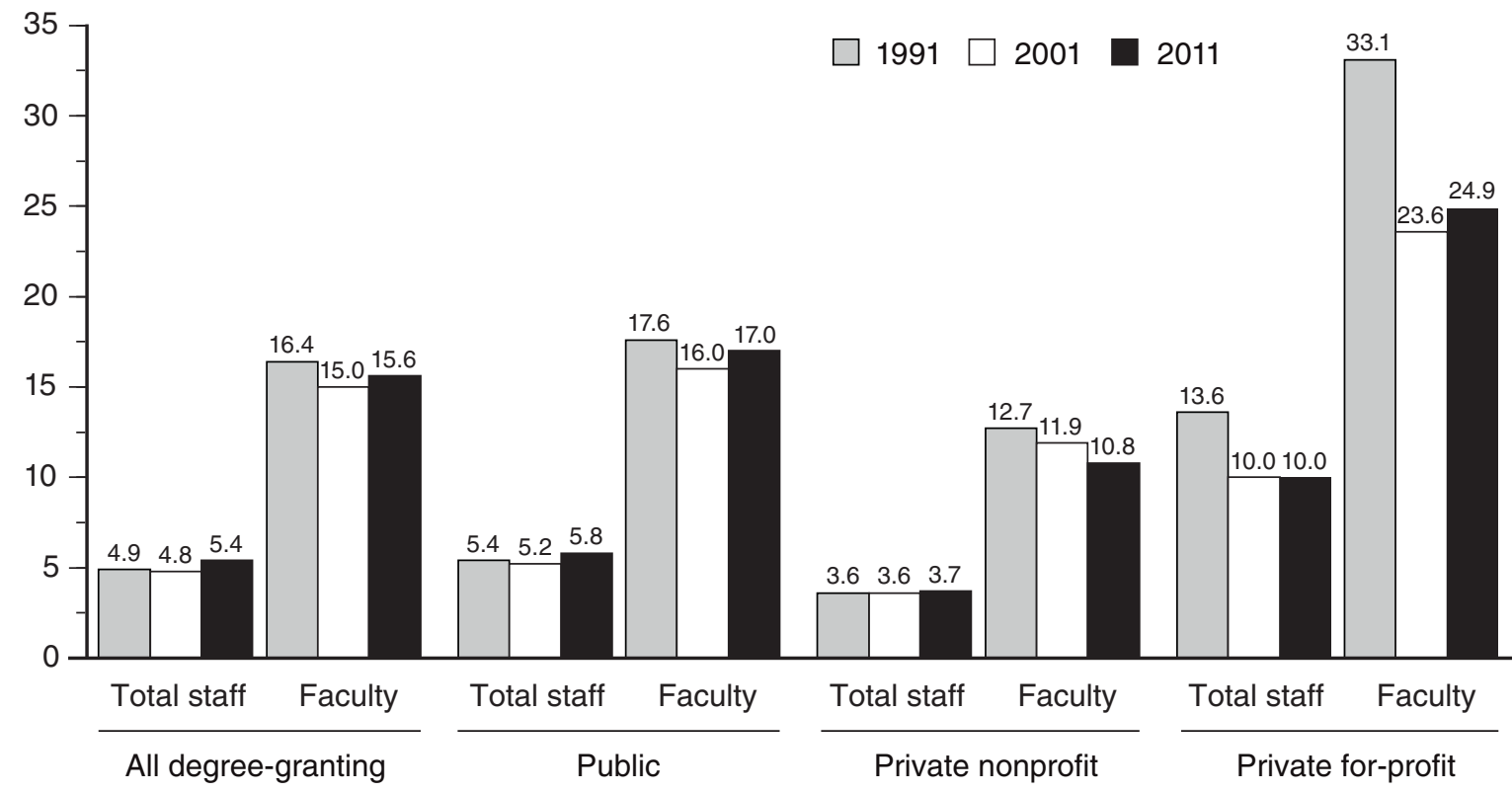

Control of institution and type of staff

SOURCE: U.S. Department of Education, National Center for Education Statistics, Integrated Postsecondary Education Data System (IPEDS), "Fall Enrollment Survey" (IPEDS-EF:91) and "Fall Staff Survey" (IPEDS-S:91); IPEDS Spring 2001 and 2012, Enrollment component; and IPEDS Winter 2001-02 and 2011-12, Human Resources component, Fall Staff section.

Figure 16. Bachelor's degrees conferred by postsecondary institutions in selected fields of study: 2001-02, 2006-07, and 2011-12

\section{Field of study}

Biological and biomedical sciences

Business

Communication, journalism, and communications technologies

Computer and information sciences

Education

Engineering and engineering technologies

Health professions and related programs

Psychology

Social sciences and history

Visual and performing arts
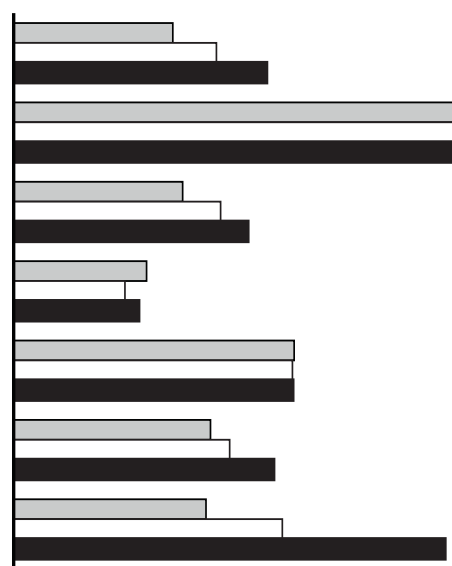

$\square$ 2001-02

$\square$ 2006-07

2011-12

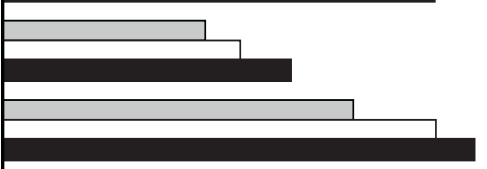

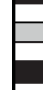

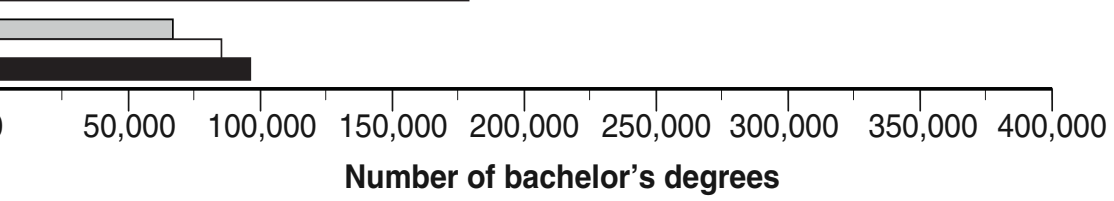

SOURCE: U.S. Department of Education, National Center for Education Statistics, Integrated Postsecondary Education Data System (IPEDS), Fall 2002, Fall 2007, and Fall 2012, Completions component. 
Figure 17. Percentage distribution of total revenues of public degree-granting postsecondary institutions, by source of funds: 2011-12

\section{Percent}

Total revenues $=\$ 317.3$ billion

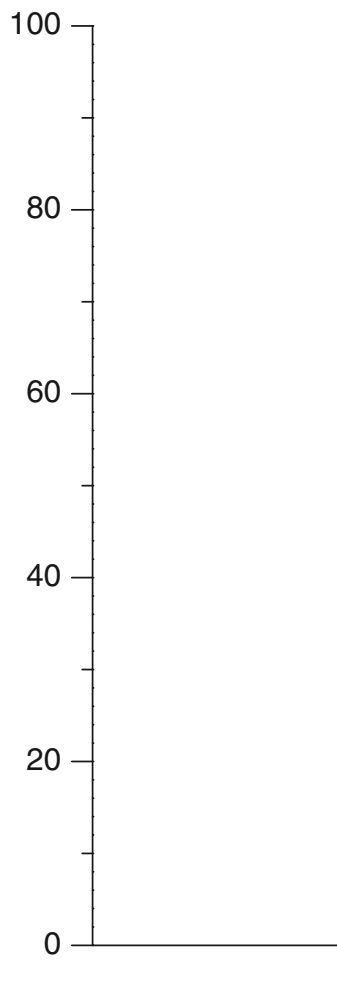

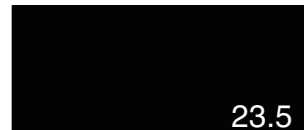

23.5
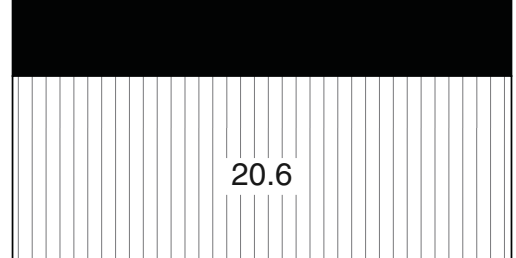

17.5

13.6
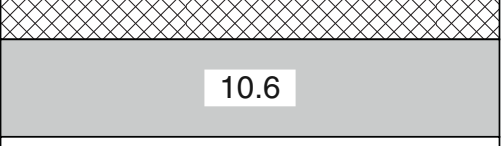

7.7

6.5
State governments ${ }^{1}$

Tuition and fees

Federal government ${ }^{2}$

Investment return, gifts, and other

Hospitals

Auxiliary enterprises

Local governments ${ }^{3}$

Source of funds

${ }^{1}$ Revenues from state governments include operating grants and contracts, nonoperating revenue appropriations, nonoperating grants, and capital appropriations.

${ }^{2}$ Revenues from the federal government include operating grants and contracts, funds for independent operations, nonoperating revenue appropriations, and nonoperating grants. ${ }^{3}$ Revenues from local governments include operating grants and contracts, nonoperating revenue appropriations, and nonoperating grants.

NOTE: Detail may not sum to totals because of rounding.

SOURCE: U.S. Department of Education, National Center for Education Statistics, Integrated Postsecondary Education Data System (IPEDS), Spring 2013, Finance component. 
Figure 18. Percentage distribution of total revenues of private nonprofit degree-granting postsecondary institutions, by source of funds: $2011-12$

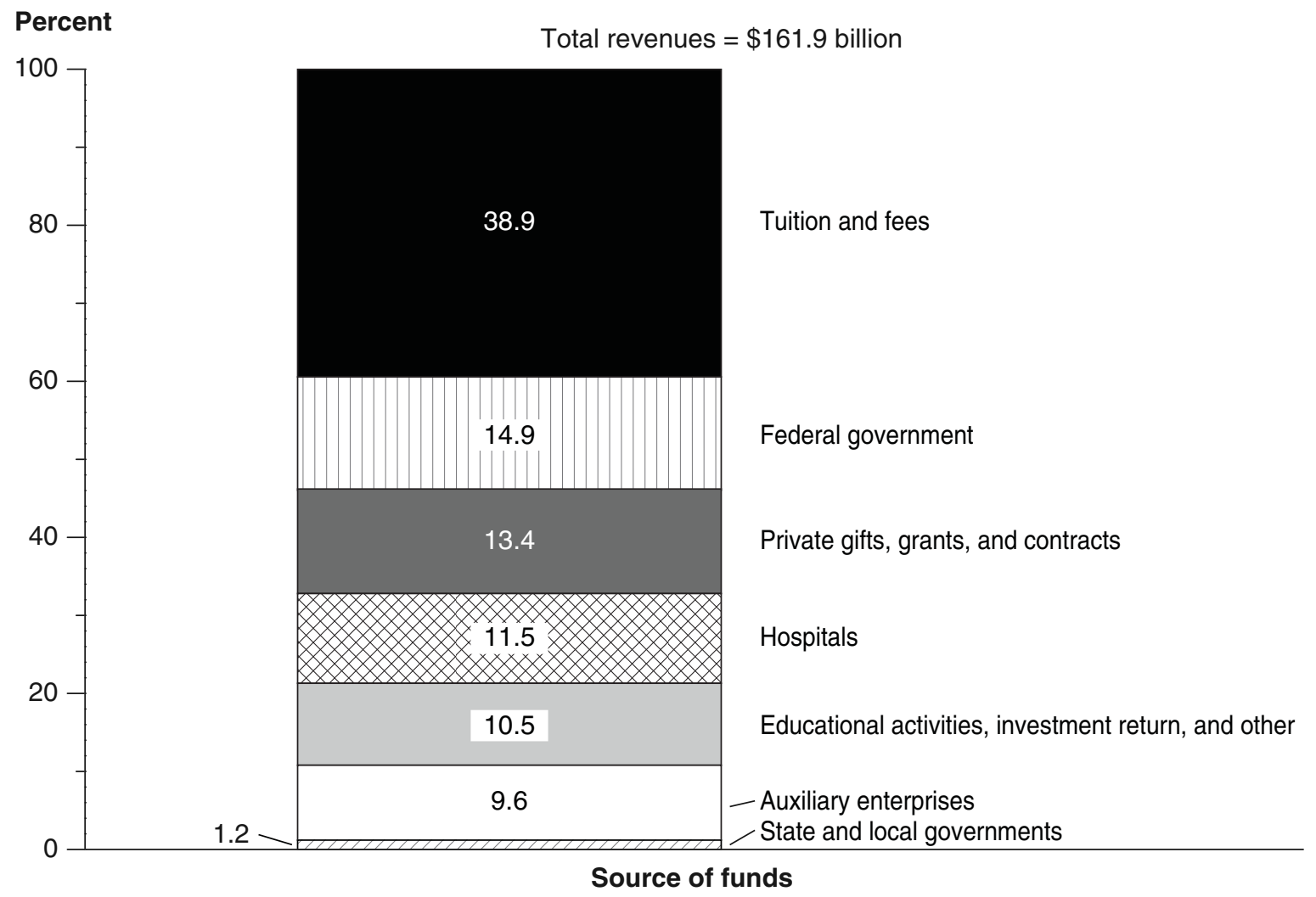

NOTE: Detail may not sum to totals because of rounding.

SOURCE: U.S. Department of Education, National Center for Education Statistics, Integrated Postsecondary Education Data System (IPEDS), Spring 2013, Finance component. 
Figure 19. Percentage distribution of total revenues of private for-profit degree-granting postsecondary institutions, by source of funds: 2011-12

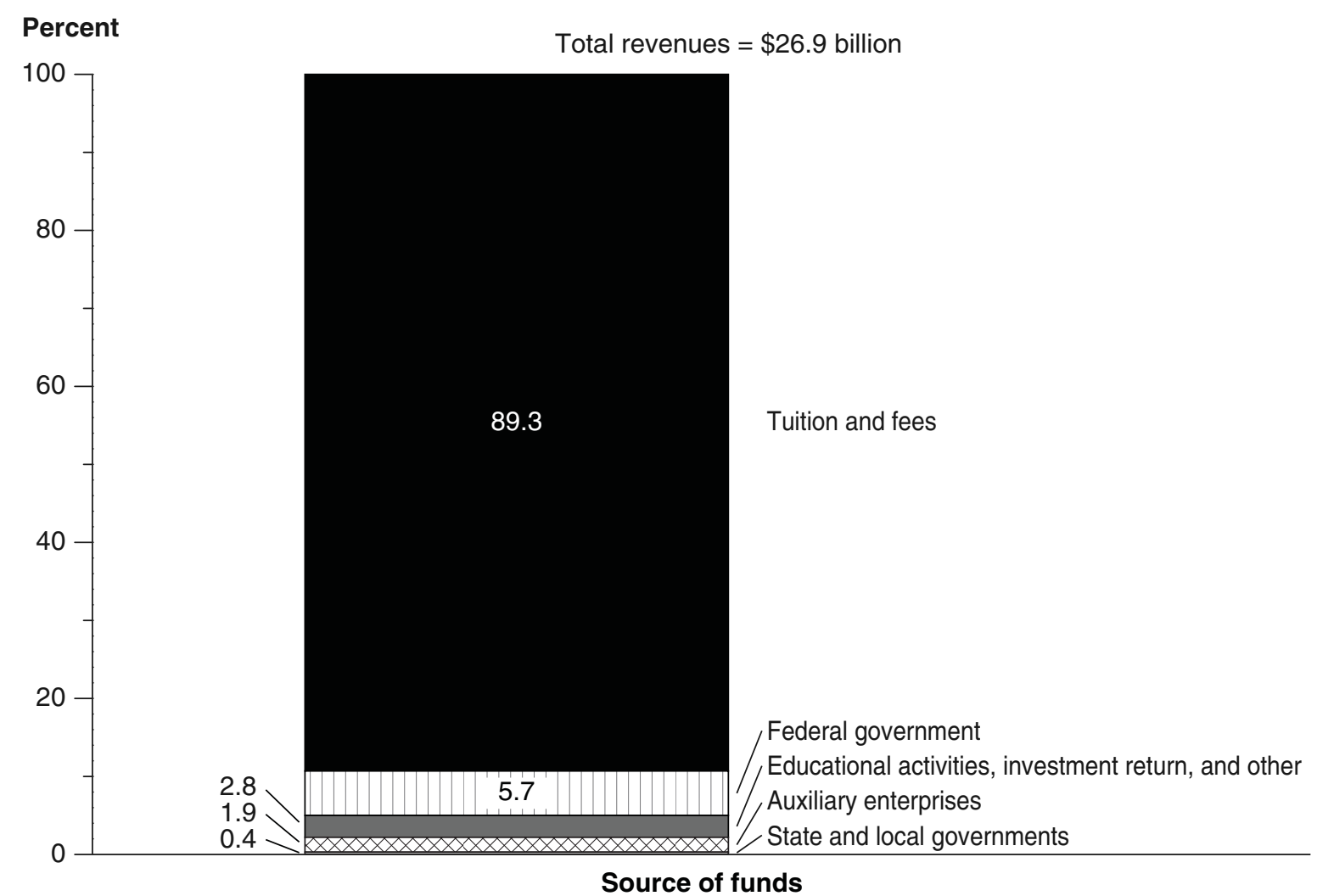

NOTE: Detail may not sum to totals because of rounding.

SOURCE: U.S. Department of Education, National Center for Education Statistics, Integrated Postsecondary Education Data System (IPEDS), Spring 2013, Finance component. 
Table 301.10. Enrollment, staff, and degrees/certificates conferred in degree-granting and non-degree-granting postsecondary institutions, by control and level of institution, sex of student, type of staff, and level of degree: Fall 2010, fall 2011, and 2011-12

\begin{tabular}{|c|c|c|c|c|c|c|c|c|c|c|c|}
\hline \multirow{3}{*}{$\begin{array}{l}\text { Level of institution, sex of student, } \\
\text { type of staff, and level of degree }\end{array}$} & \multirow[b]{3}{*}{ Total $^{1}$} & \multicolumn{5}{|c|}{ Degree-granting institutions } & \multicolumn{5}{|c|}{ Non-degree-granting institutions } \\
\hline & & \multirow[b]{2}{*}{ Total } & \multirow[b]{2}{*}{ Public } & \multicolumn{3}{|c|}{ Private } & \multirow[b]{2}{*}{ Total } & \multirow[b]{2}{*}{ Public } & \multicolumn{3}{|c|}{ Private } \\
\hline & & & & Total & Nonprofit & For-profit & & & Total & Nonprofit & For-profit \\
\hline 1 & 2 & 3 & 4 & 5 & 6 & 7 & 8 & 9 & 10 & 11 & 12 \\
\hline $\begin{array}{l}\text { Enrollment, fall } 2010 \\
\quad \text { Total }\end{array}$ & $21,588,124$ & $21,016,126$ & $15,142,809$ & $5,873,317$ & $3,854,920$ & $2,018,397$ & 571,998 & 137,464 & 434,534 & 26,986 & 407,548 \\
\hline 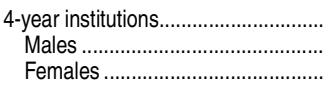 & $\begin{array}{r}13,335,777 \\
5,779,795 \\
7,555,982\end{array}$ & $\begin{array}{r}13,335,251 \\
5,779,685 \\
7,555,566\end{array}$ & $\begin{array}{l}7,924,771 \\
3,568,544 \\
4,356,227\end{array}$ & $\begin{array}{l}5,410,480 \\
2,211,141 \\
3,199,339\end{array}$ & $\begin{array}{l}3,822,260 \\
1,626,564 \\
2,195,696\end{array}$ & $\begin{array}{r}1,588,220 \\
584,577 \\
1,003,643\end{array}$ & $\begin{array}{l}526 \\
110 \\
416\end{array}$ & $\begin{array}{l}42 \\
15 \\
27\end{array}$ & $\begin{array}{r}484 \\
95 \\
389\end{array}$ & $\begin{array}{r}423 \\
79 \\
344\end{array}$ & $\begin{array}{l}61 \\
16 \\
45\end{array}$ \\
\hline 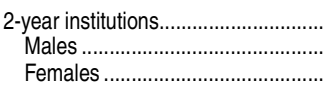 & $\begin{array}{l}7,847,996 \\
3,346,603 \\
4,501,393\end{array}$ & $\begin{array}{l}7,680,875 \\
3,265,126 \\
4,415,749\end{array}$ & $\begin{array}{l}7,218,038 \\
3,110,993 \\
4,107,045\end{array}$ & $\begin{array}{l}462,837 \\
154,133 \\
308,704\end{array}$ & $\begin{array}{l}32,660 \\
12,504 \\
20,156\end{array}$ & $\begin{array}{l}430,177 \\
141,629 \\
288,548\end{array}$ & $\begin{array}{r}167,121 \\
81,477 \\
85,644\end{array}$ & $\begin{array}{l}66,575 \\
35,616 \\
30,959\end{array}$ & $\begin{array}{r}100,546 \\
45,861 \\
54,685\end{array}$ & $\begin{array}{r}11,400 \\
3,130 \\
8,270\end{array}$ & $\begin{array}{l}89,146 \\
42,731 \\
46,415\end{array}$ \\
\hline 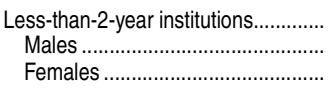 & $\begin{array}{l}404,351 \\
113,722 \\
290,629 \\
\end{array}$ & $\begin{array}{r}t \\
t \\
t \\
\end{array}$ & $\begin{array}{r}\dagger \\
\dagger \\
\dagger \\
\end{array}$ & $\begin{array}{r}\dagger \\
\dagger \\
\dagger \\
\end{array}$ & $\begin{array}{l}\dagger \\
t \\
\dagger \\
\end{array}$ & $\begin{array}{l}\dagger \\
t \\
\dagger \\
\end{array}$ & $\begin{array}{l}404,351 \\
113,722 \\
290,629 \\
\end{array}$ & $\begin{array}{l}70,847 \\
29,720 \\
41,127 \\
\end{array}$ & $\begin{array}{r}333,504 \\
84,002 \\
249,502 \\
\end{array}$ & $\begin{array}{r}15,163 \\
5,610 \\
9,553 \\
\end{array}$ & $\begin{array}{r}318,341 \\
78,392 \\
239,949 \\
\end{array}$ \\
\hline $\begin{array}{l}\text { Staff, fall } 2011 \\
\quad \text { Total } \ldots \ldots \ldots . . . . .\end{array}$ & $3,920,836$ & $3,840,980$ & $2,484,820$ & $1,356,160$ & $1,118,046$ & 238,114 & 79,856 & 24,000 & 55,856 & 5,080 & 50,776 \\
\hline 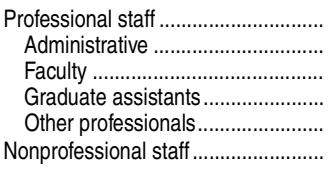 & $\begin{array}{r}2,986,568 \\
248,982 \\
1,565,504 \\
355,916 \\
816,166 \\
934,268 \\
\end{array}$ & $\begin{array}{r}2,923,961 \\
238,718 \\
1,523,615 \\
355,916 \\
805,712 \\
917,019 \\
\end{array}$ & $\begin{array}{r}1,865,269 \\
112,473 \\
953,230 \\
285,905 \\
513,661 \\
619,551 \\
\end{array}$ & $\begin{array}{r}1,058,692 \\
126,245 \\
570,385 \\
70,011 \\
292,051 \\
297,468 \\
\end{array}$ & $\begin{array}{r}843,740 \\
104,010 \\
432,733 \\
69,376 \\
237,621 \\
274,306 \\
\end{array}$ & $\begin{array}{r}214,952 \\
22,235 \\
137,652 \\
635 \\
54,430 \\
23,162 \\
\end{array}$ & $\begin{array}{r}62,607 \\
10,264 \\
41,889 \\
0 \\
10,454 \\
17,249 \\
\end{array}$ & $\begin{array}{r}17,977 \\
1,430 \\
14,716 \\
0 \\
1,831 \\
6,023 \\
\end{array}$ & $\begin{array}{r}44,630 \\
8,834 \\
27,173 \\
0 \\
8,623 \\
11,226 \\
\end{array}$ & $\begin{array}{r}3,791 \\
753 \\
2,309 \\
0 \\
729 \\
1,289 \\
\end{array}$ & $\begin{array}{r}40,839 \\
8,081 \\
24,864 \\
0 \\
7,894 \\
9,937 \\
\end{array}$ \\
\hline $\begin{array}{l}\text { Degrees/certificates conferred, } \\
\text { 2011-12 } \\
\text { Total }\end{array}$ & $4,720,590$ & $4,370,993$ & $2,780,118$ & $1,590,875$ & $1,004,473$ & 586,402 & 349,597 & 66,276 & 283,321 & 14,161 & 269,160 \\
\hline 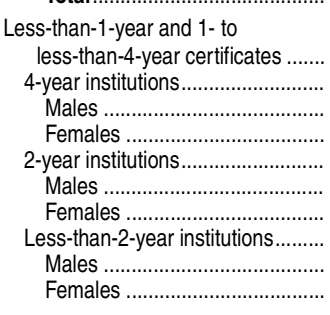 & $\begin{array}{r}987,715 \\
84,749 \\
33,574 \\
51,175 \\
638,990 \\
269,466 \\
369,524 \\
263,976 \\
70,444 \\
193,532\end{array}$ & $\begin{array}{r}638,174 \\
84,681 \\
33,562 \\
51,119 \\
553,493 \\
232,591 \\
320,902 \\
\dagger \\
\dagger \\
\dagger\end{array}$ & $\begin{array}{r}458,131 \\
46,148 \\
21,800 \\
24,348 \\
411,983 \\
192,959 \\
219,024 \\
\dagger \\
\dagger \\
\dagger\end{array}$ & $\begin{array}{r}180,043 \\
38,533 \\
11,762 \\
26,771 \\
141,510 \\
39,632 \\
101,878 \\
\dagger \\
\dagger \\
\dagger\end{array}$ & $\begin{array}{r}18,711 \\
9,905 \\
4,249 \\
5,656 \\
8,806 \\
2,421 \\
6,385 \\
\dagger \\
\dagger \\
\dagger\end{array}$ & $\begin{array}{r}161,332 \\
28,628 \\
7,513 \\
21,115 \\
132,704 \\
37,211 \\
95,493 \\
\dagger \\
\dagger \\
\dagger\end{array}$ & $\begin{array}{r}349,541 \\
68 \\
12 \\
56 \\
85,497 \\
36,875 \\
48,622 \\
263,976 \\
70,444 \\
193,532\end{array}$ & $\begin{array}{r}66,255 \\
0 \\
0 \\
0 \\
32,020 \\
14,805 \\
17,215 \\
34,235 \\
13,184 \\
21,051\end{array}$ & $\begin{array}{r}283,286 \\
68 \\
12 \\
56 \\
53,477 \\
22,070 \\
31,407 \\
229,741 \\
57,260 \\
172,481\end{array}$ & $\begin{array}{r}14,161 \\
68 \\
12 \\
56 \\
4,747 \\
1,425 \\
3,322 \\
9,346 \\
3,834 \\
5,512\end{array}$ & $\begin{array}{r}269,125 \\
0 \\
0 \\
0 \\
48,730 \\
20,645 \\
28,085 \\
220,395 \\
53,426 \\
166,969\end{array}$ \\
\hline 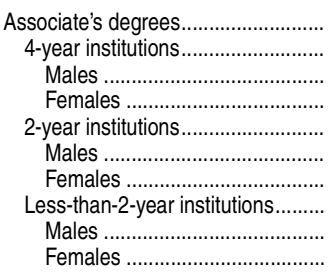 & $\begin{array}{r}1,017,538 \\
314,375 \\
118,927 \\
195,448 \\
703,128 \\
273,035 \\
430,093 \\
35 \\
28 \\
7\end{array}$ & $\begin{array}{r}1,017,482 \\
314,375 \\
118,927 \\
195,448 \\
703,107 \\
273,018 \\
430,089 \\
\dagger \\
\dagger \\
\dagger\end{array}$ & $\begin{array}{r}756,063 \\
132,719 \\
52,866 \\
79,853 \\
623,344 \\
242,900 \\
380,444 \\
\dagger \\
\dagger \\
\dagger\end{array}$ & $\begin{array}{r}261,419 \\
181,656 \\
66,061 \\
115,595 \\
79,763 \\
30,118 \\
49,645 \\
\dagger \\
\dagger \\
\dagger\end{array}$ & $\begin{array}{r}54,346 \\
46,731 \\
16,925 \\
29,806 \\
7,615 \\
2,848 \\
4,767 \\
\dagger \\
\dagger \\
\dagger\end{array}$ & $\begin{array}{r}207,073 \\
134,925 \\
49,136 \\
85,789 \\
72,148 \\
27,270 \\
44,878 \\
\dagger \\
\dagger \\
\dagger\end{array}$ & $\begin{array}{r}56 \\
0 \\
0 \\
0 \\
21 \\
17 \\
4 \\
35 \\
28 \\
7\end{array}$ & $\begin{array}{r}21 \\
0 \\
0 \\
0 \\
21 \\
17 \\
4 \\
0 \\
0 \\
0\end{array}$ & $\begin{array}{r}35 \\
0 \\
0 \\
0 \\
0 \\
0 \\
0 \\
35 \\
28 \\
7\end{array}$ & $\begin{array}{l}0 \\
0 \\
0 \\
0 \\
0 \\
0 \\
0 \\
0 \\
0 \\
0\end{array}$ & $\begin{array}{r}35 \\
0 \\
0 \\
0 \\
0 \\
0 \\
0 \\
35 \\
28 \\
7\end{array}$ \\
\hline 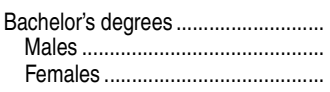 & $\begin{array}{r}1,791,046 \\
765,317 \\
1,025,729\end{array}$ & $\begin{array}{r}1,791,046 \\
765,317 \\
1,025,729\end{array}$ & $\begin{array}{r}1,131,886 \\
496,913 \\
634,973\end{array}$ & $\begin{array}{l}659,160 \\
268,404 \\
390,756\end{array}$ & $\begin{array}{l}526,506 \\
215,769 \\
310,737\end{array}$ & $\begin{array}{r}132,654 \\
52,635 \\
80,019\end{array}$ & $\begin{array}{l}0 \\
0 \\
0\end{array}$ & $\begin{array}{l}0 \\
0 \\
0\end{array}$ & $\begin{array}{l}0 \\
0 \\
0\end{array}$ & $\begin{array}{l}0 \\
0 \\
0\end{array}$ & $\begin{array}{l}0 \\
0 \\
0\end{array}$ \\
\hline 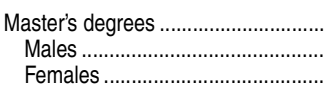 & $\begin{array}{l}754,229 \\
302,191 \\
452,038\end{array}$ & $\begin{array}{l}754,229 \\
302,191 \\
452,038\end{array}$ & $\begin{array}{l}349,311 \\
142,656 \\
206,655\end{array}$ & $\begin{array}{l}404,918 \\
159,535 \\
245,383\end{array}$ & $\begin{array}{l}325,427 \\
131,757 \\
193,670\end{array}$ & $\begin{array}{l}79,491 \\
27,778 \\
51,713\end{array}$ & $\begin{array}{l}0 \\
0 \\
0\end{array}$ & $\begin{array}{l}0 \\
0 \\
0\end{array}$ & $\begin{array}{l}0 \\
0 \\
0\end{array}$ & $\begin{array}{l}0 \\
0 \\
0\end{array}$ & $\begin{array}{l}0 \\
0 \\
0\end{array}$ \\
\hline 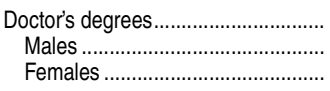 & $\begin{array}{r}170,062 \\
82,611 \\
87,451\end{array}$ & $\begin{array}{r}170,062 \\
82,611 \\
87,451\end{array}$ & $\begin{array}{l}84,727 \\
41,638 \\
43,089\end{array}$ & $\begin{array}{l}85,335 \\
40,973 \\
44,362\end{array}$ & $\begin{array}{l}79,483 \\
38,715 \\
40,768\end{array}$ & $\begin{array}{l}5,852 \\
2,258 \\
3,594\end{array}$ & $\begin{array}{l}0 \\
0 \\
0\end{array}$ & $\begin{array}{l}0 \\
0 \\
0\end{array}$ & $\begin{array}{l}0 \\
0 \\
0\end{array}$ & $\begin{array}{l}0 \\
0 \\
0\end{array}$ & $\begin{array}{l}0 \\
0 \\
0\end{array}$ \\
\hline
\end{tabular}

†Not applicable.

1 Includes both degree-granting and non-degree-granting institutions.

NOTE: Data are for postsecondary institutions participating in Title IV federal financial aid programs. Degree-granting institutions grant degrees at the associate's or higher level, while non-degree-granting institutions grant only awards below that level. The non-degreegranting classification includes some institutions transitioning to higher level program offer- ings, though still classified at a lower level; therefore, a small number of associate's degrees are shown as awarded by non-degree-granting institutions.

SOURCE: U.S. Department of Education, National Center for Education Statistics, Integrated Postsecondary Education Data System (IPEDS), Winter 2011-12, Human Resources component; Spring 2010, Enrollment component; and Fall 2012, Completions component. (This table was prepared July 2013.) 
Table 301.20. Historical summary of faculty, enrollment, degrees, and finances in degree-granting postsecondary institutions: Selected years, 1869-70 through 2011-12

\begin{tabular}{|c|c|c|c|c|c|c|c|c|c|c|c|c|c|c|c|c|}
\hline Selected characteristic & $1869-70$ & $1879-80$ & $1889-90$ & $1899-1900$ & $1909-10$ & $1919-20$ & $1929-30$ & $1939-40$ & $1949-50$ & $1959-60$ & $1969-70$ & $1979-80$ & $1989-90$ & 1999-2000 & 2009-10 & 2011-12 \\
\hline 1 & 2 & 3 & 4 & 5 & 6 & 7 & 8 & 9 & 10 & 11 & 12 & 13 & 14 & 15 & 16 & 17 \\
\hline Total institutions'............... & 563 & 811 & 998 & 977 & 951 & 1,041 & 1,409 & 1,708 & 1,851 & 2,004 & 2,525 & 3,152 & 3,535 & 4,084 & 4,495 & 4,706 \\
\hline 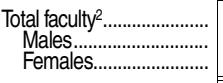 & $\begin{array}{r}5,553^{3} \\
4,887^{3} \\
666^{3} \\
\end{array}$ & $\begin{array}{r}11,522^{3} \\
7,322^{3} \\
4,194^{3} \\
\end{array}$ & \begin{tabular}{|l|}
15,809 \\
$12,704^{3}$ \\
$3,105^{3}$ \\
\end{tabular} & $\begin{aligned} 23,868 \\
19,151 \\
4,717 \\
\end{aligned}$ & $\begin{array}{r}36,480 \\
29,132 \\
7,348 \\
\end{array}$ & $\begin{array}{l}48,615 \\
35,807 \\
12,808 \\
\end{array}$ & $\begin{array}{l}82,386 \\
60,017 \\
22,369 \\
\end{array}$ & $\begin{array}{l}146,929 \\
106,328 \\
40,601 \\
\end{array}$ & $\begin{array}{r}246,722 \\
186,189 \\
60,533 \\
\end{array}$ & $\begin{array}{r}380,554 \\
296,773 \\
83,781 \\
\end{array}$ & $\begin{array}{l}450,000^{4} \\
346,000^{4} \\
104,000^{4} \\
\end{array}$ & $\begin{array}{l}675,000^{4} \\
479,000^{4} \\
196,000^{4} \\
\end{array}$ & $\begin{array}{l}824,2205 \\
533,2545 \\
289,966^{5} \\
\end{array}$ & $\begin{array}{r}1,027,8305 \\
602,4695 \\
425,661^{5} \\
\end{array}$ & $\begin{array}{r}1,439,1445 \\
761,035 \\
678,109^{5} \\
\end{array}$ & $\begin{array}{r}1,523,615^{5} \\
789^{5}, 1975 \\
734,418^{5} \\
\end{array}$ \\
\hline $\begin{array}{l}\text { Total fall enrollmentt } 6 . . . . . . . \\
\text { Males...................... } \\
\text { Females..................... }\end{array}$ & $\begin{array}{l}52,286 \\
41,160^{3} \\
11,126^{3} \\
\end{array}$ & \begin{tabular}{|l|l|}
115,817 \\
$77,972^{3}$ \\
$37,845^{3}$ \\
\end{tabular} & $\begin{array}{l}156,756 \\
100^{4}, 453^{3} \\
56,303^{3} \\
\end{array}$ & $\begin{array}{r}237,592 \\
152,254 \\
85,338 \\
\end{array}$ & $\begin{array}{l}355,213 \\
214,648^{3} \\
140,565^{3} \\
\end{array}$ & $\begin{array}{l}597,880 \\
314,938 \\
282,942 \\
\end{array}$ & $\begin{array}{r}1,100,737 \\
619,935 \\
480,802 \\
\end{array}$ & $\begin{array}{r}1,494,203 \\
893,250 \\
600,953 \\
\end{array}$ & $\begin{array}{l}2,444,900 \\
1,721,572 \\
, 723,328 \\
\end{array}$ & $\begin{array}{l}3,639,847 \\
2,332,617 \\
1,307,230 \\
\end{array}$ & $\begin{array}{l}8,004,660 \\
4,746,201 \\
3,258,459 \\
\end{array}$ & $\begin{array}{r}11,569,899 \\
5,688,877 \\
5,887,022 \\
\end{array}$ & $\begin{array}{r}13,538,560 \\
6,190,015 \\
7,348,545 \\
\end{array}$ & $\begin{array}{r}14,849,691 \\
6,515,164 \\
8,334,527 \\
\end{array}$ & $\begin{array}{r}20,427,711 \\
8,769,504 \\
11,658,207 \\
\end{array}$ & $\begin{array}{r}20,994,113 \\
9,026,499 \\
11,967,614 \\
\end{array}$ \\
\hline Degrees conferred & & & & & & & & & & & & & & & & \\
\hline $\begin{array}{l}\text { Associate's, total.............. } \\
\text { Males....................... } \\
\text { Females................... }\end{array}$ & $\bar{z}$ & $\bar{z} \quad$ & $\bar{z}$ & $\bar{z}$ & $\bar{z}$ & $\bar{z} \quad$ & $\bar{z}$ & $\bar{z}$ & $\bar{z} \quad$ & $\bar{z}$ & $\begin{array}{r}206,023 \\
117,432 \\
88,591\end{array}$ & $\begin{array}{l}400,910 \\
183,737 \\
217,773\end{array}$ & $\begin{array}{l}455,102 \\
191,195 \\
263,907\end{array}$ & $\begin{array}{l}564,933 \\
224,721 \\
340,212\end{array}$ & $\begin{array}{l}849,452 \\
322,916 \\
526,536\end{array}$ & $\begin{array}{r}1,017,538 \\
391,990 \\
625,548\end{array}$ \\
\hline $\begin{array}{r}\text { Bachelor's, total' } 7 . . . . . . . . . . . . . \\
\text { Males, } \\
\text { Females............................ }\end{array}$ & $\begin{array}{l}9,371 \\
7,993 \\
1,378\end{array}$ & $\begin{aligned} 12,896 \\
10,411 \\
2,485\end{aligned}$ & $\begin{aligned} 15,539 \\
12,857 \\
2,682\end{aligned}$ & $\begin{array}{r}27,410 \\
22,173 \\
5,237\end{array}$ & $\begin{array}{r}37,199 \\
28,762 \\
8,437\end{array}$ & $\begin{array}{l}48,622 \\
31,980 \\
16,642\end{array}$ & $\begin{array}{r}122,484 \\
73,615 \\
48,869\end{array}$ & $\begin{array}{l}186,500 \\
109,546 \\
76,954\end{array}$ & $\begin{array}{l}432,058 \\
328,841 \\
103,217\end{array}$ & $\begin{array}{l}392,440 \\
254,063 \\
138,37\end{array}$ & $\begin{array}{l}792,316 \\
451,097 \\
341,219\end{array}$ & $\begin{array}{l}929,417 \\
473,611 \\
455,806\end{array}$ & $\begin{array}{r}1,051,344 \\
491,696 \\
559,648\end{array}$ & $\begin{array}{l}1,237,875 \\
530,367 \\
707,508\end{array}$ & $\begin{array}{r}1,650,014 \\
706,633 \\
943,381\end{array}$ & $\begin{array}{l}1,791,046 \\
765,317 \\
1,025,729\end{array}$ \\
\hline 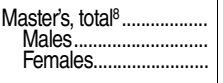 & $\begin{array}{l}0 \\
0 \\
0\end{array}$ & $\begin{array}{r}879 \\
868 \\
11\end{array}$ & $\begin{array}{r}1,015 \\
821 \\
194\end{array}$ & $\begin{array}{r}1,583 \\
1,280 \\
303\end{array}$ & $\begin{array}{r}2,113 \\
1,555 \\
558\end{array}$ & $\begin{array}{l}4,279 \\
2,985 \\
1,294\end{array}$ & $\begin{array}{r}14,969 \\
8,925 \\
6,044\end{array}$ & $\begin{array}{l}26,731 \\
16,508 \\
10,223\end{array}$ & $\begin{array}{l}58,183 \\
41,20 \\
16,963\end{array}$ & $\begin{array}{l}74,435 \\
50,898 \\
23,537\end{array}$ & $\begin{array}{r}213,589 \\
130,799 \\
82,790\end{array}$ & $\begin{array}{l}305,196 \\
156,82 \\
148,314\end{array}$ & $\begin{array}{l}330,152 \\
158,052 \\
172,100\end{array}$ & $\begin{array}{l}463,185 \\
196,129 \\
267,7056\end{array}$ & $\begin{array}{l}693,025 \\
275,197 \\
417,828\end{array}$ & $\begin{array}{l}754,229 \\
302,191 \\
452,238\end{array}$ \\
\hline 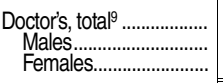 & $\begin{array}{l}1 \\
1 \\
0 \\
\end{array}$ & $\begin{array}{r}54 \\
51 \\
3 \\
\end{array}$ & $\begin{array}{r}149 \\
147 \\
2 \\
\end{array}$ & $\begin{array}{r}382 \\
359 \\
23 \\
\end{array}$ & $\begin{array}{r}443 \\
399 \\
44 \\
\end{array}$ & $\begin{array}{r}615 \\
522 \\
93 \\
\end{array}$ & $\begin{array}{r}2,299 \\
1,946 \\
353 \\
\end{array}$ & $\begin{array}{r}3,290 \\
2,861 \\
429 \\
\end{array}$ & $\begin{array}{r}6,420 \\
5,804 \\
616 \\
\end{array}$ & $\begin{array}{l}9,829 \\
8,801 \\
1,028 \\
\end{array}$ & $\begin{array}{r}59,486 \\
53,792 \\
5,694 \\
\end{array}$ & $\begin{array}{l}95,631 \\
69,526 \\
26,105 \\
\end{array}$ & $\begin{array}{r}103,508 \\
63,963 \\
39,545 \\
\end{array}$ & $\begin{array}{r}118,736 \\
64,930 \\
53,006 \\
\end{array}$ & $\begin{array}{r}158,558 \\
76,605 \\
81,953 \\
\end{array}$ & $\begin{array}{r}170,062 \\
82,611 \\
87,451 \\
\end{array}$ \\
\hline & \multicolumn{16}{|c|}{ In thousands of current dollars } \\
\hline \multicolumn{17}{|l|}{ Finances } \\
\hline $\begin{array}{l}\text { Current-fund revenue...... } \\
\text { Educational and general }\end{array}$ & - & - & - & - & $\$ 76,883$ & $\$ 199,922$ & $\$ 554,511$ & & & $\$ 5,785,537$ & $\$ 21,515,242$ & $\$ 58,519,982$ & $\$ 139,635,477$ & - & - & - \\
\hline 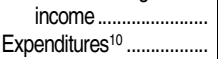 & - & - & $\begin{array}{r}\$ 21,464 \\
-\end{array}$ & $\begin{array}{r}\$ 35,084 \\
-\end{array}$ & $\begin{array}{r}67,917 \\
-\end{array}$ & $\begin{array}{r}172,929 \\
-\end{array}$ & $\begin{array}{l}483,065 \\
507,142\end{array}$ & $\begin{array}{l}571,288 \\
674,688\end{array}$ & $\begin{array}{l}1,833,845 \\
2,245,661\end{array}$ & $\begin{array}{l}4,688,352 \\
5,601,376\end{array}$ & $\begin{array}{l}16,486,177 \\
21,043,113\end{array}$ & $56,913,588$ & $\begin{array}{r}- \\
134,655,571\end{array}$ & $\$ 236,784,000$ & $\$ 446,484,000$ & $\$ 488,444,000$ \\
\hline $\begin{array}{l}\text { Value of physical property.. } \\
\text { Market value of }\end{array}$ & - & - & 95,426 & 253,599 & 457,594 & 747,333 & $2,065,049$ & $2,753,780^{11}$ & $4,799,964$ & $13,548,548$ & $42,093,580$ & $83,733,387$ & $164,635,000$ & - & & \\
\hline endowment funds..... & - & - & $78,788^{12}$ & $194,998{ }^{12}$ & $323,661^{12}$ & $569,071^{12}$ & $1,372,0688^{12}$ & $1,686,283^{12}$ & $2,601,223^{12}$ & $5,322,080^{12}$ & $11,206,632$ & $20,743,045$ & $67,978,726$ & - & $355,790,614$ & $424,587,666$ \\
\hline & \multicolumn{16}{|c|}{ In thousands of constant 2012-13 dollars ${ }^{13}$} \\
\hline \multicolumn{17}{|l|}{ Finances } \\
\hline $\begin{array}{l}\text { Current-fund revenue....... } \\
\text { Educational and general }\end{array}$ & - & - & - & - & - & - & $\$ 7,494,726$ & $\$ 11,840,107$ & $\$ 23,197,182$ & $\$ 45,553,400$ & $\$ 131,769,537$ & $\$ 174,393,813$ & $\$ 254,419,743$ & - & - & - \\
\hline 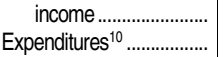 & - & $\begin{array}{l}- \\
-\end{array}$ & - & $\begin{array}{l}- \\
-\end{array}$ & $\begin{array}{l}- \\
-\end{array}$ & - & $\begin{array}{l}6,529,068 \\
6,854,491\end{array}$ & $\begin{array}{r}9,457,504 \\
11,169,261\end{array}$ & $\begin{array}{l}17,914,272 \\
21,937,177\end{array}$ & $\begin{array}{l}36,914,529 \\
44,103,377\end{array}$ & $\begin{array}{l}100,969,160 \\
128,877,995\end{array}$ & $169,606,642$ & $\begin{array}{r}- \\
245,346,215\end{array}$ & $\$ 323,586,000$ & $\$ 476,596,000$ & $\$ 496,572,000$ \\
\hline $\begin{array}{l}\text { Value of physical property.. } \\
\text { Market value of }\end{array}$ & - & - & - & - & - & - & $27,911,037$ & $45,588,015{ }^{11}$ & 46,889,384 & $106,676,775$ & $257,801,030$ & $249,531,598$ & $299,969,573$ & - & & \\
\hline endowment funds..... & - & - & - & - & - & - & $18,544,761^{12}$ & $27,915,917^{12}$ & $25,410,5544^{12}$ & $41,904,293^{12}$ & $68,634,725$ & $61,815,786$ & $123,859,139$ & - & $379,785,776$ & $431,653,399$ \\
\hline
\end{tabular}

-Not available.

${ }^{2}$ Total number of different individuals (not reduced to full-time equivalent). Beginning in 1959-60, data are for the first term of the academic year.

${ }^{3}$ Estimated

${ }^{4}$ Estimated number of senior instructional staff based on actual enrollment data for the designated year and enrollment/staff ralios tor the prior starl survey. Excludes graduate assistants.

directly comparable with figures prior to 1989-90. Excludes gradu${ }^{6}$ Data for $1869-70$ to $1939-40$ are for resident degree-credit students who enrolled at any time during the academic year 7From 1869-70 to $1959-60$, bachelor's degrees include degrees formerly classified as first-professional, such as M.D., D.D.S., and law degrees.

${ }_{9}^{8}$ Figures for years prior to $1969-70$ are not precisely comparable with later data.

Includes Ph.D., Ed.D., and comparable degrees at the doctoral level. Includes most degrees formerly classified as firstprofessional, such as M.D., D.D.S., and law degrees.
10Data for $1929-30$ and $1939-40$ include current-fund

1989-90 are current-fund expenditures culyent-fund expenditures and additions to plant value. Data for 1949-50 through rent-fund expenditures for public institutions. Data for later years are for total expenditures.
${ }^{11}$ Includes unexpended plant funds.

12Book value. Includes other nonexpendable funds.

Labor, adjusted to a school-year basis.

Labor, adjusted to a schoolyear basis. Del Dathrough 1989-90 are for institutions of higher education, while later data are for degree-granting institutions. degree-granting clissifiogtion is asy similar to thigher degrees and participate in title $V$ federal tinancial aid programs. The and excludes a few higher education institutions that did not grant degrees. Detail may not sum to totals because of rounding SOURCE: U.S. Department of Education, National Center for Education Statistics, Biennial Survey of Education in the United States; Education Directory, Colleges and Universities; Faculty and Other Professional Staff in Institutions of Higher Education; Fall Enrollment in Colleges and Universities; Earned Degrees Conferred; Financial Statistics of Institutions of Highe Education; Higher Education General Information Survey (HEGIS), "Fall Enrollment in Institutions of Higher Education,

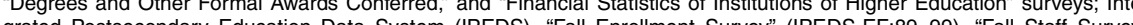
(IPEDS-S.89-99) "Finance Survey" (IPEDS-F.FY0-00), "CComptetions Survey" (IPEDS-C.90-00), and "Institution Curvey" teristics Survey" (IPEDS-IC 89-99); IPEDS Winter 2009-10 and Winter 2011-12. Human Resources component, Fall Staft section; IPEDS Spring 2010 and Spring 2012. Enrollment component: IPEDS Fall 2010 and Fall 2012, Completions component; and IPEDS Spring 2010 and Spring 2012, Finance component. (This table was prepared March 2014.) 
Table 302.10. Recent high school completers and their enrollment in 2-year and 4-year colleges, by sex: 1960 through 2012

[Standard errors appear in parentheses]

\begin{tabular}{|c|c|c|c|c|c|c|c|c|c|c|c|c|c|c|c|c|c|c|c|c|}
\hline \multirow[b]{3}{*}{ Year } & \multicolumn{5}{|c|}{$\begin{array}{l}\text { Number of high school completers } 1 \\
\text { (in thousands) }\end{array}$} & \multicolumn{15}{|c|}{ Percent of high school completers enrolled in college ${ }^{2}$} \\
\hline & \multirow{2}{*}{\multicolumn{2}{|c|}{ Total }} & \multirow{2}{*}{\multicolumn{2}{|c|}{ Males }} & \multirow[b]{2}{*}{ Females } & \multicolumn{4}{|c|}{ Total } & \multicolumn{6}{|c|}{ Males } & \multicolumn{5}{|c|}{ Females } \\
\hline & & & & & & Total & 2-year & & 4-year & & Total & & 2-year & & 4-year & & Total & 2-year & & 4-year \\
\hline$r$ & & 2 & & 3 & 4 & 5 & 6 & & 7 & & 0 & & $\overrightarrow{3}$ & & 10 & & 11 & 12 & & $\overline{13}$ \\
\hline 60. & 79 & $(43.8$ & $\overline{56}$ & $6(31.8)$ & $923(29.6)$ & $5.1(2.13)$ & $(\dagger)$ & - & $(\dagger)$ & 4.0 & (3.18) & - & $(\dagger)$ & - & $(\mathrm{t})$ & 7.9 & $(2.80)$ & $(\dagger)$ & - & $\overline{(\dagger)}$ \\
\hline & 763 & $(46.0$ & 90 & 0 (33.2) & 973 (31.3) & $8.0(2.09)$ & $(t)$ & - & $(\dagger)$ & 6.3 & (3.10) & - & $(\dagger)$ & - & $(t)$ & 1.3 & $(2.77)$ & $(t)$ & 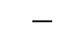 & $(+1)$ \\
\hline $62 \ldots . .>->$ & 1,838 & $(43.6$ & 872 & $2(31.5)$ & $966(30.0)$ & $49.0(2.05)$ & $(t)$ & - & $(\dagger)$ & 55.0 & (2.96) & - & $(\dagger)$ & - & $(t)$ & 43.5 & $(2.80)$ & $(t)$ & - & $(\dagger)$ \\
\hline $963 .$. & 1,741 & $(44.2$ & 794 & $4(32.1)$ & $947 \quad(30.0)$ & $45.0(2.09)$ & $(t)$ & - & $(\dagger)$ & 52.3 & (3.11) & - & $(\dagger)$ & - & $(t)$ & 39.0 & $(2.78)$ & $(t)$ & - & $(\dagger)$ \\
\hline $964 \ldots$ & 2,145 & $(43.0$ & 997 & $7(31.9)$ & 1,148 & $48.3(1.89)$ & $(\dagger)$ & - & $(\dagger)$ & 57.2 & (2.75) & - & $(t)$ & - & $(t)$ & 40.7 & (2.54) & (t) & - & $(\dagger)$ \\
\hline $965 \ldots$ & 2,659 & $(47.7$ & 1,254 & $4(35.1)$ & 1,405 (32.0) & $50.9(1.70)$ & (t) & - & $(\dagger)$ & 57.3 & (2.45) & - & (†) & - & $(t)$ & 45.3 & $(2.33)$ & $(t)$ & - & $(\dagger)$ \\
\hline $66 .$. & 2,612 & $(45.0$ & 1,207 & $7(33.8)$ & $1,405(29.0)$ & $50.1(1.72)$ & $(t)$ & - & $(\dagger)$ & 58.7 & (2.49) & - & $(\dagger)$ & - & $(t)$ & 42.7 & (2.32) & $(t)$ & - & $(\dagger)$ \\
\hline & 2,525 & $(37.9$ & 1,142 & $2(28.4)$ & $1,383(24.3)$ & 51.9 & $(\dagger)$ & - & $(\dagger)$ & 57.6 & (2.09) & - & $(\dagger)$ & - & $(\dagger)$ & 47.2 & (1.92) & - & - & 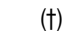 \\
\hline & 2,606 & $(37.3$ & 1,184 & 4 (28.2) & $1,422(23.8)$ & $55.4(1.39)$ & $(t)$ & - & $(t)$ & 63.2 & (2.00) & - & $(t)$ & - & $(t)$ & 48.9 & (1.89) & $(t)$ & - & (I) \\
\hline $960^{2}-x$ & 2,842 & $(36.0$ & 1,352 & $2(26.8)$ & 1,490 & $53.3(1.34)$ & $(t)$ & - & $(\dagger)$ & 60.1 & (1.90) & - & $(\dagger)$ & - & $(t)$ & 47.2 & (1.85) & $(t)$ & - & $(\dagger)$ \\
\hline 770 & 2,758 & $(37.4$ & 1,343 & $3(26.1)$ & 1,415 & $51.7(1.36$ & (†) & - & $(\dagger)$ & 2 & (1.94) & - & (†) & - & $(+)$ & 8.5 & $(1$. & - & - & (II) \\
\hline & 2,875 & $(38.0$ & 1,371 & $1(26.6)$ & 1,504 & $3.5(1)$. & $(\dagger)$ & - & $(\dagger)$ & 7.6 & (1.90) & - & $(\dagger)$ & - & $(\dagger)$ & 9.8 & $(1.8$ & $(t)$ & - & $(\dagger)$ \\
\hline & 2,964 & $(37.8$ & 1,423 & $3(27.0)$ & $1,542(26.4)$ & $49.2(1.31)$ & $(\dagger)$ & - & $(\dagger)$ & 2.7 & (1.89) & - & $(\dagger)$ & - & $(t)$ & 6.0 & $(1.81)$ & $(t)$ & - & $(\dagger)$ \\
\hline & 3,058 & $(37.1$ & 1,460 & $0(27.6)$ & $1,599(24.6)$ & $46.6(1.29)$ & $14.9(0.92)$ & 31.6 & (1.20) & 50.0 & $(1.87)$ & 14.6 & o (1.32) & 35.4 & $4(1.79)$ & 43.4 & (1.77) & $15.2(1.28)$ & 28.2 & (1.61) \\
\hline 74 & 3,101 & $(38.6$ & 1,491 & $1(27.8)$ & $1,611(26.8)$ & $47.6(1.28)$ & $15.2(0.92)$ & 2.4 & $(1.20)$ & 49.4 & $(1.85)$ & 16.6 & (1.37) & 32.8 & $3(1.74)$ & 45.9 & $(1.77)$ & $13.9(1.23)$ & 32.0 & (1.66) \\
\hline 78 & 3,185 & $(38.6$ & 1,513 & $3(27.3)$ & 1,672 & 50.7 & $18.2(0.98)$ & 2.6 & (1.19) & 52.6 & (1.83) & 19.0 & (1.44) & 33.6 & $6(1$ & 10 & (1.75) & 17.4 (1.32) & 1.6 & (1.62) \\
\hline & 2,986 & $(39.8$ & 1,451 & 1 (28.9) & $1,535(27.3)$ & $48.8(1.31)$ & $15.6(0.95)$ & 33.3 & $(1.23)$ & 47.2 & (1.87) & 14.5 & $5(1.32)$ & 32.7 & $7(1.76)$ & 50.3 & $(1.82)$ & $16.6(1.35)$ & 3.8 & (1.72) \\
\hline & 3,141 & $(40.7$ & 1,483 & $3(29.7)$ & $1,659(27.7)$ & $50.6(1.29)$ & $17.5(0.98)$ & 3.1 & (1.21) & 2.1 & $(1.87)$ & 17.2 & $2(1.41)$ & 35.0 & & 9.3 & $(1.77)$ & $17.8(1.36)$ & 1.5 & (1.65) \\
\hline & 3,163 & $(39.7$ & 1,485 & $5(29.3)$ & $1,677(26.7)$ & 50.1 (1.28) & $17.0(0.96)$ & 3.1 & (1.21) & 51.1 & (1.87) & 15.6 & (1.36) & 35.5 & 19) [ & 49.3 & (1.76) & $18.3(1.36)$ & 1.0 & (1.63) \\
\hline . & 3,160 & $(40.0$ & 1,475 & $5(29.2)$ & 1,685 (27.2) & $49.3(1.28)$ & $17.5(0.98)$ & 31.8 & $(1.20)$ & 50.4 & $(1.88)$ & 16.9 & $9(1.41)$ & 33.5 & $5(1.78)$ & 48.4 & (1.76) & $18.1(1.35)$ & 30.3 & (1.62) \\
\hline & 3,088 & $(39.4$ & 1,498 & $8(28.4)$ & $1,589(27.3)$ & $49.3(1.30)$ & $19.4(1.03)$ & 9.9 & $(1.19)$ & 6.7 & $(1.86)$ & 17.1 & (1.40) & 29.7 & $7(1.7$ & 51.8 & $(1.8$ & $21.6(1.49)$ & 0.2 & (1.66) \\
\hline & 3,056 & $(42.2$ & 1,491 & $1(30.4)$ & 1,565 & $53.9(1.30)$ & $20.5(1.05)$ & 3.5 & $(1.23)$ & 4.8 & (1. & 20.9 & $9(1$. & 33.9 & & 3.1 & $(1.8$ & $0.1(1$ & 3.0 & (2) \\
\hline & 3,100 & $(40.4$ & 1,509 & $9(29.0)$ & 1,592 & $50.6(1.36)$ & $19.1(1.07)$ & 1.5 & ; (1.26) & 49.1 & (1.95) & 17.5 & $5(1.4$ & 31.6 & & 52.0 & $(1.90)$ & $20.6(1.54)$ & 1.4 & (1.76) \\
\hline & 2,963 & $(41.6$ & 1,389 & $9(30.4)$ & $\mid 1,573$ (28.2) & $52.7(1.39)$ & $19.2(1.10)$ & 3.5 & $(1.31)$ & 51.9 & $(2.03)$ & 20.2 & (1.63) & 31.7 & $7(1.89)$ & 53.4 & (1.91) & $18.4(1.48)$ & 35.1 & $(1.82)$ \\
\hline $1984 .$. & 3,012 & $(36.5$ & 1,429 & $9(28.7)$ & $1,584 \quad(21.9)$ & $55.2(1.37)$ & $19.4(1.09)$ & 35.8 & (1.32) & 56.0 & (1.99) & 17.7 & (1.53) & 38.4 & $4 \quad(1.95)$ & 54.5 & (1.90) & $21.0(1.55)$ & 33.5 & $(1.80)$ \\
\hline & 68 & $(40.1$ & 1 & $7(28$ & $1,381 \quad(27.9)$ & $57.7(1.45)$ & $19.6(1.16)$ & & 3) & & $(2$ & 9.9 & $(1.66$ & 8.8 & & 8 & $(2$ & 193 & 7.5 & \\
\hline & 2,786 & $(38.6$ & 1,332 & $2(28.5)$ & $1,454(26.0)$ & $53.8(1.43)$ & $9.2(1.13)$ & 4.5 & $(1.37)$ & 5.8 & $(2.06)$ & 21.3 & $(1.70)$ & 34.5 & & 1.9 & (1.99) & $7.3(1.50)$ & 4.6 & (1.89) \\
\hline & 2,647 & $(40.9$ & 1,278 & $8(29.8)$ & $1,369(28.0)$ & $56.8(1.46)$ & $18.9(1.15)$ & 7.9 & (1.43) & 8.3 & $(2.09)$ & 17.3 & $(1.60)$ & 41.0 & (2.09) & 5.3 & $(2.04)$ & $20.3(1.65)$ & 5.0 & (1.95) \\
\hline & 2,673 & $(47.0$ & 1,334 & $4(34$ & $\mid 1,339$ (32.3) & 58.9 & $21.9(1$. & 1 & (1.54) & .1 & $(2$ & 21.3 & & 35.8 & & .7 & $(2$ & $2.4(1.88)$ & 8.3 & V) \\
\hline 1989 & 2,450 & (46.5 & 1,204 & $4(32.9)$ & $1,246 \quad(32.8)$ & $59.6(1.64)$ & $20.7(1.35)$ & 38.9 & $(1.63)$ & 57.6 & $(2.35)$ & 18.3 & (1.84) & 39.3 & $3(2.32)$ & 61.6 & $(2.27)$ & 23.1 (1.97) & 38.5 & (2.28) \\
\hline & 2,362 & $(43.0$ & 1,173 & $3(30.6)$ & 1,189 (30.2) & $60.1(1.60)$ & $20.1(1.31)$ & 0.0 & $(1.60)$ & 3.0 & $(2.2$ & 19.6 & $(1$. & 38.4 & 4 & 2.2 & $(2.2$ & $0.6(1$. & 1.6 & (2.28) \\
\hline & 2,276 & $(41$. & 1,140 & $0(29.0)$ & $\mid 1,136$ (29.0) & $5(1$ & $1.9(1$. & 7.7 & $(1$ & 9 & & 22.9 & & 35.0 & & 1 & (2.) & $8(2$ & .3 & \\
\hline & 2,397 & $(40.4$ & 1,216 & $6(29$ & 1,180 & $1.9(1$. & $30(1$. & 9 & $(1$ & .0 & $(2$ & 22.1 & 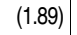 & 37.8 & & 8 & $(2$ & $3.9(1$. & 0.0 & (2.27) \\
\hline & 2,342 & $(41.4$ & 1,120 & $0(30.6)$ & $1,223(27.7)$ & $62.6(1.59)$ & $22.8(1.38)$ & 39.8 & $(1.61)$ & 9.9 & $(2.33)$ & 22.9 & $(2.00)$ & 37.0 & & 65.2 & $(2$. & $2.8(1.91)$ & 2.4 & (2.25) \\
\hline $1994 \ldots \ldots \ldots$ & 2,517 & $(38.1$ & 1,244 & $4(27.9)$ & $1,273(25.9)$ & $61.9(1.43)$ & $21.0(1.20)$ & 40.9 & $(1.45)$ & 60.6 & $(2.05)$ & 23.0 & $(1.76)$ & 37.5 & $5(2.03)$ & 63.2 & (1.99) & $19.1(1.63)$ & 44.1 & $(2.05)$ \\
\hline & 2, & $(4$ & 1,2 & $8(29$. & 1,361 (27.7) & $(1$. & $.5(1$. & & $(1$. & & $(2$. & 3 & 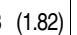 & 37.4 & & 3 & $(1$. & 11 & 3.2 & \\
\hline & 2,660 & $(40.5$ & 1,297 & 7 (29.5) & $1,363(27.7)$ & $5.0(1.4$ & 23.1 (1.26) & 1.9 & $(1.47)$ & 0.1 & $(2.0$ & 1.5 & $(1.7$ & 38.5 & & 9.7 & $(1.9$ & $4.6(1.80)$ & 5.1 & 7) \\
\hline & 2,769 & $(41.8$ & 1,354 & $4(31.0)$ & $1,415(27.9)$ & $67.0(1.38)$ & $22.8(1.23)$ & 4.3 & $(1.45)$ & 3.6 & $(2.01)$ & 21.4 & $(1.71)$ & 42.2 & & 70.3 & $(1.8$ & 4.1 (1.75) & 6.2 & $(2.04)$ \\
\hline & 2,810 & $(43.9$ & 1,452 & $2(31.0)$ & 1,358 (31.0) & 65.6 & $24.4(1.25)$ & 41.3 & $(1.43)$ & 62.4 & $(1.96)$ & 24.4 & $(1.74)$ & 38.0 & $0(1.5$ & 69.1 & (1.93) & $24.3(1.79)$ & 4.8 & (2.08) \\
\hline & 2,897 & $(41.5$ & 1,474 & $4(29.9)$ & $1,423(28.8)$ & $62.9(1.38)$ & $21.0(1.17)$ & 41.9 & (1.41) & 61.4 & $(1.95)$ & 21.0 & $(1.63)$ & 40.5 & $5(1.97)$ & 64.4 & (1.95) & $21.1 \quad(1.67)$ & 43.3 & (2.02) \\
\hline & & $(45.3$ & 1,251 & $1(33$ & 1,505 (29.7) & $3.3(1$. & $.4(1.2)$ & .9 & & & & 3.1 & & 00.0 & & 66.2 & $(1$. & $0.0(1$ & 6.2 & \\
\hline & 2,549 & $(46.5$ & 1,277 & 7 (33.7) & $1,273(32.0)$ & 61.8 & 19.6 & 42.1 & (1.51) & 60.1 & $(2.1$ & 18.6 & $(1.6$ & 41.4 & $4(2$ & 63.5 & $(2.08)$ & $0.6(1.75)$ & 2.8 & (2.13) \\
\hline & 2,796 & $(42.7$ & 1,412 & $2(31$ & $1,384(29.0)$ & $2(1$ & 21.6 & 3.6 & $(1$. & 2.1 & (1. & 20.4 & $(1$ & .7 & & 4 & $(1$ & $2.8(1$ & 6 & \\
\hline & 2,677 & $(42.2$ & 1,306 & $6(29$ & $1,372 \quad(29.7)$ & 63.9 & 21.5 & 42.5 & $(1$. & 2 & & 21.9 & & 39.3 & & 66.5 & (1.86) & $21.0(1.61)$ & 5.5 & $(1.96)$ \\
\hline $2004 \ldots .$. & 2,752 & $(40.0$ & 1,327 & $7(29.1)$ & 1,425 & $66.7(1.31)$ & $22.4(1.16)$ & 44.2 & (1.38) & 61.4 & $(1.95)$ & 21.8 & (1.65) & 39.6 & $6(1.96)$ & 71.5 & (1.74) & $23.1 \quad(1.63)$ & 48.5 & (1.93) \\
\hline & & & 1, & $2(3$ & 1,4 & 686 & (1) & & & & & & & & & & & 31 & & \\
\hline & 2,692 & $(44$ & 1,328 & $8(3 x)$ & $1,363 \quad 30$ & 66.0 & 24.7 & 1.3 & & 5.8 & & 24.9 & & 40.9 & & 3.1 & $(1$. & $4.5(1$ & 7 & \\
\hline & 2,955 & $(42.6$ & 1,511 & $1(30$ & $1,444(30.3)$ & $67.2(1.26)$ & 24.1 (1.15) & 3.1 & $(1$ & 66.1 & (1.78) & 22.7 & $(1$ & 43.4 & & 8.3 & $(1.79)$ & $5.5(1.67)$ & 2.8 & (1.90) \\
\hline & 3,151 & $(42.8$ & 1,640 & $0(29.6)$ & $1,511(30.9)$ & $68.6(1.21)$ & $27.7(1.16)$ & 40.9 & $(1.28)$ & 65.9 & $(1.71)$ & 24.9 & (1.56) & 41.0 & (1.77) & 71.6 & $(1.69)$ & $30.6(1.73)$ & 40.9 & $(1.85)$ \\
\hline $2009 . . . . . . . . . .$. & 2,937 & $(45.0$ & 1,407 & $7(32.8)$ & $1,531 \quad(30.6)$ & $70.1 \quad(1.23)$ & $27.7(1.21)$ & 42.4 & $(1.33)$ & 66.0 & $(1.84)$ & 25.1 & (1.69) & 40.9 & $9(1.91)$ & 73.8 & $(1.64)$ & $30.1(1.71)$ & 43.8 & $(1.85)$ \\
\hline & 60 & (91. & 1,679 & $9(64.6)$ & $1,482(58.4)$ & 68.1 & 26.7 (1. & 1.4 & $(1$ & 62.8 & $(1$ & 28.5 & $(2$ & 34.3 & & 4.0 & $(2$ & 24.6 & 9.5 & \\
\hline & 3,079 & $(88$ & 1,611 & $1(60$ & 1,468 (58.4) & 68.2 & 25.9 & 42.3 & $(1$. & 64.7 & $(2$ & 24.7 & $(1$ & 40.0 & & 72.2 & (1.98) & $27.3(2.17)$ & 4.9 & (2.37) \\
\hline $2012^{3}$. & 3,203 & $(96.2$ & 1,622 & $2(70.1)$ & $1,581(54.0)$ & $66.2(1.59)$ & $28.8(1.57)$ & 37.5 & $(1.60)$ & 61.3 & $(2.17)$ & 26.9 & (2.20) & 34.4 & $4(2.15)$ & 71.3 & (2.11) & $30.7(2.09)$ & 40.6 & (2.21) \\
\hline
\end{tabular}

-Not available.

†Not applicable.

1'Individuals ages 16 to 24 who graduated from high school or completed a GED during the preceding 12 months.

${ }^{2}$ Enrollment in college as of October of each year for individuals ages 16 to 24 who completed high school during the preceding 12 months.

${ }^{3}$ Beginning in 2010, standard errors were computed using replicate weights, which produced more precise values than the methodology used in prior years.
NOTE: Data are based on sample surveys of the civilian population. High school completion data in this table differ from figures appearing in other tables because of varying survey procedures and coverage. High school completers include GED recipients. Detail may not sum to totals because of rounding.

SOURCE: American College Testing Program, unpublished tabulations, derived from statistics collected by the Census Bureau, 1960 through 1969. U.S. Department of Commerce Census Bureau, Current Population Survey (CPS), October, 1970 through 2012. (This table was prepared May 2013.) 
Table 302.20. Percentage of recent high school completers enrolled in 2- and 4-year colleges, by race/ethnicity: 1960 through 2012 [Standard errors appear in parentheses]

\begin{tabular}{|c|c|c|c|c|c|c|c|c|c|c|c|c|c|c|c|c|c|c|c|c|c|c|c|c|c|c|}
\hline \multirow[b]{3}{*}{ Year } & \multirow{2}{*}{\multicolumn{10}{|c|}{$\begin{array}{l}\text { Percent of recent high school completers }{ }^{1} \text { enrolled in college }{ }^{2} \\
\text { (annual data) }\end{array}$}} & \multicolumn{16}{|c|}{ 3-year moving averages ${ }^{3}$} \\
\hline & & & & & & & & & & & \multicolumn{10}{|c|}{ Percent of recent high school completers ${ }^{1}$ enrolled in college ${ }^{2}$} & \multicolumn{6}{|c|}{ Difference between percent enrolled } \\
\hline & \multirow{2}{*}{\multicolumn{2}{|c|}{ Total }} & \multicolumn{2}{|r|}{ White } & \multicolumn{2}{|r|}{ Black } & \multicolumn{2}{|c|}{ Hispanic } & \multicolumn{2}{|r|}{ Asian } & \multicolumn{2}{|r|}{ Total } & \multicolumn{2}{|r|}{ White } & \multicolumn{2}{|r|}{ Black } & \multicolumn{2}{|c|}{ Hispanic } & \multicolumn{2}{|r|}{ Asian } & \multicolumn{2}{|c|}{ White-Black } & \multicolumn{2}{|c|}{$\begin{array}{r}\text { White- } \\
\text { Hispanic }\end{array}$} & \multicolumn{2}{|c|}{ White-Asian } \\
\hline 1 & & & & 3 & & 4 & & 5 & & 6 & & 7 & & 8 & & & & 10 & & 11 & & 12 & & 13 & & 14 \\
\hline $104^{\prime} \ldots \ldots . .$. & $\begin{array}{l}49.0 \\
45.0 \\
48.3\end{array}$ & $\begin{array}{l}(2.13) \\
(2.09) \\
(2.05) \\
(2.09) \\
(1.89)\end{array}$ & $\begin{array}{l}45.8 \\
49.5 \\
50.6 \\
45.6 \\
49.2\end{array}$ & $\begin{array}{l}(2.21) \\
(2.19) \\
(215) \\
(217) \\
(1.98)\end{array}$ & $\begin{array}{l}- \\
- \\
- \\
- \\
-\end{array}$ & 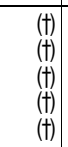 & $\begin{array}{l}- \\
- \\
- \\
- \\
-\end{array}$ & $\begin{array}{c}(t \\
+ \\
(t \\
(t \\
(t \\
+t\end{array}$ & $\begin{array}{l}- \\
- \\
- \\
- \\
-\end{array}$ & $\begin{array}{l}(+) \\
(t) \\
(t) \\
(t) \\
(t)\end{array}$ & $\begin{array}{l}46.6 \\
47.4 \\
47.4 \\
47.5 \\
48.5\end{array}$ & \begin{tabular}{|}
$(1.49)$ \\
$(1.21)$ \\
$(1.20)$ \\
$(1.16)$
\end{tabular} & $\begin{array}{l}47.7 \\
48.7 \\
48.6 \\
48.5 \\
49.2\end{array}$ & $\begin{array}{l}1.56) \\
1.26) \\
1.25)\end{array}$ & $\begin{array}{l}- \\
- \\
- \\
-\end{array}$ & $\begin{array}{l}0 \\
+ \\
+ \\
+ \\
+ \\
+ \\
+\end{array}$ & $\begin{array}{l}- \\
- \\
-\end{array}$ & $\begin{array}{l}(+) \\
(+) \\
(+) \\
(+) \\
(+)\end{array}$ & $\begin{array}{l}- \\
- \\
- \\
-\end{array}$ & $\begin{array}{c}(+) \\
(\dagger) \\
(\dagger)\end{array}$ & $\begin{array}{l}- \\
- \\
- \\
- \\
-\end{array}$ & $\begin{array}{l}(+) \\
(t) \\
(t) \\
(t) \\
(t)\end{array}$ & $\begin{array}{l}- \\
- \\
- \\
- \\
-\end{array}$ & $\begin{array}{l}(t) \\
(+) \\
(+) \\
(+) \\
(+)\end{array}$ & $\begin{array}{l}- \\
- \\
- \\
- \\
-\end{array}$ & $(+)$ \\
\hline $\begin{array}{l}965^{4} \ldots \ldots . . \\
966^{4} \ldots \ldots \ldots \\
967^{4} \ldots \ldots \ldots \\
968^{4} \ldots \ldots \ldots \\
969^{4} \ldots \ldots \ldots \\
\end{array}$ & $\begin{array}{l}50.9 \\
50.1 \\
51.9 \\
55.4 \\
53.3\end{array}$ & $\begin{array}{l}(1.70) \\
(1.72) \\
(1.42) \\
(1.39) \\
(1.34)\end{array}$ & $\begin{array}{l}51.7 \\
51.7 \\
53.0 \\
56.6 \\
55.2\end{array}$ & $\begin{array}{l}(1.78) \\
(1.79) \\
(1.50) \\
(1.47) \\
(1.41)\end{array}$ & $\begin{array}{l}- \\
- \\
- \\
-\end{array}$ & $\begin{array}{l}(t) \\
(t) \\
(t) \\
(t) \\
(t)\end{array} \mid$ & $\begin{array}{l}- \\
- \\
- \\
-\end{array}$ & $\begin{array}{c}+t \\
+t \\
+ \\
+ \\
+ \\
+t\end{array}$ & $\begin{array}{l}- \\
- \\
- \\
-\end{array}$ & $\begin{array}{l}(t) \\
(+) \\
(t) \\
(t) \\
(t)\end{array}$ & $\begin{array}{l}49.9 \\
51.0 \\
52.5 \\
53.6 \\
53.5\end{array}$ & & $\begin{array}{l}51.0 \\
52.1 \\
53.8 \\
55.0 \\
54.6\end{array}$ & & $\begin{array}{l}- \\
- \\
- \\
-\end{array}$ & $\begin{array}{l}(t \\
+ \\
+ \\
+ \\
+ \\
+\end{array}$ & $\begin{array}{l}- \\
-\end{array}$ & $\begin{array}{l}(+) \\
(+) \\
(+) \\
(+) \\
(+)\end{array}$ & $\begin{array}{l}- \\
- \\
- \\
-\end{array}$ & $\begin{array}{c}(t) \\
(+) \\
(\dagger) \\
(+) \\
(\dagger)\end{array}$ & $\begin{array}{l}- \\
- \\
- \\
-\end{array}$ & $\begin{array}{l}(t) \\
(t) \\
(t) \\
(t) \\
(t)\end{array}$ & $\begin{array}{l}- \\
- \\
- \\
-\end{array}$ & $\begin{array}{l}(t) \\
(+) \\
(+) \\
(t) \\
(t)\end{array}$ & $\begin{array}{l}- \\
- \\
- \\
- \\
-\end{array}$ & $\begin{array}{l}(\dagger) \\
(\dagger) \\
(\dagger)\end{array}$ \\
\hline & $\begin{array}{l}51.7 \\
53.5 \\
49.2\end{array}$ & $\begin{array}{l}(1.36) \\
(1.33) \\
(1.31) \\
(1.29) \\
(1.28)\end{array}$ & $\begin{array}{l}52.0 \\
54.0 \\
49.7 \\
47.8 \\
47.2\end{array}$ & $\begin{array}{l}(1.44) \\
(1.40) \\
(1.42) \\
(1.40) \\
(1.39)\end{array}$ & $\begin{array}{r}- \\
\overline{-} \\
32.6 \\
32.5 \\
47.2\end{array}$ & $\begin{array}{r}(+) \\
(+) \\
(4.62) \\
(4.30) \\
(4.58)\end{array}$ & $\begin{array}{l}- \\
- \\
45.0 \\
54.1 \\
46.9\end{array}$ & 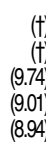 & $\begin{array}{l}- \\
- \\
- \\
-\end{array}$ & $\begin{array}{l}(t) \\
(+) \\
(+) \\
(t) \\
(t)\end{array} \mid$ & $\begin{array}{l}52.9 \\
51.5 \\
49.7 \\
47.8 \\
48.3\end{array}$ & & $\begin{array}{l}53.8 \\
51.9 \\
50.5 \\
48.2 \\
48.7\end{array}$ & & $\begin{array}{r}- \\
38.4 \\
41.4 \\
40.5\end{array}$ & $\begin{array}{r}(t \\
(t \\
(3.18 \\
(2.62 \\
(2.63\end{array}$ & $\begin{array}{r}- \\
49.9\end{array}$ & $\begin{array}{r}(+) \\
(+) \\
(6.64) \\
(5.33) \\
(5.09)\end{array}$ & $\begin{array}{l}- \\
- \\
- \\
-\end{array}$ & $\begin{array}{l}(t) \\
(t) \\
(t) \\
(t) \\
(t)\end{array}$ & $\begin{array}{c}- \\
\overline{-} \\
12.1 \\
6.8 ! \\
8.3 !\end{array}$ & $\begin{array}{r}(t) \\
(t) \\
(3.28) \\
(2.74) \\
(2.75)\end{array}$ & $\frac{-}{\ddagger}$ & $\begin{array}{l}(t) \\
(t) \\
(t)\end{array}$ & $\begin{array}{l}- \\
- \\
- \\
- \\
-\end{array}$ & $\begin{array}{l}(t) \\
(t) \\
(t)\end{array}$ \\
\hline & $\begin{array}{l}50.7 \\
48.8\end{array}$ & $\begin{array}{l}(1.26) \\
(1.31) \\
(1.29) \\
(1.28) \\
(1.28)\end{array}$ & $\begin{array}{l}51.1 \\
48.8 \\
50.8 \\
50.5 \\
49.9\end{array}$ & $\begin{array}{l}(1.37) \\
(1.43) \\
(1.41) \\
(1.41) \\
(1.41)\end{array}$ & $\begin{array}{l}41.7 \\
44.4 \\
49.5 \\
46.4 \\
46.7\end{array}$ & $\begin{array}{l}(3.97) \\
(4.08) \\
(4.65) \\
(4.51) \\
(4.69)\end{array}$ & $\begin{array}{l}58.0 \\
52.7\end{array}$ & $\begin{array}{l}(7.96 \\
(8.44 \\
(7.92\end{array}$ & $\begin{array}{l}- \\
- \\
- \\
- \\
-\end{array}$ & $\begin{array}{l}(t) \\
(t) \\
(+) \\
(t) \\
(t)\end{array} \mid$ & $\begin{array}{l}49.1 \\
50.1 \\
49.9\end{array}$ & & $\begin{array}{l}49.1 \\
50.3 \\
50.1 \\
50.4 \\
50.1\end{array}$ & & $\begin{array}{l}4.5 \\
45.2\end{array}$ & $\begin{array}{l}(2.29) \\
(2.30 \\
(2.70 \\
(2.67) \\
(2.62)\end{array}$ & 52.7 & $(4.88)$ & $\begin{array}{l}- \\
- \\
- \\
-\end{array}$ & $\begin{array}{c}(+) \\
(+)\end{array}$ & $\begin{array}{c}\ddagger \\
5.0 ! \\
\ddagger\end{array}$ & $\left.\begin{array}{r}(t) \\
(2.44)\end{array}\right]$ & $\ddagger$ & $\begin{array}{l}(t) \\
(t) \\
(t)\end{array}$ & - & $\begin{array}{l}(\dagger) \\
(\dagger)\end{array}$ \\
\hline & & $\begin{array}{l}(1.30) \\
(1.30) \\
(1.36) \\
(1.39) \\
(1.37)\end{array}$ & $\begin{array}{l}49.8 \\
54.9 \\
52.7 \\
55.0 \\
59.0\end{array}$ & $\begin{array}{l}(1.43) \\
(1.44) \\
(1.52) \\
(1.55) \\
(1.54)\end{array}$ & $\begin{array}{l}42.7 \\
42.7 \\
35.8 \\
38.2 \\
39.8\end{array}$ & $\begin{array}{l}(4.44) \\
(4.44) \\
(4.33) \\
(4.34) \\
(4.15)\end{array}$ & 52.3 & $(7.67)$ & $\begin{array}{l}- \\
- \\
- \\
-\end{array}$ & $(+)$ & & & & & 44.0 & $\begin{array}{l}(2.57 \\
(2.47 \\
(2.54\end{array}$ & 49 & $(4.89)$ & $\begin{array}{l}- \\
- \\
- \\
-\end{array}$ & $(t)$ & $7.5 !$ & (274) & $\neq$ & $(t)$ & - & $(\dagger)$ \\
\hline & & $\begin{array}{l}(1.45) \\
(1.43) \\
(1.46) \\
(1.57) \\
(1.64)\end{array}$ & $\begin{array}{l}50.8 \\
58.6 \\
61.1 \\
60.7\end{array}$ & $\begin{array}{l}(1.62) \\
(1.62) \\
(1.65) \\
(1.79) \\
(1.85)\end{array}$ & $\begin{array}{l}36.9 \\
52.2 \\
44.4 \\
53.4\end{array}$ & $\begin{array}{l}(4.38) \\
(4.82) \\
(4.91) \\
(5.27)\end{array}$ & & $\begin{array}{l}(10.14 \\
(10.51\end{array}$ & $\begin{array}{l}- \\
- \\
- \\
-\end{array}$ & 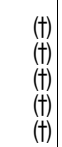 & & & & & & $\begin{array}{l}(2.55 \\
(2.71 \\
(2.65 \\
(2.98 \\
(2.98\end{array}$ & & (6.33) & $\begin{array}{l}- \\
- \\
- \\
-\end{array}$ & (4) & $\begin{array}{l}14.6 \\
10.4 ! \\
13.6\end{array}$ & & $3.8 !$ & $\begin{array}{r}5.27) \\
5.28) \\
5.13) \\
(t) \\
(\dagger)\end{array}$ & $\begin{array}{l}- \\
- \\
-\end{array}$ & (II) \\
\hline & & $\begin{array}{l}(1.60) \\
(1.62) \\
(1.58) \\
(1.59) \\
(1.43)\end{array}$ & $\begin{array}{l}64.4 \\
62.3 \\
62.9 \\
64.5\end{array}$ & $\begin{array}{l}(1.82) \\
(1.84) \\
(1.85) \\
(1.61)\end{array}$ & & $\begin{array}{l}(5.25) \\
(4.92) \\
(5.28) \\
(4.42)\end{array}$ & & $(6.28)$ & $\begin{array}{l}- \\
- \\
- \\
-\end{array}$ & $\begin{array}{l}(t) \\
(t) \\
(t)\end{array}$ & & & & & & $\begin{array}{r}(2.98 \\
(2.97 \\
(2.52\end{array}$ & & $(3.23)$ & $\begin{array}{l}- \\
- \\
- \\
-\end{array}$ & t & 11.5 & & $\begin{array}{c}\ddagger \\
1.7 ! \\
\ddagger\end{array}$ & $\begin{array}{r}(\dagger) \\
\quad(5.62) \\
(\dagger) \\
(\dagger) \\
\vdots \\
1(3.39)\end{array}$ & $\begin{array}{l}- \\
-\end{array}$ & (T) \\
\hline & & $\begin{array}{l}(1.41) \\
(1.42) \\
(1.38) \\
(1.38) \\
(1.38)\end{array}$ & $\begin{array}{l}68.2 \\
68.5 \\
66.3\end{array}$ & $\begin{array}{l}(1.64) \\
(1.67) \\
(1.64) \\
(1.61) \\
(1.64)\end{array}$ & & $\begin{array}{l}(4.20) \\
(4.03) \\
(4.12) \\
(4.05) \\
(3.86)\end{array}$ & & $(4.76)$ & $\begin{array}{l}- \\
- \\
- \\
- \\
-\end{array}$ & $\begin{array}{l}(+) \\
(\dagger)\end{array}$ & & & & & & $\begin{array}{l}(2.40 \\
(2.41 \\
(2.35 \\
(2.31 \\
(2.31\end{array}$ & $4 . .4$ & {$[284)$} & $\begin{array}{l}- \\
- \\
- \\
-\end{array}$ & (II) & $\begin{array}{l}9.3 \\
7.9 ! \\
8.3 !\end{array}$ & & 19.5 & (2.59) & $\begin{array}{l}- \\
- \\
- \\
- \\
-\end{array}$ & $(+)$ \\
\hline $0, \ldots \ldots \ldots$ & 66.7 & $\begin{array}{l}(1.41) \\
(1.48) \\
(1.31) \\
(1.35) \\
(1.31)\end{array}$ & $\begin{array}{l}65.7 \\
64.3 \\
69.1 \\
66.2 \\
68.8\end{array}$ & $\begin{array}{l}(1.66) \\
(1.72) \\
(1.55) \\
(1.61) \\
(1.57)\end{array}$ & $\begin{array}{l}54.9 \\
55.0 \\
59.4 \\
57.5 \\
62.5\end{array}$ & $\begin{array}{l}(4.11) \\
(4.17) \\
(3.90) \\
(4.25) \\
(3.77)\end{array}$ & 61.8 & $\begin{array}{l}(4.61 \\
(4.76\end{array}$ & $\begin{array}{r}- \\
\overline{-} \\
84.1 \\
75.6\end{array}$ & $\begin{array}{l}(5.10) \\
(6.13)\end{array}$ & & & & & 58.8 & $\begin{array}{r}(2.33 \\
(2.29 \\
(2.34\end{array}$ & & $\begin{array}{l}(266) \\
(260)\end{array}$ & $\begin{array}{r}- \\
\overline{-} \\
80.0 \\
81.6\end{array}$ & $\begin{array}{r}(1+1) \\
(3.99) \\
(3.37)\end{array}$ & $\begin{array}{l}8.1 ! \\
10.6\end{array}$ & $\begin{array}{l}2.46 \\
(2.51\end{array}$ & 11.7 & (2./5) & $\begin{array}{r}- \\
\overline{-} \\
-11.9 ! \\
-12.2\end{array}$ & $\begin{array}{l}(4.10) \\
(3.49)\end{array}$ \\
\hline $05^{5} \ldots \ldots \ldots$ & 70.1 & $\begin{array}{l}(1.31) \\
(1.33) \\
(1.26) \\
(1.21) \\
(1.23)\end{array}$ & $\begin{array}{l}73.2 \\
68.5 \\
69.5 \\
71.7 \\
71.3\end{array}$ & $\begin{array}{l}(1.49) \\
(1.44) \\
(1.53)\end{array}$ & $\begin{array}{l}55.7 \\
55.5 \\
55.7 \\
55.7 \\
69.5\end{array}$ & $\begin{array}{l}(4.15) \\
(4.33) \\
(3.78) \\
(3.78) \\
(3.51)\end{array}$ & 59.3 & $(3.80)$ & $\begin{array}{l}86.7 \\
82.3 \\
88.8 \\
88.4 \\
92.1\end{array}$ & $\begin{array}{l}(5.99) \\
(5.32) \\
(6.26) \\
(5.08) \\
(3.90)\end{array}$ & & & $\begin{array}{l}70.2 \\
70.4 \\
70.0 \\
70.8 \\
71.2\end{array}$ & & 62.4 & $\begin{array}{l}(2.35 \\
(2.35 \\
(2.27 \\
(2.15 \\
(2.09\end{array}$ & 60.9 & $\begin{array}{l}(225) \\
(214)\end{array}$ & $\begin{array}{l}80.9 \\
85.1 \\
85.8 \\
90.1 \\
88.1\end{array}$ & $\begin{array}{l}(3.64) \\
(3.45) \\
(3.01) \\
(2.85)\end{array}$ & $\begin{array}{r}10.5 \\
8.8\end{array}$ & $(2.26)$ & $\begin{array}{c}12.6 \\
11.9 \\
8.0 ! \\
8.6 \\
10.3\end{array}$ & (2.31) & -16.9 & $\begin{array}{l}(3.13) \\
(2.98)\end{array}$ \\
\hline & & $\begin{array}{l}(1.49) \\
(1.45) \\
(1.59)\end{array}$ & & $\begin{array}{l}(1.68) \\
(1.86) \\
(1.94)\end{array}$ & & $\begin{array}{l}(4.81) \\
(4.01) \\
(4.84)\end{array}$ & & (3.22) & $\begin{array}{l}84.7 \\
86.1 \\
81.5\end{array}$ & & $\begin{array}{l}68.8 \\
67.5 \\
67.2\end{array}$ & & & & $\begin{array}{l}66.1 \\
62.1 \\
62.1\end{array}$ & $\begin{array}{l}(2.01) \\
(2.86 \\
(3.16\end{array}$ & & (244) & $\begin{array}{l}87.4 \\
83.9 \\
83.6\end{array}$ & (3.48) & $\begin{array}{c}\ddagger \\
6.1 ! \\
\ddagger\end{array}$ & $\begin{array}{r}(t) \\
(3.04) \\
(t)\end{array}$ & 7.8 & $\begin{array}{r}(2.21) \\
(\dagger) \\
(\dagger)\end{array}$ & $\begin{array}{r}-17.3 \\
-15.7 \\
-16.6\end{array}$ & $\begin{array}{l}(2.97) \\
(3.74)\end{array}$ \\
\hline
\end{tabular}

-Not available.

!nterpret data with caution. The coefficient of variation (CV) for this estimate is between 30 and 50 percent.

‡Reporting standards not met. The coefficient of variation (CV) for this estimate is 50 percent or greater.

IIndividuals ages 16 to 24 who graduated from high school or completed a GED during the preceding 12 months.

${ }^{2}$ Enrollment in college as of October of each year for individuals ages 16 to 24 who completed high school during the preceding 12 months.

${ }^{3} \mathrm{~A}$ 3-year moving average is an arithmetic average of the year indicated, the year immediately preceding, and the year immediately following. For the first and final years of available data, a 2-year moving average is used: The moving average for 1960 reflects an average of 1960 and 1961; for Black and Hispanic data, the moving average for 1972 reflects an aver- age of 1972 and 1973; for Asian data, the moving average for 2003 reflects an average of 2003 and 2004; and the moving average for 2012 reflects an average of 2011 and 2012. Moving averages are used to produce more stable estimates.

${ }^{4}$ Prior to 1972, White data include persons of Hispanic ethnicity.

${ }^{5}$ White, Black, and Asian data exclude persons identifying themselves as two or more races.

${ }^{6}$ Beginning in 2010 , standard errors were computed using replicate weights, which produced more precise values than the methodology used in prior years.

NOTE: Race categories exclude persons of Hispanic ethnicity except where otherwise noted. Total includes persons of other racial/ethnic groups not separately shown.

SOURCE: American College Testing Program, unpublished tabulations, derived from statistics collected by the Census Bureau, 1960 through 1969. U.S. Department of Commerce, Census Bureau, Current Population Survey (CPS), October, 1970 through 2012. (This table was prepared May 2013.) 
Table 302.30. Percentage of recent high school completers enrolled in 2-year and 4-year colleges, by income level: 1975 through 2012

[Standard errors appear in parentheses]

\begin{tabular}{|c|c|c|c|c|c|c|c|c|c|c|c|c|c|c|c|c|c|c|c|c|}
\hline \multirow[b]{3}{*}{ Year } & & & & & & & & & \multicolumn{12}{|c|}{ 3-year moving averages ${ }^{3}$} \\
\hline & \multicolumn{8}{|c|}{$\begin{array}{l}\text { Percent of recent high school completers }{ }^{1} \text { enrolled in college }{ }^{2} \\
\text { (annual data) }\end{array}$} & \multicolumn{8}{|c|}{ Percent of recent high school completers ${ }^{1}$ enrolled in college ${ }^{2}$} & \multicolumn{4}{|c|}{$\begin{array}{l}\text { Difference between } \\
\text { percent enrolled }\end{array}$} \\
\hline & & Total & Low & income & Middle & income & High & income & & Total & Low & income & Middle i & income & High & income & & $\begin{array}{l}\text { tigh-low } \\
\text { income }\end{array}$ & & $\begin{array}{l}\text {-middle } \\
\text { income }\end{array}$ \\
\hline 1 & & 2 & & 3 & & 4 & & 5 & & 6 & & 7 & & 8 & & 9 & & 10 & & 11 \\
\hline 1975 & 50.7 & $(1.26)$ & 31.2 & 3.59) & 46.2 & (1.69) & 64.5 & (2.09) & 49.1 & $(0.74)$ & 34.7 & (2.74) & 43.5 & (1.22) & 63.7 & $(1.47)$ & 29.0 & (3.11) & 20.2 & 1.91) \\
\hline $1976 .$. & 48.8 & .31) & 39.1 & $(4.20)$ & 40.5 & (1.76) & 63.0 & $(2.06)$ & 50.1 & $(0.74)$ & 32.3 & $(2.17)$ & 43.8 & $(1.00)$ & 64.6 & $(1.18)$ & 32.3 & $(2.47)$ & 20.8 & 1.55) \\
\hline $1977 .$. & 50.6 & $(1.29)$ & 27.7 & (3.54) & 44.2 & $(1.76)$ & 66.3 & (2.01) & 49.9 & $(0.75)$ & 32.4 & $(2.22)$ & 43.1 & $(1.02)$ & 64.4 & $(1.18)$ & 32.1 & (2.51) & 21.4 & 1.56) \\
\hline $1978 .$. & 50.1 & $(1.28)$ & 31.4 & $(3.74)$ & 44.3 & $(1.74)$ & 64.0 & $(2.05)$ & 50.0 & $(0.74)$ & 29.8 & $(2.13)$ & 43.9 & $(1.01)$ & 64.5 & $(1.17)$ & 34.6 & (2.43) & 20.5 & 1.55) \\
\hline 1979. & 49.3 & $(1.28)$ & 30.5 & (3.78) & 43.2 & $(1.74)$ & 63.2 & (2.04) & 49.6 & $(0.74)$ & 31.6 & $(2.11)$ & 43.4 & (1.01) & 64.1 & (1.19) & 32.6 & (2.42) & 20.8 & 1.56) \\
\hline 1980 & 49.3 & $(1.30)$ & 32.5 & (3.47) & 42.5 & $(1.78)$ & 65.2 & $(2.08)$ & 50.8 & $(0.75)$ & 32.2 & $(2.14)$ & 45.0 & $(1.02)$ & 65.3 & $(1.20)$ & 33.0 & (2.45) & 20.2 & (1.57) \\
\hline 1981. & 53.9 & $(1.30)$ & 33.6 & $(3.90)$ & 49.2 & $(1.75)$ & 67.6 & $(2.09)$ & 51.3 & $(0.75)$ & 32.9 & $(2.11)$ & 44.5 & $(1.01)$ & 67.9 & $(1.19)$ & 34.9 & $(2.42)$ & 23.4 & (1.57) \\
\hline 1982. & 50.6 & $(1.36)$ & 32.8 & (3.81) & 41.7 & $(1.81)$ & 70.9 & (2.13) & 52.4 & $(0.79)$ & 33.6 & $(2.29)$ & 45.4 & $(1.06)$ & 69.6 & $(1.25)$ & 36.0 & (2.61) & 24.2 & 1.64) \\
\hline 1983.. & 52.7 & $(1.39)$ & 34.6 & $(4.02)$ & 45.2 & $(1.88)$ & 70.3 & $(2.17)$ & 52.8 & $(0.79)$ & 34.0 & $(2.20)$ & 45.1 & $(1.08)$ & 71.7 & (1.23) & 37.8 & (2.52) & 26.7 & 1.63) \\
\hline $1984 \ldots \ldots \ldots \ldots \ldots \ldots \ldots \ldots$ & 55.2 & $(1.37)$ & 34.5 & (3.62) & 48.4 & $(1.89)$ & 74.0 & $(2.09)$ & 55.1 & $(0.81)$ & 36.3 & $(2.26)$ & 48.0 & (1.11) & 72.9 & $(1.24)$ & 36.6 & (2.58) & 24.9 & $(1.66)$ \\
\hline 1985 & 57.7 & $(1.45)$ & 40.2 & $(4.14)$ & 50.6 & $(2.02)$ & 74.6 & $(2.16)$ & 55.5 & $(0.82)$ & 35.9 & $(2.18)$ & 49.1 & $(1.13)$ & 73.2 & 1.26) & 37.3 & (2.51) & 24.1 & 1.69) \\
\hline 1986. & 53.8 & $(1.43)$ & 33.9 & (3.59) & 48.5 & $(1.97)$ & 71.0 & $(2.28)$ & 56.1 & $(0.84)$ & 36.8 & $(2.23)$ & 49.6 & $(1.17)$ & 73.2 & $(1.27)$ & 36.4 & $(2.57)$ & 23.5 & (1.72) \\
\hline $1987 .$. & 56.8 & $(1.46)$ & 36.9 & (3.88) & 50.0 & $(2.07)$ & 73.8 & (2.16) & 56.5 & $(0.83)$ & 37.6 & $(2.21)$ & 51.1 & $(1.16)$ & 72.6 & $(1.30)$ & 35.0 & (2.57) & 21.5 & $(1.74)$ \\
\hline 1988. & 58.9 & $(1.57)$ & 42.5 & (4.39) & 54.7 & $(2.14)$ & 72.8 & (2.52) & 58.4 & $(0.92)$ & 42.4 & $(2.54)$ & 53.4 & (1.28) & 72.5 & $(1.44)$ & 30.2 & (2.92) & 19.1 & (1.93) \\
\hline $1989 \ldots$ & 59.6 & $(1.64)$ & 48.1 & $(4.56)$ & 55.4 & $(2.28)$ & 70.7 & (2.61) & 59.5 & $(0.94)$ & 45.6 & $(2.66)$ & 54.9 & (1.28) & 73.2 & $(1.50)$ & 27.6 & $(3.06)$ & 18.4 & (1.97) \\
\hline & 6 & $(1.60)$ & 46 & $(4.76)$ & 54.4 & $(2.14)$ & 76.6 & (2.54) & & & & (2.63) & & & 75.0 & 4) & 30.2 & & 0 & \\
\hline & 62 & (1.62) & 39.5 & $(4.50)$ & 58.4 & $(2.25)$ & 78.2 & (2.39) & 61.5 & $(0.5$ & 42.2 & $(2.62)$ & 56.5 & $(1.26)$ & 78.0 & $(1.40)$ & 35.8 & (2.97) & 21.4 & 8) \\
\hline & 61 & $(1.58)$ & 40.9 & (4.37) & 57.0 & (2.18) & 79.0 & (2.35) & 62.3 & $(0.92)$ & 43.6 & $(2.60)$ & 57.4 & $(1.26)$ & 78.8 & (1.38) & 35.3 & (2.94) & 21.4 & (1.87) \\
\hline 1993. & 62.6 & (1.59) & 50.4 & $(4.56)$ & 56.9 & $(2.15)$ & 79.3 & $(2.46)$ & 62.1 & $(0.91)$ & 44.7 & $(2.55)$ & 57.3 & (1.23) & 78.7 & $(1.39)$ & 34.0 & $(2.90)$ & 21.5 & (1.86) \\
\hline $1994 \ldots \ldots \ldots$ & 61.9 & $(1.43)$ & 43.3 & (3.96) & 57.8 & $(1.94)$ & 77.9 & $(2.22)$ & 62.1 & $(0.83)$ & 42.0 & $(2.27)$ & 57.0 & (1.14) & 80.4 & $(1.22)$ & 38.4 & (2.57) & 23.4 & (1.67) \\
\hline 19 & 6 & (1.41) & 34.2 & (3.56) & 56.0 & $(2.00)$ & 83.5 & $(1.86)$ & 63.0 & (0. & 42.1 & $(2.16)$ & 58.9 & (1) & 9.9 & 1.20) & 37.8 & 7) & 21.0 & 4) \\
\hline 199 & 65.0 & (1.42) & 48.6 & (3.78) & 62.7 & (1.95) & 78.0 & (2.27) & 64.7 & $(0.82)$ & 47.1 & $(2.18)$ & 59.9 & (1.16) & 81.3 & $(1.19)$ & 34.3 & (2.49) & 21.4 & 1.66) \\
\hline $1997 \ldots$ & 67.0 & (1.38) & 57.0 & (3.66) & 60.7 & $(1.97)$ & 82.2 & $(1.98)$ & 65.9 & $(0.80)$ & 50.6 & $(2.14)$ & 62.7 & $(1.12)$ & 79.3 & $(1.24)$ & 28.7 & (2.47) & 16.6 & 1.67) \\
\hline $1998 .$. & 6 & $(1.38)$ & 46.4 & (3.62) & 64.7 & $(1.89)$ & 77.5 & (2.21) & 6 & $(0.80)$ & 50.3 & $(2.14)$ & 61.9 & $(1.10)$ & 4 & $(1.24)$ & 28.1 & $(2.47)$ & 16.6 & $(1.66)$ \\
\hline 1999 & 62.9 & $(1.38)$ & 47.6 & (3.77) & 60.2 & $(1.87)$ & 75.4 & $(2.26)$ & 64.0 & $(0.80)$ & 47.9 & $(2.13)$ & 61.5 & $(1.10)$ & 76.6 & $(1.29)$ & 28.7 & (2.49) & 15.1 & $(1.70)$ \\
\hline $2000 \ldots$ & 63.3 & $(1.41)$ & 49.7 & (3.67) & 59.5 & $(1.97)$ & 76.9 & $(2.22)$ & 62.7 & $(0.82)$ & 47.1 & $(2.17)$ & 58.8 & $(1.14)$ & 77.4 & $(1.29)$ & 30.3 & (2.52) & 18.6 & (1.72) \\
\hline $2001 \ldots \ldots \ldots \ldots \ldots$ & 61.8 & $(1.48)$ & 43.8 & (3.81) & 56.4 & $(2.07)$ & 80.0 & $(2.19)$ & 63.5 & $(0.82)$ & 49.9 & $(2.19)$ & 59.1 & $(1.14)$ & 78.3 & $(1.28)$ & 28.4 & (2.53) & 19.3 & (1.71) \\
\hline $2002 \ldots$ & 65.2 & $(1.31)$ & 56.3 & (3.64) & 60.9 & $(1.78)$ & 78.2 & (2.12) & 63.7 & $(0.78)$ & 50.9 & $(2.14)$ & 58.4 & $(1.08)$ & 79.5 & $(1.20)$ & 28.6 & (2.45) & 21.0 & (1.61) \\
\hline 2003. & 63.9 & $(1.35)$ & 52.8 & (3.83) & 57.6 & $(1.87)$ & 80.1 & $(2.02)$ & 65.3 & $(0.77)$ & 52.5 & $(2.20)$ & 60.6 & $(1.05)$ & 79.5 & $(1.18)$ & 27.0 & (2.49) & 18.9 & (1.58) \\
\hline $2004 \ldots$ & 66.7 & (1.31) & 47.8 & (3.95) & 63.3 & (1.79) & 80.1 & (1.98) & 66.4 & $(0.77)$ & 51.4 & $(2.24)$ & 62.0 & (1.05) & 80.5 & $(1.15)$ & 29.0 & (2.52) & 18.5 & (1.56) \\
\hline & & (1.31) & 53.5 & $(3.86)$ & 65.1 & $(1.81)$ & 81.2 & (1.98) & & & 50.8 & $(2.26)$ & 63.3 & $(1.04)$ & 80.7 & 1.15) & 29.9 & & 17.4 & \\
\hline 2006 .. & 66.0 & (1.33) & 50.9 & (3.92) & 61.4 & $(1.82)$ & 80.7 & (2.01) & 67.2 & $(0.75)$ & 54.5 & $(2.18)$ & 63.3 & $(1.03)$ & 80.0 & $(1.15)$ & 25.5 & (2.47) & 16.7 & (1.55) \\
\hline $2007 \ldots$ & 67.2 & (1.26) & 58.4 & (3.57) & 63.3 & $(1.73)$ & 78.2 & (2.01) & 67.3 & $(0.73)$ & 55.3 & $(2.11)$ & 63.5 & $(0.99)$ & 80.2 & $(1.14)$ & 24.9 & $(2.40)$ & 16.8 & (1.51) \\
\hline $2008 \ldots$ & 68.6 & $(1.21)$ & 55.9 & $(3.50)$ & 65.2 & $(1.62)$ & 81.9 & $(1.90)$ & 68.6 & $(0.71)$ & 56.1 & $(2.08)$ & 65.1 & $(0.96)$ & 81.4 & $(1.11)$ & 25.3 & $(2.36)$ & 16.2 & (1.47) \\
\hline 2009 & 70.1 & $(1.23)$ & 53.9 & $(3.75)$ & 66.7 & $(1.66)$ & 84.2 & $(1.84)$ & 68.9 & $(0.70)$ & 53.3 & $(2.02)$ & 66.2 & $(0.94)$ & 82.8 & $(1.10)$ & 29.5 & $(2.30)$ & 16.6 & $(1.44)$ \\
\hline $2010^{4} \ldots$ & 68.1 & $(1.49)$ & 50.7 & $(3.88)$ & 66.7 & $(1.59)$ & 82.2 & $(2.34)$ & 68.8 & $(0.71)$ & 52.6 & $(1.97)$ & 66.5 & $(0.94)$ & 83.0 & $(1.12)$ & 30.4 & $(2.27)$ & 16.4 & (1.46) \\
\hline $2011^{4}$... & 68.2 & $(1.45)$ & 53.5 & $(4.25)$ & 66.2 & $(1.63)$ & 82.4 & $(2.46)$ & 67.5 & $(0.89)$ & 51.6 & $(2.47)$ & 65.9 & $(1.11)$ & 81.7 & $(1.42)$ & 30.1 & (2.85) & 15.9 & $(1.81)$ \\
\hline $2012^{4}$ & 66.2 & $(1.59)$ & 50.9 & $(4.39)$ & 64.7 & $(2.10)$ & 80.7 & $(2.54)$ & 67.2 & $(1.17)$ & 52.1 & $(3.24)$ & 65.5 & $(1.47)$ & 81.5 & $(1.86)$ & 29.4 & (3.74) & 16.0 & (2.37) \\
\hline
\end{tabular}

'Individuals ages 16 to 24 who graduated from high school or completed a GED during the preceding 12 months.

${ }^{2}$ Enrollment in college as of October of each year for individuals ages 16 to 24 who completed high school during the preceding 12 months.

${ }^{3} \mathrm{~A}$ 3-year moving average is an arithmetic average of the year indicated, the year immediately preceding, and the year immediately following. For 1975 and 2012, a 2-year moving average is used: The moving average for 1975 reflects an average of 1975 and 1976, and the moving average for 2012 reflects an average of 2011 and 2012. Moving averages are used to produce more stable estimates.

${ }^{4}$ Beginning in 2010 , standard errors were computed using replicate weights, which produced more precise values than the methodology used in prior years.

NOTE: Low income refers to the bottom 20 percent of all family incomes, high income refers to the top 20 percent of all family incomes, and middle income refers to the 60 percent in between.

SOURCE: U.S. Department of Commerce, Census Bureau, Current Population Survey (CPS), October, 1975 through 2012. (This table was prepared May 2013.) 
Table 302.40. Number of high schools with 12th-graders and percentage of high school graduates attending 4-year colleges, by selected high school characteristics: Selected years, 1998-99 through 2011-12

[Standard errors appear in parentheses]

\begin{tabular}{|c|c|c|c|c|c|c|c|c|c|c|c|c|c|c|c|c|c|c|}
\hline \multirow[b]{2}{*}{ Selected high school characteristic } & \multicolumn{8}{|c|}{ Number of high schools with 12th-graders } & \multirow{2}{*}{\multicolumn{2}{|c|}{$\begin{array}{r}\text { Graduation rate of } \\
\text { 12th-graders in } \\
2010-11^{1}\end{array}$}} & \multicolumn{8}{|c|}{ Percent of graduates attending 4-year colleges } \\
\hline & \multicolumn{2}{|c|}{$1998-99$} & \multicolumn{2}{|c|}{ 2002-03 } & \multicolumn{2}{|c|}{ 2006-07 } & \multicolumn{2}{|c|}{$2010-11$} & & & \multicolumn{2}{|c|}{\begin{tabular}{|r|}
$1998-99$ graduates \\
attending in \\
$1999-2000$
\end{tabular}} & \multicolumn{2}{|c|}{$\begin{array}{r}2002-03 \text { graduates } \\
\text { attending in } \\
2003-04\end{array}$} & \multicolumn{2}{|c|}{$\begin{array}{r}2006-07 \text { graduates } \\
\text { attending in } \\
2007-08\end{array}$} & \multicolumn{2}{|c|}{$\begin{array}{r}2010-11 \text { graduate } \\
\text { attending in } \\
2011-1\end{array}$} \\
\hline 1 & & 2 & & 3 & & 4 & & 5 & & 6 & & 7 & & 8 & & 9 & & 10 \\
\hline Public high schools $\ldots \ldots \ldots \ldots$ & 20,000 & $(230)$ & 2,500 & $(400)$ & 4,100 & (540) & 23,300 & $(330)$ & 88.7 & $(0.90)$ & 35.4 & $(0.43)$ & 35.0 & $(0.61)$ & 39.5 & $(0.91)$ & 39.4 & $\overline{(0.59)}$ \\
\hline $\begin{array}{l}\text { Percent of students who are Black, Hispanic, Asian, Pacific Islander, } \\
\text { American Indian/Alaska Native, or two or more races } \\
\text { Less than } 5 \text { percent } \\
5 \text { to } 19 \text { percent. } \\
20 \text { to } 49 \text { percent. } \\
50 \text { percent or more }\end{array}$ & $\begin{array}{l}6,400 \\
4,800 \\
4,000 \\
4,800\end{array}$ & $\begin{array}{l}(170) \\
(180) \\
(170) \\
(150)\end{array}$ & $\begin{array}{l}6,100 \\
5,200 \\
4,700 \\
6,500\end{array}$ & $\begin{array}{l}(220) \\
(270) \\
(180) \\
(280)\end{array}$ & $\begin{array}{l}5,200 \\
5,400 \\
6,200 \\
7,300\end{array}$ & $\begin{array}{l}(270) \\
(320) \\
(440) \\
(430)\end{array}$ & $\begin{array}{l}3,600 \\
5,700 \\
5,900 \\
8,100\end{array}$ & $\begin{array}{l}(140) \\
(310) \\
(270) \\
(320)\end{array}$ & $\begin{array}{l}94.7 \\
92.4 \\
91.2 \\
81.7\end{array}$ & $\begin{array}{l}(1.19) \\
(2.55) \\
(1.14) \\
(1.58)\end{array}$ & $\begin{array}{l}41.3 \\
36.6 \\
32.5 \\
28.7\end{array}$ & $\begin{array}{l}(0.67) \\
(0.88) \\
(0.92) \\
(0.89)\end{array}$ & $\begin{array}{l}42.6 \\
38.0 \\
34.1 \\
25.8\end{array}$ & $\begin{array}{l}(0.96) \\
(1.77) \\
(1.27) \\
(1.43)\end{array}$ & $\begin{array}{l}46.8 \\
48.4 \\
35.0 \\
30.8\end{array}$ & $\begin{array}{l}(1.54) \\
(2.06) \\
(1.89) \\
(2.00)\end{array}$ & $\begin{array}{l}43.9 \\
44.9 \\
39.6 \\
33.0\end{array}$ & $\begin{array}{l}(1.40) \\
(1.02) \\
(1.31) \\
(1.17)\end{array}$ \\
\hline 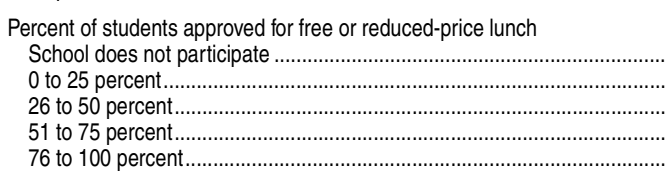 & $\begin{array}{l}2,400 \\
8,600 \\
4,800 \\
2,300 \\
2,000\end{array}$ & $\begin{array}{l}(130) \\
(180) \\
(160) \\
(140) \\
(100)\end{array}$ & $\begin{array}{l}2,400 \\
6,800 \\
6,700 \\
4,000 \\
2,600\end{array}$ & $\begin{array}{l}(230) \\
(230) \\
(220) \\
(270) \\
(260)\end{array}$ & $\begin{array}{l}2,800 \\
6,700 \\
7,300 \\
4,100 \\
3,300\end{array}$ & $\begin{array}{l}(320) \\
(360) \\
(350) \\
(290) \\
(360)\end{array}$ & $\begin{array}{l}1,900 \\
5,100 \\
6,800 \\
5,100 \\
4,300\end{array}$ & $\begin{array}{l}(250) \\
(220) \\
(230) \\
(260) \\
(230)\end{array}$ & $\begin{array}{l}72.8 \\
93.3 \\
92.8 \\
90.3 \\
82.3\end{array}$ & $\begin{array}{l}(7.11) \\
(1.02) \\
(0.91) \\
(1.06) \\
(1.93)\end{array}$ & $\begin{array}{l}30.0 \\
42.6 \\
33.4 \\
29.1 \\
22.2\end{array}$ & $\begin{array}{l}(1.75) \\
(0.67) \\
(0.81) \\
(1.57) \\
(1.35)\end{array}$ & $\begin{array}{l}23.2 \\
46.9 \\
36.7 \\
27.3 \\
20.7\end{array}$ & $\begin{array}{l}(2.26) \\
(0.78) \\
(1.08) \\
(1.58) \\
(2.79)\end{array}$ & $\begin{array}{l}25.4 \\
52.1 \\
41.5 \\
33.2 \\
26.0\end{array}$ & $\begin{array}{l}(4.12) \\
(1.63) \\
(1.44) \\
(1.91) \\
(2.93)\end{array}$ & $\begin{array}{l}27.6 \\
50.7 \\
42.5 \\
35.8 \\
29.1\end{array}$ & $\begin{array}{l}(5.24) \\
(1.42) \\
(1.00) \\
(1.35) \\
(1.66)\end{array}$ \\
\hline 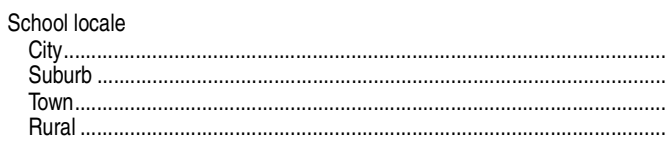 & $\begin{array}{l}- \\
\overline{-} \\
-\end{array}$ & $\begin{array}{l}(\dagger) \\
(\dagger) \\
(\dagger) \\
(\dagger) \\
\end{array}$ & $\begin{array}{l}4,500 \\
4,800 \\
3,700 \\
9,500 \\
\end{array}$ & $\begin{array}{l}(240) \\
(200) \\
(200) \\
(390) \\
\end{array}$ & $\begin{array}{r}4,800 \\
5,400 \\
3,900 \\
10,000 \\
\end{array}$ & $\begin{array}{l}(300) \\
(360) \\
(310) \\
(460) \\
\end{array}$ & $\begin{array}{r}5,100 \\
4,800 \\
3,300 \\
10,100 \\
\end{array}$ & $\begin{array}{l}(220) \\
(160) \\
(260) \\
(260)\end{array}$ & $\begin{array}{l}81.3 \\
86.1 \\
89.9 \\
93.4\end{array}$ & $\begin{array}{l}(3.11) \\
(1.50) \\
(2.21) \\
(0.67) \\
\end{array}$ & $\begin{array}{l}- \\
\overline{-} \\
-\end{array}$ & $\begin{array}{l}(+) \\
(+) \\
(\dagger) \\
(\dagger) \\
(t)\end{array}$ & $\begin{array}{l}32.5 \\
40.3 \\
31.1 \\
35.2 \\
\end{array}$ & $\begin{array}{l}(1.61) \\
(1.11) \\
(1.65) \\
(1.28) \\
\end{array}$ & $\begin{array}{l}36.1 \\
41.2 \\
35.2 \\
41.9\end{array}$ & $\begin{array}{l}(2.73) \\
(2.35) \\
(2.28) \\
(1.47) \\
\end{array}$ & & $\begin{array}{l}(1.53) \\
(1.42) \\
(1.76) \\
(0.88) \\
\end{array}$ \\
\hline Private high schools & 7,600 & $(240)$ & 200 & $(260)$ & 8,900 & $(280)$ & 8,900 & $(310)$ & 92.4 & $(1.34)$ & 55.6 & (1.74) & 56.2 & $(1.77)$ & 66.5 & $(1.57)$ & 64.3 & $(2.10)$ \\
\hline 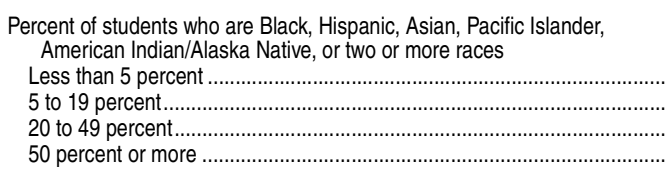 & $\begin{array}{l}2,700 \\
2,500 \\
1,400 \\
1,000\end{array}$ & $\begin{array}{l}(150) \\
(130) \\
(100) \\
(110)\end{array}$ & $\begin{array}{l}2,500 \\
2,900 \\
1,700 \\
1,100\end{array}$ & $\begin{array}{l}(180) \\
(170) \\
(140) \\
(140)\end{array}$ & $\begin{array}{l}2,100 \\
3,500 \\
2,000 \\
1,400\end{array}$ & $\begin{array}{l}(160) \\
(200) \\
(190) \\
(130)\end{array}$ & $\begin{array}{l}1,600 \\
3,100 \\
2,200 \\
1,900\end{array}$ & $\begin{array}{l}(190) \\
(230) \\
(200) \\
(190)\end{array}$ & $\begin{array}{l}96.1 \\
95.1 \\
90.4 \\
87.1\end{array}$ & $\begin{array}{l}(1.72) \\
(1.90) \\
(2.33) \\
(3.49)\end{array}$ & $\begin{array}{l}63.6 \\
55.3 \\
41.6\end{array}$ & $\begin{array}{l}(2.85) \\
(2.37) \\
(3.29) \\
(5.34)\end{array}$ & $\begin{array}{l}54.4 \\
64.2 \\
56.7 \\
38.3\end{array}$ & $\begin{array}{l}(3.31) \\
(2.71) \\
(3.70) \\
(4.52)\end{array}$ & $\begin{array}{l}68.2 \\
70.3 \\
58.7 \\
65.3\end{array}$ & $\begin{array}{l}(3.81) \\
(2.24) \\
(3.39) \\
(3.37)\end{array}$ & $\begin{array}{l}58.0 \\
67.9 \\
69.4 \\
57.6\end{array}$ & $\begin{array}{l}(6.31) \\
(3.40) \\
(3.89) \\
(5.18)\end{array}$ \\
\hline 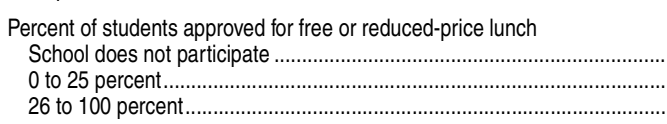 & $\begin{array}{r}6,700 \\
700 \\
\ddagger\end{array}$ & $\begin{array}{r}(230) \\
(70) \\
(\dagger)\end{array}$ & $\begin{array}{r}7,100 \\
600 \\
400\end{array}$ & $\begin{array}{r}(250) \\
(80) \\
(80)\end{array}$ & $\begin{array}{r}7,300 \\
700 \\
1,000\end{array}$ & $\begin{array}{l}(280) \\
(100) \\
(130)\end{array}$ & $\begin{array}{r}7,400 \\
600 \\
900\end{array}$ & $\begin{array}{r}(280) \\
(80) \\
(140)\end{array}$ & $\begin{array}{l}93.3 \\
96.8 \\
83.0\end{array}$ & $\begin{array}{l}(1.27) \\
(2.45) \\
(5.65)\end{array}$ & $\begin{array}{r}57.0 \\
53.8 \\
\ddagger\end{array}$ & $\begin{array}{r}(1.74) \\
(5.69) \\
(\dagger)\end{array}$ & $\begin{array}{l}56.2 \\
66.2 \\
38.9\end{array}$ & $\begin{array}{l}(2.00) \\
(4.35) \\
(6.70)\end{array}$ & $\begin{array}{l}68.3 \\
73.2 \\
46.7\end{array}$ & $\begin{array}{l}(1.77) \\
(4.64) \\
(6.86)\end{array}$ & $\begin{array}{l}66.5 \\
74.6 \\
37.8\end{array}$ & $\begin{array}{l}(2.29) \\
(5.23) \\
(8.06)\end{array}$ \\
\hline ㄴ. & $\begin{array}{l}- \\
\overline{-} \\
-\end{array}$ & $\begin{array}{l}(+) \\
(+) \\
(+) \\
(+)\end{array}$ & $\begin{array}{l}- \\
\overline{-} \\
-\end{array}$ & $\begin{array}{l}(+) \\
(+) \\
(+) \\
(+)\end{array}$ & $\begin{array}{l}1,000 \\
2,000\end{array}$ & $\begin{array}{l}(170) \\
(180) \\
(150) \\
(190)\end{array}$ & $\begin{array}{l}\ddagger \\
\ddagger \\
\ddagger \\
\ddagger\end{array}$ & $\begin{array}{l}(t) \\
(+) \\
(+) \\
(t)\end{array}$ & $\begin{array}{l}\ddagger \\
\ddagger \\
\ddagger \\
\ddagger\end{array}$ & $\begin{array}{c}(\dagger) \\
(+) \\
(\dagger) \\
(t)\end{array}$ & $\begin{array}{l}- \\
\overline{-} \\
-\end{array}$ & $\begin{array}{c}(+) \\
(+) \\
(+) \\
(t)\end{array}$ & $\begin{array}{l}\overline{-} \\
\overline{-} \\
-\end{array}$ & $\begin{array}{l}(t) \\
(t) \\
(t) \\
(t)\end{array}$ & 71.8 & $\begin{array}{l}(2.62) \\
(2.99) \\
(5.02) \\
(3.54)\end{array}$ & $\begin{array}{l}\ddagger \\
\ddagger \\
\ddagger \\
\ddagger \\
\ddagger\end{array}$ & $\begin{array}{c}(+) \\
(+) \\
(+) \\
(t)\end{array}$ \\
\hline
\end{tabular}

\section{-Not available.}

fReporting standards not met. Data may be suppressed because the response rate is under 50 percent, there are too few cases tor a reliable estimate, or the coefficient of variation (CV) is 50 percent or greater.

The 12th-grade graduation rate is the number of students who graduated from grade 12 with a diploma during the 2010-11 school year divided by 12 th-grade enrollment in October 2010.
NOTE: Data are based on a sample survey and may not be strictly comparable with data reported elsewhere. Includes all 作 published figures. Detail may not sum to totals because of rounding

SOURCE: U.S. Department of Education, National Center for Education Statistics, Schools and Staffing Survey (SASS), "Public School Teacher Data File" and "Private School Teacher Data File," 1999-2000, 2003-04, 2007-08, and 2011-12; an "Charter School Teacher Data File", 1999-2000. (This table was prepared April 2014.) 
Table 302.50. Estimated rate of 2009-10 high school graduates attending degree-granting institutions, by state: 2010

\begin{tabular}{|c|c|c|c|c|c|c|c|}
\hline \multirow[b]{2}{*}{ State } & \multicolumn{3}{|c|}{$\begin{array}{l}\text { Number of graduates from } \\
\text { high schools located in the state }\end{array}$} & \multicolumn{2}{|c|}{$\begin{array}{l}\text { Number of fall } 2010 \text { first-time freshmen } \\
\text { graduating from high school in the previous } \\
12 \text { months }\end{array}$} & \multicolumn{2}{|c|}{$\begin{array}{l}\text { Estimated rate of high school graduates } \\
\text { going to college }\end{array}$} \\
\hline & Total $^{1}$ & Public 2009-10 & Private, 2008-09 & $\begin{array}{r}\text { State residents } \\
\text { enrolled in institutions } \\
\text { in any state }{ }^{2}\end{array}$ & $\begin{array}{r}\text { State residents } \\
\text { enrolled in insti- } \\
\text { tutions in their } \\
\text { home state }\end{array}$ & In any state & $\begin{array}{r}\text { In their } \\
\text { home state }\end{array}$ \\
\hline 1 & 2 & 3 & 4 & 5 & 6 & 7 & 8 \\
\hline United States... & $3,436,835$ & $3,128,022$ & 308,813 & $2,158,258^{4}$ & $1,765,406$ & $\begin{array}{ll}62.8 \\
\end{array}$ & $\overline{51.4}$ \\
\hline Alabama & 48,443 & 43,166 & 5,277 & 31,160 & 28,165 & 64.3 & 58.1 \\
\hline Alaska...................................................... & 8,434 & 8,245 & 189 & 3,915 & 2,390 & 46.4 & 28.3 \\
\hline Arizona & 63,900 & 61,145 & 2,755 & 37,006 & 33,090 & 57.9 & 51.8 \\
\hline Arkansas & 29,606 & 28,276 & 1,330 & 19,348 & 17,624 & 65.4 & 59.5 \\
\hline California & 440,240 & 404,987 & 35,253 & 271,669 & 243,382 & 61.7 & 55.3 \\
\hline Colorado .......................... & 52,159 & 49,321 & 2,838 & 31,902 & 24,171 & 61.2 & 46.3 \\
\hline 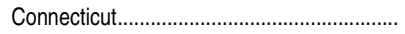 & 40,728 & 34,495 & 6,233 & 32,068 & 17,724 & 78.7 & 43.5 \\
\hline Delaware........................ & 9,980 & 8,133 & 1,847 & 4,718 & 2,745 & 47.3 & 27.5 \\
\hline District of Columbia ${ }^{5} \ldots \ldots$ & 4,941 & 3,602 & 1,339 & 2,503 & 517 & 50.7 & 10.5 \\
\hline Florida & 174,352 & 156,130 & 18,222 & 109,789 & 97,733 & 63.0 & 56.1 \\
\hline Georgia...................... & 99,883 & 91,561 & 8,322 & 67,659 & 57,253 & 67.7 & 57.3 \\
\hline 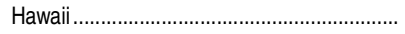 & 13,657 & 10,998 & 2,659 & 8,683 & 5,862 & 63.6 & 42.9 \\
\hline Idaho & 18,340 & 17,793 & 547 & 8,273 & 5,589 & 45.1 & 30.5 \\
\hline 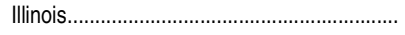 & 154,142 & 139,035 & 15,107 & 90,456 & 64,307 & 58.7 & 41.7 \\
\hline 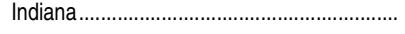 & 69,783 & 64,551 & 5,232 & 45,900 & 40,350 & 65.8 & 57.8 \\
\hline lowa .................................. & 36,711 & 34,462 & 2,249 & 24,442 & 21,209 & 66.6 & 57.8 \\
\hline 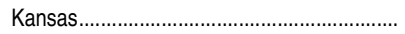 & 33,809 & 31,642 & 2,167 & 21,889 & 18,627 & 64.7 & 55.1 \\
\hline 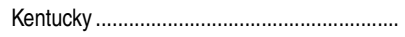 & 46,601 & 42,664 & 3,937 & 29,320 & 26,191 & 62.9 & 56.2 \\
\hline Louisiana ......................................................... & 44,709 & 36,573 & 8,136 & 28,912 & 26,094 & 64.7 & 58.4 \\
\hline Maine ............................. & 16,431 & 14,069 & 2,362 & 9,234 & 6,072 & 56.2 & 37.0 \\
\hline Maryland .................. & 68,306 & 59,078 & 9,228 & 43,730 & 28,253 & 64.0 & 41.4 \\
\hline 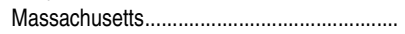 & 75,092 & 64,462 & 10,630 & 54,966 & 36,917 & 73.2 & 49.2 \\
\hline Michigan & 119,201 & 110,682 & 8,519 & 73,740 & 65,840 & 61.9 & 55.2 \\
\hline Minnesota & 63,908 & 59,667 & 4,241 & 45,340 & 32,751 & 70.9 & 51.2 \\
\hline 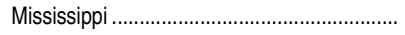 & 28,836 & 25,478 & 3,358 & 22,726 & 21,098 & 78.8 & 73.2 \\
\hline Missouri .......................... & 71,037 & 63,994 & 7,043 & 43,633 & 36,803 & 61.4 & 51.8 \\
\hline Montana...................... & 10,443 & 10,075 & 368 & 6,320 & 5,020 & 60.5 & 48.1 \\
\hline Nebraska ......................... & 21,374 & 19,370 & 2,004 & 14,858 & 12,442 & 69.5 & 58.2 \\
\hline Nevada & 21,780 & 20,956 & 824 & 11,280 & 8,511 & 51.8 & 39.1 \\
\hline 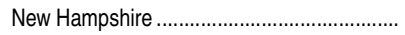 & 17,497 & 15,034 & 2,463 & 11,256 & 6,388 & 64.3 & 36.5 \\
\hline New Jersey ................................................... & 110,573 & 96,225 & 14,348 & 75,893 & 44,738 & 68.6 & 40.5 \\
\hline 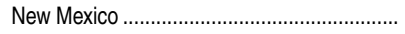 & 19,983 & 18,595 & 1,388 & 14,461 & 12,542 & 72.4 & 62.8 \\
\hline New York...................................................... & 215,105 & 183,826 & 31,279 & 148,101 & 119,445 & 68.9 & 55.5 \\
\hline North Carolina & 94,431 & 88,704 & 5,727 & 60,395 & 53,995 & 64.0 & 57.2 \\
\hline North Dakota & 7,604 & 7,155 & 449 & 5,125 & 3,841 & 67.4 & 50.5 \\
\hline Ohio & 136,740 & 123,437 & 13,303 & 84,068 & 71,583 & 61.5 & 52.3 \\
\hline Oklahoma & 40,034 & 38,503 & 1,531 & 24,100 & 21,735 & 60.2 & 54.3 \\
\hline Oregon & 37,810 & 34,671 & 3,139 & 18,072 & 13,960 & 47.8 & 36.9 \\
\hline Pennsylvania.............................................. & 149,845 & 131,182 & 18,663 & 91,298 & 75,702 & 60.9 & 50.5 \\
\hline Rhode Island & 11,726 & 9,908 & 1,818 & 7,667 & 4,907 & 65.4 & 41.8 \\
\hline South Carolina.......... & 43,511 & 40,438 & 3,073 & 29,709 & 26,706 & 68.3 & 61.4 \\
\hline South Dakota & 8,680 & 8,162 & 518 & 6,232 & 4,774 & 71.8 & 55.0 \\
\hline Tennessee & 68,627 & 62,408 & 6,219 & 42,515 & 36,038 & 62.0 & 52.5 \\
\hline 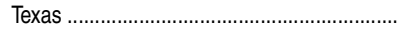 & 293,797 & 280,894 & 12,903 & 164,980 & 145,781 & 56.2 & 49.6 \\
\hline Utah & 32,751 & 31,481 & 1,270 & 17,442 & 15,970 & 53.3 & 48.8 \\
\hline 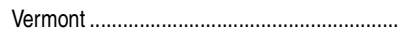 & 8,366 & 7,199 & 1,167 & 4,478 & 2,228 & 53.5 & 26.6 \\
\hline 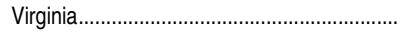 & 88,022 & 81,511 & 6,511 & 56,202 & 45,599 & 63.9 & 51.8 \\
\hline Washington ............................................... & 70,497 & 66,046 & 4,451 & 34,030 & 25,881 & 48.3 & 36.7 \\
\hline West Virginia................................................. & 18,390 & 17,651 & 739 & 10,885 & 9,696 & 59.2 & 52.7 \\
\hline Wisconsin & 70,294 & 64,687 & 5,607 & 42,241 & 34,196 & 60.1 & 48.6 \\
\hline Wyoming & 5,730 & 5,695 & 35 & 3,459 & 2,699 & 60.4 & 47.1 \\
\hline
\end{tabular}

${ }^{1}$ Total includes public high school graduates for 2009-10 and private high school graduates for 2008-09. Data on private high school graduates are not available for 2009-10.

${ }^{2}$ All U.S. resident students living in a particular state when admitted to an institution in any state. Students may be enrolled in any state.

${ }^{3}$ Students who attend institutions in their home state. Total includes 272 students attending U.S. Service Academies in their home state, not shown separately.

${ }^{4} U$.S. total includes some U.S. residents whose home state is unknown

${ }^{5} \mathrm{~A}$ percentage of the private high school graduates are not residents of the District of Columbia.
NOTE: Degree-granting institutions grant associate's or higher degrees and participate in Title IV federal financial aid programs. Detail may not sum to totals because of rounding. Some data federal financial aid programs. Detail may not sum to

SOURCE: U.S. Department of Education, National Center for Education Statistics, Common Core of Data (CCD), "NCES Common Core of Data State Dropout and Completion Data File," 2009-10; Private School Universe Survey (PSS), 2009-10; and Integrated Postsecondary Education Data System (IPEDS), Spring 2011, Enrollment component. (This table was prepared April 2012.) 
Table 302.60. Percentage of 18- to 24-year-olds enrolled in degree-granting institutions, by level of institution and sex and race/ethnicity of student: 1967 through 2012

[Standard errors appear in parentheses]

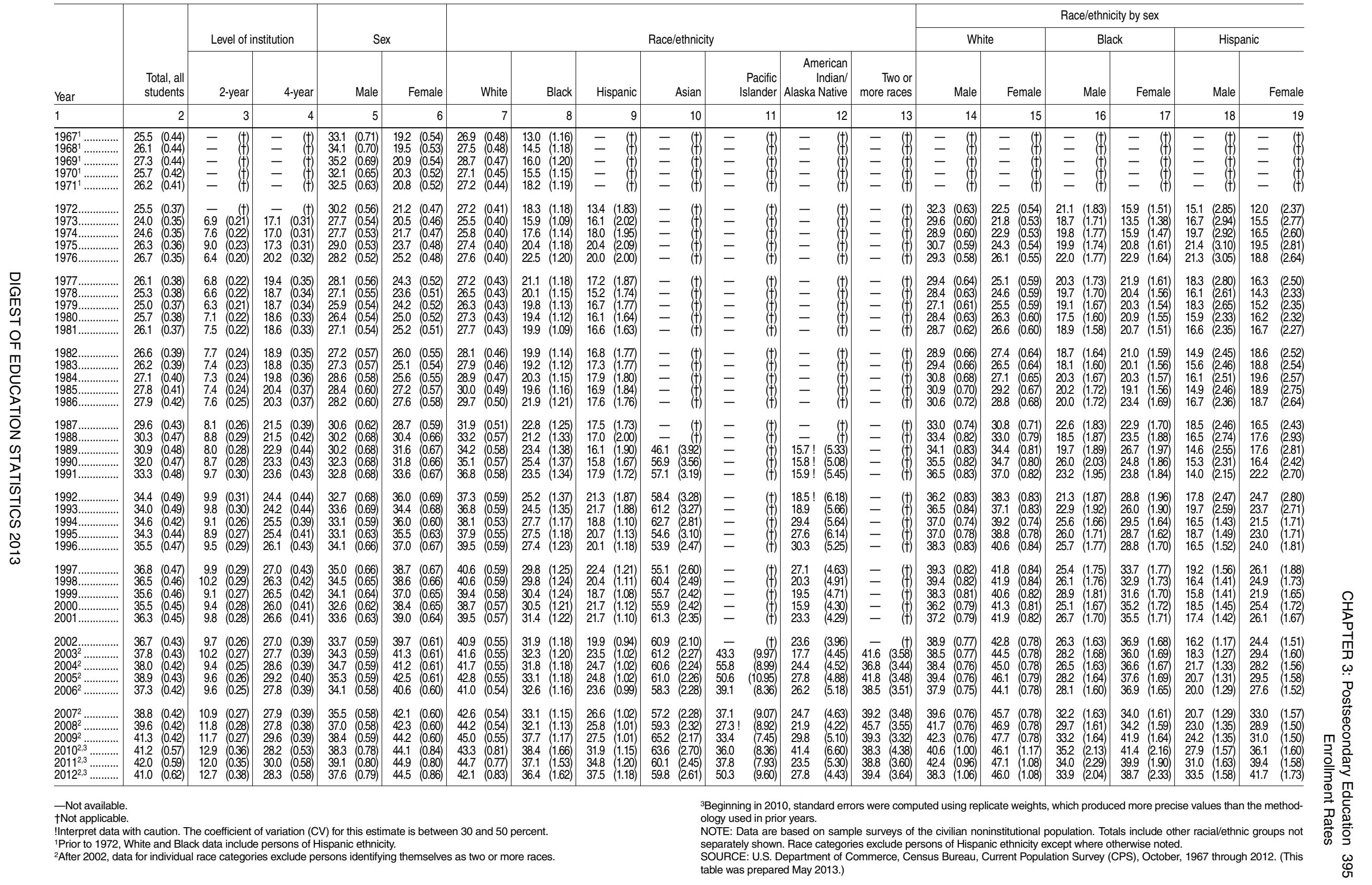


Table 303.10. Total fall enrollment in degree-granting postsecondary institutions, by attendance status, sex of student, and control of institution: Selected years, 1947 through 2023

\begin{tabular}{|c|c|c|c|c|c|c|c|c|c|c|c|}
\hline \multirow[b]{3}{*}{ Year } & \multirow{3}{*}{$\begin{array}{r}\text { Total } \\
\text { enrollment }\end{array}$} & \multicolumn{3}{|c|}{ Attendance status } & \multicolumn{3}{|c|}{ Sex of student } & \multicolumn{4}{|c|}{ Control of institution } \\
\hline & & \multirow[b]{2}{*}{ Full-time } & \multirow[b]{2}{*}{ Part-time } & \multirow{2}{*}{$\begin{array}{r}\text { Percent } \\
\text { part-time }\end{array}$} & \multirow[b]{2}{*}{ Male } & & Per & & & Private & \\
\hline & & & & & & Female & female & Public & Total & Nonprofit & For-profit \\
\hline 1 & 2 & 3 & 4 & 5 & 6 & 7 & 8 & 9 & 10 & 11 & 12 \\
\hline $1947^{1}$ & $2,338,226$ & - & - & - & $1,659,249$ & 678,977 & 29.0 & $1,152,377$ & $1,185,849$ & - & - \\
\hline 19481 .................................. & $2,403,396$ & - & - & - & $1,709,367$ & 694,029 & 28.9 & $1,185,588$ & $1,217,808$ & - & - \\
\hline $1949^{1}$ & $2,444,900$ & - & - & - & $1,721,572$ & 723,328 & 29.6 & $1,207,151$ & $1,237,749$ & - & - \\
\hline $1950^{1}$ & $2,281,298$ & - & - & - & $1,560,392$ & 720,906 & 31.6 & $1,139,699$ & $1,141,599$ & - & - \\
\hline $1951^{1} \ldots \ldots \ldots \ldots \ldots \ldots \ldots \ldots \ldots \ldots$ & $2,101,962$ & - & - & - & $1,390,740$ & 711,222 & 33.8 & $1,037,938$ & $1,064,024$ & - & - \\
\hline $1952^{1}$ & $2,134,242$ & - & - & - & $1,380,357$ & 753,885 & 35.3 & $1,101,240$ & $1,033,002$ & - & - \\
\hline $1953^{1}$ & $2,231,054$ & - & - & - & $1,422,598$ & 808,456 & 36.2 & $1,185,876$ & $1,045,178$ & - & - \\
\hline $1954^{1}$ & $2,446,693$ & - & - & - & $1,563,382$ & 883,311 & 36.1 & $1,353,531$ & $1,093,162$ & - & - \\
\hline $1955^{1} \ldots \ldots \ldots \ldots \ldots \ldots \ldots \ldots \ldots$ & $2,653,034$ & - & - & - & $1,733,184$ & 919,850 & 34.7 & $1,476,282$ & $1,176,752$ & - & - \\
\hline 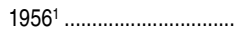 & $2,918,212$ & - & - & - & $1,911,458$ & $1,006,754$ & 34.5 & $1,656,402$ & $1,261,810$ & - & - \\
\hline 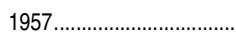 & $3,323,783$ & - & - & - & $2,170,765$ & $1,153,018$ & 34.7 & $1,972,673$ & $1,351,110$ & - & - \\
\hline 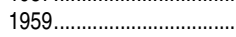 & $3,639,847$ & $2,421,016$ & $1,218,831^{2}$ & 33.5 & $2,332,617$ & $1,307,230$ & 35.9 & $2,180,982$ & $1,458,865$ & - & - \\
\hline $1961 \ldots \ldots \ldots \ldots \ldots$ & $4,145,065$ & $2,785,133$ & $1,359,932^{2}$ & 32.8 & $2,585,821$ & $1,559,244$ & 37.6 & $2,561,447$ & $1,583,618$ & - & - \\
\hline $1963 \ldots$ & $4,779,609$ & $3,183,833$ & $1,595,776^{2}$ & 33.4 & $2,961,540$ & $1,818,069$ & 38.0 & $3,081,279$ & $1,698,330$ & - & - \\
\hline $1964 \ldots \ldots \ldots \ldots \ldots \ldots \ldots \ldots$ & $5,280,020$ & $3,573,238$ & $1,706,782^{2}$ & 32.3 & $3,248,713$ & $2,031,307$ & 38.5 & $3,467,708$ & $1,812,312$ & - & - \\
\hline $1965 \ldots$ & $5,920,864$ & $4,095,728$ & $1,825,136^{2}$ & 30.8 & $3,630,020$ & $2,290,844$ & 38.7 & $3,969,596$ & $1,951,268$ & - & - \\
\hline $1966 \ldots$ & $6,389,872$ & $4,438,606$ & $1,951,266^{2}$ & 30.5 & $3,856,216$ & $2,533,656$ & 39.7 & $4,348,917$ & $2,040,955$ & - & - \\
\hline $1967 \ldots$ & $6,911,748$ & $4,793,128$ & $2,118,620^{2}$ & 30.7 & $4,132,800$ & $2,778,948$ & 40.2 & $4,816,028$ & $2,095,720$ & $2,074,041$ & 21,679 \\
\hline $1968 \ldots$ & $7,513,091$ & $5,210,155$ & $2,302,936$ & 30.7 & $4,477,649$ & $3,035,442$ & 40.4 & $5,430,652$ & $2,082,439$ & $2,061,211$ & 21,228 \\
\hline 1969 & $8,004,660$ & $5,498,883$ & $2,505,777$ & 31.3 & $4,746,201$ & $3,258,459$ & 40.7 & $5,896,868$ & $2,107,792$ & $2,087,653$ & 20,139 \\
\hline 1970. & $8,580,887$ & $5,816,290$ & $2,764,597$ & 32.2 & $5,043,642$ & $3,537,245$ & 41.2 & $6,428,134$ & $2,152,753$ & $2,134,420$ & 18,333 \\
\hline $1971 \ldots \ldots \ldots \ldots \ldots \ldots \ldots$ & $8,948,644$ & $6,077,232$ & $2,871,412$ & 32.1 & $5,207,004$ & $3,741,640$ & 41.8 & $6,804,309$ & $2,144,335$ & $2,121,913$ & 22,422 \\
\hline $1972 \ldots \ldots$ & $9,214,860$ & $6,072,389$ & $3,142,471$ & 34.1 & $5,238,757$ & $3,976,103$ & 43.1 & $7,070,635$ & $2,144,225$ & $2,123,245$ & 20,980 \\
\hline 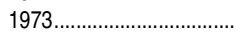 & $9,602,123$ & $6,189,493$ & $3,412,630$ & 35.5 & $5,371,052$ & $4,231,071$ & 44.1 & $7,419,516$ & $2,182,607$ & $2,148,784$ & 33,823 \\
\hline 1974 & $10,223,729$ & $6,370,273$ & $3,853,456$ & 37.7 & $5,622,429$ & $4,601,300$ & 45.0 & $7,988,500$ & $2,235,229$ & $2,200,963$ & 34,266 \\
\hline $1975 \ldots \ldots \ldots \ldots \ldots \ldots \ldots \ldots \ldots$ & $11,184,859$ & $6,841,334$ & $4,343,525$ & 38.8 & $6,148,997$ & $5,035,862$ & 45.0 & $8,834,508$ & $2,350,351$ & $2,311,448$ & 38,903 \\
\hline 1976 & $11,012,137$ & $6,717,058$ & $4,295,079$ & 39.0 & $5,810,828$ & $5,201,309$ & 47.2 & $8,653,477$ & $2,358,660$ & $2,314,298$ & 44,362 \\
\hline $1977 \ldots \ldots \ldots$ & $11,285,787$ & $6,792,925$ & $4,492,862$ & 39.8 & $5,789,016$ & $5,496,771$ & 48.7 & $8,846,993$ & $2,438,794$ & $2,386,652$ & 52,142 \\
\hline $1978 \ldots \ldots \ldots \ldots$ & $11,260,092$ & $6,667,657$ & $4,592,435$ & 40.8 & $5,640,998$ & $5,619,094$ & 49.9 & $8,785,893$ & $2,474,199$ & $2,408,331$ & 65,868 \\
\hline 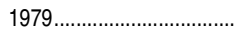 & $11,569,899$ & $6,794,039$ & $4,775,860$ & 41.3 & $5,682,877$ & $5,887,022$ & 50.9 & $9,036,822$ & $2,533,077$ & $2,461,773$ & 71,304 \\
\hline 1980. & $12,096,895$ & $7,097,958$ & $4,998,937$ & 41.3 & $5,874,374$ & $6,222,521$ & 51.4 & $9,457,394$ & $2,639,501$ & $2,527,787$ & $111,714^{3}$ \\
\hline $1981 .$. & $12,371,672$ & $7,181,250$ & $5,190,422$ & 42.0 & $5,975,056$ & $6,396,616$ & 51.7 & $9,647,032$ & $2,724,640$ & $2,572,405$ & $152,235^{3}$ \\
\hline 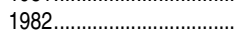 & $12,425,780$ & $7,220,618$ & $5,205,162$ & 41.9 & $6,031,384$ & $6,394,396$ & 51.5 & $9,696,087$ & $2,729,693$ & $2,552,739$ & $176,954^{3}$ \\
\hline $1983 \ldots \ldots$ & $12,464,661$ & $7,261,050$ & $5,203,611$ & 41.7 & $6,023,725$ & $6,440,936$ & 51.7 & $9,682,734$ & $2,781,927$ & $2,589,187$ & 192,740 \\
\hline $1984 \ldots \ldots \ldots$ & $12,241,940$ & $7,098,388$ & $5,143,552$ & 42.0 & $5,863,574$ & $6,378,366$ & 52.1 & $9,477,370$ & $2,764,570$ & $2,574,419$ & 190,151 \\
\hline 1985. & $12,247,055$ & $7,075,221$ & $5,171,834$ & 42.2 & $5,818,450$ & $6,428,605$ & 52.5 & $9,479,273$ & $2,767,782$ & $2,571,791$ & 195,991 \\
\hline 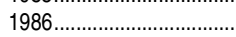 & $12,503,511$ & $7,119,550$ & $5,383,961$ & 43.1 & $5,884,515$ & $6,618,996$ & 52.9 & $9,713,893$ & $2,789,618$ & $2,572,479$ & $217,139^{4}$ \\
\hline $1987 \ldots \ldots \ldots$ & $12,766,642$ & $7,231,085$ & $5,535,557$ & 43.4 & $5,932,056$ & $6,834,586$ & 53.5 & $9,973,254$ & $2,793,388$ & $2,602,350$ & $191,038^{4}$ \\
\hline $1988 \ldots \ldots \ldots \ldots \ldots \ldots \ldots \ldots \ldots$ & $13,055,337$ & $7,436,768$ & $5,618,569$ & 43.0 & $6,001,896$ & $7,053,441$ & 54.0 & $10,161,388$ & $2,893,949$ & $2,673,567$ & 220,382 \\
\hline 1989 & $13,538,560$ & $7,660,950$ & $5,877,610$ & 43.4 & $6,190,015$ & $7,348,545$ & 54.3 & $10,577,963$ & $2,960,597$ & $2,731,174$ & 229,423 \\
\hline$\ldots$ & $13,818,637$ & $7,820,985$ & $5,997,652$ & 43.4 & $6,283,909$ & $7,534,728$ & 54.5 & $10,844,717$ & $2,973,920$ & $2,760,227$ & 213,693 \\
\hline $1991 .$. & $14,358,953$ & $8,115,329$ & $6,243,624$ & 43.5 & $6,501,844$ & $7,857,109$ & 54.7 & $11,309,563$ & $3,049,390$ & $2,819,041$ & 230,349 \\
\hline $1992 \ldots \ldots \ldots \ldots \ldots \ldots \ldots \ldots \ldots$ & $14,487,359$ & $8,162,118$ & $6,325,241$ & 43.7 & $6,523,989$ & $7,963,370$ & 55.0 & $11,384,567$ & $3,102,792$ & $2,872,523$ & 230,269 \\
\hline $1993 \ldots \ldots \ldots$ & $14,304,803$ & $8,127,618$ & $6,177,185$ & 43.2 & $6,427,450$ & $7,877,353$ & 55.1 & $11,189,088$ & $3,115,715$ & $2,888,897$ & 226,818 \\
\hline 1994 & $14,278,790$ & $8,137,776$ & $6,141,014$ & 43.0 & $6,371,898$ & $7,906,892$ & 55.4 & $11,133,680$ & $3,145,110$ & $2,910,107$ & 235,003 \\
\hline $1995 \ldots \ldots$ & $14,261,781$ & $8,128,802$ & $6,132,979$ & 43.0 & $6,342,539$ & $7,919,242$ & 55.5 & $11,092,374$ & $3,169,407$ & $2,929,044$ & 240,363 \\
\hline 1996 & $14,367,520$ & $8,302,953$ & $6,064,567$ & 42.2 & $6,352,825$ & $8,014,695$ & 55.8 & $11,120,499$ & $3,247,021$ & $2,942,556$ & 304,465 \\
\hline 1997............................. & $14,502,334$ & $8,438,062$ & $6,064,272$ & 41.8 & $6,396,028$ & $8,106,306$ & 55.9 & $11,196,119$ & $3,306,215$ & $2,977,614$ & 328,601 \\
\hline 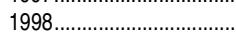 & $14,506,967$ & $8,563,338$ & $5,943,629$ & 41.0 & $6,369,265$ & $8,137,702$ & 56.1 & $11,137,769$ & $3,369,198$ & $3,004,925$ & 364,273 \\
\hline 1999 & $14,849,691$ & $8,803,139$ & $6,046,552$ & 40.7 & $6,515,164$ & $8,334,527$ & 56.1 & $11,375,739$ & $3,473,952$ & $3,055,029$ & 418,923 \\
\hline $2000 \ldots$ & $15,312,289$ & $9,009,600$ & $6,302,689$ & 41.2 & $6,721,769$ & $8,590,520$ & 56.1 & $11,752,786$ & $3,559,503$ & $3,109,419$ & 450,084 \\
\hline $2001 \ldots$ & $15,927,987$ & $9,447,502$ & $6,480,485$ & 40.7 & $6,960,815$ & $8,967,172$ & 56.3 & $12,233,156$ & $3,694,831$ & $3,167,330$ & 527,501 \\
\hline $2002 \ldots$ & $16,611,711$ & $9,946,359$ & $6,665,352$ & 40.1 & $7,202,116$ & $9,409,595$ & 56.6 & $12,751,993$ & $3,859,718$ & $3,265,476$ & 594,242 \\
\hline $2003 \ldots \ldots \ldots \ldots \ldots \ldots$ & $16,911,481$ & $10,326,133$ & $6,585,348$ & 38.9 & $7,260,264$ & $9,651,217$ & 57.1 & $12,858,698$ & $4,052,783$ & $3,341,048$ & 711,735 \\
\hline 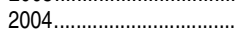 & $17,272,044$ & $10,610,177$ & $6,661,867$ & 38.6 & $7,387,262$ & $9,884,782$ & 57.2 & $12,980,112$ & $4,291,932$ & $3,411,685$ & 880,247 \\
\hline $2005 \ldots \ldots \ldots \ldots \ldots$ & $17,487,475$ & $10,797,011$ & $6,690,464$ & 38.3 & $7,455,925$ & $10,031,550$ & 57.4 & $13,021,834$ & $4,465,641$ & $3,454,692$ & $1,010,949$ \\
\hline $2006 \ldots \ldots \ldots \ldots \ldots \ldots$ & $17,758,870$ & $10,957,305$ & $6,801,565$ & 38.3 & $7,574,815$ & $10,184,055$ & 57.3 & $13,180,133$ & $4,578,737$ & $3,512,866$ & $1,065,871$ \\
\hline $2007 \ldots \ldots \ldots \ldots$ & $18,248,128$ & $11,269,892$ & $6,978,236$ & 38.2 & $7,815,914$ & $10,432,214$ & 57.2 & $13,490,780$ & $4,757,348$ & $3,571,150$ & $1,186,198$ \\
\hline $2008 \ldots \ldots \ldots \ldots \ldots$ & $19,102,814$ & $11,747,743$ & $7,355,071$ & 38.5 & $8,188,895$ & $10,913,919$ & 57.1 & $13,972,153$ & $5,130,661$ & $3,661,519$ & $1,469,142$ \\
\hline (1) & $20,427,711$ & $12,722,782$ & $7,704,929$ & 37.7 & $8,769,504$ & $11,658,207$ & 57.1 & $14,810,642$ & $5,617,069$ & $3,765,083$ & $1,851,986$ \\
\hline $2010 \ldots \ldots$ & $21,016,126$ & $13,082,267$ & $7,933,859$ & 37.8 & $9,044,811$ & $11,971,315$ & 57.0 & $15,142,809$ & $5,873,317$ & $3,854,920$ & $2,018,397$ \\
\hline $2011 \ldots \ldots \ldots$ & $20,994,113$ & $13,001,457$ & $7,992,656$ & 38.1 & $9,026,499$ & $11,967,614$ & 57.0 & $15,110,196$ & $5,883,917$ & $3,927,186$ & $1,956,731$ \\
\hline $2012 \ldots \ldots \ldots \ldots \ldots \ldots \ldots \ldots \ldots \ldots$ & $20,642,819$ & $12,737,013$ & $7,905,806$ & 38.3 & $8,919,087$ & $11,723,732$ & 56.8 & $14,880,343$ & $5,762,476$ & $3,953,578$ & $1,808,898$ \\
\hline $2013^{5} \ldots \ldots \ldots \ldots \ldots \ldots \ldots \ldots \ldots$ & $20,597,000$ & $12,742,000$ & $7,855,000$ & 38.1 & $8,985,000$ & $11,612,000$ & 56.4 & $14,857,000$ & $5,740,000$ & - & - \\
\hline $2014^{5}$ & $21,011,000$ & $12,992,000$ & $8,019,000$ & 38.2 & $9,037,000$ & $11,974,000$ & 57.0 & $15,140,000$ & $5,871,000$ & - & - \\
\hline
\end{tabular}


CHAPTER 3: Postsecondary Education 397

Total Fall Enrollment-General

Table 303.10. Total fall enrollment in degree-granting postsecondary institutions, by attendance status, sex of student, and control of institution: Selected years, 1947 through 2023-Continued

\begin{tabular}{|c|c|c|c|c|c|c|c|c|c|c|c|}
\hline \multirow[b]{3}{*}{ Year } & \multirow{3}{*}{$\begin{array}{r}\text { Total } \\
\text { enrollment }\end{array}$} & \multicolumn{3}{|c|}{ Attendance status } & \multicolumn{3}{|c|}{ Sex of student } & \multicolumn{4}{|c|}{ Control of institution } \\
\hline & & \multirow[b]{2}{*}{ Full-time } & \multirow[b]{2}{*}{ Part-time } & \multirow{2}{*}{$\begin{array}{r}\text { Percent } \\
\text { part-time }\end{array}$} & \multirow[b]{2}{*}{ Male } & \multirow[b]{2}{*}{ Female } & \multirow{2}{*}{$\begin{array}{r}\text { Percent } \\
\text { female }\end{array}$} & \multirow[b]{2}{*}{ Public } & \multicolumn{3}{|c|}{ Private } \\
\hline & & & & & & & & & Total & Nonprofit & For-profit \\
\hline 1 & 2 & 3 & 4 & 5 & 6 & 7 & 8 & 9 & 10 & 11 & 12 \\
\hline $2015^{5} \ldots \ldots \ldots \ldots \ldots \ldots \ldots \ldots \ldots \ldots \ldots$ & $21,266,000$ & $13,112,000$ & $8,154,000$ & 38.3 & $9,073,000$ & $12,193,000$ & 57.3 & $15,319,000$ & $5,947,000$ & - & - \\
\hline $2016^{5}$. & $21,586,000$ & $13,278,000$ & $8,308,000$ & 38.5 & $9,146,000$ & $12,441,000$ & 57.6 & $15,545,000$ & $6,041,000$ & - & - \\
\hline $2017^{5}$. & $21,946,000$ & $13,468,000$ & $8,478,000$ & 38.6 & $9,243,000$ & $12,703,000$ & 57.9 & $15,802,000$ & $6,144,000$ & - & - \\
\hline $2018^{5}$. & $22,227,000$ & $13,618,000$ & $8,609,000$ & 38.7 & $9,323,000$ & $12,904,000$ & 58.1 & $16,004,000$ & $6,223,000$ & - & - \\
\hline $2019^{5} \ldots \ldots \ldots \ldots \ldots \ldots \ldots \ldots \ldots \ldots$ & $22,512,000$ & $13,774,000$ & $8,737,000$ & 38.8 & $9,408,000$ & $13,104,000$ & 58.2 & $16,208,000$ & $6,304,000$ & - & - \\
\hline $2020^{5} \ldots \ldots \ldots \ldots \ldots \ldots \ldots$ & $22,797,000$ & $13,929,000$ & $8,868,000$ & 38.9 & $9,491,000$ & $13,306,000$ & 58.4 & $16,410,000$ & $6,388,000$ & - & - \\
\hline $2021^{5} \ldots \ldots \ldots \ldots \ldots$ & $23,141,000$ & $14,122,000$ & $9,020,000$ & 39.0 & $9,599,000$ & $13,543,000$ & 58.5 & $16,652,000$ & $6,489,000$ & - & - \\
\hline 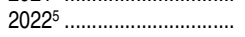 & $23,499,000$ & $14,329,000$ & $9,170,000$ & 39.0 & $9,712,000$ & $13,786,000$ & 58.7 & $16,905,000$ & $6,594,000$ & - & - \\
\hline $2023^{5} \ldots \ldots \ldots \ldots \ldots \ldots \ldots \ldots$ & $23,834,000$ & $14,520,000$ & $9,314,000$ & 39.1 & $9,817,000$ & $14,017,000$ & 58.8 & $17,143,000$ & $6,691,000$ & - & - \\
\hline
\end{tabular}

-Not available.

'Degree-credit enrollment only.

2Includes part-time resident students and all extension students (students attending courses a sites separate from the primary reporting campus). In later years, part-time student enrollment was collected as a distinct category.

${ }^{3}$ Large increases are due to the addition of schools accredited by the Accrediting Commission of Career Schools and Colleges of Technology.

${ }^{4}$ Because of imputation techniques, data are not consistent with figures for other years.

${ }^{4}$ B $\mathrm{B}$ rojected.

NOTE: Data through 1995 are for institutions of higher education, while later data are for degreegranting institutions. Degree-granting institutions grant associate's or higher degrees and partici- pate in Title IV federal financial aid programs. The degree-granting classification is very similar to the earlier higher education classification, but it includes more 2-year colleges and excludes a few higher education institutions that did not grant degrees.

SOURCE: U.S. Department of Education, National Center for Education Statistics, Biennial Survey of Education in the United States; Opening Fall Enrollment in Higher Education, 1963 through 1965; Higher Education General Information Survey (HEGIS), "Fall Enrollment in Colleges and Universities" surveys, 1966 through 1985; Integrated Postsecondary Education Data Spring 2013, Enrollment component; and Enrollment in Degree-Granting Institutions Projection Model, 1980 through 2023. (This table was prepared July 2014.) 
398 CHAPTER 3: Postsecondary Education

Total Fall Enrollment-General

Table 303.20. Total fall enrollment in all postsecondary institutions participating in Title IV programs and annual percentage change in enrollment, by degree-granting status and control of institution: 1995 through 2012

\begin{tabular}{|c|c|c|c|c|c|c|c|c|c|c|c|c|c|}
\hline \multirow[b]{3}{*}{ Year } & \multicolumn{4}{|c|}{ All Title IV institutions ${ }^{1}$} & \multicolumn{5}{|c|}{ Degree-granting institutions ${ }^{2}$} & \multicolumn{4}{|c|}{ Non-degree-granting institutions ${ }^{3}$} \\
\hline & \multirow[b]{2}{*}{ Total } & \multirow[b]{2}{*}{ Public } & \multicolumn{2}{|c|}{ Private } & \multirow[b]{2}{*}{ Total } & \multirow[b]{2}{*}{ Public } & \multicolumn{3}{|c|}{ Private } & \multirow[b]{2}{*}{ Total } & \multirow[b]{2}{*}{ Public } & \multicolumn{2}{|c|}{ Private } \\
\hline & & & Nonprofit & For-profit & & & Total & Nonprofit & For-profit & & & Nonprofit & For-profit \\
\hline \multirow[t]{2}{*}{1} & 2 & 3 & 4 & 5 & 6 & 7 & 8 & 9 & 10 & 11 & 12 & 13 & 14 \\
\hline & \multicolumn{13}{|c|}{ Enrollment } \\
\hline $1995 \ldots$ & $14,836,338$ & $11,312,491$ & $2,977,794$ & 546,053 & $14,261,781$ & $11,092,374$ & $3,169,407$ & $2,929,044$ & 240,363 & 574,557 & 220,117 & 48,750 & 305,690 \\
\hline 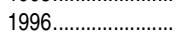 & $14,809,897$ & $11,312,775$ & $2,976,850$ & 520,272 & $14,367,520$ & $11,120,499$ & $3,247,021$ & $2,942,556$ & 304,465 & 442,377 & 192,276 & 34,294 & 215,807 \\
\hline $1997 \ldots \ldots \ldots \ldots \ldots \ldots$ & $14,900,416$ & $11,370,755$ & $3,012,106$ & 517,555 & $14,502,334$ & $11,196,119$ & $3,306,215$ & $2,977,614$ & 328,601 & 398,082 & 174,636 & 34,492 & 188,954 \\
\hline $1998 \ldots \ldots \ldots \ldots \ldots$ & $14,923,839$ & $11,330,811$ & $3,040,251$ & 552,777 & $14,506,967$ & $11,137,769$ & $3,369,198$ & $3,004,925$ & 364,273 & 416,872 & 193,042 & 35,326 & 188,504 \\
\hline 1999 & $15,262,888$ & $11,556,731$ & $3,088,233$ & 617,924 & $14,849,691$ & $11,375,739$ & $3,473,952$ & $3,055,029$ & 418,923 & 413,197 & 180,992 & 33,204 & 199,001 \\
\hline $2000 \ldots \ldots \ldots \ldots \ldots \ldots \ldots$ & $15,701,409$ & $11,891,450$ & $3,137,108$ & 672,851 & $15,312,289$ & $11,752,786$ & $3,559,503$ & $3,109,419$ & 450,084 & 389,120 & 138,664 & 27,689 & 222,767 \\
\hline $2001 \ldots \ldots \ldots \ldots \ldots \ldots \ldots$ & $16,334,134$ & $12,370,079$ & $3,198,354$ & 765,701 & $15,927,987$ & $12,233,156$ & $3,694,831$ & $3,167,330$ & 527,501 & 406,147 & 136,923 & 31,024 & 238,200 \\
\hline $2002 \ldots \ldots \ldots \ldots \ldots \ldots \ldots \ldots$ & $17,035,027$ & $12,883,071$ & $3,299,094$ & 852,862 & $16,611,711$ & $12,751,993$ & $3,859,718$ & $3,265,476$ & 594,242 & 423,316 & 131,078 & 33,618 & 258,620 \\
\hline 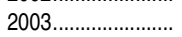 & $17,330,775$ & $12,965,502$ & $3,372,647$ & 992,626 & $16,911,481$ & $12,858,698$ & $4,052,783$ & $3,341,048$ & 711,735 & 419,294 & 106,804 & 31,599 & 280,891 \\
\hline $2004 \ldots \ldots \ldots \ldots \ldots \ldots \ldots$ & $17,710,798$ & $13,081,358$ & $3,440,559$ & $1,188,881$ & $17,272,044$ & $12,980,112$ & $4,291,932$ & $3,411,685$ & 880,247 & 438,754 & 101,246 & 28,874 & 308,634 \\
\hline $2005 \ldots$ & $17,921,804$ & $13,115,177$ & $3,484,013$ & $1,322,614$ & $17,487,475$ & $13,021,834$ & $4,465,641$ & $3,454,692$ & $1,010,949$ & 434,329 & 93,343 & 29,321 & 311,665 \\
\hline $2006 \ldots \ldots \ldots \ldots \ldots \ldots \ldots$ & $18,205,474$ & $13,281,664$ & $3,543,455$ & $1,380,355$ & $17,758,870$ & $13,180,133$ & $4,578,737$ & $3,512,866$ & $1,065,871$ & 446,604 & 101,531 & 30,589 & 314,484 \\
\hline $2007 \ldots \ldots \ldots \ldots \ldots$ & $18,671,084$ & $13,595,849$ & $3,595,207$ & $1,480,028$ & $18,248,128$ & $13,490,780$ & $4,757,348$ & $3,571,150$ & $1,186,198$ & 422,956 & 105,069 & 24,057 & 293,830 \\
\hline $2008 \ldots \ldots \ldots \ldots \ldots \ldots \ldots$ & $19,574,395$ & $14,092,109$ & $3,684,723$ & $1,797,563$ & $19,102,814$ & $13,972,153$ & $5,130,661$ & $3,661,519$ & $1,469,142$ & 471,581 & 119,956 & 23,204 & 328,421 \\
\hline $2009 \ldots \ldots \ldots \ldots \ldots \ldots$ & $20,966,826$ & $14,936,382$ & $3,791,418$ & $2,239,026$ & $20,427,711$ & $14,810,642$ & $5,617,069$ & $3,765,083$ & $1,851,986$ & 539,115 & 125,740 & 26,335 & 387,040 \\
\hline $2010 \ldots \ldots \ldots \ldots \ldots \ldots$ & $21,588,124$ & $15,280,273$ & $3,881,906$ & $2,425,945$ & $21,016,126$ & $15,142,809$ & $5,873,317$ & $3,854,920$ & $2,018,397$ & 571,998 & 137,464 & 26,986 & 407,548 \\
\hline $2011 \ldots \ldots \ldots \ldots \ldots \ldots \ldots$ & $21,557,259$ & $15,244,288$ & $3,954,529$ & $2,358,442$ & $20,994,113$ & $15,110,196$ & $5,883,917$ & $3,927,186$ & $1,956,731$ & 563,146 & 134,092 & 27,343 & 401,711 \\
\hline \multirow[t]{2}{*}{ 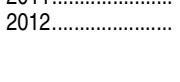 } & $21,147,055$ & $14,996,482$ & $3,975,542$ & $2,175,031$ & $20,642,819$ & $14,880,343$ & $5,762,476$ & $3,953,578$ & $1,808,898$ & 504,236 & 116,139 & 21,964 & 366,133 \\
\hline & \multicolumn{13}{|c|}{ Annual percentage change } \\
\hline 1995 to $1996 \ldots \ldots . .$. & -0.2 & $\#$ & \# & -4.7 & 0.7 & 0.3 & 2.4 & 0.5 & 26.7 & -23.0 & -12.6 & \begin{tabular}{l|l|}
-29.7 \\
\end{tabular} & -29.4 \\
\hline 1996 to $1997 \ldots \ldots . .$. & 0.6 & 0.5 & 1.2 & -0.5 & 0.9 & 0.7 & 1.8 & 1.2 & 7.9 & -10.0 & -9.2 & 0.6 & -12.4 \\
\hline 1997 to $1998 \ldots \ldots . . .$. & 0.2 & -0.4 & 0.9 & 6.8 & \# & -0.5 & 1.9 & 0.9 & 10.9 & 4.7 & 10.5 & 2.4 & -0.2 \\
\hline 1998 to $1999 \ldots \ldots . .$. & 2.3 & 2.0 & 1.6 & 11.8 & 2.4 & 2.1 & 3.1 & 1.7 & 15.0 & -0.9 & -6.2 & -6.0 & 5.6 \\
\hline 1999 to $2000 \ldots \ldots . .$. & 2.9 & 2.9 & 1.6 & 8.9 & 3.1 & 3.3 & 2.5 & 1.8 & 7.4 & -5.8 & -23.4 & -16.6 & 11.9 \\
\hline 2000 to $2001 \ldots \ldots . .$. & 4.0 & 4.0 & 2.0 & 13.8 & 4.0 & 4.1 & 3.8 & 1.9 & 17.2 & 4.4 & -1.3 & 12.0 & 6.9 \\
\hline 2001 to $2002 \ldots \ldots \ldots$ & 4.3 & 4.1 & 3.1 & 11.4 & 4.3 & 4.2 & 4.5 & 3.1 & 12.7 & 4.2 & -4.3 & 8.4 & 8.6 \\
\hline 2002 to $2003 \ldots \ldots . . .$. & 1.7 & 0.6 & 2.2 & 16.4 & 1.8 & 0.8 & 5.0 & 2.3 & 19.8 & -1.0 & -18.5 & -6.0 & 8.6 \\
\hline 2003 to $2004 \ldots \ldots \ldots$ & 2.2 & 0.9 & 2.0 & 19.8 & 2.1 & 0.9 & 5.9 & 2.1 & 23.7 & 4.6 & -5.2 & -8.6 & 9.9 \\
\hline 2004 to $2005 \ldots \ldots \ldots$ & 1.2 & 0.3 & 1.3 & 11.2 & 1.2 & 0.3 & 4.0 & 1.3 & 14.8 & -1.0 & -7.8 & 1.5 & 1.0 \\
\hline 2005 to $2006 \ldots . . . . .$. & 1.6 & 1.3 & 1.7 & 4.4 & 1.6 & 1.2 & 2.5 & 1.7 & 5.4 & 2.8 & 8.8 & 4.3 & 0.9 \\
\hline 2006 to $2007 \ldots \ldots . . .$. & 2.6 & 2.4 & 1.5 & 7.2 & 2.8 & 2.4 & 3.9 & 1.7 & 11.3 & -5.3 & 3.5 & -21.4 & -6.6 \\
\hline 2007 to $2008 \ldots \ldots . . . .$. & 4.8 & 3.7 & 2.5 & 21.5 & 4.7 & 3.6 & 7.8 & 2.5 & 23.9 & 11.5 & 14.2 & -3.5 & 11.8 \\
\hline 2008 to $2009 \ldots \ldots . .$. & 7.1 & 6.0 & 2.9 & 24.6 & 6.9 & 6.0 & 9.5 & 2.8 & 26.1 & 14.3 & 4.8 & 13.5 & 17.8 \\
\hline 2009 to $2010 \ldots \ldots . .$. & 3.0 & 2.3 & 2.4 & 8.3 & 2.9 & 2.2 & 4.6 & 2.4 & 9.0 & 6.1 & 9.3 & 2.5 & 5.3 \\
\hline 2010 to $2011 \ldots \ldots \ldots$ & -0.1 & -0.2 & 1.9 & -2.8 & -0.1 & -0.2 & 0.2 & 1.9 & -3.1 & -1.5 & -2.5 & 1.3 & -1.4 \\
\hline 2011 to $2012 \ldots \ldots . . .$. & -1.9 & -1.6 & 0.5 & -7.8 & -1.7 & -1.5 & -2.1 & 0.7 & -7.6 & -10.5 & -13.4 & -19.7 & -8.9 \\
\hline
\end{tabular}

\#Rounds to zero.

IIncludes degree-granting and non-degree-granting institutions.

${ }^{2}$ Data for 1995 are for institutions of higher education, while later data are for degree-granting institutions. Degree-granting institutions grant associate's or higher degrees and participate in Title IV federal financial aid programs. The degree-granting classification is very similar to the earlier higher education classification, but it includes more 2-year colleges and excludes a few higher education institutions that did not grant degrees.
${ }^{3}$ Data are for institutions that did not offer accredited 4-year or 2-year programs, but were participating in Title IV federal financial aid programs. Includes some institutions transitioning to higher level offerings, though still classified at a lower level.

SOURCE: U.S. Department of Education, National Center for Education Statistics, Integrated Postsecondary Education Data System (IPEDS), "Fall Enrollment Survey" (IPEDSEF:95-99); and IPEDS Spring 2001 through Spring 2013, Enrollment component. (This table was prepared October 2013.) 
Table 303.25. Total fall enrollment in degree-granting postsecondary institutions, by control and level of institution: 1970 through 2012

\begin{tabular}{|c|c|c|c|c|c|c|c|c|c|c|c|c|c|c|c|}
\hline \multirow[b]{3}{*}{ Year } & \multirow{2}{*}{\multicolumn{3}{|c|}{ All institutions }} & \multirow{2}{*}{\multicolumn{3}{|c|}{ Public institutions }} & \multicolumn{9}{|c|}{ Private institutions } \\
\hline & & & & & & & \multicolumn{3}{|c|}{ All private institutions } & \multicolumn{3}{|c|}{ Nonprofit } & \multicolumn{3}{|c|}{ For-profit } \\
\hline & Total & 4-year & 2-year & Total & 4-year & 2-year & Total & 4-year & 2-year & Total & 4-year & 2-year & Total & 4-year & 2-year \\
\hline 1 & 2 & 3 & 4 & 5 & 6 & 7 & 8 & 9 & 10 & 11 & 12 & 13 & 14 & 15 & 16 \\
\hline 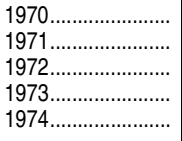 & $\begin{array}{r}8,580,887 \\
8,948,644 \\
9,214,860 \\
9,602,123 \\
10,223,729\end{array}$ & $\begin{array}{l}6,261,502 \\
6,369,355 \\
6,458,674 \\
6,590,023 \\
6,819,735\end{array}$ & $\begin{array}{l}2,319,385 \\
2,579,289 \\
2,756,186 \\
3,012,100 \\
3,403,994\end{array}$ & $\begin{array}{l}6,428,134 \\
6,804,309 \\
7,070,635 \\
7,419,516 \\
7,988,500\end{array}$ & $\begin{array}{l}4,232,722 \\
4,346,990 \\
4,429,696 \\
4,529,895 \\
4,703,018\end{array}$ & $\begin{array}{l}2,195,412 \\
2,457,319 \\
2,640,939 \\
2,889,621 \\
3,285,482\end{array}$ & $\begin{array}{l}2,152,753 \\
2,144,335 \\
2,144,225 \\
2,182,607 \\
2,235,229\end{array}$ & $\begin{array}{l}2,028,780 \\
2,022,365 \\
2,028,978 \\
2,060,128 \\
2,116,717\end{array}$ & $\begin{array}{l}123,973 \\
121,970 \\
115,247 \\
122,479 \\
118,512\end{array}$ & $\begin{array}{l}2,134,420 \\
2,121,913 \\
2,123,245 \\
2,148,784 \\
2,200,963\end{array}$ & $\begin{array}{l}2,021,121 \\
2,011,682 \\
2,019,380 \\
2,045,804 \\
2,098,599\end{array}$ & $\begin{array}{l}113,299 \\
110,231 \\
103,865 \\
102,980 \\
102,364\end{array}$ & $\begin{array}{l}18,333 \\
22,422 \\
20,980 \\
33,823 \\
34,266\end{array}$ & $\begin{array}{r}7,659 \\
10,683 \\
9,598 \\
14,324 \\
18,118\end{array}$ & $\begin{array}{l}10,674 \\
11,739 \\
11,382 \\
19,499 \\
16,148\end{array}$ \\
\hline 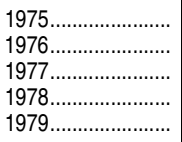 & $\begin{array}{l}11,184,859 \\
11,012,137 \\
11,285,787 \\
11,260,092 \\
11,569,899\end{array}$ & $\begin{array}{l}7,214,740 \\
7,128,816 \\
7,242,845 \\
7,231,625 \\
7,353,233\end{array}$ & $\begin{array}{l}3,970,119 \\
3,883,321 \\
4,042,942 \\
4,028,467 \\
4,216,666\end{array}$ & $\begin{array}{l}8,834,508 \\
8,653,477 \\
8,846,993 \\
8,785,893 \\
9,036,822\end{array}$ & $\begin{array}{l}4,998,142 \\
4,901,691 \\
4,945,224 \\
4,912,203 \\
4,980,012\end{array}$ & $\begin{array}{l}3,836,366 \\
3,751,786 \\
3,901,769 \\
3,873,690 \\
4,056,810\end{array}$ & $\begin{array}{l}2,350,351 \\
2,358,660 \\
2,438,794 \\
2,474,199 \\
2,533,077\end{array}$ & $\begin{array}{l}2,216,598 \\
2,227,125 \\
2,297,621 \\
2,319,422 \\
2,373,221\end{array}$ & $\begin{array}{l}133,753 \\
131,535 \\
141,173 \\
154,777 \\
159,856\end{array}$ & $\begin{array}{l}2,311,448 \\
2,314,298 \\
2,386,652 \\
2,408,331 \\
2,461,773\end{array}$ & $\begin{array}{l}2,198,451 \\
2,206,457 \\
2,277,072 \\
2,299,132 \\
2,351,364\end{array}$ & $\begin{array}{l}112,997 \\
107,841 \\
109,580 \\
109,199 \\
110,409\end{array}$ & $\begin{array}{l}38,903 \\
44,362 \\
52,142 \\
65,868 \\
71,304\end{array}$ & $\begin{array}{l}18,147 \\
20,668 \\
20,549 \\
20,290 \\
21,857\end{array}$ & $\begin{array}{l}20,756 \\
23,694 \\
31,593 \\
45,578 \\
49,447\end{array}$ \\
\hline $\begin{array}{l}1980 \ldots \ldots \ldots \ldots \\
1981 \ldots \ldots \ldots \ldots \ldots \\
1982 \ldots \ldots \ldots \ldots \ldots \ldots \\
1983 \ldots \ldots \ldots \ldots \ldots \ldots \\
1984 \ldots \ldots \ldots \ldots \ldots \ldots\end{array}$ & $\begin{array}{l}12,096,895 \\
12,371,672 \\
12,425,780 \\
12,464,661 \\
12,241,940\end{array}$ & $\begin{array}{l}7,570,608 \\
7,655,461 \\
7,654,074 \\
7,741,195 \\
7,711,167\end{array}$ & $\begin{array}{l}4,526,287 \\
4,716,211 \\
4,771,706 \\
4,723,466 \\
4,530,773\end{array}$ & $\begin{array}{l}9,457,394 \\
9,647,032 \\
9,696,087 \\
9,682,734 \\
9,477,370\end{array}$ & $\begin{array}{l}5,128,612 \\
5,166,324 \\
5,176,434 \\
5,223,404 \\
5,198,273\end{array}$ & $\begin{array}{l}4,328,782 \\
4,480,708 \\
4,519,653 \\
4,459,330 \\
4,279,097\end{array}$ & $\begin{array}{l}2,639,501 \\
2,724,640 \\
2,729,693 \\
2,781,927 \\
2,764,570\end{array}$ & $\begin{array}{l}2,441,996 \\
2,489,137 \\
2,477,640 \\
2,517,791 \\
2,512,894\end{array}$ & $\begin{array}{l}197,505^{1} \\
235,503^{1} \\
252,053^{1} \\
264,136 \\
251,676\end{array}$ & $\begin{array}{l}2,527,787 \\
2,572,405 \\
2,552,739 \\
2,589,187 \\
2,574,419\end{array}$ & $\begin{array}{l}2,413,693 \\
2,453,239 \\
2,437,763 \\
2,472,894 \\
2,466,172\end{array}$ & $\begin{array}{l}114,094 \\
119,166 \\
114,976 \\
116,293 \\
108,247\end{array}$ & $\begin{array}{l}111,714 \\
152,235 \\
176,954 \\
192,740 \\
190,151\end{array}$ & $\begin{array}{l}28,303 \\
35,898 \\
39,877 \\
44,897 \\
46,722\end{array}$ & $\begin{array}{l}83,411^{1} \\
116,337^{1} \\
137,077^{1} \\
147,843 \\
143,429\end{array}$ \\
\hline 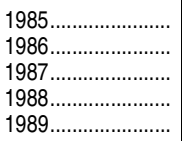 & $\begin{array}{l}12,247,055 \\
12,503,511 \\
12,766,642 \\
13,055,337 \\
13,538,560\end{array}$ & $\begin{array}{l}7,715,978 \\
7,823,963 \\
7,990,420 \\
8,180,182 \\
8,387,671\end{array}$ & $\begin{array}{l}4,531,077 \\
4,679,548 \\
4,776,222 \\
4,875,155 \\
5,150,889\end{array}$ & \begin{tabular}{r|}
$9,479,273$ \\
$9,713,893$ \\
$9,973,254$ \\
$10,161,388$ \\
$10,577,963$
\end{tabular} & $\begin{array}{l}5,209,540 \\
5,300,202 \\
5,432,200 \\
5,545,901 \\
5,694,303\end{array}$ & $\begin{array}{l}4,269,733 \\
4,413,691 \\
4,541,054 \\
4,615,487 \\
4,883,660\end{array}$ & $\begin{array}{l}2,767,782 \\
2,789,618 \\
2,793,388 \\
2,893,949 \\
2,960,597\end{array}$ & $\begin{array}{l}2,506,438 \\
2,523,761 \\
2,558,220 \\
2,634,281 \\
2,693,368\end{array}$ & \begin{tabular}{l|}
261,344 \\
$265,857^{2}$ \\
$235,168^{2}$ \\
259,668 \\
267,229
\end{tabular} & $\begin{array}{r}2,571,791 \\
2,572,479 \\
2,602,350 \\
- \\
-\end{array}$ & $\begin{array}{r}2,463,000 \\
2,470,981 \\
2,512,248 \\
- \\
-\end{array}$ & $\begin{array}{r}108,791 \\
101,498 \\
90,102 \\
- \\
-\end{array}$ & $\begin{array}{r}195,991 \\
217,139 \\
191,038 \\
- \\
-\end{array}$ & $\begin{array}{r}43,438 \\
52,780 \\
45,972 \\
- \\
-\end{array}$ & $\begin{array}{c}152,553 \\
164,359^{2} \\
145,066^{2} \\
- \\
-\end{array}$ \\
\hline 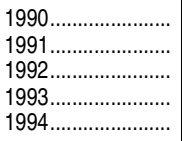 & $\begin{array}{l}13,818,637 \\
14,358,953 \\
14,487,359 \\
14,304,803 \\
14,278,790\end{array}$ & $\begin{array}{l}8,578,554 \\
8,707,053 \\
8,764,969 \\
8,738,936 \\
8,749,080\end{array}$ & $\begin{array}{l}5,240,083 \\
5,651,900 \\
5,722,390 \\
5,565,867 \\
5,529,710\end{array}$ & $\begin{array}{l}10,844,717 \\
11,309,563 \\
11,384,567 \\
11,189,088 \\
11,133,680\end{array}$ & $\begin{array}{l}5,848,242 \\
5,904,748 \\
5,900,012 \\
5,851,760 \\
5,825,213\end{array}$ & $\begin{array}{l}4,996,475 \\
5,404,815 \\
5,484,555 \\
5,337,328 \\
5,308,467\end{array}$ & $\begin{array}{l}2,973,920 \\
3,049,390 \\
3,102,792 \\
3,115,715 \\
3,145,110\end{array}$ & $\begin{array}{l}2,730,312 \\
2,802,305 \\
2,864,957 \\
2,887,176 \\
2,923,867\end{array}$ & $\begin{array}{l}243,608 \\
247,085 \\
237,835 \\
228,539 \\
221,243\end{array}$ & $\begin{array}{l}2,760,227 \\
2,819,041 \\
2,872,523 \\
2,888,897 \\
2,910,107\end{array}$ & $\begin{array}{l}2,671,069 \\
2,729,752 \\
2,789,235 \\
2,802,540 \\
2,824,500\end{array}$ & $\begin{array}{l}89,158 \\
89,289 \\
83,288 \\
86,357 \\
85,607\end{array}$ & $\begin{array}{l}213,693 \\
230,349 \\
230,269 \\
226,818 \\
235,003\end{array}$ & $\begin{array}{l}59,243 \\
72,553 \\
75,722 \\
84,636 \\
99,367\end{array}$ & $\begin{array}{l}154,450 \\
157,796 \\
154,547 \\
142,182 \\
135,636\end{array}$ \\
\hline 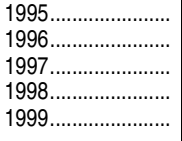 & $\begin{array}{l}14,261,781 \\
14,367,520 \\
14,502,334 \\
14,506,967 \\
14,849,691\end{array}$ & $\begin{array}{l}8,769,252 \\
8,804,193 \\
8,896,765 \\
9,017,653 \\
9,196,160\end{array}$ & $\begin{array}{l}5,492,529 \\
5,563,327 \\
5,605,569 \\
5,489,314 \\
5,653,531\end{array}$ & \begin{tabular}{l|}
$11,092,374$ \\
$11,120,499$ \\
$11,196,119$ \\
$11,137,769$ \\
$11,375,739$
\end{tabular} & $\begin{array}{l}5,814,545 \\
5,806,036 \\
5,835,433 \\
5,891,806 \\
5,977,678\end{array}$ & $\begin{array}{l}5,277,829 \\
5,314,463 \\
5,360,686 \\
5,245,963 \\
5,398,061\end{array}$ & $\begin{array}{l}3,169,407 \\
3,247,021 \\
3,306,215 \\
3,369,198 \\
3,473,952\end{array}$ & $\begin{array}{l}2,954,707 \\
2,998,157 \\
3,061,332 \\
3,125,847 \\
3,218,482\end{array}$ & $\begin{array}{l}214,700 \\
248,864 \\
244,883 \\
243,351 \\
255,470\end{array}$ & $\begin{array}{l}2,929,044 \\
2,942,556 \\
2,977,614 \\
3,004,925 \\
3,055,029\end{array}$ & $\begin{array}{l}2,853,890 \\
2,867,181 \\
2,905,820 \\
2,939,055 \\
2,991,728\end{array}$ & $\begin{array}{l}75,154 \\
75,375 \\
71,794 \\
65,870 \\
63,301\end{array}$ & $\begin{array}{l}240,363 \\
304,465 \\
328,601 \\
364,273 \\
418,923\end{array}$ & $\begin{array}{l}100,817 \\
130,976 \\
155,512 \\
186,792 \\
226,754\end{array}$ & $\begin{array}{l}139,546 \\
173,489 \\
173,089 \\
177,481 \\
192,169\end{array}$ \\
\hline 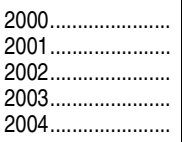 & $\begin{array}{l}15,312,289 \\
15,927,987 \\
16,611,711 \\
16,911,481 \\
17,272,044\end{array}$ & $\begin{array}{r}9,363,858 \\
9,677,408 \\
10,082,332 \\
10,417,247 \\
10,726,181\end{array}$ & $\begin{array}{l}5,948,431 \\
6,250,579 \\
6,529,379 \\
6,494,234 \\
6,545,863\end{array}$ & $\begin{array}{l}11,752,786 \\
12,233,156 \\
12,751,993 \\
12,858,698 \\
12,980,112\end{array}$ & $\begin{array}{l}6,055,398 \\
6,236,455 \\
6,481,613 \\
6,649,441 \\
6,736,536\end{array}$ & $\begin{array}{l}5,697,388 \\
5,996,701 \\
6,270,380 \\
6,209,257 \\
6,243,576\end{array}$ & $\begin{array}{l}3,559,503 \\
3,694,831 \\
3,859,718 \\
4,052,783 \\
4,291,932\end{array}$ & $\begin{array}{l}3,308,460 \\
3,440,953 \\
3,600,719 \\
3,767,806 \\
3,989,645\end{array}$ & $\begin{array}{l}251,043 \\
253,878 \\
258,999 \\
284,977 \\
302,287\end{array}$ & $\begin{array}{l}3,109,419 \\
3,167,330 \\
3,265,476 \\
3,341,048 \\
3,411,685\end{array}$ & $\begin{array}{l}3,050,575 \\
3,119,781 \\
3,218,389 \\
3,297,180 \\
3,369,435\end{array}$ & $\begin{array}{l}58,844 \\
47,549 \\
47,087 \\
43,868 \\
42,250\end{array}$ & $\begin{array}{l}450,084 \\
527,501 \\
594,242 \\
711,735 \\
880,247\end{array}$ & $\begin{array}{l}257,885 \\
321,172 \\
382,330 \\
470,626 \\
620,210\end{array}$ & $\begin{array}{l}192,199 \\
206,329 \\
211,912 \\
241,109 \\
260,037\end{array}$ \\
\hline $\begin{array}{l}2005 \ldots \ldots \ldots \ldots \\
2006 \ldots \ldots \ldots \ldots \ldots \ldots \\
2007 \ldots \ldots \ldots \ldots \ldots \ldots \\
2008 \ldots \ldots \ldots \ldots \ldots \ldots \\
2009 \ldots \ldots \ldots \ldots \ldots . . .\end{array}$ & $\begin{array}{l}17,487,475 \\
17,758,870 \\
18,248,128 \\
19,102,814 \\
20,427,711\end{array}$ & $\begin{array}{l}10,999,420 \\
11,240,330 \\
11,630,198 \\
12,131,436 \\
12,906,305\end{array}$ & $\begin{array}{l}6,488,055 \\
6,518,540 \\
6,617,930 \\
6,971,378 \\
7,521,406\end{array}$ & \begin{tabular}{l|}
$13,021,834$ \\
$13,180,133$ \\
$13,490,780$ \\
$13,972,153$ \\
$14,810,642$
\end{tabular} & $\begin{array}{l}6,837,605 \\
6,955,013 \\
7,166,661 \\
7,331,809 \\
7,709,197\end{array}$ & $\begin{array}{l}6,184,229 \\
6,225,120 \\
6,324,119 \\
6,640,344 \\
7,101,445\end{array}$ & $\begin{array}{l}4,465,641 \\
4,578,737 \\
4,757,348 \\
5,130,661 \\
5,617,069\end{array}$ & $\begin{array}{l}4,161,815 \\
4,285,317 \\
4,463,537 \\
4,799,627 \\
5,197,108\end{array}$ & $\begin{array}{l}303,826 \\
293,420 \\
293,811 \\
331,034 \\
419,961\end{array}$ & $\begin{array}{l}3,454,692 \\
3,512,866 \\
3,571,150 \\
3,661,519 \\
3,765,083\end{array}$ & $\begin{array}{l}3,411,170 \\
3,473,710 \\
3,537,664 \\
3,626,168 \\
3,730,316\end{array}$ & $\begin{array}{l}43,522 \\
39,156 \\
33,486 \\
35,351 \\
34,767\end{array}$ & $\begin{array}{l}1,010,949 \\
1,065,871 \\
1,186,198 \\
1,469,142 \\
1,851,986\end{array}$ & $\begin{array}{r}750,645 \\
811,607 \\
925,873 \\
1,173,459 \\
1,466,792\end{array}$ & $\begin{array}{l}260,304 \\
254,264 \\
260,325 \\
295,683 \\
385,194\end{array}$ \\
\hline 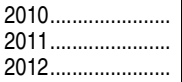 & $\begin{array}{l}21,016,126 \\
20,994,113 \\
20,642,819\end{array}$ & $\begin{array}{l}13,335,251 \\
13,494,131 \\
13,478,846\end{array}$ & $\begin{array}{l}7,680,875 \\
7,499,982 \\
7,163,973\end{array}$ & $\begin{array}{l}15,142,809 \\
15,110,196 \\
14,880,343\end{array}$ & $\begin{array}{l}7,924,771 \\
8,047,729 \\
8,092,683\end{array}$ & $\begin{array}{l}7,218,038 \\
7,062,467 \\
6,787,660\end{array}$ & $\begin{array}{l}5,873,317 \\
5,883,917 \\
5,762,476\end{array}$ & $\begin{array}{l}5,410,480 \\
5,446,402 \\
5,386,163\end{array}$ & $\begin{array}{l}462,837 \\
437,515 \\
376,313\end{array}$ & $\begin{array}{l}3,854,920 \\
3,927,186 \\
3,953,578\end{array}$ & $\begin{array}{l}3,822,260 \\
3,887,322 \\
3,915,972\end{array}$ & $\begin{array}{l}32,660 \\
39,864 \\
37,606\end{array}$ & $\begin{array}{l}2,018,397 \\
1,956,731 \\
1,808,898\end{array}$ & $\begin{array}{l}1,588,220 \\
1,559,080 \\
1,470,191\end{array}$ & $\begin{array}{l}430,177 \\
397,651 \\
338,707\end{array}$ \\
\hline
\end{tabular}

-Not available.

'Large increases are due to the addition of schools accredited by the Accrediting Commission of Career Schools and Col-

leges of Technology.
2Because of imputation techniques, data are not consistent with figures for other years,

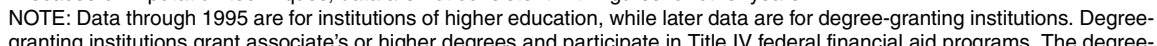

granting classification is very similar to the earlier higher education classification, but it includes more 2-year colleges and excludes a few higher education institutions that did not grant degrees.

SOURCE: U.S. Department of Education, National Center for Education Statistics, Higher Education General Information Survey (HEGIS), "Fall Enrollment in Institutions of Higher Education" surveys, 1970 through 1985; Integrated Postsecondary
Education Data System (IPEDS), "Fall Enrollment Survey" (IPEDS-EF:86-99); and IPEDS Spring 2001 through Spring 2013, Enrollment component. (This table was prepared October 2013.) 
Table 303.30. Total fall enrollment in degree-granting postsecondary institutions, by level and control of institution, attendance status, and sex of student: Selected years, 1970 through 2023

\begin{tabular}{|c|c|c|c|c|c|c|c|c|c|c|c|c|c|c|}
\hline \multirow{2}{*}{$\begin{array}{l}\text { Level and control of } \\
\text { institution, attendance } \\
\text { status, and sex of student }\end{array}$} & \multicolumn{14}{|c|}{ Actual } \\
\hline & 1970 & 1975 & $1980^{1}$ & 1985 & 1990 & 1995 & 2000 & 2005 & 2007 & 2008 & 2009 & 2010 & 2011 & 2012 \\
\hline 1 & 2 & 3 & 4 & 5 & 6 & 7 & 8 & 0 & 10 & 11 & 12 & 13 & 14 & 15 \\
\hline Total ............................ & $8,580,887$ & $11,184,859$ & $12,096,895$ & $12,247,055$ & $13,818,637$ & $, 261,781$ & $15,312,289$ & $, 487,475$ & $18,248,128$ & $19,102,814$ & $20,427,711$ & $21,016,126$ & $20,994,113$ & $20,642,819$ \\
\hline 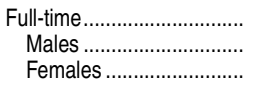 & $\begin{array}{l}5,816,290 \\
3,504,095 \\
2,312,195\end{array}$ & $\begin{array}{l}6,841,334 \\
3,926,753 \\
2,914,581\end{array}$ & $\begin{array}{l}7,097,958 \\
3,689,244 \\
3,408,714\end{array}$ & $\begin{array}{l}7,075,221 \\
3,607,720 \\
3,467,501\end{array}$ & $\begin{array}{l}7,820,985 \\
3,807,752 \\
4,013,233\end{array}$ & $\begin{array}{l}8,128,802 \\
3,807,392 \\
4,321,410\end{array}$ & $\begin{array}{l}9,009,600 \\
4,111,093 \\
4,898,507\end{array}$ & \begin{tabular}{|r|}
$10,797,011$ \\
$4,803,388$ \\
$5,993,623$ \\
\end{tabular} & \begin{tabular}{|r|}
$11,269,892$ \\
$5,029,444$ \\
$6,240,448$
\end{tabular} & \begin{tabular}{|r|}
$11,747,743$ \\
$5,234,357$ \\
$6,513,386$
\end{tabular} & \begin{tabular}{|r|}
$12,722,782$ \\
$5,670,644$ \\
$7,052,138$
\end{tabular} & $\begin{array}{r}13,082,267 \\
5,837,057 \\
7,245,210\end{array}$ & $\begin{array}{r}13,001,457 \\
5,793,411 \\
7,208,046\end{array}$ & $\begin{array}{r}12,737,013 \\
5,709,792 \\
7,027,221\end{array}$ \\
\hline 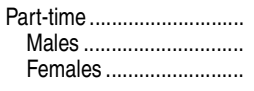 & $\begin{array}{l}2,764,597 \\
1,539,547 \\
1,225,050 \\
\end{array}$ & $\begin{array}{l}4,343,525 \\
2,222,244 \\
2,121,281 \\
\end{array}$ & $\begin{array}{l}4,998,937 \\
2,185,130 \\
2,813,807 \\
\end{array}$ & $\begin{array}{l}5,171,834 \\
2,210,730 \\
2,961,104 \\
\end{array}$ & $\begin{array}{l}5,997,652 \\
2,476,157 \\
3,521,495 \\
\end{array}$ & $\begin{array}{l}6,132,979 \\
2,535,147 \\
3,597,832 \\
\end{array}$ & $\begin{array}{l}6,302,689 \\
2,610,676 \\
3,692,013 \\
\end{array}$ & $\begin{array}{l}6,690,464 \\
2,652,537 \\
4,037,927 \\
\end{array}$ & $\begin{array}{l}6,978,236 \\
2,786,470 \\
4,191,766 \\
\end{array}$ & $\begin{array}{l}7,355,071 \\
2,954,538 \\
4,400,533 \\
\end{array}$ & $\begin{array}{l}7,704,929 \\
3,098,860 \\
4,606,069 \\
\end{array}$ & $\begin{array}{l}7,933,859 \\
3,207,754 \\
4,726,105 \\
\end{array}$ & $\begin{array}{l}7,992,656 \\
3,233,088 \\
4,759,568 \\
\end{array}$ & $\begin{array}{l}7,905,806 \\
3,209,295 \\
4,696,511 \\
\end{array}$ \\
\hline 4-yea & $6,261,502$ & $7,214,740$ & $7,570,608$ & $7,715,978$ & $8,578,554$ & $8,769,252$ & $9,363,858$ & $10,999,420$ & $11,630,198$ & $12,131,436$ & $12,906,305$ & $13,335,251$ & $13,494,131$ & $13,478,846$ \\
\hline 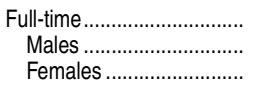 & $\begin{array}{l}4,587,379 \\
2,732,796 \\
1,854,583\end{array}$ & $\begin{array}{l}5,080,256 \\
2,891,192 \\
2,189,064\end{array}$ & $\begin{array}{l}5,344,163 \\
2,809,528 \\
2,534,635\end{array}$ & $\begin{array}{l}5,384,614 \\
2,781,412 \\
2,603,202\end{array}$ & $\begin{array}{l}5,937,023 \\
2,926,360 \\
3,010,663\end{array}$ & $\begin{array}{l}6,151,755 \\
2,929,177 \\
3,222,578\end{array}$ & $\begin{array}{l}6,792,551 \\
3,115,252 \\
3,677,299\end{array}$ & $\begin{array}{l}8,150,209 \\
3,649,622 \\
4,500,587\end{array}$ & $\begin{array}{l}8,577,299 \\
3,839,336 \\
4,737,963\end{array}$ & $\begin{array}{l}8,915,546 \\
3,984,494 \\
4,931,052\end{array}$ & $\begin{array}{l}9,474,059 \\
4,222,234 \\
5,251,825\end{array}$ & $\begin{array}{l}717,074 \\
353,627 \\
363,447\end{array}$ & $\begin{array}{l}841,421 \\
, 405,066 \\
436,355\end{array}$ & $\begin{array}{l}9,794,436 \\
4,403,960 \\
5,390,476\end{array}$ \\
\hline 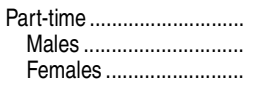 & $\begin{array}{r}1,674,123 \\
936,189 \\
737,934 \\
\end{array}$ & $\begin{array}{l}2,134,484 \\
1,092,461 \\
1,042,023 \\
\end{array}$ & $\begin{array}{l}2,226,445 \\
1,017,813 \\
1,208,632 \\
\end{array}$ & & & & $\begin{array}{l}2,571,307 \\
1,047,917 \\
1,523,390 \\
\end{array}$ & $\begin{array}{l}2,849,211 \\
1,125,935 \\
1,723,276 \\
\end{array}$ & $\begin{array}{l}3,052,899 \\
1,206,007 \\
1,846,892 \\
\end{array}$ & $\begin{array}{l}3,215,890 \\
1,268,517 \\
1,947,373 \\
\end{array}$ & $\begin{array}{l}3,432,246 \\
1,350,710 \\
2,081,536 \\
\end{array}$ & $\begin{array}{l}3,618,177 \\
1,426,058 \\
2,192,119 \\
\end{array}$ & $\begin{array}{l}3,652,710 \\
1,449,779 \\
2,202,931 \\
\end{array}$ & $\begin{array}{l}3,684,410 \\
1,470,423 \\
2,213,987 \\
\end{array}$ \\
\hline 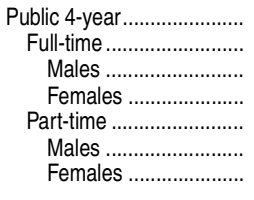 & $\begin{array}{r}4,232,722 \\
3,086,491 \\
1,813,584 \\
1,272,907 \\
1,146,231 \\
609,422 \\
536,809\end{array}$ & $\begin{array}{r}4,998,142 \\
3,469,821 \\
1,947,823 \\
1,521,998 \\
1,528,321 \\
760,469 \\
767,852\end{array}$ & $\begin{array}{r}5,128,612 \\
3,592,193 \\
1,873,397 \\
1,718,796 \\
1,536,419 \\
685,051 \\
851,368\end{array}$ & $\begin{array}{r}5,209,540 \\
3,623,341 \\
1,863,689 \\
1,759,652 \\
1,586,199 \\
693,115 \\
893,084\end{array}$ & $\begin{array}{r}5,848,242 \\
4,033,654 \\
1,982,369 \\
2,051,285 \\
1,814,588 \\
764,248 \\
1,050,340\end{array}$ & $\begin{array}{r}5,814,545 \\
4,084,711 \\
1,951,140 \\
2,133,571 \\
1,729,834 \\
720,402 \\
1,009,432\end{array}$ & $\begin{array}{r}6,055,398 \\
4,371,218 \\
2,008,618 \\
2,362,600 \\
1,684,180 \\
683,100 \\
1,001,080\end{array}$ & $\begin{array}{r}6,837,605 \\
5,021,745 \\
2,295,456 \\
2,726,289 \\
1,815,860 \\
724,375 \\
1,091,485\end{array}$ & $\begin{array}{r}7,166,661 \\
5,244,841 \\
2,417,717 \\
2,827,124 \\
1,921,820 \\
772,563 \\
1,149,257\end{array}$ & $\begin{array}{r}7,331,809 \\
5,378,123 \\
2,488,168 \\
2,889,955 \\
1,953,686 \\
788,594 \\
1,165,092\end{array}$ & $\begin{array}{r}7,709,197 \\
5,649,713 \\
2,626,170 \\
3,023,543 \\
2,059,484 \\
833,156 \\
1,226,328\end{array}$ & $\begin{array}{r}7,924,771 \\
5,811,370 \\
2,707,453 \\
3,103,917 \\
2,113,401 \\
861,091 \\
1,252,310\end{array}$ & $\begin{array}{r}8,047,729 \\
5,889,009 \\
2,743,324 \\
3,145,685 \\
2,158,720 \\
885,565 \\
1,273,155\end{array}$ & $\begin{array}{r}8,092,683 \\
5,910,198 \\
2,756,941 \\
3,153,257 \\
2,182,485 \\
901,197 \\
1,281,288\end{array}$ \\
\hline 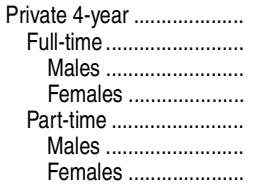 & $\begin{array}{r}2,028,780 \\
1,500,888 \\
919,212 \\
581,676 \\
527,892 \\
326,767 \\
201,125\end{array}$ & $\begin{array}{r}2,216,598 \\
1,610,435 \\
943,369 \\
667,066 \\
606,163 \\
331,992 \\
274,171\end{array}$ & $\begin{array}{r}1,751,970 \\
936,131 \\
815,839 \\
690,026 \\
332,762 \\
357,264\end{array}$ & $\begin{array}{r}2,506,438 \\
1,761,273 \\
917,723 \\
843,550 \\
745,165 \\
341,689 \\
403,476\end{array}$ & $\begin{array}{r}2,730,312 \\
1,903,369 \\
943,991 \\
959,378 \\
826,943 \\
360,532 \\
466,411\end{array}$ & $\begin{array}{r}2,954,707 \\
2,067,044 \\
978,037 \\
1,089,007 \\
887,663 \\
364,351 \\
523,312\end{array}$ & $\begin{array}{r}3,308,460 \\
2,421,333 \\
1,106,634 \\
1,314,699 \\
887,127 \\
364,817 \\
522,310\end{array}$ & \begin{tabular}{r|}
$4,161,815$ \\
$3,128,464$ \\
$1,354,166$ \\
$1,774,298$ \\
$1,033,351$ \\
401,560 \\
631,791
\end{tabular} & \begin{tabular}{r|r|}
$, 463,537$ \\
$, 332,458$ \\
$1,421,619$ \\
$1,910,839$ \\
$1,131,079$ \\
433,444 \\
697,635
\end{tabular} & $\begin{array}{r}4,799,627 \\
3,537,423 \\
1,496,326 \\
2,041,097 \\
1,262,204 \\
479,923 \\
782,281\end{array}$ & $\begin{array}{r}5,197,108 \\
3,824,346 \\
1,596,064 \\
2,228,282 \\
1,372,762 \\
517,554 \\
855,208\end{array}$ & $\begin{array}{r}5,410,480 \\
3,905,704 \\
1,646,174 \\
2,259,530 \\
1,504,776 \\
564,967 \\
939,809\end{array}$ & $\begin{array}{r}5,446,402 \\
3,952,412 \\
1,661,742 \\
2,290,670 \\
1,493,990 \\
564,214 \\
929,776\end{array}$ & $\begin{array}{r}5,386,163 \\
3,884,238 \\
1,647,019 \\
2,237,219 \\
1,501,925 \\
569,226 \\
932,699\end{array}$ \\
\hline 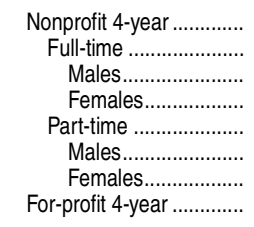 & $\begin{array}{r}2,021,121 \\
1,494,625 \\
914,020 \\
580,605 \\
526,496 \\
325,693 \\
200,803 \\
7,659 \\
\end{array}$ & $\begin{array}{r}2,198,451 \\
1,596,074 \\
930,842 \\
665,232 \\
602,377 \\
329,662 \\
272,715 \\
18,147 \\
\end{array}$ & $\begin{array}{r}2,413,693 \\
1,733,014 \\
921,253 \\
811,761 \\
680,679 \\
327,986 \\
352,693 \\
28,303 \\
\end{array}$ & $\begin{array}{r}2,463,000 \\
1,727,707 \\
894,080 \\
833,627 \\
735,293 \\
336,168 \\
399,125 \\
43,438 \\
\end{array}$ & $\begin{array}{r}2,671,069 \\
1,859,124 \\
915,100 \\
944,024 \\
811,945 \\
352,106 \\
459,839 \\
59,243 \\
\end{array}$ & $\begin{array}{r}2,853,890 \\
1,989,457 \\
931,956 \\
1,057,501 \\
864,433 \\
351,874 \\
512,559 \\
100,817 \\
\end{array}$ & $\begin{array}{r}3,050,575 \\
2,226,028 \\
996,113 \\
1,229,915 \\
824,547 \\
332,814 \\
491,733 \\
257,885 \\
\end{array}$ & $\begin{array}{r}3,411,170 \\
2,534,793 \\
1,109,075 \\
1,425,718 \\
876,377 \\
339,572 \\
536,805 \\
750,645 \\
\end{array}$ & $\begin{array}{r}3,537,664 \\
2,643,207 \\
1,159,775 \\
1,483,432 \\
894,457 \\
344,325 \\
550,132 \\
925,873 \\
\end{array}$ & $\begin{array}{r}3,626,168 \\
2,698,819 \\
1,184,895 \\
1,513,924 \\
927,349 \\
357,974 \\
569,375 \\
1,173,459 \\
\end{array}$ & $\begin{array}{r}3,730,316 \\
2,783,162 \\
1,221,375 \\
1,561,787 \\
947,154 \\
364,432 \\
582,722 \\
1,466,792 \\
\end{array}$ & $\begin{array}{r}3,822,260 \\
2,865,417 \\
1,259,919 \\
1,605,498 \\
956,843 \\
366,645 \\
590,198 \\
1,588,220 \\
\end{array}$ & $\begin{array}{r}3,887,322 \\
2,907,240 \\
1,276,006 \\
1,631,234 \\
980,082 \\
375,304 \\
604,778 \\
1,559,080 \\
\end{array}$ & $\begin{array}{r}3,915,972 \\
2,928,938 \\
1,290,080 \\
1,638,858 \\
987,034 \\
377,740 \\
609,294 \\
1,470,191 \\
\end{array}$ \\
\hline 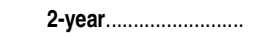 & $2,319,385$ & $3,970,119$ & $4,526,287$ & 31,077 & 240,083 & 492,529 & 948,431 & 488,055 & $\$ 17,930$ & 971,378 & 521,406 & 680,875 & 99,982 & $7,163,973$ \\
\hline 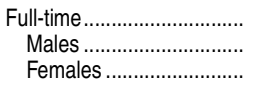 & $\begin{array}{r}1,228,911 \\
771,299 \\
457,612\end{array}$ & $\begin{array}{r}1,761,078 \\
1,035,561 \\
725,517\end{array}$ & $\begin{array}{r}1,753,795 \\
879,716 \\
874,079\end{array}$ & $\begin{array}{r}1,690,607 \\
826,308 \\
864,299\end{array}$ & $\begin{array}{r}1,883,962 \\
881,392 \\
1,002,570\end{array}$ & $\begin{array}{r}1,977,047 \\
878,215 \\
1,098,832\end{array}$ & $\begin{array}{r}2,217,049 \\
995,841 \\
1,221,208\end{array}$ & $\begin{array}{l}, 646,802 \\
, 153,766 \\
493,036\end{array}$ & $\begin{array}{l}2,692,593 \\
1,190,108 \\
1,502,485\end{array}$ & $\begin{array}{l}2,832,197 \\
1,249,863 \\
1,582,334\end{array}$ & $\begin{array}{l}3,248,723 \\
1,448,410 \\
1,800,313\end{array}$ & $\begin{array}{l}5,193 \\
3,430 \\
1,763\end{array}$ & $\begin{array}{l}3,160,036 \\
1,388,345 \\
1,771,691\end{array}$ & $\begin{array}{l}2,942,577 \\
1,305,832 \\
1,636,745\end{array}$ \\
\hline 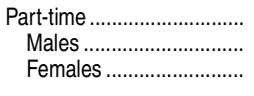 & $\begin{array}{r}1,090,474 \\
603,358 \\
487,116 \\
\end{array}$ & & & & & & & & & & & $\begin{array}{l}4,315,682 \\
1,781,696 \\
2,533,986 \\
\end{array}$ & $\begin{array}{l}4,339,946 \\
1,783,309 \\
2,556,637 \\
\end{array}$ & $\begin{array}{l}4,221,396 \\
1,738,872 \\
2,482,524 \\
\end{array}$ \\
\hline 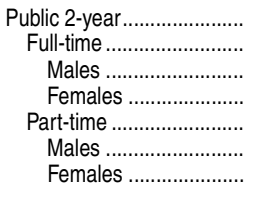 & $\begin{array}{r}2,195,412 \\
1,129,165 \\
720,440 \\
408,725 \\
1,066,247 \\
589,439 \\
476,808\end{array}$ & $\begin{array}{r}3,836,366 \\
1,662,621 \\
988,701 \\
673,920 \\
2,173,745 \\
1,107,680 \\
1,066,065\end{array}$ & $\begin{array}{r}4,328,782 \\
1,595,493 \\
811,871 \\
783,622 \\
2,733,289 \\
1,152,268 \\
1,581,021\end{array}$ & $\begin{array}{r}4,269,733 \\
1,496,905 \\
742,673 \\
754,232 \\
2,772,828 \\
1,138,011 \\
1,634,817\end{array}$ & $\begin{array}{r}4,996,475 \\
1,716,843 \\
810,664 \\
906,179 \\
3,279,632 \\
1,317,730 \\
1,961,902\end{array}$ & $\begin{array}{r}5,277,829 \\
1,840,590 \\
818,605 \\
1,021,985 \\
3,437,239 \\
1,417,488 \\
2,019,751\end{array}$ & $\begin{array}{r}5,697,388 \\
2,000,008 \\
891,282 \\
1,108,726 \\
3,697,380 \\
1,549,407 \\
2,147,973\end{array}$ & $\begin{array}{l}6,184,229 \\
2,387,016 \\
1,055,029 \\
1,331,987 \\
3,797,213 \\
1,514,363 \\
2,282,850\end{array}$ & $\begin{array}{l}6,324,119 \\
2,442,140 \\
1,098,772 \\
1,343,368 \\
3,881,979 \\
1,568,247 \\
2,313,732\end{array}$ & $\begin{array}{l}6,640,344 \\
2,548,488 \\
1,152,037 \\
1,396,451 \\
4,091,856 \\
1,671,716 \\
2,420,140\end{array}$ & $\begin{array}{l}7,101,445 \\
2,880,631 \\
1,317,630 \\
1,563,001 \\
4,220,814 \\
1,732,613 \\
2,488,201\end{array}$ & $\begin{array}{l}7,218,038 \\
2,952,480 \\
1,342,140 \\
1,610,340 \\
4,265,558 \\
1,768,853 \\
2,496,705\end{array}$ & $\begin{array}{l}7,062,467 \\
2,776,731 \\
1,258,460 \\
1,518,271 \\
4,285,736 \\
1,768,887 \\
2,516,849\end{array}$ & $\begin{array}{l}6,787,660 \\
2,615,620 \\
1,197,173 \\
1,418,447 \\
4,172,040 \\
1,725,988 \\
2,446,052\end{array}$ \\
\hline 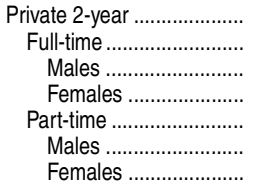 & $\begin{array}{r}123,973 \\
99,746 \\
50,859 \\
48,887 \\
24,227 \\
13,919 \\
10,308\end{array}$ & $\begin{array}{r}133,753 \\
98,457 \\
46,860 \\
51,597 \\
35,296 \\
22,103 \\
13,193\end{array}$ & $\begin{array}{r}197,505 \\
158,302 \\
67,845 \\
90,457 \\
39,203 \\
15,049 \\
24,154\end{array}$ & $\begin{array}{r}193,702 \\
83,635 \\
110,067 \\
67,642 \\
37,915 \\
29,727\end{array}$ & $\begin{array}{r}243,608 \\
167,119 \\
70,728 \\
96,391 \\
76,489 \\
33,647 \\
42,842\end{array}$ & $\begin{array}{r}214,700 \\
136,457 \\
59,610 \\
76,847 \\
78,243 \\
32,906 \\
45,337\end{array}$ & $\begin{array}{r}251,043 \\
217,041 \\
104,559 \\
112,482 \\
34,002 \\
13,352 \\
20,650\end{array}$ & $\begin{array}{r}259,786 \\
98,737 \\
161,049 \\
44,040 \\
12,239 \\
31,801\end{array}$ & $\begin{array}{r}293,811 \\
250,453 \\
91,336 \\
159,117 \\
43,358 \\
12,216 \\
31,142\end{array}$ & $\begin{array}{r}331,034 \\
283,709 \\
97,826 \\
185,883 \\
47,325 \\
14,305 \\
33,020\end{array}$ & $\begin{array}{r}368,092 \\
130,780 \\
237,312 \\
51,869 \\
15,537 \\
36,332\end{array}$ & $\begin{array}{r}462,837 \\
412,713 \\
141,290 \\
271,423 \\
50,124 \\
12,843 \\
37,281\end{array}$ & $\begin{array}{r}437,515 \\
383,305 \\
129,885 \\
253,420 \\
54,210 \\
14,422 \\
39,788\end{array}$ & $\begin{array}{r}376,313 \\
326,957 \\
108,659 \\
218,298 \\
49,356 \\
12,884 \\
36,472\end{array}$ \\
\hline $\begin{array}{r}\text { Nonprofit 2-year .............. } \\
\text { Full-time ..................... } \\
\text { Males.................. } \\
\text { Females................ } \\
\text { Part-time ..................... } \\
\text { Males................... } \\
\text { Females................ } \\
\text { For-profit 2-year .............. }\end{array}$ & $\begin{array}{r}113,299 \\
91,514 \\
46,030 \\
45,484 \\
21,785 \\
12,097 \\
9,688 \\
10,674\end{array}$ & $\begin{array}{r}112,997 \\
82,158 \\
40,548 \\
41,610 \\
30,839 \\
18,929 \\
11,910 \\
20,756\end{array}$ & $\begin{array}{l}83,009 \\
34,968 \\
48,041 \\
31,085 \\
11,445 \\
19,640 \\
83,411\end{array}$ & $\begin{array}{r}76,547 \\
30,878 \\
45,669 \\
32,244 \\
10,786 \\
21,458 \\
152,553\end{array}$ & $\begin{array}{r}62,003 \\
25,946 \\
36,057 \\
27,155 \\
7,970 \\
19,185 \\
154,450\end{array}$ & $\begin{array}{r}75,154 \\
54,033 \\
23,265 \\
30,768 \\
21,121 \\
6,080 \\
15,041 \\
139,546\end{array}$ & $\begin{array}{r}58,844 \\
46,670 \\
21,950 \\
24,720 \\
12,174 \\
4,499 \\
7,675 \\
192,199\end{array}$ & $\begin{array}{r}28,939 \\
12,086 \\
16,853 \\
14,583 \\
3,566 \\
11,017 \\
260,304\end{array}$ & $\begin{array}{r}21,295 \\
8,691 \\
12,604 \\
12,191 \\
3,003 \\
9,188 \\
260,325\end{array}$ & $\begin{array}{r}35,351 \\
23,270 \\
9,244 \\
14,026 \\
12,081 \\
2,867 \\
9,214 \\
295,683\end{array}$ & $\begin{array}{r}34,767 \\
23,483 \\
9,578 \\
13,905 \\
11,284 \\
2,721 \\
8,563 \\
385,194\end{array}$ & $\begin{array}{r}32,660 \\
23,101 \\
9,918 \\
13,183 \\
9,559 \\
2,586 \\
6,973 \\
430,177\end{array}$ & $\begin{array}{r}39,864 \\
30,579 \\
11,296 \\
19,283 \\
9,285 \\
2,544 \\
6,741 \\
397,651\end{array}$ & $\begin{array}{r}37,606 \\
29,320 \\
10,459 \\
18,861 \\
8,286 \\
2,465 \\
5,821 \\
338,707\end{array}$ \\
\hline
\end{tabular}


Table 303.30. Total fall enrollment in degree-granting postsecondary institutions, by level and control of institution, attendance status, and sex of student: Selected years, 1970 through 2023-Continued

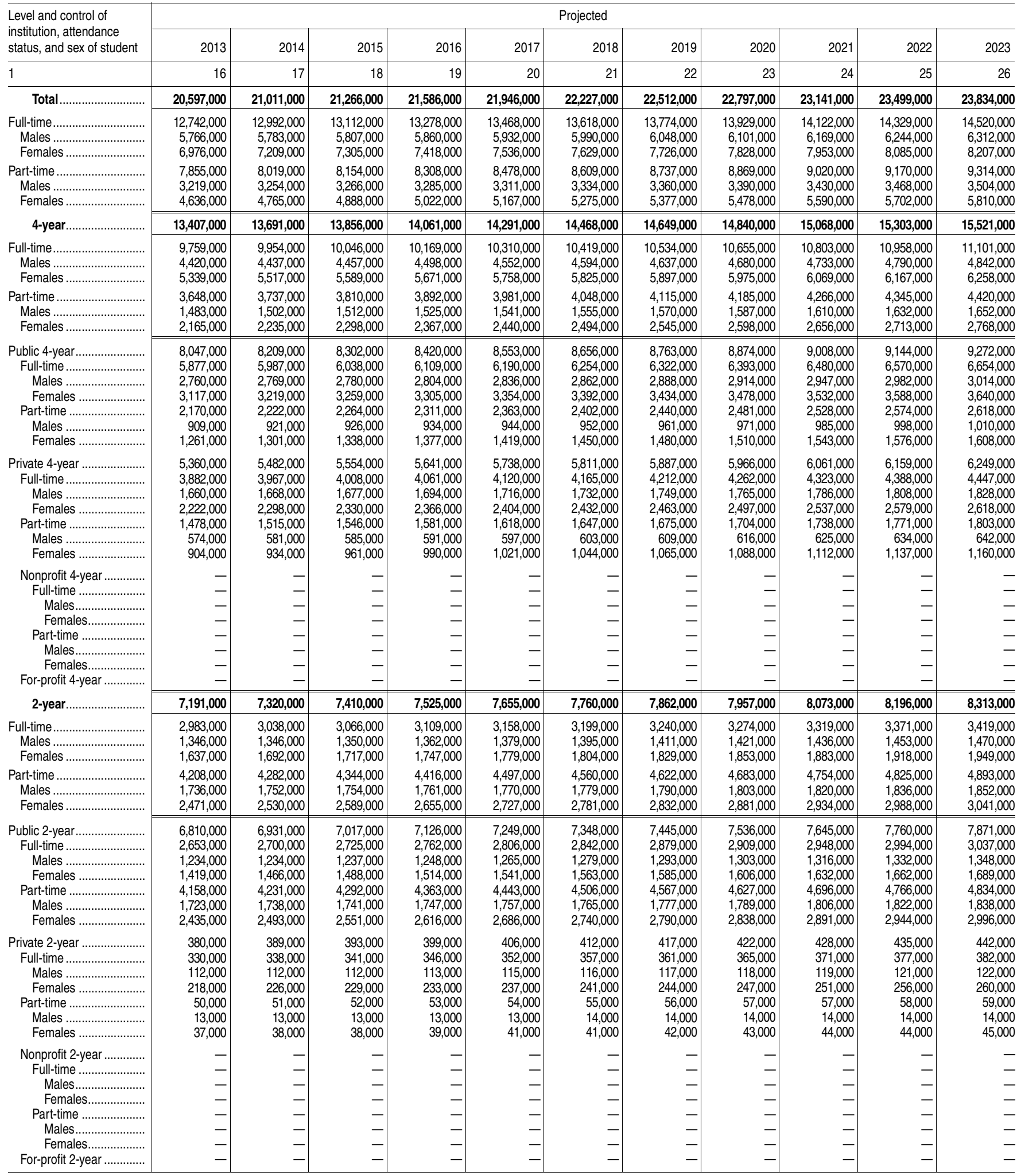

-Not available.

${ }^{1}$ Large increase in private 2-year institutions in 1980 is due to the addition of schools accredited by the Accrediting Commission of Career Schools and Colleges of Technology. NOTE: Data through 1995 are for institutions of higher education, while later data are for degree-granting institutions. Degree-granting institutions grant associate's or higher degrees and participate in Title IV federal financial aid programs. The degree-granting classification is very similar to the earlier higher education classification, but it includes more 2-year colleges and excludes a few higher education institutions that did not grant degrees. SOURCE: U.S. Department of Education, National Center for Education Statistics, Higher Education General Information Survey (HEGIS), "Fall Enrollment in Colleges and Universities" surveys, 1970 through 1985; Integrated Postsecondary Education Data System (IPEDS), "Fall Enrollment Survey" (IPEDS-EF:90-99); IPEDS Spring 2001 through Spring 2013, Enrollment component; and Enrollment in Degree-Granting Institutions Projection Model, 1980 through 2023. (This table was prepared July 2014.) 
Table 303.40. Total fall enrollment in degree-granting postsecondary institutions, by attendance status, sex, and age: Selected years, 1970 through 2023

[In thousands]

\begin{tabular}{|c|c|c|c|c|c|c|c|c|c|c|c|c|c|c|c|c|c|c|}
\hline \multirow[b]{2}{*}{ Attendance status, sex, and age } & \multirow[b]{2}{*}{1970} & & & & & & & & & & & & & & & Projec & ected & \\
\hline & & 1980 & 1990 & 2000 & 2003 & 2004 & 2005 & 2006 & 2007 & 2008 & 2009 & 2010 & 2011 & 2012 & 2013 & 2014 & 2016 & 2023 \\
\hline 1 & 2 & 3 & 4 & 5 & 6 & 7 & 8 & 9 & 10 & 11 & 12 & 13 & 14 & 15 & 16 & 17 & 18 & 19 \\
\hline All students & 581 & 12,097 & 13,819 & 15,312 & 16,911 & 17,272 & 17,487 & 17,759 & 18,248 & 19,103 & 20,428 & 21,016 & 20,994 & 20,643 & 20,597 & 21,011 & 21,586 & 3,834 \\
\hline 4 to 17 & 263 & 257 & 153 & 131 & 169 & 166 & 187 & 184 & 200 & 195 & 217 & 202 & 221 & 216 & 224 & 227 & 237 & 262 \\
\hline anc & 2,579 & 2,852 & 2,777 & 3,258 & 3,355 & 3,367 & 3,444 & 3,561 & 3,690 & 3,813 & 4,041 & 4,056 & 3,954 & 3,790 & 3,932 & 3,946 & 3,992 & 4,275 \\
\hline . & 1,885 & 2,395 & 2,593 & 3,005 & 3,391 & 3,516 & 3,563 & 3,573 & 3,570 & 3,649 & 3,945 & 4,101 & 4,267 & 4,240 & 4,462 & 4,459 & 4,429 & 4,614 \\
\hline 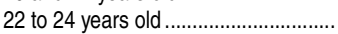 & 69 & 1,947 & 2,202 & 2,600 & 3,086 & 3,166 & 3,114 & 3,185 & 3,280 & 3,443 & 3,594 & 3,758 & 3,790 & 3,871 & 4,036 & 4,162 & 4,196 & 4,425 \\
\hline to & 1,091 & 1,843 & 2,083 & 2,044 & 2,311 & 2,418 & 2,469 & 2,506 & 2,651 & 2,840 & 3,096 & 3,253 & 3,268 & 3,218 & 3,105 & 3,233 & 3,501 & 3,846 \\
\hline 10 & 527 & 1,227 & 1,384 & 1,333 & 1,418 & 1,440 & 1,438 & 1,472 & 1,519 & 1,609 & 1,741 & 1,805 & 1,786 & 1,731 & 1,636 & 1,698 & 1,795 & 2,224 \\
\hline ver ..... & 767 & 1,577 & 2,627 & 2,942 & 3,181 & 3,199 & 3,272 & 3,277 & 3,339 & 3,554 & 3,794 & 3,840 & 3,707 & 3,577 & 3,203 & 3,286 & 3,437 & 4,188 \\
\hline ales. & 5,044 & 5,874 & 6,284 & 6,722 & 7,260 & 7,387 & 7,456 & 7,575 & 7,816 & 8,189 & 8,770 & 9,045 & 9,026 & 8,919 & 8,985 & 9,037 & 9,145 & 9,817 \\
\hline & & & & & & & & & & & & & 104 & 109 & 12 & 14 & 18 & \\
\hline & & 1,368 & 1,298 & 1,464 & 1,474 & 1,475 & 1,523 & 1,604 & 1,669 & 1,704 & 1,806 & 1,820 & 1,782 & 1,712 & 1,749 & 1,729 & 32 & 11 \\
\hline & 64 & 1,219 & 1,259 & 1,411 & 1,541 & 1,608 & 1,658 & 1,628 & 1,634 & 1,695 & 1,876 & 1,948 & 1,984 & 1,962 & 2,072 & 2,048 & 15 & ? \\
\hline & 1,004 & 1,075 & & 1,222 & 1,411 & & 1,410 & 1,445 & 1,480 & 1,555 & 1,606 & 1,723 & 1,767 & 1,862 & 78 & 2,012 & & \\
\hline & 796 & 983 & 1,024 & 908 & 1,007 & 1,039 & 1,057 & 1,040 & 1,148 & 1,222 & 1,382 & 1,410 & 1,402 & 1,347 & 1,328 & 1,366 & & \\
\hline & 200 & 564 & 605 & & 602 & 619 & & 628 & 638 & 691 & 709 & 731 & 699 & 678 & 643 & 657 & 81 & \\
\hline & 366 & 559 & 902 & 1,077 & 1,158 & 1,147 & 1,149 & 1,160 & 1,159 & 1,228 & 1,287 & 1,320 & 1,288 & 1,249 & 1,102 & 1,111 & 1,134 & 1,3 \\
\hline =ema & 3,537 & 6,223 & 7,535 & 8,591 & 9,651 & 9,885 & $\mid$\begin{tabular}{|l|}
10,032 \\
\end{tabular} & 10,184 & \begin{tabular}{|l|}
10,432 \\
\end{tabular} & 10,914 & 11,658 & 11,971 & 11,968 & 11,724 & 11,613 & 11,974 & 12,441 & 14,01 \\
\hline & & & & & & 104 & & & & & 14 & & 116 & 107 & & 113 & & \\
\hline & 1,224 & 1,484 & & & 1,880 & 1,892 & 1,920 & 1,956 & 2,021 & 2,109 & 2,236 & 2,236 & 2,172 & 2,078 & 2,182 & 2,218 & 60 & \\
\hline & 821 & & & & & & & & & 1,954 & 2,069 & 2,154 & 2,283 & & & 2,411 & & \\
\hline & 464 & 871 & & & & & & 1,740 & & 1,888 & 1,987 & & & 2,000 & & & & \\
\hline & 296 & 859 & 1,059 & & 1,304 & 1,379 & 1,413 & 1,466 & 1,502 & 1,618 & 1,713 & 1,844 & 1,866 & 370 & 1,777 & 867 & & \\
\hline & 194 & 663 & 779 & 752 & 816 & 821 & 847 & 844 & 881 & 918 & 1,032 & 1,074 & 1,087 & 1,053 & 993 & 1,041 & & 1, \\
\hline & 401 & 1,018 & 1,725 & 1,865 & 2,023 & 2,052 & 2,123 & 2,117 & 2,180 & 2,326 & 2,507 & 2,520 & 2,419 & 2,328 & 2,101 & 2,175 & 2,303 & 2, \\
\hline th & 5,816 & 198 & 7,8 & 9,010 & \begin{tabular}{|l|l|}
10,326 \\
\end{tabular} & $\mid 10,610$ & \begin{tabular}{|l|l|}
10,797 \\
\end{tabular} & \begin{tabular}{|l|l|}
10,957 \\
\end{tabular} & 1,270 & 1,748 & 2,723 & 13,082 & 13,001 & 2,737 & 12,742 & 12,992 & 13,278 & $\overline{4,520}$ \\
\hline & 246 & & & & & & & & & & & & 185 & & & & & \\
\hline & 374 & & & & & & & & & 3,359 & & & 3,351 & & & & & \\
\hline & & 2,007 & & & & & & & & 3,043 & & & 3,427 & & & 3,459 & & \\
\hline & & $\begin{array}{l}1,181 \\
1,18\end{array}$ & 1,405 & $\begin{array}{l}2,414 \\
1,714\end{array}$ & $\begin{array}{l}2,041 \\
2,083\end{array}$ & 2,143 & 2,122 & 2,127 & 2,205 & $\begin{array}{l}2,347 \\
2,47\end{array}$ & 2,535 & 2,584 & 2,580 & 2,585 & $\begin{array}{l}0,659 \\
2,659\end{array}$ & 2,747 & & \\
\hline & & & & & 1,086 & & 1,174 & 1,225 & & 1,369 & 1,520 & 1,605 & 1,600 & 1,558 & & & & \\
\hline & 11 & & & 418 & 489 & 517 & 547 & 571 & 556 & 571 & 663 & 744 & 763 & 35 & 723 & 753 & & \\
\hline 3 & 104 & 221 & 50 & 596 & 747 & 795 & 800 & 794 & 812 & 890 & 1,041 & 1,121 & 1,096 & 1,044 & 991 & 1,022 & 1,071 & 1,3 \\
\hline & 3,504 & 3,689 & 3,808 & 111 & 4,638 & 4,739 & 4,803 & 4,879 & 5,029 & 5,234 & 5,671 & 5,837 & 5,793 & 5,710 & 5,766 & 5,783 & 50 & \\
\hline & 121 & & & & & & & 52 & 74 & 73 & 78 & 71 & & & & & & \\
\hline & 1,261 & & & & & & & 1,404 & 5 & & & & & & & & & \\
\hline & & & & & & & & & & & & & & & & & & \\
\hline & 686 & 7 & & 34 & 995 & $\begin{array}{l}1,001 \\
1,0\end{array}$ & 982 & , 992 & $\begin{array}{l}1,043 \\
1,0\end{array}$ & $\begin{array}{l}1,105 \\
1,10\end{array}$ & 1,177 & $\begin{array}{l}1,214 \\
\text { S }\end{array}$ & 1,217 & 1,253 & $\begin{array}{l}1,313 \\
\end{array}$ & 1,333 & & \\
\hline & & & & & & & & 533 & & & & & & & & & & \\
\hline & 77 & & & & & & 22 & 23 & & & & & & & & & & \\
\hline & 58 & 80 & 174 & 222 & 277 & 302 & 300 & 291 & 73 & 287 & 343 & 376 & 369 & 337 & 329 & 332 & 2 & 15 \\
\hline & 2,312 & 3,409 & 3 & 899 & 5,688 & 5,871 & 5,994 & 6,078 & 6,240 & 6,513 & 7,052 & 45 & 7,208 & 027 & 976 & 09 & 18 & 8,207 \\
\hline & & & & & & & & & & & & & & & & & & \\
\hline & & & & 1 & & & & & & & & & & & & & & \\
\hline & 69 & & & & & & & & & & & & & & & & & \\
\hline & 218 & & & & & & & 1,135 & 63 & 1,242 & 1,358 & 1,370 & 1,363 & 32 & 346 & , 414 & & \\
\hline & 80 & & & & & & & & & & 505 & 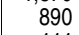 & & 852 & 302 & & & \\
\hline & & & & & & & & & & & & & & & & & & \\
\hline & 46 & 14 & 32 & 37 & 471 & 493 & 500 & 503 & 539 & 603 & 697 & 745 & 726 & 07 & 662 & 90 & 99 & \\
\hline & 2,765 & 4,999 & 5,998 & 303 & 6,585 & 662 & 6,690 & 6,802 & 6,978 & 7,355 & 7,705 & 7,934 & 7,993 & 7,906 & 7,855 & 019 & 308 & 14 \\
\hline & & & & & & & & & & & & & & & 42 & & & \\
\hline & 205 & 18 & 306 & 435 & 1 & 407 & 4 & 440 & 46 & 453 & 528 & 1 & 603 & 554 & 03 & 93 & 5 & \\
\hline & 236 & 38 & & & & & 58 & & & & & & & & & & & \\
\hline & & & & 886 & & & & & & & & & & & & & & \\
\hline & 665 & 1,2 & 1,2 & 1,1 & 1,2 & 1,2 & 1,296 & 1,2 & 1, & 1, & & & & $\begin{array}{r}1,650 \\
1\end{array}$ & $\begin{array}{l}1,599 \\
1\end{array}$ & 61 & & \\
\hline & & & & & & & & & & & & & & & & & & \\
\hline & 663 & 356 & 2,1 & 345 & 2,434 & 2,404 & 2,4 & 2,483 & 2,527 & 2,664 & & & 12 & 532 & 2,212 & 2,264 & 65 & \\
\hline & 540 & 2,185 & 2,476 & 2,611 & 22 & 18 & 2,653 & 2,696 & 2,786 & 2,955 & 3,099 & 3,208 & 3,233 & 209 & 3,219 & 3,254 & 85 & 04 \\
\hline & & & & & & & & & & & & & 20 & & & & & \\
\hline & 足 & 149 & 12 & 2 & 183 & 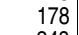 & 184 & 20 & 2 & 18 & 2 & 24 & & & 29 & 28 & & 288 \\
\hline & (1) & & & & & & & & & & & & & & & $4 \varepsilon$ & & no \\
\hline & & & 36 & & 41 & 43 & 42 & 45 & 43 & 45 & 43 & 50 & 5 & 6 & 66 & 67 & 67 & 60 \\
\hline & & 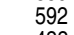 & 5 & 49 & -0 & 54 & 55 & 5 & 57 & 62 & 71 & 69 & 67 & 6 & 62 & 6 & & \\
\hline & & 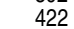 & & & & & & & & 44 & 10 & 43 & 4 & & an & & & \\
\hline & 309 & 479 & 728 & 855 & 882 & 845 & 850 & 869 & 886 & 941 & 944 & 944 & 919 & 912 & 774 & 779 & 19 & 115 \\
\hline & 225 & 2,814 & 521 & 692 & 963 & .014 & 038 & 106 & 4,192 & 101 & 4,606 & 726 & 760 & 697 & ,636 & 4,765 & 022 & 10 \\
\hline & & & & & & & & & $v_{2}$ & & & 9 & & 15 & 19 & & & \\
\hline & 112 & 159 & 179 & 22 & 23 & 23 & 23 & 24 & 24 & 265 & 303 & 316 & 331 & 31 & 411 & 405 & 412 & 441 \\
\hline & & & & & & & & & & & & 377 & TTU & 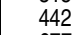 & 36 & & & 33 \\
\hline & 246 & & & & 587 & 588 & 564 & 60 & 637 & 64 & 629 & 666 & 659 & 677 & 711 & 736 & 749 & \\
\hline & 216 & 609 & 70 & 660 & 721 & 746 & 745 & 774 & 781 & 846 & 858 & 953 & 994 & 1,018 & 975 & 1,020 & 1,121 & 1,254 \\
\hline & 158 & 532 & 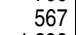 & 520 & & & 526 & 508 & 557 & 59 & 651 & 630 & 623 & . & 561 & at & & \\
\hline ance & 354 & 876 & 1,399 & 1,491 & 1,552 & 1,560 & 1,623 & 1,614 & 1,640 & 1,723 & 1,810 & 1,775 & 1,693 & 1,621 & 1,438 & 1,484 & 1,57 & 1,952 \\
\hline
\end{tabular}

NOTE: Distributions by age are estimates based on samples of the civilian noninstitutional population from the U.S. Census Bureau's Current Population Survey. Data through 1995 are for institutions of higher education, while later data are for degree-granting institutions. Degreegranting institutions grant associate's or higher degrees and participate in Title IV federal financial aid programs. The degree-granting classification is very similar to the earlier higher education classification, but it includes more 2-year colleges and excludes a few higher education institutions that did not grant degrees. Some data have been revised from previously published figures. Detail may not sum to totals because of rounding.
SOURCE: U.S. Department of Education, National Center for Education Statistics, Higher Education General Information Survey (HEGIS), "Fall Enrollment in Colleges and Universities" surveys, 1970 and 1980; Integrated Postsecondary Education Data System (IPEDS), "Fall Enrollment Survey" (IPEDS-EF:90-99); IPEDS Spring 2001 through Spring 2012, Enrollment component; and Enrollment in Degree-Granting Institutions Projection Model, 1980 through 2023. U.S. Department of Commerce, Census Bureau, Current Population Survey (CPS) October, selected years, 1970 through 2012. (This table was prepared June 2014.) 
Table 303.45. Total fall enrollment in degree-granting postsecondary institutions, by level of enrollment, sex, attendance status, and age of student: 2007, 2009, and 2011

\begin{tabular}{|c|c|c|c|c|c|c|c|c|c|c|c|c|c|}
\hline \multirow{3}{*}{$\begin{array}{l}\text { Attendance status } \\
\text { and age of student }\end{array}$} & \multirow{3}{*}{\begin{tabular}{r|} 
Fall 2007 \\
All levels \\
Total
\end{tabular}} & \multirow{2}{*}{\multicolumn{3}{|c|}{$\begin{array}{l}\text { Fall } 2009 \\
\text { All levels }\end{array}$}} & \multicolumn{9}{|c|}{ Fall 2011} \\
\hline & & & & & \multicolumn{3}{|c|}{ All levels } & \multicolumn{3}{|c|}{ Undergraduate } & \multicolumn{3}{|c|}{ Postbaccalaureate } \\
\hline & & Total & Males & Females & Total & Males & Females & Total & Males & Females & Total & Males & Females \\
\hline 1 & 2 & 3 & 4 & 5 & 6 & 7 & 8 & 9 & 10 & 11 & 12 & 13 & 14 \\
\hline 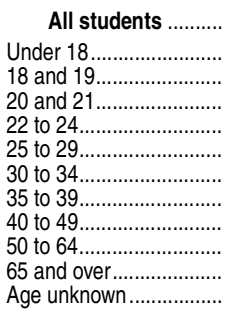 & \begin{tabular}{r|}
$18,248,128$ \\
668,426 \\
$3,963,371$ \\
$3,642,872$ \\
$3,009,713$ \\
$2,550,482$ \\
$1,365,912$ \\
980,818 \\
$1,266,171$ \\
627,603 \\
77,379 \\
95,381
\end{tabular} & \begin{tabular}{|r|}
$20,427,711$ \\
757,239 \\
$4,300,248$ \\
$4,003,222$ \\
$3,315,227$ \\
$2,961,851$ \\
$1,635,355$ \\
$1,128,666$ \\
$1,449,671$ \\
734,572 \\
69,844 \\
71,816 \\
\end{tabular} & \begin{tabular}{r|}
$8,769,504$ \\
314,150 \\
$1,946,838$ \\
$1,814,622$ \\
$1,520,388$ \\
$1,277,580$ \\
663,459 \\
426,387 \\
498,553 \\
247,034 \\
29,251 \\
31,242
\end{tabular} & \begin{tabular}{|r|}
$11,658,207$ \\
443,089 \\
$2,353,410$ \\
$2,188,600$ \\
$1,794,839$ \\
$1,684,271$ \\
971,896 \\
702,279 \\
951,118 \\
487,538 \\
40,593 \\
40,574 \\
\end{tabular} & \begin{tabular}{|r|}
$20,994,113$ \\
796,375 \\
$4,290,986$ \\
$4,160,288$ \\
$3,433,234$ \\
$3,042,737$ \\
$1,756,934$ \\
$1,122,631$ \\
$1,500,023$ \\
757,586 \\
65,158 \\
68,161 \\
\end{tabular} & \begin{tabular}{r|}
$, 026,499$ \\
330,111 \\
$1,934,931$ \\
$1,873,616$ \\
$1,574,040$ \\
$1,328,113$ \\
725,335 \\
426,511 \\
524,589 \\
252,729 \\
27,087 \\
29,437 \\
\end{tabular} & \begin{tabular}{|r|}
$11,967,614$ \\
466,264 \\
$2,356,055$ \\
$2,286,672$ \\
$1,859,194$ \\
$1,714,624$ \\
$1,031,599$ \\
696,120 \\
975,434 \\
504,857 \\
38,071 \\
38,724
\end{tabular} & \begin{tabular}{r|r}
$18,063,037$ \\
796,117 \\
$4,289,343$ \\
$4,128,526$ \\
$2,824,613$ \\
$2,109,253$ \\
$1,280,160$ \\
841,866 \\
$1,133,631$ \\
554,461 \\
55,755 \\
49,312
\end{tabular} & \begin{tabular}{r|r|}
$7,816,975$ \\
329,995 \\
$1,934,372$ \\
$1,861,923$ \\
$1,327,147$ \\
919,936 \\
512,493 \\
309,311 \\
390,017 \\
187,458 \\
22,872 \\
21,451
\end{tabular} & \begin{tabular}{r|}
$10,246,062$ \\
466,122 \\
$2,354,971$ \\
$2,266,603$ \\
$1,497,466$ \\
$1,189,317$ \\
767,667 \\
532,555 \\
743,614 \\
367,003 \\
32,883 \\
27,061
\end{tabular} & \begin{tabular}{r|}
$r, 931,076$ \\
258 \\
1,643 \\
31,762 \\
608,621 \\
933,484 \\
476,774 \\
280,765 \\
366,392 \\
203,125 \\
9,403 \\
18,849
\end{tabular} & \begin{tabular}{r|}
$1,209,524$ \\
116 \\
559 \\
11,693 \\
246,893 \\
408,177 \\
212,842 \\
117,200 \\
134,572 \\
65,271 \\
4,215 \\
7,986
\end{tabular} & $\begin{array}{r}1,721,552 \\
142 \\
1,084 \\
20,069 \\
361,728 \\
525,307 \\
263,932 \\
163,565 \\
231,820 \\
137,854 \\
5,188 \\
10,863\end{array}$ \\
\hline 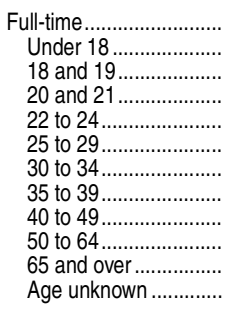 & \begin{tabular}{r|}
$11,269,892$ \\
171,784 \\
$3,383,318$ \\
$2,964,697$ \\
$1,986,776$ \\
$1,284,698$ \\
565,710 \\
347,864 \\
380,043 \\
145,757 \\
4,868 \\
34,377
\end{tabular} & $\begin{array}{r}12,722,782 \\
177,445 \\
3,640,621 \\
3,249,604 \\
2,198,573 \\
1,540,444 \\
725,901 \\
447,946 \\
501,869 \\
207,365 \\
6,642 \\
26,372\end{array}$ & \begin{tabular}{r|}
$5,670,644$ \\
71,603 \\
$1,636,522$ \\
$1,477,485$ \\
$1,047,143$ \\
705,203 \\
304,439 \\
169,775 \\
173,301 \\
70,665 \\
2,871 \\
11,637
\end{tabular} & $\begin{array}{r}7,052,138 \\
105,842 \\
2,004,099 \\
1,772,119 \\
1,151,430 \\
835,241 \\
421,462 \\
278,171 \\
328,568 \\
136,700 \\
3,771 \\
14,735\end{array}$ & $\begin{array}{r}13,001,457 \\
181,834 \\
3,569,445 \\
3,390,527 \\
2,256,745 \\
1,607,021 \\
793,548 \\
459,830 \\
551,741 \\
232,535 \\
8,656 \\
30,575\end{array}$ & $\begin{array}{r}5,793,411 \\
72,667 \\
1,596,824 \\
1,494,271 \\
1,071,907 \\
745,742 \\
342,381 \\
176,702 \\
196,711 \\
79,375 \\
3,693 \\
13,138\end{array}$ & $\begin{array}{r}7,208,046 \\
109,167 \\
1,972,621 \\
1,815,256 \\
1,184,838 \\
861,279 \\
451,167 \\
283,128 \\
355,030 \\
153,160 \\
4,963 \\
17,437\end{array}$ & $\begin{array}{r}11,359,068 \\
181,732 \\
3,567,947 \\
3,281,595 \\
1,772,646 \\
1,025,404 \\
564,393 \\
346,510 \\
422,084 \\
168,877 \\
6,081 \\
21,799\end{array}$ & $\begin{array}{r}5,070,529 \\
72,617 \\
1,596,308 \\
1,483,746 \\
869,936 \\
472,849 \\
232,067 \\
126,563 \\
146,811 \\
57,879 \\
2,577 \\
9,176\end{array}$ & & $\begin{array}{r}1,642,389 \\
102 \\
1,498 \\
27,932 \\
484,099 \\
581,617 \\
229,155 \\
113,320 \\
129,657 \\
63,658 \\
2,575 \\
8,776\end{array}$ & $\begin{array}{r}722,882 \\
50 \\
516 \\
10,525 \\
201,971 \\
272,893 \\
110,314 \\
50,139 \\
49,900 \\
21,496 \\
1,116 \\
3,962\end{array}$ & $\begin{array}{r}919,507 \\
52 \\
982 \\
17,407 \\
282,128 \\
308,724 \\
118,841 \\
63,181 \\
79,757 \\
42,162 \\
1,459 \\
4,814\end{array}$ \\
\hline 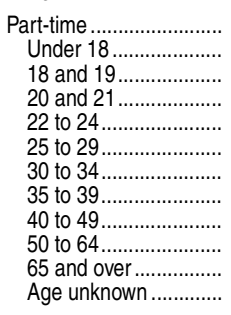 & $\begin{array}{r}6,978,236 \\
496,642 \\
580,053 \\
678,175 \\
1,022,937 \\
1,265,784 \\
800,202 \\
632,954 \\
886,128 \\
481,846 \\
72,511 \\
61,004 \\
\end{array}$ & $\begin{array}{r}7,704,929 \\
579,794 \\
659,627 \\
753,618 \\
1,116,654 \\
1,421,407 \\
909,454 \\
680,720 \\
947,802 \\
527,207 \\
63,202 \\
45,444 \\
\end{array}$ & $\begin{array}{r}3,098,860 \\
242,547 \\
310,316 \\
337,137 \\
473,245 \\
572,377 \\
359,020 \\
256,612 \\
325,252 \\
176,369 \\
26,380 \\
19,605 \\
\end{array}$ & $\begin{array}{r}4,606,069 \\
337,247 \\
349,311 \\
416,481 \\
643,409 \\
849,030 \\
550,434 \\
424,108 \\
622,550 \\
350,838 \\
36,822 \\
25,839 \\
\end{array}$ & $\begin{array}{r}7,992,656 \\
614,541 \\
721,541 \\
850,761 \\
1,176,489 \\
1,435,716 \\
963,386 \\
662,801 \\
948,282 \\
525,051 \\
56,502 \\
37,586 \\
\end{array}$ & $\begin{array}{r}3,233,088 \\
257,444 \\
338,107 \\
379,345 \\
502,133 \\
582,371 \\
382,954 \\
249,809 \\
327,878 \\
173,354 \\
23,394 \\
16,299 \\
\end{array}$ & $\begin{array}{r}4,759,568 \\
357,097 \\
383,434 \\
471,416 \\
674,356 \\
853,345 \\
580,432 \\
412,992 \\
620,404 \\
351,697 \\
33,108 \\
21,287 \\
\end{array}$ & $\begin{array}{r}6,703,969 \\
614,385 \\
721,396 \\
846,931 \\
1,051,967 \\
1,083,849 \\
715,767 \\
495,356 \\
711,547 \\
385,584 \\
49,674 \\
27,513 \\
\end{array}$ & $\begin{array}{r}2,746,446 \\
257,378 \\
338,064 \\
378,177 \\
457,211 \\
447,087 \\
280,426 \\
182,748 \\
243,206 \\
129,579 \\
20,295 \\
12,275 \\
\end{array}$ & \begin{tabular}{r|}
$3,957,523$ \\
357,007 \\
383,332 \\
468,754 \\
594,756 \\
636,762 \\
435,341 \\
312,608 \\
468,341 \\
256,005 \\
29,379 \\
15,238 \\
\end{tabular} & $\begin{array}{r}1,288,687 \\
156 \\
145 \\
3,830 \\
124,522 \\
351,867 \\
247,619 \\
167,445 \\
236,735 \\
139,467 \\
6,828 \\
10,073 \\
\end{array}$ & $\begin{array}{r}486,642 \\
66 \\
43 \\
1,168 \\
44,922 \\
135,284 \\
102,528 \\
67,061 \\
84,672 \\
43,775 \\
3,099 \\
4,024 \\
\end{array}$ & $\begin{array}{r}802,045 \\
90 \\
102 \\
2,662 \\
79,600 \\
216,583 \\
145,091 \\
100,384 \\
152,063 \\
95,692 \\
3,729 \\
6,049 \\
\end{array}$ \\
\hline & \multicolumn{13}{|c|}{ Percentage distribution } \\
\hline $\begin{array}{c}\ldots \ldots . . \\
\ldots \ldots \ldots . \\
\ldots \ldots \ldots . . \\
\ldots \ldots \ldots . .\end{array}$ & \begin{tabular}{r|r|}
100.0 \\
3.7 \\
21.7 \\
20.0 \\
16.5 \\
14.0 \\
7.5 \\
5.4 \\
6.9 \\
3.4 \\
0.4 \\
0.5
\end{tabular} & \begin{tabular}{r|}
100.0 \\
3.7 \\
21.1 \\
19.6 \\
16.2 \\
14.5 \\
8.0 \\
5.5 \\
7.1 \\
3.6 \\
0.3 \\
0.4
\end{tabular} & $\begin{array}{r}3.6 \\
22.2 \\
20.7 \\
17.3 \\
14.6 \\
7.6 \\
4.9 \\
5.7 \\
2.8 \\
0.3 \\
0.4\end{array}$ & \begin{tabular}{r|r|}
100.0 & \\
3.8 & 0.2 \\
18.8 \\
15.4 \\
14.4 \\
8.3 \\
6.0 \\
8.2 \\
4.2 \\
0.3 \\
0.3
\end{tabular} & $\begin{array}{r}14.5 \\
8.4 \\
5.3 \\
7.1 \\
3.6 \\
0.3 \\
0.3\end{array}$ & \begin{tabular}{r|}
100.0 \\
3.7 \\
21.4 \\
20.8 \\
17.4 \\
14.7 \\
8.0 \\
4.7 \\
5.8 \\
2.8 \\
0.3 \\
0.3
\end{tabular} & $\begin{array}{l}8.6 \\
5.8 \\
8.2 \\
4.2 \\
0.3 \\
0.3\end{array}$ & \begin{tabular}{r|r|}
100.0 & \\
4.4 & 23.7 \\
22.9 & 15.6 \\
11.7 & 7.1 \\
4.7 \\
6.3 \\
3.1 \\
0.3 \\
0.3
\end{tabular} & $\begin{array}{l}6.6 \\
4.0 \\
5.0 \\
2.4 \\
0.3 \\
0.3\end{array}$ & $\begin{array}{r}4.5 \\
23.0 \\
22.1 \\
14.6 \\
11.6 \\
7.5 \\
5.2 \\
7.3 \\
3.6 \\
0.3 \\
0.3\end{array}$ & \begin{tabular}{r|}
100.0 \\
$\#$ \\
0.1 \\
1.1 \\
20.8 \\
31.8 \\
16.3 \\
9.6 \\
12.5 \\
6.9
\end{tabular} & \begin{tabular}{r|r|r}
100.0 & \\
$\#$ & \\
$\#$ & 1.0 \\
20.4 & \\
33.7 \\
17.6 \\
9.7 \\
11.1 \\
5.4 \\
0.3 \\
0.7
\end{tabular} & $\begin{aligned} 100.0 \\
\# \\
0.1 \\
1.2 \\
21.0 \\
30.5 \\
15.3 \\
9.5 \\
13.5 \\
8.0 \\
0.3 \\
0.6\end{aligned}$ \\
\hline 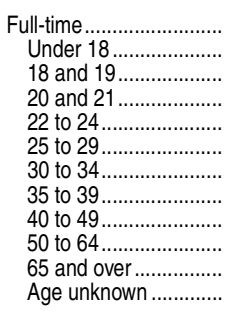 & $\begin{array}{r}100.0 \\
1.5 \\
30.0 \\
26.3 \\
17.6 \\
11.4 \\
5.0 \\
3.1 \\
3.4 \\
1.3 \\
\# \\
0.3\end{array}$ & $\begin{array}{r}100.0 \\
1.4 \\
28.6 \\
25.5 \\
17.3 \\
12.1 \\
5.7 \\
3.5 \\
3.9 \\
1.6 \\
0.1 \\
0.2\end{array}$ & $\begin{array}{r}100.0 \\
1.3 \\
28.9 \\
26.1 \\
18.5 \\
12.4 \\
5.4 \\
3.0 \\
3.1 \\
1.2 \\
0.1 \\
0.2\end{array}$ & $\begin{array}{r}100.0 \\
1.5 \\
28.4 \\
25.1 \\
16.3 \\
11.8 \\
6.0 \\
3.9 \\
4.7 \\
1.9 \\
0.1 \\
0.2\end{array}$ & $\begin{array}{r}100.0 \\
1.4 \\
27.5 \\
25.5 \\
17.4 \\
12.4 \\
6.1 \\
3.5 \\
4.2 \\
1.8 \\
0.1 \\
0.2\end{array}$ & $\begin{array}{r}100.0 \\
1.3 \\
27.6 \\
25.8 \\
18.5 \\
12.9 \\
5.9 \\
3.1 \\
3.4 \\
1.4 \\
0.1 \\
0.2\end{array}$ & $\begin{array}{r}100.0 \\
1.5 \\
27.4 \\
25.2 \\
16.4 \\
11.9 \\
6.3 \\
3.9 \\
4.9 \\
2.1 \\
0.1 \\
0.2\end{array}$ & $\begin{array}{r}100.0 \\
1.6 \\
31.4 \\
28.9 \\
15.6 \\
9.0 \\
5.0 \\
3.1 \\
3.7 \\
1.5 \\
0.1 \\
0.2\end{array}$ & \begin{tabular}{r|}
100.0 \\
1.4 \\
31.5 \\
29.3 \\
17.2 \\
9.3 \\
4.6 \\
2.5 \\
2.9 \\
1.1 \\
0.1 \\
0.2
\end{tabular} & $\begin{array}{r}100.0 \\
1.7 \\
31.4 \\
28.6 \\
14.4 \\
8.8 \\
5.3 \\
3.5 \\
4.4 \\
1.8 \\
0.1 \\
0.2\end{array}$ & $\begin{array}{r}100.0 \\
\# \\
0.1 \\
1.7 \\
29.5 \\
35.4 \\
14.0 \\
6.9 \\
7.9 \\
3.9\end{array}$ & $\begin{array}{r}100.0 \\
\# \\
0.1 \\
1.5 \\
27.9 \\
37.8 \\
15.3 \\
6.9 \\
6.9 \\
3.0 \\
0.2 \\
0.5\end{array}$ & $\begin{array}{r}100.0 \\
\# \\
0.1 \\
1.9 \\
30.7 \\
33.6 \\
12.9 \\
6.9 \\
8.7 \\
4.6 \\
0.2 \\
0.5\end{array}$ \\
\hline $\begin{array}{l}\text { Under } 18 \\
18 \text { and } 19 \ldots \ldots \ldots \ldots \ldots \ldots \\
20 \text { and } 21 \ldots \ldots \ldots \ldots \ldots \\
22 \text { to } 24 \\
25 \text { to } 29 \ldots \ldots \ldots \ldots \ldots \ldots \ldots \\
30 \text { to } 34 \\
35 \text { to } 39 \\
40 \text { to } 49 \\
50 \text { to } 64 \ldots \ldots \\
65 \text { and over } \\
\text { Age unknown }\end{array}$ & $\begin{array}{r}100.0 \\
7.1 \\
8.3 \\
9.7 \\
14.7 \\
18.1 \\
11.5 \\
9.1 \\
12.7 \\
6.9 \\
1.0 \\
0.9\end{array}$ & $\begin{aligned} 100.0 \\
7.5 \\
8.6 \\
9.8 \\
14.5 \\
18.4 \\
11.8 \\
8.8 \\
12.3 \\
6.8 \\
0.8 \\
0.6\end{aligned}$ & $\begin{array}{r}100.0 \\
7.8 \\
10.0 \\
10.9 \\
15.3 \\
18.5 \\
11.6 \\
8.3 \\
10.5 \\
5.7 \\
0.9 \\
0.6\end{array}$ & $\begin{array}{r}100.0 \\
7.3 \\
7.6 \\
9.0 \\
14.0 \\
18.4 \\
12.0 \\
9.2 \\
13.5 \\
7.6 \\
0.8 \\
0.6\end{array}$ & $\begin{array}{r}100.0 \\
7.7 \\
9.0 \\
10.6 \\
14.7 \\
18.0 \\
12.1 \\
8.3 \\
11.9 \\
6.6 \\
0.7 \\
0.5\end{array}$ & $\begin{array}{r}100.0 \\
8.0 \\
10.5 \\
11.7 \\
15.5 \\
18.0 \\
11.8 \\
7.7 \\
10.1 \\
5.4 \\
0.7 \\
0.5\end{array}$ & $\begin{array}{r}100.0 \\
7.5 \\
8.1 \\
9.9 \\
14.2 \\
17.9 \\
12.2 \\
8.7 \\
13.0 \\
7.4 \\
0.7 \\
0.4\end{array}$ & $\begin{array}{r}100.0 \\
9.2 \\
10.8 \\
12.6 \\
15.7 \\
16.2 \\
10.7 \\
7.4 \\
10.6 \\
5.8 \\
0.7 \\
0.4\end{array}$ & $\begin{array}{r}100.0 \\
9.4 \\
12.3 \\
13.8 \\
16.6 \\
16.3 \\
10.2 \\
6.7 \\
8.9 \\
4.7 \\
0.7 \\
0.4\end{array}$ & $\begin{array}{r}100.0 \\
9.0 \\
9.7 \\
11.8 \\
15.0 \\
16.1 \\
11.0 \\
7.9 \\
11.8 \\
6.5 \\
0.7 \\
0.4\end{array}$ & $\begin{array}{r}100.0 \\
\# \\
\# \\
0.3 \\
9.7 \\
27.3 \\
19.2 \\
13.0 \\
18.4 \\
10.8 \\
0.5 \\
0.8\end{array}$ & $\begin{array}{r}100.0 \\
\# \\
\# \\
0.2 \\
9.2 \\
27.8 \\
21.1 \\
13.8 \\
17.4 \\
9.0 \\
0.6 \\
0.8\end{array}$ & $\begin{array}{r}100.0 \\
\# \\
\# \\
0.3 \\
9.9 \\
27.0 \\
18.1 \\
12.5 \\
19.0 \\
11.9 \\
0.5 \\
0.8\end{array}$ \\
\hline
\end{tabular}

\#Rounds to zero.

NOTE: Degree-granting institutions grant associate's or higher degrees and participate in

Title IV federal financial aid programs. Detail may not sum to totals because of rounding.
SOURCE: U.S. Department of Education, National Center for Education Statistics, Integrated Postsecondary Education Data System (IPEDS), Spring 2008, 2010, and 2012, Enrollment component. (This table was prepared September 2012.) 
Table 303.50. Total fall enrollment in degree-granting postsecondary institutions, by level of enrollment, control and level of institution, attendance status, and age of student: 2011

\begin{tabular}{|c|c|c|c|c|c|c|c|c|c|c|c|c|c|c|}
\hline \multirow{3}{*}{$\begin{array}{l}\text { Attendance status } \\
\text { and age of student }\end{array}$} & \multicolumn{10}{|c|}{ Undergraduate } & \multicolumn{4}{|c|}{ Postbaccalaureate } \\
\hline & & & Public & & & vate, nonprof & & & ivate, for-prof & & & & & \\
\hline & Total & Total & 4-year & 2-year & Total & 4-year & 2-year & Total & 4-year & 2-year & Total & Public & nonprofit & profit \\
\hline 1 & 2 & 3 & 4 & 5 & 6 & 7 & 8 & 9 & 10 & 11 & 12 & 13 & 14 & 15 \\
\hline All students & $18,063,037$ & $13,688,792$ & $6,626,325$ & $7,062,467$ & $2,718,880$ & $2,679,016$ & 39,864 & $1,655,365$ & $1,257,714$ & 397,651 & $2,931,076$ & $1,421,404$ & $1,208,306$ & 301,366 \\
\hline Under $18 \ldots$ & 796,117 & 716,684 & 218,543 & 498,141 & 74,833 & 73,994 & 839 & 4,600 & 2,924 & 1,676 & 258 & 71 & 100 & 87 \\
\hline 18 and $19 .$. & $4,289,343$ & $3,355,112$ & $1,844,445$ & $1,510,667$ & 824,285 & 816,719 & 7,566 & 109,946 & 63,475 & 46,471 & 1,643 & 461 & 1,077 & 105 \\
\hline 20 and & $4,128,526$ & $3,137,619$ & $1,927,481$ & $1,210,138$ & 819,186 & 811,947 & 7,239 & 171,721 & 106,750 & 64,971 & 31,762 & 17,582 & 13,471 & 709 \\
\hline 22 to & $2,824,613$ & $2,234,132$ & $1,247,283$ & 986,849 & 354,688 & 348,703 & 5,985 & 235,793 & 165,858 & 69,935 & 608,621 & 335,228 & 257,730 & 15,663 \\
\hline 25 & $2,109,253$ & $1,560,039$ & 609,495 & 950,544 & 198,293 & 191,788 & 6,505 & 350,921 & 273,143 & 77,778 & 933,484 & 477,293 & 397,756 & 58,435 \\
\hline 30 to & $1,280,160$ & 887,626 & 290,381 & 597,245 & 129,891 & 125,803 & 4,088 & 262,643 & 214,794 & 47,849 & 476,774 & 232,227 & 188,119 & 56,428 \\
\hline 35 to 3 & 841,866 & 565,830 & 170,043 & 395,787 & 94,608 & 91,817 & 2,791 & 181,428 & 149,947 & 31,481 & 280,765 & 125,583 & 108,163 & 47,019 \\
\hline 40 to & $1,133,631$ & 763,973 & 210,740 & 553,233 & 138,769 & 135,614 & 3,155 & 230,889 & 192,616 & 38,273 & 366,392 & 149,450 & 141,886 & 75,056 \\
\hline 50 to & 554,461 & 398,818 & 94,504 & 304,314 & 60,867 & 59,441 & 1,426 & 94,776 & 79,237 & 15,539 & 203,125 & 8,540 & 80,335 & 44,250 \\
\hline 65 and & 55,755 & 49,703 & 7,850 & 41,853 & 3,073 & 2,986 & 87 & 2,979 & 2,180 & 799 & 9,403 & 3,830 & 3,794 & 1,779 \\
\hline Age unknown... & & 19,256 & 5,560 & 13,696 & 20,387 & 20,204 & 183 & 9,669 & 6,790 & 2,879 & 18,849 & 1,139 & 15,875 & 1,835 \\
\hline Full-time. & $11,359,068$ & $7,894,906$ & $5,118,175$ & $2,776,731$ & $2,235,815$ & $2,205,236$ & 30,579 & $1,228,347$ & 875,621 & 352,726 & $1,642,389$ & 770,834 & 702,004 & 69,551 \\
\hline Under & $\begin{array}{r}181,732 \\
\end{array}$ & 146,634 & 80,890 & 65,744 & 31,737 & 31,522 & 215 & 3,361 & 1,890 & 1,471 & 102 & 27 & & \\
\hline 18 and & $3,567,947$ & $2,669,114$ & $1,725,670$ & 943,444 & 802,267 & 795,492 & 6,775 & 96,566 & 53,057 & 43,509 & 1,498 & 404 & 1,010 & 84 \\
\hline 20 an & $3,281,595$ & $2,349,095$ & $1,745,228$ & 603,867 & 790,545 & 784,271 & 6,274 & 141,955 & 82,927 & 59,028 & 27,932 & 15,096 & 12,271 & 565 \\
\hline 22 to & $1,772,646$ & $1,298,188$ & 938,407 & 359,781 & 293,040 & 288,374 & 4,666 & 181,418 & 119,742 & 61,676 & 484,099 & 264,981 & 207,829 & 11,289 \\
\hline 25 to 2 & $1,025,404$ & 647,857 & 336,441 & 311,416 & 117,996 & 113,231 & 4,765 & 259,551 & 191,278 & 68,273 & 581,617 & 287,166 & 259,441 & 35,010 \\
\hline 30 to 3 & 564,393 & 310,836 & 129,916 & 180,920 & 65,277 & 62,434 & 2,843 & 188,280 & 146,523 & 41,757 & 229,155 & 104,392 & 93,840 & 30,923 \\
\hline 35 to 3 & 346,510 & 174,974 & 65,140 & 109,834 & 43,793 & 41,802 & 1,991 & 127,743 & 100,299 & 27,444 & 13,320 & 43,274 & 44,540 & 25,506 \\
\hline 40 to 4 & 422,084 & 205,352 & 69,269 & 136,083 & 57,822 & 55,801 & 2,021 & 158,910 & 125,945 & 32,965 & 129,657 & 39,057 & 50,008 & 40,592 \\
\hline 50 to 6 & 168,877 & 84,785 & 24,581 & 60,204 & 21,779 & 20,919 & 860 & 62,313 & 49,040 & 13,273 & 63,658 & 15,627 & 24,543 & 23,488 \\
\hline 65 & 6,081 & 3.330 & 763 & 2,567 & 757 & 706 & 51 & 1,994 & 1,259 & 735 & 2,575 & 522 & 1,135 & 918 \\
\hline Age unknown ............... & 21,799 & 4,741 & 1,870 & 2,871 & 10,802 & 10,684 & 118 & 6,256 & 3,661 & 2,595 & 8,776 & 288 & 7,324 & 1,164 \\
\hline Part-time ........ & $6,703,969$ & $5,793,886$ & $1,508,150$ & $4,285,736$ & 483,065 & 473,780 & 9,285 & 427,018 & 382,093 & 44,925 & $1,288,687$ & 650,570 & 506,302 & 131,815 \\
\hline Under 18 & 614,385 & $\begin{array}{r}570,050 \\
\end{array}$ & 137,653 & 432,397 & 43,096 & 42,472 & 624 & 1,239 & 1,034 & 205 & 156 & & & \\
\hline 18 and & 721,396 & 685,998 & 118,775 & 567,223 & 22,018 & 21,227 & 791 & 13,380 & 10 & 2,962 & 145 & 57 & 67 & 21 \\
\hline 20 and & 846,931 & 788,524 & 182,253 & 606,271 & 28, & 27,676 & 965 & 29,766 & 23,8 & 5,943 & 3,830 & 2,486 & 1,200 & 144 \\
\hline 22 to 2 & $1,051,967$ & 935,944 & 308,8 & 627,068 & 61, & 60,3 & 1,319 & 54 & & 8,259 & 124,522 & 70,247 & 49,901 & 4,374 \\
\hline 25 to 2 & $1,083,849$ & 912,182 & 273,054 & 639,128 & 80 & 78,5 & 1,740 & 91, & 81, & 9,505 & & 190,127 & 138,315 & 23,425 \\
\hline 30 to 3 & 715,767 & 576,790 & 160,465 & 416,325 & 64,614 & 63,369 & 1,245 & 74,363 & 68,2 & 6,092 & 247,619 & 127,835 & 94,279 & 25,505 \\
\hline 35 to 3 & 495,356 & 390,856 & 104,903 & 285,953 & 50, & 50,015 & 800 & 53,685 & 49, & 4,037 & & 82 & 63,623 & 21,513 \\
\hline 40 to 4 & 711,547 & 558,621 & 141,471 & 417,150 & 80, & 79,8 & 1,134 & 71,6 & & 5,308 & & & 91,878 & 34,464 \\
\hline 50 to 6 & 385,584 & 314,033 & 69,923 & 244,110 & 39,088 & 38,522 & 566 & 32,463 & 30,197 & 2,266 & 139,467 & 62,913 & 55,792 & 20,762 \\
\hline 65 and & 49,674 & 46,373 & 7,087 & 39,286 & 2,316 & 2,280 & 36 & 985 & 921 & 64 & 6,828 & 3,308 & 2,659 & 861 \\
\hline Age unknown.... & 27,513 & 14,515 & 3,690 & 10,825 & 9,585 & 9,520 & 65 & 3,413 & 3,129 & 284 & 10,073 & 851 & 8,551 & 671 \\
\hline & & & & & & & rentage & tribution & & & & & & \\
\hline All students .. & 100.0 & 100.0 & 100.0 & 100.0 & 100.0 & 100.0 & 100.0 & 100.0 & 100.0 & 100.0 & 100.0 & 100.0 & 100.0 & 100.0 \\
\hline Under $18 .$. & 4.4 & 5.2 & 3.3 & 7.1 & 2.8 & 2.8 & 2.1 & 0.3 & 0.2 & 0.4 & $\#$ & $\#$ & $\#$ & \# \\
\hline 18 and & 23.7 & 24.5 & 27.8 & 21.4 & 30.3 & 30.5 & 19.0 & 6.6 & 5. & 11. & 0.1 & $\#$ & 0.1 & \# \\
\hline & 22.9 & 22.9 & 29.1 & 17.1 & & 30.3 & 18.2 & 10.4 & 8. & 16 & 1.1 & 1.2 & 1.1 & 0.2 \\
\hline & 15.6 & 16.3 & 18.8 & 14.0 & 13.0 & 13.0 & 15.0 & 14.2 & 13. & 17 & 20.8 & 23.6 & 21.3 & 5.2 \\
\hline & 11.7 & 11.4 & 9.2 & 13.5 & 7.3 & 7.2 & 16.3 & 21.2 & 21. & 19. & 31.8 & 33.6 & 32.9 & 19.4 \\
\hline 30 & 7.1 & 6.5 & 4.4 & 8.5 & 4.8 & 4.7 & 10.3 & 15.9 & 17. & 12. & 16.3 & 16.3 & 15.6 & 18.7 \\
\hline & 4.7 & 4.1 & 2.6 & 5.6 & 3.5 & 3.4 & 7.0 & 11.0 & 11. & 7.9 & 9.6 & 8.8 & 9.0 & 15.6 \\
\hline & 6.3 & 5.6 & 3.2 & 7.8 & 5.1 & 5.1 & 7.9 & 13.9 & 15. & 9.6 & 12.5 & 10.5 & 11.7 & 24.9 \\
\hline & 3.1 & 2.9 & 1.4 & 4.3 & 2.2 & 2.2 & 3.6 & 5.7 & 6. & 3. & 6.9 & 5.5 & 6.6 & 14.7 \\
\hline & 0.3 & 0.4 & 0.1 & 0.6 & 0.1 & 0.1 & 0.2 & 0.2 & 0.2 & 0.2 & 0.3 & 0.3 & 0.3 & 0.6 \\
\hline Age & & 01 & 0.1 & 0.2 & 0.7 & 0.8 & 0.5 & 0.6 & 0.5 & 0.7 & 0.6 & 0.1 & 1.3 & 0.6 \\
\hline Full-time.. & 100.0 & 100.0 & 100.0 & 100.0 & 100.0 & 100.0 & 100.0 & 100.0 & 100.0 & 100.0 & 100.0 & 100.0 & 100.0 & 100.0 \\
\hline Under 1 & 1.6 & 1.9 & 1.6 & 2.4 & 1.4 & . & 07 & 0.3 & 10 & 0 & $\#$ & \# & $\#$ & \# \\
\hline $18 \mathrm{ar}$ & 31.4 & 33.8 & 33.7 & 34.0 & 35.9 & 36 & 22 & 7.9 & 6. & 12 & 0.1 & 0.1 & 0.1 & 0.0 \\
\hline 20 & 28.9 & 29.8 & 34.1 & 21.7 & 35.4 & 35 & 20 & 11.6 & 9. & 16 & 1.7 & 2.0 & 1.7 & 0.3 \\
\hline & 15.6 & 16.4 & 18.3 & 13.0 & 13.1 & 13.1 & 15.3 & 14 & 13.7 & 17. & 29.5 & 34 & 29.6 & 6.7 \\
\hline 25 & 9.0 & 8.2 & 6.6 & 11.2 & 5.3 & 5.1 & 15 & 21 & 21.8 & 19. & 35.4 & 37 & 37.0 & 20.6 \\
\hline 30 & 5.0 & 3.9 & 2.5 & 6.5 & 2.9 & 2.8 & 9.3 & 15.3 & 16. & 11. & 14.0 & 13 & 13.4 & 18.2 \\
\hline 35 to 3 & 3.1 & 2.2 & 1.3 & 4.0 & 2.0 & 1.9 & 6.5 & 10. & 11. & 7. & 6.9 & 5 & 6.3 & 15.0 \\
\hline 40 to 4 & 3.7 & 2.6 & 1.4 & 4.9 & 2.6 & 2.5 & 6.6 & 12.9 & 14. & 9. & 7.9 & 5.1 & 7.1 & 23.9 \\
\hline 50 to 6 & 1.5 & 1.1 & 0.5 & 2.2 & 1.0 & 0.9 & 2.8 & 5.1 & 5. & 3. & 3.9 & 2.0 & 3.5 & 13.9 \\
\hline 65 & 0.1 & 0.0 & 0.0 & 0.1 & 0.0 & 0.0 & 0.2 & 0.2 & 0.1 & 0. & 0.2 & 0.1 & 0.2 & 0.5 \\
\hline Age unkn & & 0.1 & 0.0 & 0.1 & 0.5 & 0.5 & 0.4 & 0.5 & 0.4 & 0.7 & 0.5 & 0.0 & 1.0 & 17 \\
\hline Part-time & 100.0 & 100.0 & 100.0 & 100.0 & 100.0 & 100.0 & 100.0 & 100.0 & 100.0 & 100.0 & 100.0 & 100.0 & 100.0 & 100.0 \\
\hline & 9.2 & & & 10.1 & & & 6.7 & 0.3 & 0 & 0.5 & $\#$ & \# & \# & 1 \\
\hline & 10.8 & 11.8 & 7.9 & 13.2 & 4.6 & 4.5 & 8.5 & 3.1 & 2. & 6. & $\#$ & $\#$ & $\#$ & \# \\
\hline & 12.6 & 13. & 12. & 14.1 & 5.9 & 0 & 10.4 & 7. & 6. & 13 & 0.3 & 0.4 & 0.2 & 0.1 \\
\hline & 15.7 & 16. & 20 & 14.6 & 12.8 & 12.7 & 14 & 12.7 & 12. & 18 & 9.7 & 10 & 9.9 & 3.3 \\
\hline & 16.2 & 15.7 & 18. & 14.9 & 16.6 & 16.6 & 18 & 21.4 & 21 & 21 & 27.3 & 29.2 & 27.3 & 17.8 \\
\hline 30 to 3 & 10.7 & 10.0 & 10.6 & 9.7 & 13.4 & 13.4 & 13.4 & 17.4 & 17. & 13. & 19.2 & 19.6 & 18.6 & 19.3 \\
\hline 35 to 3 & 7.4 & 6.7 & 7.0 & 6.7 & 10.5 & 10.6 & 8.6 & 12 & 13 & 9. & 13.0 & 12.7 & 12.6 & 16.3 \\
\hline 40 to 4 & 10.6 & 9.6 & 9.4 & 9.7 & 16.8 & 16.8 & 12.2 & 16.9 & 17. & 11.8 & 18.4 & 17.0 & 18.1 & 26.1 \\
\hline & 5.8 & 5.4 & 4.6 & 5.7 & 8.1 & 8.1 & 6.1 & 7.6 & 7. & 5. & 10.8 & 9.7 & 11.0 & 15.8 \\
\hline $65 a$ & 0.7 & 0.8 & 0.5 & 0.9 & 0.5 & 0.5 & 0.4 & 0.2 & 0.2 & 0. & 0.5 & 0.5 & 0.5 & 0.7 \\
\hline 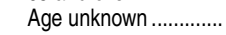 & & 0.3 & 0.2 & 0.3 & 2.0 & 2.0 & 0.7 & 0.8 & 0.8 & 0.6 & 0.8 & 0.1 & 1.7 & 0.5 \\
\hline
\end{tabular}

\#Rounds to zero.

NOTE: Degree-granting institutions grant associate's or higher degrees and participate in Title IV federal financial aid programs. Detail may not sum to totals because of rounding.
SOURCE: U.S. Department of Education, National Center for Education Statistics, Integrated Postsecondary Education Data System (IPEDS), Spring 2012, Enrollment component. (This table was prepared November 2012.) 
Table 303.55. Total fall enrollment in degree-granting postsecondary institutions, by control and level of institution, attendance status, and age of student: 2011

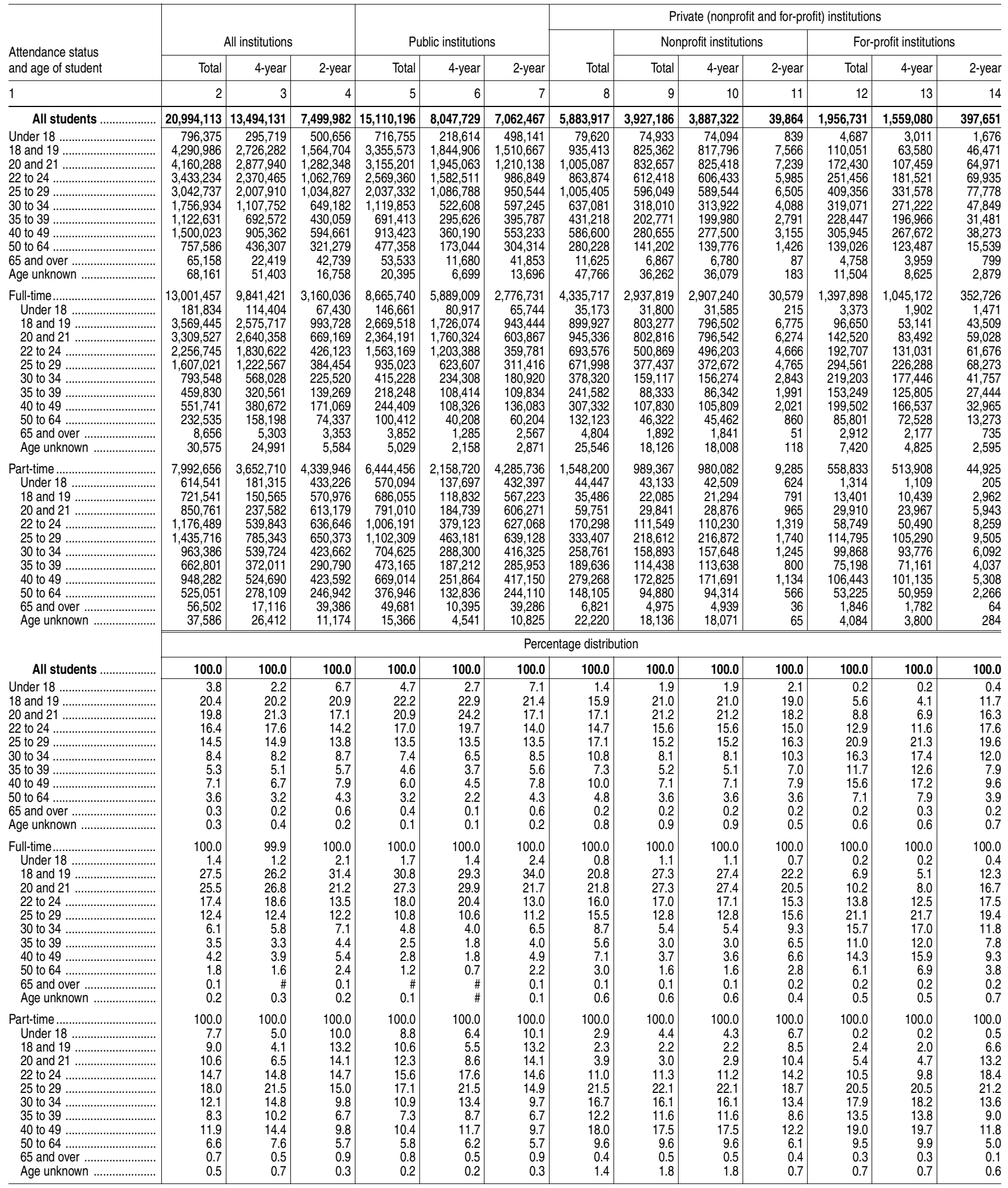

\#Rounds to zero.

NOTE: Degree-granting institutions grant associate's or higher degrees and participate in

Title IV federal financial aid programs. Detail may not sum to totals because of rounding.
SOURCE: U.S. Department of Education, National Center for Education Statistics, Integrated Postsecondary Education Data System (IPEDS), Spring 2012, Enrollment component. (This table was prepared September 2012.) 
406 CHAPTER 3: Postsecondary Education

Total Fall Enrollment-General

Table 303.60. Total fall enrollment in degree-granting postsecondary institutions, by level of enrollment, sex of student, and other selected characteristics: 2012

\begin{tabular}{|c|c|c|c|c|c|c|c|c|c|}
\hline \multirow{2}{*}{$\begin{array}{l}\text { Level and control of } \\
\text { institution and attendance } \\
\text { status of student }\end{array}$} & \multicolumn{3}{|c|}{ Total } & \multicolumn{3}{|c|}{ Undergraduate } & \multicolumn{3}{|c|}{ Postbaccalaureate } \\
\hline & Total & Males & Females & Total & Males & Females & Total & Males & Females \\
\hline 1 & 2 & 3 & 4 & 5 & 6 & 7 & 8 & 9 & 10 \\
\hline Total ............................. & $20,642,819$ & $8,919,087$ & $11,723,732$ & $17,732,431$ & $7,713,901$ & $10,018,530$ & $2,910,388$ & $1,205,186$ & $1,705,202$ \\
\hline $\begin{array}{l}\text { Full-time } \\
\text { Part-time }\end{array}$ & $\begin{array}{r}12,737,013 \\
7,905,806 \\
\end{array}$ & $\begin{array}{l}5,709,792 \\
3,209,295 \\
\end{array}$ & $\begin{array}{l}7,027,221 \\
4,696,511 \\
\end{array}$ & $\begin{array}{r}11,097,779 \\
6,634,652 \\
\end{array}$ & $\begin{array}{l}4,984,696 \\
2,729,205 \\
\end{array}$ & $\begin{array}{l}6,113,083 \\
3,905,447 \\
\end{array}$ & $\begin{array}{l}1,639,234 \\
1,271,154 \\
\end{array}$ & $\begin{array}{l}725,096 \\
480,090 \\
\end{array}$ & $\begin{array}{l}914,138 \\
791,064 \\
\end{array}$ \\
\hline 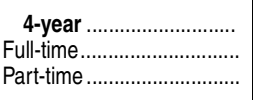 & $\begin{array}{r}13,478,846 \\
9,794,436 \\
3,684,410\end{array}$ & $\begin{array}{l}\mathbf{5 , 8 7 4 , 3 8 3} \\
4,403,960 \\
1,470,423\end{array}$ & $\begin{array}{l}7,604,463 \\
5,390,476 \\
2,213,987\end{array}$ & $\begin{array}{r}10,568,458 \\
8,155,202 \\
2,413,256\end{array}$ & $\begin{array}{r}4,669,197 \\
3,678,864 \\
990,333\end{array}$ & $\begin{array}{l}\mathbf{5}, 899,261 \\
4,476,338 \\
1,422,923\end{array}$ & $\begin{array}{l}\mathbf{2}, 910,388 \\
1,639,234 \\
1,271,154\end{array}$ & $\begin{array}{r}1,205,186 \\
725,096 \\
480,090\end{array}$ & $\begin{array}{r}1,705,202 \\
914,138 \\
791,064\end{array}$ \\
\hline 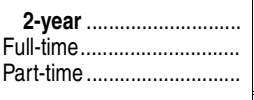 & $\begin{array}{l}7,163,973 \\
2,942,577 \\
4,221,396 \\
\end{array}$ & $\begin{array}{l}3,044,704 \\
1,305,832 \\
1,738,872 \\
\end{array}$ & $\begin{array}{l}4,119,269 \\
1,636,745 \\
2,482,524 \\
\end{array}$ & $\begin{array}{l}7,163,973 \\
2,942,577 \\
4,221,396 \\
\end{array}$ & $\begin{array}{l}3,044,704 \\
1,305,832 \\
1,738,872 \\
\end{array}$ & $\begin{array}{l}4,119,269 \\
1,636,745 \\
2,482,524 \\
\end{array}$ & $\begin{array}{l}t \\
\dagger \\
t \\
\end{array}$ & $\begin{array}{l}\dagger \\
\dagger \\
\dagger \\
\end{array}$ & $\begin{array}{l}\dagger \\
\dagger \\
\dagger \\
\end{array}$ \\
\hline Public ............................. & $14,880,343$ & $6,581,299$ & $8,299,044$ & $13,473,743$ & $5,983,450$ & $7,490,293$ & $1,406,600$ & 597,849 & 808,751 \\
\hline 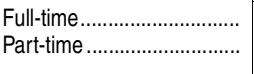 & $\begin{array}{l}8,525,818 \\
6,354,525\end{array}$ & $\begin{array}{l}3,954,114 \\
2,627,185\end{array}$ & $\begin{array}{l}4,571,704 \\
3,727,340\end{array}$ & $\begin{array}{l}7,752,356 \\
5,721,387\end{array}$ & $\begin{array}{l}3,599,518 \\
2,383,932\end{array}$ & $\begin{array}{l}4,152,838 \\
3,337,455\end{array}$ & $\begin{array}{l}773,462 \\
633,138\end{array}$ & $\begin{array}{l}354,596 \\
243,253\end{array}$ & $\begin{array}{l}418,866 \\
389,885\end{array}$ \\
\hline 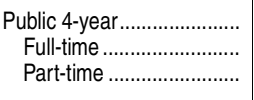 & $\begin{array}{l}8,092,683 \\
5,910,198 \\
2,182,485\end{array}$ & $\begin{array}{r}3,658,138 \\
2,756,941 \\
901,197\end{array}$ & $\begin{array}{l}4,434,545 \\
3,153,257 \\
1,281,288\end{array}$ & $\begin{array}{l}6,686,083 \\
5,136,736 \\
1,549,347\end{array}$ & $\begin{array}{r}3,060,289 \\
2,402,345 \\
657,944\end{array}$ & $\begin{array}{r}3,625,794 \\
2,734,391 \\
891,403\end{array}$ & $\begin{array}{r}1,406,600 \\
773,462 \\
633,138\end{array}$ & $\begin{array}{l}597,849 \\
354,596 \\
243,253\end{array}$ & $\begin{array}{l}808,751 \\
418,866 \\
389,885\end{array}$ \\
\hline 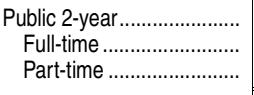 & $\begin{array}{l}6,787,660 \\
2,615,620 \\
4,172,040 \\
\end{array}$ & $\begin{array}{l}2,923,161 \\
1,197,173 \\
1,725,988 \\
\end{array}$ & $\begin{array}{l}3,864,499 \\
1,418,447 \\
2,446,052 \\
\end{array}$ & $\begin{array}{l}6,787,660 \\
2,615,620 \\
4,172,040 \\
\end{array}$ & $\begin{array}{l}2,923,161 \\
1,197,173 \\
1,725,988 \\
\end{array}$ & $\begin{array}{l}3,864,499 \\
1,418,447 \\
2,446,052 \\
\end{array}$ & $\begin{array}{l}\dagger \\
\dagger \\
\dagger \\
\end{array}$ & $\begin{array}{l}\dagger \\
\dagger \\
\dagger \\
\end{array}$ & $\begin{array}{l}\dagger \\
\dagger \\
\dagger \\
\end{array}$ \\
\hline Private ............................ & $5,762,476$ & $2,337,788$ & $3,424,688$ & $4,258,688$ & $1,730,451$ & $2,528,237$ & $1,503,788$ & 607,337 & 896,451 \\
\hline Full-time & $\begin{array}{l}4,211,195 \\
1,551,281\end{array}$ & $\begin{array}{r}1,755,678 \\
582,110\end{array}$ & $\begin{array}{r}2,455,517 \\
969,171\end{array}$ & $\begin{array}{r}3,345,423 \\
913,265\end{array}$ & $\begin{array}{r}1,385,178 \\
345,273\end{array}$ & $\begin{array}{r}1,960,245 \\
567,992\end{array}$ & $\begin{array}{l}865,772 \\
638,016\end{array}$ & $\begin{array}{l}370,500 \\
236,837\end{array}$ & $\begin{array}{l}495,272 \\
401,179\end{array}$ \\
\hline 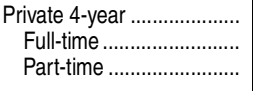 & $\begin{array}{l}5,386,163 \\
3,884,238 \\
1,501,925\end{array}$ & $\begin{array}{r}2,216,245 \\
1,647,019 \\
569,226\end{array}$ & $\begin{array}{r}3,169,918 \\
2,237,219 \\
932,699\end{array}$ & $\begin{array}{r}3,882,375 \\
3,018,466 \\
863,909\end{array}$ & $\begin{array}{r}1,608,908 \\
1,276,519 \\
332,389\end{array}$ & $\begin{array}{r}2,273,467 \\
1,741,947 \\
531,520\end{array}$ & $\begin{array}{r}1,503,788 \\
865,772 \\
638,016\end{array}$ & $\begin{array}{l}607,337 \\
370,500 \\
236,837\end{array}$ & $\begin{array}{l}896,451 \\
495,272 \\
401,179\end{array}$ \\
\hline 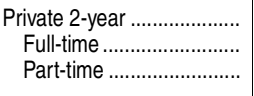 & $\begin{array}{r}376,313 \\
326,957 \\
49,356\end{array}$ & $\begin{array}{r}121,543 \\
108,659 \\
12,884\end{array}$ & $\begin{array}{r}254,770 \\
218,298 \\
36,472\end{array}$ & $\begin{array}{r}376,313 \\
326,957 \\
49,356\end{array}$ & $\begin{array}{r}121,543 \\
108,659 \\
12,884\end{array}$ & $\begin{array}{r}254,770 \\
218,298 \\
36,472\end{array}$ & $\begin{array}{l}\dagger \\
\dagger \\
t\end{array}$ & $\begin{array}{l}t \\
t \\
\dagger\end{array}$ & $\begin{array}{l}\dagger \\
\dagger \\
\dagger\end{array}$ \\
\hline 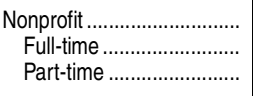 & $\begin{array}{r}3,953,578 \\
2,958,258 \\
995,320\end{array}$ & $\begin{array}{r}1,680,744 \\
1,300,539 \\
380,205\end{array}$ & $\begin{array}{r}2,272,834 \\
1,657,719 \\
615,115\end{array}$ & $\begin{array}{r}2,745,075 \\
2,249,980 \\
495,095\end{array}$ & $\begin{array}{r}1,170,305 \\
982,298 \\
188,007\end{array}$ & $\begin{array}{r}1,574,770 \\
1,267,682 \\
307,088\end{array}$ & $\begin{array}{r}1,208,503 \\
708,278 \\
500,225\end{array}$ & $\begin{array}{l}510,439 \\
318,241 \\
192,198\end{array}$ & $\begin{array}{l}698,064 \\
390,037 \\
308,027\end{array}$ \\
\hline $\begin{array}{l}\text { Nonprofit } 4 \text {-year .............. } \\
\text { Full-time ...................... } \\
\text { Part-time ..................... }\end{array}$ & $\begin{array}{r}3,915,972 \\
2,928,938 \\
987,034\end{array}$ & $\begin{array}{r}1,667,820 \\
1,290,080 \\
377,740\end{array}$ & $\begin{array}{r}2,248,152 \\
1,638,858 \\
609,294\end{array}$ & $\begin{array}{r}2,707,469 \\
2,220,660 \\
486,809\end{array}$ & $\begin{array}{r}1,157,381 \\
971,839 \\
185,542\end{array}$ & $\begin{array}{r}1,550,088 \\
1,248,821 \\
301,267\end{array}$ & $\begin{array}{r}1,208,503 \\
708,278 \\
500,225\end{array}$ & $\begin{array}{l}510,439 \\
318,241 \\
192,198\end{array}$ & $\begin{array}{l}698,064 \\
390,037 \\
308,027\end{array}$ \\
\hline $\begin{array}{c}\text { Nonprofit 2-year .............. } \\
\text { Full-time .................... } \\
\text { Part-time .................... }\end{array}$ & $\begin{array}{r}37,606 \\
29,320 \\
8,286\end{array}$ & $\begin{array}{r}12,924 \\
10,459 \\
2,465\end{array}$ & $\begin{array}{r}24,682 \\
18,861 \\
5,821\end{array}$ & $\begin{array}{r}37,606 \\
29,320 \\
8,286\end{array}$ & $\begin{array}{r}12,924 \\
10,459 \\
2,465\end{array}$ & $\begin{array}{r}24,682 \\
18,861 \\
5,821\end{array}$ & $\begin{array}{l}t \\
\dagger \\
t\end{array}$ & $\begin{array}{l}\dagger \\
\dagger \\
\dagger\end{array}$ & $\begin{array}{l}\dagger \\
\dagger \\
\dagger\end{array}$ \\
\hline 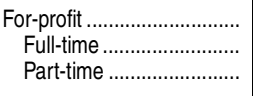 & $\begin{array}{r}1,808,898 \\
1,252,937 \\
555,961\end{array}$ & $\begin{array}{l}657,044 \\
455,139 \\
201,905\end{array}$ & $\begin{array}{r}1,151,854 \\
797,798 \\
354,056\end{array}$ & $\begin{array}{r}1,513,613 \\
1,095,443 \\
418,170\end{array}$ & $\begin{array}{l}560,146 \\
402,880 \\
157,266\end{array}$ & $\begin{array}{l}953,467 \\
692,563 \\
260,904\end{array}$ & $\begin{array}{l}295,285 \\
157,494 \\
137,791\end{array}$ & $\begin{array}{l}96,898 \\
52,259 \\
44,639\end{array}$ & $\begin{array}{r}198,387 \\
105,235 \\
93,152\end{array}$ \\
\hline $\begin{array}{r}\text { For-profit 4-year .............. } \\
\text { Full-time …................. } \\
\text { Part-time .................... }\end{array}$ & $\begin{array}{r}1,470,191 \\
955,300 \\
514,891\end{array}$ & $\begin{array}{l}548,425 \\
356,939 \\
191,486\end{array}$ & $\begin{array}{l}921,766 \\
598,361 \\
323,405\end{array}$ & $\begin{array}{r}1,174,906 \\
797,806 \\
377,100\end{array}$ & $\begin{array}{l}451,527 \\
304,680 \\
146,847\end{array}$ & $\begin{array}{l}723,379 \\
493,126 \\
230,253\end{array}$ & $\begin{array}{l}295,285 \\
157,494 \\
137,791\end{array}$ & $\begin{array}{l}96,898 \\
52,259 \\
44,639\end{array}$ & $\begin{array}{r}198,387 \\
105,235 \\
93,152\end{array}$ \\
\hline $\begin{array}{r}\text { For-profit 2-year .............. } \\
\text { Full-time ...................... } \\
\text { Part-time .................... }\end{array}$ & $\begin{array}{r}338,707 \\
297,637 \\
41,070\end{array}$ & $\begin{array}{r}108,619 \\
98,200 \\
10,419\end{array}$ & $\begin{array}{r}230,088 \\
199,437 \\
30,651\end{array}$ & $\begin{array}{r}338,707 \\
297,637 \\
41,070\end{array}$ & $\begin{array}{r}108,619 \\
98,200 \\
10,419\end{array}$ & $\begin{array}{r}230,088 \\
199,437 \\
30,651\end{array}$ & $\begin{array}{l}\dagger \\
\dagger \\
\dagger\end{array}$ & $\begin{array}{l}\dagger \\
\dagger \\
+\end{array}$ & $\begin{array}{l}\dagger \\
\dagger \\
\dagger\end{array}$ \\
\hline
\end{tabular}

†Not applicable.

NOTE: Degree-granting institutions grant associate's or higher degrees and participate in Title IV federal financial aid programs.
SOURCE: U.S. Department of Education, National Center for Education Statistics, Integrated Postsecondary Education Data System (IPEDS), Spring 2013, Enrollment component. (This table was prepared October 2013.) 
CHAPTER 3: Postsecondary Education 407 Total Fall Enrollment-General

Table 303.65. Total fall enrollment in degree-granting postsecondary institutions, by level of enrollment, sex of student, and other selected characteristics: 2011

\begin{tabular}{|c|c|c|c|c|c|c|c|c|c|}
\hline \multirow{2}{*}{$\begin{array}{l}\text { Level and control of } \\
\text { institution and attendance } \\
\text { status of student }\end{array}$} & \multicolumn{3}{|c|}{ Total } & \multicolumn{3}{|c|}{ Undergraduate } & \multicolumn{3}{|c|}{ Postbaccalaureate } \\
\hline & Total & Males & Females & Total & Males & Females & Total & Males & Females \\
\hline 1 & 2 & 3 & 4 & 5 & 6 & 7 & 8 & 9 & 10 \\
\hline 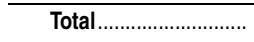 & $20,994,113$ & $9,026,499$ & $11,967,614$ & $18,063,037$ & $7,816,975$ & $10,246,062$ & $2,931,076$ & $1,209,524$ & $1,721,552$ \\
\hline $\begin{array}{l}\text { Full-time } \\
\text { Part-time }\end{array}$ & $\begin{array}{r}13,001,457 \\
7,992,656 \\
\end{array}$ & $\begin{array}{l}5,793,411 \\
3,233,088 \\
\end{array}$ & $\begin{array}{l}7,208,046 \\
4,759,568 \\
\end{array}$ & $\begin{array}{r}11,359,068 \\
6,703,969 \\
\end{array}$ & $\begin{array}{l}5,070,529 \\
2,746,446 \\
\end{array}$ & $\begin{array}{l}6,288,539 \\
3,957,523 \\
\end{array}$ & $\begin{array}{l}1,642,389 \\
1,288,687 \\
\end{array}$ & $\begin{array}{l}722,882 \\
486,642 \\
\end{array}$ & $\begin{array}{l}919,507 \\
802,045 \\
\end{array}$ \\
\hline 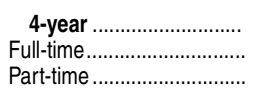 & $\begin{array}{r}13,494,131 \\
9,841,421 \\
3,652,710\end{array}$ & $\begin{array}{l}\mathbf{5 , 8 5 4 , 8 4 5} \\
4,405,066 \\
1,449,779\end{array}$ & $\begin{array}{l}7,639,286 \\
5,436,355 \\
2,202,931\end{array}$ & $\begin{array}{r}10,563,055 \\
8,199,032 \\
2,364,023\end{array}$ & $\begin{array}{r}4,645,321 \\
3,682,184 \\
963,137\end{array}$ & 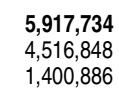 & $\begin{array}{l}2,931,076 \\
1,642,389 \\
1,288,687\end{array}$ & $\begin{array}{r}1,209,524 \\
722,882 \\
486,642\end{array}$ & $\begin{array}{r}1,721,552 \\
919,507 \\
802,045\end{array}$ \\
\hline 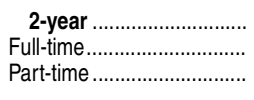 & $\begin{array}{l}7,499,982 \\
3,160,036 \\
4,339,946 \\
\end{array}$ & $\begin{array}{l}3,171,654 \\
1,388,345 \\
1,783,309 \\
\end{array}$ & $\begin{array}{l}4,328,328 \\
1,771,691 \\
2,556,637 \\
\end{array}$ & $\begin{array}{l}7,499,982 \\
3,160,036 \\
4,339,946 \\
\end{array}$ & $\begin{array}{l}3,171,654 \\
1,388,345 \\
1,783,309 \\
\end{array}$ & $\begin{array}{l}4,328,328 \\
1,771,691 \\
2,556,637 \\
\end{array}$ & $\begin{array}{l}\dagger \\
\dagger \\
\dagger \\
\end{array}$ & $\begin{array}{l}t \\
\dagger \\
\dagger \\
\end{array}$ & $\begin{array}{l}\dagger \\
\dagger \\
\dagger \\
\end{array}$ \\
\hline Public ............................. & $15,110,196$ & $6,656,236$ & $8,453,960$ & $13,688,792$ & $6,055,488$ & $7,633,304$ & $1,421,404$ & 600,748 & 820,656 \\
\hline 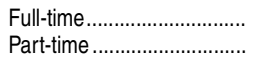 & $\begin{array}{l}8,665,740 \\
6,444,456\end{array}$ & $\begin{array}{l}, 001,784 \\
2,654,452\end{array}$ & $\begin{array}{l}4,663,956 \\
3,790,004\end{array}$ & $\begin{array}{l}7,894,906 \\
5,793,886\end{array}$ & $\begin{array}{l}3,648,772 \\
2,406,716\end{array}$ & $\begin{array}{l}4,246,134 \\
3,387,170\end{array}$ & $\begin{array}{l}770,834 \\
650,570\end{array}$ & $\begin{array}{l}353,012 \\
247,736\end{array}$ & $\begin{array}{l}417,822 \\
402,834\end{array}$ \\
\hline 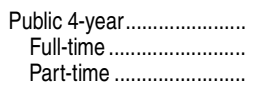 & $\begin{array}{l}8,047,729 \\
5,889,009 \\
2,158,720\end{array}$ & $\begin{array}{r}3,628,889 \\
2,743,324 \\
885,565\end{array}$ & $\begin{array}{l}4,418,840 \\
3,145,685 \\
1,273,155\end{array}$ & $\begin{array}{l}6,626,325 \\
5,118,175 \\
1,508,150\end{array}$ & $\begin{array}{r}3,028,141 \\
2,390,312 \\
637,829\end{array}$ & $\begin{array}{r}3,598,184 \\
2,727,863 \\
870,321\end{array}$ & $\begin{array}{r}1,421,404 \\
770,834 \\
650,570\end{array}$ & $\begin{array}{l}600,748 \\
353,012 \\
247,736\end{array}$ & $\begin{array}{l}820,656 \\
417,822 \\
402,834\end{array}$ \\
\hline 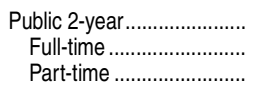 & $\begin{array}{l}7,062,467 \\
2,776,731 \\
4,285,736 \\
\end{array}$ & $\begin{array}{l}3,027,347 \\
1,258,460 \\
1,768,887 \\
\end{array}$ & $\begin{array}{l}4,035,120 \\
1,518,271 \\
2,516,849 \\
\end{array}$ & $\begin{array}{l}7,062,467 \\
2,776,731 \\
4,285,736 \\
\end{array}$ & $\begin{array}{l}3,027,347 \\
1,258,460 \\
1,768,887 \\
\end{array}$ & $\begin{array}{l}4,035,120 \\
1,518,271 \\
2,516,849 \\
\end{array}$ & $\begin{array}{l}\dagger \\
\dagger \\
\dagger \\
\end{array}$ & $\begin{array}{l}\dagger \\
\dagger \\
\dagger \\
\end{array}$ & $\begin{array}{l}\dagger \\
\dagger \\
\dagger \\
\end{array}$ \\
\hline Private ............................ & $5,883,917$ & $2,370,263$ & $3,513,654$ & $4,374,245$ & $1,761,487$ & $2,612,758$ & $1,509,672$ & 608,776 & 900,896 \\
\hline 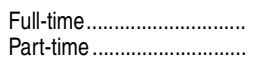 & $\begin{array}{l}4,335,717 \\
1,548,200\end{array}$ & $\begin{array}{r}1,791,627 \\
578,636\end{array}$ & $\begin{array}{r}2,544,090 \\
969,564\end{array}$ & $\begin{array}{r}3,464,162 \\
910,083\end{array}$ & $\begin{array}{r}1,421,757 \\
339,730\end{array}$ & $\begin{array}{r}2,042,405 \\
570,353\end{array}$ & $\begin{array}{l}871,555 \\
638,117\end{array}$ & $\begin{array}{l}369,870 \\
238,906\end{array}$ & $\begin{array}{l}501,685 \\
399,211\end{array}$ \\
\hline 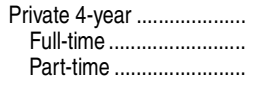 & $\begin{array}{l}5,446,402 \\
3,952,412 \\
1,493,990\end{array}$ & $\begin{array}{r}2,225,956 \\
1,661,742 \\
564,214\end{array}$ & $\begin{array}{r}3,220,446 \\
2,290,670 \\
929,776\end{array}$ & $\begin{array}{r}3,936,730 \\
3,080,857 \\
855,873\end{array}$ & $\begin{array}{r}1,617,180 \\
1,291,872 \\
325,308\end{array}$ & $\begin{array}{r}2,319,550 \\
1,788,985 \\
530,565\end{array}$ & $\begin{array}{r}1,509,672 \\
871,555 \\
638,117\end{array}$ & $\begin{array}{l}608,776 \\
369,870 \\
238,906\end{array}$ & $\begin{array}{l}900,896 \\
501,685 \\
399,211\end{array}$ \\
\hline 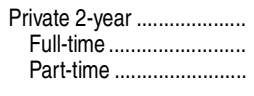 & $\begin{array}{r}437,515 \\
383,305 \\
54,210\end{array}$ & $\begin{array}{r}144,307 \\
129,885 \\
14,422\end{array}$ & $\begin{array}{r}293,208 \\
253,420 \\
39,788\end{array}$ & $\begin{array}{r}437,515 \\
383,305 \\
54,210\end{array}$ & $\begin{array}{r}144,307 \\
129,885 \\
14,422\end{array}$ & $\begin{array}{r}293,208 \\
253,420 \\
39,788\end{array}$ & $\begin{array}{l}\dagger \\
\dagger \\
\dagger\end{array}$ & $\begin{array}{l}\dagger \\
\dagger \\
\dagger\end{array}$ & $\begin{array}{l}\dagger \\
\dagger \\
\dagger\end{array}$ \\
\hline 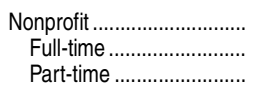 & $\begin{array}{r}3,927,186 \\
2,937,819 \\
989,367\end{array}$ & $\begin{array}{r}1,665,150 \\
1,287,302 \\
377,848\end{array}$ & $\begin{array}{r}2,262,036 \\
1,650,517 \\
611,519\end{array}$ & $\begin{array}{r}2,718,880 \\
2,235,815 \\
483,065\end{array}$ & $\begin{array}{r}1,154,936 \\
971,842 \\
183,094\end{array}$ & $\begin{array}{r}1,563,944 \\
1,263,973 \\
299,971\end{array}$ & $\begin{array}{r}1,208,306 \\
702,004 \\
506,302\end{array}$ & $\begin{array}{l}510,214 \\
315,460 \\
194,754\end{array}$ & $\begin{array}{l}698,092 \\
386,544 \\
311,548\end{array}$ \\
\hline $\begin{array}{l}\text { Nonprofit 4-year ............. } \\
\text { Full-time ....................... } \\
\text { Part-time .................... }\end{array}$ & $\begin{array}{r}3,887,322 \\
2,907,240 \\
980,082\end{array}$ & $\begin{array}{r}1,651,310 \\
1,276,006 \\
375,304\end{array}$ & $\begin{array}{r}2,236,012 \\
1,631,234 \\
604,778\end{array}$ & $\begin{array}{r}2,679,016 \\
2,205,236 \\
473,780\end{array}$ & $\begin{array}{r}1,141,096 \\
960,546 \\
180,550\end{array}$ & $\begin{array}{r}1,537,920 \\
1,244,690 \\
293,230\end{array}$ & $\begin{array}{r}1,208,306 \\
702,004 \\
506,302\end{array}$ & $\begin{array}{l}510,214 \\
315,460 \\
194,754\end{array}$ & $\begin{array}{l}698,092 \\
386,544 \\
311,548\end{array}$ \\
\hline $\begin{array}{r}\text { Nonprofit 2-year .............. } \\
\text { Full-time ..................... } \\
\text { Part-time .................... }\end{array}$ & $\begin{array}{r}39,864 \\
30,579 \\
9,285\end{array}$ & $\begin{array}{r}13,840 \\
11,296 \\
2,544\end{array}$ & $\begin{array}{r}26,024 \\
19,283 \\
6,741\end{array}$ & $\begin{array}{r}39,864 \\
30,579 \\
9,285\end{array}$ & $\begin{array}{r}13,840 \\
11,296 \\
2,544\end{array}$ & $\begin{array}{r}26,024 \\
19,283 \\
6,741\end{array}$ & $\begin{array}{l}\dagger \\
\dagger \\
\dagger\end{array}$ & $\begin{array}{l}\dagger \\
\dagger \\
+\end{array}$ & $\begin{array}{l}\dagger \\
\dagger \\
\dagger\end{array}$ \\
\hline 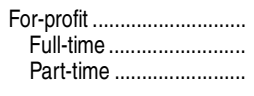 & $\begin{array}{r}1,956,731 \\
1,397,898 \\
558,833\end{array}$ & $\begin{array}{l}705,113 \\
504,325 \\
200,788\end{array}$ & $\begin{array}{r}1,251,618 \\
893,573 \\
358,045\end{array}$ & $\begin{array}{r}1,655,365 \\
1,228,347 \\
427,018\end{array}$ & $\begin{array}{l}606,551 \\
449,915 \\
156,636\end{array}$ & $\begin{array}{r}1,048,814 \\
778,432 \\
270,382\end{array}$ & $\begin{array}{l}301,366 \\
169,551 \\
131,815\end{array}$ & $\begin{array}{l}98,562 \\
54,410 \\
44,152\end{array}$ & $\begin{array}{r}202,804 \\
115,141 \\
87,663\end{array}$ \\
\hline 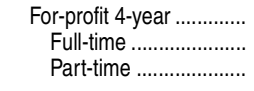 & $\begin{array}{r}1,559,080 \\
1,045,172 \\
513,908\end{array}$ & $\begin{array}{l}574,646 \\
385,736 \\
188,910\end{array}$ & $\begin{array}{l}984,434 \\
659,436 \\
324,998\end{array}$ & $\begin{array}{r}1,257,714 \\
875,621 \\
382,093\end{array}$ & $\begin{array}{l}476,084 \\
331,326 \\
144,758\end{array}$ & $\begin{array}{l}781,630 \\
544,295 \\
237,335\end{array}$ & $\begin{array}{l}301,366 \\
169,551 \\
131,815\end{array}$ & $\begin{array}{l}98,562 \\
54,410 \\
44,152\end{array}$ & $\begin{array}{r}202,804 \\
115,141 \\
87,663\end{array}$ \\
\hline $\begin{array}{l}\text { For-profit 2-year .............. } \\
\text { Full-time ....................... } \\
\text { Part-time ................... }\end{array}$ & $\begin{array}{r}397,651 \\
352,726 \\
44,925\end{array}$ & $\begin{array}{r}130,467 \\
118,589 \\
11,878\end{array}$ & $\begin{array}{r}267,184 \\
234,137 \\
33,047\end{array}$ & $\begin{array}{r}397,651 \\
352,726 \\
44,925 \\
\end{array}$ & $\begin{array}{r}130,467 \\
118,589 \\
11,878\end{array}$ & $\begin{array}{r}267,184 \\
234,137 \\
33,047\end{array}$ & $\begin{array}{l}\dagger \\
\dagger \\
\dagger\end{array}$ & $\begin{array}{l}\dagger \\
\dagger \\
t\end{array}$ & $\begin{array}{l}\dagger \\
\dagger \\
\dagger\end{array}$ \\
\hline
\end{tabular}

†Not applicable.

NOTE: Degree-granting institutions grant associate's or higher degrees and participate in Title IV federal financial aid programs.
SOURCE: U.S. Department of Education, National Center for Education Statistics, Integrated Postsecondary Education Data System (IPEDS), Spring 2012, Enrollment component. (This table was prepared September 2012.) 
Table 303.70. Total undergraduate fall enrollment in degree-granting postsecondary institutions, by attendance status, sex of student, and control and level of institution: Selected years, 1970 through 2023

\begin{tabular}{|c|c|c|c|c|c|c|c|c|c|c|c|c|c|}
\hline \multirow[b]{2}{*}{ Level and year } & \multirow[b]{2}{*}{ Total } & \multirow[b]{2}{*}{ Full-time } & \multirow[b]{2}{*}{ Part-time } & \multirow[b]{2}{*}{ Males } & \multirow[b]{2}{*}{ Females } & \multicolumn{2}{|c|}{ Males } & \multicolumn{2}{|c|}{ Females } & \multirow[b]{2}{*}{ Public } & \multicolumn{3}{|c|}{ Private } \\
\hline & & & & & & Full-time & Part-time & Full-time & Part-time & & Total & Nonprofit & For-profit \\
\hline 1 & 2 & 3 & 4 & 5 & 6 & 7 & 8 & 9 & 10 & 11 & 12 & 13 & 14 \\
\hline \multicolumn{14}{|l|}{ Total, all levels } \\
\hline 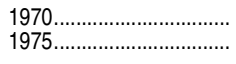 & $\begin{array}{l}7,368,644 \\
9,679,455\end{array}$ & $\begin{array}{l}5,280,064 \\
6,168,396\end{array}$ & $\begin{array}{l}2,088,580 \\
3,511,059\end{array}$ & $\begin{array}{l}4,249,702 \\
5,257,005\end{array}$ & $\begin{array}{l}3,118,942 \\
4,422,450\end{array}$ & $\begin{array}{l}3,096,371 \\
3,459,328\end{array}$ & $\begin{array}{l}1,153,331 \\
1,797,677\end{array}$ & $\begin{array}{l}2,183,693 \\
2,709,068\end{array}$ & $\begin{array}{r}935,249 \\
1,713,382\end{array}$ & $\begin{array}{l}5,620,255 \\
7,826,032\end{array}$ & $\begin{array}{l}1,748,389 \\
1,853,423\end{array}$ & $\begin{array}{l}1,730,133 \\
1,814,844\end{array}$ & $\begin{array}{l}18,256 \\
38,579\end{array}$ \\
\hline 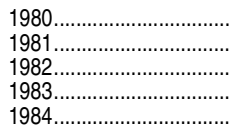 & $\begin{array}{l}10,475,055 \\
10,754,522 \\
10,825,062 \\
10,845,995 \\
10,618,071\end{array}$ & $\begin{array}{l}6,361,744 \\
6,449,068 \\
6,483,805 \\
6,514,034 \\
6,347,653\end{array}$ & $\begin{array}{l}4,113,311 \\
4,305,454 \\
4,341,257 \\
4,331,961 \\
4,270,418\end{array}$ & $\begin{array}{l}5,000,177 \\
5,108,271 \\
5,170,494 \\
5,158,300 \\
5,006,813\end{array}$ & $\begin{array}{l}5,474,878 \\
5,646,251 \\
5,654,568 \\
5,687,695 \\
5,611,258\end{array}$ & $\begin{array}{l}3,226,857 \\
3,260,473 \\
3,299,436 \\
3,304,247 \\
3,194,930\end{array}$ & $\begin{array}{l}1,773,320 \\
1,847,798 \\
1,871,058 \\
1,854,053 \\
1,811,883\end{array}$ & $\begin{array}{l}3,134,887 \\
3,188,595 \\
3,184,369 \\
3,209,787 \\
3,152,723\end{array}$ & $\begin{array}{l}2,339,991 \\
2,457,656 \\
2,470,199 \\
2,477,908 \\
2,458,535\end{array}$ & $\begin{array}{l}8,441,955 \\
8,648,363 \\
8,713,073 \\
8,697,118 \\
8,493,491\end{array}$ & $\begin{array}{l}2,033,100 \\
2,106,159 \\
2,111,989 \\
2,148,877 \\
2,124,580\end{array}$ & $\begin{array}{l}1,926,703 \\
1,958,848 \\
1,939,389 \\
1,961,076 \\
1,940,310\end{array}$ & $\begin{array}{l}106,397 \\
147,311 \\
172,600 \\
187,801 \\
184,270\end{array}$ \\
\hline 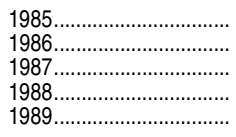 & $\begin{array}{l}10,596,674 \\
10,797,975 \\
11,046,235 \\
11,316,548 \\
11,742,531\end{array}$ & $\begin{array}{l}6,319,592 \\
6,352,073 \\
6,462,549 \\
6,642,428 \\
6,840,696\end{array}$ & $\begin{array}{l}4,277,082 \\
4,445,902 \\
4,583,686 \\
4,674,120 \\
4,901,835\end{array}$ & $\begin{array}{l}4,962,080 \\
5,017,505 \\
5,068,457 \\
5,137,644 \\
5,310,990\end{array}$ & $\begin{array}{l}5,634,594 \\
5,780,470 \\
5,977,778 \\
6,178,904 \\
6,431,541\end{array}$ & $\begin{array}{l}3,156,446 \\
3,146,330 \\
3,163,676 \\
3,206,442 \\
3,278,647\end{array}$ & $\begin{array}{l}1,805,634 \\
1,871,175 \\
1,904,781 \\
1,931,202 \\
2,032,343\end{array}$ & $\begin{array}{l}3,163,146 \\
3,205,743 \\
3,298,873 \\
3,435,986 \\
3,562,049\end{array}$ & $\begin{array}{l}2,471,448 \\
2,574,727 \\
2,678,905 \\
2,742,918 \\
2,869,492\end{array}$ & $\begin{array}{l}8,477,125 \\
8,660,716 \\
8,918,589 \\
9,103,146 \\
9,487,742\end{array}$ & $\begin{array}{l}2,119,549 \\
2,137,259 \\
2,127,646 \\
2,213,402 \\
2,254,789\end{array}$ & $\begin{array}{r}1,928,996 \\
1,928,294 \\
1,939,942 \\
- \\
-\end{array}$ & $\begin{array}{r}190,553 \\
208,965 \\
187,704 \\
- \\
-\end{array}$ \\
\hline $\begin{array}{l}1990 \\
1991 \\
1992 \\
1993 \ldots \ldots \ldots \ldots \ldots \ldots \ldots \ldots \ldots \\
1994\end{array}$ & $\begin{array}{l}11,959,106 \\
12,439,287 \\
12,537,700 \\
12,323,959 \\
12,262,608\end{array}$ & $\begin{array}{l}6,976,030 \\
7,221,412 \\
7,244,442 \\
7,179,482 \\
7,168,706\end{array}$ & $\begin{array}{l}4,983,076 \\
5,217,875 \\
5,293,258 \\
5,144,477 \\
5,093,902\end{array}$ & $\begin{array}{l}5,379,759 \\
5,571,003 \\
5,582,936 \\
5,483,682 \\
5,422,113\end{array}$ & $\begin{array}{l}6,579,347 \\
6,868,284 \\
6,954,764 \\
6,840,277 \\
6,840,495\end{array}$ & $\begin{array}{l}3,336,535 \\
3,435,526 \\
3,424,739 \\
3,381,997 \\
3,341,591\end{array}$ & $\begin{array}{l}2,043,224 \\
2,135,477 \\
2,158,197 \\
2,101,685 \\
2,080,522\end{array}$ & $\begin{array}{l}3,639,495 \\
3,785,886 \\
3,819,703 \\
3,797,485 \\
3,827,115\end{array}$ & $\begin{array}{l}2,939,852 \\
3,082,398 \\
3,135,061 \\
3,042,792 \\
3,013,380\end{array}$ & $\begin{array}{r}9,709,596 \\
10,147,957 \\
10,216,297 \\
10,011,787 \\
9,945,128\end{array}$ & $\begin{array}{l}2,249,510 \\
2,291,330 \\
2,321,403 \\
2,312,172 \\
2,317,480\end{array}$ & $\begin{array}{l}2,043,407 \\
2,072,354 \\
2,101,721 \\
2,099,197 \\
2,100,465\end{array}$ & $\begin{array}{l}206,103 \\
218,976 \\
219,682 \\
212,975 \\
217,015\end{array}$ \\
\hline 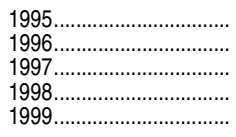 & $\begin{array}{l}12,231,719 \\
12,326,948 \\
12,450,587 \\
12,436,937 \\
12,739,445\end{array}$ & $\begin{array}{l}7,145,268 \\
7,298,839 \\
7,418,598 \\
7,538,711 \\
7,753,548\end{array}$ & $\begin{array}{l}5,086,451 \\
5,028,109 \\
5,031,989 \\
4,898,226 \\
4,985,897\end{array}$ & $\begin{array}{l}5,401,130 \\
5,420,672 \\
5,468,532 \\
5,446,133 \\
5,584,234\end{array}$ & $\begin{array}{l}6,830,589 \\
6,906,276 \\
6,982,055 \\
6,990,804 \\
7,155,211\end{array}$ & $\begin{array}{l}3,296,610 \\
3,339,108 \\
3,379,597 \\
3,428,161 \\
3,524,586\end{array}$ & $\begin{array}{l}2,104,520 \\
2,081,564 \\
2,088,935 \\
2,017,972 \\
2,059,648\end{array}$ & $\begin{array}{l}3,848,658 \\
3,959,731 \\
4,039,001 \\
4,110,550 \\
4,228,962\end{array}$ & $\begin{array}{l}2,981,931 \\
2,946,545 \\
2,943,054 \\
2,880,254 \\
2,926,249\end{array}$ & \begin{tabular}{|r|}
$9,903,626$ \\
$9,935,283$ \\
$10,007,479$ \\
$9,950,212$ \\
$10,174,228$
\end{tabular} & $\begin{array}{l}2,328,093 \\
2,391,665 \\
2,443,108 \\
2,486,725 \\
2,565,217\end{array}$ & $\begin{array}{l}2,104,693 \\
2,112,318 \\
2,139,824 \\
2,152,655 \\
2,185,290\end{array}$ & $\begin{array}{l}223,400 \\
279,347 \\
303,284 \\
334,070 \\
379,927\end{array}$ \\
\hline 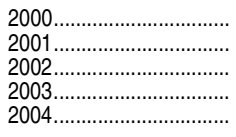 & \begin{tabular}{|l|}
$13,155,393$ \\
$13,715,610$ \\
$14,257,077$ \\
$14,480,364$ \\
$14,780,630$
\end{tabular} & $\begin{array}{l}7,922,926 \\
8,327,640 \\
8,734,252 \\
9,045,253 \\
9,284,336\end{array}$ & $\begin{array}{l}5,232,467 \\
5,387,970 \\
5,522,825 \\
5,435,111 \\
5,496,294\end{array}$ & $\begin{array}{l}5,778,268 \\
6,004,431 \\
6,192,390 \\
6,227,372 \\
6,340,048\end{array}$ & $\begin{array}{l}7,377,125 \\
7,711,179 \\
8,064,687 \\
8,252,992 \\
8,440,582\end{array}$ & $\begin{array}{l}3,588,246 \\
3,768,630 \\
3,934,168 \\
4,048,682 \\
4,140,628\end{array}$ & $\begin{array}{l}2,190,022 \\
2,235,801 \\
2,258,222 \\
2,178,690 \\
2,199,420\end{array}$ & $\begin{array}{l}4,334,680 \\
4,559,010 \\
4,800,084 \\
4,996,571 \\
5,143,708\end{array}$ & $\begin{array}{l}3,042,445 \\
3,152,169 \\
3,264,603 \\
3,256,421 \\
3,296,874\end{array}$ & \begin{tabular}{|l|}
$10,539,322$ \\
$10,985,871$ \\
$11,432,855$ \\
$11,523,103$ \\
$11,650,580$
\end{tabular} & $\begin{array}{l}2,616,071 \\
2,729,739 \\
2,824,222 \\
2,957,261 \\
3,130,050\end{array}$ & $\begin{array}{l}2,213,180 \\
2,257,718 \\
2,306,091 \\
2,346,673 \\
2,389,366\end{array}$ & $\begin{array}{l}402,891 \\
472,021 \\
518,131 \\
610,588 \\
740,684\end{array}$ \\
\hline 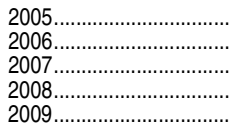 & \begin{tabular}{|l|}
$14,963,964$ \\
$15,184,302$ \\
$15,603,771$ \\
$16,365,738$ \\
$17,565,320$
\end{tabular} & \begin{tabular}{|r|}
$9,446,430$ \\
$9,571,079$ \\
$9,840,978$ \\
$10,254,930$ \\
$11,143,499$
\end{tabular} & $\begin{array}{l}5,517,534 \\
5,613,223 \\
5,762,793 \\
6,110,808 \\
6,421,821\end{array}$ & & $\begin{array}{l}8,555,093 \\
8,670,546 \\
8,876,171 \\
9,299,115 \\
9,969,839\end{array}$ & $\begin{array}{l}4,200,863 \\
4,264,606 \\
4,396,868 \\
4,577,431 \\
4,976,727\end{array}$ & & & $\begin{array}{l}3,309,526 \\
3,364,073 \\
3,432,061 \\
3,621,616 \\
3,803,067\end{array}$ & \begin{tabular}{|l|}
$11,697,730$ \\
$11,847,426$ \\
$12,137,583$ \\
$12,591,217$ \\
$13,386,593$
\end{tabular} & & $\begin{array}{l}2,418,368 \\
2,448,240 \\
2,470,327 \\
2,536,532 \\
2,593,361\end{array}$ & $\begin{array}{r}847,866 \\
888,636 \\
995,861 \\
1,237,989 \\
1,585,366\end{array}$ \\
\hline 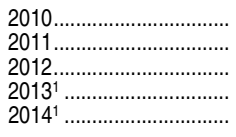 & $\begin{array}{l}18,078,672 \\
18,063,037 \\
17,732,431 \\
17,650,000 \\
17,968,000\end{array}$ & \begin{tabular}{|l|}
$11,451,568$ \\
$11,359,068$ \\
$11,097,779$ \\
$11,052,000$ \\
$11,242,000$
\end{tabular} & $\begin{array}{l}6,627,104 \\
6,703,969 \\
6,634,652 \\
6,598,000 \\
6,726,000\end{array}$ & $\begin{array}{l}7,835,163 \\
7,816,975 \\
7,713,901 \\
7,729,000 \\
7,759,000\end{array}$ & \begin{tabular}{|r|}
$10,243,509$ \\
$10,246,062$ \\
$10,018,530$ \\
$9,921,000$ \\
$10,209,000$
\end{tabular} & $\begin{array}{l}5,117,497 \\
5,070,529 \\
4,984,696 \\
4,999,000 \\
5,001,000\end{array}$ & & & $\begin{array}{l}3,909,438 \\
3,957,523 \\
3,905,447 \\
3,867,000 \\
3,968,000\end{array}$ & $\begin{array}{l}13,704,290 \\
13,688,792 \\
13,473,743 \\
13,428,000 \\
13,666,000\end{array}$ & $\begin{array}{l}4,374,382 \\
4,374,245 \\
4,258,688 \\
4,222,000 \\
4,302,000\end{array}$ & $\begin{array}{r}2,653,404 \\
2,718,880 \\
2,745,075 \\
- \\
-\end{array}$ & $\begin{array}{r}1,720,978 \\
1,655,365 \\
1,513,613 \\
-\end{array}$ \\
\hline 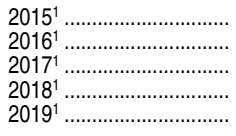 & \begin{tabular}{|l|}
$18,155,000$ \\
$18,397,000$ \\
$18,677,000$ \\
$18,904,000$ \\
$19,134,000$
\end{tabular} & \begin{tabular}{|l|}
$11,325,000$ \\
$11,448,000$ \\
$11,596,000$ \\
$11,720,000$ \\
$11,850,000$
\end{tabular} & $\begin{array}{l}6,830,000 \\
6,949,000 \\
7,082,000 \\
7,184,000 \\
7,284,000\end{array}$ & $\begin{array}{l}7,777,000 \\
7,827,000 \\
7,899,000 \\
7,962,000 \\
8,030,000\end{array}$ & \begin{tabular}{|l|}
$10,378,000$ \\
$10,571,000$ \\
$10,778,000$ \\
$10,942,000$ \\
$11,104,000$
\end{tabular} & $\begin{array}{l}5,012,000 \\
5,049,000 \\
5,103,000 \\
5,151,000 \\
5,199,000\end{array}$ & $\begin{array}{l}2,765,000 \\
2,778,000 \\
2,796,000 \\
2,812,000 \\
2,831,000\end{array}$ & $\begin{array}{l}6,313,000 \\
6,400,000 \\
6,493,000 \\
6,570,000 \\
6,651,000\end{array}$ & $\begin{array}{l}4,065,000 \\
4,171,000 \\
4,286,000 \\
4,372,000 \\
4,453,000\end{array}$ & $\begin{array}{l}13,812,000 \\
14,000,000 \\
14,218,000 \\
14,394,000 \\
14,571,000\end{array}$ & $\begin{array}{l}4,343,000 \\
4,397,000 \\
4,459,000 \\
4,510,000 \\
4,563,000\end{array}$ & $\begin{array}{l}- \\
- \\
- \\
-\end{array}$ & - \\
\hline $\begin{array}{l}2020^{1} \\
2021^{1} \\
2022^{1} \\
2023^{1}\end{array}$ & \begin{tabular}{|l|}
$19,360,000$ \\
$19,634,000$ \\
$19,917,000$ \\
$20,186,000$
\end{tabular} & $\begin{array}{l}11,974,000 \\
12,130,000 \\
12,296,000 \\
12,452,000\end{array}$ & $\begin{array}{l}7,386,000 \\
7,504,000 \\
7,621,000 \\
7,734,000\end{array}$ & $\begin{array}{l}8,095,000 \\
8,180,000 \\
8,269,000 \\
8,353,000\end{array}$ & \begin{tabular}{|l|}
$11,265,000$ \\
$11,454,000$ \\
$11,648,000$ \\
$11,833,000$
\end{tabular} & $\begin{array}{l}5,242,000 \\
5,296,000 \\
5,356,000 \\
5,413,000\end{array}$ & $\begin{array}{l}2,853,000 \\
2,883,000 \\
2,912,000 \\
2,940,000\end{array}$ & $\begin{array}{l}6,733,000 \\
6,834,000 \\
6,939,000 \\
7,039,000\end{array}$ & $\begin{array}{l}4,533,000 \\
4,621,000 \\
4,708,000 \\
4,794,000\end{array}$ & $\begin{array}{l}14,744,000 \\
14,953,000 \\
15,169,000 \\
15,375,000\end{array}$ & $\begin{array}{l}4,616,000 \\
4,681,000 \\
4,747,000 \\
4,810,000\end{array}$ & $\begin{array}{l}- \\
- \\
-\end{array}$ & $\begin{array}{l}- \\
- \\
-\end{array}$ \\
\hline \multicolumn{14}{|l|}{ 2-year institutions ${ }^{2}$} \\
\hline 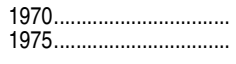 & $\begin{array}{l}2,318,956 \\
3,965,726\end{array}$ & $\begin{array}{l}1,228,909 \\
1,761,009\end{array}$ & $\begin{array}{l}1,090,047 \\
2,204,717\end{array}$ & $\begin{array}{l}1,374,426 \\
2,163,604\end{array}$ & $\begin{array}{r}944,530 \\
1,802,122\end{array}$ & $\begin{array}{r}771,298 \\
1,035,531\end{array}$ & $\begin{array}{r}603,128 \\
1,128,073\end{array}$ & $\begin{array}{l}457,611 \\
725,478\end{array}$ & $\begin{array}{r}486,919 \\
1,076,644\end{array}$ & $\begin{array}{l}2,194,983 \\
3,831,973\end{array}$ & $\begin{array}{l}123,973 \\
133,753\end{array}$ & $\begin{array}{l}113,299 \\
112,997\end{array}$ & $\begin{array}{l}10,674 \\
20,756\end{array}$ \\
\hline 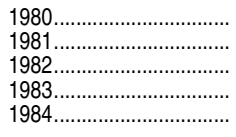 & $\begin{array}{l}4,525,097 \\
4,715,403 \\
4,770,712 \\
4,723,466 \\
4,530,337\end{array}$ & $\begin{array}{l}1,753,637 \\
1,795,858 \\
1,839,704 \\
1,826,801 \\
1,703,786\end{array}$ & $\begin{array}{l}2,771,460 \\
2,919,545 \\
2,931,008 \\
2,896,665 \\
2,826,551\end{array}$ & $\begin{array}{l}2,046,642 \\
2,124,136 \\
2,169,802 \\
2,131,109 \\
2,016,463\end{array}$ & $\begin{array}{l}2,478,455 \\
2,591,267 \\
2,600,910 \\
2,592,357 \\
2,513,874\end{array}$ & $\begin{array}{l}879,619 \\
897,657 \\
930,606 \\
914,704 \\
841,347\end{array}$ & $\begin{array}{l}1,167,023 \\
1,226,479 \\
1,239,196 \\
1,216,405 \\
1,175,116\end{array}$ & $\begin{array}{l}874,018 \\
898,201 \\
909,098 \\
912,097 \\
862,439\end{array}$ & $\begin{array}{l}1,604,437 \\
1,693,066 \\
1,691,812 \\
1,680,260 \\
1,651,435\end{array}$ & $\begin{array}{l}4,327,592 \\
4,479,900 \\
4,518,659 \\
4,459,330 \\
4,278,661\end{array}$ & $\begin{array}{l}197,505 \\
235,503 \\
252,053 \\
264,136 \\
251,676\end{array}$ & $\begin{array}{l}114,094 \\
119,166 \\
114,976 \\
116,293 \\
108,247\end{array}$ & $\begin{array}{r}83,411 \\
116,337 \\
137,077 \\
147,843 \\
143,429\end{array}$ \\
\hline $\begin{array}{l}1985 . . \\
1986 . . \\
1987 . . \\
1988 . . \\
1989 . .\end{array}$ & $\begin{array}{l}4,531,077 \\
4,679,548 \\
4,776,222 \\
4,875,155 \\
5,150,889\end{array}$ & $\begin{array}{l}1,690,607 \\
1,696,261 \\
1,708,669 \\
1,743,592 \\
1,855,701\end{array}$ & $\begin{array}{l}2,840,470 \\
2,983,287 \\
3,067,553 \\
3,131,563 \\
3,295,188\end{array}$ & $\begin{array}{l}2,002,234 \\
2,060,932 \\
2,072,823 \\
2,089,689 \\
2,216,800\end{array}$ & $\begin{array}{l}2,528,843 \\
2,618,616 \\
2,703,399 \\
2,785,466 \\
2,934,089\end{array}$ & $\begin{array}{l}826,308 \\
824,551 \\
820,167 \\
818,593 \\
869,688\end{array}$ & $\begin{array}{l}1,175,926 \\
1,236,381 \\
1,252,656 \\
1,271,096 \\
1,347,112\end{array}$ & $\begin{array}{l}864,299 \\
871,710 \\
888,502 \\
924,999 \\
986,013\end{array}$ & $\begin{array}{l}1,664,544 \\
1,746,906 \\
1,814,897 \\
1,860,467 \\
1,948,076\end{array}$ & $\begin{array}{l}4,269,733 \\
4,413,691 \\
4,541,054 \\
4,615,487 \\
4,883,660\end{array}$ & $\begin{array}{l}261,344 \\
265,857 \\
235,168 \\
259,668 \\
267,229\end{array}$ & $\begin{array}{l}791 \\
498 \\
102 \\
- \\
-\end{array}$ & $\begin{array}{r}152,553 \\
164,359 \\
145,066 \\
-\end{array}$ \\
\hline 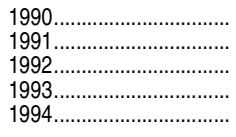 & $\begin{array}{l}5,240,083 \\
5,651,900 \\
5,722,349 \\
5,565,561 \\
5,529,609\end{array}$ & $\begin{array}{l}1,883,962 \\
2,074,530 \\
2,080,005 \\
2,043,319 \\
2,031,713\end{array}$ & $\begin{array}{l}3,356,121 \\
3,577,370 \\
3,642,344 \\
3,522,242 \\
3,497,896\end{array}$ & $\begin{array}{l}2,232,769 \\
2,401,910 \\
2,413,266 \\
2,345,396 \\
2,323,161\end{array}$ & $\begin{array}{l}3,007,314 \\
3,249,990 \\
3,309,083 \\
3,220,165 \\
3,206,448\end{array}$ & $\begin{array}{l}881,392 \\
961,397 \\
951,816 \\
928,216 \\
911,589\end{array}$ & $\begin{array}{l}1,351,377 \\
1,440,513 \\
1,461,450 \\
1,417,180 \\
1,411,572\end{array}$ & $\begin{array}{l}1,002,570 \\
1,113,133 \\
1,128,189 \\
1,115,103 \\
1,120,124\end{array}$ & $\begin{array}{l}2,004,744 \\
2,136,857 \\
2,180,894 \\
2,105,062 \\
2,086,324\end{array}$ & $\begin{array}{l}4,996,475 \\
5,404,815 \\
5,484,514 \\
5,337,022 \\
5,308,366\end{array}$ & $\begin{array}{l}243,608 \\
247,085 \\
237,835 \\
228,539 \\
221,243\end{array}$ & $\begin{array}{l}89,158 \\
89,289 \\
83,288 \\
86,357 \\
85,607\end{array}$ & $\begin{array}{l}154,450 \\
157,796 \\
154,547 \\
142,182 \\
135,636\end{array}$ \\
\hline 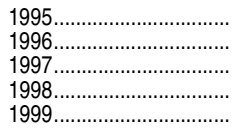 & $\begin{array}{l}5,492,098 \\
5,562,780 \\
5,605,569 \\
5,489,314 \\
5,653,256\end{array}$ & $\begin{array}{l}1,977,046 \\
2,072,215 \\
2,095,171 \\
2,085,906 \\
2,167,242\end{array}$ & $\begin{array}{l}3,515,052 \\
3,490,565 \\
3,510,398 \\
3,403,408 \\
3,486,014\end{array}$ & $\begin{array}{l}2,328,500 \\
2,358,792 \\
2,389,711 \\
2,333,334 \\
2,413,322\end{array}$ & $\begin{array}{l}3,163,598 \\
3,203,988 \\
3,215,858 \\
3,155,980 \\
3,239,934\end{array}$ & $\begin{array}{l}878,215 \\
916,452 \\
931,394 \\
936,421 \\
979,203\end{array}$ & $\begin{array}{l}1,450,285 \\
1,442,340 \\
1,458,317 \\
1,396,913 \\
1,434,119\end{array}$ & $\begin{array}{l}1,098,831 \\
1,155,763 \\
1,163,777 \\
1,149,485 \\
1,188,039\end{array}$ & $\begin{array}{l}2,064,767 \\
2,048,225 \\
2,052,081 \\
2,006,495 \\
2,051,895\end{array}$ & $\begin{array}{l}5,277,398 \\
5,314,038 \\
5,360,686 \\
5,245,963 \\
5,397,786\end{array}$ & $\begin{array}{l}214,700 \\
248,742 \\
244,883 \\
243,351 \\
255,470\end{array}$ & $\begin{array}{l}75,154 \\
75,253 \\
71,794 \\
65,870 \\
63,301\end{array}$ & $\begin{array}{l}139,546 \\
173,489 \\
173,089 \\
177,481 \\
192,169\end{array}$ \\
\hline $\begin{array}{l}2000 \\
2001 \\
2002 \ldots \ldots \\
2003 \ldots \ldots \ldots\end{array}$ & $\begin{array}{l}5,948,104 \\
6,250,529 \\
6,529,198 \\
6,493,862 \\
6,545,570\end{array}$ & $\begin{array}{l}2,217,044 \\
2,374,490 \\
2,556,032 \\
2,650,337 \\
2,683,489\end{array}$ & $\begin{array}{l}3,731,060 \\
3,876,039 \\
3,973,166 \\
3,843,525 \\
3,862,081\end{array}$ & $\begin{array}{l}2,558,520 \\
2,675,193 \\
2,753,405 \\
2,689,928 \\
2,697,507\end{array}$ & $\begin{array}{l}3,389,584 \\
3,575,336 \\
3,775,793 \\
3,803,934 \\
3,848,063\end{array}$ & $\begin{array}{r}995,839 \\
1,066,281 \\
1,135,669 \\
1,162,555 \\
1,166,554\end{array}$ & $\begin{array}{l}1,562,681 \\
1,608,912 \\
1,617,736 \\
1,527,373 \\
1,530,953\end{array}$ & $\begin{array}{l}1,221,205 \\
1,308,209 \\
1,420,363 \\
1,487,782 \\
1,516,935\end{array}$ & $\begin{array}{l}2,168,379 \\
2,267,127 \\
2,355,430 \\
2,316,152 \\
2,331,128\end{array}$ & $\begin{array}{l}5,697,061 \\
5,996,651 \\
6,270,199 \\
6,208,885 \\
6,243,344\end{array}$ & $\begin{array}{l}251,043 \\
253,878 \\
258,999 \\
284,977 \\
302,226\end{array}$ & $\begin{array}{l}58,844 \\
47,549 \\
47,087 \\
43,868 \\
42,250\end{array}$ & $\begin{array}{l}192,199 \\
206,329 \\
211,912 \\
241,109 \\
259,976\end{array}$ \\
\hline
\end{tabular}


Table 303.70. Total undergraduate fall enrollment in degree-granting postsecondary institutions, by attendance status, sex of student, and control and level of institution: Selected years, 1970 through 2023-Continued

\begin{tabular}{|c|c|c|c|c|c|c|c|c|c|c|c|c|c|}
\hline \multirow[b]{2}{*}{ Level and year } & \multirow[b]{2}{*}{ Total } & \multirow[b]{2}{*}{ Full-time } & \multirow[b]{2}{*}{ Part-time } & \multirow[b]{2}{*}{ Males } & \multirow[b]{2}{*}{ Females } & \multicolumn{2}{|c|}{ Males } & \multicolumn{2}{|c|}{ Females } & \multirow[b]{2}{*}{ Public } & \multicolumn{3}{|c|}{ Private } \\
\hline & & & & & & Full-time & Part-time & Full-time & Part-time & & Total & Nonprofit & For-profit \\
\hline 1 & 2 & 3 & 4 & 5 & 6 & 7 & 8 & 9 & 10 & 11 & 12 & 13 & 14 \\
\hline $\begin{array}{l}2005 \ldots . . . . \\
2006 \ldots . . . \\
2007 \ldots . . .\end{array}$ & $\begin{array}{l}6,487,826 \\
6,518,291 \\
6,617,621 \\
6,971,105 \\
7,521,405\end{array}$ & $\begin{array}{l}2,646,763 \\
2,643,222 \\
2,692,491 \\
2,832,110 \\
3,248,723\end{array}$ & $\begin{array}{l}3,841,063 \\
3,875,069 \\
3,925,130 \\
4,138,995 \\
4,272,682\end{array}$ & $\begin{array}{l}2,680,299 \\
2,704,654 \\
2,770,457 \\
2,935,793 \\
3,196,560\end{array}$ & $\begin{array}{l}3,807,527 \\
3,813,637 \\
3,847,164 \\
4,035,312 \\
4,324,845\end{array}$ & $\begin{array}{l}1,153,759 \\
1,159,800 \\
1,190,067 \\
1,249,832 \\
1,448,410\end{array}$ & $\begin{array}{l}1,526,540 \\
1,544,854 \\
1,580,390 \\
1,685,961 \\
1,748,150\end{array}$ & $\begin{array}{l}1,493,004 \\
1,483,422 \\
1,502,424 \\
1,582,278 \\
1,800,313\end{array}$ & $\begin{array}{l}2,314,523 \\
2,330,215 \\
2,344,740 \\
2,453,034 \\
2,524,532\end{array}$ & $\begin{array}{l}6,184,000 \\
6,224,871 \\
6,323,810 \\
6,640,071 \\
7,101,444\end{array}$ & $\begin{array}{l}303,826 \\
293,420 \\
293,811 \\
331,034 \\
419,961\end{array}$ & $\begin{array}{l}43,522 \\
39,156 \\
33,486 \\
35,351 \\
34,767\end{array}$ & $\begin{array}{l}260,304 \\
254,264 \\
260,325 \\
295,683 \\
385,194\end{array}$ \\
\hline $2013^{1}$ & $\begin{array}{l}7,680,875 \\
7,499,982 \\
7,163,973 \\
7,191,000 \\
7,320,000\end{array}$ & $\begin{array}{l}3,365,193 \\
3,160,036 \\
2,942,577 \\
2,983,000 \\
3,038,000\end{array}$ & $\begin{array}{l}4,315,682 \\
4,339,946 \\
4,221,396 \\
4,208,000 \\
4,282,000\end{array}$ & $\begin{array}{l}3,265,126 \\
3,171,654 \\
3,044,704 \\
3,082,000 \\
3,098,000\end{array}$ & $\begin{array}{l}4,415,749 \\
4,328,328 \\
4,119,269 \\
4,108,000 \\
4,222,000\end{array}$ & $\begin{array}{l}1,483,430 \\
1,388,345 \\
1,305,832 \\
1,346,000 \\
1,346,000\end{array}$ & & $\begin{array}{l}1,881,763 \\
1,771,691 \\
1,636,745 \\
1,637,000 \\
1,692,000\end{array}$ & & & $\begin{array}{l}462,837 \\
437,515 \\
376,313 \\
380,000 \\
389,000\end{array}$ & $\begin{array}{r}32,660 \\
39,864 \\
37,606 \\
- \\
-\end{array}$ & $\begin{array}{r}430,177 \\
397,651 \\
338,707 \\
-\end{array}$ \\
\hline 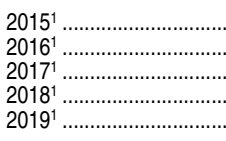 & $\begin{array}{l}7,410,000 \\
7,525,000 \\
7,655,000 \\
7,760,000 \\
7,862,000\end{array}$ & $\begin{array}{l}3,066,000 \\
3,109,000 \\
3,158,000 \\
3,199,000 \\
3,240,000\end{array}$ & $\begin{array}{l}4,344,000 \\
4,416,000 \\
4,497,000 \\
4,560,000 \\
4,622,000\end{array}$ & $\begin{array}{l}3,104,000 \\
3,122,000 \\
3,150,000 \\
3,174,000 \\
3,201,000\end{array}$ & $\begin{array}{l}306,000 \\
402,000 \\
505,000 \\
585,000 \\
662,000\end{array}$ & $\begin{array}{l}1,350,000 \\
1,362,000 \\
1,379,000 \\
1,395,000 \\
1,411,000\end{array}$ & $\begin{array}{l}1,754,000 \\
1,761,000 \\
1,770,000 \\
1,779,000 \\
1,790,000\end{array}$ & $\begin{array}{l}1,717,000 \\
1,747,000 \\
1,779,000 \\
1,804,000 \\
1,829,000\end{array}$ & $\begin{array}{l}2,589,000 \\
2,655,000 \\
2,727,000 \\
2,781,000 \\
2,832,000\end{array}$ & & & $\begin{array}{l}- \\
- \\
- \\
-\end{array}$ & $\begin{array}{l}- \\
- \\
- \\
-\end{array}$ \\
\hline $\begin{array}{l}2020^{1} \\
2021^{1} \\
2022^{1} \\
2023^{1}\end{array}$ & $\begin{array}{l}7,957,000 \\
8,073,000 \\
8,196,000 \\
8,313,000\end{array}$ & $\begin{array}{l}3,274,000 \\
3,319,000 \\
3,371,000 \\
3,419,000\end{array}$ & $\begin{array}{l}4,683,000 \\
4,754,000 \\
4,825,000 \\
4,893,000\end{array}$ & $\begin{array}{l}3,224,000 \\
3,255,000 \\
3,290,000 \\
3,322,000\end{array}$ & $\begin{array}{l}4,734,000 \\
4,818,000 \\
4,906,000 \\
4,990,000\end{array}$ & $\begin{array}{l}1,421,000 \\
1,436,000 \\
1,453,000 \\
1,470,000\end{array}$ & $\begin{array}{l}1,803,000 \\
1,820,000 \\
1,836,000 \\
1,852,000\end{array}$ & $\begin{array}{l}1,853,000 \\
1,883,000 \\
1,918,000 \\
1,949,000\end{array}$ & $\begin{array}{l}2,881,000 \\
2,934,000 \\
2,988,000 \\
3,041,000\end{array}$ & $\begin{array}{r}7,536,000 \\
7,645,000 \\
7,760,000 \\
7,871,000\end{array}$ & $\begin{array}{l}422,000 \\
428,000 \\
435,000 \\
442,000\end{array}$ & $\begin{array}{l}- \\
- \\
-\end{array}$ & $\begin{array}{l}- \\
-\end{array}$ \\
\hline \multicolumn{14}{|l|}{-year institutions } \\
\hline & $\begin{array}{l}5,049,688 \\
5,713,729\end{array}$ & $\begin{array}{l}4,051,155 \\
4,407,387\end{array}$ & $\begin{array}{r}998,533 \\
1,306,342\end{array}$ & $\begin{array}{l}2,875,276 \\
3,093,401\end{array}$ & $\begin{array}{l}2,174,412 \\
2,620,328\end{array}$ & $\begin{array}{l}2,325,073 \\
2,423,797\end{array}$ & $\begin{array}{l}550,203 \\
669,604\end{array}$ & $\begin{array}{l}1,726,082 \\
1,983,590\end{array}$ & $\begin{array}{l}448,330 \\
636,738\end{array}$ & $\begin{array}{l}3,425,272 \\
3,994,059\end{array}$ & $\begin{array}{l}1,624,416 \\
1,719,670\end{array}$ & $\begin{array}{l}1,616,834 \\
1,701,847\end{array}$ & $\begin{array}{r}7,582 \\
17,823\end{array}$ \\
\hline $980 \ldots \ldots \ldots \ldots$ & $\begin{array}{l}5,949,958 \\
6,039,119 \\
6,054,350 \\
6,122,529 \\
6,087,734\end{array}$ & $\begin{array}{l}4,608,107 \\
4,653,210 \\
4,644,101 \\
4,687,233 \\
4,643,867\end{array}$ & $\begin{array}{l}1,341,851 \\
1,385,909 \\
1,410,249 \\
1,435,296 \\
1,443,867\end{array}$ & $\begin{array}{l}2,953,535 \\
2,984,135 \\
3,000,692 \\
3,027,191 \\
2,990,350\end{array}$ & & $\begin{array}{l}2,347,238 \\
2,362,816 \\
2,368,830 \\
2,389,543 \\
2,353,583\end{array}$ & $\begin{array}{l}606,297 \\
621,319 \\
631,862 \\
637,648 \\
636,767\end{array}$ & & $\begin{array}{l}735,554 \\
764,590 \\
778,387 \\
797,648 \\
807,100\end{array}$ & & & & $\begin{array}{l}22,986 \\
30,974 \\
35,523 \\
39,958 \\
40,841\end{array}$ \\
\hline & $\begin{array}{l}6,065,597 \\
6,118,427 \\
6,270,013 \\
6,441,393 \\
6,591,642\end{array}$ & & & & & & & & & & & $\begin{array}{r}0,205 \\
6,796 \\
9,840 \\
- \\
-\end{array}$ & $\begin{array}{r}38,000 \\
44,606 \\
42,638 \\
- \\
-\end{array}$ \\
\hline & $\begin{array}{l}6,719,023 \\
6,787,387 \\
6,815,351 \\
6,758,398 \\
6,732,999\end{array}$ & & & & & & & & & & & & $\begin{array}{l}51,653 \\
61,180 \\
65,135 \\
70,793 \\
81,379\end{array}$ \\
\hline & $\begin{array}{l}6,739,621 \\
6,764,168 \\
6,845,018 \\
6,947,623 \\
7,086,189\end{array}$ & $\begin{array}{l}5,168,222 \\
5,226,624 \\
5,323,427 \\
5,452,805 \\
5,586,306\end{array}$ & & & & & & & & & & & $\begin{array}{r}83,854 \\
105,858 \\
130,195 \\
156,589 \\
187,758\end{array}$ \\
\hline 2000 & $\begin{array}{l}7,207,289 \\
7,465,081 \\
7,727,879 \\
7,986,502 \\
8,235,060\end{array}$ & $\begin{array}{l}5,705,882 \\
5,953,150 \\
6,178,220 \\
6,394,916 \\
6,600,847\end{array}$ & & & & & & & $\begin{array}{l}874,066 \\
885,042 \\
909,173 \\
940,269 \\
965,746\end{array}$ & & & & $\begin{array}{l}210,692 \\
265,692 \\
306,219 \\
369,479 \\
480,708\end{array}$ \\
\hline $2005 .$. & \begin{tabular}{|r|}
$8,476,138$ \\
$8,666,011$ \\
$8,986,150$ \\
$9,394,633$ \\
$10,043,915$
\end{tabular} & $\begin{array}{l}6,799,667 \\
6,927,857 \\
7,148,487 \\
7,422,820 \\
7,894,776\end{array}$ & $\begin{array}{l}1,676,471 \\
1,738,154 \\
1,837,663 \\
1,971,813 \\
2,149,139\end{array}$ & $\begin{array}{l}3,728,572 \\
3,809,102 \\
3,957,143 \\
4,130,830 \\
4,398,921\end{array}$ & & & $\begin{array}{l}681,468 \\
704,296 \\
750,342 \\
803,231 \\
870,604\end{array}$ & & & & & & $\begin{array}{r}587,562 \\
634,372 \\
735,536 \\
942,306 \\
1,200,172\end{array}$ \\
\hline $2014^{1} \ldots \ldots \ldots \ldots$ & \begin{tabular}{|l|}
$10,397,797$ \\
$10,563,055$ \\
$10,568,458$ \\
$10,459,000$ \\
$10,648,000$
\end{tabular} & $\begin{array}{l}8,086,375 \\
8,199,032 \\
8,155,202 \\
8,069,000 \\
8,205,000\end{array}$ & $\begin{array}{l}2,311,422 \\
2,364,023 \\
2,413,256 \\
2,390,000 \\
2,444,000\end{array}$ & $\begin{array}{l}4,570,037 \\
4,645,321 \\
4,669,197 \\
4,647,000 \\
4,661,000\end{array}$ & & & $\begin{array}{r}935,970 \\
963,137 \\
990,333 \\
994,000 \\
1,006,000\end{array}$ & & $\begin{array}{l}1,375,452 \\
1,400,886 \\
1,422,923 \\
1,396,000 \\
1,438,000\end{array}$ & & & $\begin{array}{c}744 \\
016 \\
469 \\
- \\
-\end{array}$ & $\begin{array}{l}1,290,801 \\
1,257,714 \\
1,174,906\end{array}$ \\
\hline 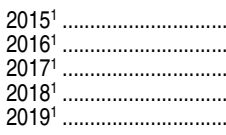 & $\begin{array}{l}10,745,000 \\
10,873,000 \\
11,022,000 \\
11,144,000 \\
11,272,000\end{array}$ & $\begin{array}{l}8,259,000 \\
8,340,000 \\
8,438,000 \\
8,521,000 \\
8,610,000\end{array}$ & $\begin{array}{l}2,486,000 \\
2,533,000 \\
2,584,000\end{array}$ & $\begin{array}{l}4,673,000 \\
4,704,000 \\
4,749,000 \\
4,788,000 \\
4,829,000\end{array}$ & & $\begin{array}{l}3,663,000 \\
3,687,000 \\
3,724,000 \\
3,755,000 \\
3,788,000\end{array}$ & $\begin{array}{l}1,011,000 \\
1,017,000 \\
1,026,000 \\
1,033,000 \\
1,041,000\end{array}$ & & $\begin{array}{l}1,475,000 \\
1,516,000 \\
1,559,000 \\
1,591,000 \\
1,621,000\end{array}$ & & & $\begin{array}{l}- \\
- \\
-\end{array}$ & $\begin{array}{l}- \\
- \\
-\end{array}$ \\
\hline 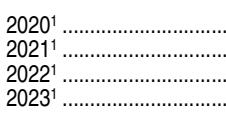 & $\begin{array}{l}11,561,000 \\
11,721,000 \\
11,873,000\end{array}$ & $\begin{array}{l}8,700,000 \\
8,811,000 \\
8,925,000 \\
9,033,000\end{array}$ & & & & & & & & & & $\begin{array}{l}- \\
- \\
- \\
-\end{array}$ & - \\
\hline
\end{tabular}

\section{-Not available.}

'Projected.

'Beginning in 1980, 2-year institutions include schools accredited by the Accrediting Commission of Career Schools and Colleges of Technology.

NOTE: Data include unclassified undergraduate students. Data through 1995 are for institutions of higher education, while later data are for degree-granting institutions. Degreegranting institutions grant associate's or higher degrees and participate in Title IV federal financial aid programs. The degree-granting classification is very similar to the earlie higher education classification, but it includes more 2-year colleges and excludes a few higher education institutions that did not grant degrees.

SOURCE: U.S. Department of Education, National Center for Education Statistics, Higher Education General Information Survey (HEGIS), "Fall Enrollment in Colleges and Universities" surveys, 1970 through 1985; Integrated Postsecondary Education Data System (IPEDS), "Fall Enrollment Survey" (IPEDS-EF:86-99); IPEDS Spring 2001 through Spring 2013, Enrollment component; and Enrollment in Degree-Granting Institutions Projection Model, 1980 through 2023. (This table was prepared July 2014.) 
Table 303.80. Total postbaccalaureate fall enrollment in degree-granting postsecondary institutions, by attendance status, sex of student, and control of institution: 1967 through 2023

\begin{tabular}{|c|c|c|c|c|c|c|c|c|c|c|c|c|c|}
\hline \multirow[b]{2}{*}{ Year } & \multirow[b]{2}{*}{ Total } & \multirow[b]{2}{*}{ Full-time } & \multirow[b]{2}{*}{ Part-time } & \multirow[b]{2}{*}{ Males } & \multirow[b]{2}{*}{ Females } & \multicolumn{2}{|c|}{ Males } & \multicolumn{2}{|c|}{ Females } & \multicolumn{2}{|c|}{ Males } & \multicolumn{2}{|c|}{ Females } \\
\hline & & & & & & Full-time & Part-time & Full-time & Part-time & Public & Private & Public & Private \\
\hline 1 & 2 & 3 & 4 & 5 & 6 & 7 & 8 & 9 & 10 & 11 & 12 & 13 & 14 \\
\hline $1967 .$. & 896,065 & 448,238 & 447,827 & 630,701 & 265,364 & 354,628 & 276,073 & 93,610 & 171,754 & 351,947 & 278,754 & 170,676 & 94,688 \\
\hline 1968 & $1,037,377$ & 469,747 & 567,630 & 696,649 & 340,728 & 358,686 & 337,963 & 111,061 & 229,667 & 410,609 & 286,040 & 238,048 & 102,680 \\
\hline 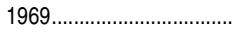 & $1,120,175$ & 506,833 & 613,342 & 738,673 & 381,502 & 383,630 & 355,043 & 123,203 & 258,299 & 457,126 & 281,547 & 281,425 & 100,077 \\
\hline $1970 \ldots$ & $1,212,243$ & 536,226 & 676,017 & 793,940 & 418,303 & 407,724 & 386,216 & 128,502 & 289,801 & 496,757 & 297,183 & 311,122 & 107,181 \\
\hline 1971 & $1,204,390$ & 564,236 & 640,154 & 789,131 & 415,259 & 428,167 & 360,964 & 136,069 & 279,190 & 513,570 & 275,561 & 305,604 & 109,655 \\
\hline 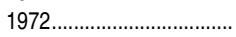 & $1,272,421$ & 583,299 & 689,122 & 810,164 & 462,257 & 436,533 & 373,631 & 146,766 & 315,491 & 506,950 & 303,214 & 341,081 & 121,176 \\
\hline 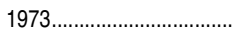 & $1,342,452$ & 610,935 & 731,517 & 833,453 & 508,999 & 444,219 & 389,234 & 166,716 & 342,283 & 523,274 & 310,179 & 373,830 & 135,169 \\
\hline $1974 \ldots \ldots \ldots \ldots \ldots$ & $1,425,001$ & 643,927 & 781,074 & 856,847 & 568,154 & 454,706 & 402,141 & 189,221 & 378,933 & 538,573 & 318,274 & 418,197 & 149,957 \\
\hline $1975 \ldots \ldots \ldots \ldots \ldots \ldots \ldots \ldots \ldots \ldots$ & $1,505,404$ & 672,938 & 832,466 & 891,992 & 613,412 & 467,425 & 424,567 & 205,513 & 407,899 & 560,041 & 331,951 & 448,435 & 164,977 \\
\hline $1976 \ldots \ldots \ldots \ldots \ldots \ldots$ & $1,577,546$ & 683,825 & 893,721 & 904,551 & 672,995 & 459,286 & 445,265 & 224,539 & 448,456 & 555,912 & 348,639 & 477,203 & 195,792 \\
\hline $1977 \ldots \ldots \ldots \ldots \ldots \ldots$ & $1,569,084$ & 698,902 & 870,182 & 891,819 & 677,265 & 462,038 & 429,781 & 236,864 & 440,401 & 535,748 & 356,071 & 468,265 & 209,000 \\
\hline $1978 \ldots$ & $1,575,693$ & 704,831 & 870,862 & 879,931 & 695,762 & 458,865 & 421,066 & 245,966 & 449,796 & 519,150 & 360,781 & 479,458 & 216,304 \\
\hline $1979 \ldots \ldots$ & $1,571,922$ & 714,624 & 857,298 & 862,754 & 709,168 & 456,197 & 406,557 & 258,427 & 450,741 & 503,949 & 358,805 & 486,042 & 223,126 \\
\hline 1980 & $1,621,840$ & 736,214 & 885,626 & 874,197 & 747,643 & 462,387 & 411,810 & 273,827 & 473,816 & 507,587 & 366,610 & 507,852 & 239,791 \\
\hline $1981 \ldots$ & $1,617,150$ & 732,182 & 884,968 & 866,785 & 750,365 & 452,364 & 414,421 & 279,818 & 470,547 & 496,825 & 369,960 & 501,844 & 248,521 \\
\hline 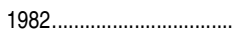 & $1,600,718$ & 736,813 & 863,905 & 860,890 & 739,828 & 453,519 & 407,371 & 283,294 & 456,534 & 493,122 & 367,768 & 489,892 & 249,936 \\
\hline 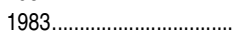 & $1,618,666$ & 747,016 & 871,650 & 865,425 & 753,241 & 455,540 & 409,885 & 291,476 & 461,765 & 493,356 & 372,069 & 492,260 & 260,981 \\
\hline $1984 \ldots \ldots . . .$. & $1,623,869$ & 750,735 & 873,134 & 856,761 & 767,108 & 452,579 & 404,182 & 298,156 & 468,952 & 484,963 & 371,798 & 498,916 & 268,192 \\
\hline 1985 & $1,650,381$ & 755,629 & 894,752 & 856,370 & 794,011 & 451,274 & & 304,355 & & 484,940 & ,430 & 7,208 & 803 \\
\hline 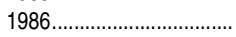 & $1,705,536$ & 767,477 & 938,059 & 867,010 & 838,526 & 452,717 & 414,293 & 314,760 & 523,766 & 503,107 & 363,903 & 550,070 & 288,456 \\
\hline $1987 \ldots \ldots \ldots \ldots \ldots \ldots$ & $1,720,407$ & 768,536 & 951,871 & 863,599 & 856,808 & 447,212 & 416,387 & 321,324 & 535,484 & 497,117 & 366,482 & 557,548 & 299,260 \\
\hline 1988. & $1,738,789$ & 794,340 & 944,449 & 864,252 & 874,537 & 455,337 & 408,915 & 339,003 & 535,534 & 495,461 & 368,791 & 562,781 & 311,756 \\
\hline 1989 & $1,796,029$ & 820,254 & 975,775 & 879,025 & 917,004 & 461,596 & 417,429 & 358,658 & 558,346 & 504,528 & 374,497 & 585,693 & 331,311 \\
\hline 1990. & $1,859,531$ & 844,955 & $1,014,576$ & 904,150 & 955,381 & 471,217 & 432,933 & 373,738 & 581,643 & 522,136 & 382,014 & 612,985 & 342,396 \\
\hline $1991 \ldots$ & $1,919,666$ & 893,917 & $1,025,749$ & 930,841 & 988,825 & 493,849 & 436,992 & 400,068 & 588,757 & 535,422 & 395,419 & 626,184 & 362,641 \\
\hline 1992 & $1,949,659$ & 917,676 & $1,031,983$ & 941,053 & $1,008,606$ & 502,166 & 438,887 & 415,510 & 593,096 & 537,471 & 403,582 & 630,799 & 377,807 \\
\hline 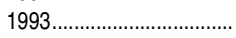 & $1,980,844$ & 948,136 & $1,032,708$ & 943,768 & $1,037,076$ & 508,574 & 435,194 & 439,562 & 597,514 & 537,245 & 406,523 & 640,056 & 397,020 \\
\hline 1994 & $2,016,182$ & 969,070 & $1,047,112$ & 949,785 & $1,066,397$ & 513,592 & 436,193 & 455,478 & 610,919 & 535,759 & 414,026 & 652,793 & 413,604 \\
\hline $1995 \ldots$ & $2,030,062$ & 983,534 & $1,046,528$ & 941,409 & $1,088,653$ & & & & & & & & \\
\hline 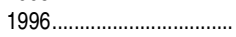 & $2,040,572$ & $1,004,114$ & $1,036,458$ & 932,153 & $1,108,419$ & 512,100 & 420,053 & 492,014 & 616,405 & 519,702 & 412,451 & 665,514 & 442,905 \\
\hline 1997 & $2,051,747$ & $1,019,464$ & $1,032,283$ & 927,496 & $1,124,251$ & 510,845 & 416,651 & 508,619 & 615,632 & 515,823 & 411,673 & 672,817 & 451,434 \\
\hline 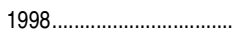 & $2,070,030$ & $1,024,627$ & $1,045,403$ & 923,132 & $1,146,898$ & 505,492 & 417,640 & 519,135 & 627,763 & 507,763 & 415,369 & 679,794 & 467,104 \\
\hline 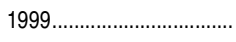 & $2,110,246$ & $1,049,591$ & $1,060,655$ & 930,930 & $1,179,316$ & 508,930 & 422,000 & 540,661 & 638,655 & 510,779 & 420,151 & 690,732 & 488,584 \\
\hline $2000 \ldots$ & $2,156,896$ & $1,086,674$ & $1,070,222$ & 943,501 & $1,213,395$ & 522,847 & 420,654 & 563,827 & 649,568 & 510,309 & 433,192 & 703,155 & 510,240 \\
\hline $2001 \ldots \ldots \ldots \ldots \ldots \ldots \ldots \ldots$ & $2,212,377$ & $1,119,862$ & $1,092,515$ & 956,384 & $1,255,993$ & 531,260 & 425,124 & 588,602 & 667,391 & 523,597 & 432,787 & 723,688 & 532,305 \\
\hline $2002 \ldots \ldots \ldots \ldots \ldots \ldots \ldots \ldots \ldots \ldots$ & $2,354,634$ & $1,212,107$ & $1,142,527$ & $1,009,726$ & $1,344,908$ & 566,930 & 442,796 & 645,177 & 699,731 & 551,729 & 457,997 & 767,409 & 577,499 \\
\hline $2003 \ldots \ldots \ldots \ldots \ldots \ldots \ldots \ldots$ & $2,431,117$ & $1,280,880$ & $1,150,237$ & $1,032,892$ & $1,398,225$ & 589,190 & 443,702 & 691,690 & 706,535 & 555,903 & 476,989 & 779,692 & 618,533 \\
\hline 2004 & $2,491,414$ & $1,325,841$ & $1,165,573$ & $1,047,214$ & $1,444,200$ & 598,727 & 448,487 & 727,114 & 717,086 & 550,236 & 496,978 & 779,296 & 664,904 \\
\hline $2005 \ldots$ & $2,523,511$ & $1,350,581$ & $1,172,930$ & $1,047,054$ & $1,476,457$ & 602,525 & 444,529 & 748,056 & 728,401 & 543,221 & 503,833 & 780,883 & 695,574 \\
\hline $2006 \ldots$ & $2,574,568$ & $1,386,226$ & $1,188,342$ & $1,061,059$ & $1,513,509$ & 614,709 & 446,350 & 771,517 & 741,992 & 545,554 & 515,505 & 787,153 & 726,356 \\
\hline 2007 & $2,644,357$ & $1,428,914$ & $1,215,443$ & $1,088,314$ & $1,556,043$ & 632,576 & 455,738 & 796,338 & 759,705 & 556,727 & 531,587 & 796,470 & 759,573 \\
\hline $2008 \ldots \ldots \ldots \ldots \ldots \ldots \ldots$ & $2,737,076$ & $1,492,813$ & $1,244,263$ & $1,122,272$ & $1,614,804$ & 656,926 & 465,346 & 835,887 & 778,917 & 568,550 & 553,722 & 812,386 & 802,418 \\
\hline 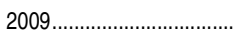 & $2,862,391$ & $1,579,283$ & $1,283,108$ & $1,174,023$ & $1,688,368$ & 693,917 & 480,106 & 885,366 & 803,002 & 592,273 & 581,750 & 831,776 & 856,592 \\
\hline $2010 \ldots$ & $2,937,454$ & $1,630,699$ & $1,306,755$ & $1,209,648$ & $1,727,806$ & 719,560 & 490,088 & & 816,667 & 603,406 & 606,242 & 835,113 & 892,693 \\
\hline $2011 \ldots \ldots \ldots \ldots$ & $2,931,076$ & $1,642,389$ & $1,288,687$ & $1,209,524$ & $1,721,552$ & 722,882 & 486,642 & 919,507 & 802,045 & 600,748 & 608,776 & 820,656 & 900,896 \\
\hline 2012 & $2,910,388$ & $1,639,234$ & $1,271,154$ & $1,205,186$ & $1,705,202$ & 725,096 & 480,090 & 914,138 & 791,064 & 597,849 & 607,337 & 808,751 & 896,451 \\
\hline $2013^{1} \ldots \ldots \ldots \ldots \ldots \ldots \ldots \ldots$ & $2,947,000$ & $1,690,000$ & $1,258,000$ & $1,255,000$ & $1,692,000$ & 767,000 & 489,000 & 923,000 & 769,000 & 623,000 & 632,000 & 806,000 & 886,000 \\
\hline $2014^{1} \ldots \ldots$ & $3,043,000$ & $1,750,000$ & $1,294,000$ & $1,278,000$ & $1,765,000$ & 782,000 & 496,000 & 968,000 & 798,000 & 634,000 & 643,000 & 840,000 & 925,000 \\
\hline $2015^{1}$.. & $3,111,000$ & $1,787,000$ & $1,324,000$ & $1,296,000$ & $1,815,000$ & 795,000 & 501,000 & 992,000 & 823,000 & 643,000 & 653,000 & 864,000 & 951,000 \\
\hline $2016^{1}$.. & $3,189,000$ & $1,830,000$ & $1,359,000$ & $1,319,000$ & $1,870,000$ & 811,000 & 508,000 & $1,019,000$ & 851,000 & 654,000 & 664,000 & 890,000 & 980,000 \\
\hline $2017^{1} \ldots \ldots \ldots \ldots \ldots \ldots \ldots$ & $3,269,000$ & $1,873,000$ & $1,396,000$ & $1,344,000$ & $1,925,000$ & 829,000 & 515,000 & $1,044,000$ & 881,000 & 667,000 & 677,000 & 917,000 & $1,008,000$ \\
\hline $2018^{1}$ & $3,323,000$ & $1,898,000$ & $1,425,000$ & $1,361,000$ & $1,962,000$ & 839,000 & 522,000 & $1,059,000$ & 903,000 & 675,000 & 686,000 & 935,000 & $1,027,000$ \\
\hline $2019^{1} \ldots \ldots \ldots \ldots \ldots \ldots \ldots \ldots \ldots$ & $3,378,000$ & $1,925,000$ & $1,453,000$ & $1,378,000$ & $2,000,000$ & 849,000 & 529,000 & $1,076,000$ & 924,000 & 684,000 & 694,000 & 953,000 & $1,047,000$ \\
\hline 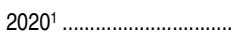 & $3,437,000$ & $1,955,000$ & $1,482,000$ & $1,396,000$ & $2,041,000$ & 860,000 & 537,000 & $1,095,000$ & 945,000 & 693,000 & 703,000 & 973,000 & $1,068,000$ \\
\hline $2021^{1} \ldots \ldots$. & $3,507,000$ & $1,992,000$ & $1,516,000$ & $1,419,000$ & $2,088,000$ & 873,000 & 546,000 & $1,119,000$ & 969,000 & 704,000 & 715,000 & 995,000 & $1,093,000$ \\
\hline $2022^{1}$ & $3,582,000$ & $2,033,000$ & $1,549,000$ & $1,443,000$ & $2,138,000$ & 888,000 & 556,000 & $1,145,000$ & 993,000 & 716,000 & 727,000 & $1,019,000$ & $1,119,000$ \\
\hline $2023^{1} \ldots \ldots \ldots \ldots \ldots \ldots \ldots \ldots$ & $3,648,000$ & $2,068,000$ & $1,580,000$ & $1,464,000$ & $2,184,000$ & 899,000 & 565,000 & $1,169,000$ & $1,016,000$ & 727,000 & 737,000 & $1,041,000$ & $1,143,000$ \\
\hline
\end{tabular}

${ }^{1}$ Projected.

NOTE: Data include unclassified graduate students. Data through 1995 are for institutions of higher education, while later data are for degree-granting institutions. Degree-granting institutions grant associate's or higher degrees and participate in Title IV federal financial aid programs. The degree-granting classification is very similar to the earlier higher education classification, but it includes more 2-year colleges and excludes a few higher education institutions that did not grant degrees.
SOURCE: U.S. Department of Education, National Center for Education Statistics, Higher Education General Information Survey (HEGIS), "Fall Enrollment in Colleges and Universities" surveys, 1967 through 1985; Integrated Postsecondary Education Data System (IPEDS), "Fall Enrollment Survey" (IPEDS-EF:86-99); IPEDS Spring 2001 through Spring 2013, Enrollment component; and Enrollment in Degree-Granting Institutions Projection Model, 1980 through 2023. (This table was prepared July 2014.) 
Table 303.90. Fall enrollment and number of degree-granting postsecondary institutions, by control and religious affiliation of institution: Selected years, 1980 through 2012

\begin{tabular}{|c|c|c|c|c|c|c|c|c|c|c|c|c|c|c|c|c|}
\hline \multirow[b]{3}{*}{ Control and religious affiliation of institution } & \multicolumn{6}{|c|}{ Total enrollment } & \multicolumn{5}{|c|}{ Enrollment, fall 2012} & \multirow{2}{*}{\multicolumn{5}{|c|}{ Number of institutions ${ }^{1}$}} \\
\hline & \multirow[b]{2}{*}{ Fall 1980} & \multirow[b]{2}{*}{ Fall 1990} & \multirow[b]{2}{*}{ Fall 2000} & \multirow[b]{2}{*}{ Fall 2009} & \multirow[b]{2}{*}{ Fall 2010} & \multirow[b]{2}{*}{ Fall 2011} & \multirow[b]{2}{*}{ Total } & \multicolumn{2}{|c|}{ Full-time } & \multicolumn{2}{|c|}{ Part-time } & & & & & \\
\hline & & & & & & & & Males & Females & Males & Females & Fall 1980 & Fall 1990 & Fall 2000 & Fall 2010 & Fall 2012 \\
\hline 1 & 2 & 3 & 4 & 5 & 6 & 7 & 8 & 9 & 10 & 11 & 12 & 13 & 14 & 15 & 16 & $\overline{17}$ \\
\hline All institutions & $12,096,895$ & $13,818,637$ & $15,312,289$ & $20,427,711$ & $21,016,126$ & $20,994,113$ & $20,642,819$ & $5,709,792$ & $7,027,221$ & $3,209,295$ & $4,696,511$ & 3,226 & 3,501 & 4,056 & 4,589 & 4,726 \\
\hline 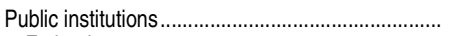 & $9,457,394$ & $10,844,717$ & $11,752,786$ & $14,810,642$ & $15,142,809$ & $15,110,196$ & $14,880,343$ & $3,954,114$ & $4,571,704$ & $2,627,185$ & $3,727,340$ & 1,493 & 1,548 & 1,676 & 1,652 & 1,623 \\
\hline 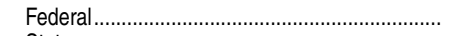 & 50,989 & 50,669 & 16,917 & 21,722 & 21,622 & 21,304 & 20,691 & 13,745 & 5,228 & 554 & 1,164 & 12 & 17 & 12 & 14 & 14 \\
\hline 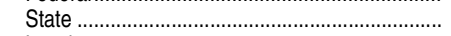 & $\left({ }^{2}\right)$ & $7,181,380$ & $9,548,090$ & $12,104,170$ & $12,366,422$ & $12,346,172$ & $12,195,526$ & $3,441,305$ & $3,995,532$ & $1,959,329$ & $2,799,360$ & (2) & 978 & 1,355 & 1,331 & 1,315 \\
\hline Local ..... & & $3,508,941$ & $2,078,090$ & $2,478,076$ & $2,541,036$ & $2,526,884$ & $2,453,053$ & 444,170 & 506,234 & 631,280 & 871,369 & (') & 523 & 277 & 261 & 256 \\
\hline 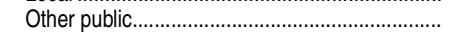 & $9,406,405$ & 103,727 & 109,689 & 206,674 & 213,729 & 215,836 & 211,073 & 54,894 & 64,710 & 36,022 & 55,447 & 1,481 & 30 & 32 & 46 & 38 \\
\hline Private institutions ............... & $2,639,501$ & $2,973,920$ & $3,559,503$ & $5,617,069$ & $5,873,317$ & $5,883,917$ & $5,762,476$ & $1,755,678$ & $2,455,517$ & 582,110 & 969,171 & 1,733 & 1,953 & 2,380 & 2,937 & 3,103 \\
\hline 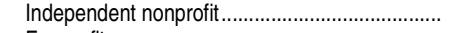 & $1,521,614$ & $1,474,818$ & $1,577,242$ & $1,953,136$ & $1,995,440$ & $2,054,854$ & $2,064,076$ & 703,075 & 849,765 & 202,650 & 308,586 & 795 & 709 & 729 & 736 & 765 \\
\hline 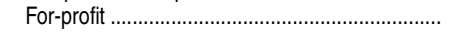 & 111,714 & 213,693 & 450,084 & $1,851,986$ & $2,018,397$ & $1,956,731$ & $1,808,898$ & 455,139 & 797,798 & 201,905 & 354,056 & 164 & 322 & 724 & 1,310 & 1,451 \\
\hline 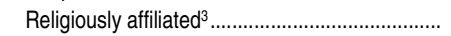 & $1,006,173$ & $1,285,409$ & $1,532,177$ & $1,811,947$ & $1,859,480$ & $1,872,332$ & $1,889,502$ & 597,464 & 807,954 & 177,555 & 306,529 & 774 & 922 & 927 & 891 & 887 \\
\hline Advent Christian Church .... & 143 & & - & - & & - & - & - & - & - & - & 1 & - & - & - & \\
\hline Zion Church....... & 1,091 & 88 & 34 & 1,485 & 1,536 & 1,537 & 1,459 & 784 & 609 & 36 & 30 & 3 & 1 & 1 & 3 & \\
\hline hodist Episcopal.... & 4,541 & 3,220 & 5,980 & 2,677 & 2,674 & 2,355 & 2,491 & 1,117 & 1,222 & 68 & 84 & 6 & 5 & 6 & 5 & 6 \\
\hline 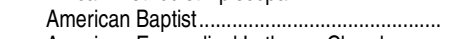 & 6,131 & 10,800 & 15,410 & 14,716 & 15,120 & 15,027 & 14,229 & 4,207 & 5,475 & 1,520 & 3,027 & 11 & 15 & 17 & 18 & 18 \\
\hline American Evangelical Lutheran Church.......... & - & - & 743 & 1,387 & 1,340 & 1,415 & 1,315 & 593 & 660 & 28 & 34 & - & - & 1 & 1 & 1 \\
\hline American Lutheran and Lutheran Church in & & & & & & & & & & & & & & & & \\
\hline ................ & 3,092 & - & 1,460 & - & - & - & - & - & - & - & - & 3 & - & 1 & - & - \\
\hline eran............... & 21,608 & - & - & - & - & - & - & - & - & - & - & 13 & - & - & - & - \\
\hline 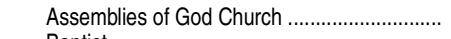 & 7,814 & 8,307 & 14,272 & 15,137 & 15,806 & 15,451 & 15,320 & 5,275 & 6,453 & 1,653 & 1,939 & 10 & 11 & 14 & 16 & 15 \\
\hline Baptist... & 38,231 & 99,510 & 107,610 & 165,848 & 174,481 & 172,946 & 112,351 & 36,221 & 47,394 & 11,685 & 17,051 & 33 & 69 & 68 & 69 & 70 \\
\hline Brethren Church ................................................. & 3,925 & 958 & 2,088 & 8,191 & 8,449 & 7,766 & 7,979 & 2,189 & 2,939 & 1,486 & 1,365 & 3 & 3 & 3 & 3 & \\
\hline Brethren in Christ Church .. & 1,301 & 2,239 & 2,797 & - & - & - & - & - & - & - & - & 1 & 1 & 1 & - & - \\
\hline Christian & 1,705 & 2,519 & $\begin{array}{r}5,278 \\
\end{array}$ & 6,331 & 6,465 & 6,536 & $\begin{array}{r}6,688 \\
-6,5\end{array}$ & 2,156 & 2,952 & 616 & 964 & 3 & 4 & 4 & 4 & \\
\hline Christian & 14,913 & 30,397 & 35,984 & 50,064 & 52,839 & 54,401 & 54,915 & 15,585 & 23,297 & 6,328 & 9,705 & 12 & 18 & 16 & 18 & 18 \\
\hline ind Churches of Christ .. & 1,342 & 2,263 & 7,277 & 9,263 & 10,128 & 10,483 & 10,700 & 4,277 & 4,499 & 1,034 & 890 & 7 & 8 & 18 & 18 & 18 \\
\hline Christian Methodist Episcopal......................... & 2,486 & 2,174 & 1,502 & 4,901 & 4,817 & 4,514 & 4,048 & 2,014 & 1,901 & 53 & 80 & 4 & 4 & 1 & 3 & \\
\hline 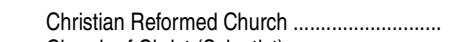 & 5,408 & 4,488 & 5,999 & 5,665 & 5,625 & 5,647 & 5,697 & 2,623 & 2,722 & 197 & 155 & 3 & 2 & 3 & 3 & 3 \\
\hline Church & 2,773 & 2,557 & & & - & - & - & - & - & - & - & 6 & 8 & - & - & - \\
\hline …………....... & & 249 & & - & - & - & - & - & - & - & - & - & 1 & - & - & - \\
\hline 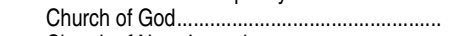 & 6,082 & 5,627 & 12,540 & 15,117 & 16,731 & 17,093 & 17,821 & 5,114 & 7,863 & 2,021 & 2,823 & 9 & 9 & 7 & 7 & \\
\hline 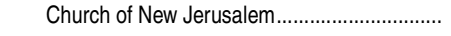 & 170 & - & - & - & - & & - & 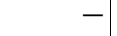 & 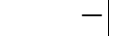 & & & 1 & - & - & - & \\
\hline Church of the Brethren....................................... & 8,482 & 4,463 & 4,187 & 5,861 & 6,154 & 6,028 & 6,261 & 2,431 & 3,148 & 283 & 399 & 6 & 5 & 4 & 5 & 6 \\
\hline Church 0 & 11,716 & 10,779 & 16,661 & 21,389 & 21,144 & 20,866 & 21,401 & 6,159 & 9,976 & 1,944 & 3,322 & 10 & 9 & 12 & 10 & 10 \\
\hline ......... & 9,343 & 14,611 & 30,140 & 34,996 & 35,538 & 36,450 & 35,871 & 11,567 & 14,866 & 3,511 & 5,927 & 9 & 19 & 19 & 17 & 17 \\
\hline Cumberland Presbyterian. & 594 & 746 & 1,112 & 3,247 & $\begin{array}{r}4,652 \\
-12\end{array}$ & 5,744 & 6,500 & 2,332 & 2,915 & 503 & 750 & 2 & 2 & 2 & 2 & 0 \\
\hline Episcopal Church, R & & & & - & - & - & 1,204 & 56 & 406 & 92 & 650 & 1 & - & - & - & \\
\hline 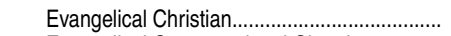 & - & - & - & - & - & - & 74,372 & 14,974 & 19,470 & 15,801 & 24,127 & - & - & - & - & \\
\hline ional Church................. & 80 & 88 & 148 & 159 & 153 & 125 & 123 & & 15 & 57 & 30 & 1 & 1 & 1 & 1 & \\
\hline hurch of America...... & 1,401 & 1,035 & 2,387 & 3,186 & 3,233 & 3,220 & 3,141 & 742 & 1,182 & 399 & 818 & 1 & 1 & 1 & 1 & \\
\hline America............... & 833 & 2,355 & 4,022 & 3,106 & 2,926 & 3,215 & 2,651 & 782 & 538 & 802 & 529 & 1 & 2 & 3 & 2 & 2 \\
\hline Evangelical Lutheran Church ................................. & 743 & 49,210 & 49,085 & 56,088 & 56,162 & 55,889 & 52,122 & 20,597 & 26,321 & 2,057 & 3,147 & 3 & 33 & 34 & 33 & 31 \\
\hline 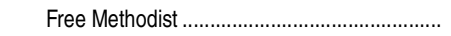 & 5,543 & 5,902 & 7,323 & 12,090 & 12,270 & 12,412 & 12,254 & 3,323 & 6,044 & 839 & 2,048 & 5 & 3 & 4 & 5 & \\
\hline Free Will Baptist Churc & 1,132 & 1,177 & 2,378 & 574 & 528 & 534 & 568 & 226 & 181 & 92 & 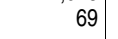 & 4 & 3 & 4 & 3 & \\
\hline Friends United M & 1,109 & & & & & & & & & & & 1 & - & - & - & \\
\hline Friends & 5,157 & 5,844 & 10,898 & 13,786 & 13,876 & 13,570 & 12,921 & 4,523 & 5,699 & 1,101 & 1,598 & 5 & 6 & 8 & 7 & 7 \\
\hline General Conference Mennonite Church ......... & 820 & 1,243 & 1,059 & & - & & & + & & & & 2 & 2 & 1 & - & \\
\hline 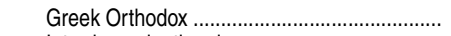 & 204 & 148 & 132 & 203 & 220 & 222 & 209 & 151 & 55 & 2 & 1 & 1 & 1 & 1 & 1 & \\
\hline 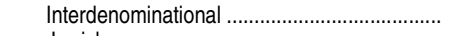 & 1,254 & 11,103 & 9,788 & 23,060 & 30,162 & 34,475 & 39,376 & 13,088 & 15,898 & 4,887 & 5,503 & 4 & 17 & 14 & 30 & 32 \\
\hline Jewish. & 5,738 & 12,217 & 14,182 & 8,468 & 12,755 & 14,716 & 15,120 & 9,551 & 3,510 & 614 & 1,445 & 24 & 63 & 62 & 36 & 35 \\
\hline 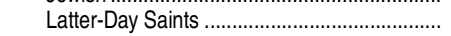 & 39,172 & 42,274 & 44,680 & 53,249 & 53,514 & 57,150 & 63,027 & 24,587 & 25,230 & 5,991 & 7,219 & 4 & 4 & 4 & 4 & 4 \\
\hline Lutheran Church-Missouri Synod .................. & 11,727 & 13,827 & 18,866 & 26,384 & 28,255 & 29,288 & 30,332 & 7,366 & 11,476 & 3,588 & 7,902 & 15 & 14 & 13 & 12 & 12 \\
\hline
\end{tabular}

See notes at end of table. 


\begin{tabular}{|c|c|c|c|c|c|c|c|c|c|c|c|c|c|c|c|c|}
\hline \multirow[b]{3}{*}{ Control and religious affiliation of institution } & \multicolumn{6}{|c|}{ Total enrollment } & \multicolumn{5}{|c|}{ Enrollment, fall 2012} & \multirow{2}{*}{\multicolumn{5}{|c|}{ Number of institutions ${ }^{1}$}} \\
\hline & \multirow[b]{2}{*}{ Fall 1980} & \multirow[b]{2}{*}{ Fall 1990} & \multirow[b]{2}{*}{ Fall 2000} & \multirow[b]{2}{*}{ Fall 2009} & \multirow[b]{2}{*}{ Fall 2010} & \multirow[b]{2}{*}{ Fall 2011} & \multirow[b]{2}{*}{ Total } & \multicolumn{2}{|c|}{ Full-time } & \multicolumn{2}{|c|}{ Part-time } & & & & & \\
\hline & & & & & & & & Males & Females & Males & Females & Fall 1980 & Fall 1990 & Fall 2000 & Fall 2010 & Fall 2012 \\
\hline 1 & 2 & 3 & 4 & 5 & 6 & 7 & 8 & 9 & 10 & 11 & 12 & 13 & 14 & 15 & 16 & 17 \\
\hline $\begin{array}{l}\text { Lutheran Church in America } \\
\text { Mennonite Brethren Church } \\
\text { Mennonite Church .................................................................. } \\
\text { Missionary Church Inc. ................................ } \\
\text { Moravian Church }\end{array}$ & $\begin{array}{r}23,877 \\
1,344 \\
4,008 \\
487 \\
2,434\end{array}$ & $\begin{array}{r}5,796 \\
1,864 \\
2,859 \\
699 \\
2,511\end{array}$ & $\begin{array}{l}4,322 \\
2,390 \\
3,553 \\
1,647 \\
2,939\end{array}$ & $\begin{array}{l}8,264 \\
3,426 \\
4,325 \\
2,165 \\
3,042\end{array}$ & $\begin{array}{l}8,240 \\
4,136 \\
4,263 \\
2,152 \\
3,095\end{array}$ & $\begin{array}{l}8,111 \\
4,302 \\
4,366 \\
2,074 \\
3,132\end{array}$ & $\begin{array}{l}8,193 \\
4,121 \\
4,236 \\
1,963 \\
3,075\end{array}$ & $\begin{array}{r}3,244 \\
1,150 \\
1,472 \\
509 \\
630\end{array}$ & $\begin{array}{r}4,160 \\
1,848 \\
1,943 \\
929 \\
1,679\end{array}$ & $\begin{array}{l}264 \\
368 \\
277 \\
163 \\
151\end{array}$ & $\begin{array}{l}525 \\
755 \\
544 \\
362 \\
615\end{array}$ & \begin{tabular}{r|r}
20 \\
3 \\
6 \\
1 \\
2
\end{tabular} & $\begin{array}{l}5 \\
3 \\
5 \\
1 \\
2\end{array}$ & \begin{tabular}{l|l}
2 \\
3 \\
5 \\
1 \\
2
\end{tabular} & $\begin{array}{l}3 \\
3 \\
6 \\
1 \\
2\end{array}$ & $\begin{array}{l}3 \\
2 \\
6 \\
1 \\
2\end{array}$ \\
\hline $\begin{array}{l}\text { Multiple Protestant denominations................... } \\
\text { North American Baptist................................. } \\
\text { Original Free Will Baptist............................ } \\
\text { Pentecostal Holiness Church ......................... } \\
\text { Presbyterian U.S.A. }\end{array}$ & $\begin{array}{r}5,526 \\
155 \\
767 \\
47,144\end{array}$ & $\begin{array}{r}211 \\
- \\
566 \\
77,700\end{array}$ & $\begin{array}{r}4,690 \\
124 \\
- \\
976 \\
78,950\end{array}$ & $\begin{array}{r}5,341 \\
125 \\
3,569 \\
1,124 \\
84,691\end{array}$ & $\begin{array}{r}5,350 \\
120 \\
3,855 \\
1,272 \\
85,692\end{array}$ & $\begin{array}{r}5,400 \\
141 \\
3,825 \\
1,504 \\
86,441\end{array}$ & $\begin{array}{r}5,274 \\
148 \\
3,714 \\
1,524 \\
86,699\end{array}$ & $\begin{array}{r}1,282 \\
30 \\
590 \\
598 \\
31,683\end{array}$ & $\begin{array}{r}1,474 \\
29 \\
939 \\
600 \\
42,539\end{array}$ & $\begin{array}{r}1,581 \\
55 \\
638 \\
130 \\
3,979\end{array}$ & $\begin{array}{r}937 \\
34 \\
1,547 \\
196 \\
8,498\end{array}$ & \begin{tabular}{r|}
8 \\
1 \\
-3 \\
57
\end{tabular} & \begin{tabular}{r|}
1 \\
- \\
3 \\
70
\end{tabular} & \begin{tabular}{r|}
7 \\
1 \\
-2 \\
64
\end{tabular} & \begin{tabular}{r|}
6 \\
1 \\
1 \\
3 \\
58
\end{tabular} & $\begin{array}{r}6 \\
1 \\
1 \\
3 \\
59\end{array}$ \\
\hline 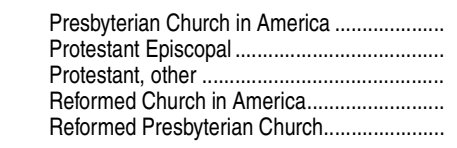 & $\begin{array}{r}- \\
5,396 \\
4,072 \\
2,713 \\
2,014\end{array}$ & $\begin{array}{r}1,877 \\
4,559 \\
38,136 \\
5,525 \\
1,556\end{array}$ & $\begin{array}{r}4,499 \\
5,479 \\
30,116 \\
6,002 \\
2,355\end{array}$ & $\begin{array}{r}2,174 \\
5,036 \\
16,207 \\
6,514 \\
2,949\end{array}$ & $\begin{array}{r}2,071 \\
5,006 \\
13,361 \\
6,555 \\
2,982\end{array}$ & $\begin{array}{r}1,792 \\
4,604 \\
14,628 \\
6,501 \\
2,866\end{array}$ & $\begin{array}{r}1,803 \\
4,202 \\
16,167 \\
6,502 \\
2,700\end{array}$ & $\begin{array}{r}722 \\
1,879 \\
5,149 \\
2,610 \\
1,136\end{array}$ & $\begin{array}{r}668 \\
2,029 \\
5,770 \\
3,448 \\
1,175\end{array}$ & $\begin{array}{r}271 \\
143 \\
2,445 \\
196 \\
231\end{array}$ & $\begin{array}{r}142 \\
151 \\
2,803 \\
248 \\
158\end{array}$ & $\begin{array}{r}- \\
12 \\
11 \\
4 \\
4\end{array}$ & \begin{tabular}{r|r}
1 \\
9 \\
44 \\
4 \\
2
\end{tabular} & $\begin{array}{r}5 \\
12 \\
34 \\
5 \\
2\end{array}$ & \begin{tabular}{r|r}
2 \\
11 \\
22 \\
5 \\
3
\end{tabular} & $\begin{array}{r}2 \\
9 \\
24 \\
5 \\
3\end{array}$ \\
\hline 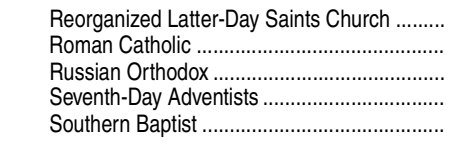 & $\begin{array}{r}4,274 \\
422,842 \\
47 \\
19,168 \\
85,281\end{array}$ & $\begin{array}{r}4,793 \\
530,585 \\
38 \\
15,771 \\
49,493\end{array}$ & $\begin{array}{r}3,390 \\
636,336 \\
106 \\
19,223 \\
54,275\end{array}$ & $\begin{array}{r}-7 \\
735,713 \\
79 \\
24,818 \\
46,689\end{array}$ & $\begin{array}{r}-\overline{7} \\
751,089 \\
60 \\
25,430 \\
49,882\end{array}$ & $\begin{array}{r}- \\
749,877 \\
53 \\
25,751 \\
51,832\end{array}$ & $\begin{array}{r}746,942 \\
55 \\
26,343 \\
52,610\end{array}$ & $\begin{array}{r}- \\
219,870 \\
42 \\
8,360 \\
14,586\end{array}$ & $\begin{array}{r}- \\
323,224 \\
4 \\
11,358 \\
20,099\end{array}$ & $\begin{array}{r}-\overline{6} \\
67,493 \\
8 \\
2,258 \\
7,025\end{array}$ & $\begin{array}{r}-7 \\
136,355 \\
1 \\
4,367 \\
10,900\end{array}$ & \begin{tabular}{r|r}
2 \\
229 \\
1 \\
11 \\
54
\end{tabular} & \begin{tabular}{r|r}
1 \\
239 \\
1 \\
11 \\
29
\end{tabular} & $\begin{array}{r}2 \\
239 \\
1 \\
13 \\
32\end{array}$ & $\begin{array}{r}- \\
237 \\
1 \\
14 \\
22\end{array}$ & $\begin{array}{r}- \\
234 \\
1 \\
13 \\
22\end{array}$ \\
\hline 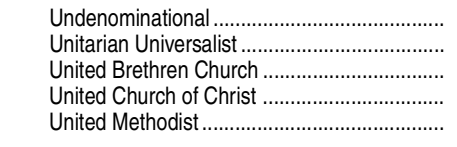 & $\begin{array}{r}- \\
87 \\
545 \\
14,169 \\
127,099\end{array}$ & $\begin{array}{r}6,758 \\
82 \\
601 \\
20,175 \\
148,851\end{array}$ & $\begin{array}{r}23,573 \\
132 \\
938 \\
23,709 \\
171,109\end{array}$ & $\begin{array}{r}27,071 \\
171 \\
1,270 \\
27,507 \\
202,913\end{array}$ & $\begin{array}{r}27,745 \\
166 \\
1,260 \\
20,528 \\
206,744\end{array}$ & $\begin{array}{r}29,650 \\
190 \\
1,260 \\
17,724 \\
206,268\end{array}$ & $\begin{array}{r}29,966 \\
227 \\
1,204 \\
17,473 \\
204,506\end{array}$ & $\begin{array}{r}8,556 \\
31 \\
441 \\
5,434 \\
74,113\end{array}$ & $\begin{array}{r}11,631 \\
57 \\
628 \\
7,012 \\
95,123\end{array}$ & $\begin{array}{r}4,476 \\
55 \\
55 \\
1,711 \\
12,899\end{array}$ & $\begin{array}{r}5,303 \\
84 \\
80 \\
3,316 \\
22,371\end{array}$ & $\begin{array}{r}- \\
2 \\
1 \\
16 \\
91\end{array}$ & $\begin{array}{r}14 \\
2 \\
1 \\
18 \\
96\end{array}$ & $\begin{array}{r}16 \\
2 \\
1 \\
18 \\
100\end{array}$ & $\begin{array}{r}16 \\
2 \\
1 \\
17 \\
96\end{array}$ & $\begin{array}{r}18 \\
2 \\
1 \\
15 \\
94\end{array}$ \\
\hline $\begin{array}{l}\text { Wesleyan Church .................................................... } \\
\text { Wisconsin Evangelical Lutheran Synod } \\
\text { Other religiously affiliated }\end{array}$ & $\begin{array}{r}3,583 \\
808 \\
462\end{array}$ & $\begin{array}{r}5,311 \\
931 \\
5,743\end{array}$ & $\begin{array}{r}11,128 \\
1,660 \\
2,534\end{array}$ & $\begin{array}{r}20,492 \\
1,603 \\
8,041\end{array}$ & $\begin{array}{r}20,670 \\
1,677 \\
8,526\end{array}$ & $\begin{array}{r}20,577 \\
1,799 \\
8,589\end{array}$ & $\begin{array}{r}20,160 \\
1,889 \\
5,340\end{array}$ & $\begin{array}{r}6,252 \\
799 \\
1,665\end{array}$ & $\begin{array}{r}11,425 \\
870 \\
2,377\end{array}$ & $\begin{array}{l}920 \\
108 \\
367\end{array}$ & $\begin{array}{r}1,563 \\
112 \\
931\end{array}$ & $\begin{array}{l}5 \\
1 \\
1\end{array}$ & $\begin{array}{l}4 \\
3 \\
9\end{array}$ & $\begin{array}{l}4 \\
2 \\
4\end{array}$ & $\begin{array}{r}6 \\
2 \\
13\end{array}$ & $\begin{array}{r}6 \\
2 \\
11\end{array}$ \\
\hline
\end{tabular}

- Not available.

${ }^{1}$ Counts of institutions in this table may be lower than reported in other tables, because counts in this table include only institutions reporting separate enrollment data.

"Included under "Other public."

${ }^{3}$ Religious affiliation as reported by institution

DOTE: Data for 1980 and 1990 are for institutions of higher education, while later data are for degree-granting institutions. degree-granting classification is very similar to the earlier higher education classification, but it includes more 2-year colleges and excludes a few higher education institutions that did not grant degrees. Some data have been revised from previously

SOURCE: U.S. Department of Education, National Center for Education Statistics, Higher Education General Information Survey (HEGIS), "Fall Enrollment in Institutions of Higher Education" and "Institutional Characteristics" surveys, 1980; Integrated Postsecondary Education Data System (IPEDS), "Fall Enrollment Survey" (IPEDS-EF:90) and "Institutional CharacterMarch 2014.) 
CHAPTER 3: Postsecondary Education 413

Total Fall Enrollment-State-Level

Table 304.10. Total fall enrollment in degree-granting postsecondary institutions, by state or jurisdiction: Selected years, 1970 through 2012

\begin{tabular}{|c|c|c|c|c|c|c|c|c|c|c|c|}
\hline State or jurisdiction & Fall 1970 & Fall 1980 & Fall 1990 & Fall 2000 & Fall 2007 & Fall 2008 & Fall 2009 & Fall 2010 & Fall 2011 & Fall 2012 & $\begin{array}{r}\text { Percent } \\
\text { change, } \\
2007 \text { to } 2012\end{array}$ \\
\hline 1 & 2 & 3 & 4 & 5 & 6 & 7 & 8 & 9 & 10 & 11 & 12 \\
\hline 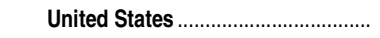 & $8,580,887$ & $12,096,895$ & $13,818,637$ & $15,312,289$ & $18,248,128$ & $19,102,814$ & $20,427,711$ & $21,016,126$ & $20,994,113$ & $20,642,819$ & 13.1 \\
\hline Alabama & 103,936 & 164,306 & 218,589 & 233,962 & 268,183 & 310,941 & 311,740 & 327,327 & 318,686 & 310,311 & 15.7 \\
\hline Alaska.. & 9,471 & 21,296 & 29,833 & 27,953 & 30,616 & 30,717 & 32,406 & 33,653 & 34,932 & 32,797 & 7.1 \\
\hline Arizona .. & 109,619 & 202,716 & 264,148 & 342,490 & 624,147 & 704,245 & 828,631 & 795,388 & 796,986 & 736,379 & 18.0 \\
\hline 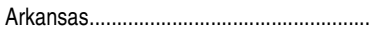 & 52,039 & 77,607 & 90,425 & 115,172 & 152,168 & 158,374 & 168,352 & 175,895 & 179,281 & 176,458 & 16.0 \\
\hline California & $1,257,245$ & $1,790,993$ & $1,808,740$ & $2,256,708$ & $2,529,522$ & $2,652,241$ & $2,735,579$ & $2,714,172$ & $2,685,893$ & $2,621,460$ & 3.6 \\
\hline Colorado ......... & 123,395 & 162,916 & 227,131 & 263,872 & 310,637 & 325,232 & 352,034 & 372,025 & 365,820 & 362,935 & 16.8 \\
\hline 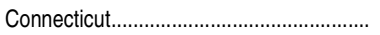 & 124,700 & 159,632 & 168,604 & 161,243 & 179,005 & 184,178 & 191,806 & 199,384 & 201,638 & 201,658 & 12.7 \\
\hline Delaware & 25,260 & 32,939 & 42,004 & 43,897 & 52,343 & 53,088 & 55,174 & 55,731 & 56,516 & 58,128 & 11.1 \\
\hline 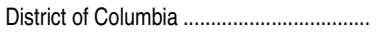 & 77,158 & 86,675 & 79,551 & 72,689 & 115,153 & 126,110 & 136,851 & 91,992 & 90,213 & 90,150 & -21.7 \\
\hline 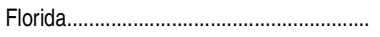 & 235,525 & 411,891 & 588,086 & 707,684 & 913,793 & 972,699 & $1,053,221$ & $1,125,469$ & $1,143,698$ & $1,154,929$ & 26.4 \\
\hline Georgia. & 126,511 & 184,159 & 251,786 & 346,204 & 453,711 & 476,581 & 532,493 & 568,723 & 565,459 & 545,358 & 20.2 \\
\hline Hawaii... & 36,562 & 47,181 & 56,436 & 60,182 & 66,601 & 70,104 & 74,809 & 78,073 & 79,018 & 78,456 & 17.8 \\
\hline Idaho.... & 34,567 & 43,018 & 51,881 & 65,594 & 78,846 & 80,456 & 84,450 & 85,201 & 90,142 & 108,008 & 37.0 \\
\hline 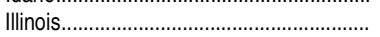 & 452,146 & 644,245 & 729,246 & 743,918 & 837,018 & 859,242 & 900,824 & 906,889 & 892,881 & 867,110 & 3.6 \\
\hline Indiana & 192,668 & 247,253 & 284,832 & 314,334 & 380,477 & 401,956 & 441,294 & 459,423 & 457,824 & 447,262 & 17.6 \\
\hline lowa ....... & 108,902 & 140,449 & 170,515 & 188,974 & 256,259 & 286,891 & 350,631 & 381,842 & 372,146 & 361,183 & 40.9 \\
\hline 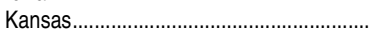 & 102,485 & 136,605 & 163,733 & 179,968 & 194,102 & 198,991 & 210,843 & 214,859 & 216,662 & 213,786 & 10.1 \\
\hline 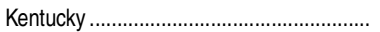 & 98,591 & 143,066 & 177,852 & 188,341 & 258,213 & 257,583 & 277,907 & 291,102 & 293,766 & 282,125 & 9.3 \\
\hline Louisiana & 120,728 & 160,058 & 186,840 & 223,800 & 224,754 & 236,375 & 251,853 & 263,638 & 265,856 & 258,825 & 15.2 \\
\hline Maine & 34,134 & 43,264 & 57,186 & 58,473 & 67,173 & 67,796 & 70,170 & 72,985 & 72,297 & 72,810 & 8.4 \\
\hline Maryland... & 149,607 & 225,526 & 259,700 & 273,745 & 327,597 & 338,914 & 358,941 & 377,967 & 380,097 & 374,496 & 14.3 \\
\hline Massachusetts......... & 303,809 & 418,415 & 417,833 & 421,142 & 463,366 & 477,056 & 497,290 & 508,302 & 508,554 & 516,331 & 11.4 \\
\hline Michigan .................... & 392,726 & 520,131 & 569,803 & 567,631 & 643,279 & 652,799 & 686,049 & 698,125 & 685,526 & 663,825 & 3.2 \\
\hline 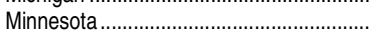 & 160,788 & 206,691 & 253,789 & 293,445 & 392,393 & 411,055 & 442,281 & 465,336 & 457,752 & 451,661 & 15.1 \\
\hline 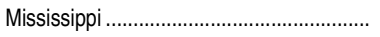 & 73,967 & 102,364 & 122,883 & 137,389 & 155,232 & 160,441 & 173,136 & 178,197 & 179,090 & 176,665 & 13.8 \\
\hline Missouri.. & 183,930 & 234,421 & 289,899 & 321,348 & 384,366 & 396,409 & 424,944 & 444,695 & 456,997 & 441,371 & 14.8 \\
\hline Montana.... & 30,062 & 35,177 & 35,876 & 42,240 & 47,371 & 47,840 & 51,588 & 53,312 & 54,042 & 53,254 & 12.4 \\
\hline 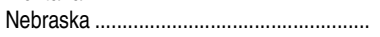 & 66,915 & 89,488 & 112,831 & 112,117 & 127,378 & 130,458 & 138,645 & 144,682 & 142,875 & 139,578 & 9.6 \\
\hline Nevada & 13,669 & 40,455 & 61,728 & 87,893 & 116,276 & 120,490 & 125,320 & 129,360 & 121,013 & 118,300 & 1.7 \\
\hline 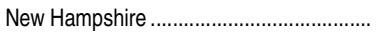 & 29,400 & 46,794 & 59,510 & 61,718 & 70,724 & 71,739 & 74,234 & 75,594 & 77,444 & 82,678 & 16.9 \\
\hline New Jersey & 216,121 & 321,610 & 324,286 & 335,945 & 398,136 & 410,160 & 432,127 & 444,091 & 443,750 & 439,965 & 10.5 \\
\hline New Mexico. & 44,461 & 58,283 & 85,500 & 110,739 & 134,375 & 142,413 & 152,752 & 162,652 & 157,555 & 156,424 & 16.4 \\
\hline New York & 806,479 & 992,237 & $1,048,286$ & $1,043,395$ & $1,172,811$ & $1,234,858$ & $1,289,604$ & $1,305,595$ & $1,318,142$ & $1,309,986$ & 11.7 \\
\hline 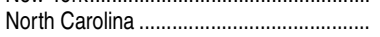 & 171,925 & 287,537 & 352,138 & 404,652 & 502,330 & 528,977 & 568,865 & 586,042 & 585,013 & 578,031 & 15.1 \\
\hline 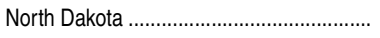 & 31,495 & 34,069 & 37,878 & 40,248 & 49,945 & 51,327 & 54,433 & 56,903 & 55,772 & 55,169 & 10.5 \\
\hline Ohio. & 376,267 & 489,145 & 557,690 & 549,553 & 630,497 & 653,585 & 711,095 & 744,947 & 735,026 & 818 & 12.6 \\
\hline Oklahon & 110,155 & 160,295 & 173,221 & 178,016 & 206,382 & 206,757 & 220,650 & 230,573 & 230,154 & 228,464 & 10.7 \\
\hline 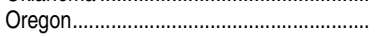 & 122,177 & 157,458 & 165,741 & 183,065 & 202,928 & 220,474 & 243,412 & 250,331 & 259,061 & 254,695 & 25.5 \\
\hline 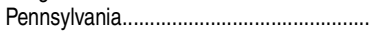 & 411,044 & 507,716 & 604,060 & 609,521 & 725,397 & 740,288 & 778,123 & 803,593 & 787,789 & 777,242 & 7.1 \\
\hline 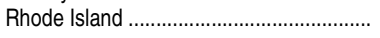 & 45,898 & 66,869 & 78,273 & 75,450 & 82,900 & 83,893 & 84,673 & 85,110 & 84,644 & 83,952 & 1.3 \\
\hline 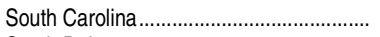 & 69,518 & 132,476 & 159,302 & 185,931 & 217,755 & 230,695 & 246,667 & 257,293 & 260,002 & 259,617 & 19.2 \\
\hline South Dakota & 30,639 & 32,761 & 34,208 & 43,221 & 49,747 & 50,444 & 53,342 & 58,370 & 55,899 & 56,058 & 12.7 \\
\hline 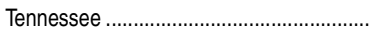 & 135,103 & 204,581 & 226,238 & 263,910 & 297,785 & 307,610 & 332,918 & 351,988 & 350,275 & 343,641 & 15.4 \\
\hline 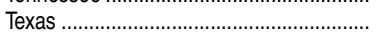 & 442,225 & 701,391 & 901,437 & $1,033,973$ & $1,269,098$ & $1,327,148$ & $1,447,868$ & $1,536,858$ & $1,564,387$ & $1,540,298$ & 21.4 \\
\hline Utah & 81,687 & 93,987 & 121,303 & 163,776 & 203,679 & 217,224 & 236,590 & 252,107 & 264,396 & 267,309 & 31.2 \\
\hline Vermont & 22,209 & 30,628 & 36,398 & 35,489 & 42,191 & 42,946 & 44,975 & 45,572 & 45,143 & 44,703 & 6.0 \\
\hline 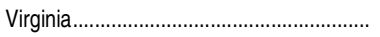 & 151,915 & 280,504 & 353,442 & 381,893 & 478,268 & 500,796 & 545,036 & 576,010 & 588,465 & 588,696 & 23.1 \\
\hline 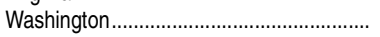 & 183,544 & 303,603 & 263,384 & 320,840 & 352,075 & 362,535 & 382,532 & 388,110 & 372,841 & 365,514 & 3.8 \\
\hline 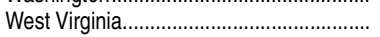 & 63,153 & 81,973 & 84,790 & 87,888 & 116,848 & 125,333 & 142,484 & 152,431 & 162,308 & 162,179 & 38.8 \\
\hline Wisconsin & 202,058 & 269,086 & 299,774 & 307,179 & 343,747 & 352,875 & 373,228 & 383,986 & 376,603 & 369,732 & 7.6 \\
\hline 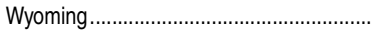 & 15,220 & 21,147 & 31,326 & 30,004 & 35,246 & 35,936 & 37,093 & 38,298 & 38,092 & 37,812 & 7.3 \\
\hline U.S. Service Academies ${ }^{1}$...... & 17,079 & 49,808 & 48,692 & 13,475 & 15,285 & 15,539 & 15,748 & 15,925 & 15,692 & 15,227 & -0.4 \\
\hline 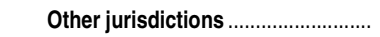 & 67,237 & 137,749 & 164,618 & 194,633 & 226,849 & 236,167 & 243,792 & 264,237 & 267,159 & 259,943 & 14.6 \\
\hline American Samoa & 0 & 976 & 1,219 & 297 & 1,767 & 1,806 & 2,189 & 2,193 & 2,091 & 1,795 & 1.6 \\
\hline Federated States of Micronesia.................. & 0 & 224 & 975 & 1,576 & 2,379 & 2,457 & 3,401 & 2,699 & 2,915 & 2,744 & 15.3 \\
\hline Guam & 2,719 & 3,217 & 4,741 & 5,215 & 5,244 & 5,351 & 5,755 & 6,188 & 6,360 & 5,924 & 13.0 \\
\hline 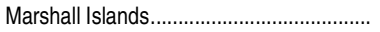 & 0 & 0 & 0 & 328 & 557 & 689 & 847 & 869 & 989 & 1,123 & 101.6 \\
\hline 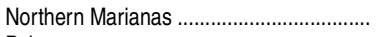 & 0 & 0 & 661 & 1,078 & 901 & 791 & 989 & 1,137 & 1,046 & 1,178 & 30.7 \\
\hline Palau & 0 & 0 & 491 & 581 & 668 & 502 & 651 & 694 & 742 & 680 & 1.8 \\
\hline Puerto Rico & 63,073 & 131,184 & 154,065 & 183,290 & 212,949 & 222,178 & 227,358 & 247,724 & 250,402 & 244,076 & 14.6 \\
\hline 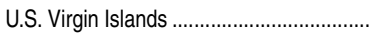 & 1,445 & 2,148 & 2,466 & 2,268 & 2,384 & 2,393 & 2,602 & 2,733 & 2,614 & 2,423 & 1.6 \\
\hline
\end{tabular}

1Data for 2000 and later years reflect a substantial reduction in the number of Department of Defense institutions included in the IPEDS survey.

NOTE: Data through 1990 are for institutions of higher education, while later data are for degree-granting institutions. Degree-granting institutions grant associate's or higher degrees and participate in Title IV federal financial aid programs. The degree-granting classification is very similar to the earlier higher education classification, but it includes more 2-year colleges and excludes a few higher education institutions that did not grant degrees.
SOURCE: U.S. Department of Education, National Center for Education Statistics, Higher Education General Information Survey (HEGIS), "Fall Enrollment in Colleges and Universities" surveys, 1970 and 1980; Integrated Postsecondary Education Data System (IPEDS), "Fall Enrollment Survey" (IPEDS-EF:90); and IPEDS Spring 2001 through Spring 2013, Enrollment component. (This table was prepared November 2013.) 
Table 304.15. Total fall enrollment in public degree-granting postsecondary institutions, by state or jurisdiction: Selected years, 1970 through 2012

\begin{tabular}{|c|c|c|c|c|c|c|c|c|c|c|c|}
\hline State or jurisdiction & Fall 1970 & Fall 1980 & Fall 1990 & Fall 2000 & Fall 2007 & Fall 2008 & Fall 2009 & Fall 2010 & Fall 2011 & Fall 2012 & $\begin{array}{r}\text { Percent } \\
\text { change, } \\
2007 \text { to } 2012 \\
\end{array}$ \\
\hline 1 & 2 & 3 & 4 & 5 & 6 & 7 & 8 & 9 & 10 & 11 & 12 \\
\hline United States. & $6,428,134$ & $9,457,394$ & $10,844,717$ & $11,752,786$ & $13,490,780$ & $13,972,153$ & $14,810,642$ & $15,142,809$ & $15,110,196$ & $14,880,343$ & 10.3 \\
\hline 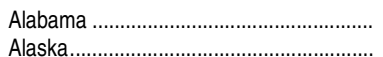 & $\begin{array}{r}87,884 \\
8,563\end{array}$ & $\begin{array}{r}143,674 \\
20,561\end{array}$ & $\begin{array}{r}195,939 \\
27,792\end{array}$ & $\begin{array}{r}207,435 \\
26,559\end{array}$ & $\begin{array}{r}237,632 \\
29,381\end{array}$ & $\begin{array}{r}245,040 \\
29,167\end{array}$ & $\begin{array}{r}260,277 \\
30,493\end{array}$ & $\begin{array}{r}267,083 \\
32,303\end{array}$ & $\begin{array}{r}260,523 \\
32,158\end{array}$ & $\begin{array}{r}251,045 \\
30,595\end{array}$ & $\begin{array}{l}5.6 \\
4.1\end{array}$ \\
\hline Arizona ... & 107,315 & 194,034 & 248,213 & 284,522 & 332,154 & 331,310 & 350,435 & 366,976 & 366,116 & 359,229 & 8.2 \\
\hline Arkansas... & 43,599 & 66,068 & 78,645 & 101,775 & 135,525 & 140,706 & 149,474 & 155,780 & 158,760 & 157,224 & 16.0 \\
\hline California . & $1,123,529$ & $1,599,838$ & $1,594,710$ & $1,927,771$ & $2,136,087$ & $2,239,487$ & $2,289,470$ & $2,223,648$ & $2,178,629$ & $2,129,152$ & -0.3 \\
\hline Colorado ... & 108,562 & 145,598 & 200,653 & 217,897 & 227,984 & 235,265 & 255,438 & 269,407 & 269,298 & 272,444 & 19.5 \\
\hline Connect & 73,391 & 97,788 & 109,556 & 101,027 & 114,072 & 118,694 & 123,211 & 127,194 & 126,487 & 124,952 & 9.5 \\
\hline Delaware.. & 21,151 & 28,325 & 34,252 & 34,194 & 39,092 & 38,952 & 40,428 & 40,408 & 40,698 & 41,113 & 5.2 \\
\hline District of Columbia .. & 12,194 & 13,900 & 11,990 & 5,499 & 5,608 & 5,584 & 5,253 & 5,840 & 5,280 & 5,476 & -2.4 \\
\hline Florida.... & 189,450 & 334,349 & 489,081 & 556,912 & 683,328 & 709,593 & 759,479 & 790,027 & 803,200 & 804,693 & 17.8 \\
\hline Georgia. & 101,900 & 140,158 & 196,413 & 271,755 & 359,883 & 376,468 & 418,037 & 436,109 & 428,708 & 422,189 & 17.3 \\
\hline Hawai & 32,963 & 43,269 & 45,728 & 44,579 & 50,454 & 53,526 & 57,945 & 60,090 & 60,330 & 60,295 & 19.5 \\
\hline …………....... & 27,072 & 34,491 & 41,315 & 53,751 & 60,526 & 61,190 & 63,261 & 64,204 & 65,753 & 78,781 & 30.2 \\
\hline 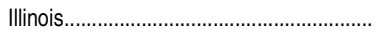 & 315,634 & 491,274 & 551,333 & 534,155 & 550,940 & 560,411 & 588,741 & 585,515 & 577,043 & 557,137 & 1.1 \\
\hline Indiana & 136,739 & 189,224 & 223,953 & 240,023 & 278,951 & 296,950 & 325,072 & 337,705 & 340,264 & 333,769 & 19.7 \\
\hline lowa. & 68,390 & 97,454 & 7,834 & 135,008 & 4,644 & 7,019 & 70,870 & 81 & 491 & 73,558 & 12.2 \\
\hline Kansas...... & 88,215 & 121,987 & 149,117 & 159,976 & 170,054 & 172,640 & 182,736 & 185,623 & 186,475 & 183,976 & 8.2 \\
\hline ................................... & 77,240 & 114,884 & 147,095 & 151,973 & 211,234 & 208,970 & 221,508 & 229,725 & 233,427 & 224,092 & 6.1 \\
\hline 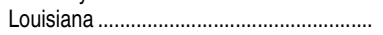 & 101,127 & 136,703 & 158,290 & 189,213 & 193,316 & 203,098 & 215,511 & 224,811 & 225,210 & 220,971 & 14.3 \\
\hline Maine & 25,405 & 31,878 & 41,500 & 40,662 & 48,357 & 48,191 & 49,668 & 51,482 & 50,253 & 50,270 & 4.0 \\
\hline Marylar & 118,988 & 195,051 & 20,783 & 223,797 & 269,719 & 280,603 & 298,185 & 309,779 & 314,383 & 10,503 & 15.1 \\
\hline Massa & 116,127 & 183,765 & 36,035 & 183,248 & 198,700 & 205,820 & 218,999 & 224,493 & 227,005 & 228,178 & 14.8 \\
\hline …………….... & 339,625 & 454,147 & 487,359 & 467,861 & 519,449 & 528,040 & 553,022 & 562,444 & 554,741 & 540,242 & 4.0 \\
\hline Minnesota ........................................... & 130,567 & 162,379 & 199,211 & 218,617 & 250,397 & 256,633 & 270,336 & 276,176 & 274,192 & 272,290 & 8.7 \\
\hline 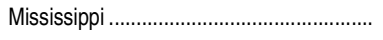 & 64,968 & 90,661 & 109,038 & 125,355 & 139,931 & 144,224 & 155,517 & 159,695 & 160,611 & 157,995 & 12.9 \\
\hline Missouri & 132,540 & 165,179 & 200,093 & 201,509 & 223,155 & 228,737 & 245,568 & 256,119 & 260,585 & 257,430 & 15.4 \\
\hline ……….......... & 27,287 & 31,178 & 31,865 & 37,387 & 42,857 & 43,565 & 46,653 & 48,261 & 48,912 & 48,333 & 12.8 \\
\hline Nebraska ..................... & 51,454 & 73,509 & 94,614 & 88,531 & 96,680 & 99,593 & 104,149 & 107,980 & 106,794 & 104,166 & 7.7 \\
\hline Nevada ...................................................... & 13,576 & 40,280 & 61,242 & 83,120 & 104,797 & 108,559 & 112,397 & 113,103 & 105,048 & 103,619 & -1.1 \\
\hline New Hampshire .......................................... & 15,979 & 24,119 & 32,163 & 35,870 & 41,982 & 42,192 & 43,507 & 44,072 & 43,333 & 43,289 & 3.1 \\
\hline WW Je & 145,373 & 247,028 & 261,601 & 266,921 & 318,296 & 328,838 & 348,934 & 358,256 & 359,458 & 356,456 & 12.0 \\
\hline .......... & 40,795 & 55,077 & 83,403 & 101,450 & 124,773 & 132,983 & 143,101 & 150,856 & 146,515 & 146,792 & 17.6 \\
\hline New Yo & 449,437 & 563,251 & 616,884 & 583,417 & 652,428 & 892 & 712,466 & 500 & 731,914 & 722,274 & 10.7 \\
\hline North Carolina ... & 123,761 & 228,154 & 285,405 & 329,422 & 410,746 & 434,976 & 470,239 & 475,598 & 470,989 & 465,684 & 13.4 \\
\hline North Dakota ...... & 30,192 & 31,709 & 34,690 & 36,014 & 43,016 & 44,268 & 46,727 & 48,904 & 48,868 & 48,929 & 13.7 \\
\hline is & 281,099 & 381,765 & 17,613 & 1 & 460,240 & 21 & 02 & 547,551 & 542,774 & 338 & 13.9 \\
\hline Or & 438 & 88 & 3 & 99 & 43 & 53 & 189 & 197 & 373 & 111 & 9.8 \\
\hline & 108,483 & 1 & 14 & 56 & 60 & & & & 466 & 212,310 & 28.5 \\
\hline Pennsylvania & 232,982 & 292,499 & 343,478 & 339,229 & 396,774 & 404,976 & 425,979 & 432,889 & 428,269 & 425,890 & 7.3 \\
\hline Rhode Island .. & 25,527 & 35,052 & 42,350 & 38,458 & 41,503 & 42,601 & 43,409 & 43,224 & 43,254 & 43,204 & 4.1 \\
\hline So $-a t a r a t$ & 47,101 & 1 & 4 & 15 & 180 & 18 & 200 & 30 & 208,302 & 209,023 & 15.8 \\
\hline Sou & 0 & 24,328 & & 67 & & & & & 43,729 & 44,185 & 13.5 \\
\hline$\ldots$ & 98,897 & 156,835 & 175,049 & 202,530 & 208,524 & 214,140 & 231,741 & 242,486 & 241,917 & 235,010 & 12.7 \\
\hline 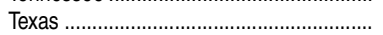 & 365,522 & 613,552 & 802,314 & 896,534 & $1,109,666$ & $1,163,132$ & $1,258,841$ & $1,334,885$ & $1,367,005$ & $1,347,860$ & 21.5 \\
\hline Utah & 49,588 & 59,598 & 86,108 & 123,046 & 147,982 & 158,037 & 170,921 & 178,599 & 179,208 & 171,001 & 15.6 \\
\hline Vern & & 4 & & & & & 28 & & 132 & 501 & 6.7 \\
\hline & & & & & & & & & & 753 & 10.6 \\
\hline 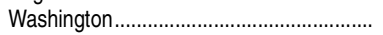 & 162,718 & 276,028 & 227,632 & 273,928 & 301,793 & 312,071 & 328,391 & 330,874 & 317,066 & 311,497 & 3.2 \\
\hline$\ldots$ & 51,36 & 71,228 & 74,108 & 76,136 & 87,838 & 88,695 & 94,533 & 96,104 & 95,634 & 93,017 & 5.9 \\
\hline 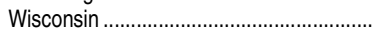 & 170,374 & 235,179 & 253,529 & 249,737 & 273,708 & 280,394 & 295,090 & 301,212 & 296,795 & 293,416 & 7.2 \\
\hline Wyoming ..................................... & 15,220 & 21,121 & 30,623 & 28,715 & 33,705 & 34,426 & 35,682 & 36,292 & 36,368 & 35,859 & 6.4 \\
\hline U.S. Service Academies' & 17,079 & 49,808 & 48,692 & 13,475 & 15,285 & 15,539 & 15,748 & 15,925 & 15,692 & 15,227 & -0.4 \\
\hline Other jurisdictions .......... & 46,680 & 60,692 & 66,244 & 84,464 & 80,958 & 82,424 & 87,030 & 83,719 & 78,928 & 78,369 & -3.2 \\
\hline America & & 976 & 1,219 & 297 & 1,767 & 1,806 & 2,189 & 2,193 & 2,091 & 1,795 & 1.6 \\
\hline Federated States of Micronesia................. & 0 & 224 & 975 & 1,576 & 2,379 & 2,457 & 3,401 & 2,699 & 2,915 & 2,744 & 15.3 \\
\hline 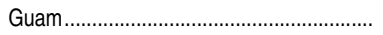 & 2,719 & 3,217 & 4,741 & 5,215 & 5,077 & 5,202 & 5,661 & 6,103 & 6,274 & 5,847 & 15.2 \\
\hline 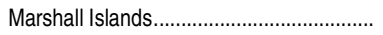 & 0 & 0 & 0 & 328 & 557 & 689 & 847 & 869 & 989 & 1,123 & 101.6 \\
\hline ......................... & 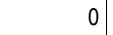 & 0 & 661 & 1,078 & 901 & 791 & 989 & 1,137 & 1,046 & 1,178 & 30.7 \\
\hline 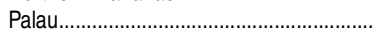 & 0 & 0 & 491 & 581 & 668 & 502 & 651 & 694 & 742 & 680 & 1.8 \\
\hline 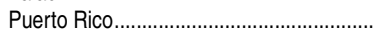 & 42,516 & 54,127 & 55,691 & 73,121 & 67,225 & 68,584 & 70,690 & 67,291 & 62,257 & 62,579 & -6.9 \\
\hline U.S. Virgin Islands ..................................... & 1,445 & 2,148 & 2,466 & 2,268 & 2,384 & 2,393 & 2,602 & 2,733 & 2,614 & 2,423 & 1.6 \\
\hline
\end{tabular}

'Data for 2000 and later years reflect a substantial reduction in the number of Department of Defense institutions included in the IPEDS survey.

NOTE: Data through 1990 are for institutions of higher education, while later data are for degree-granting institutions. Degree-granting institutions grant associate's or higher degrees and participate in Title IV federal financial aid programs. The degree-granting classification is very similar to the earlier higher education classification, but it includes more 2-year colleges and excludes a few higher education institutions that did not grant degrees.
SOURCE: U.S. Department of Education, National Center for Education Statistics, Higher Education General Information Survey (HEGIS), "Fall Enrollment in Colleges and Universities" surveys, 1970 and 1980; Integrated Postsecondary Education Data System (IPEDS), "Fall Enrollment Survey" (IPEDS-EF:90); and IPEDS Spring 2001 through Spring 2013, Enrollment component. (This table was prepared November 2013.) 


\begin{tabular}{|c|c|c|c|c|c|c|c|c|c|c|c|}
\hline State or jurisdiction & Fall 1970 & Fall 1980 & Fall 1990 & Fall 2000 & Fall 2007 & Fall 2008 & Fall 2009 & Fall 2010 & Fall 2011 & Fall 2012 & $\begin{array}{r}\text { Percent } \\
\text { change, } \\
2007 \text { to } 2012 \\
\end{array}$ \\
\hline 1 & 2 & 3 & 4 & 5 & 6 & 7 & 8 & 9 & 10 & 11 & 12 \\
\hline 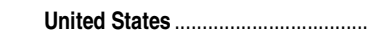 & $2,152,753$ & $2,639,501$ & $2,973,920$ & $3,559,503$ & $4,757,348$ & $5,130,661$ & $5,617,069$ & $5,873,317$ & $5,883,917$ & $5,762,476$ & 21.1 \\
\hline Alabama .............. & 16,052 & 20,632 & 22,650 & 26,527 & 30,551 & 65,901 & 51,463 & 60,244 & 58,163 & 59,266 & 94.0 \\
\hline Alaska......................................... & 908 & 735 & 2,041 & 1,394 & 1,235 & 1,550 & 1,913 & 1,350 & 2,774 & 2,202 & 78.3 \\
\hline 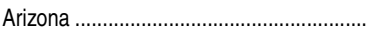 & 2,304 & 8,682 & 15,935 & 57,968 & 291,993 & 372,935 & 478,196 & 428,412 & 430,870 & 377,150 & 29.2 \\
\hline 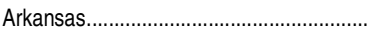 & 8,440 & 11,539 & 11,780 & 13,397 & 16,643 & 17,668 & 18,878 & 20,115 & 20,521 & 19,234 & 15.6 \\
\hline California ………………………………...... & 133,716 & 191,155 & 214,030 & 328,937 & 393,435 & 412,754 & 446,109 & 490,524 & 507,264 & 492,308 & 25.1 \\
\hline Colorado. & 14,833 & 17,318 & 26,478 & 45,975 & 82,653 & 89,967 & 96,596 & 102,618 & 96,522 & 90,491 & 9.5 \\
\hline Connecticut.. & 51,309 & 61,844 & 59,048 & 60,216 & 64,933 & 65,484 & 68,595 & 72,190 & 75,151 & 76,706 & 18.1 \\
\hline Delaware.... & 4,109 & 4,614 & 7,752 & 9,703 & 13,251 & 14,136 & 14,746 & 15,323 & 15,818 & 17,015 & 28.4 \\
\hline District of Columbia .......... & 64,964 & 72,775 & 67,561 & 67,190 & 109,545 & 120,526 & 131,598 & 86,152 & 84,933 & 84,674 & -22.7 \\
\hline 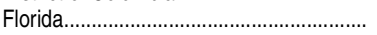 & 46,075 & 77,542 & 99,005 & 150,772 & 230,465 & 263,106 & 293,742 & 335,442 & 340,498 & 350,236 & 52.0 \\
\hline Georgia.... & 24,611 & 44,001 & 55,373 & 74,449 & 93,828 & 100,113 & 114,456 & 132,614 & 136,751 & 123,169 & 31.3 \\
\hline Hawaii.... & 3,599 & 3,912 & 10,708 & 15,603 & 16,147 & 16,578 & 16,864 & 17,983 & 18,688 & 18,161 & 12.5 \\
\hline Idaho........ & 7,495 & 8,527 & 10,566 & 11,843 & 18,320 & 19,266 & 21,189 & 20,997 & 24,389 & 29,227 & 59.5 \\
\hline Illinois.... & 136,512 & 152,971 & 177,913 & 209,763 & 286,078 & 298,831 & 312,083 & 321,374 & 315,838 & 309,973 & 8.4 \\
\hline Indiana.... & 55,929 & 58,029 & 60,879 & 74,311 & 101,526 & 105,006 & 116,222 & 121,718 & 117,560 & 113,493 & 11.8 \\
\hline lowa ... & 40,512 & 42,995 & 52,681 & 53,966 & 101,615 & 129,872 & 179,761 & 204,061 & 193,655 & 187,625 & 84.6 \\
\hline Kansas..... & 14,270 & 14,618 & 14,616 & 19,992 & 24,048 & 26,351 & 28,107 & 29,236 & 30,187 & 29,810 & 24.0 \\
\hline 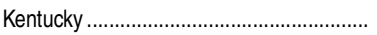 & 21,351 & 28,182 & 30,757 & 36,368 & 46,979 & 48,613 & 56,399 & 61,377 & 60,339 & 58,033 & 23.5 \\
\hline ․․…………...... & 19,601 & 23,355 & 28,550 & 34,587 & 31,438 & 33,277 & 36,342 & 38,827 & 40,646 & 37,854 & 20.4 \\
\hline 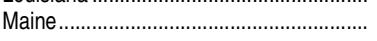 & 8,729 & 11,386 & 15,686 & 17,811 & 18,816 & 19,605 & 20,502 & 21,503 & 22,044 & 22,540 & 19.8 \\
\hline ryla & 30,619 & 30,475 & 38,917 & 49,948 & 57,878 & 58,311 & 60,756 & 68,188 & 65,714 & 63,993 & 10.6 \\
\hline Massachusetts... & 187,682 & 234,650 & 231,798 & 237,894 & 264,666 & 271,236 & 278,291 & 283,809 & 281,549 & 288,153 & 8.9 \\
\hline Michigan ……………………………......... & 53,101 & 65,984 & 82,444 & 99,770 & 123,830 & 124,759 & 133,027 & 135,681 & 130,785 & 123,583 & -0.2 \\
\hline 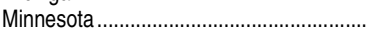 & 30,221 & 44,312 & 54,578 & 74,828 & 141,996 & 154,422 & 171,945 & 189,160 & 183,560 & 179,371 & 26.3 \\
\hline 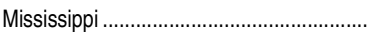 & 8,999 & 11,703 & 13,845 & 12,034 & 15,301 & 16,217 & 17,619 & 18,502 & 18,479 & 18,670 & 22.0 \\
\hline Missouri... & 51,390 & 69,242 & 89,806 & 119,839 & 161,211 & 167,672 & 179,376 & 188,576 & 196,412 & 183,941 & 14.1 \\
\hline Montan & 2,775 & 3,999 & 4,011 & 4,853 & 4,514 & 4,275 & 4,935 & 5,051 & 5,130 & 4,921 & 9.0 \\
\hline Nebraska ...... & 15,461 & 15,979 & 18,217 & 23,586 & 30,698 & 30,865 & 34,496 & 36,702 & 36,081 & 35,412 & 15.4 \\
\hline 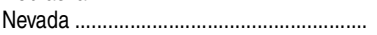 & 93 & 175 & 486 & 4,773 & 11,479 & 11,931 & 12,923 & 16,257 & 15,965 & 14,681 & 27.9 \\
\hline New Hampshire ................ & 13,421 & 22,675 & 27,347 & 25,848 & 28,742 & 29,547 & 30,727 & 31,522 & 34,111 & 39,389 & 37.0 \\
\hline New Jersey.. & 70,748 & 74,582 & 62,685 & 69,024 & 79,840 & 81,322 & 83,193 & 85,835 & 84,292 & 83,509 & 4.6 \\
\hline 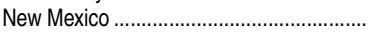 & 3,666 & 3,206 & 2,097 & 9,289 & 9,602 & 9,430 & 9,651 & 11,796 & 11,040 & 9,632 & 0.3 \\
\hline 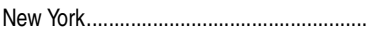 & 357,042 & 428,986 & 431,402 & 459,978 & 520,383 & 558,966 & 577,138 & 582,095 & 586,228 & 587,712 & 12.9 \\
\hline North Carolina ............................................ & 48,164 & 59,383 & 66,733 & 75,230 & 91,584 & 94,001 & 98,626 & 110,444 & 114,024 & 112,347 & 22.7 \\
\hline 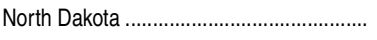 & 1,303 & 2,360 & 3,188 & 4,234 & 6,929 & 7,059 & 7,706 & 7,999 & 6,904 & 6,240 & -9.9 \\
\hline Ohio .......... & 95,168 & 107,380 & 130,077 & 138,392 & 170,257 & 178,064 & 189,093 & 197,396 & 192,252 & 185,480 & 8.9 \\
\hline 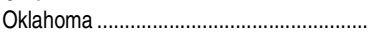 & 18 & 23,107 & 22,148 & 24,317 & 28,739 & 28,504 & 30,697 & 32,931 & 32,781 & 33,353 & 16.1 \\
\hline Oreg & 13 & 17 & 21 & 28 & 37,668 & 38,959 & 42,166 & 42,329 & 43,595 & 42,385 & 12.5 \\
\hline Pennsylvania.... & 178,062 & 215,217 & 260,582 & 270,292 & 328,623 & 335,312 & 352,144 & 370,704 & 359,520 & 351,352 & 6.9 \\
\hline Rhode Island ...... & 20,371 & 31,817 & 35,923 & 36,992 & 41,397 & 41,292 & 41,264 & 41,886 & 41,390 & 40,748 & -1.6 \\
\hline Sout & 22,417 & 24,793 & 28,168 & 30,412 & 37,276 & 43,442 & 46,463 & 52,213 & 51,700 & 50,594 & 35.7 \\
\hline ........... & 6,703 & 8,433 & 7,612 & 8,364 & 10,830 & 10,701 & 11,668 & 13,801 & 12,170 & 11,873 & 9.6 \\
\hline Tenn & 36,206 & 47,746 & 51,189 & 61,380 & 89,261 & 93,470 & 101,177 & 109,502 & 108,358 & 108,631 & 21.7 \\
\hline 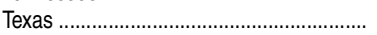 & 76,703 & 87,839 & 99,123 & 137,439 & 159,432 & 164,016 & 189,027 & 201,973 & 197,382 & 192,438 & 20.7 \\
\hline Utah .................... & 32,099 & 34,389 & 35,195 & 40,730 & 55,697 & 59,187 & 65,669 & 73,508 & 85,188 & 96,308 & 72.9 \\
\hline & 9,673 & 12,644 & 38 & 468 & 362 & 394 & 947 & 048 & 011 & 202 & 4.8 \\
\hline ........ & 28,636 & 34,004 & 62,156 & 68,113 & 107,782 & 117,675 & 143,943 & 167,006 & 174,704 & 178,943 & 66.0 \\
\hline ………..... & 20,826 & 27,575 & 35,752 & 46,912 & 50,282 & 50,464 & 54,141 & 57,236 & 55,775 & 54,017 & 7.4 \\
\hline 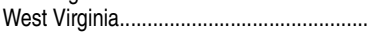 & 11,790 & 10,745 & 10,682 & 11,752 & 29,010 & 36,638 & 47,951 & 56,327 & 66,674 & 69,162 & 138.4 \\
\hline$\ldots$ & 31,684 & 33,907 & 46,245 & 57,442 & 70,039 & 72,481 & 78,138 & 82,774 & 79,808 & 76,316 & 9.0 \\
\hline Wyoming ................................................... & 0 & 26 & 703 & 1,289 & 1,541 & 1,510 & 1,411 & 2,006 & 1,724 & 1,953 & 26.7 \\
\hline Other jurisdictions ................................. & 20,557 & 77,057 & 98,374 & 110,169 & 145,891 & 153,743 & 156,762 & 180,518 & 188,231 & 181,574 & 24.5 \\
\hline American S & 0 & 0 & 0 & 0 & 0 & 0 & 0 & 0 & 0 & 0 & $\dagger$ \\
\hline Federated States of Micronesia..... & 0 & 0 & 0 & 0 & 0 & 0 & 0 & 0 & 0 & 0 & \\
\hline Guam... & 0 & 0 & 0 & 0 & 167 & 149 & 94 & 85 & 86 & 77 & -53.9 \\
\hline ․․․… & 0 & 0 & 0 & 0 & 0 & 0 & 0 & 0 & 0 & 0 & $\dagger$ \\
\hline Northern Marianas ....................................... & 0 & 0 & 0 & 0 & 0 & 0 & 0 & 0 & 0 & 0 & \\
\hline Palau & & & 0 & 0 & 0 & 0 & 0 & 0 & 0 & 0 & \\
\hline Puerto Rico......................................... & 20,557 & 77,057 & 98,374 & 110,169 & 145,724 & 153,594 & 156,668 & 180,433 & 188,145 & 181,497 & 24.5 \\
\hline U.S. Virgin Islands ............................... & 0 & 0 & 0 & 0 & 0 & 0 & 0 & 0 & 0 & 0 & r \\
\hline
\end{tabular}

†Not applicable.

NOTE: Data through 1990 are for institutions of higher education, while later data are for degree-granting institutions. Degree-granting institutions grant associate's or higher degrees and participate in Title IV federal financial aid programs. The degree-granting classification is very similar to the earlier higher education classification, but it includes more 2-year colleges and excludes a few higher education institutions that did not grant degrees.
SOURCE: U.S. Department of Education, National Center for Education Statistics, Higher Education General Information Survey (HEGIS), "Fall Enrollment in Colleges and Universities" surveys, 1970 and 1980; Integrated Postsecondary Education Data System (IPEDS), "Fall Enrollment Survey" (IPEDS-EF:90); and IPEDS Spring 2001 through Spring 2013, Enrollment component. (This table was prepared November 2013.) 
Table 304.30. Total fall enrollment in degree-granting postsecondary institutions, by attendance status, sex, and state or jurisdiction: 2011 and 2012

\begin{tabular}{|c|c|c|c|c|c|c|c|c|c|c|c|}
\hline \multirow[b]{3}{*}{ State or jurisdiction } & \multicolumn{5}{|c|}{ Fall 2011} & \multicolumn{5}{|c|}{ Fall 2012} & \multirow{3}{*}{$\begin{array}{r}\text { Percent } \\
\text { change in } \\
\text { total, } 2011 \text { to } \\
2012\end{array}$} \\
\hline & \multirow[b]{2}{*}{ Total } & \multicolumn{2}{|c|}{ Full-time } & \multicolumn{2}{|c|}{ Part-time } & \multirow[b]{2}{*}{ Total } & \multicolumn{2}{|c|}{ Full-time } & \multicolumn{2}{|c|}{ Part-time } & \\
\hline & & Males & Females & Males & Females & & Males & Females & Males & Females & \\
\hline 1 & 2 & 3 & 4 & 5 & 6 & 7 & 8 & 9 & 10 & 11 & 12 \\
\hline United States. & $20,994,113$ & $5,793,411$ & $7,208,046$ & $3,233,088$ & $4,759,568$ & $20,642,819$ & $5,709,792$ & $7,027,221$ & $3,209,295$ & $4,696,511$ & $\overline{-1.7}$ \\
\hline Alabama .................... & 318,686 & 94,898 & 122,423 & 38,673 & 62,692 & 310,311 & 90,166 & 117,546 & 41,347 & 61,252 & -2.6 \\
\hline Alaska......... & 34,932 & 7,083 & 9,274 & 6,781 & 11,794 & 32,797 & 6,903 & 8,590 & 6,319 & 10,985 & -6.1 \\
\hline Arizona & 796,986 & 205,806 & 354,835 & 91,949 & 144,396 & 736,379 & 189,906 & 312,036 & 90,374 & 144,063 & -7.6 \\
\hline 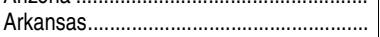 & 179,281 & 49,477 & 65,758 & 23,931 & 40,115 & 176,458 & 48,732 & 64,126 & 23,991 & 39,609 & -1.6 \\
\hline California & $2,685,893$ & 648,067 & 784,708 & 571,364 & 681,754 & $2,621,460$ & 643,499 & 767,810 & 552,645 & 657,506 & -2.4 \\
\hline Colorado .... & 365,820 & 98,210 & 119,205 & 62,624 & 85,781 & 362,935 & 96,877 & 112,802 & 64,992 & 88,264 & -0.8 \\
\hline 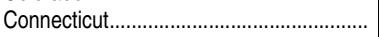 & 201,638 & 58,060 & 69,781 & 27,245 & 46,552 & 201,658 & 57,725 & 69,247 & 27,619 & 47,067 & \# \\
\hline 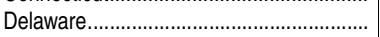 & 56,516 & 16,093 & 21,125 & 7,023 & 12,275 & 58,128 & 16,066 & 21,225 & 7,613 & 13,224 & 2.9 \\
\hline District of Columbia & 90,213 & 26,711 & 36,300 & 10,839 & 16,363 & 90,150 & 26,516 & 36,262 & 10,630 & 16,742 & -0.1 \\
\hline 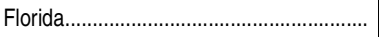 & $1,143,698$ & 289,075 & 375,661 & 187,262 & 291,700 & $1,154,929$ & 289,914 & 378,372 & 191,569 & 295,074 & 1.0 \\
\hline Georgia. & 565,459 & 156,407 & 222,985 & 68,259 & 117,808 & 545,358 & 152,101 & 208,500 & 67,696 & 117,061 & -3.6 \\
\hline Hawaii.... & 79,018 & 19,096 & 24,862 & 14,312 & 20,748 & 78,456 & 19,490 & 25,199 & 13,913 & 19,854 & -0.7 \\
\hline Idaho........ & 90,142 & 28,742 & 32,783 & 11,426 & 17,191 & 108,008 & 30,739 & 35,113 & 16,971 & 25,185 & 19.8 \\
\hline 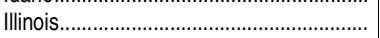 & 892,881 & 235,886 & 278,792 & 152,573 & 225,630 & 867,110 & 227,236 & 266,645 & 148,020 & 225,209 & -2.9 \\
\hline Indiana & 457,824 & 138,440 & 167,996 & 61,999 & 89,389 & 447,262 & 133,079 & 160,786 & 62,940 & 90,457 & -2.3 \\
\hline lowa .... & 372,146 & 100,307 & 147,367 & 44,652 & 79,820 & 361,183 & 100,278 & 145,603 & 41,747 & 73,555 & -2.9 \\
\hline 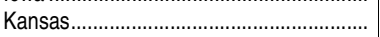 & 216,662 & 61,922 & 68,512 & 34,110 & 52,118 & 213,786 & 60,888 & 67,483 & 34,658 & 50,757 & -1.3 \\
\hline 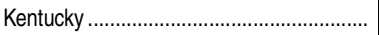 & 293,766 & 75,623 & 103,815 & 49,958 & 64,370 & 282,125 & 74,587 & 100,132 & 45,150 & 62,256 & -4.0 \\
\hline 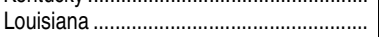 & 265,856 & 75,330 & 105,013 & 31,867 & 53,646 & 258,825 & 72,570 & 100,621 & 32,283 & 53,351 & -2.6 \\
\hline Maine & 72,297 & 20,524 & 25,255 & 9,472 & 17,046 & 72,810 & 20,401 & 25,248 & 9,805 & 17,356 & 0.7 \\
\hline 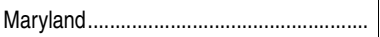 & 380,097 & 90,290 & 109,546 & 71,013 & 109,248 & 374,496 & 89,744 & 107,029 & 70,872 & 106,851 & -1.5 \\
\hline Massachusetts... & 508,554 & 159,064 & 190,790 & 60,359 & 98,341 & 516,331 & 162,118 & 193,131 & 61,486 & 99,596 & 1.5 \\
\hline 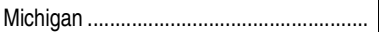 & 685,526 & 183,511 & 213,721 & 116,324 & 171,970 & 663,825 & 179,840 & 207,038 & 112,648 & 164,299 & -3.2 \\
\hline 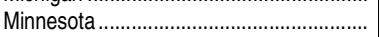 & 457,752 & 112,757 & 145,958 & 71,687 & 127,350 & 451,661 & 110,594 & 141,701 & 71,213 & 128,153 & -1.3 \\
\hline Mississippi .............................................. & 179,090 & 55,459 & 82,141 & 13,887 & 27,603 & 176,665 & 54,869 & 80,688 & 14,145 & 26,963 & -1.4 \\
\hline Missouri .. & 456,997 & 123,224 & 152,613 & 70,336 & 110,824 & 441,371 & 121,509 & 148,853 & 69,223 & 101,786 & -3.4 \\
\hline 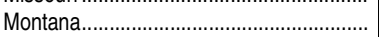 & 54,042 & 19,372 & 20,253 & 5,485 & 8,932 & 53,254 & 18,976 & 19,808 & 5,671 & 8,799 & -1.5 \\
\hline 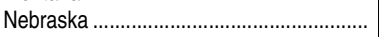 & 142,875 & 42,911 & 49,973 & 20,756 & 29,235 & 139,578 & 41,450 & 48,031 & 20,921 & 29,176 & -2.3 \\
\hline Nevada & 121,013 & 27,182 & 33,990 & 25,987 & 33,854 & 118,300 & 27,068 & 33,356 & 24,999 & 32,877 & -2.2 \\
\hline 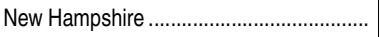 & 77,444 & 24,270 & 28,506 & 8,977 & 15,691 & 82,678 & 25,317 & 30,563 & 9,939 & 16,859 & 6.8 \\
\hline 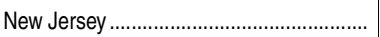 & 443,750 & 132,636 & 147,550 & 68,115 & 95,449 & 439,965 & 131,690 & 144,883 & 68,052 & 95,340 & -0.9 \\
\hline New Mexico & 157,555 & 36,731 & 46,941 & 30,599 & 43,284 & 156,424 & 36,365 & 45,782 & 30,625 & 43,652 & -0.7 \\
\hline 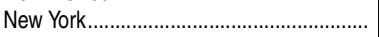 & $1,318,142$ & 414,697 & 504,700 & 154,755 & 243,990 & $1,309,986$ & 411,826 & 499,646 & 154,560 & 243,954 & -0.6 \\
\hline 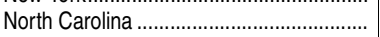 & 585,013 & 159,628 & 215,238 & 77,826 & 132,321 & 578,031 & 159,799 & 212,823 & 76,001 & 129,408 & -1.2 \\
\hline 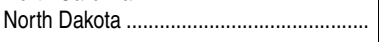 & 55,772 & 19,782 & 19,197 & 7,549 & 9,244 & 55,169 & 19,615 & 19,025 & 7,364 & 9,165 & -1.1 \\
\hline Ohio .... & 735,026 & 220,931 & 263,701 & 95,035 & 155,359 & 709,818 & 210,520 & 247,915 & 96,385 & 154,998 & -3.4 \\
\hline Oklahoma & 230,154 & 66,533 & 79,988 & 33,961 & 49,672 & 228,464 & 66,449 & 78,857 & 34,412 & 48,746 & -0.7 \\
\hline 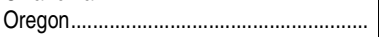 & 259,061 & 74,097 & 85,555 & 42,973 & 56,436 & 254,695 & 72,887 & 84,896 & 42,191 & 54,721 & -1.7 \\
\hline 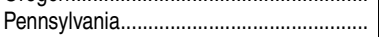 & 787,789 & 263,348 & 302,884 & 80,606 & 140,951 & 777,242 & 258,272 & 296,753 & 83,360 & 138,857 & -1.3 \\
\hline Rhode Island & 84,644 & 28,743 & 34,054 & 8,216 & 13,631 & 83,952 & 28,211 & 33,864 & 8,256 & 13,621 & -0.8 \\
\hline South Carolina... & 260,002 & 76,361 & 102,147 & 28,075 & 53,419 & 259,617 & 76,606 & 101,081 & 28,338 & 53,592 & -0.1 \\
\hline South Dakota & 55,899 & 16,843 & 18,118 & 7,135 & 13,803 & 56,058 & 16,578 & 17,585 & 7,667 & 14,228 & 0.3 \\
\hline Tennessee & 350,275 & 108,153 & 139,426 & 37,575 & 65,121 & 343,641 & 106,090 & 135,801 & 38,069 & 63,681 & -1.9 \\
\hline 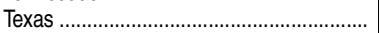 & $1,564,387$ & 381,177 & 459,221 & 295,554 & 428,435 & $1,540,298$ & 376,249 & 452,397 & 289,986 & 421,666 & -1.5 \\
\hline Utah & 264,396 & 83,165 & 87,058 & 45,555 & 48,618 & 267,309 & 87,394 & 93,358 & 42,011 & 44,546 & 1.1 \\
\hline Vermont.. & 45,143 & 16,782 & 17,135 & 3,657 & 7,569 & 44,703 & 16,654 & 16,928 & 3,695 & 7,426 & -1.0 \\
\hline Virginia...................... & 588,465 & 158,972 & 197,154 & 93,464 & 138,875 & 588,696 & 158,832 & 194,281 & 94,933 & 140,650 & \# \\
\hline 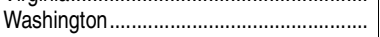 & 372,841 & 115,436 & 135,475 & 51,547 & 70,383 & 365,514 & 115,203 & 134,609 & 49,003 & 66,699 & -2.0 \\
\hline 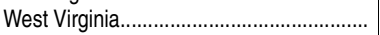 & 162,308 & 40,037 & 46,944 & 40,113 & 35,214 & 162,179 & 38,488 & 44,270 & 43,340 & 36,081 & -0.1 \\
\hline Wisconsin & 376,603 & 112,079 & 128,017 & 52,271 & 84,236 & 369,732 & 109,774 & 125,483 & 52,520 & 81,955 & -1.8 \\
\hline 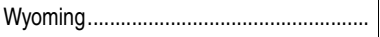 & 38,092 & 10,846 & 10,570 & 7,356 & 9,320 & 37,812 & 10,968 & 10,402 & 7,105 & 9,337 & -0.7 \\
\hline U.S. Service Academies .... & 15,692 & 12,637 & 3,032 & 21 & 2 & 15,227 & 12,164 & 3,038 & 23 & 2 & -3.0 \\
\hline 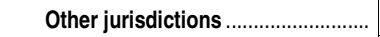 & 267,159 & 90,834 & 126,960 & 19,542 & 29,823 & 259,943 & 88,041 & 122,014 & 19,818 & 30,070 & -2.7 \\
\hline 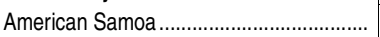 & 2,091 & 401 & 623 & 428 & 639 & 1,795 & 207 & 355 & 463 & 770 & -14.2 \\
\hline 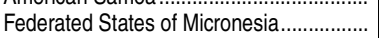 & 2,915 & 925 & 1,095 & 432 & 463 & 2,744 & 786 & 996 & 465 & 497 & -5.9 \\
\hline Guam & 6,360 & 1,429 & 2,196 & 1,255 & 1,480 & 5,924 & 1,539 & 2,179 & 939 & 1,267 & -6.9 \\
\hline 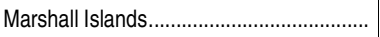 & 989 & 408 & 413 & 91 & 77 & 1,123 & 394 & 380 & 192 & 157 & 13.5 \\
\hline Northern Marianas ........................................ & 1,046 & 355 & 565 & 55 & 71 & 1,178 & 413 & 596 & 71 & 98 & 12.6 \\
\hline 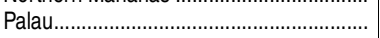 & 742 & 225 & 283 & 90 & 144 & 680 & 203 & 220 & 94 & 163 & -8.4 \\
\hline Puerto Rico................................................. & 250,402 & 86,626 & 120,737 & 16,920 & 26,119 & 244,076 & 84,029 & 116,287 & 17,354 & 26,406 & -2.5 \\
\hline U.S. Virgin Islands & 2,614 & 465 & 1,048 & 271 & 830 & 2,423 & 470 & 1,001 & 240 & 712 & -7.3 \\
\hline
\end{tabular}

\#Rounds to zero.

NOTE: Degree-granting institutions grant associate's or higher degrees and participate in Title IV federal financial aid programs.
SOURCE: U.S. Department of Education, National Center for Education Statistics, Integrated Postsecondary Education Data System (IPEDS), Spring 2012 and Spring 2013, Enrollment component. (This table was prepared November 2013.) 
CHAPTER 3: Postsecondary Education 417 Total Fall Enrollment-State-Level

Table 304.35. Total fall enrollment in public degree-granting postsecondary institutions, by attendance status, sex, and state or jurisdiction: 2011 and 2012

\begin{tabular}{|c|c|c|c|c|c|c|c|c|c|c|c|}
\hline \multirow[b]{3}{*}{ State or jurisdiction } & \multicolumn{5}{|c|}{ Fall 2011} & \multicolumn{5}{|c|}{ Fall 2012} & \multirow{3}{*}{$\begin{array}{r}\text { Percent } \\
\text { change in } \\
\text { total, } 2011 \\
\text { to } 2012\end{array}$} \\
\hline & \multirow[b]{2}{*}{ Total } & \multicolumn{2}{|c|}{ Full-time } & \multicolumn{2}{|c|}{ Part-time } & \multirow[b]{2}{*}{ Total } & \multicolumn{2}{|c|}{ Full-time } & \multicolumn{2}{|c|}{ Part-time } & \\
\hline & & Males & Females & Males & Females & & Males & Females & Males & Females & \\
\hline 1 & 2 & 3 & 4 & 5 & 6 & 7 & 8 & 9 & 10 & 11 & 12 \\
\hline United States & $15,110,196$ & $4,001,784$ & $4,663,956$ & $2,654,452$ & $3,790,004$ & $14,880,343$ & $3,954,114$ & $4,571,704$ & $2,627,185$ & $3,727,340$ & -1.5 \\
\hline Alabama ...................... & 260,523 & 73,628 & 97,344 & 34,085 & 55,466 & 251,045 & 71,945 & 93,788 & 32,510 & 52,802 & -3.6 \\
\hline Alaska................. & 32,158 & 6,438 & 7,501 & 6,669 & 11,550 & 30,595 & 6,258 & 7,291 & 6,230 & 10,816 & -4.9 \\
\hline Arizona & 366,116 & 87,030 & 95,411 & 77,043 & 106,632 & 359,229 & 86,638 & 93,387 & 75,039 & 104,165 & -1.9 \\
\hline Arkansas................. & 158,760 & 42,205 & 56,713 & 22,579 & 37,263 & 157,224 & 41,840 & 55,557 & 22,657 & 37,170 & -1.0 \\
\hline California & $2,178,629$ & 479,517 & 556,124 & 523,555 & 619,433 & $2,129,152$ & 477,812 & 549,712 & 505,652 & 595,976 & -2.3 \\
\hline Colorado. & 269,298 & 73,209 & 77,909 & 50,607 & 67,573 & 272,444 & 73,746 & 76,955 & 52,816 & 68,927 & 1.2 \\
\hline Connecticut.. & 126,487 & 34,197 & 38,208 & 20,853 & 33,229 & 124,952 & 33,661 & 37,289 & 20,812 & 33,190 & -1.2 \\
\hline Delaware..... & 40,698 & 12,554 & 16,490 & 4,307 & 7,347 & 41,113 & 12,579 & 16,690 & 4,429 & 7,415 & 1.0 \\
\hline District of Colu & 5,280 & 1,310 & 1,295 & 1,236 & 1,439 & 5,476 & 1,012 & 1,368 & 1,094 & 2,002 & 3.7 \\
\hline 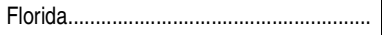 & 803,200 & 187,590 & 235,680 & 150,177 & 229,753 & 804,693 & 185,061 & 230,703 & 155,165 & 233,764 & 0.2 \\
\hline Georgia. & 428,708 & 117,667 & 152,452 & 58,615 & 99,974 & 422,189 & 116,805 & 148,785 & 58,145 & 98,454 & -1.5 \\
\hline wii & 60,330 & 14,195 & 17,098 & 11,539 & 17,498 & 60,295 & 14,296 & 17,574 & 11,486 & 16,939 & -0.1 \\
\hline Idaho.... & 65,753 & 20,535 & 21,740 & 9,312 & 14,166 & 78,781 & 22,044 & 23,382 & 13,319 & 20,036 & 19.8 \\
\hline Illinois..... & 577,043 & 143,369 & 158,798 & 113,543 & 161,333 & 557,137 & 138,611 & 152,096 & 110,132 & 156,298 & -3.4 \\
\hline Indiana...... & 340,264 & 98,763 & 113,088 & 53,345 & 75,068 & 333,769 & 94,954 & 108,383 & 54,542 & 75,890 & -1.9 \\
\hline lowa. & 178,491 & 54,359 & 56,714 & 29,141 & 38,277 & 173,558 & 53,368 & 55,170 & 28,264 & 36,756 & -2.8 \\
\hline$\ldots$ & 186,475 & 53,510 & 57,377 & 30,198 & 45,390 & 183,976 & 52,523 & 56,452 & 30,723 & 44,278 & -1.3 \\
\hline Kentucky ...... & 233,427 & 59,278 & 76,561 & 44,202 & 53,386 & 224,092 & 58,865 & 74,487 & 39,582 & 51,158 & -4.0 \\
\hline 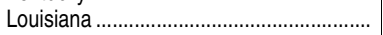 & 225,210 & 63,565 & 84,452 & 29,415 & 47,778 & 220,971 & 61,516 & 81,310 & 29,932 & 48,213 & -1.9 \\
\hline Maine..... & 50,253 & 13,771 & 15,153 & 8,027 & 13,302 & 50,270 & 13,583 & 14,935 & 8,390 & 13,362 & \# \\
\hline Maryland. & 314,383 & 71,875 & 86,141 & 61,724 & 94,643 & 310,503 & 71,637 & 84,012 & 62,083 & 92,771 & -1.2 \\
\hline IVI & 227,005 & 60,841 & 68,308 & 36,533 & 61,323 & 228,178 & 60,775 & 67,748 & 37,560 & 62,095 & 0.5 \\
\hline $\mathrm{Mi}$ & 554,741 & 150,639 & 169,994 & 95,828 & 138,280 & 540,242 & 148,522 & 166,376 & 93,249 & 132,095 & -2.6 \\
\hline Minnesota. & 274,192 & 77,119 & 81,320 & 48,457 & 67,296 & 272,290 & 76,149 & 79,119 & 48,443 & 68,579 & -0.7 \\
\hline Mississippi .... & 160,611 & 50,246 & 72,448 & 12,899 & 25,018 & 157,995 & 50,031 & 72,399 & 12,580 & 22,985 & -1.6 \\
\hline Missou & 260,585 & 73,745 & 88,363 & 37,719 & 60,758 & 257,430 & 72,697 & 86,575 & 38,311 & 59,847 & -1.2 \\
\hline 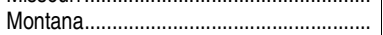 & 48,912 & 17,553 & 17,798 & 5,194 & 8,367 & 48,333 & 17,161 & 17,340 & 5,451 & 8,381 & -1.2 \\
\hline $\mathrm{Nel}$ & 106,794 & 31,846 & 34,229 & 17,249 & 23,470 & 104,166 & 30,865 & 32,943 & 17,278 & 23,080 & -2.5 \\
\hline$\ldots \ldots \ldots \ldots$ & 105,048 & 21,463 & 26,158 & 24,865 & 32,562 & 103,619 & 21,765 & 26,031 & 24,010 & 31,813 & -1.4 \\
\hline New Hampshire ... & 43,333 & 13,802 & 15,899 & 5,221 & 8,411 & 43,289 & 13,607 & 15,744 & 5,401 & 8,537 & -0.1 \\
\hline New & 359,458 & 102,919 & 116,488 & 58,634 & 81,417 & 356,456 & 101,921 & 113,758 & 58,813 & 81,964 & -0.8 \\
\hline …………..... & 146,515 & 33,351 & 40,788 & 30,177 & 42,199 & 146,792 & 33,402 & 40,576 & 30,195 & 42,619 & 0.2 \\
\hline & 731,914 & 221,975 & 258,766 & 99,852 & 151,321 & 722,274 & 220,235 & 254 & 98,896 & 148,255 & -1.3 \\
\hline$\ldots \ldots \ldots \ldots \ldots . .$. & 470,989 & 120,830 & 162,738 & 70,809 & 116,612 & 465,684 & 121,607 & 160,989 & 68,844 & 114,244 & -1.1 \\
\hline North Dakota & 48,868 & 17,903 & 16,072 & 6,896 & 7,997 & 48,929 & 17,914 & 16,164 & 6,769 & 8,082 & 0.1 \\
\hline Ohio ....... & 542,774 & 159,209 & 182,034 & 77,805 & 123,726 & 524,338 & 151,224 & 170,151 & 79,080 & 123,883 & -3.4 \\
\hline & 197,373 & 53,521 & 65,293 & 31,836 & 46,723 & 11 & 53,377 & 63 & 6 & 45,646 & -1.1 \\
\hline Ore & 215,466 & 60,660 & 64,737 & 39,299 & 50,770 & 212,310 & 59,575 & 64,246 & 38,945 & 49,544 & -1.5 \\
\hline Penns & 428,269 & 143,720 & 154,213 & 48,471 & 81,865 & 425,890 & 140,662 & 150,364 & 52,245 & 82,619 & -0.6 \\
\hline Rhode Island . & 43,254 & 10,956 & 14,603 & 6,268 & 11,427 & 43,204 & 11,002 & 14,375 & 6,329 & 11,498 & -0.1 \\
\hline South & 208,302 & 59,754 & 76,869 & 24,920 & 46,759 & 209,023 & 60,447 & 76,3 & 25,224 & 47,025 & 0.3 \\
\hline . & 43,729 & 14,472 & 14,180 & 5,284 & 9,793 & 44,185 & 14 & 13,8 & 5,763 & 10,312 & 1.0 \\
\hline Tenness & 241,917 & 70,361 & 87,891 & 30,913 & 52,752 & 235,010 & 68,366 & 84,263 & 30,773 & 51,608 & -2.9 \\
\hline & $1,367,005$ & 315,542 & 372,041 & 276,036 & 403,386 & $1,347,860$ & 312,322 & 367,538 & 271,188 & 396,812 & -1.4 \\
\hline Utah .......................... & 179,208 & 48,255 & 44,649 & 41,805 & 44,499 & 171,001 & 47,487 & 44,362 & 38,302 & 40,850 & -4.6 \\
\hline & 27,132 & 8,425 & 9,629 & 2,832 & 6,246 & 26,501 & 8,253 & 9,3 & 2,775 & 6,082 & -2.3 \\
\hline & 413,761 & 111,489 & 131,895 & 69,514 & 100,863 & 409,753 & 111,553 & 130,367 & 69,603 & 98,230 & -1.0 \\
\hline 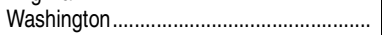 & 317,066 & 97,531 & 108,843 & 46,840 & 63,852 & 311,497 & 97,742 & 109,129 & 44,455 & 60,171 & -1.8 \\
\hline & 95,634 & 33,000 & 37,072 & 9,778 & 15,784 & 93,017 & 32,482 & 36,557 & 8,989 & 14,989 & -2.7 \\
\hline 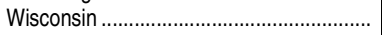 & 296,795 & 90,180 & 94,940 & 44,969 & 66,706 & 293,416 & 88,627 & 93,587 & 45,428 & 65,774 & -1.1 \\
\hline Wyoming & 36,368 & 9,275 & 10,417 & 7,356 & 9,320 & 35,859 & 9,185 & 10,232 & 7,105 & 9,337 & -1.4 \\
\hline U.S. Service Academies.... & 15,692 & 12,637 & 3,032 & 21 & 2 & 15,227 & 12,164 & 3,038 & 23 & 2 & -3.0 \\
\hline Other jurisdictions ............ & 78,928 & 27,762 & 38,614 & 5,282 & 7,270 & 78,369 & 28,016 & 37,607 & 5,295 & 7,451 & -0.7 \\
\hline Americ & 2,091 & 401 & 623 & 428 & 639 & 1,795 & 207 & 355 & 463 & 770 & -14.2 \\
\hline Federated & 2,915 & 925 & 1,095 & 432 & 463 & 2,744 & 786 & 996 & 465 & 497 & -5.9 \\
\hline & 6,274 & 1,402 & 2,170 & 1,235 & 1,467 & 5,847 & 1,512 & 2,154 & 925 & 1,256 & -6.8 \\
\hline Marshall Islands... & 989 & 408 & 413 & 91 & 77 & 1,123 & 394 & 380 & 192 & 157 & 13.5 \\
\hline Northern Marianas .............................. & 1,046 & 355 & 565 & 55 & 71 & 1,178 & 413 & 596 & 71 & 98 & 12.6 \\
\hline Palau...... & 742 & 225 & 283 & 90 & 144 & 680 & 203 & 220 & 94 & 163 & -8.4 \\
\hline Puerto $\mathrm{R}$ & 62,257 & 23,581 & 32,417 & 2,680 & 3,579 & 62,579 & 24,031 & 31,905 & 2,845 & 3,798 & 0.5 \\
\hline U.S. Virgin Islands .. & 2,614 & 465 & 1,048 & 271 & 830 & 2,423 & 470 & 1,001 & 240 & 712 & -7.3 \\
\hline
\end{tabular}

\#Rounds to zero.

NOTE: Degree-granting institutions grant associate's or higher degrees and participate in Title IV federal financial aid programs.
SOURCE: U.S. Department of Education, National Center for Education Statistics, Integrated Postsecondary Education Data System (IPEDS), Spring 2012 and Spring 2013, Enrollment component. (This table was prepared November 2013.) 
Table 304.40. Total fall enrollment in private degree-granting postsecondary institutions, by attendance status, sex, and state or jurisdiction: 2011 and 2012

\begin{tabular}{|c|c|c|c|c|c|c|c|c|c|c|c|}
\hline \multirow[b]{3}{*}{ State or jurisdiction } & \multicolumn{5}{|c|}{ Fall 2011} & \multicolumn{5}{|c|}{ Fall 2012} & \multirow{3}{*}{$\begin{array}{r}\text { Percent } \\
\text { change in } \\
\text { total, } 2011 \\
\text { to } 2012\end{array}$} \\
\hline & \multirow[b]{2}{*}{ Total } & \multicolumn{2}{|c|}{ Full-time } & \multicolumn{2}{|c|}{ Part-time } & \multirow[b]{2}{*}{ Total } & \multicolumn{2}{|c|}{ Full-time } & \multicolumn{2}{|c|}{ Part-time } & \\
\hline & & Males & Females & Males & Females & & Males & Females & Males & Females & \\
\hline 1 & 2 & 3 & 4 & 5 & 6 & 7 & 8 & 9 & 10 & 11 & 12 \\
\hline United States ........................ & $5,883,917$ & $1,791,627$ & $2,544,090$ & 578,636 & 969,564 & $5,762,476$ & $1,755,678$ & $2,455,517$ & 582,110 & 969,171 & -2.1 \\
\hline Alabama ............. & 58,163 & 21,270 & 25,079 & 4,588 & 7,226 & 59,266 & 18,221 & 23,758 & 8,837 & 8,450 & 1.9 \\
\hline 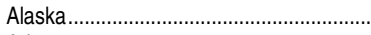 & 2,774 & 645 & 1,773 & 112 & 244 & 2,202 & 645 & 1,299 & 89 & 169 & -20.6 \\
\hline Arizona & 430,870 & 118,776 & 259,424 & 14,906 & 37,764 & 377,150 & 103,268 & 218,649 & 15,335 & 39,898 & -12.5 \\
\hline Arkansas............. & 20,521 & 7,272 & 9,045 & 1,352 & 2,852 & 19,234 & 6,892 & 8,569 & 1,334 & 2,439 & -6.3 \\
\hline California .... & 507,264 & 168,550 & 228,584 & 47,809 & 62,321 & 492,308 & 165,687 & 218,098 & 46,993 & 61,530 & -2.9 \\
\hline Colorado. & 96,522 & 25,001 & 41,296 & 12,017 & 18,208 & 90,491 & 23,131 & 35,847 & 12,176 & 19,337 & -6.2 \\
\hline Connecticut.. & 75,151 & 23,863 & 31,573 & 6,392 & 13,323 & 76,706 & 24,064 & 31,958 & 6,807 & 13,877 & 2.1 \\
\hline Delaware........ & 15,818 & 3,539 & 4,635 & 2,716 & 4,928 & 17,015 & 3,487 & 4,535 & 3,184 & 5,809 & 7.6 \\
\hline District of Columbia ........................... & 84,933 & 25,401 & 35,005 & 9,603 & 14,924 & 84,674 & 25,504 & 34,894 & 9,536 & 14,740 & -0.3 \\
\hline 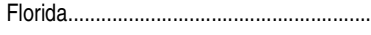 & 340,498 & 101,485 & 139,981 & 37,085 & 61,947 & 350,236 & 104,853 & 147,669 & 36,404 & 61,310 & 2.9 \\
\hline Georgia.. & 136,751 & 38,740 & 70,533 & 9,644 & 17,834 & 123,169 & 35,296 & 59,715 & 9,551 & 18,607 & -9.9 \\
\hline Hawaii..... & 18,688 & 4,901 & 7,764 & 2,773 & 3,250 & 18,161 & 5,194 & 7,625 & 2,427 & 2,915 & -2.8 \\
\hline Idaho............ & 24,389 & 8,207 & 11,043 & 2,114 & 3,025 & 29,227 & 8,695 & 11,731 & 3,652 & 5,149 & 19.8 \\
\hline 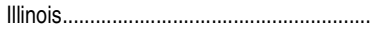 & 315,838 & 92,517 & 119,994 & 39,030 & 64,297 & 309,973 & 88,625 & 114,549 & 37,888 & 68,911 & -1.9 \\
\hline Indiana & 117,560 & 39,677 & 54,908 & 8,654 & 14,321 & 113,493 & 38,125 & 52,403 & 8,398 & 14,567 & -3.5 \\
\hline lowa. & 193,655 & 45,948 & 90,653 & 15,511 & 41,543 & 187,625 & 46,910 & 90,433 & 13,483 & 36,799 & -3.1 \\
\hline Kansas..... & 30,187 & 8,412 & 11,135 & 3,912 & 6,728 & 29,810 & 8,365 & 11,031 & 3,935 & 6,479 & -1.2 \\
\hline Kentucky .... & 60,339 & 16,345 & 27,254 & 5,756 & 10,984 & 58,033 & 15,722 & 25,645 & 5,568 & 11,098 & -3.8 \\
\hline Louisiana ... & 40,646 & 11,765 & 20,561 & 2,452 & 5,868 & 37,854 & 11,054 & 19,311 & 2,351 & 5,138 & -6.9 \\
\hline Maine......... & 22,044 & 6,753 & 10,102 & 1,445 & 3,744 & 22,540 & 6,818 & 10,313 & 1,415 & 3,994 & 2.3 \\
\hline Maryland. & 65,714 & 18,415 & 23,405 & 9,289 & 14,605 & 63,993 & 18,107 & 23,017 & 8,789 & 14,080 & -2.6 \\
\hline Massachusetts. & 281,549 & 98,223 & 122,482 & 23,826 & 37,018 & 288,153 & 101,343 & 125,383 & 23,926 & 37,501 & 2.3 \\
\hline Michigan ... & 130,785 & 32,872 & 43,727 & 20,496 & 33,690 & 123,583 & 31,318 & 40,662 & 19,399 & 32,204 & -5.5 \\
\hline Minnesota... & 183,560 & 35,638 & 64,638 & 23,230 & 60,054 & 179,371 & 34,445 & 62,582 & 22,770 & 59,574 & -2.3 \\
\hline Mississippi .... & 18,479 & 5,213 & 9,693 & 988 & 2,585 & 18,670 & 4,838 & 8,289 & 1,565 & 3,978 & 1.0 \\
\hline Missouri. & 196,412 & 49,479 & 64,250 & 32,617 & 50,066 & 183,941 & 48,812 & 62,278 & 30,912 & 41,939 & -6.3 \\
\hline 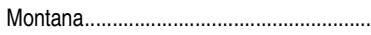 & 5,130 & 1,819 & 2,455 & 291 & 565 & 4,921 & 1,815 & 2,468 & 220 & 418 & -4.1 \\
\hline Nebraska... & 36,081 & 11,065 & 15,744 & 3,507 & 5,765 & 35,412 & 10,585 & 15,088 & 3,643 & 6,096 & -1.9 \\
\hline$\ldots$ & 15,965 & 5,719 & 7,832 & 1,122 & 1,292 & 14,681 & 5,303 & 7,325 & 989 & 1,064 & -8.0 \\
\hline New Hampshire ........ & 34,111 & 10,468 & 12,607 & 3,756 & 7,280 & 39,389 & 11,710 & 14,819 & 4,538 & 8,322 & 15.5 \\
\hline New Jersey & 84,292 & 29,717 & 31,062 & 9,481 & 14,032 & 83,509 & 29,769 & 31,125 & 9,239 & 13,376 & -0.9 \\
\hline New $\mathrm{N}$ & 11,040 & 3,380 & 6,153 & 422 & 1,085 & 9,632 & 2,963 & 5,206 & 430 & 1,033 & -12.8 \\
\hline New York..... & 586,228 & 192,722 & 245,934 & 54,903 & 92,669 & 587,712 & 191,591 & 244,758 & 55,664 & 95,699 & 0.3 \\
\hline North Carolina ... & 114,024 & 38,798 & 52,500 & 7,017 & 15,709 & 112,347 & 38,192 & 51,834 & 7,157 & 15,164 & -1.5 \\
\hline North Dakota ........ & 6,904 & 1,879 & 3,125 & 653 & 1,247 & 6,240 & 1,701 & 2,861 & 595 & 1,083 & -9.6 \\
\hline & 192,252 & 61,722 & 81,667 & 17,230 & 31,633 & 185,480 & 59,296 & 77,764 & 17,305 & 31,115 & -3.5 \\
\hline Okl & 32,781 & 13,012 & 14,695 & 2,125 & 2,949 & 33,353 & 13,072 & 14,925 & 2,256 & 3,100 & 1.7 \\
\hline Oregon & 43,595 & 13,437 & 20,818 & 3,674 & 5,666 & 42,385 & 13,312 & 20,650 & 3,246 & 5,177 & -2.8 \\
\hline Pennsylvania.... & 359,520 & 119,628 & 148,671 & 32,135 & 59,086 & 351,352 & 117,610 & 146,389 & 31,115 & 56,238 & -2.3 \\
\hline Rhode Island ......... & 41,390 & 17,787 & 19,451 & 1,948 & 2,204 & 40,748 & 17,209 & 19,489 & 1,927 & 2,123 & -1.6 \\
\hline Sou & 51,700 & 16,607 & 25,278 & 3,155 & 6,660 & 50,594 & 16,159 & 24,754 & 3,114 & 6,567 & -2.1 \\
\hline Sol & 12,170 & 2,371 & 3,938 & 1,851 & 4,010 & 11,873 & 2,337 & 3,716 & 1,904 & 3,916 & -2.4 \\
\hline$\ldots$ & 108,358 & 37,792 & 51,535 & 6,662 & 12,369 & 108,631 & 37,724 & 51,538 & 7,296 & 12,073 & 0.3 \\
\hline 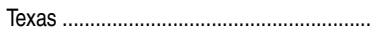 & 197,382 & 65,635 & 87,180 & 19,518 & 25,049 & 192,438 & 63,927 & 84,859 & 18,798 & 24,854 & -2.5 \\
\hline Utah ........................ & 85,188 & 34,910 & 42,409 & 3,750 & 4,119 & 96,308 & 39,907 & 48,996 & 3,709 & 3,696 & 13.1 \\
\hline Vern & 18,011 & 8,357 & 7,506 & 825 & 1,323 & 18,202 & 8,401 & 7,537 & 920 & 1,344 & 1.1 \\
\hline Virg & 174,704 & 47,483 & 65,259 & 23,950 & 38,012 & 178,943 & 47,279 & 63,914 & 25,330 & 42,420 & 2.4 \\
\hline Washington...... & 55,775 & 17,905 & 26,632 & 4,707 & 6,531 & 54,017 & 17,461 & 25,480 & 4,548 & 6,528 & -3.2 \\
\hline West Virginia... & 66,674 & 7,037 & 9,872 & 30,335 & 19,430 & 69,162 & 6,006 & 7,713 & 34,351 & 21,092 & 3.7 \\
\hline Wisconsin & 79,808 & 21,899 & 33,077 & 7,302 & 17,530 & 76,316 & 21,147 & 31,896 & 7,092 & 16,181 & -4.4 \\
\hline Wyoming .................. & 1,724 & 1,571 & 153 & 0 & 0 & 1,953 & 1,783 & 170 & 0 & 0 & 13.3 \\
\hline 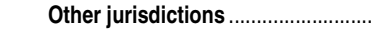 & 188,231 & 63,072 & 88,346 & 14,260 & 22,553 & 181,574 & 60,025 & 84,407 & 14,523 & 22,619 & -3.5 \\
\hline American Samoa ... & & 0 & 0 & 0 & 0 & 0 & 0 & 0 & 0 & 0 & 1 \\
\hline Federated States of Micronesia.... & 0 & 0 & 0 & 0 & 0 & 0 & 0 & 0 & 0 & 0 & \\
\hline Guam... & 86 & 27 & 26 & 20 & 13 & 77 & 27 & 25 & 14 & 11 & -10.5 \\
\hline Marshall Islands. & 0 & 0 & 0 & 0 & 0 & 0 & 0 & 0 & 0 & 0 & $\dagger$ \\
\hline Northern Marianas ...................... & 0 & 0 & 0 & 0 & 0 & 0 & 0 & 0 & 0 & 0 & $\dagger$ \\
\hline Palau......... & 0 & 0 & 0 & 0 & 0 & 0 & 0 & 0 & 0 & 0 & 1 \\
\hline Puerto Rico & 188,145 & 63,045 & 88,320 & 14,240 & 22,540 & 181,497 & 59,998 & 84,382 & 14,509 & 22,608 & -3.5 \\
\hline U.S. Virgin Islands .................................. & & 0 & 0 & 0 & 0 & 0 & 0 & 0 & 0 & & $\dagger$ \\
\hline
\end{tabular}

†Not applicable.

NOTE: Degree-granting institutions grant associate's or higher degrees and participate in Title IV federal financial aid programs.
SOURCE: U.S. Department of Education, National Center for Education Statistics, Integrated Postsecondary Education Data System (IPEDS), Spring 2012 and Spring 2013 , Enrollment component. (This table was prepared November 2013.) 
CHAPTER 3: Postsecondary Education 419

Total Fall Enrollment-State-Level

Table 304.45. Total fall enrollment in private nonprofit degree-granting postsecondary institutions, by attendance status, sex, and state or jurisdiction: 2011 and 2012

\begin{tabular}{|c|c|c|c|c|c|c|c|c|c|c|c|}
\hline \multirow[b]{3}{*}{ State or jurisdiction } & \multicolumn{5}{|c|}{ Fall 2011} & \multicolumn{5}{|c|}{ Fall 2012} & \multirow{3}{*}{$\begin{array}{r}\text { Percen } \\
\text { change in } \\
\text { total, } 2011 \\
\text { to } 2012\end{array}$} \\
\hline & \multirow[b]{2}{*}{ Total } & \multicolumn{2}{|c|}{ Full-time } & \multicolumn{2}{|c|}{ Part-time } & \multirow[b]{2}{*}{ Total } & \multicolumn{2}{|c|}{ Full-time } & \multicolumn{2}{|c|}{ Part-time } & \\
\hline & & Males & Females & Males & Females & & Males & Females & Males & Females & \\
\hline 1 & 2 & 3 & 4 & 5 & 6 & 7 & 8 & 9 & 10 & 11 & 12 \\
\hline 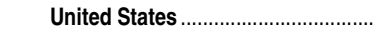 & $3,927,186$ & $1,287,302$ & $1,650,517$ & 377,848 & 611,519 & $3,953,578$ & $1,300,539$ & $1,657,719$ & 380,205 & 615,115 & 0.7 \\
\hline Alabama .................. & 26,437 & 9,557 & 12,756 & 1,618 & 2,506 & 26,109 & 9,721 & 12,634 & 1,392 & 2,362 & -1.2 \\
\hline 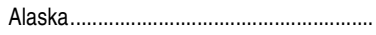 & 742 & 146 & 240 & 112 & 244 & 715 & 178 & 279 & 89 & 169 & -3.6 \\
\hline Arizona & 9,261 & 3,991 & 2,825 & 1,122 & 1,323 & 9,101 & 4,058 & 2,806 & 1,095 & 1,142 & -1.7 \\
\hline 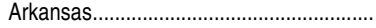 & 17,860 & 6,383 & 7,583 & 1,228 & 2,666 & 17,152 & 6,249 & 7,417 & 1,210 & 2,276 & -4.0 \\
\hline 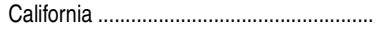 & 293,641 & 96,633 & 129,118 & 28,455 & 39,435 & 297,254 & 99,153 & 132,475 & 26,817 & 38,809 & 1.2 \\
\hline Colorado & 34,009 & 8,589 & 12,698 & 4,964 & 7,758 & 33,519 & 8,340 & 12,265 & 5,071 & 7,843 & -1.4 \\
\hline Connecticut..... & 67,728 & 22,623 & 29,081 & 5,059 & 10,965 & 67,765 & 22,732 & 29,198 & 4,905 & 10,930 & 0.1 \\
\hline 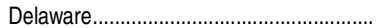 & 15,379 & 3,508 & 4,610 & 2,591 & 4,670 & 16,628 & 3,449 & 4,492 & 3,081 & 5,606 & 8.1 \\
\hline District of Columbia & 78,644 & 24,935 & 34,378 & 8,050 & 11,281 & 79,000 & 25,051 & 34,327 & 8,016 & 11,606 & 0.5 \\
\hline Florida & 180,369 & 56,271 & 69,583 & 23,614 & 30,901 & 179,932 & 57,107 & 69,764 & 23,391 & 29,670 & -0.2 \\
\hline Georgia. & 72,779 & 23,669 & 36,428 & 4,622 & 8,060 & 73,233 & 23,795 & 35,988 & 5,038 & 8,412 & 0.6 \\
\hline (1) & 14,751 & 3,762 & 6,115 & 2,385 & 2,489 & 14,292 & 3,967 & 6,088 & 2,056 & 2,181 & -3.1 \\
\hline 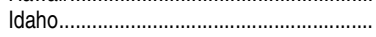 & 21,618 & 7,288 & 9,398 & 2,031 & 2,901 & 26,749 & 7,936 & 10,197 & 3,577 & 5,039 & 23.7 \\
\hline 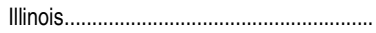 & 230,848 & 75,373 & 95,658 & 22,068 & 37,749 & 227,827 & 74,821 & 94,707 & 21,580 & 36,719 & -1.3 \\
\hline Indiana & 88,942 & 32,441 & 40,982 & 5,579 & 9,940 & 88,915 & 32,333 & 41,064 & 5,639 & 9,879 & $\#$ \\
\hline lowa ....... & 57,486 & 20,519 & 25,517 & 3,856 & 7,594 & 56,207 & 20,459 & 24,888 & 3,542 & 7,318 & -2.2 \\
\hline Kansas.... & 26,200 & 7,526 & 9,387 & 3,578 & 5,709 & 25,871 & 7,494 & 9,340 & 3,574 & 5,463 & -1.3 \\
\hline Kentucky .... & 39,818 & 11,750 & 17,465 & 3,648 & 6,955 & 40,223 & 11,895 & 17,382 & 3,657 & 7,289 & 1.0 \\
\hline 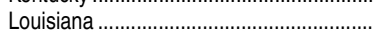 & 29,561 & 9,124 & 14,082 & 1,994 & 4,361 & 28,881 & 8,893 & 14,060 & 2,022 & 3,906 & -2.3 \\
\hline Maine & 20,565 & 6,572 & 9,561 & 1,310 & 3,122 & 21,121 & 6,630 & 9,771 & 1,281 & 3,439 & 2.7 \\
\hline 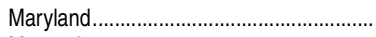 & 54,849 & 15,338 & 20,804 & 7,329 & 11,378 & 54,917 & 15,469 & 20,701 & 7,286 & 11,461 & 0.1 \\
\hline 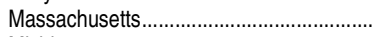 & 274,194 & 95,650 & 120,056 & 22,931 & 35,557 & 281,119 & 99,115 & 122,819 & 23,104 & 36,081 & 2.5 \\
\hline Michigan & 120,221 & 29,100 & 39,121 & 19,279 & 32,721 & 114,798 & 28,481 & 37,204 & 18,243 & 30,870 & -4.5 \\
\hline Minnesota & 72,146 & 22,852 & 31,929 & 6,192 & 11,173 & 71,446 & 22,776 & 31,723 & 6,067 & 10,880 & -1.0 \\
\hline 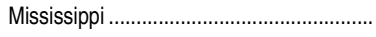 & 15,571 & 4,809 & 7,880 & 852 & 2,030 & 16,053 & 4,502 & 6,771 & 1,422 & 3,358 & 3.1 \\
\hline 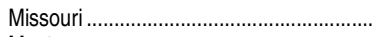 & 154,623 & 39,390 & 49,877 & 26,375 & 38,981 & 154,225 & 39,664 & 49,835 & 26,514 & 38,212 & -0.3 \\
\hline Montana... & 5,130 & 1,819 & 2,455 & 291 & 565 & 4,921 & 1,815 & 2,468 & 220 & 418 & -4.1 \\
\hline 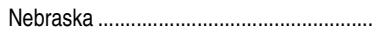 & 33,108 & 10,248 & 14,309 & 3,262 & 5,289 & 32,781 & 9,927 & 13,882 & 3,388 & 5,584 & -1.0 \\
\hline Nevada & 3,554 & 1,394 & 1,575 & 185 & 400 & 3,421 & 1,428 & 1,503 & 148 & 342 & -3.7 \\
\hline 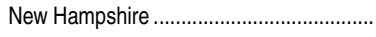 & 29,901 & 9,616 & 11,792 & 2,979 & 5,514 & 35,681 & 10,613 & 13,360 & 4,173 & 7,535 & 19.3 \\
\hline 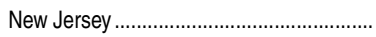 & 74,861 & 27,504 & 27,062 & 8,097 & 12,198 & 74,391 & 27,721 & 27,187 & 7,958 & 11,525 & -0.6 \\
\hline New Mexico & 1,217 & 405 & 434 & 71 & 307 & 1,334 & 396 & 449 & 114 & 375 & 9.6 \\
\hline 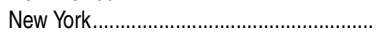 & 531,816 & 176,319 & 218,136 & 51,424 & 85,937 & 535,676 & 176,687 & 218,206 & 52,157 & 88,626 & 0.7 \\
\hline 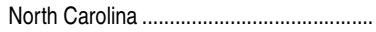 & 94,121 & 34,594 & 45,470 & 4,590 & 9,467 & 94,055 & 34,440 & 45,024 & 4,901 & 9,690 & -0.1 \\
\hline 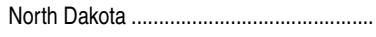 & 5,655 & 1,755 & 2,734 & 448 & 718 & 5,240 & 1,629 & 2,571 & 401 & 639 & -7.3 \\
\hline Ohio & 147,433 & 51,233 & 60,274 & 12,877 & 23,049 & 146,271 & 50,636 & 59,015 & 13,496 & 23,124 & -0.8 \\
\hline Oklahoma & 23,406 & 8,980 & 9,933 & 1,841 & 2,652 & 23,988 & 9,230 & 10,084 & 1,956 & 2,718 & 2.5 \\
\hline Oregon & 33,624 & 10,661 & 16,115 & 2,733 & 4,115 & 33,370 & 10,860 & 16,360 & 2,463 & 3,687 & -0.8 \\
\hline Pennsylvania & 298,353 & 101,695 & 127,442 & 23,847 & 45,369 & 296,691 & 102,225 & 127,655 & 23,073 & 43,738 & -0.6 \\
\hline Rhode Island & 41,390 & 17,787 & 19,451 & 1,948 & 2,204 & 40,748 & 17,209 & 19,489 & 1,927 & 2,123 & -1.6 \\
\hline South Carolina.... & 35,216 & 12,256 & 17,818 & 1,842 & 3,300 & 34,601 & 12,124 & 17,494 & 1,853 & 3,130 & -1.7 \\
\hline 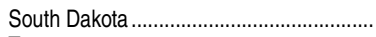 & 7,407 & 1,956 & 3,096 & 868 & 1,487 & 7,273 & 2,011 & 3,037 & 869 & 1,356 & -1.8 \\
\hline 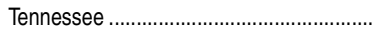 & 80,924 & 28,986 & 39,052 & 4,705 & 8,181 & 82,816 & 29,444 & 39,836 & 5,231 & 8,305 & 2.3 \\
\hline 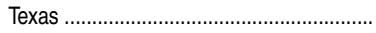 & 135,699 & 46,027 & 56,168 & 14,390 & 19,114 & 136,125 & 46,504 & 56,600 & 14,097 & 18,924 & 0.3 \\
\hline Utah & 70,416 & 29,844 & 35,367 & 2,756 & 2,449 & 81,270 & 34,722 & 41,291 & 2,819 & 2,438 & 15.4 \\
\hline Vermont & 17,454 & 8,117 & 7,327 & 746 & 1,264 & 17,685 & 8,195 & 7,382 & 836 & 1,272 & 1.3 \\
\hline 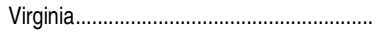 & 118,271 & 31,469 & 43,536 & 17,092 & 26,174 & 128,309 & 32,626 & 45,452 & 19,166 & 31,065 & 8.5 \\
\hline 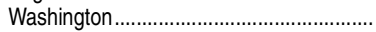 & 43,548 & 13,852 & 20,636 & 3,552 & 5,508 & 43,162 & 13,840 & 20,360 & 3,449 & 5,513 & -0.9 \\
\hline 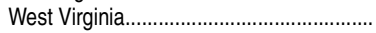 & 12,015 & 4,145 & 5,463 & 817 & 1,590 & 7,680 & 3,300 & 3,581 & 292 & 507 & -36.1 \\
\hline Wisconsin & 64,425 & 18,841 & 27,740 & 5,645 & 12,199 & 63,037 & 18,689 & 27,238 & 5,549 & 11,561 & -2.2 \\
\hline 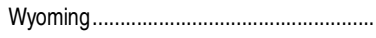 & 0 & 0 & 0 & 0 & 0 & 0 & 0 & 0 & 0 & 0 & $\dagger$ \\
\hline 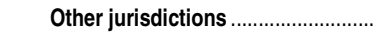 & 143,754 & 45,501 & 66,543 & 12,445 & 19,265 & 138,660 & 43,601 & 63,631 & 12,331 & 19,097 & -3.5 \\
\hline American Samoa & 0 & 0 & 0 & 0 & 0 & 0 & 0 & 0 & 0 & 0 & $\bar{\dagger}$ \\
\hline Federated States of Micronesia................... & 0 & 0 & 0 & 0 & 0 & 0 & 0 & 0 & 0 & 0 & $\dagger$ \\
\hline Guam & 86 & 27 & 26 & 20 & 13 & 77 & 27 & 25 & 14 & 11 & -10.5 \\
\hline 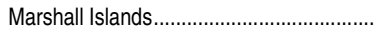 & 0 & 0 & 0 & 0 & 0 & 0 & 0 & 0 & 0 & 0 & $\dagger$ \\
\hline 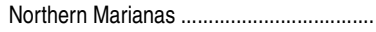 & 0 & 0 & 0 & 0 & 0 & 0 & 0 & 0 & 0 & 0 & $\dagger$ \\
\hline 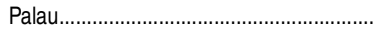 & 0 & 0 & 0 & 0 & 0 & 0 & 0 & 0 & 0 & 0 & $\dagger$ \\
\hline 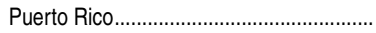 & 143,668 & 45,474 & 66,517 & 12,425 & 19,252 & 138,583 & 43,574 & 63,606 & 12,317 & 19,086 & -3.5 \\
\hline U.S. Virgin Islands & 0 & 0 & 0 & 0 & 0 & 0 & 0 & 0 & 0 & 0 & $\dagger$ \\
\hline
\end{tabular}

†Not applicable.

\#Rounds to zero.

NOTE: Degree-granting institutions grant associate's or higher degrees and participate in Title IV federal financial aid programs.
SOURCE: U.S. Department of Education, National Center for Education Statistics, Integrated Postsecondary Education Data System (IPEDS), Spring 2012 and Spring 2013 Enrollment component. (This table was prepared November 2013.) 
Table 304.50. Total fall enrollment in private for-profit degree-granting postsecondary institutions, by attendance status, sex, and state or jurisdiction: 2011 and 2012

\begin{tabular}{|c|c|c|c|c|c|c|c|c|c|c|c|}
\hline \multirow[b]{3}{*}{ State or jurisdiction } & \multicolumn{5}{|c|}{ Fall 2011} & \multicolumn{5}{|c|}{ Fall 2012} & \multirow{3}{*}{$\begin{array}{r}\text { Percent } \\
\text { change in } \\
\text { total, } 2011 \\
\text { to } 2012\end{array}$} \\
\hline & \multirow[b]{2}{*}{ Total } & \multicolumn{2}{|c|}{ Full-time } & \multicolumn{2}{|c|}{ Part-time } & \multirow[b]{2}{*}{ Total } & \multicolumn{2}{|c|}{ Full-time } & \multicolumn{2}{|c|}{ Part-time } & \\
\hline & & Males & Females & Males & Females & & Males & Females & Males & Females & \\
\hline 1 & 2 & 3 & 4 & 5 & 6 & 7 & 8 & 9 & 10 & 11 & 12 \\
\hline United States ........................ & $1,956,731$ & 504,325 & 893,573 & 200,788 & 358,045 & $1,808,898$ & 455,139 & 797,798 & 201,905 & 354,056 & -7.6 \\
\hline Alabama & 31,726 & 11,713 & 12,323 & 2,970 & 4,720 & 33,157 & 8,500 & 11,124 & 7,445 & 6,088 & 4.5 \\
\hline 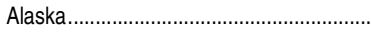 & 2,032 & 499 & 1,533 & 0 & & 1,487 & 467 & 1,020 & 0 & 0 & -26.8 \\
\hline Arizona & 421,609 & 114,785 & 256,599 & 13,784 & 36,441 & 368,049 & 99,210 & 215,843 & 14,240 & 38,756 & -12.7 \\
\hline 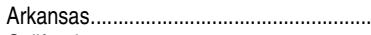 & 2,661 & 889 & 1,462 & 124 & 186 & 2,082 & 643 & 1,152 & 124 & 163 & -21.8 \\
\hline$\ldots \ldots \ldots \ldots \ldots \ldots \ldots \ldots \ldots \ldots \ldots \ldots \ldots$ & 213,623 & 71,917 & 99,466 & 19,354 & 22,886 & 195,054 & 66,534 & 85,623 & 20,176 & 22,721 & -8.7 \\
\hline Colorado... & 62,513 & 16,412 & 28,598 & 7,053 & 10,450 & 56,972 & 14,791 & 23,582 & 7,105 & 11,494 & -8.9 \\
\hline Connecticut.... & 7,423 & 1,240 & 2,492 & 1,333 & 2,358 & 8,941 & 1,332 & 2,760 & 1,902 & 2,947 & 20.4 \\
\hline Delaware............................................... & 439 & 31 & 25 & 125 & 258 & 387 & 38 & 43 & 103 & 203 & -11.8 \\
\hline District of Columbia & 6,289 & 466 & 627 & 1,553 & 3,643 & 5,674 & 453 & 567 & 1,520 & 3,134 & -9.8 \\
\hline Florida & 160,129 & 45,214 & 70,398 & 13,471 & 31,046 & 170,304 & 47,746 & 77,905 & 13,013 & 31,640 & 6.4 \\
\hline Georgia... & 63,972 & 15,071 & 34,105 & 5,022 & 9,774 & 49,936 & 11,501 & 23,727 & 4,513 & 10,195 & -21.9 \\
\hline$\ldots$ & 3,937 & 1,139 & 1,649 & 388 & 761 & 3,869 & 1,227 & 1,537 & 371 & 734 & -1.7 \\
\hline Idaho & 2,771 & 919 & 1,645 & 83 & 124 & 2,478 & 759 & 1,534 & 75 & 110 & -10.6 \\
\hline 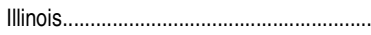 & 84,990 & 17,144 & 24,336 & 16,962 & 26,548 & 82,146 & 13,804 & 19,842 & 16,308 & 32,192 & -3.3 \\
\hline Indiana......... & 28,618 & 7,236 & 13,926 & 3,075 & 4,381 & 24,578 & 5,792 & 11,339 & 2,759 & 4,688 & -14.1 \\
\hline lowa.. & 136,169 & 25,429 & 65,136 & 11,655 & 33,949 & 131,418 & 26,451 & 65,545 & 9,941 & 29,481 & -3.5 \\
\hline Kansas........ & 3,987 & 886 & 1,748 & 334 & 1,019 & 3,939 & 871 & 1,691 & 361 & 1,016 & -1.2 \\
\hline Kentucky ........ & 20,521 & 4,595 & 9,789 & 2,108 & 4,029 & 17,810 & 3,827 & 8,263 & 1,911 & 3,809 & -13.2 \\
\hline Louisiana ……………………......... & 11,085 & 2,641 & 6,479 & 458 & 1,507 & 8,973 & 2,161 & 5,251 & 329 & 1,232 & -19.1 \\
\hline Maine.......... & 1,479 & 181 & 541 & 135 & 622 & 1,419 & 188 & 542 & 134 & 555 & -4.1 \\
\hline Maryland. & 10,865 & 3,077 & 2,601 & 1,960 & 3,227 & 9,076 & 2,638 & 2,316 & 1,503 & 2,619 & -16.5 \\
\hline Massachusetts. & 7,355 & 2,573 & 2,426 & 895 & 1,461 & 7,034 & 2,228 & 2,564 & 822 & 1,420 & -4.4 \\
\hline Michigan ............ & 10,564 & 3,772 & 4,606 & 1,217 & 969 & 8,785 & 2,837 & 3,458 & 1,156 & 1,334 & -16.8 \\
\hline 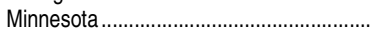 & 111,414 & 12,786 & 32,709 & 17,038 & 48,881 & 107,925 & 11,669 & 30,859 & 16,703 & 48,694 & -3.1 \\
\hline Mississippi ..... & 2,908 & 404 & 1,813 & 136 & 555 & 2,617 & 336 & 1,518 & 143 & 620 & -10.0 \\
\hline Missouri... & 41,789 & 10,089 & 14,373 & 6,242 & 11,085 & 29,716 & 9,148 & 12,443 & 4,398 & 3,727 & -28.9 \\
\hline Montana & & 0 & & 0 & 0 & 0 & 0 & 0 & 0 & 0 & \\
\hline Nebraska & 2,973 & 817 & 1,435 & 245 & 476 & 2,631 & 658 & 1,206 & 255 & 512 & -11.5 \\
\hline Nevada & 12,411 & 4,325 & 6,257 & 937 & 892 & 11,260 & 3,875 & 5,822 & 841 & 722 & -9.3 \\
\hline New Hampshire ........ & 4,210 & 852 & 815 & 777 & 1,766 & 3,708 & 1,097 & 1,459 & 365 & 787 & -11.9 \\
\hline New J & 9,431 & 2,213 & 4,000 & 1,384 & 1,834 & 9,118 & 2,048 & 3,938 & 1,281 & 1,851 & -3.3 \\
\hline New Mexico .. & 9,823 & 2,975 & 5,719 & 351 & 778 & 8,298 & 2,567 & 4,757 & 316 & 658 & -15.5 \\
\hline New York............................................. & 54,412 & 16,403 & 27,798 & 3,479 & 6,732 & 52,036 & 14,904 & 26,552 & 3,507 & 7,073 & -4.4 \\
\hline North Carolina ......................................... & 19,903 & 4,204 & 7,030 & 2,427 & 6,242 & 18,292 & 3,752 & 6,810 & 2,256 & 5,474 & -8.1 \\
\hline North Dakota ......................................... & 1,249 & 124 & 391 & 205 & 529 & 1,000 & 72 & 290 & 194 & 444 & -19.9 \\
\hline Ohi & 44,819 & 10,489 & 21,393 & 4,353 & 8,584 & 39,209 & 8,660 & 18,749 & 3,809 & 7,991 & -12.5 \\
\hline Oklaho & 9,375 & 4,032 & 4,762 & 284 & 297 & 9,365 & 3,842 & 4,841 & 300 & 382 & -0.1 \\
\hline Oregon.............. & 9,971 & 2,776 & 4,703 & 941 & 1,551 & 9,015 & 2,452 & 4,290 & 783 & 1,490 & -9.6 \\
\hline Pennsylvania..... & 61,167 & 17,933 & 21,229 & 8,288 & 13,717 & 54,661 & 15,385 & 18,734 & 8,042 & 12,500 & -10.6 \\
\hline Rhode Island ............................................... & & & 0 & 0 & 0 & 0 & 0 & & 0 & 0 & $\dagger$ \\
\hline ...................... & 16,484 & 4,351 & 7,460 & 1,313 & 3,360 & 15,993 & 4,035 & 7,260 & 1,261 & 3,437 & -3.0 \\
\hline South & 4,763 & 415 & 842 & 983 & 2,523 & 4,600 & 326 & 679 & 1,035 & 2,560 & -3.4 \\
\hline Tennessee .......................................... & 27,434 & 8,806 & 12,483 & 1,957 & 4,188 & 25,815 & 8,280 & 11,702 & 2,065 & 3,768 & -5.9 \\
\hline Texas & 61,683 & 19,608 & 31,012 & 5,128 & 5,935 & 56,313 & 17,423 & 28,259 & 4,701 & 5,930 & -8.7 \\
\hline Utah & 14,772 & 5,066 & 7,042 & 994 & 1,670 & 15,038 & 5,185 & 7,705 & 890 & 1,258 & 1.8 \\
\hline Verm & 557 & 240 & 179 & 79 & 59 & 517 & 206 & 155 & 84 & 72 & -7.2 \\
\hline Virgini & 56,433 & 16,014 & 21,723 & 6,858 & 11,838 & 50,634 & 14,653 & 18,462 & 6,164 & 11,355 & -10.3 \\
\hline Washington........ & 12,227 & 4,053 & 5,996 & 1,155 & 1,023 & 10,855 & 3,621 & 5,120 & 1,099 & 1,015 & -11.2 \\
\hline West Virginia.... & 54,659 & 2,892 & 4,409 & 29,518 & 17,840 & 61,482 & 2,706 & 4,132 & 34,059 & 20,585 & 12.5 \\
\hline Wisconsin & 15,383 & 3,058 & 5,337 & 1,657 & 5,331 & 13,279 & 2,458 & 4,658 & 1,543 & 4,620 & -13.7 \\
\hline Wyoming............. & 1,724 & 1,571 & 153 & 0 & 0 & 1,953 & 1,783 & 170 & 0 & 0 & 13.3 \\
\hline 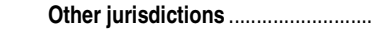 & 44,477 & 17,571 & 21,803 & 1,815 & 3,288 & 42,914 & 16,424 & 20,776 & 2,192 & 3,522 & -3.5 \\
\hline American Samoa.. & & 0 & 0 & 0 & 0 & 0 & 0 & 0 & 0 & 0 & 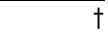 \\
\hline Federated States of Micronesia... & 0 & 0 & 0 & 0 & 0 & 0 & 0 & 0 & 0 & 0 & \\
\hline Guam & 0 & 0 & 0 & 0 & 0 & 0 & 0 & 0 & 0 & 0 & $\dagger$ \\
\hline Marshall Islands.. & 0 & 0 & 0 & 0 & 0 & 0 & 0 & 0 & 0 & 0 & $\dagger$ \\
\hline Northern Marianas ...................... & 0 & 0 & 0 & 0 & 0 & 0 & 0 & 0 & 0 & 0 & $t$ \\
\hline Palau................................ & 0 & 0 & 0 & 0 & 0 & 0 & 0 & 0 & 0 & 0 & $t$ \\
\hline Puerto Rico & 44,477 & 17,571 & 21,803 & 1,815 & 3,288 & 42,914 & 16,424 & 20,776 & 2,192 & 3,522 & -3.5 \\
\hline U.S. Virgin Islands ............................ & & 0 & 0 & 0 & 0 & 0 & 0 & 0 & 0 & 0 & $\dagger$ \\
\hline
\end{tabular}

$\dagger$ Not applicable.

NOTE: Degree-granting institutions grant associate's or higher degrees and participate in Title IV federal financial aid programs.
SOURCE: U.S. Department of Education, National Center for Education Statistics, Integrated Postsecondary Education Data System (IPEDS), Spring 2012 and Spring 2013 Enrollment component. (This table was prepared November 2013.) 
Table 304.60. Total fall enrollment in degree-granting postsecondary institutions, by control and level of institution and state or jurisdiction: 2011 and 2012

\begin{tabular}{|c|c|c|c|c|c|c|c|c|c|c|c|c|}
\hline \multirow[b]{3}{*}{ State or jurisdiction } & \multicolumn{6}{|c|}{ Fall 2011} & \multicolumn{6}{|c|}{ Fall 2012} \\
\hline & \multirow{2}{*}{$\begin{array}{l}\text { Public } \\
\text { 4-year }\end{array}$} & \multirow{2}{*}{$\begin{array}{l}\text { Public } \\
\text { 2-year }\end{array}$} & \multicolumn{2}{|c|}{ Private 4-year } & \multicolumn{2}{|c|}{ Private 2-year } & \multirow{2}{*}{$\begin{array}{l}\text { Public } \\
\text { 4-year }\end{array}$} & \multirow{2}{*}{$\begin{array}{l}\text { Public } \\
\text { 2-year }\end{array}$} & Private & -year & Private & year \\
\hline & & & Nonprofit & For-profit & Nonprofit & For-profit & & & Nonprofit & For-profit & Nonprofit & For-profit \\
\hline 1 & 2 & 3 & 4 & 5 & 6 & 7 & 8 & 9 & 10 & 11 & 12 & 13 \\
\hline United States .................. & $8,047,729$ & $7,062,467$ & $3,887,322$ & $1,559,080$ & 39,864 & 397,651 & $8,092,683$ & $6,787,660$ & $3,915,972$ & $1,470,191$ & 37,606 & 338,707 \\
\hline Alabama …………............... & 167,349 & 93,174 & 25,814 & 27,977 & 623 & 3,749 & 164,770 & 86,275 & 25,591 & 30,012 & 518 & 3,145 \\
\hline 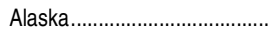 & 31,184 & 974 & 742 & 1,651 & 0 & 381 & 29,837 & 758 & 715 & 1,259 & 0 & 228 \\
\hline Arizona …………………..... & 138,870 & 227,246 & 9,261 & 407,603 & 0 & 14,006 & 141,562 & 217,667 & 9,101 & 357,200 & 0 & 10,849 \\
\hline Arkansas.................................. & 96,483 & 62,277 & 17,498 & 2,404 & 362 & 257 & 97,380 & 59,844 & 16,833 & 1,897 & 319 & 185 \\
\hline California ................................ & 657,885 & $1,520,744$ & 292,167 & 125,154 & 1,474 & 88,469 & 669,831 & $1,459,321$ & 295,589 & 126,964 & 1,665 & 68,090 \\
\hline Colorado ...... & 169,441 & 99,857 & 33,894 & 51,004 & 115 & 11,509 & 174,650 & 97,794 & 33,274 & 46,900 & 245 & 10,072 \\
\hline Connecticut............................ & 68,813 & 57,674 & 67,001 & 7,049 & 727 & 374 & 66,724 & 58,228 & 67,765 & 8,669 & 0 & 272 \\
\hline Delaware................................ & 25,643 & 15,055 & 15,132 & 439 & 247 & 0 & 26,180 & 14,933 & 16,417 & 387 & 211 & 0 \\
\hline District of Columbia .................... & 5,280 & & 78,644 & 6,289 & 0 & 0 & 5,476 & & 79,000 & 5,674 & 0 & 0 \\
\hline Florida................................. & 717,439 & 85,761 & 179,325 & 119,600 & 1,044 & 40,529 & 732,643 & 72,050 & 178,302 & 126,147 & 1,630 & 44,157 \\
\hline Georgia. & 265,698 & 163,010 & 72,252 & 54,780 & 527 & 9,192 & 274,522 & 147,667 & 72,729 & 41,588 & 504 & 8,348 \\
\hline$\ldots \ldots \ldots \ldots \ldots \ldots \ldots \ldots \ldots$ & 30,757 & 29,573 & 14,751 & 1,986 & 0 & 1,951 & 30,962 & 29,333 & 14,292 & 2,158 & 0 & 1,711 \\
\hline Idaho........ & 49,087 & 16,666 & 21,618 & 2,214 & 0 & 557 & 53,141 & 25,640 & 26,749 & 1,970 & 0 & 508 \\
\hline |llinois...................................... & 203,670 & 373,373 & 229,926 & 75,575 & 922 & 9,415 & 198,407 & 358,730 & 227,109 & 74,136 & 718 & 8,010 \\
\hline Indiana & 233,855 & 106,409 & 88,409 & 21,775 & 533 & 6,843 & 233,497 & 100,272 & 88,476 & 18,873 & 439 & 5,705 \\
\hline lowa & 72,589 & 105,902 & 57,293 & 135,406 & 193 & 763 & 73,150 & 100,408 & 56,004 & 131,134 & 203 & 284 \\
\hline Kansas.. & 100,893 & 85,582 & 24,020 & 2,374 & 2,180 & 1,613 & 100,745 & 83,231 & 23,591 & 2,390 & 2,280 & 1,549 \\
\hline Kentucky. & 125,537 & 107,890 & 39,818 & 16,655 & 0 & 3,866 & 126,510 & 97,582 & 40,223 & 14,497 & 0 & 3,313 \\
\hline Louisiana. & 144,616 & 80,594 & 28,287 & 3,938 & 1,274 & 7,147 & 142,929 & 78,042 & 27,827 & 3,541 & 1,054 & 5,432 \\
\hline Maine & 32,092 & 18,161 & 20,280 & 973 & 285 & 506 & 32,002 & 18,268 & 20,836 & 962 & 285 & 457 \\
\hline Maryland... & 165,783 & 148,600 & 54,849 & 7,810 & 0 & 3,055 & 165,489 & 145,014 & 54,917 & 6,392 & 0 & 2,684 \\
\hline Massachusetts........................ & 121,888 & 105,117 & 273,088 & 5,195 & 1,106 & 2,160 & 122,884 & 105,294 & 280,160 & 5,170 & 959 & 1,864 \\
\hline Michigan ................................ & 303,554 & 251,187 & 120,160 & 8,849 & 61 & 1,715 & 302,129 & 238,113 & 114,718 & 7,152 & 80 & 1,633 \\
\hline Minnesota ................................ & 139,037 & 135,155 & 72,058 & 109,108 & 88 & 2,306 & 137,156 & 135,134 & 71,359 & 106,074 & 87 & 1,851 \\
\hline Mississippi ....... & 79,926 & 80,685 & 15,571 & 566 & 0 & 2,342 & 80,435 & 77,560 & 16,053 & 564 & 0 & 2,053 \\
\hline Missouri... & 147,011 & 113,574 & 153,402 & 32,517 & 1,221 & 9,272 & 148,382 & 109,048 & 153,018 & 22,751 & 1,207 & 6,965 \\
\hline Montana..... & 39,343 & 9,569 & 4,666 & 0 & 464 & 0 & 39,091 & 9,242 & 4,514 & 0 & 407 & 0 \\
\hline ..…………....... & 58,756 & 48,038 & 32,917 & 2,123 & 191 & 850 & 58,786 & 45,380 & 32,620 & 2,022 & 161 & 609 \\
\hline$\ldots$ & 93,917 & 11,131 & 3,554 & 7,557 & 0 & 4,854 & 92,016 & 11,603 & 3,421 & 6,495 & 0 & 4,765 \\
\hline 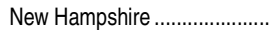 & 28,998 & 14,335 & 29,610 & 4,210 & 291 & 0 & 28,642 & 14,647 & 35,397 & 3,708 & 284 & 0 \\
\hline New Jersey... & 182,706 & 176,752 & 74,861 & 7,161 & 0 & 2,270 & 183,668 & 172,788 & 74,391 & 6,215 & 0 & 2,903 \\
\hline ................ & 64,828 & 81,687 & 1,217 & 7,851 & 0 & 1,972 & 65,673 & 81,119 & 1,334 & 6,622 & 0 & 1,676 \\
\hline New York............................... & 396,760 & 335,154 & 527,083 & 31,380 & 4,733 & 23,032 & 393,208 & 329,066 & 531,501 & 31,685 & 4,175 & 20,351 \\
\hline North Carolina .... & 220,305 & 250,684 & 93,442 & 15,744 & 679 & 4,159 & 221,010 & 244,674 & 93,349 & 14,790 & 706 & 3,502 \\
\hline 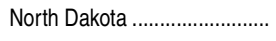 & 41,661 & 7,207 & 5,655 & 1,249 & 0 & 0 & 42,061 & 6,868 & 5,240 & 1,000 & 0 & 0 \\
\hline Ohio & 343,335 & 199,439 & 144,571 & 18,263 & 2,862 & 26,556 & 334,866 & 189,472 & 144,251 & 22,970 & 2,020 & 16,239 \\
\hline Oklah & 3,468 & 70,905 & 23,406 & 5,246 & 0 & 4,129 & 358 & 68,753 & 23,988 & 4,891 & 0 & 4,474 \\
\hline Oregon ................................. & 102,656 & 112,810 & 33,624 & 5,717 & 0 & 4,254 & 103,463 & 108,847 & 33,370 & 5,452 & 0 & 3,563 \\
\hline Pennsylvania..... & 278,865 & 149,404 & 290,728 & 24,706 & 7,625 & 36,461 & 281,541 & 144,349 & 288,180 & 23,346 & 8,511 & 31,315 \\
\hline Rhode Island ......... & 25,361 & 17,893 & 41,390 & & 0 & & 25,320 & 17,884 & 40,748 & & 0 & \\
\hline South & 105,575 & 102,727 & 34,237 & 13,456 & 979 & 3,028 & 107,063 & 101,960 & 33,651 & 11,939 & 950 & 4,054 \\
\hline Sou & 37,387 & 6,342 & 7,071 & 4 & 336 & & 37,838 & 6,347 & 6,979 & 4,600 & 294 & 0 \\
\hline Tennessee ... & 145,765 & 96,152 & 79,283 & 16,148 & 1,641 & 11,286 & 142,708 & 92,302 & 81,307 & 15,752 & 1,509 & 10,063 \\
\hline Texas. & 638,296 & 728,709 & 131,137 & 31,797 & 4,562 & 29,886 & 646,849 & 701,011 & 132,490 & 30,468 & 3,635 & 25,845 \\
\hline 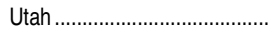 & 133,907 & 45,301 & 68,429 & 12,938 & 1,987 & 1,834 & 141,004 & 29,997 & 79,079 & 13,143 & 2,191 & 1,895 \\
\hline Vermont ...... & 20,554 & 6,578 & 16,966 & 557 & 488 & 0 & 20,190 & 6,311 & 17,685 & 517 & 0 & 0 \\
\hline Virginiz & 214,906 & 198,855 & 118,271 & 46,016 & 0 & 10,417 & 215,326 & 194,427 & 127,983 & 41,745 & 326 & 8,889 \\
\hline Washington ............................ & 168,778 & 148,288 & 43,504 & 7,316 & 44 & 4,911 & 172,186 & 139,311 & 43,129 & 6,538 & 33 & 4,317 \\
\hline ia ................................... & 72,965 & 22,669 & 12,015 & 51,910 & 0 & 2,749 & 71,856 & 21,161 & 7,680 & 59,185 & 0 & 2,297 \\
\hline Wisconsin ............................... & 182,640 & 114,155 & 64,425 & 13,957 & 0 & 1,426 & 182,437 & 110,979 & 63,037 & 12,502 & 0 & 777 \\
\hline 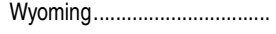 & 12,925 & 23,443 & 0 & 124 & 0 & 1,600 & 12,903 & 22,956 & 0 & 145 & 0 & 1,808 \\
\hline U.S. Service Academies......... & 15,692 & 0 & $\dagger$ & $\dagger$ & $\dagger$ & $\dagger$ & 15,227 & 0 & $\dagger$ & $\dagger$ & $\dagger$ & $\dagger$ \\
\hline Other jurisdictions ........ & 66,660 & 12,268 & 140,861 & 10,980 & 2,893 & 33,497 & 68,501 & 9,868 & 137,856 & 11,836 & 804 & 31,078 \\
\hline American Samoa ..................... & 0 & 2,091 & 0 & 0 & 0 & 0 & 1,795 & 0 & 0 & 0 & 0 & 0 \\
\hline Federated & & & & & & & & & & & & \\
\hline Micr & 0 & 2,915 & 0 & 0 & 0 & 0 & 0 & 2,744 & 0 & 0 & 0 & 0 \\
\hline Guam.... & 3,721 & 2,553 & 86 & 0 & 0 & 0 & 3,702 & 2,145 & 77 & 0 & 0 & 0 \\
\hline Marshall Islands..................... & 0 & 989 & 0 & 0 & 0 & 0 & 0 & 1,123 & 0 & 0 & 0 & 0 \\
\hline Northern Marianas ................. & 1,046 & 0 & 0 & 0 & 0 & 0 & 1,178 & 0 & 0 & 0 & 0 & 0 \\
\hline Palau................................... & & 742 & 0 & 0 & 0 & 0 & 0 & 680 & 0 & 0 & 0 & 0 \\
\hline Puerto Rico........................... & 59,279 & 2,978 & 140,775 & 10,980 & 2,893 & 33,497 & 59,403 & 3,176 & 137,779 & 11,836 & 804 & 31,078 \\
\hline U.S. Virgin Islands ................. & 2,614 & 0 & 0 & 0 & 0 & 0 & 2,423 & 0 & 0 & 0 & 0 & 0 \\
\hline
\end{tabular}

†Not applicable.

NOTE: Degree-granting institutions grant associate's or higher degrees and participate in Title IV federal financial aid programs.
SOURCE: US. Department of Education, National Center for Education Statistics, Integrated Postsecondary Education Data System (IPEDS), Spring 2012 and Spring 2013 Enrollment component. (This table was prepared November 2013.) 
Table 304.70. Total fall enrollment in degree-granting postsecondary institutions, by level of enrollment and state or jurisdiction: Selected years, 2000 through 2012

\begin{tabular}{|c|c|c|c|c|c|c|c|c|c|c|c|c|}
\hline \multirow[b]{2}{*}{ State or jurisdiction } & \multicolumn{6}{|c|}{ Undergraduate } & \multicolumn{6}{|c|}{ Postbaccalaureate } \\
\hline & Fall 2000 & Fall 2005 & Fall 2009 & Fall 2010 & Fall 2011 & Fall 2012 & Fall 2000 & Fall 2005 & Fall 2009 & Fall 2010 & Fall 2011 & Fall 2012 \\
\hline 1 & 2 & 3 & 4 & 5 & 6 & 7 & 8 & 9 & 10 & 11 & 12 & $\overline{13}$ \\
\hline United States & $13,155,393$ & $14,963,964$ & $17,565,320$ & $18,078,672$ & $18,063,037$ & $17,732,431$ & $2,156,896$ & $2,523,511$ & $2,862,391$ & $2,937,454$ & $2,931,076$ & $2,910,388$ \\
\hline abama .. & 201,389 & 219,253 & 267,870 & 281,849 & 274,305 & 265,917 & 32,573 & 37,136 & 43,870 & 45,478 & 44,381 & 44,394 \\
\hline ska... & 26,222 & 27,903 & 29,605 & 30,779 & 32,104 & 30,018 & 1,731 & 2,328 & 2,801 & 2,874 & 2,828 & 2,779 \\
\hline 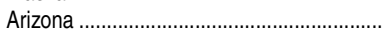 & 299,529 & 456,881 & 706,866 & 673,600 & 675,037 & 621,610 & 42,961 & 88,716 & 121,765 & 121,788 & 121,949 & 114,769 \\
\hline ansa & 104,580 & 129,484 & 151,136 & 157,162 & 159,909 & 157,504 & 10,592 & 13,788 & 17,216 & 18,733 & 19,372 & 18,954 \\
\hline 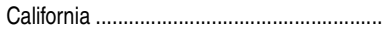 & $2,012,213$ & $2,135,461$ & $2,464,524$ & 2,443,985 & 2,419,777 & $2,359,659$ & 244,495 & 264,372 & 271,055 & 270,187 & 266,116 & 261,801 \\
\hline lorac & 220,059 & 249,616 & 296,283 & 3,434 & 308,124 & 305,234 & 43,813 & 53,056 & 55,751 & 58,591 & 57,696 & 57,701 \\
\hline & 127,715 & 141,332 & 156,228 & 3,291 & 165,707 & 166,812 & 33,528 & 33,343 & 35,578 & 36,093 & 35,931 & 34,846 \\
\hline & 7,930 & 43,382 & 45,605 & ,321 & 46,942 & 47,816 & 5,967 & 8,230 & 9,569 & 9,410 & 9,574 & 10,312 \\
\hline trict & 40,703 & 62,888 & 83,548 & 50,330 & 48,459 & 47,699 & 31,986 & 42,009 & 53,303 & 41,662 & 41,754 & 42,451 \\
\hline 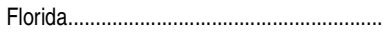 & 623,071 & 764,577 & 927,044 & 994,236 & $1,011,562$ & $1,023,813$ & 84,613 & 108,085 & 126,177 & 131,233 & 132,136 & 131,116 \\
\hline orri & 296,980 & 372,269 & 466,011 & 499,166 & 495,187 & 476,813 & 49,224 & 54,381 & 66,482 & 69,557 & 70,272 & 68,545 \\
\hline & 51,783 & 57,843 & 65,139 & 68,244 & 69,595 & 69,272 & $\begin{array}{r}8,399 \\
\end{array}$ & 9,240 & 9,670 & 9,829 & $\begin{array}{r}9,423 \\
\end{array}$ & 9,184 \\
\hline & 58,644 & 70,335 & 76,666 & 76,998 & 82,297 & 99,901 & 6,950 & 7,373 & 7,784 & 8,203 & 7,845 & 8,107 \\
\hline & 623,018 & 692,401 & 746,733 & $74 \varepsilon$ & 735,435 & 713,711 & 120,900 & 140,566 & 154,091 & 157,924 & 157,446 & 153,399 \\
\hline dala & 273,198 & 312,058 & 386,748 & 403,963 & 402,172 & 392,625 & 41,136 & 49,195 & 4,546 & 5,460 & 652 & 54,637 \\
\hline & 5,360 & 203,453 & 5,000 & 1 & 8,242 & 18 & 14 & 69 & 5,631 & 2,831 & 304 & 65 \\
\hline & 156,385 & 8,065 & 15 & & & & & & 028 & & & \\
\hline & 4,183 & 36 & 88 & & & & & & & & & \\
\hline &, 517 & 008 & 03 & & 90 & & & 55 & 50 & & 32,366 & 556 \\
\hline aine. & 728 & 57,622 & 013 & t, 178 & 2,924 & 3,084 &, 745 & 7,929 & 8,157 & 8,807 & 9,373 & 726 \\
\hline & 221,952 & 252,964 & 289,527 & 5,358 & 307,345 & 302,485 & 793 & 187 & 9,414 & 2,609 & 752 & \\
\hline & 320,012 & & 30 & & & & & & & & & \\
\hline & 18 & 45 & & & & & & & & & & \\
\hline & 32 & 16 & 74 & & & & & & & & & \\
\hline ississipp & 123,299 & 133,642 & 153,914 & 157,464 & 158,179 & 155,386 & 14,090 & 6,815 & 9,222 & 20,733 & 20,911 & 1,279 \\
\hline & 266,802 & 304,992 & 347,189 & 366,934 & 378,424 & 363,308 & 54,546 & 69,453 & 77,755 & 77,761 & 78,573 & 63 \\
\hline & 38,481 & $\begin{array}{r}43,403 \\
\end{array}$ & 47,061 & 18,476 & 49,143 & 48,424 & & 4,447 & 4,527 & 4,836 & $\begin{array}{r}4,899 \\
\end{array}$ & \\
\hline & 96,759 & 103,581 & 116,384 & & & & & & 22,261 & & & 23 \\
\hline & 79,053 & 99,548 & 3,104 & 743 & & 106,854 & 840 & & & 17 & & \\
\hline ew $\mathrm{H}$ & 51,990 & 59,081 & 61,181 & 62,447 & 63,420 & 66,770 & 9,728 & 10,812 & 3,053 & 13,147 & 44,024 & 15,908 \\
\hline & 284,785 & 1,118 & 88,528 & 0,059 & 38 & 376,901 & 60 & 8,640 & 99 & 32 & 69 & 63 \\
\hline & 96,377 & & & & & & & 89 & & & & \\
\hline & 23 & 458 & 1,04 & & & & & & & & & \\
\hline & 358,912 & 426,106 & 502,991 & 504 & 515,436 & 508,270 &, 740 & 286 & 5,874 & 38 & 69,577 & \\
\hline North D & 36,899 & 44,153 & 48,330 & 0,003 & 48,630 & 48,123 & 3,349 & 5,236 & 6,103 & 6,900 & 7,142 & ,046 \\
\hline & 469,999 & 1 & 618,699 & & 3 & 618,887 & & 86,459 & & & & \\
\hline & 21 & & & & & & & & & & & \\
\hline & 05 & & & & & & & & & & & \\
\hline & 506,948 & 19 & & & & & & & & & & \\
\hline Rhode Is & 77 & 70,518 & 73,805 & 73,974 & 73,949 & 3,338 &, 383 & 0,864 & 0,868 & 1,136 & 695 & \\
\hline & J & 35,252 & & & & & & 25,192 & & & & \\
\hline & 37,497 & 13206 & & & & & & & & & & \\
\hline & 230,376 & 243,912 & & & & & & & 40 & & 990 & 48,352 \\
\hline & 905,649 & 1,09 & & & & & & & & & & \\
\hline Ut & 149,954 & 182,892 & 214,133 & 228,175 & 239,189 & 239,025 & 13,822 & 17,799 & 22,457 & 23,932 & 25,207 & 28,284 \\
\hline & & & & & & & & & & & 1 & \\
\hline & & & & & & & & & & & & \\
\hline & 290,292 & 44 & & & & & & & & & 348 & 35,897 \\
\hline & & & & & & & & & & & b33 & 26,024 \\
\hline & 271,839 & 296,743 & 330,761 & & 30 & 73 & 35,340 & 38,515 & 42,467 & 42,483 & 41,373 & 39,959 \\
\hline Wy & 26,811 & 31,684 & 34,404 & 35,466 & 35,330 & 35,103 & 3,193 & 3,650 & 2,689 & 2,832 & 2,762 & 2,709 \\
\hline U.S. Service Acade & 13,475 & 15,265 & 15,730 & 15,905 & 15,669 & 15,202 & & 0 & 18 & 20 & 23 & 25 \\
\hline . & 174,410 & 193,766 & 213,421 & 34,281 & 37,048 & 31,363 & 223 &, 399 &, 371 & 9,956 & ,111 &, 580 \\
\hline & & & & & & & & & 0 & & & 0 \\
\hline & 1,576 & 2,283 & 3,401 & 2,699 & 2,915 & & 0 & 0 & 0 & 0 & 0 & \\
\hline & 4,746 & 5,850 & 5,484 & 5,857 & 6,009 & 5,631 & 469 & 214 & 271 & 331 & 351 & 293 \\
\hline & 328 & 604 & 847 & 869 & 989 & 1,123 & 0 & 0 & 0 & 0 & 0 & 0 \\
\hline & 1,078 & 967 & 989 & 1,137 & $\begin{array}{r}1,046 \\
\end{array}$ & 1,178 & 0 & 0 & 0 & 0 & 0 & 0 \\
\hline & 581 & 651 & 651 & 694 & 742 & 680 & 0 & 0 & 0 & 0 & 0 & \\
\hline & 163,690 & 179,647 & 197,429 & 218,312 & 220,857 & 215,972 & 19,600 & 28,978 & 29,929 & 29,412 & 29,545 & 28,104 \\
\hline U.S. Virg & 2,114 & 2,185 & 2,431 & 2,520 & 2,399 & 2,240 & 154 & 207 & 171 & 213 & 215 & 183 \\
\hline
\end{tabular}

NOTE: Degree-granting institutions grant associate's or higher degrees and participate in Title IV federal financial aid programs.
SOURCE: U.S. Department of Education, National Center for Education Statistics, Integrated Postsecondary Education Data System (IPEDS), Spring 2001 through Spring 2013 Enrollment component. (This table was prepared November 2013.) 
Table 304.80. Total fall enrollment in degree-granting postsecondary institutions, by control, level of enrollment, level of institution, and state or jurisdiction: 2012

\begin{tabular}{|c|c|c|c|c|c|c|c|c|c|c|c|c|}
\hline \multirow[b]{3}{*}{ State or jurisdiction } & \multicolumn{4}{|c|}{ Public } & \multicolumn{8}{|c|}{ Private } \\
\hline & \multicolumn{3}{|c|}{ Undergraduate } & \multirow{2}{*}{$\begin{array}{r}\text { Post- } \\
\text { bacca- } \\
\text { laureate }\end{array}$} & \multicolumn{5}{|c|}{ Undergraduate } & \multicolumn{3}{|c|}{ Postbaccalaureate } \\
\hline & Total & 4-year & 2-year & & Total & $\begin{array}{r}\text { Nonprofit } \\
4 \text {-year }\end{array}$ & $\begin{array}{r}\text { For-profit } \\
4 \text {-year }\end{array}$ & $\begin{array}{r}\text { Nonprofit } \\
2 \text {-year }\end{array}$ & $\begin{array}{r}\text { For-profit } \\
\text { 2-year }\end{array}$ & Total & $\begin{array}{r}\text { Nonprofit } \\
4 \text {-year }\end{array}$ & $\begin{array}{r}\text { For-profit } \\
4 \text {-year }\end{array}$ \\
\hline 1 & 2 & 3 & 4 & 5 & 6 & 7 & 8 & 9 & 10 & 11 & 12 & 13 \\
\hline United States. & $13,473,743$ & $6,686,083$ & $6,787,660$ & $1,406,600$ & $4,258,688$ & $2,707,469$ & $1,174,906$ & 37,606 & 338,707 & $1,503,788$ & $1,208,503$ & 295,285 \\
\hline Alabama ..................... & 216,535 & 130,260 & 86,275 & 34,510 & 49,382 & 21,674 & 24,045 & 518 & 3,145 & 9,884 & 3,917 & 5,967 \\
\hline aska........................... & 28,034 & 27,276 & 758 & 2,561 & 1,984 & 497 & 1,259 & 0 & 228 & 218 & 218 & \\
\hline zona.. & 332,352 & 114,685 & 217,667 & 26,877 & 289,258 & 3,503 & 274,906 & 0 & 10,849 & 87,892 & 5,598 & 82,294 \\
\hline 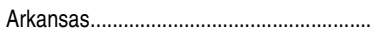 & 141,323 & 81,479 & 59,844 & 15,901 & 16,181 & 13,973 & 1,704 & 319 & 185 & 3,053 & 2,860 & 193 \\
\hline California & $2,023,402$ & 564,081 & $1,459,321$ & 105,750 & 336,257 & 161,047 & 105,455 & 1,665 & 68,090 & 156,051 & 134,542 & 21,509 \\
\hline olorado .......... & 238,951 & 141,157 & 97,794 & 33,493 & 66,283 & 19,606 & 36,360 & 245 & 10,072 & 24,208 & 13,668 & 10,540 \\
\hline onnecticu & 111,481 & 53,253 & 58,228 & 13,471 & 55,331 & 47,176 & 7,883 & 0 & 272 & 21,375 & 20,589 & 786 \\
\hline Delaware.... & 37,012 & 22,079 & 14,933 & 4,101 & 10,804 & 10,297 & 296 & 211 & 0 & 6,211 & 6,120 & 91 \\
\hline District of Columbia & 4,857 & 4,857 & & 619 & 42,842 & 39,085 & 3,757 & 0 & 0 & 41,832 & 39,915 & 1,917 \\
\hline Florida........................ & 738,862 & 666,812 & 72,050 & 65,831 & 284,951 & 124,905 & 114,259 & 1,630 & 44,157 & 65,285 & 53,397 & 11,888 \\
\hline eorgia.. & 382,476 & 234,809 & 147,667 & 39,713 & 94,337 & 51,705 & 33,780 & 504 & 8,348 & 28,832 & 21,024 & 7,808 \\
\hline waii. & 53,935 & 24,602 & 29,333 & 6,360 & 15,337 & 12,131 & 1,495 & 0 & 1,711 & 2,824 & 2,161 & 663 \\
\hline 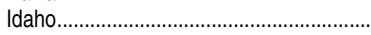 & 71,476 & 45,836 & 25,640 & 7,305 & 28,425 & 25,977 & 1,940 & 0 & 508 & 802 & 772 & 30 \\
\hline$\ldots$ & 507,197 & 148,467 & 358,730 & 49,940 & 206,514 & 137,447 & 60,339 & 718 & 8,010 & 103,459 & 89,662 & 13,797 \\
\hline Indiana...................... & 295,297 & 195,025 & 100,272 & 38,472 & 97,328 & 72,773 & 18,411 & 439 & 5,705 & 16,165 & 15,703 & 462 \\
\hline lowa.. & 158,615 & 58,207 & 100,408 & 14,943 & 156,803 & 44,565 & 111,751 & 203 & 284 & 30,822 & 11,439 & 19,383 \\
\hline ․․………..... & 162,950 & 79,719 & 83,231 & 21,026 & 24,918 & 18,706 & & 2,280 & 1,549 & 4,892 & 4,885 & 7 \\
\hline tucky.. & 200,102 & 102,520 & 97,582 & 23,990 & 45,840 & 29,709 & 12,818 & 0 & 3,313 & 12,193 & 10,514 & 1,679 \\
\hline Louisiana. & 197,648 & 119,606 & 78,042 & 23,323 & 29,621 & 19,897 & 3,238 & 1,054 & 5,432 & 8,233 & 7,930 & 303 \\
\hline Maine......... & 46,007 & 27,739 & 18,268 & 4,263 & 17,077 & 15,383 & 952 & 285 & 457 & 5,463 & 5,453 & 10 \\
\hline Maryland. & 265,180 & 120,166 & 145,014 & 45,323 & 37,305 & 29,564 & 5,057 & 0 & 2,684 & 26,688 & 25,353 & 1,335 \\
\hline 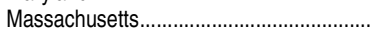 & 201,040 & 95,746 & 105,294 & 27,138 & 180,792 & 173,059 & 4,910 & 959 & 1,864 & 107,361 & 107,101 & 260 \\
\hline 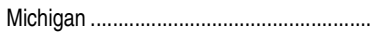 & 473,592 & 235,479 & 238,113 & 66,650 & 101,918 & 93,559 & 6,646 & 80 & 633 & 665 & 159 & 506 \\
\hline & 247,522 & 112,388 & 135,134 & 24,768 & 88,225 & 50,565 & 35,722 & 87 & 1,851 & 91,146 & 20,794 & 70,352 \\
\hline Mississippi & 141,605 & 64,045 & 77,560 & 16,390 & 13,781 & 11,275 & 453 & 0 & 2,053 & 4,889 & 4,778 & 111 \\
\hline Misso & 230,947 & 121,899 & 109,048 & 26,483 & 132,361 & 03,671 & 20,518 & 1,207 & 6,965 & 51,580 & 49,347 & 2,233 \\
\hline Monta & 43,667 & 34,425 & 9,242 & 4,666 & 4,757 & 4,350 & & 407 & 0 & 164 & 164 & \\
\hline 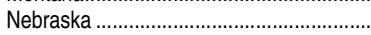 & 90,630 & 45,250 & 45,380 & 13,536 & 25,091 & 22,378 & 1,943 & 161 & 609 & 10,321 & 10,242 & 79 \\
\hline Nevada ... & 95,487 & 83,884 & 11,603 & 8,132 & 11,367 & 884 & 5,718 & 0 & 4,765 & 3,314 & 2,537 & 777 \\
\hline New Hampshire ............ & 39,172 & 24,525 & 14,647 & 4,117 & 27,598 & 23,723 & 3,591 & 284 & 0 & 11,791 & 11,674 & 117 \\
\hline owerce & 318,677 & 145,889 & 172,788 & 37,779 & 58,224 & 49,637 & 5,684 & 0 & 2,903 & 25,285 & 24,754 & 531 \\
\hline New & 3,345 & 52,226 & 81,119 & 3,447 & 8,428 & 684 & 6,068 & 0 & 1,676 & 1,204 & 650 & 554 \\
\hline$(\cdots \cdots \cdots$ & 652,778 & 323,712 & 329,066 & 69,496 & 418,273 & 364,666 & 29,081 & 4,175 & 20,351 & 169,439 & 166,835 & 2,604 \\
\hline North Carol & 420,434 & 175,760 & 244,674 & 45,250 & 87,836 & 72,615 & 11,013 & 706 & 3,502 & 24,511 & 20,734 & 3,777 \\
\hline North Dakot & 42,738 & 35,870 & 6,868 & 6,191 & 5,385 & 4,385 & 1,000 & 0 & 0 & 855 & & \\
\hline Ohin & 464,084 & 274,612 & 189,472 & 60,254 & 154,803 & 114,940 & 21,604 & 2,020 & 16,239 & 30,677 & 29,311 & 1,366 \\
\hline & 173,639 & 104,886 & 68,753 & 21,472 & 28,425 & 19,228 & 4,723 & 0 & 4,474 & 4,928 & 4,760 & 168 \\
\hline & 194,691 & 85,844 & 108,847 & 17,619 & 30,503 & 21,722 & 5,218 & 0 & 3,563 & 11,882 & 11,648 & 234 \\
\hline & 378,805 & 234,456 & 144,349 & 47,085 & 261,543 & 199,686 & 22,031 & 8,511 & 31,315 & 809 & 88,494 & 1,315 \\
\hline Rhode Islar & 38,813 & 20,929 & 17,884 & 4,391 & 34,525 & $\begin{array}{l}34,525 \\
\end{array}$ & & 0 & 0 & 6,223 & 6,223 & \\
\hline 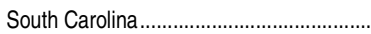 & 189,392 & 87,432 & 101,960 & 19,631 & 44,443 & 30,043 & 9,396 & 950 & 4,054 & 6,151 & 3,608 & 2,543 \\
\hline & 38,626 & 32,279 & & 5,559 & 10,633 & 6,217 & 4,122 & 294 & 0 & 1,240 & 762 & 478 \\
\hline$\ldots \ldots \ldots \ldots$ & 209,423 & 117,121 & 92,302 & 25,587 & 85,866 & 60,506 & $\begin{array}{l}13,788 \\
\end{array}$ & 1,509 & 0,063 & 22,765 & 20,801 & 1,964 \\
\hline & $1,210,112$ & 509,101 & 701,011 & 137,748 & 152,740 & 56 & & & & 9,698 & 36,634 & 3,064 \\
\hline Utah.... & 158,627 & 128,630 & 29,997 & 12,374 & 80,398 & 64,939 & 11,373 & 2,191 & 1,895 & 15,910 & 14,140 & 1,770 \\
\hline & 24,179 & 17,868 & 6,311 & 2,322 & 3,619 & 3,102 & 517 & 0 & & 4,583 & 4,583 & 0 \\
\hline & 360,859 & 166,432 & 194,427 & 48,894 & & & 5,835 & 326 & 8,889 & & 41,340 & 5,910 \\
\hline & 288,656 & 149,345 & 139,311 & 22,841 & 40,961 & 30,851 & 5,760 & 33 & 4,317 & 056 & 12,278 & 778 \\
\hline & 80,594 & 59,433 & 21,161 & 12,423 & 55,561 & 6,683 & 46,581 & 0 & 2,297 & 3,601 & 997 & 12,604 \\
\hline & 269,565 & 158,586 & 110,979 & 23,851 & 60,208 & 47,457 & 11,974 & 0 & 777 & 16,108 & 15,580 & 528 \\
\hline 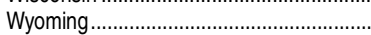 & 33,150 & 10,194 & 22,956 & 2,709 & 1,953 & 0 & 145 & 0 & 1,808 & 0 & 0 & 0 \\
\hline U.S. Service Academies ... & 15,202 & 15,202 & 0 & 25 & $\dagger$ & $\dagger$ & $\dagger$ & $\dagger$ & $\dagger$ & $\dagger$ & $\dagger$ & $\dagger$ \\
\hline Other jurisdictions ............................ & 71,872 & 62,004 & 9,868 & 6,497 & 159,491 & 116,551 & 11,058 & 804 & 31,078 & 22,083 & 21,305 & 778 \\
\hline American Samoa.. & 1,795 & 1,795 & 0 & 0 & 0 & 0 & t & 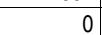 & 0 & 0 & 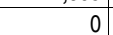 & \\
\hline of Microne & 2,744 & & 2,744 & 0 & 0 & 0 & 0 & 0 & 0 & 0 & 0 & 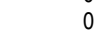 \\
\hline & 5,556 & 3,411 & 2,145 & 291 & 75 & 75 & 0 & 0 & 0 & 2 & 2 & 0 \\
\hline . & 1,123 & 0 & 1,123 & 0 & 0 & 0 & 0 & 0 & 0 & 0 & 0 & 0 \\
\hline North & 1,178 & 1,178 & 0 & 0 & 0 & 0 & 0 & 0 & 0 & 0 & 0 & 0 \\
\hline Pala & 680 & & 680 & 0 & 0 & 0 & 0 & 0 & 0 & 0 & 0 & 0 \\
\hline 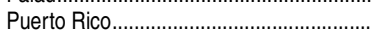 & 56,556 & 53,380 & 3,176 & 6,023 & 159,416 & 116,476 & 11,058 & 804 & 31,078 & 22,081 & 21,303 & 778 \\
\hline U.S. Virgin Islands .... & 2,240 & 2,240 & 0 & 183 & 0 & 0 & 0 & 0 & 0 & 0 & 0 & 0 \\
\hline
\end{tabular}

$†$ Not applicable.

NOTE: Degree-granting institutions grant associate's or higher degrees and participate in Title IV federal financial aid programs.
SOURCE: U.S. Department of Education, National Center for Education Statistics, Integrated Postsecondary Education Data System (IPEDS), Spring 2013, Enrollment component. (This table was prepared November 2013.) 
Table 305.10. Total fall enrollment of first-time degree/certificate-seeking students in degree-granting postsecondary institutions, by attendance status, sex of student, and level and control of institution: 1955 through 2023

\begin{tabular}{|c|c|c|c|c|c|c|c|c|c|c|c|c|c|}
\hline \multirow[b]{2}{*}{ Year } & \multirow[b]{2}{*}{ Total } & \multirow[b]{2}{*}{ Full-time } & \multirow[b]{2}{*}{ Part-time } & \multicolumn{3}{|c|}{ Males } & \multicolumn{3}{|c|}{ Females } & \multicolumn{2}{|c|}{ 4-year } & \multicolumn{2}{|c|}{ 2-year } \\
\hline & & & & Total & Full-time & Part-time & Total & Full-time & Part-time & Public & Private & Public & Private \\
\hline 1 & 2 & 3 & 4 & 5 & 6 & 7 & 8 & 9 & 10 & 11 & 12 & 13 & 14 \\
\hline $\begin{array}{l}1955^{1} \\
1956^{1} \\
1957^{1} \\
1958^{1} \\
1959^{1}\end{array}$ & $\begin{array}{l}670,013 \\
717,504 \\
723,879 \\
775,308 \\
821,520\end{array}$ & $\begin{array}{l}- \\
- \\
- \\
-\end{array}$ & $\begin{array}{l}- \\
- \\
- \\
-\end{array}$ & $\begin{array}{l}415,604 \\
442,903 \\
441,969 \\
465,422 \\
487,890\end{array}$ & $\begin{array}{l}- \\
- \\
- \\
-\end{array}$ & $\begin{array}{l}- \\
- \\
- \\
-\end{array}$ & $\begin{array}{l}254,409 \\
274,601 \\
281,910 \\
309,886 \\
333,630\end{array}$ & $\begin{array}{l}- \\
- \\
- \\
-\end{array}$ & $\begin{array}{l}- \\
- \\
- \\
-\end{array}$ & $\begin{array}{l}283,084^{2} \\
292,743^{2} \\
293,544^{2} \\
328,242^{2} \\
348,150^{2}\end{array}$ & 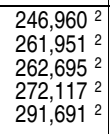 & $\begin{array}{l}117,288^{2} \\
137,406^{2} \\
140,522^{2} \\
146,379^{2} \\
153,393^{2}\end{array}$ & $\begin{array}{l}22,681^{2} \\
25,404^{2} \\
27,118^{2} \\
28,570^{2} \\
28,286^{2}\end{array}$ \\
\hline $\begin{array}{l}1960^{1} \\
1961^{1} \\
1962^{1} \\
1963^{1} \\
1964^{1}\end{array}$ & $\begin{array}{r}923,069 \\
1,018,361 \\
1,030,554 \\
1,046,424 \\
1,224,840\end{array}$ & $\begin{array}{l}- \\
- \\
- \\
-\end{array}$ & $\begin{array}{l}- \\
- \\
- \\
-\end{array}$ & $\begin{array}{l}539,512 \\
591,913 \\
598,099 \\
604,282 \\
701,524\end{array}$ & $\begin{array}{l}- \\
- \\
-\end{array}$ & $\begin{array}{l}- \\
- \\
- \\
-\end{array}$ & $\begin{array}{l}383,557 \\
426,448 \\
432,455 \\
442,142 \\
523,316\end{array}$ & $\begin{array}{l}- \\
- \\
- \\
-\end{array}$ & $\begin{array}{l}- \\
- \\
- \\
-\end{array}$ & $\begin{array}{c}395,884^{2} \\
438,135^{2} \\
445,191^{2} \\
-\overline{5}^{2}\end{array}$ & $\begin{array}{c}313,209^{2} \\
336,449^{2} \\
324,923^{2} \\
\overline{363,348^{2}}\end{array}$ & $\begin{array}{c}181,860^{2} \\
210,101^{2} \\
224,537^{2} \\
\overline{275,413^{2}}\end{array}$ & $\begin{array}{c}32,116^{2} \\
33,676^{2} \\
35,903^{2} \\
-\overline{4}^{2}\end{array}$ \\
\hline 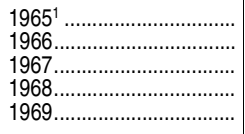 & $\begin{array}{l}1,441,822 \\
1,554,337 \\
1,640,936 \\
1,892,849 \\
1,967,104\end{array}$ & $\begin{array}{r}- \\
1,335,512 \\
1,470,653 \\
1,525,290\end{array}$ & $\begin{array}{r}- \\
305,424 \\
422,196 \\
441,814\end{array}$ & $\begin{array}{r}829,215 \\
889,516 \\
931,127 \\
1,082,367 \\
1,118,269\end{array}$ & $\begin{array}{r}- \\
761,299 \\
847,005 \\
876,280\end{array}$ & $\begin{array}{r}- \\
169,828 \\
235,362 \\
241,989\end{array}$ & $\begin{array}{l}612,607 \\
664,821 \\
709,809 \\
810,482 \\
848,835\end{array}$ & $\begin{array}{r}- \\
574,213 \\
623,648 \\
649,010\end{array}$ & $\begin{array}{r}- \\
135,596 \\
186,834 \\
199,825\end{array}$ & $\begin{array}{l}642,233^{2} \\
626,472^{2} \\
644,525 \\
724,377 \\
699,167\end{array}$ & $\begin{array}{l}398,7922 \\
382,8892 \\
368,300 \\
378,052 \\
391,508\end{array}$ & $\begin{array}{l}347,788^{2} \\
478,459^{2} \\
561,488 \\
718,562 \\
814,132\end{array}$ & $\begin{array}{l}53,009^{2} \\
66,517^{2} \\
66,623 \\
71,858 \\
62,297\end{array}$ \\
\hline 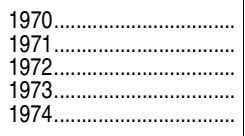 & $\begin{array}{l}2,063,397 \\
2,119,018 \\
2,152,778 \\
2,226,041 \\
2,365,761\end{array}$ & $\begin{array}{l}1,587,072 \\
1,606,036 \\
1,574,197 \\
1,607,269 \\
1,673,333\end{array}$ & $\begin{array}{l}476,325 \\
512,982 \\
578,581 \\
618,772 \\
692,428\end{array}$ & $\begin{array}{l}1,151,960 \\
1,170,518 \\
1,157,501 \\
1,182,173 \\
1,243,790\end{array}$ & $\begin{array}{l}896,281 \\
895,715 \\
858,254 \\
867,314 \\
896,077\end{array}$ & $\begin{array}{l}255,679 \\
274,803 \\
299,247 \\
314,859 \\
347,713\end{array}$ & $\begin{array}{r}911,437 \\
948,500 \\
995,277 \\
1,043,868 \\
1,121,971\end{array}$ & $\begin{array}{l}690,791 \\
710,321 \\
715,943 \\
739,955 \\
777,256\end{array}$ & $\begin{array}{l}220,646 \\
238,179 \\
279,334 \\
303,913 \\
344,715\end{array}$ & $\begin{array}{l}717,449 \\
704,052 \\
680,337 \\
698,777 \\
745,637\end{array}$ & $\begin{array}{l}395,886 \\
384,695 \\
380,982 \\
378,994 \\
386,391\end{array}$ & $\begin{array}{r}890,703 \\
971,295 \\
1,036,616 \\
1,089,182 \\
1,175,759\end{array}$ & $\begin{array}{l}59,359 \\
58,976 \\
54,843 \\
59,088 \\
57,974\end{array}$ \\
\hline 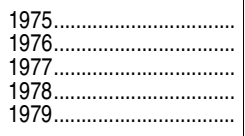 & $\begin{array}{l}2,515,155 \\
2,347,014 \\
2,394,426 \\
2,389,627 \\
2,502,896\end{array}$ & $\begin{array}{l}1,763,296 \\
1,662,333 \\
1,680,916 \\
1,650,848 \\
1,706,732\end{array}$ & $\begin{array}{l}751,859 \\
684,681 \\
713,510 \\
738,779 \\
796,164\end{array}$ & $\begin{array}{l}1,327,935 \\
1,170,326 \\
1,155,856 \\
1,141,777 \\
1,179,846\end{array}$ & $\begin{array}{l}942,198 \\
854,597 \\
839,848 \\
817,294 \\
840,315\end{array}$ & $\begin{array}{l}385,737 \\
315,729 \\
316,008 \\
324,483 \\
339,531\end{array}$ & $\begin{array}{l}1,187,220 \\
1,176,688 \\
1,238,570 \\
1,247,850 \\
1,323,050\end{array}$ & $\begin{array}{l}821,098 \\
807,736 \\
841,068 \\
833,554 \\
866,417\end{array}$ & $\begin{array}{l}366,122 \\
368,952 \\
397,502 \\
414,296 \\
456,633\end{array}$ & $\begin{array}{l}771,725 \\
717,373 \\
737,497 \\
736,703 \\
760,119\end{array}$ & $\begin{array}{l}395,440 \\
413,961 \\
404,631 \\
406,669 \\
415,126\end{array}$ & $\begin{array}{l}1,283,523 \\
1,152,944 \\
1,185,648 \\
1,173,544 \\
1,253,854\end{array}$ & $\begin{array}{l}64,467 \\
62,736 \\
66,650 \\
72,711 \\
73,797\end{array}$ \\
\hline 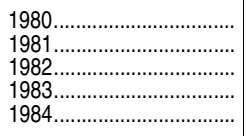 & $\begin{array}{l}2,587,644 \\
2,595,421 \\
2,505,466 \\
2,443,703 \\
2,356,898\end{array}$ & $\begin{array}{l}1,749,928 \\
1,737,714 \\
1,688,620 \\
1,678,071 \\
1,613,185\end{array}$ & $\begin{array}{l}837,716 \\
857,707 \\
816,846 \\
765,632 \\
743,713\end{array}$ & $\begin{array}{l}1,218,961 \\
1,217,680 \\
1,199,237 \\
1,159,049 \\
1,112,303\end{array}$ & $\begin{array}{l}862,458 \\
851,833 \\
837,223 \\
824,609 \\
786,099\end{array}$ & $\begin{array}{l}356,503 \\
365,847 \\
362,014 \\
334,440 \\
326,204\end{array}$ & $\begin{array}{l}1,368,683 \\
1,377,741 \\
1,306,229 \\
1,284,654 \\
1,244,595\end{array}$ & $\begin{array}{l}887,470 \\
885,881 \\
851,397 \\
853,462 \\
827,086\end{array}$ & $\begin{array}{l}481,213 \\
491,860 \\
454,832 \\
431,192 \\
417,509\end{array}$ & $\begin{array}{l}765,395 \\
754,007 \\
730,775 \\
728,244 \\
713,790\end{array}$ & $\begin{array}{l}417,937 \\
419,257 \\
404,252 \\
403,882 \\
402,959\end{array}$ & $\begin{array}{l}1,313,591 \\
1,318,436 \\
1,254,193 \\
1,189,869 \\
1,130,311\end{array}$ & $\begin{array}{l}90,721^{3} \\
103,721^{3} \\
116,246^{3} \\
121,708^{3} \\
109,838\end{array}$ \\
\hline 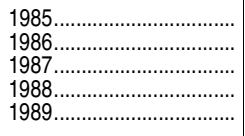 & $\begin{array}{l}2,292,222 \\
2,219,208 \\
2,246,359 \\
2,378,803 \\
2,341,035\end{array}$ & $\begin{array}{l}1,602,038 \\
1,589,451 \\
1,626,719 \\
1,698,927 \\
1,656,594\end{array}$ & $\begin{array}{l}690,184 \\
629,757 \\
619,640 \\
679,876 \\
684,441\end{array}$ & $\begin{array}{l}1,075,736 \\
1,046,527 \\
1,046,615 \\
1,100,026 \\
1,094,750\end{array}$ & $\begin{array}{l}774,858 \\
768,856 \\
779,226 \\
807,319 \\
791,295\end{array}$ & $\begin{array}{l}300,878 \\
277,671 \\
267,389 \\
292,707 \\
303,455\end{array}$ & $\begin{array}{l}1,216,486 \\
1,172,681 \\
1,199,744 \\
1,278,777 \\
1,246,285\end{array}$ & $\begin{array}{l}827,180 \\
820,595 \\
847,493 \\
891,608 \\
865,299\end{array}$ & $\begin{array}{l}389,306 \\
352,086 \\
352,251 \\
387,169 \\
380,986\end{array}$ & $\begin{array}{l}717,199 \\
719,974 \\
757,833 \\
783,358 \\
762,217\end{array}$ & $\begin{array}{l}398,556 \\
391,673 \\
405,113 \\
425,907 \\
413,836\end{array}$ & $\begin{array}{r}1,060,275 \\
990,973 \\
979,820 \\
1,048,914 \\
1,048,529\end{array}$ & $\begin{array}{l}116,192 \\
116,588 \\
103,593 \\
120,624 \\
116,453\end{array}$ \\
\hline $\begin{array}{l}1990 \\
1991 \\
1992 \\
1993 \ldots \ldots \ldots \ldots \ldots \ldots \ldots \ldots . . . \\
1994\end{array}$ & $\begin{array}{l}2,256,624 \\
2,277,920 \\
2,184,113 \\
2,160,710 \\
2,133,205\end{array}$ & $\begin{array}{l}1,617,118 \\
1,652,983 \\
1,603,737 \\
1,608,274 \\
1,603,106\end{array}$ & $\begin{array}{l}639,506 \\
624,937 \\
580,376 \\
552,436 \\
530,099\end{array}$ & $\begin{array}{r}1,045,191 \\
1,068,433 \\
1,013,058 \\
1,007,647 \\
984,558\end{array}$ & $\begin{array}{l}771,372 \\
798,043 \\
760,290 \\
762,240 \\
751,081\end{array}$ & $\begin{array}{l}273,819 \\
270,390 \\
252,768 \\
245,407 \\
233,477\end{array}$ & $\begin{array}{l}1,211,433 \\
1,209,487 \\
1,171,055 \\
1,153,063 \\
1,148,647\end{array}$ & $\begin{array}{l}845,746 \\
854,940 \\
843,447 \\
846,034 \\
852,025\end{array}$ & $\begin{array}{l}365,687 \\
354,547 \\
327,608 \\
307,029 \\
296,622\end{array}$ & $\begin{array}{l}727,264 \\
717,697 \\
697,393 \\
702,273 \\
709,042\end{array}$ & $\begin{array}{l}400,120 \\
392,904 \\
408,306 \\
410,688 \\
405,917\end{array}$ & $\begin{array}{r}1,041,097 \\
1,070,048 \\
993,074 \\
973,545 \\
952,468\end{array}$ & $\begin{array}{l}88,143 \\
97,271 \\
85,340 \\
74,204 \\
65,778\end{array}$ \\
\hline 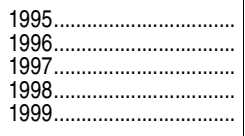 & $\begin{array}{l}2,168,831 \\
2,274,319 \\
2,219,255 \\
2,212,593 \\
2,357,590\end{array}$ & \begin{tabular}{|l|}
$1,646,812$ \\
$1,739,852$ \\
$1,733,512$ \\
$1,775,412$ \\
$1,849,741$
\end{tabular} & $\begin{array}{l}522,019 \\
534,467 \\
485,743 \\
437,181 \\
507,849\end{array}$ & $\begin{array}{l}1,001,052 \\
1,046,662 \\
1,026,058 \\
1,022,656 \\
1,094,539\end{array}$ & $\begin{array}{l}767,185 \\
805,982 \\
806,054 \\
825,577 \\
865,545\end{array}$ & $\begin{array}{l}233,867 \\
240,680 \\
220,004 \\
197,079 \\
228,994\end{array}$ & $\begin{array}{l}1,167,779 \\
1,227,657 \\
1,193,197 \\
1,189,937 \\
1,263,051\end{array}$ & $\begin{array}{l}879,627 \\
933,870 \\
927,458 \\
949,835 \\
984,196\end{array}$ & $\begin{array}{l}288,152 \\
293,787 \\
265,739 \\
240,102 \\
278,855\end{array}$ & $\begin{array}{l}731,836 \\
741,164 \\
755,362 \\
792,772 \\
819,503\end{array}$ & $\begin{array}{l}419,025 \\
427,442 \\
442,397 \\
460,948 \\
474,223\end{array}$ & $\begin{array}{l}954,595 \\
989,536 \\
923,954 \\
858,417 \\
955,499\end{array}$ & $\begin{array}{r}63,375 \\
116,177 \\
97,542 \\
100,456 \\
108,365\end{array}$ \\
\hline $2000 \ldots$ & $\begin{array}{l}2,427,551 \\
2,497,078 \\
2,570,611 \\
2,591,754 \\
2,630,243\end{array}$ & \begin{tabular}{|l|}
$1,918,093$ \\
$1,989,179$ \\
$2,053,065$ \\
$2,102,394$ \\
$2,147,546$
\end{tabular} & $\begin{array}{l}509,458 \\
507,899 \\
517,546 \\
489,360 \\
482,697\end{array}$ & $\begin{array}{l}1,123,948 \\
1,152,837 \\
1,170,609 \\
1,175,856 \\
1,190,268\end{array}$ & $\begin{array}{l}894,432 \\
926,393 \\
945,938 \\
965,075 \\
981,591\end{array}$ & $\begin{array}{l}229,516 \\
226,444 \\
224,671 \\
210,781 \\
208,677\end{array}$ & $\begin{array}{l}1,303,603 \\
1,344,241 \\
1,400,002 \\
1,415,898 \\
1,439,975\end{array}$ & $\begin{array}{l}1,023,661 \\
1,062,786 \\
1,107,127 \\
1,137,319 \\
1,165,955\end{array}$ & $\begin{array}{l}279,942 \\
281,455 \\
292,875 \\
278,579 \\
274,020\end{array}$ & $\begin{array}{l}842,228 \\
866,619 \\
886,297 \\
918,602 \\
925,249\end{array}$ & $\begin{array}{l}498,532 \\
508,030 \\
517,621 \\
537,726 \\
562,485\end{array}$ & $\begin{array}{r}952,175 \\
988,726 \\
1,037,267 \\
1,004,428 \\
1,009,082\end{array}$ & $\begin{array}{l}134,616 \\
133,703 \\
129,426 \\
130,998 \\
133,427\end{array}$ \\
\hline 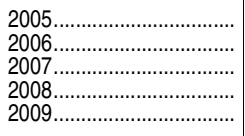 & $\begin{array}{l}2,657,338 \\
2,707,213 \\
2,776,168 \\
3,024,723 \\
3,210,237\end{array}$ & $\begin{array}{l}2,189,884 \\
2,219,853 \\
2,293,855 \\
2,427,740 \\
2,586,840\end{array}$ & $\begin{array}{l}467,454 \\
487,360 \\
482,313 \\
596,983 \\
623,397\end{array}$ & $\begin{array}{l}1,200,055 \\
1,228,665 \\
1,267,030 \\
1,389,302 \\
1,479,801\end{array}$ & $\begin{array}{r}995,610 \\
1,015,585 \\
1,052,600 \\
1,115,500 \\
1,192,553\end{array}$ & $\begin{array}{l}204,445 \\
213,080 \\
214,430 \\
273,802 \\
287,248\end{array}$ & $\begin{array}{l}1,457,283 \\
1,478,548 \\
1,509,138 \\
1,635,421 \\
1,730,436\end{array}$ & $\begin{array}{l}1,194,274 \\
1,204,268 \\
1,241,255 \\
1,312,240 \\
1,394,287\end{array}$ & $\begin{array}{l}263,009 \\
274,280 \\
267,883 \\
323,181 \\
336,149\end{array}$ & $\begin{array}{r}953,903 \\
990,262 \\
1,023,543 \\
1,053,838 \\
1,090,769\end{array}$ & $\begin{array}{l}606,712 \\
598,412 \\
633,296 \\
673,581 \\
713,284\end{array}$ & $\begin{array}{r}977,224 \\
1,013,080 \\
1,016,262 \\
1,186,576 \\
1,275,630\end{array}$ & $\begin{array}{l}119,499 \\
105,459 \\
103,067 \\
110,728 \\
130,554\end{array}$ \\
\hline 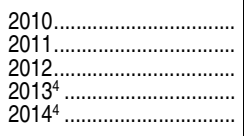 & $\begin{array}{l}3,156,949 \\
3,093,077 \\
2,990,280 \\
2,979,000 \\
3,031,000\end{array}$ & $\begin{array}{r}2,532,858 \\
2,479,137 \\
2,406,038 \\
- \\
-\end{array}$ & $\begin{array}{r}624,091 \\
613,940 \\
584,242 \\
- \\
-\end{array}$ & $\begin{array}{l}1,461,707 \\
1,424,596 \\
1,385,096 \\
1,390,000 \\
1,395,000\end{array}$ & $\begin{array}{r}1,171,619 \\
1,140,566 \\
1,114,025 \\
- \\
-\end{array}$ & $\begin{array}{r}290,088 \\
284,030 \\
271,071 \\
- \\
-\end{array}$ & $\begin{array}{l}1,695,242 \\
1,668,481 \\
1,605,184 \\
1,589,000 \\
1,636,000\end{array}$ & $\begin{array}{r}1,361,239 \\
1,338,571 \\
1,292,013 \\
- \\
-\end{array}$ & $\begin{array}{r}334,003 \\
329,910 \\
313,171 \\
- \\
-\end{array}$ & $\begin{array}{r}1,110,675 \\
1,131,807 \\
1,127,832 \\
- \\
-\end{array}$ & $\begin{array}{r}676,027 \\
656,938 \\
642,686 \\
- \\
-\end{array}$ & $\begin{array}{r}1,236,477 \\
1,195,286 \\
1,133,486 \\
- \\
-\end{array}$ & $\begin{array}{r}133,770 \\
109,046 \\
86,276 \\
- \\
-\end{array}$ \\
\hline 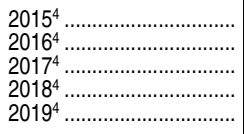 & $\begin{array}{l}3,061,000 \\
3,101,000 \\
3,147,000 \\
3,185,000 \\
3,223,000\end{array}$ & $\begin{array}{l}- \\
- \\
- \\
-\end{array}$ & $\begin{array}{l}- \\
- \\
- \\
-\end{array}$ & $\begin{array}{l}1,399,000 \\
1,407,000 \\
1,421,000 \\
1,432,000 \\
1,444,000\end{array}$ & $\begin{array}{l}- \\
- \\
- \\
-\end{array}$ & $\begin{array}{l}- \\
- \\
-\end{array}$ & $\begin{array}{l}1,663,000 \\
1,694,000 \\
1,727,000 \\
1,753,000 \\
1,779,000\end{array}$ & $\begin{array}{l}- \\
- \\
- \\
-\end{array}$ & $\begin{array}{l}- \\
- \\
- \\
-\end{array}$ & $\begin{array}{l}- \\
- \\
- \\
-\end{array}$ & $\begin{array}{l}- \\
- \\
-\end{array}$ & $\begin{array}{l}- \\
z \\
-\end{array}$ & $\begin{array}{l}- \\
- \\
-\end{array}$ \\
\hline 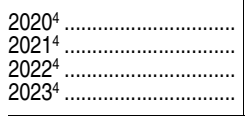 & $\begin{array}{l}3,261,000 \\
3,306,000 \\
3,353,000 \\
3,398,000\end{array}$ & $\begin{array}{l}- \\
- \\
-\end{array}$ & $\begin{array}{l}- \\
- \\
-\end{array}$ & $\begin{array}{l}1,456,000 \\
1,471,000 \\
1,487,000 \\
1,502,000\end{array}$ & $\begin{array}{l}- \\
- \\
-\end{array}$ & $\begin{array}{l}- \\
- \\
-\end{array}$ & $\begin{array}{l}1,805,000 \\
1,835,000 \\
1,866,000 \\
1,896,000\end{array}$ & $\begin{array}{l}- \\
- \\
-\end{array}$ & $\begin{array}{l}- \\
- \\
-\end{array}$ & $\begin{array}{l}- \\
- \\
-\end{array}$ & $\begin{array}{l}- \\
- \\
-\end{array}$ & $\begin{array}{l}- \\
- \\
-\end{array}$ & $\begin{array}{l}- \\
- \\
-\end{array}$ \\
\hline
\end{tabular}

-Not available.

Excludes first-time degree/certificate-seeking students in occupational programs not creditable towards a bachelor's degree.

2Data for 2-year branches of 4-year college systems are aggregated with the 4-year institutions. ${ }^{3}$ Large increases are due to the addition of schools accredited by the Accrediting Commission of Career Schools and Colleges of Technology.

${ }^{4}$ Projected.

NOTE: Data through 1995 are for institutions of higher education, while later data are for degree-granting institutions. Degree-granting institutions grant associate's or higher degrees and participate in Title IV federal financial aid programs. The degree-granting classification is very similar to the earlier higher education classification, but it includes more 2-year colleges and excludes a few higher education institutions that did not grant degrees. Alaska and Hawaii are included in all years.

SOURCE: U.S. Department of Education, National Center for Education Statistics, Biennial Survey of Education in the United States; Opening Fall Enrollment in Higher Education, 1963 through 1965; Higher Education General Information Survey (HEGIS), "Fall Enrollment in Colleges and Universities" surveys, 1966 through 1985; Integrated Postsecondary Education Data System (IPEDS), "Fall Enrollment Survey" (IPEDS-EF:86-99); IPEDS Spring 2001 through Spring 2013, Enrollment component; and First-Time Freshmen Projection Model, 1975 through 2023. (This table was prepared July 2014.) 
Table 305.20. Total fall enrollment of first-time degree/certificate-seeking students in degree-granting postsecondary institutions, by attendance status, sex of student, control of institution, and state or jurisdiction: Selected years, 2000 through 2012

\begin{tabular}{|c|c|c|c|c|c|c|c|c|c|c|c|c|c|c|}
\hline \multirow[b]{3}{*}{ State or jurisdiction } & \multirow{3}{*}{$\begin{array}{r}\text { Total, } \\
\text { fall } 2000\end{array}$} & \multirow{3}{*}{$\begin{array}{r}\text { Total, } \\
\text { fall } 2005\end{array}$} & \multirow{3}{*}{$\begin{array}{r}\text { Total, } \\
\text { fall } 2009\end{array}$} & \multirow{3}{*}{$\begin{array}{r}\text { Total, } \\
\text { fall } 2010\end{array}$} & \multirow{3}{*}{$\begin{array}{r}\text { Total, } \\
\text { fall } 2011\end{array}$} & \multicolumn{9}{|c|}{ Fall 2012} \\
\hline & & & & & & \multirow[b]{2}{*}{ Total } & \multicolumn{3}{|c|}{ Full-time } & & Part-time & & & \\
\hline & & & & & & & Total & Males & Females & Total & Males & Females & Public & Private \\
\hline 1 & 2 & 3 & 4 & 5 & 6 & 7 & 8 & 9 & 10 & 11 & 12 & 13 & 14 & 15 \\
\hline United States ... & $2,427,551$ & $2,657,338$ & $3,210,237$ & $3,156,949$ & $3,093,077$ & $2,990,280$ & $2,406,038$ & $1,114,025$ & $1,292,013$ & 584,242 & 271,071 & 313,171 & $2,261,318$ & 728,962 \\
\hline Alabama .... & 43,411 & 42,461 & 52,976 & 53,020 & 50,575 & 51,975 & 44,764 & 19,724 & 25,040 & 7,211 & 2,997 & 4,214 & 43,638 & 8,337 \\
\hline aska.... & 2,432 & 2,899 & 3,770 & 4,349 & 4,891 & 4,474 & 3,588 & 1,500 & 2,088 & 886 & 381 & 505 & 3,311 & 1,163 \\
\hline zona .. & 46,646 & 76,987 & 108,769 & 76,099 & 89,071 & 79,100 & 59,328 & 24,812 & 34,516 & 19,772 & 8,987 & 10,785 & 53,480 & 25,620 \\
\hline kansas & 22,695 & 24,480 & 8,607 & 29,242 & 29,100 & 28,830 & 26,003 & 11,843 & 14,160 & 2,827 & 1,262 & 1,565 & 25,333 & 3,497 \\
\hline$\ldots$ & 246,128 & 266,989 & 427,276 & 401,859 & 392,870 & 373,490 & 238,329 & 110,339 & 127,990 & 135,161 & 68,993 & 66,168 & 319,988 & 53,502 \\
\hline Colorado. & 43,201 & 47,330 & 59,123 & 54,423 & 51,070 & 47,226 & 36,115 & 17,668 & 18,447 & 11,111 & 5,138 & 5,973 & 38,096 & 9,130 \\
\hline & 24,212 & 27,520 & 31,282 & 32,719 & 32,307 & 32,193 & 26,622 & 280 & & 5,571 & 2,407 & 3,164 &, 921 & 12,272 \\
\hline .………....... & 7,636 & 8,763 & 9,219 & 8,854 & 10,259 & 9,655 & 8,422 & 641 & 4,781 & 1,233 & 526 & 707 & 8,054 & 1,601 \\
\hline trict & 9,150 & 11,334 & 15,728 & 10,744 & 9,790 & 9,546 & 8,596 & 445 & 151 & 950 & 335 & 615 & 607 & 8,939 \\
\hline ................. & 109,931 & 136,694 & 166,939 & 176,291 & 173,353 & 165,420 & 128,014 & 55,806 & 72,208 & 37,406 & 16,384 & 1,022 & 17,827 & 47,593 \\
\hline eorgi & 67,616 & 74,267 & 97,882 & 100,200 & 92,098 &, 437 & 71,829 & ,883 & 9,946 & 16,608 & 7,149 & 9,459 & 71,093 & 17,344 \\
\hline & 8,931 & 8,466 & 10,406 & 10,937 & 10,522 & 10,271 & 7,688 & 73 & 415 & 2,583 & & & 8,506 & 1,765 \\
\hline t & 10,669 & 12,549 & 12,964 & 12,668 & 13,032 & 14,232 & 11,997 & 5,593 & 6,404 & 2,235 & 3 & 2 & 10,463 & 3,769 \\
\hline & 107,592 & 111,724 & 123,789 & 114,549 & 109,229 & 104,815 & 86,221 & 41,393 & 44,828 & 18,594 & 879 & 15 & 2,442 & 32,373 \\
\hline ..................... & 59,320 & 61,915 & 78,777 & 82,362 & 75,217 & 72,021 & 60,245 & 27,973 & 32,272 & 11,776 & 5,681 & 6,095 & 53,700 & 18,321 \\
\hline a & 39,564 & 242 & 240 & 7,222 & 44,514 & 637 &, 916 & 72 &, 844 & 6,721 & 13 & 4,589 & 17 & 14,620 \\
\hline & 31,424 & 29,173 & 7777 & 3,563 & 32,773 & 7 & & & & 4, & & & & 42 \\
\hline 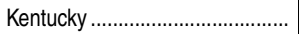 & 34,140 & 37,766 & 403 & 3,717 & 41,728 & 40,401 & 34,964 & & 39 & 5,437 & 2 & & & 7,951 \\
\hline & 45,383 & 32,018 & 378 & 3,106 & 44,741 & 42,183 & & & 94 & 5,965 & 2,585 & & 6,082 & 6,101 \\
\hline Maine & 9,231 & 11,181 & 11,598 & 12,176 & 12,364 & 12,433 & 10,196 & 4,935 & 261 & 2,237 & 747 & 1,490 & 7,881 & 4,552 \\
\hline Maryland &, 552 & 44,288 & 25 & 1,096 & 5 & 2 & 3 & 1 & 18,772 & 09 & 5,556 & 3 & 93 & 09 \\
\hline & 044 & 73 & 3 & 864 & 72 & 0 & & & & 5 & & & & \\
\hline & 84,998 & 93,221 & 101,933 & 1,486 & 99,386 & 51 & 47 & & & 21? & & 0 & & 53 \\
\hline & 63,893 & 2 & 8 & 55,803 & 3 & 5 & & & & 8,357 & & & & 12,929 \\
\hline Mississip & 30,356 & 33,665 & 301 & 36,978 & 35,162 & 34,534 & 30,501 & 179 & 7,322 & 4,033 & 1,562 & 2,471 & 31,927 & 2,607 \\
\hline Miccouri & 48,639 & 8 & 63,226 & 3 & 64,056 & 9 & 53,023 & 170 & 8,853 & 8,436 & 4,076 & 4,360 & 1.1 & 18 \\
\hline & & & & & & & & & & 0 & $5 c$ & & & 977 \\
\hline & 027 & 5 & 901 & 245 & 68 & 201 & 4 & & 66 & 2,007 & 89 & 5 & 39 & 3,562 \\
\hline & 490 & & 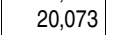 & 2 & 59 & 0 & & & & 5,421 & 2,598 & 2,8 & 33 & 1,557 \\
\hline New Hamps & 13,143 & 12,692 & 13,208 & 13,613 & 13,439 & 13,761 & 11,894 & 5,512 & 382 & 1,867 & 810 & 1,057 & 8,670 & 5,091 \\
\hline New Jerse & 52,233 & 6 & 69,460 & 4 & 67,420 & 65607 & & 743 & 29,161 & 9,009 & 4,301 & 4,708 & 9 & 10,218 \\
\hline & 1 & & & & & & & & & 3 & & & & \\
\hline & 168,181 & 181,328 & ,999 & 198,504 & 196,605 & 191,958 & 88 & & 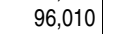 & 10,390 & & 5,482 & & 76,812 \\
\hline 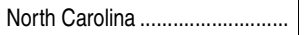 & 69,343 & 79,628 & 673 & 93,244 & 91,804 & 94,267 & & & & 19,537 & & 81 & 441 & 19,826 \\
\hline North D & 8,929 & 8,296 & 082 & 9,069 & 9,201 & 9,034 & 8,680 & 668 & 012 & 354 & 170 & 184 & 8,102 & 932 \\
\hline & 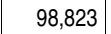 & 0 & 120,546 & 2 & 5 & & & & & 15,864 & & & & 40 \\
\hline & & & & & & & & & & 5 , & & & & \\
\hline 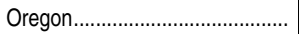 & 946 & & 37,661 & 8 & & & & & & 7,793 & & & & 5,735 \\
\hline & 5,578 & 13 & 1 & 1 & & 7 & & & & 16,278 & & & & 56,887 \\
\hline Rhode Island ....... & 13,789 & 15,277 & 5,800 & 5,698 & 15,826 & 15,454 & 13,643 & 215 & 7,428 & 1,811 & 00 & 952 & 773 & 7,681 \\
\hline & & 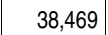 & 47,807 & & & & & & & 7,22 & 3006 & 4,2 & & \\
\hline & 8,5 & & & & & & & & & 95 & 3 & 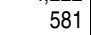 & & 1,567 \\
\hline & 43,327 & 76 & $\mathrm{U}_{6}$ &, 588 & 51 & 4 & & & & 6,639 & & & & \\
\hline & 1813 & 202,388 & (1) & 229,483 & 238,367 & & & & & 62,286 & & & & 33,989 \\
\hline Utah .............................. & 24,953 & 501 & 067 & 4 & 32,712 & 0,184 & 25,072 & 453 & 3,619 & 5,112 & 61 & 2,495 & 1,375 & 09 \\
\hline & & & & & & & & & & & & & & \\
\hline & & & & & & & & & & & & & & \\
\hline & 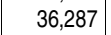 & 7 & 4 & & & & & & & 4, & & & & \\
\hline & & & & & & & & & & 058 & & & & 8,986 \\
\hline & 53,662 & 55,326 & 61,3 & 61,257 & 58,111 & & & & & 9,763 & 129 & 634 & & 10,357 \\
\hline Wyomin & 4,209 & 6,661 & 6,45 & 6,042 & 5,851 & 5,759 & 4,790 & 2,536 & 2,254 & 969 & 463 & 506 & 5,254 & 505 \\
\hline U.S. Service Academies ............... & 3,818 & 4,225 & 4,368 & 4,359 & 4,016 & 3,782 & 3,782 & 2,981 & 801 & 0 & 0 & 0 & 3,782 & $\dagger$ \\
\hline Other jurisdictions ........... & 39,609 & 1,800 & 45,246 & 52,208 & 54,920 & 51,926 & 18,802 & 22,027 & 6,775 & 3,124 & 1,386 & 1,738 & 16,104 & 35,822 \\
\hline . & 29 & 597 & 58 & 657 & 737 & 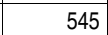 & 67 & 00 & 44 & 47 & 20 & 2 & 545 & 0 \\
\hline & 78 & 761 & 92 & 653 & 742 & 700 & 51 & 21 & 30 & 18 & 7 & 76 & 70 & \\
\hline & 770 & 1,117 & 874 & 1,043 & 1,063 & 961 & 686 & 289 & 39 & 275 & 122 & 153 & 939 & 22 \\
\hline & 199 & 12 & 25 & 240 & $37 \%$ & 34 & 33 & 163 & 168 & 18 & 1 & 6 & 349 & 0 \\
\hline ............ & 333 & 199 & 306 & 360 & 287 & 322 & 288 & 141 & 147 & 34 & 14 & 20 & 322 & 0 \\
\hline & 147 & 105 & 87 & 114 & 125 & 236 & 185 & 99 & 86 & 51 & 26 & 25 & 236 & \\
\hline & 36,773 & 8,648 & 41,735 & 48,658 & 1,141 & 48,414 & 46,375 & 20,974 & 5,401 & 2,039 & 914 & 1,125 & 12,614 & 35,800 \\
\hline lands .......................... & 304 & 361 & 480 & 483 & 453 & 399 & 351 & 119 & 232 & 48 & 20 & 28 & 399 & \\
\hline
\end{tabular}

†Not applicable.

NOTE: Degree-granting institutions grant associate's or higher degrees and participate in Title IV federal financial aid programs.
SOURCE: U.S. Department of Education, National Center for Education Statistics, Integrated Postsecondary Education Data System (IPEDS), Spring 2001 through Spring 2013, Enrollment component. (This table was prepared November 2013.) 
Table 305.30. Number and percentage of degree-granting postsecondary institutions with first-year undergraduates using various selection criteria for admission, by control and level of institution: Selected years, 2000-01 through 2012-13

\begin{tabular}{|c|c|c|c|c|c|c|c|c|c|c|c|c|c|c|c|}
\hline \multirow[b]{3}{*}{ Selection criteria } & \multicolumn{3}{|c|}{ All institutions } & \multicolumn{3}{|c|}{ Public institutions } & \multicolumn{9}{|c|}{ Private institutions } \\
\hline & \multirow[b]{2}{*}{ Total } & \multirow[b]{2}{*}{ 4-year } & \multirow[b]{2}{*}{ 2-year } & \multirow[b]{2}{*}{ Total } & \multirow[b]{2}{*}{ 4-year } & & & & & & Ionprofit & & & or-profit & \\
\hline & & & & & & 2-year & Total & 4-year & 2-year & Total & 4-year & 2-year & Total & 4-year & 2-year \\
\hline 1 & 2 & 3 & 4 & 5 & 6 & 7 & 8 & 9 & 10 & 11 & 12 & 13 & 14 & 15 & 16 \\
\hline & & & & & & umber of & stitutions & with first-y & ear under & aduates & & & & & \\
\hline $2000-01 \ldots$ & 3,717 & 2,034 & 1,683 & 1,647 & 580 & 1,067 & 2,070 & 1,454 & 616 & 1,383 & 1,247 & 136 & 687 & 207 & 480 \\
\hline $2005-06 \ldots$ & 3,880 & 2,198 & 1,682 & 1,638 & 588 & 1,050 & 2,242 & 1,610 & 632 & 1,351 & 1,240 & 111 & 891 & 370 & 521 \\
\hline 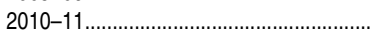 & 4,209 & 2,487 & 1,722 & 1,614 & 637 & 977 & 2,595 & 1,850 & 745 & 1,321 & 1,238 & 83 & 1,274 & 612 & 662 \\
\hline 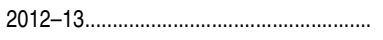 & 4,295 & 2,609 & 1,686 & 1,581 & 648 & 933 & 2,714 & 1,961 & 753 & 1,346 & 1,251 & 95 & 1,368 & 710 & 658 \\
\hline & & & & & & & Perce & of institu & & & & & & & \\
\hline Open admissions & & & & & & & & & & & & & & & \\
\hline$\ldots \ldots \ldots \ldots \ldots \ldots \ldots \ldots \ldots$ & 40.2 & 12.9 & 73.2 & 63.8 & 12.1 & 91.9 & 21.4 & 13.3 & 40.7 & 14.0 & 11.7 & 34.6 & 36.5 & 22.7 & 42.5 \\
\hline $2005-06 \ldots \ldots \ldots \ldots \ldots \ldots \ldots \ldots \ldots \ldots \ldots \ldots$ & 44.7 & 18.3 & 79.3 & 66.1 & 13.6 & 95.4 & 29.2 & 20.1 & 52.4 & 15.3 & 13.1 & 40.5 & 50.2 & 43.5 & 54.9 \\
\hline $2010-11 \ldots \ldots \ldots \ldots \ldots \ldots \ldots \ldots \ldots \ldots \ldots \ldots \ldots$ & 47.2 & 22.5 & 82.9 & 65.7 & 17.7 & 96.9 & 35.8 & 24.2 & 64.6 & 15.4 & 13.0 & 51.8 & 56.8 & 46.7 & 66.2 \\
\hline $2012-13, \ldots \ldots \ldots \ldots \ldots \ldots$ & 50.6 & 26.2 & 88.5 & 64.9 & 17.7 & 97.6 & 42.3 & 29.0 & 77.2 & 16.3 & 13.7 & 50.5 & 67.9 & 55.8 & 81.0 \\
\hline Some admission requirements ${ }^{1}$ & & & & & & & & & & & & & & & \\
\hline $2000-0$ & 58.4 & 85.8 & 25.1 & 35.4 & 87.4 & 7.1 & 76.6 & 85.2 & 56.3 & 84.5 & 86.8 & 63.2 & 60.7 & 75.4 & 54.4 \\
\hline $2005-06 \ldots \ldots .$. & 53.4 & 80.5 & 18.0 & 33.6 & 86.1 & 4.3 & 67.9 & 78.5 & 40.8 & 84.2 & 86.5 & 57.7 & 43.2 & 51.6 & 37.2 \\
\hline $2010-11 \ldots$ & 50.1 & 75.6 & 13.3 & 34.3 & 82.3 & 3.1 & 59.9 & 73.3 & 26.7 & 84.3 & 86.7 & 48.2 & 34.7 & 46.2 & 24.0 \\
\hline $2012-13 \ldots . .$. & 48.1 & 72.6 & 10.0 & 35.1 & 82.3 & 2.4 & 55.6 & 69.5 & 19.5 & 82.2 & 85.9 & 33.7 & 29.5 & 40.6 & 17.5 \\
\hline Secondary grades & & & & & & & & & & & & & & & \\
\hline 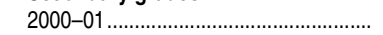 & 34.6 & 58.7 & 5.5 & 23.9 & 63.4 & 2.4 & 43.0 & 56.7 & 10.7 & 60.1 & 64.1 & 23.5 & 8.7 & 12.6 & 7.1 \\
\hline $2005-0$ & 34.1 & 57.1 & 4.2 & 25.9 & 68.4 & 2.2 & 40.1 & 53.0 & 7.4 & 62.8 & 66.2 & 25.2 & 5.7 & 8.6 & 3.6 \\
\hline $2010-11$ & 33.3 & 54.2 & 3.2 & 27.8 & 67.8 & 1.7 & 36.7 & 49.5 & 5.1 & 66.0 & 68.7 & 26.5 & 6.4 & 10.6 & 2.4 \\
\hline $2012-13 \ldots \ldots \ldots \ldots \ldots \ldots \ldots \ldots \ldots$ & 34.1 & 54.2 & 3.0 & 29.3 & 69.1 & 1.7 & 36.8 & 49.2 & 4.6 & 66.0 & 69.4 & 21.1 & 8.2 & 13.7 & 2.3 \\
\hline Secondary class rank & & & & & & & & & & & & & & & \\
\hline & 13.7 & 24.3 & 1.0 & 10.9 & 30.3 & 0.3 & 16.0 & 21.9 & 2.3 & 23.2 & 25.1 & 5.9 & 1.6 & 2.4 & 1.3 \\
\hline $2005-0$ & 11.3 & 19.4 & 0.7 & 10.4 & 28.7 & 0.2 & 11.9 & 16.0 & 1.6 & 19.3 & 20.5 & 6.3 & 0.7 & 0.8 & 0.6 \\
\hline 20 & 8.4 & 13.9 & 0.4 & 9.2 & 22.9 & 0.3 & 7.8 & 10.8 & 0.5 & 15.0 & 15.8 & 3.6 & 0.4 & 0.7 & 0.2 \\
\hline $2012-13 \ldots \ldots \ldots \ldots \ldots \ldots \ldots \ldots \ldots \ldots \ldots$ & 8.1 & 13.1 & 0.3 & 8.9 & 21.5 & 0.2 & 7.6 & 10.3 & 0.4 & 12.9 & 13.8 & 1.1 & 2.3 & 4.1 & 0.3 \\
\hline Secondary school record & & & & & & & & & & & & & & & \\
\hline 20 & 45.8 & 70.3 & 16.2 & 29.4 & 72.9 & 5.8 & 58.7 & 69.2 & 34.1 & 73.2 & 75.5 & 52.2 & 29.5 & 30.9 & 29.0 \\
\hline $2005-0$ & 48.5 & 73.3 & 15.9 & 30.8 & 78.2 & 4.2 & 61.4 & 71.6 & 35.4 & 77.6 & 79.7 & 55.0 & 36.7 & 44.3 & 31.3 \\
\hline 20 & 45.8 & 70.1 & 10.8 & 33.0 & 78.8 & 3.1 & 53.8 & 67.1 & 20.9 & 77.1 & 79.4 & 42.2 & 29.7 & 42.2 & 18.3 \\
\hline $2012-13$ & 44.4 & 67.7 & 8.3 & 33.6 & 78.5 & 2.4 & 50.6 & 64.0 & 15.7 & 75.1 & 78.6 & 29.5 & 26.5 & 38.5 & 13.7 \\
\hline College preparatory program & & & & & & & & & & & & & & & \\
\hline $2000-$ & 15.5 & 27.3 & 1.2 & 16.2 & 44.0 & 1.1 & 14.9 & 20.7 & 1.3 & 22.1 & 24.1 & 4.4 & 0.4 & 0.5 & 0.4 \\
\hline $2005-0$ & 15.2 & 26.4 & 0.6 & 17.4 & 47.1 & 0.8 & 13.6 & 18.8 & 0.3 & 22 & 24.3 & 1.8 & 0.2 & 0.5 & 0.0 \\
\hline $2010-1$ & 14.7 & 24.4 & 0.6 & 18.3 & 45.4 & 0.7 & 12.4 & 17.1 & 0.5 & 24.0 & 25.4 & 2.4 & 0.3 & 0.3 & 0.3 \\
\hline $2012-13 \ldots .$. & 14.2 & 23.2 & 0.5 & 18.9 & 45.1 & 0.8 & 11.5 & 15.9 & 0.1 & 23.3 & 24.9 & 1.1 & 0.0 & 0.0 & 0.0 \\
\hline Recommer & & & & & & & & & & & & & & & \\
\hline & 20.4 & 34.4 & 3.5 & 2.7 & 7.4 & 0.2 & 34.4 & 45.1 & 9.3 & 46.6 & 49.2 & 22.8 & 10.0 & 20.8 & 5.4 \\
\hline ……........ & 19.2 & 31.9 & 2.5 & 2.9 & 7.7 & 0.2 & 31.1 & 40.8 & 6.3 & 49.1 & 51.5 & 23.4 & 3.7 & 5.1 & 2.7 \\
\hline 201 & 18.1 & 29.2 & 2.1 & 3.3 & 8.3 & 0.1 & 27.2 & 36.3 & 4.7 & 51.6 & 53.3 & 25.3 & 2.0 & 2.0 & 2.1 \\
\hline $2012-13 \ldots .$. & 17.9 & 28.2 & 1.8 & 4.0 & 9.6 & 0.1 & 25.9 & 34.4 & 3.9 & 50.3 & 52.8 & 17.9 & 2.0 & 2.1 & 1.8 \\
\hline Demonstration of competencies ${ }^{2}$ & & & & & & & & & & & & & & & \\
\hline & 8.0 & 12.1 & 3.0 & 2.2 & 5.0 & 0.7 & 12.7 & 15.0 & 7.1 & 12. & 12.7 & 7.4 & 13.7 & 29.0 & 7.1 \\
\hline & 7.0 & 9.8 & 3.3 & 2.3 & 6.1 & 0.2 & 10.3 & 11.1 & 8.4 & 10.2 & 10.3 & 9.0 & 10.5 & 13.8 & 8.3 \\
\hline $2010-1$ & 5.8 & 8.0 & 2.5 & 1.8 & 4.6 & 0.0 & 8.2 & 9.2 & 5.8 & 8.9 & 8.8 & 9.6 & 7.6 & 10.1 & 5.3 \\
\hline $2012-13 \ldots$ & 4.4 & 6.3 & 1.5 & 1.6 & 4.0 & 0.0 & 6.0 & 7.1 & 3.3 & 8.3 & 8.4 & 7.4 & 3.8 & 4.8 & 2.7 \\
\hline Test scores ${ }^{3}$ & & & & & & & & & & & & & & & \\
\hline & 47.2 & 72.5 & 16.7 & 33.2 & 83.4 & 5.8 & 58.5 & 68.2 & 35.6 & 70.3 & 73.4 & 41.9 & 34.6 & 36.7 & 33.8 \\
\hline & 36.5 & 62.5 & 2.6 & 31.1 & 82.3 & 2.4 & 40.5 & 55.2 & 3.0 & 65.7 & 70.5 & 12.6 & 2.2 & 4.1 & 1.0 \\
\hline & 31.3 & 51.6 & 1.9 & 30.4 & 73.9 & 1.9 & 31.8 & 43.9 & 1.7 & 61.6 & 64.9 & 13.3 & 0.9 & 1.6 & 0.3 \\
\hline $2012-13 \ldots$ & 30.1 & 48.7 & 1.3 & 31.2 & 73.9 & 1.5 & 29.4 & 40.3 & 1.1 & 58.6 & 62.5 & 7.4 & 0.7 & 1.3 & 0.2 \\
\hline TOEFL $^{4}$ & & & & & & & & & & & & & & & \\
\hline $2000-01$. & 43.4 & 71.2 & 9.9 & 30.2 & 77.4 & 4.6 & 54.0 & 68.7 & 19.2 & 66. & 70.1 & 30.9 & 29.3 & 60.4 & 15.8 \\
\hline $2005-06 \ldots$ & 41.5 & 67.9 & 7.1 & 31.0 & 79.3 & 3.9 & 49.3 & 63.8 & 12.3 & 67.0 & 70.6 & 27.0 & 22.4 & 41.1 & 9.2 \\
\hline $2010-1$ & 38.7 & 61.9 & 5.1 & 29.8 & 71.4 & 2.7 & 44.2 & 58.6 & 8.3 & 66.3 & 69.1 & 25.3 & 21.3 & 37.6 & 6.2 \\
\hline $2012-13 \ldots$ & 38.0 & 59.9 & 4.2 & 30.3 & 71.1 & 1.9 & 42.5 & 56.1 & 6.9 & 65.0 & 68.9 & 13.7 & 20.3 & 33.7 & 5.9 \\
\hline $\begin{array}{l}\text { No admission requirements, only } \\
\text { recommendations for admission }\end{array}$ & & & & & & & & & & & & & & & \\
\hline $2000-01 \ldots \ldots$ & 1.4 & 1.2 & 1.7 & 0.8 & 0.5 & 0.9 & 1.9 & 1.5 & 2.9 & 1.5 & 1.4 & 2.2 & 2.8 & 1.9 & 3.1 \\
\hline $2005-06 \ldots \ldots .$. & 1.8 & 1.1 & 2.7 & 0.3 & 0.3 & 0.3 & 2.9 & 1.4 & 6.8 & 0.5 & 0.4 & 1.8 & 6.6 & 4.9 & 7.9 \\
\hline $2010-11 \ldots .$. & 2.7 & 1.9 & 3.8 & 0.0 & 0.0 & 0.0 & 4.3 & 2.5 & 8.7 & 0.3 & 0.3 & 0.0 & 8.5 & 7.0 & 9.8 \\
\hline $2012-13, \ldots \ldots \ldots \ldots \ldots \ldots \ldots \ldots \ldots \ldots \ldots \ldots$ & 1.3 & 1.2 & 1.5 & 0.0 & 0.0 & 0.0 & 2.1 & 1.6 & 3.3 & 1.5 & 0.4 & 15.8 & 2.6 & 3.7 & 1.5 \\
\hline
\end{tabular}

${ }^{1}$ Many institutions have more than one admission requirement. ${ }^{2}$ Formal demonstration of competencies (e.g., portfolios, certificates of mastery, assessment instruments).

${ }^{3}$ Includes SAT, ACT, or other admission tests.

${ }^{4}$ Test of English as a Foreign Language.
NOTE: Degree-granting institutions grant associate's or higher degrees and participate in Title IV federal financial aid programs. Excludes institutions not enrolling any first-time degree/certificate-seeking undergraduates. Detail may not sum to totals because of rounding. SOURCE: US. Department of Education, National Center for Education Statistics, Integrated Postsecondary Education Data System (IPEDS), Fall 2000 through Fall 2012, Institutional Characteristics component. (This table was prepared August 2013.) 
Table 305.40. Acceptance rates; number of applications, admissions, and enrollees; and enrollees' SAT and ACT scores for degree-granting postsecondary institutions with first-year undergraduates, by control and level of institution: 2012-13

\begin{tabular}{|c|c|c|c|c|c|c|c|c|c|c|c|c|c|c|c|}
\hline \multirow{3}{*}{$\begin{array}{l}\text { Acceptance rates, applications, admissions, } \\
\text { enrollees, and SAT and ACT scores }\end{array}$} & \multicolumn{3}{|c|}{ All institutions } & \multicolumn{3}{|c|}{ Public institutions } & \multicolumn{9}{|c|}{ Private institutions } \\
\hline & \multirow[b]{2}{*}{ Total } & \multirow[b]{2}{*}{ 4-year } & \multirow[b]{2}{*}{ 2-year } & \multirow[b]{2}{*}{ Total } & \multirow[b]{2}{*}{ 4-year } & \multirow[b]{2}{*}{ 2-year } & \multirow[b]{2}{*}{ Total } & \multirow[b]{2}{*}{ 4-year } & \multirow[b]{2}{*}{ 2-year } & \multicolumn{3}{|c|}{ Nonprofit } & \multicolumn{3}{|c|}{ For-profit } \\
\hline & & & & & & & & & & Total & 4-year & 2-year & Total & 4-year & 2-year \\
\hline 1 & 2 & 3 & 4 & 5 & 6 & 7 & 8 & 9 & 10 & 11 & 12 & 13 & 14 & 15 & 16 \\
\hline 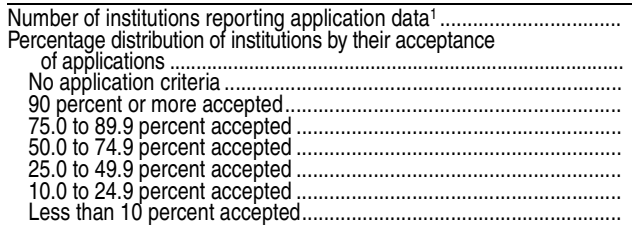 & \begin{tabular}{r|}
4,264 \\
100.0 \\
51.0 \\
6.2 \\
12.0 \\
21.5 \\
7.6 \\
1.3 \\
0.4
\end{tabular} & \begin{tabular}{r|}
2,585 \\
100.0 \\
26.4 \\
7.7 \\
17.8 \\
33.7 \\
11.7 \\
2.1 \\
0.6
\end{tabular} & \begin{tabular}{r|r|}
1,679 \\
100.0 \\
8.9 \\
3.9 \\
2.9 \\
2.8 \\
1.3 \\
0.2 \\
0.1
\end{tabular} & \begin{tabular}{r|}
1,579 \\
100.0 \\
65.0 \\
2.8 \\
9.4 \\
16.1 \\
6.1 \\
0.5 \\
0.2
\end{tabular} & $\begin{array}{r}646 \\
100.0 \\
17.8 \\
5.9 \\
22.4 \\
37.9 \\
14.4 \\
1.1 \\
0.5\end{array}$ & $\begin{array}{r}933 \\
100.0 \\
97.6 \\
0.6 \\
0.3 \\
1.0 \\
0.3 \\
0.1 \\
0.0\end{array}$ & \begin{tabular}{r|}
2,685 \\
100.0 \\
42.8 \\
8.2 \\
13.5 \\
24.7 \\
8.5 \\
1.8 \\
0.5
\end{tabular} & $\begin{array}{r}1,939 \\
100.0 \\
29.3 \\
8.3 \\
16.3 \\
32.2 \\
10.8 \\
2.4 \\
0.6\end{array}$ & $\begin{array}{r}746 \\
100.0 \\
77.9 \\
7.9 \\
6.2 \\
5.1 \\
2.5 \\
0.3 \\
0.1\end{array}$ & $\begin{array}{r}1,335 \\
100.0 \\
16.5 \\
8.8 \\
15.3 \\
40.3 \\
14.8 \\
3.4 \\
0.9\end{array}$ & $\begin{array}{r}1,242 \\
100.0 \\
13.8 \\
9.0 \\
15.9 \\
41.9 \\
14.9 \\
3.5 \\
0.9\end{array}$ & \begin{tabular}{r|}
93 \\
100.0 \\
51.6 \\
5.4 \\
6.5 \\
19.4 \\
14.0 \\
2.2 \\
1.1
\end{tabular} & $\begin{array}{r}1,350 \\
100.0 \\
68.8 \\
7.6 \\
11.7 \\
9.3 \\
2.3 \\
0.2 \\
0.1\end{array}$ & $\begin{array}{r}697 \\
100.0 \\
56.8 \\
7.0 \\
16.9 \\
15.1 \\
3.6 \\
0.4 \\
0.1\end{array}$ & $\begin{array}{r}65 . \\
100 . \\
81 . \\
8 . \\
6 . \\
3 .\end{array}$ \\
\hline 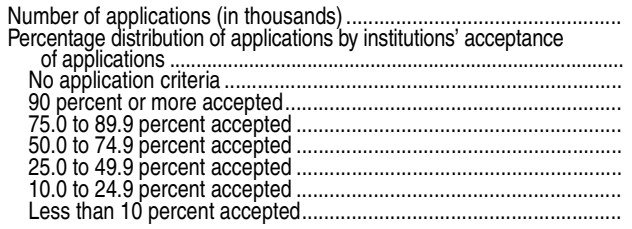 & $\begin{array}{r}8,847 \\
100.0 \\
\dagger \\
\quad 3.2 \\
15.5 \\
44.2 \\
27.3 \\
6.8 \\
3.0\end{array}$ & $\begin{array}{r}8,739 \\
100.0 \\
\dagger \\
2.8 \\
15.5 \\
44.4 \\
27.5 \\
6.8 \\
3.0\end{array}$ & $\begin{array}{r}108 \\
100.0 \\
\dagger \\
38.0 \\
16.8 \\
29.3 \\
12.9 \\
2.7 \\
0.4\end{array}$ & $\begin{array}{r}4,814 \\
100.0 \\
\dagger \\
+.9 \\
18.4 \\
46.9 \\
27.5 \\
2.3 \\
1.0\end{array}$ & $\begin{array}{r}4,754 \\
100.0 \\
\dagger \\
3.4 \\
18.6 \\
47.1 \\
27.7 \\
2.2 \\
1.0\end{array}$ & $\begin{array}{r}60 \\
100.0 \\
\dagger \\
45.2 \\
8.0 \\
32.2 \\
10.0 \\
4.7 \\
0.0\end{array}$ & $\begin{array}{r}4,033 \\
100.0 \\
+ \\
2.4 \\
12.0 \\
40.9 \\
27.1 \\
12.2 \\
5.3\end{array}$ & $\begin{array}{r}3,986 \\
100.0 \\
\dagger \\
2.1 \\
11.8 \\
41.1 \\
27.2 \\
12.3 \\
5.4\end{array}$ & $\begin{array}{r}47 \\
100.0 \\
\vdots \\
28.7 \\
28.2 \\
25.5 \\
16.6 \\
0.1 \\
0.9\end{array}$ & $\begin{array}{r}3,871 \\
100.0 \\
\dagger \\
1.7 \\
11.1 \\
41.3 \\
27.6 \\
12.7 \\
5.6\end{array}$ & $\begin{array}{r}3,856 \\
100.0 \\
1 \\
11.7 \\
11.2 \\
41.2 \\
27.6 \\
12.7 \\
5.6\end{array}$ & $\begin{array}{r}15 \\
100.0 \\
\dagger \\
4.1 \\
2.6 \\
46.9 \\
43.3 \\
0.3 \\
2.9\end{array}$ & $\begin{array}{r}162 \\
100.0 \\
\vdots \\
20.0 \\
32.5 \\
32.8 \\
14.7 \\
0.1 \\
\#\end{array}$ & $\begin{array}{r}130 \\
100.0 \\
\vdots \\
15.0 \\
30.6 \\
37.0 \\
17.3 \\
0.1 \\
\#\end{array}$ & $\begin{array}{r}100.0 \\
\dagger \\
40.1 \\
40.0 \\
15.6 \\
4.2 \\
0.0 \\
0.0\end{array}$ \\
\hline 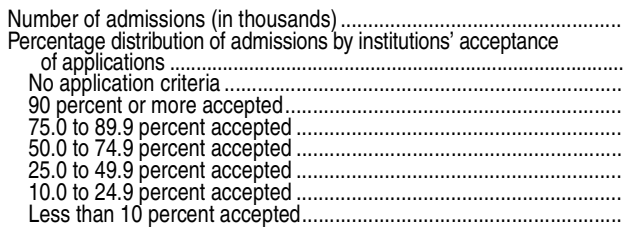 & $\begin{array}{r}4,922 \\
100.0 \\
\dagger \\
5.4 \\
22.6 \\
50.1 \\
19.3 \\
2.2 \\
0.4\end{array}$ & $\begin{array}{r}4,840 \\
100.0 \\
4 \\
4.7 \\
22.7 \\
50.5 \\
19.5 \\
2.2 \\
0.4\end{array}$ & $\begin{array}{r}82 \\
100.0 \\
\dagger \\
49.2 \\
18.3 \\
25.0 \\
7.1 \\
0.4 \\
\#\end{array}$ & $\begin{array}{r}2,874 \\
100.0 \\
6.1 \\
25.1 \\
49.5 \\
18.4 \\
0.8 \\
0.1\end{array}$ & $\begin{array}{r}2,827 \\
100.0 \\
\dagger \\
5.2 \\
25.3 \\
49.9 \\
18.6 \\
0.8 \\
0.1\end{array}$ & $\begin{array}{r}47 \\
100.0 \\
\dagger \\
58.2 \\
8.6 \\
27.0 \\
5.5 \\
0.7 \\
0.0\end{array}$ & $\begin{array}{r}2,048 \\
100.0 \\
t \\
4.5 \\
19.2 \\
50.9 \\
20.6 \\
4.1 \\
0.8\end{array}$ & $\begin{array}{r}2,012 \\
100.0 \\
\quad t \\
4.0 \\
18.9 \\
51.4 \\
20.8 \\
4.2 \\
0.8\end{array}$ & $\begin{array}{r}35 \\
100.0 \\
t \\
37.3 \\
31.1 \\
22.4 \\
9.2 \\
\# \\
0.1\end{array}$ & $\begin{array}{r}1,931 \\
100.0 \\
t \\
3.2 \\
18.1 \\
52.2 \\
21.4 \\
4.3 \\
0.8\end{array}$ & $\begin{array}{r}1,923 \\
100.0 \\
\dagger \\
3.2 \\
18.1 \\
52.2 \\
21.3 \\
4.4 \\
0.8\end{array}$ & $\begin{array}{r}8 \\
100.0 \\
1 \\
6.9 \\
4.0 \\
56.0 \\
32.7 \\
0.1 \\
0.4\end{array}$ & $\begin{array}{r}117 \\
100.0 \\
t \\
26.6 \\
36.9 \\
28.8 \\
7.6 \\
\# \\
0.0\end{array}$ & $\begin{array}{r}90 \\
100.0 \\
\dagger \\
20.6 \\
36.3 \\
33.8 \\
9.3 \\
\# \\
0.0\end{array}$ & $\begin{array}{r}32.3 \\
2.1 \\
0.0 \\
0.0\end{array}$ \\
\hline 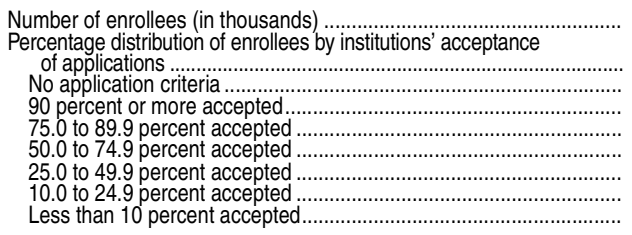 & $\begin{array}{r}1,551 \\
100.0 \\
\dagger \\
7.1 \\
22.7 \\
48.8 \\
17.7 \\
2.8 \\
0.9\end{array}$ & \begin{tabular}{r|}
1,503 \\
100.0 \\
$\dagger$ \\
5.9 \\
22.8 \\
49.4 \\
18.0 \\
2.9 \\
0.9
\end{tabular} & \begin{tabular}{r|r}
48 & \\
100.0 & $\dagger$ \\
44.3 & 20.9 \\
27.8 & 6.1 \\
0.7 \\
0.1
\end{tabular} & $\begin{array}{r}997 \\
100.0 \\
t \\
7.3 \\
24.8 \\
49.9 \\
16.8 \\
0.8 \\
0.3\end{array}$ & $\begin{array}{r}971 \\
100.0 \\
\dagger \\
6.2 \\
25.1 \\
50.4 \\
17.1 \\
0.8 \\
0.3\end{array}$ & \begin{tabular}{r|}
26 \\
98.7 \\
$\dagger$ \\
48.4 \\
12.9 \\
32.1 \\
5.3 \\
$\#$ \\
0.0
\end{tabular} & \begin{tabular}{r|}
554 \\
100.0 \\
$\dagger$ \\
6.9 \\
19.0 \\
46.7 \\
19.2 \\
6.3 \\
1.9
\end{tabular} & $\begin{array}{r}532 \\
100.0 \\
t \\
5.6 \\
18.5 \\
47.6 \\
19.7 \\
6.6 \\
2.0\end{array}$ & $\begin{array}{r}22 \\
100.0 \\
\vdots \\
39.5 \\
30.5 \\
22.7 \\
7.1 \\
\# \\
0.1\end{array}$ & $\begin{array}{r}486 \\
100.0 \\
\dagger \\
4.5 \\
16.6 \\
48.8 \\
20.6 \\
7.2 \\
2.2\end{array}$ & $\begin{array}{r}482 \\
100.0 \\
\dagger \\
4.5 \\
16.7 \\
48.7 \\
20.6 \\
7.3 \\
2.2\end{array}$ & $\begin{array}{r}5 \\
100.0 \\
t \\
9.8 \\
5.1 \\
60.4 \\
23.9 \\
0.1 \\
0.7\end{array}$ & $\begin{array}{r}67 \\
100.0 \\
+ \\
23.9 \\
36.2 \\
30.9 \\
8.9 \\
\# \\
0.0\end{array}$ & $\begin{array}{r}50 \\
100.0 \\
\dagger \\
15.9 \\
35.8 \\
37.2 \\
11.1 \\
\# \\
0.0\end{array}$ & $\begin{array}{r}100.0 \\
t \\
47.5 \\
37.4 \\
12.5 \\
2.6 \\
0.0 \\
0.0\end{array}$ \\
\hline 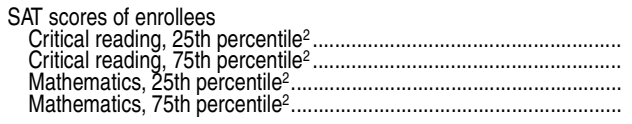 & $\begin{array}{l}469 \\
579 \\
478 \\
587\end{array}$ & $\begin{array}{l}470 \\
581 \\
479 \\
588\end{array}$ & $\begin{array}{l}409 \\
504 \\
404 \\
514\end{array}$ & $\begin{array}{l}457 \\
564 \\
471 \\
579\end{array}$ & $\begin{array}{l}458 \\
565 \\
472 \\
580\end{array}$ & $\begin{array}{l}408 \\
519 \\
414 \\
530\end{array}$ & $\begin{array}{l}476 \\
588 \\
482 \\
592\end{array}$ & $\begin{array}{l}476 \\
590 \\
483 \\
594\end{array}$ & $\begin{array}{l}411 \\
488 \\
391 \\
495\end{array}$ & $\begin{array}{l}476 \\
589 \\
483 \\
593\end{array}$ & $\begin{array}{l}477 \\
590 \\
484 \\
594\end{array}$ & $\begin{array}{l}404 \\
486 \\
3888 \\
490\end{array}$ & $\begin{array}{l}437 \\
541 \\
433 \\
552\end{array}$ & $\begin{array}{l}434 \\
546 \\
434 \\
553\end{array}$ & \\
\hline 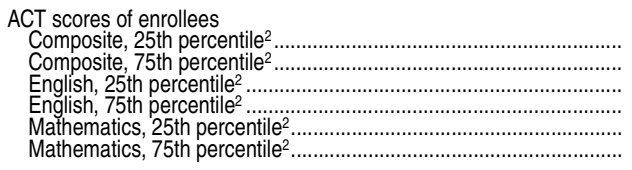 & $\begin{array}{l}20.4 \\
25.3 \\
19.3 \\
25.6 \\
19.4 \\
25.2\end{array}$ & $\begin{array}{l}20.4 \\
25.4 \\
19.4 \\
25.7 \\
19.5 \\
25.2\end{array}$ & $\begin{array}{l}17.0 \\
21.4 \\
15.6 \\
21.3 \\
16.6 \\
21.3\end{array}$ & $\begin{array}{l}19.7 \\
24.5 \\
18.6 \\
24.7 \\
19.0 \\
24.6\end{array}$ & $\begin{array}{l}19.8 \\
24.6 \\
18.7 \\
24.8 \\
19.0 \\
24.7\end{array}$ & $\begin{array}{l}16.5 \\
21.1 \\
15.2 \\
21.4 \\
16.1 \\
20.8\end{array}$ & $\begin{array}{l}20.7 \\
25.8 \\
19.8 \\
26.1 \\
19.7 \\
25.5\end{array}$ & $\begin{array}{l}20.8 \\
25.9 \\
19.8 \\
26.2 \\
19.7 \\
25.6\end{array}$ & $\begin{array}{l}18.0 \\
21.9 \\
16.4 \\
21.1 \\
17.5 \\
22.1\end{array}$ & $\begin{array}{l}20.8 \\
25.9 \\
19.8 \\
26.2 \\
19.7 \\
25.5\end{array}$ & $\begin{array}{l}18.8 \\
23.8 \\
19.1 \\
25.1 \\
18.8 \\
24.3\end{array}$ & $\begin{array}{l}18.0 \\
21.9 \\
16.4 \\
21.1 \\
17.5 \\
22.1\end{array}$ & $\begin{array}{l}18.8 \\
23.8 \\
19.1 \\
25.1 \\
18.8 \\
24.3\end{array}$ & $\begin{array}{l}18.8 \\
23.8 \\
19.1 \\
25.1 \\
18.8 \\
24.3\end{array}$ & \\
\hline
\end{tabular}

†Not applicable.
\#Rounds to zero.

\#Rounds to zero.

The total on this table differs slightly from other counts of institutions with first-year undergraduates because approximately 0.7 percent of these institutions did not report application information.
${ }^{2}$ Data are only for institutions that require test scores for admission. Relatively few 2-year institutions require test scores for

NOTE: Degree-granting institutions grant associate's or higher degrees and participate in Title IV federal financial aid programs. Excludes institutions not enrolling any first-time degree/certificate-seeking undergraduates. Detail may not sum to totals because of rounding.

SOURCE. U.S. Departiont of Education, National Center for Education Statistics, Integrated Postsecondary Education Da admission. The SAT Critical reading and Mathematics scales range from 200 to 800 . The ACT Composite, English, and MathSystem (IPEDS), Fall 2012, Institutional Characteristics component. (This table was prepared August 2013. 


\begin{tabular}{|c|c|c|c|c|c|c|c|c|c|c|c|c|c|c|c|c|c|c|c|c|c|c|}
\hline \multirow{2}{*}{$\begin{array}{l}\text { Level of enrollment, sex, attendance } \\
\text { status, and race/ethnicity of student }\end{array}$} & \multicolumn{11}{|c|}{ Fall enrollment (in thousands) } & \multicolumn{11}{|c|}{ Percentage distribution of U.S. residents } \\
\hline & 1976 & 1980 & 1990 & 2000 & 2005 & 2007 & 2008 & 2009 & 2010 & 2011 & 2012 & 1976 & 1980 & 1990 & 2000 & 2005 & 2007 & 2008 & 2009 & 2010 & 2011 & 2012 \\
\hline 1 & 2 & 3 & 4 & 5 & 6 & 7 & 8 & 9 & 10 & 11 & 12 & 13 & 14 & 15 & 16 & 17 & 18 & 19 & 20 & 21 & 22 & 23 \\
\hline All students, total & $10,985.6$ & $12,086.8$ & $13,818.6$ & $15,312.3$ & $17,487.5$ & $18,248.1$ & $19,102.8$ & $20,427.7$ & $21,016.1$ & $20,994.1$ & $20,642.8$ & 100.0 & 100.0 & 100.0 & 100.0 & 100.0 & 100.0 & 100.0 & 100.0 & 100.0 & 100.0 & 100.0 \\
\hline ite . & $9,076.1$ & \begin{tabular}{|l|}
$9,833.0$ \\
\end{tabular} & \begin{tabular}{|l|}
$10,722.5$ \\
\end{tabular} & $10,462.1$ & $111,495.4$ & $11,756.2$ & $12,088.8$ & \begin{tabular}{|l|}
$12,730.8$ \\
\end{tabular} & $12,722.5$ & $12,394.2$ & $|11,981.1|$ & 84.3 & 83.5 & 79.9 & 70.8 & 68.0 & 66.7 & 65.5 & 64.5 & \begin{tabular}{|c|}
62.7 \\
\end{tabular} & 61.2 & 60.3 \\
\hline al, selected races/et & & & & & & & & $7,012.1$ & $7,584.0$ & $7,859.5$ & & & & & & & & & & & & 39.7 \\
\hline & 1,0 & $1,106.8$ & $1,247.0$ & $1,730.3$ & $2,214.6$ & 2,38 & $2,584.5$ & $2,919.8$ & & $3,067.9$ & 1 & 9.6 & 9.4 & 9.3 & 11 & & & & & .0 & & 14.9 \\
\hline HI & & 471.7 & 782.4 & $1,461.8$ & $1,882.0$ & $2,076.2$ & $2,272.9$ & $2,546.7$ & $2,741.4$ & $2,890.1$ & 2,97 & 3.6 & 4.0 & 5.8 & 9.9 & 11.1 & 11.8 & 12.3 & 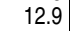 & .5 & 14.3 & 15.0 \\
\hline Asia & 197.9 & 286.4 & 572.4 & 978.2 & $1,134.4$ & $1,217.9$ & \begin{tabular}{|l|}
$1,302.8$ \\
\end{tabular} & $1,337.7$ & $1,282.2$ & $1,282.5$ & $1,259.2$ & 1.8 & 2.4 & 4.3 & 6.6 & 6.7 & 6.9 & 7.1 & 6.8 & 6.3 & 6.3 & 6.3 \\
\hline & 二 & $=$ & $=$ & $=$ & - & 二 & 二 & 二 & $1,218.1$ & $\begin{array}{r}1,216.6 \\
65.9\end{array}$ & \begin{tabular}{|l||}
$1,195.6$ \\
636
\end{tabular} & 二 & $=$ & $=$ & $=$ & 二 & 二 & 二 & 二 & $\begin{array}{l}6.0 \\
0.3\end{array}$ & $\begin{array}{l}6.0 \\
0.3\end{array}$ & 6.0 \\
\hline Ameri & $76 . \overline{1}$ & 83.9 & $102 . \overline{8}$ & $151 . \overline{2}$ & $176 . \overline{3}$ & $190 . \overline{0}$ & $193 . \overline{3}$ & $207 . \overline{9}$ & $\begin{array}{r}196.4 \\
\end{array}$ & $\begin{array}{l}0.9 \\
186.1\end{array}$ & $\begin{array}{r}63.6 \\
172.9\end{array}$ & $0 . \overline{7}$ & $0 . \overline{7}$ & $0 . \overline{8}$ & $1 . \overline{0}$ & 1.0 & 1.1 & 1.0 & $\overline{1.1}$ & $\begin{array}{l}1.0 \\
1.0\end{array}$ & $\begin{array}{l}0.3 \\
0.9\end{array}$ & 0.9 \\
\hline ................ & & & & & & & & & & & $505.1 \|$ & - & - & - & - & - & - & - & - & 1.6 & 2.1 & 2.5 \\
\hline Nonresident a & 218.7 & 305.0 & 391.5 & 528.7 & 584.8 & 624.5 & 660.6 & 684.8 & 709.6 & 740.5 & 782.9 & $\dagger$ & $\dagger$ & $\dagger$ & $\dagger$ & $\dagger$ & $\dagger$ & $\dagger$ & $\dagger$ & $\dagger$ & $\dagger$ & $\dagger$ \\
\hline Male. & $5,794.4$ & $5,868.1$ & $6,283.9$ & 6,721.8 & $7,455.9$ & $7,815.9$ & $8,188.9$ & $8,769.5$ & $9,044.8$ & $9,026.5$ & 8,919.1 & 100.0 & 100.0 & 100.0 & 100.0 & 100.0 & 100.0 & 100.0 & 100.0 & 100.0 & 100.0 & 100.0 \\
\hline White.. & $\begin{array}{l}4,813.7 \\
4\end{array}$ & $4,772.9$ & $4,861.0$ & $4,634.6$ & $5,007.2$ & $5,146.1$ & $5,302.9$ & $5,594.4$ & $5,606.8$ & $5,453.8$ & $5,285.0$ & 85.3 & 84.4 & 80.5 & 72.1 & 701 & 100.0 & 100.0 & 66.6 & 10.0 & 0.0 & 62.2 \\
\hline Total, se & 826.6 & 884.4 & $1,176.6$ & $1,789.8$ & $2,139.2$ & $2,336.6$ & $2,532.8$ & $2,808.4$ & $3,057.6$ & $3,173.6$ & $4 \|$ & 14.7 & 15.6 & 19.5 & 27.9 & 29.9 & 31 & 32 & 4 & & 8 & 37.8 \\
\hline & 46 & 463.7 & 484.7 & 635.3 & 774.1 & & 911.8 & $1,037.1$ & $1,089.1$ & $1,103.5$ & 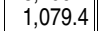 & 8. & & 0.4 & & & & 11 & & & & 12.7 \\
\hline & 209.7 & 231.6 & 353.9 & 627.1 & 774.6 & & 946.7 & $1,066.3$ & $1,154.6$ & $1,214.2$ & 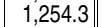 & 3.7 & 4.1 & 5.9 & & & 11 & 12 & & & & 14.8 \\
\hline ic Islander... & 108.4 & 151.3 & 294.9 & 465.9 & 522.0 & 562.5 & 597.4 & 621.5 & 600.8 & 602.4 & 7 & 1.9 & 2.7 & 4.9 & 7.3 & 7.3 & 7.5 & 7.6 & 7.4 & 6.9 & 1.0 & 7.0 \\
\hline 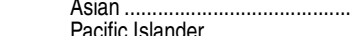 & - & - & $=$ & - & - & 二 & - & - & 572.3 & 573.4 & \begin{tabular}{rl||}
565.3 & \\
28.5 &
\end{tabular} & 二 & 二 & $=$ & - & 二 & - & 二 & 二 & $\begin{array}{l}6.6 \\
0.3\end{array}$ & 3 & 6.7 \\
\hline & 385 & 37.8 & 43.1 & 61.4 & $68 . \overline{4}$ & 74.4 & 76.9 & 83.4 & $\begin{array}{l}28.6 \\
78.8\end{array}$ & & 28.5 & $\overline{0.7}$ & 07 & $\overline{0}$ & 10 & $\overline{10}$ & $\overline{10}$ & $\overline{10}$ & $\overline{10}$ & 0.9 & 0.3 & 0.3 \\
\hline $\begin{array}{l}\text { Ame } \\
\text { Two }\end{array}$ & 38.5 & 01.0 & 40.11 & 01.4 & 00.4 & 14.4 & 10.9 & 00.4 & $\begin{array}{r}78.8 \\
134.3\end{array}$ & $\begin{array}{r}73.7 \\
179.8\end{array}$ & $\begin{array}{r}68.6 \\
213.3\end{array}$ & -1 & - & -1 & - & - & - & - & - & $\begin{array}{l}0.9 \\
1.6\end{array}$ & $\begin{array}{l}0.9 \\
2.1\end{array}$ & $\begin{array}{l}0.8 \\
2.5\end{array}$ \\
\hline 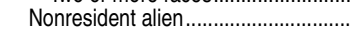 & 154.1 & 210.8 & 246.3 & 297.3 & 309.5 & 333.2 & 353.3 & 366.7 & 380.3 & 399.1 & 424.7 & $\dagger$ & $\dagger$ & $\dagger$ & $\dagger$ & $\dagger$ & $\dagger$ & $\dagger$ & $\dagger$ & $t$ & $t$ & $t$ \\
\hline Femal & $5,191.2$ & $6,218.7$ & 7,534.7 & $8,590.5$ & $10,031.6$ & $10,432.2$ & $10,913.9$ & $11,658.2$ & $11,971.3$ & $11,967.6$ & $11,723.7$ & 100.0 & 100.0 & 100.0 & 100.0 & 100.0 & 100.0 & 100.0 & 100.0 & 100.0 & 100.0 & 100.0 \\
\hline 1 The & $4,262.4$ & $5,060.1$ & $5,861.5$ & $5,827.5$ & 6,488.2 & $6,610.1$ & $6,785.9$ & $7,136.4$ & 7,115.7 & $6,940.3$ & & 100.0 & 82.6 & 79.3 & 69.7 & 70.0 & & & & & & 58.9 \\
\hline ies... & 864.2 & $1,064.4$ & $1,528.1$ & $2,531.7$ & $3,268.0$ & $3,530.9$ & $3,820.7$ & $4,203.7$ & 4,52 & $4,685.9$ & 4, & 16.9 & 17.4 & 20.7 & 30.3 & 33 & 34.8 & & 37.1 & & 40.3 & 41.1 \\
\hline B & 563.1 & 643.0 & 762.3 & $1,095.0$ & $1,440.4$ & $1,545.3$ & $1,672.7$ & $1,882.7$ & 1,94 & $1,964.5$ & 7 & 11.0 & & & & & & & 16.6 & & & 16.6 \\
\hline & 174.1 & 240.1 & 428.5 & 834.7 & $1,107.3$ & $1,214.5$ & $1,326.1$ & $1,480.4$ & $1,586.9$ & $1,676.0$ & $1,725.1$ & 3.4 & 3.9 & 5.8 & 10.0 & 11.4 & $\begin{array}{l}12.0 \\
12.0\end{array}$ & $\begin{array}{l}12.5 \\
\end{array}$ & $\begin{array}{l}13.1 \\
1\end{array}$ & & 14.4 & 15.2 \\
\hline re... & 89.4 & 135.2 & 277.5 & 512.3 & 612.4 & 655.4 & 705.4 & 716.1 & & 680.1 & & 1.7 & 2.2 & 3.8 & 6.1 & 6.3 & 6.5 & 6.7 & 6.3 & & & 5.9 \\
\hline & 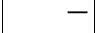 & 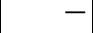 & - & - & - & - & - & - & 645.9 & 643.2 & 63 & - & - & - & - & - & - & - & - & & & 5.5 \\
\hline & 376 & $46 \overline{1}$ & 597 & 897 & 1079 & 1156 & 1164 & 1245 & $\begin{array}{r}35.5 \\
1176\end{array}$ & $\begin{array}{r}36.9 \\
1124\end{array}$ & & $\overline{07}$ & 08 & 08 & $\overline{11}$ & 11 & $\overline{11}$ & $\overline{11}$ & $\overline{11}$ & 10 & 1 & 0.3 \\
\hline Am & 37.6 & 46.1 & 39.1 & 89.1 & 1.9 & 15.6 & 1110.4 & $1<4.5$ & $\begin{array}{l}1171.6 \\
1910\end{array}$ & $\begin{array}{l}112.4 \\
253.1\end{array}$ & $\begin{array}{l}104.3 \\
291.8\end{array}$ & 0.1 & 0.8 & 0.8 & -1 & 1.1 & 1.1 & 1.1 & 1.1 & $\begin{array}{l}1.0 \\
1.6\end{array}$ & $\begin{array}{l}1.0 \\
2.2\end{array}$ & 2.6 \\
\hline Nonresic & 64.6 & 94.2 & 145.2 & 231.4 & 275.3 & 291.2 & 307.3 & 318.1 & 329.2 & 341.4 & 358.2 & $\dagger$ & $\dagger$ & $\dagger$ & $\dagger$ & $\dagger$ & $\dagger$ & $\dagger$ & $\dagger$ & $\dagger$ & $\dagger$ & $\dagger$ \\
\hline II-tii & $6,703.6$ & $7,088.9$ & $7,821.0$ & $9,009.6$ & $10,797.0$ & $11,269.9$ & $11,747.7$ & $12,722.8$ & $13,082.3$ & $13,001.5$ & 12, & 100.0 & 100.0 & 100.0 & 100.0 & 100.0 & 100.0 & 100.0 & 100.0 & 10 & 10 & 100.0 \\
\hline & & $5,717.0$ & $6,016.5$ & $6,231.1$ & .5 & & & 8 & & & & & 834 & 9 & & & 68.6 & & & & & 61.9 \\
\hline To & $\begin{array}{l}1,030.9 \\
\end{array}$ & $\begin{array}{l}1,137.5 \\
\end{array}$ & $1,514.9$ & $2,368.5$ & 3,1 & 3,3 & $3,631.9$ & $4,101.7$ & & 4,6 & & 15.8 & 16.6 & 20.1 & 27 & & 31.4 & 3 & & & 37 & 38.1 \\
\hline & 659.2 & 685.6 & 718.3 & 982.6 & $1,321.7$ & $1,416.1$ & 1,5 & $1,763.7$ & 1,80 & 1,80 & 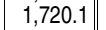 & 10.1 & 10 & 9.5 & 11.4 & & 13 & 13 & & & & 14.2 \\
\hline & 211.1 & $247.0^{\circ}$ & 394.7 & 710.3 & 979.7 & $\begin{array}{l}1,082.9 \\
1,08.9\end{array}$ & $1,177.2$ & $\begin{array}{l}1,362.4 \\
1\end{array}$ & $\begin{array}{l}1,499.7 \\
\end{array}$ & $\begin{array}{l}1,592.3 \\
\end{array}$ & 1,63 & $\begin{array}{r}3.1 \\
3.2\end{array}$ & 3 & 5.2 & $\begin{array}{r}8.3 \\
\end{array}$ & & $\begin{array}{l}10.0 \\
10.0\end{array}$ & 10. & $\begin{array}{l}11.2 \\
11.2\end{array}$ & & 12 & $\begin{array}{l}13.5 \\
13.5\end{array}$ \\
\hline ASIE & 117.7 & 162.0 & 347.4 & 591.2 & 710.1 & 770.0 & 808.9 & 848.6 & 821.0 & 821.7 & 81 & 1.8 & 2.4 & 4.6 & 6.9 & 6.9 & 7.1 & 7.2 & 7.0 & & & 6.7 \\
\hline & - & t & 1 & 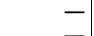 & 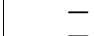 & - & 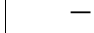 & - & & & & t & - & - & - & t & 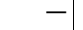 & 1 & 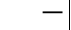 & & & 6.4 \\
\hline & - & - & & & & & & - & & 1 & & - & - & - & 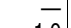 & - & -1 & - & - & & & \\
\hline ka Native ... & 43.0 & 43.0 & 54.4 & 84.4 & 105.6 & 113.0 & 115.1 & 127.0 & 118.2 & 110.7 & 102. & 0.7 & 0.6 & 0.7 & 1.0 & 1.0 & 1.0 & 1.0 & 1.0 & 0. & 0. & 0.8 \\
\hline $\begin{array}{l}\text { Two } \\
\text { Nonre }\end{array}$ & 160.0 & 234.4 & 289.6 & 410.0 & 459.4 & 493.7 & 522.3 & 5423 & & $\begin{array}{l}289.7 \\
598.0\end{array}$ & $\begin{array}{l}340 \\
641\end{array}$ & $t$ & t & t & t & t & $t$ & t & t & t & 3 & 2.8 \\
\hline Tourle & & & & & & & & & 500.1 & 000.0 & VTh & & & & & & & & & 1 & & 1 \\
\hline Part-ti & $4,282.1$ & $4,997.9$ & 5,997.7 & 2.7 & .5 & 2 & 1 & 9 & 9 & 7 & 7, & 100.0 & 10 & 100.0 & 10 & 100 & 10 & 100 & 10 & 10 & 10 & 100.0 \\
\hline & & & & & & & & & & & & & & & & & & & & & & 57.9 \\
\hline Tot & 659.9 & 811.3 & $1,189.8$ & $1,953.0$ & $2,290.1$ & $2,485.4$ & & $2,910.4$ & 3, & & & 15.6 & 16.5 & 20.2 & & 34 & 36 & 37 & & & 4 & 42.1 \\
\hline & 373.8 & 421.2 & 528.7 & 747.7 & $\begin{array}{r}8 \\
\quad 892.9\end{array}$ & 967.2 & $1,053.7$ & $1,156.2$ & $\begin{array}{l}1,229.5 \\
\text {. }\end{array}$ & .1 & 1, & 8.9 & 8.5 & 9.0 & & 13 & 14 & 14 & 15 & & 16 & 16.0 \\
\hline & 172.7 & 224.8 & 387.7 & 751.5 & 902.2 & 993.2 & $1,095.7$ & $1,184.3$ & $\begin{array}{l}1,241.8 \\
\text {. }\end{array}$ & $1,297.8$ & $1,347.0$ & 4.1 & 4.6 & 6.6 & 12.2 & 13. & 14.5 & 15.2 & 15.7 & 15 & 16 & 17.3 \\
\hline Asian & 80.2 & 124.4 & 225.1 & 387.1 & 424.3 & 447.9 & 493.9 & 489.1 & 461.2 & 460.8 & 443.8 & 1.9 & 2.5 & 3.8 & 6.3 & 6.5 & 6.5 & 6.8 & 6.5 & & 5 & 5.7 \\
\hline & & & & & & & & & & 434.0 & 41 & & & & & & & & & & & \\
\hline & - & - & - & - & 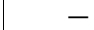 & & & & & 26.8 & 26.7 & - & 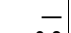 & - & & - & & _ & _ & & & 5 \\
\hline ka Native...... & 33.1 & 40.9 & 48.4 & 66.8 & 70.7 & 77.0 & 78.2 & 80.9 & 78.2 & 75.4 & 70.8 & 0.8 & 0.8 & 0.8 & 1.1 & 1.1 & 1.1 & 1.1 & 1.1 & & & .9 \\
\hline $\begin{array}{l}\text { Two or } \mathrm{m} \\
\text { Nonresiden }\end{array}$ & 58.7 & 70.6 & 101.8 & 118.7 & 125.5 & 130.8 & 138.3 & 142.6 & $\begin{array}{l}108.4 \\
143.5\end{array}$ & $\begin{array}{l}143.2 \\
142.5\end{array}$ & $\begin{array}{l}165.0 \\
141.5\end{array}$ & $\dagger$ & $\dagger$ & $\dagger$ & $\dagger$ & $\dagger$ & $\dagger$ & $\bar{\dagger}$ & $\bar{\dagger}$ & $\begin{aligned} 1.4 \\
\dagger\end{aligned}$ & $\begin{array}{r}1.8 \\
+\end{array}$ & $\begin{aligned} 2.1 \\
t\end{aligned}$ \\
\hline & & & & & & & & & & & & & & & & & & & & & & \\
\hline
\end{tabular}




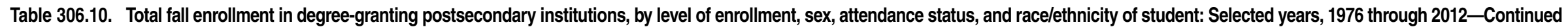

\begin{tabular}{|c|c|c|c|c|c|c|c|c|c|c|c|c|c|c|c|c|c|c|c|c|c|c|}
\hline \multirow{2}{*}{$\begin{array}{l}\text { Level of enrollment, sex, attendance } \\
\text { status, and race/ethnicity of student }\end{array}$} & \multicolumn{11}{|c|}{ Fall enrollment (in thousands) } & \multicolumn{11}{|c|}{ Percentage distribution of U.S. residents } \\
\hline & 1976 & 1980 & 1990 & 2000 & 2005 & 2007 & 2008 & 2009 & 2010 & 2011 & 2012 & 1976 & 1980 & 1990 & 2000 & 2005 & 2007 & 2008 & 2009 & 2010 & 2011 & 2012 \\
\hline 1 & 2 & 3 & 4 & 5 & 6 & 7 & 8 & 9 & 10 & 11 & 12 & 13 & 14 & 15 & 16 & 17 & 18 & 19 & 20 & 21 & 22 & 23 \\
\hline Undergraduate, total. & $9,419.0$ & $10,469.1$ & $11,959.1$ & $13,155.4$ & $14,964.0$ & $15,603.8$ & $16,365.7$ & $17,565.3$ & $18,078.7$ & $18,063.0$ & $17,732.4$ & 100.0 & 100.0 & 100.0 & 100.0 & 100.0 & 100.0 & 100.0 & 100.0 & 100.0 & 100.0 & 100.0 \\
\hline ite... & $7,740.5$ & $8,480.7$ & $9,272.6$ & $8,983.5$ & $9,828.6$ & $10,046.6$ & $10,339.2$ & $10,915.3$ & $10,897.7$ & $10,611.6$ & $10,247.4$ & 83.4 & 82.7 & 79.0 & 69.8 & 67.1 & 65.8 & 64.6 & 63.5 & 61.6 & 60.2 & 59.3 \\
\hline tal, sele & $1,535.3$ & $1,778.5$ & $2,467.7$ & 384.0 & 820.7 & $5,221.9$ & $5,666.2$ & 6,271.6 & 6,780.7 & $7,029.1$ & $7,034.6$ & 16.6 & 17.3 & 21.0 & 30.2 & 32.9 & 342 & 35.4 & 36.5 & 38.4 & 39.8 & 40.7 \\
\hline . & 943.4 & $1,018.8$ & $1,147.2$ & $1,548.9$ & $1,955.4$ & $2,092.6$ & $2,269.3$ & $2,577.4$ & 2,676.5 & $2,698.9$ & 2 & 10.2 & 9.9 & 9.8 & 12.0 & 13.3 & 13.7 & 14.2 & 15.0 & 15.1 & 15.3 & 15.0 \\
\hline Hispanic & 352.9 & 433.1 & 724.6 & $1,351.0$ & $1,733.6$ & $1,915.9$ & $2,103.5$ & $2,362.5$ & 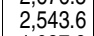 & $2,685.1$ & $2,766.1$ & 3.8 & 4.2 & 6.2 & 10.5 & 11.8 & 12.5 & 13.1 & 13.7 & 14.4 & 15.2 & 16.0 \\
\hline Asian/Pacific Islander.. & 169.3 & 248.7 & 500.5 & 845.5 & 971.4 & $1,042.1$ & $1,117.9$ & $1,142.3$ & 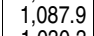 & $1,085.1$ & 1,063.2 & 1.8 & 2.4 & 4.3 & 6.6 & 6.6 & 6.8 & 7.0 & 6.6 & 6.2 & 6.2 & 6.2 \\
\hline lander................ & - & - & - & - & - & - & & & $\begin{array}{r}1,030.3 \\
57.6\end{array}$ & $\begin{array}{r}1,025.8 \\
59.3\end{array}$ & $\begin{array}{r}1,006.5 \\
56.7\end{array}$ & - & $=$ & - & $=$ & $=$ & - & - & $=$ & $\begin{array}{l}5.8 \\
0.3\end{array}$ & $\begin{array}{l}5.8 \\
0.3\end{array}$ & $\begin{array}{l}5.8 \\
0.3\end{array}$ \\
\hline Alaska Native ......... & 69.7 & 77.9 & 95.5 & 138.5 & 160.4 & 171.3 & 175.6 & 189.4 & 179.3 & 169.9 & 157.5 & 0.8 & 0.8 & 0.8 & 1.1 & 1.1 & $\overline{1.1}$ & $\overline{1.1}$ & 1.1 & 1.0 & 1.0 & 0.9 \\
\hline $\begin{array}{l}\text { To or more races } \\
\text { Nonresident alien }\end{array}$ & 143.2 & 209.9 & 218.7 & 288.0 & 314.7 & 335.3 & 360.3 & 378.4 & $\begin{array}{l}293.5 \\
400.3\end{array}$ & $\begin{array}{l}390.2 \\
422.3\end{array}$ & $\begin{array}{l}455.0 \\
450.5\end{array}$ & $\bar{\dagger}$ & $\bar{\dagger}$ & $\bar{\dagger}$ & $\bar{\dagger}$ & $\dagger$ & $\dagger$ & $\dagger$ & $\bar{\dagger}$ & $\begin{aligned} 1.7 \\
\dagger\end{aligned}$ & $\begin{aligned} 2.2 \\
\dagger\end{aligned}$ & $\begin{array}{r}2.6 \\
\dagger\end{array}$ \\
\hline Male..... & $4,896.8$ & $4,997.4$ & $5,379.8$ & $5,778.3$ & 108.9 & 27.6 & 66.6 & 595.5 & 335.2 & 317.0 & 3.9 & 100.0 & 100.0 & 100.0 & 100.0 & 100.0 & 100.0 & 100.0 & 100.0 & 100.0 & 100.0 & 100.0 \\
\hline . & $4,052.2$ & $4,054.9$ & $4,184.4$ & $4,010.1$ & 330.4 & 455.9 & 598.6 & 860.2 & $4,861.9$ & $4,722.9$ & $4,571.9$ & 84.4 & 83.5 & 79.6 & 71.3 & 69.2 & 67.9 & 66.8 & 65.6 & 63.7 & 62.1 & 61.1 \\
\hline Total, sel & 748.2 & 802.7 & $1,069.3$ & $1,618.0$ & $1,926.6$ & $2,107.5$ & $2,290.3$ & $2,546.2$ & $2,771.0$ & $2,876.5$ & $2,904.9$ & 15.6 & 16.5 & 20.4 & 28.7 & 30.8 & 32.1 & 33.2 & 34.4 & 36.3 & 37.9 & 38.9 \\
\hline sul, or & 430.7 & 428.2 & 448.0 & 577.0 & 697.5 & 754.1 & 821.3 & 938.3 & 982.9 & 994.9 & 969.7 & 9.0 & 8.8 & 8.5 & 10.3 & 11.1 & 11.5 & 11.9 & 12.7 & 12.9 & 13.1 & 13.0 \\
\hline & 191.7 & 211.2 & 326.9 & 582.6 & 718.5 & 802.0 & 884.0 & 997.3 & $1,079.9$ & $1,136.2$ & $1,173.0$ & 4.0 & 4.3 & 6.2 & 10.4 & 11.5 & $\begin{array}{l}12.2 \\
\end{array}$ & 12.8 & 13.5 & 14.1 & 15.0 & 15.7 \\
\hline Asian & 91.1 & 128.5 & 254.5 & 401.9 & 448.1 & 483.6 & 514.6 & 534.0 & 513.6 & 513.9 & 505.5 & 1.9 & 2.6 & 4.8 & 7.1 & 7.2 & 7.4 & 7.5 & 7.2 & 6.7 & 6.8 & 6.8 \\
\hline , & & & & & & & & & 487.6 & 487.4 & 479.9 & - & - & - & - & & - & - & - & 6.4 & 4 & 6.4 \\
\hline & - & - & - & - & - & - & - & - & 26.0 & 26.4 & 25.6 & - & - & - & - & - & - & - & - & 0.3 & 0.3 & 0.3 \\
\hline ra Native ..... & 34.8 & 34.8 & 39.9 & 56.4 & 62.5 & 67.8 & 70.3 & 76.5 & 72.4 & $\begin{array}{r}67.8 \\
1636\end{array}$ & 62.9 & 0.7 & 0.7 & 0.8 & 1.0 & 1.0 & 1.0 & 1.0 & 1.0 & 0.9 & 0.9 & 0.8 \\
\hline 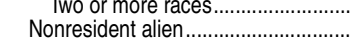 & 96.4 & 139.8 & 126.1 & 150.2 & 151.8 & 164.2 & 177.7 & 189.1 & $\begin{array}{l}122.3 \\
202.2\end{array}$ & $\begin{array}{l}163.6 \\
217.6\end{array}$ & $\begin{array}{l}193.8 \\
237.1\end{array}$ & $t^{t}$ & $\begin{array}{ll}t \\
\text { s. }\end{array}$ & $t^{\prime}$ & $\begin{array}{ll}t \\
\end{array}$ & $\dagger$ & $\dagger$ & $\dagger$ & t & $\begin{array}{r}1.6 \\
+\end{array}$ & $\begin{aligned} 2.2 \\
+\end{aligned}$ & $\begin{array}{r}2.6 \\
t\end{array}$ \\
\hline & & & & & & & & & & & & & & & & & & & & & & \\
\hline 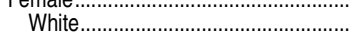 & $\begin{array}{l}3,688.3 \\
3,68.1\end{array}$ & $4,425.8$ & $\begin{array}{l}6,088.2 \\
5,2\end{array}$ & $\begin{array}{r}4,973.1 \\
4.37 .1\end{array}$ & $\begin{array}{l}8,455.1 \\
5,498.2\end{array}$ & $\begin{array}{l}8,866.2 \\
5,590.6\end{array}$ & \begin{tabular}{|l|}
$9,299.1$ \\
$5,740.6$
\end{tabular} & $\begin{array}{l}9,969.8 \\
6,055.0\end{array}$ & $\begin{array}{r}10,243.5 \\
6,035.7\end{array}$ & $\begin{array}{r}10,246.1 \\
5,888.6\end{array} \mid$ & $\begin{array}{r}10,018.5 \\
5,675.5\end{array}$ & $\begin{array}{r}100.0 \\
82.4\end{array}$ & $\begin{array}{r}10.0 \\
81.9\end{array}$ & $\begin{array}{r}100.0 \\
78.4\end{array}$ & $\begin{array}{r}10.0 \\
68.7\end{array}$ & $\begin{array}{r}100.0 \\
65.5\end{array}$ & $\begin{array}{r}r 100.0 \\
64.2\end{array}$ & $\begin{array}{r}100.0 \\
63.0\end{array}$ & $\begin{array}{r}r 00.0 \\
61.9\end{array}$ & $\begin{array}{r}10.0 \\
60.1\end{array}$ & $\begin{array}{r}100.0 \\
58.6\end{array}$ & $\begin{array}{r}100.0 \\
57.9\end{array}$ \\
\hline es......... & 787.0 & 975.8 & $1,398.5$ & $2,266.0$ & $2,894.0$ & $3,114.4$ & $3,375.9$ & $3,725.4$ & $4,009.7$ & $4,152.7$ & $4,129.7$ & 17.6 & $\begin{array}{l}18.1 \\
\text {. }\end{array}$ & 21.6 & 31.3 & 34.5 & 35.8 & 37.0 & 38.1 & 39.9 & 41.4 & 42.1 \\
\hline & 512.7 & 590.6 & 699.2 & 971.9 & $1,257.8$ & $1,338.5$ & $1,448.0$ & $1,639.1$ & $1,693.6$ & $1,703.9$ & 1 & 11.5 & 10.9 & 10.8 & 13.4 & 15.0 & 15.4 & 15.9 & 16.8 & 16.9 & 17.0 & 16.6 \\
\hline & 161.2 & 221.8 & 397.6 & 768.4 & $1,015.0$ & $1,113.9$ & $1,219.5$ & $1,365.2$ & $1,463.7$ & $1,548.8$ & $1,593.0$ & 3.6 & 4.1 & 6.1 & 10.6 & 12.1 & 12.8 & 13.4 & 14.0 & 14.6 & 15.4 & 16.2 \\
\hline A & 78.2 & 120.2 & 246.0 & 443.6 & 523.2 & 558.5 & 603.2 & 608.3 & 574.3 & 571.2 & 557.7 & 1.7 & 2.2 & 3.8 & 6.1 & 6.2 & 6.4 & 6.6 & 6.2 & 57 & 5.7 & 5.7 \\
\hline & & & & & & & & & 542.7 & 538.3 & 526.6 & & & & & & - & - & -1 & 5.4 & 5.4 & 5.4 \\
\hline & - & - & - & - & - & - & - & - & 31.6 & 32.9 & 31.1 & - & - & - & - & - & - & - & - & 0.3 & 0.3 & 0.3 \\
\hline ska Native..... & 34.9 & 43.1 & 55.5 & 82.1 & 98.0 & 103.6 & 105.2 & 112.9 & 106.9 & 102.1 & 94.6 & 0.8 & 0.8 & 0.9 & 1.1 & 1.2 & 1.2 & 1.2 & 1.2 & 1.1 & 1.0 & 1.0 \\
\hline 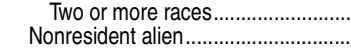 & 46.8 & 70.1 & 92.6 & 137.8 & 162.9 & 171.2 & 182.6 & 189.4 & $\begin{array}{l}171.2 \\
198.1\end{array}$ & $\begin{array}{l}226.6 \\
204.7\end{array}$ & $\begin{array}{l}261.3 \\
213.3\end{array}$ & $\dagger$ & $\dagger$ & $\bar{\dagger}$ & $\dagger$ & $\dagger$ & $\dagger$ & 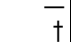 & $\dagger$ & $\begin{array}{r}1.7 \\
\dagger\end{array}$ & $\begin{aligned} 2.3 \\
t\end{aligned}$ & $\begin{aligned} 2.7 \\
t\end{aligned}$ \\
\hline ureate, total $\ldots \ldots \ldots \ldots$ & $1,566.6$ & $1,617.7$ & 1.859 .5 & $2,156.9$ & $2,523.5$ & $2,644.4$ & 737.1 & $2,862.4$ & 7.5 & $2,931.1$ & 2,91 & 1000 & 1000 & 1000 & 100.0 & 100.0 & 1000 & 1000 & 1000 & 100.0 & 1000 & 1000 \\
\hline ............. & $1,335.6$ & $1,352.4$ & $1,449.8$ & $1,478.6$ & 8 & .7 & & 5.5 & & & & 896 & 88.8 & 86.0 & 77.2 & 740 & 700.0 & 718 & 71 & 100.0 & 682 & 673 \\
\hline & 155.5 & 170.3 & 237.0 & 437.5 & 6 & & 687.2 & 740.5 & & 830.4 & & 10.4 & 11.2 & 14.0 & 22.8 & 26 & 27.4 & & & & & 007 \\
\hline B & 89.7 & 87.9 & 99.8 & 181.4 & 12 & 8 & 315.2 & 342.4 & & & & 6.0 & 5.8 & 5.9 & 9. & 11.5 & 12.3 & 12.9 & 13.4 & & 14.1 & 14.3 \\
\hline & 30.9 & 38.6 & 57.9 & 110.8 & 148.4 & 160.3 & 169.4 & 184.2 & & 205.0 & & 2.1 & 2.5 & 3.4 & 5.8 & 6.6 & 6.8 & 7.0 & 7.2 & & 7.8 & 8.3 \\
\hline Asi & 28.6 & 37.7 & 72.0 & 132.7 & 163.0 & 175.8 & 184.9 & 195.4 & 194.3 & 197.4 & 19 & 1.9 & 2.5 & 4.3 & 6.9 & 7.2 & 7.5 & 7.6 & 7.6 & 7. & 6 & 7.6 \\
\hline rom & 20.0 & 年 & 12.0 & What & . & 110.0 & (0) & 100.7 & 187.8 & 190.8 & 18 & 1.0 & 2.0 & 7.0 & 0.0 & 1.2 & 1.0 & 1.0 & 1.0 & & 3 & 7.3 \\
\hline & - & - & - & - & - & - & - & - & 6.5 & 6.6 & 6.9 & - & - & - & - & - & - & - & - & U. & 0.3 & 0.3 \\
\hline aska Native.......... & 6.4 & 6.0 & 7.3 & 12.6 & 15.9 & 18.7 & 17.7 & 18.5 & 17.1 & 16.1 & 15.4 & 0.4 & 0.4 & 0.4 & 0.7 & 0.7 & 0.8 & 0.7 & 0.7 & 0. & 0.6 & 0.6 \\
\hline 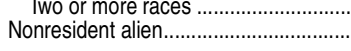 & 75.5 & 95.1 & 172.7 & 240.7 & 270.1 & 289.1 & 300.3 & 306.4 & $\begin{array}{r}31.8 \\
309.3\end{array}$ & $\begin{array}{r}42.1 \\
318.1\end{array}$ & $\begin{array}{r}50.1 \\
332.4\end{array}$ & $\dagger$ & $\dagger$ & $\dagger$ & $\dagger$ & 11 & $\dagger$ & $\dagger$ & $\dagger$ & $\dagger$ & $\stackrel{.6}{\dagger}$ & 9 \\
\hline Male & 897.6 & 870.7 & 904.2 & 943.5 & $1,047.1$ & $1,088.3$ & $1,122.3$ & $1,174.0$ & $1,209.6$ & $1,209.5$ & 1,20 & 100.0 & 100.0 & 100.0 & 100.0 & 100.0 & 100.0 & 100.0 & 100.0 & 100.0 & 100.0 & 100.0 \\
\hline & & & & & & & & & & & & & & & & & & & & & & \\
\hline Tot & 78.4 & & & 171.9 & & & & & & & & y. & . & & 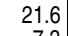 & & 24.9 & 6 & 26 & & & 2 \\
\hline & 39.2 & & & & 76.6 & 84.0 & & & & & & 4. & 4 & 7 & 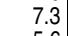 & 8 & 9.1 & 6 & & 10. & 6 & 0.8 \\
\hline & 18.1 & 0.7 & 27.0 & 44.5 & 56.1 & 59.6 & & 69.0 & & & & 2.2 & 2.5 & 3.4 & 3.0 & 6.3 & 6.5 & 6.6 & . & 7. & 6 & 8.0 \\
\hline Asia & 17.4 & 22.8 & 40.4 & 64.0 & 73.9 & 78.9 & 82.7 & 87.5 & 2 & 88.6 & & 2.1 & 2.8 & 5.2 & 8.0 & 8.3 & 8.6 & 8.7 & 8.8 & 8. & 6 & 8.7 \\
\hline & & & & & & & - & & 84.7 & 86.0 & 85.4 & & - & - & & & - & - & & 8. & 4 & 8.4 \\
\hline & $\overline{7}$ & - & ? & - & - & $\bar{C}$ & - & - & 2.5 & 2.6 & 2.8 & - & - & $\overline{0}$ & - & -7 & - & $\overline{7}$ & - & 0 & 0.3 & 0.3 \\
\hline $\begin{array}{l}\text { Alaska Native ...... } \\
\text { es........................ }\end{array}$ & 3.7 & 3.0 & 3.2 & 5.0 & 5.9 & 6.6 & 6.5 & 6.9 & $\begin{array}{r}6.4 \\
12.0\end{array}$ & $\begin{array}{r}5.9 \\
16.2\end{array}$ & $\begin{array}{r}5.7 \\
19.6\end{array}$ & 0.4 & 0.4 & 0.4 & $\stackrel{0.6}{-}$ & 0.7 & 0.7 & 0.7 & $\begin{array}{c}0.7 \\
-\end{array}$ & $\begin{array}{l}0.6 \\
1.2\end{array}$ & $\begin{array}{l}0.6 \\
1.6\end{array}$ & $\begin{array}{l}0.6 \\
1.9\end{array}$ \\
\hline Nonresident alien ............................ & 57.7 & 71.0 & 120.2 & 147.1 & 157.7 & 169.1 & 175.5 & 177.7 & 178.1 & 181.5 & 187.5 & $\dagger$ & $\dagger$ & $\dagger$ & $\dagger$ & $\dagger$ & $\dagger$ & $\dagger$ & $\dagger$ & $\dagger$ & $\dagger$ & $\dagger$ \\
\hline
\end{tabular}

See notes at end of table. 


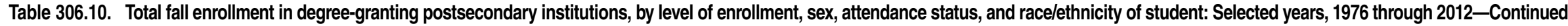

\begin{tabular}{|c|c|c|c|c|c|c|c|c|c|c|c|c|c|c|c|c|c|c|c|c|c|c|}
\hline \multirow{2}{*}{$\begin{array}{l}\text { Level of enrollment, sex, attendance } \\
\text { status, and race/ethnicity of student }\end{array}$} & \multicolumn{11}{|c|}{ Fall enrollment (in thousands) } & \multicolumn{11}{|c|}{ Percentage distribution of U.S. residents } \\
\hline & 1976 & 1980 & 1990 & 2000 & 2005 & 2007 & 2008 & 2009 & 2010 & 2011 & 2012 & 1976 & 1980 & 1990 & 2000 & 2005 & 2007 & 2008 & 2009 & 2010 & 2011 & 2012 \\
\hline 1 & 2 & 3 & 4 & 5 & 6 & 7 & 8 & 9 & 10 & 11 & 12 & 13 & 14 & 15 & 16 & 17 & 18 & 19 & 20 & 21 & 22 & 23 \\
\hline Female........... & 669.1 & 747.0 & 955.4 & $1,213.4$ & $1,476.5$ & $1,556.0$ & $1,614.8$ & $1,688.4$ & $1,727.8$ & $1,721.6$ & $1,705.2$ & 100.0 & 100.0 & 100.0 & 100.0 & 100.0 & 100.0 & 100.0 & 100.0 & 100.0 & 100.0 & 100.0 \\
\hline 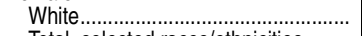 & 574.1 & 634.3 & 773.2 & 854.1 & 990.0 & $1,019.5$ & $1,045.3$ & $1,081.4$ & $1,080.0$ & $1,051.7$ & $1,020.6$ & 88.1 & 87.7 & 85.6 & 76.3 & 72.6 & 71.0 & 70.2 & 69.3 & 67.6 & 66.4 & 65.4 \\
\hline Total, selected races/ethnicities...... & 77.2 & 88.6 & 129.6 & 265.7 & 374.0 & 416.5 & 444.8 & 478.3 & 516.7 & 533.3 & 539.7 & 11.9 & 12.3 & 14.4 & 23.7 & 27.4 & 29.0 & 29.8 & 30.7 & 32.4 & 33.6 & 34.6 \\
\hline 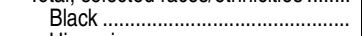 & 50.5 & 52.4 & 63.1 & 123.1 & 182.6 & 206.8 & 224.7 & 243.6 & 256.0 & 260.6 & 259.6 & 7.7 & 7.2 & 7.0 & 11.0 & 13.4 & 14.4 & 15.1 & 15.6 & 16.0 & 16.4 & 16.6 \\
\hline 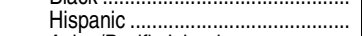 & 12.8 & 18.3 & 30.9 & 66.3 & 92.3 & 100.7 & 106.7 & 115.2 & 123.2 & 127.1 & 132.1 & 2.0 & 2.5 & 3.4 & 5.9 & 6.8 & 7.0 & 7.2 & 7.4 & 7.7 & 8.0 & 8.5 \\
\hline 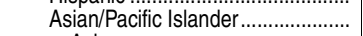 & 11.2 & 15.0 & 31.5 & 68.7 & 89.1 & 97.0 & 102.2 & 107.9 & 107.1 & 108.9 & 107.8 & 1.7 & 2.1 & 3.5 & 6.1 & 6.5 & 6.8 & 6.9 & 6.9 & 6.7 & 6.9 & 6.9 \\
\hline Asian. & . & - & - & - & - & - & & - & 103.1 & 104.8 & 103.7 & & 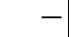 & & & & - & & 4 & 6.5 & 6.6 & 6.6 \\
\hline Pacific Islander & - & - & - & $\overline{7}$ & - & - & - & - & 3.9 & 4.0 & 4.1 & - & - & - & - & - & - & - & - & 0.2 & 0.3 & 0.3 \\
\hline American Indian/Alaska Native ..... & 2.7 & 3.0 & 4.1 & 7.6 & 10.0 & 12.1 & 11.2 & 11.6 & 10.7 & 10.3 & 9.8 & 0.4 & 0.4 & 0.5 & 0.7 & 0.7 & 0.8 & 0.8 & 0.7 & 0.7 & 0.6 & 0.6 \\
\hline 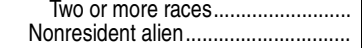 & $17 \overline{8}$ & $24 . \overline{1}$ & $52 . \overline{5}$ & $93 \overline{6}$ & $112 . \overline{4}$ & $120 . \overline{1}$ & $124 \overline{8}$ & $128 \overline{7}$ & $\begin{array}{r}19.7 \\
131.1\end{array}$ & $\begin{array}{r}26.5 \\
136.6\end{array}$ & $\begin{array}{r}30.5 \\
144.9\end{array}$ & $\bar{t}$ & $\bar{t}$ & $\bar{t}$ & $\dagger$ & $\bar{t}$ & $\bar{t}$ & $\bar{t}$ & $\bar{t}$ & $\begin{aligned} & 1.2 \\
& t\end{aligned}$ & $\begin{aligned} 1.7 \\
t\end{aligned}$ & 2.0 \\
\hline
\end{tabular}

-Not available.

Not applicable.

lier higher education classification, but it includes more 2-year colleges and excludes a few higher education institutions that did not grant degrees. Detail may not sum to totals because of rounding.

SOURCE: U.S. Department of Education, National Center for Education Statistics, Higher Education General Information

NOTE. Race categories exclude persons of Hispanic ethnicity. Because of underreporting and nonreporting of racia//ethnic

data, some figures are slightly lower than corresponding data in other tables. Data through 1990 are for instiutions of higher Dala System (IPEDS), "Fall Enrollment Survey" (IPEDS-EF:90); and IPEDS Spring 2001 through Spring 2013, Enrollment ared November 2013.) 
Table 306.20. Total fall enrollment in degree-granting postsecondary institutions, by level and control of institution and race/ethnicity of student: Selected years, 1976 through 2012

\begin{tabular}{|c|c|c|c|c|c|c|c|c|c|c|c|c|c|c|c|c|c|c|c|c|c|c|}
\hline \multirow{2}{*}{$\begin{array}{l}\text { Level and control of institution } \\
\text { and race/ethnicity of student }\end{array}$} & \multicolumn{11}{|c|}{ Fall enrollment (in thousands) } & \multicolumn{11}{|c|}{ Percentage distribution of U.S. residents } \\
\hline & 1976 & 1980 & 1990 & 2000 & 2005 & 2007 & 2008 & 2009 & 2010 & 2011 & 2012 & 1976 & 1980 & 1990 & 2000 & 2005 & 2007 & 2008 & 2009 & 2010 & 2011 & 2012 \\
\hline 1 & 2 & 3 & 4 & 5 & 6 & 7 & 8 & 9 & 10 & 11 & 12 & 13 & 14 & 15 & 16 & 17 & 18 & 19 & 20 & 21 & 22 & 23 \\
\hline All students, total. & $10,985.6$ & $12,086.8$ & $13,818.6$ & $15,312.3$ & $17,487.5$ & $18,248.1$ & $19,102.8$ & $20,427.7$ & $21,016.1$ & $20,994.1$ & $20,642.8$ & 100.0 & 100.0 & 100.0 & 100.0 & 100.0 & 100.0 & 100.0 & 100.0 & 100.0 & 100.0 & 100.0 \\
\hline hite. & $9,076.1$ & $9,833.0$ & $10,722.5$ & $10,462.1$ & $11,495.4$ & $11,756.2$ & $12,088.8$ & $12,730.8$ & $12,722.5$ & $12,394.2$ & $11,981.1$ & 84.3 & 83.5 & 79.9 & 70.8 & 68.0 & 66.7 & 65.5 & 64.5 & 62.7 & 61.2 & 60.3 \\
\hline .... & $1,690.8$ & $1,948.8$ & 704.7 & 321.5 & 407.2 & $5,867.4$ & $6,353.5$ & $7,012.1$ & $7,584.0$ & 859.5 & 878.8 & 15.7 & 16.5 & 20.1 & 29. & 20 & 33.3 & 4.5 & 35.5 & 37.3 & 38.8 & 9.7 \\
\hline .. & 1, & $1,106.8$ & $1,247.0$ & $1,730.3$ & 6 & 2 & .5 & $2,919.8$ & 8.8 & 7.9 & 1 & 9.6 & 9.4 & 9.3 & 11.7 & 13.1 & 13.5 & 14.0 & 4.8 & 0 & 15.1 & 14.9 \\
\hline pan & 383.8 & 471.7 & 782.4 & $1,461.8$ & $1,882.0$ & $2,076.2$ & $2,272.9$ & $2,546.7$ & 2,741.4 & $2,890.1$ & $2,979.4$ & 3.6 & 4.0 & 5.8 & 9.9 & 11.1 & 11.8 & 12.3 & 12.9 & 3.5 & 14.3 & 15.0 \\
\hline Asian/Pacific Islander.. & 197.9 & 286.4 & 572.4 & 978.2 & $1,134.4$ & $1,217.9$ & $1,302.8$ & $1,337.7$ & $1,282.2$ & $1,282.5$ & 1,259.2 & 1.8 & 2.4 & 4.3 & 6.6 & 6.7 & 6.9 & 7.1 & 6.8 & 6.3 & 6.3 & 6.3 \\
\hline …………....... & - & - & - & - & - & & & & $\begin{array}{r}1,218.1 \\
640\end{array}$ & $\begin{array}{l}1,216.6 \\
65.9\end{array}$ & $\begin{array}{r}1,195.6 \\
636\end{array}$ & - & $=$ & - & $=$ & $=$ & - & $=$ & - & $\begin{array}{l}6.0 \\
0.3\end{array}$ & $\begin{array}{l}6.0 \\
0.3\end{array}$ & $\begin{array}{l}6.0 \\
0.3\end{array}$ \\
\hline aska Native... & 76.1 & 83.9 & $102 . \overline{8}$ & $151 . \overline{2}$ & $176 . \overline{3}$ & $190 . \overline{0}$ & $193 . \overline{3}$ & 207.9 & $\begin{array}{r}04.0 \\
196.4\end{array}$ & $\begin{array}{r}05.9 \\
186.1\end{array}$ & $\begin{array}{r}\text { 03.. } \\
172.9 \\
\end{array}$ & $\overline{0.7}$ & $\overline{0.7}$ & $0 . \overline{8}$ & $\overline{1.0}$ & $\overline{1.0}$ & $\overline{1.1}$ & $\overline{1.0}$ & $\overline{1.1}$ & $\begin{array}{l}0.3 \\
1.0\end{array}$ & $\begin{array}{l}0.3 \\
0.9\end{array}$ & 0.9 \\
\hline - & & & & & & & & & & 432.9 & 505.1 & - & + & - & - & - & - & - & - & 1.6 & 2.1 & 2.5 \\
\hline$\ldots$ & 218.7 & 305.0 & 391.5 & 528.7 & 584.8 & 624.5 & 660.6 & 684.8 & 709.6 & 740.5 & 782.9 & $\dagger$ & $\dagger$ & $\dagger$ & $\dagger$ & $\dagger$ & $\dagger$ & $\dagger$ & $\dagger$ & $\dagger$ & $\dagger$ & $\dagger$ \\
\hline $\begin{array}{l}\text { Public... } \\
\text { White }\end{array}$ & $8,641.0$ & $9,456.4$ & $\begin{array}{r}10,844.7 \\
8385.4\end{array}$ & $11,752.8$ & $13,021.8$ & $13,490.8$ & $13,972.2$ & $14,810.6$ & $15,142.8$ & $15,110.2$ & $14,880.3$ & $\begin{array}{r}100.0 \\
8.5\end{array}$ & 100.0 & 100.0 & 100.0 & 100.0 & 100.0 & 100.0 & 100.0 & 100.0 & 100.0 & 100.0 \\
\hline & $\mid \begin{array}{r}7,094.5 \\
1,401\end{array}$ & $7,656.1$ & $\left|\begin{array}{l}8,385.4 \\
2109\end{array}\right|$ & 7,963.4 & 8,518.2 & & $\mid \begin{array}{l}8,817.7 \\
17075\end{array}$ & $\left|\begin{array}{l}9,234.6 \\
5125\end{array}\right|$ & & & 8, & $\begin{array}{r}83.5 \\
1.5\end{array}$ & $\begin{array}{r}82.7 \\
17 .\end{array}$ & $\begin{array}{r}79.2 \\
70.9\end{array}$ & $\begin{array}{r}69.8 \\
202\end{array}$ & $\begin{array}{r}67.3 \\
227\end{array}$ & $\begin{array}{r}66.0 \\
210\end{array}$ & $\begin{array}{r}65.1 \\
319\end{array}$ & $\begin{array}{r}64.3 \\
35 .\end{array}$ & $\begin{array}{r}62.5 \\
375\end{array}$ & 61.0 & 0.0 \\
\hline S................ & $\begin{array}{r}1,401.2 \\
8312\end{array}$ & \begin{tabular}{|r|}
$1,596.2$ \\
876.1
\end{tabular} \mid & \begin{tabular}{|r|r}
$2,199.2$ \\
9764
\end{tabular} \mid & \begin{tabular}{|l}
$3,446.3$ \\
$1319 ?$
\end{tabular} & $\begin{array}{l}4,130.8 \\
1504\end{array}$ & $\begin{array}{l}4,448.8 \\
1667\end{array}$ & $\left|\begin{array}{|}4,727.5 \\
1759 ?\end{array}\right|$ & $5,135.2$ & $\begin{array}{l}5,501.4 \\
19886\end{array}$ & $\mid$ & 5,74 & $\begin{array}{r}r 6.5 \\
98\end{array}$ & $\begin{array}{r}17.3 \\
95\end{array}$ & 20.8 & 30.2 & $\begin{array}{l}32.7 \\
125\end{array}$ & $\begin{array}{l}34.0 \\
127\end{array}$ & 34.9 & 35.7 & 37.5 & 39.0 & 40.0 \\
\hline$\ldots \ldots \ldots$. & $\begin{array}{l}831.2 \\
336.8\end{array}$ & $\begin{array}{l}8 / 6.1 \\
406 ?\end{array}$ & $\begin{array}{l}9 / 6.4 \\
6714\end{array}$ & $\begin{array}{ll}19.2 \\
293\end{array}$ & $\begin{array}{l}1,580.4 \\
15256\end{array}$ & $\left|\begin{array}{l}1,667.6 \\
16854\end{array}\right|$ & $\left|\begin{array}{|l}1,759.2 \\
18324\end{array}\right|$ & $\begin{array}{l}1,937.2 \\
2017\end{array}$ & $\begin{array}{l}1,988.6 \\
21574\end{array}$ & 3 & 0 & $\begin{array}{c}9.8 \\
40\end{array}$ & 9.5 & 9.2 & 11 & $\begin{array}{l}12.5 \\
1\end{array}$ & $\begin{array}{l}12.7 \\
120\end{array}$ & $\begin{array}{r}13.0 \\
1135\end{array}$ & 13.5 & 13.5 & 13.8 & 13.5 \\
\hline$\ldots$ & 336 & $\begin{array}{l}406.2 \\
230\end{array}$ & 671.4 & $1,229.3$ & $1,525.6$ & $1,685.4$ & $1,832.4$ & $2,017.7$ & $2,157.4$ & 2,275.8 & $2,365.9$ & 4.0 & 4.4 & 6.3 & 10.8 & 12.1 & 12.9 & 13.5 & 14.0 & 14.7 & 15.5 & 16.5 \\
\hline Asi & 165.7 & 239.7 & 461.0 & 770.5 & 881.9 & 942.5 & 982.9 & $1,018.5$ & 969.5 & 958.3 & 942.5 & 2.0 & 2.6 & 4.4 & 6.8 & 7.0 & 7.2 & 7.3 & 7.1 & 6.6 & 6.5 & 6.6 \\
\hline & - & - & - & - & - & - & - & - & & 915.3 & 901.1 & - & & & & - & & & & & & $f=$ \\
\hline & & & & & & & & & 44.0 & 43.0 & 41.4 & - & - & - & - & - & - & & & & & 0.3 \\
\hline tive ...... & 67.5 & 74.2 & 90.4 & 127.3 & 143.0 & 153.3 & 153.0 & 161.8 & 151.0 & 142.4 & 131.7 & 0.8 & 0.8 & 0.9 & 1.1 & 1.1 & 1.2 & 1.1 & 1.1 & 1.0 & 1.0 & 0.9 \\
\hline & & 10 & & & & & & & & $\begin{array}{r}313.5 \\
17.1\end{array}$ & 370.4 & - & - & - & - & - & - & - & - & 1.6 & 2.1 & 2.6 \\
\hline Nonreside & 145.3 & 204.2 & 260.0 & 343.1 & 372.8 & 401.7 & 427.0 & 440.8 & 454.3 & 471.7 & 498.6 & $\dagger$ & $\dagger$ & $\dagger$ & $\dagger$ & $\dagger$ & $\dagger$ & $\dagger$ & $\dagger$ & $\dagger$ & $\dagger$ & t \\
\hline Private & $2,344.6$ & $2,630.4$ & $2,973.9$ & $3,559.5$ & $4,465.6$ & $4,757.3$ & $5,130.7$ & $5,617.1$ & $5,873.3$ & 5,883.9 & 5,762.5 & 100.0 & 100.0 & 100.0 & 100.0 & 100.0 & 100.0 & 100.0 & 100.0 & 100.0 & 100.0 & 100.0 \\
\hline & & & & & & & & 6.2 & & & & & & | & 74.1 & & & & & & & \\
\hline ethnicities ......... & 289.6 & 352.7 & 505.5 & 875.2 & $1,276.4$ & $1,418.6$ & $1,625.9$ & $1,876.9$ & 6 & 1 & & 12 & 13 & 17 & & 30.0 & & & & & & \\
\hline & 201.8 & 230.7 & 270.6 & 411.1 & 634.2 & & & 982.7 & .1 & 054.6 & .1 & 8.9 & 9.1 & 9.5 & 12.2 & 14.9 & 15.8 & 16.9 & 18.3 & 18 & 18.8 & 18.7 \\
\hline & 47.0 & 65.6 & 111.0 & 232.5 & 356.4 & 390.7 & 440.5 & 529.0 & 584.1 & 614.3 & 613.6 & 2.1 & 2.6 & 3.9 & 6.9 & 8.4 & 8.6 & 9.0 & 9.8 & 10 & 10.9 & 11.2 \\
\hline & 32.2 & 46.7 & 111.5 & 207.7 & 252.4 & 275.4 & 319.9 & 319.1 & & 324.2 & 316.7 & 1.4 & 1.8 & 3.9 & 6.2 & 5.9 & 6.1 & 6.5 & 5.9 & & 5.8 & 5.8 \\
\hline & the. & . & 117.0 & . & LVL. & 210.7 & 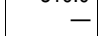 & | & & 301.2 & & 1.7 & 1.0 & 0.0 & 0.4 & 0.0 & 0.1 & 0.0 & 0.0 & & 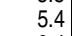 & 5.4 \\
\hline & - & - & - & - & - & - & - & - & 20.0 & 22.9 & 22.2 & - & - & - & - & - & - & - & - & & 4 & J. \\
\hline Native ..... & 8.6 & 9.7 & 12.4 & 23.9 & 33.3 & 36.7 & 40.3 & 46.1 & 45.4 & 43.6 & 41.2 & 0.4 & 0.4 & 0.4 & 0.7 & 0.8 & 0.8 & 0.8 & 0.9 & & 8 & $0.8 \quad-$ \\
\hline $\begin{array}{l}\text { Two } \\
\text { Nonre }\end{array}$ & 73.4 & 100.8 & 131.4 & 185.6 & 212.0 & 222.8 & & 244.0 & $\begin{array}{r}90.4 \\
255.3\end{array}$ & $\begin{array}{l}119.3 \\
268.7\end{array}$ & $\begin{array}{l}134.7 \\
284.3\end{array}$ & $t$ & $t$ & $t$ & $t$ & t & $\bar{t}$ & $t$ & $\bar{t}$ & T & $\begin{array}{r}2.1 \\
t\end{array}$ & 2.5 \\
\hline 4-year, & 7106.5 & & & & & $11630 ?$ & 121314 & 129063 & & & 12,790 & 1000 & 1000 & & & & & & & & & \\
\hline s & $\frac{T, 100.5}{5}$ & 7,565.4 & 778.6 &, 363.9 & 10,999.4 & 11,630.2 & 12,131.4 & $12,906.3$ & $13,335.3$ & $13,494.1$ & $13,478.8$ & 100.0 & 100.0 & 100.0 & 100.0 & 100.0 & 100.0 & 100.0 & 100.0 & 100.0 & 100.0 & 100.0 \\
\hline & $\begin{array}{r}5,999.0 \\
9310\end{array}$ & 6,274.5 & \begin{tabular}{|c|c}
$6,768.1$ \\
1
\end{tabular} & 58.0 & 9 & $7,781.0$ & 1 & $8,357.4$ & & & & 86 & 85 & 82 & 74 & 71 & 70 & & 67 & 66 & 64 & 63.7 \\
\hline , & $\begin{array}{l}931.0 \\
603.7\end{array}$ & $\begin{array}{r}1,049.9 \\
634\end{array}$ & \begin{tabular}{|r|r|}
$1,486.1$ \\
722
\end{tabular} & $\begin{array}{r}2,266.1 \\
995\end{array}$ & $\begin{array}{l}3,009.5 \\
13134\end{array}$ & 5 & & $3,964.4$ & & & & 87 & $\begin{array}{r}14.3 \\
87\end{array}$ & 88 & 112 & 125 & 130 & $\begin{array}{l}31.0 \\
13.5\end{array}$ & 3 & & & \\
\hline & 17 & 21 & $\begin{array}{r}\quad \begin{array}{r}2<2.0 \\
358.2\end{array} \\
\end{array}$ & $\begin{array}{l}617.9 \\
617.9\end{array}$ & $\begin{array}{l}1,400.5 \\
900.5\end{array}$ & $\begin{array}{l}1,441.1 \\
1,008.7\end{array}$ & $\begin{array}{l}1,0003.0 \\
1,092.2\end{array}$ & $\begin{array}{l}1,237.7 \\
1.0\end{array}$ & 1 & & 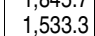 & $\begin{array}{l}0.1 \\
2.5\end{array}$ & $\begin{array}{l}.1 .1 \\
3.0\end{array}$ & $\begin{array}{l}0.0 \\
4.3\end{array}$ & $\begin{array}{r}6.2 \\
6.9\end{array}$ & $\begin{array}{r}7.0 \\
8.6\end{array}$ & 9. & 9. & & & 11 & 2.0 \\
\hline Asi & 118.7 & 162.1 & 357.2 & 576.3 & 700.0 & 761.5 & 823.4 & 842.0 & & & & 1.7 & 2.2 & 4.3 & 6.5 & 6.7 & 6.9 & 1.11 & 6.8 & & & 6.5 \\
\hline & & & & & & & & & & & & & & & & & & & & & 2 & 6.2 \\
\hline & - & - & - & - & - & - & - & - & & 38.6 & & - & - & - & - & - & - & - & - & & 0.3 & 0.6 \\
\hline ra Native..... & 35.0 & 36.9 & 47.9 & 76.5 & 95.6 & 108.6 & 107.8 & 117.7 & 109.0 & 105.1 & 98.0 & 0.5 & 0.5 & 0.6 & 0.9 & 0.9 & 1.0 & 0.9 & 1.0 & & 正 & 08 \\
\hline & & & & & 931 & & & & & & & + & & & & & & & & & 2.1 & 2.6 \\
\hline & 170.5 & 240.9 & $3<4.3$ & 439.1 & 493.1 & 528.7 & 555.9 & 584.6 & & & & $\uparrow$ & $\uparrow$ & $\top$ & $\dagger$ & $\top$ & $\uparrow$ & $\uparrow$ & $\dagger$ & $\dagger$ & $\dagger$ & $\dagger$ \\
\hline Pul & $4,892.9$ & $5,127.6$ & $5,848.2$ & $6,055.4$ & 6 & .7 & & 9.2 & & & & 100 & 100.0 & 10 & 100.0 & 100.0 & & 10 & & 10 & 10 & \\
\hline & & $4,243.0$ & 4, & 4, & 1 & & & 7.8 & & & & 86 & & 81 & 74 & 71. & & & & & & \\
\hline Tota & 666.7 & 740.8 & $1,046.2$ & $1,486.4$ & $1,876.9$ & $2,045.3$ & $2,128.2$ & $2,307.6$ & 2,4 & $2,640.8$ & 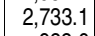 & 13.9 & 14.9 & 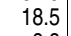 & & 28. & 29 . & & & & & \\
\hline 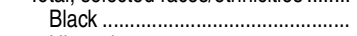 & 4 & & 495 & 627.8 & 754.0 & 80 & & 896.7 & & & & 10 & 8 & 8 & & 2 & 11.7 & & & & & \\
\hline & 129.3 & 156.4 & 262.5 & 420.0 & 595.6 & 668.6 & 709.9 & 794.1 & & & & 2.7 & 5 & 4 & 7 & g. & 9 & & & & & .1 \\
\hline Asi & 87.5 & 117.2 & 250.6 & 381.3 & 460.1 & 498.5 & 518.3 & 540.1 & & & & 1.8 & 2.4 & 4.4 & 6.6 & 7.0 & 7.3 & 7. & 3 & 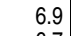 & $y$ & 7.0 \\
\hline & & & & & & & & & & 512.5 & & & & & & & $\cdots$ & - & & 7 & & 6.7 \\
\hline & - & - & - & - & - & - & - & - & 18.1 & & 19.0 & - & - & - & - & - & - & - & - &.$<$ & 2 & 0.2 \\
\hline a Native & 28.2 & 29.0 & 38.0 & 57.2 & 67.2 & 76.5 & 72.6 & 76.7 & son & 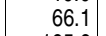 & 61.3 & 0.6 & 0.6 & 0.7 & 1.0 & 1.0 & 1.1 & 1.0 & 1.0 & & & 0.8 \\
\hline & & & & & & & & & & & & & & & & & & & & & 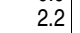 & .7 \\
\hline Nonresident alien...... & 106.0 & 143.8 & 196.4 & 257.8 & 282.6 & 307.8 & 324.4 & 343.7 & 357.8 & 379.2 & 407.3 & 1 & $\dagger$ & & $\dagger$ & $\dagger$ & $\dagger$ & 11 & 11 & & $\dagger$ & $\dagger$ \\
\hline
\end{tabular}

See notes at end of table. 


\begin{tabular}{|c|c|c|c|c|c|c|c|c|c|c|c|c|c|c|c|c|c|c|c|c|c|c|}
\hline \multirow{2}{*}{$\begin{array}{l}\text { Level and control of institution } \\
\text { and race/ethnicity of student }\end{array}$} & \multicolumn{11}{|c|}{ Fall enrollment (in thousands) } & \multicolumn{11}{|c|}{ Percentage distribution of U.S. residents } \\
\hline & 1976 & 1980 & 1990 & 2000 & 2005 & 2007 & 2008 & 2009 & 2010 & 2011 & 2012 & 1976 & 1980 & 1990 & 2000 & 2005 & 2007 & 2008 & 2009 & 2010 & 2011 & 2012 \\
\hline 1 & 2 & 3 & 4 & 5 & 6 & 7 & & & 10 & 11 & 12 & 13 & 17 & 15 & 10 & 17 & 18 & 19 & 20 & 21 & 22 & 23 \\
\hline 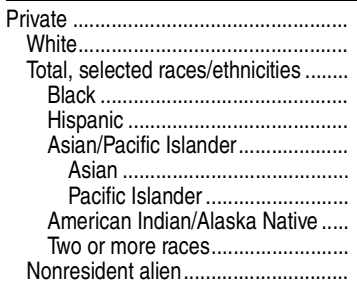 & $\begin{array}{r}2,213.6 \\
1,878.8 \\
264.3 \\
182.0 \\
44.3 \\
31.2 \\
- \\
- \\
6.8 \\
70.5\end{array}$ & $\begin{array}{r}2,437.8 \\
2,031.5 \\
309.2 \\
196.1 \\
60.2 \\
44.9 \\
\overline{-} \\
7.9 \\
\overline{-} \\
97.1\end{array}$ & $\begin{array}{r}2,730.3 \\
2,162.5 \\
439.8 \\
227.7 \\
95.7 \\
106.6 \\
- \\
\overline{9} .9 \\
\\
127.9\end{array}$ & $\begin{array}{r}3,308.5 \\
2,346.9 \\
779.7 \\
367.6 \\
197.9 \\
195.0 \\
- \\
\overline{-} \\
19.3 \\
181 . \overline{9}\end{array}$ & $\begin{array}{r}4,161.8 \\
2,818.8 \\
1,132.5 \\
559.4 \\
304.9 \\
239.8 \\
- \\
\overline{-} \\
28.4 \\
210 . \overline{4}\end{array}$ & $\begin{array}{r}4,463.5 \\
2,967.5 \\
1,275.3 \\
640.0 \\
340.1 \\
263.1 \\
\overline{-} \\
32.1 \\
220.8\end{array}$ & $\begin{array}{r}4,799.6 \\
3,107.9 \\
1,460.2 \\
737.6 \\
382.3 \\
305.1 \\
- \\
- \\
35.2 \\
\overline{-} \\
231 . \overline{5}\end{array}$ & $\begin{array}{r}5,197.1 \\
3,299.5 \\
1,656.7 \\
870.3 \\
443.6 \\
301.8 \\
- \\
41.0 \\
240.8\end{array}$ & $\begin{array}{r}r, 410.5 \\
, 327.7 \\
1,831.6 \\
928.4 \\
485.9 \\
295.5 \\
277.7 \\
17.8 \\
39.5 \\
82.4 \\
251.2\end{array}$ & $\begin{aligned}, 446.4 \\
, 279.3 \\
, 901.8 \\
939.0 \\
507.8 \\
306.3 \\
286.6 \\
19.7 \\
39.0 \\
109.7 \\
265.4\end{aligned}$ & \begin{tabular}{rl|}
, 386.2 & \\
$3,191.9$ & $1,912.3$ \\
922.1 & \\
525.5 & \\
300.3 & 280.6 \\
19.8 & 36.7 \\
126.7 & \\
281.9 &
\end{tabular} & $\begin{array}{r}100.0 \\
87.7 \\
12.3 \\
8.5 \\
2.1 \\
1.5 \\
- \\
0.3 \\
\\
\dagger\end{array}$ & $\begin{array}{r}100.0 \\
86.8 \\
13.2 \\
8.4 \\
2.6 \\
1.9 \\
- \\
- \\
0.3 \\
- \\
\end{array}$ & $\begin{array}{r}100.0 \\
83.1 \\
16.9 \\
8.7 \\
3.7 \\
4.1 \\
- \\
- \\
0.4 \\
\end{array}$ & $\begin{array}{r}100.0 \\
75.1 \\
24.9 \\
11.8 \\
6.3 \\
6.2 \\
- \\
\overline{0.6} \\
\bar{\dagger}\end{array}$ & $\begin{array}{r}100.0 \\
71.3 \\
28.7 \\
14.2 \\
7.7 \\
6.1 \\
- \\
0.7 \\
\dagger \\
\end{array}$ & $\begin{array}{r}100.0 \\
69.9 \\
30.1 \\
15.1 \\
8.0 \\
6.2 \\
- \\
\overline{-} \\
.8 \\
\end{array}$ & $\begin{array}{r}100.0 \\
68.0 \\
32.0 \\
16.1 \\
8.4 \\
6.7 \\
- \\
\overline{0.8} \\
\bar{\dagger}\end{array}$ & $\begin{array}{r}100.0 \\
66.6 \\
33.4 \\
17.6 \\
9.0 \\
6.1 \\
- \\
\overline{0.8} \\
\dagger \\
\end{array}$ & $\begin{array}{r}100.0 \\
64.5 \\
35.5 \\
18.0 \\
9.4 \\
5.7 \\
5.4 \\
0.3 \\
0.8 \\
1.6 \\
\dagger\end{array}$ & $\begin{aligned} 100.0 \\
63.3 \\
36.7 \\
18.1 \\
9.8 \\
5.9 \\
5.5 \\
0.4 \\
0.8 \\
2.1 \\
\dagger\end{aligned}$ & $\begin{array}{r}100.0 \\
62.5 \\
37.5 \\
18.1 \\
10.3 \\
5.9 \\
5.5 \\
0.4 \\
0.7 \\
2.5\end{array}$ \\
\hline 2-year, total .... & $3,879.1$ & $4,521.4$ & $5,240.1$ & $5,948.4$ & 6,488.1 & $6,617.9$ & 6,971.4 & ,521.4 & 680.9 & $7,500.0$ & $7,164.0$ & 100.0 & 100.0 & 100.0 & 100.0 & 100.0 & 100.0 & 100.0 & 100.0 & 100.0 & 100.0 & 100.0 \\
\hline 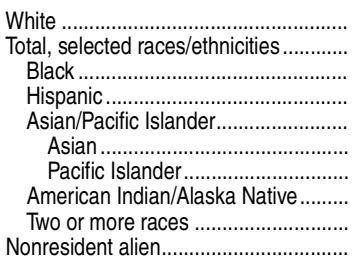 & \begin{tabular}{r|}
$3,077.1$ \\
759.8 \\
429.3 \\
210.2 \\
79.2 \\
- \\
$\overline{-}$ \\
41.2 \\
$-\overline{-}$ \\
42.2
\end{tabular} & $\begin{array}{r}3,558.5 \\
898.9 \\
472.5 \\
255.1 \\
124.3 \\
- \\
47.0 \\
\overline{-} \\
64.1\end{array}$ & $\begin{array}{r}3,954.3 \\
1,218.6 \\
524.3 \\
424.2 \\
215.2 \\
- \\
54.9 \\
- \\
67.1\end{array}$ & $\begin{array}{r}3,804.1 \\
2,055.4 \\
734.9 \\
843.9 \\
401.9 \\
- \\
74.7 \\
- \\
89.0\end{array}$ & $\begin{array}{r}3,998.6 \\
2,397.7 \\
901.1 \\
981.5 \\
434.4 \\
- \\
80.7 \\
- \\
91.8\end{array}$ & $\begin{array}{r}3,975.2 \\
2,546.9 \\
941.7 \\
1,067.4 \\
456.4 \\
- \\
81.4 \\
- \\
95.8\end{array}$ & $\begin{array}{r}4,101.6 \\
2,765.0 \\
1,019.5 \\
1,180.7 \\
479.4 \\
- \\
- \\
85.5 \\
- \\
104.7\end{array}$ & $\begin{array}{r}4,373.4 \\
3,047.8 \\
1,152.8 \\
1,309.0 \\
495.7 \\
- \\
- \\
90.3 \\
100.2\end{array}$ & \begin{tabular}{r|}
$4,324.4$ \\
$3,255.9$ \\
$1,197.7$ \\
$1,386.4$ \\
463.8 \\
435.7 \\
28.1 \\
87.4 \\
120.5 \\
100.6
\end{tabular} & $\begin{array}{r}4,087.2 \\
3,316.9 \\
1,197.1 \\
1,436.6 \\
444.7 \\
417.4 \\
27.3 \\
81.0 \\
157.6 \\
95.9\end{array}$ & \begin{tabular}{r||}
$3,837.0$ \\
$3,233.3$ \\
$1,116.4$ \\
$1,446.1$ \\
423.7 \\
398.9 \\
24.8 \\
74.9 \\
172.1 \\
93.6
\end{tabular} & $\begin{array}{r}80.2 \\
19.8 \\
11.2 \\
5.5 \\
2.1 \\
- \\
\overline{7} \\
1.1 \\
\bar{\dagger}\end{array}$ & $\begin{array}{r}79.8 \\
20.2 \\
10.6 \\
5.7 \\
2.8 \\
- \\
\overline{1.1}\end{array}$ & $\begin{array}{r}10.1 \\
8.2 \\
4.2 \\
- \\
\overline{1.1} \\
\bar{\dagger}\end{array}$ & $\begin{array}{r}64.9 \\
35.1 \\
12.5 \\
14.4 \\
6.9 \\
- \\
\overline{1} \\
\overline{1.3} \\
\dagger\end{array}$ & $\begin{array}{r}62.5 \\
37.5 \\
14.1 \\
15.3 \\
6.8 \\
- \\
\overline{1} \\
- \\
t\end{array}$ & $\begin{array}{r}60.9 \\
39.1 \\
14.4 \\
16.4 \\
7.0 \\
- \\
1.2 \\
\dagger\end{array}$ & $\begin{array}{r}59.7 \\
40.3 \\
14.8 \\
17.2 \\
7.0 \\
- \\
\overline{1} \\
- \\
\dagger\end{array}$ & $\begin{array}{r}58.9 \\
41.1 \\
15.5 \\
17.6 \\
6.7 \\
- \\
\overline{1.2} \\
\bar{t}\end{array}$ & $\begin{array}{r}15.8 \\
18.3 \\
6.1 \\
5.7 \\
0.4 \\
1.2 \\
1.6 \\
\dagger\end{array}$ & $\begin{array}{r}16.2 \\
19.4 \\
6.0 \\
5.6 \\
0.4 \\
1.1 \\
2.1 \\
\dagger\end{array}$ & $\begin{array}{r}54.3 \\
45.7 \\
15.8 \\
20.5 \\
6.0 \\
5.6 \\
0.4 \\
1.1 \\
2.4\end{array}$ \\
\hline 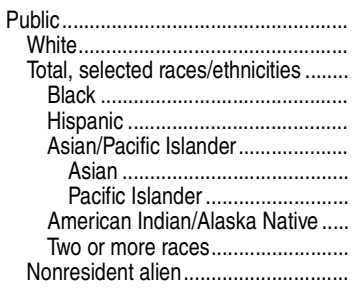 & $\begin{array}{r}3,748.1 \\
2,974.3 \\
734.5 \\
409.5 \\
207.5 \\
78.2 \\
- \\
-\overline{-} \\
39.3 \\
39.2\end{array}$ & $\begin{array}{r}4,328.8 \\
3,413.1 \\
855.4 \\
437.9 \\
249.8 \\
122.5 \\
- \\
\overline{-} \\
45.2 \\
60.3\end{array}$ & $\begin{array}{r}4,996.5 \\
3,779.8 \\
1,153.0 \\
481.4 \\
408.9 \\
210.3 \\
- \\
- \\
52.4 \\
-\overline{63.6}\end{array}$ & $\begin{array}{r}5,697.4 \\
3,652.2 \\
1,959.9 \\
691.4 \\
809.2 \\
389.2 \\
- \\
70.1 \\
\overline{-} \\
85.2\end{array}$ & $\begin{array}{r}6,184.2 \\
3,840.1 \\
2,253.9 \\
826.3 \\
930.0 \\
421.8 \\
- \\
\overline{7} \\
75.7 \\
-\overline{-} \\
90.2\end{array}$ & $\begin{array}{r}6,324.1 \\
3,826.7 \\
2,403.6 \\
865.9 \\
1,016.8 \\
444.1 \\
- \\
76.8 \\
\overline{-} \\
93.9\end{array}$ & $\begin{array}{r}6,640.3 \\
3,938.5 \\
2,599.3 \\
931.9 \\
1,122.5 \\
464.5 \\
- \\
-\overline{-} \\
80.4 \\
-\overline{-} \\
102.6\end{array}$ & $\begin{array}{r}7,101.4 \\
4,176.8 \\
2,827.6 \\
1,040.4 \\
1,223.6 \\
478.4 \\
- \\
- \\
85.1 \\
-\overline{9} \\
97.1\end{array}$ & $\begin{array}{r}7,218.0 \\
4,116.7 \\
3,004.8 \\
1,076.0 \\
1,288.2 \\
446.7 \\
420.8 \\
25.9 \\
81.5 \\
112.5 \\
96.5\end{array}$ & $\begin{array}{r}7,062.5 \\
3,907.4 \\
, 062.6 \\
1,081.4 \\
1,330.1 \\
426.8 \\
402.8 \\
24.0 \\
76.3 \\
147.9 \\
92.5 \\
9\end{array}$ & \begin{tabular}{r||r||}
$3,787.7$ & \\
$3,082.0$ & \\
, 014.4 & \\
, 358.1 & \\
407.4 & \\
385.0 & \\
22.4 & \\
70.4 & \\
164.1 & \\
91.2 &
\end{tabular} & $\begin{array}{r}100.0 \\
80.2 \\
19.8 \\
11.0 \\
5.6 \\
2.1 \\
- \\
\overline{1.1}\end{array}$ & $\begin{array}{r}100.0 \\
80.0 \\
20.0 \\
10.3 \\
5.9 \\
2.9 \\
\overline{-} \\
\overline{1.1}\end{array}$ & $\begin{array}{r}100.0 \\
76.6 \\
23.4 \\
9.8 \\
8.3 \\
4.3 \\
- \\
\overline{1.1}\end{array}$ & $\begin{array}{r}100.0 \\
65.1 \\
34.9 \\
12.3 \\
14.4 \\
6.9 \\
- \\
\overline{1} \\
1.2\end{array}$ & $\begin{array}{r}100.0 \\
63.0 \\
37.0 \\
13.6 \\
15.3 \\
6.9 \\
- \\
\overline{1} .2\end{array}$ & $\begin{array}{r}100.0 \\
61.4 \\
38.6 \\
13.9 \\
16.3 \\
7.1 \\
- \\
\overline{1} \\
\bar{\dagger}\end{array}$ & $\begin{array}{r}100.0 \\
60.2 \\
39.8 \\
14.3 \\
17.2 \\
7.1 \\
- \\
\overline{1} \\
\overline{1.2} \\
\bar{\dagger}\end{array}$ & $\begin{array}{r}100.0 \\
59.6 \\
40.4 \\
14.9 \\
17.5 \\
6.8 \\
- \\
\overline{1.2} \\
\bar{\dagger}\end{array}$ & $\begin{array}{r}100.0 \\
57.8 \\
42.2 \\
15.1 \\
18.1 \\
6.3 \\
5.9 \\
0.4 \\
1.1 \\
1.6 \\
\dagger\end{array}$ & $\begin{array}{r}100.0 \\
56.1 \\
43.9 \\
15.5 \\
19.1 \\
6.1 \\
5.8 \\
0.3 \\
1.1 \\
2.1 \\
\dagger\end{array}$ & $\begin{array}{r}100.0 \\
55.0 \\
45.0 \\
15.1 \\
20.3 \\
6.1 \\
5.7 \\
0.3 \\
1.1 \\
2.5\end{array}$ \\
\hline 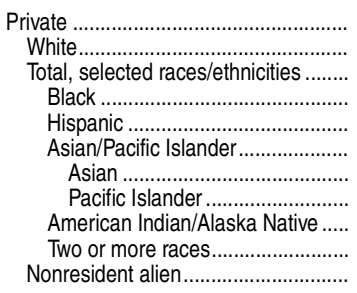 & $\begin{array}{r}131.0 \\
102.8 \\
25.3 \\
19.8 \\
2.6 \\
0.9 \\
- \\
\overline{1.8} \\
\overline{3.0}\end{array}$ & $\begin{array}{r}192.6 \\
145.4 \\
43.5 \\
34.6 \\
5.3 \\
1.8 \\
- \\
- \\
1.8 \\
3.7\end{array}$ & $\begin{array}{r}65.6 \\
42.9 \\
15.3 \\
4.9 \\
- \\
2.5 \\
3.5\end{array}$ & $\begin{array}{r}251.0 \\
151.8 \\
95.5 \\
43.5 \\
34.7 \\
12.7 \\
- \\
\\
4.5 \\
- \\
3.8\end{array}$ & $\begin{array}{r}303.8 \\
158.4 \\
143.8 \\
74.8 \\
51.4 \\
12.6 \\
- \\
\overline{5.0} \\
\overline{1.6}\end{array}$ & $\begin{array}{r}293.8 \\
148.5 \\
143.3 \\
75.7 \\
50.6 \\
12.3 \\
- \\
\overline{4.6} \\
\overline{2.0}\end{array}$ & \begin{tabular}{r|}
331.0 \\
163.2 \\
165.7 \\
87.7 \\
58.2 \\
14.8 \\
- \\
\\
5.0 \\
2.1
\end{tabular} & $\begin{array}{r}420.0 \\
196.6 \\
220.2 \\
112.4 \\
85.4 \\
17.3 \\
- \\
\overline{5.1} \\
\overline{3} \\
\end{array}$ & \begin{tabular}{r|}
251.0 \\
121.8 \\
98.2 \\
17.1 \\
14.9 \\
2.2 \\
5.9 \\
8.0 \\
4.1
\end{tabular} & $\begin{array}{r}437.5 \\
179.8 \\
254.3 \\
115.6 \\
106.5 \\
17.9 \\
14.6 \\
3.3 \\
4.7 \\
9.6 \\
3.4\end{array}$ & $\begin{array}{r}16.3 \\
13.9 \\
2.4 \\
4.5 \\
8.0 \\
2.4\end{array}$ & $\begin{array}{r}100.0 \\
80.3 \\
19.7 \\
15.5 \\
2.1 \\
0.7 \\
- \\
\overline{-} \\
1.4 \\
\dagger\end{array}$ & $\begin{array}{r}100.0 \\
77.0 \\
23.0 \\
18.3 \\
2.8 \\
1.0 \\
- \\
\overline{1.0} \\
\bar{\dagger}\end{array}$ & $\begin{array}{r}100.0 \\
72.7 \\
27.3 \\
17.9 \\
6.4 \\
2.0 \\
- \\
\overline{1.1} \\
\bar{\dagger}\end{array}$ & $\begin{array}{r}100.0 \\
61.4 \\
38.6 \\
17.6 \\
14.0 \\
5.1 \\
- \\
\overline{1} \\
\overline{1.8} \\
\bar{\dagger}\end{array}$ & $\begin{array}{r}100.0 \\
52.4 \\
47.6 \\
24.7 \\
17.0 \\
4.2 \\
- \\
\overline{1} \\
1.6 \\
\bar{\dagger}\end{array}$ & $\begin{array}{r}100.0 \\
50.9 \\
49.1 \\
26.0 \\
17.3 \\
4.2 \\
- \\
\overline{1.6} \\
\bar{t}\end{array}$ & $\begin{array}{r}100.0 \\
49.6 \\
50.4 \\
26.7 \\
17.7 \\
4.5 \\
- \\
\overline{1} .5 \\
\bar{\dagger}\end{array}$ & $\begin{array}{r}100.0 \\
47.2 \\
52.8 \\
27.0 \\
20.5 \\
4.2 \\
- \\
\overline{1} \\
1.2 \\
\bar{\dagger}\end{array}$ & \begin{tabular}{r|}
45.0 \\
54.7 \\
26.5 \\
21.4 \\
3.7 \\
3.3 \\
0.5 \\
1.3 \\
1.8 \\
$\dagger$
\end{tabular} & $\begin{array}{r}24.5 \\
4.1 \\
3.4 \\
0.8 \\
1.1 \\
2.2 \\
\dagger\end{array}$ & $\begin{array}{r}100.0 \\
41.4 \\
58.6 \\
27.3 \\
23.5 \\
4.4 \\
3.7 \\
0.6 \\
1.2 \\
2.1\end{array}$ \\
\hline
\end{tabular}

-Not available.

†Not applicable.

NOTE: Race categories exclude persons of Hispanic ethnicity. Because of underreporting and nonreporting of racial/ethnic data, some igures a slghty lower than corresponding data in olher tables. Data through tign are tor insthilons of higher degrees and participate in Title IV federal financial aid programs. The degree-granting classification is very similar to the ear- lier higher education classification, but it includes more 2-year colleges and excludes a few higher education institutions that

did not grant degrees. Detail may not sum to totals because of rounding.
SOURCE: U.S. Department of Education, National Center for Education Statistics, Higher Education General Information Data System (IPEDS) "Fall Enrollment Survey" (IPEDS-EF-90): and IPEDS Spring 2001 through Spring 2013, Enrollment component. (This table was prepared November 2013.) 
Table 306.30. Fall enrollment of U.S. residents in degree-granting postsecondary institutions, by race/ethnicity: 1998 through 2023

\begin{tabular}{|c|c|c|c|c|c|c|c|c|c|c|c|c|c|c|c|c|c|c|}
\hline \multirow[b]{3}{*}{ Year } & \multicolumn{9}{|c|}{ Enrollment (in thousands) } & \multicolumn{9}{|c|}{ Percentage distribution } \\
\hline & \multirow[b]{2}{*}{ Total } & \multirow[b]{2}{*}{ White } & \multirow[b]{2}{*}{ Black } & \multirow[b]{2}{*}{ Hispanic } & \multicolumn{3}{|c|}{ Asian/Pacific Islander } & \multirow{2}{*}{$\begin{array}{r}\text { American } \\
\text { Indian/ } \\
\text { Alaska } \\
\text { Native }\end{array}$} & \multirow{2}{*}{$\begin{array}{r}\text { Two or } \\
\text { more } \\
\text { races }\end{array}$} & \multirow[b]{2}{*}{ Total } & \multirow[b]{2}{*}{ White } & \multirow[b]{2}{*}{ Black } & \multirow[b]{2}{*}{ Hispanic } & \multicolumn{3}{|c|}{ Asian/Pacific Islander } & \multirow{2}{*}{$\begin{array}{r}\text { American } \\
\text { Indian/ } \\
\text { Alaska } \\
\text { Native }\end{array}$} & \multirow{2}{*}{$\begin{array}{l}\text { Two or } \\
\text { more } \\
\text { races }\end{array}$} \\
\hline & & & & & Total & Asian & $\begin{array}{r}\text { Pacific } \\
\text { Islander }\end{array}$ & & & & & & & Total & Asian & $\begin{array}{r}\text { Pacific } \\
\text { Islander }\end{array}$ & & \\
\hline 1 & 2 & 3 & 4 & 5 & 6 & 7 & 8 & 9 & 10 & 11 & 12 & 13 & 14 & 15 & 16 & 17 & 18 & 19 \\
\hline 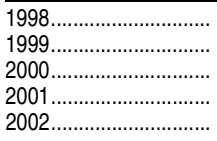 & $\begin{array}{l}14,063 \\
14,361 \\
14,784 \\
15,363 \\
16,021\end{array}$ & $\begin{array}{l}10,179 \\
10,329 \\
10,462 \\
10,775 \\
11,140\end{array}$ & $\begin{array}{l}1,583 \\
1,649 \\
1,730 \\
1,850 \\
1,979\end{array}$ & $\begin{array}{l}1,257 \\
1,324 \\
1,462 \\
1,561 \\
1,662\end{array}$ & $\begin{array}{r}900 \\
914 \\
978 \\
1,019 \\
1,074\end{array}$ & \begin{tabular}{l|}
- \\
- \\
- \\
- \\
-
\end{tabular} & \begin{tabular}{l|}
- \\
- \\
- \\
- \\
-
\end{tabular} & $\begin{array}{l}144 \\
146 \\
151 \\
158 \\
166\end{array}$ & $\begin{array}{l}- \\
- \\
- \\
-\end{array}$ & $\begin{array}{l}100.0 \\
100.0 \\
100.0 \\
100.0 \\
100.0\end{array}$ & $\begin{array}{l}72.4 \\
71.9 \\
70.8 \\
70.1 \\
69.5\end{array}$ & $\begin{array}{l}11.3 \\
11.5 \\
11.7 \\
12.0 \\
12.4\end{array}$ & $\begin{array}{r}8.9 \\
9.2 \\
9.9 \\
10.2 \\
10.4\end{array}$ & $\begin{array}{l}6.4 \\
6.4 \\
6.6 \\
6.6 \\
6.7\end{array}$ & $\begin{array}{l}- \\
- \\
- \\
-\end{array}$ & $\begin{array}{l}- \\
- \\
- \\
- \\
-\end{array}$ & $\begin{array}{l}1.0 \\
1.0 \\
1.0 \\
1.0 \\
1.0\end{array}$ & $\begin{array}{l}- \\
- \\
- \\
-\end{array}$ \\
\hline 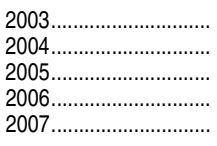 & $\begin{array}{l}16,314 \\
16,682 \\
16,903 \\
17,163 \\
17,624\end{array}$ & $\begin{array}{l}11,281 \\
11,423 \\
11,495 \\
11,572 \\
11,756\end{array}$ & $\begin{array}{l}2,068 \\
2,165 \\
2,215 \\
2,280 \\
2,383\end{array}$ & $\begin{array}{l}1,716 \\
1,810 \\
1,882 \\
1,964 \\
2,076\end{array}$ & $\begin{array}{l}1,076 \\
1,109 \\
1,134 \\
1,165 \\
1,218\end{array}$ & $\begin{array}{l}- \\
- \\
- \\
-\end{array}$ & $\begin{array}{l}- \\
- \\
- \\
- \\
-\end{array}$ & $\begin{array}{l}173 \\
176 \\
176 \\
181 \\
190\end{array}$ & $\begin{array}{l}- \\
- \\
- \\
- \\
-\end{array}$ & $\begin{array}{l}100.0 \\
100.0 \\
100.0 \\
100.0 \\
100.0\end{array}$ & $\begin{array}{l}69.1 \\
68.5 \\
68.0 \\
67.4 \\
66.7\end{array}$ & $\begin{array}{l}12.7 \\
13.0 \\
13.1 \\
13.3 \\
13.5\end{array}$ & $\begin{array}{l}10.5 \\
10.8 \\
11.1 \\
11.4 \\
11.8\end{array}$ & $\begin{array}{l}6.6 \\
6.6 \\
6.7 \\
6.8 \\
6.9\end{array}$ & $\begin{array}{l}- \\
- \\
- \\
-\end{array}$ & $\begin{array}{l}- \\
- \\
- \\
- \\
-\end{array}$ & $\begin{array}{l}1.1 \\
1.1 \\
1.0 \\
1.1 \\
1.1\end{array}$ & $\begin{array}{l}- \\
- \\
- \\
-\end{array}$ \\
\hline 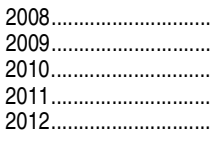 & $\begin{array}{l}18,442 \\
19,743 \\
20,307 \\
20,254 \\
19,860\end{array}$ & $\begin{array}{l}12,089 \\
12,731 \\
12,723 \\
12,394 \\
11,981\end{array}$ & $\begin{array}{l}2,584 \\
2,920 \\
3,039 \\
3,068 \\
2,962\end{array}$ & $\begin{array}{l}2,273 \\
2,547 \\
2,741 \\
2,890 \\
2,979\end{array}$ & $\begin{array}{l}1,303 \\
1,338 \\
1,282 \\
1,282 \\
1,259\end{array}$ & $\begin{array}{r}- \\
\overline{-} \\
1,218 \\
1,217 \\
1,196\end{array}$ & $\begin{array}{l}- \\
- \\
64 \\
66 \\
64\end{array}$ & $\begin{array}{l}193 \\
208 \\
196 \\
186 \\
173\end{array}$ & $\begin{array}{r}- \\
- \\
325 \\
433 \\
505\end{array}$ & $\begin{array}{l}100.0 \\
100.0 \\
100.0 \\
100.0 \\
100.0\end{array}$ & $\begin{array}{l}65.5 \\
64.5 \\
62.7 \\
61.2 \\
60.3\end{array}$ & $\begin{array}{l}14.0 \\
14.8 \\
15.0 \\
15.1 \\
14.9\end{array}$ & $\begin{array}{l}12.3 \\
12.9 \\
13.5 \\
14.3 \\
15.0\end{array}$ & $\begin{array}{l}7.1 \\
6.8 \\
6.3 \\
6.3 \\
6.3\end{array}$ & $\begin{array}{l}- \\
6.0 \\
6.0 \\
6.0\end{array}$ & $\begin{array}{l}- \\
-\overline{0} \\
0.3 \\
0.3\end{array}$ & $\begin{array}{l}1.0 \\
1.1 \\
1.0 \\
0.9 \\
0.9\end{array}$ & $\begin{array}{l}- \\
- \\
1.6 \\
2.1 \\
2.5\end{array}$ \\
\hline $\begin{array}{l}2013^{1} \\
2014^{1} \\
2015^{1} \\
2016^{1} \\
2017^{1}\end{array}$ & $\begin{array}{l}19,806 \\
20,185 \\
20,408 \\
20,692 \\
21,015\end{array}$ & $\begin{array}{l}12,025 \\
12,145 \\
12,181 \\
12,254 \\
12,354\end{array}$ & $\begin{array}{l}2,887 \\
2,985 \\
3,073 \\
3,169 \\
3,268\end{array}$ & $\begin{array}{l}2,985 \\
3,116 \\
3,204 \\
3,301 \\
3,404\end{array}$ & $\begin{array}{l}1,236 \\
1,255 \\
1,261 \\
1,271 \\
1,284\end{array}$ & $\begin{array}{l}- \\
- \\
- \\
-\end{array}$ & $\begin{array}{l}- \\
- \\
- \\
- \\
-\end{array}$ & $\begin{array}{l}169 \\
170 \\
170 \\
171 \\
171\end{array}$ & $\begin{array}{l}504 \\
513 \\
519 \\
526 \\
534\end{array}$ & $\begin{array}{l}100.0 \\
100.0 \\
100.0 \\
100.0 \\
100.0\end{array}$ & $\begin{array}{l}60.7 \\
60.2 \\
59.7 \\
59.2 \\
58.8\end{array}$ & $\begin{array}{l}14.6 \\
14.8 \\
15.1 \\
15.3 \\
15.6\end{array}$ & $\begin{array}{l}15.1 \\
15.4 \\
15.7 \\
16.0 \\
16.2\end{array}$ & $\begin{array}{l}6.2 \\
6.2 \\
6.2 \\
6.1 \\
6.1\end{array}$ & $\begin{array}{l}- \\
- \\
- \\
-\end{array}$ & $\begin{array}{l}- \\
- \\
- \\
-\end{array}$ & $\begin{array}{l}0.9 \\
0.8 \\
0.8 \\
0.8 \\
0.8\end{array}$ & $\begin{array}{l}2.5 \\
2.5 \\
2.5 \\
2.5 \\
2.5\end{array}$ \\
\hline $\begin{array}{l}2018^{1} \\
2019^{1} \\
2020^{1} \\
2021^{1} \\
2022^{1} \\
2023^{1}\end{array}$ & $\begin{array}{l}21,261 \\
21,508 \\
21,752 \\
22,049 \\
22,357 \\
22,642\end{array}$ & $\begin{array}{l}12,421 \\
12,490 \\
12,551 \\
12,642 \\
12,740 \\
12,813\end{array}$ & $\begin{array}{l}3,342 \\
3,409 \\
3,477 \\
3,554 \\
3,629 \\
3,705\end{array}$ & $\begin{array}{l}3,493 \\
3,583 \\
3,675 \\
3,774 \\
3,877 \\
3,981\end{array}$ & $\begin{array}{l}1,294 \\
1,308 \\
1,323 \\
1,345 \\
1,369 \\
1,391\end{array}$ & $\begin{array}{l}- \\
- \\
- \\
- \\
-\end{array}$ & $\begin{array}{l}- \\
- \\
- \\
- \\
-\end{array}$ & $\begin{array}{l}171 \\
172 \\
172 \\
173 \\
174 \\
175\end{array}$ & $\begin{array}{l}541 \\
547 \\
553 \\
561 \\
569 \\
576\end{array}$ & $\begin{array}{l}100.0 \\
100.0 \\
100.0 \\
100.0 \\
100.0 \\
100.0\end{array}$ & $\begin{array}{l}58.4 \\
58.1 \\
57.7 \\
57.3 \\
57.0 \\
56.6\end{array}$ & $\begin{array}{l}15.7 \\
15.8 \\
16.0 \\
16.1 \\
16.2 \\
16.4\end{array}$ & $\begin{array}{l}16.4 \\
16.7 \\
16.9 \\
17.1 \\
17.3 \\
17.6\end{array}$ & $\begin{array}{l}6.1 \\
6.1 \\
6.1 \\
6.1 \\
6.1 \\
6.1\end{array}$ & $\begin{array}{l}- \\
- \\
- \\
- \\
-\end{array}$ & $\begin{array}{l}- \\
- \\
- \\
- \\
-\end{array}$ & $\begin{array}{l}0.8 \\
0.8 \\
0.8 \\
0.8 \\
0.8 \\
0.8\end{array}$ & $\begin{array}{l}2.5 \\
2.5 \\
2.5 \\
2.5 \\
2.5 \\
2.5\end{array}$ \\
\hline
\end{tabular}

-Not available.

1 Projected.

NOTE: Race categories exclude persons of Hispanic ethnicity. Prior to 2010, institutions were not required to report separate data on Asians, Pacific Islanders, and students of two or more races. Detail may not sum to totals because of rounding.
SOURCE: U.S. Department of Education, National Center for Education Statistics, Integrated Postsecondary Education Data System (IPEDS), "Fall Enrollment Survey" (IPEDSEF:98-99); IPEDS Spring 2001 through Spring 2013, Enrollment component; and Enrollment in Degree-Granting Institutions by Race/Ethnicity Projection Model, 1980 through 2023. (This table was prepared May 2014.) 
Table 306.40. Fall enrollment of males and females and specific racial/ethnic groups in degree-granting postsecondary institutions, by control and level of institution and percentage of U.S. resident enrollment in the same racial/ethnic group: 2012

\begin{tabular}{|c|c|c|c|c|c|c|c|c|c|c|c|c|c|c|c|c|c|c|c|c|}
\hline \multirow[b]{3}{*}{$\begin{array}{l}\text { Sex, racial/ethnic group, } \\
\text { and percentage of U.S. } \\
\text { resident enrollment }\end{array}$} & \multirow[b]{3}{*}{$\begin{array}{r}\text { Total, all } \\
\text { institutions }\end{array}$} & \multicolumn{8}{|c|}{ Public institutions } & \multicolumn{8}{|c|}{ Nonprofit institutions } & \multicolumn{3}{|c|}{ For-profit institutions } \\
\hline & & \multirow[b]{2}{*}{ Total } & \multicolumn{6}{|c|}{ 4-year } & \multirow[b]{2}{*}{ 2-year } & \multirow[b]{2}{*}{ Total | } & \multicolumn{6}{|c|}{ 4-year } & \multirow[b]{2}{*}{ 2-year } & \multirow[b]{2}{*}{ Total } & \multirow[b]{2}{*}{ 4-year } & \multirow[b]{2}{*}{ 2-year } \\
\hline & & & \begin{tabular}{|l|} 
Research \\
university, \\
very high
\end{tabular} & $\begin{array}{r}\text { Research } \\
\text { university, } \\
\text { high }^{2} \\
\end{array}$ & $\begin{array}{l}\text { Doctorall } \\
\text { research }\end{array}$ & Master's $^{4}$ & $\begin{array}{r}\begin{array}{r}\text { Baccalau- } \\
\text { reate }\end{array} \\
\end{array}$ & $\begin{array}{c}\text { Special } \\
\text { focus }^{6}\end{array}$ & & & \begin{tabular}{|l|} 
Research \\
university, \\
very high
\end{tabular} & $\begin{array}{r}\text { Research } \\
\text { university, } \\
\text { high }^{2}\end{array}$ & $\begin{array}{l}\text { Doctorall } \\
\text { research }\end{array}$ & Master's $^{4}$ & $\begin{array}{r}\text { Baccalau- } \\
\text { reate }^{5}\end{array}$ & $\begin{array}{r}\text { Special } \\
\text { focus }^{6}\end{array}$ & & & & \\
\hline 1 & 2 & 3 & 4 & 5 & 6 & 7 & 8 & 9 & 10 & 11 & 12 & 13 & 14 & 15 & 16 & 17 & 18 & 19 & 20 & 21 \\
\hline $\begin{array}{l}\text { All institutions } \\
\text { Total enrollment .. }\end{array}$ & & & & & & & & & & & & & & & & & & & & \\
\hline \multicolumn{21}{|c|}{ 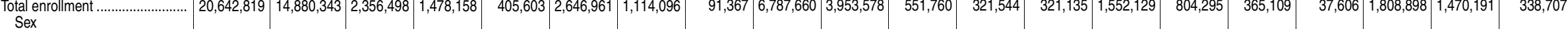 } \\
\hline $\begin{array}{l}\text { Male ........ } \\
\text { Female .... }\end{array}$ & $\begin{array}{r}8,919,087 \\
11,723,732\end{array}$ & $\begin{array}{l}6,581,299 \\
8,299,044\end{array}$ & $\left.\mid \begin{array}{l}1,161,849 \\
1,194,649\end{array}\right]$ & $\begin{array}{l}692,608 \\
785,550\end{array}$ & $\begin{array}{l}168,165 \\
237,438\end{array}$ & $\begin{array}{l}1,111,765 \\
1,535,196\end{array}$ & $\begin{array}{l}488,884 \\
625,212\end{array}$ & $\begin{array}{l}34,867 \\
56,500\end{array}$ & $\begin{array}{l}2,923,161 \\
3,864,499\end{array}$ & $\left|\begin{array}{l}1,680,744 \\
2,272,834\end{array}\right|$ & $\begin{array}{l}272,489 \\
279,271\end{array}$ & $\begin{array}{l}148,438 \\
173,106\end{array}$ & $\begin{array}{l}130,474 \\
190,661\end{array}$ & $\begin{array}{l}602,429 \\
949,700\end{array}$ & $\begin{array}{l}336,541 \\
467,754\end{array}$ & $\begin{array}{l}177,449 \\
187,660\end{array}$ & $\begin{array}{l}12,924 \\
24,682\end{array}$ & $\begin{array}{r}657,044 \\
1,151,854\end{array} \mid$ & $\begin{array}{l}548,425 \\
921,766\end{array}$ & $\begin{array}{l}108,619 \\
230,088\end{array}$ \\
\hline $\begin{array}{l}\text { Race/ethnicity } \\
\text { White................ }\end{array}$ & \begin{tabular}{|l|l|}
$11,981,143$ \\
\end{tabular} & 8.634 .283 & & 946.199 & 239868 & 1626342 & 630751 & 51070 & 3682040 & 2504216 & 70911 & 100105 & 195010 & 07090 & 507105 & (1 & & & & \\
\hline 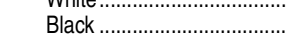 & $2,962,140$ & $1,937,002$ & {$\left[\begin{array}{r}1,40,095 \\
150,761\end{array}\right]$} & 149,831 & $\begin{array}{r}209,000 \\
97,670\end{array}$ & $\begin{array}{r}1,020,434 \\
346,336\end{array}$ & $\begin{array}{l}171,071 \\
171,151\end{array}$ & $\begin{array}{r}0,950 \\
6,950\end{array}$ & $\begin{array}{l}-3,002,049 \\
1,014,383\end{array}$ & $\begin{array}{r}2,540,216 \\
493,692\end{array}$ & $\begin{array}{r}284,111 \\
32,326\end{array}$ & $\begin{array}{r}198,125 \\
31,476\end{array}$ & $\begin{array}{r}885,016 \\
39,513\end{array}$ & $\left|\begin{array}{r}1,037,886 \\
213,302\end{array}\right|$ & $\begin{array}{l}547,185 \\
126,775\end{array}$ & $\begin{array}{r}233,251 \\
39,464\end{array}$ & $\begin{array}{l}18,042 \\
10,836\end{array}$ & $\begin{array}{l}842,644 \\
531,446\end{array}$ & $\begin{array}{l}705,754 \\
442,217\end{array}$ & $\begin{array}{l}136,890 \\
01220\end{array}$ \\
\hline Hispanic .... & $2,979,443$ & $2,365,856$ & 225,126 & 175,644 & 36,047 & 351,379 & 212,715 & 6,872 & $1,358,073$ & 335,619 & 44,775 & 26,838 & 39,806 & 141,068 & 54,686 & 23,571 & 4,875 & 277,968 & 194,797 & 83,171 \\
\hline Asian.. & $1,195,578$ & 901,054 & 234,082 & 71,780 & 10,043 & 146,991 & 41,451 & 11,741 & 384,966 & 237,392 & 75,586 & 21,296 & 24,191 & 60,988 & 22,032 & 31,768 & 1,531 & 57,132 & 44,726 & 12,406 \\
\hline $\begin{array}{l}\text { Pacific Islander........................ } \\
\text { American Indian/ }\end{array}$ & 63,609 & 41,446 & 4,906 & 2,761 & 366 & 6,000 & 4,860 & 120 & 22,433 & 10,243 & 598 & 798 & 813 & 4,513 & 1,977 & 1,374 & 170 & 11,920 & 9,681 & 2,239 \\
\hline Alaska Native ................ & 172,923 & 131,745 & 11,853 & 11,180 & 1,691 & 19,651 & 9,123 & 7,810 & 70,437 & 22,464 & 1,528 & 1,390 & 1,437 & 8,441 & 4,495 & 4,303 & 870 & 18,714 & 15,096 & 3,618 \\
\hline Two or more races... & 505,092 & 370,400 & 65,787 & 36,653 & 8,008 & 67,696 & 26,456 & 1,719 & 164,081 & 89,275 & 16,378 & 7,462 & 7,734 & 30,901 & 17,801 & 8,459 & 540 & 45,417 & 37,929 & 7,488 \\
\hline 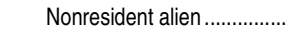 & 782,891 & 498,557 & 206,888 & 84,110 & 11,910 & 82,566 & 17,669 & 4,176 & 91,238 & 260,677 & 95,858 & 34,159 & 22,625 & 55,030 & 29,344 & 22,919 & 742 & 23,657 & 21,991 & 1,666 \\
\hline $\begin{array}{l}\text { White enrollment, by } \\
\text { percentage White }\end{array}$ & & & & & & & & & & & & & & & & & & & & \\
\hline 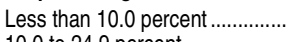 & 37,408 & 31,015 & & 606 & 2,293 & 4,895 & 7,340 & 163 & 15,718 & 2,484 & 0 & 283 & 9 & 615 & 1,098 & 227 & 252 & 3,909 & 1,935 & 1,974 \\
\hline ……...... & 207,935 & 165,551 & 30 & 8,277 & 4,495 & 18,287 & 10,802 & & 115,260 & 8,307 & & & 685 & 3,434 & 2,019 & 1,340 & 829 & 34,077 & & 12,943 \\
\hline 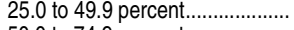 & $1,563,602$ & $1,156,101$ & 123,427 & 62,588 & 11,735 & 187,484 & 64,312 & 5,816 & 700,739 & 147,516 & 15,311 & 11,312 & 22,787 & 62,375 & 21,235 & 10,898 & 3,598 & 259,985 & 218,219 & 41,766 \\
\hline 50.0 to 74.9 percent.... & $4,788,899$ & $3,196,976$ & 556,586 & 349,888 & 99,170 & 481,707 & 249,477 & 24,463 & $1,435,685$ & $1,135,428$ & 246,747 & 103,312 & 104,347 & 437,793 & 120,147 & 118,797 & 4,285 & 456,495 & 412,220 & 44,275 \\
\hline 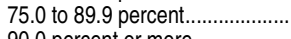 & $4,593,528$ & $3,492,922$ & 756,403 & 485,084 & 120,307 & 761,534 & 225,252 & 21,537 & $1,122,805$ & $1,028,860$ & 22,653 & 83,218 & 57,188 & 474,954 & 316,917 & 67,325 & 6,605 & 71,746 & 43,608 & 28,138 \\
\hline 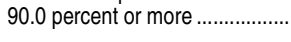 & 789,771 & 591,718 & 12,249 & 39,756 & 1,868 & 172,435 & 73,568 & 0 & 291,842 & 181,621 & & & & 58,715 & 85,769 & 34,664 & 2,473 & 16,432 & 8,638 & 7,794 \\
\hline $\begin{array}{l}\text { Black enrollment, by } \\
\text { percentage Black }\end{array}$ & & & & & & & & & & & & & & & & & & & & \\
\hline Less than 10.0 percent ............... & 518,975 & 381,850 & 87,439 & 35,195 & 6,598 & 77,423 & 19,404 & 2,830 & 152,961 & 124,879 & 28,304 & 15,286 & 7,820 & 39,516 & 22,299 & 11,311 & 343 & 12,246 & 7,282 & 4,964 \\
\hline 100 t & 921,282 & 695,461 & 51,987 & 23 & 32,697 & 103,465 & 63,179 & 3,563 & 46,747 & 50,843 & 4,022 & 469 & 19,082 & 88,356 & 25,329 & 11,766 & 1,819 & 74,978 & 58,225 & 16,753 \\
\hline 25.0 to 49.9 percent.. & 953,394 & 530,293 & 11,335 & 12,843 & 9,205 & 71,357 & 58,284 & 120 & 367,149 & 118,818 & 0 & 7,039 & 9,281 & 72,533 & 19,141 & 6,828 & 3,996 & 304,283 & 273,290 & 30,993 \\
\hline 50.0 to 74.9 percent.. & 230,241 & 114,965 & & & 6,118 & 13,153 & 6,331 & 437 & 88,926 & 22,928 & 0 & 0 & 0 & 5,276 & 9,892 & 5,309 & 2,451 & 92,348 & 69,266 & 23,082 \\
\hline & & 121,291 & 0 & & 28,505 & 35,453 & 13,108 & 0 & 44,225 & 13,045 & 0 & & & 6,257 & 4,318 & 1,189 & 1,281 & 42,293 & 29,040 & 13,253 \\
\hline 90.0 percent or more .... & 161,619 & 93,142 & 0 & 7,970 & 14,547 & 45,485 & 10,765 & 0 & 14,375 & 63,179 & 0 & 8,682 & 3,330 & 1,364 & 45,796 & 3,061 & 946 & 5,298 & 3,114 & 2,184 \\
\hline $\begin{array}{l}\text { Hispanic enrollment, by } \\
\text { percentage Hispanic }\end{array}$ & & & & & & & & & & & & & & & & & & & & \\
\hline Less than 10.0 perce & 539,282 & 369,000 & 75,338 & 40,622 & 12,053 & 73,287 & 28,101 & 2,279 & 137,320 & 123,944 & 21,542 & 8,579 & 5,326 & 51,173 & 25,873 & 10,714 & 737 & 46,338 & 41,577 & 4,761 \\
\hline & 020 &, 033 & & (200 & 11,976 & & 40,464 & 3,707 & 260,666 & 139,513 & 19,346 & 11,688 & 26,371 & 54,110 & 15,929 & 10,819 & 1,250 & 87,387 & 75,348 & 12,039 \\
\hline & 942,0 & 803,100 & 35,165 & 22,947 & 4,573 & 111,317 & 64,629 & 886 & 563,583 & 56,109 & 3,887 & 6,571 & 6,396 & 25,660 & 10,173 & 1,024 & 2,398 & 82,813 & 50,36 & 32,446 \\
\hline 50.0 to 74.9 percent.................... & 504,366 & 448,884 & & 37,860 & 7,445 & 44,980 & 49,195 & 0 & 309,404 & 12,641 & 0 & 0 & 1,713 & 10,125 & 231 & 572 & 0 & 42,841 & 20,143 & 22,698 \\
\hline 75.0 to 89.9 percent....................... & 101,338 & 88,629 & 0 & 17,946 & 0 & & & 0 & 70,683 & 1,691 & 0 & 0 & 0 & 0 & 1,035 & 166 & 490 & 11,018 & 3,283 & 7,735 \\
\hline 90.0 percent or more ................... & 92,502 & 83,210 & 0 & & 0 & 36,467 & 30,326 & 0 & 16,417 & 1,721 & 0 & 0 & 0 & 0 & 1,445 & 276 & 0 & 7,571 & 4,079 & 3,492 \\
\hline $\begin{array}{l}\text { Asian enrollment, by } \\
\text { percentage Asian }\end{array}$ & & & & & & & & & & & & & & & & & & & & \\
\hline Less than 10.0 percent... & 506,355 & 369,870 & 79,541 & 36,825 & 10,043 & 52,325 & 23,852 & 1,578 & 165,706 & 98,600 & 5,470 & 12,780 & 11,296 & 43,902 & 16,884 & 7,710 & 558 & 37,885 & 31,826 & 6,059 \\
\hline 10.0 to & 472,155 & 340,544 & 77,465 & 34,955 & 0 & 60,162 & 15,240 & 6,101 & 146,621 & 117,980 & 69,569 & 7,416 & 10,690 & 14,824 & 4,544 & 10,609 & 328 & 13,631 & 9,763 & 3,868 \\
\hline 25.0 to 49.9 percent... & 214,081 & 190,640 & 77,076 & 0 & 0 & 34,504 & 2,359 & 4,062 & 72,639 & 19,371 & 547 & 1,100 & 2,205 & 2,040 & 604 & 12,230 & 645 & 4,070 & 2,670 & 1,400 \\
\hline 50.0 to 74.9 percent... & 1,825 & 0 & 0 & 0 & 0 & 0 & 0 & 0 & 0 & 564 & 0 & 0 & 0 & 0 & 0 & 564 & 0 & 1,261 & 182 & 1,079 \\
\hline & 451 & 0 & 0 & 0 & 0 & 0 & 0 & 0 & 0 & 451 & 0 & 0 & 0 & 0 & 0 & 45 & 0 & 0 & 0 & 0 \\
\hline 90.0 percent or more & 711 & 0 & 0 & 0 & 0 & 0 & 0 & 0 & 0 & 426 & 0 & 0 & 0 & 222 & 0 & 204 & 0 & 285 & 285 & 0 \\
\hline
\end{tabular}


Table 306.40. Fall enrollment of males and females and specific racial/ethnic groups in degree-granting postsecondary institutions, by control and level of institution and percentage of U.S. resident enrollment in the same racial/ethnic group: 2012-Continued

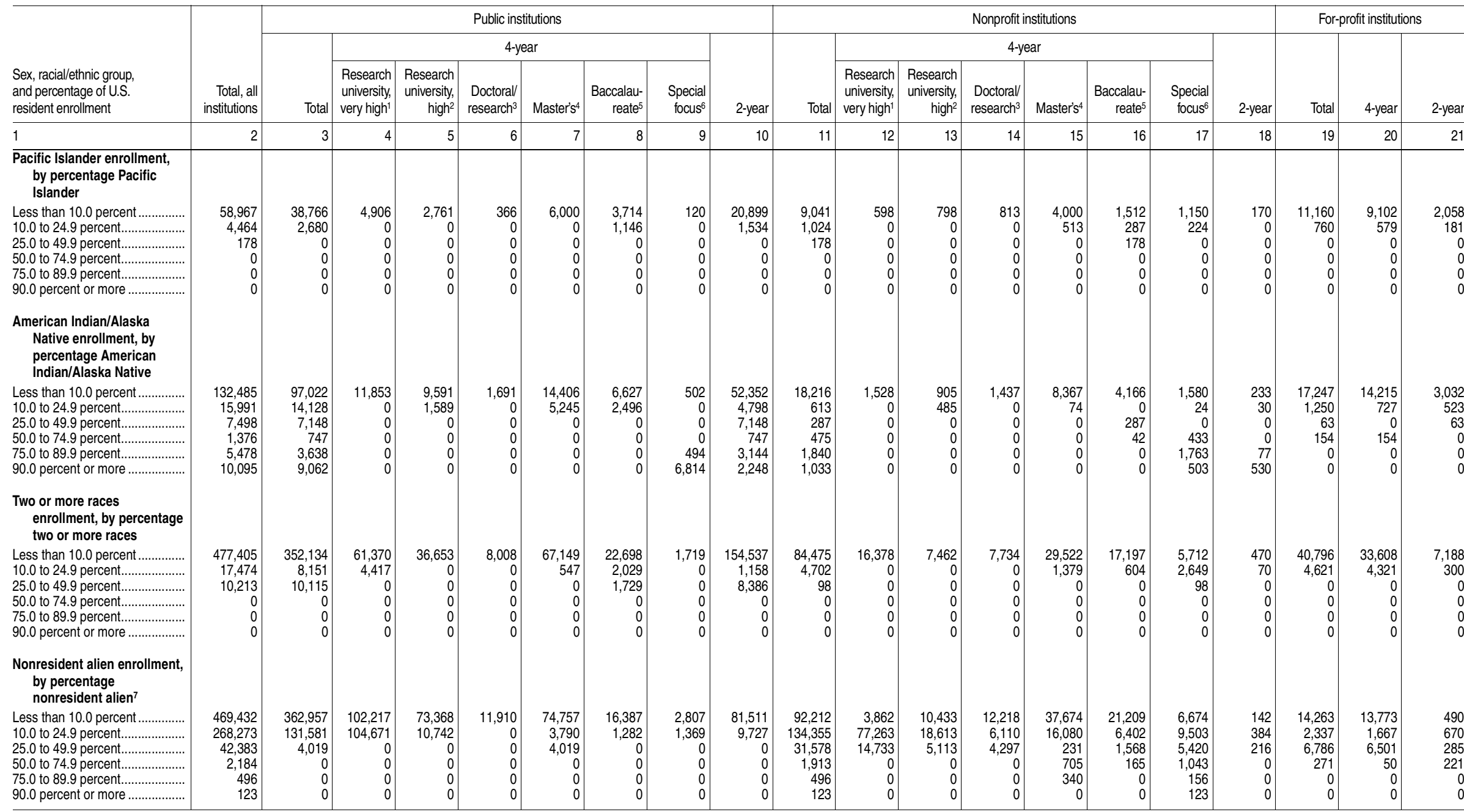

1Research universities with a very high level of research activity. ${ }^{2}$ Research universities with a high level of research activity.

Institutions that award at least 20 doctor's degrees per year, but did not have high levels of research activity.

4nstitutions that award at least 50 master's degrees per year.
5 Institutions that primarily emphasize undergraduate education. Also includes institutions classified as 4 -year under the IPEDS F Four-year insiturions that award degres primarily in single fields of sidy, such as medicine, business, fine arts, theolog engineering.
${ }^{7}$ Nonresident alien enrollment percentages based on total enrollment in the institution, rather than on the U.S. resident enrollment NOTE: Relative levels of research activity for research universities were determined by an analysis of research and development expenditures, science and engineering research stafling, and doctoral degrees conferred, by field. Further information on the research index ranking may be obtained from hitp:///classilications.carnegiefoundation.org/resources/. Degree-granting institutions grant associate's or higher degrees and participate in Title IV federal financial aid programs. Race calegories exclude persons of SOURCE: US. Depa

System (IPEDS), Spring 2013, Enrollment component. (This table was prepared November 2013.) 


\begin{tabular}{|c|c|c|c|c|c|c|c|c|c|c|c|c|c|c|c|c|c|c|c|c|c|c|}
\hline \multirow[b]{3}{*}{$\begin{array}{l}\text { Level of enrollment and } \\
\text { race/ethnicity of student }\end{array}$} & \multirow[b]{3}{*}{$\begin{array}{r}\text { Total, all } \\
\text { institutions }\end{array}$} & \multicolumn{9}{|c|}{ Public institutions } & \multicolumn{9}{|c|}{ Nonprofit institutions } & \multirow{2}{*}{\multicolumn{3}{|c|}{ For-profit institutions }} \\
\hline & & \multicolumn{8}{|c|}{ 4-year } & \multirow[b]{2}{*}{ 2-year } & \multirow[b]{2}{*}{ Total } & \multicolumn{7}{|c|}{ 4-year } & \multirow[b]{2}{*}{ 2-year } & & & \\
\hline & & Total & Total & $\begin{array}{l}\text { Research } \\
\text { university, } \\
\text { very hight }\end{array}$ & \begin{tabular}{|r|} 
Research \\
university, \\
high $^{2}$
\end{tabular} & $\begin{array}{r}\text { Doctoral// } \\
\text { research } \\
\text { university }{ }^{3}\end{array}$ & Master's ${ }^{4}$ & $\begin{array}{r}\text { Bacca- } \\
\text { laureate }{ }^{5}\end{array}$ & $\begin{array}{r}\text { Special } \\
\text { foccus }^{6}\end{array}$ & & & Total & \begin{tabular}{|l|} 
Research \\
university, \\
very high"
\end{tabular} & $\begin{array}{r}\text { Research } \\
\text { university, } \\
\text { high }^{2}\end{array}$ & $\begin{array}{r}\text { Doctorall } \\
\text { research } \\
\text { university }\end{array}$ & Master's ${ }^{4}$ & $\begin{array}{r}\text { Bacca- } \\
\text { laureate }^{5}\end{array}$ & $\begin{array}{r}\text { Special } \\
\text { focus }^{6}\end{array}$ & & Total & 4-year & 2-year \\
\hline 1 & 2 & 3 & 4 & 5 & 6 & 7 & 8 & 9 & 10 & 11 & 12 & 13 & 14 & 15 & 16 & 17 & 18 & 19 & 20 & 21 & 22 & 23 \\
\hline & & & & & & & & & & & Fall enr & ollment & & & & & & & & & & \\
\hline All students, total ..... & $20,642,819$ & \begin{tabular}{|l|}
$14,880,343$ \\
\end{tabular} & $8,092,683$ & $2,356,498$ & $1,478,158$ & 405,603 & $2,646,961$ & $1,114,096$ & 91,367 & $6,787,660$ & \begin{tabular}{|l|}
$3,953,578$ \\
\end{tabular} & $3,915,972$ & \begin{tabular}{|l|}
551,760 \\
\end{tabular} & 321,544 & 321,135 & $1,552,129$ & 804,295 & 365,109 & 37,606 & $1,808,898$ & \begin{tabular}{|l|}
$1,470,191$ \\
\end{tabular} & 338,707 \\
\hline White $\ldots \ldots$ & $11,981,143$ & \begin{tabular}{|l|}
$8,634,283$ \\
\end{tabular} & $4,952,234$ & $1,457,095$ & 946,199 & 239,868 & $1,626,342$ & 630,751 & 51,979 & $3,682,049$ & \begin{tabular}{|l|}
$2,504,216$ \\
\end{tabular} & $2,486,174$ & 284,711 & 198,125 & 185,016 & $1,037,886$ & 547,185 & 233,251 & 18,042 & 842,644 & 705,754 & 136,890 \\
\hline 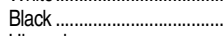 & $2,962,140$ & \begin{tabular}{|l|}
$1,937,002$ \\
\end{tabular} & 922,619 & 150,761 & 149,831 & $\begin{array}{r}97,670 \\
\end{array}$ & 346,336 & 171,071 & 6,950 & $1,014,383$ & $\begin{array}{r}493,692 \\
\end{array}$ & 482,856 & 32,326 & 31,476 & 39,513 & 213,302 & 126,775 & 39,464 & 10,836 & 531,446 & 440,217 & 91,229 \\
\hline Hispanic.. & $2,979,443$ & \begin{tabular}{|l|}
$2,365,856$ \\
\end{tabular} & $1,007,783$ & 225,126 & 175,644 & 36,047 & 351,379 & 212,715 & 6,872 & $\begin{array}{l}1,358,073 \\
\end{array}$ & 335,619 & 330,744 & 44,775 & 26,838 & 39,806 & 141,068 & 54,686 & 23,571 & 4,875 & 277,968 & 194,797 & 83,171 \\
\hline Asian. & $1,195,578$ & \begin{tabular}{|r|} 
\\
$\mid 4,001,054$
\end{tabular} & 516,088 & 234,082 & 71,780 & 10,043 & 146,991 & 41,451 & 11,741 & 384,966 & 237,392 & 235,861 & 75,586 & 21,296 & 24,191 & 60,988 & 22,032 & 31,768 & 1,531 & 57,132 & 44,726 & 12,406 \\
\hline Pacific Islander...... & 63,609 & 41,446 & 19,013 & $\begin{array}{r}4,906 \\
4,40\end{array}$ & 2,761 & 366 & 6,000 & $\begin{array}{r}41,860 \\
4,860\end{array}$ & 120 & 22,433 & $\begin{array}{r}10,243 \\
1\end{array}$ & $\begin{array}{l}10,073 \\
\end{array}$ & 598 & 798 & $\begin{array}{r}2,1013 \\
813\end{array}$ & $\begin{array}{r}4,513 \\
4,30\end{array}$ & 1,977 & 1,374 & 170 & 11,920 & 9,681 & 2,239 \\
\hline $\begin{array}{l}\text { American In } \\
\text { Alaska }\end{array}$ & 172,923 & 131,745 & 61,308 & 11,853 & 11,180 & 1.691 & 19,651 & 9,123 & 7.810 & 70,437 & 22.464 & 21,594 & 1.528 & 1,390 & 1.437 & 8.441 & 4,45 & 4303 & 870 & 18714 & 15096 & 3.618 \\
\hline Two or more & 505,092 & 370,400 & 206,319 & 65,787 & 36,653 & 8,008 & 67,696 & 26,456 & 1,719 & 164,081 & 89,275 & 88,735 & 16,378 & 7,462 & 7,734 & 30,901 & $\begin{array}{r}4,7,801 \\
17,4\end{array}$ & $\begin{array}{l}4,400 \\
8,459\end{array}$ & 540 & 45,417 & 37,929 & $\begin{array}{l}3,010 \\
7,488\end{array}$ \\
\hline Nonresident alien................ & 782,891 & 498,557 & 407,319 & $\begin{aligned} 206,888 \\
\end{aligned}$ & 84,110 & 11,910 & 82,566 & 17,669 & 4,176 & 91,238 & 260,677 & 259,935 & 95,858 & 34,159 & 22,625 & 55,030 & 29,344 & 22,919 & 742 & 23,657 & 21,991 & 1,666 \\
\hline Undergraduate...................... & $17,732,431$ & $|13,473,743|$ & $6,686,083$ & $1,776,450$ & $1,173,031$ & 324,679 & $2,278,377$ & $1,105,089$ & 28,457 & $6,787,660$ & $2,745,075$ & $2,707,469$ & 269,217 & 195,897 & 197,460 & $1,106,094$ & 755,782 & 183,019 & 37,606 & $1,513,613$ & 1,174,906 & 338,707 \\
\hline 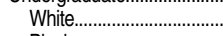 & $10,247,379$ & 7,768,679 & $4,086,630$ & $1,111,599$ & 752,208 & 192,569 & $1,390,923$ & 624,490 & 14,841 & $3,682,049$ & $1,773,000$ & $1,754,958$ & 142,378 & 129,294 & 112,354 & 741,864 & 511,687 & 117,381 & 18,042 & 705,700 & 568,810 & 136,890 \\
\hline Black. & $2,592,844$ & $1,807,074$ & 792,691 & 119,207 & 125,638 & 80,488 & 295,919 & 169,919 & 1,520 & $1,014,383$ & 358,539 & 347,703 & 16,637 & 16,497 & 23,948 & 147,934 & 120,509 & 22,178 & 10,836 & 427,231 & 336,002 & 91,229 \\
\hline Hispanic.............................. & \begin{tabular}{|l|}
$2,766,058$ \\
\end{tabular} & $2,260,410$ & 902,337 & 190,757 & 152,559 & 29,356 & 315,396 & 212,208 & 2,061 & $1,358,073$ & 251,444 & 246,569 & 27,578 & 16,507 & 27,516 & 109,403 & 52,287 & 13,278 & 4,875 & 254,204 & 171,033 & 83,171 \\
\hline 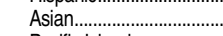 & $1,006,462$ & \begin{tabular}{|r|} 
\\
815,732
\end{tabular} & 430,766 & 193,197 & 58,182 & 7,495 & 129,300 & 41,020 & 1,572 & 384,966 & 146,053 & 144,522 & 43,763 & 13,473 & 15,331 & 40,507 & 20,421 & 11,027 & 1,531 & 44,677 & 32,271 & 12,406 \\
\hline Pacific Islander......... & 56,692 & 39,238 & 16,805 & 3,954 & 2,269 & 308 & 5,413 & 4,810 & 51 & 22,433 & 7,394 & 7,224 & 211 & 507 & 528 & 3,389 & 1,863 & 726 & 170 & 10,060 & 7,821 & 2,239 \\
\hline American Indian/Alaska & & & & & & & & & & & & & & & & & & & & & & \\
\hline $\begin{array}{l}\text { Native.................................. } \\
\text { Two or more res........ }\end{array}$ & $\begin{array}{l}157,493 \\
455,026\end{array}$ & $\begin{array}{l}123,925 \\
346,734\end{array}$ & $\begin{array}{r}53,488 \\
182,653\end{array}$ & $\begin{array}{r}9,081 \\
55,511\end{array}$ & $\begin{array}{r}9,386 \\
31,606\end{array}$ & $\begin{array}{l}1,319 \\
6,835\end{array}$ & $\begin{array}{l}17,181 \\
61,812\end{array}$ & $\begin{array}{r}9,066 \\
26,260\end{array}$ & $\begin{array}{r}7,455 \\
629\end{array}$ & $\begin{array}{r}70,437 \\
164,081\end{array}$ & $\begin{array}{l}17,448 \\
68,270\end{array}$ & $\begin{array}{l}16,578 \\
67,730\end{array}$ & $\begin{array}{r}843 \\
10,570\end{array}$ & $\begin{array}{r}908 \\
5,377\end{array}$ & $\begin{array}{r}830 \\
5625\end{array}$ & $\begin{array}{r}6,285 \\
24596\end{array}$ & $\begin{array}{r}4,174 \\
17,184\end{array}$ & $\begin{array}{l}3,538 \\
4,378\end{array}$ & $\begin{array}{l}870 \\
540\end{array}$ & $\begin{array}{l}16,120 \\
40,022\end{array}$ & $\begin{array}{l}12,502 \\
32,534\end{array}$ & $\begin{array}{l}3,618 \\
7,488\end{array}$ \\
\hline Nonresident alien............. & 450,477 & 311,951 & 220,713 & 93,144 & 41,183 & 6,309 & 62,433 & 17,316 & 328 & 91,238 & $\begin{array}{l}122,927 \\
127\end{array}$ & 122,185 & $\begin{array}{l}27,237 \\
\end{array}$ & $\begin{aligned} 13,334 \\
13,34\end{aligned}$ & 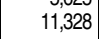 & 32,116 & 27,657 & 10,513 & 742 & 15,599 & 13,933 & $\begin{array}{l}1,480 \\
1,666\end{array}$ \\
\hline Postbaccalaureate................ & $2,910,388$ & 1,406,600 & $1,406,600$ & 580,048 & 305,127 & 80,924 & 368,584 & 9,007 & 62,910 & $\dagger$ & $1,208,503$ & $1,208,503$ & 282,543 & 125,647 & 123,675 & 446,035 & 48,513 & 182,090 & $\dagger$ & 295,285 & 295,285 & $\dagger$ \\
\hline & \begin{tabular}{|l|}
$1,733,764$ \\
\end{tabular} & 865,604 & 865,604 & & & 47,299 & & 6,261 & 37,138 & $\dot{\dagger}$ & 731,216 & 731,216 & 142,333 & & & 296,022 & 35,498 & 115,870 & $\dagger$ & 136,944 & & $\dagger$ \\
\hline Black.. & 369,296 & 129,928 & 129,928 & 31,554 & 24,193 & 17,182 & 50,417 & 1,152 & 5,430 & $\dagger$ & 135,153 & 135,153 & 15,689 & 14,979 & 15,565 & 65,368 & 6,266 & 17,286 & $\dagger$ & 104,215 & 104,215 & $\dagger$ \\
\hline & 213,385 & $\begin{array}{l}105,446 \\
\end{array}$ & 105,446 & 34,369 & 23,085 & 6,691 & 35,983 & 507 & 4,811 & $\dagger$ & 84,175 & 84,175 & 17,197 & 10,331 & 12,290 & 31,665 & 2,399 & 10,293 & $\dagger$ & 23,764 & 23,764 & $t$ \\
\hline As & 189,116 & 85,322 & 85,322 & 40,885 & 13,598 & 2,548 & 17,691 & 431 & 10,169 & $\dagger$ & 91,339 & 91,339 & 31,823 & 7,823 & 8,860 & 20,481 & 1,611 & 20,741 & $\dagger$ & 12,455 & 12,455 & $\dagger$ \\
\hline Pacific Islander ......... & 6,917 & 2,208 & 2,208 & 952 & 492 & 58 & 587 & 50 & 69 & $\dagger$ & 2,849 & 2,849 & 387 & 291 & 285 & 1,124 & 114 & 648 & $\dagger$ & 1,860 & 1,860 & $\dagger$ \\
\hline $\begin{array}{l}\text { American Indian/Alaska } \\
\text { Native.............................. }\end{array}$ & 15,430 & 7,820 & 7,820 & 2,772 & 1,794 & 372 & 2,470 & 57 & 355 & $\dagger$ & 5,016 & 5.016 & 685 & 482 & 607 & 2,156 & 321 & 765 & t & 2.594 & 2.594 & $\dagger$ \\
\hline Two or more races............... & 50,066 & 23,666 & 23,666 & 10,276 & 5,047 & 1,173 & 5,884 & 196 & 1,090 & & 21,005 & 21,005 & 5,808 & 2,085 & 2,109 & 6,305 & 617 & 4,08 & & 5,3 & 5,3 & $\dagger$ \\
\hline Nonresident alien ............. & 332,414 & 186,606 & 186,606 & 113,744 & 42,927 & 5,601 & 20,133 & 353 & 3,848 & $t$ & $\begin{array}{r}137,750 \\
\end{array}$ & 137,750 & 68,621 & 20,825 & 11,297 & 22,914 & 1,687 & 12,406 & $\dagger$ & 8,058 & 8,058 & $\dagger$ \\
\hline & & & & & & & & & & Percent & age distributi & on of U.S. $r$ & esidents & & & & & & & & & \\
\hline U.S. residents, total........ & 100.0 & 100.0 & 100.0 & 100.0 & 100.0 & 100.0 & 100.0 & 100.0 & 100.0 & 100.0 & 100.0 & 100.0 & 100.0 & 100.0 & 100.0 & 100.0 & 100.0 & 100.0 & 100.0 & 100.0 & 100.0 & 100.0 \\
\hline & 60.3 & 60.0 & 64.4 & 67.8 & 67 & & 6 & 57.5 & 59.6 & 55.0 & 67.8 & 68.0 & 62.5 & 68.9 & 62.0 & 69.3 & 70 & 68.2 & 48.9 & 47.2 & 48.7 & 40.6 \\
\hline 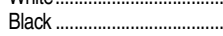 & 14.9 & 13.5 & 12.0 & 7.0 & 10 & & 13 & 15.6 & 8.0 & 15.1 & 13.4 & 13.2 & 7.1 & 11.0 & 1 & 14 & 16 & 11 & & & & +0.0 \\
\hline $\mathrm{His}$ & 15.0 & 16.5 & 13.1 & 10.5 & 12.6 & 9.2 & 13.7 & 19.4 & 7.9 & 20.3 & 9.1 & 9.0 & 9.8 & 9.3 & 13.3 & 9.4 & 7.1 & 6. & 13.2 & 15. & 13.5 & 24.7 \\
\hline Asi & 6.0 & 6.3 & 6.7 & 10.9 & 5.1 & 2.6 & 5.7 & 3.8 & 13.5 & 5.7 & 6.4 & 6.5 & 16.6 & 7.4 & 8.1 & 4.1 & 2.8 & 9.3 & 4.2 & 3.2 & 3.1 & 3.7 \\
\hline Pacific & 0.3 & 0.3 & 0.2 & 0.2 & 0.2 & 0.1 & 0.2 & 0.4 & 0.1 & 0.3 & 0.3 & 0.3 & 0.1 & 0.3 & 0.3 & 0.3 & 0.3 & 0.4 & 0.5 & 0.7 & 0.7 & 0.7 \\
\hline Americ & & & & & & & & & & & & & & & & & & 13 & & 10 & 10 & \\
\hline $\begin{array}{l}\text { Alaska Native.................. } \\
\text { Two or more races............ }\end{array}$ & $\begin{array}{l}0.9 \\
2.5\end{array}$ & $\begin{array}{l}0.9 \\
2.6\end{array}$ & $\begin{array}{l}0.8 \\
2.7\end{array}$ & $\begin{array}{l}0.6 \\
3.1\end{array}$ & $\begin{array}{l}0.8 \\
2.6\end{array}$ & $\begin{array}{l}0.4 \\
2.0\end{array}$ & $\begin{array}{l}0.8 \\
2.6\end{array}$ & $\begin{array}{l}0.8 \\
2.4\end{array}$ & $\begin{array}{l}9.0 \\
2.0\end{array}$ & $\begin{array}{l}1.1 \\
2.5\end{array}$ & $\begin{array}{l}0.6 \\
2.4\end{array}$ & $\begin{array}{l}0.6 \\
2.4\end{array}$ & $\begin{array}{l}0.3 \\
3.6\end{array}$ & $\begin{array}{l}0.5 \\
2.6\end{array}$ & $\begin{array}{l}0.5 \\
2.6\end{array}$ & $\begin{array}{l}0.6 \\
2.1\end{array}$ & $\begin{array}{l}0.6 \\
2.3\end{array}$ & $\begin{array}{l}1.3 \\
2.5\end{array}$ & $\begin{array}{l}2.4 \\
1.5\end{array}$ & $\begin{array}{l}1.0 \\
2.5\end{array}$ & $\begin{array}{l}1.0 \\
2.6\end{array}$ & $\begin{array}{l}1.1 \\
2.2\end{array}$ \\
\hline Undergraduate....................... & & 100.0 & 100.0 & 100.0 & 100.0 & 100.0 & 100.0 & 100.0 & 100.0 & 100.0 & 100.0 & 100.0 & 100.0 & 100.0 & 100.0 & 100.0 & 100.0 & 100.0 & 100.0 & 100.0 & 100.0 & 100.0 \\
\hline & 59.3 & 59.0 & 63.2 & 66.0 & 66.5 & 60.5 & 62.8 & 57.4 & 52.8 & 55.0 & 67.6 & 67.9 & 58.8 & 70.8 & 60.4 & 69.1 & 70.3 & 68.0 & 48.9 & 47.1 & 49.0 & 40.6 \\
\hline Blac & $\begin{array}{l}59.0 \\
15.0\end{array}$ & $\begin{array}{l}5.0 \\
13.7\end{array}$ & $\begin{array}{l}03.2 \\
12.3\end{array}$ & $\begin{array}{r}00.0 \\
7.1\end{array}$ & $\begin{array}{l}0.5 \\
11.1\end{array}$ & $\begin{array}{l}0.5 \\
25.3\end{array}$ & $\begin{array}{l}0.8 \\
13.4\end{array}$ & $\begin{array}{l}57.4 \\
15.6\end{array}$ & $\begin{array}{r}5.8 \\
5.4\end{array}$ & $\begin{array}{l}5.0 \\
15.1\end{array}$ & $\begin{array}{l}0.0 \\
13.7\end{array}$ & $\begin{array}{l}0.9 \\
13.4\end{array}$ & $\begin{array}{r}5.8 \\
6.9\end{array}$ & $\begin{array}{r}r .8 \\
9.0\end{array}$ & $\begin{array}{l}0.4 \\
12.9\end{array}$ & $\begin{array}{l}90.1 \\
13.8\end{array}$ & $\begin{array}{l}10.5 \\
16.6\end{array}$ & $\begin{array}{l}0.0 \\
12.9\end{array}$ & $\begin{array}{l}48.9 \\
29.4\end{array}$ & $\begin{array}{l}4.1 . \\
28.5\end{array}$ & $\begin{array}{l}48.9 \\
28.9\end{array}$ & 27.1 \\
\hline Hisp & 16.0 & 17.2 & 14.0 & 11.3 & 13.5 & 9.2 & 14.2 & 19.5 & 7.3 & 20.3 & 9.6 & 9.5 & 11.4 & 9.0 & 14.8 & 10.2 & 7.2 & 7.7 & 13.2 & 17.0 & 14.7 & 24.7 \\
\hline & 5.8 & 6.2 & 6.7 & 11.5 & 5.1 & 2.4 & 5.8 & 3.8 & 5.6 & $\begin{array}{r}0.0 \\
5.7\end{array}$ & $\begin{array}{l}5.0 \\
5.6\end{array}$ & 5.6 & $\begin{array}{l}11.4 \\
18.1\end{array}$ & 7.4 & $\begin{array}{r}8.0 \\
8.2\end{array}$ & $\begin{array}{r}3.4 \\
3.8\end{array}$ & 2.8 & 6.4 & $\begin{array}{r}40.6 \\
4.2\end{array}$ & 3.0 & $\begin{array}{r}2.8 \\
2.8\end{array}$ & $\begin{array}{r}3.1 \\
3.7\end{array}$ \\
\hline $\mathrm{Pac}$ & 0.3 & 0.3 & 0.3 & 0.2 & 0.2 & 0.1 & 0.2 & $\begin{array}{l}0.4 \\
0.4\end{array}$ & $\begin{array}{l}.0 .2 \\
0.2\end{array}$ & 0.3 & $\begin{array}{l}0.0 \\
0.3\end{array}$ & 0.3 & 0.1 & 0.3 & 0.3 & 0.3 & 0.3 & $\begin{array}{l}0.4 \\
0.4\end{array}$ & 0.5 & 0.7 & 0.7 & $\begin{array}{l}0.7 \\
0.7\end{array}$ \\
\hline $\begin{array}{l}\text { American Indian/Alaska } \\
\text { Native }\end{array}$ & 0.9 & 0.9 & 08 & 0.5 & 0 & 0 & 08 & 0.8 & 2 & 11 & 07 & 06 & 0.3 & 0 & 0.4 & 6 & 0 & 21 & 24 & 11 & 11 & 11 \\
\hline Two or more races............ & 2.6 & 2.6 & 2.8 & 3.3 & $\begin{array}{l}2.0 \\
2.8\end{array}$ & $\begin{array}{l}2.4 \\
2.1\end{array}$ & 2.8 & 2.4 & 2.2 & 2.5 & $\begin{array}{l}2.6 \\
2.6\end{array}$ & 2.6 & 4.4 & 2.9 & 3.0 & 2.3 & 2.4 & 2.5 & $\begin{array}{l}2.4 \\
1.5\end{array}$ & 2.7 & 2.8 & 2.2 \\
\hline
\end{tabular}

See notes at end of table. 
Table 306.50. Total fall enrollment in degree-granting postsecondary institutions, by control and level of institution, level of enrollment, and race/ethnicity of student: 2012-Continued

\begin{tabular}{|c|c|c|c|c|c|c|c|c|c|c|c|c|c|c|c|c|c|c|c|c|c|c|}
\hline \multirow[b]{3}{*}{$\begin{array}{l}\text { Level of enrollment and } \\
\text { race/ethnicity of student }\end{array}$} & \multirow[b]{3}{*}{$\begin{array}{r}\text { Total, all } \\
\text { institutions }\end{array}$} & \multicolumn{9}{|c|}{ Public institutions } & \multicolumn{9}{|c|}{ Nonprofit institutions } & \multirow{2}{*}{\multicolumn{3}{|c|}{ For-profit institutions }} \\
\hline & & \multirow[b]{2}{*}{ Total } & \multicolumn{7}{|c|}{ 4-year } & \multirow[b]{2}{*}{ 2-year } & \multirow[b]{2}{*}{ Total } & \multicolumn{7}{|c|}{ 4-year } & \multirow[b]{2}{*}{ 2-year } & & & \\
\hline & & & Total & \begin{tabular}{|l|} 
Research \\
university, \\
very high'
\end{tabular} & \begin{tabular}{|r|} 
Research \\
university, \\
high $^{2}$ \\
\end{tabular} & \begin{tabular}{|r|} 
Doctoral/ \\
research \\
university $^{3}$ \\
\end{tabular} & Master's ${ }^{4}$ & $\begin{array}{r}\text { Bacca- } \\
\text { laureate }^{5}\end{array}$ & $\begin{array}{c}\text { Special } \\
\text { focus }^{6}\end{array}$ & & & Total & \begin{tabular}{|c|} 
Research \\
university, \\
very high
\end{tabular} & \begin{tabular}{|r|} 
Research \\
university, \\
high $^{2}$
\end{tabular} & \begin{tabular}{|r|} 
Doctorall \\
research \\
university $^{3}$ \\
\end{tabular} & Master's ${ }^{4}$ & $\begin{array}{r}\text { Bacca- } \\
\text { laureate }{ }^{5}\end{array}$ & $\begin{array}{r}\text { Special } \\
\text { focus }^{6}\end{array}$ & & Total & 4-year & 2-year \\
\hline 1 & 2 & 3 & 4 & 5 & 6 & 7 & 8 & 9 & 10 & 11 & 12 & 13 & 14 & 15 & 16 & 17 & 18 & 19 & 20 & 21 & 22 & 23 \\
\hline 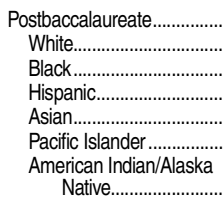 & $\begin{array}{r}100.0 \\
67.3 \\
14.3 \\
8.3 \\
7.3 \\
0.3 \\
0.6\end{array}$ & $\begin{array}{r}100.0 \\
71.0 \\
10.6 \\
8.6 \\
7.0 \\
0.2 \\
0.6\end{array}$ & $\begin{array}{r}100.0 \\
71.0 \\
10.6 \\
8.6 \\
7.0 \\
0.2 \\
0.6\end{array}$ & $\begin{array}{r}100.0 \\
74.1 \\
6.8 \\
7.4 \\
8.8 \\
0.2 \\
0.6\end{array}$ & $\begin{array}{r}100.0 \\
74.0 \\
9.2 \\
8.8 \\
5.2 \\
0.2 \\
0.7\end{array}$ & $\begin{array}{r}100.0 \\
62.8 \\
22.8 \\
8.9 \\
3.4 \\
0.1 \\
0.5\end{array}$ & $\begin{array}{r}100.0 \\
67.6 \\
14.5 \\
10.3 \\
5.1 \\
0.2 \\
0.7\end{array}$ & $\begin{array}{r}100.0 \\
72.3 \\
13.3 \\
5.9 \\
5.0 \\
0.6 \\
0.7\end{array}$ & $\begin{array}{r}100.0 \\
62.9 \\
9.2 \\
8.1 \\
17.2 \\
0.1 \\
0.6\end{array}$ & $\begin{array}{l}t \\
\dagger \\
\dagger \\
\dagger \\
\dagger \\
\dagger \\
t\end{array}$ & $\begin{array}{r}100.0 \\
68.3 \\
12.6 \\
7.9 \\
8.5 \\
0.3 \\
0.5\end{array}$ & $\begin{array}{r}100.0 \\
68.3 \\
12.6 \\
7.9 \\
8.5 \\
0.3 \\
0.5\end{array}$ & $\begin{array}{r}100.0 \\
66.5 \\
7.3 \\
8.0 \\
14.9 \\
0.2 \\
0.3\end{array}$ & $\begin{array}{r}100.0 \\
65.7 \\
14.3 \\
9.9 \\
7.5 \\
0.3 \\
0.5\end{array}$ & $\begin{array}{r}100.0 \\
64.7 \\
13.9 \\
10.9 \\
7.9 \\
0.3 \\
0.5\end{array}$ & $\begin{array}{r}100.0 \\
70.0 \\
15.4 \\
7.5 \\
4.8 \\
0.3 \\
0.5\end{array}$ & $\begin{array}{r}100.0 \\
75.8 \\
13.4 \\
5.1 \\
3.4 \\
0.2 \\
0.7\end{array}$ & $\begin{array}{r}100.0 \\
68.3 \\
10.2 \\
6.1 \\
12.2 \\
0.4 \\
0.5 \\
\end{array}$ & $\begin{array}{l}\dagger \\
+ \\
\dagger \\
\dagger \\
t \\
+ \\
+\end{array}$ & $\begin{array}{r}100.0 \\
47.7 \\
36.3 \\
8.3 \\
4.3 \\
0.6 \\
0.9\end{array}$ & $\begin{array}{r}100.0 \\
47.7 \\
36.3 \\
8.3 \\
4.3 \\
0.6 \\
0.9\end{array}$ & $\begin{array}{l}\dagger \\
\dagger \\
\dagger \\
\dagger \\
\dagger \\
\dagger \\
\dagger\end{array}$ \\
\hline Two or more races................ & 1.9 & 1.9 & 1.9 & 2.2 & 1.9 & 1.6 & 1.7 & 2.3 & 1.8 & $\dagger$ & 2.0 & 2.0 & 2.7 & 2.0 & $\begin{array}{l}1.9 \\
1.9\end{array}$ & 1.5 & 1.3 & 2.4 & $\dagger$ & 1.9 & 1.9 & $\dagger$ \\
\hline
\end{tabular}

\section{†Not applicable.}

with a very high level of research activity.

Institutions that award at least 20 doctor's degrees per year, but did not have high levels of research activity.

Institutions that award at least 50 master's degrees per year. IPEDS system, which had been classified as 2-year in the Carnegie system because they primarily award associate's

${ }_{6}^{6}$ Four-year institutions that award degrees primarily in single fields of study, such as medicine, business, fine arts, theology NOTE: Relative

ment and engineering research staffing, and doctoral degrees conferred, by field. Further information institutions grant associate's or higher degrees and participate in Title IV federal financial aid programs. Race categories exclude persons of Hispanic ethnicity. degrees.

System (IP.S. Department of Education, National Center for Education Statistics, Integrated Postsecondary Education Data (This table was prepared November 2013.) 
Table 306.60. Fall enrollment in degree-granting postsecondary institutions, by race/ethnicity of student and state or jurisdiction: 2012

\begin{tabular}{|c|c|c|c|c|c|c|c|c|c|c|c|c|c|c|c|c|c|}
\hline \multirow[b]{2}{*}{ State or jurisdiction } & \multicolumn{9}{|c|}{ Number } & \multicolumn{8}{|c|}{ Percentage distribution of U.S. residents } \\
\hline & Total & White & Black & Hispanic & Asian & $\begin{array}{r}\text { Pacific } \\
\text { Islander }\end{array}$ & $\begin{array}{r}\text { American } \\
\text { Indian/ } \\
\text { Alaska } \\
\text { Native }\end{array}$ & $\begin{array}{r}\text { Two or } \\
\text { more races }\end{array}$ & $\begin{array}{r}\text { Non- } \\
\text { resident } \\
\text { alien }\end{array}$ & Total & White & Black & Hispanic & Asian & $\begin{array}{r}\text { Pacific } \\
\text { Islander }\end{array}$ & $\begin{array}{r}\text { American } \\
\text { Indian/ } \\
\text { Alaska } \\
\text { Native }\end{array}$ & $\begin{array}{r}\text { Two or more } \\
\text { races }\end{array}$ \\
\hline 1 & 2 & 3 & 4 & 5 & 6 & 7 & 8 & 9 & 10 & 11 & 12 & 13 & 14 & 15 & 16 & 17 & 18 \\
\hline United States $\ldots . . . \ldots \ldots \ldots \ldots \ldots \ldots \ldots$ & $20,642,819$ & $11,981,143$ & $2,962,140$ & $2,979,443$ & $1,195,578$ & 63,609 & 172,923 & 505,092 & 782,891 & 100.0 & 60.3 & 14.9 & 15.0 & 6.0 & 0.3 & 0.9 & 2.5 \\
\hline Alabama & 310,311 & 191,653 & 92,602 & 8,216 & 5,130 & 282 & 2,341 & 3,600 & 6,487 & 100.0 & 63.1 & 30.5 & 2.7 & 1.7 & 0.1 & 0.8 & 1.2 \\
\hline Alaska & 32,797 & 20,584 & 1,109 & 2,486 & 1,559 & 261 & 3,677 & 2,406 & 715 & 100.0 & 64.2 & 3.5 & 7.7 & 4.9 & 0.8 & 11.5 & 7.5 \\
\hline Arizona & 736,379 & 403,607 & 115,300 & 135,585 & 22,630 & 4,007 & 19,185 & 18,296 & 17,769 & 100.0 & 56.2 & 16.0 & 18.9 & 3.1 & 0.6 & 2.7 & 2.5 \\
\hline 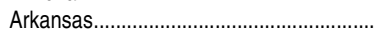 & 176,458 & 122,860 & 32,690 & 7,571 & 2,736 & 179 & 1,558 & 3,979 & 4,885 & 100.0 & 71.6 & 19.1 & 4.4 & 1.6 & 0.1 & 0.9 & 2.3 \\
\hline 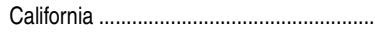 & $2,621,460$ & 890,525 & 187,692 & 905,947 & 408,668 & 16,198 & 12,866 & 99,622 & 99,942 & 100.0 & 35.3 & 7.4 & 35.9 & 16.2 & 0.6 & 0.5 & 4.0 \\
\hline Colorado ........ & 362,935 & 244,458 & 27,669 & 53,267 & 12,027 & 933 & 3,886 & 11,599 & 9,096 & 100.0 & 69.1 & 7.8 & 15.1 & 3.4 & 0.3 & 1.1 & 3.3 \\
\hline Connecticut... & 201,658 & 128,581 & 25,222 & 25,370 & 9,349 & 261 & 586 & 4,054 & 8,235 & 100.0 & 66.5 & 13.0 & 13.1 & 4.8 & 0.1 & 0.3 & 2.1 \\
\hline Delaware & 58,128 & 35,573 & 12,692 & 3,306 & 2,164 & 71 & 189 & 1,205 & 2,928 & 100.0 & 64.4 & 23.0 & 6.0 & 3.9 & 0.1 & 0.3 & 2.2 \\
\hline District of Columbia ........................................ & 90,150 & 43,022 & 24,175 & 6,322 & 5,927 & 174 & 422 & 1,924 & 8,184 & 100.0 & 52.5 & 29.5 & 7.7 & 7.2 & 0.2 & 0.5 & 2.3 \\
\hline Florida............... & $1,154,929$ & 554,691 & 231,049 & 267,272 & 36,003 & 2,480 & 4,720 & 26,424 & 32,290 & 100.0 & 49.4 & 20.6 & 23.8 & 3.2 & 0.2 & 0.4 & 2.4 \\
\hline Georgia....... & 545,358 & 278,142 & 186,086 & 28,715 & 22,881 & 808 & 1,734 & 10,654 & 16,338 & 100.0 & 52.6 & 35.2 & 5.4 & 4.3 & 0.2 & 0.3 & 2.0 \\
\hline 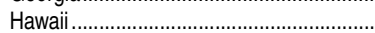 & 78,456 & 15,103 & 1,760 & 7,602 & 24,506 & 6,935 & 268 & 17,524 & 4,758 & 100.0 & 20.5 & $\begin{array}{r}2.4 \\
2.4\end{array}$ & 10.3 & 33.3 & 9.4 & 0.4 & 23.8 \\
\hline Idaho & 108,008 & 88,425 & 1,284 & 9,628 & $\begin{array}{r}1,752 \\
\end{array}$ & 769 & 1,263 & 1,577 & 3,310 & 100.0 & 84.5 & 1.2 & 9.2 & 1.7 & 0.7 & 1.2 & 1.5 \\
\hline 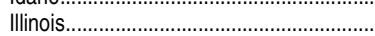 & 867,110 & 507,070 & 131,989 & 125,718 & 49,493 & 2,089 & 2,577 & 15,717 & 32,457 & 100.0 & 60.8 & 15.8 & 15.1 & 5.9 & 0.3 & 0.3 & 1.9 \\
\hline 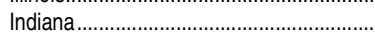 & 447,262 & 335,390 & 47,903 & 21,446 & 9,801 & 320 & 1,394 & 8,534 & 22,474 & 100.0 & 79.0 & 11.3 & 5.0 & 2.3 & 0.1 & 0.3 & 2.0 \\
\hline lowa ........ & 361,183 & 255,717 & 55,447 & 22,327 & 7,180 & 1,108 & 2,793 & 5,510 & 11,101 & 100.0 & 73.0 & 15.8 & 6.4 & 2.1 & 0.3 & 0.8 & 1.6 \\
\hline 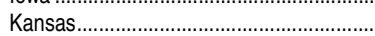 & 213,786 & 155,205 & 16,204 & 15,680 & 5,305 & 327 & 2,920 & 5,181 & 12,964 & 100.0 & 77.3 & 8.1 & 7.8 & 2.6 & 0.2 & 1.5 & 2.6 \\
\hline 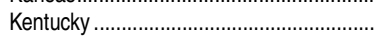 & 282,125 & 231,271 & 28,387 & 6,643 & 3,869 & 307 & 827 & 5,046 & 5,775 & 100.0 & 83.7 & 10.3 & 2.4 & 1.4 & 0.1 & 0.3 & 1.8 \\
\hline 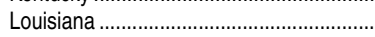 & 258,825 & 147,305 & 82,190 & 10,948 & 5,860 & 226 & 1,498 & 4,139 & 6,659 & 100.0 & 58.4 & 32.6 & 4.3 & 2.3 & 0.1 & 0.6 & 1.6 \\
\hline Maine & 72,810 & 64,222 & 2,017 & 1,553 & 1,390 & 206 & 799 & 1,275 & 1,348 & 100.0 & 89.9 & 2.8 & 2.2 & 1.9 & 0.3 & 1.1 & 1.8 \\
\hline Maryland... & 374,496 & 188,836 & 108,182 & 24,378 & 24,308 & 736 & 1,169 & 9,519 & 17,368 & 100.0 & 52.9 & 30.3 & 6.8 & 6.8 & 0.2 & 0.3 & 2.7 \\
\hline 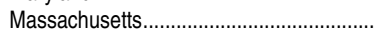 & 516,331 & 328,247 & 44,292 & 48,408 & 37,499 & 526 & 1,315 & 12,913 & 43,131 & 100.0 & 69.4 & 9.4 & 10.2 & 7.9 & 0.1 & 0.3 & 2.7 \\
\hline Michigan & 663,825 & 472,796 & 97,815 & 23,589 & 22,306 & 882 & 4,749 & 13,584 & 28,104 & 100.0 & 74.4 & 15.4 & 3.7 & 3.5 & 0.1 & 0.7 & 2.1 \\
\hline 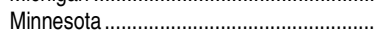 & 451,661 & 319,361 & 63,035 & 18,865 & 19,926 & 635 & 3,883 & 12,714 & 13,242 & 100.0 & 72.8 & 14.4 & 4.3 & 4.5 & 0.1 & 0.9 & 2.9 \\
\hline 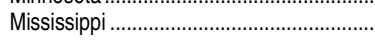 & 176,665 & 97,562 & 69,674 & 2,852 & 1,898 & 138 & 738 & 1,452 & 2,351 & 100.0 & 56.0 & 40.0 & 1.6 & 1.1 & 0.1 & 0.4 & 0.8 \\
\hline 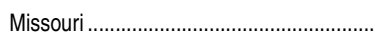 & 441,371 & 322,252 & 62,942 & 17,139 & 11,617 & 740 & 2,466 & 8,973 & 15,242 & 100.0 & 75.6 & 14.8 & 4.0 & 2.7 & 0.2 & 0.6 & 2.1 \\
\hline 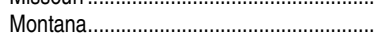 & 53,254 & 43,460 & 409 & 1,622 & 662 & 100 & 4,352 & 1,170 & $\begin{array}{r}1,479 \\
\end{array}$ & 100.0 & 83.9 & 0.8 & 3.1 & 1.3 & 0.2 & 8.4 & 2.3 \\
\hline Nebraska & 139,578 & 111,323 & 8.169 & 8,922 & 3.447 & 254 & 1,161 & 1.930 & 4,372 & 100.0 & 82.3 & 6.0 & 6.6 & 2.5 & 0.2 & 0.9 & 1.4 \\
\hline 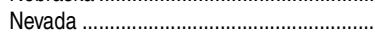 & 118,300 & 61,132 & 10,054 & 24,640 & 11,672 & 1,812 & 1,191 & 5,474 & 2,325 & 100.0 & 52.7 & 8.7 & 21.2 & 10.1 & 1.6 & 1.0 & 4.7 \\
\hline 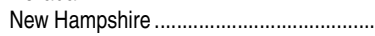 & 82,678 & 67,886 & 3,333 & 4,250 & 2,719 & 71 & 474 & 1,181 & 2,764 & 100.0 & 84.9 & 4.2 & 5.3 & 3.4 & 0.1 & 0.6 & 1.5 \\
\hline New Jersey & 439,965 & 231,485 & 64,331 & 79,793 & 36,732 & 1,759 & 1,656 & 7,242 & 16,967 & 100.0 & 54.7 & 15.2 & 18.9 & 8.7 & 0.4 & 0.4 & 1.7 \\
\hline 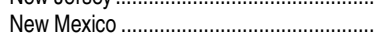 & 156,424 & 57,146 & 4,801 & 69,861 & 2,572 & 404 & 14,469 & 2,775 & 4,396 & 100.0 & 37.6 & $\begin{array}{r}3.2 \\
.2\end{array}$ & 46.0 & 1.7 & 0.3 & 9.5 & 1.8 \\
\hline New York & $1,309,986$ & 702,587 & 183,052 & 193,540 & 113,494 & 2,781 & 4,729 & 20,925 & 88,878 & 100.0 & 57.5 & 15.0 & 15.8 & 9.3 & 0.2 & 0.4 & 1.7 \\
\hline 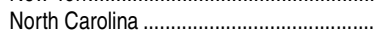 & 578,031 & 350,950 & 148,251 & 29,019 & 15,549 & 726 & 6,902 & 9,908 & 16,726 & 100.0 & 62.5 & 26.4 & 5.2 & 2.8 & 0.1 & 1.2 & 1.8 \\
\hline 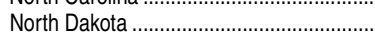 & 55,169 & 45,094 & 1,548 & 1,293 & 653 & 76 & 2,573 & 951 & 2,981 & 100.0 & 86.4 & 3.0 & 2.5 & 1.3 & 0.1 & 4.9 & 1.8 \\
\hline Ohio.... & 709,818 & 532,862 & 97,005 & 21,692 & 15,314 & 541 & 2.518 & 12.890 & 26.996 & 100.0 & 78.0 & 14.2 & 3.2 & 2.2 & 0.1 & 0.4 & 1.9 \\
\hline 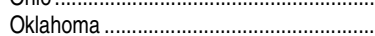 & 228,464 & 144,188 & 23,236 & 13,794 & 5,653 & 364 & 19,801 & 12,082 & $\begin{array}{r}9,346 \\
9,30\end{array}$ & 100.0 & 65.8 & 10.6 & $\begin{array}{ll}.6 \\
6.3\end{array}$ & 2.6 & 0.2 & 9.0 & 5.5 \\
\hline Oregon & 254,695 & 184,925 & 7,930 & 23,422 & 13,293 & 1,731 & 3,666 & 9,467 & 10,261 & 100.0 & 75.7 & 3.2 & 9.6 & 5.4 & 0.7 & 1.5 & 3.9 \\
\hline 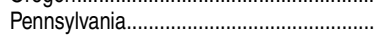 & 777,242 & 557,555 & 90,828 & 42,313 & 34,757 & 984 & 2,038 & 14,069 & 34,698 & 100.0 & 75.1 & 12.2 & 5.7 & 4.7 & 0.1 & 0.3 & 1.9 \\
\hline 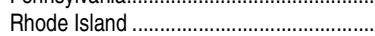 & 83,952 & 59,026 & 5,788 & 8,855 & 3,553 & 60 & 325 & 1,732 & 4,613 & 100.0 & 74.4 & 7.3 & 11.2 & 4.5 & 0.1 & 0.4 & 2.2 \\
\hline
\end{tabular}

See notes at end of table. 
Table 306.60. Fall enrollment in degree-granting postsecondary institutions, by race/ethnicity of student and state or jurisdiction: 2012-Continued

\begin{tabular}{|c|c|c|c|c|c|c|c|c|c|c|c|c|c|c|c|c|c|}
\hline \multirow[b]{2}{*}{ State or jurisdiction } & \multicolumn{9}{|c|}{ Number } & \multicolumn{8}{|c|}{ Percentage distribution of U.S. residents } \\
\hline & Total & White & Black & Hispanic & Asian & $\begin{array}{r}\text { Pacific } \\
\text { Islander }\end{array}$ & $\begin{array}{r}\text { American } \\
\text { Indian/ } \\
\text { Alaska } \\
\text { Native }\end{array}$ & $\begin{array}{r}\text { Two or } \\
\text { more races }\end{array}$ & $\begin{array}{r}\text { Non- } \\
\text { resident } \\
\text { alien }\end{array}$ & Total & White & Black & Hispanic & Asian & $\begin{array}{r}\text { Pacific } \\
\text { Islander }\end{array}$ & $\begin{array}{r}\text { American } \\
\text { Indian/ } \\
\text { Alaska } \\
\text { Native }\end{array}$ & $\begin{array}{r}\text { Two or more } \\
\text { races }\end{array}$ \\
\hline 1 & 2 & 3 & 4 & 5 & 6 & 7 & 8 & 9 & 10 & 11 & 12 & 13 & 14 & 15 & 16 & 17 & 18 \\
\hline South Carolina.... & 259,617 & 162,624 & 73,900 & 8,332 & 3,979 & 348 & 1,073 & 4,726 & 4,635 & 100.0 & 63.8 & 29.0 & 3.3 & 1.6 & 0.1 & 0.4 & 1.9 \\
\hline South Dakota ........................... & 56,058 & 46,144 & 1,854 & 1,350 & 532 & 94 & 3,509 & 1,176 & 1,399 & 100.0 & 84.4 & 3.4 & 2.5 & 1.0 & 0.2 & 6.4 & 2.2 \\
\hline Tennessee & 343,641 & 239,307 & 70,334 & 10,776 & 6,726 & 290 & 1,115 & 7,487 & 7,606 & 100.0 & 71.2 & 20.9 & 3.2 & 2.0 & 0.1 & 0.3 & 2.2 \\
\hline Texas ................. & $1,540,298$ & 644,116 & 211,637 & 510,328 & 80,136 & 2,523 & 6,786 & 28,101 & 56,671 & 100.0 & 43.4 & 14.3 & 34.4 & 5.4 & 0.2 & 0.5 & 1.9 \\
\hline Utah & 267,309 & 210,953 & 9,134 & 21,578 & 6,836 & 2,006 & 2,419 & 6,255 & 8,128 & 100.0 & 81.4 & 3.5 & 8.3 & 2.6 & 0.8 & 0.9 & 2.4 \\
\hline Vermont... & 44,703 & 38,187 & 1,212 & 1,832 & 1,072 & 40 & 232 & 1,121 & 1,007 & 100.0 & 87.4 & 2.8 & 4.2 & 2.5 & 0.1 & 0.5 & 2.6 \\
\hline 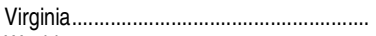 & 588,696 & 348,379 & 133,460 & 37,478 & 32,734 & 1,581 & 2,420 & 16,369 & 16,275 & 100.0 & 60.9 & 23.3 & 6.5 & 5.7 & 0.3 & 0.4 & 2.9 \\
\hline Washington ........................................ & 365,514 & 238,192 & 17,101 & 33,879 & 32,010 & 2,159 & 4,902 & 18,753 & 18,518 & 100.0 & 68.6 & 4.9 & 9.8 & 9.2 & 0.6 & 1.4 & 5.4 \\
\hline 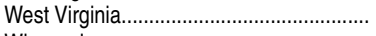 & 162,179 & 123,383 & 19,869 & 8,079 & 2,607 & 743 & 781 & 3,491 & 3,226 & 100.0 & 77.6 & 12.5 & 5.1 & 1.6 & 0.5 & 0.5 & 2.2 \\
\hline Wisconsin & 369,732 & 295,035 & 24,023 & 17,712 & 11,989 & 408 & 3,284 & 7,014 & 10,267 & 100.0 & 82.1 & 6.7 & 4.9 & 3.3 & 0.1 & 0.9 & 2.0 \\
\hline 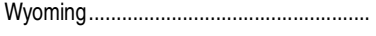 & 37,812 & 31,992 & 561 & 2,669 & 341 & 78 & 637 & 539 & 995 & 100.0 & 86.9 & 1.5 & 7.2 & 0.9 & 0.2 & 1.7 & 1.5 \\
\hline U.S. Service Academies..... & 15,227 & 10,754 & 913 & 1,581 & 762 & 78 & 87 & 843 & 209 & 100.0 & 71.6 & 6.1 & 10.5 & 5.1 & 0.5 & 0.6 & 5.6 \\
\hline Other jurisdictions ....................... & 259,943 & 1,022 & 2,291 & 242,670 & 2,922 & 9,956 & 114 & 353 & 615 & 100.0 & 0.4 & 0.9 & 93.6 & 1.1 & 3.8 & \# & 0.1 \\
\hline American Samoa .................................... & 1,795 & 2 & 0 & 0 & 16 & 1,639 & 0 & 0 & 138 & 100.0 & 0.1 & 0.0 & 0.0 & 1.0 & 98.9 & 0.0 & 0.0 \\
\hline Federated States of Micronesia... & 2,744 & 4 & 0 & 0 & 2 & 2,738 & 0 & 0 & 0 & 100.0 & 0.1 & 0.0 & 0.0 & 0.1 & 99.8 & 0.0 & 0.0 \\
\hline 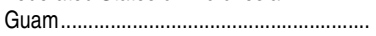 & 5,924 & 200 & 26 & 36 & 2,434 & 3,159 & 7 & 6 & 56 & 100.0 & 3.4 & 0.4 & 0.6 & 41.5 & 53.8 & 0.1 & 0.1 \\
\hline Marshall Islands............................................ & 1,123 & 0 & 0 & 0 & 0 & 1,109 & 0 & 0 & 14 & 100.0 & 0.0 & 0.0 & 0.0 & 0.0 & 100.0 & 0.0 & 0.0 \\
\hline Northern Marianas .................................... & 1,178 & 15 & 3 & 2 & 319 & 625 & 1 & 68 & 145 & 100.0 & 1.5 & 0.3 & 0.2 & 30.9 & 60.5 & 0.1 & 6.6 \\
\hline Palau & 680 & 1 & 1 & 0 & 6 & 672 & 0 & 0 & 0 & 100.0 & 0.1 & 0.1 & 0.0 & 0.9 & 98.8 & 0.0 & 0.0 \\
\hline Puerto Rico........................................... & 244,076 & 663 & 265 & 242,486 & 139 & 14 & 105 & 279 & 125 & 100.0 & 0.3 & 0.1 & 99.4 & 0.1 & \# & \# & 0.1 \\
\hline 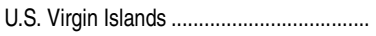 & 2,423 & 137 & 1,996 & 146 & 6 & 0 & 1 & 0 & 137 & 100.0 & 6.0 & 87.3 & 6.4 & 0.3 & 0.0 & \# & 0.0 \\
\hline
\end{tabular}

\#Rounds to zero.

Ters degrees and participate in Title IV federal financial aid programs. Detail may not sum to totals because of rounding.
SOURCE: US. Department of Education, National Center for Education Statistics, Integrated Postsecondary Education Data System (IPEDS), Spring 2013, Enrollment component. (This table was prepared November 2013.) 
Table 306.70. Fall enrollment in degree-granting postsecondary institutions, by race/ethnicity of student and state or jurisdiction: 2011

\begin{tabular}{|c|c|c|c|c|c|c|c|c|c|c|c|c|c|c|c|c|c|}
\hline \multirow[b]{2}{*}{ State or jurisdiction } & \multicolumn{9}{|c|}{ Number } & \multicolumn{8}{|c|}{ Percentage distribution of U.S. residents } \\
\hline & Total & White & Black & Hispanic & Asian & $\begin{array}{r}\text { Pacific } \\
\text { Islander }\end{array}$ & $\begin{array}{r}\text { American } \\
\text { Indian/ } \\
\text { Alaska } \\
\text { Native }\end{array}$ & $\begin{array}{r}\text { Two or } \\
\text { more races }\end{array}$ & $\begin{array}{r}\text { Non- } \\
\text { resident } \\
\text { alien }\end{array}$ & Total & White & Black & Hispanic & Asian & $\begin{array}{r}\text { Pacific } \\
\text { Islander }\end{array}$ & $\begin{array}{r}\text { American } \\
\text { Indian/ } \\
\text { Alaska } \\
\text { Native }\end{array}$ & $\begin{array}{r}\text { Two or more } \\
\text { races }\end{array}$ \\
\hline 1 & 2 & 3 & 4 & 5 & 6 & 7 & 8 & 9 & 10 & 11 & 12 & 13 & 14 & 15 & 16 & 17 & 18 \\
\hline United States .................................. & $20,994,113$ & $12,394,153$ & $3,067,947$ & $2,890,111$ & $1,216,562$ & 65,916 & 186,076 & 432,873 & 740,475 & 100.0 & 61.2 & 15.1 & 14.3 & 6.0 & 0.3 & 0.9 & 2.1 \\
\hline Alabama & 318,686 & 195,754 & 98,038 & 7,826 & 4,961 & 305 & 2,375 & 3,175 & 6,252 & 100.0 & 62.7 & 31.4 & 2.5 & 1.6 & 0.1 & 0.8 & 1.0 \\
\hline Alaska................................... & 34,932 & 22,345 & 1,188 & 2,538 & 1,522 & 287 & 4,087 & 2,128 & 837 & 100.0 & 65.5 & 3.5 & 7.4 & 4.5 & 0.8 & 12.0 & 6.2 \\
\hline 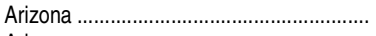 & 796,986 & 447,967 & 128,049 & 136,931 & 23,283 & 4,276 & 20,992 & 16,554 & 18,934 & 100.0 & 57.6 & 16.5 & 17.6 & 3.0 & 0.5 & 2.7 & 2.1 \\
\hline 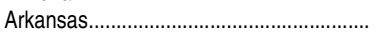 & 179,281 & 125,185 & 34,683 & 6,926 & 2,707 & 213 & 1,759 & 3,039 & 4,769 & 100.0 & 71.7 & 19.9 & 4.0 & 1.6 & 0.1 & 1.0 & 1.7 \\
\hline California & $2,685,893$ & 952,701 & 201,878 & 890,272 & 424,132 & 17,715 & 15,194 & 89,576 & 94,425 & 100.0 & 36.8 & 7.8 & 34.4 & 16.4 & 0.7 & 0.6 & 3.5 \\
\hline Colorado ....... & 365,820 & 250,535 & 29,371 & 50,152 & 12,666 & 1,053 & 4,242 & 9,413 & 8,388 & 100.0 & 70.1 & 8.2 & 14.0 & 3.5 & 0.3 & 1.2 & 2.6 \\
\hline 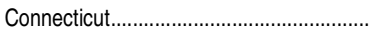 & 201,638 & 131,955 & 23,822 & 24,038 & 9,296 & 207 & 604 & 3,780 & 7,936 & 100.0 & 68.1 & 12.3 & 12.4 & 4.8 & 0.1 & 0.3 & 2.0 \\
\hline Delaware............................................. & 56,516 & 35,318 & 12,301 & 3,153 & 1,970 & 76 & 186 & 934 & 2,578 & 100.0 & 65.5 & 22.8 & 5.8 & 3.7 & 0.1 & 0.3 & 1.7 \\
\hline 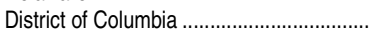 & 90,213 & 43,263 & 25,599 & 5,863 & 5,785 & 121 & 292 & 1,649 & 7,641 & 100.0 & 52.4 & 31.0 & 7.1 & 7.0 & 0.1 & 0.4 & 2.0 \\
\hline 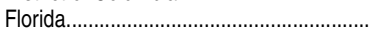 & $1,143,698$ & 562,862 & 230,863 & 257,389 & 36,313 & 2,129 & 4,591 & 18,082 & 31,469 & 100.0 & 50.6 & 20.8 & 23.1 & 3.3 & 0.2 & 0.4 & 1.6 \\
\hline Georgia... & 565,459 & 289,472 & 197,288 & 27,499 & 22,294 & 878 & 1,991 & 10,667 & 15,370 & 100.0 & 52.6 & 35.9 & 5.0 & 4.1 & 0.2 & 0.4 & 1.9 \\
\hline Hawaii ................ & 79,018 & 15,788 & 1,977 & 7,349 & 24,621 & 7,608 & 289 & 16,963 & 4,423 & 100.0 & 21.2 & 2.7 & 9.9 & 33.0 & 10.2 & 0.4 & 22.7 \\
\hline Idaho & 90,142 & 75,608 & 995 & 6,584 & 1,504 & 755 & 1,162 & 1,272 & 2,262 & 100.0 & 86.0 & 1.1 & 7.5 & 1.7 & 0.9 & 1.3 & 1.4 \\
\hline 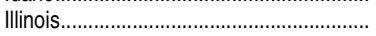 & 892,881 & 528,843 & 140,827 & 122,957 & 49,097 & 2,043 & 2,767 & 14,666 & 31,681 & 100.0 & 61.4 & 16.4 & 14.3 & 5.7 & 0.2 & 0.3 & 1.7 \\
\hline Indiana & 457,824 & 348,448 & 49,365 & 20,171 & 9,819 & 297 & 1,584 & 7,207 & 20,933 & 100.0 & 79.8 & 11.3 & 4.6 & 2.2 & 0.1 & 0.4 & 1.6 \\
\hline lowa ............... & 372,146 & 267,419 & 56,175 & 21,724 & 7,792 & 1,178 & 3,036 & 4,501 & 10,321 & 100.0 & 73.9 & 15.5 & 6.0 & 2.2 & 0.3 & 0.8 & 1.2 \\
\hline 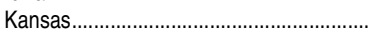 & 216,662 & 159,159 & 17,024 & 14,685 & 5,490 & 288 & 3,074 & 4,197 & 12,745 & 100.0 & 78.1 & 8.3 & 7.2 & 2.7 & 0.1 & 1.5 & 2.1 \\
\hline 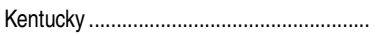 & 293,766 & 243,179 & 30,205 & 6,037 & 3,769 & 286 & 829 & 4,582 & 4,879 & 100.0 & 84.2 & 10.5 & 2.1 & 1.3 & 0.1 & 0.3 & 1.6 \\
\hline Louisiana ……………………………… & 265,856 & 153,686 & 83,203 & 10,469 & 6,260 & 263 & 1,760 & 3,211 & 7,004 & 100.0 & 59.4 & 32.1 & 4.0 & 2.4 & 0.1 & 0.7 & 1.2 \\
\hline Maine & 72,297 & 64,018 & 1,940 & 1,624 & 1,368 & 61 & 877 & 1,169 & 1,240 & 100.0 & 90.1 & 2.7 & 2.3 & 1.9 & 0.1 & 1.2 & 1.6 \\
\hline Maryland....... & 380,097 & 193,270 & 113,506 & 22,427 & 24,380 & 686 & 1,240 & 8,186 & 16,402 & 100.0 & 53.1 & 31.2 & 6.2 & 6.7 & 0.2 & 0.3 & 2.3 \\
\hline Massachusetts....................................... & 508,554 & 330,153 & 43,063 & 46,247 & 36,267 & 459 & 1,528 & 11,682 & 39,155 & 100.0 & 70.3 & 9.2 & 9.9 & 7.7 & 0.1 & 0.3 & 2.5 \\
\hline Michigan & 685,526 & 491,140 & 104,641 & 22,992 & 21,702 & 873 & 4,987 & 12,910 & 26,281 & 100.0 & 74.5 & 15.9 & 3.5 & 3.3 & 0.1 & 0.8 & 2.0 \\
\hline 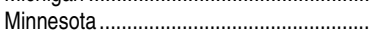 & 457,752 & 327,279 & 61,785 & 17,960 & 19,627 & 607 & 3,879 & 11,808 & 14,807 & 100.0 & 73.9 & 13.9 & 4.1 & 4.4 & 0.1 & 0.9 & 2.7 \\
\hline Mississippi & 179,090 & 97,301 & 72,941 & 2,605 & 1,776 & 138 & 772 & 1,115 & 2,442 & 100.0 & 55.1 & 41.3 & 1.5 & 1.0 & 0.1 & 0.4 & 0.6 \\
\hline Missouri .... & 456,997 & 334,853 & 67,932 & 16,769 & 11,700 & 833 & 2,669 & 7,676 & 14,565 & 100.0 & 75.7 & 15.4 & 3.8 & 2.6 & 0.2 & 0.6 & 1.7 \\
\hline Montana & 54,042 & 44,328 & 407 & 1,568 & 563 & 103 & 4,601 & 1,096 & 1,376 & 100.0 & 84.2 & 0.8 & 3.0 & 1.1 & 0.2 & 8.7 & 2.1 \\
\hline Nebraska ................................................ & 142,875 & 115,025 & 8,666 & 8,254 & 3,423 & 252 & 1,303 & 1,756 & 4,196 & 100.0 & 82.9 & 6.2 & 6.0 & 2.5 & 0.2 & 0.9 & 1.3 \\
\hline Nevada ........... & 121,013 & 64,703 & 10,981 & 23,090 & 11,925 & 1,950 & 1,348 & 4,638 & 2,378 & 100.0 & 54.5 & 9.3 & 19.5 & 10.1 & 1.6 & 1.1 & 3.9 \\
\hline New Hampshire ............................................ & 77,444 & 64,966 & 2,547 & 3,548 & 2,354 & 64 & 451 & 961 & 2,553 & 100.0 & 86.7 & 3.4 & 4.7 & 3.1 & 0.1 & 0.6 & 1.3 \\
\hline New Jersey & 443,750 & 238,359 & 65,423 & 77,594 & 36,319 & 1,748 & 1,332 & 5,645 & 17,330 & 100.0 & 55.9 & 15.3 & 18.2 & 8.5 & 0.4 & 0.3 & 1.3 \\
\hline 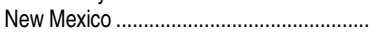 & 157,555 & 59,199 & 4,860 & 69,282 & 2,618 & 370 & 14,399 & 2,822 & 4,005 & 100.0 & 38.6 & 3.2 & 45.1 & 1.7 & 0.2 & 9.4 & 1.8 \\
\hline New York & $1,318,142$ & 725,136 & 185,722 & 186,320 & 113,438 & 2,897 & 4,992 & 17,969 & 81,668 & 100.0 & 58.6 & 15.0 & 15.1 & 9.2 & 0.2 & 0.4 & 1.5 \\
\hline 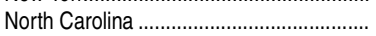 & 585,013 & 359,706 & 152,224 & 26,679 & 15,025 & 694 & 7,092 & 7,663 & 15,930 & 100.0 & 63.2 & 26.7 & 4.7 & 2.6 & 0.1 & 1.2 & 1.3 \\
\hline 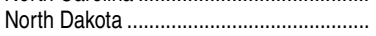 & 55,772 & 45,522 & 1,496 & 1,238 & 748 & 67 & 2,801 & 754 & 3,146 & 100.0 & 86.5 & 2.8 & 2.4 & 1.4 & 0.1 & 5.3 & 1.4 \\
\hline 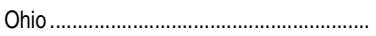 & 735,026 & 556,130 & 104,719 & 20,539 & 15,460 & 470 & 2,874 & 10,291 & 24,543 & 100.0 & 78.3 & 14.7 & 2.9 & 2.2 & 0.1 & 0.4 & 1.4 \\
\hline Oklahoma & 230,154 & 148,159 & 23,812 & 12,201 & 5,814 & 350 & 21,472 & 9,235 & 9,111 & 100.0 & 67.0 & 10.8 & 5.5 & 2.6 & 0.2 & 9.7 & 4.2 \\
\hline Oregon & 259,061 & 192,385 & 7,710 & 22,609 & 13,346 & 1,808 & 4,082 & 8,017 & 9,104 & 100.0 & 77.0 & 3.1 & 9.0 & 5.3 & 0.7 & 1.6 & 3.2 \\
\hline Pennsylvania & 787,789 & 573,057 & 93,374 & 40,619 & 33,986 & 1,076 & 2,144 & 11,956 & 31,577 & 100.0 & 75.8 & 12.3 & 5.4 & 4.5 & 0.1 & 0.3 & 1.6 \\
\hline Rhode Island ………………………..... & 84,644 & 60,835 & 5,800 & 8,336 & 3,778 & 57 & 329 & 1,171 & 4,338 & 100.0 & 75.8 & 7.2 & 10.4 & 4.7 & 0.1 & 0.4 & 1.5 \\
\hline
\end{tabular}

See notes at end of table. 
Table 306.70. Fall enrollment in degree-granting postsecondary institutions, by race/ethnicity of student and state or jurisdiction: 2011-Continued

\begin{tabular}{|c|c|c|c|c|c|c|c|c|c|c|c|c|c|c|c|c|c|}
\hline \multirow[b]{2}{*}{ State or jurisdiction } & \multicolumn{9}{|c|}{ Number } & \multicolumn{8}{|c|}{ Percentage distribution of U.S. residents } \\
\hline & Total & White & Black & Hispanic & Asian & $\begin{array}{r}\text { Pacific } \\
\text { Islander }\end{array}$ & $\begin{array}{r}\text { American } \\
\text { Indian/ } \\
\text { Alaska } \\
\text { Native }\end{array}$ & $\begin{array}{r}\text { Two or } \\
\text { more races }\end{array}$ & $\begin{array}{r}\text { Non- } \\
\text { resident } \\
\text { alien }\end{array}$ & Total & White & Black & Hispanic & Asian & $\begin{array}{r}\text { Pacific } \\
\text { Islander }\end{array}$ & $\begin{array}{r}\text { American } \\
\text { Indian/ } \\
\text { Alaska } \\
\text { Native }\end{array}$ & $\begin{array}{r}\text { Two or more } \\
\text { races }\end{array}$ \\
\hline 1 & 2 & 3 & 4 & 5 & 6 & 7 & 8 & 9 & 10 & 11 & 12 & 13 & 14 & 15 & 16 & 17 & 18 \\
\hline South Carolina.... & 260,002 & 164,107 & 75,260 & 7,370 & 3,715 & 346 & 1,092 & 3,972 & 4,230 & 100.0 & 64.1 & 29.4 & 2.9 & 1.5 & 0.1 & 0.4 & 1.6 \\
\hline South Dakota...................... & 55,899 & 46,646 & 1,516 & 1,226 & 529 & 107 & 3,747 & 851 & 1,277 & 100.0 & 85.4 & 2.8 & 2.2 & 1.0 & 0.2 & 6.9 & 1.6 \\
\hline Tennessee & 350,275 & 244,781 & 73,761 & 10,024 & 6,800 & 339 & 1,165 & 6,658 & 6,747 & 100.0 & 71.3 & 21.5 & 2.9 & 2.0 & 0.1 & 0.3 & 1.9 \\
\hline Texas ................. & $1,564,387$ & 675,557 & 221,052 & 498,127 & 81,422 & 2,556 & 7,808 & 22,808 & 55,057 & 100.0 & 44.8 & 14.6 & 33.0 & 5.4 & 0.2 & 0.5 & 1.5 \\
\hline Utah & 264,396 & 213,343 & 7,001 & 21,058 & 6,384 & 1,933 & 2,754 & 4,835 & 7,088 & 100.0 & 82.9 & 2.7 & 8.2 & 2.5 & 0.8 & 1.1 & 1.9 \\
\hline Vermont... & 45,143 & 39,171 & 1,138 & 1,586 & 1,044 & 36 & 260 & 966 & 942 & 100.0 & 88.6 & 2.6 & 3.6 & 2.4 & 0.1 & 0.6 & 2.2 \\
\hline 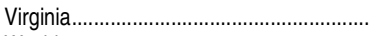 & 588,465 & 351,322 & 135,201 & 36,092 & 32,117 & 1,636 & 2,452 & 13,790 & 15,855 & 100.0 & 61.4 & 23.6 & 6.3 & 5.6 & 0.3 & 0.4 & 2.4 \\
\hline Washington ........................................ & 372,841 & 250,934 & 17,978 & 31,551 & 33,185 & 2,335 & 5,427 & 15,009 & 16,422 & 100.0 & 70.4 & 5.0 & 8.9 & 9.3 & 0.7 & 1.5 & 4.2 \\
\hline 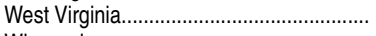 & 162,308 & 126,061 & 12,432 & 7,051 & 9,247 & 474 & 1,058 & 2,954 & 3,031 & 100.0 & 79.1 & 7.8 & 4.4 & 5.8 & 0.3 & 0.7 & 1.9 \\
\hline Wisconsin & 376,603 & 303,460 & 24,734 & 16,911 & 12,000 & 418 & 3,506 & 5,941 & 9,633 & 100.0 & 82.7 & 6.7 & 4.6 & 3.3 & 0.1 & 1.0 & 1.6 \\
\hline 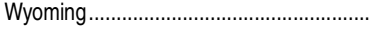 & 38,092 & 32,522 & 489 & 2,491 & 347 & 95 & 719 & 432 & 997 & 100.0 & 87.7 & 1.3 & 6.7 & 0.9 & 0.3 & 1.9 & 1.2 \\
\hline U.S. Service Academies..... & 15,692 & 11,328 & 985 & 1,560 & 874 & 100 & 102 & 541 & 202 & 100.0 & 73.1 & 6.4 & 10.1 & 5.6 & 0.6 & 0.7 & 3.5 \\
\hline Other jurisdictions ....................... & 267,159 & 1,071 & 2,493 & 248,224 & 2,928 & 10,663 & 68 & 1,070 & 642 & 100.0 & 0.4 & 0.9 & 93.1 & 1.1 & 4.0 & 0.0 & 0.4 \\
\hline American Samoa & 2,091 & 4 & 0 & 1 & 7 & 1,933 & 0 & 0 & 146 & 100.0 & 0.2 & 0.0 & 0.1 & 0.4 & 99.4 & 0.0 & 0.0 \\
\hline Federated States of Micronesia... & 2,915 & 3 & 0 & 0 & 2 & 2,910 & 0 & 0 & 0 & 100.0 & 0.1 & 0.0 & 0.0 & 0.1 & 99.8 & 0.0 & 0.0 \\
\hline 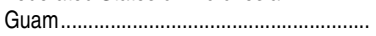 & 6,360 & 246 & 42 & 34 & 2,492 & 3,483 & 9 & 4 & 50 & 100.0 & 3.9 & 0.7 & 0.5 & 39.5 & 55.2 & 0.1 & 0.1 \\
\hline Marshall Islands............................................ & 989 & 0 & 0 & 0 & 0 & 984 & 1 & 0 & 4 & 100.0 & 0.0 & 0.0 & 0.0 & 0.0 & 99.9 & 0.1 & 0.0 \\
\hline Northern Marianas .................................... & 1,046 & 13 & 5 & 5 & 251 & 599 & 1 & 49 & 123 & 100.0 & 1.4 & 0.5 & 0.5 & 27.2 & 64.9 & 0.1 & 5.3 \\
\hline Palau & 742 & 0 & 1 & 0 & 6 & 733 & 2 & 0 & 0 & 100.0 & 0.0 & 0.1 & 0.0 & 0.8 & 98.8 & 0.3 & 0.0 \\
\hline Puerto Rico........................................... & 250,402 & 639 & 354 & 248,004 & 161 & 20 & 47 & 998 & 179 & 100.0 & 0.3 & 0.1 & 99.1 & 0.1 & \# & \# & 0.4 \\
\hline 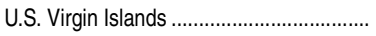 & 2,614 & 166 & 2,091 & 180 & 9 & 1 & 8 & 19 & 140 & 100.0 & 6.7 & 84.5 & 7.3 & 0.4 & \# & 0.3 & 0.8 \\
\hline
\end{tabular}

\#Rounds to zero.

.

SOURCE: U.S. Department of Education, National Center for Education Statistics, Integrated Postsecondary Education Data degrees and participate in Title IV federal financial aid programs. Detail may not sum to totals because of rounding. 
Table 307.10. Full-time-equivalent fall enrollment in degree-granting postsecondary institutions, by control and level of institution: 1967 through 2023

\begin{tabular}{|c|c|c|c|c|c|c|c|c|c|c|c|c|c|}
\hline \multirow[b]{3}{*}{ Year } & \multirow{2}{*}{\multicolumn{3}{|c|}{ All institutions }} & \multirow{2}{*}{\multicolumn{3}{|c|}{ Public institutions }} & \multicolumn{7}{|c|}{ Private institutions } \\
\hline & & & & & & & \multirow[b]{2}{*}{ Total } & \multicolumn{3}{|c|}{ 4-year } & \multicolumn{3}{|c|}{ 2-year } \\
\hline & Total & 4-year & 2-year & Total & 4-year & 2-year & & Total & Nonprofit & For-profit & Total & Nonprofit & For-profit \\
\hline 1 & 2 & 3 & 4 & 5 & 6 & 7 & 8 & 9 & 10 & 11 & 12 & 13 & 14 \\
\hline $1967 .$. & $5,499,360$ & $4,448,302$ & $1,051,058$ & $3,777,701$ & $2,850,432$ & 927,269 & $1,721,659$ & $1,597,870$ & - & - & 123,789 & - & - \\
\hline $1968 \ldots$ & $5,977,768$ & $4,729,522$ & $1,248,246$ & $4,248,639$ & $3,128,057$ & $1,120,582$ & $1,729,129$ & $1,601,465$ & - & - & 127,664 & - & - \\
\hline $1969 \ldots \ldots \ldots \ldots \ldots \ldots \ldots \ldots \ldots$ & $6,333,357$ & $4,899,034$ & $1,434,323$ & $4,577,353$ & $3,259,323$ & $1,318,030$ & $1,756,004$ & $1,639,711$ & - & - & 116,293 & - & - \\
\hline ............................. & $6,737,819$ & $5,145,422$ & $1,592,397$ & $4,953,144$ & $3,468,569$ & $1,484,575$ & $1,784,675$ & $1,676,853$ & - & - & 107,822 & - & - \\
\hline $1971 .$. & $7,148,558$ & $5,357,647$ & $1,790,911$ & $5,344,402$ & $3,660,626$ & $1,683,776$ & $1,804,156$ & $1,697,021$ & - & - & 107,135 & - & - \\
\hline $1972 \ldots$ & $7,253,757$ & $5,406,833$ & $1,846,924$ & $5,452,854$ & $3,706,238$ & $1,746,616$ & $1,800,903$ & $1,700,595$ & - & - & 100,308 & - & - \\
\hline $1973 .$. & $7,453,463$ & $5,439,230$ & $2,014,233$ & $5,629,563$ & $3,721,037$ & $1,908,526$ & $1,823,900$ & $1,718,193$ & - & - & 105,707 & - & - \\
\hline $1974 \ldots$ & $7,805,452$ & $5,606,247$ & $2,199,205$ & $5,944,799$ & $3,847,543$ & $2,097,256$ & $1,860,653$ & $1,758,704$ & - & - & 101,949 & - & - \\
\hline 1975 & $8,479,698$ & $5,900,408$ & $2,579,290$ & $6,522,319$ & $4,056,502$ & $2,465,817$ & $1,957,379$ & $1,843,906$ & - & - & 113,473 & - & - \\
\hline 1976. & $8,312,502$ & $5,848,001$ & $2,464,501$ & $6,349,903$ & $3,998,450$ & $2,351,453$ & $1,962,599$ & $1,849,551$ & - & - & 113,048 & - & - \\
\hline $1977 .$. & $8,415,339$ & $5,935,076$ & $2,480,263$ & $6,396,476$ & $4,039,071$ & $2,357,405$ & $2,018,863$ & $1,896,005$ & - & - & 122,858 & - & - \\
\hline 1978. & $8,348,482$ & $5,932,357$ & $2,416,125$ & $6,279,199$ & $3,996,126$ & $2,283,073$ & $2,069,283$ & $1,936,231$ & - & - & 133,052 & - & - \\
\hline $1979 \ldots \ldots \ldots \ldots$ & $8,487,317$ & $6,016,072$ & $2,471,245$ & $6,392,617$ & $4,059,304$ & $2,333,313$ & $2,094,700$ & $1,956,768$ & - & - & 137,932 & - & - \\
\hline 1980. & $8,819,013$ & $6,161,372$ & $2,657,641$ & $6,642,294$ & $4,158,267$ & $2,484,027$ & $2,176,719$ & $2,003,105$ & - & - & $173,614^{1}$ & - & - \\
\hline 1981. & $9,014,521$ & $6,249,847$ & $2,764,674$ & $6,781,300$ & $4,208,506$ & $2,572,794$ & $2,233,221$ & $2,041,341$ & - & - & 191,8801 & - & - \\
\hline $1982 \ldots$ & $9,091,648$ & $6,248,923$ & $2,842,725$ & $6,850,589$ & $4,220,648$ & $2,629,941$ & $2,241,059$ & $2,028,275$ & - & - & 212,784 & - & - \\
\hline 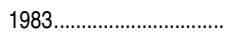 & $9,166,398$ & $6,325,222$ & $2,841,176$ & $6,881,479$ & $4,265,807$ & $2,615,672$ & $2,284,919$ & $2,059,415$ & - & - & 225,504 & - & - \\
\hline 1984 & $8,951,695$ & $6,292,711$ & $2,658,984$ & $6,684,664$ & $4,237,895$ & $2,446,769$ & $2,267,031$ & $2,054,816$ & - & - & 212,215 & - & - \\
\hline 1985 & $8,943,433$ & $6,294,339$ & $2,649,094$ & $6,667,781$ & $4,239,622$ & $2,428,159$ & $2,275,652$ & $2,054,717$ & - & - & 220,935 & - & - \\
\hline 1986. & $9,064,165$ & $6,360,325$ & $2,703,842$ & $6,778,045$ & $4,295,494$ & $2,482,551$ & $2,286,122$ & $2,064,831$ & - & - & $221,291^{2}$ & - & - \\
\hline $1987 \ldots \ldots \ldots$ & $9,229,736$ & $6,486,504$ & $2,743,230$ & $6,937,690$ & $4,395,728$ & $2,541,961$ & $2,292,045$ & $2,090,776$ & - & - & 201,2692 & - & - \\
\hline 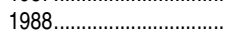 & $9,464,271$ & $6,664,146$ & $2,800,125$ & $7,096,905$ & $4,505,774$ & $2,591,131$ & $2,367,366$ & $2,158,372$ & - & - & 208,994 & - & - \\
\hline $1989 \ldots \ldots \ldots \ldots \ldots \ldots \ldots \ldots \ldots$ & $9,780,881$ & $6,813,602$ & $2,967,279$ & $7,371,590$ & $4,619,828$ & $2,751,762$ & $2,409,291$ & $2,193,774$ & - & - & 215,517 & - & - \\
\hline 1990 & $9,983,436$ & $6,968,008$ & 3,01 & 7,5 & 4,7 & 2,8 & $2,425,454$ & 7,959 & 7,668 & 50,291 & 495 & 72,785 & 124,710 \\
\hline 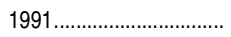 & $10,360,606$ & $7,081,454$ & $3,279,152$ & $7,862,845$ & $4,795,704$ & $3,067,141$ & $2,497,761$ & $2,285,750$ & $2,223,463$ & 62,287 & 212,011 & 72,545 & 139,466 \\
\hline $1992 \ldots \ldots \ldots$ & $10,436,776$ & $7,129,379$ & $3,307,397$ & $7,911,701$ & $4,797,884$ & $3,113,817$ & $2,525,075$ & $2,331,495$ & $2,267,373$ & 64,122 & 193,580 & 66,647 & 126,933 \\
\hline 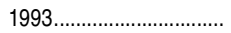 & $10,351,415$ & $7,120,921$ & $3,230,494$ & $7,812,394$ & $4,765,983$ & $3,046,411$ & $2,539,021$ & $2,354,938$ & $2,282,643$ & 72,295 & 184,083 & 70,469 & 113,614 \\
\hline $1994 \ldots \ldots$ & $10,348,072$ & $7,137,341$ & $3,210,731$ & $7,784,396$ & $4,749,524$ & $3,034,872$ & $2,563,676$ & $2,387,817$ & $2,301,063$ & 86,754 & 175,859 & 69,578 & 106,281 \\
\hline $1995 .$. & $10,334,956$ & $7,172,844$ & $3,162,112$ & 815 & $4,757,223$ & $2,994,592$ & $2,583,141$ & $2,415,621$ & $2,328,730$ & 86,891 & 167,520 & 62,416 & 104 \\
\hline 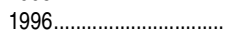 & $10,481,886$ & $7,234,541$ & $3,247,345$ & $7,794,895$ & $4,767,117$ & $3,027,778$ & $2,686,991$ & $2,467,424$ & $2,353,561$ & 113,863 & 219,567 & 63,954 & 155,613 \\
\hline $1997 \ldots \ldots \ldots \ldots \ldots$ & $10,615,028$ & $7,338,794$ & $3,276,234$ & $7,869,764$ & $4,813,849$ & $3,055,915$ & $2,745,264$ & $2,524,945$ & $2,389,627$ & 135,318 & 220,319 & 61,761 & 158,558 \\
\hline $1998 \ldots \ldots \ldots \ldots$ & $10,698,775$ & $7,467,828$ & $3,230,947$ & $7,880,135$ & $4,868,857$ & $3,011,278$ & $2,818,640$ & $2,598,971$ & $2,436,188$ & 162,783 & 219,669 & 56,834 & 162,835 \\
\hline $1999^{3} \ldots \ldots \ldots \ldots \ldots \ldots \ldots \ldots \ldots$ & $10,974,519$ & $7,634,247$ & $3,340,272$ & $8,059,240$ & $4,949,851$ & $3,109,389$ & $2,915,279$ & $2,684,396$ & $2,488,140$ & 196,256 & 230,883 & 53,956 & 176,927 \\
\hline $2000 \ldots \ldots \ldots \ldots \ldots \ldots$ & $11,267,025$ & $7,795,139$ & $3,471,886$ & $8,266,932$ & $5,025,588$ & $3,241,344$ & $3,000,093$ & $2,769,551$ & $2,549,676$ & 219,875 & 230,542 & 51,503 & 179,039 \\
\hline $2001 \ldots \ldots \ldots$ & $11,765,945$ & $8,087,980$ & $3,677,965$ & $8,639,154$ & $5,194,035$ & $3,445,119$ & $3,126,791$ & $2,893,945$ & $2,612,833$ & 281,112 & 232,846 & 41,037 & 191,809 \\
\hline $2002 \ldots \ldots \ldots \ldots \ldots \ldots \ldots$ & $12,331,319$ & $8,439,064$ & $3,892,255$ & $9,061,411$ & $5,406,283$ & $3,655,128$ & $3,269,908$ & $3,032,781$ & $2,699,702$ & 333,079 & 237,127 & 40,110 & 197,017 \\
\hline 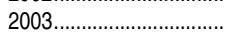 & $12,687,597$ & $8,744,188$ & $3,943,409$ & $9,240,724$ & $5,557,680$ & $3,683,044$ & $3,446,873$ & $3,186,508$ & $2,776,850$ & 409,658 & 260,365 & 36,815 & 223,550 \\
\hline $2004 \ldots \ldots \ldots \ldots \ldots \ldots \ldots$ & $13,000,994$ & $9,018,024$ & $3,982,970$ & $9,348,081$ & $5,640,650$ & $3,707,431$ & $3,652,913$ & $3,377,374$ & $2,837,251$ & 540,123 & 275,539 & 34,202 & 241,337 \\
\hline $2005 .$. & $13,200,790$ & $9,261,634$ & $3,939,156$ & $9,390,216$ & $5,728,327$ & $3,661,889$ & $3,810,574$ & $3,533,307$ & $2,878,354$ & 654,953 & 277,267 & 34,729 & 242,538 \\
\hline $2006 \ldots$ & $13,403,097$ & $9,456,166$ & $3,946,931$ & $9,503,558$ & $5,824,768$ & $3,678,790$ & $3,899,539$ & $3,631,398$ & $2,936,172$ & 695,226 & 268,141 & 31,203 & 236,938 \\
\hline $2007 \ldots \ldots$ & $13,782,702$ & $9,769,560$ & $4,013,142$ & $9,739,709$ & $5,994,230$ & $3,745,479$ & $4,042,993$ & $3,775,330$ & $2,993,729$ & 781,601 & 267,663 & 26,134 & 241,529 \\
\hline $2008 \ldots \ldots \ldots \ldots \ldots \ldots \ldots$ & $14,394,238$ & $10,169,454$ & $4,224,784$ & $10,061,812$ & $6,139,525$ & $3,922,287$ & $4,332,426$ & $4,029,929$ & $3,060,308$ & 969,621 & 302,497 & 28,065 & 274,432 \\
\hline $2009 \ldots \ldots \ldots \ldots$ & $15,495,892$ & $10,809,494$ & $4,686,398$ & $10,750,132$ & $6,452,407$ & $4,297,725$ & $4,745,760$ & $4,357,087$ & $3,149,743$ & $1,207,344$ & 388,673 & 27,959 & 360,714 \\
\hline 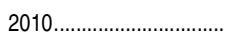 & $15,943,343$ & $11,126,152$ & $4,817,191$ & $11,020,752$ & $6,636,175$ & $4,384,577$ & $4,922,591$ & $4,489,977$ & $3,235,803$ & $1,254,174$ & 432,614 & 26,896 & 405,718 \\
\hline 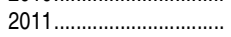 & $15,885,804$ & $11,265,364$ & $4,620,440$ & $10,948,542$ & $6,732,931$ & $4,215,611$ & $4,937,262$ & $4,532,433$ & $3,286,805$ & $1,245,628$ & 404,829 & 34,268 & 370,561 \\
\hline 2012 & $15,594,638$ & $11,231,758$ & $4,362,880$ & $10,780,749$ & $6,764,423$ & $4,016,326$ & $4,813,889$ & $4,467,335$ & $3,311,250$ & $1,156,085$ & 346,554 & 32,609 & 313,945 \\
\hline $2013^{4}$ & $15,581,330$ & $11,182,910$ & $4,398,420$ & $10,774,870$ & $6,726,640$ & $4,048,230$ & $4,806,460$ & $4,456,270$ & - & - & 350,190 & - & - \\
\hline 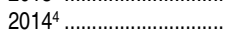 & $15,891,020$ & $11,413,030$ & $4,477,990$ & $10,977,620$ & $6,857,500$ & $4,120,120$ & $4,913,400$ & $4,555,530$ & - & - & 357,860 & - & - \\
\hline $2015^{4}$. & $16,060,590$ & $11,533,090$ & $4,527,500$ & $11,090,430$ & $6,924,800$ & $4,165,640$ & $4,970,160$ & $4,608,300$ & - & - & 361,860 & - & - \\
\hline $2016^{4}$. & $16,282,740$ & $11,688,370$ & $4,594,380$ & $11,240,490$ & $7,013,460$ & $4,227,030$ & $5,042,250$ & $4,674,910$ & - & - & 367,340 & - & - \\
\hline $2017^{4}$. & $16,534,430$ & $11,863,600$ & $4,670,830$ & $11,412,230$ & $7,114,860$ & $4,297,380$ & $5,122,200$ & $4,748,740$ & - & - & 373,460 & - & - \\
\hline $2018^{4}$. & $16,732,180$ & $11,998,930$ & $4,733,250$ & $11,549,110$ & $7,194,350$ & $4,354,760$ & $5,183,070$ & $4,804,580$ & - & - & 378,490 & - & - \\
\hline $2019^{4}$ & $16,934,890$ & $12,139,910$ & $4,794,980$ & $11,688,730$ & $7,277,260$ & $4,411,470$ & $5,246,160$ & $4,862,650$ & - & - & 383,510 & - & - \\
\hline $2020^{4}$ & $17,137,260$ & $12,287,620$ & $4,849,640$ & $11,825,450$ & $7,363,670$ & $4,461,780$ & $5,311,810$ & $4,923,950$ & - & - & 387,860 & - & - \\
\hline $2021^{4}$. & $17,385,110$ & $12,466,900$ & $4,918,210$ & $11,993,390$ & $7,468,650$ & $4,524,740$ & $5,391,720$ & $4,998,240$ & - & - & 393,480 & - & - \\
\hline $2022^{4} \ldots \ldots \ldots \ldots \ldots \ldots \ldots \ldots \ldots$ & $17,646,730$ & $12,652,750$ & $4,993,980$ & $12,171,220$ & $7,577,140$ & $4,594,080$ & $5,475,500$ & $5,075,610$ & - & - & 399,900 & - & - \\
\hline $2023^{4} \ldots \ldots \ldots \ldots \ldots \ldots \ldots \ldots$ & $17,890,360$ & $12,824,930$ & $5,065,430$ & $12,337,690$ & $7,678,120$ & $4,659,570$ & $5,552,670$ & $5,146,810$ & - & - & 405,860 & - & - \\
\hline
\end{tabular}

\section{-Not available.}

${ }^{1}$ Large increases are due to the addition of schools accredited by the Accrediting Commission of Career Schools and Colleges of Technology.

${ }^{2}$ Because of imputation techniques, data are not consistent with figures for other years. ${ }^{3}$ Revised from previously published figures.

${ }^{4}$ Projected.

NOTE: Full-time-equivalent enrollment is the full-time enrollment, plus the full-time equivalent of the part-time students. Data through 1995 are for institutions of higher education, while later data are for degree-granting institutions. Degree-granting institutions grant associate's or higher degrees and participate in Title IV federal financial aid programs. The degree-granting classification is very similar to the earlier higher education classification, but it includes more 2-year colleges and excludes a few higher education institutions that did not grant degrees. SOURCE: U.S. Department of Education, National Center for Education Statistics, Higher Education General Information Survey (HEGIS), "Fall Enrollment in Colleges and Universities" surveys, 1967 through 1985; Integrated Postsecondary Education Data System (IPEDS), "Fall Enrollment Survey" (IPEDS-EF:86-99); IPEDS Spring 2001 through Spring 2013, Enrollment component; and Enrollment in Degree-Granting Institutions Projection Model, 1980 through 2023. (This table was prepared March 2014.) 
CHAPTER 3: Postsecondary Education 443

Full-Time-Equivalent Fall Enrollment

Table 307.20. Full-time-equivalent fall enrollment in degree-granting postsecondary institutions, by control and level of institution and state or jurisdiction: 2000, 2010, and 2012

\begin{tabular}{|c|c|c|c|c|c|c|c|c|c|c|c|c|}
\hline \multirow[b]{3}{*}{ State or jurisdiction } & \multicolumn{6}{|c|}{ Public } & \multirow{2}{*}{\multicolumn{2}{|c|}{$\begin{array}{c}\text { Private } \\
\text { nonprofit 4-year }\end{array}$}} & \multicolumn{4}{|c|}{ Private for-profit } \\
\hline & \multicolumn{3}{|c|}{ 4-year } & \multicolumn{3}{|c|}{ 2-year } & & & \multicolumn{2}{|c|}{ 4-year } & \multicolumn{2}{|c|}{ 2-year } \\
\hline & 2000 & 2010 & 2012 & 2000 & 2010 & 2012 & 2010 & 2012 & 2010 & 2012 & 2010 & 2012 \\
\hline 1 & 2 & 3 & 4 & 5 & 6 & 7 & 8 & 9 & 10 & 11 & 12 & 13 \\
\hline United States .............................. & $5,025,588$ & $6,636,175$ & $6,764,423$ & $3,241,344$ & $4,384,577$ & $4,016,326$ & $3,235,803$ & $3,311,250$ & $1,254,174$ & $1,156,085$ & 405,718 & 313,945 \\
\hline Alabama .......... & 111,322 & 140,235 & 138,226 & 48,545 & 68,677 & 58,419 & 22,982 & 23,299 & 23,469 & 22,067 & 2,960 & 2,868 \\
\hline 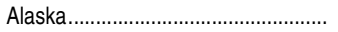 & 16,335 & 20,618 & 19,987 & 473 & 357 & 331 & 529 & 558 & 618 & 1,259 & 0 & 228 \\
\hline rizona ......................................... & 87,301 & 120,269 & 125,460 & 85,778 & 122,717 & 116,126 & 7,487 & 7,725 & 370,314 & 324,788 & 15,601 & 10,821 \\
\hline 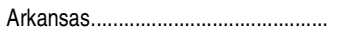 & 57,897 & 77,388 & 80,027 & 21,519 & 41,223 & 38,973 & 14,596 & 14,695 & 2,450 & 1,722 & 683 & 185 \\
\hline$\ldots \ldots \ldots \ldots \ldots \ldots \ldots \ldots$ & 476,027 & 582,256 & 614,268 & 707,558 & 858,919 & 788,112 & 245,340 & 255,299 & 101,818 & 105,101 & 78,213 & 63,838 \\
\hline Colorado. & 109,844 & 134,234 & 141,051 & 41,322 & 59,383 & 53,411 & 25,447 & 25,376 & 50,513 & 35,811 & 11,481 & 9,829 \\
\hline ......................... & 46,826 & 58,329 & 57,275 & 20,934 & 34,116 & 32,567 & 57,013 & 58,059 & 3,757 & 5,763 & 257 & 229 \\
\hline 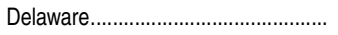 & 20,427 & 23,125 & 24,399 & 6,939 & 10,103 & 9,006 & 10,550 & 11,113 & 218 & 200 & 0 & 0 \\
\hline District of Columbia & 3,364 & 3,964 & 3,619 & & & 0 & 65,755 & 66,905 & 3,789 & 2,832 & 0 & 0 \\
\hline Florida............................................ & 190,472 & 484,158 & 524,543 & 173,433 & 78,027 & 44,213 & 132,175 & 145,917 & 101,338 & 101,667 & 39,605 & 41,496 \\
\hline Georgia. & 136,069 & 224,447 & 233,723 & 66,571 & 118,388 & 88,386 & 63,337 & 64,486 & 37,341 & 33,252 & 9,047 & 7,708 \\
\hline$\ldots$ & 17,015 & 24,136 & 24,702 & 14,996 & 17,786 & 17,285 & 11,244 & 11,709 & 1,670 & 1,930 & 1,459 & 1,268 \\
\hline$\ldots \ldots \ldots \ldots \ldots \ldots \ldots . .$. & 34,125 & 40,828 & 41,691 & 6,807 & 9,847 & 16,050 & 16,641 & 21,515 & 1,951 & 1,857 & 777 & 508 \\
\hline 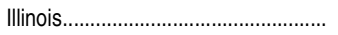 & 164,592 & 178,192 & 172,891 & 186,533 & 228,507 & 209,152 & 190,040 & 191,330 & 58,301 & 45,444 & 9,365 & 7,150 \\
\hline$\ldots \ldots \ldots \ldots \ldots \ldots \ldots . .$. & 155,982 & 194,407 & 192,278 & 28,131 & 66,664 & 58,682 & 79,154 & 79,095 & 18,495 & 14,873 & 9,169 & 5,185 \\
\hline wa & 61,763 & 64,706 & 66,374 & 44,717 & 71,021 & 64,472 & 50,034 & 49,391 & 107,172 & 107,106 & 565 & 284 \\
\hline 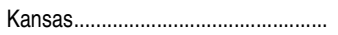 & 74,307 & 84,263 & 84,709 & 39,457 & 53,257 & 50,825 & 17,882 & 18,107 & 1,424 & 1,554 & 1,987 & 1,549 \\
\hline$\ldots$ & 86,080 & 105,269 & 106,972 & 32,239 & 65,402 & 58,567 & 31,912 & 33,513 & 13,529 & 11,509 & 5,478 & 2,824 \\
\hline 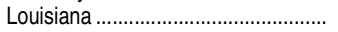 & 126,372 & 124,062 & 121,662 & 27,130 & 52,670 & 49,410 & 23,509 & 24,201 & 3,939 & 3,236 & 6,570 & 4,795 \\
\hline Maine......... & 24,678 & 26,208 & 25,145 & 4,797 & 11,475 & 11,350 & 16,928 & 18,040 & 0 & 630 & 1,303 & 371 \\
\hline Maryland. & 94,929 & 125,536 & 128,697 & 57,367 & 85,789 & 81,882 & 42,957 & 43,372 & 5,403 & 3,962 & 4,143 & 2,603 \\
\hline usetts & 78,452 & 97,474 & 100,067 & 47,972 & 64,952 & 63,611 & 239,338 & 244,143 & 4,181 & 4,041 & 2,108 & 1,633 \\
\hline lichiga & 223,981 & 257,896 & 258,475 & 101,794 & 155,152 & 135,674 & 91,258 & 84,740 & 8,772 & 6,048 & 1,473 & 1,225 \\
\hline 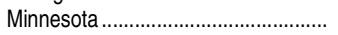 & 95,345 & 114,954 & 113,099 & 65,167 & 89,858 & 83,620 & 62,150 & 60,979 & 71,929 & 66,020 & 2,200 & 1,773 \\
\hline 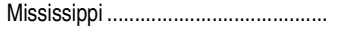 & 56,107 & 67,989 & 71,204 & 47,245 & 68,868 & 63,885 & 13,601 & 13,126 & 289 & 354 & 2,470 & 1,801 \\
\hline Missour & 99,187 & 120,985 & 123,926 & 46,793 & 74,399 & 70,470 & 113,197 & 113,883 & 17,403 & 17,923 & 10,736 & 6,851 \\
\hline$\ldots \ldots \ldots \ldots \ldots \ldots \ldots \ldots$ & 28,278 & 32,375 & 33,366 & 3,900 & 7,790 & 6,308 & 4,073 & 4,153 & 0 & 0 & 0 & 0 \\
\hline (5) & 44,374 & 50,013 & 50,158 & 20,812 & 30,680 & 27,856 & 27,915 & 27,166 & 2,151 & 1,575 & 1,026 & 591 \\
\hline …………..... & 27,631 & 68,001 & 63,747 & 20,468 & 6,571 & 5,793 & 3,028 & 3,120 & 6,841 & 5,685 & 5,151 & 4,625 \\
\hline New Hampshire ....... & 21,064 & 26,146 & 25,842 & 5,442 & 9,172 & 8,395 & 22,504 & 28,336 & 3,898 & 3,008 & 0 & 0 \\
\hline . & 111,449 & 144,174 & 148,797 & 79,367 & 125,787 & 117,155 & 63,112 & 62,435 & 5,993 & 4,764 & 1,891 & 2,452 \\
\hline New & 39,779 & 52,199 & 53,022 & 29,541 & 49,580 & 46,520 & 1,012 & 1,033 & 6,646 & 6,031 & 3,316 & 1,676 \\
\hline & 269,664 & 328,542 & 328,634 & 168,911 & 242,030 & 235,012 & 440,008 & 446,378 & 28,067 & 27,485 & 21,681 & 18,131 \\
\hline 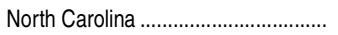 & 140,203 & 193,970 & 194,157 & 96,999 & 158,786 & 151,922 & 83,927 & 84,436 & 10,980 & 10,508 & 2,430 & 3,070 \\
\hline North Dakota & 24,728 & 35,435 & 35,218 & 6,515 & 4,572 & 4,467 & 4,832 & 4,604 & 1,154 & 613 & & \\
\hline Ohin & 215,993 & 292,493 & 283,043 & 02740 & 75 & 30 & 90 & 7 & 3,678 & 18,109 & 29,699 & 13,941 \\
\hline 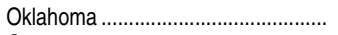 & 79,786 & 102,472 & 10 & 7 & 44 & & & & 5,434 & 4,486 & 4,551 & 4,464 \\
\hline$\ldots$ & 59,588 & 82,751 & 86,511 & 46,099 & 69,826 & 8,636 & 28,591 & 29,592 & 4,297 & 4,300 & 3,791 & 3,335 \\
\hline ................ & 211,132 & 257,017 & 255,093 & 58,759 & 93,183 & 83,306 & 248,155 & 248,529 & 18,016 & 13,575 & 37,525 & 28,619 \\
\hline Rhode Island ..... & 17,967 & 21,720 & 21,763 & 8,650 & 10,107 & 9,895 & 39,093 & 38,271 & 0 & 0 & & \\
\hline Oouth & 74,3 & & & 41,8 & 66,8 & UT, & 31,078 & 30,625 & 11,467 & 9,784 & 2,603 & 3,347 \\
\hline 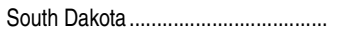 & & 0 & & & 5 & 5 , & 7,133 & 5,777 & 2,834 & 2,415 & 0 & \\
\hline 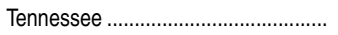 & 99,636 & 125,069 & 123,166 & 53,146 & 64,802 & 58,786 & 69,240 & 73,154 & 15,154 & 12,614 & 12,607 & 9,648 \\
\hline & 358,523 & 506,2 & & 268,057 & 404,932 & 387,468 & & & 24,809 & 25,182 & 39,258 & 24,666 \\
\hline Utah & 71,982 & 100,176 & 106,024 & 16,454 & 26,052 & 16,141 & 56,824 & 76,233 & 8,902 & 12,055 & 1,413 & 1,680 \\
\hline$V_{e}$ & 13,581 & & & & & & & & 61 & 422 & 0 & 0 \\
\hline & 147,370 & 18 & 190,101 & 72,913 & & 28 & & & 36,067 & 32,164 & 9,321 & 7,805 \\
\hline$\ldots$ & 83,899 & 143,033 & 147,173 & 114,754 & 109,154 & 97,392 & 37,741 & 37,618 & 7,050 & 5,374 & 5,098 & 4,192 \\
\hline & 58,171 & & & 3,969 & 609 & 14,243 & 11,487 & 7,191 & 8,867 & 26,016 & 2,819 & 2,163 \\
\hline 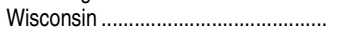 & 130,661 & 160,463 & 159,033 & 56,195 & 68,861 & 62,740 & 53,254 & 52,562 & 11,044 & 8,826 & 2,009 & 710 \\
\hline Wyoming............................................. & 9,665 & 11,089 & 11,061 & 10,588 & 14,676 & 14,032 & 0 & 0 & 127 & 145 & 1,879 & 1,808 \\
\hline U.S. Service Academies.. & 13,475 & 15,912 & 15,211 & 0 & 0 & 0 & $\dagger$ & $\dagger$ & $\dagger$ & 1 & $\dagger$ & $\dagger$ \\
\hline Other jurisdictions ...................... & 66,376 & 65,847 & 62,741 & 7,200 & 8,758 & 7,768 & 113,455 & 118,683 & 9,417 & 9,251 & 30,467 & 30,197 \\
\hline Amer & & 0 & 1,060 & 214 & & & of & 0 & 0 & & 0 & 0 \\
\hline Federated & 0 & 0 & 0 & 1,308 & 2,243 & 2,105 & 0 & 0 & 0 & 0 & 0 & 0 \\
\hline & 2,802 & 3,074 & 3,095 & 777 & 1,424 & 1,366 & 73 & 62 & 0 & 0 & 0 & 0 \\
\hline Islands... & 0 & 0 & 0 & 166 & 739 & 891 & 0 & 0 & 0 & 0 & 0 & 0 \\
\hline as ........................ & 0 & 1,031 & 1,077 & 707 & 0 & 0 & 0 & 0 & 0 & 0 & 0 & 0 \\
\hline Palau......................................... & & 0 & & 450 & 541 & 509 & 0 & 0 & 0 & 0 & 0 & 0 \\
\hline Puerto Rico........ & 61,987 & 59,658 & 55,659 & 3,578 & 2,536 & 2,897 & 113,382 & 118,621 & 9,417 & 9,251 & 30,467 & 30,197 \\
\hline U.S. Virgin Islands . & 1,587 & 2,084 & 1,850 & 0 & 0 & 0 & 0 & 0 & 0 & 0 & 0 & \\
\hline
\end{tabular}

†Not applicable.

NOTE: Full-time-equivalent enrollment is the full-time enrollment, plus the full-time equivalent of the part-time students. Degree-granting institutions grant associate's or higher degrees and participate in Title IV federal financial aid programs.
SOURCE: U.S. Department of Education, National Center for Education Statistics, Integrated Postsecondary Education Data System (IPEDS), Spring 2001, 2011, and 2013, Enrollment component. (This table was prepared February 2014.) 
Table 307.30. Full-time-equivalent fall enrollment in degree-granting postsecondary institutions, by control of institution and state or jurisdiction: 2000, 2010, and 2012

\begin{tabular}{|c|c|c|c|c|c|c|c|c|c|c|c|c|}
\hline \multirow[b]{2}{*}{ State or jurisdiction } & \multicolumn{3}{|c|}{ Total } & \multicolumn{3}{|c|}{ Public } & \multicolumn{3}{|c|}{ Private nonprofit } & \multicolumn{3}{|c|}{ Private for-profit } \\
\hline & 2000 & 2010 & 2012 & 2000 & 2010 & 2012 & 2000 & 2010 & 2012 & 2000 & 2010 & 2012 \\
\hline 1 & 2 & 3 & 4 & 5 & 6 & 7 & 8 & 9 & 10 & 11 & 12 & 13 \\
\hline United States. & $11,267,025$ & $15,943,343$ & $15,594,638$ & 266,932 & $11,020,752$ & $10,780,749$ & $2,601,179$ & $3,262,699$ & $3,343,859$ & 398,914 & $1,659,892$ & $1,470,030$ \\
\hline labama ....................... & 184,031 & 258,323 & 245,397 & 159,867 & 208,912 & 196,645 & 20,605 & 22,982 & 23,817 & 3,559 & 26,429 & 24,935 \\
\hline ska... & 17,787 & 22,122 & 22,363 & 16,808 & 20,975 & 20,318 & 672 & 529 & 558 & 307 & 618 & 1,487 \\
\hline zona. & 225,396 & 636,388 & 584,920 & 173,079 & 242,986 & 241,586 & 8,079 & 7,487 & 7,725 & 44,238 & 385,915 & 335,609 \\
\hline 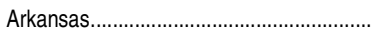 & 91,886 & 136,340 & 135,921 & 79,416 & 118,611 & 119,000 & 11,713 & 14,596 & 15,014 & 757 & 3,133 & 1,907 \\
\hline Californi & $1,468,486$ & $1,867,757$ & $1,828,255$ & $1,183,585$ & $1,441,175$ & $1,402,380$ & 214,444 & 246,551 & 256,936 & 70,457 & 180,031 & 168,939 \\
\hline olorac & 188,117 & 281,186 & 265,713 & 151,166 & 193,617 & 194,462 & 20,991 & 25,575 & 25,611 & 15,960 & 61,994 & 45,640 \\
\hline ." &, 954 & 153,746 & 153,893 & 67,760 & 92,445 & 89,842 & 48,648 & 57,287 & 58,059 & 1,546 & 4,014 & 5,992 \\
\hline law & 34,057 & 44,208 & 44,918 & 27,366 & 33,228 & 33,405 & 6,691 & 10,762 & 11,313 & 0 & 218 & 200 \\
\hline$\cdots \cdots \cdots$ & 59,560 & 73,508 & 73,356 & 3,364 & 3,964 & 3,619 & 54,177 & 65,755 & 66,905 & 2,019 & 3,789 & 2,832 \\
\hline Florida... & 486,818 & 835,538 & 859,387 & 363,905 & 562,185 & 568,756 & 90,530 & 132,410 & 147,468 & 32,383 & 140,943 & 143,163 \\
\hline Geornia & 268,707 & 453,075 & 428,058 & 202,640 & 342,835 & 322,109 & 57,444 & 63,852 & 64,989 & 8,623 & 46,388 & 40,960 \\
\hline ....... $>$ > & 45,329 & 56,295 & 56,894 & 32,011 & & 41,987 & 11,521 & 11,244 & 11,709 & 1,797 & 3,129 & 3,198 \\
\hline$x_{1}$ & 52,353 & 70,044 & 81,621 & 40,932 & 50,675 & 57,741 & 10,751 & 16,641 & 21,515 & 670 & 2,728 & 2,365 \\
\hline & 520,087 & 665,391 & 626,626 & 351,125 & 406,699 & 382,043 & 150,578 & 191,026 & 191,989 & 18,384 & 67,666 & 52,594 \\
\hline .................. & 250,998 & 368,371 & 350,465 & 184,113 & 261,071 & 250,960 & 60,387 & 79,636 & 79,447 & 6,498 & 27,664 & 20,058 \\
\hline ( & 152,505 & 293,658 & 37,800 & 106,480 & 27 & 6 & 3,735 & 50,194 & 19 & 2,290 & 87,737 & 107,390 \\
\hline & 129,839 & 160,543 & 158,987 & 113,764 & & & 05 & 19,612 & 50 & 470 & 3,411 & 3,103 \\
\hline 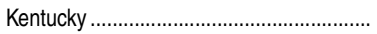 & 149,395 & 221,590 & 213,385 & 118,319 & & & 59 & 31,912 & & 7,217 & 19,007 & 14,333 \\
\hline & 183,661 & 210,750 & 4,358 & 153,502 & & 72 & 346 & 23,509 & 5,255 & 4,513 & 0,509 & 8,031 \\
\hline …………........ & 43,384 & 56,112 & 55,730 & 29,475 & 37,683 & 36,495 & 13,020 & 17,126 & 18,234 & 889 & 1,303 & 1,001 \\
\hline ryul & 188,887 & 263,828 & 260516 & 152,296 & 25 & 79 & 45 & 42,957 & 72 & 2,146 & 9,546 & 6,565 \\
\hline & ,984 & 408,790 & & & & & & 75 & & 815 & 6,289 & 5,674 \\
\hline & 402,019 & 514,551 & & 32 & & & & 91,258 & & 3,100 & 10,245 & 7,273 \\
\hline " & 223,232 & 341,190 & 325,563 & 160,512 & 12 & 19 & 2,974 & 62,249 & 51 & 9,746 & 4,129 & 67,793 \\
\hline Mississippi & 113,804 & 153,217 & 150,370 & 103,352 & 136,857 & 135,089 & 10,073 & 13,601 & 13,126 & 379 & 2,759 & 2,155 \\
\hline Miscouri & 237,161 & 337,834 & 333,819 & 145,980 & 195,384 & 194,396 & 82,425 & 114,311 & 114,649 & 8,756 & 28,139 & 24,774 \\
\hline & 05 & & 年 & & & & 3,827 & 4,515 & 4,533 & 0 & & \\
\hline & 3 & 11 & & 36 & & & 18,956 & 28,067 & 27 & 1,851 & 3,177 & 2,166 \\
\hline & 77 & 592 & & 48,099 & & & 455 & 3,028 & & 4,023 & & 10,310 \\
\hline Jew Hamp & 48,230 & 61,970 & 65,762 & 26,506 & 35,318 & 34,237 & 8,732 & 22,754 & 28,517 & 2,992 & 3,898 & 3,008 \\
\hline & 245,447 & 340,957 & 335,603 & 190,816 & 269.961 & 265,952 & 48,751 & 63,112 & 62,43 & 5,880 & 7,884 & 7,216 \\
\hline & 77,415 & 53 & & & & & & $\begin{array}{r}1,012 \\
\end{array}$ & & 4,821 & 9,962 & 7,707 \\
\hline & 826,078 & $1,063,893$ & $1,058,801$ & 438,575 & & 46 & 355,832 & 443,573 & 39 & 31,671 & 49,748 & 45,616 \\
\hline & 305,805 & 450,757 & 2 & 23 & & & & 84,591 & & 476 & 410 & 578 \\
\hline North Da & 35,230 & 46,556 & 44,902 & 31,243 & 40,007 & 39,685 & 3,876 & 5,395 & 4,604 & 111 & 1,154 & 613 \\
\hline & 30 & 7 & & & & & & & & 34 & & ,050 \\
\hline & & & & & & & & & & 3,2 & 85 & 50 \\
\hline & & 18 & & & & & & & & 2,939 & & 635 \\
\hline & 29 & 660,545 & & 26 & & & & 04 & & 28,702 & 541 & 42,194 \\
\hline Rhode Island ...................... & 9,639 & 70,920 & 9,929 & 6,617 & 1,827 & 1,658 & 32,813 & 39,093 & 38,271 & 209 & & 0 \\
\hline & 143,343 & 206,384 & 206,482 & 116,113 & & & 26,504 & 31,989 & 31,55 & 726 & 14,070 & 13,131 \\
\hline & & & & & & & 47 & 7,331 & & 2,051 & 34 & 2,415 \\
\hline & 0 & 28 & & & & & & & & & & \\
\hline & 741,012 & $1,087,240$ & $1,080,551$ & 626,580 & & & 8,445 & 111,993 & 85 & 15,987 & 4,067 & 49,848 \\
\hline Utah & 125,622 & 194,870 & 213,961 & 88,436 & 126,228 & 122,165 & 32,727 & 58,327 & 78,061 & 4,459 & 10,315 & 13,735 \\
\hline Vomont $5 \mathrm{C}$ & 29,099 & 38,3 & 37 & 15,4 & 21,575 & 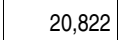 & 13,336 & 16,197 & 16395 & 33 & 615 & 422 \\
\hline & 277,270 & & & & & & & & & 12,162 & & 39,969 \\
\hline & 236,609 & & & 198 & & & & & & 30 & & 9,566 \\
\hline & & & & & & & & & & & & 28,179 \\
\hline & 232,912 & 296,073 & & 18 & & & 416 & 53,696 & & 1,640 & 053 & 9,536 \\
\hline s & 21,542 & 27,771 & 27,046 & 20,253 & 25,765 & 25,093 & & & & 1,289 & 2,006 & 1,953 \\
\hline U.S. Service Academies.... & 13,475 & 15,912 & 15,211 & 13,475 & 15,912 & 15,211 & $\dagger$ & $\dagger$ & 1 & $\dagger$ & $t$ & 1 \\
\hline distinns & 166,039 & 232,201 & 229,444 & 73,576 & 74,605 & 70,509 & 1,642 & $\begin{array}{l}117,712 \\
\end{array}$ & 9,487 & 0,821 & 9,884 & 39,448 \\
\hline American & 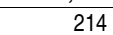 & & & 214 & & & & & & & t & \\
\hline & 1,308 & 2,2 & & 1,308 & 2,2 & & 0 & 0 & & 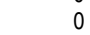 & 0 & 0 \\
\hline & 3,579 & 4,571 & 4,5 & 3,579 & 4,4 & 4,461 & 0 & 73 & 62 & 0 & 0 & 0 \\
\hline & 166 & 739 & 891 & 166 & 739 & 891 & 0 & 0 & 0 & 0 & 0 & 0 \\
\hline No & 707 & 1,031 & 1,077 & 707 & 1,031 & 1,077 & 0 & 0 & 0 & 0 & 0 & 0 \\
\hline & 450 & 541 & 50 & 450 & 541 & 509 & 0 & 0 & & 0 & 0 & 0 \\
\hline & 158,028 & 219,717 & 217,429 & 65,565 & 62,194 & 58,556 & 81,642 & 117,639 & 119,425 & 10,821 & 39,884 & 39,448 \\
\hline U.S. Virgin Islands ................. & 1,587 & 2,084 & 1,850 & 1,587 & 2,084 & 1,850 & 0 & 0 & 0 & 0 & & S \\
\hline
\end{tabular}

†Not applicable.

NOTE: Full-time-equivalent enrollment is the full-time enrollment, plus the full-time equivalent of the part-time students. Degree-granting institutions grant associate's or higher degrees and participate in Title IV federal financial aid programs.
SOURCE: U.S. Department of Education, National Center for Education Statistics, Integrated Postsecondary Education Data System (IPEDS), Spring 2001, 2011, and 2013, Enrollment component. (This table was prepared February 2014.) 
Table 308.10. Total 12-month enrollment in degree-granting postsecondary institutions, by control and level of institution and state or jurisdiction: 2010-11 and 2011-12

\begin{tabular}{|c|c|c|c|c|c|c|c|c|c|c|c|c|c|c|}
\hline \multirow[b]{3}{*}{ State or jurisdiction } & \multicolumn{7}{|c|}{$2010-11$} & \multicolumn{7}{|c|}{$2011-12$} \\
\hline & \multirow[b]{2}{*}{ Total } & \multirow{2}{*}{$\begin{array}{l}\text { Public } \\
\text { 4-year }\end{array}$} & \multirow{2}{*}{$\begin{array}{l}\text { Public } \\
\text { 2-year }\end{array}$} & \multicolumn{2}{|c|}{ Private 4-year } & \multicolumn{2}{|c|}{ Private 2-year } & \multirow[b]{2}{*}{ Total } & \multirow{2}{*}{$\begin{array}{l}\text { Public } \\
\text { 4-year }\end{array}$} & \multirow{2}{*}{$\begin{array}{l}\text { Public } \\
2 \text {-year }\end{array}$} & \multicolumn{2}{|c|}{ Private 4-year } & \multicolumn{2}{|c|}{ Private 2-year } \\
\hline & & & & Nonprofit & For-profit & Nonprofit & For-profit & & & & Nonprofit & For-profit & Nonprofit & For-profit \\
\hline 1 & 2 & 3 & 4 & 5 & 6 & 7 & 8 & 9 & 10 & 11 & 12 & 13 & 14 & 15 \\
\hline United States .......... & $28,577,250$ & $9,639,068$ & $10,888,549$ & $4,700,961$ & $2,591,334$ & 60,531 & 696,807 & $28,176,519$ & $9,731,902$ & $10,528,608$ & $4,737,789$ & $2,509,477$ & 57,773 & 610,970 \\
\hline 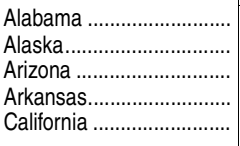 & $\begin{array}{r}431,219 \\
58,668 \\
1,238,668 \\
228,659 \\
3,748,013\end{array}$ & $\begin{array}{r}199,730 \\
50,440 \\
153,735 \\
113,404 \\
704,867\end{array}$ & $\begin{array}{r}142,027 \\
3,401 \\
391,187 \\
91,228 \\
2,365,390\end{array}$ & $\begin{array}{r}29,169 \\
998 \\
11,438 \\
18,809 \\
342,786\end{array}$ & $\begin{array}{r}54,015 \\
3,347 \\
658,175 \\
4,128 \\
189,165\end{array}$ & $\begin{array}{r}983 \\
0 \\
0 \\
727 \\
2,175\end{array}$ & $\begin{array}{r}5,295 \\
482 \\
24,133 \\
363 \\
143,630\end{array}$ & $\begin{array}{r}423,697 \\
60,103 \\
1,161,102 \\
230,899 \\
3,580,296\end{array}$ & $\begin{array}{r}196,566 \\
50,420 \\
156,435 \\
115,684 \\
713,254\end{array}$ & $\begin{array}{r}134,767 \\
3,125 \\
374,569 \\
90,944 \\
2,199,798\end{array}$ & $\begin{array}{r}30,034 \\
969 \\
11,522 \\
19,822 \\
349,029\end{array}$ & $\begin{array}{r}56,005 \\
5,128 \\
598,773 \\
3,520 \\
190,819\end{array}$ & $\begin{array}{r}1,126 \\
0 \\
0 \\
627 \\
2,573\end{array}$ & $\begin{array}{r}5,199 \\
461 \\
19,803 \\
302 \\
124,823\end{array}$ \\
\hline 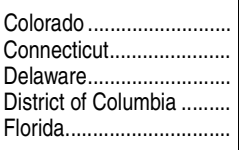 & $\begin{array}{r}519,767 \\
251,521 \\
70,098 \\
114,264 \\
1,591,385\end{array}$ & $\begin{array}{r}212,840 \\
80,661 \\
27,338 \\
12,786 \\
959,011\end{array}$ & $\begin{array}{r}152,065 \\
82,134 \\
21,653 \\
0 \\
121,506\end{array}$ & $\begin{array}{r}41,754 \\
77,513 \\
20,167 \\
89,433 \\
250,162\end{array}$ & $\begin{array}{r}94,588 \\
9,891 \\
699 \\
12,045 \\
184,598\end{array}$ & $\begin{array}{r}205 \\
699 \\
241 \\
0 \\
1,804\end{array}$ & $\begin{array}{r}18,315 \\
623 \\
0 \\
0 \\
74,304\end{array}$ & $\begin{array}{r}526,358 \\
254,715 \\
70,107 \\
110,775 \\
1,612,393\end{array}$ & $\begin{array}{r}218,066 \\
79,384 \\
27,710 \\
11,468 \\
988,432\end{array}$ & $\begin{array}{r}162,544 \\
81,663 \\
20,912 \\
0 \\
105,628\end{array}$ & $\begin{array}{r}41,941 \\
78,762 \\
20,508 \\
88,572 \\
247,764\end{array}$ & $\begin{array}{r}85,464 \\
14,343 \\
714 \\
10,735 \\
193,991\end{array}$ & $\begin{array}{r}418 \\
0 \\
263 \\
0 \\
2,323\end{array}$ & $\begin{array}{r}17,925 \\
563 \\
0 \\
0 \\
74,255\end{array}$ \\
\hline 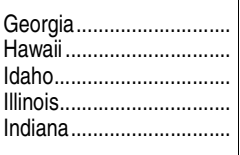 & $\begin{array}{r}775,768 \\
101,719 \\
126,866 \\
1,374,177 \\
621,156\end{array}$ & $\begin{array}{r}312,123 \\
36,226 \\
69,043 \\
234,270 \\
280,361\end{array}$ & $\begin{array}{r}272,664 \\
40,703 \\
23,822 \\
714,219 \\
174,746\end{array}$ & $\begin{array}{r}81,359 \\
19,182 \\
28,421 \\
278,977 \\
107,108\end{array}$ & $\begin{array}{r}90,733 \\
2,480 \\
4,497 \\
130,095 \\
45,893\end{array}$ & $\begin{array}{r}707 \\
0 \\
0 \\
1,672 \\
705\end{array}$ & $\begin{array}{r}18,182 \\
3,128 \\
1,083 \\
14,944 \\
12,343\end{array}$ & $\begin{array}{r}731,023 \\
101,481 \\
142,195 \\
1,350,322 \\
609,700\end{array}$ & $\begin{array}{r}327,961 \\
36,801 \\
67,914 \\
231,761 \\
277,945\end{array}$ & $\begin{array}{r}223,573 \\
40,254 \\
35,900 \\
709,319 \\
175,313\end{array}$ & $\begin{array}{r}82,684 \\
18,643 \\
33,939 \\
276,377 \\
106,896\end{array}$ & $\begin{array}{r}80,454 \\
2,766 \\
3,629 \\
116,826 \\
40,229\end{array}$ & $\begin{array}{r}591 \\
0 \\
0 \\
1,327 \\
630\end{array}$ & $\begin{array}{r}15,760 \\
3,017 \\
813 \\
14,712 \\
8,687\end{array}$ \\
\hline 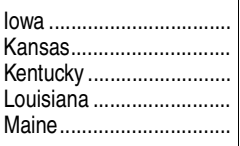 & $\begin{array}{r}573,112 \\
302,317 \\
374,660 \\
338,898 \\
92,858\end{array}$ & $\begin{array}{r}81,663 \\
118,769 \\
143,327 \\
170,388 \\
41,448\end{array}$ & $\begin{array}{r}154,937 \\
140,236 \\
149,965 \\
118,570 \\
24,565\end{array}$ & $\begin{array}{l}77,891 \\
33,022 \\
44,135 \\
31,846 \\
23,894\end{array}$ & $\begin{array}{r}256,861 \\
3,464 \\
29,594 \\
6,622 \\
1,775\end{array}$ & $\begin{array}{r}212 \\
3,510 \\
0 \\
2,281 \\
339\end{array}$ & $\begin{array}{r}1,548 \\
3,316 \\
7,639 \\
9,191 \\
837\end{array}$ & $\begin{array}{r}557,823 \\
298,578 \\
374,000 \\
338,468 \\
94,341\end{array}$ & $\begin{array}{r}82,466 \\
119,555 \\
145,802 \\
169,434 \\
40,412\end{array}$ & $\begin{array}{r}148,981 \\
136,155 \\
148,670 \\
118,826 \\
26,531\end{array}$ & $\begin{array}{l}71,036 \\
32,727 \\
46,577 \\
32,595 \\
24,910\end{array}$ & $\begin{array}{r}254,492 \\
3,808 \\
26,357 \\
6,000 \\
1,363\end{array}$ & $\begin{array}{r}236 \\
3,521 \\
0 \\
2,340 \\
338\end{array}$ & $\begin{array}{r}612 \\
2,812 \\
6,594 \\
9,273 \\
787\end{array}$ \\
\hline 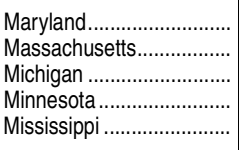 & $\begin{array}{l}490,738 \\
640,116 \\
914,789 \\
625,729 \\
235,071\end{array}$ & $\begin{array}{r}200,097 \\
155,148 \\
348,701 \\
166,281 \\
89,697\end{array}$ & $\begin{array}{l}204,819 \\
146,851 \\
388,613 \\
195,301 \\
119,418\end{array}$ & $\begin{array}{r}66,660 \\
325,968 \\
159,591 \\
88,927 \\
20,162\end{array}$ & $\begin{array}{r}12,949 \\
7,045 \\
15,104 \\
171,955 \\
931\end{array}$ & $\begin{array}{r}0 \\
1,601 \\
33 \\
138 \\
0\end{array}$ & $\begin{array}{l}6,213 \\
3,503 \\
2,747 \\
3,127 \\
4,863\end{array}$ & $\begin{array}{l}496,859 \\
644,559 \\
889,359 \\
614,033 \\
233,236\end{array}$ & $\begin{array}{r}206,298 \\
157,597 \\
350,216 \\
165,865 \\
93,372\end{array}$ & $\begin{array}{l}206,316 \\
146,318 \\
366,518 \\
193,118 \\
114,041\end{array}$ & $\begin{array}{r}67,386 \\
329,493 \\
155,522 \\
85,975 \\
20,598\end{array}$ & $\begin{array}{r}11,920 \\
6,457 \\
13,090 \\
165,851 \\
1,012\end{array}$ & $\begin{array}{r}0 \\
1,453 \\
61 \\
136 \\
0\end{array}$ & $\begin{array}{l}4,939 \\
3,241 \\
3,952 \\
3,088 \\
4,213\end{array}$ \\
\hline 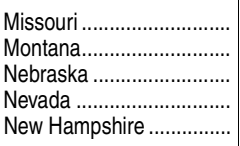 & $\begin{array}{r}614,390 \\
68,083 \\
205,496 \\
178,375 \\
98,788\end{array}$ & $\begin{array}{r}172,478 \\
46,861 \\
68,593 \\
136,387 \\
35,313\end{array}$ & $\begin{array}{r}163,508 \\
15,050 \\
87,993 \\
18,405 \\
22,883\end{array}$ & $\begin{array}{r}207,324 \\
5,440 \\
43,403 \\
4,332 \\
34,014\end{array}$ & $\begin{array}{r}53,159 \\
0 \\
3,752 \\
11,103 \\
6,032\end{array}$ & $\begin{array}{r}1,731 \\
732 \\
214 \\
0 \\
546\end{array}$ & $\begin{array}{r}16,190 \\
0 \\
1,541 \\
8,148 \\
0\end{array}$ & $\begin{array}{r}609,947 \\
68,163 \\
202,861 \\
165,857 \\
101,998\end{array}$ & $\begin{array}{r}174,338 \\
47,315 \\
68,882 \\
126,539 \\
34,652\end{array}$ & $\begin{array}{r}161,182 \\
14,835 \\
86,459 \\
16,617 \\
22,638\end{array}$ & $\begin{array}{r}205,839 \\
5,364 \\
42,465 \\
4,100 \\
39,206\end{array}$ & $\begin{array}{r}52,240 \\
0 \\
3,441 \\
10,581 \\
5,054\end{array}$ & $\begin{array}{r}1,609 \\
649 \\
265 \\
0 \\
448\end{array}$ & $\begin{array}{r}14,739 \\
0 \\
1,349 \\
8,020 \\
0\end{array}$ \\
\hline 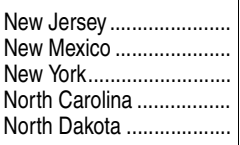 & $\begin{array}{r}569,223 \\
220,705 \\
1,663,077 \\
757,889 \\
70,168\end{array}$ & $\begin{array}{r}206,987 \\
78,373 \\
487,903 \\
255,979 \\
50,438\end{array}$ & $\begin{array}{r}260,569 \\
125,836 \\
468,089 \\
364,911 \\
9,375\end{array}$ & $\begin{array}{r}87,569 \\
1,386 \\
616,067 \\
105,325 \\
7,667\end{array}$ & $\begin{array}{r}10,318 \\
11,479 \\
44,403 \\
24,061 \\
2,688\end{array}$ & $\begin{array}{r}0 \\
0 \\
7,053 \\
804 \\
0\end{array}$ & $\begin{array}{r}3,780 \\
3,631 \\
39,562 \\
6,809 \\
0\end{array}$ & $\begin{array}{r}566,613 \\
216,076 \\
1,673,814 \\
751,635 \\
70,816\end{array}$ & $\begin{array}{r}209,777 \\
78,244 \\
483,588 \\
253,249 \\
51,457\end{array}$ & $\begin{array}{r}256,689 \\
122,960 \\
471,510 \\
359,336 \\
9,779\end{array}$ & $\begin{array}{r}86,159 \\
1,528 \\
624,806 \\
106,403 \\
7,664\end{array}$ & $\begin{array}{r}9,632 \\
10,400 \\
49,653 \\
24,418 \\
1,916\end{array}$ & $\begin{array}{r}0 \\
0 \\
6,229 \\
791 \\
0\end{array}$ & $\begin{array}{r}4,356 \\
2,944 \\
38,028 \\
7,438 \\
0\end{array}$ \\
\hline 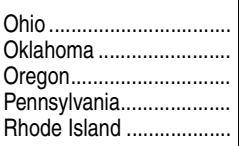 & $\begin{array}{r}991,748 \\
303,176 \\
374,342 \\
1,019,681 \\
101,327\end{array}$ & $\begin{array}{r}414,419 \\
155,889 \\
129,300 \\
322,893 \\
30,124\end{array}$ & $\begin{array}{r}312,053 \\
105,322 \\
190,726 \\
224,967 \\
24,411\end{array}$ & $\begin{array}{r}175,637 \\
26,726 \\
39,258 \\
340,101 \\
46,792\end{array}$ & $\begin{array}{r}31,216 \\
8,396 \\
8,354 \\
52,597 \\
0\end{array}$ & $\begin{array}{r}4,036 \\
0 \\
0 \\
11,402 \\
0\end{array}$ & $\begin{array}{r}54,387 \\
6,843 \\
6,704 \\
67,721 \\
0\end{array}$ & $\begin{array}{l}966,766 \\
300,108 \\
376,675 \\
996,327 \\
100,938\end{array}$ & $\begin{array}{r}414,062 \\
153,575 \\
131,500 \\
326,798 \\
29,888\end{array}$ & $\begin{array}{r}299,171 \\
103,064 \\
189,869 \\
219,873 \\
24,616\end{array}$ & $\begin{array}{r}175,399 \\
28,199 \\
39,863 \\
337,476 \\
46,434\end{array}$ & $\begin{array}{r}42,535 \\
7,954 \\
8,760 \\
45,304 \\
0\end{array}$ & $\begin{array}{r}3,384 \\
0 \\
0 \\
12,313 \\
0\end{array}$ & $\begin{array}{r}32,215 \\
7,316 \\
6,683 \\
54,563 \\
0\end{array}$ \\
\hline 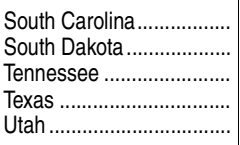 & $\begin{array}{r}331,280 \\
74,210 \\
438,901 \\
2,107,806 \\
340,784\end{array}$ & $\begin{array}{r}120,680 \\
48,983 \\
165,464 \\
745,399 \\
167,343\end{array}$ & $\begin{array}{r}141,742 \\
7,878 \\
134,081 \\
1,098,175 \\
68,989\end{array}$ & $\begin{array}{r}42,274 \\
9,134 \\
89,832 \\
152,335 \\
77,982\end{array}$ & $\begin{array}{r}21,301 \\
7,566 \\
26,762 \\
49,343 \\
20,991\end{array}$ & $\begin{array}{r}1,032 \\
649 \\
2,929 \\
8,222 \\
2,463\end{array}$ & $\begin{array}{r}4,251 \\
0 \\
19,833 \\
54,332 \\
3,016\end{array}$ & $\begin{array}{r}335,091 \\
73,936 \\
435,925 \\
2,117,481 \\
350,906\end{array}$ & $\begin{array}{r}123,023 \\
49,115 \\
166,829 \\
757,492 \\
185,635\end{array}$ & $\begin{array}{r}143,839 \\
7,838 \\
131,704 \\
1,102,140 \\
48,876\end{array}$ & $\begin{array}{r}42,056 \\
8,611 \\
92,132 \\
153,606 \\
89,916\end{array}$ & $\begin{array}{r}18,465 \\
7,876 \\
25,468 \\
49,890 \\
20,629\end{array}$ & $\begin{array}{r}1,050 \\
496 \\
2,834 \\
6,647 \\
2,574\end{array}$ & $\begin{array}{r}6,658 \\
0 \\
16,958 \\
47,706 \\
3,276\end{array}$ \\
\hline 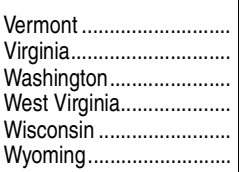 & $\begin{array}{r}59,997 \\
783,117 \\
554,551 \\
231,331 \\
507,252 \\
53,987\end{array}$ & $\begin{array}{r}25,199 \\
252,945 \\
220,802 \\
87,275 \\
218,455 \\
14,902\end{array}$ & $\begin{array}{r}11,395 \\
289,033 \\
262,689 \\
31,972 \\
172,444 \\
36,033\end{array}$ & $\begin{array}{r}22,016 \\
141,580 \\
50,316 \\
16,749 \\
88,330 \\
0\end{array}$ & $\begin{array}{r}780 \\
80,800 \\
11,446 \\
89,944 \\
24,013 \\
181\end{array}$ & $\begin{array}{r}607 \\
0 \\
79 \\
0 \\
0 \\
0\end{array}$ & $\begin{array}{r}0 \\
18,759 \\
9,219 \\
5,391 \\
4,010 \\
2,871\end{array}$ & $\begin{array}{r}60,059 \\
798,903 \\
525,030 \\
242,223 \\
492,783 \\
53,384\end{array}$ & $\begin{array}{r}24,693 \\
257,162 \\
222,991 \\
86,491 \\
213,300 \\
14,707\end{array}$ & $\begin{array}{r}11,009 \\
290,976 \\
234,613 \\
30,836 \\
168,253 \\
36,143\end{array}$ & $\begin{array}{r}23,672 \\
159,130 \\
49,538 \\
8,260 \\
85,682 \\
0\end{array}$ & $\begin{array}{r}685 \\
75,212 \\
10,010 \\
112,395 \\
23,004 \\
209\end{array}$ & $\begin{array}{r}0 \\
428 \\
93 \\
0 \\
0 \\
0\end{array}$ & $\begin{array}{r}0 \\
15,995 \\
7,785 \\
4,241 \\
2,544 \\
2,325\end{array}$ \\
\hline U.S. Service Academies.. & 17,330 & 17,330 & $\dagger$ & $\dagger$ & $\dagger$ & $\dagger$ & $\dagger$ & 15,782 & 15,782 & $\dagger$ & $\dagger$ & $\dagger$ & $\dagger$ & $\dagger$ \\
\hline Other jurisdictions. & 316,745 & 77,534 & 16,699 & 159,097 & 15,409 & 4,491 & 43,515 & 317,216 & 75,532 & 14,469 & 166,691 & 15,451 & 1,431 & $4 \overline{43,642}$ \\
\hline $\begin{array}{l}\text { American Samoa ........... } \\
\text { Federated States of }\end{array}$ & 2,744 & 0 & 2,744 & 0 & 0 & 0 & 0 & 2,621 & 2,621 & 0 & 0 & 0 & 0 & $\overline{0}$ \\
\hline 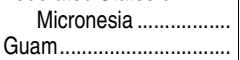 & $\begin{array}{l}5,097 \\
8,105\end{array}$ & $\begin{array}{r}0 \\
4,427\end{array}$ & $\begin{array}{l}5,097 \\
3,574\end{array}$ & $\begin{array}{r}0 \\
104\end{array}$ & $\begin{array}{l}0 \\
0\end{array}$ & $\begin{array}{l}0 \\
0\end{array}$ & $\begin{array}{l}0 \\
0\end{array}$ & $\begin{array}{l}5,457 \\
8,005\end{array}$ & $\begin{array}{r}0 \\
4,427\end{array}$ & $\begin{array}{l}5,457 \\
3,481\end{array}$ & $\begin{array}{r}0 \\
97\end{array}$ & $\begin{array}{l}0 \\
0\end{array}$ & $\begin{array}{l}0 \\
0\end{array}$ & $\begin{array}{l}0 \\
0\end{array}$ \\
\hline Marshall Islands................... & 1,176 & 0 & 1,176 & 0 & 0 & 0 & 0 & 1,310 & 0 & 1,310 & 0 & 0 & 0 & 0 \\
\hline Northern Marianas ........... & 1,388 & 1,388 & 0 & 0 & 0 & 0 & 0 & 1,332 & 1,332 & 0 & 0 & 0 & 0 & 0 \\
\hline Palau.................................. & 922 & & 922 & 0 & 0 & 0 & 0 & 981 & 0 & 981 & 0 & 0 & 0 & 0 \\
\hline 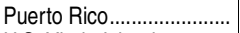 & 293,893 & 68,299 & 3,186 & 158,993 & 15,409 & 4,491 & 43,515 & 294,265 & 63,907 & 3,240 & 166 & 15,451 & 1,431 & 43,642 \\
\hline U.S. Virgin Islands ............. & 3,420 & 3,420 & 0 & 0 & 0 & 0 & 0 & 3,245 & 3,245 & 0 & 0 & 0 & 0 & 0 \\
\hline
\end{tabular}

†Not applicable.

NOTE: Includes students who enrolled at any point during a 12-month period ending during the summer of the academic year indicated. Degree-granting institutions grant associate's or higher degrees and participate in Title IV federal financial aid programs.
SOURCE: U.S. Department of Education, National Center for Education Statistics, Integrated Postsecondary Education Data System (IPEDS), Fall 2011 and Fall 2012, 12-Month Enrollment component. (This table was prepared August 2013.) 
Table 308.20. Total 12-month enrollment in degree-granting postsecondary institutions, by control of institution and state or jurisdiction: Selected years, 2004-05 through 2011-12

\begin{tabular}{|c|c|c|c|c|c|c|c|c|c|c|c|c|c|c|}
\hline \multirow[b]{2}{*}{ State or jurisdiction } & \multicolumn{5}{|c|}{ Total } & \multicolumn{3}{|c|}{ Public } & \multicolumn{3}{|c|}{ Private nonprofit } & \multicolumn{3}{|c|}{ Private for-profit } \\
\hline & 2004-05 & 2008-09 & 2009-10 & 2010-11 & 2011-12 & 2004-05 & 2010-11 & 2011-12 & 2004-05 & 2010-11 & 2011-12 & 2004-05 & 2010-11 & 2011-12 \\
\hline 1 & 2 & 3 & 4 & 5 & 6 & 7 & 8 & 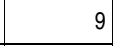 & 10 & 11 & 12 & 13 & 14 & 15 \\
\hline United States & \begin{tabular}{|l|}
$23,798,595$ \\
\end{tabular} & \begin{tabular}{|l|}
$26,556,839$ \\
\end{tabular} & \begin{tabular}{|l|}
$27,995,144$ \\
\end{tabular} & $28,577,250$ & \begin{tabular}{|l|}
$28,176,519$ \\
\end{tabular} & \begin{tabular}{|l|l}
$18,058,078$ \\
\end{tabular} & \begin{tabular}{|l|}
$20,527,617$ \\
\end{tabular} & \begin{tabular}{|l|}
$20,260,510$ \\
\end{tabular} & 222,755 & 761,492 & $4,795,562$ & $1,517,762$ & $3,288,141$ & $3,120,447$ \\
\hline labama . & 349,783 & 397,025 & 420,768 & 431,219 & 423,697 & 310,878 & 341,757 & 331,333 & 28,847 & 30,152 & 31,160 & 10,058 & 59,310 & 61,204 \\
\hline aska... & 53,786 & 52,746 & 57,498 & 58,668 & 60,103 & 51,689 & 53,841 & 53,545 & 1,253 & 998 & 969 & 844 & 3,829 & 5,589 \\
\hline izona & 821,240 & $1,179,910$ & $1,207,129$ & $1,238,668$ & $1,161,102$ & 499,192 & 544,922 & 531,004 & 13,162 & 11,438 & 11,522 & 308,886 & 682,308 & 618,576 \\
\hline kansa: & 182,497 & 209,599 & 222,868 & 228,659 & 230,899 & 164,751 & 204,632 & 206,628 & 15,260 & 19,536 & 20,449 & 2,486 & 4,491 & 3,822 \\
\hline alifor & $3,341,107$ & $3,855,218$ & $3,836,938$ & 3,748,013 & $3,580,296$ & $2,843,929$ & $3,070,257$ & $2,913,052$ & 327,661 & 344,961 & 351,602 & 169,517 & 332,795 & 315,642 \\
\hline olorac & 428,215 & 449,034 & 503,248 & 519,767 & 526,358 & 333,100 & 364,905 & 380,610 & 40,144 & 41,959 & 42,359 & 54,971 & 112,903 & 103,389 \\
\hline & 219,327 & 233,656 & 244,048 & 251,521 & 254,715 & 144,681 & 162,795 & 161,047 & 71,235 & 78,212 & 78,762 & 3,411 & 10,514 & 14,906 \\
\hline & 63,817 & 67,200 & 69,293 & 70,098 & 70,107 & 47,148 & 48,991 & 48,622 & 16,669 & 20,408 & 20,771 & 0 & 699 & 714 \\
\hline & 129,349 & 171,721 & 114,243 & 114,264 & 110,775 & 10,095 & 12,786 & 11,468 & 81,718 & 89,433 & 88,572 & 37,536 & 12,045 & 10,735 \\
\hline lorida... & $1,232,578$ & $1,386,473$ & $1,513,905$ & $1,591,385$ & $1,612,393$ & 912,150 & $1,080,517$ & $1,094,060$ & 191,789 & 251,966 & 250,087 & 128,639 & 258,902 & 268,246 \\
\hline orgia & 569,805 & 654,592 & 743,300 & 775,768 & 731,023 & 466,589 & 584,787 & 551,534 & 70,449 & 82,066 & 83,275 & 32,767 & 108,915 & 96,214 \\
\hline & 92,643 & 93,047 & 99,350 & 101,719 & 101,481 & 67,835 & 76,929 & 77,055 & 20,749 & 19 & 18,643 & 4,059 & 5,608 & 5,783 \\
\hline & 108,415 & 116,005 & 120,785 & 126,866 & 142,195 & 84,627 & 92,865 & 103,814 & 20,802 & 28,421 & 33,939 & 2,986 & 5,580 & 4,442 \\
\hline & $1,293,156$ & $1,334,965$ & $1,379,087$ & $1,374,177$ & $1,350,322$ & 933,506 & 948,489 & 941,080 & 257,053 & 280,649 & 277,704 & 102,597 & 145,039 & 131,538 \\
\hline (Itranlc & 488,374 & 551,453 & 606,235 & 621,156 & 609,700 & 363,817 & 455,107 & 453,258 & 103,295 & 107,813 & 07,526 & 21,262 & 58,236 & 48,916 \\
\hline lowa & 309,318 & 468,334 & 539,894 & 573,112 & 557,823 & 200,039 & 236,600 & 31,447 & 72,538 & 78,103 & 71,272 & 36,741 & 258,409 & 255,104 \\
\hline & 6,293 & 291,173 & 298,004 & 302,317 & 78 & & & & 32,480 & & 48 & 2,035 & & \\
\hline & 3,785 & 333,269 & 362,208 & 374,660 & 374,000 & 248,402 & 3,292 & 472 & 33,565 & 5 & 46,577 & 21,818 & 37, & 32,951 \\
\hline & 323,630 & 309,699 & 337,290 & 338,898 & 338,468 & 276,599 & 38,958 & 288,260 & 34,050 & & 34,935 & 12,981 & & 5,273 \\
\hline Vianline.... & 88,644 & 89,020 & 90,608 & 92,858 & 94,341 & 64,380 & 66,013 & 66,943 & 22,474 & 24,233 & 25,248 & 1,790 & 2,612 & 2,150 \\
\hline rvyland & 412,867 & 448,804 & 483,478 & 490,738 & 496,859 & 340,538 & 404,916 & 12,614 & 64,377 & 66,660 & 67,386 & 7,952 & 19,1 & 16,859 \\
\hline & 5,872 & 612,639 & 631991 & 0,116 & 4,559 & 316 & & & 293,677 & & & 5,879 & & \\
\hline & 4,731 & 873,323 & 909,664 & 4,789 & 889,359 & 14 & & & 141,670 & 159, & 55,583 & 13,047 & 17, & 17,042 \\
\hline & 9,986 & 562,086 & 609,434 & 625,729 & 614,033 & 448 & 82 & 83 & 83,577 & & 86,111 & 67,961 & 175 & 168,939 \\
\hline Mississippi & 206,917 & 208,491 & 228,648 & 235,071 & 233,236 & 187,594 & 209,115 & 207,413 & 17,299 & 62 & 0,598 & 2,024 & 5,794 & 225 \\
\hline & 504,860 & 547,541 & 585,165 & 614,390 & 609,947 & 289,162 & 35,986 & 35,520 & 187,886 & 209,0 & 207,448 & 7,812 & 49 & 6,979 \\
\hline & 259 & 2,959 & 67,990 &, 083 & 8,163 & 53,889 & 61,911 & 2,150 & 6,370 & & 6,013 & & & \\
\hline & 178,595 & 199,457 & 205,786 & 5,496 & 202,861 & 140,544 & 586 & 41 & 34,369 & 7 & 42,730 & 3,682 & 33 & 4,790 \\
\hline & 153,540 & 167,602 & 176,886 & 178,375 & 5,857 & 136,158 & 154,792 & 56 & 1,087 & 4,3 & 4,100 & 16,295 & 19, & 18,601 \\
\hline New & 92,067 & 94,578 & 97,595 & 98,788 & 101,998 & 52,671 & 58,196 & 7,290 & 31,809 & 34,560 & 39,654 & 7,587 & 6,032 & 054 \\
\hline Now lorcove & 4,892 & 5 & 557, & 9,223 & 3 & 88 & 56 & ( & 80,936 & 9 & 59 & 8,868 & 14,098 & 88 \\
\hline & 0,031 & 1 & & & & & & & 5,007 & & & 9,599 & & \\
\hline & $1,457,951$ & $1,583,029$ & $1,629,904$ & $1,663,077$ & 1,67 & 82 & & & 560,583 & 0 & 35 & 76,519 & & \\
\hline & 7,309 & 694,804 & 744,508 & 757,889 & 751,635 & 537,735 & 620,890 & 2,585 & 94,361 & 106 & 107,194 & 5,213 & 0 & 856 \\
\hline North Ue & 62,743 & 63,411 & 67,286 & 70,168 & 70,816 & 54,671 & 59,813 & 61,236 & 7,090 & 7,667 & 7,664 & 982 & 2,688 & 916 \\
\hline Dhio & 809,712 & 886,676 & 953,395 & 991,748 & 966,766 & 601,853 & 726,472 & 713,233 & 167,235 & 179,6 & 178,783 & 40,624 & 85,6 & 74,750 \\
\hline & 0,437 & & & & & & & & 27,920 & & & 10,073 & & \\
\hline & 6,574 & 313184 & 363,315 & 374,342 & & & 26 & & 31,580 & 39 & 39,863 & & & 15,443 \\
\hline & 868,185 & 942,541 & $1,009,693$ & $1,019,681$ & 27 & 493,773 & 547,860 & 71 & 307,862 & 351,503 & 349,789 & 66,550 & & 99,867 \\
\hline Rhode I & 99,103 & 101,282 & 102,211 & 101,327 & 100,938 & 52,263 & 54,535 & 54,504 & 45,906 & 46,792 & 46,434 & 934 & & \\
\hline th & 268,590 & 299,389 & 323,668 & 331,280 & 335,091 & 221,632 & 262,422 & 266,862 & 43,450 & 43, & 43,106 & 3,508 & 2 & 123 \\
\hline & & & & & & & & & 9,858 & & & 5,561 & & \\
\hline & 353,167 & 390,220 & 426,013 & 438,901 & 435,925 & 254,104 & 299,545 & 33 & 72,505 & 92 & 94,966 & 26,558 & 46 & 42,426 \\
\hline & $1,695,267$ & $1,862,048$ & $2,010,650$ & $2,107,806$ & $2,117,481$ & $1,492,623$ & $1,843,574$ & $1,859,632$ & 148,812 & 16 & 160,253 & 53,832 & & 97,596 \\
\hline Utar & 278,798 & 298,907 & 319,218 & 340,784 & 350,906 & 213,428 & 236,332 & 234,511 & 50,268 & 80,445 & 92,490 & 15,102 & 24,007 & 23,905 \\
\hline & & 7,416 & 651 & & & & & & 711 & & & 443 & & 85 \\
\hline & & & 6 & & & 58 & & & & & & 0,195 & 9 & 91,207 \\
\hline & 0,108 & 538, & & & & & & & 52,896 & & 49,631 & 15,802 & & \\
\hline & 5,082 & & & & & & & & & & & 5,962 & & 116,636 \\
\hline & 444,120 & 470,405 & 496,703 & 507,252 & 492,783 & 353,215 & 390,899 & 381,553 & 83,180 & 88,330 & 85,682 & 7,725 & 28,023 & 25,548 \\
\hline Wyomin & 48,651 & 55,730 & 52,585 & 53,987 & 53,384 & 45,756 & 50,935 & 50,850 & 0 & 0 & 0 & 2,895 & 3,052 & 2,534 \\
\hline U.S. Service Academies.. & 16,159 & 17,029 & 17,128 & 17,330 & 15,782 & 16,159 & 17,330 & 15,782 & $\dagger$ & $\dagger$ & $\dagger$ & $\dagger$ & $\dagger$ & $\dagger$ \\
\hline Other jurisdictions. & 258,744 & $\begin{array}{l}276,492 \\
\end{array}$ & 312,713 & 316,745 & 317,216 & 95,808 & 94,233 & 90,001 & \begin{tabular}{ll|}
136,708 \\
\end{tabular} & $\begin{array}{l}163,588 \\
\end{array}$ & \begin{tabular}{ll|}
168,122 \\
\end{tabular} & \begin{tabular}{l|l|}
26,228 \\
\end{tabular} & \begin{tabular}{|l|}
58,924 \\
\end{tabular} & 59,093 \\
\hline Americ & 2,299 & 2,576 & 2,900 & 2,744 & 2,621 & 2,299 & 2,744 & 2,621 & 0 & 0 & 0 & 0 & 0 & 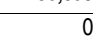 \\
\hline & & & & & & & & & & & & & & \\
\hline & 3,570 & 3,2 & 4,805 & 5,097 & 5,457 & 3,5 & $5, c$ & 5,4 & 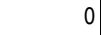 & 0 & 0 & 0 & 0 & 0 \\
\hline & 7,125 & 7,116 & 7,621 & 8,105 & 8,005 & 6,936 & 8,001 & & 189 & 104 & 97 & 0 & 0 & 0 \\
\hline & 466 & 952 & 1,164 & 1,176 & 1,310 & 466 & 1,176 & 1,3 & 0 & 0 & 0 & 0 & 0 & 0 \\
\hline & 1,590 & 1,126 & 1,134 & 1,388 & 1,332 & 1,590 & 1,388 & 1,332 & 0 & 0 & 0 & 0 & 0 & 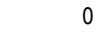 \\
\hline & 987 & 837 & 990 & 922 & 981 & 987 & 922 & 981 & 0 & 0 & 0 & 0 & 0 & \\
\hline & 239,442 & 257,499 & 290,716 & 293,893 & 294,265 & 76,695 & 71,485 & 67,147 & 136,519 & 163,484 & 168,025 & 26,228 & 924 & \\
\hline U.S. Virgin Islands .. & 3,265 & 3,159 & 3,383 & 3,420 & 3,245 & 3,265 & 3,420 & 3,245 & 0 & 0 & & 0 & 0 & \\
\hline
\end{tabular}

†Not applicable.

NOTE: Includes students who enrolled at any point during a 12-month period ending during the summer of the academic year indicated. Degree-granting institutions grant associate's or higher degrees and participate in Title IV federal financial aid programs.
SOURCE: U.S. Department of Education, National Center for Education Statistics, Integrated Postsecondary Education Data System (IPEDS), Fall 2005 through Fall 2012, 12 Month Enrollment component. (This table was prepared August 2013.) 
CHAPTER 3: Postsecondary Education 447 Student Residence and Migration

Table 309.10. Residence and migration of all first-time degree/certificate-seeking undergraduates in degree-granting postsecondary institutions, by state or jurisdiction: Fall 2012

\begin{tabular}{|c|c|c|c|c|c|c|c|c|}
\hline \multirow[b]{2}{*}{ State or jurisdiction } & \multirow{2}{*}{$\begin{array}{r}\text { Total } \\
\text { first-time } \\
\text { enrollment } \\
\text { in institutions } \\
\text { located in the state }\end{array}$} & \multicolumn{2}{|c|}{ State residents enrolled in institutions } & \multicolumn{2}{|c|}{ Ratio of in-state students } & \multicolumn{3}{|c|}{ Migration of students } \\
\hline & & In any state ${ }^{1}$ & In their home state & $\begin{array}{r}\text { To first-time } \\
\text { enrollment } \\
\text { (col. 4/col. 2) }\end{array}$ & $\begin{array}{r}\text { To residents } \\
\text { enrolled in any } \\
\text { state (col. } 4 / \mathrm{col} .3)\end{array}$ & $\begin{array}{r}\text { Out of state } \\
\text { (col. } 3-\text { col. } 4)\end{array}$ & $\begin{array}{r}\text { Into state } \\
(\text { col. } 2 \text { - col. } 4)\end{array}$ & $\begin{array}{r}\mathrm{Ne} \\
(\mathrm{col} .8-\mathrm{col} .7)\end{array}$ \\
\hline 1 & 2 & 3 & 4 & 5 & 6 & 7 & 8 & 9 \\
\hline United States .............. & $2,990,280$ & $2,904,789$ & $2,386,491$ & 0.80 & 0.82 & 518,298 & 603,789 & 103,804 \\
\hline 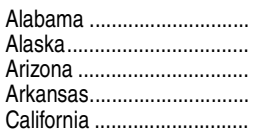 & $\begin{array}{r}51,975 \\
4,474 \\
79,100 \\
28,830 \\
373,490\end{array}$ & $\begin{array}{r}43,246 \\
5,407 \\
54,993 \\
26,521 \\
373,234\end{array}$ & $\begin{array}{r}37,115 \\
3,565 \\
49,530 \\
23,137 \\
334,689\end{array}$ & $\begin{array}{l}0.71 \\
0.80 \\
0.63 \\
0.80 \\
0.90\end{array}$ & $\begin{array}{l}0.86 \\
0.66 \\
0.90 \\
0.87 \\
0.90\end{array}$ & $\begin{array}{r}6,131 \\
1,842 \\
5,463 \\
3,384 \\
38,545 \\
\end{array}$ & $\begin{array}{r}14,860 \\
909 \\
29,570 \\
5,693 \\
38,801\end{array}$ & $\begin{array}{r}8,729 \\
-933 \\
24,107 \\
2,309 \\
256\end{array}$ \\
\hline 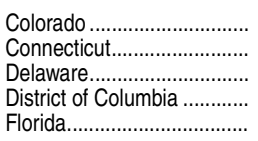 & $\begin{array}{r}47,226 \\
32,193 \\
9,655 \\
9,546 \\
165,420\end{array}$ & $\begin{array}{r}46,262 \\
37,763 \\
8,236 \\
3,660 \\
155,906\end{array}$ & $\begin{array}{r}36,786 \\
22,229 \\
5,812 \\
822 \\
138,198\end{array}$ & $\begin{array}{l}0.78 \\
0.69 \\
0.60 \\
0.09 \\
0.84\end{array}$ & $\begin{array}{l}0.80 \\
0.59 \\
0.71 \\
0.22 \\
0.89\end{array}$ & $\begin{array}{r}9,476 \\
15,534 \\
2,424 \\
2,838 \\
17,708\end{array}$ & $\begin{array}{r}10,440 \\
9,964 \\
3,843 \\
8,724 \\
27,222\end{array}$ & $\begin{array}{r}964 \\
-5,570 \\
1,419 \\
5,886 \\
9,514\end{array}$ \\
\hline 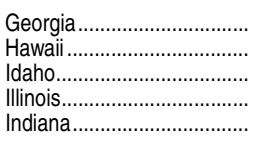 & $\begin{array}{r}88,437 \\
10,271 \\
14,232 \\
104,815 \\
72,021\end{array}$ & $\begin{array}{r}94,075 \\
11,785 \\
13,181 \\
121,378 \\
63,907\end{array}$ & $\begin{array}{r}75,554 \\
8,223 \\
9,758 \\
88,244 \\
55,683\end{array}$ & $\begin{array}{l}0.85 \\
0.80 \\
0.69 \\
0.84 \\
0.77\end{array}$ & $\begin{array}{l}0.80 \\
0.70 \\
0.74 \\
0.73 \\
0.87\end{array}$ & $\begin{array}{r}18,521 \\
3,562 \\
3,423 \\
33,134 \\
8,224\end{array}$ & $\begin{array}{r}12,883 \\
2,048 \\
4,474 \\
16,571 \\
16,338\end{array}$ & $\begin{array}{r}-5,638 \\
-1,514 \\
1,051 \\
-16,563 \\
8,114\end{array}$ \\
\hline 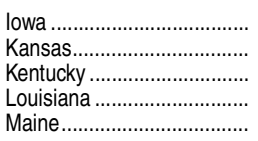 & $\begin{array}{l}43,637 \\
32,737 \\
40,401 \\
42,183 \\
12,433\end{array}$ & $\begin{array}{l}30,326 \\
29,396 \\
37,616 \\
41,092 \\
11,723\end{array}$ & $\begin{array}{r}26,472 \\
25,260 \\
32,443 \\
36,307 \\
8,368\end{array}$ & $\begin{array}{l}0.61 \\
0.77 \\
0.80 \\
0.86 \\
0.67\end{array}$ & $\begin{array}{l}0.87 \\
0.86 \\
0.86 \\
0.88 \\
0.71\end{array}$ & $\begin{array}{l}3,854 \\
4,136 \\
5,173 \\
4,785 \\
3,355\end{array}$ & $\begin{array}{r}17,165 \\
7,477 \\
7,958 \\
5,876 \\
4,065\end{array}$ & $\begin{array}{r}13,311 \\
3,341 \\
2,785 \\
1,091 \\
710\end{array}$ \\
\hline 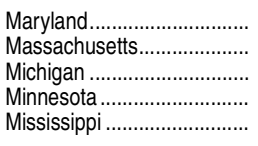 & $\begin{array}{l}48,002 \\
76,090 \\
95,351 \\
49,875 \\
34,534\end{array}$ & $\begin{array}{l}56,744 \\
66,891 \\
94,844 \\
53,821 \\
33,565\end{array}$ & $\begin{array}{l}38,418 \\
47,487 \\
84,214 \\
39,387 \\
28,379\end{array}$ & $\begin{array}{l}0.80 \\
0.62 \\
0.88 \\
0.79 \\
0.82\end{array}$ & $\begin{array}{l}0.68 \\
0.71 \\
0.89 \\
0.73 \\
0.85\end{array}$ & $\begin{array}{r}18,326 \\
19,404 \\
10,630 \\
14,434 \\
5,186\end{array}$ & $\begin{array}{r}9,584 \\
28,603 \\
11,137 \\
10,488 \\
6,155\end{array}$ & $\begin{array}{r}-8,742 \\
9,199 \\
507 \\
-3,946 \\
969\end{array}$ \\
\hline 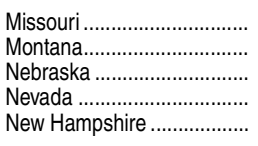 & $\begin{array}{r}61,459 \\
8,918 \\
18,201 \\
15,890 \\
13,761\end{array}$ & $\begin{array}{r}56,784 \\
8,162 \\
17,713 \\
18,185 \\
12,571\end{array}$ & $\begin{array}{r}47,436 \\
6,403 \\
14,422 \\
14,206 \\
7,029\end{array}$ & $\begin{array}{l}0.77 \\
0.72 \\
0.79 \\
0.89 \\
0.51\end{array}$ & $\begin{array}{l}0.84 \\
0.78 \\
0.81 \\
0.78 \\
0.56\end{array}$ & $\begin{array}{l}9,348 \\
1,759 \\
3,291 \\
3,979 \\
5,542\end{array}$ & $\begin{array}{r}14,023 \\
2,515 \\
3,779 \\
1,684 \\
6,732\end{array}$ & $\begin{array}{r}4,675 \\
756 \\
488 \\
-2,295 \\
1,190\end{array}$ \\
\hline 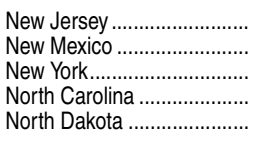 & $\begin{array}{r}65,607 \\
20,094 \\
191,958 \\
94,267 \\
9,034\end{array}$ & $\begin{array}{r}94,844 \\
19,877 \\
185,923 \\
89,821 \\
6,077\end{array}$ & $\begin{array}{r}59,969 \\
16,903 \\
153,169 \\
78,229 \\
4,446\end{array}$ & $\begin{array}{l}0.91 \\
0.84 \\
0.80 \\
0.83 \\
0.49\end{array}$ & $\begin{array}{l}0.63 \\
0.85 \\
0.82 \\
0.87 \\
0.73\end{array}$ & $\begin{array}{r}34,875 \\
2,974 \\
32,754 \\
11,592 \\
1,631\end{array}$ & $\begin{array}{r}5,638 \\
3,191 \\
38,789 \\
16,038 \\
4,588\end{array}$ & $\begin{array}{r}-29,237 \\
217 \\
6,035 \\
4,446 \\
2,957\end{array}$ \\
\hline 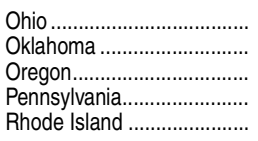 & $\begin{array}{r}110,404 \\
36,821 \\
32,765 \\
132,337 \\
15,454\end{array}$ & $\begin{array}{r}107,587 \\
31,918 \\
29,126 \\
116,270 \\
9,800\end{array}$ & $\begin{array}{r}90,886 \\
28,157 \\
24,067 \\
96,033 \\
6,772\end{array}$ & $\begin{array}{l}0.82 \\
0.76 \\
0.73 \\
0.73 \\
0.44\end{array}$ & $\begin{array}{l}0.84 \\
0.88 \\
0.83 \\
0.83 \\
0.69\end{array}$ & $\begin{array}{r}16,701 \\
3,761 \\
5,059 \\
20,237 \\
3,028\end{array}$ & $\begin{array}{r}19,518 \\
8,664 \\
8,698 \\
36,304 \\
8,682\end{array}$ & $\begin{array}{r}2,817 \\
4,903 \\
3,639 \\
16,067 \\
5,654\end{array}$ \\
\hline 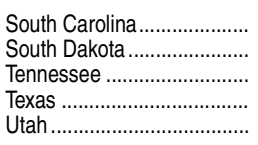 & $\begin{array}{r}48,307 \\
9,301 \\
54,594 \\
231,755 \\
30,184\end{array}$ & $\begin{array}{r}43,055 \\
7,834 \\
54,165 \\
240,386 \\
22,955\end{array}$ & $\begin{array}{r}37,572 \\
6,090 \\
44,914 \\
213,713 \\
20,845\end{array}$ & $\begin{array}{l}0.78 \\
0.65 \\
0.82 \\
0.92 \\
0.69\end{array}$ & $\begin{array}{l}0.87 \\
0.78 \\
0.83 \\
0.89 \\
0.91\end{array}$ & $\begin{array}{r}5,483 \\
1,744 \\
9,251 \\
26,673 \\
2,110\end{array}$ & $\begin{array}{r}10,735 \\
3,211 \\
9,680 \\
18,042 \\
9,339\end{array}$ & $\begin{array}{r}5,252 \\
1,467 \\
429 \\
-8,631 \\
7,229\end{array}$ \\
\hline 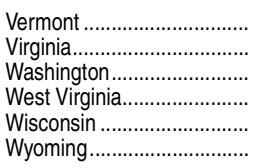 & $\begin{array}{r}7,881 \\
82,270 \\
40,961 \\
25,018 \\
56,570 \\
5,759\end{array}$ & $\begin{array}{r}5,114 \\
75,068 \\
44,646 \\
13,928 \\
54,482 \\
4,613\end{array}$ & $\begin{array}{r}2,696 \\
61,590 \\
33,911 \\
12,141 \\
44,951 \\
3,590\end{array}$ & $\begin{array}{l}0.34 \\
0.75 \\
0.83 \\
0.49 \\
0.79 \\
0.62\end{array}$ & $\begin{array}{l}0.53 \\
0.82 \\
0.76 \\
0.87 \\
0.83 \\
0.78\end{array}$ & $\begin{array}{r}2,418 \\
13,478 \\
10,735 \\
1,787 \\
9,531 \\
1,023\end{array}$ & $\begin{array}{r}5,185 \\
20,680 \\
7,050 \\
12,877 \\
11,619 \\
2,169\end{array}$ & $\begin{array}{r}2,767 \\
7,202 \\
-3,685 \\
11,090 \\
2,088 \\
1,146\end{array}$ \\
\hline $\begin{array}{l}\text { U.S. Service Academies ...... } \\
\text { State unknown }{ }^{4} \ldots \ldots \ldots \ldots \ldots . . . .\end{array}$ & $\begin{array}{r}3,782 \\
+ \\
\end{array}$ & $\begin{array}{r}\dagger \\
18,313 \\
\end{array}$ & $\begin{array}{c}271^{3} \\
\dagger \\
\end{array}$ & $\begin{array}{l}\dagger \\
\dagger \\
\end{array}$ & $\begin{array}{l}\dagger \\
\dagger \\
\end{array}$ & $\begin{array}{r}-271 \\
18,313 \\
\end{array}$ & $\begin{array}{r}3,511 \\
\dagger \\
\end{array}$ & $\begin{array}{r}3,782 \\
-18,313 \\
\end{array}$ \\
\hline Other jurisdictions .... & 51,926 & 53,269 & 51,397 & 0.99 & 0.96 & 1,872 & 529 & $-1,343$ \\
\hline $\begin{array}{l}\text { American Samoa } \\
\text { Federated States of }\end{array}$ & 545 & 646 & 545 & 1.00 & 0.84 & 101 & 0 & -101 \\
\hline 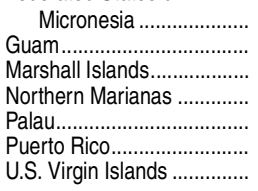 & $\begin{array}{r}700 \\
961 \\
349 \\
322 \\
236 \\
48,414 \\
399 \\
\end{array}$ & $\begin{array}{r}809 \\
1,074 \\
353 \\
380 \\
193 \\
49,043 \\
771 \\
\end{array}$ & $\begin{array}{r}700 \\
873 \\
336 \\
318 \\
176 \\
48,070 \\
379 \\
\end{array}$ & $\begin{array}{l}1.00 \\
0.91 \\
0.96 \\
0.99 \\
0.75 \\
0.99 \\
0.95\end{array}$ & $\begin{array}{l}0.87 \\
0.81 \\
0.95 \\
0.84 \\
0.91 \\
0.98 \\
0.49\end{array}$ & $\begin{array}{r}109 \\
201 \\
17 \\
62 \\
17 \\
973 \\
392 \\
\end{array}$ & $\begin{array}{r}0 \\
88 \\
13 \\
4 \\
60 \\
344 \\
20 \\
\end{array}$ & $\begin{array}{r}-109 \\
-113 \\
-4 \\
-58 \\
43 \\
-629 \\
-372 \\
\end{array}$ \\
\hline $\begin{array}{l}\text { Foreign countries................. } \\
\text { Residence unknown ........... }\end{array}$ & $\begin{array}{l}\dagger \\
\dagger\end{array}$ & $\begin{array}{r}74,425 \\
9,723\end{array}$ & $\begin{array}{l}+ \\
\dagger\end{array}$ & $\begin{array}{l}+ \\
\dagger\end{array}$ & $\begin{array}{l}+ \\
\dagger\end{array}$ & $\begin{array}{r}74,425 \\
9,723\end{array}$ & $\begin{array}{l}\dagger \\
\dagger\end{array}$ & $\begin{array}{r}-74,425 \\
-9,723\end{array}$ \\
\hline
\end{tabular}

$†$ Not applicable.

'Students residing in a particular state when admitted to an institution anywhere-either in their home state or another state.

${ }^{2}$ Includes students coming to U.S. colleges from foreign countries and other jurisdictions.

${ }^{3}$ Students whose residence is in the same state as the service academy.

${ }^{4}$ Institution unable to determine student's home state.
NOTE: Includes all first-time postsecondary students enrolled at reporting institutions. Degree-granting institutions grant associate's or higher degrees and participate in Title IV federal financial aid programs.

SOURCE: U.S. Department of Education, National Center for Education Statistics, Integrated Postsecondary Education Data System (IPEDS), Spring 2013, Enrollment component. (This table was prepared March 2014.) 
Table 309.20. Residence and migration of all first-time degree/certificate-seeking undergraduates in degree-granting postsecondary institutions who graduated from high school in the previous 12 months, by state or jurisdiction: Fall 2012

\begin{tabular}{|c|c|c|c|c|c|c|c|c|}
\hline \multirow[b]{2}{*}{ State or jurisdiction } & \multirow{2}{*}{$\begin{array}{r}\text { Total } \\
\text { first-time } \\
\text { enrollment } \\
\text { in institutions } \\
\text { located in the state }\end{array}$} & \multicolumn{2}{|c|}{ State residents enrolled in institutions } & \multicolumn{2}{|c|}{ Ratio of in-state students } & \multicolumn{3}{|c|}{ Migration of students } \\
\hline & & In any state ${ }^{1}$ & In their home state & $\begin{array}{r}\text { To first-time } \\
\text { enrollment } \\
\text { (col. 4/col. 2) }\end{array}$ & $\begin{array}{r}\text { To residents } \\
\text { enrolled in any } \\
\text { state (col. } 4 / \mathrm{col} .3)\end{array}$ & $\begin{array}{r}\text { Out of state } \\
\text { (col. } 3 \text { - col. 4) }\end{array}$ & $\begin{array}{r}\text { Into state } \\
(\text { col. } 2 \text { - col. 4) }\end{array}$ & $\begin{array}{r}\text { Net } \\
\text { (col. 8- col. 7) }\end{array}$ \\
\hline 1 & 2 & 3 & 4 & 5 & 6 & 7 & 8 & 9 \\
\hline United States .............. & $2,174,664$ & $2,130,794$ & $1,728,467$ & 0.79 & 0.81 & 402,327 & 446,197 & 43,870 \\
\hline 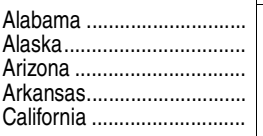 & $\begin{array}{r}36,929 \\
2,909 \\
41,144 \\
23,356 \\
251,328\end{array}$ & $\begin{array}{r}29,694 \\
3,728 \\
35,184 \\
20,184 \\
263,867\end{array}$ & $\begin{array}{r}26,535 \\
2,413 \\
31,132 \\
18,244 \\
231,247\end{array}$ & $\begin{array}{l}0.72 \\
0.83 \\
0.76 \\
0.78 \\
0.92\end{array}$ & $\begin{array}{l}0.89 \\
0.65 \\
0.88 \\
0.90 \\
0.88\end{array}$ & $\begin{array}{r}3,159 \\
1,315 \\
4,052 \\
1,940 \\
32,620\end{array}$ & \begin{tabular}{r|}
10,394 \\
496 \\
10,012 \\
5,112 \\
20,081
\end{tabular} & $\begin{array}{r}7,235 \\
-819 \\
5,960 \\
3,172 \\
-12,539\end{array}$ \\
\hline 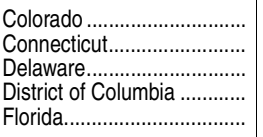 & $\begin{array}{r}30,290 \\
26,044 \\
8,110 \\
8,284 \\
107,684\end{array}$ & $\begin{array}{r}31,143 \\
31,658 \\
6,500 \\
2,463 \\
107,701\end{array}$ & $\begin{array}{r}23,271 \\
17,396 \\
4,632 \\
450 \\
94,996\end{array}$ & $\begin{array}{l}0.77 \\
0.67 \\
0.57 \\
0.05 \\
0.88\end{array}$ & $\begin{array}{l}0.75 \\
0.55 \\
0.71 \\
0.18 \\
0.88\end{array}$ & $\begin{array}{r}7,872 \\
14,262 \\
1,868 \\
2,013 \\
12,705\end{array}$ & $\begin{array}{r}7,019 \\
8,648 \\
3,478 \\
7,834 \\
12,688\end{array}$ & $\begin{array}{r}-853 \\
-5,614 \\
1,610 \\
5,821 \\
-17\end{array}$ \\
\hline 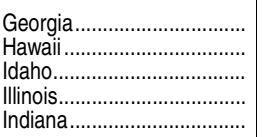 & $\begin{array}{r}64,940 \\
7,578 \\
9,776 \\
76,062 \\
51,440\end{array}$ & $\begin{array}{r}66,480 \\
9,036 \\
8,782 \\
92,463 \\
44,638\end{array}$ & $\begin{array}{r}55,396 \\
6,091 \\
6,179 \\
63,671 \\
38,843\end{array}$ & $\begin{array}{l}0.85 \\
0.80 \\
0.63 \\
0.84 \\
0.76\end{array}$ & $\begin{array}{l}0.83 \\
0.67 \\
0.70 \\
0.69 \\
0.87\end{array}$ & $\begin{array}{r}11,084 \\
2,945 \\
2,603 \\
28,792 \\
5,795\end{array}$ & $\begin{array}{r}9,544 \\
1,487 \\
3,597 \\
12,391 \\
12,597\end{array}$ & $\begin{array}{r}-1,540 \\
-1,458 \\
994 \\
-16,401 \\
6,802\end{array}$ \\
\hline 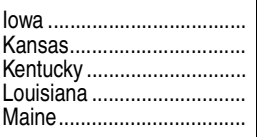 & $\begin{array}{r}30,961 \\
24,867 \\
32,752 \\
31,144 \\
8,515\end{array}$ & $\begin{array}{r}23,487 \\
22,234 \\
29,315 \\
28,829 \\
8,681\end{array}$ & $\begin{array}{r}20,342 \\
19,053 \\
26,111 \\
26,024 \\
5,829\end{array}$ & $\begin{array}{l}0.66 \\
0.77 \\
0.80 \\
0.84 \\
0.68\end{array}$ & $\begin{array}{l}0.87 \\
0.86 \\
0.89 \\
0.90 \\
0.67\end{array}$ & $\begin{array}{l}3,145 \\
3,181 \\
3,204 \\
2,805 \\
2,852\end{array}$ & $\begin{array}{r}10,619 \\
5,814 \\
6,641 \\
5,120 \\
2,686\end{array}$ & $\begin{array}{r}7,474 \\
2,633 \\
3,437 \\
2,315 \\
-166\end{array}$ \\
\hline 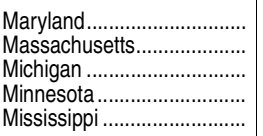 & $\begin{array}{l}33,372 \\
62,442 \\
72,420 \\
38,710 \\
26,764\end{array}$ & $\begin{array}{l}41,030 \\
53,835 \\
70,816 \\
43,264 \\
23,438\end{array}$ & $\begin{array}{l}25,773 \\
36,133 \\
63,272 \\
30,237 \\
21,752\end{array}$ & $\begin{array}{l}0.77 \\
0.58 \\
0.87 \\
0.78 \\
0.81\end{array}$ & $\begin{array}{l}0.63 \\
0.67 \\
0.89 \\
0.70 \\
0.93\end{array}$ & $\begin{array}{r}15,257 \\
17,702 \\
7,544 \\
13,027 \\
1,686\end{array}$ & $\begin{array}{r}7,599 \\
26,309 \\
9,148 \\
8,473 \\
5,012\end{array}$ & $\begin{array}{r}-7,658 \\
8,607 \\
1,604 \\
-4,554 \\
3,326\end{array}$ \\
\hline 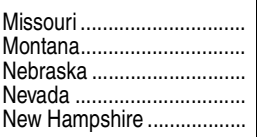 & $\begin{array}{r}46,105 \\
6,763 \\
15,046 \\
10,744 \\
11,259\end{array}$ & $\begin{array}{r}42,789 \\
5,903 \\
14,754 \\
12,274 \\
10,417\end{array}$ & $\begin{array}{r}35,671 \\
4,598 \\
11,970 \\
9,302 \\
5,618\end{array}$ & $\begin{array}{l}0.77 \\
0.68 \\
0.80 \\
0.87 \\
0.50\end{array}$ & $\begin{array}{l}0.83 \\
0.78 \\
0.81 \\
0.76 \\
0.54\end{array}$ & $\begin{array}{l}7,118 \\
1,305 \\
2,784 \\
2,972 \\
4,799\end{array}$ & $\begin{array}{r}10,434 \\
2,165 \\
3,076 \\
1,442 \\
5,641\end{array}$ & $\begin{array}{r}3,316 \\
860 \\
292 \\
-1,530 \\
842\end{array}$ \\
\hline 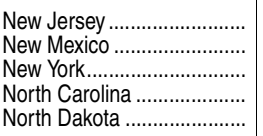 & $\begin{array}{r}45,452 \\
15,117 \\
151,519 \\
68,858 \\
7,425\end{array}$ & $\begin{array}{r}72,487 \\
14,831 \\
146,313 \\
62,035 \\
4,752\end{array}$ & $\begin{array}{r}41,075 \\
12,903 \\
117,820 \\
55,085 \\
3,527\end{array}$ & $\begin{array}{l}0.90 \\
0.85 \\
0.78 \\
0.80 \\
0.48\end{array}$ & $\begin{array}{l}0.57 \\
0.87 \\
0.81 \\
0.89 \\
0.74\end{array}$ & $\begin{array}{r}31,412 \\
1,928 \\
28,493 \\
6,950 \\
1,225\end{array}$ & $\begin{array}{r}4,377 \\
2,214 \\
33,699 \\
13,773 \\
3,898\end{array}$ & $\begin{array}{r}-27,035 \\
286 \\
5,206 \\
6,823 \\
2,673\end{array}$ \\
\hline 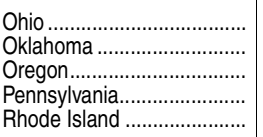 & $\begin{array}{r}85,138 \\
27,102 \\
20,188 \\
101,256 \\
13,110\end{array}$ & $\begin{array}{r}81,445 \\
22,668 \\
17,441 \\
86,959 \\
7,715\end{array}$ & $\begin{array}{r}69,067 \\
20,209 \\
13,275 \\
70,507 \\
5,056\end{array}$ & $\begin{array}{l}0.81 \\
0.75 \\
0.66 \\
0.70 \\
0.39\end{array}$ & $\begin{array}{l}0.85 \\
0.89 \\
0.76 \\
0.81 \\
0.66\end{array}$ & $\begin{array}{r}12,378 \\
2,459 \\
4,166 \\
16,452 \\
2,659\end{array}$ & $\begin{array}{r}16,071 \\
6,893 \\
6,913 \\
30,749 \\
8,054\end{array}$ & $\begin{array}{r}3,693 \\
4,434 \\
2,747 \\
14,297 \\
5,395\end{array}$ \\
\hline $\begin{array}{l}\text { South Carolina .................. } \\
\text { South Dakota ....................... } \\
\text { Tennessee ......................... } \\
\text { Texas } \\
\text { Utah }\end{array}$ & $\begin{array}{r}35,530 \\
7,136 \\
42,207 \\
166,881 \\
22,087\end{array}$ & $\begin{array}{r}29,018 \\
5,825 \\
41,024 \\
176,845 \\
16,653\end{array}$ & $\begin{array}{r}26,154 \\
4,443 \\
34,337 \\
156,551 \\
15,101\end{array}$ & $\begin{array}{l}0.74 \\
0.62 \\
0.81 \\
0.94 \\
0.68\end{array}$ & $\begin{array}{l}0.90 \\
0.76 \\
0.84 \\
0.89 \\
0.91\end{array}$ & $\begin{array}{r}2,864 \\
1,382 \\
6,687 \\
20,294 \\
1,552\end{array}$ & $\begin{array}{r}9,376 \\
2,693 \\
7,870 \\
10,330 \\
6,986\end{array}$ & $\begin{array}{r}6,512 \\
1,311 \\
1,183 \\
-9,964 \\
5,434\end{array}$ \\
\hline 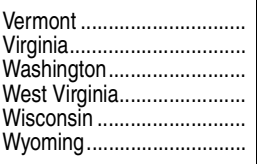 & $\begin{array}{r}6,940 \\
62,756 \\
32,069 \\
14,869 \\
44,346 \\
4,015\end{array}$ & $\begin{array}{r}4,139 \\
58,037 \\
34,166 \\
10,249 \\
41,710 \\
3,170\end{array}$ & $\begin{array}{r}2,040 \\
47,590 \\
25,854 \\
9,110 \\
33,973 \\
2,426\end{array}$ & $\begin{array}{l}0.29 \\
0.76 \\
0.81 \\
0.61 \\
0.77 \\
0.60\end{array}$ & $\begin{array}{l}0.49 \\
0.82 \\
0.76 \\
0.89 \\
0.81 \\
0.77\end{array}$ & $\begin{array}{r}2,099 \\
10,447 \\
8,312 \\
1,139 \\
7,737 \\
744\end{array}$ & $\begin{array}{r}4,900 \\
15,166 \\
6,215 \\
5,759 \\
10,373 \\
1,589\end{array}$ & $\begin{array}{r}2,801 \\
4,719 \\
-2,097 \\
4,620 \\
2,636 \\
845\end{array}$ \\
\hline 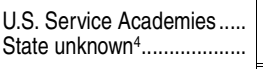 & $\begin{array}{r}2,925 \\
\dagger \\
\end{array}$ & $\begin{array}{r}\dagger \\
8,725 \\
\end{array}$ & $\begin{array}{c}183^{3} \\
\dagger\end{array}$ & $\begin{array}{l}t \\
t \\
\end{array}$ & $\dagger$ & $\begin{array}{r}-183 \\
8,725 \\
\end{array}$ & $\begin{array}{r}2,742 \\
\dagger\end{array}$ & $\begin{array}{r}2,925 \\
-8,725 \\
\end{array}$ \\
\hline Other jurisdictions .... & 35,629 & 36,890 & 35,429 & 0.99 & 0.96 & 1,461 & 200 & $-1,261$ \\
\hline 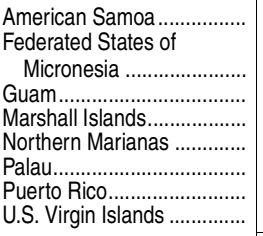 & $\begin{array}{r}405 \\
0 \\
694 \\
0 \\
243 \\
184 \\
33,806 \\
297 \\
\end{array}$ & $\begin{array}{r}489 \\
73 \\
795 \\
10 \\
288 \\
164 \\
34,529 \\
542 \\
\end{array}$ & $\begin{array}{r}405 \\
0 \\
038 \\
0 \\
240 \\
150 \\
33,710 \\
286 \\
\end{array}$ & $\begin{array}{r}1.00 \\
\dagger \\
0.92 \\
\dagger \\
0.99 \\
0.82 \\
1.00 \\
0.96 \\
\end{array}$ & $\begin{array}{r}0.83 \\
\dagger \\
0.80 \\
\dagger \\
0.83 \\
0.91 \\
0.98 \\
0.53 \\
\end{array}$ & $\begin{array}{r}84 \\
73 \\
157 \\
10 \\
48 \\
14 \\
819 \\
256 \\
\end{array}$ & $\begin{array}{r}0 \\
0 \\
0 \\
56 \\
0 \\
3 \\
34 \\
96 \\
11 \\
\end{array}$ & $\begin{array}{r}-84 \\
-73 \\
-101 \\
-10 \\
-45 \\
20 \\
-723 \\
-245 \\
\end{array}$ \\
\hline $\begin{array}{l}\text { Foreign countries................ } \\
\text { Residence unknown ........... }\end{array}$ & $\begin{array}{l}+ \\
t\end{array}$ & $\begin{array}{r}42,609 \\
\dagger \\
\end{array}$ & $t$ & $\begin{array}{l}\dagger \\
\dagger\end{array}$ & $\begin{array}{l}+ \\
\dagger\end{array}$ & $\begin{array}{r}42,609 \\
\dagger \\
\end{array}$ & $\begin{array}{l}+ \\
\dagger\end{array}$ & $\begin{array}{r}-42,609 \\
\dagger\end{array}$ \\
\hline
\end{tabular}

†Not applicable.

${ }^{1}$ Students residing in a particular state when admitted to an institution anywhere-either in their home state or another state.

${ }^{2}$ Includes students coming to U.S. colleges from foreign countries and other jurisdictions. ${ }^{3}$ Students whose residence is in the same state as the service academy.

${ }^{4}$ Institution unable to determine student's home state.
NOTE: Includes all first-time postsecondary students who graduated from high school in the previous 12 months and were enrolled at reporting institutions. Degree-granting institutions grant associate's or higher degrees and participate in Title IV federal financial aid programs. SOURCE: U.S. Department of Education, National Center for Education Statistics, Integrated Postsecondary Education Data System (IPEDS), Spring 2013, Enrollment component. (This table was prepared March 2014.) 
Table 309.30. Residence and migration of all first-time degree/certificate-seeking undergraduates in 4-year degree-granting postsecondary institutions who graduated from high school in the previous 12 months, by state or jurisdiction: Fall 2012

\begin{tabular}{|c|c|c|c|c|c|c|c|c|}
\hline \multirow[b]{2}{*}{ State or jurisdiction } & \multirow{2}{*}{$\begin{array}{r}\text { Total } \\
\text { first-time } \\
\text { enrollment } \\
\text { in institutions } \\
\text { located in the state }\end{array}$} & \multicolumn{2}{|c|}{ State residents enrolled in institutions } & \multicolumn{2}{|c|}{ Ratio of in-state students } & \multicolumn{3}{|c|}{ Migration of students } \\
\hline & & In any state ${ }^{1}$ & In their home state & $\begin{array}{r}\text { To first-time } \\
\text { enrollment } \\
\text { (col. 4/col. 2) }\end{array}$ & $\begin{array}{r}\text { To residents } \\
\text { enrolled in any } \\
\text { state (col. } 4 / \text { col. } 3 \text { ) }\end{array}$ & $\begin{array}{r}\text { Out of state } \\
\text { (col. } 3-\text { col. 4) }\end{array}$ & $\begin{array}{r}\text { Into state } \\
(\text { col. } 2 \text { - col. 4) }\end{array}$ & $\begin{array}{r}\text { Net } \\
\text { (col. 8- col. 7) }\end{array}$ \\
\hline 1 & 2 & 3 & 4 & 5 & 6 & 7 & 8 & ( \\
\hline United States .............. & $1,499,980$ & $1,459,647$ & $1,082,610$ & 0.72 & 0.74 & 377,037 & 417,370 & 40,333 \\
\hline 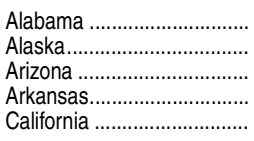 & $\begin{array}{r}23,638 \\
2,847 \\
23,520 \\
16,875 \\
124,883\end{array}$ & $\begin{array}{r}17,337 \\
3,539 \\
18,047 \\
13,561 \\
139,950\end{array}$ & $\begin{array}{r}14,652 \\
2,353 \\
14,323 \\
11,943 \\
108,241\end{array}$ & $\begin{array}{l}0.62 \\
0.83 \\
0.61 \\
0.71 \\
0.87\end{array}$ & $\begin{array}{l}0.85 \\
0.66 \\
0.79 \\
0.88 \\
0.77\end{array}$ & $\begin{array}{r}2,685 \\
1,186 \\
3,724 \\
1,618 \\
31,709\end{array}$ & $\begin{array}{r}8,986 \\
494 \\
9,197 \\
4,932 \\
16,642\end{array}$ & $\begin{array}{r}6,301 \\
-692 \\
5,473 \\
3,314 \\
-15,067\end{array}$ \\
\hline 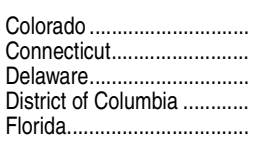 & $\begin{array}{r}23,789 \\
18,775 \\
6,075 \\
8,284 \\
97,356\end{array}$ & $\begin{array}{r}24,468 \\
24,238 \\
4,504 \\
2,183 \\
96,970\end{array}$ & $\begin{array}{r}17,181 \\
10,174 \\
2,727 \\
450 \\
85,067\end{array}$ & $\begin{array}{l}0.72 \\
0.54 \\
0.45 \\
0.05 \\
0.87\end{array}$ & $\begin{array}{l}0.70 \\
0.42 \\
0.61 \\
0.21 \\
0.88\end{array}$ & $\begin{array}{r}7,287 \\
14,064 \\
1,777 \\
1,733 \\
11,903\end{array}$ & $\begin{array}{r}6,608 \\
8,601 \\
3,348 \\
7,834 \\
12,289\end{array}$ & $\begin{array}{r}-679 \\
-5,463 \\
1,571 \\
6,101 \\
386\end{array}$ \\
\hline 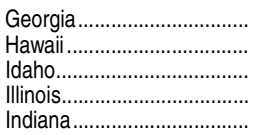 & $\begin{array}{r}50,398 \\
4,274 \\
7,731 \\
48,729 \\
42,880\end{array}$ & $\begin{array}{r}52,049 \\
5,669 \\
6,460 \\
64,682 \\
35,783\end{array}$ & $\begin{array}{r}41,749 \\
2,900 \\
4,318 \\
36,735 \\
30,492\end{array}$ & $\begin{array}{l}0.83 \\
0.68 \\
0.56 \\
0.75 \\
0.71\end{array}$ & $\begin{array}{l}0.80 \\
0.51 \\
0.67 \\
0.57 \\
0.85\end{array}$ & $\begin{array}{r}10,300 \\
2,769 \\
2,142 \\
27,947 \\
5,291\end{array}$ & $\begin{array}{r}8,649 \\
1,374 \\
3,413 \\
11,994 \\
12,388\end{array}$ & $\begin{array}{r}-1,651 \\
-1,395 \\
1,271 \\
-15,953 \\
7,097\end{array}$ \\
\hline 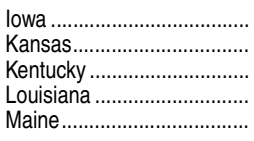 & $\begin{array}{r}19,572 \\
14,534 \\
23,498 \\
23,625 \\
6,634\end{array}$ & $\begin{array}{r}13,175 \\
13,470 \\
20,182 \\
20,982 \\
6,854\end{array}$ & $\begin{array}{r}10,308 \\
10,481 \\
17,234 \\
18,634 \\
4,054\end{array}$ & $\begin{array}{l}0.53 \\
0.72 \\
0.73 \\
0.79 \\
0.61\end{array}$ & $\begin{array}{l}0.78 \\
0.78 \\
0.85 \\
0.89 \\
0.59\end{array}$ & $\begin{array}{l}2,867 \\
2,989 \\
2,948 \\
2,348 \\
2,800\end{array}$ & $\begin{array}{l}9,264 \\
4,053 \\
6,264 \\
4,991 \\
2,580\end{array}$ & $\begin{array}{r}6,397 \\
1,064 \\
3,316 \\
2,643 \\
-220\end{array}$ \\
\hline 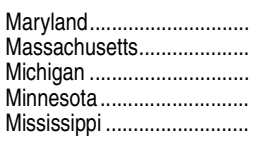 & $\begin{array}{l}18,385 \\
51,041 \\
49,983 \\
25,729 \\
10,771\end{array}$ & $\begin{array}{r}26,515 \\
42,689 \\
48,202 \\
30,754 \\
7,931\end{array}$ & \begin{tabular}{r|r|}
11,714 \\
25,218 \\
41,108 \\
18,394 \\
6,408
\end{tabular} & $\begin{array}{l}0.64 \\
0.49 \\
0.82 \\
0.71 \\
0.59\end{array}$ & $\begin{array}{l}0.44 \\
0.59 \\
0.85 \\
0.60 \\
0.81\end{array}$ & $\begin{array}{r}14,801 \\
17,471 \\
7,094 \\
12,360 \\
1,523\end{array}$ & $\begin{array}{r}6,671 \\
25,823 \\
8,875 \\
7,335 \\
4,363\end{array}$ & $\begin{array}{r}-8,130 \\
8,352 \\
1,781 \\
-5,025 \\
2,840\end{array}$ \\
\hline 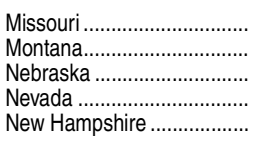 & $\begin{array}{r}30,848 \\
5,803 \\
10,697 \\
9,482 \\
8,654\end{array}$ & $\begin{array}{r}26,917 \\
4,711 \\
10,182 \\
10,738 \\
7,499\end{array}$ & $\begin{array}{r}20,721 \\
3,702 \\
7,944 \\
8,081 \\
3,077\end{array}$ & $\begin{array}{l}0.67 \\
0.64 \\
0.74 \\
0.85 \\
0.36\end{array}$ & $\begin{array}{l}0.77 \\
0.79 \\
0.78 \\
0.75 \\
0.41\end{array}$ & $\begin{array}{l}6,196 \\
1,009 \\
2,238 \\
2,657 \\
4,422\end{array}$ & $\begin{array}{r}10,127 \\
2,101 \\
2,753 \\
1,401 \\
5,577\end{array}$ & $\begin{array}{r}3,931 \\
1,092 \\
515 \\
-1,256 \\
1,155\end{array}$ \\
\hline 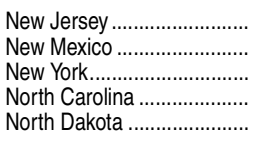 & $\begin{array}{r}26,297 \\
7,896 \\
106,726 \\
46,835 \\
6,483\end{array}$ & $\begin{array}{r}52,974 \\
7,993 \\
101,866 \\
40,243 \\
3,723\end{array}$ & $\begin{array}{r}22,096 \\
6,342 \\
73,912 \\
33,772 \\
2,893\end{array}$ & $\begin{array}{l}0.84 \\
0.80 \\
0.69 \\
0.72 \\
0.45\end{array}$ & $\begin{array}{l}0.42 \\
0.79 \\
0.73 \\
0.84 \\
0.78\end{array}$ & $\begin{array}{r}30,878 \\
1,651 \\
27,954 \\
6,471 \\
830\end{array}$ & $\begin{array}{r}4,201 \\
1,554 \\
32,814 \\
13,063 \\
3,590\end{array}$ & $\begin{array}{r}-26,677 \\
-97 \\
4,860 \\
6,592 \\
2,760\end{array}$ \\
\hline 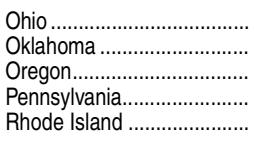 & $\begin{array}{l}69,385 \\
19,243 \\
14,786 \\
81,632 \\
10,860\end{array}$ & $\begin{array}{r}65,633 \\
15,139 \\
12,474 \\
67,545 \\
5,428\end{array}$ & $\begin{array}{r}53,830 \\
13,172 \\
8,543 \\
51,821 \\
2,875\end{array}$ & $\begin{array}{l}0.78 \\
0.68 \\
0.58 \\
0.63 \\
0.26\end{array}$ & $\begin{array}{l}0.82 \\
0.87 \\
0.68 \\
0.77 \\
0.53\end{array}$ & $\begin{array}{r}11,803 \\
1,967 \\
3,931 \\
15,724 \\
2,553\end{array}$ & $\begin{array}{r}15,555 \\
6,071 \\
6,243 \\
29,811 \\
7,985\end{array}$ & $\begin{array}{r}3,752 \\
4,104 \\
2,312 \\
14,087 \\
5,432\end{array}$ \\
\hline 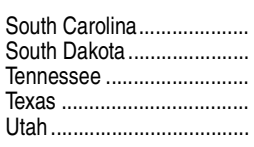 & $\begin{array}{r}23,275 \\
6,111 \\
29,690 \\
93,616 \\
20,482\end{array}$ & $\begin{array}{r}16,964 \\
4,744 \\
28,690 \\
104,937 \\
15,123\end{array}$ & $\begin{array}{r}14,365 \\
3,571 \\
22,480 \\
85,548 \\
13,830\end{array}$ & $\begin{array}{l}0.62 \\
0.58 \\
0.76 \\
0.91 \\
0.68\end{array}$ & $\begin{array}{l}0.85 \\
0.75 \\
0.78 \\
0.82 \\
0.91\end{array}$ & $\begin{array}{r}2,599 \\
1,173 \\
6,210 \\
19,389 \\
1,293\end{array}$ & $\begin{array}{l}8,910 \\
2,540 \\
7,210 \\
8,068 \\
6,652\end{array}$ & $\begin{array}{r}6,311 \\
1,367 \\
1,000 \\
-11,321 \\
5,359\end{array}$ \\
\hline 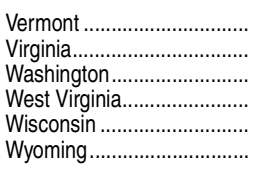 & $\begin{array}{r}6,505 \\
42,732 \\
24,698 \\
12,855 \\
36,139 \\
1,499\end{array}$ & $\begin{array}{r}3,632 \\
38,716 \\
26,538 \\
8,214 \\
33,014 \\
1,411\end{array}$ & $\begin{array}{r}1,627 \\
28,737 \\
18,681 \\
7,249 \\
25,952 \\
748\end{array}$ & $\begin{array}{l}0.25 \\
0.67 \\
0.76 \\
0.56 \\
0.72 \\
0.50\end{array}$ & $\begin{array}{l}0.45 \\
0.74 \\
0.70 \\
0.88 \\
0.79 \\
0.53\end{array}$ & $\begin{array}{r}2,005 \\
9,979 \\
7,857 \\
965 \\
7,062 \\
663\end{array}$ & $\begin{array}{r}4,878 \\
13,995 \\
6,017 \\
5,606 \\
10,187 \\
751\end{array}$ & $\begin{array}{r}2,873 \\
4,016 \\
-1,840 \\
4,641 \\
3,125 \\
88\end{array}$ \\
\hline $\begin{array}{l}\text { U.S. Service Academies ...... } \\
\text { State unknown }{ }^{4} \ldots \ldots\end{array}$ & $\begin{array}{r}2,925 \\
+ \\
\end{array}$ & $\begin{array}{r}\dagger \\
4,405 \\
\end{array}$ & $\begin{array}{c}183^{3} \\
+ \\
\end{array}$ & $\dagger$ & $\begin{array}{l}\dagger \\
t\end{array}$ & $\begin{array}{r}-183 \\
4,405 \\
\end{array}$ & $\begin{array}{r}2,742 \\
+ \\
\end{array}$ & $\begin{array}{r}2,925 \\
-4,405 \\
\end{array}$ \\
\hline Other jurisdictions .... & 30,142 & 31,291 & 29,982 & 0.99 & 0.96 & 1,309 & 160 & $-1,149$ \\
\hline $\begin{array}{l}\text { American Samoa ................. } \\
\text { Federated States of }\end{array}$ & 405 & 464 & 405 & 1.00 & 0.87 & 59 & 0 & -59 \\
\hline 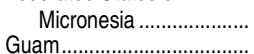 & $\begin{array}{r}\dagger \\
528\end{array}$ & $\begin{array}{r}34 \\
622\end{array}$ & $\begin{array}{r}\dagger \\
473\end{array}$ & $\begin{array}{r}\dagger \\
0.90\end{array}$ & $\begin{array}{r}\dagger \\
0.76\end{array}$ & $\begin{array}{r}34 \\
149\end{array}$ & $\begin{array}{r}0 \\
55\end{array}$ & $\begin{array}{l}-34 \\
-94\end{array}$ \\
\hline 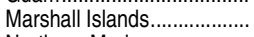 & $t$ & 6 & $t$ & & $t$ & $\begin{array}{r}r 0 \\
6\end{array}$ & 0 & \\
\hline $\begin{array}{l}\text { Northern Marianas .............. } \\
\text { Palau }\end{array}$ & $\begin{aligned} 243 \\
+\end{aligned}$ & $\begin{array}{r}285 \\
12\end{array}$ & $\begin{aligned} 240 \\
+\end{aligned}$ & 0.99 & 0.84 & $\begin{array}{l}45 \\
12\end{array}$ & 3 & $\begin{array}{l}-42 \\
-12\end{array}$ \\
\hline 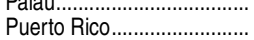 & 28,669 & 29,347 & 28,578 & 1.00 & 0.97 & $\begin{array}{r}12 \\
769\end{array}$ & 91 & $\begin{array}{r}-12 \\
-678\end{array}$ \\
\hline U.S. Virgin Islands ................ & 297 & 521 & 286 & 0.96 & 0.55 & 235 & 11 & -224 \\
\hline 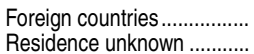 & $t$ & 39,184 & $t$ & $t$ & $t$ & 39,184 & $\dagger$ & $-39,184$ \\
\hline Residence unknown ............ & $\dagger$ & & $\dagger$ & $\dagger$ & $\dagger$ & & $\dagger$ & \\
\hline
\end{tabular}

†Not applicable.

Students residing in a particular state when admitted to an institution anywhere-either in their home state or another state.

Includes students coming to U.S. colleges from foreign countries and other jurisdictions.

${ }^{3}$ Students whose residence is in the same state as the service academy.

${ }^{4}$ Institution unable to determine student's home state.
NOTE: Includes all first-time postsecondary students who graduated from high school in the previous 12 months and were enrolled at reporting institutions. Degree-granting institutions grant associate's or higher degrees and participate in Title IV federal financial aid programs.

SOURCE: U.S. Department of Education, National Center for Education Statistics, Integrated Postsecondary Education Data System (IPEDS), Spring 2013, Enrollment component. (This table was prepared March 2014.) 
450 CHAPTER 3: Postsecondary Education

Study Abroad and Foreign Students

Table 310.10. Number of U.S. students studying abroad and percentage distribution, by sex, race/ethnicity, and other selected characteristics: Selected years, 1996-97 through 2010-11

\begin{tabular}{|c|c|c|c|c|c|c|c|c|c|c|c|c|c|}
\hline $\begin{array}{l}\text { Sex, race/ethnicity, } \\
\text { and other selected } \\
\text { characteristics }\end{array}$ & $1996-97$ & $2000-01$ & $2001-02$ & $2002-03$ & 2003-04 & 2004-05 & $2005-06$ & $2006-07$ & $2007-08$ & 2008-09 & $2009-10$ & $2010-11$ & $\begin{array}{r}\text { Change } 2000-01 \\
\text { to } 2010-11\end{array}$ \\
\hline 1 & 2 & 3 & 4 & 5 & 6 & 7 & 8 & 9 & 10 & 11 & 12 & 13 & 14 \\
\hline \multirow{3}{*}{ Total .......................... } & \multicolumn{12}{|c|}{ Number } & Percent change \\
\hline & 99,448 & 154,168 & 160,920 & 174,629 & 191,231 & 205,983 & 223,534 & 241,791 & 262,416 & 260,327 & 270,604 & 273,996 & 77.7 \\
\hline & \multicolumn{12}{|c|}{ Percentage distribution } & $\begin{array}{r}\text { Change in } \\
\text { percentage points }\end{array}$ \\
\hline Sex & 100.0 & 100.0 & 100.0 & 100.0 & 100.0 & 100.0 & 100.0 & 100.0 & 100.0 & 100.0 & 100.0 & 100.0 & $t$ \\
\hline Male & 35.1 & 35.0 & 35.1 & 35.3 & 34.4 & 34.5 & 34.5 & 34.9 & 34.9 & 35.8 & 36.5 & 35.6 & 0.6 \\
\hline Female & 64.9 & 65.0 & 64.9 & 64.7 & 65.6 & 65.5 & 65.5 & 65.1 & 65.1 & 64.2 & 63.5 & 64.4 & -0.6 \\
\hline Race/ethnicity ....................... & 100.0 & 100.0 & 100.0 & 100.0 & 100.0 & 100.0 & 100.0 & 100.0 & 100.0 & 100.0 & 100.0 & 100.0 & $\dagger$ \\
\hline White & 83.9 & 84.3 & 82.9 & 83.2 & 83.7 & 83.0 & 83.0 & 81.9 & 81.8 & 80.5 & 78.7 & 77.8 & -6.5 \\
\hline Black & 3.5 & 3.5 & 3.5 & 3.4 & 3.4 & 3.5 & 3.5 & 3.8 & 4.0 & 4.2 & 4.7 & 4.8 & 1.3 \\
\hline 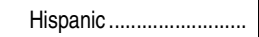 & 5.1 & 5.4 & 5.4 & 5.1 & 5.0 & 5.6 & 5.4 & 6.0 & 5.9 & 6.0 & 6.4 & 6.9 & 1.5 \\
\hline Asian/Pacific Islander..... & 5.0 & 5.4 & 5.8 & 6.0 & 6.1 & 6.3 & 6.3 & 6.7 & 6.6 & 7.3 & 7.9 & 7.9 & 2.5 \\
\hline $\begin{array}{l}\text { American Indian/ } \\
\quad \text { Alaska Native ............ }\end{array}$ & 0.3 & 0.5 & 0.4 & 0.5 & 0.5 & 0.4 & 0.6 & 0.5 & 0.5 & 0.5 & 0.5 & 0.5 & \# \\
\hline Two or more races .......... & 2.1 & 0.9 & 2.0 & 1.8 & 1.3 & 1.2 & 1.2 & 1.2 & 1.2 & 1.6 & 1.9 & 2.1 & 1.2 \\
\hline Academic level...................... & 100.0 & 100.0 & 100.0 & 100.0 & 100.0 & 100.0 & 100.0 & 100.0 & 100.0 & 100.0 & 100.0 & 100.0 & $\dagger$ \\
\hline 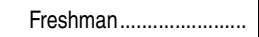 & 2.4 & 3.1 & 3.2 & 2.9 & 3.0 & 3.1 & 3.7 & 3.3 & 3.5 & 3.4 & 3.5 & 3.3 & 0.2 \\
\hline Sophomore ........................ & 12.8 & 14.0 & 13.6 & 11.8 & 12.0 & 12.2 & 12.8 & 12.9 & 13.1 & 13.9 & 13.2 & 12.6 & -1.4 \\
\hline 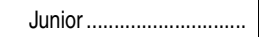 & 41.3 & 38.9 & 40.7 & 38.0 & 34.7 & 35.8 & 34.2 & 36.6 & 35.9 & 36.8 & 35.8 & 35.8 & -3.1 \\
\hline Senior & 18.3 & 20.0 & 20.4 & 20.2 & 19.3 & 19.6 & 19.8 & 21.3 & 21.3 & 21.6 & 21.8 & 23.4 & 3.4 \\
\hline Associate's students ...... & 1.9 & 0.9 & 1.5 & 2.1 & 1.6 & 2.7 & 2.7 & 2.7 & 2.2 & 1.1 & 0.1 & 0.2 & -0.7 \\
\hline Bachelor's unspecified ... & 14.7 & 13.5 & 11.0 & 15.3 & 16.3 & 15.2 & 14.9 & 12.5 & 13.4 & 11.3 & 11.0 & 10.3 & -3.2 \\
\hline Master's level or higher .. & 7.8 & 8.3 & 8.7 & 9.1 & 8.6 & 8.9 & 10.0 & 10.5 & 10.5 & 11.8 & 14.0 & 13.5 & 5.2 \\
\hline Other academic level ..... & 0.8 & 1.1 & 0.8 & 0.7 & 4.2 & 2.5 & 1.9 & $\#$ & 0.1 & $\#$ & 1.0 & 0.9 & -0.2 \\
\hline 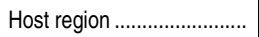 & 100.0 & 100.0 & 100.0 & 100.0 & 100.0 & 100.0 & 100.0 & 100.0 & 100.0 & 100.0 & 100.0 & 100.0 & $\dagger$ \\
\hline Africa.................................. & 2.6 & 2.9 & 2.9 & 2.8 & 3.0 & 3.5 & 3.8 & 4.2 & 4.5 & 5.3 & 5.5 & 5.1 & 2.2 \\
\hline Asia $^{1} \ldots \ldots \ldots \ldots \ldots \ldots \ldots \ldots$ & 6.1 & 6.0 & 6.8 & 5.6 & 6.9 & 8.0 & 9.3 & 10.3 & 11.1 & 11.4 & 12.0 & 11.7 & 5.7 \\
\hline Europe $^{2} \ldots \ldots \ldots \ldots \ldots \ldots$ & 64.6 & 63.3 & 62.7 & 63.1 & 61.0 & 60.3 & 58.3 & 57.4 & 56.3 & 54.5 & 53.5 & 54.6 & -8.7 \\
\hline Latin America ${ }^{3}$................ & 15.3 & 14.5 & 14.5 & 15.3 & 15.2 & 14.4 & 15.2 & 15.0 & 15.3 & 15.4 & 15.0 & 14.6 & 0.1 \\
\hline Middle East ${ }^{2} \ldots \ldots \ldots \ldots \ldots \ldots$ & 1.8 & 0.9 & 0.7 & 0.2 & 0.4 & 1.0 & 1.2 & 1.1 & 1.3 & 1.4 & 1.8 & 1.8 & 0.9 \\
\hline North America ${ }^{3,4} \ldots \ldots \ldots \ldots . . .$. & 0.7 & 0.7 & 0.8 & 0.7 & 0.6 & 0.5 & 0.5 & 0.6 & 0.4 & 0.5 & 0.7 & 0.6 & -0.1 \\
\hline 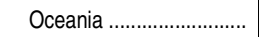 & 4.4 & 6.0 & 6.8 & 7.3 & 7.4 & 6.7 & 6.3 & 5.7 & 5.3 & 5.5 & 5.0 & 4.8 & -1.2 \\
\hline Multiple destinations ...... & 4.6 & 5.6 & 4.9 & 5.1 & 5.5 & 5.6 & 5.5 & 5.6 & 5.7 & 6.0 & 6.5 & 6.8 & 1.2 \\
\hline Duration of stay...................... & 100.0 & 100.0 & 100.0 & 100.0 & 100.0 & 100.0 & 100.0 & 100.0 & 100.0 & 100.0 & 100.0 & 100.0 & $\dagger$ \\
\hline 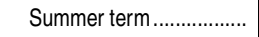 & 32.8 & 33.7 & 34.4 & 32.7 & 37.0 & 37.2 & 37.2 & 38.7 & 38.1 & 35.8 & 37.8 & 37.7 & 4.0 \\
\hline One semester ..................... & 40.2 & 38.5 & 39.0 & 40.3 & 38.1 & 37.5 & 36.9 & 36.3 & 35.5 & 37.3 & 35.8 & 34.5 & -4.0 \\
\hline $\begin{array}{l}8 \text { weeks or less during } \\
\text { academic year........... }\end{array}$ & 3.3 & 7.4 & 7.3 & 9.4 & 8.9 & 8.0 & 9.5 & 9.8 & 11.0 & 11.7 & 11.9 & 13.3 & 5.9 \\
\hline January term....................... & 6.8 & 7.0 & 6.0 & 5.6 & 5.7 & 6.0 & 5.4 & 6.8 & 7.2 & 7.0 & 6.9 & 7.1 & 0.1 \\
\hline Academic year ................... & 10.7 & 7.3 & 7.8 & 6.7 & 6.0 & 6.0 & 5.3 & 4.3 & 4.1 & 4.1 & 3.8 & 3.7 & -3.6 \\
\hline One quarter ....................... & 4.0 & 4.1 & 3.9 & 3.8 & 3.3 & 3.3 & 3.3 & 3.4 & 3.4 & 3.3 & 3.1 & 3.0 & -1.1 \\
\hline 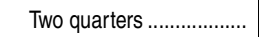 & 0.9 & 0.6 & 0.5 & 0.4 & 0.5 & 1.3 & 0.9 & 0.5 & 0.6 & 0.5 & 0.4 & 0.5 & -0.1 \\
\hline Calendar year ..................... & 0.2 & 0.6 & 0.5 & 0.5 & 0.2 & 0.2 & 0.2 & 0.1 & 0.1 & 0.1 & 0.1 & 0.1 & -0.5 \\
\hline 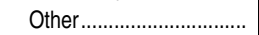 & 1.2 & 0.8 & 0.6 & 0.6 & 0.3 & 0.5 & 1.3 & 0.1 & \# & 0.2 & 0.1 & 0.1 & -0.7 \\
\hline
\end{tabular}

†Not applicable.

\#Rounds to zero.

${ }^{1}$ Asia excludes the Middle Eastern countries (Bahrain, Iran, Iraq, Israel, Jordan, Kuwait, Lebanon, Oman, the Palestinian Authority, Qatar, Saudi Arabia, Syria, the United Arab Emirates, and Yemen).

${ }^{2}$ Cyprus and Turkey were classified as being in the Middle East prior to 2004-05, but in Europe for 2004-05 and later years. Data for years prior to 2004-05 have been revised for comparability.
${ }^{3}$ Mexico and Central America are included in Latin America, not in North America. ${ }^{4}$ Includes Antarctica from 2002-03 onward.

NOTE: Detail may not sum to totals because of rounding.

SOURCE: Institute of International Education, Open Doors: Report on International Educational Exchange, 2012. (This table was prepared May 2013.) 


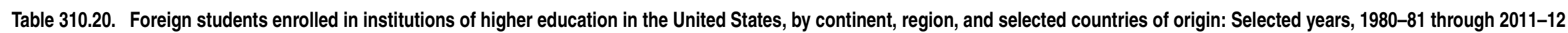

\begin{tabular}{|c|c|c|c|c|c|c|c|c|c|c|c|c|c|c|c|c|c|c|c|c|}
\hline \multirow{2}{*}{$\begin{array}{l}\text { Continent, region, and } \\
\text { selected countries of origin }\end{array}$} & \multicolumn{2}{|c|}{$1980-81$} & \multicolumn{2}{|c|}{$1985-86$} & \multicolumn{2}{|c|}{$1990-91$} & \multicolumn{2}{|c|}{$1995-96$} & \multicolumn{2}{|c|}{$2000-01$} & \multicolumn{2}{|c|}{$2005-06$} & \multicolumn{2}{|c|}{$2008-09$} & \multicolumn{2}{|c|}{$2009-10$} & \multicolumn{2}{|c|}{ 2010-11 } & \multicolumn{2}{|c|}{ 2011-12 } \\
\hline & Number & Percent & Number & Percent & Number & Percent & Number & Percent & Number & Percent & Number & Percent & Number & Percent & Number & Percent & Number & Percent & Number & Percent \\
\hline 1 & 2 & 3 & 4 & 5 & 6 & 7 & 8 & 9 & 10 & 11 & 12 & 13 & 14 & 15 & 16 & 17 & 18 & 19 & 20 & 21 \\
\hline 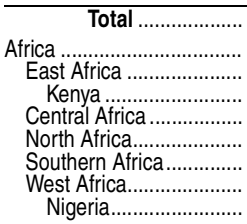 & \begin{tabular}{r|}
311,880 \\
38,180 \\
6,260 \\
1,930 \\
1,130 \\
7,310 \\
1,480 \\
22,000 \\
17,350
\end{tabular} & \begin{tabular}{rl|}
100.0 \\
12.2 \\
2.0 \\
0.6 \\
0.4 \\
2.3 \\
0.5 \\
7.1 \\
5.6
\end{tabular} & \begin{tabular}{r|}
343,780 \\
34,190 \\
6,730 \\
1,720 \\
1,540 \\
5,980 \\
2,360 \\
17,580 \\
13,710
\end{tabular} & \begin{tabular}{rl|}
100.0 \\
9.9 \\
2.0 \\
0.5 \\
0.4 \\
1.7 \\
0.7 \\
5.1 \\
4.0
\end{tabular} & \begin{tabular}{rl|}
407,272 \\
23,803 \\
7,592 \\
2,357 \\
1,647 \\
4,541 \\
2,835 \\
7,178 \\
3,714
\end{tabular} & \begin{tabular}{r|}
100.0 \\
5.8 \\
1.9 \\
0.6 \\
0.4 \\
1.1 \\
0.7 \\
1.8 \\
0.9
\end{tabular} & $\begin{array}{r}453,787 \\
20,844 \\
7,596 \\
2,934 \\
1,346 \\
3,422 \\
2,657 \\
5,818 \\
2,093\end{array}$ & \begin{tabular}{r|}
100.00 \\
4.6 \\
1.7 \\
0.6 \\
0.3 \\
0.8 \\
0.6 \\
1.3 \\
0.5
\end{tabular} & \begin{tabular}{r|}
547,873 \\
34,217 \\
13,516 \\
6,229 \\
11,859 \\
5,184 \\
3,304 \\
10,346 \\
3,820
\end{tabular} & \begin{tabular}{r|}
100.0 \\
6.2 \\
2.5 \\
1.1 \\
0.3 \\
0.9 \\
0.6 \\
1.9 \\
0.7
\end{tabular} & \begin{tabular}{rl|}
564,766 \\
36,308 \\
13,635 \\
6,559 \\
2,825 \\
3,770 \\
2,232 \\
13,846 \\
6,192
\end{tabular} & \begin{tabular}{rl|}
100.0 \\
6.4 \\
2.4 \\
1.2 \\
0.5 \\
0.7 \\
0.4 \\
2.5 \\
1.1
\end{tabular} & \begin{tabular}{r|}
671,616 \\
36,937 \\
10,411 \\
5,877 \\
2,819 \\
4,229 \\
5,693 \\
13,837 \\
6,256
\end{tabular} & \begin{tabular}{rl|}
100.0 \\
5.5 \\
1.6 \\
0.9 \\
0.4 \\
0.6 \\
0.8 \\
2.1 \\
0.9
\end{tabular} & $\begin{array}{r}690,923 \\
37,062 \\
9,872 \\
5,384 \\
2,872 \\
4,941 \\
5,313 \\
14,064 \\
6,568\end{array}$ & \begin{tabular}{rl|}
100.0 \\
5.4 \\
1.4 \\
0.8 \\
0.4 \\
0.7 \\
0.8 \\
2.0 \\
1.0
\end{tabular} & \begin{tabular}{rl|}
723,277 \\
36,890 \\
8,863 \\
4,666 \\
2,831 \\
5,420 \\
5,330 \\
14,446 \\
7,148
\end{tabular} & \begin{tabular}{r|}
100.0 \\
5.1 \\
1.2 \\
0.6 \\
0.4 \\
0.7 \\
0.7 \\
2.0 \\
1.0
\end{tabular} & \begin{tabular}{rl|}
764,495 \\
35,502 \\
7,827 \\
3,898 \\
2,778 \\
5,456 \\
5,196 \\
14,245 \\
7,028
\end{tabular} & $\begin{array}{r}\mathbf{1 0 0 . 0} \\
4.6 \\
1.0 \\
0.5 \\
0.4 \\
0.7 \\
0.7 \\
1.9 \\
0.9\end{array}$ \\
\hline 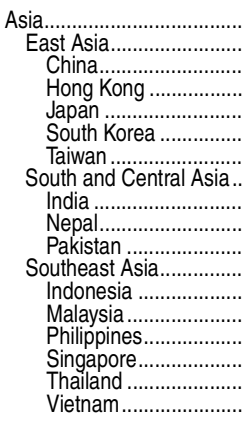 & $\begin{array}{r}94,640 \\
51,650 \\
2,770 \\
9,660 \\
13,500 \\
6,150 \\
19,460 \\
14,540 \\
9,250 \\
250 \\
2,990 \\
28,450 \\
3,250 \\
6,010 \\
3,390 \\
1,320 \\
6,550 \\
6,490\end{array}$ & $\begin{array}{r}30.3 \\
16.6 \\
0.9 \\
3.1 \\
4.3 \\
2.0 \\
6.2 \\
4.7 \\
3.0 \\
0.1 \\
1.0 \\
9.1 \\
1.0 \\
1.9 \\
1.1 \\
0.4 \\
2.1 \\
2.1\end{array}$ & $\begin{array}{r}156,830 \\
80,720 \\
13,980 \\
10,710 \\
13,360 \\
18,660 \\
23,770 \\
25,800 \\
16,070 \\
390 \\
5,440 \\
50,310 \\
8,210 \\
23,020 \\
3,920 \\
3,930 \\
6,940 \\
3,270\end{array}$ & $\begin{array}{r}45.6 \\
23.5 \\
4.1 \\
3.1 \\
3.9 \\
5.4 \\
6.9 \\
7.5 \\
4.7 \\
0.1 \\
1.6 \\
14.6 \\
2.4 \\
6.7 \\
1.1 \\
1.1 \\
2.0 \\
1.0\end{array}$ & $\begin{array}{r}229,825 \\
146,017 \\
39,597 \\
12,625 \\
36,611 \\
23,362 \\
33,531 \\
42,366 \\
28,857 \\
670 \\
7,725 \\
41,441 \\
9,524 \\
13,606 \\
4,273 \\
4,495 \\
7,092 \\
1,396\end{array}$ & $\begin{array}{r}56.4 \\
35.9 \\
9.7 \\
3.1 \\
9.0 \\
5.7 \\
8.2 \\
10.4 \\
7.1 \\
0.2 \\
1.9 \\
10.2 \\
2.3 \\
3.3 \\
1.0 \\
1.1 \\
1.7 \\
0.3\end{array}$ & $\begin{array}{r}259,893 \\
16,617 \\
39,613 \\
12,018 \\
45,531 \\
36,231 \\
32,702 \\
45,401 \\
31,743 \\
1,219 \\
6,427 \\
47,774 \\
12,820 \\
14,015 \\
3,127 \\
4,098 \\
12,165 \\
922\end{array}$ & $\begin{array}{r}57.3 \\
36.7 \\
8.7 \\
2.6 \\
10.0 \\
8.0 \\
7.2 \\
10.0 \\
7.0 \\
0.3 \\
1.4 \\
10.5 \\
2.8 \\
3.1 \\
0.7 \\
0.9 \\
2.7 \\
0.2\end{array}$ & $\begin{array}{r}302,058 \\
189,371 \\
59,939 \\
7,627 \\
46,497 \\
45,685 \\
28,566 \\
71,765 \\
54,664 \\
2,618 \\
6,948 \\
40,916 \\
11,625 \\
7,795 \\
3,139 \\
4,166 \\
11,187 \\
2,022\end{array}$ & $\begin{array}{r}55.1 \\
34.6 \\
10.9 \\
1.4 \\
8.5 \\
8.3 \\
5.2 \\
13.1 \\
10.0 \\
0.5 \\
1.3 \\
7.5 \\
2.1 \\
1.4 \\
0.6 \\
0.8 \\
2.0 \\
0.4\end{array}$ & $\begin{array}{r}327,785 \\
197,576 \\
62,582 \\
7,849 \\
38,712 \\
59,022 \\
27,876 \\
94,965 \\
76,503 \\
6,061 \\
5,759 \\
35,244 \\
7,575 \\
5,515 \\
3,758 \\
3,909 \\
8,765 \\
4,597\end{array}$ & $\begin{array}{r}58.0 \\
35.0 \\
11.1 \\
1.4 \\
6.9 \\
10.5 \\
4.9 \\
16.8 \\
13.5 \\
1.1 \\
1.0 \\
6.2 \\
1.3 \\
1.0 \\
0.7 \\
0.7 \\
1.6 \\
0.8\end{array}$ & $\begin{array}{r}415,000 \\
244,952 \\
98,235 \\
8,329 \\
29,264 \\
75,065 \\
28,065 \\
129,572 \\
103,260 \\
11,581 \\
5,298 \\
44,395 \\
7,509 \\
5,942 \\
4,226 \\
3,989 \\
8,736 \\
12,823\end{array}$ & $\begin{array}{r}61.8 \\
35.9 \\
14.6 \\
1.2 \\
4.4 \\
11.2 \\
4.2 \\
19.3 \\
15.4 \\
1.7 \\
0.8 \\
6.6 \\
1.1 \\
0.9 \\
0.6 \\
0.6 \\
1.3 \\
1.9\end{array}$ & $\begin{array}{r}435,667 \\
261,125 \\
127,628 \\
8,034 \\
24,842 \\
72,153 \\
26,685 \\
130,725 \\
104,897 \\
11,233 \\
5,222 \\
43,817 \\
6,943 \\
6,190 \\
3,815 \\
4,051 \\
8,531 \\
13,112\end{array}$ & $\begin{array}{r}63.1 \\
37.8 \\
18.5 \\
1.2 \\
3.6 \\
10.4 \\
3.9 \\
18.9 \\
15.2 \\
1.6 \\
0.8 \\
6.3 \\
1.0 \\
0.9 \\
0.6 \\
0.6 \\
1.2 \\
1.9\end{array}$ & $\begin{array}{r}461,903 \\
286,925 \\
157,558 \\
8,136 \\
21,290 \\
73,351 \\
24,818 \\
128,958 \\
103,895 \\
10,301 \\
5,045 \\
46,020 \\
6,942 \\
6,735 \\
3,604 \\
4,, 316 \\
8,236 \\
14,888\end{array}$ & $\begin{array}{r}63.9 \\
39.7 \\
21.8 \\
1.1 \\
2.9 \\
10.1 \\
3.4 \\
17.8 \\
14.4 \\
1.4 \\
0.7 \\
6.4 \\
1.0 \\
0.9 \\
0.5 \\
0.6 \\
1.1 \\
2.1\end{array}$ & $\begin{array}{r}489,970 \\
319,515 \\
194,029 \\
8,032 \\
19,966 \\
72,295 \\
23,250 \\
124,392 \\
100,270 \\
9,621 \\
4,600 \\
46,063 \\
7,131 \\
6,743 \\
33,194 \\
4,505 \\
7,626 \\
15,572\end{array}$ & $\begin{array}{r}64.1 \\
41.8 \\
25.4 \\
1.1 \\
2.6 \\
9.5 \\
3.0 \\
16.3 \\
13.1 \\
1.3 \\
0.6 \\
6.0 \\
0.9 \\
0.9 \\
0.4 \\
0.6 \\
1.0 \\
2.0\end{array}$ \\
\hline 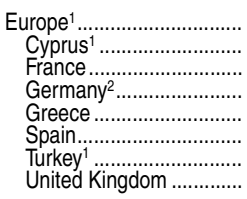 & $\begin{array}{r}28,650 \\
720 \\
2,570 \\
3,310 \\
3,750 \\
950 \\
2,600 \\
4,440\end{array}$ & $\begin{array}{l}9.2 \\
0.2 \\
0.8 \\
1.1 \\
1.2 \\
0.3 \\
0.8 \\
1.4\end{array}$ & $\begin{array}{r}38,910 \\
2,140 \\
3,680 \\
4,730 \\
4,440 \\
1,740 \\
2,460 \\
5,940\end{array}$ & $\begin{array}{r}11.3 \\
0.6 \\
1.1 \\
1.4 \\
1.3 \\
0.5 \\
0.7 \\
1.7\end{array}$ & $\begin{array}{r}55,422 \\
1,710 \\
5,633 \\
7,003 \\
4,357 \\
4,304 \\
4,078 \\
7,298\end{array}$ & $\begin{array}{r}13.6 \\
0.4 \\
1.4 \\
1.7 \\
1.1 \\
1.1 \\
1.0 \\
1.8\end{array}$ & $\begin{array}{r}76,855 \\
1,819 \\
5,710 \\
9,017 \\
3,365 \\
4,809 \\
7,678 \\
7,799\end{array}$ & $\begin{array}{r}16.9 \\
0.4 \\
1.3 \\
2.0 \\
0.7 \\
1.1 \\
1.7 \\
1.7\end{array}$ & $\begin{array}{r}93,784 \\
2,217 \\
7,273 \\
10,128 \\
2,768 \\
4,156 \\
10,983 \\
8,139\end{array}$ & $\begin{array}{r}17.1 \\
0.4 \\
1.3 \\
1.8 \\
0.5 \\
0.8 \\
2.0 \\
1.5\end{array}$ & $\begin{array}{r}84,697 \\
1,111 \\
6,640 \\
8,829 \\
2,088 \\
3,455 \\
11,622 \\
8,274\end{array}$ & $\begin{array}{r}15.0 \\
0.2 \\
1.2 \\
1.6 \\
0.4 \\
0.6 \\
2.1 \\
1.5\end{array}$ & $\begin{array}{r}87,648 \\
696 \\
7,421 \\
9,679 \\
1,896 \\
3,849 \\
13,263 \\
8,701\end{array}$ & $\begin{array}{r}13.1 \\
0.1 \\
1.1 \\
1.4 \\
0.3 \\
0.6 \\
2.0 \\
1.3\end{array}$ & $\begin{array}{r}85,084 \\
586 \\
7,716 \\
9,548 \\
1,837 \\
3,971 \\
12,397 \\
8,861\end{array}$ & $\begin{array}{r}12.3 \\
0.1 \\
1.1 \\
1.4 \\
0.3 \\
0.6 \\
1.8 \\
1.3\end{array}$ & $\begin{array}{r}84,296 \\
470 \\
8,098 \\
9,458 \\
1,874 \\
4,330 \\
12,184 \\
8,947\end{array}$ & $\begin{array}{r}11.7 \\
0.1 \\
1.1 \\
1.3 \\
0.3 \\
0.6 \\
1.7 \\
1.2\end{array}$ & $\begin{array}{r}85,423 \\
438 \\
8,232 \\
9,347 \\
1,922 \\
4,924 \\
11,973 \\
9,186\end{array}$ & $\begin{array}{r}11.2 \\
0.1 \\
1.1 \\
1.2 \\
0.3 \\
0.6 \\
1.6 \\
1.2\end{array}$ \\
\hline 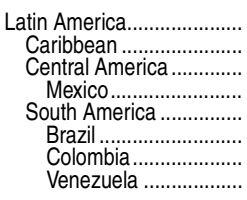 & $\begin{array}{r}49,810 \\
10,650 \\
12,970 \\
6,730 \\
26,190 \\
2,870 \\
3,930 \\
11,750\end{array}$ & $\begin{array}{r}16.0 \\
3.4 \\
4.2 \\
2.2 \\
8.4 \\
0.9 \\
1.3 \\
3.8\end{array}$ & $\begin{array}{r}45,480 \\
11,100 \\
12,740 \\
5,460 \\
21,640 \\
2,840 \\
4,010 \\
7,040\end{array}$ & $\begin{array}{r}13.2 \\
3.2 \\
3.7 \\
1.6 \\
6.3 \\
0.8 \\
1.2 \\
2.0\end{array}$ & $\begin{array}{r}47,318 \\
12,349 \\
15,949 \\
6,739 \\
19,019 \\
3,898 \\
3,183 \\
2,894\end{array}$ & $\begin{array}{r}11.6 \\
3.0 \\
3.9 \\
1.7 \\
4.7 \\
1.0 \\
0.8 \\
0.7\end{array}$ & $\begin{array}{r}47,253 \\
10,737 \\
14,220 \\
8,687 \\
22,296 \\
5,497 \\
3,462 \\
4,456\end{array}$ & $\begin{array}{r}10.4 \\
2.4 \\
3.1 \\
1.9 \\
4.9 \\
1.2 \\
0.8 \\
1.0\end{array}$ & $\begin{array}{r}63,634 \\
14,423 \\
16,764 \\
10,670 \\
32,447 \\
8,846 \\
6,765 \\
5,217\end{array}$ & $\begin{array}{r}11.6 \\
2.6 \\
3.1 \\
1.9 \\
5.9 \\
1.6 \\
1.2 \\
1.0\end{array}$ & $\begin{array}{r}64,769 \\
13,855 \\
19,709 \\
13,931 \\
31,205 \\
7,009 \\
6,835 \\
4,792\end{array}$ & $\begin{array}{r}11.5 \\
2.5 \\
3.5 \\
2.5 \\
5.5 \\
1.2 \\
1.2 \\
0.8\end{array}$ & $\begin{array}{r}67,731 \\
13,320 \\
21,430 \\
14,850 \\
32,961 \\
8,767 \\
7,013 \\
4,678\end{array}$ & $\begin{array}{r}10.1 \\
2.0 \\
3.2 \\
2.2 \\
4.9 \\
1.3 \\
1.0 \\
0.7\end{array}$ & $\begin{array}{r}65,632 \\
13,112 \\
19,956 \\
13,450 \\
32,564 \\
8,786 \\
6,920 \\
4,958\end{array}$ & $\begin{array}{l}9.5 \\
1.9 \\
2.9 \\
1.9 \\
4.7 \\
1.3 \\
1.0 \\
0.7\end{array}$ & $\begin{array}{r}64,169 \\
11,644 \\
20,361 \\
13,713 \\
32,164 \\
8,777 \\
6,456 \\
5,491\end{array}$ & $\begin{array}{l}8.9 \\
1.6 \\
2.8 \\
1.9 \\
4.4 \\
1.2 \\
0.9 \\
0.8\end{array}$ & $\begin{array}{r}64,021 \\
10,987 \\
20,432 \\
13,893 \\
32,602 \\
9,029 \\
6,295 \\
6,281\end{array}$ & $\begin{array}{l}8.4 \\
1.4 \\
2.7 \\
1.8 \\
4.3 \\
1.2 \\
0.8 \\
0.8\end{array}$ \\
\hline 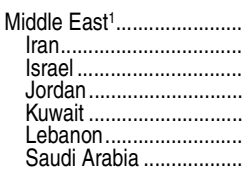 & $\begin{array}{r}81,390 \\
47,550 \\
2,710 \\
6,140 \\
2,990 \\
6,770 \\
10,440\end{array}$ & $\begin{array}{r}26.1 \\
15.2 \\
0.9 \\
2.0 \\
1.0 \\
2.2 \\
3.3\end{array}$ & $\begin{array}{r}48,120 \\
14,210 \\
2,600 \\
6,590 \\
3,810 \\
7,090 \\
6,900\end{array}$ & $\begin{array}{r}14.0 \\
4.1 \\
0.8 \\
1.9 \\
1.1 \\
2.1 \\
2.0\end{array}$ & $\begin{array}{r}27,636 \\
6,262 \\
2,977 \\
4,321 \\
1,624 \\
3,899 \\
3,584\end{array}$ & $\begin{array}{l}6.8 \\
1.5 \\
0.7 \\
1.1 \\
0.4 \\
1.0 \\
0.9\end{array}$ & $\begin{array}{r}21,066 \\
2,628 \\
2,637 \\
2,222 \\
3,035 \\
1,554 \\
4,191\end{array}$ & $\begin{array}{l}4.6 \\
0.6 \\
0.6 \\
0.5 \\
0.7 \\
0.3 \\
0.9\end{array}$ & $\begin{array}{r}23,658 \\
1,844 \\
3,402 \\
2,187 \\
3,045 \\
2,005 \\
5,273\end{array}$ & $\begin{array}{l}4.3 \\
0.3 \\
0.6 \\
0.4 \\
0.6 \\
0.4 \\
1.0\end{array}$ & $\begin{array}{r}17,806 \\
2,420 \\
3,419 \\
1,733 \\
1,703 \\
1,950 \\
3,448\end{array}$ & \begin{tabular}{l|}
3.2 \\
0.4 \\
0.6 \\
0.3 \\
0.3 \\
0.3 \\
0.6
\end{tabular} & $\begin{array}{r}29,140 \\
3,533 \\
3,060 \\
2,225 \\
2,031 \\
1,823 \\
12,661\end{array}$ & $\begin{array}{l}4.3 \\
0.5 \\
0.5 \\
0.3 \\
0.3 \\
0.3 \\
1.9\end{array}$ & $\begin{array}{r}33,797 \\
4,731 \\
2,778 \\
1,995 \\
2,442 \\
1,608 \\
15,810\end{array}$ & $\begin{array}{l}4.9 \\
0.7 \\
0.4 \\
0.3 \\
0.4 \\
0.2 \\
2.3\end{array}$ & $\begin{array}{r}42,543 \\
5,626 \\
2,701 \\
2,002 \\
2,998 \\
1,462 \\
22,704\end{array}$ & $\begin{array}{l}5.9 \\
0.8 \\
0.4 \\
0.3 \\
0.4 \\
0.2 \\
3.1\end{array}$ & $\begin{array}{r}56,664 \\
6,982 \\
2,490 \\
2,062 \\
3,722 \\
1,350 \\
34,139\end{array}$ & $\begin{array}{l}7.4 \\
0.9 \\
0.3 \\
0.3 \\
0.5 \\
0.2 \\
4.5\end{array}$ \\
\hline $\begin{array}{l}\text { North America } \\
\text { Canada }\end{array}$ & $\begin{array}{l}14,790 \\
14,320\end{array}$ & $\begin{array}{l}4.7 \\
4.6\end{array}$ & $\begin{array}{l}16,030 \\
15,410\end{array}$ & $\begin{array}{l}4.7 \\
4.5\end{array}$ & $\begin{array}{l}18,949 \\
18,350\end{array}$ & $\begin{array}{l}4.7 \\
4.5\end{array}$ & $\begin{array}{l}23,644 \\
23,005\end{array}$ & $\begin{array}{l}5.2 \\
5.1\end{array}$ & $\begin{array}{l}25,888 \\
25,279\end{array}$ & $\begin{array}{l}4.7 \\
4.6\end{array}$ & $\begin{array}{l}28,699 \\
28,202\end{array}$ & $\begin{array}{l}5.1 \\
5.0\end{array}$ & $\begin{array}{l}30,107 \\
29,697\end{array}$ & $\begin{array}{l}4.5 \\
4.4\end{array}$ & $\begin{array}{l}28,574 \\
28,145\end{array}$ & $\begin{array}{l}4.1 \\
4.1\end{array}$ & $\begin{array}{l}27,941 \\
27,546\end{array}$ & $\begin{array}{l}3.9 \\
3.8\end{array}$ & $\begin{array}{l}27,210 \\
26,821\end{array}$ & $\begin{array}{l}3.6 \\
3.5\end{array}$ \\
\hline 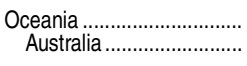 & $\begin{array}{l}4,180 \\
1,530\end{array}$ & $\begin{array}{l}1.3 \\
0.5\end{array}$ & $\begin{array}{l}4,030 \\
1,530\end{array}$ & $\begin{array}{l}1.2 \\
0.4\end{array}$ & $\begin{array}{l}4,230 \\
1,906\end{array}$ & $\begin{array}{l}1.0 \\
0.5\end{array}$ & $\begin{array}{l}4,202 \\
2,244\end{array}$ & $\begin{array}{l}0.9 \\
0.5\end{array}$ & $\begin{array}{l}4,624 \\
2,645\end{array}$ & $\begin{array}{l}0.8 \\
0.5\end{array}$ & $\begin{array}{l}4,702 \\
2,806\end{array}$ & $\begin{array}{l}0.8 \\
0.5\end{array}$ & $\begin{array}{l}5,053 \\
3,203\end{array}$ & $\begin{array}{l}0.8 \\
0.5\end{array}$ & $\begin{array}{l}5,091 \\
3,296\end{array}$ & $\begin{array}{l}0.7 \\
0.5\end{array}$ & $\begin{array}{l}5,610 \\
3,777\end{array}$ & $\begin{array}{l}0.8 \\
0.5\end{array}$ & $\begin{array}{l}5,697 \\
3,848\end{array}$ & $\begin{array}{l}0.7 \\
0.5\end{array}$ \\
\hline Unidentified $^{4} \ldots \ldots \ldots \ldots \ldots \ldots \ldots$ & 240 & 0.1 & 190 & 0.1 & 89 & \# & 30 & $\#$ & 10 & \# & \# & \# & $\#$ & \# & 16 & \# & 10 & \# & 8 & $\#$ \\
\hline
\end{tabular}

\#Rounds to zero.

NOTE: Includes foreign students enrolled in American Samoa, Guam, Puerto Rico, and the U.S. Virgin Islands. Totals and sub-

${ }^{1}$ Cyprus and Turkey were classified as being in the Middle East prior to 2004-05, but in Europe for 2004-05 and later years. Data for years prior to 2004-05 have been revised for comparability.

NOTE: Includes foreign students enrolled in American Samoa, Guam, Puerto Rico, and the U.S. Virgin Islands. Totals and sub-
totals include other countries not shown separately. Region totals may not sum to continent totals, because some continent 'Data for 1980-81 and 1985-86 are for West Germany (Federal Republic of Germany before unification).

${ }_{4}$ Place

totals include students who are not classified by country or region. Data are
migrated to this country). Detail may not sum to totals because of rounding.

SOURCE: Institute of International Education, Open Doors: Report on International Educational Exchange, 1981 through 2012 (selected years). (This table was prepared May 2013.) 
Table 311.10. Number and percentage distribution of students enrolled in postsecondary institutions, by level, disability status, and selected student characteristics: 2007-08 and 2011-12

[Standard errors appear in parentheses]

\begin{tabular}{|c|c|c|c|c|c|c|c|c|c|c|c|c|c|c|c|c|c|c|}
\hline \multirow[b]{3}{*}{ Selected student characteristic } & \multicolumn{12}{|c|}{ Undergraduate } & \multicolumn{6}{|c|}{ Postbaccalaureate, 2011-12 } \\
\hline & \multicolumn{6}{|c|}{$2007-08$} & \multicolumn{6}{|c|}{ 2011-12 } & \multirow{2}{*}{\multicolumn{2}{|c|}{ All students }} & \multirow{2}{*}{\multicolumn{2}{|c|}{$\begin{array}{r}\text { Students with } \\
\text { disabilities }\end{array}$}} & \multirow{2}{*}{\multicolumn{2}{|c|}{$\begin{array}{l}\text { Nondisabled } \\
\text { students }\end{array}$}} \\
\hline & \multicolumn{2}{|c|}{ All students } & \multicolumn{2}{|c|}{$\begin{array}{r}\text { Students with } \\
\text { disabilities }^{1}\end{array}$} & \multicolumn{2}{|c|}{$\begin{array}{r}\text { Nondisabled } \\
\text { students }\end{array}$} & \multicolumn{2}{|c|}{ All students } & \multicolumn{2}{|c|}{$\begin{array}{r}\text { Students with } \\
\text { disabilities }^{1}\end{array}$} & \multicolumn{2}{|c|}{$\begin{array}{r}\text { Nondisabled } \\
\text { students }\end{array}$} & & & & & & \\
\hline 1 & & 2 & & 3 & & 4 & & 5 & & 6 & & 7 & & 8 & & 9 & & 10 \\
\hline Number of & 20,762 & $(-)$ & 2,270 & $(-)$ & 18,492 & $(-)$ & 23,055 & $(-)$ & 563 & $(-)$ & 20,493 & $(-)$ & 682 & $(-)$ & 95 & $(-)$ & 487 & $(-)$ \\
\hline ercent & 100.0 & & 10.9 & $(0.19)$ & 89.1 & $(0.19)$ & 100.0 & $(t)$ & 11.1 & $(0.17)$ & 88.9 & $(0.17)$ & 00.0 & $(t)$ & 5.3 & $0.36)$ & 94.7 & (0.36) \\
\hline$x(p$ & 100.0 & & 100.0 & & 100.0 & $(\dagger)$ & 100.0 & (†) & 0.0 & (†) & 0.0 & (†) & 0.0 & (†) & 0.0 & (†) & 100.0 & $(\dagger)$ \\
\hline Male. & 43.0 & $(0.32)$ & 42.6 & $(0.82)$ & 43.0 & $(0.32)$ & 43.0 & $(0.11)$ & 43.7 & $(0.80)$ & 42.9 & $(0.14)$ & 39.7 & 68) & 5.7 & $.58)$ & 40.0 & .73) \\
\hline remal & & $(0.32)$ & & $(0.82)$ & 57.0 & $(0.32)$ & 57.0 & $(0.11)$ & 56.3 & $(0.80)$ & 57.1 & $(0.14)$ & 60.3 & $(0.68)$ & 64.3 & (2.58) & 60.0 & (0.73) \\
\hline ce/ethn & 100.0 & $(\dagger)$ & 100.0 & $(\dagger)$ & 100.0 & (†) & 100.0 & (†) & 100.0 & †) & 0.0 & (†) & 0.0 & (†) & 0.0 & $(\dagger)$ & 00.0 & $(\dagger)$ \\
\hline White. & 61.2 & $(0.37)$ & 65.6 & $(0.81)$ & 60.7 & $(0.39)$ & 57.9 & $(0.42)$ & 58.0 & $(0.85)$ & 7.9 & $(0.44)$ & 6 & $(0.73)$ & & 76) & 8 & .77) \\
\hline Bla & 14.4 & $(0.31)$ & 13.1 & $(0.55)$ & 14.6 & $(0.32)$ & 16.1 & $(0.30)$ & 17.6 & $(0.57)$ & & $(0.32)$ & .8 & & & 4) & 71.6 & 1.53) \\
\hline His & 14.3 & $(0.29)$ & 12.5 & (0.59) & 14.5 & $(0.30)$ & 16.0 & $(0.37)$ & 14.9 & $(0.65)$ & 3.2 & $(0.38)$ & 8.7 & ) & & 11) & 8.6 & 40) \\
\hline & 5.9 & $(0.17)$ & 4.3 & $(0.37)$ & 6.1 & $(0.17)$ & 5.6 & $(0.15)$ & 4.0 & $(0.31)$ & 8 & $(0.17)$ & 12.9 & (1) & 10.4 & $2.09)$ & 13.0 & 47) \\
\hline$P c_{c}$ & 0.7 & $(0.06)$ & 0.5 & $(0.09)$ & 0.7 & $(0.06)$ & 0.5 & $(0.04)$ & 0.7 & $(0.14)$ & 0.5 & $(0.04)$ & 0.6 & $(0.1$ & $\ddagger$ & $(t)$ & 0.6 & $(0.12)$ \\
\hline Am & 0.8 & $(0.09)$ & 0.8 & $(0.12)$ & 0.8 & $(0.09)$ & 0.9 & $(0.07)$ & 1.2 & $(0.20)$ & 0.9 & $(0.07)$ & $0.4 !$ & $(0.15$ & + & (t) & $0.4 !$ & $(0.15)$ \\
\hline 0 & 0.3 & $(0.03)$ & 0.3 & $(0.08)$ & 0.3 & $(0.03)$ & - & (†) & - & (T) & - & $(\mathrm{t})$ & - & (T) & - & (T) & - & (†) \\
\hline Two o & 2.4 & $(0.09)$ & 2.9 & $(0.26)$ & 2.3 & $(0.09)$ & 3.0 & $(0.08)$ & 3.6 & $(0.28)$ & 2.9 & $(0.08)$ & 2.0 & $(0.18)$ & 2.5 & $(0.64)$ & 2.0 & $(0.19)$ \\
\hline & 100.0 & (†) & 100.0 & (†) & 100.0 & (t) & 100.0 & (†) & 100.0 & (t) & 100.0 & †) & 00.0 & (t) & 100.0 & 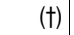 & 100.0 & (†) \\
\hline & 58.3 & $(0.29)$ & 52.1 & $(0.77)$ & 59.0 & $(0.31)$ & 56.2 & $(0.33)$ & 45.3 & $(0.89)$ & 57.6 & $(0.33)$ & 11.4 & ) & 8.4 & 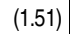 & 11.5 & $(0.41)$ \\
\hline 24 & 17.9 & $(0.19)$ & 20.9 & $(0.70)$ & 17.6 & $(0.20)$ & 18.4 & $(0.22)$ & 18.8 & $(0.65)$ & 18.4 & $(0.23)$ & 40.3 & $(0.79)$ & 35.3 & (3.26) & 40.5 & $(0.79)$ \\
\hline 30 or & 23.8 & $(0.26)$ & 27.0 & $(0.70)$ & 23.4 & $(0.29)$ & 25.4 & $(0.28)$ & 35.8 & $(0.89)$ & 24.0 & $(0.28)$ & 48.4 & $(0.84)$ & 56.3 & $(3.36)$ & 47.9 & $(0.85)$ \\
\hline tenc & 100.0 & (†) & 100.0 & (†) & 100.0 & (t) & 100.0 & (t) & 100.0 & (†) & 00.0 & & 100.0 & 1 & 100.0 & 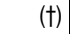 & 100.0 & ( $\mathrm{t})$ \\
\hline & 36.8 & $(0.24)$ & 32.3 & $(0.70)$ & 37.4 & $(0.26)$ & 38.4 & $(0.32)$ & 33.0 & $(0.74)$ & 39.1 & $(0.32)$ & 37.8 & ..72) & 2 & $2.69)$ & 37.8 & $(0.75)$ \\
\hline Part-ti & 63.2 & $(0.24)$ & 67.7 & $(0.70)$ & 62.6 & $(0.26)$ & 61.6 & $(0.32)$ & 67.0 & $(0.74)$ & 60.9 & $(0.32)$ & 62.2 & $(0.72)$ & 61.8 & $(2.69)$ & 62.2 & $(0.75)$ \\
\hline$d e$ & 100.0 & (†) & 100.0 & (†) & 100.0 & (t) & 100.0 & (†) & 100.0 & (t) & 0.0 & & - & & 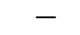 & & & (†) \\
\hline & 13.5 & $(0.18)$ & 10.6 & $(0.44)$ & 13. & $(0.19)$ & 12.1 & $(0.19)$ & 9.4 & $(0.41)$ & 12.5 & $(0.20$ & - & 11 & - & & - & (†) \\
\hline & 5.1 & $(0.33)$ & 57.6 & $(0.73)$ & 54.8 & $(0.34)$ & 46.1 & $(0.54)$ & 48.9 & $(0.97)$ & 45.7 & $(0.55$ & - & $(t$ & - & $(\dagger$ & - & $(\dagger)$ \\
\hline & 23.8 & $(0.31)$ & 24.2 & $(0.65)$ & 23.7 & $(0.32)$ & 33.5 & $(0.55)$ & 34.2 & $(1.02)$ & 33.5 & $(0.54$ & - & (t) & - & (†) & - & $(\dagger)$ \\
\hline Atten & 7.7 & $(0.15)$ & 7.5 & $(0.34)$ & 7.7 & $(0.15)$ & 8.3 & $(0.28)$ & 7.4 & $(0.44)$ & 8.4 & $(0.28)$ & - & (t) & - & (†) & - & $(\dagger)$ \\
\hline $\mathrm{De}$ & 100.0 & †) & 100.0 & (†) & 100.0 & (t) & 100.0 & (†) & 100.0 & (†) & 100.0 & $(t)$ & 100.0 & (t) & 100.0 & $(\dagger$ & 100.0 & (†) \\
\hline & 51.3 & $(0.31)$ & 44.8 & (0.71) & 52.1 & $(0.33)$ & 48.7 & $(0.31)$ & 37.5 & $(0.80)$ & 50.1 & $(0.32)$ & - & †) & - & (†) & - & 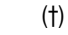 \\
\hline Inc & 15.7 & $(0.22)$ & 20.2 & $(0.67)$ & 15.1 & $(0.22)$ & 17.8 & $(0.22)$ & 22.9 & $(0.65)$ & 17.2 & $(0.23)$ & 49.8 & $(0.74)$ & 53.0 & $2.77)$ & 49.6 & $(0.75)$ \\
\hline & 6.6 & $(0.14)$ & 7.2 & $(0.44)$ & 6.5 & $(0.15)$ & 6.0 & $(0.18)$ & 7.1 & $(0.40)$ & 5.8 & $(0.19)$ & 15.4 & $(0.53)$ & 12.3 & $(2.46)$ & 15.5 & $(0.56)$ \\
\hline Indepe & 26.4 & $(0.32)$ & 27.7 & $(0.78)$ & 26.2 & $(0.32)$ & 27.5 & $(0.28)$ & 32.5 & $(0.86)$ & 26.9 & $(0.29)$ & 34.8 & $(0.74)$ & 34.7 & (2.92) & 34.8 & $(0.73)$ \\
\hline Veter & 100.0 & ) & 100.0 & $(\dagger)$ & 100.0 & (t) & 100.0 & (t) & 100.0 & (t) & 100.0 & & 100.0 & & 100.0 & & 100.0 & (t) \\
\hline & 3.3 & $(0.12)$ & 4.6 & $(0.33)$ & 3.2 & $(0.12)$ & 3.7 & $(0.12)$ & 6.9 & $(0.49)$ & 3.3 & $(0.12)$ & 3.0 & $(0.25)$ & 4.4 & D.98) & 2.9 & $(0.25)$ \\
\hline Not ve & 96.7 & $(0.12)$ & 95.4 & $(0.33)$ & 96.8 & $(0.12)$ & 96.3 & $(0.12)$ & 93.1 & $(0.49)$ & 96.7 & $(0.12)$ & 97.0 & $(0.25)$ & 95.6 & $(0.98)$ & 97.1 & $(0.25)$ \\
\hline Field & 100.0 & ) & 100.0 & (†) & 100.0 & (t) & 100.0 & (†) & 100.0 & (t) & 100.0 & (†) & 100.0 & (t) & 100.0 & (†) & 100.0 & (†) \\
\hline & 16.3 & (0.27) & 14.9 & $(0.66)$ & 16.5 & $(0.28)$ & 15.1 & $(0.20)$ & 13.6 & $(0.58)$ & 15.3 & $(0.21)$ & 16.7 & $(0.66)$ & 18.5 & 4.53) & 16 & $(0.69)$ \\
\hline & 5.7 & $(0.13)$ & 5.2 & $(0.31)$ & 5.7 & $(0.14)$ & 5.1 & $(0.14)$ & 4.6 & $(0.36)$ & 5.2 & $(0.14)$ & 21.1 & $(0.66)$ & 22.2 & (3.24) & 21.0 & $(0.68)$ \\
\hline & 8.9 & $(0.27)$ & 8.6 & $(0.59)$ & 8.9 & $(0.19)$ & 9.3 & $(0.19)$ & 8.9 & $(0.58)$ & 9.3 & $(0.18)$ & 8.6 & $(0.36)$ & 7.8 & 5) & 8 & (0.38) \\
\hline & 14.6 & $(0.27)$ & 15.1 & $(0.67)$ & 14.5 & $(0.27)$ & 18.5 & $(0.33)$ & 17.9 & $(0.67)$ & 18.6 & $(0.33)$ & 18.4 & $(0.53)$ & 15.9 & (2.47) & 18.6 & $(0.54)$ \\
\hline & 15.0 & $(0.26)$ & 16.8 & $(0.64)$ & 14.8 & $(0.26)$ & 16.6 & $(0.30)$ & 18.2 & $(0.76)$ & 16.3 & $(0.31)$ & 7.2 & $(0.46)$ & 8.0 & (1.53) & 7.1 & $(0.48)$ \\
\hline & - & $(+)$ & - & $(+)$ & - & (t) & - & (†) & - & (†) & - & †) & 4.0 & $(0.21)$ & 5.8 & D.98) & 9 & $(0.21)$ \\
\hline & 6.0 & $(0.11)$ & 5.4 & $(0.30)$ & 6.1 & $(0.12)$ & 7.2 & $(0.14)$ & 5.9 & $(0.37)$ & 7.3 & $(0.15)$ & 5.2 & $(0.27)$ & 3.7 & $(0.71)$ & 3 & $(0.27)$ \\
\hline & 6.2 & $(0.11)$ & 6.1 & $(0.38)$ & 6.2 & $(0.12)$ & 6.8 & $(0.16)$ & 7.2 & $(0.48)$ & 6.7 & $(0.15)$ & 6.6 & $(0.41)$ & 7.3 & (1.18) & 6.6 & $(0.40)$ \\
\hline & 2.5 & $(0.18)$ & 2.5 & $(0.25)$ & 2.5 & $(0.19)$ & 3.1 & $(0.15)$ & 4.1 & $(0.35)$ & 3.0 & $(0.15)$ & - & t) ( & - & (†) & - & (†) \\
\hline & 14.3 & $(0.33)$ & 14.5 & $(0.70)$ & 14.3 & $(0.34)$ & 5.3 & $(0.24)$ & 5.7 & $(0.50)$ & 5.3 & $(0.24)$ & 2.8 & $(0.30)$ & $2.2 !$ & $(0.94)$ & 2.8 & $(0.30)$ \\
\hline & 10.5 & .21) & 10.8 & $(0.44)$ & 10.4 & $(0.21)$ & 13.0 & $(0.24)$ & 13.8 & $(0.52)$ & 12.9 & $(0.26)$ & 9.4 & $(0.42)$ & 8.6 & (1.42) & 9.5 & (0.43) \\
\hline
\end{tabular}

-Not available.

!nterpret data with caution. The coefficient of variation (CV) for this estimate is between 30 and 50 percent.

tReporting standards not met. Either there are too few cases for a reliable estimate or the coefficient of variation $(\mathrm{CV})$ is 50 percent or greater.

Students with disabilities are those who reported that they had one or more of the following conditions: a specific learning disability, a visual handicap, hard of hearing, deafness, a speech disability, an orthopedic handicap, or a health impairment.
NOTE: Data are based on a sample survey of students who enrolled at any time during the school year. Data for 2007-08 include Puerto Rico, which is excluded from the 2011-12 data. Detail may not sum to totals because of survey item nonresponse and rounding. Race categories exclude persons of Hispanic ethnicity.

SOURCE: U.S. Department of Education, National Center for Education Statistics, 2007-08 and 2011-12 National Postsecondary Student Aid Study (NPSAS:08 and NPSAS:12). (This table was prepared January 2014.) 
Table 311.15. Number and percentage of students enrolled in degree-granting postsecondary institutions, by distance education participation, location of student, level of enrollment, and control and level of institution: Fall 2012

\begin{tabular}{|c|c|c|c|c|c|c|c|c|c|c|c|c|c|c|c|c|c|c|c|c|}
\hline \multirow[b]{4}{*}{$\begin{array}{l}\text { Level of enrollment; control } \\
\text { and level of institution }\end{array}$} & \multicolumn{10}{|c|}{ Number of students } & \multicolumn{10}{|c|}{ Percent of students } \\
\hline & \multirow[b]{3}{*}{ Total } & \multirow[b]{3}{*}{$\begin{array}{r}\text { No } \\
\text { distance } \\
\text { education } \\
\text { courses }\end{array}$} & \multicolumn{8}{|c|}{ Taking any distance education course(s) } & \multirow[b]{3}{*}{ Total } & \multirow[b]{3}{*}{\begin{tabular}{|r|} 
No \\
distance \\
education \\
courses
\end{tabular}} & \multicolumn{8}{|c|}{ Taking any distance education course(s) } \\
\hline & & & \multirow[b]{2}{*}{$\begin{array}{r}\text { Total, any } \\
\text { distance } \\
\text { education } \\
\text { course(s) }\end{array}$} & \multirow[b]{2}{*}{$\begin{array}{r}\text { At least } \\
\text { one, but } \\
\text { not all, of } \\
\text { student's } \\
\text { courses }\end{array}$} & \multicolumn{6}{|c|}{ Exclusively distance education courses by location of student } & & & \multirow[b]{2}{*}{\begin{tabular}{|r|} 
Total, any \\
distance \\
education \\
course(s)
\end{tabular}} & \multirow[b]{2}{*}{$\begin{array}{r}\text { At least } \\
\text { one, but } \\
\text { not all, of } \\
\text { student's } \\
\text { courses }\end{array}$} & \multicolumn{6}{|c|}{ Exclusively distance education courses by location of student } \\
\hline & & & & & Total & $\begin{array}{r}\text { Same } \\
\text { state }\end{array}$ & $\begin{array}{r}\text { Different } \\
\text { state }\end{array}$ & $\begin{array}{r}\text { State not } \\
\text { known }\end{array}$ & 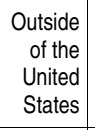 & $\begin{array}{l}\text { Location } \\
\text { unknown }\end{array}$ & & & & & Total & $\begin{array}{r}\text { Same } \\
\text { state }\end{array}$ & $\begin{array}{r}\text { Different } \\
\text { state }\end{array}$ & $\begin{array}{r}\text { State not } \\
\text { known }\end{array}$ & 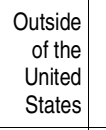 & $\begin{array}{l}\text { Location } \\
\text { unknown }\end{array}$ \\
\hline 1 & 2 & 3 & 4 & 5 & 6 & 7 & 8 & 9 & 10 & 11 & 12 & 13 & 14 & 15 & 16 & 17 & 18 & 19 & 20 & 21 \\
\hline $\begin{array}{l}\text { All students } \\
\text { Total . }\end{array}$ & $20,642,819$ & $15,198,118$ & $5,444,701$ & $2,806,048$ & $2,638,653$ & $1,336,873$ & $1,176,009$ & 36,779 & 33,561 & 55,431 & 100.0 & 73.6 & 26.4 & 13.6 & 12.8 & 6.5 & 5.7 & 0.2 & 0.2 & 0.3 \\
\hline 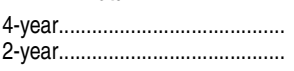 & \begin{tabular}{r|}
$13,478,846$ \\
$7,163,973$ \\
\end{tabular} & $\begin{array}{l}9,933,125 \\
5,264,993 \\
\end{array}$ & $\begin{array}{l}3,545,721 \\
1,898,980\end{array}$ & $\begin{array}{l}1,602,681 \\
1,203,367\end{array}$ & $\begin{array}{r}1,943,040 \\
695,613\end{array}$ & $\begin{array}{l}719,968 \\
616,905\end{array}$ & $\begin{array}{r}1,126,882 \\
49,127\end{array}$ & $\begin{array}{l}20,246 \\
16,533\end{array}$ & $\begin{array}{r}29,310 \\
4,251\end{array}$ & $\begin{array}{r}46,634 \\
8,797\end{array}$ & $\begin{array}{l}100.0 \\
100.0\end{array}$ & $\begin{array}{l}73.7 \\
73.5\end{array}$ & $\begin{array}{l}26.3 \\
26.5\end{array}$ & $\begin{array}{l}11.9 \\
16.8\end{array}$ & \begin{tabular}{r|r}
14.4 \\
9.7
\end{tabular} & $\begin{array}{l}5.3 \\
8.6\end{array}$ & $\begin{array}{l}8.4 \\
0.7\end{array}$ & $\begin{array}{l}0.2 \\
0.2\end{array}$ & $\begin{array}{l}0.2 \\
0.1\end{array}$ & $\begin{array}{l}0.3 \\
0.1\end{array}$ \\
\hline 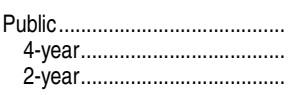 & $\begin{array}{r}14,880,343 \\
8,092,683 \\
6,787,660\end{array}$ & $\begin{array}{r}11,227,331 \\
6,294,576 \\
4,932,755\end{array}$ & $\begin{array}{l}3,653,012 \\
1,798,107 \\
1,854,905\end{array}$ & $\begin{array}{l}2,405,021 \\
1,223,398 \\
1,181,623\end{array}$ & $\begin{array}{r}1,247,991 \\
574,709 \\
673,282\end{array}$ & $\begin{array}{r}1,031,658 \\
420,801 \\
610,857\end{array}$ & $\begin{array}{r}145,655 \\
112,732 \\
32,923\end{array}$ & $\begin{array}{r}23,173 \\
6,644 \\
16,529\end{array}$ & $\begin{array}{r}13,277 \\
9,073 \\
4,204\end{array}$ & $\begin{array}{r}34,228 \\
25,459 \\
8,769\end{array}$ & $\begin{array}{l}100.0 \\
100.0 \\
100.0\end{array}$ & $\begin{array}{l}75.5 \\
77.8 \\
72.7\end{array}$ & $\begin{array}{l}24.5 \\
22.2 \\
27.3\end{array}$ & $\begin{array}{l}16.2 \\
15.1 \\
17.4\end{array}$ & $\begin{array}{l}8.4 \\
7.1 \\
9.9\end{array}$ & $\begin{array}{l}6.9 \\
5.2 \\
9.0\end{array}$ & $\begin{array}{l}1.0 \\
1.4 \\
0.5\end{array}$ & $\begin{array}{l}0.2 \\
0.1 \\
0.2\end{array}$ & $\begin{array}{l}0.1 \\
0.1 \\
0.1\end{array}$ & $\begin{array}{l}0.2 \\
0.3 \\
0.1\end{array}$ \\
\hline \multirow{2}{*}{$\begin{array}{r}\text { Private } \\
\text { Nonprofit }\end{array}$} & & & & & & & & & & & & & & & & & & & & \\
\hline & $3,953,578$ & 3,226,385 & 727,193 & 259,696 & 467,497 & 183,450 & 253,173 & 9,050 & 7,378 & 14,446 & 100.0 & 81.6 & 18.4 & 6.6 & 11.8 & 4.6 & 6.4 & 0.2 & 0.2 & 0.4 \\
\hline ................ & $3,915,972$ & $3,191,643$ & 724,329 & 257,599 & 466,730 & 182,984 & 252,872 & 9,050 & 7,378 & 14,446 & 100.0 & 81.5 & 18.5 & 6.6 & 11.9 & 4.7 & 6.5 & 0.2 & 0.2 & 0.4 \\
\hline & 37,606 & $\begin{array}{r}34,742 \\
\end{array}$ & 2,864 & 2,097 & 767 & 466 & 301 & 0 & & & 100.0 & 92.4 & 7.6 & 5.6 & 2.0 & 1.2 & 0.8 & 0.0 & 0.0 & 0.0 \\
\hline For-profit . & $1,808,898$ & \begin{tabular}{|}
744,402 \\
\end{tabular} & $1,064,496$ & 141,331 & 923,165 & 121,765 & 777,181 & 4,556 & 12,906 & 6,757 & 100.0 & 41.2 & 58.8 & 7.8 & 51.0 & 6.7 & 43.0 & 0.3 & 0.7 & 0.4 \\
\hline 4-year.... & $1,470,191$ & \begin{tabular}{|r|}
446,906 \\
\end{tabular} & $1,023,285$ & 121,684 & 901,601 & 116,183 & 761,278 & 4,552 & 12,859 & 6,729 & 100.0 & 30.4 & 69.6 & 8.3 & 61.3 & 7.9 & 51.8 & 0.3 & 0.9 & 0.5 \\
\hline 2-year..... & 338,707 & 297,496 & 41,211 & 19,647 & 21,564 & 5,582 & 15,903 & 4 & 47 & 28 & 100.0 & 87.8 & 12.2 & 5.8 & 6.4 & 1.6 & 4.7 & $\#$ & $\#$ & $\#$ \\
\hline $\begin{array}{l}\text { Undergraduate } \\
\text { Total ... }\end{array}$ & $17,732,431$ & $13,154,496$ & $4,577,935$ & $2,578,625$ & 1,999,310 & $1,083,445$ & 823,255 & 32,325 & 20,012 & 40,273 & 100.0 & 74.2 & 25.8 & 14.5 & 11.3 & 6.1 & 4.6 & 0.2 & 0.1 & 0.2 \\
\hline 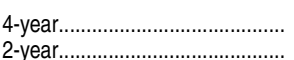 & \begin{tabular}{|r|}
$10,568,458$ \\
$7,163,973$ \\
\end{tabular} & \begin{tabular}{|l|}
$7,889,503$ \\
$5,264,993$ \\
\end{tabular} & $\begin{array}{l}2,678,955 \\
1,898,980\end{array}$ & $\begin{array}{l}1,375,258 \\
1,203,367\end{array}$ & $\begin{array}{r}1,303,697 \\
695,613\end{array}$ & $\begin{array}{l}466,540 \\
616,905\end{array}$ & $\begin{array}{r}774,128 \\
49,127\end{array}$ & $\begin{array}{l}15,792 \\
16,533\end{array}$ & $\begin{array}{r}15,761 \\
4,251\end{array}$ & $\begin{array}{r}31,476 \\
8,797\end{array}$ & $\begin{array}{l}100.0 \\
100.0\end{array}$ & $\begin{array}{l}74.7 \\
73.5\end{array}$ & $\begin{array}{l}25.3 \\
26.5\end{array}$ & $\begin{array}{l}13.0 \\
16.8\end{array}$ & $\begin{array}{r}2.3 \\
9.7\end{array}$ & $\begin{array}{l}4.4 \\
8.6\end{array}$ & $\begin{array}{l}7.3 \\
0.7\end{array}$ & $\begin{array}{l}0.1 \\
0.2\end{array}$ & $\begin{array}{l}0.1 \\
0.1\end{array}$ & $\begin{array}{l}0.3 \\
0.1\end{array}$ \\
\hline 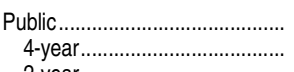 & $\begin{array}{r}13,473,743 \\
6,686,083 \\
\end{array}$ & $\begin{array}{r}10,162,767 \\
5,230,012 \\
\end{array}$ & $\begin{array}{l}3,310,976 \\
1,456,071 \\
1,0,0\end{array}$ & $\begin{array}{l}2,271,201 \\
1,089,578 \\
1,010\end{array}$ & $\begin{array}{r}1,039,775 \\
366,493\end{array}$ & $\begin{array}{l}893,018 \\
282,161\end{array}$ & $\begin{array}{r}88,675 \\
55,752 \\
\end{array}$ & $\begin{array}{r}22,088 \\
5,559\end{array}$ & $\begin{array}{l}9,610 \\
5,406\end{array}$ & $\begin{array}{l}26,384 \\
17,615\end{array}$ & $\begin{array}{l}100.0 \\
100.0\end{array}$ & $\begin{array}{r}75.4 \\
78.2\end{array}$ & $\begin{array}{l}24.6 \\
21.8\end{array}$ & \begin{tabular}{r|}
16.9 \\
16.3
\end{tabular} & $\begin{array}{r}7.7 \\
5.5 \\
0.5\end{array}$ & $\begin{array}{r}6.6 \\
4.2 \\
\end{array}$ & $\begin{array}{l}0.7 \\
0.8\end{array}$ & $\begin{array}{l}0.2 \\
0.1\end{array}$ & $\begin{array}{l}0.1 \\
0.1\end{array}$ & $\begin{array}{l}0.2 \\
0.3\end{array}$ \\
\hline \multirow{2}{*}{\multicolumn{21}{|c|}{ Private ........... }} \\
\hline & & & & & & & & & & & & & & & & & & & & \\
\hline $\begin{array}{l}\text { Tonpro } \\
4 \text {-yea }\end{array}$ & $2,707,469$ & $\left|\begin{array}{l}2,300,902 \\
2,266,220\end{array}\right|$ & $\begin{array}{l}444,113 \\
441,249\end{array}$ & $\begin{array}{l}181,70 \\
179,633\end{array}$ & $\begin{array}{l}202,363 \\
261,616\end{array}$ & $\begin{array}{l}95,383 \\
94,917\end{array}$ & $\begin{array}{l}148,544 \\
148,243\end{array}$ & $6,0,578$ & $\begin{array}{l}3,035 \\
3,035\end{array}$ & 8,843 & 100.0 & $\begin{array}{l}83.8 \\
83.7\end{array}$ & $\begin{array}{l}10.2 \\
16.3\end{array}$ & $\begin{array}{l}6.6 \\
6.6\end{array}$ & $\begin{array}{l}9.0 \\
9.7\end{array}$ & $\begin{array}{l}3.5 \\
3.5\end{array}$ & $\begin{array}{l}5.4 \\
5.5\end{array}$ & $\begin{array}{l}0.2 \\
0.2\end{array}$ & $\begin{array}{l}.1 \\
0.1\end{array}$ & 0.3 \\
\hline 2-ye & 37,606 & 34,742 & 2,864 & 2,097 & 767 & 466 & 301 & 0 & 0 & & 100.0 & 92.4 & 7.6 & 5.6 & 2.0 & 1.2 & 0.8 & 0.0 & 0.0 & 0.0 \\
\hline 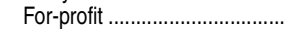 & $1,513,613$ & 690,767 & 822,846 & 125,694 & 697,152 & 95,044 & 586,036 & 3,659 & 7,367 & 5,046 & 100.0 & 45.6 & 54.4 & 8.3 & 46.1 & 6.3 & 38.7 & 0.2 & 0.5 & 0.3 \\
\hline 4-year & $1,174,906$ & 393,271 & 781,635 & 106,047 & 675,588 & 89,462 & 570,133 & 3,655 & 7,320 & 5,018 & 100.0 & 33.5 & 66.5 & 9.0 & 57.5 & 7.6 & 48.5 & 0.3 & 0.6 & 0.4 \\
\hline 2-year...................... & 338,707 & \begin{tabular}{|}
297,496 \\
\end{tabular} & 41,211 & 19,647 & 21,564 & 5,582 & 15,903 & 4 & 47 & 28 & 100.0 & 87.8 & 12.2 & 5.8 & 6.4 & 1.6 & 4.7 & \# & \# & $\#$ \\
\hline $\begin{array}{l}\text { Postbaccalaureate } \\
\text { Total }\end{array}$ & 2,910,388 & 2,043,622 & 866,766 & 227,423 & 639,343 & 253,428 & 352,754 & 4,454 & 13,549 & 15,158 & 100.0 & 70.2 & 29.8 & 7.8 & 22.0 & 8.7 & 12.1 & 0.2 & 0.5 & 0.5 \\
\hline \multirow{3}{*}{ 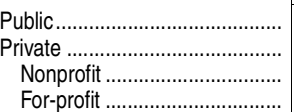 } & $1,406,600$ & \begin{tabular}{|l|}
$1,064,564$ \\
\end{tabular} & 342,036 & 133,820 & 208,216 & 138,640 & 56,980 & 1,085 & 3,667 & 7,844 & 100.0 & 75.7 & 24.3 & 9.5 & 14.8 & 9.9 & 4.1 & \begin{tabular}{l|l} 
& \\
\end{tabular} & 0.3 & 0.6 \\
\hline & $1,208,503$ & 925,423 & 283,080 & 77,966 & 205,114 & 88,067 & 104,629 & 2,472 & 4,343 & 5,603 & 100.0 & 76.6 & 23.4 & 6.5 & 17.0 & 7.3 & 8.7 & 0.2 & 0.4 & 0.5 \\
\hline & 295,285 & 53,635 & 241,650 & 15,637 & 226,013 & 26,721 & 191,145 & 897 & 5,539 & 1,711 & 100.0 & 18.2 & 81.8 & 5.3 & 76.5 & 9.0 & 64.7 & 0.3 & 1.9 & 0.6 \\
\hline
\end{tabular}

\#Rounds to zero.
NOTE: Degree-granting institutions grant associate's or higher degrees and participate in Title IV federal financial aid programs.
SOURCE. US. Department of Education, National Center for Education Statistics, Integrated Postsecondary Education Data System (IPEDS), Spring 2013, Enrollment component. (This table was prepared November 2013.) 
Table 311.20. Number and percentage of undergraduate students taking night, weekend, or online classes, by selected characteristics: 2011-12

[Standard errors appear in parentheses]

\begin{tabular}{|c|c|c|c|c|c|c|c|c|c|c|c|c|c|c|c|c|c|}
\hline \multirow[b]{3}{*}{ Selected characteristic } & \multicolumn{3}{|c|}{$\begin{array}{l}\text { Total taking any night, } \\
\text { weekend, or online classes }\end{array}$} & \multicolumn{12}{|c|}{ Percent of students taking night, weekend, or online classes } & & \\
\hline & \multirow[b]{2}{*}{$\begin{array}{r}\text { Number of students } \\
\text { (in thousands) }\end{array}$} & \multirow{2}{*}{\multicolumn{2}{|c|}{ Percent of students }} & \multicolumn{4}{|c|}{ Night classes } & \multicolumn{4}{|c|}{ Weekend classes } & \multicolumn{4}{|c|}{ Online classes } & \multirow{2}{*}{\multicolumn{2}{|c|}{$\begin{array}{l}\text { Percent of students } \\
\text { whose entire degree } \\
\text { program is online? }\end{array}$}} \\
\hline & & & & \multicolumn{2}{|c|}{$\begin{array}{r}\text { Any } \\
\text { night classes }\end{array}$} & \multicolumn{2}{|c|}{$\begin{array}{r}\text { Exclusively } \\
\text { night classes }\end{array}$} & \multicolumn{2}{|c|}{$\begin{array}{r}\text { Any } \\
\text { weekend classes }\end{array}$} & \multicolumn{2}{|c|}{$\begin{array}{r}\text { Exclusively } \\
\text { weekend classes }\end{array}$} & \multicolumn{2}{|c|}{$\begin{array}{r}\text { Any } \\
\text { online classes }\end{array}$} & \multicolumn{2}{|c|}{$\begin{array}{r}\text { Exclusively } \\
\text { online classes }\end{array}$} & & \\
\hline 1 & 2 & & 3 & & 4 & & 5 & & 6 & & 7 & & 8 & & 9 & & 10 \\
\hline 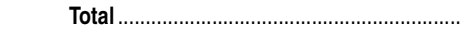 & 11,917 & 51.7 & (0.33) & 32.4 & $(0.29)$ & 5.2 & $(0.14)$ & 7.0 & $(0.17)$ & 0.3 & $(0.03)$ & 32.0 & (0.33) & 8.4 & $(0.20)$ & 6.5 & $(0.18)$ \\
\hline 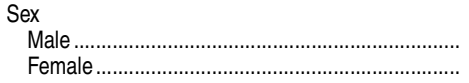 & $\begin{array}{l}4,865 \\
7,052\end{array}$ & $\begin{array}{l}49.0 \\
53.7\end{array}$ & $\begin{array}{l}(0.46) \\
(0.40)\end{array}$ & $\begin{array}{l}32.0 \\
32.7\end{array}$ & $\begin{array}{l}(0.40) \\
(0.39)\end{array}$ & $\begin{array}{l}5.1 \\
5.3\end{array}$ & $\begin{array}{l}(0.18) \\
(0.19)\end{array}$ & $\begin{array}{l}6.7 \\
7.2\end{array}$ & $\begin{array}{l}(0.22) \\
(0.22)\end{array}$ & $\begin{array}{l}0.3 \\
0.3\end{array}$ & $\begin{array}{l}(0.05) \\
(0.04)\end{array}$ & $\begin{array}{l}28.5 \\
34.5\end{array}$ & $\begin{array}{l}(0.45) \\
(0.39)\end{array}$ & $\begin{array}{l}6.5 \\
9.8\end{array}$ & $\begin{array}{l}(0.25) \\
(0.24)\end{array}$ & $\begin{array}{l}4.9 \\
7.7\end{array}$ & $\begin{array}{l}(0.24) \\
(0.21)\end{array}$ \\
\hline \multicolumn{18}{|l|}{ Race/ethnicity } \\
\hline White... & 7,019 & 52.6 & (0.45) & 32.5 & $(0.39)$ & 4.9 & $(0.18)$ & 6.3 & $(0.20)$ & 0.2 & $(0.04)$ & 33.5 & $(0.41)$ & 9.0 & $(0.24)$ & 6.8 & $(0.21)$ \\
\hline 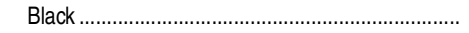 & 1,930 & 52.0 & (0.68) & 30.8 & $(0.59)$ & 6.0 & $(0.28)$ & 7.8 & $(0.41)$ & 0.5 & $(0.10)$ & 32.7 & $(0.70)$ & 10.7 & $(0.57)$ & 9.1 & $(0.56)$ \\
\hline Hispanic... & 1,863 & 50.4 & $(0.64)$ & 33.9 & $(0.61)$ & 6.3 & $(0.40)$ & 8.3 & $(0.36)$ & 0.4 & $(0.08)$ & 27.9 & $(0.57)$ & 5.5 & $(0.29)$ & 4.3 & $(0.24)$ \\
\hline Asian........ & 588 & 45.5 & (1.22) & 31.0 & (1.18) & 3.3 & $(0.41)$ & 7.4 & $(0.62)$ & $\ddagger$ & $(t)$ & 26.0 & $(1.06)$ & 4.2 & $(0.45)$ & 2.9 & $(0.35)$ \\
\hline 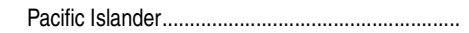 & 64 & 54.4 & (3.80) & 45.8 & (3.84) & $4.6 !$ & $(1.46)$ & 11.2 & $(2.40)$ & \# & $(+)$ & 29.9 & (3.18) & $3.5 !$ & (1.33) & $3.1 !$ & $(1.29)$ \\
\hline American Indian/Alaska Native ................................ & 107 & 51.2 & (2.75) & 31.8 & $(2.44)$ & 6.6 & (1.56) & 6.7 & $(1.38)$ & $\ddagger$ & $(\dagger)$ & 32.6 & (2.56) & 9.1 & $(1.60)$ & 7.0 & (1.43) \\
\hline Two or more races ................................................ & 346 & 50.5 & (1.63) & 31.9 & (1.48) & 4.9 & $(0.83)$ & 7.4 & $(0.76)$ & $0.3 !$ & $(0.15)$ & 30.6 & (1.48) & 8.3 & $(0.93)$ & 5.5 & $(0.69)$ \\
\hline \multicolumn{18}{|l|}{ Age } \\
\hline 15 through $23 \ldots$ & 5,884 & 45.4 & (0.38) & 29.8 & $(0.32)$ & 3.0 & $(0.11)$ & 5.2 & $(0.17)$ & 0.2 & $(0.02)$ & 26.5 & $(0.36)$ & 4.5 & $(0.16)$ & 3.2 & $(0.13)$ \\
\hline 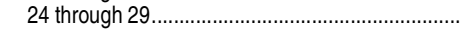 & 2,474 & 58.2 & $(0.71)$ & 36.6 & $(0.70)$ & 7.7 & $(0.40)$ & 9.0 & $(0.38)$ & 0.3 & $(0.06)$ & 36.5 & $(0.67)$ & 10.4 & $(0.43)$ & 8.0 & $(0.41)$ \\
\hline 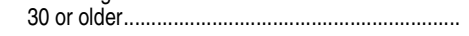 & 3,559 & 60.9 & $(0.63)$ & 35.3 & $(0.69)$ & 8.5 & $(0.34)$ & 9.5 & $(0.34)$ & 0.6 & $(0.10)$ & 40.9 & $(0.64)$ & 15.6 & $(0.51)$ & 13.0 & $(0.50)$ \\
\hline \multicolumn{18}{|l|}{ Attendance status } \\
\hline Exclusively full-time.... & 5,579 & 48.0 & $(0.43)$ & 30.3 & $(0.35)$ & 3.9 & $(0.16)$ & 6.0 & $(0.20)$ & 0.2 & $(0.03)$ & 28.8 & $(0.41)$ & 7.6 & $(0.22)$ & 6.5 & $(0.20)$ \\
\hline 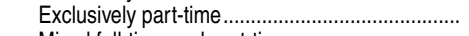 & 4,136 & 56.6 & $(0.62)$ & 34.8 & $(0.57)$ & 8.3 & $(0.32)$ & 8.3 & $(0.31)$ & 0.5 & $(0.09)$ & 35.3 & $(0.62)$ & 10.7 & $(0.42)$ & 7.4 & $(0.38)$ \\
\hline Mixed full-time and part-time ...................................... & 2,203 & 53.5 & $(0.60)$ & 34.3 & $(0.54)$ & 3.3 & $(0.19)$ & 7.3 & $(0.33)$ & 0.2 & $(0.04)$ & 35.0 & $(0.62)$ & 6.4 & $(0.31)$ & 5.0 & $(0.28)$ \\
\hline \multicolumn{18}{|l|}{ Had job during academic year ${ }^{3}$} \\
\hline & 8,219 & 57.2 & (0.40) & 35.9 & $(0.35)$ & 6.1 & $(0.19)$ & 7.9 & $(0.21)$ & 0.3 & $(0.04)$ & 36.2 & $(0.42)$ & 9.8 & $(0.26)$ & 7.6 & $(0.24)$ \\
\hline No & 3,699 & 42.5 & $(0.45)$ & 26.7 & $(0.38)$ & 3.9 & $(0.19)$ & 5.5 & $(0.24)$ & 0.2 & $(0.04)$ & 24.9 & $(0.42)$ & 6.1 & $(0.25)$ & 4.8 & $(0.20)$ \\
\hline \multicolumn{18}{|l|}{ Dependency status } \\
\hline Dependent ........... & 4,994 & 44.5 & (0.39) & 29.5 & $(0.34)$ & 2.6 & $(0.11)$ & 4.9 & $(0.18)$ & 0.1 & $(0.02)$ & 25.5 & $(0.36)$ & 3.9 & $(0.16)$ & 2.7 & $(0.12)$ \\
\hline Independent, no dependents, not married $\ldots . . . . . . . .$. & 2,331 & 55.1 & $(0.71)$ & 35.5 & $(0.69)$ & 7.5 & $(0.42)$ & 8.2 & $(0.34)$ & 0.3 & $(0.07)$ & 33.6 & $(0.63)$ & 8.9 & $(0.38)$ & 6.7 & $(0.33)$ \\
\hline Independent, no dependents, married.................. & 736 & 58.8 & $(1.27)$ & 36.5 & $(1.28)$ & 7.8 & $(0.76)$ & 8.3 & $(0.70)$ & $0.5 !$ & $(0.17)$ & 37.4 & $(1.22)$ & 11.7 & $(0.75)$ & 10.1 & $(0.72)$ \\
\hline Independent, with dependents, not married ${ }^{4} \ldots \ldots . .$. & 2,040 & 58.2 & (0.72) & 34.3 & $(0.79)$ & 8.2 & $(0.41)$ & 9.4 & $(0.39)$ & 0.5 & $(0.10)$ & 38.2 & $(0.67)$ & 12.7 & (0.48) & 10.7 & $(0.45)$ \\
\hline Independent, with dependents, married ................ & 1,817 & 64.0 & $(0.84)$ & 35.2 & $(0.84)$ & 7.7 & $(0.50)$ & 9.8 & $(0.50)$ & 0.6 & (0.15) & 44.9 & $(0.92)$ & 18.8 & $(0.77)$ & 14.7 & $(0.75)$ \\
\hline \multicolumn{18}{|l|}{ Control of institution } \\
\hline Public ........................ & 8,796 & 52.0 & (0.38) & 33.0 & $(0.32)$ & 4.3 & (0.15) & 6.6 & $(0.19)$ & 0.3 & $(0.04)$ & 33.2 & $(0.39)$ & 6.3 & $(0.21)$ & 4.0 & $(0.16)$ \\
\hline Privat & 1,291 & 42.9 & $(0.91)$ & 30.6 & $(0.90)$ & 3.8 & $(0.38)$ & 5.2 & $(0.41)$ & $0.2 !$ & $(0.07)$ & 21.0 & $(0.85)$ & 5.8 & $(0.61)$ & 4.5 & $(0.57)$ \\
\hline 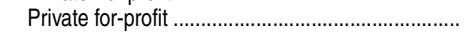 & 1,830 & 58.7 & $(0.74)$ & 31.2 & $(0.71)$ & 11.7 & $(0.48)$ & 10.9 & $(0.50)$ & 0.6 & $(0.09)$ & 35.5 & $(0.83)$ & 22.2 & $(0.79)$ & 21.6 & $(0.82)$ \\
\hline
\end{tabular}

\section{†Not applicable.}

\#!nterpret data with caution. The coefficient of variation (CV) for this estimate is between 30 and 50 percent.

†Reporting standards not met. Either there are too few cases for a reliable estimate or the coefficient of variation (CV) is 50

${ }^{3}$ Excludes work-study/assistantships.

percent or greater.

4IIncludes separated.
NOTE: Night classes start after 6:00 p.m. on Monday through Thursday nights; weekend classes start after 6:00 p.m. on Friday or take place any time on Saturday or Sunday; and online classes are taught only online. Detail may not sum to totals because of rounding. Race categories exclude persons of Hispanic ethnicity.

SOURCE: U.S. Department of Education, National Center for Education Statistics, 2011-12 National Postsecondary Student the total.

Aid Study (NPSAS:12). (This table was prepared March 2014.) 
Table 311.30. Number and percentage of graduate students taking night, weekend, or online classes, by selected characteristics: 2011-12

[Standard errors appear in parentheses]

\begin{tabular}{|c|c|c|c|c|c|c|c|c|c|c|c|c|c|c|c|}
\hline \multirow[b]{3}{*}{ Selected characteristic } & \multirow{2}{*}{\multicolumn{3}{|c|}{$\begin{array}{l}\text { Total taking any night, } \\
\text { weekend, or online classes }{ }^{1}\end{array}$}} & \multicolumn{12}{|c|}{ Percent of students taking night, weekend, or online classes } \\
\hline & & & & \multicolumn{4}{|c|}{ Night classes } & \multicolumn{4}{|c|}{ Weekend classes } & \multicolumn{4}{|c|}{ Online classes } \\
\hline & $\begin{array}{r}\text { Number of students } \\
\text { (in thousands) }\end{array}$ & \multicolumn{2}{|c|}{ Percent of students } & \multicolumn{2}{|c|}{ Any night classes } & \multicolumn{2}{|c|}{ Exclusively night classes } & \multicolumn{2}{|c|}{ Any weekend classes } & \multicolumn{2}{|c|}{$\begin{array}{r}\text { Exclusively } \\
\text { weekend classes }\end{array}$} & \multicolumn{2}{|c|}{ Any online classes } & \multicolumn{2}{|c|}{ Exclusively online classes } \\
\hline 1 & 2 & & 3 & & 4 & & 5 & & 6 & & 7 & & 8 & & 9 \\
\hline & \multicolumn{3}{|c|}{ Total ................................................................ } & 33.6 & $(0.70)$ & 9.4 & $(0.43)$ & 11.8 & $(0.49)$ & 2.0 & $(0.24)$ & 36.0 & (0.74) & & \\
\hline 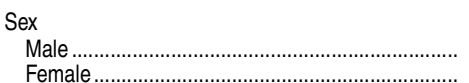 & $\begin{array}{r}849 \\
1.460\end{array}$ & $\begin{array}{l}58.0 \\
65.8\end{array}$ & $\begin{array}{l}(1.29) \\
(0.94)\end{array}$ & $\begin{array}{l}33.4 \\
33.8\end{array}$ & $\begin{array}{l}(1.20) \\
(0.85)\end{array}$ & $\begin{array}{l}9.6 \\
9.3\end{array}$ & $\begin{array}{l}(0.73) \\
(0.52)\end{array}$ & $\begin{array}{l}10.9 \\
12.4\end{array}$ & $\begin{array}{l}(0.86) \\
(0.68)\end{array}$ & $\begin{array}{l}1.6 \\
2.3\end{array}$ & $\begin{array}{l}(0.31) \\
(0.34)\end{array}$ & $\begin{array}{l}31.5 \\
39.0\end{array}$ & $\begin{array}{l}(1.17) \\
(0.97)\end{array}$ & $\begin{array}{l}17.8 \\
21.7\end{array}$ & $\begin{array}{l}(1.03) \\
(0.84)\end{array}$ \\
\hline \multicolumn{16}{|l|}{ Race/ethnicity } \\
\hline White................ & 1,483 & 63.4 & $(0.92)$ & 33.6 & $(0.82)$ & 9.1 & $(0.56)$ & 11.4 & $(0.61)$ & 1.8 & $(0.26)$ & 36.9 & (0.98) & 20.2 & $(0.92)$ \\
\hline 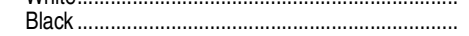 & 319 & 73.6 & (1.66) & 33.7 & (1.94) & 10.8 & $(1.23)$ & 10.8 & $(1.06)$ & 2.2 & $(0.54)$ & 48.8 & (2.12) & 33.0 & (1.75) \\
\hline 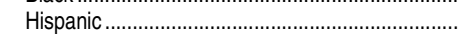 & 221 & 68.6 & (2.24) & 38.8 & (2.56) & 14.3 & $(2.05)$ & 14.2 & (1.77) & $3.8 !$ & $(1.27)$ & $\begin{array}{l}48.8 \\
34.6\end{array}$ & (2.73) & $\begin{array}{l}3.0 \\
19.3\end{array}$ & $(2.51)$ \\
\hline Asian . & 211 & 44.5 & (1.92) & 30.4 & (1.99) & 7.0 & $(1.16)$ & 12.3 & (1.61) & $2.0 !$ & $(0.70)$ & 19.4 & (1.67) & 7.5 & (1.28) \\
\hline Pacific Islander.............................................. & 14 & 70.8 & $(11.38)$ & $29.9 !$ & $(12.43)$ & $\ddagger$ & $(t)$ & $18.9 !$ & $(8.14)$ & $\ddagger$ & $(t)$ & 44.2 & $(11.10)$ & $20.3 !$ & (9.95) \\
\hline American Indian/Alaska Native ............................ & 12 & 75.0 & $(10.31)$ & $28.7 !$ & $(10.01)$ & $16.6 !$ & $(7.55)$ & $\ddagger$ & $\begin{aligned}0.14) \\
(\dagger)\end{aligned}$ & $\neq$ & $(\dagger)$ & 55.1 & (12.39) & $42.5 !$ & $(15.09)$ \\
\hline 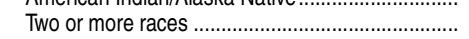 & 48 & 63.5 & $(4.17)$ & 36.6 & (4.48) & $5.4 !$ & (2.02) & $15.8 !$ & $(4.78)$ & 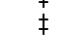 & $\begin{array}{c}110) \\
(t)\end{array}$ & 40.4 & $(4.24)$ & 20.9 & $(3.82)$ \\
\hline \multicolumn{16}{|l|}{ Age } \\
\hline 15 through $23 \ldots$ & 196 & 46.8 & (1.94) & 36.3 & (1.93) & 8.4 & $(1.11)$ & 8.1 & $(1.18)$ & $0.7 !$ & $(0.33)$ & 19.5 & (1.45) & 4.5 & (0.74) \\
\hline 24 through $29 \ldots \ldots \ldots$ & 852 & 57.4 & (1.20) & 33.4 & (1.07) & 8.7 & $(0.58)$ & 10.6 & $(0.68)$ & 1.6 & $(0.32)$ & 30.8 & (1.05) & 15.8 & $(0.95)$ \\
\hline 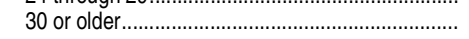 & 1,261 & 70.8 & $(0.95)$ & 33.3 & (1.09) & 10.3 & $(0.65)$ & 13.6 & $(0.82)$ & 2.7 & $(0.40)$ & 44.3 & (1.21) & 27.4 & (1.07) \\
\hline \multicolumn{16}{|l|}{ Attendance status } \\
\hline Exclusively full-time & 910 & 53.1 & (1.11) & 27.5 & $(0.96)$ & 6.0 & $(0.51)$ & 8.9 & $(0.58)$ & 1.3 & $(0.30)$ & 31.7 & (1.16) & 18.4 & (1.04) \\
\hline Exclusively part-time ……………………………..... & 1,013 & 72.6 & (1.08) & 39.0 & (1.24) & 13.5 & $(0.89)$ & 14.4 & $(0.91)$ & 2.8 & $(0.43)$ & 41.0 & (1.21) & 22.7 & (1.19) \\
\hline Mixed full-time and part-time ................................ & 386 & 67.3 & (1.75) & 39.2 & (1.60) & 9.9 & $(1.19)$ & 14.1 & $(1.28)$ & 2.1 & $(0.41)$ & 36.9 & (1.98) & 19.1 & (1.69) \\
\hline \multicolumn{16}{|l|}{ Had job during academic year ${ }^{2}$} \\
\hline 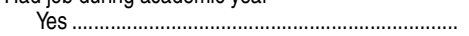 & 1,837 & 73.7 & $(0.87)$ & 37.8 & $(0.86)$ & 11.4 & $(0.57)$ & 13.6 & $(0.65)$ & 2.7 & $(0.32)$ & 43.7 & $(0.91)$ & 26.3 & (0.79) \\
\hline №.......................... & 472 & 39.7 & (1.22) & 25.0 & $(1.11)$ & 5.2 & $(0.50)$ & 7.9 & $(0.73)$ & $0.7 !$ & $(0.24)$ & 19.9 & (1.12) & 7.2 & $(0.82)$ \\
\hline \multicolumn{16}{|l|}{ Dependency status } \\
\hline Dependent …………………………………….... & - & - & $\left(\begin{array}{l}(t) \\
0\end{array}\right.$ & - & $(t)$ & - & $(t)$ & - & $(t)$ & - & $(t)$ & - & $\left(\begin{array}{l}(t) \\
(0)\end{array}\right.$ & - & $(t)$ \\
\hline Independent, no dependents, not married ${ }^{3} \ldots \ldots \ldots . . . .$. & 1,025 & 55.5 & $(1.03)$ & 34.0 & $(0.98)$ & 8.5 & $(0.52)$ & 11.1 & $(0.64)$ & 1.5 & $(0.31)$ & 28.1 & $(0.88)$ & 13.2 & $(0.74)$ \\
\hline Independent, no dependents, married................... & 345 & 62.6 & (1.89) & 32.7 & (1.68) & 9.2 & $(1.21)$ & 11.3 & (1.37) & $2.1 !$ & $(0.67)$ & 36.1 & (1.75) & 21.0 & (1.63) \\
\hline Independent, with dependents, not married ${ }^{3} \ldots \ldots \ldots$ & 284 & 79.3 & (1.71) & 35.1 & (2.57) & 10.2 & $(1.55)$ & 14.9 & (1.68) & 3.7 & $(1.02)$ & 52.0 & (2.49) & 33.4 & (2.48) \\
\hline Independent, with dependents, married. & 654 & 70.8 & (1.52) & 33.0 & (1.42) & 11.0 & $(0.96)$ & 12.3 & (1.13) & 2.4 & $(0.49)$ & 45.6 & (1.60) & 28.3 & (1.55) \\
\hline \multicolumn{16}{|l|}{ Control of institution } \\
\hline 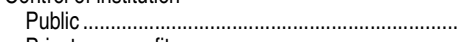 & 1,002 & 57.4 & $(0.95)$ & 34.3 & $(0.97)$ & 7.6 & $(0.51)$ & 9.9 & $(0.63)$ & 2.0 & $(0.29)$ & 32.8 & $(0.93)$ & 14.1 & $(0.72)$ \\
\hline Private nonprofit...................................................... & 924 & 61.8 & (1.14) & 38.1 & $(1.17)$ & 12.8 & $(0.84)$ & 15.2 & $(0.88)$ & 2.3 & $(0.42)$ & 28.5 & (1.16) & 13.8 & (1.08) \\
\hline Private for-profit ...... & 382 & 86.7 & (2.12) & 16.1 & $(1.70)$ & 5.0 & $(0.79)$ & 8.0 & $(1.08)$ & $1.1 !$ & $(0.37)$ & 74.1 & (2.09) & 65.3 & (2.58) \\
\hline
\end{tabular}

\section{-Not available.}

TNot applicable.
!nterpret data with caution. The coefficient of variation (CV) for this estimate is between 30 and 50 percent.

$\neq$ Reporting standards not met. The coefficient of variation (CV) for this estimate is 50 percent or greater.

'Students who reported taking more than one type of class (e.g., night classes and online classes) are counted only once in

the total.

Includes separated.

NOTE: Night classes start after 6:00 p.m. on Monday through Thursday nights; weekend classes start after 6:00 p.m. on Frie any time on Saturday or Sunday; and online classes are taught only online. Detail may not sum to totals SOURCE: U.S. Department of Education, National Center for Education Statistics, 2011-12 National Postsecondary Student Aid Study (NPSAS:12). (This table was prepared March 2014.) 
Table 311.33. Selected statistics for degree-granting postsecondary institutions that primarily offer online programs, by control of institution and selected characteristics: 2012

\begin{tabular}{|c|c|c|c|c|c|c|c|c|c|c|}
\hline \multirow[b]{2}{*}{ Selected characteristic } & \multirow[b]{2}{*}{$\begin{array}{r}\text { All } \\
\text { institutions }\end{array}$} & \multicolumn{5}{|c|}{ Primarily online institutions ${ }^{1}$} & \multicolumn{4}{|c|}{ Other institutions ${ }^{1}$} \\
\hline & & Total & $\begin{array}{r}\text { Percent of all } \\
\text { institutions }\end{array}$ & Public & Nonprofit & For-profit & Total & Public & Nonprofit & For-profit \\
\hline 1 & 2 & 3 & 4 & 5 & 6 & 7 & 8 & 9 & 10 & 11 \\
\hline 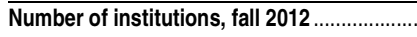 & 4,726 & 56 & 1.2 & 4 & 14 & 38 & 4,670 & 1,619 & 1,638 & 1,413 \\
\hline $\begin{array}{l}\text { Fall } 2012 \text { enrollment } \\
\text { Total enrollment }\end{array}$ & $20,642,819$ & 833,786 & 4.0 & 35,996 & 94,904 & 702,886 & $19,809,033$ & $14,844,347$ & $3,858,674$ & $1,106,012$ \\
\hline 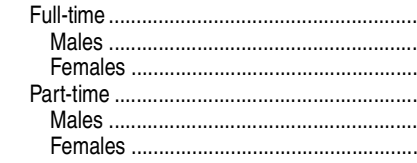 & $\begin{array}{r}12,737,013 \\
5,709,792 \\
7,027,221 \\
7,905,806 \\
3,209,295 \\
4,696,511\end{array}$ & $\begin{array}{l}531,813 \\
167,073 \\
364,740 \\
301,973 \\
123,762 \\
178,211\end{array}$ & $\begin{array}{l}4.2 \\
2.9 \\
5.2 \\
3.8 \\
3.9 \\
3.8\end{array}$ & $\begin{array}{r}3,944 \\
1,770 \\
2,174 \\
32,052 \\
16,565 \\
15,487\end{array}$ & $\begin{array}{l}47,465 \\
18,700 \\
28,765 \\
47,439 \\
19,284 \\
28,155\end{array}$ & $\begin{array}{r}480,404 \\
146,603 \\
333,801 \\
222,482 \\
87,913 \\
134,569\end{array}$ & $\begin{array}{r}12,205,200 \\
5,542,719 \\
6,662,481 \\
7,603,833 \\
3,085,533 \\
4,518,300\end{array}$ & $\begin{array}{l}8,521,874 \\
3,952,344 \\
4,569,530 \\
6,322,473 \\
2,610,620 \\
3,711,853\end{array}$ & $\begin{array}{r}2,910,793 \\
1,281,839 \\
1,628,954 \\
947,881 \\
360,921 \\
586,960\end{array}$ & $\begin{array}{l}772,533 \\
308,536 \\
463,997 \\
333,479 \\
113,992 \\
219,487\end{array}$ \\
\hline 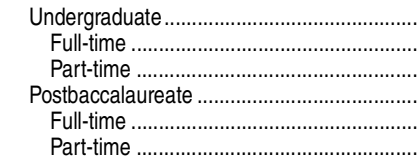 & $\begin{array}{r}17,732,431 \\
11,097,779 \\
6,634,652 \\
2,910,388 \\
1,639,234 \\
1,271,154\end{array}$ & $\begin{array}{r}627,628 \\
408,007 \\
219,621 \\
206,158 \\
123,806 \\
82,352\end{array}$ & $\begin{array}{l}3.5 \\
3.7 \\
3.3 \\
7.1 \\
7.6 \\
6.5\end{array}$ & $\begin{array}{r}29,695 \\
3,313 \\
26,382 \\
6,301 \\
631 \\
5,670\end{array}$ & $\begin{array}{r}78,613 \\
35,953 \\
42,660 \\
16,291 \\
11,512 \\
4,779\end{array}$ & $\begin{array}{r}519,320 \\
368,741 \\
150,579 \\
183,566 \\
111,663 \\
71,903\end{array}$ & $\begin{array}{r}17,104,803 \\
10,689,772 \\
6,415,031 \\
2,704,230 \\
1,515,428 \\
1,188,802\end{array}$ & $\begin{array}{r}13,444,048 \\
7,749,043 \\
5,695,005 \\
1,400,299 \\
772,831 \\
627,468\end{array}$ & $\begin{array}{r}2,666,462 \\
2,214,027 \\
452,435 \\
1,192,212 \\
696,766 \\
495,446\end{array}$ & $\begin{array}{r}994,293 \\
726,702 \\
267,591 \\
111,719 \\
45,831 \\
65,888\end{array}$ \\
\hline $\begin{array}{l}\text { White } \\
\text { Black } \\
\text { Asianic } \\
\text { Pacific Islander. } \\
\text { American Indian/Alaska Native } \\
\text { Two or more races } \\
\text { Nonresident alien }\end{array}$ & $\begin{array}{r}11,981,143 \\
2,962,140 \\
2,979,443 \\
1,195,578 \\
63,609 \\
172,923 \\
505,092 \\
782,891\end{array}$ & $\begin{array}{r}457,908 \\
242,495 \\
72,964 \\
17,253 \\
5,551 \\
8,613 \\
20,471 \\
8,531\end{array}$ & $\begin{array}{l}3.8 \\
8.2 \\
2.4 \\
1.4 \\
8.7 \\
5.0 \\
4.1 \\
1.1\end{array}$ & $\begin{array}{r}25,110 \\
4,793 \\
3,364 \\
1,251 \\
181 \\
206 \\
587 \\
504\end{array}$ & $\begin{array}{r}64,320 \\
16,710 \\
6,823 \\
2,868 \\
445 \\
677 \\
2,347 \\
714\end{array}$ & $\begin{array}{r}368,478 \\
220,992 \\
62,777 \\
13,134 \\
4,925 \\
7,730 \\
17,537 \\
7,313\end{array}$ & $\begin{array}{r}11,523,235 \\
2,719,645 \\
2,906,479 \\
1,178,325 \\
58,058 \\
164,310 \\
484,621 \\
774,360\end{array}$ & $\begin{array}{r}8,609,173 \\
1,932,209 \\
2,362,492 \\
899,803 \\
41,265 \\
131,539 \\
369,813 \\
498,053\end{array}$ & $\begin{array}{r}2,439,896 \\
476,982 \\
328,796 \\
234,524 \\
9,798 \\
21,787 \\
86,928 \\
259,963\end{array}$ & $\begin{array}{r}474,166 \\
310,454 \\
215,191 \\
43,998 \\
6,995 \\
10,984 \\
27,880 \\
16,344\end{array}$ \\
\hline 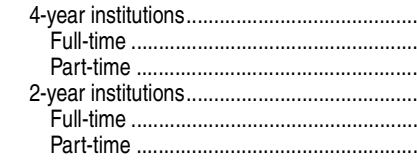 & $\begin{array}{r}13,478,846 \\
9,794,436 \\
3,684,410 \\
7,163,973 \\
2,942,577 \\
4,221,396\end{array}$ & $\begin{array}{r}833,382 \\
531,601 \\
301,781 \\
404 \\
212 \\
192\end{array}$ & \begin{tabular}{r|}
6.2 \\
5.4 \\
8.2 \\
$\#$ \\
$\#$ \\
$\#$ \\
$\#$
\end{tabular} & $\begin{array}{r}35,996 \\
3,944 \\
32,052 \\
0 \\
0 \\
0\end{array}$ & $\begin{array}{r}94,904 \\
47,465 \\
47,439 \\
0 \\
0 \\
0\end{array}$ & $\begin{array}{r}702,482 \\
480,192 \\
222,290 \\
404 \\
212 \\
192\end{array}$ & $\begin{array}{r}12,645,464 \\
9,262,835 \\
3,382,629 \\
7,163,569 \\
2,942,365 \\
4,221,204\end{array}$ & $\begin{array}{l}8,056,687 \\
5,906,254 \\
2,150,433 \\
6,787,660 \\
2,615,620 \\
4,172,040\end{array}$ & $\begin{array}{r}3,821,068 \\
2,881,473 \\
939,595 \\
37,606 \\
29,320 \\
8,286\end{array}$ & $\begin{array}{r}767,709 \\
475,108 \\
292,601 \\
338,303 \\
297,425 \\
40,878\end{array}$ \\
\hline Earned degrees conferred, 2011-12 & & & & & & & & & & \\
\hline $\begin{array}{l}\text { Associate's. } \\
\text { Males } \\
\text { Females }\end{array}$ & $\begin{array}{r}1,017,538 \\
391,990 \\
625,548\end{array}$ & $\begin{array}{l}61,792 \\
18,554 \\
43,238\end{array}$ & $\begin{array}{l}6.1 \\
4.7 \\
6.9\end{array}$ & $\begin{array}{l}831 \\
574 \\
257\end{array}$ & $\begin{array}{l}2,566 \\
1,074 \\
1,492\end{array}$ & $\begin{array}{l}58,395 \\
16,906 \\
41,489\end{array}$ & $\begin{array}{l}955,746 \\
373,436 \\
582,310\end{array}$ & $\begin{array}{l}755,253 \\
295,209 \\
460,044\end{array}$ & $\begin{array}{l}51,780 \\
18,699 \\
33,081\end{array}$ & $\begin{array}{r}148,713 \\
59,528 \\
89,185\end{array}$ \\
\hline 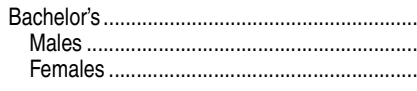 & $\begin{array}{r}1,791,046 \\
765,317 \\
1,025,729\end{array}$ & $\begin{array}{l}77,987 \\
29,220 \\
48,767\end{array}$ & $\begin{array}{l}4.4 \\
3.8 \\
4.8\end{array}$ & $\begin{array}{l}3,692 \\
1,750 \\
1,942\end{array}$ & $\begin{array}{l}7,486 \\
3,357 \\
4,129\end{array}$ & $\begin{array}{l}66,809 \\
24,113 \\
42,696\end{array}$ & $\begin{array}{r}1,713,059 \\
736,097 \\
976,962\end{array}$ & $\begin{array}{r}1,128,194 \\
495,163 \\
633,031\end{array}$ & $\begin{array}{l}519,020 \\
212,412 \\
306,608\end{array}$ & $\begin{array}{l}65,845 \\
28,522 \\
37,323\end{array}$ \\
\hline 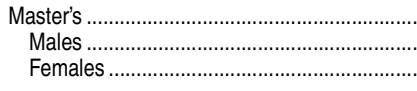 & $\begin{array}{l}754,229 \\
302,191 \\
452,038\end{array}$ & $\begin{array}{l}52,445 \\
17,778 \\
34,667\end{array}$ & $\begin{array}{l}7.0 \\
5.9 \\
7.7\end{array}$ & $\begin{array}{l}831 \\
419 \\
412\end{array}$ & $\begin{array}{l}3,502 \\
1,260 \\
2,242\end{array}$ & $\begin{array}{l}48,112 \\
16,099 \\
32,013\end{array}$ & $\begin{array}{l}701,784 \\
284,413 \\
417,371\end{array}$ & $\begin{array}{l}348,480 \\
142,237 \\
206,243\end{array}$ & $\begin{array}{l}321,925 \\
130,497 \\
191,428\end{array}$ & $\begin{array}{l}31,379 \\
11,679 \\
19,700\end{array}$ \\
\hline 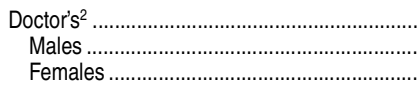 & $\begin{array}{r}170,062 \\
82,611 \\
87,451\end{array}$ & $\begin{array}{r}2,590 \\
959 \\
1,631\end{array}$ & $\begin{array}{l}1.5 \\
1.2 \\
1.9\end{array}$ & $\begin{array}{l}0 \\
0 \\
0\end{array}$ & $\begin{array}{l}47 \\
21 \\
26 \\
\end{array}$ & $\begin{array}{r}2,543 \\
938 \\
1,605\end{array}$ & $\begin{array}{r}167,472 \\
81,652 \\
85,820\end{array}$ & $\begin{array}{l}84,727 \\
41,638 \\
43,089\end{array}$ & $\begin{array}{l}79,436 \\
38,694 \\
40,742\end{array}$ & $\begin{array}{l}3,309 \\
1,320 \\
1,989 \\
\end{array}$ \\
\hline $\begin{array}{l}\text { First-time students' rates of graduation } \\
\text { from and retention at first institution } \\
\text { attended } \\
\text { Among full-time bachelor's degree-seekers } \\
\text { starting at } 4 \text {-year institutions in } 2006 \text {, } \\
\text { percent earning bachelor's degree }\end{array}$ & & & & & & & & & & \\
\hline 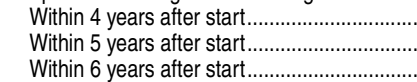 & $\begin{array}{l}39.0 \\
54.9 \\
59.2\end{array}$ & $\begin{array}{r}8.1 \\
10.6 \\
12.2\end{array}$ & $\begin{array}{c}t \\
t \\
t\end{array}$ & $\begin{array}{l}\ddagger \\
\ddagger \\
\ddagger\end{array}$ & $\begin{array}{l}19.7 \\
26.0 \\
32.3\end{array}$ & $\begin{array}{r}7.6 \\
9.9 \\
11.3\end{array}$ & $\begin{array}{l}39.1 \\
55.0 \\
59.3\end{array}$ & $\begin{array}{l}32.8 \\
51.9 \\
57.2\end{array}$ & $\begin{array}{l}52.9 \\
63.2 \\
65.5\end{array}$ & $\begin{array}{l}24.2 \\
29.6 \\
33.4\end{array}$ \\
\hline $\begin{array}{l}\text { Among full-time degree/certificate-seekers } \\
\text { starting at 2-year institutions in } 2009, \\
\text { percent completing credential within } 150 \\
\text { percent of normal time....................................... }\end{array}$ & 31.0 & 69.1 & $\dagger$ & $\ddagger$ & $\ddagger$ & 69.1 & 31.0 & 19.8 & 62.3 & 62.8 \\
\hline $\begin{array}{l}\text { Among degree-seekers starting in } 2011, \\
\text { percent returning in } 2012 \\
\text { Full-time entrants } \\
\text { Part-time entrants }\end{array}$ & $\begin{array}{l}71.8 \\
42.2\end{array}$ & $\begin{array}{l}36.7 \\
44.0\end{array}$ & $\begin{array}{l}t \\
t\end{array}$ & $\begin{array}{r}\ddagger \\
56.3\end{array}$ & $\begin{array}{l}77.8 \\
35.8\end{array}$ & $\begin{array}{l}35.8 \\
44.0\end{array}$ & $\begin{array}{l}71.9 \\
42.2\end{array}$ & $\begin{array}{l}70.3 \\
42.3\end{array}$ & $\begin{array}{l}79.8 \\
45.0\end{array}$ & $\begin{array}{l}62.9 \\
37.9\end{array}$ \\
\hline
\end{tabular}

†Not applicable.

\#Rounds to zero.

†Reporting standards not met (too few cases for a reliable estimate).

${ }^{1}$ Primarily online institutions have more than 90 percent of their students attending classes exclusively online. Other institutions may have some online offerings, but they are not primarily online.

IIncludes Ph.D., Ed.D., and comparable degrees at the doctoral level. Includes most degrees formerly classified as first-professional, such as M.D., D.D.S., and law degrees.
NOTE: Degree-granting institutions grant associate's or higher degrees and participate in Title IV federal financial aid programs.

SOURCE: U.S. Department of Education, National Center for Education Statistics, Integrated Postsecondary Education Data System (IPEDS), Spring 2013, Enrollment component; IPEDS, Fall 2012, Completions component; and IPEDS, Spring 2013, Graduation Rates component. (This table was prepared May 2014.) 
Table 311.40. Percentage of first-year undergraduate students who reported taking remedial education courses, by selected student and institution characteristics: 2003-04, 2007-08, and 2011-12

[Standard errors appear in parentheses]

\begin{tabular}{|c|c|c|c|c|c|c|c|c|c|c|c|c|c|c|c|c|}
\hline \multirow{3}{*}{$\begin{array}{l}\text { Selected student or } \\
\text { institution characteristic }\end{array}$} & \multicolumn{12}{|c|}{ 2003-04 first-year undergraduates ${ }^{1}$} & \multirow{2}{*}{\multicolumn{4}{|c|}{$\begin{array}{c}\text { 2007-08 first-year undergraduates }{ }^{1} \\
\begin{array}{c}\text { Percent who took } \\
\text { any remedial courses }\end{array} \\
\end{array}$}} \\
\hline & \multicolumn{4}{|c|}{$\begin{array}{l}\text { Percent who took } \\
\text { any remedial courses }\end{array}$} & \multicolumn{8}{|c|}{ Percent who took specific remedial courses in 2003-04 } & & & & \\
\hline & & Ever & & $03-04$ & & English & Mat & ematics & & Reading & & Writing & & Ever & $\ln 2$ & $07-08$ \\
\hline 1 & & 2 & & 3 & & 4 & & 5 & & 6 & & 7 & & 8 & & 9 \\
\hline Total & 34.7 & $(0.37)$ & 19.1 & $(0.29)$ & 5.7 & $(0.22)$ & 14.6 & $(0.26)$ & 5.5 & $(0.17)$ & 6.9 & $(0.18)$ & 36.1 & (0.38) & 19.9 & $(0.35)$ \\
\hline 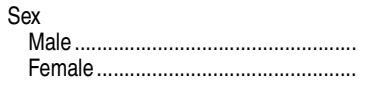 & $\begin{array}{l}32.9 \\
36.0\end{array}$ & $\begin{array}{l}(0.52) \\
(0.55)\end{array}$ & $\begin{array}{l}18.3 \\
19.7\end{array}$ & $\begin{array}{l}(0.45) \\
(0.39)\end{array}$ & $\begin{array}{l}5.5 \\
5.8\end{array}$ & $\begin{array}{l}(0.30) \\
(0.23)\end{array}$ & $\begin{array}{l}13.9 \\
15.0\end{array}$ & $\begin{array}{l}(0.41) \\
(0.33)\end{array}$ & $\begin{array}{l}5.2 \\
5.8\end{array}$ & $\begin{array}{l}(0.22) \\
(0.24)\end{array}$ & $\begin{array}{l}6.6 \\
7.1\end{array}$ & $\begin{array}{l}(0.27) \\
(0.26)\end{array}$ & $\begin{array}{l}33.0 \\
38.6\end{array}$ & $\begin{array}{l}(0.53) \\
(0.51)\end{array}$ & $\begin{array}{l}19.2 \\
20.5\end{array}$ & $\begin{array}{l}(0.50) \\
(0.46)\end{array}$ \\
\hline 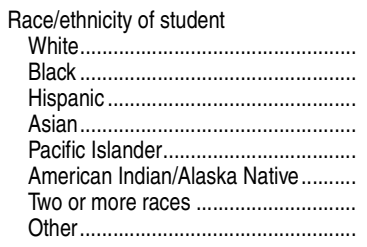 & $\begin{array}{l}31.7 \\
41.2 \\
37.5 \\
39.6 \\
40.8 \\
44.8 \\
33.9 \\
31.1\end{array}$ & $\begin{array}{l}(0.42) \\
(0.99) \\
(0.92) \\
(1.72) \\
(5.11) \\
(4.33) \\
(2.01) \\
(2.78)\end{array}$ & $\begin{array}{l}17.7 \\
22.4 \\
20.9 \\
17.6 \\
22.4 \\
23.6 \\
20.8 \\
17.2\end{array}$ & $\begin{array}{l}(0.35) \\
(0.76) \\
(0.69) \\
(1.56) \\
(4.55) \\
(3.10) \\
(1.80) \\
(2.34)\end{array}$ & $\begin{array}{c}4.9 \\
7.5 \\
6.4 \\
8.2 \\
10.2 ! \\
3.4 \\
4.7 \\
5.0\end{array}$ & $\begin{array}{l}(0.21) \\
(0.52) \\
(0.52) \\
(1.09) \\
(4.18) \\
(0.99) \\
(0.90) \\
(1.35)\end{array}$ & $\begin{array}{l}13.5 \\
17.1 \\
16.5 \\
10.9 \\
19.8 \\
17.3 \\
14.8 \\
14.3\end{array}$ & $\begin{array}{l}(0.32) \\
(0.66) \\
(0.63) \\
(1.19) \\
(4.64) \\
(2.79) \\
(1.48) \\
(2.12)\end{array}$ & $\begin{array}{c}4.4 \\
7.8 \\
6.9 \\
7.0 \\
10.1 ! \\
8.4 \\
4.9 \\
6.1\end{array}$ & $\begin{array}{l}(0.18) \\
(0.49) \\
(0.49) \\
(0.83) \\
(4.07) \\
(2.28) \\
(0.98) \\
(1.30)\end{array}$ & $\begin{array}{c}6.4 \\
6.9 \\
8.1 \\
8.4 \\
11.3 ! \\
8.0 \\
6.5 \\
6.9\end{array}$ & $\begin{array}{l}(0.22) \\
(0.44) \\
(0.48) \\
(0.93) \\
(4.00) \\
(2.35) \\
(1.12) \\
(1.63)\end{array}$ & $\begin{array}{l}31.3 \\
45.1 \\
42.7 \\
38.9 \\
39.9 \\
48.0 \\
32.3 \\
35.2\end{array}$ & $\begin{array}{r}(0.46) \\
(0.99) \\
(1.08) \\
(2.05) \\
(4.63) \\
(4.65) \\
(2.29) \\
(6.000)\end{array}$ & $\begin{array}{l}17.7 \\
24.4 \\
22.5 \\
20.0 \\
19.1 \\
29.6 \\
20.4 \\
21.7\end{array}$ & $\begin{array}{l}(0.41) \\
(0.86) \\
(0.78) \\
(1.90) \\
(3.90) \\
(3.87) \\
(2.06) \\
(5.11)\end{array}$ \\
\hline 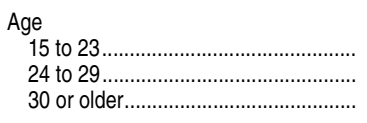 & $\begin{array}{l}33.6 \\
34.9 \\
37.4\end{array}$ & $\begin{array}{l}(0.41) \\
(1.02) \\
(0.86)\end{array}$ & $\begin{array}{l}21.3 \\
15.9 \\
15.6\end{array}$ & $\begin{array}{l}(0.38) \\
(0.78) \\
(0.51)\end{array}$ & $\begin{array}{l}6.5 \\
4.3 \\
4.5\end{array}$ & $\begin{array}{l}(0.28) \\
(0.40) \\
(0.35)\end{array}$ & $\begin{array}{l}16.0 \\
12.8 \\
12.1\end{array}$ & $\begin{array}{l}(0.34) \\
(0.65) \\
(0.51)\end{array}$ & $\begin{array}{l}6.4 \\
4.0 \\
4.4\end{array}$ & $\begin{array}{l}(0.22) \\
(0.40) \\
(0.32)\end{array}$ & $\begin{array}{l}8.2 \\
5.0 \\
4.6\end{array}$ & $\begin{array}{l}(0.22) \\
(0.55) \\
(0.31)\end{array}$ & $\begin{array}{l}34.5 \\
39.5 \\
37.9\end{array}$ & $\begin{array}{l}(0.46) \\
(0.96) \\
(0.83)\end{array}$ & $\begin{array}{l}22.0 \\
19.3 \\
15.2\end{array}$ & $\begin{array}{l}(0.42) \\
(0.86) \\
(0.67)\end{array}$ \\
\hline 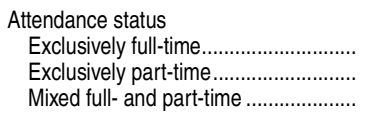 & $\begin{array}{l}31.3 \\
37.4 \\
40.9\end{array}$ & $\begin{array}{l}(0.46) \\
(0.65) \\
(0.96)\end{array}$ & $\begin{array}{l}19.0 \\
17.9 \\
23.5\end{array}$ & $\begin{array}{l}(0.37) \\
(0.51) \\
(0.84)\end{array}$ & $\begin{array}{l}5.7 \\
5.3 \\
7.1\end{array}$ & $\begin{array}{l}(0.22) \\
(0.31) \\
(0.56)\end{array}$ & $\begin{array}{l}14.0 \\
14.0 \\
18.6\end{array}$ & $\begin{array}{l}(0.35) \\
(0.46) \\
(0.79)\end{array}$ & $\begin{array}{l}5.6 \\
5.0 \\
7.1\end{array}$ & $\begin{array}{l}(0.22) \\
(0.28) \\
(0.47)\end{array}$ & $\begin{array}{l}7.5 \\
5.6 \\
8.3\end{array}$ & $\begin{array}{l}(0.23) \\
(0.28) \\
(0.45)\end{array}$ & $\begin{array}{l}31.4 \\
39.8 \\
42.5\end{array}$ & $\begin{array}{l}(0.53) \\
(0.70) \\
(0.98)\end{array}$ & $\begin{array}{l}19.3 \\
18.9 \\
26.2\end{array}$ & $\begin{array}{l}(0.45) \\
(0.59) \\
(0.93)\end{array}$ \\
\hline 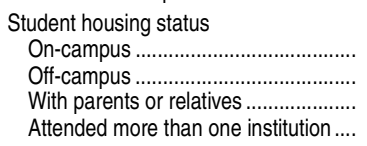 & $\begin{array}{l}24.5 \\
35.8 \\
37.6 \\
36.5\end{array}$ & $\begin{array}{l}(0.70) \\
(0.59) \\
(0.60) \\
(1.18)\end{array}$ & $\begin{array}{l}16.8 \\
16.9 \\
24.2 \\
18.3\end{array}$ & $\begin{array}{l}(0.56) \\
(0.40) \\
(0.59) \\
(0.99)\end{array}$ & $\begin{array}{l}4.8 \\
5.1 \\
7.1 \\
6.4\end{array}$ & $\begin{array}{l}(0.30) \\
(0.30) \\
(0.37) \\
(0.58)\end{array}$ & $\begin{array}{l}11.3 \\
13.3 \\
18.3 \\
14.5\end{array}$ & $\begin{array}{l}(0.49) \\
(0.35) \\
(0.52) \\
(0.98)\end{array}$ & $\begin{array}{l}4.8 \\
4.6 \\
7.6 \\
5.0\end{array}$ & $\begin{array}{l}(0.31) \\
(0.22) \\
(0.35) \\
(0.48)\end{array}$ & $\begin{array}{l}8.2 \\
5.5 \\
8.6 \\
6.3\end{array}$ & $\begin{array}{l}(0.40) \\
(0.28) \\
(0.36) \\
(0.48)\end{array}$ & $\begin{array}{l}23.2 \\
37.2 \\
39.4 \\
36.1\end{array}$ & $\begin{array}{l}(0.84) \\
(0.57) \\
(0.77) \\
(1.13)\end{array}$ & $\begin{array}{l}17.1 \\
17.7 \\
24.9 \\
20.3\end{array}$ & $\begin{array}{l}(0.76) \\
(0.48) \\
(0.64) \\
(0.99)\end{array}$ \\
\hline 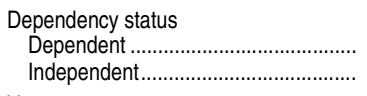 & $\begin{array}{l}33.3 \\
36.3\end{array}$ & $\begin{array}{l}(0.45) \\
(0.62)\end{array}$ & $\begin{array}{l}21.9 \\
16.1\end{array}$ & $\begin{array}{l}(0.40) \\
(0.39)\end{array}$ & $\begin{array}{l}6.6 \\
4.8\end{array}$ & $\begin{array}{l}(0.27) \\
(0.27)\end{array}$ & $\begin{array}{l}16.3 \\
12.7\end{array}$ & $\begin{array}{l}(0.35) \\
(0.37)\end{array}$ & $\begin{array}{l}6.5 \\
4.5\end{array}$ & $\begin{array}{l}(0.24) \\
(0.23)\end{array}$ & $\begin{array}{l}8.6 \\
5.0\end{array}$ & $\begin{array}{l}(0.23) \\
(0.27)\end{array}$ & $\begin{array}{l}34.3 \\
38.0\end{array}$ & $\begin{array}{l}(0.50) \\
(0.59)\end{array}$ & $\begin{array}{l}22.8 \\
17.0\end{array}$ & $\begin{array}{l}(0.46) \\
(0.50)\end{array}$ \\
\hline 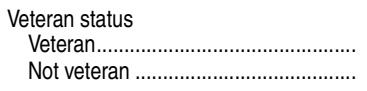 & $\begin{array}{l}35.8 \\
34.7\end{array}$ & $\begin{array}{l}(2.32) \\
(0.39)\end{array}$ & $\begin{array}{l}13.2 \\
19.3\end{array}$ & $\begin{array}{l}(1.52) \\
(0.30)\end{array}$ & $\begin{array}{l}1.9 \\
5.8\end{array}$ & $\begin{array}{l}(0.51) \\
(0.22)\end{array}$ & $\begin{array}{r}9.8 \\
14.7\end{array}$ & $\begin{array}{l}(1.40) \\
(0.27)\end{array}$ & $\begin{array}{l}3.1 \\
5.6\end{array}$ & $\begin{array}{l}(0.68) \\
(0.18)\end{array}$ & $\begin{array}{l}4.3 \\
6.9\end{array}$ & $\begin{array}{l}(0.84) \\
(0.18)\end{array}$ & $\begin{array}{l}35.9 \\
36.1\end{array}$ & $\begin{array}{l}(2.37) \\
(0.38)\end{array}$ & $\begin{array}{l}17.1 \\
20.0\end{array}$ & $\begin{array}{l}(2.09) \\
(0.35)\end{array}$ \\
\hline 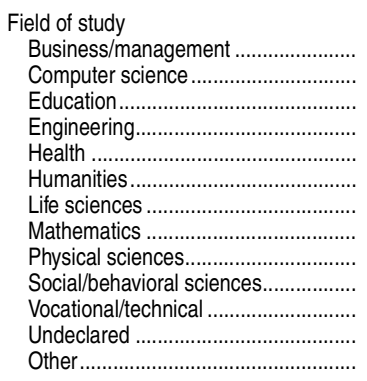 & $\begin{array}{l}36.3 \\
33.7 \\
41.1 \\
30.3 \\
36.9 \\
34.1 \\
31.1 \\
23.0 \\
23.7 \\
33.2 \\
38.4 \\
33.5 \\
33.2\end{array}$ & $\begin{array}{l}(0.98) \\
(1.59) \\
(1.58) \\
(1.81) \\
(0.82) \\
(1.28) \\
(1.82) \\
(5.55) \\
(4.35) \\
(2.06) \\
(2.09) \\
(0.67) \\
(1.51)\end{array}$ & $\begin{array}{l}19.5 \\
19.1 \\
22.9 \\
16.2 \\
19.6 \\
18.9 \\
19.6 \\
11.0 ! \\
12.8 \\
19.3 \\
18.3 \\
19.2 \\
17.9\end{array}$ & $\begin{array}{l}(0.95) \\
(1.37) \\
(1.13) \\
(1.42) \\
(0.67) \\
(0.94) \\
(1.71) \\
(4.43) \\
(3.45) \\
(1.57) \\
(1.59) \\
(0.58) \\
(1.07)\end{array}$ & $\begin{array}{c}5.5 \\
4.7 \\
6.3 \\
5.4 \\
6.1 \\
5.7 \\
5.7 \\
\ddagger \\
7.4 ! \\
5.5 \\
5.0 \\
5.9 \\
5.2\end{array}$ & $\begin{array}{r}(0.41) \\
(0.66) \\
(0.74) \\
(0.79) \\
(0.48) \\
(0.46) \\
(1.26) \\
(\dagger) \\
(2.82) \\
(0.90) \\
(0.85) \\
(0.37) \\
(0.67)\end{array}$ & $\begin{array}{c}14.6 \\
14.6 \\
17.4 \\
12.7 \\
15.4 \\
14.3 \\
14.5 \\
9.3 ! \\
5.2 ! \\
14.5 \\
14.4 \\
14.4 \\
13.6\end{array}$ & $\begin{array}{r}(0.99) \\
(1.26) \\
(1.000) \\
(1.25) \\
(0.62) \\
(0.88) \\
(1.47) \\
(4.26) \\
(2.11) \\
(1.38) \\
(1.39) \\
(0.49) \\
(0.95)\end{array}$ & $\begin{array}{c}6.0 \\
5.3 \\
6.3 \\
4.7 \\
5.7 \\
5.0 \\
5.4 \\
\ddagger \\
6.3 ! \\
6.5 \\
5.6 \\
5.1 \\
6.1\end{array}$ & $\begin{array}{r}(0.44) \\
(0.82) \\
(0.72) \\
(0.76) \\
(0.43) \\
(0.52) \\
(1.21) \\
(t) \\
(3.02) \\
(1.000) \\
(1.000) \\
(0.33) \\
(0.56)\end{array}$ & $\begin{array}{r}7.3 \\
5.6 \\
8.7 \\
6.6 \\
6.2 \\
7.3 \\
8.0 \\
\ddagger \\
\ddagger \\
8.6 \\
4.7 \\
7.2 \\
5.8\end{array}$ & $\begin{array}{r}(0.60) \\
(0.73) \\
(0.86) \\
(0.91) \\
(0.49) \\
(0.52) \\
(1.20) \\
(\dagger) \\
(\dagger) \\
(1.04) \\
(0.60) \\
(0.37) \\
(0.56)\end{array}$ & $\begin{array}{l}37.0 \\
34.4 \\
40.5 \\
33.2 \\
38.3 \\
38.5 \\
31.2 \\
40.8 \\
24.2 \\
35.2 \\
31.4 \\
35.6 \\
34.6\end{array}$ & $\begin{array}{l}(1.13) \\
(2.25) \\
(1.91) \\
(1.77) \\
(0.94) \\
(0.95) \\
(1.91) \\
(6.22) \\
(4.43) \\
(2.17) \\
(1.90) \\
(1.27) \\
(1.20)\end{array}$ & $\begin{array}{l}21.6 \\
19.6 \\
22.9 \\
18.9 \\
18.8 \\
22.7 \\
20.6 \\
15.4 ! \\
14.7 \\
23.5 \\
15.8 \\
19.8 \\
18.3\end{array}$ & $\begin{array}{l}(1.04) \\
(1.74) \\
(1.48) \\
(1.55) \\
(0.83) \\
(0.85) \\
(1.74) \\
(5.13) \\
(3.72) \\
(1.95) \\
(1.73) \\
(1.13) \\
(0.96)\end{array}$ \\
\hline $\begin{array}{l}\text { Type of institution } \\
\text { Public less-than-2-year ....................... } \\
\text { Public 2-year ..................................... } \\
\text { Public 4-year nondoctorate ................ } \\
\text { Public 4-year doctorate .................... } \\
\text { Private nonprofit less-than-4-year...... } \\
\text { Private nonprofit 4-year nondoctorate. } \\
\text { Private nonprofit 4-year doctorate....... } \\
\text { Private for-profit less-than-2-year....... } \\
\text { Private for-profit } 2 \text { years or more ........ }\end{array}$ & $\begin{array}{l}30.6 \\
41.4 \\
34.1 \\
25.7 \\
30.8 \\
25.7 \\
18.4 \\
24.1 \\
25.3\end{array}$ & $\begin{array}{l}(1.85) \\
(0.59) \\
(1.75) \\
(1.11) \\
(1.87) \\
(1.19) \\
(1.64) \\
(0.48) \\
(1.63)\end{array}$ & $\begin{array}{r}10.9 \\
23.0 \\
21.3 \\
16.3 \\
12.6 \\
14.4 \\
11.7 \\
7.8 \\
11.7\end{array}$ & $\begin{array}{l}(1.09) \\
(0.47) \\
(1.11) \\
(0.63) \\
(1.69) \\
(0.81) \\
(1.37) \\
(0.23) \\
(1.04)\end{array}$ & $\begin{array}{l}4.8 \\
6.9 \\
5.3 \\
4.4 \\
4.2 \\
5.2 \\
2.5 \\
3.1 \\
4.1\end{array}$ & $\begin{array}{l}(0.80) \\
(0.33) \\
(0.60) \\
(0.34) \\
(0.93) \\
(0.70) \\
(0.53) \\
(0.18) \\
(0.50)\end{array}$ & $\begin{array}{r}9.4 \\
18.3 \\
16.3 \\
11.6 \\
10.1 \\
9.4 \\
7.5 \\
4.7 \\
7.5\end{array}$ & $\begin{array}{l}(1.05) \\
(0.42) \\
(1.04) \\
(0.60) \\
(1.33) \\
(0.56) \\
(1.34) \\
(0.16) \\
(0.75)\end{array}$ & $\begin{array}{l}4.0 \\
7.1 \\
5.2 \\
3.9 \\
2.7 \\
3.9 \\
2.9 \\
2.2 \\
3.3\end{array}$ & $\begin{array}{l}(0.86) \\
(0.28) \\
(0.55) \\
(0.39) \\
(0.71) \\
(0.42) \\
(0.56) \\
(0.19) \\
(0.45)\end{array}$ & $\begin{array}{l}3.9 \\
7.2 \\
8.5 \\
8.1 \\
4.8 \\
6.7 \\
6.3 \\
3.5 \\
4.9\end{array}$ & $\begin{array}{l}(0.90) \\
(0.27) \\
(0.62) \\
(0.42) \\
(1.14) \\
(0.79) \\
(0.90) \\
(0.22) \\
(0.70)\end{array}$ & $\begin{array}{l}31.9 \\
41.8 \\
38.9 \\
25.0 \\
32.6 \\
25.9 \\
22.7 \\
26.6 \\
28.8\end{array}$ & $\begin{array}{l}(1.99) \\
(0.54) \\
(1.23) \\
(1.03) \\
(3.07) \\
(1.73) \\
(1.63) \\
(0.95) \\
(1.42)\end{array}$ & $\begin{array}{r}9.0 \\
23.7 \\
25.4 \\
17.8 \\
10.6 \\
16.4 \\
13.1 \\
5.7 \\
11.3\end{array}$ & $\begin{array}{l}(0.89) \\
(0.48) \\
(1.12) \\
(0.85) \\
(2.37) \\
(1.43) \\
(1.34) \\
(0.47) \\
(1.16)\end{array}$ \\
\hline
\end{tabular}


Table 311.40. Percentage of first-year undergraduate students who reported taking remedial education courses, by selected student and institution characteristics: 2003-04, 2007-08, and 2011-12-Continued

[Standard errors appear in parentheses]

\begin{tabular}{|c|c|c|c|c|c|c|c|c|c|c|c|c|c|c|}
\hline \multirow[b]{3}{*}{$\begin{array}{l}\text { Selected student or } \\
\text { institution characteristic }\end{array}$} & \multicolumn{14}{|c|}{ 2011-12 first-year undergraduates ${ }^{1}$} \\
\hline & \multirow[b]{2}{*}{$\begin{array}{r}\text { Total number of } \\
\text { students } \\
\text { (in thousands) }\end{array}$} & \multicolumn{5}{|c|}{ Students who took any remedial courses } & \multicolumn{8}{|c|}{ Percent who took specific remedial courses in 2011-12 } \\
\hline & & Perc & $\begin{array}{l}\text { nt who } \\
\text { er took }\end{array}$ & $\begin{array}{r}\text { Number who } \\
\text { took in 2011-12 } \\
\text { (in thousands) }\end{array}$ & $\begin{array}{r}\text { Percent } v \\
\text { in }\end{array}$ & $\begin{array}{l}\text { no took } \\
11-12\end{array}$ & & English & Matl & matics & & Reading & & Writing \\
\hline 1 & 10 & & 11 & 12 & & 13 & & 14 & & 15 & & 16 & & 17 \\
\hline Total & 9,437 & 32.6 & $(0.42)$ & 1,864 & 19.7 & $(0.36)$ & 10.0 & $(0.25)$ & 16.2 & $(0.34)$ & 7.4 & $(0.23)$ & 7.5 & $(0.25)$ \\
\hline 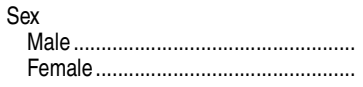 & $\begin{array}{l}4,079 \\
5,359\end{array}$ & $\begin{array}{l}30.8 \\
34.0\end{array}$ & $\begin{array}{l}(0.61) \\
(0.52)\end{array}$ & $\begin{array}{r}811 \\
1,053\end{array}$ & $\begin{array}{l}19.9 \\
19.7\end{array}$ & $\begin{array}{l}(0.55) \\
(0.46)\end{array}$ & $\begin{array}{r}10.4 \\
9.7\end{array}$ & $\begin{array}{l}(0.37) \\
(0.35)\end{array}$ & $\begin{array}{l}16.0 \\
16.3\end{array}$ & $\begin{array}{l}(0.49) \\
(0.43)\end{array}$ & $\begin{array}{l}7.2 \\
7.5\end{array}$ & $\begin{array}{l}(0.32) \\
(0.29)\end{array}$ & $\begin{array}{l}7.6 \\
7.4\end{array}$ & $\begin{array}{l}(0.36) \\
(0.26)\end{array}$ \\
\hline 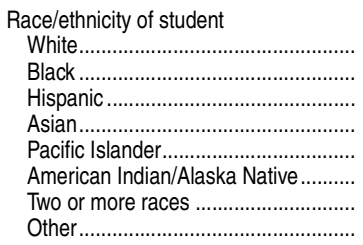 & $\begin{array}{r}4,997 \\
1,871 \\
1,728 \\
410 \\
46 \\
106 \\
280 \\
-\end{array}$ & $\begin{array}{r}29.4 \\
37.6 \\
35.8 \\
37.6 \\
33.4 \\
34.9 \\
29.8 \\
-\end{array}$ & $\begin{array}{r}(0.51) \\
(0.89) \\
(0.99) \\
(2.25) \\
(5.16) \\
(4.11) \\
(2.02) \\
(\dagger)\end{array}$ & $\begin{array}{r}885 \\
416 \\
388 \\
94 \\
7 \\
21 \\
53 \\
-\end{array}$ & $\begin{array}{r}17.7 \\
22.2 \\
22.4 \\
23.0 \\
15.2 \\
19.8 \\
19.0 \\
-\end{array}$ & $\begin{array}{r}(0.47) \\
(0.75) \\
(0.81) \\
(1.75) \\
(3.50) \\
(2.79) \\
(1.68) \\
(\dagger)\end{array}$ & $\begin{array}{c}8.1 \\
12.8 \\
11.5 \\
14.6 \\
9.6 ! \\
10.2 \\
9.8 \\
-\end{array}$ & $\begin{array}{r}(0.33) \\
(0.54) \\
(0.56) \\
(1.53) \\
(3.15) \\
(2.03) \\
(1.56) \\
(\dagger)\end{array}$ & $\begin{array}{r}14.7 \\
18.2 \\
18.7 \\
15.2 \\
11.9 \\
17.4 \\
15.4 \\
-\end{array}$ & $\begin{array}{r}(0.43) \\
(0.72) \\
(0.76) \\
(1.19) \\
(3.11) \\
(2.79) \\
(1.58) \\
(\dagger)\end{array}$ & $\begin{array}{r}5.8 \\
10.1 \\
8.4 \\
11.1 \\
4.2 \\
9.0 \\
5.5 \\
-\end{array}$ & $\begin{array}{r}(0.29) \\
(0.53) \\
(0.46) \\
(1.57) \\
(1.25) \\
(2.03) \\
(1.01) \\
(\dagger)\end{array}$ & $\begin{array}{c}6.3 \\
9.2 \\
8.5 \\
11.5 \\
5.5 ! \\
7.1 \\
5.7 \\
-\end{array}$ & $\begin{array}{r}(0.29) \\
(0.55) \\
(0.48) \\
(1.52) \\
(1.65) \\
(1.71) \\
(0.91) \\
(\dagger)\end{array}$ \\
\hline 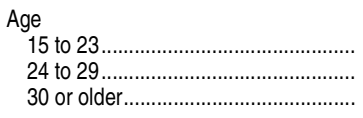 & $\begin{array}{l}5,549 \\
1,618 \\
2,270\end{array}$ & $\begin{array}{l}31.0 \\
34.4 \\
35.4\end{array}$ & $\begin{array}{l}(0.49) \\
(1.12) \\
(0.94)\end{array}$ & $\begin{array}{r}1,169 \\
278 \\
417\end{array}$ & $\begin{array}{l}21.1 \\
17.2 \\
18.4\end{array}$ & $\begin{array}{l}(0.38) \\
(0.91) \\
(0.82)\end{array}$ & $\begin{array}{r}10.6 \\
8.3 \\
9.7\end{array}$ & $\begin{array}{l}(0.30) \\
(0.61) \\
(0.53)\end{array}$ & $\begin{array}{l}17.3 \\
14.2 \\
14.9\end{array}$ & $\begin{array}{l}(0.36) \\
(0.86) \\
(0.73)\end{array}$ & $\begin{array}{l}7.6 \\
6.4 \\
7.6\end{array}$ & $\begin{array}{l}(0.24) \\
(0.55) \\
(0.57)\end{array}$ & $\begin{array}{l}7.7 \\
6.4 \\
7.7\end{array}$ & $\begin{array}{l}(0.28) \\
(0.52) \\
(0.56)\end{array}$ \\
\hline 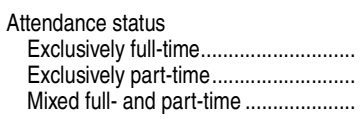 & $\begin{array}{l}4,774 \\
3,280 \\
1,383\end{array}$ & $\begin{array}{l}28.1 \\
37.4 \\
37.0\end{array}$ & $\begin{array}{l}(0.48) \\
(0.81) \\
(0.95)\end{array}$ & $\begin{array}{l}840 \\
699 \\
324\end{array}$ & $\begin{array}{l}17.6 \\
21.3 \\
23.4\end{array}$ & $\begin{array}{l}(0.41) \\
(0.78) \\
(0.74)\end{array}$ & $\begin{array}{r}9.1 \\
10.3 \\
12.2\end{array}$ & $\begin{array}{l}(0.28) \\
(0.50) \\
(0.57)\end{array}$ & $\begin{array}{l}14.2 \\
17.7 \\
19.5\end{array}$ & $\begin{array}{l}(0.41) \\
(0.71) \\
(0.71)\end{array}$ & $\begin{array}{l}6.6 \\
7.7 \\
9.3\end{array}$ & $\begin{array}{l}(0.27) \\
(0.43) \\
(0.53)\end{array}$ & $\begin{array}{l}6.7 \\
7.9 \\
9.1\end{array}$ & $\begin{array}{l}(0.26) \\
(0.50) \\
(0.50)\end{array}$ \\
\hline $\begin{array}{l}\text { Student housing status } \\
\text { On-campus ........................................ } \\
\text { Off-campus ................................. } \\
\text { With parents or relatives ................... } \\
\text { Attended more than one institution .... }\end{array}$ & $\begin{array}{r}1,055 \\
4,326 \\
3,462 \\
594\end{array}$ & $\begin{array}{l}17.9 \\
34.0 \\
35.3 \\
32.7\end{array}$ & $\begin{array}{l}(0.78) \\
(0.65) \\
(0.78) \\
(1.09)\end{array}$ & $\begin{array}{l}148 \\
846 \\
768 \\
101\end{array}$ & $\begin{array}{l}14.1 \\
19.6 \\
22.2 \\
17.0\end{array}$ & $\begin{array}{l}(0.67) \\
(0.63) \\
(0.61) \\
(0.95)\end{array}$ & $\begin{array}{r}6.5 \\
9.7 \\
11.6 \\
8.9\end{array}$ & $\begin{array}{l}(0.48) \\
(0.41) \\
(0.43) \\
(0.77)\end{array}$ & $\begin{array}{l}10.9 \\
15.9 \\
18.5 \\
14.1\end{array}$ & $\begin{array}{l}(0.58) \\
(0.58) \\
(0.56) \\
(0.86)\end{array}$ & $\begin{array}{l}3.9 \\
7.8 \\
8.2 \\
5.7\end{array}$ & $\begin{array}{l}(0.37) \\
(0.41) \\
(0.37) \\
(0.56)\end{array}$ & $\begin{array}{l}5.0 \\
7.8 \\
8.1 \\
6.3\end{array}$ & $\begin{array}{l}(0.46) \\
(0.43) \\
(0.42) \\
(0.62)\end{array}$ \\
\hline 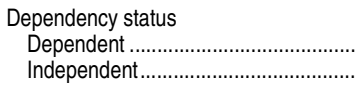 & $\begin{array}{l}4,543 \\
4,894\end{array}$ & $\begin{array}{l}31.2 \\
33.9\end{array}$ & $\begin{array}{l}(0.53) \\
(0.57)\end{array}$ & $\begin{array}{r}1,001 \\
863\end{array}$ & $\begin{array}{l}22.0 \\
17.6\end{array}$ & $\begin{array}{l}(0.42) \\
(0.52)\end{array}$ & $\begin{array}{r}11.0 \\
9.0\end{array}$ & $\begin{array}{l}(0.34) \\
(0.34)\end{array}$ & $\begin{array}{l}17.9 \\
14.5\end{array}$ & $\begin{array}{l}(0.41) \\
(0.50)\end{array}$ & $\begin{array}{l}8.0 \\
6.8\end{array}$ & $\begin{array}{l}(0.27) \\
(0.34)\end{array}$ & $\begin{array}{l}8.1 \\
6.9\end{array}$ & $\begin{array}{l}(0.31) \\
(0.30)\end{array}$ \\
\hline 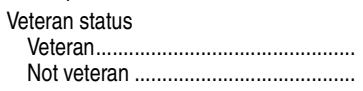 & $\begin{array}{r}310 \\
9,127\end{array}$ & $\begin{array}{l}31.4 \\
32.7\end{array}$ & $\begin{array}{l}(2.21) \\
(0.42)\end{array}$ & $\begin{array}{r}54 \\
1,809\end{array}$ & $\begin{array}{l}17.4 \\
19.8\end{array}$ & $\begin{array}{l}(1.74) \\
(0.37)\end{array}$ & $\begin{array}{r}8.5 \\
10.1\end{array}$ & $\begin{array}{l}(1.22) \\
(0.26)\end{array}$ & $\begin{array}{l}15.9 \\
16.2\end{array}$ & $\begin{array}{l}(1.67) \\
(0.35)\end{array}$ & $\begin{array}{l}3.3 \\
7.5\end{array}$ & $\begin{array}{l}(0.68) \\
(0.24)\end{array}$ & $\begin{array}{l}5.2 \\
7.6\end{array}$ & $\begin{array}{l}(0.97) \\
(0.25)\end{array}$ \\
\hline 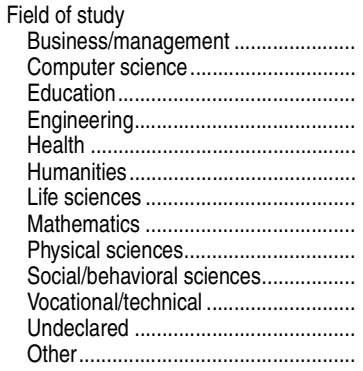 & $\begin{array}{r}1,203 \\
402 \\
387 \\
409 \\
2,023 \\
1,776 \\
416 \\
24 \\
58 \\
392 \\
431 \\
299 \\
1,350\end{array}$ & $\begin{array}{l}32.7 \\
29.3 \\
36.0 \\
33.1 \\
34.6 \\
36.6 \\
26.7 \\
14.3 ! \\
29.2 \\
27.7 \\
26.9 \\
31.8 \\
29.3\end{array}$ & $\begin{array}{l}(1.11) \\
(1.69) \\
(1.84) \\
(1.88) \\
(0.74) \\
(1.03) \\
(1.71) \\
(4.57) \\
(4.72) \\
(1.87) \\
(1.94) \\
(2.10) \\
(0.94)\end{array}$ & $\begin{array}{r}238 \\
70 \\
84 \\
86 \\
381 \\
424 \\
75 \\
\ddagger \\
14 \\
78 \\
68 \\
66 \\
225\end{array}$ & $\begin{array}{c}19.8 \\
17.4 \\
21.6 \\
20.9 \\
18.8 \\
23.9 \\
17.9 \\
8.4 ! \\
24.7 \\
19.8 \\
15.7 \\
22.0 \\
16.7\end{array}$ & $\begin{array}{l}(0.85) \\
(1.40) \\
(1.53) \\
(1.63) \\
(0.70) \\
(0.91) \\
(1.11) \\
(2.81) \\
(4.59) \\
(1.38) \\
(1.59) \\
(1.86) \\
(0.77)\end{array}$ & $\begin{array}{r}10.5 \\
8.9 \\
10.6 \\
11.0 \\
9.1 \\
11.7 \\
9.1 \\
4.6 ! \\
17.2 \\
9.1 \\
7.6 \\
10.7 \\
9.4\end{array}$ & $\begin{array}{l}(0.72) \\
(1.14) \\
(1.08) \\
(1.22) \\
(0.55) \\
(0.60) \\
(0.92) \\
(2.26) \\
(4.25) \\
(0.87) \\
(1.12) \\
(1.53) \\
(0.64)\end{array}$ & $\begin{array}{c}15.3 \\
14.0 \\
16.4 \\
15.4 \\
16.7 \\
19.6 \\
14.2 \\
7.6 \text { ! } \\
20.8 \\
16.6 \\
13.0 \\
17.4 \\
13.9\end{array}$ & $\begin{array}{l}(0.75) \\
(1.29) \\
(1.23) \\
(1.33) \\
(0.67) \\
(0.80) \\
(1.01) \\
(2.67) \\
(4.24) \\
(1.37) \\
(1.56) \\
(1.68) \\
(0.70)\end{array}$ & $\begin{array}{l}8.7 \\
6.2 \\
7.9 \\
7.9 \\
6.7 \\
8.9 \\
6.4 \\
\ddagger \\
8.9 ! \\
6.0 \\
5.9 \\
7.9 \\
6.4\end{array}$ & $\begin{array}{r}(0.66) \\
(1.02) \\
(1.03) \\
(1.23) \\
(0.45) \\
(0.62) \\
(0.89) \\
(\dagger) \\
(3.16) \\
(0.88) \\
(0.85) \\
(1.41) \\
(0.52)\end{array}$ & $\begin{array}{c}8.2 \\
6.8 \\
7.2 \\
9.1 \\
6.7 \\
8.9 \\
7.1 \\
6.2 ! \\
13.6 \\
7.6 \\
5.7 \\
6.6 \\
6.7\end{array}$ & $\begin{array}{l}(0.60) \\
(1.16) \\
(0.90) \\
(1.22) \\
(0.39) \\
(0.60) \\
(0.82) \\
(2.51) \\
(3.98) \\
(0.79) \\
(1.02) \\
(1.13) \\
(0.56)\end{array}$ \\
\hline $\begin{array}{l}\text { Type of institution } \\
\text { Public less-than-2-year ....................... } \\
\text { Public 2-year .................................. } \\
\text { Public 4-year nondoctorate ............... } \\
\text { Public 4-year doctorate .................... } \\
\text { Private nonprofit less-than-4-year...... } \\
\text { Private nonprofit 4-year nondoctorate. } \\
\text { Private nonprofit 4-year doctorate....... } \\
\text { Private for-profit less-than-2-year....... } \\
\text { Private for-profit 2 years or more ........ }\end{array}$ & $\begin{array}{r}58 \\
5,038 \\
817 \\
893 \\
58 \\
375 \\
356 \\
402 \\
1,439\end{array}$ & $\begin{array}{l}30.2 \\
40.3 \\
37.8 \\
21.9 \\
22.3 \\
24.4 \\
14.6 \\
16.7 \\
20.9\end{array}$ & $\begin{array}{l}(6.13) \\
(0.67) \\
(2.12) \\
(0.84) \\
(4.25) \\
(1.66) \\
(1.85) \\
(0.74) \\
(0.74)\end{array}$ & $\begin{array}{r}7 \\
1,289 \\
198 \\
139 \\
6 \\
58 \\
34 \\
15 \\
118\end{array}$ & $\begin{array}{c}12.2 ! \\
25.6 \\
24.3 \\
15.6 \\
9.4 ! \\
15.3 \\
9.6 \\
3.8 \\
8.2\end{array}$ & $\begin{array}{l}(3.86) \\
(0.64) \\
(1.30) \\
(0.80) \\
(3.42) \\
(1.23) \\
(1.24) \\
(0.56) \\
(0.37)\end{array}$ & $\begin{array}{r}8.5 ! \\
13.2 \\
10.2 \\
6.8 \\
5.9 \\
7.8 \\
4.0 \\
2.2 \\
5.2\end{array}$ & $\begin{array}{l}(4.11) \\
(0.43) \\
(0.79) \\
(0.47) \\
(1.73) \\
(1.04) \\
(0.65) \\
(0.39) \\
(0.34)\end{array}$ & $\begin{array}{c}10.5 ! \\
21.0 \\
20.4 \\
12.8 \\
8.1 ! \\
10.9 \\
7.3 \\
3.4 \\
6.6\end{array}$ & $\begin{array}{l}(3.34) \\
(0.60) \\
(1.25) \\
(0.71) \\
(2.86) \\
(1.06) \\
(1.26) \\
(0.57) \\
(0.36)\end{array}$ & $\begin{array}{c}6.5 ! \\
10.3 \\
6.9 \\
3.5 \\
\ddagger \\
4.9 \\
3.4 ! \\
1.9 \\
3.2\end{array}$ & $\begin{array}{r}(3.19) \\
(0.38) \\
(0.78) \\
(0.33) \\
(\dagger) \\
(0.77) \\
(1.03) \\
(0.46) \\
(0.24)\end{array}$ & $\begin{array}{l}1.6 ! \\
9.7 \\
7.9 \\
4.5 \\
3.5 ! \\
7.0 \\
4.2 \\
1.7 \\
4.3\end{array}$ & $\begin{array}{l}(0.75) \\
(0.41) \\
(0.88) \\
(0.45) \\
(1.64) \\
(0.97) \\
(0.70) \\
(0.39) \\
(0.29)\end{array}$ \\
\hline
\end{tabular}

-Not available.

†Not applicable.

!nterpret data with caution. The coefficient of variation (CV) for this estimate is between 30 and 50 percent.

†Reporting standards not met. The coefficient of variation (CV) is 50 percent or greater. ${ }^{1}$ Student status was determined by accumulation of credits. Students attending postsecondary education part time, or not completing the credit accumulation requirements for second-yea status, could be considered first-year students for more than one year.
NOTE: Data are based on a sample survey of students who enrolled at any time during the school year. Percentages of students who took remedial courses are based on student reports. Data for 2003-04 and 2007-08 include Puerto Rico, which is excluded from the 2011-12 data Detail may not sum to totals because of survey item nonresponse and rounding. Race categories exclude persons of Hispanic ethnicity.

SOURCE: U.S. Department of Education, National Center for Education Statistics, 2003-04, 2007-08, and 2011-12 National Postsecondary Student Aid Study (NPSAS:04, NPSAS:08, and NPSAS:12). (This table was prepared March 2014.) 


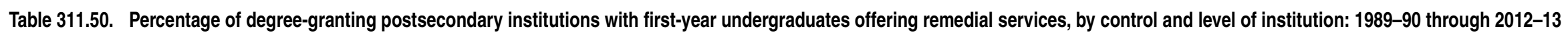

\begin{tabular}{|c|c|c|c|c|c|c|c|c|c|c|c|c|c|c|c|}
\hline \multirow[b]{3}{*}{ Year } & \multirow{2}{*}{\multicolumn{3}{|c|}{ Public and private }} & \multirow{2}{*}{\multicolumn{3}{|c|}{ Public }} & \multicolumn{9}{|c|}{ Private } \\
\hline & & & & & & & \multicolumn{3}{|c|}{ Total } & \multicolumn{3}{|c|}{ Nonprofit } & \multicolumn{3}{|c|}{ For-profit } \\
\hline & Total & 4-year & 2-year & Total & 4-year & 2-year & Total & 4-year & 2-year & Total & 4-year & 2-year & Total & 4-year & 2-year \\
\hline 1 & 2 & 3 & 4 & 5 & 6 & 7 & 8 & 9 & 10 & 11 & 12 & 13 & 14 & 15 & 16 \\
\hline $1989-90$ & 76.6 & 69.6 & 87.2 & 92.4 & 82.9 & 98.2 & 64.1 & 64.5 & 63.0 & 65.0 & 64.2 & 71.8 & 59.5 & 71.7 & 57.0 \\
\hline $1990-91 \ldots$ & 77.7 & 70.6 & 88.4 & 93.0 & 83.5 & 98.9 & 65.6 & 65.6 & 65.5 & 65.6 & 64.9 & 71.3 & 65.6 & 81.3 & 62.0 \\
\hline $1991-92 \ldots \ldots$ & 78.6 & 71.4 & 89.2 & 93.9 & 84.5 & 99.6 & 66.3 & 66.4 & 65.8 & 66.2 & 65.8 & 69.9 & 66.6 & 79.2 & 63.2 \\
\hline $1992-93$ & 78.5 & 71.5 & 88.8 & 93.5 & 84.5 & 98.8 & 66.4 & 66.5 & 65.8 & 66.7 & 66.2 & 71.5 & 64.6 & 73.7 & 62.0 \\
\hline $1993-94 \ldots \ldots \ldots \ldots \ldots \ldots \ldots \ldots \ldots \ldots \ldots$ & 79.0 & 72.2 & 89.5 & 93.5 & 84.6 & 98.7 & 67.4 & 67.5 & 67.0 & 67.7 & 67.0 & 73.5 & 65.6 & 76.3 & 62.1 \\
\hline $1994-95$ & 79.8 & 73.6 & 89.1 & 93.7 & 85.3 & 98.6 & 68.6 & 69.2 & 66.6 & 69.3 & 68.7 & 74.0 & 65.2 & 76.0 & 60.8 \\
\hline $1995-96 \ldots$ & 79.5 & 73.0 & 89.4 & 93.7 & 85.4 & 98.6 & 68.0 & 68.4 & 66.3 & 68.9 & 68.3 & 73.3 & 63.5 & 69.2 & 60.5 \\
\hline $1996-97$ & 80.0 & 73.1 & 91.0 & 94.0 & 85.1 & 99.2 & 68.6 & 68.6 & 68.4 & 69.2 & 68.3 & 77.3 & 65.2 & 72.7 & 60.8 \\
\hline $1997-98$ & 76.7 & 72.5 & 82.2 & 93.8 & 85.2 & 98.7 & 64.2 & 67.8 & 55.1 & 69.0 & 68.3 & 75.4 & 51.7 & 63.9 & 47.5 \\
\hline 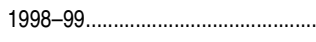 & 76.1 & 72.0 & 81.5 & 93.6 & 84.2 & 99.0 & 63.6 & 67.7 & 52.8 & 68.6 & 68.3 & 71.6 & 51.1 & 63.4 & 46.2 \\
\hline $1999-2000 \ldots$ & 76.1 & 71.6 & 82.2 & 93.5 & 83.6 & 99.2 & 63.9 & 67.4 & 54.4 & 69.2 & 68.5 & 76.7 & 51.5 & 60.1 & 47.7 \\
\hline $2000-01$ & 75.1 & 71.4 & 80.4 & 93.1 & 81.7 & 99.7 & 62.8 & 67.9 & 48.8 & 67.6 & 67.0 & 73.6 & 52.7 & 72.9 & 41.8 \\
\hline $2001-02 \ldots \ldots \ldots \ldots \ldots$ & 73.3 & 69.0 & 79.5 & 92.3 & 79.9 & 99.4 & 60.2 & 65.3 & 45.0 & 66.1 & 65.5 & 72.6 & 48.0 & 64.5 & 37.3 \\
\hline $2002-03 \ldots \ldots \ldots$ & 72.5 & 67.6 & 79.5 & 91.7 & 78.4 & 99.4 & 59.0 & 63.9 & 44.8 & 65.4 & 64.7 & 74.0 & 45.6 & 59.6 & 37.2 \\
\hline 2003-04 & 72.1 & 67.1 & 79.7 & 91.3 & 77.3 & 99.5 & 59.0 & 63.7 & 44.8 & 65.0 & 64.0 & 77.1 & 47.4 & 62.0 & 37.3 \\
\hline $2004-05$ & 72.6 & 67.4 & 80.3 & 90.6 & 75.6 & 99.6 & 60.4 & 64.7 & 47.4 & 63.1 & 62.5 & 71.4 & 55.4 & 73.7 & 42.2 \\
\hline $2005-06$ & 72.2 & 66.9 & 80.2 & 90.2 & 75.2 & 99.3 & 60.4 & 64.2 & 48.8 & 62.2 & 61.3 & 74.3 & 57.2 & 75.0 & 43.4 \\
\hline $2006-07$ & 72.8 & 67.5 & 80.9 & 90.4 & 75.6 & 99.5 & 61.4 & 64.9 & 50.6 & 62.2 & 61.3 & 74.8 & 60.1 & 77.0 & 45.8 \\
\hline $2007-08$ & 72.4 & 67.2 & 80.9 & 89.7 & 74.1 & 99.5 & 61.6 & 64.9 & 51.0 & 61.4 & 60.6 & 73.9 & 61.8 & 78.4 & 47.2 \\
\hline $2008-09$ & 72.6 & 67.9 & 80.2 & 89.9 & 74.5 & 99.6 & 62.1 & 65.8 & 50.5 & 61.4 & 60.8 & 70.7 & 63.1 & 80.4 & 47.2 \\
\hline $2009-10 \ldots \ldots \ldots \ldots \ldots \ldots$ & 72.7 & 68.3 & 79.7 & 89.8 & 75.3 & 99.6 & 62.5 & 66.1 & 52.1 & 61.2 & 60.6 & 72.9 & 64.3 & 81.2 & 49.4 \\
\hline $2010-111 \ldots$ & 72.0 & 69.2 & 76.7 & 89.6 & 75.5 & 99.4 & 62.1 & 67.2 & 47.3 & 61.2 & 60.6 & 71.3 & 63.3 & 82.9 & 44.1 \\
\hline $2011-12 \ldots \ldots \ldots \ldots \ldots \ldots$ & 70.4 & 67.1 & 75.9 & 89.6 & 75.7 & 99.5 & 60.0 & 64.6 & 46.3 & 60.2 & 60.3 & 59.0 & 59.8 & 73.8 & 44.4 \\
\hline $2012-13 \ldots \ldots \ldots$ & 70.7 & 67.8 & 75.8 & 89.3 & 75.5 & 99.5 & 60.9 & 65.5 & 46.9 & 60.3 & 60.5 & 56.7 & 61.6 & 75.4 & 45.4 \\
\hline Change in percentage points & & & & & & & & & & & & & & & \\
\hline 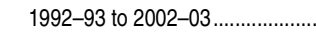 & -6.0 & -3.9 & -9.3 & -1.8 & -6.1 & 0.6 & -7.3 & -2.7 & -21.1 & -1.3 & -1.5 & 2.5 & -19.0 & -14.1 & -24.8 \\
\hline $2002-03$ to $2012-13 \ldots \ldots \ldots \ldots$ & -1.8 & 0.2 & -3.7 & -2.4 & -3.0 & \# & 1.9 & 1.6 & 2.1 & -5.1 & -4.2 & -17.3 & 16.0 & 15.9 & 8.2 \\
\hline
\end{tabular}

\#Rounds to zero.

NOTE: Remedial services are instructional activities designed for students deficient in the general competencies necessary for a regular postsecondary curriculum and educational setting. Data through 1995-96 are for institutions of higher education,
while later data are for degree-granting institutions. Degree-granting institutions grant associate's or higher degrees and par- ticipate in Title IV federal financial aid programs. Excludes institutions not enrolling any first-time degree/certificate-seeking undergraduates.

SOURCE: U.S. Department of Education, National Center for Education Statistics, Integrated Postsecondary Education Data System (IPEDS), "Institutional Characteristics Survey" (IPEDS-IC:89-99); and Fall 2000 through Fall 2012, Institutional Characteristics component. (This table was prepared August 2013.) 


\begin{tabular}{|c|c|c|c|c|c|c|c|c|c|c|c|c|c|c|c|c|c|c|c|c|c|c|}
\hline \multirow[b]{4}{*}{ Major field of study ${ }^{1}$} & \multicolumn{21}{|c|}{ Undergraduate } & \multirow{4}{*}{\begin{tabular}{|r}
$\begin{array}{r}\text { Post- } \\
\text { bacca- } \\
\text { laureate }\end{array}$ \\
$\begin{array}{r}\text { Total (in } \\
\text { thousands) }\end{array}$ \\
\end{tabular}} \\
\hline & \multirow[b]{3}{*}{$\begin{array}{r}\text { Total (in } \\
\text { thousands) }\end{array}$} & \multicolumn{5}{|c|}{ All students } & & \multicolumn{7}{|c|}{ 2-year and less-than-2-year institutions ${ }^{2}$} & \multicolumn{7}{|c|}{ 4-year institutions } & \\
\hline & & \multicolumn{6}{|c|}{ Percentage distribution, by age } & \multirow[b]{2}{*}{$\begin{array}{r}\text { Total (in } \\
\text { thousands) }\end{array}$} & \multicolumn{6}{|c|}{ Percentage distribution, by age } & \multirow[b]{2}{*}{$\begin{array}{r}\text { Total (in } \\
\text { thousands) }\end{array}$} & \multicolumn{6}{|c|}{ Percentage distribution, by age } & \\
\hline & & & Under 25 & & 25 to 35 & & Over 35 & & & Under 25 & & 25 to 35 & & Over 35 & & & Under 25 & & 25 to 35 & & Over 35 & \\
\hline 1 & 2 & & 3 & & 4 & & 5 & 6 & & 7 & & 8 & & 9 & 10 & & 11 & & 12 & & 13 & 14 \\
\hline Total ............................. & 23,055 & 60.5 & $(0.31)$ & 23.9 & $(0.25)$ & 15.5 & $(0.28)$ & 11,990 & 55.3 & $(0.42)$ & 26.9 & $(0.38)$ & 17.8 & $(0.33)$ & 11,065 & 66.2 & $(0.46)$ & 20.8 & (0.34) & 13.1 & $(0.39)$ & $\overline{3,682}$ \\
\hline 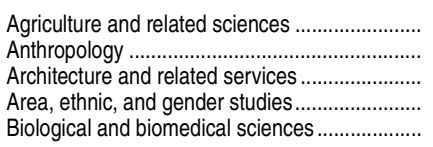 & $\begin{array}{r}132 \\
55 \\
88 \\
40 \\
719\end{array}$ & $\begin{array}{l}68.0 \\
78.8 \\
73.2 \\
74.6 \\
86.2\end{array}$ & $\begin{array}{l}(3.71) \\
(4.20) \\
(3.97) \\
(4.86) \\
(0.98)\end{array}$ & $\begin{array}{l}15.0 \\
20.5 \\
19.4 \\
14.2 \\
11.8\end{array}$ & $\begin{array}{l}(2.48) \\
(4.12) \\
(3.47) \\
(3.78) \\
(0.90)\end{array}$ & $\begin{array}{r}17.0 \\
\ddagger \\
7.4 ! \\
11.2 ! \\
2.0\end{array}$ & $\begin{array}{r}(3.37) \\
(\dagger) \\
(2.47) \\
(3.80) \\
(0.49)\end{array}$ & \begin{tabular}{r|}
60 \\
11 \\
32 \\
10 \\
223
\end{tabular} & $\begin{array}{l}51.5 \\
67.2 \\
58.9 \\
66.8 \\
79.1\end{array}$ & $\begin{array}{r}(5.55) \\
(10.91) \\
(7.86) \\
(10.87) \\
(2.05)\end{array}$ & $\begin{array}{l}18.7 \\
32.8 ! \\
24.5 ! \\
22.1 ! \\
17.4\end{array}$ & $\begin{array}{r}(3.94) \\
(10.91) \\
(7.86) \\
(9.91) \\
(1.93)\end{array}$ & $\begin{array}{c}29.8 \\
\# \\
16.6 ! \\
\ddagger \\
3.5 !\end{array}$ & $\begin{array}{r}(5.62) \\
(\dagger) \\
(5.88) \\
(\dagger) \\
(1.18)\end{array}$ & $\begin{array}{r}72 \\
45 \\
56 \\
30 \\
496\end{array}$ & $\begin{array}{l}81.7 \\
81.5 \\
81.2 \\
77.2 \\
89.4\end{array}$ & $\begin{array}{l}(3.83) \\
(4.65) \\
(3.42) \\
(5.43) \\
(1.14)\end{array}$ & $\begin{array}{c}12.0 \\
17.6 \\
16.6 \\
11.6 ! \\
9.3\end{array}$ & $\begin{array}{l}(3.00) \\
(4.50) \\
(3.36) \\
(3.99) \\
(1.04)\end{array}$ & $\begin{array}{c}6.3 ! \\
\ddagger \\
\ddagger \\
11.2 ! \\
1.3 !\end{array}$ & $\begin{array}{r}(3.05) \\
(\dagger) \\
(\dagger) \\
(4.75) \\
(0.48)\end{array}$ & $\begin{array}{r}12 \\
12 \\
27 \\
8 \\
100\end{array}$ \\
\hline 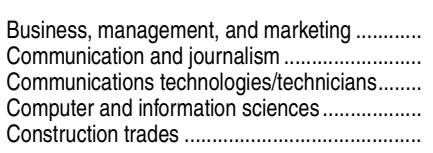 & $\begin{array}{r}3,487 \\
425 \\
99 \\
942 \\
86\end{array}$ & $\begin{array}{l}54.3 \\
83.8 \\
63.2 \\
47.5 \\
53.9\end{array}$ & $\begin{array}{l}(0.68) \\
(1.38) \\
(3.88) \\
(1.39) \\
(3.63)\end{array}$ & $\begin{array}{l}26.7 \\
11.5 \\
24.0 \\
32.3 \\
25.3\end{array}$ & $\begin{array}{l}(0.59) \\
(1.13) \\
(3.49) \\
(1.30) \\
(3.22)\end{array}$ & $\begin{array}{r}19.0 \\
4.7 \\
12.9 \\
20.2 \\
20.7\end{array}$ & $\begin{array}{l}(0.60) \\
(0.86) \\
(2.32) \\
(1.14) \\
(3.98)\end{array}$ & $\begin{array}{r}1,399 \\
96 \\
53 \\
467 \\
78\end{array}$ & $\begin{array}{l}53.7 \\
77.9 \\
59.6 \\
47.0 \\
52.5\end{array}$ & $\begin{array}{l}(1.04) \\
(3.26) \\
(4.72) \\
(2.19) \\
(3.91)\end{array}$ & $\begin{array}{l}27.4 \\
14.0 \\
25.0 \\
30.7 \\
25.9\end{array}$ & $\begin{array}{l}(1.00) \\
(2.35) \\
(4.44) \\
(1.85) \\
(3.55)\end{array}$ & $\begin{array}{r}18.9 \\
8.0 \\
15.4 \\
22.3 \\
21.6\end{array}$ & $\begin{array}{l}(1.09) \\
(2.32) \\
(3.81) \\
(1.75) \\
(4.25)\end{array}$ & $\begin{array}{r}2,089 \\
329 \\
46 \\
475 \\
8\end{array}$ & $\begin{array}{l}54.7 \\
85.5 \\
67.3 \\
48.0 \\
66.7\end{array}$ & $\begin{array}{r}(0.99) \\
(1.46) \\
(6.18) \\
(1.69) \\
(10.97)\end{array}$ & $\begin{array}{l}26.3 \\
10.8 \\
22.8 \\
33.9 \\
20.1 !\end{array}$ & $\begin{array}{l}(0.87) \\
(1.23) \\
(5.43) \\
(1.84) \\
(6.75)\end{array}$ & $\begin{array}{r}19.0 \\
3.7 \\
10.0 \\
18.1 \\
\ddagger\end{array}$ & $\begin{array}{r}(0.77) \\
(0.82) \\
(2.79) \\
(1.42) \\
(\dagger)\end{array}$ & $\begin{array}{r}615 \\
32 \\
\ddagger \\
104 \\
\ddagger\end{array}$ \\
\hline 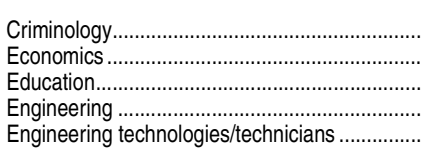 & $\begin{array}{r}39 \\
118 \\
1,175 \\
697 \\
390\end{array}$ & $\begin{array}{l}73.5 \\
86.0 \\
65.4 \\
79.5 \\
50.3\end{array}$ & $\begin{array}{l}(4.96) \\
(3.23) \\
(1.12) \\
(1.21) \\
(2.14)\end{array}$ & $\begin{array}{l}14.9 \\
13.2 \\
19.2 \\
15.9 \\
29.5\end{array}$ & $\begin{array}{l}(3.82) \\
(3.19) \\
(0.84) \\
(1.16) \\
(1.91)\end{array}$ & $\begin{array}{r}11.6 ! \\
\ddagger \\
15.4 \\
4.6 \\
20.2\end{array}$ & $\begin{array}{r}(4.15) \\
(\dagger \\
(1.03) \\
(0.70) \\
(1.83)\end{array}$ & $\begin{array}{r}10 \\
14 \\
495 \\
238 \\
254\end{array}$ & $\begin{array}{l}66.2 \\
67.0 \\
57.1 \\
67.2 \\
44.5\end{array}$ & $\begin{array}{r}(10.90) \\
(12.45) \\
(1.79) \\
(2.36) \\
(2.58)\end{array}$ & $\begin{array}{l}\ddagger \\
\text { ‡ } \\
30.6 ! \\
23.7 \\
23.6 \\
30.5\end{array}$ & $\begin{array}{r}(\dagger) \\
(12.52) \\
(1.49) \\
(2.48) \\
(2.63)\end{array}$ & $\begin{array}{r}\ddagger \\
\ddagger \\
19.2 \\
9.2 \\
25.0\end{array}$ & $\begin{array}{r}(\dagger) \\
(\dagger) \\
(1.77) \\
(1.72) \\
(2.44)\end{array}$ & $\begin{array}{r}29 \\
104 \\
679 \\
459 \\
136\end{array}$ & $\begin{array}{l}76.1 \\
88.6 \\
71.5 \\
85.9 \\
61.3\end{array}$ & $\begin{array}{l}(4.99) \\
(3.28) \\
(1.39) \\
(1.18) \\
(3.80)\end{array}$ & $\begin{array}{l}16.1 \\
10.9 \\
15.9 \\
11.9 \\
27.6\end{array}$ & $\begin{array}{l}(4.44) \\
(3.23) \\
(0.90) \\
(1.15) \\
(2.83)\end{array}$ & $\begin{array}{r}7.8 ! \\
\ddagger \\
12.6 \\
2.2 \\
11.1\end{array}$ & $\begin{array}{r}(3.50) \\
(\dagger \\
(1.14) \\
(0.47) \\
(2.46)\end{array}$ & $\begin{array}{r}\ddagger \\
18 \\
775 \\
176 \\
11\end{array}$ \\
\hline 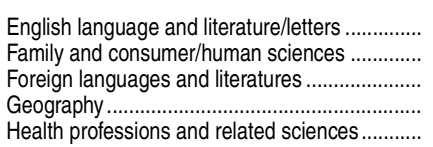 & $\begin{array}{r}282 \\
225 \\
96 \\
17 \\
4,271\end{array}$ & $\begin{array}{l}77.2 \\
60.8 \\
71.5 \\
59.4 \\
48.5\end{array}$ & $\begin{array}{r}(2.18) \\
(2.69) \\
(3.80) \\
(10.54) \\
(0.73)\end{array}$ & $\begin{array}{l}11.9 \\
20.7 \\
24.6 ! \\
30.8\end{array}$ & $\begin{array}{l}(2.20) \\
(3.28) \\
(7.87) \\
(0.70)\end{array}$ & $\begin{array}{r}21.3 \\
7.8 \\
\ddagger \\
20.7\end{array}$ & $\begin{array}{r}(1.29) \\
(2.02) \\
(+) \\
(0.62)\end{array}$ & $\begin{array}{r}82 \\
117 \\
27 \\
\ddagger \\
2,790\end{array}$ & $\begin{array}{r}65.4 \\
55.9 \\
60.4 \\
\ddagger \\
45.6\end{array}$ & $\begin{array}{r}(5.02) \\
(4.11) \\
(7.53) \\
(\dagger) \\
(0.88)\end{array}$ & $\begin{array}{r}19.1 \\
23.4 \\
\ddagger \\
33.5\end{array}$ & $\begin{array}{r}(3.37) \\
(6.66) \\
(\dagger) \\
(0.80)\end{array}$ & $\begin{array}{l}20.6 \\
25.1 \\
16.2 ! \\
\ddagger \\
20.9\end{array}$ & $\begin{array}{r}(4.17) \\
(3.63) \\
(5.00) \\
(\dagger) \\
(0.75)\end{array}$ & $\begin{array}{r}201 \\
108 \\
69 \\
\ddagger \\
1,482\end{array}$ & $\begin{array}{r}82.1 \\
66.1 \\
76.0 \\
\ddagger \\
54.0\end{array}$ & $\begin{array}{r}(2.16) \\
(4.12) \\
(4.11) \\
(\dagger) \\
(1.10)\end{array}$ & $\begin{array}{r}11.9 \\
16.6 \\
19.6 \\
\ddagger \\
25.7\end{array}$ & $\begin{array}{r}(2.64) \\
(3.88) \\
(t) \\
(1.04)\end{array}$ & $\begin{array}{c}6.1 \\
17.3 \\
4.5 ! \\
\ddagger \\
20.3\end{array}$ & $\begin{array}{r}(1.33) \\
(3.08) \\
(2.04) \\
(\dagger) \\
(0.97)\end{array}$ & $\begin{array}{r}55 \\
11 \\
26 \\
\ddagger \\
679\end{array}$ \\
\hline 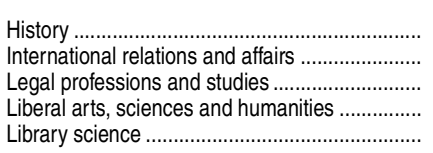 & $\begin{array}{r}206 \\
40 \\
177 \\
2,341 \\
\ddagger\end{array}$ & $\begin{array}{r}77.7 \\
86.4 \\
45.7 \\
62.6 \\
\ddagger\end{array}$ & $\begin{array}{r}(2.83) \\
(5.51) \\
(3.46) \\
(0.89) \\
(\dagger)\end{array}$ & $\begin{array}{l}16.4 \\
13.6 ! \\
30.5 \\
23.7 \\
\ddagger\end{array}$ & $\begin{array}{r}(2.24) \\
(5.51) \\
(2.44) \\
(0.75) \\
(\dagger)\end{array}$ & $\begin{array}{r}5.9 \\
\# \\
23.8 \\
13.7 \\
\ddagger\end{array}$ & $\begin{array}{r}(1.59) \\
(t) \\
(2.75) \\
(0.68) \\
(\dagger)\end{array}$ & $\begin{array}{r}43 \\
\ddagger \\
96 \\
1,857 \\
\ddagger\end{array}$ & $\begin{array}{r}78.5 \\
\ddagger \\
45.7 \\
63.0 \\
\ddagger\end{array}$ & $\begin{array}{r}(5.39) \\
(\dagger) \\
(5.02) \\
(0.93) \\
(\dagger)\end{array}$ & $\begin{array}{c}17.3 ! \\
\ddagger \\
27.1 \\
24.0 \\
\ddagger\end{array}$ & $\begin{array}{r}(5.28) \\
(\dagger) \\
(3.40) \\
(0.86) \\
(\dagger)\end{array}$ & $\begin{array}{r}\ddagger \\
\ddagger \\
27.1 \\
13.0 \\
\ddagger\end{array}$ & $\begin{array}{r}(\dagger) \\
(\dagger) \\
(4.04) \\
(0.76) \\
(\dagger)\end{array}$ & $\begin{array}{r}163 \\
33 \\
80 \\
484 \\
\ddagger\end{array}$ & $\begin{array}{r}77.5 \\
87.2 \\
45.6 \\
61.0 \\
\ddagger\end{array}$ & $\begin{array}{r}(3.35) \\
(5.48) \\
(4.17) \\
(2.43) \\
(\dagger)\end{array}$ & $\begin{array}{l}16.2 \\
12.8 ! \\
34.6 \\
22.6 \\
\ddagger\end{array}$ & $\begin{array}{r}(1.63) \\
(t)\end{array}$ & $\begin{array}{r}6.3 \\
\# \\
19.8 \\
16.4 \\
\ddagger\end{array}$ & $\begin{array}{r}(1.86) \\
(\dagger) \\
(3.22) \\
(1.79) \\
(\dagger)\end{array}$ & $\begin{array}{r}26 \\
15 \\
146 \\
17 \\
21\end{array}$ \\
\hline 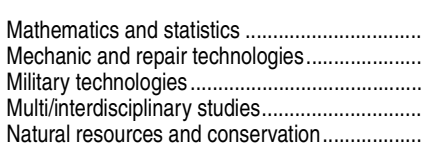 & $\begin{array}{r}111 \\
376 \\
\ddagger \\
283 \\
121\end{array}$ & $\begin{array}{r}86.2 \\
54.7 \\
\ddagger \\
61.4 \\
79.3\end{array}$ & $\begin{array}{r}(2.43) \\
(\dagger) \\
(2.35) \\
(3.13)\end{array}$ & $\begin{array}{r}10.8 \\
27.8 \\
\ddagger \\
24.7 \\
11.7\end{array}$ & $\begin{array}{r}(1.93) \\
(\dagger) \\
(2.04) \\
(1.92)\end{array}$ & $\begin{array}{r}3.0 ! \\
17.5 \\
\ddagger \\
13.9 \\
9.0\end{array}$ & $\begin{array}{r}(1.13) \\
(1.72) \\
(\dagger) \\
(1.91) \\
(2.52)\end{array}$ & $\begin{array}{r}28 \\
341 \\
\ddagger \\
117 \\
39\end{array}$ & $\begin{array}{r}70.9 \\
54.0 \\
\ddagger \\
60.7 \\
79.1\end{array}$ & $\begin{array}{r}(6.04) \\
(2.43) \\
(\dagger) \\
(3.66) \\
(5.64)\end{array}$ & $\begin{array}{r}25.1 \\
29.1 \\
\ddagger \\
26.1 \\
11.6\end{array}$ & $\begin{array}{r}(6.26) \\
(1.94) \\
(\dagger) \\
(3.46) \\
(3.02)\end{array}$ & $\begin{array}{r}\ddagger \\
17.0 \\
\ddagger \\
13.3 \\
9.3 !\end{array}$ & $\begin{array}{r}(1.80) \\
(\dagger) \\
(2.89) \\
(4.51)\end{array}$ & $\begin{array}{r}82 \\
35 \\
\ddagger \\
166 \\
82\end{array}$ & $\begin{array}{r}91.5 \\
62.3 \\
\ddagger \\
61.9 \\
79.4\end{array}$ & $\begin{array}{r}(2.17) \\
(8.37) \\
(\dagger) \\
(2.99) \\
(3.42)\end{array}$ & $\begin{array}{c}5.8 ! \\
15.0 ! \\
\ddagger \\
23.8 \\
11.7\end{array}$ & $\begin{array}{r}(1.84) \\
(5.50) \\
(t) \\
(2.44) \\
(2.28)\end{array}$ & $\begin{array}{c}2.6 ! \\
22.7 \\
\ddagger \\
14.3 \\
8.8 !\end{array}$ & $\begin{array}{r}(1.22) \\
(6.78) \\
(\dagger) \\
(2.63) \\
(2.81)\end{array}$ & $\begin{array}{r}25 \\
\neq \\
\ddagger \\
36 \\
22\end{array}$ \\
\hline 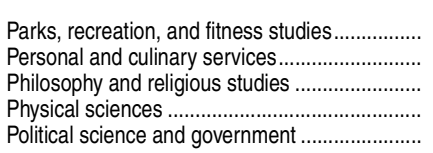 & $\begin{array}{r}253 \\
562 \\
64 \\
207 \\
175\end{array}$ & $\begin{array}{l}85.8 \\
57.2 \\
71.6 \\
80.4 \\
87.7\end{array}$ & $\begin{array}{l}(1.65) \\
(2.01) \\
(6.19) \\
(2.65) \\
(2.11)\end{array}$ & $\begin{array}{r}10.1 \\
27.3 \\
22.4 \\
13.3 \\
9.6\end{array}$ & $\begin{array}{l}(1.50) \\
(1.44) \\
(5.96) \\
(1.90) \\
(1.79)\end{array}$ & $\begin{array}{c}4.1 \\
15.5 \\
6.1 ! \\
6.4 \\
2.7 !\end{array}$ & $\left.\begin{array}{l}(1.22) \\
(1.53) \\
(2.67) \\
(1.75) \\
(1.01)\end{array}\right)$ & $\begin{array}{r}67 \\
500 \\
13 \\
67 \\
35\end{array}$ & $\begin{array}{l}74.9 \\
57.3 \\
82.3 \\
69.8 \\
74.2\end{array}$ & $\begin{array}{r}(3.95) \\
(2.16) \\
(10.84) \\
(5.11) \\
(8.12)\end{array}$ & $\begin{array}{r}17.2 \\
27.1 \\
\ddagger \\
19.0 \\
20.9 !\end{array}$ & $\begin{array}{r}(3.73) \\
(1.40) \\
(\dagger) \\
(3.14) \\
(7.21)\end{array}$ & $\begin{array}{c}7.9 ! \\
15.5 \\
\ddagger \\
11.2 ! \\
\ddagger\end{array}$ & $\begin{array}{r}(0.11) \\
(1.59) \\
(\dagger) \\
(4.37) \\
(\dagger)\end{array}$ & $\begin{array}{r}186 \\
63 \\
51 \\
140 \\
140\end{array}$ & $\begin{array}{l}89.7 \\
56.6 \\
68.9 \\
85.5 \\
91.2\end{array}$ & $\begin{array}{l}(1.71) \\
(5.75) \\
(6.93) \\
(2.97) \\
(1.67)\end{array}$ & $\begin{array}{r}7.6 \\
28.3 \\
26.7 \\
10.5 \\
6.7\end{array}$ & $(1.38)$ & $\begin{array}{c}2.7 ! \\
15.0 \\
\ddagger \\
4.0 ! \\
2.1 !\end{array}$ & $\begin{array}{r}(1.28) \\
(4.41) \\
(\dagger) \\
(1.62) \\
(0.96)\end{array}$ & $\begin{array}{r}17 \\
\ddagger \\
20 \\
61 \\
17\end{array}$ \\
\hline 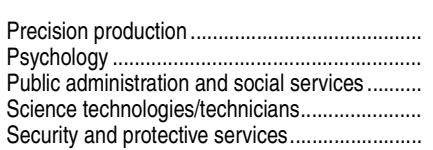 & $\begin{array}{r}103 \\
794 \\
305 \\
41 \\
970\end{array}$ & $\begin{array}{l}50.9 \\
69.0 \\
46.0 \\
49.2 \\
59.5\end{array}$ & $\begin{array}{l}(1.49) \\
(2.14) \\
(6.78) \\
(1.76)\end{array}$ & $\begin{array}{l}20.3 \\
29.5 \\
28.2 \\
26.9\end{array}$ & $\begin{array}{l}(1.24) \\
(2.23) \\
(6.33) \\
(1.13)\end{array}$ & $\begin{array}{l}10.7 \\
24.4 \\
22.5 \\
13.7\end{array}$ & $\begin{array}{l}(0.92) \\
(2.08) \\
(5.67) \\
(1.37)\end{array}$ & $\begin{array}{r}99 \\
210 \\
131 \\
32 \\
476\end{array}$ & $\begin{array}{l}66.7 \\
45.2 \\
43.7 \\
66.5\end{array}$ & $\begin{array}{l}(2.95) \\
(3.54) \\
(7.27) \\
(1.76)\end{array}$ & $\begin{array}{l}23.1 \\
27.2 \\
29.3 \\
25.6\end{array}$ & $\begin{array}{l}(2.53) \\
(3.13) \\
(7.59) \\
(1.61)\end{array} \mid$ & $\begin{array}{r}10.3 \\
27.5 \\
27.1 \\
7.9\end{array}$ & $\begin{array}{l}(1.88) \\
(3.34) \\
(7.12) \\
(0.93)\end{array}$ & $\begin{array}{r}\mp \\
584 \\
174 \\
\ddagger \\
\ddagger \\
494\end{array}$ & $\begin{array}{r}69.9 \\
46.7 \\
\ddagger \\
52.6\end{array}$ & $\begin{array}{r}(1.60) \\
(2.76) \\
(+) \\
(2.70)\end{array} \mid$ & $\begin{array}{r}\ddagger \\
19.3 \\
31.2 \\
\ddagger \\
28.1\end{array}$ & $\begin{array}{r}(1.39) \\
(3.14) \\
(+) \\
(1.53)\end{array}$ & $\begin{array}{r}\ddagger \\
10.8 \\
22.1 \\
\ddagger \\
19.2\end{array}$ & $\begin{array}{r}(\mathrm{T}) \\
(1.08) \\
(2.48) \\
(\dagger) \\
(2.36)\end{array} \mid$ & $\begin{array}{r}\dagger \\
150 \\
124 \\
\neq \\
4 \\
43\end{array}$ \\
\hline
\end{tabular}

\footnotetext{
See notes at end of table.
} 
Table 311.60. Enrollment in postsecondary education, by level of enrollment, level of institution, student age, and major field of study: 2011-12-Continued

[Standard errors appear in parentheses]

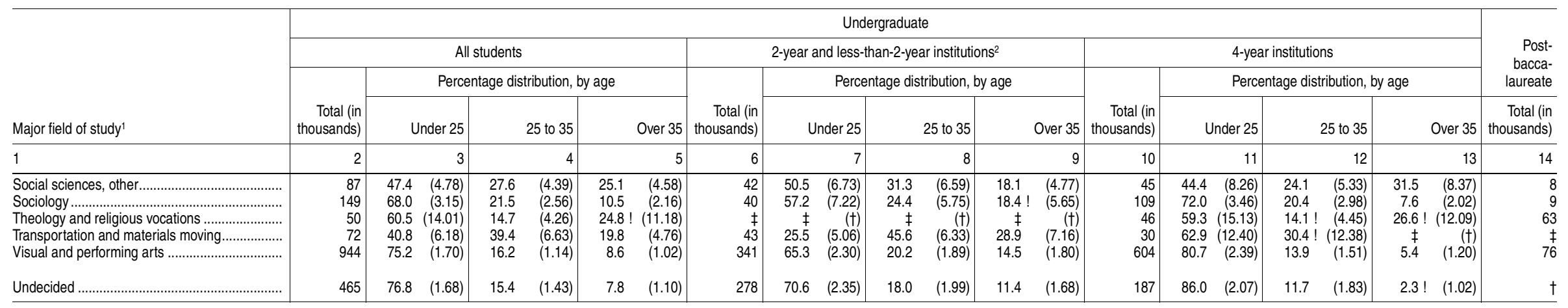

†Not applicable.

\#Rounds to zero. !Interpret data with caution. The coefficient of variation (CV) for this estimate is between 30 and 50 percent.
†Reporting standards not met. Either there are too few cases for a reliable estimate or the coefficient of variation (CV) is 50

percent or greater. dents who had decided on, but not yet declared, an intended major. The "Undecided" category consists of undergraduate students who had neither declared nor decided on a major.
${ }^{2}$ Also includes students attending more than one institution.

NOTE: Because of different survey editing and processing procedures, enrollment data in this table may differ from those appearing in other tables. Includes students who enrolled at any time during the 2011-12 academic year. Data exclude Puerto Rico. Data have been revised from previously published figures. Detail may not sum to totals because of rounding.

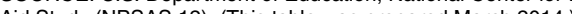


Table 311.70. Course enrollments in languages other than English compared with total enrollment at degree-granting postsecondary institutions, by enrollment level, institution level, and language: Selected years, 1965 through 2009

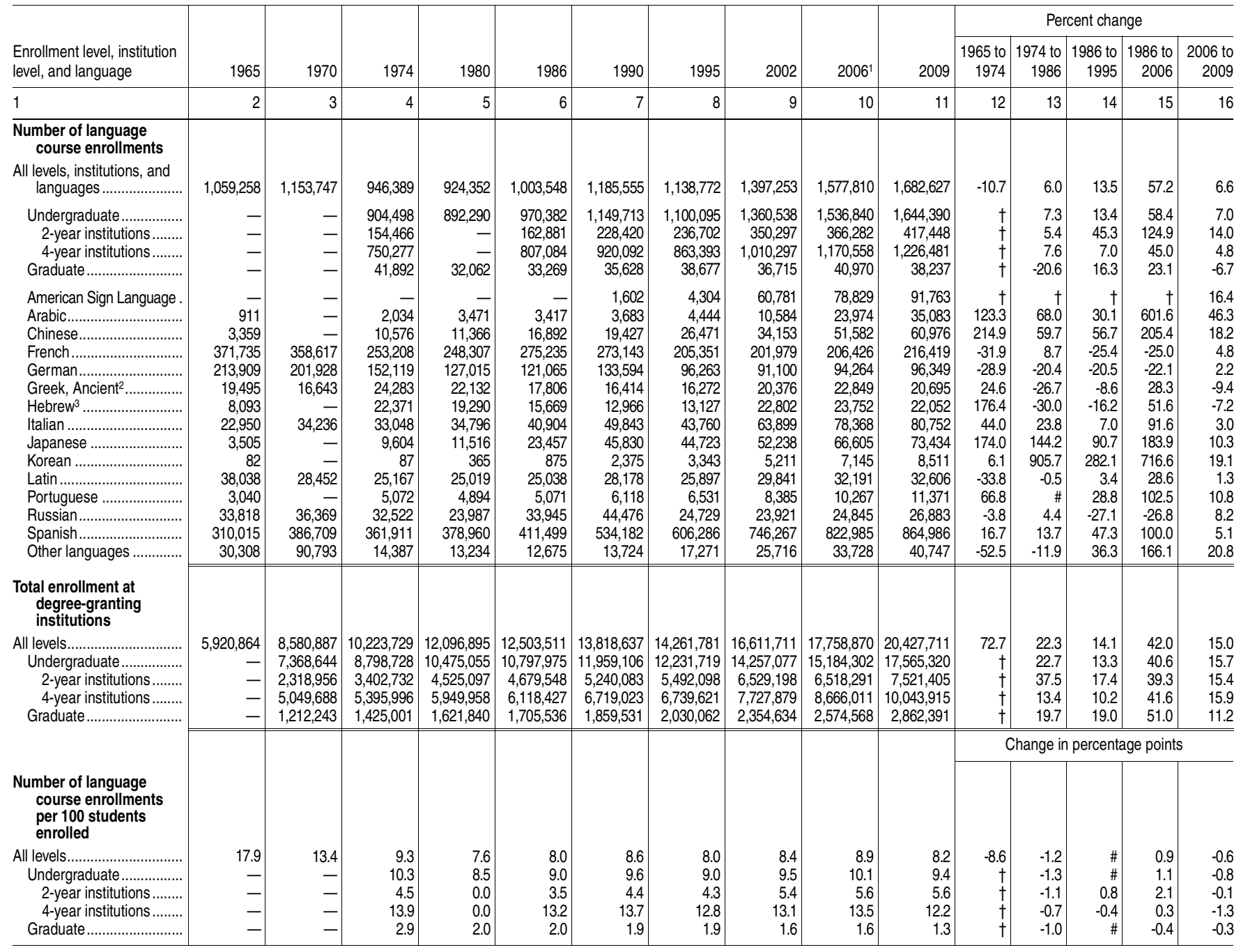

-Not available.

$\dagger$ Not applicable.

\#Rounds to zero.

IIn 2006, a few 2-year institutions reported a total of 226 graduate course enrollments (86 in Spanish and 140 in American Sign Language). In this table, these 226 enrollments are shown as undergraduate enrollments in 2-year institutions; these enrollments are not included under graduate enrollments.

${ }^{2}$ The apparent drop in Ancient Greek from 2006 to 2009 may be attributed to changes in reporting. Some premodern Greek language categories, such as Koine Greek and Old Testament Greek, were reported for the first time in 2009. In previous surveys, these languages may have been reported under the category "Ancient Greek."

${ }^{3}$ For 1990 and later years, includes only "Modern Hebrew" and "Biblical Hebrew"; other reported categories of Hebrew courses are excluded.

NOTE: The number of course enrollments is not the same as the number of students studying a given language. A single student majoring in a language may be enrolled in more than one class in that language. Unless otherwise noted, enrollments do not include those in classical, religious, or regional dialects of the language. Data through 1995 are for institutions of higher education, while later data are for degree-granting institutions. Degreegranting institutions grant associate's or higher degrees and participate in Title IV federal financial aid programs. The degree-granting classification is very similar to the earlier higher education classification, but it includes more 2-year colleges and excludes a few higher education institutions that did not grant degrees. (See Appendix A: Guide to Sources for details.)

SOURCE: The Modern Language Association of America, Enrollments in Languages Other Than English in United States Institutions of Higher Education, Fall 2009, Table 2c; and MLA historical enrollment data, 1958-70, 1971-86, 1990-98, and 2002-09, retrieved July 21,2011 , from http://www.mla.org/about search flsurvey. U.S. Department of Education, National Center for Education Statistics, Opening Fall Enrollment in Higher Education, 1965; Higher Education General Information Survey (HEGIS), "Fall Enrollment in Institutions of Higher Education" surveys, 1970 through 1980; Integrated Postsecondary Education Data System (IPEDS), "Fall Enrollment Survey" (IPEDS-EF:86-95); and IPEDS Spring 2003 through Spring 2010, Enrollment component. (This table was prepared July 2011.) 


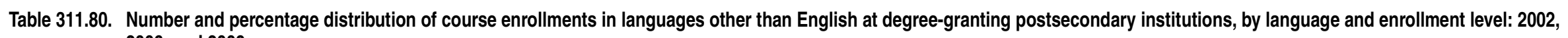
2006, and 2009

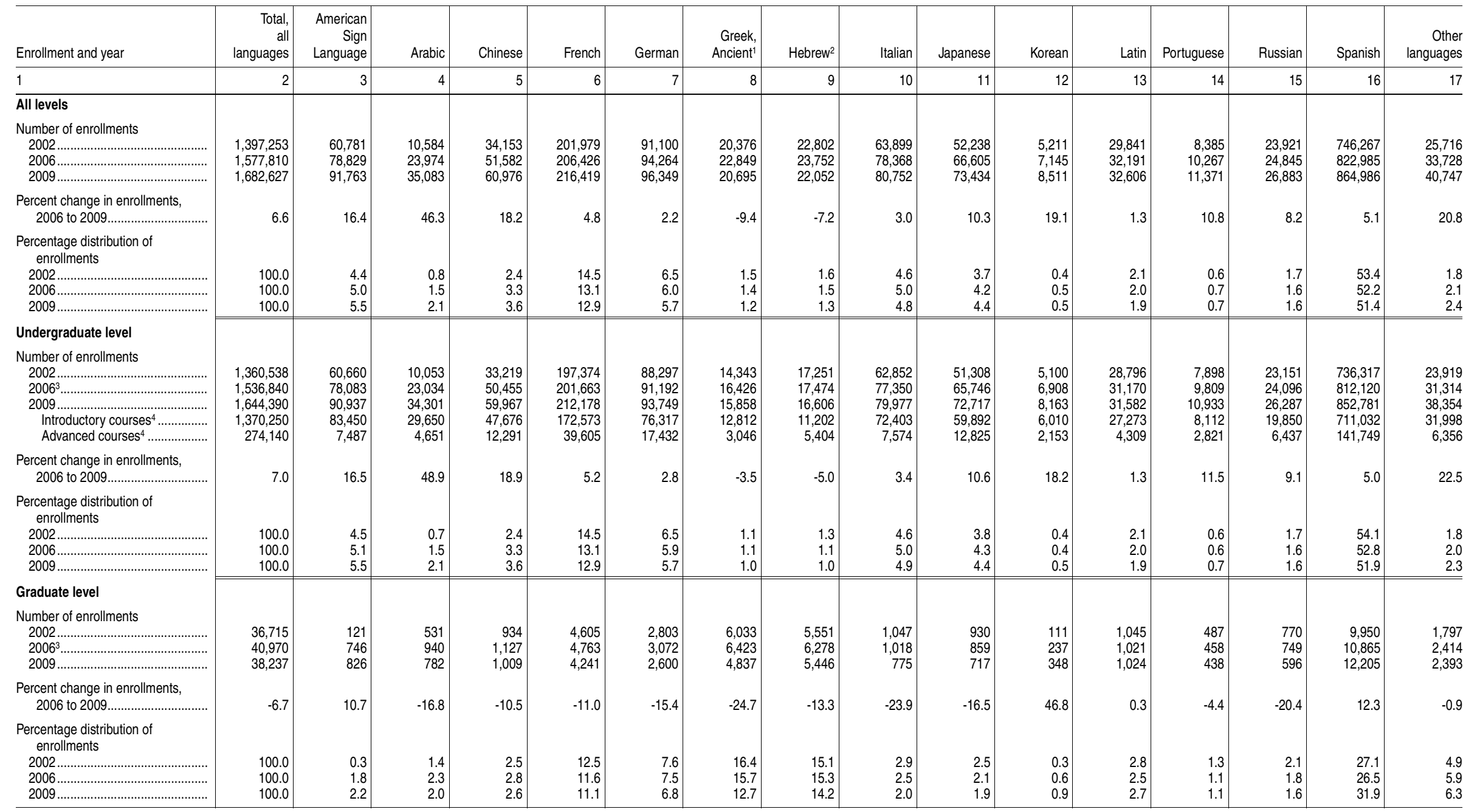

'The apparent drop in Ancient Greek from 2006 to 2009 may be attributed to changes in reporting. Some premodern Greek language categories, such as Koine Greek and Old Testament Greek, were reported for the first time in 2009. In previous surlanguage categories, such as Koine Greek and Old Testament Greek, were reported
veys, these languages may have been reported under the category "Ancient Greek."

"Includes only "Modern Hebrew" and "Biblical Hebrew"; other reported categories of Hebrew courses are excluded.

${ }^{3}$ In 2006, a few 2-year institutions reported a total of 226 graduate course enrollments (86 in Spanish and 140 in American Sign Language). In this table, these 226 enrollments are shown as undergraduate enrollments; these enrollments are not

${ }^{4}$ Introductory courses are first- and second-year courses. Advanced courses are third- and fourth-year courses.

in a language may be guages do not include classical, religious, or regional dialects. Degree-granting institutions grant associate's or higher degrees and participate in Title IV federal financial aid programs.

SOURCE: The Modern Language Association of America, MLA historical enrollment data, 2002-09, retrieved July 21, 2011, from http://www.mla.org/about search flsurvey. (This table was prepared July 2011.) 
Table 311.90. Graduate enrollment in science and engineering programs in degree-granting postsecondary institutions, by discipline: Fall 1999 through fall 2011

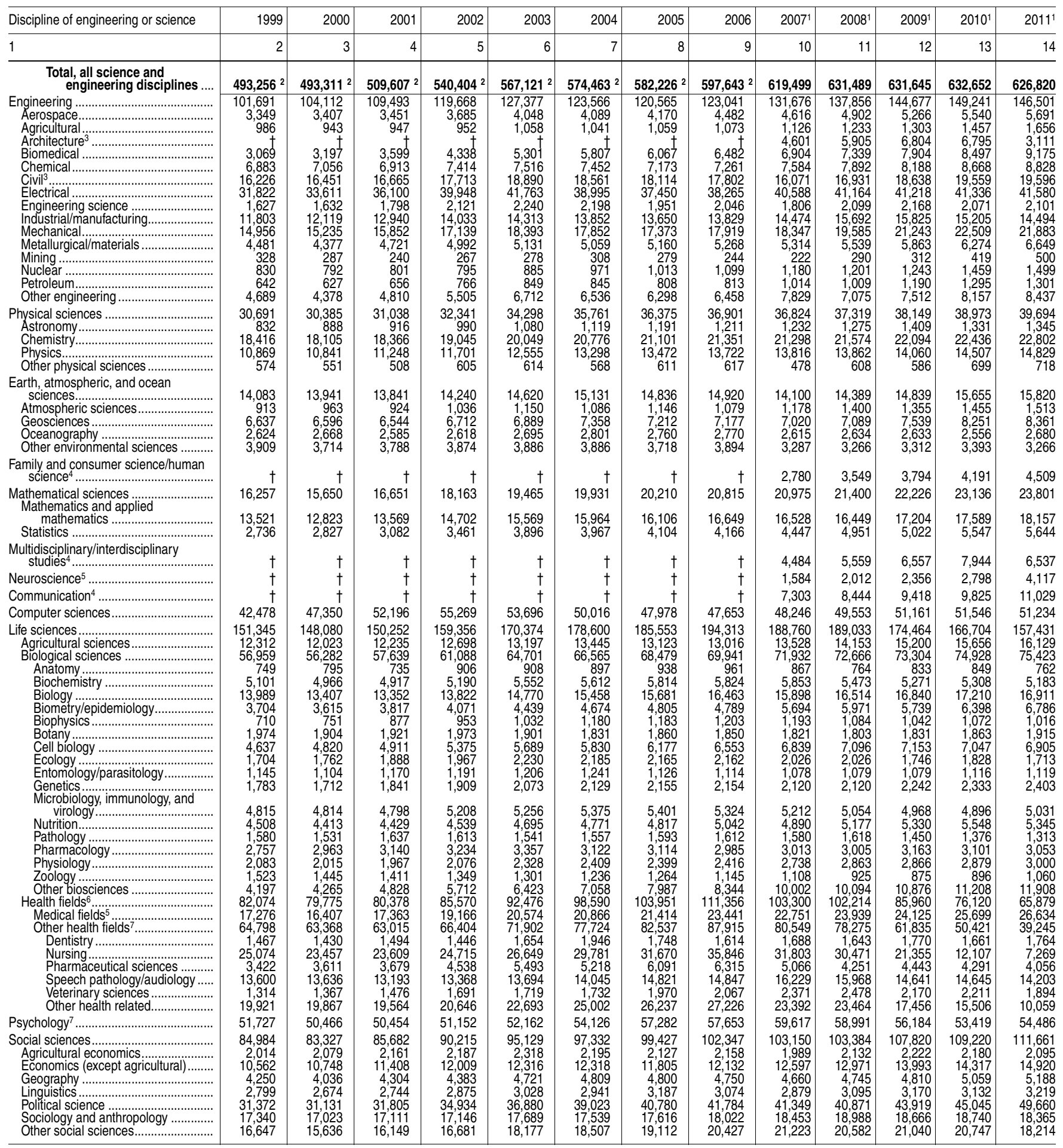

†Not applicable.

'Data for 2007 and later years may not be comparable to previous years' data because some surveyed fields were reclassified, new fields were added, and the survey was redesigned to improve coverage and coding.

'Because three fields were added to the survey in 2007, previous years' totals for all fields are not comparable to the totals for 2007 and later years.

${ }^{3}$ Before 2007, architecture was included under civil engineering instead of being reported as a separate field of engineering

${ }^{4}$ Three science fields-family and consumer science/human science, multidisciplinary/ interdisciplinary studies, and communication - were added to the survey in 2007; some of the data may have been reported under other fields prior to 2007.

${ }^{5}$ Before 2007, neuroscience was included under the health/medical field of neurology instead of being reported as a separate field of science.
${ }^{6}$ Excludes enrollments in practitioner-oriented programs, which have the primary purpose of providing the knowledge and skills required for credentials or licensure to practice in a medical or other health field.

${ }^{7}$ For 2008 and later years, enrollment declines in psychology and in other health fields such as nursing may be due to more rigorous follow-up with institutions to exclude enrollments in practitioner-oriented graduate degree programs. Examples of excluded programs are those leading to DNP, PsyD, and DPT degrees.

NOTE: The survey on which this table is based includes institutions in other jurisdictions, including Guam, Puerto Rico, and the U.S. Virgin Islands. Detail may not sum to totals because of rounding. Some data have been revised from previously published figures. SOURCE: National Science Foundation, National Center for Science and Engineering Statistics, NSF-NIH Survey of Graduate Students and Postdoctorates in Science and Engineering, 1999 through 2011. (This table was prepared February 2014.) 
CHAPTER 3: Postsecondary Education 465

Large Institutions and Institutions Serving Specific Groups

Table 312.10. Enrollment of the 120 largest degree-granting college and university campuses, by selected characteristics and institution: Fall 2012

\begin{tabular}{|c|c|c|c|c|c|c|c|c|c|c|c|}
\hline Institution & State & Rank $^{1}$ & Control2 & Level & $\begin{array}{r}\text { Total } \\
\text { enroll- } \\
\text { ment }\end{array}$ & Institution & State & Rank $^{1}$ & Control2 & Level & $\begin{array}{r}\text { Total } \\
\text { enroll- } \\
\text { ment }\end{array}$ \\
\hline 1 & 2 & 3 & 4 & 5 & 6 & 1 & 2 & 3 & 4 & $\sigma$ & 6 \\
\hline 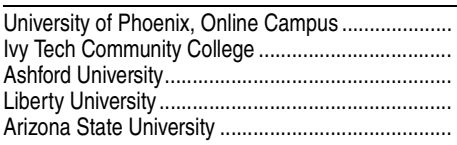 & $\begin{array}{r}\text { AZ } \\
\text { IN } \\
\text { IA } \\
\text { VA } \\
\text { AZ }\end{array}$ & $\begin{array}{l}1 \\
2 \\
3 \\
4 \\
5\end{array}$ & \begin{tabular}{|r|} 
PrivFp \\
Public \\
PrivFp \\
PrivNp \\
Public
\end{tabular} & $\begin{array}{l}\text { 4-year } \\
\text { 2-year } \\
\text { 4-year } \\
\text { 4-year } \\
\text { 4-year }\end{array}$ & \begin{tabular}{r|}
256,402 \\
100,272 \\
77,734 \\
74,372 \\
73,378
\end{tabular} & 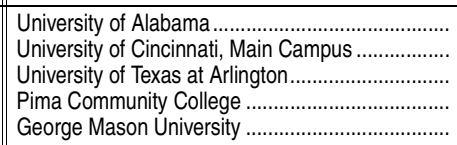 & \begin{tabular}{l|}
$\mathrm{AL}$ \\
$\mathrm{OH}$ \\
$\mathrm{TX}$ \\
$\mathrm{AZ}$ \\
$\mathrm{VA}$
\end{tabular} & $\begin{array}{l}61 \\
62 \\
63 \\
64 \\
65\end{array}$ & $\begin{array}{l}\text { Public } \\
\text { Public } \\
\text { Public } \\
\text { Public } \\
\text { Public }\end{array}$ & $\begin{array}{l}\text { 4-year } \\
\text { 4-year } \\
\text { 4-year } \\
\text { 2-year } \\
\text { 4-year }\end{array}$ & $\begin{array}{l}33,503 \\
33,347 \\
33,239 \\
32,988 \\
32,961\end{array}$ \\
\hline 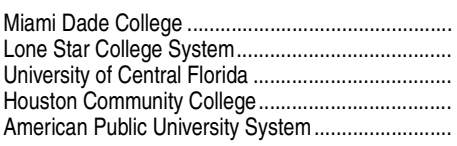 & $\begin{array}{r}\mathrm{FL} \\
\mathrm{TX} \\
\mathrm{FL} \\
\mathrm{TX} \\
\mathrm{WV}\end{array}$ & $\begin{array}{r}6 \\
7 \\
8 \\
9 \\
10\end{array}$ & $\begin{array}{l}\text { Public } \\
\text { Public } \\
\text { Public } \\
\text { Public } \\
\text { PrivFp }\end{array}$ & $\begin{array}{l}\text { 4-year } \\
\text { 2-year } \\
\text { 4-year } \\
\text { 2-year } \\
\text { 4-year }\end{array}$ & $\begin{array}{l}66,701 \\
60,428 \\
59,601 \\
58,476 \\
58,115\end{array}$ & 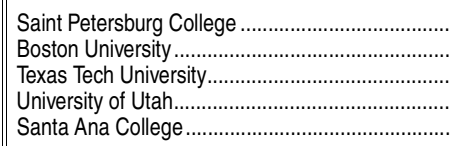 & $\begin{array}{l}\mathrm{FL} \\
\mathrm{MA} \\
\mathrm{TX} \\
\mathrm{UT} \\
\mathrm{CA}\end{array}$ & $\begin{array}{l}66 \\
67 \\
68 \\
69 \\
70\end{array}$ & $\begin{array}{r}\text { Public } \\
\text { PrivNp } \\
\text { Public } \\
\text { Public } \\
\text { Public }\end{array}$ & $\begin{array}{l}\text { 4-year } \\
\text { 4-year } \\
\text { 4-year } \\
\text { 4-year } \\
\text { 2-year }\end{array}$ & $\begin{array}{l}32,612 \\
32,603 \\
32,467 \\
32,388 \\
32,354\end{array}$ \\
\hline 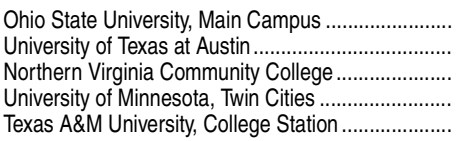 & $\begin{array}{r}\mathrm{OH} \\
\mathrm{TX} \\
\mathrm{VA} \\
\mathrm{MN} \\
\mathrm{TX}\end{array}$ & $\begin{array}{l}11 \\
12 \\
13 \\
14 \\
15\end{array}$ & $\begin{array}{l}\text { Public } \\
\text { Public } \\
\text { Public } \\
\text { Public } \\
\text { Public }\end{array}$ & $\begin{array}{l}\text { 4-year } \\
\text { 4-year } \\
\text { 2-year } \\
\text { 4-year } \\
\text { 4-year }\end{array}$ & $\begin{array}{l}56,387 \\
52,186 \\
51,864 \\
51,853 \\
50,627\end{array}$ & 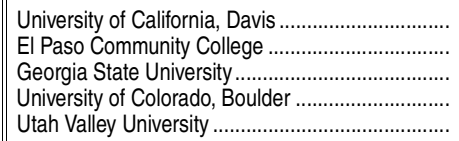 & $\begin{array}{l}\text { CA } \\
\text { TX } \\
\text { GA } \\
\text { CO } \\
\text { UT }\end{array}$ & $\begin{array}{l}71 \\
72 \\
73 \\
74 \\
75\end{array}$ & $\begin{array}{l}\text { Public } \\
\text { Public } \\
\text { Public } \\
\text { Public } \\
\text { Public }\end{array}$ & $\begin{array}{l}\text { 4-year } \\
\text { 2-year } \\
\text { 4-year } \\
\text { 4-year } \\
\text { 4-year }\end{array}$ & $\begin{array}{l}32,354 \\
32,127 \\
32,087 \\
31,945 \\
31,562\end{array}$ \\
\hline 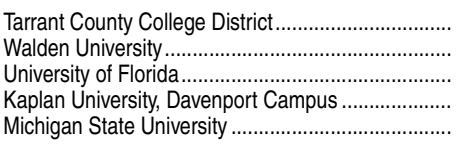 & $\begin{array}{r}\mathrm{TX} \\
\mathrm{MN} \\
\mathrm{FL} \\
\mathrm{IA} \\
\mathrm{MI}\end{array}$ & $\begin{array}{l}16 \\
17 \\
18 \\
19 \\
20\end{array}$ & \begin{tabular}{|c|} 
Public \\
PrivFp \\
Public \\
PrivFp \\
Public
\end{tabular} & $\begin{array}{l}\text { 2-year } \\
\text { 4-year } \\
\text { 4-year } \\
\text { 4-year } \\
\text { 4-year }\end{array}$ & $\begin{array}{l}50,439 \\
50,209 \\
49,913 \\
48,865 \\
48,783\end{array}$ & 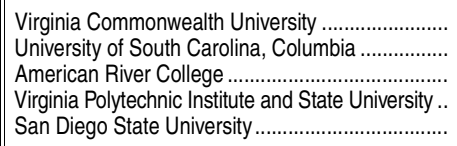 & $\begin{array}{l}\text { VA } \\
\text { SC } \\
\text { CA } \\
\text { VA } \\
\text { CA }\end{array}$ & $\begin{array}{l}76 \\
77 \\
78 \\
79 \\
80\end{array}$ & $\begin{array}{l}\text { Public } \\
\text { Public } \\
\text { Public } \\
\text { Public } \\
\text { Public }\end{array}$ & $\begin{array}{l}\text { 4-year } \\
\text { 4-year } \\
\text { 2-year } \\
\text { 4-year } \\
\text { 4-year }\end{array}$ & $\begin{array}{l}31,445 \\
31,288 \\
31,088 \\
31,087 \\
30,843\end{array}$ \\
\hline 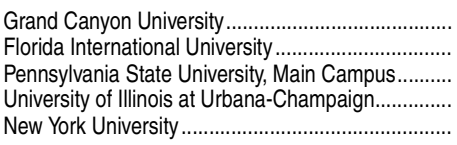 & \begin{tabular}{r|}
$\mathrm{AZ}$ \\
$\mathrm{FL}$ \\
$\mathrm{PA}$ \\
$\mathrm{IL}$ \\
$\mathrm{NY}$
\end{tabular} & $\begin{array}{l}21 \\
22 \\
23 \\
24 \\
25\end{array}$ & \begin{tabular}{|r|} 
PrivFp \\
Public \\
Public \\
Public \\
PrivNp
\end{tabular} & $\begin{array}{l}\text { 4-year } \\
\text { 4-year } \\
\text { 4-year } \\
\text { 4-year } \\
\text { 4-year }\end{array}$ & $\begin{array}{l}48,650 \\
46,171 \\
45,783 \\
44,520 \\
44,516\end{array}$ & 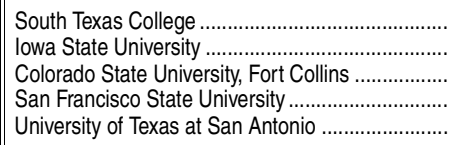 & $\begin{array}{r}\mathrm{TX} \\
\mathrm{IA} \\
\mathrm{CO} \\
\mathrm{CA} \\
\mathrm{TX}\end{array}$ & $\begin{array}{l}81 \\
82 \\
83 \\
84 \\
85\end{array}$ & $\begin{array}{l}\text { Public } \\
\text { Public } \\
\text { Public } \\
\text { Public } \\
\text { Public }\end{array}$ & $\begin{array}{l}\text { 4-year } \\
\text { 4-year } \\
\text { 4-year } \\
\text { 4-year } \\
\text { 4-year }\end{array}$ & $\begin{array}{l}30,824 \\
30,748 \\
30,659 \\
30,500 \\
30,474\end{array}$ \\
\hline 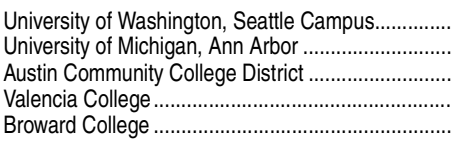 & $\begin{array}{c}\text { WA } \\
\mathrm{Ml} \\
\mathrm{TX} \\
\mathrm{FL} \\
\mathrm{FL}\end{array}$ & $\begin{array}{l}26 \\
27 \\
28 \\
29 \\
30\end{array}$ & $\begin{array}{l}\text { Public } \\
\text { Public } \\
\text { Public } \\
\text { Public } \\
\text { Public }\end{array}$ & $\begin{array}{l}\text { 4-year } \\
\text { 4-year } \\
\text { 2-year } \\
\text { 4-year } \\
\text { 4-year }\end{array}$ & $\begin{array}{l}43,485 \\
43,426 \\
43,315 \\
42,915 \\
42,309\end{array}$ & 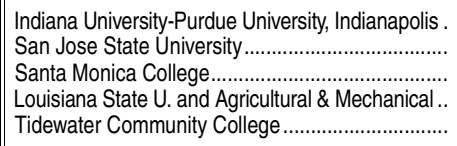 & $\begin{array}{l}\text { IN } \\
\text { CA } \\
\text { CA } \\
\text { LA } \\
\text { VA }\end{array}$ & $\begin{array}{l}86 \\
87 \\
88 \\
89 \\
90\end{array}$ & $\begin{array}{l}\text { Public } \\
\text { Public } \\
\text { Public } \\
\text { Public } \\
\text { Public }\end{array}$ & $\begin{array}{l}\text { 4-year } \\
\text { 4-year } \\
\text { 2-year } \\
\text { 4-year } \\
\text { 2-year }\end{array}$ & $\begin{array}{l}30,451 \\
30,448 \\
30,254 \\
30,225 \\
30,134\end{array}$ \\
\hline 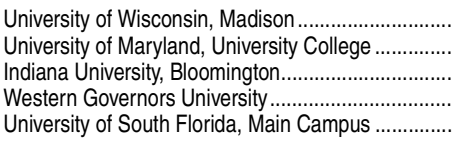 & $\begin{array}{r}\text { WI } \\
\mathrm{MD} \\
\mathrm{IN} \\
\mathrm{UT} \\
\mathrm{FL}\end{array}$ & $\begin{array}{l}31 \\
32 \\
33 \\
34 \\
35\end{array}$ & $\begin{array}{r}\text { Public } \\
\text { Public } \\
\text { Public } \\
\text { PrivNp } \\
\text { Public }\end{array}$ & $\begin{array}{l}\text { 4-year } \\
\text { 4-year } \\
\text { 4-year } \\
\text { 4-year } \\
\text { 4-year }\end{array}$ & $\begin{array}{l}42,269 \\
42,268 \\
42,133 \\
41,369 \\
41,116\end{array}$ & 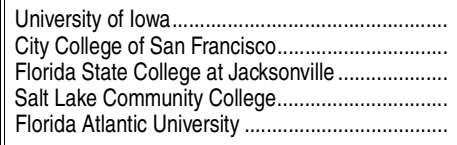 & $\begin{array}{l}\text { IA } \\
\mathrm{CA} \\
\mathrm{FL} \\
\mathrm{UT} \\
\mathrm{FL}\end{array}$ & $\begin{array}{l}91 \\
92 \\
93 \\
94 \\
95\end{array}$ & $\begin{array}{l}\text { Public } \\
\text { Public } \\
\text { Public } \\
\text { Public } \\
\text { Public }\end{array}$ & $\begin{array}{l}\text { 4-year } \\
\text { 2-year } \\
\text { 4-year } \\
\text { 2-year } \\
\text { 4-year }\end{array}$ & $\begin{array}{l}30,129 \\
30,106 \\
30,053 \\
29,997 \\
29,994\end{array}$ \\
\hline 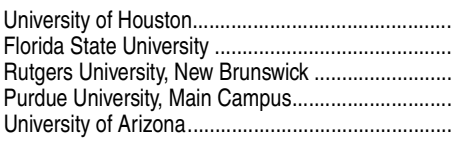 & \begin{tabular}{r|}
$\mathrm{TX}$ \\
$\mathrm{FL}$ \\
$\mathrm{NJ}$ \\
$\mathrm{IN}$ \\
$\mathrm{AZ}$
\end{tabular} & $\begin{array}{l}36 \\
37 \\
38 \\
39 \\
40\end{array}$ & $\begin{array}{l}\text { Public } \\
\text { Public } \\
\text { Public } \\
\text { Public } \\
\text { Public }\end{array}$ & $\begin{array}{l}\text { 4-year } \\
\text { 4-year } \\
\text { 4-year } \\
\text { 4-year } \\
\text { 4-year }\end{array}$ & $\begin{array}{l}40,747 \\
40,695 \\
40,434 \\
40,393 \\
40,223\end{array}$ & 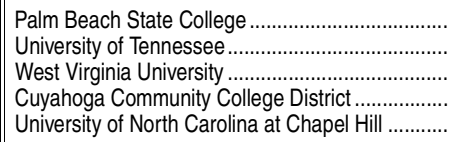 & $\begin{array}{l}\mathrm{FL} \\
\mathrm{TN} \\
\mathrm{WV} \\
\mathrm{OH} \\
\mathrm{NC}\end{array}$ & $\begin{array}{r}96 \\
97 \\
98 \\
99 \\
100\end{array}$ & $\begin{array}{l}\text { Public } \\
\text { Public } \\
\text { Public } \\
\text { Public } \\
\text { Public }\end{array}$ & $\begin{array}{l}\text { 4-year } \\
\text { 4-year } \\
\text { 4-year } \\
\text { 2-year } \\
\text { 4-year }\end{array}$ & $\begin{array}{l}29,974 \\
29,833 \\
29,707 \\
29,701 \\
29,278\end{array}$ \\
\hline 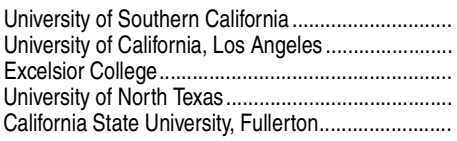 & $\begin{array}{l}\text { CA } \\
\text { CA } \\
\text { NY } \\
\text { TX } \\
\text { CA }\end{array}$ & $\begin{array}{l}41 \\
42 \\
43 \\
44 \\
45\end{array}$ & \begin{tabular}{|r|} 
PrivNp \\
Public \\
PrivNp \\
Public \\
Public
\end{tabular} & $\begin{array}{l}\text { 4-year } \\
\text { 4-year } \\
\text { 4-year } \\
\text { 4-year } \\
\text { 4-year }\end{array}$ & $\begin{array}{l}39,958 \\
39,945 \\
39,728 \\
37,950 \\
37,677\end{array}$ & 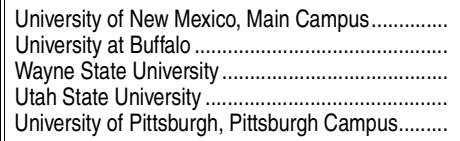 & $\begin{array}{l}\text { NM } \\
\text { NY } \\
\text { MI } \\
\text { UT } \\
\text { PA }\end{array}$ & $\begin{array}{l}101 \\
102 \\
103 \\
104 \\
105\end{array}$ & $\begin{array}{l}\text { Public } \\
\text { Public } \\
\text { Public } \\
\text { Public } \\
\text { Public }\end{array}$ & $\begin{array}{l}\text { 4-year } \\
\text { 4-year } \\
\text { 4-year } \\
\text { 4-year } \\
\text { 4-year }\end{array}$ & $\begin{array}{l}29,033 \\
28,952 \\
28,938 \\
28,786 \\
28,769\end{array}$ \\
\hline 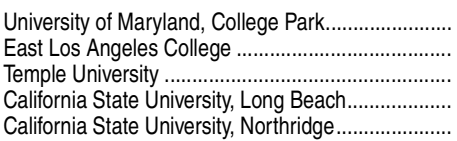 & $\begin{array}{l}\mathrm{MD} \\
\mathrm{CA} \\
\mathrm{PA} \\
\mathrm{CA} \\
\mathrm{CA}\end{array}$ & $\begin{array}{l}46 \\
47 \\
48 \\
49 \\
50\end{array}$ & $\begin{array}{l}\text { Public } \\
\text { Public } \\
\text { Public } \\
\text { Public } \\
\text { Public }\end{array}$ & $\begin{array}{l}\text { 4-year } \\
\text { 2-year } \\
\text { 4-year } \\
\text { 4-year } \\
\text { 4-year }\end{array}$ & $\begin{array}{l}37,248 \\
37,055 \\
36,744 \\
36,279 \\
36,164\end{array}$ & 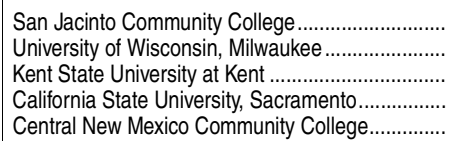 & $\begin{array}{l}\text { TX } \\
\text { WI } \\
\mathrm{OH} \\
\mathrm{CA} \\
\mathrm{NM}\end{array}$ & $\begin{array}{l}106 \\
107 \\
108 \\
109 \\
110\end{array}$ & $\begin{array}{l}\text { Public } \\
\text { Public } \\
\text { Public } \\
\text { Public } \\
\text { Public }\end{array}$ & $\begin{array}{l}\text { 2-year } \\
\text { 4-year } \\
\text { 4-year } \\
\text { 4-year } \\
\text { 2-year }\end{array}$ & $\begin{array}{l}28,721 \\
28,712 \\
28,602 \\
28,539 \\
28,323\end{array}$ \\
\hline 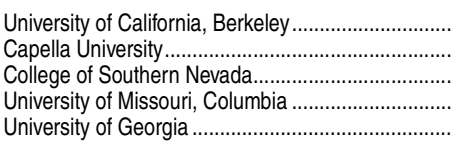 & $\begin{array}{l}\text { CA } \\
\text { MN } \\
\text { NV } \\
\text { MO } \\
\text { GA }\end{array}$ & $\begin{array}{l}51 \\
52 \\
53 \\
54 \\
55\end{array}$ & $\begin{array}{l}\text { Public } \\
\text { PrivFp } \\
\text { Public } \\
\text { Public } \\
\text { Public }\end{array}$ & $\begin{array}{l}\text { 4-year } \\
\text { 4-year } \\
\text { 4-year } \\
\text { 4-year } \\
\text { 4-year }\end{array}$ & $\begin{array}{l}35,893 \\
35,754 \\
35,678 \\
34,704 \\
34,519\end{array}$ & 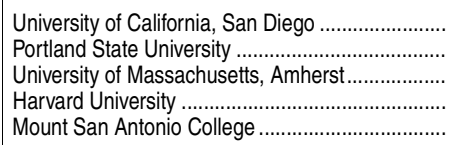 & $\begin{array}{l}\text { CA } \\
\text { OR } \\
\text { MA } \\
\text { MA } \\
\text { CA }\end{array}$ & $\begin{array}{l}111 \\
112 \\
113 \\
114 \\
115\end{array}$ & $\begin{array}{r}\text { Public } \\
\text { Public } \\
\text { Public } \\
\text { PrivNp } \\
\text { Public }\end{array}$ & $\begin{array}{l}\text { 4-year } \\
\text { 4-year } \\
\text { 4-year } \\
\text { 4-year } \\
\text { 2-year }\end{array}$ & $\begin{array}{l}28,294 \\
28,287 \\
28,236 \\
28,147 \\
28,036\end{array}$ \\
\hline 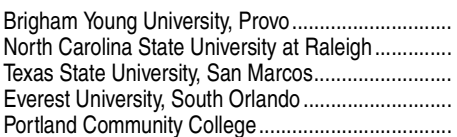 & $\begin{array}{l}\text { UT } \\
\text { NC } \\
\text { TX } \\
\text { FL } \\
\text { OR }\end{array}$ & $\begin{array}{l}56 \\
57 \\
58 \\
59 \\
60\end{array}$ & \begin{tabular}{|r|} 
PrivNp \\
Public \\
Public \\
PrivFp \\
Public
\end{tabular} & $\begin{array}{l}\text { 4-year } \\
\text { 4-year } \\
\text { 4-year } \\
\text { 4-year } \\
\text { 2-year }\end{array}$ & $\begin{array}{l}34,409 \\
34,340 \\
34,225 \\
33,852 \\
33,767\end{array}$ & 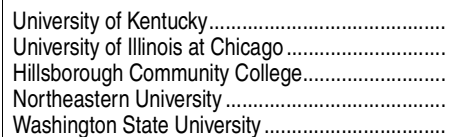 & $\begin{array}{l}\text { KY } \\
\text { IL } \\
\text { FL } \\
\text { MA } \\
\text { WA }\end{array}$ & $\begin{array}{l}116 \\
117 \\
118 \\
119 \\
120\end{array}$ & $\begin{array}{r}\text { Public } \\
\text { Public } \\
\text { Public } \\
\text { PrivNp } \\
\text { Public }\end{array}$ & $\begin{array}{l}\text { 4-year } \\
\text { 4-year } \\
\text { 2-year } \\
\text { 4-year } \\
\text { 4-year }\end{array}$ & $\begin{array}{l}28,034 \\
27,875 \\
27,754 \\
27,694 \\
27,679\end{array}$ \\
\hline
\end{tabular}

${ }^{1}$ College and university campuses ranked by fall 2012 enrollment data. 2 "PrivNp" stands for private nonprofit. "PrivFp" stands for private for-profit.

NOTE: Degree-granting institutions grant associate's or higher degrees and participate in Title IV

federal financial aid programs. Includes online and distance education courses.
SOURCE: U.S. Department of Education, National Center for Education Statistics, Integrated Postsecondary Education Data System (IPEDS), Spring 2013, Enrollment component. (This table was prepared May 2014.) 
Table 312.20. Selected statistics for degree-granting postsecondary institutions enrolling more than 15,000 students in 2012 , by selected institution and student characteristics: Selected years, 1990 through 2011-12

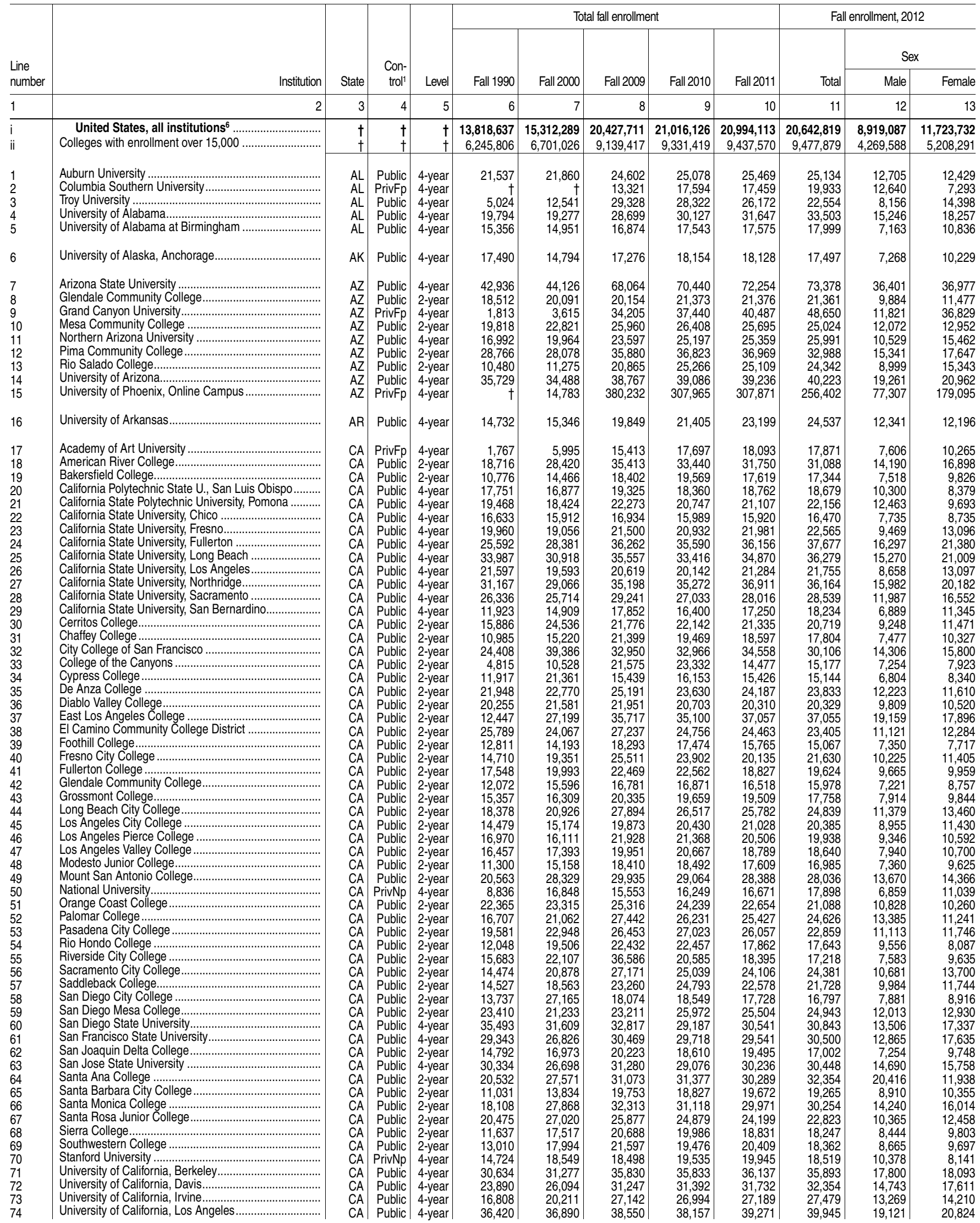


Table 312.20. Selected statistics for degree-granting postsecondary institutions enrolling more than 15,000 students in 2012 , by selected institution and student characteristics: Selected years, 1990 through 2011-12-Continued

\begin{tabular}{|c|c|c|c|c|c|c|c|c|c|c|c|c|c|}
\hline \multicolumn{5}{|c|}{ Fall enrollment, 2012} & \multicolumn{5}{|c|}{ Earned degrees/certificates conferred, 2011-12 } & \multirow{3}{*}{$\begin{array}{r}\text { Total } \\
\text { expenses and } \\
\text { deductions, } \\
2011-12 \\
\text { (in thousands) }\end{array}$} & \multicolumn{2}{|c|}{ Full-time-equivalent enrollment } & \multirow[b]{3}{*}{$\begin{array}{r}\text { Line } \\
\text { number }\end{array}$} \\
\hline \multicolumn{2}{|c|}{ Attendance status } & \multirow[b]{2}{*}{$\begin{array}{r}\text { Percent } \\
\text { minority }{ }^{3}\end{array}$} & \multicolumn{2}{|c|}{ Student level } & \multirow[b]{2}{*}{ Certificates $^{4}$} & & & & & & & & \\
\hline Full-time & Part-time & & $\begin{array}{r}\text { Under- } \\
\text { graduate }\end{array}$ & $\begin{array}{r}\text { Postbacca- } \\
\text { laureate }\end{array}$ & & Associate's & Bachelor's & Master's & Doctor's ${ }^{5}$ & & Fall 2011 & Fall 2012 & \\
\hline 14 & 15 & 16 & 17 & 18 & 19 & 20 & 21 & 22 & 23 & 24 & 25 & 26 & 27 \\
\hline $\begin{array}{r}12,737,013 \\
5,926,700 \\
\end{array}$ & $\begin{array}{l}7,905,806 \\
3,551,179 \\
\end{array}$ & $\begin{array}{l}39.7 \\
42.3 \\
\end{array}$ & $\begin{array}{r}17,732,431 \\
7,914,808 \\
\end{array}$ & $\begin{array}{l}2,910,388 \\
1,563,071 \\
\end{array}$ & $\begin{array}{l}638,174 \\
130,589 \\
\end{array}$ & $\begin{array}{r}1,017,538 \\
348,437 \\
\end{array}$ & $\begin{array}{r}1,791,046 \\
938,876 \\
\end{array}$ & $\begin{array}{l}754,229 \\
400,408 \\
\end{array}$ & $\begin{array}{r}170,062 \\
92,761 \\
\end{array}$ & $\begin{array}{r}\$ 488,444,393 \\
248,806,202 \\
\end{array}$ & $\begin{array}{r}15,885,804 \\
7,214,668 \\
\end{array}$ & $\begin{array}{r}15,594,638 \\
7,220,807 \\
\end{array}$ & ii \\
\hline $\begin{array}{l}21,094 \\
10,934 \\
10,918 \\
28,758 \\
11,965\end{array}$ & $\begin{array}{r}4,040 \\
8,999 \\
11,636 \\
4,745 \\
6,034\end{array}$ & $\begin{array}{l}13.6 \\
38.6 \\
50.1 \\
18.8 \\
33.0\end{array}$ & $\begin{array}{l}20,175 \\
14,802 \\
17,912 \\
28,026 \\
11,291\end{array}$ & $\begin{array}{l}4,959 \\
5,131 \\
4,642 \\
5,477 \\
6,708\end{array}$ & $\begin{array}{r}0 \\
23 \\
0 \\
0 \\
22\end{array}$ & $\begin{array}{r}0 \\
681 \\
511 \\
0 \\
0\end{array}$ & $\begin{array}{l}4,286 \\
1,943 \\
2,671 \\
4,482 \\
1,986\end{array}$ & $\begin{array}{l}1,097 \\
1,287 \\
1,719 \\
1,571 \\
1,483\end{array}$ & $\begin{array}{r}477 \\
3 \\
7 \\
427 \\
565\end{array}$ & $\begin{array}{r}784,684 \\
52,036 \\
253,280 \\
790,098 \\
2,134,955\end{array}$ & $\begin{array}{l}22,875 \\
15,942 \\
17,794 \\
28,965 \\
13,927\end{array}$ & $\begin{array}{l}22,628 \\
14,469 \\
15,474 \\
30,583 \\
14,274\end{array}$ & $\begin{array}{l}1 \\
2 \\
3 \\
4 \\
5\end{array}$ \\
\hline 8,116 & 9,381 & 35.4 & 16,498 & 999 & 204 & 759 & 971 & 276 & 0 & 291,652 & 12,245 & 11,870 & 6 \\
\hline $\begin{array}{r}59,062 \\
7,335 \\
5,834 \\
8,102 \\
20,291 \\
11,893 \\
3,699 \\
34,715 \\
256,402\end{array}$ & $\begin{array}{r}14,316 \\
14,026 \\
42,816 \\
16,922 \\
5,700 \\
21,095 \\
20,643 \\
5,508 \\
0\end{array}$ & $\begin{array}{l}35.4 \\
47.8 \\
50.4 \\
40.6 \\
31.7 \\
52.8 \\
37.8 \\
37.8 \\
44.6\end{array}$ & $\begin{array}{r}59,382 \\
21,361 \\
31,158 \\
25,024 \\
21,768 \\
32,988 \\
24,342 \\
31,565 \\
208,742\end{array}$ & $\begin{array}{r}13,996 \\
0 \\
17,492 \\
0 \\
4,223 \\
0 \\
0 \\
8,658 \\
47,660\end{array}$ & $\begin{array}{r}991 \\
1,668 \\
0 \\
2,053 \\
345 \\
3,124 \\
4,023 \\
0 \\
311\end{array}$ & $\begin{array}{r}0 \\
1,506 \\
0 \\
2,062 \\
0 \\
2,775 \\
553 \\
0 \\
39,341\end{array}$ & $\begin{array}{r}13,210 \\
0 \\
4,330 \\
0 \\
4,207 \\
0 \\
0 \\
6,351 \\
32,432\end{array}$ & $\begin{array}{r}4,007 \\
0 \\
6,385 \\
0 \\
1,546 \\
0 \\
0 \\
1,568 \\
18,602\end{array}$ & \begin{tabular}{r|}
828 \\
0 \\
11 \\
0 \\
109 \\
0 \\
0 \\
850 \\
524
\end{tabular} & $\begin{array}{r}1,614,926 \\
108,163 \\
344,606 \\
134,060 \\
427,495 \\
202,185 \\
107,179 \\
1,627,782 \\
2,235,450\end{array}$ & $\begin{array}{r}64,594 \\
12,160 \\
17,976 \\
14,489 \\
21,521 \\
21,532 \\
11,009 \\
35,974 \\
307,871\end{array}$ & $\begin{array}{r}64,635 \\
12,044 \\
22,466 \\
13,783 \\
22,495 \\
18,975 \\
10,630 \\
36,848 \\
256,402\end{array}$ & $\begin{array}{r}7 \\
8 \\
9 \\
9 \\
10 \\
11 \\
12 \\
13 \\
14 \\
15\end{array}$ \\
\hline 19,508 & 5,029 & 18.1 & 20,350 & 4,187 & 0 & 0 & 3,130 & 1,140 & 295 & 679,217 & 20,201 & 21,433 & 16 \\
\hline 10,053 & 7,818 & 47.4 & 11,801 & 6,070 & 0 & 168 & 1,125 & 883 & 0 & 268,162 & 13,264 & 13,096 & 17 \\
\hline 7,430 & 23,658 & 49.7 & 31,088 & 0 & 1,247 & 2,207 & 0 & 0 & 0 & 158,435 & 15,733 & 15,373 & 18 \\
\hline 5,339 & 12,005 & 71.8 & 17,344 & 0 & 905 & 843 & 0 & 0 & 0 & 120,846 & 9,185 & 9,370 & 19 \\
\hline 17,769 & 910 & 33.9 & 17,680 & 999 & 0 & 0 & 3,713 & 433 & 0 & 352,190 & 18,203 & 18,126 & 20 \\
\hline 18,429 & 3,727 & 73.8 & 20,542 & 1,614 & 0 & 0 & 3,940 & 505 & 0 & 278,962 & 18,860 & 19,891 & 21 \\
\hline 14,835 & 1,635 & 36.5 & 15,316 & 1,154 & 0 & 0 & 3,572 & 434 & 0 & 230,747 & 15,011 & 15,477 & 22 \\
\hline 19,018 & 3,547 & 68.0 & 19,719 & 2,846 & 0 & 0 & 3,444 & 954 & 33 & 283,945 & 19,823 & 20,408 & 23 \\
\hline 28,445 & 9,232 & 68.0 & 32,379 & 5,298 & 0 & 0 & 6,724 & 1,565 & 19 & 453,997 & 30,468 & 32,048 & 24 \\
\hline 28,543 & 7,736 & 72.4 & 31,053 & 5,226 & 0 & 0 & 6,171 & 1,740 & 20 & 434,215 & 30,271 & 31,556 & 25 \\
\hline 16,844 & 4,911 & 87.9 & 18,111 & 3,644 & 0 & 0 & 2,994 & 994 & 0 & 261,826 & 18,264 & 18,750 & 26 \\
\hline 27,902 & 8,262 & 65.4 & 31,442 & 4,722 & 0 & 0 & 6,520 & 1,885 & 24 & 448,510 & 31,341 & 31,133 & 27 \\
\hline 22,388 & 6,151 & 60.1 & 25,624 & 2,915 & 0 & 0 & 4,861 & 1,043 & 2 & 355,281 & 24,550 & 24,820 & 28 \\
\hline 15,012 & 3,222 & 75.9 & 16,055 & 2,179 & 0 & 0 & 2,983 & 654 & 9 & 260,885 & 15,249 & 16,257 & 29 \\
\hline 6,643 & 14,076 & 89.0 & 20,719 & 0 & 508 & 1,119 & 0 & 0 & 0 & 153,566 & 11,852 & 11,369 & 30 \\
\hline 5,403 & 12,401 & 78.1 & 17,804 & 0 & 811 & 1,498 & 0 & 0 & 0 & 137,044 & 10,459 & 9,566 & 31 \\
\hline 9,376 & 20,730 & 75.0 & 30,106 & 0 & 1,752 & 993 & 0 & 0 & 0 & 355,057 & 18,646 & 16,336 & 32 \\
\hline 5,873 & 9,304 & 57.8 & 15,177 & 0 & 396 & 1,091 & 0 & 0 & 0 & 133,184 & 8,403 & 8,997 & 33 \\
\hline 4,442 & 10,702 & 74.5 & 15,144 & 0 & 749 & 744 & 0 & 0 & 0 & 105,238 & 8,257 & 8,035 & 34 \\
\hline 10,365 & 13,468 & 74.2 & 23,833 & 0 & 537 & 1,258 & 0 & 0 & 0 & 178,966 & 15,029 & 14,887 & 35 \\
\hline 7,471 & 12,858 & 53.9 & 20,329 & 0 & 806 & 679 & 0 & 0 & 0 & 110,071 & 11,590 & 11,788 & 36 \\
\hline 6,855 & 30,200 & 90.4 & 37,055 & 0 & 1,743 & 1,569 & 0 & 0 & 0 & 175,942 & 17,789 & 16,994 & 37 \\
\hline 7,061 & 16,344 & 83.8 & 23,405 & 0 & 516 & 1,656 & 0 & 0 & 0 & 184,367 & 13,178 & 12,548 & 38 \\
\hline 5,028 & 10,039 & 58.2 & 15,067 & 0 & 574 & 588 & 0 & 0 & 0 & 127,025 & 8,741 & 8,398 & 39 \\
\hline 7,218 & 14,412 & 75.5 & 21,630 & 0 & 510 & 984 & 0 & 0 & 0 & 141,051 & 11,179 & 12,057 & 40 \\
\hline 4,094 & 15,530 & 72.5 & 19,624 & 0 & 324 & 1,320 & 0 & 0 & 0 & 157,857 & 9,307 & 9,308 & 41 \\
\hline 7,532 & 8,446 & 47.0 & 15,978 & 0 & 325 & 437 & 0 & 0 & 0 & 129,912 & 9,430 & 10,368 & 42 \\
\hline 6,092 & 11,666 & 53.7 & 17,758 & 0 & 706 & 1,103 & 0 & 0 & 0 & 86,532 & 11,071 & 10,009 & 43 \\
\hline 9,405 & 15,434 & 82.5 & 24,839 & 0 & 1,444 & 872 & 0 & 0 & 0 & 220,469 & 13,729 & 14,587 & 44 \\
\hline 5,364 & 15,021 & 78.9 & 20,385 & 0 & 307 & 464 & 0 & 0 & 0 & 111,030 & 11,072 & 10,407 & 45 \\
\hline 5,537 & 14,401 & 68.0 & 19,938 & 0 & 568 & 1,031 & 0 & 0 & 0 & 114,849 & 10,768 & 10,372 & 46 \\
\hline 4,529 & 14,111 & 67.1 & 18,640 & 0 & 889 & 719 & 0 & 0 & 0 & 113,301 & 9,623 & 9,267 & 47 \\
\hline 5,769 & 11,216 & 58.2 & 16,985 & 0 & 395 & 1,224 & 0 & 0 & 0 & 89,766 & 10,063 & 9,535 & 48 \\
\hline 10,749 & 17,287 & 85.7 & 28,036 & 0 & 732 & 1,769 & 0 & 0 & 0 & 225,791 & 15,525 & 16,553 & 49 \\
\hline 9,667 & 8,231 & 52.4 & 9,482 & 8,416 & 0 & 115 & 1,453 & 3,112 & 0 & 191,699 & 11,188 & 12,857 & 50 \\
\hline 7,908 & 13,180 & 61.4 & 21,088 & 0 & 571 & 1,569 & 0 & 0 & 0 & 150,830 & 13,663 & 12,333 & 51 \\
\hline 8,102 & 16,524 & 52.4 & 24,626 & 0 & 1,832 & 1,854 & 0 & 0 & 0 & 171,211 & 14,394 & 13,650 & 52 \\
\hline 8,092 & 14,767 & 81.6 & 22,859 & 0 & 722 & 1,603 & 0 & 0 & 0 & 180,887 & 14,787 & 13,050 & 53 \\
\hline 4,828 & 12,815 & 90.4 & 17,643 & 0 & 140 & 960 & 0 & 0 & 0 & 111,515 & 9,264 & 9,130 & 54 \\
\hline 4,102 & 13,116 & 74.8 & 17,218 & 0 & 1,210 & 1,675 & 0 & 0 & 0 & 136,707 & 9,135 & 8,506 & 55 \\
\hline 6,028 & 18,353 & 70.3 & 24,381 & 0 & 405 & 1,494 & 0 & 0 & 0 & 122,732 & 12,185 & 12,190 & 56 \\
\hline 6,523 & 15,205 & 41.3 & 21,728 & 0 & 1,447 & 1,090 & 0 & 0 & 0 & 119,838 & 12,090 & 11,628 & 57 \\
\hline 3,722 & 13,075 & 73.9 & 16,797 & 0 & 460 & 699 & 0 & 0 & 0 & 114,877 & 8,538 & 8,112 & 58 \\
\hline 6,128 & 18,815 & 62.1 & 24,943 & 0 & 334 & 1,070 & 0 & 0 & 0 & 102,530 & 12,779 & 12,445 & 59 \\
\hline 25,748 & 5,095 & 56.2 & 25,990 & 4,853 & 0 & 0 & 5,822 & 1,778 & 70 & 473,235 & 27,203 & 27,714 & 60 \\
\hline 24,969 & 5,531 & 67.0 & 26,449 & 4,051 & 0 & 0 & 5,559 & 1,432 & 19 & 455,013 & 26,064 & 27,135 & 61 \\
\hline 6,427 & 10,575 & 73.6 & 17,002 & 0 & 418 & 2,882 & 0 & 0 & 0 & 156,227 & 11,685 & 9,977 & 62 \\
\hline 23,420 & 7,028 & 70.8 & 25,157 & 5,291 & 0 & 0 & 4,901 & 2,715 & 0 & 406,889 & 25,852 & 26,164 & 63 \\
\hline 5,041 & 27,313 & 68.0 & 32,354 & 0 & 1,313 & 1,526 & 0 & 0 & 0 & 143,227 & 13,225 & 14,211 & 64 \\
\hline 7,943 & 11,322 & 50.9 & 19,265 & 0 & 1,049 & 1,738 & 0 & 0 & 0 & 153,636 & 11,890 & 11,744 & 65 \\
\hline 10,603 & 19,651 & 69.2 & 30,254 & 0 & 1,505 & 1,229 & 0 & 0 & 0 & 239,688 & 17,607 & 17,201 & 66 \\
\hline 7,092 & 15,731 & 41.2 & 22,823 & 0 & 3,012 & 1,665 & 0 & 0 & 0 & 156,436 & 13,311 & 12,373 & 67 \\
\hline 6,943 & 11,304 & 36.0 & 18,247 & 0 & 407 & 1,908 & 0 & 0 & 0 & 123,470 & 11,292 & 10,738 & 68 \\
\hline 5,471 & 12,891 & 76.2 & 18,362 & 0 & 399 & 988 & 0 & 0 & 0 & 140,942 & 11,920 & 9,799 & 69 \\
\hline 15,477 & 3,042 & 47.2 & 7,063 & 11,456 & 0 & 0 & 1,715 & 2,278 & 1,019 & $3,766,310$ & 17,073 & 16,640 & 70 \\
\hline 34,399 & 1,494 & 59.7 & 25,774 & 10,119 & 0 & 0 & 7,526 & 2,164 & 1,264 & $2,238,595$ & 35,091 & 34,971 & 71 \\
\hline 31,109 & 1,245 & 60.4 & 25,666 & 6,688 & 0 & 0 & 6,738 & 989 & 1,002 & $3,346,385$ & 30,940 & 31,585 & 72 \\
\hline 26,654 & 825 & 74.1 & 22,216 & 5,263 & 0 & 0 & 6,378 & 1,105 & 572 & $2,188,515$ & 26,666 & 26,966 & 73 \\
\hline 38,950 & 995 & 60.8 & 27,941 & 12,004 & 0 & 0 & 7,391 & 2,921 & 1,326 & $5,251,698$ & 38,572 & 39,334 & 74 \\
\hline
\end{tabular}


468 CHAPTER 3: Postsecondary Education

Large Institutions and Institutions Serving Specific Groups

Table 312.20. Selected statistics for degree-granting postsecondary institutions enrolling more than 15,000 students in 2012 , by selected institution and student characteristics: Selected years, 1990 through 2011-12-Continued

\begin{tabular}{|c|c|c|c|c|c|c|c|c|c|c|c|c|}
\hline \multirow{3}{*}{$\begin{array}{l}\text { Line } \\
\text { number }\end{array}$} & \multirow[b]{3}{*}{ Institution } & \multirow[b]{3}{*}{ State } & \multirow{3}{*}{$\begin{array}{l}\text { Con- } \\
\text { trol }\end{array}$} & \multirow[b]{3}{*}{ Level } & \multicolumn{5}{|c|}{ Total fall enrollment } & \multicolumn{3}{|c|}{ Fall enrollment, 2012} \\
\hline & & & & & \multirow[b]{2}{*}{ Fall 1990} & \multirow[b]{2}{*}{ Fall 2000} & \multirow[b]{2}{*}{ Fall 2009} & \multirow[b]{2}{*}{ Fall 2010} & & & $\mathrm{Se}$ & \\
\hline & & & & & & & & & Fall 2011 & Total & Male & Female \\
\hline 1 & 2 & 3 & 4 & 5 & 6 & 7 & 8 & 9 & 10 & 11 & 12 & 13 \\
\hline $\begin{array}{l}75 \\
76 \\
77 \\
78 \\
79\end{array}$ & 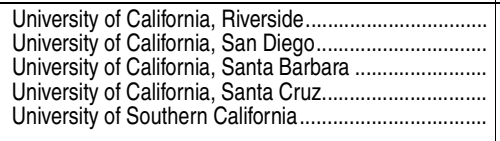 & $\begin{array}{l}\text { CA } \\
C A \\
C A \\
C A \\
C A\end{array}$ & \begin{tabular}{|c|} 
Public \\
Public \\
Public \\
Public \\
PrivNp
\end{tabular} & $\begin{array}{l}\text { 4-year } \\
\text { 4-year } \\
\text { 4-year } \\
\text { 4-year } \\
\text { 4-year }\end{array}$ & $\begin{array}{r}8,708 \\
17,790 \\
18,385 \\
10,054 \\
28,374\end{array}$ & $\begin{array}{l}13,015 \\
20,197 \\
19,962 \\
12,144 \\
29,194\end{array}$ & $\begin{array}{l}19,384 \\
28,418 \\
22,850 \\
16,775 \\
34,824\end{array}$ & $\begin{array}{l}20,692 \\
29,176 \\
22,218 \\
17,187 \\
36,896\end{array}$ & $\begin{array}{l}20,900 \\
28,593 \\
21,685 \\
17,454 \\
38,010\end{array}$ & $\begin{array}{l}20,947 \\
28,294 \\
21,927 \\
17,404 \\
39,958\end{array}$ & $\begin{array}{r}10,281 \\
14,850 \\
10,600 \\
8,258 \\
19,345\end{array}$ & $\begin{array}{r}10,666 \\
13,444 \\
11,327 \\
9,146 \\
20,613\end{array}$ \\
\hline $\begin{array}{l}80 \\
81 \\
82 \\
83 \\
84 \\
85 \\
86\end{array}$ & 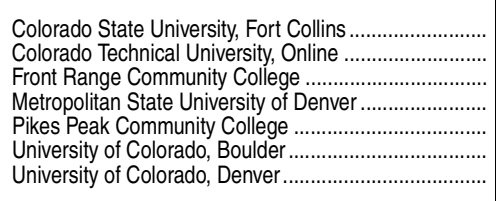 & $\begin{array}{l}\text { CO } \\
\text { CO } \\
\text { CO } \\
\text { CO } \\
\text { CO } \\
\text { CO } \\
\text { CO }\end{array}$ & $\begin{array}{l}\text { Public } \\
\text { PrivFp } \\
\text { Public } \\
\text { Public } \\
\text { Public } \\
\text { Public } \\
\text { Public }\end{array}$ & $\begin{array}{l}\text { 4-year } \\
\text { 4-year } \\
\text { 2-year } \\
\text { 4-year } \\
\text { 2-year } \\
\text { 4-year } \\
\text { 4-year }\end{array}$ & $\begin{array}{r}26,828 \\
\dagger \\
9,706 \\
17,400 \\
7,788 \\
28,600 \\
11,512\end{array}$ & $\begin{array}{r}26,807 \\
\dagger \\
12,962 \\
17,688 \\
9,997 \\
29,352 \\
13,737\end{array}$ & $\begin{array}{l}28,902 \\
30,924 \\
18,713 \\
22,837 \\
13,572 \\
33,010 \\
23,715\end{array}$ & $\begin{array}{l}30,155 \\
29,588 \\
20,092 \\
23,948 \\
15,299 \\
32,697 \\
24,108\end{array}$ & $\begin{array}{l}30,467 \\
24,617 \\
20,568 \\
23,789 \\
14,725 \\
32,558 \\
22,495\end{array}$ & $\begin{array}{l}30,659 \\
22,608 \\
20,527 \\
23,381 \\
15,175 \\
31,945 \\
22,396\end{array}$ & $\begin{array}{r}14,916 \\
7,856 \\
8,670 \\
10,800 \\
6,410 \\
17,498 \\
9,732\end{array}$ & $\begin{array}{r}15,743 \\
14,752 \\
11,857 \\
12,581 \\
8,765 \\
14,447 \\
12,664\end{array}$ \\
\hline 87 & University of Connecticut.. & CT & Public & 4-year & 25,497 & 19,393 & 25,029 & 25,498 & 25,868 & 25,483 & 12,788 & 12,695 \\
\hline 88 & University of Delaware............. & $\mathrm{DE}$ & Public & 4-year & 20,818 & 19,072 & 21,138 & 21,177 & 21,489 & 21,856 & 9,657 & 12,199 \\
\hline $\begin{array}{l}89 \\
90\end{array}$ & 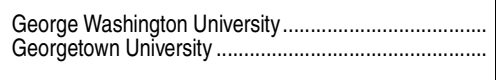 & $\begin{array}{l}\mathrm{DC} \\
\mathrm{DC}\end{array}$ & $\begin{array}{l}\text { PrivNp } \\
\text { PrivNp }\end{array}$ & $\begin{array}{l}\text { 4-year } \\
\text { 4-year }\end{array}$ & $\begin{array}{l}19,103 \\
11,525\end{array}$ & $\begin{array}{l}20,527 \\
12,427\end{array}$ & $\begin{array}{l}25,061 \\
16,520\end{array}$ & $\begin{array}{l}25,135 \\
16,937\end{array}$ & $\begin{array}{l}25,260 \\
17,130\end{array}$ & $\begin{array}{l}25,653 \\
17,357\end{array}$ & $\begin{array}{r}11,299 \\
8,152\end{array}$ & $\begin{array}{r}14,354 \\
9,205\end{array}$ \\
\hline 91 & Broward College.... & $\mathrm{FL}$ & Public & 4-year & 24,365 & 27,389 & 60 & 40,375 & 42,198 & 42,309 & 20 & 24,989 \\
\hline 92 & Daytona State College..... & $\mathrm{FL}$ & Public & 4-year & 10,950 & 10,420 & 17,352 & 18,497 & 16,555 & 15,184 & 6,054 & 9,130 \\
\hline 93 & Eastern Florida State College & $\mathrm{FL}$ & Public & 2-year & 14,319 & 13,265 & 17,853 & 18,096 & 17,917 & 17,202 & 7,159 & 10,043 \\
\hline 94 & Edison State College............................... & $\mathrm{FL}$ & Public & 4-year & 8,919 & 8,919 & 16,034 & 16,951 & 17,107 & 15,731 & 6,246 & 9,485 \\
\hline $\begin{array}{l}95 \\
96\end{array}$ & $\begin{array}{l}\text { Emory-ridade Aeronautical University, worriawide.......... } \\
\text { Everest University, South Orlando........................... }\end{array}$ & $\begin{array}{l}\mathrm{FL} \\
\mathrm{FL}\end{array}$ & $\begin{array}{l}\text { PrivNp } \\
\text { PrivFp }\end{array}$ & $\begin{array}{l}\text { 4-year } \\
\text { 4-year }\end{array}$ & & $\begin{array}{r}\dagger \\
938\end{array}$ & $\begin{array}{r}15,249 \\
7,799\end{array}$ & $\begin{array}{l}15,488 \\
16,022\end{array}$ & $\begin{array}{l}15,320 \\
25,537\end{array}$ & $\begin{array}{l}15,562 \\
33,852\end{array}$ & $\begin{array}{r}13,476 \\
7,499\end{array}$ & $\begin{array}{r}2,086 \\
26,353\end{array}$ \\
\hline 97 & Florida Atlantic University ................................. & $\mathrm{FL}$ & Public & 4-year & 12,767 & 21,046 & 27,637 & 28,270 & 29,246 & 29,994 & $\begin{array}{r}12,893 \\
\end{array}$ & 17,101 \\
\hline 98 & Florida International Unive & $\mathrm{FL}$ & Public & 4-year & 22,466 & 31,945 & 39, & 42,197 & 44,616 & 46,171 & 20,357 & 25,814 \\
\hline 99 & Florida State College at Jacksonville.... & $\mathrm{FL}$ & Public & 4-year & 20,974 & 20,838 & 28 & 28,642 & 30,863 & 30,053 & 12,157 & 17,896 \\
\hline 100 & Florida State University ......................................... & $\mathrm{FL}$ & Public & 4-year & 28,170 & 33,971 & 39 & 40,416 & 41,087 & 40,695 & 18,246 & 22,449 \\
\hline 101 & 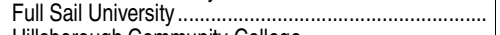 & $\mathrm{FL}$ & PrivFp & 4-year & & 1,910 & 7,516 & 15,695 & 20,160 & 23,497 & 17,246 & 6,251 \\
\hline 102 & Hillsborough Community College .................................... & $\mathrm{FL}$ & Public & 2-year & 19,134 & 18,497 & 26,964 & 27,955 & 28,329 & 27,754 & 11,833 & 15,921 \\
\hline 103 & Indian F & $\mathrm{FL}$ & Public & 4-year & 12,774 & 13,186 & & & 17,528 & 17,816 & & 10,668 \\
\hline 104 & Keiser University, Fort Lauderdale. & $\mathrm{FL}$ & PrivNp & 4-year & 104 & 3,086 & 16,8 & 16,968 & 17,042 & 16,713 & 5,175 & 11,538 \\
\hline 105 & Miami Dade College ........ & $\mathrm{FL}$ & Public & & 50,078 & $\begin{array}{l}0,000 \\
46,834\end{array}$ & 59, & $\begin{array}{l}61,674 \\
61\end{array}$ & 63,736 & 66,701 & 27,756 & 38,945 \\
\hline 106 & Nova Southeastern University ....... & $\mathrm{FL}$ & PrivNp & 4-year & 9,562 & 18,587 & & 28,741 & 28,457 & 26,808 & 8,254 & 18,554 \\
\hline 107 & Palm Beach State College ............... & $\mathrm{FL}$ & Public & 4-year & 18,392 & 17,326 & 28,017 & 29,534 & 29,354 & 29,974 & 12,947 & 17,027 \\
\hline 108 & Saint Leo University....... & $\mathrm{FL}$ & PrivNp & 4-year & 5,308 & 8,720 & 14,339 & 15,565 & 15,564 & 15,986 & 6,659 & 9,327 \\
\hline 109 & Saint Petersburg College.............. & $\mathrm{FL}$ & Public & 4-year & 20,012 & 19,900 & 29,282 & 31,793 & 33,128 & 32,612 & 12 & 19,724 \\
\hline 110 & Santa Fe College...... & $\mathrm{FL}$ & Public & $\begin{array}{l}\text { 4-yead } \\
\text { 4-year }\end{array}$ & 11,053 & 12,464 & 15,043 & $\begin{array}{l}51,745 \\
15,74\end{array}$ & $\begin{array}{l}5,150 \\
15,493\end{array}$ & $\begin{array}{l}0<, 01< \\
15,362\end{array}$ & $\begin{array}{r}r,, 000 \\
6,824\end{array}$ & $\begin{array}{r}1,1,1<4 \\
8,538\end{array}$ \\
\hline 11 & Seminole State College of & $\mathrm{FL}$ & Public & 4-year & 7,799 & $\begin{array}{r}9,042 \\
\end{array}$ & 17 & $\begin{array}{l}18,028 \\
\end{array}$ & 18, & 19,450 & 8,041 & $\begin{array}{r}0,000 \\
11,409\end{array}$ \\
\hline 112 & University of Central Florida .... & $\mathrm{FL}$ & Public & $\begin{array}{l}\text { 4-yead } \\
\text { 4-year }\end{array}$ & 21,541 & $\begin{array}{r}3,042 \\
33,713\end{array}$ & 53,401 & $\begin{array}{l}10,0<0 \\
56,106\end{array}$ & $\begin{array}{r}1,0,044 \\
58,465\end{array}$ & 59,601 & $\begin{array}{r}0,041 \\
26,781\end{array}$ & 32,820 \\
\hline 113 & University of Florida........................... & $\mathrm{FL}$ & Public & 4-year & 35,477 & 45,114 & 50,691 & 49,827 & 49,589 & 49,913 & 23,039 & 26,874 \\
\hline 114 & Univer & $\mathrm{FL}$ & PrivNp & 4-year & 13,841 & 63 & 15,629 & 15,657 & 16, & 16,172 & 7,944 & 8,228 \\
\hline 11 & Univers & $\mathrm{FL}$ & Public & 4-year & 8,021 & 12,550 & 16 & & & 16,201 & 7,040 & 9,161 \\
\hline 116 & University of South Florida, Main Campus ... & $\mathrm{FL}$ & Public & 4-year & 32,326 & 35,561 & & & 39, & 41,116 & $\begin{array}{r}1,040 \\
17,658\end{array}$ & 23,458 \\
\hline 117 & Valencia College..... & $\mathrm{FL}$ & Public & 4-year & 18,438 & 27,565 & 39,008 & 41,583 & 42,631 & 42,915 & 18,612 & 24,303 \\
\hline 118 & Technology, Main Campus .............. & GA & Public & 4-year & 12.241 & 14.805 & 20,291 & 20,720 & 20,941 & 21.557 & 14.974 & 6,583 \\
\hline 110 & & $\mathrm{GA}$ & Public & 2-year & 13,944 & & & & & & & \\
\hline 100 & .............. & $\mathrm{GA}$ & Public & 4-year & 12,249 & 14,184 & & 19,691 & 20 & 20,574 & 9 , & 10,625 \\
\hline 12 & ………..... & $\mathrm{GA}$ & Public & 4-year & 23,336 & 23,625 & & 31,533 & & 32,087 & & \\
\hline 122 & & $\mathrm{GA}$ & Public & 4-year & 10,018 & 13,360 & 22,389 & 23,452 & 24,1 & 24,604 & 10,255 & 14,349 \\
\hline 123 & University of Georgia....................... & $\mathrm{GA}$ & Public & 4-year & 28,395 & 31,288 & 34,885 & 34,677 & 34,816 & 34,519 & 14,715 & 19,804 \\
\hline 124 & University of Hawaii at Manoa... & $\mathrm{HI}$ & Public & 4-year & 18,799 & 17,263 & 20,435 & 20,337 & 20,429 & 20,426 & 9,118 & 11,308 \\
\hline 125 & & $\mathrm{ID}$ & Public & 4-year & 13,367 & 16,287 & 18,933 & 19,992 & 19,664 & 22,344 & 0,194 & \\
\hline 126 & (1) & ID & PrivNp & 4-year & 7,795 & 8,949 & 14,944 & 14,933 & $\begin{array}{l}18,004 \\
18,110\end{array}$ & $\begin{array}{l}22,344 \\
23,261\end{array}$ & $\begin{array}{r}10,012 \\
10,012\end{array}$ & $\begin{array}{l}12,100 \\
13,249\end{array}$ \\
\hline 127 & & $\mathrm{IL}$ & Public & $2-y e r-y-y$ & 29,185 & 8.862 & 27.0 & 26,722 & 26 & 26,156 & 12 & 13,774 \\
\hline 101 & & IL & Public & & 13 & , & & & & 17,577 & & \\
\hline & ePaul Univers & IL & PrivNp & 4-year & 15,711 & 20,548 & & 25,145 & 25, & 24,966 & 11,697 & 13,269 \\
\hline 736 & 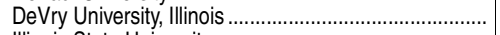 & IL & Privfp & $4-y$ & & $\begin{array}{r}4,095 \\
\end{array}$ & & 00,859 & & & 11,876 & \\
\hline 131 & 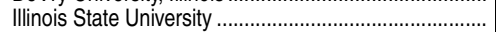 & IL & Public & 4-year & 22,662 & $\begin{array}{l}4,755 \\
20,750\end{array}$ & 21 & 21,134 & 21 & $\begin{array}{l}20,706 \\
20\end{array}$ & $\begin{array}{r}9,158 \\
9,150\end{array}$ & 11,548 \\
\hline 132 & 管 & IL & Public & 2-year & 9, & & & & & & 6,864 & 8,725 \\
\hline 133 & & IL & PrivNp & 4-year & 14, & 55 & & & & & 5,727 & 9,993 \\
\hline 134 & College.... & IL & Public & 2-year & 13,601 & 12,972 & 17,774 & 17,387 & & 16,650 & 7,822 & 8,828 \\
\hline $\begin{array}{l}104 \\
135\end{array}$ & 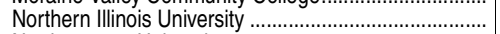 & IL & Public & $\begin{array}{l}\text {-year } \\
\text { 4-year }\end{array}$ & 24,509 & $\begin{array}{l}12,248 \\
23,248\end{array}$ & 24 & $\begin{array}{r}11,001 \\
23,850\end{array}$ & $\begin{array}{l}10, \\
22\end{array}$ & $\begin{array}{l}10,050 \\
21,869\end{array}$ & $\begin{array}{r}1,0.2 \\
10,530\end{array}$ & $\begin{array}{r}0,0<\circ \\
11,339 \\
\end{array}$ \\
\hline 136 & orthv & IL & PrivNp & 4-year & 17. & 16,952 & & & 20,959 & 21,215 & & 10,127 \\
\hline 137 & rbondale. & IL & Public & 4-year & 24,078 & 552 & & 20,037 & & $\begin{array}{l}21,81 \\
18,847\end{array}$ & 10,207 & 8,640 \\
\hline 138 & & IL & PrivNp & 4-year & 10, & 12,531 & & 15 & & 15,245 & 8,781 & 6,464 \\
\hline 139 & jo & $\mathrm{IL}$ & Public & 4-year & 24,959 & 24,942 & & 27,850 & 28,091 & 27,875 & 12,705 & 15,170 \\
\hline 140 & Iniversity of Illinois at Urbana-Champaign ......... & IIL & Public & 4-year & 38,163 & 38,465 & 43,881 & 43,862 & 44,407 & 44,520 & 24,361 & 20,159 \\
\hline 141 & $E_{2}$ & $\mathrm{IN}$ & Public & $4-$ & & 19,004 & & 3 & & & & \\
\hline 142 & & IN & Public & & 35, & 37, & & & & 42 & & 21,134 \\
\hline 143 & -Purdue University, Indianapolis..... & IN & Public & 4-year & 27,517 & 27,525 & 30 & $\begin{array}{r}40,566 \\
30,404\end{array}$ & 30 & 30,451 & 13,142 & 17,309 \\
\hline 14 & 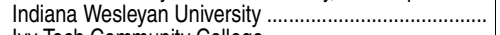 & IN & PrivNp & 4-year & 2,719 & 7,088 & 15,345 & 15,953 & 15,872 & 15,580 & 5,435 & 10,145 \\
\hline 145 & Ivy Tech Com & IN & Public & 2-year & 4,871 & 6,748 & 19,533 & 20,847 & 21,046 & 100,272 & 40,483 & 59,789 \\
\hline
\end{tabular}

See notes at end of table. 
Table 312.20. Selected statistics for degree-granting postsecondary institutions enrolling more than 15,000 students in 2012, by selected institution and student characteristics: Selected years, 1990 through 2011-12-Continued

\begin{tabular}{|c|c|c|c|c|c|c|c|c|c|c|c|c|c|}
\hline \multicolumn{5}{|c|}{ Fall enrollment, 2012} & \multicolumn{5}{|c|}{ Earned degrees/certificates conferred, 2011-12 } & \multirow{3}{*}{$\begin{array}{r}\text { Total } \\
\text { expenses and } \\
\text { deductions, } \\
2011-12 \\
\text { (in thousands) }^{2}\end{array}$} & \multicolumn{2}{|c|}{ Full-time-equivalent enrollment } & \multirow[b]{3}{*}{$\begin{array}{r}\text { Line } \\
\text { number }\end{array}$} \\
\hline \multicolumn{2}{|c|}{ Attendance status } & \multirow[b]{2}{*}{$\begin{array}{r}\text { Percent } \\
\text { minority }\end{array}$} & Studen & & & & & & & & & & \\
\hline Full-time & Part-time & & $\begin{array}{r}\text { Under- } \\
\text { graduate }\end{array}$ & $\begin{array}{r}\text { Postbacca- } \\
\text { laureate }\end{array}$ & Certificates $^{4}$ & Associate's & Bachelor's & Master's & Doctors's $^{5}($ & & Fall 2011 & Fall 2012 & \\
\hline 14 & 15 & 16 & 17 & 18 & 19 & 20 & 21 & 22 & 23 & 24 & 25 & 26 & 27 \\
\hline $\begin{array}{l}20,350 \\
27,341 \\
21,500 \\
16,928 \\
34,824\end{array}$ & $\begin{array}{r}597 \\
953 \\
427 \\
476 \\
5,134\end{array}$ & \begin{tabular}{l|}
80.5 \\
67.4 \\
51.9 \\
56.9 \\
52.2
\end{tabular} & $\begin{array}{l}18,539 \\
22,676 \\
18,977 \\
15,978 \\
18,316\end{array}$ & \begin{tabular}{r|}
2,408 \\
5,618 \\
2,950 \\
1,426 \\
21,642 \\
\end{tabular} & \begin{tabular}{l|l}
0 \\
0 \\
0 \\
0 \\
0
\end{tabular} & $\begin{array}{l}0 \\
0 \\
0 \\
0 \\
0\end{array}$ & $\begin{array}{l}4,040 \\
6,526 \\
5,358 \\
4,301 \\
4,539\end{array}$ & $\begin{array}{r}467 \\
1,106 \\
624 \\
290 \\
6,136\end{array}$ & \begin{tabular}{r|}
263 \\
717 \\
346 \\
172 \\
1,518 \\
\end{tabular} & $\begin{array}{r}665,128 \\
3,315,449 \\
884,612 \\
600,393 \\
3,165,396\end{array}$ & $\begin{array}{l}20,551 \\
28,035 \\
21,388 \\
17,135 \\
34,972\end{array}$ & $\begin{array}{l}20,587 \\
27,715 \\
21,666 \\
17,118 \\
36,793\end{array}$ & $\begin{array}{l}75 \\
76 \\
77 \\
78 \\
79\end{array}$ \\
\hline 23,216 & 7,443 & 17.7 & 23,252 & 7,407 & 0 & 0 & 4,527 & 1,568 & 362 & 892,826 & 25,903 & 26,030 & 80 \\
\hline 14,891 & 7,717 & 48.6 & 20,132 & 2,476 & 0 & 4,533 & 2,427 & 1,333 & 0 & 254,814 & 20,305 & 17,916 & 81 \\
\hline 6,635 & 13,892 & 23.6 & 20,527 & 0 & 1,733 & 1,466 & 0 & 0 & 0 & 99,958 & 11,357 & 11,299 & 82 \\
\hline 13,593 & 9,788 & 34.5 & 23,019 & 362 & 0 & 0 & 2,973 & 65 & 0 & 154,490 & 18,102 & 17,539 & 83 \\
\hline 5,723 & 9,452 & 32.8 & 15,175 & 0 & 685 & 956 & 0 & 0 & 0 & $\begin{array}{l}77,795 \\
\end{array}$ & 8,881 & 8,896 & 84 \\
\hline 26,098 & 5,847 & 19.5 & 25,941 & 6,004 & 0 & 0 & 5,865 & 1,333 & 525 & $1,090,663$ & 29,004 & 28,309 & 85 \\
\hline 11,721 & 10,675 & 30.4 & 13,103 & 9,293 & 0 & 0 & 1,931 & 2,032 & 636 & $1,383,662$ & 15,809 & 15,807 & 86 \\
\hline 21,932 & 3,551 & 25.8 & 17,528 & 7,955 & 0 & 25 & 5,149 & 1,603 & 773 & $1,835,757$ & 23,549 & 23,250 & 87 \\
\hline 19,458 & 2,398 & 18.6 & 18,202 & 3,654 & 0 & 303 & 3,535 & 785 & 262 & 863,423 & 19,982 & 20,391 & 88 \\
\hline 17,391 & 8,262 & 31.8 & 10,464 & 15,189 & 146 & 130 & 2,296 & 3,883 & 1,050 & $1,048,449$ & 20,166 & 20,555 & 89 \\
\hline 14,197 & 3,160 & 29.1 & 7,552 & 9,805 & 7 & 0 & 1,871 & 2,838 & 934 & $1,146,339$ & 15,300 & 15,407 & 90 \\
\hline 12,890 & 29,419 & 74.9 & 42,309 & 0 & 943 & 6,218 & 281 & 0 & 0 & 259,274 & 25,308 & 24,762 & 91 \\
\hline 7,257 & 7,927 & 27.7 & 15,184 & 0 & 1,512 & 2,758 & 355 & 0 & 0 & 131,602 & 11,139 & 10,456 & 92 \\
\hline 6,337 & 10,865 & 27.2 & 17,202 & 0 & 1,134 & 3,112 & 0 & 0 & 0 & 106,861 & 10,501 & 9,985 & 93 \\
\hline 5,092 & 10,639 & 38.5 & 15,731 & 0 & 286 & 2,399 & 294 & 0 & 0 & 93,620 & 10,381 & 9,385 & 94 \\
\hline 5,327 & 10,235 & 37.0 & 10,435 & 5,127 & 0 & 447 & 1,928 & 1,686 & 0 & & 9,158 & 9,319 & 95 \\
\hline $\begin{array}{r}3,3,33 \\
\end{array}$ & 15,519 & 63.3 & 33,635 & 217 & 275 & 889 & $\begin{array}{r}203 \\
203\end{array}$ & 51 & 0 & 126,341 & 17,296 & 24,428 & 96 \\
\hline 17,561 & 12,433 & 48.5 & 25,105 & 4,889 & 0 & 251 & 4,892 & 1,259 & 117 & 466,926 & 21,836 & 22,453 & 97 \\
\hline 29,944 & 16,227 & 85.9 & 37,475 & 8,696 & 0 & 74 & 7,238 & 2,953 & 381 & 772,327 & 34,949 & 36,376 & 98 \\
\hline 9,614 & 20,439 & 44.2 & 30,053 & 0 & 2,365 & 5,744 & 392 & 0 & 0 & 218,185 & 18,883 & 17,862 & 99 \\
\hline 34,672 & 6,023 & 29.4 & 32,171 & 8,524 & 0 & 163 & 7,860 & 2,142 & 850 & 977,075 & 37,323 & 36,994 & 100 \\
\hline 23,497 & & 55.2 & 21,371 & 2,126 & 384 & 175 & 2,572 & 1,355 & 0 & 318,572 & 20,160 & 23,497 & 101 \\
\hline $\begin{array}{l}20,098 \\
12,098\end{array}$ & 15,656 & 54.8 & 27,754 & r, 0 & $\begin{array}{r}1,547 \\
\end{array}$ & 3,843 & | & | & 0 & $\begin{array}{l}184,161 \\
1\end{array}$ & 17,418 & 17,354 & 102 \\
\hline 6,091 & 11,725 & 36.3 & 17,816 & 0 & 1,216 & 2,691 & 306 & 0 & 0 & 116,697 & 10,758 & 10,823 & 103 \\
\hline 11,244 & 5,469 & 53.8 & 15,842 & 871 & 2 & 4,021 & 639 & 226 & 0 & 293,547 & 13,169 & 13,385 & 104 \\
\hline 26,211 & 40,490 & 92.3 & 66,701 & 0 & $1,49 \overline{7}$ & 11,959 & 667 & 0 & 0 & 437,469 & 41,588 & 42,550 & 105 \\
\hline 13,699 & 13,109 & 60.7 & 5,739 & 21,069 & 5 & 4 & 1,518 & 4,229 & 1,800 & 583,936 & 20,098 & 18,730 & 106 \\
\hline 10,177 & 19,797 & 55.9 & 29,974 & & 1,743 & 4,021 & 157 & 0 & 0 & 158,856 & 18,331 & 18,166 & 107 \\
\hline 11,868 & 4,118 & 53.1 & 12,770 & 3,216 & 21 & 883 & 2,709 & 1,061 & 0 & 128,411 & 13,221 & 13,485 & 108 \\
\hline 9,528 & 23,084 & 29.2 & 32,612 & 0 & 584 & 4,019 & 1,044 & 0 & 0 & 205,583 & 19,738 & 18,843 & 109 \\
\hline 6,174 & 9,188 & 36.7 & 15,362 & 0 & 556 & 2,912 & 66 & 0 & 0 & 105,064 & 10,111 & 9,882 & 110 \\
\hline 7,559 & 11,891 & 47.2 & 19,450 & 0 & 1,720 & 2,811 & 17 & 0 & 0 & 118,992 & 12,059 & 12,358 & 111 \\
\hline 40,606 & 18,995 & 38.6 & 51,010 & 8,591 & 0 & 316 & 11,514 & 2,392 & 266 & 822,265 & 47,850 & 48,072 & 112 \\
\hline 42,865 & 7,048 & 36.2 & 32,776 & 17,137 & 0 & 210 & 8,601 & 3,924 & 1,954 & $2,316,406$ & 45,445 & 45,520 & 113 \\
\hline $\begin{array}{l}14,987 \\
\end{array}$ & 1,185 & 46.0 & 10,590 & 5,582 & 0 & 0 & 2,429 & r, 979 & . & $2,431,467$ & 15,253 & 15,446 & 114 \\
\hline 11,031 & 5,170 & 27.3 & 14,398 & 1,803 & 0 & 380 & 3,113 & 577 & 43 & 241,424 & 13,189 & 13,072 & 115 \\
\hline 29,212 & 11,904 & 38.7 & 31,125 & 9,991 & 0 & 151 & 7,610 & 2,512 & 416 & $1,079,230$ & 32,607 & 33,825 & 116 \\
\hline 16,998 & 25,917 & 60.9 & 42,915 & 0 & 4,055 & 7,974 & 0 & 0 & 0 & 231,416 & 27,796 & 27,457 & 117 \\
\hline 18,848 & 2,709 & 35.2 & 14,527 & 7,030 & 0 & 0 & 2,873 & 1,932 & 483 & $1,274,216$ & 19,264 & 19,880 & 118 \\
\hline 9,676 & 13,943 & 65.8 & 23,619 & 0 & 14 & 2,113 & 0 & 0 & 0 & 189,073 & 16,873 & 14,357 & 119 \\
\hline 16,739 & 3,835 & 33.9 & 17,993 & 2,581 & 0 & 0 & 2,788 & 732 & 78 & 292,023 & 17,977 & 18,217 & 120 \\
\hline 23,175 & 8,912 & 59.2 & 24,656 & 7,431 & 0 & 0 & 4,378 & 2,266 & 437 & 593,195 & 26,389 & 26,674 & 121 \\
\hline 17,782 & 6,822 & 31.3 & 22,684 & 1,920 & 29 & 0 & 3,532 & $\begin{array}{r}-, 428 \\
728\end{array}$ & 22 & 301,305 & 20,173 & 20,489 & 122 \\
\hline 31,099 & 3,420 & 23.2 & 26,259 & 8,260 & 0 & 0 & 6,861 & 1,689 & 903 & $1,215,189$ & 32,748 & 32,409 & 123 \\
\hline 14,927 & 5,499 & 76.2 & 14,655 & 5,771 & 0 & 0 & 3,026 & 1,223 & 406 & 953,986 & 16,884 & 17,028 & 124 \\
\hline 13,485 & 8,859 & 15.7 & 19,477 & 2,867 & 0 & 218 & 2,587 & 664 & 11 & 313,645 & 15,920 & 16,971 & 125 \\
\hline 15,235 & 8,026 & 13.0 & 23,261 & 0 & 0 & 1,371 & 3,172 & 0 & 0 & 194,212 & 15,502 & 18,388 & 126 \\
\hline 9,62 & 16,528 & 39.2 & 26,156 & 0 & 1,273 & 1,912 & 0 & 0 & 0 & 186,063 & 15,086 & 15,177 & 127 \\
\hline 4,945 & 12,632 & 48 & 17,577 & 0 & 783 & 1,253 & 0 & 0 & 0 & 131,979 & 9,300 & 9,186 & 128 \\
\hline 19,002 & 5,964 & 37 & 16,498 & 8,468 & 4 & 0 & 3,646 & 2,672 & 412 & 516,280 & 21,494 & 21,311 & 129 \\
\hline 6,379 & 17,867 & 42 & 24,055 & 191 & 0 & 1,241 & 2,704 & 74 & 0 & 214,021 & 15,877 & 13,396 & 130 \\
\hline 18,309 & 2,397 & 17.0 & 18,257 & 2,449 & 0 & & 4,452 & 857 & 50 & 499,181 & 19,768 & 19,223 & 131 \\
\hline 6,013 & 9,576 & 37.8 & 15,589 & $2,+40$ & 466 & 1,588 & $\begin{array}{r}4,460 \\
0\end{array}$ & 0 & $\begin{array}{r}0 \\
0\end{array}$ & 127,071 & 9,400 & 9,228 & 132 \\
\hline 13,299 & 2,421 & 30.7 & 9,723 & 5,997 & 4 & 0 & 2,396 & 1,627 & 537 & 445,893 & 14,475 & 14,232 & 133 \\
\hline 6,983 & 9,667 & 35.0 & 16,650 & 0 & 724 & 1,822 & 0 & 0 & 0 & 116,513 & 10,954 & 10,229 & 134 \\
\hline 16,714 & 5,155 & 33 & 16,552 & 5,317 & 0 & 0 & 3,924 & 1,539 & 201 & 572,949 & 19,540 & 18,664 & 135 \\
\hline 17,188 & 4,027 & 34.9 & 9,376 & 11,839 & 212 & 0 & 2,184 & 3,161 & 898 & $1,791,451$ & 18,579 & 18,736 & 136 \\
\hline 15,061 & 3,786 & 31.4 & 14,130 & 4,717 & 0 & 46 & 3,843 & 983 & 358 & 756,580 & 17,342 & 16,503 & 137 \\
\hline 12,720 & 2,525 & 36.0 & 5,618 & 9,627 & 0 & 0 & 1,242 & 2,706 & 715 & $3,101,540$ & 13,421 & 13,685 & 138 \\
\hline 23,071 & 4,804 & 51.6 & 16,678 & 11,197 & 0 & 0 & 3,813 & 2,088 & 912 & $2,373,871$ & 24,926 & 24,862 & 139 \\
\hline 40,704 & 3,816 & 32.6 & 32,281 & 12,239 & 3 & 0 & 7,727 & 3,218 & 1,210 & $2,157,496$ & 41,979 & 42,133 & 140 \\
\hline 17,317 & 3,736 & 11.9 & 16,652 & 4,401 & 0 & 239 & 3,299 & 1,360 & 65 & 419,467 & 19,351 & 18,713 & 141 \\
\hline 37,263 & 4,870 & 17.0 & 32,371 & 9,762 & 206 & 19 & 7,284 & 2,532 & 748 & $1,303,654$ & 39,522 & 39,084 & 142 \\
\hline 20,223 & 10,228 & 22.5 & 22,271 & 8,180 & 426 & 201 & 3,744 & 1,816 & 771 & $1,118,030$ & 24,296 & 24,179 & 143 \\
\hline 13,934 & 1,646 & \begin{tabular}{ll|}
24.2 & \\
23.2 &
\end{tabular} & $\begin{array}{r}11,103 \\
10270\end{array}$ & 4,477 & $\begin{array}{r}73 \\
\end{array}$ & $\begin{array}{r}677 \\
8940\end{array}$ & 2,702 & 1,726 & 11 & 179,232 & 14,835 & 14,576 & 144 \\
\hline 37,662 & 62,610 & $23.3 \mid$ & 100,272 & 0 & 6,573 & 8,940 & 0 & 0 & 0 & 660,093 & 12,046 & 58,682 & 145 \\
\hline
\end{tabular}


470 CHAPTER 3: Postsecondary Education

Large Institutions and Institutions Serving Specific Groups

Table 312.20. Selected statistics for degree-granting postsecondary institutions enrolling more than 15,000 students in 2012 , by selected institution and student characteristics: Selected years, 1990 through 2011-12-Continued

\begin{tabular}{|c|c|c|c|c|c|c|c|c|c|c|c|c|}
\hline \multirow{3}{*}{$\begin{array}{l}\text { Line } \\
\text { number }\end{array}$} & \multirow[b]{3}{*}{ Institution } & \multirow[b]{3}{*}{ State } & \multirow{3}{*}{$\begin{array}{c}\text { Con- } \\
\text { trol }^{1}\end{array}$} & \multirow[b]{3}{*}{ Level } & \multicolumn{5}{|c|}{ Total fall enrollment } & \multicolumn{3}{|c|}{ Fall enrollment, 2012} \\
\hline & & & & & & & & & & & $\mathrm{Se}$ & \\
\hline & & & & & Fall 1990 & Fall 2000 & Fall 2009 & Fall 2010 & Fall 2011 & Total & Male & Female \\
\hline 1 & 2 & 3 & 4 & 5 & 6 & 7 & 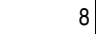 & 9 & 10 & 11 & 12 & 13 \\
\hline $\begin{array}{l}146 \\
147\end{array}$ & 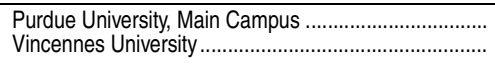 & $\begin{array}{l}\mathrm{N} \\
\mathrm{IN}\end{array}$ & $\begin{array}{l}\text { Public } \\
\text { Public }\end{array}$ & \begin{tabular}{l|l|} 
4-year \\
4-year
\end{tabular} & $\begin{array}{r}37,588 \\
9,162\end{array}$ & $\begin{array}{r}39,667 \\
9,169\end{array}$ & $\begin{array}{l}41,052 \\
13,947\end{array}$ & $\begin{array}{l}41,063 \\
16,595\end{array}$ & $\begin{array}{l}40,849 \\
17,140\end{array}$ & $\begin{array}{l}40,393 \\
17,530\end{array}$ & $\begin{array}{r}23,638 \\
9,582\end{array}$ & $\begin{array}{r}16,755 \\
7,948\end{array}$ \\
\hline $\begin{array}{l}148 \\
149 \\
150 \\
151 \\
152 \\
153\end{array}$ & 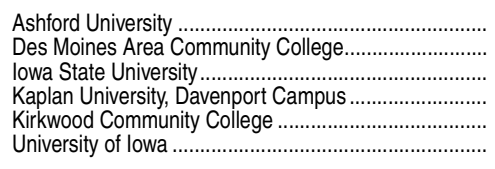 & $\begin{array}{l}\text { IA } \\
\text { IA } \\
\text { IA } \\
\mid A \\
\text { IA } \\
\mid A\end{array}$ & $\begin{array}{l}\text { PrivFp } \\
\text { Public } \\
\text { Public } \\
\text { Privp } \\
\text { Public } \\
\text { Public }\end{array}$ & $\begin{array}{l}\text { 4-year } \\
\text { 2-year } \\
\text { 4-year } \\
\text { 4-year } \\
\text { 2-year } \\
\text { 4-year }\end{array}$ & $\begin{array}{r}311 \\
10,553 \\
25,737 \\
641 \\
8,623 \\
28,785\end{array}$ & $\begin{array}{r}616 \\
10,998 \\
26,845 \\
376 \\
11,645 \\
28,311\end{array}$ & $\begin{array}{l}46,835 \\
22,324 \\
27,945 \\
71,011 \\
17,841 \\
28,987\end{array}$ & $\begin{array}{l}63,096 \\
24,658 \\
28,682 \\
77,966 \\
18,456 \\
29,518\end{array}$ & $\begin{array}{l}74,596 \\
25,425 \\
29,611 \\
56,606 \\
17,625 \\
29,810\end{array}$ & $\begin{array}{l}77,734 \\
23,685 \\
30,748 \\
48,865 \\
16,659 \\
30,129\end{array}$ & $\begin{array}{r}21,987 \\
10,901 \\
17,215 \\
12,457 \\
7,950 \\
14,558\end{array}$ & $\begin{array}{r}55,747 \\
12,784 \\
13,533 \\
36,408 \\
8,709 \\
15,571\end{array}$ \\
\hline $\begin{array}{l}154 \\
155 \\
156\end{array}$ & 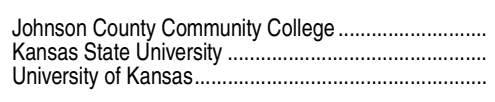 & $\begin{array}{l}\text { KS } \\
\text { KS } \\
\text { KS }\end{array}$ & $\begin{array}{l}\text { Public } \\
\text { Public } \\
\text { Public }\end{array}$ & $\begin{array}{l}\text { 2-year } \\
\text { 4-year } \\
\text { 4-year }\end{array}$ & $\begin{array}{l}13,740 \\
21,137 \\
26,434\end{array}$ & $\begin{array}{l}16,383 \\
21,929 \\
25,920\end{array}$ & $\begin{array}{l}20,385 \\
23,581 \\
29,242\end{array}$ & $\begin{array}{l}20,865 \\
23,588 \\
28,697\end{array}$ & $\begin{array}{l}21,020 \\
23,863 \\
27,939\end{array}$ & $\begin{array}{l}20,421 \\
24,378 \\
27,135\end{array}$ & $\begin{array}{r}9,453 \\
12,410 \\
13,220\end{array}$ & $\begin{array}{l}10,968 \\
11,968 \\
13,915\end{array}$ \\
\hline $\begin{array}{l}157 \\
158 \\
159 \\
160 \\
161\end{array}$ & 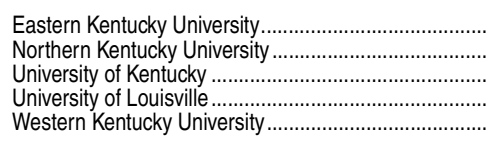 & $\begin{array}{l}K Y \\
K Y \\
K Y \\
K Y \\
K Y\end{array}$ & $\begin{array}{l}\text { Public } \\
\text { Public } \\
\text { Public } \\
\text { Public } \\
\text { Public }\end{array}$ & $\begin{array}{l}\text { 4-year } \\
\text { 4-year } \\
\text { 4-year } \\
\text { 4-year } \\
\text { 4-year }\end{array}$ & $\begin{array}{l}15,290 \\
11,254 \\
22,538 \\
22,979 \\
15,170\end{array}$ & $\begin{array}{l}13,285 \\
12,080 \\
23,114 \\
19,771 \\
15,481\end{array}$ & $\begin{array}{l}16,268 \\
15,378 \\
26,295 \\
21,016 \\
20,712\end{array}$ & $\begin{array}{l}16,567 \\
15,716 \\
27,108 \\
21,234 \\
20,897\end{array}$ & $\begin{array}{l}16,062 \\
15,724 \\
27,226 \\
21,152 \\
21,036\end{array}$ & $\begin{array}{l}15,968 \\
15,634 \\
28,034 \\
21,239 \\
21,110\end{array}$ & $\begin{array}{r}7,019 \\
6,882 \\
13,475 \\
10,150 \\
8,635\end{array}$ & $\begin{array}{r}8,949 \\
8,752 \\
14,559 \\
11,089 \\
12,475\end{array}$ \\
\hline $\begin{array}{l}162 \\
163 \\
164 \\
165\end{array}$ & 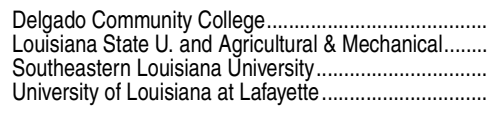 & $\begin{array}{l}\angle A \\
\angle A \\
L A \\
L A\end{array}$ & $\begin{array}{l}\text { Public } \\
\text { Public } \\
\text { Public } \\
\text { Public }\end{array}$ & $\begin{array}{l}\text { 2-year } \\
\text { 4-year } \\
\text { 4-year } \\
\text { 4-year }\end{array}$ & $\begin{array}{l}11,614 \\
26,112 \\
10,262 \\
15,764\end{array}$ & $\begin{array}{l}12,784 \\
31,527 \\
14,525 \\
15,742\end{array}$ & $\begin{array}{l}16,758 \\
28,643 \\
15,151 \\
16,361\end{array}$ & $\begin{array}{l}18,767 \\
29,451 \\
15,338 \\
16,763\end{array}$ & $\begin{array}{l}20,436 \\
29,718 \\
15,403 \\
16,885\end{array}$ & $\begin{array}{l}18,096 \\
30,225 \\
15,591 \\
16,688\end{array}$ & $\begin{array}{r}6,036 \\
14,754 \\
5,920 \\
7,241\end{array}$ & $\begin{array}{r}12,060 \\
15,471 \\
9,671 \\
9,447\end{array}$ \\
\hline $\begin{array}{l}166 \\
167 \\
168 \\
169 \\
170 \\
171 \\
172\end{array}$ & 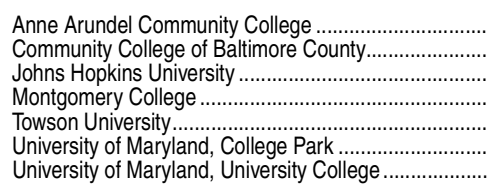 & $\begin{array}{l}\mathrm{MD} \\
\mathrm{MD} \\
\mathrm{MD} \\
\mathrm{MD} \\
\mathrm{MD} \\
\mathrm{MD} \\
\mathrm{MD}\end{array}$ & $\begin{array}{l}\text { Public } \\
\text { Public } \\
\text { PrivNp } \\
\text { Public } \\
\text { Public } \\
\text { Public } \\
\text { Public }\end{array}$ & $\begin{array}{l}\text { 2-year } \\
\text { 2-year } \\
\text { 4-year } \\
\text { 2-year } \\
\text { 4-year } \\
\text { 4-year } \\
\text { 4-year }\end{array}$ & $\begin{array}{r}12,148 \\
\dagger \\
13,363 \\
14,361 \\
15,035 \\
34,829 \\
14,476\end{array}$ & $\begin{array}{l}11,761 \\
18,168 \\
17,774 \\
20,923 \\
16,729 \\
33,189 \\
18,276\end{array}$ & $\begin{array}{l}16,741 \\
23,584 \\
20,383 \\
26,147 \\
21,177 \\
37,195 \\
37,347\end{array}$ & $\begin{array}{l}17,665 \\
26,425 \\
20,977 \\
26,015 \\
21,840 \\
37,641 \\
39,577\end{array}$ & $\begin{array}{l}17,957 \\
26,271 \\
20,996 \\
26,996 \\
21,464 \\
37,631 \\
42,713\end{array}$ & $\begin{array}{l}17,650 \\
25,188 \\
20,871 \\
27,453 \\
21,960 \\
37,248 \\
42,268\end{array}$ & $\begin{array}{r}6,990 \\
9,653 \\
10,329 \\
12,892 \\
8,244 \\
19,688 \\
20,206\end{array}$ & $\begin{array}{l}10,660 \\
15,535 \\
10,542 \\
14,561 \\
13,716 \\
17,560 \\
22,062\end{array}$ \\
\hline $\begin{array}{l}173 \\
174 \\
175 \\
176 \\
177 \\
178\end{array}$ & 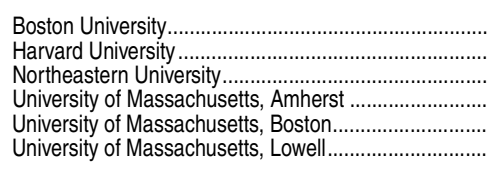 & $\begin{array}{l}\text { MA } \\
\text { MA } \\
\text { MA } \\
\text { MA } \\
\text { MA } \\
\text { MA }\end{array}$ & $\begin{array}{l}\text { PrivNp } \\
\text { PrivNp } \\
\text { Privinp } \\
\text { Public } \\
\text { Public } \\
\text { Public }\end{array}$ & $\begin{array}{l}\text { 4-year } \\
\text { 4-year } \\
\text { 4-year } \\
\text { 4-year } \\
\text { 4-year } \\
\text { 4-year }\end{array}$ & $\begin{array}{l}27,996 \\
22,851 \\
30,510 \\
26,025 \\
13,723 \\
14,259\end{array}$ & $\begin{array}{l}28,318 \\
24,279 \\
23,897 \\
24,416 \\
13,346 \\
12,189\end{array}$ & $\begin{array}{l}31,960 \\
27,651 \\
27,537 \\
27,016 \\
14,912 \\
13,602\end{array}$ & $\begin{array}{l}32,727 \\
27,594 \\
29,519 \\
27,569 \\
15,454 \\
14,702\end{array}$ & $\begin{array}{l}32,439 \\
27,392 \\
26,959 \\
28,084 \\
15,741 \\
15,431\end{array}$ & $\begin{array}{l}32,603 \\
28,147 \\
27,694 \\
28,236 \\
15,874 \\
16,294\end{array}$ & $\begin{array}{r}13,794 \\
14,293 \\
13,567 \\
14,279 \\
6,499 \\
9,517\end{array}$ & $\begin{array}{r}18,809 \\
13,854 \\
14,127 \\
13,957 \\
9,375 \\
6,777\end{array}$ \\
\hline $\begin{array}{l}179 \\
180 \\
181 \\
182 \\
183 \\
184 \\
185 \\
186 \\
187 \\
188 \\
189 \\
190 \\
191 \\
192\end{array}$ & 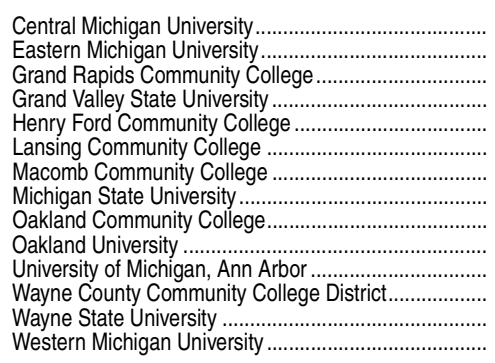 & $\begin{array}{l}\mathrm{MI} \\
\mathrm{MI} \\
\mathrm{MI} \\
\mathrm{MI} \\
\mathrm{MI} \\
\mathrm{MI} \\
\mathrm{MI} \\
\mathrm{MI} \\
\mathrm{MI} \\
\mathrm{MI} \\
\mathrm{MI} \\
\mathrm{MI} \\
\mathrm{MI} \\
\mathrm{MI}\end{array}$ & $\begin{array}{l}\text { Public } \\
\text { Public } \\
\text { Public } \\
\text { Public } \\
\text { Public } \\
\text { Public } \\
\text { Public } \\
\text { Public } \\
\text { Public } \\
\text { Public } \\
\text { Public } \\
\text { Public } \\
\text { Public } \\
\text { Public }\end{array}$ & $\begin{array}{l}\text { 4-year } \\
\text { 4-year } \\
\text { 2-year } \\
\text { 4-year } \\
\text { 2-year } \\
\text { 2-year } \\
\text { 2-year } \\
\text { 4-year } \\
\text { 2-year } \\
\text { 4-year } \\
\text { 4-year } \\
\text { 2-year } \\
\text { 4-year } \\
\text { 4-year }\end{array}$ & $\begin{array}{l}18,286 \\
25,011 \\
12,054 \\
11,725 \\
16,147 \\
22,343 \\
31,538 \\
44,307 \\
28,069 \\
12,400 \\
36,391 \\
11,986 \\
33,872 \\
26,989\end{array}$ & $\begin{array}{r}26,845 \\
23,561 \\
13,400 \\
18,569 \\
12,742 \\
16,011 \\
22,001 \\
43,366 \\
23,188 \\
15,235 \\
38,103 \\
9,008 \\
30,408 \\
28,657\end{array}$ & $\begin{array}{l}27,247 \\
22,893 \\
16,944 \\
24,408 \\
17,542 \\
21,123 \\
24,376 \\
47,071 \\
28,042 \\
18,918 \\
41,674 \\
20,770 \\
31,786 \\
24,576\end{array}$ & $\begin{array}{l}28,292 \\
23,565 \\
17,870 \\
24,541 \\
18,525 \\
21,969 \\
24,468 \\
46,985 \\
28,925 \\
19,053 \\
41,924 \\
21,198 \\
31,505 \\
25,045\end{array}$ & $\begin{array}{l}28,194 \\
23,419 \\
17,575 \\
24,662 \\
17,650 \\
20,640 \\
23,969 \\
47,825 \\
29,158 \\
19,379 \\
42,716 \\
20,440 \\
30,765 \\
25,086\end{array}$ & $\begin{array}{l}27,626 \\
23,518 \\
17,448 \\
24,654 \\
17,338 \\
19,082 \\
23,729 \\
48,783 \\
27,296 \\
19,740 \\
43,426 \\
18,176 \\
28,938 \\
24,598\end{array}$ & $\begin{array}{r}11,780 \\
9,601 \\
8,212 \\
9,981 \\
7,542 \\
8,604 \\
11,184 \\
23,648 \\
11,776 \\
7,799 \\
22,737 \\
6,004 \\
12,287 \\
11,857\end{array}$ & $\begin{array}{r}15,846 \\
13,917 \\
9,236 \\
14,673 \\
9,796 \\
10,478 \\
12,545 \\
25,135 \\
15,520 \\
11,941 \\
20,689 \\
12,172 \\
16,651 \\
12,741\end{array}$ \\
\hline $\begin{array}{l}193 \\
194 \\
195 \\
196 \\
197\end{array}$ & 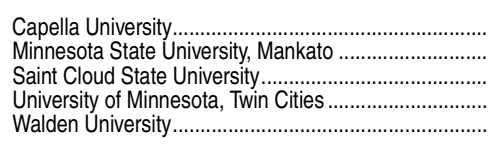 & $\begin{array}{l}\mathrm{MN} \\
\mathrm{MN} \\
\mathrm{MN} \\
\mathrm{MN} \\
\mathrm{MN}\end{array}$ & $\begin{array}{l}\text { PrivFp } \\
\text { Public } \\
\text { Public } \\
\text { Public } \\
\text { PrivFp }\end{array}$ & $\begin{array}{l}\text { 4-year } \\
\text { 4-year } \\
\text { 4-year } \\
\text { 4-year } \\
\text { 4-year }\end{array}$ & $\begin{array}{r}16,575 \\
17,075 \\
57,168 \\
422\end{array}$ & $\begin{array}{r}36 \\
12,842 \\
15,181 \\
45,481 \\
1,544\end{array}$ & $\begin{array}{l}31,998 \\
14,955 \\
18,123 \\
51,659 \\
40,714\end{array}$ & $\begin{array}{l}39,457 \\
15,435 \\
18,650 \\
51,721 \\
47,456\end{array}$ & $\begin{array}{l}36,375 \\
15,709 \\
17,604 \\
52,557 \\
48,982\end{array}$ & $\begin{array}{l}35,754 \\
15,441 \\
16,922 \\
51,853 \\
50,209\end{array}$ & $\begin{array}{r}9,163 \\
7,368 \\
8,115 \\
25,130 \\
11,637\end{array}$ & $\begin{array}{r}26,591 \\
8,073 \\
8,807 \\
26,723 \\
38,572\end{array}$ \\
\hline $\begin{array}{l}198 \\
199 \\
200\end{array}$ & 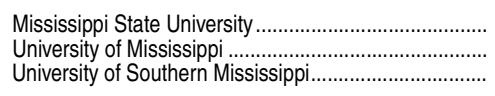 & $\begin{array}{l}\text { MS } \\
\text { MS } \\
\text { MS }\end{array}$ & $\begin{array}{l}\text { Public } \\
\text { Public } \\
\text { Public }\end{array}$ & $\begin{array}{l}\text { 4-year } \\
\text { 4-year } \\
\text { 4-year }\end{array}$ & $\begin{array}{l}14,391 \\
11,288 \\
13,490\end{array}$ & $\begin{array}{l}16,561 \\
12,118 \\
14,509\end{array}$ & $\begin{array}{l}18,601 \\
15,932 \\
15,300\end{array}$ & $\begin{array}{l}19,644 \\
17,085 \\
15,778\end{array}$ & $\begin{array}{l}20,424 \\
18,224 \\
16,604\end{array}$ & $\begin{array}{l}20,365 \\
18,794 \\
16,468\end{array}$ & $\begin{array}{r}10,492 \\
8,482 \\
6,256\end{array}$ & $\begin{array}{r}9,873 \\
10,312 \\
10,212\end{array}$ \\
\hline $\begin{array}{l}201 \\
202 \\
203 \\
204 \\
205 \\
206 \\
207 \\
208 \\
209 \\
210\end{array}$ & 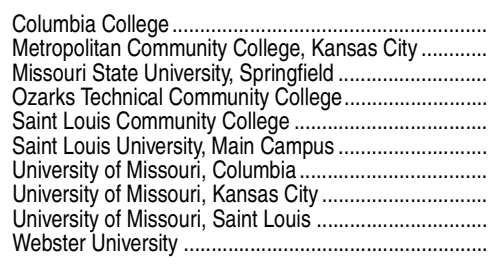 & $\begin{array}{l}\text { MO } \\
\text { MO } \\
\text { MO } \\
\text { MO } \\
\text { MO } \\
\text { MO } \\
\text { MO } \\
\text { MO } \\
\text { MO } \\
\text { MO }\end{array}$ & $\begin{array}{c}\text { PrivNp } \\
\text { Public } \\
\text { Public } \\
\text { Public } \\
\text { Public } \\
\text { PrivNp } \\
\text { Public } \\
\text { Public } \\
\text { Public } \\
\text { PrivNp }\end{array}$ & \begin{tabular}{l|l} 
4-year \\
2-year \\
4-year \\
2-year \\
2-year \\
4-year \\
4-year \\
4-year \\
4-year \\
4-year
\end{tabular} & $\begin{array}{r}4,214 \\
9,625 \\
19,480 \\
335 \\
32,347 \\
12,891 \\
25,058 \\
11,263 \\
15,393 \\
8,745\end{array}$ & $\begin{array}{r}7,948 \\
8,117 \\
17,703 \\
6,343 \\
6,749 \\
13,847 \\
23,309 \\
12,762 \\
15,397 \\
13,783\end{array}$ & $\begin{array}{r}15,556 \\
6,292 \\
20,371 \\
12,884 \\
8,207 \\
16,317 \\
31,237 \\
14,799 \\
16,534 \\
19,372\end{array}$ & $\begin{array}{r}16,962 \\
6,539 \\
20,472 \\
13,907 \\
8,716 \\
17,709 \\
32,341 \\
15,259 \\
16,791 \\
19,342\end{array}$ & $\begin{array}{r}18,091 \\
6,209 \\
20,276 \\
15,179 \\
29,200 \\
17,859 \\
33,762 \\
15,473 \\
16,809 \\
19,224\end{array}$ & $\begin{array}{l}17,830 \\
20,141 \\
20,629 \\
15,123 \\
26,603 \\
17,640 \\
34,704 \\
15,990 \\
16,705 \\
18,456\end{array}$ & $\begin{array}{r}7,183 \\
8,487 \\
8,875 \\
6,357 \\
10,523 \\
7,306 \\
16,296 \\
6,793 \\
6,749 \\
7,662\end{array}$ & $\begin{array}{r}10,647 \\
11,654 \\
11,754 \\
8,766 \\
16,080 \\
10,334 \\
18,408 \\
9,197 \\
9,956 \\
10,794\end{array}$ \\
\hline $\begin{array}{l}211 \\
212\end{array}$ & 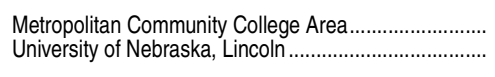 & $\begin{array}{l}\mathrm{NE} \\
\mathrm{NE}\end{array}$ & $\begin{array}{l}\text { Public } \\
\text { Public }\end{array}$ & $\begin{array}{l}\text { 2-year } \\
\text { 4-year }\end{array}$ & $\begin{array}{r}8,516 \\
24,453\end{array}$ & $\begin{array}{l}11,534 \\
22,268\end{array}$ & $\begin{array}{l}17,003 \\
24,100\end{array}$ & $\begin{array}{l}18,523 \\
24,610\end{array}$ & $\begin{array}{l}18,518 \\
24,593\end{array}$ & $\begin{array}{l}17,376 \\
24,207\end{array}$ & $\begin{array}{r}7,672 \\
12,889\end{array}$ & $\begin{array}{r}9,704 \\
11,318\end{array}$ \\
\hline $\begin{array}{l}213 \\
214\end{array}$ & University of Nevada, Las Vegas ................................................ & $\begin{array}{l}\mathrm{NV} \\
\mathrm{NV}\end{array}$ & $\left|\begin{array}{l}\text { Public } \\
\text { Public }\end{array}\right|$ & $\begin{array}{c}\text { 4-year } \\
4 \text {-year }\end{array}$ & $\begin{array}{l}14,161 \\
17,937\end{array}$ & $\begin{array}{l}29,905 \\
22,041\end{array}$ & $\begin{array}{l}42,108 \\
29,080\end{array}$ & 28,203 & 27,364 & $\begin{array}{l}35,678 \\
27,389\end{array}$ & $\begin{array}{l}16,217 \\
12,229\end{array}$ & $\begin{array}{l}19,461 \\
15,160\end{array}$ \\
\hline
\end{tabular}

See notes at end of table. 
Table 312.20. Selected statistics for degree-granting postsecondary institutions enrolling more than 15,000 students in 2012, by selected institution and student characteristics: Selected years, 1990 through 2011-12-Continued

\begin{tabular}{|c|c|c|c|c|c|c|c|c|c|c|c|c|c|}
\hline \multicolumn{5}{|c|}{ Fall enrollment, 2012} & \multicolumn{5}{|c|}{ Earned degrees/certificates conferred, 2011-12 } & \multirow{3}{*}{$\begin{array}{r}\text { Total } \\
\text { expenses and } \\
\text { deductions, } \\
2011-12 \\
\text { (in thousands) } \\
\end{array}$} & \multicolumn{2}{|c|}{ Full-time-equivalent enrollment } & \multirow[b]{3}{*}{$\begin{array}{r}\text { Line } \\
\text { number }\end{array}$} \\
\hline \multicolumn{2}{|c|}{ Attendance status } & \multirow[b]{2}{*}{$\begin{array}{r}\text { Percent } \\
\text { minority }\end{array}$} & \multicolumn{2}{|c|}{ Student level } & \multirow[b]{2}{*}{ Certificates $^{4}$} & & & & & & & & \\
\hline Full-time & Part-time & & $\begin{array}{r}\text { Under- } \\
\text { graduate }\end{array}$ & $\begin{array}{r}\text { Postbacca- } \\
\text { laureate }\end{array}$ & & Associate's & Bachelor's & Master's & Doctor's $^{5}$ & & Fall 2011 & Fall 2012 & \\
\hline 14 & 15 & 16 & 17 & 18 & 19 & 20 & 21 & 22 & 23 & 24 & 25 & 26 & 27 \\
\hline $\begin{array}{r}35,551 \\
6,199 \\
\end{array}$ & $\begin{array}{r}4,842 \\
11,331\end{array}$ & $\begin{array}{l}17.1 \\
17.3\end{array}$ & $\begin{array}{l}31,284 \\
17,530\end{array}$ & $\begin{array}{r}9,109 \\
0\end{array}$ & $\begin{array}{l}332 \\
129\end{array}$ & $\begin{array}{r}406 \\
1,396\end{array}$ & $\begin{array}{r}7,064 \\
108\end{array}$ & $\begin{array}{r}1,622 \\
0\end{array}$ & $\begin{array}{r}880 \\
0\end{array}$ & $\begin{array}{r}1,563,099 \\
126,195\end{array}$ & $\begin{array}{l}37,833 \\
10,914\end{array}$ & $\begin{array}{l}37,382 \\
10,772\end{array}$ & $\begin{array}{l}146 \\
147\end{array}$ \\
\hline $\begin{array}{r}77,690 \\
8,433 \\
27,296 \\
10,812 \\
8,046 \\
24,572\end{array}$ & $\begin{array}{r}44 \\
15,252 \\
3,452 \\
38,053 \\
8,613 \\
5,557\end{array}$ & $\begin{array}{l}51.3 \\
18.8 \\
12.4 \\
43.3 \\
17.3 \\
15.1\end{array}$ & $\begin{array}{l}69,380 \\
23,685 \\
25,553 \\
38,048 \\
16,659 \\
21,999\end{array}$ & $\begin{array}{r}8,354 \\
0 \\
5,195 \\
10,817 \\
0 \\
8,130\end{array}$ & $\begin{array}{r}0 \\
1,040 \\
0 \\
61 \\
520 \\
51\end{array}$ & $\begin{array}{r}1,352 \\
2,463 \\
0 \\
4,677 \\
2,253 \\
0\end{array}$ & \begin{tabular}{r|r}
11,583 & 0 \\
0 & \\
4,881 \\
6,415 \\
0 \\
4,351
\end{tabular} & $\begin{array}{r}4,083 \\
0 \\
926 \\
2,747 \\
0 \\
1,468\end{array}$ & $\begin{array}{r}0 \\
0 \\
520 \\
124 \\
0 \\
948\end{array}$ & $\begin{array}{r}444,034 \\
147,321 \\
998,313 \\
677,174 \\
136,693 \\
2,575,001\end{array}$ & $\begin{array}{l}74,587 \\
14,852 \\
27,481 \\
29,655 \\
11,983 \\
26,430\end{array}$ & $\begin{array}{l}77,707 \\
13,554 \\
28,600 \\
25,671 \\
10,938 \\
26,680\end{array}$ & $\begin{array}{l}148 \\
149 \\
150 \\
151 \\
152 \\
153\end{array}$ \\
\hline 6,728 & 13,693 & 21.6 & 20,421 & & 1,466 & 1,558 & 0 & $\begin{array}{r}0 \\
070\end{array}$ & 0 & 183,995 & 11,721 & 11,325 & 154 \\
\hline $\begin{array}{l}20,275 \\
23,059\end{array}$ & $\begin{array}{l}4,103 \\
4,076\end{array}$ & $\begin{array}{l}15.4 \\
18.4\end{array}$ & $\begin{array}{l}19,853 \\
19,169\end{array}$ & $\begin{array}{l}4,525 \\
7,966\end{array}$ & $\begin{array}{r}0 \\
10\end{array}$ & $\begin{array}{r}49 \\
0\end{array}$ & $\begin{array}{l}3,507 \\
4,331\end{array}$ & $\begin{array}{r}979 \\
1731\end{array}$ & $\begin{array}{l}267 \\
821\end{array}$ & $\begin{array}{r}697,555 \\
1137,526\end{array}$ & $\begin{array}{l}21,235 \\
25,342\end{array}$ & $\begin{array}{l}21,845 \\
24619\end{array}$ & $\begin{array}{l}155 \\
156\end{array}$ \\
\hline 11.919 & 4.049 & 10.9 & 13.947 & 2,021 & 40 & 177 & 2.259 & 734 & 9 & 277,584 & 13558 & 13.496 & 157 \\
\hline 10,718 & 4,916 & 11.3 & 13,012 & 2,622 & 29 & 118 & $\begin{array}{l}2,980 \\
1,98\end{array}$ & 493 & 168 & $\begin{array}{l}218,438 \\
\end{array}$ & $\begin{array}{l}12,647 \\
12,60\end{array}$ & $\begin{array}{l}10,490 \\
12,626\end{array}$ & 158 \\
\hline 25,076 & 2,958 & 15.3 & 20,827 & 7,207 & 20 & 0 & 3,735 & 1,231 & 888 & $2,381,156$ & 25,408 & 26,214 & 159 \\
\hline 16,137 & 5,102 & 20.8 & 15,724 & 5,515 & 28 & 11 & 2,702 & 1,377 & 546 & 836,174 & 18,035 & 18,130 & 160 \\
\hline 14,753 & 6,357 & 16.7 & 18,101 & 3,009 & 52 & 271 & 2,652 & 973 & 20 & 315,698 & 17,281 & 17,229 & 161 \\
\hline 8,007 & 10,089 & 61.5 & 18,096 & 0 & 1,103 & 1,253 & 0 & 0 & 0 & 143,820 & 13,382 & 11,394 & 162 \\
\hline 27,170 & 3,055 & 21.4 & 24,626 & 5,599 & 0 & 0 & 4,600 & 1,234 & 624 & $1,014,378$ & 27,950 & 28,356 & 163 \\
\hline 10,920 & 4,671 & 26.7 & 14,231 & 1,360 & 0 & 62 & 1,966 & 371 & 16 & 169,444 & 12,822 & 12,767 & 164 \\
\hline 13,421 & 3,267 & 27.7 & 15,144 & 1,544 & 0 & 0 & 2,296 & 344 & 49 & 249,965 & 15,049 & 14,712 & 165 \\
\hline 5,098 & 12,552 & 31.9 & 17,650 & 0 & 677 & 1,567 & 0 & 0 & 0 & 143,650 & 9,570 & 9,312 & 166 \\
\hline 8,373 & 16,815 & 51.6 & 25,188 & 0 & 604 & 2,132 & 0 & 0 & 0 & 224,210 & 14,781 & 14,018 & 167 \\
\hline 13,133 & 7,738 & 35.4 & 6,023 & 14,848 & 0 & & 1,647 & 4,785 & 609 & $4,445,646$ & 16,114 & 16,091 & 168 \\
\hline 9,888 & 17,565 & 67.3 & 27,453 & 0 & 352 & 2,383 & 0 & 0 & 0 & 287,767 & 15,526 & 15,785 & 169 \\
\hline 17,052 & 4,908 & 27.2 & 17,988 & 3,972 & 0 & 0 & 4,101 & 1,096 & 19 & 353,998 & 18,604 & 18,917 & 170 \\
\hline 32,274 & 4,974 & 38.4 & 26,538 & 10,710 & 51 & 0 & 7,043 & 2,451 & 657 & $1,551,720$ & 34,274 & 34,159 & 171 \\
\hline 6,421 & 35,847 & 55.3 & 28,273 & 13,995 & 659 & 398 & 3,882 & 3,284 & 47 & 339,103 & 20,149 & 20,313 & 172 \\
\hline 26,059 & 6,544 & 32.6 & 18,306 & 14,297 & 0 & 0 & 4,117 & 4,237 & 1,177 & $1,621,685$ & 28,559 & 28,577 & 173 \\
\hline 20,396 & 7,751 & 38.1 & 10,564 & 17,583 & 0 & 9 & 1,774 & 4,023 & 1,474 & $4,041,698$ & 22,809 & 23,394 & 174 \\
\hline 19,030 & 8,664 & 29.7 & 16,640 & 11,054 & 0 & 36 & 3,793 & 3,122 & 678 & 827,220 & 21,654 & 22,367 & 175 \\
\hline 22,634 & 5,602 & 21.3 & 21,928 & 6,308 & 206 & 61 & 5,203 & 1,305 & 305 & 920,528 & 24,650 & 24,729 & 176 \\
\hline 9,668 & 6,206 & 42.0 & 12,124 & 3,750 & 30 & 0 & 2,109 & 988 & 45 & 321,318 & 11,914 & 12,067 & 177 \\
\hline 9,850 & 6,444 & 27.2 & 12,287 & 4,007 & 110 & 36 & 1,836 & 739 & 93 & 311,434 & 11,753 & 12,330 & 178 \\
\hline 20,271 & 7,355 & 19.4 & 21,332 & 6,294 & 0 & 0 & 3,834 & 2,104 & 107 & 427,714 & 23,635 & 23,047 & 179 \\
\hline 14,265 & 9,253 & 30.3 & 18,927 & 4,591 & 0 & 0 & 2,808 & 1,159 & 16 & 375,963 & 17,585 & 17,849 & 180 \\
\hline 6,264 & 11,184 & 26.1 & 17,448 & 0 & 129 & 1,736 & 0 & 0 & 0 & 148,598 & 10,344 & 10,019 & 181 \\
\hline 19,767 & 4,887 & 14.1 & 21,317 & 3,337 & 7 & 0 & 4,308 & 997 & 42 & 390,672 & 21,530 & 21,646 & 182 \\
\hline 6,779 & 10,559 & 44.9 & 17,338 & 0 & 359 & 1,498 & 0 & 0 & 0 & 117,652 & 10,522 & 10,324 & 183 \\
\hline 7,179 & 11,903 & 22.5 & 19,082 & 0 & 1,872 & 1,734 & 0 & 0 & 0 & 140,904 & 10,828 & 11,175 & 184 \\
\hline 7,624 & 16,105 & 20.1 & 23,729 & 0 & 879 & 2,868 & 0 & 0 & 0 & 152,969 & 13,654 & 13,031 & 185 \\
\hline 42,565 & 6,218 & 19.0 & 37,354 & 11,429 & 100 & $\begin{array}{l}2,000 \\
0\end{array}$ & 8,221 & 2,045 & 962 & $\begin{array}{l}1,966,271 \\
\end{array}$ & 43,986 & $\begin{array}{l}44,946 \\
\end{array}$ & 186 \\
\hline 8,662 & 18,634 & 35.9 & 27,296 & 0 & 424 & 2,415 & 0 & 0 & 0 & 199,631 & 16,185 & 14,918 & 187 \\
\hline 13,319 & 6,421 & 18.1 & 16,190 & 3,550 & 0 & 0 & 2,640 & 860 & 98 & $\begin{array}{l}264,022 \\
\end{array}$ & 15,521 & 15,822 & 188 \\
\hline 40,966 & 2,460 & 27.5 & 27,979 & 15,447 & 0 & 0 & 6,490 & 4,086 & 1,566 & $5,651,202$ & 41,163 & 41,895 & 189 \\
\hline 3,903 & 14,273 & 84.3 & 18,176 & 0 & 1,172 & 1,464 & 0 & 0 & 0 & 143,247 & 9,735 & 8,695 & 190 \\
\hline 18,314 & 10,624 & 38.4 & 19,342 & 9,596 & 5 & 0 & 2,634 & 2,150 & 807 & 823,642 & 23,345 & 22,444 & 191 \\
\hline 17,466 & 7,132 & 20.4 & 19,478 & 5,120 & 0 & 0 & 3,988 & 1,281 & 117 & 522,380 & 20,738 & 20,178 & 192 \\
\hline 2,076 & 33,678 & 53.4 & 8,087 & 27,667 & 0 & 0 & 756 & 4,348 & 810 & 373,234 & 15,421 & 15,018 & 193 \\
\hline 12,125 & 3,316 & 13.1 & 13,504 & 1,937 & 61 & 56 & 2,367 & 541 & 6 & 187,757 & 13,675 & 13,408 & 194 \\
\hline 11,071 & 5,851 & 14.3 & 15,233 & 1,689 & 4 & 141 & 2,492 & 490 & 10 & 186,587 & $\begin{array}{l}14,094 \\
\end{array}$ & $\begin{array}{l}13,387 \\
\end{array}$ & 195 \\
\hline 38,921 & 12,932 & 19.3 & 34,469 & 17,384 & 214 & 0 & 7,617 & 3,413 & 1,680 & $2,720,766$ & 43,943 & 43,823 & 196 \\
\hline 30,597 & 19,612 & 53.0 & 8,696 & 41,513 & 0 & 0 & 711 & 5,468 & 545 & 422,015 & 37,882 & 38,174 & 197 \\
\hline 17,010 & 3,355 & 26.5 & 16,390 & 3,975 & 0 & 0 & 2,922 & 852 & 212 & 600,605 & 18,304 & 18,281 & 198 \\
\hline 16,949 & 1,845 & 23.4 & 16,060 & 2,734 & 0 & 0 & 2,661 & 684 & 353 & 422,791 & 17,118 & 17,664 & 199 \\
\hline 12,804 & 3,664 & 36.1 & 13,658 & 2,810 & 0 & 0 & 2,520 & 748 & 203 & 317,443 & 14,270 & 14,224 & 200 \\
\hline 10,359 & 7,471 & 37.5 & 16,940 & 890 & 41 & 1,520 & 2,707 & 316 & 0 & 83,769 & 13,585 & 13,286 & 201 \\
\hline 7,736 & 12,405 & 33.7 & 20,141 & 0 & 505 & 1,889 & & 0 & 0 & & 3,832 & 11,901 & 202 \\
\hline 15,165 & 5,464 & 11.8 & 17,434 & 3,195 & 29 & 0 & 3,073 & 1,091 & 46 & 275,564 & 17,104 & 17,308 & 203 \\
\hline 7,374 & 7,749 & 5.9 & 15,123 & 0 & 173 & 1,471 & 0 & 0 & 0 & 78,056 & 10,043 & 9,976 & 204 \\
\hline 10,796 & 15,807 & 45.9 & 26,603 & 0 & 461 & 2,113 & 0 & 0 & 0 & 236,182 & 18,187 & 16,103 & 205 \\
\hline 10,750 & 6,890 & 20.9 & 12,513 & 5,127 & 0 & 0 & 1,629 & 859 & 644 & 686,802 & 13,502 & 13,438 & 206 \\
\hline 30,304 & 4,400 & 15.7 & 26,960 & 7,744 & 0 & 0 & 5,528 & 1,631 & 666 & $1,877,387$ & 31,064 & 31,970 & 207 \\
\hline 9,809 & 6,181 & 28.2 & 10,614 & 5,376 & 0 & 0 & 1,749 & 999 & 543 & 355,184 & 11,953 & 12,200 & 208 \\
\hline 7,071 & 9,634 & 24.7 & 13,335 & 3,370 & 0 & 0 & 1,963 & 872 & 121 & 207,843 & 10,905 & 10,860 & 209 \\
\hline 5,841 & 12,615 & 51.1 & 3,502 & 14,954 & 64 & 0 & 816 & 5,525 & 4 & 198,982 & 11,213 & 10,671 & 210 \\
\hline 6,617 & 10,759 & 27.6 & 17,376 & 0 & 419 & 1,460 & 0 & 0 & 0 & 113,539 & 11,250 & 10,229 & 211 \\
\hline 20,580 & 3,627 & 11.9 & 19,103 & 5,104 & 0 & 5 & 3,719 & 1,017 & 391 & 870,484 & 22,342 & 21,948 & 212 \\
\hline 9,690 & 25,988 & 57.1 & 35,678 & 0 & 236 & 2,098 & 14 & 0 & 0 & 190,274 & 20,994 & 20,177 & 213 \\
\hline 18,175 & 9,214 & 52.9 & 22,429 & 4,960 & 14 & 0 & 3,670 & 1,217 & $397 \mid$ & 479,020 & 21,900 & 21,782 & 214 \\
\hline
\end{tabular}


472 CHAPTER 3: Postsecondary Education

Large Institutions and Institutions Serving Specific Groups

Table 312.20. Selected statistics for degree-granting postsecondary institutions enrolling more than 15,000 students in 2012 , by selected institution and student characteristics: Selected years, 1990 through 2011-12-Continued

\begin{tabular}{|c|c|c|c|c|c|c|c|c|c|c|c|c|}
\hline \multirow{3}{*}{$\begin{array}{l}\text { Line } \\
\text { number }\end{array}$} & \multirow[b]{3}{*}{ Institution } & \multirow[b]{3}{*}{ State } & \multirow{3}{*}{$\begin{array}{c}\text { Con- } \\
\text { trol }\end{array}$} & \multirow[b]{3}{*}{ Level } & \multicolumn{5}{|c|}{ Total fall enrollment } & \multicolumn{3}{|c|}{ Fall enrollment, 2012} \\
\hline & & & & & & & & & & & Se & \\
\hline & & & & & Fall 1990 & Fall 2000 & Fall 2009 & Fall 2010 & Fall 2011 & Total & Male & Female \\
\hline 1 & 2 & 3 & 4 & 5 & 6 & 7 & 0 & 9 & 10 & 11 & 12 & 13 \\
\hline 215 & 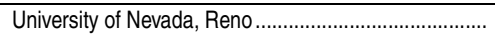 & NV & Public & 4-year & 11,487 & 13,149 & 16,875 & 17,680 & 18,004 & 18,227 & 8,607 & 9,620 \\
\hline $\begin{array}{l}216 \\
217\end{array}$ & 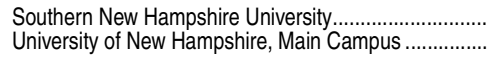 & $\begin{array}{l}\mathrm{NH} \\
\mathrm{NH}\end{array}$ & $\begin{array}{l}\text { Privinp } \\
\text { Public }\end{array}$ & $\begin{array}{l}\text { 4-year } \\
\text { 4-year }\end{array}$ & $\begin{array}{r}6,403 \\
13,260\end{array}$ & $\begin{array}{r}4,584 \\
14,689\end{array}$ & $\begin{array}{r}7,119 \\
15,253\end{array}$ & $\begin{array}{r}8,034 \\
15,095\end{array}$ & $\begin{array}{l}11,851 \\
15,128\end{array}$ & $\begin{array}{l}17,454 \\
15,267\end{array}$ & $\begin{array}{l}7,296 \\
6,909\end{array}$ & $\begin{array}{r}10,158 \\
8,358\end{array}$ \\
\hline $\begin{array}{l}218 \\
219 \\
220 \\
221 \\
222\end{array}$ & 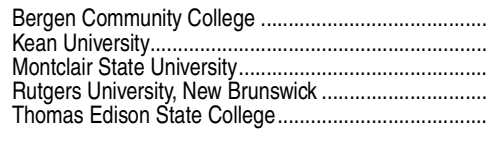 & $\begin{array}{l}\mathrm{NJ} \\
\mathrm{NJ} \\
\mathrm{NJ} \\
\mathrm{NJ} \\
\mathrm{NJ}\end{array}$ & \begin{tabular}{|l|} 
Public \\
Public \\
Public \\
Public \\
Public
\end{tabular} & $\begin{array}{l}\text { 2-year } \\
\text { 4-year } \\
\text { 4-year } \\
\text { 4-year } \\
\text { 4-year }\end{array}$ & $\begin{array}{r}12,119 \\
13,303 \\
13,067 \\
33,016 \\
7,813\end{array}$ & $\begin{array}{r}11,993 \\
11,468 \\
13,502 \\
35,236 \\
8,137\end{array}$ & $\begin{array}{l}16,469 \\
15,051 \\
18,171 \\
37,366 \\
18,206\end{array}$ & $\begin{array}{l}17,197 \\
15,939 \\
18,402 \\
38,912 \\
18,736\end{array}$ & $\begin{array}{l}17,271 \\
16,187 \\
18,498 \\
39,950 \\
20,251\end{array}$ & $\begin{array}{l}17,015 \\
15,391 \\
18,382 \\
40,434 \\
20,606\end{array}$ & $\begin{array}{r}8,409 \\
5,683 \\
6,679 \\
19,679 \\
10,999\end{array}$ & $\begin{array}{r}8,606 \\
9,708 \\
11,703 \\
20,755 \\
9,607\end{array}$ \\
\hline $\begin{array}{l}223 \\
224 \\
225\end{array}$ & 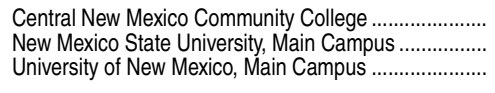 & $\begin{array}{l}N M \\
N M \\
N M\end{array}$ & $\begin{array}{l}\text { Public } \\
\text { Public } \\
\text { Public }\end{array}$ & $\begin{array}{l}\text { 2-year } \\
\text { 4-year } \\
\text { 4-year }\end{array}$ & $\begin{array}{r}9,739 \\
14,812 \\
23,950\end{array}$ & $\begin{array}{l}17,265 \\
14,958 \\
23,670\end{array}$ & $\begin{array}{l}27,999 \\
18,526 \\
27,241\end{array}$ & $\begin{array}{l}29,948 \\
18,600 \\
28,688\end{array}$ & $\begin{array}{l}27,677 \\
18,024 \\
28,977\end{array}$ & $\begin{array}{l}28,323 \\
17,651 \\
29,033\end{array}$ & $\begin{array}{r}12,360 \\
8,027 \\
12,799\end{array}$ & $\begin{array}{r}15,963 \\
9,624 \\
16,234\end{array}$ \\
\hline $\begin{array}{l}226 \\
227 \\
228 \\
229 \\
230 \\
231 \\
232 \\
233 \\
234 \\
235 \\
236 \\
237 \\
238 \\
239 \\
249 \\
240 \\
241 \\
242 \\
243 \\
244 \\
245 \\
246 \\
247 \\
248 \\
249 \\
250\end{array}$ & 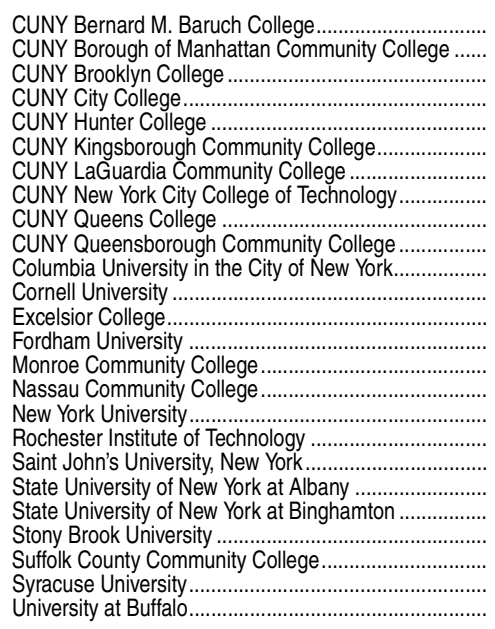 & $\begin{array}{l}N Y \\
N Y \\
N Y \\
N Y \\
N Y \\
N Y \\
N Y \\
N Y \\
N Y \\
N Y \\
N Y \\
N Y \\
N Y \\
N Y \\
N Y \\
N Y \\
N Y \\
N Y \\
N Y \\
N Y \\
N Y \\
N Y \\
N Y \\
N Y \\
N Y\end{array}$ & \begin{tabular}{|l} 
Public \\
Public \\
Public \\
Public \\
Public \\
Public \\
Public \\
Public \\
Public \\
Public \\
PrivNp \\
PrivNp \\
Prive \\
Privenp \\
Public \\
Public \\
PriNp \\
PrivNp \\
PrivNp \\
Public \\
Public \\
Public \\
Public \\
Privp \\
Public
\end{tabular} & $\begin{array}{l}\text { 4-year } \\
\text { 2-year } \\
\text { 4-year } \\
\text { 4-year } \\
\text { 4-year } \\
\text { 2-year } \\
\text { 2-year } \\
\text { 4-year } \\
\text { 4-year } \\
\text { 2-year } \\
\text { 4-year } \\
\text { 4-year } \\
\text { 4-year } \\
\text { 4-year } \\
\text { 2-year } \\
\text { 2-year } \\
\text { 4-year } \\
\text { 4-year } \\
\text { 4-year } \\
\text { 4-year } \\
\text { 4-year } \\
\text { 4-year } \\
\text { 2-year } \\
\text { 4-year } \\
\text { 4-year }\end{array}$ & $\begin{array}{r}15,849 \\
14,819 \\
16,605 \\
14,085 \\
19,639 \\
13,809 \\
9,167 \\
10,908 \\
18,072 \\
12,184 \\
18,242 \\
11,533 \\
13,303 \\
13,158 \\
13,545 \\
21,537 \\
32,813 \\
12,31 \\
19,105 \\
17,400 \\
12,202 \\
17,624 \\
\dagger \\
21,900 \\
27,638\end{array}$ & $\begin{array}{r}15,698 \\
15,875 \\
15,039 \\
11,055 \\
20,011 \\
14,801 \\
11,778 \\
11,028 \\
15,061 \\
10,598 \\
19,639 \\
12,043 \\
18,067 \\
13,650 \\
15,315 \\
19,621 \\
37,150 \\
14,106 \\
18,621 \\
16,751 \\
12,473 \\
19,924 \\
\dagger \\
18, \\
18,186 \\
24,830\end{array}$ & $\begin{array}{l}16,195 \\
21,424 \\
17,094 \\
16,212 \\
22,168 \\
18,204 \\
17,028 \\
15,399 \\
20,711 \\
15,507 \\
24,230 \\
20,633 \\
34,629 \\
14,544 \\
18,976 \\
22,719 \\
43,404 \\
15,445 \\
20,352 \\
18,020 \\
14,709 \\
24,681 \\
24,822 \\
19,638 \\
28,881\end{array}$ & $\begin{array}{l}17,063 \\
22,534 \\
16,912 \\
15,416 \\
22,407 \\
18,606 \\
17,569 \\
15,366 \\
20,906 \\
15,316 \\
25,208 \\
20,939 \\
32,029 \\
15,158 \\
18,995 \\
23,767 \\
43,797 \\
15,792 \\
21,354 \\
17,615 \\
14,895 \\
24,363 \\
26,719 \\
20,407 \\
29,117\end{array}$ & $\begin{array}{l}18,055 \\
24,463 \\
16,835 \\
16,005 \\
22,822 \\
19,261 \\
18,623 \\
15,961 \\
20,993 \\
16,837 \\
26,050 \\
21,131 \\
35,608 \\
15,189 \\
17,699 \\
23,550 \\
43,911 \\
16,166 \\
21,067 \\
17,114 \\
14,746 \\
23,920 \\
26,787 \\
20,829 \\
28,849\end{array}$ & $\begin{array}{l}17,373 \\
24,537 \\
16,524 \\
16,023 \\
23,005 \\
18,934 \\
19,287 \\
16,207 \\
20,100 \\
15,711 \\
26,471 \\
21,424 \\
39,728 \\
15,170 \\
17,296 \\
23,340 \\
44,516 \\
16,357 \\
21,1087 \\
17,312 \\
15,308 \\
23,996 \\
26,219 \\
21,029 \\
28,952\end{array}$ & $\begin{array}{r}8,898 \\
10,440 \\
6,493 \\
7,484 \\
7,092 \\
8,460 \\
8,060 \\
8,946 \\
7,969 \\
7,253 \\
13,086 \\
11,042 \\
16,414 \\
6,573 \\
8,007 \\
11,690 \\
18,646 \\
11,095 \\
9,246 \\
8,413 \\
8,053 \\
12,098 \\
12,217 \\
9,567 \\
15,188\end{array}$ & $\begin{array}{r}8,475 \\
14,097 \\
10,031 \\
8,539 \\
15,913 \\
10,474 \\
11,227 \\
7,261 \\
12,131 \\
8,458 \\
13,385 \\
10,382 \\
23,314 \\
8,597 \\
9,289 \\
11,650 \\
25,870 \\
51,262 \\
11,841 \\
8,899 \\
7,255 \\
11,848 \\
14,002 \\
11,462 \\
13,764\end{array}$ \\
\hline $\begin{array}{l}251 \\
252 \\
253 \\
254 \\
255 \\
256 \\
257 \\
258 \\
259\end{array}$ & 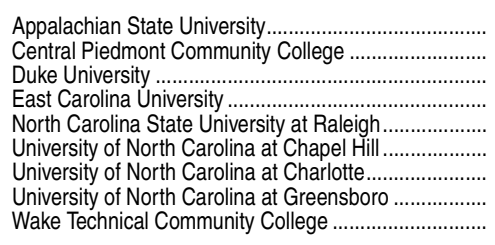 & $\begin{array}{l}N C \\
N C \\
N C \\
N C \\
N C \\
N C \\
N C \\
N C \\
N C\end{array}$ & \begin{tabular}{|l|} 
Public \\
Public \\
PrivNp \\
Public \\
Public \\
Public \\
Public \\
Public \\
Public
\end{tabular} & $\begin{array}{l}\text { 4-year } \\
\text { 2-year } \\
\text { 4-year } \\
\text { 4-year } \\
\text { 4-year } \\
\text { 4-year } \\
\text { 4-year } \\
\text { 4-year } \\
\text { 2-year }\end{array}$ & $\begin{array}{r}11,931 \\
16,311 \\
11,293 \\
17,564 \\
27,199 \\
23,878 \\
14,699 \\
12,882 \\
6,129\end{array}$ & $\begin{array}{r}13,227 \\
14,908 \\
12,192 \\
18,750 \\
28,619 \\
24,892 \\
17,241 \\
13,125 \\
9,654\end{array}$ & $\begin{array}{l}16,968 \\
19,364 \\
14,350 \\
27,654 \\
33,819 \\
28,916 \\
24,701 \\
21,306 \\
15,203\end{array}$ & $\begin{array}{l}17,222 \\
19,921 \\
15,016 \\
27,783 \\
34,376 \\
29,390 \\
25,063 \\
18,771 \\
17,071\end{array}$ & $\begin{array}{l}17,344 \\
19,840 \\
115,427 \\
27,386 \\
34,767 \\
29,137 \\
25,277 \\
18,627 \\
19,158\end{array}$ & $\begin{array}{l}17,589 \\
19,498 \\
15,386 \\
26,947 \\
34,340 \\
29,278 \\
26,232 \\
18,516 \\
20,440\end{array}$ & $\begin{array}{r}8,005 \\
8,556 \\
7,727 \\
10,732 \\
19,176 \\
12,283 \\
12,854 \\
6,321 \\
9,155\end{array}$ & $\begin{array}{r}9,584 \\
10,942 \\
7,659 \\
16,215 \\
15,164 \\
16,995 \\
13,378 \\
12,195 \\
11,285\end{array}$ \\
\hline 260 & University of North Dakota & ND & Public & 4-year & 11,659 & 11,031 & 13,172 & 14,194 & 14,697 & 15,250 & 7,993 & 7,257 \\
\hline $\begin{array}{l}261 \\
262 \\
263 \\
264 \\
265 \\
266 \\
267 \\
268 \\
269 \\
269 \\
270 \\
271 \\
272 \\
273 \\
274 \\
275\end{array}$ & 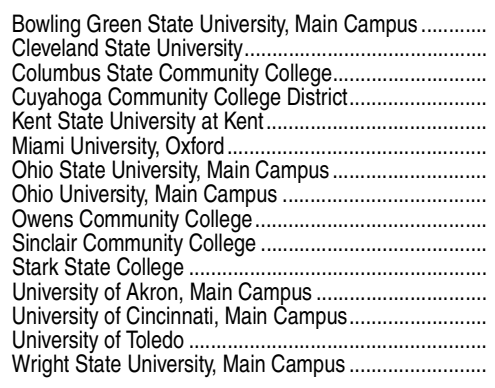 & $\begin{array}{l}\mathrm{OH} \\
\mathrm{OH} \\
\mathrm{OH} \\
\mathrm{OH} \\
\mathrm{OH} \\
\mathrm{OH} \\
\mathrm{OH} \\
\mathrm{OH} \\
\mathrm{OH} \\
\mathrm{OH} \\
\mathrm{OH} \\
\mathrm{OH} \\
\mathrm{OH} \\
\mathrm{OH} \\
\mathrm{OH}\end{array}$ & $\begin{array}{l}\text { Public } \\
\text { Public } \\
\text { Public } \\
\text { Public } \\
\text { Public } \\
\text { Public } \\
\text { Public } \\
\text { Public } \\
\text { Public } \\
\text { Public } \\
\text { Public } \\
\text { Public } \\
\text { Public } \\
\text { Public } \\
\text { Public }\end{array}$ & $\begin{array}{l}\text { 4-year } \\
\text { 4-year } \\
\text { 2-year } \\
\text { 2-year } \\
\text { 4-year } \\
\text { 4-year } \\
\text { 4-year } \\
\text { 4-year } \\
\text { 2-year } \\
\text { 2-year } \\
\text {-year } \\
\text { 4-year } \\
\text { 4-year } \\
\text { 4-year } \\
\text { 4-year }\end{array}$ & $\begin{array}{r}18,657 \\
19,214 \\
13,290 \\
23,157 \\
24,434 \\
15,835 \\
54,087 \\
18,505 \\
6,857 \\
16,367 \\
3,996 \\
28,801 \\
31,013 \\
24,691 \\
16,393\end{array}$ & $\begin{array}{r}18,096 \\
15,294 \\
18,094 \\
19,518 \\
21,924 \\
16,757 \\
47,952 \\
19,920 \\
15,845 \\
19,026 \\
4,507 \\
21,363 \\
27,327 \\
19,491 \\
13,964\end{array}$ & $\begin{array}{l}17,309 \\
16,216 \\
28,539 \\
29,807 \\
25,127 \\
16,884 \\
55,014 \\
22,647 \\
22,530 \\
21,561 \\
12,476 \\
25,959 \\
31,134 \\
23,064 \\
17,558\end{array}$ & $\begin{array}{l}17,706 \\
17,386 \\
30,513 \\
31,250 \\
26,509 \\
17,4772 \\
56,064 \\
25,108 \\
20,031 \\
21,994 \\
14,826 \\
27,076 \\
32,283 \\
23,085 \\
18,447\end{array}$ & $\begin{array}{l}17,577 \\
17,229 \\
30,921 \\
30,853 \\
27,855 \\
17,395 \\
56,867 \\
26,201 \\
17,245 \\
21,106 \\
15,536 \\
27,470 \\
33,329 \\
22,610 \\
18,304\end{array}$ & $\begin{array}{l}17,286 \\
17,278 \\
25,863 \\
29,701 \\
28,602 \\
17,683 \\
56,387 \\
27,402 \\
16,973 \\
19,537 \\
15,655 \\
26,581 \\
33,347 \\
21,453 \\
16,780\end{array}$ & $\begin{array}{r}7,542 \\
7,725 \\
11,406 \\
11,374 \\
11,555 \\
8,015 \\
29,038 \\
11,304 \\
8,378 \\
8,409 \\
6,259 \\
13,494 \\
15,517 \\
10,638 \\
7,873\end{array}$ & $\begin{array}{r}9,744 \\
9,553 \\
14,457 \\
18,327 \\
17,047 \\
9,668 \\
27,349 \\
16,098 \\
8,595 \\
11,128 \\
9,396 \\
13,087 \\
17,830 \\
10,815 \\
8,907\end{array}$ \\
\hline $\begin{array}{l}276 \\
277 \\
278 \\
279\end{array}$ & 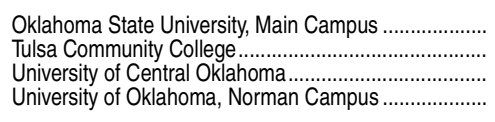 & $\begin{array}{l}\text { OK } \\
\text { OK } \\
\text { OK } \\
\text { OK }\end{array}$ & $\begin{array}{l}\text { Public } \\
\text { Public } \\
\text { Public } \\
\text { Public }\end{array}$ & $\begin{array}{l}\text { 4-year } \\
\text { 2-year } \\
\text { 4-year } \\
\text { 4-year }\end{array}$ & $\begin{array}{l}19,827 \\
17,955 \\
14,232 \\
20,774\end{array}$ & $\begin{array}{l}18,676 \\
16,270 \\
14,099 \\
24,205\end{array}$ & $\begin{array}{l}23,033 \\
19,730 \\
16,092 \\
25,881\end{array}$ & $\begin{array}{l}23,667 \\
20,577 \\
17,101 \\
26,476\end{array}$ & $\begin{array}{l}24,390 \\
20,154 \\
17,239 \\
27,138\end{array}$ & $\begin{array}{l}25,708 \\
19,557 \\
17,211 \\
27,507\end{array}$ & $\begin{array}{r}13,453 \\
7,539 \\
7,252 \\
13,891\end{array}$ & $\begin{array}{r}12,255 \\
12,018 \\
9,959 \\
13,616\end{array}$ \\
\hline $\begin{array}{l}280 \\
281 \\
282 \\
283\end{array}$ & 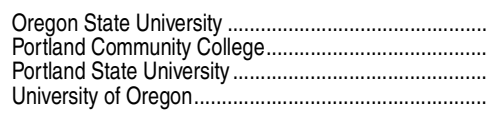 & $\begin{array}{l}\mathrm{OR} \\
\mathrm{OR} \\
\mathrm{OR} \\
\mathrm{OR}\end{array}$ & $\begin{array}{l}\text { Public } \\
\text { Public } \\
\text { Public } \\
\text { Public }\end{array}$ & $\begin{array}{l}\text { 4-year } \\
\text { 2-year } \\
4 \text {-year } \\
\text { 4-year }\end{array}$ & $\begin{array}{l}16,361 \\
21,888 \\
16,921 \\
18,840\end{array}$ & $\begin{array}{l}16,758 \\
24,209 \\
18,889 \\
17,801\end{array}$ & $\begin{array}{l}21,950 \\
30,161 \\
27,901 \\
22,335\end{array}$ & $\begin{array}{l}23,753 \\
32,013 \\
28,035 \\
23,342\end{array}$ & $\begin{array}{l}24,962 \\
34,632 \\
28,584 \\
24,396\end{array}$ & $\begin{array}{l}26,363 \\
33,767 \\
28,287 \\
24,518\end{array}$ & $\begin{array}{l}13,942 \\
15,828 \\
13,061 \\
11,751\end{array}$ & $\begin{array}{l}12,421 \\
17,939 \\
15,226 \\
12,767\end{array}$ \\
\hline $\begin{array}{l}284 \\
285 \\
286\end{array}$ & $\begin{array}{l}\text { Community College of Allegheny County..................... } \\
\text { Community College of Philadelphia ………………..... } \\
\text { Drexel University............................................... }\end{array}$ & $\begin{array}{l}\mathrm{PA} \\
\mathrm{PA} \\
\mathrm{PA}\end{array}$ & \begin{tabular}{|c|} 
Public \\
Public \\
PrivNp
\end{tabular} & $\begin{array}{l}\text { 2-year } \\
\text { 2-year } \\
\text { 4-year }\end{array}$ & $\begin{array}{l}20,553 \\
15,151 \\
11,926\end{array}$ & $\begin{array}{l}15,556 \\
15,953 \\
13,128\end{array}$ & $\begin{array}{l}20,520 \\
19,048 \\
22,493\end{array}$ & $\begin{array}{l}20,706 \\
19,503 \\
23,637\end{array}$ & $\begin{array}{l}20,430 \\
19,751 \\
24,860\end{array}$ & $\begin{array}{l}19,567 \\
18,920 \\
25,500\end{array}$ & $\begin{array}{r}8,107 \\
6,983 \\
12,415\end{array}$ & $\begin{array}{l}11,460 \\
11,937 \\
13,085\end{array}$ \\
\hline
\end{tabular}


Table 312.20. Selected statistics for degree-granting postsecondary institutions enrolling more than 15,000 students in 2012, by selected institution and student characteristics: Selected years, 1990 through 2011-12-Continued

\begin{tabular}{|c|c|c|c|c|c|c|c|c|c|c|c|c|c|}
\hline \multicolumn{5}{|c|}{ Fall enrollment, 2012} & \multicolumn{5}{|c|}{ Earned degrees/certificates conferred, 2011-12 } & \multirow{3}{*}{$\begin{array}{r}\text { Total } \\
\text { expenses and } \\
\text { deductions, } \\
2011-12 \\
\text { (in thousands) }\end{array}$} & \multicolumn{2}{|c|}{ Full-time-equivalent enrollment } & \multirow[b]{3}{*}{$\begin{array}{r}\text { Line } \\
\text { number }\end{array}$} \\
\hline Attendan & tatus & & Studen & & & & & & & & & & \\
\hline Full-time & Part-time & $\begin{array}{r}\text { Percent } \\
\text { minority }\end{array}$ & $\begin{array}{r}\text { Under- } \\
\text { graduate }\end{array}$ & $\begin{array}{r}\text { Postbacca- } \\
\text { laureate }\end{array}$ & Certificates $^{4}$ & Associate's & Bachelor's & Master's & Doctor's ${ }^{5}$ & & Fall 2011 & Fall 2012 & \\
\hline 14 & 15 & 16 & 17 & 18 & 19 & 20 & 21 & 22 & 23 & 24 & 25 & 26 & 27 \\
\hline 13,733 & 4,494 & 30.4 & $\begin{array}{ll}15,082 \\
\end{array}$ & 3,145 & 0 & 0 & 2,603 & 663 & 176 & 519,577 & 15,145 & 15,470 & 215 \\
\hline $\begin{array}{r}8,297 \\
13,614\end{array}$ & $\begin{array}{l}9,157 \\
1,653\end{array}$ & $\begin{array}{r}25.6 \\
8.8\end{array}$ & $\begin{array}{l}11,110 \\
12,804\end{array}$ & $\begin{array}{l}6,344 \\
2,463\end{array}$ & $\begin{array}{r}41 \\
0\end{array}$ & $\begin{array}{l}163 \\
139\end{array}$ & $\begin{array}{l}1,063 \\
2,658\end{array}$ & $\begin{array}{r}1,074 \\
772\end{array}$ & $\begin{array}{l}10 \\
58\end{array}$ & $\begin{array}{c}126,952 \\
520,288\end{array}$ & $\begin{array}{r}8,358 \\
14,045\end{array}$ & $\begin{array}{l}11,852 \\
14,231\end{array}$ & $\begin{array}{l}216 \\
217\end{array}$ \\
\hline 9,696 & 7,319 & 53.2 & 17,015 & 0 & 67 & 1,972 & 0 & 0 & 0 & 120,543 & 12,424 & 12,153 & 218 \\
\hline 10,715 & 4,676 & 53.3 & 12,895 & 2,496 & 0 & & 2,569 & 720 & 8 & 227,586 & 13,245 & 12,532 & 219 \\
\hline $\begin{array}{l}13,573 \\
\end{array}$ & 4,809 & 41.8 & $\begin{array}{r}14,432 \\
\end{array}$ & 3,950 & 93 & 0 & 3,144 & 1,015 & 18 & 321,473 & 15,504 & 15,398 & 220 \\
\hline 35,331 & 5,103 & 48.0 & 31,593 & 8,841 & 0 & 0 & 6,843 & 1,959 & 632 & $1,948,937$ & 36,806 & $\begin{array}{l}37,242 \\
\end{array}$ & 221 \\
\hline 150 & 20,456 & 33.8 & 19,406 & 1,200 & 11 & 677 & 2,393 & 152 & 0 & 57,401 & 8,125 & 8,355 & 222 \\
\hline 9,324 & 18,999 & 63.7 & 28,323 & 0 & 2,928 & 2,750 & 0 & 0 & 0 & 164,753 & 15,620 & 15,703 & 223 \\
\hline $\begin{array}{r}3,404 \\
13,40\end{array}$ & 4,247 & 62.0 & 14,276 & 3,375 & 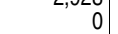 & 12 & 2,441 & 875 & 102 & 460,281 & 14,984 & 15,049 & 224 \\
\hline 20,666 & $\begin{array}{l}4,347 \\
8,367\end{array}$ & 56.0 & 22,773 & 6,260 & 0 & 0 & 3,400 & 1,247 & 496 & $1,704,355$ & 23,895 & 23,930 & 225 \\
\hline 11,171 & 6,202 & 62.9 & 13,777 & 3,596 & 0 & 0 & 2.716 & 1,465 & 0 & 263,257 & 14,035 & 13,557 & 226 \\
\hline 16,151 & 8,386 & 89.4 & 24,537 & & 0 & 3,017 & & & 0 & 290,694 & 18,762 & 18,966 & 227 \\
\hline $\begin{array}{r}0,110 \\
9,766\end{array}$ & $\begin{array}{l}\text {, U., } \\
6,758\end{array}$ & $\begin{array}{l}59.4 \\
56.0\end{array}$ & $\begin{array}{l}2,031 \\
13,099\end{array}$ & 3,425 & 3 & . 0 & 2,474 & 1,138 & 0 & 273,776 & . & $\begin{array}{l}12,900 \\
12,372\end{array}$ & 228 \\
\hline 9,998 & 6,025 & 78.0 & 12,983 & 3,040 & 0 & 0 & 1,975 & 909 & 2 & $\begin{array}{l}364,332 \\
364\end{array}$ & 12,309 & 12,322 & 229 \\
\hline 13,341 & 9,664 & 56.0 & 16,708 & 6,297 & 10 & 0 & 2,707 & 2,091 & 0 & 346,622 & 16,738 & 17,036 & 230 \\
\hline 10,858 & 8,076 & 65.2 & 18,934 & 0 & 20 & 2,270 & 0 & 0 & 0 & 180,060 & 13,910 & 13,569 & 231 \\
\hline $\begin{array}{l}10,016 \\
10,0\end{array}$ & 9,271 & 85.3 & 19,287 & 0 & 64 & 2,982 & 0 & 0 & 0 & 207,422 & 13,138 & 13,129 & 232 \\
\hline $\begin{array}{l}10,018 \\
10,0\end{array}$ & 6,189 & $\begin{array}{l}85.0 \\
85.0\end{array}$ & 16,207 & 0 & $\begin{array}{l}04 \\
12\end{array}$ & 1,074 & 847 & 0 & 0 & $\begin{array}{l}189,133 \\
189,4<2\end{array}$ & . & 12,516 & 233 \\
\hline $\begin{array}{l}11,715 \\
\end{array}$ & 8,385 & 54.0 & 16,187 & 3,913 & 0 & & 3,063 & 1,247 & 0 & 319,176 & 15,360 & 14,952 & 234 \\
\hline 9,383 & 6,328 & 79.1 & 15,711 & & 14 & 1,737 & 0 & 0 & 0 & 147,811 & 12,016 & 11,508 & 235 \\
\hline 22,097 & 4,374 & 43.1 & 7,814 & 18,657 & 0 & 0 & 2,022 & 6,794 & 1,329 & $3,425,061$ & 23,430 & 23,774 & 236 \\
\hline 21,346 & 78 & 43.3 & 14,261 & 7,163 & 0 & 0 & 3,596 & 2,150 & 775 & $1,752,090$ & 21,073 & 21,376 & 237 \\
\hline $\begin{array}{r}21,040 \\
0\end{array}$ & 39,728 & $\begin{array}{l}38.3 \\
38.0\end{array}$ & 37,707 & $\begin{array}{l}2,021 \\
2,10\end{array}$ & 59 & 2,177 & 2,790 & $\begin{array}{r}r, 109 \\
199\end{array}$ & 0 & $\begin{array}{r}72,166 \\
7\end{array}$ & $\begin{array}{l}13,971 \\
13\end{array}$ & 15,585 & 238 \\
\hline 11,961 & r $\begin{array}{r}3,, 200 \\
3,209\end{array}$ & $\begin{array}{l}30.0 \\
33.6\end{array}$ & $\begin{array}{r}3,101 \\
8,325\end{array}$ & $\begin{array}{l}2,0<1 \\
6,845\end{array}$ & r & - 2,171 & $\begin{array}{l}2,919 \\
1,919\end{array}$ & 2,063 & 593 & $\begin{array}{r}12,100 \\
496,206\end{array}$ & 13,194 & $\begin{array}{l}13,503 \\
13,194\end{array}$ & $\begin{array}{l}230 \\
239\end{array}$ \\
\hline 10,554 & 6,742 & 34.5 & 17,296 & & 194 & 2,703 & & - & 0 & 154,687 & 13,244 & 12,818 & 240 \\
\hline 14,560 & 8,780 & 52.7 & 23,340 & & 118 & 3,013 & 0 & 0 & 0 & 210,155 & 17,831 & 17,508 & 241 \\
\hline 34,964 & 9,552 & 42.2 & 22,498 & 22,018 & 86 & 313 & 5,009 & 6,876 & 1,481 & $3,830,879$ & 37,922 & 38,626 & 242 \\
\hline 14,300 & 2,057 & 22.5 & 13,711 & 2,646 & 63 & 193 & 2,407 & 926 & $\begin{array}{r}16 \\
16\end{array}$ & $\begin{array}{r}487,320 \\
\end{array}$ & 14,948 & 15,100 & 243 \\
\hline 13,923 & 7,164 & 50.9 & 15,840 & 5,247 & 81 & 44 & 2,287 & 1,353 & 622 & 437,122 & 17,008 & 16,713 & 244 \\
\hline $\begin{array}{l}15,003 \\
14,243\end{array}$ & $\begin{array}{l}3,104 \\
3,069\end{array}$ & $\begin{array}{l}50.9 \\
33.0\end{array}$ & $\begin{array}{l}12,040 \\
12,878\end{array}$ & $\begin{array}{l}4,<41 \\
4,434\end{array}$ & $\begin{array}{r}0 \\
0\end{array}$ & $\begin{array}{r}44 \\
0\end{array}$ & $\begin{array}{l}2,201 \\
3,046\end{array}$ & $\begin{array}{l}1,203 \\
1,265\end{array}$ & $\begin{array}{l}022 \\
158\end{array}$ & 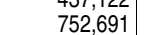 & $\begin{array}{l}17,000 \\
15,188\end{array}$ & 15,387 & 245 \\
\hline 13,586 & 1,722 & 33.9 & 12,356 & 2,952 & 0 & 0 & $\begin{array}{l}0,0,120 \\
3,121\end{array}$ & $\mid$ & 151 & $\begin{array}{l}412,489 \\
42,0\end{array}$ & 13,667 & 14,227 & 246 \\
\hline $\begin{array}{l}19,803 \\
\end{array}$ & 4,143 & 45.6 & 15,837 & 8,109 & 0 & 0 & 3,882 & 1,767 & 537 & $2,083,652$ & 21,231 & 21,355 & 247 \\
\hline 14,843 & 11,376 & 32.0 & 26,219 & 0 & 110 & 3,438 & 0 & 0 & 0 & 247,938 & 19,000 & 18,662 & 248 \\
\hline 18,803 & 2,226 & 31.3 & 14,798 & 6,231 & 3 & 4 & 3,077 & 1,918 & 341 & 810,091 & 19,368 & 19,660 & 249 \\
\hline 24,033 & 4,919 & 29.7 & 19,514 & 9,438 & 10 & 0 & 4,493 & 2,247 & 913 & 944,395 & 25,633 & 25,886 & 250 \\
\hline 15,665 & 1,924 & 10.4 & 15,712 & 1,877 & 0 & 0 & 3,435 & 798 & 13 & 348,256 & 16,265 & 16,397 & 251 \\
\hline 7,121 & 12,377 & 48.0 & 19,498 & & 911 & 1,634 & 0 & 0 & 0 & 160,342 & 11,793 & 11,276 & 252 \\
\hline $\begin{array}{l}14,924 \\
\end{array}$ & 462 & 36.4 & 6,655 & 8,731 & 0 & $\mid$ & 1,799 & 1,941 & 1,010 & $4,485,592$ & 15,166 & 15,100 & 253 \\
\hline $\begin{array}{l}20,834 \\
20\end{array}$ & 6,113 & $\begin{array}{l}52.4 \\
22.9\end{array}$ & 21,298 & $\begin{array}{l}5,1049 \\
5,64\end{array}$ & 0 & 0 & $\begin{array}{l}4,174 \\
4\end{array}$ & $\begin{array}{l}1,698 \\
1,698\end{array}$ & . & $\begin{array}{r}4,40,096 \\
756,875\end{array}$ & 23,494 & 23,170 & 254 \\
\hline 27,108 & 7,232 & 20.7 & 24,833 & 9,507 & 0 & 154 & 5,464 & 2,358 & 525 & $1,207,993$ & 30,219 & 29,849 & 255 \\
\hline $\begin{array}{l}24,498 \\
24\end{array}$ & 4,780 & 28.8 & $\begin{array}{l}18,503 \\
\end{array}$ & 10,775 & 4 & 0 & $\begin{array}{l}5,445 \\
4,440\end{array}$ & 2,006 & 1,179 & 2,523,886 & 26,042 & 26,267 & 256 \\
\hline $\begin{array}{l}24,490 \\
20,014\end{array}$ & $\begin{array}{l}4,100 \\
6,218\end{array}$ & $\begin{array}{l}20.0 \\
33.6\end{array}$ & 21,179 & 5,053 & $\begin{array}{l}4 \\
0\end{array}$ & 0 & $\begin{array}{l}4,460 \\
3,964\end{array}$ & $\begin{array}{l}2,212 \\
1,212\end{array}$ & $\begin{array}{r}r \\
118\end{array}$ & $\mid$ & 21,506 & $\begin{array}{l}22,394 \\
22,394\end{array}$ & 257 \\
\hline 14,398 & 4,118 & 36.9 & 15,039 & 3,477 & 0 & 0 & 2,958 & 906 & 113 & 361,997 & 16,034 & 15,970 & 258 \\
\hline 7,641 & 12,799 & 40.5 & 20,440 & & 872 & 1,444 & & 0 & 0 & 129,845 & 10,068 & 11,938 & 259 \\
\hline 11,382 & 3,868 & 11.6 & 11,953 & 3,297 & 78 & 0 & 1,709 & 647 & 263 & 415,698 & 12,424 & 12,877 & 260 \\
\hline 15,078 & 2,208 & 17.8 & 14,815 & 2,471 & 0 & 0 & 2,731 & 902 & 86 & 344,484 & 16,124 & 15,922 & 261 \\
\hline 10,458 & 6,820 & 30.2 & 11,808 & 5,470 & 0 & 0 & 2,066 & 1,463 & 239 & 289,139 & 12,923 & 13,060 & 262 \\
\hline 9,013 & 16,850 & 32.9 & 25,863 & 0 & 1,384 & 2,222 & 0 & 0 & 0 & 229,347 & 18,839 & 14,670 & 263 \\
\hline $\begin{array}{r}10,586 \\
\end{array}$ & 19,115 & 41.7 & 29,701 & 0 & 469 & 2,186 & 0 & 0 & 0 & 303,920 & 18,067 & 17,004 & 264 \\
\hline $\begin{array}{l}21,682 \\
21\end{array}$ & 6,920 & 15.8 & 22,436 & 6,166 & $\begin{array}{r}4 \\
92\end{array}$ & 0 & 4,383 & 1,546 & 259 & 494,510 & 23,669 & 24,355 & 265 \\
\hline $\begin{array}{l}21,002 \\
15,713\end{array}$ & 1,970 & 12.1 & $\begin{array}{l}2,400 \\
15,081\end{array}$ & $\begin{array}{l}2,602 \\
2,100 \\
\end{array}$ & $\begin{array}{l}92 \\
35\end{array}$ & 254 & $\mid$ & $\mid$ & 58 & . & $\begin{array}{l}20,279 \\
16,209\end{array}$ & $\begin{array}{l}2,050 \\
16,443\end{array}$ & 266 \\
\hline $\begin{array}{l}15,13 \\
49,000\end{array}$ & $\begin{array}{l}1,910 \\
7,387\end{array}$ & $\begin{array}{l}12.1 \\
18.9\end{array}$ & . 43,058 & $\begin{array}{r}2,00< \\
13,329\end{array}$ & $\begin{array}{r}35 \\
0\end{array}$ & $\begin{array}{r}254 \\
0\end{array}$ & $\begin{array}{r}3,813 \\
10,926\end{array}$ & $\begin{array}{r}032 \\
3,144\end{array}$ & $\begin{array}{r}58 \\
1,628\end{array}$ & $\begin{array}{r}4 / 8,644 \\
4,549,124\end{array}$ & $\begin{array}{l}10,279 \\
51,864\end{array}$ & $\begin{array}{l}10,443 \\
51,846\end{array}$ & $\begin{array}{l}260 \\
267\end{array}$ \\
\hline 19.501 & 7901 & 12.1 & 22.685 & 4.717 & 248 & 115 & 5.465 & 1,187 & 246 & 535,974 & 22,466 & 22.603 & 268 \\
\hline 5,967 & 11,006 & 24.5 & 16,973 & $\begin{array}{r}1 \\
0\end{array}$ & $\begin{array}{l}407 \\
407\end{array}$ & 1,189 & r & | & $\begin{array}{r}240 \\
0\end{array}$ & $\begin{array}{l}126,158 \\
126\end{array}$ & 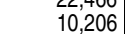 & $\begin{array}{r}2,000 \\
9,662\end{array}$ & 269 \\
\hline 7,630 & 11,907 & 23.3 & 19,537 & 0 & 2,280 & 2,050 & 0 & 0 & 0 & 165,662 & 13,274 & 11,628 & 270 \\
\hline 4,677 & 10,978 & 25.6 & 15,655 & 0 & 209 & 1,134 & 0 & 0 & 0 & 109,483 & $\begin{array}{r}8,830 \\
8,8\end{array}$ & $\begin{array}{r}8,363 \\
\end{array}$ & 271 \\
\hline $\begin{array}{r}4,017 \\
19,517\end{array}$ & 7,064 & $\begin{array}{l}25.0 \\
22.1\end{array}$ & 22,123 & 4,458 & 152 & $\begin{array}{r}1,134 \\
483\end{array}$ & 2,848 & 1,139 & 245 & $\begin{array}{r}495,165 \\
495,0\end{array}$ & $\begin{array}{l}0,0.030 \\
23,136\end{array}$ & $\begin{array}{r}0,303 \\
22,284\end{array}$ & 272 \\
\hline 25,289 & 8,058 & 17.3 & 23,096 & 10,251 & 287 & 147 & $\begin{array}{l}2,400 \\
4,498\end{array}$ & 2,410 & 703 & 971,287 & 28,423 & 28,347 & 273 \\
\hline $\begin{array}{l}16,618 \\
16,00\end{array}$ & 4,835 & 24.8 & 16,837 & $\begin{array}{r}4,616 \\
\end{array}$ & 34 & 70 & 2,808 & $\begin{array}{l}2,152 \\
1,152\end{array}$ & 555 & 859,503 & 19,603 & 18,506 & 274 \\
\hline 13,037 & 3,743 & 22.4 & 13,143 & 3,637 & 0 & $\begin{array}{r}0 \\
0\end{array}$ & 2,512 & 1,370 & 139 & 397,132 & 16,010 & 14,509 & 275 \\
\hline 19,597 & 6.111 & 23.7 & 20,323 & 5,385 & & & 3.781 & 1,234 & 296 & 779,269 & 20,732 & 21.924 & 276 \\
\hline $\begin{array}{r}19,9911 \\
6,994\end{array}$ & 12,563 & $\begin{array}{l}20.1 \\
36.1\end{array}$ & $\begin{array}{l}2,0<0 \\
19,557\end{array}$ & & 368 & 2,250 & $\begin{array}{l}3,101 \\
0\end{array}$ & $\begin{array}{r}-54 \\
0\end{array}$ & $\begin{array}{r}290 \\
0\end{array}$ & $\begin{array}{l}14,289 \\
141,282\end{array}$ & . & $\begin{array}{l}2,1,9<4 \\
11,212\end{array}$ & 277 \\
\hline 11,721 & 5,490 & 32.1 & 15,379 & 1,832 & 2 & 58 & 2,385 & 611 & 0 & 182,627 & 13,950 & 13,889 & 278 \\
\hline 21,272 & 6,235 & 30.1 & 21,109 & 6,398 & 0 & 0 & 3,882 & 1,829 & 404 & 825,424 & 23,416 & 23,653 & 279 \\
\hline 21,084 & 5,279 & 22.8 & 21,8 & 4,555 & 0 & 0 & 3,932 & 774 & 349 & 826,649 & 22,072 & & 280 \\
\hline $\begin{array}{l}14,282 \\
\end{array}$ & 19,485 & 29.8 & 33,767 & $\begin{array}{l}4 \\
4,000 \\
0\end{array}$ & 928 & 3,232 & 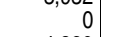 & 0 & 0 & $\begin{array}{l}0<0,049 \\
295,318\end{array}$ & 21,138 & 20,824 & 281 \\
\hline 17,168 & 11,119 & 27.2 & 22,770 & 5,517 & 0 & 0 & 4,320 & 1,654 & 65 & 473,652 & 21,736 & 21,535 & 282 \\
\hline 21,914 & 2,604 & 22.4 & 20,809 & 3,709 & 0 & 0 & 4,272 & 986 & 331 & 742,953 & 22,879 & 22,938 & 283 \\
\hline 7,259 & 12,308 & 26.5 & 19,567 & 0 & 810 & 1,982 & 0 & 0 & 0 & 136,087 & 12,224 & 11,391 & 284 \\
\hline 5,100 & 13,820 & 70.4 & 18,920 & 0 & 179 & 1,798 & 0 & 0 & 0 & 160,888 & 10,311 & 9,740 & 285 \\
\hline 18,009 & 7,491 & 31.1 & 15,876 & 9,624 & 117 & 17 & 2,820 & 2,382 & 621 & 867,745 & 20,264 & 20,902 & 286 \\
\hline
\end{tabular}

See notes at end of table. 
474 CHAPTER 3: Postsecondary Education

Large Institutions and Institutions Serving Specific Groups

Table 312.20. Selected statistics for degree-granting postsecondary institutions enrolling more than 15,000 students in 2012 , by selected institution and student characteristics: Selected years, 1990 through 2011-12-Continued

\begin{tabular}{|c|c|c|c|c|c|c|c|c|c|c|c|c|}
\hline \multirow{3}{*}{$\begin{array}{l}\text { Line } \\
\text { number }\end{array}$} & \multirow[b]{3}{*}{ Institution } & \multirow[b]{3}{*}{ State } & \multirow{3}{*}{$\begin{array}{c}\text { Con- } \\
\text { trol }^{1}\end{array}$} & \multirow[b]{3}{*}{ Level } & \multicolumn{5}{|c|}{ Total fall enrollment } & \multicolumn{3}{|c|}{ Fall enrollment, 2012} \\
\hline & & & & & \multirow[b]{2}{*}{ Fall 1990} & \multirow[b]{2}{*}{ Fall 2000} & \multirow[b]{2}{*}{ Fall 2009} & \multirow[b]{2}{*}{ Fall 2010} & \multirow[b]{2}{*}{ Fall 2011} & \multirow[b]{2}{*}{ Total } & \multicolumn{2}{|c|}{ Sex } \\
\hline & & & & & & & & & & & Male & Female \\
\hline 1 & 2 & 3 & 4 & 5 & 6 & 7 & 8 & 9 & 10 & 11 & 12 & 13 \\
\hline $\begin{array}{l}287 \\
288 \\
289 \\
290 \\
291 \\
292 \\
293\end{array}$ & 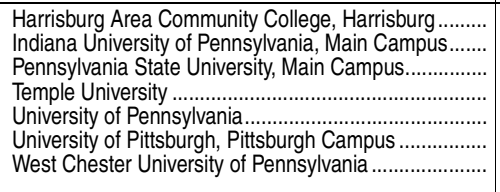 & $\begin{array}{l}\mathrm{PA} \\
\mathrm{PA} \\
\mathrm{PA} \\
\mathrm{PA} \\
\mathrm{PA} \\
\mathrm{PA} \\
\mathrm{PA}\end{array}$ & \begin{tabular}{|l|} 
Public \\
Public \\
Public \\
Public \\
Privp \\
Public \\
Public
\end{tabular} & $\begin{array}{l}\text { 2-year } \\
\text { 4-year } \\
\text { 4-year } \\
\text { 4-year } \\
\text { 4-year } \\
\text { 4-year } \\
\text { 4-year }\end{array}$ & \begin{tabular}{r|}
8,355 \\
14,398 \\
38,864 \\
29,714 \\
21,868 \\
28,120 \\
12,076
\end{tabular} & \begin{tabular}{r|}
7,572 \\
13,410 \\
40,571 \\
28,355 \\
21,853 \\
26,329 \\
12,272
\end{tabular} & $\begin{array}{l}22,529 \\
14,638 \\
45,185 \\
36,507 \\
24,599 \\
28,328 \\
14,211\end{array}$ & $\begin{array}{l}23,210 \\
15,126 \\
45,233 \\
37,367 \\
25,007 \\
28,823 \\
14,490\end{array}$ & \begin{tabular}{l|}
22,595 \\
15,340 \\
45,628 \\
36,855 \\
24,832 \\
28,766 \\
15,100
\end{tabular} & $\begin{array}{l}21,945 \\
15,596 \\
45,783 \\
36,744 \\
24,725 \\
28,769 \\
15,411\end{array}$ & $\begin{array}{r}8,193 \\
6,905 \\
24,672 \\
17,602 \\
11,707 \\
13,993 \\
6,068\end{array}$ & $\begin{array}{r}13,752 \\
8,691 \\
21,111 \\
19,142 \\
13,018 \\
14,776 \\
9,343\end{array}$ \\
\hline $\begin{array}{l}294 \\
295\end{array}$ & $\begin{array}{l}\text { Community College of Rhode Island ............................. } \\
\text { University of Rhode Island..................................... }\end{array}$ & $\begin{array}{l}\mathrm{RI} \\
\mathrm{RI}\end{array}$ & $\begin{array}{l}\text { Public } \\
\text { Public }\end{array}$ & $\begin{array}{l}2 \text {-year } \\
\text { 4-year }\end{array}$ & $\begin{array}{l}16,620 \\
16,047\end{array}$ & $\begin{array}{l}15,583 \\
14,362\end{array}$ & $\begin{array}{l}17,760 \\
16,389\end{array}$ & $\begin{array}{l}17,775 \\
16,294\end{array}$ & $\begin{array}{l}17,893 \\
16,317\end{array}$ & $\begin{array}{l}17,884 \\
16,451\end{array}$ & $\begin{array}{l}7,109 \\
7,413\end{array}$ & $\begin{array}{r}10,775 \\
9,038\end{array}$ \\
\hline $\begin{array}{l}296 \\
297 \\
298\end{array}$ & 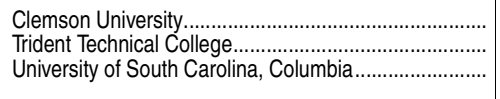 & $\begin{array}{l}\mathrm{SC} \\
\mathrm{SC} \\
\mathrm{SC}\end{array}$ & $\begin{array}{l}\text { Public } \\
\text { Public } \\
\text { Public }\end{array}$ & $\begin{array}{l}\text { 4-year } \\
\text { 2-year } \\
\text { 4-year }\end{array}$ & $\begin{array}{r}15,714 \\
6,939 \\
25,613\end{array}$ & $\begin{array}{l}17,465 \\
10,246 \\
23,728\end{array}$ & $\begin{array}{l}19,111 \\
14,834 \\
28,482\end{array}$ & $\begin{array}{l}19,453 \\
15,790 \\
29,599\end{array}$ & $\begin{array}{l}19,914 \\
16,781 \\
30,721\end{array}$ & $\begin{array}{l}20,768 \\
17,224 \\
31,288\end{array}$ & $\begin{array}{r}11,205 \\
6,568 \\
14,015\end{array}$ & $\begin{array}{r}9,563 \\
10,656 \\
17,273\end{array}$ \\
\hline $\begin{array}{l}299 \\
300 \\
301 \\
302\end{array}$ & 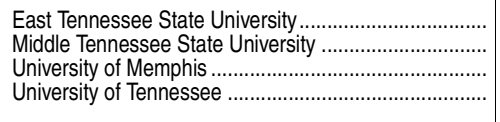 & $\begin{array}{l}\text { TN } \\
\text { TN } \\
\text { TN } \\
\text { TN }\end{array}$ & $\begin{array}{l}\text { Public } \\
\text { Public } \\
\text { Public } \\
\text { Public }\end{array}$ & $\begin{array}{l}\text { 4-year } \\
\text { 4-year } \\
\text { 4-year } \\
\text { 4-year }\end{array}$ & $\begin{array}{l}11,590 \\
14,865 \\
20,681 \\
26,055\end{array}$ & $\begin{array}{l}11,063 \\
19,121 \\
19,986 \\
25,890\end{array}$ & $\begin{array}{l}14,421 \\
25,188 \\
21,424 \\
29,934\end{array}$ & $\begin{array}{l}14,952 \\
26,430 \\
22,420 \\
30,300\end{array}$ & $\begin{array}{l}15,250 \\
26,442 \\
22,725 \\
30,194\end{array}$ & $\begin{array}{l}15,133 \\
25,394 \\
22,139 \\
29,833\end{array}$ & $\begin{array}{r}6,338 \\
11,754 \\
8,771 \\
14,824\end{array}$ & $\begin{array}{r}8,795 \\
13,640 \\
13,368 \\
15,009\end{array}$ \\
\hline $\begin{array}{l}303 \\
304 \\
305 \\
306 \\
307 \\
308 \\
309 \\
310 \\
311 \\
312 \\
313 \\
314 \\
315 \\
316 \\
317 \\
318 \\
319 \\
320 \\
321 \\
322 \\
323 \\
324 \\
325 \\
326 \\
327 \\
328 \\
329\end{array}$ & 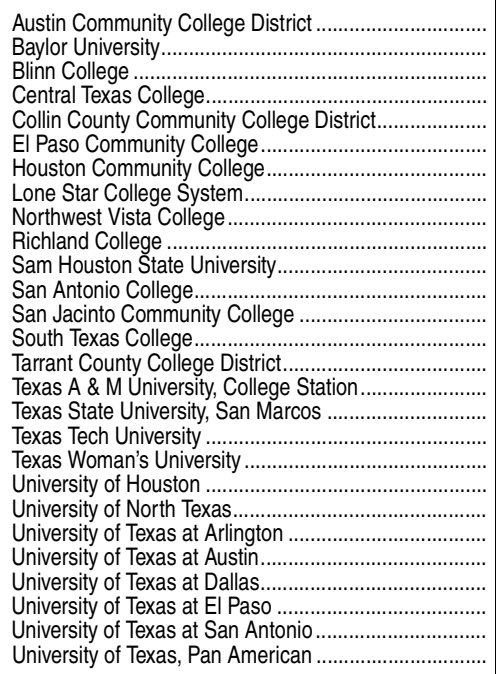 & 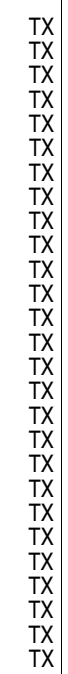 & $\begin{array}{l}\text { Public } \\
\text { PrivNp } \\
\text { Public } \\
\text { Public } \\
\text { Public } \\
\text { Public } \\
\text { Public } \\
\text { Public } \\
\text { Public } \\
\text { Public } \\
\text { Public } \\
\text { Public } \\
\text { Public } \\
\text { Public } \\
\text { Public } \\
\text { Public } \\
\text { Public } \\
\text { Public } \\
\text { Pubbic } \\
\text { Public } \\
\text { Public } \\
\text { Public } \\
\text { Public } \\
\text { Public } \\
\text { Public } \\
\text { Public } \\
\text { Public }\end{array}$ & $\begin{array}{l}\text { 2-year } \\
\text { 4-year } \\
\text { 2-year } \\
\text { 2-year } \\
\text { 2-year } \\
\text { 2-year } \\
\text { 2-year } \\
\text { 2-year } \\
\text { 2-year } \\
\text { 2-year } \\
\text { 4-year } \\
\text { 2-year } \\
\text { 2-year } \\
\text { 4-year } \\
\text { 2-year } \\
\text { 4-year } \\
\text { 4-year } \\
\text { 4-year } \\
\text { 4-year } \\
\text { 4-year } \\
\text { 4-year } \\
\text { 4-year } \\
\text { 4-year } \\
\text { 4-year } \\
\text { 4-year } \\
\text { 4-year } \\
\text { 4-year }\end{array}$ & $\begin{array}{r}24,251 \\
12,014 \\
6,849 \\
4,815 \\
9,059 \\
17,081 \\
36,437 \\
15,653 \\
\dagger \\
12,567 \\
12,753 \\
20,083 \\
9,424 \\
\dagger \\
28,161 \\
41,171 \\
20,940 \\
25,363 \\
9,850 \\
33,115 \\
27,160 \\
24,782 \\
49,617 \\
8,558 \\
16,524 \\
15,489 \\
12,337\end{array}$ & $\begin{array}{r}25,735 \\
13,719 \\
11,588 \\
14,636 \\
12,996 \\
18,001 \\
40,929 \\
24,554 \\
3,893 \\
12,537 \\
12,358 \\
19,253 \\
10,507 \\
11,319 \\
26,868 \\
44,026 \\
22,423 \\
24,558 \\
8,404 \\
32,123 \\
27,054 \\
20,424 \\
49,996 \\
10,945 \\
15,224 \\
18,830 \\
12,759\end{array}$ & $\begin{array}{l}40,248 \\
14,614 \\
17,173 \\
24,133 \\
24,872 \\
28,168 \\
54,942 \\
46,504 \\
14,587 \\
18,201 \\
16,772 \\
24,135 \\
27,011 \\
26,338 \\
44,355 \\
48,702 \\
30,803 \\
30,049 \\
13,338 \\
37,000 \\
35,003 \\
28,085 \\
50,995 \\
15,783 \\
21,011 \\
28,955 \\
18,337\end{array}$ & $\begin{array}{l}44,100 \\
14,900 \\
17,755 \\
26,055 \\
27,069 \\
29,909 \\
60,303 \\
54,412 \\
15,921 \\
19,201 \\
17,291 \\
25,269 \\
28,549 \\
27,692 \\
49,108 \\
49,129 \\
32,572 \\
31,637 \\
14,180 \\
38,752 \\
36,305 \\
32,975 \\
51,195 \\
17,128 \\
22,106 \\
30,258 \\
18,744\end{array}$ & $\begin{array}{l}45,100 \\
15,029 \\
18,106 \\
26,995 \\
27,593 \\
30,723 \\
63,015 \\
63,029 \\
16,067 \\
20,000 \\
17,527 \\
25,567 \\
29,392 \\
29,604 \\
50,062 \\
50,230 \\
34,087 \\
32,327 \\
14,718 \\
39,820 \\
37,818 \\
33,439 \\
51,112 \\
18,864 \\
22,640 \\
30,968 \\
19,034\end{array}$ & $\begin{array}{l}43,315 \\
15,364 \\
17,839 \\
22,443 \\
27,424 \\
32,127 \\
58,476 \\
60,428 \\
15,992 \\
19,552 \\
18,461 \\
23,134 \\
28,721 \\
30,824 \\
50,439 \\
50,627 \\
34,225 \\
32,467 \\
15,168 \\
40,747 \\
37,950 \\
33,239 \\
52,186 \\
19,727 \\
22,749 \\
30,474 \\
19,302\end{array}$ & $\begin{array}{r}19,141 \\
6,599 \\
8,572 \\
11,657 \\
11,935 \\
13,720 \\
24,162 \\
23,790 \\
7,138 \\
8,857 \\
7,555 \\
9,485 \\
12,328 \\
13,068 \\
20,695 \\
26,939 \\
14,971 \\
17,549 \\
1,670 \\
20,588 \\
17,353 \\
14,513 \\
25,795 \\
11,028 \\
10,463 \\
15,754 \\
8,501\end{array}$ & $\begin{array}{r}24,174 \\
8,765 \\
9,267 \\
10,786 \\
15,489 \\
18,407 \\
34,314 \\
36,638 \\
8,854 \\
10,695 \\
10,906 \\
13,649 \\
16,393 \\
17,756 \\
29,744 \\
23,688 \\
19,254 \\
14,918 \\
13,498 \\
20,159 \\
20,597 \\
18,726 \\
26,391 \\
8,699 \\
12,286 \\
14,720 \\
10,801\end{array}$ \\
\hline $\begin{array}{l}330 \\
331 \\
332 \\
333 \\
334 \\
335 \\
336\end{array}$ & 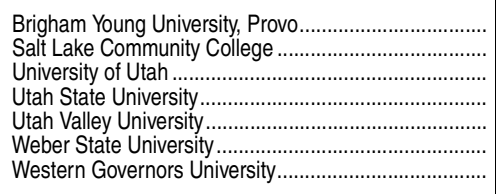 & $\begin{array}{l}\mathrm{UT} \\
\mathrm{UT} \\
\mathrm{UT} \\
\mathrm{UT} \\
\mathrm{UT} \\
\mathrm{UT} \\
\mathrm{UT}\end{array}$ & \begin{tabular}{|l|} 
PrivNp \\
Public \\
Public \\
Public \\
Public \\
Public \\
PrivNp
\end{tabular} & $\begin{array}{l}\text { 4-year } \\
\text { 2-year } \\
\text { 4-year } \\
\text { 4-year } \\
\text { 4-year } \\
\text { 4-year } \\
\text { 4-year }\end{array}$ & $\begin{array}{r}31,662 \\
13,344 \\
24,922 \\
15,155 \\
7,879 \\
13,449 \\
\dagger\end{array}$ & $\begin{array}{r}32,554 \\
21,596 \\
24,948 \\
21,490 \\
20,946 \\
16,050 \\
205\end{array}$ & $\begin{array}{l}34,130 \\
34,966 \\
29,284 \\
15,612 \\
28,765 \\
23,001 \\
15,870\end{array}$ & $\begin{array}{l}33,841 \\
34,654 \\
30,819 \\
16,472 \\
32,670 \\
24,048 \\
22,497\end{array}$ & $\begin{array}{l}34,101 \\
33,420 \\
31,660 \\
26,757 \\
33,395 \\
25,301 \\
30,970\end{array}$ & $\begin{array}{l}34,409 \\
29,997 \\
32,388 \\
28,786 \\
31,562 \\
26,532 \\
41,369\end{array}$ & $\begin{array}{l}17,978 \\
14,617 \\
18,021 \\
13,012 \\
17,612 \\
12,546 \\
16,847\end{array}$ & $\begin{array}{l}16,431 \\
15,380 \\
14,367 \\
15,774 \\
13,950 \\
13,986 \\
24,522\end{array}$ \\
\hline $\begin{array}{l}337 \\
338 \\
339 \\
340 \\
341 \\
342 \\
343 \\
344 \\
345\end{array}$ & 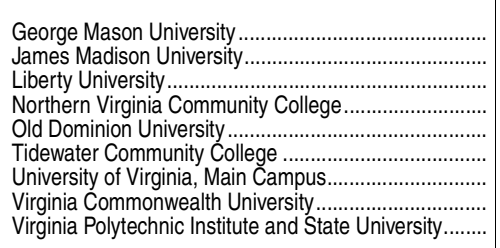 & $\begin{array}{l}V A \\
V A \\
V A \\
V A \\
V A \\
V A \\
V A \\
V A \\
V A\end{array}$ & \begin{tabular}{|l|} 
Public \\
Public \\
PrivNp \\
Public \\
Public \\
Public \\
Public \\
Public \\
Public
\end{tabular} & $\begin{array}{l}\text { 4-year } \\
\text { 4-year } \\
\text { 4-year } \\
\text { 2-year } \\
\text { 4-year } \\
\text { 2-year } \\
\text { 4-year } \\
\text { 4-year } \\
\text { 4-year }\end{array}$ & $\begin{array}{l}20,308 \\
11,251 \\
18,533 \\
35,194 \\
16,729 \\
17,726 \\
21,110 \\
21,764 \\
25,568\end{array}$ & $\begin{array}{r}23,408 \\
15,326 \\
6,192 \\
37,073 \\
18,969 \\
20,184 \\
22,411 \\
24,066 \\
27,869\end{array}$ & $\begin{array}{l}32,067 \\
18,971 \\
46,312 \\
46,619 \\
24,013 \\
30,447 \\
24,355 \\
32,172 \\
30,870\end{array}$ & $\begin{array}{l}32,562 \\
19,434 \\
56,625 \\
48,996 \\
24,466 \\
31,308 \\
24,391 \\
32,027 \\
31,006\end{array}$ & $\begin{array}{l}33,320 \\
19,722 \\
64,096 \\
50,044 \\
24,753 \\
32,101 \\
24,297 \\
31,627 \\
30,936\end{array}$ & $\begin{array}{l}32,961 \\
19,927 \\
74,372 \\
51,864 \\
24,670 \\
30,134 \\
23,907 \\
31,445 \\
31,087\end{array}$ & $\begin{array}{r}15,145 \\
7,958 \\
30,775 \\
25,037 \\
11,159 \\
12,354 \\
10,971 \\
13,567 \\
18,079\end{array}$ & $\begin{array}{l}17,816 \\
11,969 \\
43,597 \\
26,827 \\
13,511 \\
117,780 \\
12,936 \\
17,878 \\
13,008\end{array}$ \\
\hline $\begin{array}{l}346 \\
347\end{array}$ & 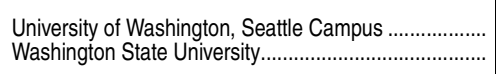 & $\begin{array}{l}\text { WA } \\
\text { WA }\end{array}$ & $\begin{array}{l}\text { Public } \\
\text { Public }\end{array}$ & $\begin{array}{l}\text { 4-year } \\
\text { 4-year }\end{array}$ & $\begin{array}{l}33,854 \\
18,412\end{array}$ & $\begin{array}{l}36,139 \\
20,492\end{array}$ & $\begin{array}{l}45,943 \\
26,101\end{array}$ & $\begin{array}{l}42,451 \\
26,308\end{array}$ & $\begin{array}{l}42,444 \\
27,329\end{array}$ & $\begin{array}{l}43,485 \\
27,679\end{array}$ & $\begin{array}{l}20,861 \\
13,564\end{array}$ & $\begin{array}{l}22,624 \\
14,115\end{array}$ \\
\hline $\begin{array}{l}348 \\
349\end{array}$ & 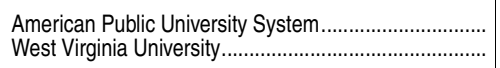 & $\begin{array}{l}\text { WV } \\
\text { WV }\end{array}$ & $\begin{array}{l}\text { Privep } \\
\text { Public }\end{array}$ & $\begin{array}{l}\text { 4-year } \\
\text { 4-year }\end{array}$ & $20,854^{\top}$ & 21,987 & $\begin{array}{l}31,331 \\
28,898\end{array}$ & $\begin{array}{l}39,296 \\
29,306\end{array}$ & $\begin{array}{l}50,838 \\
29,617\end{array}$ & $\begin{array}{l}58,115 \\
29,707\end{array}$ & $\begin{array}{l}35,784 \\
15,458\end{array}$ & $\begin{array}{l}22,331 \\
14,249\end{array}$ \\
\hline $\begin{array}{l}350 \\
351 \\
352 \\
353\end{array}$ & 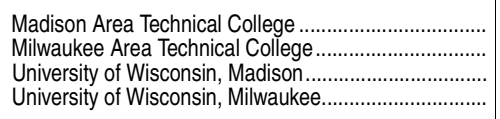 & $\begin{array}{l}W 1 \\
W 1 \\
W I \\
W I\end{array}$ & $\begin{array}{l}\text { Public } \\
\text { Public } \\
\text { Public } \\
\text { Public }\end{array}$ & $\begin{array}{l}\text { 4-year } \\
\text { 2-year } \\
\text { 4-year } \\
\text { 4-year }\end{array}$ & $\begin{array}{l}12,410 \\
21,600 \\
43,209 \\
26,020\end{array}$ & $\begin{array}{l}14,474 \\
14,296 \\
40,658 \\
23,578\end{array}$ & $\begin{array}{l}16,610 \\
20,215 \\
41,654 \\
30,418\end{array}$ & $\begin{array}{l}17,463 \\
19,827 \\
42,180 \\
30,470\end{array}$ & $\begin{array}{l}16,405 \\
19,480 \\
41,946 \\
29,350\end{array}$ & $\begin{array}{l}16,139 \\
18,118 \\
42,269 \\
28,712\end{array}$ & $\begin{array}{r}7,180 \\
7,950 \\
20,601 \\
13,623\end{array}$ & $\begin{array}{r}8,959 \\
10,168 \\
21,668 \\
15,089\end{array}$ \\
\hline
\end{tabular}

-Not available.

†Not applicable.

1"PrivNp" stands for private nonprofit. "PrivFp" stands for private for-profit.

${ }^{2}$ Includes private and some public institutions reporting total expenses and deductions under

Financial Accounting Standards Board (FASB) reporting standards and public institutions reporting total expenses and deductions under Governmental Accounting Standards Board (GASB) 34/35 reporting standards.

${ }^{3}$ Combined enrollment of Black, Hispanic, Asian/Pacific Islander, American Indian/Alaska Native, and Two or more races students who are U.S. citizens or resident aliens as a percentage of total enrollment, excluding nonresident aliens. 
Table 312.20. Selected statistics for degree-granting postsecondary institutions enrolling more than 15,000 students in 2012, by selected institution and student characteristics: Selected years, 1990 through 2011-12-Continued

\begin{tabular}{|c|c|c|c|c|c|c|c|c|c|c|c|c|c|}
\hline \multicolumn{5}{|c|}{ Fall enrollment, 2012} & \multicolumn{5}{|c|}{ Earned degrees/certificates conferred, 2011-12 } & \multirow{3}{*}{$\begin{array}{r}\text { Total } \\
\text { expenses and } \\
\text { deductions, } \\
2011-12 \\
\text { (in thousands) }^{2}\end{array}$} & \multicolumn{2}{|c|}{ Full-time-equivalent enrollment } & \multirow[b]{3}{*}{$\begin{array}{r}\text { Line } \\
\text { number }\end{array}$} \\
\hline \multicolumn{2}{|c|}{ Attendance status } & \multirow[b]{2}{*}{$\begin{array}{c}\text { Percent } \\
\text { minority }\end{array}$} & \multicolumn{2}{|c|}{ Student level } & \multirow[b]{2}{*}{ Certificates $^{4}$} & \multirow[b]{2}{*}{ Associate's } & \multirow[b]{2}{*}{ Bachelor's } & \multirow[b]{2}{*}{ Master's } & \multirow[b]{2}{*}{ Doctor's ${ }^{5}$} & & & & \\
\hline Full-time & Part-time & & $\begin{array}{l}\text { Under- } \\
\text { graduate }\end{array}$ & $\begin{array}{r}\text { Postbacca- } \\
\text { laureate }\end{array}$ & & & & & & & Fall 2011 & Fall 2012 & \\
\hline 14 & 15 & 16 & 17 & 18 & 19 & 20 & 21 & 22 & 23 & 24 & 25 & 26 & 27 \\
\hline $\begin{array}{r}6,882 \\
13,507 \\
43,691 \\
31,089 \\
21,416 \\
24,962 \\
12,891\end{array}$ & \begin{tabular}{r|}
15,063 \\
2,089 \\
2,092 \\
5,655 \\
3,309 \\
3,807 \\
2,520
\end{tabular} & \begin{tabular}{l|}
25.1 \\
16.3 \\
19.0 \\
33.1 \\
38.7 \\
18.5 \\
17.3
\end{tabular} & \begin{tabular}{l|}
21,945 \\
13,275 \\
39,192 \\
27,567 \\
11,678 \\
18,429 \\
13,297
\end{tabular} & \begin{tabular}{r|}
0 \\
2,321 \\
6,591 \\
9,177 \\
13,047 \\
10,340 \\
2,114
\end{tabular} & $\begin{array}{r}350 \\
96 \\
137 \\
103 \\
0 \\
955 \\
6\end{array}$ & $\begin{array}{r}2,020 \\
24 \\
42 \\
2 \\
0 \\
0 \\
0\end{array}$ & \begin{tabular}{r|}
0 \\
2,171 \\
10,970 \\
5,866 \\
2,841 \\
4,294 \\
2,692
\end{tabular} & $\begin{array}{r}0 \\
615 \\
1,314 \\
1,442 \\
3,565 \\
2,384 \\
645\end{array}$ & $\begin{array}{r}0 \\
149 \\
755 \\
1,154 \\
1,189 \\
1,059 \\
0\end{array}$ & $\begin{array}{r}199,388 \\
239,305 \\
4,411,164 \\
2,214,956 \\
5,865,047 \\
1,789,025 \\
217,720\end{array}$ & \begin{tabular}{l|}
12,509 \\
14,073 \\
44,330 \\
33,362 \\
22,683 \\
26,248 \\
13,456
\end{tabular} & $\begin{array}{l}11,939 \\
14,298 \\
44,502 \\
33,267 \\
22,695 \\
26,388 \\
13,851\end{array}$ & $\begin{array}{l}287 \\
288 \\
289 \\
290 \\
291 \\
292 \\
293\end{array}$ \\
\hline $\begin{array}{r}5,857 \\
13,779\end{array}$ & $\begin{array}{r}12,027 \\
2,672\end{array}$ & $\begin{array}{l}33.2 \\
19.7\end{array}$ & $\begin{array}{l}17,884 \\
13,376\end{array}$ & $\begin{array}{r}0 \\
3,075\end{array}$ & $\begin{array}{r}236 \\
0\end{array}$ & $\begin{array}{r}1,545 \\
0\end{array}$ & $\begin{array}{r}0 \\
2,614\end{array}$ & $\begin{array}{r}0 \\
577\end{array}$ & $\begin{array}{r}0 \\
229\end{array}$ & $\begin{array}{l}116,924 \\
463,745\end{array}$ & $\begin{array}{l}10,055 \\
14,564\end{array}$ & $\begin{array}{r}9,895 \\
14,806\end{array}$ & $\begin{array}{l}294 \\
295\end{array}$ \\
\hline $\begin{array}{r}18,413 \\
7,557 \\
26,718\end{array}$ & $\begin{array}{l}2,355 \\
9,667 \\
4,570\end{array}$ & $\begin{array}{l}13.7 \\
41.2 \\
21.4\end{array}$ & $\begin{array}{l}16,562 \\
17,224 \\
23,363\end{array}$ & $\begin{array}{r}4,206 \\
0 \\
7,925\end{array}$ & $\begin{array}{r}0 \\
1,395 \\
16\end{array}$ & $\begin{array}{r}0 \\
1,250 \\
7\end{array}$ & $\begin{array}{r}3,441 \\
0 \\
4,556\end{array}$ & $\begin{array}{r}1,060 \\
0 \\
1,749\end{array}$ & $\begin{array}{r}220 \\
0 \\
674\end{array}$ & $\begin{array}{l}666,685 \\
130,130 \\
810,746\end{array}$ & $\begin{array}{l}18,495 \\
10,651 \\
27,681\end{array}$ & $\begin{array}{l}19,303 \\
10,803 \\
28,443\end{array}$ & $\begin{array}{l}296 \\
297 \\
298\end{array}$ \\
\hline $\begin{array}{l}12,041 \\
19,381 \\
14,875 \\
26,270\end{array}$ & $\begin{array}{l}3,092 \\
6,013 \\
7,264 \\
3,563\end{array}$ & $\begin{array}{l}12.4 \\
28.3 \\
46.0 \\
16.3\end{array}$ & $\begin{array}{l}12,267 \\
22,371 \\
17,653 \\
20,916\end{array}$ & $\begin{array}{l}2,866 \\
3,023 \\
4,486 \\
8,917\end{array}$ & $\begin{array}{l}0 \\
0 \\
0 \\
0\end{array}$ & $\begin{array}{l}0 \\
0 \\
0 \\
0\end{array}$ & $\begin{array}{l}2,146 \\
3,911 \\
2,724 \\
4,578\end{array}$ & $\begin{array}{r}608 \\
811 \\
1,000 \\
1,773\end{array}$ & $\begin{array}{r}218 \\
20 \\
271 \\
1,110\end{array}$ & $\begin{array}{r}315,005 \\
362,290 \\
432,427 \\
1,613,228\end{array}$ & $\begin{array}{l}13,519 \\
22,763 \\
18,236 \\
27,757\end{array}$ & $\begin{array}{l}13,244 \\
21,722 \\
17,708 \\
27,614\end{array}$ & $\begin{array}{l}299 \\
300 \\
301 \\
302\end{array}$ \\
\hline 9,905 & 33,410 & 47.5 & 43,315 & 0 & 827 & 1,789 & 0 & 0 & 0 & 282,322 & 22,180 & 21,122 & 303 \\
\hline $\begin{array}{r}14,730 \\
\end{array}$ & 634 & 31.4 & 12,918 & 2,446 & 0 & 0 & 2,623 & 651 & 308 & 473,174 & 14,677 & 14,975 & 304 \\
\hline 9,531 & 8,308 & 34.0 & 17,839 & 0 & 376 & 804 & 0 & 0 & 0 & 92,090 & 12,684 & 12,320 & 305 \\
\hline 5,393 & 17,050 & 54.9 & 22,443 & 0 & 781 & 2,929 & 0 & 0 & 0 & 126,545 & 13,185 & 11,117 & 306 \\
\hline 9,676 & 17,748 & 40.7 & 27,424 & 0 & 256 & 1,817 & 0 & 0 & 0 & 137,876 & 15,807 & 15,635 & 307 \\
\hline 10,424 & 21,703 & 91.6 & 32,127 & 0 & 638 & 3,790 & 0 & 0 & 0 & 174,557 & 18,210 & 17,711 & 308 \\
\hline 18,476 & 40,000 & 82.0 & 58,476 & 0 & 1,259 & 3,860 & 0 & 0 & 0 & 382,634 & 33,803 & 31,905 & 309 \\
\hline $\begin{array}{l}19,633 \\
\end{array}$ & 40,795 & 61.9 & 60,428 & 0 & $\begin{array}{l}1,427 \\
1,40\end{array}$ & 4,208 & 0 & 0 & 0 & 368,546 & 34,579 & 33,329 & 310 \\
\hline 3,935 & 12,057 & 70.9 & 15,992 & 0 & 198 & 1,126 & 0 & 0 & 0 & 66,246 & 8,193 & 7,983 & 311 \\
\hline 4,905 & 14,647 & 68.4 & 19,552 & 0 & 185 & 1,227 & 0 & 0 & 0 & 80,875 & 10,271 & 9,823 & 312 \\
\hline 13,753 & 4,708 & 38.3 & 15,611 & 2,850 & 0 & $\begin{array}{r}1, \mathrm{CL} \\
0\end{array}$ & 2,978 & 894 & 53 & 250,686 & 14,736 & 15,567 & 313 \\
\hline 5,836 & 17,298 & 68.3 & 23,134 & 0 & 573 & 1,879 & 0 & 0 & 0 & 147,072 & 12,973 & 11,644 & 314 \\
\hline 8,625 & 20,096 & 66.7 & 28,721 & 0 & 1,587 & 2,840 & 0 & 0 & 0 & 196,568 & 16,023 & 15,372 & 315 \\
\hline $\begin{array}{r}10,492 \\
\end{array}$ & 20,332 & 97.3 & 30,824 & 0 & 1,563 & 2,292 & 109 & 0 & 0 & 148,863 & 18,390 & 18,697 & 316 \\
\hline $\begin{array}{l}10,456 \\
17,466\end{array}$ & $\begin{array}{l}\quad 0,002 \\
32,973\end{array}$ & 52.9 & 50,439 & 0 & $\begin{array}{l}1,259 \\
1,20\end{array}$ & $\begin{array}{l}2,292 \\
3,365\end{array}$ & 0 & 0 & 0 & $\begin{array}{l}340,209 \\
340,209\end{array}$ & $\begin{array}{l}10,090 \\
28,452\end{array}$ & $\begin{array}{l}28,536 \\
28,531\end{array}$ & $\begin{array}{l}317 \\
317\end{array}$ \\
\hline $\begin{array}{l}44,231 \\
\end{array}$ & 6,396 & 29.2 & 40,103 & 10,524 & $\mid$ & r, 0 & 9,073 & 2,126 & 790 & $2,004,062$ & - 46,689 & 46,707 & 318 \\
\hline 26,703 & 7,522 & 40.7 & 29,458 & 4,767 & 0 & 0 & 5,395 & 1,322 & 74 & 501,250 & 29,326 & 29,643 & 319 \\
\hline 27,512 & 4,955 & 30.4 & 26,481 & 5,986 & 0 & 0 & 4,918 & 1,512 & 467 & 683,288 & 29,384 & 29,425 & 320 \\
\hline 8,415 & 6,753 & 51.3 & 8,776 & 6,392 & 0 & 0 & 1,873 & 1,647 & 206 & 179,140 & 11,002 & 10,962 & 321 \\
\hline 29,181 & 11,566 & 64.4 & 32,760 & 7,987 & 0 & 0 & 5,414 & 1,991 & 798 & 817,291 & 33,168 & 33,749 & 322 \\
\hline 27,148 & 10,802 & 41.8 & 30,593 & 7,357 & 0 & 0 & $\begin{array}{l}0,459 \\
6,449\end{array}$ & $\begin{array}{l}2,003 \\
2,03\end{array}$ & 237 & 572,352 & 30,649 & 31,336 & 323 \\
\hline 19,327 & 13,912 & 53.6 & 25,761 & 7,478 & 0 & 0 & $\begin{array}{l}5,712 \\
5,72\end{array}$ & $\begin{array}{l}2,00 \\
3,186\end{array}$ & 170 & 462,784 & 24,730 & 24,761 & 324 \\
\hline 47,990 & 4,196 & 44.6 & 39,955 & 12,231 & 715 & 0 & 8,821 & 3,104 & 1,372 & $2,381,045$ & 48,493 & 49,628 & 325 \\
\hline 14,310 & 5,417 & 49.6 & 12,029 & 7,698 & 0 & 0 & 2,468 & 2,212 & 191 & 418,993 & 15,429 & 16,375 & 326 \\
\hline 14,119 & 8,630 & 89.6 & 19,217 & 3,532 & 0 & 0 & 3,047 & 1,135 & 72 & 382,268 & 17,564 & 17,514 & 327 \\
\hline 23,168 & 7,306 & 66.7 & 25,979 & 4,495 & 0 & 0 & 4,225 & 1,104 & 77 & 495,497 & 26,319 & 26,011 & 328 \\
\hline 13,439 & 5,863 & 96.0 & 16,570 & 2,732 & 0 & 0 & 2,502 & 739 & 11 & 250,147 & 15,369 & 15,736 & 329 \\
\hline 30,364 & 4,045 & 11.9 & 31,060 & 3,349 & 0 & 0 & 7,026 & 1,163 & 239 & 909,697 & 31,639 & 31,938 & 330 \\
\hline & 20,859 & 24.4 & 29,997 & & 640 & 3,550 & & & 0 & 201,739 & 17,463 & 16,141 & 331 \\
\hline $\begin{array}{r}23,263 \\
23,26\end{array}$ & $\begin{array}{r}0,125 \\
9,125\end{array}$ & $\begin{array}{l}18.8 \\
18.4\end{array}$ & 24,840 & 7,548 & $\begin{array}{r}040 \\
0\end{array}$ & 0 & 4,919 & 1,809 & 718 & $2,995,811$ & 26,195 & 26,870 & 332 \\
\hline 16,566 & 12,220 & 11.2 & 25,445 & 3,341 & 82 & 973 & 3,371 & 990 & 99 & 564,379 & 20,017 & 21,404 & 333 \\
\hline 16,745 & 14,817 & 15.5 & 31,405 & 157 & 92 & 1,831 & 2,612 & 24 & 0 & 264,691 & 23,730 & 22,718 & 334 \\
\hline 12,088 & 14,444 & 23.1 & 25,868 & 664 & 50 & 1,997 & 2,157 & 292 & 0 & 198,806 & 17,206 & 17,901 & 335 \\
\hline 41,369 & & 24.4 & 31,353 & 10,016 & 0 & 0 & 3,608 & 2,048 & 0 & 187,522 & 30,970 & 41,369 & 336 \\
\hline 20,297 & 12,664 & 40.8 & 20,653 & 12,308 & 0 & 0 & 4,718 & 2,899 & 428 & 694,431 & 25,126 & 25,061 & 337 \\
\hline 18,392 & 1,535 & 15.8 & 18,107 & 1,820 & 0 & 0 & 4,096 & 779 & 13 & 418,154 & 18,762 & 18,980 & 338 \\
\hline 34,444 & 39,928 & 34.8 & 46,133 & 28,239 & 45 & 657 & 5,874 & 5,093 & 690 & 417,056 & 44,503 & 49,930 & 339 \\
\hline $\begin{array}{l}19,209 \\
19,\end{array}$ & 32,655 & 56.2 & 51,864 & 0 & 2,524 & 5,452 & $\begin{array}{l}0,0 \\
0\end{array}$ & r & 0 & 286,224 & 29,348 & 30,172 & 340 \\
\hline $\begin{array}{l}16,826 \\
\end{array}$ & 7,844 & 39.6 & 19,612 & 5,058 & 0 & 0 & 3,715 & 1,143 & 208 & 376,580 & 19,753 & 19,859 & 341 \\
\hline 11,865 & 18,269 & 50.4 & 30,134 & r & 992 & 2,923 & & r & $\begin{array}{r}0 \\
0\end{array}$ & $\begin{array}{l}181,229 \\
\end{array}$ & 19,407 & 17,999 & 342 \\
\hline 20,984 & 2,923 & 27.9 & 15,822 & 8,085 & 0 & 0 & 3,726 & 1,742 & 904 & $2,366,239$ & 22,199 & 22,079 & 343 \\
\hline 24,924 & 6,521 & 40.3 & 23,661 & 7,784 & 21 & 0 & 4,625 & 1,740 & 748 & 837,971 & 27,421 & 27,445 & 344 \\
\hline 28,263 & 2,824 & 21.4 & 23,859 & 7,228 & 0 & 50 & 5,825 & 1,603 & 560 & $1,094,047$ & 29,044 & 29,305 & 345 \\
\hline 37,177 & 6,308 & 40.2 & 29,475 & 14,010 & 0 & 0 & 7,887 & 3,132 & 1,273 & $3,970,537$ & 38,813 & 39,594 & 346 \\
\hline 23,375 & 4,304 & 25.2 & 23,135 & 4,544 & 88 & 0 & 5,297 & 802 & 380 & 884,048 & 24,712 & 25,059 & 347 \\
\hline 3,898 & 54,217 & 40.1 & 45,772 & 12,343 & 241 & 970 & 3,047 & 2,761 & 0 & 219,729 & 22,247 & 25,071 & 348 \\
\hline 25,895 & 3,812 & 12.1 & 22,827 & 6,880 & 0 & 0 & 4,204 & 1,642 & 601 & 993,692 & 27,299 & 27,346 & 349 \\
\hline & 10,747 & 21.4 & 16,097 & 42 & 2,811 & 1,385 & 0 & 0 & 0 & 195,529 & 9,949 & 9,728 & 350 \\
\hline 5,770 & 12,348 & 50.6 & 18,118 & & 1,536 & 1,533 & 0 & 0 & 0 & 239,768 & 10,734 & 9,916 & 351 \\
\hline 38,034 & 4,235 & 16.6 & 30,301 & 11,968 & 0 & 0 & 6,422 & 2,069 & 1,514 & $2,350,306$ & 39,296 & 39,655 & 352 \\
\hline 22,425 & 6,287 & 23.5 & 23,776 & 4,936 & 0 & 0 & 4,170 & 1,446 & 183 & 509,504 & 25,537 & 24,867 & 353 \\
\hline
\end{tabular}

${ }^{4}$ Includes less-than-1-year awards and 1- to less-than-4-year awards (excluding associate's degrees) conferred by degree-granting institutions.

${ }^{5}$ Includes Ph.D., Ed.D., and comparable degrees at the doctoral level, as well as such degrees as M.D., D.D.S., and law degrees that were formerly classified as first-professional degrees. ${ }^{6}$ Data for total enrollment in 1990 are for institutions of higher education, rather than degreegranting institutions.
NOTE: Degree-granting institutions grant associate's or higher degrees and participate in Title V federal financial aid programs. Includes online and distance education courses. SOURCE: U.S. Department of Education, National Center for Education Statistics, Integrated Postsecondary Education Data System (IPEDS), "Fall Enrollment Survey" (IPEDS-EF:90); Spring 2001 through Spring 2013, Enrollment and Finance components; and Fall 2012, Completions component. (This table was prepared May 2014.) 
476 CHAPTER 3: Postsecondary Education

Large Institutions and Institutions Serving Specific Groups

Table 312.30. Enrollment and degrees conferred in degree-granting women's colleges, by selected characteristics and institution: Fall 2012 and 2011-12

\begin{tabular}{|c|c|c|c|c|c|c|c|c|c|c|c|c|}
\hline \multirow[b]{2}{*}{ Institution ${ }^{1}$} & \multirow[b]{2}{*}{ State } & \multicolumn{7}{|c|}{ Enrollment, fall 2012} & \multicolumn{4}{|c|}{ Degrees awarded to females, $2011-12$} \\
\hline & & Total & Females & $\begin{array}{r}\text { Percent } \\
\text { female }\end{array}$ & $\begin{array}{r}\text { Males, } \\
\text { full-time }\end{array}$ & $\begin{array}{r}\text { Females, } \\
\text { full-time }\end{array}$ & $\begin{array}{r}\text { Males, part- } \\
\text { time }\end{array}$ & $\begin{array}{l}\text { Females, } \\
\text { part-time }\end{array}$ & Associate's & Bachelor's & Master's & Doctor's \\
\hline 1 & 2 & 3 & 4 & 5 & 6 & 7 & 8 & 9 & 10 & 11 & 12 & 13 \\
\hline Total ................................... & $t$ & 81,854 & 76,538 & 93.5 & 2,291 & 56,227 & 3,025 & 20,311 & 729 & 12,493 & 5,583 & 326 \\
\hline $\begin{array}{l}\text { Judson College ..................... } \\
\text { Mills College ......................... } \\
\text { Mount Saint Mary's College... } \\
\text { Scripps College ...................... } \\
\text { University of Saint Joseph ..... }\end{array}$ & $\begin{array}{l}\mathrm{AL} \\
\mathrm{CA} \\
\mathrm{CA} \\
\mathrm{CA} \\
\mathrm{CT}\end{array}$ & $\begin{array}{r}357 \\
1,545 \\
3,146 \\
962 \\
2,525\end{array}$ & $\begin{array}{r}347 \\
1,437 \\
2,831 \\
959 \\
2,302\end{array}$ & $\begin{array}{l}97.2 \\
93.0 \\
90.0 \\
99.7 \\
91.2\end{array}$ & \begin{tabular}{r|}
1 \\
99 \\
182 \\
3 \\
67
\end{tabular} & \begin{tabular}{r|}
292 \\
1,288 \\
2,157 \\
953 \\
1,094
\end{tabular} & $\begin{array}{r}9 \\
9 \\
133 \\
0 \\
156\end{array}$ & $\begin{array}{r}55 \\
149 \\
674 \\
6 \\
1,208\end{array}$ & $\begin{array}{r}\dagger \\
\dagger \\
146 \\
\dagger \\
\dagger\end{array}$ & $\begin{array}{r}56 \\
250 \\
387 \\
234 \\
199\end{array}$ & $\begin{array}{r}\dagger \\
184 \\
96 \\
\dagger \\
360\end{array}$ & $\begin{array}{r}\dagger \\
5 \\
21 \\
\dagger \\
0\end{array}$ \\
\hline $\begin{array}{l}\text { Trinity Washington University..... } \\
\text { Agnes Scott College ............... } \\
\text { Brenau University .................. } \\
\text { Spelman College ................... } \\
\text { Wesleyan College .................. }\end{array}$ & $\begin{array}{l}\mathrm{DC} \\
\mathrm{GA} \\
\mathrm{GA} \\
\mathrm{GA} \\
\mathrm{GA}\end{array}$ & $\begin{array}{r}2,663 \\
885 \\
2,777 \\
2,145 \\
715\end{array}$ & $\begin{array}{r}2,431 \\
877 \\
2,369 \\
2,145 \\
683\end{array}$ & $\begin{array}{r}91.3 \\
99.1 \\
85.3 \\
100.0 \\
95.5\end{array}$ & $\begin{array}{r}47 \\
8 \\
166 \\
0 \\
5\end{array}$ & $\begin{array}{r}1,272 \\
861 \\
1,262 \\
2,074 \\
472\end{array}$ & \begin{tabular}{r|}
185 \\
0 \\
242 \\
0 \\
27
\end{tabular} & $\begin{array}{r}1,159 \\
16 \\
1,107 \\
71 \\
211\end{array}$ & $\begin{array}{r}14 \\
\dagger \\
6 \\
\dagger \\
\dagger\end{array}$ & $\begin{array}{r}234 \\
166 \\
358 \\
467 \\
78\end{array}$ & $\begin{array}{r}174 \\
2 \\
260 \\
\dagger \\
46\end{array}$ & $\begin{array}{l}\dagger \\
\dagger \\
\dagger \\
\dagger \\
\dagger\end{array}$ \\
\hline $\begin{array}{l}\text { Lexington College................... } \\
\text { Saint Mary-of-the-Woods }\end{array}$ & $\mathrm{IL}$ & 45 & 45 & 100.0 & 0 & 39 & 0 & 6 & 1 & 9 & $\dagger$ & $\dagger$ \\
\hline 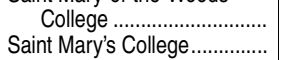 & $\begin{array}{l}\text { IN } \\
\text { IN }\end{array}$ & $\begin{array}{l}1,030 \\
1,469\end{array}$ & $\begin{array}{r}974 \\
1,469\end{array}$ & $\begin{array}{r}94.6 \\
100.0\end{array}$ & $\begin{array}{r}24 \\
0\end{array}$ & $\begin{array}{r}564 \\
1,456\end{array}$ & $\begin{array}{r}32 \\
0\end{array}$ & $\begin{array}{r}410 \\
13\end{array}$ & $\begin{array}{l}4 \\
\dagger\end{array}$ & $\begin{array}{l}146 \\
399\end{array}$ & $\begin{array}{r}55 \\
\dagger\end{array}$ & $\begin{array}{l}\dagger \\
\dagger\end{array}$ \\
\hline $\begin{array}{l}\text { Midway College ..................... } \\
\text { Notre Dame of Maryland }\end{array}$ & KY & 1,575 & 1,301 & 82.6 & 136 & 912 & 138 & 389 & 115 & 183 & 26 & $\dagger$ \\
\hline University ........................... & MD & 2,864 & 2,497 & 87.2 & 85 & 753 & 282 & 1,744 & $\dagger$ & 281 & 324 & 10 \\
\hline $\begin{array}{l}\text { Bay Path College..................... } \\
\text { Mount Holyoke College.......... } \\
\text { Simmons College ................... } \\
\text { Smith College ....................... } \\
\text { Wellesley College .................. }\end{array}$ & $\begin{array}{l}\text { MA } \\
\text { MA } \\
\text { MA } \\
\text { MA } \\
\text { MA }\end{array}$ & $\begin{array}{l}2,370 \\
2,347 \\
4,830 \\
3,212 \\
2,482\end{array}$ & $\begin{array}{l}2,286 \\
2,341 \\
4,427 \\
3,132 \\
2,442\end{array}$ & $\begin{array}{l}96.5 \\
99.7 \\
91.7 \\
97.5 \\
98.4\end{array}$ & $\begin{array}{r}56 \\
3 \\
76 \\
67 \\
0\end{array}$ & $\begin{array}{l}1,568 \\
2,307 \\
2,373 \\
3,058 \\
2,368\end{array}$ & $\begin{array}{r}28 \\
3 \\
327 \\
13 \\
40\end{array}$ & $\begin{array}{r}718 \\
34 \\
2,054 \\
74 \\
74\end{array}$ & $\begin{array}{r}56 \\
t \\
t \\
t \\
t\end{array}$ & $\begin{array}{l}384 \\
566 \\
499 \\
652 \\
559\end{array}$ & $\begin{array}{r}194 \\
1 \\
936 \\
146 \\
\dagger\end{array}$ & $\begin{array}{r}\dagger \\
\dagger \\
74 \\
6 \\
\dagger\end{array}$ \\
\hline $\begin{array}{l}\text { College of Saint Benedict.......... } \\
\text { St. Catherine University .......... } \\
\text { Cottey College ........................ } \\
\text { Stephens College ................. } \\
\text { College of Saint Mary ............. }\end{array}$ & $\begin{array}{l}\text { MN } \\
\text { MN } \\
\text { MO } \\
\text { MO } \\
\text { NE }\end{array}$ & $\begin{array}{r}2,070 \\
5,075 \\
292 \\
882 \\
1,037\end{array}$ & $\begin{array}{r}2,070 \\
4,824 \\
292 \\
847 \\
1,003\end{array}$ & $\begin{array}{r}100.0 \\
95.1 \\
100.0 \\
96.0 \\
96.7\end{array}$ & $\begin{array}{r}0 \\
113 \\
0 \\
22 \\
16\end{array}$ & $\begin{array}{r}2,037 \\
3,287 \\
288 \\
685 \\
792\end{array}$ & $\begin{array}{r}0 \\
138 \\
0 \\
13 \\
18\end{array}$ & $\begin{array}{r}33 \\
1,537 \\
4 \\
162 \\
211\end{array}$ & $\begin{array}{r}\dagger \\
210 \\
107 \\
2 \\
66\end{array}$ & $\begin{array}{r}455 \\
541 \\
0 \\
185 \\
69\end{array}$ & $\begin{array}{r}\dagger \\
438 \\
\dagger \\
70 \\
119\end{array}$ & $\begin{array}{r}\dagger \\
37 \\
\dagger \\
\dagger \\
13\end{array}$ \\
\hline $\begin{array}{l}\text { College of Saint Elizabeth......... } \\
\text { Barnard College.................. } \\
\text { College of New Rochelle ....... } \\
\text { Bennett College for Women... } \\
\text { Meredith College ..................... }\end{array}$ & $\begin{array}{l}\mathrm{NJ} \\
\mathrm{NY} \\
\mathrm{NY} \\
\mathrm{NC} \\
\mathrm{NC}\end{array}$ & $\begin{array}{r}1,687 \\
2,504 \\
4,131 \\
707 \\
1,944\end{array}$ & $\begin{array}{r}1,507 \\
2,504 \\
3,701 \\
707 \\
1,900\end{array}$ & $\begin{array}{r}89.3 \\
100.0 \\
89.6 \\
100.0 \\
97.7\end{array}$ & $\begin{array}{r}38 \\
0 \\
275 \\
0 \\
8\end{array}$ & $\begin{array}{r}683 \\
2,466 \\
2,618 \\
646 \\
1,667\end{array}$ & $\begin{array}{r}142 \\
0 \\
155 \\
0 \\
36\end{array}$ & $\begin{array}{r}824 \\
38 \\
1,083 \\
61 \\
233\end{array}$ & $\begin{array}{l}\dagger \\
\dagger \\
\dagger \\
\dagger \\
\dagger\end{array}$ & $\begin{array}{l}230 \\
592 \\
706 \\
108 \\
357\end{array}$ & $\begin{array}{r}179 \\
\dagger \\
250 \\
\dagger \\
92\end{array}$ & $\begin{array}{r}13 \\
\dagger \\
\dagger \\
\dagger \\
\dagger\end{array}$ \\
\hline $\begin{array}{l}\text { Salem College ....................... } \\
\text { Ursuline College ................... } \\
\text { Bryn Mawr College ................ } \\
\text { Carlow University.................. } \\
\text { Cedar Crest College ............... }\end{array}$ & $\begin{array}{l}\mathrm{NC} \\
\mathrm{OH} \\
\mathrm{PA} \\
\mathrm{PA} \\
\mathrm{PA}\end{array}$ & $\begin{array}{l}1,165 \\
1,496 \\
1,765 \\
2,922 \\
1,567\end{array}$ & $\begin{array}{l}1,100 \\
1,317 \\
1,670 \\
2,459 \\
1,478\end{array}$ & $\begin{array}{l}94.4 \\
88.0 \\
94.6 \\
84.2 \\
94.3\end{array}$ & $\begin{array}{r}22 \\
89 \\
81 \\
169 \\
26\end{array}$ & $\begin{array}{r}779 \\
653 \\
1,575 \\
1,560 \\
713\end{array}$ & $\begin{array}{r}43 \\
90 \\
14 \\
294 \\
63\end{array}$ & $\begin{array}{r}321 \\
664 \\
95 \\
899 \\
765\end{array}$ & $\begin{array}{l}\dagger \\
\dagger \\
\dagger \\
\dagger \\
\dagger\end{array}$ & $\begin{array}{l}136 \\
239 \\
306 \\
289 \\
329\end{array}$ & $\begin{array}{r}26 \\
150 \\
99 \\
234 \\
59\end{array}$ & $\begin{array}{r}\dagger \\
0 \\
10 \\
24 \\
\dagger\end{array}$ \\
\hline $\begin{array}{l}\text { Chatham University ............... } \\
\text { Moore College of Art and } \\
\text { Design .......................... } \\
\text { Columbia College .................. } \\
\text { Converse College .................. } \\
\text { Hollins University ................. }\end{array}$ & $\begin{array}{l}\mathrm{PA} \\
\mathrm{PA} \\
\mathrm{SC} \\
\mathrm{SC} \\
\mathrm{VA}\end{array}$ & $\begin{array}{r}2,178 \\
529 \\
1,257 \\
1,216 \\
794\end{array}$ & $\begin{array}{r}1,885 \\
\\
525 \\
1,203 \\
1,098 \\
750\end{array}$ & $\begin{array}{l}86.5 \\
99.2 \\
95.7 \\
90.3 \\
94.5\end{array}$ & $\begin{array}{r}174 \\
2 \\
31 \\
25 \\
15\end{array}$ & $\begin{array}{r}1,311 \\
475 \\
949 \\
715 \\
636\end{array}$ & $\begin{array}{r}119 \\
2 \\
23 \\
93 \\
29\end{array}$ & $\begin{array}{r}574 \\
50 \\
254 \\
383 \\
114\end{array}$ & $\begin{array}{l}\dagger \\
\dagger \\
\dagger \\
\dagger \\
\dagger\end{array}$ & $\begin{array}{r}205 \\
98 \\
228 \\
152 \\
185\end{array}$ & $\begin{array}{r}316 \\
\\
15 \\
150 \\
139 \\
92\end{array}$ & $\begin{array}{r}113 \\
\dagger \\
\dagger \\
\dagger \\
\dagger\end{array}$ \\
\hline $\begin{array}{l}\text { Mary Baldwin College ................ } \\
\text { Sweet Briar College ................ } \\
\text { Alverno College ................... } \\
\text { Mount Mary College .............. }\end{array}$ & $\begin{array}{l}\text { VA } \\
\text { VA } \\
\text { WI } \\
\text { WI }\end{array}$ & $\begin{array}{r}1,791 \\
739 \\
2,522 \\
1,640\end{array}$ & $\begin{array}{r}1,658 \\
711 \\
2,463 \\
1,571\end{array}$ & $\begin{array}{l}92.6 \\
96.2 \\
97.7 \\
95.8\end{array}$ & $\begin{array}{l}65 \\
25 \\
37 \\
33\end{array}$ & $\begin{array}{r}1,087 \\
683 \\
1,735 \\
1,064\end{array}$ & $\begin{array}{r}68 \\
3 \\
22 \\
36\end{array}$ & $\begin{array}{r}571 \\
28 \\
728 \\
507\end{array}$ & $\begin{array}{l}\dagger \\
\dagger \\
2 \\
\dagger\end{array}$ & $\begin{array}{l}250 \\
154 \\
406 \\
166\end{array}$ & $\begin{array}{r}105 \\
11 \\
80 \\
155\end{array}$ & $\begin{array}{l}\dagger \\
\dagger \\
\dagger \\
0\end{array}$ \\
\hline
\end{tabular}

†Not applicable.

'Data are for colleges and universities identified by the Women's College Coalition as women's colleges in 2014. Excludes women's colleges whose IPEDS data are reported together with a coed institution or coordinate men's college. The following institutions were excluded for this reason: the Colorado Women's College of the University of Denver; Douglass Residential College of Rutgers University; and Russell Sage College of the Sage Colleges.

SOURCE: U.S. Department of Education, National Center for Education Statistics, Integrated Postsecondary Education Data System (IPEDS), Spring 2013, Enrollment component; and Fall 2012, Completions component. (This table was prepared June 2014.) 
CHAPTER 3: Postsecondary Education 477 Large Institutions and Institutions Serving Specific Groups

Table 312.40. Enrollment and degrees conferred in degree-granting postsecondary institutions that serve large proportions of Hispanic undergraduate students, by institution level and control, percentage Hispanic, degree level, and other selected characteristics: Fall 2012 and 2011-12

\begin{tabular}{|c|c|c|c|c|c|c|c|c|c|c|}
\hline \multirow[b]{2}{*}{ State and institution } & \multirow[b]{2}{*}{$\begin{array}{r}\text { Level } \\
\text { and control }\end{array}$} & \multicolumn{5}{|c|}{ Enrollment, fall 2012} & \multicolumn{4}{|c|}{ Degrees awarded to Hispanics, 2011-12 } \\
\hline & & Total & Hispanic & $\begin{array}{r}\text { Percent } \\
\text { Hispanic }^{2}\end{array}$ & $\begin{array}{r}\text { Hispanic } \\
\text { under- } \\
\text { graduate }\end{array}$ & $\begin{array}{r}\text { Hispanic } \\
\text { postbacca- } \\
\text { laureate }\end{array}$ & Associate's & Bachelor's & Master's & Doctor's ${ }^{3}$ \\
\hline 1 & 2 & 3 & 4 & 5 & 6 & 7 & 8 & 9 & 10 & 11 \\
\hline $\begin{array}{l}\text { Total, } 50 \text { states and District of Columbia } \\
\text { Total, } 50 \text { states, District of Columbia, } \\
\text { and Puerto Rico }\end{array}$ & $\begin{array}{l}\dagger \\
\dagger\end{array}$ & $\begin{array}{l}3,870,646 \\
4,112,250\end{array}$ & $\begin{array}{r}1,659,622 \\
1,899,755\end{array}$ & $\begin{array}{r}42.9 \\
46.2\end{array}$ & $\begin{array}{r}1,598,858 \\
1,813,625\end{array}$ & $\begin{array}{l}60,764 \\
86,130\end{array}$ & $\begin{array}{r}94,684 \\
102,619\end{array}$ & $\begin{array}{l}58,480 \\
76,926\end{array}$ & $\begin{array}{l}14,094 \\
18,700\end{array}$ & $\begin{array}{l}1,297 \\
2,138\end{array}$ \\
\hline 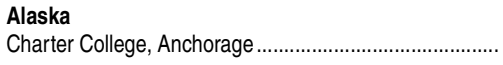 & 5 & 1,259 & 417 & 33.1 & 417 & $\dagger$ & 154 & 9 & $\dagger$ & $\dagger$ \\
\hline $\begin{array}{l}\text { Arizona } \\
\text { Argosy University, Phoenix } \ldots \ldots \ldots \ldots \ldots \ldots \ldots \ldots \ldots \ldots \ldots \ldots \ldots \ldots \ldots \ldots \ldots \ldots \ldots \ldots \ldots \ldots \ldots \ldots\end{array}$ & & & & & & & & & & \\
\hline $\begin{array}{l}\text { Argosy University, Phoenix } \\
\text { Arizona College of Allied Health }\end{array}$ & $\begin{array}{l}5 \\
6\end{array}$ & $\begin{array}{l}752 \\
573\end{array}$ & $\begin{array}{l}129 \\
258\end{array}$ & $\begin{array}{l}17.2 \\
45.0\end{array}$ & $\begin{array}{r}49 \\
258\end{array}$ & $\begin{array}{r}80 \\
\dagger\end{array}$ & $\begin{array}{r}\dagger \\
28\end{array}$ & $\begin{array}{l}0 \\
\dagger\end{array}$ & $\begin{array}{l}3 \\
\dagger\end{array}$ & $\begin{array}{l}0 \\
\dagger\end{array}$ \\
\hline Arizona Western College & 2 & 7,877 & 5,061 & 64.3 & 5,061 & $\dagger$ & 338 & $\dagger$ & $\dagger$ & $\dagger$ \\
\hline Art Institute of Phoenix & 5 & 1,018 & 482 & 47.3 & 482 & $\dagger$ & 31 & 57 & $\dagger$ & $\dagger$ \\
\hline Art Institute of Tucson & 5 & 436 & 253 & 58.0 & 253 & $\dagger$ & 19 & 17 & $\dagger$ & $\dagger$ \\
\hline 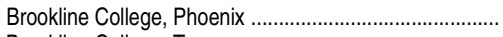 & 5 & 1,186 & 358 & 30.2 & 358 & $\dagger$ & 25 & 3 & $\dagger$ & $\dagger$ \\
\hline 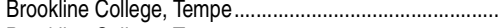 & 6 & 386 & 130 & 33.7 & 130 & $\dagger$ & 10 & $\dagger$ & $\dagger$ & $\dagger$ \\
\hline Brookline College, Tucson & 5 & 524 & 296 & 56.5 & 296 & $\dagger$ & 76 & $\dagger$ & $\dagger$ & $\dagger$ \\
\hline 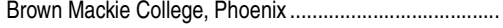 & 5 & 578 & 193 & 33.4 & 193 & $\dagger$ & 45 & 1 & $\dagger$ & $\dagger$ \\
\hline 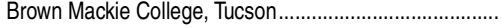 & 5 & 784 & 337 & 43.0 & 337 & $\dagger$ & 92 & 8 & $\dagger$ & $\dagger$ \\
\hline 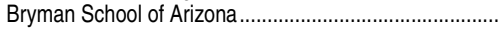 & 6 & 604 & 239 & 39.6 & 239 & $\dagger$ & 43 & $\dagger$ & $\dagger$ & $\dagger$ \\
\hline Carrington College, Mesa & 6 & 685 & 172 & 25.1 & 172 & $\dagger$ & 9 & $\dagger$ & $\dagger$ & $\dagger$ \\
\hline Carrington College, Phoenix.... & 5 & 560 & 271 & 48.4 & 271 & $\dagger$ & 3 & 1 & $\dagger$ & $\dagger$ \\
\hline Carrington College, Phoenix Westside .............................. & 6 & 542 & 153 & 28.2 & 153 & $\dagger$ & 35 & $\dagger$ & $\dagger$ & $\dagger$ \\
\hline 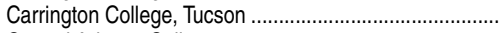 & 6 & 399 & 237 & 59.4 & 237 & $\dagger$ & 11 & $\dagger$ & $\dagger$ & $\dagger$ \\
\hline Central Arizona College & 2 & 7,018 & 2,168 & 30.9 & 2,168 & $\dagger$ & 131 & $\dagger$ & $\dagger$ & $\dagger$ \\
\hline Cochise College & 2 & 4,516 & 1,829 & 40.5 & 1,829 & $\dagger$ & 274 & $\dagger$ & $\dagger$ & $\dagger$ \\
\hline 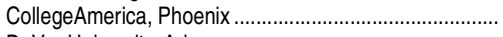 & 5 & 382 & 118 & 30.9 & 118 & $\dagger$ & 39 & $\dagger$ & $\dagger$ & $\dagger$ \\
\hline 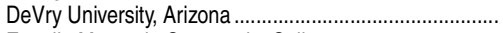 & 5 & 1,419 & 396 & 27.9 & 396 & $\dagger$ & 11 & 49 & $\dagger$ & $\dagger$ \\
\hline Estrella Mountain Community College .............................. & 2 & 8,361 & 3,777 & 45.2 & 3,777 & $\dagger$ & 222 & $\dagger$ & $\dagger$ & $\dagger$ \\
\hline 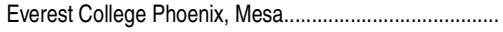 & 5 & 303 & 88 & 29.0 & 88 & $\dagger$ & 12 & 1 & $\dagger$ & $\dagger$ \\
\hline Fortis College, Phoenix & 6 & 260 & 126 & 48.5 & 126 & $\dagger$ & 4 & $\dagger$ & $\dagger$ & $\dagger$ \\
\hline Frank Lloyd Wright School of Architecture............................ & 3 & 17 & 2 & 11.8 & 1 & 1 & $\dagger$ & 0 & 0 & $\dagger$ \\
\hline 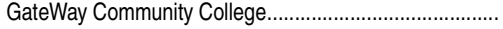 & 2 & 6,720 & 2,337 & 34.8 & 2,337 & $\dagger$ & 90 & $\dagger$ & $\dagger$ & $\dagger$ \\
\hline 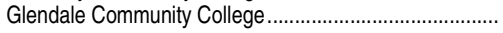 & 2 & 21,361 & 6,742 & 31.6 & 6,742 & $\dagger$ & 341 & $\dagger$ & $\dagger$ & $\dagger$ \\
\hline 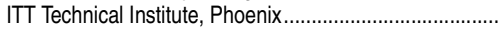 & 5 & 331 & 96 & 29.0 & 96 & $\dagger$ & 30 & 0 & $\dagger$ & $\dagger$ \\
\hline 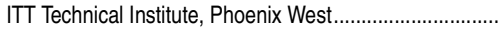 & 5 & 196 & 83 & 42.3 & 83 & $\dagger$ & 0 & 0 & $\dagger$ & $\dagger$ \\
\hline 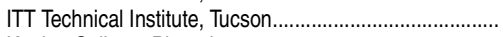 & 5 & 460 & 187 & 40.7 & 187 & $\dagger$ & 44 & 7 & $\dagger$ & $\dagger$ \\
\hline 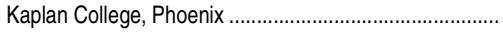 & 6 & 419 & 139 & 33.2 & 139 & $\dagger$ & 21 & $\dagger$ & $\dagger$ & $\dagger$ \\
\hline 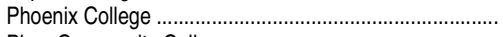 & 2 & 12,228 & 5,370 & 43.9 & 5,370 & $\dagger$ & 359 & $\dagger$ & $\dagger$ & $\dagger$ \\
\hline 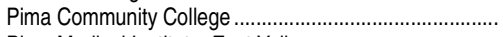 & 2 & 32,988 & 12,802 & 38.8 & 12,802 & $\dagger$ & 875 & $\dagger$ & $\dagger$ & $\dagger$ \\
\hline 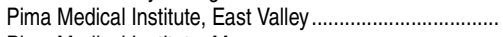 & 6 & 502 & 130 & 25.9 & 130 & $\dagger$ & 2 & $\dagger$ & $\dagger$ & $\dagger$ \\
\hline 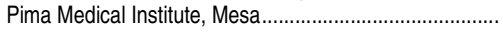 & 6 & 1,401 & 384 & 27.4 & 384 & $\dagger$ & 21 & $\dagger$ & $\dagger$ & $\dagger$ \\
\hline 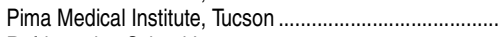 & 5 & 1,811 & 713 & 39.4 & 713 & $\dagger$ & 73 & 16 & $\dagger$ & $\dagger$ \\
\hline 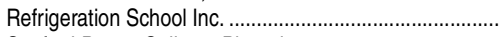 & 6 & 632 & 177 & 28.0 & 177 & $\dagger$ & 17 & $\dagger$ & $\dagger$ & $\dagger$ \\
\hline 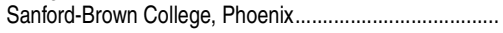 & 6 & 513 & 238 & 46.4 & 238 & $\dagger$ & 5 & $\dagger$ & $\dagger$ & $\dagger$ \\
\hline 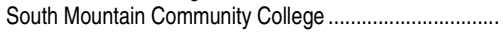 & 2 & 4,843 & 2,265 & 46.8 & 2,265 & $\dagger$ & 191 & $\dagger$ & $\dagger$ & $\dagger$ \\
\hline Southwest University of Visual Arts, Tucson........................ & 5 & 268 & 91 & 34.0 & 91 & 0 & $\dagger$ & 13 & 0 & $\dagger$ \\
\hline 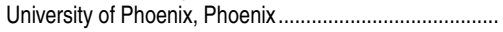 & 5 & 5,536 & 1,314 & 23.7 & 1,011 & 303 & $\dagger$ & 116 & 65 & $\dagger$ \\
\hline University of Phoenix, Southern Arizona ........................... & 5 & 2,135 & 958 & 44.9 & 803 & 155 & $\dagger$ & 83 & 36 & $\dagger$ \\
\hline California & & & & & & & & & & \\
\hline Academy of Couture Art & 5 & 22 & 8 & 36.4 & 8 & $\dagger$ & 1 & 0 & $\dagger$ & $\dagger$ \\
\hline 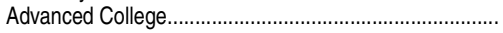 & 6 & 134 & 98 & 73.1 & 98 & $\dagger$ & 1 & $\dagger$ & $\dagger$ & $\dagger$ \\
\hline 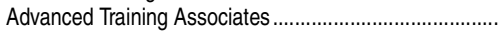 & 6 & 82 & 22 & 26.8 & 22 & $\dagger$ & 0 & $\dagger$ & $\dagger$ & $\dagger$ \\
\hline 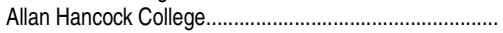 & 2 & 10,837 & 5,332 & 49.2 & 5,332 & $\dagger$ & 407 & $\dagger$ & $\dagger$ & $\dagger$ \\
\hline 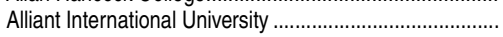 & 3 & 3,489 & 709 & 20.3 & 78 & 631 & $\dagger$ & 14 & 81 & 49 \\
\hline 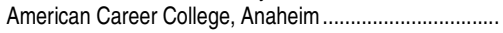 & 6 & 1,748 & 890 & 50.9 & 890 & $\dagger$ & 55 & $\dagger$ & $\dagger$ & $\dagger$ \\
\hline 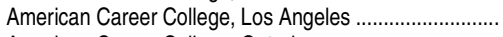 & 6 & 1,743 & 1,085 & 62.2 & 1,085 & $\dagger$ & 42 & $\dagger$ & $\dagger$ & $\dagger$ \\
\hline 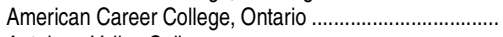 & 6 & 1,574 & 885 & 56.2 & 885 & $\dagger$ & 53 & $\dagger$ & $\dagger$ & $\dagger$ \\
\hline 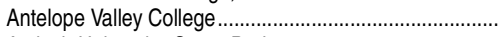 & 2 & 14,135 & 5,208 & 36.8 & 5,208 & $\dagger$ & 244 & $\dagger$ & $\dagger$ & $\dagger$ \\
\hline 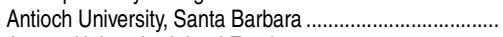 & 3 & 382 & 115 & 30.1 & 48 & 67 & $\dagger$ & 12 & 19 & 0 \\
\hline 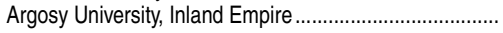 & 5 & 730 & 276 & 37.8 & 162 & 114 & $\dagger$ & 2 & 2 & 0 \\
\hline 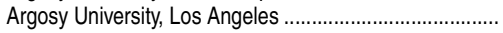 & 5 & 612 & 191 & 31.2 & 104 & 87 & $\dagger$ & 2 & 0 & 0 \\
\hline 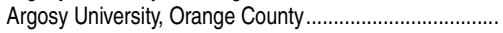 & 5 & 742 & 221 & 29.8 & 120 & 101 & $\dagger$ & 1 & 2 & 3 \\
\hline Argosy University, San Diego & 5 & 437 & 123 & 28.1 & 68 & 55 & $\dagger$ & 0 & 0 & 0 \\
\hline Art Institute of California, Argosy U., Hollywood ................... & 5 & 2,090 & 1,025 & 49.0 & 1,025 & $\dagger$ & 1 & 7 & $\dagger$ & $\dagger$ \\
\hline Art Institute of California, Argosy U., Inland Empire ......... & 5 & 2,315 & 1,299 & 56.1 & 1,299 & $\dagger$ & 11 & 43 & $\dagger$ & $\dagger$ \\
\hline Art Institute of California, Argosy U., Los Angeles........... & 5 & 1,949 & 1,456 & 74.7 & 1,456 & $\dagger$ & 67 & 80 & $\dagger$ & $\dagger$ \\
\hline Art Institute of California, Argosy U., Orange County ...... & 5 & 1,920 & 1,156 & 60.2 & 1,156 & $\dagger$ & 53 & 48 & $\dagger$ & $\dagger$ \\
\hline Art Institute of California, Argosy U., Sacramento ............ & 5 & 1,285 & 486 & 37.8 & 486 & $\dagger$ & 11 & 18 & $\dagger$ & $\dagger$ \\
\hline Art Institute of California, Argosy U., San Diego............... & 5 & 1,979 & 1,460 & 73.8 & 1,460 & $\dagger$ & 83 & 94 & $\dagger$ & $\dagger$ \\
\hline Art Institute of California, Argosy U., San Francisco........ & 5 & 1,448 & 628 & 43.4 & 628 & 0 & 12 & 51 & 1 & $\dagger$ \\
\hline Art Institute of California, Argosy U., Silicon Valley .......... & 5 & 654 & 269 & 41.1 & 269 & $\dagger$ & 18 & 24 & $\dagger$ & $\dagger$ \\
\hline 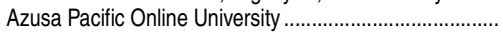 & 3 & 505 & 189 & 37.4 & 189 & $\dagger$ & 0 & 0 & $\dagger$ & $\dagger$ \\
\hline
\end{tabular}

See notes at end of table. 
Table 312.40. Enrollment and degrees conferred in degree-granting postsecondary institutions that serve large proportions of Hispanic undergraduate students, by institution level and control, percentage Hispanic, degree level, and other selected characteristics: Fall 2012 and 2011-12-Continued

\begin{tabular}{|c|c|c|c|c|c|c|c|c|c|c|}
\hline \multirow[b]{2}{*}{ State and institution } & \multirow[b]{2}{*}{$\begin{array}{r}\text { Level } \\
\text { and control }{ }^{1}\end{array}$} & \multicolumn{5}{|c|}{ Enrollment, fall 2012} & \multicolumn{4}{|c|}{ Degrees awarded to Hispanics, 2011-12 } \\
\hline & & Total & Hispanic & $\begin{array}{r}\text { Percent } \\
\text { Hispanic }^{2}\end{array}$ & $\begin{array}{r}\text { Hispanic } \\
\text { under- } \\
\text { graduate }\end{array}$ & $\begin{array}{r}\text { Hispanic } \\
\text { postbacca- } \\
\text { laureate }\end{array}$ & Associate's & Bachelor's & Master's & Doctor's ${ }^{3}$ \\
\hline 1 & 2 & 3 & 4 & 5 & 6 & 7 & 8 & 9 & 10 & 11 \\
\hline 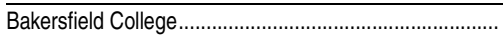 & 2 & 17,344 & 9,815 & 56.6 & 9,815 & $\dagger$ & 420 & $\dagger$ & $\dagger$ & $\bar{\dagger}$ \\
\hline 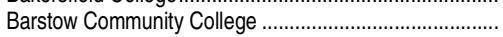 & 2 & 3,153 & 1,181 & 37.5 & 1,181 & $\dagger$ & 105 & $\dagger$ & $t$ & $\dagger$ \\
\hline 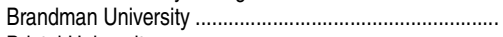 & 3 & 6,785 & 1,620 & 23.9 & 959 & 661 & 7 & 143 & 139 & 0 \\
\hline 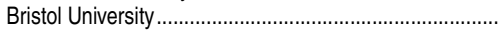 & 5 & 37 & 18 & 48.6 & 18 & 0 & $\dagger$ & $\dagger$ & 0 & $\dagger$ \\
\hline 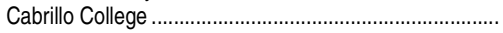 & 2 & 13,559 & 5,033 & 37.1 & 5,033 & $\dagger$ & 315 & $\dagger$ & $\dagger$ & $\dagger$ \\
\hline 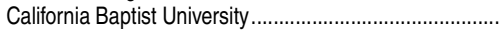 & 3 & 6,031 & 1,739 & 28.8 & 1,434 & 305 & $\dagger$ & 179 & 82 & $\dagger$ \\
\hline 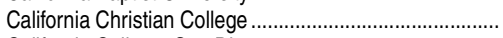 & 3 & 35 & 11 & 31.4 & 11 & $\dagger$ & 1 & 1 & t & $\dagger$ \\
\hline 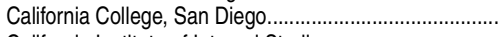 & 5 & 1,139 & 375 & 32.9 & 375 & $\dagger$ & 120 & 28 & 0 & $\dagger$ \\
\hline 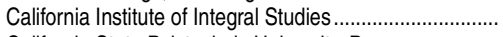 & 3 & 1,350 & 144 & 10.7 & 25 & 119 & $\dagger$ & 11 & 13 & 5 \\
\hline California State Polytechnic University, Pomona ................ & 1 & 22,156 & 8,134 & 36.7 & 7,639 & 495 & $\dagger$ & 1,102 & 85 & $\dagger$ \\
\hline 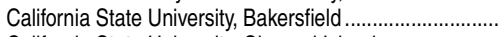 & 1 & 8,520 & 4,391 & 51.5 & 3,901 & 490 & $\dagger$ & 560 & 101 & $\dagger$ \\
\hline California State University, Channel Islands ....................... & 1 & 4,920 & 2,010 & 40.9 & 1,948 & 62 & $\dagger$ & 305 & 22 & $\dagger$ \\
\hline California State University, Dominguez Hills ...................... & 1 & 13,933 & 6,946 & 49.9 & 6,126 & 820 & $\dagger$ & 893 & 188 & $\dagger$ \\
\hline 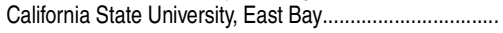 & 1 & 13,851 & 3,216 & 23.2 & 2,898 & 318 & $\dagger$ & 412 & 89 & 0 \\
\hline 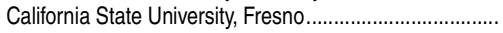 & 1 & 22,565 & 9,352 & 41.4 & 8,371 & 981 & $\dagger$ & 1,124 & 264 & 7 \\
\hline 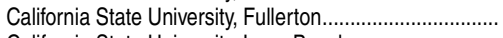 & 1 & 37,677 & 13,282 & 35.3 & 12,051 & 1,231 & $\dagger$ & 1,950 & 226 & 3 \\
\hline 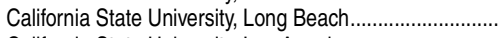 & 1 & 36,279 & 12,872 & 35.5 & 11,461 & 1,411 & $\dagger$ & 1,596 & 379 & 3 \\
\hline 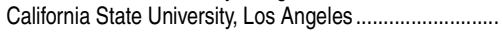 & 1 & 21,755 & 12,521 & 57.6 & 11,059 & 1,462 & $\dagger$ & 1,101 & 273 & $\dagger$ \\
\hline 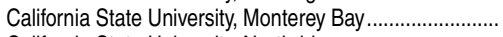 & 1 & 5,609 & 2,238 & 39.9 & 2,110 & 128 & $\dagger$ & 262 & 20 & $\dagger$ \\
\hline 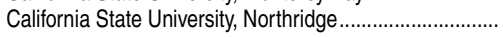 & 1 & 36,164 & 13,804 & 38.2 & 12,653 & 1,151 & $\dagger$ & 1,720 & 285 & 1 \\
\hline 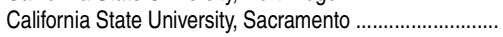 & 1 & 28,539 & 6,987 & 24.5 & 6,455 & 532 & $\dagger$ & 823 & 138 & 1 \\
\hline California State University, San Bernardino ........................ & 1 & 18,234 & 9,650 & 52.9 & 8,913 & 737 & $\dagger$ & 1,224 & 172 & 3 \\
\hline 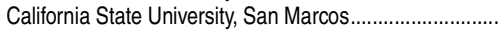 & 1 & 10,610 & 3,683 & 34.7 & 3,530 & 153 & $\dagger$ & 413 & 27 & $\dagger$ \\
\hline 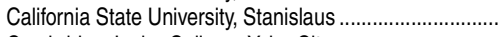 & 1 & 8,882 & 3,958 & 44.6 & 3,472 & 486 & $\dagger$ & 517 & 71 & 1 \\
\hline 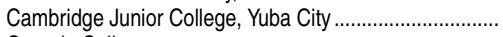 & 6 & 129 & 42 & 32.6 & 42 & $\dagger$ & 5 & $\dagger$ & $t$ & $\dagger$ \\
\hline Canada College & 2 & 6,658 & 3,177 & 47.7 & 3,177 & $\dagger$ & 132 & $\dagger$ & $\dagger$ & $\dagger$ \\
\hline 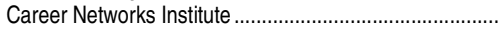 & 6 & 576 & 221 & 38.4 & 221 & $\dagger$ & 0 & $\dagger$ & $\dagger$ & $\dagger$ \\
\hline 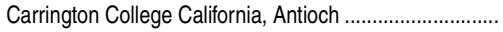 & 6 & 318 & 97 & 30.5 & 97 & $\dagger$ & 11 & $\dagger$ & $\dagger$ & $\dagger$ \\
\hline Carrington College California, Emeryville........................... & 6 & 148 & 54 & 36.5 & 54 & $\dagger$ & 6 & $\dagger$ & $\dagger$ & $\dagger$ \\
\hline 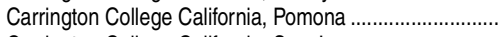 & 6 & 206 & 113 & 54.9 & 113 & $\dagger$ & 1 & $\dagger$ & $\dagger$ & $\dagger$ \\
\hline Carrington College California, San Jose ............................ & 6 & 646 & 295 & 45.7 & 295 & $\dagger$ & 62 & $\dagger$ & $\dagger$ & $\dagger$ \\
\hline Carrington College California, San Leandro ....................... & 6 & 471 & 189 & 40.1 & 189 & $\dagger$ & 14 & $\dagger$ & $\dagger$ & $\dagger$ \\
\hline 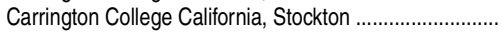 & 6 & 362 & 130 & 35.9 & 130 & $\dagger$ & 46 & $\dagger$ & $\dagger$ & $\dagger$ \\
\hline 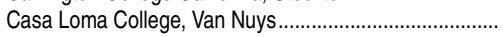 & 4 & 581 & 259 & 44.6 & 259 & $\dagger$ & 9 & $\dagger$ & $\dagger$ & $\dagger$ \\
\hline Cerritos College. & 2 & 20,719 & 13,866 & 66.9 & 13,866 & $\dagger$ & 557 & $\dagger$ & $\dagger$ & $\dagger$ \\
\hline 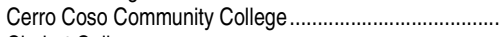 & 2 & 4,549 & 1,240 & 27.3 & 1,240 & $\dagger$ & 38 & $\dagger$ & $\dagger$ & $\dagger$ \\
\hline 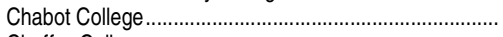 & 2 & 13,112 & 4,627 & 35.3 & 4,627 & $\dagger$ & 175 & $\dagger$ & $\dagger$ & $\dagger$ \\
\hline Chaffey College & 2 & 17,804 & 10,281 & 57.7 & 10,281 & $\dagger$ & 688 & $\dagger$ & $\dagger$ & $\dagger$ \\
\hline Citrus College & 2 & 11,750 & 6,802 & 57.9 & 6,802 & $\dagger$ & 583 & $\dagger$ & $\dagger$ & $\dagger$ \\
\hline College of San Mateo & 2 & 9,548 & 2,796 & 29.3 & 2,796 & $\dagger$ & 107 & $\dagger$ & $\dagger$ & $\dagger$ \\
\hline College of the Canyons & 2 & 15,177 & 6,026 & 39.7 & 6,026 & $\dagger$ & 309 & $\dagger$ & $\dagger$ & $\dagger$ \\
\hline 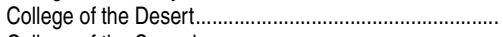 & 2 & 9,075 & 5,851 & 64.5 & 5,851 & $\dagger$ & 321 & $\dagger$ & $\dagger$ & $\dagger$ \\
\hline College of the Sequoias & 2 & 10,947 & 6,415 & 58.6 & 6,415 & $\dagger$ & 370 & $\dagger$ & $\dagger$ & $\dagger$ \\
\hline 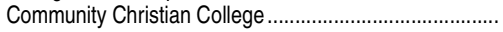 & 4 & 110 & 48 & 43.6 & 48 & $\dagger$ & 1 & $\dagger$ & $\dagger$ & $\dagger$ \\
\hline Concorde Career College, Garden Grove .......................... & 6 & 1,006 & 430 & 42.7 & 430 & $\dagger$ & 12 & $\dagger$ & $\dagger$ & $\dagger$ \\
\hline Concorde Career College, North Hollywood ....................... & 6 & 1,050 & 447 & 42.6 & 447 & $\dagger$ & 32 & $\dagger$ & $\dagger$ & $\dagger$ \\
\hline Concorde Career College, San Bernardino........................ & 6 & 911 & 453 & 49.7 & 453 & $\dagger$ & 36 & $\dagger$ & $\dagger$ & $\dagger$ \\
\hline 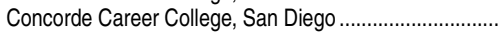 & 6 & 649 & 276 & 42.5 & 276 & $\dagger$ & 11 & $\dagger$ & $\dagger$ & $\dagger$ \\
\hline 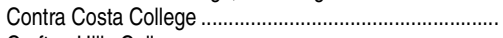 & 2 & 6,899 & 2,457 & 35.6 & 2,457 & $\dagger$ & 191 & $\dagger$ & $\dagger$ & $\dagger$ \\
\hline Crafton Hills College & 2 & 5,280 & 2,130 & 40.3 & 2,130 & $\dagger$ & 111 & $\dagger$ & $\dagger$ & $\dagger$ \\
\hline Cuesta College & 2 & 9,834 & 2,702 & 27.5 & 2,702 & $\dagger$ & 114 & $\dagger$ & $\dagger$ & $\dagger$ \\
\hline Cuyamaca College & 2 & 8,453 & 2,559 & 30.3 & 2,559 & $\dagger$ & 114 & $\dagger$ & $\dagger$ & $\dagger$ \\
\hline Cypress College & 2 & 15,144 & 6,346 & 41.9 & 6,346 & $\dagger$ & 221 & $\dagger$ & $\dagger$ & $\dagger$ \\
\hline 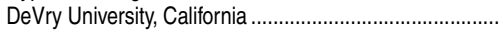 & 5 & 9,173 & 3,637 & 39.6 & 3,637 & $\dagger$ & 92 & 340 & $\dagger$ & $\dagger$ \\
\hline 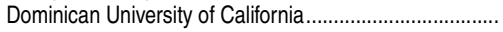 & 3 & 2,207 & 490 & 22.2 & 412 & 78 & $\dagger$ & 56 & 29 & $\dagger$ \\
\hline 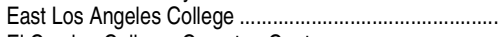 & 2 & 37,055 & 25,950 & 70.0 & 25,950 & $\dagger$ & 1,090 & $\dagger$ & $\dagger$ & $\dagger$ \\
\hline 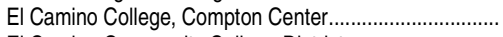 & 2 & 7,510 & 3,361 & 44.8 & 3,361 & $\dagger$ & 91 & $\dagger$ & $\dagger$ & $\dagger$ \\
\hline 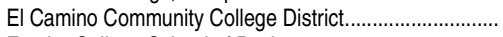 & 2 & 23,405 & 10,662 & 45.6 & 10,662 & $\dagger$ & 608 & $\dagger$ & $\dagger$ & $\dagger$ \\
\hline Empire College School of Business .................................. & 6 & 398 & 122 & 30.7 & 122 & $\dagger$ & 34 & $\dagger$ & $\dagger$ & $\dagger$ \\
\hline Everest College, Anaheim & 6 & 718 & 461 & 64.2 & 461 & $\dagger$ & 31 & $\dagger$ & $\dagger$ & $\dagger$ \\
\hline 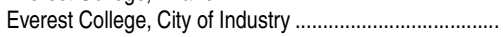 & 6 & 995 & 875 & 87.9 & 875 & $\dagger$ & 0 & $\dagger$ & $\dagger$ & $\dagger$ \\
\hline 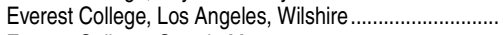 & 6 & 279 & 161 & 57.7 & 161 & $\dagger$ & 2 & $\dagger$ & $\dagger$ & $\dagger$ \\
\hline 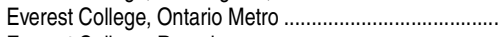 & 5 & 1,034 & 655 & 63.3 & 655 & $\dagger$ & 190 & 27 & $\dagger$ & $\dagger$ \\
\hline Everest College, Reseda & 6 & 699 & 461 & 66.0 & 461 & $\dagger$ & 1 & $\dagger$ & $\dagger$ & $\dagger$ \\
\hline 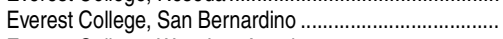 & 6 & 820 & 446 & 54.4 & 446 & $\dagger$ & 29 & $\dagger$ & $\dagger$ & $\dagger$ \\
\hline 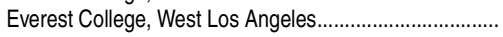 & 6 & 431 & 228 & 52.9 & 228 & $\dagger$ & 35 & $\dagger$ & $\dagger$ & $\dagger$ \\
\hline 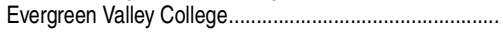 & 2 & 9,267 & 3,857 & 41.6 & 3,857 & $\dagger$ & 180 & $\dagger$ & $\dagger$ & $\dagger$ \\
\hline Fashion Institute of Design \& Merchandising, Orange County . & 6 & 293 & 100 & 34.1 & 100 & $\dagger$ & $\dagger$ & $\dagger$ & $\dagger$ & $\dagger$ \\
\hline Fashion Institute of Design \& Merchandising, San Diego .. & 6 & 181 & 73 & 40.3 & 73 & $\dagger$ & 8 & $\dagger$ & $\dagger$ & $\dagger$ \\
\hline Fremont College & 5 & 360 & 198 & 55.0 & 198 & $\dagger$ & 63 & 1 & $\dagger$ & $\dagger$ \\
\hline 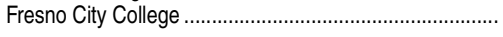 & 2 & 21,630 & 10,609 & 49.0 & 10,609 & $\dagger$ & 346 & $\dagger$ & $\dagger$ & $\dagger$ \\
\hline
\end{tabular}


CHAPTER 3: Postsecondary Education 479

Large Institutions and Institutions Serving Specific Groups

Table 312.40. Enrollment and degrees conferred in degree-granting postsecondary institutions that serve large proportions of Hispanic undergraduate students, by institution level and control, percentage Hispanic, degree level, and other selected characteristics: Fall 2012 and 2011-12-Continued

\begin{tabular}{|c|c|c|c|c|c|c|c|c|c|c|}
\hline \multirow[b]{2}{*}{ State and institution } & \multirow[b]{2}{*}{$\begin{array}{r}\text { Level } \\
\text { and control } \\
\end{array}$} & \multicolumn{5}{|c|}{ Enrollment, fall 2012} & \multicolumn{4}{|c|}{ Degrees awarded to Hispanics, 2011-12 } \\
\hline & & Total & Hispanic & $\begin{array}{r}\text { Percent } \\
\text { Hispanic }^{2}\end{array}$ & $\begin{array}{r}\text { Hispanic } \\
\text { under- } \\
\text { graduate }\end{array}$ & $\begin{array}{r}\text { Hispanic } \\
\text { postbacca- } \\
\text { laureate }\end{array}$ & Associate's & Bachelor's & Master's & Doctor's $^{3}$ \\
\hline 1 & 2 & 3 & 4 & 5 & 6 & 7 & 8 & 9 & 10 & 11 \\
\hline Fresno Pacific University.. & 3 & 3,353 & 1,294 & 38.6 & 1,072 & 222 & 0 & 287 & 36 & $\bar{\dagger}$ \\
\hline Fullerton College .............. & 2 & 19,624 & 9,833 & 50.1 & 9,833 & $t$ & 600 & $t$ & $t$ & $\dagger$ \\
\hline Gavilan College ........................ & 2 & 6,670 & 3,326 & 49.9 & 3,326 & $\dagger$ & 207 & $\dagger$ & $\dagger$ & $\dagger$ \\
\hline Glendale Community College..... & 2 & 15,978 & 4,702 & 29.4 & 4,702 & $\dagger$ & 77 & $\dagger$ & $\dagger$ & $\dagger$ \\
\hline Golden West College..................... & 2 & 12,333 & 3,563 & 28.9 & 3,563 & $\dagger$ & 155 & $\dagger$ & $\dagger$ & $\dagger$ \\
\hline Grossmont College ......................................... & 2 & 17,758 & 5,285 & 29.8 & 5,285 & $\dagger$ & 206 & $\dagger$ & $\dagger$ & \\
\hline Hands-on Medical Massage School ...................... & 6 & 45 & 14 & 31.1 & 14 & $\dagger$ & 2 & $\dagger$ & $\dagger$ & $\dagger$ \\
\hline 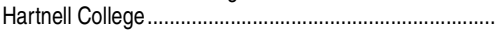 & 2 & 8,377 & 6,303 & 75.2 & 6,303 & $\dagger$ & 377 & $\dagger$ & $\dagger$ & $\dagger$ \\
\hline Heald College, Concord & 6 & 1,657 & 537 & 32.4 & 537 & $\dagger$ & 136 & $\dagger$ & $\dagger$ & $\dagger$ \\
\hline Heald College, Fresno & 6 & 1,993 & 1,193 & 59.9 & 1,193 & $\dagger$ & 209 & $\dagger$ & $\dagger$ & $\dagger$ \\
\hline Heald College, Hayward ........ & 6 & 1,419 & 580 & 40.9 & 580 & $\dagger$ & 210 & $\dagger$ & $\dagger$ & $\dagger$ \\
\hline Heald College, Modesto ......... & 6 & 1,016 & 589 & 58.0 & 589 & $\dagger$ & 59 & $\dagger$ & $\dagger$ & $\dagger$ \\
\hline Heald College, Salinas ......... & 6 & 1,261 & 908 & 72.0 & 908 & $\dagger$ & 354 & $\dagger$ & $\dagger$ & $\dagger$ \\
\hline Heald College, San Francisco ……………………….... & 6 & 1,228 & 408 & 33.2 & 408 & $t$ & 132 & $\dagger$ & $t$ & $\dagger$ \\
\hline Heald College, San Jose .................................................. & 6 & 1,738 & 904 & 52.0 & 904 & $\dagger$ & 281 & $\dagger$ & $\dagger$ & $\dagger$ \\
\hline Heald College, Stockton ……………………………….... & 6 & 1,665 & 676 & 40.6 & 676 & $\dagger$ & 156 & $\dagger$ & $\dagger$ & $\dagger$ \\
\hline 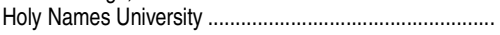 & 3 & 1,353 & 321 & 23.7 & 246 & 75 & $t$ & 27 & 12 & $\dagger$ \\
\hline Humboldt State University ........................................... & 1 & 8,116 & 1,974 & 24.3 & 1,930 & 44 & $t$ & 157 & 15 & $\dagger$ \\
\hline Humphreys College, Stockton and Modesto ................. & 3 & 1,089 & 426 & 39.1 & 361 & 65 & 22 & 45 & 0 & 8 \\
\hline ICDC College............. & 6 & 4,298 & 1,591 & 37.0 & 1,591 & $\dagger$ & 118 & $\dagger$ & $\dagger$ & $\dagger$ \\
\hline Imperial Valley College ........... & 2 & 7,699 & 7,363 & 95.6 & 7,363 & $t$ & 541 & $\dagger$ & $\dagger$ & $\dagger$ \\
\hline Institute of Technology Inc... & 6 & 2,763 & 1,067 & 38.6 & 1,067 & $\dagger$ & 188 & $\dagger$ & $t$ & $t$ \\
\hline ITT Technical Institute, Clovis..... & 5 & 486 & 262 & 53.9 & 262 & $\dagger$ & 70 & 14 & $\dagger$ & $\dagger$ \\
\hline ITT Technical Institute, Corona .... & 5 & 444 & 198 & 44.6 & 198 & $t$ & 24 & 0 & $t$ & $\dagger$ \\
\hline ITT Technical Institute, Culver City ...................... & 5 & 336 & 172 & 51.2 & 172 & $t$ & 39 & 0 & $t$ & $\dagger$ \\
\hline ITT Technical Institute, Lathrop............ & 5 & 544 & 223 & 41.0 & 223 & $t$ & 68 & 31 & $t$ & $\dagger$ \\
\hline ITT Technical Institute, Oakland ..................................... & 5 & 131 & 42 & 32.1 & 42 & $t$ & 0 & 0 & $t$ & $\dagger$ \\
\hline ITT Technical Institute, Orange .................................... & 5 & 926 & 490 & 52.9 & 490 & $t$ & 131 & 43 & $\dagger$ & $\dagger$ \\
\hline ITT Technical Institute, Oxnard ............................... & 5 & 359 & 188 & 52.4 & 188 & $\dagger$ & 38 & 28 & $\dagger$ & $\dagger$ \\
\hline ITT Technical Institute, San Bernardino ..................... & 5 & 932 & 472 & 50.6 & 472 & $\dagger$ & 182 & 46 & $\dagger$ & $\dagger$ \\
\hline ITT Technical Institute, San Diego ................................ & 5 & 1,385 & 458 & 33.1 & 458 & $\dagger$ & 126 & 34 & $\dagger$ & $\dagger$ \\
\hline ITT Technical Institute, San Dimas ..................... & 5 & 451 & 243 & 53.9 & 243 & $\dagger$ & 70 & 50 & $\dagger$ & $\dagger$ \\
\hline ITT Technical Institute, Sylmar...................................... & 5 & 672 & 406 & 60.4 & 406 & $\dagger$ & 142 & 38 & $\dagger$ & $\dagger$ \\
\hline 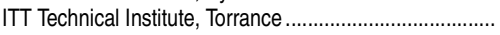 & 5 & 552 & 302 & 54.7 & 302 & $\dagger$ & 136 & 37 & $\dagger$ & $\dagger$ \\
\hline ITT Technical Institute, West Covina.................................. & 5 & 398 & 290 & 72.9 & 290 & $\dagger$ & 86 & 0 & $\dagger$ & $\dagger$ \\
\hline Kaplan College, Bakersfield ...................................... & 6 & 524 & 397 & 75.8 & 397 & $\dagger$ & 63 & $\dagger$ & $\dagger$ & $\dagger$ \\
\hline Kaplan College, Chula Vista & 6 & 313 & 245 & 78.3 & 245 & $\dagger$ & 41 & $\dagger$ & $\dagger$ & $\dagger$ \\
\hline Kaplan College, Fresno ……………………………......... & 6 & 376 & 263 & 69.9 & 263 & $\dagger$ & 58 & $\dagger$ & $\dagger$ & $\dagger$ \\
\hline Kaplan College, Modesto ………………………........ & 6 & 548 & 296 & 54.0 & 296 & $\dagger$ & 52 & $\dagger$ & $\dagger$ & $\dagger$ \\
\hline Kaplan College, Palm Springs ...................................... & 6 & 386 & 266 & 68.9 & 266 & $\dagger$ & 35 & $\dagger$ & $\dagger$ & $\dagger$ \\
\hline Kaplan College, Riverside ........................................... & 6 & 310 & 171 & 55.2 & 171 & $t$ & 6 & $\dagger$ & $t$ & $\dagger$ \\
\hline Kaplan College, Sacramento...... & 6 & 558 & 165 & 29.6 & 165 & $\dagger$ & 21 & $\dagger$ & $\dagger$ & $\dagger$ \\
\hline Kaplan College, San Diego & 6 & 1,363 & 377 & 27.7 & 377 & $\dagger$ & 39 & $\dagger$ & $\dagger$ & $\dagger$ \\
\hline Kaplan College, Stockton ......... & 6 & 263 & 120 & 45.6 & 120 & $t$ & 16 & $\dagger$ & $\dagger$ & $\dagger$ \\
\hline Kaplan College, Vista & 6 & 800 & 330 & 41.3 & 330 & $\dagger$ & 20 & $\dagger$ & $\dagger$ & $\dagger$ \\
\hline La Sierra University ............................................ & 3 & 2,393 & 865 & 36.1 & 805 & 60 & $\dagger$ & 57 & 15 & 0 \\
\hline 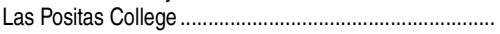 & 2 & 8,558 & 2,258 & 26.4 & 2,258 & $\dagger$ & 86 & $\dagger$ & $\dagger$ & $\dagger$ \\
\hline Le Cordon Bleu College of Culinary Arts, Pasadena....... & 6 & 2,436 & 860 & 35.3 & 860 & $\dagger$ & 164 & $\dagger$ & $\dagger$ & $\dagger$ \\
\hline Long Beach City College .................................................. & 2 & 24,839 & 12,158 & 48.9 & 12,158 & $\dagger$ & 270 & $\dagger$ & $t$ & $\dagger$ \\
\hline Los Angeles City College & 2 & 20,385 & 9,888 & 48.5 & 9,888 & $\dagger$ & 181 & $\dagger$ & $\dagger$ & $\dagger$ \\
\hline Los Angeles Co. College of Nursing and Allied Health.... & 2 & 211 & 74 & 35.1 & 74 & $\dagger$ & 26 & $\dagger$ & $\dagger$ & $\dagger$ \\
\hline 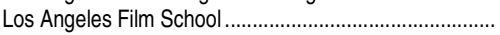 & 5 & 2,464 & 704 & 28.6 & 704 & $\dagger$ & 87 & $\dagger$ & $\dagger$ & $\dagger$ \\
\hline Los Angeles Harbor College......... & 2 & 9,647 & 5,410 & 56.1 & 5,410 & $\dagger$ & 235 & $\dagger$ & $\dagger$ & $\dagger$ \\
\hline Los Angeles Mission College ... & 2 & 9,674 & 7,332 & 75.8 & 7,332 & $\dagger$ & 335 & $\dagger$ & $\dagger$ & $\dagger$ \\
\hline Los Angeles ORT College, Los Angeles ......................... & 4 & 355 & 89 & 25.1 & 89 & $\dagger$ & 18 & $\dagger$ & $\dagger$ & $\dagger$ \\
\hline Los Angeles ORT College, Van Nuys............................... & 4 & 170 & 62 & 36.5 & 62 & $\dagger$ & 5 & $\dagger$ & $\dagger$ & $\dagger$ \\
\hline Los Angeles Pierce College ...... & 2 & 19,938 & 9,103 & 45.7 & 9,103 & $\dagger$ & 309 & $\dagger$ & $\dagger$ & $\dagger$ \\
\hline Los Angeles Southwest College & 2 & 6,743 & 2,463 & 36.5 & 2,463 & $\dagger$ & 51 & $\dagger$ & $\dagger$ & $\dagger$ \\
\hline Los Angeles Trade Technical College ............................. & 2 & 13,749 & 7,939 & 57.7 & 7,939 & $\dagger$ & 188 & $\dagger$ & $\dagger$ & $\dagger$ \\
\hline Los Angeles Valley College & 2 & 18,640 & 9,262 & 49.7 & 9,262 & $\dagger$ & 256 & $\dagger$ & $\dagger$ & $\dagger$ \\
\hline Los Medanos College............ & 2 & 8,554 & 3,055 & 35.7 & 3,055 & $\dagger$ & 220 & $\dagger$ & $\dagger$ & $\dagger$ \\
\hline Marymount College ........ & 3 & 1,001 & 347 & 34.7 & 347 & $\dagger$ & 9 & 4 & $\dagger$ & $\dagger$ \\
\hline Mayfield College ......... & 6 & 291 & 171 & 58.8 & 171 & $\dagger$ & $\dagger$ & $\dagger$ & $\dagger$ & $\dagger$ \\
\hline Mendocino College.............................. & 2 & 3,788 & 941 & 24.8 & 941 & $\dagger$ & 56 & $\dagger$ & $\dagger$ & $\dagger$ \\
\hline Merced College .............. & 2 & 10,267 & 5,677 & 55.3 & 5,677 & $\dagger$ & 325 & $\dagger$ & $\dagger$ & $\dagger$ \\
\hline 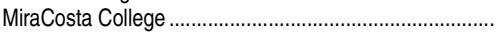 & 2 & 14,723 & 4,547 & 30.9 & 4,547 & $\dagger$ & 226 & $\dagger$ & $\dagger$ & $\dagger$ \\
\hline Modesto Junior College ........... & 2 & 16,985 & 7,137 & 42.0 & 7,137 & $\dagger$ & 341 & $\dagger$ & $\dagger$ & $\dagger$ \\
\hline Monterey Peninsula College ................................................ & 2 & 10,048 & 2,975 & 29.6 & 2,975 & $t$ & 80 & $\dagger$ & $\dagger$ & $\dagger$ \\
\hline 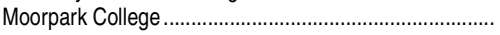 & 2 & 14,605 & 4,011 & 27.5 & 4,011 & $\dagger$ & 266 & $\dagger$ & $\dagger$ & $\dagger$ \\
\hline 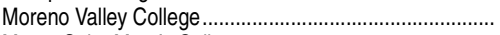 & 2 & 9,079 & 4,745 & 52.3 & 4,745 & $t$ & 243 & $\dagger$ & $\dagger$ & $\dagger$ \\
\hline Mount Saint Mary's College .......................................... & 3 & 3,146 & 1,749 & 55.6 & 1,422 & 327 & 69 & 176 & 44 & 2 \\
\hline
\end{tabular}

See notes at end of table. 
Table 312.40. Enrollment and degrees conferred in degree-granting postsecondary institutions that serve large proportions of Hispanic undergraduate students, by institution level and control, percentage Hispanic, degree level, and other selected characteristics: Fall 2012 and 2011-12-Continued

\begin{tabular}{|c|c|c|c|c|c|c|c|c|c|c|}
\hline \multirow[b]{2}{*}{ State and institution } & \multirow[b]{2}{*}{$\begin{array}{r}\text { Level } \\
\text { and control }{ }^{1}\end{array}$} & \multicolumn{5}{|c|}{ Enrollment, fall 2012} & \multicolumn{4}{|c|}{ Degrees awarded to Hispanics, 2011-12 } \\
\hline & & Total & Hispanic & $\begin{array}{r}\text { Percent } \\
\text { Hispanic }^{2}\end{array}$ & $\begin{array}{r}\text { Hispanic } \\
\text { under- } \\
\text { graduate }\end{array}$ & $\begin{array}{r}\text { Hispanic } \\
\text { postbacca- } \\
\text { laureate }\end{array}$ & Associate's & Bachelor's & Master's & Doctor's ${ }^{3}$ \\
\hline 1 & 2 & 3 & 4 & 5 & 6 & 7 & 8 & 9 & 10 & 11 \\
\hline 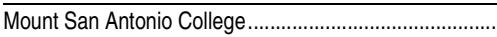 & 2 & 28,036 & 16,117 & 57.5 & 16,117 & $\dagger$ & 829 & $\dagger$ & $\dagger$ & $\dagger$ \\
\hline Mount San Jacinto Community College District................ & 2 & 14,180 & 5,854 & 41.3 & 5,854 & $\dagger$ & 419 & $\dagger$ & $\dagger$ & $\dagger$ \\
\hline Mount Sierra College & 5 & 548 & 288 & 52.6 & 288 & $\dagger$ & $\dagger$ & 14 & $\dagger$ & $\dagger$ \\
\hline 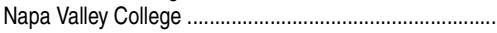 & 2 & 6,287 & 2,257 & 35.9 & 2,257 & $\dagger$ & 177 & $\dagger$ & $\dagger$ & $\dagger$ \\
\hline 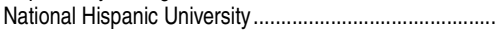 & 5 & 787 & 516 & 65.6 & 322 & 194 & 1 & 20 & 1 & $\dagger$ \\
\hline 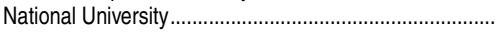 & 3 & 17,898 & 4,487 & 25.1 & 2,527 & 1,960 & 19 & 222 & 433 & $\dagger$ \\
\hline 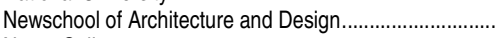 & 5 & 577 & 180 & 31.2 & 142 & 38 & $\dagger$ & 7 & 6 & $\dagger$ \\
\hline 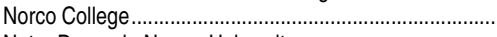 & 2 & 9,664 & 5,051 & 52.3 & 5,051 & $\dagger$ & 260 & $\dagger$ & $\dagger$ & $\dagger$ \\
\hline 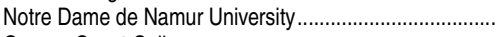 & 3 & 2,001 & 546 & 27.3 & 406 & 140 & $\dagger$ & 60 & 19 & $\dagger$ \\
\hline 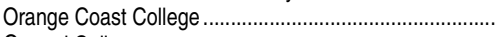 & 2 & 21,088 & 6,752 & 32.0 & 6,752 & $\dagger$ & 325 & $\dagger$ & $\dagger$ & $\dagger$ \\
\hline 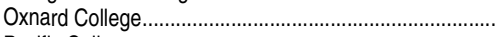 & 2 & 7,060 & 4,923 & 69.7 & 4,923 & $\dagger$ & 317 & $\dagger$ & $\dagger$ & $\dagger$ \\
\hline 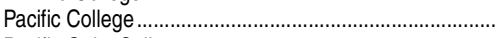 & 5 & 257 & 157 & 61.1 & 157 & $\dagger$ & 7 & 0 & $\dagger$ & $\dagger$ \\
\hline 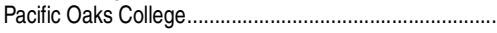 & 3 & 959 & 482 & 50.3 & 225 & 257 & $\dagger$ & 17 & 16 & $\dagger$ \\
\hline Pacific Union College & 3 & 1,564 & 400 & 25.6 & 400 & $\dagger$ & 13 & 40 & 0 & $\dagger$ \\
\hline 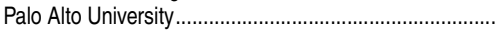 & 3 & 876 & 112 & 12.8 & 47 & 65 & $\dagger$ & 4 & 11 & 4 \\
\hline 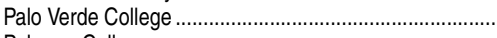 & 2 & 2,927 & 1,122 & 38.3 & 1,122 & $\dagger$ & 39 & $\dagger$ & $\dagger$ & $\dagger$ \\
\hline 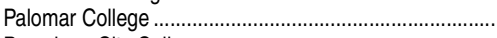 & 2 & 24,626 & 8,866 & 36.0 & 8,866 & $\dagger$ & 546 & $\dagger$ & $\dagger$ & $\dagger$ \\
\hline 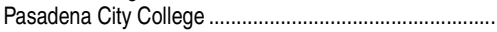 & 2 & 22,859 & 10,210 & 44.7 & 10,210 & $\dagger$ & 477 & $\dagger$ & $\dagger$ & $\dagger$ \\
\hline 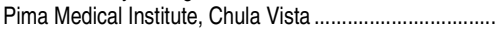 & 6 & 981 & 449 & 45.8 & 449 & $\dagger$ & 33 & $\dagger$ & $\dagger$ & $\dagger$ \\
\hline 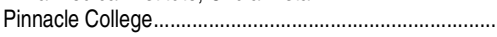 & 6 & 161 & 55 & 34.2 & 55 & $\dagger$ & 0 & $\dagger$ & $\dagger$ & $\dagger$ \\
\hline 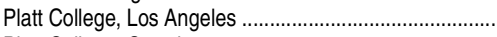 & 5 & 515 & 393 & 76.3 & 393 & $\dagger$ & 138 & 24 & $\dagger$ & $\dagger$ \\
\hline Platt College, Ontario & 5 & 559 & 337 & 60.3 & 337 & $\dagger$ & 154 & 32 & $\dagger$ & $\dagger$ \\
\hline 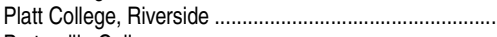 & 5 & 161 & 95 & 59.0 & 95 & $\dagger$ & 0 & 0 & $\dagger$ & $\dagger$ \\
\hline 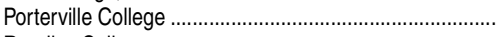 & 2 & 3,919 & 2,602 & 66.4 & 2,602 & $\dagger$ & 206 & $\dagger$ & $\dagger$ & $\dagger$ \\
\hline 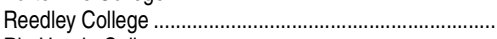 & 2 & 13,737 & 7,602 & 55.3 & 7,602 & $\dagger$ & 279 & $\dagger$ & $\dagger$ & $\dagger$ \\
\hline 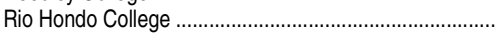 & 2 & 17,643 & 13,871 & 78.6 & 13,871 & $\dagger$ & 688 & $\dagger$ & $\dagger$ & $\dagger$ \\
\hline Riverside City College & 2 & 17,218 & 9,072 & 52.7 & 9,072 & $\dagger$ & 662 & $\dagger$ & $\dagger$ & $\dagger$ \\
\hline Sacramento City College & 2 & 24,381 & 6,540 & 26.8 & 6,540 & $\dagger$ & 328 & $\dagger$ & $\dagger$ & $\dagger$ \\
\hline 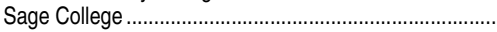 & 6 & 584 & 181 & 31.0 & 181 & $\dagger$ & 4 & $\dagger$ & $\dagger$ & $\dagger$ \\
\hline 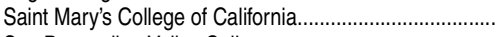 & 3 & 4,228 & 1,062 & 25.1 & 812 & 250 & 6 & 116 & 51 & 0 \\
\hline 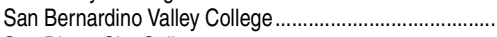 & 2 & 12,031 & 7,332 & 60.9 & 7,332 & $\dagger$ & 386 & $\dagger$ & $\dagger$ & $\dagger$ \\
\hline San Diego City College & 2 & 16,797 & 7,832 & 46.6 & 7,832 & $\dagger$ & 247 & $\dagger$ & $\dagger$ & $\dagger$ \\
\hline 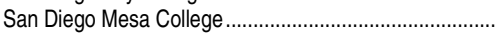 & 2 & 24,943 & 7,606 & 30.5 & 7,606 & $\dagger$ & 214 & $\dagger$ & $\dagger$ & $\dagger$ \\
\hline 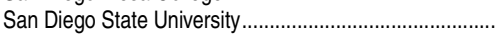 & 1 & 30,843 & 8,958 & 29.0 & 7,949 & 1,009 & $\dagger$ & 1,356 & 243 & 16 \\
\hline 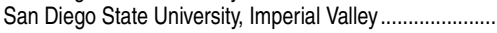 & 1 & 788 & 743 & 94.3 & 635 & 108 & $\dagger$ & 195 & 15 & $\dagger$ \\
\hline 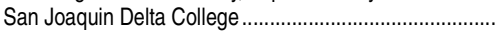 & 2 & 17,002 & 6,619 & 38.9 & 6,619 & $\dagger$ & 903 & $\dagger$ & $\dagger$ & $\dagger$ \\
\hline 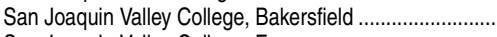 & 6 & 743 & 421 & 56.7 & 421 & $\dagger$ & 260 & $\dagger$ & $\dagger$ & $\dagger$ \\
\hline 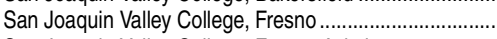 & 6 & 738 & 420 & 56.9 & 420 & $\dagger$ & 266 & $\dagger$ & $\dagger$ & $\dagger$ \\
\hline San Joaquin Valley College, Fresno Aviation ..................... & 6 & 83 & 26 & 31.3 & 26 & $\dagger$ & 20 & $\dagger$ & $\dagger$ & $\dagger$ \\
\hline 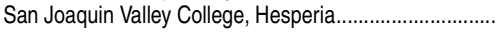 & 6 & 694 & 357 & 51.4 & 357 & $\dagger$ & 248 & $\dagger$ & $\dagger$ & $\dagger$ \\
\hline 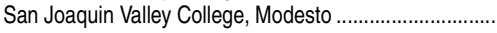 & 6 & 322 & 171 & 53.1 & 171 & $\dagger$ & 137 & $\dagger$ & $\dagger$ & $\dagger$ \\
\hline San Joaquin Valley College, Rancho Cucamonga ........... & 6 & 746 & 471 & 63.1 & 471 & $\dagger$ & 408 & $\dagger$ & $\dagger$ & $\dagger$ \\
\hline 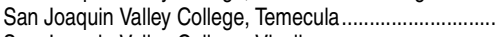 & 6 & 314 & 152 & 48.4 & 152 & $\dagger$ & 0 & $\dagger$ & $\dagger$ & $\dagger$ \\
\hline 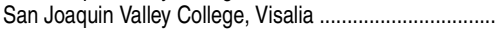 & 6 & 1,892 & 776 & 41.0 & 776 & $\dagger$ & 426 & $\dagger$ & $\dagger$ & $\dagger$ \\
\hline San Jose City College & 2 & 9,919 & 4,203 & 42.4 & 4,203 & $\dagger$ & 131 & $\dagger$ & $\dagger$ & $\dagger$ \\
\hline Santa Ana College & 2 & 32,354 & 17,308 & 53.5 & 17,308 & $\dagger$ & 852 & $\dagger$ & $\dagger$ & $\dagger$ \\
\hline Santa Barbara Business College, Bakersfield .................... & 5 & 602 & 424 & 70.4 & 424 & $\dagger$ & 161 & 0 & $\dagger$ & $\dagger$ \\
\hline Santa Barbara Business College, Santa Maria ................... & 5 & 219 & 150 & 68.5 & 150 & $\dagger$ & 47 & 0 & $\dagger$ & $\dagger$ \\
\hline 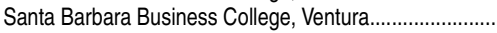 & 5 & 336 & 201 & 59.8 & 201 & 0 & 64 & 0 & 0 & $\dagger$ \\
\hline Santa Barbara City College & 2 & 19,265 & 6,655 & 34.5 & 6,655 & $\dagger$ & 457 & $\dagger$ & $\dagger$ & $\dagger$ \\
\hline 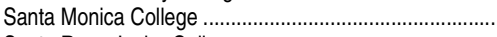 & 2 & 30,254 & 11,002 & 36.4 & 11,002 & $\dagger$ & 333 & $\dagger$ & $\dagger$ & $\dagger$ \\
\hline 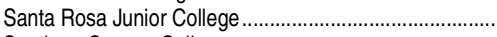 & 2 & 22,823 & 6,410 & 28.1 & 6,410 & $\dagger$ & 324 & $\dagger$ & $\dagger$ & $\dagger$ \\
\hline 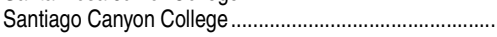 & 2 & 11,579 & 5,392 & 46.6 & 5,392 & $\dagger$ & 280 & $\dagger$ & $\dagger$ & $\dagger$ \\
\hline 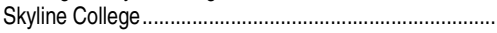 & 2 & 9,563 & 2,638 & 27.6 & 2,638 & $\dagger$ & 165 & $\dagger$ & $\dagger$ & $\dagger$ \\
\hline Solano Community College & 2 & 9,772 & 2,437 & 24.9 & 2,437 & $\dagger$ & 141 & $\dagger$ & $\dagger$ & $\dagger$ \\
\hline 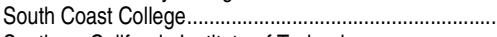 & 6 & 392 & 154 & 39.3 & 154 & $\dagger$ & 7 & $\dagger$ & $\dagger$ & $\dagger$ \\
\hline Southern California Institute of Technology .......................... & 5 & 538 & 250 & 46.5 & 250 & $\dagger$ & 1 & 28 & $\dagger$ & $\dagger$ \\
\hline Southwestern College & 2 & 18,362 & 10,144 & 55.2 & 10,144 & $\dagger$ & 555 & $\dagger$ & $\dagger$ & $\dagger$ \\
\hline 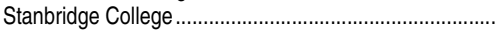 & 5 & 221 & 61 & 27.6 & 61 & $\dagger$ & 1 & 0 & $\dagger$ & $\dagger$ \\
\hline 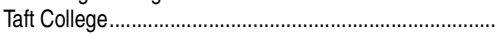 & 2 & 5,418 & 2,645 & 48.8 & 2,645 & $\dagger$ & 120 & $\dagger$ & $\dagger$ & $\dagger$ \\
\hline United Education Institute, Huntington Park ....................... & 6 & 3,104 & 2,371 & 76.4 & 2,371 & t & 54 & $\dagger$ & $\dagger$ & $\dagger$ \\
\hline 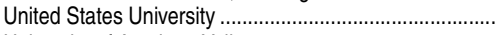 & 5 & 266 & 166 & 62.4 & 125 & 41 & $\dagger$ & 48 & 5 & $\dagger$ \\
\hline 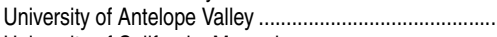 & 5 & 801 & 374 & 46.7 & 370 & 4 & 32 & 4 & 0 & $\dagger$ \\
\hline 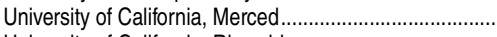 & 1 & 5,760 & 2,240 & 38.9 & 2,201 & 39 & $\dagger$ & 189 & 5 & 2 \\
\hline 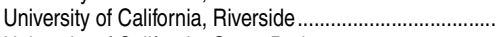 & 1 & 20,947 & 6,854 & 32.7 & 6,576 & 278 & $\dagger$ & 1,119 & 54 & 20 \\
\hline 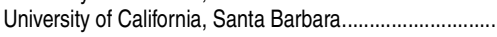 & 1 & 21,927 & 5,066 & 23.1 & 4,779 & 287 & $\dagger$ & 1,164 & 69 & 23 \\
\hline 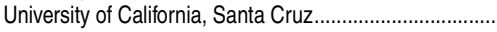 & 1 & 17,404 & 4,736 & 27.2 & 4,552 & 184 & $\dagger$ & 716 & 32 & 13 \\
\hline 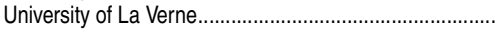 & 3 & 8,628 & 3,707 & 43.0 & 2,599 & 1,108 & $\dagger$ & 445 & 326 & 33 \\
\hline 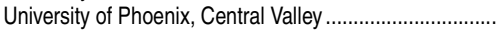 & 5 & 2,734 & 1,255 & 45.9 & 1,100 & 155 & $\dagger$ & 86 & 26 & $\dagger$ \\
\hline 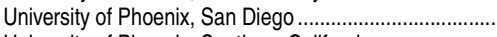 & 5 & 6,689 & 2,780 & 41.6 & 2,516 & 264 & $\dagger$ & 136 & 53 & $\dagger$ \\
\hline 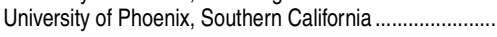 & 5 & 10,660 & 4,590 & 43.1 & 4,111 & 479 & $\dagger$ & 311 & 131 & $\dagger$ \\
\hline
\end{tabular}


CHAPTER 3: Postsecondary Education 481 Large Institutions and Institutions Serving Specific Groups

Table 312.40. Enrollment and degrees conferred in degree-granting postsecondary institutions that serve large proportions of Hispanic undergraduate students, by institution level and control, percentage Hispanic, degree level, and other selected characteristics: Fall 2012 and 2011-12-Continued

\begin{tabular}{|c|c|c|c|c|c|c|c|c|c|c|}
\hline \multirow[b]{2}{*}{ State and institution } & \multirow[b]{2}{*}{$\begin{array}{r}\text { Level } \\
\text { and control }{ }^{1}\end{array}$} & \multicolumn{5}{|c|}{ Enrollment, fall 2012} & \multicolumn{4}{|c|}{ Degrees awarded to Hispanics, 2011-12 } \\
\hline & & Total & Hispanic & $\begin{array}{r}\text { Percent } \\
\text { Hispanic }^{2}\end{array}$ & $\begin{array}{r}\text { Hispanic } \\
\text { under- } \\
\text { graduate }\end{array}$ & $\begin{array}{r}\text { Hispanic } \\
\text { postbacca- } \\
\text { laureate }\end{array}$ & Associate's & Bachelor's & Master's & Doctor's ${ }^{3}$ \\
\hline 1 & 2 & 3 & 4 & 5 & 6 & 7 & 8 & 9 & 10 & 11 \\
\hline 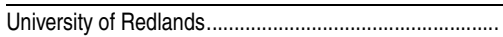 & 3 & 4,956 & 1,455 & 29.4 & 981 & 474 & $\dagger$ & 134 & 82 & $\overline{2}$ \\
\hline 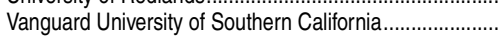 & 3 & 2,309 & 616 & 26.7 & 563 & 53 & $\dagger$ & 89 & 12 & $\dagger$ \\
\hline 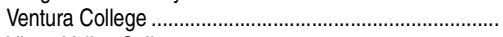 & 2 & 13,030 & 7,009 & 53.8 & 7,009 & $\dagger$ & 506 & $\dagger$ & $\dagger$ & $\dagger$ \\
\hline 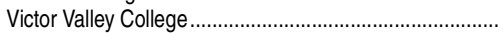 & 2 & 11,947 & 5,297 & 44.3 & 5,297 & $\dagger$ & 262 & $\dagger$ & $\dagger$ & $\dagger$ \\
\hline 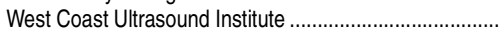 & 6 & 783 & 218 & 27.8 & 218 & $\dagger$ & $\dagger$ & $\dagger$ & $\dagger$ & $\dagger$ \\
\hline 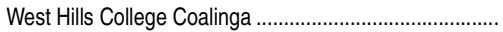 & 2 & 2,572 & 1,585 & 61.6 & 1,585 & $\dagger$ & 130 & $\dagger$ & $\dagger$ & $\dagger$ \\
\hline 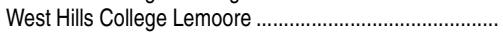 & 2 & 3,752 & 1,957 & 52.2 & 1,957 & $\dagger$ & 145 & $\dagger$ & $\dagger$ & $\dagger$ \\
\hline 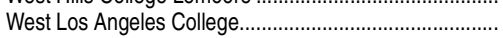 & 2 & 10,590 & 4,233 & 40.0 & 4,233 & $t$ & 124 & $\dagger$ & $\dagger$ & $\dagger$ \\
\hline 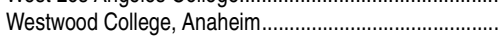 & 5 & 931 & 696 & 74.8 & 696 & $t$ & 11 & 139 & $t$ & $\dagger$ \\
\hline 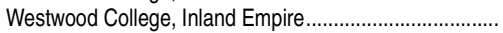 & 5 & 1,092 & 788 & 72.2 & 788 & $\dagger$ & 10 & 141 & $\dagger$ & $\dagger$ \\
\hline 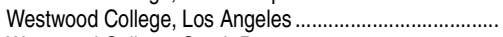 & 5 & 2,773 & 789 & 28.5 & 757 & 32 & 12 & 156 & 4 & $\dagger$ \\
\hline 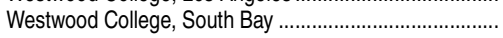 & 5 & 659 & 366 & 55.5 & 366 & t & 2 & 63 & $\dagger$ & $\dagger$ \\
\hline 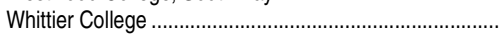 & 3 & 2,369 & 868 & 36.6 & 675 & 193 & $\dagger$ & 112 & 19 & 26 \\
\hline 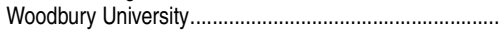 & 3 & 1,771 & 502 & 28.3 & 444 & 58 & $\dagger$ & 63 & 42 & $\dagger$ \\
\hline 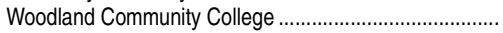 & 2 & 2,675 & 1,277 & 47.7 & 1,277 & $\dagger$ & 91 & $\dagger$ & $\dagger$ & $\dagger$ \\
\hline Wyotech, Fremont. & 6 & 1,452 & 534 & 36.8 & 534 & $\dagger$ & 10 & $\dagger$ & $\dagger$ & $\dagger$ \\
\hline Wyotech, Long Beach & 6 & 1,477 & 910 & 61.6 & 910 & $\dagger$ & 14 & $\dagger$ & $\dagger$ & $\dagger$ \\
\hline 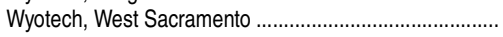 & 6 & 1,417 & 420 & 29.6 & 420 & $\dagger$ & 15 & $\dagger$ & $\dagger$ & $\dagger$ \\
\hline 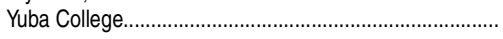 & 2 & 7,224 & 2,064 & 28.6 & 2,064 & $\dagger$ & 96 & $\dagger$ & $\dagger$ & $\dagger$ \\
\hline \multicolumn{11}{|l|}{ Colorado } \\
\hline Academy of Natural Therapy Inc. . & 6 & 70 & 24 & 34.3 & 24 & $\dagger$ & 5 & $\dagger$ & $\dagger$ & $\dagger$ \\
\hline Adams State University & 1 & 3,290 & 923 & 28.1 & 779 & 144 & 32 & 81 & 32 & $\dagger$ \\
\hline Aims Community College & 2 & 4,983 & 1,484 & 29.8 & 1,484 & $\dagger$ & 106 & $\dagger$ & $\dagger$ & $\dagger$ \\
\hline 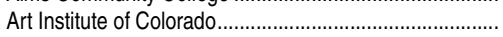 & 5 & 1,972 & 515 & 26.1 & 515 & $\dagger$ & 28 & 35 & $\dagger$ & $\dagger$ \\
\hline 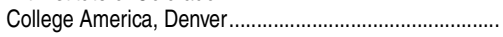 & 5 & 581 & 177 & 30.5 & 177 & $\dagger$ & 34 & 6 & $\dagger$ & $\dagger$ \\
\hline 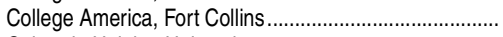 & 5 & 234 & 59 & 25.2 & 59 & $\dagger$ & 23 & 6 & $\dagger$ & $\dagger$ \\
\hline 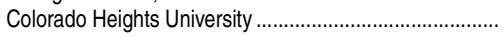 & 3 & 127 & 45 & 35.4 & 44 & 1 & $\dagger$ & 1 & 0 & $\dagger$ \\
\hline 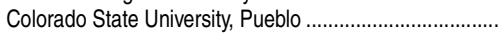 & 1 & 6,805 & 1,796 & 26.4 & 1,650 & 146 & $\dagger$ & 170 & 14 & $\dagger$ \\
\hline 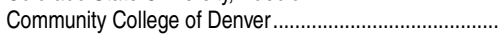 & 2 & 11,901 & 3,530 & 29.7 & 3,530 & $\dagger$ & 127 & $\dagger$ & $\dagger$ & $\dagger$ \\
\hline 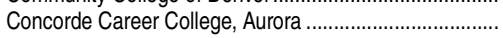 & 6 & 764 & 226 & 29.6 & 226 & $\dagger$ & 18 & $\dagger$ & $\dagger$ & $\dagger$ \\
\hline Everest College, Aurora & 6 & 443 & 147 & 33.2 & 147 & $\dagger$ & 15 & $\dagger$ & $t$ & $\dagger$ \\
\hline Everest College, Thornton & 6 & 407 & 201 & 49.4 & 201 & $\dagger$ & 38 & $\dagger$ & $\dagger$ & $\dagger$ \\
\hline 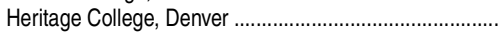 & 6 & 616 & 248 & 40.3 & 248 & $\dagger$ & 71 & $\dagger$ & $\dagger$ & $\dagger$ \\
\hline Institute of Business and Medical Careers .......................... & 6 & 260 & 81 & 31.2 & 81 & $\dagger$ & 15 & $\dagger$ & $\dagger$ & $\dagger$ \\
\hline 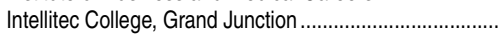 & 6 & 678 & 221 & 32.6 & 221 & $\dagger$ & 90 & $\dagger$ & $\dagger$ & $\dagger$ \\
\hline 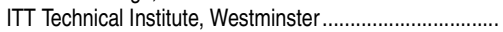 & 5 & 249 & 76 & 30.5 & 76 & $\dagger$ & 29 & 4 & $\dagger$ & $\dagger$ \\
\hline 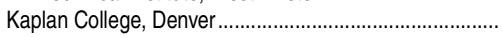 & 6 & 23 & 16 & 69.6 & 16 & $\dagger$ & 13 & $\dagger$ & $t$ & $\dagger$ \\
\hline 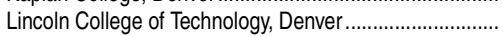 & 6 & 1,436 & 410 & 28.6 & 410 & $t$ & 34 & $\dagger$ & $t$ & $\dagger$ \\
\hline Otero Junior College & 2 & 1,456 & 438 & 30.1 & 438 & $t$ & 45 & $\dagger$ & $t$ & $\dagger$ \\
\hline 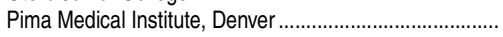 & 6 & 1,178 & 436 & 37.0 & 436 & $\dagger$ & 14 & $\dagger$ & $\dagger$ & $\dagger$ \\
\hline 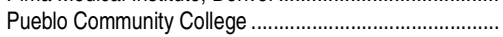 & 2 & 7,432 & 2,301 & 31.0 & 2,301 & $\dagger$ & 199 & $\dagger$ & $\dagger$ & $\dagger$ \\
\hline 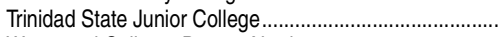 & 2 & 1,691 & 729 & 43.1 & 729 & $\dagger$ & 82 & $\dagger$ & $\dagger$ & $\dagger$ \\
\hline 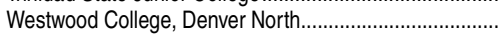 & 5 & 455 & 173 & 38.0 & 173 & $\dagger$ & 13 & 11 & $\dagger$ & $\dagger$ \\
\hline 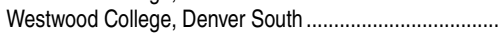 & 5 & 310 & 120 & 38.7 & 120 & $\dagger$ & 26 & 13 & $\dagger$ & $\dagger$ \\
\hline \multicolumn{11}{|l|}{ Connecticut } \\
\hline Capital Community College ......... & 2 & 4,425 & 1,362 & 30.8 & 1,362 & $\dagger$ & 117 & $\dagger$ & $\dagger$ & $\dagger$ \\
\hline 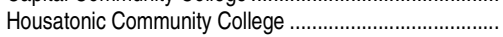 & 2 & 6,077 & 1,663 & 27.4 & 1,663 & $\dagger$ & 125 & $\dagger$ & $t$ & $\dagger$ \\
\hline 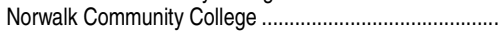 & 2 & 6,810 & 2,192 & 32.2 & 2,192 & $\dagger$ & 142 & $\dagger$ & $\dagger$ & $\dagger$ \\
\hline 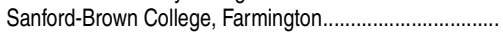 & 6 & 272 & 81 & 29.8 & 81 & $\dagger$ & 21 & $\dagger$ & $\dagger$ & $\dagger$ \\
\hline \multicolumn{11}{|l|}{ Florida } \\
\hline Acupuncture and Massage College.................................. & 5 & 172 & 101 & 58.7 & 16 & 85 & $\dagger$ & 16 & 16 & $\dagger$ \\
\hline Al Miami International University of Art and Design ......... & 5 & 3,517 & 2,589 & 73.6 & 2,503 & 86 & 58 & 247 & 9 & $\dagger$ \\
\hline American InterContinental University, South Florida ........ & 5 & 467 & 166 & 35.5 & 135 & 31 & 25 & 46 & 31 & $\dagger$ \\
\hline 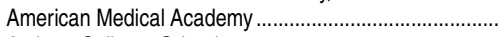 & 6 & 220 & 185 & 84.1 & 185 & $\dagger$ & 25 & $\dagger$ & $\dagger$ & $\dagger$ \\
\hline 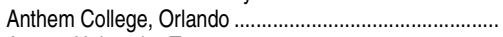 & 6 & 370 & 169 & 45.7 & 169 & $\dagger$ & 15 & $\dagger$ & $\dagger$ & $\dagger$ \\
\hline 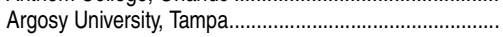 & 5 & 506 & 83 & 16.4 & 24 & 59 & $\dagger$ & 0 & 1 & 0 \\
\hline 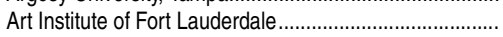 & 5 & 2,239 & 1,027 & 45.9 & 1,027 & $\dagger$ & 128 & 119 & $\dagger$ & $\dagger$ \\
\hline 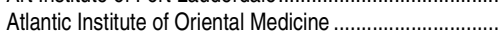 & 3 & 156 & 53 & 34.0 & 10 & 43 & $\dagger$ & 12 & 12 & $\dagger$ \\
\hline 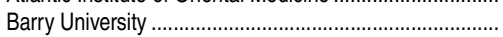 & 3 & 9,070 & 2,689 & 29.6 & 1,464 & 1,225 & $\dagger$ & 253 & 191 & 18 \\
\hline 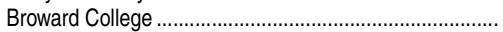 & 1 & 42,309 & 14,725 & 34.8 & 14,725 & $\dagger$ & 1,914 & 59 & $\dagger$ & $\dagger$ \\
\hline 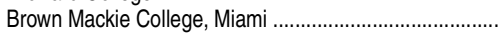 & 5 & 1,016 & 273 & 26.9 & 273 & $\dagger$ & 49 & 6 & $\dagger$ & $\dagger$ \\
\hline 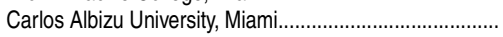 & 3 & 1,046 & 765 & 73.1 & 207 & 558 & $\dagger$ & 94 & 125 & 19 \\
\hline 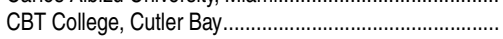 & 6 & 216 & 103 & 47.7 & 103 & $\dagger$ & 19 & $\dagger$ & $\dagger$ & $\dagger$ \\
\hline Chamberlain College of Nursing, Florida......................... & 5 & 586 & 153 & 26.1 & 153 & $\dagger$ & $\dagger$ & 5 & $\dagger$ & $\dagger$ \\
\hline 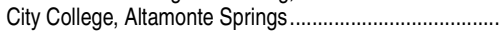 & 4 & 338 & 112 & 33.1 & 112 & $\dagger$ & 26 & $\dagger$ & $\dagger$ & $\dagger$ \\
\hline 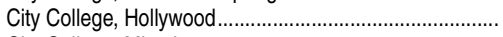 & 4 & 84 & 31 & 36.9 & 31 & $\dagger$ & 0 & $\dagger$ & $\dagger$ & $\dagger$ \\
\hline 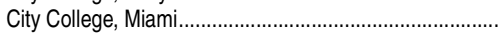 & 3 & 338 & 231 & 68.3 & 231 & $\dagger$ & 62 & 14 & $\dagger$ & $\dagger$ \\
\hline College of Business and Technology, Flagler .................... & 6 & 358 & 358 & 100.0 & 358 & $\dagger$ & 79 & $\dagger$ & $\dagger$ & $\dagger$ \\
\hline College of Business and Technology, Hialeah .................. & 6 & 310 & 310 & 100.0 & 310 & $\dagger$ & 90 & $\dagger$ & $\dagger$ & $\dagger$ \\
\hline College of Business and Technology, Kendall .................. & 5 & 48 & 45 & 93.8 & 45 & $\dagger$ & 35 & 0 & $\dagger$ & $\dagger$ \\
\hline 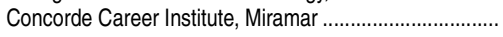 & 6 & 476 & 149 & 31.3 & 149 & $\dagger$ & 13 & $\dagger$ & $\dagger$ & $\dagger$ \\
\hline
\end{tabular}

See notes at end of table. 
Table 312.40. Enrollment and degrees conferred in degree-granting postsecondary institutions that serve large proportions of Hispanic undergraduate students, by institution level and control, percentage Hispanic, degree level, and other selected characteristics: Fall 2012 and 2011-12-Continued

\begin{tabular}{|c|c|c|c|c|c|c|c|c|c|c|}
\hline \multirow[b]{2}{*}{ State and institution } & \multirow[b]{2}{*}{$\begin{array}{r}\text { Level } \\
\text { and control }{ }^{1}\end{array}$} & \multicolumn{5}{|c|}{ Enrollment, fall 2012} & \multicolumn{4}{|c|}{ Degrees awarded to Hispanics, 2011-12 } \\
\hline & & Total & Hispanic & $\begin{array}{r}\text { Percent } \\
\text { Hispanic }^{2}\end{array}$ & $\begin{array}{r}\text { Hispanic } \\
\text { under- } \\
\text { graduate }\end{array}$ & $\begin{array}{r}\text { Hispanic } \\
\text { postbacca- } \\
\text { laureate }\end{array}$ & Associate's & Bachelor's & Master's & Doctor's ${ }^{3}$ \\
\hline 1 & 2 & 3 & 4 & 5 & 6 & 7 & 8 & 9 & 10 & 11 \\
\hline 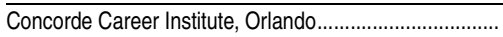 & 6 & 249 & 89 & 35.7 & 89 & $t$ & 0 & $\dagger$ & 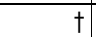 & $\bar{\dagger}$ \\
\hline 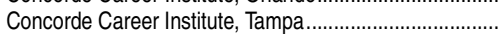 & 6 & 614 & 199 & 32.4 & 199 & $\dagger$ & 10 & $\dagger$ & $\dagger$ & $\dagger$ \\
\hline 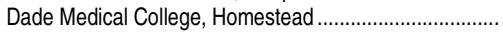 & 6 & 324 & 220 & 67.9 & 220 & $\dagger$ & 58 & $\dagger$ & $\dagger$ & $\dagger$ \\
\hline 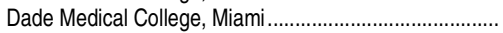 & 6 & 868 & 729 & 84.0 & 729 & $\dagger$ & 220 & $\dagger$ & $\dagger$ & $\dagger$ \\
\hline Dade Medical College, Miami Lakes ..................................... & 6 & 456 & 350 & 76.8 & 350 & $\dagger$ & 135 & $\dagger$ & $\dagger$ & $\dagger$ \\
\hline DeVry University, Florida & 5 & 2,920 & 967 & 33.1 & 967 & $\dagger$ & 38 & 147 & $\dagger$ & $\dagger$ \\
\hline 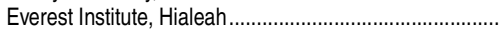 & 6 & 461 & 335 & 72.7 & 335 & $\dagger$ & 54 & $\dagger$ & $\dagger$ & $\dagger$ \\
\hline 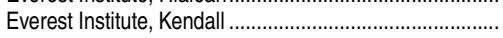 & 6 & 525 & 375 & 71.4 & 375 & $\dagger$ & 37 & $\dagger$ & $\dagger$ & $\dagger$ \\
\hline 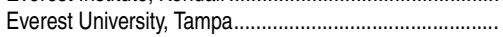 & 5 & 873 & 291 & 33.3 & 285 & 6 & 61 & 14 & 1 & $\dagger$ \\
\hline 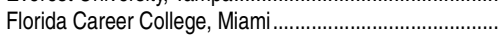 & 5 & 5,793 & 1,932 & 33.4 & 1,932 & $\dagger$ & 159 & 46 & $\dagger$ & $\dagger$ \\
\hline Florida College of Natural Health, Maitland ....................... & 6 & 421 & 143 & 34.0 & 143 & $\dagger$ & 10 & $\dagger$ & $\dagger$ & $\dagger$ \\
\hline Florida College of Natural Health, Miami............................ & 6 & 248 & 175 & 70.6 & 175 & $\dagger$ & 18 & $\dagger$ & $\dagger$ & $\dagger$ \\
\hline Florida College of Natural Health, Pompano Beach......... & 6 & 267 & 86 & 32.2 & 86 & $\dagger$ & 13 & $\dagger$ & $\dagger$ & $\dagger$ \\
\hline 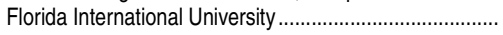 & 1 & 46,171 & 29,073 & 63.0 & 25,367 & 3,706 & 45 & 4,549 & 1,316 & 138 \\
\hline Florida National University, Main Campus ........................... & 5 & 2,506 & 2,274 & 90.7 & 2,257 & 17 & 456 & 50 & $\dagger$ & $\dagger$ \\
\hline 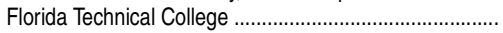 & 6 & 3,790 & 2,145 & 56.6 & 2,145 & $\dagger$ & 115 & $\dagger$ & $\dagger$ & $\dagger$ \\
\hline 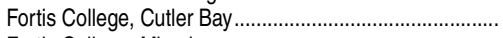 & 5 & 65 & 33 & 50.8 & 33 & $\dagger$ & 0 & $\dagger$ & $\dagger$ & $\dagger$ \\
\hline Fortis College, Miami & 6 & 336 & 314 & 93.5 & 314 & $\dagger$ & 121 & $\dagger$ & $\dagger$ & $\dagger$ \\
\hline Fortis College, Winter Park...... & 6 & 265 & 68 & 25.7 & 68 & $\dagger$ & 5 & $\dagger$ & $\dagger$ & $\dagger$ \\
\hline 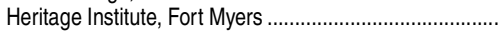 & 6 & 668 & 218 & 32.6 & 218 & $\dagger$ & 108 & $\dagger$ & $\dagger$ & $\dagger$ \\
\hline 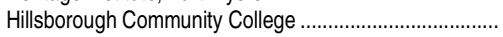 & 2 & 27,754 & 7,714 & 27.8 & 7,714 & $t$ & 833 & $\dagger$ & $\dagger$ & $\dagger$ \\
\hline 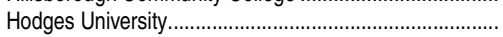 & 3 & 2,244 & 766 & 34.1 & 726 & 40 & 78 & 71 & 13 & $\dagger$ \\
\hline International Academy of Design and Technology, Orlando. & 5 & 460 & 196 & 42.6 & 196 & $t$ & 3 & 23 & $\dagger$ & $\dagger$ \\
\hline ITT Technical Institute, Fort Lauderdale ............................ & 5 & 550 & 174 & 31.6 & 174 & $\dagger$ & 61 & 10 & t & $\dagger$ \\
\hline ITT Technical Institute, Fort Myers.................................... & 5 & 323 & 80 & 24.8 & 80 & $\dagger$ & 19 & 0 & $\dagger$ & $\dagger$ \\
\hline 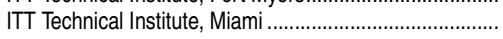 & 5 & 442 & 351 & 79.4 & 351 & $\dagger$ & 145 & 31 & $\dagger$ & $\dagger$ \\
\hline 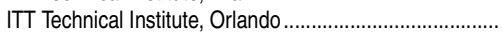 & 5 & 329 & 126 & 38.3 & 126 & t & 0 & 0 & $t$ & $\dagger$ \\
\hline Johnson \& Wales University, North Miami ............................ & 3 & 1,990 & 571 & 28.7 & 571 & $\dagger$ & 50 & 33 & $\dagger$ & $\dagger$ \\
\hline 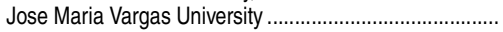 & 5 & 113 & 97 & 85.8 & 90 & 7 & 5 & 3 & 0 & $\dagger$ \\
\hline 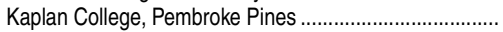 & 6 & 20 & 5 & 25.0 & 5 & $\dagger$ & 7 & $\dagger$ & $\dagger$ & $\dagger$ \\
\hline 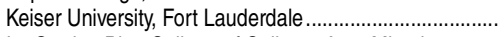 & 3 & 16,713 & 4,395 & 26.3 & 4,173 & 222 & 1,019 & 178 & 42 & 0 \\
\hline Le Cordon Bleu College of Culinary Arts, Miami .............. & 6 & 1,175 & 806 & 68.6 & 806 & $\dagger$ & 354 & $\dagger$ & $\dagger$ & $\dagger$ \\
\hline Le Cordon Bleu College of Culinary Arts, Orlando........... & 6 & 1,309 & 380 & 29.0 & 380 & $\dagger$ & 145 & $\dagger$ & $\dagger$ & $\dagger$ \\
\hline 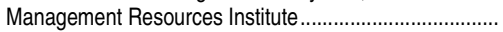 & 6 & 736 & 699 & 95.0 & 699 & $\dagger$ & 0 & $\dagger$ & $\dagger$ & $\dagger$ \\
\hline 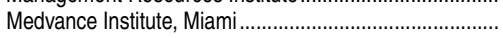 & 6 & 243 & 181 & 74.5 & 181 & $\dagger$ & 16 & $\dagger$ & $t$ & $\dagger$ \\
\hline 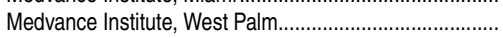 & 6 & 561 & 169 & 30.1 & 169 & $\dagger$ & 20 & $\dagger$ & $t$ & $\dagger$ \\
\hline 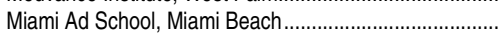 & 6 & 171 & 54 & 31.6 & 54 & $t$ & 0 & $\dagger$ & $\dagger$ & $\dagger$ \\
\hline 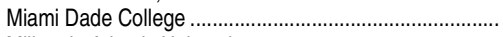 & 1 & 66,701 & 48,066 & 72.1 & 48,066 & $\dagger$ & 7,958 & 399 & $\dagger$ & $\dagger$ \\
\hline 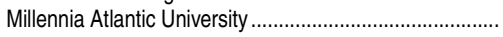 & 5 & 92 & 38 & 41.3 & 26 & 12 & 5 & 3 & 12 & $\dagger$ \\
\hline 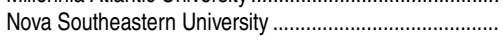 & 3 & 26,808 & 6,571 & 24.5 & 1,964 & 4,607 & 2 & 498 & 1,007 & 319 \\
\hline 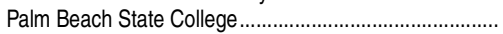 & 1 & 29,974 & 7,597 & 25.3 & 7,597 & $\dagger$ & 870 & 38 & $\dagger$ & $\dagger$ \\
\hline Polytechnic University of Puerto Rico, Miami ................... & 3 & 122 & 121 & 99.2 & 53 & 68 & $\dagger$ & 17 & 25 & $\dagger$ \\
\hline Polytechnic University of Puerto Rico, Orlando .................. & 3 & 155 & 155 & 100.0 & 112 & 43 & $\dagger$ & 27 & 18 & $\dagger$ \\
\hline 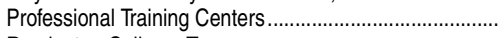 & 5 & 574 & 553 & 96.3 & 553 & $\dagger$ & 102 & 0 & $\dagger$ & $\dagger$ \\
\hline Remington College, Tampa & 3 & 214 & 63 & 29.4 & 63 & $\dagger$ & 10 & 0 & $\dagger$ & $\dagger$ \\
\hline 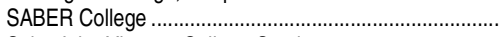 & 4 & 549 & 490 & 89.3 & 490 & $\dagger$ & 34 & $\dagger$ & $\dagger$ & $\dagger$ \\
\hline 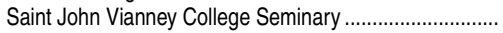 & 3 & 95 & 35 & 36.8 & 27 & 8 & $\dagger$ & 13 & $\dagger$ & $\dagger$ \\
\hline 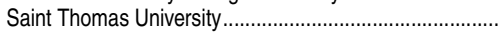 & 3 & 2,484 & 985 & 39.7 & 483 & 502 & $\dagger$ & 87 & 84 & 77 \\
\hline Sanford-Brown Institute, Fort Lauderdale .......................... & 6 & 545 & 197 & 36.1 & 197 & $\dagger$ & 19 & $\dagger$ & $\dagger$ & $\dagger$ \\
\hline Sanford-Brown Institute, Orlando & 6 & 476 & 223 & 46.8 & 223 & $\dagger$ & 5 & $\dagger$ & $\dagger$ & $\dagger$ \\
\hline South Florida State College & 1 & 2,800 & 791 & 28.3 & 791 & $\dagger$ & 77 & $\dagger$ & $\dagger$ & $\dagger$ \\
\hline 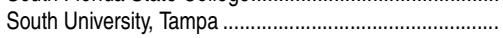 & 5 & 878 & 205 & 23.3 & 156 & 49 & 1 & 7 & 0 & $\dagger$ \\
\hline 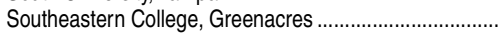 & 6 & 1,341 & 392 & 29.2 & 392 & $\dagger$ & 98 & $\dagger$ & $\dagger$ & $\dagger$ \\
\hline 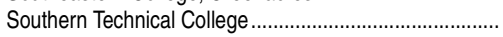 & 6 & 1,404 & 351 & 25.0 & 351 & $\dagger$ & 152 & $\dagger$ & $\dagger$ & $\dagger$ \\
\hline 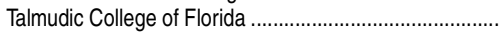 & 3 & 46 & 11 & 23.9 & 9 & 2 & $\dagger$ & 1 & 1 & $\dagger$ \\
\hline 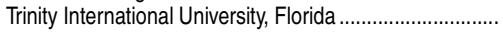 & 3 & 367 & 162 & 44.1 & 134 & 28 & $\dagger$ & 8 & 12 & $\dagger$ \\
\hline 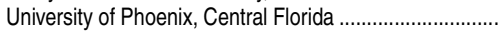 & 5 & 1,242 & 380 & 30.6 & 342 & 38 & $\dagger$ & 32 & 14 & $\dagger$ \\
\hline 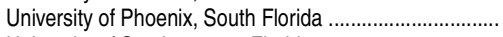 & 5 & 1,783 & 594 & 33.3 & 475 & 119 & $\dagger$ & 49 & 46 & $\dagger$ \\
\hline 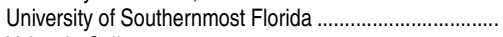 & 6 & 111 & 38 & 34.2 & 38 & $\dagger$ & 12 & $\dagger$ & $\dagger$ & $\dagger$ \\
\hline Valencia College & 1 & 42,915 & 14,482 & 33.7 & 14,482 & $\dagger$ & 2,129 & 0 & $\dagger$ & $\dagger$ \\
\hline Georgia & & & & & & & & & & \\
\hline Interactive College of Technology, Gainesville..................... & 6 & 46 & 23 & 50.0 & 23 & $\dagger$ & $\dagger$ & $\dagger$ & $\dagger$ & $\dagger$ \\
\hline Illinois & & & & & & & & & & \\
\hline City Colleges of Chicago, Harold Washington College.... & 2 & 8,947 & 3,171 & 35.4 & 3,171 & $\dagger$ & 178 & $\dagger$ & $\dagger$ & $\dagger$ \\
\hline City Colleges of Chicago, Harry S Truman College ......... & 2 & 11,925 & 4,695 & 39.4 & 4,695 & $\dagger$ & 103 & $\dagger$ & $\dagger$ & $\dagger$ \\
\hline City Colleges of Chicago, Richard J. Daley College ......... & 2 & 9,410 & 6,570 & 69.8 & 6,570 & $\dagger$ & 198 & $\dagger$ & $\dagger$ & $\dagger$ \\
\hline City Colleges of Chicago, Wilbur Wright College.............. & 2 & 12,468 & 6,743 & 54.1 & 6,743 & $\dagger$ & 303 & $\dagger$ & $\dagger$ & $\dagger$ \\
\hline College of Lake County & 2 & 17,577 & 5,503 & 31.3 & 5,503 & $t$ & 196 & $\dagger$ & $\dagger$ & $\dagger$ \\
\hline Coyne College & 6 & 717 & 222 & 31.0 & 222 & $\dagger$ & 53 & $\dagger$ & $\dagger$ & $\dagger$ \\
\hline 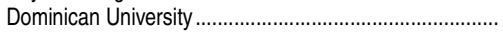 & 3 & 3,589 & 880 & 24.5 & 691 & 189 & $\dagger$ & 101 & 51 & 0 \\
\hline Elgin Community College & 2 & 11,554 & 4,247 & 36.8 & 4,247 & $\dagger$ & 197 & $\dagger$ & $\dagger$ & $\dagger$ \\
\hline
\end{tabular}


CHAPTER 3: Postsecondary Education 483 Large Institutions and Institutions Serving Specific Groups

Table 312.40. Enrollment and degrees conferred in degree-granting postsecondary institutions that serve large proportions of Hispanic undergraduate students, by institution level and control, percentage Hispanic, degree level, and other selected characteristics: Fall 2012 and 2011-12-Continued

\begin{tabular}{|c|c|c|c|c|c|c|c|c|c|c|}
\hline \multirow[b]{2}{*}{ State and institution } & \multirow[b]{2}{*}{$\begin{array}{r}\text { Level } \\
\text { and control }{ }^{1}\end{array}$} & \multicolumn{5}{|c|}{ Enrollment, fall 2012} & \multicolumn{4}{|c|}{ Degrees awarded to Hispanics, 2011-12 } \\
\hline & & Total & Hispanic & $\begin{array}{r}\text { Percent } \\
\text { Hispanic }^{2}\end{array}$ & $\begin{array}{r}\text { Hispanic } \\
\text { under- } \\
\text { graduate }\end{array}$ & $\begin{array}{r}\text { Hispanic } \\
\text { postbacca- } \\
\text { laureate }\end{array}$ & Associate's & Bachelor's & Master's & Doctor's ${ }^{3}$ \\
\hline 1 & 2 & 3 & 4 & 5 & 6 & 7 & 8 & 9 & 10 & 11 \\
\hline 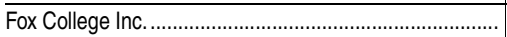 & 6 & 400 & 136 & 34.0 & 136 & $t$ & 61 & $\dagger$ & $\dagger$ & $\dagger$ \\
\hline 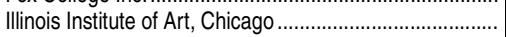 & 5 & 2,558 & 894 & 34.9 & 894 & $\dagger$ & 33 & 61 & $\dagger$ & $\dagger$ \\
\hline Illinois Institute of Art, Schaumburg & 5 & 1,267 & 414 & 32.7 & 414 & $\dagger$ & 3 & 27 & $\dagger$ & $\dagger$ \\
\hline ITT Technical Institute, Mount Prospect.............................. & 5 & 276 & 80 & 29.0 & 80 & $\dagger$ & 29 & 8 & $\dagger$ & $\dagger$ \\
\hline 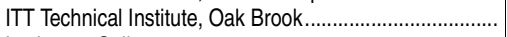 & 5 & 362 & 139 & 38.4 & 139 & $\dagger$ & 28 & 9 & $\dagger$ & $\dagger$ \\
\hline Lexington College & 3 & 45 & 13 & 28.9 & 13 & $\dagger$ & 0 & 3 & $\dagger$ & $\dagger$ \\
\hline Lincoln College of Technology, Melrose Park .................... & 6 & 1,065 & 572 & 53.7 & 572 & $\dagger$ & 144 & $\dagger$ & $\dagger$ & $\dagger$ \\
\hline 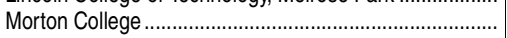 & 2 & 5,088 & 4,273 & 84.0 & 4,273 & $t$ & 286 & $\dagger$ & $\dagger$ & $\dagger$ \\
\hline 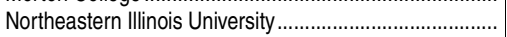 & 1 & 11,149 & 3,471 & 31.1 & 3,166 & 305 & $\dagger$ & 427 & 68 & $\dagger$ \\
\hline 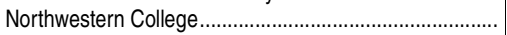 & 6 & 623 & 189 & 30.3 & 189 & $\dagger$ & 41 & $\dagger$ & $\dagger$ & $\dagger$ \\
\hline Northwestern College, Southwestern ................................. & 6 & 804 & 218 & 27.1 & 218 & $\dagger$ & 52 & $\dagger$ & $\dagger$ & $\dagger$ \\
\hline 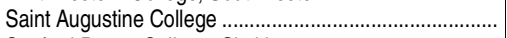 & 3 & 1,612 & 1,445 & 89.6 & 1,445 & $\dagger$ & 220 & 11 & $\dagger$ & $\dagger$ \\
\hline 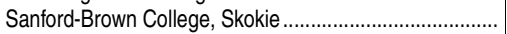 & 6 & 309 & 95 & 30.7 & 95 & $\dagger$ & 0 & $\dagger$ & $\dagger$ & $\dagger$ \\
\hline 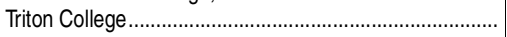 & 2 & 13,938 & 5,479 & 39.3 & 5,479 & $\dagger$ & 284 & $\dagger$ & $\dagger$ & $\dagger$ \\
\hline Waubonsee Community College ....................................... & 2 & 11,146 & 3,619 & 32.5 & 3,619 & $\dagger$ & 184 & $\dagger$ & $\dagger$ & $\dagger$ \\
\hline 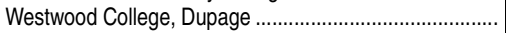 & 5 & 278 & 83 & 29.9 & 83 & $\dagger$ & 0 & 24 & $\dagger$ & $\dagger$ \\
\hline Westwood College, O'Hare Airport...................................... & 5 & 477 & 224 & 47.0 & 224 & $\dagger$ & 3 & 62 & $\dagger$ & $\dagger$ \\
\hline \multicolumn{11}{|l|}{ Indiana } \\
\hline 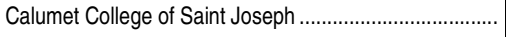 & 3 & 1,030 & 295 & 28.6 & 265 & 30 & 9 & 57 & 13 & $\dagger$ \\
\hline \multicolumn{11}{|l|}{ Kansas } \\
\hline Dodge City Community College ......................................... & 2 & 1,864 & 598 & 32.1 & 598 & $\dagger$ & 52 & $\dagger$ & $\dagger$ & $\dagger$ \\
\hline Donnelly College & 3 & 441 & 194 & 44.0 & 194 & $\dagger$ & 7 & 2 & $\dagger$ & $\dagger$ \\
\hline 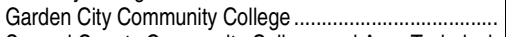 & 2 & 2,059 & 648 & 31.5 & 648 & $\dagger$ & 76 & $\dagger$ & $\dagger$ & $\dagger$ \\
\hline Seward County Community College and Area Technical & 2 & 1973 & 781 & 396 & 781 & + & 51 & + & $t$ & t \\
\hline \multicolumn{11}{|l|}{ Massachusetts } \\
\hline Cambridge College & 3 & 3,378 & 593 & 17.6 & 319 & 274 & $\dagger$ & 55 & 108 & 0 \\
\hline 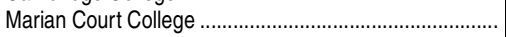 & 4 & 174 & 46 & 26.4 & 46 & t & 11 & $\dagger$ & t & $\dagger$ \\
\hline Northern Essex Community College .................................. & 2 & 7,312 & 2,493 & 34.1 & 2,493 & $t$ & 117 & $\dagger$ & $\dagger$ & $\dagger$ \\
\hline 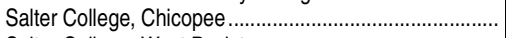 & 6 & 110 & 47 & 42.7 & 47 & $\dagger$ & 0 & $\dagger$ & $\dagger$ & $\dagger$ \\
\hline Salter College, West Boylston ....................................... & 6 & 822 & 225 & 27.4 & 225 & $\dagger$ & 18 & $\dagger$ & $\dagger$ & $\dagger$ \\
\hline Springfield Technical Community College ......................... & 2 & 7,011 & 1,729 & 24.7 & 1,729 & $\dagger$ & 124 & $\dagger$ & $\dagger$ & $\dagger$ \\
\hline Urban College of Boston & 4 & 511 & 251 & 49.1 & 251 & $\dagger$ & 55 & $\dagger$ & $\dagger$ & $\dagger$ \\
\hline \multicolumn{11}{|l|}{ Nevada } \\
\hline Art Institute of Las Vegas...................... & 5 & 1,085 & 717 & 66.1 & 717 & $\dagger$ & 18 & 30 & $\dagger$ & $\dagger$ \\
\hline 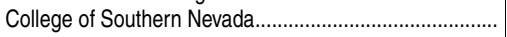 & 1 & 35,678 & 9,435 & 26.4 & 9,435 & $\dagger$ & 420 & 0 & $\dagger$ & $\dagger$ \\
\hline 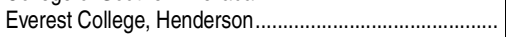 & 6 & 934 & 303 & 32.4 & 303 & $\dagger$ & 81 & $\dagger$ & $\dagger$ & $\dagger$ \\
\hline 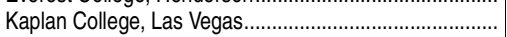 & 6 & 871 & 243 & 27.9 & 243 & $\dagger$ & 26 & $\dagger$ & $\dagger$ & $\dagger$ \\
\hline 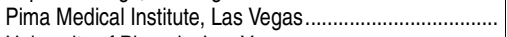 & 6 & 1,089 & 330 & 30.3 & 330 & $\dagger$ & 21 & $\dagger$ & $\dagger$ & $\dagger$ \\
\hline 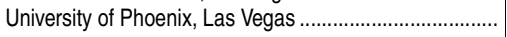 & 5 & 2,531 & 602 & 23.8 & 524 & 78 & $\dagger$ & 53 & 28 & $\dagger$ \\
\hline New Jersey & & & & & & & & & & \\
\hline Bergen Community College & 2 & 17,015 & 5,250 & 30.9 & 5,250 & $\dagger$ & 461 & $\dagger$ & $\dagger$ & $\dagger$ \\
\hline Berkeley College, Woodland Park ....................................... & 5 & 2,878 & 1,213 & 42.1 & 1,213 & $\dagger$ & 96 & 194 & $\dagger$ & $\dagger$ \\
\hline 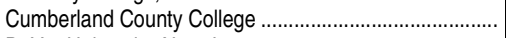 & 2 & 3,944 & 1,020 & 25.9 & 1,020 & $\dagger$ & 110 & $\dagger$ & $\dagger$ & $\dagger$ \\
\hline DeVry University, New Jersey.............................................. & 5 & 1,679 & 502 & 29.9 & 502 & $\dagger$ & 39 & 44 & $\dagger$ & $\dagger$ \\
\hline Eastern International College, Belleville ............................. & 6 & 212 & 105 & 49.5 & 105 & $\dagger$ & 10 & $\dagger$ & $\dagger$ & $\dagger$ \\
\hline Eastern International College, Jersey City .......................... & 6 & 227 & 118 & 52.0 & 118 & $\dagger$ & 9 & $\dagger$ & $\dagger$ & $\dagger$ \\
\hline Essex County College & 2 & 11,979 & 3,080 & 25.7 & 3,080 & $t$ & 281 & $\dagger$ & $\dagger$ & $\dagger$ \\
\hline Fairleigh Dickinson University, Metropolitan .................... & 3 & 9,130 & 2,097 & 23.0 & 1,825 & 272 & 43 & 191 & 89 & 0 \\
\hline 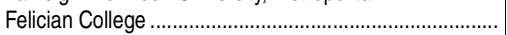 & 3 & 2,109 & 549 & 26.0 & 494 & 55 & 8 & 56 & 15 & $\dagger$ \\
\hline Hudson County Community College .................................. & 2 & 9,397 & 5,548 & 59.0 & 5,548 & $\dagger$ & 480 & $\dagger$ & $\dagger$ & $\dagger$ \\
\hline 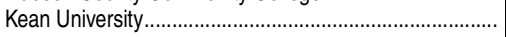 & 1 & 15,391 & 3,774 & 24.5 & 3,373 & 401 & $\dagger$ & 512 & 97 & 1 \\
\hline 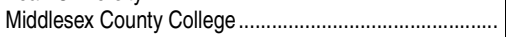 & 2 & 12,898 & 3,638 & 28.2 & 3,638 & $\dagger$ & 395 & $\dagger$ & $\dagger$ & $\dagger$ \\
\hline 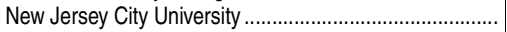 & 1 & 8,492 & 3,009 & 35.4 & 2,526 & 483 & $\dagger$ & 381 & 80 & $\dagger$ \\
\hline Passaic County Community College ................................. & 2 & 9,782 & 5,368 & 54.9 & 5,368 & $\dagger$ & 248 & $\dagger$ & $\dagger$ & $\dagger$ \\
\hline 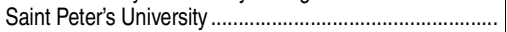 & 3 & 3,045 & 769 & 25.3 & 626 & 143 & 3 & 118 & 35 & $\dagger$ \\
\hline 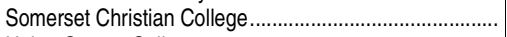 & 3 & 360 & 102 & 28.3 & 102 & $\dagger$ & 1 & 13 & $\dagger$ & $\dagger$ \\
\hline Union County College .......................................................... & 2 & 12,146 & 4,285 & 35.3 & 4,285 & $\dagger$ & 155 & $\dagger$ & $\dagger$ & $\dagger$ \\
\hline 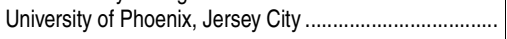 & 5 & 488 & 159 & 32.6 & 159 & $\dagger$ & $\dagger$ & 4 & $\dagger$ & $\dagger$ \\
\hline New Mexico & & & & & & & & & & \\
\hline 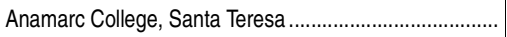 & 6 & 106 & 106 & 100.0 & 106 & $\dagger$ & 10 & 0 & $\dagger$ & $\dagger$ \\
\hline 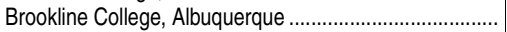 & 5 & 404 & 269 & 66.6 & 269 & $\dagger$ & 72 & 0 & $\dagger$ & $\dagger$ \\
\hline Brown Mackie College, Albuquerque .................................... & 5 & 752 & 350 & 46.5 & 350 & $\dagger$ & 6 & 0 & $\dagger$ & $\dagger$ \\
\hline 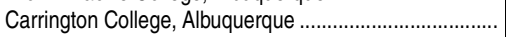 & 6 & 628 & 342 & 54.5 & 342 & $\dagger$ & 58 & $\dagger$ & $\dagger$ & $\dagger$ \\
\hline Central New Mexico Community College ........................... & 2 & 28,323 & 13,200 & 46.6 & 13,200 & $t$ & 1,199 & $\dagger$ & $\dagger$ & $\dagger$ \\
\hline 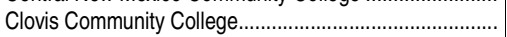 & 2 & 3,672 & 1,101 & 30.0 & 1,101 & $\dagger$ & 58 & $t$ & $\dagger$ & $\dagger$ \\
\hline Eastern New Mexico University, Main Campus ................ & 1 & 5,804 & 2,021 & 34.8 & 1,659 & 362 & 5 & 159 & 30 & $\dagger$ \\
\hline Eastern New Mexico University, Roswell ........................... & 2 & 4,193 & 2,090 & 49.8 & 2,090 & $\dagger$ & 138 & $\dagger$ & $\dagger$ & $\dagger$ \\
\hline Eastern New Mexico University, Ruidoso ............................ & 2 & 1,058 & 348 & 32.9 & 348 & $\dagger$ & 10 & $\dagger$ & $\dagger$ & $\dagger$ \\
\hline ITT Technical Institute, Albuquerque.................................... & 5 & 536 & 223 & 41.6 & 223 & $\dagger$ & 83 & 16 & $\dagger$ & $\dagger$ \\
\hline
\end{tabular}

See notes at end of table. 
Table 312.40. Enrollment and degrees conferred in degree-granting postsecondary institutions that serve large proportions of Hispanic undergraduate students, by institution level and control, percentage Hispanic, degree level, and other selected characteristics: Fall 2012 and 2011-12-Continued

\begin{tabular}{|c|c|c|c|c|c|c|c|c|c|c|}
\hline \multirow[b]{2}{*}{ State and institution } & \multirow[b]{2}{*}{$\begin{array}{r}\text { Level } \\
\text { and control }{ }^{1}\end{array}$} & \multicolumn{5}{|c|}{ Enrollment, fall 2012} & \multicolumn{4}{|c|}{ Degrees awarded to Hispanics, 2011-12 } \\
\hline & & Total & Hispanic & $\begin{array}{r}\text { Percent } \\
\text { Hispanic }^{2}\end{array}$ & $\begin{array}{r}\text { Hispanic } \\
\text { under- } \\
\text { graduate }\end{array}$ & $\begin{array}{r}\text { Hispanic } \\
\text { postbacca- } \\
\text { laureate }\end{array}$ & Associate's & Bachelor's & Master's & Doctor's ${ }^{3}$ \\
\hline 1 & 2 & 3 & 4 & 5 & 6 & 7 & 8 & 9 & 10 & 11 \\
\hline 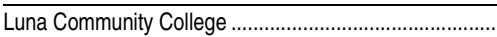 & 2 & 1,739 & 1,320 & 75.9 & 1,320 & $\dagger$ & 84 & $\dagger$ & $\dagger$ & $\bar{\dagger}$ \\
\hline 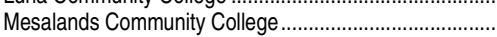 & 2 & 672 & 185 & 27.5 & 185 & $t$ & 23 & $\dagger$ & $t$ & $\dagger$ \\
\hline 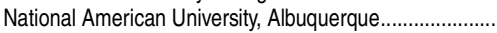 & 5 & 486 & 188 & 38.7 & 188 & $\dagger$ & 12 & 19 & $\dagger$ & $\dagger$ \\
\hline National American University, Albuquerque West............. & 5 & 327 & 139 & 42.5 & 139 & $\dagger$ & 2 & 5 & $\dagger$ & $\dagger$ \\
\hline 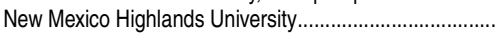 & 1 & 3,729 & 2,061 & 55.3 & 1,404 & 657 & 0 & 191 & 179 & $\dagger$ \\
\hline New Mexico Institute of Mining and Technology ................. & 1 & 2,105 & 477 & 22.7 & 407 & 70 & 1 & 43 & 10 & 0 \\
\hline 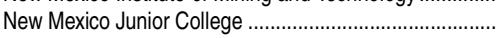 & 2 & 2,949 & 1,316 & 44.6 & 1,316 & $t$ & 75 & $\dagger$ & $t$ & $\dagger$ \\
\hline 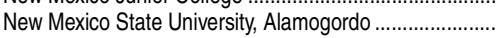 & 2 & 3,173 & 1,313 & 41.4 & 1,313 & $\dagger$ & 80 & $\dagger$ & $\dagger$ & $\dagger$ \\
\hline 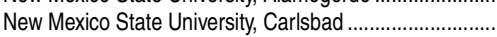 & 2 & 2,060 & 1,101 & 53.4 & 1,101 & $t$ & 49 & $\dagger$ & $t$ & $\dagger$ \\
\hline 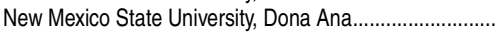 & 2 & 9,270 & 6,673 & 72.0 & 6,673 & $\dagger$ & 646 & $\dagger$ & $\dagger$ & $\dagger$ \\
\hline 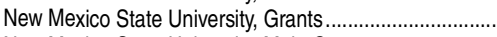 & 2 & 1,141 & 556 & 48.7 & 556 & $\dagger$ & 25 & $\dagger$ & $\dagger$ & $\dagger$ \\
\hline New Mexico State University, Main Campus ....................... & 1 & 17,651 & 8,787 & 49.8 & 7,580 & 1,207 & 8 & 1,059 & 285 & 20 \\
\hline 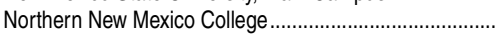 & 1 & 1,633 & 1,129 & 69.1 & 1,111 & 18 & 69 & 40 & t & $\dagger$ \\
\hline 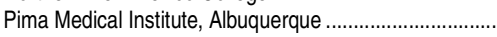 & 6 & 942 & 524 & 55.6 & 524 & $\dagger$ & 22 & $\dagger$ & $\dagger$ & $\dagger$ \\
\hline 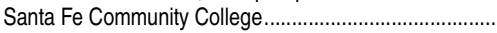 & 2 & 4,956 & 2,605 & 52.6 & 2,605 & $\dagger$ & 142 & $\dagger$ & $\dagger$ & $\dagger$ \\
\hline Southwest University of Visual Arts, Albuquerque............ & 5 & 235 & 100 & 42.6 & 100 & $\dagger$ & $\dagger$ & 11 & $\dagger$ & $\dagger$ \\
\hline 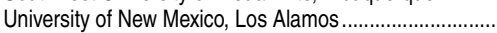 & 2 & 683 & 296 & 43.3 & 296 & $\dagger$ & 10 & $\dagger$ & $\dagger$ & $\dagger$ \\
\hline 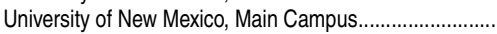 & 1 & 29,033 & 11,434 & 39.4 & 9,745 & 1,689 & $\dagger$ & 1,298 & 332 & 107 \\
\hline 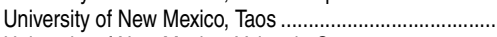 & 2 & 1,660 & 1,067 & 64.3 & 1,067 & $\dagger$ & 29 & $\dagger$ & $\dagger$ & $\dagger$ \\
\hline 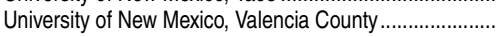 & 2 & 2,322 & 1,500 & 64.6 & 1,500 & t & 105 & $\dagger$ & $\dagger$ & $\dagger$ \\
\hline 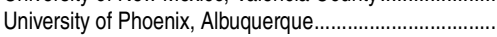 & 5 & 3,193 & 2,442 & 76.5 & 2,154 & 288 & $\dagger$ & 365 & 112 & $\dagger$ \\
\hline University of the Southwest & 3 & 760 & 248 & 32.6 & 169 & 79 & t & 20 & 10 & $\dagger$ \\
\hline 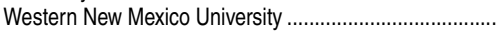 & 1 & 3,549 & 1,996 & 56.2 & 1,757 & 239 & 72 & 75 & 39 & $\dagger$ \\
\hline \multicolumn{11}{|l|}{ New York } \\
\hline Art Institute of New York City ... & 6 & 1,480 & 846 & 57.2 & 846 & $\dagger$ & 118 & $\dagger$ & $\dagger$ & $\dagger$ \\
\hline ASA College & 6 & 4,691 & 1,917 & 40.9 & 1,917 & $\dagger$ & 676 & $\dagger$ & $\dagger$ & $\dagger$ \\
\hline 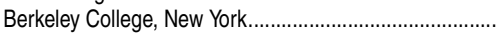 & 5 & 4,864 & 1,450 & 29.8 & 1,450 & $t$ & 61 & 169 & $\dagger$ & $\dagger$ \\
\hline 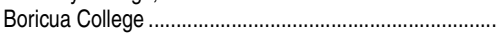 & 3 & 1,235 & 1,035 & 83.8 & 992 & 43 & 169 & 129 & 16 & $\dagger$ \\
\hline 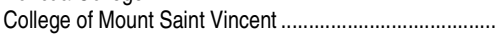 & 3 & 1,951 & 702 & 36.0 & 633 & 69 & 0 & 79 & 19 & $\dagger$ \\
\hline 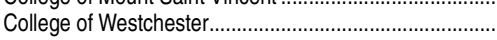 & 5 & 1,127 & 460 & 40.8 & 460 & $t$ & 95 & 37 & $\dagger$ & $\dagger$ \\
\hline CUNY, Borough of Manhattan Community College .......... & 2 & 24,537 & 10,312 & 42.0 & 10,312 & t & 955 & $\dagger$ & $t$ & $\dagger$ \\
\hline 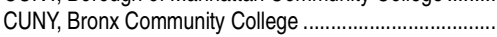 & 2 & 11,287 & 7,030 & 62.3 & 7,030 & $t$ & 729 & $\dagger$ & $\dagger$ & $\dagger$ \\
\hline CUNY, City College & 1 & 16,023 & 5,095 & 31.8 & 4,358 & 737 & $\dagger$ & 595 & 144 & 0 \\
\hline 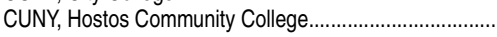 & 2 & 6,455 & 3,904 & 60.5 & 3,904 & $\dagger$ & 403 & $\dagger$ & $\dagger$ & $\dagger$ \\
\hline 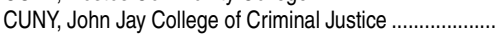 & 1 & 14,996 & 5,934 & 39.6 & 5,534 & 400 & 71 & 782 & 107 & $\dagger$ \\
\hline 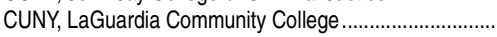 & 2 & 19,287 & 7,902 & 41.0 & 7,902 & $\dagger$ & 1,023 & $\dagger$ & t & $\dagger$ \\
\hline 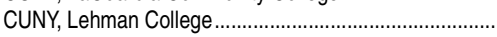 & 1 & 11,862 & 5,734 & 48.3 & 4,949 & 785 & $\dagger$ & 869 & 209 & $\dagger$ \\
\hline CUNY, New York City College of Technology...................... & 1 & 16,207 & 4,613 & 28.5 & 4,613 & t & 225 & 194 & t & $\dagger$ \\
\hline 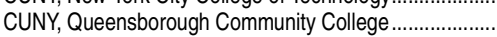 & 2 & 15,711 & 4,558 & 29.0 & 4,558 & $t$ & 365 & $\dagger$ & $t$ & $\dagger$ \\
\hline DeVry College of New York & 5 & 1,562 & 592 & 37.9 & 592 & t & 6 & 33 & t & $\dagger$ \\
\hline 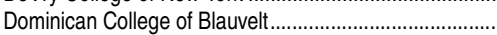 & 3 & 2,051 & 481 & 23.5 & 453 & 28 & 0 & 40 & 4 & 2 \\
\hline 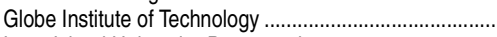 & 5 & 740 & 208 & 28.1 & 208 & $\dagger$ & 13 & 0 & $\dagger$ & $\dagger$ \\
\hline 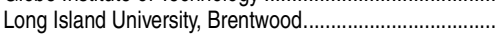 & 3 & 340 & 45 & 13.2 & 9 & 36 & $\dagger$ & 2 & 8 & $\dagger$ \\
\hline 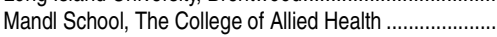 & 6 & 900 & 427 & 47.4 & 427 & $\dagger$ & 107 & $\dagger$ & $\dagger$ & $\dagger$ \\
\hline 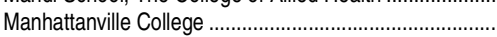 & 3 & 2,948 & 539 & 18.3 & 450 & 89 & $\dagger$ & 55 & 18 & 0 \\
\hline Mercy College. & 3 & 11,454 & 3,384 & 29.5 & 2,690 & 694 & 15 & 245 & 196 & 3 \\
\hline Mildred Elley & 6 & 617 & 193 & 31.3 & 193 & $\dagger$ & 3 & $\dagger$ & $\dagger$ & $\dagger$ \\
\hline 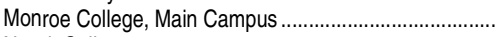 & 5 & 6,997 & 3,126 & 44.7 & 3,015 & 111 & 616 & 389 & 31 & $\dagger$ \\
\hline 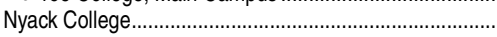 & 3 & 3,318 & 818 & 24.7 & 510 & 308 & 5 & 94 & 44 & 0 \\
\hline Pacific College of Oriental Medicine, New York ................. & 5 & 561 & 69 & 12.3 & 42 & 27 & 16 & 0 & 5 & $\dagger$ \\
\hline 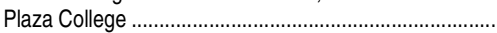 & 5 & 766 & 227 & 29.6 & 227 & $\dagger$ & 54 & 11 & $\dagger$ & $\dagger$ \\
\hline 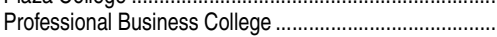 & 4 & 1,090 & 310 & 28.4 & 310 & $t$ & 60 & $\dagger$ & $t$ & $\dagger$ \\
\hline 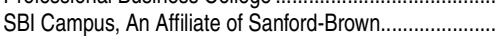 & 6 & 340 & 121 & 35.6 & 121 & t & 21 & $\dagger$ & $t$ & $\dagger$ \\
\hline 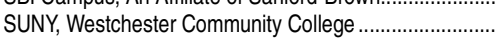 & 2 & 13,997 & 4,034 & 28.8 & 4,034 & $t$ & 262 & $\dagger$ & $t$ & $\dagger$ \\
\hline 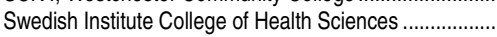 & 6 & 426 & 136 & 31.9 & 136 & $t$ & 34 & $\dagger$ & 0 & $\dagger$ \\
\hline 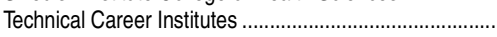 & 6 & 3,603 & 1,496 & 41.5 & 1,496 & t & 369 & $\dagger$ & $\dagger$ & $\dagger$ \\
\hline Vaughn College of Aeronautics and Technology .............. & 3 & 1,812 & 738 & 40.7 & 735 & 3 & 53 & 22 & 0 & $\dagger$ \\
\hline 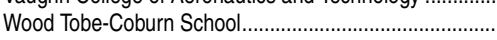 & 6 & 523 & 292 & 55.8 & 292 & t & 133 & $\dagger$ & $\dagger$ & $\dagger$ \\
\hline \multicolumn{11}{|l|}{ Oklahoma } \\
\hline Career Point College ........ & 6 & 274 & 118 & 43.1 & 118 & $t$ & 0 & $\dagger$ & $\dagger$ & $\dagger$ \\
\hline \multicolumn{11}{|l|}{ Oregon } \\
\hline Mount Angel Seminary ...... & 3 & 183 & 60 & 32.8 & 22 & 38 & $\dagger$ & 6 & 11 & $\dagger$ \\
\hline \multicolumn{11}{|l|}{ Pennsylvania } \\
\hline 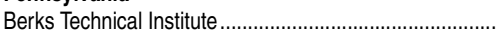 & 6 & 1,139 & 422 & 37.1 & 422 & $\dagger$ & 77 & $\dagger$ & $\dagger$ & $\dagger$ \\
\hline Consolidated School of Business, Lancaster ...................... & 6 & 110 & 41 & 37.3 & 41 & $\dagger$ & 13 & $\dagger$ & $\dagger$ & $\dagger$ \\
\hline 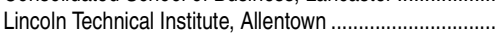 & 6 & 637 & 182 & 28.6 & 182 & $\dagger$ & 19 & $\dagger$ & $\dagger$ & $\dagger$ \\
\hline Pace Institute & 6 & 251 & 158 & 62.9 & 158 & $\dagger$ & 24 & $\dagger$ & $t$ & $\dagger$ \\
\hline 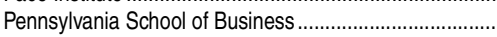 & 6 & 259 & 127 & 49.0 & 127 & $\dagger$ & 20 & $\dagger$ & $\dagger$ & $\dagger$ \\
\hline
\end{tabular}


CHAPTER 3: Postsecondary Education 485 Large Institutions and Institutions Serving Specific Groups

Table 312.40. Enrollment and degrees conferred in degree-granting postsecondary institutions that serve large proportions of Hispanic undergraduate students, by institution level and control, percentage Hispanic, degree level, and other selected characteristics: Fall 2012 and 2011-12-Continued

\begin{tabular}{|c|c|c|c|c|c|c|c|c|c|c|}
\hline \multirow[b]{2}{*}{ State and institution } & \multirow[b]{2}{*}{$\begin{array}{r}\text { Level } \\
\text { and control }{ }^{1}\end{array}$} & \multicolumn{5}{|c|}{ Enrollment, fall 2012} & \multicolumn{4}{|c|}{ Degrees awarded to Hispanics, 2011-12 } \\
\hline & & Total & Hispanic & $\begin{array}{r}\text { Percent } \\
\text { Hispanic }^{2}\end{array}$ & $\begin{array}{r}\text { Hispanic } \\
\text { under- } \\
\text { graduate }\end{array}$ & $\begin{array}{r}\text { Hispanic } \\
\text { postbacca- } \\
\text { laureate }\end{array}$ & Associate's & Bachelor's & Master's & Doctor's ${ }^{3}$ \\
\hline 1 & 2 & 3 & 4 & 5 & 6 & 7 & 8 & 9 & 10 & 11 \\
\hline Texas & & & & & & & & & & \\
\hline Allied Health Careers....... & 6 & 199 & 112 & 56.3 & 112 & $\dagger$ & 21 & $\dagger$ & $\dagger$ & $\dagger$ \\
\hline Alvin Community College . & 2 & 5,109 & 1,439 & 28.2 & 1,439 & $\dagger$ & 131 & $\dagger$ & $\dagger$ & $\dagger$ \\
\hline 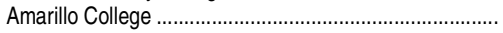 & 2 & 11,530 & 4,009 & 34.8 & 4,009 & $\dagger$ & 242 & $\dagger$ & $\dagger$ & $\dagger$ \\
\hline 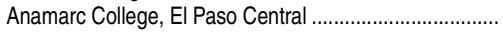 & 6 & 234 & 208 & 88.9 & 208 & $\dagger$ & 14 & $\dagger$ & $\dagger$ & $\dagger$ \\
\hline Angelo State University & 1 & 6,888 & 1,869 & 27.1 & 1,713 & 156 & 33 & 167 & 42 & 1 \\
\hline 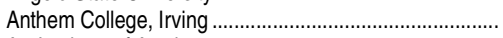 & 6 & 291 & 109 & 37.5 & 109 & $\dagger$ & $\dagger$ & $\dagger$ & t & $\dagger$ \\
\hline 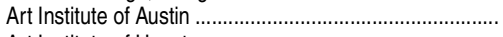 & 5 & 1,555 & 679 & 43.7 & 679 & $\dagger$ & 6 & 43 & $\dagger$ & $\dagger$ \\
\hline Art Institute of Houston & 5 & 2,459 & 1,123 & 45.7 & 1,123 & $\dagger$ & 61 & 86 & $\dagger$ & $\dagger$ \\
\hline 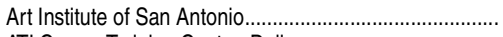 & 5 & 953 & 536 & 56.2 & 536 & $\dagger$ & 0 & 0 & $\dagger$ & $\dagger$ \\
\hline 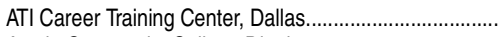 & 6 & 65 & 22 & 33.8 & 22 & $\dagger$ & 7 & $\dagger$ & $\dagger$ & $\dagger$ \\
\hline 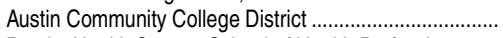 & 2 & 43,315 & 13,084 & 30.2 & 13,084 & $\dagger$ & 451 & $\dagger$ & $\dagger$ & $\dagger$ \\
\hline Baptist Health System School of Health Professions ....... & 5 & 450 & 192 & 42.7 & 192 & $\dagger$ & 72 & $\dagger$ & $\dagger$ & $\dagger$ \\
\hline 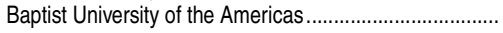 & 3 & 200 & 166 & 83.0 & 166 & $\dagger$ & 5 & 20 & $\dagger$ & $\dagger$ \\
\hline Brazosport College & 1 & 4,047 & 1,410 & 34.8 & 1,410 & $\dagger$ & 118 & 4 & $\dagger$ & $\dagger$ \\
\hline Brookhaven College & 2 & 12,790 & 4,319 & 33.8 & 4,319 & $\dagger$ & 179 & $\dagger$ & $\dagger$ & $\dagger$ \\
\hline 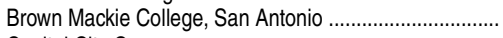 & 5 & 724 & 411 & 56.8 & 411 & $\dagger$ & 1 & 0 & $\dagger$ & $\dagger$ \\
\hline Capitol City Careers & 6 & 19 & 12 & 63.2 & 12 & $\dagger$ & 2 & $\dagger$ & $\dagger$ & $\dagger$ \\
\hline 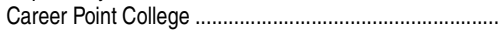 & 5 & 1,208 & 660 & 54.6 & 660 & $\dagger$ & 92 & $\dagger$ & $\dagger$ & $\dagger$ \\
\hline 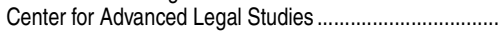 & 5 & 195 & 47 & 24.1 & 37 & 10 & 16 & $\dagger$ & $\dagger$ & $\dagger$ \\
\hline 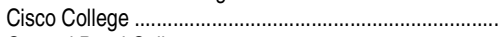 & 2 & 3,914 & 970 & 24.8 & 970 & $\dagger$ & 61 & $\dagger$ & $\dagger$ & $\dagger$ \\
\hline Coastal Bend College & 2 & 3,745 & 2,485 & 66.4 & 2,485 & $t$ & 197 & $\dagger$ & $\dagger$ & $\dagger$ \\
\hline 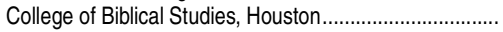 & 3 & 489 & 129 & 26.4 & 129 & $\dagger$ & 5 & 6 & $\dagger$ & $\dagger$ \\
\hline 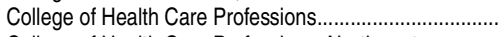 & 6 & 196 & 81 & 41.3 & 81 & $\dagger$ & 0 & $\dagger$ & $\dagger$ & $\dagger$ \\
\hline College of Health Care Professions, Northwest ................ & 6 & 663 & 317 & 47.8 & 317 & $\dagger$ & 2 & $\dagger$ & $\dagger$ & $\dagger$ \\
\hline College of the Mainland & 2 & 4,010 & 1,058 & 26.4 & 1,058 & $\dagger$ & 88 & $\dagger$ & $\dagger$ & $\dagger$ \\
\hline 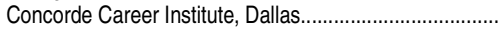 & 6 & 242 & 73 & 30.2 & 73 & $\dagger$ & 0 & $\dagger$ & $\dagger$ & $\dagger$ \\
\hline 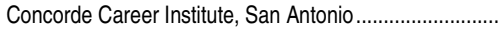 & 6 & 296 & 216 & 73.0 & 216 & $\dagger$ & 0 & $\dagger$ & $\dagger$ & $\dagger$ \\
\hline 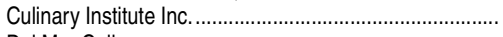 & 6 & 403 & 165 & 40.9 & 165 & $\dagger$ & 30 & $\dagger$ & $\dagger$ & $\dagger$ \\
\hline 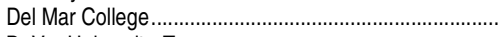 & 2 & 11,030 & 6,594 & 59.8 & 6,594 & $\dagger$ & 616 & $\dagger$ & $\dagger$ & $\dagger$ \\
\hline 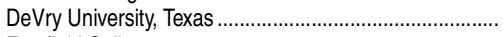 & 5 & 3,240 & 967 & 29.8 & 967 & $\dagger$ & 48 & 153 & $\dagger$ & $\dagger$ \\
\hline Eastfield College & 2 & 14,178 & 5,458 & 38.5 & 5,458 & $\dagger$ & 254 & $\dagger$ & $\dagger$ & $\dagger$ \\
\hline El Centro College & 2 & 11,296 & 4,320 & 38.2 & 4,320 & $\dagger$ & 208 & $\dagger$ & $\dagger$ & $\dagger$ \\
\hline 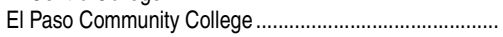 & 2 & 32,127 & 27,703 & 86.2 & 27,703 & $\dagger$ & 3,244 & $\dagger$ & $\dagger$ & $\dagger$ \\
\hline 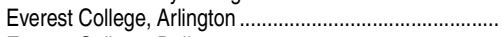 & 6 & 655 & 214 & 32.7 & 214 & $\dagger$ & 14 & $\dagger$ & $\dagger$ & $\dagger$ \\
\hline 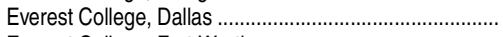 & 6 & 1,047 & 302 & 28.8 & 302 & $\dagger$ & 17 & $\dagger$ & $\dagger$ & $\dagger$ \\
\hline 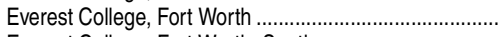 & 6 & 526 & 178 & 33.8 & 178 & $\dagger$ & 16 & $\dagger$ & $\dagger$ & $\dagger$ \\
\hline 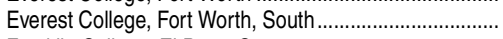 & 6 & 515 & 198 & 38.4 & 198 & $\dagger$ & 0 & $\dagger$ & $\dagger$ & $\dagger$ \\
\hline Franklin College, El Paso, Cromo & 6 & 245 & 206 & 84.1 & 206 & $\dagger$ & 5 & $\dagger$ & $\dagger$ & $\dagger$ \\
\hline Franklin College, El Paso, North Zarogosa Road .............. & 6 & 311 & 288 & 92.6 & 288 & $\dagger$ & 5 & $\dagger$ & $\dagger$ & $\dagger$ \\
\hline 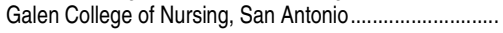 & 6 & 920 & 416 & 45.2 & 416 & $\dagger$ & 79 & $\dagger$ & $\dagger$ & $\dagger$ \\
\hline 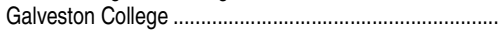 & 2 & 2,197 & 702 & 32.0 & 702 & $\dagger$ & 56 & $\dagger$ & $\dagger$ & $\dagger$ \\
\hline 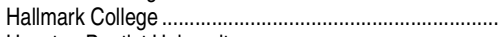 & 5 & 756 & 390 & 51.6 & 390 & $\dagger$ & 99 & 14 & $\dagger$ & $\dagger$ \\
\hline 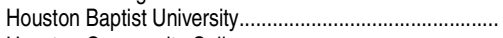 & 3 & 2,589 & 677 & 26.1 & 584 & 93 & 0 & 81 & 20 & $\dagger$ \\
\hline 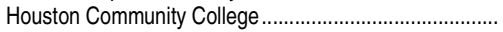 & 2 & 58,476 & 18,303 & 31.3 & 18,303 & $\dagger$ & 975 & $\dagger$ & $\dagger$ & $\dagger$ \\
\hline Howard College & 2 & 4,494 & 1,935 & 43.1 & 1,935 & $\dagger$ & 117 & $\dagger$ & $\dagger$ & $\dagger$ \\
\hline 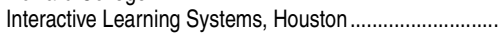 & 6 & 40 & 19 & 47.5 & 19 & $\dagger$ & $\dagger$ & $\dagger$ & $\dagger$ & $\dagger$ \\
\hline Interactive Learning Systems, North Houston .................. & 6 & 15 & 9 & 60.0 & 9 & $\dagger$ & $\dagger$ & $\dagger$ & $\dagger$ & $\dagger$ \\
\hline Interactive Learning Systems, Pasadena .......................... & 6 & 14 & 11 & 78.6 & 11 & $\dagger$ & $\dagger$ & $\dagger$ & $\dagger$ & $\dagger$ \\
\hline International Academy of Design and Technology, San Antonio .. & 5 & 431 & 257 & 59.6 & 257 & $\dagger$ & 45 & 31 & $\dagger$ & $\dagger$ \\
\hline 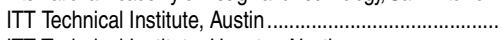 & 5 & 506 & 179 & 35.4 & 179 & $\dagger$ & 65 & 7 & $\dagger$ & $\dagger$ \\
\hline ITT Technical Institute, Houston North ............................... & 5 & 667 & 224 & 33.6 & 224 & $\dagger$ & 100 & 5 & $\dagger$ & $\dagger$ \\
\hline 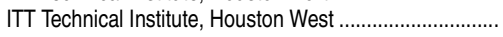 & 5 & 594 & 215 & 36.2 & 215 & $t$ & 66 & 18 & $\dagger$ & $\dagger$ \\
\hline 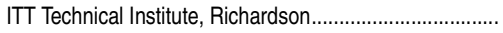 & 5 & 665 & 166 & 25.0 & 166 & $\dagger$ & 45 & 10 & $\dagger$ & $\dagger$ \\
\hline 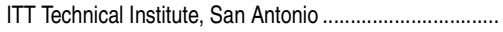 & 5 & 710 & 372 & 52.4 & 372 & $\dagger$ & 84 & 12 & $\dagger$ & $\dagger$ \\
\hline 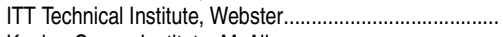 & 5 & 321 & 102 & 31.8 & 102 & $\dagger$ & 45 & 3 & $\dagger$ & $\dagger$ \\
\hline 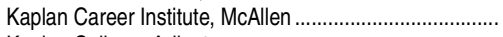 & 6 & 678 & 665 & 98.1 & 665 & $\dagger$ & 109 & $\dagger$ & $\dagger$ & $\dagger$ \\
\hline 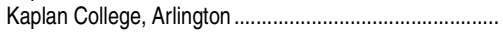 & 6 & 456 & 208 & 45.6 & 208 & $\dagger$ & 21 & $\dagger$ & $\dagger$ & $\dagger$ \\
\hline 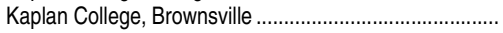 & 6 & 479 & 468 & 97.7 & 468 & $\dagger$ & 15 & $\dagger$ & $\dagger$ & $\dagger$ \\
\hline 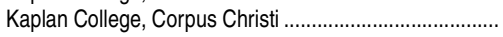 & 6 & 492 & 365 & 74.2 & 365 & $\dagger$ & 35 & $\dagger$ & $\dagger$ & $\dagger$ \\
\hline 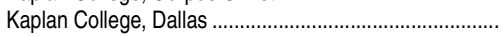 & 6 & 320 & 129 & 40.3 & 129 & $\dagger$ & 15 & $\dagger$ & $\dagger$ & $\dagger$ \\
\hline Kaplan College, El Paso & 6 & 743 & 642 & 86.4 & 642 & $\dagger$ & 41 & $\dagger$ & $\dagger$ & $\dagger$ \\
\hline Kaplan College, Fort Worth .......... & 6 & 268 & 108 & 40.3 & 108 & $\dagger$ & 8 & $\dagger$ & $\dagger$ & $\dagger$ \\
\hline 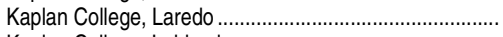 & 6 & 287 & 284 & 99.0 & 284 & $\dagger$ & 28 & $\dagger$ & $\dagger$ & $\dagger$ \\
\hline 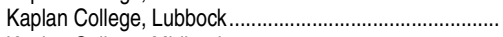 & 6 & 333 & 201 & 60.4 & 201 & $\dagger$ & 20 & $\dagger$ & $\dagger$ & $\dagger$ \\
\hline 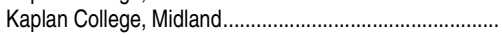 & 6 & 170 & 113 & 66.5 & 113 & $\dagger$ & 1 & $\dagger$ & $\dagger$ & $\dagger$ \\
\hline Kaplan College, San Antonio & 6 & 548 & 444 & 81.0 & 444 & $\dagger$ & 48 & $\dagger$ & $\dagger$ & $\dagger$ \\
\hline Kaplan College, San Antonio, San Pedro .............................. & 6 & 730 & 477 & 65.3 & 477 & $\dagger$ & 37 & $\dagger$ & $\dagger$ & $\dagger$ \\
\hline 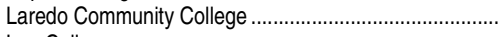 & 2 & 9,356 & 9,054 & 96.8 & 9,054 & $\dagger$ & 729 & $\dagger$ & $\dagger$ & $\dagger$ \\
\hline 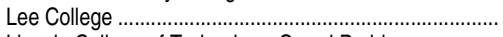 & 2 & 6,049 & 2,149 & 35.5 & 2,149 & $\dagger$ & 166 & $\dagger$ & $\dagger$ & $\dagger$ \\
\hline Lincoln College of Technology, Grand Prairie ................... & 6 & 730 & 263 & 36.0 & 263 & $\dagger$ & 5 & $\dagger$ & $\dagger$ & $\dagger$ \\
\hline
\end{tabular}

See notes at end of table. 
Table 312.40. Enrollment and degrees conferred in degree-granting postsecondary institutions that serve large proportions of Hispanic undergraduate students, by institution level and control, percentage Hispanic, degree level, and other selected characteristics: Fall 2012 and 2011-12-Continued

\begin{tabular}{|c|c|c|c|c|c|c|c|c|c|c|}
\hline \multirow[b]{2}{*}{ State and institution } & \multirow[b]{2}{*}{$\begin{array}{r}\text { Level } \\
\text { and control }{ }^{1}\end{array}$} & \multicolumn{5}{|c|}{ Enrollment, fall 2012} & \multicolumn{4}{|c|}{ Degrees awarded to Hispanics, 2011-12 } \\
\hline & & Total & Hispanic & $\begin{array}{r}\text { Percent } \\
\text { Hispanic }^{2}\end{array}$ & $\begin{array}{r}\text { Hispanic } \\
\text { under- } \\
\text { graduate }\end{array}$ & $\begin{array}{r}\text { Hispanic } \\
\text { postbacca- } \\
\text { laureate }\end{array}$ & Associate's & Bachelor's & Master's & Doctor's ${ }^{3}$ \\
\hline 1 & 2 & 3 & 4 & 5 & 6 & 7 & 8 & 9 & 10 & 11 \\
\hline 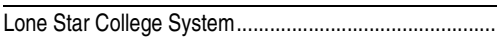 & 2 & 60,428 & 20,329 & 33.6 & 20,329 & $\dagger$ & 1,135 & $\dagger$ & $\dagger$ & $\bar{\dagger}$ \\
\hline Midland College & 1 & 5,530 & 2,269 & 41.0 & 2,269 & $t$ & 158 & 7 & $t$ & $\dagger$ \\
\hline 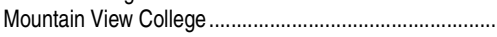 & 2 & 9,068 & 4,990 & 55.0 & 4,990 & $\dagger$ & 294 & $\dagger$ & $\dagger$ & $\dagger$ \\
\hline North Lake College............ & 2 & 11,397 & 3,923 & 34.4 & 3,923 & $\dagger$ & 232 & $\dagger$ & $\dagger$ & $\dagger$ \\
\hline Northwest Vista College & 2 & 15,992 & 9,395 & 58.7 & 9,395 & $\dagger$ & 529 & $\dagger$ & $\dagger$ & $\dagger$ \\
\hline 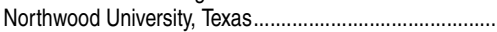 & 3 & 816 & 222 & 27.2 & 217 & 5 & 2 & 38 & 3 & $\dagger$ \\
\hline 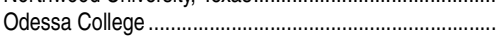 & 2 & 5,039 & 2,803 & 55.6 & 2,803 & $\dagger$ & 199 & $\dagger$ & $\dagger$ & $\dagger$ \\
\hline 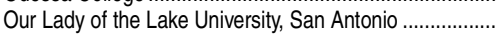 & 3 & 2,799 & 1,713 & 61.2 & 1,072 & 641 & $\dagger$ & 207 & 116 & 4 \\
\hline 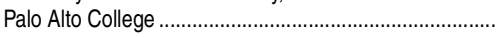 & 2 & 8,568 & 6,090 & 71.1 & 6,090 & $\dagger$ & 533 & $\dagger$ & $t$ & $\dagger$ \\
\hline 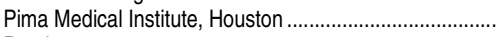 & 6 & 574 & 280 & 48.8 & 280 & $\dagger$ & 2 & $\dagger$ & $\dagger$ & $\dagger$ \\
\hline 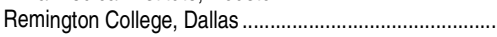 & 4 & 988 & 406 & 41.1 & 406 & $\dagger$ & 122 & $\dagger$ & $\dagger$ & $\dagger$ \\
\hline 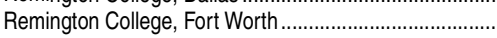 & 4 & 489 & 141 & 28.8 & 141 & $\dagger$ & 20 & $\dagger$ & $t$ & $\dagger$ \\
\hline 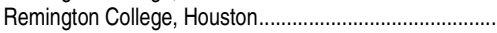 & 4 & 367 & 130 & 35.4 & 130 & $\dagger$ & 42 & $\dagger$ & $\dagger$ & $\dagger$ \\
\hline 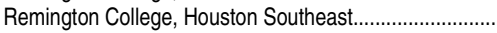 & 4 & 293 & 122 & 41.6 & 122 & $\dagger$ & 7 & $\dagger$ & $\dagger$ & $\dagger$ \\
\hline 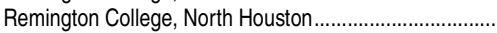 & 4 & 545 & 241 & 44.2 & 241 & $\dagger$ & 38 & $\dagger$ & $\dagger$ & $\dagger$ \\
\hline 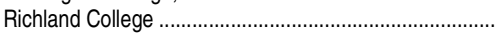 & 2 & 19,552 & 5,674 & 29.0 & 5,674 & $\dagger$ & 286 & $\dagger$ & $\dagger$ & $\dagger$ \\
\hline 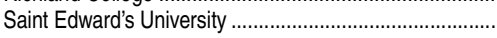 & 3 & 5,095 & 1,688 & 33.1 & 1,499 & 189 & $\dagger$ & 287 & 80 & $\dagger$ \\
\hline 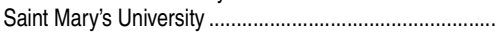 & 3 & 3,941 & 2,198 & 55.8 & 1,751 & 447 & $\dagger$ & 343 & 70 & 71 \\
\hline Saint Philip's College & 2 & 10,313 & 5,494 & 53.3 & 5,494 & $\dagger$ & 411 & $\dagger$ & $\dagger$ & $\dagger$ \\
\hline San Antonio College. & 2 & 23,134 & 13,007 & 56.2 & 13,007 & $t$ & 916 & $\dagger$ & $\dagger$ & $\dagger$ \\
\hline 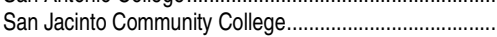 & 2 & 28,721 & 13,732 & 47.8 & 13,732 & $t$ & 1,014 & $\dagger$ & $t$ & $\dagger$ \\
\hline 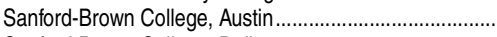 & 6 & 101 & 28 & 27.7 & 28 & $\dagger$ & 0 & $\dagger$ & $\dagger$ & $\dagger$ \\
\hline 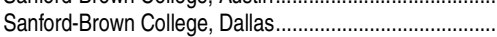 & 6 & 606 & 168 & 27.7 & 168 & t & 4 & $\dagger$ & $t$ & $\dagger$ \\
\hline 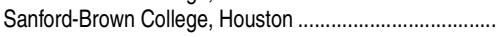 & 6 & 822 & 332 & 40.4 & 332 & $\dagger$ & 40 & $\dagger$ & $\dagger$ & $\dagger$ \\
\hline 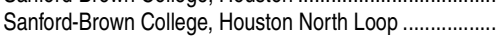 & 6 & 266 & 91 & 34.2 & 91 & t & 10 & $\dagger$ & $\dagger$ & $\dagger$ \\
\hline 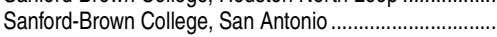 & 6 & 211 & 92 & 43.6 & 92 & $\dagger$ & 11 & $\dagger$ & $\dagger$ & $\dagger$ \\
\hline 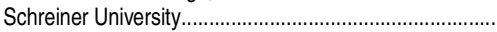 & 3 & 1,126 & 315 & 28.0 & 298 & 17 & 0 & 43 & 7 & $\dagger$ \\
\hline South Plains College & 2 & 9,444 & 3,264 & 34.6 & 3,264 & $\dagger$ & 227 & $\dagger$ & $\dagger$ & $\dagger$ \\
\hline 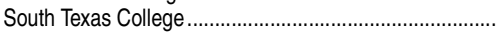 & 1 & 30,824 & 29,583 & 96.0 & 29,583 & $\dagger$ & 2,138 & 104 & $\dagger$ & $\dagger$ \\
\hline 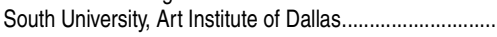 & 5 & 1,613 & 618 & 38.3 & 615 & 3 & 26 & 36 & $\dagger$ & $\dagger$ \\
\hline 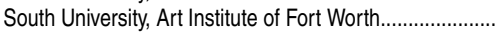 & 5 & 398 & 112 & 28.1 & 112 & $\dagger$ & 2 & 0 & $\dagger$ & $\dagger$ \\
\hline South University, Austin & 5 & 110 & 35 & 31.8 & 35 & 0 & 0 & $\dagger$ & $\dagger$ & $\dagger$ \\
\hline Southwest Collegiate Institute for the Deaf......................... & 2 & 143 & 55 & 38.5 & 55 & $\dagger$ & 3 & $\dagger$ & $\dagger$ & $\dagger$ \\
\hline 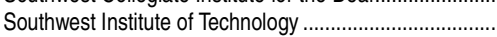 & 6 & 16 & 10 & 62.5 & 10 & $t$ & 5 & $\dagger$ & $t$ & $\dagger$ \\
\hline 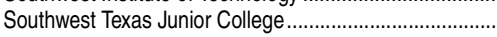 & 2 & 5,908 & 4,943 & 83.7 & 4,943 & $\dagger$ & 462 & $\dagger$ & $\dagger$ & $\dagger$ \\
\hline 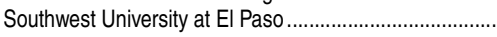 & 5 & 1,155 & 1,066 & 92.3 & 1,066 & $\dagger$ & 99 & $\dagger$ & $\dagger$ & $\dagger$ \\
\hline 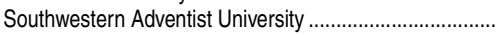 & 3 & 806 & 275 & 34.1 & 270 & 5 & 0 & 53 & 0 & $\dagger$ \\
\hline 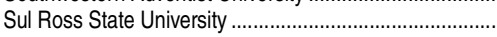 & 1 & 2,680 & 1,681 & 62.7 & 1,255 & 426 & 2 & 224 & 113 & $\dagger$ \\
\hline 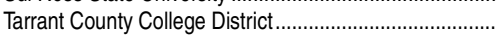 & 2 & 50,439 & 13,042 & 25.9 & 13,042 & t & 704 & $\dagger$ & $\dagger$ & $\dagger$ \\
\hline 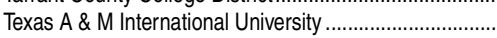 & 1 & 7,213 & 6,740 & 93.4 & 6,052 & 688 & $\dagger$ & 723 & 179 & 0 \\
\hline 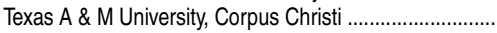 & 1 & 10,508 & 4,573 & 43.5 & 3,990 & 583 & $\dagger$ & 616 & 146 & 12 \\
\hline 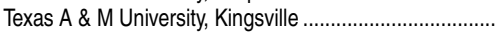 & 1 & 11,350 & 7,445 & 65.6 & 6,159 & 1,286 & $\dagger$ & 966 & 288 & 13 \\
\hline 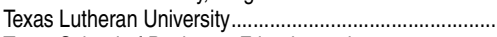 & 3 & 1,315 & 387 & 29.4 & 384 & 3 & $\dagger$ & 58 & $\dagger$ & $\dagger$ \\
\hline 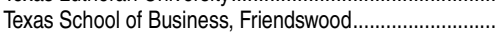 & 6 & 313 & 124 & 39.6 & 124 & $\dagger$ & 6 & $\dagger$ & t & $\dagger$ \\
\hline Texas School of Business, North & 6 & 473 & 190 & 40.2 & 190 & $\dagger$ & 40 & $\dagger$ & $\dagger$ & $\dagger$ \\
\hline 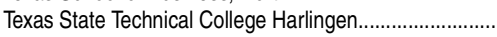 & 2 & 5,509 & 4,938 & 89.6 & 4,938 & $\dagger$ & 335 & $\dagger$ & $\dagger$ & $\dagger$ \\
\hline 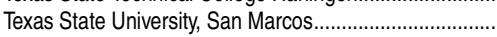 & 1 & 34,225 & 9,817 & 28.7 & 8,791 & 1,026 & $\dagger$ & 1,291 & 243 & 14 \\
\hline 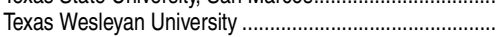 & 3 & 3,204 & 562 & 17.5 & 398 & 164 & $\dagger$ & 87 & 19 & 21 \\
\hline University of Houston & 1 & 40,747 & 10,210 & 25.1 & 9,355 & 855 & $\dagger$ & 1,339 & 203 & 72 \\
\hline University of Houston, Clear Lake & 1 & 8,153 & 2,065 & 25.3 & 1,488 & 577 & $\dagger$ & 326 & 106 & 2 \\
\hline 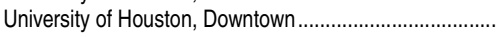 & 1 & 13,916 & 5,333 & 38.3 & 5,271 & 62 & $\dagger$ & 786 & 10 & $\dagger$ \\
\hline University of Houston, Victoria & 1 & 4,335 & 1,054 & 24.3 & 788 & 266 & $\dagger$ & 126 & 52 & $\dagger$ \\
\hline 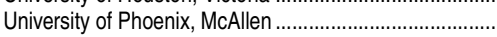 & 5 & 107 & 103 & 96.3 & 91 & 12 & $\dagger$ & 0 & $\dagger$ & $\dagger$ \\
\hline University of Phoenix, San Antonio & 5 & 1,167 & 501 & 42.9 & 434 & 67 & $\dagger$ & 35 & 22 & $\dagger$ \\
\hline University of Saint Thomas & 3 & 3,626 & 1,135 & 31.3 & 587 & 548 & $\dagger$ & 110 & 142 & 0 \\
\hline 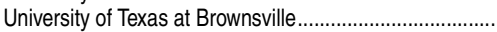 & 1 & 13,636 & 12,098 & 88.7 & 11,254 & 844 & 966 & 1,056 & 161 & 4 \\
\hline 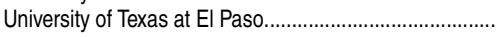 & 1 & 22,749 & 17,946 & 78.9 & 15,806 & 2,140 & $\dagger$ & 2,413 & 691 & 33 \\
\hline 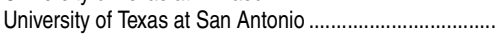 & 1 & 30,474 & 13,989 & 45.9 & 12,392 & 1,597 & $\dagger$ & 1,919 & 394 & 17 \\
\hline University of Texas Health Science Center at San Antonio .. & 1 & 3,249 & 886 & 27.3 & 317 & 569 & $\dagger$ & 193 & 55 & 68 \\
\hline 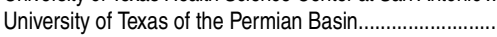 & 1 & 4,021 & 1,714 & 42.6 & 1,499 & 215 & $\dagger$ & 236 & 43 & $\dagger$ \\
\hline 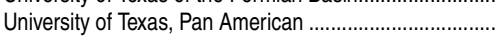 & 1 & 19,302 & 17,629 & 91.3 & 15,317 & 2,312 & $\dagger$ & 2,228 & 586 & 7 \\
\hline University of the Incarnate Word & 3 & 8,442 & 4,829 & 57.2 & 4,032 & 797 & 2 & 616 & 189 & 29 \\
\hline 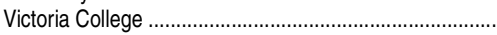 & 2 & 4,484 & 1,796 & 40.1 & 1,796 & t & 94 & $\dagger$ & $\dagger$ & $\dagger$ \\
\hline Virginia College, Austin & 6 & 549 & 228 & 41.5 & 228 & $t$ & 31 & $\dagger$ & $\dagger$ & $\dagger$ \\
\hline 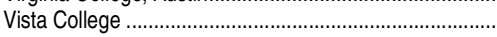 & 6 & 2,220 & 1,327 & 59.8 & 1,327 & $\dagger$ & 126 & $\dagger$ & $\dagger$ & $\dagger$ \\
\hline 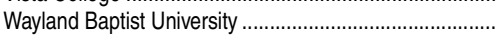 & 3 & 6,834 & 1,697 & 24.8 & 1,353 & 344 & 65 & 295 & 86 & $\dagger$ \\
\hline Western Technical College, Diana Drive.............................. & 6 & 520 & 391 & 75.2 & 391 & $\dagger$ & 79 & $\dagger$ & $\dagger$ & $\dagger$ \\
\hline 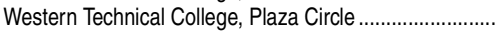 & 6 & 806 & 681 & 84.5 & 681 & $\dagger$ & 201 & $\dagger$ & $\dagger$ & $\dagger$ \\
\hline Western Texas College & 2 & 2,469 & 574 & 23.2 & 574 & $\dagger$ & 52 & $\dagger$ & $\dagger$ & $\dagger$ \\
\hline 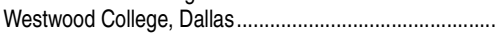 & 5 & 71 & 21 & 29.6 & 21 & $\dagger$ & 17 & 6 & $\dagger$ & $\dagger$ \\
\hline
\end{tabular}


CHAPTER 3: Postsecondary Education 487 Large Institutions and Institutions Serving Specific Groups

Table 312.40. Enrollment and degrees conferred in degree-granting postsecondary institutions that serve large proportions of Hispanic undergraduate students, by institution level and control, percentage Hispanic, degree level, and other selected characteristics: Fall 2012 and 2011-12-Continued

\begin{tabular}{|c|c|c|c|c|c|c|c|c|c|c|}
\hline \multirow[b]{2}{*}{ State and institution } & \multirow[b]{2}{*}{$\begin{array}{r}\text { Level } \\
\text { and control }{ }^{1}\end{array}$} & \multicolumn{5}{|c|}{ Enrollment, fall 2012} & \multicolumn{4}{|c|}{ Degrees awarded to Hispanics, 2011-12 } \\
\hline & & Total & Hispanic & $\begin{array}{r}\text { Percent } \\
\text { Hispanic }^{2}\end{array}$ & $\begin{array}{r}\text { Hispanic } \\
\text { under- } \\
\text { graduate }\end{array}$ & $\begin{array}{r}\text { Hispanic } \\
\text { postbacca- } \\
\text { laureate }\end{array}$ & Associate's & Bachelor's & Master's & Doctor's ${ }^{3}$ \\
\hline 1 & 2 & 3 & 4 & 5 & 6 & 7 & 8 & 9 & 10 & 11 \\
\hline 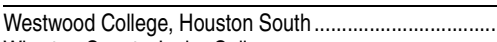 & 5 & 46 & 26 & 56.5 & 26 & $\dagger$ & 22 & 4 & $\dagger$ & $\bar{\dagger}$ \\
\hline 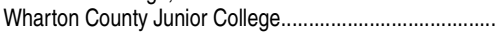 & 2 & 7,407 & 2,459 & 33.2 & 2,459 & $\dagger$ & 129 & $\dagger$ & $\dagger$ & $\dagger$ \\
\hline Utah & & & & & & & & & & \\
\hline 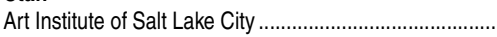 & 5 & 604 & 224 & 37.1 & 224 & $\dagger$ & 9 & 2 & $\dagger$ & $\dagger$ \\
\hline 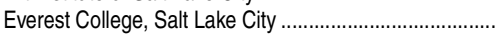 & 5 & 374 & 106 & 28.3 & 106 & $\dagger$ & 11 & 0 & $\dagger$ & $\dagger$ \\
\hline Virginia & & & & & & & & & & \\
\hline 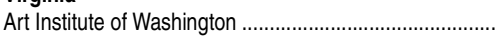 & 5 & 1,557 & 496 & 31.9 & 496 & $\dagger$ & 29 & 37 & $\dagger$ & $\dagger$ \\
\hline Everest College, McLean & 6 & 335 & 107 & 31.9 & 107 & $\dagger$ & 7 & $\dagger$ & $\dagger$ & $\dagger$ \\
\hline 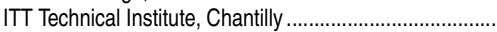 & 5 & 607 & 152 & 25.0 & 152 & $\dagger$ & 25 & 18 & $\dagger$ & $\dagger$ \\
\hline 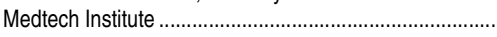 & 6 & 1,545 & 618 & 40.0 & 618 & $\dagger$ & 1 & $\dagger$ & $\dagger$ & $\dagger$ \\
\hline Washington & & & & & & & & & & \\
\hline Art Institute of Seattle & 5 & 1,703 & 486 & 28.5 & 486 & $\dagger$ & 22 & 16 & $\dagger$ & $\dagger$ \\
\hline 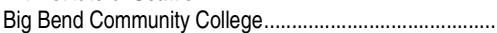 & 2 & 1,840 & 576 & 31.3 & 576 & $\dagger$ & 122 & $\dagger$ & $t$ & $\dagger$ \\
\hline 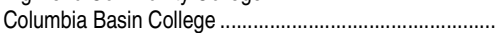 & 1 & 6,294 & 1,734 & 27.6 & 1,734 & $t$ & 226 & 1 & $t$ & $\dagger$ \\
\hline 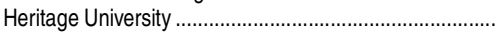 & 3 & 1,150 & 584 & 50.8 & 503 & 81 & 3 & 59 & 24 & $\dagger$ \\
\hline 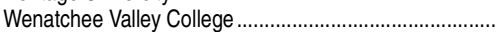 & 2 & 3,668 & 1,021 & 27.8 & 1,021 & $t$ & 135 & $\dagger$ & $t$ & $\dagger$ \\
\hline 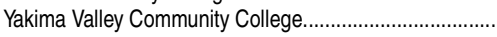 & 2 & 4,302 & 1,849 & 43.0 & 1,849 & $\dagger$ & 206 & $\dagger$ & $\dagger$ & $\dagger$ \\
\hline Wyoming & & & & & & & & & & \\
\hline University of Phoenix, Cheyenne... & 5 & 70 & 23 & 32.9 & 23 & $\dagger$ & $\dagger$ & 0 & $\dagger$ & $\dagger$ \\
\hline Puerto Rico & & & & & & & & & & \\
\hline 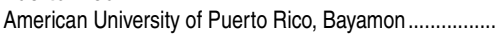 & 3 & 1,172 & 1,172 & 100.0 & 1,077 & 95 & 23 & 153 & 48 & $\dagger$ \\
\hline 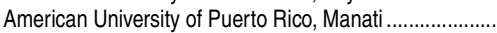 & 3 & 1,120 & 1,120 & 100.0 & 1,057 & 63 & 22 & 158 & 12 & $\dagger$ \\
\hline 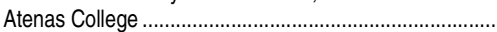 & 3 & 1,390 & 1,390 & 100.0 & 1,390 & $t$ & 119 & 39 & $\dagger$ & $\dagger$ \\
\hline Atlantic University College & 3 & 1,416 & 1,416 & 100.0 & 1,349 & 67 & 23 & 177 & 21 & $\dagger$ \\
\hline 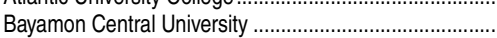 & 3 & 2,256 & 2,244 & 99.5 & 1,998 & 246 & 15 & 301 & 119 & $\dagger$ \\
\hline 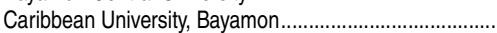 & 3 & 1,869 & 1,869 & 100.0 & 1,597 & 272 & 26 & 156 & 68 & $\dagger$ \\
\hline 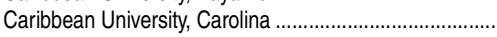 & 3 & 925 & 925 & 100.0 & 779 & 146 & 34 & 50 & 35 & $\dagger$ \\
\hline 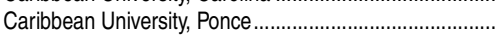 & 3 & 1,674 & 1,674 & 100.0 & 1,222 & 452 & 31 & 113 & 88 & $\dagger$ \\
\hline 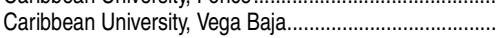 & 3 & 673 & 673 & 100.0 & 530 & 143 & 24 & 40 & 51 & $\dagger$ \\
\hline 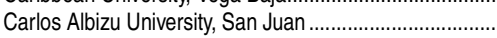 & 3 & 930 & 927 & 99.7 & 161 & 766 & $\dagger$ & 42 & 136 & 66 \\
\hline 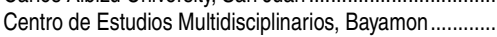 & 3 & 712 & 712 & 100.0 & 712 & t & 133 & 18 & t & $\dagger$ \\
\hline Centro de Estudios Multidisciplinarios, Humacao ............ & 3 & 785 & 785 & 100.0 & 785 & $\dagger$ & 203 & 34 & $\dagger$ & $\dagger$ \\
\hline Centro de Estudios Multidisciplinarios, San Juan............. & 3 & 1,243 & 1,243 & 100.0 & 1,243 & $\dagger$ & 394 & 54 & $\dagger$ & $\dagger$ \\
\hline Colegio de Cinematografía, Artes y Television .................. & 6 & 854 & 854 & 100.0 & 854 & $\dagger$ & 65 & $\dagger$ & $\dagger$ & $\dagger$ \\
\hline 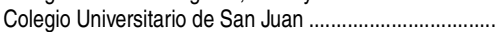 & 1 & 1,570 & 1,570 & 100.0 & 1,570 & $\dagger$ & 260 & 150 & $\dagger$ & $\dagger$ \\
\hline 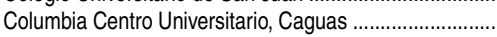 & 5 & 1,744 & 1,744 & 100.0 & 1,616 & 128 & 231 & 146 & 26 & $\dagger$ \\
\hline Columbia Centro Universitario, Yauco ............................. & 5 & 363 & 363 & 100.0 & 363 & $t$ & 85 & 47 & $t$ & $\dagger$ \\
\hline Dewey University & 3 & 2,628 & 2,628 & 100.0 & 2,568 & 60 & 285 & 205 & $t$ & t \\
\hline Dewey University, Carolina & 4 & 804 & 804 & 100.0 & 804 & $t$ & + & $t$ & $\dagger$ & $t$ \\
\hline EDIC College & 6 & 916 & 916 & 100.0 & 916 & t & 167 & 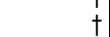 & 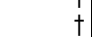 & $\dagger$ \\
\hline 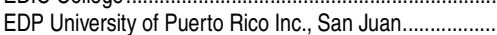 & 3 & 1,198 & 1,198 & 100.0 & 1,141 & 57 & 71 & 77 & 14 & $\dagger$ \\
\hline EDP University of Puerto Rico Inc., San Sebastian ......... & 3 & 1,145 & 1,144 & 99.9 & 1,144 & $\dagger$ & 109 & 50 & $\dagger$ & $\dagger$ \\
\hline Escuela de Artes Plasticas de Puerto Rico & 1 & 489 & 488 & 99.8 & 488 & $t$ & $\dagger$ & 55 & $\dagger$ & $\dagger$ \\
\hline 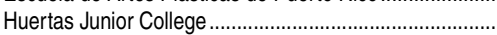 & 6 & 1,490 & 1,490 & 100.0 & 1,490 & $t$ & 372 & $\dagger$ & $\dagger$ & $\dagger$ \\
\hline 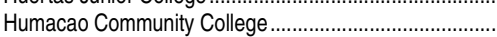 & 3 & 763 & 763 & 100.0 & 763 & $t$ & 137 & 9 & $\dagger$ & $\dagger$ \\
\hline 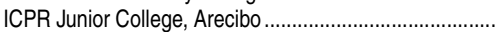 & 6 & 434 & 434 & 100.0 & 434 & $\dagger$ & 33 & $\dagger$ & $\dagger$ & $\dagger$ \\
\hline 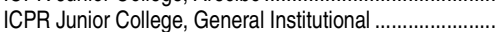 & 6 & 682 & 682 & 100.0 & 682 & $\dagger$ & 32 & $\dagger$ & $\dagger$ & $t$ \\
\hline 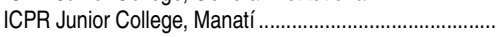 & 6 & 441 & 441 & 100.0 & 441 & $\dagger$ & $\dagger$ & $\dagger$ & $\dagger$ & $\dagger$ \\
\hline 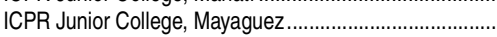 & 6 & 445 & 445 & 100.0 & 445 & $t$ & 58 & $\dagger$ & $\dagger$ & $\dagger$ \\
\hline 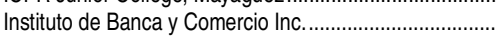 & 6 & 19,470 & 19,358 & 99.4 & 19,358 & $t$ & 32 & $\dagger$ & $\dagger$ & $\dagger$ \\
\hline Instituto Tecnologico de Puerto Rico, Recinto de Guayama... & 2 & 861 & 861 & 100.0 & 861 & $t$ & 173 & $\dagger$ & $\dagger$ & t \\
\hline Instituto Tecnologico de Puerto Rico, Recinto de Manati... & 2 & 974 & 974 & 100.0 & 974 & $t$ & 203 & 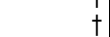 & 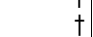 & $\dagger$ \\
\hline Instituto Tecnologico de Puerto Rico, Recinto de Ponce. & 2 & 651 & 651 & 100.0 & 651 & t & 798 & t & 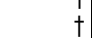 & t \\
\hline Instituto Tecnologico de Puerto Rico, Recinto de San Juan. & 2 & 690 & 690 & 100.0 & 690 & t & 149 & 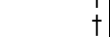 & t & $\dagger$ \\
\hline Inter American University of Puerto Rico, Aguadill.......... & 3 & 4,631 & 4,626 & 99.9 & 4,322 & 304 & 79 & 314 & 71 & $\dagger$ \\
\hline Inter American University of Puerto Rico, Arecibo............. & 3 & 4,965 & 4,959 & 99.9 & 4,505 & 454 & 114 & 305 & 88 & $\dagger$ \\
\hline Inter American University of Puerto Rico, Barranqu......... & 3 & 2,161 & 2,157 & 99.8 & 2,097 & 60 & 105 & 206 & 30 & $\dagger$ \\
\hline Inter American University of Puerto Rico, Bayamon.......... & 3 & 4,934 & 4,927 & 99.9 & 4,796 & 131 & 40 & 462 & 18 & $\dagger$ \\
\hline Inter American University of Puerto Rico, Fajardo............. & 3 & 2,211 & 2,209 & 99.9 & 2,175 & 34 & 13 & 186 & 12 & $\dagger$ \\
\hline Inter American University of Puerto Rico, Guayama ........ & 3 & 2,249 & 2,249 & 100.0 & 2,152 & 97 & 64 & 206 & 17 & $\dagger$ \\
\hline Inter American University of Puerto Rico, Metro............... & 3 & 10,703 & 10,629 & 99.3 & 7,655 & 2,974 & 149 & 862 & 452 & 26 \\
\hline Inter American University of Puerto Rico, Ponce............. & 3 & 5,983 & 5,972 & 99.8 & 5,565 & 407 & 154 & 514 & 48 & $\dagger$ \\
\hline Inter American University of Puerto Rico, San German .. & 3 & 5,355 & 5,349 & 99.9 & 4,569 & 780 & 57 & 469 & 147 & 29 \\
\hline Mech-Tech College LLC & 6 & 2,992 & 2,992 & 100.0 & 2,992 & $\dagger$ & 235 & $\dagger$ & $\dagger$ & $\dagger$ \\
\hline National University College, Arecibo & 5 & 1,657 & 1,657 & 100.0 & 1,657 & $\dagger$ & 260 & 112 & $\dagger$ & $\dagger$ \\
\hline 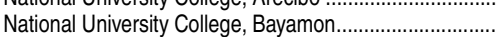 & 5 & 3,732 & 3,732 & 100.0 & 3,642 & 90 & 300 & 172 & 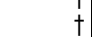 & $\dagger$ \\
\hline 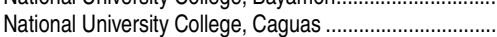 & 5 & 492 & 492 & 100.0 & $\begin{array}{r}0,042 \\
492\end{array}$ & $t$ & 0 & 0 & $t$ & $\dagger$ \\
\hline 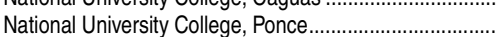 & 5 & 987 & 987 & 100.0 & 987 & t & 109 & 142 & + & t \\
\hline 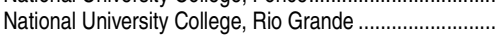 & 5 & 1,613 & 1,613 & 100.0 & 1,613 & $\dagger$ & 165 & 135 & $\dagger$ & $\dagger$ \\
\hline 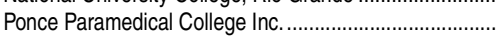 & 6 & 3,354 & 3,354 & 100.0 & 3,354 & $t$ & 285 & $\dagger$ & $\dagger$ & $\dagger$ \\
\hline
\end{tabular}

See notes at end of table. 
488 CHAPTER 3: Postsecondary Education

Large Institutions and Institutions Serving Specific Groups

Table 312.40. Enrollment and degrees conferred in degree-granting postsecondary institutions that serve large proportions of Hispanic undergraduate students, by institution level and control, percentage Hispanic, degree level, and other selected characteristics: Fall 2012 and 2011-12-Continued

\begin{tabular}{|c|c|c|c|c|c|c|c|c|c|c|}
\hline \multirow[b]{2}{*}{ State and institution } & \multirow[b]{2}{*}{$\begin{array}{r}\text { Level } \\
\text { and control }{ }^{1}\end{array}$} & \multicolumn{5}{|c|}{ Enrollment, fall 2012} & \multicolumn{4}{|c|}{ Degrees awarded to Hispanics, 2011-12 } \\
\hline & & Total & Hispanic & $\begin{array}{r}\text { Percent } \\
\text { Hispanic }^{2}\end{array}$ & $\begin{array}{r}\text { Hispanic } \\
\text { under- } \\
\text { graduate }\end{array}$ & $\begin{array}{r}\text { Hispanic } \\
\text { postbacca- } \\
\text { laureate }\end{array}$ & Associate's & Bachelor's & Master's & Doctor's ${ }^{3}$ \\
\hline 1 & 2 & 3 & 4 & 5 & 6 & 7 & 8 & 9 & 10 & 11 \\
\hline 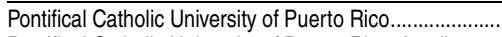 & 3 & 8,553 & 8,508 & 99.5 & 6,133 & 2,375 & 16 & 619 & 175 & 280 \\
\hline Pontifical Catholic University of Puerto Rico, Arecibo...... & 3 & 929 & 918 & 98.8 & 615 & 303 & 17 & 36 & 46 & $\dagger$ \\
\hline Pontifical Catholic University of Puerto Rico, Mayaguez . & 3 & 1,537 & 1,536 & 99.9 & 1,422 & 114 & 5 & 118 & 15 & $\dagger$ \\
\hline 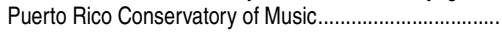 & 1 & 456 & 424 & 93.0 & 378 & 46 & $\dagger$ & 53 & 5 & $\dagger$ \\
\hline San Juan Bautista School of Medicine ................................ & 3 & 262 & 241 & 92.0 & 16 & 225 & $\dagger$ & $\dagger$ & $\dagger$ & 21 \\
\hline Universal Technology College of Puerto Rico.................... & 3 & 1,217 & 1,217 & 100.0 & 1,217 & $\dagger$ & 205 & $\dagger$ & $\dagger$ & $\dagger$ \\
\hline 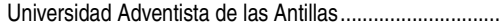 & 3 & 1,312 & 1,245 & 94.9 & 1,180 & 65 & 9 & 103 & 19 & $\dagger$ \\
\hline 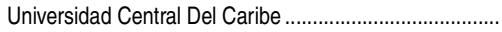 & 3 & 498 & 479 & 96.2 & 161 & 318 & 15 & 5 & 14 & 45 \\
\hline Universidad Del Este & 3 & 13,630 & 13,630 & 100.0 & 12,489 & 1,141 & 249 & 1,173 & 282 & $\dagger$ \\
\hline Universidad Del Turabo & 3 & 17,040 & 17,040 & 100.0 & 14,333 & 2,707 & 119 & 1,319 & 832 & 29 \\
\hline 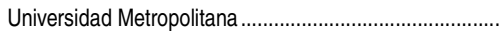 & 3 & 13,616 & 13,616 & 100.0 & 11,293 & 2,323 & 153 & 1,256 & 532 & 1 \\
\hline 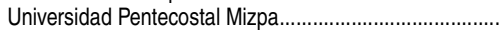 & 3 & 372 & 372 & 100.0 & 340 & 32 & 18 & 26 & $\dagger$ & $\dagger$ \\
\hline Universidad Politecnica de Puerto Rico, Hato Rey........... & 3 & 4,743 & 4,743 & 100.0 & 4,031 & 712 & $\dagger$ & 522 & 221 & $\dagger$ \\
\hline 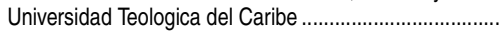 & 3 & 172 & 172 & 100.0 & 172 & $\dagger$ & $\dagger$ & 24 & $\dagger$ & $\dagger$ \\
\hline University of Phoenix, Puerto Rico & 5 & 1,248 & 1,196 & 95.8 & 658 & 538 & $\dagger$ & 107 & 255 & $\dagger$ \\
\hline 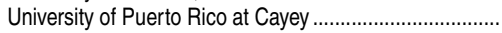 & 1 & 3,641 & 3,641 & 100.0 & 3,641 & $\dagger$ & $\dagger$ & 483 & $\dagger$ & $\dagger$ \\
\hline 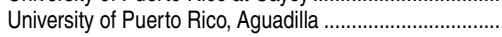 & 1 & 2,974 & 2,943 & 99.0 & 2,943 & $\dagger$ & 12 & 309 & $\dagger$ & $\dagger$ \\
\hline University of Puerto Rico, Arecibo & 1 & 3,693 & 3,693 & 100.0 & 3,693 & $\dagger$ & 95 & 516 & $\dagger$ & $\dagger$ \\
\hline 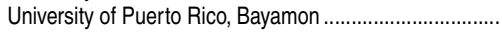 & 1 & 5,062 & 5,062 & 100.0 & 5,062 & $\dagger$ & 41 & 528 & $\dagger$ & $\dagger$ \\
\hline 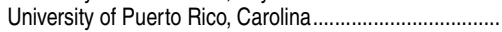 & 1 & 3,837 & 3,733 & 97.3 & 3,733 & $\dagger$ & 85 & 539 & $\dagger$ & $\dagger$ \\
\hline University of Puerto Rico, Humacao ......................... & 1 & 3,603 & 3,542 & 98.3 & 3,542 & $\dagger$ & 85 & 424 & $\dagger$ & $\dagger$ \\
\hline University of Puerto Rico, Mayaguez................. & 1 & 11,984 & 11,984 & 100.0 & 11,054 & 930 & $\dagger$ & 1,797 & 128 & 13 \\
\hline University of Puerto Rico, Medical Sciences ...... & 1 & 2,270 & 2,236 & 98.5 & 475 & 1,761 & 55 & 165 & 237 & 186 \\
\hline 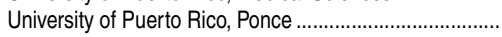 & 1 & 3,089 & 3,089 & 100.0 & 3,089 & $\dagger$ & 93 & 321 & t & $\dagger$ \\
\hline 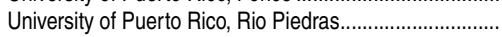 & 1 & 15,259 & 14,978 & 98.2 & 11,865 & 3,113 & $\dagger$ & 1,122 & 179 & 145 \\
\hline 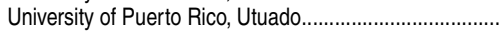 & 1 & 1,476 & 1,008 & 68.3 & 1,008 & $\dagger$ & 73 & 59 & $\dagger$ & $\dagger$ \\
\hline 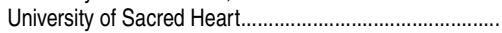 & 3 & 6,335 & 6,335 & 100.0 & 5,498 & 837 & 154 & 663 & 165 & $\dagger$ \\
\hline
\end{tabular}

†Not applicable.

11 = 4-year public; 2 = 2-year public; 3 = 4-year private nonprofit; 4 = 2-year private nonprofit; $5=4$-year private for-profit; and $6=2$-year private for-profit

${ }^{2}$ Hispanic headcount enrollment (U.S. citizens and permanent residents only) as a percentage of total headcount enrollment, including both resident and nonresident students. Hispanic and total headcount enrollment include graduate as well as undergraduate students.

Includes Ph.D., Ed.D., and comparable degrees at the doctoral level, as well as such degrees as M.D., D.D.S., and law degrees that were formerly classified as first-professional degrees.
NOTE: Degree-granting institutions grant associate's or higher degrees and participate in Title IV federal financial aid programs. This table includes institutions that serve large proportions of Hispanic undergraduate students, defined as institutions with a full-time-equivalent undergraduate enrollment of Hispanic students at 25 percent or more of full-time-equivalent undergraduate enrollment of U.S. citizens. Data for Hispanics include only persons who were U.S. citizens or permanent residents.

SOURCE: U.S. Department of Education, National Center for Education Statistics, Integrated Postsecondary Education Data System (IPEDS), Spring 2013, Enrollment component; and Fall 2012, Completions component. (This table was prepared July 2014.) 
Table 312.50. Fall enrollment and degrees conferred in degree-granting tribally controlled postsecondary institutions, by state and institution: Selected years, fall 2000 through fall 2012, and 2010-11 and 2011-12

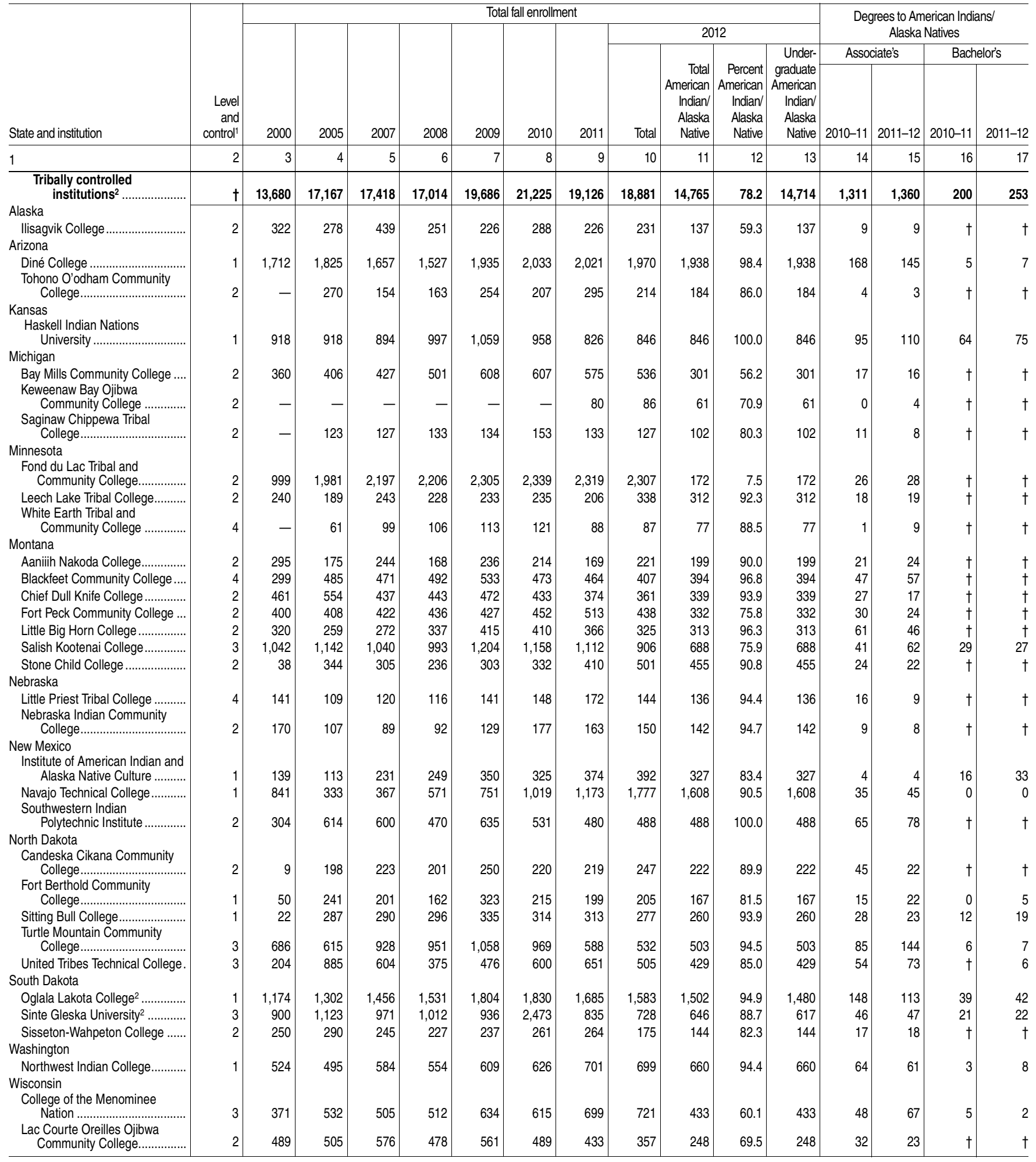

-Not available.

†Not applicable.

11 = public, 4-year; 2 = public, 2-year; 3 = private nonprofit, 4 -year; and 4 = private nonprofit, 2-year.

2“Total American Indian/Alaska Native” enrollment (column 11) includes graduate students and therefore does not equal "Undergraduate American Indian/Alaska Native" enrollment (column 13).
NOTE: This table only includes institutions that were in operation during the 2012-13 academic year. They are all members of the American Indian Higher Education Consortium and with few exceptions, are tribally controlled and located on reservations. Degree-granting institutions grant associate's or higher degrees and participate in Title IV federal financial aid programs. Totals include persons of other racial/ethnic groups not separately identified.

SOURCE: U.S. Department of Education, National Center for Education Statistics, Integrated Postsecondary Education Data System (IPEDS), Spring 2013, Enrollment component; and Fall 2011 and Fall 2012, Completions component. (This table was prepared April 2014.) 
Table 313.10. Fall enrollment, degrees conferred, and expenditures in degree-granting historically Black colleges and universities, by institution: 2011, 2012, and 2011-12

\begin{tabular}{|c|c|c|c|c|c|c|c|c|c|c|c|}
\hline \multirow[b]{2}{*}{ Institution } & \multirow[b]{2}{*}{ State } & \multirow{2}{*}{$\begin{array}{r}\text { Level and } \\
\text { control }^{1}\end{array}$} & \multirow{2}{*}{$\begin{array}{r}\text { Total } \\
\text { enroll- } \\
\text { ment, } \\
\text { fall } 2011\end{array}$} & \multicolumn{2}{|c|}{ Enrollment, fall 2012} & \multirow{2}{*}{$\begin{array}{r}\text { Full-time- } \\
\text { equivalent } \\
\text { enrollment, } \\
\text { fall } 2012\end{array}$} & \multicolumn{4}{|c|}{ Degrees conferred, 2011-12 } & \multirow{2}{*}{\begin{tabular}{|r} 
Total \\
expenditures, \\
$2011-12$ \\
(in thousands)
\end{tabular}} \\
\hline & & & & Total & $\begin{array}{r}\text { Black } \\
\text { enrollment }\end{array}$ & & Associate's & Bachelor's & Master's & Doctor's $^{2}$ & \\
\hline 1 & 2 & 3 & 4 & 5 & 6 & 7 & 8 & 9 & 10 & 11 & 12 \\
\hline Total ............................ & $t$ & $\dagger$ & 323,616 & 312,438 & 251,530 & 270,716 & 4,631 & 34,013 & 7,654 & 2,285 & $\$ 7,734,318$ \\
\hline 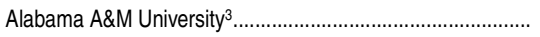 & $\mathrm{AL}$ & 1 & 4,922 & 4,853 & 4,511 & 4,455 & $\dagger$ & 532 & 195 & 11 & 139,478 \\
\hline Alabama State University …………………........ & $\mathrm{AL}$ & 1 & 5,425 & 5,816 & 5,502 & 5,292 & $\dagger$ & 542 & 184 & 43 & 149,723 \\
\hline Bishop State Community College & $\mathrm{AL}$ & 2 & 3,982 & 3,791 & 2,386 & 2,581 & 307 & $\dagger$ & $\dagger$ & $\dagger$ & 35,405 \\
\hline Concordia College, Alabama... & $\mathrm{AL}$ & 3 & 719 & 611 & 587 & 583 & 25 & 20 & $\dagger$ & $\dagger$ & 10,792 \\
\hline Gadsden State Community College ..................... & $\mathrm{AL}$ & 2 & 6,731 & 5,882 & 1,211 & 4,073 & 634 & $\dagger$ & $\dagger$ & $\dagger$ & 54,667 \\
\hline H. Councill Trenholm State Technical College .......... & $\mathrm{AL}$ & 2 & 1,721 & 1,445 & 889 & 1,016 & 179 & $\dagger$ & $\dagger$ & $\dagger$ & 20,596 \\
\hline J. F. Drake State Community and Technical College .............. & $\mathrm{AL}$ & 2 & 1,223 & 1,248 & 644 & 790 & 71 & $\dagger$ & $\dagger$ & $\dagger$ & 13,383 \\
\hline Lawson State Community College, Birmingham Campus..... & $\mathrm{AL}$ & 2 & 4,205 & 3,419 & 2,797 & 2,448 & 280 & $\dagger$ & $\dagger$ & $\dagger$ & 37,034 \\
\hline 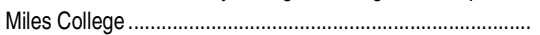 & $\mathrm{AL}$ & 3 & 1,634 & 1,691 & 1,636 & 1,635 & $\dagger$ & 222 & $t$ & $t$ & 26,112 \\
\hline 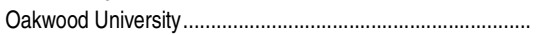 & $\mathrm{AL}$ & 3 & 2,006 & 2,019 & 1,784 & 1,937 & 4 & 311 & 9 & $\dagger$ & 47,823 \\
\hline Selma University & $\mathrm{AL}$ & 3 & 547 & 643 & 633 & 566 & 1 & 23 & 8 & $\dagger$ & 2,735 \\
\hline Shelton State Community College, C. A. Fredd campus ........ & $\mathrm{AL}$ & 2 & 5,307 & 5,104 & 1,916 & 3,506 & 355 & $\dagger$ & $\dagger$ & $\dagger$ & 43,495 \\
\hline 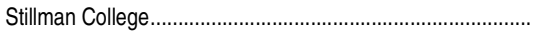 & $\mathrm{AL}$ & 3 & 1,072 & 1,019 & 934 & 973 & $\dagger$ & 135 & $\dagger$ & $\dagger$ & 19,551 \\
\hline Talladega College ……………………………………........ & $\mathrm{AL}$ & 3 & 712 & 1,203 & 1,123 & 1,175 & $\dagger$ & 85 & $\dagger$ & $\dagger$ & 13,421 \\
\hline 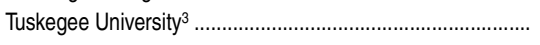 & $\mathrm{AL}$ & 3 & 3,152 & 3,117 & 2,916 & 3,043 & $\dagger$ & 354 & 18 & 71 & 139,451 \\
\hline Arkansas Baptist College .... & AR & 3 & 1,193 & 1,082 & 1,011 & 979 & 52 & 48 & $\dagger$ & $\dagger$ & 14,859 \\
\hline Philander Smith College ………………………………......... & AR & 3 & 732 & 666 & 604 & 636 & $\dagger$ & 118 & $\dagger$ & $\dagger$ & 17,278 \\
\hline Shorter College .................................................... & $A R$ & 4 & (4) & 52 & 52 & 52 & 0 & $\dagger$ & $\dagger$ & $\dagger$ & 746 \\
\hline University of Arkansas at Pine Bluff ${ }^{3}$.. & AR & 1 & 3,188 & 2,828 & 2,651 & 2,629 & $\dagger$ & 461 & 37 & $\dagger$ & 73,735 \\
\hline Delaware State University ${ }^{3} \ldots$ & $\mathrm{DE}$ & 1 & 4,154 & 4,324 & 3,055 & 4,008 & $\dagger$ & 505 & 112 & 15 & 113,086 \\
\hline Howard University......... & $\mathrm{DC}$ & 3 & 10,583 & 10,002 & 8,682 & 9,351 & $t$ & 1,321 & 398 & 516 & 841,601 \\
\hline University of the District of Columbia ${ }^{3} \ldots \ldots \ldots \ldots \ldots . . . . . . . .$. & $\mathrm{DC}$ & 1 & 4,921 & 5,110 & 3,927 & 3,349 & 170 & 398 & 63 & $t$ & 147,034 \\
\hline Bethune-Cookman University... & $\mathrm{FL}$ & 3 & 3,578 & 3,543 & 3,268 & 3,452 & $t$ & 549 & 17 & $t$ & 64,326 \\
\hline Edward Waters College .... & $\mathrm{FL}$ & 3 & 751 & 925 & 877 & 918 & $t$ & 103 & $t$ & $t$ & 20,776 \\
\hline Florida A\&M University ${ }^{3} \ldots$. & $\mathrm{FL}$ & 1 & 13,204 & 12,057 & 10,951 & 11,309 & 59 & 1,466 & 270 & 331 & 285,422 \\
\hline 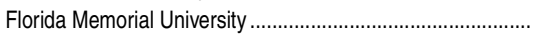 & $\mathrm{FL}$ & 3 & 1,735 & 1,579 & 1,364 & 1,505 & $\dagger$ & 192 & 14 & $\dagger$ & 43,402 \\
\hline Albany State University... & $\mathrm{GA}$ & 1 & 4,663 & 4,275 & 3,919 & 3,757 & $t$ & 620 & 168 & $t$ & 78,014 \\
\hline Clark Atlanta University ... & $\mathrm{GA}$ & 3 & 3,843 & 3,419 & 3,330 & 3,128 & $\dagger$ & 550 & 152 & 26 & 89,196 \\
\hline 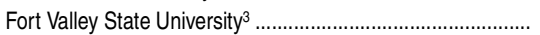 & $\mathrm{GA}$ & 1 & 3,896 & 3,568 & 3,343 & 3,261 & $\dagger$ & 375 & 50 & $t$ & 85,996 \\
\hline Interdenominational Theological Center............ & $\mathrm{GA}$ & 3 & 425 & 827 & 811 & 461 & $\dagger$ & $\dagger$ & 70 & 7 & 9,049 \\
\hline Morehouse College ........ & GA & 3 & 2,438 & 2,374 & 2,301 & 2,280 & $\dagger$ & 388 & $\dagger$ & $\dagger$ & 91,415 \\
\hline Morehouse School of Medicine ..................... & GA & 3 & 344 & 360 & 308 & 353 & $\dagger$ & $\dagger$ & 25 & 54 & 143,379 \\
\hline 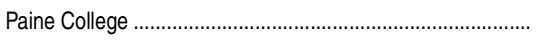 & GA & 3 & 891 & 837 & 776 & 793 & $\dagger$ & 100 & $\dagger$ & $\dagger$ & 23,696 \\
\hline Savannah State University .................................. & GA & 1 & 4,552 & 4,582 & 4,028 & 4,195 & 0 & 395 & 59 & $\dagger$ & 89,125 \\
\hline Spelman College .................. & GA & 3 & 2,170 & 2,145 & 2,061 & 2,102 & $\dagger$ & 467 & $\dagger$ & $\dagger$ & 87,140 \\
\hline 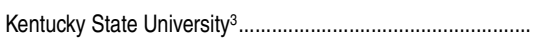 & KY & 1 & 2,746 & 2,524 & 1,667 & 2,142 & 53 & 229 & 64 & $\dagger$ & 75,702 \\
\hline Dillard University......... & $\mathrm{LA}$ & 3 & 1,249 & 1,307 & 1,263 & 1,255 & $t$ & 133 & $t$ & $\dagger$ & 48,576 \\
\hline Grambling & LA & 1 & 5,207 & 5,277 & 4,692 & 4,838 & 16 & 686 & 197 & 6 & 104,227 \\
\hline Southern University and A\&M College ${ }^{3} \ldots \ldots \ldots .$. & $\mathrm{LA}$ & 1 & 6,866 & 6,397 & 5,984 & 5,577 & $\dagger$ & 798 & 294 & 43 & 143,356 \\
\hline Southern University at New Orleans ................. & LA & 1 & 3,245 & 2,820 & 2,687 & 2,224 & 27 & 304 & 153 & $\dagger$ & 46,813 \\
\hline Southern Unive & LA & 2 & 2,831 & 2,937 & 2,556 & 2,261 & 325 & $\dagger$ & $\dagger$ & $\dagger$ & 33,213 \\
\hline 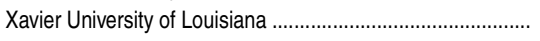 & LA & 3 & 3,399 & 3,178 & 2,342 & 3,056 & $\dagger$ & 360 & 59 & 147 & 103,434 \\
\hline Bowie State Univer & MD & 1 & 5,608 & 5,421 & 4,791 & 4,476 & $\dagger$ & 688 & 284 & 9 & 81,024 \\
\hline Coppin State College........................................ & MD & 1 & 3,813 & 3,612 & 3,166 & 2,984 & $\dagger$ & 460 & 58 & $\dagger$ & 84,094 \\
\hline 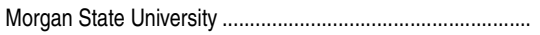 & $\mathrm{MD}$ & 1 & 8,018 & 7,952 & 6,686 & 7,060 & $\dagger$ & 902 & 255 & 37 & 190,970 \\
\hline University of Maryland, Eastern Shore ${ }^{3} \ldots \ldots \ldots . . . .$. & MD & 1 & 4,509 & 4,454 & 3,120 & 4,107 & $\dagger$ & 627 & 78 & 53 & 110,572 \\
\hline Alcorn State University ${ }^{3} . .$. & MS & 1 & 4,018 & 3,950 & 3,666 & 3,410 & 22 & 380 & 161 & $\dagger$ & 81,737 \\
\hline Coahoma Community College ............................ & MS & 2 & 2,999 & 2,305 & 2,242 & 2,043 & 303 & $\dagger$ & $\dagger$ & $\dagger$ & 35,386 \\
\hline Hinds Community College, Utica Campus............................... & MS & 2 & 1,006 & 767 & 744 & 688 & 80 & $\dagger$ & $\dagger$ & $\dagger$ & - \\
\hline Jackson State University...................................... & MS & 1 & 8,903 & 8,819 & 7,970 & 7,262 & $\dagger$ & 1,064 & 412 & 60 & 191,547 \\
\hline Mississippi Valley State University.... & MS & 1 & 2,452 & 2,479 & 2,368 & 2,147 & $\dagger$ & 345 & 128 & $\dagger$ & 59,533 \\
\hline Rust College... & MS & 3 & 922 & 934 & 899 & 889 & 7 & 111 & $\dagger$ & $\dagger$ & 15,939 \\
\hline Tougaloo College........ & MS & 3 & 945 & 972 & 941 & 949 & 3 & 167 & $\dagger$ & $\dagger$ & 25,165 \\
\hline
\end{tabular}

See notes at end of table. 
CHAPTER 3: Postsecondary Education 491 Historically Black Colleges and Universities

Table 313.10. Fall enrollment, degrees conferred, and expenditures in degree-granting historically Black colleges and universities, by institution: 2011, 2012, and 2011-12-Continued

\begin{tabular}{|c|c|c|c|c|c|c|c|c|c|c|c|}
\hline \multirow[b]{2}{*}{ Institution } & \multirow[b]{2}{*}{ State } & \multirow{2}{*}{$\begin{array}{r}\text { Level and } \\
\text { control }^{1}\end{array}$} & \multirow{2}{*}{$\begin{array}{r}\text { Total } \\
\text { enroll- } \\
\text { ment, } \\
\text { fall } 2011\end{array}$} & \multicolumn{2}{|c|}{ Enrollment, fall 2012} & \multirow{2}{*}{$\begin{array}{r}\text { Full-time- } \\
\text { equivalent } \\
\text { enrollment, } \\
\text { fall } 2012\end{array}$} & \multicolumn{4}{|c|}{ Degrees conferred, 2011-12 } & \multirow{2}{*}{\begin{tabular}{|r} 
Total \\
expenditures, \\
$2011-12$ \\
(in thousands)
\end{tabular}} \\
\hline & & & & Total & enrollment & & Associate's & Bachelor's & Master's & Doctor's $^{2}$ & \\
\hline 1 & 2 & 3 & 4 & 5 & 6 & 7 & 8 & 9 & 10 & 11 & 12 \\
\hline 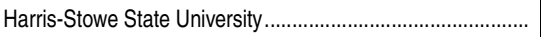 & MO & 1 & 1,590 & 1,484 & 1,265 & 1,253 & $\dagger$ & 160 & $\dagger$ & $\dagger$ & 27,483 \\
\hline 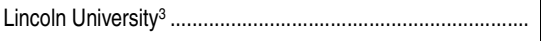 & MO & 1 & 3,388 & 3,205 & 1,131 & 2,478 & 73 & 302 & 55 & $\dagger$ & 54,820 \\
\hline Bennett College for Women & NC & 3 & 736 & 707 & 673 & 670 & $\dagger$ & 108 & $\dagger$ & $\dagger$ & 21,124 \\
\hline 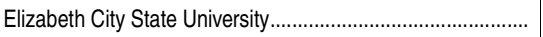 & NC & 1 & 2,930 & 2,878 & 2,344 & 2,659 & $\dagger$ & 406 & 23 & $\dagger$ & 81,509 \\
\hline 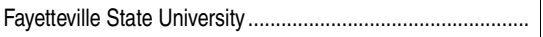 & NC & 1 & 5,930 & 6,060 & 4,277 & 4,953 & $\dagger$ & 991 & 159 & 1 & 109,959 \\
\hline 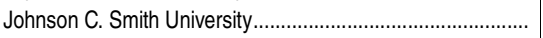 & NC & 3 & 1,543 & 1,669 & 1,463 & 1,631 & $\dagger$ & 275 & $\dagger$ & $\dagger$ & 44,081 \\
\hline Livingstone College ......................................................... & NC & 3 & 1,140 & 1,111 & 1,096 & 1,103 & $\dagger$ & 110 & $\dagger$ & $\dagger$ & 25,974 \\
\hline 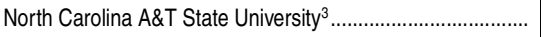 & NC & 1 & 10,881 & 10,636 & 9,110 & 9,609 & $\dagger$ & 1,278 & 358 & 29 & 274,150 \\
\hline North Carolina Central University .......................................... & NC & 1 & 8,359 & 8,604 & 6,948 & 7,523 & $\dagger$ & 918 & 438 & 165 & 189,765 \\
\hline 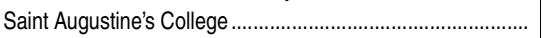 & NC & 3 & 1,506 & 1,442 & 1,396 & 1,392 & $\dagger$ & 210 & $\dagger$ & $\dagger$ & 36,884 \\
\hline 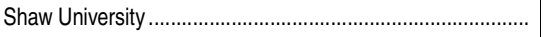 & NC & 3 & 2,405 & 2,183 & 2,108 & 2,064 & $\dagger$ & 347 & 29 & $\dagger$ & 48,646 \\
\hline 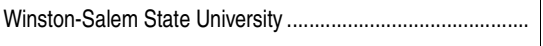 & NC & 1 & 6,163 & 5,689 & 4,295 & 5,125 & $\dagger$ & 1,295 & 177 & 0 & 141,617 \\
\hline Central State University ........ & $\mathrm{OH}$ & 1 & 2,503 & 2,152 & 2,080 & 1,987 & $\dagger$ & 264 & 1 & $\dagger$ & 64,769 \\
\hline 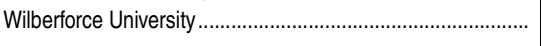 & $\mathrm{OH}$ & 3 & 608 & 518 & 508 & 511 & $\dagger$ & 124 & 2 & $\dagger$ & 14,257 \\
\hline 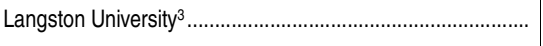 & OK & 1 & 2,840 & 2,518 & 2,053 & 2,174 & 16 & 305 & 92 & 13 & 55,100 \\
\hline 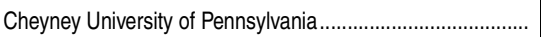 & $\mathrm{PA}$ & 1 & 1,200 & 1,284 & 1,226 & 1,224 & 1 & 172 & 29 & $\dagger$ & 44,867 \\
\hline 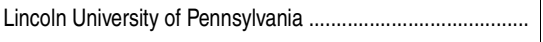 & $\mathrm{PA}$ & 1 & 2,240 & 2,101 & 1,975 & 1,956 & $\dagger$ & 292 & 199 & $\dagger$ & 57,397 \\
\hline 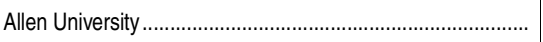 & SC & 3 & 644 & 672 & 668 & 659 & $\dagger$ & 79 & $\dagger$ & $\dagger$ & 23,404 \\
\hline 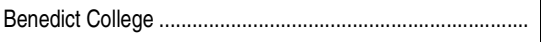 & SC & 3 & 3,213 & 2,917 & 2,889 & 2,889 & $\dagger$ & 382 & $\dagger$ & $\dagger$ & 66,788 \\
\hline Claflin College & SC & 3 & 1,961 & 1,946 & 1,787 & 1,904 & $\dagger$ & 333 & 39 & $\dagger$ & 43,639 \\
\hline 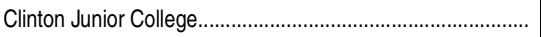 & SC & 4 & 176 & 139 & 138 & 136 & 55 & $\dagger$ & $\dagger$ & $\dagger$ & 3,340 \\
\hline Denmark Technical College ................................................. & SC & 2 & 1,607 & 2,003 & 1,928 & 1,882 & 107 & $\dagger$ & $\dagger$ & $\dagger$ & 22,360 \\
\hline 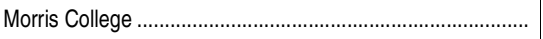 & SC & 3 & 979 & 874 & 861 & 867 & $\dagger$ & 131 & $\dagger$ & $\dagger$ & 20,043 \\
\hline 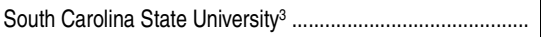 & SC & 1 & 4,326 & 3,807 & 3,596 & 3,453 & $\dagger$ & 583 & 130 & 10 & 122,422 \\
\hline 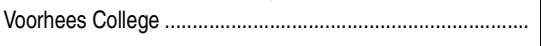 & SC & 3 & 642 & 648 & 619 & 641 & $\dagger$ & 92 & $\dagger$ & $\dagger$ & 17,939 \\
\hline 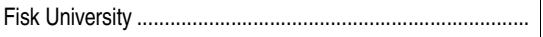 & TN & 3 & 533 & 620 & 565 & 595 & $\dagger$ & 55 & 20 & $\dagger$ & 26,026 \\
\hline Lane College & TN & 3 & 2,002 & 1,512 & 1,512 & 1,495 & $\dagger$ & 288 & $\dagger$ & $\dagger$ & 29,511 \\
\hline 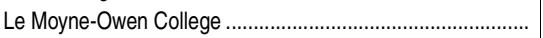 & TN & 3 & 1,091 & 1,078 & 1,069 & 999 & $\dagger$ & 129 & $\dagger$ & $\dagger$ & 16,744 \\
\hline 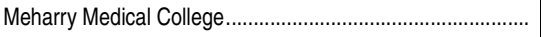 & TN & 3 & 772 & 782 & 666 & 782 & $\dagger$ & $\dagger$ & 21 & 152 & 135,793 \\
\hline 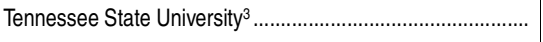 & TN & 1 & 9,165 & 8,740 & 6,118 & 7,053 & 139 & 963 & 404 & 72 & 178,862 \\
\hline 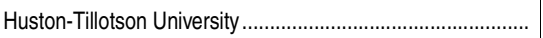 & TX & 3 & 904 & 918 & 662 & 847 & $\dagger$ & 130 & $\dagger$ & $\dagger$ & 17,910 \\
\hline Jarvis Christian College ................................................... & TX & 3 & 511 & 603 & 506 & 577 & $\dagger$ & 58 & $\dagger$ & $\dagger$ & 11,930 \\
\hline Paul Quinn College & $\mathrm{TX}$ & 3 & 201 & 192 & 166 & 185 & $\dagger$ & 24 & $\dagger$ & $\dagger$ & 7,424 \\
\hline 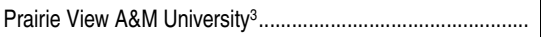 & $\mathrm{TX}$ & 1 & 8,425 & 8,336 & 6,920 & 7,414 & $\dagger$ & 1,026 & 445 & 17 & 178,198 \\
\hline Saint Philip's College & TX & 2 & 10,710 & 10,313 & 1,127 & 4,709 & 912 & $\dagger$ & $\dagger$ & $\dagger$ & 79,087 \\
\hline 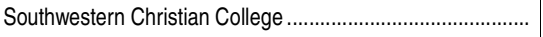 & $\mathrm{TX}$ & 3 & 216 & 206 & 182 & 199 & 40 & 5 & $\dagger$ & $\dagger$ & 6,119 \\
\hline 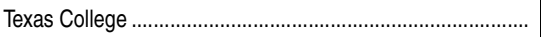 & $\mathrm{TX}$ & 3 & 878 & 845 & 734 & 838 & 20 & 87 & $\dagger$ & $\dagger$ & 11,830 \\
\hline Texas Southern University & TX & 1 & 9,730 & 9,646 & 7,918 & 8,449 & $\dagger$ & 774 & 326 & 291 & 212,207 \\
\hline 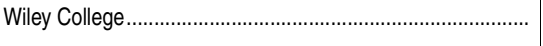 & $\mathrm{TX}$ & 3 & 1,356 & 1,401 & 1,198 & 1,345 & 2 & 175 & $\dagger$ & $\dagger$ & 23,956 \\
\hline Hampton University & VA & 3 & 5,221 & 4,765 & 4,191 & 4,630 & 0 & 830 & 144 & 79 & 161,283 \\
\hline Norfolk State University & VA & 1 & 7,091 & 7,100 & 6,226 & 6,219 & 77 & 813 & 261 & 5 & 151,097 \\
\hline Saint Paul's College & VA & 3 & 410 & 112 & 107 & 111 & $\dagger$ & 68 & $\dagger$ & $\dagger$ & 15,696 \\
\hline Virginia State University ${ }^{3}$ & VA & 1 & 5,890 & 6,208 & 5,789 & 5,698 & 21 & 836 & 135 & 3 & 144,686 \\
\hline Virginia Union University. & VA & 3 & 1,678 & 1,751 & 1,715 & 1,719 & $\dagger$ & 153 & 103 & 12 & 30,559 \\
\hline 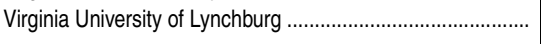 & VA & 3 & 597 & 540 & 529 & 388 & 29 & 18 & 8 & 7 & 9,797 \\
\hline 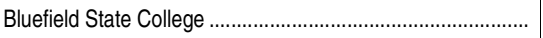 & WV & 1 & 1,929 & 1,935 & 199 & 1,725 & 93 & 239 & $\dagger$ & $\dagger$ & 25,252 \\
\hline West Virginia State University ............................................. & WV & 1 & 2,827 & 2,644 & 429 & 2,187 & $\dagger$ & 414 & 11 & $\dagger$ & 55,102 \\
\hline 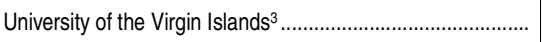 & $\mathrm{VI}$ & 1 & 2,614 & 2,423 & 1,996 & 1,850 & 73 & 237 & 53 & $\dagger$ & 88,683 \\
\hline
\end{tabular}

-Not available.

†Not applicable.

1 = public, 4 -year; 2 = public, 2 -year; 3 = private nonprofit, 4 -year; and 4 = private nonprofit,

2-year.

Includes Ph.D., Ed.D., and comparable degrees at the doctoral level, as well as such degrees as M.D., D.D.S., and law degrees that were formerly classified as first-professional degrees.

Land-grant institution.

Institution was not eligible for Title IV federal financial aid programs in 2011

NOTE: Degree-granting institutions grant associate's or higher degrees and participate in Title IV federal financial aid programs. Excludes historically Black colleges and universities that are not participating in Title IV programs. Historically Black colleges and universities are degree-granting institutions established prior to 1964 with the principal mission of educating Black Americans. Federal regulations, 20 U.S. Code, Section 1061 (2), allow for certain exceptions to the founding date. Totals include persons of other racial/ethnic groups not separately identified. Detail may not sum to totals because of rounding.

SOURCE: U.S. Department of Education, National Center for Education Statistics, Integrated Postsecondary Education Data System (IPEDS), Fall 2012, Completions component; Spring 2012 and Spring 2013, Enrollment component; and Spring 2013, Finance component. (This table was prepared May 2014.) 
Table 313.20. Fall enrollment in degree-granting historically Black colleges and universities, by sex of student and level and control of institution: Selected years, 1976 through 2012

\begin{tabular}{|c|c|c|c|c|c|c|c|c|c|c|c|}
\hline \multirow[b]{2}{*}{ Year } & \multirow{2}{*}{$\begin{array}{r}\text { Total } \\
\text { enrollment }\end{array}$} & \multirow[b]{2}{*}{ Males } & \multirow[b]{2}{*}{ Females } & \multirow[b]{2}{*}{ 4-year } & \multirow[b]{2}{*}{ 2-year } & \multicolumn{3}{|c|}{ Public } & \multicolumn{3}{|c|}{ Private } \\
\hline & & & & & & Total & 4-year & 2-year & Total & 4-year & 2-year \\
\hline \multirow[t]{2}{*}{1} & 2 & 3 & 4 & 5 & 6 & 7 & 8 & 9 & 10 & 11 & 12 \\
\hline & \multicolumn{11}{|c|}{ All students } \\
\hline $1976 .$. & 222,613 & 104,669 & 117,944 & 206,676 & 15,937 & 156,836 & 143,528 & 13,308 & 65,777 & 63,148 & 2,629 \\
\hline $1980 \ldots$ & 233,557 & 106,387 & 127,170 & 218,009 & 15,548 & 168,217 & 155,085 & 13,132 & 65,340 & 62,924 & 2,416 \\
\hline $1982 \ldots$ & 228,371 & 104,897 & 123,474 & 212,017 & 16,354 & 165,871 & 151,472 & 14,399 & 62,500 & 60,545 & 1,955 \\
\hline $1984 \ldots$ & 227,519 & 102,823 & 124,696 & 212,844 & 14,675 & 164,116 & 151,289 & 12,827 & 63,403 & 61,555 & 1,848 \\
\hline 1985 & 225,801 & 100,698 & 125,103 & 210,648 & 15,153 & 163,677 & 150,002 & 13,675 & 62,124 & 60,646 & 1,478 \\
\hline 1986. & 223,275 & 97,523 & 125,752 & 207,231 & 16,044 & 162,048 & 147,631 & 14,417 & 61,227 & 59,600 & 1,627 \\
\hline $1987 \ldots$ & 227,994 & 97,085 & 130,909 & 211,654 & 16,340 & 165,486 & 150,560 & 14,926 & 62,508 & 61,094 & 1,414 \\
\hline 1988 & 239,755 & 100,561 & 139,194 & 223,250 & 16,505 & 173,672 & 158,606 & 15,066 & 66,083 & 64,644 & 1,439 \\
\hline $1989 \ldots$ & 249,096 & 102,484 & 146,612 & 232,890 & 16,206 & 181,151 & 166,481 & 14,670 & 67,945 & 66,409 & 1,536 \\
\hline $1990 \ldots \ldots \ldots$ & 257,152 & 105,157 & 151,995 & 240,497 & 16,655 & 187,046 & 171,969 & 15,077 & 70,106 & 68,528 & 1,578 \\
\hline 1991. & 269,335 & 110,442 & 158,893 & 252,093 & 17,242 & 197,847 & 182,204 & 15,643 & 71,488 & 69,889 & 1,599 \\
\hline$\ldots \ldots \ldots \ldots \ldots \ldots \ldots \ldots \ldots \ldots$ & 279,541 & 114,622 & 164,919 & 261,089 & 18,452 & 204,966 & 188,143 & 16,823 & 74,575 & 72,946 & 1,629 \\
\hline 1993....................................... & 282,856 & 116,397 & 166,459 & 262,430 & 20,426 & 208,197 & 189,032 & 19,165 & 74,659 & 73,398 & 1,261 \\
\hline 1994 & 280,071 & 114,006 & 166,065 & 259,997 & 20,074 & 206,520 & 187,735 & 18,785 & 73,551 & 72,262 & 1,289 \\
\hline 1995 & 278,725 & 112,637 & 166,088 & 259,409 & 19,316 & 204,726 & 186,278 & 18,448 & 73,999 & 73,131 & 868 \\
\hline $1996 .$. & 273,018 & 109,498 & 163,520 & 253,654 & 19,364 & 200,569 & 182,063 & 18,506 & 72,449 & 71,591 & 858 \\
\hline $1997 \ldots$ & 269,167 & 106,865 & 162,302 & 248,860 & 20,307 & 194,674 & 175,297 & 19,377 & 74,493 & 73,563 & 930 \\
\hline $1998 \ldots$ & 273,472 & 108,752 & 164,720 & 248,931 & 24,541 & 198,603 & 174,776 & 23,827 & 74,869 & 74,155 & 714 \\
\hline $1999 \ldots$ & 274,321 & 108,301 & 166,020 & 249,156 & 25,165 & 199,826 & 175,364 & 24,462 & 74,495 & 73,792 & 703 \\
\hline $2000 \ldots \ldots \ldots \ldots \ldots \ldots \ldots$ & 275,680 & 108,164 & 167,516 & 250,710 & 24,970 & 199,725 & 175,404 & 24,321 & 75,955 & 75,306 & 649 \\
\hline $2001 .$. & 289,985 & 112,874 & 177,111 & 260,547 & 29,438 & 210,083 & 181,346 & 28,737 & 79,902 & 79,201 & 701 \\
\hline $2002 \ldots$ & 299,041 & 115,466 & 183,575 & 269,020 & 30,021 & 218,433 & 189,183 & 29,250 & 80,608 & 79,837 & 771 \\
\hline 2003 & 306,727 & 117,795 & 188,932 & 274,326 & 32,401 & 228,096 & 196,077 & 32,019 & 78,631 & 78,249 & 382 \\
\hline$\ldots$ & 308,939 & 118,129 & 190,810 & 276,136 & 32,803 & 231,179 & 198,810 & 32,369 & 77,760 & 77,326 & 434 \\
\hline $2005 \ldots$ & 311,768 & 120,023 & 191,745 & 272,666 & 39,102 & 235,875 & 197,200 & 38,675 & 75,893 & 75,466 & 427 \\
\hline 2006. & 308,774 & 118,865 & 189,909 & 272,770 & 36,004 & 234,505 & 198,676 & 35,829 & 74,269 & 74,094 & 175 \\
\hline $2007 .$. & 306,515 & 118,640 & 187,875 & 270,915 & 35,600 & 233,807 & 198,300 & 35,507 & 72,708 & 72,615 & 93 \\
\hline $2008 \ldots$ & 313,491 & 121,873 & 191,618 & 274,568 & 38,923 & 235,824 & 197,025 & 38,799 & 77,667 & 77,543 & 124 \\
\hline ……………...... & 322,789 & 125,666 & 197,123 & 280,062 & 42,727 & 246,595 & 204,016 & 42,579 & 76,194 & 76,046 & 148 \\
\hline $2010 \ldots . .$. & 326,614 & 127,437 & 199,177 & 283,099 & 43,515 & 249,146 & 205,774 & 43,372 & 77,468 & 77,325 & 143 \\
\hline $2011 \ldots \ldots \ldots \ldots \ldots \ldots \ldots$ & 323,616 & 126,145 & 197,471 & 281,118 & 42,498 & 246,653 & 204,331 & 42,322 & 76,963 & 76,787 & 176 \\
\hline 2012 & 312,438 & 121,722 & 190,716 & 273,033 & 39,405 & 237,782 & 198,568 & 39,214 & 74,656 & 74,465 & 191 \\
\hline & & & & & & r students & & & & & \\
\hline $1976 \ldots$ & 190,305 & 84,492 & 105,813 & \begin{tabular}{|l|}
179,848 \\
\end{tabular} & 10,457 & 129,770 & 121,851 & 7,919 & 60,535 & 57,997 & 2,538 \\
\hline $1980 \ldots$ & 190,989 & 81,818 & 109,171 & 181,237 & 9,752 & 131,661 & 124,236 & 7,425 & 59,328 & 57,001 & 2,327 \\
\hline $1982 \ldots$ & 182,639 & 78,874 & 103,765 & 171,942 & 10,697 & 126,368 & 117,562 & 8,806 & 56,271 & 54,380 & 1,891 \\
\hline $1984 \ldots$ & 180,803 & 76,819 & 103,984 & 171,401 & 9,402 & 124,445 & 116,845 & 7,600 & 56,358 & 54,556 & 1,802 \\
\hline $1986 \ldots$ & 178,628 & 74,276 & 104,352 & 167,971 & 10,657 & 123,555 & 114,502 & 9,053 & 55,073 & 53,469 & 1,604 \\
\hline 1988 & 194,151 & 78,268 & 115,883 & 183,402 & 10,749 & 133,786 & 124,438 & 9,348 & 60,365 & 58,964 & 1,401 \\
\hline 1990. & 208,682 & 82,897 & 125,785 & 198,237 & 10,445 & 144,204 & 134,924 & 9,280 & 64,478 & 63,313 & 1,165 \\
\hline $1991 \ldots$ & 218,366 & 87,380 & 130,986 & 207,449 & 10,917 & 152,864 & 143,411 & 9,453 & 65,502 & 64,038 & 1,464 \\
\hline $1992 .$. & 228,963 & 91,949 & 137,014 & 217,614 & 11,349 & 159,585 & 149,754 & 9,831 & 69,378 & 67,860 & 1,518 \\
\hline 1993.. & 231,198 & 93,110 & 138,088 & 219,431 & 11,767 & 161,444 & 150,867 & 10,577 & 69,754 & 68,564 & 1,190 \\
\hline 1994. & 230,162 & 91,908 & 138,254 & 218,565 & 11,597 & 161,098 & 150,682 & 10,416 & 69,064 & 67,883 & 1,181 \\
\hline 1995. & 229,418 & 91,132 & 138,286 & 218,379 & 11,039 & 159,925 & 149,661 & 10,264 & 69,493 & 68,718 & 775 \\
\hline ........... & 224,201 & 88,306 & 135,895 & 213,309 & 10,892 & 156,851 & 146,753 & 10,098 & 67,350 & 66,556 & 794 \\
\hline $1997 .$. & 222,331 & 86,641 & 135,690 & 210,741 & 11,590 & 153,039 & 142,326 & 10,713 & 69,292 & 68,415 & 877 \\
\hline 1998. & 223,745 & 87,163 & 136,582 & 211,822 & 11,923 & 154,244 & 142,985 & 11,259 & 69,501 & 68,837 & 664 \\
\hline 1990 & 226,592 & 87,987 & 138,605 & 213,779 & 12,813 & 156,292 & 144,166 & 12,126 & 70,300 & 69,613 & 687 \\
\hline 2000. & 227,239 & 87,319 & 139,920 & 215,172 & 12,067 & 156,706 & 145,277 & 11,429 & 70,533 & 69,895 & 638 \\
\hline 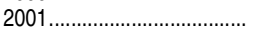 & 238,638 & 90,718 & 147,920 & 224,417 & 14,221 & 164,354 & 150,831 & 13,523 & 74,284 & 73,586 & 698 \\
\hline 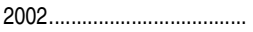 & 247,292 & 93,538 & 153,754 & 231,834 & 15,458 & 172,203 & 157,507 & 14,696 & 75,089 & 74,327 & 762 \\
\hline $2003 \ldots$ & 253,257 & 95,703 & 157,554 & 236,753 & 16,504 & 180,104 & 163,977 & 16,127 & 73,153 & 72,776 & 377 \\
\hline$\ldots \ldots \ldots \ldots$ & 257,545 & 96,750 & 160,795 & 241,030 & 16,515 & 184,708 & 168,619 & 16,089 & 72,837 & 72,411 & 426 \\
\hline $2005 \ldots$ & 256,584 & 96,891 & 159,693 & 238,030 & 18,554 & 186,047 & 167,916 & 18,131 & 70,537 & 70,114 & 423 \\
\hline ..................... & 255,150 & 96,508 & 158,642 & 238,446 & 16,704 & 185,894 & 169,365 & 16,529 & 69,256 & 69,081 & 175 \\
\hline ............. & 253,415 & 96,313 & 157,102 & 236,885 & 16,530 & 185,344 & 168,906 & 16,438 & 68,071 & 67,979 & 92 \\
\hline $2008 \ldots . .$. & 258,403 & 98,634 & 159,769 & 240,133 & 18,270 & 186,446 & 168,299 & 18,147 & 71,957 & 71,834 & 123 \\
\hline $2009 .$. & 264,090 & 100,550 & 163,540 & 243,954 & 20,136 & 194,088 & 174,099 & 19,989 & 70,002 & 69,855 & 147 \\
\hline $2010 \ldots$ & 265,911 & 101,644 & 164,267 & 245,163 & 20,748 & 193,843 & 173,238 & 20,605 & 72,068 & 71,925 & 143 \\
\hline - & 263,414 & 100,516 & 162,898 & 242,860 & 20,554 & 192,014 & 171,636 & 20,378 & 71,400 & 71,224 & 176 \\
\hline $2012 \ldots$ & 251,530 & 96,084 & 155,446 & 232,900 & 18,630 & 183,019 & 164,579 & 18,440 & 68,511 & 68,321 & 190 \\
\hline
\end{tabular}

NOTE: Historically Black colleges and universities are degree-granting institutions established prior to 1964 with the principal mission of educating Black Americans. Federal regulations, 20 U.S. Code, Section 1061 (2), allow for certain exceptions to the founding date. Data through 1995 are for institutions of higher education, while later data are for degreegranting institutions. Degree-granting institutions grant associate's or higher degrees and participate in Title IV federal financial aid programs. The degree-granting classification is very similar to the earlier higher education classification, but it includes more 2-year colleges and excludes a few higher education institutions that did not grant degrees.

SOURCE: U.S. Department of Education, National Center for Education Statistics, Highe Education General Information Survey (HEGIS), "Fall Enrollment in Colleges and Universities," 1976 through 1985 surveys; Integrated Postsecondary Education Data System (IPEDS), "Fall Enrollment Survey" (IPEDS-EF:86-99); and IPEDS Spring 2001 through Spring 2013, Enrollment component. (This table was prepared May 2014.) 
CHAPTER 3: Postsecondary Education 493 Historically Black Colleges and Universities

Table 313.30. Selected statistics on degree-granting historically Black colleges and universities, by control and level of institution: Selected years, 1990 through 2012

\begin{tabular}{|c|c|c|c|c|c|c|c|}
\hline \multirow[b]{2}{*}{ Selected statistics } & \multirow[b]{2}{*}{ Total } & \multicolumn{3}{|c|}{ Public } & \multicolumn{3}{|c|}{ Private } \\
\hline & & Total & 4-year & 2-year & Total & 4-year & 2-year \\
\hline 1 & 2 & 3 & 4 & 5 & 6 & 7 & 8 \\
\hline 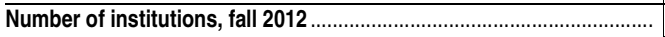 & 101 & 51 & 40 & 11 & 50 & 48 & 2 \\
\hline 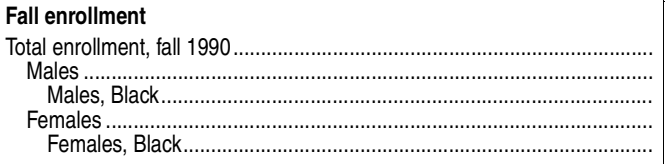 & $\begin{array}{r}257,152 \\
105,157 \\
82,897 \\
151,995 \\
125,785\end{array}$ & $\begin{array}{r}187,046 \\
76,541 \\
57,255 \\
110,505 \\
86,949\end{array}$ & $\begin{array}{r}171,969 \\
70,220 \\
54,041 \\
101,749 \\
80,883\end{array}$ & $\begin{array}{r}15,077 \\
6,321 \\
3,214 \\
8,756 \\
6,066\end{array}$ & $\begin{array}{l}70,106 \\
28,616 \\
25,642 \\
41,490 \\
38,836\end{array}$ & $\begin{array}{l}68,528 \\
28,054 \\
25,198 \\
40,474 \\
38,115\end{array}$ & $\begin{array}{r}1,578 \\
562 \\
444 \\
1,016 \\
721\end{array}$ \\
\hline 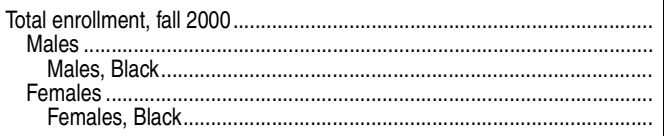 & $\begin{array}{r}275,680 \\
108,164 \\
87,319 \\
167,516 \\
139,920\end{array}$ & $\begin{array}{r}199,725 \\
78,186 \\
60,029 \\
121,539 \\
96,677\end{array}$ & $\begin{array}{r}175,404 \\
68,322 \\
56,017 \\
107,082 \\
89,260\end{array}$ & $\begin{array}{r}24,321 \\
9,864 \\
4,012 \\
14,457 \\
7,417\end{array}$ & $\begin{array}{l}75,955 \\
29,978 \\
27,290 \\
45,977 \\
43,243\end{array}$ & $\begin{array}{l}75,306 \\
29,771 \\
27,085 \\
45,535 \\
42,810\end{array}$ & $\begin{array}{l}649 \\
207 \\
205 \\
442 \\
433\end{array}$ \\
\hline 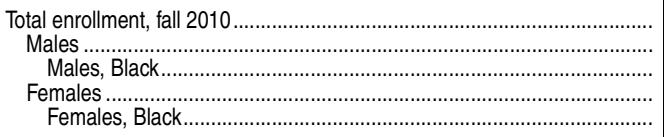 & $\begin{array}{l}326,614 \\
127,437 \\
101,644 \\
199,177 \\
164,267\end{array}$ & $\begin{array}{r}249,146 \\
95,883 \\
72,668 \\
153,263 \\
121,175\end{array}$ & $\begin{array}{r}205,774 \\
78,528 \\
65,552 \\
127,246 \\
107,686\end{array}$ & $\begin{array}{r}43,372 \\
17,355 \\
7,116 \\
26,017 \\
13,489\end{array}$ & $\begin{array}{l}77,468 \\
31,554 \\
28,976 \\
45,914 \\
43,092\end{array}$ & $\begin{array}{l}77,325 \\
31,482 \\
28,904 \\
45,843 \\
43,021\end{array}$ & $\begin{array}{r}143 \\
72 \\
72 \\
71 \\
71\end{array}$ \\
\hline 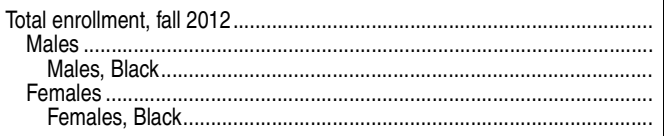 & $\begin{array}{r}312,438 \\
121,722 \\
96,084 \\
190,716 \\
155,446\end{array}$ & $\begin{array}{r}237,782 \\
90,928 \\
68,207 \\
146,854 \\
114,812\end{array}$ & $\begin{array}{r}198,568 \\
75,191 \\
61,571 \\
123,377 \\
103,008\end{array}$ & $\begin{array}{r}39,214 \\
15,737 \\
6,636 \\
23,477 \\
11,804\end{array}$ & $\begin{array}{l}74,656 \\
30,794 \\
27,877 \\
43,862 \\
40,634\end{array}$ & $\begin{array}{l}74,465 \\
30,690 \\
27,773 \\
43,775 \\
40,548\end{array}$ & $\begin{array}{r}191 \\
104 \\
104 \\
87 \\
86\end{array}$ \\
\hline 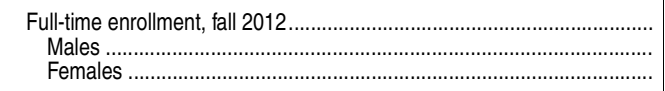 & $\begin{array}{r}245,872 \\
98,626 \\
148,837\end{array}$ & $\begin{array}{r}176,792 \\
70,192 \\
106,600\end{array}$ & $\begin{array}{r}157,476 \\
62,075 \\
95,401\end{array}$ & $\begin{array}{r}19,316 \\
8,117 \\
11,199\end{array}$ & $\begin{array}{l}69,080 \\
28,434 \\
42,237\end{array}$ & $\begin{array}{l}68,894 \\
28,333 \\
40,561\end{array}$ & $\begin{array}{r}186 \\
101 \\
85\end{array}$ \\
\hline 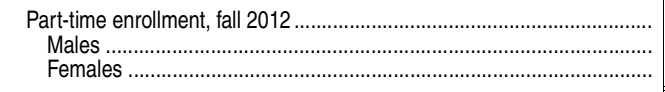 & $\begin{array}{l}66,566 \\
23,096 \\
43,470 \\
\end{array}$ & $\begin{array}{l}60,990 \\
20,736 \\
40,254 \\
\end{array}$ & $\begin{array}{l}41,092 \\
13,116 \\
27,976 \\
\end{array}$ & $\begin{array}{r}19,898 \\
7,620 \\
12,278 \\
\end{array}$ & $\begin{array}{l}5,576 \\
2,360 \\
3,216 \\
\end{array}$ & $\begin{array}{l}5,571 \\
2,357 \\
3,214 \\
\end{array}$ & $\begin{array}{l}5 \\
3 \\
2 \\
\end{array}$ \\
\hline Earned degrees conferred, 2011-12 & & & & & & & \\
\hline 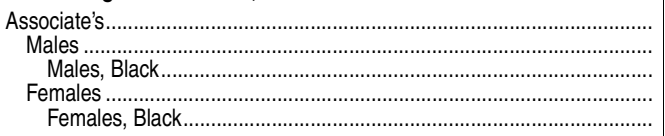 & $\begin{array}{r}4,631 \\
1,579 \\
625 \\
3,052 \\
1,651\end{array}$ & $\begin{array}{r}4,393 \\
1,460 \\
526 \\
2,933 \\
1,538\end{array}$ & $\begin{array}{r}840 \\
190 \\
99 \\
650 \\
334\end{array}$ & $\begin{array}{r}3,553 \\
1,270 \\
427 \\
2,283 \\
1,204\end{array}$ & $\begin{array}{r}238 \\
119 \\
99 \\
119 \\
113\end{array}$ & $\begin{array}{r}183 \\
95 \\
75 \\
88 \\
82\end{array}$ & $\begin{array}{l}55 \\
24 \\
24 \\
31 \\
31\end{array}$ \\
\hline 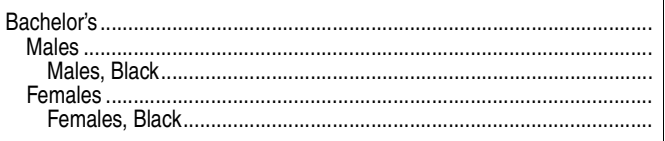 & $\begin{array}{r}34,013 \\
11,780 \\
9,833 \\
22,233 \\
19,123\end{array}$ & $\begin{array}{r}24,045 \\
8,406 \\
6,759 \\
15,639 \\
12,914\end{array}$ & $\begin{array}{r}24,045 \\
8,406 \\
6,759 \\
15,639 \\
12,914\end{array}$ & $\begin{array}{l}t \\
t \\
t \\
t \\
t\end{array}$ & $\begin{array}{l}9,968 \\
3,374 \\
3,074 \\
6,594 \\
6,209\end{array}$ & $\begin{array}{l}9,968 \\
3,374 \\
3,074 \\
6,594 \\
6,209\end{array}$ & $\begin{array}{l}\dagger \\
\dagger \\
\dagger \\
\dagger \\
\dagger\end{array}$ \\
\hline 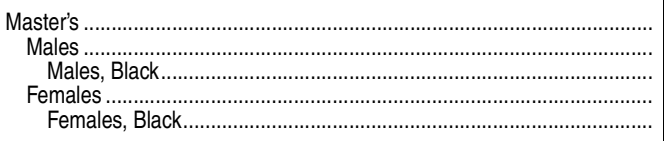 & $\begin{array}{l}7,654 \\
2,332 \\
1,576 \\
5,322 \\
3,948\end{array}$ & $\begin{array}{l}6,518 \\
1,976 \\
1,285 \\
4,542 \\
3,278\end{array}$ & $\begin{array}{l}6,518 \\
1,976 \\
1,285 \\
4,542 \\
3,278\end{array}$ & $\begin{array}{l}t \\
t \\
t \\
t \\
t\end{array}$ & $\begin{array}{r}1,136 \\
356 \\
291 \\
780 \\
670\end{array}$ & $\begin{array}{r}1,136 \\
356 \\
291 \\
780 \\
670\end{array}$ & $\begin{array}{l}\dagger \\
\dagger \\
\dagger \\
\dagger \\
\dagger\end{array}$ \\
\hline 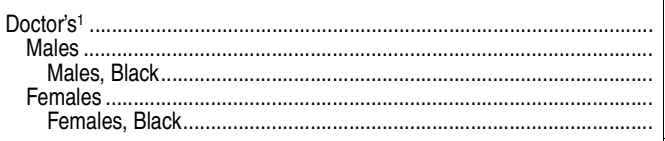 & $\begin{array}{r}2,285 \\
913 \\
524 \\
1,372 \\
944\end{array}$ & $\begin{array}{r}1,214 \\
499 \\
226 \\
715 \\
442\end{array}$ & $\begin{array}{r}1,214 \\
499 \\
226 \\
715 \\
442\end{array}$ & $\begin{array}{l}t \\
t \\
t \\
t \\
t\end{array}$ & $\begin{array}{r}1,071 \\
414 \\
298 \\
657 \\
502\end{array}$ & $\begin{array}{r}1,071 \\
414 \\
298 \\
657 \\
502\end{array}$ & $\begin{array}{l}\dagger \\
\dagger \\
\dagger \\
\dagger \\
\dagger\end{array}$ \\
\hline Financial statistics, $2011-12^{2}$ & \multicolumn{7}{|c|}{ In thousands of current dollars } \\
\hline 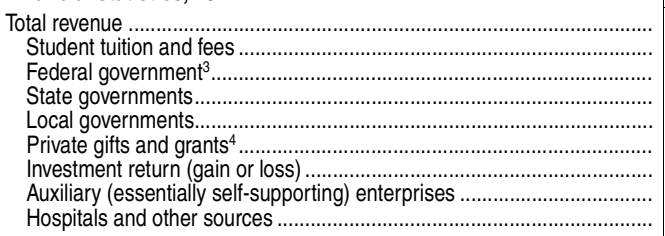 & $\begin{array}{r}\$ 7,885,680 \\
1,798,213 \\
2,282,322 \\
1,894,960 \\
110,642 \\
351,507 \\
-83,271 \\
860,291 \\
671,017\end{array}$ & \begin{tabular}{r|}
$\$ 5,208,919$ \\
943,209 \\
$1,415,372$ \\
$1,825,546$ \\
91,996 \\
105,272 \\
31,446 \\
525,576 \\
270,503
\end{tabular} & \begin{tabular}{r|}
$\$ 4,802,727$ \\
895,296 \\
$1,231,672$ \\
$1,697,442$ \\
62,872 \\
104,897 \\
30,893 \\
518,338 \\
261,317
\end{tabular} & \begin{tabular}{r|}
$\$ 406,193$ \\
47,913 \\
183,701 \\
128,103 \\
29,124 \\
375 \\
553 \\
7,238 \\
9,185
\end{tabular} & $\begin{array}{r}\$ 2,676,760 \\
855,004 \\
866,949 \\
69,415 \\
18,646 \\
246,235 \\
-114,717 \\
334,714 \\
400,514\end{array}$ & \begin{tabular}{r|}
$2,672,510$ \\
854,508 \\
865,503 \\
69,415 \\
18,646 \\
244,841 \\
$-114,729$ \\
333,812 \\
400,514
\end{tabular} & $\begin{array}{r}\$ 4,250 \\
496 \\
1,446 \\
0 \\
0 \\
1,394 \\
12 \\
902 \\
0\end{array}$ \\
\hline 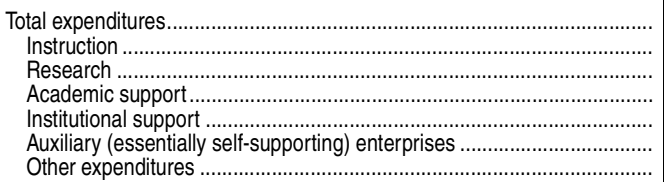 & $\begin{array}{r}7,734,318 \\
1,958,551 \\
463,800 \\
522,044 \\
1,132,392 \\
746,153 \\
2,911,377\end{array}$ & $\begin{array}{r}4,963,760 \\
1,347,622 \\
309,023 \\
372,900 \\
628,204 \\
546,358 \\
1,759,652\end{array}$ & $\begin{array}{r}4,589,134 \\
1,224,585 \\
308,522 \\
346,405 \\
578,169 \\
536,091 \\
1,595,363\end{array}$ & $\begin{array}{r}374,626 \\
123,037 \\
502 \\
26,495 \\
50,036 \\
10,267 \\
164,289\end{array}$ & $\begin{array}{r}2,770,558 \\
610,929 \\
154,777 \\
149,145 \\
504,188 \\
199,795 \\
1,151,725\end{array}$ & $\begin{array}{r}2,766,473 \\
609,700 \\
154,708 \\
149,145 \\
503,287 \\
199,715 \\
1,149,918\end{array}$ & $\begin{array}{r}4,086 \\
1,229 \\
68 \\
0 \\
901 \\
80 \\
1,807\end{array}$ \\
\hline
\end{tabular}

†Not applicable.

1'Includes Ph.D., Ed.D., and comparable degrees at the doctoral level, as well as such degrees as M.D., D.D.S., and law degrees that were formerly classified as first-professional degrees.

${ }^{2}$ Totals (column 2) of public and private institutions together are approximate because public and private nonprofit institutions fill out different survey forms with different accounting concepts.

${ }^{3}$ Includes independent operations.

${ }^{4}$ Includes contributions from affiliated entities.

NOTE: Degree-granting institutions grant associate's or higher degrees and participate in

Title IV federal financial aid programs. Historically Black colleges and universities are degree-granting institutions established prior to 1964 with the principal mission of educating Black Americans. Federal regulations, 20 U.S. Code, Section 1061 (2), allow for certain exceptions to the founding date. Federal, state, and local governments revenue includes appropriations, grants, and contracts. Totals include persons of other racial/ethnic groups not separately identified. Detail may not sum to totals because of rounding.

SOURCE: U.S. Department of Education, National Center for Education Statistics, Integrated Postsecondary Education Data System (IPEDS), "Fall Enrollment Survey" (IPEDS-EF:90); IPEDS Spring 2001, Spring 2011, and Spring 2013, Enrollment component; IPEDS Spring 2013, Finance component; and IPEDS Fall 2012, Completions component. (This table was prepared May 2014.) 
Table 314.10. Total and full-time-equivalent (FTE) staff and FTE student/FTE staff ratios in postsecondary institutions participating in Title IV programs, by degree-granting status, control of institution, and primary occupation: Fall 1991, fall 2001, and fall 2011

\begin{tabular}{|c|c|c|c|c|c|c|c|c|c|c|c|c|}
\hline \multirow[b]{3}{*}{$\begin{array}{l}\text { Degree-granting status, control of institution, and } \\
\text { primary occupation }\end{array}$} & \multicolumn{4}{|c|}{ Fall 1991} & \multicolumn{4}{|c|}{ Fall 2001} & \multicolumn{4}{|c|}{ Fall 2011} \\
\hline & \multicolumn{2}{|c|}{ Total } & \multicolumn{2}{|c|}{$\begin{array}{l}\text { Full-time-equivalent } \\
\text { (FTE) }\end{array}$} & \multicolumn{2}{|c|}{ Total } & \multicolumn{2}{|c|}{$\begin{array}{l}\text { Full-time-equivalent } \\
\text { (FTE) }\end{array}$} & \multicolumn{2}{|c|}{ Total } & \multicolumn{2}{|c|}{$\begin{array}{l}\text { Full-time-equivalent } \\
\text { (FTE) }\end{array}$} \\
\hline & Number & Percent & Total & $\begin{array}{r}\mathrm{FTE} \\
\text { students } \\
\text { per } \\
\text { FTE staff }\end{array}$ & Number & Percent & Total & $\begin{array}{r}\mathrm{FTE} \\
\text { students } \\
\text { per } \\
\text { FTE staff }\end{array}$ & Number & Percent & Total & $\begin{array}{r}\mathrm{FTE} \\
\text { students } \\
\text { per } \\
\text { FTE staff }\end{array}$ \\
\hline 1 & 2 & 3 & 4 & 5 & 6 & 7 & 8 & 9 & 10 & 11 & 12 & $\overline{13}$ \\
\hline All postsecondary institutions.. & $2,591,896$ & 100.0 & $2,131,463$ & 4.9 & $3,134,008$ & 100.0 & $2,476,887$ & 4.9 & $3,920,836$ & 100.0 & $3,024,572$ & 5.4 \\
\hline Professional staff.. & \begin{tabular}{|l|}
$1,633,066$ \\
\end{tabular} & 63.0 & $1,273,795$ & 8.1 & $2,170,237$ & 69.2 & $1,628,322$ & 7.4 & $2,986,568$ & 76.2 & $2,196,507$ & 7.5 \\
\hline Executive/administrative/managerial... & 149,630 & 5.8 & 146,460 & 70.7 & 156,088 & 5.0 & 153,008 & 79.1 & 248,982 & 6.4 & 244,773 & 66.9 \\
\hline Faculty (instruction/research/public service)...... & 853,687 & 32.9 & 652,252 & 15.9 & $1,138,734$ & 36.3 & 800,870 & 15.1 & $1,565,504$ & 39.9 & $1,046,421$ & 15.6 \\
\hline Graduate assistants.................. & 197,813 & 7.6 & 81,495 & 127.1 & 261,261 & 8.3 & 107,999 & 112.1 & 355,916 & 9.1 & 147,617 & 110.9 \\
\hline Other professionals........ & 431,936 & 16.7 & 393,589 & 26.3 & 614,154 & 19.6 & 566,446 & 21.4 & 816,166 & 20.8 & 757,696 & 21.6 \\
\hline Nonprofessional sta & 958,830 & 37.0 & 857,668 & 12.1 & 963,771 & 30.8 & 848,565 & 14.3 & 934,268 & 23.8 & 828,065 & 19.8 \\
\hline Degree-granting institutions ${ }^{1}$ & & & & & & & & & & & & \\
\hline Total & $2,545,235$ & 100.0 & $2,094,628$ & 4.9 & $3,083,353$ & 100.0 & $2,436,473$ & 4.8 & $3,840,980$ & 100.0 & $2,961,224$ & 5.4 \\
\hline Professional staff ... & \begin{tabular}{|l|}
$1,595,460$ \\
\end{tabular} & 62.7 & $1,244,588$ & 8.3 & $2,132,150$ & 69.2 & $1,598,710$ & 7.4 & $2,923,961$ & 76.1 & $2,147,560$ & 7.4 \\
\hline Executive/administrative/managerial... & 144,755 & 5.7 & 141,718 & 73.1 & 152,038 & 4.9 & 149,051 & 78.9 & 238,718 & 6.2 & 234,895 & 67.6 \\
\hline Faculty (instruction/research/public service)...... & 826,252 & 32.5 & 632,565 & 16.4 & $1,113,183$ & 36.1 & 783,036 & 15.0 & $1,523,615$ & 39.7 & $1,017,020$ & 15.6 \\
\hline Graduate assistants ......................... & 197,751 & 7.8 & 81,467 & 127.2 & 261,136 & 8.5 & 107,943 & 109.0 & 355,916 & 9.3 & 147,617 & 107.6 \\
\hline Other prof & 426,702 & 16.8 & 388,838 & 26.6 & 605,793 & 19.6 & 558,680 & 21.1 & 805,712 & 21.0 & 748,028 & 21.2 \\
\hline Nonprofessional staff & 949,775 & 37.3 & 850,040 & 12.2 & 951,203 & 30.8 & 837,763 & 14.0 & 917,019 & 23.9 & 813,664 & 19.5 \\
\hline Public.. & $1,783,328$ & 100.0 & $1,449,398$ & 5.4 & $2,136,970$ & 100.0 & $1,660,294$ & 5.2 & $2,484,820$ & 100.0 & $1,891,866$ & 5.8 \\
\hline Professional staff ................................. & \begin{tabular}{|l|}
$1,133,264$ \\
\end{tabular} & 63.5 & 868,112 & 9.1 & $1,477,953$ & 69.2 & $1,083,384$ & 8.0 & $1,865,269$ & 75.1 & $1,348,674$ & 8.1 \\
\hline Executive/administrative/managerial............... & 84,446 & 4.7 & 82,835 & 94.9 & 82,811 & 3.9 & 80,942 & 106.7 & 112,473 & 4.5 & 110,609 & 99.0 \\
\hline Faculty (instruction/research/public service).. & 580,908 & 32.6 & 446,113 & 17.6 & 771,124 & 36.1 & 539,581 & 16.0 & 953,230 & 38.4 & 645,542 & 17.0 \\
\hline Graduate assistants ....... & 173,560 & 9.7 & 70,707 & 111.2 & 219,475 & 10.3 & 89,412 & 96.6 & 285,905 & 11.5 & 116,475 & 94.0 \\
\hline Other $p$ & 294,350 & 16.5 & 268,458 & 29.3 & 404,543 & 18.9 & 373,449 & 23.1 & 513,661 & 20.7 & 76,047 & 23.0 \\
\hline Nonprofessional staff... & 650,064 & 36.5 & 581,286 & 13.5 & 659,017 & 30.8 & 576,910 & 15.0 & 619,551 & 24.9 & 543,192 & 20.2 \\
\hline $\mathbf{P}$ & 742,924 & 100.0 & 630,445 & 3.6 & 880,586 & 100.0 & 728,910 & 3.6 & $1,118,046$ & 100.0 & 908,455 & 3.7 \\
\hline Professional staff ............................. & 447,795 & 60.3 & 365,487 & 6.3 & 598,857 & 68.0 & 477,076 & 5.6 & 843,740 & 75.5 & 658,560 & 5.0 \\
\hline Executive/administrative/managerial.. & 58,023 & 7.8 & 56,634 & 40.5 & 63,749 & 7.2 & 62,671 & 42.3 & 104,010 & 9.3 & 102,228 & 32.5 \\
\hline Faculty (instruction/research/public service).. & 236,066 & 31.8 & 180,348 & 12.7 & 306,487 & 34.8 & 223,400 & 11.9 & 432,733 & 38.7 & 306,604 & 10.8 \\
\hline Graduate assistants .......................................... & 24,054 & 3.2 & 10,700 & 214.6 & 39,954 & 4.5 & 17,772 & 149.3 & 69,376 & 6.2 & 30,859 & 107.6 \\
\hline Other professionals .............. & 129,652 & 17.5 & 117,805 & 19.5 & 188,667 & 21.4 & 173,233 & 15.3 & 237,621 & 21.3 & 218,868 & 15.2 \\
\hline Nonprofessional staff ........................................ & 295,129 & 39.7 & 264,958 & 8.7 & 281,729 & 32.0 & 251,834 & 10.5 & 274,306 & 24.5 & 249,895 & 13.3 \\
\hline Privat & 18,983 & 100.0 & 14,786 & 13.6 & 65,797 & 100.0 & 47,270 & 10.0 & 238,114 & 100.0 & 160,903 & 10.0 \\
\hline Professional staff ... & 14,401 & 75.9 & 10,989 & 18.4 & 55,340 & 84.1 & 38,251 & 12.4 & 214,952 & 90.3 & 140,326 & 11.5 \\
\hline Executive/administrative/man & 2,286 & 12.0 & 2,249 & 89.7 & 5,478 & 8.3 & 5,438 & 87.0 & 22,235 & 9.3 & 22,057 & 73.3 \\
\hline Faculty (instruction/research/public service).. & 9,278 & 48.9 & 6,104 & 33.1 & 35,572 & 54.1 & 20,055 & 23.6 & 137,652 & 57.8 & 64,873 & 24.9 \\
\hline Graduate assistants .......................................... & 137 & 0.7 & 61 & $3,310.7$ & 1,707 & 2.6 & 759 & 622.8 & 635 & 0.3 & 282 & $5,721.9$ \\
\hline Other professionals... & 2,700 & 14.2 & 2,575 & 78.4 & 12,583 & 19.1 & 11,998 & 39.4 & 54,430 & 22.9 & 53,113 & 30.4 \\
\hline Nonprofessional staff ......................................... & 4,582 & 24.1 & 3,797 & 53.1 & 10,457 & 15.9 & 9,019 & 52.4 & 23,162 & 9.7 & 20,577 & 78.5 \\
\hline Non-degree- & & & & & & & & & & & & \\
\hline & 46,661 & 100.0 & 36,834 & 8.2 & 50,655 & 100.0 & 40,414 & 8.3 & 79,856 & 100.0 & 63,348 & 7.6 \\
\hline Professional staff. & 37,606 & 80.6 & 29,207 & 10.4 & 38,087 & 75.2 & 29,611 & 11.4 & 62,607 & 78.4 & 48,947 & 9.8 \\
\hline Executive/admini & 4,875 & 10.4 & 4,742 & 63.8 & 4,050 & 8.0 & 3,957 & 85.2 & 10,264 & 12.9 & 9,878 & 48.8 \\
\hline Faculty (instruction/research/public service)...... & 27,435 & 58.8 & 19,687 & 15.4 & 25,551 & 50.4 & 17,834 & 18.9 & 41,889 & 52.5 & 29,401 & 16.4 \\
\hline Graduate assistants............... & 62 & 0.1 & 28 & $10,964.2$ & 125 & 0.2 & 55 & $6,098.1$ & 0 & 0.0 & 0 & $\dagger$ \\
\hline & 5,234 & 11.2 & 4,750 & 63.7 & 8,361 & 16.5 & 7,765 & 43.4 & 10,454 & 13.1 & 9,668 & 49.9 \\
\hline Nonprofessional staff... & 9,055 & 19.4 & 7,627 & 39.6 & 12,568 & 24.8 & 10,802 & 31.2 & 17,249 & 21.6 & 14,400 & 33.5 \\
\hline
\end{tabular}

†Not applicable.

'Data for 1991 are for institutions of higher education, while later data are for degree-granting institutions. Degree-granting institutions grant associate's or higher degrees and participate in Title IV federal financial aid programs. The degree-granting classification is very similar to the earlier higher education classification, but it includes more 2-year colleges and excludes a few higher education institutions that did not grant degrees.

${ }^{2}$ Data are for institutions that did not offer accredited 4-year or 2-year degree programs, but were participating in Title IV federal financial aid programs. Includes some institutions transitioning to higher level program offerings, though still classified at a lower level.
NOTE: Full-time-equivalent staff is the full-time staff, plus the full-time equivalent of the parttime staff. Beginning in 2011, includes institutions with fewer than 15 full-time employees; these institutions did not report staff data prior to 2007. By definition, all graduate assistants are part time. Detail may not sum to totals because of rounding

SOURCE: U.S. Department of Education, National Center for Education Statistics, Integrated Postsecondary Education Data System (IPEDS), "Fall Enrollment Survey" (IPEDS-EF:91) and "Fall Staff Survey" (IPEDS-S:91); IPEDS Spring 2001 and 2012, Enrollment component; and IPEDS Winter 2001-02 and 2011-12, Human Resources component, Fall Staff section. (This table was prepared January 2013.) 
Table 314.20. Employees in degree-granting postsecondary institutions, by sex, employment status, control and level of institution, and primary occupation: Selected years, fall 1991 through fall 2011

\begin{tabular}{|c|c|c|c|c|c|c|c|c|c|c|c|c|}
\hline $\begin{array}{l}\text { Sex, employment status, control and level of } \\
\text { institution, and primary occupation }\end{array}$ & 1991 & 1993 & 1995 & 1997 & 1999 & 2001 & 2003 & 2005 & 2007 & 2009 & 2011 & $\begin{array}{r}\text { Percent } \\
\text { change, } \\
2001 \text { to } \\
2011\end{array}$ \\
\hline 1 & 2 & 3 & 4 & 5 & 6 & 7 & 8 & 9 & 10 & 11 & 12 & 13 \\
\hline All institutions & $2,545,235$ & $2,602,612$ & $2,662,075$ & $2,752,504$ & $2,883,175$ & $3,083,353$ & $3,187,907$ & $3,379,087$ & $3,561,428$ & $3,723,419$ & $3,840,980$ & 24.6 \\
\hline Professional staff.. & $1,595,460$ & $1,687,287$ & $1,744,867$ & $1,835,916$ & $1,950,861$ & $2,132,150$ & $2,268,268$ & $2,459,885$ & $2,629,401$ & $2,782,149$ & $2,923,961$ & 37.1 \\
\hline Executive/administra & 144,755 & 143,675 & 147,445 & 151,363 & 159,888 & 152,038 & 184,913 & 196,324 & 217,518 & 230,579 & 238,718 & 57.0 \\
\hline Faculty (instruction/research/public service)....... & 826,252 & 915,474 & 931,706 & 989,813 & $1,027,830$ & $1,113,183$ & $1,173,593$ & $1,290,426$ & $1,371,390$ & $1,439,144$ & $1,523,615$ & 36.9 \\
\hline 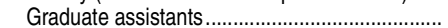 & 197,751 & 202,819 & 215,909 & 222,724 & 239,738 & 261,136 & 292,061 & 317,141 & 328,979 & 342,393 & 355,916 & 36.3 \\
\hline Other professional. & 426,702 & 425,319 & 449,807 & 472,016 & 523,405 & 605,793 & 617,701 & 655,994 & 711,514 & 770,033 & 805,712 & 33.0 \\
\hline Nonprofessional staff. & 949,775 & 915,325 & 917,208 & 916,588 & 932,314 & 951,203 & 919,639 & 919,202 & 932,027 & 941,270 & 917,019 & -3.6 \\
\hline Males. & $1,227,591$ & $1,256,037$ & $1,274,676$ & $1,315,311$ & $1,365,812$ & $1,451,773$ & $1,496,867$ & $1,581,498$ & $1,650,350$ & $1,709,636$ & $1,754,713$ & 20.9 \\
\hline Professional staff. & 895,591 & 930,933 & 946,134 & 982,870 & $1,026,882$ & $1,105,053$ & $1,160,417$ & $1,240,030$ & $1,302,131$ & $1,353,915$ & $1,402,698$ & 26.9 \\
\hline Executive/administ & 85,423 & 82,748 & 82,127 & 81,931 & 83,883 & 79,348 & 91,604 & 95,223 & 102,258 & 106,892 & 109,374 & 37.8 \\
\hline Faculty (instruction/r & 525,599 & 561,123 & 562,893 & 587,420 & 602,469 & 644,514 & 663,723 & 714,453 & 743,812 & 761,035 & 789,197 & 22.4 \\
\hline Graduate assistants & 119,125 & 120,384 & 123,962 & 125,873 & 132,607 & 142,120 & 156,881 & 167,529 & 173,121 & 180,941 & 188,468 & 32.6 \\
\hline Other profe & 165,444 & 166,678 & 177,152 & 187,646 & 207,923 & 239,071 & 248,209 & 262,825 & 282,940 & 305,047 & 315,659 & 32.0 \\
\hline 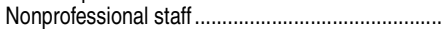 & 332,000 & 325,104 & 328,542 & 332,441 & 338,930 & 346,720 & 336,450 & 341,468 & 348,219 & 355,721 & 352,015 & 1.5 \\
\hline Females & $1,317,644$ & $1,346,575$ & $1,387,399$ & $1,437,193$ & $1,517,363$ & $1,631,580$ & $1,691,040$ & $1,797,589$ & $1,911,078$ & $2,013,783$ & $2,086,267$ & 27.9 \\
\hline Professional staff. & 699,869 & 756,354 & 798,733 & 853,046 & 923,979 & $1,027,097$ & $1,107,851$ & $1,219,855$ & $1,327,270$ & $1,428,234$ & $1,521,263$ & 48.1 \\
\hline Executive/administr & 59,332 & 60,927 & 65,318 & 69,432 & 76,005 & 72,690 & 93,309 & 101,101 & 115,260 & 123,687 & 129,344 & 77.9 \\
\hline Faculty (instruction/research/public service)...... & 300,653 & 354,351 & 368,813 & 402,393 & 425,361 & 468,669 & 509,870 & 575,973 & 627,578 & 678,109 & 734,418 & 56.7 \\
\hline 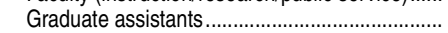 & 78,626 & 82,435 & 91,947 & 96,851 & 107,131 & 119,016 & 135,180 & 149,612 & 155,858 & 161,452 & 167,448 & 40.7 \\
\hline Other professional. & 261,258 & 258,641 & 272,655 & 284,370 & 315,482 & 366,722 & 369,492 & 393,169 & 428,574 & 464,986 & 490,053 & 33.6 \\
\hline Nonprofessional staff.... & 617,775 & 590,221 & 588,666 & 584,147 & 593,384 & 604,483 & 583,189 & 577,734 & 583,808 & 585,549 & 565,004 & -6.5 \\
\hline Full-ti & $1,812,912$ & $1,783,510$ & $1,801,371$ & $1,828,507$ & $1,918,676$ & $2,043,208$ & $2,083,142$ & $2,179,864$ & $2,281,223$ & $2,381,702$ & $2,435,533$ & 19.2 \\
\hline Professional staff. & $1,031,797$ & $1,039,094$ & $1,066,510$ & $1,104,834$ & $1,180,173$ & $1,283,684$ & $1,337,568$ & $1,432,107$ & $1,526,823$ & $1,619,517$ & $1,693,088$ & 31.9 \\
\hline Executive/administ & 139,116 & 137,834 & 140,990 & 144,529 & 153,722 & 146,523 & 178,691 & 190,078 & 210,257 & 222,282 & 231,602 & 58.1 \\
\hline $\mathrm{l} /$ research/public service)....... & 535,623 & 545,706 & 550,822 & 568,719 & 590,937 & 617,868 & 630,092 & 675,624 & 703,463 & 728,977 & 761,619 & 23.3 \\
\hline 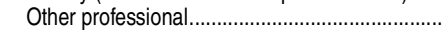 & 357,058 & 355,554 & 374,698 & 391,586 & 435,514 & 519,293 & 528,785 & 566,405 & 613,103 & 668,258 & 699,867 & 34.8 \\
\hline Nonprofessional staff & 781,115 & 744,416 & 734,861 & 723,673 & 738,503 & 759,524 & 745,574 & 747,757 & 754,400 & 762,185 & 742,445 & -2.2 \\
\hline Part-time.. & 732,323 & 819,102 & 860,704 & 923,997 & 964,499 & $1,040,145$ & $1,104,765$ & $1,199,223$ & $1,280,205$ & $1,341,717$ & $1,405,447$ & 35.1 \\
\hline Professional staff. & 563,663 & 648,193 & 678,357 & 731,082 & 770,688 & 848,466 & 930,700 & $1,027,778$ & $1,102,578$ & $1,162,632$ & $1,230,873$ & 45.1 \\
\hline Executive/admin & 5,639 & 5,841 & 6,455 & 6,834 & 6,166 & 5,515 & 6,222 & 6,246 & 7,261 & 8,297 & 7,116 & 29.0 \\
\hline //research/public service)....... & 290,629 & 369,768 & 380,884 & 421,094 & 436,893 & 495,315 & 543,501 & 614,802 & 667,927 & 710,167 & 761,996 & 53.8 \\
\hline Graduate assistants.. & 197,751 & 202,819 & 215,909 & 222,724 & 239,738 & 261,136 & 292,061 & 317,141 & 328,979 & 342,393 & 355,916 & 36.3 \\
\hline Other professional... & 69,644 & 69,765 & 75,109 & 80,430 & 87,891 & 86,500 & 88,916 & 89,589 & 98,411 & 101,775 & 105,845 & 22.4 \\
\hline 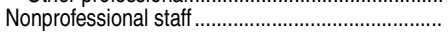 & 168,660 & 170,909 & 182,347 & 192,915 & 193,811 & 191,679 & 174,065 & 171,445 & 177,627 & 179,085 & 174,574 & -8.9 \\
\hline Publi & $1,341,914$ & $1,333,533$ & $1,383,476$ & $1,418,661$ & $1,470,842$ & $1,558,576$ & $1,569,870$ & $1,656,709$ & $1,741,699$ & $1,803,724$ & $1,843,204$ & 18.3 \\
\hline Professional staff ... & 826,633 & 855,913 & 893,345 & 932,972 & 987,622 & $1,069,161$ & $1,115,312$ & $1,200,168$ & $1,278,894$ & $1,336,958$ & $1,390,625$ & 30.1 \\
\hline Executive/admin & 63,674 & 59,678 & 60,590 & 61,984 & 64,336 & 60,245 & 70,397 & 74,241 & 81,364 & 84,355 & 84,911 & 40.9 \\
\hline Faculty (instruction/research/public service)....... & 358,376 & 374,021 & 384,399 & 404,109 & 417,086 & 438,459 & 450,123 & 486,691 & 518,221 & 539,901 & 575,534 & 31.3 \\
\hline 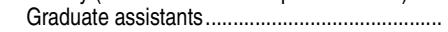 & 144,344 & 916 & 178,342 & 182,481 & 196 & 260 & 239,600 & 257,578 & 266,429 & 275,872 & 285,905 & 31.0 \\
\hline Other $p$ & 260,239 & 251,298 & 270,014 & 284,398 & 309,807 & 352,197 & 355,192 & 381,658 & 412,880 & 436,830 & 444,275 & 26.1 \\
\hline 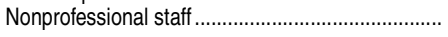 & 515,281 & 477,620 & 490,131 & 485,689 & 483,220 & 489,415 & 454,558 & 456,541 & 462,805 & 466,766 & 452,579 & -7.5 \\
\hline Privat & 734,509 & 762,034 & 770,004 & 786,634 & 857,820 & 912,924 & 988,895 & $1,073,764$ & $1,157,226$ & $1,229,784$ & $1,297,486$ & 42.1 \\
\hline Professional staff. & 442,524 & 473,372 & 495,383 & 517,485 & 569,579 & 627,364 & 701,244 & 179 & 867,234 & 934,298 & $1,008,814$ & 60.8 \\
\hline Executive/administrative/managerial... & 57,148 & 59,230 & 62,314 & 62,580 & 69,626 & 65,739 & 84,306 & 90,415 & 103,183 & 111,616 & 118,268 & 79.9 \\
\hline Faculty (instruction/research/public service)...... & 232,893 & 251,948 & 262,660 & 278,541 & 296,737 & 325,713 & 364,166 & 430,305 & 472,628 & 498,582 & 540,093 & 65.8 \\
\hline Graduate assistants. & 23,989 & 28,880 & 33,853 & 36,064 & 38,597 & 41,611 & 52,101 & 59,147 & 62,550 & 66,521 & 70,011 & 68.3 \\
\hline Other professional.... & 128,494 & 133,314 & 136,556 & 140,300 & 164,619 & 194,301 & 200,671 & 209,312 & 228,873 & 257,579 & 280,442 & 44.3 \\
\hline Nonprofessional staff... & 291,985 & 288,662 & 274,621 & 269,149 & 288,241 & 285,560 & 287,651 & 284,585 & 289,992 & 295,486 & 288,672 & 1.1 \\
\hline Public 2-year. & 441,414 & 478,980 & 482,454 & 512,086 & 517,967 & 578,394 & 593,466 & 610,978 & 620,784 & 638,352 & 641,616 & 10.9 \\
\hline Professional staff. & 306,631 & 337,371 & 336,661 & 358,367 & 364,703 & 408,792 & 422,756 & 440,536 & 449,372 & 467,760 & 474,644 & 16.1 \\
\hline Executive/administrative/managerial... & 20,772 & 21,531 & 21,806 & 22,822 & 21,459 & 22,566 & 25,872 & 26,770 & 27,363 & 27,827 & 27,562 & 22.1 \\
\hline Faculty (instruction/research/public service)....... & 222,532 & 276,413 & 272,434 & 290,451 & 296,239 & 332,665 & 341,643 & 354,497 & 358,925 & 373,778 & 377,696 & 13.5 \\
\hline 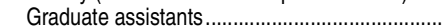 & 29,216 & 2,762 & 3,401 & 3,561 & 4,170 & 1,215 & 323 & 374 & 0 & 0 & 0 & -100.0 \\
\hline Other professional.... & 34,111 & 36,665 & 39,020 & 41,533 & 42,835 & 52,346 & 54,918 & 58,895 & 63,084 & 66,155 & 69,386 & 32.6 \\
\hline Nonprofessional staff & 134,783 & 141,609 & 145,793 & 153,719 & 153,264 & 169,602 & 170,710 & 170,442 & 171,412 & 170,592 & 166,972 & -1.6 \\
\hline Private 2-year. & 27,398 & 28,065 & 26,141 & 35,123 & 36,546 & 33,459 & 35,676 & 37,636 & 41,719 & 51,559 & 58,674 & 75.4 \\
\hline Professional staff ........ & 19,672 & 20,631 & 19,478 & 27,092 & 28,957 & 26,833 & 28,956 & 30,002 & 33,901 & 43,133 & 49,878 & 85.9 \\
\hline 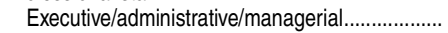 & 3,161 & 3,236 & 2,735 & 3,977 & 4,467 & 3,488 & 4,338 & 4,898 & 5,608 & 6,781 & 7,977 & 128.7 \\
\hline Faculty (instruction/research/public service)...... & 12,451 & 13,092 & 12,213 & 16,712 & 17,768 & 16,346 & 17,661 & 18,933 & 21,616 & 26,883 & 30,292 & 85.3 \\
\hline 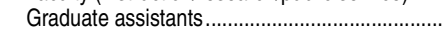 & 202 & 261 & 313 & 618 & 578 & 50 & 37 & 42 & 0 & 0 & 0 & -100.0 \\
\hline Other & 3,858 & 4,042 & 4,217 & 5,785 & 6,144 & 6,949 & 6,920 & 6,129 & 6,677 & 9,469 & 11,609 & 67.1 \\
\hline 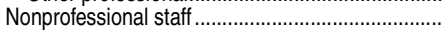 & 7,726 & 7,434 & 6,663 & 8,031 & 7,589 & 6,626 & 6,720 & 7,634 & 7,818 & 8,426 & 8,796 & 32.7 \\
\hline
\end{tabular}

NOTE: Data through 1995 are for institutions of higher education, while later data are for degree-granting institutions. Degree-granting institutions grant associate's or higher degrees and participate in Title IV federal financial aid programs. The degree-granting classification is very similar to the earlier higher education classification, but it includes more 2-year colleges and excludes a few higher education institutions that did not grant degrees. Beginning in
2007, includes institutions with fewer than 15 full-time employees; these institutions did not report staff data prior to 2007. By definition, all graduate assistants are part time. SOURCE: U.S. Department of Education, National Center for Education Statistics, Integrated Postsecondary Education Data System (IPEDS), "Fall Staff Survey" (IPEDS-S:91-99); and IPEDS Winter 2001-02 through Winter 2011-12, Human Resources component, Fall Staff section. (This table was prepared July 2012.) 
Table 314.30. Employees in degree-granting postsecondary institutions, by employment status, sex, control and level of institution, and primary occupation: Fall 2011

\begin{tabular}{|c|c|c|c|c|c|c|c|c|c|c|c|c|}
\hline \multirow[b]{3}{*}{$\begin{array}{l}\text { Control and level of institution } \\
\text { and primary occupation }\end{array}$} & \multicolumn{5}{|c|}{ Full-time and part-time } & \multicolumn{4}{|c|}{ Full-time } & \multicolumn{3}{|c|}{ Part-time } \\
\hline & \multicolumn{2}{|c|}{ Total } & \multirow[b]{2}{*}{ Males } & \multicolumn{2}{|c|}{ Females } & \multicolumn{2}{|c|}{ Total } & \multirow[b]{2}{*}{ Males } & \multirow[b]{2}{*}{ Females } & \multirow[b]{2}{*}{ Total } & \multirow[b]{2}{*}{ Males } & \multirow[b]{2}{*}{ Females } \\
\hline & Number & $\begin{array}{r}\text { Percentage } \\
\text { distribution }\end{array}$ & & Number & $\begin{array}{r}\text { Percent } \\
\text { of all } \\
\text { employees } \\
\end{array}$ & Number & $\begin{array}{r}\text { Percent } \\
\text { of all } \\
\text { employees } \\
\end{array}$ & & & & & \\
\hline 1 & 2 & 3 & 4 & 5 & 6 & 7 & 8 & 9 & 10 & 11 & 12 & 13 \\
\hline All institutions & $3,840,980$ & 100.0 & $1,754,713$ & $2,086,267$ & 54.3 & $2,435,533$ & 63.4 & $1,098,940$ & $1,336,593$ & $1,405,447$ & 655,773 & 749,674 \\
\hline Professional staff... & $2,923,961$ & 76.1 & $1,402,698$ & $1,521,263$ & 52.0 & $1,693,088$ & 57.9 & 811,575 & 881,513 & $1,230,873$ & 591,123 & 639,750 \\
\hline Executive/administrative/managerial.......... & 238,718 & 6.2 & 109,374 & 129,344 & 54.2 & 231,602 & 97.0 & 106,655 & 124,947 & 7,116 & 2,719 & 4,397 \\
\hline Faculty (instruction/research/public service). & $1,523,615$ & 39.7 & 789,197 & 734,418 & 48.2 & 761,619 & 50.0 & 426,982 & 334,637 & 761,996 & 362,215 & 399,781 \\
\hline Graduate assistants. & 355,916 & 9.3 & 188,468 & 167,448 & 47.0 & $\dagger$ & $\dagger$ & $\dagger$ & $\dagger$ & 355,916 & 188,468 & 167,448 \\
\hline Other professional ..... & 805,712 & 21.0 & 315,659 & 490,053 & 60.8 & 699,867 & 86.9 & 277,938 & 421,929 & 105,845 & 37,721 & 68,124 \\
\hline Nonprofessional staff.. & 917,019 & 23.9 & 352,015 & 565,004 & 61.6 & 742,445 & 81.0 & 287,365 & 455,080 & 174,574 & 64,650 & 109,924 \\
\hline Technical and parapro & 196,651 & 5.1 & 81,492 & 115,159 & 58.6 & 156,484 & 79.6 & 65,811 & 90,673 & 40,167 & 15,681 & 24,486 \\
\hline Clerical and secret & 426,174 & 11.1 & 65,047 & 361,127 & 84.7 & 333,195 & 78.2 & 40,647 & 292,548 & 92,979 & 24,400 & 68,579 \\
\hline Skilled crafts... & 60,664 & 1.6 & 57,030 & 3,634 & 6.0 & 58,143 & 95.8 & 55,238 & 2,905 & 2,521 & 1,792 & 729 \\
\hline Service and maintenance.... & 233,530 & 6.1 & 148,446 & 85,084 & 36.4 & 194,623 & 83.3 & 125,669 & 68,954 & 38,907 & 22,777 & 16,130 \\
\hline Public 4-year & $1,843,204$ & 100.0 & 865,368 & 977,836 & 53.1 & $1,237,611$ & 67.1 & 576,822 & 660,789 & 605,593 & 288,546 & 317,047 \\
\hline Professional staff ... & $1,390,625$ & 75.4 & 685,308 & 705,317 & 50.7 & 855,208 & 61.5 & 422,781 & 432,427 & 535,417 & 262,527 & 272,890 \\
\hline Executive/administrativ & 84,911 & 4.6 & 41,416 & 43,495 & 51.2 & 82,238 & 96.9 & 40,279 & 41,959 & 2,673 & 1,137 & 1,536 \\
\hline Faculty (instruction/research/public service). & 575,534 & 31.2 & 316,533 & 259,001 & 45.0 & 382,151 & 66.4 & 223,503 & 158,648 & 193,383 & 93,030 & 100,353 \\
\hline Graduate assistar & 285,905 & 15.5 & 151,064 & 134,841 & 47.2 & $\dagger$ & $\dagger$ & $\dagger$ & $\dagger$ & 285,905 & 151,064 & 134,841 \\
\hline Other profession & 444,275 & 24.1 & 176,295 & 267,980 & 60.3 & 390,819 & 88.0 & 158,999 & 231,820 & 53,456 & 17,296 & 36,160 \\
\hline Nonprofessional staff. & 452,579 & 24.6 & 180,060 & 272,519 & 60.2 & 382,403 & 84.5 & 154,041 & 228,362 & 70,176 & 26,019 & 44,157 \\
\hline Technical and paraprofessionals. & 102,992 & 5.6 & 42,594 & 60,398 & 58.6 & 85,804 & 83.3 & 35,959 & 49,845 & 17,188 & 6,635 & 10,553 \\
\hline Clerical and sec & 190,112 & 10.3 & 27,411 & 162,701 & 85.6 & 153,828 & 80.9 & 17,267 & 136,561 & 36,284 & 10,144 & 26,140 \\
\hline Skilled crafts..................... & 40,186 & 2.2 & 38,105 & 2,081 & 5.2 & 39,048 & 97.2 & 37,202 & 1,846 & 1,138 & 903 & 235 \\
\hline Service and maintena & 119,289 & 6.5 & 71,950 & 47,339 & 39.7 & 103,723 & 87.0 & 63,613 & 40,110 & 15,566 & 8,337 & 7,229 \\
\hline Public 2-yea & 641,616 & 100.0 & 272,023 & 369,593 & 57.6 & 301,099 & 46.9 & 121,164 & 179,935 & 340,517 & 150,859 & 189,658 \\
\hline Professional staff..... & 474,644 & 74.0 & 209,950 & 264,694 & 55.8 & 192,113 & 40.5 & 81,317 & 110,796 & 282,531 & 128,633 & 153,898 \\
\hline Executive/ & 27,562 & 4.3 & 12,210 & 15,352 & 55.7 & 26,869 & 97.5 & 11,931 & 14,938 & 693 & 279 & 414 \\
\hline Faculty (instruction/r & 377,696 & 58.9 & 172,950 & 204,746 & 54.2 & 113,241 & 30.0 & 51,258 & 61,983 & 264,455 & 121,692 & 142,763 \\
\hline 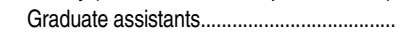 & & 0.0 & & & $\dagger$ & & $\dagger$ & & & & & \\
\hline Other profession & 69,386 & 10.8 & 24,790 & 44,596 & 64.3 & 52,003 & 74.9 & 18,128 & 33,875 & 17,383 & 6,662 & 10,721 \\
\hline Nonprofessional staff. & 166,972 & 26.0 & 62,073 & 104,899 & 62.8 & 108,986 & 65.3 & 39,847 & 69,139 & 57,986 & 22,226 & 35,760 \\
\hline Technical and $\mathrm{p}$ & 42,106 & 6.6 & 17,179 & 24,927 & 59.2 & 27,498 & 65.3 & 11,237 & 16,261 & 14,608 & 5,942 & 8,666 \\
\hline Clerical and secretarial...................... & 83,245 & 13.0 & 13,945 & 69,300 & 83.2 & 50,524 & 60.7 & 4,730 & 45,794 & 32,721 & 9,215 & 23,506 \\
\hline Skilled & 5,411 & 0.8 & 4,828 & 583 & 10.8 & 4,689 & 86.7 & 4,380 & 309 & 722 & 448 & 274 \\
\hline Service and maintenance....... & 36,210 & 5.6 & 26,121 & 10,089 & 27.9 & 26,275 & 72.6 & 19,500 & 6,775 & 9,935 & 6,621 & 3,314 \\
\hline Private 4 -year ${ }^{1} \ldots$. & $1,297,486$ & 100.0 & 595,441 & 702,045 & 54.1 & 859,551 & 66.2 & 387,385 & 472,166 & 437,935 & 208,056 & 229,879 \\
\hline Professional staff .......... & $1,008,814$ & 77.8 & 488,283 & 520,531 & 51.6 & 615,041 & 61.0 & 295,853 & 319,188 & 393,773 & 192,430 & 201,343 \\
\hline Executive/administrative/managerial ............. & 118,268 & 9.1 & 52,636 & 65,632 & 55.5 & 114,715 & 97.0 & 51,411 & 63,304 & 3,553 & 1,225 & 2,328 \\
\hline ublic service). & 540,093 & 41.6 & 287,390 & 252,703 & 46.8 & 254,005 & 47.0 & 147,043 & 106,962 & 286,088 & 140,347 & 145,741 \\
\hline Graduate & 70,011 & 5.4 & 37,4 & 32,607 & 46.6 & & $\dagger$ & $\dagger$ & $\dagger$ & 70,011 & 37,404 & 32,607 \\
\hline Other professional . & 280,442 & 21.6 & 110,853 & 169,589 & 60.5 & 246,321 & 87.8 & 97,399 & 148,922 & 34,121 & 13,454 & 20,667 \\
\hline Nonprofessional staff.. & 288,672 & 22.2 & 107,158 & 181,514 & 62.9 & 244,510 & 84.7 & 91,532 & 152,978 & 44,162 & 15,626 & 28,536 \\
\hline Technical a & 50,607 & 3.9 & 21,308 & 29,299 & 57.9 & 42,613 & 84.2 & 18,331 & 24,282 & 7,994 & 2,977 & 5,017 \\
\hline Clerical & 146,474 & 11.3 & 22,490 & 123,984 & 84.6 & 123,775 & 84.5 & 17,690 & 106,085 & 22,699 & 4,800 & 17,899 \\
\hline Skilled craft & 14,981 & 1.2 & 14,036 & 945 & 6.3 & 14,341 & 95.7 & 13,608 & 733 & 640 & 428 & 212 \\
\hline Service and maintenan & 76,610 & 5.9 & 49,324 & 27,286 & 35.6 & 63,781 & 83.3 & 41,903 & 21,878 & 12,829 & 7,421 & 5,408 \\
\hline Private nonprofit 4-year ... & $1,110,832$ & 100.0 & 513,560 & 597,272 & 53.8 & 773,297 & 69.6 & 351,396 & 421,901 & 337,535 & 162,164 & 175,371 \\
\hline 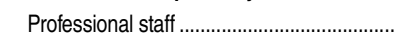 & 837,737 & 75.4 & 411,536 & 426,201 & 50.9 & 541,784 & 64.7 & 264,045 & 277,739 & 295,953 & 147,491 & 148,462 \\
\hline Executive/administrative/managerial & 103,098 & 9.3 & 45,875 & 57,223 & 55.5 & 99,735 & 96.7 & 44,722 & 55,013 & 3,363 & 1,153 & 2,210 \\
\hline Faculty (instruction/research/public & & & & & & & & & & & & \\
\hline & 428,905 & 38.6 & 235,238 & 193,667 & 45.2 & 238,219 & 55.5 & 138,887 & 99,332 & 190,686 & 96,351 & 94,335 \\
\hline Graduate assista & 69,376 & 6.2 & 37,134 & 32,242 & 46.5 & & $\dagger$ & & & 69,376 & 37,134 & 32,242 \\
\hline Other professional. & 236,358 & 21.3 & 93,289 & 143,069 & 60.5 & 203,830 & 86.2 & 80,436 & 123,394 & 32,528 & 12,853 & 19,675 \\
\hline Nonprofessio & 273,095 & 24.6 & 102,024 & 171,071 & 62.6 & 231,513 & 84.8 & 87,351 & 144,162 & 41,582 & 14,673 & 26,909 \\
\hline Technical and pa & 48,986 & 4.4 & 20,418 & 28,568 & 58.3 & 41,522 & 84.8 & 17,672 & 23,850 & 7,464 & 2,746 & 4,718 \\
\hline Clerical & 134,307 & 12.1 & 19,600 & 114,707 & 85.4 & 113,113 & 84.2 & 15,138 & 97,975 & 21,194 & 4,462 & 16,732 \\
\hline Skilled crafts............. & 14,883 & 1.3 & 13,960 & 923 & 6.2 & 14,263 & 95.8 & 13,545 & 718 & 620 & 415 & 205 \\
\hline Service and maintenance.......................... & 74,919 & 6.7 & 48,046 & 26,873 & 35.9 & 62,615 & 83.6 & 40,996 & 21,619 & 12,304 & 7,050 & 5,254 \\
\hline
\end{tabular}


Table 314.30. Employees in degree-granting postsecondary institutions, by employment status, sex, control and level of institution, and primary occupation: Fall 2011-Continued

\begin{tabular}{|c|c|c|c|c|c|c|c|c|c|c|c|c|}
\hline \multirow[b]{3}{*}{$\begin{array}{l}\text { Control and level of institution } \\
\text { and primary occupation }\end{array}$} & \multicolumn{5}{|c|}{ Full-time and part-time } & \multicolumn{4}{|c|}{ Full-time } & \multicolumn{3}{|c|}{ Part-time } \\
\hline & \multicolumn{2}{|c|}{ Total } & \multirow[b]{2}{*}{ Males } & \multicolumn{2}{|c|}{ Females } & \multicolumn{2}{|c|}{ Total } & \multirow[b]{2}{*}{ Males } & \multirow[b]{2}{*}{ Females } & \multirow[b]{2}{*}{ Total } & \multirow[b]{2}{*}{ Males } & \multirow[b]{2}{*}{ Females } \\
\hline & Number & $\begin{array}{r}\text { Percentage } \\
\text { distribution }\end{array}$ & & Number & $\begin{array}{r}\text { Percent } \\
\text { of all } \\
\text { employees }\end{array}$ & Number & $\begin{array}{r}\text { Percent } \\
\text { of all } \\
\text { employees }\end{array}$ & & & & & \\
\hline 1 & 2 & 3 & 4 & 5 & 6 & 7 & 8 & 9 & 10 & 11 & 12 & $\overline{13}$ \\
\hline 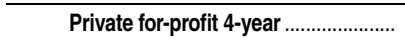 & 186,654 & 100.0 & 81,881 & 104,773 & 56.1 & 86,254 & 46.2 & 35,989 & 50,265 & 100,400 & 45,892 & 54,508 \\
\hline Professional staff .................................... & 171,077 & 91.7 & 76,747 & 94,330 & 55.1 & 73,257 & 42.8 & 31,808 & 41,449 & 97,820 & 44,939 & 52,881 \\
\hline Executive/administrative/managerial........ & 15,170 & 8.1 & 6,761 & 8,409 & 55.4 & 14,980 & 98.7 & 6,689 & 8,291 & 190 & 72 & 118 \\
\hline 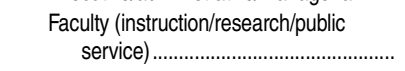 & 111,188 & 59.6 & 52,152 & 59,036 & 53.1 & 15,786 & 14.2 & 8,156 & 7,630 & 95,402 & 43,996 & 51,406 \\
\hline 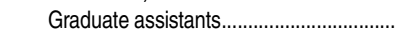 & 635 & 0.3 & 270 & 365 & 57.5 & $t$ & $\dagger$ & $\dagger$ & $t$ & 635 & 270 & 365 \\
\hline 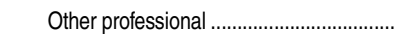 & 44,084 & 23.6 & 17,564 & 26,520 & 60.2 & 42,491 & 96.4 & 16,963 & 25,528 & 1,593 & 601 & 992 \\
\hline Nonprofessional staff... & 15,577 & 8.3 & 5,134 & 10,443 & 67.0 & 12,997 & 83.4 & 4,181 & 8,816 & 2,580 & 953 & 1,627 \\
\hline Technical and paraprofessionals .... & 1,621 & 0.9 & 890 & 731 & 45.1 & 1,091 & 67.3 & 659 & 432 & 530 & 231 & 299 \\
\hline Clerical and secretarial............................... & 12,167 & 6.5 & 2,890 & 9,277 & 76.2 & 10,662 & 87.6 & 2,552 & 8,110 & 1,505 & 338 & 1,167 \\
\hline 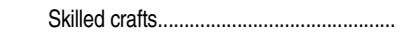 & 98 & 0.1 & 76 & 22 & 22.4 & 78 & 79.6 & 63 & 15 & 20 & 13 & 7 \\
\hline Service and maintenance............................ & 1,691 & 0.9 & 1,278 & 413 & 24.4 & 1,166 & 69.0 & 907 & 259 & 525 & 371 & 154 \\
\hline Private 2-year ${ }^{1}$. & 58,674 & 100.0 & 21,881 & 36,793 & 62.7 & 37,272 & 63.5 & 13,569 & 23,703 & 21,402 & 8,312 & 13,090 \\
\hline Professional staff ....... & 49,878 & 85.0 & 19,157 & 30,721 & 61.6 & 30,726 & 61.6 & 11,624 & 19,102 & 19,152 & 7,533 & 11,619 \\
\hline Executive/administr & 7,977 & 13.6 & 3,112 & 4,865 & 61.0 & 7,780 & 97.5 & 3,034 & 4,746 & 197 & 78 & 119 \\
\hline Faculty (instructio & 30,292 & 51.6 & 12,324 & 17,968 & 59.3 & 12,222 & 40.3 & 5,178 & 7,044 & 18,070 & 7,146 & 10,924 \\
\hline Graduate assistar & & 0.0 & 0 & 0 & $t$ & $t$ & $t$ & $\dagger$ & $t$ & 0 & 0 & 0 \\
\hline 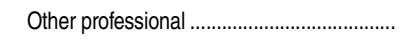 & 11,609 & 19.8 & 3,721 & 7,888 & 67.9 & 10,724 & 92.4 & 3,412 & 7,312 & 885 & 309 & 576 \\
\hline Nonprofessional staff..... & 8,796 & 15.0 & 2,724 & 6,072 & 69.0 & 6,546 & 74.4 & 1,945 & 4,601 & 2,250 & 779 & 1,471 \\
\hline Technical a & 946 & 1.6 & 411 & 535 & 56.6 & 569 & 60.1 & 284 & 285 & 377 & 127 & 250 \\
\hline Clerical and secretarial..... & 6,343 & 10.8 & 1,201 & 5,142 & 81.1 & 5,068 & 79.9 & 960 & 4,108 & 1,275 & 241 & 1,034 \\
\hline 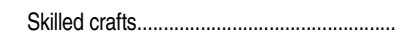 & 86 & 0.1 & 61 & 25 & 29.1 & 65 & 75.6 & 48 & 17 & 21 & 13 & 8 \\
\hline 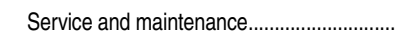 & 1,421 & 2.4 & 1,051 & 370 & 26.0 & 844 & 59.4 & 653 & 191 & 577 & 398 & 179 \\
\hline Private nonprofit 2-year & 7,214 & 100.0 & 2,800 & 4,414 & 61.2 & 4,417 & 61.2 & 1,644 & 2,773 & 2,797 & 1,156 & 1,641 \\
\hline Professional staff ..... & 6,003 & 83.2 & 2,348 & 3,655 & 60.9 & 3,592 & 59.8 & 1,350 & 2,242 & 2,411 & 998 & $\overline{1,413}$ \\
\hline Executive/administrative/managerial .... & 912 & 12.6 & 370 & 542 & 59.4 & 865 & 94.8 & 354 & 511 & 47 & 16 & 31 \\
\hline Faculty (instruction/research/public & & & & & & & & & & & & \\
\hline service & 3,828 & 53.1 & 1,527 & 2,301 & 60.1 & 1,645 & 43.0 & 618 & 1,027 & 2,183 & 909 & 1,274 \\
\hline 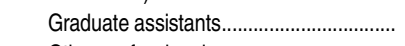 & 0 & 0.0 & 0 & 0 & $t$ & t & $\dagger$ & t & t & 0 & 0 & 0 \\
\hline Other professional ...... & 1,263 & 17.5 & 451 & 812 & 64.3 & 1,082 & 85.7 & 378 & 704 & 181 & 73 & 108 \\
\hline Nonprofessional staff... & 1,211 & 16.8 & 452 & 759 & 62.7 & 825 & 68.1 & 294 & 531 & 386 & 158 & 228 \\
\hline Technical and paraprofessionals ......... & 172 & 2.4 & 93 & 79 & 45.9 & 124 & 72.1 & 67 & 57 & 48 & 26 & 22 \\
\hline Clerical and secretarial.......... & 645 & 8.9 & 66 & 579 & 89.8 & 465 & 72.1 & 44 & 421 & 180 & 22 & 158 \\
\hline 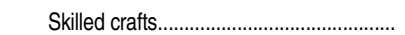 & 36 & 0.5 & 27 & 9 & 25.0 & 24 & 66.7 & 21 & 3 & 12 & 6 & 6 \\
\hline 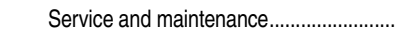 & 358 & 5.0 & 266 & 92 & 25.7 & 212 & 59.2 & 162 & 50 & 146 & 104 & 42 \\
\hline Private for-profit 2-year & 51,460 & 100.0 & 19,081 & 32,379 & 62.9 & 32,855 & 63.8 & 11,925 & 20,930 & 18,605 & 7,156 & 11,449 \\
\hline 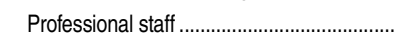 & 43,875 & 85.3 & 16,809 & 27,066 & 61.7 & 27,134 & 61.8 & 10,274 & 16,860 & 16,741 & 6,535 & 10,206 \\
\hline Executive/administrative/managerial........ & 7,065 & 13.7 & 2,742 & 4,323 & 61.2 & 6,915 & 97.9 & 2,680 & 4,235 & 150 & 62 & 88 \\
\hline $\begin{array}{l}\text { Faculty (instruction/research/public } \\
\text { service) }\end{array}$ & 26.464 & 51.4 & 10,797 & 15,667 & 592 & 10.577 & 40.0 & 4.560 & 6.017 & 15,887 & 6,237 & 9.650 \\
\hline 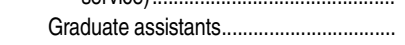 & 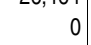 & 0.0 & 0 & 0 & † & $\dagger$ & $\dagger$ & $\dagger$ & $\dagger$ & 0 & 0 & 0 \\
\hline Other professional ............ & 10,346 & 20.1 & 3,270 & 7,076 & 68.4 & 9,642 & 93.2 & 3,034 & 6,608 & 704 & 236 & 468 \\
\hline Nonprofessional staff. & 7,585 & 14.7 & 2,272 & 5,313 & 70.0 & 5,721 & 75.4 & 1,651 & 4,070 & 1,864 & 621 & 1,243 \\
\hline Technical and paraprofessionals .............. & 774 & 1.5 & 318 & 456 & 58.9 & 445 & 57.5 & 217 & 228 & 329 & 101 & 228 \\
\hline Clerical and secretarial .............................. & 5,698 & 11.1 & 1,135 & 4,563 & 80.1 & 4,603 & 80.8 & 916 & 3,687 & 1,095 & 219 & 876 \\
\hline 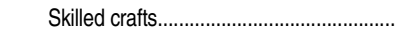 & 50 & 0.1 & 34 & 16 & 32.0 & 41 & 82.0 & 27 & 14 & 9 & 7 & 2 \\
\hline Service and maintenance & 1,063 & 2.1 & 785 & 278 & 26.2 & 632 & 59.5 & 491 & 141 & 431 & 294 & 137 \\
\hline
\end{tabular}

†Not applicable.

Includes nonprofit and for-profit private institutions.

NOTE: Degree-granting institutions grant associate's or higher degrees and participate in Title IV federal financial aid programs. Includes institutions with fewer than 15 full-time employees; these institutions did not report staff data prior to 2007. By definition, all graduate assistants are part time. Detail may not sum to totals because of rounding.

SOURCE: U.S. Department of Education, National Center for Education Statistics, Integrated Postsecondary Education Data System (IPEDS), Winter 2011-12, Human Resources component, Fall Staff section. (This table was prepared July 2012.) 
Table 314.40. Employees in degree-granting postsecondary institutions, by race/ethnicity, sex, employment status, control and level of institution, and primary occupation: Fall 2011

\begin{tabular}{|c|c|c|c|c|c|c|c|c|c|c|c|c|}
\hline \multirow[b]{2}{*}{$\begin{array}{l}\text { Sex, employment status, control and level } \\
\text { of institution, and primary occupation }\end{array}$} & \multirow[b]{2}{*}{ Total } & \multirow[b]{2}{*}{ White } & \multicolumn{8}{|c|}{ Minority } & \multirow[b]{2}{*}{$\begin{array}{r}\text { Race/ } \\
\text { ethnicity } \\
\text { unknown }\end{array}$} & \multirow[b]{2}{*}{$\begin{array}{r}\text { Nonresiden } \\
\text { alien }\end{array}$} \\
\hline & & & Total & Percent ${ }^{1}$ & Black & Hispanic & Asian & $\begin{array}{r}\text { Pacific } \\
\text { Islander }\end{array}$ & $\begin{array}{r}\text { American } \\
\text { Indian/ } \\
\text { Alaska } \\
\text { Native }\end{array}$ & $\begin{array}{r}\text { Two or } \\
\text { more races }\end{array}$ & & \\
\hline 1 & 2 & 3 & 4 & 5 & 6 & 7 & 8 & 9 & 10 & 11 & 12 & 13 \\
\hline All institutions ................................... & $3,840,980$ & $2,641,977$ & 886,588 & 25.1 & 376,063 & 238,830 & 213,807 & 7,864 & 20,808 & 29,216 & 144,366 & $\overline{168,049}$ \\
\hline 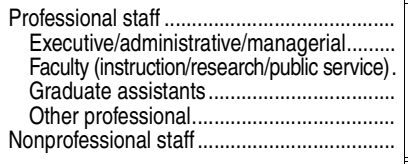 & $\begin{array}{r}2,923,961 \\
238,718 \\
1,523,615 \\
355,916 \\
805,712 \\
917,019 \\
\end{array}$ & $\begin{array}{r}2,057,876 \\
186,384 \\
1,124,745 \\
179,433 \\
567,314 \\
584,101 \\
\end{array}$ & $\begin{array}{r}582,639 \\
46,633 \\
284,394 \\
56,936 \\
194,676 \\
303,949 \\
\end{array}$ & \begin{tabular}{l|}
22.1 \\
20.0 \\
20.2 \\
24.1 \\
25.5 \\
34.2 \\
\end{tabular} & $\begin{array}{r}223,408 \\
22,495 \\
105,292 \\
13,736 \\
81,885 \\
152,655 \\
\end{array}$ & $\begin{array}{r}140,021 \\
12,816 \\
65,271 \\
14,028 \\
47,906 \\
98,809 \\
\end{array}$ & $\begin{array}{r}177,622 \\
8,217 \\
94,065 \\
23,107 \\
52,233 \\
36,185 \\
\end{array}$ & $\begin{array}{r}5,572 \\
351 \\
3,069 \\
549 \\
1,603 \\
2,292 \\
\end{array}$ & $\begin{array}{r}13,814 \\
1,227 \\
7,235 \\
1,193 \\
4,159 \\
6,994 \\
\end{array}$ & $\begin{array}{r}22,202 \\
1,527 \\
9,462 \\
4,323 \\
6,890 \\
7,014 \\
\end{array}$ & $\begin{array}{r}122,456 \\
4,717 \\
71,823 \\
23,074 \\
22,842 \\
21,910 \\
\end{array}$ & $\begin{array}{r}160,990 \\
984 \\
42,653 \\
96,473 \\
20,880 \\
7,059 \\
\end{array}$ \\
\hline 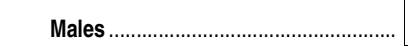 & $1,754,713$ & $1,210,791$ & 371,721 & 23.5 & 141,656 & 101,701 & 104,131 & 3,411 & 8,847 & 11,975 & 70,554 & 101,647 \\
\hline 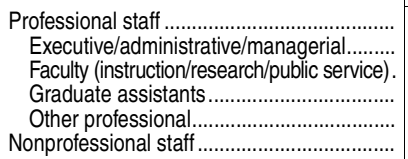 & $\begin{array}{r}1,402,698 \\
109,374 \\
789,197 \\
188,468 \\
315,659 \\
352,015\end{array}$ & $\begin{array}{r}988,566 \\
87,761 \\
585,856 \\
90,684 \\
224,265 \\
222,225\end{array}$ & $\begin{array}{r}254,665 \\
18,849 \\
140,179 \\
26,335 \\
69,302 \\
117,056\end{array}$ & $\begin{array}{l}20.5 \\
17.7 \\
19.3 \\
22.5 \\
23.6 \\
34.5\end{array}$ & $\begin{array}{r}84,620 \\
8,572 \\
43,797 \\
5,351 \\
26,900 \\
57,036\end{array}$ & $\begin{array}{r}62,069 \\
5,198 \\
33,028 \\
6,480 \\
17,363 \\
39,632\end{array}$ & $\begin{array}{r}89,903 \\
3,783 \\
54,076 \\
11,721 \\
20,323 \\
14,228\end{array}$ & $\begin{array}{r}2,495 \\
167 \\
1,393 \\
277 \\
658 \\
916\end{array}$ & $\begin{array}{r}6,040 \\
523 \\
3,460 \\
529 \\
1,528 \\
2,807\end{array}$ & $\begin{array}{r}9,538 \\
606 \\
4,425 \\
1,977 \\
2,530 \\
2,437\end{array}$ & $\begin{array}{r}61,017 \\
2,224 \\
36,475 \\
12,238 \\
10,080 \\
9,537\end{array}$ & $\begin{array}{r}98,450 \\
540 \\
26,687 \\
59,211 \\
12,012 \\
3,197\end{array}$ \\
\hline Females................ & $2,086,267$ & $1,431,186$ & 514,867 & 26.5 & 234,407 & 137,129 & 109,676 & 4,453 & 11,961 & 17,241 & 73,812 & 66,402 \\
\hline 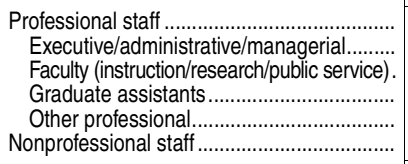 & $\begin{array}{r}1,521,263 \\
129,344 \\
734,418 \\
167,448 \\
490,053 \\
565,004 \\
\end{array}$ & $\begin{array}{r}1,069,310 \\
98,623 \\
538,889 \\
88,749 \\
343,049 \\
361,876 \\
\end{array}$ & $\begin{array}{r}327,974 \\
27,784 \\
144,215 \\
30,601 \\
125,374 \\
186,893 \\
\end{array}$ & $\begin{array}{l}23.5 \\
22.0 \\
21.1 \\
25.6 \\
26.8 \\
34.1\end{array}$ & $\begin{array}{r}138,788 \\
13,923 \\
61,495 \\
8,385 \\
54,985 \\
95,619 \\
\end{array}$ & $\begin{array}{r}77,952 \\
7,618 \\
32,243 \\
7,548 \\
30,543 \\
59,177 \\
\end{array}$ & $\begin{array}{r}87,719 \\
4,434 \\
39,989 \\
11,386 \\
31,910 \\
21,957 \\
\end{array}$ & $\begin{array}{r}3,077 \\
184 \\
1,676 \\
272 \\
945 \\
1,376 \\
\end{array}$ & $\begin{array}{r}7,774 \\
704 \\
3,775 \\
664 \\
2,631 \\
4,187 \\
\end{array}$ & $\begin{array}{r}12,664 \\
921 \\
5,037 \\
2,346 \\
4,360 \\
4,577 \\
\end{array}$ & $\begin{array}{r}61,439 \\
2,493 \\
35,348 \\
10,836 \\
12,762 \\
12,373 \\
\end{array}$ & $\begin{array}{r}62,540 \\
444 \\
15,966 \\
37,262 \\
8,868 \\
3,862 \\
\end{array}$ \\
\hline Full-time & $2,435,533$ & $1,708,829$ & 616,778 & 26.5 & 265,974 & 166,970 & 148,225 & 4,753 & 14,110 & 16,746 & 52,917 & 57,009 \\
\hline 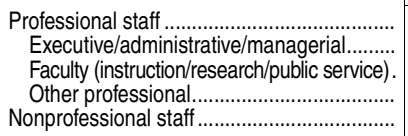 & $\begin{array}{r}1,693,088 \\
231,602 \\
761,619 \\
699,867 \\
742,445\end{array}$ & $\begin{array}{r}1,235,717 \\
180,522 \\
563,689 \\
491,506 \\
473,112\end{array}$ & $\begin{array}{r}366,583 \\
45,645 \\
147,517 \\
173,421 \\
250,195\end{array}$ & $\begin{array}{l}22.9 \\
20.2 \\
20.7 \\
26.1 \\
34.6\end{array}$ & $\begin{array}{r}137,245 \\
22,124 \\
41,649 \\
73,472 \\
128,729\end{array}$ & $\begin{array}{l}86,565 \\
12,577 \\
31,331 \\
42,657 \\
80,405\end{array}$ & $\begin{array}{r}119,613 \\
7,922 \\
65,438 \\
46,253 \\
28,612\end{array}$ & $\begin{array}{r}3,183 \\
339 \\
1,449 \\
1,395 \\
1,570\end{array}$ & $\begin{array}{l}8,383 \\
1,199 \\
3,529 \\
3,655 \\
5,727\end{array}$ & $\begin{array}{r}11,594 \\
1,484 \\
4,121 \\
5,989 \\
5,152\end{array}$ & $\begin{array}{r}38,489 \\
4,536 \\
17,000 \\
16,953 \\
14,428\end{array}$ & $\begin{array}{r}52,299 \\
899 \\
33,413 \\
17,987 \\
4,710\end{array}$ \\
\hline Part-time.......... & $1,405,447$ & 933,148 & 269,810 & 22.4 & 110,089 & 71,860 & 65,582 & 3,111 & 6,698 & 12,470 & 91,449 & 111,040 \\
\hline 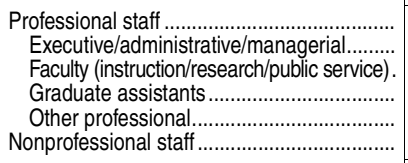 & $\begin{array}{r}1,230,873 \\
7,116 \\
761,996 \\
355,916 \\
105,845 \\
174,574 \\
\end{array}$ & $\begin{array}{r}822,159 \\
5,862 \\
561,056 \\
179,433 \\
75,808 \\
110,989 \\
\end{array}$ & $\begin{array}{r}216,056 \\
988 \\
136,877 \\
56,936 \\
21,255 \\
53,754 \\
\end{array}$ & $\begin{array}{l}20.8 \\
14.4 \\
19.6 \\
24.1 \\
21.9 \\
32.6\end{array}$ & $\begin{array}{r}86,163 \\
371 \\
63,643 \\
13,736 \\
8,413 \\
23,926 \\
\end{array}$ & $\begin{array}{r}53,456 \\
239 \\
33,940 \\
14,028 \\
5,249 \\
18,404 \\
\end{array}$ & $\begin{array}{r}58,009 \\
295 \\
28,627 \\
23,107 \\
5,980 \\
7,573 \\
\end{array}$ & $\begin{array}{r}2,389 \\
12 \\
1,620 \\
549 \\
208 \\
722 \\
\end{array}$ & $\begin{array}{r}5,431 \\
28 \\
3,706 \\
1,193 \\
504 \\
1,267 \\
\end{array}$ & $\begin{array}{r}10,608 \\
43 \\
5,341 \\
4,323 \\
901 \\
1,862 \\
\end{array}$ & $\begin{array}{r}83,967 \\
181 \\
54,823 \\
23,074 \\
5,889 \\
7,482 \\
\end{array}$ & $\begin{array}{r}108,691 \\
85 \\
9,240 \\
96,473 \\
2,893 \\
2,349 \\
\end{array}$ \\
\hline 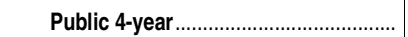 & $1,843,204$ & $1,233,523$ & 431,633 & 25.9 & 168,729 & 114,476 & 121,067 & 2,912 & 10,736 & 13,713 & 58,715 & 119,333 \\
\hline 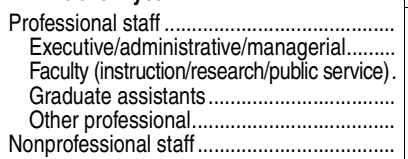 & $\begin{array}{r}1,390,625 \\
84,911 \\
575,534 \\
285,905 \\
444,275 \\
452,579\end{array}$ & $\begin{array}{r}945,006 \\
66,353 \\
419,577 \\
147,122 \\
311,954 \\
288,517\end{array}$ & $\begin{array}{r}280,536 \\
16,968 \\
110,291 \\
46,355 \\
106,922 \\
151,097\end{array}$ & $\begin{array}{l}22.9 \\
20.4 \\
20.8 \\
24.0 \\
25.5 \\
34.4\end{array}$ & $\begin{array}{r}91,210 \\
8,405 \\
30,671 \\
11,101 \\
41,033 \\
77,519\end{array}$ & $\begin{array}{r}66,656 \\
4,354 \\
24,565 \\
11,670 \\
26,067 \\
47,820\end{array}$ & $\begin{array}{r}103,273 \\
3,177 \\
48,374 \\
18,435 \\
33,287 \\
17,794\end{array}$ & $\begin{array}{r}2,025 \\
81 \\
780 \\
444 \\
720 \\
887\end{array}$ & $\begin{array}{r}6,931 \\
527 \\
2,871 \\
1,045 \\
2,488 \\
3,805\end{array}$ & $\begin{array}{r}10,441 \\
424 \\
3,030 \\
3,660 \\
3,327 \\
3,272\end{array}$ & $\begin{array}{r}49,159 \\
1,172 \\
20,368 \\
15,699 \\
11,920 \\
9,556\end{array}$ & $\begin{array}{r}115,924 \\
418 \\
25,298 \\
76,729 \\
13,479 \\
3,409\end{array}$ \\
\hline Private 4-year.. & $1,297,486$ & 906,570 & 288,527 & 24.1 & 129,943 & 71,026 & 69,834 & 2,670 & 4,727 & 10,327 & 57,341 & 45,048 \\
\hline 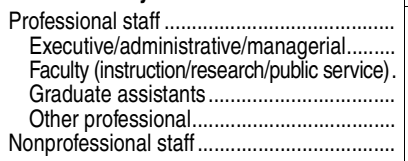 & $\begin{array}{r}1,008,814 \\
118,268 \\
540,093 \\
70,011 \\
280,442 \\
288,672\end{array}$ & $\begin{array}{r}721,680 \\
93,231 \\
396,614 \\
32,311 \\
199,524 \\
184,890\end{array}$ & $\begin{array}{r}194,497 \\
21,783 \\
97,185 \\
10,581 \\
64,948 \\
94,030\end{array}$ & $\begin{array}{l}21.2 \\
18.9 \\
19.7 \\
24.7 \\
24.6 \\
33.7\end{array}$ & $\begin{array}{r}80,669 \\
10,134 \\
39,077 \\
2,635 \\
28,823 \\
49,274\end{array}$ & $\begin{array}{r}42,407 \\
6,047 \\
18,915 \\
2,358 \\
15,087 \\
28,619\end{array}$ & $\begin{array}{r}57,921 \\
4,138 \\
32,451 \\
4,672 \\
16,660 \\
11,913\end{array}$ & $\begin{array}{r}2,005 \\
204 \\
1,085 \\
105 \\
611 \\
665\end{array}$ & $\begin{array}{r}3,359 \\
397 \\
1,856 \\
148 \\
958 \\
1,368\end{array}$ & $\begin{array}{r}8,136 \\
863 \\
3,801 \\
663 \\
2,809 \\
2,191\end{array}$ & $\begin{array}{r}49,923 \\
2,776 \\
30,995 \\
7,375 \\
8,777 \\
7,418\end{array}$ & $\begin{array}{r}42,714 \\
478 \\
15,299 \\
19,744 \\
7,193 \\
2,334\end{array}$ \\
\hline 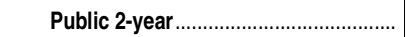 & 641,616 & 466,533 & 145,954 & 23.8 & 67,607 & 46,468 & 21,022 & 1,944 & 4,946 & 3,967 & 25,538 & 3,591 \\
\hline 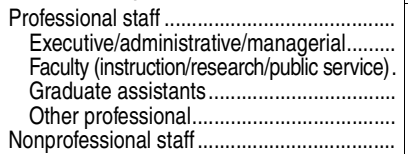 & $\begin{array}{r}474,644 \\
27,562 \\
377,696 \\
0 \\
69,386 \\
166,972\end{array}$ & $\begin{array}{r}360,297 \\
21,423 \\
289,262 \\
\dagger \\
49,612 \\
106,236\end{array}$ & $\begin{array}{r}91,249 \\
5,598 \\
67,649 \\
\dagger \\
18,002 \\
54,705\end{array}$ & $\begin{array}{r}20.2 \\
20.7 \\
19.0 \\
\dagger \\
26.6 \\
34.0\end{array}$ & $\begin{array}{r}43,329 \\
2,947 \\
30,708 \\
\dagger \\
9,674 \\
24,278\end{array}$ & $\begin{array}{r}25,826 \\
1,579 \\
19,247 \\
\dagger \\
5,000 \\
20,642\end{array}$ & $\begin{array}{r}14,899 \\
663 \\
12,257 \\
\dagger \\
1,979 \\
6,123\end{array}$ & $\begin{array}{r}1,290 \\
35 \\
1,052 \\
\dagger \\
203 \\
654\end{array}$ & $\begin{array}{r}3,211 \\
247 \\
2,336 \\
\dagger \\
628 \\
1,735\end{array}$ & $\begin{array}{r}2,694 \\
127 \\
2,049 \\
\dagger \\
518 \\
1,273\end{array}$ & $\begin{array}{r}20,806 \\
470 \\
18,764 \\
\dagger \\
1,572 \\
4,732\end{array}$ & $\begin{array}{r}2,292 \\
71 \\
2,021 \\
\dagger \\
200 \\
1,299\end{array}$ \\
\hline Private 2-year......................................... & 58,674 & 35,351 & 20,474 & 36.7 & 9,784 & 6,860 & 1,884 & 338 & 399 & 1,209 & 2,772 & 77 \\
\hline 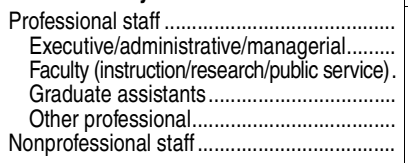 & $\begin{array}{r}49,878 \\
7,977 \\
30,292 \\
0 \\
11,609 \\
8,796\end{array}$ & $\begin{array}{r}30,893 \\
5,377 \\
19,292 \\
\dagger \\
6,224 \\
4,458\end{array}$ & $\begin{array}{r}16,357 \\
2,284 \\
9,269 \\
\dagger \\
4,804 \\
4,117\end{array}$ & $\begin{array}{r}34.6 \\
29.8 \\
32.5 \\
\dagger \\
43.6 \\
48.0\end{array}$ & $\begin{array}{r}8,200 \\
1,009 \\
4,836 \\
\dagger \\
2,355 \\
1,584\end{array}$ & $\begin{array}{r}5,132 \\
836 \\
2,544 \\
\dagger \\
1,752 \\
1,728\end{array}$ & $\begin{array}{r}1,529 \\
239 \\
983 \\
\dagger \\
307 \\
355\end{array}$ & $\begin{array}{r}252 \\
31 \\
152 \\
\dagger \\
69 \\
86\end{array}$ & $\begin{array}{r}313 \\
56 \\
172 \\
\dagger \\
85 \\
86\end{array}$ & $\begin{array}{r}931 \\
113 \\
582 \\
\dagger \\
236 \\
278\end{array}$ & $\begin{array}{r}2,568 \\
299 \\
1,696 \\
\dagger \\
573 \\
204\end{array}$ & $\begin{array}{r}60 \\
17 \\
35 \\
\dagger \\
8 \\
17\end{array}$ \\
\hline
\end{tabular}

†Not applicable.

Combined total of staff who were Black, Hispanic, Asian, Pacific Islander, American Indian/ Alaska Native, and of two or more races as a percentage of total staff, excluding race/ethnicity unknown and nonresident alien.

Race/ethnicity not collected.

NOTE: Degree-granting institutions grant associate's or higher degrees and participate in Title IV federal financial aid programs. Includes institutions with fewer than 15 full-time employees; these institutions did not report staff data prior to 2007. By definition, all graduate assistants are part time. Race categories exclude persons of Hispanic ethnicity.

SOURCE: U.S. Department of Education, National Center for Education Statistics, Integrated Postsecondary Education Data System (IPEDS), Winter 2011-12, Human Resources component, Fall Staff section. (This table was prepared July 2012.) 
Table 314.50. Ratios of full-time-equivalent (FTE) students to FTE staff and FTE faculty in public degree-granting postsecondary institutions, by level of institution and state or jurisdiction: Fall 2011

\begin{tabular}{|c|c|c|c|c|c|c|c|c|c|c|c|c|c|c|}
\hline \multirow[b]{2}{*}{ State or jurisdiction } & \multicolumn{3}{|c|}{ Full-time-equivalent (FTE) staff } & \multicolumn{3}{|c|}{ FTE faculty } & \multicolumn{2}{|c|}{$\begin{array}{l}\text { FTE faculty as a } \\
\text { percent of FTE staff }\end{array}$} & \multicolumn{3}{|c|}{ FTE students per FTE staff } & \multicolumn{3}{|c|}{ FTE students per FTE faculty } \\
\hline & Total & 4-year & 2-year & Total & 4-year & 2-year & 4-year & 2-year & Total & 4-year & 2-year & Total & 4-year & 2-year \\
\hline 1 & 2 & 3 & 4 & 5 & 6 & 7 & 8 & 9 & 10 & 11 & 12 & 13 & 14 & 15 \\
\hline 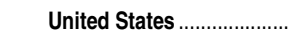 & $1,891,866$ & $1,472,137$ & 419,729 & 645,542 & 445,572 & 199,970 & 30.3 & 47.6 & 5.8 & 4.6 & 10.0 & 17.0 & 15.1 & 21.1 \\
\hline Alabama & 38,871 & 32,435 & 6,436 & 11,813 & 8,663 & 3,150 & 26.7 & 48.9 & 5.2 & 4.3 & 10.0 & 17.2 & 16.1 & 20.4 \\
\hline Alaska.......... & 5,400 & 5,242 & 157 & 1,832 & 1,788 & 45 & 34.1 & 28.4 & 3.9 & 4.0 & 2.6 & 11.6 & 11.6 & 9.3 \\
\hline Arizona .. & 36,083 & 24,893 & 11,189 & 11,971 & 6,655 & 5,316 & 26.7 & 47.5 & 6.8 & 5.0 & 10.9 & 20.5 & 18.6 & 22.9 \\
\hline Arkansas.............. & 22,313 & 17,269 & 5,044 & 6,947 & 4,802 & 2,144 & 27.8 & 42.5 & 5.4 & 4.6 & 8.2 & 17.3 & 16.5 & 19.2 \\
\hline California & 185,657 & 127,751 & 57,906 & 71,505 & 40,405 & 31,100 & 31.6 & 53.7 & 7.7 & 4.7 & 14.2 & 19.9 & 14.9 & 26.5 \\
\hline Colorado. & 35,487 & 30,482 & 5,005 & 16,804 & 14,339 & 2,465 & 47.0 & 49.3 & 5.5 & 4.5 & 11.0 & 11.5 & 9.6 & 22.4 \\
\hline Connecticut.. & 16,715 & 13,500 & 3,215 & 5,584 & 3,815 & 1,769 & 28.3 & 55.0 & 5.5 & 4.3 & 10.2 & 16.4 & 15.3 & 18.6 \\
\hline Delaware.......................... & 6,838 & 5,545 & 1,293 & 2,038 & 1,403 & 634 & 25.3 & 49.1 & 4.8 & 4.3 & 7.1 & 16.2 & 17.0 & 14.5 \\
\hline District of Columbia ........................ & 1,234 & 1,234 & 0 & 389 & 389 & 0 & 31.5 & $\dagger$ & 3.0 & 3.0 & $\dagger$ & 9.5 & 9.5 & \\
\hline 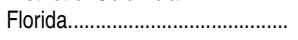 & 78,359 & 72,488 & 5,871 & 26,318 & 23,920 & 2,398 & 33.0 & 40.8 & 7.3 & 7.2 & 8.9 & 21.7 & 21.7 & 21.8 \\
\hline$\ldots \ldots \ldots \ldots \ldots \ldots$ & 58,879 & 46,268 & 12,611 & 18,348 & 12,594 & 5,754 & 27.2 & 45.6 & 5.6 & 4.9 & 8.0 & 17.8 & 18.0 & 17.5 \\
\hline$\ldots \ldots \ldots \ldots \ldots . .$. & 8,027 & 6,300 & 1,727 & 3,012 & 2,158 & 854 & 34.3 & 49.5 & 5.2 & 3.9 & 10.0 & 13.8 & 11.3 & 20.3 \\
\hline$\ldots$ & 8,618 & 7,135 & 1,484 & 3,115 & 2,489 & 627 & 34.9 & 42.2 & 5.9 & 5.7 & 6.9 & 16.4 & 16.4 & 16.3 \\
\hline 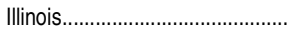 & 71,155 & 49,795 & 21,361 & 20,986 & 11,636 & 9,349 & 23.4 & 43.8 & 5.6 & 3.5 & 10.3 & 18.9 & 15.2 & 23.5 \\
\hline Indiana ............................................ & 47,513 & 42,036 & 5,477 & 15,696 & 12,765 & 2,931 & 30.4 & 53.5 & 5.4 & 4.6 & 11.8 & 16.5 & 15.2 & 22.0 \\
\hline lowa ........ & 25,515 & 18,993 & 6,521 & 8,261 & 5,500 & 2,761 & 29.0 & 42.3 & 5.3 & 3.5 & 10.5 & 16.2 & 11.9 & 24.8 \\
\hline$\ldots \ldots \ldots \ldots . .$. & 26,157 & 19,216 & 6,941 & 9,152 & 6,293 & 2,859 & 32.8 & 41.2 & 5.3 & 4.4 & 7.6 & 15.0 & 13.5 & 18.5 \\
\hline Kentucky ............ & 34,948 & 28,509 & 6,439 & 10,745 & 7,691 & 3,055 & 27.0 & 47.4 & 4.9 & 3.7 & 10.0 & 15.9 & 13.8 & 21.1 \\
\hline Louisiana ……………………........ & 29,125 & 24,781 & 4,344 & 9,967 & 7,575 & 2,393 & 30.6 & 55.1 & 6.0 & 5.0 & 12.1 & 17.6 & 16.3 & 22.0 \\
\hline Maine & 6,627 & 5,533 & 1,093 & 2,285 & 1,668 & 617 & 30.1 & 56.4 & 5.5 & 4.5 & 10.6 & 16.1 & 15.1 & 18.8 \\
\hline Maryland.. & 42,910 & 30,825 & 12,085 & 16,982 & 11,442 & 5,540 & 37.1 & 45.8 & 5.0 & 4.2 & 7.0 & 12.6 & 11.2 & 15.4 \\
\hline Massachusetts... & 30,487 & 22,762 & 7,724 & 10,432 & 7,121 & 3,311 & 31.3 & 42.9 & 5.4 & 4.4 & 8.3 & 15.7 & 14.0 & 19.4 \\
\hline Michigan ……………….......... & 72,522 & 58,646 & 13,876 & 25,777 & 18,995 & 6,782 & 32.4 & 48.9 & 5.6 & 4.4 & 10.4 & 15.6 & 13.6 & 21.3 \\
\hline 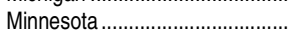 & 33,692 & 25,885 & 7,807 & 11,503 & 7,677 & 3,826 & 29.7 & 49.0 & 5.9 & 4.4 & 10.9 & 17.3 & 14.9 & 22.2 \\
\hline Mississippi ................................. & 29,522 & 22,474 & 7,048 & 7,924 & 4,674 & 3,249 & 20.8 & 46.1 & 4.6 & 3.1 & 9.3 & 17.2 & 15.1 & 20.2 \\
\hline Missouri.. & 38,791 & 30,862 & 7,929 & 12,637 & 9,309 & 3,328 & 30.2 & 42.0 & 5.1 & 4.0 & 9.3 & 15.6 & 13.2 & 22.3 \\
\hline$(\cdots \cdots \cdots \cdots \cdots \cdots$ & 7,626 & 6,594 & 1,032 & 2,585 & 2,173 & 411 & 33.0 & 39.9 & 5.3 & 5.1 & 6.5 & 15.6 & 15.5 & 16.2 \\
\hline 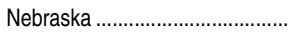 & 17,504 & 14,226 & 3,278 & 5,594 & 4,031 & 1,563 & 28.3 & 47.7 & 4.6 & 3.5 & 9.2 & 14.4 & 12.5 & 19.2 \\
\hline Nevada ……………………… & 9,629 & 9,094 & 535 & 3,480 & 3,187 & 293 & 35.0 & 54.7 & 7.3 & 7.1 & 10.4 & 20.1 & 20.2 & 19.1 \\
\hline New Hampshire ............................... & 6,267 & 4,922 & 1,345 & 2,290 & 1,516 & 774 & 30.8 & 57.5 & 5.5 & 5.3 & 6.2 & 15.1 & 17.2 & 10.9 \\
\hline New Jersev & 47,365 & 36,407 & 10,958 & 15,507 & 10,666 & 4,841 & 29.3 & 44.2 & 5.7 & 4.1 & 11.1 & 17.4 & 13.9 & 25.1 \\
\hline New Mexic & 20,013 & 14,594 & 5,419 & 6,146 & 3,914 & 2,232 & 26.8 & 41.2 & 5.0 & 3.6 & 8.7 & 16.2 & 13.4 & 21.1 \\
\hline New $Y$ & 75,982 & 53,146 & 22,836 & 30,535 & 20,180 & 10,354 & 38.0 & 45.3 & 7.5 & 6.2 & 10.5 & 18.7 & 16.4 & 23.3 \\
\hline North Carolina & 72,139 & 49,179 & 22,960 & 25,938 & 13,634 & 12,304 & 27.7 & 53.6 & 4.8 & 3.9 & 6.8 & 13.4 & 14.2 & 12.6 \\
\hline North Dakota .... & 8,328 & 7,587 & 741 & 2,674 & 2,384 & 290 & 31.4 & 39.1 & 4.8 & 4.6 & 6.2 & 14.8 & 14.7 & 15.9 \\
\hline Ohin & 78,885 & 65,696 & 13,189 & 23,639 & 17,376 & 6,263 & 26.4 & 47.5 & 5.2 & 4.4 & 9.3 & 17.5 & 16.7 & 19.6 \\
\hline Oklaho & 29,029 & 2 & 4,760 & 8,712 & 6,870 & 1,843 & 28.3 & 38.7 & 5.1 & 4.3 & 9.2 & 16.9 & 15.1 & 23.7 \\
\hline Orego & 28,489 & 2 & 8,388 & 10,753 & 7,098 & 3, & 35.3 & 43.6 & 5.5 & 4.3 & 8.5 & 14.6 & 12.1 & 19.6 \\
\hline Pennsylvania... & 65,125 & 55,430 & 9,695 & 24,411 & 19,653 & 4,757 & 35.5 & 49.1 & 5.3 & 4.6 & 9.1 & 14.1 & 13.0 & 18.5 \\
\hline Rhode Island ............................. & 4,668 & 3,779 & 889 & 1,885 & 1,404 & 481 & 37.2 & 54.1 & 6.8 & 5.8 & 11.3 & 16.9 & 15.5 & 20.9 \\
\hline South Carolina $\ldots \ldots \ldots \ldots \ldots \ldots \ldots$ & 28,367 & 21,567 & 6,801 & 9,552 & 6,259 & 3,293 & 29.0 & 48.4 & 5.7 & 4.4 & 9.7 & 16.9 & 15.3 & 20.0 \\
\hline South Dakota. & 5,976 & 5,294 & 682 & 2,115 & 1,754 & 361 & 33.1 & 53.0 & 5.8 & 5.5 & 8.1 & 16.3 & 16.5 & 15.3 \\
\hline Tennessee ................................ & 32,902 & 26,843 & 6,059 & 10,801 & 7,820 & 2,980 & 29.1 & 49.2 & 5.7 & 4.7 & 10.3 & 17.4 & 16.1 & 20.9 \\
\hline Texas & 177,130 & 132,830 & 44,300 & 52,290 & 32,474 & 19,816 & 24.4 & 44.7 & 5.2 & 3.9 & 9.2 & 17.7 & 16.0 & 20.5 \\
\hline Utah & 20,739 & 17,961 & 2,778 & 7,325 & 6,184 & 1,141 & 34.4 & 41.1 & 6.0 & 5.6 & 9.0 & 17.1 & 16.3 & 21.8 \\
\hline & 5,348 & & 410 & 1,959 & 36 & 222 & 35.2 & 54.2 & 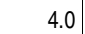 & 3.7 & 7.2 & 10.9 & 10.6 & 13.4 \\
\hline & 53,135 & 44,097 & 9,038 & 18,975 & 13,994 & 4,981 & 31.7 & 55.1 & 5 & 4.3 & 12.6 & 15 & 13.5 & 22.9 \\
\hline ton ....................................... & 43,309 & 33,161 & 10,148 & 13,787 & 9,322 & 4,465 & 28.1 & 44.0 & 5.7 & 4.3 & 10.1 & 17.8 & 15.4 & 22.9 \\
\hline 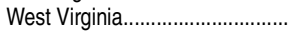 & 13,228 & 11,892 & 1,336 & 5,092 & 4,280 & 812 & 36.0 & 60.8 & 6.0 & 5.4 & 11.3 & 15.6 & 15.0 & 18.6 \\
\hline Wisconsin & 41,816 & 32,581 & 9,236 & 14,468 & 9,831 & 4,637 & 30.2 & 50.2 & 5.4 & 4.9 & 7.1 & 15.5 & 16.2 & 14.1 \\
\hline 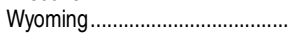 & 5,611 & 3,277 & 2,334 & 2,069 & 1,128 & 941 & 34.4 & 40.3 & 4.5 & 3.4 & 6.1 & 12.3 & 9.8 & 15.2 \\
\hline U.S. Service Academies.. & 1,814 & 1,814 & 0 & 938 & 938 & 0 & 51.7 & $\dagger$ & 8.6 & 8.6 & $\dagger$ & 16.7 & 16.7 & $t$ \\
\hline Other jurisdictions ............ & 15,324 & 13,782 & 1,543 & 4,972 & 4,304 & 668 & 31.2 & 43.3 & 4.6 & 4.5 & 6.0 & 14.3 & 14.4 & 13.9 \\
\hline American & 300 & 0 & 300 & 84 & 0 & 84 & $\dagger$ & 27.9 & 4.6 & 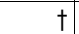 & 4.6 & 16.5 & $\dagger$ & 16.5 \\
\hline ates of Micronesia. & 330 & 0 & 330 & 105 & 0 & 105 & $\dagger$ & 31.8 & 7.0 & $\dagger$ & 7.0 & 22.1 & $\dagger$ & 22.1 \\
\hline Guam & 962 & 686 & 276 & 403 & 255 & 148 & 37.1 & 53.6 & 4.7 & 4.5 & 5.2 & 11.3 & 12.2 & 9.7 \\
\hline Marshall Islands........................... & 169 & 0 & 169 & 61 & 0 & 61 & $t$ & 36.1 & 5.2 & $t$ & 5.2 & 14.4 & $\dagger$ & 14.4 \\
\hline Northern Marianas ........................... & 165 & 165 & 0 & 60 & 60 & 0 & 36.4 & $\dagger$ & 5.9 & 5.9 & $\dagger$ & 16.2 & 16.2 & \\
\hline 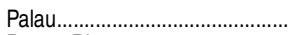 & 164 & & 164 & 51 & 0 & 51 & $\dagger$ & 31.2 & 3.6 & $\dagger$ & 3.6 & 11.5 & $\dagger$ & 11.5 \\
\hline Puerto Rico.... & 12,669 & 12,365 & 304 & 4,047 & 3,829 & 219 & 31.0 & 72.0 & 4.6 & 4.5 & 8.8 & 14.4 & 14.6 & 12.3 \\
\hline U.S. Virgin Islands ........................ & 565 & 565 & 0 & 161 & 161 & 0 & 28.5 & $\dagger$ & 3.5 & 3.5 & $\dagger$ & 12.1 & 12.1 & $\dagger$ \\
\hline
\end{tabular}

†Not applicable.

NOTE: Full-time-equivalent staff is the full-time staff, plus the full-time equivalent of the parttime staff. Degree-granting institutions grant associate's or higher degrees and participate in Title IV federal financial aid programs. Data are for all degree-granting institutions, including those with fewer than 15 employees. Detail may not sum to totals because of rounding.
SOURCE: U.S. Department of Education, National Center for Education Statistics, Integrated Postsecondary Education Data System (IPEDS), Winter 2011-12, Human Resources component, Fall Staff section; and Spring 2012, Enrollment component. (This table was prepared January 2013.) 
Table 314.60. Ratios of full-time-equivalent (FTE) students to FTE staff and FTE faculty in private degree-granting postsecondary institutions, by level of institution and state or jurisdiction: Fall 2011

\begin{tabular}{|c|c|c|c|c|c|c|c|c|c|c|c|c|c|c|}
\hline \multirow[b]{2}{*}{ State or jurisdiction } & \multicolumn{4}{|c|}{ Full-time-equivalent (FTE) staff } & \multicolumn{4}{|c|}{ FTE faculty } & \multicolumn{2}{|c|}{$\begin{array}{c}\text { FTE faculty as a } \\
\text { percent of FTE staff }\end{array}$} & \multicolumn{2}{|c|}{$\begin{array}{l}\text { FTE students } \\
\text { per FTE staff }\end{array}$} & \multicolumn{2}{|c|}{$\begin{array}{l}\text { FTE students } \\
\text { per FTE faculty }\end{array}$} \\
\hline & $\begin{array}{r}\text { All } \\
\text { private }\end{array}$ & $\begin{array}{r}\text { Nonprofit } \\
4 \text {-year }\end{array}$ & $\begin{array}{r}\text { Nonprofit } \\
2 \text {-year }\end{array}$ & For-profit & All private & $\begin{array}{r}\text { Nonprofit } \\
4 \text {-year }\end{array}$ & \begin{tabular}{r|} 
Nonprofit \\
2 -year
\end{tabular} & For-profit & $\begin{array}{r}\text { Nonprofit } \\
4 \text {-year }\end{array}$ & For-profit & $\begin{array}{r}\text { Nonprofit } \\
4 \text {-year }\end{array}$ & For-profit & $\begin{array}{r}\text { Nonprofit } \\
4 \text {-year }\end{array}$ & For-profit \\
\hline 1 & 2 & 3 & 4 & 5 & 6 & 7 & 8 & 9 & 10 & 11 & 12 & 13 & 14 & 15 \\
\hline United States... & $1,069,358$ & 903,021 & 5,434 & 160,903 & 371,478 & 304,204 & 2,400 & 64,874 & 33.7 & 40.3 & 3.6 & 10.0 & 10.8 & 24.9 \\
\hline Alabama ........ & 6,601 & 4,565 & 72 & 1,965 & 2,412 & 1,674 & 30 & 708 & 36.7 & 36.1 & 5.1 & 13.8 & 13.9 & 38.2 \\
\hline Alaska.......... & 562 & 165 & 0 & 396 & 241 & 76 & 0 & 165 & 45.9 & 41.6 & 3.2 & 5.1 & 6.9 & 12.3 \\
\hline Arizona ............................................. & 27,144 & 1,686 & 0 & 25,457 & 10,997 & 551 & 0 & 10,446 & 32.7 & 41.0 & 4.6 & 15.4 & 14.1 & 37.4 \\
\hline Arkansas..................................... & 3,176 & 2,874 & 40 & 263 & 1,111 & 970 & 13 & 128 & 33.8 & 48.6 & 5.3 & 9.4 & 15.6 & 19.3 \\
\hline 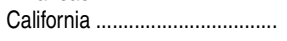 & 92,893 & 73,729 & 234 & 18,930 & 32,652 & 24,610 & 93 & 7,949 & 33.4 & 42.0 & 3.4 & 9.9 & 10.2 & 23.6 \\
\hline Colorado & 10,594 & 5,460 & 24 & 5,110 & 3,978 & 2,012 & 8 & 1,958 & 36.9 & 38.3 & 4.8 & 10.1 & 13.0 & 26.5 \\
\hline onnecticl & 24,340 & 23,451 & 51 & 838 & 8,531 & 8,206 & 31 & 293 & 35.0 & 35.0 & 2.5 & 6.2 & 7.0 & 17.7 \\
\hline Delaware............. & 1,355 & 1,281 & 37 & 37 & 615 & 589 & 16 & 11 & 46.0 & 28.9 & 8.4 & 5.6 & 18.2 & 19.3 \\
\hline District of Columbia ....................... & 21,236 & 20,481 & 0 & 755 & 7,085 & 6,500 & 0 & 584 & 31.7 & 77.4 & 3.3 & 4.1 & 10.3 & 5.3 \\
\hline Florida......................................... & 46,576 & 32,395 & 138 & 14,044 & 17,296 & 11,816 & 72 & 5,408 & 36.5 & 38.5 & 4.5 & 9.5 & 12.4 & 24.6 \\
\hline Georgia. & 24,901 & 20,399 & 80 & 4,423 & 9,231 & 7,165 & 29 & 2,036 & 35.1 & 46.0 & 3.2 & 12.4 & 9.0 & 27.0 \\
\hline$\ldots$ & 2,051 & 1,705 & 0 & 345 & 889 & 736 & 0 & 152 & 43.2 & 44.1 & 6.9 & 9.4 & 16.0 & 21.3 \\
\hline laho..................................... & 2,331 & 1,919 & 0 & 411 & 1,070 & 901 & 0 & 169 & 46.9 & 41.2 & 9.7 & 6.4 & 20.7 & 15.6 \\
\hline 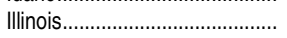 & 64,454 & 55,280 & 86 & 9,088 & 21,818 & 18,788 & 38 & 2,992 & 34.0 & 32.9 & 3.5 & 6.4 & 10.3 & 19.5 \\
\hline Indiana & 20,851 & 17,977 & 75 & 2,799 & 6,741 & 5,615 & 26 & 1,100 & 31.2 & 39.3 & 4.4 & 8.6 & 14.1 & 21.9 \\
\hline owa & 20,372 & 10,204 & 35 & 10,132 & 6,680 & 3,781 & 23 & 2,876 & 37.1 & 28.4 & 4.9 & 10.7 & 13.3 & 37.7 \\
\hline ……..... & 4,264 & 3,451 & 372 & 442 & 1,662 & 1,377 & 114 & 171 & 39.9 & 38.6 & 5.3 & 7.2 & 13.3 & 18.5 \\
\hline entucky... & 8,616 & 6,259 & 0 & 2,357 & 3,425 & 2,330 & 0 & 1,095 & 37.2 & 46.5 & 5.3 & 7.1 & 14.3 & 15.3 \\
\hline 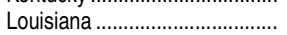 & 8,645 & 7,455 & 161 & 1,029 & 3,031 & 2,450 & 75 & 506 & 32.9 & 49.2 & 3.3 & 9.6 & 10.0 & 19.6 \\
\hline Maine...... & 4,484 & 4,297 & 44 & 143 & 1,429 & 1,348 & 30 & 50 & 31.4 & 35.3 & 4.1 & 7.1 & 13.1 & 20.2 \\
\hline Maryland. & 24,236 & 23,465 & 0 & 771 & 6,596 & 6,295 & 0 & 302 & 26.8 & 39.1 & 1.8 & 10.0 & 6.9 & 25.5 \\
\hline lass & 167 & 95 & 105 & 667 & 27,884 & 27,508 & 70 & 306 & 34.2 & 45.9 & 3.0 & 8.9 & 8.6 & 19.4 \\
\hline ichigan . & 14,353 & 13,238 & 11 & 1,104 & 5,834 & 5,345 & 4 & 484 & 40.4 & 43.9 & 6.7 & 8.4 & 16.5 & 19.1 \\
\hline Minnesota. & 18,821 & 12,644 & 36 & 6,140 & 7,894 & 5,003 & 11 & 2,879 & 39.6 & 46.9 & 4.9 & 11.6 & 12.3 & 24.7 \\
\hline Mississippi .... & 2,625 & 2,244 & 0 & 381 & 1,033 & 874 & 0 & 159 & 39.0 & 41.7 & 6.1 & 6.5 & 15.8 & 15.6 \\
\hline lissouri & 33,106 & 30,129 & 138 & 2,839 & 11,646 & 10,482 & 68 & 1,096 & 34.8 & 38.6 & 3.8 & 11.0 & 10.9 & 28.5 \\
\hline ont & 983 & 885 & 99 & 0 & 368 & 337 & 31 & 0 & 38.1 & $\dagger$ & 4.7 & $\dagger$ & 12.4 & $\dagger$ \\
\hline ebras & 6,062 & 5,669 & 46 & 347 & 2,048 & 1,890 & 12 & 145 & 33.3 & 41.9 & 4.9 & 7.3 & 14.7 & 17.4 \\
\hline Nevada .. & 1,599 & 551 & 0 & 1,048 & 747 & 270 & 0 & 476 & 49.1 & 45.4 & 5.8 & 10.8 & 11.8 & 23.7 \\
\hline 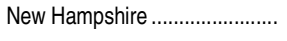 & 7,663 & 7,194 & 46 & 422 & 2,241 & 2,035 & 31 & 175 & 28.3 & 41.4 & 3.4 & 6.3 & 12.0 & 15.3 \\
\hline New Jersey ........... & 16,294 & 15,231 & 0 & 1,063 & 5,649 & 5,231 & 0 & 418 & 34.3 & 39.3 & 4.1 & 7.0 & 11.9 & 17.9 \\
\hline$\cdots$ & 1,119 & 267 & 0 & 852 & 497 & 87 & 0 & 410 & 32.6 & 48.1 & 3.7 & 10.7 & 11.3 & 22.3 \\
\hline ․․․․……..... & 142,639 & 135,910 & 582 & 6,148 & 48,640 & 45,907 & 320 & 2,412 & 33.8 & 39.2 & 3.3 & 7.8 & 9.7 & 20.0 \\
\hline No & 37,734 & 35,839 & 127 & 1,768 & 10,128 & 9,425 & 41 & 662 & 26.3 & 37.4 & 2.4 & 8.3 & 9.0 & 22.1 \\
\hline 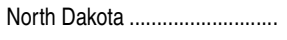 & 1,139 & 1,013 & 0 & 127 & 430 & 381 & 0 & 49 & 37.6 & 38.4 & 4.9 & 6.3 & 13.0 & 16.5 \\
\hline hio... & 32,539 & 27,266 & 391 & 4,882 & 12,541 & 10,187 & 179 & 2,176 & 37.4 & 44.6 & 4.5 & 7.6 & 12.1 & 17.0 \\
\hline aho & 5,649 & 4,548 & 0 & 1,101 & 2,010 & 1,525 & 0 & 485 & 33.5 & 44.0 & 4.5 & 8.2 & 13.5 & 18.6 \\
\hline$\ldots \ldots \ldots . . .$. & 7,088 & 6,107 & 0 & 981 & 2,896 & 2,444 & 0 & 452 & 40.0 & 46.1 & 4.8 & 8.6 & 12.0 & 18.7 \\
\hline Per & 79,008 & 71,435 & 1,171 & 6,403 & 27,381 & 24,142 & 507 & 2,732 & 33.8 & 42.7 & 3.5 & 7.5 & 10.3 & 17.5 \\
\hline Rhode Island .... & 9,659 & 9,659 & 0 & 0 & 3,014 & 3,014 & 0 & 0 & 31.2 & $\dagger$ & 4.0 & $\dagger$ & 12.9 & $\dagger$ \\
\hline South & 8,551 & 5,817 & 168 & 2,566 & 2,874 & 2,077 & 49 & 748 & 35.7 & 29.1 & 5.3 & 1.0 & 15.0 & 3.4 \\
\hline & 1,911 & 1,222 & 34 & 654 & 669 & 490 & 18 & 161 & 40.1 & 24.6 & 4.8 & 4.0 & 11.9 & 16.3 \\
\hline ……….... & 38,501 & 35,614 & 177 & 2,711 & 9,445 & 8,171 & 75 & 1,199 & 22.9 & 44.2 & 2.0 & 8.7 & 8.8 & 19.8 \\
\hline 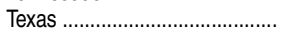 & 36,240 & 29,497 & 540 & 6,204 & 13,169 & 10,440 & 245 & 2,484 & 35.4 & 40.0 & 3.8 & 8.9 & 10.6 & 22.1 \\
\hline 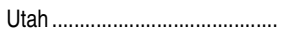 & 8,627 & 7,075 & 106 & 1,447 & 3,191 & 2,470 & 54 & 667 & 34.9 & 46.1 & 9.3 & 9.1 & 26.5 & 19.7 \\
\hline Verm & 4,238 & 3,899 & 198 & 142 & 1,404 & 1,287 & 82 & 36 & 33.0 & 25.3 & 4.0 & 3.3 & 12.2 & 13.2 \\
\hline & 22,257 & 16,521 & 0 & & 8 & 6,040 & 0 & 2,509 & 36.6 & 43.7 & 5.6 & 7.9 & 15.2 & 18.0 \\
\hline We & 8,865 & 7,626 & 11 & 29 & 3,664 & 3,151 & 5 & 509 & 41.3 & 41.4 & 5.0 & 8.9 & 12.0 & 21.4 \\
\hline West V & 4,308 & 2,141 & 0 & 2,167 & 1,805 & 744 & 0 & 1,061 & 34.7 & 49.0 & 4.9 & 11.9 & 14.2 & 24.3 \\
\hline 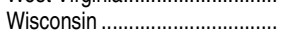 & 16,694 & 14,889 & 0 & 1,805 & 6,262 & 5,457 & 0 & 805 & 36.7 & 44.6 & 3.6 & 6.2 & 9.8 & 13.8 \\
\hline Wyoming..... & 236 & 0 & 0 & 236 & 78 & 0 & 0 & 78 & $\dagger$ & 33.2 & $\dagger$ & 7.3 & $\dagger$ & 22.0 \\
\hline Other jurisdictions .......... & 15,424 & 11,649 & 328 & 3,446 & 6,294 & 4,589 & 146 & 1,559 & 39.4 & 45.2 & 10.4 & 12.0 & 26.5 & 26.5 \\
\hline$\ldots \ldots \ldots . .$. & 0 & 0 & 0 & 0 & 0 & 0 & & 0 & $\dagger$ & & $\dagger$ & $\dagger$ & $\dagger$ & $\bar{\dagger}$ \\
\hline Federated States & 0 & 0 & 0 & 0 & 0 & 0 & 0 & 0 & & $\dagger$ & $\dagger$ & $\dagger$ & $\dagger$ & \\
\hline Gua & 47 & 47 & 0 & 0 & 11 & 11 & 0 & 0 & 24.2 & $\dagger$ & 1.4 & $\dagger$ & 5.8 & $\dagger$ \\
\hline Marshall Islands....... & 0 & 0 & 0 & 0 & 0 & 0 & 0 & 0 & $\dagger$ & $\dagger$ & $\dagger$ & $\dagger$ & $\dagger$ & $\dagger$ \\
\hline Northern Marianas .................... & 0 & 0 & 0 & 0 & 0 & 0 & 0 & 0 & $\dagger$ & $\dagger$ & $\dagger$ & $\dagger$ & $\dagger$ & $\dagger$ \\
\hline ․․․․․․……....... & 0 & 0 & 0 & 0 & 0 & 0 & 0 & 0 & $\dagger$ & $\dagger$ & $\dagger$ & $\dagger$ & $\dagger$ & \\
\hline Puerto Rico & 15,377 & 11,603 & 328 & 3,446 & 6,282 & 4,578 & 146 & 1,559 & 39.5 & 45.2 & 10.5 & 12.0 & 26.5 & 26.5 \\
\hline U.S. Virgin Islands ........................ & 0 & 0 & 0 & 0 & 0 & 0 & 0 & 0 & $\dagger$ & $\dagger$ & $\dagger$ & $\dagger$ & $\dagger$ & $\dagger$ \\
\hline
\end{tabular}

†Not applicable.

NOTE: Full-time-equivalent staff is the full-time staff, plus the full-time equivalent of the parttime staff. Degree-granting institutions grant associate's or higher degrees and participate in Title IV federal financial aid programs. Data are for all degree-granting institutions, including those with fewer than 15 employees. Detail may not sum to totals because of rounding.
SOURCE: U.S. Department of Education, National Center for Education Statistics, Integrated Postsecondary Education Data System (IPEDS), Winter 2011-12, Human Resources component, Fall Staff section; and Spring 2012, Enrollment component. (This table was prepared January 2013.) 
Table 315.10. Number of instructional faculty in degree-granting postsecondary institutions, by employment status, sex, control, and level of institution: Selected years, fall 1970 through fall 2011

\begin{tabular}{|c|c|c|c|c|c|c|c|c|c|c|c|c|c|}
\hline \multirow[b]{3}{*}{ Year } & \multirow[b]{3}{*}{ Total } & \multicolumn{3}{|c|}{ Employment status } & \multicolumn{3}{|c|}{ Sex } & \multicolumn{4}{|c|}{ Control } & \multicolumn{2}{|c|}{ Level } \\
\hline & & \multirow[b]{2}{*}{ Full-time } & \multirow[b]{2}{*}{ Part-time } & \multirow{2}{*}{$\begin{array}{l}\text { Percent } \\
\text { full-time }\end{array}$} & \multirow[b]{2}{*}{ Males } & \multirow[b]{2}{*}{ Females } & \multirow{2}{*}{$\begin{array}{r}\text { Percent } \\
\text { female }\end{array}$} & \multirow[b]{2}{*}{ Public } & \multicolumn{3}{|c|}{ Private } & \multirow[b]{2}{*}{ 4-year } & \multirow[b]{2}{*}{ 2-year } \\
\hline & & & & & & & & & Total & Nonprofit & For-profit & & \\
\hline 1 & 2 & 3 & 4 & 5 & 6 & 7 & 8 & 9 & 10 & 11 & 12 & 13 & 14 \\
\hline 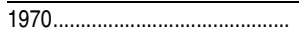 & 474,000 & 369,000 & 104,000 & 77.8 & - & - & - & 314,000 & 160,000 & - & - & 382,000 & 92,000 \\
\hline $1971^{1}$ & 492,000 & 379,000 & 113,000 & 77.0 & - & - & - & 333,000 & 159,000 & - & - & 387,000 & 105,000 \\
\hline 1972 & 500,000 & 380,000 & 120,000 & 76.0 & - & - & - & 343,000 & 157,000 & - & - & 384,000 & 116,000 \\
\hline $1973^{1}$ & 527,000 & 389,000 & 138,000 & 73.8 & - & - & - & 365,000 & 162,000 & - & - & 401,000 & 126,000 \\
\hline $19744^{1}$ & 567,000 & 406,000 & 161,000 & 71.6 & - & - & - & 397,000 & 170,000 & - & - & 427,000 & 140,000 \\
\hline 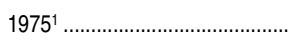 & 628,000 & 440,000 & 188,000 & 70.1 & - & - & - & 443,000 & 185,000 & - & - & 467,000 & 161,000 \\
\hline $1976 \ldots$ & 633,000 & 434,000 & 199,000 & 68.6 & - & - & - & 449,000 & 184,000 & - & - & 467,000 & 166,000 \\
\hline 1977 & 678,000 & 448,000 & 230,000 & 66.1 & - & - & - & 492,000 & 186,000 & - & - & 485,000 & 193,000 \\
\hline $1979^{1}$ & 675,000 & 445,000 & 230,000 & 65.9 & - & - & - & 488,000 & 187,000 & - & - & 494,000 & 182,000 \\
\hline $1980^{1}$ & 686,000 & 450,000 & 236,000 & 65.6 & - & - & - & 495,000 & 191,000 & - & - & 494,000 & 192,000 \\
\hline $1981 \ldots \ldots \ldots$ & 705,000 & 461,000 & 244,000 & 65.4 & - & - & - & 509,000 & 196,000 & - & - & 493,000 & 212,000 \\
\hline $1982^{1}$ & 710,000 & 462,000 & 248,000 & 65.1 & - & - & - & 506,000 & 204,000 & - & - & 493,000 & 217,000 \\
\hline 1983 & 724,000 & 471,000 & 254,000 & 65.1 & - & - & - & 512,000 & 212,000 & - & - & 504,000 & 220,000 \\
\hline 19841 & 717,000 & 462,000 & 255,000 & 64.4 & - & - & - & 505,000 & 212,000 & - & - & 504,000 & 213,000 \\
\hline $1985^{1}$ & 715,000 & 459,000 & 256,000 & 64.2 & - & - & - & 503,000 & 212,000 & - & - & 504,000 & 211,000 \\
\hline $1986^{1} \ldots \ldots$ & 722,000 & 459,000 & 263,000 & 63.6 & - & - & - & 510,000 & 212,000 & - & - & 506,000 & 216,000 \\
\hline $1987^{2} \ldots \ldots \ldots \ldots \ldots \ldots \ldots \ldots \ldots \ldots \ldots \ldots \ldots$ & 793,070 & 523,420 & 269,650 & 66.0 & 529,413 & 263,657 & 33.2 & 552,749 & 240,321 & - & - & 547,505 & 245,565 \\
\hline $1989^{2} \ldots \ldots \ldots$ & 824,220 & 524,426 & 299,794 & 63.6 & 534,254 & 289,966 & 35.2 & 577,298 & 246,922 & - & - & 583,700 & 240,520 \\
\hline $1991^{2}$ & 826,252 & 535,623 & 290,629 & 64.8 & 525,599 & 300,653 & 36.4 & 580,908 & 245,344 & 236,066 & 9,278 & 591,269 & 234,983 \\
\hline $1993^{2}$ & 915,474 & 545,706 & 369,768 & 59.6 & 561,123 & 354,351 & 38.7 & 650,434 & 265,040 & 254,130 & 10,910 & 625,969 & 289,505 \\
\hline $1995^{2}$ & 931,706 & 550,822 & 380,884 & 59.1 & 562,893 & 368,813 & 39.6 & 656,833 & 274,873 & 260,900 & 13,973 & 647,059 & 284,647 \\
\hline $1997^{2}$ & 989,813 & 568,719 & 421,094 & 57.5 & 587,420 & 402,393 & 40.7 & 694,560 & 295,253 & 271,257 & 23,996 & 682,650 & 307,163 \\
\hline $1999^{2}$ & $1,027,830$ & 590,937 & 436,893 & 57.5 & 602,469 & 425,361 & 41.4 & 713,325 & 314,505 & 284,652 & 29,853 & 713,823 & 314,007 \\
\hline $2001^{2} \ldots \ldots \ldots \ldots \ldots \ldots \ldots \ldots \ldots$ & $1,113,183$ & 617,868 & 495,315 & 55.5 & 644,514 & 468,669 & 42.1 & 771,124 & 342,059 & 306,487 & 35,572 & 764,172 & 349,011 \\
\hline $2003^{2}$ & $1,173,593$ & 630,092 & 543,501 & 53.7 & 663,723 & 509,870 & 43.4 & 791,766 & 381,827 & 330,097 & 51,730 & 814,289 & 359,304 \\
\hline 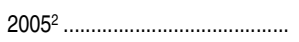 & $1,290,426$ & 675,624 & 614,802 & 52.4 & 714,453 & 575,973 & 44.6 & 841,188 & 449,238 & 361,523 & 87,715 & 916,996 & 373,430 \\
\hline 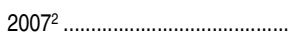 & $1,371,390$ & 703,463 & 667,927 & 51.3 & 743,812 & 627,578 & 45.8 & 877,146 & 494,244 & 385,875 & 108,369 & 990,849 & 380,541 \\
\hline $2009^{2}$ & $1,439,144$ & 728,977 & 710,167 & 50.7 & 761,035 & 678,109 & 47.1 & 913,679 & 525,465 & 408,561 & 116,904 & $1,038,483$ & 400,661 \\
\hline $2011^{2} \ldots \ldots \ldots \ldots$ & $1,523,615$ & 761,619 & 761,996 & 50.0 & 789,197 & 734,418 & 48.2 & 953,230 & 570,385 & 432,733 & 137,652 & $1,115,627$ & 407,988 \\
\hline
\end{tabular}

-Not available.

'Estimated on the basis of enrollment. For methodological details on estimates, see National Center for Education Statistics, Projections of Education Statistics to 2000.

${ }^{2}$ Because of revised survey methods, data are not directly comparable with figures for years prior to 1987.

NOTE: Includes faculty members with the title of professor, associate professor, assistant professor, instructor, lecturer, assisting professor, adjunct professor, or interim professor (or the equivalent). Excluded are graduate students with titles such as graduate or teaching fellow who assist senior faculty. Data through 1995 are for institutions of higher education, while later data are for degree-granting institutions. Degree-granting institutions grant associate's or higher degrees and participate in Title IV federal financial aid programs. The degree-granting classification is very similar to the earlier higher education classification, but it includes more 2-year colleges and excludes a few higher education institutions that did not grant degrees. Beginning in 2007, includes institutions with fewer than 15 full-time employees; these institutions did not report staff data prior to 2007. Detail may not sum to totals because of rounding.

SOURCE: U.S. Department of Education, National Center for Education Statistics, Higher Education General Information Survey (HEGIS), Employees in Institutions of Higher Education, 1970 and 1972, and "Staff Survey" 1976; Projections of Education Statistics to 2000; Integrated Postsecondary Education Data System (IPEDS), "Fall Staff Survey" (IPEDS-S:87-99); IPEDS Winter 2001-02 through Winter 2011-12, Human Resources component, Fall Staff section; and U.S. Equal Employment Opportunity Commission, Higher Education Staff Information Survey (EEO-6), 1977, 1981, and 1983. (This table was prepared July 2012.) 
Table 315.20. Full-time instructional faculty in degree-granting postsecondary institutions, by race/ethnicity, sex, and academic rank: Fall 2007, fall 2009, and fall 2011

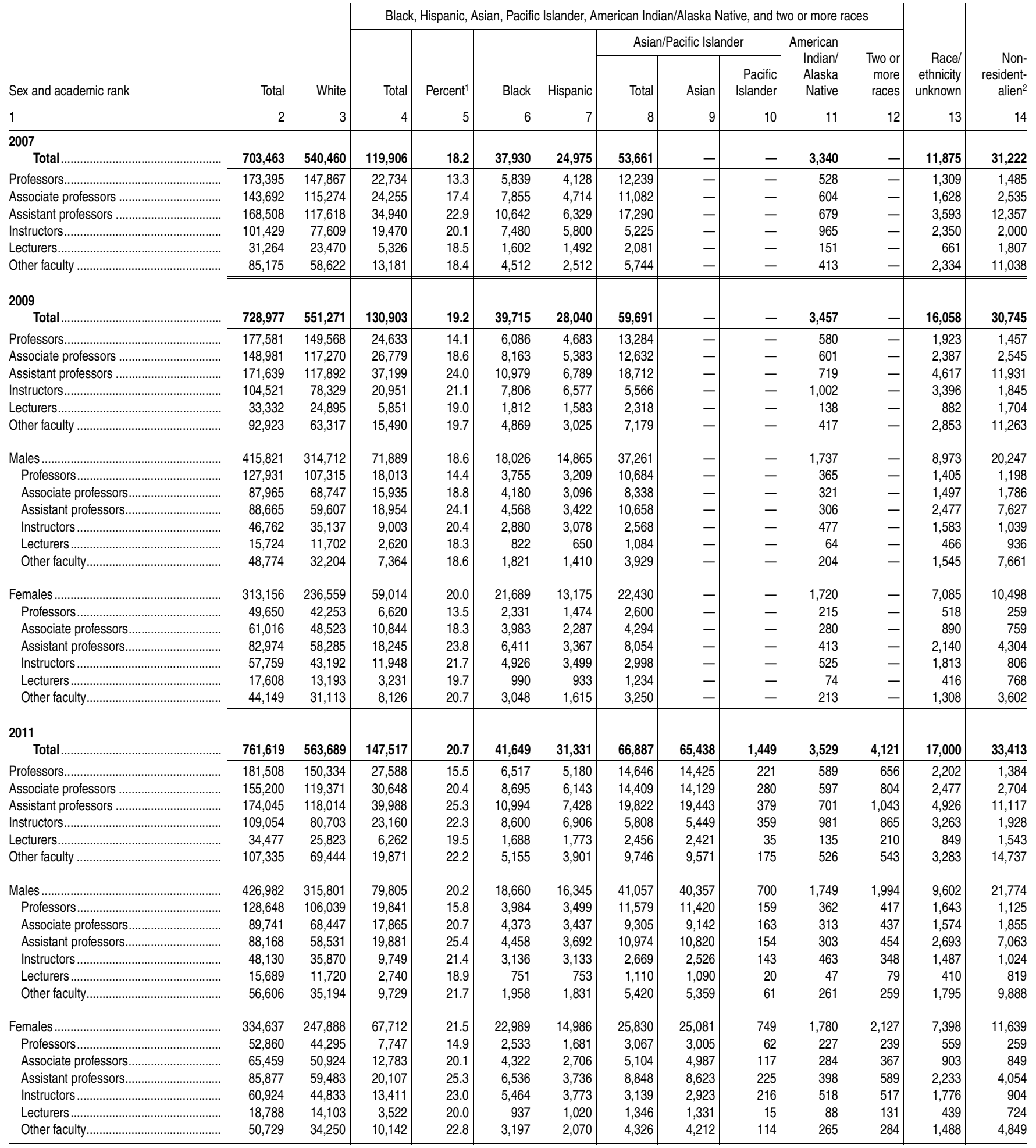

-Not available.

${ }^{1}$ Combined total of faculty who were Black, Hispanic, Asian, Pacific Islander, American Indian/Alaska Native, and of two or more races as a percentage of total faculty, excluding race/ethnicity unknown and nonresident alien.

${ }^{2}$ Race/ethnicity not collected.

NOTE: Degree-granting institutions grant associate's or higher degrees and participate in Title IV federal financial aid programs. Includes institutions with fewer than 15 full-time employees; these institutions did not report staff data prior to 2007. Race categories exclude persons of Hispanic ethnicity.

SOURCE: U.S. Department of Education, National Center for Education Statistics, Integrated Postsecondary Education Data System (IPEDS), Winter 2007-08, Winter 2009-10, and Winter 2011-12, Human Resources component, Fall Staff section. (This table was prepared July 2012.) 


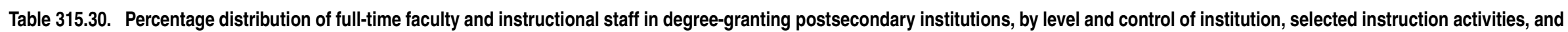
number of classes taught for credit: Fall 2003

[Standard errors appear in parentheses]

\begin{tabular}{|c|c|c|c|c|c|c|c|c|c|c|c|c|c|c|c|c|c|c|c|c|c|}
\hline \multirow[b]{2}{*}{ Instruction activity and number of classes } & \multirow{2}{*}{\multicolumn{2}{|c|}{ All institutions }} & \multicolumn{4}{|c|}{ Research } & \multicolumn{4}{|c|}{ Doctoral } & \multicolumn{4}{|c|}{ Comprehensive } & \multirow{2}{*}{\multicolumn{2}{|c|}{ Private liberal arts }} & \multirow{2}{*}{\multicolumn{2}{|c|}{ Public 2-year }} & \multirow{2}{*}{\multicolumn{2}{|c|}{ Other }} & \\
\hline & & & & Public & & Private & & Public & & Private & & Public & & Private & & & & & & & \\
\hline 1 & & 2 & & 3 & & 4 & & 5 & & 6 & & 7 & & 8 & & 9 & & 10 & & 11 & \\
\hline 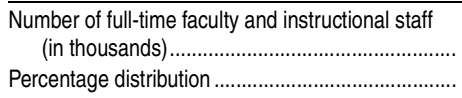 & $\begin{array}{l}681.8 \\
100.0\end{array}$ & $\begin{array}{r}(0.05) \\
(\dagger)\end{array}$ & $\begin{array}{r}162.1 \\
23.8\end{array}$ & $\begin{array}{l}(0.85) \\
(0.12)\end{array}$ & $\begin{array}{r}63.5 \\
9.3\end{array}$ & $\begin{array}{l}(1.58) \\
(0.23)\end{array}$ & $\begin{array}{r}51.3 \\
7.5\end{array}$ & $\begin{array}{l}(0.76) \\
(0.11)\end{array}$ & $\begin{array}{r}21.7 \\
3.2\end{array}$ & $\begin{array}{l}(0.79) \\
(0.12)\end{array}$ & $\begin{array}{r}107.3 \\
15.7\end{array}$ & $\begin{array}{l}(2.98) \\
(0.44)\end{array}$ & $\begin{array}{r}41.4 \\
6.1\end{array}$ & $\begin{array}{l}(1.59) \\
(0.23)\end{array}$ & $\begin{array}{r}49.6 \\
7.3\end{array}$ & $\begin{array}{l}(1.80) \\
(0.26)\end{array}$ & $\begin{array}{r}114.6 \\
16.8\end{array}$ & $\begin{array}{l}(1.09) \\
(0.16)\end{array}$ & $\begin{array}{l}70.2 \\
10.3\end{array}$ & $\begin{array}{l}(3.36) \\
(0.49)\end{array}$ & \\
\hline Average hours worked per week ............................. & 53.3 & $(0.13)$ & 55.6 & $(0.21)$ & 55.8 & $(0.42)$ & 54.0 & $(0.38)$ & 52.4 & $(0.59)$ & 53.2 & $(0.31)$ & 51.8 & $(0.53)$ & 54.0 & $(0.39)$ & 49.2 & $(0.34)$ & 53.1 & $(0.49)$ & \\
\hline 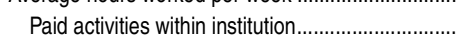 & 45.4 & $(0.12)$ & 48.8 & $(0.19)$ & 47.8 & $(0.36)$ & 45.9 & $(0.31)$ & 44.7 & $(0.47)$ & 44.4 & $(0.27)$ & 42.9 & $(0.55)$ & 45.6 & $(0.39)$ & 40.9 & $(0.27)$ & 45.1 & $(0.59)$ & \\
\hline Unpaid activities within institution ............................. & 3.8 & $(0.04)$ & 3.1 & $(0.08)$ & 3.3 & $(0.15)$ & 3.9 & $(0.14)$ & 3.8 & $(0.20)$ & 4.4 & $(0.13)$ & 4.4 & $(0.15)$ & 4.4 & $(0.11)$ & 4.2 & $(0.12)$ & 3.6 & $(0.22)$ & \\
\hline Paid activities outside institution ........................... & 2.2 & $(0.05)$ & 1.8 & $(0.08)$ & 2.7 & $(0.21)$ & 2.1 & $(0.13)$ & 2.3 & $(0.25)$ & 2.3 & $(0.12)$ & 2.2 & $(0.17)$ & 2.0 & $(0.13)$ & 2.3 & $(0.12)$ & 2.8 & $(0.24)$ & \\
\hline Unpaid activities outside institution .......................... & 1.9 & $(0.03)$ & 1.9 & $(0.05)$ & 2.0 & $(0.09)$ & 2.1 & $(0.11)$ & 1.7 & $(0.11)$ & 2.1 & $(0.09)$ & 2.3 & $(0.12)$ & 2.0 & $(0.14)$ & 1.7 & $(0.08)$ & 1.6 & $(0.10)$ & \\
\hline 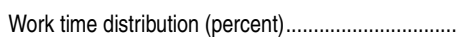 & 100.0 & $(\dagger)$ & 100.0 & $(\dagger)$ & 100.0 & $(\dagger)$ & 100.0 & $(2.08)$ & 100.0 & $(\dagger)$ & 100.0 & $(t)$ & 100.0 & $(\dagger)$ & 100.0 & $(t)$ & 100.0 & $(\dagger)$ & 100.0 & $(\dagger)$ & \\
\hline 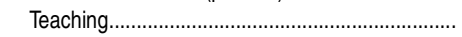 & 58.2 & $(0.27)$ & 43.5 & $(0.43)$ & 43.1 & $(0.76)$ & 55.5 & $(0.72)$ & 55.0 & (1.15) & 64.7 & $(0.70)$ & 67.5 & $(0.78)$ & 65.9 & $(0.80)$ & 78.4 & $(0.65)$ & 55.0 & $(1.61)$ & \\
\hline 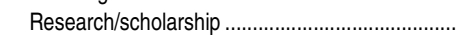 & 20.0 & $(0.44)$ & 33.2 & $(0.42)$ & 34.0 & $(0.84)$ & 22.3 & $(0.72)$ & 24.6 & $(0.84)$ & 15.0 & $(0.49)$ & 11.2 & $(0.57)$ & 12.7 & $(0.67)$ & 3.7 & $(0.26)$ & 18.7 & $(0.97)$ & \\
\hline $\begin{array}{l}\text { Other activities (administration, professional } \\
\text { growth, etc.) }\end{array}$ & 21.7 & $(0.17)$ & 23.2 & $(0.45)$ & 22.8 & $(0.67)$ & 22.2 & $(0.64)$ & 20.4 & $(1.21)$ & 20.4 & $(0.66)$ & 21.3 & (0.75) & 21.3 & $(0.73)$ & 17.9 & $(0.54)$ & 26.3 & $(1.27)$ & \\
\hline $\begin{array}{l}\text { Faculty/staff distribution by instruction } \\
\text { activity (percent) }\end{array}$ & & & & & & & & & & & & & & & & & & & & & \\
\hline Distribution by hours taught per week ......... & 100.0 & $(\dagger)$ & 100.0 & $(\dagger)$ & 100.0 & $(\dagger)$ & 100.0 & $(\dagger)$ & 100.0 & $(\dagger)$ & 100.0 & $(\dagger)$ & 100.0 & $(\dagger)$ & 100.0 & $(t)$ & 100.0 & $(\dagger)$ & 100.0 & $(\dagger)$ & \\
\hline Less than $4.0 \ldots \ldots .$. & 30.3 & $(0.44)$ & 48.9 & $(0.83)$ & 52.2 & (1.31) & 30.0 & $(1.70)$ & 26.5 & (1.74) & 16.3 & $(1.08)$ & 14.9 & $(1.06)$ & 15.5 & $(1.15)$ & 14.5 & $(0.86)$ & 36.0 & (2.35) & \\
\hline 4.0 to 5.9 & 5.8 & $(0.21)$ & 8.4 & $(0.50)$ & 8.8 & $(0.77)$ & 6.0 & $(0.58)$ & 8.4 & $(1.37)$ & 4.1 & $(0.53)$ & 4.1 & $(0.57)$ & 4.1 & $(0.57)$ & 2.5 & $(0.33)$ & 6.7 & $(0.99)$ & \\
\hline 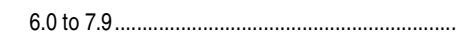 & 13.8 & $(0.37)$ & 20.0 & $(0.80)$ & 15.2 & (1.20) & 22.2 & $(1.14)$ & 22.0 & $(1.77)$ & 12.0 & $(0.78)$ & 11.0 & (1.43) & 13.3 & $(1.48)$ & 4.4 & $(0.60)$ & 9.0 & $(0.88)$ & \\
\hline 8.0 to 9.9 & 12.5 & $(0.30)$ & 9.0 & $(0.49)$ & 9.3 & $(0.87)$ & 16.9 & $(1.20)$ & 19.3 & (1.76) & 21.5 & $(0.93)$ & 18.7 & $(1.78)$ & 19.5 & $(1.83)$ & 5.7 & $(0.61)$ & 7.2 & $(0.98)$ & \\
\hline 10.0 to $14.9 \ldots \ldots$ & 18.2 & $(0.39)$ & 7.9 & $(0.55)$ & 8.8 & $(0.88)$ & 15.1 & $(1.13)$ & 15.0 & $(1.53)$ & 31.5 & $(1.24)$ & 32.7 & $(2.15)$ & 33.5 & $(1.93)$ & 14.7 & $(0.90)$ & 19.6 & $(1.95)$ & \\
\hline 15.0 or more & 19.4 & $(0.40)$ & 5.8 & $(0.43)$ & 5.7 & $(0.67)$ & 9.7 & $(0.92)$ & 8.7 & (1.34) & 14.6 & $(0.93)$ & 18.5 & $(1.92)$ & 14.1 & $(1.39)$ & 58.2 & $(1.47)$ & 21.5 & $(1.73)$ & \\
\hline Distribution by number of students taught ................ & 100.0 & $(\dagger)$ & 100.0 & (†) & 100.0 & $(\dagger)$ & 100.0 & (†) & 100.0 & $(\dagger)$ & 100.0 & $(t)$ & 100.0 & $(\dagger)$ & 100.0 & $(t)$ & 100.0 & $(t)$ & 100.0 & $(\dagger)$ & \\
\hline Less than 25 & 30.6 & $(0.46)$ & 46.0 & $(0.84)$ & 51.5 & (1.56) & 29.7 & $(1.53)$ & 31.9 & $(1.88)$ & 16.8 & $(1.25)$ & 16.5 & (1.23) & 20.8 & $(1.44)$ & 15.9 & $(0.94)$ & 36.8 & $(1.96)$ & \\
\hline 25 to 49 & 17.0 & $(0.34)$ & 17.0 & $(0.83)$ & 16.9 & $(1.06)$ & 17.1 & $(0.99)$ & 18.8 & $(1.74)$ & 17.9 & $(0.96)$ & 22.7 & $(1.57)$ & 25.4 & $(1.62)$ & 12.0 & $(0.77)$ & 13.4 & $(1.41)$ & \\
\hline 50 to 74 & 16.2 & $(0.33)$ & 11.9 & $(0.69)$ & 10.0 & $(0.99)$ & 16.3 & $(1.29)$ & 20.9 & $(1.64)$ & 18.7 & $(0.77)$ & 26.5 & (1.32) & 24.4 & $(1.40)$ & 16.2 & $(0.86)$ & 14.4 & $(1.07)$ & \\
\hline 75 to 99 & 13.0 & $(0.30)$ & 7.6 & $(0.51)$ & 6.2 & $(0.57)$ & 13.9 & $(0.91)$ & 11.2 & $(0.95)$ & 17.5 & $(0.86)$ & 17.6 & (1.15) & 15.8 & $(1.09)$ & 18.1 & $(0.78)$ & 11.5 & $(1.03)$ & \\
\hline 100 to 149 & 14.2 & $(0.39)$ & 7.6 & $(0.54)$ & 7.0 & $(0.78)$ & 13.2 & $(0.87)$ & 9.9 & $(1.21)$ & 19.4 & $(1.22)$ & 13.1 & $(1.61)$ & 10.6 & $(0.96)$ & 25.7 & $(0.98)$ & 14.9 & $(1.58)$ & \\
\hline 150 or more & 9.0 & $(0.27)$ & 9.8 & $(0.59)$ & 8.4 & $(0.73)$ & 9.8 & $(0.87)$ & 7.4 & $(1.04)$ & 9.7 & $(0.85)$ & 3.6 & $(0.72)$ & 3.0 & $(0.62)$ & 12.1 & $(0.86)$ & 8.9 & $(0.63)$ & \\
\hline $\begin{array}{l}\text { Distribution by student classroom contact hours per } \\
\text { week }\end{array}$ & 100.0 & $(t)$ & 100.0 & (†) & 100.0 & $(t)$ & 100.0 & $(\dagger)$ & 100.0 & (†) & 100.0 & $(\mathrm{t})$ & 100.0 & $(t)$ & 100.0 & ( & 100.0 & $(\dagger)$ & 100.0 & $(\dagger)$ & \\
\hline Less than 50 & 24.2 & $(0.40)$ & 38.3 & $(0.83)$ & 42.7 & $(1.33)$ & 23.2 & $(1.52)$ & 22.0 & $(1.53)$ & 11.9 & $(1.04)$ & 12.6 & $(1.02)$ & 12.2 & $(1.05)$ & 11.9 & $(0.77)$ & 30.8 & $(1.87)$ & \\
\hline 50 to 99 & 5.3 & $(0.23)$ & 7.7 & $(0.56)$ & 7.0 & $(0.82)$ & 6.4 & $(0.68)$ & 7.0 & $(1.20)$ & 4.3 & $(0.52)$ & 2.7 & $(0.55)$ & 4.9 & $(0.48)$ & 2.5 & $(0.39)$ & 5.2 & $(0.88)$ & \\
\hline 100 to $199 \ldots \ldots \ldots$ & 7.1 & $(0.20)$ & 9.4 & $(0.54)$ & 10.7 & $(0.87)$ & 8.0 & $(0.88)$ & 8.6 & $(1.38)$ & 6.2 & $(0.62)$ & 4.5 & $(0.66)$ & 7.2 & $(1.02)$ & 3.4 & $(0.43)$ & 6.1 & $(0.99)$ & \\
\hline 200 to 349 & 9.0 & $(0.28)$ & 10.9 & $(0.52)$ & 10.4 & $(0.83)$ & 10.4 & $(0.88)$ & 12.8 & $(1.74)$ & 8.6 & $(0.71)$ & 10.9 & (1.38) & 11.9 & $(1.27)$ & 3.6 & $(0.54)$ & 6.8 & $(0.79)$ & \\
\hline 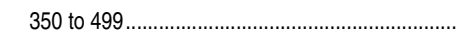 & 7.7 & $(0.24)$ & 8.0 & $(0.44)$ & 8.1 & $(0.83)$ & 10.6 & $(1.03)$ & 11.5 & $(1.03)$ & 7.9 & $(0.91)$ & 10.2 & $(0.79)$ & 12.4 & $(0.93)$ & 3.5 & $(0.40)$ & 4.6 & $(0.70)$ & \\
\hline 500 or more & 46.8 & $(0.44)$ & 25.6 & $(0.74)$ & 21.2 & $(1.21)$ & 41.4 & $(1.36)$ & 38.0 & $(1.81)$ & 61.1 & $(1.46)$ & 59.1 & $(1.75)$ & 51.4 & (2.13) & 75.0 & $(1.16)$ & 46.6 & $(2.30)$ & \\
\hline Distribution by total classroom credit hours............... & 100.0 & $(t)$ & 100.0 & $(\dagger)$ & 100.0 & $(\dagger)$ & 100.0 & $(\dagger)$ & 100.0 & $(\dagger)$ & 100.0 & $(t)$ & 100.0 & $(t)$ & 100.0 & $(t)$ & 100.0 & $(t)$ & 100.0 & $(t)$ & \\
\hline Less than 4.0 & 31.8 & $(0.54)$ & 48.9 & $(0.82)$ & 52.1 & (1.55) & 30.1 & $(1.46)$ & 29.0 & $(1.75)$ & 18.0 & $(1.03)$ & 17.5 & (1.44) & 23.7 & $(2.18)$ & 15.4 & $(0.84)$ & 38.1 & (2.23) & \\
\hline 4.0 to 5.9 & 6.6 & $(0.22)$ & 9.4 & $(0.54)$ & 10.2 & $(0.63)$ & 6.8 & $(0.67)$ & 10.5 & $(1.53)$ & 3.5 & $(0.35)$ & 4.5 & $(0.61)$ & 5.6 & $(0.67)$ & 3.7 & $(0.44)$ & 7.0 & $(0.83)$ & $5 \stackrel{2}{2}$ \\
\hline 6.0 to $7.9 \ldots \ldots$. & 15.0 & $(0.37)$ & 21.6 & $(0.66)$ & 14.0 & $(1.04)$ & 25.1 & $(1.29)$ & 21.3 & $(1.71)$ & 14.2 & $(0.94)$ & 12.2 & $(1.04)$ & 11.4 & (1.15) & 6.6 & $(0.72)$ & 10.1 & $(1.07)$ & \\
\hline 8.0 to 9.9 & 14.8 & $(0.33)$ & 10.4 & $(0.60)$ & 10.7 & $(0.84)$ & 19.9 & $(1.28)$ & 20.8 & $(1.47)$ & 25.3 & $(1.15)$ & 23.4 & (1.73) & 19.1 & $(1.16)$ & 8.1 & $(0.60)$ & 10.0 & $(1.19)$ & \\
\hline 10.0 to 14.9 & 20.2 & $(0.38)$ & 7.7 & $(0.51)$ & 9.7 & $(0.99)$ & 14.8 & (1.17) & 13.2 & $(1.40)$ & 32.0 & $(1.20)$ & 35.4 & $(1.94)$ & 32.5 & $(2.20)$ & 24.3 & $(1.28)$ & 22.3 & $(1.38)$ & D \\
\hline 15.0 or more & 11.6 & $(0.31)$ & 1.9 & $(0.24)$ & 3.2 & $(0.52)$ & 3.3 & $(0.64)$ & 5.2 & $(0.99)$ & 7.0 & $(0.88)$ & 6.9 & $(0.71)$ & 7.7 & $(1.28)$ & 41.8 & $(1.50)$ & 12.5 & $(1.17)$ & \\
\hline
\end{tabular}

See notes at end of table. 


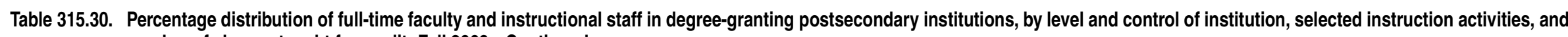
number of classes taught for credit: Fall 2003-Continued

[Standard errors appear in parentheses]

\begin{tabular}{|c|c|c|c|c|c|c|c|c|c|c|c|c|c|c|c|c|c|c|c|c|}
\hline \multirow[b]{2}{*}{ Instruction activity and number of classes } & \multirow{2}{*}{\multicolumn{2}{|c|}{ All institutions }} & \multicolumn{4}{|c|}{ Research } & \multicolumn{4}{|c|}{ Doctoral } & \multicolumn{4}{|c|}{ Comprehensive } & \multirow{2}{*}{\multicolumn{2}{|c|}{ Private liberal arts }} & \multirow{2}{*}{\multicolumn{2}{|c|}{ Public 2-year }} & \multirow{2}{*}{\multicolumn{2}{|c|}{ Other }} \\
\hline & & & & Public & & Private & & Public & & Private & & Public & & Private & & & & & & \\
\hline 1 & & 2 & & 3 & & 4 & & 5 & & 6 & & 7 & & 8 & & 9 & & 10 & & 11 \\
\hline \multicolumn{21}{|l|}{$\begin{array}{l}\text { Faculty/staff distribution by number of classes } \\
\text { taught for credit (percent) }\end{array}$} \\
\hline $\begin{array}{l}\text { Faculty/staff with undergraduate classes only, } \\
\text { by total for-credit courses }\end{array}$ & 100.0 & $(\dagger)$ & 100.0 & $(\dagger)$ & 100.0 & $(\dagger)$ & 100.0 & $(\dagger)$ & 100.0 & $(\dagger)$ & 100.0 & $(\dagger)$ & 100.0 & $(\dagger)$ & 100.0 & $(\dagger)$ & 100.0 & $(\dagger)$ & 100.0 & $(\dagger)$ \\
\hline 1 . & 11.0 & $(0.43)$ & 24.2 & $(2.40)$ & 20.2 & (2.97) & 14.1 & $(2.91)$ & 10.0 & (2.52) & 10.5 & $(1.31)$ & 9.3 & (1.13) & 9.9 & $(0.98)$ & 8.7 & $(0.75)$ & 11.2 & (2.17) \\
\hline 2 & 17.4 & $(0.62)$ & 38.0 & $(2.80)$ & 31.2 & $(3.96)$ & 24.2 & $(3.05)$ & 38.6 & $(5.05)$ & 14.6 & $(1.51)$ & 18.5 & $(2.14)$ & 22.7 & (2.32) & 10.7 & $(0.77)$ & 13.7 & (2.29) \\
\hline З & 23.7 & $(0.65)$ & 22.6 & $(2.21)$ & 30.8 & (3.42) & 31.1 & $(2.98)$ & 37.3 & $(3.60)$ & 28.6 & $(1.89)$ & 30.3 & (2.48) & 34.3 & (2.57) & 16.0 & $(0.96)$ & 17.3 & (2.77) \\
\hline 4 & 21.9 & $(0.73)$ & 10.8 & $(1.43)$ & 11.7 & (2.99) & 20.4 & (1.92) & 10.9 & (2.75) & 33.3 & $(1.87)$ & 30.7 & (2.77) & 21.1 & (2.22) & 16.9 & $(1.00)$ & 28.4 & (2.48) \\
\hline 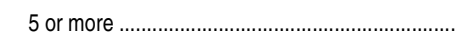 & 26.1 & $(0.70)$ & 4.4 & $(0.86)$ & 6.1 & $(1.74)$ & 10.1 & $(1.97)$ & $3.2 !$ & $(1.15)$ & 13.0 & $(1.56)$ & 11.2 & $(1.53)$ & 12.0 & $(1.44)$ & 47.6 & $(1.49)$ & 29.4 & (2.14) \\
\hline \multicolumn{21}{|l|}{ Faculty/staff with graduate classes only, by total } \\
\hline 1 & 40.1 & $(1.21)$ & 50.4 & $(2.17)$ & 48.0 & $(3.69)$ & 34.3 & $(3.04)$ & 25.9 & $(4.02)$ & 23.6 & $(3.86)$ & 13.0 & $(3.72)$ & $15.8 !$ & $(6.35)$ & $\ddagger$ & $(t)$ & 37.8 & $(3.15)$ \\
\hline 2 & 31.0 & $(1.07)$ & 26.3 & $(1.81)$ & 27.9 & (2.93) & 39.1 & (3.32) & 50.7 & $(4.02)$ & 33.6 & $(5.32)$ & 28.7 & $(4.00)$ & $31.6 !$ & (12.42) & $\ddagger$ & $(t)$ & 32.9 & (2.93) \\
\hline З3 & 16.7 & $(0.88)$ & 14.3 & $(1.38)$ & 13.3 & $(2.60)$ & 16.3 & $(2.76)$ & 14.1 & (3.52) & 29.6 & $(4.35)$ & 36.3 & (4.99) & $22.7 !$ & $(9.79)$ & $\ddagger$ & $(\dagger)$ & 13.4 & (2.48) \\
\hline 4 & 7.1 & $(0.80)$ & 4.5 & $(1.24)$ & 7.4 & (2.07) & 7.4 & $(2.04)$ & $3.7 !$ & $(1.44)$ & $10.1 !$ & $(3.39)$ & 16.5 & (3.92) & $16.7 !$ & $(8.04)$ & $\ddagger$ & $(\dagger)$ & $7.2 !$ & (2.21) \\
\hline 5 or more & 5.1 & $(0.52)$ & 4.4 & $(0.69)$ & 3.4 ! & $(1.33)$ & $\ddagger$ & $(\dagger)$ & $5.7 !$ & $(2.80)$ & $3.1 !$ & $(1.52)$ & 5.5 ! & (2.85) & $\ddagger$ & $(t)$ & $\ddagger$ & $(t)$ & 8.7 & (1.94) \\
\hline \multicolumn{21}{|l|}{ Faculty/staff with both undergraduate and graduate } \\
\hline 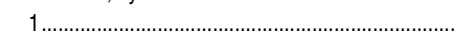 & 23.3 & $(0.68)$ & 32.5 & $(1.37)$ & 38.4 & $(1.89)$ & 21.1 & $(2.17)$ & 20.2 & $(2.37)$ & 9.0 & $(1.04)$ & 10.3 & (2.14) & 9.4 & $(2.00)$ & $\ddagger$ & $(\dagger)$ & 24.8 & (3.18) \\
\hline 2 & 33.4 & $(0.83)$ & 44.3 & $(1.36)$ & 42.8 & $(2.33)$ & 37.1 & (2.15) & 37.8 & $(2.58)$ & 19.6 & $(1.30)$ & 19.0 & $(2.78)$ & 18.3 & (2.62) & $\ddagger$ & $(\dagger)$ & 18.7 & $(3.00)$ \\
\hline З & 24.3 & $(0.70)$ & 15.5 & $(0.99)$ & 12.4 & $(1.37)$ & 26.5 & $(1.75)$ & 32.0 & $(3.01)$ & 38.1 & $(1.91)$ & 34.8 & $(2.85)$ & 29.5 & (3.77) & $\ddagger$ & $(\dagger)$ & 21.2 & $(3.06)$ \\
\hline 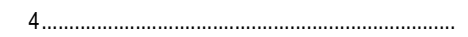 & 12.2 & $(0.54)$ & 4.5 & $(0.64)$ & 3.7 & $(1.06)$ & 10.1 & $(1.37)$ & $6.6 !$ & (2.02) & 23.4 & $(1.69)$ & 24.4 & (3.39) & 27.5 & (3.74) & $\ddagger$ & $(\dagger)$ & 16.6 & (3.55) \\
\hline 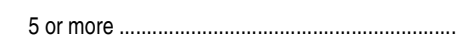 & 6.7 & $(0.43)$ & 3.1 & $(0.45)$ & 2.8 & $(0.78)$ & 5.2 & $(0.75)$ & $\neq$ & $(t)$ & 9.9 & $(1.01)$ & 11.4 & $(2.07)$ & 15.2 & (3.65) & $\ddagger$ & $(t)$ & 18.6 & (2.88) \\
\hline
\end{tabular}

\section{†Not applicable}

IInterpret data with caution. The coefficient of variation (CV) for this estimate is between 30 and 50 percent

fReporting standards not met. Either there are too few cases for a reliable estimate or the coefficient of variation (CV) is 50 percent or greater.

Dent

NOTE: Degree-granting institutions grant associate's or higher degrees and participate in Title IV federal financial aid prototals because of rounding. SOURCE: U.S. Department of Education, National Center for Educ 


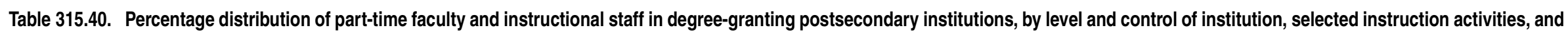
number of classes taught for credit: Fall 2003

[Standard errors appear in parentheses]

\begin{tabular}{|c|c|c|c|c|c|c|c|c|c|c|c|c|c|c|c|c|c|c|c|c|c|}
\hline \multirow[b]{2}{*}{ Instruction activity and number of classes } & \multirow{2}{*}{\multicolumn{2}{|c|}{ All institutions }} & \multicolumn{4}{|c|}{ Research } & \multicolumn{4}{|c|}{ Doctoral } & \multicolumn{4}{|c|}{ Comprehensive } & \multirow{2}{*}{\multicolumn{2}{|c|}{ Private liberal arts }} & \multirow{2}{*}{\multicolumn{2}{|c|}{ Public 2-year }} & \multirow{2}{*}{\multicolumn{2}{|c|}{ Other }} & \\
\hline & & & & Public & & Private & & Public & & Private & & Public & & Private & & & & & & & \\
\hline 1 & & 2 & & 3 & & 4 & & 5 & & 6 & & 7 & & 8 & & 9 & & 10 & & 11 & \\
\hline 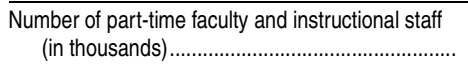 & 530.0 & $(0.02)$ & 39.7 & $(0.78)$ & 23.2 & $(0.96)$ & 20.8 & $(0.82)$ & 15.4 & $(0.83)$ & 60.3 & $(2.49)$ & 53.5 & $(2.17)$ & 28.4 & $(2.19)$ & 230.1 & $(2.00)$ & 58.7 & $(3.38)$ & \\
\hline Percentage distribution & 100.0 & $(\dagger)$ & 7.5 & $(0.15)$ & 4.4 & $(0.18)$ & 3.9 & $(0.15)$ & 2.9 & $(0.16)$ & 11.4 & $(0.47)$ & 10.1 & $(0.41)$ & 5.4 & $(0.41)$ & 43.4 & $(0.38)$ & 11.1 & $(0.64)$ & \\
\hline $\begin{array}{l}\text { Average hours worked per week } \\
\text { Paid activinities within....................... }\end{array}$ & $\begin{array}{l}39.9 \\
13.7\end{array}$ & $\begin{array}{l}(0.30) \\
(0.13)\end{array}$ & $\begin{array}{l}41.1 \\
19.0\end{array}$ & $\begin{array}{l}(0.85) \\
(0.61)\end{array}$ & $\begin{array}{l}42.6 \\
14.0\end{array}$ & $\begin{array}{l}(1.24) \\
(0.65)\end{array}$ & $\begin{array}{l}43.5 \\
16.4\end{array}$ & $\begin{array}{l}(1.37) \\
(0.76)\end{array}$ & $\begin{array}{l}42.1 \\
13.5\end{array}$ & $\begin{array}{l}(1.29) \\
(0.97)\end{array}$ & $\begin{array}{l}38.8 \\
14.9\end{array}$ & $\begin{array}{l}(1.01) \\
(0.48)\end{array}$ & $\begin{array}{l}42.7 \\
12.1\end{array}$ & $\begin{array}{l}(1.14) \\
(0.56)\end{array}$ & $\begin{array}{l}39.6 \\
13.5\end{array}$ & $\begin{array}{l}(1.23) \\
(0.73)\end{array}$ & $\begin{array}{l}38.0 \\
12.5\end{array}$ & $\begin{array}{l}(0.45) \\
(0.19)\end{array}$ & $\begin{array}{l}41.8 \\
14.2\end{array}$ & $\begin{array}{l}(1.18) \\
(0.46)\end{array}$ & \\
\hline Unpaid activities within institution ............................. & 1.7 & $(0.06)$ & 1.8 & $(0.25)$ & 2.5 & $(0.25)$ & 2.3 & $(0.28)$ & 2.8 & $(0.37)$ & 2.3 & $(0.19)$ & 2.7 & $(0.12)$ & 2.6 & $(0.17)$ & 2.1 & $(0.08)$ & 2.5 & $(0.17)$ & \\
\hline Paid activities outside institution ........................... & 22.1 & $(0.28)$ & 18.3 & $(0.98)$ & 23.9 & $(1.34)$ & 23.3 & (1.55) & 24.1 & $(1.40)$ & 19.9 & $(1.00)$ & 26.6 & (1.38) & 21.9 & $(0.98)$ & 21.6 & $(0.41)$ & 23.3 & $(1.06)$ & \\
\hline Unpaid activities outside institution .......................... & 2.3 & $(0.06)$ & 2.0 & $(0.25)$ & 2.2 & $(0.25)$ & 1.6 & $(0.28)$ & 1.7 & $(0.37)$ & 1.8 & $(0.19)$ & 1.3 & $(0.12)$ & 1.6 & $(0.17)$ & 1.7 & $(0.08)$ & 1.8 & $(0.17)$ & \\
\hline 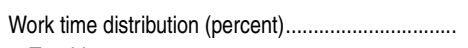 & 100.0 & $(\dagger)$ & 100.0 & $(\dagger)$ & 100.0 & $(\dagger)$ & 100.0 & $(t)$ & 100.0 & $(\dagger)$ & 100.0 & $(t)$ & 100.0 & $(\dagger)$ & 100.0 & $(\dagger)$ & 100.0 & $(\dagger)$ & 100.0 & $(\dagger)$ & \\
\hline Teaching. & 88.3 & $(0.32)$ & 74.1 & $(1.79)$ & 80.6 & $(1.89)$ & 84.9 & (1.71) & 87.2 & $(1.87)$ & 90.8 & $(0.83)$ & 90.4 & $(0.70)$ & 90.2 & $(1.20)$ & 91.3 & $(0.43)$ & 85.4 & $(1.19)$ & \\
\hline 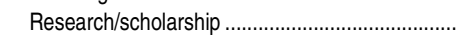 & 3.9 & $(0.80)$ & 13.3 & $(1.62)$ & 7.0 & $(0.97)$ & 7.4 & $(1.35)$ & 5.2 & (1.42) & 3.2 & $(0.46)$ & 2.4 & $(0.49)$ & 2.6 & $(0.54)$ & 2.1 & $(0.21)$ & 4.4 & $(0.61)$ & \\
\hline $\begin{array}{l}\text { Other activities (administration, professional } \\
\quad \text { growth, etc.) }\end{array}$ & 7.8 & $(0.20)$ & 12.6 & $(1.04)$ & 12.4 & $(1.75)$ & 7.6 & $(1.03)$ & 7.6 & $(1.22)$ & 6.0 & $(0.63)$ & 7.2 & $(0.81)$ & 7.2 & $(0.92)$ & 6.6 & $(0.40)$ & 10.3 & $(0.93)$ & \\
\hline $\begin{array}{l}\text { Faculty/staff distribution by instruction } \\
\text { activity (percent) }\end{array}$ & & & & & & & & & & & & & & & & & & & & & \\
\hline Distribution by hours taught per week .......... & 100.0 & $(\dagger)$ & 100.0 & $(t)$ & 100.0 & $(\mathrm{t})$ & 100.0 & (t) & 100.0 & $(\dagger)$ & 100.0 & $(t)$ & 100.0 & $(t)$ & 100.0 & $(\dagger)$ & 100.0 & $(t)$ & 100.0 & $(\dagger)$ & \\
\hline Less than & 45.3 & $(0.80)$ & 58.1 & $(2.25)$ & 62.4 & $(3.87)$ & 53.3 & $(2.71)$ & 48.0 & (2.67) & 45.5 & $(1.68)$ & 39.8 & (2.34) & 44.8 & (2.96) & 41.3 & $(1.30)$ & 46.5 & (2.46) & \\
\hline 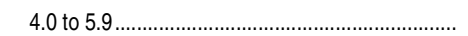 & 12.2 & $(0.48)$ & 9.3 & $(1.25)$ & 12.9 & $(2.46)$ & 12.5 & (1.49) & 15.0 & (1.57) & 9.7 & $(1.25)$ & 17.7 & $(2.07)$ & 13.2 & $(1.73)$ & 11.7 & $(0.71)$ & 12.6 & $(1.62)$ & \\
\hline 6.0 to 7.9 & 14.3 & $(0.57)$ & 12.5 & $(1.50)$ & 10.1 & $(1.69)$ & 14.5 & $(1.76)$ & 14.3 & $(2.01)$ & 19.4 & $(1.68)$ & 12.9 & (2.14) & 13.8 & $(1.98)$ & 14.5 & $(1.04)$ & 13.0 & $(1.72)$ & \\
\hline 8.0 to 9.9 & 10.4 & $(0.47)$ & 8.9 & $(1.22)$ & 5.6 & $(1.46)$ & 8.3 & $(1.82)$ & 7.8 & (1.58) & 10.8 & $(1.11)$ & 11.7 & (1.93) & 10.7 & (1.54) & 11.3 & $(0.73)$ & 9.5 & $(1.45)$ & \\
\hline 10.0 to $14.9 \ldots \ldots \ldots \ldots$ & 9.4 & $(0.47)$ & 7.5 & $(1.27)$ & $3.0 !$ & (1.16) & 5.5 & $(1.29)$ & 7.3 & (2.03) & 8.0 & $(1.27)$ & 7.7 & (1.29) & 8.3 & (1.55) & 11.7 & $(0.99)$ & 9.8 & $(1.27)$ & \\
\hline 15.0 or more & 8.3 & $(0.43)$ & 3.6 & $(0.90)$ & $6.0 !$ & (1.94) & 5.9 & $(1.50)$ & 7.6 & $(1.26)$ & 6.5 & $(1.05)$ & 10.3 & (1.61) & 9.1 & $(2.38)$ & 9.5 & $(0.67)$ & 8.5 & $(1.19)$ & \\
\hline Distribution by number of students taught ................ & 100.0 & $(\dagger)$ & 100.0 & $(t)$ & 100.0 & $(t)$ & 100.0 & $(\dagger)$ & 100.0 & $(\dagger)$ & 100.0 & $(\dagger)$ & 100.0 & $(\dagger)$ & 100.0 & $(\dagger)$ & 100.0 & $(t)$ & 100.0 & $(\dagger)$ & \\
\hline Less than $25 \ldots \ldots \ldots \ldots \ldots \ldots \ldots$ & 52.0 & $(0.82)$ & 55.6 & $(2.16)$ & 68.9 & (3.98) & 44.6 & $(2.68)$ & 56.9 & (3.29) & 41.6 & $(2.07)$ & 57.9 & (2.45) & 60.5 & (2.34) & 49.7 & $(1.37)$ & 54.0 & (3.15) & \\
\hline 25 to 49 & 24.9 & $(0.58)$ & 17.4 & $(1.54)$ & 16.9 & (2.13) & 27.4 & $(2.51)$ & 20.7 & $(2.48)$ & 24.5 & $(2.10)$ & 29.4 & $(1.90)$ & 24.1 & $(1.76)$ & 26.7 & $(0.97)$ & 22.6 & $(2.74)$ & \\
\hline 50 to 74 & 12.1 & $(0.54)$ & 11.6 & $(1.23)$ & $3.7 !$ & (1.15) & 12.5 & $(1.71)$ & 9.8 & (2.48) & 17.5 & $(1.52)$ & 8.5 & $(0.77)$ & 10.0 & $(1.65)$ & 12.9 & $(0.95)$ & 11.7 & $(1.55)$ & \\
\hline 75 to 99 & 5.8 & $(0.30)$ & 5.4 & $(0.89)$ & $4.1 !$ & $(1.57)$ & 7.6 & $(1.52)$ & 6.8 & (1.62) & 6.7 & $(1.22)$ & 2.0 & $(0.44)$ & 3.7 & $(0.97)$ & 6.2 & $(0.48)$ & 7.5 & $(1.18)$ & \\
\hline 100 to 149 & 3.4 & $(0.23)$ & 4.8 & $(1.07)$ & $2.0 !$ & $(0.72)$ & $4.2 !$ & (1.46) & $2.9 !$ & $(0.89)$ & 7.2 & $(1.14)$ & $1.8 !$ & $(0.55)$ & $\ddagger$ & $(t)$ & 3.2 & $(0.41)$ & $2.4 !$ & $(0.76)$ & \\
\hline 150 or more & 1.9 & $(0.19)$ & 5.2 & $(0.96)$ & 4.5 & (1.35) & 3.7 & $(0.94)$ & $2.8 !$ & (1.12) & 2.6 & $(0.59)$ & $\ddagger$ & $(\dagger)$ & $\ddagger$ & $(\dagger)$ & 1.2 & $(0.35)$ & 1.7 & $(0.44)$ & \\
\hline $\begin{array}{l}\text { Distribution by student classroom contact hours per } \\
\text { week }\end{array}$ & 100.0 & $(\dagger)$ & 100.0 & $(t)$ & 100.0 & $(\mathrm{t})$ & 100.0 & (†) & 100.0 & $(t)$ & 100.0 & $(t)$ & 100.0 & $(t)$ & 100.0 & $(\dagger)$ & 100.0 & $(t)$ & 100.0 & & \\
\hline Less than 50 & 33.9 & $(0.80)$ & 41.6 & $(2.52)$ & 53.4 & (3.89) & 27.7 & $(2.98)$ & 40.2 & (2.67) & 25.4 & $(1.88)$ & 36.0 & (2.52) & 38.2 & $(2.66)$ & 31.3 & $(1.34)$ & 36.7 & $(3.40)$ & \\
\hline 50 to 99 & 17.0 & $(0.54)$ & 13.1 & $(1.46)$ & 17.5 & $(2.13)$ & 23.0 & (3.38) & 17.0 & $(2.30)$ & 18.9 & $(1.40)$ & 19.5 & (1.53) & 17.4 & $(1.97)$ & 16.6 & $(0.96)$ & 14.5 & $(1.65)$ & \\
\hline 100 to 199 & 13.2 & $(0.49)$ & 13.3 & $(1.51)$ & 8.5 & $(1.44)$ & 14.2 & $(2.34)$ & 7.5 & $(1.56)$ & 14.8 & $(1.72)$ & 13.3 & (1.65) & 14.1 & $(2.01)$ & 13.4 & $(0.82)$ & 13.5 & $(2.19)$ & \\
\hline 200 to 349 & 11.2 & $(0.46)$ & 10.8 & $(1.29)$ & 5.6 & $(1.42)$ & 10.9 & (1.97) & 12.3 & $(1.88)$ & 10.3 & $(1.80)$ & 13.5 & $(0.93)$ & 10.1 & $(1.26)$ & 11.4 & $(0.66)$ & 12.1 & (1.62) & \\
\hline 350 to $499 \ldots \ldots \ldots \ldots \ldots \ldots$ & 7.2 & $(0.34)$ & 6.1 & $(0.98)$ & $3.0 !$ & $(0.96)$ & 7.7 & $(1.74)$ & 8.5 & $(1.74)$ & 10.2 & $(1.0)$ & 4.5 & $(0.64)$ & 5.5 & $(0.95)$ & 8.0 & $(0.69)$ & 6.0 & $(0.93)$ & \\
\hline 500 or more & 17.5 & $(0.58)$ & 15.1 & $(1.89)$ & 12.1 & $(2.50)$ & 16.5 & $(2.29)$ & 14.5 & (2.58) & 20.3 & $(1.97)$ & 13.3 & (1.53) & 14.6 & $(2.85)$ & 19.3 & $(0.98)$ & 17.2 & $(1.87)$ & \\
\hline Distribution by total classroom credit hours.............. & 100.0 & $(\dagger)$ & 100.0 & $(t)$ & 100.0 & $(t)$ & 100.0 & $(\dagger)$ & 100.0 & $(\dagger)$ & 100.0 & $(\dagger)$ & 100.0 & $(\dagger)$ & 100.0 & $(\dagger)$ & 100.0 & $(\dagger)$ & 100.0 & $(\dagger)$ & \\
\hline Less than $4.0 \ldots \ldots \ldots \ldots \ldots$ & 53.3 & $(0.89)$ & 59.8 & $(2.39)$ & 67.5 & $(3.65)$ & 62.2 & $(2.96)$ & 55.4 & (2.34) & 52.0 & $(2.05)$ & 51.3 & (2.05) & 58.9 & (2.14) & 50.2 & $(1.43)$ & 52.2 & $(3.00)$ & \\
\hline 4.0 to 5.9 & 11.7 & $(0.52)$ & 12.2 & (1.52) & 11.8 & (2.12) & 10.8 & (1.63) & 10.6 & $(1.81)$ & 9.3 & $(1.09)$ & 14.1 & $(1.77)$ & 10.3 & (1.68) & 12.2 & $(0.75)$ & 11.5 & $(1.68)$ & \\
\hline 6.0 to $7.9 \ldots$ & 16.9 & $(0.55)$ & 12.8 & $(1.61)$ & 10.2 & $(2.20)$ & 14.9 & $(1.96)$ & 18.7 & (2.12) & 23.1 & $(2.10)$ & 18.1 & $(1.22)$ & 15.4 & $(1.81)$ & 16.5 & $(0.98)$ & 17.5 & (1.62) & \\
\hline 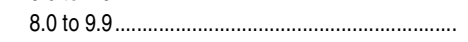 & 9.4 & $(0.42)$ & 8.2 & $(0.92)$ & 6.2 & $(1.22)$ & 8.5 & $(1.64)$ & 8.3 & $(2.03)$ & 9.5 & $(0.99)$ & 9.0 & $(1.08)$ & 8.3 & $(1.34)$ & 10.8 & $(0.81)$ & 7.4 & $(1.33)$ & \\
\hline 10.0 to $14.9 \ldots \ldots$. & 6.6 & $(0.35)$ & 5.6 & (1.48) & $1.8 !$ & $(0.75)$ & 3.6 & $(0.97)$ & 4.8 & (1.22) & 3.8 & $(0.81)$ & 5.2 & $(0.82)$ & $5.1 !$ & $(1.57)$ & 8.1 & $(0.62)$ & 9.2 & $(1.54)$ & \\
\hline 15.0 or more & 2.1 & $(0.21)$ & $1.4 !$ & $(0.58)$ & $2.5 !$ & $(0.91)$ & $\ddagger$ & $(\dagger)$ & $2.2 !$ & $(0.78)$ & 2.2 & $(0.57)$ & 2.3 & $(0.64)$ & $2.0 !$ & $(0.80)$ & 2.2 & $(0.31)$ & 2.2 & $(0.63)$ & \\
\hline
\end{tabular}

See notes at end of table. 


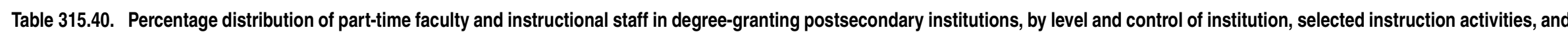
number of classes taught for credit: Fall 2003-Continued

[Standard errors appear in parentheses]

\begin{tabular}{|c|c|c|c|c|c|c|c|c|c|c|c|c|c|c|c|c|c|c|c|c|}
\hline \multirow[b]{2}{*}{ Instruction activity and number of classes } & \multirow{2}{*}{\multicolumn{2}{|c|}{ All institutions }} & \multicolumn{4}{|c|}{ Research } & \multicolumn{4}{|c|}{ Doctoral } & \multicolumn{4}{|c|}{ Comprehensive } & \multirow{2}{*}{\multicolumn{2}{|c|}{ Private liberal arts }} & \multirow{2}{*}{\multicolumn{2}{|c|}{ Public 2-year }} & \multirow{2}{*}{\multicolumn{2}{|c|}{ Other }} \\
\hline & & & & Public & & Private & & Public & & Private & & Public & & Private & & & & & & \\
\hline 1 & & 2 & & 3 & & 4 & & 5 & & 6 & & 7 & & 8 & & 9 & & 10 & & 11 \\
\hline \multicolumn{21}{|l|}{$\begin{array}{l}\text { Faculty/staff distribution by number of classes } \\
\text { taught for credit (percent) }\end{array}$} \\
\hline $\begin{array}{l}\text { Faculty/staff with undergraduate classes only, } \\
\text { by total for-credit courses }\end{array}$ & 100.0 & $(\dagger)$ & 100.0 & $(t)$ & 100.0 & $(†)$ & 100.0 & $(t)$ & 100.0 & $(\mathrm{t})$ & 100.0 & (t) & 100.0 & $(\dagger)$ & 100.0 & (t) & 100.0 & ( t) & 100.0 & $(\dagger)$ \\
\hline 1 & 49.2 & $(0.90)$ & 53.1 & $(3.85)$ & 62.3 & $(5.20)$ & 58.8 & $(4.27)$ & 45.4 & $(4.58)$ & 48.4 & $(2.43)$ & 54.1 & $(2.78)$ & 53.7 & (3.42) & 47.9 & $(1.20)$ & 43.2 & $(3.57)$ \\
\hline 2 & 29.7 & $(0.86)$ & 31.2 & $(3.04)$ & 28.5 & $(5.51)$ & 26.9 & (3.12) & 39.8 & (4.33) & 33.1 & (2.35) & 29.2 & $(2.27)$ & 25.0 & (2.20) & 29.3 & $(1.24)$ & 29.7 & $(2.70)$ \\
\hline 3 & 12.5 & $(0.47)$ & 9.4 & $(1.83)$ & $6.9 !$ & $(2.33)$ & 11.5 & (2.36) & 13.1 & (3.15) & 10.8 & $(1.26)$ & 9.4 & $(1.35)$ & 10.2 & $(1.62)$ & 13.9 & $(0.84)$ & 13.7 & $(1.71)$ \\
\hline 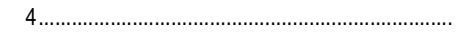 & 5.3 & $(0.41)$ & $4.6 !$ & $(1.41)$ & $\ddagger$ & $(\dagger)$ & $\ddagger$ & $(\mathrm{t})$ & $\ddagger$ & $(\dagger)$ & 4.0 & $(1.06)$ & 5.4 & $(1.08)$ & $5.6 !$ & (1.95) & 5.9 & $(0.65)$ & 6.9 & $(1.73)$ \\
\hline 5 or more & 3.3 & $(0.32)$ & $\ddagger$ & $(\dagger)$ & $\ddagger$ & (†) & $2.6 !$ & $(1.27)$ & $\ddagger$ & $(\dagger)$ & 3.7 & $(0.95)$ & $1.8 !$ & $(0.77)$ & $5.5 !$ & (1.69) & 3.1 & $(0.44)$ & 6.5 & $(1.87)$ \\
\hline $\begin{array}{l}\text { Faculty/staff with graduate classes only, by total } \\
\text { for-credit courses }\end{array}$ & 100.0 & $(\dagger)$ & 100.0 & $(\dagger)$ & 100.0 & $(\dagger)$ & 100.0 & $(\mathrm{t})$ & 100.0 & $(\dagger)$ & 100.0 & $(\dagger)$ & 100.0 & $(\dagger)$ & 100.0 & $(\mathrm{t})$ & $\ddagger$ & $(\dagger)$ & 100.0 & $(\dagger)$ \\
\hline 1 & 72.6 & (1.73) & 71.7 & $(5.24)$ & 81.7 & (4.89) & 81.8 & $(4.93)$ & 72.2 & (5.28) & 74.8 & (5.62) & 62.2 & $(3.67)$ & 69.9 & $(6.67)$ & $\ddagger$ & $(t)$ & 75.6 & $(5.21)$ \\
\hline 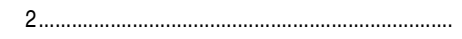 & 16.6 & (1.30) & 20.6 & $(4.61)$ & $7.4 !$ & $(3.23)$ & $10.8 !$ & $(4.07)$ & 16.2 & $(4.50)$ & $12.9 !$ & $(4.45)$ & 23.3 & $(2.37)$ & $18.8 !$ & $(5.77)$ & $\ddagger$ & $(\dagger)$ & 16.4 & $(3.91)$ \\
\hline 3... & 5.3 & $(0.93)$ & $\ddagger$ & $(t)$ & $5.7 !$ & $(2.74)$ & $\ddagger$ & $(t)$ & $\ddagger$ & $(t)$ & $\ddagger$ & $(\dagger)$ & $7.6 !$ & $(2.41)$ & $\ddagger$ & $(\dagger)$ & $\ddagger$ & $(\dagger)$ & $\ddagger$ & $(\dagger)$ \\
\hline 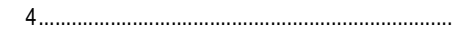 & 3.1 & $(0.81)$ & $\ddagger$ & $(\dagger)$ & $\ddagger$ & $(t)$ & $\ddagger$ & $(\dagger)$ & $4.0 !$ & (1.41) & $\ddagger$ & $(\dagger)$ & $3.9 !$ & $(1.32)$ & $\ddagger$ & $(t)$ & $\ddagger$ & $(t)$ & $\ddagger$ & $(\dagger)$ \\
\hline 5 or more & 2.4 & $(0.53)$ & $\ddagger$ & $(\dagger)$ & $\ddagger$ & $(t)$ & $\ddagger$ & $(t)$ & $\ddagger$ & $(\dagger)$ & $\ddagger$ & $(\dagger)$ & $2.9 !$ & $(1.38)$ & $\ddagger$ & $(t)$ & $\ddagger$ & $(\dagger)$ & $3.0 !$ & $(1.45)$ \\
\hline $\begin{array}{l}\text { Faculty/staff with both undergraduate and graduate } \\
\text { classes, by total for-credit courses.......................... }\end{array}$ & 100.0 & $(\dagger)$ & 100.0 & $(\dagger)$ & 100.0 & (†) & 100.0 & $(\dagger)$ & 100.0 & $(\dagger)$ & 100.0 & $(\dagger)$ & 100.0 & $(\dagger)$ & 100.0 & $(\mathrm{t})$ & $\ddagger$ & $(\dagger)$ & 100.0 & $(\dagger)$ \\
\hline 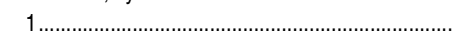 & 46.5 & (2.05) & 51.3 & $(5.19)$ & 46.4 & (10.59) & 59.3 & $(5.24)$ & 63.7 & $(8.93)$ & 38.0 & $(6.03)$ & 38.9 & $(4.23)$ & 44.1 & (8.69) & $\ddagger$ & $(\dagger)$ & 47.4 & $(6.18)$ \\
\hline$\ldots$ & 28.7 & (1.96) & 29.6 & $(4.47)$ & 36.3 & $(8.39)$ & $18.5 !$ & $(6.24)$ & $18.1 !$ & $(5.75)$ & 30.7 & $(3.91)$ & 32.7 & $(5.11)$ & 35.1 & (9.57) & $\ddagger$ & $(\dagger)$ & 23.9 & $(5.54)$ \\
\hline 3 & 13.5 & (1.79) & 11.3 & $(3.25)$ & $\ddagger$ & $(t)$ & $16.9 !$ & $(6.27)$ & $\ddagger$ & $(t)$ & 17.8 & $(4.04)$ & 16.6 & $(3.72)$ & $12.3 !$ & $(4.69)$ & $\ddagger$ & $(\dagger)$ & $\ddagger$ & $(\dagger)$ \\
\hline 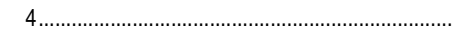 & 5.9 & $(1.19)$ & $3.3 !$ & (1.63) & $\ddagger$ & (†) & $\ddagger$ & $(\dagger)$ & $\ddagger$ & $(t)$ & 7.9 ! & (3.54) & $\ddagger$ & $(\dagger)$ & $5.8 !$ & (2.25) & $\ddagger$ & $(\dagger)$ & $10.0 !$ & $(4.03)$ \\
\hline 5 or more & 5.4 & (1.18) & $4.4 !$ & $(2.08)$ & $\ddagger$ & $(\dagger)$ & $\ddagger$ & $(\mathrm{t})$ & $\ddagger$ & $(\dagger)$ & $5.7 !$ & (2.75) & $6.4 !$ & $(2.36)$ & $\ddagger$ & $(\dagger)$ & $\ddagger$ & $(t)$ & $9.2 !$ & $(4.56)$ \\
\hline
\end{tabular}

NOTE: Degree-granting institutions grant associate's or higher degrees and participate in Title IV federal financial aid programs. Totals may differ from figures reported in other tables because of varying survey methodologies. Detail may not sum to totals because of rounding.
SOURCE: U.S. Department of Education, National Center for Education Statistics, 2004 National Study of Postsecondary Faculty (NSOPF:04). (This table was prepared December 2008.) 


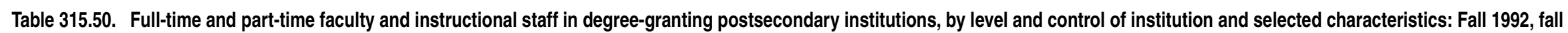
1998, and fall 2003

[Standard errors appear in parentheses]

\begin{tabular}{|c|c|c|c|c|c|c|c|c|c|c|c|c|c|c|c|c|c|c|c|c|c|c|c|c|}
\hline \multirow[b]{3}{*}{ Selected characteristic } & \multirow{2}{*}{\multicolumn{4}{|c|}{$\begin{array}{c}\text { Number } \\
\text { (in thousands) }\end{array}$}} & \multicolumn{20}{|c|}{ Fall 2003} \\
\hline & & & & & & \multirow[b]{2}{*}{ Total } & \multicolumn{4}{|c|}{ Research } & \multicolumn{4}{|c|}{ Doctoral } & \multicolumn{4}{|c|}{ Comprehensive } & \multirow{2}{*}{\multicolumn{2}{|c|}{$\begin{array}{r}\text { Private liberal } \\
\text { arts }\end{array}$}} & \multirow{2}{*}{\multicolumn{2}{|c|}{ Public 2-year }} & \multirow{2}{*}{\multicolumn{2}{|c|}{ Other }} \\
\hline & 1992 & 1998 & & 2003 & & & & Public & & Private & & Public & & Private & & Public & & Private & & & & & & \\
\hline 1 & 2 & 3 & & 4 & & 5 & & 6 & & 7 & & 8 & & 9 & & 10 & & 11 & & 12 & & 13 & & 14 \\
\hline \multirow[t]{3}{*}{ 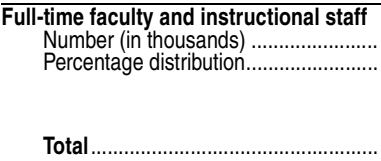 } & \multirow[t]{2}{*}{$\begin{array}{r}528.3 \\
\dagger\end{array}$} & \multirow[t]{2}{*}{$\begin{array}{r}560.4 \\
\dagger\end{array}$} & \multirow[t]{2}{*}{$\begin{array}{r}681.8 \\
\dagger\end{array}$} & \multirow[t]{2}{*}{$\begin{array}{r}(0.05) \\
(\dagger)\end{array}$} & $\begin{array}{l}681.8 \\
100.0 \\
\end{array}$ & $\begin{array}{r}(0.05) \\
(\dagger)\end{array}$ & $\begin{array}{r}162.1 \\
23.8 \\
\end{array}$ & $\begin{array}{l}(0.85) \\
(0.12)\end{array}$ & $\begin{array}{r}63.5 \\
9.3 \\
\end{array}$ & $\begin{array}{l}1.58) \\
(0.23)\end{array}$ & $\begin{array}{r}51.3 \\
7.5 \\
\end{array}$ & $\begin{array}{l}(0.76) \\
(0.11)\end{array}$ & $\begin{array}{r}21.7 \\
3.2 \\
\end{array}$ & $\begin{array}{l}(0.79) \\
(0.12)\end{array}$ & $\begin{array}{r}107.3 \\
15.7 \\
\end{array}$ & $\left(\begin{array}{l}2.98 \\
(0.44)\end{array}\right)$ & $\begin{array}{r}41.4 \\
6.1 \\
\end{array}$ & $\begin{array}{l}(1.59) \\
0.23)\end{array}$ & $\begin{array}{r}49.6 \\
7.3 \\
\end{array}$ & $\left(\begin{array}{l}1.80) \\
0.26\end{array}\right)$ & $\begin{array}{r}114.6 \\
16.8 \\
\end{array}$ & $\left.\begin{array}{l}1.09 \\
0.16\end{array}\right)$ & $\begin{array}{l}70.2 \\
10.3 \\
\end{array}$ & $\left.\begin{array}{l}3.36 \\
(0.49\end{array}\right)$ \\
\hline & & & & & \multicolumn{20}{|c|}{ Percentage distribution of full-time faculty and instructional staff } \\
\hline & 528.3 & 560.4 & 681.8 & $(0.05)$ & 100.0 & $(\dagger)$ & 100.0 & $(t)$ & 100.0 & (t) & 100.0 & (t) & 100.0 & $(t)$ & 100.0 & (t) & 100.0 & $(t)$ & 100.0 & $(t)$ & 100.0 & $(t)$ & 100.0 & $(\dagger)$ \\
\hline 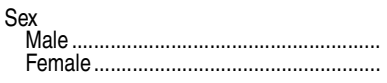 & $\begin{array}{l}352.7 \\
175.5\end{array}$ & $\begin{array}{l}356.9 \\
203.5\end{array}$ & $\begin{array}{l}420.4 \\
261.4\end{array}$ & $(-)$ & $\begin{array}{l}61.7 \\
38.3\end{array}$ & $\left(\begin{array}{l}0.35) \\
0.35)\end{array}\right.$ & $\begin{array}{l}69.9 \\
30.1\end{array}$ & $\left(\begin{array}{l}0.62) \\
0.62)\end{array}\right.$ & $\begin{array}{l}68.8 \\
31.2\end{array}$ & $\left(\begin{array}{l}0.90) \\
0.90\end{array}\right.$ & $\begin{array}{l}62.8 \\
37.2\end{array}$ & $\left(\begin{array}{l}1.29) \\
1.29\end{array}\right)$ & $\begin{array}{l}66.7 \\
33.3\end{array}$ & $\left.\begin{array}{l}(2.04) \\
(2.04)\end{array}\right)$ & $\begin{array}{l}58.8 \\
41.2\end{array}$ & $\left(\begin{array}{l}0.84) \\
0.84)\end{array}\right.$ & $\begin{array}{l}57.6 \\
42.4\end{array}$ & $\begin{array}{l}(2.03) \\
(2.03)\end{array}$ & $\begin{array}{l}59.7 \\
40.3\end{array}$ & $\left(\begin{array}{l}1.14 \\
1.14\end{array}\right)$ & $\begin{array}{l}50.5 \\
49.5\end{array}$ & $\left(\begin{array}{l}1.08 \\
1.08\end{array}\right)$ & $\begin{array}{l}60.3 \\
39.7\end{array}$ & $\left(\begin{array}{l}1.41 \\
1.41\end{array}\right)$ \\
\hline 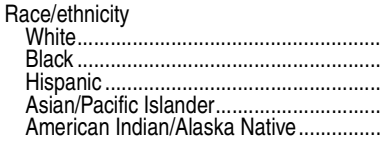 & $\begin{array}{r}456.7 \\
27.4 \\
13.9 \\
27.7 \\
2.6\end{array}$ & $\begin{array}{r}477.0 \\
28.4 \\
18.5 \\
32.5 \\
4.0\end{array}$ & $\begin{array}{r}547.7 \\
38.1 \\
23.8 \\
62.3 \\
10.0\end{array}$ & $\left(\begin{array}{l}- \\
- \\
-\end{array}\right)$ & $\begin{array}{r}80.3 \\
5.6 \\
3.5 \\
9.1 \\
1.5\end{array}$ & $\left.\begin{array}{l}(0.27) \\
0.17 \\
0.10 \\
0.16 \\
0.11\end{array}\right)$ & $\begin{array}{r}79.0 \\
3.7 \\
2.9 \\
13.2 \\
1.1\end{array}$ & $\begin{array}{l}(0.50) \\
0.26 \\
0.18 \\
0.45 \\
0.17)\end{array}$ & $\begin{array}{r}77.6 \\
4.9 \\
3.5 \\
12.8 \\
1.2 !\end{array}$ & $\begin{array}{l}(0.73) \\
0.49 \\
0.36 \\
0.63 \\
(0.40)\end{array}$ & $\begin{array}{r}81.3 \\
4.1 \\
2.9 \\
10.1 \\
1.6\end{array}$ & $\begin{array}{l}(1.33) \\
0.50 \\
0.37 \\
1.17 \\
0.35)\end{array}$ & $\begin{array}{r}82.7 \\
5.1 \\
2.2 \\
9.3 \\
0.7 !\end{array}$ & $\left(\begin{array}{l}1.55 \\
0.79 \\
0.59 \\
1.40 \\
0.36\end{array}\right)$ & $\begin{array}{r}78.0 \\
8.7 \\
3.6 \\
7.9 \\
1.8\end{array}$ & $\begin{array}{l}(1.12) \\
0.73 \\
0.23 \\
0.34 \\
(0.50)\end{array}$ & $\begin{array}{l}85.6 \\
4.8 \\
2.4 \\
5.9 \\
1.2 !\end{array}$ & $\left.\begin{array}{l}(1.02) \\
0.65 \\
0.36 \\
0.74 \\
0.38)\end{array}\right)$ & $\begin{array}{r}86.0 \\
6.3 \\
2.3 \\
3.8 \\
1.6\end{array}$ & $\begin{array}{l}(0.81) \\
0.69 \\
0.26 \\
0.33 \\
0.31)\end{array}$ & $\begin{array}{r}80.9 \\
6.9 \\
5.8 \\
4.2 \\
2.2\end{array}$ & $\left.\begin{array}{l}(0.84) \\
0.43 \\
0.44 \\
0.44 \\
0.36)\end{array}\right)$ & $\begin{array}{c}79.8 \\
4.7 \\
3.1 \\
11.3 \\
1.0 !\end{array}$ & $\left.\begin{array}{l}1.14 \\
0.81 \\
0.44 \\
0.94 \\
0.32\end{array}\right)$ \\
\hline 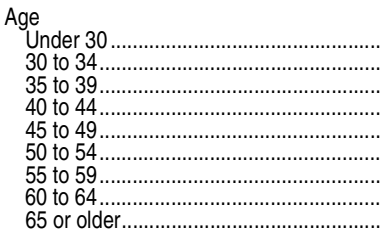 & $\begin{array}{r}7.6 \\
35.4 \\
66.8 \\
90.2 \\
97.7 \\
94.9 \\
67.3 \\
44.6 \\
23.8\end{array}$ & $\begin{array}{r}8.8 \\
32.2 \\
60.1 \\
81.9 \\
96.8 \\
104.7 \\
90.2 \\
55.0 \\
30.6\end{array}$ & $\begin{array}{r}11.9 \\
47.2 \\
77.1 \\
92.6 \\
105.3 \\
114.4 \\
111.6 \\
78.3 \\
43.3\end{array}$ & $\begin{array}{l}\text { - } \\
- \\
- \\
- \\
- \\
-\end{array}$ & $\begin{array}{r}1.7 \\
6.9 \\
11.3 \\
13.6 \\
15.4 \\
16.8 \\
16.4 \\
11.5 \\
6.3\end{array}$ & $\begin{array}{l}(0.13) \\
0.21 \\
0.29 \\
0.31 \\
0.32 \\
0.34) \\
0.37 \\
0.31 \\
0.23)\end{array}$ & $\begin{array}{r}1.7 \\
7.5 \\
12.8 \\
15.3 \\
15.9 \\
16.3 \\
13.9 \\
10.7 \\
6.0\end{array}$ & $\begin{array}{l}(0.24) \\
0.44 \\
0.58) \\
0.57 \\
0.53 \\
0.66 \\
0.66 \\
(0.58 \\
0.40)\end{array}$ & $\begin{array}{r}1.5 \\
8.6 \\
14.3 \\
15.0 \\
14.6 \\
14.6 \\
12.0 \\
10.9 \\
8.6\end{array}$ & $\begin{array}{l}(0.28) \\
0.89 \\
1.35 \\
0.75 \\
1.24 \\
0.87 \\
0.61 \\
0.74 \\
0.64)\end{array}$ & $\begin{array}{r}1.8 \\
7.2 \\
11.8 \\
11.9 \\
16.5 \\
16.0 \\
15.1 \\
13.8 \\
5.9\end{array}$ & $\begin{array}{l}(0.37) \\
0.82 \\
0.95 \\
0.83 \\
1.38 \\
1.09 \\
1.01 \\
0.90 \\
0.83)\end{array}$ & $\begin{array}{r}1.3 ! \\
5.9 \\
8.9 \\
11.8 \\
16.0 \\
14.9 \\
16.5 \\
12.8 \\
11.8\end{array}$ & $\begin{array}{c}(0.444 \\
0.73 \\
1.45 \\
1.36 \\
1.89 \\
(1.34) \\
1.60 \\
1.54 \\
(1.53)\end{array}$ & $\begin{array}{r}1.7 \\
6.5 \\
10.1 \\
12.1 \\
15.2 \\
16.6 \\
17.3 \\
13.4 \\
7.1\end{array}$ & $\begin{array}{l}(0.29) \\
0.74) \\
0.86 \\
0.78 \\
0.75 \\
0.90 \\
0.89 \\
0.72 \\
0.67)\end{array}$ & $\begin{array}{r}2.3 \\
7.0 \\
996 \\
14.4 \\
13.0 \\
17.1 \\
16.8 \\
12.9 \\
6.8\end{array}$ & $\begin{array}{c}(0.56) \\
0.92 \\
0.88 \\
1.15 \\
1.18 \\
1.26 \\
1.24 \\
1.42 \\
0.78)\end{array}$ & $\begin{array}{r}2.1 \\
8.9 \\
12.8 \\
12.3 \\
14.3 \\
16.5 \\
15.6 \\
11.8 \\
5.7\end{array}$ & $\begin{array}{r}(0.41) \\
(.73) \\
1.22 \\
0.75 \\
(1.10 \\
(1.0) \\
(0.87) \\
(1.10 \\
0.80)\end{array}$ & $\begin{array}{r}1.8 \\
5.1 \\
9.0 \\
12.7 \\
14.7 \\
19.3 \\
21.9 \\
10.5 \\
4.9\end{array}$ & $\begin{array}{l}(0.36) \\
0.52 \\
0.70 \\
0.88) \\
0.70 \\
0.84 \\
1.05 \\
(0.68) \\
(0.67)\end{array}$ & $\begin{array}{c}1.7 ! \\
6.4 \\
11.1 \\
14.4 \\
18.0 \\
17.1 \\
16.8 \\
9.4 \\
5.2\end{array}$ & $\left.\begin{array}{l}0.68 \\
0.75 \\
1.05 \\
1.38 \\
1.36 \\
1.35 \\
1.46 \\
0.83 \\
0.59\end{array}\right)$ \\
\hline 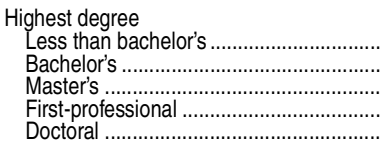 & $\begin{array}{r}6.3 \\
20.9 \\
155.8 \\
58.3 \\
283.8\end{array}$ & $\begin{array}{r}6.7 \\
22.5 \\
156.0 \\
51.7 \\
323.5\end{array}$ & $\begin{array}{r}10.0 \\
29.4 \\
179.8 \\
56.1 \\
406.6\end{array}$ & $\left(\begin{array}{l}- \\
- \\
-\end{array}\right)$ & $\begin{array}{r}1.5 \\
4.3 \\
26.4 \\
8.2 \\
59.6\end{array}$ & $\left.\begin{array}{l}(0.12) \\
0.24 \\
0.39 \\
0.30 \\
0.48\end{array}\right)$ & $\begin{array}{r}0.2 ! \\
2.0 \\
12.3 \\
11.8 \\
73.7\end{array}$ & $\begin{array}{l}(0.09) \\
0.27 \\
0.49 \\
0.53 \\
0.61)\end{array}$ & $\begin{array}{r}\ddagger \\
2.0 \\
9.9 \\
18.4 \\
69.4\end{array}$ & $\left.\begin{array}{l}(0.41 \\
0.93 \\
1.19 \\
1.45\end{array}\right)$ & $\begin{array}{r}0.2 ! \\
2.9 \\
20.3 \\
41.7 \\
71.9\end{array}$ & $\begin{array}{l}(0.09) \\
0.51) \\
1.19 \\
0.49 \\
(1.30)\end{array}$ & $\begin{array}{r}\ddagger \\
1.6 \\
12.9 \\
9.7 \\
75.4\end{array}$ & $\left(\begin{array}{c}(\mathrm{T}) \\
(1.47 \\
1.47 \\
(2.03)\end{array}\right)$ & $\begin{array}{r}0.1 ! \\
3.1 \\
22.7 \\
2.0 \\
72.1\end{array}$ & $\begin{array}{l}(0.07) \\
0.63 \\
1.08 \\
0.30 \\
(1.34)\end{array}$ & 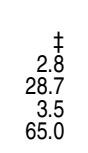 & $\left(\begin{array}{l}0.58 \\
2.10 \\
0.89 \\
(2.47)\end{array} \mid\right.$ & $\begin{array}{l}0.8 ! \\
2.1 \\
27.2 \\
0.9 \\
69.1\end{array}$ & $\begin{array}{l}(0.26) \\
0.53 \\
1.71 \\
0.18 \\
1.92)\end{array}$ & $\begin{array}{r}6.1 \\
11.1 \\
63.3 \\
1.6 \\
17.9\end{array}$ & $\left.\begin{array}{l}(0.58) \\
0.97 \\
1.22 \\
0.30 \\
1.13\end{array}\right)$ & $\begin{array}{r}2.4 \\
6.9 \\
25.5 \\
21.3 \\
43.8\end{array}$ & $\begin{array}{l}(0.64) \\
0.82 \\
1.68 \\
1.99 \\
(2.47)\end{array}$ \\
\hline 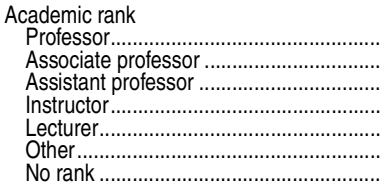 & $\begin{array}{r}160.6 \\
123.7 \\
124.3 \\
73.9 \\
11.9 \\
17.1 \\
16.9\end{array}$ & $\begin{array}{r}172.2 \\
132.0 \\
125.0 \\
74.9 \\
14.1 \\
26.3 \\
15.8\end{array}$ & $\begin{array}{r}194.4 \\
149.6 \\
158.1 \\
82.7 \\
21.9 \\
56.5 \\
18.6\end{array}$ & $\begin{array}{l}\left(\begin{array}{l}3.67) \\
(2.56 \\
(2.81 \\
(2.85 \\
(1.48 \\
2.15 \\
(1.28)\end{array}\right)\end{array}$ & $\begin{array}{r}28.5 \\
21.9 \\
23.2 \\
12.1 \\
3.2 \\
8.3 \\
2.7\end{array}$ & 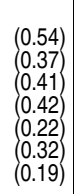 & $\begin{array}{r}33.8 \\
23.3 \\
22.5 \\
4.3 \\
4.6 \\
10.6 \\
0.8\end{array}$ & 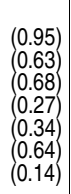 & $\begin{array}{r}34.0 \\
22.0 \\
26.6 \\
5.0 \\
4.9 \\
7.1 \\
\neq\end{array}$ & $\left.\begin{array}{r}(1.15) \\
1.12 \\
1.38 \\
0.79 \\
0.59 \\
0.54 \\
(\dagger)\end{array}\right)$ & $\begin{array}{r}27.3 \\
25.9 \\
23.5 \\
9.0 \\
5.4 \\
8.5 \\
\ddagger\end{array}$ & $\left.\begin{array}{c}1.34) \\
1.54 \\
1.36 \\
0.94 \\
0.80 \\
0.59 \\
(\dagger)\end{array}\right)$ & $\begin{array}{r}30.3 \\
31.6 \\
21.6 \\
4.5 \\
2.5 \\
8.9 \\
\ddagger\end{array}$ & $\left.\begin{array}{r}2.37) \\
1.73 \\
1.63 \\
(0.89 \\
(0.40) \\
(1.23 \\
(\dagger)\end{array}\right)$ & $\begin{array}{r}29.8 \\
23.2 \\
28.3 \\
7.6 \\
5.4 \\
5.7 \\
0.1 !\end{array}$ & $\left.\begin{array}{l}(1.23) \\
1.30 \\
(1.08) \\
(0.81 \\
(0.99) \\
0.94 \\
(0.05)\end{array}\right)$ & $\begin{array}{c}24.8 \\
27.0 \\
31.8 \\
6.8 \\
1.9 ! \\
7.3 \\
0.5\end{array}$ & $\left.\begin{array}{c}(1.61) \\
(1.41 \\
(2.0) \\
(1.02 \\
(0.67) \\
1.12 \\
(0.10)\end{array}\right)$ & $\begin{array}{r}28.5 \\
24.6 \\
30.3 \\
6.6 \\
1.0 \\
8.8 \\
\ddagger\end{array}$ & $\begin{array}{r}1.79 \\
1.27 \\
1.14 \\
0.91 \\
0.23 \\
1.11 \\
(\dagger)\end{array}$ & $\begin{array}{r}21.7 \\
12.1 \\
10.3 \\
37.5 \\
0.3 \\
8.3 \\
9.8\end{array}$ & $\begin{array}{l}1.89) \\
1.22 \\
1.12 \\
2.13 \\
(0.09) \\
0.80 \\
(0.88)\end{array}$ & $\begin{array}{r}22.9 \\
22.3 \\
25.2 \\
13.9 \\
0.9 \\
7.9 \\
7.0\end{array}$ & $\begin{array}{l}1.39 \\
1.47 \\
1.37 \\
1.30 \\
(0.27) \\
0.90 \\
(1.14)\end{array}$ \\
\hline 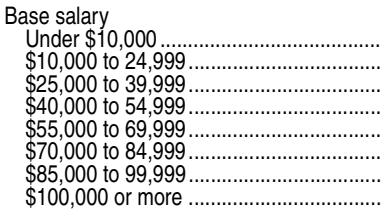 & $\begin{array}{r}13.8 \\
29.4 \\
181.8 \\
163.8 \\
76.7 \\
32.1 \\
11.1 \\
19.6\end{array}$ & $\begin{array}{r}9.7 \\
19.3 \\
123.7 \\
171.1 \\
106.2 \\
57.9 \\
28.1 \\
44.4\end{array}$ & $\begin{array}{r}4.4 \\
19.0 \\
79.7 \\
192.4 \\
147.7 \\
94.8 \\
50.7 \\
93.1\end{array}$ & $\begin{array}{l}(0.49) \\
1.03 \\
2.90 \\
3.09 \\
3.54 \\
2.19 \\
1.98 \\
2.29\end{array}$ & $\begin{array}{r}0.7 \\
2.8 \\
11.7 \\
28.2 \\
21.7 \\
13.9 \\
7.4 \\
13.7\end{array}$ & $\begin{array}{l}(0.07) \\
(0.15 \\
0.42 \\
0.45 \\
0.52 \\
0.32 \\
0.29 \\
0.34)\end{array}$ & $\begin{array}{r}0.8 \\
2.5 \\
8.0 \\
19.2 \\
18.9 \\
15.3 \\
11.1 \\
24.1\end{array}$ & $\begin{array}{l}(0.19) \\
0.28 \\
0.49 \\
0.78 \\
0.58 \\
0.64 \\
0.54 \\
0.76\end{array}$ & $\begin{array}{r}0.7 ! \\
3.0 \\
5.6 \\
15.5 \\
15.4 \\
16.0 \\
9.8 \\
34.0\end{array}$ & $\begin{array}{l}0.31 \\
0.44 \\
0.66 \\
1.13 \\
0.99 \\
1.01 \\
0.80 \\
1.20\end{array}$ & $\begin{array}{r}0.8 ! \\
3.8 \\
13.0 \\
27.4 \\
22.3 \\
14.7 \\
7.8 \\
10.2\end{array}$ & $\begin{array}{l}(0.26) \\
0.55 \\
0.65 \\
1.10 \\
1.05 \\
1.03 \\
0.79 \\
0.82)\end{array}$ & $\begin{array}{r}\ddagger \\
1.7 ! \\
6.6 \\
21.3 \\
26.4 \\
15.6 \\
10.1 \\
18.2\end{array}$ & $\begin{array}{r}(t) \\
(0.74) \\
1.03 \\
2.12 \\
2.02 \\
(1.52) \\
1.32 \\
(1.63)\end{array} \mid$ & $\begin{array}{r}0.5 ! \\
3.1 \\
12.2 \\
34.0 \\
24.1 \\
14.7 \\
8.1 \\
3.3\end{array}$ & $\left(\begin{array}{l}0.20 \\
0.36 \\
1.12 \\
1.40 \\
1.26 \\
1.21 \\
0.78 \\
0.46)\end{array}\right.$ & $\begin{array}{r}\ddagger \\
2.9 \\
12.8 \\
38.8 \\
24.9 \\
10.5 \\
4.0 \\
5.8\end{array}$ & 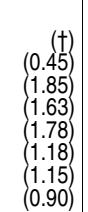 & $\begin{array}{c}0.6 ! \\
2.6 \\
15.2 \\
39.6 \\
23.1 \\
11.2 \\
3.7 \\
4.0\end{array}$ & $\left.\begin{array}{l}(0.18) \\
0.58 \\
1.38 \\
1.64 \\
1.34 \\
1.46 \\
0.56 \\
0.57)\end{array}\right)$ & $\begin{array}{r}0.6 \\
2.9 \\
18.0 \\
37.1 \\
24.3 \\
12.9 \\
3.6 \\
0.8\end{array}$ & $\left.\begin{array}{c}(0.15) \\
0.42 \\
1.44 \\
1.48 \\
1.58 \\
1.10 \\
0.59 \\
0.21)\end{array}\right)$ & $\begin{array}{c}0.9 ! \\
2.4 \\
12.0 \\
25.7 \\
20.9 \\
12.0 \\
5.7 \\
20.4\end{array}$ & $\left.\begin{array}{l}(0.35) \\
(0.59 \\
1.28 \\
1.55 \\
1.43 \\
1.38 \\
0.58 \\
2.00\end{array}\right)$ \\
\hline
\end{tabular}




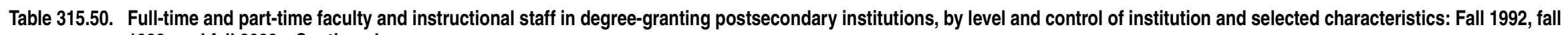
1998, and fall 2003-Continued

[Standard errors appear in parentheses]

\begin{tabular}{|c|c|c|c|c|c|c|c|c|c|c|c|c|c|c|c|c|c|c|c|c|c|c|c|c|}
\hline \multirow[b]{3}{*}{ Selected characteristic } & \multirow{2}{*}{\multicolumn{4}{|c|}{$\begin{array}{c}\text { Number } \\
\text { (in thousands) }\end{array}$}} & \multicolumn{20}{|c|}{ Fall 2003} \\
\hline & & & & & & \multirow[b]{2}{*}{ Total } & \multicolumn{4}{|c|}{ Research } & \multicolumn{4}{|c|}{ Doctoral } & \multicolumn{4}{|c|}{ Comprehensive } & \multirow{2}{*}{\multicolumn{2}{|c|}{$\begin{array}{r}\text { Private liberal } \\
\text { arts }\end{array}$}} & \multirow{2}{*}{\multicolumn{2}{|c|}{ Public 2-year }} & \multirow{2}{*}{\multicolumn{2}{|c|}{ Other }} \\
\hline & 1992 & 1998 & & 2003 & & & & Public & & Private & & Public & & Private & & Public & & Private & & & & & & \\
\hline 1 & 2 & 3 & & 4 & & 5 & & 6 & & 7 & & 8 & & 9 & & 10 & & 11 & & 12 & & 13 & & 14 \\
\hline \multirow[t]{3}{*}{ 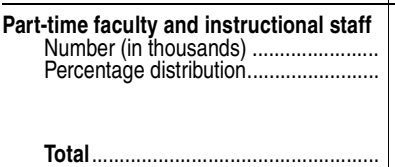 } & \multirow[t]{2}{*}{$\begin{array}{r}376.7 \\
\dagger\end{array}$} & \multirow[t]{2}{*}{$\begin{array}{r}416.0 \\
\dagger\end{array}$} & \multirow[t]{2}{*}{$\begin{array}{r}530.0 \\
\dagger\end{array}$} & \multirow[t]{2}{*}{$\begin{array}{r}(0.02) \\
f\end{array}$} & 30.0 & $\begin{array}{r}(0.02) \\
(\dagger)\end{array}$ & $\begin{array}{r}39.7 \\
7.5\end{array}$ & $\begin{array}{l}(0.78) \\
(0.15)\end{array}$ & $\begin{array}{r}23.2 \\
4.4\end{array}$ & $\begin{array}{l}(0.96) \\
0.18)\end{array}$ & $\begin{array}{r}20.8 \\
3.9\end{array}$ & $\begin{array}{l}(0.82) \\
(0.15)\end{array}$ & $\begin{array}{r}15.4 \\
2.9\end{array}$ & $\left.\begin{array}{l}(0.83) \\
0.16\end{array}\right)$ & $\begin{array}{l}60.3 \\
11.4\end{array}$ & $\left(\begin{array}{l}2.49 \\
0.47\end{array}\right)$ & $\begin{array}{l}53.5 \\
10.1\end{array}$ & $\left(\begin{array}{l}2.17) \\
(0.41)\end{array}\right.$ & $\begin{array}{r}28.4 \\
5.4\end{array}$ & $\begin{array}{l}2.19 \\
0.41)\end{array}$ & $\begin{array}{r}230.1 \\
43.4\end{array}$ & $(2.00)$ & $\begin{array}{l}58.7 \\
11.1\end{array}$ & $\left.\begin{array}{l}3.38 \\
0.64)\end{array}\right)$ \\
\hline & & & & & \multicolumn{20}{|c|}{ Percentage distribution of part-time faculty and instructional staff } \\
\hline & 376.7 & 416.0 & 530.0 & $(0.02)$ & 100.0 & $(\dagger)$ & 0.0 & $(\dagger)$ & 0.0 & $(t)$ & 100.0 & $(t)$ & 100.0 & $(\dagger)$ & 100.0 & $(t)$ & 100.0 & $(t)$ & 00.0 & $(t)$ & 100.0 & $(t)$ & 100.0 & $(\dagger)$ \\
\hline 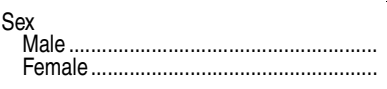 & $\begin{array}{l}208.7 \\
168.0\end{array}$ & $\begin{array}{l}217.0 \\
199.1\end{array}$ & $\begin{array}{l}275.9 \\
254.1\end{array}$ & $(-)$ & $\begin{array}{l}52.1 \\
47.9\end{array}$ & $\left.\begin{array}{l}(0.45) \\
(0.45)\end{array}\right)$ & $\begin{array}{l}50.4 \\
49.6\end{array}$ & $\left(\begin{array}{l}1.97) \\
1.97\end{array}\right)$ & $\begin{array}{l}60.2 \\
39.8\end{array}$ & $\left(\begin{array}{l}1.92) \\
(1.92)\end{array}\right.$ & $\begin{array}{l}50.2 \\
49.8\end{array}$ & $\begin{array}{l}(2.26) \\
(2.26)\end{array}$ & $\begin{array}{l}58.4 \\
41.6\end{array}$ & $\begin{array}{l}(3.34) \\
(3.34)\end{array}$ & $\begin{array}{l}50.0 \\
50.0\end{array}$ & $\left(\begin{array}{l}1.59) \\
1.59\end{array}\right)$ & $\begin{array}{l}3.9 \\
6.1\end{array}$ & $\left(\begin{array}{l}1.53 \\
1.53\end{array}\right)$ & $\begin{array}{l}0.3 \\
9.7\end{array}$ & $\left(\begin{array}{l}1.95) \\
1.95\end{array}\right)$ & $\begin{array}{l}50.7 \\
49.3\end{array}$ & $(0.57)$ & $\begin{array}{l}55.4 \\
44.6\end{array}$ & $\left(\begin{array}{l}1.66 \\
1.66\end{array}\right)$ \\
\hline 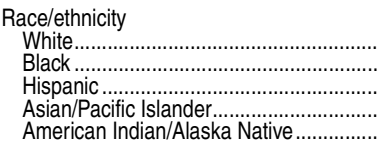 & $\begin{array}{r}332.8 \\
18.3 \\
11.2 \\
12.2 \\
2.3\end{array}$ & $\begin{array}{r}364.4 \\
18.9 \\
15.5 \\
13.2 \\
4.0\end{array}$ & $\begin{array}{r}451.6 \\
29.7 \\
18.7 \\
20.3 \\
9.7\end{array}$ & $\left(\begin{array}{l}- \\
- \\
-\end{array}\right.$ & $\begin{array}{r}85.2 \\
5.6 \\
3.5 \\
3.8 \\
1.8\end{array}$ & $\begin{array}{l}(0.38) \\
0.20 \\
0.13 \\
0.22 \\
0.22)\end{array}$ & $\begin{array}{l}82.4 \\
2.7 \\
3.2 \\
9.9 \\
1.8 !\end{array}$ & $\left.\begin{array}{l}(1.63) \\
0.72 \\
0.56 \\
1.39 \\
0.68\end{array}\right)$ & $\begin{array}{c}85.8 \\
4.1 \\
2.5 ! \\
6.4 \\
\ddagger\end{array}$ & $\begin{array}{r}(1.78) \\
1.14 \\
0.78 \\
1.05 \\
(\dagger)\end{array}$ & $\begin{array}{c}87.9 \\
2.4 ! \\
4.1 \\
4.5 \\
\ddagger\end{array}$ & $\begin{array}{r}(2.19) \\
1.01 \\
0.81 \\
1.14 \\
(\dagger)\end{array}$ & $\begin{array}{r}88.9 \\
2.8 ! \\
2.8 \\
4.9 ! \\
\ddagger\end{array}$ & $\begin{array}{r}(1.99) \\
0.99 \\
(0.66) \\
(1.79) \\
(\dagger)\end{array} \mid$ & $\begin{array}{r}87.2 \\
4.7 \\
3.1 \\
3.3 \\
1.7 !\end{array}$ & $\begin{array}{l}1.89 \\
1.20 \\
0.39 \\
0.59 \\
0.61)\end{array}$ & $\begin{array}{l}91.0 \\
2.8 \\
2.4 \\
1.9 ! \\
1.9\end{array}$ & $\begin{array}{l}(0.85) \\
0.40 \\
0.30 \\
0.61 \\
0.42\end{array} \mid$ & $\begin{array}{l}86.2 \\
8.1 \\
2.1 \\
2.7 \\
0.9 !\end{array}$ & $\left.\begin{array}{l}1.59 \\
1.27 \\
0.48 \\
0.63 \\
0.35\end{array}\right)$ & $\begin{array}{r}83.7 \\
6.9 \\
4.4 \\
2.9 \\
2.1\end{array}$ & $\begin{array}{l}(0.54) \\
0.25 \\
0.21 \\
0.23 \\
0.38\end{array} \mid$ & $\begin{array}{l}83.0 \\
7.2 \\
3.0 \\
4.7 \\
2.1\end{array}$ & $\left.\begin{array}{l}(1.84) \\
1.02 \\
0.57 \\
1.02 \\
0.70\end{array}\right)$ \\
\hline 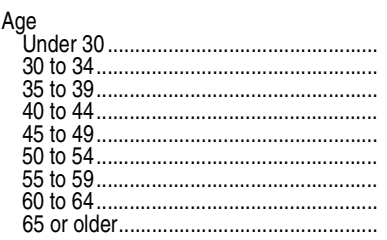 & $\begin{array}{l}20.5 \\
35.9 \\
58.9 \\
70.0 \\
68.0 \\
45.1 \\
28.8 \\
22.9 \\
26.6\end{array}$ & $\begin{array}{l}15.1 \\
37.1 \\
47.2 \\
60.4 \\
72.1 \\
69.8 \\
47.1 \\
28.8 \\
38.4\end{array}$ & $\begin{array}{l}22.8 \\
43.4 \\
54.6 \\
61.0 \\
76.5 \\
82.8 \\
77.0 \\
51.6 \\
60.3\end{array}$ & $\begin{array}{l}- \\
- \\
- \\
- \\
- \\
- \\
-\end{array}$ & $\begin{array}{r}4.3 \\
8.2 \\
10.3 \\
11.5 \\
14.4 \\
15.6 \\
14.5 \\
9.7 \\
11.4\end{array}$ & $\left.\begin{array}{l}0.30) \\
0.38 \\
0.48 \\
0.44 \\
0.48 \\
0.42 \\
0.48 \\
0.50 \\
0.46)\end{array}\right)$ & $\begin{array}{r}5.6 \\
10.0 \\
8.7 \\
12.9 \\
15.6 \\
14.5 \\
12.1 \\
8.4 \\
12.3\end{array}$ & $\left.\begin{array}{c}(0.94) \\
1.32 \\
1.36 \\
1.78 \\
1.51 \\
1.39 \\
1.53 \\
1.38 \\
(1.49)\end{array}\right)$ & $\begin{array}{r}3.1 ! \\
8.8 \\
9.4 \\
11.4 \\
16.0 \\
12.2 \\
14.4 \\
9.6 \\
15.1\end{array}$ & $\left.\begin{array}{c}(1.11) \\
1.79 \\
1.48 \\
1.81 \\
1.54 \\
1.49 \\
(2.14) \\
1.78 \\
(1.95)\end{array}\right)$ & $\begin{array}{r}8.9 \\
6.8 \\
8.3 \\
13.2 \\
16.3 \\
16.3 \\
13.5 \\
8.0 \\
8.7\end{array}$ & $\begin{array}{c}(1.75) \\
1.20 \\
1.74 \\
2.26 \\
2.42 \\
2.27 \\
1.99 \\
1.86 \\
(1.61)\end{array}$ & $\begin{array}{r}4.8 ! \\
6.5 \\
12.5 \\
11.2 \\
7.9 \\
16.5 \\
14.2 \\
12.5 \\
13.8\end{array}$ & $\left.\begin{array}{l}(1.58) \\
1.81 \\
2.38 \\
2.26 \\
1.93 \\
2.76 \\
2.99 \\
(2.58) \\
2.90\end{array}\right)$ & $\begin{array}{r}5.7 \\
8.1 \\
11.1 \\
11.9 \\
11.3 \\
13.6 \\
14.8 \\
11.2 \\
12.2\end{array}$ & $\left.\begin{array}{l}(1.04) \\
1.11 \\
1.55 \\
1.34 \\
1.17 \\
1.50 \\
1.35 \\
1.30 \\
1.19\end{array}\right)$ & $\begin{array}{r}1.8 \\
7.9 \\
9.7 \\
10.1 \\
14.3 \\
18.5 \\
14.2 \\
10.5 \\
13.1\end{array}$ & $\left.\begin{array}{l}(0.51) \\
1.16 \\
0.88 \\
1.18 \\
1.27 \\
1.24 \\
1.32 \\
1.38 \\
(1.85)\end{array}\right)$ & $\begin{array}{r}3.8 \\
8.9 \\
10.8 \\
12.2 \\
14.0 \\
15.0 \\
13.7 \\
9.5 \\
12.1\end{array}$ & $\left.\begin{array}{l}(0.72) \\
1.33 \\
1.78 \\
1.37 \\
1.95 \\
1.66 \\
1.69 \\
1.41 \\
1.93\end{array}\right)$ & $\begin{array}{r}4.4 \\
8.2 \\
10.4 \\
11.3 \\
14.6 \\
15.9 \\
15.3 \\
9.7 \\
10.1\end{array}$ & $\begin{array}{l}(0.46) \\
0.68 \\
0.74) \\
0.78 \\
0.75 \\
0.72 \\
0.71) \\
0.85 \\
0.77)\end{array} \mid$ & $\begin{array}{r}3.1 \\
7.6 \\
10.8 \\
11.3 \\
17.1 \\
15.8 \\
14.1 \\
8.5 \\
11.7\end{array}$ & $\left.\begin{array}{l}(0.72 \\
1.11 \\
1.35 \\
1.40 \\
1.84 \\
1.57 \\
1.59 \\
1.25 \\
2.06\end{array}\right)$ \\
\hline 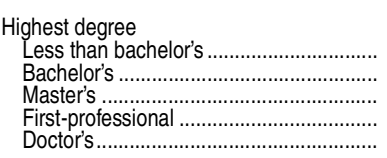 & $\begin{array}{r}17.2 \\
62.7 \\
190.2 \\
39.6 \\
58.9\end{array}$ & $\begin{array}{r}20.3 \\
58.8 \\
225.1 \\
36.0 \\
75.8\end{array}$ & $\begin{array}{r}41.1 \\
83.8 \\
273.1 \\
38.5 \\
93.5\end{array}$ & $\left(\begin{array}{l}- \\
- \\
-\end{array}\right)$ & $\begin{array}{r}7.8 \\
15.8 \\
51.5 \\
7.3 \\
17.6\end{array}$ & $\begin{array}{l}(0.59) \\
0.55 \\
0.80 \\
0.39 \\
0.60)\end{array}$ & $\begin{array}{r}2.2 \\
9.9 \\
35.6 \\
16.7 \\
35.6\end{array}$ & $\begin{array}{l}(0.59) \\
1.32 \\
2.39 \\
1.98 \\
(2.56)\end{array}$ & $\begin{array}{l}1 \\
10.9 \\
36.6 \\
21.3 \\
28.7\end{array}$ & 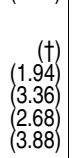 & $\begin{array}{r}\ddagger \\
13.9 \\
53.8 \\
7.7 \\
24.1\end{array}$ & 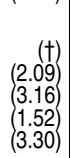 & $\begin{array}{r}2.1 ! \\
7.6 ! \\
41.7 \\
13.6 \\
35.0\end{array}$ & $\left.\begin{array}{l}(0.76) \\
2.48 \\
3.47 \\
2.41 \\
2.65\end{array}\right)$ & $\begin{array}{r}2.1 \\
13.1 \\
57.8 \\
4.2 \\
22.7\end{array}$ & $\left.\begin{array}{l}(0.61) \\
1.84 \\
2.32 \\
0.79 \\
1.83\end{array}\right)$ & $\begin{array}{r}0.7 ! \\
7.5 \\
64.4 \\
42.8 \\
22.6\end{array}$ & $\left.\begin{array}{l}(0.28) \\
1.08 \\
2.33 \\
0.90 \\
1.88\end{array}\right)$ & $\begin{array}{l}0.9 ! \\
8.6 \\
61.0 \\
7.2 \\
22.2\end{array}$ & $\left.\begin{array}{l}(0.38) \\
1.52 \\
2.21 \\
1.50 \\
2.09\end{array}\right)$ & $\begin{array}{r}14.3 \\
21.5 \\
52.1 \\
3.3 \\
8.7\end{array}$ & $\left.\begin{array}{l}1.21 \\
1.17 \\
1.63 \\
0.49 \\
0.66)\end{array}\right)$ & $\begin{array}{r}7.6 \\
15.9 \\
44.7 \\
14.4 \\
17.4\end{array}$ & $\left.\begin{array}{l}(1.51) \\
1.67 \\
3.32 \\
1.83 \\
2.28\end{array}\right)$ \\
\hline 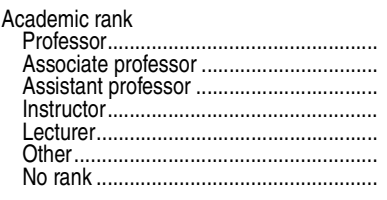 & $\begin{array}{r}32.3 \\
22.5 \\
24.2 \\
215.4 \\
45.3 \\
27.6 \\
9.3\end{array}$ & $\begin{array}{r}30.2 \\
19.4 \\
23.1 \\
205.4 \\
46.3 \\
75.2 \\
16.5\end{array}$ & $\begin{array}{r}23.3 \\
14.6 \\
19.8 \\
187.7 \\
40.9 \\
230.9 \\
12.8\end{array}$ & $\begin{array}{l}(1.58) \\
1.18 \\
1.53 \\
4.42 \\
(.15) \\
(4.51) \\
(1.07)\end{array}$ & $\begin{array}{r}4.4 \\
2.8 \\
3.7 \\
35.4 \\
7.7 \\
43.6 \\
2.4\end{array}$ & $\left.\begin{array}{l}(0.30) \\
0.22 \\
0.29 \\
0.83 \\
0.41 \\
0.85 \\
0.20\end{array}\right)$ & $\begin{array}{r}8.1 \\
4.3 \\
11.0 \\
20.8 \\
21.5 \\
33.3 \\
1.0 !\end{array}$ & $\left.\begin{array}{l}(1.54) \\
0.94) \\
(1.49 \\
1.72 \\
1.67 \\
2.17 \\
0.30\end{array}\right)$ & $\begin{array}{r}5.6 \\
6.0 \\
11.9 \\
18.2 \\
18.6 \\
38.2 \\
\ddagger\end{array}$ & $\left.\begin{array}{r}(1.18) \\
1.45 \\
3.02 \\
1.92 \\
2.30 \\
2.49 \\
(\dagger)\end{array}\right)$ & $\begin{array}{c}4.6 ! \\
2.6 ! \\
3.3 \\
28.7 \\
13.2 \\
45.4 \\
2.3 !\end{array}$ & $\left.\begin{array}{l}(1.43) \\
1.14 \\
0.80 \\
2.27 \\
2.07 \\
2.50 \\
0.80\end{array}\right)$ & $\begin{array}{r}5.7 \\
2.9 ! \\
7.0 \\
20.1 \\
9.6 \\
53.4 \\
\ddagger\end{array}$ & $\left.\begin{array}{r}1.40 \\
1.103 \\
1.73 \\
3.53 \\
1.72 \\
(3.25) \\
(\dagger)\end{array}\right)$ & $\begin{array}{r}5.7 \\
2.1 ! \\
2.0 \\
25.4 \\
15.8 \\
47.7 \\
1.2 !\end{array}$ & $\left.\begin{array}{l}1.01 \\
0.69 \\
0.49 \\
2.41 \\
2.18 \\
3.01 \\
0.39\end{array}\right)$ & $\begin{array}{r}2.4 \\
3.1 \\
3.0 \\
21.9 \\
8.6 \\
59.7 \\
1.2\end{array}$ & $\left.\begin{array}{l}(0.55) \\
0.79 \\
0.86 \\
(1.64) \\
2.32 \\
3.84 \\
0.32\end{array}\right)$ & $\begin{array}{l}4.4 \\
4.7 \\
5.1 ! \\
24.5 \\
6.7 \\
52.2 \\
2.3 !\end{array}$ & $\left.\begin{array}{l}(0.85) \\
1.11 \\
1.81 \\
2.13 \\
1.72 \\
3.03 \\
0.70\end{array}\right)$ & $\begin{array}{r}3.2 \\
1.5 \\
0.8 \\
48.5 \\
2.7 \\
40.5 \\
2.8\end{array}$ & $\left.\begin{array}{l}(0.52) \\
0.27 \\
0.20 \\
1.54 \\
0.42 \\
1.38 \\
0.39\end{array}\right)$ & $\begin{array}{r}6.0 \\
4.8 \\
8.3 \\
35.2 \\
2.7 \\
38.3 \\
4.6\end{array}$ & $\begin{array}{l}1.03 \\
1.07 \\
1.24 \\
(2.66 \\
(.80) \\
3.23 \\
(1.0)\end{array}$ \\
\hline 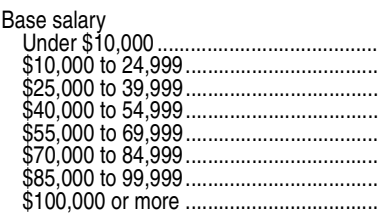 & $\begin{array}{r}280.5 \\
68.1 \\
15.8 \\
5.3 \\
2.2 \\
1.1 \\
0.9 \\
2.7\end{array}$ & $\begin{array}{r}256.2 \\
112.4 \\
26.3 \\
11.8 \\
4.2 \\
2.4 \\
\# \\
\#\end{array}$ & $\begin{array}{r}340.5 \\
140.8 \\
27.5 \\
9.6 \\
4.7 \\
1.9 \\
1.5 \\
3.5\end{array}$ & $\begin{array}{l}(3.17) \\
3.17 \\
1.72 \\
0.74 \\
0.78 \\
0.35 \\
0.39 \\
0.53\end{array}$ & $\begin{array}{r}64.2 \\
26.6 \\
5.2 \\
1.8 \\
0.9 \\
0.4 \\
0.3 \\
0.7\end{array}$ & $\begin{array}{l}(0.60) \\
0.60 \\
0.32 \\
0.14 \\
0.15 \\
0.07 \\
0.07 \\
0.10)\end{array}$ & $\begin{array}{r}43.7 \\
29.3 \\
12.2 \\
5.8 \\
3.0 \\
2.2 \\
1.0 ! \\
2.9\end{array}$ & $\begin{array}{l}(2.35) \\
2.32 \\
1.38 \\
1.05 \\
0.65 \\
0.57 \\
0.46 \\
0.63)\end{array}$ & $\begin{array}{r}54.7 \\
27.5 \\
7.7 \\
5.0 \\
2.0 ! \\
\neq \\
\neq \\
\neq\end{array}$ & $\begin{array}{r}2.80 \\
2.55 \\
1.76 \\
1.18 \\
1.00 \\
(\dagger \\
+\vdots \\
(\dagger)\end{array}$ & $\begin{array}{c}65.1 \\
24.7 \\
5.7 \\
1.9 ! \\
\ddagger \\
\neq \\
\neq \\
\neq\end{array}$ & $\begin{array}{r}(2.94) \\
2.63 \\
1.48 \\
0.70 \\
(+) \\
+ \\
+ \\
(\dagger)\end{array}$ & $\begin{array}{c}59.3 \\
30.3 \\
4.8 ! \\
3.0 ! \\
\neq \\
\neq \\
\neq \\
\neq\end{array}$ & 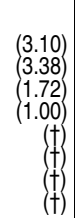 & $\begin{array}{r}66.0 \\
26.3 \\
4.9 \\
1.6 \\
\ddagger \\
\neq \\
\neq \\
\neq \\
\ddagger\end{array}$ & $\begin{array}{r}2.44 \\
2.05 \\
1.09 \\
0.44 \\
+1 \\
+1 \\
+1 \\
(†)\end{array} \mid$ & $\begin{array}{c}71.8 \\
21.4 \\
4.4 \\
0.9 ! \\
0.8 ! \\
\neq \\
\neq \\
\neq\end{array}$ & $\left.\begin{array}{r}2.97) \\
2.40 \\
1.15 \\
0.31 \\
0.31 \\
(\dagger) \\
+ \\
(†)\end{array}\right)$ & $\begin{array}{c}67.5 \\
23.4 \\
5.3 \\
1.1 ! \\
1.6 ! \\
\ddagger \\
\neq \\
\ddagger\end{array}$ & 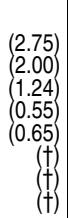 & $\begin{array}{c}66.6 \\
28.1 \\
4.1 \\
0.5 ! \\
0.4 ! \\
\ddagger \\
\ddagger \\
0.1 !\end{array}$ & $\begin{array}{r}1.02 \\
0.97 \\
0.46 \\
0.15 \\
0.14 \\
(\dagger) \\
(t) \\
(0.07)\end{array} \mid$ & $\begin{array}{r}63.5 \\
24.6 \\
4.7 \\
4.0 \\
\ddagger \\
0.9 ! \\
\ddagger \\
1.8 !\end{array}$ & $\begin{array}{r}(1.97) \\
1.74 \\
0.92 \\
0.83 \\
(\dagger) \\
(0.30 \\
(\dagger) \\
(0.56)\end{array}$ \\
\hline
\end{tabular}

-Not available.

\section{\#Rounds to zero.}

Interpret data with caution. The coefficient of variation (CV) for this estimate is between 30 and 50 percent. †Reporting standards not met. Either there are too few cases for a reliable estimate or the coefficient of variation (CV) is 50 percent or greater.
NOTE: Degree-granting institutions grant associate's or higher degrees and participate in Title IV federal financial aid programs. Totals may differ from figures reported in other tables because of varying survey methodologies. Race categories exclude perde.

SOURCE: U.S. Department of Education, National Center for Education Statistics, 1993, 1999, and 2004 National Study of Postsecondary Faculty (NSOPF:93;99;04). (This table was prepared January 2009.) 
Table 315.60. Full-time and part-time faculty and instructional staff in degree-granting postsecondary institutions, by race/ethnicity, sex, and selected characteristics: Fall 2003

[Standard errors appear in parentheses]

\begin{tabular}{|c|c|c|c|c|c|c|c|c|c|c|c|c|c|c|c|c|c|c|c|c|c|c|c|}
\hline \multirow[b]{2}{*}{ Selected characteristic } & \multirow{2}{*}{\multicolumn{2}{|c|}{$\begin{array}{r}\text { Number } \\
\text { (in thousands) }\end{array}$}} & \multirow[b]{2}{*}{ Percent } & \multicolumn{4}{|c|}{ White } & \multicolumn{4}{|c|}{ Black } & \multicolumn{4}{|c|}{ Hispanic } & \multicolumn{4}{|c|}{ Asian/Pacific Islander } & \multicolumn{4}{|c|}{ American Indian/Alaska Native } \\
\hline & & & & & Male & & Female & & Male & & Female & & Male & & Female & & Male & & Female & & Male & & Female \\
\hline 1 & & 2 & 3 & & 4 & & 5 & & 6 & & 7 & & 8 & & 9 & & 10 & & 11 & & 12 & & 13 \\
\hline Full-time faculty and instructional staff & & & & & & & & & & & & & & & & & & & & & & & \\
\hline 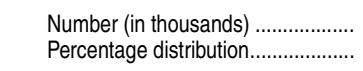 & $\begin{array}{r}681.8 \\
\dagger\end{array}$ & $\begin{array}{r}(0.05) \\
(\dagger) \\
\end{array}$ & $\begin{array}{r}\dagger \\
100.0 \\
\end{array}$ & $\begin{array}{r}338.4 \\
49.6 \\
\end{array}$ & $\begin{array}{l}2.63) \\
0.39) \\
\end{array}$ & $\begin{array}{r}209.3 \\
30.7 \\
\end{array}$ & $\begin{array}{l}(2.45) \\
(0.36) \\
\end{array}$ & $\begin{array}{r}19.5 \\
2.9 \\
\end{array}$ & $\begin{array}{l}(1.03) \\
(0.15)\end{array}$ & $\begin{array}{r}18.5 \\
2.7 \\
\end{array}$ & $\begin{array}{l}(0.87) \\
(0.13)\end{array}$ & $\begin{array}{r}13.4 \\
2.0\end{array}$ & $\begin{array}{l}(0.60) \\
(0.09)\end{array}$ & $\begin{array}{r}10.4 \\
1.5 \\
\end{array}$ & $\begin{array}{l}(0.56) \\
(0.08) \\
\end{array}$ & $\begin{array}{r}43.2 \\
6.3 \\
\end{array}$ & $\begin{array}{l}(1.00) \\
(0.15)\end{array}$ & $\begin{array}{r}19.0 \\
2.8\end{array}$ & $\begin{array}{l}(1.03) \\
(0.15) \\
\end{array}$ & $\begin{array}{l}5.8 \\
0.8\end{array}$ & $\begin{array}{l}(0.57) \\
(0.08) \\
\end{array}$ & $\begin{array}{l}4.2 \\
0.6 \\
\end{array}$ & $\begin{array}{l}(0.50) \\
(0.07) \\
\end{array}$ \\
\hline 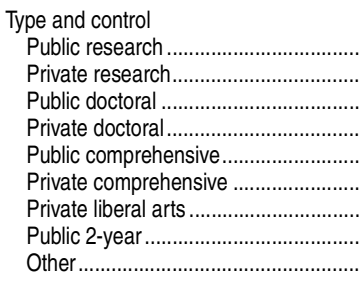 & $\begin{array}{r}162.1 \\
63.5 \\
51.3 \\
21.7 \\
107.3 \\
41.4 \\
49.6 \\
114.6 \\
70.2\end{array}$ & $\begin{array}{l}(0.85) \\
(1.58) \\
(0.76) \\
(0.79) \\
(2.98) \\
(1.59) \\
(1.80) \\
(1.09) \\
(3.36)\end{array}$ & $\begin{array}{l}100.0 \\
100.0 \\
100.0 \\
100.0 \\
100.0 \\
100.0 \\
100.0 \\
100.0 \\
100.0\end{array}$ & $\begin{array}{l}55.4 \\
54.7 \\
50.2 \\
56.0 \\
45.9 \\
48.9 \\
51.9 \\
40.8 \\
48.3\end{array}$ & $\begin{array}{l}(0.67) \\
(1.00) \\
(1.48) \\
(2.39) \\
(1.03) \\
(2.00) \\
(1.20) \\
(1.19) \\
(1.65)\end{array}$ & $\begin{array}{l}23.6 \\
22.9 \\
31.1 \\
26.7 \\
32.1 \\
36.7 \\
34.1 \\
40.1 \\
31.5\end{array}$ & $\begin{array}{l}(0.59) \\
(0.80) \\
(1.22) \\
(1.94) \\
(0.98) \\
(1.93) \\
(0.99) \\
(0.90) \\
(1.20)\end{array}$ & $\begin{array}{l}2.1 \\
2.2 \\
2.1 \\
3.0 \\
4.7 \\
2.3 \\
3.5 \\
3.1 \\
2.4\end{array}$ & $\begin{array}{l}(0.27) \\
(0.30) \\
(0.44) \\
(0.70) \\
(0.64) \\
(0.53) \\
(0.56) \\
(0.29) \\
(0.59)\end{array}$ & $\begin{array}{l}1.7 \\
2.7 \\
2.0 \\
2.1 \\
4.0 \\
2.4 \\
2.8 \\
3.8 \\
2.3\end{array}$ & $\begin{array}{l}(0.19) \\
(0.37) \\
(0.30) \\
(0.42) \\
(0.42) \\
(0.44) \\
(0.36) \\
(0.34) \\
(0.59)\end{array}$ & $\begin{array}{l}1.8 \\
2.1 \\
1.6 \\
1.4 ! \\
2.1 \\
1.6 \\
1.0 \\
3.0 \\
1.7\end{array}$ & $\begin{array}{l}(0.16) \\
(0.30) \\
(0.20) \\
(0.49) \\
(0.20) \\
(0.31) \\
(0.20) \\
(0.38) \\
(0.36)\end{array}$ & $\begin{array}{l}1.1 \\
1.4 \\
1.3 \\
0.8 ! \\
1.6 \\
0.8 \\
1.3 \\
2.7 \\
1.5\end{array}$ & $\begin{array}{l}(0.15) \\
(0.31) \\
(0.27) \\
(0.38) \\
(0.19) \\
(0.22) \\
(0.27) \\
(0.34) \\
(0.29)\end{array}$ & $\begin{array}{r}10.0 \\
8.9 \\
7.9 \\
5.8 \\
5.3 \\
4.1 \\
2.2 \\
2.2 \\
7.2\end{array}$ & $\begin{array}{l}(0.47) \\
(0.66) \\
(1.27) \\
(1.06) \\
(0.40) \\
(0.65) \\
(0.28) \\
(0.27) \\
(0.87)\end{array}$ & $\begin{array}{l}3.2 \\
3.9 \\
2.2 \\
3.5 \\
2.6 \\
1.9 \\
1.5 \\
2.1 \\
4.1\end{array}$ & $\begin{array}{l}(0.35) \\
(0.48) \\
(0.56) \\
(0.93) \\
(0.28) \\
(0.53) \\
(0.29) \\
(0.39) \\
(0.78)\end{array}$ & $\begin{array}{c}0.6 \\
0.8 ! \\
1.0 ! \\
\ddagger \\
0.8 \\
0.6 ! \\
1.0 \\
1.3 \\
0.7 !\end{array}$ & $\begin{array}{r}(0.14) \\
(0.39) \\
(0.32) \\
(\dagger) \\
(0.23) \\
(0.26) \\
(0.24) \\
(0.30) \\
(0.34)\end{array}$ & $\begin{array}{c}0.6 \\
\ddagger \\
0.6 ! \\
\ddagger \\
1.0 ! \\
\ddagger \\
0.6 ! \\
0.8 \\
0.3 !\end{array}$ & $\begin{array}{r}(0.11) \\
(\dagger) \\
(0.22) \\
(\dagger) \\
(0.33) \\
(\dagger) \\
(0.18) \\
(0.19) \\
(0.14)\end{array}$ \\
\hline 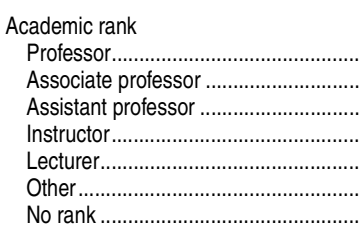 & $\begin{array}{r}194.4 \\
149.6 \\
158.1 \\
82.7 \\
21.9 \\
56.5 \\
18.6\end{array}$ & $\begin{array}{l}(3.67) \\
(2.56) \\
(2.81) \\
(2.85) \\
(1.48) \\
(2.15) \\
(1.28)\end{array}$ & $\begin{array}{l}100.0 \\
100.0 \\
100.0 \\
100.0 \\
100.0 \\
100.0 \\
100.0\end{array}$ & $\begin{array}{l}65.5 \\
51.6 \\
41.0 \\
38.2 \\
36.7 \\
38.8 \\
40.2\end{array}$ & $\begin{array}{l}(0.74) \\
(0.98) \\
(0.83) \\
(1.23) \\
(2.59) \\
(1.51) \\
(2.37)\end{array}$ & $\begin{array}{l}20.3 \\
28.4 \\
33.6 \\
41.2 \\
43.9 \\
39.8 \\
43.0\end{array}$ & $\begin{array}{l}(0.61) \\
(0.78) \\
(0.81) \\
(1.09) \\
(2.21) \\
(1.37) \\
(2.45)\end{array}$ & $\begin{array}{l}2.6 \\
3.1 \\
3.1 \\
3.2 \\
2.9 ! \\
2.5 \\
1.5 !\end{array}$ & $\begin{array}{l}(0.27) \\
(0.42) \\
(0.37) \\
(0.56) \\
(0.91) \\
(0.54) \\
(0.52)\end{array}$ & $\begin{array}{l}1.1 \\
2.4 \\
3.8 \\
4.4 \\
3.0 ! \\
3.9 \\
2.0 !\end{array}$ & $\begin{array}{l}(0.21) \\
(0.26) \\
(0.38) \\
(0.57) \\
(0.91) \\
(0.56) \\
(0.83)\end{array}$ & $\begin{array}{l}1.8 \\
1.7 \\
2.3 \\
2.5 \\
1.3 ! \\
1.7 \\
2.3 !\end{array}$ & $\begin{array}{l}(0.13) \\
(0.19) \\
(0.22) \\
(0.37) \\
(0.38) \\
(0.22) \\
(0.75)\end{array}$ & $\begin{array}{l}0.8 \\
1.3 \\
1.9 \\
2.3 \\
3.8 \\
2.2 \\
0.7 !\end{array}$ & $\begin{array}{l}(0.13) \\
(0.15) \\
(0.15) \\
(0.31) \\
(0.77) \\
(0.35) \\
(0.24)\end{array}$ & $\begin{array}{l}5.7 \\
7.0 \\
8.7 \\
3.1 \\
2.4 ! \\
7.0 \\
4.5\end{array}$ & $\begin{array}{l}(0.42) \\
(0.52) \\
(0.49) \\
(0.44) \\
(0.89) \\
(0.98) \\
(1.17)\end{array}$ & $\begin{array}{l}1.1 \\
2.9 \\
4.3 \\
3.1 \\
4.0 \\
2.8 \\
3.8 !\end{array}$ & $\begin{array}{l}(0.21) \\
(0.36) \\
(0.35) \\
(0.48) \\
(0.99) \\
(0.56) \\
(1.39)\end{array}$ & $\begin{array}{l}0.8 \\
1.0 \\
0.7 \\
0.9 \\
1.3 ! \\
0.8 ! \\
\ddagger\end{array}$ & $\begin{array}{l}.14) \\
.21) \\
.16) \\
.26)\end{array}$ & $\begin{array}{l}0.4 \\
0.5 \\
0.6 \\
1.1 \\
0.7 ! \\
0.6 ! \\
\ddagger\end{array}$ & $\begin{array}{r}(0.12) \\
(0.11) \\
(0.15) \\
(0.31) \\
(0.30) \\
(0.18) \\
(\dagger)\end{array}$ \\
\hline 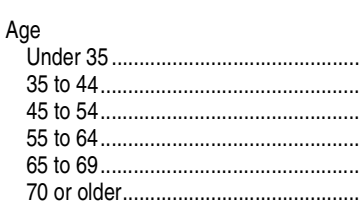 & $\begin{array}{r}59.1 \\
169.8 \\
219.7 \\
190.0 \\
31.8 \\
11.5\end{array}$ & $\begin{array}{l}(1.77) \\
(2.78) \\
(3.28) \\
(3.10) \\
(1.43) \\
(0.67)\end{array}$ & $\begin{array}{l}100.0 \\
100.0 \\
100.0 \\
100.0 \\
100.0 \\
100.0\end{array}$ & $\begin{array}{l}39.4 \\
43.7 \\
47.0 \\
57.1 \\
67.6 \\
69.0\end{array}$ & $\begin{array}{l}(1.31) \\
(0.96) \\
(0.86) \\
(0.74) \\
(2.05) \\
(3.16)\end{array}$ & $\begin{array}{l}20.2 \\
15.7\end{array}$ & $\begin{array}{l}(1.36) \\
(0.82) \\
(0.79) \\
(0.59) \\
(1.82) \\
(2.71)\end{array}$ & $\begin{array}{l}2.9 \\
2.7 \\
3.1 \\
2.8 \\
1.7 \\
5.4\end{array}$ & $\begin{array}{l}(0.53) \\
(0.31) \\
(0.28) \\
(0.26) \\
(0.50) \\
(1.54)\end{array}$ & $\begin{array}{l}4.7 \\
3.4 \\
2.6 \\
1.9 \\
2.0 ! \\
\ddagger\end{array}$ & $\begin{array}{r}(0.62) \\
(0.36) \\
(0.22) \\
(0.17) \\
(0.61) \\
(\dagger)\end{array}$ & $\begin{array}{r}2.5 \\
2.8 \\
1.8 \\
1.4 \\
1.6 \\
\ddagger\end{array}$ & $\begin{array}{r}(0.40) \\
(0.25) \\
(0.17) \\
(0.12) \\
(0.44) \\
(\dagger)\end{array}$ & $\begin{array}{l}2.8 \\
1.8 \\
1.6 \\
1.1 \\
0.4 ! \\
\ddagger\end{array}$ & $\begin{array}{r}(0.41) \\
(0.18) \\
(0.18) \\
(0.13) \\
(0.19) \\
(\dagger)\end{array}$ & $\begin{array}{l}8.9 \\
9.3 \\
5.7 \\
4.1 \\
4.5 \\
3.8 !\end{array}$ & $\begin{array}{l}(0.85) \\
(0.45) \\
(0.32) \\
(0.36) \\
(0.94) \\
(1.40)\end{array}$ & $\begin{array}{l}4.2 \\
5.0 \\
2.2 \\
1.4 \\
1.1 ! \\
\ddagger\end{array}$ & $\begin{array}{r}(0.70) \\
(0.44) \\
(0.25) \\
(0.24) \\
(0.42) \\
(\dagger)\end{array}$ & $\begin{array}{c}0.6 ! \\
0.8 \\
1.0 \\
0.9 \\
\ddagger \\
\ddagger\end{array}$ & 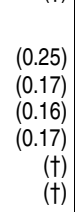 & $\begin{array}{l}0.5 ! \\
0.5 \\
0.6 \\
0.7 \\
\ddagger \\
\ddagger\end{array}$ & $\begin{array}{r}(0.17) \\
(0.16) \\
(0.12) \\
(0.12) \\
(+) \\
(\dagger)\end{array}$ \\
\hline 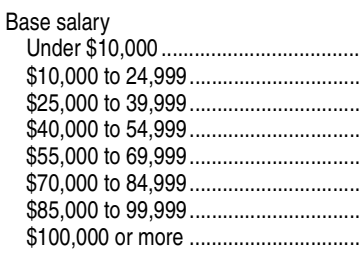 & $\begin{array}{r}4.4 \\
19.0 \\
79.7 \\
192.4 \\
147.7 \\
94.8 \\
50.7 \\
93.1\end{array}$ & $\begin{array}{l}(0.49) \\
(1.03) \\
(2.90) \\
(3.09) \\
(3.54) \\
(2.19) \\
(1.98) \\
(2.29)\end{array}$ & $\begin{array}{l}100.0 \\
100.0 \\
100.0 \\
100.0 \\
100.0 \\
100.0 \\
100.0 \\
100.0\end{array}$ & $\begin{array}{l}39.1 \\
43.2 \\
36.0 \\
42.2 \\
48.7 \\
55.8 \\
61.9 \\
66.9\end{array}$ & $\begin{array}{l}(5.71) \\
(2.61) \\
(1.21) \\
(0.95) \\
(0.88) \\
(1.29) \\
(1.58) \\
(0.99)\end{array}$ & $\begin{array}{l}34.2 \\
34.8 \\
44.5 \\
38.2 \\
31.9 \\
24.2 \\
18.5 \\
13.7\end{array}$ & $\begin{array}{l}(2.40) \\
(1.25) \\
(0.79) \\
(0.80) \\
(1.14) \\
(1.03) \\
(0.74)\end{array}$ & $\begin{array}{l}5.8 \\
1.3 \\
2.9 \\
2.7 \\
3.1 \\
2.9 \\
3.8 \\
2.4\end{array}$ & $\begin{array}{l}(0.37) \\
(0.55) \\
(0.27) \\
(0.35) \\
(0.39) \\
(0.69) \\
(0.38)\end{array}$ & $\begin{array}{r}\ddagger \\
3.2 \\
3.7 \\
3.7 \\
2.5 \\
1.7 \\
1.5 \\
1.6\end{array}$ & $\begin{array}{r}(\dagger) \\
(0.89) \\
(0.46) \\
(0.37) \\
(0.28) \\
(0.40) \\
(0.38) \\
(0.33)\end{array}$ & $\begin{array}{r}\ddagger \\
2.1 \\
1.8 \\
1.9 \\
2.0 \\
2.4 \\
1.5 \\
2.1\end{array}$ & $\begin{array}{l}(t) \\
(0.61) \\
(0.29) \\
(0.18) \\
(0.25) \\
(0.34) \\
(0.41) \\
(0.29)\end{array}$ & $\begin{array}{l}4.4 ! \\
2.4 \\
2.1 \\
1.8 \\
1.6 \\
1.0 \\
1.0 \\
0.8\end{array}$ & $\begin{array}{l}(1.96) \\
(0.60) \\
(0.28) \\
(0.14) \\
(0.21) \\
(0.20) \\
(0.28) \\
(0.17)\end{array}$ & $\begin{array}{l}7.8 ! \\
6.5 \\
3.8 \\
5.0 \\
6.0 \\
8.1 \\
8.3 \\
9.0\end{array}$ & $\begin{array}{l}(3.27) \\
(1.23) \\
(0.68) \\
(0.43) \\
(0.43) \\
(0.67) \\
(1.06) \\
(0.80)\end{array}$ & $\begin{array}{r}\ddagger \\
4.6 \\
3.6 \\
2.6 \\
2.6 \\
2.6 \\
2.5 \\
2.8\end{array}$ & $\begin{array}{l}(\dagger) \\
(0.93) \\
(0.48) \\
(0.27) \\
(0.31) \\
(0.41) \\
(0.57) \\
(0.50)\end{array}$ & $\begin{array}{l}\ddagger \\
\ddagger \\
0.7 ! \\
1.0 \\
1.0 \\
0.9 \\
0.8 ! \\
0.6 !\end{array}$ & $\begin{array}{r}(t) \\
(+) \\
(0.26) \\
(0.15) \\
(0.23) \\
(0.23) \\
(0.24) \\
(0.20)\end{array}$ & $\begin{array}{l}\ddagger \\
\ddagger \\
1.1 ! \\
0.8 \\
0.9 \\
0.6 \\
0.5 ! \\
\ddagger \\
\ddagger\end{array}$ & $\begin{array}{r}(\dagger) \\
(0.48) \\
(0.23) \\
(0.14) \\
(0.15) \\
(0.19) \\
(\dagger) \\
(\dagger)\end{array}$ \\
\hline $\begin{array}{l}\text { Under } \$ 10,000 \\
\$ 10,000 \text { to } 24,999 \\
\$ 25,000 \text { to } 39,999 . \\
\$ 40,000 \text { to } 54,999 \\
\$ 55,000 \text { to } 69,999 . \\
\$ 70,000 \text { to } 84,999\end{array}$ & $\begin{array}{r}\ddagger \\
3.0 \\
20.1 \\
55.0 \\
86.2 \\
75.2 \\
95.0 \\
347.3\end{array}$ & $\begin{array}{r}(\dagger) \\
(0.33) \\
(1.13) \\
(1.76) \\
(1.56) \\
(2.19) \\
(2.16) \\
(3.57)\end{array}$ & $\begin{array}{l}100.0 \\
100.0 \\
100.0 \\
100.0 \\
100.0 \\
100.0 \\
100.0 \\
100.0\end{array}$ & $\begin{array}{r}\ddagger \\
42.0 \\
36.5 \\
39.8 \\
43.1 \\
50.6 \\
46.7 \\
50.9\end{array}$ & $\begin{array}{r}(\dagger) \\
(6.54) \\
(2.68) \\
(1.66) \\
(1.23) \\
(1.20) \\
(1.15) \\
(0.52)\end{array}$ & $\begin{array}{r}\ddagger \\
29.3 \\
39.0 \\
38.4 \\
34.2 \\
31.2 \\
32.5 \\
27.5\end{array}$ & $\begin{array}{l}(6.12) \\
(2.28) \\
(1.42) \\
(1.21) \\
(1.11) \\
(0.83) \\
(0.52)\end{array}$ & $\begin{array}{c}\ddagger \\
\ddagger \\
1.4 ! \\
3.3 ! \\
2.9 \\
4.1 \\
2.4 \\
2.8 \\
2.6\end{array}$ & $\begin{array}{l}(1.13) \\
(1.56) \\
(0.59) \\
(0.50) \\
(0.40) \\
(0.39) \\
(0.18)\end{array}$ & $\begin{array}{r}\ddagger \\
\ddagger \\
4.5 \\
4.2 \\
4.4 \\
2.8 \\
3.0 \\
1.9\end{array}$ & $\begin{array}{r}(\dagger) \\
(\dagger) \\
(0.97) \\
(0.59) \\
(0.42) \\
(0.45) \\
(0.58) \\
(0.16)\end{array}$ & $\begin{array}{r}\ddagger \\
\ddagger \\
\neq .5 \\
2.5 \\
2.1 \\
1.9 \\
2.7 \\
1.7\end{array}$ & $\begin{array}{r}(t) \\
(t) \\
(0.43) \\
(0.35) \\
(0.29) \\
(0.26) \\
(0.32) \\
(0.14)\end{array}$ & $\begin{array}{r}\ddagger \\
\neq \\
2.5 \\
1.9 \\
1.9 \\
1.3 \\
1.6 \\
1.3\end{array}$ & $\begin{array}{r}(+) \\
(+) \\
(0.62) \\
(0.29) \\
(0.29) \\
(0.17) \\
(0.24) \\
(0.11)\end{array}$ & $\begin{array}{c}\ddagger \\
9.8 ! \\
7.3 \\
6.2 \\
5.6 \\
6.3 \\
7.0 \\
6.3\end{array}$ & $\begin{array}{l}(3.74) \\
(1.56) \\
(0.80) \\
(0.56) \\
(0.59) \\
(0.81) \\
(0.29)\end{array}$ & $\begin{array}{l}\ddagger \\
8.7 ! \\
3.8 \\
2.5 \\
2.5 \\
2.1 \\
2.5 \\
3.0\end{array}$ & $\begin{array}{l}(3.59) \\
(0.95) \\
(0.51) \\
(0.37) \\
(0.40) \\
(0.50) \\
(0.24)\end{array}$ & $\begin{array}{c}\ddagger \\
\neq \\
\ddagger \\
\neq \\
0.4 ! \\
1.1 \\
0.9 ! \\
0.6 ! \\
0.9\end{array}$ & $\begin{array}{r}(t) \\
(t) \\
(t) \\
(0.18) \\
(0.26) \\
(0.30) \\
(0.18) \\
(0.11)\end{array}$ & $\begin{array}{l}\ddagger \\
\ddagger \\
0.9 ! \\
1.2 \\
1.0 \\
0.5 ! \\
0.5 \\
0.4\end{array}$ & $\begin{array}{r}(\dagger) \\
(\dagger) \\
(0.29) \\
(0.31) \\
(0.29) \\
(0.17) \\
(0.14) \\
(0.07)\end{array}$ \\
\hline
\end{tabular}

See notes at end of table. 
[Standard errors appear in parentheses]

\begin{tabular}{|c|c|c|c|c|c|c|c|c|c|c|c|c|c|c|c|c|c|c|c|c|c|c|c|}
\hline \multirow[b]{2}{*}{ Selected characteristic } & \multirow{2}{*}{\multicolumn{2}{|c|}{$\begin{array}{r}\text { Number } \\
\text { (in thousands) }\end{array}$}} & \multirow[b]{2}{*}{ Percent } & \multicolumn{4}{|c|}{ White } & \multicolumn{4}{|c|}{ Black } & \multicolumn{4}{|c|}{ Hispanic } & \multicolumn{4}{|c|}{ Asian/Pacific Islander } & \multicolumn{4}{|c|}{ American Indian/Alaska Native } \\
\hline & & & & & Male & & Female & & Male & & Female & & Male & & emale & & Male & & Female & & Male & & Female \\
\hline 1 & & 2 & 3 & & 4 & & 5 & & 6 & & 7 & & 8 & & 9 & & 10 & & 11 & & 12 & & 13 \\
\hline \multicolumn{24}{|l|}{$\begin{array}{l}\text { Part-time faculty } \\
\text { and instructional staff }\end{array}$} \\
\hline 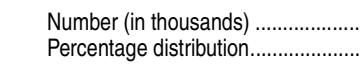 & $\begin{array}{r}530.0 \\
\ddagger\end{array}$ & $\begin{array}{r}(0.02) \\
(t)\end{array}$ & $\begin{array}{r}\dagger \\
100.0 \\
\end{array}$ & $\begin{array}{r}235.5 \\
44.4 \\
\end{array}$ & $\begin{array}{l}(2.44) \\
(0.46) \\
\end{array}$ & $\begin{array}{r}216.1 \\
40.8 \\
\end{array}$ & $\begin{array}{l}(2.87) \\
(0.54) \\
\end{array}$ & $\begin{array}{r}13.8 \\
2.6 \\
\end{array}$ & $\begin{array}{l}(0.91) \\
(0.17)\end{array}$ & $\begin{array}{r}15.9 \\
3.0 \\
\end{array}$ & $\begin{array}{l}(0.75) \\
(0.14) \\
\end{array}$ & $\begin{array}{r}10.2 \\
1.9 \\
\end{array}$ & $\begin{array}{l}(0.61) \\
(0.12) \\
\end{array}$ & $\begin{array}{l}8.5 \\
1.6 \\
\end{array}$ & $\begin{array}{l}(0.56) \\
(0.10)\end{array}$ & $\begin{array}{r}10.9 \\
2.1 \\
\end{array}$ & $\begin{array}{l}(0.82) \\
(0.15)\end{array}$ & $\begin{array}{l}9.4 \\
1.8 \\
\end{array}$ & $\begin{array}{l}(0.97) \\
(0.18)\end{array}$ & $\begin{array}{l}5.5 \\
1.0 \\
\end{array}$ & $\begin{array}{l}(0.78) \\
(0.15) \\
\end{array}$ & $\begin{array}{l}4.2 \\
0.8\end{array}$ & $\begin{array}{l}(0.77) \\
(0.15) \\
\end{array}$ \\
\hline 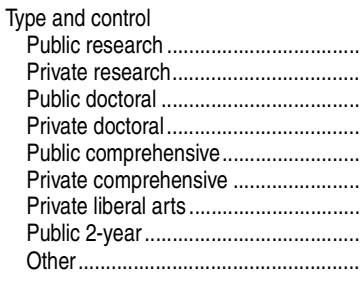 & $\begin{array}{r}39.7 \\
23.2 \\
20.8 \\
15.4 \\
60.3 \\
53.5 \\
28.4 \\
230.1 \\
58.7\end{array}$ & $\begin{array}{l}(0.78) \\
(0.96) \\
(0.82) \\
(0.83) \\
(2.49) \\
(2.17) \\
(2.19) \\
(2.00) \\
(3.38)\end{array}$ & $\begin{array}{l}100.0 \\
100.0 \\
100.0 \\
100.0 \\
100.0 \\
100.0 \\
100.0 \\
100.0 \\
100.0\end{array}$ & $\begin{array}{l}41.7 \\
51.1 \\
44.3 \\
51.7 \\
43.1 \\
49.1 \\
44.2 \\
42.8 \\
45.7\end{array}$ & $\begin{array}{l}(1.93) \\
(2.51) \\
(2.27) \\
(3.99) \\
(1.34) \\
(1.43) \\
(1.98) \\
(0.70) \\
(1.83)\end{array}$ & $\begin{array}{l}40.7 \\
34.7 \\
43.6 \\
37.3 \\
44.1 \\
41.9 \\
42.0 \\
41.0 \\
37.3\end{array}$ & $\begin{array}{l}(2.12) \\
(2.29) \\
(2.39) \\
(3.60) \\
(2.18) \\
(1.56) \\
(2.14) \\
(0.67) \\
(2.14)\end{array}$ & $\begin{array}{l}1.1 ! \\
2.7 ! \\
\ddagger \\
1.7 ! \\
2.3 ! \\
1.7 \\
2.5 ! \\
2.9 \\
4.2\end{array}$ & $\begin{array}{r}(0.37) \\
(1.00) \\
(\dagger) \\
(0.77) \\
(0.74) \\
(0.34) \\
(0.85) \\
(0.22) \\
(0.79)\end{array}$ & $\begin{array}{l}1.6 ! \\
1.4 ! \\
1.0 ! \\
1.1 ! \\
2.4 ! \\
1.1 \\
5.6 \\
4.0 \\
3.0\end{array}$ & $\begin{array}{l}(0.60) \\
(0.57) \\
(0.47) \\
(0.55) \\
(0.79) \\
(0.21) \\
(1.24) \\
(0.18) \\
(0.74)\end{array}$ & $\begin{array}{l}1.5 \\
1.5 ! \\
1.9 ! \\
1.6 ! \\
1.6 \\
1.0 \\
1.1 ! \\
2.4 \\
2.2\end{array}$ & $\begin{array}{l}(0.40) \\
(0.62) \\
(0.68) \\
(0.64) \\
(0.31) \\
(0.19) \\
(0.42) \\
(0.20) \\
(0.53)\end{array}$ & $\begin{array}{l}1.7 \\
\ddagger \\
2.2 \\
1.2 ! \\
1.5 \\
1.4 \\
1.0 ! \\
2.0 \\
0.8\end{array}$ & $\begin{array}{r}(0.43) \\
(\dagger) \\
(0.61) \\
(0.36) \\
(0.32) \\
(0.26) \\
(0.35) \\
(0.19) \\
(0.22)\end{array}$ & $\begin{array}{l}4.5 \\
3.6 \\
2.6 ! \\
3.4 ! \\
2.0 \\
1.1 ! \\
1.7 ! \\
1.5 \\
2.4 !\end{array}$ & $\begin{array}{l}(1.03) \\
(1.07) \\
(0.86) \\
(1.06) \\
(0.38) \\
(0.54) \\
(0.61) \\
(0.18) \\
(0.75)\end{array}$ & $\begin{array}{l}5.4 \\
2.8 \\
1.9 ! \\
\ddagger \\
1.3 ! \\
0.8 ! \\
1.1 ! \\
1.4 \\
2.4 !\end{array}$ & $\begin{array}{r}(0.90) \\
(0.77) \\
(0.83) \\
(\dagger) \\
(0.43) \\
(0.35) \\
(0.49) \\
(0.19) \\
(0.92)\end{array}$ & $\begin{array}{c}1.6 ! \\
\ddagger \\
\ddagger \\
\ddagger \\
1.0 ! \\
1.0 ! \\
0.9 ! \\
1.1 \\
1.0 !\end{array}$ & $\begin{array}{r}(0.67) \\
(+) \\
(+) \\
(+) \\
(0.43) \\
(0.30) \\
(0.35) \\
(0.23) \\
(0.40)\end{array}$ & $\begin{array}{c}\ddagger \\
\ddagger \\
\ddagger \\
\ddagger \\
\ddagger \\
0.9 ! \\
\ddagger \\
1.0 \\
1.1 !\end{array}$ & $\begin{array}{r}(\dagger) \\
(\dagger) \\
(\dagger) \\
(\dagger) \\
(+) \\
(0.32) \\
(+) \\
(0.25) \\
(0.50)\end{array}$ \\
\hline 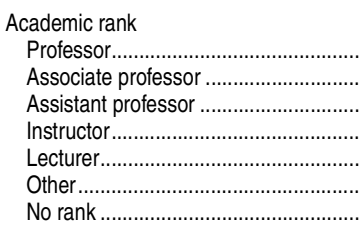 & $\begin{array}{r}23.3 \\
14.6 \\
19.8 \\
187.7 \\
40.9 \\
230.9 \\
12.8\end{array}$ & $\begin{array}{l}(1.58) \\
(1.18) \\
(1.53) \\
(4.42) \\
(2.15) \\
(4.51) \\
(1.07)\end{array}$ & $\begin{array}{l}100.0 \\
100.0 \\
100.0 \\
100.0 \\
100.0 \\
100.0 \\
100.0\end{array}$ & $\begin{array}{l}59.3 \\
43.7 \\
38.8 \\
41.5 \\
41.4 \\
46.5 \\
43.8\end{array}$ & $\begin{array}{l}(2.83) \\
(4.03) \\
(3.39) \\
(1.09) \\
(2.05) \\
(1.01) \\
(3.52)\end{array}$ & $\begin{array}{l}25.0 \\
39.5 \\
42.7 \\
43.9 \\
40.1 \\
39.9 \\
39.8\end{array}$ & $\begin{array}{l}(2.60) \\
(3.88) \\
(3.37) \\
(1.11) \\
(1.96) \\
(1.04) \\
(4.63)\end{array}$ & $\begin{array}{l}4.0 \\
2.8 ! \\
2.8 ! \\
2.5 \\
2.7 \\
2.5 \\
\ddagger\end{array}$ & $\begin{array}{r}(1.17) \\
(0.84) \\
(1.19) \\
(0.30) \\
(0.63) \\
(0.29) \\
(\dagger)\end{array}$ & $\begin{array}{c}2.6 ! \\
\ddagger \\
\ddagger \\
3.4 \\
2.1 ! \\
3.1 \\
0.9 !\end{array}$ & $\begin{array}{r}(0.84) \\
(\dagger) \\
(\dagger) \\
(0.25) \\
(0.77) \\
(0.28) \\
(0.43)\end{array}$ & $\begin{array}{r}\ddagger \\
\ddagger \\
\ddagger \\
2.2 \\
2.1 \\
1.8 \\
2.8 !\end{array}$ & $\begin{array}{r}(\dagger) \\
(\dagger) \\
(\dagger) \\
(0.24) \\
(0.45) \\
(0.23) \\
(1.31)\end{array}$ & $\begin{array}{l}1.0 ! \\
1.4 ! \\
1.0 ! \\
1.7 \\
1.7 \\
1.5 \\
3.5 !\end{array}$ & $\begin{array}{l}(0.41) \\
(0.49) \\
(0.42) \\
(0.22) \\
(0.42) \\
(0.17) \\
(1.34)\end{array}$ & $\begin{array}{l}3.6 \\
6.3 ! \\
4.8 ! \\
1.6 \\
3.7 \\
1.5 \\
2.0 !\end{array}$ & $\begin{array}{l}(0.96) \\
(2.27) \\
(1.65) \\
(0.25) \\
(0.80) \\
(0.22) \\
(0.94)\end{array}$ & $\begin{array}{r}\ddagger \\
\ddagger \\
6.0 \\
1.6 \\
4.2 \\
1.3 \\
\ddagger\end{array}$ & $\begin{array}{r}(t) \\
(\dagger) \\
(1.62) \\
(0.28) \\
(0.93) \\
(0.31) \\
(\dagger)\end{array}$ & $\begin{array}{r}\ddagger \\
\ddagger \\
\ddagger \\
1.1 \\
1.6 ! \\
0.9 \\
\ddagger\end{array}$ & $\begin{array}{r}(t) \\
(t) \\
(t) \\
(0.26) \\
(0.56) \\
(0.22) \\
(\dagger)\end{array}$ & $\begin{aligned} \ddagger \\
\ddagger \\
\ddagger \\
0.6 \\
\ddagger \\
1.0 \\
\ddagger\end{aligned}$ & $\begin{array}{r}(\dagger) \\
(\dagger) \\
(\dagger) \\
(0.18) \\
(t) \\
(0.22) \\
(\dagger)\end{array}$ \\
\hline $\begin{array}{l}\text { Age } \\
\text { Under } 35 \\
35 \text { to } 44 \\
45 \text { to } 54 \\
55 \text { to } 64 . \\
65 \text { to } 69 \\
70 \text { or older }\end{array}$ & $\begin{array}{r}66.2 \\
115.6 \\
159.3 \\
128.6 \\
33.5 \\
26.8\end{array}$ & $\begin{array}{l}(2.30) \\
(3.03) \\
(3.22) \\
(3.31) \\
(1.81) \\
(1.83)\end{array}$ & $\begin{array}{l}100.0 \\
100.0 \\
100.0 \\
100.0 \\
100.0\end{array}$ & $\begin{array}{l}35.3 \\
40.7 \\
41.7 \\
48.2 \\
62.8 \\
58.3\end{array}$ & $\begin{array}{l}(1.73) \\
(1.42) \\
(1.13) \\
(1.09) \\
(3.10) \\
(2.99)\end{array}$ & $\begin{array}{l}43.1 \\
41.5 \\
44.0 \\
40.4 \\
27.6 \\
30.7\end{array}$ & $\begin{array}{l}(2.04) \\
(1.41) \\
(1.17) \\
(1.06) \\
(2.83) \\
(3.32)\end{array}$ & $\begin{array}{l}2.6 \\
2.9 \\
2.1 \\
2.3 ! \\
2.4 !\end{array}$ & $\begin{array}{l}(0.63) \\
(0.39) \\
(0.34) \\
(0.35) \\
(0.81) \\
(0.79)\end{array}$ & $\begin{array}{l}4.3 \\
3.0 \\
3.2 \\
2.8 \\
0.9 ! \\
1.6 !\end{array}$ & $\begin{array}{l}(0.53) \\
(0.33) \\
(0.33) \\
(0.35) \\
(0.32) \\
(0.70)\end{array}$ & $\begin{array}{l}3.0 \\
2.5 \\
1.6 \\
1.3 \\
1.6 ! \\
2.5 !\end{array}$ & $\begin{array}{l}(0.49) \\
(0.30) \\
(0.24) \\
(0.30) \\
(0.54) \\
(0.87)\end{array}$ & $\begin{array}{c}3.0 \\
2.4 \\
1.5 \\
0.6 \\
1.3 ! \\
\ddagger\end{array}$ & $\begin{array}{r}(0.35) \\
(0.32) \\
(0.19) \\
(0.10) \\
(0.55) \\
(\dagger)\end{array}$ & $\begin{array}{l}2.4 \\
2.6 \\
2.1 \\
1.6 \\
1.3 ! \\
2.1 !\end{array}$ & $\begin{array}{l}(0.52) \\
(0.37) \\
(0.35) \\
(0.32) \\
(0.52) \\
(0.65)\end{array}$ & $\begin{array}{r}3.6 \\
2.9 \\
1.3 \\
0.9 \\
\ddagger \\
\ddagger\end{array}$ & $\begin{array}{r}(0.93) \\
(0.45) \\
(0.26) \\
(0.23) \\
(+) \\
(\dagger)\end{array}$ & $\begin{array}{c}1.6 ! \\
0.7 ! \\
0.9 \\
1.1 ! \\
1.5 ! \\
\ddagger\end{array}$ & $\begin{array}{r}(0.68) \\
(0.24) \\
(0.24) \\
(0.34) \\
(0.63) \\
(t)\end{array}$ & $\begin{array}{c}\ddagger \\
1.2 \\
0.8 ! \\
1.0 \\
\ddagger \\
\ddagger\end{array}$ & $\begin{array}{r}(+) \\
(0.30) \\
(0.27) \\
(0.26) \\
(\dagger) \\
(\dagger)\end{array}$ \\
\hline $\begin{array}{l}\$ 10,000 \text { to } 24,999 \\
\$ 25,000 \text { to } 39,999\end{array}$ & $\begin{array}{r}340.5 \\
140.8 \\
27.5 \\
9.6 \\
4.7 \\
1.9 \\
1.5 \\
3.5\end{array}$ & $\begin{array}{l}(3.17) \\
(3.17) \\
(1.72) \\
(0.74) \\
(0.78) \\
(0.35) \\
(0.39) \\
(0.53)\end{array}$ & $\begin{array}{l}100.0 \\
100.0 \\
100.0 \\
100.0 \\
100.0 \\
100.0 \\
100.0\end{array}$ & $\begin{array}{l}45.4 \\
41.3 \\
47.3 \\
48.2 \\
45.5 \\
39.0 \\
33.4 ! \\
47.4\end{array}$ & $\begin{array}{r}(0.68) \\
(1.36) \\
(3.06) \\
(4.55) \\
(6.46) \\
(11.51) \\
(13.01) \\
(7.01)\end{array}$ & $\begin{array}{l}39.9 \\
43.6 \\
38.8 \\
34.0 \\
40.4 \\
43.0 \\
51.7 \\
37.1\end{array}$ & $\begin{array}{r}(0.77) \\
(1.50) \\
(2.72) \\
(4.33) \\
(6.35) \\
(10.25) \\
(13.73) \\
(5.35)\end{array}$ & $\begin{array}{r}2.6 \\
2.8 \\
3.3 \\
\ddagger \\
\ddagger \\
\ddagger \\
\ddagger \\
\ddagger\end{array}$ & $\begin{array}{r}(0.23) \\
(0.38) \\
(0.83) \\
(\dagger) \\
(\dagger) \\
(\dagger) \\
(\dagger) \\
(\dagger)\end{array}$ & $\begin{array}{c}3.5 \\
2.3 \\
\ddagger \\
1.4 ! \\
\ddagger \\
\neq \\
\ddagger \\
\ddagger\end{array}$ & $\begin{array}{r}(0.23) \\
(0.25) \\
(\dagger) \\
(0.68) \\
(\dagger) \\
(\dagger) \\
(\dagger) \\
(\dagger)\end{array}$ & $\begin{array}{c}1.9 \\
2.1 \\
1.2 ! \\
3.2 ! \\
\ddagger \\
\neq \\
\ddagger \\
\ddagger\end{array}$ & $\begin{array}{r}(0.17) \\
(0.26) \\
(0.58) \\
(1.19) \\
(+) \\
(+) \\
(+) \\
(+)\end{array}$ & $\begin{array}{c}1.6 \\
1.8 \\
1.6 ! \\
\ddagger \\
2.2 ! \\
\neq \\
\neq \\
\ddagger\end{array}$ & $\begin{array}{r}(0.12) \\
(0.24) \\
(0.55) \\
(\dagger) \\
(1.08) \\
(\dagger) \\
(\dagger) \\
(\dagger)\end{array}$ & $\begin{array}{c}1.6 \\
2.3 \\
3.2 ! \\
6.2 ! \\
\ddagger \\
\neq \\
\ddagger \\
10.8 !\end{array}$ & $\begin{array}{r}(0.17) \\
(0.40) \\
(1.02) \\
(2.60) \\
(t) \\
(t) \\
(t) \\
(5.15)\end{array}$ & $\begin{array}{c}1.4 \\
2.4 \\
1.9 ! \\
3.8 ! \\
\ddagger \\
\ddagger \\
\ddagger \\
\ddagger\end{array}$ & $\begin{array}{r}(0.26) \\
(0.40) \\
(0.61) \\
(1.70) \\
(\dagger) \\
(\dagger) \\
(\dagger) \\
(\dagger)\end{array}$ & $\begin{array}{r}1.1 \\
0.9 \\
\ddagger \\
\ddagger \\
\ddagger \\
\ddagger \\
\ddagger \\
\ddagger \\
\ddagger\end{array}$ & $\begin{array}{r}(0.20) \\
(0.25) \\
(t) \\
(t) \\
(t) \\
(t) \\
(t) \\
(t)\end{array}$ & $\begin{array}{c}1.0 \\
0.5 ! \\
\ddagger \\
\ddagger \\
\ddagger \\
\ddagger \\
\ddagger \\
\ddagger\end{array}$ & $\begin{array}{r}(0.20) \\
(0.18) \\
(+) \\
(+) \\
(+) \\
(+) \\
(t) \\
(t)\end{array}$ \\
\hline $\begin{array}{l}\text { Total household income } \\
\text { Under } \$ 10,000 \\
\$ 10,000 \text { to } 24,999 \\
\$ 25,000 \text { to } 39,999 \\
\$ 40,000 \text { to } 54,999 \\
\$ 55,000 \text { to } 69,999 \\
\$ 70,000 \text { to } 84,999 \\
\$ 85,000 \text { to } 99,999\end{array}$ & $\begin{array}{r}1.3 \\
28.5 \\
47.7 \\
55.7 \\
87.2 \\
58.1 \\
66.4 \\
185.1\end{array}$ & $\begin{array}{l}(0.37) \\
(1.93) \\
(1.92) \\
(2.52) \\
(2.95) \\
(2.66) \\
(2.39) \\
(3.59)\end{array}$ & $\begin{array}{l}100.0 \\
100.0 \\
100.0 \\
100.0 \\
100.0 \\
100.0 \\
100.0 \\
100.0\end{array}$ & $\begin{array}{r}\ddagger \\
36.5 \\
35.5 \\
38.1 \\
41.1 \\
44.7 \\
48.6 \\
34.9\end{array}$ & $\begin{array}{r}(\dagger) \\
(3.33) \\
(2.27) \\
(2.05) \\
(1.50) \\
(2.15) \\
(1.85) \\
(0.68)\end{array}$ & $\begin{array}{l}46.4 ! \\
42.5 \\
46.5 \\
46.2 \\
43.0 \\
41.2 \\
38.4 \\
37.0\end{array}$ & $\begin{array}{r}(14.12) \\
(3.42) \\
(2.32) \\
(2.35) \\
(1.48) \\
(2.38) \\
(1.81) \\
(0.91)\end{array}$ & $\begin{array}{c}\ddagger \\
2.0 ! \\
3.4 \\
3.2 \\
1.9 \\
2.3 \\
2.4 \\
2.8\end{array}$ & $\begin{array}{r}(\dagger) \\
(0.71) \\
(0.58) \\
(0.71) \\
(0.38) \\
(0.44) \\
(0.59) \\
(0.32)\end{array}$ & $\begin{array}{r}\ddagger \\
4.0 \\
3.9 \\
3.4 \\
4.1 \\
2.3 \\
3.1 \\
2.1\end{array}$ & $\begin{array}{r}(\dagger) \\
(0.80) \\
(0.66) \\
(0.52) \\
(0.38) \\
(0.57) \\
(0.52) \\
(0.26)\end{array}$ & $\begin{array}{c}\ddagger \\
\neq .7 ! \\
2.2 \\
3.1 \\
1.7 \\
2.3 \\
1.8 \\
1.5\end{array}$ & $\begin{array}{r}(\dagger) \\
(0.53) \\
(0.44) \\
(0.67) \\
(0.37) \\
(0.41) \\
(0.37) \\
(0.21)\end{array}$ & $\begin{array}{r}\ddagger \\
2.4 \\
1.8 \\
2.5 \\
2.5 \\
1.3 \\
1.2 \\
1.0\end{array}$ & $\begin{array}{r}(\mathrm{t}) \\
(0.55) \\
(0.47) \\
(0.60) \\
(0.35) \\
(0.34) \\
(0.34) \\
(0.17)\end{array}$ & 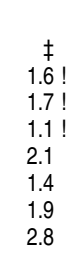 & $\begin{array}{r}(\dagger) \\
(0.76) \\
(0.55) \\
(0.40) \\
(0.42) \\
(0.41) \\
(0.49) \\
(0.34)\end{array}$ & $\begin{array}{l}\ddagger \\
3.5 ! \\
2.9 ! \\
1.1 ! \\
1.6 \\
2.0 \\
1.3 ! \\
1.6\end{array}$ & $\begin{array}{r}(\dagger) \\
(1.71) \\
(0.92) \\
(0.35) \\
(0.45) \\
(0.58) \\
(0.41) \\
(0.25)\end{array}$ & $\begin{array}{c}\ddagger \\
3.7 ! \\
1.1 ! \\
\ddagger \\
0.8 ! \\
1.1 ! \\
0.6 ! \\
0.8\end{array}$ & $\begin{array}{r}(\dagger) \\
(1.34) \\
(0.46) \\
(\dagger) \\
(0.27) \\
(0.41) \\
(0.29) \\
(0.22)\end{array}$ & $\begin{array}{c}\ddagger \\
2.2 ! \\
1.0 ! \\
0.5 ! \\
1.0 ! \\
1.1 ! \\
0.7 ! \\
0.4 !\end{array}$ & $\begin{array}{r}(\dagger) \\
(1.01) \\
(0.43) \\
(0.21) \\
(0.37) \\
(0.37) \\
(0.25) \\
(0.17)\end{array}$ \\
\hline
\end{tabular}

†Not applicable. †Reporting standards not met. Either there are too few cases for a reliable estimate or the coefficient of variation (CV) is 50 percent or greater.
NOTE: Degree-granting institutions grant associate's or higher degrees and participate in Title IV federal financial aid programs Totals may differ from figures reported in other tables because of varying survey methodologies. Race categories exclude perSOURCE: U.S. Department of Education, National Center for Education Statistics, 2003 National Study of Postsecondary Faculty (NSOPF:04). (This table was prepared January 2009.) 
Table 315.70. Full-time and part-time faculty and instructional staff in degree-granting postsecondary institutions, by field and faculty characteristics: Fall 1992, fall 1998, and fall 2003

[Standard errors appear in parentheses]

\begin{tabular}{|c|c|c|c|c|c|c|c|c|c|c|c|c|c|c|c|c|c|c|c|c|c|c|c|c|c|c|}
\hline \multirow[b]{2}{*}{$\begin{array}{l}\text { Selected faculty and } \\
\text { instructional staff } \\
\text { characteristic }\end{array}$} & \multicolumn{4}{|c|}{$\begin{array}{c}\text { Number } \\
\text { (in thousands) }\end{array}$} & \multicolumn{22}{|c|}{ Fall 2003} \\
\hline & | 1992 & Fall 1998 & \multicolumn{2}{|c|}{ Fall 2003} & \multicolumn{2}{|c|}{ All fields } & \multicolumn{2}{|c|}{$\begin{array}{r}\text { Agriculture } \\
\text { and home } \\
\text { economics }\end{array}$} & \multicolumn{2}{|c|}{ Business } & \multicolumn{2}{|c|}{ Education } & \multicolumn{2}{|c|}{ Engineering } & \multicolumn{2}{|c|}{ Fine arts } & \multicolumn{2}{|r|}{ Health } & \multicolumn{2}{|c|}{ Humanities ${ }^{1}$} & \multicolumn{2}{|c|}{$\begin{array}{r}\text { Natural } \\
\text { sciences }\end{array}$} & \multicolumn{2}{|c|}{$\begin{array}{r}\text { Social } \\
\text { sciences }^{3}\end{array}$} & \multicolumn{2}{|r|}{ Other ${ }^{4}$} \\
\hline 1 & 2 & 3 & & 4 & & 5 & & 6 & & 7 & & 8 & & 9 & & 10 & & 11 & & 12 & & 13 & & 14 & & 15 \\
\hline \multirow[t]{2}{*}{$\begin{array}{l}\text { Full-time faculty and } \\
\text { instructional staff } \\
\text { Number (in thousands) ... } \\
\text { Percentage distribution.... }\end{array}$} & \multirow[t]{2}{*}{$\begin{array}{r}528 \\
\dagger\end{array}$} & \multirow[t]{2}{*}{$\begin{array}{r}560 \\
\dagger\end{array}$} & \multirow[t]{2}{*}{$\begin{array}{r}682 \\
\dagger\end{array}$} & \multirow[t]{2}{*}{$\begin{array}{l}(\#) \\
(\dagger)\end{array}$} & $\begin{array}{l}681.8 \\
100.0 \\
\end{array}$ & $\begin{array}{r}(0.05) \\
(t) \\
\end{array}$ & $\begin{array}{r}16.9 \\
2.5 \\
\end{array}$ & $\begin{array}{l}(0.80) \\
(0.12)\end{array}$ & $\begin{array}{r}43.2 \\
6.3 \\
\end{array}$ & $\begin{array}{l}(1.40) \\
(0.21)\end{array}$ & $\begin{array}{r}50.9 \\
7.5 \\
\end{array}$ & $\begin{array}{l}(1.89) \\
(0.28)\end{array}$ & $\begin{array}{r}33.4 \\
4.9 \\
\end{array}$ & $\begin{array}{l}(1.32) \\
(0.19)\end{array}$ & $\begin{array}{r}43.3 \\
6.3 \\
\end{array}$ & $\begin{array}{l}(1.68) \\
(0.25)\end{array}$ & $\begin{array}{l}93.9 \\
13.8 \\
\end{array}$ & $\begin{array}{l}(2.67) \\
(0.39)\end{array}$ & $\begin{array}{r}58.8 \\
8.6 \\
\end{array}$ & $\begin{array}{l}(1.82) \\
(0.27)\end{array}$ & $\begin{array}{r}127.2 \\
18.7 \\
\end{array}$ & $\begin{array}{l}(2.19) \\
(0.32)\end{array}$ & $\begin{array}{l}88.7 \\
13.0 \\
\end{array}$ & $\begin{array}{l}(2.07) \\
(0.30)\end{array}$ & $\begin{array}{r}125.5 \\
18.4 \\
\end{array}$ & $\begin{array}{l}(2.36) \\
(0.35) \\
\end{array}$ \\
\hline & & & & & \multicolumn{22}{|c|}{ Percentage distribution of full-time faculty and instructional staff } \\
\hline Total..... & 528 & 560 & 682 & (\#) & 100.0 & $(t)$ & 100.0 & (t) & 100.0 & (t) & 100.0 & (†) & 100.0 & (t) & 100.0 & ( & 100.0 & $(t)$ & 100.0 & ( & 100.0 & (t) & 100.0 & (†) & 100.0 & $(t)$ \\
\hline 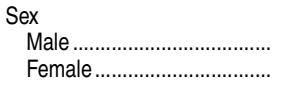 & $\begin{array}{l}353 \\
176\end{array}$ & $\begin{array}{l}357 \\
203\end{array}$ & $\begin{array}{l}420 \\
261\end{array}$ & $\begin{array}{l}(-) \\
(-)\end{array}$ & $\begin{array}{l}61.7 \\
38.3\end{array}$ & $\begin{array}{l}(0.35) \\
(0.35)\end{array}$ & $\begin{array}{l}64.6 \\
35.4\end{array}$ & $\begin{array}{l}(2.88) \\
(2.88)\end{array}$ & $\begin{array}{l}68.5 \\
31.5\end{array}$ & & & $\begin{array}{l}(1.57) \\
(1.57)\end{array}$ & $\begin{array}{r}91.5 \\
8.5\end{array}$ & $\begin{array}{l}(1.06) \\
(1.06)\end{array}$ & $\begin{array}{l}61.9 \\
38.1\end{array}$ & $\begin{array}{l}(1.38) \\
(1.38)\end{array}$ & $\begin{array}{l}46.7 \\
53.3\end{array}$ & $\begin{array}{l}(1.32) \\
(1.32)\end{array}$ & $\begin{array}{l}45.3 \\
54.7\end{array}$ & $\begin{array}{l}(1.47) \\
(1.47)\end{array}$ & $\begin{array}{l}74.5 \\
25.5\end{array}$ & $\begin{array}{l}(0.88) \\
(0.88)\end{array}$ & $\begin{array}{l}64.3 \\
35.7\end{array}$ & $\begin{array}{l}1.13) \\
1.13)\end{array}$ & $\begin{array}{l}64.0 \\
36.0\end{array}$ & $\begin{array}{l}(0.94) \\
(0.94)\end{array}$ \\
\hline 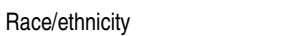 & & & & & & & & & & & & & & & & & & & & & & & & & & \\
\hline 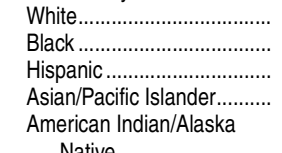 & \begin{tabular}{r|}
457 \\
27 \\
14 \\
28
\end{tabular} & $\begin{array}{r}477 \\
28 \\
19 \\
33\end{array}$ & $\begin{array}{r}548 \\
38 \\
24 \\
62\end{array}$ & $\begin{array}{l}(-) \\
(-) \\
(-) \\
(-) \\
(-) \\
\end{array}$ & $\begin{array}{r}80.3 \\
5.6 \\
3.5 \\
9.1 \\
\end{array}$ & $\begin{array}{l}(0.27) \\
(0.17) \\
(0.10) \\
(0.16)\end{array}$ & $\begin{array}{l}87.8 \\
2.3 ! \\
2.5 ! \\
6.4\end{array}$ & $\begin{array}{l}(1.61) \\
(0.76) \\
(0.76) \\
(1.34)\end{array}$ & $\begin{array}{r}79.5 \\
4.5 \\
2.3 \\
12.2 \\
\end{array}$ & $\begin{array}{l}(1.51) \\
(0.79) \\
(0.51) \\
(1.22) \\
(0.27)\end{array}$ & $\begin{array}{r}80.5 \\
7.8 \\
4.7 \\
4.8 \\
\end{array}$ & $\begin{array}{l}(1.26) \\
(1.01) \\
(0.63) \\
(0.70)\end{array}$ & $\begin{array}{r}70.9 \\
5.4 \\
2.6 \\
20.1\end{array}$ & $\begin{array}{l}(1.85) \\
(0.99) \\
(0.47) \\
(1.64)\end{array}$ & $\begin{array}{r}86.4 \\
6.0 \\
3.3 \\
2.9 \\
\end{array}$ & $\begin{array}{l}(1.24) \\
(0.88) \\
(0.75) \\
(0.74) \\
\end{array}$ & $\begin{array}{r}79.7 \\
5.0 \\
3.0 \\
10.7 \\
\end{array}$ & \begin{tabular}{l|}
$(0.84)$ \\
$(0.50)$ \\
$(0.32)$ \\
$(0.79)$ \\
$(0.32$
\end{tabular} & $\begin{array}{r}80.7 \\
5.6 \\
6.7 \\
5.2 \\
\end{array}$ & $\begin{array}{l}(1.31) \\
(0.58) \\
(0.53) \\
(0.94)\end{array}$ & $\begin{array}{r}77.8 \\
4.1 \\
2.9 \\
14.3 \\
\end{array}$ & $\begin{array}{l}(0.75) \\
(0.48) \\
(0.30) \\
(0.69) \\
(0.17)\end{array}$ & $\begin{array}{r}81.4 \\
7.3 \\
4.0 \\
5.9 \\
\end{array}$ & $\begin{array}{l}(1.09) \\
(0.72) \\
(0.47) \\
(0.71)\end{array}$ & $\begin{array}{r}82.0 \\
6.1 \\
2.9 \\
7.1\end{array}$ & $\begin{array}{l}(0.69) \\
(0.44) \\
(0.33) \\
(0.49)\end{array}$ \\
\hline Native & 3 & 4 & 10 & $(-)$ & 1.5 & $(0.11)$ & $1.0 !$ & (0.49) & 1.6 & $(0.37)$ & 2.2 & $(0.40)$ & $\ddagger$ & (t) & 1.4 & $(0.38)$ & 1.6 & $(0.33)$ & 1.8 & $(0.35)$ & 0.8 & $(0.17)$ & 1.4 & $(0.22)$ & 1.8 & $(0.32)$ \\
\hline 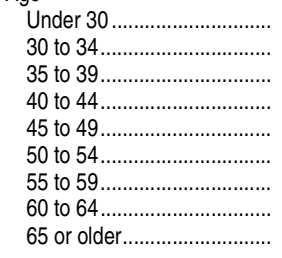 & \begin{tabular}{r|}
8 \\
35 \\
67 \\
90 \\
98 \\
95 \\
67 \\
45 \\
24
\end{tabular} & \begin{tabular}{r|}
9 \\
32 \\
60 \\
82 \\
97 \\
105 \\
90 \\
55 \\
31
\end{tabular} & $\begin{array}{r}12 \\
47 \\
77 \\
93 \\
105 \\
114 \\
112 \\
78 \\
43\end{array}$ & $\begin{array}{l}(-) \\
(-) \\
(-) \\
(-) \\
(-) \\
(-) \\
(-) \\
(-) \\
(-) \\
(-)\end{array}$ & $\begin{array}{r}1.7 \\
6.9 \\
11.3 \\
13.6 \\
15.4 \\
16.8 \\
16.4 \\
11.5 \\
6.3\end{array}$ & $\begin{array}{l}(0.13) \\
(0.21) \\
(0.29) \\
(0.31) \\
(0.32) \\
(0.34) \\
(0.37) \\
(0.31) \\
(0.23)\end{array}$ & $\begin{array}{c}2.0 ! \\
5.6 \\
7.5 \\
13.3 \\
15.4 \\
25.3 \\
16.8 \\
10.4 \\
3.7 !\end{array}$ & $\begin{array}{l}(0.67) \\
(1.27) \\
(1.19) \\
(1.63) \\
(1.84) \\
(2.31) \\
(1.83) \\
(1.61) \\
(1.20)\end{array}$ & $\begin{array}{r}0.7 ! \\
4.0 \\
11.0 \\
11.8 \\
17.9 \\
19.0 \\
18.8 \\
10.9 \\
5.9\end{array}$ & $\begin{array}{l}(0.31) \\
(0.71) \\
(1.15) \\
(1.43) \\
(1.51) \\
(1.30) \\
(1.32) \\
(1.11) \\
(0.74)\end{array}$ & $\begin{array}{r}2.6 \\
6.8 \\
7.6 \\
9.9 \\
12.7 \\
17.6 \\
21.9 \\
13.7 \\
7.2\end{array}$ & $\begin{array}{l}(0.78) \\
(0.83) \\
(0.95) \\
(1.03) \\
(1.04) \\
(1.27) \\
(1.43) \\
(1.27) \\
(0.74)\end{array}$ & $\begin{array}{c}1.6 ! \\
7.0 \\
11.3 \\
15.0 \\
17.1 \\
15.2 \\
15.1 \\
10.3 \\
7.5\end{array}$ & $\begin{array}{l}(0.48) \\
(.099) \\
(1.18) \\
(1.21) \\
(1.70) \\
(1.61) \\
(2.32) \\
(1.33) \\
(1.09)\end{array}$ & $\begin{array}{r}1.6 \\
6.2 \\
10.5 \\
12.3 \\
18.0 \\
18.5 \\
16.8 \\
11.4 \\
4.7\end{array}$ & $\begin{array}{l}(0.45) \\
(0.84) \\
(1.20) \\
(1.75) \\
(1.42) \\
(1.38) \\
(1.58) \\
(1.12) \\
(0.82)\end{array}$ & $\begin{array}{r}1.1 \\
6.3 \\
13.1 \\
15.0 \\
17.3 \\
19.9 \\
15.4 \\
7.8 \\
4.1\end{array}$ & $\begin{array}{l}(0.26) \\
(0.60) \\
(0.88) \\
(0.91) \\
(0.95) \\
(1.03) \\
(0.80) \\
(0.62) \\
(0.51)\end{array}$ & $\begin{array}{r}1.8 \\
8.2 \\
10.9 \\
13.6 \\
14.8 \\
14.1 \\
16.6 \\
12.9 \\
7.0\end{array}$ & $\begin{array}{l}(0.33) \\
(0.74) \\
(0.88) \\
(1.15) \\
(1.24) \\
(1.04) \\
(1.07) \\
(1.07) \\
(0.81)\end{array}$ & $\begin{array}{r}1.3 \\
6.8 \\
12.0 \\
15.4 \\
15.5 \\
14.8 \\
13.3 \\
12.5 \\
8.5\end{array}$ & $\begin{array}{l}(0.21) \\
(0.41) \\
(0.65) \\
(0.79) \\
(0.86) \\
(0.64) \\
(0.75) \\
(0.64) \\
(0.54)\end{array}$ & $\begin{array}{r}1.8 \\
7.6 \\
12.7 \\
13.7 \\
12.9 \\
14.2 \\
16.2 \\
14.0 \\
6.8\end{array}$ & $\begin{array}{l}(0.35) \\
(0.47) \\
(0.92) \\
(0.79) \\
(0.79) \\
(0.89) \\
(0.85) \\
(0.76) \\
(0.59)\end{array}$ & $\begin{array}{r}2.7 \\
7.9 \\
10.9 \\
12.8 \\
15.0 \\
17.1 \\
17.3 \\
10.6 \\
5.6\end{array}$ & $\begin{array}{l}(0.41) \\
(0.52) \\
(0.74) \\
(0.69) \\
(0.66) \\
(0.93) \\
(0.73) \\
(0.61) \\
(0.53)\end{array}$ \\
\hline $\begin{array}{l}\text { Highest degree } \\
\text { Less than bac } \\
\text { Bachelor's ..... } \\
\text { Master's ....... } \\
\text { First-professio } \\
\text { Doctor's......... }\end{array}$ & $\begin{array}{r}6 \\
21 \\
156 \\
58 \\
284\end{array}$ & \begin{tabular}{r|}
7 \\
23 \\
156 \\
52 \\
324
\end{tabular} & $\begin{array}{r}10 \\
29 \\
180 \\
56 \\
407\end{array}$ & $\begin{array}{l}(-) \\
(-) \\
(-) \\
(-) \\
(-)\end{array}$ & $\begin{array}{r}1.5 \\
4.3 \\
26.4 \\
8.2 \\
59.6\end{array}$ & $\begin{array}{l}(0.12) \\
(0.24) \\
(0.39) \\
(0.30) \\
(0.48)\end{array}$ & $\begin{array}{r}\ddagger \\
6.4 \\
29.2 \\
\ddagger \\
63.0\end{array}$ & $\begin{array}{r}(\dagger) \\
(1.71) \\
(2.18) \\
(\dagger) \\
(2.74)\end{array}$ & $\begin{array}{r}\ddagger \\
4.0 \\
31.8 \\
2.1 \\
61.9\end{array}$ & $\begin{array}{r}(\dagger) \\
(0.80) \\
(1.69) \\
(0.45) \\
(1.73)\end{array}$ & $\begin{array}{c}1.7 ! \\
4.0 \\
35.5 \\
1.1 ! \\
57.7\end{array}$ & $\begin{array}{l}(0.74) \\
(0.64) \\
(1.37) \\
(0.35) \\
(1.53)\end{array}$ & $\begin{array}{r}2.6 \\
6.5 \\
13.2 \\
\ddagger \\
77.1\end{array}$ & $\begin{array}{r}(0.77) \\
(1.22) \\
(1.64) \\
(t) \\
(2.08)\end{array}$ & $\begin{array}{c}1.4 ! \\
9.1 \\
53.9 \\
1.1 ! \\
34.6\end{array}$ & $\begin{array}{l}(0.46) \\
(1.10) \\
(1.82) \\
(0.41) \\
(1.96)\end{array}$ & $\begin{array}{r}1.7 \\
5.5 \\
22.9 \\
41.1 \\
28.9\end{array}$ & $\begin{array}{l}(0.31) \\
(0.69) \\
(1.16) \\
(1.32) \\
(1.06)\end{array}$ & $\begin{array}{c}\ddagger \\
1.1 \\
35.1 \\
0.4 ! \\
63.2\end{array}$ & $\begin{array}{r}(\dagger) \\
(0.31) \\
(1.42) \\
(0.18) \\
(1.43)\end{array}$ & $\begin{array}{r}\ddagger \\
1.4 \\
14.9 \\
3.0 \\
80.6\end{array}$ & $\begin{array}{r}(\dagger) \\
(0.23) \\
(0.72) \\
(0.35) \\
(0.67)\end{array}$ & $\begin{array}{r}\ddagger \\
1.0 \\
12.5 \\
0.5 ! \\
86.0\end{array}$ & $\begin{array}{l}(0.26) \\
(0.72) \\
(0.19) \\
(0.74)\end{array}$ & $\begin{array}{r}4.4 \\
7.9 \\
34.4 \\
8.7 \\
44.6\end{array}$ & $\begin{array}{l}(0.54) \\
(0.67) \\
(1.24) \\
(0.76) \\
(1.23)\end{array}$ \\
\hline 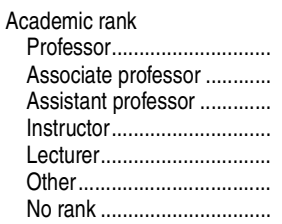 & $\begin{array}{r}161 \\
124 \\
124 \\
74 \\
12 \\
17 \\
17\end{array}$ & $\begin{array}{r}172 \\
132 \\
125 \\
75 \\
14 \\
26 \\
16\end{array}$ & $\left.\begin{array}{r}194 \\
150 \\
158 \\
83 \\
22 \\
57 \\
19\end{array}\right\}$ & $\begin{array}{l}(3.67) \\
(2.56) \\
(2.81) \\
(2.85) \\
(1.48) \\
(2.15) \\
(1.28)\end{array}$ & $\begin{array}{r}28.5 \\
21.9 \\
23.2 \\
12.1 \\
3.2 \\
8.3 \\
2.7\end{array}$ & $\begin{array}{l}(0.54) \\
(0.37) \\
(0.41) \\
(0.42) \\
(0.22) \\
(0.32) \\
(0.19)\end{array}$ & $\begin{array}{l}33.0 \\
21.0 \\
19.2 \\
9.9 \\
3.4 ! \\
11.8 \\
\ddagger\end{array}$ & $\begin{array}{r}(2.71) \\
(2.55) \\
(1.79) \\
(1.60) \\
(1.50) \\
(2.16) \\
(\dagger)\end{array}$ & $\begin{array}{r}22.6 \\
23.4 \\
13.4 \\
3.6 \\
4.9 \\
3.0\end{array}$ & $\begin{array}{l}(1.32) \\
(1.51) \\
(1.37) \\
(0.68) \\
(0.64) \\
(0.68)\end{array}$ & $\begin{array}{c}17.6 \\
23.8 \\
12.6 \\
3.0 \\
18.2 \\
2.9 !\end{array}$ & $\begin{array}{l}(1.07) \\
(1.56) \\
(1.18) \\
(0.60) \\
(1.57) \\
(1.05)\end{array}$ & $\begin{array}{l}25.3 \\
19.6 \\
9.1 \\
2.0 \\
5.4 \\
0.9 !\end{array}$ & $\begin{array}{l}(1.69) \\
(1.77) \\
(1.67) \\
(1.39) \\
(0.52) \\
(0.82) \\
(0.38)\end{array} \mid$ & $\begin{array}{r}23.7 \\
23.2 \\
9.7 \\
4.3 \\
7.1 \\
3.6 !\end{array}$ & $\begin{array}{l}(1.64) \\
(1.75) \\
(1.01) \\
(0.64) \\
(1.03) \\
(1.24)\end{array}$ & $\begin{array}{r}23.5 \\
32.2 \\
15.3 \\
1.9 \\
5.5 \\
1.5\end{array}$ & $\begin{array}{l}(0.96) \\
(1.12) \\
(0.90) \\
(0.37) \\
(0.50) \\
(0.27)\end{array}$ & $\begin{array}{r}26.2 \\
20.0 \\
21.7 \\
14.9 \\
7.9 \\
5.7 \\
3.6\end{array}$ & $\begin{array}{l}(1.27) \\
(1.30) \\
(1.17) \\
(0.78) \\
(0.69) \\
(0.67)\end{array}$ & $\begin{array}{r}35.5 \\
23.4 \\
21.1 \\
7.7 \\
2.1 \\
6.7 \\
3.5\end{array}$ & $\begin{array}{l}(0.93) \\
(0.82) \\
(0.56) \\
(0.25) \\
(0.48) \\
(0.48)\end{array}$ & $\begin{array}{r}35.4 \\
22.8 \\
24.8 \\
5.7 \\
2.3 \\
6.4 \\
2.6\end{array}$ & $\begin{array}{l}(0.97) \\
(1.22) \\
(0.53) \\
(0.42) \\
(0.67) \\
(0.47)\end{array}$ & $\begin{array}{r}23.5 \\
19.9 \\
19.2 \\
18.7 \\
3.6 \\
12.4 \\
2.7\end{array}$ & $\begin{array}{l}(1.09) \\
(1.08) \\
(0.73) \\
(1.02) \\
(0.57) \\
(0.76) \\
(0.36)\end{array}$ \\
\hline
\end{tabular}

See notes at end of table. 

[Standard errors appear in parentheses]

\begin{tabular}{|c|c|c|c|c|c|c|c|c|c|c|c|c|c|c|c|c|c|c|c|c|c|c|c|c|c|c|}
\hline \multirow[b]{2}{*}{$\begin{array}{l}\text { Selected faculty and } \\
\text { instructional staff } \\
\text { characteristic }\end{array}$} & \multicolumn{4}{|c|}{$\begin{array}{c}\text { Number } \\
\text { (in thousands) }\end{array}$} & \multicolumn{22}{|c|}{ Fall 2003} \\
\hline & Fall 1992 & Fall 1998 & \multicolumn{2}{|c|}{ Fall 2003} & & All fields & \multicolumn{2}{|c|}{$\begin{array}{r}\text { Agriculture } \\
\text { and home } \\
\text { economics }\end{array}$} & \multicolumn{2}{|c|}{ Business } & \multicolumn{2}{|c|}{ Education } & \multicolumn{4}{|c|}{ Engineering } & & Health & \multicolumn{2}{|c|}{ Humanities $^{1}$} & \multicolumn{4}{|c|}{$\begin{array}{r}\text { Social } \\
\text { sciences }^{3}\end{array}$} & \multicolumn{2}{|r|}{ Other ${ }^{4}$} \\
\hline 1 & 2 & 3 & & 4 & & 5 & & 6 & & 7 & & 8 & & 9 & & 10 & & 11 & & 12 & & 13 & & 14 & & 15 \\
\hline \multirow[t]{3}{*}{$\begin{array}{l}\text { Part-time faculty and } \\
\text { instructional staff } \\
\text { Number (in thousands) ... } \\
\text { Percentage distribution... }\end{array}$} & \multirow[t]{3}{*}{$\begin{array}{r}377 \\
\dagger\end{array}$} & \multirow[t]{3}{*}{$\begin{array}{r}416 \\
\dagger\end{array}$} & \multirow[t]{2}{*}{$\begin{array}{r}530 \\
\dagger\end{array}$} & \multirow[t]{2}{*}{$\begin{array}{l}(\#) \\
(\dagger)\end{array}$} & $\begin{array}{l}530.0 \\
100.0 \\
\end{array}$ & $\begin{array}{r}(0.02) \\
(+) \\
\end{array}$ & $\begin{array}{l}7.3 \\
1.4 \\
\end{array}$ & $\begin{array}{l}(0.97) \\
(0.18) \\
\end{array}$ & $\begin{array}{r}44.9 \\
8.5 \\
\end{array}$ & $\begin{array}{l}(2.98) \\
(0.56) \\
\end{array}$ & $\begin{array}{l}63.5 \\
12.0 \\
\end{array}$ & $\begin{array}{l}(2.57) \\
(0.48)\end{array}$ & $\begin{array}{r}14.0 \\
2.7\end{array}$ & $\begin{array}{l}(1.49) \\
(0.28)\end{array}$ & $\begin{array}{r}47.8 \\
9.0\end{array}$ & $\begin{array}{l}(3.65) \\
(0.69)\end{array}$ & $\begin{array}{l}57.8 \\
10.9 \\
\end{array}$ & $\begin{array}{l}(3.06) \\
(0.58)\end{array}$ & $\begin{array}{l}58.9 \\
11.1 \\
\end{array}$ & $\begin{array}{l}(2.05) \\
(0.39)\end{array}$ & $\begin{array}{l}63.7 \\
12.0 \\
\end{array}$ & $\begin{array}{l}(2.46) \\
(0.46)\end{array}$ & $\begin{array}{l}53.0 \\
10.0 \\
\end{array}$ & $\begin{array}{l}(2.39) \\
(0.45)\end{array}$ & $\begin{array}{r}119.2 \\
22.5 \\
\end{array}$ & $\begin{array}{l}(3.48) \\
(0.66) \\
\end{array}$ \\
\hline & & & & & \multicolumn{22}{|c|}{ Percentage distribution of part-time faculty and instructional staff } \\
\hline & & & 530 & (\#) & 100.0 & $(\dagger)$ & 100.0 & $(\dagger)$ & 100.0 & $(\dagger)$ & 100.0 & $(t)$ & 100.0 & $(t)$ & 100.0 & $(t)$ & 100.0 & $(t)$ & 100.0 & $(\dagger)$ & 100.0 & $(t)$ & 100.0 & $(t)$ & 100.0 & $(+)$ \\
\hline 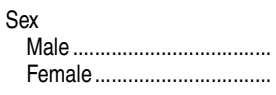 & $\begin{array}{l}209 \\
168\end{array}$ & $\begin{array}{l}217 \\
199\end{array}$ & $\begin{array}{l}276 \\
254\end{array}$ & $\begin{array}{l}(-) \\
(-)\end{array}$ & $\begin{array}{l}52.1 \\
47.9\end{array}$ & $\begin{array}{l}(0.45) \\
(0.45)\end{array}$ & $\begin{array}{l}32.0 \\
68.0\end{array}$ & $\begin{array}{l}(6.05) \\
(6.05)\end{array}$ & $\begin{array}{l}69.6 \\
30.4\end{array}$ & $\begin{array}{l}(1.89) \\
(1.89)\end{array}$ & $\begin{array}{l}29.1 \\
70.9\end{array}$ & $\begin{array}{l}(1.71) \\
(1.71)\end{array}$ & $\begin{array}{r}90.8 \\
9.2\end{array}$ & $\begin{array}{l}(2.68) \\
(2.68)\end{array}$ & $\begin{array}{l}51.4 \\
48.6\end{array}$ & $\begin{array}{l}(2.26) \\
(2.26)\end{array}$ & $\begin{array}{l}34.5 \\
65.5\end{array}$ & $\begin{array}{l}(1.60) \\
(1.60)\end{array}$ & $\begin{array}{l}31.6 \\
68.4\end{array}$ & $\begin{array}{l}(1.86) \\
(1.86)\end{array}$ & $\begin{array}{l}58.2 \\
41.8\end{array}$ & $\begin{array}{l}(2.22) \\
(2.22)\end{array}$ & $\begin{array}{l}60.5 \\
39.5\end{array}$ & $\begin{array}{l}(1.90) \\
(1.90)\end{array}$ & $\begin{array}{l}66.2 \\
33.8\end{array}$ & $\begin{array}{l}(1.41) \\
(1.41)\end{array}$ \\
\hline Race/ethnicity & & & & & & & & & & & & & & & & & & & & & & & & & & \\
\hline & 333 & 364 & 452 & $(-)$ & 85.2 & $(0.38)$ & 91.4 & $(3.66)$ & 86.8 & (1.54) & 85.1 & $(1.34)$ & 85.4 & $(2.89)$ & 88.7 & $(1.22)$ & 85.0 & $(1.14)$ & 83.0 & $(1.14)$ & 83.4 & $(1.35)$ & 84.2 & (1.62) & 85.5 & $(0.80)$ \\
\hline Black ...... & 18 & 19 & 30 & $(-)$ & 5.6 & $(0.20)$ & $\ddagger$ & $(t)$ & 6.7 & $(0.96)$ & 6.6 & $(0.98)$ & $\ddagger$ & $(t)$ & 3.0 & $(0.70)$ & 5.2 & $(0.68)$ & 5.0 & $(0.71)$ & 6.0 & $(0.66)$ & 5.8 & $(0.75)$ & 6.5 & $(0.57)$ \\
\hline Hispanic. & 11 & 16 & 19 & $(-)^{\prime}$ & 3.5 & $(0.13)$ & $\ddagger$ & $(\dagger)$ & 2.2 ! & $(0.79)$ & 5.1 & $(0.71)$ & 2.6 & $(0.64)$ & 2.7 & $(0.52)$ & 2.2 & $(0.47)$ & 6.5 & $(0.81)$ & 2.2 & $(0.40)$ & 3.7 & $(0.61)$ & 3.6 & $(0.39)$ \\
\hline Asian $/ \mathrm{Pa}$ & 12 & 13 & 20 & $(-)$ & 3.8 & $(0.22)$ & $\ddagger$ & $(\dagger)$ & 3.0 & $(0.80)$ & 1.6 & $(0.43)$ & 8.4 & (2.11) & 2.9 & $(0.70)$ & 6.5 & $(1.17)$ & 4.2 & $(0.71)$ & 7.1 & $(0.89)$ & $2.7 !$ & $(1.04)$ & 2.5 & $(0.34)$ \\
\hline $\begin{array}{l}\text { American Indian/Alaska } \\
\text { Native............................... }\end{array}$ & 2 & 4 & 10 & $(-)$ & 1.8 & $(0.22)$ & $\ddagger$ & (t) & $1.4 !$ & $(0.54)$ & 1.5 & $(0.37)$ & $\ddagger$ & T) & $2.8 !$ & $(0.84)$ & $1.0 !$ & $(0.35)$ & 1.3 & $(0.38)$ & $1.4 !$ & $(0.60)$ & 36 & 108 & & \\
\hline Age & & & & & & & & & & & & & & & & & & & & & & & 0.0 & $(0.91)$ & & (0.00) \\
\hline Under 30 & 20 & 15 & 23 & $(-)$ & 4.3 & $(0.30)$ & 6.4 ! & (2.51) & $2.3 !$ & $(0.70)$ & 2.7 & $(0.64)$ & $\ddagger$ & (t) & 4.4 & $(0.79)$ & 3.7 & $(0.72)$ & 5.7 & $(0.95)$ & 7.2 & (1.15) & 3.5 & $(0.66)$ & 4.3 & $(0.60)$ \\
\hline 30 to 3 & 36 & 37 & 43 & $(-)$ & 8.2 & $(0.38)$ & $7.7 !$ & (2.78) & 6.7 & (1.28) & 7.0 & $(1.03)$ & $\ddagger$ & $(t)$ & 9.4 & (1.24) & 8.9 & (1.01) & 10.0 & $(1.01)$ & 7.6 & $(1.16)$ & 10.6 & $(1.17)$ & 7.7 & $(0.62)$ \\
\hline$\ldots$ & 59 & 47 & 55 & $(-)$ & 10.3 & $(0.48)$ & $5.5 !$ & (1.97) & 9.6 & (1.49) & 8.7 & (1.2 & $10.7 !$ & (3.34) & 11.7 & (1.38) & 9.5 & (1.34) & 8.7 & $(1.07)$ & 10.2 & $(1.16)$ & 9.9 & $(1.27)$ & 12.6 & $(1.20)$ \\
\hline$\ldots \ldots \ldots$ & 70 & 60 & 61 & $(-)$ & 11.5 & $(0.44)$ & $6.3 !$ & (2.79) & 10.5 & (1.35) & 7.9 & $(0.88)$ & 15.6 & $(3.25)$ & 12.0 & (1.13) & 14.9 & $(1.54)$ & 9.2 & $(0.91)$ & 10.1 & $(1.19)$ & 11.2 & (1.26) & 13.8 & $(0.96)$ \\
\hline 45 & 68 & 72 & 76 & $(-)^{\prime}$ & 14.4 & $(0.48)$ & $17.4 !$ & (5.26) & 13.1 & (1.45) & 11.7 & (1.12) & $11.4 !$ & (3.50) & 16.4 & (1.68) & 19.7 & (1.56) & 14.3 & $(1.65)$ & 9.5 & $(1.05)$ & 13.1 & (1.24) & 16.5 & (1.13) \\
\hline & 45 & 70 & 83 & $(-)$ & 15.6 & $(0.42)$ & 16.4 & $(4.15)$ & 16.3 & (1.42) & 17.4 & $(1.41)$ & 22.3 & (3.60) & 18.4 & $(1.76)$ & 15.9 & $(1.55)$ & 14.1 & $(1.35)$ & 11.9 & $(1.34)$ & 11.1 & (1.29) & 17.1 & (1.15) \\
\hline …. & 29 & 47 & 77 & $(-)$ & 14.5 & $(0.48)$ & 17.6 & (4.45) & 17.9 & (2.01) & 15.5 & $(1.58)$ & 11.7 & $(2.89)$ & 14.6 & (1.78) & 11.5 & $(1.27)$ & 13.8 & $(1.46)$ & 15.6 & $(1.56)$ & 17.5 & $(1.88)$ & 12.8 & $(0.82)$ \\
\hline 60 to 6 & 23 & 29 & 52 & $(-)$ & 9.7 & $(0.50)$ & 18.0 & $(5.10)$ & 11.5 & (1.25) & 13.1 & $(1.26)$ & $6.5 !$ & (1.96) & 5.7 & $(1.05)$ & 6.7 & (1.13) & 12.7 & (1.42) & 12.8 & $(1.67)$ & 10.9 & (1.29) & 6.6 & $(0.76)$ \\
\hline 65 or older.... & 27 & 38 & 60 & $(-)$ & 11.4 & $(0.46)$ & $4.7 !$ & $(2.09)$ & 12.2 & (1.65) & 15.8 & $(1.26)$ & 17.2 & (3.46) & 7.4 & $(1.33)$ & 9.3 & $(1.22)$ & 11.6 & $(1.50)$ & 15.0 & $(1.99)$ & 12.2 & (1.48) & 8.6 & (0.79) \\
\hline Highest degree & & & & & & & & & & & & & & & & & & & & & & & & & & \\
\hline & 17 & 20 & & $(-)$ & 7.8 & $(0.59)$ & $5.5 !$ & (2.53) & $1.8 !$ & $(0.79)$ & 3.7 & $(0.96)$ & 17.1 & (4.44) & 9.1 & (1.42) & 17.3 & $(1.86)$ & $\ddagger$ & $(t)$ & $\ddagger$ & $(t)$ & $0.5 !$ & $(0.25)$ & 16.2 & (1.31) \\
\hline & 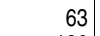 & & 84 & $(-)$ & 15.8 & $(0.55)$ & 26.7 & $(5.80)$ & 13.9 & $(1.84)$ & 12.0 & $(1.25)$ & 17.9 & (3.50) & 28.2 & $(2.09)$ & 16.2 & $(1.61)$ & 12.9 & $(1.65)$ & 16.1 & $(1.46)$ & 3.2 & $(0.82)$ & 19.4 & $(1.11)$ \\
\hline Master's & 190 & 225 & 273 & $(-)$ & 51.5 & $(0.80)$ & 50.3 & (6.09) & 66.5 & (2.34) & 63.0 & $(1.8$ & 32.3 & (4.61) & 54.7 & $(2.95)$ & 30.2 & (1.86) & 70.2 & $(2.33)$ & 49.0 & (1.94) & 55.5 & $(1.83)$ & 41.6 & (1.56) \\
\hline First-pr & 40 & 36 & 39 & $(-)$ & 7.3 & $(0.39)$ & $\ddagger$ & $(t)$ & 6.3 & $(1.10)$ & 1.9 & $(0.4$ & $\ddagger$ & $(t)$ & 0.9 ! & $(0.39)$ & 25.2 & (2.12) & 2.3 & $(0.55)$ & 4.3 & $(0.85)$ & 3.1 & $(0.62)$ & 11.2 & $(1.00)$ \\
\hline Doctor's............. & 59 & 76 & 94 & $(-)$ & 17.6 & $(0.60)$ & 15.5 & (4.57) & 11.5 & (1.48) & 19.4 & (1.61) & 31.2 & (4.13) & 7.1 & (1.39) & 11.1 & $(1.28)$ & 13.4 & $(1.80)$ & 29.7 & (1.72) & 37.7 & (1.90) & 11.7 & $(0.94)$ \\
\hline Academic rank & & & & & & & & & & & & & & & & & & & & & & & & & & \\
\hline & 32 & 30 & 23 & (1.6) & 4.4 & $(0.30)$ & $8.9 !$ & $(4.03)$ & & $(1.06)$ & 3.4 & $(0.5$ & $5.9 !$ & (2.27) & 3.9 & $(1.05)$ & 5.4 & $(0.84)$ & 3.5 & $(0.7$ & 4.8 & $(0.82)$ & 4.7 & $(1.01)$ & 4.1 & $(0.63)$ \\
\hline & 23 & 19 & 15 & (1.2) & 2.8 & $(0.22)$ & $\ddagger$ & $(t)$ & $2.3 !$ & $(0.74)$ & 1.9 & 10. & $5.7 !$ & (2.24) & 3.7 & $(0.92)$ & 5.4 & $(0.89)$ & 1.6 & $(0.3$ & 3.3 & $(0.63)$ & 2.9 & $(0$. & 1.6 & $(0.30)$ \\
\hline Assistant & 24 & 23 & 20 & (1.5) & 3.7 & $(0.2$ & $\ddagger$ & & $1.5 !$ & $(0.55)$ & 2.0 & $(0.5$ & $\ddagger$ & $(t)$ & 3.6 & $(0.86)$ & 15.1 & (1.64) & $1.7 !$ & $(0.64)$ & 2.8 & $(0.66)$ & 3.7 & $(0.89)$ & 1.7 & $(0.34)$ \\
\hline & 215 & 205 & 188 & (4.4) & 35.4 & $(0.83)$ & 39.9 & (5.70) & 29.2 & $(2.00)$ & 37.0 & $(2.1$ & 25.3 & (4.10) & 33.6 & (2.12) & 36.5 & (2.40) & 42.9 & $(2.29)$ & 32.4 & (2.05) & 30.4 & $(1.85)$ & 38.2 & $(1.54)$ \\
\hline Lect & 45 & 46 & 41 & (2.1) & 7.7 & $(0.41)$ & 14.8 & (4.39) & 7.6 & (1.52) & 6.8 & $(0.9$ & 9.3 & (2.49) & 9.7 & (1.16) & 4.7 & $(0.93)$ & 11.2 & $(1.10)$ & 7.8 & (1.02) & 9.5 & $(1.20)$ & 5.8 & $(0.67)$ \\
\hline Other.. & 28 & 75 & 231 & (4.5) & 43.6 & $(0.85)$ & 30.8 & (5.98) & 51.8 & $(2.46)$ & 46.6 & $(1.7$ & 49.4 & $(5.02)$ & 42.4 & $(3.00)$ & 30.5 & $(1.88)$ & 37.4 & $(2.23)$ & 45.8 & (2.02) & 46.0 & $(2.22)$ & 46.6 & (1.47) \\
\hline No rank ... & 9 & 16 & 13 & (1.1) & 2.4 & $(0.20)$ & $\ddagger$ & $(\dagger)$ & 3.0 & $(0.75)$ & 2.1 & $(0.59)$ & $\ddagger$ & $(t)$ & 3.2 ! & $(1.10)$ & 2.4 & $(0.68)$ & 1.7 & $(0.49)$ & 3.1 & $(0.79)$ & 2.8 & $(0.71)$ & 2.1 & $(0.40)$ \\
\hline
\end{tabular}

\section{-Not available.}

†Not applicable.
\#Rounds to zero.

!Interpret data with caution. The coefficient of variation (CV) for this estimate is between 30 and 50 percent $\ddagger$ Reporting standards not met. Either there are too few cases for a reliable estimate or the coefficient of variation (CV) is 50 percent or greater.

Excludes history and philosophy.
Includes history

4Includes philosophy, law, occupationally specific programs, computer sciences, and other.
NOTE: Degree-granting institutions grant associate's or higher degrees and participate in Title IV federal financial aid programs. Totals may differ from figures reported in other tables because of varying survey methodologies. Race categories exclude persons of Hispanic ethnicity. Detall may not sum to totals because of survey item nonresponse and rounding. SOURCE: U.S. Department of Education, National Center for Education Statistics, 1993, 1999, and 2004 National Study of
Postsecondary Faculty (NSOPF:93;99;04). (This table was prepared January 2009.) 
Table 315.80. Full-time and part-time faculty and instructional staff in degree-granting postsecondary institutions, by race/ethnicity, sex, and program area: Fall 1998 and fall 2003

[Standard errors appear in parentheses]

\begin{tabular}{|c|c|c|c|c|c|c|c|c|c|c|c|c|c|c|c|c|c|c|c|c|c|c|c|c|c|}
\hline \multirow[b]{3}{*}{ Program area } & & & & & \multicolumn{21}{|c|}{ Percentage distribution, fall 2003} \\
\hline & \multicolumn{4}{|c|}{ Number (in thousands) } & \multicolumn{5}{|c|}{ White } & \multicolumn{4}{|c|}{ Black } & \multicolumn{4}{|c|}{ Hispanic } & \multicolumn{4}{|c|}{ Asian/Pacific Islander } & \multicolumn{4}{|c|}{ American Indian/Alaska Native } \\
\hline & \multicolumn{2}{|c|}{ Fall 1998} & \multicolumn{2}{|c|}{ Fall 2003} & Total & \multicolumn{2}{|r|}{ Male } & \multicolumn{2}{|r|}{ Female } & \multicolumn{2}{|r|}{ Male } & \multicolumn{2}{|r|}{ Female } & \multicolumn{2}{|r|}{ Male } & \multicolumn{2}{|r|}{ Female } & \multicolumn{2}{|r|}{ Male } & & Female & & Male & & Female \\
\hline 1 & & 2 & & 3 & 4 & & 5 & & 6 & & 7 & & 8 & & 9 & & 10 & & 11 & & 12 & & 13 & & 14 \\
\hline $\begin{array}{l}\text { Full-time faculty and } \\
\text { instructional staff ... }\end{array}$ & 560 & $(4.8)$ & 682 & $(\#)$ & 100.0 & 49.6 & $(0.39)$ & 30.7 & $(0.36)$ & 2.9 & $(0.15)$ & 2.7 & $(0.13)$ & 2.0 & $(0.09)$ & 1.5 & $(0.08)$ & 6.3 & $(0.15)$ & 2.8 & $(0.15)$ & 0.8 & $(0.08)$ & 0.6 & $(0.07)$ \\
\hline $\begin{array}{l}\text { Agriculture and home } \\
\text { economics................... }\end{array}$ & 10 & $(0.4)$ & 17 & $(0.8)$ & 100.0 & 58.9 & $(3.03)$ & 28.9 & $(2.72)$ & $\ddagger$ & $(t)$ & $1.8 !$ & $(0.73)$ & $1.2 !$ & $(0.46)$ & $1.3 !$ & $(0.52)$ & $3.6 !$ & $(1.13)$ & $2.8 !$ & $(0.86)$ & $\ddagger$ & $(\dagger)$ & $\ddagger$ & $(\dagger)$ \\
\hline Business ....................... & 39 & (1.1) & 43 & (1.4) & 100.0 & 53.2 & $(1.49)$ & 26.2 & (1.71) & 2.5 & $(0.73)$ & 2.0 & $(0.44)$ & 1.8 & $(0.48)$ & $0.5 !$ & $(0.16)$ & 9.7 & $(1.06)$ & 2.5 & $(0.46)$ & 1.3 & $(0.35)$ & $0.4 !$ & $(0.17)$ \\
\hline Communications.............. & 10 & $(1.0)$ & 16 & (1.4) & 100.0 & 48.1 & $(3.39)$ & 38.7 & (3.30) & $2.0 !$ & $(0.73)$ & 3.3 & $(0.94)$ & $1.9 !$ & $(0.58)$ & $1.5 !$ & $(0.59)$ & $1.9 !$ & $(0.87)$ & $\ddagger$ & $(t)$ & $\ddagger$ & $(t)$ & $\ddagger$ & $(t)$ \\
\hline Education ...................... & 40 & (1.4) & 51 & (1.9) & 100.0 & 32.5 & (1.49) & 48.0 & $(1.64)$ & 3.0 & $(0.60)$ & 4.9 & $(0.64)$ & 1.5 & $(0.34)$ & 3.2 & $(0.52)$ & $1.3 !$ & $(0.43)$ & 3.5 & $(0.59)$ & 0.9 & $(0.25)$ & 1.3 & $(0.34)$ \\
\hline Teacher education..... & 14 & $(0.6)$ & 18 & (1.0) & 100.0 & 31.1 & $(2.31)$ & 54.4 & $(2.54)$ & $2.1 !$ & $(0.86)$ & 5.2 & $(1.10)$ & $\ddagger$ & $(\dagger)$ & 3.1 & $(0.89)$ & $\ddagger$ & $(t)$ & $2.1 !$ & $(0.87)$ & $\ddagger$ & $(\dagger)$ & $\ddagger$ & $(t)$ \\
\hline Other education .......... & 26 & $(1.3)$ & 33 & (1.5) & 100.0 & 33.3 & $(2.09)$ & 44.4 & (2.46) & 3.4 & $(0.84)$ & 4.7 & $(0.75)$ & 2.2 & $(0.51)$ & 3.2 & $(0.57)$ & $1.9 !$ & $(0.64)$ & 4.2 & $(0.81)$ & $1.1 !$ & $(0.40)$ & $1.5 !$ & $(0.45)$ \\
\hline Engineering .............. & 25 & $(0.9)$ & 33 & (1.3) & 100.0 & 65.6 & (1.93) & 5.3 & $(0.90)$ & 4.9 & $(0.84)$ & $\ddagger$ & $(\dagger)$ & 2.2 & $(0.42)$ & $0.4 !$ & $(0.17)$ & 17.9 & (1.61) & 2.2 & $(0.63)$ & $\ddagger$ & $(t)$ & $\ddagger$ & $(\dagger)$ \\
\hline Fine arts .................. & 33 & (1.4) & 43 & (1.7) & 100.0 & 52.8 & $(1.68)$ & 33.6 & $(1.36)$ & 4.4 & $(0.83)$ & 1.6 & $(0.34)$ & 2.0 & $(0.59)$ & $1.3 !$ & $(0.44)$ & 1.5 & $(0.42)$ & $1.4 !$ & $(0.59)$ & $1.2 !$ & $(0.36)$ & $\ddagger$ & $(\dagger)$ \\
\hline Health sciences ............ & 84 & $(2.0)$ & 94 & (2.7) & 100.0 & 36.2 & $(1.23)$ & 43.5 & (1.15) & 1.6 & $(0.26)$ & 3.4 & $(0.44)$ & 1.6 & $(0.25)$ & 1.4 & $(0.19)$ & 6.6 & $(0.60)$ & 4.1 & $(0.57)$ & $0.7 !$ & $(0.22)$ & 1.0 & $(0.28)$ \\
\hline First-professional ......... & 40 & (1.6) & 45 & (1.7) & 100.0 & 53.9 & $(1.58)$ & 20.1 & (1.42) & 2.2 & $(0.49)$ & 2.5 & $(0.58)$ & 2.2 & $(0.40)$ & 1.3 & $(0.30)$ & 10.6 & $(1.08)$ & 5.3 & $(0.89)$ & $1.1 !$ & $(0.37)$ & $\ddagger$ & $(t)$ \\
\hline Nursing ....................... & 20 & $(0.6)$ & 20 & (1.2) & 100.0 & 3.5 & $(0.86)$ & 84.6 & $(2.21)$ & $\ddagger$ & $(t)$ & 5.3 & $(1.29)$ & $\ddagger$ & $(t)$ & $0.7 !$ & $(0.27)$ & $\ddagger$ & $(t)$ & $3.4 !$ & $(1.10)$ & $\ddagger$ & $(t)$ & $1.8 !$ & $(0.85)$ \\
\hline Other health sciences ............. & 24 & $(1.0)$ & 29 & (1.4) & 100.0 & 31.0 & $(1.98)$ & 52.0 & (2.05) & $1.5 !$ & $(0.50)$ & 3.6 & $(0.84)$ & 1.6 & $(0.44)$ & 1.9 & $(0.48)$ & 4.8 & $(1.02)$ & 2.6 & $(0.71)$ & $\ddagger$ & $(t)$ & $0.7 !$ & $(0.31)$ \\
\hline Humanities... & 81 & $(1.8)$ & 90 & (2.4) & 100.0 & 47.3 & $(1.40)$ & 35.0 & (1.33) & 2.4 & $(0.43)$ & 2.6 & $(0.39)$ & 2.2 & $(0.24)$ & 2.9 & $(0.31)$ & 2.9 & $(0.48)$ & 2.9 & $(0.54)$ & 0.9 & $(0.23)$ & 0.9 & $(0.25)$ \\
\hline English and literature ............... & 40 & $(1.2)$ & 39 & (1.5) & 100.0 & 38.8 & $(1.90)$ & 46.0 & (2.10) & 2.1 & $(0.45)$ & 4.5 & $(0.70)$ & 1.3 & $(0.27)$ & 1.9 & $(0.50)$ & $0.8 !$ & $(0.34)$ & $2.7 !$ & $(0.87)$ & $0.5 !$ & $(0.18)$ & 1.4 & $(0.39)$ \\
\hline Foreign languages ................... & 15 & $(0.8)$ & 20 & (1.0) & 100.0 & 36.2 & $(1.86)$ & 36.7 & $(2.07)$ & $2.7 !$ & $(0.89)$ & $0.9 !$ & $(0.46)$ & 5.1 & $(0.75)$ & 8.3 & $(1.07)$ & 4.0 & $(1.11)$ & 4.5 & $(1.01)$ & $\ddagger$ & $(t)$ & $\ddagger$ & $(\dagger)$ \\
\hline History ................................ & 14 & $(0.6)$ & 18 & $(1.0)$ & 100.0 & 59.4 & $(2.90)$ & 23.0 & (2.12) & 2.7 & $(0.80)$ & $2.4 !$ & $(0.94)$ & $1.9 !$ & $(0.71)$ & $1.2 !$ & $(0.52)$ & 5.0 & $(1.49)$ & 3.2 & $(0.91)$ & $1.0 !$ & $(0.45)$ & $\ddagger$ & $(\dagger)$ \\
\hline Philosophy .................................. & 12 & $(0.8)$ & 13 & (1.0) & 100.0 & 72.3 & (3.55) & 16.6 & (2.33) & $2.3 !$ & (1.11) & $\ddagger$ & $(\dagger)$ & $1.0 !$ & $(0.35)$ & $\ddagger$ & $(t)$ & $4.0 !$ & $(1.49)$ & $\ddagger$ & $(t)$ & $\ddagger$ & $(t)$ & $\ddagger$ & $(\dagger)$ \\
\hline Law........ & 8 & $(0.6)$ & 10 & (1.0) & 100.0 & 54.5 & $(3.56)$ & 29.9 & (3.63) & $3.3 !$ & $(1.10)$ & $\ddagger$ & $(\dagger)$ & $\ddagger$ & $(t)$ & $2.4 !$ & $(1.15)$ & $2.8 !$ & $(1.36)$ & $\ddagger$ & $(\dagger)$ & $\ddagger$ & $(t)$ & $\ddagger$ & $(\dagger)$ \\
\hline Natural sciences ..................... & 111 & $(2.1)$ & 151 & (2.5) & 100.0 & 57.3 & $(1.12)$ & 20.3 & $(0.80)$ & 2.5 & $(0.31)$ & 1.5 & $(0.22)$ & 2.0 & $(0.20)$ & 0.9 & $(0.15)$ & 11.2 & $(0.65)$ & 3.3 & $(0.35)$ & 0.6 & $(0.16)$ & $0.3 !$ & $(0.09)$ \\
\hline Biological sciences ............. & 40 & $(1.3)$ & 59 & (1.7) & 100.0 & 55.4 & $(1.69)$ & 21.6 & $(1.30)$ & 2.2 & $(0.48)$ & 1.2 & $(0.28)$ & 1.9 & $(0.39)$ & 1.2 & $(0.31)$ & 11.1 & $(1.13)$ & 4.8 & $(0.67)$ & $\ddagger$ & $(t)$ & $0.3 !$ & $(0.12)$ \\
\hline Physical sciences.................... & 27 & $(0.8)$ & 36 & (1.3) & 100.0 & 68.9 & $(2.03)$ & 12.8 & (1.50) & 2.6 & $(0.59)$ & $0.7 !$ & $(0.31)$ & 1.4 & $(0.29)$ & $0.6 !$ & $(0.19)$ & 9.4 & $(1.05)$ & 3.0 & $(0.64)$ & $\ddagger$ & $(\dagger)$ & $\ddagger$ & $(\dagger)$ \\
\hline Mathematics ........................... & 26 & $(1.0)$ & 32 & (1.3) & 100.0 & 52.2 & $(2.15)$ & 22.7 & $(1.84)$ & 3.8 & $(0.67)$ & 2.6 & $(0.67)$ & 2.8 & $(0.67)$ & $0.7 !$ & $(0.28)$ & 11.7 & $(1.41)$ & $1.8 !$ & $(0.67)$ & $1.2 !$ & $(0.56)$ & $\ddagger$ & $(\dagger)$ \\
\hline Computer sciences...................... & 17 & $(0.9)$ & 24 & (1.2) & 100.0 & 51.0 & $(2.74)$ & 25.1 & (2.15) & $1.5 !$ & $(0.59)$ & 2.0 & $(0.58)$ & 2.3 & $(0.52)$ & $0.9 !$ & $(0.31)$ & 13.5 & $(1.69)$ & $2.0 !$ & $(0.66)$ & $1.1 !$ & $(0.48)$ & $\ddagger$ & $(t)$ \\
\hline Social sciences................ & 58 & (1.3) & 70 & (1.8) & 100.0 & 52.2 & $(1.46)$ & 29.0 & $(1.23)$ & 3.7 & $(0.45)$ & 4.1 & $(0.81)$ & 2.6 & $(0.36)$ & 1.7 & $(0.35)$ & 3.4 & $(0.58)$ & 1.9 & $(0.48)$ & 0.9 & $(0.25)$ & 0.6 & $(0.15)$ \\
\hline Economics & 9 & $(0.6)$ & 12 & $(0.7)$ & 100.0 & 62.3 & $(3.46)$ & 18.0 & (3.09) & 3.5 & $(0.92)$ & $\ddagger$ & $(t)$ & $3.1 !$ & (1.13) & $\ddagger$ & $(t)$ & 8.9 & $(2.18)$ & $\ddagger$ & $(t)$ & $\ddagger$ & $(t)$ & $\ddagger$ & $(t)$ \\
\hline Political science ...................... & 8 & $(0.5)$ & 10 & (0.7) & 100.0 & 67.1 & (3.74) & 16.8 & (2.59) & $2.8 !$ & (1.19) & $\ddagger$ & $(t)$ & $5.1 !$ & $(1.57)$ & $\ddagger$ & $(t)$ & 2.9 ! & $(1.31)$ & $\ddagger$ & $(t)$ & $\ddagger$ & $(\dagger)$ & $\ddagger$ & $(t)$ \\
\hline Psychology ................................ & 20 & $(0.7)$ & 25 & (1.1) & 100.0 & 46.3 & $(2.33)$ & 37.8 & (2.16) & 3.4 & $(1.01)$ & $5.0 !$ & (1.99) & 1.6 & $(0.42)$ & 2.7 & $(0.70)$ & $1.1 !$ & $(0.49)$ & $1.2 !$ & $(0.39)$ & $\ddagger$ & $(\dagger)$ & $\ddagger$ & $(\dagger)$ \\
\hline Sociology ………………......... & 9 & $(0.4)$ & 9 & $(0.6)$ & 100.0 & 49.9 & (3.72) & 30.1 & (3.42) & $3.9 !$ & (1.69) & $8.0 !$ & $(2.43)$ & $3.0 !$ & $(0.97)$ & $\ddagger$ & $(\dagger)$ & $\ddagger$ & $(t)$ & $\ddagger$ & $(\dagger)$ & $\ddagger$ & $(t)$ & $\ddagger$ & $(\mathrm{t})$ \\
\hline Other social sciences............... & 13 & $(0.6)$ & 14 & $(0.9)$ & 100.0 & 45.2 & (3.59) & 30.5 & (3.09) & 4.8 & (1.33) & $3.9 !$ & $(1.28)$ & $1.9 !$ & $(0.80)$ & 2.4 & $(0.71)$ & $4.7 !$ & $(1.50)$ & $3.7 !$ & $(1.22)$ & $1.9 !$ & $(0.75)$ & $1.1 !$ & $(0.54)$ \\
\hline $\begin{array}{l}\text { Occupationally specific } \\
\text { programs }\end{array}$ & 16 & $(0.8)$ & 27 & (1.1) & 100.0 & 60.7 & (2.47) & 24.2 & (2.16) & 4.2 & $(1.16)$ & 1.9 & $(0.55)$ & 2.5 & $(0.63)$ & $0.8 !$ & $(0.26)$ & $2.0 !$ & $(0.92)$ & $1.4 !$ & $(0.46$ & $1.9 !$ & $(0.62)$ & $\ddagger$ & (†) \\
\hline All other programs ................ & 44 & $(1.2)$ & 29 & (1.4) & 100.0 & 42.0 & $(2.03)$ & 37.4 & $(2.00)$ & 4.7 & $(1.01)$ & 6.0 & $(1.01)$ & 1.7 & $(0.44)$ & $1.7 !$ & $(0.53)$ & $3.2 !$ & $(0.99)$ & $2.0 !$ & $(0.64)$ & $0.7 !$ & $(0.31)$ & $0.6 !$ & $(0.28)$ \\
\hline
\end{tabular}

See notes at end of table. 
[Standard errors appear in parentheses]

\begin{tabular}{|c|c|c|c|c|c|c|c|c|c|c|c|c|c|c|c|c|c|c|c|c|c|c|c|c|c|}
\hline \multirow[b]{3}{*}{ Program area } & & & & & \multicolumn{21}{|c|}{ Percentage distribution, fall 2003} \\
\hline & \multicolumn{4}{|c|}{ Number (in thousands) } & \multicolumn{5}{|c|}{ White } & \multicolumn{4}{|c|}{ Black } & \multicolumn{4}{|c|}{ Hispanic } & \multicolumn{4}{|c|}{ Asian/Pacific Islander } & \multicolumn{4}{|c|}{ American Indian/Alaska Native } \\
\hline & \multicolumn{2}{|c|}{ Fall 1998} & \multicolumn{2}{|c|}{ Fall 2003} & Total & \multicolumn{2}{|r|}{ Male } & \multicolumn{2}{|r|}{ Female } & \multicolumn{2}{|r|}{ Male } & \multicolumn{2}{|r|}{ Female } & \multicolumn{2}{|r|}{ Male } & \multicolumn{2}{|r|}{ Female } & \multicolumn{2}{|r|}{ Male } & & Female & & Male & & Female \\
\hline 1 & & 2 & & 3 & 4 & & 5 & & 6 & & 7 & & 8 & & 9 & & 10 & & 11 & & 12 & & 13 & & $\overline{14}$ \\
\hline $\begin{array}{l}\text { Part-time faculty and } \\
\text { instructional staff ....... }\end{array}$ & 416 & (5.9) & 530 & (\#) & 100.0 & 44.4 & $(0.46)$ & 40.8 & $(0.54)$ & 2.6 & $(0.17)$ & 3.0 & $(0.14)$ & 1.9 & $(0.12)$ & 1.6 & $(0.10)$ & 2.1 & $(0.15)$ & 1.8 & $(0.18)$ & 1.0 & $(0.15)$ & 0.8 & (0.15) \\
\hline $\begin{array}{l}\text { Agriculture and home } \\
\text { economics ........... }\end{array}$ & 3 & $(0.2)$ & 7 & $(1.0)$ & 100.0 & 30.8 & $(6.24)$ & 60.6 & (6.30) & $\ddagger$ & (†) & $\ddagger$ & (†) & $\ddagger$ & $(t)$ & $\ddagger$ & (t) & $\ddagger$ & $(\dagger)$ & $\ddagger$ & $(t)$ & $\ddagger$ & $(\dagger)$ & $\ddagger$ & \\
\hline Business.... & 32 & (1.8) & 45 & (3.0) & 100.0 & 60.6 & (1.96) & 26.2 & (1.73) & 4.3 & $(0.70)$ & 2.3 & $(0.54)$ & $1.7 !$ & $(0.77)$ & $\ddagger$ & $(\dagger)$ & $2.0 !$ & $(0.69)$ & $\ddagger$ & $(\dagger)$ & $\ddagger$ & $(\dagger)$ & $\ddagger$ & $(\dagger)$ \\
\hline 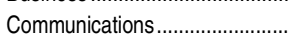 & 10 & $(1.0)$ & 14 & $(1.2)$ & 100.0 & 47.7 & $(3.71)$ & 39.3 & (3.89) & $2.1 !$ & $(0.97)$ & $2.8 !$ & $(0.95)$ & $\ddagger$ & $(t)$ & $\ddagger$ & $(\dagger)$ & $\ddagger$ & $(t)$ & $\ddagger$ & $(\dagger)$ & $\ddagger$ & $(t)$ & $\ddagger$ & $(\dagger)$ \\
\hline Education & 34 & (1.6) & 64 & (2.6) & 100.0 & 25.3 & (1.65) & 59.8 & (2.11) & 1.4 & $(0.41)$ & 5.2 & $(0.90)$ & 1.7 & $(0.37)$ & 3.4 & $(0.49)$ & $0.4 !$ & $(0.19)$ & $1.3 !$ & $(0.38)$ & $0.3 !$ & $(0.15)$ & $1.2 !$ & $(0.36)$ \\
\hline Teacher education................ & 13 & $(1.0)$ & 29 & (1.8) & 100.0 & 22.2 & $(2.41)$ & 63.9 & (2.84) & $0.9 !$ & $(0.35)$ & 6.4 & (1.17) & $1.3 !$ & $(0.41)$ & 2.2 & $(0.52)$ & $\ddagger$ & $(\dagger)$ & $\ddagger$ & $(\dagger)$ & $\ddagger$ & $(\dagger)$ & $1.6 !$ & $(0.69)$ \\
\hline Other education .... & 20 & (1.2) & 34 & $(1.8)$ & 100.0 & 27.9 & (2.53) & 56.4 & (2.98) & $1.9 !$ & $(0.66)$ & 4.1 & $(1.17)$ & 2.0 & $(0.57)$ & 4.5 & $(0.77)$ & $\ddagger$ & $(\dagger)$ & $1.6 !$ & $(0.60)$ & $\ddagger$ & $(\dagger)$ & $0.8 !$ & $(0.37)$ \\
\hline Engineering .............. & 9 & $(0.8)$ & 14 & (1.5) & 100.0 & 78.6 & $(3.70)$ & $6.8 !$ & $(2.77)$ & $\ddagger$ & $(\dagger)$ & $\ddagger$ & $(\dagger)$ & 1.7 & $(0.46)$ & $\ddagger$ & $(\dagger)$ & 8.0 & (2.13) & $\ddagger$ & $(\dagger)$ & $\ddagger$ & $(\dagger)$ & $\ddagger$ & $(†)$ \\
\hline Fine arts. & 38 & (1.5) & 48 & (3.6) & 100.0 & 44.8 & (2.06) & 43.9 & (2.44) & $1.7 !$ & $(0.54)$ & 1.3 & $(0.34)$ & 1.8 & $(0.49)$ & 0.9 & $(0.25)$ & $1.0 !$ & $(0.36)$ & $1.9 !$ & $(0.58)$ & $2.1 !$ & $(0.84)$ & $0.7 !$ & $(0.30)$ \\
\hline Health sciences ........... & 49 & (2.2) & 58 & (3.1) & 100.0 & 27.9 & $(1.65)$ & 57.1 & $(1.74)$ & $1.2 !$ & $(0.41)$ & 4.0 & $(0.52)$ & $0.8 !$ & $(0.26)$ & 1.4 & $(0.38)$ & 4.0 & $(0.87)$ & 2.4 & $(0.72)$ & $\ddagger$ & $(t)$ & $0.5 !$ & $(0.23)$ \\
\hline First-professional ..................... & 15 & (1.3) & 17 & (1.2) & 100.0 & 47.2 & (3.33) & 34.7 & (3.64) & $\ddagger$ & $(\dagger)$ & $2.1 !$ & $(0.92)$ & $\ddagger$ & $(\dagger)$ & $\ddagger$ & $(t)$ & $6.4 !$ & $(2.10)$ & $5.1 !$ & $(2.41)$ & $\ddagger$ & $(\dagger)$ & $\ddagger$ & $(\dagger)$ \\
\hline Nursing .............................. & 12 & $(0.8)$ & 13 & (1.3) & 100.0 & $\neq$ & $(t)$ & 86.3 & (2.04) & $\ddagger$ & $(\dagger)$ & 8.0 & $(1.30)$ & $\ddagger$ & $(\dagger)$ & $1.4 !$ & $(0.56)$ & $\ddagger$ & $(\dagger)$ & $\ddagger$ & $(\dagger)$ & $\ddagger$ & $(\dagger)$ & $\ddagger$ & $(\dagger)$ \\
\hline Other health sciences ............. & 21 & (1.7) & 28 & (2.0) & 100.0 & 29.4 & $(2.86)$ & 56.4 & (3.07) & $\ddagger$ & $(\dagger)$ & 3.2 & $(0.76)$ & $0.8 !$ & $(0.32)$ & $1.7 !$ & $(0.70)$ & 4.3 & $(1.23)$ & $1.4 !$ & $(0.56)$ & $\ddagger$ & $(\dagger)$ & $\ddagger$ & $(\dagger)$ \\
\hline Human & 74 & (2.1) & 80 & (2.5) & 100.0 & 35.9 & (1.52) & 49.2 & (1.61) & 1.6 & $(0.35)$ & 2.9 & $(0.45)$ & 2.3 & 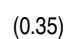 & 2.9 & $(0.44)$ & $0.9 !$ & $(0.30)$ & 2.7 & $(0.55)$ & $1.0 !$ & $(0.33)$ & $0.6 !$ & $(0.22)$ \\
\hline English and lit & 43 & (1.4) & 44 & (1.9) & 100.0 & 29.5 & (2.31) & 58.5 & (2.47) & 1.2 & $(0.33)$ & 4.3 & $(0.78)$ & $1.0 !$ & $(0.35)$ & 1.3 & $(0.37)$ & $1.0 !$ & $(0.41)$ & 1.6 & $(0.46)$ & $0.8 !$ & $(0.34)$ & $0.8 !$ & $(0.29)$ \\
\hline Foreign languages ............................. & 12 & (1.2) & 15 & (1.2) & 100.0 & 16.6 & (3.57) & 52.0 & (3.38) & $\ddagger$ & $(\dagger)$ & $2.0 !$ & $(0.80)$ & 7.2 & $(1.50)$ & 11.4 & $(1.97)$ & $\ddagger$ & $(t)$ & 7.9 & (2.18) & $\ddagger$ & $(t)$ & $\ddagger$ & $(\dagger)$ \\
\hline History......................................... & 11 & (0.7) & 11 & (1.0) & 100.0 & 61.1 & (4.58) & 28.9 & $(4.15)$ & $\ddagger$ & $(\dagger)$ & $\ddagger$ & $(t)$ & $2.5 !$ & (1.05) & $\ddagger$ & $(\dagger)$ & $\ddagger$ & $(\dagger)$ & $\ddagger$ & $(\dagger)$ & $\ddagger$ & $(\dagger)$ & $\ddagger$ & $(\dagger)$ \\
\hline Philosophy ................................. & 9 & $(0.6)$ & 10 & (1.2) & 100.0 & 65.7 & $(4.20)$ & 26.0 & $(4.60)$ & $3.5 !$ & (1.71) & $\ddagger$ & $(t)$ & $\ddagger$ & $(t)$ & $\ddagger$ & $(t)$ & $\ddagger$ & $(\dagger)$ & $\ddagger$ & $(t)$ & $\ddagger$ & $(\dagger)$ & $\ddagger$ & $(\dagger)$ \\
\hline Law ................. & 11 & $(0.8)$ & 11 & (1.2) & 100.0 & 52.6 & (4.43) & 32.8 & (4.18) & $4.4 !$ & $(1.41)$ & $2.0 !$ & $(0.82)$ & $2.2 !$ & $(1.05)$ & $\ddagger$ & $(t)$ & $\ddagger$ & $(\dagger)$ & $\ddagger$ & $(\dagger)$ & $\ddagger$ & $(\dagger)$ & $\ddagger$ & $(\dagger)$ \\
\hline Natural sciences .......................... & 65 & (2.2) & 90 & (2.9) & 100.0 & 50.5 & (1.72) & 32.4 & (1.73) & 3.8 & $(0.44)$ & 2.7 & $(0.36)$ & 1.9 & $(0.41)$ & 0.7 & $(0.16)$ & 4.2 & $(0.61)$ & 2.3 & $(0.46)$ & $1.0 !$ & $(0.34)$ & $0.5 !$ & $(0.26)$ \\
\hline Biolog & 11 & $(0.9)$ & 16 & $(1.0)$ & 100.0 & 41.7 & (3.76) & 40.1 & (3.78) & $2.2 !$ & $(0.67)$ & $2.1 !$ & $(0.90)$ & $1.0 !$ & $(0.39)$ & $1.0 !$ & $(0.40)$ & $5.6 !$ & (2.32) & $5.3 !$ & $(1.63)$ & $\ddagger$ & $(\dagger)$ & $\ddagger$ & $(\dagger)$ \\
\hline Physical sciences........................ & 11 & $(0.8)$ & 16 & (1.1) & 100.0 & 57.8 & (3.30) & 28.7 & (3.42) & $3.9 !$ & $(1.37)$ & $\ddagger$ & $(\dagger)$ & $\ddagger$ & $(t)$ & $0.9 !$ & $(0.41)$ & $3.1 !$ & $(1.06)$ & $2.6 !$ & $(0.99)$ & $\ddagger$ & $(\dagger)$ & $\ddagger$ & $(\dagger)$ \\
\hline Mathen & 24 & (1.4) & 32 & (2.3) & 100.0 & 46.6 & (3.20) & 36.0 & $(3.04)$ & 4.4 & $(0.78)$ & 3.1 & $(0.83)$ & $1.4 !$ & $(0.48)$ & $0.5 !$ & $(0.24)$ & 3.9 & $(0.85)$ & $1.8 !$ & $(0.64)$ & $\ddagger$ & $(\dagger)$ & $\ddagger$ & $(\dagger)$ \\
\hline Computer sciences.................. & 19 & (1.2) & 26 & (1.7) & 100.0 & 56.4 & (2.98) & 25.3 & (2.64) & 4.1 & $(1.03)$ & 3.7 & $(0.60)$ & $3.0 !$ & $(0.93)$ & $\ddagger$ & $(t)$ & 4.2 & $(1.10)$ & $\ddagger$ & $(t)$ & $1.4 !$ & $(0.63)$ & $\ddagger$ & $(\dagger)$ \\
\hline Social sci & 41 & (2.4) & 42 & (2.0) & 100.0 & 49.8 & $(1.85)$ & 32.9 & (2.09) & 3.7 & (0.68) & 3.0 & $(0.66)$ & 2.5 & $(0.65)$ & 1.5 & $(0.31)$ & $\ddagger$ & $(\dagger)$ & $\ddagger$ & $(\dagger)$ & $1.5 !$ & $(0.65)$ & $2.0 !$ & $(0.62)$ \\
\hline Economics & 4 & $(0.5)$ & 5 & $(0.8)$ & 100.0 & 68.6 & (7.36) & $9.3 !$ & $(4.08)$ & $7.2 !$ & (3.52) & $\ddagger$ & $(\dagger)$ & $\ddagger$ & $(\dagger)$ & $\ddagger$ & $(t)$ & $\ddagger$ & $(\dagger)$ & $\ddagger$ & $(t)$ & $\ddagger$ & $(\dagger)$ & $\ddagger$ & $(\dagger)$ \\
\hline Political science ...................... & 4 & $(0.4)$ & 5 & $(0.8)$ & 100.0 & 71.1 & (5.32) & $11.9 !$ & (3.93) & $5.7 !$ & (2.79) & $\ddagger$ & $(\dagger)$ & $\ddagger$ & $(t)$ & $\ddagger$ & $(\dagger)$ & $\ddagger$ & $(\dagger)$ & $\ddagger$ & $(\dagger)$ & $\ddagger$ & $(\dagger)$ & $\ddagger$ & $(\dagger)$ \\
\hline Psychol & 18 & (2.1) & 18 & (1.2) & 100.0 & 42.2 & (3.36) & 44.4 & (3.12) & $2.0 !$ & $(0.7)$ & $3.0 !$ & $(0.91)$ & $1.4 !$ & $(0.64)$ & $1.7 !$ & $(0.58)$ & $\ddagger$ & $(\dagger)$ & $\ddagger$ & $(\dagger)$ & $\ddagger$ & $(\dagger)$ & $2.2 !$ & $(0.93)$ \\
\hline Sociology …………………….... & 6 & $(0.5)$ & 7 & $(0.9)$ & 100.0 & 44.6 & $(6.09)$ & 30.7 & (6.03) & $4.0 !$ & $(1.61)$ & $4.1 !$ & $(1.54)$ & $\ddagger$ & $(t)$ & $1.6 !$ & $(0.76)$ & $\ddagger$ & $(t)$ & $\ddagger$ & $(t)$ & $\ddagger$ & $(\mathrm{t})$ & $\ddagger$ & $(\dagger)$ \\
\hline Other social sciences............... & 10 & (0.9) & 8 & $(0.8)$ & 100.0 & 46.2 & (4.24) & 36.4 & (4.19) & $\ddagger$ & $(t)$ & $4.5 !$ & $(1.85)$ & $\ddagger$ & $(t)$ & $1.9 !$ & $(0.83)$ & $\ddagger$ & $(t)$ & $2.8 !$ & $(1.29)$ & $\ddagger$ & $(t)$ & $\ddagger$ & $(\dagger)$ \\
\hline $\begin{array}{l}\text { Occupationally specific } \\
\text { programs }\end{array}$ & 17 & (11) & 37 & (2.4) & 1000 & 682 & (251) & 186 & (2.19) & 4.5 & (103) & $18 !$ & $(0,63)$ & 40 & $(0.92)$ & 061 & $(0,23)$ & \pm & (t) & t & (t) & $11 !$ & $(0,50)$ & t & (t) \\
\hline All other programs & 35 & $(1.6)$ & 19 & $(1.2)$ & 100.0 & 41.8 & (3.30) & 42.6 & (2.95) & $2.5 !$ & $(0.81)$ & 5.5 & $(1.46)$ & $1.9 !$ & $(0.58)$ & $2.6 !$ & $(0.90)$ & $\ddagger$ & $(t)$ & $1.2 !$ & $(0.63)$ & $\ddagger$ & $(\dagger)$ & $\ddagger$ & (†) \\
\hline
\end{tabular}

†Not applicable.

\#Rounds to zero.

The coeficient of variation (CV) for this estimate is between 30 and 50 percent

Cither there are too few cases for a reliable estimate or the coefficient of variation (CV) is 50 percent or greater.

NOTE: Degree-granting institutions grant associate's or higher degrees and participate in Title IV federal financial aid programs. Totals may differ from figures reported in other tables because of varying survey methodologies. Race categories SOURCE:

ondary Faculty (NSOPF:99;04). (This table was prepared December 2008.) 
Table 316.10. Average salary of full-time instructional faculty on 9-month contracts in degree-granting postsecondary institutions, by academic rank, control and level of institution, and sex: Selected years, 1970-71 through 2012-13

\begin{tabular}{|c|c|c|c|c|c|c|c|c|c|c|c|c|c|}
\hline \multirow[b]{2}{*}{ Sex and academic year } & \multirow[b]{2}{*}{ All faculty } & \multicolumn{6}{|c|}{ Academic rank } & \multicolumn{3}{|c|}{ Public institutions } & \multicolumn{3}{|c|}{ Private institutions } \\
\hline & & Professor & $\begin{array}{l}\text { Associate } \\
\text { professor }\end{array}$ & $\begin{array}{l}\text { Assistant } \\
\text { professor }\end{array}$ & Instructor & Lecturer & No rank & Total & 4-year & 2-year & Total & 4-year & 2-year \\
\hline 1 & 2 & 3 & 4 & 5 & 6 & 7 & 8 & 9 & 10 & 11 & 12 & 13 & 14 \\
\hline & \multicolumn{13}{|c|}{ Current dollars } \\
\hline 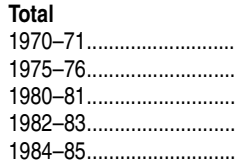 & $\begin{array}{r}\$ 12,710 \\
16,659 \\
23,302 \\
27,196 \\
30,447\end{array}$ & $\begin{array}{r}\$ 17,958 \\
22,649 \\
30,753 \\
35,540 \\
39,743\end{array}$ & $\begin{array}{r}\$ 13,563 \\
17,065 \\
23,214 \\
26,921 \\
29,945\end{array}$ & $\begin{array}{r}\$ 11,176 \\
13,986 \\
18,901 \\
22,056 \\
24,668\end{array}$ & $\begin{array}{l}\$ 9,360 \\
13,672 \\
15,178 \\
17,601 \\
20,230\end{array}$ & $\begin{array}{r}\$ 11,196 \\
12,906 \\
17,301 \\
20,072 \\
22,334\end{array}$ & $\begin{array}{r}\$ 12,333 \\
15,196 \\
22,334 \\
25,557 \\
27,683\end{array}$ & $\begin{array}{r}\$ 12,953 \\
16,942 \\
23,745 \\
27,488 \\
30,646\end{array}$ & $\begin{array}{r}\$ 13,121 \\
17,400 \\
24,373 \\
28,293 \\
31,764\end{array}$ & $\begin{array}{r}\$ 12,644 \\
15,820 \\
22,177 \\
25,567 \\
27,864\end{array}$ & $\begin{array}{r}\$ 11,619 \\
15,921 \\
22,093 \\
26,393 \\
29,910\end{array}$ & $\begin{array}{r}\$ 11,824 \\
16,116 \\
22,325 \\
26,691 \\
30,247\end{array}$ & $\begin{array}{l}\$ 8,664 \\
10,901 \\
15,065 \\
16,595 \\
18,510\end{array}$ \\
\hline $\begin{array}{l}1985-86 \ldots \ldots \ldots \\
1987-88 \ldots \ldots \ldots \ldots \ldots \ldots \\
1989-90 \ldots \ldots \ldots \ldots \ldots \ldots \ldots \ldots \ldots \ldots \\
1990-91 \\
1991-92\end{array}$ & $\begin{array}{l}32,392 \\
35,897 \\
40,133 \\
42,165 \\
43,851\end{array}$ & $\begin{array}{l}42,268 \\
47,040 \\
52,810 \\
55,540 \\
57,433\end{array}$ & $\begin{array}{l}31,787 \\
35,231 \\
39,392 \\
41,414 \\
42,929\end{array}$ & $\begin{array}{l}26,277 \\
29,110 \\
32,689 \\
34,434 \\
35,745\end{array}$ & $\begin{array}{l}20,918 \\
22,728 \\
25,030 \\
26,332 \\
30,916\end{array}$ & $\begin{array}{l}23,770 \\
25,977 \\
28,990 \\
30,097 \\
30,456\end{array}$ & $\begin{array}{l}29,088 \\
31,532 \\
34,559 \\
36,395 \\
37,783\end{array}$ & $\begin{array}{l}32,750 \\
36,231 \\
40,416 \\
42,317 \\
43,641\end{array}$ & $\begin{array}{l}34,033 \\
37,840 \\
42,365 \\
44,510 \\
45,638\end{array}$ & $\begin{array}{l}29,590 \\
32,209 \\
35,516 \\
37,055 \\
38,959\end{array}$ & $\begin{array}{l}31,402 \\
35,049 \\
39,464 \\
41,788 \\
44,376\end{array}$ & $\begin{array}{l}31,732 \\
35,346 \\
39,817 \\
42,224 \\
44,793\end{array}$ & $\begin{array}{l}19,436 \\
21,867 \\
24,601 \\
24,088 \\
25,673\end{array}$ \\
\hline 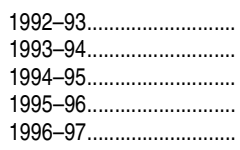 & $\begin{array}{l}44,714 \\
46,364 \\
47,811 \\
49,309 \\
50,829\end{array}$ & $\begin{array}{l}58,788 \\
60,649 \\
62,709 \\
64,540 \\
66,659\end{array}$ & $\begin{array}{l}43,945 \\
45,278 \\
46,713 \\
47,966 \\
49,307\end{array}$ & $\begin{array}{l}36,625 \\
37,630 \\
38,756 \\
39,696 \\
40,687\end{array}$ & $\begin{array}{l}28,499 \\
28,828 \\
29,665 \\
30,344 \\
31,193\end{array}$ & $\begin{array}{l}30,543 \\
32,729 \\
33,198 \\
34,136 \\
34,962\end{array}$ & $\begin{array}{l}37,771 \\
40,584 \\
41,227 \\
42,996 \\
44,200\end{array}$ & $\begin{array}{l}44,197 \\
45,920 \\
47,432 \\
48,837 \\
50,303\end{array}$ & $\begin{array}{l}46,515 \\
48,019 \\
49,738 \\
51,172 \\
52,718\end{array}$ & $\begin{array}{l}38,935 \\
41,040 \\
42,101 \\
43,295 \\
44,584\end{array}$ & $\begin{array}{l}45,985 \\
47,465 \\
48,741 \\
50,466 \\
52,112\end{array}$ & $\begin{array}{l}46,427 \\
47,880 \\
49,379 \\
50,819 \\
52,443\end{array}$ & $\begin{array}{l}26,105 \\
28,435 \\
25,613 \\
31,915 \\
32,628\end{array}$ \\
\hline 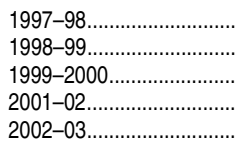 & $\begin{array}{l}52,335 \\
54,097 \\
55,888 \\
59,742 \\
61,330\end{array}$ & $\begin{array}{l}68,731 \\
71,322 \\
74,410 \\
80,792 \\
83,466\end{array}$ & $\begin{array}{l}50,828 \\
52,576 \\
54,524 \\
58,724 \\
60,471\end{array}$ & $\begin{array}{l}41,830 \\
43,348 \\
44,978 \\
48,796 \\
50,552\end{array}$ & $\begin{array}{l}32,449 \\
33,819 \\
34,918 \\
46,959 \\
48,304\end{array}$ & $\begin{array}{l}35,484 \\
36,819 \\
38,194 \\
41,798 \\
42,622\end{array}$ & $\begin{array}{l}45,268 \\
46,250 \\
47,389 \\
46,569 \\
46,338\end{array}$ & $\begin{array}{l}51,638 \\
53,319 \\
55,011 \\
58,524 \\
60,014\end{array}$ & $\begin{array}{l}54,114 \\
55,948 \\
57,950 \\
62,013 \\
63,486\end{array}$ & $\begin{array}{l}45,919 \\
47,285 \\
48,240 \\
50,837 \\
52,330\end{array}$ & $\begin{array}{l}54,039 \\
55,981 \\
58,013 \\
62,818 \\
64,533\end{array}$ & $\begin{array}{l}54,379 \\
56,284 \\
58,323 \\
63,088 \\
64,814\end{array}$ & $\begin{array}{l}33,592 \\
34,821 \\
35,925 \\
33,139 \\
34,826\end{array}$ \\
\hline 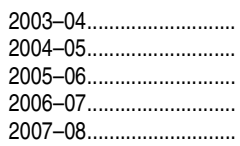 & $\begin{array}{l}62,579 \\
64,234 \\
66,172 \\
68,585 \\
71,085\end{array}$ & $\begin{array}{l}85,333 \\
88,158 \\
91,208 \\
94,870 \\
98,548\end{array}$ & $\begin{array}{l}61,746 \\
63,558 \\
65,714 \\
68,153 \\
70,826\end{array}$ & $\begin{array}{l}51,798 \\
53,308 \\
55,106 \\
57,143 \\
59,294\end{array}$ & $\begin{array}{l}49,065 \\
49,730 \\
50,883 \\
53,278 \\
55,325\end{array}$ & $\begin{array}{l}43,648 \\
44,514 \\
45,896 \\
47,478 \\
49,392\end{array}$ & $\begin{array}{l}47,725 \\
48,942 \\
50,425 \\
52,161 \\
54,405\end{array}$ & $\begin{array}{l}60,874 \\
62,346 \\
64,158 \\
66,566 \\
68,981\end{array}$ & $\begin{array}{l}64,340 \\
66,053 \\
67,951 \\
70,460 \\
72,857\end{array}$ & $\begin{array}{l}53,076 \\
53,932 \\
55,405 \\
57,466 \\
59,646\end{array}$ & $\begin{array}{l}66,666 \\
68,755 \\
71,016 \\
73,419 \\
76,133\end{array}$ & $\begin{array}{l}66,932 \\
68,995 \\
71,263 \\
73,636 \\
76,341\end{array}$ & $\begin{array}{l}36,322 \\
37,329 \\
38,549 \\
41,138 \\
43,402\end{array}$ \\
\hline 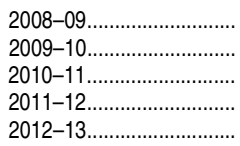 & $\begin{array}{l}73,570 \\
74,625 \\
75,472 \\
76,570 \\
77,301\end{array}$ & $\begin{array}{l}102,346 \\
103,684 \\
104,957 \\
107,091 \\
108,310\end{array}$ & $\begin{array}{l}73,439 \\
74,126 \\
75,103 \\
76,175 \\
77,089\end{array}$ & $\begin{array}{l}61,550 \\
62,246 \\
63,140 \\
64,009 \\
64,632\end{array}$ & $\begin{array}{l}56,918 \\
57,797 \\
57,943 \\
58,349 \\
57,495\end{array}$ & $\begin{array}{l}51,188 \\
52,177 \\
52,549 \\
53,361 \\
53,394\end{array}$ & $\begin{array}{l}56,370 \\
56,807 \\
56,549 \\
56,922 \\
58,254\end{array}$ & $\begin{array}{l}71,237 \\
72,183 \\
72,704 \\
73,503 \\
73,909\end{array}$ & $\begin{array}{l}75,245 \\
76,153 \\
76,861 \\
77,843 \\
78,111\end{array}$ & $\begin{array}{l}61,433 \\
62,265 \\
62,301 \\
62,568 \\
62,781\end{array}$ & $\begin{array}{l}79,147 \\
80,385 \\
81,892 \\
83,534 \\
85,000\end{array}$ & $\begin{array}{l}79,410 \\
80,603 \\
82,094 \\
83,695 \\
85,167\end{array}$ & $\begin{array}{l}43,542 \\
44,748 \\
45,146 \\
47,805 \\
44,978\end{array}$ \\
\hline \multicolumn{14}{|l|}{ Males } \\
\hline 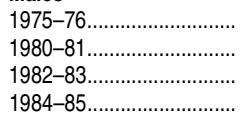 & $\begin{array}{l}17,414 \\
24,499 \\
28,664 \\
32,182\end{array}$ & $\begin{array}{l}22,902 \\
31,082 \\
35,956 \\
40,269\end{array}$ & $\begin{array}{l}17,209 \\
23,451 \\
27,262 \\
30,392\end{array}$ & $\begin{array}{l}14,174 \\
19,227 \\
22,586 \\
25,330\end{array}$ & $\begin{array}{l}14,430 \\
15,545 \\
18,160 \\
21,159\end{array}$ & $\begin{array}{l}13,579 \\
18,281 \\
21,225 \\
23,557\end{array}$ & $\begin{array}{l}15,761 \\
23,170 \\
26,541 \\
28,670\end{array}$ & $\begin{array}{l}17,661 \\
24,873 \\
28,851 \\
32,240\end{array}$ & $\begin{array}{l}18,121 \\
25,509 \\
29,661 \\
33,344\end{array}$ & $\begin{array}{l}16,339 \\
22,965 \\
26,524 \\
28,891\end{array}$ & $\begin{array}{l}16,784 \\
23,493 \\
28,159 \\
32,028\end{array}$ & $\begin{array}{l}16,946 \\
23,669 \\
28,380 \\
32,278\end{array}$ & $\begin{array}{l}11,378 \\
16,075 \\
17,346 \\
19,460\end{array}$ \\
\hline 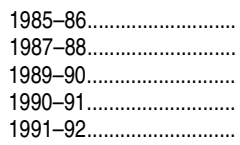 & $\begin{array}{l}34,294 \\
38,112 \\
42,763 \\
45,065 \\
46,848\end{array}$ & $\begin{array}{l}42,833 \\
47,735 \\
53,650 \\
56,549 \\
58,494\end{array}$ & $\begin{array}{l}32,273 \\
35,823 \\
40,131 \\
42,239 \\
43,814\end{array}$ & $\begin{array}{l}27,094 \\
30,086 \\
33,781 \\
35,636 \\
36,969\end{array}$ & $\begin{array}{l}21,693 \\
23,645 \\
25,933 \\
27,388 \\
33,359\end{array}$ & $\begin{array}{l}25,238 \\
27,652 \\
31,162 \\
32,398 \\
32,843\end{array}$ & $\begin{array}{l}30,267 \\
32,747 \\
35,980 \\
38,036 \\
39,422\end{array}$ & $\begin{array}{l}34,528 \\
38,314 \\
42,959 \\
45,084 \\
46,483\end{array}$ & $\begin{array}{l}35,786 \\
39,898 \\
44,834 \\
47,168 \\
48,401\end{array}$ & $\begin{array}{l}30,758 \\
33,477 \\
37,081 \\
38,787 \\
40,811\end{array}$ & $\begin{array}{l}33,656 \\
37,603 \\
42,312 \\
45,019 \\
47,733\end{array}$ & $\begin{array}{l}33,900 \\
37,817 \\
42,595 \\
45,319 \\
48,042\end{array}$ & $\begin{array}{l}20,412 \\
22,641 \\
25,218 \\
25,937 \\
26,825\end{array}$ \\
\hline $\begin{array}{l}1992-93 \\
1993-94 \ldots \ldots \ldots \ldots \ldots \\
1994-95 \ldots \ldots \ldots \ldots \ldots \ldots \ldots \\
1995-96 \ldots \ldots \ldots \ldots \ldots \ldots \ldots \ldots \\
1996-97\end{array}$ & $\begin{array}{l}47,866 \\
49,579 \\
51,228 \\
52,814 \\
54,465\end{array}$ & $\begin{array}{l}59,972 \\
61,857 \\
64,046 \\
65,949 \\
68,214\end{array}$ & $\begin{array}{l}44,855 \\
46,229 \\
47,705 \\
49,037 \\
50,457\end{array}$ & $\begin{array}{l}37,842 \\
38,794 \\
39,923 \\
40,858 \\
41,864\end{array}$ & $\begin{array}{l}29,583 \\
29,815 \\
30,528 \\
30,940 \\
31,738\end{array}$ & $\begin{array}{l}32,512 \\
34,796 \\
35,082 \\
36,135 \\
36,932\end{array}$ & $\begin{array}{l}39,365 \\
42,251 \\
43,103 \\
44,624 \\
45,688\end{array}$ & $\begin{array}{l}47,175 \\
48,956 \\
50,629 \\
52,163 \\
53,737\end{array}$ & $\begin{array}{l}49,392 \\
50,989 \\
52,874 \\
54,448 \\
56,162\end{array}$ & $\begin{array}{l}40,725 \\
42,938 \\
44,020 \\
45,209 \\
46,393\end{array}$ & $\begin{array}{l}49,518 \\
51,076 \\
52,653 \\
54,364 \\
56,185\end{array}$ & $\begin{array}{l}49,837 \\
51,397 \\
53,036 \\
54,649 \\
56,453\end{array}$ & $\begin{array}{l}27,402 \\
30,783 \\
29,639 \\
33,301 \\
34,736\end{array}$ \\
\hline 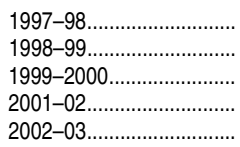 & $\begin{array}{l}56,115 \\
58,048 \\
60,084 \\
64,320 \\
66,126\end{array}$ & $\begin{array}{l}70,468 \\
73,260 \\
76,478 \\
83,356 \\
86,191\end{array}$ & $\begin{array}{l}52,041 \\
53,830 \\
55,939 \\
60,300 \\
62,226\end{array}$ & $\begin{array}{l}43,017 \\
44,650 \\
46,414 \\
50,518 \\
52,441\end{array}$ & $\begin{array}{l}33,070 \\
34,741 \\
35,854 \\
48,844 \\
50,272\end{array}$ & $\begin{array}{l}37,481 \\
38,976 \\
40,202 \\
44,519 \\
45,469\end{array}$ & $\begin{array}{l}46,822 \\
47,610 \\
48,788 \\
48,049 \\
47,412\end{array}$ & $\begin{array}{l}55,191 \\
57,038 \\
58,984 \\
62,835 \\
64,564\end{array}$ & $\begin{array}{l}57,744 \\
59,805 \\
62,030 \\
66,577 \\
68,322\end{array}$ & $\begin{array}{l}47,690 \\
48,961 \\
50,033 \\
52,360 \\
53,962\end{array}$ & $\begin{array}{l}58,293 \\
60,392 \\
62,631 \\
67,871 \\
69,726\end{array}$ & $\begin{array}{l}58,576 \\
60,641 \\
62,905 \\
68,100 \\
69,976\end{array}$ & $\begin{array}{l}36,157 \\
38,040 \\
38,636 \\
33,395 \\
34,291\end{array}$ \\
\hline 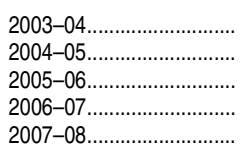 & $\begin{array}{l}67,485 \\
69,337 \\
71,569 \\
74,167 \\
76,935\end{array}$ & $\begin{array}{r}88,262 \\
91,290 \\
94,733 \\
98,563 \\
102,555\end{array}$ & $\begin{array}{l}63,466 \\
65,394 \\
67,654 \\
70,168 \\
72,940\end{array}$ & $\begin{array}{l}53,649 \\
55,215 \\
57,099 \\
59,150 \\
61,368\end{array}$ & $\begin{array}{l}50,985 \\
51,380 \\
52,519 \\
55,061 \\
57,116\end{array}$ & $\begin{array}{l}46,214 \\
46,929 \\
48,256 \\
49,641 \\
51,804\end{array}$ & $\begin{array}{l}48,973 \\
50,102 \\
51,811 \\
53,665 \\
56,196\end{array}$ & $\begin{array}{l}65,476 \\
67,130 \\
69,191 \\
71,797 \\
74,389\end{array}$ & $\begin{array}{l}69,248 \\
71,145 \\
73,353 \\
76,072 \\
78,673\end{array}$ & $\begin{array}{l}54,623 \\
55,398 \\
56,858 \\
58,971 \\
61,166\end{array}$ & $\begin{array}{l}72,021 \\
74,318 \\
76,941 \\
79,491 \\
82,681\end{array}$ & $\begin{array}{l}72,250 \\
74,540 \\
77,143 \\
79,663 \\
82,850\end{array}$ & $\begin{array}{l}35,604 \\
34,970 \\
38,215 \\
41,196 \\
42,995\end{array}$ \\
\hline 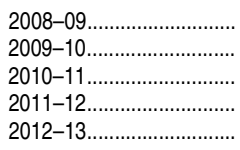 & $\begin{array}{l}79,706 \\
80,885 \\
81,868 \\
83,154 \\
84,026\end{array}$ & $\begin{array}{l}106,759 \\
108,227 \\
109,656 \\
112,068 \\
113,595\end{array}$ & $\begin{array}{l}75,634 \\
76,401 \\
77,423 \\
78,559 \\
79,508\end{array}$ & $\begin{array}{l}63,726 \\
64,450 \\
65,392 \\
66,300 \\
66,937\end{array}$ & $\begin{array}{l}58,819 \\
59,799 \\
59,792 \\
60,064 \\
59,161\end{array}$ & $\begin{array}{l}53,777 \\
54,946 \\
55,435 \\
56,363 \\
56,190\end{array}$ & $\begin{array}{l}58,341 \\
58,649 \\
58,392 \\
58,833 \\
60,386\end{array}$ & $\begin{array}{l}76,897 \\
77,951 \\
78,603 \\
79,550 \\
80,072\end{array}$ & $\begin{array}{l}81,394 \\
82,428 \\
83,288 \\
84,443 \\
84,822\end{array}$ & $\begin{array}{l}62,870 \\
63,698 \\
63,683 \\
63,932 \\
64,152\end{array}$ & $\begin{array}{l}86,008 \\
87,386 \\
88,996 \\
90,838 \\
92,485\end{array}$ & $\begin{array}{l}86,205 \\
87,549 \\
89,155 \\
90,974 \\
92,632\end{array}$ & $\begin{array}{l}43,871 \\
44,500 \\
44,542 \\
45,250 \\
42,906\end{array}$ \\
\hline
\end{tabular}

See notes at end of table. 
516 CHAPTER 3: Postsecondary Education

Faculty Salaries and Benefits

Table 316.10. Average salary of full-time instructional faculty on 9-month contracts in degree-granting postsecondary institutions, by academic rank, control and level of institution, and sex: Selected years, 1970-71 through 2012-13-Continued

\begin{tabular}{|c|c|c|c|c|c|c|c|c|c|c|c|c|c|}
\hline \multirow[b]{2}{*}{ Sex and academic year } & \multirow[b]{2}{*}{ All faculty } & \multicolumn{6}{|c|}{ Academic rank } & \multicolumn{3}{|c|}{ Public institutions } & \multicolumn{3}{|c|}{ Private institutions } \\
\hline & & Professor & $\begin{array}{c}\text { Associate } \\
\text { professor }\end{array}$ & $\begin{array}{l}\text { Assistant } \\
\text { professor }\end{array}$ & Instructor & Lecturer & No rank & Total & 4-year & 2-year & Total & 4-year & 2-year \\
\hline 1 & 2 & 3 & 4 & 5 & 6 & 7 & 8 & 9 & 10 & 11 & 12 & 13 & 14 \\
\hline $\begin{array}{l}\text { Females } \\
1975-76 \\
1980-81 \ldots \ldots \\
1982-83 \ldots \ldots \\
1984-85 \ldots \ldots\end{array}$ & $\begin{array}{l}14,308 \\
19,996 \\
23,261 \\
25,941\end{array}$ & $\begin{array}{l}20,308 \\
27,959 \\
32,221 \\
35,824\end{array}$ & $\begin{array}{l}16,364 \\
22,295 \\
25,738 \\
28,517\end{array}$ & $\begin{array}{l}13,522 \\
18,302 \\
21,130 \\
23,575\end{array}$ & $\begin{array}{l}12,572 \\
14,854 \\
17,102 \\
19,362\end{array}$ & $\begin{array}{l}11,901 \\
16,168 \\
18,830 \\
21,004\end{array}$ & $\begin{array}{l}14,094 \\
20,843 \\
23,855 \\
26,050\end{array}$ & $\begin{array}{l}14,762 \\
20,673 \\
23,892 \\
26,566\end{array}$ & $\begin{array}{l}14,758 \\
20,608 \\
23,876 \\
26,813\end{array}$ & $\begin{array}{l}14,769 \\
20,778 \\
23,917 \\
26,172\end{array}$ & $\begin{array}{l}13,030 \\
18,073 \\
21,451 \\
24,186\end{array}$ & $\begin{array}{l}13,231 \\
18,326 \\
21,785 \\
24,560\end{array}$ & $\begin{array}{l}10,201 \\
13,892 \\
15,845 \\
17,575\end{array}$ \\
\hline $\begin{array}{l}1985-86 \\
1987-88 \ldots \\
1989-90 \\
1990-91 \ldots \ldots \\
1991-92\end{array}$ & $\begin{array}{l}27,576 \\
30,499 \\
34,183 \\
35,881 \\
37,534\end{array}$ & $\begin{array}{l}38,252 \\
42,371 \\
47,663 \\
49,728 \\
51,621\end{array}$ & $\begin{array}{l}30,300 \\
33,528 \\
37,469 \\
39,329 \\
40,766\end{array}$ & $\begin{array}{l}24,966 \\
27,600 \\
31,090 \\
32,724 \\
34,063\end{array}$ & $\begin{array}{l}20,237 \\
21,962 \\
24,320 \\
25,534 \\
28,873\end{array}$ & $\begin{array}{l}22,273 \\
24,370 \\
26,995 \\
28,111 \\
28,550\end{array}$ & $\begin{array}{l}27,171 \\
29,605 \\
32,528 \\
34,179 \\
35,622\end{array}$ & $\begin{array}{l}28,299 \\
31,215 \\
34,796 \\
36,459 \\
37,800\end{array}$ & $\begin{array}{l}28,680 \\
31,820 \\
35,704 \\
37,573 \\
38,634\end{array}$ & $\begin{array}{l}27,693 \\
30,228 \\
33,307 \\
34,720 \\
36,517\end{array}$ & $\begin{array}{l}25,523 \\
28,621 \\
32,650 \\
34,359 \\
36,828\end{array}$ & $\begin{array}{l}25,889 \\
28,946 \\
33,010 \\
34,898 \\
37,309\end{array}$ & $\begin{array}{l}18,504 \\
21,215 \\
24,002 \\
22,585 \\
24,683\end{array}$ \\
\hline 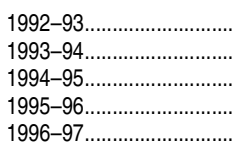 & $\begin{array}{l}38,385 \\
40,058 \\
41,369 \\
42,871 \\
44,325\end{array}$ & $\begin{array}{l}52,755 \\
54,746 \\
56,555 \\
58,318 \\
60,160\end{array}$ & $\begin{array}{l}41,861 \\
43,178 \\
44,626 \\
45,803 \\
47,101\end{array}$ & $\begin{array}{l}35,032 \\
36,169 \\
37,352 \\
38,345 \\
39,350\end{array}$ & $\begin{array}{l}27,700 \\
28,136 \\
29,072 \\
29,940 \\
30,819\end{array}$ & $\begin{array}{l}28,922 \\
31,048 \\
31,677 \\
32,584 \\
33,415\end{array}$ & $\begin{array}{l}35,792 \\
38,474 \\
38,967 \\
41,085 \\
42,474\end{array}$ & $\begin{array}{l}38,356 \\
40,118 \\
41,548 \\
42,871 \\
44,306\end{array}$ & $\begin{array}{l}39,470 \\
41,031 \\
42,663 \\
43,986 \\
45,402\end{array}$ & $\begin{array}{l}36,710 \\
38,707 \\
39,812 \\
41,086 \\
42,531\end{array}$ & $\begin{array}{l}38,460 \\
39,902 \\
40,908 \\
42,871 \\
44,374\end{array}$ & $\begin{array}{l}38,987 \\
40,378 \\
41,815 \\
43,236 \\
44,726\end{array}$ & $\begin{array}{l}25,068 \\
26,142 \\
22,851 \\
30,671 \\
30,661\end{array}$ \\
\hline $\begin{array}{l}1997-98 \ldots \ldots \ldots \ldots \ldots . . \\
1998-99 \ldots \ldots \ldots \ldots . . \\
1999-2000 \ldots \ldots \ldots . . \\
2001-02 \ldots \ldots \ldots \ldots . . \\
2002-03 \ldots \ldots \ldots \ldots . .\end{array}$ & $\begin{array}{l}45,775 \\
47,421 \\
48,997 \\
52,662 \\
54,105\end{array}$ & $\begin{array}{l}61,965 \\
64,236 \\
67,079 \\
72,542 \\
75,028\end{array}$ & $\begin{array}{l}48,597 \\
50,347 \\
52,091 \\
56,186 \\
57,716\end{array}$ & $\begin{array}{l}40,504 \\
41,894 \\
43,367 \\
46,824 \\
48,380\end{array}$ & $\begin{array}{l}32,011 \\
33,152 \\
34,228 \\
45,262 \\
46,573\end{array}$ & $\begin{array}{l}33,918 \\
35,115 \\
36,607 \\
39,538 \\
40,265\end{array}$ & $\begin{array}{l}43,491 \\
44,723 \\
45,865 \\
45,003 \\
45,251\end{array}$ & $\begin{array}{l}45,648 \\
47,247 \\
48,714 \\
52,123 \\
53,435\end{array}$ & $\begin{array}{l}46,709 \\
48,355 \\
50,168 \\
53,895 \\
55,121\end{array}$ & $\begin{array}{l}43,943 \\
45,457 \\
46,340 \\
49,290 \\
50,717\end{array}$ & $\begin{array}{l}46,106 \\
47,874 \\
49,737 \\
54,149 \\
55,881\end{array}$ & $\begin{array}{l}46,466 \\
48,204 \\
50,052 \\
54,434 \\
56,158\end{array}$ & $\begin{array}{l}30,995 \\
31,524 \\
32,951 \\
32,921 \\
35,296\end{array}$ \\
\hline $\begin{array}{l}2003-04 \ldots \ldots \ldots \ldots \ldots \\
2004-05 \ldots \ldots \ldots \ldots \ldots \\
2005-06 \ldots \ldots \ldots \ldots \ldots \\
2006-07 \ldots \ldots \ldots \ldots \ldots \\
2007-08 \ldots \ldots \ldots \ldots \ldots \\
.\end{array}$ & \begin{tabular}{l|}
55,378 \\
56,926 \\
58,665 \\
61,016 \\
63,347
\end{tabular} & $\begin{array}{l}76,652 \\
79,160 \\
81,514 \\
85,090 \\
88,301\end{array}$ & $\begin{array}{l}59,095 \\
60,809 \\
62,860 \\
65,237 \\
67,816\end{array}$ & $\begin{array}{l}49,689 \\
51,154 \\
52,901 \\
54,974 \\
57,111\end{array}$ & $\begin{array}{l}47,404 \\
48,351 \\
49,533 \\
51,832 \\
53,889\end{array}$ & $\begin{array}{l}41,536 \\
42,455 \\
43,934 \\
45,693 \\
47,407\end{array}$ & $\begin{array}{l}46,519 \\
47,860 \\
49,172 \\
50,812 \\
52,837\end{array}$ & $\begin{array}{l}54,408 \\
55,780 \\
57,462 \\
59,781 \\
62,129\end{array}$ & $\begin{array}{l}56,117 \\
57,714 \\
59,437 \\
61,875 \\
64,226\end{array}$ & $\begin{array}{l}51,591 \\
52,566 \\
54,082 \\
56,127 \\
58,318\end{array}$ & $\begin{array}{l}57,921 \\
59,919 \\
61,830 \\
64,246 \\
66,528\end{array}$ & $\begin{array}{l}58,192 \\
60,143 \\
62,092 \\
64,481 \\
66,745\end{array}$ & $\begin{array}{l}36,896 \\
39,291 \\
38,786 \\
41,099 \\
43,670\end{array}$ \\
\hline 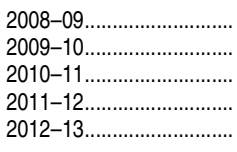 & $\begin{array}{l}65,638 \\
66,653 \\
67,461 \\
68,470 \\
69,114 \\
\end{array}$ & $\begin{array}{l}91,522 \\
92,835 \\
94,032 \\
95,840 \\
96,680 \\
\end{array}$ & $\begin{array}{l}70,375 \\
71,019 \\
72,001 \\
73,053 \\
73,991 \\
\end{array}$ & $\begin{array}{l}59,286 \\
60,001 \\
60,893 \\
61,761 \\
62,382 \\
\end{array}$ & $\begin{array}{l}55,424 \\
56,246 \\
56,506 \\
57,013 \\
56,188 \\
\end{array}$ & $\begin{array}{l}49,078 \\
49,945 \\
50,227 \\
51,001 \\
51,200 \\
\end{array}$ & $\begin{array}{l}54,649 \\
55,211 \\
54,985 \\
55,319 \\
56,461 \\
\end{array}$ & $\begin{array}{l}64,231 \\
65,144 \\
65,615 \\
66,375 \\
66,706 \\
\end{array}$ & $\begin{array}{l}66,393 \\
67,283 \\
67,937 \\
68,897 \\
69,150 \\
\end{array}$ & $\begin{array}{l}60,195 \\
61,047 \\
61,138 \\
61,433 \\
61,652 \\
\end{array}$ & $\begin{array}{l}69,300 \\
70,516 \\
72,088 \\
73,617 \\
75,002\end{array}$ & $\begin{array}{l}69,593 \\
70,756 \\
72,302 \\
73,776 \\
75,166\end{array}$ & $\begin{array}{l}43,344 \\
44,892 \\
45,518 \\
49,382 \\
46,407 \\
\end{array}$ \\
\hline $2012-13 \ldots \ldots \ldots \ldots \ldots \ldots \ldots \ldots$ & \multicolumn{13}{|c|}{ Constant 2012-13 dollars ${ }^{1}$} \\
\hline $\begin{array}{l}\text { Total } \\
1970-71 \ldots \ldots \ldots \ldots \\
1975-76 \ldots \ldots \ldots \ldots \ldots \\
1980-81 \ldots \ldots \ldots \ldots \ldots \ldots \\
1982-83 \ldots \ldots \ldots \ldots \ldots \ldots \ldots \\
1984-85 \ldots \ldots \ldots \ldots \ldots \ldots \ldots\end{array}$ & $\begin{array}{l}74,019 \\
69,494 \\
62,233 \\
64,104 \\
66,599\end{array}$ & $\begin{array}{r}104,582 \\
94,485 \\
82,133 \\
83,772 \\
86,933\end{array}$ & $\begin{array}{l}78,991 \\
71,190 \\
61,998 \\
63,456 \\
65,501\end{array}$ & $\begin{array}{l}65,087 \\
58,345 \\
50,479 \\
51,989 \\
53,958\end{array}$ & $\begin{array}{l}54,509 \\
57,037 \\
40,536 \\
41,488 \\
44,251\end{array}$ & $\begin{array}{l}65,204 \\
53,839 \\
46,206 \\
47,312 \\
48,853\end{array}$ & $\begin{array}{l}71,827 \\
63,392 \\
59,648 \\
60,241 \\
60,553\end{array}$ & $\begin{array}{l}75,438 \\
70,676 \\
63,416 \\
64,793 \\
67,034\end{array}$ & $\begin{array}{l}76,417 \\
72,587 \\
65,094 \\
66,690 \\
69,480\end{array}$ & $\begin{array}{l}73,637 \\
65,994 \\
59,229 \\
60,265 \\
60,949\end{array}$ & $\begin{array}{l}67,664 \\
66,416 \\
59,004 \\
62,212 \\
65,424\end{array}$ & $\begin{array}{l}68,863 \\
67,232 \\
59,624 \\
62,914 \\
66,162\end{array}$ & $\begin{array}{l}50,458 \\
45,474 \\
40,235 \\
39,117 \\
40,488\end{array}$ \\
\hline $\begin{array}{l}1985-86 \ldots \ldots \ldots \ldots \ldots \ldots \ldots . . . \\
1987-88 \ldots \ldots \ldots \ldots \ldots \ldots \ldots . . \\
1989-90 \ldots \ldots \ldots \ldots \ldots \ldots \ldots . . . \\
1990-91 \ldots \ldots \ldots \ldots \ldots \ldots \ldots . . . \\
1991-92 \ldots \ldots \ldots \ldots \ldots \ldots \ldots . . .\end{array}$ & $\begin{array}{l}68,867 \\
71,691 \\
73,123 \\
72,844 \\
73,405\end{array}$ & $\begin{array}{l}89,865 \\
93,945 \\
96,221 \\
95,950 \\
96,139\end{array}$ & $\begin{array}{l}67,581 \\
70,361 \\
71,774 \\
71,545 \\
71,860\end{array}$ & $\begin{array}{l}55,867 \\
58,137 \\
59,560 \\
59,488 \\
59,836\end{array}$ & $\begin{array}{l}44,473 \\
45,390 \\
45,605 \\
45,490 \\
51,751\end{array}$ & $\begin{array}{l}50,537 \\
51,879 \\
52,821 \\
51,996 \\
50,981\end{array}$ & $\begin{array}{l}61,843 \\
62,974 \\
62,967 \\
62,875 \\
63,247\end{array}$ & $\begin{array}{l}69,629 \\
72,358 \\
73,639 \\
73,107 \\
73,053\end{array}$ & $\begin{array}{l}72,356 \\
75,572 \\
77,190 \\
76,894 \\
76,395\end{array}$ & $\begin{array}{l}62,910 \\
64,326 \\
64,712 \\
64,015 \\
65,216\end{array}$ & $\begin{array}{l}66,763 \\
69,998 \\
71,904 \\
72,192 \\
74,282\end{array}$ & $\begin{array}{l}67,464 \\
70,591 \\
72,548 \\
72,946 \\
74,980\end{array}$ & $\begin{array}{l}41,322 \\
43,671 \\
44,824 \\
41,614 \\
42,975\end{array}$ \\
\hline $\begin{array}{l}1992-93 \ldots \ldots \ldots \\
1993-94 \ldots \ldots \\
1994-95 \ldots \ldots \ldots \ldots \\
1995-96 \ldots \ldots \ldots \ldots \\
1996-97\end{array}$ & $\begin{array}{l}72,581 \\
73,360 \\
73,542 \\
73,837 \\
74,002\end{array}$ & $\begin{array}{l}95,426 \\
95,962 \\
96,456 \\
96,644 \\
97,048\end{array}$ & $\begin{array}{l}71,333 \\
71,640 \\
71,853 \\
71,825 \\
71,786\end{array}$ & $\begin{array}{l}59,451 \\
59,540 \\
59,613 \\
59,442 \\
59,235\end{array}$ & $\begin{array}{l}46,261 \\
45,613 \\
45,629 \\
45,439 \\
45,414\end{array}$ & $\begin{array}{l}49,578 \\
51,785 \\
51,064 \\
51,116 \\
50,900\end{array}$ & $\begin{array}{l}61,311 \\
64,214 \\
63,414 \\
64,383 \\
64,351\end{array}$ & $\begin{array}{l}71,742 \\
72,657 \\
72,958 \\
73,130 \\
73,235\end{array}$ & $\begin{array}{l}75,505 \\
75,978 \\
76,505 \\
76,627 \\
76,751\end{array}$ & $\begin{array}{l}63,201 \\
64,935 \\
64,758 \\
64,831 \\
64,909\end{array}$ & $\begin{array}{l}74,644 \\
75,102 \\
74,971 \\
75,569 \\
75,869\end{array}$ & $\begin{array}{l}75,362 \\
75,758 \\
75,953 \\
76,098 \\
76,351\end{array}$ & $\begin{array}{l}42,375 \\
44,991 \\
39,396 \\
47,790 \\
47,503\end{array}$ \\
\hline $\begin{array}{l}1997-98 \ldots \ldots \ldots \ldots . . . \\
1998-99 \ldots \ldots \ldots \ldots . . . \\
1999-2000 \ldots \ldots \ldots . . \\
2001-02 \ldots \ldots \ldots \ldots . . . \\
2002-03 \ldots \ldots \ldots \ldots \ldots . . .\end{array}$ & $\begin{array}{l}74,859 \\
76,062 \\
76,376 \\
77,564 \\
77,914\end{array}$ & $\begin{array}{r}98,312 \\
100,282 \\
101,688 \\
104,895 \\
106,037\end{array}$ & $\begin{array}{l}72,703 \\
73,923 \\
74,511 \\
76,243 \\
76,822\end{array}$ & $\begin{array}{l}59,832 \\
60,949 \\
61,467 \\
63,353 \\
64,222\end{array}$ & $\begin{array}{l}46,414 \\
47,550 \\
47,718 \\
60,968 \\
61,366\end{array}$ & $\begin{array}{l}50,756 \\
51,768 \\
52,195 \\
54,268 \\
54,148\end{array}$ & $\begin{array}{l}64,750 \\
65,030 \\
64,761 \\
60,462 \\
58,869\end{array}$ & $\begin{array}{l}73,861 \\
74,969 \\
75,178 \\
75,983 \\
76,243\end{array}$ & \begin{tabular}{l|}
77,404 \\
78,664 \\
79,193 \\
80,513 \\
80,653
\end{tabular} & $\begin{array}{l}65,682 \\
66,484 \\
65,925 \\
66,003 \\
66,481\end{array}$ & $\begin{array}{l}77,297 \\
78,712 \\
79,280 \\
81,558 \\
81,984\end{array}$ & $\begin{array}{l}77,783 \\
79,137 \\
79,703 \\
81,910 \\
82,341\end{array}$ & $\begin{array}{l}48,049 \\
48,959 \\
49,094 \\
43,025 \\
44,243\end{array}$ \\
\hline $\begin{array}{l}2003-04 \\
2004-05 \\
2005-06 \\
2006-07 \\
2007-08\end{array}$ & \begin{tabular}{r|}
77,799 \\
77,524 \\
76,933 \\
77,728 \\
77,683
\end{tabular} & $\begin{array}{l}106,088 \\
106,398 \\
106,040 \\
107,517 \\
107,695\end{array}$ & $\begin{array}{l}76,763 \\
76,708 \\
76,400 \\
77,238 \\
77,400\end{array}$ & $\begin{array}{l}64,396 \\
64,337 \\
64,067 \\
64,760 \\
64,798\end{array}$ & $\begin{array}{l}60,998 \\
60,019 \\
59,157 \\
60,380 \\
60,461\end{array}$ & $\begin{array}{l}54,264 \\
53,724 \\
53,360 \\
53,808 \\
53,976\end{array}$ & $\begin{array}{l}59,333 \\
59,068 \\
58,625 \\
59,115 \\
59,454\end{array}$ & $\begin{array}{l}75,679 \\
75,244 \\
74,592 \\
75,440 \\
75,384\end{array}$ & $\begin{array}{l}79,989 \\
79,719 \\
79,001 \\
79,853 \\
79,619\end{array}$ & $\begin{array}{l}65,985 \\
65,090 \\
64,415 \\
65,127 \\
65,182\end{array}$ & $\begin{array}{l}82,880 \\
82,980 \\
82,565 \\
83,207 \\
83,199\end{array}$ & $\begin{array}{l}83,210 \\
83,270 \\
82,852 \\
83,453 \\
83,427\end{array}$ & $\begin{array}{l}45,155 \\
45,052 \\
44,817 \\
46,623 \\
47,431\end{array}$ \\
\hline $\begin{array}{l}2008-09 \\
2009-10 \\
2010-11 \ldots \\
2011-12 \\
2012-13\end{array}$ & $\begin{array}{l}79,292 \\
79,658 \\
78,976 \\
77,845 \\
77,301\end{array}$ & $\begin{array}{l}110,306 \\
110,677 \\
109,830 \\
108,873 \\
108,310\end{array}$ & $\begin{array}{l}79,150 \\
79,125 \\
78,590 \\
77,443 \\
77,089\end{array}$ & $\begin{array}{l}66,337 \\
66,444 \\
66,071 \\
65,074 \\
64,632\end{array}$ & $\begin{array}{l}61,344 \\
61,695 \\
60,633 \\
59,320 \\
57,495\end{array}$ & $\begin{array}{l}55,169 \\
55,696 \\
54,989 \\
54,249 \\
53,394\end{array}$ & $\begin{array}{l}60,754 \\
60,638 \\
59,175 \\
57,870 \\
58,254\end{array}$ & $\begin{array}{l}76,777 \\
77,051 \\
76,079 \\
74,726 \\
73,909\end{array}$ & $\begin{array}{l}81,097 \\
81,289 \\
80,430 \\
79,138 \\
78,111\end{array}$ & $\begin{array}{l}66,211 \\
66,464 \\
65,193 \\
63,610 \\
62,781\end{array}$ & $\begin{array}{l}85,302 \\
85,806 \\
85,695 \\
84,925 \\
85,000\end{array}$ & $\begin{array}{l}85,585 \\
86,039 \\
85,905 \\
85,088 \\
85,167\end{array}$ & $\begin{array}{l}46,928 \\
47,766 \\
47,242 \\
48,601 \\
44,978\end{array}$ \\
\hline
\end{tabular}


Table 316.10. Average salary of full-time instructional faculty on 9-month contracts in degree-granting postsecondary institutions, by academic rank, control and level of institution, and sex: Selected years, 1970-71 through 2012-13-Continued

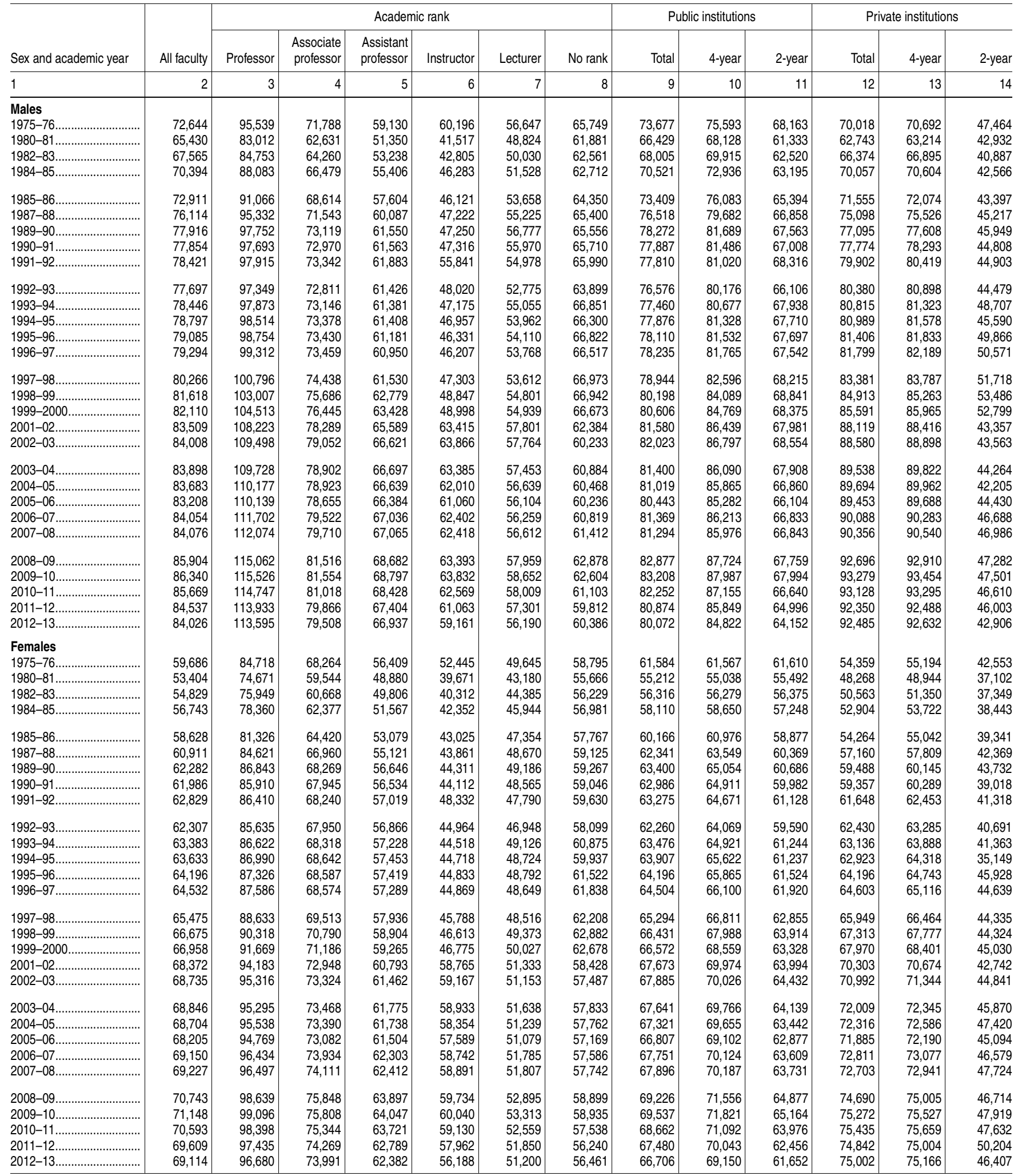

${ }^{1}$ Constant dollars based on the Consumer Price Index, prepared by the Bureau of Labor Statistics, U.S. Department of Labor, adjusted to an academic-year basis.

NOTE: Data through 1995-96 are for institutions of higher education, while later data are for degree-granting institutions. Degree-granting institutions grant associate's or higher degrees and participate in Title IV federal financial aid programs. Data for 1987-88 and later years include imputations for nonrespondent institutions.
SOURCE: U.S. Department of Education, National Center for Education Statistics, Higher Education General Information Survey (HEGIS), "Faculty Salaries, Tenure, and Fringe Benefits" surveys, 1970-71 through 1985-86; Integrated Postsecondary Education Data System (IPEDS), "Salaries, Tenure, and Fringe Benefits of Full-Time Instructional Faculty Survey" (IPEDS-SA:87-99); and IPEDS Winter 2001-02 through Winter 2011-12 and Spring 2013, Human Resources component, Salaries section. (This table was prepared March 2014.) 
Table 316.20. Average salary of full-time instructional faculty on 9-month contracts in degree-granting postsecondary institutions, by academic rank, sex, and control and level of institution: Selected years, 1999-2000 through 2012-13

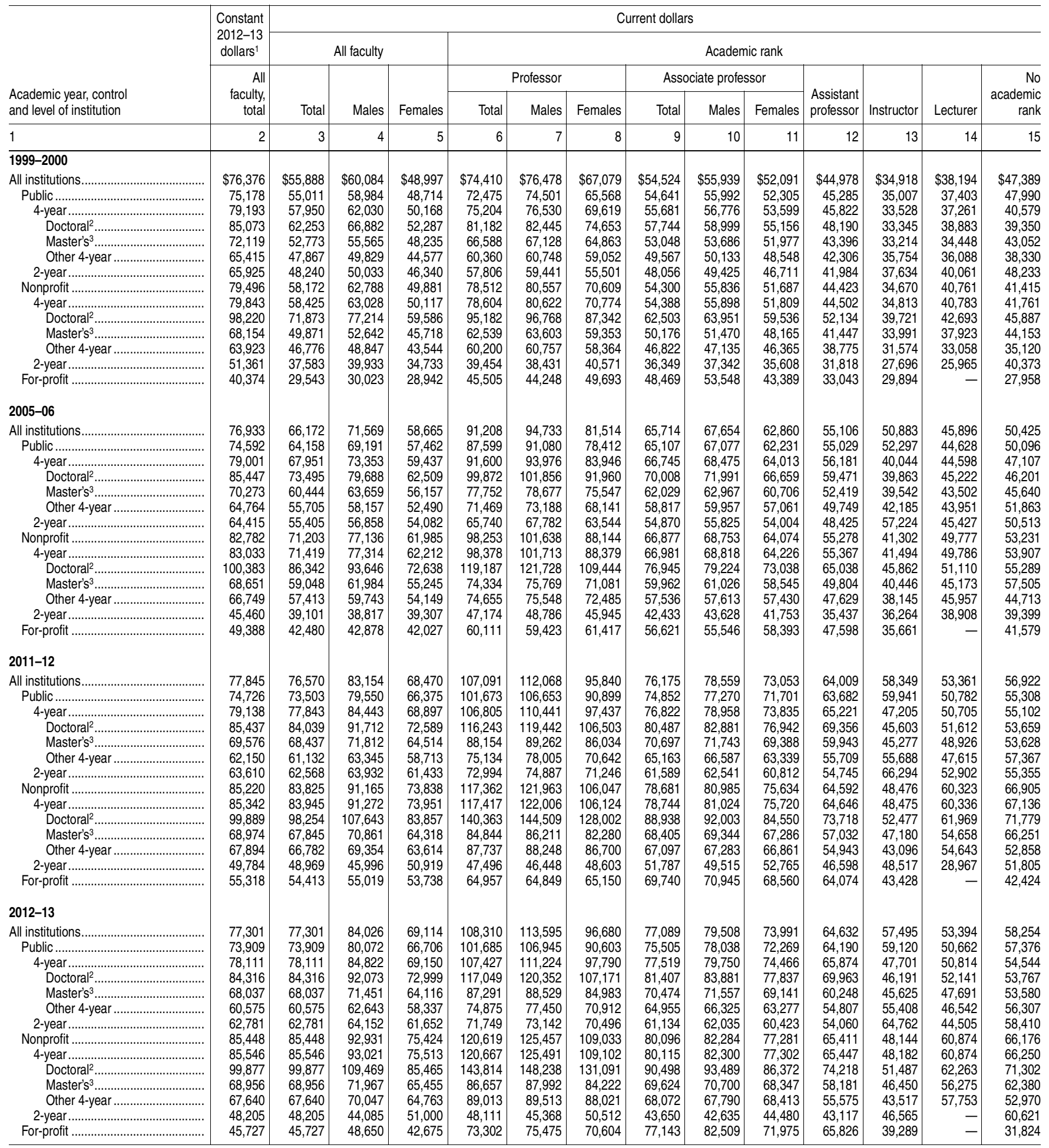

-Not available.

${ }^{1}$ Constant dollars based on the Consumer Price Index, prepared by the Bureau of Labor Statistics, U.S. Department of Labor, adjusted to an academic-year basis.

${ }^{2}$ Institutions that awarded 20 or more doctor's degrees during the previous academic year.

${ }^{3}$ Institutions that awarded 20 or more master's degrees, but less than 20 doctor's degrees, during the previous academic year.
NOTE: Degree-granting institutions grant associate's or higher degrees and participate in Title IV federal financial aid programs. Some data have been revised from previously published figures. SOURCE: U.S. Department of Education, National Center for Education Statistics, Integrated Postsecondary Education Data System (IPEDS), "Salaries, Tenure, and Fringe Benefits of FullTime Instructional Faculty Survey" (IPEDS-SA:99), and Winter 2005-06 through Winter 2011-12 and Spring 2013, Human Resources component, Salaries section. (This table was prepared March 2014.) 
Table 316.30. Average salary of full-time instructional faculty on 9-month contracts in degree-granting postsecondary institutions, by control and level of institution and state or jurisdiction: 2012-13

[In current dollars]

\begin{tabular}{|c|c|c|c|c|c|c|c|c|c|c|c|c|c|c|}
\hline \multirow[b]{3}{*}{ State or jurisdiction } & \multirow{3}{*}{$\begin{array}{r}\text { All } \\
\text { institu- } \\
\text { tions }\end{array}$} & \multicolumn{6}{|c|}{ Public institutions } & \multicolumn{6}{|c|}{ Nonprofit institutions } & \multirow{3}{*}{$\begin{array}{c}\text { For-profit } \\
\text { institutions }\end{array}$} \\
\hline & & \multirow[b]{2}{*}{ Total } & \multicolumn{4}{|c|}{ 4-year institutions } & \multirow[b]{2}{*}{ 2-year } & \multirow[b]{2}{*}{ Total } & & 4 -year ins & stitutions & & & \\
\hline & & & Total & Doctoral $^{1}$ & Master's $^{2}$ & Other & & & Total & Doctoral $^{1}$ & Master's $^{2}$ & Other & 2-year & \\
\hline 1 & 2 & 3 & 4 & 5 & 6 & 7 & 8 & 9 & 10 & 11 & 12 & 13 & 14 & 15 \\
\hline United States & $\$ 77,301$ & $\$ 73,909$ & $\$ 78,111$ & $\$ 84,316$ & $\$ 68,037$ & $\$ 60,575$ & $\$ 62,781$ & $\$ 85,448$ & $\$ 85,546$ & $\$ 99,877$ & $\$ 68,956$ & $\$ 67,640$ & $\$ 48,205$ & $\$ 45,727$ \\
\hline abama & 67,167 & 69,104 & 73,882 & 79,486 & 60,981 & 68,071 & 54,997 & 57,154 & 57,154 & 64,988 & 50,274 & 49,795 & $t$ & \\
\hline & ,295 & 374 & 77,440 & 81,152 & 5,075 & & 50 & & 54,063 & & & & it & \\
\hline & 3,045 & 78,555 & 83,691 & 84,163 & & 71 & 69,360 & 58,993 & 58,993 & & 3,373 & 71,773 & $t$ & 70,486 \\
\hline & 56,415 & 56,453 & 61,203 & 65,460 & 51,020 & 51 & 44,170 & 56,164 & 56,189 & 62,710 & 6,828 & 51,126 & & \\
\hline . & 91,862 & 88,786 & 94,223 & 106,300 & 77,447 & 73,485 & 82,505 & 103,249 & 103,249 & 112,503 & 31,982 & 89,258 & $\dagger$ & 48,168 \\
\hline lorad & 72,613 & 71,234 & 76,705 & 83,645 & 59,353 & 63,659 & 47,339 & 82,152 & 82,152 & 83,972 & 2,306 & 62,503 & $\dagger$ & 31,893 \\
\hline & 94,524 & 85,944 & 91,336 & 8 & & & 69,383 & 103 & & & & 56 & & 61,939 \\
\hline &, 781 & 97,822 & 101,666 & 8 & 97 & & 78,075 & 86,505 & 86 & 34 & 4,385 & & $\dagger$ & \\
\hline & 99,140 & 82,067 & 82,067 & 11 & 77,810 & & & 100,647 & & & 000 & & 1 & 33,150 \\
\hline Fontat & 71,836 & 70,180 & 71,288 & 80,114 & 67,057 & 58,337 & 52,915 & 76,805 & 76,805 & 89,041 & 69,086 & 57,407 & $\dagger$ & 72,031 \\
\hline ieorgia.... & 69,625 & 67,874 & 69,973 & 7,358 & 8,527 & 59 & 5,489 & ,959 & 973 & 91,874 & 4,862 & 0,681 & $\ddagger$ & $\dagger$ \\
\hline & 967 & 79,346 & & & & & & & & & & & & \\
\hline & 60,762 & 61, & 6 & 7 & 67,937 & 49,551 & 98 & 47 & 47 & & 98 & & $\dagger$ & \\
\hline & 749 & 76,090 & $7 \mathrm{~s}$ & & 38 & & 59 & & & 930 & 10 & & & 951 \\
\hline 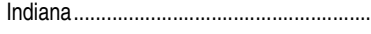 & 73,823 & 72,943 & 78,211 & 84,771 & 1,204 & 55,424 & 43,112 & 75,596 & 75,596 & 89,405 & 0,768 & $\$ 4,293$ & t & \\
\hline & 71,614 & 77,617 & 86,911 & 55 & 0,469 & & 54,966 & 62,330 & 62,330 & 8,849 & 5,444 & 2,916 & T & 6,041 \\
\hline & 63,575 & 65,981 & & & & 66,216 & & & & & & & 43,524 & \\
\hline & 386 & 63,618 & 68, & 73 & 209 & & 89 & 33 & & 81 & 48 & 74 & & \\
\hline & 980 & 59,473 & 64 & & 5,305 & 01 & & & & & & & & 111 \\
\hline Madne... & 70,349 & 67,520 & 71,956 & 77,728 & & 60,201 & 52,527 & 75,740 & 75,983 & 65,544 & 55,481 & 86,013 & 51,930 & \\
\hline rul & 76,229 & 73,484 & 77,145 & 28 & 64,840 & $\dagger$ & 66,417 & 86,284 & 86,284 & 660 & 5,462 & 97 & $\dagger$ & \\
\hline & 100,114 & 81,216 & & & & & 33 & 107,868 & & & & & 631 & 65,606 \\
\hline & 81,811 & 84,387 & & & & 242 & & & & & & & & \\
\hline & & 71 & & & & 228 & & & & & & & $\dagger$ & 49,740 \\
\hline & 58,709 & 58,853 & 63,476 & 65,740 & 52,356 & & 51,099 & 57,340 & 57,340 & 66,696 & 88,912 & $+2,475$ & $\dagger$ & \\
\hline & ,804 & 6 & 7 & & 59,628 & 484 & 54,254 & & & 24 & 50 & & $\dagger$ & 512 \\
\hline & & & & & & & & & & & & & 35,678 & \\
\hline & & 69 & & & 03 & & & & & 79,727 & & & & $\dagger$ \\
\hline & 88 & 79,091 & 80,526 & & & 24 & 64 & & & & & & & \\
\hline W & 85,155 & 80,729 & 87,988 & 6,420 & 75,569 & 85,285 & 52,046 & 91,566 & 91,566 & 119,949 & 67,416 & 68,462 & + & $\dagger$ \\
\hline ow Jercer & 97,292 & 95,003 & 103,633 & 109,927 & 96,231 & & 73,174 & 102,715 & 102,715 & 120,032 & 77,305 & 71,835 & † & \\
\hline & 63,004 & 63,004 & & & & 67 & & & & & & & & \\
\hline & 75 & 76,415 & & & & 98 & 33 & 96 & & & 17 & & 26 & 394 \\
\hline & 64 & 67,222 & & & & 7 & & & & & & & & 040 \\
\hline & 63,2 & 65,675 & 67,413 & 73,864 & 57,536 & 52,125 & 52,128 & 49,086 & 49,086 & 52,188 & & 46,726 & + & \\
\hline & 72,472 & 75,080 & 79,083 & 3 & 54,796 & 9 & 60,120 & 69,350 & 69 & 53 & 87 & 68,987 & 52,909 & 15,127 \\
\hline & & & & & & & & & & & & & & 1 \\
\hline & 0 & 6 & & & & & & & & & & & & I \\
\hline & & & & & & 7,254 & & & & & & & 380 & 53,903 \\
\hline & 89,435 & 72,374 & 75,990 & 80,797 & 67,731 & & 61,249 & 101,310 & 101,310 & 123,303 & 6,115 & & $\dagger$ & + \\
\hline & 63,668 & 65,590 & 74 & & 65,284 & 333 & & U & 7 & T & 7 & 74 & 49,852 & 52,308 \\
\hline & 5000 & 60 & & & & & & & & & & & & + \\
\hline & & & & & & & & & & & & & & \\
\hline & 72,450 & 70,521 & & & & & & & & & & 048 & & $\ddagger$ \\
\hline & 68,886 & 68,303 & 70,317 & 79,913 & 61,961 & 55,038 & 49,735 & 7,000 & 8,366 & 0,785 & 71,995 & & 787 & \\
\hline lomont & 74,293 & 754 & 754 & 83,693 & 59,207 & 56,990 & & 73 & 73,213 & & 76,805 & 2,451 & $\dagger$ & \\
\hline & & & & & & & & & & & & & & 498 \\
\hline & 6 & 68 & & & & 30 & & & & & & & $f$ & 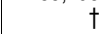 \\
\hline & & & & & & & & & & & & & & 446 \\
\hline & 70,431 & 72,250 & & & 58,689 & 90,577 & 75,483 & 64,284 & 284 & 72,291 & 59,833 & 743 & $t$ & 55,687 \\
\hline wry & 69,566 & 69,566 & 78,955 & 78,955 & $\dagger$ & & 58,606 & & $\dagger$ & $\dagger$ & & & $\dagger$ & \\
\hline U.S. Ser & 102,568 & 102,568 & 102,568 & $\dagger$ & $\dagger$ & 102,568 & $\dagger$ & $\dagger$ & $\dagger$ & $\dagger$ & $t$ & $t$ & $\dagger$ & $\dagger$ \\
\hline Other & 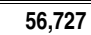 & 63,271 & 63,271 & 191 & ,763 & 52,257 & 182 & 788 & 788 & 402 & 979 & 028 & $\dagger$ & $\overline{315}$ \\
\hline & 2 & & 29,767 & $\dagger$ & & 29,767 & & & & & & & & \\
\hline & & & & $\dagger$ & & & & & & & & & & \\
\hline & Le, & 62,641 & 66,229 & $\dagger$ & 229 & & & $\dagger$ & $\dagger$ & $T$ & & & & \\
\hline & 58,174 & 58,174 & & t & & & & & $t$ & & & & & \\
\hline & 43,216 & 43,216 & 43,216 & $\dagger$ & + & 43,216 & $\dagger$ & & & I & 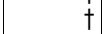 & 1 & & \\
\hline & & & & & & & $\dagger$ & & & & & & & \\
\hline & 59,357 & 65,265 & 65,265 & , 191 & 71,629 & 56,733 & $\dagger$ & 26,788 & 26,788 & 31,402 & 29,979 & 028 & & 315 \\
\hline U.S. Virgin & 62,810 & 62,810 & 62,810 & † & 62,810 & & $\dagger$ & $\dagger$ & $\dagger$ & $\dagger$ & $\dagger$ & $\dagger$ & $\dagger$ & t \\
\hline
\end{tabular}

†Not applicable.

fReporting standards not met (too few cases).

${ }^{1}$ Institutions that awarded 20 or more doctor's degrees during the previous academic year.

2Institutions that awarded 20 or more master's degrees, but less than 20 doctor's degrees, dur-

ing the previous academic year.
NOTE: Degree-granting institutions grant associate's or higher degrees and participate in Title IV federal financial aid programs. Data include imputations for nonrespondent institutions.

SOURCE: U.S. Department of Education, National Center for Education Statistics, Integrated Postsecondary Education Data System (IPEDS), Spring 2013, Human Resources component, Salaries section. (This table was prepared March 2014.) 
Table 316.40. Average salary of full-time instructional faculty on 9-month contracts in degree-granting postsecondary institutions, by control and level of institution and state or jurisdiction: 2011-12

[In current dollars]

\begin{tabular}{|c|c|c|c|c|c|c|c|c|c|c|c|c|c|c|}
\hline \multirow[b]{3}{*}{ State or jurisdiction } & \multirow{3}{*}{$\begin{array}{r}\text { All } \\
\text { institu- } \\
\text { tions }\end{array}$} & \multicolumn{6}{|c|}{ Public institutions } & \multicolumn{6}{|c|}{ Nonprofit institutions } & \multirow{3}{*}{$\begin{array}{l}\text { For-profit } \\
\text { institutions }\end{array}$} \\
\hline & & \multirow[b]{2}{*}{ Total } & \multicolumn{4}{|c|}{ 4-year institutions } & \multirow[b]{2}{*}{ 2-year } & \multirow[b]{2}{*}{ Total } & \multicolumn{4}{|c|}{ 4-year institutions } & \multirow[b]{2}{*}{ 2-year } & \\
\hline & & & Total & Doctoral $^{1}$ & Master's ${ }^{2}$ & Other & & & Total & Doctoral $^{1}$ & Master's ${ }^{2}$ & Other & & \\
\hline 1 & 2 & 3 & 4 & 5 & 6 & 7 & 8 & 9 & 10 & 11 & 12 & 13 & 14 & 15 \\
\hline United States ........... & 76,570 & 73,503 & $\$ 77,843$ & $\$ 84,039$ & $\$ 68,437$ & $\$ 61,132$ & $\$ 62,568$ & $\$ 83,825$ & $\$ 83,945$ & $\$ 98,254$ & $\$ 67,845$ & $\$ 66,782$ & $\$ 48,969$ & $\$ 54,413$ \\
\hline 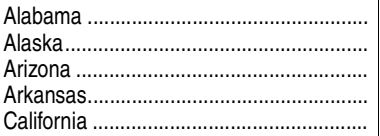 & $\begin{array}{l}65,998 \\
73,864 \\
77,222 \\
56,191 \\
92,320\end{array}$ & $\begin{array}{l}67,603 \\
74,716 \\
77,781 \\
56,375 \\
89,985\end{array}$ & $\begin{array}{l}73,069 \\
74,716 \\
83,012 \\
61,170 \\
94,427\end{array}$ & $\begin{array}{r}78,816 \\
76,825 \\
83,399 \\
67,386 \\
104,699\end{array}$ & $\begin{array}{r}60,933 \\
73,263 \\
\dagger \\
53,631 \\
77,896\end{array}$ & $\begin{array}{r}69,121 \\
\dagger \\
51,679 \\
56,694 \\
73,981\end{array}$ & $\begin{array}{l}53,336 \\
74,654 \\
68,210 \\
44,254 \\
84,743\end{array}$ & \begin{tabular}{r|}
57,427 \\
54,664 \\
57,495 \\
55,150 \\
100,640
\end{tabular} & $\begin{array}{r}57,427 \\
54,664 \\
57,495 \\
55,150 \\
100,640\end{array}$ & $\begin{array}{r}65,816 \\
\dagger \\
\dagger \\
\dagger \\
108,550\end{array}$ & $\begin{array}{l}54,035 \\
54,664 \\
41,179 \\
59,011 \\
77,875\end{array}$ & \begin{tabular}{r|}
45,208 \\
$\dagger$ \\
68,171 \\
52,428 \\
93,764
\end{tabular} & $\begin{array}{l}\dagger \\
\dagger \\
\dagger \\
\dagger \\
t\end{array}$ & $\begin{array}{r}54,540 \\
\dagger \\
65,245 \\
\ddagger \\
77,013\end{array}$ \\
\hline 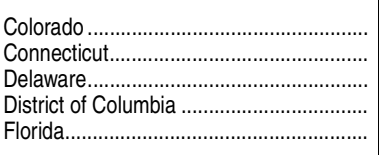 & $\begin{array}{l}70,383 \\
93,210 \\
92,312 \\
99,141 \\
71,329\end{array}$ & $\begin{array}{l}68,966 \\
85,603 \\
92,411 \\
87,476 \\
69,713\end{array}$ & $\begin{array}{l}73,709 \\
90,678 \\
98,408 \\
87,476 \\
71,196\end{array}$ & $\begin{array}{r}79,032 \\
102,544 \\
103,974 \\
126,712 \\
79,728\end{array}$ & $\begin{array}{l}54,907 \\
79,868 \\
63,587 \\
83,182 \\
67,890\end{array}$ & $\begin{array}{r}61,728 \\
\dagger \\
\dagger \\
\dagger \\
57,476\end{array}$ & $\begin{array}{r}45,945 \\
70,106 \\
64,295 \\
\dagger \\
53,194\end{array}$ & $\begin{array}{r}79,384 \\
101,225 \\
91,901 \\
100,214 \\
76,052\end{array}$ & $\begin{array}{r}79,384 \\
101,381 \\
91,901 \\
100,214 \\
76,052\end{array}$ & $\begin{array}{r}81,572 \\
111,519 \\
94,077 \\
101,256 \\
87,963\end{array}$ & $\begin{array}{l}78,582 \\
87,293 \\
75,522 \\
57,898 \\
68,085\end{array}$ & $\begin{array}{r}58,243 \\
79,625 \\
\dagger \\
\dagger \\
56,416\end{array}$ & $\begin{array}{r}\dagger \\
60,264 \\
\dagger \\
\dagger \\
\dagger\end{array}$ & $\begin{array}{r}70,509 \\
45,641 \\
\ddagger \\
64,695 \\
85,127\end{array}$ \\
\hline 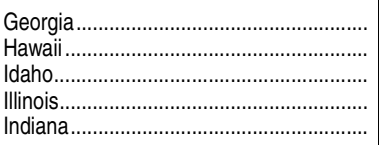 & $\begin{array}{l}68,530 \\
78,370 \\
58,903 \\
80,111 \\
73,459\end{array}$ & $\begin{array}{l}66,670 \\
79,282 \\
59,579 \\
74,374 \\
72,971\end{array}$ & $\begin{array}{l}69,349 \\
84,877 \\
61,458 \\
77,311 \\
77,961\end{array}$ & $\begin{array}{l}81,244 \\
86,682 \\
62,979 \\
81,900 \\
84,179\end{array}$ & $\begin{array}{r}58,063 \\
\dagger \\
62,486 \\
64,865 \\
62,088\end{array}$ & $\begin{array}{r}53,920 \\
68,200 \\
48,221 \\
\dagger \\
54,853\end{array}$ & $\begin{array}{l}44,630 \\
66,731 \\
50,021 \\
69,216 \\
44,767\end{array}$ & $\begin{array}{l}74,312 \\
74,040 \\
51,915 \\
88,313 \\
74,457\end{array}$ & $\begin{array}{l}74,324 \\
74,040 \\
51,915 \\
88,352 \\
74,602\end{array}$ & $\begin{array}{r}93,226 \\
\dagger \\
\dagger \\
105,918 \\
89,420\end{array}$ & $\begin{array}{l}64,006 \\
72,181 \\
50,855 \\
68,495 \\
58,682\end{array}$ & $\begin{array}{l}57,687 \\
88,337 \\
52,830 \\
60,585 \\
64,643\end{array}$ & $\begin{array}{r}\ddagger \\
\dagger \\
\dagger \\
4,999 \\
3,078\end{array}$ & $\begin{array}{r}54,730 \\
\dagger \\
\dagger \\
41,026 \\
\dagger\end{array}$ \\
\hline 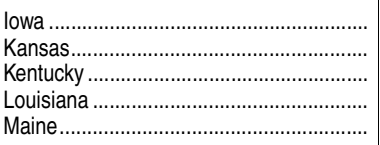 & $\begin{array}{l}69,902 \\
63,848 \\
61,554 \\
64,453 \\
71,775\end{array}$ & $\begin{array}{l}74,901 \\
66,240 \\
62,835 \\
61,589 \\
67,807\end{array}$ & $\begin{array}{l}85,500 \\
73,031 \\
68,162 \\
65,220 \\
71,857\end{array}$ & $\begin{array}{l}90,451 \\
78,024 \\
77,349 \\
71,090 \\
77,471\end{array}$ & $\begin{array}{l}67,886 \\
56,774 \\
59,403 \\
55,510 \\
57,121\end{array}$ & $\begin{array}{r}\dagger \\
65,393 \\
\dagger \\
47,601 \\
57,764\end{array}$ & $\begin{array}{l}54,134 \\
51,152 \\
49,028 \\
48,134 \\
53,330\end{array}$ & $\begin{array}{l}61,878 \\
48,713 \\
56,501 \\
76,827 \\
77,875\end{array}$ & $\begin{array}{l}61,878 \\
48,880 \\
56,501 \\
76,827 \\
78,285\end{array}$ & $\begin{array}{r}68,674 \\
\dagger \\
59,340 \\
83,493 \\
62,684\end{array}$ & $\begin{array}{l}55,658 \\
51,944 \\
51,645 \\
54,244 \\
53,698\end{array}$ & $\begin{array}{l}62,294 \\
43,411 \\
59,560 \\
57,646 \\
87,919\end{array}$ & $\begin{array}{r}\dagger \\
44,410 \\
\dagger \\
\dagger \\
61,232\end{array}$ & $\begin{array}{r}46,114 \\
\ddagger \\
56,235 \\
\ddagger\end{array}$ \\
\hline 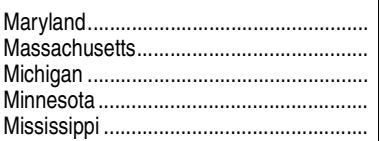 & $\begin{array}{l}75,721 \\
96,523 \\
81,359 \\
71,060 \\
56,368\end{array}$ & $\begin{array}{l}72,927 \\
77,019 \\
84,022 \\
71,111 \\
56,548\end{array}$ & $\begin{array}{l}76,475 \\
83,420 \\
85,875 \\
78,419 \\
61,952\end{array}$ & $\begin{array}{l}85,201 \\
91,796 \\
87,639 \\
94,327 \\
64,284\end{array}$ & $\begin{array}{l}64,959 \\
70,752 \\
71,157 \\
69,672 \\
51,475\end{array}$ & $\begin{array}{r}\dagger \\
\dagger \\
00 \\
11 \\
+ \\
\dagger\end{array}$ & $\begin{array}{l}66,086 \\
60,050 \\
75,607 \\
60,401 \\
49,037\end{array}$ & $\begin{array}{r}85,108 \\
105,250 \\
65,892 \\
71,480 \\
55,080\end{array}$ & $\begin{array}{r}85,108 \\
105,273 \\
65,892 \\
71,544 \\
55,080\end{array}$ & $\begin{array}{r}112,384 \\
117,152 \\
85,330 \\
76,571 \\
66,222\end{array}$ & $\begin{array}{l}70,594 \\
83,440 \\
59,439 \\
62,776 \\
55,110\end{array}$ & $\begin{array}{l}73,072 \\
84,798 \\
65,604 \\
72,680 \\
40,774\end{array}$ & $\begin{array}{r}\dagger \\
45,879 \\
\dagger \\
43,860 \\
\dagger\end{array}$ & $\begin{array}{r}61,150 \\
64,943 \\
\dagger \\
41,043 \\
46,960\end{array}$ \\
\hline 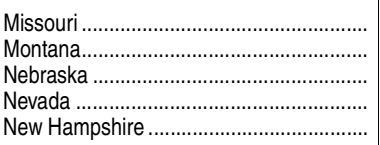 & $\begin{array}{l}68,547 \\
57,198 \\
67,684 \\
79,496 \\
80,698\end{array}$ & $\begin{array}{l}65,152 \\
58,556 \\
70,016 \\
79,723 \\
79,072\end{array}$ & $\begin{array}{l}68,506 \\
61,288 \\
75,491 \\
81,142 \\
86,108\end{array}$ & $\begin{array}{l}75,654 \\
64,140 \\
80,881 \\
89,961 \\
94,514\end{array}$ & $\begin{array}{r}58,974 \\
55,434 \\
62,347 \\
\dagger \\
73,196\end{array}$ & $\begin{array}{r}47,691 \\
47,282 \\
\dagger \\
64,610 \\
83,278\end{array}$ & $\begin{array}{l}54,931 \\
42,491 \\
52,994 \\
64,473 \\
53,996\end{array}$ & $\begin{array}{l}74,907 \\
48,676 \\
60,784 \\
60,965 \\
83,405\end{array}$ & $\begin{array}{l}74,907 \\
49,627 \\
60,913 \\
60,965 \\
83,405\end{array}$ & $\begin{array}{r}90,802 \\
\dagger \\
74,712 \\
\dagger \\
\dagger \\
103,350\end{array}$ & $\begin{array}{l}58,197 \\
50,505 \\
55,094 \\
60,965 \\
63,835\end{array}$ & $\begin{array}{r}51,212 \\
49,338 \\
52,452 \\
\dagger \\
61,850\end{array}$ & $\begin{array}{r}\dagger \\
38,340 \\
48,667 \\
\dagger \\
\dagger\end{array}$ & $\begin{array}{r}57,244 \\
\dagger \\
\dagger \\
\dagger \\
56,157\end{array}$ \\
\hline 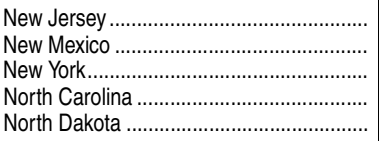 & $\begin{array}{l}95,945 \\
62,196 \\
88,638 \\
68,153 \\
62,134\end{array}$ & $\begin{array}{l}94,536 \\
61,925 \\
81,693 \\
64,798 \\
63,870\end{array}$ & $\begin{array}{r}102,292 \\
67,894 \\
86,517 \\
77,785 \\
65,581\end{array}$ & $\begin{array}{r}106,881 \\
73,579 \\
101,986 \\
83,195 \\
72,384\end{array}$ & $\begin{array}{l}95,357 \\
56,188 \\
82,739 \\
67,657 \\
56,187\end{array}$ & $\begin{array}{r}\dagger \\
44,484 \\
72,407 \\
67,812 \\
49,416\end{array}$ & $\begin{array}{l}73,679 \\
48,170 \\
71,696 \\
47,582 \\
50,647\end{array}$ & $\begin{array}{l}99,526 \\
73,851 \\
95,009 \\
78,909 \\
49,371\end{array}$ & $\begin{array}{l}99,526 \\
73,851 \\
95,050 \\
79,163 \\
49,371\end{array}$ & $\begin{array}{r}115,433 \\
\dagger \\
104,344 \\
102,820 \\
52,380\end{array}$ & $\begin{array}{r}76,250 \\
73,851 \\
75,561 \\
55,493 \\
\dagger\end{array}$ & $\begin{array}{r}68,959 \\
\dagger \\
76,880 \\
57,159 \\
46,859\end{array}$ & $\begin{array}{r}\dagger \\
\dagger \\
3,175 \\
3,615 \\
\dagger\end{array}$ & $\begin{array}{r}63,170 \\
60,000 \\
42,195 \\
76,386 \\
\dagger\end{array}$ \\
\hline 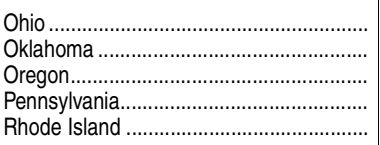 & $\begin{array}{l}72,355 \\
62,687 \\
68,890 \\
81,942 \\
86,931\end{array}$ & $\begin{array}{l}74,339 \\
62,619 \\
68,207 \\
79,483 \\
72,584\end{array}$ & $\begin{array}{l}77,951 \\
66,524 \\
70,507 \\
82,895 \\
76,262\end{array}$ & $\begin{array}{l}80,672 \\
72,155 \\
74,747 \\
90,480 \\
82,535\end{array}$ & $\begin{array}{l}57,579 \\
58,424 \\
55,607 \\
79,501 \\
65,186\end{array}$ & $\begin{array}{r}60,209 \\
48,202 \\
58,972 \\
65,300 \\
\dagger\end{array}$ & $\begin{array}{l}60,848 \\
47,429 \\
64,664 \\
61,319 \\
61,078\end{array}$ & $\begin{array}{l}68,317 \\
62,980 \\
71,034 \\
84,653 \\
96,354\end{array}$ & $\begin{array}{l}68,368 \\
62,980 \\
71,034 \\
84,966 \\
96,354\end{array}$ & $\begin{array}{r}76,991 \\
74,497 \\
74,372 \\
97,476 \\
102,380\end{array}$ & $\begin{array}{l}60,582 \\
54,491 \\
61,397 \\
69,060 \\
89,506\end{array}$ & $\begin{array}{r}67,962 \\
38,596 \\
76,388 \\
74,949 \\
\dagger\end{array}$ & $\begin{array}{r}59,770 \\
\dagger \\
\dagger \\
45,373 \\
\dagger\end{array}$ & $\begin{array}{r}41,619 \\
\dagger \\
\dagger \\
48,430 \\
\dagger\end{array}$ \\
\hline arolina & $\begin{array}{l}61,027 \\
56,633 \\
65,592 \\
70,637 \\
74,816\end{array}$ & $\begin{array}{l}62,766 \\
58,057 \\
62,693 \\
68,738 \\
67,097\end{array}$ & $\begin{array}{l}70,967 \\
60,492 \\
67,578 \\
75,971 \\
70,213\end{array}$ & $\begin{array}{l}81,543 \\
60,880 \\
68,998 \\
81,485 \\
79,848\end{array}$ & $\begin{array}{l}63,803 \\
62,334 \\
57,015 \\
62,179 \\
60,494\end{array}$ & $\begin{array}{r}53,278 \\
43,267 \\
\dagger \\
53,864 \\
60,510\end{array}$ & $\begin{array}{l}46,371 \\
46,050 \\
47,106 \\
53,639 \\
50,433\end{array}$ & $\begin{array}{l}56,642 \\
50,321 \\
71,431 \\
79,527 \\
95,925\end{array}$ & $\begin{array}{l}56,901 \\
50,321 \\
71,431 \\
79,873 \\
96,383\end{array}$ & $\begin{array}{r}\dagger \\
\dagger \\
92,105 \\
91,432 \\
99,622\end{array}$ & $\begin{array}{l}60,058 \\
47,129 \\
56,196 \\
65,277 \\
72,500\end{array}$ & $\begin{array}{r}52,758 \\
51,948 \\
52,686 \\
55,276 \\
\dagger\end{array}$ & $\begin{array}{r}45,517 \\
\dagger \\
\dagger \\
32,983 \\
58,873\end{array}$ & $\begin{array}{r}44,801 \\
\ddagger \\
53,585 \\
48,792 \\
\ddagger\end{array}$ \\
\hline $\begin{array}{l}\text { Vermont } \\
\text { Virginia } \\
\text { Washington } \\
\text { West Virginia. } \\
\text { Wisconsin } \\
\text { Wyoming }\end{array}$ & $\begin{array}{l}71,030 \\
69,146 \\
60,041 \\
70,265 \\
70,155\end{array}$ & $\begin{array}{l}74,387 \\
76,004 \\
68,385 \\
61,928 \\
72,111 \\
70,155\end{array}$ & $\begin{array}{l}74,387 \\
81,096 \\
74,562 \\
64,314 \\
71,416 \\
79,618\end{array}$ & $\begin{array}{l}81,757 \\
88,790 \\
82,919 \\
70,691 \\
82,019 \\
79,618\end{array}$ & $\begin{array}{r}58,874 \\
65,798 \\
67,222 \\
57,769 \\
58,433 \\
\dagger\end{array}$ & $\begin{array}{r}57,083 \\
67,246 \\
57,330 \\
53,630 \\
92,742 \\
\dagger\end{array}$ & $\begin{array}{r}\dagger \\
58,444 \\
55,862 \\
47,874 \\
73,519 \\
59,135\end{array}$ & $\begin{array}{r}73,622 \\
59,377 \\
72,196 \\
47,673 \\
63,572 \\
\dagger\end{array}$ & $\begin{array}{r}75,854 \\
59,377 \\
72,196 \\
47,673 \\
63,572 \\
\dagger\end{array}$ & $\begin{array}{r}\dagger \\
59,618 \\
79,121 \\
49,585 \\
72,710 \\
\dagger\end{array}$ & $\begin{array}{r}77,690 \\
57,273 \\
61,868 \\
46,665 \\
58,401 \\
\dagger\end{array}$ & $\begin{array}{r}52,796 \\
60,110 \\
66,922 \\
46,876 \\
56,572 \\
+\end{array}$ & $\begin{array}{r}47 \\
+ \\
t \\
+ \\
t \\
t\end{array}$ & $\begin{array}{r}\dagger \\
268 \\
\ddagger \\
\ddagger \\
\dagger \\
\dagger\end{array}$ \\
\hline . Service Acauermies ............................ & 107,148 & 107,148 & 101,140 & $\dagger$ & $\dagger$ & 107,148 & $\dagger$ & $\dagger$ & $\dagger$ & $\dagger$ & $\dagger$ & $\dagger$ & $\dagger$ & $\dagger$ \\
\hline Other jurisdictions ............................ & 59,955 & 60,586 & 65,693 & 61,608 & 69,908 & 60,543 & 35,050 & 477,777 & 477,777 & 51,555 & 43,044 & 24,250 & 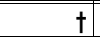 & 1 \\
\hline 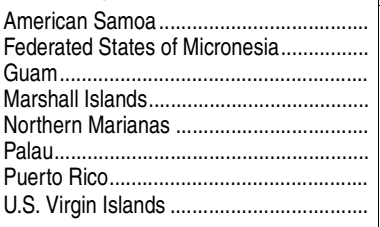 & $\begin{array}{r}30,168 \\
23,762 \\
58,864 \\
29,944 \\
42,309 \\
\dagger \\
65,121 \\
63,494\end{array}$ & $\begin{array}{r}30,168 \\
23,762 \\
59,330 \\
29,944 \\
42,309 \\
\dagger \\
66,321 \\
63,494\end{array}$ & $\begin{array}{r}\dagger \\
\dagger \\
65,915 \\
\dagger \\
42,309 \\
\dagger \\
66,321 \\
63,494\end{array}$ & $\begin{array}{r}\dagger \\
\dagger \\
\dagger \\
\dagger \\
\dagger \\
\dagger \\
61,608 \\
\dagger\end{array}$ & $\begin{array}{r}\dagger \\
\dagger \\
65,915 \\
\dagger \\
\dagger \\
\dagger \\
71,888 \\
63,494\end{array}$ & $\begin{array}{r}t \\
t \\
t \\
t \\
42,309 \\
t \\
61,262 \\
\dagger\end{array}$ & $\begin{array}{r}30,168 \\
23,762 \\
50,915 \\
29,944 \\
\dagger \\
\dagger \\
\dagger \\
\dagger\end{array}$ & \begin{tabular}{r|}
$\dagger$ \\
$\dagger$ \\
20,667 \\
$\dagger$ \\
$\dagger$ \\
$t$ \\
48,607 \\
$\dagger$ \\
\end{tabular} & $\begin{array}{r}\dagger \\
\dagger \\
20,667 \\
\dagger \\
\dagger \\
\dagger \\
\dagger \\
48,607 \\
\dagger\end{array}$ & $\begin{array}{r}\dagger \\
\dagger \\
\dagger \\
\dagger \\
\dagger \\
\dagger \\
51,555 \\
\dagger\end{array}$ & $\begin{array}{r}\dagger \\
\dagger \\
\dagger \\
\dagger \\
\dagger \\
\dagger \\
43,044 \\
+\end{array}$ & $\begin{array}{r}\dagger \\
\dagger \\
20,667 \\
\dagger \\
\dagger \\
\dagger \\
\ddagger \\
\dagger\end{array}$ & $\begin{array}{l}t \\
t \\
t \\
t \\
t \\
t \\
t \\
t\end{array}$ & 1 \\
\hline
\end{tabular}

†Not applicable.

†Reporting standards not met (too few cases).

Institutions that awarded 20 or more doctor's degrees during the previous academic year.

2Institutions that awarded 20 or more master's degrees, but less than 20 doctor's degrees, dur-

ing the previous academic year.
NOTE: Degree-granting institutions grant associate's or higher degrees and participate in Title IV federal financial aid programs. Data include imputations for nonrespondent institutions. Some data have been revised from previously published figures.

SOURCE: U.S. Department of Education, National Center for Education Statistics, Integrated Postsecondary Education Data System (IPEDS), Winter 2011-12, Human Resources component, Salaries section. (This table was prepared March 2014.) 
Table 316.50. Average salary of full-time instructional faculty on 9-month contracts in 4-year degree-granting postsecondary institutions, by control and classification of institution, academic rank of faculty, and state or jurisdiction: 2012-13

[In current dollars]

\begin{tabular}{|c|c|c|c|c|c|c|c|c|c|c|c|c|}
\hline \multirow[b]{2}{*}{ State or jurisdiction } & \multicolumn{3}{|c|}{ Public doctoral ${ }^{1}$} & \multicolumn{3}{|c|}{ Public master's ${ }^{2}$} & \multicolumn{3}{|c|}{ Nonprofit doctoral $^{1}$} & \multicolumn{3}{|c|}{ Nonprofit master's ${ }^{2}$} \\
\hline & Professor & $\begin{array}{l}\text { Associate } \\
\text { professor }\end{array}$ & $\begin{array}{l}\text { Assistant } \\
\text { professor }\end{array}$ & Professor & $\begin{array}{c}\text { Associate } \\
\text { professor }\end{array}$ & $\begin{array}{l}\text { Assistant } \\
\text { professor }\end{array}$ & Professor & $\begin{array}{c}\text { Associate } \\
\text { professor }\end{array}$ & $\begin{array}{c}\text { Assistant } \\
\text { professor }\end{array}$ & Professor & $\begin{array}{c}\text { Associate } \\
\text { professor }\end{array}$ & $\begin{array}{l}\text { Assistant } \\
\text { professor }\end{array}$ \\
\hline 1 & 2 & 3 & 4 & 6 & 6 & 7 & 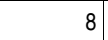 & 0 & 10 & 11 & 12 & $\overline{13}$ \\
\hline United States. & $\$ 117,049$ & $\$ 81,407$ & $\$ 69,963$ & $\$ 87,291$ & $\$ 70,474$ & $\$ 60,248$ & $\$ 143,814$ & \begin{tabular}{l|}
$\$ 90,498$ \\
\end{tabular} & $\$ 74,218$ & $\$ 86,657$ & $\$ 69,624$ & $\$ 58,181$ \\
\hline 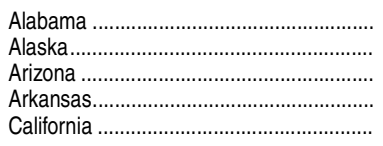 & $\begin{array}{r}113,876 \\
113,682 \\
117,827 \\
92,227 \\
133,774\end{array}$ & $\begin{array}{l}79,555 \\
81,684 \\
81,762 \\
68,906 \\
88,431\end{array}$ & $\begin{array}{l}65,152 \\
67,538 \\
71,824 \\
62,447 \\
78,816\end{array}$ & $\begin{array}{r}78,498 \\
102,753 \\
\dagger \\
66,216 \\
93,049\end{array}$ & $\begin{array}{r}65,177 \\
79,109 \\
\dagger \\
54,414 \\
75,770\end{array}$ & $\begin{array}{r}54,809 \\
66,885 \\
\dagger \\
49,898 \\
68,504\end{array}$ & $\begin{array}{r}85,763 \\
\dagger \\
\dagger \\
75,296 \\
149,596\end{array}$ & \begin{tabular}{r|}
67,504 \\
$\dagger$ \\
$\dagger$ \\
63,921 \\
98,747
\end{tabular} & $\begin{array}{r}55,956 \\
\dagger \\
\dagger \\
58,161 \\
83,434\end{array}$ & $\begin{array}{r}61,825 \\
67,416 \\
\ddagger \\
63,746 \\
99,699\end{array}$ & $\begin{array}{l}52,371 \\
56,317 \\
63,092 \\
60,041 \\
80,086\end{array}$ & $\begin{array}{r}46,982 \\
47,158 \\
\ddagger \\
51,655 \\
67,226\end{array}$ \\
\hline 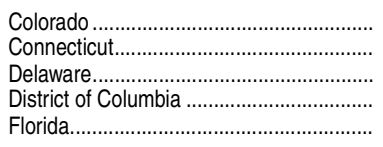 & $\begin{array}{l}114,901 \\
135,885 \\
141,691 \\
148,833 \\
109,330\end{array}$ & $\begin{array}{r}84,950 \\
92,085 \\
97,167 \\
115,000 \\
78,003\end{array}$ & $\begin{array}{l}71,627 \\
74,559 \\
82,431 \\
85,788 \\
69,303\end{array}$ & $\begin{array}{r}79,407 \\
96,902 \\
87,419 \\
101,864 \\
96,525\end{array}$ & $\begin{array}{l}63,605 \\
78,071 \\
69,473 \\
76,643 \\
71,929\end{array}$ & $\begin{array}{l}55,334 \\
63,153 \\
66,589 \\
59,525 \\
60,429\end{array}$ & $\begin{array}{l}125,997 \\
163,142 \\
152,547 \\
144,936 \\
122,128\end{array}$ & $\begin{array}{r}81,390 \\
89,362 \\
117,386 \\
94,479 \\
82,423\end{array}$ & $\begin{array}{l}72,872 \\
77,511 \\
97,370 \\
78,388 \\
71,548\end{array}$ & $\begin{array}{r}113,777 \\
120,062 \\
74,865 \\
73,179 \\
89,317\end{array}$ & $\begin{array}{l}72,826 \\
86,422 \\
64,322 \\
65,766 \\
71,907\end{array}$ & $\begin{array}{l}60,594 \\
71,493 \\
54,544 \\
69,162 \\
60,283\end{array}$ \\
\hline 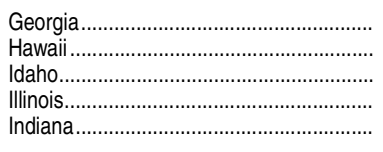 & $\begin{array}{r}108,683 \\
111,111 \\
85,346 \\
119,673 \\
118,452\end{array}$ & $\begin{array}{l}76,338 \\
84,582 \\
67,037 \\
81,910 \\
82,566\end{array}$ & $\begin{array}{l}67,156 \\
73,217 \\
58,548 \\
71,242 \\
70,584\end{array}$ & $\begin{array}{r}75,350 \\
\dagger \\
98,034 \\
91,610 \\
86,434\end{array}$ & $\begin{array}{r}63,592 \\
\dagger \\
71,093 \\
71,453 \\
67,558\end{array}$ & $\begin{array}{r}54,504 \\
+ \\
56,345 \\
62,470 \\
58,110\end{array}$ & $\begin{array}{r}131,154 \\
\dagger \\
\dagger \\
156,477 \\
128,663\end{array}$ & $\begin{array}{r}83,769 \\
\dagger \\
\dagger \\
92,054 \\
81,038\end{array}$ & $\begin{array}{r}68,201 \\
\dagger \\
\dagger \\
81,195 \\
70,103\end{array}$ & $\begin{array}{l}72,687 \\
84,165 \\
60,845 \\
82,644 \\
74,419\end{array}$ & $\begin{array}{l}58,459 \\
72,725 \\
51,396 \\
68,790 \\
62,726\end{array}$ & $\begin{array}{l}52,466 \\
60,071 \\
42,903 \\
57,832 \\
52,337\end{array}$ \\
\hline 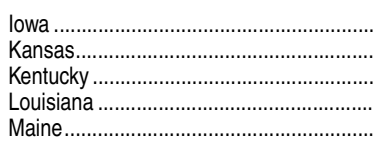 & $\begin{array}{r}123,740 \\
107,337 \\
104,075 \\
96,765 \\
95,457\end{array}$ & $\begin{array}{l}85,673 \\
75,046 \\
73,671 \\
70,808 \\
75,159\end{array}$ & $\begin{array}{l}74,880 \\
64,075 \\
63,072 \\
63,377 \\
61,472\end{array}$ & $\begin{array}{r}87,708 \\
73,476 \\
76,892 \\
73,244 \\
\dagger\end{array}$ & $\begin{array}{r}70,247 \\
59,756 \\
61,893 \\
60,511 \\
\dagger\end{array}$ & $\begin{array}{r}61,296 \\
54,934 \\
53,387 \\
52,610 \\
\dagger\end{array}$ & $\begin{array}{r}90,172 \\
\dagger \\
79,657 \\
123,372 \\
87,793\end{array}$ & $\begin{array}{r}68,178 \\
\dagger \\
63,076 \\
83,352 \\
72,645\end{array}$ & $\begin{array}{r}56,031 \\
\dagger \\
53,694 \\
69,293 \\
64,713\end{array}$ & $\begin{array}{l}68,305 \\
61,590 \\
61,200 \\
67,921 \\
74,108\end{array}$ & $\begin{array}{l}56,964 \\
53,547 \\
53,445 \\
54,802 \\
55,882\end{array}$ & $\begin{array}{l}49,390 \\
49,329 \\
45,355 \\
53,057 \\
49,721\end{array}$ \\
\hline 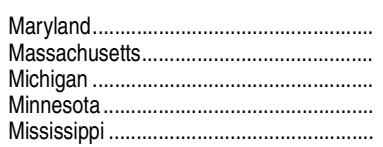 & $\begin{array}{r}119,314 \\
128,755 \\
121,176 \\
126,782 \\
92,960\end{array}$ & $\begin{array}{l}85,563 \\
95,589 \\
83,719 \\
86,677 \\
71,314\end{array}$ & $\begin{array}{l}76,759 \\
79,441 \\
71,537 \\
77,293 \\
62,350\end{array}$ & $\begin{array}{l}85,751 \\
86,867 \\
93,896 \\
82,305 \\
65,207\end{array}$ & $\begin{array}{l}68,222 \\
71,290 \\
77,065 \\
67,834 \\
54,057\end{array}$ & $\begin{array}{l}61,561 \\
62,301 \\
64,611 \\
58,599 \\
52,254\end{array}$ & $\begin{array}{r}147,178 \\
164,211 \\
108,093 \\
99,424 \\
83,979\end{array}$ & $\begin{array}{r}95,041 \\
101,382 \\
76,237 \\
74,892 \\
67,390\end{array}$ & $\begin{array}{l}81,940 \\
89,452 \\
67,060 \\
61,725 \\
59,091\end{array}$ & $\begin{array}{r}83,190 \\
117,703 \\
72,492 \\
76,874 \\
76,096\end{array}$ & $\begin{array}{l}66,756 \\
82,930 \\
60,091 \\
66,000 \\
57,718\end{array}$ & $\begin{array}{l}58,856 \\
65,554 \\
51,079 \\
55,031 \\
52,345\end{array}$ \\
\hline 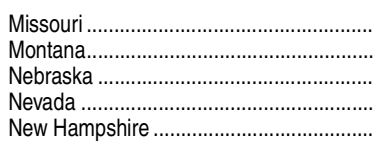 & $\begin{array}{r}101,285 \\
76,966 \\
103,329 \\
118,121 \\
116,758\end{array}$ & $\begin{array}{l}73,191 \\
62,566 \\
76,248 \\
84,526 \\
90,711\end{array}$ & $\begin{array}{l}61,754 \\
61,201 \\
69,860 \\
69,809 \\
72,862\end{array}$ & $\begin{array}{r}74,695 \\
71,108 \\
77,788 \\
\dagger \\
89,968\end{array}$ & $\begin{array}{r}60,777 \\
62,439 \\
62,930 \\
\dagger \\
74,047\end{array}$ & $\begin{array}{r}51,822 \\
52,095 \\
52,143 \\
\dagger \\
61,127\end{array}$ & $\begin{array}{r}138,496 \\
\dagger \\
106,245 \\
\dagger \\
150,044\end{array}$ & $\begin{array}{r}84,204 \\
\dagger \\
77,367 \\
\dagger \\
97,228\end{array}$ & $\begin{array}{r}71,681 \\
\dagger \\
64,393 \\
\dagger \\
67,803\end{array}$ & $\begin{array}{l}72,618 \\
55,970 \\
64,263 \\
71,919 \\
84,115\end{array}$ & $\begin{array}{l}60,496 \\
46,893 \\
55,070 \\
65,478 \\
72,258\end{array}$ & $\begin{array}{l}51,845 \\
42,122 \\
50,345 \\
62,542 \\
52,169\end{array}$ \\
\hline 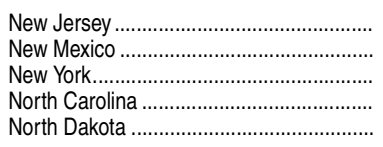 & $\begin{array}{r}149,954 \\
98,259 \\
131,739 \\
121,494 \\
99,043\end{array}$ & $\begin{array}{r}101,586 \\
72,718 \\
92,390 \\
81,350 \\
77,325\end{array}$ & $\begin{array}{l}84,216 \\
63,623 \\
75,936 \\
73,287 \\
66,195\end{array}$ & $\begin{array}{r}119,833 \\
71,053 \\
90,674 \\
89,279 \\
76,044\end{array}$ & $\begin{array}{l}95,161 \\
58,592 \\
72,218 \\
71,163 \\
62,291\end{array}$ & $\begin{array}{l}76,241 \\
51,520 \\
60,865 \\
62,284 \\
54,048\end{array}$ & $\begin{array}{r}168,282 \\
\dagger \\
154,224 \\
153,421 \\
68,401\end{array}$ & $\begin{array}{r}93,263 \\
\dagger \\
97,771 \\
92,067 \\
65,732\end{array}$ & $\begin{array}{r}83,238 \\
\dagger \\
76,699 \\
75,803 \\
52,144\end{array}$ & $\begin{array}{r}95,140 \\
\dagger \\
97,077 \\
67,788 \\
\dagger\end{array}$ & $\begin{array}{r}81,864 \\
\dagger \\
77,139 \\
59,256 \\
\dagger\end{array}$ & $\begin{array}{r}64,604 \\
\dagger \\
64,947 \\
53,097 \\
+\end{array}$ \\
\hline 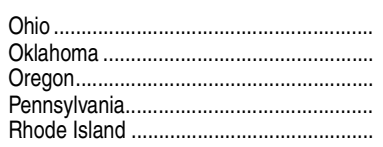 & $\begin{array}{l}111,772 \\
102,395 \\
103,964 \\
129,129 \\
103,140\end{array}$ & $\begin{array}{l}80,397 \\
73,003 \\
78,898 \\
89,431 \\
77,007\end{array}$ & $\begin{array}{l}68,950 \\
62,858 \\
71,168 \\
69,118 \\
66,609\end{array}$ & $\begin{array}{r}72,621 \\
74,933 \\
73,054 \\
103,099 \\
78,664\end{array}$ & $\begin{array}{l}58,924 \\
82,086 \\
67,080\end{array}$ & $\begin{array}{l}52,832 \\
56,170 \\
46,957 \\
65,317 \\
57,452\end{array}$ & $\begin{array}{r}109,255 \\
93,101 \\
98,183 \\
141,050 \\
157,248\end{array}$ & $\begin{array}{r}74,460 \\
71,891 \\
74,225 \\
91,529 \\
101,670\end{array}$ & $\begin{array}{l}63,394 \\
59,144 \\
62,005 \\
78,783 \\
85,880\end{array}$ & $\begin{array}{r}74,679 \\
67,201 \\
78,993 \\
90,130 \\
111,848\end{array}$ & $\begin{array}{l}63,670 \\
58,674 \\
65,418 \\
71,641 \\
84,732\end{array}$ & $\begin{array}{l}53,150 \\
50,917 \\
54,925 \\
60,512 \\
70,990\end{array}$ \\
\hline 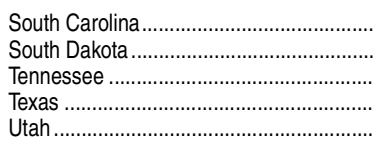 & $\begin{array}{r}120,635 \\
83,811 \\
98,308 \\
121,559 \\
110,647\end{array}$ & $\begin{array}{l}85,286 \\
67,547 \\
73,657 \\
82,550 \\
75,337\end{array}$ & $\begin{array}{l}75,220 \\
60,150 \\
61,672 \\
72,471 \\
64,224\end{array}$ & $\begin{array}{l}82,838 \\
82,906 \\
75,801 \\
84,195 \\
76,289\end{array}$ & $\begin{array}{l}66,519 \\
67,863 \\
66,081 \\
67,767 \\
63,666\end{array}$ & $\begin{array}{l}58,958 \\
56,816 \\
52,703 \\
61,114 \\
55,999\end{array}$ & $\begin{array}{r}\dagger \\
\dagger \\
133,291 \\
128,717 \\
110,754\end{array}$ & $\begin{array}{r}\dagger \\
87,576 \\
88,657 \\
79,869\end{array}$ & $\begin{array}{r}\dagger \\
\dagger \\
72,982 \\
78,612 \\
68,274\end{array}$ & $\begin{array}{l}75,474 \\
65,321 \\
66,015 \\
83,422 \\
85,472\end{array}$ & $\begin{array}{l}58,545 \\
52,941 \\
54,625 \\
67,440 \\
72,374\end{array}$ & $\begin{array}{l}52,740 \\
50,966 \\
48,470 \\
56,356 \\
59,550\end{array}$ \\
\hline 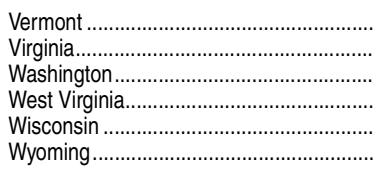 & $\begin{array}{r}115,985 \\
124,185 \\
107,097 \\
92,062 \\
103,642 \\
106,226\end{array}$ & $\begin{array}{l}85,441 \\
83,458 \\
79,686 \\
75,746 \\
75,096 \\
76,016\end{array}$ & $\begin{array}{l}69,453 \\
70,256 \\
73,280 \\
62,680 \\
69,178 \\
67,426\end{array}$ & $\begin{array}{r}71,511 \\
84,710 \\
84,227 \\
70,980 \\
71,018 \\
\dagger\end{array}$ & $\begin{array}{r}55,534 \\
67,436 \\
70,255 \\
59,930 \\
60,191 \\
+\end{array}$ & $\begin{array}{r}44,908 \\
60,128 \\
67,632 \\
52,065 \\
56,503 \\
\dagger\end{array}$ & $\begin{array}{r}115,063 \\
106,575 \\
69,231 \\
98,890 \\
\dagger\end{array}$ & $\begin{array}{r}83,141 \\
79,604 \\
56,008 \\
74,478 \\
\dagger\end{array}$ & $\begin{array}{r}47,527 \\
64,920 \\
50,989 \\
62,883 \\
\dagger\end{array}$ & $\begin{array}{r}103,009 \\
69,947 \\
77,526 \\
56,521 \\
73,834 \\
\dagger\end{array}$ & $\begin{array}{r}74,285 \\
59,141 \\
62,238 \\
49,352 \\
60,703 \\
\dagger\end{array}$ & $\begin{array}{r}64,838 \\
52,165 \\
55,615 \\
44,214 \\
53,218 \\
\dagger\end{array}$ \\
\hline U.S. Service Academies............................. & $\dagger$ & $\dagger$ & $\dagger$ & $\dagger$ & $\dagger$ & $\dagger$ & $\dagger$ & $\dagger$ & $t$ & $\dagger$ & $\dagger$ & 1 \\
\hline ictions... & 65,512 & $t$ & 50,566 & 80,156 & \begin{tabular}{l|l|}
66,908 \\
\end{tabular} & 57,702 & 50,061 & 30,556 & 23,343 & $t$ & $t$ & $\bar{\dagger}$ \\
\hline 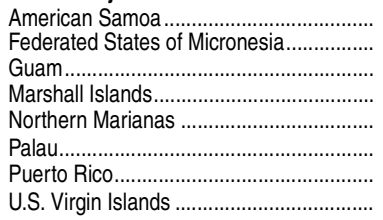 & \begin{tabular}{r|r}
$t$ \\
$t$ \\
$\dagger$ \\
$\dagger$ \\
65,512 \\
+
\end{tabular} & $\begin{array}{l}+ \\
\dagger \\
\dagger \\
\dagger \\
+ \\
\dagger \\
\dagger \\
\dagger\end{array}$ & $\begin{array}{r}t \\
t \\
t \\
\dagger \\
\dagger \\
50,566 \\
+\end{array}$ & $\begin{array}{r}\dagger \\
89,134 \\
\dagger \\
\dagger \\
\dagger \\
79,604 \\
77,944\end{array}$ & $\begin{array}{r}70,677 \\
\dagger \\
\dagger \\
t \\
65,807 \\
66,815\end{array}$ & $\begin{aligned} & \dagger \\
& \dagger \\
& 55,034 \\
& \dagger \\
&+ \\
& \dagger \\
& 60,216 \\
& 53,062\end{aligned}$ & $\begin{array}{r}1 \\
t \\
t \\
t \\
t \\
50,061 \\
\dagger\end{array}$ & $\begin{array}{r}t \\
t \\
t \\
\dagger \\
\dagger \\
t \\
30,556 \\
\dagger\end{array}$ & $\begin{array}{r}t \\
\dagger \\
\dagger \\
\dagger \\
\dagger \\
\dagger \\
23,343 \\
\dagger\end{array}$ & $\begin{array}{l}+ \\
t \\
+ \\
\dagger \\
\dagger \\
\dagger \\
\dagger \\
\dagger\end{array}$ & $\begin{array}{l}t \\
t \\
t \\
t \\
t \\
t \\
t \\
t\end{array}$ & \\
\hline
\end{tabular}

†Not applicable.

†Reporting standards not met (too few cases).

'Institutions that awarded 20 or more doctor's degrees during the previous academic year.

'Institutions that awarded 20 or more master's degrees, but less than 20 doctor's degrees, during the previous academic year.
NOTE: Degree-granting institutions grant associate's or higher degrees and participate in Title IV federal financial aid programs. Data include imputations for nonrespondent institutions.

SOURCE: U.S. Department of Education, National Center for Education Statistics, Integrated Postsecondary Education Data System (IPEDS), Spring 2013, Human Resources component, Salaries section. (This table was prepared March 2014.) 
Table 316.60. Average salary of full-time instructional faculty on 9-month contracts in 4-year degree-granting postsecondary institutions, by control and classification of institution, academic rank of faculty, and state or jurisdiction: 2011-12

[In current dollars]

\begin{tabular}{|c|c|c|c|c|c|c|c|c|c|c|c|c|}
\hline \multirow[b]{2}{*}{ State or jurisdiction } & \multicolumn{3}{|c|}{ Public doctoral ${ }^{1}$} & \multicolumn{3}{|c|}{ Public master's ${ }^{2}$} & \multicolumn{3}{|c|}{ Nonprofit doctoral $^{1}$} & \multicolumn{3}{|c|}{ Nonprofit master's ${ }^{2}$} \\
\hline & Professor & $\begin{array}{c}\text { Associate } \\
\text { professor }\end{array}$ & $\begin{array}{l}\text { Assistant } \\
\text { professor }\end{array}$ & Professor & $\begin{array}{l}\text { Associate } \\
\text { professor }\end{array}$ & $\begin{array}{c}\text { Assistant } \\
\text { professor }\end{array}$ & Professor & $\begin{array}{l}\text { Associate } \\
\text { professor }\end{array}$ & $\begin{array}{l}\text { Assistant } \\
\text { professor }\end{array}$ & Professor & $\begin{array}{c}\text { Associate } \\
\text { professor }\end{array}$ & $\begin{array}{l}\text { Assistant } \\
\text { professor }\end{array}$ \\
\hline 1 & 2 & 3 & 4 & 5 & 6 & 7 & 8 & 9 & 10 & 11 & 12 & 13 \\
\hline United States.. & $\$ 116,243$ & $\$ 80,487$ & $\$ 69,356$ & $\$ 88,154$ & $\$ 70,697$ & $\$ 59,943$ & $\$ 140,363$ & $\$ 88,938$ & $\$ 73,718$ & $\$ 84,844$ & $\$ 68,405$ & $\$ 57,032$ \\
\hline 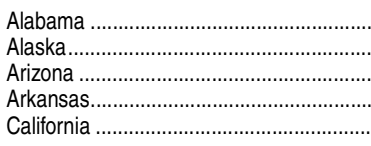 & \begin{tabular}{rl|}
112,322 \\
102,796 \\
116,467 \\
97,787 \\
132,732
\end{tabular} & $\begin{array}{l}79,115 \\
78,865 \\
81,048 \\
69,743 \\
87,213\end{array}$ & $\begin{array}{l}64,694 \\
65,732 \\
70,488 \\
64,113 \\
77,946\end{array}$ & $\begin{array}{r}79,496 \\
98,668 \\
\dagger \\
69,644 \\
93,939\end{array}$ & $\begin{array}{r}65,537 \\
77,380 \\
\dagger \\
58,010 \\
75,835\end{array}$ & $\begin{array}{r}54,817 \\
66,365 \\
\dagger \\
51,508 \\
66,915\end{array}$ & $\begin{array}{r}87,903 \\
\dagger \\
\dagger \\
\dagger \\
144,350\end{array}$ & $\begin{array}{r}70,565 \\
\dagger \\
\dagger \\
\dagger \\
96,500\end{array}$ & \begin{tabular}{r|}
52,758 \\
$\dagger$ \\
$\dagger$ \\
$\dagger$ \\
81,329
\end{tabular} & $\begin{array}{r}67,718 \\
68,302 \\
\dagger \\
71,073 \\
93,733\end{array}$ & $\begin{array}{r}57,213 \\
57,984 \\
\dagger \\
60,862 \\
75,795\end{array}$ & $\begin{array}{r}45,392 \\
49,256 \\
\dagger \\
52,495 \\
66,113\end{array}$ \\
\hline 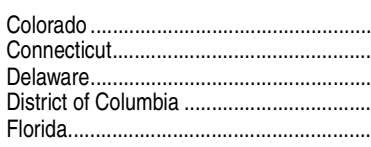 & $\begin{array}{l}108,635 \\
138,639 \\
139,178 \\
148,545 \\
111,216\end{array}$ & $\begin{array}{r}81,639 \\
91,659 \\
94,661 \\
115,000 \\
77,178\end{array}$ & $\begin{array}{r}68,638 \\
73,167 \\
81,954 \\
\ddagger \\
69,077\end{array}$ & $\begin{array}{r}71,054 \\
96,072 \\
78,554 \\
101,054 \\
94,659\end{array}$ & $\begin{array}{l}58,515 \\
76,918 \\
64,313 \\
79,500 \\
75,957\end{array}$ & $\begin{array}{l}51,620 \\
61,916 \\
59,104 \\
61,895 \\
63,677\end{array}$ & $\begin{array}{l}117,156 \\
161,270 \\
132,389 \\
141,641 \\
120,875\end{array}$ & $\begin{array}{l}79,047 \\
88,224 \\
95,009 \\
93,826 \\
81,730\end{array}$ & $\begin{array}{l}71,575 \\
75,751 \\
73,454 \\
78,196 \\
71,193\end{array}$ & $\begin{array}{r}105,955 \\
117,300 \\
83,885 \\
65,956 \\
87,758\end{array}$ & $\begin{array}{l}68,689 \\
83,836 \\
76,515 \\
60,093 \\
71,544\end{array}$ & $\begin{array}{l}58,678 \\
69,008 \\
62,424 \\
51,083 \\
58,271\end{array}$ \\
\hline $\begin{array}{l}\text { Georgia. } \\
\text { Hawaii } \\
\text { daho. } \\
\text { llinois... } \\
\text { ndiana }\end{array}$ & $\begin{array}{r}113,920 \\
110,839 \\
83,769 \\
116,118 \\
118,247\end{array}$ & $\begin{array}{l}78,838 \\
84,933 \\
63,774 \\
78,197 \\
80,792\end{array}$ & $\begin{array}{l}69,933 \\
71,992 \\
57,492 \\
70,964 \\
69,827\end{array}$ & $\begin{array}{r}76,394 \\
\dagger \\
78,867 \\
87,732 \\
83,162\end{array}$ & $\begin{array}{r}62,119 \\
\dagger \\
64,973 \\
69,901 \\
65,648\end{array}$ & $\begin{array}{r}53,518 \\
\dagger \\
56,505 \\
61,674 \\
59,247\end{array}$ & $\begin{array}{r}133,018 \\
\dagger \\
\dagger \\
154,745 \\
127,256\end{array}$ & $\begin{array}{r}84,416 \\
\dagger \\
\dagger \\
91,149 \\
80,399\end{array}$ & $\begin{array}{r}71,812 \\
\dagger \\
\dagger \\
81,644 \\
69,921\end{array}$ & $\begin{array}{l}71,335 \\
92,142 \\
59,696 \\
84,224 \\
70,063\end{array}$ & $\begin{array}{l}57,935 \\
76,442 \\
50,861 \\
71,150 \\
59,431\end{array}$ & $\begin{array}{l}50,979 \\
68,503 \\
41,794 \\
58,298 \\
51,196\end{array}$ \\
\hline 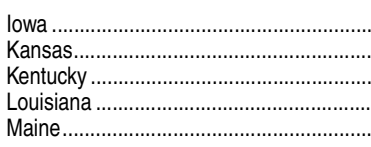 & $\begin{array}{r}123,503 \\
107,760 \\
106,021 \\
97,470 \\
96,988\end{array}$ & $\begin{array}{l}83,668 \\
74,655 \\
75,956 \\
72,574 \\
74,600\end{array}$ & $\begin{array}{l}73,609 \\
63,595 \\
66,966 \\
61,313 \\
60,809\end{array}$ & $\begin{array}{l}87,088 \\
73,303 \\
81,221 \\
73,280 \\
72,795\end{array}$ & $\begin{array}{l}68,943 \\
58,195 \\
63,727 \\
60,711 \\
55,748\end{array}$ & $\begin{array}{l}58,856 \\
54,025 \\
53,875 \\
53,078 \\
48,951\end{array}$ & $\begin{array}{r}90,905 \\
\dagger \\
71,201 \\
120,980 \\
85,821\end{array}$ & $\begin{array}{r}65,933 \\
\dagger \\
57,716 \\
84,709 \\
68,778\end{array}$ & $\begin{array}{r}57,571 \\
\dagger \\
50,981 \\
66,944 \\
62,778\end{array}$ & $\begin{array}{l}68,924 \\
60,430 \\
62,037 \\
61,997 \\
69,149\end{array}$ & $\begin{array}{l}56,818 \\
53,047 \\
52,564 \\
52,820 \\
54,677\end{array}$ & $\begin{array}{l}49,853 \\
47,940 \\
45,532 \\
52,495 \\
48,819\end{array}$ \\
\hline linnesota & $\begin{array}{r}116,516 \\
119,994 \\
118,147 \\
128,594 \\
93,057\end{array}$ & $\begin{array}{l}85,174 \\
89,968 \\
82,643 \\
84,652 \\
69,774\end{array}$ & $\begin{array}{l}77,117 \\
74,470 \\
70,383 \\
79,439 \\
61,442\end{array}$ & $\begin{array}{l}86,306 \\
83,177 \\
87,121 \\
84,054 \\
62,964\end{array}$ & $\begin{array}{l}68,113 \\
68,100 \\
74,534 \\
67,802 \\
53,930\end{array}$ & $\begin{array}{l}61,276 \\
59,599 \\
60,383 \\
59,382 \\
50,361\end{array}$ & $\begin{array}{r}156,354 \\
160,483 \\
111,517 \\
101,501 \\
84,974\end{array}$ & $\begin{array}{r}114,498 \\
100,357 \\
81,698 \\
76,378 \\
62,032\end{array}$ & $\begin{array}{l}95,789 \\
88,345 \\
70,866 \\
62,372 \\
57,732\end{array}$ & $\begin{array}{r}90,895 \\
114,715 \\
71,085 \\
74,907 \\
71,675\end{array}$ & $\begin{array}{l}70,541 \\
79,987 \\
58,975 \\
63,341 \\
55,306\end{array}$ & $\begin{array}{l}61,663 \\
64,327 \\
51,082 \\
53,858 \\
48,782\end{array}$ \\
\hline 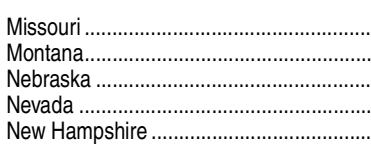 & $\begin{array}{r}101,456 \\
81,318 \\
108,880 \\
119,576 \\
114,251\end{array}$ & $\begin{array}{l}72,862 \\
64,113 \\
77,336 \\
86,001 \\
87,983\end{array}$ & $\begin{array}{l}61,991 \\
58,194 \\
68,869 \\
70,801 \\
72,306\end{array}$ & $\begin{array}{r}74,203 \\
67,628 \\
76,691 \\
\dagger \\
86,775\end{array}$ & $\begin{array}{r}59,961 \\
59,428 \\
63,114 \\
\dagger \\
71,345\end{array}$ & $\begin{array}{r}50,695 \\
51,893 \\
51,973 \\
\dagger \\
59,983\end{array}$ & $\begin{array}{r}131,546 \\
\dagger \\
102,079 \\
\dagger \\
137,928\end{array}$ & $\begin{array}{r}79,251 \\
\dagger \\
70,296 \\
\dagger \\
88,117\end{array}$ & $\begin{array}{r}69,965 \\
\dagger \\
60,083 \\
\dagger \\
65,283\end{array}$ & $\begin{array}{l}71,709 \\
58,576 \\
65,602 \\
76,564 \\
81,171\end{array}$ & & $\begin{array}{l}50,246 \\
42,906 \\
49,752 \\
52,625 \\
51,683\end{array}$ \\
\hline 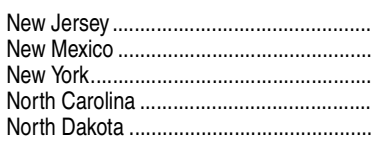 & \begin{tabular}{r|}
144,448 \\
94,818 \\
132,987 \\
121,219 \\
96,484
\end{tabular} & $\begin{array}{l}99,002 \\
70,456 \\
93,105 \\
80,421 \\
75,893\end{array}$ & $\begin{array}{l}81,039 \\
61,909 \\
75,593 \\
72,079 \\
65,379\end{array}$ & $\begin{array}{r}119,855 \\
68,062 \\
106,630 \\
88,368 \\
75,936\end{array}$ & $\begin{array}{l}93,868 \\
57,156 \\
81,798 \\
71,083 \\
60,103\end{array}$ & $\begin{array}{l}75,549 \\
49,907 \\
68,337 \\
60,613 \\
52,725\end{array}$ & $\begin{array}{r}161,988 \\
\dagger \\
148,229 \\
150,948 \\
62,511\end{array}$ & $\begin{array}{r}92,456 \\
\dagger \\
94,491 \\
89,887 \\
56,896\end{array}$ & $\begin{array}{r}80,364 \\
\dagger \\
78,329 \\
74,863 \\
48,964\end{array}$ & $\begin{array}{r}95,828 \\
55,673 \\
94,272 \\
65,427 \\
\dagger\end{array}$ & $\begin{array}{r}81,154 \\
48,039 \\
75,528 \\
58,238 \\
\dagger\end{array}$ & $\begin{array}{r}63,017 \\
39,410 \\
63,050 \\
51,442 \\
\dagger\end{array}$ \\
\hline 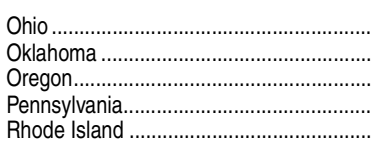 & $\begin{array}{l}111,466 \\
101,410 \\
103,110 \\
126,887 \\
105,162\end{array}$ & $\begin{array}{l}78,594 \\
72,067 \\
77,457 \\
89,044 \\
79,611\end{array}$ & $\begin{array}{l}66,711 \\
62,061 \\
68,394 \\
71,610 \\
65,820\end{array}$ & $\begin{array}{r}72,833 \\
72,127 \\
70,273 \\
103,589 \\
75,875\end{array}$ & $\begin{array}{l}60,760 \\
62,076 \\
57,749 \\
82,619 \\
64,067\end{array}$ & $\begin{array}{l}52,706 \\
55,761 \\
46,568 \\
65,862 \\
56,051\end{array}$ & $\begin{array}{r}107,326 \\
96,056 \\
99,040 \\
137,620 \\
146,551\end{array}$ & $\begin{array}{l}73,279 \\
72,773 \\
72,092 \\
90,322 \\
84,532\end{array}$ & $\begin{array}{l}63,146 \\
60,074 \\
60,590 \\
76,697 \\
73,929\end{array}$ & $\begin{array}{r}73,137 \\
64,698 \\
73,856 \\
88,522 \\
111,159\end{array}$ & $\begin{array}{l}62,247 \\
55,826 \\
62,191 \\
71,558 \\
88,227\end{array}$ & $\begin{array}{l}51,225 \\
48,123 \\
53,253 \\
59,909 \\
71,196\end{array}$ \\
\hline $\begin{array}{l}\text { South Dakota } \\
\text { Tennessee } \\
\text { Texas }\end{array}$ & $\begin{array}{r}111,370 \\
80,916 \\
92,872 \\
117,954 \\
105,007\end{array}$ & $\begin{array}{l}79,974 \\
65,294 \\
70,268 \\
79,537 \\
75,236\end{array}$ & $\begin{array}{l}71,386 \\
56,858 \\
59,110 \\
71,013 \\
66,926\end{array}$ & $\begin{array}{l}80,293 \\
80,951 \\
72,162 \\
81,649 \\
75,093\end{array}$ & $\begin{array}{l}65,754 \\
64,815 \\
58,612 \\
66,741 \\
62,995\end{array}$ & $\begin{array}{l}57,101 \\
55,108 \\
49,593 \\
58,899 \\
52,273\end{array}$ & $\begin{array}{r}\dagger \\
\dagger \\
130,879 \\
126,240 \\
125,313\end{array}$ & $\begin{array}{r}\dagger \\
\dagger \\
83,841 \\
86,247 \\
93,056\end{array}$ & $\begin{array}{r}\dagger \\
\dagger \\
67,478 \\
76,351 \\
81,575\end{array}$ & $\begin{array}{l}76,117 \\
60,792 \\
66,290 \\
83,163 \\
88,949\end{array}$ & $\begin{array}{l}59,444 \\
49,120 \\
55,898 \\
66,207 \\
69,218\end{array}$ & $\begin{array}{l}52,022 \\
42,484 \\
48,670 \\
55,033 \\
62,116\end{array}$ \\
\hline 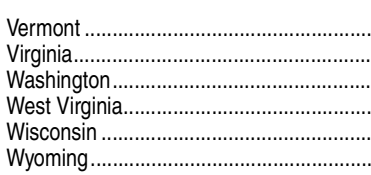 & $\begin{array}{r}113,338 \\
125,415 \\
106,990 \\
90,995 \\
107,391 \\
107,794\end{array}$ & $\begin{array}{l}84,380 \\
84,882 \\
79,674 \\
72,576 \\
75,034 \\
76,393\end{array}$ & $\begin{array}{l}68,509 \\
69,859 \\
72,290 \\
60,255 \\
69,013 \\
66,824\end{array}$ & $\begin{array}{r}70,741 \\
83,332 \\
82,898 \\
70,677 \\
71,521 \\
\dagger\end{array}$ & $\begin{array}{r}56,550 \\
65,693 \\
68,426 \\
61,427 \\
60,471 \\
+\end{array}$ & $\begin{array}{r}44,682 \\
59,170 \\
65,033 \\
52,635 \\
55,315 \\
+\end{array}$ & $\begin{array}{r}\dagger \\
108,499 \\
109,517 \\
64,807 \\
98,430 \\
\dagger\end{array}$ & $\begin{array}{r}\dagger \\
78,990 \\
77,776 \\
54,342 \\
75,675 \\
\dagger\end{array}$ & $\begin{array}{r}\dagger \\
45,298 \\
66,299 \\
45,287 \\
62,526 \\
\dagger\end{array}$ & $\begin{array}{r}103,377 \\
70,928 \\
76,749 \\
57,086 \\
72,429 \\
\dagger\end{array}$ & $\begin{array}{r}71,823 \\
57,439 \\
62,571 \\
48,644 \\
60,924 \\
+\end{array}$ & $\begin{array}{r}65,095 \\
51,269 \\
55,989 \\
43,248 \\
52,272 \\
\dagger\end{array}$ \\
\hline U.S. Service Academies.......... & $\dagger$ & $\dagger$ & $\dagger$ & $\dagger$ & $\dagger$ & $\dagger$ & $\dagger$ & $\dagger$ & $t$ & $t$ & $\dagger$ & $\dagger$ \\
\hline ions.... & 76,284 & 63,508 & 57,090 & 80,486 & 66,882 & 59,556 & 71,933 & 67,925 & 51,720 & 69,360 & 54,600 & $4 \overline{46,100}$ \\
\hline $\begin{array}{l}\text { Americ } \\
\text { Federa }\end{array}$ & & & & & & $\begin{array}{l}t \\
t\end{array}$ & 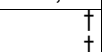 & & & +1 & $t$ & \\
\hline & & & & 87,370 & 70,792 & 56,612 & 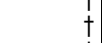 & & & 1 & $\dagger$ & \\
\hline & & & & & & $t$ & & & & + & $\dagger$ & \\
\hline $\begin{array}{l}\text { Northern Marianas ........... } \\
\text { Palau....................................... }\end{array}$ & & & & & & & $\begin{array}{l}\dagger \\
\dagger\end{array}$ & & & t & $\begin{array}{c}\dagger \\
t\end{array}$ & \\
\hline & 78 & 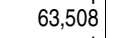 & 090 & 79,768 & & 61,960 & 1,933 & 67,925 & & & 300 & \\
\hline 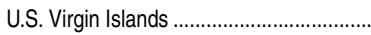 & & $\dagger$ & & 82,436 & 64,760 & 54,446 & $\dagger$ & $\dagger$ & $\uparrow$ & $\dagger$ & $\dagger$ & 1 \\
\hline
\end{tabular}

†Not applicable.

†Reporting standards not met (too few cases).

'Institutions that awarded 20 or more doctor's degrees during the previous academic year.

'Institutions that awarded 20 or more master's degrees, but less than 20 doctor's degrees, during the previous academic year.
NOTE: Degree-granting institutions grant associate's or higher degrees and participate in Title IV federal financial aid programs. Data include imputations for nonrespondent institutions. Some data have been revised from previously published figures.

SOURCE: U.S. Department of Education, National Center for Education Statistics, Integrated Postsecondary Education Data System (IPEDS), Winter 2011-12, Human Resources component, Salaries section. (This table was prepared March 2014.) 
Table 316.70. Average benefit expenditure for full-time instructional faculty on 9-month contracts in degree-granting postsecondary institutions, by type of benefit and control of institution: Selected years, 1977-78 through 2010-11

\begin{tabular}{|c|c|c|c|c|c|c|c|c|c|c|c|c|c|c|}
\hline \multirow[b]{3}{*}{$\begin{array}{l}\text { Control of institution } \\
\text { and year }\end{array}$} & \multirow{3}{*}{$\begin{array}{r}\text { Average } \\
\text { total } \\
\text { benefit per } \\
\text { full-time } \\
\text { faculty } \\
\text { member }\end{array}$} & \multicolumn{13}{|c|}{ Average benefit expenditure per full-time faculty member receiving benefit } \\
\hline & & \multicolumn{3}{|c|}{ Retirement plans } & \multirow[b]{2}{*}{$\begin{array}{r}\text { Medical/ } \\
\text { dental } \\
\text { plans }\end{array}$} & \multirow{2}{*}{$\begin{array}{r}\text { Guaran- } \\
\text { teed } \\
\text { disability } \\
\text { income } \\
\text { protection }\end{array}$} & \multirow{2}{*}{$\begin{array}{r}\text { Tuition } \\
\text { plan for } \\
\text { depen- } \\
\text { dents }\end{array}$} & \multirow[b]{2}{*}{$\begin{array}{r}\text { Housing } \\
\text { plan }\end{array}$} & \multirow[b]{2}{*}{$\begin{array}{r}\text { Social } \\
\text { Security } \\
\text { taxes }\end{array}$} & \multirow{2}{*}{\begin{tabular}{|} 
Unemploy- \\
ment \\
compen- \\
sation \\
taxes
\end{tabular}} & \multirow[b]{2}{*}{$\begin{array}{c}\text { Group life } \\
\text { insurance }\end{array}$} & \multirow{2}{*}{$\begin{array}{r}\text { Worker's } \\
\text { compen- } \\
\text { sation } \\
\text { taxes }\end{array}$} & \multirow[b]{2}{*}{$\begin{array}{r}\text { Other } \\
\text { insurance }\end{array}$} & \multirow[b]{2}{*}{$\begin{array}{r}\text { Other } \\
\text { benefits }\end{array}$} \\
\hline & & Total & $\begin{array}{r}\text { within } \\
5 \text { years }\end{array}$ & $\begin{array}{r}\text { after } \\
5 \text { years }\end{array}$ & & & & & & & & & & \\
\hline 1 & 2 & 3 & 4 & 5 & 6 & 7 & 8 & 9 & 10 & 11 & 12 & 13 & 14 & 15 \\
\hline & \multicolumn{14}{|c|}{ Current dollars } \\
\hline 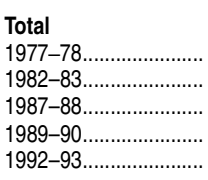 & $\begin{array}{r}\$ 3,203 \\
5,799 \\
7,227 \\
8,241 \\
10,473\end{array}$ & $\begin{array}{r}\$ 1,725 \\
2,731 \\
3,677 \\
4,048 \\
4,397\end{array}$ & $\begin{array}{r}\$ 1,739 \\
2,741 \\
3,494 \\
3,974 \\
4,391\end{array}$ & $\begin{array}{r}\$ 1,691 \\
2,703 \\
4,028 \\
4,192 \\
4,410\end{array}$ & $\begin{array}{l}\$ 521 \\
1,111 \\
1,682 \\
2,339 \\
3,266\end{array}$ & $\begin{array}{l}\$ 96 \\
151 \\
132 \\
147 \\
179\end{array}$ & $\begin{array}{r}\$ 1,410 \\
1,993 \\
1,585 \\
2,070 \\
2,196\end{array}$ & $\begin{array}{r}\$ 886 \\
1,639 \\
2,004 \\
2,643 \\
2,574\end{array}$ & $\begin{array}{l}\$ 899 \\
1,712 \\
2,379 \\
2,764 \\
3,168\end{array}$ & $\begin{array}{r}\$ 109 \\
146 \\
134 \\
121 \\
143\end{array}$ & $\begin{array}{r}\$ 105 \\
138 \\
178 \\
182 \\
237\end{array}$ & $\begin{array}{r}\$ 80 \\
114 \\
190 \\
49 \\
344\end{array}$ & $\begin{array}{l}- \\
- \\
- \\
- \\
-\end{array}$ & $\begin{array}{r}\$ 288 \\
915 \\
716 \\
637 \\
874\end{array}$ \\
\hline $\begin{array}{l}1997-98 \ldots \ldots \\
1998-99 \ldots \ldots \\
1999-2000 \\
2001-02 \ldots \\
2002-03 \ldots\end{array}$ & $\begin{array}{l}12,263 \\
12,580 \\
13,227 \\
14,408 \\
15,552\end{array}$ & $\begin{array}{l}5,289 \\
5,256 \\
5,292 \\
5,541 \\
5,781\end{array}$ & $\begin{array}{l}5,195 \\
5,268 \\
5,365 \\
5,738 \\
6,039\end{array}$ & $\begin{array}{l}5,498 \\
5,228 \\
5,125 \\
5,126 \\
5,208\end{array}$ & $\begin{array}{l}3,535 \\
3,726 \\
3,989 \\
4,792 \\
5,396\end{array}$ & $\begin{array}{l}218 \\
213 \\
237 \\
250 \\
264\end{array}$ & $\begin{array}{l}2,765 \\
3,012 \\
3,362 \\
3,487 \\
3,308\end{array}$ & $\begin{array}{l}4,100 \\
3,698 \\
4,187 \\
4,931 \\
4,329\end{array}$ & $\begin{array}{l}3,562 \\
3,668 \\
3,793 \\
4,079 \\
4,158\end{array}$ & $\begin{array}{l}158 \\
152 \\
146 \\
164 \\
170\end{array}$ & $\begin{array}{l}195 \\
190 \\
190 \\
231 \\
211\end{array}$ & $\begin{array}{l}340 \\
347 \\
343 \\
402 \\
411\end{array}$ & $\begin{array}{r}\$ 1,501 \\
1,267 \\
1,512 \\
668 \\
797\end{array}$ & $\begin{array}{r}1,043 \\
845 \\
1,303 \\
1,267 \\
1,263\end{array}$ \\
\hline 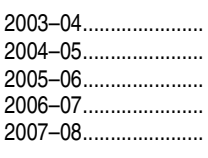 & \begin{tabular}{l|}
16,437 \\
17,269 \\
18,082 \\
18,783 \\
19,756
\end{tabular} & $\begin{array}{l}5,895 \\
6,211 \\
6,402 \\
6,710 \\
7,033\end{array}$ & $\begin{array}{l}6,161 \\
6,429 \\
6,571 \\
6,851 \\
7,142\end{array}$ & $\begin{array}{l}5,281 \\
5,682 \\
6,010 \\
6,361 \\
6,767\end{array}$ & $\begin{array}{l}5,919 \\
6,314 \\
6,863 \\
7,217 \\
7,635\end{array}$ & $\begin{array}{l}261 \\
272 \\
280 \\
280 \\
282\end{array}$ & $\begin{array}{l}3,506 \\
4,072 \\
4,511 \\
5,029 \\
5,607\end{array}$ & $\begin{array}{l}6,101 \\
4,176 \\
5,599 \\
6,914 \\
7,436\end{array}$ & $\begin{array}{l}4,260 \\
4,354 \\
4,451 \\
4,627 \\
4,773\end{array}$ & $\begin{array}{l}191 \\
225 \\
228 \\
176 \\
168\end{array}$ & $\begin{array}{l}215 \\
199 \\
210 \\
217 \\
215\end{array}$ & $\begin{array}{l}435 \\
481 \\
473 \\
484 \\
509\end{array}$ & $\begin{array}{r}951 \\
853 \\
1,095 \\
1,226 \\
1,172\end{array}$ & $\begin{array}{l}1,452 \\
1,637 \\
1,457 \\
1,564 \\
1,706\end{array}$ \\
\hline 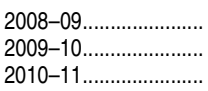 & $\begin{array}{l}20,332 \\
20,978 \\
21,744\end{array}$ & $\begin{array}{l}7,222 \\
7,292 \\
7,436\end{array}$ & $\begin{array}{l}7,396 \\
7,472 \\
7,672\end{array}$ & $\begin{array}{l}6,797 \\
6,846 \\
6,883\end{array}$ & $\begin{array}{l}7,900 \\
8,389 \\
8,843\end{array}$ & $\begin{array}{l}291 \\
276 \\
281\end{array}$ & $\begin{array}{l}5,596 \\
6,016 \\
6,396\end{array}$ & $\begin{array}{l}9,001 \\
8,729 \\
9,071\end{array}$ & $\begin{array}{l}4,918 \\
4,993 \\
5,042\end{array}$ & $\begin{array}{l}169 \\
180 \\
219\end{array}$ & $\begin{array}{l}213 \\
211 \\
210\end{array}$ & $\begin{array}{l}498 \\
499 \\
502\end{array}$ & $\begin{array}{l}1,156 \\
1,155 \\
1,191\end{array}$ & $\begin{array}{l}1,540 \\
1,561 \\
1,546\end{array}$ \\
\hline 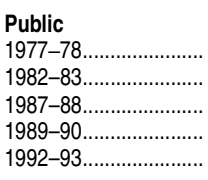 & $\begin{array}{r}3,252 \\
5,920 \\
7,146 \\
8,361 \\
10,280\end{array}$ & $\begin{array}{l}1,791 \\
2,846 \\
3,815 \\
4,186 \\
4,467\end{array}$ & $\begin{array}{l}1,833 \\
2,880 \\
3,602 \\
4,128 \\
4,469\end{array}$ & $\begin{array}{l}1,724 \\
2,776 \\
4,086 \\
4,259 \\
4,464\end{array}$ & $\begin{array}{r}560 \\
1,189 \\
1,757 \\
2,425 \\
3,352\end{array}$ & $\begin{array}{r}99 \\
153 \\
140 \\
154 \\
188\end{array}$ & $\begin{array}{l}430 \\
576 \\
404 \\
605 \\
693\end{array}$ & $\begin{array}{r}846 \\
1,027 \\
1,172 \\
1,767 \\
1,135\end{array}$ & $\begin{array}{r}911 \\
1,741 \\
2,399 \\
2,771 \\
3,122\end{array}$ & $\begin{array}{r}99 \\
139 \\
109 \\
97 \\
117\end{array}$ & $\begin{array}{l}105 \\
140 \\
180 \\
182 \\
250\end{array}$ & $\begin{array}{r}88 \\
115 \\
192 \\
60 \\
318\end{array}$ & $\begin{array}{l}- \\
- \\
- \\
-\end{array}$ & $\begin{array}{r}94 \\
980 \\
611 \\
602 \\
827\end{array}$ \\
\hline 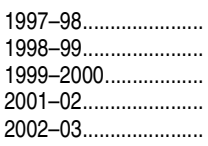 & $\begin{array}{l}12,114 \\
12,192 \\
12,756 \\
13,919 \\
15,097\end{array}$ & $\begin{array}{l}5,432 \\
5,249 \\
5,258 \\
5,437 \\
5,703\end{array}$ & $\begin{array}{l}5,302 \\
5,230 \\
5,297 \\
5,641 \\
5,968\end{array}$ & $\begin{array}{l}5,617 \\
5,276 \\
5,200 \\
5,158 \\
5,323\end{array}$ & $\begin{array}{l}3,646 \\
3,830 \\
4,131 \\
4,936 \\
5,565\end{array}$ & $\begin{array}{l}219 \\
202 \\
237 \\
254 \\
274\end{array}$ & $\begin{array}{l}830 \\
828 \\
962 \\
994 \\
978\end{array}$ & $\begin{array}{r}2,614 \\
1,826 \\
2,283 \\
686 \\
2,415\end{array}$ & $\begin{array}{l}3,482 \\
3,553 \\
3,660 \\
3,930 \\
4,005\end{array}$ & $\begin{array}{l}133 \\
127 \\
121 \\
137 \\
142\end{array}$ & $\begin{array}{l}187 \\
183 \\
176 \\
233 \\
198\end{array}$ & $\begin{array}{l}340 \\
348 \\
347 \\
402 \\
402\end{array}$ & $\begin{array}{r}1,643 \\
1,252 \\
1,603 \\
694 \\
872\end{array}$ & $\begin{array}{r}1,175 \\
709 \\
1,272 \\
1,162 \\
1,274\end{array}$ \\
\hline $\begin{array}{l}2003-04 \ldots \ldots \ldots \ldots \ldots \ldots . . . \\
2004-05 \ldots \ldots \ldots \ldots \ldots \ldots \ldots . . . \\
2005-06 \ldots \ldots \ldots \ldots \ldots \ldots . . . \\
2006-0\end{array}$ & $\begin{array}{l}15,916 \\
16,769 \\
17,594 \\
18,299 \\
19,245\end{array}$ & $\begin{array}{l}5,757 \\
6,104 \\
6,308 \\
6,620 \\
6,994\end{array}$ & $\begin{array}{l}6,044 \\
6,321 \\
6,458 \\
6,743 \\
7,071\end{array}$ & $\begin{array}{l}5,330 \\
5,760 \\
6,078 \\
6,419 \\
6,872\end{array}$ & $\begin{array}{l}6,127 \\
6,498 \\
7,126 \\
7,446 \\
7,858\end{array}$ & $\begin{array}{l}262 \\
274 \\
279 \\
281 \\
289\end{array}$ & $\begin{array}{l}1,022 \\
1,280 \\
1,483 \\
1,609 \\
1,815\end{array}$ & $\begin{array}{r}4,589 \\
3,655 \\
4,418 \\
393 \\
3,382\end{array}$ & $\begin{array}{l}4,073 \\
4,161 \\
4,237 \\
4,409 \\
4,542\end{array}$ & $\begin{array}{l}173 \\
202 \\
210 \\
149 \\
136\end{array}$ & $\begin{array}{l}206 \\
189 \\
202 \\
202 \\
197\end{array}$ & $\begin{array}{l}425 \\
479 \\
446 \\
494 \\
520\end{array}$ & $\begin{array}{r}901 \\
866 \\
1,209 \\
1,303 \\
1,209\end{array}$ & $\begin{array}{l}1,334 \\
1,725 \\
1,299 \\
1,523 \\
1,516\end{array}$ \\
\hline & $\begin{array}{l}19,778 \\
20,435 \\
21,234\end{array}$ & $\begin{array}{l}7,156 \\
7,237 \\
7,360\end{array}$ & $\begin{array}{r}7,292 \\
7,387 \\
7,616\end{array}$ & $\begin{array}{l}6,941 \\
6,998 \\
6,977\end{array}$ & $\begin{array}{l}8,079 \\
8,613 \\
9,053\end{array}$ & $\begin{array}{l}291 \\
276 \\
269\end{array}$ & $\begin{array}{l}1,876 \\
1,972 \\
2,317\end{array}$ & $\begin{array}{l}4,635 \\
4,276 \\
4,802\end{array}$ & $\begin{array}{l}4,657 \\
4,717 \\
4,750\end{array}$ & $\begin{array}{l}138 \\
148 \\
196\end{array}$ & $\begin{array}{l}194 \\
189 \\
192\end{array}$ & $\begin{array}{l}511 \\
509 \\
514\end{array}$ & $\begin{array}{l}1,245 \\
1,269 \\
1,253\end{array}$ & $\begin{array}{l}1,475 \\
1,543 \\
1,322\end{array}$ \\
\hline 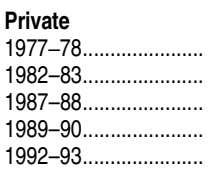 & $\begin{array}{r}3,071 \\
5,462 \\
7,438 \\
7,954 \\
10,958\end{array}$ & $\begin{array}{l}1,509 \\
2,340 \\
3,280 \\
3,657 \\
4,206\end{array}$ & $\begin{array}{l}1,542 \\
2,404 \\
3,306 \\
3,718 \\
4,259\end{array}$ & $\begin{array}{r}905 \\
1,295 \\
2,906 \\
2,478 \\
2,877\end{array}$ & $\begin{array}{r}404 \\
886 \\
1,488 \\
2,112 \\
3,039\end{array}$ & $\begin{array}{r}89 \\
146 \\
120 \\
134 \\
163\end{array}$ & $\begin{array}{l}2,025 \\
3,403 \\
3,666 \\
4,259 \\
4,523\end{array}$ & $\begin{array}{r}890 \\
1,798 \\
2,303 \\
3,032 \\
2,956\end{array}$ & $\begin{array}{r}873 \\
1,648 \\
2,337 \\
2,750 \\
3,267\end{array}$ & $\begin{array}{l}131 \\
170 \\
197 \\
188 \\
212\end{array}$ & $\begin{array}{l}103 \\
134 \\
175 \\
182 \\
207\end{array}$ & $\begin{array}{r}60 \\
113 \\
184 \\
25 \\
402\end{array}$ & $\begin{array}{l}- \\
- \\
- \\
- \\
-\end{array}$ & $\begin{array}{l}838 \\
212 \\
977 \\
712 \\
957\end{array}$ \\
\hline 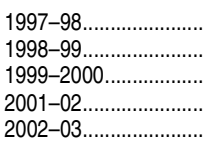 & $\begin{array}{l}12,629 \\
13,519 \\
14,366 \\
15,644 \\
16,660\end{array}$ & $\begin{array}{l}4,915 \\
5,274 \\
5,380 \\
5,818 \\
5,981\end{array}$ & $\begin{array}{l}5,023 \\
5,327 \\
5,471 \\
5,897 \\
6,153\end{array}$ & $\begin{array}{l}2,531 \\
3,879 \\
3,354 \\
4,518 \\
2,983\end{array}$ & $\begin{array}{l}3,255 \\
3,468 \\
3,638 \\
4,416 \\
4,964\end{array}$ & $\begin{array}{l}216 \\
231 \\
237 \\
245 \\
249\end{array}$ & $\begin{array}{l}5,513 \\
6,722 \\
6,951 \\
7,159 \\
6,943\end{array}$ & $\begin{array}{l}4,228 \\
3,936 \\
4,349 \\
5,083 \\
4,348\end{array}$ & $\begin{array}{l}3,735 \\
3,915 \\
4,074 \\
4,414 \\
4,490\end{array}$ & $\begin{array}{l}222 \\
219 \\
213 \\
242 \\
247\end{array}$ & $\begin{array}{l}209 \\
205 \\
215 \\
225 \\
236\end{array}$ & $\begin{array}{l}339 \\
345 \\
335 \\
403 \\
429\end{array}$ & $\begin{array}{r}1,207 \\
1,313 \\
1,331 \\
628 \\
629\end{array}$ & $\begin{array}{r}897 \\
1,020 \\
1,342 \\
1,450 \\
1,248\end{array}$ \\
\hline 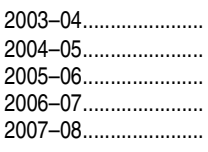 & $\begin{array}{l}17,687 \\
18,465 \\
19,258 \\
19,942 \\
20,984\end{array}$ & $\begin{array}{l}6,245 \\
6,483 \\
6,637 \\
6,935 \\
7,131\end{array}$ & $\begin{array}{l}6,346 \\
6,603 \\
6,756 \\
7,027 \\
7,257\end{array}$ & $\begin{array}{l}4,225 \\
4,092 \\
5,037 \\
5,382 \\
4,843\end{array}$ & $\begin{array}{l}5,395 \\
5,849 \\
6,195 \\
6,632 \\
7,062\end{array}$ & $\begin{array}{l}259 \\
269 \\
281 \\
278 \\
272\end{array}$ & $\begin{array}{r}7,481 \\
7,600 \\
8,594 \\
9,610 \\
10,368\end{array}$ & $\begin{array}{l}6,104 \\
4,455 \\
6,001 \\
7,750 \\
7,474\end{array}$ & $\begin{array}{l}4,667 \\
4,775 \\
4,914 \\
5,097 \\
5,275\end{array}$ & $\begin{array}{l}239 \\
284 \\
275 \\
248 \\
253\end{array}$ & $\begin{array}{l}231 \\
217 \\
223 \\
246 \\
248\end{array}$ & $\begin{array}{l}457 \\
484 \\
528 \\
465 \\
487\end{array}$ & $\begin{array}{r}1,057 \\
821 \\
860 \\
1,049 \\
1,098\end{array}$ & $\begin{array}{l}1,584 \\
1,527 \\
1,658 \\
1,619 \\
1,944\end{array}$ \\
\hline 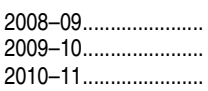 & $\begin{array}{l}21,656 \\
22,258 \\
22,927\end{array}$ & $\begin{array}{l}7,385 \\
7,426 \\
7,626\end{array}$ & $\begin{array}{l}7,564 \\
7,608 \\
7,761\end{array}$ & $\begin{array}{l}4,195 \\
3,951 \\
4,797\end{array}$ & $\begin{array}{l}7,442 \\
7,824 \\
8,323\end{array}$ & $\begin{array}{l}292 \\
275 \\
299\end{array}$ & $\begin{array}{r}9,941 \\
10,805 \\
11,330\end{array}$ & $\begin{array}{l}9,017 \\
8,750 \\
9,091\end{array}$ & $\begin{array}{l}5,489 \\
5,590 \\
5,664\end{array}$ & $\begin{array}{l}251 \\
265 \\
281\end{array}$ & $\begin{array}{l}251 \\
250 \\
244\end{array}$ & $\begin{array}{l}472 \\
479 \\
479\end{array}$ & $\begin{array}{r}985 \\
919 \\
1,059\end{array}$ & $\begin{array}{l}1,628 \\
1,580 \\
1,819\end{array}$ \\
\hline
\end{tabular}


524 CHAPTER 3: Postsecondary Education

Faculty Salaries and Benefits

Table 316.70. Average benefit expenditure for full-time instructional faculty on 9-month contracts in degree-granting postsecondary institutions, by type of benefit and control of institution: Selected years, 1977-78 through 2010-11-Continued

\begin{tabular}{|c|c|c|c|c|c|c|c|c|c|c|c|c|c|c|}
\hline \multirow[b]{3}{*}{$\begin{array}{l}\text { Control of institution } \\
\text { and year }\end{array}$} & \multirow{3}{*}{$\begin{array}{r}\text { Average } \\
\text { total } \\
\text { benefit per } \\
\text { full-time } \\
\text { faculty } \\
\text { member }\end{array}$} & \multicolumn{13}{|c|}{ Average benefit expenditure per full-time faculty member receiving benefit } \\
\hline & & \multicolumn{3}{|c|}{ Retirement plans } & \multirow[b]{2}{*}{$\begin{array}{r}\text { Medical/ } \\
\text { dental } \\
\text { plans }\end{array}$} & \multirow{2}{*}{$\begin{array}{r}\text { Guaran- } \\
\text { teed } \\
\text { disability } \\
\text { income } \\
\text { protection }\end{array}$} & \multirow{2}{*}{$\begin{array}{r}\text { Tuition } \\
\text { plan for } \\
\text { depen- } \\
\text { dents }\end{array}$} & \multirow[b]{2}{*}{$\begin{array}{r}\text { Housing } \\
\text { plan }\end{array}$} & \multirow[b]{2}{*}{$\begin{array}{r}\text { Social } \\
\text { Security } \\
\text { taxes }\end{array}$} & \multirow{2}{*}{\begin{tabular}{|r|} 
Unemploy- \\
ment \\
compen- \\
sation \\
taxes
\end{tabular}} & \multirow[b]{2}{*}{$\begin{array}{l}\text { Group life } \\
\text { insurance }\end{array}$} & \multirow{2}{*}{$\begin{array}{r}\text { Worker's } \\
\text { compen- } \\
\text { sation } \\
\text { taxes }\end{array}$} & \multirow[b]{2}{*}{$\begin{array}{r}\text { Other } \\
\text { insurance }\end{array}$} & \multirow[b]{2}{*}{$\begin{array}{r}\text { Other } \\
\text { benefits }\end{array}$} \\
\hline & & Total & $\begin{array}{r}\text { Vested } \\
\text { within } \\
5 \text { years }\end{array}$ & $\begin{array}{r}\text { Vested } \\
\text { after } \\
5 \text { years }\end{array}$ & & & & & & & & & & \\
\hline 1 & 2 & 3 & 4 & 5 & 6 & 7 & 8 & 9 & 10 & 11 & 12 & 13 & 14 & 15 \\
\hline & \multicolumn{14}{|c|}{ Constant 2012-13 dollars ${ }^{1}$} \\
\hline $\begin{array}{l}\text { Total } \\
1977-78 \ldots \ldots \ldots \ldots \ldots \\
1982-83 \ldots \ldots \ldots \ldots \ldots \ldots \ldots \\
1987-88 \ldots \ldots \ldots \ldots \ldots \ldots \\
1989-90 \ldots \ldots \ldots \ldots \ldots \ldots \ldots \\
1992-93 \ldots \ldots \ldots \ldots \ldots \ldots \ldots \ldots\end{array}$ & $\begin{array}{l}11,832 \\
13,668 \\
14,433 \\
15,015 \\
16,999\end{array}$ & $\begin{array}{l}6,370 \\
6,437 \\
7,343 \\
7,376 \\
7,138\end{array}$ & $\begin{array}{l}6,425 \\
6,461 \\
6,978 \\
7,241 \\
7,128\end{array}$ & $\begin{array}{l}6,247 \\
6,371 \\
8,045 \\
7,638 \\
7,159\end{array}$ & $\begin{array}{l}1,924 \\
2,620 \\
3,359 \\
4,261 \\
5,302\end{array}$ & $\begin{array}{l}354 \\
355 \\
264 \\
267 \\
290\end{array}$ & $\begin{array}{l}5,208 \\
4,698 \\
3,165 \\
3,772 \\
3,565\end{array}$ & $\begin{array}{l}3,274 \\
3,863 \\
4,002 \\
4,816 \\
4,178\end{array}$ & $\begin{array}{l}3,322 \\
4,035 \\
4,751 \\
5,036 \\
5,142\end{array}$ & $\begin{array}{l}401 \\
345 \\
268 \\
221 \\
232\end{array}$ & $\begin{array}{l}386 \\
326 \\
356 \\
332 \\
385\end{array}$ & $\begin{array}{r}295 \\
270 \\
379 \\
89 \\
558\end{array}$ & $\begin{array}{l}- \\
- \\
- \\
-\end{array}$ & $\begin{array}{l}1,062 \\
2,156 \\
1,429 \\
1,160 \\
1,419\end{array}$ \\
\hline 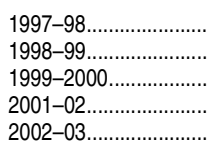 & $\begin{array}{l}17,541 \\
17,688 \\
18,075 \\
18,706 \\
19,758\end{array}$ & $\begin{array}{l}7,565 \\
7,390 \\
7,232 \\
7,194 \\
7,345\end{array}$ & $\begin{array}{l}7,430 \\
7,407 \\
7,331 \\
7,450 \\
7,673\end{array}$ & $\begin{array}{l}7,864 \\
7,350 \\
7,004 \\
6,656 \\
6,616\end{array}$ & $\begin{array}{l}5,057 \\
5,238 \\
5,451 \\
6,221 \\
6,856\end{array}$ & $\begin{array}{l}312 \\
300 \\
324 \\
325 \\
335\end{array}$ & $\begin{array}{l}3,956 \\
4,235 \\
4,594 \\
4,528 \\
4,203\end{array}$ & $\begin{array}{l}5,864 \\
5,199 \\
5,721 \\
6,403 \\
5,499\end{array}$ & $\begin{array}{l}5,096 \\
5,157 \\
5,184 \\
5,296 \\
5,282\end{array}$ & $\begin{array}{l}225 \\
214 \\
200 \\
213 \\
216\end{array}$ & $\begin{array}{l}278 \\
268 \\
259 \\
300 \\
268\end{array}$ & $\begin{array}{l}486 \\
488 \\
469 \\
522 \\
522\end{array}$ & $\begin{array}{r}2,147 \\
1,781 \\
2,066 \\
867 \\
1,012\end{array}$ & $\begin{array}{l}1,491 \\
1,189 \\
1,781 \\
1,644 \\
1,604\end{array}$ \\
\hline 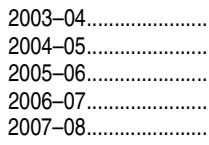 & $\begin{array}{l}20,435 \\
20,841 \\
21,023 \\
21,287 \\
21,590\end{array}$ & $\begin{array}{l}7,329 \\
7,497 \\
7,443 \\
7,604 \\
7,686\end{array}$ & $\begin{array}{l}7,659 \\
7,759 \\
7,640 \\
7,764 \\
7,805\end{array}$ & $\begin{array}{l}6,565 \\
6,858 \\
6,988 \\
7,209 \\
7,395\end{array}$ & $\begin{array}{l}7,359 \\
7,620 \\
7,980 \\
8,179 \\
8,344\end{array}$ & $\begin{array}{l}324 \\
329 \\
325 \\
317 \\
309\end{array}$ & $\begin{array}{l}4,359 \\
4,915 \\
5,245 \\
5,700 \\
6,127\end{array}$ & $\begin{array}{l}7,585 \\
5,040 \\
6,510 \\
7,835 \\
8,126\end{array}$ & $\begin{array}{l}5,297 \\
5,255 \\
5,174 \\
5,243 \\
5,216\end{array}$ & $\begin{array}{l}237 \\
272 \\
265 \\
200 \\
184\end{array}$ & $\begin{array}{l}267 \\
240 \\
244 \\
246 \\
235\end{array}$ & $\begin{array}{l}541 \\
580 \\
550 \\
549 \\
556\end{array}$ & $\begin{array}{l}1,182 \\
1,029 \\
1,273 \\
1,389 \\
1,281\end{array}$ & $\begin{array}{l}1,805 \\
1,976 \\
1,694 \\
1,772 \\
1,865\end{array}$ \\
\hline $\begin{array}{l}2008-09 \ldots \ldots \ldots \ldots \ldots \ldots \\
2009-10 \ldots \ldots \ldots \ldots \ldots \ldots . . . \\
2010-11 \ldots \ldots \ldots \ldots \ldots \ldots \ldots\end{array}$ & $\begin{array}{l}21,913 \\
22,393 \\
22,754\end{array}$ & $\begin{array}{l}7,783 \\
7,783 \\
7,781\end{array}$ & $\begin{array}{l}7,971 \\
7,976 \\
8,028\end{array}$ & $\begin{array}{l}7,326 \\
7,308 \\
7,202\end{array}$ & $\begin{array}{l}8,514 \\
8,955 \\
9,254\end{array}$ & $\begin{array}{l}314 \\
294 \\
294\end{array}$ & $\begin{array}{l}6,032 \\
6,422 \\
6,693\end{array}$ & $\begin{array}{l}9,701 \\
9,318 \\
9,492\end{array}$ & $\begin{array}{l}5,301 \\
5,330 \\
5,276\end{array}$ & $\begin{array}{l}182 \\
192 \\
230\end{array}$ & $\begin{array}{l}230 \\
225 \\
220\end{array}$ & $\begin{array}{l}537 \\
533 \\
525\end{array}$ & $\begin{array}{l}1,246 \\
1,232 \\
1,246\end{array}$ & $\begin{array}{l}1,659 \\
1,666 \\
1,618\end{array}$ \\
\hline $\begin{array}{l}\text { Public } \\
1977-78 \ldots \ldots \ldots \ldots \ldots \ldots \\
1982-83 \ldots \ldots \ldots \ldots \ldots \\
1987-88 \ldots \ldots \ldots \ldots \ldots \ldots \\
1989-90 \\
1992-93 \ldots \ldots \ldots \ldots \ldots \ldots \ldots \ldots \ldots\end{array}$ & $\begin{array}{l}12,011 \\
13,955 \\
14,272 \\
15,234 \\
16,688\end{array}$ & $\begin{array}{l}6,615 \\
6,709 \\
7,619 \\
7,627 \\
7,251\end{array}$ & $\begin{array}{l}6,770 \\
6,789 \\
7,195 \\
7,521 \\
7,255\end{array}$ & $\begin{array}{l}6,368 \\
6,544 \\
8,160 \\
7,760 \\
7,246\end{array}$ & $\begin{array}{l}2,070 \\
2,802 \\
3,510 \\
4,419 \\
5,441\end{array}$ & $\begin{array}{l}367 \\
361 \\
280 \\
281 \\
304\end{array}$ & $\begin{array}{r}1,588 \\
1,358 \\
808 \\
1,103 \\
1,125\end{array}$ & $\begin{array}{l}3,126 \\
2,421 \\
2,340 \\
3,219 \\
1,842\end{array}$ & $\begin{array}{l}3,366 \\
4,104 \\
4,790 \\
5,048 \\
5,068\end{array}$ & $\begin{array}{l}366 \\
327 \\
218 \\
176 \\
189\end{array}$ & $\begin{array}{l}388 \\
330 \\
359 \\
332 \\
406\end{array}$ & $\begin{array}{l}326 \\
271 \\
384 \\
109 \\
517\end{array}$ & $\begin{array}{l}- \\
- \\
- \\
-\end{array}$ & $\begin{array}{r}346 \\
2,311 \\
1,221 \\
1,096 \\
1,343\end{array}$ \\
\hline $\begin{array}{l}1997-98 \\
1998-99 \ldots \ldots \ldots \ldots \ldots \\
1999-2000 \\
2001-02 \\
2002-03 \ldots \ldots \ldots \ldots \ldots \ldots \ldots \ldots \ldots \ldots \ldots \ldots . . .\end{array}$ & $\begin{array}{l}17,327 \\
17,143 \\
17,433 \\
18,071 \\
19,179\end{array}$ & $\begin{array}{l}7,770 \\
7,380 \\
7,185 \\
7,059 \\
7,245\end{array}$ & $\begin{array}{l}7,584 \\
7,354 \\
7,238 \\
7,323 \\
7,582\end{array}$ & $\begin{array}{l}8,035 \\
7,418 \\
7,106 \\
6,697 \\
6,762\end{array}$ & $\begin{array}{l}5,215 \\
5,385 \\
5,646 \\
6,408 \\
7,070\end{array}$ & $\begin{array}{l}314 \\
283 \\
324 \\
330 \\
349\end{array}$ & $\begin{array}{l}1,187 \\
1,164 \\
1,314 \\
1,291 \\
1,243\end{array}$ & $\begin{array}{r}3,739 \\
2,567 \\
3,120 \\
891 \\
3,068\end{array}$ & $\begin{array}{l}4,981 \\
4,995 \\
5,002 \\
5,102 \\
5,088\end{array}$ & $\begin{array}{l}191 \\
178 \\
165 \\
179 \\
180\end{array}$ & $\begin{array}{l}268 \\
257 \\
241 \\
303 \\
252\end{array}$ & $\begin{array}{l}487 \\
490 \\
475 \\
522 \\
510\end{array}$ & $\begin{array}{r}2,350 \\
1,760 \\
2,190 \\
901 \\
1,108\end{array}$ & $\begin{array}{r}1,681 \\
997 \\
1,738 \\
1,508 \\
1,618\end{array}$ \\
\hline $\begin{array}{l}2003-04 \ldots \ldots \ldots \ldots \\
2004-05 \ldots \ldots \ldots \ldots \ldots \ldots \\
2005-06 \ldots \ldots \ldots \ldots \ldots \ldots \ldots \\
2006-07 \ldots \ldots \ldots \ldots \ldots \ldots \ldots \\
2007-08 \ldots \ldots \ldots \ldots \ldots \ldots\end{array}$ & $\begin{array}{l}19,787 \\
20,238 \\
20,455 \\
20,739 \\
21,031\end{array}$ & $\begin{array}{l}7,157 \\
7,366 \\
7,334 \\
7,502 \\
7,643\end{array}$ & $\begin{array}{l}7,514 \\
7,629 \\
7,508 \\
7,642 \\
7,727\end{array}$ & $\begin{array}{l}6,626 \\
6,952 \\
7,067 \\
7,274 \\
7,510\end{array}$ & $\begin{array}{l}7,617 \\
7,842 \\
8,285 \\
8,439 \\
8,588\end{array}$ & $\begin{array}{l}326 \\
331 \\
324 \\
319 \\
316\end{array}$ & $\begin{array}{l}1,270 \\
1,545 \\
1,724 \\
1,824 \\
1,983\end{array}$ & $\begin{array}{r}5,704 \\
4,411 \\
5,136 \\
446 \\
3,696\end{array}$ & $\begin{array}{l}5,064 \\
5,022 \\
4,926 \\
4,996 \\
4,963\end{array}$ & $\begin{array}{l}215 \\
244 \\
244 \\
169 \\
149\end{array}$ & $\begin{array}{l}256 \\
228 \\
235 \\
229 \\
216\end{array}$ & $\begin{array}{l}528 \\
578 \\
519 \\
560 \\
568\end{array}$ & $\begin{array}{l}1,120 \\
1,045 \\
1,406 \\
1,477 \\
1,322\end{array}$ & $\begin{array}{l}1,659 \\
2,082 \\
1,511 \\
1,726 \\
1,656\end{array}$ \\
\hline $\begin{array}{l}2008-09 \ldots \ldots \ldots \ldots \ldots \ldots \\
2009-10 \ldots \ldots \ldots \ldots \ldots \ldots . . . \\
2010-11 \ldots \ldots \ldots \ldots \ldots \ldots \ldots\end{array}$ & $\begin{array}{l}21,316 \\
21,814 \\
22,220\end{array}$ & $\begin{array}{l}7,713 \\
7,725 \\
7,702\end{array}$ & $\begin{array}{l}7,859 \\
7,885 \\
7,969\end{array}$ & $\begin{array}{l}7,481 \\
7,470 \\
7,301\end{array}$ & $\begin{array}{l}8,707 \\
9,194 \\
9,473\end{array}$ & $\begin{array}{l}313 \\
295 \\
282\end{array}$ & $\begin{array}{l}2,022 \\
2,105 \\
2,424\end{array}$ & $\begin{array}{l}4,995 \\
4,565 \\
5,024\end{array}$ & $\begin{array}{l}5,019 \\
5,035 \\
4,971\end{array}$ & $\begin{array}{l}149 \\
158 \\
205\end{array}$ & $\begin{array}{l}209 \\
202 \\
201\end{array}$ & $\begin{array}{l}550 \\
543 \\
538\end{array}$ & $\begin{array}{l}1,342 \\
1,355 \\
1,311\end{array}$ & $\begin{array}{l}1,590 \\
1,648 \\
1,384\end{array}$ \\
\hline $\begin{array}{l}\text { Private } \\
1977-78 \\
1982-83 \ldots \ldots \ldots \ldots \ldots \ldots \ldots \\
1987-88 \ldots \ldots \ldots \ldots \ldots \ldots \\
1989-90 \\
1992-93 \ldots \ldots \ldots \ldots \ldots \ldots \ldots \ldots \ldots \ldots \ldots \ldots \ldots\end{array}$ & $\begin{array}{l}11,345 \\
12,875 \\
14,854 \\
14,493 \\
17,787\end{array}$ & $\begin{array}{l}5,573 \\
5,516 \\
6,551 \\
6,664 \\
6,828\end{array}$ & $\begin{array}{l}5,695 \\
5,666 \\
6,603 \\
6,774 \\
6,913\end{array}$ & $\begin{array}{l}3,344 \\
3,054 \\
5,804 \\
4,515 \\
4,671\end{array}$ & $\begin{array}{l}1,494 \\
2,089 \\
2,972 \\
3,848 \\
4,933\end{array}$ & $\begin{array}{l}329 \\
344 \\
239 \\
244 \\
265\end{array}$ & $\begin{array}{l}7,481 \\
8,021 \\
7,322 \\
7,760 \\
7,342\end{array}$ & $\begin{array}{l}3,286 \\
4,238 \\
4,600 \\
5,524 \\
4,798\end{array}$ & $\begin{array}{l}3,223 \\
3,885 \\
4,668 \\
5,011 \\
5,303\end{array}$ & $\begin{array}{l}483 \\
401 \\
394 \\
343 \\
344\end{array}$ & $\begin{array}{l}382 \\
317 \\
349 \\
332 \\
336\end{array}$ & $\begin{array}{r}222 \\
266 \\
367 \\
45 \\
652\end{array}$ & $\begin{array}{l}- \\
- \\
- \\
-\end{array}$ & $\begin{array}{r}3,095 \\
501 \\
1,951 \\
1,298 \\
1,553\end{array}$ \\
\hline 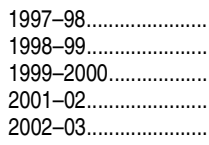 & $\begin{array}{l}18,064 \\
19,008 \\
19,633 \\
20,311 \\
21,165\end{array}$ & $\begin{array}{l}7,031 \\
7,416 \\
7,352 \\
7,553 \\
7,599\end{array}$ & $\begin{array}{l}7,185 \\
7,491 \\
7,477 \\
7,657 \\
7,816\end{array}$ & $\begin{array}{l}3,620 \\
5,454 \\
4,583 \\
5,866 \\
3,790\end{array}$ & $\begin{array}{l}4,655 \\
4,876 \\
4,971 \\
5,734 \\
6,307\end{array}$ & $\begin{array}{l}309 \\
324 \\
324 \\
318 \\
316\end{array}$ & $\begin{array}{l}7,885 \\
9,451 \\
9,499 \\
9,295 \\
8,821\end{array}$ & $\begin{array}{l}6,048 \\
5,533 \\
5,943 \\
6,600 \\
5,524\end{array}$ & $\begin{array}{l}5,343 \\
5,504 \\
5,568 \\
5,731 \\
5,704\end{array}$ & $\begin{array}{l}318 \\
308 \\
291 \\
314 \\
313\end{array}$ & $\begin{array}{l}299 \\
289 \\
294 \\
293 \\
300\end{array}$ & $\begin{array}{l}485 \\
485 \\
457 \\
523 \\
545\end{array}$ & $\begin{array}{r}1,726 \\
1,845 \\
1,819 \\
815 \\
799\end{array}$ & $\begin{array}{l}1,283 \\
1,435 \\
1,833 \\
1,883 \\
1,585\end{array}$ \\
\hline 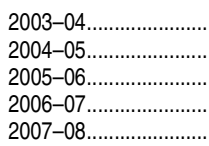 & $\begin{array}{l}21,989 \\
22,285 \\
22,390 \\
22,601 \\
22,932\end{array}$ & $\begin{array}{l}7,764 \\
7,825 \\
7,717 \\
7,859 \\
7,793\end{array}$ & $\begin{array}{l}7,889 \\
7,970 \\
7,855 \\
7,964 \\
7,931\end{array}$ & $\begin{array}{l}5,253 \\
4,939 \\
5,856 \\
6,100 \\
5,293\end{array}$ & $\begin{array}{l}6,707 \\
7,060 \\
7,202 \\
7,517 \\
7,718\end{array}$ & $\begin{array}{l}322 \\
325 \\
327 \\
315 \\
297\end{array}$ & $\begin{array}{r}9,301 \\
9,172 \\
9,991 \\
10,892 \\
11,331\end{array}$ & $\begin{array}{l}7,589 \\
5,377 \\
6,977 \\
8,783 \\
8,168\end{array}$ & $\begin{array}{l}5,802 \\
5,764 \\
5,713 \\
5,776 \\
5,765\end{array}$ & $\begin{array}{l}297 \\
343 \\
320 \\
281 \\
276\end{array}$ & $\begin{array}{l}288 \\
262 \\
259 \\
278 \\
271\end{array}$ & $\begin{array}{l}568 \\
584 \\
613 \\
526 \\
532\end{array}$ & $\begin{array}{r}1,314 \\
991 \\
1,000 \\
1,189 \\
1,199\end{array}$ & $\begin{array}{l}1,969 \\
1,843 \\
1,928 \\
1,835 \\
2,125\end{array}$ \\
\hline 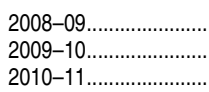 & $\begin{array}{l}23,340 \\
23,759 \\
23,992\end{array}$ & $\begin{array}{l}7,959 \\
7,927 \\
7,981\end{array}$ & $\begin{array}{l}8,152 \\
8,121 \\
8,121\end{array}$ & $\begin{array}{l}4,521 \\
4,218 \\
5,020\end{array}$ & $\begin{array}{l}8,021 \\
8,352 \\
8,709\end{array}$ & $\begin{array}{l}315 \\
293 \\
312\end{array}$ & $\begin{array}{l}10,714 \\
11,533 \\
11,856\end{array}$ & $\begin{array}{l}9,719 \\
9,341 \\
9,513\end{array}$ & $\begin{array}{l}5,916 \\
5,967 \\
5,927\end{array}$ & $\begin{array}{l}271 \\
283 \\
294\end{array}$ & $\begin{array}{l}270 \\
267 \\
255\end{array}$ & $\begin{array}{l}509 \\
511 \\
501\end{array}$ & $\begin{array}{r}1,062 \\
981 \\
1,109\end{array}$ & $\begin{array}{l}1,755 \\
1,686 \\
1,903\end{array}$ \\
\hline
\end{tabular}

-Not available.

${ }^{1}$ Constant dollars based on the Consumer Price Index, prepared by the Bureau of Labor Statistics, U.S. Department of Labor, adjusted to an academic-year basis.

NOTE: Data through 1992-93 are for institutions of higher education, while later data are for degree-granting institutions. Degree-granting institutions grant associate's or higher degrees and participate in Title IV federal financial aid programs.
SOURCE: U.S. Department of Education, National Center for Education Statistics, Higher Education General Information Survey (HEGIS), "Faculty Salaries, Tenure, and Fringe Benefits" surveys, 1977-78 and 1982-83; Integrated Postsecondary Education Data System (IPEDS), "Salaries, Tenure, and Fringe Benefits of Full-Time Instructional Faculty Survey" (IPEDS-SA:87-99); and IPEDS Winter 2001-02 through Winter 2010-11, Human Resources component, Salaries section. (This table was prepared October 2013.) 
Table 316.80. Percentage of full-time instructional faculty with tenure for degree-granting postsecondary institutions with a tenure system, by academic rank, sex, and control and level of institution: Selected years, 1993-94 through 2011-12

\begin{tabular}{|c|c|c|c|c|c|c|c|c|c|c|c|c|c|c|c|c|}
\hline \multirow{3}{*}{$\begin{array}{l}\text { Academic year, control } \\
\text { and level of institution }\end{array}$} & \multirow{3}{*}{$\begin{array}{r}\text { Percent of } \\
\text { institutions } \\
\text { with tenure } \\
\text { systems }\end{array}$} & \multicolumn{15}{|c|}{ Percent of full-time instructional faculty with tenure } \\
\hline & & \multicolumn{3}{|c|}{ Total } & \multicolumn{3}{|c|}{ Professor } & \multicolumn{3}{|c|}{ Associate professor } & \multicolumn{3}{|c|}{ Assistant professor } & \multirow[b]{2}{*}{ Instructor } & \multirow[b]{2}{*}{ Lecturer } & \\
\hline & & Total & Male & Female & Total & Male & Female & Total & Male & Female & Total & Male & Female & & & rank \\
\hline 1 & 2 & 3 & 4 & 5 & 6 & 7 & 8 & 9 & 10 & 11 & 12 & 13 & 14 & 15 & 16 & 17 \\
\hline $1993-94$ & & & & & & & & & & & & & & & & \\
\hline All institutions... & 62.6 & 56.2 & 62.6 & 42.7 & 91.9 & 92.8 & 87.7 & 76.8 & 77.5 & 75.1 & 14.4 & 13.6 & 15.5 & 38.3 & 10.8 & 26.0 \\
\hline Public institutions ............ & 73.6 & 58.9 & 65.4 & 45.6 & 92.6 & 93.6 & 87.5 & 80.8 & 81.6 & 78.9 & 17.1 & 16.1 & 18.5 & 45.5 & 7.2 & 28.6 \\
\hline 4-year .......................... & 92.6 & 56.3 & 63.5 & 39.3 & 94.3 & 94.7 & 92.0 & 80.4 & 81.2 & 78.4 & 13.8 & 13.0 & 14.8 & 4.4 & 5.4 & 6.1 \\
\hline Doctoral ${ }^{1} \ldots . .$. & 100.0 & 54.5 & 62.1 & 35.0 & 94.2 & 94.7 & 90.1 & 81.3 & 82.1 & 79.2 & 7.3 & 6.7 & 8.3 & 2.8 & 2.1 & 5.4 \\
\hline 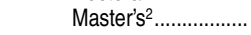 & 98.3 & 60.5 & 67.7 & 46.1 & 95.4 & 95.5 & 95.0 & 79.3 & 80.0 & 77.7 & 23.0 & 23.0 & 22.9 & 6.4 & 11.7 & 11.0 \\
\hline Other ............................. & 76.4 & 51.1 & 56.3 & 40.0 & 88.4 & 88.8 & 86.4 & 76.5 & 77.3 & 74.8 & 22.7 & 22.8 & 22.6 & 4.6 & 15.0 & 6.4 \\
\hline 2-year............................. & 62.1 & 69.9 & 75.4 & 63.0 & 80.7 & 83.7 & 75.5 & 84.2 & 86.4 & 81.5 & 47.7 & 51.1 & 44.6 & 68.9 & 39.9 & 65.7 \\
\hline Nonprofit institutions ....... & 62.0 & 49.5 & 56.0 & 35.5 & 90.3 & 90.8 & 88.1 & 67.6 & 68.1 & 66.5 & 9.0 & 8.7 & 9.4 & 6.1 & 21.9 & 18.9 \\
\hline 4-year ............... & 66.3 & 49.5 & 56.0 & 35.4 & 90.3 & 90.8 & 88.0 & 67.6 & 68.1 & 66.5 & 9.0 & 8.7 & 9.4 & 5.5 & 21.6 & 15.7 \\
\hline Doctoral ${ }^{1} \ldots$ & 90.5 & 47.6 & 53.5 & 31.9 & 90.5 & 90.8 & 88.5 & 62.5 & 63.4 & 60.0 & 3.7 & 3.7 & 3.7 & 8.9 & 29.2 & 15.4 \\
\hline Master's ${ }^{2} \ldots$ & 76.5 & 51.8 & 59.2 & 38.2 & 90.8 & 91.1 & 89.8 & 71.3 & 72.2 & 69.6 & 13.4 & 13.6 & 13.1 & 2.6 & 0.7 & 10.5 \\
\hline Other ............................. & 58.3 & 50.4 & $\begin{aligned} & 57.4 \\
&\end{aligned}$ & 37.2 & 89.4 & 90.4 & 85.1 & 70.6 & 70.9 & 70.2 & 11.9 & 11.9 & 11.9 & 3.9 & 3.4 & 20.0 \\
\hline 2-year .............................. & 26.1 & 47.9 & 54.5 & 38.5 & 88.0 & 84.3 & 94.3 & 63.8 & 65.1 & 62.7 & 12.0 & 12.3 & 11.9 & 20.0 & 86.7 & 68.6 \\
\hline For-profit institutions ....... & 7.8 & 33.8 & 39.0 & 27.8 & 95.2 & 94.1 & 100.0 & - & - & - & $\ddagger$ & $\ddagger$ & $\ddagger$ & 32.9 & - & - \\
\hline $1999-2000$ & & & & & & & & & & & & & & & & \\
\hline All institutions & 55.0 & 53.7 & 59.6 & 43.2 & 92.8 & 93.1 & 91.2 & 76.8 & 76.9 & 76.7 & 11.8 & 11.0 & 12.9 & 34.1 & 3.4 & 18.3 \\
\hline Public ins & 72.8 & 55.9 & 62.0 & 45.6 & 93.9 & 94.4 & 91.9 & 81.0 & 812 & & 14.1 & 13.1 & 15.4 & 39.8 & 4.1 & 21.2 \\
\hline 4-year. & 94.6 & 53.2 & 60.3 & 39.3 & 94.2 & 94.6 & 92.5 & 80.8 & 81.0 & 80.3 & 10.0 & 9.5 & 10.6 & 3.9 & 3.0 & 4.0 \\
\hline 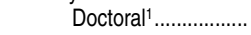 & 100.0 & 50.4 & 58.0 & 34.5 & 92.9 & 93.6 & 89.3 & 79.9 & 80.2 & 79.4 & 4.7 & 4.4 & 5.2 & 2.1 & 1.5 & 1.4 \\
\hline 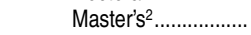 & 95.5 & 59.1 & 66.0 & 48.0 & 96.9 & 96.9 & 96.8 & 82.7 & 83.0 & 82.1 & 18.1 & 17.8 & 18.5 & 6.4 & 5.9 & 25.3 \\
\hline Other .............................. & 86.3 & 54.7 & 61.2 & 43.2 & 94.9 & 95.1 & 94.0 & 80.7 & 81.3 & 79.7 & 21.8 & 24.1 & 18.8 & 5.8 & 7.2 & 49.3 \\
\hline 2-year.............................. & 60.3 & 67.7 & 70.6 & 64.5 & 91.2 & 92.2 & 89.7 & 83.3 & 83.6 & 83.1 & 53.8 & 56.0 & 52.0 & 60.4 & 21.2 & 64.4 \\
\hline Nonprofit institutions ....... & 59.0 & 48.2 & 54.2 & 36.8 & 90.3 & 90.5 & 89.7 & 68.0 & 67.8 & 68.4 & 7.5 & 6.8 & 8.2 & 1.8 & 1.2 & 7.4 \\
\hline & 63.4 & 48.1 & 54.1 & 36.7 & 003 & 90.5 & 85 & 680 & 67 & 6 & 7. & 6. & 8.1 & 1. & 1.2 & 4.1 \\
\hline Doctoral ${ }^{1} \ldots$ & 81.2 & 43.4 & 49.6 & 29.6 & 88.6 & 88.7 & 87.6 & 62.6 & 62.8 & 62.2 & 3.0 & 2.8 & 3.2 & 1.0 & 1.3 & 0.5 \\
\hline 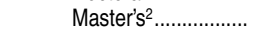 & 72.6 & 52.3 & 59.4 & 41.4 & 91.2 & 91.6 & 90.0 & 72.0 & 73.0 & 70.3 & 12.1 & 11.9 & 12.3 & 0.9 & 0.8 & 22.3 \\
\hline Other ......... & 54.9 & 53.5 & 59.3 & 44.0 & 93.5 & 93.8 & 92.8 & 73.1 & 71.2 & 76.0 & 9.9 & 9.4 & 10.5 & 3.6 & 1.6 & 23.5 \\
\hline 2 -year ............ & 14.0 & 59.7 & 63.3 & 53.6 & 96.0 & 96.0 & 96.0 & 57.1 & 61.3 & 54.3 & 31.6 & 36.7 & 28.3 & 30.2 & - & 65.8 \\
\hline For-profit institutions ....... & 4.0 & 77.4 & 77.2 & 77.6 & 47.4 & 50.0 & 33.3 & - & - & - & - & - & - & 86.1 & - & 71.9 \\
\hline 2009-10 & & & & & & & & & & & & & & & & \\
\hline All institutior & 47.8 & 48.7 & 54.5 & 40.6 & 90.3 & 90.7 & 89.3 & 74.6 & 74.5 & 74.6 & 7.2 & 6.9 & 7.6 & 28.2 & 1.4 & 24.7 \\
\hline ons ... & 71.2 & 50.6 & 56.3 & 42.9 & 91.6 & 92.0 & & 78.3 & 78.4 & 7 & 9.1 & 8.4 & 9.8 & 33.7 & 1.8 & 30.2 \\
\hline & 90.9 & 47.9 & 54.6 & 38.0 & 92.0 & 92.2 & & 78.7 & 78. & & 5.7 & 5.4 & 6.0 & 2.5 & 1.2 & 7.5 \\
\hline cto & 99.5 & 45.7 & 52.9 & 34.1 & 90.2 & 90.6 & 88 & 75.6 & 75.7 & 75 & 2.4 & 2.2 & 2.6 & 0.9 & 0.7 & 1.6 \\
\hline 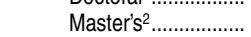 & 98.6 & 53.5 & 60.0 & 45.6 & 97 & 97.5 & 97.4 & 86.0 & 86.2 & 85 & 11.3 & 11.5 & 11.2 & 3.2 & 1.8 & 8.7 \\
\hline Othe & 72.4 & 51.2 & 55. & 46.1 & 92 & 93.3 & & 84.6 & 85 & & 20.5 & 21 & 19.6 & 11.8 & 3.0 & 58.7 \\
\hline 2-year.... & 57.7 & 64.1 & 67.2 & 61.4 & 88.2 & 89.6 & 86.9 & 74.1 & 75.2 & 73.3 & 45.2 & 48.3 & 42.9 & 58.4 & 22.6 & 67.6 \\
\hline Nonprofit institutions ....... & 57.1 & 44.3 & 50.6 & 35.2 & 87.8 & 88.2 & 86 & 67.2 & 67.0 & 67 & 3.8 & 3.8 & 3.7 & 0.6 & 0.3 & 7.1 \\
\hline & 59.5 & 44.3 & 50.6 & 35.2 & 87.8 & 88.2 & & 67.2 & 67.0 & & 3.8 & 3.8 & 3.7 & 0.5 & 0.3 & 7.0 \\
\hline Detor & 83.8 & 39.7 & 46.6 & 28.4 & 85.6 & 86.4 & 82.7 & 59.7 & 60.2 & 50 & 1.8 & 1.9 & 1.7 & 0.2 & 0.2 & 1.0 \\
\hline Mast & 65.8 & 49.8 & 55.7 & 42.4 & 89.7 & 90.1 & 88 & 74.0 & 74.1 & 7 & 7.2 & 7. & 6.8 & 0.7 & 0.2 & 20.4 \\
\hline Other & 47.4 & 53.4 & 59. & 45.8 & 93 & 92.9 & 93 & 79.4 & 78.6 & 8 & 4.8 & 5.0 & 4.5 & 1.6 & 1.6 & 45.7 \\
\hline $2-1$ & 12.9 & 38.5 & 49 & 31 & 86.7 & $\ddagger$ & 70 & 59.3 & 64.7 & & 20.5 & 18.5 & 21.4 & 8.2 & $\ddagger$ & 30.0 \\
\hline For-profit institutions ....... & 1.5 & 51.0 & 58.6 & 42.1 & 75.5 & 74.7 & 77.8 & 8.5 & 3.2 & 12.5 & $\ddagger$ & $\ddagger$ & $\ddagger$ & 87.3 & $\ddagger$ & \\
\hline 2011-12 & & & & & & & & & & & & & & & & \\
\hline All institut| & & 48.5 & 54.2 & 41. & 89.7 & 90.1 & 88 & 74.9 & 75.0 & 74 & 6.9 & 6.4 & 7.3 & 27. & 1.3 & 23.8 \\
\hline $\mathrm{Pu}$ & 71.6 & 50.7 & 56.2 & 43.6 & & 91.5 & & 786 & 78. & & 8. & 8.1 & 9.6 & 33.1 & 1.7 & 29.6 \\
\hline & & 48.0 & 54.5 & & & 91.6 & & 78 & & & 5.5 & 5.2 & 5.8 & 2.9 & 1.1 & 9.6 \\
\hline Doctor & 99.6 & 46.0 & 52.9 & 35.5 & 90.0 & 90.4 & 88.5 & 76.2 & 76.5 & 75 & 2.5 & 2.3 & 2.8 & 1.1 & 0.7 & 1.3 \\
\hline Maste & 97.5 & 55.6 & 61.9 & 48.3 & 97.6 & 97.6 & 97 & 88.6 & 88.9 & 88 & 13.3 & 13.3 & 13.3 & 1.8 & 2.4 & 7.1 \\
\hline Oth & 70.2 & 54.2 & 57. & 50.4 & 93.2 & 94.3 & 91.2 & 87.8 & 87.7 & 87 & 24.3 & 25.1 & 23.5 & 21.3 & 2.7 & 63.9 \\
\hline 2-year ………………......... & 57.8 & 64.7 & 67.3 & 62.4 & 88.7 & 89.9 & 87.6 & 75.1 & 76.2 & 74.1 & 44.0 & 46.2 & 42.4 & 58.9 & 17.2 & 69.7 \\
\hline Nonprofit institutions ....... & 55.6 & 43.7 & 49.9 & 35.1 & 87.0 & 87.3 & 86.3 & 67.8 & 67.4 & 68 & 3.3 & 3.4 & 3.3 & 0.4 & 0.3 & 6.7 \\
\hline & 58.6 & 43.7 & 49. & & 87 & 87.3 & & 67 & 67.4 & & 3. & 3.4 & 3.3 & 0.4 & 0.3 & 6.6 \\
\hline Docto & 76.4 & 40.2 & 46.9 & 30.3 & 85.0 & 85.6 & 82.9 & 62.0 & 62.3 & 6 & 2.2 & 2.4 & 2.0 & 0.3 & 0.1 & 0.7 \\
\hline Mast & 59.3 & 51.0 & 56.4 & 44.7 & 90.9 & 90.7 & 91.3 & 76.7 & 76.5 & 76 & 6.7 & 6.5 & 7.0 & 0.7 & 1.3 & 32.6 \\
\hline & 43.1 & 54.5 & 60.5 & 47.1 & 94.4 & 94.3 & 94.5 & 84.4 & 83.0 & 86.2 & 4.4 & 4.6 & 4.2 & 0.5 & 0.0 & 54.9 \\
\hline 2-year ........................... & 8.0 & 31.4 & 41.1 & 25.2 & $\ddagger$ & $\ddagger$ & + & 46.3 & 66.7 & 42.9 & 12.3 & 22.2 & 7.7 & 5.1 & $\ddagger$ & 33.3 \\
\hline For-profit institutions ........ & 1.3 & 31.0 & 31.4 & 30.7 & 72.3 & $73.8^{\top}$ & 69.2 & 30.8 & 18.9 & 41.5 & 1.6 & $\ddagger$ & $\ddagger$ & 54.4 & $\ddagger$ & 5.0 \\
\hline
\end{tabular}

-Not available.

fReporting standards not met (too few cases).

Institutions that awarded 20 or more doctor's degrees during the previous academic year.

'Institutions that awarded 20 or more master's degrees, but less than 20 doctor's degrees, during the previous academic year.

NOTE: The coverage of this table differs from similar tables published in editions of the Digest prior to 2003. Previous tenure tabulations included only instructional staff classified as full-time faculty; this table includes all staff with full-time instructional duties, including faculty and other instructional staff. Data for 1993-94 are for institutions of higher education, while later data are for degree-granting institutions. Degree-granting institutions grant associate's or higher degrees and participate in Title IV federal financial aid programs. The degree-granting classification is very similar to the earlier higher education classification, but it includes more 2-year colleges and excludes a few higher education institutions that did not grant degrees. Beginning in 2009 includes institutions with fewer than 15 full-time employees; institutions with fewer than 15 employees did not report staff data prior to 2007-08.

SOURCE: U.S. Department of Education, National Center for Education Statistics, Integrated Postsecondary Education Data System (IPEDS), "Fall Staff Survey" (IPEDS-S:93-99); and Winter 2009-10 and Winter 2011-12, Human Resources component, Fall Staff section. (This table was prepared July 2012. 
Table 317.10. Degree-granting postsecondary institutions, by control and level of institution: Selected years, 1949-50 through 2012-13

\begin{tabular}{|c|c|c|c|c|c|c|c|c|c|c|c|c|c|c|c|}
\hline \multirow[b]{3}{*}{ Year } & \multicolumn{3}{|c|}{ All institutions } & \multicolumn{3}{|c|}{ Public } & \multicolumn{9}{|c|}{ Private } \\
\hline & \multirow[b]{2}{*}{ Total } & \multirow[b]{2}{*}{ 4-year } & \multirow[b]{2}{*}{ 2-year } & \multirow[b]{2}{*}{ Total } & \multirow[b]{2}{*}{ 4-year } & & & & & & Jonprofit & & & or-profit & \\
\hline & & & & & & 2-year & Total & total & total & Total & 4-year & 2-year & Total & 4-year & 2-year \\
\hline 1 & 2 & 3 & 4 & 5 & 6 & 7 & 8 & 9 & 10 & 11 & 12 & 13 & 14 & 15 & 16 \\
\hline Excluding branch campuses & & & & & & & & & & & & & & & \\
\hline (1) & 1,851 & 1,327 & 524 & 641 & 344 & 297 & 1,210 & 983 & 227 & - & - & - & - & - & - \\
\hline$\ldots$ & 2,004 & 1,422 & 582 & 695 & 367 & 328 & 1,309 & 1,055 & 254 & - & - & - & - & - & - \\
\hline 1969-70 & 2,525 & 1,639 & 886 & 1,060 & 426 & 634 & 1,465 & 1,213 & 252 & - & - & - & - & - & - \\
\hline $1970-71 \ldots \ldots \ldots \ldots \ldots$ & 2,556 & 1,665 & 891 & 1,089 & 435 & 654 & 1,467 & 1,230 & 237 & - & - & - & - & - & - \\
\hline $1971-72 \ldots \ldots \ldots \ldots \ldots$ & 2,606 & 1,675 & 931 & 1,137 & 440 & 697 & 1,469 & 1,235 & 234 & - & - & - & - & - & - \\
\hline $1972-73 \ldots$. & 2,665 & 1,701 & 964 & 1,182 & 449 & 733 & 1,483 & 1,252 & 231 & - & - & - & - & - & - \\
\hline $1973-74 \ldots \ldots \ldots$ & 2,720 & 1,717 & 1,003 & 1,200 & 440 & 760 & 1,520 & 1,277 & 243 & - & - & - & - & - & - \\
\hline $1974-75 \ldots \ldots \ldots \ldots$ & 2,747 & 1,744 & 1,003 & 1,214 & 447 & 767 & 1,533 & 1,297 & 236 & - & - & - & - & - & - \\
\hline $1975-76$ & 2,765 & 1,767 & 998 & 1,219 & 447 & 772 & 1,546 & 1,320 & 226 & - & - & - & - & - & - \\
\hline $1976-77 \ldots \ldots \ldots \ldots \ldots \ldots \ldots \ldots \ldots \ldots \ldots \ldots \ldots \ldots \ldots \ldots \ldots \ldots$ & 2,785 & 1,783 & 1,002 & 1,231 & 452 & 779 & 1,554 & 1,331 & 223 & - & - & - & - & - & - \\
\hline (n) & 2,826 & 1,808 & 1,018 & 1,241 & 454 & 787 & 1,585 & 1,354 & 231 & - & - & - & - & - & - \\
\hline 1978-79.. & 2,954 & 1,843 & 1,111 & 1,308 & 463 & 845 & 1,646 & 1,380 & 266 & - & 一 & - & - & - & - \\
\hline $1979-80 .$. & 2,975 & 1,863 & 1,112 & 1,310 & 464 & 846 & 1,665 & 1,399 & 266 & - & - & - & - & - & - \\
\hline 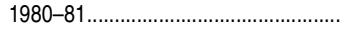 & 3,056 & 1,861 & 1,195 & 1,334 & 465 & 869 & 1,722 & 1,396 & $326^{1}$ & 一 & 一 & - & - & - & - \\
\hline 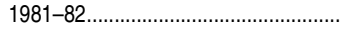 & 3,083 & 1,883 & 1,200 & 1,340 & 471 & 869 & 1,743 & 1,412 & 3311 & - & - & - & - & - & - \\
\hline 1982-83.. & 3,111 & 1,887 & 1,224 & 1,336 & 472 & 864 & 1,775 & 1,415 & $360^{1}$ & - & - & - & - & - & - \\
\hline $1983-84 \ldots \ldots \ldots \ldots$ & 3,117 & 1,914 & 1,203 & 1,325 & 474 & 851 & 1,792 & 1,440 & 352 & - & - & - & - & - & - \\
\hline 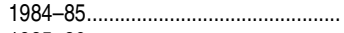 & 3,146 & 1,911 & 1,235 & 1,329 & 461 & 868 & 1,817 & 1,450 & 367 & - & - & - & - & - & - \\
\hline 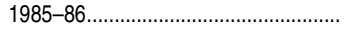 & 3,155 & 1,915 & 1,240 & 1,326 & 461 & 865 & 1,829 & 1,454 & 375 & - & - & - & - & - & - \\
\hline Including branch campuses & & & & & & & & & & & & & & & \\
\hline 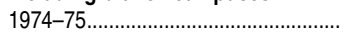 & 3,004 & 1,866 & 1,138 & 1,433 & 537 & 896 & 1,571 & 1,329 & 242 & - & - & - & - & - & - \\
\hline $1975-76$ & 3,026 & 1,898 & 1,128 & 1,442 & 545 & 897 & 1,584 & 1,353 & 231 & - & - & - & - & - & - \\
\hline (1) & 3,046 & 1,913 & 1,133 & 1,455 & 550 & 905 & 1,591 & 1,363 & 228 & 1,536 & 1,348 & 188 & 55 & 15 & 40 \\
\hline 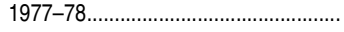 & 3,095 & 1,938 & 1,157 & 1,473 & 552 & 921 & 1,622 & 1,386 & 236 & - & - & - & - & - & - \\
\hline 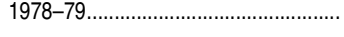 & 3,134 & 1,941 & 1,193 & 1,474 & 550 & 924 & 1,660 & 1,391 & 269 & 1,564 & 1,376 & 188 & 96 & 15 & 81 \\
\hline $1979-80$. & 3,152 & 1,957 & 1,195 & 1,475 & 549 & 926 & 1,677 & 1,408 & 269 & - & - & - & - & - & - \\
\hline $1980-81$. & 3,231 & 1,957 & 1,274 & 1,497 & 552 & 945 & 1,734 & 1,405 & 3291 & 1,569 & 1,387 & 182 & 165 & 18 & 147 \\
\hline 1981-82 & 3,253 & 1,979 & 1,274 & 1,498 & 558 & 940 & 1,755 & 1,421 & 3341 & 一 & - & - & - & - & - \\
\hline 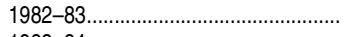 & 3,280 & 1,984 & 1,296 & 1,493 & 560 & 933 & 1,787 & 1,424 & $363^{1}$ & - & - & - & - & - & - \\
\hline 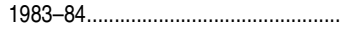 & 3,284 & 2,013 & 1,271 & 1,481 & 565 & 916 & 1,803 & 1,448 & 355 & - & - & - & - & - & - \\
\hline $1984-85 .$. & 3,331 & 2,025 & 1,306 & 1,501 & 566 & 935 & 1,830 & 1,459 & 371 & 1,616 & 1,430 & 186 & 214 & 29 & 185 \\
\hline 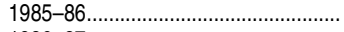 & 3,340 & 2,029 & 1,311 & 1,498 & 566 & 932 & 1,842 & 1,463 & 379 & 一 & - & - & - & - & - \\
\hline $1986-87 .$. & 3,406 & 2,070 & 1,336 & 1,533 & 573 & 960 & 1,873 & 1,497 & 376 & 1,635 & 1,462 & 173 & 238 & 35 & 203 \\
\hline 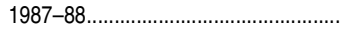 & 3,587 & 2,135 & 1,452 & 1,591 & 599 & 992 & 1,996 & 1,536 & 460 & 1,673 & 1,487 & 186 & 323 & 49 & 274 \\
\hline 1988-89... & 3,565 & 2,129 & 1,436 & 1,582 & 598 & 984 & 1,983 & 1,531 & 452 & 1,658 & 1,478 & 180 & 325 & 53 & 272 \\
\hline 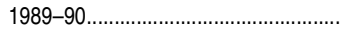 & 3,535 & 2,127 & 1,408 & 1,563 & 595 & 968 & 1,972 & 1,532 & 440 & 1,656 & 1,479 & 177 & 316 & 53 & 263 \\
\hline $1990-91 \ldots$ & 3,559 & 2,141 & 1,418 & 1,567 & 595 & 972 & 1,992 & 1,546 & 446 & 1,649 & 1,482 & 167 & 343 & 64 & 279 \\
\hline (2) & 3,601 & 2,157 & 1,444 & 1,598 & 599 & 999 & 2,003 & 1,558 & 445 & 1,662 & 1,486 & 176 & 341 & 72 & 269 \\
\hline 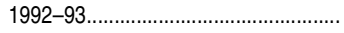 & 3,638 & 2,169 & 1,469 & 1,624 & 600 & 1,024 & 2,014 & 1,569 & 445 & 1,672 & 1,493 & 179 & 342 & 76 & 266 \\
\hline $1993-94 .$. & 3,632 & 2,190 & 1,442 & 1,625 & 604 & 1,021 & 2,007 & 1,586 & 421 & 1,687 & 1,506 & 181 & 320 & 80 & 240 \\
\hline 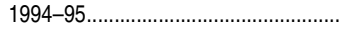 & 3,688 & 2,215 & 1,473 & 1,641 & 605 & 1,036 & 2,047 & 1,610 & 437 & 1,702 & 1,510 & 192 & 345 & 100 & 245 \\
\hline $1995-96 .$. & 3,706 & 2,244 & 1,462 & 1,655 & 608 & 1,047 & 2,051 & 1,636 & 415 & 1,706 & 1,519 & 187 & 345 & 117 & 228 \\
\hline $1996-97 \ldots \ldots$. & 4,009 & 2,267 & 1,742 & 1,702 & 614 & 1,088 & 2,307 & 1,653 & 654 & 1,693 & 1,509 & 184 & 614 & 144 & 470 \\
\hline (1) & 4,064 & 2,309 & 1,755 & 1,707 & 615 & 1,092 & 2,357 & 1,694 & 663 & 1,707 & 1,528 & 179 & 650 & 166 & 484 \\
\hline $1998-99 \ldots$ & 4,048 & 2,335 & 1,713 & 1,681 & 612 & 1,069 & 2,367 & 1,723 & 644 & 1,695 & 1,531 & 164 & 672 & 192 & 480 \\
\hline 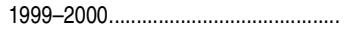 & 4,084 & 2,363 & 1,721 & 1,682 & 614 & 1,068 & 2,402 & 1,749 & 653 & 1,681 & 1,531 & 150 & 721 & 218 & 503 \\
\hline $2000-01 .$. & 4,182 & 2,450 & 1,732 & 1,698 & 622 & 1,076 & 2,484 & 1,828 & 656 & 1,695 & 1,551 & 144 & 789 & 277 & 512 \\
\hline $2001-02$. & 4,197 & 2,487 & 1,710 & 1,713 & 628 & 1,085 & 2,484 & 1,859 & 625 & 1,676 & 1,541 & 135 & 808 & 318 & 490 \\
\hline 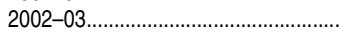 & 4,168 & 2,466 & 1,702 & 1,712 & 631 & 1,081 & 2,456 & 1,835 & 621 & 1,665 & 1,538 & 127 & 791 & 297 & 494 \\
\hline $2003-04 \ldots \ldots \ldots \ldots \ldots$ & 4,236 & 2,530 & 1,706 & 1,720 & 634 & 1,086 & 2,516 & 1,896 & 620 & 1,664 & 1,546 & 118 & 852 & 350 & 502 \\
\hline 2004-05 & 4,216 & 2,533 & 1,683 & 1,700 & 639 & 1,061 & 2,516 & 1,894 & 622 & 1,637 & 1,525 & 112 & 879 & 369 & 510 \\
\hline $2005-06$ & 4,276 & 2,582 & 1,694 & 1,693 & 640 & 1,053 & 2,583 & 1,942 & 641 & 1,647 & 1,534 & 113 & 936 & 408 & 528 \\
\hline 2006-07 & 4,314 & 2,629 & 1,685 & 1,688 & 643 & 1,045 & 2,626 & 1,986 & 640 & 1,640 & 1,533 & 107 & 986 & 453 & 533 \\
\hline 2007-08 & 4,352 & 2,675 & 1,677 & 1,685 & 653 & 1,032 & 2,667 & 2,022 & 645 & 1,624 & 1,532 & 92 & 1,043 & 490 & 553 \\
\hline (1) & 4,409 & 2,719 & 1,690 & 1,676 & 652 & 1,024 & 2,733 & 2,067 & 666 & 1,629 & 1,537 & 92 & 1,104 & 530 & 574 \\
\hline $2009-10$. & 4,495 & 2,774 & 1,721 & 1,672 & 672 & 1,000 & 2,823 & 2,102 & 721 & 1,624 & 1,539 & 85 & 1,199 & 563 & 636 \\
\hline $2010-11 .$. & 4,599 & 2,870 & 1,729 & 1,656 & 678 & 978 & 2,943 & 2,192 & 751 & 1,630 & 1,543 & 87 & 1,313 & 649 & 664 \\
\hline $2011-12 \ldots$ & 4,706 & 2,968 & 1,738 & 1,649 & 682 & 967 & 3,057 & 2,286 & 771 & 1,653 & 1,553 & 100 & 1,404 & 733 & 671 \\
\hline $2012-13 \ldots \ldots \ldots$ & 4,726 & 3,026 & 1,700 & 1,623 & 689 & 934 & 3,103 & 2,337 & 766 & 1,652 & 1,555 & 97 & 1,451 & 782 & 669 \\
\hline
\end{tabular}

-Not available.

'Large increases are due to the addition of schools accredited by the Accrediting Commission of Career Schools and Colleges of Technology.

NOTE: Data through 1995-96 are for institutions of higher education, while later data are for degree-granting institutions. Degree-granting institutions grant associate's or higher degrees and participate in Title IV federal financial aid programs. Changes in counts of institutions over time are partly affected by increasing or decreasing numbers of institutions submitting separate data for branch campuses.
SOURCE: U.S. Department of Education, National Center for Education Statistics, Education Directory, Colleges and Universities, 1949-50 through 1965-66; Higher Education General Information Survey (HEGIS), "Institutional Characteristics of Colleges and Universities" surveys, 1966-67 through 1985-86; Integrated Postsecondary Education Data System (IPEDS), "Institutional Characteristics Survey" (IPEDS-IC:86-99); and IPEDS Fall 2000 through Fall 2012, Institutional Characteristics component. (This table was prepared August 2013.) 
Table 317.20. Degree-granting postsecondary institutions, by control and level of institution and state or jurisdiction: 2012-13

\begin{tabular}{|c|c|c|c|c|c|c|c|c|c|c|c|c|c|c|c|c|c|c|c|c|c|c|}
\hline \multirow[b]{2}{*}{ State or jurisdiction } & \multirow[b]{2}{*}{ Total } & \multirow[b]{2}{*}{\begin{tabular}{|r|} 
All public \\
institutions
\end{tabular}} & \multicolumn{7}{|c|}{ Public 4-year institutions } & \multirow[b]{2}{*}{$\begin{array}{l}\text { Public } \\
\text { 2-year }\end{array}$} & \multirow[b]{2}{*}{$\begin{array}{r}\text { All } \\
\text { nonprofit } \\
\text { institutions }\end{array}$} & \multicolumn{7}{|c|}{ Nonprofit 4-year institutions } & \multirow[b]{2}{*}{$\begin{array}{r}\text { Nonprofit } \\
2 \text {-year }\end{array}$} & \multicolumn{3}{|c|}{ For-profit institutions } \\
\hline & & & Total & $\begin{array}{l}\text { Research } \\
\text { university, } \\
\text { very high }\end{array}$ & $\begin{array}{r}\text { Research } \\
\text { university, } \\
\text { high }^{2}\end{array}$ & $\begin{array}{r}\text { Doctorall } \\
\text { research } \\
\text { university }^{3}\end{array}$ & Master's $^{4}$ & $\begin{array}{r}\text { Bacca- } \\
\text { laureate }^{5}\end{array}$ & $\begin{array}{r}\text { Special } \\
\text { focus }^{6}\end{array}$ & & & Total & $\begin{array}{c}\text { Research } \\
\text { university, } \\
\text { very high }{ }^{1}\end{array}$ & $\begin{array}{r}\text { Research } \\
\text { university, } \\
\text { high }^{2}\end{array}$ & $\begin{array}{r}\text { Doctorall } \\
\text { research } \\
\text { university } \\
\end{array}$ & Master's ${ }^{4}$ & $\begin{array}{r}\text { Bacca- } \\
\text { laureate }^{5}\end{array}$ & $\begin{array}{r}\text { Special } \\
\text { focus }^{6}\end{array}$ & & Total & 4-year & 2-year \\
\hline 1 & 2 & 3 & 4 & 5 & 6 & 7 & 8 & 9 & 10 & 11 & 12 & 13 & 14 & 15 & 16 & 17 & 18 & 19 & 20 & 21 & 22 & 23 \\
\hline United States ............. & 4,726 & 1,623 & 689 & 73 & 73 & 28 & 271 & 197 & 47 & 934 & 1,652 & 1,555 & 34 & 25 & 48 & 364 & 513 & 571 & 97 & 1,451 & 782 & 669 \\
\hline Alabama .............................. & 77 & 39 & 14 & 2 & 3 & 0 & 8 & 1 & 0 & 25 & 20 & 19 & 0 & 0 & 0 & 2 & 12 & 5 & 1 & 18 & 11 & 7 \\
\hline 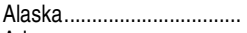 & 9 & 5 & 3 & 0 & 1 & 0 & 2 & 0 & 0 & 2 & 2 & 2 & 0 & 0 & 0 & 1 & 0 & 1 & 0 & 2 & 1 & 1 \\
\hline Arizona …………………......... & 87 & 24 & 4 & 2 & 1 & 0 & 0 & 0 & 1 & 20 & 11 & 11 & 0 & 0 & 0 & 2 & 3 & 6 & 0 & 52 & 36 & 16 \\
\hline 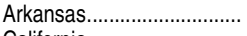 & 52 & 33 & 11 & 1 & 0 & 1 & 6 & 2 & 1 & 22 & 14 & 12 & 0 & 0 & 0 & 1 & 9 & 2 & 2 & 5 & 4 & 1 \\
\hline California ................................. & 457 & 149 & 35 & 8 & 1 & 0 & 21 & 3 & 2 & 114 & 141 & 135 & 3 & 1 & 10 & 25 & 23 & 73 & 6 & 167 & 87 & 80 \\
\hline Colorado ............................. & 93 & 28 & 14 & 2 & 2 & 1 & 4 & 5 & 0 & 14 & 13 & 11 & 0 & 1 & 0 & 3 & 2 & 5 & 2 & 52 & 30 & 22 \\
\hline Connecticut............................ & 46 & 21 & 9 & 1 & 0 & 0 & 4 & 4 & 0 & 12 & 19 & 19 & 1 & 0 & 0 & 9 & 5 & 4 & 0 & 6 & 5 & 1 \\
\hline Delaware............................... & 12 & 5 & 2 & 1 & 0 & 0 & 1 & 0 & 0 & 3 & 5 & 4 & 0 & 0 & 1 & 0 & 1 & 2 & 1 & 2 & 2 & 0 \\
\hline District of Columbia ............ & 20 & 2 & 2 & 0 & 0 & 0 & 1 & 0 & 1 & 0 & 14 & 14 & 2 & 2 & 1 & 2 & 0 & 7 & 0 & 4 & 4 & 0 \\
\hline Florida....................................... & 239 & 41 & 35 & 4 & 2 & 2 & 4 & 23 & 0 & 6 & 65 & 61 & 1 & 1 & 3 & 13 & 22 & 21 & 4 & 133 & 66 & 67 \\
\hline Georgia ................................. & 142 & 61 & 30 & 3 & 0 & 1 & 11 & 14 & 1 & 31 & 35 & 33 & 1 & 0 & 1 & 4 & 19 & 8 & 2 & 46 & 26 & 20 \\
\hline Hawaii ........................................ & 21 & 10 & 4 & 1 & 0 & 0 & 0 & 3 & 0 & 6 & 7 & 7 & 0 & 0 & 0 & 2 & 2 & 3 & 0 & 4 & 3 & 1 \\
\hline Idaho .......................................... & 19 & 8 & 4 & 0 & 2 & 0 & 1 & 1 & 0 & 4 & 4 & 4 & 0 & 0 & 0 & 1 & 2 & 1 & 0 & 7 & 6 & 1 \\
\hline Illinois............................... & 186 & 60 & 12 & 2 & 2 & 1 & 7 & 0 & 0 & 48 & 83 & 80 & 2 & 2 & 4 & 17 & 18 & 37 & 3 & 43 & 26 & 17 \\
\hline Indiana...................................... & 85 & 16 & 15 & 2 & 2 & 1 & 6 & 3 & 1 & 1 & 40 & 39 & 1 & 0 & 0 & 9 & 19 & 10 & 1 & 29 & 19 & 10 \\
\hline lowa ...... & 67 & 19 & 3 & 2 & 0 & 0 & 1 & 0 & 0 & 16 & 34 & 33 & 0 & 0 & 0 & 6 & 18 & 9 & 1 & 14 & 13 & 1 \\
\hline Kansas..................................... & 67 & 32 & 8 & 1 & 2 & 0 & 4 & 0 & 1 & 24 & 24 & 22 & 0 & 0 & 0 & 6 & 12 & 4 & 2 & 11 & 6 & 5 \\
\hline Kentucky ............................ & 80 & 24 & 8 & 2 & 0 & 0 & 5 & 1 & 0 & 16 & 27 & 27 & 0 & 0 & 1 & 6 & 13 & 7 & 0 & 29 & 19 & 10 \\
\hline Louisiana ……………............. & 72 & 35 & 17 & 1 & 3 & 0 & 9 & 1 & 3 & 18 & 13 & 10 & 1 & 0 & 0 & 2 & 4 & 3 & 3 & 24 & 9 & 15 \\
\hline 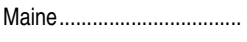 & 32 & 15 & 8 & 0 & 1 & 0 & 1 & 6 & 0 & 7 & 15 & 13 & 0 & 0 & 0 & 3 & 6 & 4 & 2 & 2 & 1 & 1 \\
\hline Maryland....... & 64 & 29 & 13 & 1 & 1 & 2 & 7 & 1 & 1 & 16 & 23 & 23 & 1 & 0 & 0 & 6 & 6 & 10 & 0 & 12 & 7 & 5 \\
\hline Massachusetts....................... & 125 & 30 & 14 & 1 & 2 & 0 & 7 & 2 & 2 & 16 & 84 & 81 & 5 & 3 & 1 & 15 & 24 & 33 & 3 & 11 & 6 & 5 \\
\hline 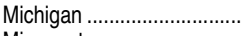 & 116 & 46 & 15 & 3 & 2 & 2 & 7 & 1 & 0 & 31 & 50 & 49 & 0 & 0 & 1 & 11 & 23 & 14 & 1 & 20 & 14 & 6 \\
\hline Minnesota & 119 & 43 & 12 & 1 & 0 & 0 & 8 & 3 & 0 & 31 & 36 & 35 & 0 & 0 & 3 & 6 & 12 & 14 & 1 & 40 & 34 & 6 \\
\hline 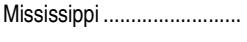 & 42 & 24 & 9 & 1 & 3 & 0 & 4 & 0 & 1 & 15 & 9 & 9 & 0 & 0 & 0 & 3 & 4 & 2 & 0 & 9 & 3 & 6 \\
\hline Missouri .............................. & 133 & 27 & 13 & 1 & 3 & 0 & 6 & 3 & 0 & 14 & 56 & 53 & 1 & 1 & 1 & 11 & 12 & 27 & 3 & 50 & 27 & 23 \\
\hline Montana & 22 & 17 & 6 & 1 & 1 & 0 & 1 & 3 & 0 & 11 & 5 & 4 & 0 & 0 & 0 & 0 & 3 & 1 & 1 & 0 & 0 & 0 \\
\hline Nebraska ............................... & 43 & 15 & 7 & 1 & 0 & 1 & 3 & 1 & 1 & 8 & 18 & 16 & 0 & 0 & 0 & 5 & 7 & 4 & 2 & 10 & 6 & 4 \\
\hline Nevada ................................. & 27 & 7 & 6 & 0 & $\begin{array}{r}2 \\
2\end{array}$ & 0 & 0 & 4 & 0 & 1 & 3 & $\begin{array}{r}3 \\
-1\end{array}$ & 0 & 0 & 0 & 1 & 0 & 2 & 0 & 17 & 9 & 8 \\
\hline New Hampshire ....................... & 27 & 12 & 5 & 0 & 1 & 0 & 2 & 2 & 0 & 7 & 13 & 11 & 1 & 0 & 0 & 5 & 3 & 2 & 2 & 2 & 2 & 0 \\
\hline New Jersey ........................... & 70 & 33 & 14 & 1 & 2 & 0 & 10 & 0 & 1 & 19 & 27 & 27 & 1 & 1 & 1 & 10 & 2 & 12 & 0 & 10 & 5 & 5 \\
\hline New Mexico ......................... & 44 & 28 & 9 & 1 & 1 & 0 & 4 & 1 & 2 & 19 & 3 & 3 & 0 & 0 & 0 & 1 & 2 & 0 & 0 & 13 & 10 & 3 \\
\hline New York................................... & 303 & 78 & 43 & 4 & 1 & 1 & 21 & 12 & 4 & 35 & 178 & 164 & 6 & 5 & 7 & 40 & 27 & 79 & 14 & 47 & 21 & 26 \\
\hline North Carolina ......................... & 149 & 75 & 16 & 2 & 1 & 3 & 7 & 2 & 1 & 59 & 49 & 48 & 1 & 1 & 0 & 7 & 27 & 12 & 1 & 25 & 17 & 8 \\
\hline North Dakota ............................ & 21 & 14 & 9 & 1 & 1 & 0 & 1 & 4 & 2 & 5 & 6 & 6 & 0 & 0 & 0 & 1 & 1 & 4 & 0 & 1 & 1 & 0 \\
\hline Ohio & 225 & 60 & 35 & 2 & 8 & 0 & 1 & 23 & 1 & 25 & 73 & 66 & 1 & 1 & 2 & 20 & 19 & 23 & 7 & 92 & 32 & 60 \\
\hline Oklahoma & 66 & 29 & 17 & 1 & 1 & 0 & 8 & 5 & 2 & 12 & 14 & 14 & 0 & 0 & 1 & 4 & 6 & 3 & 0 & 23 & 11 & 12 \\
\hline$\ldots \ldots \ldots \ldots \ldots \ldots \ldots$ & 65 & 26 & 9 & 2 & 1 & 0 & 3 & 2 & 1 & 17 & 24 & 24 & 0 & 0 & 0 & 5 & 7 & 12 & 0 & 15 & 8 & 7 \\
\hline Pennsylvania........................ & 267 & 61 & 45 & 2 & 1 & 1 & 18 & 21 & 2 & 16 & 120 & 106 & 2 & 3 & 2 & 30 & 36 & 33 & 14 & 86 & 12 & 74 \\
\hline 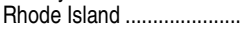 & 13 & 3 & 2 & 0 & 1 & 0 & 1 & 0 & 0 & 1 & 10 & 10 & 1 & 0 & 0 & 5 & 1 & 3 & 0 & 0 & 0 & 0 \\
\hline 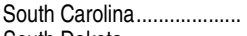 & 79 & 33 & 13 & 1 & 1 & 1 & 5 & 4 & 1 & 20 & 24 & 22 & 0 & 0 & 0 & 5 & 14 & 3 & 2 & 22 & 12 & 10 \\
\hline South Dakota......................... & 25 & 12 & 7 & 0 & 2 & 0 & 2 & 1 & 2 & 5 & 8 & 7 & 0 & 0 & 0 & 0 & 5 & 2 & 1 & 5 & 5 & 0 \\
\hline Tennessee ................................ & 112 & 22 & 9 & 1 & 1 & 3 & 4 & 0 & 0 & 13 & 49 & 45 & 1 & 0 & 2 & 11 & 15 & 16 & 4 & 41 & 24 & 17 \\
\hline Texas ................................... & 271 & 108 & 45 & 3 & 6 & 7 & 16 & 5 & 8 & 63 & 63 & 55 & 1 & 2 & 2 & 17 & 14 & 19 & 8 & 100 & 43 & 57 \\
\hline Utah & 42 & 8 & 7 & 1 & 1 & 0 & 2 & 3 & 0 & 1 & 4 & 3 & 0 & 1 & 0 & 2 & 0 & 0 & 1 & 30 & 24 & 6 \\
\hline
\end{tabular}


Table 317.20. Degree-granting postsecondary institutions, by control and level of institution and state or jurisdiction: 2012-13-Continued

\begin{tabular}{|c|c|c|c|c|c|c|c|c|c|c|c|c|c|c|c|c|c|c|c|c|c|c|}
\hline \multirow[b]{2}{*}{ State or jurisdiction } & \multirow[b]{2}{*}{ Total } & \multirow[b]{2}{*}{\begin{tabular}{|r|} 
All public \\
institutions
\end{tabular}} & \multicolumn{7}{|c|}{ Public 4-year institutions } & \multirow[b]{2}{*}{$\begin{array}{l}\text { Public } \\
\text { 2-year }\end{array}$} & \multirow[b]{2}{*}{$\begin{array}{r}\text { All } \\
\text { nonprofit } \\
\text { institutions }\end{array}$} & \multicolumn{7}{|c|}{ Nonprofit 4-year institutions } & \multirow[b]{2}{*}{\begin{tabular}{|r|} 
Nonprofit \\
2 -year \\
\end{tabular}} & \multicolumn{3}{|c|}{ For-profit institutions } \\
\hline & & & Total & \begin{tabular}{|c|} 
Research \\
university, \\
very high'
\end{tabular} & $\begin{array}{r}\text { Research } \\
\text { university, } \\
\text { high }^{2}\end{array}$ & \begin{tabular}{|r|} 
Doctorall \\
research \\
university \\
\end{tabular} & Master's ${ }^{4}$ & $\begin{array}{r}\text { Bacca- } \\
\text { laureate }^{5}\end{array}$ & $\begin{array}{r}\text { Special } \\
\text { focus }^{6}\end{array}$ & & & Total & \begin{tabular}{|c|} 
Research \\
university, \\
very high
\end{tabular} & $\begin{array}{r}\text { Research } \\
\text { university, } \\
\text { high }^{2}\end{array}$ & \begin{tabular}{|c|} 
Doctorall \\
research \\
university \\
\end{tabular} & Master's ${ }^{4}$ & $\begin{array}{r}\text { Bacca- } \\
\text { laureate }^{5}\end{array}$ & $\begin{array}{r}\text { Special } \\
\text { focus }^{6}\end{array}$ & & Total & 4-year & 2-year \\
\hline 1 & 2 & 3 & 4 & 5 & 6 & 7 & 8 & 9 & 10 & 11 & 12 & 13 & 14 & 15 & 16 & 17 & 18 & 19 & 20 & 21 & 22 & 23 \\
\hline 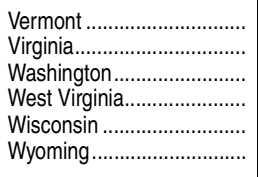 & $\begin{array}{r}24 \\
132 \\
87 \\
43 \\
91 \\
11\end{array}$ & $\begin{array}{r}6 \\
40 \\
43 \\
23 \\
31 \\
8\end{array}$ & \begin{tabular}{r|}
5 \\
16 \\
17 \\
13 \\
14 \\
1
\end{tabular} & $\begin{array}{l}0 \\
3 \\
2 \\
0 \\
1 \\
0\end{array}$ & \begin{tabular}{l|l}
1 & \\
3 & \\
0 & \\
1 & \\
1 & \\
1 &
\end{tabular} & $\begin{array}{l}0 \\
0 \\
0 \\
0 \\
0 \\
0\end{array}$ & \begin{tabular}{r|}
1 \\
7 \\
6 \\
3 \\
10 \\
0
\end{tabular} & $\begin{array}{l}3 \\
2 \\
7 \\
8 \\
2 \\
0\end{array}$ & $\begin{array}{l}0 \\
1 \\
2 \\
1 \\
0 \\
0\end{array}$ & $\begin{array}{r}1 \\
24 \\
26 \\
10 \\
17 \\
7\end{array}$ & \begin{tabular}{r|}
17 \\
38 \\
24 \\
8 \\
30 \\
0
\end{tabular} & $\begin{array}{r}17 \\
37 \\
23 \\
8 \\
30 \\
0\end{array}$ & $\begin{array}{l}0 \\
0 \\
0 \\
0 \\
0 \\
0\end{array}$ & $\begin{array}{l}0 \\
0 \\
0 \\
0 \\
0 \\
0\end{array}$ & $\begin{array}{l}0 \\
1 \\
0 \\
0 \\
3 \\
0\end{array}$ & $\begin{array}{r}4 \\
7 \\
10 \\
0 \\
8 \\
0\end{array}$ & $\begin{array}{r}11 \\
20 \\
5 \\
7 \\
10 \\
0\end{array}$ & $\begin{array}{l}2 \\
9 \\
8 \\
1 \\
9 \\
0\end{array}$ & $\begin{array}{l}0 \\
1 \\
1 \\
0 \\
0 \\
0\end{array}$ & $\begin{array}{r}1 \\
54 \\
20 \\
12 \\
30 \\
3\end{array}$ & \begin{tabular}{r|r|}
1 & 30 \\
12 & \\
3 & 27 \\
2 &
\end{tabular} & $\begin{array}{r}0 \\
24 \\
8 \\
9 \\
3 \\
1\end{array}$ \\
\hline U.S. Service Academies.... & 5 & 5 & 5 & 0 & 0 & 0 & 0 & 5 & 0 & 0 & $\dagger$ & $\dagger$ & $\dagger$ & $\dagger$ & $\dagger$ & $\dagger$ & $\dagger$ & $\dagger$ & $\dagger$ & $\dagger$ & $\dagger$ & $\dagger$ \\
\hline Other jurisdictions ... & 91 & 26 & 18 & 0 & 1 & 1 & 1 & 12 & 3 & 8 & 47 & 46 & 0 & 0 & 3 & 12 & 19 & 12 & 1 & 18 & 8 & 10 \\
\hline $\begin{array}{l}\text { American Samoa............... } \\
\text { Federated States }\end{array}$ & & 1 & 1 & 0 & 0 & 0 & 0 & 1 & 0 & 0 & 0 & 0 & 0 & 0 & 0 & 0 & 0 & 0 & 0 & 0 & 0 & 0 \\
\hline 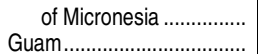 & $\begin{array}{l}1 \\
3\end{array}$ & $\begin{array}{l}1 \\
2\end{array}$ & $\begin{array}{l}0 \\
1\end{array}$ & $\begin{array}{l}0 \\
0\end{array}$ & $\begin{array}{l}0 \\
0\end{array}$ & $\begin{array}{l}0 \\
0\end{array}$ & $\begin{array}{l}0 \\
1\end{array}$ & $\begin{array}{l}0 \\
0\end{array}$ & $\begin{array}{l}0 \\
0\end{array}$ & $\begin{array}{l}1 \\
1\end{array}$ & $\begin{array}{l}0 \\
1\end{array}$ & $\begin{array}{l}0 \\
1\end{array}$ & $\begin{array}{l}0 \\
0\end{array}$ & $\begin{array}{l}0 \\
0\end{array}$ & $\begin{array}{l}0 \\
0\end{array}$ & $\begin{array}{l}0 \\
0\end{array}$ & $\begin{array}{l}0 \\
0\end{array}$ & $\begin{array}{l}0 \\
1\end{array}$ & $\begin{array}{l}0 \\
0\end{array}$ & $\begin{array}{l}0 \\
0\end{array}$ & $\begin{array}{l}0 \\
0\end{array}$ & $\begin{array}{l}0 \\
0\end{array}$ \\
\hline Marshall Islands...................... & 1 & 1 & 0 & 0 & 0 & 0 & 0 & 0 & 0 & 1 & 0 & 0 & 0 & 0 & 0 & 0 & 0 & 0 & 0 & 0 & 0 & 0 \\
\hline Northern Marianas ............. & 1 & 1 & 1 & 0 & 0 & 0 & 0 & 1 & 0 & 0 & 0 & 0 & 0 & 0 & 0 & 0 & 0 & 0 & 0 & 0 & 0 & 0 \\
\hline Palau............................... & 1 & 1 & 0 & 0 & 0 & 0 & 0 & 0 & 0 & 1 & 0 & 0 & 0 & 0 & 0 & 0 & 0 & 0 & 0 & 0 & 0 & 0 \\
\hline Puerto Rico............................. & 82 & 18 & 14 & 0 & 1 & 1 & 0 & 9 & 3 & 4 & 46 & 45 & 0 & 0 & 3 & 12 & 19 & 11 & 1 & 18 & 8 & 10 \\
\hline U.S. Virgin Islands .................. & 1 & 1 & 1 & 0 & 0 & 0 & 0 & 1 & 0 & 0 & 0 & 0 & 0 & 0 & 0 & 0 & 0 & 0 & 0 & 0 & 0 & 0 \\
\hline
\end{tabular}

\section{†Not applicable.}

. Research universities with a high level of research activity.

Institutions that award at least 20 doctor's degrees per year, but did not have a high level of research activity. Institutions that award at least 50 master's degrees per year.

Four

study, such as medicine, business, fine arts, theology,

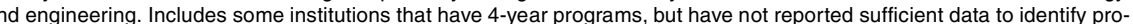

gram category. Also includes institutions classified as 4-year under the IPEDS system, which had been classified as 2-year A

NOTE: Branch campuses are counted as separate institutions. Relative levels of research activity for research universities Were determined by an analysis of research and development expenditures, science and engineering research staffing

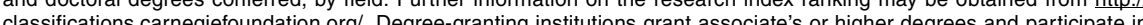
Title IV federal financial aid programs.

Eduction Statistics, Integrated Postsecondary Education Data System (IPEDS), Fall 2012, Institutional Characteristics component. (This table was prepared August 2013.) 
Table 317.30. Number of non-degree-granting Title IV institutions offering postsecondary education, by control of institution and state or jurisdiction: Selected years, 2000-01 through 2012-13

\begin{tabular}{|c|c|c|c|c|c|c|c|c|c|c|c|c|c|c|c|c|c|c|}
\hline \multirow[b]{3}{*}{ State or jurisdiction } & \multirow[b]{3}{*}{$\mid \begin{array}{r}2000-01, \\
\text { total }\end{array}$} & \multirow[b]{3}{*}{$\begin{array}{r}2005-06, \\
\text { total }\end{array}$} & \multirow[b]{3}{*}{$\begin{array}{r}2009-10, \\
\text { total }\end{array}$} & \multicolumn{5}{|c|}{$2010-11$} & \multicolumn{5}{|c|}{$2011-12$} & \multicolumn{5}{|c|}{$2012-13$} \\
\hline & & & & \multirow[b]{2}{*}{ Total } & & & Private & & & & & Private & & & & & Private & \\
\hline & & & & & Public & Total & $\begin{array}{l}\text { Non- } \\
\text { profit }\end{array}$ & $\begin{array}{l}\text { For- } \\
\text { profit }\end{array}$ & Total & Public & Total & $\begin{array}{l}\text { Non- } \\
\text { profit }\end{array}$ & $\begin{array}{c}\text { For- } \\
\text { profit }\end{array}$ & Total & Public & Total & $\begin{array}{l}\text { Non- } \\
\text { profit }\end{array}$ & $\begin{array}{l}\text { For- } \\
\text { profit }\end{array}$ \\
\hline 1 & 2 & 3 & 4 & 5 & 6 & 7 & 8 & 9 & 10 & 11 & 12 & 13 & 14 & 15 & 16 & 17 & 18 & 19 \\
\hline United States .... & 2,297 & 2,187 & 2,247 & 2,422 & 359 & 2,063 & 182 & 1,881 & 2,528 & 362 & 2,166 & 177 & 1,989 & 2,527 & 358 & 2,169 & 168 & 2,001 \\
\hline Alabama ..................... & 10 & 9 & 10 & 9 & 0 & 9 & 1 & 8 & 12 & 0 & 12 & 1 & 11 & 13 & 0 & 13 & 1 & 12 \\
\hline Alaska.......... & 3 & 2 & 3 & 3 & 1 & 2 & 1 & 1 & 2 & 1 & 1 & 1 & 0 & 2 & 1 & 1 & 1 & 0 \\
\hline izona & 33 & 34 & 38 & 42 & 3 & 39 & 0 & 39 & 48 & 2 & 46 & 0 & 46 & 50 & 2 & 48 & 1 & 47 \\
\hline Arkansas........ & 36 & 32 & 33 & 32 & 2 & 30 & 2 & 28 & 36 & 2 & 34 & 2 & 32 & 34 & 2 & 32 & 2 & 30 \\
\hline California ................................ & 230 & 235 & 230 & 248 & 13 & 235 & 21 & 214 & 262 & 14 & 248 & 22 & 226 & 265 & 12 & 253 & 24 & 229 \\
\hline Colorado. & 21 & 26 & 31 & 33 & 3 & 30 & 3 & 27 & 39 & 3 & 36 & 4 & 32 & 40 & 3 & 37 & 3 & 34 \\
\hline nnec & 37 & 36 & 43 & 59 & 13 & 46 & 5 & 41 & 56 & 11 & 45 & 3 & 42 & 50 & 11 & 39 & 3 & 36 \\
\hline elaware & 4 & 6 & 7 & 8 & 0 & 8 & 1 & 7 & 8 & 0 & 8 & 1 & 7 & 8 & 0 & 8 & 1 & 7 \\
\hline District of Columbia ..... & 5 & 6 & 5 & 5 & 0 & 5 & 1 & 4 & 4 & 0 & 4 & 1 & 3 & 4 & 0 & 4 & 1 & 3 \\
\hline 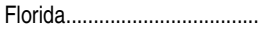 & 124 & 126 & 148 & 150 & 41 & 109 & 7 & 102 & 153 & 43 & 110 & 4 & 106 & 152 & 42 & 110 & 4 & 106 \\
\hline Georgia... & 38 & 44 & 42 & 46 & 1 & 45 & 2 & 43 & 46 & 1 & 45 & 2 & 43 & 45 & 1 & 44 & 1 & 43 \\
\hline waii & 6 & 5 & 4 & 5 & 0 & 5 & 1 & 4 & 7 & 0 & 7 & 1 & 6 & 6 & 0 & 6 & 0 & 6 \\
\hline ho.......................... & 11 & 13 & 14 & 17 & 0 & 17 & 0 & 17 & 19 & 1 & 18 & 0 & 18 & 23 & 1 & 22 & 0 & 22 \\
\hline Illinois......... & 88 & 94 & 98 & 108 & 2 & 106 & 8 & 98 & 117 & 2 & 115 & 10 & 105 & 116 & 3 & 113 & 10 & 103 \\
\hline Indiana ........................ & 34 & 28 & 35 & 42 & 3 & 39 & 1 & 38 & 48 & 4 & 44 & 1 & 43 & 49 & 4 & 45 & 1 & 44 \\
\hline owa. & 27 & 26 & 26 & 26 & 0 & 26 & 2 & 24 & 28 & 0 & 28 & 2 & 26 & 28 & 0 & 28 & 2 & 26 \\
\hline ansas.... & 23 & 25 & 20 & 22 & 1 & 21 & 1 & 20 & 22 & 1 & 21 & 0 & 21 & 25 & 1 & 24 & 0 & 24 \\
\hline Kentucky ... & 52 & 32 & 30 & 30 & 0 & 30 & 2 & 28 & 32 & 0 & 32 & 2 & 30 & 32 & 0 & 32 & 2 & 30 \\
\hline Louisia & 57 & 57 & 60 & 47 & 0 & 47 & 2 & 45 & 51 & 0 & 51 & 2 & 49 & 52 & 0 & 52 & 2 & 50 \\
\hline Maine....... & 11 & 9 & 10 & 7 & 0 & 7 & 0 & 7 & 8 & 0 & 8 & 0 & 8 & 8 & 0 & 8 & 0 & 0 \\
\hline Maryland.................. & 34 & 27 & 32 & 32 & 0 & 32 & 0 & 32 & 33 & 0 & 33 & 0 & 33 & 31 & 0 & 31 & 0 & 31 \\
\hline Mass & 60 & 61 & 62 & 75 & 12 & 63 & 3 & 60 & 73 & 11 & 62 & 3 & 59 & 68 & 11 & 57 & 3 & 54 \\
\hline Michig & 72 & 65 & 82 & 89 & 1 & 88 & 3 & 85 & 86 & 1 & 85 & 2 & 83 & 83 & 1 & 82 & 2 & 80 \\
\hline Minn & 20 & 21 & 22 & 26 & 0 & 26 & 2 & 24 & 26 & 0 & 26 & 2 & 24 & 27 & 0 & 27 & 2 & 25 \\
\hline Mississippi ...................... & 16 & 20 & 19 & 20 & 0 & 20 & 0 & 20 & 20 & 0 & 20 & 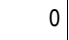 & 20 & 20 & 0 & 20 & 0 & 20 \\
\hline Missou & 69 & 61 & 63 & 74 & 31 & 43 & 4 & 39 & 80 & 34 & 46 & 3 & 43 & 77 & 30 & 47 & 3 & 44 \\
\hline Montan & 10 & 8 & 6 & 8 & 0 & 8 & 0 & 8 & 9 & 0 & a & 0 & 9 & 9 & 0 & 9 & 0 & 9 \\
\hline Nebras & 12 & 10 & 8 & 7 & 0 & 7 & 1 & 6 & 7 & 0 & 7 & 1 & 6 & 7 & 0 & 7 & 1 & 6 \\
\hline Nevada .. & 10 & 9 & 16 & 18 & 0 & 18 & 1 & 17 & 20 & 0 & 20 & 1 & 19 & 23 & 0 & 23 & 1 & 22 \\
\hline New Hampshire .... & 11 & 14 & 14 & 14 & 0 & 14 & 1 & 13 & 15 & 0 & 15 & 1 & 14 & 15 & 0 & 15 & 1 & 14 \\
\hline w. & 89 & 91 & 83 & 87 & 5 & 82 & 9 & 73 & 90 & 5 & 85 & 8 & 77 & 94 & 5 & 89 & 8 & 81 \\
\hline New M & 6 & 7 & 6 & 7 & 0 & 7 & 0 & 7 & 8 & 0 & 8 & 0 & 8 & 8 & 0 & 8 & 0 & 8 \\
\hline New Yc & 152 & 133 & 139 & 151 & 33 & 118 & 33 & 85 & 156 & 33 & 123 & 32 & 91 & 155 & 33 & 122 & 30 & 92 \\
\hline North C & 36 & 29 & 33 & 42 & 1 & 41 & 2 & 39 & 43 & 1 & 42 & 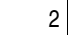 & 40 & 44 & 1 & 43 & ? & 41 \\
\hline North Dakota .......................... & 5 & 5 & 8 & 8 & 0 & 8 & 0 & 8 & 8 & 0 & 8 & 0 & 8 & 8 & 0 & 8 & 0 & 8 \\
\hline $\mathrm{Ol}$ & 130 & 119 & 126 & 138 & 54 & 84 & 9 & 75 & 139 & 53 & 86 & 0 & 78 & 140 & 53 & 87 & 6 & 81 \\
\hline & 84 & 78 & 82 & 83 & 47 & 36 & 0 & 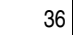 & 82 & 47 & 3 & 0 & & 7 & 47 & & 0 & 31 \\
\hline or & 28 & 27 & 24 & 26 & 0 & 26 & 1 & 25 & 30 & 0 & 30 & 3 & 27 & 29 & 0 & 29 & 3 & 26 \\
\hline & 167 & 131 & 123 & 126 & 34 & 92 & 22 & 70 & 127 & 34 & 93 & 22 & 71 & 125 & 34 & 91 & 21 & 70 \\
\hline Rhode Island ....................... & 12 & 10 & 10 & 11 & 0 & 11 & 2 & 9 & 11 & 0 & 11 & 2 & 9 & 11 & 0 & 11 & 2 & 0 \\
\hline South Carolina..... & 14 & 21 & 23 & 27 & 1 & 26 & 0 & 26 & 33 & 1 & 32 & 1 & 31 & 33 & 1 & 32 & 1 & 31 \\
\hline Sou & 5 & 6 & c & 6 & 0 & 6 & 3 & 3 & 6 & 0 & f & 3 & 3 & 6 & 0 & 6 & 3 & 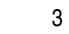 \\
\hline Tenn & 54 & 58 & 58 & 66 & 26 & 40 & 1 & 39 & 72 & 26 & 46 & 1 & 45 & 72 & 26 & 46 & 1 & 45 \\
\hline$\ldots \ldots \ldots \ldots \ldots \ldots$ & 161 & 169 & 154 & 170 & 0 & 170 & 4 & 166 & 174 & 0 & 174 & 4 & 170 & 175 & 0 & 175 & 4 & 171 \\
\hline Utah & 26 & 24 & 30 & 34 & 5 & 29 & 0 & 29 & 38 & 5 & 33 & 0 & 33 & 40 & 7 & 33 & 0 & 33 \\
\hline & 3 & 4 & 4 & 4 & 1 & 3 & 0 & 3 & 4 & 1 & 3 & 0 & & 3 & 0 & 3 & 0 & 3 \\
\hline & 56 & 42 & 34 & 33 & 7 & 26 & 5 & 21 & 36 & 7 & 29 & 5 & 24 & 40 & 8 & 32 & 4 & 28 \\
\hline & 42 & 37 & 36 & 37 & 1 & 36 & 3 & 33 & 37 & 1 & 36 & 0 & 33 & 38 & 1 & 37 & 3 & 34 \\
\hline W & 36 & 31 & 27 & 33 & 17 & 16 & 5 & 11 & 32 & 17 & 15 & 5 & 10 & 33 & 17 & 16 & 5 & 11 \\
\hline (1). & 24 & 22 & 29 & 30 & 0 & 30 & 7 & 23 & 34 & 0 & 34 & 6 & 28 & 32 & 0 & 32 & 3 & 29 \\
\hline 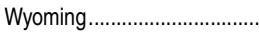 & 3 & 2 & 1 & 1 & 0 & 1 & 0 & 1 & 1 & 0 & 1 & 0 & 1 & 1 & 0 & 1 & 0 & 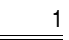 \\
\hline Other jurisdictions ....... & 74 & 74 & 68 & 68 & 2 & 66 & 11 & 55 & 70 & 2 & 68 & 11 & 57 & 72 & 2 & 70 & 13 & 57 \\
\hline American Samoa. & 0 & 0 & 0 & 0 & 0 & 0 & 0 & & 0 & 0 & 0 & 0 & 0 & 0 & 0 & 0 & 0 & 0 \\
\hline & 0 & 0 & 0 & 0 & 0 & 0 & 0 & 0 & 0 & 0 & 0 & 0 & 0 & 0 & 0 & 0 & 0 & 0 \\
\hline Marian & 0 & 0 & 0 & 0 & 0 & 0 & 0 & 0 & 0 & 0 & 0 & 0 & 0 & 0 & 0 & 0 & 0 & 0 \\
\hline & 0 & 0 & 0 & 0 & 0 & 0 & 0 & 0 & 0 & 0 & 0 & 0 & 0 & 0 & 0 & 0 & 0 & 0 \\
\hline Pue & 74 & 74 & 68 & 68 & 2 & 66 & 11 & 55 & 70 & 2 & 68 & 11 & 57 & 72 & 2 & 70 & 13 & 57 \\
\hline U.S. Virgin Islands ................. & 0 & 0 & 0 & 0 & 0 & 0 & 0 & 0 & 0 & 0 & 0 & 0 & 0 & 0 & 0 & 0 & 0 & \\
\hline
\end{tabular}

NOTE: Includes all institutions that participated in Title IV federal financial aid programs but did not grant degrees at the associate's or higher level.
SOURCE: U.S. Department of Education, National Center for Education Statistics, Integrated Postsecondary Education Data System (IPEDS), Fall 2000 through Fall 2012, Institutional Characteristics component. (This table was prepared August 2013.) 
Table 317.40. Number of degree-granting postsecondary institutions and enrollment in these institutions, by enrollment size, control, and level of institution: Fall 2012

\begin{tabular}{|c|c|c|c|c|c|c|c|c|c|c|}
\hline \multirow[b]{2}{*}{ Control and level of institution } & \multicolumn{10}{|c|}{ Number of institutions, by enrollment size of institution } \\
\hline & Total & Under 200 & 200 to 499 & 500 to 999 & $\begin{array}{r}1,000 \text { to } \\
2,499\end{array}$ & $\begin{array}{r}2,500 \text { to } \\
4,999\end{array}$ & $\begin{array}{r}5,000 \text { to } \\
9,999\end{array}$ & $\begin{array}{r}10,000 \text { to } \\
19,999\end{array}$ & $\begin{array}{r}20,000 \text { to } \\
29,999\end{array}$ & $\begin{array}{r}30,000 \text { or } \\
\text { more }\end{array}$ \\
\hline 1 & 2 & 3 & 4 & 5 & 6 & 7 & 8 & 9 & 10 & 11 \\
\hline $\begin{array}{l}\text { Number of institutions } \\
\text { Total }\end{array}$ & 4,726 & 571 & 802 & 666 & 918 & 673 & 508 & 361 & 134 & 93 \\
\hline 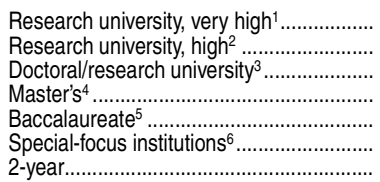 & $\begin{array}{r}107 \\
98 \\
88 \\
703 \\
853 \\
1,177 \\
1,700\end{array}$ & \begin{tabular}{r|}
0 \\
0 \\
1 \\
0 \\
21 \\
345 \\
204
\end{tabular} & $\begin{array}{r}0 \\
0 \\
1 \\
13 \\
80 \\
366 \\
342\end{array}$ & $\begin{array}{r}0 \\
0 \\
1 \\
22 \\
195 \\
239 \\
209\end{array}$ & \begin{tabular}{r|} 
\\
1 \\
13 \\
138 \\
366 \\
156 \\
243
\end{tabular} & \begin{tabular}{r|}
0 \\
3 \\
14 \\
219 \\
133 \\
52 \\
252
\end{tabular} & $\begin{array}{r}9 \\
14 \\
22 \\
185 \\
32 \\
11 \\
235\end{array}$ & \begin{tabular}{r|}
21 \\
43 \\
25 \\
93 \\
14 \\
8 \\
157
\end{tabular} & $\begin{array}{r}35 \\
26 \\
8 \\
19 \\
3 \\
0 \\
43\end{array}$ & $\begin{array}{r}41 \\
11 \\
3 \\
14 \\
9 \\
0 \\
15\end{array}$ \\
\hline 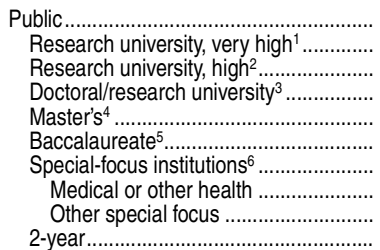 & $\begin{array}{r}1,623 \\
73 \\
73 \\
28 \\
271 \\
198 \\
46 \\
29 \\
17 \\
934\end{array}$ & $\begin{array}{l}6 \\
0 \\
0 \\
0 \\
0 \\
0 \\
1 \\
0 \\
1 \\
5\end{array}$ & $\begin{array}{r}34 \\
0 \\
0 \\
0 \\
0 \\
1 \\
8 \\
3 \\
5 \\
25\end{array}$ & $\begin{array}{r}61 \\
0 \\
0 \\
0 \\
1 \\
19 \\
9 \\
5 \\
4 \\
32\end{array}$ & \begin{tabular}{r|}
261 \\
0 \\
0 \\
1 \\
10 \\
58 \\
13 \\
7 \\
6 \\
179
\end{tabular} & $\begin{array}{r}375 \\
0 \\
0 \\
1 \\
47 \\
70 \\
13 \\
12 \\
1 \\
244\end{array}$ & $\begin{array}{r}393 \\
2 \\
7 \\
4 \\
116 \\
27 \\
2 \\
2 \\
0 \\
0 \\
235\end{array}$ & $\begin{array}{r}298 \\
5 \\
34 \\
16 \\
74 \\
13 \\
0 \\
0 \\
0 \\
156\end{array}$ & $\begin{array}{r}117 \\
28 \\
22 \\
6 \\
16 \\
2 \\
0 \\
0 \\
0 \\
43\end{array}$ & $\begin{array}{r}78 \\
38 \\
10 \\
0 \\
7 \\
8 \\
0 \\
0 \\
0 \\
15\end{array}$ \\
\hline 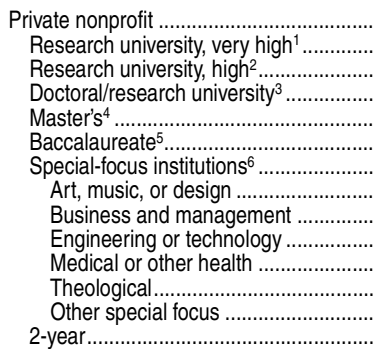 & $\begin{array}{r}1,652 \\
34 \\
25 \\
48 \\
362 \\
514 \\
572 \\
60 \\
28 \\
11 \\
135 \\
296 \\
42 \\
97\end{array}$ & $\begin{array}{r}270 \\
0 \\
0 \\
1 \\
0 \\
14 \\
221 \\
11 \\
6 \\
5 \\
23 \\
170 \\
6 \\
34\end{array}$ & $\begin{array}{r}250 \\
0 \\
0 \\
1 \\
10 \\
40 \\
158 \\
16 \\
4 \\
2 \\
40 \\
85 \\
11 \\
41\end{array}$ & $\begin{array}{r}237 \\
0 \\
0 \\
0 \\
12 \\
113 \\
96 \\
18 \\
8 \\
1 \\
29 \\
27 \\
13 \\
16\end{array}$ & \begin{tabular}{r|r}
468 \\
1 \\
1 \\
6 \\
101 \\
284 \\
69 \\
11 \\
4 \\
2 \\
31 \\
11 \\
10 \\
6
\end{tabular} & $\begin{array}{r}255 \\
0 \\
3 \\
13 \\
158 \\
59 \\
22 \\
3 \\
4 \\
0 \\
11 \\
2 \\
2 \\
0\end{array}$ & $\begin{array}{r}97 \\
7 \\
7 \\
16 \\
61 \\
2 \\
4 \\
0 \\
2 \\
0 \\
1 \\
1 \\
0 \\
0\end{array}$ & $\begin{array}{r}54 \\
16 \\
9 \\
9 \\
17 \\
1 \\
2 \\
1 \\
0 \\
1 \\
0 \\
0 \\
0 \\
0\end{array}$ & $\begin{array}{r}14 \\
7 \\
4 \\
2 \\
0 \\
1 \\
0 \\
0 \\
0 \\
0 \\
0 \\
0 \\
0 \\
0\end{array}$ & $\begin{array}{l}7 \\
3 \\
1 \\
0 \\
3 \\
0 \\
0 \\
0 \\
0 \\
0 \\
0 \\
0 \\
0 \\
0\end{array}$ \\
\hline 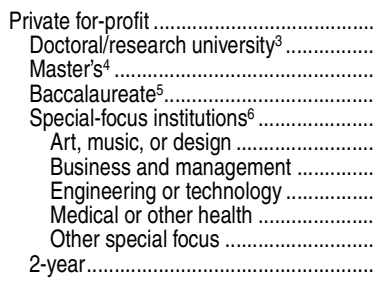 & $\begin{array}{r}1,451 \\
12 \\
70 \\
141 \\
559 \\
82 \\
238 \\
157 \\
68 \\
14 \\
669\end{array}$ & \begin{tabular}{r|}
295 \\
0 \\
0 \\
7 \\
123 \\
5 \\
63 \\
26 \\
27 \\
2 \\
165
\end{tabular} & \begin{tabular}{r|r}
518 \\
0 \\
3 \\
39 \\
200 \\
18 \\
89 \\
76 \\
15 \\
2 \\
276
\end{tabular} & $\begin{array}{r}368 \\
1 \\
9 \\
63 \\
134 \\
25 \\
41 \\
49 \\
15 \\
4 \\
161\end{array}$ & $\begin{array}{r}189 \\
6 \\
27 \\
24 \\
74 \\
26 \\
28 \\
5 \\
10 \\
5 \\
58\end{array}$ & $\begin{array}{r}43 \\
0 \\
14 \\
4 \\
17 \\
6 \\
10 \\
0 \\
0 \\
1 \\
8\end{array}$ & $\begin{array}{r}18 \\
2 \\
8 \\
3 \\
5 \\
0 \\
4 \\
1 \\
0 \\
0 \\
0\end{array}$ & $\begin{array}{l}9 \\
0 \\
2 \\
0 \\
6 \\
2 \\
3 \\
0 \\
1 \\
0 \\
1\end{array}$ & $\begin{array}{l}3 \\
0 \\
3 \\
0 \\
0 \\
0 \\
0 \\
0 \\
0 \\
0 \\
0\end{array}$ & $\begin{array}{l}8 \\
3 \\
4 \\
1 \\
0 \\
0 \\
0 \\
0 \\
0 \\
0 \\
0\end{array}$ \\
\hline
\end{tabular}

See notes at end of table. 
Table 317.40. Number of degree-granting postsecondary institutions and enrollment in these institutions, by enrollment size, control, and level of institution: Fall 2012-Continued

\begin{tabular}{|c|c|c|c|c|c|c|c|c|c|c|}
\hline \multirow[b]{2}{*}{ Control and level of institution } & \multicolumn{10}{|c|}{ Enrollment, by enrollment size of institution } \\
\hline & Total & Under 200 & 200 to 499 & 500 to 999 & $\begin{array}{r}1,000 \text { to } \\
2,499\end{array}$ & $\begin{array}{r}2,500 \text { to } \\
4,999\end{array}$ & $\begin{array}{r}5,000 \text { to } \\
9,999\end{array}$ & $\begin{array}{r}10,000 \text { to } \\
19,999\end{array}$ & $\begin{array}{r}20,000 \text { to } \\
29,999\end{array}$ & $\begin{array}{r}30,000 \text { or } \\
\text { more }\end{array}$ \\
\hline 1 & 12 & 13 & 14 & 15 & 16 & 17 & 18 & 19 & 20 & 21 \\
\hline $\begin{array}{l}\text { Number of institutions } \\
\text { Total }\end{array}$ & $20,642,819$ & 63,377 & 268,303 & 469,837 & $1,517,262$ & $2,398,485$ & $3,605,330$ & $5,007,338$ & $3,294,363$ & $4,018,524$ \\
\hline 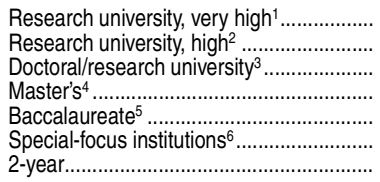 & $\begin{array}{r}2,908,258 \\
1,799,702 \\
1,095,092 \\
4,677,747 \\
2,082,735 \\
915,312 \\
7,163,973\end{array}$ & \begin{tabular}{r|}
0 \\
0 \\
108 \\
0 \\
2,799 \\
37,607 \\
22,863
\end{tabular} & $\begin{array}{r}0 \\
0 \\
343 \\
4,822 \\
30,001 \\
119,683 \\
113,454\end{array}$ & $\begin{array}{r}0 \\
0 \\
742 \\
16,021 \\
144,221 \\
165,766 \\
143,087\end{array}$ & $\begin{array}{r}2,243 \\
2,261 \\
22,399 \\
249,601 \\
597,764 \\
235,422 \\
407,572\end{array}$ & $\begin{array}{r}0 \\
11,759 \\
51,593 \\
786,171 \\
452,722 \\
174,250 \\
921,990\end{array}$ & $\begin{array}{r}63,275 \\
106,418 \\
161,590 \\
1,292,989 \\
220,085 \\
72,534 \\
1,688,439\end{array}$ & \begin{tabular}{r|}
296,534 \\
640,655 \\
322,420 \\
$1,254,767$ \\
212,021 \\
110,050 \\
$2,170,891$
\end{tabular} & $\begin{array}{r}886,826 \\
659,397 \\
193,532 \\
436,982 \\
76,616 \\
0 \\
1,041,010\end{array}$ & $\begin{array}{r}1,659,380 \\
379,212 \\
342,365 \\
636,394 \\
346,506 \\
0 \\
654,667\end{array}$ \\
\hline 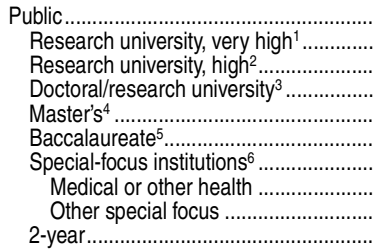 & $\begin{array}{r}14,880,343 \\
2,356,498 \\
1,478,158 \\
405,603 \\
2,646,961 \\
1,114,096 \\
91,367 \\
71,324 \\
20,043 \\
6,787,660\end{array}$ & $\begin{array}{r}850 \\
0 \\
0 \\
0 \\
0 \\
0 \\
169 \\
0 \\
169 \\
681\end{array}$ & $\begin{array}{r}12,370 \\
0 \\
0 \\
0 \\
0 \\
414 \\
2,754 \\
1,083 \\
1,671 \\
9,202\end{array}$ & $\begin{array}{r}47,802 \\
0 \\
0 \\
0 \\
604 \\
15,621 \\
7,483 \\
4,301 \\
3,182 \\
24,094\end{array}$ & $\begin{array}{r}463,010 \\
0 \\
0 \\
2,255 \\
20,752 \\
98,513 \\
24,639 \\
13,400 \\
11,239 \\
316,851\end{array}$ & $\begin{array}{r}1,375,106 \\
0 \\
0 \\
3,807 \\
182,374 \\
251,725 \\
42,982 \\
39,200 \\
3,782 \\
894,218\end{array}$ & $\begin{array}{r}2,823,111 \\
14,448 \\
56,543 \\
31,759 \\
832,076 \\
186,506 \\
13,340 \\
13,340 \\
0 \\
1,688,439\end{array}$ & $\begin{array}{r}4,170,945 \\
81,427 \\
518,446 \\
220,303 \\
996,963 \\
195,308 \\
0 \\
0 \\
0 \\
2,158,498\end{array}$ & $\begin{array}{r}2,885,161 \\
718,320 \\
558,366 \\
147,479 \\
366,631 \\
53,355 \\
0 \\
0 \\
0 \\
0 \\
1,041,010\end{array}$ & $\begin{array}{r}3,101,988 \\
1,542,303 \\
344,803 \\
0 \\
247,561 \\
312,654 \\
0 \\
0 \\
0 \\
654,667\end{array}$ \\
\hline 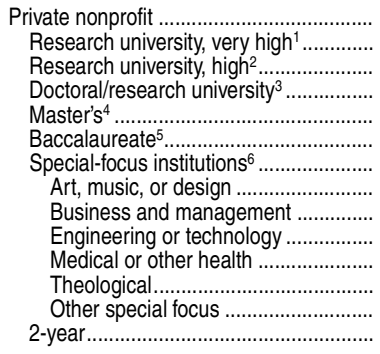 & $\begin{array}{r}3,953,578 \\
551,760 \\
321,544 \\
321,135 \\
1,552,129 \\
804,295 \\
365,109 \\
61,769 \\
37,124 \\
21,140 \\
120,932 \\
91,124 \\
33,020 \\
37,606\end{array}$ & $\begin{array}{r}29,543 \\
0 \\
0 \\
108 \\
0 \\
1,819 \\
23,522 \\
1,011 \\
761 \\
498 \\
2,646 \\
17,953 \\
653 \\
4,094\end{array}$ & $\begin{array}{r}81,299 \\
0 \\
0 \\
343 \\
3,532 \\
14,988 \\
49,217 \\
5,377 \\
1,088 \\
830 \\
13,152 \\
25,117 \\
3,653 \\
13,219\end{array}$ & $\begin{array}{r}173,617 \\
0 \\
0 \\
0 \\
9,273 \\
83,943 \\
69,451 \\
12,774 \\
5,364 \\
905 \\
21,700 \\
19,209 \\
9,499 \\
10,950\end{array}$ & $\begin{array}{r}776,227 \\
2,243 \\
2,261 \\
11,134 \\
188,038 \\
464,289 \\
98,919 \\
18,830 \\
5,052 \\
3,345 \\
42,715 \\
15,809 \\
13,168 \\
9,343\end{array}$ & $\begin{array}{r}879,516 \\
0 \\
11,759 \\
47,786 \\
559,219 \\
188,608 \\
72,144 \\
12,713 \\
12,177 \\
0 \\
34,709 \\
6,498 \\
6,047 \\
0\end{array}$ & $\begin{array}{r}651,824 \\
48,827 \\
49,875 \\
113,594 \\
403,624 \\
10,674 \\
25,230 \\
0 \\
12,682 \\
0 \\
6,010 \\
6,538 \\
0 \\
0\end{array}$ & $\begin{array}{r}715,746 \\
215,107 \\
122,209 \\
102,117 \\
232,974 \\
16,713 \\
26,626 \\
11,064 \\
0 \\
15,562 \\
0 \\
0 \\
0 \\
0\end{array}$ & $\begin{array}{r}338,851 \\
168,506 \\
101,031 \\
46,053 \\
0 \\
23,261 \\
0 \\
0 \\
0 \\
0 \\
0 \\
0 \\
0 \\
0\end{array}$ & $\begin{array}{r}306,955 \\
117,077 \\
34,409 \\
0 \\
155,469 \\
0 \\
0 \\
0 \\
0 \\
0 \\
0 \\
0 \\
0 \\
0\end{array}$ \\
\hline 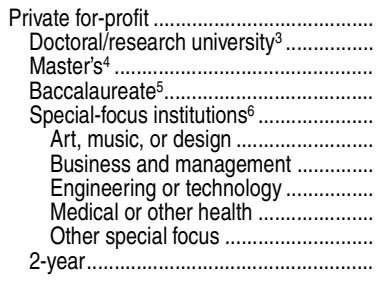 & $\begin{array}{r}1,808,898 \\
368,354 \\
478,657 \\
164,344 \\
458,836 \\
116,558 \\
212,135 \\
73,207 \\
43,319 \\
13,617 \\
338,707\end{array}$ & $\begin{array}{r}32,984 \\
0 \\
0 \\
980 \\
13,916 \\
488 \\
7,473 \\
2,933 \\
2,862 \\
160 \\
18,088\end{array}$ & $\begin{array}{r}174,634 \\
0 \\
1,290 \\
14,599 \\
67,712 \\
6,498 \\
29,048 \\
26,479 \\
4,841 \\
846 \\
91,033\end{array}$ & $\begin{array}{r}248,418 \\
742 \\
6,144 \\
44,657 \\
88,832 \\
16,928 \\
29,389 \\
30,730 \\
9,306 \\
2,479 \\
108,043\end{array}$ & $\begin{array}{r}278,025 \\
9,010 \\
40,811 \\
34,962 \\
111,864 \\
43,769 \\
39,748 \\
7,272 \\
14,412 \\
6,663 \\
81,378\end{array}$ & $\begin{array}{r}143,863 \\
0 \\
44,578 \\
12,389 \\
59,124 \\
20,361 \\
35,294 \\
0 \\
0 \\
3,469 \\
27,772\end{array}$ & $\begin{array}{r}130,395 \\
16,237 \\
57,289 \\
22,905 \\
33,964 \\
0 \\
28,171 \\
5,793 \\
0 \\
0 \\
0\end{array}$ & $\begin{array}{r}120,647 \\
0 \\
24,830 \\
0 \\
83,424 \\
28,514 \\
43,012 \\
0 \\
11,898 \\
0 \\
12,393\end{array}$ & $\begin{array}{r}70,351 \\
0 \\
70,351 \\
0 \\
0 \\
0 \\
0 \\
0 \\
0 \\
0 \\
0\end{array}$ & $\begin{array}{r}609,581 \\
342,365 \\
233,364 \\
33,852 \\
0 \\
0 \\
0 \\
0 \\
0 \\
0 \\
0\end{array}$ \\
\hline
\end{tabular}

${ }^{1}$ Research universities with a very high level of research activity. ${ }^{2}$ Research universities with a high level of research activity.

Institutions that award at least 20 doctor's degrees per year, but did not have a high level of research activity.

${ }^{4}$ Institutions that award at least 50 master's degrees per year.

Institutions that primarily emphasize undergraduate education. Also includes institutions classified as 4-year under the IPEDS system, which had been classified as 2-year in the Carnegie system because they primarily award associate's degrees.

${ }^{6}$ Special-focus 4-year institutions award degrees primarily in single fields of study, such as medicine, business, fine arts, theology, and engineering.
NOTE: Degree-granting institutions grant associate's or higher degrees and participate in Title IV federal financial aid programs. Relative levels of research activity for research universities were determined by an analysis of research and development expenditures, science and engineering research staffing, and doctoral degrees conferred, by field. Further information on the research index ranking may be obtained from http://classifications.carnegiefoundation.org/resources/. SOURCE: U.S. Department of Education, National Center for Education Statistics, Integrated Postsecondary Education Data System (IPEDS), Spring 2013, Enrollment component. (This table was prepared May 2014.) 
Table 317.50. Degree-granting postsecondary institutions that have closed their doors, by control and level of institution: 1969-70 through 2012-13

\begin{tabular}{|c|c|c|c|c|c|c|c|c|c|c|c|c|c|c|c|}
\hline \multirow[b]{3}{*}{ Year } & \multirow{2}{*}{\multicolumn{3}{|c|}{ All institutions }} & \multirow{2}{*}{\multicolumn{3}{|c|}{ Public }} & \multicolumn{9}{|c|}{ Private } \\
\hline & & & & & & & \multicolumn{3}{|c|}{ Total } & \multicolumn{3}{|c|}{ Nonprofit } & \multicolumn{3}{|c|}{ For-profit } \\
\hline & Total & 4-year & 2-year & Total & 4-year & 2-year & Total & 4-year & 2-year & Total & 4-year & 2-year & Total & 4-year & 2-year \\
\hline 1 & 2 & 3 & 4 & 5 & 6 & 7 & 8 & 9 & 10 & 11 & 12 & 13 & 14 & 15 & 16 \\
\hline $\begin{array}{l}\text { Excluding branch campuses } \\
1969-70 \\
1970-71 \\
1971-72 \\
1972-73 \\
1973-74\end{array}$ & $\begin{array}{l}18 \\
32 \\
12 \\
19 \\
18\end{array}$ & \begin{tabular}{r|}
8 \\
9 \\
3 \\
12 \\
11
\end{tabular} & $\begin{array}{r}10 \\
23 \\
9 \\
7 \\
7\end{array}$ & $\begin{array}{l}3 \\
9 \\
3 \\
2 \\
0\end{array}$ & $\begin{array}{l}0 \\
0 \\
0 \\
0 \\
0\end{array}$ & $\begin{array}{l}3 \\
9 \\
3 \\
2 \\
0\end{array}$ & $\begin{array}{r}15 \\
23 \\
9 \\
17 \\
18\end{array}$ & $\begin{array}{r}8 \\
9 \\
3 \\
12 \\
11\end{array}$ & $\begin{array}{r}7 \\
14 \\
6 \\
5 \\
7\end{array}$ & $\begin{array}{l}- \\
\bar{z} \\
\overline{-}\end{array}$ & $\begin{array}{l}- \\
- \\
- \\
-\end{array}$ & $\begin{array}{l}- \\
- \\
- \\
-\end{array}$ & $\begin{array}{l}- \\
\overline{-} \\
\overline{-}\end{array}$ & $\begin{array}{l}- \\
\bar{z} \\
\bar{z}\end{array}$ & $\begin{array}{l}\bar{z} \\
\bar{z} \\
\bar{z}\end{array}$ \\
\hline 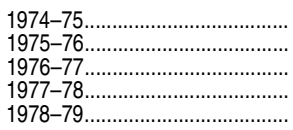 & \begin{tabular}{r|r}
17 \\
8 \\
8 \\
12 \\
9
\end{tabular} & $\begin{array}{r}13 \\
6 \\
5 \\
9 \\
4\end{array}$ & $\begin{array}{l}4 \\
2 \\
3 \\
3 \\
5\end{array}$ & $\begin{array}{l}3 \\
2 \\
0 \\
0 \\
0\end{array}$ & $\begin{array}{l}0 \\
1 \\
0 \\
0 \\
0\end{array}$ & $\begin{array}{l}3 \\
1 \\
0 \\
0 \\
0\end{array}$ & $\begin{array}{r}14 \\
6 \\
8 \\
12 \\
9\end{array}$ & $\begin{array}{r}13 \\
5 \\
5 \\
9 \\
4\end{array}$ & $\begin{array}{l}1 \\
1 \\
3 \\
3 \\
5\end{array}$ & $\begin{array}{l}- \\
\overline{-} \\
\overline{-}\end{array}$ & $\begin{array}{l}- \\
- \\
- \\
-\end{array}$ & $\begin{array}{l}- \\
- \\
- \\
-\end{array}$ & $\begin{array}{l}- \\
\overline{-} \\
\overline{-}\end{array}$ & $\begin{array}{l}- \\
- \\
- \\
-\end{array}$ & $\begin{array}{l}- \\
= \\
-\end{array}$ \\
\hline $\begin{array}{l}1979-80 \\
1980-81 \\
1981-82 \\
1982-83 \\
1983-84 \ldots \ldots\end{array}$ & $\begin{array}{l}6 \\
4 \\
7 \\
7 \\
4\end{array}$ & $\begin{array}{l}5 \\
3 \\
6 \\
4 \\
4\end{array}$ & $\begin{array}{l}1 \\
1 \\
1 \\
3 \\
0\end{array}$ & $\begin{array}{l}0 \\
0 \\
0 \\
0 \\
0\end{array}$ & $\begin{array}{l}0 \\
0 \\
0 \\
0 \\
0\end{array}$ & $\begin{array}{l}0 \\
0 \\
0 \\
0 \\
0\end{array}$ & $\begin{array}{l}6 \\
4 \\
7 \\
7 \\
4\end{array}$ & $\begin{array}{l}5 \\
3 \\
6 \\
4 \\
4\end{array}$ & $\begin{array}{l}1 \\
1 \\
1 \\
3 \\
0\end{array}$ & $\begin{array}{l}- \\
\bar{z} \\
- \\
-\end{array}$ & $\begin{array}{l}- \\
- \\
- \\
-\end{array}$ & $\begin{array}{l}- \\
- \\
- \\
-\end{array}$ & $\begin{array}{l}- \\
- \\
- \\
-\end{array}$ & $\begin{array}{l}- \\
- \\
- \\
-\end{array}$ & $\begin{array}{l}- \\
z \\
- \\
-\end{array}$ \\
\hline $\begin{array}{l}1984-8556 \\
1985-86 \\
1986-87 \text { and } 1987-88 \\
1988-89 \\
1989-90\end{array}$ & $\begin{array}{r}4 \\
10 \\
25 \\
14 \\
12\end{array}$ & $\begin{array}{r}4 \\
6 \\
19 \\
6 \\
6\end{array}$ & $\begin{array}{l}0 \\
4 \\
6 \\
8 \\
6\end{array}$ & $\begin{array}{l}0 \\
1 \\
1 \\
0 \\
0\end{array}$ & $\begin{array}{l}0 \\
0 \\
0 \\
0 \\
0\end{array}$ & $\begin{array}{l}0 \\
1 \\
1 \\
0 \\
0\end{array}$ & $\begin{array}{r}4 \\
9 \\
24 \\
14 \\
12\end{array}$ & $\begin{array}{r}4 \\
6 \\
19 \\
6 \\
6\end{array}$ & $\begin{array}{l}0 \\
3 \\
5 \\
8 \\
6\end{array}$ & $\begin{array}{l}- \\
- \\
- \\
-\end{array}$ & $\begin{array}{l}- \\
- \\
- \\
-\end{array}$ & $\begin{array}{l}- \\
\overline{-} \\
\overline{-}\end{array}$ & $\begin{array}{l}- \\
- \\
- \\
-\end{array}$ & $\begin{array}{l}- \\
- \\
- \\
-\end{array}$ & $\begin{array}{l}- \\
= \\
- \\
-\end{array}$ \\
\hline $\begin{array}{l}1990-91 \ldots \ldots \ldots \ldots \\
1991-92\end{array}$ & $\begin{array}{l}10 \\
10 \\
\end{array}$ & $\begin{array}{l}4 \\
7 \\
\end{array}$ & $\begin{array}{l}6 \\
3 \\
\end{array}$ & $\begin{array}{l}0 \\
0\end{array}$ & $\begin{array}{l}0 \\
0\end{array}$ & $\begin{array}{l}0 \\
0\end{array}$ & $\begin{array}{l}10 \\
10\end{array}$ & $\begin{array}{l}4 \\
7\end{array}$ & $\begin{array}{l}6 \\
3 \\
\end{array}$ & $=$ & $\begin{array}{l}- \\
-\end{array}$ & $\overline{-}$ & $\overline{-}$ & $\overline{-}$ & $\overline{-}$ \\
\hline $\begin{array}{l}\text { Including branch campuses } \\
1969-70 \\
1970-71 \ldots \\
1971-72 \ldots \\
1972-73 \ldots\end{array}$ & $\begin{array}{l}24 \\
35 \\
14 \\
21 \\
20\end{array}$ & \begin{tabular}{r|}
10 \\
10 \\
5 \\
12 \\
12
\end{tabular} & $\begin{array}{r}14 \\
25 \\
9 \\
9 \\
8\end{array}$ & $\begin{array}{r}5 \\
11 \\
3 \\
4 \\
1\end{array}$ & $\begin{array}{l}1 \\
0 \\
0 \\
0 \\
0\end{array}$ & $\begin{array}{r}4 \\
11 \\
3 \\
4 \\
1\end{array}$ & $\begin{array}{l}19 \\
24 \\
11 \\
17 \\
19\end{array}$ & $\begin{array}{r}9 \\
10 \\
5 \\
12 \\
12\end{array}$ & $\begin{array}{r}10 \\
14 \\
6 \\
5 \\
7\end{array}$ & $\begin{array}{l}- \\
- \\
- \\
-\end{array}$ & $\begin{array}{l}- \\
- \\
- \\
-\end{array}$ & $\begin{array}{l}- \\
\overline{-} \\
-\end{array}$ & $\begin{array}{l}- \\
- \\
- \\
-\end{array}$ & $\begin{array}{l}\overline{-} \\
\overline{-} \\
-\end{array}$ & $\begin{array}{l}- \\
\overline{-} \\
- \\
-\end{array}$ \\
\hline 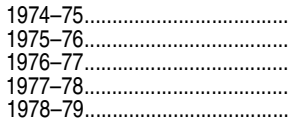 & $\begin{array}{r}18 \\
9 \\
9 \\
12 \\
9\end{array}$ & $\begin{array}{r}13 \\
7 \\
6 \\
9 \\
4\end{array}$ & $\begin{array}{l}5 \\
2 \\
3 \\
3 \\
5\end{array}$ & $\begin{array}{l}4 \\
2 \\
0 \\
0 \\
0\end{array}$ & $\begin{array}{l}0 \\
1 \\
0 \\
0 \\
0\end{array}$ & $\begin{array}{l}4 \\
1 \\
0 \\
0 \\
0\end{array}$ & $\begin{array}{r}14 \\
7 \\
9 \\
12 \\
9\end{array}$ & $\begin{array}{r}13 \\
6 \\
6 \\
9 \\
4\end{array}$ & $\begin{array}{l}1 \\
1 \\
3 \\
3 \\
5\end{array}$ & $\begin{array}{l}- \\
= \\
- \\
-\end{array}$ & $\begin{array}{l}- \\
- \\
- \\
-\end{array}$ & $\begin{array}{l}- \\
- \\
- \\
-\end{array}$ & $\begin{array}{l}- \\
- \\
- \\
-\end{array}$ & $\begin{array}{l}- \\
= \\
= \\
-\end{array}$ & $\begin{array}{l}- \\
= \\
=\end{array}$ \\
\hline $\begin{array}{l}1979-80 \\
1980-81 \\
1981-82 \\
1982-83 \\
1983-84\end{array}$ & $\begin{array}{l}6 \\
4 \\
7 \\
7 \\
5\end{array}$ & $\begin{array}{l}5 \\
3 \\
6 \\
4 \\
5\end{array}$ & $\begin{array}{l}1 \\
1 \\
1 \\
3 \\
0\end{array}$ & $\begin{array}{l}0 \\
0 \\
0 \\
0 \\
1\end{array}$ & $\begin{array}{l}0 \\
0 \\
0 \\
0 \\
1\end{array}$ & $\begin{array}{l}0 \\
0 \\
0 \\
0 \\
0\end{array}$ & $\begin{array}{l}6 \\
4 \\
7 \\
7 \\
4\end{array}$ & $\begin{array}{l}5 \\
3 \\
6 \\
4 \\
4\end{array}$ & \begin{tabular}{l|}
1 \\
1 \\
1 \\
3 \\
0
\end{tabular} & $\begin{array}{l}- \\
\bar{z} \\
\overline{-}\end{array}$ & $\begin{array}{l}- \\
= \\
= \\
-\end{array}$ & $\begin{array}{l}- \\
\overline{-} \\
\overline{-}\end{array}$ & $\begin{array}{l}- \\
- \\
- \\
-\end{array}$ & $\begin{array}{l}- \\
\overline{-} \\
\overline{-}\end{array}$ & $\begin{array}{l}- \\
= \\
=\end{array}$ \\
\hline 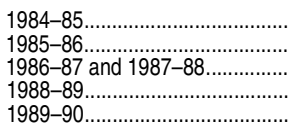 & \begin{tabular}{r|}
4 \\
12 \\
26 \\
14 \\
19
\end{tabular} & \begin{tabular}{r|}
4 \\
8 \\
19 \\
6 \\
8
\end{tabular} & $\begin{array}{r}0 \\
4 \\
7 \\
8 \\
11\end{array}$ & $\begin{array}{l}0 \\
1 \\
1 \\
0 \\
0\end{array}$ & $\begin{array}{l}0 \\
1 \\
0 \\
0 \\
0\end{array}$ & $\begin{array}{l}0 \\
0 \\
1 \\
0 \\
0\end{array}$ & $\begin{array}{r}4 \\
11 \\
25 \\
14 \\
19\end{array}$ & $\begin{array}{r}4 \\
7 \\
19 \\
6 \\
8\end{array}$ & $\begin{array}{r}0 \\
4 \\
6 \\
8 \\
11\end{array}$ & $\begin{array}{l}- \\
- \\
- \\
-\end{array}$ & $\begin{array}{l}- \\
- \\
- \\
-\end{array}$ & $\begin{array}{l}- \\
- \\
- \\
-\end{array}$ & $\begin{array}{l}- \\
- \\
- \\
-\end{array}$ & $\begin{array}{l}- \\
= \\
= \\
-\end{array}$ & $\begin{array}{l}- \\
z \\
-\end{array}$ \\
\hline $\begin{array}{l}1990-91 \\
1991-92 \\
1992-93 \\
1993-94 \ldots \ldots \ldots \\
1994-95\end{array}$ & $\begin{array}{l}18 \\
26 \\
23 \\
38 \\
15\end{array}$ & $\begin{array}{r}6 \\
8 \\
6 \\
11 \\
8\end{array}$ & $\begin{array}{r}12 \\
18 \\
17 \\
27 \\
7\end{array}$ & $\begin{array}{l}0 \\
1 \\
0 \\
1 \\
2\end{array}$ & $\begin{array}{l}0 \\
0 \\
0 \\
0 \\
0\end{array}$ & $\begin{array}{l}0 \\
1 \\
0 \\
1 \\
2\end{array}$ & $\begin{array}{l}18 \\
25 \\
23 \\
37 \\
13\end{array}$ & $\begin{array}{r}6 \\
8 \\
6 \\
11 \\
8\end{array}$ & $\begin{array}{r}12 \\
17 \\
17 \\
26 \\
5\end{array}$ & $\begin{array}{r}7 \\
8 \\
6 \\
13 \\
8\end{array}$ & \begin{tabular}{r|}
5 \\
7 \\
5 \\
10 \\
7
\end{tabular} & \begin{tabular}{l|l}
2 \\
1 \\
1 \\
3 \\
1
\end{tabular} & $\begin{array}{r}11 \\
17 \\
17 \\
24 \\
5\end{array}$ & \begin{tabular}{l|}
1 \\
1 \\
1 \\
1 \\
1
\end{tabular} & $\begin{array}{r}10 \\
16 \\
16 \\
23 \\
4\end{array}$ \\
\hline 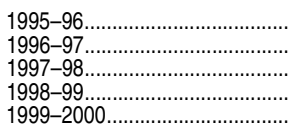 & $\begin{array}{r}21 \\
36 \\
5 \\
7 \\
16\end{array}$ & \begin{tabular}{r|r}
8 \\
13 \\
0 \\
1 \\
3
\end{tabular} & $\begin{array}{r}13 \\
23 \\
5 \\
6 \\
13\end{array}$ & $\begin{array}{l}1 \\
2 \\
0 \\
1 \\
3\end{array}$ & $\begin{array}{l}1 \\
0 \\
0 \\
0 \\
0\end{array}$ & $\begin{array}{l}0 \\
2 \\
0 \\
1 \\
3\end{array}$ & $\begin{array}{r}20 \\
34 \\
5 \\
6 \\
13\end{array}$ & $\begin{array}{r}7 \\
13 \\
0 \\
1 \\
3\end{array}$ & $\begin{array}{r}13 \\
21 \\
5 \\
5 \\
10\end{array}$ & \begin{tabular}{r|r}
9 \\
14 \\
1 \\
2 \\
8
\end{tabular} & $\begin{array}{r}7 \\
10 \\
0 \\
0 \\
3\end{array}$ & \begin{tabular}{l|}
2 \\
4 \\
1 \\
2 \\
5
\end{tabular} & $\begin{array}{r}11 \\
20 \\
4 \\
4 \\
5\end{array}$ & $\begin{array}{l}0 \\
3 \\
0 \\
1 \\
0\end{array}$ & $\begin{array}{r}11 \\
17 \\
4 \\
3 \\
5\end{array}$ \\
\hline $\begin{array}{l}2000-01 \\
2001-02 \\
2002-03 \\
2003-04 \ldots \ldots \\
2004-05\end{array}$ & \begin{tabular}{r|r}
14 \\
14 \\
13 \\
12 \\
3
\end{tabular} & $\begin{array}{l}9 \\
2 \\
7 \\
5 \\
1\end{array}$ & $\begin{array}{r}5 \\
12 \\
6 \\
7 \\
2\end{array}$ & $\begin{array}{l}0 \\
0 \\
0 \\
0 \\
0\end{array}$ & $\begin{array}{l}0 \\
0 \\
0 \\
0 \\
0\end{array}$ & $\begin{array}{l}0 \\
0 \\
0 \\
0 \\
0\end{array}$ & $\begin{array}{r}14 \\
14 \\
13 \\
12 \\
3\end{array}$ & $\begin{array}{l}9 \\
2 \\
7 \\
5 \\
1\end{array}$ & $\begin{array}{r}5 \\
12 \\
6 \\
7 \\
2\end{array}$ & $\begin{array}{l}8 \\
1 \\
6 \\
8 \\
1\end{array}$ & $\begin{array}{l}8 \\
1 \\
6 \\
5 \\
1\end{array}$ & $\begin{array}{l}0 \\
0 \\
0 \\
3 \\
0\end{array}$ & $\begin{array}{r}6 \\
13 \\
7 \\
4 \\
2\end{array}$ & $\begin{array}{l}1 \\
1 \\
1 \\
0 \\
0\end{array}$ & $\begin{array}{r}5 \\
12 \\
6 \\
4 \\
2\end{array}$ \\
\hline $2005-06$ & $\begin{array}{l}11 \\
13\end{array}$ & $\begin{array}{l}6 \\
4\end{array}$ & $\begin{array}{l}5 \\
9\end{array}$ & $\begin{array}{l}1 \\
0\end{array}$ & $\begin{array}{l}1 \\
0\end{array}$ & $\begin{array}{l}0 \\
0\end{array}$ & $\begin{array}{l}10 \\
13\end{array}$ & $\begin{array}{l}5 \\
4\end{array}$ & $\begin{array}{l}5 \\
9\end{array}$ & $\begin{array}{l}5 \\
6\end{array}$ & $\begin{array}{l}4 \\
4\end{array}$ & $\begin{array}{l}1 \\
2\end{array}$ & $\begin{array}{l}5 \\
7\end{array}$ & $\begin{array}{l}1 \\
0\end{array}$ & $\begin{array}{l}4 \\
7\end{array}$ \\
\hline $2007-08 \ldots \ldots$ & 26 & 10 & 16 & 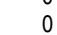 & 0 & 0 & 26 & 10 & 16 & 9 & $\begin{array}{l}4 \\
6\end{array}$ & $\begin{array}{ccc}2 \\
3\end{array}$ & 17 & 4 & 13 \\
\hline$-09 \ldots \ldots \ldots \ldots \ldots \ldots \ldots \ldots \ldots \ldots \ldots \ldots \ldots \ldots \ldots \ldots$ & 16 & 6 & 10 & 0 & 0 & 0 & 16 & 6 & 10 & 6 & 5 & 1 & 10 & 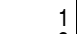 & \\
\hline 2009-10 & 17 & 11 & 6 & 0 & 0 & 0 & 17 & 11 & 6 & 9 & 9 & 0 & 8 & 2 & 6 \\
\hline $2010-11 \ldots \ldots \ldots \ldots \ldots \ldots \ldots \ldots \ldots$ & 20 & 9 & 11 & 0 & 0 & 0 & 20 & 9 & 11 & 7 & 6 & 1 & 13 & 3 & 10 \\
\hline $\begin{array}{l}2011-12 \\
2012-13 \ldots \ldots \ldots\end{array}$ & $\begin{array}{l}10 \\
21\end{array}$ & $\begin{array}{l}5 \\
3\end{array}$ & $\begin{array}{r}5 \\
18\end{array}$ & $\begin{array}{l}4 \\
1\end{array}$ & 1 & $\begin{array}{l}4 \\
0\end{array} \mid$ & 20 & $\begin{array}{l}5 \\
2\end{array}$ & $\begin{array}{r}1 \\
18\end{array}$ & $\begin{array}{l}2 \\
4\end{array}$ & $\begin{array}{l}2 \\
2\end{array}$ & $\begin{array}{l}0 \\
2\end{array}$ & $\begin{array}{r}4 \\
16\end{array}$ & $\begin{array}{l}3 \\
0\end{array}$ & $\begin{array}{r}1 \\
16\end{array}$ \\
\hline
\end{tabular}

-Not available.

NOTE: This table indicates the year by which the institution no longer operated (generally it closed at the end of or during the prior year). Data through 1995-96 are for institutions of higher education, while later data are for degree-granting institutions. Degree-granting institutions grant associate's or higher degrees and participate in Title IV federal financial aid programs. The degree-granting classification is very similar to the earlier higher education classification, but it includes more 2-year colleges and excludes a few higher education institutions that did not grant degrees.
SOURCE: U.S. Department of Education, National Center for Education Statistics, Education Directory, Higher Education, 1969-70 through 1974-75; Education Directory, Colleges and Universities, 1975-76 through 1985-86; 1982-83 Supplement to the Education Directory, Colleges and Universities; Integrated Postsecondary Education Data System (IPEDS), "Institutional Characteristics Survey" (IPEDS-IC:86-99); and IPEDS Fall 2000 through Fall 2012, Institutional Characteristics component. (This table was prepared July 2014.) 
Table 318.10. Degrees conferred by degree-granting postsecondary institutions, by level of degree and sex of student: Selected years, 1869-70 through 2023-24

\begin{tabular}{|c|c|c|c|c|c|c|c|c|c|c|c|c|c|c|c|c|}
\hline \multirow[b]{2}{*}{ Year } & \multicolumn{4}{|c|}{ Associate's degrees } & \multicolumn{4}{|c|}{ Bachelor's degrees } & \multicolumn{4}{|c|}{ Master's degrees } & \multicolumn{4}{|c|}{ Doctor's degrees ${ }^{1}$} \\
\hline & Total & Males & Females & $\begin{array}{r}\text { Percent } \\
\text { female }\end{array}$ & Total & Males & Females & $\begin{array}{l}\text { rcent } \\
\text { male }\end{array}$ & Total & Males & emales & $\begin{array}{l}\text { rcent } \\
\text { male }\end{array}$ & Total & Males & Females & $\begin{array}{l}\text { Percent } \\
\text { female }\end{array}$ \\
\hline & 2 & 3 & 4 & 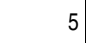 & 0 & 7 & 8 & & 10 & 11 & 12 & 13 & 14 & 15 & 16 & 17 \\
\hline $\begin{array}{l}869-70 \ldots \ldots \ldots \ldots . . . \\
879-80 \ldots \ldots \ldots \ldots \ldots . . \\
889-90 \ldots \ldots \ldots \ldots \ldots . . \\
899-1900 \ldots \ldots \ldots . . . \\
909-10 \ldots \ldots \ldots \ldots . . .\end{array}$ & $\begin{array}{l}- \\
- \\
- \\
- \\
-\end{array}$ & $\begin{array}{l}- \\
- \\
- \\
- \\
-\end{array}$ & $\begin{array}{l}- \\
- \\
- \\
-\end{array}$ & $\begin{array}{l}- \\
- \\
- \\
-\end{array}$ & \begin{tabular}{r|}
$9,371^{2}$ \\
$12,896^{2}$ \\
$15,539^{2}$ \\
$27,410^{2}$ \\
$37,199^{2}$
\end{tabular} & \begin{tabular}{r|}
$7,993^{2}$ \\
$10,411^{2}$ \\
$12,857^{2}$ \\
$22,173^{2}$ \\
$28,762^{2}$
\end{tabular} & \begin{tabular}{l|}
$1,378^{2}$ \\
$2,485^{2}$ \\
$2,682^{2}$ \\
$5,237^{2}$ \\
$8,437^{2}$
\end{tabular} & $\begin{array}{l}14.7 \\
19.3 \\
17.3 \\
19.1 \\
22.7\end{array}$ & $\begin{array}{r}0 \\
879 \\
1,015 \\
1,583 \\
2,113\end{array}$ & $\begin{array}{r}0 \\
868 \\
821 \\
1,280 \\
1,555\end{array}$ & \begin{tabular}{r|}
0 \\
11 \\
194 \\
303 \\
558
\end{tabular} & \begin{tabular}{r|}
$\overline{1.3}$ \\
19.1 \\
19.1 \\
26.4
\end{tabular} & \begin{tabular}{r|}
1 \\
54 \\
149 \\
382 \\
443
\end{tabular} & $\begin{array}{r}1 \\
51 \\
147 \\
359 \\
399\end{array}$ & \begin{tabular}{r|r}
0 \\
3 \\
2 \\
23 \\
44
\end{tabular} & $\begin{array}{l}0.0 \\
5.6 \\
1.3\end{array}$ \\
\hline $\begin{array}{l}19-20 \ldots \ldots \ldots \ldots \ldots . . \\
29-30 \ldots \ldots \ldots \ldots \ldots . . \\
39-40 \ldots \ldots \ldots \ldots \ldots . . \\
49-50 \ldots \ldots \ldots \ldots \ldots . . . \\
59-60 \ldots \ldots \ldots \ldots \ldots . . . \\
69-70 \ldots \ldots \ldots \ldots \ldots . . .\end{array}$ & $\begin{array}{r}- \\
\bar{z} \\
\bar{z} \\
206,023\end{array}$ & $\begin{array}{r}- \\
\overline{-} \\
\overline{-} \\
117,432\end{array}$ & $\begin{array}{c}- \\
- \\
- \\
= \\
\bar{z}, 591\end{array}$ & $\begin{array}{r}- \\
- \\
- \\
\overline{-} \\
43.0\end{array}$ & $\begin{array}{r}48,622^{2} \\
122,484^{2} \\
186,500^{2} \\
432,058^{2} \\
392,440^{2} \\
792,316^{2}\end{array}$ & $\begin{array}{r}31,980^{2} \\
73,615^{2} \\
109,546^{2} \\
328,841^{2} \\
254,063^{2} \\
451,097\end{array}$ & $\begin{array}{r}16,642^{2} \\
48,869^{2} \\
76,954^{2} \\
103,217^{2} \\
138,377^{2} \\
341,219\end{array}$ & $\begin{array}{l}34.2 \\
39.9 \\
41.3 \\
23.9 \\
35.3 \\
43.1\end{array}$ & $\begin{array}{r}4,279 \\
14,969 \\
26,731 \\
58,183 \\
74,435 \\
213,589\end{array}$ & $\begin{array}{r}2,985 \\
8,925 \\
16,508 \\
41,220 \\
50,898 \\
130,799\end{array}$ & $\begin{array}{r}1,294 \\
6,044 \\
10,223 \\
16,963 \\
23,537 \\
82,790\end{array}$ & $\begin{array}{l}30.2 \\
40.4 \\
38.2 \\
29.2 \\
31.6 \\
38.8\end{array}$ & $\begin{array}{r}615 \\
2,299 \\
3,290 \\
6,420 \\
9,829 \\
59,486\end{array}$ & $\begin{array}{r}522 \\
1,946 \\
2,861 \\
5,804 \\
8,801 \\
53,792\end{array}$ & $\begin{array}{r}93 \\
353 \\
429 \\
616 \\
1,028 \\
5,694\end{array}$ & $\begin{array}{r}15.1 \\
15.4 \\
13.0 \\
9.6 \\
10.5\end{array}$ \\
\hline $\begin{array}{l}972-73 \ldots \ldots \ldots \ldots \ldots . . \\
973-74 \ldots \ldots \ldots \ldots \ldots . . . \\
974-75 \ldots \ldots \ldots \ldots \ldots \ldots . . .\end{array}$ & $\begin{array}{l}252,311 \\
292,014 \\
316,174 \\
343,924 \\
360,171\end{array}$ & $\begin{array}{l}144,144 \\
166,227 \\
175,413 \\
188,591 \\
191,017\end{array}$ & \begin{tabular}{|l|}
108,167 \\
125,787 \\
140,761 \\
155,333 \\
169,154
\end{tabular} & $\begin{array}{l}42.9 \\
43.1 \\
44.5 \\
45.2 \\
47.0\end{array}$ & $\begin{array}{l}922,362 \\
945,776 \\
922,933\end{array}$ & 504,841 & $\begin{array}{l}418,463 \\
418,092\end{array}$ & $\begin{array}{l}43.4 \\
43.6 \\
43.8 \\
44.2 \\
45.3\end{array}$ & $\begin{array}{l}235,564 \\
257,201 \\
268,654 \\
282,074 \\
297,545\end{array}$ & $\begin{array}{l}143,083 \\
155,010 \\
159,569 \\
162,606 \\
166,318\end{array}$ & $\begin{array}{r}92,481 \\
102,191 \\
109,085 \\
119,468 \\
131,227\end{array}$ & $\begin{array}{l}39.3 \\
39.7 \\
40.6 \\
42.4 \\
44.1\end{array}$ & $\begin{array}{l}64,998 \\
71,206 \\
79,512 \\
82,591 \\
84,904\end{array}$ & $\begin{array}{l}58,137 \\
63,353 \\
69,959 \\
71,131 \\
71,025\end{array}$ & $\begin{array}{r}6,861 \\
7,853 \\
9,553 \\
11,460 \\
13,879\end{array}$ & $\begin{array}{l}10.6 \\
11.0 \\
12.0 \\
13.9\end{array}$ \\
\hline $\begin{array}{l}77-78 \ldots \ldots \ldots \ldots \ldots . . . \\
78-79 \ldots \ldots \ldots \ldots \ldots \ldots . . . \\
79-80 \ldots \ldots \ldots \ldots \ldots \ldots . . .\end{array}$ & $\begin{array}{l}391,454 \\
406,377 \\
412,246 \\
402,702 \\
400,910\end{array}$ & $\begin{array}{l}9,996 \\
0,842 \\
4,718 \\
2,091 \\
3,737\end{array}$ & $\begin{array}{l}181,458 \\
195,535 \\
207,528 \\
210,611 \\
217,173\end{array}$ & $\begin{array}{l}50.3 \\
52.3 \\
54.2\end{array}$ & $\begin{array}{l}921,390 \\
929,417\end{array}$ & $\begin{array}{l}4 / /, 344 \\
473,611\end{array}$ & $\begin{array}{l}444,046 \\
455,806\end{array}$ & $\begin{array}{l}47.1 \\
48.2 \\
49.0\end{array}$ & $\begin{array}{l}317,477 \\
323,025 \\
317,987 \\
307,686 \\
305,196\end{array}$ & $\begin{array}{l}172,519 \\
173,090 \\
166,857 \\
159,111 \\
156,882\end{array}$ & $\begin{array}{l}44,958 \\
49,935 \\
51,130 \\
48,575 \\
48,314\end{array}$ & $\begin{array}{l}45.7 \\
46.4 \\
47.5 \\
48.3 \\
48.6\end{array}$ & $\begin{array}{l}91,007 \\
91,730 \\
92,345 \\
94,971 \\
95,631\end{array}$ & $\begin{array}{l}73,888 \\
72,209 \\
70,283 \\
70,452 \\
69,526\end{array}$ & $\begin{array}{l}17,119 \\
19,521 \\
22,062 \\
24,519 \\
26,105\end{array}$ & $\begin{array}{l}18.8 \\
21.3 \\
23.9 \\
25.8 \\
27.3\end{array}$ \\
\hline $\begin{array}{c}80-81 \ldots \ldots \ldots \ldots \ldots . . . \\
81-82 \ldots \ldots \ldots \ldots \ldots \ldots . . \\
82-83 \ldots \ldots \ldots \ldots \ldots . . . \\
83-84 \ldots \ldots \ldots \ldots \ldots \ldots . . \\
84-85 \ldots \ldots \ldots \ldots \ldots . . .\end{array}$ & $\begin{array}{l}416,377 \\
434,526 \\
449,620 \\
452,240 \\
454,712\end{array}$ & $\begin{array}{l}188,638 \\
196,944 \\
203,991 \\
202,704 \\
202,932\end{array}$ & $\begin{array}{l}227,739 \\
237,582 \\
245,629 \\
249,536 \\
251,780\end{array}$ & $\begin{array}{l}54.7 \\
54.7\end{array}$ & $\begin{array}{l}935,140 \\
952,998 \\
969,510\end{array}$ & 482,528 & $\begin{array}{l}465,257 \\
479,634 \\
490,370 \\
491,990 \\
496,949\end{array}$ & $\begin{array}{l}50.6 \\
50.5 \\
50.7\end{array}$ & $\begin{array}{l}302,637 \\
302,447 \\
296,415 \\
291,141 \\
293,472\end{array}$ & $\begin{array}{l}52,979 \\
51,349 \\
50,092 \\
99,268 \\
\end{array}$ & & $\begin{array}{l}49.5 \\
50.0 \\
49.4 \\
48.7 \\
49.1\end{array}$ & $\begin{array}{r}98,016 \\
97,838 \\
99,335 \\
100,799 \\
100,785\end{array}$ & & & $\begin{array}{l}29.0 \\
29.9 \\
31.8 \\
32.8 \\
34.2\end{array}$ \\
\hline 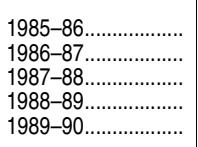 & $\begin{array}{l}446,047 \\
436,304 \\
435,085 \\
436,764 \\
455,102\end{array}$ & $\begin{array}{l}6,166 \\
0,839 \\
0,047 \\
6,316 \\
1,195\end{array}$ & \begin{tabular}{|l|}
249,881 \\
245,465 \\
245,038 \\
250,448 \\
263,907
\end{tabular} & $\begin{array}{l}56.0 \\
56.3 \\
56.3 \\
57.3 \\
58.0\end{array}$ & $\begin{array}{r}987,823 \\
991,264 \\
994,829 \\
1,018,755 \\
1,051,344\end{array}$ & & & & & \begin{tabular}{|l|}
149,373 \\
147,063 \\
150,243 \\
153,993 \\
158,052
\end{tabular} & & 52.1 & $\begin{array}{l}00,280 \\
98,477 \\
99,139 \\
00,51 \\
03,508\end{array}$ & & & $\begin{array}{l}35.0 \\
36.2 \\
36.4 \\
37.3 \\
38.2\end{array}$ \\
\hline $\begin{array}{r}990-91 \ldots \ldots \ldots \ldots \ldots . . . \\
991-92 \ldots \ldots \ldots \ldots \ldots . . . \\
992-93 \ldots \ldots \ldots \ldots \ldots . . . \\
993-94 \ldots \ldots \ldots \ldots \ldots . . . \\
994-95 \ldots \ldots \ldots \ldots \ldots \ldots . . .\end{array}$ & $\begin{array}{l}481,720 \\
504,231 \\
514,756 \\
530,632 \\
539,691\end{array}$ & $\begin{array}{l}198,634 \\
207,481 \\
211,964 \\
215,261 \\
218,352\end{array}$ & $\begin{array}{l}283,086 \\
296,750 \\
302,792 \\
315,371 \\
321,339\end{array}$ & $\begin{array}{l}58.8 \\
58.9 \\
58.8 \\
59.4 \\
59.5\end{array}$ & $\begin{array}{l}1,094,538 \\
1,136,553 \\
1,165,178 \\
1,169,275 \\
1,160,134\end{array}$ & 526,131 & & & & & & 53. & $\begin{array}{l}105,547 \\
109,554 \\
112,072 \\
112,636 \\
114,266\end{array}$ & & & $\begin{array}{l}39.1 \\
39.2 \\
40.1 \\
40.7 \\
41.1\end{array}$ \\
\hline $\begin{array}{l}95-96 \ldots \ldots \ldots \ldots \ldots . . . \\
96-97 \ldots \ldots \ldots \ldots \ldots \ldots . . . \\
97-98 \ldots \ldots \ldots \ldots \ldots \ldots . . . \\
98-99 \ldots \ldots \ldots \ldots \ldots \ldots . . . \\
99-2000 \ldots \ldots \ldots \ldots \ldots . . .\end{array}$ & $\begin{array}{l}555,216 \\
571,226 \\
558,555 \\
564,984 \\
564,933\end{array}$ & $\begin{array}{l}219,514 \\
223,948 \\
217,613 \\
220,508 \\
224,721\end{array}$ & \begin{tabular}{|l|}
335,702 \\
347,278 \\
340,942 \\
344,476 \\
340,212
\end{tabular} & & $\begin{array}{l}1,164,792 \\
1,172,879 \\
1,184,406 \\
1,202,239 \\
1,237,875\end{array}$ & 530,367 & 707,508 & & & $\begin{array}{l}185,270 \\
188,718 \\
190,230 \\
196,129\end{array}$ & & & \begin{tabular}{r|}
115,507 \\
118,747 \\
118,735 \\
116,700 \\
118,736
\end{tabular} & & & $\begin{array}{l}41.8 \\
42.4 \\
43.4 \\
44.0 \\
45.3\end{array}$ \\
\hline 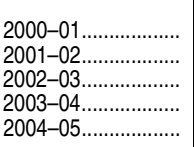 & & $\begin{array}{l}231,645 \\
238,109 \\
253,451 \\
260,033 \\
267,536\end{array}$ & \begin{tabular}{|l|}
347,220 \\
357,024 \\
380,565 \\
405,268 \\
429,124
\end{tabular} & & $\begin{array}{l}1,244,171 \\
1,291,900 \\
1,348,811 \\
1,399,542 \\
1,439,264\end{array}$ & 613,000 & $\begin{array}{l}804,117 \\
826,264\end{array}$ & 57.4 & $\begin{array}{l}473,502 \\
487,313 \\
518,699 \\
564,272 \\
580,151\end{array}$ & \begin{tabular}{|l|}
197,770 \\
202,604 \\
215,172 \\
233,056 \\
237,155
\end{tabular} & $\begin{array}{l}3,10< \\
4,709 \\
3,527 \\
31,216 \\
2,996\end{array}$ & 59.1 & $\begin{array}{l}119,585 \\
119,663 \\
121,579 \\
126,087 \\
134,387\end{array}$ & $\begin{array}{l}62,731 \\
62,730 \\
63,981 \\
67,257\end{array}$ & $\begin{array}{l}56,932 \\
88,849 \\
32,106 \\
77,130\end{array}$ & $\begin{array}{l}46.3 \\
47.6 \\
48.4 \\
49.3 \\
50.0\end{array}$ \\
\hline & $\begin{array}{l}728,114 \\
750,164 \\
787,325 \\
849,452\end{array}$ & $\begin{array}{l}270,095 \\
275,187 \\
282,521 \\
298,141 \\
322,916\end{array}$ & \begin{tabular}{|l|}
442,971 \\
452,927 \\
467,643 \\
489,184 \\
526,536
\end{tabular} & $\begin{array}{l}62.1 \\
62.2 \\
62.3 \\
62.1 \\
62.0\end{array}$ & $\begin{array}{l}1,485,242 \\
1,524,092 \\
1,563,069 \\
1,601,368 \\
1,650,014\end{array}$ & 706,633 & 943,381 & 57.2 & $\begin{array}{l}599,731 \\
610,597 \\
630,666 \\
662,079 \\
693,025\end{array}$ & $\begin{array}{l}242,189 \\
250,169 \\
263,538 \\
275,197\end{array}$ & $\begin{array}{l}368,408 \\
380,497 \\
398,541 \\
417,828\end{array}$ & 60.3 & \begin{tabular}{l|}
138,056 \\
144,690 \\
149,378 \\
154,425 \\
158,558
\end{tabular} & $\begin{array}{l}71,308 \\
73,453 \\
75,639 \\
76,605\end{array}$ & $\begin{array}{l}73,382 \\
75,925 \\
78,786 \\
81,953\end{array}$ & 51.7 \\
\hline $\begin{array}{c}011-12 \ldots \ldots \ldots \ldots \ldots . . \\
012-13^{3} \ldots \ldots \ldots \ldots \ldots . . . \\
013-14^{3} \ldots \ldots \ldots \ldots \ldots \ldots . . \\
014-15^{3} \ldots \ldots \ldots \ldots \ldots \ldots . .\end{array}$ & $\begin{array}{l}1,017,538 \\
1,042,000 \\
1,031,000 \\
1,046,000\end{array}$ & $\begin{array}{l}406,000 \\
409,000 \\
418,000\end{array}$ & $\begin{array}{l}625,548 \\
636,000 \\
623,000 \\
628,000\end{array}$ & $\begin{array}{l}61.7 \\
61.5 \\
61.0 \\
60.4 \\
60.0\end{array}$ & $\begin{array}{l}1,715,913 \\
1,791,046 \\
1,818,000 \\
1,844,000 \\
1,835,000\end{array}$ & 778,000 & $\begin{array}{l}1,056,000 \\
1,057,000\end{array}$ & & $\begin{array}{l}730,635 \\
754,229 \\
762,000 \\
791,000 \\
821,000\end{array}$ & $\begin{array}{l}302,191 \\
306,000 \\
316,000 \\
327,000\end{array}$ & $\begin{array}{l}452,038 \\
456,000 \\
475,000 \\
495,000\end{array}$ & 60.3 & $\begin{array}{l}163,765 \\
170,062 \\
173,900 \\
177,000 \\
177,500\end{array}$ & $\begin{array}{l}79,654 \\
82,611 \\
85,900 \\
87,300 \\
88,000\end{array}$ & $\begin{array}{l}87,451 \\
88,000 \\
89,700 \\
89,600\end{array}$ & $\begin{array}{l}50.7 \\
50.5\end{array}$ \\
\hline $\begin{array}{l}016-17^{3} \\
017-18^{3} \ldots \ldots \ldots \ldots \ldots \ldots . . . \\
018-19^{3} \ldots \ldots \ldots \ldots \ldots . . . \\
019-20^{3} \ldots \ldots \ldots \ldots \ldots . . .\end{array}$ & $\begin{array}{l}1,156,000 \\
1,197,000 \\
1,239,000\end{array}$ & $\begin{array}{l}460,000 \\
476,000 \\
492,000\end{array}$ & $\begin{array}{l}671,000 \\
696,000 \\
721,000 \\
746,000\end{array}$ & $\begin{array}{l}59.9 \\
60.1 \\
60.2 \\
60.2 \\
60.2\end{array}$ & $\begin{array}{l}1,902,000 \\
1,926,000 \\
1,953,000\end{array}$ & 808,000 & $\begin{array}{l}1,147,000 \\
1,145,000\end{array}$ & 58.6 & $\begin{array}{l}844,000 \\
867,000 \\
892,000 \\
915,000 \\
935,000\end{array}$ & $\begin{array}{l}340,000 \\
348,000 \\
356,000 \\
361,000\end{array}$ & $\begin{array}{l}527,000 \\
544,000 \\
559,000 \\
575,000\end{array}$ & 61.5 & $\begin{array}{l}182,400 \\
187,600 \\
190,900 \\
194,100 \\
197,600\end{array}$ & $\begin{array}{l}90,100 \\
92,300 \\
93,500 \\
94,900 \\
96,500\end{array}$ & $\begin{array}{r}95,300 \\
97,300 \\
99,200 \\
101,100\end{array}$ & 51.2 \\
\hline 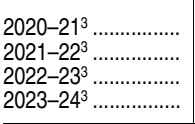 & $\left|\begin{array}{l}1,365,000 \\
1,410,000\end{array}\right|$ & $\begin{array}{l}540,000 \\
556,000\end{array}$ & $\begin{array}{l}797,000 \\
825,000 \\
854,000\end{array}$ & $\begin{array}{l}60.3 \\
60.4 \\
60.6\end{array}$ & $\begin{array}{l}2,031,000 \\
2,061,000\end{array}$ & 842,000 & $1,219,000$ & $\begin{array}{l}59.0 \\
59.1\end{array}$ & $\begin{array}{r}957,000 \\
981,000 \\
1,007,000 \\
1,032,000\end{array}$ & $\begin{array}{l}371,000 \\
378,000 \\
385,000\end{array}$ & $\begin{array}{l}629,000 \\
647,000\end{array}$ & 62.7 & $\begin{array}{l}200,300 \\
202,800 \\
205,500 \\
208,500\end{array}$ & $\begin{array}{r}98,500 \\
99,300 \\
100,300\end{array}$ & $\begin{array}{l}106,200 \\
108,100\end{array}$ & $\begin{array}{l}51.4 \\
51.7 \\
51.8\end{array}$ \\
\hline
\end{tabular}

-Not available.

${ }^{1}$ Includes Ph.D., Ed.D., and comparable degrees at the doctoral level. Includes most degrees formerly classified as first-professional, such as M.D., D.D.S., and law degrees.

Includes some degrees classified as master's or doctor's degrees in later years.

${ }^{3}$ Projected.

NOTE: Data through 1994-95 are for institutions of higher education, while later data are for degree-granting institutions. Degree-granting institutions grant associate's or higher degrees and participate in Title IV federal financial aid programs. Some data have been revised from previously published figures. Detail may not sum to totals because of rounding.

SOURCE: U.S. Department of Education, National Center for Education Statistics, Earned Degrees Conferred, 1869-70 through 1964-65; Higher Education General Information Survey (HEGIS), "Degrees and Other Formal Awards Conferred" surveys, 1965-66 through 1985-86; Integrated Postsecondary Education Data System (IPEDS), "Completions Survey" (IPEDSC:87-99); IPEDS Fall 2000 through Fall 2012, Completions component; and Degrees Conferred Projection Model, 1980-81 through 2023-24. (This table was prepared March 2014.) 
Table 318.20. Bachelor's, master's, and doctor's degrees conferred by degree-granting institutions, by field of study: Selected years, 1970-71 through 2011-12

\begin{tabular}{|c|c|c|c|c|c|c|c|c|c|c|c|c|c|c|c|c|}
\hline \multirow[b]{2}{*}{ Degree and year } & \multicolumn{8}{|c|}{ Number of degrees conferred } & \multicolumn{8}{|c|}{ Percentage distribution of degrees conferred } \\
\hline & Total degrees & Humanities ${ }^{1}$ & $\begin{array}{c}\text { Social and } \\
\text { behavioral } \\
\text { sciences }^{2}\end{array}$ & \begin{tabular}{|r|} 
Natural \\
sciences and \\
mathematics \\
\end{tabular} & $\begin{array}{r}\text { Computer } \\
\text { sciences and } \\
\text { engineering } \\
\end{array}$ & Education & Business & Other fields $s^{5}$ & Total degrees & Humanities $^{1}$ & $\begin{array}{c}\text { Social and } \\
\text { behavioral }^{2} \\
\text { sciences }^{2}\end{array}$ & $\begin{array}{r}\text { Natural } \\
\text { sciences and } \\
\text { mathematics }^{3}\end{array}$ & \begin{tabular}{|r|} 
Computer \\
sciences and \\
engineering
\end{tabular} & Education & Business & Other fields ${ }^{5}$ \\
\hline 1 & 2 & 3 & 4 & 5 & 6 & 7 & 8 & 9 & 10 & 11 & 12 & 13 & 14 & 15 & 16 & 17 \\
\hline $\begin{array}{l}\text { Bachelor's degrees } \\
1970-71 \\
1975-76 \ldots \\
1980-81 \\
1985-86 \\
1990-91 \ldots\end{array}$ & $\begin{array}{r}839,730 \\
925,7446 \\
935,140 \\
987,283 \\
1,094,538\end{array}$ & $\begin{array}{l}143,549 \\
150,736 \\
134,139 \\
132,891 \\
172,485\end{array}$ & $\begin{array}{l}193,511 \\
176,674 \\
141,581 \\
144,468 \\
183,762\end{array}$ & $\begin{array}{l}81,916 \\
91,596 \\
78,092 \\
76,228 \\
70,209\end{array}$ & $\begin{array}{r}52,570 \\
52,328 \\
90,476 \\
139,459 \\
104,910\end{array}$ & $\begin{array}{r}176,307 \\
154,437 \\
108,074 \\
87,147 \\
110,807\end{array}$ & $\begin{array}{l}115,396 \\
143,171 \\
200,521 \\
236,700 \\
249,165\end{array}$ & $\begin{array}{r}76,481 \\
156,804 \\
182,257 \\
180,930 \\
203,200\end{array}$ & $\begin{array}{l}100.0 \\
100.0 \\
100.0 \\
100.0 \\
100.0\end{array}$ & $\begin{array}{l}17.1 \\
16.3 \\
14.3 \\
13.5 \\
15.8\end{array}$ & $\begin{array}{l}23.0 \\
19.1 \\
15.1 \\
13.6 \\
16.8\end{array}$ & $\begin{array}{l}9.8 \\
9.9 \\
8.4 \\
7.7 \\
6.4\end{array}$ & $\begin{array}{r}6.3 \\
5.7 \\
9.7 \\
14.1 \\
9.6\end{array}$ & $\begin{array}{r}21.0 \\
16.7 \\
11.6 \\
8 \\
80.1 \\
10.1\end{array}$ & $\begin{array}{r}13.7 \\
15.5 \\
21.4 \\
24.0 \\
22.8\end{array}$ & $\begin{array}{r}9.1 \\
16.9 \\
19.5 \\
18.3 \\
18.6\end{array}$ \\
\hline 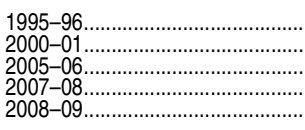 & $\begin{array}{r}1,164,792 \\
1,24,4171 \\
1,485,242 \\
1,563,069 \\
1,601,368\end{array}$ & $\begin{array}{l}193,404 \\
214,107 \\
261,696 \\
274,535 \\
278,387\end{array}$ & $\begin{array}{l}199,895 \\
201,681 \\
249,619 \\
259,950 \\
262,771\end{array}$ & $\begin{array}{r}93,443 \\
89,772 \\
105,899 \\
117,200 \\
121,009\end{array}$ & $\begin{array}{l}102,503 \\
117,011 \\
128,886 \\
122,084 \\
122,408\end{array}$ & $\begin{array}{l}105,384 \\
105,458 \\
107,238 \\
102,582 \\
101,708\end{array}$ & $\begin{array}{l}226,623 \\
263,515 \\
318,042 \\
335,254 \\
347,985\end{array}$ & $\begin{array}{l}243,540 \\
252,627 \\
313,862 \\
351,464 \\
367,100\end{array}$ & $\begin{array}{l}100.0 \\
100.0 \\
100.0 \\
100.0 \\
100.0\end{array}$ & $\begin{array}{l}16.6 \\
117.2 \\
17.6 \\
17.6 \\
17.4\end{array}$ & $\begin{array}{l}17.2 \\
16.2 \\
16.8 \\
16.6 \\
16.4\end{array}$ & $\begin{array}{l}8.0 \\
7.2 \\
7.1 \\
7.5 \\
7.6\end{array}$ & $\begin{array}{l}8.8 \\
9.4 \\
8.7 \\
7.8 \\
7.6\end{array}$ & $\begin{array}{l}9.0 \\
8.5 \\
7.2 \\
6.6 \\
6.4\end{array}$ & $\begin{array}{l}19.5 \\
21.2 \\
21.4 \\
21.4 \\
21.7\end{array}$ & $\begin{array}{l}20.9 \\
20.3 \\
21.1 \\
22.5 \\
22.9\end{array}$ \\
\hline 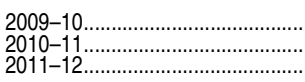 & $\begin{array}{l}1,650,014 \\
1,715,913 \\
1,791,046\end{array}$ & $\begin{array}{l}280,993 \\
288,371 \\
295,221\end{array}$ & $\begin{array}{l}269,996 \\
278,037 \\
287,529\end{array}$ & $\begin{array}{l}125,809 \\
131,897 \\
141,354\end{array}$ & $\begin{array}{l}128,318 \\
136,189 \\
145,924\end{array}$ & $\begin{array}{l}101,265 \\
103,992 \\
105,785\end{array}$ & $\begin{array}{l}358,293 \\
36,2093 \\
366,815\end{array}$ & $\begin{array}{l}385,340 \\
412,334 \\
448,418\end{array}$ & $\begin{array}{l}100.0 \\
100.0 \\
100.0\end{array}$ & $\begin{array}{l}17.0 \\
16.8 \\
16.5\end{array}$ & $\begin{array}{l}16.4 \\
16.2 \\
16.1\end{array}$ & $\begin{array}{l}7.6 \\
7.7 \\
7.9\end{array}$ & $\begin{array}{l}7.8 \\
7.9 \\
8.1\end{array}$ & $\begin{array}{l}6.1 \\
6.1 \\
5.9\end{array}$ & $\begin{array}{l}21.7 \\
21.3 \\
20.5\end{array}$ & $\begin{array}{l}23.4 \\
24.0 \\
25.0\end{array}$ \\
\hline 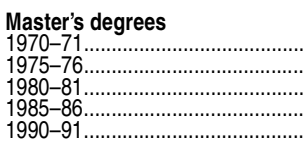 & $\begin{array}{l}235,564 \\
317,477 \\
302,637 \\
295,850 \\
342,863\end{array}$ & $\begin{array}{l}34,510 \\
37,079 \\
35,130 \\
34,834 \\
35,984\end{array}$ & $\begin{array}{l}22,256 \\
26,120 \\
22,168 \\
20,409 \\
23,582\end{array}$ & $\begin{array}{l}17,152 \\
15,742 \\
13,579 \\
14,055 \\
13,664\end{array}$ & $\begin{array}{l}18,535 \\
19,403 \\
21,434 \\
30,216 \\
34,774\end{array}$ & $\begin{array}{r}87,666 \\
126,061 \\
96,713 \\
74,816 \\
87,352\end{array}$ & $\begin{array}{l}26,490 \\
42,592 \\
57,888 \\
66,676 \\
78,255\end{array}$ & $\begin{array}{l}28,955 \\
50,480 \\
55,725 \\
54,844 \\
69,252\end{array}$ & $\begin{array}{l}100.0 \\
100.0 \\
100.0 \\
100.0 \\
100.0\end{array}$ & $\begin{array}{l}14.6 \\
11.7 \\
11.6 \\
11.8 \\
10.5\end{array}$ & $\begin{array}{l}9.4 \\
8.2 \\
7.3 \\
6.9 \\
6.9\end{array}$ & $\begin{array}{l}7.3 \\
5.0 \\
4.5 \\
4.8 \\
4.0\end{array}$ & $\begin{array}{r}7.9 \\
6.1 \\
7.1 \\
10.2 \\
10.1\end{array}$ & $\begin{array}{l}37.2 \\
39.7 \\
32.0 \\
25.3 \\
25.5\end{array}$ & $\begin{array}{l}11.2 \\
13.4 \\
19.1 \\
22.5 \\
22.8\end{array}$ & $\begin{array}{l}12.3 \\
15.9 \\
18.4 \\
18.5 \\
20.2\end{array}$ \\
\hline 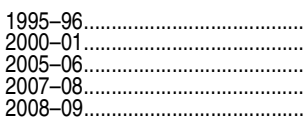 & $\begin{array}{l}412,180 \\
473,502 \\
599,731 \\
630,666 \\
662,079\end{array}$ & $\begin{array}{l}40,795 \\
40,625 \\
49,584 \\
52,087 \\
53,198\end{array}$ & $\begin{array}{l}30,164 \\
30,330 \\
37,139 \\
39,926 \\
42,655\end{array}$ & $\begin{array}{l}16,154 \\
15,360 \\
19,574 \\
20,730 \\
21,090\end{array}$ & $\begin{array}{l}39,422 \\
44,098 \\
50,444 \\
51,517 \\
55,908\end{array}$ & $\begin{array}{l}104,936 \\
127,829 \\
174,620 \\
175,880 \\
178,564\end{array}$ & $\begin{array}{r}93,554 \\
115,602 \\
146,406 \\
155,637 \\
168,375\end{array}$ & $\begin{array}{r}87,155 \\
99,658 \\
121,964 \\
134,889 \\
142,289\end{array}$ & $\begin{array}{l}100.0 \\
100.0 \\
100.0 \\
100.0 \\
100.0\end{array}$ & $\begin{array}{l}9.9 \\
8.6 \\
8.3 \\
8.3 \\
8.0\end{array}$ & $\begin{array}{l}7.3 \\
6.4 \\
6.2 \\
6.3 \\
6.4\end{array}$ & $\begin{array}{l}3.9 \\
3.2 \\
3.3 \\
3.3 \\
3.2\end{array}$ & $\begin{array}{l}9.6 \\
9.3 \\
8.4 \\
8.2 \\
8.4\end{array}$ & $\begin{array}{l}25.5 \\
27.0 \\
29.1 \\
27.9 \\
27.0\end{array}$ & $\begin{array}{l}22.7 \\
24.4 \\
24.4 \\
24.7 \\
25.4\end{array}$ & $\begin{array}{l}21.1 \\
21.0 \\
20.3 \\
21.4 \\
21.5\end{array}$ \\
\hline 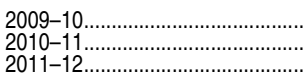 & $\begin{array}{l}693,025 \\
730,635 \\
754,229\end{array}$ & $\begin{array}{l}54,927 \\
57,137 \\
59,979\end{array}$ & $\begin{array}{l}43,974 \\
46,135 \\
48,723\end{array}$ & $\begin{array}{l}22,422 \\
23,556 \\
25,570\end{array}$ & $\begin{array}{l}57,299 \\
62,680 \\
66,014\end{array}$ & $\begin{array}{l}182,139 \\
185,009 \\
178,062\end{array}$ & $\begin{array}{l}177,684 \\
187,213 \\
191,571\end{array}$ & $\begin{array}{l}154,580 \\
168,905 \\
184,310\end{array}$ & $\begin{array}{l}100.0 \\
100.0 \\
100.0\end{array}$ & $\begin{array}{l}7.9 \\
7.8 \\
8.0\end{array}$ & $\begin{array}{l}6.3 \\
6.3 \\
6.5\end{array}$ & $\begin{array}{l}3.2 \\
3.2 \\
3.4\end{array}$ & $\begin{array}{l}8.3 \\
8.6 \\
8.8\end{array}$ & $\begin{array}{l}26.3 \\
25.3 \\
23.6\end{array}$ & $\begin{array}{l}25.6 \\
25.6 \\
25.4\end{array}$ & $\begin{array}{l}22.3 \\
23.1 \\
24.4\end{array}$ \\
\hline 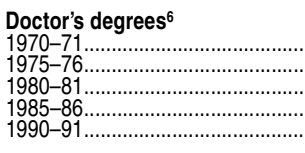 & $\begin{array}{r}64,998 \\
91,007 \\
98,016 \\
100,280 \\
105,547\end{array}$ & $\begin{array}{l}4,402 \\
5,461 \\
4,827 \\
4,648 \\
4,858\end{array}$ & $\begin{array}{l}5,804 \\
7,314 \\
6,698 \\
6,548 \\
6,944\end{array}$ & $\begin{array}{l}9,126 \\
7,591 \\
7,473 \\
7,668 \\
9,378\end{array}$ & $\begin{array}{l}3,816 \\
3,118 \\
2,860 \\
3,800 \\
6,006\end{array}$ & $\begin{array}{l}6,041 \\
7,202 \\
7,279 \\
6,610 \\
6,189\end{array}$ & $\begin{array}{r}774 \\
906 \\
808 \\
923 \\
1,185\end{array}$ & $\begin{array}{l}35,035 \\
59,415 \\
68,071 \\
70,083 \\
70,987\end{array}$ & $\begin{array}{l}100.0 \\
100.0 \\
100.0 \\
10.0 \\
100.0\end{array}$ & $\begin{array}{l}6.8 \\
6.0 \\
4.9 \\
4.6 \\
4.6\end{array}$ & $\begin{array}{l}8.9 \\
8.0 \\
6.8 \\
6.5 \\
6.6\end{array}$ & $\begin{array}{r}14.0 \\
8.3 \\
7.6 \\
7.6 \\
8.9\end{array}$ & $\begin{array}{l}5.9 \\
3.4 \\
2.9 \\
3.8 \\
5.7\end{array}$ & $\begin{array}{l}9.3 \\
7.9 \\
7.4 \\
6.6 \\
5.9\end{array}$ & $\begin{array}{l}1.2 \\
1.0 \\
0.8 \\
0.9 \\
1.1\end{array}$ & $\begin{array}{l}53.9 \\
65.3 \\
69.4 \\
69.9 \\
67.3\end{array}$ \\
\hline 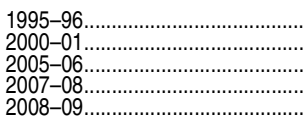 & $\begin{array}{l}115,507 \\
119,585 \\
138,056 \\
149,378 \\
154,425\end{array}$ & $\begin{array}{l}6,356 \\
6,466 \\
6,628 \\
7,049 \\
7,261\end{array}$ & $\begin{array}{l}7,901 \\
9,021 \\
8,835 \\
9,355 \\
9,711\end{array}$ & $\begin{array}{l}10,997 \\
10,190 \\
12,097 \\
13,754 \\
14,271\end{array}$ & $\begin{array}{l}7,223 \\
6,315 \\
8,734 \\
9,675 \\
9,381\end{array}$ & $\begin{array}{l}6,246 \\
6,284 \\
7,584 \\
8,491 \\
9,028\end{array}$ & $\begin{array}{l}1,366 \\
1,180 \\
1,711 \\
2,084 \\
2,123\end{array}$ & $\begin{array}{r}75,418 \\
80,129 \\
92,467 \\
98,970 \\
102,650\end{array}$ & $\begin{array}{l}100.0 \\
10.0 \\
100.0 \\
100.0 \\
100.0\end{array}$ & $\begin{array}{l}5.5 \\
5.4 \\
4.8 \\
4.7 \\
4.7\end{array}$ & $\begin{array}{l}6.8 \\
7.5 \\
6.4 \\
6.3 \\
6.3\end{array}$ & $\begin{array}{l}9.5 \\
8.5 \\
8.8 \\
9.2 \\
9.2\end{array}$ & $\begin{array}{l}6.3 \\
5.3 \\
6.3 \\
6.5 \\
6.1\end{array}$ & $\begin{array}{l}5.4 \\
5.3 \\
5.5 \\
5.7 \\
5.8\end{array}$ & \begin{tabular}{l|}
1.2 \\
1.0 \\
1.2 \\
1.4 \\
1.4
\end{tabular} & $\begin{array}{l}65.3 \\
67.0 \\
67.0 \\
66.3 \\
66.5\end{array}$ \\
\hline 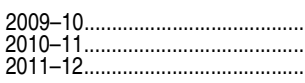 & $\begin{array}{l}158,558 \\
163,765 \\
170,062\end{array}$ & $\begin{array}{l}7,739 \\
8,360 \\
8,733\end{array}$ & $\begin{array}{r}9,778 \\
10,241 \\
10,525\end{array}$ & $\begin{array}{l}14,321 \\
14,574 \\
14,974\end{array}$ & $\begin{array}{r}9,370 \\
10,013 \\
10,554\end{array}$ & $\begin{array}{l}9,233 \\
9,623 \\
9,990\end{array}$ & $\begin{array}{l}2,245 \\
2,286 \\
2,531\end{array}$ & $\begin{array}{l}105,872 \\
108,668 \\
112,755\end{array}$ & $\begin{array}{l}100.0 \\
100.0 \\
100.0\end{array}$ & $\begin{array}{l}4.9 \\
5.1 \\
5.1\end{array}$ & $\begin{array}{l}6.2 \\
6.3 \\
6.2\end{array}$ & $\begin{array}{l}9.0 \\
8.9 \\
8.8\end{array}$ & $\begin{array}{l}5.9 \\
6.1 \\
6.2\end{array}$ & $\begin{array}{l}5.8 \\
5.9 \\
5.9\end{array}$ & $\begin{array}{l}1.4 \\
1.4 \\
1.5\end{array}$ & $\begin{array}{l}66.8 \\
66.4 \\
66.3\end{array}$ \\
\hline
\end{tabular}

IIncludes degrees in Area, ethnic, cultural, gender, and group studies; English language and literature/letters; Foreign languages, literatures, and linguistics; Liberal arts and sciences, general studies, and humanifies; Mutit/interdisciplinary studies; Philosophy and religious studies; Theology and religious vocations; and Visual and performing arts.

2Includes Psychology; Social sciences; and History.

matics and statistics; and Physical sciences and science technologies. 4Includes Computer and information sciences; Engineering; and Engineering technologies.

grams: Communications natural resources; Architecture and related services; Communication, journalism, and related programs; Homeland security, law enforcement, and firefighting; Legal professions and studies; Library science; Military technologies and applied sciences; Parks, recreation, leisure, and fitness studies; Precision production; Public administration and social services; Transportation and materials moving; and Not classified by field of study.

formerly classified as firstprofessional, such as M.D., D.D.S., and law degrees.
NOTE: Data are for postsecondary institutions participating in Title IV federal financial aid programs. The new Classification of

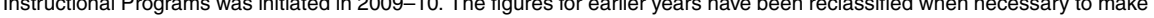
them conform to the new taxonomy. To facilitate trend comparisons, certain aggregations have been made of the degree

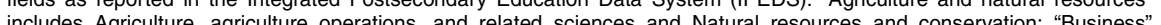
includes Business, management marketing, and related support services and Personal and culinary services; and "Engineering technologies" includes Engineering technologies and engineering-related fields, Construction trades, and Mechanic and repair technologies/technicians. Detail may not sum to totals because of rounding.

SOURCE: U.S. Department of Education, National Center for Education Statistics, Higher Education General Information Survey (HEGIS), "Degrees and Olner Formal Awards Conterred surveys, 1970-71 through 1985-86; Integrated Postsecondary Education Data System (IPEDS), "Completions Survey” (IPEDS-C:91-96); and IPEDS Fall 2001 through Fall 2012, Com- 
Table 318.30. Bachelor's, master's, and doctor's degrees conferred by postsecondary institutions, by sex of student and discipline division: 2011-12

\begin{tabular}{|c|c|c|c|c|c|c|c|c|c|}
\hline \multirow[b]{2}{*}{ Discipline division } & \multicolumn{3}{|c|}{ Bachelor's degrees } & \multicolumn{3}{|c|}{ Master's degrees } & \multicolumn{3}{|c|}{ Doctor's degrees ${ }^{1}$} \\
\hline & Total & Males & Females & Total & Males & Females & Total & Males & Females \\
\hline 1 & 2 & 3 & 4 & 5 & 6 & 7 & 8 & 9 & 10 \\
\hline All fields, total..................... & $1,791,046$ & 765,317 & $1,025,729$ & 754,229 & 302,191 & 452,038 & 170,062 & 82,611 & 87,451 \\
\hline 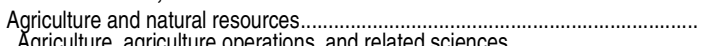 & 30,929 & 15,453 & 15,476 & 6,390 & 3,026 & 3,364 & 1,333 & 721 & 612 \\
\hline 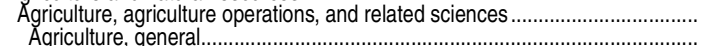 & $\begin{array}{r}16,252 \\
1,596\end{array}$ & $\begin{array}{r}7,867 \\
918\end{array}$ & $\begin{array}{r}8,385 \\
678\end{array}$ & $\begin{array}{r}2,586 \\
316\end{array}$ & 1,207 & $\begin{array}{l}1,379 \\
183\end{array}$ & $\begin{array}{r}748 \\
21\end{array}$ & $\begin{array}{r}411 \\
11\end{array}$ & $\begin{array}{r}337 \\
10\end{array}$ \\
\hline Agricultural business and management, general........ & 1,018 & 684 & 334 & $\begin{array}{r}510 \\
60\end{array}$ & 33 & $\begin{array}{r}100 \\
27\end{array}$ & 0 & 0 & \\
\hline Agribusiness/agricultural business operations...... & 1,452 & 1,001 & 451 & 30 & 16 & 14 & 0 & 0 & \\
\hline $\begin{array}{l}\text { Agricultural economics ................................. } \\
\text { Farm/farm and ranch magement }\end{array}$ & 1,420 & 1,026 & $\begin{aligned} 394 \\
28\end{aligned}$ & $\begin{array}{r}432 \\
8\end{array}$ & 252 & $\begin{array}{r}180 \\
3\end{array}$ & 147 & 95 & 52 \\
\hline $\begin{array}{l}\text { Farm/farm and ranch management ................. } \\
\text { Agricultural/farm supplies retailing and wholesaling .... }\end{array}$ & $\begin{array}{r}118 \\
91\end{array}$ & $\begin{array}{l}90 \\
44\end{array}$ & $\begin{array}{l}28 \\
47\end{array}$ & $\begin{array}{l}8 \\
0\end{array}$ & $\begin{array}{l}5 \\
0\end{array}$ & $\begin{array}{l}3 \\
0\end{array}$ & $\begin{array}{l}0 \\
0\end{array}$ & $\begin{array}{c}0 \\
0\end{array}$ & $\begin{array}{l}0 \\
0\end{array}$ \\
\hline 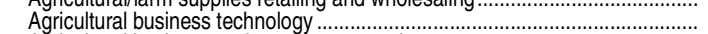 & 11 & 8 & $\begin{array}{r}41 \\
3\end{array}$ & 0 & 0 & 0 & 0 & 0 & 0 \\
\hline Agricultural business and management, other ................... & 42 & 23 & 19 & 4 & 2 & 2 & 0 & 0 & \\
\hline $\begin{array}{l}\text { Agricultural mechanization, general................... } \\
\text { Agricultural production operations, general ....... }\end{array}$ & $\begin{array}{r}273 \\
79\end{array}$ & $\begin{array}{r}252 \\
52\end{array}$ & $\begin{array}{l}21 \\
27\end{array}$ & $\begin{array}{r}0 \\
14\end{array}$ & $\begin{array}{l}0 \\
5\end{array}$ & $\begin{array}{l}0 \\
9\end{array}$ & $\begin{array}{l}0 \\
0\end{array}$ & $\begin{array}{l}0 \\
0\end{array}$ & $\begin{array}{l}0 \\
0\end{array}$ \\
\hline Animal/livestock husbandry and production ..... & 172 & 57 & 115 & 0 & 0 & 0 & 0 & 0 & \\
\hline $\begin{array}{l}\text { Aquaculture } \\
\text { Crop production }\end{array}$ & $\begin{array}{l}77 \\
25\end{array}$ & $\begin{array}{l}51 \\
21\end{array}$ & $\begin{array}{r}26 \\
4\end{array}$ & $\begin{array}{r}31 \\
7\end{array}$ & $\begin{array}{r}19 \\
6\end{array}$ & $\begin{array}{r}12 \\
1\end{array}$ & $\begin{array}{l}6 \\
1\end{array}$ & $\begin{array}{l}3 \\
1\end{array}$ & 3 \\
\hline Horse husbandry/lequine science and management ................................ & 69 & 3 & 66 & $\begin{aligned} 0 \\
0\end{aligned}$ & 0 & $\begin{aligned} 0 \\
11\end{aligned}$ & 0 & $\begin{array}{l}1 \\
0\end{array}$ & \\
\hline 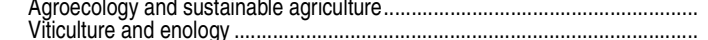 & $\begin{array}{l}27 \\
88\end{array}$ & $\begin{array}{l}14 \\
45\end{array}$ & $\begin{array}{l}13 \\
43\end{array}$ & $\begin{array}{r}19 \\
6\end{array}$ & $\begin{array}{l}8 \\
4\end{array}$ & $\begin{array}{r}11 \\
2\end{array}$ & $\begin{array}{l}3 \\
0\end{array}$ & $\begin{array}{l}2 \\
0\end{array}$ & $\begin{array}{l}1 \\
0\end{array}$ \\
\hline Agricultural and food products processing.............................. & 110 & 56 & 54 & 2 & 1 & $\begin{array}{ccccc}c \\
1\end{array}$ & 8 & 5 & 3 \\
\hline 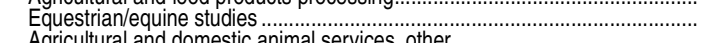 & 287 & 14 & 273 & 0 & 0 & 0 & 0 & 0 & 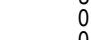 \\
\hline 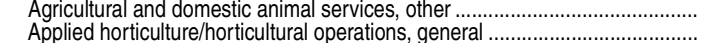 & $\begin{array}{r}1 \\
164\end{array}$ & 91 & $\begin{array}{r}1 \\
73\end{array}$ & $\begin{array}{r}0 \\
16\end{array}$ & $\begin{array}{l}0 \\
4\end{array}$ & \begin{tabular}{r|}
0 \\
12
\end{tabular} & $\begin{array}{l}0 \\
4\end{array}$ & $\begin{array}{l}0 \\
1\end{array}$ & $\begin{array}{l}0 \\
3\end{array}$ \\
\hline 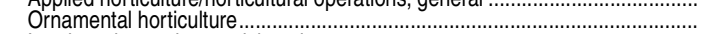 & 113 & 70 & 43 & 5 & 0 & 3 & 8 & 4 & \\
\hline 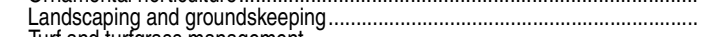 & 167 & 118 & 49 & 3 & 1 & 2 & 0 & 0 & 0 \\
\hline 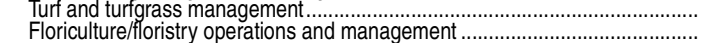 & $\begin{array}{r}143 \\
4\end{array}$ & $\begin{array}{r}136 \\
0\end{array}$ & 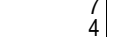 & $\begin{array}{l}3 \\
0\end{array}$ & & $\begin{array}{l}0 \\
0\end{array}$ & $\begin{array}{l}0 \\
0\end{array}$ & $\begin{array}{l}0 \\
0\end{array}$ & $\begin{array}{l}0 \\
0\end{array}$ \\
\hline 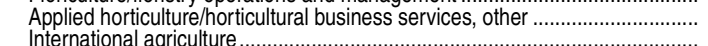 & 23 & 20 & 3 & $\begin{array}{ll}0 \\
0\end{array}$ & 0 & $\begin{aligned} 0 \\
0 \\
11\end{aligned}$ & 0 & 0 & 0 \\
\hline $\begin{array}{l}\text { International agriculture } \\
\text { Agricultural and extension education services }\end{array}$ & $\begin{array}{l}37 \\
40\end{array}$ & $\begin{array}{l}18 \\
19\end{array}$ & $\begin{array}{l}19 \\
21\end{array}$ & $\begin{array}{l}28 \\
63\end{array}$ & $\begin{array}{l}17 \\
30\end{array}$ & $\begin{array}{l}11 \\
33\end{array}$ & $\begin{array}{l}0 \\
5\end{array}$ & $\begin{array}{l}0 \\
2\end{array}$ & $\begin{array}{l}0 \\
3\end{array}$ \\
\hline $\begin{array}{l}\text { Agricultural communication/journalism .................................................................. } \\
\text { Agricultural public services other }\end{array}$ & $\begin{array}{r}351 \\
88\end{array}$ & $\begin{array}{r}101 \\
51\end{array}$ & $\begin{array}{r}250 \\
37\end{array}$ & $\begin{array}{r}32 \\
0\end{array}$ & 7 & 25 & 0 & 0 & 0 \\
\hline 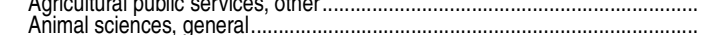 & 4,627 & 987 & 3,640 & 382 & 128 & 254 & 129 & 69 & 60 \\
\hline 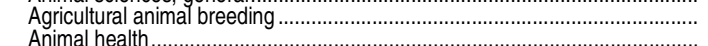 & 2 & 1 & 1 & $\begin{array}{r}11 \\
8\end{array}$ & 1 & $\begin{array}{r}10 \\
8\end{array}$ & 5 & 2 & 3 \\
\hline $\begin{array}{l}\text { Anmal nealun .............................. } \\
\text { Animal nutrition...................... }\end{array}$ & 0 & 0 & 0 & $\begin{array}{l}8 \\
0\end{array}$ & 0 & $\begin{array}{l}8 \\
0\end{array}$ & 3 & 2 & 1 \\
\hline Dairy science ....……………….... & 151 & 61 & 90 & 15 & & 10 & 6 & 5 & 1 \\
\hline 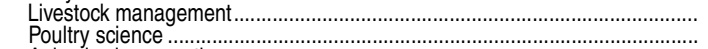 & $\begin{array}{r}20 \\
127\end{array}$ & $\begin{array}{r}4 \\
60\end{array}$ & $\begin{array}{l}16 \\
67\end{array}$ & $\begin{array}{r}1 \\
17\end{array}$ & & $\begin{array}{r}1 \\
10\end{array}$ & $\begin{array}{l}3 \\
9\end{array}$ & $\begin{array}{l}1 \\
5\end{array}$ & $\begin{array}{l}2 \\
4\end{array}$ \\
\hline 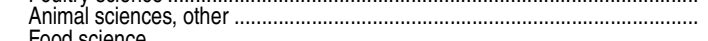 & 67 & 16 & 51 & 3 & $2^{2}$ & 1 & 0 & 0 & 0 \\
\hline $\begin{array}{l}\text { Food science } \\
\text { Food technology and processing..... }\end{array}$ & $\begin{array}{r}1,141 \\
33\end{array}$ & $\begin{array}{r}369 \\
13\end{array}$ & $\begin{array}{r}7 / 2 \\
20\end{array}$ & $\begin{array}{r}351 \\
3\end{array}$ & $\begin{array}{r}101 \\
1\end{array}$ & $\begin{aligned} 250 \\
2\end{aligned}$ & $\begin{array}{r}125 \\
0\end{array}$ & $\begin{array}{r}48 \\
0\end{array}$ & $\begin{array}{c}77 \\
0\end{array}$ \\
\hline 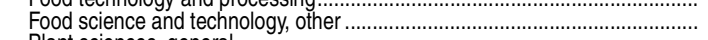 & 0 & 0 & 0 & 35 & 10 & 25 & 3 & 1 & 2 \\
\hline $\begin{array}{l}\text { Plant sciences, general.. } \\
\text { Agronomy and crop science }\end{array}$ & 307 & 223 & $\begin{array}{r}84 \\
117\end{array}$ & 72 & 40 & 32 & 35 & 19 & 16 \\
\hline $\begin{array}{l}\text { Agronomy and crop science ................................ } \\
\text { Horticultural science ................................... }\end{array}$ & $\begin{array}{l}481 \\
582\end{array}$ & $\begin{array}{l}364 \\
340\end{array}$ & $\begin{array}{l}111 \\
242\end{array}$ & $\begin{array}{r}194 \\
98\end{array}$ & $\begin{array}{r}147 \\
48\end{array}$ & $\begin{array}{c}47 \\
50\end{array}$ & 41 & $\begin{array}{l}51 \\
22\end{array}$ & $\begin{array}{l}28 \\
19\end{array}$ \\
\hline Agricultural and horticultural plant breeding ....................................................... & 2 & $\begin{array}{r}1 \\
23\end{array}$ & 1 & 37 & 21 & 16 & 16 & 9 & 7 \\
\hline 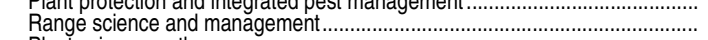 & 106 & 74 & $\begin{array}{l}10 \\
32\end{array}$ & 45 & 26 & $\begin{array}{r}5 \\
19 \\
\end{array}$ & $\begin{array}{l}0 \\
7\end{array}$ & $\begin{array}{lll}0 \\
3\end{array}$ & 4 \\
\hline $\begin{array}{l}\text { Plant sciences, other ........................ } \\
\text { Soil science and agronomy general }\end{array}$ & 34 & 23 & $\begin{array}{l}11 \\
34\end{array}$ & $\begin{array}{r}48 \\
-14\end{array}$ & 26 & 22 & 23 & 16 & 7 \\
\hline 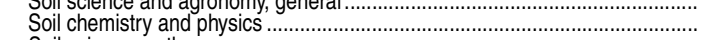 & $\begin{array}{r}110 \\
19\end{array}$ & 14 & $\begin{array}{r}44 \\
5\end{array}$ & $\begin{array}{r}124 \\
5\end{array}$ & $\begin{array}{r}00 \\
1\end{array}$ & $\begin{array}{r}01 \\
4 \\
\end{array}$ & $\begin{array}{r}40 \\
0\end{array}$ & $\begin{array}{r}20 \\
0\end{array}$ & $\begin{aligned} 20 \\
0\end{aligned}$ \\
\hline $\begin{array}{l}\text { Soil sciences, other } \\
\text { Agriculture, agriculture operations, and related sciences, other.......... }\end{array}$ & $\begin{array}{r}39 \\
273\end{array}$ & $\begin{array}{r}21 \\
208\end{array}$ & $\begin{array}{l}18 \\
65\end{array}$ & $\begin{array}{l}12 \\
31\end{array}$ & $\begin{array}{r}7 \\
15\end{array}$ & $\begin{array}{r}5 \\
16\end{array}$ & $\begin{array}{l}8 \\
7\end{array}$ & $\begin{array}{l}2 \\
6\end{array}$ & $\begin{array}{l}6 \\
1\end{array}$ \\
\hline ces and conservatio & 14,677 & 7,586 & 7,091 & 3,804 & 1,819 & 1,985 & 585 & 310 & \\
\hline 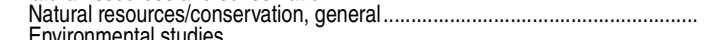 & 1,427 & 782 & 645 & 587 & 233 & $\begin{array}{r}354 \\
384\end{array}$ & $\begin{array}{r}80 \\
58\end{array}$ & 36 & 44 \\
\hline Environ & 4,343 & $\begin{array}{l}2,315 \\
2,122\end{array}$ & 2,221 & 927 & $\begin{array}{l}3 / 3 \\
412\end{array}$ & $\begin{array}{l}384 \\
515\end{array}$ & $\begin{array}{r}58 \\
158\end{array}$ & 78 & 80 \\
\hline Natural resources conservation and research, other... & 32 & 14 & 18 & 38 & 24 & 14 & 5 & $\begin{array}{r}r \\
2 \\
\end{array}$ & 3 \\
\hline Natural resources management and policy. & 520 & 289 & 231 & 570 & 249 & 321 & 24 & $1 \overline{2}$ & 12 \\
\hline $\begin{array}{l}\text { Natural } \mathrm{r} \\
\text { Water w }\end{array}$ & & $\begin{array}{l}33 \\
47\end{array}$ & 23 & $\begin{array}{r}7 \\
73\end{array}$ & $2^{2}$ & $\begin{array}{r}5 \\
53\end{array}$ & 10 & 4 & 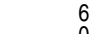 \\
\hline $\begin{array}{l}\text { Water, w } \\
\text { Land us }\end{array}$ & 47 & $\begin{array}{l}41 \\
32\end{array}$ & $\begin{array}{l}32 \\
15\end{array}$ & 77 & 51 & 26 & 8 & 6 & $\begin{array}{l}0 \\
2\end{array}$ \\
\hline Natural resource recreation & 31 & 22 & 9 & 0 & 0 & 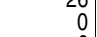 & $\begin{array}{l}\vdots \\
0\end{array}$ & 0 & 0 \\
\hline rotective services .. & 29 & 24 & 5 & 0 & & 0 & 0 & 0 & 0 \\
\hline$\ldots \ldots \ldots \ldots \ldots \ldots \ldots \ldots \ldots \ldots .$. & 289 & 141 & $\begin{array}{r}148 \\
145\end{array}$ & 25 & 10 & $\begin{array}{r}15 \\
30\end{array}$ & 2 & $\begin{array}{r}2 \\
10\end{array}$ & 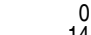 \\
\hline 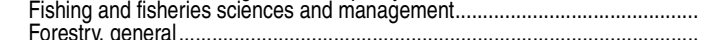 & $\begin{array}{l}339 \\
537\end{array}$ & $\begin{array}{l}1 / 4 \\
412\end{array}$ & $\begin{array}{l}145 \\
125\end{array}$ & $\begin{array}{r}68 \\
307\end{array}$ & 169 & 138 & 61 & $\begin{array}{r}18 \\
32\end{array}$ & 14 \\
\hline Forest sciences and biology .................... & 161 & 135 & 26 & 103 & 70 & 33 & 51 & 36 & 15 \\
\hline 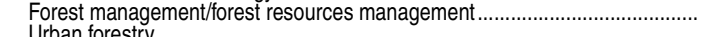 & 147 & 124 & 23 & $\begin{array}{r}36 \\
5\end{array}$ & 24 & 12 & 5 & $\begin{array}{r}3 \\
3 \\
3\end{array}$ & \\
\hline $\begin{array}{l}\text { Urban forestry } \\
\text { Wood science and wood products/pulp and paper technology }\end{array}$ & 68 & 59 & 9 & $20^{2}$ & 13 & $\frac{2}{7}$ & 10 & $\begin{array}{r}3 \\
5\end{array}$ & $\frac{2}{5}$ \\
\hline Forest resources production and management....... & 6 & 6 & 0 & 19 & 12 & 7 & 7 & 3 & \\
\hline Forest technology/technician ...................................... & 11 & 99 & $\overline{8}$ & $\begin{aligned} 0 \\
26\end{aligned}$ & 0 & $\begin{array}{r}0 \\
0\end{array}$ & 11 & $\begin{array}{c}6 \\
2 \\
\end{array}$ & 5 \\
\hline $\begin{array}{l}\text { Forestry, } \\
\text { Wildlife a }\end{array}$ & 1,160 & 642 & 518 & 152 & $\begin{array}{llll}14 \\
91\end{array}$ & 61 & 40 & 24 & 16 \\
\hline Natural & & 13 & 0 & 10 & & 6 & 8 & 8 & \\
\hline Architecture and related services ............ & 9,728 & 5,567 & 4,161 & 8,448 & 4,504 & 3,944 & 255 & 147 & 108 \\
\hline munity and regiona nlan. & $\begin{array}{l}6,040 \\
843\end{array}$ & 3,540 & 2,500 & $\begin{array}{l}4,557 \\
, 441\end{array}$ & 2,667 & $\begin{array}{l}1,890 \\
1241\end{array}$ & $\begin{array}{r}135 \\
82\end{array}$ & $\begin{array}{r}79 \\
44\end{array}$ & $\begin{array}{l}56 \\
38\end{array}$ \\
\hline sign/architecture ... & $\begin{array}{l}840 \\
756\end{array}$ & 458 & $\begin{array}{r}303 \\
298\end{array}$ & $\begin{array}{r}<, 441 \\
142\end{array}$ & 72 & $\begin{array}{r}1,41 \\
70\end{array}$ & 24 & $\begin{array}{l}44 \\
17\end{array}$ & $\frac{00}{7}$ \\
\hline & 502 & 32 & 470 & 184 & 26 & 158 & 0 & 0 & 0 \\
\hline criticism genera & 1,006 & $\begin{array}{r}622 \\
28\end{array}$ & $\begin{array}{r}384 \\
38\end{array}$ & $\begin{array}{r}735 \\
39 \\
\end{array}$ & 303 & 432 & 2 & $\begin{array}{c}0 \\
3 \\
\end{array}$ & \\
\hline $\begin{array}{l}\text { Architectural history and criticism, } g \\
\text { Architectural technology/technician }\end{array}$ & 244 & 171 & $\begin{array}{r}50 \\
73\end{array}$ & 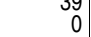 & $\begin{aligned} & r-1 \\
& 0\end{aligned}$ & $\begin{array}{r}22 \\
0\end{array}$ & $\begin{array}{llll}4 & & & \end{array}$ & 0 & 0 \\
\hline Architectural and building sc & 93 & 11 & 30 & 71 & 45 & 26 & U & 0 & \\
\hline technology, other.... & $\begin{array}{l}0 \\
0\end{array}$ & 0 & $\begin{array}{l}0 \\
0\end{array}$ & $\begin{array}{r}16 \\
146\end{array}$ & $\begin{array}{r}11 \\
120\end{array}$ & $\begin{array}{r}5 \\
26\end{array}$ & 2 & 1 & \\
\hline $\begin{array}{l}\text { Real estate development ............................ } \\
\text { Architecture and related services, other.......... }\end{array}$ & 178 & 113 & 65 & 117 & 43 & 74 & 6 & 3 & \\
\hline
\end{tabular}


Table 318.30. Bachelor's, master's, and doctor's degrees conferred by postsecondary institutions, by sex of student and discipline division: 2011-12-Continued

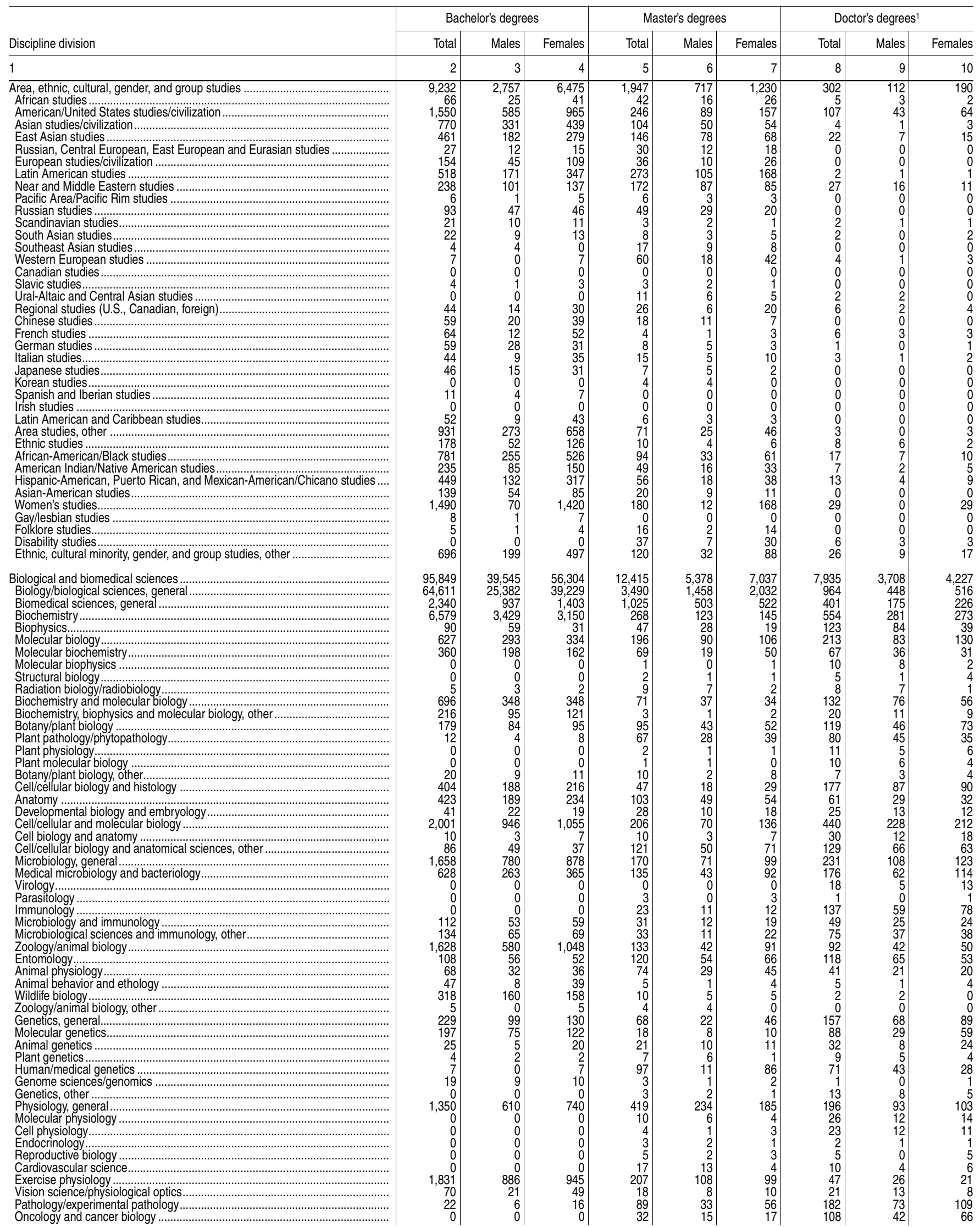


CHAPTER 3: Postsecondary Education 537 Summary of Degrees Conferred

Table 318.30. Bachelor's, master's, and doctor's degrees conferred by postsecondary institutions, by sex of student and discipline division: 2011-12-Continued

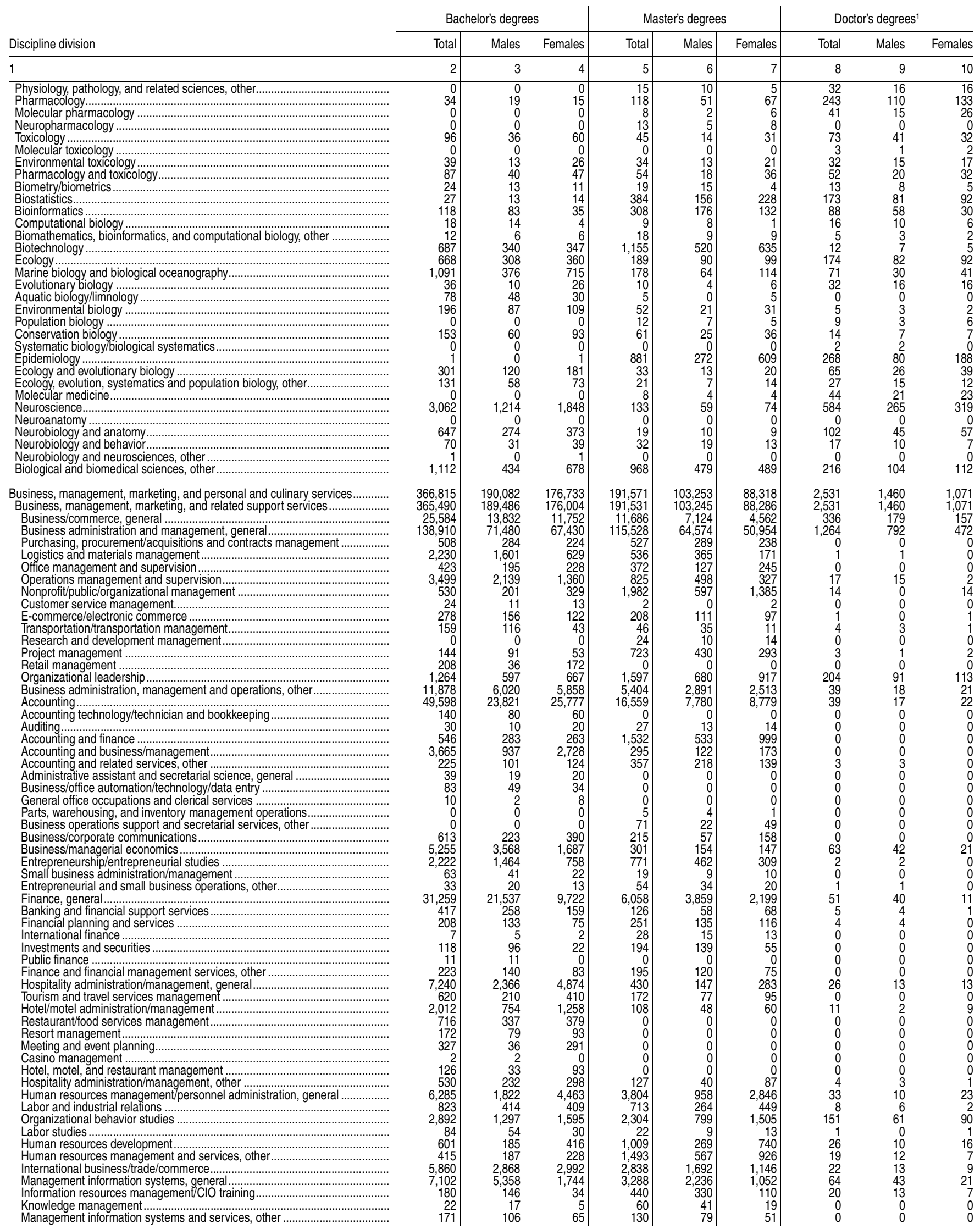

See notes at end of table. 
Table 318.30. Bachelor's, master's, and doctor's degrees conferred by postsecondary institutions, by sex of student and discipline division: 2011-12-Continued

\begin{tabular}{|c|c|c|c|c|c|c|c|c|c|}
\hline \multirow[b]{2}{*}{ Discipline division } & \multicolumn{3}{|c|}{ Bachelor's degrees } & \multicolumn{3}{|c|}{ Master's degrees } & \multicolumn{3}{|c|}{ Doctor's degrees ${ }^{1}$} \\
\hline & Total & Males & Females & Total & Males & Females & Total & Males & Females \\
\hline 1 & 2 & 3 & 4 & 5 & 6 & 7 & 8 & 9 & $\overline{10}$ \\
\hline 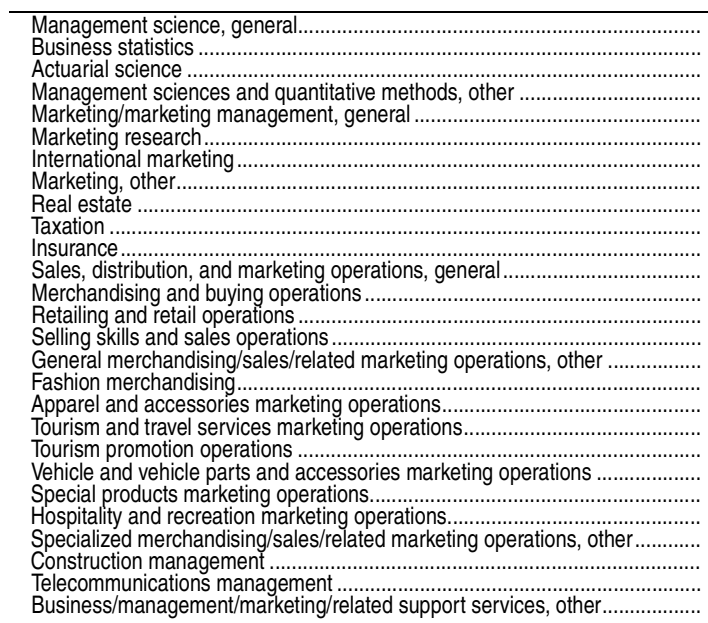 & $\begin{array}{r}3,029 \\
32 \\
913 \\
230 \\
30,701 \\
51 \\
130 \\
1,068 \\
582 \\
0 \\
737 \\
1,106 \\
42 \\
224 \\
399 \\
90 \\
2,511 \\
851 \\
23 \\
95 \\
84 \\
154 \\
42 \\
99 \\
2,608 \\
1 \\
3,104\end{array}$ & \begin{tabular}{r|}
1,787 \\
22 \\
520 \\
156 \\
14,250 \\
25 \\
14 \\
496 \\
425 \\
0 \\
479 \\
553 \\
11 \\
61 \\
242 \\
40 \\
103 \\
64 \\
8 \\
24 \\
72 \\
60 \\
35 \\
27 \\
2,352 \\
0 \\
1,600
\end{tabular} & $\begin{array}{r}1,242 \\
10 \\
393 \\
74 \\
16,451 \\
26 \\
116 \\
572 \\
157 \\
0 \\
258 \\
553 \\
31 \\
163 \\
157 \\
50 \\
2,408 \\
787 \\
15 \\
71 \\
12 \\
94 \\
7 \\
72 \\
256 \\
1 \\
1,504\end{array}$ & $\begin{array}{r}903 \\
58 \\
355 \\
145 \\
1,843 \\
107 \\
102 \\
159 \\
733 \\
1,809 \\
110 \\
194 \\
27 \\
4 \\
0 \\
0 \\
6 \\
8 \\
0 \\
0 \\
0 \\
13 \\
0 \\
36 \\
275 \\
3 \\
1,185\end{array}$ & $\begin{array}{r}479 \\
29 \\
233 \\
98 \\
731 \\
48 \\
43 \\
66 \\
571 \\
924 \\
59 \\
77 \\
1 \\
1 \\
0 \\
0 \\
2 \\
0 \\
0 \\
0 \\
0 \\
10 \\
0 \\
10 \\
214 \\
2 \\
626\end{array}$ & $\begin{array}{r}424 \\
29 \\
122 \\
47 \\
1,112 \\
59 \\
59 \\
93 \\
162 \\
885 \\
51 \\
117 \\
26 \\
3 \\
0 \\
0 \\
4 \\
8 \\
0 \\
0 \\
0 \\
3 \\
0 \\
26 \\
61 \\
1 \\
559\end{array}$ & $\begin{array}{r}7 \\
0 \\
0 \\
8 \\
30 \\
2 \\
2 \\
6 \\
3 \\
0 \\
1 \\
3 \\
0 \\
0 \\
0 \\
0 \\
0 \\
0 \\
0 \\
0 \\
0 \\
0 \\
0 \\
0 \\
3 \\
0 \\
30\end{array}$ & $\begin{array}{r}7 \\
0 \\
0 \\
6 \\
18 \\
0 \\
1 \\
4 \\
2 \\
0 \\
0 \\
1 \\
0 \\
0 \\
0 \\
0 \\
0 \\
0 \\
0 \\
0 \\
0 \\
0 \\
0 \\
0 \\
3 \\
0 \\
19 \\
\\
\\
\\
\end{array}$ & $\begin{array}{r}0 \\
0 \\
0 \\
2 \\
12 \\
2 \\
1 \\
2 \\
1 \\
0 \\
1 \\
2 \\
0 \\
0 \\
0 \\
0 \\
0 \\
0 \\
0 \\
0 \\
0 \\
0 \\
0 \\
0 \\
0 \\
0 \\
11\end{array}$ \\
\hline 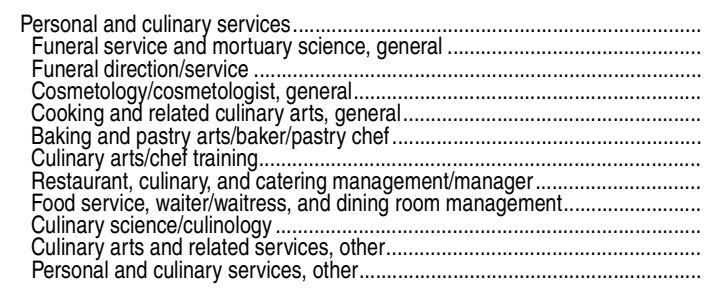 & \begin{tabular}{r|}
1,325 \\
133 \\
27 \\
1 \\
0 \\
51 \\
431 \\
604 \\
0 \\
23 \\
52 \\
3
\end{tabular} & \begin{tabular}{r|r}
596 & \\
48 & 13 \\
0 & 0 \\
0 & \\
206 & \\
293 & \\
0 & \\
9 & 22 \\
1 &
\end{tabular} & \begin{tabular}{r|r}
729 \\
85 \\
14 \\
1 \\
0 \\
47 \\
225 \\
311 \\
0 \\
14 \\
30 \\
2
\end{tabular} & \begin{tabular}{r|}
40 \\
0 \\
0 \\
0 \\
0 \\
0 \\
0 \\
0 \\
0 \\
0 \\
40 \\
0
\end{tabular} & $\begin{array}{l}8 \\
0 \\
0 \\
0 \\
0 \\
0 \\
0 \\
0 \\
0 \\
0 \\
8 \\
0\end{array}$ & $\begin{array}{r}32 \\
0 \\
0 \\
0 \\
0 \\
0 \\
0 \\
0 \\
0 \\
0 \\
32 \\
0\end{array}$ & $\begin{array}{l}0 \\
0 \\
0 \\
0 \\
0 \\
0 \\
0 \\
0 \\
0 \\
0 \\
0 \\
0\end{array}$ & $\begin{array}{l}0 \\
0 \\
0 \\
0 \\
0 \\
0 \\
0 \\
0 \\
0 \\
0 \\
0 \\
0\end{array}$ & $\begin{array}{l}0 \\
0 \\
0 \\
0 \\
0 \\
0 \\
0 \\
0 \\
0 \\
0 \\
0 \\
0\end{array}$ \\
\hline 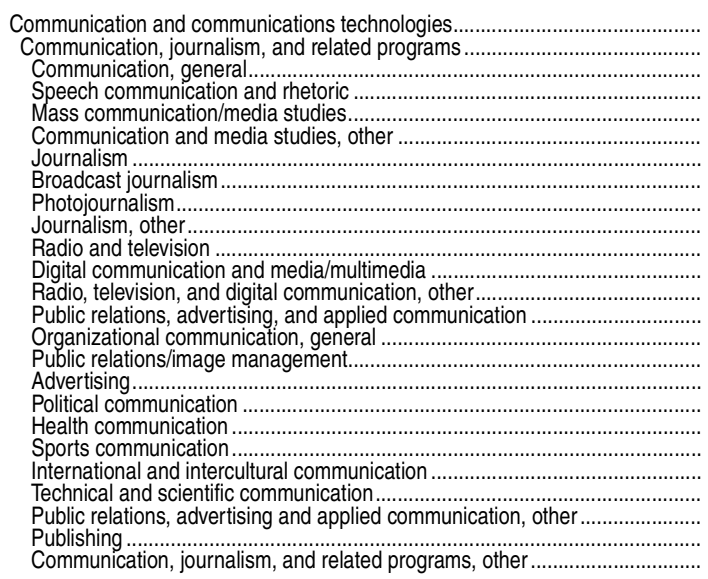 & $\begin{array}{r}88,752 \\
83,70 \\
6,715 \\
30,766 \\
9,064 \\
1,001 \\
12,249 \\
1,082 \\
170 \\
685 \\
5,034 \\
1,596 \\
785 \\
1,050 \\
1,0036 \\
4,121 \\
4,728 \\
76 \\
59 \\
38 \\
26 \\
28 \\
964 \\
2 \\
1,695\end{array}$ & $\begin{array}{r}33,525 \\
29,921 \\
2,123 \\
10,911 \\
3,318 \\
550 \\
4,082 \\
460 \\
59 \\
213 \\
2,857 \\
933 \\
408 \\
269 \\
343 \\
885 \\
1,436 \\
32 \\
16 \\
29 \\
7 \\
9 \\
249 \\
1 \\
731\end{array}$ & $\begin{array}{r}55,227 \\
53,449 \\
4,592 \\
19,855 \\
5,746 \\
1,251 \\
8,167 \\
622 \\
111 \\
472 \\
2,177 \\
663 \\
377 \\
781 \\
693 \\
3,236 \\
3,292 \\
44 \\
43 \\
9 \\
19 \\
19 \\
715 \\
1 \\
964\end{array}$ & $\begin{array}{r}9,496 \\
9,005 \\
490 \\
2,165 \\
1,110 \\
644 \\
1,706 \\
82 \\
9 \\
194 \\
210 \\
296 \\
16 \\
14 \\
157 \\
508 \\
344 \\
0 \\
132 \\
20 \\
46 \\
25 \\
152 \\
172 \\
513\end{array}$ & $\begin{array}{r}3,065 \\
2,760 \\
142 \\
668 \\
374 \\
190 \\
586 \\
24 \\
2 \\
53 \\
95 \\
163 \\
5 \\
5 \\
40 \\
85 \\
100 \\
0 \\
19 \\
14 \\
8 \\
9 \\
31 \\
28 \\
119\end{array}$ & $\begin{array}{r}6,431 \\
6,245 \\
348 \\
1,497 \\
736 \\
454 \\
1,120 \\
58 \\
7 \\
141 \\
115 \\
133 \\
11 \\
9 \\
117 \\
423 \\
244 \\
0 \\
113 \\
6 \\
38 \\
16 \\
121 \\
144 \\
394\end{array}$ & $\begin{array}{r}567 \\
563 \\
70 \\
240 \\
116 \\
44 \\
16 \\
0 \\
0 \\
0 \\
13 \\
11 \\
0 \\
0 \\
4 \\
0 \\
8 \\
0 \\
10 \\
0 \\
0 \\
7 \\
0 \\
0 \\
24\end{array}$ & $\begin{array}{r}242 \\
239 \\
30 \\
91 \\
49 \\
22 \\
9 \\
0 \\
0 \\
0 \\
8 \\
8 \\
0 \\
0 \\
2 \\
0 \\
4 \\
0 \\
1 \\
0 \\
0 \\
3 \\
0 \\
0 \\
12\end{array}$ & $\begin{array}{r}325 \\
324 \\
40 \\
149 \\
67 \\
22 \\
7 \\
0 \\
0 \\
0 \\
5 \\
3 \\
0 \\
0 \\
2 \\
0 \\
4 \\
0 \\
9 \\
0 \\
0 \\
4 \\
0 \\
0 \\
12\end{array}$ \\
\hline 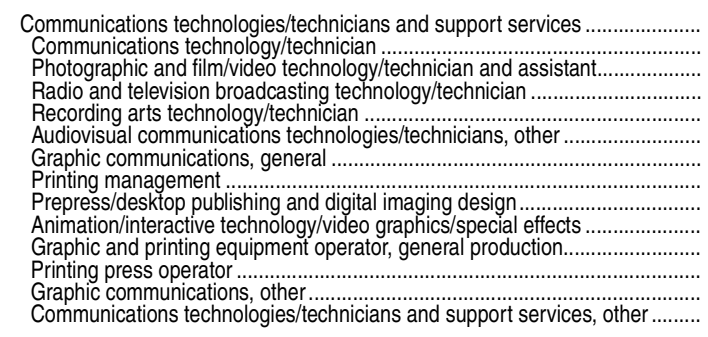 & $\begin{array}{r}4,982 \\
111 \\
81 \\
553 \\
1,281 \\
122 \\
255 \\
54 \\
105 \\
2,158 \\
62 \\
25 \\
27 \\
148\end{array}$ & $\begin{array}{r}3,604 \\
81 \\
51 \\
329 \\
1,157 \\
89 \\
101 \\
24 \\
39 \\
1,600 \\
33 \\
18 \\
17 \\
65\end{array}$ & $\begin{array}{r}1,378 \\
30 \\
30 \\
224 \\
124 \\
33 \\
154 \\
30 \\
66 \\
558 \\
29 \\
7 \\
10 \\
83\end{array}$ & \begin{tabular}{r|r}
491 \\
31 \\
0 \\
94 \\
25 \\
0 \\
0 \\
3 \\
0 \\
272 \\
0 \\
0 \\
8 \\
58
\end{tabular} & $\begin{array}{r}305 \\
9 \\
0 \\
35 \\
19 \\
0 \\
0 \\
1 \\
0 \\
197 \\
0 \\
0 \\
4 \\
40\end{array}$ & $\begin{array}{r}186 \\
22 \\
0 \\
59 \\
6 \\
0 \\
0 \\
2 \\
0 \\
75 \\
0 \\
0 \\
4 \\
18\end{array}$ & $\begin{array}{l}4 \\
4 \\
0 \\
0 \\
0 \\
0 \\
0 \\
0 \\
0 \\
0 \\
0 \\
0 \\
0 \\
0\end{array}$ & $\begin{array}{l}3 \\
3 \\
0 \\
0 \\
0 \\
0 \\
0 \\
0 \\
0 \\
0 \\
0 \\
0 \\
0 \\
0\end{array}$ & $\begin{array}{l}1 \\
1 \\
0 \\
0 \\
0 \\
0 \\
0 \\
0 \\
0 \\
0 \\
0 \\
0 \\
0 \\
0\end{array}$ \\
\hline 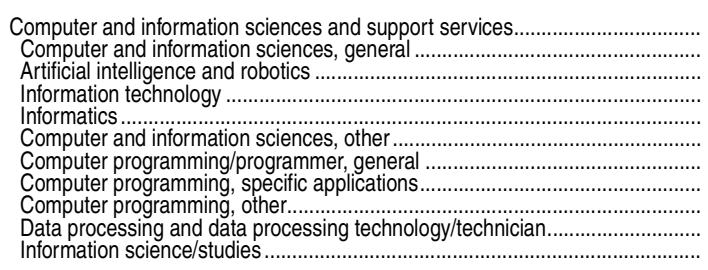 & $\begin{array}{r}47,384 \\
10,779 \\
0 \\
5,895 \\
212 \\
147 \\
1,293 \\
137 \\
0 \\
104 \\
5,711\end{array}$ & $\begin{array}{r}38,773 \\
9,143 \\
0 \\
4,727 \\
170 \\
116 \\
1,080 \\
123 \\
0 \\
82 \\
4,378\end{array}$ & $\begin{array}{r}8,611 \\
1,636 \\
0 \\
1,168 \\
42 \\
31 \\
213 \\
14 \\
0 \\
22 \\
1,333\end{array}$ & $\begin{array}{r}20,917 \\
4,824 \\
72 \\
2,468 \\
248 \\
85 \\
59 \\
12 \\
0 \\
0 \\
3,873\end{array}$ & $\begin{array}{r}15,129 \\
3,665 \\
58 \\
1,745 \\
83 \\
71 \\
45 \\
9 \\
0 \\
0 \\
2,538\end{array}$ & $\begin{array}{r}5,788 \\
1,159 \\
14 \\
723 \\
165 \\
14 \\
14 \\
3 \\
0 \\
0 \\
1,335\end{array}$ & $\begin{array}{r}1,698 \\
619 \\
24 \\
68 \\
0 \\
1 \\
9 \\
0 \\
0 \\
0 \\
153\end{array}$ & $\begin{array}{r}1,332 \\
502 \\
21 \\
48 \\
0 \\
0 \\
8 \\
0 \\
0 \\
0 \\
79\end{array}$ & $\begin{array}{r}366 \\
117 \\
3 \\
20 \\
0 \\
1 \\
1 \\
0 \\
0 \\
0 \\
74\end{array}$ \\
\hline
\end{tabular}


Table 318.30. Bachelor's, master's, and doctor's degrees conferred by postsecondary institutions, by sex of student and discipline division: 2011-12-Continued

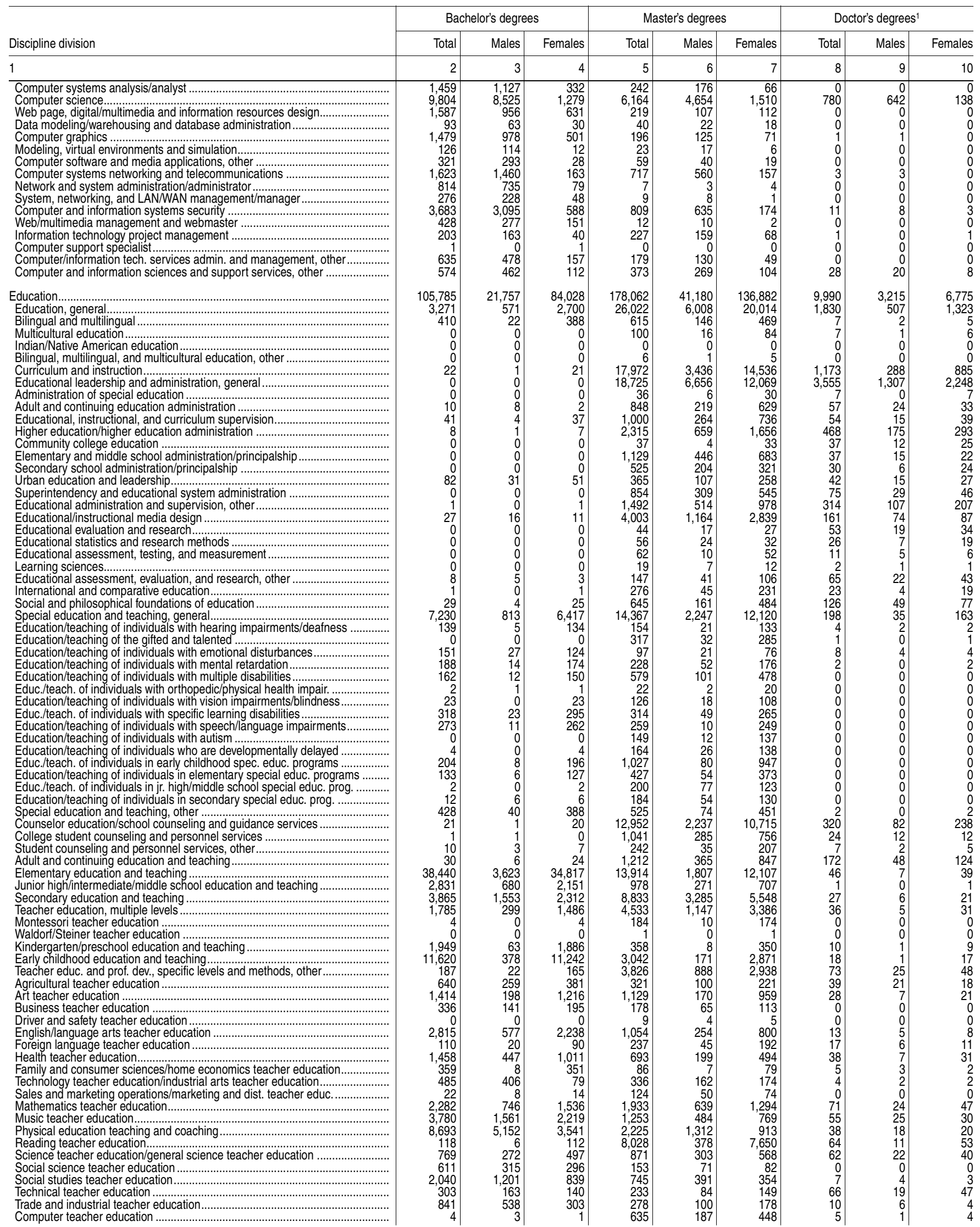


Table 318.30. Bachelor's, master's, and doctor's degrees conferred by postsecondary institutions, by sex of student and discipline division: 2011-12-Continued

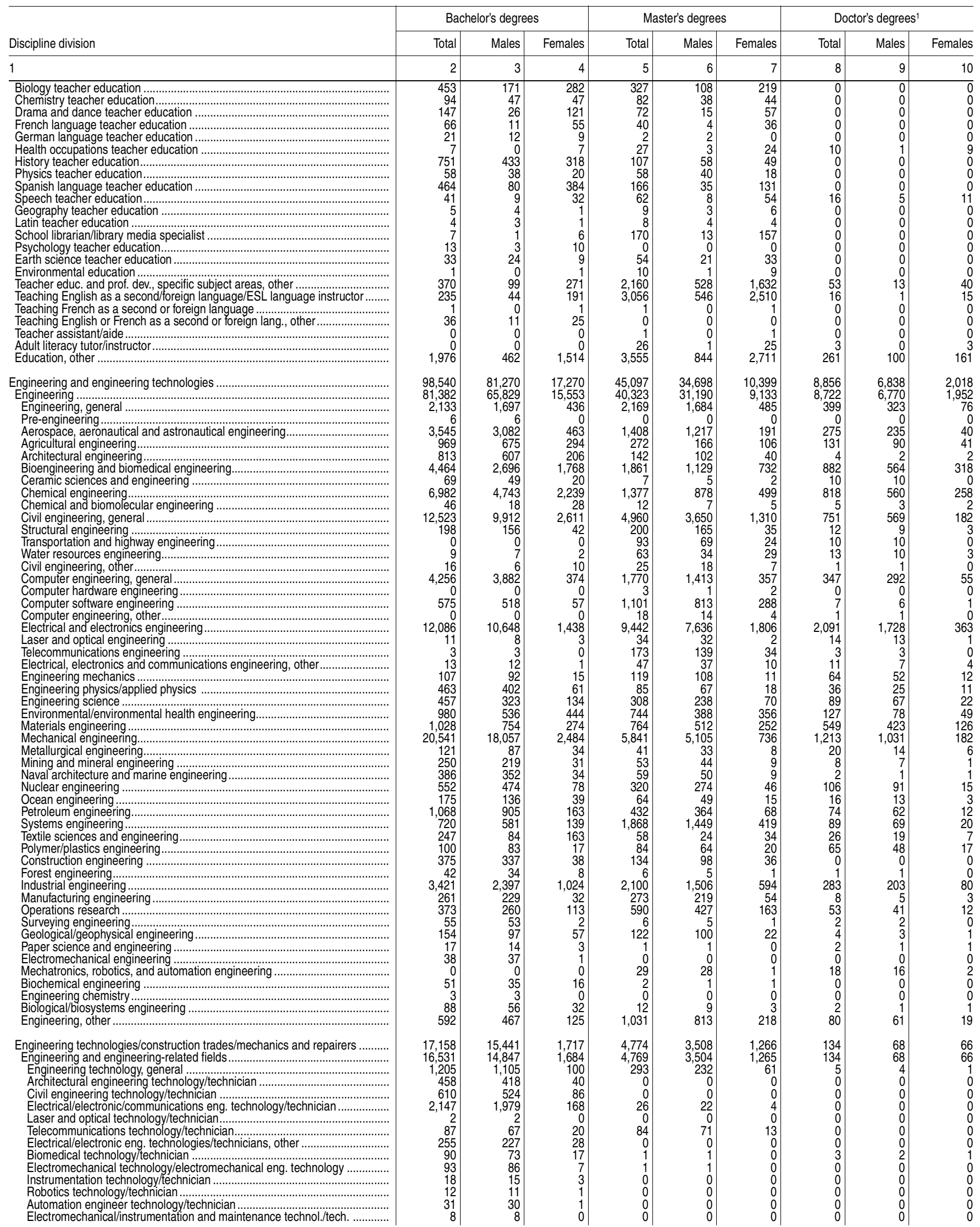


CHAPTER 3: Postsecondary Education 541 Summary of Degrees Conferred

Table 318.30. Bachelor's, master's, and doctor's degrees conferred by postsecondary institutions, by sex of student and discipline division: 2011-12-Continued

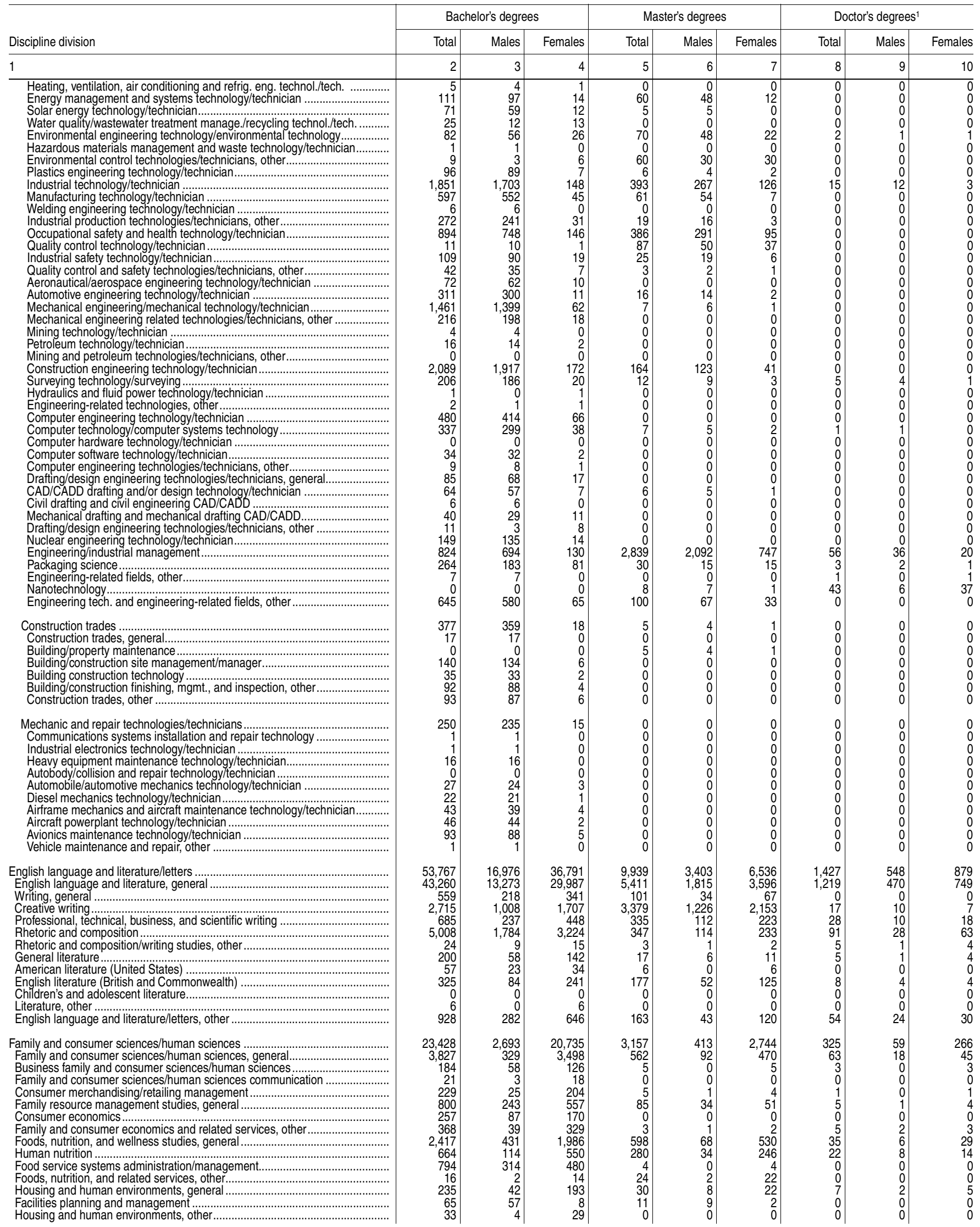

See notes at end of table. 
542 CHAPTER 3: Postsecondary Education

Summary of Degrees Conferred

Table 318.30. Bachelor's, master's, and doctor's degrees conferred by postsecondary institutions, by sex of student and discipline division: 2011-12-Continued

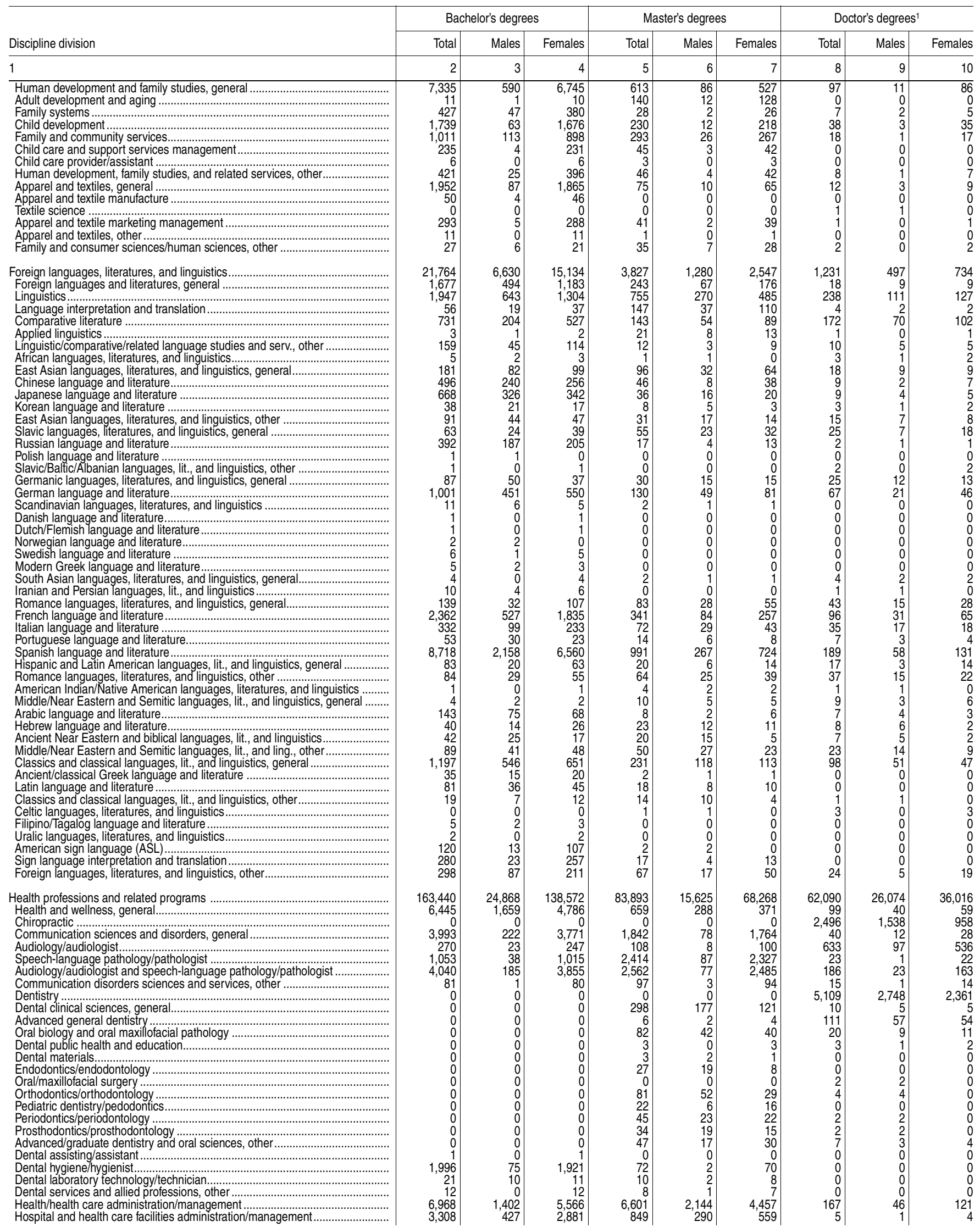

See notes at end of table. 
Table 318.30. Bachelor's, master's, and doctor's degrees conferred by postsecondary institutions, by sex of student and discipline division: 2011-12-Continued

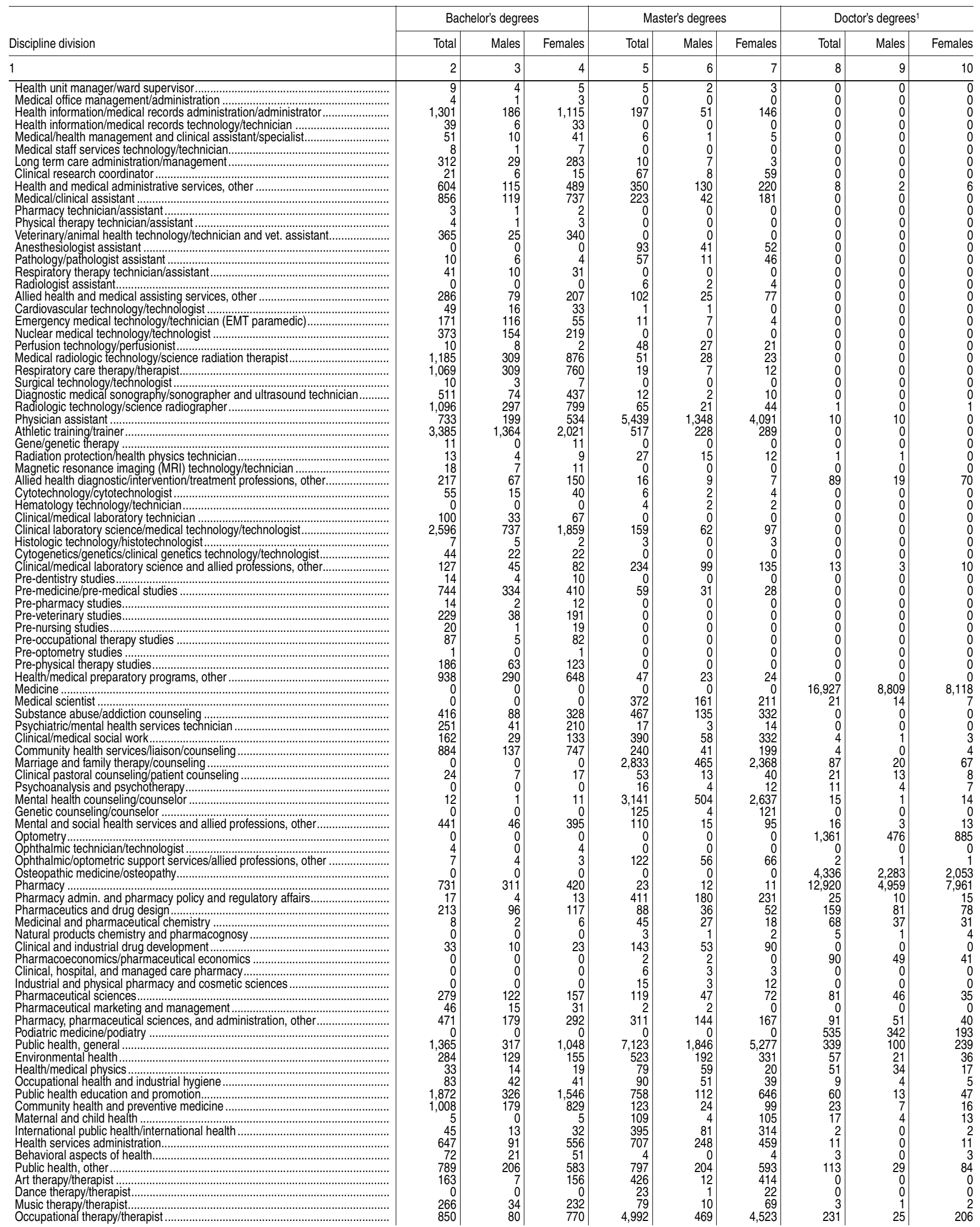


Table 318.30. Bachelor's, master's, and doctor's degrees conferred by postsecondary institutions, by sex of student and discipline division: 2011-12-Continued

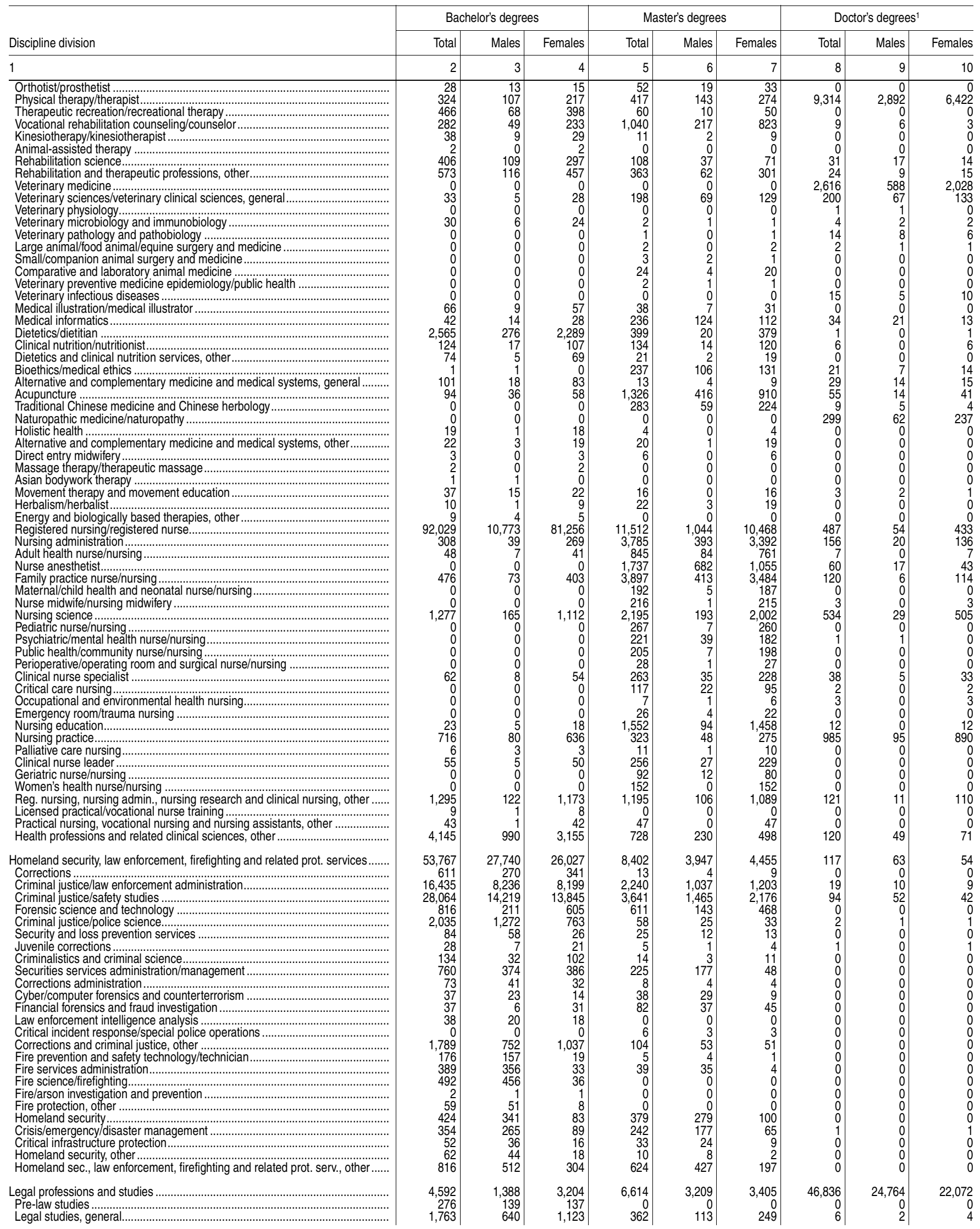

See notes at end of table. 
Table 318.30. Bachelor's, master's, and doctor's degrees conferred by postsecondary institutions, by sex of student and discipline division: 2011-12-Continued

\begin{tabular}{|c|c|c|c|c|c|c|c|c|c|}
\hline \multirow[b]{2}{*}{ Discipline division } & \multicolumn{3}{|c|}{ Bachelor's degrees } & \multicolumn{3}{|c|}{ Master's degrees } & \multicolumn{3}{|c|}{ Doctor's degrees ${ }^{1}$} \\
\hline & Total & Males & Females & Total & Males & Females & Total & Males & Females \\
\hline 1 & 2 & 3 & 4 & 5 & 6 & 7 & 8 & 9 & 10 \\
\hline 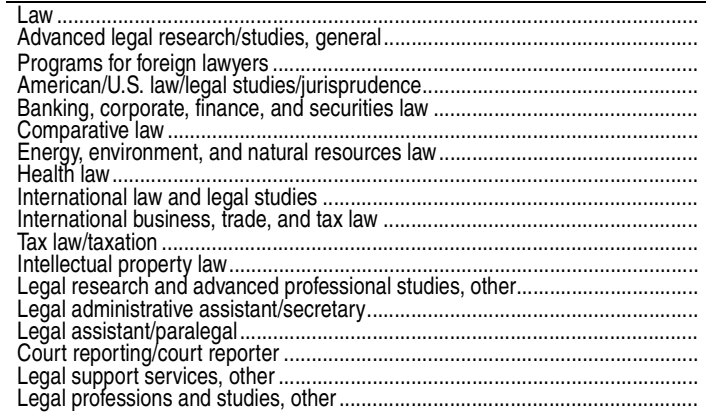 & $\begin{array}{r}0 \\
96 \\
0 \\
28 \\
0 \\
0 \\
2 \\
0 \\
1 \\
0 \\
0 \\
0 \\
0 \\
1 \\
2,009 \\
14 \\
0 \\
402\end{array}$ & \begin{tabular}{r|}
0 \\
49 \\
0 \\
6 \\
0 \\
0 \\
1 \\
0 \\
1 \\
0 \\
0 \\
0 \\
0 \\
0 \\
395 \\
0 \\
0 \\
157
\end{tabular} & $\begin{array}{r}0 \\
47 \\
0 \\
22 \\
0 \\
0 \\
1 \\
0 \\
0 \\
0 \\
0 \\
0 \\
0 \\
1 \\
1,614 \\
14 \\
0 \\
245\end{array}$ & $\begin{array}{r}0 \\
1,304 \\
808 \\
247 \\
235 \\
62 \\
98 \\
162 \\
332 \\
139 \\
691 \\
119 \\
604 \\
0 \\
105 \\
0 \\
8 \\
1,338\end{array}$ & $\begin{array}{r}0 \\
650 \\
400 \\
100 \\
131 \\
36 \\
56 \\
34 \\
156 \\
83 \\
428 \\
68 \\
344 \\
0 \\
17 \\
0 \\
3 \\
590\end{array}$ & $\begin{array}{r}0 \\
654 \\
408 \\
147 \\
104 \\
26 \\
42 \\
128 \\
176 \\
56 \\
263 \\
51 \\
260 \\
0 \\
88 \\
0 \\
5 \\
748\end{array}$ & $\begin{array}{r}46,445 \\
136 \\
0 \\
25 \\
0 \\
0 \\
12 \\
6 \\
42 \\
0 \\
35 \\
19 \\
28 \\
0 \\
0 \\
0 \\
0 \\
82\end{array}$ & $\begin{array}{r}24,576 \\
66 \\
0 \\
13 \\
0 \\
0 \\
7 \\
2 \\
22 \\
0 \\
15 \\
8 \\
18 \\
0 \\
0 \\
0 \\
0 \\
35\end{array}$ & $\begin{array}{r}21,869 \\
70 \\
0 \\
12 \\
0 \\
0 \\
5 \\
4 \\
20 \\
0 \\
20 \\
11 \\
10 \\
0 \\
0 \\
0 \\
0 \\
47\end{array}$ \\
\hline 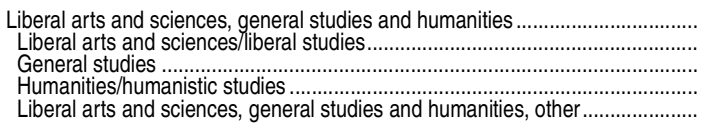 & $\begin{array}{r}46,925 \\
26,247 \\
15,044 \\
2,577 \\
3,057\end{array}$ & $\begin{array}{r}16,944 \\
8,573 \\
6,244 \\
867 \\
1,260\end{array}$ & $\begin{array}{r}29,981 \\
17,674 \\
8,800 \\
1,710 \\
1,797\end{array}$ & $\begin{array}{r}3,791 \\
2,176 \\
163 \\
644 \\
808\end{array}$ & $\begin{array}{r}1,490 \\
841 \\
50 \\
239 \\
360\end{array}$ & $\begin{array}{r}2,301 \\
1,335 \\
113 \\
405 \\
448\end{array}$ & $\begin{array}{r}93 \\
13 \\
4 \\
75 \\
1\end{array}$ & $\begin{array}{r}32 \\
6 \\
0 \\
25 \\
1\end{array}$ & $\begin{array}{r}61 \\
7 \\
4 \\
50 \\
0\end{array}$ \\
\hline Library science & $\begin{array}{r}95 \\
95 \\
0\end{array}$ & $\begin{array}{l}7 \\
7 \\
0\end{array}$ & $\begin{array}{r}88 \\
88 \\
0\end{array}$ & $\begin{array}{r}7,441 \\
7,228 \\
213\end{array}$ & $\begin{array}{r}1,425 \\
1,389 \\
36\end{array}$ & $\begin{array}{r}6,016 \\
5,839 \\
177\end{array}$ & $\begin{array}{r}60 \\
60 \\
0\end{array}$ & $\begin{array}{r}24 \\
24 \\
0\end{array}$ & $\begin{array}{r}36 \\
36 \\
0\end{array}$ \\
\hline 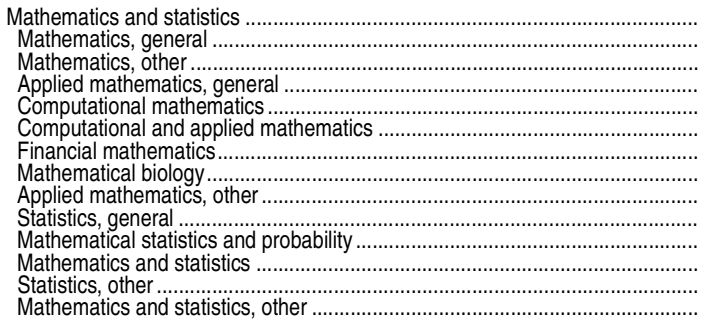 & $\begin{array}{r}18,842 \\
15,670 \\
290 \\
1,330 \\
66 \\
48 \\
41 \\
2 \\
184 \\
864 \\
110 \\
30 \\
40 \\
167\end{array}$ & $\begin{array}{r}10,723 \\
8,743 \\
166 \\
871 \\
52 \\
27 \\
22 \\
1 \\
137 \\
505 \\
64 \\
23 \\
26 \\
86\end{array}$ & $\begin{array}{r}8,119 \\
6,927 \\
124 \\
459 \\
14 \\
21 \\
19 \\
1 \\
47 \\
359 \\
46 \\
7 \\
14 \\
81\end{array}$ & $\begin{array}{r}6,245 \\
2,881 \\
24 \\
813 \\
24 \\
48 \\
275 \\
1 \\
110 \\
1,832 \\
124 \\
53 \\
12 \\
48\end{array}$ & $\begin{array}{r}3,694 \\
1,765 \\
12 \\
531 \\
18 \\
34 \\
162 \\
0 \\
74 \\
950 \\
78 \\
29 \\
9 \\
32\end{array}$ & $\begin{array}{r}2,551 \\
1,116 \\
12 \\
282 \\
6 \\
14 \\
113 \\
1 \\
36 \\
882 \\
46 \\
24 \\
3 \\
16\end{array}$ & $\begin{array}{r}1,669 \\
1,061 \\
6 \\
206 \\
13 \\
19 \\
2 \\
0 \\
13 \\
323 \\
19 \\
0 \\
1 \\
6\end{array}$ & $\begin{array}{r}1,198 \\
803 \\
4 \\
137 \\
11 \\
14 \\
2 \\
0 \\
8 \\
205 \\
10 \\
0 \\
0 \\
4\end{array}$ & $\begin{array}{r}471 \\
258 \\
2 \\
69 \\
2 \\
5 \\
0 \\
0 \\
5 \\
118 \\
9 \\
0 \\
1 \\
2\end{array}$ \\
\hline 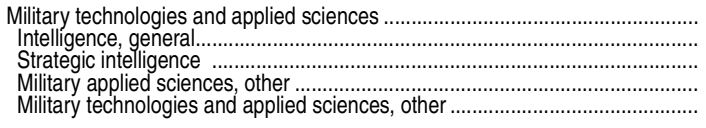 & $\begin{array}{r}86 \\
7 \\
0 \\
41 \\
38\end{array}$ & $\begin{array}{r}69 \\
4 \\
0 \\
38 \\
27\end{array}$ & $\begin{array}{r}17 \\
3 \\
0 \\
3 \\
11\end{array}$ & $\begin{array}{r}29 \\
0 \\
27 \\
2 \\
0\end{array}$ & $\begin{array}{r}21 \\
0 \\
20 \\
1 \\
0\end{array}$ & $\begin{array}{l}8 \\
0 \\
7 \\
1 \\
0\end{array}$ & $\begin{array}{l}0 \\
0 \\
0 \\
0 \\
0\end{array}$ & $\begin{array}{l}0 \\
0 \\
0 \\
0 \\
0\end{array}$ & $\begin{array}{l}0 \\
0 \\
0 \\
0 \\
0\end{array}$ \\
\hline 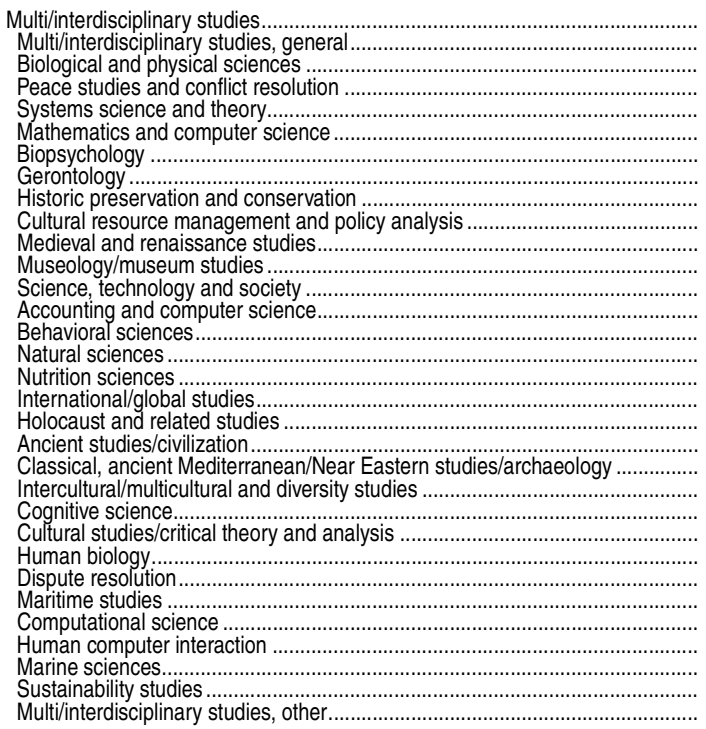 & $\begin{array}{r}45,716 \\
2,099 \\
2,181 \\
393 \\
217 \\
167 \\
189 \\
253 \\
113 \\
0 \\
47 \\
24 \\
549 \\
3 \\
5,161 \\
567 \\
1,623 \\
4,990 \\
6 \\
121 \\
123 \\
117 \\
522 \\
134 \\
490 \\
0 \\
20 \\
3 \\
0 \\
44 \\
250 \\
25,310\end{array}$ & $\begin{array}{r}14,594 \\
795 \\
903 \\
147 \\
138 \\
124 \\
56 \\
26 \\
32 \\
0 \\
13 \\
7 \\
310 \\
1 \\
895 \\
194 \\
271 \\
1,875 \\
3 \\
51 \\
55 \\
28 \\
230 \\
53 \\
135 \\
0 \\
6 \\
2 \\
0 \\
18 \\
121 \\
8,105\end{array}$ & $\begin{array}{r}31,122 \\
1,304 \\
1,278 \\
246 \\
79 \\
43 \\
133 \\
227 \\
81 \\
0 \\
34 \\
17 \\
239 \\
2 \\
4,266 \\
373 \\
1,352 \\
3,115 \\
3 \\
70 \\
68 \\
89 \\
292 \\
81 \\
355 \\
0 \\
14 \\
1 \\
0 \\
26 \\
129 \\
17,205\end{array}$ & $\begin{array}{r}7,745 \\
31 \\
371 \\
587 \\
209 \\
37 \\
4 \\
374 \\
216 \\
29 \\
16 \\
460 \\
132 \\
12 \\
82 \\
141 \\
648 \\
1,170 \\
6 \\
2 \\
3 \\
86 \\
82 \\
3 \\
0 \\
219 \\
0 \\
26 \\
59 \\
38 \\
197 \\
2,505\end{array}$ & $\begin{array}{r}2,988 \\
12 \\
137 \\
199 \\
100 \\
27 \\
1 \\
53 \\
50 \\
6 \\
8 \\
58 \\
56 \\
7 \\
28 \\
41 \\
94 \\
731 \\
0 \\
1 \\
2 \\
21 \\
38 \\
0 \\
0 \\
79 \\
0 \\
23 \\
38 \\
8 \\
87 \\
1,083\end{array}$ & $\begin{array}{r}4,757 \\
19 \\
234 \\
388 \\
109 \\
10 \\
3 \\
321 \\
166 \\
23 \\
8 \\
402 \\
76 \\
5 \\
54 \\
100 \\
554 \\
439 \\
6 \\
1 \\
1 \\
65 \\
44 \\
3 \\
0 \\
140 \\
0 \\
3 \\
21 \\
30 \\
110 \\
1,422\end{array}$ & $\begin{array}{r}727 \\
46 \\
56 \\
36 \\
17 \\
13 \\
5 \\
23 \\
2 \\
1 \\
9 \\
0 \\
19 \\
0 \\
26 \\
6 \\
123 \\
0 \\
0 \\
5 \\
7 \\
1 \\
31 \\
1 \\
0 \\
0 \\
0 \\
5 \\
5 \\
6 \\
2 \\
282\end{array}$ & $\begin{array}{r}297 \\
13 \\
28 \\
14 \\
12 \\
12 \\
1 \\
2 \\
1 \\
0 \\
5 \\
0 \\
7 \\
0 \\
9 \\
1 \\
26 \\
0 \\
0 \\
3 \\
4 \\
1 \\
20 \\
0 \\
0 \\
0 \\
0 \\
4 \\
4 \\
5 \\
2 \\
123\end{array}$ & $\begin{array}{r}430 \\
33 \\
28 \\
22 \\
5 \\
1 \\
4 \\
21 \\
1 \\
1 \\
4 \\
0 \\
12 \\
0 \\
17 \\
5 \\
97 \\
0 \\
0 \\
2 \\
3 \\
0 \\
11 \\
1 \\
0 \\
0 \\
0 \\
1 \\
1 \\
1 \\
0 \\
159\end{array}$ \\
\hline 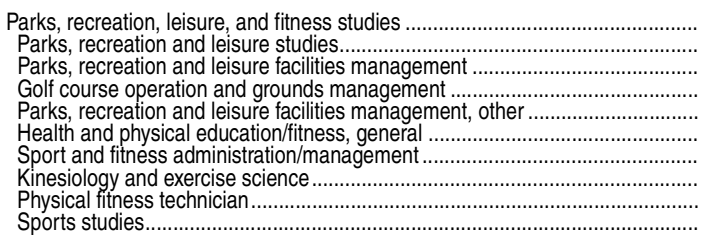 & $\begin{array}{r}38,993 \\
2,672 \\
2,970 \\
25 \\
7 \\
8,235 \\
6,734 \\
16,696 \\
36 \\
202 \\
202\end{array}$ & $\begin{array}{r}20,830 \\
1,269 \\
1,575 \\
21 \\
4 \\
4,239 \\
4,936 \\
7,907 \\
17 \\
157\end{array}$ & $\begin{array}{r}18,163 \\
1,403 \\
1,395 \\
4 \\
3 \\
3,996 \\
1,798 \\
8,789 \\
19 \\
45\end{array}$ & $\begin{array}{r}7,047 \\
302 \\
427 \\
0 \\
0 \\
1,173 \\
3,013 \\
1,980 \\
0 \\
77\end{array}$ & $\begin{array}{r}3,938 \\
121 \\
238 \\
0 \\
0 \\
617 \\
1,912 \\
987 \\
0 \\
37\end{array}$ & $\begin{array}{r}3,109 \\
181 \\
189 \\
0 \\
0 \\
556 \\
1,101 \\
993 \\
0 \\
40\end{array}$ & $\begin{array}{r}288 \\
24 \\
17 \\
0 \\
0 \\
22 \\
22 \\
175 \\
0 \\
0\end{array}$ & $\begin{array}{r}161 \\
5 \\
11 \\
0 \\
0 \\
11 \\
16 \\
106 \\
0 \\
0\end{array}$ & $\begin{array}{r}127 \\
19 \\
6 \\
0 \\
0 \\
11 \\
6 \\
69 \\
0 \\
0\end{array}$ \\
\hline
\end{tabular}


546 CHAPTER 3: Postsecondary Education

Summary of Degrees Conferred

Table 318.30. Bachelor's, master's, and doctor's degrees conferred by postsecondary institutions, by sex of student and discipline division: 2011-12-Continued

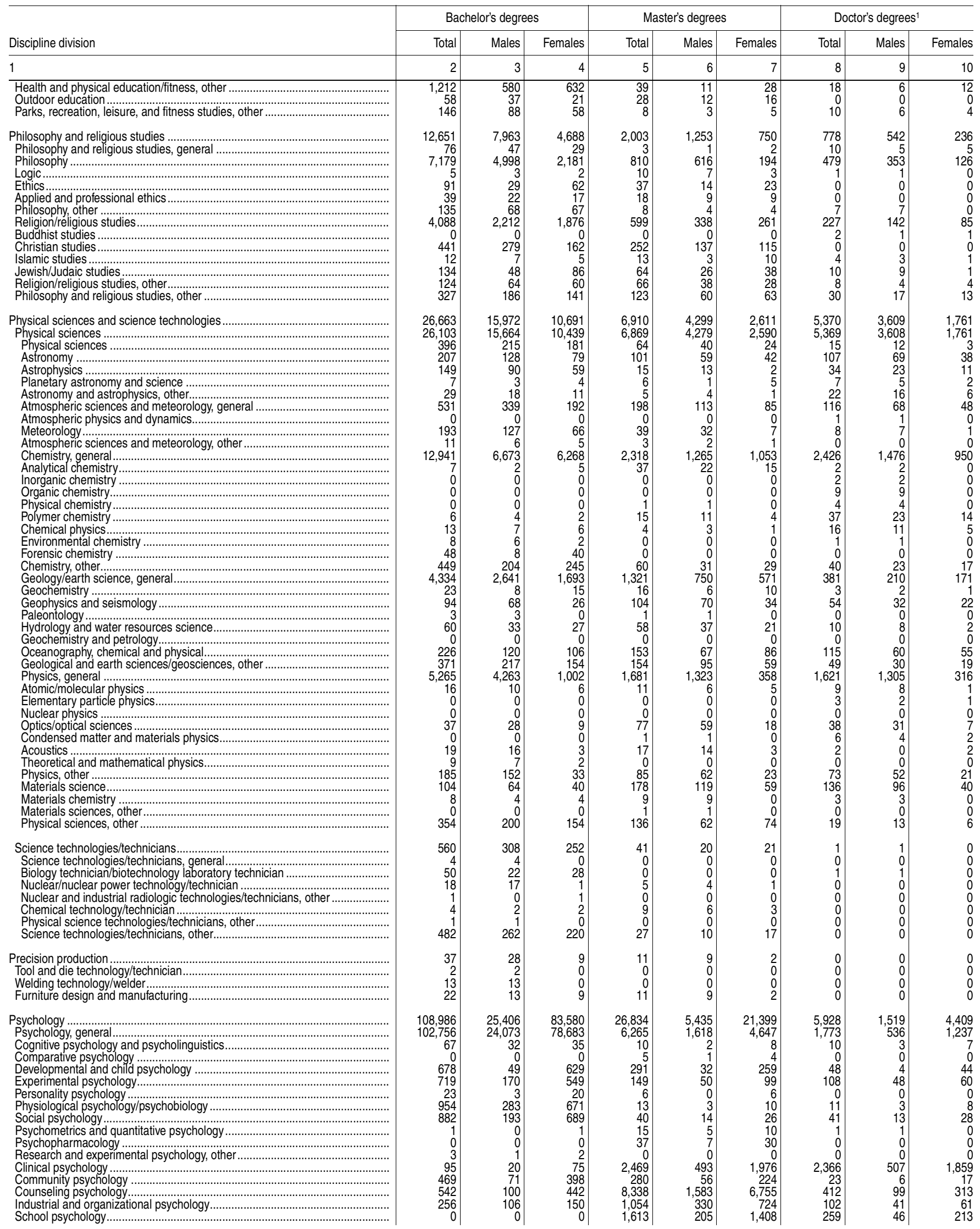

See notes at end of table. 
Table 318.30. Bachelor's, master's, and doctor's degrees conferred by postsecondary institutions, by sex of student and discipline division: 2011-12-Continued

\begin{tabular}{|c|c|c|c|c|c|c|c|c|c|}
\hline \multirow[b]{2}{*}{ Discipline division } & \multicolumn{3}{|c|}{ Bachelor's degrees } & \multicolumn{3}{|c|}{ Master's degrees } & \multicolumn{3}{|c|}{ Doctor's degrees ${ }^{1}$} \\
\hline & Total & Males & Females & Total & Males & Females & Total & Males & Females \\
\hline 1 & 2 & 3 & 4 & 5 & 6 & 7 & 8 & 9 & 10 \\
\hline 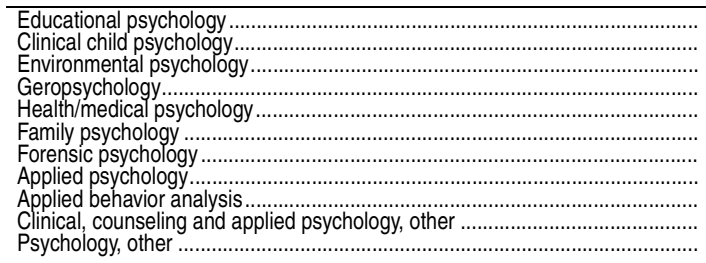 & \begin{tabular}{r|r}
131 \\
1 \\
20 \\
0 \\
30 \\
7 \\
524 \\
297 \\
52 \\
1 \\
478
\end{tabular} & \begin{tabular}{r|r}
8 \\
0 \\
15 \\
0 \\
9 \\
1 \\
85 \\
53 \\
15 \\
0 \\
119
\end{tabular} & 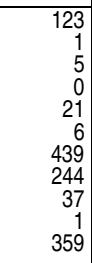 & $\begin{array}{r}1,367 \\
28 \\
25 \\
1 \\
38 \\
43 \\
722 \\
580 \\
181 \\
626 \\
2,638\end{array}$ & $\begin{array}{r}237 \\
4 \\
9 \\
0 \\
9 \\
5 \\
102 \\
83 \\
29 \\
119 \\
439\end{array}$ & $\begin{array}{r}1,130 \\
24 \\
16 \\
1 \\
29 \\
38 \\
620 \\
497 \\
152 \\
507 \\
2,199\end{array}$ & $\begin{array}{r}470 \\
26 \\
8 \\
1 \\
6 \\
1 \\
37 \\
8 \\
30 \\
53 \\
134\end{array}$ & $\begin{array}{r}138 \\
5 \\
3 \\
0 \\
2 \\
0 \\
5 \\
2 \\
10 \\
5 \\
42\end{array}$ & $\begin{array}{r}332 \\
21 \\
5 \\
1 \\
4 \\
1 \\
32 \\
6 \\
20 \\
48 \\
92\end{array}$ \\
\hline 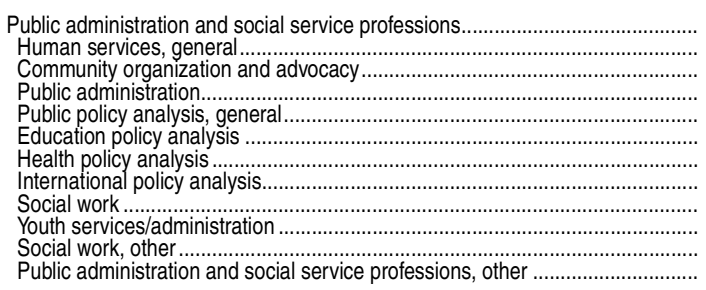 & $\begin{array}{r}29,695 \\
6,310 \\
2,022 \\
3,259 \\
1,108 \\
0 \\
67 \\
0 \\
16,642 \\
18 \\
39 \\
230\end{array}$ & $\begin{array}{r}5,385 \\
812 \\
454 \\
1,640 \\
503 \\
0 \\
11 \\
0 \\
1,885 \\
4 \\
1 \\
75\end{array}$ & $\begin{array}{r}24,310 \\
5,498 \\
1,568 \\
1,619 \\
605 \\
0 \\
56 \\
0 \\
14,757 \\
14 \\
38 \\
155\end{array}$ & $\begin{array}{r}41,680 \\
1,773 \\
604 \\
12,926 \\
2,728 \\
15 \\
36 \\
40 \\
22,305 \\
12 \\
77 \\
1,164\end{array}$ & $\begin{array}{r}10,475 \\
316 \\
167 \\
5,441 \\
1,280 \\
3 \\
15 \\
25 \\
2,931 \\
0 \\
9 \\
288\end{array}$ & $\begin{array}{r}31,205 \\
1,457 \\
437 \\
7,485 \\
1,448 \\
12 \\
21 \\
15 \\
19,374 \\
12 \\
68 \\
876\end{array}$ & $\begin{array}{r}884 \\
48 \\
8 \\
219 \\
221 \\
7 \\
0 \\
0 \\
298 \\
0 \\
0 \\
83\end{array}$ & $\begin{array}{r}338 \\
18 \\
2 \\
117 \\
96 \\
2 \\
0 \\
0 \\
71 \\
0 \\
0 \\
32\end{array}$ & $\begin{array}{r}546 \\
30 \\
6 \\
102 \\
125 \\
5 \\
0 \\
0 \\
227 \\
0 \\
0 \\
51\end{array}$ \\
\hline 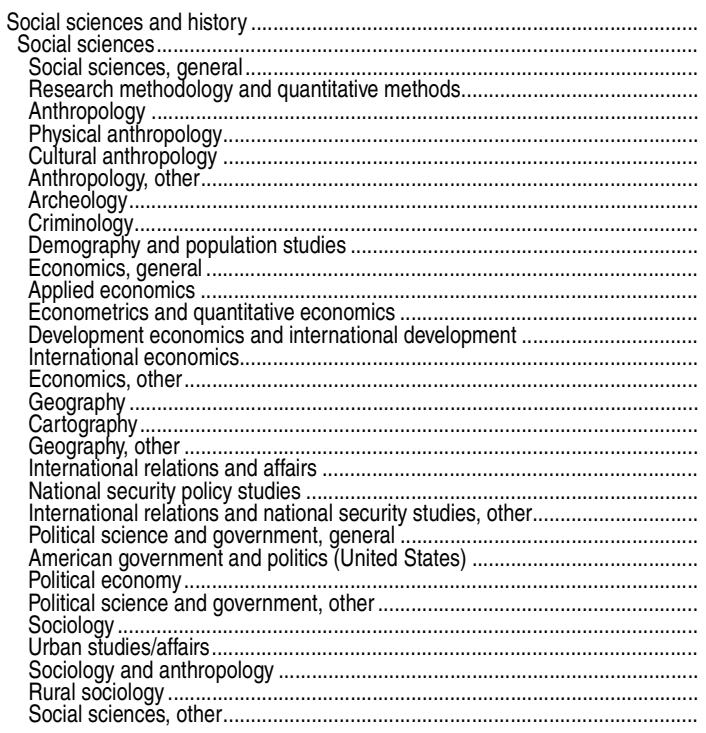 & $\begin{array}{r}178,543 \\
143,422 \\
9,656 \\
0 \\
10,679 \\
58 \\
4 \\
93 \\
264 \\
6,313 \\
0 \\
26,425 \\
281 \\
374 \\
233 \\
242 \\
440 \\
4,807 \\
167 \\
171 \\
9,719 \\
12 \\
113 \\
38,789 \\
172 \\
110 \\
729 \\
30,132 \\
1,105 \\
334 \\
20 \\
1,980\end{array}$ & $\begin{array}{r}90,634 \\
69,664 \\
3,361 \\
0 \\
3,073 \\
18 \\
1 \\
29 \\
70 \\
3,223 \\
0 \\
18,698 \\
182 \\
261 \\
66 \\
125 \\
294 \\
3,136 \\
132 \\
94 \\
3,786 \\
12 \\
48 \\
21,787 \\
99 \\
65 \\
368 \\
9,295 \\
504 \\
96 \\
9 \\
832\end{array}$ & $\begin{array}{r}87,909 \\
73,758 \\
6,295 \\
0 \\
7,606 \\
40 \\
3 \\
64 \\
194 \\
3,090 \\
0 \\
7,727 \\
99 \\
113 \\
167 \\
117 \\
146 \\
1,671 \\
35 \\
77 \\
5,933 \\
0 \\
65 \\
17,002 \\
73 \\
45 \\
361 \\
20,837 \\
601 \\
238 \\
11 \\
1,148\end{array}$ & $\begin{array}{r}21,889 \\
17,734 \\
602 \\
5 \\
1,185 \\
12 \\
0 \\
36 \\
46 \\
732 \\
94 \\
2,896 \\
264 \\
27 \\
398 \\
213 \\
92 \\
929 \\
177 \\
20 \\
4,610 \\
160 \\
53 \\
2,226 \\
171 \\
0 \\
111 \\
1,696 \\
479 \\
10 \\
1 \\
489\end{array}$ & $\begin{array}{r}10,983 \\
8,741 \\
204 \\
3 \\
396 \\
5 \\
0 \\
7 \\
11 \\
252 \\
52 \\
1,840 \\
187 \\
18 \\
140 \\
107 \\
47 \\
538 \\
132 \\
15 \\
2,249 \\
107 \\
28 \\
1,229 \\
104 \\
0 \\
66 \\
574 \\
211 \\
2 \\
1 \\
216\end{array}$ & $\begin{array}{r}10,906 \\
8,993 \\
398 \\
2 \\
789 \\
7 \\
0 \\
29 \\
35 \\
480 \\
42 \\
1,056 \\
77 \\
9 \\
258 \\
106 \\
45 \\
391 \\
45 \\
5 \\
2,361 \\
53 \\
25 \\
997 \\
67 \\
0 \\
45 \\
1,122 \\
268 \\
8 \\
0 \\
273\end{array}$ & $\begin{array}{r}4,597 \\
3,628 \\
24 \\
0 \\
563 \\
4 \\
0 \\
8 \\
10 \\
53 \\
9 \\
1,055 \\
29 \\
0 \\
24 \\
15 \\
7 \\
275 \\
4 \\
1 \\
85 \\
0 \\
0 \\
739 \\
0 \\
0 \\
7 \\
626 \\
62 \\
0 \\
0 \\
28\end{array}$ & $\begin{array}{r}2,464 \\
1,931 \\
13 \\
0 \\
203 \\
2 \\
0 \\
2 \\
4 \\
20 \\
2 \\
709 \\
18 \\
0 \\
17 \\
12 \\
2 \\
168 \\
3 \\
0 \\
44 \\
0 \\
0 \\
444 \\
0 \\
0 \\
3 \\
231 \\
26 \\
0 \\
0 \\
8\end{array}$ & $\begin{array}{r}2,133 \\
1,697 \\
11 \\
0 \\
360 \\
2 \\
0 \\
6 \\
6 \\
33 \\
7 \\
346 \\
11 \\
0 \\
7 \\
3 \\
5 \\
107 \\
1 \\
1 \\
41 \\
0 \\
0 \\
295 \\
0 \\
0 \\
4 \\
395 \\
36 \\
0 \\
0 \\
20\end{array}$ \\
\hline 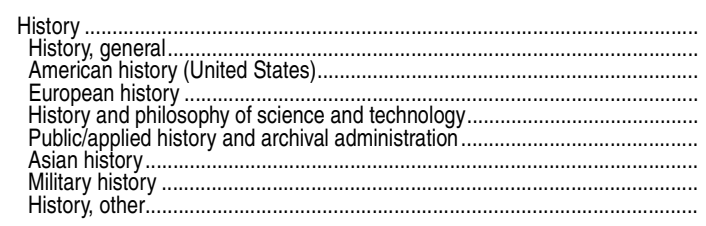 & $\begin{array}{r}35,121 \\
34,384 \\
82 \\
31 \\
122 \\
22 \\
2 \\
25 \\
453\end{array}$ & $\begin{array}{r}20,970 \\
20,571 \\
46 \\
16 \\
49 \\
7 \\
2 \\
25 \\
254\end{array}$ & $\begin{array}{r}14,151 \\
13,813 \\
36 \\
15 \\
73 \\
15 \\
0 \\
0 \\
199\end{array}$ & $\begin{array}{r}4,155 \\
3,557 \\
53 \\
5 \\
37 \\
182 \\
0 \\
171 \\
150\end{array}$ & $\begin{array}{r}2,242 \\
1,902 \\
20 \\
2 \\
19 \\
39 \\
0 \\
151 \\
109\end{array}$ & $\begin{array}{r}1,913 \\
1,655 \\
33 \\
3 \\
18 \\
143 \\
0 \\
20 \\
41\end{array}$ & $\begin{array}{r}969 \\
917 \\
7 \\
0 \\
24 \\
3 \\
1 \\
0 \\
17\end{array}$ & $\begin{array}{r}533 \\
503 \\
2 \\
0 \\
17 \\
0 \\
1 \\
0 \\
10\end{array}$ & $\begin{array}{r}436 \\
414 \\
5 \\
0 \\
7 \\
3 \\
0 \\
0 \\
7\end{array}$ \\
\hline 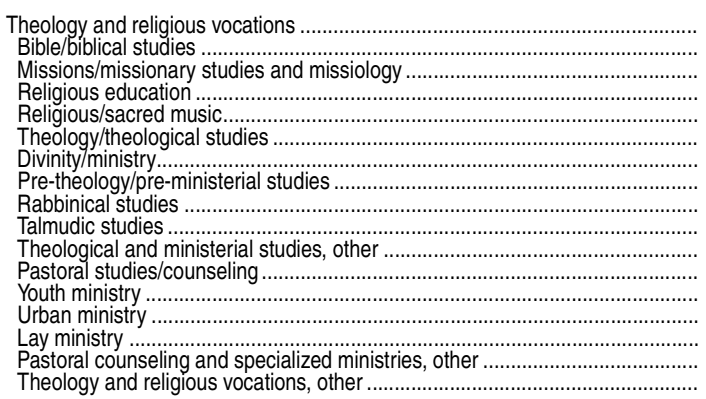 & $\begin{array}{r}9,369 \\
2,920 \\
519 \\
839 \\
297 \\
1,092 \\
190 \\
169 \\
0 \\
1,459 \\
376 \\
404 \\
560 \\
46 \\
62 \\
117 \\
319\end{array}$ & $\begin{array}{r}6,275 \\
1,883 \\
199 \\
419 \\
171 \\
718 \\
124 \\
138 \\
0 \\
1,459 \\
211 \\
278 \\
383 \\
18 \\
43 \\
42 \\
189\end{array}$ & $\begin{array}{r}3,094 \\
1,037 \\
320 \\
420 \\
126 \\
374 \\
66 \\
31 \\
0 \\
0 \\
165 \\
126 \\
177 \\
28 \\
19 \\
75 \\
130\end{array}$ & $\begin{array}{r}13,396 \\
547 \\
273 \\
610 \\
103 \\
4,188 \\
4,913 \\
0 \\
136 \\
430 \\
575 \\
752 \\
57 \\
51 \\
68 \\
145 \\
548\end{array}$ & $\begin{array}{r}8,582 \\
409 \\
144 \\
339 \\
51 \\
2,800 \\
3,210 \\
0 \\
91 \\
428 \\
351 \\
299 \\
28 \\
33 \\
29 \\
61 \\
309\end{array}$ & $\begin{array}{r}4,814 \\
138 \\
129 \\
271 \\
52 \\
1,388 \\
1,703 \\
0 \\
45 \\
2 \\
224 \\
453 \\
29 \\
18 \\
39 \\
84 \\
239\end{array}$ & $\begin{array}{r}2,447 \\
28 \\
125 \\
62 \\
0 \\
533 \\
1,029 \\
0 \\
27 \\
38 \\
279 \\
96 \\
0 \\
15 \\
0 \\
18 \\
197\end{array}$ & $\begin{array}{r}1,857 \\
24 \\
93 \\
34 \\
0 \\
392 \\
793 \\
0 \\
27 \\
38 \\
222 \\
61 \\
0 \\
11 \\
0 \\
14 \\
148\end{array}$ & $\begin{array}{r}590 \\
4 \\
32 \\
28 \\
0 \\
141 \\
236 \\
0 \\
0 \\
0 \\
57 \\
35 \\
0 \\
4 \\
0 \\
4 \\
49\end{array}$ \\
\hline 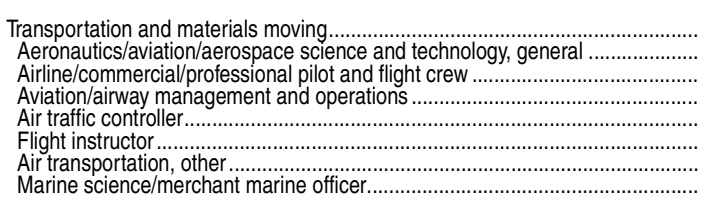 & $\begin{array}{r}4,876 \\
2,718 \\
755 \\
836 \\
222 \\
8 \\
18 \\
319\end{array}$ & $\begin{array}{r}4,305 \\
2,438 \\
674 \\
704 \\
181 \\
7 \\
15 \\
286\end{array}$ & $\begin{array}{r}571 \\
280 \\
81 \\
132 \\
41 \\
1 \\
3 \\
33\end{array}$ & $\begin{array}{r}1,702 \\
149 \\
1,264 \\
242 \\
0 \\
0 \\
47 \\
0\end{array}$ & $\begin{array}{r}1,441 \\
122 \\
1,095 \\
190 \\
0 \\
0 \\
34 \\
0\end{array}$ & $\begin{array}{r}261 \\
27 \\
169 \\
52 \\
0 \\
0 \\
13 \\
0\end{array}$ & $\begin{array}{l}0 \\
0 \\
0 \\
0 \\
0 \\
0 \\
0 \\
0\end{array}$ & $\begin{array}{l}0 \\
0 \\
0 \\
0 \\
0 \\
0 \\
0 \\
0\end{array}$ & $\begin{array}{l}0 \\
0 \\
0 \\
0 \\
0 \\
0 \\
0 \\
0\end{array}$ \\
\hline
\end{tabular}


548 CHAPTER 3: Postsecondary Education

Summary of Degrees Conferred

Table 318.30. Bachelor's, master's, and doctor's degrees conferred by postsecondary institutions, by sex of student and discipline division: 2011-12-Continued

\begin{tabular}{|c|c|c|c|c|c|c|c|c|c|}
\hline \multirow[b]{2}{*}{ Discipline division } & \multicolumn{3}{|c|}{ Bachelor's degrees } & \multicolumn{3}{|c|}{ Master's degrees } & \multicolumn{3}{|c|}{ Doctor's degrees ${ }^{1}$} \\
\hline & Total & Males & Females & Total & Males & Females & Total & Males & Females \\
\hline 1 & 2 & 3 & 4 & 5 & 6 & 7 & 8 & 9 & 10 \\
\hline Visual and performing arts .................. & 95,797 & 37,158 & 58,639 & 17,331 & 7,331 & 10,000 & 1,728 & 790 & 938 \\
\hline 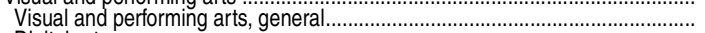 & 1,656 & 624 & 1,032 & 148 & 64 & 84 & 12 & 7 & 5 \\
\hline 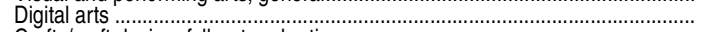 & 373 & 242 & 131 & 103 & 71 & 32 & 0 & 0 & 0 \\
\hline 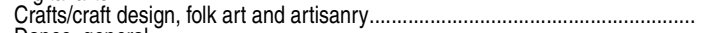 & 125 & 35 & 90 & 2 & 1 & 1 & 0 & 0 & 0 \\
\hline Dance, general & 2,104 & 212 & 1,892 & 237 & 36 & 201 & 10 & 0 & 10 \\
\hline Ballet. & 23 & 3 & 20 & 4 & 0 & 4 & 0 & 0 & 0 \\
\hline Dance, other & 16 & & 15 & 2 & 0 & 2 & 3 & 0 & 3 \\
\hline 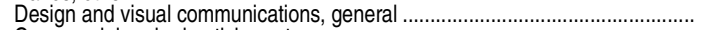 & 3,086 & 1,083 & 2,003 & 510 & 196 & 314 & 3 & 1 & 2 \\
\hline 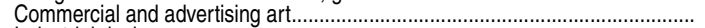 & 1,484 & 554 & 930 & 115 & 50 & 65 & 0 & 0 & 0 \\
\hline Industrial design & 1,476 & 935 & 541 & 179 & 101 & 78 & 0 & 0 & 0 \\
\hline 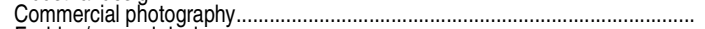 & 415 & 135 & 280 & 12 & 5 & 7 & 0 & 0 & 0 \\
\hline 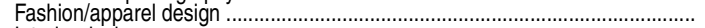 & 2,379 & 194 & 2,185 & 196 & 16 & 180 & 3 & 0 & 3 \\
\hline 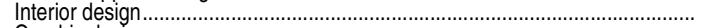 & 3,708 & 311 & 3,397 & 466 & 57 & 409 & 0 & 0 & 0 \\
\hline Graphic design & 5,972 & 2,379 & 3,593 & 235 & 91 & 144 & 0 & 0 & 0 \\
\hline 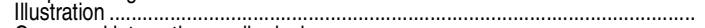 & 1,557 & 592 & 965 & 134 & 64 & 70 & 0 & 0 & 0 \\
\hline 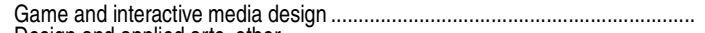 & 1,211 & 1,006 & 205 & 121 & 80 & 41 & 0 & 0 & 0 \\
\hline & 941 & 334 & 607 & 284 & 118 & 166 & 5 & 0 & 5 \\
\hline 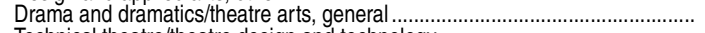 & 9,218 & 3,374 & 5,844 & 1,210 & 495 & 715 & 95 & 43 & 52 \\
\hline 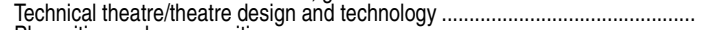 & 571 & 278 & 293 & 142 & 55 & 87 & 0 & 0 & 0 \\
\hline Playwriting and screenwriting & 150 & 91 & 59 & 188 & 97 & 91 & 0 & 0 & 0 \\
\hline 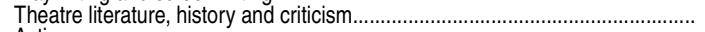 & 33 & 7 & 26 & 8 & 3 & 5 & 1 & 0 & 1 \\
\hline Acting & 596 & 250 & 346 & 205 & 98 & 107 & 0 & 0 & 0 \\
\hline Directing and theatrical production & 63 & 29 & 34 & 83 & 35 & 48 & 0 & 0 & 0 \\
\hline 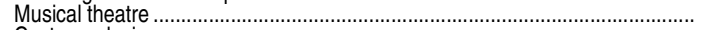 & 306 & 120 & 186 & 0 & 0 & 0 & 0 & 0 & 0 \\
\hline Costume design .................................................... & 10 & 4 & 6 & 3 & 1 & 2 & 0 & 0 & 0 \\
\hline 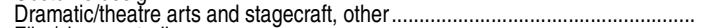 & 313 & 112 & 201 & 44 & 23 & 21 & 4 & 1 & 3 \\
\hline 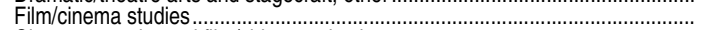 & 3,072 & 1,910 & 1,162 & 382 & 222 & 160 & 41 & 20 & 21 \\
\hline 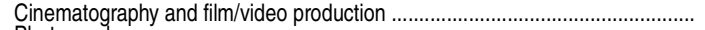 & 4,628 & 3,202 & 1,426 & 813 & 469 & 344 & 5 & 5 & 0 \\
\hline Photography & 1,865 & 596 & 1,269 & 259 & 120 & 139 & 0 & 0 & 0 \\
\hline Documentary production & 11 & 4 & 7 & 10 & 4 & 6 & 0 & 0 & 0 \\
\hline 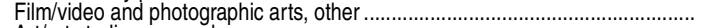 & 928 & 529 & 399 & 92 & 53 & 39 & 0 & 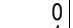 & 0 \\
\hline Art/art studies, general & 12,769 & 3,861 & 8,908 & 804 & 346 & 458 & 12 & 1 & 11 \\
\hline 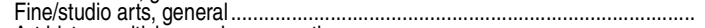 & 10,155 & 3,234 & 6,921 & 1,414 & 622 & 792 & 0 & 0 & 0 \\
\hline 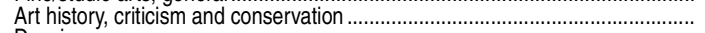 & 3,597 & 429 & 3,168 & 939 & 128 & 811 & 200 & 46 & 154 \\
\hline 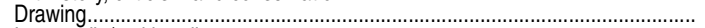 & 300 & 87 & 213 & 31 & 14 & 17 & 0 & 0 & 0 \\
\hline Intermedia/multimedia & 441 & 212 & 229 & 41 & 25 & 16 & 0 & 0 & 0 \\
\hline Painting & 692 & 214 & 478 & 224 & 93 & 131 & 0 & 0 & 0 \\
\hline Sculpture & 322 & 142 & 180 & 70 & 31 & 39 & 0 & 0 & 0 \\
\hline 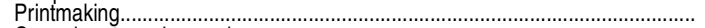 & 179 & 60 & 119 & 55 & 25 & 30 & 0 & 0 & 0 \\
\hline 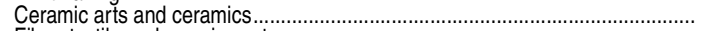 & 209 & 81 & 128 & 52 & 20 & 32 & 0 & 0 & 0 \\
\hline 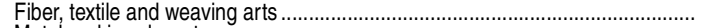 & 203 & 11 & 192 & 47 & 6 & 41 & 2 & 1 & 1 \\
\hline 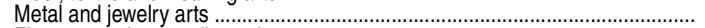 & 129 & 17 & 112 & 34 & 7 & 27 & 0 & 0 & 0 \\
\hline 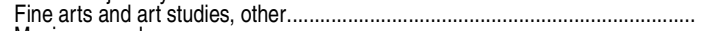 & 1,341 & 439 & 902 & 322 & 105 & 217 & 0 & 0 & 0 \\
\hline 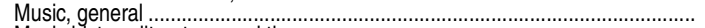 & 7,763 & 4,102 & 3,661 & 1,994 & 1,001 & 993 & 593 & 333 & 260 \\
\hline 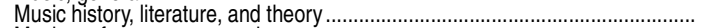 & 113 & 47 & 66 & 45 & 23 & 22 & 19 & 8 & 11 \\
\hline 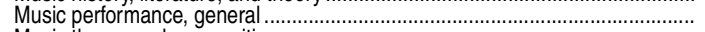 & 4,202 & 2,222 & 1,980 & 2,333 & 1,136 & 1,197 & 402 & 162 & 240 \\
\hline 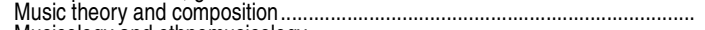 & 508 & 376 & 132 & 273 & 189 & 84 & 68 & 50 & 18 \\
\hline 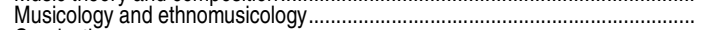 & 42 & 27 & 15 & 60 & 31 & 29 & 52 & 21 & 31 \\
\hline 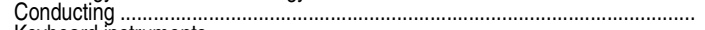 & 5 & 2 & 3 & 115 & 76 & 39 & 29 & 26 & 3 \\
\hline Keyboard instruments & 135 & 61 & 74 & 151 & 48 & 103 & 46 & 12 & 4 \\
\hline Voice and opera & 306 & 96 & 210 & 209 & 64 & 145 & 16 & 5 & 11 \\
\hline 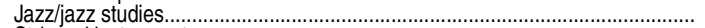 & 301 & 253 & 48 & 151 & 127 & 24 & 6 & 6 & 0 \\
\hline Stringed instruments & 196 & 101 & 95 & 192 & 91 & 101 & 36 & 14 & 22 \\
\hline Music pedagogy & 68 & 20 & 48 & 50 & 11 & 39 & 16 & 4 & 12 \\
\hline 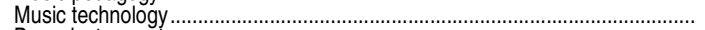 & 111 & 88 & 23 & 17 & 15 & 2 & 0 & 0 & 0 \\
\hline 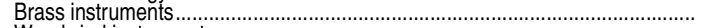 & 21 & 17 & 4 & 25 & 17 & 8 & 3 & 2 & 1 \\
\hline Woodwind instruments & 40 & 25 & 15 & 48 & 17 & 31 & 3 & 2 & 1 \\
\hline 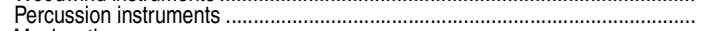 & 23 & 19 & 4 & 7 & 5 & 2 & 1 & 1 & 0 \\
\hline 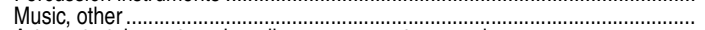 & 754 & 463 & 291 & 290 & 174 & 116 & 19 & 12 & 7 \\
\hline Arts, entertainment, and media management, general ............. & 161 & 52 & 109 & 159 & 32 & 127 & 0 & 0 & 0 \\
\hline Fine and studio arts management & 623 & 231 & 392 & 457 & 73 & 384 & 0 & 0 & 0 \\
\hline 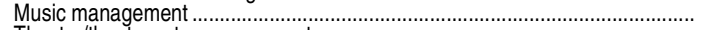 & 1,253 & 771 & 482 & 0 & 0 & 0 & 0 & 0 & 0 \\
\hline Theatre/theatre arts management & 83 & 30 & 53 & 50 & 8 & 42 & 0 & 0 & 0 \\
\hline 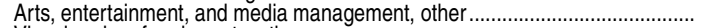 & 21 & 8 & 13 & 1 & 0 & 1 & 0 & 0 & 0 \\
\hline 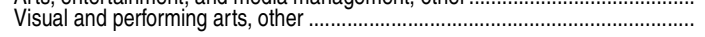 & 441 & 214 & 227 & 484 & 146 & 338 & 23 & 7 & 16 \\
\hline Not classified by field of study ..... & 0 & 0 & 0 & 0 & 0 & 0 & 0 & 0 & 0 \\
\hline
\end{tabular}

IIncludes Ph.D., Ed.D., and comparable degrees at the doctoral level. Includes most degrees formerly classified as first-professional, such as M.D., D.D.S., and law degrees.

NOTE: Data are for postsecondary institutions participating in Title IV federal financial aid programs. Aggregations by field of study derived from the Classification of Instructional Programs developed by the National Center for Education Statistics.
SOURCE: U.S. Department of Education, National Center for Education Statistics, Integrated Postsecondary Education Data System (IPEDS), Fall 2012, Completions component. (This table was prepared July 2013.) 
Table 318.40. Degrees/certificates conferred by postsecondary institutions, by control of institution and level of degree: 1969-70 through 2011-12

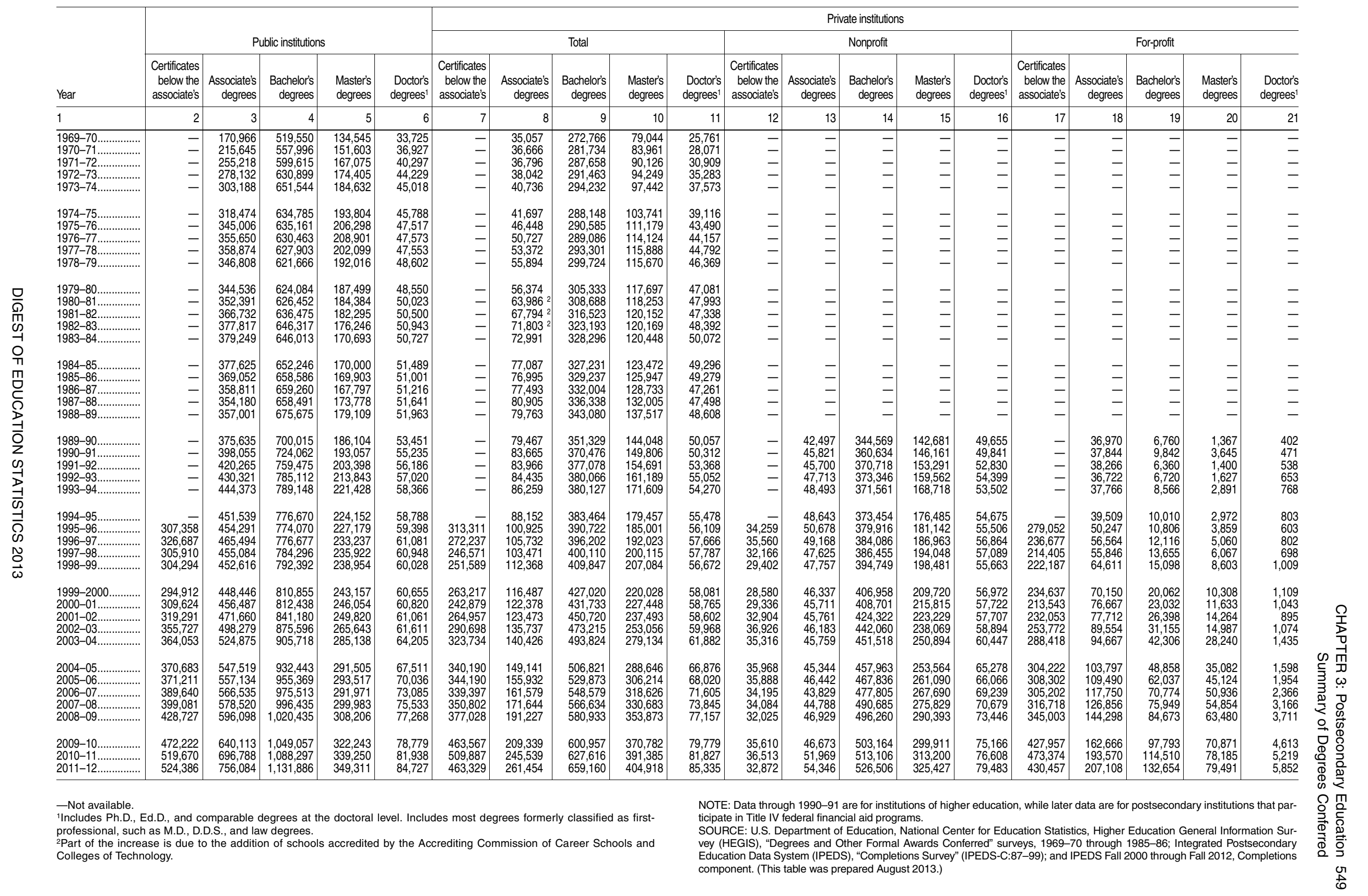


Table 318.50. Degrees conferred by postsecondary institutions, by control of institution, level of degree, and field of study: 2011-12

\begin{tabular}{|c|c|c|c|c|c|c|c|c|c|c|c|c|c|c|c|c|}
\hline \multirow[b]{2}{*}{ Field of study } & \multicolumn{4}{|c|}{ All institutions } & \multicolumn{4}{|c|}{ Public institutions } & \multicolumn{4}{|c|}{ Private nonprofit institutions } & \multicolumn{4}{|c|}{ Private for-profit institutions } \\
\hline & $\begin{array}{r}\text { Associate's } \\
\text { degrees }\end{array}$ & $\begin{array}{r}\text { Bachelor's } \\
\text { degrees }\end{array}$ & $\begin{array}{l}\text { Master's } \\
\text { degrees }\end{array}$ & $\begin{array}{r}\text { Doctor's } \\
\text { degrees }^{1}\end{array}$ & $\begin{array}{r}\text { Associate's } \\
\text { degrees }\end{array}$ & $\begin{array}{r}\text { Bachelor's } \\
\text { degrees }\end{array}$ & $\begin{array}{l}\text { Master's } \\
\text { degrees }\end{array}$ & $\begin{array}{r}\text { Doctor's } \\
\text { degrees }^{1}\end{array}$ & $\begin{array}{r}\text { Associate's } \\
\text { degrees }\end{array}$ & $\begin{array}{r}\text { Bachelor's } \\
\text { degrees }\end{array}$ & $\begin{array}{l}\text { Master's } \\
\text { degrees }\end{array}$ & $\begin{array}{r}\text { Doctor's } \\
\text { degrees }^{1}\end{array}$ & $\begin{array}{r}\text { Associate's } \\
\text { degrees }\end{array}$ & $\begin{array}{r}\text { Bachelor's } \\
\text { degrees }\end{array}$ & $\begin{array}{l}\text { Master's } \\
\text { degrees }\end{array}$ & $\begin{array}{r}\text { Doctor's } \\
\text { degrees }\end{array}$ \\
\hline 1 & 2 & 3 & 4 & 5 & 6 & 7 & 8 & 9 & 10 & 11 & 12 & 13 & 14 & 15 & 16 & 17 \\
\hline 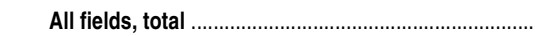 & $1,017,538$ & $1,791,046$ & 754,229 & 170,062 & 756,084 & $1,131,886$ & 349,311 & 84,727 & 54,346 & 526,506 & 325,427 & 79,483 & 207,108 & 132,654 & 79,491 & 5,852 \\
\hline 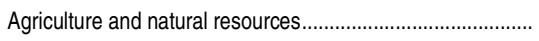 & 7,066 & 30,929 & 6,390 & 1,333 & 6,785 & 25,963 & 4,985 & 1,255 & 281 & 4,644 & 1,315 & 78 & 0 & 322 & 90 & $\overline{0}$ \\
\hline Architecture and related services....... & 593 & 9,728 & 8,448 & 255 & 562 & 7,055 & 5,207 & 190 & 31 & 2,620 & 3,140 & 65 & 0 & 53 & 101 & 0 \\
\hline Area, ethnic, cultural, gender, and group studies ............... & 194 & 9,232 & 1,947 & 302 & 181 & 6,012 & 1,156 & 180 & 13 & 3,219 & 791 & 122 & 0 & 1 & 0 & 0 \\
\hline Biological and biomedical sciences.. & 3,834 & 95,849 & 12,415 & 7,935 & 3,694 & 65,732 & 7,525 & 5,300 & 138 & 29,979 & 4,890 & 2,635 & 2 & 138 & 0 & 0 \\
\hline 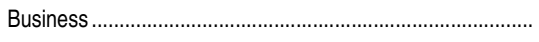 & 142,338 & 366,815 & 191,571 & 2,531 & 83,893 & 202,276 & 66,464 & 961 & 11,585 & 111,974 & 88,410 & 689 & 46,860 & 52,565 & 36,697 & 881 \\
\hline Communication, journalism, and related programs ...... & 3,495 & 83,770 & 9,005 & 563 & 3,243 & 58,473 & 4,032 & 465 & 102 & 23,876 & 4,756 & 98 & 150 & 1,421 & 217 & 0 \\
\hline Communications technologies..................... & 5,000 & 4,982 & 491 & 4 & 3,198 & 1,285 & 85 & 0 & 162 & 1,415 & 239 & 4 & 1,640 & 2,282 & 167 & 0 \\
\hline Computer and information sciences................................. & 41,161 & 47,384 & 20,917 & 1,698 & 20,422 & 23,176 & 10,510 & 1,170 & 1,879 & 11,132 & 8,269 & 498 & 18,860 & 13,076 & 2,138 & 30 \\
\hline Construction trades .. & 5,752 & 377 & 5 & 0 & 4,563 & 359 & 5 & 0 & 212 & 17 & 0 & 0 & 977 & 1 & 0 & 0 \\
\hline 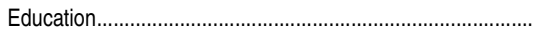 & 20,531 & 105,785 & 178,062 & 9,990 & 16,499 & 73,277 & 85,247 & 5,676 & 738 & 29,283 & 76,115 & 3,009 & 3,294 & 3,225 & 16,700 & 1,305 \\
\hline Engineering ... & 3,382 & 81,382 & 40,323 & 8,722 & 3,310 & 62,850 & 26,883 & 6,404 & 29 & 18,218 & 13,191 & 2,318 & 43 & 314 & 249 & 0 \\
\hline Engineering technologies and engineering-related fields ${ }^{2} \ldots$. & 36,510 & 16,531 & 4,769 & 134 & 24,097 & 12,894 & 2,874 & 56 & 1,398 & 1,782 & 1,632 & 78 & 11,015 & 1,855 & 263 & 0 \\
\hline English language and literature/letters ............... & 2,137 & 53,767 & 9,939 & 1,427 & 1,518 & 37,640 & 6,282 & 1,084 & 21 & 15,859 & 3,468 & 343 & 598 & 268 & 189 & 0 \\
\hline Family and consumer sciences ......................................... & 9,503 & 23,428 & 3,157 & 325 & 8,821 & 19,221 & 1,983 & 270 & 452 & 3,949 & 842 & 45 & 230 & 258 & 332 & 10 \\
\hline Foreign languages, literatures, and linguistics..... & 1,980 & 21,764 & 3,827 & 1,231 & 1,689 & 15,559 & 2,778 & 786 & 291 & 6,198 & 1,049 & 445 & 0 & 7 & 0 & 0 \\
\hline Health profes & 218,041 & 163,440 & 83,893 & 62,090 & 129,382 & 91,828 & 38,206 & 1,830 & 18,059 & 52,023 & 35,123 & 29,282 & 70,600 & 19,589 & 10,564 & 978 \\
\hline Homeland security, law enforcement, and firefighting ............ & 50,695 & 53,767 & 8,402 & 117 & 28,921 & 30,599 & 3,236 & 85 & 1,922 & 11,250 & 2,645 & 5 & 19,852 & 11,918 & 2,521 & 27 \\
\hline Legal professions and studies .................... & 12,182 & 4,592 & 6,614 & 46,836 & 6,350 & 2,299 & 1,694 & 15,554 & 680 & 1,272 & 4,728 & 29,686 & 5,152 & 1,021 & 192 & 1,596 \\
\hline Liberal arts and sciences, general studies, and humanities .. & 336,554 & 46,925 & 3,791 & 93 & 322,318 & 32,304 & 1,396 & 43 & 10,641 & 14,394 & 2,343 & 22 & 3,595 & 227 & 52 & 28 \\
\hline Library science & 159 & 95 & 7,441 & 60 & 159 & 95 & 6,146 & 59 & 0 & 0 & 1,295 & 1 & 0 & 0 & 0 & 0 \\
\hline Mathe & 1,529 & 18,842 & 6,245 & 1,669 & 1,514 & 12,776 & 4,496 & 1,248 & 15 & 6,065 & 1,749 & 421 & 0 & 1 & 0 & 0 \\
\hline Mechanic and repair technologies/technicians.... & 20,714 & 250 & 0 & 0 & 12,566 & 178 & 0 & 0 & 1,726 & 72 & 0 & 0 & 6,422 & 0 & 0 & 0 \\
\hline Military technologies and applied sciences ....................... & 986 & 86 & 29 & 0 & 959 & 57 & 27 & 0 & 13 & 7 & 2 & 0 & 14 & 22 & 0 & 0 \\
\hline Multi/interdisciplinary studies....... & 27,267 & 45,716 & 7,745 & 727 & 21,692 & 31,063 & 4,249 & 490 & 270 & 9,763 & 2,845 & 237 & 5,305 & 4,890 & 651 & 0 \\
\hline Parks, recreation, leisure and fitness studies .................. & 3,123 & 38,993 & 7,047 & 288 & 1,940 & 28,756 & 5,086 & 271 & 244 & 9,873 & 1,797 & 17 & 939 & 364 & 164 & 0 \\
\hline Philosc & 308 & 12,651 & 2,003 & 778 & 135 & 5,735 & 664 & 351 & 173 & 6,735 & 1,220 & 426 & 0 & 181 & 119 & 1 \\
\hline 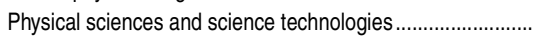 & 5,824 & 26,663 & 6,910 & 5,370 & 5,742 & 18,643 & 5,237 & 3,827 & 81 & 8,016 & 1,673 & 1,543 & 1 & 4 & 0 & 0 \\
\hline Precision production ............................ & 3,320 & 37 & 11 & 0 & 2,975 & 8 & 0 & 0 & 88 & 29 & 11 & 0 & 257 & 0 & 0 & 0 \\
\hline Psychology .... & 4,717 & 108,986 & 26,834 & 5,928 & 4,372 & 72,921 & 8,282 & 2,398 & 275 & 32,754 & 14,103 & 2,660 & 70 & 3,311 & 4,449 & 870 \\
\hline Public administration and social service professions.............. & 9,143 & 29,695 & 41,680 & 884 & 5,752 & 18,017 & 24,694 & 513 & 474 & 8,517 & 15,164 & 253 & 2,917 & 3,161 & 1,822 & 118 \\
\hline Social & 14,132 & 178,543 & 21,889 & 4,597 & 14,007 & 121,679 & 11,898 & 3,046 & 95 & 54,181 & 9,410 & 1,551 & 30 & 2,683 & 301 & 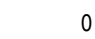 \\
\hline & 13,321 & 143,422 & 17,734 & 3,628 & 13,227 & & 9,068 & 2,404 & 83 & 43,353 & 8,422 & 1,224 & 11 & 2,326 & 244 & 0 \\
\hline & 811 & 35,121 & 4,155 & 969 & 780 & 23,936 & 2,830 & 642 & 12 & 10,828 & 988 & 327 & 19 & 357 & 337 & 0 \\
\hline Theology and religious vocations ............ & 839 & 9,369 & 13,396 & 2,447 & 1 & 1 & 0 & 0 & 817 & 9,286 & 13,341 & 2,441 & 21 & 82 & 55 & 6 \\
\hline Transportation and materials moving.......................................... & 2,098 & 4,876 & 1,702 & 0 & 1,591 & 2,204 & 86 & 0 & 430 & 2,552 & 1,561 & 0 & 77 & 120 & 55 & 0 \\
\hline Visual and performing arts & 22,431 & 95,797 & 17,331 & 1,728 & 13,233 & 50,951 & 7,898 & 1,215 & 1,011 & 35,552 & 8,310 & 511 & 8,187 & 9,294 & 1,123 & 2 \\
\hline
\end{tabular}

IIncludes Ph.D., Ed.D., and comparable degrees at the doctoral level, as well as such degrees as M.D., D.D.S., and law degrees that were formerly classified as first-professional degrees.

"Excludes "Construction trades" and Mechanic and repair technologies/technicians," which are listed separately.

NOTE: Data are for postsecondary institutions participating in Tite IV federal financial aid programs. To facilitate trend com-
Data System (IPEDS): "Agriculture and natural resources" includes Agriculture, agriculture operations, and related sciences and Natural resources and conservation; and "Business" includes Business management, marketing, and related support services and Personal and culinary services.

nal Center for Education Statistics, Integrated Postsecondary Education Data System (IPEDS), Fall 2012, Completions component. (This table was prepared July 2013.) 
Table 318.60. Number of postsecondary institutions conferring degrees, by control, level of degree, and field of study: 2011-12

\begin{tabular}{|c|c|c|c|c|c|c|c|c|c|c|c|c|c|c|c|c|}
\hline \multirow[b]{2}{*}{ Field of study } & \multicolumn{4}{|c|}{ All institutions } & \multicolumn{4}{|c|}{ Public institutions } & \multicolumn{4}{|c|}{ Private nonprofit institutions } & \multicolumn{4}{|c|}{ Private for-profit institutions } \\
\hline & $\begin{array}{r}\text { Associate's } \\
\text { degrees }\end{array}$ & $\begin{array}{r}\text { Bachelor's } \\
\text { degrees }\end{array}$ & $\begin{array}{l}\text { Master's } \\
\text { degrees }\end{array}$ & $\begin{array}{r}\text { Doctor's } \\
\text { degrees }^{1}\end{array}$ & $\begin{array}{r}\text { Associate's } \\
\text { degrees }\end{array}$ & $\begin{array}{r}\text { Bachelor's } \\
\text { degrees }\end{array}$ & $\begin{array}{l}\text { Master's } \\
\text { degrees }\end{array}$ & $\begin{array}{r}\text { Doctor's } \\
\text { degrees }^{1}\end{array}$ & $\begin{array}{r}\text { Associate's } \\
\text { degrees }\end{array}$ & $\begin{array}{r}\text { Bachelor's } \\
\text { degrees }\end{array}$ & $\begin{array}{r}\text { Master's } \\
\text { degrees }\end{array}$ & $\begin{array}{r}\text { Doctor's } \\
\text { degrees }^{1}\end{array}$ & $\begin{array}{r}\text { Associate's } \\
\text { degrees }\end{array}$ & $\begin{array}{r}\text { Bachelor's } \\
\text { degrees }\end{array}$ & $\begin{array}{l}\text { Master's } \\
\text { degrees }\end{array}$ & $\begin{array}{r}\text { Doctor's } \\
\text { degrees }^{1}\end{array}$ \\
\hline 1 & 2 & 3 & 4 & 5 & 6 & 7 & 8 & 9 & 10 & 11 & 12 & 13 & 14 & 15 & 16 & 17 \\
\hline All fields, total .................................................... & 2,968 & 2,533 & 1,881 & 885 & 1,248 & 645 & 526 & 316 & 589 & 1,303 & 1,090 & 520 & 1,131 & 585 & 265 & 49 \\
\hline Agriculture and natural resources............................................... & 483 & 677 & 231 & 98 & 458 & 313 & 175 & 92 & 25 & 358 & 55 & 6 & 0 & 6 & 1 & 0 \\
\hline Architecture and related services ............................................. & 75 & 192 & 147 & 38 & 72 & 119 & 96 & 28 & 3 & 71 & 49 & 10 & 0 & 2 & 2 & 0 \\
\hline Area, ethnic, cultural, gender, and group studies ................... & 58 & 484 & 139 & 51 & 52 & 235 & 88 & 34 & 6 & 248 & 51 & 17 & 0 & 1 & 0 & 0 \\
\hline 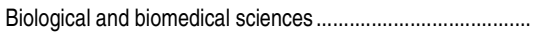 & 271 & 1,338 & 488 & 256 & 251 & 518 & 349 & 179 & 19 & 812 & 139 & 77 & 1 & 8 & 0 & 0 \\
\hline 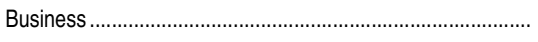 & 1,938 & 1,987 & 1,211 & 191 & 1,097 & 583 & 420 & 97 & 264 & 925 & 580 & 66 & 577 & 479 & 211 & 28 \\
\hline Communication, journalism, and related programs ................. & 293 & 1,157 & 324 & 71 & 250 & 448 & 209 & 56 & 31 & 669 & 111 & 15 & 12 & 40 & 4 & 0 \\
\hline Communications technologies $\ldots \ldots \ldots \ldots \ldots \ldots \ldots \ldots \ldots \ldots \ldots \ldots \ldots \ldots$ & 326 & 207 & 16 & 1 & 283 & 49 & 5 & 0 & 9 & 73 & 9 & 1 & 34 & 85 & 2 & 0 \\
\hline 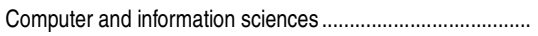 & 1,513 & 1,514 & 490 & 169 & 902 & 509 & 286 & 114 & 90 & 667 & 150 & 53 & 521 & 338 & 54 & 2 \\
\hline 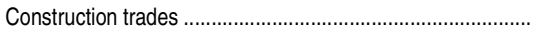 & 345 & 16 & 1 & 0 & 311 & 14 & 1 & 0 & 10 & 1 & 0 & 0 & 24 & 1 & 0 & 0 \\
\hline Education & 745 & 1,243 & 1,166 & 383 & 637 & 458 & 465 & 219 & 81 & 757 & 624 & 140 & 27 & 28 & 77 & 24 \\
\hline Engineering .............. & 324 & 498 & 320 & 208 & 311 & 277 & 209 & 151 & 7 & 203 & 104 & 57 & 6 & 18 & 7 & 0 \\
\hline Engineering technologies and engineering-related fields ${ }^{2} \ldots$ & 1,162 & 372 & 163 & 20 & 855 & 219 & 115 & 12 & 49 & 60 & 46 & 8 & 258 & 93 & 2 & 0 \\
\hline English language and literature/letters ....................................... & 178 & 1,325 & 483 & 152 & 169 & 508 & 319 & 103 & 8 & 810 & 162 & 49 & 1 & 7 & 2 & 0 \\
\hline Family and consumer sciences/human sciences .................. & 573 & 342 & 158 & 46 & 540 & 198 & 113 & 37 & 22 & 137 & 43 & 8 & 11 & 7 & 2 & 1 \\
\hline Foreign languages, literatures, and linguistics....... & 195 & 925 & 228 & 100 & 186 & 414 & 166 & 67 & 9 & 509 & 62 & 33 & 0 & 2 & 0 & 0 \\
\hline Health professions and related programs... & 1,968 & 1,383 & 974 & 457 & 1,071 & 517 & 382 & 218 & 205 & 663 & 480 & 223 & 692 & 203 & 112 & 16 \\
\hline Homeland security, law enforcement, and firefighting ........... & 1,384 & 994 & 268 & 21 & 856 & 336 & 150 & 18 & 93 & 371 & 90 & 2 & 435 & 287 & 28 & 1 \\
\hline Legal professions and studies ........................................... & 818 & 240 & 136 & 208 & 426 & 70 & 51 & 83 & 50 & 108 & 80 & 117 & 342 & 62 & 5 & 8 \\
\hline Liberal arts and sciences, general studies, and humanities .. & 1,390 & 917 & 186 & 12 & 1,084 & 385 & 94 & 6 & 269 & 506 & 90 & 5 & 37 & 26 & 2 & 1 \\
\hline 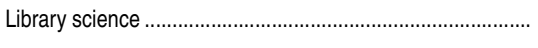 & 34 & 7 & 66 & 12 & 34 & 7 & 53 & 11 & 0 & 0 & 13 & 1 & 0 & 0 & 0 & 0 \\
\hline Mathematics and statistics ....... & 197 & 1,190 & 351 & 173 & 189 & 492 & 271 & 123 & 8 & 697 & 80 & 50 & 0 & 1 & 0 & 0 \\
\hline Mechanic and repair technologies/technicians...................... & 702 & 20 & 0 & 0 & 613 & 12 & 0 & 0 & 26 & 8 & 0 & 0 & 63 & 0 & 0 & 0 \\
\hline 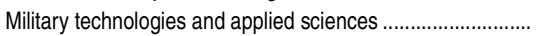 & 13 & 5 & 2 & 0 & 8 & 2 & 1 & 0 & 3 & 2 & 1 & 0 & 2 & 1 & 0 & 0 \\
\hline 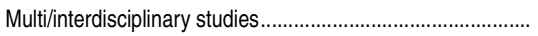 & 371 & 905 & 322 & 110 & 341 & 343 & 189 & 77 & 18 & 521 & 131 & 33 & 12 & 41 & 2 & 0 \\
\hline 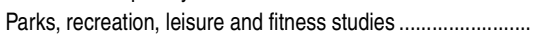 & 264 & 811 & 256 & 45 & 220 & 333 & 185 & 41 & 15 & 464 & 65 & 4 & 29 & 14 & 6 & 0 \\
\hline Philosophy and religious studies ............................. & 61 & 932 & 223 & 115 & 43 & 316 & 94 & 57 & 18 & 614 & 128 & 57 & 0 & 2 & 1 & 1 \\
\hline 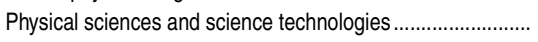 & 358 & 1,085 & 338 & 214 & 345 & 477 & 249 & 148 & 12 & 607 & 89 & 66 & 1 & 1 & 0 & 0 \\
\hline Precision production & 351 & 7 & 2 & 0 & 333 & 1 & 0 & 0 & 9 & 6 & 2 & 0 & 9 & 0 & 0 & 0 \\
\hline Psychology & 206 & 1,414 & 658 & 305 & 189 & 515 & 319 & 150 & 16 & 861 & 309 & 133 & 1 & 38 & 30 & 22 \\
\hline 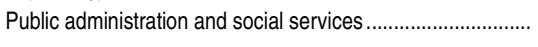 & 352 & 788 & 483 & 120 & 304 & 337 & 298 & 79 & 28 & 406 & 158 & 39 & 20 & 45 & 27 & 2 \\
\hline Social sciences and history. & 265 & 1,365 & 469 & 187 & 239 & 524 & 316 & 130 & 23 & 822 & 150 & 57 & 3 & 19 & 3 & 0 \\
\hline 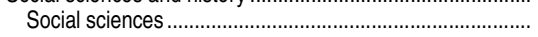 & 250 & 1,266 & 389 & 172 & 226 & 510 & 264 & 120 & 22 & 739 & 123 & 52 & 2 & 17 & 2 & 0 \\
\hline 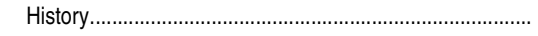 & 107 & 1,233 & 362 & 141 & 101 & 486 & 274 & 96 & 5 & 741 & 86 & 45 & 1 & 6 & 2 & 0 \\
\hline Theology and religious vocations & 90 & 415 & 355 & 151 & 1 & 1 & 0 & 0 & 87 & 411 & 354 & 150 & 2 & 3 & 1 & 1 \\
\hline 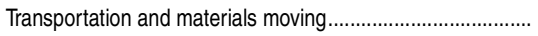 & 106 & 83 & 14 & 0 & 91 & 50 & 5 & 0 & 10 & 29 & 7 & 0 & 5 & 4 & 2 & 0 \\
\hline Visual and performing arts & 891 & 1,455 & 453 & 111 & 579 & 493 & 258 & 73 & 57 & 833 & 183 & 37 & 255 & 129 & 12 & 1 \\
\hline
\end{tabular}

IIncludes Ph.D., Ed.D., and comparable degrees at the doctoral level, as well as such degrees as M.D., D.D.S., and law

degrees that were formerly classified as first-professional degrees.
2Excludes "Construction trades" and "Mechanic and repair technologies/technicians," which are listed separately.

NOTE: Data are for postsecondary institutions participaling in Title IV tederal financial aid programs. To facilitate trend cation Data System (IPEDS): "Agriculture and natural resources" includes Agriculture, agriculture operations, and related sciences and Natural resources and conservation; and "Business" includes Business management, marketing, and related support services and Personal and culinary services. 
Table 319.10. Degrees conferred by postsecondary institutions, by control, level of degree, and state or jurisdiction: 2011-12

\begin{tabular}{|c|c|c|c|c|c|c|c|c|c|c|c|c|}
\hline \multirow[b]{2}{*}{ State or jurisdiction } & \multicolumn{4}{|c|}{ Public } & \multicolumn{4}{|c|}{ Private nonprofit } & \multicolumn{4}{|c|}{ Private for-profit } \\
\hline & $\begin{array}{r}\text { Associate's } \\
\text { degrees }\end{array}$ & $\begin{array}{r}\text { Bachelor's } \\
\text { degrees }\end{array}$ & $\begin{array}{l}\text { Master's } \\
\text { degrees }\end{array}$ & $\begin{array}{r}\text { Doctor's } \\
\text { degrees }^{1}\end{array}$ & $\begin{array}{r}\text { Associate's } \\
\text { degrees }\end{array}$ & $\begin{array}{r}\text { Bachelor's } \\
\text { degrees }\end{array}$ & $\begin{array}{c}\text { Master's } \\
\text { degrees }\end{array}$ & $\begin{array}{r}\text { Doctor's } \\
\text { degrees }^{1}\end{array}$ & $\begin{array}{r}\text { Associate's } \\
\text { degrees }\end{array}$ & $\begin{array}{r}\text { Bachelor's } \\
\text { degrees }\end{array}$ & $\begin{array}{l}\text { Master's } \\
\text { degrees }\end{array}$ & $\begin{array}{r}\text { Doctor's } \\
\text { degrees }^{1}\end{array}$ \\
\hline 1 & 2 & 3 & 4 & 5 & 6 & 7 & 8 & 9 & 10 & 11 & 12 & 13 \\
\hline United States .............................. & 756,084 & $1,131,886$ & 349,311 & 84,727 & 54,346 & 526,506 & 325,427 & 79,483 & 207,108 & 132,654 & 79,491 & 5,852 \\
\hline Alabama & 10,284 & 21,529 & 9,288 & 1,733 & 144 & 3,619 & 674 & 520 & 2,724 & 2,291 & 1,440 & $\overline{3}$ \\
\hline 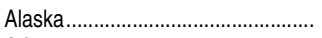 & 1,120 & 1,612 & 650 & 50 & 15 & 80 & 53 & 0 & 571 & 58 & 0 & 0 \\
\hline Arizona & 16,823 & 23,775 & 7,121 & 1,787 & 8 & 937 & 1,298 & 595 & 46,159 & 39,995 & 27,759 & 1,151 \\
\hline 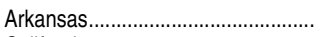 & 8,122 & 11,458 & 4,775 & 855 & 121 & 2,558 & 487 & 58 & 402 & 173 & 58 & 0 \\
\hline 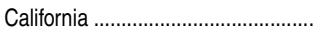 & 89,284 & 125,326 & 29,548 & 6,900 & 1,189 & 34,681 & 33,074 & 10,141 & 24,139 & 12,403 & 5,880 & 407 \\
\hline Colorado ......... & 7,814 & 22,575 & 6,980 & 1,668 & 351 & 3,996 & 4,655 & 589 & 8,774 & 4,565 & 3,771 & 95 \\
\hline 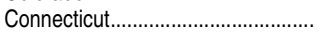 & 5,420 & 11,145 & 3,253 & 801 & 832 & 9,112 & 6,021 & 1,153 & 259 & 453 & 183 & 0 \\
\hline 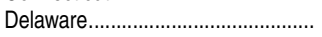 & 1,735 & 4,040 & 897 & 277 & 199 & 1,821 & 1,764 & 308 & 13 & 24 & 19 & 0 \\
\hline 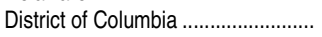 & 170 & 398 & 65 & 93 & 156 & 8,439 & 9,841 & 3,474 & 137 & 375 & 307 & 0 \\
\hline 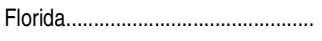 & 79,362 & 61,446 & 17,149 & 4,395 & 7,419 & 22,527 & 13,376 & 3,895 & 15,778 & 7,006 & 3,334 & 1,195 \\
\hline Georgia... & 14,496 & 33,656 & 10,928 & 2,341 & 1,212 & 9,886 & 4,923 & 1,542 & 3,020 & 2,679 & 1,939 & 385 \\
\hline 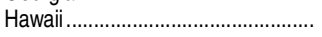 & 3,054 & 4,055 & 1,287 & 494 & 554 & 1,858 & 685 & 0 & 591 & 103 & 143 & 39 \\
\hline 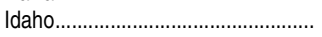 & 2,847 & 5,980 & 1,765 & 331 & 1,385 & 3,667 & 248 & 0 & 708 & 134 & 28 & 0 \\
\hline 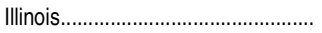 & 32,516 & 34,658 & 12,630 & 2,970 & 1,687 & 30,227 & 26,245 & 5,007 & 7,415 & 7,570 & 4,763 & 152 \\
\hline Indiana & 12,267 & 29,853 & 9,275 & 2,549 & 1,822 & 14,752 & 4,757 & 913 & 5,341 & 927 & 183 & 0 \\
\hline lowa ........... & 12,735 & 11,672 & 2,976 & 1,480 & 645 & 10,558 & 2,264 & 1,353 & 7,135 & 18,446 & 6,860 & 124 \\
\hline 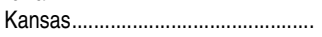 & 8,925 & 15,004 & 5,306 & 1,324 & 624 & 3,935 & 1,702 & 128 & 669 & 60 & 13 & 0 \\
\hline 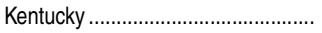 & 9,757 & 16,202 & 6,057 & 1,631 & 727 & 4,667 & 2,996 & 215 & 4,196 & 662 & 358 & 89 \\
\hline 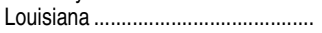 & 5,938 & 18,582 & 5,142 & 1,583 & 595 & 3,202 & 1,994 & 1,002 & 1,174 & 231 & 139 & 0 \\
\hline 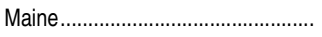 & 2,593 & 4,581 & 927 & 153 & 230 & 3,098 & 970 & 230 & 498 & 5 & 0 & 0 \\
\hline 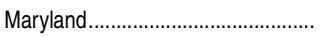 & 14,250 & 23,931 & 9,892 & 2,142 & 18 & 6,401 & 7,626 & 680 & 888 & 531 & 327 & 0 \\
\hline 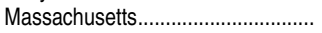 & 10,998 & 18,121 & 5,823 & 678 & 1,589 & 37,246 & 30,038 & 7,468 & 1,058 & 456 & 94 & 0 \\
\hline Michigan & 27,059 & 43,645 & 16,582 & 4,008 & 4,838 & 13,591 & 4,709 & 1,876 & 1,425 & 579 & 101 & 0 \\
\hline 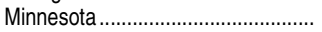 & 16,575 & 21,319 & 5,349 & 1,703 & 700 & 10,850 & 5,043 & 1,163 & 3,205 & 2,811 & 10,217 & 1,417 \\
\hline 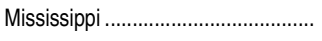 & 12,305 & 11,214 & 3,452 & 1,050 & 61 & 2,302 & 1,355 & 167 & 630 & 0 & 2 & 0 \\
\hline 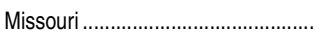 & 11,575 & 20,984 & 6,808 & 1,446 & 2,959 & 17,867 & 13,557 & 3,223 & 5,361 & 4,837 & 614 & 0 \\
\hline 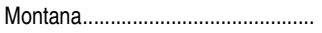 & 2,201 & 4,680 & 1,209 & 372 & 163 & 704 & 77 & 0 & 0 & 0 & 0 & 0 \\
\hline 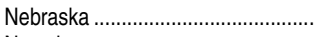 & 4,870 & 8,401 & 2,764 & 732 & 249 & 5,675 & 2,397 & 660 & 642 & 172 & 17 & 0 \\
\hline Nevada & 3,853 & 6,625 & 1,880 & 573 & 0 & 309 & 361 & 377 & 1,497 & 705 & 363 & 0 \\
\hline 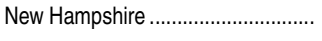 & 2,143 & 5,244 & 1,170 & 67 & 377 & 3,637 & 2,632 & 413 & 599 & 389 & 23 & 0 \\
\hline 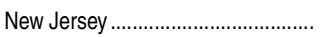 & 20,516 & 29,144 & 8,544 & 2,177 & 195 & 9,847 & 6,871 & 945 & 932 & 813 & 75 & 0 \\
\hline 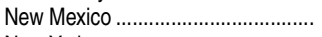 & 6,992 & 7,281 & 2,881 & 614 & 0 & 110 & 151 & 0 & 717 & 868 & 227 & 0 \\
\hline 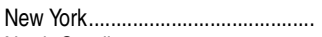 & 50,397 & 58,090 & 19,653 & 2,919 & 8,907 & 67,696 & 50,855 & 11,888 & 10,350 & 3,640 & 898 & 2 \\
\hline 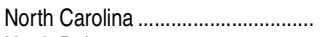 & 24,874 & 35,589 & 11,445 & 2,300 & 1,252 & 14,361 & 4,922 & 1,891 & 1,546 & 772 & 581 & 229 \\
\hline 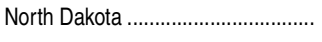 & 1,972 & 5,060 & 1,244 & 443 & 244 & 616 & 481 & 37 & 35 & 3 & 0 & 0 \\
\hline Ohio & 23,897 & 44,626 & 15,324 & 4,373 & 2,829 & 21,094 & 8,326 & 1,619 & 9,145 & 1,016 & 498 & 0 \\
\hline Oklahoma & 9,824 & 15,965 & 5,164 & 1,319 & 198 & 3,653 & 1,260 & 409 & 1,491 & 228 & 57 & 0 \\
\hline Oregon & 11,212 & 15,800 & 4,228 & 1,003 & 55 & 4,827 & 3,238 & 907 & 1,370 & 487 & 75 & 0 \\
\hline 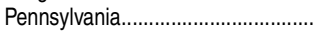 & 16,988 & 46,493 & 12,009 & 3,429 & 3,065 & 42,326 & 24,397 & 5,946 & 9,822 & 1,850 & 379 & 0 \\
\hline 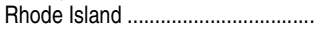 & 1,545 & 3,921 & 811 & 234 & 1,992 & 7,093 & 1,755 & 511 & 0 & 0 & 0 & 0 \\
\hline South Carolina & 8,953 & 16,566 & 4,367 & 1,313 & 429 & 5,275 & 1,140 & 53 & 1,408 & 1,132 & 465 & 238 \\
\hline 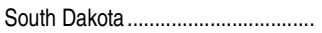 & 2,119 & 4,040 & 1,084 & 353 & 213 & 1,002 & 225 & 0 & 367 & 350 & 158 & 0 \\
\hline 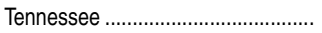 & 9,497 & 19,981 & 5,885 & 1,763 & 744 & 11,363 & 5,648 & 1,376 & 3,307 & 965 & 396 & 13 \\
\hline 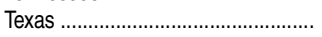 & 59,683 & 89,186 & 35,319 & 7,499 & 1,300 & 19,775 & 9,035 & 2,571 & 6,369 & 2,363 & 953 & 34 \\
\hline 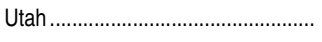 & 10,662 & 14,426 & 3,429 & 817 & 469 & 11,185 & 3,613 & 239 & 2,170 & 943 & 627 & 128 \\
\hline Vermont & 923 & 3,517 & 522 & 207 & 200 & 2,703 & 1,952 & 208 & 73 & 63 & 0 & 0 \\
\hline 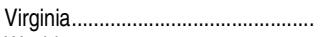 & 18,074 & 35,099 & 11,967 & 3,250 & 811 & 13,888 & 7,694 & 1,948 & 7,314 & 4,011 & 1,855 & 130 \\
\hline 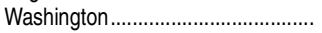 & 27,833 & 24,384 & 5,531 & 1,689 & 66 & 7,232 & 3,841 & 851 & 1,078 & 760 & 223 & 21 \\
\hline 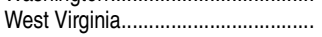 & 3,056 & 9,102 & 2,701 & 880 & 93 & 1,083 & 252 & 106 & 1,782 & 3,099 & 2,939 & 0 \\
\hline 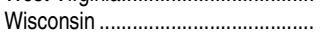 & 13,288 & 26,178 & 5,757 & 1,762 & 415 & 9,175 & 3,949 & 828 & 2,588 & 649 & 150 & 0 \\
\hline 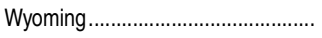 & 2,688 & 2,062 & 489 & 197 & 0 & 0 & 0 & 0 & 236 & 2 & 0 & 0 \\
\hline U.S. Service Academies ................... & 0 & 3,665 & 9 & 0 & $\dagger$ & $\dagger$ & $\dagger$ & $\dagger$ & $\dagger$ & $\dagger$ & $\dagger$ & $\dagger$ \\
\hline Other jurisdictions .................. & 3,288 & 8,170 & 942 & 514 & 3,418 & 11,240 & 3,864 & 891 & 2,429 & 948 & 503 & $\overline{0}$ \\
\hline 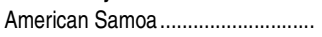 & 269 & 2 & 0 & 0 & 0 & 0 & 0 & 0 & 0 & 0 & 0 & $\overline{0}$ \\
\hline Federated States of Micronesia...... & 262 & 0 & 0 & 0 & 0 & 0 & 0 & 0 & 0 & 0 & 0 & 0 \\
\hline Guam & 274 & 386 & 129 & 0 & 4 & 22 & 3 & 0 & 0 & 0 & 0 & 0 \\
\hline 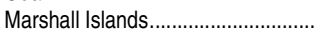 & 71 & 0 & 0 & 0 & 0 & 0 & 0 & 0 & 0 & 0 & 0 & 0 \\
\hline 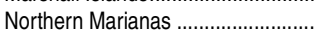 & 103 & 14 & 0 & 0 & 0 & 0 & 0 & 0 & 0 & 0 & 0 & 0 \\
\hline 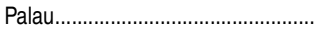 & 85 & 0 & 0 & 0 & 0 & 0 & 0 & 0 & 0 & 0 & 0 & 0 \\
\hline 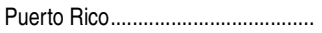 & 2,151 & 7,531 & 760 & 514 & 3,414 & 11,218 & 3,861 & 891 & 2,429 & 948 & 503 & 0 \\
\hline 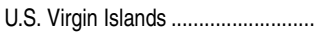 & 73 & 237 & 53 & 0 & 0 & 0 & 0 & 0 & 0 & 0 & 0 & 0 \\
\hline
\end{tabular}

†Not applicable.

1 Includes Ph.D., Ed.D., and comparable degrees at the doctoral level. Includes most degrees formerly classified as first-professional, such as M.D., D.D.S., and law degrees.

NOTE: Data are for postsecondary institutions participating in Title IV federal financial aid programs.
SOURCE: U.S. Department of Education, National Center for Education Statistics, Integrated Postsecondary Education Data System (IPEDS), Fall 2012, Completions component. (This table was prepared August 2013.) 
Table 319.20. Degrees conferred by postsecondary institutions, by level of degree and state or jurisdiction: 2008-09 through 2011-12

\begin{tabular}{|c|c|c|c|c|c|c|c|c|c|c|c|c|}
\hline \multirow[b]{2}{*}{ State or jurisdiction } & \multicolumn{4}{|c|}{$2009-10$} & \multicolumn{4}{|c|}{$2010-11$} & \multicolumn{4}{|c|}{ 2011-12 } \\
\hline & $\begin{array}{r}\text { Associate's } \\
\text { degrees }\end{array}$ & $\begin{array}{r}\text { Bachelor's } \\
\text { degrees }\end{array}$ & $\begin{array}{l}\text { Master's } \\
\text { degrees }\end{array}$ & $\begin{array}{r}\text { Doctor's } \\
\text { degrees }^{1}\end{array}$ & $\begin{array}{r}\text { Associate's } \\
\text { degrees }\end{array}$ & $\begin{array}{r}\text { Bachelor's } \\
\text { degrees }\end{array}$ & $\begin{array}{l}\text { Master's } \\
\text { degrees }\end{array}$ & $\begin{array}{r}\text { Doctor's } \\
\text { degrees }^{1}\end{array}$ & $\begin{array}{r}\text { Associate's } \\
\text { degrees }\end{array}$ & $\begin{array}{r}\text { Bachelor's } \\
\text { degrees }\end{array}$ & $\begin{array}{l}\text { Master's } \\
\text { degrees }\end{array}$ & $\begin{array}{r}\text { Doctor's } \\
\text { degrees }^{1}\end{array}$ \\
\hline 1 & 2 & 3 & 4 & 5 & 6 & 7 & 8 & 9 & 10 & 11 & 12 & 13 \\
\hline United States ............. & 849,452 & $1,650,014$ & 693,025 & 158,558 & 942,327 & $1,715,913$ & 730,635 & 163,765 & $1,017,538$ & $1,791,046$ & 754,229 & 170,062 \\
\hline Alabama .... & 10,198 & 25,686 & 11,291 & 2,079 & 11,795 & 27,248 & 11,888 & 2,144 & 13,152 & 27,439 & 11,402 & 2,256 \\
\hline Alaska.... & 1,182 & 1,619 & 681 & 45 & 1,523 & 1,770 & 693 & 46 & 1,706 & 1,750 & 703 & 50 \\
\hline Arizona ... & 50,252 & 44,339 & 34,860 & 2,684 & 58,991 & 50,928 & 36,231 & 2,937 & 62,990 & 64,707 & 36,178 & 3,533 \\
\hline Arkansas... & 7,172 & 12,523 & 4,126 & 804 & 10,181 & 13,259 & 4,793 & 813 & 8,645 & 14,189 & 5,320 & 913 \\
\hline 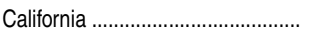 & 102,018 & 164,234 & 65,050 & 16,382 & 107,675 & 169,623 & 67,439 & 17,140 & 114,612 & 172,410 & 68,502 & 17,448 \\
\hline Colorado... & 14,552 & 28,546 & 13,054 & 2,205 & 16,145 & 29,540 & 14,246 & 2,170 & 16,939 & 31,136 & 15,406 & 2,352 \\
\hline Connecticut.. & 5,523 & 19,483 & 8,639 & 1,834 & 6,079 & 19,735 & 9,131 & 1,808 & 6,511 & 20,710 & 9,457 & 1,954 \\
\hline Delaware.... & 1,712 & 5,505 & 2,452 & 528 & 1,820 & 5,877 & 2,705 & 546 & 1,947 & 5,885 & 2,680 & 585 \\
\hline District of Columbia ........................... & 447 & 8,927 & 9,285 & 3,394 & 555 & 8,402 & 10,078 & 3,458 & 463 & 9,212 & 10,213 & 3,567 \\
\hline Florida & 79,644 & 83,471 & 29,726 & 9,107 & 86,254 & 86,281 & 31,766 & 9,297 & 102,559 & 90,979 & 33,859 & 9,485 \\
\hline Georgia... & 15,583 & 42,452 & 16,304 & 3,958 & 17,949 & 45,075 & 17,533 & 4,005 & 18,728 & 46,221 & 17,790 & 4,268 \\
\hline Hawaii...... & 3,238 & 5,401 & 2,028 & 381 & 3,766 & 5,751 & 2,062 & 529 & 4,199 & 6,016 & 2,115 & 533 \\
\hline Idaho....... & 3,490 & 9,466 & 1,680 & 306 & 3,919 & 9,171 & 1,790 & 321 & 4,940 & 9,781 & 2,041 & 331 \\
\hline Illinois..... & 38,263 & 70,847 & 41,548 & 7,625 & 40,009 & 71,580 & 43,011 & 7,846 & 41,618 & 72,455 & 43,638 & 8,129 \\
\hline Indiana....... & 16,727 & 41,687 & 13,673 & 3,250 & 18,603 & 43,519 & 14,337 & 3,386 & 19,430 & 45,532 & 14,215 & 3,462 \\
\hline lowa & 15,834 & 30,323 & 7,452 & 2,744 & 19,290 & 36,266 & 9,982 & 3,112 & 20,515 & 40,676 & 12,100 & 2,957 \\
\hline Kansas..... & 8,424 & 17,835 & 6,722 & 1,388 & 9,501 & 18,191 & 7,227 & 1,476 & 10,218 & 18,999 & 7,021 & 1,452 \\
\hline Kentucky .............................. & 11,707 & 20,389 & 7,976 & 1,591 & 13,029 & 21,078 & 8,350 & 1,812 & 14,680 & 21,531 & 9,411 & 1,935 \\
\hline Louisiana ............................. & 5,849 & 20,893 & 6,641 & 2,381 & 7,236 & 21,509 & 7,017 & 2,236 & 7,707 & 22,015 & 7,275 & 2,585 \\
\hline Maine..... & 2,718 & 7,088 & 1,829 & 348 & 3,309 & 7,347 & 1,766 & 367 & 3,321 & 7,684 & 1,897 & 383 \\
\hline Maryland. & 12,446 & 28,012 & 16,019 & 2,665 & 13,921 & 29,247 & 16,975 & 2,652 & 15,156 & 30,863 & 17,845 & 2,822 \\
\hline Massachusetts.. & 12,396 & 52,223 & 32,136 & 7,485 & 12,900 & 53,749 & 33,905 & 7,637 & 13,645 & 55,823 & 35,955 & 8,146 \\
\hline Michigan .... & 29,318 & 56,061 & 21,176 & 5,589 & 30,859 & 56,217 & 21,252 & 5,807 & 33,322 & 57,815 & 21,392 & 5,884 \\
\hline Minnesota ............................. & 18,453 & 31,952 & 21,015 & 4,173 & 20,480 & 33,386 & 21,823 & 4,352 & 20,480 & 34,980 & 20,609 & 4,283 \\
\hline 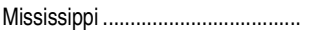 & 9,824 & 12,953 & 4,203 & 1,154 & 11,440 & 13,230 & 4,676 & 1,170 & 12,996 & 13,516 & 4,809 & 1,217 \\
\hline Missouri... & 15,802 & 39,670 & 19,403 & 4,651 & 18,534 & 41,648 & 20,697 & 4,656 & 19,895 & 43,688 & 20,979 & 4,669 \\
\hline Montana.... & 1,745 & 5,232 & 1,140 & 309 & 2,058 & 5,512 & 1,201 & 357 & 2,364 & 5,384 & 1,286 & 372 \\
\hline Nebraska .............................. & 4,860 & 12,596 & 4,364 & 1,392 & 5,351 & 13,510 & 4,684 & 1,371 & 5,761 & 14,248 & 5,178 & 1,392 \\
\hline Nevada & 4,068 & 7,345 & 2,652 & 830 & 4,997 & 7,556 & 2,720 & 839 & 5,350 & 7,639 & 2,604 & 950 \\
\hline 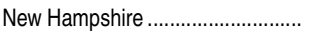 & 2,933 & 9,396 & 3,458 & 459 & 3,062 & 9,479 & 3,666 & 448 & 3,119 & 9,270 & 3,825 & 480 \\
\hline New Je & 19,268 & 36,025 & 14,146 & 3,011 & 21,124 & 37,087 & 14,427 & 3,101 & 21,643 & 39,804 & 15,490 & 3,122 \\
\hline New Mexico. & 5,234 & 7,774 & 3,057 & 544 & 6,552 & 8,179 & 3,266 & 583 & 7,709 & 8,259 & 3,259 & 614 \\
\hline New York.... & 61,618 & 123,703 & 68,258 & 14,155 & 66,644 & 127,205 & 70,225 & 14,230 & 69,654 & 129,426 & 71,406 & 14,809 \\
\hline North Carolina .......................... & 22,879 & 46,826 & 15,395 & 3,955 & 25,154 & 48,670 & 16,226 & 4,116 & 27,672 & 50,722 & 16,948 & 4,420 \\
\hline North Dakota . & 2,411 & 5,727 & 1,392 & 447 & 2,552 & 5,674 & 1,572 & 456 & 2,251 & 5,679 & 1,725 & 480 \\
\hline Ohio & 29,332 & 61,085 & 22,187 & 5,828 & 33,479 & 63,882 & 22,636 & 6,033 & 35,871 & 66,736 & 24,148 & 5,992 \\
\hline Oklaho & 9,723 & 19,535 & 5,947 & 1,586 & 10,710 & 19,511 & 6,356 & 1,611 & 11,513 & 19,846 & 6,481 & 1,728 \\
\hline 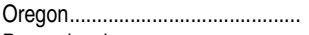 & 9,129 & 18,873 & 6,779 & 1,849 & 10,945 & 19,542 & 7,326 & 1,849 & 12,637 & 21,114 & 7,541 & 1,910 \\
\hline Pennsylvania........................... & 27,517 & 87,162 & 33,902 & 9,135 & 29,241 & 88,205 & 36,016 & 9,316 & 29,875 & 90,669 & 36,785 & 9,375 \\
\hline Rhode Island .................................... & 3,590 & 10,647 & 2,396 & 746 & 3,461 & 10,863 & 2,545 & 709 & 3,537 & 11,014 & 2,566 & 745 \\
\hline South Carolina ................... & 8,727 & 21,905 & 5,676 & 1,496 & 9,771 & 23,034 & 5,849 & 1,606 & 10,790 & 22,973 & 5,972 & 1,604 \\
\hline 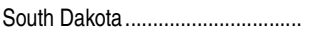 & 1,952 & 4,976 & 1,309 & 307 & 2,601 & 5,211 & 1,427 & 300 & 2,699 & 5,392 & 1,467 & 353 \\
\hline Tennessee .................................... & 10,645 & 29,857 & 10,627 & 2,655 & 12,478 & 31,026 & 11,099 & 2,989 & 13,548 & 32,309 & 11,929 & 3,152 \\
\hline 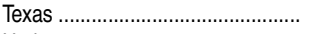 & 55,048 & 104,657 & 39,739 & 9,318 & 58,609 & 107,438 & 42,039 & 9,705 & 67,352 & 111,324 & 45,307 & 10,104 \\
\hline 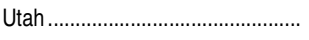 & 11,054 & 21,931 & 5,804 & 936 & 12,398 & 24,461 & 6,995 & 1,087 & 13,301 & 26,554 & 7,669 & 1,184 \\
\hline Vermont... & 1,266 & 5,888 & 2,244 & 381 & 1,223 & 6,100 & 2,377 & 388 & 1,196 & 6,283 & 2,474 & 415 \\
\hline & 21,010 & 45,324 & 18,889 & 4,633 & 24,193 & 49,077 & 20,697 & 4,923 & 26,199 & 52,998 & 21,516 & 5,328 \\
\hline Washington .............................. & 23,068 & 30,551 & 9,766 & 2,366 & 27,045 & 31,398 & 9,850 & 2,412 & 28,977 & 32,376 & 9,595 & 2,561 \\
\hline nia..................... & 3,989 & 12,032 & 5,064 & 943 & 4,688 & 12,978 & 5,884 & 1,007 & 4,931 & 13,284 & 5,892 & 986 \\
\hline$\ldots$ & 12,752 & 34,110 & 9,476 & 2,347 & 15,012 & 35,279 & 9,695 & 2,418 & 16,291 & 36,002 & 9,856 & 2,590 \\
\hline 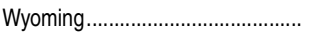 & 2,862 & 1,791 & 388 & 179 & 3,216 & 1,860 & 482 & 188 & 2,924 & 2,064 & 489 & 197 \\
\hline U.S. Service Academies .............. & 0 & 3,481 & 1 & 0 & 0 & 3,549 & 2 & 0 & 0 & 3,665 & 9 & 0 \\
\hline Other jurisdictions................ & 6,982 & 18,213 & 5,503 & 1,342 & 7,690 & 18,316 & 5,820 & 1,421 & 9,135 & 20,358 & 5,309 & 1,405 \\
\hline American Samoa ........... & 242 & 0 & 0 & 0 & 216 & 0 & 0 & 0 & 269 & 2 & 0 & 0 \\
\hline Federated States of Micronesia.... & 222 & 0 & 0 & 0 & 267 & 0 & 0 & 0 & 262 & 0 & 0 & 0 \\
\hline Guam & 185 & 338 & 121 & 0 & 119 & 375 & 134 & 0 & 278 & 408 & 132 & 0 \\
\hline Marshall Islands........................... & 49 & 0 & 0 & 0 & 68 & 0 & 0 & 0 & 71 & 0 & 0 & 0 \\
\hline Northern Marianas ........................ & 60 & 19 & 0 & 0 & 105 & 14 & 0 & 0 & 103 & 14 & 0 & 0 \\
\hline Palau.......................................... & 46 & 0 & 0 & 0 & 26 & 0 & 0 & 0 & 85 & 0 & 0 & 0 \\
\hline Puerto Rico............................... & 6,104 & 17,604 & 5,327 & 1,342 & 6,814 & 17,698 & 5,652 & 1,421 & 7,994 & 19,697 & 5,124 & 1,405 \\
\hline U.S. Virgin Islands .............................. & 74 & 252 & 55 & 0 & 75 & 229 & 34 & 0 & 73 & 237 & 53 & 0 \\
\hline
\end{tabular}

${ }^{1}$ Includes Ph.D., Ed.D., and comparable degrees at the doctoral level. Includes most degrees formerly classified as first-professional, such as M.D., D.D.S., and law degrees.

NOTE: Data are for postsecondary institutions participating in Title IV federal financial aid programs.
SOURCE: U.S. Department of Education, National Center for Education Statistics, Integrated Postsecondary Education Data System (IPEDS), Fall 2010 through Fall 2012, Completions component. (This table was prepared August 2013.) 
Table 319.30. Bachelor's degrees conferred by postsecondary institutions, by field of study and state or jurisdiction: 2011-12

\begin{tabular}{|c|c|c|c|c|c|c|c|c|c|c|c|}
\hline State or jurisdiction & Total & Humanities $^{1}$ & Psychology & $\begin{array}{r}\text { Social } \\
\text { sciences } \\
\text { and history }\end{array}$ & $\begin{array}{r}\text { Natural } \\
\text { sciences }^{2}\end{array}$ & $\begin{array}{r}\text { Computer } \\
\text { sciences }\end{array}$ & Engineering $^{3}$ & Education & $\begin{array}{r}\text { Business/ } \\
\text { management }\end{array}$ & $\begin{array}{r}\text { Health } \\
\text { professions } \\
\text { and related } \\
\text { programs }\end{array}$ & Other fields ${ }^{4}$ \\
\hline 1 & 2 & 3 & 4 & 5 & 6 & 7 & 8 & 9 & 10 & 11 & 12 \\
\hline United States ................... & $1,791,046$ & 295,221 & 108,986 & 178,543 & 141,354 & 47,384 & 98,540 & 105,785 & 366,815 & 163,440 & 284,978 \\
\hline $\begin{array}{l}\text { Alabama } \\
\text { Alaska } \\
\text { Arizona } \\
\text { Arkansas } \\
\text { California }\end{array}$ & $\begin{array}{r}27,439 \\
1,750 \\
64,707 \\
14,189 \\
172,410\end{array}$ & $\begin{array}{r}2,581 \\
299 \\
8,671 \\
2,202 \\
35,416\end{array}$ & $\begin{array}{r}1,475 \\
117 \\
2,101 \\
725 \\
12,570\end{array}$ & $\begin{array}{r}1,780 \\
147 \\
2,733 \\
950 \\
24,661\end{array}$ & $\begin{array}{r}1,986 \\
152 \\
2,482 \\
1,124 \\
16,776\end{array}$ & $\begin{array}{r}584 \\
35 \\
3,711 \\
287 \\
3,905\end{array}$ & $\begin{array}{r}2,080 \\
152 \\
1,528 \\
561 \\
9,982\end{array}$ & $\begin{array}{r}2,576 \\
102 \\
3,400 \\
1,416 \\
2,626\end{array}$ & $\begin{array}{r}6,648 \\
310 \\
21,202 \\
2,783 \\
30,771\end{array}$ & $\begin{array}{r}2,795 \\
163 \\
9,274 \\
1,769 \\
10,373\end{array}$ & $\begin{array}{r}4,934 \\
273 \\
9,605 \\
2,372 \\
25,330\end{array}$ \\
\hline 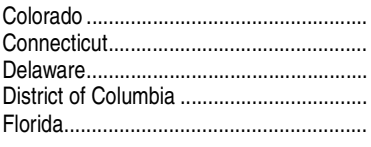 & $\begin{array}{r}31,136 \\
20,710 \\
5,885 \\
9,212 \\
90,979\end{array}$ & $\begin{array}{r}5,217 \\
4,128 \\
707 \\
1,279 \\
10,891\end{array}$ & $\begin{array}{r}1,802 \\
1,640 \\
305 \\
532 \\
6,024\end{array}$ & $\begin{array}{r}3,411 \\
3,003 \\
562 \\
2,768 \\
8,375\end{array}$ & $\begin{array}{r}2,747 \\
1,713 \\
307 \\
536 \\
5,816\end{array}$ & $\begin{array}{r}864 \\
244 \\
127 \\
179 \\
2,369\end{array}$ & $\begin{array}{r}2,042 \\
924 \\
314 \\
266 \\
4,411\end{array}$ & $\begin{array}{r}235 \\
690 \\
460 \\
69 \\
5,581\end{array}$ & $\begin{array}{r}7,401 \\
3,466 \\
1,456 \\
1,745 \\
21,957\end{array}$ & $\begin{array}{r}2,197 \\
1,908 \\
600 \\
663 \\
8,955\end{array}$ & $\begin{array}{r}5,220 \\
2,994 \\
1,047 \\
1,175 \\
16,600\end{array}$ \\
\hline 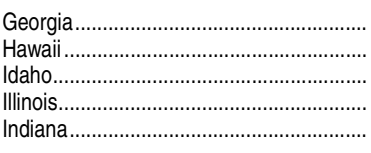 & $\begin{array}{r}46,221 \\
6,016 \\
9,781 \\
72,455 \\
45,532\end{array}$ & $\begin{array}{r}6,904 \\
898 \\
1,469 \\
12,475 \\
6,969\end{array}$ & $\begin{array}{r}2,672 \\
409 \\
465 \\
4,103 \\
1,859\end{array}$ & $\begin{array}{r}4,234 \\
726 \\
703 \\
6,217 \\
3,297\end{array}$ & $\begin{array}{r}3,778 \\
387 \\
738 \\
5,247 \\
2,991\end{array}$ & $\begin{array}{r}1,425 \\
132 \\
239 \\
2,501 \\
1,313\end{array}$ & $\begin{array}{r}2,451 \\
139 \\
488 \\
3,628 \\
3,514\end{array}$ & $\begin{array}{r}4,289 \\
403 \\
1,201 \\
5,897 \\
3,612\end{array}$ & $\begin{array}{r}10,072 \\
1,358 \\
1,603 \\
15,340 \\
9,712\end{array}$ & $\begin{array}{r}3,742 \\
610 \\
1,215 \\
5,692 \\
4,908\end{array}$ & $\begin{array}{r}6,654 \\
954 \\
1,660 \\
11,355 \\
7,357\end{array}$ \\
\hline 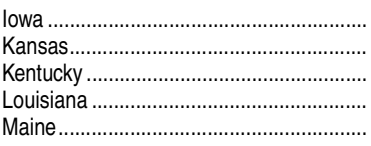 & $\begin{array}{r}40,676 \\
18,999 \\
21,531 \\
22,015 \\
7,684\end{array}$ & $\begin{array}{l}3,716 \\
2,755 \\
3,097 \\
3,922 \\
1,340\end{array}$ & $\begin{array}{r}3,417 \\
718 \\
1,151 \\
1,217 \\
470\end{array}$ & $\begin{array}{l}4,034 \\
1,387 \\
1,650 \\
1,711 \\
1,049\end{array}$ & $\begin{array}{r}1,851 \\
1,120 \\
1,544 \\
1,793 \\
828\end{array}$ & $\begin{array}{r}955 \\
432 \\
349 \\
320 \\
78\end{array}$ & $\begin{array}{r}1,332 \\
1,205 \\
1,029 \\
1,377 \\
431\end{array}$ & $\begin{array}{r}3,335 \\
1,779 \\
2,195 \\
1,644 \\
580\end{array}$ & $\begin{array}{r}10,493 \\
4,633 \\
3,933 \\
4,462 \\
902\end{array}$ & $\begin{array}{r}3,772 \\
1,936 \\
2,070 \\
2,408 \\
830\end{array}$ & $\begin{array}{l}7,771 \\
3,034 \\
4,513 \\
3,161 \\
1,176\end{array}$ \\
\hline 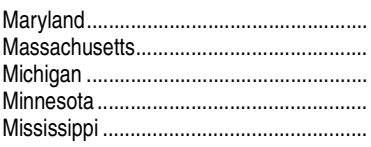 & $\begin{array}{l}30,863 \\
55,823 \\
57,815 \\
34,980 \\
13,516\end{array}$ & $\begin{array}{r}4,321 \\
10,060 \\
7,455 \\
5,582 \\
1,822\end{array}$ & $\begin{array}{r}2,118 \\
3,989 \\
3,214 \\
2,200 \\
812\end{array}$ & $\begin{array}{r}4,103 \\
7,279 \\
4,466 \\
3,105 \\
852\end{array}$ & $\begin{array}{l}2,764 \\
4,984 \\
4,659 \\
3,618 \\
1,168\end{array}$ & $\begin{array}{r}1,977 \\
1,346 \\
1,566 \\
959 \\
167\end{array}$ & $\begin{array}{r}1,352 \\
3,351 \\
4,608 \\
1,423 \\
705\end{array}$ & $\begin{array}{l}1,446 \\
1,449 \\
3,743 \\
2,722 \\
1,855\end{array}$ & $\begin{array}{r}5,584 \\
10,779 \\
12,104 \\
7,158 \\
2,729\end{array}$ & $\begin{array}{l}2,432 \\
4,483 \\
5,923 \\
2,866 \\
1,383\end{array}$ & $\begin{array}{r}4,766 \\
8,103 \\
10,077 \\
5,347 \\
2,023\end{array}$ \\
\hline 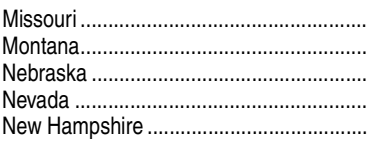 & $\begin{array}{r}43,688 \\
5,384 \\
14,248 \\
7,639 \\
9,270\end{array}$ & $\begin{array}{r}5,688 \\
807 \\
1,346 \\
995 \\
1,529\end{array}$ & $\begin{array}{r}2,570 \\
254 \\
663 \\
460 \\
743\end{array}$ & $\begin{array}{r}2,524 \\
503 \\
1,000 \\
655 \\
1,134\end{array}$ & $\begin{array}{r}2,695 \\
487 \\
855 \\
515 \\
682\end{array}$ & $\begin{array}{r}1,066 \\
65 \\
395 \\
194 \\
176\end{array}$ & $\begin{array}{r}2,157 \\
485 \\
508 \\
345 \\
462\end{array}$ & $\begin{array}{r}3,300 \\
505 \\
1,451 \\
459 \\
480\end{array}$ & $\begin{array}{r}9,777 \\
885 \\
3,873 \\
2,024 \\
1,927\end{array}$ & $\begin{array}{r}7,147 \\
407 \\
1,768 \\
789 \\
590\end{array}$ & $\begin{array}{r}6,764 \\
986 \\
2,389 \\
1,203 \\
1,547\end{array}$ \\
\hline 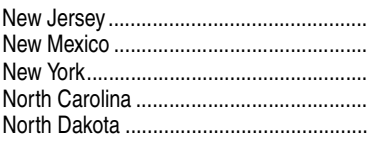 & $\begin{array}{r}39,804 \\
8,259 \\
129,426 \\
50,722 \\
5,679\end{array}$ & $\begin{array}{r}7,590 \\
1,597 \\
26,738 \\
6,375 \\
493\end{array}$ & $\begin{array}{r}3,317 \\
476 \\
9,837 \\
3,473 \\
224\end{array}$ & $\begin{array}{r}4,852 \\
619 \\
15,279 \\
5,302 \\
225\end{array}$ & $\begin{array}{r}3,516 \\
662 \\
10,433 \\
4,701 \\
377\end{array}$ & $\begin{array}{r}826 \\
147 \\
3,041 \\
1,106 \\
126\end{array}$ & $\begin{array}{r}1,968 \\
622 \\
6,228 \\
2,863 \\
454\end{array}$ & $\begin{array}{r}2,115 \\
813 \\
7,011 \\
4,083 \\
572\end{array}$ & $\begin{array}{r}7,197 \\
1,559 \\
23,911 \\
9,014 \\
1,122\end{array}$ & $\begin{array}{r}2,733 \\
600 \\
9,896 \\
4,092 \\
787\end{array}$ & $\begin{array}{r}5,690 \\
1,164 \\
17,052 \\
9,713 \\
1,299\end{array}$ \\
\hline 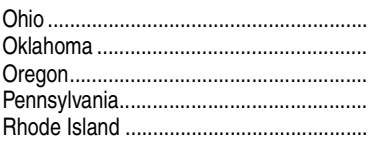 & $\begin{array}{l}66,736 \\
19,846 \\
21,114 \\
90,669 \\
11,014\end{array}$ & $\begin{array}{r}8,826 \\
3,554 \\
4,628 \\
14,279 \\
1,548\end{array}$ & $\begin{array}{r}3,411 \\
905 \\
1,413 \\
5,220 \\
569\end{array}$ & $\begin{array}{l}5,684 \\
1,041 \\
2,869 \\
8,531 \\
1,001\end{array}$ & $\begin{array}{r}4,803 \\
1,382 \\
1,535 \\
7,962 \\
843\end{array}$ & $\begin{array}{r}1,352 \\
424 \\
408 \\
2,655 \\
258\end{array}$ & $\begin{array}{r}4,375 \\
1,341 \\
1,100 \\
5,608 \\
443\end{array}$ & $\begin{array}{r}5,586 \\
1,748 \\
600 \\
6,308 \\
488\end{array}$ & $\begin{array}{r}13,314 \\
4,183 \\
3,352 \\
17,248 \\
2,866\end{array}$ & $\begin{array}{r}8,460 \\
1,712 \\
1,645 \\
9,654 \\
625\end{array}$ & $\begin{array}{r}10,925 \\
3,556 \\
3,564 \\
13,204 \\
2,373\end{array}$ \\
\hline 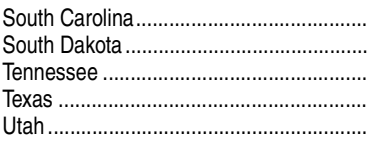 & $\begin{array}{r}22,973 \\
5,392 \\
32,309 \\
111,324 \\
26,554\end{array}$ & $\begin{array}{r}3,151 \\
560 \\
6,026 \\
23,326 \\
3,316\end{array}$ & $\begin{array}{r}1,332 \\
235 \\
1,864 \\
5,905 \\
1,287\end{array}$ & $\begin{array}{r}2,328 \\
402 \\
2,735 \\
8,871 \\
2,371\end{array}$ & $\begin{array}{r}2,463 \\
421 \\
2,289 \\
8,993 \\
1,801\end{array}$ & $\begin{array}{r}361 \\
186 \\
593 \\
2,030 \\
1,311\end{array}$ & $\begin{array}{r}1,031 \\
428 \\
1,618 \\
6,835 \\
1,299\end{array}$ & $\begin{array}{r}1,915 \\
475 \\
2,529 \\
2,130 \\
3,008\end{array}$ & $\begin{array}{r}5,519 \\
779 \\
5,971 \\
22,700 \\
4,744\end{array}$ & $\begin{array}{r}1,620 \\
875 \\
3,149 \\
10,217 \\
3,313\end{array}$ & $\begin{array}{r}3,253 \\
1,031 \\
5,535 \\
20,317 \\
4,104\end{array}$ \\
\hline 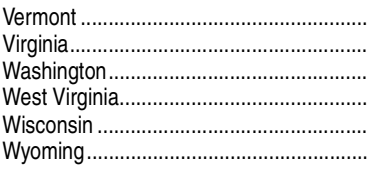 & $\begin{array}{r}6,283 \\
52,998 \\
32,376 \\
13,284 \\
36,002 \\
2,064\end{array}$ & $\begin{array}{r}1,450 \\
11,000 \\
7,272 \\
2,980 \\
5,283 \\
209\end{array}$ & $\begin{array}{r}422 \\
4,018 \\
1,843 \\
554 \\
1,725 \\
136\end{array}$ & $\begin{array}{r}871 \\
6,605 \\
4,517 \\
1,122 \\
3,327 \\
156\end{array}$ & $\begin{array}{r}557 \\
4,308 \\
3,055 \\
771 \\
3,474 \\
194\end{array}$ & $\begin{array}{r}180 \\
2,274 \\
849 \\
399 \\
776 \\
18\end{array}$ & $\begin{array}{r}266 \\
2,859 \\
1,745 \\
719 \\
1,978 \\
201\end{array}$ & $\begin{array}{r}282 \\
1,336 \\
1,393 \\
848 \\
2,767 \\
278\end{array}$ & $\begin{array}{r}813 \\
10,081 \\
5,237 \\
2,189 \\
7,484 \\
249\end{array}$ & $\begin{array}{r}333 \\
3,633 \\
2,072 \\
919 \\
3,225 \\
212\end{array}$ & $\begin{array}{r}1,109 \\
6,884 \\
4,393 \\
2,783 \\
5,963 \\
411\end{array}$ \\
\hline U.S. Service Academies.. & 3,665 & 479 & 25 & 816 & 471 & 104 & 1,309 & 0 & 196 & 0 & 265 \\
\hline Other jurisdictions. & 20,358 & 1,020 & 927 & 750 & 1,711 & 650 & 1,378 & 2,269 & 5,586 & 3,116 & 2,951 \\
\hline American Samoa ........... & 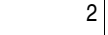 & 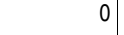 & 0 & 0 & 0 & 0 & 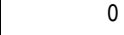 & 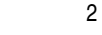 & 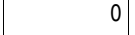 & 0 & 0 \\
\hline 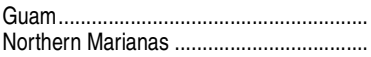 & $\begin{array}{r}408 \\
14\end{array}$ & $\begin{array}{r}59 \\
0\end{array}$ & $\begin{array}{r}15 \\
0\end{array}$ & $\begin{array}{r}18 \\
0\end{array}$ & $\begin{array}{r}21 \\
0\end{array}$ & $\begin{array}{r}11 \\
0\end{array}$ & $\begin{array}{l}0 \\
0\end{array}$ & $\begin{array}{l}78 \\
14\end{array}$ & $\begin{array}{r}80 \\
0\end{array}$ & $\begin{array}{r}33 \\
0\end{array}$ & 93 \\
\hline 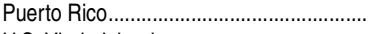 & 19,697 & 951 & 889 & 723 & 1,659 & 629 & 1,378 & 2,145 & 5,406 & 3,070 & 2,847 \\
\hline 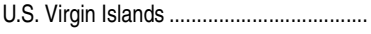 & 237 & 10 & 23 & 9 & 31 & 10 & 0 & 30 & 100 & 13 & \\
\hline
\end{tabular}

'Includes degrees in area, ethnic, cultural, and gender studies; English language and literature/letters; foreign languages, literatures, and linguistics; liberal arts and sciences, general studies and humanities; multi/interdisciplinary studies; philosophy and religious studies; theology and religious vocations; and visual and performing arts.

Includes biological and biomedical sciences; physical sciences; science technologies/ technicians; and mathematics and statistics.

Includes engineering; engineering technologies/technicians; mechanic and repair technologies/technicians; and construction trades.

${ }^{4}$ Includes agriculture, agricultural operations, and related sciences; natural resources and conservation; architecture and related services; communication, journalism, and related programs; communications technologies/technicians and support services; family and consumer services/human sciences; legal professions and studies; library science; military technologies and applied sciences; parks, recreation, leisure, and fitness studies; homeland security, law enforcement, and firefighting; public administration and social service professions; transportation and materials moving; and not classified by field of study. NOTE: Data are for postsecondary institutions participating in Title IV federal financial aid programs. This table includes only those jurisdictions with 4-year institutions.

SOURCE: U.S. Department of Education, National Center for Education Statistics, Integrated Postsecondary Education Data System (IPEDS), Fall 2012, Completions component. (This table was prepared August 2013.) 
Table 319.40. Master's degrees conferred by postsecondary institutions, by field of study and state or jurisdiction: 2011-12

\begin{tabular}{|c|c|c|c|c|c|c|c|c|c|c|c|}
\hline State or jurisdiction & Total & Humanities $^{1}$ & Psychology & $\begin{array}{r}\text { Social } \\
\text { sciences and } \\
\text { history }\end{array}$ & $\begin{array}{r}\text { Natural } \\
\text { sciences }^{2}\end{array}$ & $\begin{array}{r}\text { Computer } \\
\text { sciences }\end{array}$ & Engineering $^{3}$ & Education & $\begin{array}{r}\text { Business/ } \\
\text { management }\end{array}$ & $\begin{array}{r}\text { Health } \\
\text { professions } \\
\text { and related } \\
\text { programs }\end{array}$ & Other fields ${ }^{4}$ \\
\hline 1 & 2 & 3 & 4 & 5 & 6 & 7 & 8 & 9 & 10 & 11 & 12 \\
\hline United States ................... & 754,229 & 59,979 & 26,834 & 21,889 & 25,570 & 20,917 & 45,097 & 178,062 & 191,571 & 83,893 & 100,417 \\
\hline 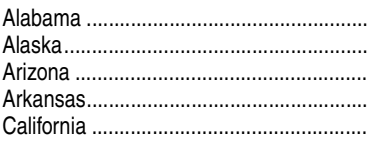 & \begin{tabular}{r|}
11,402 \\
703 \\
36,178 \\
5,320 \\
68,502
\end{tabular} & $\begin{array}{r}386 \\
52 \\
757 \\
227 \\
7,588\end{array}$ & $\begin{array}{r}384 \\
37 \\
2,512 \\
38 \\
4,038\end{array}$ & $\begin{array}{r}225 \\
14 \\
234 \\
77 \\
2,142\end{array}$ & $\begin{array}{r}241 \\
35 \\
388 \\
163 \\
2,349\end{array}$ & \begin{tabular}{r|r|}
163 \\
7 \\
425 \\
66 \\
2,161
\end{tabular} & $\begin{array}{r}901 \\
69 \\
800 \\
341 \\
6,282\end{array}$ & $\begin{array}{r}2,860 \\
296 \\
10,707 \\
2,510 \\
12,821\end{array}$ & $\begin{array}{r}3,074 \\
82 \\
13,728 \\
695 \\
14,724\end{array}$ & $\begin{array}{r}1,540 \\
15 \\
4,168 \\
577 \\
7,325\end{array}$ & $\begin{array}{r}1,628 \\
96 \\
2,459 \\
626 \\
9,072\end{array}$ \\
\hline 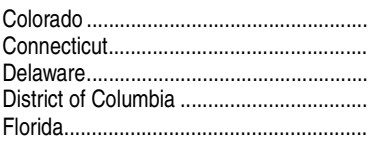 & $\begin{array}{r}15,406 \\
9,457 \\
2,680 \\
10,213 \\
33,859\end{array}$ & $\begin{array}{r}935 \\
911 \\
83 \\
1,196 \\
1,637\end{array}$ & $\begin{array}{r}893 \\
289 \\
41 \\
124 \\
1,117\end{array}$ & $\begin{array}{r}530 \\
275 \\
62 \\
1,309 \\
694\end{array}$ & $\begin{array}{r}457 \\
556 \\
112 \\
550 \\
1,040\end{array}$ & $\begin{array}{r}783 \\
233 \\
38 \\
254 \\
493\end{array}$ & $\begin{array}{r}1,031 \\
645 \\
62 \\
520 \\
2,311\end{array}$ & $\begin{array}{r}2,708 \\
2,315 \\
822 \\
781 \\
5,284\end{array}$ & $\begin{array}{r}5,178 \\
2,053 \\
921 \\
2,010 \\
11,431\end{array}$ & $\begin{array}{r}982 \\
1,007 \\
216 \\
785 \\
4,385\end{array}$ & $\begin{array}{r}1,909 \\
1,173 \\
323 \\
2,684 \\
5,467\end{array}$ \\
\hline 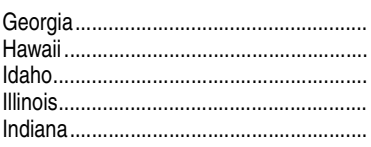 & $\begin{array}{r}17,790 \\
2,115 \\
2,041 \\
43,638 \\
14,215\end{array}$ & $\begin{array}{r}1,729 \\
200 \\
130 \\
3,077 \\
1,379\end{array}$ & $\begin{array}{r}259 \\
160 \\
18 \\
1,793 \\
289\end{array}$ & $\begin{array}{r}417 \\
76 \\
48 \\
1,076 \\
292\end{array}$ & $\begin{array}{r}639 \\
79 \\
115 \\
1,499 \\
562\end{array}$ & $\begin{array}{r}501 \\
25 \\
12 \\
1,657 \\
288\end{array}$ & $\begin{array}{r}1,110 \\
73 \\
184 \\
2,019 \\
1,039\end{array}$ & $\begin{array}{r}3,950 \\
507 \\
607 \\
10,006 \\
2,741\end{array}$ & $\begin{array}{r}4,880 \\
497 \\
290 \\
13,038 \\
4,229\end{array}$ & $\begin{array}{r}2,391 \\
159 \\
237 \\
3,856 \\
1,530\end{array}$ & $\begin{array}{r}1,914 \\
339 \\
400 \\
5,617 \\
1,866\end{array}$ \\
\hline 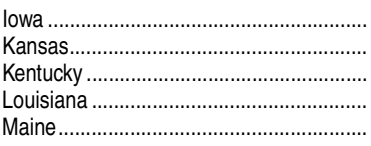 & $\begin{array}{r}12,100 \\
7,021 \\
9,411 \\
7,275 \\
1,897\end{array}$ & $\begin{array}{l}564 \\
657 \\
719 \\
563 \\
151\end{array}$ & $\begin{array}{r}232 \\
151 \\
449 \\
168 \\
27\end{array}$ & $\begin{array}{r}73 \\
196 \\
197 \\
142 \\
7\end{array}$ & \begin{tabular}{r|}
207 \\
181 \\
303 \\
423 \\
29
\end{tabular} & $\begin{array}{r}396 \\
114 \\
155 \\
125 \\
3\end{array}$ & $\begin{array}{r}327 \\
462 \\
316 \\
342 \\
34\end{array}$ & $\begin{array}{r}3,133 \\
1,970 \\
3,392 \\
1,466 \\
792\end{array}$ & $\begin{array}{r}4,566 \\
1,409 \\
1,395 \\
1,689 \\
243\end{array}$ & $\begin{array}{r}1,352 \\
672 \\
1,159 \\
1,195 \\
342\end{array}$ & $\begin{array}{r}1,250 \\
1,209 \\
1,326 \\
1,162 \\
269\end{array}$ \\
\hline 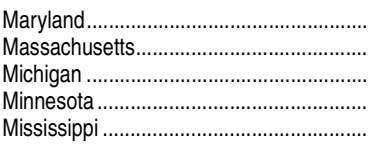 & $\begin{array}{r}17,845 \\
35,955 \\
21,392 \\
20,609 \\
4,809\end{array}$ & $\begin{array}{r}1,212 \\
3,107 \\
1,240 \\
937 \\
184\end{array}$ & $\begin{array}{r}295 \\
980 \\
446 \\
1,403 \\
85\end{array}$ & $\begin{array}{r}1,013 \\
1,442 \\
452 \\
173 \\
93\end{array}$ & $\begin{array}{r}1,058 \\
1,110 \\
898 \\
348 \\
475\end{array}$ & $\begin{array}{r}1,374 \\
929 \\
566 \\
587 \\
49\end{array}$ & $\begin{array}{r}1,014 \\
2,149 \\
2,097 \\
527 \\
150\end{array}$ & $\begin{array}{l}3,130 \\
7,969 \\
4,542 \\
5,904 \\
1,771\end{array}$ & $\begin{array}{r}5,170 \\
9,782 \\
5,599 \\
4,212 \\
838\end{array}$ & $\begin{array}{r}1,907 \\
3,377 \\
2,167 \\
3,849 \\
529\end{array}$ & $\begin{array}{r}1,672 \\
5,110 \\
3,385 \\
2,669 \\
635\end{array}$ \\
\hline 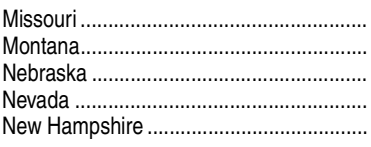 & $\begin{array}{r}20,979 \\
1,286 \\
5,178 \\
2,604 \\
3,825\end{array}$ & $\begin{array}{r}1,189 \\
116 \\
277 \\
112 \\
135\end{array}$ & $\begin{array}{r}792 \\
35 \\
109 \\
41 \\
32\end{array}$ & $\begin{array}{r}589 \\
55 \\
282 \\
79 \\
69\end{array}$ & $\begin{array}{r}445 \\
76 \\
189 \\
83 \\
75\end{array}$ & $\begin{array}{r}390 \\
9 \\
138 \\
40 \\
86\end{array}$ & $\begin{array}{r}843 \\
75 \\
171 \\
112 \\
172\end{array}$ & $\begin{array}{r}4,204 \\
368 \\
1,668 \\
913 \\
1,063\end{array}$ & $\begin{array}{r}7,717 \\
116 \\
1,162 \\
599 \\
1,451\end{array}$ & $\begin{array}{r}2,380 \\
127 \\
579 \\
360 \\
418\end{array}$ & $\begin{array}{r}2,430 \\
309 \\
603 \\
265 \\
324\end{array}$ \\
\hline 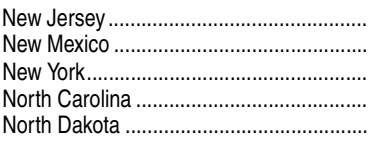 & $\begin{array}{r}15,490 \\
3,259 \\
71,406 \\
16,948 \\
1,725\end{array}$ & $\begin{array}{r}1,409 \\
309 \\
7,647 \\
1,293 \\
42\end{array}$ & $\begin{array}{r}473 \\
66 \\
2,025 \\
174 \\
43\end{array}$ & $\begin{array}{r}357 \\
135 \\
2,770 \\
537 \\
26\end{array}$ & $\begin{array}{r}708 \\
159 \\
2,581 \\
657 \\
56\end{array}$ & $\begin{array}{r}678 \\
43 \\
2,359 \\
613 \\
33\end{array}$ & $\begin{array}{r}1,474 \\
279 \\
3,708 \\
1,179 \\
73\end{array}$ & $\begin{array}{r}3,569 \\
865 \\
18,432 \\
3,591 \\
336\end{array}$ & $\begin{array}{r}3,327 \\
680 \\
13,296 \\
4,219 \\
328\end{array}$ & $\begin{array}{r}1,584 \\
438 \\
6,988 \\
2,274 \\
513\end{array}$ & $\begin{array}{r}1,911 \\
285 \\
11,600 \\
2,411 \\
275\end{array}$ \\
\hline 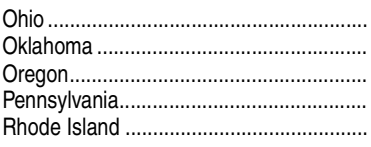 & $\begin{array}{r}24,148 \\
6,481 \\
7,541 \\
36,785 \\
2,566\end{array}$ & $\begin{array}{r}2,031 \\
795 \\
759 \\
2,781 \\
251\end{array}$ & $\begin{array}{r}657 \\
236 \\
242 \\
1,286 \\
87\end{array}$ & $\begin{array}{l}663 \\
133 \\
143 \\
860 \\
117\end{array}$ & $\begin{array}{r}950 \\
227 \\
268 \\
1,197 \\
170\end{array}$ & $\begin{array}{r}313 \\
165 \\
77 \\
1,275 \\
57\end{array}$ & $\begin{array}{r}1,619 \\
594 \\
372 \\
2,407 \\
113\end{array}$ & $\begin{array}{r}5,928 \\
1,280 \\
2,759 \\
9,758 \\
518\end{array}$ & $\begin{array}{r}5,858 \\
1,618 \\
1,329 \\
7,550 \\
713\end{array}$ & $\begin{array}{r}3,169 \\
625 \\
801 \\
5,001 \\
128\end{array}$ & $\begin{array}{r}2,960 \\
808 \\
791 \\
4,670 \\
412\end{array}$ \\
\hline 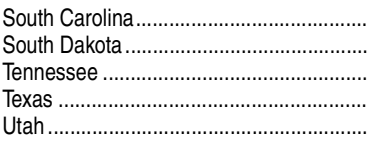 & $\begin{array}{r}5,972 \\
1,467 \\
11,929 \\
45,307 \\
7,669\end{array}$ & $\begin{array}{r}476 \\
80 \\
948 \\
3,775 \\
316\end{array}$ & $\begin{array}{r}131 \\
77 \\
395 \\
1,416 \\
186\end{array}$ & $\begin{array}{r}111 \\
28 \\
223 \\
1,133 \\
125\end{array}$ & $\begin{array}{r}245 \\
66 \\
328 \\
1,784 \\
191\end{array}$ & $\begin{array}{r}54 \\
68 \\
106 \\
1,620 \\
194\end{array}$ & $\begin{array}{r}367 \\
126 \\
425 \\
3,329 \\
374\end{array}$ & $\begin{array}{r}1,779 \\
334 \\
3,474 \\
10,594 \\
2,038\end{array}$ & $\begin{array}{r}1,300 \\
328 \\
2,942 \\
11,729 \\
2,506\end{array}$ & $\begin{array}{r}688 \\
181 \\
1,843 \\
4,516 \\
908\end{array}$ & $\begin{array}{r}821 \\
179 \\
1,245 \\
5,411 \\
831\end{array}$ \\
\hline 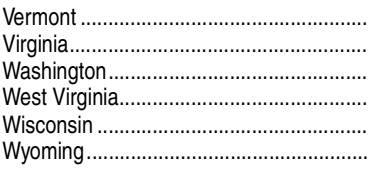 & $\begin{array}{r}2,474 \\
21,516 \\
9,595 \\
5,892 \\
9,856 \\
489\end{array}$ & $\begin{array}{r}585 \\
2,856 \\
735 \\
751 \\
621 \\
69\end{array}$ & $\begin{array}{r}63 \\
1,144 \\
486 \\
59 \\
344 \\
7\end{array}$ & $\begin{array}{r}471 \\
616 \\
156 \\
643 \\
287 \\
22\end{array}$ & \begin{tabular}{r|r|}
37 & \\
468 & \\
346 & 117 \\
288 & 42
\end{tabular} & $\begin{array}{r}67 \\
766 \\
167 \\
59 \\
131 \\
5\end{array}$ & $\begin{array}{r}57 \\
1,120 \\
490 \\
143 \\
606 \\
55\end{array}$ & $\begin{array}{r}405 \\
5,026 \\
2,290 \\
1,179 \\
2,615 \\
92\end{array}$ & $\begin{array}{r}356 \\
4,835 \\
2,217 \\
1,089 \\
2,530 \\
43\end{array}$ & $\begin{array}{r}121 \\
1,729 \\
1,058 \\
474 \\
1,218 \\
50\end{array}$ & $\begin{array}{r}312 \\
2,956 \\
1,650 \\
1,378 \\
1,216 \\
104\end{array}$ \\
\hline U.S. Service Academies........ & 9 & 0 & 0 & 0 & 0 & 0 & 9 & 0 & 0 & 0 & 0 \\
\hline Other jurisdictions. & 5,309 & 220 & 300 & 43 & 122 & 98 & 269 & 1,451 & 1,565 & 606 & 635 \\
\hline American Samoa ............. & . & 0 & 0 & 0 & 0 & 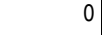 & 0 & . & 0 & 0 & 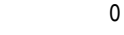 \\
\hline 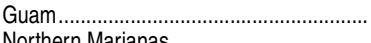 & 132 & 0 & 3 & $\begin{array}{l}0 \\
0\end{array}$ & 0 & 0 & 0 & $\begin{array}{r}84 \\
0\end{array}$ & $\begin{array}{r}15 \\
0\end{array}$ & $\begin{array}{l}0 \\
0\end{array}$ & $\begin{array}{r}19 \\
0\end{array}$ \\
\hline $\begin{array}{l}\text { Northern Marianas } \\
\text { Puerto Rico }\end{array}$ & $\begin{array}{r}0 \\
5,124\end{array}$ & $\begin{array}{r}0 \\
212\end{array}$ & $\begin{array}{r}0 \\
297\end{array}$ & $\begin{array}{r}0 \\
43\end{array}$ & $\begin{array}{r}0 \\
119\end{array}$ & $\begin{array}{r}0 \\
98\end{array}$ & 269 & $\begin{array}{r}0 \\
1,338\end{array}$ & $\begin{array}{r}0 \\
1,542\end{array}$ & $\begin{array}{r}0 \\
606\end{array}$ & 600 \\
\hline 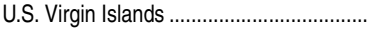 & 53 & 0 & 0 & 0 & 0 & 0 & 0 & 29 & 8 & 0 & 16 \\
\hline
\end{tabular}

'Includes degrees in area, ethnic, cultural, and gender studies; English language and literature/letters; foreign languages, literatures, and linguistics; liberal arts and sciences, general studies and humanities; multi/interdisciplinary studies; philosophy and religious studies; theology and religious vocations; and visual and performing arts.

Includes biological and biomedical sciences; physical sciences; science technologies/ technicians; and mathematics and statistics.

Includes engineering; engineering technologies/technicians; mechanic and repair technologies/technicians; and construction trades.

${ }^{4}$ Includes agriculture, agricultural operations, and related sciences; natural resources and conservation; architecture and related services; communication, journalism, and related programs; communications technologies/technicians and support services; family and consumer services/human sciences; legal professions and studies; library science; military technologies and applied sciences; parks, recreation, leisure, and fitness studies; homeland security, law enforcement, and firefighting; public administration and social service professions; transportation and materials moving; and not classified by field of study. NOTE: Data are for postsecondary institutions participating in Title IV federal financial aid programs. This table includes only those jurisdictions with 4-year institutions.

SOURCE: U.S. Department of Education, National Center for Education Statistics, Integrated Postsecondary Education Data System (IPEDS), Fall 2012, Completions component. (This table was prepared August 2013.) 


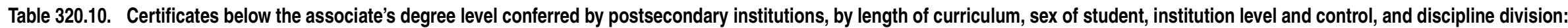
2011-12

\begin{tabular}{|c|c|c|c|c|c|c|c|c|c|c|c|c|c|c|c|c|}
\hline \multirow[b]{3}{*}{ Discipline division } & \multicolumn{8}{|c|}{ Less-than-1-year awards } & \multicolumn{8}{|c|}{ 1- to less-than-4-year awards } \\
\hline & \multirow[b]{2}{*}{ Total } & \multicolumn{2}{|c|}{ Sex } & \multicolumn{2}{|c|}{ Institution level } & \multicolumn{3}{|c|}{ Institution control } & \multicolumn{3}{|c|}{ Sex } & \multicolumn{2}{|c|}{ Institution level } & \multicolumn{3}{|c|}{ Institution control } \\
\hline & & Males & Females & $\begin{array}{r}\text { Non- } \\
\text { degree- } \\
\text { granting } \\
\text { (less- } \\
\text { than- } \\
2 \text {-year) }\end{array}$ & $\begin{array}{r}\text { Degree- } \\
\text { granting } \\
\text { (2-year } \\
\text { and } \\
4 \text {-year) }\end{array}$ & Public & Nonprofit & For-profit & Total & Males & Females & $\begin{array}{r}\text { Non- } \\
\text { degree- } \\
\text { granting } \\
\text { (less- } \\
\text { than- } \\
\text { 2-year) }\end{array}$ & $\begin{array}{r}\text { Degree- } \\
\text { granting } \\
(2-\text {-year } \\
\text { and 4- } \\
\text { year) }\end{array}$ & Public & Nonprofit & For-profit \\
\hline 1 & 2 & 3 & 4 & 5 & 6 & 7 & 8 & 9 & 10 & 11 & 12 & 13 & 14 & 15 & 16 & 17 \\
\hline \multirow{5}{*}{ 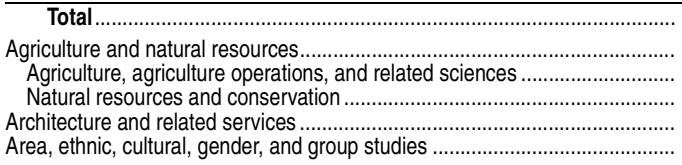 } & 463,849 & 194,832 & 269,017 & 125,908 & 337,941 & 306,815 & 13,772 & 143,262 & 523,866 & 178,652 & 345,214 & 223,633 & 300,233 & 217,571 & 19,100 & 287,195 \\
\hline & 3,380 & 2,366 & 1,014 & 150 & 3,230 & 3,274 & 23 & 83 & 2,397 & 1,516 & 881 & 130 & 2,267 & 2,226 & 99 & 72 \\
\hline & $\begin{array}{r}2,442 \\
938\end{array}$ & $\begin{array}{r}1,564 \\
802\end{array}$ & $\begin{array}{l}878 \\
136\end{array}$ & $\begin{array}{r}150 \\
0\end{array}$ & $\begin{array}{r}2,292 \\
938\end{array}$ & $\begin{array}{r}2,345 \\
929\end{array}$ & $\begin{array}{r}16 \\
7\end{array}$ & $\begin{array}{r}81 \\
2\end{array}$ & $\begin{array}{r}2,247 \\
150\end{array}$ & $\begin{array}{r}1,405 \\
111\end{array}$ & 39 & $\begin{array}{r}130 \\
0\end{array}$ & $\begin{array}{r}2,117 \\
150\end{array}$ & $\begin{array}{r}2,091 \\
135\end{array}$ & $\begin{array}{l}84 \\
15\end{array}$ & $\begin{array}{r}72 \\
0\end{array}$ \\
\hline & $\begin{array}{l}900 \\
196\end{array}$ & $\begin{array}{l}\text { ouc } \\
121\end{array}$ & $\begin{array}{r}100 \\
75\end{array}$ & 0 & $\begin{array}{l}950 \\
196\end{array}$ & $\begin{array}{l}9<9 \\
148\end{array}$ & 47 & $\begin{array}{l}2 \\
1\end{array}$ & $\begin{array}{l}100 \\
127\end{array}$ & $\begin{array}{r}111 \\
64\end{array}$ & $\begin{array}{l}39 \\
63\end{array}$ & $\begin{array}{r}0 \\
10\end{array}$ & $\begin{array}{l}150 \\
117\end{array}$ & $\begin{array}{l}735 \\
110\end{array}$ & $\begin{array}{l}15 \\
17\end{array}$ & 0 \\
\hline & 461 & 124 & 337 & 0 & 461 & 432 & 29 & 0 & 87 & 32 & 55 & 0 & 87 & 83 & 4 & \\
\hline \multirow{8}{*}{ 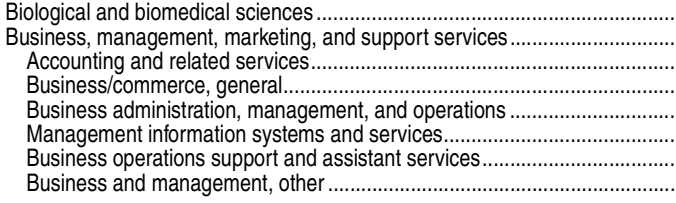 } & 115 & 55 & 60 & 13 & 102 & 100 & 5 & 10 & 102 & 34 & 68 & 47 & 55 & 88 & 1 & 13 \\
\hline & 44,223 & 13,667 & 30,556 & 3,912 & 40,311 & 39,323 & 1,244 & 3,656 & 23,566 & 6,330 & 17,236 & 4,126 & 19,440 & 19,316 & 1,448 & 2,802 \\
\hline & 9,259 & 2,310 & 6,949 & 792 & 8,467 & 8,0 & 106 & 1,095 & & & 4,1 & 933 & & & 481 & 528 \\
\hline & 1,9 & 97 & 94 & 4 & 1,0 & 1,7 & & 2 & & & & & & & & 45 \\
\hline & 7,5 & 2,8 & 4,69 & 49 & 7,4 & 7,1 & 26 & 15 & & 1,0 & 1,9 & & & & & \\
\hline & & 392 & 284 & 302 & 374 & 37 & & 24 & & & 1 & & 3 & & & \\
\hline & 12,316 & 2,375 & 9,941 & 1,965 & 10,351 & 10,743 & 103 & 1,470 & 8,7 & 1,2 & 7,5 & 2,17 & 6,6 & 6,6 & 532 & 1,640 \\
\hline & 12,508 & 4,771 & 7,737 & 800 & 11,708 & 11,308 & 534 & 666 & 4,181 & 1,517 & 2,66 & 733 & 3,448 & 3,363 & 399 & 419 \\
\hline \multirow{3}{*}{$\begin{array}{l}\text { Communication, journalism, and related programs } \\
\text { Communications technologies... } \\
\text { Computer and information sciences and support services.... } \\
\text { Construction trades }\end{array}$} & 1,735 & 905 & 830 & 798 & 937 & 895 & 73 & 767 & 1,257 & 746 & 511 & 769 & 488 & 309 & 158 & 790 \\
\hline & 2,537 & 1,620 & 917 & 821 & 1,716 & 1,603 & 26 & 908 & 2,988 & 2,253 & & 1,844 & 1,144 & & 27 & \\
\hline & $\begin{array}{l}16,930 \\
10,885\end{array}$ & $\begin{array}{l}11,680 \\
10384\end{array}$ & $\begin{array}{r}5,250 \\
501\end{array}$ & $\begin{array}{l}2,240 \\
2101\end{array}$ & $\begin{array}{r}14,690 \\
8784\end{array}$ & $\begin{array}{r}13,824 \\
0 \\
538\end{array}$ & 209 & $2,897 \mid$ & 9,326 & $\begin{array}{r}7,111 \\
13714\end{array}$ & 2,2 & $\begin{array}{r}2,227 \\
420\end{array}$ & $\begin{array}{r}7,099 \\
10201\end{array}$ & $\begin{array}{l}6,012 \\
8790\end{array}$ & $\begin{array}{l}446 \\
610\end{array}$ & 2,868 \\
\hline \multirow{4}{*}{ 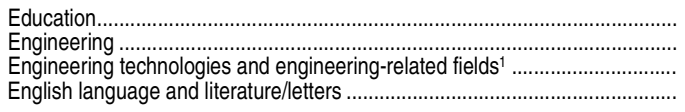 } & 5,197 & 807 & 4,390 & 102 & 5,095 & 4,121 & 309 & 767 & 3.160 & 374 & 2,786 & 67 & 2.753 & 2,123 & 572 & 465 \\
\hline & 456 & 343 & 113 & 61 & 395 & 455 & & 0 & 226 & 199 & 27 & 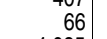 & $\begin{array}{r}2,160 \\
160\end{array}$ & 177 & 28 & 21 \\
\hline & 15,984 & 13,851 & 2,133 & 2,612 & 13,372 & 13,555 & 99 & 2,330 & 15,920 & 14,432 & 1,488 & 4,085 & 11,835 & 7,670 & 410 & 7,840 \\
\hline & & & 1,028 & 610 & 985 & & 635 & 401 & 330 & 105 & 22 & 65 & & 101 & 18 & 211 \\
\hline 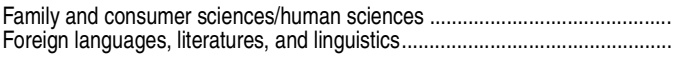 & $\begin{array}{r}13,579 \\
1,043\end{array}$ & $\begin{array}{r}1,551 \\
218\end{array}$ & $\begin{array}{r}12,028 \\
825\end{array}$ & $\begin{array}{r}1,115 \\
0\end{array}$ & $\begin{array}{r}12,464 \\
1,043\end{array}$ & $\begin{array}{r}13,433 \\
927\end{array}$ & $\begin{array}{l}50 \\
83\end{array}$ & $\begin{array}{l}96 \\
33\end{array}$ & $\begin{array}{r}3,354 \\
623\end{array}$ & $\begin{array}{r}242 \\
98\end{array}$ & $\begin{array}{r}3,112 \\
525\end{array}$ & $\begin{array}{r}273 \\
5\end{array}$ & $\begin{array}{r}3,081 \\
618\end{array}$ & $\begin{array}{r}3,319 \\
599\end{array}$ & $\begin{array}{l}35 \\
24\end{array}$ & $\begin{array}{l}0 \\
0\end{array}$ \\
\hline \multirow{13}{*}{ 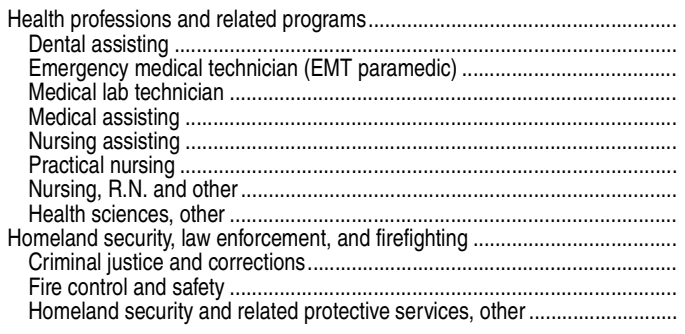 } & 189,739 & 35,918 & 153,821 & 61,307 & 128,432 & 100,631 & 6,468 & 82,640 & 227,547 & 32,743 & 194,804 & 86,998 & 140,549 & 73,762 & 10,018 & 143,767 \\
\hline & 8,136 & 790 & 7,346 & 2,888 & 5,248 & 1,438 & 278 & 6,420 & 15,623 & 1,557 & 14,0 & 5,107 & 10,516 & 4,228 & 42 & 11,353 \\
\hline & 16,166 & $10,77 \varepsilon$ & 5,388 & 1,3 & 14,8 & 15,8 & & & 4,8 & 3,6 & & 44 & & & & 351 \\
\hline & 13,257 & 2,406 & 10,851 & $\begin{array}{r}3,051 \\
\end{array}$ & 10,206 & 9,071 & 275 & 3,911 & 4,955 & 1,313 & 3,6 & 1,465 & 3,4 & 2,9 & 515 & 1,537 \\
\hline & $\begin{array}{l}45,230 \\
\end{array}$ & 7,214 & $\begin{array}{l}38,016 \\
0,171\end{array}$ & 17,638 & $\begin{array}{r}27,592 \\
\end{array}$ & 8,948 & 2,927 & 33,355 & 84,434 & 10,254 & 74,180 & 36,152 & 48,282 & 9,424 & 2,020 & 72,990 \\
\hline & 45,078 & 5,907 & 39,171 & 11,359 & 33,719 & 38,066 & 807 & 6,205 & 874 & 90 & 784 & 203 & 671 & 358 & 41 & 475 \\
\hline & 5,878 & 701 & 5,177 & 466 & 5,412 & 5,454 & & 393 & 56,797 & 7,048 & 49,749 & 19,097 & 37,700 & 36,882 & 2,256 & 17,659 \\
\hline & 1,851 & & 1,644 & & 1,820 & 1,695 & 2 & 154 & 3,948 & 525 & 3,4 & 2,298 & 1,650 & 1,301 & 2,404 & 243 \\
\hline & 54,143 & 7,915 & 46,228 & 24,512 & 29,6 & 20,1 & 2,091 & 31,911 & 56,0 & 8,295 & 47,7 & 22,234 & & & 2,501 & 39,159 \\
\hline & 23,308 & 17,844 & 5,464 & 3,093 & 20,2 & 21, & 373 & 1,013 & 6,2 & 4,1 & 2,1 & 299 & & & 157 & 787 \\
\hline & 15,699 & 11,021 & 4,678 & 1,227 & 14,472 & 15,217 & 304 & 178 & 4,9 & 2,9 & 1,9 & 289 & & & 37 & 772 \\
\hline & 6,499 & 6,049 & 450 & 1,498 & 5,001 & 6,469 & 15 & 15 & 1,13 & 1,05 & 8 & 10 & 1,12 & 1,1 & 0 & 0 \\
\hline & 1,110 & 774 & 336 & 368 & 742 & 236 & 54 & 820 & 181 & 87 & 94 & 0 & 181 & 46 & 120 & 15 \\
\hline \multirow[t]{2}{*}{ 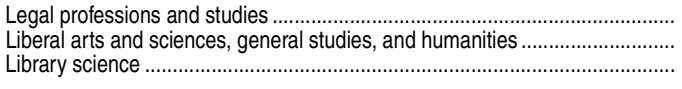 } & $\begin{array}{r}2,221 \\
5,736 \\
221\end{array}$ & $\begin{array}{r}339 \\
2,138 \\
34\end{array}$ & $\begin{array}{r}1,882 \\
3,598 \\
187\end{array}$ & $\begin{array}{r}256 \\
0 \\
0\end{array}$ & $\begin{array}{r}1,965 \\
5,736 \\
221\end{array}$ & $\begin{array}{r}1,474 \\
5,732 \\
221\end{array}$ & $\begin{array}{r}76 \\
4 \\
0\end{array}$ & $\begin{array}{r}671 \\
0 \\
0\end{array}$ & $\begin{array}{r}3,252 \\
28,029 \\
127\end{array}$ & $\begin{array}{r}518 \\
11,183 \\
8\end{array}$ & $\begin{array}{r}2,734 \\
16,846 \\
119\end{array}$ & $\begin{array}{r}596 \\
0 \\
0\end{array}$ & $\begin{array}{r}2,656 \\
28,029 \\
127\end{array}$ & $\begin{array}{r}2,304 \\
28,022 \\
123\end{array}$ & $\begin{array}{r}205 \\
7 \\
4\end{array}$ & $\begin{array}{r}743 \\
0 \\
0\end{array}$ \\
\hline & & & & & & & & & & & & & & & & \\
\hline \multirow{3}{*}{ 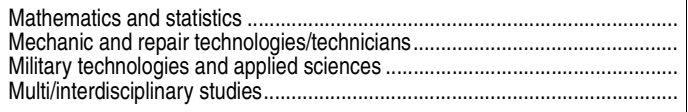 } & $\begin{array}{r}39 \\
33,741\end{array}$ & $\begin{array}{r}35 \\
31,773\end{array}$ & $\begin{array}{r}4 \\
1,968\end{array}$ & $\begin{array}{r}0 \\
4,499\end{array}$ & $\begin{array}{r}39 \\
29,242\end{array}$ & $\begin{array}{r}30 \\
30,196\end{array}$ & $\begin{array}{r}9 \\
660\end{array}$ & $\begin{array}{r}0 \\
2,885\end{array}$ & $\begin{array}{r}13 \\
52,053\end{array}$ & $\begin{array}{r}9 \\
49,994\end{array}$ & $\begin{array}{r}4 \\
2,059\end{array}$ & $\begin{array}{r}0 \\
25,211\end{array}$ & $\begin{array}{r}13 \\
26,842\end{array}$ & $\begin{array}{r}11 \\
21,607\end{array}$ & $\begin{array}{r}2 \\
805\end{array}$ & $\begin{array}{r}0 \\
29,641\end{array}$ \\
\hline & 39 & 33 & 6 & 0 & 39 & 27 & 0 & 12 & 3 & & 0 & 0 & 3 & 3 & 0 & 0 \\
\hline & 1,315 & 538 & 777 & 14 & 1,301 & 830 & 62 & 423 & 1,080 & 512 & 568 & 0 & 1,080 & 1,044 & 36 & \\
\hline $\begin{array}{l}\text { Parks, recreation, leisure, and fitness studies } \\
\text { Personal and culinary services }\end{array}$ & $\begin{array}{r}836 \\
39,649\end{array}$ & $\begin{array}{r}448 \\
7,159\end{array}$ & $\begin{array}{r}388 \\
32,490\end{array}$ & $\begin{array}{r}203 \\
27,846\end{array}$ & $\begin{array}{r}633 \\
11,803\end{array}$ & $\begin{array}{r}499 \\
8,546\end{array}$ & $\begin{array}{r}30 \\
310\end{array}$ & $\begin{array}{r}307 \\
30,793\end{array}$ & $\begin{array}{r}816 \\
100,077\end{array}$ & $\begin{array}{r}482 \\
13,165\end{array}$ & $\begin{array}{r}334 \\
86,912\end{array}$ & $\begin{array}{r}231 \\
85,038\end{array}$ & $\begin{array}{r}585 \\
15,039\end{array}$ & $\begin{array}{r}349 \\
14,112\end{array}$ & $\begin{array}{r}0 \\
1,241\end{array}$ & $\begin{array}{r}467 \\
84,724\end{array}$ \\
\hline 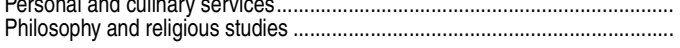 & $\begin{array}{r}39,649 \\
67\end{array}$ & $\begin{array}{r}1,159 \\
32\end{array}$ & $\begin{array}{r}3<, 490 \\
35\end{array}$ & $\begin{array}{r}21,840 \\
0\end{array}$ & $\begin{array}{r}11,003 \\
67\end{array}$ & $\begin{array}{r}8,540 \\
50\end{array}$ & $\begin{array}{r}310 \\
17\end{array}$ & $\begin{aligned} 30,193 \\
3\end{aligned}$ & $\begin{array}{r}100,0 / 1 \\
38\end{array}$ & $\begin{array}{r}13,105 \\
19\end{array} \mid$ & $\begin{aligned} 80,912 \\
19\end{aligned}$ & $\begin{array}{r}80,038 \\
0\end{array}$ & 38 & $\mid \begin{aligned} 14,16 \\
0\end{aligned}$ & $\begin{aligned} r, 241 \\
38\end{aligned}$ & $\begin{array}{r}04,1 / 24 \\
0\end{array}$ \\
\hline
\end{tabular}

See notes at end of table. 


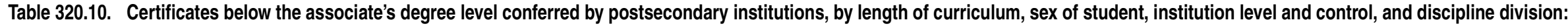
2011-12-Continued

\begin{tabular}{|c|c|c|c|c|c|c|c|c|c|c|c|c|c|c|c|c|}
\hline \multirow[b]{3}{*}{ Discipline division } & \multicolumn{8}{|c|}{ Less-than-1-year awards } & \multicolumn{8}{|c|}{ 1- to less-than-4-year awards } \\
\hline & \multirow[b]{2}{*}{ Total } & \multicolumn{2}{|c|}{ Sex } & \multicolumn{2}{|c|}{ Institution level } & \multicolumn{3}{|c|}{ Institution control } & \multirow[b]{2}{*}{ Total } & \multicolumn{2}{|c|}{ Sex } & \multicolumn{2}{|c|}{ Institution level } & \multicolumn{3}{|c|}{ Institution control } \\
\hline & & Males & Females & $\begin{array}{r}\text { Non- } \\
\text { degree- } \\
\text { granting } \\
\text { (less- } \\
\text { than- } \\
2 \text {-year) }\end{array}$ & $\begin{array}{r}\text { Degree- } \\
\text { granting } \\
\text { (2-year } \\
\text { and } \\
4 \text {-year })\end{array}$ & Public & Nonprofit & For-profit & & Males & Females & $\begin{array}{r}\text { Non- } \\
\text { degree- } \\
\text { granting } \\
\text { (less- } \\
\text { than- } \\
2 \text {-year) }\end{array}$ & $\begin{array}{r}\text { Degree- } \\
\text { granting } \\
\text { (2-year } \\
\text { and 4- } \\
\text { year) }\end{array}$ & Public & Nonprofit & For-profit \\
\hline 1 & 2 & 3 & 4 & 5 & 6 & 7 & 8 & 9 & 10 & 11 & 12 & 13 & 14 & 15 & 16 & 17 \\
\hline 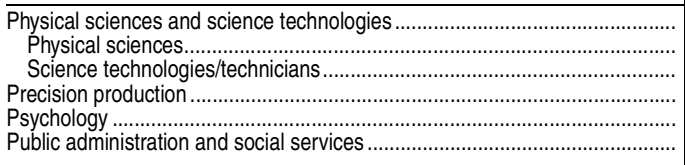 & $\begin{array}{r}558 \\
42 \\
516 \\
15,380 \\
23 \\
1,275\end{array}$ & $\begin{array}{r}421 \\
30 \\
391 \\
14,620 \\
9 \\
264\end{array}$ & $\begin{array}{r}137 \\
12 \\
125 \\
760 \\
14 \\
1,011\end{array}$ & \begin{tabular}{r|}
108 \\
0 \\
108 \\
2,011 \\
0 \\
8
\end{tabular} & $\begin{array}{r}450 \\
42 \\
408 \\
13,369 \\
23 \\
1,267\end{array}$ & $\begin{array}{r}468 \\
42 \\
426 \\
14,135 \\
17 \\
1,208\end{array}$ & $\begin{array}{r}0 \\
0 \\
0 \\
531 \\
6 \\
67\end{array}$ & $\begin{array}{r}90 \\
0 \\
90 \\
714 \\
0 \\
0\end{array}$ & $\begin{array}{r}497 \\
17 \\
480 \\
13,059 \\
84 \\
687\end{array}$ & $\begin{array}{r}362 \\
13 \\
349 \\
12,430 \\
15 \\
123\end{array}$ & $\begin{array}{r}135 \\
4 \\
131 \\
629 \\
69 \\
564\end{array}$ & $\begin{array}{r}3 \\
0 \\
3 \\
4,090 \\
0 \\
0\end{array}$ & $\begin{array}{r}494 \\
17 \\
477 \\
8,969 \\
84 \\
687\end{array}$ & $\begin{array}{r}488 \\
17 \\
471 \\
9,515 \\
77 \\
679\end{array}$ & $\begin{array}{r}0 \\
0 \\
0 \\
635 \\
7 \\
8\end{array}$ & $\begin{array}{r}9 \\
0 \\
9 \\
2,909 \\
0 \\
0\end{array}$ \\
\hline 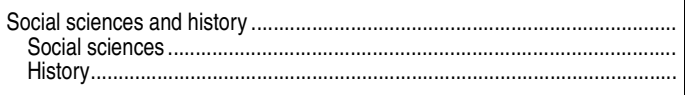 & $\begin{array}{r}726 \\
700 \\
26\end{array}$ & $\begin{array}{r}428 \\
421 \\
7\end{array}$ & $\begin{array}{r}298 \\
279 \\
19\end{array}$ & $\begin{array}{l}0 \\
0 \\
0\end{array}$ & $\begin{array}{r}726 \\
700 \\
26\end{array}$ & $\begin{array}{r}651 \\
627 \\
24\end{array}$ & $\begin{array}{r}75 \\
73 \\
2\end{array}$ & $\begin{array}{l}0 \\
0 \\
0\end{array}$ & $\begin{array}{r}373 \\
371 \\
2\end{array}$ & $\begin{array}{r}204 \\
204 \\
0\end{array}$ & $\begin{array}{r}169 \\
167 \\
2\end{array}$ & $\begin{array}{l}0 \\
0 \\
0\end{array}$ & $\begin{array}{r}373 \\
371 \\
2\end{array}$ & $\begin{array}{r}325 \\
324 \\
1\end{array}$ & \begin{tabular}{r|}
48 \\
47 \\
1
\end{tabular} & $\begin{array}{l}0 \\
0 \\
0\end{array}$ \\
\hline 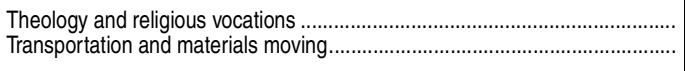 & $\begin{array}{r}146 \\
23,686\end{array}$ & $\begin{array}{r}64 \\
21,641\end{array}$ & $\begin{array}{r}82 \\
2,045\end{array}$ & $\begin{array}{r}0 \\
9,869\end{array}$ & $\begin{array}{r}146 \\
13,817\end{array}$ & $\begin{array}{r}4 \\
14,755\end{array}$ & $\begin{array}{l}142 \\
771\end{array}$ & 8,160 & $\begin{array}{r}1,153 \\
824\end{array}$ & $\begin{array}{r}545 \\
766\end{array}$ & $\begin{array}{r}608 \\
58\end{array}$ & $\begin{array}{l}670 \\
313\end{array}$ & $\begin{array}{l}483 \\
511\end{array}$ & $\begin{array}{r}0 \\
571\end{array}$ & $\begin{array}{r}1,153 \\
20\end{array}$ & $\begin{array}{r}0 \\
233\end{array}$ \\
\hline 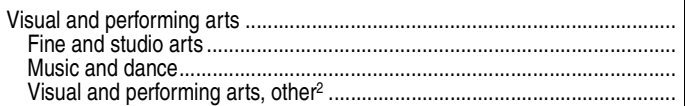 & $\begin{array}{r}6,828 \\
841 \\
473 \\
5,514\end{array}$ & $\begin{array}{r}2,835 \\
298 \\
371 \\
2,166\end{array}$ & $\begin{array}{r}3,993 \\
543 \\
102 \\
3,348\end{array}$ & $\begin{array}{r}2,159 \\
714 \\
0 \\
1,445\end{array}$ & $\begin{array}{r}4,669 \\
127 \\
473 \\
4,069\end{array}$ & $\begin{array}{r}3,232 \\
123 \\
226 \\
2,883\end{array}$ & $\begin{array}{r}688 \\
526 \\
3 \\
159\end{array}$ & $\begin{array}{r}2,908 \\
192 \\
244 \\
2,472\end{array}$ & $\begin{array}{r}9,981 \\
4,722 \\
713 \\
4,546\end{array}$ & $\begin{array}{r}4,217 \\
1,781 \\
521 \\
1,915\end{array}$ & $\begin{array}{r}5,764 \\
2,941 \\
192 \\
2,631\end{array}$ & $\begin{array}{r}1,901 \\
9 \\
200 \\
1,692\end{array}$ & $\begin{array}{r}8,080 \\
4,713 \\
513 \\
2,854\end{array}$ & $\begin{array}{r}6,936 \\
4,700 \\
159 \\
2,077\end{array}$ & $\begin{array}{r}811 \\
22 \\
179 \\
610\end{array}$ & $\begin{array}{r}2,234 \\
0 \\
375 \\
1,859\end{array}$ \\
\hline $\begin{array}{l}\text { "Excludes "Construction trades" and "Mechanic and repair technologies/tect } \\
\text { 2Includes design and applied arts, drama and theatre arts, film and photogra } \\
\text { and studio arts" or "Music and dance." }\end{array}$ & $\begin{array}{l}\text { is," w } \\
\text { itss, a }\end{array}$ & the & $\begin{array}{l}\text { oarate } \\
\text { ot inc }\end{array}$ & & & $\begin{array}{l}\text { grant degr } \\
\text { SOURCE: } \\
\text { System (IF }\end{array}$ & $\begin{array}{l}\text { U.S. Depar } \\
\text { EDSS), Fall }\end{array}$ & $\begin{array}{l}\text { rtment of } \\
\text { 2012, Con }\end{array}$ & ons co & onent. (T & $\begin{array}{l}\text {-degree-g } \\
\text { er for Ed } \\
\text { is table we }\end{array}$ & $\begin{array}{l}\text { ederal finar } \\
\text { ting institut } \\
\text { ion Statist } \\
\text { repared O }\end{array}$ & $\begin{array}{l}\text { ons grant } \\
\text { s, Integra } \\
\text { tober } 201\end{array}$ & $\begin{array}{l}\text { De } \\
\text { ward } \\
\text { stse }\end{array}$ & $\begin{array}{l}\text {-grantir } \\
\text { low tha: } \\
\text { dary Ed }\end{array}$ & $\begin{array}{l}\text { stitutions } \\
\text { I. } \\
\text { on Data }\end{array}$ \\
\hline
\end{tabular}


Table 320.20. Certificates below the associate's degree level conferred by postsecondary institutions, by race/ethnicity and sex of student: 1998-99 through 2011-12

\begin{tabular}{|c|c|c|c|c|c|c|c|c|c|c|c|c|c|c|c|}
\hline \multirow[b]{2}{*}{ Year and sex } & \multicolumn{8}{|c|}{ Number of certificates conferred to U.S. citizens and nonresident aliens } & \multicolumn{7}{|c|}{ Percentage distribution of certificates conferred to U.S. citizens } \\
\hline & Total & White & Black & Hispanic & $\begin{array}{r}\text { Asian/ } \\
\text { Pacific } \\
\text { Islander }\end{array}$ & $\begin{array}{r}\text { American } \\
\text { Indian/ } \\
\text { Alaska } \\
\text { Native }\end{array}$ & $\begin{array}{r}\text { Two or } \\
\text { more } \\
\text { races }\end{array}$ & $\begin{array}{r}\text { Non- } \\
\text { resident } \\
\text { alien }\end{array}$ & Total & White & Black & Hispanic & $\begin{array}{r}\text { Asian/ } \\
\text { Pacific } \\
\text { Islander }\end{array}$ & $\begin{array}{r}\text { American } \\
\text { Indian/ } \\
\text { Alaska } \\
\text { Native }\end{array}$ & $\begin{array}{r}\text { Two or } \\
\text { more } \\
\text { races }\end{array}$ \\
\hline 1 & 2 & 3 & 4 & 5 & 6 & 7 & 8 & 9 & 10 & 11 & 12 & 13 & 14 & 15 & 16 \\
\hline \multicolumn{16}{|l|}{ Total } \\
\hline $1998-99 \ldots$. & 555,883 & 345,359 & 92,800 & 76,833 & 27,920 & 7,510 & - & 5,461 & 100.0 & 62.7 & 16.9 & 14.0 & 5.1 & 1.4 & - \\
\hline $1999-2000 \ldots . .$. & 558,129 & 337,546 & 97,329 & 81,132 & 29,361 & 6,966 & - & 5,795 & 100.0 & 61.1 & 17.6 & 14.7 & 5.3 & 1.3 & - \\
\hline $2000-01 \ldots . .$. & 552,503 & 333,478 & 99,397 & 78,528 & 28,123 & 6,598 & - & 6,379 & 100.0 & 61.1 & 18.2 & 14.4 & 5.1 & 1.2 & - \\
\hline $2001-02 .$. & 584,248 & 352,559 & 106,647 & 83,950 & 27,490 & 7,430 & - & 6,172 & 100.0 & 61.0 & 18.4 & 14.5 & 4.8 & 1.3 & - \\
\hline $2002-03 \ldots \ldots \ldots \ldots \ldots \ldots \ldots$ & 646,425 & 382,289 & 120,582 & 95,499 & 32,981 & 8,117 & - & 6,957 & 100.0 & 59.8 & 18.9 & 14.9 & 5.2 & 1.3 & - \\
\hline $2003-04 \ldots . .$. & 687,787 & 402,989 & 129,891 & 107,216 & 32,819 & 8,375 & - & 6,497 & 100.0 & 59.2 & 19.1 & 15.7 & 4.8 & 1.2 & - \\
\hline $2004-05 \ldots . . .$. & 710,873 & 415,670 & 133,601 & 114,089 & 32,783 & 8,150 & - & 6,580 & 100.0 & 59.0 & 19.0 & 16.2 & 4.7 & 1.2 & - \\
\hline $2005-06 \ldots . .$. & 715,401 & 412,077 & 135,460 & 118,853 & 34,110 & 8,400 & - & 6,501 & 100.0 & 58.1 & 19.1 & 16.8 & 4.8 & 1.2 & - \\
\hline $2006-07 \ldots . .$. & 729,037 & 420,585 & 139,995 & 119,501 & 32,962 & 8,793 & - & 7,201 & 100.0 & 58.3 & 19.4 & 16.6 & 4.6 & 1.2 & - \\
\hline $2007-08 \ldots \ldots$. & 749,883 & 430,187 & 145,181 & 122,676 & 35,985 & 8,596 & - & 7,258 & 100.0 & 57.9 & 19.5 & 16.5 & 4.8 & 1.2 & - \\
\hline $2008-09 \ldots . .$. & 805,755 & 451,107 & 161,954 & 138,550 & 37,804 & 9,510 & - & 6,830 & 100.0 & 56.5 & 20.3 & 17.3 & 4.7 & 1.2 & - \\
\hline $2009-10 \ldots . . .$. & 935,789 & 511,270 & 191,646 & 171,874 & 41,404 & 12,125 & - & 7,470 & 100.0 & 55.1 & 20.6 & 18.5 & 4.5 & 1.3 & - \\
\hline $2010-11 \ldots . .$. & $1,029,557$ & 557,163 & 207,389 & 186,943 & 44,431 & 11,194 & 15,142 & 7,295 & 100.0 & 54.5 & 20.3 & 18.3 & 4.3 & 1.1 & 1.5 \\
\hline $2011-12 \ldots$ & 987,715 & 534,931 & 190,120 & 186,738 & 42,985 & 10,608 & 14,114 & 8,219 & 100.0 & 54.6 & 19.4 & 19.1 & 4.4 & 1.1 & 1.4 \\
\hline \multicolumn{16}{|l|}{ Males } \\
\hline $1998-99 .$. & 219,872 & 144,735 & 29,875 & 27,719 & 11,742 & 3,061 & - & 2,740 & 100.0 & 66.7 & 13.8 & 12.8 & 5.4 & 1.4 & - \\
\hline 1999-2000.. & 226,110 & 143,634 & 33,792 & 30,337 & 13,082 & 2,862 & - & 2,403 & 100.0 & 64.2 & 15.1 & 13.6 & 5.8 & 1.3 & - \\
\hline $2000-01 \ldots . .$. & 223,951 & 143,144 & 34,381 & 28,685 & 12,072 & 2,719 & - & 2,950 & 100.0 & 64.8 & 15.6 & 13.0 & 5.5 & 1.2 & - \\
\hline $2001-02 \ldots \ldots$. & 235,275 & 152,226 & 36,482 & 29,749 & 10,938 & 3,226 & - & 2,654 & 100.0 & 65.4 & 15.7 & 12.8 & 4.7 & 1.4 & - \\
\hline $2002-03 \ldots \ldots . .$. & 254,238 & 161,001 & 40,080 & 33,925 & 12,930 & 3,506 & - & 2,796 & 100.0 & 64.0 & 15.9 & 13.5 & 5.1 & 1.4 & - \\
\hline $2003-04 \ldots$ & 257,138 & 161,684 & 40,809 & 36,157 & 12,713 & 3,135 & - & 2,640 & 100.0 & 63.5 & 16.0 & 14.2 & 5.0 & 1.2 & - \\
\hline $2004-05 \ldots . .$. & 259,261 & 161,126 & 41,644 & 38,297 & 12,448 & 3,068 & - & 2,678 & 100.0 & 62.8 & 16.2 & 14.9 & 4.9 & 1.2 & - \\
\hline $2005-06 .$. & 259,737 & 158,747 & 41,863 & 40,752 & 12,790 & 3,219 & - & 2,366 & 100.0 & 61.7 & 16.3 & 15.8 & 5.0 & 1.3 & - \\
\hline $2006-07 \ldots$ & 269,589 & 164,939 & 44,870 & 40,958 & 12,622 & 3,527 & - & 2,673 & 100.0 & 61.8 & 16.8 & 15.3 & 4.7 & 1.3 & - \\
\hline $2007-08 .$. & 283,266 & 172,398 & 48,024 & 43,085 & 13,527 & 3,452 & - & 2,780 & 100.0 & 61.5 & 17.1 & 15.4 & 4.8 & 1.2 & - \\
\hline $2008-09 \ldots .$. & 302,615 & 179,968 & 53,948 & 47,876 & 14,354 & 3,862 & - & 2,607 & 100.0 & 60.0 & 18.0 & 16.0 & 4.8 & 1.3 & - \\
\hline $2009-10 \ldots$. & 355,380 & 205,335 & 65,492 & 60,820 & 15,933 & 5,079 & - & 2,721 & 100.0 & 58.2 & 18.6 & 17.2 & 4.5 & 1.4 & - \\
\hline $2010-11 \ldots . .$. & 391,683 & 223,759 & 71,853 & 66,374 & 16,997 & 4,761 & 4,982 & 2,957 & 100.0 & 57.6 & 18.5 & 17.1 & 4.4 & 1.2 & 1.3 \\
\hline $2011-12 \ldots \ldots \ldots \ldots \ldots \ldots \ldots . .$. & 373,484 & 213,520 & 65,143 & 65,744 & 16,154 & 4,497 & 4,940 & 3,486 & 100.0 & 57.7 & 17.6 & 17.8 & 4.4 & 1.2 & 1.3 \\
\hline \multicolumn{16}{|l|}{ Females } \\
\hline $1998-99 \ldots . .$. & 336,011 & 200,624 & 62,925 & 49,114 & 16,178 & 4,449 & - & 2,721 & 100.0 & 60.2 & 18.9 & 14.7 & 4.9 & 1.3 & - \\
\hline $1999-2000 \ldots . .$. & 332,019 & 193,912 & 63,537 & 50,795 & 16,279 & 4,104 & - & 3,392 & 100.0 & 59.0 & 19.3 & 15.5 & 5.0 & 1.2 & - \\
\hline $2000-01 \ldots$. & 328,552 & 190,334 & 65,016 & 49,843 & 16,051 & 3,879 & - & 3,429 & 100.0 & 58.5 & 20.0 & 15.3 & 4.9 & 1.2 & - \\
\hline $2001-02 .$. & 348,973 & 200,333 & 70,165 & 54,201 & 16,552 & 4,204 & - & 3,518 & 100.0 & 58.0 & 20.3 & 15.7 & 4.8 & 1.2 & - \\
\hline $2002-03 \ldots$. & 392,187 & 221,288 & 80,502 & 61,574 & 20,051 & 4,611 & - & 4,161 & 100.0 & 57.0 & 20.7 & 15.9 & 5.2 & 1.2 & - \\
\hline $2003-04 \ldots .$. & 30,649 & 241,305 & 89,082 & 71,059 & 20,106 & 5,240 & - & 3,857 & 100.0 & 56.5 & 20.9 & 16.6 & 4.7 & 1.2 & - \\
\hline $2004-05 \ldots .$. & 451,612 & 254,544 & 91,957 & 75,792 & 20,335 & 5,082 & - & 3,902 & 100.0 & 56.9 & 20.5 & 16.9 & 4.5 & 1.1 & - \\
\hline 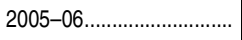 & 455,664 & 253,330 & 93,597 & 78,101 & 21,320 & 5,181 & - & 4,135 & 100.0 & 56.1 & 20.7 & 17.3 & 4.7 & 1.1 & - \\
\hline $2006-07 \ldots$ & 459,448 & 255,646 & 95,125 & 78,543 & 20,340 & 5,266 & - & 4,528 & 100.0 & 56.2 & 20.9 & 17.3 & 4.5 & 1.2 & - \\
\hline 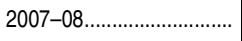 & 466,617 & 257,789 & 97,157 & 79,591 & 22,458 & 5,144 & - & 4,478 & 100.0 & 55.8 & 21.0 & 17.2 & 4.9 & 1.1 & - \\
\hline $2008-09 \ldots$ & 503,140 & 271,139 & 108,006 & 90,674 & 23,450 & 5,648 & - & 4,223 & 100.0 & 54.3 & 21.6 & 18.2 & 4.7 & 1.1 & - \\
\hline $2009-10 \ldots$. & 580,409 & 305,935 & 126,154 & 111,054 & 25,471 & 7,046 & - & 4,749 & 100.0 & 53.1 & 21.9 & 19.3 & 4.4 & 1.2 & - \\
\hline $2010-11 \ldots \ldots \ldots \ldots \ldots \ldots \ldots . .$. & 637,874 & 333,404 & 135,536 & 120,569 & 27,434 & 6,433 & 10,160 & 4,338 & 100.0 & 52.6 & 21.4 & 19.0 & 4.3 & 1.0 & 1.6 \\
\hline $2011-12 \ldots \ldots \ldots \ldots \ldots \ldots$ & 614,231 & 321,411 & 124,977 & 120,994 & 26,831 & 6,111 & 9,174 & 4,733 & 100.0 & 52.7 & 20.5 & 19.9 & 4.4 & 1.0 & 1.5 \\
\hline
\end{tabular}

一Not available.

NOTE: Includes less-than-1-year awards and 1- to less-than-4-year awards (excluding associate's degrees) conferred by postsecondary institutions participating in Title IV federal financial aid programs. Race categories exclude persons of Hispanic ethnicity. Reported racial/ethnic distributions of students by level of degree, field of degree, and sex were used to estimate race/ethnicity for students whose race/ethnicity was not reported. Detail may not sum to totals because of rounding

SOURCE: U.S. Department of Education, National Center for Education Statistics, Integrated Postsecondary Education Data System (IPEDS), "Completions Survey" (IPEDSC:99); and IPEDS Fall 2000 through Fall 2012, Completions component. (This table was prepared July 2013.) 
Table 321.10. Associate's degrees conferred by postsecondary institutions, by sex of student and discipline division: 2001-02 through 2011-12

\begin{tabular}{|c|c|c|c|c|c|c|c|c|c|c|c|c|c|}
\hline \multirow[b]{2}{*}{ Discipline division } & \multirow[b]{2}{*}{$2001-02$} & \multirow[b]{2}{*}{$2002-03$} & \multirow[b]{2}{*}{ 2003-04 } & \multirow[b]{2}{*}{$2004-05$} & \multirow[b]{2}{*}{$2005-06$} & \multirow[b]{2}{*}{$2006-07$} & \multirow[b]{2}{*}{$2007-08$} & \multirow[b]{2}{*}{ 2008-09 } & \multirow[b]{2}{*}{$2009-10$} & \multirow[b]{2}{*}{$2010-11$} & \multicolumn{3}{|c|}{$2011-12$} \\
\hline & & & & & & & & & & & Total & Males & Females \\
\hline 1 & 2 & 3 & 4 & 5 & 6 & 7 & 8 & $y$ & 10 & 11 & 12 & 13 & 14 \\
\hline 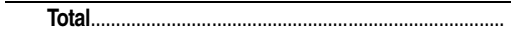 & 595,133 & 634,016 & 665,301 & 696,660 & 713,066 & 728,114 & 750,164 & 787,325 & 849,452 & 942,327 & $1,017,538$ & 391,990 & 625,548 \\
\hline 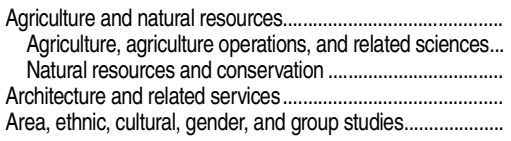 & $\begin{array}{r}6,494 \\
5,125 \\
1,369 \\
443 \\
94\end{array}$ & $\begin{array}{r}6,210 \\
4,892 \\
1,318 \\
440 \\
120\end{array}$ & $\begin{array}{r}6,283 \\
4,959 \\
1,324 \\
492 \\
105\end{array}$ & $\begin{array}{r}6,404 \\
5,137 \\
1,267 \\
583 \\
115\end{array}$ & $\begin{array}{r}6,168 \\
4,958 \\
1,210 \\
656 \\
124\end{array}$ & $\begin{array}{r}5,838 \\
4,638 \\
1,200 \\
517 \\
164\end{array}$ & $\begin{array}{r}5,738 \\
4,554 \\
1,184 \\
568 \\
169\end{array}$ & \begin{tabular}{r|r|}
5,724 \\
4,525 \\
1,199 \\
596 \\
173
\end{tabular} & \begin{tabular}{r|}
5,894 \\
4,615 \\
1,279 \\
552 \\
199
\end{tabular} & $\begin{array}{r}6,425 \\
4,920 \\
1,505 \\
569 \\
209\end{array}$ & $\begin{array}{r}7,066 \\
5,398 \\
1,668 \\
593 \\
194\end{array}$ & $\begin{array}{r}4,606 \\
3,356 \\
1,250 \\
332 \\
62\end{array}$ & $\begin{array}{r}2,460 \\
2,042 \\
418 \\
261 \\
132\end{array}$ \\
\hline 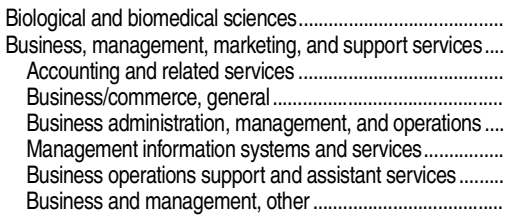 & $\begin{array}{r}1,534 \\
86,713 \\
12,315 \\
12,936 \\
26,890 \\
6,417 \\
11,508 \\
16,647\end{array}$ & $\begin{array}{r}1,496 \\
89,627 \\
13,229 \\
13,054 \\
28,943 \\
5,600 \\
11,524 \\
17,277\end{array}$ & $\begin{array}{r}1,456 \\
92,065 \\
14,506 \\
13,387 \\
31,522 \\
4,214 \\
11,400 \\
17,036\end{array}$ & $\begin{array}{r}1,709 \\
96,067 \\
13,988 \\
12,050 \\
37,258 \\
2,812 \\
11,196 \\
18,763\end{array}$ & $\begin{array}{r}1,827 \\
96,933 \\
13,620 \\
13,297 \\
39,152 \\
2,179 \\
10,044 \\
18,641\end{array}$ & $\begin{array}{r}2,060 \\
99,998 \\
14,232 \\
12,725 \\
43,667 \\
2,007 \\
8,864 \\
18,503\end{array}$ & $\begin{array}{r}2,200 \\
104,566 \\
15,965 \\
12,473 \\
47,911 \\
1,237 \\
7,841 \\
19,139\end{array}$ & $\begin{array}{r}2,364 \\
111,521 \\
16,731 \\
13,067 \\
52,938 \\
1,103 \\
7,549 \\
20,133\end{array}$ & $\begin{array}{r}2,664 \\
116,904 \\
17,994 \\
14,547 \\
46,137 \\
1,221 \\
7,388 \\
29,617\end{array}$ & $\begin{array}{r}3,245 \\
121,728 \\
20,179 \\
15,083 \\
46,249 \\
1,244 \\
8,257 \\
30,716\end{array}$ & $\begin{array}{r}3,834 \\
121,972 \\
20,142 \\
17,303 \\
45,248 \\
1,017 \\
8,950 \\
29,312\end{array}$ & $\begin{array}{r}1,280 \\
42,916 \\
5,023 \\
7,157 \\
18,629 \\
671 \\
877 \\
10,559\end{array}$ & $\begin{array}{r}2,554 \\
79,056 \\
15,119 \\
10,146 \\
26,619 \\
346 \\
8,073 \\
18,753\end{array}$ \\
\hline 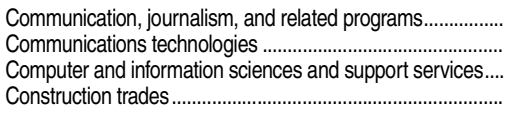 & $\begin{array}{r}2,819 \\
3,006 \\
40,127 \\
2,639\end{array}$ & $\begin{array}{r}2,589 \\
3,304 \\
46,234 \\
3,009\end{array}$ & $\begin{array}{r}2,444 \\
3,401 \\
41,845 \\
3,560\end{array}$ & $\begin{array}{r}2,545 \\
3,516 \\
36,173 \\
3,512\end{array}$ & $\begin{array}{r}2,629 \\
3,380 \\
31,246 \\
3,850\end{array}$ & $\begin{array}{r}2,609 \\
3,095 \\
27,712 \\
3,895\end{array}$ & $\begin{array}{r}2,620 \\
4,237 \\
28,296 \\
4,309\end{array}$ & $\begin{array}{r}2,722 \\
4,803 \\
30,006 \\
4,252\end{array}$ & $\begin{array}{r}2,839 \\
4,419 \\
32,466 \\
4,617\end{array}$ & $\begin{array}{r}3,051 \\
4,209 \\
37,677 \\
5,402\end{array}$ & $\begin{array}{r}3,495 \\
5,000 \\
41,161 \\
5,752\end{array}$ & $\begin{array}{r}1,625 \\
3,429 \\
32,290 \\
5,483\end{array}$ & $\begin{array}{r}1,870 \\
1,571 \\
8,871 \\
269\end{array}$ \\
\hline 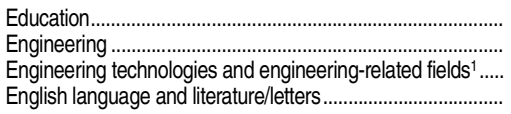 & $\begin{array}{r}9,611 \\
1,681 \\
40,217 \\
864\end{array}$ & $\begin{array}{r}11,205 \\
2,166 \\
39,998 \\
896\end{array}$ & $\begin{array}{r}12,465 \\
2,726 \\
36,915 \\
828\end{array}$ & $\begin{array}{r}13,329 \\
2,430 \\
33,548 \\
995\end{array}$ & $\begin{array}{r}14,475 \\
2,154 \\
30,461 \\
1,105\end{array}$ & $\begin{array}{r}13,021 \\
2,128 \\
29,199 \\
1,249\end{array}$ & $\begin{array}{r}13,108 \\
2,279 \\
29,334 \\
1,402\end{array}$ & $\begin{array}{r}14,123 \\
2,177 \\
30,434 \\
1,525\end{array}$ & $\begin{array}{r}17,048 \\
2,508 \\
31,850 \\
1,658\end{array}$ & $\begin{array}{r}20,459 \\
2,825 \\
35,521 \\
2,019\end{array}$ & $\begin{array}{r}20,531 \\
3,382 \\
36,510 \\
2,137\end{array}$ & $\begin{array}{r}2,633 \\
2,931 \\
32,224 \\
708\end{array}$ & $\begin{array}{r}17,898 \\
451 \\
4,286 \\
1,429\end{array}$ \\
\hline $\begin{array}{l}\text { Family and consumer sciences/human sciences................... } \\
\text { Foreign languages, literatures, and linguistics ..................... }\end{array}$ & $\begin{array}{l}9,208 \\
1,085\end{array}$ & $\begin{array}{l}9,496 \\
1,050\end{array}$ & $\begin{array}{l}9,478 \\
1,047\end{array}$ & $\begin{array}{l}9,707 \\
1,234\end{array}$ & $\begin{array}{l}9,488 \\
1,161\end{array}$ & $\begin{array}{l}9,124 \\
1,207\end{array}$ & $\begin{array}{l}8,613 \\
1,258\end{array}$ & $\begin{array}{l}9,020 \\
1,627\end{array}$ & $\begin{array}{l}9,573 \\
1,683\end{array}$ & $\begin{array}{l}8,532 \\
1,876\end{array}$ & $\begin{array}{l}9,503 \\
1,980\end{array}$ & $\begin{array}{l}369 \\
417\end{array}$ & $\begin{array}{l}9,134 \\
1,563\end{array}$ \\
\hline $\begin{array}{l}\text { Health professions and related programs } \\
\text { Dental assisting. } \\
\text { Emergency medical technician (EMT paramedic). } \\
\text { Medical lab technician } \\
\text { Medical assisting } \\
\text { Nursing assisting } \\
\text { Practical nursing } \\
\text { Nursing, R.N. and other } \\
\text { Health sciences, other } \\
\text { Homeland security, law enforcement, and firefighting } \\
\text { Criminal justice and corrections. } \\
\text { Fire control and safety...... } \\
\text { Homeland security and related protective services, other. }\end{array}$ & $\begin{array}{r}82,361 \\
5,237 \\
1,203 \\
5,134 \\
11,102 \\
0 \\
814 \\
40,800 \\
18,071 \\
16,689 \\
13,603 \\
2,619 \\
467\end{array}$ & $\begin{array}{r}90,716 \\
5,498 \\
1,410 \\
5,146 \\
11,920 \\
8 \\
916 \\
45,117 \\
20,701 \\
18,614 \\
15,155 \\
2,941 \\
518\end{array}$ & $\begin{array}{r}106,208 \\
5,652 \\
1,617 \\
5,571 \\
15,543 \\
4 \\
1,049 \\
51,552 \\
25,220 \\
20,573 \\
17,040 \\
3,012 \\
521\end{array}$ & $\begin{array}{r}122,520 \\
5,813 \\
1,825 \\
6,346 \\
19,005 \\
38 \\
1,388 \\
58,007 \\
30,098 \\
23,749 \\
19,942 \\
3,366 \\
441\end{array}$ & $\begin{array}{r}134,931 \\
6,085 \\
1,980 \\
6,411 \\
22,267 \\
101 \\
1,481 \\
62,095 \\
34,511 \\
26,425 \\
22,351 \\
3,554 \\
520\end{array}$ & $\begin{array}{r}145,436 \\
6,313 \\
2,008 \\
7,171 \\
23,491 \\
158 \\
1,509 \\
66,516 \\
38,270 \\
28,208 \\
23,917 \\
3,811 \\
480\end{array}$ & $\begin{array}{r}155,816 \\
6,642 \\
2,140 \\
6,617 \\
24,276 \\
329 \\
1,417 \\
73,277 \\
41,118 \\
29,590 \\
25,588 \\
3,937 \\
65\end{array}$ & $\begin{array}{r}165,163 \\
6,633 \\
2,270 \\
6,822 \\
25,981 \\
385 \\
1,299 \\
77,929 \\
43,844 \\
33,033 \\
28,996 \\
3,970 \\
67\end{array}$ & $\begin{array}{r}177,686 \\
7,063 \\
2,412 \\
7,798 \\
29,985 \\
1 \\
1,999 \\
81,277 \\
47,151 \\
37,260 \\
32,754 \\
4,307 \\
199\end{array}$ & $\begin{array}{r}201,831 \\
7,481 \\
2,895 \\
9,334 \\
39,232 \\
38 \\
2,069 \\
83,021 \\
57,761 \\
44,923 \\
40,023 \\
4,603 \\
297\end{array}$ & $\begin{array}{r}218,041 \\
7,790 \\
3,352 \\
10,949 \\
46,598 \\
36 \\
2,081 \\
84,379 \\
62,856 \\
50,695 \\
45,525 \\
4,602 \\
568\end{array}$ & $\begin{array}{r}34,018 \\
359 \\
2,366 \\
2,451 \\
6,252 \\
4 \\
220 \\
11,974 \\
10,392 \\
27,045 \\
22,352 \\
4,300 \\
393\end{array}$ & $\begin{array}{r}184,023 \\
7,431 \\
986 \\
8,498 \\
40,346 \\
32 \\
1,861 \\
72,405 \\
52,464 \\
23,650 \\
23,173 \\
302 \\
175\end{array}$ \\
\hline 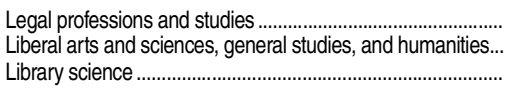 & $\begin{array}{r}7,815 \\
207,163 \\
96\end{array}$ & $\begin{array}{r}8,412 \\
217,361 \\
87\end{array}$ & $\begin{array}{r}9,466 \\
227,650 \\
114\end{array}$ & $\begin{array}{r}9,885 \\
240,131 \\
108\end{array}$ & $\begin{array}{r}10,509 \\
244,689 \\
136\end{array}$ & $\begin{array}{r}10,391 \\
250,030 \\
84\end{array}$ & $\begin{array}{r}9,465 \\
254,012 \\
117\end{array}$ & $\begin{array}{r}9,062 \\
263,853 \\
116\end{array}$ & $\begin{array}{r}10,003 \\
284,775 \\
112\end{array}$ & $\begin{array}{r}11,620 \\
306,670 \\
160\end{array}$ & $\begin{array}{r}12,182 \\
336,554 \\
159\end{array}$ & $\begin{array}{r}1,679 \\
129,179 \\
19\end{array}$ & $\begin{array}{r}10,503 \\
207,375 \\
140\end{array}$ \\
\hline 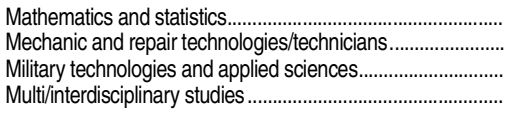 & $\begin{array}{r}685 \\
12,063 \\
62 \\
13,205\end{array}$ & $\begin{array}{r}732 \\
12,028 \\
85 \\
14,067\end{array}$ & $\begin{array}{r}801 \\
12,553 \\
293 \\
14,794\end{array}$ & $\begin{array}{r}807 \\
13,619 \\
355 \\
13,888\end{array}$ & $\begin{array}{r}753 \\
14,454 \\
610 \\
14,473\end{array}$ & $\begin{array}{r}827 \\
15,432 \\
781 \\
15,838\end{array}$ & $\begin{array}{r}855 \\
15,297 \\
851 \\
16,255\end{array}$ & $\begin{array}{r}930 \\
16,066 \\
721 \\
15,459\end{array}$ & $\begin{array}{r}1,051 \\
16,305 \\
668 \\
17,671\end{array}$ & $\begin{array}{r}1,644 \\
19,969 \\
856 \\
23,729\end{array}$ & $\begin{array}{r}1,529 \\
20,714 \\
986 \\
27,267\end{array}$ & $\begin{array}{r}1,050 \\
19,709 \\
770 \\
10,171\end{array}$ & $\begin{array}{r}479 \\
1,005 \\
216 \\
17,096\end{array}$ \\
\hline 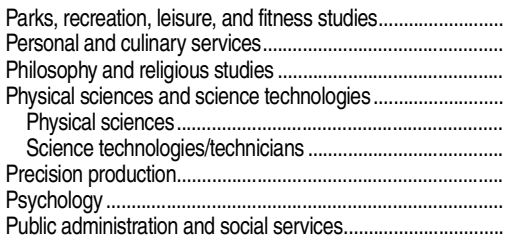 & $\begin{array}{r}764 \\
9,325 \\
359 \\
2,318 \\
1,356 \\
962 \\
2,260 \\
1,705 \\
3,323\end{array}$ & $\begin{array}{r}805 \\
12,607 \\
379 \\
2,201 \\
1,152 \\
1,049 \\
2,287 \\
1,785 \\
3,534\end{array}$ & $\begin{array}{r}923 \\
14,239 \\
404 \\
2,687 \\
1,599 \\
1,088 \\
1,968 \\
1,887 \\
3,728\end{array}$ & $\begin{array}{r}966 \\
16,311 \\
422 \\
2,825 \\
1,637 \\
1,188 \\
2,039 \\
1,942 \\
4,027\end{array}$ & $\begin{array}{r}1,128 \\
17,162 \\
367 \\
2,910 \\
1,741 \\
1,169 \\
1,977 \\
1,944 \\
4,415\end{array}$ & $\begin{array}{r}1,251 \\
16,103 \\
375 \\
3,412 \\
2,023 \\
1,389 \\
1,973 \\
2,213 \\
4,338\end{array}$ & $\begin{array}{r}1,344 \\
16,592 \\
458 \\
3,395 \\
1,980 \\
1,415 \\
1,968 \\
2,412 \\
4,192\end{array}$ & $\begin{array}{r}1,587 \\
16,327 \\
191 \\
3,621 \\
2,194 \\
1,427 \\
2,126 \\
3,949 \\
4,178\end{array}$ & $\begin{array}{r}2,016 \\
16,467 \\
256 \\
4,140 \\
2,378 \\
1,762 \\
2,787 \\
6,582 \\
4,526\end{array}$ & $\begin{array}{r}2,366 \\
18,258 \\
283 \\
5,078 \\
3,148 \\
1,930 \\
3,254 \\
3,866 \\
7,472\end{array}$ & $\begin{array}{r}3,123 \\
20,366 \\
308 \\
5,824 \\
3,652 \\
2,172 \\
3,320 \\
4,717 \\
9,143\end{array}$ & $\begin{array}{r}1,998 \\
9,103 \\
181 \\
3,404 \\
2,072 \\
1,332 \\
3,118 \\
1,093 \\
1,382\end{array}$ & $\begin{array}{r}1,125 \\
11,263 \\
127 \\
2,420 \\
1,580 \\
840 \\
202 \\
3,624 \\
7,761\end{array}$ \\
\hline 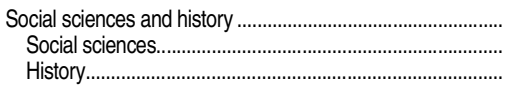 & $\begin{array}{r}5,593 \\
5,304 \\
289\end{array}$ & $\begin{array}{r}5,720 \\
5,404 \\
316\end{array}$ & $\begin{array}{r}6,245 \\
5,875 \\
370\end{array}$ & $\begin{array}{r}6,533 \\
6,233 \\
300\end{array}$ & $\begin{array}{r}6,730 \\
6,308 \\
422\end{array}$ & $\begin{array}{r}7,080 \\
6,673 \\
407\end{array}$ & $\begin{array}{r}7,812 \\
7,358 \\
454\end{array}$ & $\begin{array}{r}9,142 \\
8,657 \\
485\end{array}$ & $\begin{array}{r}10,649 \\
10,108 \\
541\end{array}$ & $\begin{array}{r}12,767 \\
12,067 \\
700\end{array}$ & $\begin{array}{r}14,132 \\
13,321 \\
811\end{array}$ & $\begin{array}{r}5,139 \\
4,650 \\
489\end{array}$ & $\begin{array}{r}8,993 \\
8,671 \\
322\end{array}$ \\
\hline $\begin{array}{l}\text { Theology and religious vocations......... } \\
\text { Transportation and materials moving .. }\end{array}$ & $\begin{array}{r}414 \\
1,122\end{array}$ & $\begin{array}{r}425 \\
1,211\end{array}$ & $\begin{array}{r}492 \\
1,217\end{array}$ & $\begin{array}{r}581 \\
1,435\end{array}$ & $\begin{array}{r}570 \\
1,472\end{array}$ & $\begin{array}{r}608 \\
1,674\end{array}$ & $\begin{array}{r}582 \\
1,550\end{array}$ & $\begin{array}{r}675 \\
1,430\end{array}$ & $\begin{array}{r}613 \\
1,444\end{array}$ & $\begin{array}{r}758 \\
1,697\end{array}$ & $\begin{array}{r}839 \\
2,098\end{array}$ & $\begin{array}{r}423 \\
1,782\end{array}$ & $\begin{array}{l}416 \\
316\end{array}$ \\
\hline 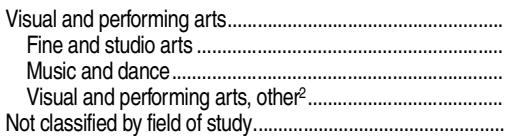 & $\begin{array}{r}20,911 \\
1,518 \\
1,637 \\
17,756 \\
365\end{array}$ & $\begin{array}{r}23,120 \\
1,760 \\
2,093 \\
19,267 \\
0\end{array}$ & $\begin{array}{r}23,949 \\
1,450 \\
2,584 \\
19,915 \\
0\end{array}$ & $\begin{array}{r}22,650 \\
1,614 \\
2,333 \\
18,703 \\
0\end{array}$ & $\begin{array}{r}21,754 \\
1,638 \\
2,389 \\
17,727 \\
0\end{array}$ & $\begin{array}{r}20,244 \\
1,753 \\
2,290 \\
16,201 \\
0\end{array}$ & $\begin{array}{r}18,890 \\
1,705 \\
1,317 \\
15,868 \\
14\end{array}$ & $\begin{array}{r}18,629 \\
2,015 \\
1,151 \\
15,463 \\
0\end{array}$ & $\begin{array}{r}19,567 \\
2,277 \\
1,335 \\
15,955 \\
0\end{array}$ & $\begin{array}{r}21,379 \\
2,405 \\
1,356 \\
17,618 \\
0\end{array}$ & $\begin{array}{r}22,431 \\
2,341 \\
1,683 \\
18,407 \\
0\end{array}$ & $\begin{array}{r}9,422 \\
746 \\
1,084 \\
7,592 \\
0\end{array}$ & $\begin{array}{r}13,009 \\
1,595 \\
599 \\
10,815\end{array}$ \\
\hline
\end{tabular}

'Excludes "Construction trades" and "Mechanic and repair technologies/technicians," which are listed separately.

${ }^{2}$ Includes design and applied arts, drama and theatre arts, film and photographic arts, and all other arts not included under "Fine and studio arts" or "Music and dance."

NOTE: Data are for postsecondary institutions participating in Title IV federal financial aid programs.
SOURCE: U.S. Department of Education, National Center for Education Statistics, Inte grated Postsecondary Education Data System (IPEDS), "Completions Survey" (IPEDSC:98-99); and IPEDS Fall 2002 through Fall 2012, Completions component. (This table was prepared July 2013.) 
Table 321.20. Associate's degrees conferred by postsecondary institutions, by race/ethnicity and sex of student: Selected years, 1976-77 through 2011-12

\begin{tabular}{|c|c|c|c|c|c|c|c|c|c|c|c|c|c|c|c|}
\hline \multirow[b]{2}{*}{ Year and sex } & \multicolumn{8}{|c|}{ Number of degrees conferred to U.S. citizens and nonresident aliens } & \multicolumn{7}{|c|}{ Percentage distribution of degrees conferred to U.S. citizens } \\
\hline & Total & White & Black & Hispanic & $\begin{array}{r}\text { Asian/ } \\
\text { Pacific } \\
\text { Islander }\end{array}$ & $\begin{array}{r}\text { American } \\
\text { Indian/ } \\
\text { Alaska } \\
\text { Native } \\
\end{array}$ & $\begin{array}{r}\text { Two or } \\
\text { more } \\
\text { races }\end{array}$ & $\begin{array}{r}\text { Non- } \\
\text { resident } \\
\text { alien }\end{array}$ & Total & White & Black & Hispanic & $\begin{array}{r}\text { Asian/ } \\
\text { Pacific } \\
\text { Islander }\end{array}$ & \begin{tabular}{r|} 
American \\
Indian/ \\
Alaska \\
Native
\end{tabular} & $\begin{array}{l}\text { Two or } \\
\text { more } \\
\text { races }\end{array}$ \\
\hline 1 & 2 & 3 & 4 & 5 & 6 & 7 & 8 & 9 & 10 & 11 & 12 & 13 & 14 & 15 & 16 \\
\hline 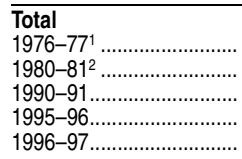 & $\begin{array}{l}404,956 \\
410,174 \\
481,720 \\
555,216 \\
571,226\end{array}$ & $\begin{array}{l}342,290 \\
339,167 \\
391,264 \\
426,106 \\
429,464\end{array}$ & $\begin{array}{l}33,159 \\
35,330 \\
38,835 \\
52,014 \\
56,306\end{array}$ & $\begin{array}{l}16,636 \\
17,800 \\
25,540 \\
38,254 \\
43,549\end{array}$ & $\begin{array}{r}7,044 \\
8,650 \\
15,257 \\
23,138 \\
25,159\end{array}$ & $\begin{array}{l}2,498 \\
2,584 \\
3,871 \\
5,573 \\
5,984\end{array}$ & $\begin{array}{l}- \\
- \\
- \\
-\end{array}$ & $\begin{array}{r}3,329 \\
6,643 \\
6,953 \\
10,131 \\
10,764\end{array}$ & $\begin{array}{l}100.0 \\
100.0 \\
100.0 \\
100.0 \\
100.0\end{array}$ & $\begin{array}{l}85.2 \\
84.0 \\
82.4 \\
78.2 \\
76.6\end{array}$ & $\begin{array}{r}8.3 \\
8.8 \\
8.2 \\
9.5 \\
10.0\end{array}$ & $\begin{array}{l}4.1 \\
4.4 \\
5.4 \\
7.0 \\
7.8\end{array}$ & $\begin{array}{l}1.8 \\
2.1 \\
3.2 \\
4.2 \\
4.5\end{array}$ & $\begin{array}{l}0.6 \\
0.6 \\
0.8 \\
1.0 \\
1.1\end{array}$ & $\begin{array}{l}- \\
\overline{-} \\
\overline{-}\end{array}$ \\
\hline $\begin{array}{l}1997-98 \ldots \\
1998-99 \ldots \\
1999-2000 \\
2000-01 \\
2001-02\end{array}$ & $\begin{array}{l}558,555 \\
564,984 \\
564,933 \\
578,865 \\
595,133\end{array}$ & $\begin{array}{l}413,561 \\
412,985 \\
408,822 \\
411,075 \\
417,733\end{array}$ & $\begin{array}{l}55,314 \\
58,417 \\
60,208 \\
63,855 \\
67,343\end{array}$ & $\begin{array}{l}45,876 \\
48,845 \\
51,563 \\
57,288 \\
60,003\end{array}$ & $\begin{array}{l}25,196 \\
27,628 \\
27,778 \\
28,463 \\
30,945\end{array}$ & $\begin{array}{l}6,246 \\
6,395 \\
6,474 \\
6,623 \\
6,832\end{array}$ & $\begin{array}{l}- \\
- \\
- \\
-\end{array}$ & $\begin{array}{l}12,362 \\
10,714 \\
10,088 \\
11,561 \\
12,277\end{array}$ & $\begin{array}{l}100.0 \\
100.0 \\
100.0 \\
100.0 \\
100.0\end{array}$ & $\begin{array}{l}75.7 \\
74.5 \\
73.7 \\
72.5 \\
71.7\end{array}$ & $\begin{array}{l}10.1 \\
10.5 \\
10.9 \\
11.3 \\
11.6\end{array}$ & \begin{tabular}{r|}
8.4 \\
8.8 \\
9.3 \\
10.1 \\
10.3
\end{tabular} & $\begin{array}{l}4.6 \\
5.0 \\
5.0 \\
5.0 \\
5.3\end{array}$ & $\begin{array}{l}1.1 \\
1.2 \\
1.2 \\
1.2 \\
1.2\end{array}$ & $\begin{array}{l}- \\
- \\
- \\
-\end{array}$ \\
\hline $\begin{array}{l}2002-03 \ldots \ldots \ldots \ldots \ldots \ldots \ldots . . \\
2003-04 \ldots \ldots \ldots \ldots \ldots \ldots \ldots \ldots \ldots \\
2004-05 \ldots \ldots \ldots \ldots \ldots \ldots \ldots \ldots \ldots \\
2005-06 \ldots \ldots \ldots \ldots \ldots \ldots \ldots \ldots \\
2006-07 \ldots \ldots \ldots \ldots \ldots \ldots \ldots \ldots \\
.\end{array}$ & $\begin{array}{l}634,016 \\
665,301 \\
696,660 \\
713,066 \\
728,114\end{array}$ & $\begin{array}{l}438,261 \\
456,047 \\
475,513 \\
485,297 \\
491,572\end{array}$ & $\begin{array}{l}75,609 \\
81,183 \\
86,402 \\
89,784 \\
91,529\end{array}$ & $\begin{array}{l}66,673 \\
72,270 \\
78,557 \\
80,854 \\
85,410\end{array}$ & $\begin{array}{l}32,629 \\
33,149 \\
33,669 \\
35,201 \\
37,266\end{array}$ & $\begin{array}{l}7,461 \\
8,119 \\
8,435 \\
8,552 \\
8,583\end{array}$ & $\begin{array}{l}- \\
- \\
- \\
-\end{array}$ & $\begin{array}{l}13,383 \\
14,533 \\
14,084 \\
13,378 \\
13,754 \\
13\end{array}$ & $\begin{array}{l}100.0 \\
100.0 \\
100.0 \\
100.0 \\
100.0\end{array}$ & $\begin{array}{l}70.6 \\
70.1 \\
69.7 \\
69.4 \\
68.8\end{array}$ & $\begin{array}{l}12.2 \\
12.5 \\
12.7 \\
12.8 \\
12.8\end{array}$ & $\begin{array}{l}10.7 \\
11.1 \\
11.5 \\
11.6 \\
12.0\end{array}$ & $\begin{array}{l}5.3 \\
5.1 \\
4.9 \\
5.0 \\
5.2\end{array}$ & $\begin{array}{l}1.2 \\
1.2 \\
1.2 \\
1.2 \\
1.2\end{array}$ & $\begin{array}{l}- \\
\overline{-} \\
\overline{-}\end{array}$ \\
\hline 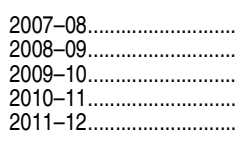 & $\begin{array}{r}750,164 \\
787,325 \\
849,452 \\
942,327 \\
1,017,538\end{array}$ & $\begin{array}{l}501,079 \\
522,985 \\
552,863 \\
604,110 \\
632,802\end{array}$ & $\begin{array}{r}95,702 \\
101,487 \\
113,905 \\
128,703 \\
141,886\end{array}$ & $\begin{array}{r}91,274 \\
97,921 \\
112,211 \\
125,616 \\
151,621\end{array}$ & $\begin{array}{l}38,843 \\
40,914 \\
44,021 \\
45,876 \\
48,707\end{array}$ & $\begin{array}{r}8,849 \\
8,834 \\
10,337 \\
10,173 \\
10,711\end{array}$ & $\begin{array}{r}- \\
\overline{-} \\
11,275 \\
14,759\end{array}$ & $\begin{array}{l}14,417 \\
15,184 \\
16,115 \\
16,574 \\
17,052\end{array}$ & $\begin{array}{l}100.0 \\
100.0 \\
100.0 \\
100.0 \\
100.0\end{array}$ & $\begin{array}{l}68.1 \\
67.7 \\
66.3 \\
65.3 \\
63.2\end{array}$ & $\begin{array}{l}13.0 \\
13.1 \\
13.7 \\
13.9 \\
14.2\end{array}$ & $\begin{array}{l}12.4 \\
12.7 \\
13.5 \\
13.6 \\
15.2\end{array}$ & $\begin{array}{l}5.3 \\
5.3 \\
5.3 \\
5.0 \\
4.9\end{array}$ & $\begin{array}{l}1.2 \\
1.1 \\
1.2 \\
1.1 \\
1.1\end{array}$ & $\begin{array}{l}\overline{-} \\
\overline{1.2} \\
1.5\end{array}$ \\
\hline $\begin{array}{l}1976-77^{1} \\
1980-81^{2} \\
1990-91 \ldots \ldots \ldots \ldots \ldots \ldots \ldots \ldots \\
1995-96 \ldots \ldots \ldots \ldots \ldots \ldots \ldots \ldots \\
1996-97 \ldots \ldots \ldots \ldots \ldots \ldots \ldots \ldots \ldots\end{array}$ & $\begin{array}{l}209,672 \\
183,819 \\
198,634 \\
219,514 \\
223,948\end{array}$ & $\begin{array}{l}178,236 \\
151,242 \\
161,858 \\
169,230 \\
168,882\end{array}$ & $\begin{array}{l}15,330 \\
14,290 \\
14,143 \\
17,941 \\
19,394\end{array}$ & $\begin{array}{r}9,105 \\
8,327 \\
10,738 \\
15,740 \\
17,990\end{array}$ & $\begin{array}{r}3,630 \\
4,557 \\
7,164 \\
10,229 \\
10,937\end{array}$ & $\begin{array}{l}1,216 \\
1,108 \\
1,439 \\
1,993 \\
2,068\end{array}$ & $\begin{array}{l}- \\
- \\
- \\
-\end{array}$ & $\begin{array}{l}2,155 \\
4,295 \\
3,292 \\
4,381 \\
4,677\end{array}$ & $\begin{array}{l}100.0 \\
100.0 \\
100.0 \\
100.0 \\
100.0\end{array}$ & $\begin{array}{l}85.9 \\
84.2 \\
82.9 \\
78.7 \\
77.0\end{array}$ & $\begin{array}{l}8.3 \\
8.8\end{array}$ & $\begin{array}{l}4.4 \\
4.6 \\
5.5 \\
7.3 \\
8.2\end{array}$ & $\begin{array}{l}1.7 \\
2.5 \\
3.7 \\
4.8 \\
5.0\end{array}$ & $\begin{array}{l}0.6 \\
0.6 \\
0.7 \\
0.9 \\
0.9\end{array}$ & $\begin{array}{l}- \\
\overline{-} \\
-\end{array}$ \\
\hline $\begin{array}{l}1998-99 \ldots \ldots \ldots \ldots \\
1999-2000 \ldots \ldots \ldots \ldots \ldots \ldots \ldots \\
2000-01 \ldots \ldots \ldots \ldots \ldots \ldots \ldots \ldots \\
2001-02 \ldots \ldots \ldots \ldots \ldots \ldots \ldots \ldots \ldots\end{array}$ & $\begin{array}{l}217,613 \\
220,508 \\
224,721 \\
231,645 \\
238,109\end{array}$ & $\begin{array}{l}161,212 \\
162,339 \\
164,317 \\
166,322 \\
170,622\end{array}$ & $\begin{array}{l}18,686 \\
19,844 \\
20,968 \\
22,147 \\
22,806\end{array}$ & $\begin{array}{l}19,484 \\
20,947 \\
23,350 \\
23,963\end{array}$ & $\begin{array}{l}10,953 \\
11,688 \\
12,009 \\
12,339 \\
13,256\end{array}$ & $\begin{array}{l}2,252 \\
2,234 \\
2,222 \\
2,294 \\
2,308\end{array}$ & $\begin{array}{l}- \\
- \\
- \\
-\end{array}$ & $\begin{array}{l}5,402 \\
4,919 \\
4,258 \\
5,193 \\
5,154\end{array}$ & $\begin{array}{l}100.0 \\
100.0 \\
100.0 \\
100.0 \\
100.0\end{array}$ & $\begin{array}{l}76.0 \\
75.3 \\
74.5 \\
73.4 \\
73.2\end{array}$ & $\begin{array}{l}8.8 \\
9.2 \\
9.5 \\
9.8 \\
9.8\end{array}$ & $\begin{array}{r}9.0 \\
9.0 \\
9.5 \\
10.3 \\
10.3\end{array}$ & $\begin{array}{l}5.2 \\
5.4 \\
5.4 \\
5.4 \\
5.7\end{array}$ & $\begin{array}{l}1.1 \\
1.0 \\
1.0 \\
1.0 \\
1.0\end{array}$ & $\begin{array}{l}- \\
z \\
z \\
-\end{array}$ \\
\hline $\begin{array}{l}2002-03 \ldots \ldots \\
2003-04 \ldots \\
2004-05 \ldots \ldots \\
2005-06 \ldots \ldots \\
2006-07\end{array}$ & $\begin{array}{l}253,451 \\
260,033 \\
267,536 \\
270,095 \\
275,187\end{array}$ & $\begin{array}{l}179,163 \\
183,819 \\
188,569 \\
190,139 \\
191,565\end{array}$ & $\begin{array}{l}25,591 \\
25,961 \\
27,151 \\
27,619 \\
28,273\end{array}$ & $\begin{array}{l}26,461 \\
27,828 \\
29,658 \\
30,040 \\
31,646\end{array}$ & $\begin{array}{l}14,057 \\
13,907 \\
13,802 \\
14,224 \\
15,510\end{array}$ & $\begin{array}{l}2,618 \\
2,740 \\
2,774 \\
2,774 \\
2,873\end{array}$ & $\begin{array}{l}- \\
- \\
- \\
-\end{array}$ & $\begin{array}{l}5,561 \\
5,778 \\
5,582 \\
5,299 \\
5,320\end{array}$ & $\begin{array}{l}100.0 \\
100.0 \\
100.0 \\
100.0 \\
100.0\end{array}$ & $\begin{array}{l}72.3 \\
72.3 \\
72.0 \\
71.8 \\
71.0\end{array}$ & $\begin{array}{l}10.3 \\
10.2 \\
10.4 \\
10.4 \\
10.5\end{array}$ & $\begin{array}{l}10.7 \\
10.9 \\
11.3 \\
11.3 \\
11.7\end{array}$ & $\begin{array}{l}5.7 \\
5.5 \\
5.3 \\
5.4 \\
5.7\end{array}$ & $\begin{array}{l}1.1 \\
1.1 \\
1.1 \\
1.0 \\
1.1\end{array}$ & $\begin{array}{l}- \\
- \\
- \\
-\end{array}$ \\
\hline $\begin{array}{l}2007-08 \\
2008-09 \ldots \\
2009-10 \\
2010-11 \ldots \\
2011-12\end{array}$ & $\begin{array}{l}282,521 \\
298,141 \\
322,916 \\
361,309 \\
391,990\end{array}$ & $\begin{array}{l}194,099 \\
203,086 \\
216,072 \\
238,078 \\
250,994\end{array}$ & $\begin{array}{l}30,016 \\
31,994 \\
36,136 \\
41,596 \\
46,124\end{array}$ & $\begin{array}{l}42,232 \\
47,682 \\
57,840\end{array}$ & $\begin{array}{l}15,936 \\
17,156 \\
18,264 \\
19,181 \\
20,462\end{array}$ & $\begin{array}{l}3,624 \\
3,724 \\
3,916\end{array}$ & $\begin{array}{r}- \\
- \\
4,257 \\
5,543\end{array}$ & $\begin{array}{l}5,650 \\
6,092 \\
6,588 \\
6,791 \\
7,111\end{array}$ & $\begin{array}{l}100.0 \\
100.0 \\
100.0 \\
100.0 \\
100.0\end{array}$ & $\begin{array}{l}70.1 \\
69.5 \\
68.3 \\
67.2 \\
65.2\end{array}$ & $\begin{array}{l}11.4 \\
11.7 \\
12.0\end{array}$ & $\begin{array}{l}12.2 \\
12.6 \\
13.4 \\
13.4 \\
15.0\end{array}$ & $\begin{array}{l}5.8 \\
5.9 \\
5.8 \\
5.4 \\
5.3\end{array}$ & $\begin{array}{l}1.1 \\
1.1 \\
1.1 \\
1.1 \\
1.0\end{array}$ & $\begin{array}{l}- \\
\overline{-} \\
1.2 \\
1.4\end{array}$ \\
\hline $\begin{array}{l}1976-77^{1} \\
1980-81^{2} \\
1990-91 \\
1995-96 \ldots \ldots \\
1996-97 \ldots \ldots\end{array}$ & $\begin{array}{l}195,284 \\
226,355 \\
283,086 \\
335,702 \\
347,278\end{array}$ & $\begin{array}{l}164,054 \\
187,925 \\
229,406 \\
256,876 \\
260,582\end{array}$ & $\begin{array}{l}17,829 \\
21,040 \\
24,692 \\
34,073 \\
36,912\end{array}$ & $\begin{array}{r}7,531 \\
9,473 \\
14,802 \\
22,514 \\
25,559\end{array}$ & $\begin{array}{r}3,414 \\
4,093 \\
8,093 \\
12,909 \\
14,222\end{array}$ & $\begin{array}{l}1,282 \\
1,476 \\
2,432 \\
3,580 \\
3,916\end{array}$ & $\begin{array}{l}- \\
- \\
- \\
-\end{array}$ & $\begin{array}{l}1,174 \\
2,348 \\
3,661 \\
5,750 \\
6,087\end{array}$ & $\begin{array}{l}100.0 \\
100.0 \\
100.0 \\
100.0 \\
100.0\end{array}$ & $\begin{array}{l}82.1 \\
77.9 \\
76.4\end{array}$ & $\begin{array}{r}9.2 \\
9.4 \\
8.8 \\
10.3 \\
10.8\end{array}$ & $\begin{array}{l}3.9 \\
4.2 \\
5.3 \\
6.8 \\
7.5\end{array}$ & $\begin{array}{l}1.8 \\
1.8 \\
2.9 \\
3.9 \\
4.2\end{array}$ & $\begin{array}{l}0.7 \\
0.7 \\
0.9 \\
1.1 \\
1.1\end{array}$ & $\begin{array}{l}- \\
z \\
z \\
-\end{array}$ \\
\hline $\begin{array}{l}1997-98 \\
1998-99 \\
1999-2000 \\
2000-01 \\
2001-02\end{array}$ & $\begin{array}{l}340,942 \\
344,476 \\
340,212 \\
347,220 \\
357,024\end{array}$ & $\begin{array}{l}252,349 \\
250,646 \\
244,505 \\
244,753 \\
247,111\end{array}$ & $\begin{array}{l}36,628 \\
33,573 \\
39,240 \\
41,708 \\
44,537\end{array}$ & $\begin{array}{l}26,768 \\
29,361 \\
30,616 \\
33,938 \\
36,040\end{array}$ & $\begin{array}{l}14,243 \\
15,940 \\
15,769 \\
16,124 \\
17,689\end{array}$ & $\begin{array}{l}3,994 \\
4,161 \\
4,252 \\
4,329 \\
4,524\end{array}$ & $\begin{array}{l}- \\
- \\
- \\
-\end{array}$ & $\begin{array}{l}6,960 \\
5,795 \\
5,830 \\
6,368 \\
7,123\end{array}$ & $\begin{array}{l}100.0 \\
100.0 \\
100.0 \\
100.0 \\
100.0\end{array}$ & $\begin{array}{l}71.8 \\
70.6\end{array}$ & $\begin{array}{l}11.0 \\
11.4\end{array}$ & $\begin{array}{r}8.0 \\
8.7 \\
9.2 \\
10.0 \\
10.3\end{array}$ & $\begin{array}{l}4.3 \\
4.7 \\
4.7 \\
4.7 \\
5.1\end{array}$ & \begin{tabular}{l|}
1.2 \\
1.2 \\
1.3 \\
1.3 \\
1.3
\end{tabular} & $\begin{array}{l}- \\
- \\
- \\
-\end{array}$ \\
\hline 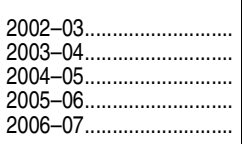 & $\begin{array}{l}380,565 \\
405,268 \\
429,124 \\
442,971 \\
452,927\end{array}$ & $\begin{array}{l}259,098 \\
272,228 \\
286,944 \\
295,158 \\
300,007\end{array}$ & $\begin{array}{l}50,018 \\
55,222 \\
59,251 \\
62,165 \\
63,256\end{array}$ & $\begin{array}{l}40,212 \\
44,442 \\
48,899 \\
50,814 \\
53,764\end{array}$ & $\begin{array}{l}18,572 \\
19,242 \\
19,867 \\
20,977 \\
21,756\end{array}$ & $\begin{array}{l}4,843 \\
5,379 \\
5,661 \\
5,778 \\
5,710\end{array}$ & $\begin{array}{l}- \\
- \\
- \\
-\end{array}$ & $\begin{array}{l}7,822 \\
8,755 \\
8,502 \\
8,079 \\
8,434\end{array}$ & $\begin{array}{l}100.0 \\
100.0 \\
100.0 \\
100.0 \\
100.0\end{array}$ & $\begin{array}{l}69.5 \\
68.7 \\
68.2 \\
67.9 \\
67.5\end{array}$ & $\begin{array}{l}13.4 \\
13.9 \\
14.1 \\
14.3 \\
14.2\end{array}$ & $\begin{array}{l}10.8 \\
11.2 \\
11.6 \\
11.7 \\
12.1\end{array}$ & $\begin{array}{l}5.0 \\
4.9 \\
4.7 \\
4.8 \\
4.9\end{array}$ & $\begin{array}{l}1.3 \\
1.4 \\
1.3 \\
1.3 \\
1.3\end{array}$ & $\begin{array}{l}- \\
- \\
- \\
-\end{array}$ \\
\hline $\begin{array}{l}2007-08 \\
2008-09 \\
2009-10 \\
2010-11 \\
2011-12\end{array}$ & $\begin{array}{l}467,643 \\
489,184 \\
526,536 \\
581,018 \\
625,548\end{array}$ & $\begin{array}{l}306,980 \\
319,899 \\
336,791 \\
366,032 \\
381,808\end{array}$ & $\begin{array}{l}65,686 \\
69,493 \\
77,769 \\
87,107 \\
95,762\end{array}$ & $\begin{array}{l}61,182 \\
69,979 \\
77,934 \\
93,781\end{array}$ & $\begin{array}{l}23,758 \\
25,757 \\
26,695 \\
28,245\end{array}$ & $\begin{array}{l}5,760 \\
6,713 \\
6,449 \\
6,795\end{array}$ & $\begin{array}{r}- \\
\overline{-} \\
7,018 \\
9,216\end{array}$ & $\begin{array}{l}9,092 \\
9,527 \\
9,783 \\
9,941\end{array}$ & $\begin{array}{l}100.0 \\
100.0 \\
100.0 \\
100.0\end{array}$ & $\begin{array}{l}66.6 \\
65.1 \\
64.1 \\
62.0\end{array}$ & $\begin{array}{l}14.5 \\
15.0 \\
15.2 \\
15.6\end{array}$ & $\begin{array}{l}12.7 \\
13.5 \\
13.6 \\
15.2\end{array}$ & $\begin{array}{l}5.0 \\
4.9 \\
5.0 \\
4.7 \\
4.6\end{array}$ & $\begin{array}{l}1.3 \\
1.2 \\
1.3 \\
1.1 \\
1.1\end{array}$ & $\begin{array}{l}- \\
\overline{-} \\
1.2 \\
1.5\end{array}$ \\
\hline
\end{tabular}

-Not available.

${ }^{1}$ Excludes 1,170 males and 251 females whose racial/ethnic group was not available. ${ }^{2}$ Excludes 4,819 males and 1,384 females whose racial/ethnic group was not available. NOTE: Data through 1990-91 are for institutions of higher education, while later data are for postsecondary institutions participating in Title IV federal financial aid programs. Race categories exclude persons of Hispanic ethnicity. For 1989-90 and later years, reported racial/ethnic distributions of students by level of degree, field of degree, and sex were used to estimate race/ ethnicity for students whose race/ethnicity was not reported. Detail may not sum to totals because of rounding.

SOURCE: U.S. Department of Education, National Center for Education Statistics, Higher Education General Information Survey (HEGIS), "Degrees and Other Formal Awards Conferred" surveys, 1976-77 and 1980-81; Integrated Postsecondary Education Data System (IPEDS), "Completions Survey" (IPEDS-C:90-99); and IPEDS Fall 2000 through Fall 2012, Completions component. (This table was prepared July 2013.) 
Table 321.30. Associate's degrees conferred by postsecondary institutions, by race/ethnicity and field of study: 2010-11 and 2011-12

\begin{tabular}{|c|c|c|c|c|c|c|c|c|c|c|c|c|c|c|c|c|c|c|c|c|}
\hline \multirow[b]{3}{*}{ Field of study } & \multicolumn{10}{|c|}{$2010-11$} & \multicolumn{10}{|c|}{$2011-12$} \\
\hline & \multirow[b]{2}{*}{ Total } & \multirow[b]{2}{*}{ White } & \multirow[b]{2}{*}{ Black } & \multirow[b]{2}{*}{ Hispanic } & \multicolumn{3}{|c|}{ Asian/Pacific Islander } & \multirow{2}{*}{$\begin{array}{r}\text { American } \\
\text { Indian/ } \\
\text { Alaska } \\
\text { Native }\end{array}$} & \multirow{2}{*}{$\begin{array}{r}\text { Two or } \\
\text { more } \\
\text { races }\end{array}$} & \multirow{2}{*}{$\begin{array}{r}\text { Non- } \\
\text { resident } \\
\text { alien }\end{array}$} & \multirow[b]{2}{*}{ Total } & \multirow[b]{2}{*}{ White } & \multirow[b]{2}{*}{ Black } & \multirow[b]{2}{*}{ Hispanic } & \multicolumn{3}{|c|}{ Asian/Pacific Islander } & \multirow{2}{*}{$\begin{array}{r}\text { American } \\
\text { Indian/ } \\
\text { Alaska } \\
\text { Native }\end{array}$} & \multirow{2}{*}{$\begin{array}{r}\text { Two or } \\
\text { more } \\
\text { races }\end{array}$} & \\
\hline & & & & & Total & Asian & $\begin{array}{r}\text { Pacific } \\
\text { Islander }\end{array}$ & & & & & & & & Total & Asian & $\begin{array}{r}\text { Pacific } \\
\text { Islander }\end{array}$ & & & $\begin{array}{l}\text { resident } \\
\text { alien }\end{array}$ \\
\hline 1 & 2 & 3 & 4 & 5 & 6 & 7 & 8 & 9 & 10 & 11 & 12 & 13 & 14 & 15 & 16 & 17 & 18 & 19 & 20 & 21 \\
\hline All fields, total .. & 942,327 & 604,110 & 128,703 & 125,616 & 45,876 & 41,474 & 4,402 & 10,173 & 11,275 & 16,574 & $1,017,538$ & 632,802 & 141,886 & 151,621 & 48,707 & 44,829 & 3,878 & 10,711 & 14,759 & 17,052 \\
\hline natural resources.... & 6,425 & 5,942 & 56 & 209 & 54 & 42 & 12 & 93 & 39 & 32 & 7,066 & 6,473 & 81 & 259 & 58 & 44 & 14 & 114 & 57 & 24 \\
\hline chitectu & 569 & 310 & 24 & 161 & 53 & 51 & 2 & 4 & 2 & 15 & 593 & 291 & 33 & 188 & 52 & 49 & 3 & 1 & 7 & 21 \\
\hline tural, gender, and group studies ... & 209 & 45 & 24 & 38 & 4 & 3 & 1 & 90 & 3 & 5 & 194 & 37 & 18 & 45 & 13 & 10 & 3 & 72 & 4 & 5 \\
\hline Biologic & 3,245 & 1,656 & 281 & 653 & 480 & 436 & 44 & 50 & 36 & 89 & 3,834 & 1,841 & 325 & 939 & 509 & 499 & 10 & 70 & 57 & 93 \\
\hline Business... & 139,986 & 84,192 & 23,901 & 16,601 & 7,701 & 6,979 & 722 & 1,660 & 1,789 & 4,142 & 142,338 & 83,468 & 24,090 & 18,924 & 7,923 & 7,342 & 581 & 1,614 & 2,149 & 4,170 \\
\hline Communication, journalism, and related programs.. & 3,051 & 1,955 & 286 & 506 & 153 & 131 & 22 & 20 & 30 & 101 & 3,495 & 2,104 & 379 & 655 & 156 & 133 & 23 & 27 & 61 & 113 \\
\hline omm & 4,209 & 2,956 & 535 & 414 & 134 & 126 & 8 & 39 & 67 & 64 & 5,000 & 3,376 & 585 & 600 & 206 & 194 & 12 & 41 & 124 & 68 \\
\hline nation sciences ......................... & 37,677 & 25,050 & 5,911 & 3,730 & 1,747 & 1,613 & 134 & 349 & 335 & 555 & 41,161 & 26,919 & 6,303 & 4,532 & 2,028 & 1,863 & 165 & 392 & 494 & 493 \\
\hline 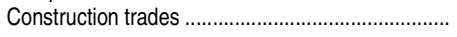 & 5,402 & 4,282 & 518 & 385 & 83 & 76 & 7 & 78 & 44 & 12 & 5,752 & 4,461 & 632 & 387 & 92 & 75 & 17 & 91 & 75 & 14 \\
\hline Education.. & 20,459 & 13,278 & 2,948 & 2,952 & 416 & 329 & 87 & 477 & 195 & 193 & 20,531 & 12,957 & 3,056 & 3,230 & 373 & 332 & 41 & 482 & 213 & 220 \\
\hline nain & 2,825 & 1,794 & 187 & 367 & 229 & 207 & 22 & 43 & 25 & 180 & 3,382 & 2,121 & 241 & 423 & 305 & 283 & 22 & 27 & 27 & 238 \\
\hline ngin & & & & & & & & & & & & & & & & & & & & \\
\hline fiel & 35,521 & 25,100 & 4,296 & 3,958 & 1,187 & 1,087 & 100 & 393 & 310 & 277 & 36,510 & 25,631 & 4,449 & 4,276 & 1,179 & 1,091 & 88 & 381 & 347 & 247 \\
\hline nglist & 2,019 & 1,080 & 244 & 476 & 161 & 150 & 11 & 15 & 17 & 26 & 2,137 & 1,141 & 232 & 512 & 150 & 139 & 11 & 22 & 38 & 42 \\
\hline Famil & 8,532 & 4,430 & 1,893 & 1,602 & 336 & 305 & 31 & 76 & 65 & 130 & 9,503 & 4,839 & 2,093 & 1,843 & 422 & 391 & 31 & 99 & 90 & 117 \\
\hline Foreign languages, literatures, and linguistic & 1,876 & 1,193 & 84 & 421 & 62 & 48 & 14 & 16 & 29 & 71 & 1,980 & 1,215 & 104 & 519 & 56 & 51 & $\tau-5$ & 6 & 24 & 56 \\
\hline ealth $p$ & 201,831 & 139,071 & 28,024 & 19,513 & 9,524 & 8,655 & 869 & 1,804 & 2,208 & 1,687 & 218,041 & 146,666 & 31,225 & 23,793 & 9,966 & 9,256 & 710 & 1,995 & 2,769 & 1,627 \\
\hline ting.... & 44,923 & 27,248 & 7,667 & 7,691 & 1,039 & 827 & 212 & 466 & 670 & 142 & 50,695 & 28,818 & 8,814 & 10,538 & 1,189 & 970 & 219 & 499 & 650 & 187 \\
\hline Legal pr & 11,620 & 7,440 & 1,967 & 1,534 & 322 & 269 & 53 & 112 & 176 & 69 & 12,182 & 7,594 & 2,063 & 1,846 & 300 & 276 & 24 & 132 & 181 & 66 \\
\hline d sciences, general studies, and & 6,670 & 192,864 & 37,996 & 47,746 & & 13,287 & 1,441 & 023 & 3,996 & 6,317 & 336,554 & 204,241 & 44,336 & 57252 & 15483 & 4.207 & 276 & 215 & 428 & 599 \\
\hline Library science....... & 160 & 128 & 5 & 20 & 型 & 3 & 0 & 1 & 3 & 0 & 159 & 128 & 1 & 18 & 7 & 6 & 1 & 3 & 1 & 1 \\
\hline & 1,644 & 778 & 103 & 385 & 256 & 254 & 2 & 24 & 23 & 75 & 1,529 & 703 & 64 & 420 & 212 & 207 & 5 & 23 & 21 & 86 \\
\hline & 19,969 & 14,078 & 2,077 & 2,493 & 685 & 601 & 84 & 304 & 222 & 110 & 20,714 & 14,302 & 2,031 & 2,861 & 704 & 613 & 91 & 325 & 350 & 141 \\
\hline diled sclences .................. & 856 & 582 & 96 & 110 & 47 & 40 & 7 & 8 & 13 & 0 & 986 & 653 & 150 & 101 & 55 & 45 & 10 & 7 & 20 & 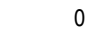 \\
\hline & 23,729 & 13,787 & 2,111 & 4,038 & 2,775 & 2,625 & 150 & 208 & 242 & 568 & 27,267 & 15,174 & 2,386 & 5,240 & 3,234 & 3,079 & 155 & 201 & 442 & 590 \\
\hline Parks, rec & 2,366 & 1,457 & 350 & 372 & 88 & 64 & 24 & 38 & 21 & 40 & 3,123 & 1,889 & 404 & 533 & 106 & 92 & 14 & 53 & 58 & 80 \\
\hline & 283 & 152 & 47 & 53 & 25 & 24 & 1 & 4 & 1 & 1 & 308 & 166 & 75 & 50 & $u$ & 3 & 0 & 0 & 5 & 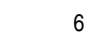 \\
\hline & 5,078 & 2,866 & 618 & 644 & 524 & 493 & 31 & 65 & 66 & 295 & 5,824 & 3,107 & 669 & 908 & 644 & 620 & 24 & 63 & 100 & 333 \\
\hline Precis & 3,254 & 2,741 & 153 & 216 & 79 & 68 & 11 & 39 & 20 & 6 & 3,320 & 2,784 & 151 & 220 & 74 & 69 & 5 & 50 & 32 & 9 \\
\hline & 3,866 & 2,125 & 334 & 1,003 & 204 & 185 & 19 & 87 & 57 & 56 & 4,717 & 2,317 & 446 & 1,453 & 280 & 259 & 21 & 94 & 90 & 37 \\
\hline Public administration and social services ...................... & 7,472 & 3,889 & 2,181 & 1,040 & 132 & 100 & 32 & 131 & 67 & 32 & 9,143 & 4,697 & 2,709 & 1,319 & 133 & 108 & 25 & 134 & 97 & 54 \\
\hline $\begin{array}{l}\text { Social sc } \\
\text { Social } \\
\text { History }\end{array}$ & $\begin{array}{l}12,767 \\
12,067 \\
700\end{array}$ & $\begin{array}{r}6,316 \\
5,856 \\
460\end{array}$ & $\begin{array}{r}1,464 \\
1,433 \\
31\end{array}$ & $\begin{array}{r}3,056 \\
2,888 \\
168\end{array}$ & $\begin{array}{r}1,261 \\
1,244 \\
17\end{array}$ & $\begin{array}{r}1,110 \\
1,096 \\
14\end{array}$ & $\begin{array}{r}151 \\
148 \\
3\end{array}$ & $\begin{array}{r}241 \\
236 \\
5\end{array}$ & $\begin{array}{r}207 \\
195 \\
12\end{array}$ & $\begin{array}{r}222 \\
215 \\
7\end{array}$ & $\begin{array}{r}14,132 \\
13,321 \\
811\end{array}$ & $\begin{array}{r}6,695 \\
6,166 \\
529\end{array}$ & $\begin{array}{r}1,390 \\
1,359 \\
31\end{array}$ & $\begin{array}{r}3,902 \\
3,703 \\
199\end{array}$ & $\begin{array}{r}1,353 \\
1,328 \\
25\end{array}$ & $\begin{array}{l}1,202 \\
1,182 \\
20\end{array}$ & $\begin{array}{r}151 \\
146 \\
5\end{array}$ & $\begin{array}{r}234 \\
226 \\
8\end{array}$ & $\begin{array}{r}329 \\
317 \\
12\end{array}$ & $\begin{array}{l}229 \\
222 \\
7\end{array}$ \\
\hline Theolos & 758 & 520 & 167 & 36 & 13 & 10 & 3 & 7 & 1 & 14 & 839 & 558 & 189 & 67 & o & 5 & 3 & , & 7 & $\gamma$ \\
\hline Transpo & 1,697 & 1,137 & 126 & 253 & 94 & 90 & 4 & 14 & 29 & 44 & 2,098 & 1,446 & 134 & 294 & 111 & 97 & 14 & 22 & 20 & 71 \\
\hline Visual & 21,379 & 13,668 & 2,029 & 2,940 & 1,277 & 1,186 & 91 & 194 & 267 & 1,004 & 22,431 & 13,990 & 2,028 & 3,474 & 1,323 & 1,219 & 104 & 217 & 392 & 1,007 \\
\hline Other and not classified........................................... & 0 & 0 & 0 & 0 & 0 & 0 & 0 & 0 & 0 & 0 & 0 & 0 & 0 & 0 & 0 & 0 & 0 & 0 & 0 & 0 \\
\hline
\end{tabular}

'Excludes "Construction trades" and "Mechanic and repair technologies/technicians," which are listed separately.

NOTE: Data are for postsecondary institutions participating in Titte IV federal financial aid programs. Race categories exclude per-

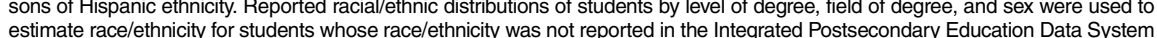

resources and conservation; and "Business" includes Business management, marketing, and related support services and Personal and culinary services.

Education Statistics, Integrated Postsecondary Education Data Sys(IPEDS): "Agriculture and natural resources" includes Agriculture, agriculture operations, and related sciences and Natural 
Table 321.40. Associate's degrees conferred to males by postsecondary institutions, by race/ethnicity and field of study: 2010-11 and 2011-12

\begin{tabular}{|c|c|c|c|c|c|c|c|c|c|c|c|c|c|c|c|c|c|c|c|c|}
\hline \multirow[b]{3}{*}{ Field of study } & \multicolumn{10}{|c|}{$2010-11$} & \multicolumn{10}{|c|}{ 2011-12 } \\
\hline & \multirow[b]{2}{*}{ Total } & \multirow[b]{2}{*}{ White } & \multirow[b]{2}{*}{ Black } & \multirow[b]{2}{*}{ Hispanic } & \multicolumn{3}{|c|}{ Asian/Pacific Islander } & \multirow{2}{*}{\begin{tabular}{|r} 
American \\
Indian/ \\
Alaska \\
Native \\
\end{tabular}} & \multirow{2}{*}{$\begin{array}{r}\text { Two or } \\
\text { more } \\
\text { races }\end{array}$} & \multirow[b]{2}{*}{$\begin{array}{c}\text { Non- } \\
\text { resident } \\
\text { alien }\end{array}$} & \multirow[b]{2}{*}{ Total } & \multirow[b]{2}{*}{ White } & \multirow[b]{2}{*}{ Black } & \multirow[b]{2}{*}{ Hispanic } & \multicolumn{3}{|c|}{ Asian/Pacific Islander } & \multirow{2}{*}{$\begin{array}{r}\text { American } \\
\text { Indian/ } \\
\text { Alaska } \\
\text { Native } \\
\end{array}$} & \multirow[b]{2}{*}{$\begin{array}{r}\text { Two or } \\
\text { more } \\
\text { races }\end{array}$} & \\
\hline & & & & & Total & Asian & $\begin{array}{r}\text { Pacific } \\
\text { Islander }\end{array}$ & & & & & & & & Total & Asian & $\begin{array}{r}\text { Pacific } \\
\text { Islander }\end{array}$ & & & $\begin{array}{r}\text { resident } \\
\text { alien }\end{array}$ \\
\hline 1 & 2 & 3 & 4 & 5 & 6 & 7 & 8 & 9 & 10 & 11 & 12 & 13 & 14 & 15 & 16 & 17 & 18 & 19 & 20 & 21 \\
\hline All fields, total. & 361,309 & 238,078 & 41,596 & 47,682 & 19,181 & 7,443 & 1,738 & 3,724 & 4,257 & 6,791 & 391,990 & 250,994 & 46,124 & 57,840 & 20,462 & 18,839 & 1,623 & 3,916 & 5,543 & 7,111 \\
\hline Agriculture and natural resources.... & 4,089 & 3,822 & 35 & 123 & 26 & 18 & 8 & 51 & 17 & 15 & 4,606 & 4,256 & 52 & 156 & 29 & 19 & 10 & 67 & 32 & 14 \\
\hline chitecture and related services ............................ & 310 & 146 & 14 & 108 & 34 & 34 & 0 & 2 & 0 & 6 & 332 & 144 & 15 & 123 & 33 & 31 & 2 & 1 & 3 & 13 \\
\hline yender, and group studies ... & 60 & 10 & 5 & 15 & 2 & 1 & 1 & 28 & 0 & 0 & 62 & 7 & 9 & 15 & 7 & 4 & 3 & 23 & 1 & 0 \\
\hline Biological a & 1,116 & 576 & 92 & 219 & 169 & 152 & 17 & 11 & 14 & 35 & 1,280 & 637 & 103 & 284 & 178 & 173 & 5 & 21 & 21 & 36 \\
\hline Business .... & 51,171 & 31,677 & 7,199 & 6,260 & 3,119 & 2,847 & 272 & 572 & 705 & 1,639 & 52,019 & 30,991 & 7,686 & 7,248 & 3,179 & 2,963 & 216 & 515 & 774 & 1,626 \\
\hline Communication, journalism, and related programs.. & 1,411 & 953 & 137 & 208 & 60 & 47 & 13 & 9 & 16 & 28 & 1,625 & 1,025 & 166 & 295 & 68 & 59 & 9 & 19 & 21 & 31 \\
\hline Comm & 2,774 & 1,932 & 390 & 269 & 86 & 81 & 5 & 22 & 45 & 30 & 3,429 & 2,263 & 459 & 417 & 134 & 122 & 12 & 31 & 83 & 42 \\
\hline 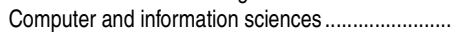 & 29,060 & 19,743 & 4,093 & 2,961 & 1,383 & 1,290 & 93 & 231 & 262 & 387 & 32,290 & 21,516 & 4,504 & 3,665 & 1,591 & 1,471 & 120 & 278 & 360 & 376 \\
\hline 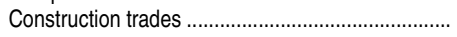 & 5,105 & 4,077 & 478 & 354 & 79 & 72 & 7 & 73 & 35 & 9 & 5,483 & 4,283 & 589 & 361 & 88 & 72 & 16 & 86 & 64 & 12 \\
\hline Education & 2,733 & 1,900 & 311 & 307 & 57 & 45 & 12 & 95 & 27 & 36 & 2,633 & 1,767 & 334 & 364 & 37 & 34 & 3 & 75 & 30 & 26 \\
\hline $\begin{array}{l}\text { Engine } \\
\text { Engine }\end{array}$ & 2,426 & 1,552 & 154 & 306 & 199 & 178 & 21 & 38 & 23 & 154 & 2,931 & 1,897 & 207 & 342 & 244 & 227 & 17 & 17 & 25 & 199 \\
\hline fields 1 & 31,094 & 22,208 & 3,616 & 3,441 & 1,026 & 941 & 85 & 332 & 250 & 221 & 32,224 & 22,839 & 3,800 & 3,786 & 999 & 927 & 72 & 331 & 281 & 188 \\
\hline nglish lan & 647 & 335 & 62 & 180 & 56 & 52 & 4 & 4 & 3 & 7 & 708 & 373 & 71 & 175 & 60 & 56 & 4 & 6 & 7 & 16 \\
\hline Family & 358 & 166 & 75 & 76 & 19 & 17 & 2 & 4 & 7 & 11 & 369 & 189 & 84 & 58 & 20 & 20 & 3 & 3 & 6 & 6 \\
\hline Foreign languages, literatures, and linguistics................. & 377 & 203 & 16 & 97 & 23 & 18 & 5 & 2 & 10 & 26 & 417 & 216 & 18 & 131 & 27 & 25 & 2 & 1 & 6 & 18 \\
\hline ealth professions and related programs & 30,073 & 19,380 & 3,649 & 3,478 & 2,479 & 2,283 & 196 & 275 & 407 & 405 & 34,018 & 21,783 & 4,062 & 4,370 & 2,596 & 2,390 & 206 & 308 & 501 & 398 \\
\hline Homelar & 23,931 & 16,252 & 2,597 & 3,796 & 711 & 579 & 132 & 202 & 302 & 71 & 27,045 & 17,376 & 3,080 & 5,200 & 778 & 670 & 108 & 206 & 310 & 95 \\
\hline Legal p & 1,835 & 1,100 & 330 & 271 & 79 & 70 & 9 & 26 & 21 & 8 & 1,679 & 923 & 331 & 297 & 61 & 58 & 3 & 28 & 26 & 13 \\
\hline sciences, general studies, and & 118,556 & 76,780 & 13,026 & 17,332 & 6,209 & 5,631 & 578 & 1,044 & 1,493 & 2,672 & 129,179 & 81,106 & 14,820 & 20,822 & 6,486 & 5,967 & 519 & 1,154 & 1,994 & 2,797 \\
\hline Library science.................................. & & 15 & 0 & & 1 & 血 & 0 & 0 & 0 & 然 & & 10 & & & 4 & 3 & 1 & 0 & 1 & \\
\hline & 1,024 & 521 & 55 & 226 & 139 & 137 & 2 & 14 & 14 & 55 & 1,050 & 481 & 52 & 289 & 139 & 138 & 1 & 18 & 17 & 54 \\
\hline & 18,998 & 13,455 & 1,933 & 2,369 & 663 & 581 & 82 & 269 & 205 & 104 & 19,709 & 13,634 & 1,896 & 2,731 & 686 & 598 & 88 & 299 & 330 & 133 \\
\hline Milita & 693 & 481 & 72 & 88 & 38 & 33 & 5 & 5 & 9 & 0 & 770 & 529 & 99 & 81 & 42 & 34 & 8 & 5 & 14 & 0 \\
\hline & 8,905 & 5,401 & 620 & 1,436 & 1,057 & 1,008 & 49 & 78 & 90 & 223 & 10,171 & 5,863 & 745 & 1,830 & 1,259 & 1,212 & 47 & 71 & 170 & 233 \\
\hline Parks, recreation, leisu & 1,432 & 863 & 253 & 200 & 55 & 35 & 20 & 20 & 12 & 29 & 1,998 & 1,234 & 272 & 289 & 77 & 65 & 12 & 37 & 35 & 54 \\
\hline Shilo & 177 & 113 & 22 & 34 & 0 & 5 & 1 & 2 & 0 & 0 & 181 & 114 & 29 & 30 & 1 & 1 & 0 & 1 & 4 & 2 \\
\hline Physic & 2,958 & 1,840 & 265 & 373 & 241 & 231 & 10 & 35 & 31 & 173 & 3,404 & 1,934 & 274 & 546 & 355 & 342 & 13 & 36 & 55 & 204 \\
\hline Precisic & 3,024 & 2,556 & 141 & 202 & 73 & 63 & 10 & 29 & 17 & 6 & 3,118 & 2,631 & 130 & 207 & 72 & 68 & 4 & 40 & 29 & 9 \\
\hline Psych & 896 & 460 & 65 & 253 & 67 & 62 & 5 & 26 & 13 & 12 & 1,093 & 536 & 87 & 329 & 98 & 88 & 10 & 17 & 21 & 5 \\
\hline Public administration and social services ...... & 1,025 & 488 & 328 & 142 & 31 & 23 & 8 & 20 & 11 & 5 & 1,382 & 664 & 457 & 194 & 16 & 14 & 2 & 22 & 16 & 13 \\
\hline Soc & 4,511 & 2,412 & 417 & 984 & 450 & 408 & 42 & 88 & 83 & 77 & 5,139 & 2,560 & 432 & 1,3 & 508 & 455 & 53 & 78 & 135 & 98 \\
\hline 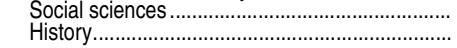 & $\begin{array}{r}4,111 \\
400\end{array}$ & $\begin{array}{r}2,155 \\
257\end{array}$ & $\begin{array}{r}398 \\
19\end{array}$ & $\begin{array}{l}880 \\
104\end{array}$ & $\begin{array}{r}441 \\
9\end{array}$ & $\begin{array}{r}400 \\
8\end{array}$ & $\begin{array}{r}41 \\
1\end{array}$ & $\begin{array}{r}85 \\
3\end{array}$ & $\begin{array}{r}77 \\
6\end{array}$ & $\begin{array}{r}75 \\
2\end{array}$ & $\begin{array}{r}4,650 \\
489\end{array}$ & $\begin{array}{r}2,237 \\
323\end{array}$ & $\begin{array}{r}411 \\
21\end{array}$ & $\begin{array}{r}1,215 \\
113\end{array}$ & $\begin{array}{r}493 \\
15\end{array}$ & $\begin{array}{r}444 \\
11\end{array}$ & $\begin{array}{r}49 \\
4\end{array}$ & $\begin{array}{r}73 \\
5\end{array}$ & $\begin{array}{r}128 \\
7\end{array}$ & 93 \\
\hline Theology and religious & 395 & 271 & 82 & 19 & 9 & 8 & 1 & 5 & 1 & 8 & 423 & 280 & 94 & 31 & 7 & 4 & 3 & 1 & 5 & 5 \\
\hline Transpc & 1,418 & 980 & 97 & 207 & 76 & 73 & 3 & 13 & 24 & 21 & 1,782 & 1,256 & 115 & 234 & 91 & 81 & 10 & 19 & 15 & 52 \\
\hline Visual and perform & 8,706 & 5,410 & 967 & 1,343 & 459 & 419 & 40 & 99 & 110 & 318 & 9,422 & 5,677 & 1,052 & 1,608 & 489 & 448 & 41 & 102 & 151 & 343 \\
\hline Other and not classified...... & 0 & 0 & 0 & 0 & 0 & 0 & 0 & 0 & 0 & 0 & 0 & 0 & 0 & 0 & 0 & 0 & 0 & 0 & 0 & $x^{2}+2>$ \\
\hline
\end{tabular}

1Excludes "Construction trades" and "Mechanic and repair technologies/technicians," which are listed separately.
NOTE: Data are for postsecondary institutions participating in Title IV federal financial aid programs. Race categotes

NOTE: Data are for postsecondary institutions participating in Title IV federal financial aid programs. Race categories exclude perestimate race/ethnicity for students whose race/ethnicity was not reported. To facilitate trend comparisons, certain agregations have been made of the degree fields as reported in the Integrated Postsecondary Education Data System (IPEDS): "Agriculture and natural resources" includes Agriculture, agriculture operations, and related sciences and Natural resources and conservation; and "Uusiness" Includes Business management, marketing, and related support services and Personal and culinary services.
SOURCE: U.S. Department of Education, National Center for Education Statistics, Integrated Postsecondary Education Data System (IPEDS), Fall 2011 and Fall 2012, Completions component. (This table was prepared July 2013.) 
Table 321.50. Associate's degrees conferred to females by postsecondary institutions, by race/ethnicity and field of study: 2010-11 and 2011-12

\begin{tabular}{|c|c|c|c|c|c|c|c|c|c|c|c|c|c|c|c|c|c|c|c|c|}
\hline \multirow[b]{3}{*}{ Field of study } & \multicolumn{10}{|c|}{ 2010-11 } & \multicolumn{10}{|c|}{ 2011-12 } \\
\hline & \multirow[b]{2}{*}{ Total } & \multirow[b]{2}{*}{ White } & \multirow[b]{2}{*}{ Black } & \multirow[b]{2}{*}{ Hispanic } & \multicolumn{3}{|c|}{ Asian/Pacific Islander } & \multirow{2}{*}{\begin{tabular}{|r|} 
American \\
Indian/ \\
Alaska \\
Native \\
\end{tabular}} & \multirow{2}{*}{$\begin{array}{r}\text { Two or } \\
\text { more } \\
\text { races }\end{array}$} & \multirow{2}{*}{$\begin{array}{r}\text { Non- } \\
\text { resident } \\
\text { alien }\end{array}$} & \multirow[b]{2}{*}{ Total } & \multirow[b]{2}{*}{ White } & \multirow[b]{2}{*}{ Black } & \multirow[b]{2}{*}{ Hispanic } & \multicolumn{3}{|c|}{ Asian/Pacific Islander } & \multirow{2}{*}{\begin{tabular}{|r|} 
American \\
Indian/ \\
Alaska \\
Native \\
\end{tabular}} & \multirow{2}{*}{$\begin{array}{r}\text { Two or } \\
\text { more } \\
\text { races }\end{array}$} & \multirow{2}{*}{$\begin{array}{r}\text { Non- } \\
\text { residen } \\
\text { alien }\end{array}$} \\
\hline & & & & & Total & Asian & $\begin{array}{r}\text { Pacific } \\
\text { Islander }\end{array}$ & & & & & & & & Total & Asian & $\begin{array}{r}\text { Pacific } \\
\text { Islander }\end{array}$ & & & \\
\hline 1 & 2 & 3 & 4 & 5 & 6 & 7 & 8 & 9 & 10 & 11 & 12 & 13 & 14 & 15 & 16 & 17 & 18 & 19 & 20 & 21 \\
\hline All fields, total .................................. & 581,018 & 366,032 & 87,107 & 77,934 & 26,695 & 24,031 & 2,664 & 6,449 & 7,018 & 9,783 & 625,548 & 381,808 & 95,762 & 93,781 & 28,245 & 25,990 & 2,255 & 6,795 & 9,216 & 9,941 \\
\hline Agriculture and natural resources............................. & 2,336 & 2,120 & 21 & 86 & 28 & 24 & 4 & 42 & 22 & 17 & 2,460 & 2,217 & 29 & 103 & 29 & 25 & 4 & 47 & 25 & 10 \\
\hline Architecture and related services.... & 259 & 164 & 10 & 53 & 19 & 17 & 2 & 2 & 2 & 9 & 261 & 147 & 18 & 65 & 19 & 18 & 1 & 0 & 4 & 8 \\
\hline Area, ethnic, cultural, gender, and group studies ... & 149 & 35 & 19 & 23 & 2 & 2 & 0 & 62 & 3 & 5 & 132 & 30 & 9 & 30 & 6 & 6 & 0 & 49 & 3 & 5 \\
\hline Biological and biomedical sciences ......................... & 2,129 & 1,080 & 189 & 434 & 311 & 284 & 27 & 39 & 22 & 54 & 2,554 & 1,204 & 222 & 655 & 331 & 326 & 5 & 49 & 36 & 57 \\
\hline 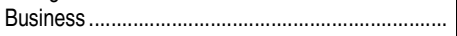 & 88,815 & 52,515 & 16,702 & 10,341 & 4,582 & 4,132 & 450 & 1,088 & 1,084 & 2,503 & 90,319 & 52,477 & 16,404 & 11,676 & 4,744 & 4,379 & 365 & 1,099 & 1,375 & 2,544 \\
\hline Communication, journalism, and related programs.. & 1,640 & 1,002 & 149 & 298 & 93 & 84 & 9 & 11 & 14 & 73 & 1,870 & 1,079 & 213 & 360 & 88 & 74 & 14 & 8 & 40 & 82 \\
\hline Communications technologies... & 1,435 & 1,024 & 145 & 145 & 48 & 45 & 3 & 17 & 22 & 34 & 1,571 & 1,113 & 126 & 183 & 72 & 72 & 0 & 10 & 41 & 26 \\
\hline Computer and information sciences............................. & 8,617 & 5,307 & 1,818 & 769 & 364 & 323 & 41 & 118 & 73 & 168 & 8,871 & 5,403 & 1,799 & 867 & 437 & 392 & 45 & 114 & 134 & 117 \\
\hline 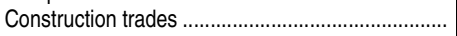 & 297 & 205 & 40 & 31 & 4 & 4 & 0 & 5 & 9 & 3 & 269 & 178 & 43 & 26 & 4 & 3 & 1 & 5 & 11 & 2 \\
\hline Education & 17,726 & 11,378 & 2,637 & 2,645 & 359 & 284 & 75 & 382 & 168 & 157 & 17,898 & 11,190 & 2,722 & 2,866 & 336 & 298 & 38 & 407 & 183 & 194 \\
\hline $\begin{array}{l}\text { Engineering } \\
\text { Engineering technologies and engineering-related }\end{array}$ & 399 & 242 & 33 & 61 & 30 & 29 & 1 & 5 & 2 & 26 & 451 & 224 & 34 & 81 & 61 & 56 & 5 & 10 & 2 & 39 \\
\hline 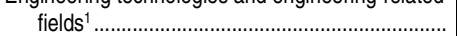 & 4,427 & 2,892 & 680 & 517 & 161 & 146 & 15 & 61 & 60 & 56 & 4,286 & 2,792 & 649 & 490 & 180 & 164 & 16 & 50 & 66 & 59 \\
\hline English language and literature/letters .................... & 1,372 & 745 & 182 & 296 & 105 & 98 & 7 & 11 & 14 & 19 & 1,429 & 768 & 161 & 337 & 90 & 83 & 7 & 16 & 31 & 26 \\
\hline Family and consumer sciences/human sciences ... & 8,174 & 4,264 & 1,818 & 1,526 & 317 & 288 & 29 & 72 & 58 & 119 & 9,134 & 4,650 & 2,009 & 1,785 & 399 & 371 & 28 & 96 & 84 & 111 \\
\hline Foreign languages, literatures, and linguistics................. & 1,499 & 990 & 68 & 324 & 39 & 30 & 9 & 14 & 19 & 45 & 1,563 & 999 & 86 & 388 & 29 & 26 & 3 & 5 & 18 & 38 \\
\hline Health professions and related programs... & 171,758 & 119,691 & 24,375 & 16,035 & 7,045 & 6,372 & 673 & 1,529 & 1,801 & 1,282 & 184,023 & 124,883 & 27,163 & 19,423 & 7,370 & 6,866 & 504 & 1,687 & 2,268 & 1,229 \\
\hline Homeland security, law enforcement, and firefighting.... & 20,992 & 10,996 & 5,070 & 3,895 & 328 & 248 & 80 & 264 & 368 & 71 & 23,650 & 11,442 & 5,734 & 5,338 & 411 & 300 & 111 & 293 & 340 & 92 \\
\hline Legal professions and studies ............................. & 9,785 & 6,340 & 1,637 & 1,263 & 243 & 199 & 44 & 86 & 155 & 61 & 10,503 & 6,671 & 1,732 & 1,549 & 239 & 218 & 21 & 104 & 155 & 53 \\
\hline $\begin{array}{l}\text { Liberal arts and sciences, general studies, and } \\
\text { humanities }\end{array}$ & 188.114 & 116084 & 24970 & 30.414 & 8519 & 7656 & 863 & 1979 & 2503 & 3645 & 207375 & 123135 & 29516 & 36430 & 8997 & 8240 & 757 & 2061 & 3131 & \\
\hline Library science........................................ & $\begin{array}{r}180,114 \\
139\end{array}$ & $\begin{array}{r}110,084 \\
113\end{array}$ & $\begin{array}{r}24,910 \\
5\end{array}$ & $\begin{array}{r}30,414 \\
15\end{array}$ & $\begin{array}{r}8,019 \\
2\end{array}$ & $\begin{array}{r}r, 000 \\
2\end{array}$ & $\begin{array}{r}r 03 \\
0\end{array}$ & $\begin{array}{r}r, 9 / 9 \\
1\end{array}$ & $\begin{array}{r}2,003 \\
3\end{array}$ & $\begin{array}{r}3,045 \\
0\end{array}$ & $\begin{array}{r}20 /, 3 / 5 \\
140\end{array}$ & $\begin{array}{r}123,135 \\
118\end{array}$ & 29,510 & $\begin{array}{r}30,430 \\
14\end{array}$ & $\begin{array}{r}8,991 \\
3\end{array}$ & $\begin{array}{r}8,240 \\
3\end{array}$ & $\begin{array}{r}100 \\
0\end{array}$ & $\begin{array}{r}2,001 \\
3\end{array}$ & $\begin{array}{r}3,434 \\
0\end{array}$ & $\begin{array}{r}3,802 \\
1\end{array}$ \\
\hline Mathem & 620 & 257 & 48 & 159 & 117 & 117 & 0 & 10 & 9 & 20 & 479 & 222 & 12 & 131 & 73 & 69 & 4 & 5 & 4 & 32 \\
\hline Mechanic and repair technologies/technicians .............. & 971 & 623 & 144 & 124 & 22 & 20 & 2 & 35 & 17 & 6 & 1,005 & 668 & 135 & 130 & 18 & 15 & 3 & 26 & 20 & 8 \\
\hline and applied sciences ................... & 163 & 101 & 24 & 22 & 9 & 7 & 2 & 3 & 4 & 0 & 216 & 124 & 51 & 20 & 13 & 11 & 2 & 2 & 6 & 0 \\
\hline Multi/interdisciplinary studies .... & 14,824 & 8,386 & 1,491 & 2,602 & 1,718 & 1,617 & 101 & 130 & 152 & 345 & 17,096 & 9,311 & 1,641 & 3,410 & 1,975 & 1,867 & 108 & 130 & 272 & 357 \\
\hline Parks, recreation, leisure, and fitness studies.................. & 934 & 594 & 97 & 172 & 33 & 29 & 4 & 18 & 9 & 11 & 1,125 & 655 & 132 & 244 & 29 & 27 & 2 & 16 & 23 & 26 \\
\hline Philos & 106 & 39 & 25 & 19 & 19 & 19 & 0 & 2 & 1 & 1 & 127 & 52 & 46 & 20 & 2 & 2 & 0 & 2 & 1 & 4 \\
\hline Physical sciences and science technologies.................. & 2,120 & 1,026 & 353 & 271 & 283 & 262 & 21 & 30 & 35 & 122 & 2,420 & 1,173 & 395 & 362 & 289 & 278 & 11 & 27 & 45 & 129 \\
\hline 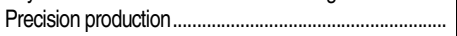 & 230 & 185 & 12 & 14 & 6 & 5 & 1 & 10 & 3 & 0 & 202 & 153 & 21 & 13 & 2 & 1 & 1 & 10 & 3 & 0 \\
\hline Psychology............................................................. & 2,970 & 1,665 & 269 & 750 & 137 & 123 & 14 & 61 & 44 & 44 & 3,624 & 1,781 & 359 & 1,124 & 182 & 171 & 11 & 77 & 69 & 32 \\
\hline Public administration and social services ...................... & 6,447 & 3,401 & 1,853 & 898 & 101 & 77 & 24 & 111 & 56 & 27 & 7,761 & 4,033 & 2,252 & 1,125 & 117 & 94 & 23 & 112 & 81 & 41 \\
\hline $\begin{array}{l}\text { Social sciences and history } \\
\text { Social sciences } \ldots \ldots \\
\text { History } \ldots \ldots\end{array}$ & $\begin{array}{r}8,256 \\
7,956 \\
300\end{array}$ & $\begin{array}{r}3,904 \\
3,701 \\
203\end{array}$ & $\begin{array}{r}1,047 \\
1,035 \\
12\end{array}$ & $\begin{array}{r}2,072 \\
2,008 \\
64\end{array}$ & $\begin{array}{r}811 \\
803 \\
8\end{array}$ & $\begin{array}{r}702 \\
696 \\
6\end{array}$ & $\begin{array}{r}109 \\
107 \\
2\end{array}$ & $\begin{array}{r}153 \\
151 \\
2\end{array}$ & $\begin{array}{r}124 \\
118 \\
6\end{array}$ & $\begin{array}{r}145 \\
140 \\
5\end{array}$ & $\begin{array}{l}8,993 \\
8,671 \\
322\end{array}$ & $\begin{array}{l}4,135 \\
3,929 \\
206\end{array}$ & $\begin{array}{r}958 \\
948 \\
10\end{array}$ & $\begin{array}{r}2,574 \\
2,488 \\
86\end{array}$ & $\begin{array}{r}845 \\
835 \\
10\end{array}$ & $\begin{array}{r}747 \\
738 \\
9\end{array}$ & $\begin{array}{r}98 \\
97 \\
1\end{array}$ & $\begin{array}{r}156 \\
153 \\
3\end{array}$ & $\begin{array}{r}194 \\
189 \\
5\end{array}$ & $\begin{array}{r}131 \\
129 \\
2\end{array}$ \\
\hline Theology and religious vocations & 363 & 249 & 85 & 17 & 4 & 2 & 2 & 2 & 0 & 6 & 416 & 278 & 95 & 36 & 1 & 1 & 0 & 1 & 2 & 3 \\
\hline on and materials $n$ & 279 & 157 & 29 & 46 & 18 & 17 & 1 & 1 & 5 & 23 & 316 & 190 & 19 & 60 & 20 & 16 & 4 & 3 & 5 & 19 \\
\hline 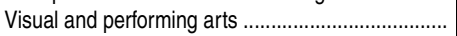 & 12,673 & 8,258 & 1,062 & 1,597 & 818 & 767 & 51 & 95 & 157 & 686 & 13,009 & 8,313 & 976 & 1,866 & 834 & 771 & 63 & 115 & 241 & 664 \\
\hline 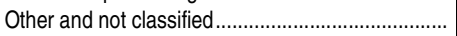 & 0 & 0 & 0 & 0 & 0 & 0 & 0 & 0 & 0 & 0 & & 0 & 0 & 0 & 0 & 0 & 0 & 0 & 0 & 0 \\
\hline
\end{tabular}

'Excludes "Construction trades" and "Mechanic and repair technologies/technicians," which are listed separately.

NOTE: Data are for postsecondary institutions participating in Titte IV federal financial aid programs. Race categories exclude per-

estimate race/ethnicity for students whose race/ethnicity was not reported. To facilitate trend comparisons, certain aggregations

and natural resources" includes Agriculture, agriculture operations, and related sciences and Natural resources and conservation SOURCE: US. Depues Business manage, a have been made of the degree fields as reported in the Integrated Postsecondary Education Data System (IPEDS): "Agriculture 
Table 322.10. Bachelor's degrees conferred by postsecondary institutions, by field of study: Selected years, 1970-71 through 2010-11

\begin{tabular}{|c|c|c|c|c|c|c|c|c|c|c|c|c|c|c|c|c|c|c|}
\hline Field of study & 970-71 & $1975-76$ & $1980-81$ & $1985-86$ & $1990-91$ & $1995-96$ & $2000-01$ & 2001-02 & $2002-03$ & 2003-04 & 2004-05 & $2005-06$ & $2006-07$ & $2007-08$ & $2008-09$ & $2009-10$ & 2010-11 & 2011-12 \\
\hline 1 & 2 & 3 & 4 & 5 & 6 & 7 & 8 & 9 & 10 & 11 & 12 & 13 & 14 & 15 & 16 & 17 & 18 & 19 \\
\hline Total .. & 9,730 & 25,746 & 5,140 & 7,823 & $1,094,538$ & $1,164,792$ & $1,244,171$ & $1,291,900$ & $1,348,811$ & $1,399,542$ & $1,439,264$ & $1,485,242$ & \begin{tabular}{|l|}
$1,524,092$ \\
\end{tabular} & $1,563,069$ & $1,601,368$ & $1,650,014$ & $1,715,913$ & $1,791,046$ \\
\hline riculture and natural resources. & 12,672 & 19,402 & 21,886 & 16,823 & 13,124 & 21,425 & 23,370 & 23,331 & 23,348 & 22,835 & 23,002 & 23,053 & 3,133 & 24,113 & 24,988 & 26,336 & 28,623 & 30,929 \\
\hline & 5,570 & 9,146 & 9,455 & 9,119 & 9,781 & 8,352 & 8,480 & 8,808 & 9,056 & 8,838 & 9,237 & 9,515 & 9,717 & 9,805 & 10,119 & 10,051 & 9,832 & 9,728 \\
\hline es......... & 2,579 & 3,577 & 2,887 & 3,021 & 4,776 & 5,633 & 6,160 & 6,390 & 6,634 & 7,181 & 7,569 & 7,879 & 8,194 & 8,454 & 8,772 & 8,621 & 9,100 & 9,232 \\
\hline . & 35,705 & 54,154 & 43,078 & 38,395 & 39,482 & 61,014 & 60,576 & 60,309 & 61,294 & 62,624 & 65,915 & 70,607 & 76,832 & 79,829 & 82,825 & 86,400 & 90,003 & 95,849 \\
\hline 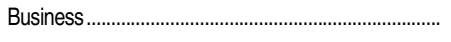 & 115,396 & 143,171 & 200,521 & 236,700 & 249,165 & 226,623 & 263,515 & 278,217 & 293,391 & 307,149 & 311,574 & 318,042 & 327,531 & 335,254 & 347,985 & 358,293 & 365,093 & 366,815 \\
\hline ommunication, journalism, and related programs.... & 10,324 & 20,045 & 29,428 & ,666 & 1,650 & 47,320 & 8,013 & 2,791 & 7,895 & 0,968 & 2,715 & 3,955 & 74,783 & 76,382 & 78,009 & 31,266 & 3,274 & 83,770 \\
\hline & 478 & 1,237 & 1,854 & 479 & 1,397 & 853 & 1,178 & 1,245 & 1,933 & 2,034 & 2,523 & 2,981 & 3,637 & 4,666 & 5,100 & 4,782 & 358 & 4,982 \\
\hline . & 2,388 & 5,652 & 15,121 & 42,337 & 25,159 & 24,506 & 44,142 & 50,365 & 57,433 & 59,488 & 54,111 & 47,480 & 42,170 & 38,476 & 37,994 & 39,589 & 43,072 & 47,384 \\
\hline & 176,307 & 154,437 & 108,074 & 87,147 & 110,807 & 105,384 & 105,458 & 106,295 & 105,845 & 106,278 & 105,451 & 107,238 & 105,641 & 102,582 & 101,708 & 101,265 & 103,992 & 105,785 \\
\hline nglir & 45,034 & 38,733 & 63,642 & 77,391 & 2,448 & 62,168 & 58,209 & 59,536 & 62,567 & 63,410 & 64,707 & 66,841 & 6,874 & 68,431 & 68,911 & 72,654 & 76,376 & 81,382 \\
\hline & 148 & 943 & 11,713 & 19,731 & 3 & 15,829 & 14,660 & 4 & 4 & 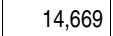 & t & 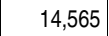 & & 15,1 & 15,5 & 75 & 41 & 17,158 \\
\hline & 63,914 & 41,452 & 31,922 & ,083 & ,064 & 49,928 & 50,569 & 75 & 99 & 384 & 79 & & 22 & 38 & 55,462 & 53,231 & 44 & 3,767 \\
\hline & 167 & 17,409 &, 370 & ,847 & 920 & 4,353 & 21 & & 29 & , 172 & & 75 & 00 & 70 & 05 & 18 & 44 & 23,428 \\
\hline & 20,988 & 17,068 & 11,638 & 0 & ,937 & 14,832 & 16,128 &, 258 & 6,912 & 7,754 & 18,386 &, 410 & 20,275 & 20,977 & 21,158 & 21,516 & 1,706 & 21,764 \\
\hline Health professions a & 25,223 & 53,885 & 63,665 & 65,309 & 59,875 & 86,087 & 75,933 & 72,887 & 71,261 & 73,934 & 80,685 & 91,973 & 101,810 & 111,478 & 120,488 & 129,634 & 143,430 & 163,440 \\
\hline & & 12,507 & 707 & 12701 & 16,806 & 24,810 & 1 & 5,536 & 6,200 & & & & 9,206 & 0225 & & 43,667 & 02 & 67 \\
\hline & 545 & 531 & 776 & 1,223 & 1,827 & 2,123 & 1,991 & 2,003 & 2,474 & 2,841 & 3,161 & 3,302 & 3,596 & 3,771 & 3,822 & 3,886 & 4,429 & 4,592 \\
\hline & & 18,855 & 21,643 & , 336 &, 526 & 33,997 & 962 & ,333 & , ,480 & 2,106 &, 751 & , 898 & , 255 & 3,940 & , 096 & 46,953 & 6,727 & 46,925 \\
\hline & 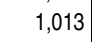 & 843 & 375 & 155 & 90 & 58 & 52 & 74 & 99 & 72 & 76 & 76 & 82 & 68 & 78 & 85 & 96 & 95 \\
\hline nait & 24,801 & 15,984 & 11,078 & 16,122 & 14,393 & 12,713 & 11,171 & 11,950 & 12,505 & 3,327 & 14,351 & 14,770 & 14,954 & 5,192 & 15,496 & 16,030 & 17,182 & 18,842 \\
\hline & 357 & 9 & 42 & 255 & 183 & & 21 & & & 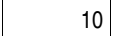 & 0 & 33 & 168 & 39 & 55 & 56 & 4 & 86 \\
\hline & 6,324 & 13,709 & 12,986 & 13,754 & 17,774 & 26,885 & 6,478 & 3,049 & 7,449 & 8,047 & 28,939 & 0,583 & 2,111 & 4,174 & 35,375 & 7,648 & 2,228 & 5,716 \\
\hline & 1,621 & 5,182 & & 4,623 & & 12,974 & 17,948 &, 885 & 132 & 164 & & & & 931 & 1,667 & ;318 & 24 & 8,993 \\
\hline & 8,149 & 8,447 & 6,776 & 0,050 & 7,423 & 7,541 & 8,717 & 9,473 & 10,344 & 11,152 & 11,584 & ,985 & ,969 & 2,257 & 12,444 & 12,504 & 2,836 & 12,651 \\
\hline Physical & 21,410 & 21,458 & 23,936 & 21,711 & 16,334 & 19,716 & 18,025 & 17,890 & 18,038 & 18,131 & 19,104 & 20,522 & 21,291 & 22,179 & 22,688 & 23,379 & 24,712 & 26,663 \\
\hline & 0 & 0 & 0 & 2 & & 12 & 31 & 47 & $4<$ & 01 & 64 & 55 & 20 & & 20 & 29 & 40 & $3 \pi$ \\
\hline & 38,187 & ,278 & ,068 & 228 & 655 & 416 & 645 & ,775 & 3,650 & 098 & 614 & 134 & 039 & 587 & 271 & 216 & 893 & 108,986 \\
\hline & 5466 & & 07 & & & & & & & & & & & & 851 & ,414 & & 29,695 \\
\hline So & 155,324 & 126,396 & 100,513 & 93,840 & 125,107 & 126,479 & 128,036 & 132,874 & 143,256 & 150,357 & 156,892 & 161,485 & 164,183 & 167,363 & 168,500 & 172,780 & 177,144 & 178,543 \\
\hline Theolos & 3,720 & 5,490 & 5,808 & 5,510 & 4,799 & 5,292 & 6,945 & 7,762 & 7,962 & 8,126 & 9,284 & 8,548 & 8,696 & 8,992 & 8,940 & 8,718 & 9,074 & 9,369 \\
\hline & & 225 & 263 & & 2,622 & 3,561 & & 4,020 & 4,631 & 4,824 & 4,904 & 5,349 & & 5,203 & 5,189 & 4,998 & 4,941 & 4,876 \\
\hline . & ,394 & 42,138 & 40,479 & 37,241 & 42,186 & 49,296 & 61,148 & 66,773 & 71,482 & 77,181 & 80,955 & 83,297 & 5,186 & 37,703 & 89,140 & 91,802 & 93,956 & 95,797 \\
\hline Not classified by field of study .................. & & & & & 13,258 & 1,756 & 783 & 264 & & & & & & 377 & . & & & \\
\hline
\end{tabular}

NOTE: Data through 1990-91 are for institutions of higher education, while later data are for postsecondary institutions that participate in Title IV federal financial aid programs. The new Classification of Instructional Programs was initiated in facilitate trend comparisons, certain aggregations have been made of the degree fields as reported in the Integrated Postsecondary Education Data System (IPEDS): "Agriculture and natural resources" includes Agriculture, agriculture operations, and

related support services and Personal and culinary services; and "Engineering technologies" includes Engineering technologies and engineering-related fields, Construction trades, and Mechanic and repair technologies/technicians.
SOURCE: U.S. Department of Education, National Center for Education Statistics. Higher Education Gent

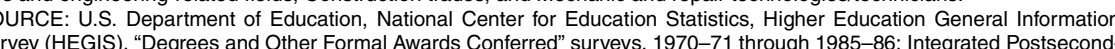
ary Education Data System (IPEDS), "Completions Survey" (IPEDS-C:91-99); and IPEDS Fall 2000 through Fall 2012, Com-
pletions component. (This table was prepared July 2013.) related sciences and Natural resources and conservation; "Business" includes Business, management, marketing, and 
Table 322.20. Bachelor's degrees conferred by postsecondary institutions, by race/ethnicity and sex of student: Selected years, 1976-77 through 2011-12

\begin{tabular}{|c|c|c|c|c|c|c|c|c|c|c|c|c|c|c|c|}
\hline \multirow[b]{2}{*}{ Year and sex } & \multicolumn{8}{|c|}{ Number of degrees conferred to U.S. citizens and nonresident aliens } & \multicolumn{7}{|c|}{ Percentage distribution of degrees conferred to U.S. citizens } \\
\hline & Total & White & Black & Hispanic & $\begin{array}{r}\text { Asian/ } \\
\text { Pacific } \\
\text { Islander }\end{array}$ & $\begin{array}{r}\text { American } \\
\text { Indian/ } \\
\text { Alaska } \\
\text { Native }\end{array}$ & $\begin{array}{r}\text { Two or } \\
\text { more } \\
\text { races }\end{array}$ & $\begin{array}{r}\text { Non- } \\
\text { resident } \\
\text { alien }\end{array}$ & Total & White & Black & Hispanic & $\begin{array}{r}\text { Asian/ } \\
\text { Pacific } \\
\text { Islander }\end{array}$ & $\begin{array}{r}\text { American } \\
\text { Indian/ } \\
\text { Alaska } \\
\text { Native } \\
\end{array}$ & $\begin{array}{r}\text { Two or } \\
\text { more } \\
\text { races }\end{array}$ \\
\hline 1 & 2 & 3 & 4 & 5 & 6 & 7 & 8 & 9 & 10 & 11 & 12 & 13 & 14 & 15 & 16 \\
\hline 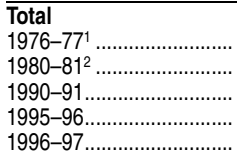 & $\begin{array}{r}917,900 \\
934,800 \\
1,094,538 \\
1,164,792 \\
1,172,879\end{array}$ & $\begin{array}{l}807,688 \\
807,319 \\
914,093 \\
905,846 \\
900,809\end{array}$ & $\begin{array}{l}58,636 \\
60,673 \\
66,375 \\
91,496 \\
94,349\end{array}$ & $\begin{array}{l}18,743 \\
21,832 \\
37,342 \\
58,351 \\
62,509\end{array}$ & $\begin{array}{l}13,793 \\
18,794 \\
42,529 \\
64,433 \\
68,859\end{array}$ & $\begin{array}{l}3,326 \\
3,593 \\
4,583 \\
6,976 \\
7,425\end{array}$ & $\begin{array}{l}- \\
- \\
- \\
-\end{array}$ & $\begin{array}{l}15,714 \\
22,589 \\
29,616 \\
37,690 \\
38,928\end{array}$ & $\begin{array}{l}100.0 \\
100.0 \\
100.0 \\
100.0 \\
100.0\end{array}$ & $\begin{array}{l}89.5 \\
88.5 \\
85.8 \\
80.4 \\
79.4\end{array}$ & $\begin{array}{l}6.5 \\
6.7 \\
6.2 \\
8.1 \\
8.3\end{array}$ & $\begin{array}{l}2.1 \\
2.4 \\
3.5 \\
5.2 \\
5.5\end{array}$ & $\begin{array}{l}1.5 \\
2.1 \\
4.0 \\
5.7 \\
6.1\end{array}$ & $\begin{array}{l}0.4 \\
0.4 \\
0.4 \\
0.6 \\
0.7\end{array}$ & $\begin{array}{l}- \\
- \\
-\end{array}$ \\
\hline $\begin{array}{l}1997-98 . \ldots . \\
1998-99 \ldots \ldots \ldots \\
1999-2000 \ldots \ldots \ldots \ldots \ldots \ldots \\
2000-01 \ldots \ldots \ldots \ldots \ldots \ldots \ldots \ldots \\
2001-02 \ldots \ldots \ldots \ldots \ldots \ldots \ldots \ldots\end{array}$ & $\begin{array}{l}1,184,406 \\
1,202,239 \\
1,237,875 \\
1,244,171 \\
1,291,900\end{array}$ & $\begin{array}{l}901,344 \\
909,562 \\
929,102 \\
927,357 \\
958,597\end{array}$ & $\begin{array}{r}98,251 \\
101,910 \\
108,018 \\
111,307 \\
116,623\end{array}$ & $\begin{array}{l}66,005 \\
69,735 \\
75,063 \\
77,745 \\
82,966\end{array}$ & $\begin{array}{r}71,678 \\
74,126 \\
77,909 \\
78,902 \\
83,093\end{array}$ & $\begin{array}{l}7,903 \\
8,658 \\
8,717 \\
9,049 \\
9,165\end{array}$ & $\begin{array}{l}- \\
- \\
- \\
-\end{array}$ & $\begin{array}{l}39,225 \\
38,248 \\
39,066 \\
39,811 \\
41,456\end{array}$ & $\begin{array}{l}100.0 \\
100.0 \\
100.0 \\
100.0 \\
100.0\end{array}$ & $\begin{array}{l}78.7 \\
78.1 \\
77.5 \\
77.0 \\
76.7\end{array}$ & $\begin{array}{l}8.6 \\
8.8 \\
9.0 \\
9.2 \\
9.3\end{array}$ & $\begin{array}{l}5.8 \\
6.0 \\
6.3 \\
6.5 \\
6.6\end{array}$ & $\begin{array}{l}6.3 \\
6.4 \\
6.5 \\
6.6 \\
6.6\end{array}$ & $\begin{array}{l}0.7 \\
0.7 \\
0.7 \\
0.8 \\
0.7\end{array}$ & $\begin{array}{l}- \\
- \\
- \\
-\end{array}$ \\
\hline $\begin{array}{l}2002-03 \\
2003-04 \\
2004-05 \\
2005-06 \\
2006-07\end{array}$ & $\begin{array}{l}1,348,811 \\
1,399,542 \\
1,439,264 \\
1,485,242 \\
1,524,092\end{array}$ & $\begin{array}{r}994,616 \\
1,026,114 \\
1,049,141 \\
1,075,561 \\
1,099,850\end{array}$ & $\begin{array}{l}124,253 \\
131,241 \\
136,122 \\
142,420 \\
146,653\end{array}$ & $\begin{array}{r}89,029 \\
94,644 \\
101,124 \\
107,588 \\
114,936\end{array}$ & $\begin{array}{r}87,964 \\
92,073 \\
97,209 \\
102,376 \\
105,297\end{array}$ & $\begin{array}{r}9,875 \\
10,638 \\
10,307 \\
10,940 \\
11,455\end{array}$ & $\begin{array}{l}- \\
- \\
- \\
-\end{array}$ & $\begin{array}{l}43,074 \\
44,832 \\
45,361 \\
46,357 \\
45,901\end{array}$ & $\begin{array}{l}100.0 \\
100.0 \\
100.0 \\
100.0 \\
100.0\end{array}$ & $\begin{array}{l}76.2 \\
75.7 \\
75.3 \\
74.7 \\
74.4\end{array}$ & $\begin{array}{l}9.5 \\
9.7 \\
9.8 \\
9.9 \\
9.9\end{array}$ & $\begin{array}{l}6.8 \\
7.0 \\
7.3 \\
7.5 \\
7.8\end{array}$ & $\begin{array}{l}6.7 \\
6.8 \\
7.0 \\
7.1 \\
7.1\end{array}$ & $\begin{array}{l}0.8 \\
0.8 \\
0.7 \\
0.8 \\
0.8\end{array}$ & $\begin{array}{l}- \\
- \\
- \\
-\end{array}$ \\
\hline $\begin{array}{l}2007-08 \\
2008-09 \\
2009-10 \\
2010-11 \\
2011-12\end{array}$ & $\begin{array}{l}1,563,069 \\
1,601,368 \\
1,650,014 \\
1,715,913 \\
1,791,046\end{array}$ & $\begin{array}{l}1,122,675 \\
1,144,614 \\
1,167,499 \\
1,182,405 \\
1,211,565\end{array}$ & $\begin{array}{l}152,457 \\
156,615 \\
164,844 \\
173,017 \\
185,518\end{array}$ & $\begin{array}{l}123,048 \\
129,527 \\
140,316 \\
154,063 \\
169,646\end{array}$ & $\begin{array}{l}109,058 \\
112,508 \\
117,422 \\
121,066 \\
126,147\end{array}$ & $\begin{array}{l}11,509 \\
12,221 \\
12,399 \\
11,933 \\
11,483\end{array}$ & $\begin{array}{r}- \\
\overline{-} \\
20,804 \\
27,181\end{array}$ & $\begin{array}{l}44,322 \\
45,883 \\
47,534 \\
52,625 \\
59,506\end{array}$ & $\begin{array}{l}100.0 \\
100.0 \\
100.0 \\
100.0 \\
100.0\end{array}$ & $\begin{array}{l}73.9 \\
73.6 \\
72.9 \\
71.1 \\
70.0\end{array}$ & $\begin{array}{l}10.0 \\
10.1 \\
10.3 \\
10.4 \\
10.7\end{array}$ & $\begin{array}{l}8.1 \\
8.3 \\
8.8 \\
9.3 \\
9.8\end{array}$ & $\begin{array}{l}7.2 \\
7.2 \\
7.3 \\
7.3 \\
7.3\end{array}$ & $\begin{array}{l}0.8 \\
0.8 \\
0.8 \\
0.7 \\
0.7\end{array}$ & $\begin{array}{l}\overline{-} \\
\overline{1.3} \\
1.6\end{array}$ \\
\hline $\begin{array}{l}\text { Males } \\
1976-77^{1} \\
1980-81^{2} \ldots \ldots \ldots \ldots \ldots \ldots \ldots \ldots \ldots \ldots \\
1990-91 \ldots \ldots \ldots \ldots \ldots \ldots \ldots \ldots \\
1995-96 \ldots \ldots \ldots \ldots \ldots \ldots \ldots \ldots \\
1996-97\end{array}$ & $\begin{array}{l}494,424 \\
469,625 \\
504,045 \\
522,454 \\
520,515\end{array}$ & $\begin{array}{l}438,161 \\
406,173 \\
421,290 \\
409,565 \\
403,366\end{array}$ & $\begin{array}{l}25,147 \\
24,511 \\
24,800 \\
32,974 \\
33,616\end{array}$ & $\begin{array}{l}10,318 \\
10,810 \\
16,598 \\
25,029 \\
26,318\end{array}$ & $\begin{array}{r}7,638 \\
10,107 \\
21,203 \\
30,669 \\
32,521\end{array}$ & $\begin{array}{l}1,804 \\
1,700 \\
1,938 \\
2,885 \\
2,996\end{array}$ & $\begin{array}{l}- \\
- \\
- \\
-\end{array}$ & $\begin{array}{l}11,356 \\
16,324 \\
18,216 \\
21,332 \\
21,698\end{array}$ & $\begin{array}{l}100.0 \\
100.0 \\
100.0 \\
100.0 \\
100.0\end{array}$ & $\begin{array}{l}90.7 \\
89.6 \\
86.7 \\
81.7 \\
80.9\end{array}$ & $\begin{array}{l}5.2 \\
5.4 \\
5.1 \\
6.6 \\
6.7\end{array}$ & $\begin{array}{l}2.1 \\
2.4 \\
3.4 \\
5.0 \\
5.3\end{array}$ & $\begin{array}{l}1.6 \\
2.2 \\
4.4 \\
6.1 \\
6.5\end{array}$ & $\begin{array}{l}0.4 \\
0.4 \\
0.4 \\
0.6 \\
0.6\end{array}$ & $\begin{array}{l}- \\
- \\
- \\
-\end{array}$ \\
\hline $\begin{array}{l}1997-98 \ldots \ldots \ldots \\
1998-99 \ldots \ldots \ldots \ldots \ldots \ldots \ldots . . \\
1999-2000 \ldots \ldots \ldots \ldots \ldots \ldots \ldots \\
2000-01 \ldots \ldots \ldots \ldots \ldots \ldots \ldots . \\
2001-02 \ldots \ldots \ldots \ldots \ldots \ldots \ldots . . \\
.\end{array}$ & $\begin{array}{l}519,956 \\
519,961 \\
530,367 \\
531,840 \\
549,816\end{array}$ & $\begin{array}{l}399,553 \\
398,310 \\
402,954 \\
401,780 \\
414,892\end{array}$ & $\begin{array}{l}34,510 \\
34,856 \\
37,029 \\
38,103 \\
39,196\end{array}$ & $\begin{array}{l}27,677 \\
28,477 \\
30,304 \\
31,368 \\
32,951\end{array}$ & $\begin{array}{l}33,445 \\
34,179 \\
35,853 \\
35,865 \\
37,660\end{array}$ & $\begin{array}{l}3,151 \\
3,407 \\
3,463 \\
3,700 \\
3,624\end{array}$ & $\begin{array}{l}- \\
- \\
- \\
-\end{array}$ & $\begin{array}{l}21,620 \\
20,732 \\
20,764 \\
21,024 \\
21,493\end{array}$ & $\begin{array}{l}100.0 \\
100.0 \\
100.0 \\
100.0 \\
100.0\end{array}$ & $\begin{array}{l}80.2 \\
79.8 \\
79.1 \\
78.7 \\
78.5\end{array}$ & $\begin{array}{l}6.9 \\
7.0 \\
7.3 \\
7.5 \\
7.4\end{array}$ & $\begin{array}{l}5.6 \\
5.7 \\
5.9 \\
6.1 \\
6.2\end{array}$ & $\begin{array}{l}6.7 \\
6.8 \\
7.0 \\
7.0 \\
7.1\end{array}$ & $\begin{array}{l}0.6 \\
0.7 \\
0.7 \\
0.7 \\
0.7\end{array}$ & $\begin{array}{l}- \\
- \\
- \\
-\end{array}$ \\
\hline $\begin{array}{l}2002-03 \\
2003-04 \\
2004-05 \\
2005-06 \\
2006-07\end{array}$ & $\begin{array}{l}573,258 \\
595,425 \\
613,000 \\
630,600 \\
649,570\end{array}$ & $\begin{array}{l}430,248 \\
445,483 \\
456,592 \\
467,467 \\
480,558\end{array}$ & $\begin{array}{l}41,494 \\
43,851 \\
45,810 \\
48,079 \\
49,685\end{array}$ & $\begin{array}{l}35,101 \\
37,288 \\
39,490 \\
41,814 \\
44,750\end{array}$ & $\begin{array}{l}40,230 \\
41,360 \\
43,711 \\
45,809 \\
47,582\end{array}$ & $\begin{array}{l}3,870 \\
4,244 \\
4,143 \\
4,203 \\
4,505\end{array}$ & $\begin{array}{l}- \\
- \\
- \\
-\end{array}$ & $\begin{array}{l}22,315 \\
23,199 \\
23,254 \\
23,228 \\
22,490\end{array}$ & $\begin{array}{l}100.0 \\
100.0 \\
100.0 \\
100.0 \\
100.0\end{array}$ & $\begin{array}{l}78.1 \\
77.9 \\
77.4 \\
77.0 \\
76.6\end{array}$ & $\begin{array}{l}7.5 \\
7.7 \\
7.8 \\
7.9 \\
7.9\end{array}$ & $\begin{array}{l}6.4 \\
6.5 \\
6.7 \\
6.9 \\
7.1\end{array}$ & $\begin{array}{r}7.3 \\
7.2 \\
7.4 \\
7.5 \\
7.6\end{array}$ & $\begin{array}{l}0.7 \\
0.7 \\
0.7 \\
0.7 \\
0.7\end{array}$ & $\begin{array}{l}- \\
- \\
- \\
-\end{array}$ \\
\hline $\begin{array}{l}2007-08 \\
2008-09 \\
2009-10 \\
2010-11 \\
2011-12\end{array}$ & $\begin{array}{l}667,928 \\
685,382 \\
706,633 \\
734,133 \\
765,317\end{array}$ & $\begin{array}{l}492,137 \\
503,357 \\
513,717 \\
519,883 \\
532,077\end{array}$ & $\begin{array}{l}52,247 \\
53,473 \\
56,171 \\
59,119 \\
63,610\end{array}$ & $\begin{array}{l}47,884 \\
50,629 \\
55,092 \\
60,742 \\
67,060\end{array}$ & $\begin{array}{l}49,485 \\
50,741 \\
53,377 \\
55,290 \\
57,510\end{array}$ & $\begin{array}{l}4,523 \\
4,849 \\
4,875 \\
4,798 \\
4,468\end{array}$ & $\begin{array}{r}- \\
\bar{z} \\
8,123 \\
10,922\end{array}$ & $\begin{array}{l}21,652 \\
22,333 \\
23,401 \\
26,178 \\
29,670\end{array}$ & $\begin{array}{l}100.0 \\
100.0 \\
100.0 \\
100.0 \\
100.0\end{array}$ & $\begin{array}{l}76.1 \\
75.9 \\
75.2 \\
73.4 \\
72.3\end{array}$ & $\begin{array}{l}8.1 \\
8.1 \\
8.2 \\
8.4 \\
8.6\end{array}$ & $\begin{array}{l}7.4 \\
7.6 \\
8.1 \\
8.6 \\
9.1\end{array}$ & $\begin{array}{l}7.7 \\
7.7 \\
7.8 \\
7.8 \\
7.8\end{array}$ & $\begin{array}{l}0.7 \\
0.7 \\
0.7 \\
0.7 \\
0.6\end{array}$ & $\begin{array}{l}\overline{-} \\
\overline{-} \\
1.1 \\
1.5\end{array}$ \\
\hline 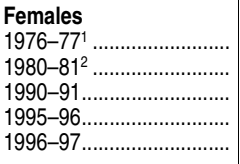 & $\begin{array}{l}423,476 \\
465,175 \\
590,493 \\
642,338 \\
652,364\end{array}$ & $\begin{array}{l}369,527 \\
401,146 \\
492,803 \\
496,281 \\
497,443\end{array}$ & $\begin{array}{l}33,489 \\
36,162 \\
41,575 \\
58,522 \\
60,733\end{array}$ & $\begin{array}{r}8,425 \\
11,022 \\
20,744 \\
33,322 \\
36,191\end{array}$ & $\begin{array}{r}6,155 \\
8,687 \\
21,326 \\
33,764 \\
36,338\end{array}$ & $\begin{array}{l}1,522 \\
1,893 \\
2,645 \\
4,091 \\
4,429\end{array}$ & $\begin{array}{l}- \\
- \\
- \\
-\end{array}$ & $\begin{array}{r}4,358 \\
6,265 \\
11,400 \\
16,358 \\
17,230\end{array}$ & $\begin{array}{l}100.0 \\
100.0 \\
100.0 \\
100.0 \\
100.0\end{array}$ & $\begin{array}{l}88.2 \\
87.4 \\
85.1 \\
79.3 \\
78.3\end{array}$ & $\begin{array}{l}8.0 \\
7.9 \\
7.2 \\
9.3 \\
9.6\end{array}$ & $\begin{array}{l}2.0 \\
2.4 \\
3.6 \\
5.3 \\
5.7\end{array}$ & $\begin{array}{l}1.5 \\
1.9 \\
3.7 \\
5.4 \\
5.7\end{array}$ & $\begin{array}{l}0.4 \\
0.4 \\
0.5 \\
0.7 \\
0.7\end{array}$ & $\begin{array}{l}- \\
- \\
- \\
-\end{array}$ \\
\hline $\begin{array}{l}1997-98 \ldots \\
1998-99 \ldots \\
1999-2000 \\
2000-01 \\
2001-02\end{array}$ & $\begin{array}{l}664,450 \\
682,278 \\
707,508 \\
712,331 \\
742,084\end{array}$ & $\begin{array}{l}501,791 \\
511,252 \\
526,148 \\
525,577 \\
543,705\end{array}$ & $\begin{array}{l}63,741 \\
67,054 \\
70,989 \\
73,204 \\
77,427\end{array}$ & $\begin{array}{l}38,328 \\
41,258 \\
44,759 \\
46,377 \\
50,015\end{array}$ & $\begin{array}{l}38,233 \\
39,947 \\
42,056 \\
43,037 \\
45,433\end{array}$ & $\begin{array}{l}4,752 \\
5,251 \\
5,254 \\
5,349 \\
5,541\end{array}$ & $\begin{array}{l}- \\
- \\
- \\
-\end{array}$ & $\begin{array}{l}17,605 \\
17,516 \\
18,302 \\
18,787 \\
19,963\end{array}$ & $\begin{array}{l}100.0 \\
100.0 \\
100.0 \\
100.0 \\
100.0\end{array}$ & $\begin{array}{l}77.6 \\
76.9 \\
76.3 \\
75.8 \\
75.3\end{array}$ & $\begin{array}{r}9.9 \\
10.1 \\
10.3 \\
10.6 \\
10.7\end{array}$ & $\begin{array}{l}5.9 \\
6.2 \\
6.5 \\
6.7 \\
6.9\end{array}$ & $\begin{array}{l}5.9 \\
6.0 \\
6.1 \\
6.2 \\
6.3\end{array}$ & $\begin{array}{l}0.7 \\
0.8 \\
0.8 \\
0.8 \\
0.8\end{array}$ & $\begin{array}{l}- \\
- \\
- \\
-\end{array}$ \\
\hline 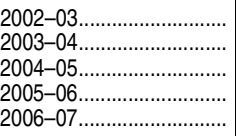 & $\begin{array}{l}775,553 \\
804,117 \\
826,264 \\
854,642 \\
874,522\end{array}$ & $\begin{array}{l}564,368 \\
580,631 \\
592,549 \\
608,094 \\
619,292\end{array}$ & $\begin{array}{l}82,759 \\
87,390 \\
90,312 \\
94,341 \\
96,968\end{array}$ & $\begin{array}{l}53,928 \\
57,356 \\
61,634 \\
65,774 \\
70,186\end{array}$ & $\begin{array}{l}47,734 \\
50,713 \\
53,498 \\
56,567 \\
57,715\end{array}$ & $\begin{array}{l}6,005 \\
6,394 \\
6,164 \\
6,737 \\
6,950\end{array}$ & $\begin{array}{l}- \\
- \\
- \\
-\end{array}$ & $\begin{array}{l}20,759 \\
21,633 \\
22,107 \\
23,129 \\
23,411\end{array}$ & $\begin{array}{l}100.0 \\
100.0 \\
100.0 \\
100.0 \\
100.0\end{array}$ & $\begin{array}{l}74.8 \\
74.2 \\
73.7 \\
73.1 \\
72.8\end{array}$ & $\begin{array}{l}11.0 \\
11.2 \\
11.2 \\
11.3 \\
11.4\end{array}$ & $\begin{array}{l}7.1 \\
7.3 \\
7.7 \\
7.9 \\
8.2\end{array}$ & $\begin{array}{l}6.3 \\
6.5 \\
6.7 \\
6.8 \\
6.8\end{array}$ & $\begin{array}{l}0.8 \\
0.8 \\
0.8 \\
0.8 \\
0.8\end{array}$ & $\begin{array}{l}- \\
- \\
- \\
-\end{array}$ \\
\hline 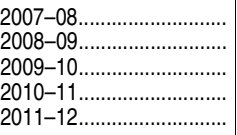 & $\begin{array}{r}895,141 \\
915,986 \\
943,381 \\
981,780 \\
1,025,729\end{array}$ & $\begin{array}{l}630,538 \\
641,257 \\
653,782 \\
662,522 \\
679,488\end{array}$ & $\begin{array}{l}103,142 \\
108,673 \\
113,898 \\
121,908\end{array}$ & $\begin{array}{r}75,164 \\
78,898 \\
85,224 \\
93,321 \\
102,586\end{array}$ & $\begin{array}{l}61,767 \\
64,045 \\
65,776 \\
68,637\end{array}$ & $\begin{array}{l}6,986 \\
7,372 \\
7,524 \\
7,135 \\
7,015\end{array}$ & $\begin{array}{r}- \\
\bar{z} \\
12,681 \\
16,259\end{array}$ & $\begin{array}{l}23,550 \\
24,133 \\
26,447 \\
29,836\end{array}$ & $\begin{array}{l}100.0 \\
100.0 \\
100.0 \\
100.0\end{array}$ & $\begin{array}{l}72.3 \\
71.9 \\
71.1 \\
69.3 \\
68.2\end{array}$ & $\begin{array}{l}11.6 \\
11.8 \\
11.9 \\
12.2\end{array}$ & $\begin{array}{r}8.6 \\
8.8 \\
9.3 \\
9.8 \\
10.3\end{array}$ & $\begin{array}{l}6.8 \\
6.9 \\
7.0 \\
6.9 \\
6.9\end{array}$ & $\begin{array}{l}0.8 \\
0.8 \\
0.8 \\
0.7 \\
0.7\end{array}$ & $\begin{array}{l}- \\
\overline{-} \\
1.3 \\
1.6\end{array}$ \\
\hline
\end{tabular}

-Not available.

${ }^{1}$ Excludes 1,121 males and 528 females whose racial/ethnic group was not available. ${ }^{2}$ Excludes 258 males and 82 females whose racial/ethnic group was not available. NOTE: Data through 1990-91 are for institutions of higher education, while later data are for postsecondary institutions participating in Title IV federal financial aid programs. Race categories exclude persons of Hispanic ethnicity. For 1989-90 and later years, reported racial/ ethnic distributions of students by level of degree, field of degree, and sex were used to esti- mate race/ethnicity for students whose race/ethnicity was not reported. Detail may not sum to totals because of rounding

SOURCE: U.S. Department of Education, National Center for Education Statistics, Higher Education General Information Survey (HEGIS), "Degrees and Other Formal Awards Conferred" surveys, 1976-77 and 1980-81; Integrated Postsecondary Education Data System (IPEDS), "Completions Survey" (IPEDS-C:90-99); and IPEDS Fall 2000 through Fall 2012, Completions component. (This table was prepared July 2013.) 


\begin{tabular}{|c|c|c|c|c|c|c|c|c|c|c|c|c|c|c|c|c|c|c|c|c|}
\hline \multirow[b]{3}{*}{ Field of study } & \multicolumn{10}{|c|}{$2010-11$} & \multicolumn{10}{|c|}{$2011-12$} \\
\hline & \multirow[b]{2}{*}{ Total } & \multirow[b]{2}{*}{ White } & \multirow[b]{2}{*}{ Black } & \multirow[b]{2}{*}{ Hispanic } & \multicolumn{3}{|c|}{ Asian/Pacific Islander } & \multirow{2}{*}{\begin{tabular}{|r|} 
American \\
Indian/ \\
Alaska \\
Native \\
\end{tabular}} & \multirow{2}{*}{$\begin{array}{r}\text { Two or } \\
\text { more } \\
\text { races }\end{array}$} & \multirow[b]{2}{*}{$\begin{array}{r}\text { Non- } \\
\text { resident } \\
\text { alien } \\
\end{array}$} & \multirow[b]{2}{*}{ Total } & \multirow[b]{2}{*}{ White } & \multirow[b]{2}{*}{ Black } & \multirow[b]{2}{*}{ Hispanic } & \multicolumn{3}{|c|}{ Asian/Pacific Islander } & \multirow{2}{*}{\begin{tabular}{|r|} 
American \\
Indian/ \\
Alaska \\
Native \\
\end{tabular}} & \multirow[b]{2}{*}{$\begin{array}{r}\text { Two or } \\
\text { more } \\
\text { races }\end{array}$} & \\
\hline & & & & & Total & Asian & $\begin{array}{r}\text { Pacific } \\
\text { Islander }\end{array}$ & & & & & & & & Total & Asian & $\begin{array}{r}\text { Pacific } \\
\text { Islander }\end{array}$ & & & $\begin{array}{r}\text { resident } \\
\text { alien }\end{array}$ \\
\hline 1 & 2 & 3 & 4 & 5 & 6 & 7 & 8 & 9 & 10 & 11 & 12 & 13 & 14 & 15 & 16 & 17 & 18 & 19 & 20 & 21 \\
\hline All fields, total . & $1,715,913$ & $1,182,405$ & 3,017 & 154,063 & 121,066 & 116,794 & 4,272 & 11,933 & 20,804 & 52,625 & $1,791,046$ & $1,211,565$ & 185,518 & 169,646 & 126,147 & 21,521 & 4,626 & 11,483 & 27,181 & 59,506 \\
\hline iral resources... & \begin{tabular}{|l|}
28,623 \\
\end{tabular} & \begin{tabular}{|r|}
24,278 \\
\end{tabular} & 811 & 1,469 & 1,121 & 1,080 & 41 & 240 & 268 & 436 & 30,929 & \begin{tabular}{|r|}
25,948 \\
\end{tabular} & 937 & 1,610 & 1,258 & 1,204 & 54 & 256 & 454 & 466 \\
\hline chitecture & 9,832 & 6,619 & 493 & 1,228 & 874 & 857 & 17 & 51 & 116 & 451 & 9,728 & 6,421 & 504 & 1,174 & 884 & 871 & 13 & 48 & 126 & 571 \\
\hline dies ... & 9,100 & 4,534 & 1,447 & 1,446 & 986 & 943 & 43 & 206 & 266 & 215 & 9,232 & 4,502 & 1,323 & 1,593 & 1,088 & 1,043 & 45 & 192 & 294 & 240 \\
\hline Ologic & 90,003 & 56,460 & 6,885 & 6,960 & 15,234 & 15,008 & 226 & 567 & 1,178 & 2,719 & 95,849 & 59,565 & 7,231 & 7,872 & 16,169 & 15,907 & 262 & 590 & 1,631 & 2,791 \\
\hline Business... & 365,093 & 238,786 & 42,572 & 32,394 & 27,510 & 26,583 & 927 & 2,269 & 3,541 & 18,021 & 366,815 & 232,695 & 44,246 & 34,349 & 28,054 & 26,970 & 1,084 & 2,142 & 4,348 & 20,981 \\
\hline Communication, journalism, and related programs.. & 83,274 & 60,577 & 8,761 & 6,958 & 3,674 & 3,492 & 182 & 486 & 1,008 & 1,810 & 83,770 & 59,834 & 9,209 & 7,356 & 3,624 & 3,428 & 196 & 427 & 1,290 & 2,030 \\
\hline & 4,858 & 3,360 & 519 & 494 & 264 & 257 & 7 & 27 & 69 & 125 & 4,982 & 3,248 & 545 & 563 & 268 & 258 & 10 & 正 & 119 & 213 \\
\hline Compu & 43,072 & 28,031 & 4,914 & 3,390 & 3,916 & 3,804 & 112 & 251 & 545 & 2,025 & 47,384 & 30,211 & 5,410 & 4,008 & 4,413 & 4,254 & 159 & 257 & 725 & 2,360 \\
\hline Construct & 328 & 295 & 8 & 11 & 8 & 5 & 3 & 1 & 1 & & 377 & 326 & 10 & 26 & & 9 & 0 & 1 & 2 & \\
\hline Education & 103,992 & 85,234 & 7,115 & 6,585 & 2,290 & 1,843 & 447 & 856 & 787 & 1,125 & 105,785 & 86,084 & 7,641 & 6,966 & 2,150 & 1,954 & 196 & 768 & 1,051 & 1,125 \\
\hline Engineering & 76,376 & 51,718 & 3,245 & 5,549 & 9,344 & 9,220 & 124 & 334 & 925 & 5,261 & 81,382 & 54,237 & 3,327 & 6,268 & 9,733 & 9,561 & 172 & 318 & 1,161 & 6,338 \\
\hline $\begin{aligned} \text { Engin } \\
\text { fie }\end{aligned}$ & 187 & 11,989 & 1,506 & 1,229 & 71 & 65 & 17 & 155 & 137 & 460 & 16,531 & 12,176 & 1,683 & 1,161 & 689 & 666 & 23 & & 178 & 495 \\
\hline nglis & 52,744 & 40,147 & 3,942 & 4,507 & 2,473 & 2,367 & 106 & | & 786 & 557 & 53,767 & 40,160 & 4,138 & 4,982 & 2,511 & 2,410 & 101 & & 1,111 & 546 \\
\hline Family a & 22,444 & 16,065 & 2,623 & 1,837 & 1,17 & 1,132 & 39 & 196 & 238 & 314 & 23,428 & 16,471 & 2,932 & 2,015 & 1,202 & 1,166 & 36 & 164 & 311 & 333 \\
\hline Foreign languages, literatures, and linguistics........ & 21,706 & 14,821 & 922 & 3,684 & 1,321 & 1,297 & 24 & 128 & 384 & 446 & 21,764 & 14,612 & 944 & 3,975 & 1,261 & 1,235 & 26 & 99 & 442 & 431 \\
\hline Health pr & 143,430 & 102,05 & 17,119 & 9,882 & 9,91 & 9,506 & 408 & 963 & 1,412 & 2,085 & 163,440 & 114,113 & 19,766 & 11,993 & 12,138 & 11,563 & 575 & 956 & 2,168 & 2,306 \\
\hline omela & & & & & & & & & & & & & & & & & & & & \\
\hline & 47,602 & 28,088 & 9,687 & 7,241 & 1,349 & 1,225 & 124 & 439 & 538 & 260 & 53,767 & 31,051 & 11,089 & 8,472 & 1,569 & 1,390 & 179 & 434 & 842 & 310 \\
\hline Legal pro & 4,429 & 2,769 & 787 & 547 & 219 & 211 & 8 & 26 & 53 & 28 & 4,592 & 2,785 & 821 & 586 & 232 & 223 & 9 & 29 & 71 & 68 \\
\hline $\begin{array}{l}\text { Liberal ar } \\
\text { and } h\end{array}$ & & & & & & & & & & & & & & & & & & & & \\
\hline 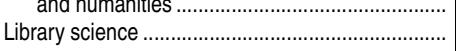 & $\begin{array}{r}927 \\
96\end{array}$ & $\begin{array}{r}31,056 \\
85\end{array}$ & $\begin{array}{r}6,833 \\
3\end{array}$ & $\begin{array}{r}4,9911 \\
3\end{array}$ & $\begin{array}{r}1,680 \\
3\end{array}$ & $\begin{array}{r}1,552 \\
3\end{array}$ & $\begin{array}{r}128 \\
0\end{array}$ & $\begin{array}{r}532 \\
0\end{array}$ & $\begin{array}{r}632 \\
2\end{array}$ & $\begin{array}{r}63 \\
0\end{array}$ & $\begin{array}{r}, 925 \\
95\end{array}$ & $\begin{array}{r}1,138 \\
89\end{array}$ & $\begin{array}{r}6,664 \\
2\end{array}$ & $\begin{array}{r}29 \\
3\end{array}$ & $\begin{array}{r}737 \\
1\end{array}$ & $\begin{array}{r}1,605 \\
1\end{array}$ & $\begin{array}{r}132 \\
0\end{array}$ & $\begin{array}{r}21 \\
0\end{array}$ & $\begin{array}{r}221 \\
0\end{array}$ & $\begin{array}{r}915 \\
0\end{array}$ \\
\hline othometing & 17,182 & 11,836 & 840 & 1,158 & 1,858 & 1,822 & 36 & 85 & 216 & 1,189 & 18,842 & 12,737 & 976 & 1,308 & 1,876 & 1,837 & 39 & 59 & 247 & 1,639 \\
\hline & 226 & 158 & 13 & 18 & 14 & 13 & 1 & 4 & 1 & 18 & 250 & 171 & 12 & 17 & 12 & 12 & 0 & 5 & 1 & 32 \\
\hline & 64 & 43 & 16 & 2 & 0 & 0 & 0 & 2 & 1 & 0 & 86 & 51 & 25 & 6 & 0 & 0 & 0 & 1 & 1 & 2 \\
\hline & 42,228 & 28,286 & 4,375 & 5,254 & 2,656 & 2,557 & 99 & 352 & 516 & 789 & 45,716 & 30,096 & 5,054 & 5,951 & 2,639 & 2,532 & 107 & 357 & 707 & 912 \\
\hline Parks, recreation, leisure, and fitness studies ...... & 35,924 & 26,998 & 3,548 & 2,763 & 1,363 & 1,246 & 117 & 284 & 394 & 574 & 38,993 & 29,174 & 3,750 & 3,178 & 1,498 & 1,387 & 111 & 267 & 523 & 603 \\
\hline Philos & 836 & 9,752 & 963 & 970 & 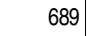 & 66 & 29 & 79 & 191 & 192 & 12 & 9 , & 96 & 1,05 & 62 & 5 & 24 & 85 & 254 & 200 \\
\hline & 24,712 & 17,842 & 1,329 & 1,466 & 2,538 & 2,491 & 47 & 149 & 340 & 1,048 & 26,663 & 18,983 & 1,541 & 1,681 & 2,741 & 2,702 & 39 & 154 & 447 & 1,116 \\
\hline & & 29 & & & & & 0 & 0 & 0 & 5 & & 30 & & & 2 & 2 & 0 & 0 & 2 & \\
\hline & 100,893 & 66,122 & 12,397 & 11,629 & 6,797 & 6,583 & 214 & 691 & 1,580 & 1,677 & 108,986 & 70,011 & 13,524 & 13,326 & 7,330 & 7,085 & 245 & 753 & 2,037 & 2,005 \\
\hline Public administration and social services..... & 26,774 & 15,336 & 6,093 & 3,305 & 968 & 876 & 92 & 293 & 497 & 282 & 29,695 & 16,967 & 6,914 & 3,732 & 1,013 & 907 & 106 & 287 & 462 & 320 \\
\hline Social scie & 177,144 & 118,979 & 16,682 & 18,108 & $\begin{array}{r}13,670 \\
13\end{array}$ & 13,261 & 409 & 1,238 & 2,556 & 5,911 & 178,543 & 117,854 & 17,145 & 19,548 & $\begin{array}{l}13,020 \\
11701\end{array}$ & 12,550 & 470 & 1,115 & 3,463 & 6,398 \\
\hline & $\begin{array}{r}142,145 \\
34,999\end{array}$ & $\begin{array}{l}90,734 \\
28,245\end{array}$ & $\begin{array}{r}15,051 \\
1,631\end{array}$ & $\begin{array}{r}15,192 \\
2,916\end{array}$ & $\begin{array}{r}12,442 \\
1,228\end{array}$ & $\begin{array}{r}12,077 \\
1,184\end{array}$ & $\begin{array}{r}365 \\
44\end{array}$ & $\begin{array}{r}1,001 \\
237\end{array}$ & $\begin{array}{r}2,073 \\
483\end{array}$ & $\begin{array}{r}5,652 \\
259\end{array}$ & $\begin{array}{r}143,422 \\
35,121\end{array}$ & $\begin{array}{l}89,730 \\
28,124\end{array}$ & $\begin{array}{r}15,425 \\
1,720\end{array}$ & $\begin{array}{r}16,581 \\
2,967\end{array}$ & $\begin{array}{r}11,791 \\
1,229\end{array}$ & $\begin{array}{r}11,382 \\
1,168\end{array}$ & $\begin{array}{r}409 \\
61\end{array}$ & $\begin{array}{l}887 \\
228\end{array}$ & $\begin{array}{r}2,860 \\
603\end{array}$ & $\begin{array}{r}6,148 \\
250\end{array}$ \\
\hline & 9,074 & 7,555 & 585 & 380 & 240 & 215 & 25 & 39 & 58 & 217 & 9,369 & 7,750 & 637 & 385 & 232 & 216 & 16 & 42 & 88 & 235 \\
\hline & 4,941 & 3,812 & 285 & 379 & 215 & 206 & 9 & 42 & 58 & 150 & 4,876 & 3,737 & 343 & 380 & 185 & 163 & 22 & 44 & 53 & 134 \\
\hline & 93,956 & 68,690 & 5,679 & 8,302 & 5,991 & 5,780 & 211 & 616 & 1,510 & 3,168 & 95,797 & 68,864 & 6,109 & 9,080 & 5,987 & 5,812 & 175 & 618 & 1,751 & 3,388 \\
\hline Other and not classified...... & & 0 & 0 & 0 & 0 & 0 & 0 & 0 & 0 & 0 & 0 & & 0 & 0 & 0 & 0 & 0 & 0 & 0 & \\
\hline
\end{tabular}

'Excludes "Construction trades" and "Mechanic and repair technologies/technicians," which are listed separately. NOTE: Data are for postsecondary institutions participating in Title IV federal financial aid programs. Race categories exclude persons of Hispanic ethnicity. Reported racial/ethnic distributions of students by level of degree, field of degree, and sex were used to been made of the degree fields as reported in the Integrated Postsecondary Education Data System (IPEDS): "Agriculture and natu- ral resources" includes Agriculture, agriculture operations, and related sciences and Natural resources and conservation; and "Business" includes Business management, marketing, and related support services and Personal and culinary services. Education Data Sys- 
Table 322.40. Bachelor's degrees conferred to males by postsecondary institutions, by race/ethnicity and field of study: 2010-11 and 2011-12

\begin{tabular}{|c|c|c|c|c|c|c|c|c|c|c|c|c|c|c|c|c|c|c|c|c|}
\hline \multirow[b]{3}{*}{ Field of study } & \multicolumn{10}{|c|}{ 2010-11 } & \multicolumn{10}{|c|}{ 2011-12 } \\
\hline & \multirow[b]{2}{*}{ Total } & \multirow[b]{2}{*}{ White } & \multirow[b]{2}{*}{ Black } & \multirow[b]{2}{*}{ Hispanic } & \multicolumn{3}{|c|}{ Asian/Pacific Islander } & \multirow{2}{*}{$\begin{array}{r}\text { American } \\
\text { Indian/ } \\
\text { Alaska } \\
\text { Native }\end{array}$} & \multirow{2}{*}{$\begin{array}{c}\text { Two or } \\
\text { more } \\
\text { races }\end{array}$} & \multirow{2}{*}{$\begin{array}{r}\text { Non- } \\
\text { resident } \\
\text { alien }\end{array}$} & \multirow[b]{2}{*}{ Total } & \multirow[b]{2}{*}{ White } & \multirow[b]{2}{*}{ Black } & \multirow[b]{2}{*}{ Hispanic } & \multicolumn{3}{|c|}{ Asian/Pacific Islander } & \multirow{2}{*}{$\begin{array}{r}\text { American } \\
\text { Indian/ } \\
\text { Alaska } \\
\text { Native }\end{array}$} & \multirow{2}{*}{$\begin{array}{c}\text { Two or } \\
\text { more } \\
\text { races }\end{array}$} & \\
\hline & & & & & Total & Asian & $\begin{array}{r}\text { Pacific } \\
\text { Islander }\end{array}$ & & & & & & & & Total & Asian & $\begin{array}{r}\text { Pacific } \\
\text { Islander }\end{array}$ & & & $\begin{array}{r}\text { resident } \\
\text { alien }\end{array}$ \\
\hline 1 & 2 & 3 & 4 & 5 & 6 & 7 & 8 & 9 & 10 & 11 & 12 & 13 & 14 & 15 & 16 & 17 & 18 & 19 & 20 & 21 \\
\hline All fields, total .. & 734,133 & 519,883 & 59,119 & 60,742 & 55,290 & 53,590 & 1,700 & 4,798 & 8,123 & 26,178 & 765,317 & 532,077 & 63,610 & 67,060 & 57,510 & 55,514 & 1,996 & 4,468 & 10,922 & 29,670 \\
\hline Agriculture and natural resources........... & 14,675 & 12,705 & 394 & 658 & 474 & 453 & 21 & 119 & 118 & 207 & 15,453 & 13,289 & 417 & 715 & 512 & 490 & 22 & 116 & 194 & $\frac{210}{210}$ \\
\hline Architecture & 5,696 & 3,981 & 295 & 726 & 393 & 384 & 9 & 27 & 59 & 215 & 5,567 & 3,797 & 280 & 679 & 444 & 440 & 4 & 27 & 69 & 271 \\
\hline group studies ... & 2,801 & 1,409 & 449 & 412 & 305 & 290 & 15 & 86 & 68 & 72 & 2,757 & 1,394 & 379 & 456 & 315 & 296 & 19 & 60 & 80 & 73 \\
\hline Biological and biomedical sciences ............................ & 36,892 & 23,681 & 2,011 & 2,777 & 6,657 & 6,565 & 92 & 242 & 471 & 1,053 & 39,545 & 25,271 & 2,157 & 3,116 & 6,979 & 6,872 & 107 & 224 & 657 & 1,141 \\
\hline 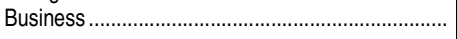 & 187,081 & 129,878 & 16,339 & 15,002 & 13,832 & 13,370 & 462 & 1,081 & 1,668 & 9,281 & 190,082 & 128,226 & 17,540 & 16,162 & 14,322 & 13,781 & 541 & 975 & 2,169 & 10,688 \\
\hline Communication, journalism, and related programs.. & 29,515 & 21,936 & 3,013 & 2,316 & 1,212 & 1,144 & 68 & 156 & 311 & 571 & 29,921 & 21,907 & 3,211 & 2,471 & 1,174 & 1,107 & 67 & 137 & 406 & 615 \\
\hline Commu & 3,508 & 2,478 & 334 & 355 & 184 & 181 & 3 & 22 & 50 & 85 & 3,604 & 2,348 & 368 & 445 & 190 & 184 & 6 & 16 & 88 & 149 \\
\hline Computer and information sciences....... & 35,478 & 23,907 & 3,411 & 2,762 & 3,122 & 3,026 & 96 & 210 & 435 & 1,631 & 38,773 & 25,681 & 3,756 & 3,261 & 3,426 & 3,311 & 115 & 200 & 577 & 1,872 \\
\hline Construction trades ............................................. & 303 & 273 & 7 & & 8 & 5 & 3 & 1 & 1 & 4 & 359 & 313 & 9 & 23 & 9 & 9 & 0 & 1 & 2 & 2 \\
\hline Education & 21,195 & 17,350 & 1,692 & 1,097 & 449 & 398 & 51 & 187 & 156 & 264 & 21,757 & 17,708 & 1,777 & 1,196 & 441 & 390 & 51 & 173 & 198 & 264 \\
\hline $\begin{array}{l}\text { Engineering ......................................................... } \\
\text { Engineering technologies and engine-related }\end{array}$ & 62,119 & 42,980 & 2,401 & 4,391 & 7,214 & 7,117 & 97 & 250 & 687 & 4,196 & 65,829 & 44,791 & 2,429 & 4,944 & 7,491 & 7,359 & 132 & 246 & 895 & 5,033 \\
\hline 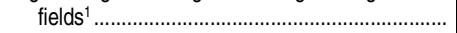 & 14,469 & 10,929 & 1,235 & 1,076 & 600 & 584 & 16 & 129 & 115 & 385 & 14,847 & 11,141 & 1,359 & 1,008 & 621 & 600 & 21 & 131 & 150 & 437 \\
\hline English langu & 16,916 & 13,178 & 1,031 & 1,470 & 729 & 705 & 24 & 103 & 246 & 159 & 16,976 & 13,007 & 1,058 & 1,614 & 745 & 716 & 29 & 104 & 312 & 136 \\
\hline Family and consumer sciences/human sciences ... & 2,762 & 1,829 & 401 & 231 & 181 & 175 & 6 & 33 & 24 & 63 & 2,693 & 1,747 & 432 & 214 & 188 & 179 & 9 & 15 & 37 & 60 \\
\hline Foreign languages, literatures, and linguistics........ & 6,720 & 4,772 & 260 & 1,022 & 385 & 374 & 11 & 48 & 103 & 130 & 6,630 & 4,679 & 252 & 1,021 & 377 & 365 & 12 & 38 & 138 & 125 \\
\hline Health professions and related $p$ & 21,536 & 14,469 & 2,361 & 1,650 & 2,239 & 2,162 & 77 & 160 & 202 & 455 & 24,868 & 16,389 & 2,704 & 2,101 & 2,661 & 2,534 & 127 & 128 & 354 & 531 \\
\hline Homeland se & & & & & & & & & & & & & & & & & 10 & & & \\
\hline $\begin{array}{r}\text { firefightil } \\
\text { Legal profes }\end{array}$ & $\begin{array}{r}24,361 \\
1,317\end{array}$ & $\begin{array}{r}10,268 \\
882\end{array}$ & $\begin{array}{r}3,490 \\
174\end{array}$ & $\begin{array}{r}3,235 \\
145\end{array}$ & $\begin{array}{r}808 \\
82\end{array}$ & $\begin{array}{r}740 \\
79\end{array}$ & $\begin{array}{r}68 \\
3\end{array}$ & $\begin{array}{r}214 \\
9\end{array}$ & $\begin{array}{r}225 \\
17\end{array}$ & $\begin{array}{r}121 \\
8\end{array}$ & $\begin{array}{r}27,740 \\
1,388\end{array}$ & 18,2311 & 3,983 & 3,866 & 956 & $\begin{array}{r}854 \\
81\end{array}$ & 102 & $\begin{array}{r}178 \\
6\end{array}$ & $\begin{array}{r}374 \\
23\end{array}$ & 151 \\
\hline $\begin{array}{l}\text { ces, general studies, } \\
\text {. }\end{array}$ & & & & & & & & & & & & & & & 83 & 81 & & 0 & 23 & 28 \\
\hline and $\mathrm{r}$ & 16,488 & 11,422 & 2,331 & 1,329 & 547 & 494 & 53 & 175 & 223 & 461 & 16,944 & 11,784 & 2,317 & 1,406 & 626 & 570 & 56 & 185 & 282 & 344 \\
\hline Library science ............................................. & 13 & 12 & 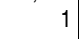 & 0 & 0 & 0 & 0 & 0 & 0 & 0 & & & 0 & 0 & 0 & . & 0 & 0 & 0 & \\
\hline the & 9,783 & 6,759 & 418 & 654 & 1,113 & 1,094 & 19 & 49 & 119 & 671 & 10,723 & 7,287 & 508 & 713 & 1,104 & 1,085 & 19 & 37 & 151 & 923 \\
\hline M & 209 & 147 & 13 & 14 & 13 & 12 & 1 & 4 & 1 & 17 & 235 & 164 & 10 & 17 & 12 & 12 & 0 & 3 & 1 & 28 \\
\hline Military technologies and applied sciences ............ & 50 & 35 & 10 & 2 & 0 & 0 & 0 & 2 & 1 & 0 & 69 & 42 & 18 & 5 & 0 & 0 & 0 & 1 & 1 & 2 \\
\hline Multi/interdisciplinary studies................................... & 13,602 & 9,488 & 1,327 & 1,299 & 917 & 870 & 47 & 114 & 155 & 302 & 14,594 & 9,986 & 1,502 & 1,534 & 883 & 849 & 34 & 114 & 240 & 335 \\
\hline Parks, recreation, leisure, and fitness studies ........ & 18,936 & 14,025 & 2,029 & 1,485 & 743 & 683 & 60 & 164 & 184 & 306 & 20,830 & 15,352 & 2,211 & 1,760 & 791 & 732 & 59 & 142 & 243 & 331 \\
\hline .............. & 8,149 & 6,317 & 499 & 647 & 399 & 381 & 18 & 46 & 115 & 126 & 7,963 & 6,118 & 483 & 664 & 372 & 352 & 20 & 50 & 154 & 122 \\
\hline id science technologies.......... & 14,782 & 11,130 & 590 & 851 & 1,327 & 1,301 & 26 & 87 & 195 & 602 & 15,972 & 11,925 & 621 & 962 & 1,481 & 1,459 & 22 & 85 & 242 & 656 \\
\hline Precision production ... & 22 & 19 & & & & & 0 & 0 & 0 & 1 & 28 & 23 & 2 & 1 & 2 & 2 & 0 & 0 & 0 & 0 \\
\hline$\ldots$ & 23,229 & 15,563 & 2,338 & 2,500 & 1,916 & 1,866 & 50 & 147 & 363 & 402 & 25,406 & 16,661 & 2,593 & 2,905 & 2,110 & 2,040 & 70 & 192 & 496 & 449 \\
\hline Public administration and social services............... & 4,908 & 2,978 & 899 & 572 & 243 & 226 & 17 & 44 & 102 & 70 & 5,385 & 3,159 & 1,092 & 643 & 266 & 237 & 29 & 47 & 95 & 83 \\
\hline $\begin{array}{l}\text { Social sciences and history........ } \\
\text { Social sciences. }\end{array}$ & $\begin{array}{l}89,814 \\
68,991\end{array}$ & $\begin{array}{l}64,249 \\
47,057\end{array}$ & $\begin{array}{l}6,303 \\
5,523\end{array}$ & $\begin{array}{l}7,944 \\
6,274\end{array}$ & $\begin{array}{l}6,600 \\
5,934\end{array}$ & $\begin{array}{l}6,413 \\
5,769\end{array}$ & $\begin{array}{l}187 \\
165\end{array}$ & $\begin{array}{l}591 \\
450\end{array}$ & $\begin{array}{r}1,143 \\
896\end{array}$ & $\begin{array}{l}2,984 \\
2,857\end{array}$ & $\begin{array}{l}90,634 \\
69,664\end{array}$ & $\begin{array}{l}63,675 \\
46.466\end{array}$ & $\begin{array}{l}6,626 \\
5,765\end{array}$ & $\begin{array}{l}8,618 \\
6,982\end{array}$ & $\begin{array}{l}6,391 \\
5,711\end{array}$ & $\begin{array}{l}6,178 \\
5,537\end{array}$ & $\begin{array}{l}213 \\
174\end{array}$ & $\begin{array}{l}513 \\
389\end{array}$ & $\begin{array}{l}1,579 \\
1,256\end{array}$ & $\begin{array}{l}3,232 \\
3,095\end{array}$ \\
\hline & 20,823 & 17,192 & 780 & 1,670 & 666 & 644 & 22 & 141 & 247 & , 127 & 20,970 & 17,209 & 861 & 1,636 & 680 & 641 & 39 & 124 & $\begin{array}{l}1,200 \\
323\end{array}$ & 137 \\
\hline Theology and religious vocations ............................... & 6,118 & 5,218 & 325 & 218 & 156 & 142 & 14 & 28 & 29 & 144 & 6,275 & 5,329 & 345 & 230 & 152 & 142 & 10 & 20 & 54 & 145 \\
\hline terials moving....................... & 4,345 & 3,393 & 239 & 334 & 182 & 174 & 8 & 34 & 47 & 116 & 4,305 & 3,333 & 297 & 323 & 160 & 141 & 19 & 32 & 46 & 114 \\
\hline Visual and performing arts ... & 36,341 & 26,223 & 2,499 & 3,558 & 2,259 & 2,181 & 78 & 236 & 490 & 1,076 & 37,158 & 26,413 & 2,689 & 3,823 & 2,226 & 2,147 & 79 & 272 & 615 & 1,120 \\
\hline Other and not classified.......................................... & & 0 & 0 & 0 & 0 & 0 & 0 & 0 & 0 & 0 & & & 0 & 0 & 0 & 0 & 0 & 0 & 0 & 0 \\
\hline
\end{tabular}

'Excludes "Construction trades" and "Mechanic and repair technologies/technicians," which are listed separately. NOTE: Data are for postsecondary institutions participating in Title IV federal financial aid programs. Race categories exclude persons of Hispanic ethnicity. Reported racial/ethnic distributions of students by level of degree, field of degree, and sex were used to

ral resources" includes Agriculture, agriculture operations, and related sciences and Natural resources and conservation; and "Busness" includes Business management, marketing, and related support services and Personal and culinary services. Some data have

SOURCE: U.S. Department of Education, National Center for Education Statistics, Integrated Posts.
tem (IPEDS). Fall 2011 and Fall 2012, Completions component (This table was prepared July 2013.)

been made of the degree fields as reported in the Integrated Postsecondary Education Data System (IPEDS): "Agriculture and natu- 


\begin{tabular}{|c|c|c|c|c|c|c|c|c|c|c|c|c|c|c|c|c|c|c|c|c|}
\hline \multirow[b]{3}{*}{ Field of study } & \multicolumn{10}{|c|}{$2010-11$} & \multicolumn{10}{|c|}{$2011-12$} \\
\hline & \multirow[b]{2}{*}{ Total } & \multirow[b]{2}{*}{ White } & \multirow[b]{2}{*}{ Black } & \multirow[b]{2}{*}{ Hispanic } & \multicolumn{3}{|c|}{ Asian/Pacific Islander } & \multirow{2}{*}{$\begin{array}{r}\text { American } \\
\text { Indian/ } \\
\text { Alaska } \\
\text { Native }\end{array}$} & \multirow{2}{*}{$\begin{array}{r}\text { Two or } \\
\text { more } \\
\text { races }\end{array}$} & \multirow{2}{*}{$\begin{array}{l}\text { Non- } \\
\text { resident } \\
\text { alien }\end{array}$} & \multirow[b]{2}{*}{ Total } & \multirow[b]{2}{*}{ White } & \multirow[b]{2}{*}{ Black } & \multirow[b]{2}{*}{ Hispanic } & \multicolumn{3}{|c|}{ Asian/Pacific Islander } & \multirow{2}{*}{$\begin{array}{r}\text { American } \\
\text { Indian/ } \\
\text { Alaska } \\
\text { Native }\end{array}$} & \multirow[b]{2}{*}{$\begin{array}{r}\text { Two or } \\
\text { more } \\
\text { races }\end{array}$} & \\
\hline & & & & & Total & Asian & $\begin{array}{r}\text { Pacific } \\
\text { Islander }\end{array}$ & & & & & & & & Total & Asian & $\begin{array}{r}\text { Pacific } \\
\text { Islander }\end{array}$ & & & $\begin{array}{r}\text { resident } \\
\text { alien }\end{array}$ \\
\hline 1 & 2 & 3 & 4 & 5 & 6 & 7 & 8 & 9 & 10 & 11 & 12 & 13 & 14 & 15 & 16 & 17 & 18 & 19 & 20 & 21 \\
\hline All fields, total ....... & 1,780 & 662,522 & 113,898 & 93,321 & 65,776 & 63,204 & 2,572 & 7,135 & 12,681 & 26,447 & $1,025,729$ & 679,488 & 121,908 & 102,586 & 68,637 & 66,007 & 2,630 & 7,015 & 16,259 & 29,836 \\
\hline Agriculture and $\mathrm{n}$ & 13,948 & 11,573 & 417 & 811 & 647 & 627 & 20 & 121 & 150 & 229 & 15,476 & 12,659 & 520 & 895 & 746 & 714 & 32 & 140 & 260 & 256 \\
\hline ………........ & 4,136 & 2,638 & 198 & 502 & 481 & 473 & 8 & 24 & 57 & 236 & 4,161 & 2,624 & 224 & 495 & 440 & 431 & 9 & 21 & 57 & 300 \\
\hline up studies & 6,299 & 3,125 & 998 & 1,034 & 681 & 653 & 28 & 120 & 198 & 143 & 6,475 & 3,108 & 944 & 1,137 & 773 & 747 & 26 & 132 & 214 & 167 \\
\hline Biologic & 53,111 & 32,779 & 4,874 & 4,183 & 8,577 & 8,443 & 134 & 325 & 707 & 1,666 & 56,304 & 34,294 & 5,074 & 4,756 & 9,190 & 9,035 & 155 & 366 & 974 & 1,650 \\
\hline Business... & 178,012 & 108,908 & 26,233 & 17,392 & 13,678 & 13,213 & 465 & 1,188 & 1,873 & 8,740 & 176,733 & 104,469 & 26,706 & 18,187 & 13,732 & 13,189 & 543 & 1,167 & 2,179 & 10,293 \\
\hline ommunication, journalism, and & 7,759 & 38,641 & 5,748 & 4,642 & 2,462 & 2,348 & 114 & 330 & 697 & 1,239 & 53,849 & 37,927 & 5,998 & 4,885 & 2,450 & 2,321 & 129 & 290 & 884 & 1,415 \\
\hline $\mathrm{mm}$ & 50 & 882 & 185 & 139 & 80 & 76 & 4 & 5 & 19 & 40 & 1,378 & 900 & 177 & 118 & 78 & 74 & 4 & 10 & 31 & 64 \\
\hline Comp & 7,594 & 4,124 & 1,503 & 628 & 794 & 778 & 16 & 41 & 110 & 394 & 8,611 & 4,530 & 1,654 & 747 & 987 & 943 & 44 & 57 & 148 & 488 \\
\hline Constr & 25 & 22 & & 2 & 0 & 0 & 0 & 0 & 0 & 0 & 18 & 13 & 1 & 3 & 0 & 0 & 0 & 0 & 0 & 1 \\
\hline Education .................................... & 82,797 & 67,884 & 5,423 & 5,488 & 1,841 & 1,445 & 396 & 669 & 631 & 861 & 84,028 & 68,376 & 5,864 & 5,770 & 1,709 & 1,564 & 145 & 595 & 853 & 861 \\
\hline Engineering ...................................................... & 14,257 & 8,738 & 844 & 1,158 & 2,130 & 2,103 & 27 & 84 & 238 & 1,065 & 15,553 & 9,446 & 898 & 1,324 & 2,242 & 2,202 & 40 & 72 & 266 & 1,305 \\
\hline fie & 1,718 & 1,060 & 271 & 153 & 111 & 11 & 1 & 26 & 22 & 75 & 1,684 & 1,035 & 324 & 153 & 68 & 66 & 2 & 18 & 28 & 58 \\
\hline Englis & 35,828 & 26,969 & 2,911 & 3,037 & 1,744 & 1,662 & 82 & 229 & 540 & 398 & 36,791 & 27,153 & 3,080 & 3,368 & 1,766 & 1,694 & 72 & 215 & 799 & 410 \\
\hline Family & 19,682 & 14,236 & 2,222 & 1,606 & 990 & 957 & 33 & 163 & 214 & 251 & 20,735 & 14,724 & 2,500 & 1,801 & 1,014 & 987 & 27 & 149 & 274 & 273 \\
\hline Foreign languages, lit & 14,986 & 10,049 & 662 & 2,662 & 936 & 923 & 13 & 80 & 281 & 316 & 15,134 & 9,933 & 692 & 2,954 & 884 & 870 & 14 & 61 & 304 & 306 \\
\hline Health pr & 121,894 & 87,586 & 14,758 & 8,232 & 7,675 & 7,344 & 331 & 803 & 1,210 & 1,630 & 138,572 & 97,724 & 17,062 & 9,892 & 9,477 & 9,029 & 448 & 828 & 1,814 & 1,775 \\
\hline Hom & & & & & & & & & & & & & & & & & & & & \\
\hline & 23,241 & 11,820 & 6,197 & 4,006 & 541 & 485 & 56 & 225 & 313 & 139 & 26,027 & 12,820 & 7,106 & 4,605 & 613 & 536 & 77 & 256 & 468 & 159 \\
\hline ns and studies .................... & 3,112 & 1,887 & 613 & 402 & 137 & 132 & 5 & 17 & 36 & 20 & 3,204 & 1,885 & 636 & 423 & 149 & 142 & 7 & 23 & 48 & 40 \\
\hline iber & & & & & & & & & & & & & & & & & & & & \\
\hline Libra & $\begin{array}{r}30,239 \\
83\end{array}$ & $\begin{array}{r}19,634 \\
73\end{array}$ & $\begin{array}{r}4,522 \\
2\end{array}$ & $\begin{array}{r}3,582 \\
3\end{array}$ & 1,133 & $\begin{array}{r}1,058 \\
2\end{array}$ & $\begin{array}{r}75 \\
0\end{array}$ & 357 & $\begin{array}{r}409 \\
2\end{array}$ & 602 & $\begin{array}{r}29,981 \\
88\end{array}$ & $\begin{array}{r}19,354 \\
82\end{array}$ & 4,447 & $\begin{array}{r}3,623 \\
3\end{array}$ & 1,111 & 1,035 & 76 & $\begin{array}{r}336 \\
0\end{array}$ & $\begin{array}{r}539 \\
0\end{array}$ & 571 \\
\hline a & 7,399 & 5,077 & 422 & 504 & 745 & $\sigma_{2}$ & 17 & 36 & 97 | & 518 & 8,119 & 450 & 468 & 595 & 772 & 752 & 20 & 2 & 96 & 716 \\
\hline & 17 & 11 & 0 & 4 & 1 & 1 & 0 & $\begin{array}{r}r \\
0\end{array}$ & 0 & 10 & $\begin{array}{l}0,19 \\
15\end{array}$ & 0,400 & 400 & 595 & $7 / 2$ & re $\begin{array}{r}52 \\
0\end{array}$ & $\begin{array}{r}20 \\
0\end{array}$ & $\begin{array}{r}22 \\
2\end{array}$ & $\begin{array}{r}90 \\
0\end{array}$ & 716 \\
\hline $\mathrm{M}$ & 14 & 8 & 6 & 0 & 0 & 0 & 0 & 0 & 0 & 0 & 17 & 9 & 7 & 1 & 0 & 0 & 0 & 0 & 0 & 0 \\
\hline & 28,626 & 18,798 & 3,048 & 3,955 & 1,739 & 1,687 & 52 & 238 & 361 & 487 & 31,122 & 20,110 & 3,552 & 4,417 & 1,756 & 1,683 & 73 & 243 & 467 & 577 \\
\hline Parks, recreation, leisure, and fitness studies ........ & 16,988 & 12,973 & 1,519 & 1,278 & 620 & 563 & 57 & 120 & 210 & 268 & 18,163 & 13,822 & 1,539 & 1,418 & 707 & 655 & 52 & 125 & 280 & 272 \\
\hline Philosophy & 4,687 & 3,43 & 464 & 323 & 290 & 279 & 11 & 33 & 76 & 66 & 4,688 & 3,356 & 481 & 388 & 250 & 246 & 4 & 35 & 100 & 78 \\
\hline ce technologies..... & 9,930 & 6,712 & 739 & 615 & 1,211 & 1,190 & 21 & 62 & 145 & 446 & 10,691 & 7,058 & 920 & 719 & 1,260 & 1,243 & 17 & 69 & 205 & 460 \\
\hline & 21 & 10 & & 3 & & 4 & 0 & 0 & 0 & 4 & & & 0 & 0 & 0 & 0 & 0 & 0 & 2 & 0 \\
\hline & 77,664 & 50,559 & 10,059 & 9,129 & 4,881 & 4,717 & 164 & 544 & 1,217 & 1,275 & 83,580 & 53,350 & 10,931 & 10,421 & 5,220 & 5,045 & 175 & 561 & 1,541 & 1,556 \\
\hline Public administration and social services.... & 21,866 & 12,358 & 5,194 & 2,733 & 725 & 650 & 75 & 249 & 395 & 212 & 24,310 & 13,808 & 5,822 & 3,089 & 747 & 670 & 77 & 240 & 367 & 237 \\
\hline 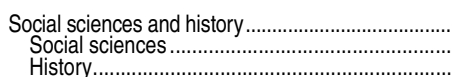 & $\begin{array}{l}87,330 \\
73,154 \\
14,176\end{array}$ & $\begin{array}{l}54,730 \\
43,67 \\
11,053\end{array}$ & $\begin{array}{r}10,379 \\
9,528 \\
851\end{array}$ & $\begin{array}{r}10,164 \\
8,918 \\
1,246\end{array}$ & $\begin{array}{r}7,070 \\
6,508 \\
562\end{array}$ & $\begin{array}{l}6,848 \\
6,308 \\
540\end{array}$ & $\begin{array}{r}222 \\
200 \\
22\end{array}$ & $\begin{array}{r}647 \\
551 \\
96\end{array}$ & $\begin{array}{l}1,413 \\
1,177 \\
236\end{array}$ & $\begin{array}{r}2,927 \\
2,795 \\
132\end{array}$ & $\begin{array}{l}87,909 \\
73,758 \\
14,151\end{array}$ & $\begin{array}{l}54,179 \\
43,264 \\
10,915\end{array}$ & $\begin{array}{r}10,519 \\
9,660 \\
859\end{array}$ & $\begin{array}{r}10,930 \\
9,599 \\
1,331\end{array}$ & $\begin{array}{r}6,629 \\
6,080 \\
549\end{array}$ & $\begin{array}{r}6,372 \\
5,845 \\
527\end{array}$ & $\begin{array}{r}257 \\
235 \\
22\end{array}$ & $\begin{array}{l}602 \\
498 \\
104\end{array}$ & $\begin{array}{l}1,884 \\
1,604 \\
280\end{array}$ & $\begin{array}{l}3,166 \\
3,053 \\
113\end{array}$ \\
\hline se & 2,956 & 2,337 & 260 & 162 & 84 & 73 & 11 & 11 & 29 & 73 & 3,094 & 2,421 & 292 & 155 & 80 & 74 & 6 & 22 & 34 & 90 \\
\hline & 596 & 419 & 46 & 45 & 33 & 32 & 1 & 8 & 11 & 34 & 571 & 404 & 46 & 57 & 25 & 22 & 3 & 12 & 7 & 20 \\
\hline$[\cdots \cdots \cdots \cdots \cdots \cdots$ & 57,615 & 42,467 & 3,180 & 4,744 & 3,732 & 3,599 & 133 & 380 & 1,020 & 2,092 & 58,639 & 42,451 & 3,420 & 5,257 & 3,761 & 3,665 & 96 & 346 & 1,136 & 2,268 \\
\hline 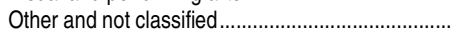 & 0 & 0 & 0 & 0 & 正 & 0 & 0 & 0 & 0 & 0 & 0 & 0 & 0 & 0 & 0 & 0 & 0 & 0 & 0 & 0 \\
\hline
\end{tabular}

"Excludes "Construction trades" and "Mechanic and repair technologies/technicians," which are listed separately. NOTE: Data are for postsecondary institutions participating in Tite IV federal financial aid programs. Race categories exclude persons of Hispanic ethnicity. Reported racial/ethnic distributions of students by level of degree, field of degree, and sex were used to been made of the degree fields as reported in the Integrated Postsecondary Education Data System (IPEDS): "Agriculture and natu- ral resources" includes Agriculture, agriculture operations, and related sciences and Natural resources and conservation; and "Business" includes Business management, marketing, and related support services and Personal and culinary services. Some data have ben revised from previously published figures.

(ation System (IPEDS), Fall 2011 and Fall 2012, Completions component. (This table was prepared July 2013.) 
Table 323.10. Master's degrees conferred by postsecondary institutions, by field of study: Selected years, 1970-71 through 2011-12

\begin{tabular}{|c|c|c|c|c|c|c|c|c|c|c|c|c|c|c|c|c|c|c|}
\hline Field of study & $1970-71$ & $1975-76$ & $1980-81$ & $1985-86$ & $1990-91$ & $1995-96$ & $2000-01$ & $2001-02$ & $2002-03$ & $2003-04$ & $2004-05$ & $2005-06$ & $2006-07$ & $2007-08$ & $2008-09$ & $2009-10$ & $2010-11$ & 201 \\
\hline 1 & 2 & 3 & 4 & 5 & 6 & 7 & 8 & 9 & 10 & 11 & 12 & 13 & 14 & 15 & 16 & 17 & 18 & \\
\hline Total .. & 35,564 & 317,477 & 302,637 & 95,850 & 342,863 & 412,180 & 473,502 & 487,313 & 518,699 & 564,272 & 580,151 & 599,731 & 610,597 & 630,666 & 662,079 & 693,025 & 730,635 & \\
\hline Agriculture and natural resources.... & 2,457 & 3,340 & 4,003 & 3,801 & 3,295 & 4,551 & 4,272 & 4,503 & 4,492 & 4,783 & 4,746 & 4,640 & 4,623 & 4,684 & 4,877 & 5,211 & 5,773 & \\
\hline Architecture and related services....... & 1,705 & 3,215 & 3,153 & 3,260 & 3,490 & 3,993 & 4,302 & 4,566 & 4,925 & 5,424 & 5,674 & 5,743 & 5,951 & 6,065 & 6,587 & 7,280 & 7,788 & \\
\hline d group studies........ & 1,032 & 993 & 802 & 915 & 1,233 & 1,652 & 1,555 & 1,541 & 1,509 & 1,683 & 1,755 & 2,080 & 1,699 & 1,778 & 1,779 & 1,775 & 1,914 & \\
\hline Biological a & 5,625 & 6,457 & 5,766 & 5,064 & 4,834 & 6,593 & 7,017 & 7,011 & 7,050 & 7,732 & 8,284 & 8,781 & 8,898 & 9,689 & 10,017 & 10,725 & 11,327 & \\
\hline Business... & 26,490 & 42,592 & 57,888 & 66,676 & 78,255 & 93,554 & 115,602 & 119,725 & 127,685 & 139,347 & 142,617 & 146,406 & 150,211 & 155,637 & 168,375 & 177,684 & 187,213 & \\
\hline Communication, journalism, and related programs.... & 1,770 & 2,961 & 2,896 & 3,500 & 4,123 & 5,080 & 5,218 & 5,510 & 6,053 & 6,535 & 6,762 & 7,244 & 6,773 & 6,915 & 7,092 & 7,636 & 8,303 & \\
\hline Comm & 86 & 165 & 209 & 308 & 204 & 481 & 427 & 470 & 442 & 365 & 433 & 501 & 499 & 631 & 475 & 463 & 502 & \\
\hline Computer and information sciences...................... & 1,588 & 2,603 & 4,218 & 8,070 & 9,324 & 10,579 & 16,911 & 17,173 & 19,509 & 20,143 & 18,416 & 17,055 & 16,232 & 17,087 & 17,907 & 17,953 & 19,446 & \\
\hline 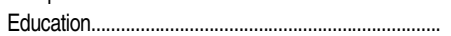 & 87,666 & 126,061 & 96,713 & 74,816 & 87,352 & 104,936 & 127,829 & 135,189 & 147,883 & 162,345 & 167,490 & 174,620 & 176,572 & 175,880 & 178,564 & 182,139 & 185,009 & 178 , \\
\hline 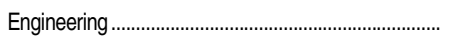 & 16,813 & 16,472 & 16,893 & 21,529 & 24,454 & 26,789 & 25,174 & 24,838 & 28,251 & 32,554 & 32,488 & 30,848 & 29,299 & 31,557 & 34,546 & 35,088 & 38,719 & \\
\hline 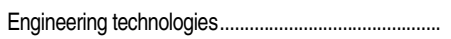 & 134 & 328 & 323 & 617 & 996 & 2,054 & 2,013 & 2,149 & 2,332 & 2,499 & 2,500 & 2,541 & 2,690 & 2,873 & 3,455 & 4,258 & 4,515 & \\
\hline Englist & 10,441 & 8,599 & 5,742 & 5,335 & 6,784 & 7,657 & 6,763 & 7,097 & 7,428 & 7,956 & 8,468 & 8,845 & 8,742 & 9,161 & 9,261 & 9,201 & 9,476 & \\
\hline s........ & 1,452 & 2,179 & 2,570 & 2,011 & 1,541 & 1,712 & 1,838 & 1,683 & 1,607 & 1,794 & 1,827 & 1,983 & 2,080 & 2,199 & 2,453 & 2,580 & 2,918 & \\
\hline 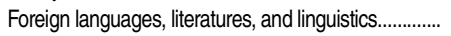 & 5,480 & 4,432 & 2,934 & 2,690 & 3,049 & 3,443 & 3,035 & 3,075 & 3,049 & 3,124 & 3,407 & 3,539 & 3,443 & 3,565 & 3,592 & 3,755 & 3,727 & \\
\hline Health professions and related programs...................... & 5,330 & 12,164 & 16,176 & 18,603 & 21,354 & 33,920 & 43,623 & 43,560 & 42,748 & 44,939 & 46,703 & 51,380 & 54,531 & 58,120 & 62,620 & 69,084 & 75,579 & \\
\hline Homela & 194 & 1,197 & 1,538 & 1,074 & 1,108 & 1,812 & 2,514 & 2,935 & 2,956 & 3,717 & 3,991 & 4,277 & 4,906 & 5,760 & 6,128 & 6,714 & 7,433 & \\
\hline Legal & 955 & 1,442 & 1,832 & 1,924 & 2,057 & 2,751 & 3,829 & 4,053 & 4,141 & 4,243 & 4,170 & 4,453 & 4,486 & 4,815 & 5,150 & 5,734 & 6,300 & \\
\hline & & & & & & & & & & & & & & & & & & \\
\hline & 885 & 2,633 & 2,375 & 1,586 & 2,213 & 2,778 & 3,193 & 2,754 & 3,314 & 3,697 & 3,680 & 3,702 & 3,634 & 3,797 & 3,728 & 3,804 & 971 & \\
\hline tims & 7,001 & 8,037 & 4,859 & 3,564 & 4,763 & 5,099 & 4,727 & 5,113 & 295 & 6,015 & 6,213 & 6,448 & 6,767 & 7,162 & 7,091 & 7,448 & 7,727 & \\
\hline Mathem & 5,191 & 3,857 & 2,567 & 3,131 & 3,549 & 3,651 & 3,209 & 3,350 & 3,620 & 4,191 & 4,477 & 4,730 & 4,884 & 4,980 & 5,211 & 5,634 & 5,843 & \\
\hline & 2 & 0 & 43 & 83 & 0 & 136 & 0 & 0 & 0 & 0 & 0 & 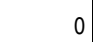 & 202 & 0 & 3 & 0 & 0 & \\
\hline & 924 & 1,283 & 2,356 & 2,869 & 2,079 & 2,713 & 3,413 & 3,634 & 3,721 & 3,972 & 4,167 & 4,391 & 4,611 & 5,165 & 5,225 & 5,973 & 6,748 & \\
\hline nd fitness studies.............. & 218 & 571 & 643 & 570 & 483 & 1,684 & 2,354 & 2,580 & 2,978 & 3,199 & 3,740 & 3,992 & 4,110 & 4,440 & 4,822 & 5,617 & 6,553 & \\
\hline & 1,326 & 1,358 & 1,231 & 1,193 & 1,471 & 1,363 & 1,386 & 1,371 & 1,578 & 1,578 & 1,647 & 1,739 & 1,716 & 1,879 & 1,859 & 2,043 & 1,833 & \\
\hline Physical sciences and science technologies...... & 6,336 & 5,428 & 5,246 & 5,860 & 5,281 & 5,910 & 5,134 & 5,082 & 5,196 & 5,714 & 5,823 & 6,063 & 6,012 & 6,061 & 5,862 & 6,063 & 6,386 & \\
\hline & 0 & 0 & 0 & 0 & 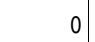 & 0 & 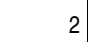 & 6 & 0 & 13 & 0 & 0 & 3 & 3 & 10 & 10 & & \\
\hline & 717 & 0,167 & 0,223 & 9,845 & 11,349 & 15,152 & \$,539 &, 357 & 7,161 & 17,898 & 18,830 & 19,770 & 1,037 & 1,431 & 23,415 & 23,752 & 5,051 & \\
\hline ervices.... & 7,785 & 15,209 & 17,803 & 15,692 & 17,905 & 24,229 & 25,268 & 25,448 & 25,903 & 28,250 & 29,552 & 30,510 & 31,131 & 33,029 & 33,933 & 35,729 & 38,634 & \\
\hline & 16,539 & 15,953 & 11,945 & 10,564 & 12,233 & 15,012 & 13,791 & 14,112 & 14,630 & 16,110 & 16,952 & 17,369 & 17,665 & 18,495 & 19,240 & 20,222 & 21,084 & \\
\hline Theology and religious vocations..... & 7,747 & 8,964 & 11,061 & 11,826 & 10,498 & 10,909 & 9,876 & 10,104 & 10,493 & 10,818 & 11,348 & 11,758 & 12,436 & 12,578 & 12,836 & 12,824 & 13,191 & \\
\hline & 0 & 0 & 0 & 454 & 406 & 919 & 756 & 709 & 765 & 728 & 802 & 784 & 985 & 982 & 1,048 & 1,074 & 1,390 & \\
\hline & 6,675 & 8,817 & 8,629 & 8,420 & 8,657 & 10,280 & 11,404 & 11,595 & 11,982 & 12,906 & 13,183 & 13,530 & 13,767 & 14,164 & 14,918 & 15,552 & 16,277 & \\
\hline Not classified by field of study ....................... & 0 & 0 & & & 8,523 & 780 & 528 & 24 & 0 & 0 & 0 & & 0 & 84 & 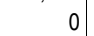 & . & & \\
\hline
\end{tabular}

NOTE: Data through 1990-91 are for institutions of higher education, while later data are for postsecondary institutions that participate in Title IV federal financial aid programs. The new Classification of Instructional Programs was initiated in facilitate trend comparisons, ondary Education Data System (IPEDS): "Agriculture and natural resources" includes Agriculture, agriculture operations, and

related support services and Personal and culinary services; and "Engineering technologies" includes Engineering technologies and engineering-related fields, Construction trades, and Mechanic and repair technologies/technicians. 1970-71 through 1985-86: Integrated Postsecondary Education Data System (IPEDS), "Completions Survey" (IPEDS-C:91-99); and IPEDS Fall 2000 through Fall 2012, Completions component. (This table was prepared July 2013.) 
Table 323.20. Master's degrees conferred by postsecondary institutions, by race/ethnicity and sex of student: Selected years, 1976-77 through 2011-12

\begin{tabular}{|c|c|c|c|c|c|c|c|c|c|c|c|c|c|c|c|}
\hline \multirow[b]{2}{*}{ Year and sex } & \multicolumn{8}{|c|}{ Number of degrees conferred to U.S. citizens and nonresident aliens } & \multicolumn{7}{|c|}{ Percentage distribution of degrees conferred to U.S. citizens } \\
\hline & Total & White & Black & Hispanic & $\begin{array}{r}\text { Asian/ } \\
\text { Pacific } \\
\text { Islander }\end{array}$ & $\begin{array}{r}\text { American } \\
\text { Indian/ } \\
\text { Alaska } \\
\text { Native } \\
\end{array}$ & $\begin{array}{r}\text { Two or } \\
\text { more } \\
\text { races }\end{array}$ & $\begin{array}{r}\text { Non- } \\
\text { resident } \\
\text { alien }\end{array}$ & Total & White & Black & Hispanic & $\begin{array}{r}\text { Asian/ } \\
\text { Pacific } \\
\text { Islander }\end{array}$ & $\begin{array}{r}\text { American } \\
\text { Indian/ } \\
\text { Alaska } \\
\text { Native }\end{array}$ & $\begin{array}{r}\text { Two or } \\
\text { more } \\
\text { races }\end{array}$ \\
\hline 1 & 2 & 3 & 4 & 5 & 6 & 7 & 8 & 9 & 10 & 11 & 12 & 13 & 14 & 15 & 16 \\
\hline 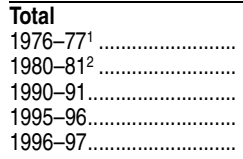 & $\begin{array}{l}322,463 \\
301,081 \\
342,863 \\
412,180 \\
425,260\end{array}$ & $\begin{array}{l}271,402 \\
247,475 \\
265,927 \\
302,790 \\
309,637\end{array}$ & $\begin{array}{l}21,252 \\
17,436 \\
17,023 \\
26,323 \\
28,875\end{array}$ & $\begin{array}{r}6,136 \\
6,534 \\
8,981 \\
14,553 \\
15,560\end{array}$ & $\begin{array}{r}5,127 \\
6,348 \\
11,869 \\
18,505 \\
19,372\end{array}$ & $\begin{array}{l}1,018 \\
1,044 \\
1,189 \\
1,793 \\
1,954\end{array}$ & $\begin{array}{l}- \\
- \\
- \\
-\end{array}$ & $\begin{array}{l}17,528 \\
22,244 \\
37,874 \\
48,216 \\
49,862\end{array}$ & $\begin{array}{l}100.0 \\
100.0 \\
100.0 \\
100.0 \\
100.0\end{array}$ & $\begin{array}{l}89.0 \\
88.8 \\
87.2 \\
83.2 \\
82.5\end{array}$ & $\begin{array}{l}7.0 \\
6.3 \\
5.6 \\
7.2 \\
7.7\end{array}$ & $\begin{array}{l}2.0 \\
2.3 \\
2.9 \\
4.0 \\
4.1\end{array}$ & $\begin{array}{l}1.7 \\
2.3 \\
3.9 \\
5.1 \\
5.2\end{array}$ & $\begin{array}{l}0.3 \\
0.4 \\
0.4 \\
0.5 \\
0.5\end{array}$ & $\begin{array}{l}- \\
- \\
-\end{array}$ \\
\hline $\begin{array}{l}1997-98 \\
1998-99 \\
1999-2000 \\
2000-01 \\
2001-02\end{array}$ & $\begin{array}{l}436,037 \\
446,038 \\
463,185 \\
473,502 \\
487,313\end{array}$ & $\begin{array}{l}312,752 \\
318,555 \\
324,990 \\
324,211 \\
331,427\end{array}$ & $\begin{array}{l}30,703 \\
33,010 \\
36,606 \\
38,853 \\
41,006\end{array}$ & $\begin{array}{l}16,370 \\
17,781 \\
19,379 \\
21,661 \\
22,517\end{array}$ & $\begin{array}{l}21,415 \\
22,262 \\
23,523 \\
24,544 \\
25,681\end{array}$ & $\begin{array}{l}2,068 \\
2,075 \\
2,263 \\
2,496 \\
2,632\end{array}$ & $\begin{array}{l}- \\
- \\
- \\
-\end{array}$ & $\begin{array}{l}52,729 \\
52,355 \\
56,424 \\
61,737 \\
64,050\end{array}$ & $\begin{array}{l}100.0 \\
100.0 \\
100.0 \\
100.0 \\
100.0\end{array}$ & $\begin{array}{l}81.6 \\
80.9 \\
79.9 \\
78.7 \\
78.3\end{array}$ & $\begin{array}{l}8.0 \\
8.4 \\
9.0 \\
9.4 \\
9.7\end{array}$ & $\begin{array}{l}4.3 \\
4.5 \\
4.8 \\
5.3 \\
5.3\end{array}$ & $\begin{array}{l}5.6 \\
5.7 \\
5.8 \\
6.0 \\
6.1\end{array}$ & $\begin{array}{l}0.5 \\
0.5 \\
0.6 \\
0.6 \\
0.6\end{array}$ & $\begin{array}{l}- \\
- \\
- \\
-\end{array}$ \\
\hline $\begin{array}{l}2002-03 \\
2003-04 \\
2004-05 \\
2005-06 \\
2006-07\end{array}$ & $\begin{array}{l}518,699 \\
564,272 \\
580,151 \\
599,731 \\
610,597\end{array}$ & $\begin{array}{l}346,003 \\
373,448 \\
383,246 \\
397,439 \\
403,562\end{array}$ & $\begin{array}{l}45,150 \\
51,402 \\
55,330 \\
59,806 \\
63,412\end{array}$ & $\begin{array}{l}25,200 \\
29,806 \\
31,639 \\
32,567 \\
34,967\end{array}$ & $\begin{array}{l}27,492 \\
31,202 \\
33,042 \\
34,289 \\
36,491\end{array}$ & $\begin{array}{l}2,886 \\
3,206 \\
3,310 \\
3,519 \\
3,589\end{array}$ & $\begin{array}{l}- \\
- \\
- \\
-\end{array}$ & $\begin{array}{l}71,968 \\
75,208 \\
73,584 \\
72,111 \\
68,576\end{array}$ & $\begin{array}{l}100.0 \\
100.0 \\
100.0 \\
100.0 \\
100.0\end{array}$ & $\begin{array}{l}77.5 \\
76.4 \\
75.7 \\
75.3 \\
74.5\end{array}$ & $\begin{array}{l}10.1 \\
10.5 \\
10.9 \\
11.3 \\
11.7\end{array}$ & $\begin{array}{l}5.6 \\
6.1 \\
6.2 \\
6.2 \\
6.5\end{array}$ & $\begin{array}{l}6.2 \\
6.4 \\
6.5 \\
6.5 \\
6.7\end{array}$ & $\begin{array}{l}0.6 \\
0.7 \\
0.7 \\
0.7 \\
0.7\end{array}$ & $\begin{array}{l}- \\
- \\
- \\
-\end{array}$ \\
\hline $\begin{array}{l}2007-08 \\
2008-09 \\
2009-10 \\
2010-11 \\
2011-12\end{array}$ & $\begin{array}{l}630,666 \\
662,079 \\
693,025 \\
730,635 \\
754,229\end{array}$ & $\begin{array}{l}413,179 \\
427,891 \\
445,038 \\
462,903 \\
469,639\end{array}$ & $\begin{array}{l}65,914 \\
70,839 \\
76,458 \\
80,706 \\
85,315\end{array}$ & $\begin{array}{l}36,972 \\
39,582 \\
43,535 \\
46,787 \\
51,264\end{array}$ & $\begin{array}{l}37,722 \\
40,257 \\
42,702 \\
43,728 \\
45,400\end{array}$ & $\begin{array}{l}3,777 \\
3,777 \\
3,960 \\
3,948 \\
3,674\end{array}$ & $\begin{array}{r}- \\
\overline{-} \\
6,700 \\
9,780\end{array}$ & $\begin{array}{l}73,102 \\
79,733 \\
81,332 \\
85,863 \\
89,157\end{array}$ & $\begin{array}{l}100.0 \\
100.0 \\
100.0 \\
100.0 \\
100.0\end{array}$ & $\begin{array}{l}74.1 \\
73.5 \\
72.8 \\
71.8 \\
70.6\end{array}$ & $\begin{array}{l}11.8 \\
12.2 \\
12.5 \\
12.5 \\
12.8\end{array}$ & $\begin{array}{l}6.6 \\
6.8 \\
7.1 \\
7.3 \\
7.7\end{array}$ & $\begin{array}{l}6.8 \\
6.9 \\
7.0 \\
6.8 \\
6.8\end{array}$ & $\begin{array}{l}0.7 \\
0.6 \\
0.6 \\
0.6 \\
0.6\end{array}$ & $\begin{array}{l}- \\
\overline{-} \\
1.0 \\
1.5\end{array}$ \\
\hline $\begin{array}{l}\text { Males } \\
1976-71^{1} \ldots \ldots \ldots \ldots \ldots \ldots \ldots \ldots \\
1980-81^{2} \ldots \ldots \ldots \ldots \ldots \ldots \ldots \ldots \\
1990-91 \ldots \ldots \ldots \ldots \ldots \ldots \ldots \ldots \\
1995-96 \ldots \ldots \ldots \ldots \ldots \ldots \ldots \ldots \\
1996-97 \ldots \ldots \ldots \ldots \ldots \ldots \ldots \ldots\end{array}$ & $\begin{array}{l}172,703 \\
151,602 \\
160,842 \\
183,481 \\
185,270\end{array}$ & $\begin{array}{l}144,042 \\
120,927 \\
117,993 \\
128,325 \\
128,946\end{array}$ & $\begin{array}{l}7,970 \\
6,418 \\
6,201 \\
8,758 \\
9,252\end{array}$ & $\begin{array}{l}3,328 \\
3,155 \\
4,017 \\
5,940 \\
6,335\end{array}$ & $\begin{array}{l}3,128 \\
3,830 \\
6,765 \\
9,644 \\
9,488\end{array}$ & $\begin{array}{l}565 \\
507 \\
495 \\
713 \\
743\end{array}$ & $\begin{array}{l}- \\
- \\
- \\
-\end{array}$ & $\begin{array}{l}13,670 \\
16,765 \\
25,371 \\
30,101 \\
30,506\end{array}$ & $\begin{array}{l}100.0 \\
100.0 \\
100.0 \\
100.0 \\
100.0\end{array}$ & $\begin{array}{l}90.6 \\
89.7 \\
87.1 \\
83.7 \\
83.3\end{array}$ & $\begin{array}{l}5.0 \\
4.8 \\
4.6 \\
5.7 \\
6.0\end{array}$ & $\begin{array}{l}2.1 \\
2.3 \\
3.0 \\
3.9 \\
4.1\end{array}$ & $\begin{array}{l}2.0 \\
2.8 \\
5.0 \\
6.3 \\
6.1\end{array}$ & $\begin{array}{l}0.4 \\
0.4 \\
0.4 \\
0.5 \\
0.5\end{array}$ & $\begin{array}{l}- \\
- \\
- \\
-\end{array}$ \\
\hline $\begin{array}{l}1997-98 \\
1998-99 \\
1999-2000 \\
2000-01 \\
2001-02\end{array}$ & $\begin{array}{l}188,718 \\
190,230 \\
196,129 \\
197,770 \\
202,604\end{array}$ & $\begin{array}{l}128,987 \\
129,912 \\
131,221 \\
128,516 \\
131,316\end{array}$ & $\begin{array}{r}9,978 \\
10,346 \\
11,642 \\
11,878 \\
12,119\end{array}$ & $\begin{array}{l}6,612 \\
7,044 \\
7,738 \\
8,371 \\
8,539\end{array}$ & $\begin{array}{l}10,500 \\
10,638 \\
11,299 \\
11,561 \\
11,956\end{array}$ & $\begin{array}{l}792 \\
794 \\
845 \\
925 \\
995\end{array}$ & $\begin{array}{l}- \\
- \\
- \\
-\end{array}$ & $\begin{array}{l}31,849 \\
31,496 \\
33,384 \\
36,519 \\
37,679\end{array}$ & $\begin{array}{l}100.0 \\
100.0 \\
100.0 \\
100.0 \\
100.0\end{array}$ & $\begin{array}{l}82.2 \\
81.8 \\
80.6 \\
79.7 \\
79.6\end{array}$ & $\begin{array}{l}6.4 \\
6.5 \\
7.2 \\
7.4 \\
7.3\end{array}$ & $\begin{array}{l}4.2 \\
4.4 \\
4.8 \\
5.2 \\
5.2\end{array}$ & $\begin{array}{l}6.7 \\
6.7 \\
6.9 \\
7.2 \\
7.2\end{array}$ & $\begin{array}{l}0.5 \\
0.5 \\
0.5 \\
0.6 \\
0.6\end{array}$ & $\begin{array}{l}- \\
- \\
- \\
-\end{array}$ \\
\hline 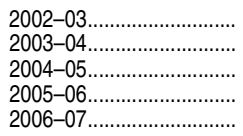 & $\begin{array}{l}215,172 \\
233,056 \\
237,155 \\
241,656 \\
242,189\end{array}$ & $\begin{array}{l}135,938 \\
146,369 \\
150,076 \\
153,666 \\
154,241\end{array}$ & $\begin{array}{l}13,224 \\
15,027 \\
16,136 \\
17,384 \\
18,333\end{array}$ & $\begin{array}{r}9,389 \\
10,929 \\
11,501 \\
11,739 \\
12,473\end{array}$ & $\begin{array}{l}12,704 \\
14,551 \\
15,238 \\
16,031 \\
16,728\end{array}$ & $\begin{array}{l}1,043 \\
1,137 \\
1,167 \\
1,252 \\
1,275\end{array}$ & $\begin{array}{l}- \\
- \\
- \\
-\end{array}$ & $\begin{array}{l}42,874 \\
45,043 \\
43,037 \\
41,584 \\
39,139\end{array}$ & $\begin{array}{l}100.0 \\
100.0 \\
100.0 \\
100.0 \\
100.0\end{array}$ & $\begin{array}{l}78.9 \\
77.9 \\
77.3 \\
76.8 \\
76.0\end{array}$ & $\begin{array}{l}7.7 \\
8.0 \\
8.3 \\
8.7 \\
9.0\end{array}$ & $\begin{array}{l}5.4 \\
5.8 \\
5.9 \\
5.9 \\
6.1\end{array}$ & $\begin{array}{l}7.4 \\
7.7 \\
7.8 \\
8.0 \\
8.2\end{array}$ & $\begin{array}{l}0.6 \\
0.6 \\
0.6 \\
0.6 \\
0.6\end{array}$ & $\begin{array}{l}- \\
- \\
- \\
-\end{array}$ \\
\hline $\begin{array}{l}2009-10 \ldots \ldots \ldots \ldots \ldots \ldots \ldots \\
2010-11 \ldots \ldots \ldots \ldots \ldots \ldots \ldots \ldots \\
2011-12 \ldots \ldots \ldots \ldots \ldots \ldots \ldots \ldots \ldots\end{array}$ & $\begin{array}{l}250,169 \\
263,538 \\
275,197 \\
291,551 \\
302,191\end{array}$ & $\begin{array}{l}157,596 \\
162,994 \\
170,203 \\
177,780 \\
182,960\end{array}$ & $\begin{array}{l}18,761 \\
20,174 \\
22,120 \\
23,741 \\
25,143\end{array}$ & $\begin{array}{l}13,189 \\
14,324 \\
15,525 \\
17,213 \\
18,849\end{array}$ & $\begin{array}{l}17,476 \\
18,724 \\
19,535 \\
20,050 \\
20,774\end{array}$ & $\begin{array}{l}1,293 \\
1,350 \\
1,415 \\
1,409 \\
1,297\end{array}$ & $\begin{array}{r}- \\
\overline{-} \\
2,594 \\
3,512\end{array}$ & $\begin{array}{l}41,854 \\
45,972 \\
46,399 \\
48,764 \\
49,656\end{array}$ & $\begin{array}{l}100.0 \\
100.0 \\
100.0 \\
100.0 \\
100.0\end{array}$ & $\begin{array}{l}75.7 \\
74.9 \\
74.4 \\
73.2 \\
72.4\end{array}$ & $\begin{array}{r}9.0 \\
9.3 \\
9.7 \\
9.8 \\
10.0\end{array}$ & $\begin{array}{l}6.3 \\
6.6 \\
6.8 \\
7.1 \\
7.5\end{array}$ & $\begin{array}{l}8.4 \\
8.6 \\
8.5 \\
8.3 \\
8.2\end{array}$ & $\begin{array}{l}0.6 \\
0.6 \\
0.6 \\
0.6 \\
0.5\end{array}$ & $\begin{array}{l}- \\
\overline{-} \\
1.1 \\
1.4\end{array}$ \\
\hline $\begin{array}{l}1976-771^{1} \\
1980-81^{2} \\
1990-91 \\
1995-96 \\
1996-97\end{array}$ & $\begin{array}{l}149,760 \\
149,479 \\
182,021 \\
228,699 \\
239,990\end{array}$ & $\begin{array}{l}127,360 \\
126,548 \\
147,934 \\
174,465 \\
180,691\end{array}$ & $\begin{array}{l}13,282 \\
11,018 \\
10,822 \\
17,565 \\
19,623\end{array}$ & $\begin{array}{l}2,808 \\
3,379 \\
4,964 \\
8,613 \\
9,225\end{array}$ & $\begin{array}{l}1,999 \\
2,518 \\
5,104 \\
8,861 \\
9,884\end{array}$ & $\begin{array}{r}453 \\
537 \\
694 \\
1,080 \\
1,211\end{array}$ & $\begin{array}{l}- \\
- \\
- \\
-\end{array}$ & $\begin{array}{r}3,858 \\
5,479 \\
12,503 \\
18,115 \\
19,356\end{array}$ & $\begin{array}{l}100.0 \\
100.0 \\
100.0 \\
100.0 \\
100.0\end{array}$ & $\begin{array}{l}87.3 \\
87.9 \\
87.3 \\
82.8 \\
81.9\end{array}$ & $\begin{array}{l}9.1 \\
7.7 \\
6.4 \\
8.3 \\
8.9\end{array}$ & $\begin{array}{l}1.9 \\
2.3 \\
2.9 \\
4.1 \\
4.2\end{array}$ & $\begin{array}{l}1.4 \\
1.7 \\
3.0 \\
4.2 \\
4.5\end{array}$ & $\begin{array}{l}0.3 \\
0.4 \\
0.4 \\
0.5 \\
0.5\end{array}$ & $\begin{array}{l}- \\
- \\
- \\
-\end{array}$ \\
\hline $\begin{array}{l}1997-98 \\
1998-99 \\
1999-2000 \\
2000-01 \\
2001-02\end{array}$ & $\begin{array}{l}247,319 \\
255,808 \\
267,056 \\
275,732 \\
284,709\end{array}$ & $\begin{array}{l}183,765 \\
188,643 \\
193,769 \\
195,695 \\
200,111\end{array}$ & $\begin{array}{l}20,725 \\
22,664 \\
24,964 \\
26,975 \\
28,887\end{array}$ & $\begin{array}{r}9,758 \\
10,737 \\
11,641 \\
13,290 \\
13,978\end{array}$ & $\begin{array}{l}10,915 \\
11,624 \\
12,224 \\
12,983 \\
13,725\end{array}$ & $\begin{array}{l}1,276 \\
1,281 \\
1,418 \\
1,571 \\
1,637\end{array}$ & $\begin{array}{l}- \\
- \\
- \\
-\end{array}$ & $\begin{array}{l}20,880 \\
20,859 \\
23,040 \\
25,218 \\
26,371\end{array}$ & $\begin{array}{l}100.0 \\
100.0 \\
100.0 \\
100.0 \\
100.0\end{array}$ & $\begin{array}{l}81.2 \\
80.3 \\
79.4 \\
78.1 \\
77.5\end{array}$ & $\begin{array}{r}9.2 \\
9.6 \\
10.2 \\
10.8 \\
11.2\end{array}$ & $\begin{array}{l}4.3 \\
4.6 \\
4.8 \\
5.3 \\
5.4\end{array}$ & $\begin{array}{l}4.8 \\
4.9 \\
5.0 \\
5.2 \\
5.3\end{array}$ & $\begin{array}{l}0.6 \\
0.5 \\
0.6 \\
0.6 \\
0.6\end{array}$ & $\begin{array}{l}- \\
- \\
- \\
-\end{array}$ \\
\hline $2005-06 \ldots$ & $\begin{array}{l}303,527 \\
331,216 \\
342,996 \\
358,075 \\
368,408\end{array}$ & $\begin{array}{l}210,065 \\
227,079 \\
233,170 \\
243,773 \\
249,321\end{array}$ & $\begin{array}{l}31,926 \\
36,375 \\
39,194 \\
42,422 \\
45,079\end{array}$ & $\begin{array}{l}20,138 \\
20,828 \\
22,494\end{array}$ & $\begin{array}{l}14,788 \\
16,651 \\
17,804 \\
18,258 \\
19,763\end{array}$ & $\begin{array}{l}2,143 \\
2,267 \\
2,314\end{array}$ & $\begin{array}{l}- \\
- \\
- \\
-\end{array}$ & $\begin{array}{l}29,094 \\
30,165 \\
30,547 \\
30,527 \\
29,437\end{array}$ & $\begin{array}{l}100.0 \\
100.0 \\
100.0 \\
100.0 \\
100.0\end{array}$ & $\begin{array}{l}76.5 \\
75.4 \\
74.6 \\
74.4 \\
73.6\end{array}$ & $\begin{array}{l}11.6 \\
12.1 \\
12.5 \\
13.0 \\
13.3\end{array}$ & $\begin{array}{l}5.8 \\
6.3 \\
6.4 \\
6.4 \\
6.6\end{array}$ & $\begin{array}{l}5.4 \\
5.5 \\
5.7 \\
5.6 \\
5.8\end{array}$ & $\begin{array}{l}0.7 \\
0.7 \\
0.7 \\
0.7 \\
0.7\end{array}$ & $\begin{array}{l}- \\
- \\
- \\
-\end{array}$ \\
\hline 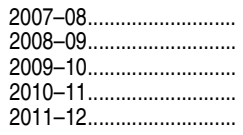 & $\begin{array}{l}380,497 \\
398,541 \\
417,828 \\
439,084 \\
452,038\end{array}$ & $\begin{array}{l}255,583 \\
264,897 \\
274,835 \\
285,123 \\
286,679\end{array}$ & $\begin{array}{l}50,665 \\
54,338 \\
56,965 \\
60,172\end{array}$ & $\begin{array}{l}25,258 \\
28,010 \\
29,574 \\
32,415\end{array}$ & $\begin{array}{l}21,533 \\
23,167 \\
23,678 \\
24,626\end{array}$ & $\begin{array}{l}2,427 \\
2,545 \\
2,539 \\
2,377\end{array}$ & $\begin{array}{r}- \\
\overline{-} \\
4, \overline{106} \\
6,268\end{array}$ & $\begin{array}{l}33,761 \\
34,933 \\
37,099 \\
39,501\end{array}$ & $\begin{array}{l}100.0 \\
100.0 \\
100.0 \\
100.0\end{array}$ & $\begin{array}{l}73.2 \\
72.6 \\
71.8 \\
70.9 \\
69.5\end{array}$ & $\begin{array}{l}13.5 \\
13.9 \\
14.2 \\
14.2 \\
14.6\end{array}$ & $\begin{array}{l}6.8 \\
6.9 \\
7.3 \\
7.4 \\
7.9\end{array}$ & $\begin{array}{l}5.8 \\
5.9 \\
6.1 \\
5.9 \\
6.0\end{array}$ & $\begin{array}{l}0.7 \\
0.7 \\
0.7 \\
0.6 \\
0.6\end{array}$ & $\begin{array}{l}\overline{-} \\
\overline{1} \\
1.0\end{array}$ \\
\hline
\end{tabular}

-Not available.

1Excludes 387 males and 175 females whose racial/ethnic group was not available. 'Excludes 1,377 males and 179 females whose racial/ethnic group was not available. NOTE: Data through 1990-91 are for institutions of higher education, while later data are for postsecondary institutions participating in Title IV federal financial aid programs. Race categories exclude persons of Hispanic ethnicity. For 1989-90 and later years, reported racial/ethnic distributions of students by level of degree, field of degree, and sex were used to estimate race/ethnicity for students whose race/ethnicity was not reported. Detail may not sum to totals because of rounding.

SOURCE: U.S. Department of Education, National Center for Education Statistics, Higher Education General Information Survey (HEGIS), "Degrees and Other Forma Awards Conferred" surveys, 1976-77 and 1980-81; Integrated Postsecondary Education Data System (IPEDS), "Completions Survey" (IPEDS-C:90-99); and IPEDS Fall 2000 through Fall 2012, Completions component. (This table was prepared July 2013.) 
Table 323.30. Master's degrees conferred by postsecondary institutions, by race/ethnicity and field of study: 2010-11 and 2011-12

\begin{tabular}{|c|c|c|c|c|c|c|c|c|c|c|c|c|c|c|c|c|c|c|c|c|}
\hline \multirow[b]{3}{*}{ Field of study } & \multicolumn{10}{|c|}{$2010-11$} & \multicolumn{10}{|c|}{ 2011-12 } \\
\hline & \multirow[b]{2}{*}{ Total } & \multirow[b]{2}{*}{ White } & \multirow[b]{2}{*}{ Black } & \multirow[b]{2}{*}{ Hispanic } & \multicolumn{3}{|c|}{ Asian/Pacific Islander } & \multirow{2}{*}{$\begin{array}{r}\text { American } \\
\text { Indian/ } \\
\text { Alaska } \\
\text { Native }\end{array}$} & \multirow{2}{*}{$\begin{array}{c}\text { Two or } \\
\text { more } \\
\text { races }\end{array}$} & \multirow{2}{*}{$\begin{array}{l}\text { Non- } \\
\text { resident } \\
\text { alien }\end{array}$} & \multirow[b]{2}{*}{ Total } & \multirow[b]{2}{*}{ White } & \multirow[b]{2}{*}{ Black } & \multirow[b]{2}{*}{ Hispanic } & \multicolumn{3}{|c|}{ Asian/Pacific Islander } & \multirow{2}{*}{$\begin{array}{r}\text { American } \\
\text { Indian/ } \\
\text { Alaska } \\
\text { Native }\end{array}$} & \multirow{2}{*}{$\begin{array}{r}\text { Two or } \\
\text { more } \\
\text { races }\end{array}$} & \\
\hline & & & & & Total & Asian & $\begin{array}{r}\text { Pacific } \\
\text { Islander }\end{array}$ & & & & & & & & Total & Asian & $\begin{array}{r}\text { Pacific } \\
\text { Islander }\end{array}$ & & & $\begin{array}{r}\text { resident } \\
\text { alien }\end{array}$ \\
\hline 1 & 2 & 3 & 4 & 5 & 6 & 7 & 8 & 9 & 10 & 11 & 12 & 13 & 14 & 15 & 16 & 17 & 18 & 19 & 20 & 21 \\
\hline All fields, total & 730,635 & 462,903 & 80,706 & 46,787 & 43,728 & 42,381 & 1,347 & 3,948 & 6,700 & 85,863 & 754,229 & 469,639 & 85,315 & 51,264 & 45,400 & 43,773 & 1,627 & 3,674 & 9,780 & 89,157 \\
\hline Agriculture $\mathrm{a}$ & 5,773 & 4,166 & 218 & 222 & 233 & 229 & 4 & 38 & 53 & 843 & 6,390 & 4,699 & 194 & 255 & 261 & 253 & 8 & 37 & 79 & 865 \\
\hline rchitectur & 7,788 & 5, & 336 & 538 & 549 & 542 & 7 & 37 & 72 & 1,239 & 8,448 & 5,395 & 361 & 645 & 56 & 552 & 10 & 29 & 105 & 1,351 \\
\hline der, and group studies ... & 1,914 & 1,071 & 213 & 200 & 115 & 109 & 6 & 26 & 34 & 255 & 1,947 & 1,057 & 181 & 245 & 119 & 104 & 15 & 32 & 60 & 253 \\
\hline Biologic & 11,327 & 6,461 & 691 & 600 & 1,464 & 1,437 & 27 & 46 & 129 & 1,936 & 12,415 & 6,979 & 750 & 665 & 1,634 & 1,605 & 29 & 55 & 185 & 2,147 \\
\hline Business.. & 187,213 & 105,520 & 26,712 & 11,680 & 15,378 & 14,906 & 472 & 921 & 1,618 & 25,384 & 191,571 & 105,268 & 28,086 & 12,865 & 16,196 & 15,667 & 529 & 882 & 2,222 & 26,052 \\
\hline Communication, journalism, and related programs.. & 8,303 & 5,136 & 868 & 577 & 365 & 359 & 6 & 38 & 106 & 1,213 & 9,005 & 5,444 & 982 & 641 & 388 & 374 & 14 & 35 & 166 & 1,349 \\
\hline $\mathrm{mm}$ & 502 & 214 & 46 & 23 & 27 & 27 & 0 & 2 & 0 & 190 & 491 & 211 & 35 & 36 & 19 & 19 & 0 & 5 & 2 & 183 \\
\hline ation sciences .............. & 19,446 & 6,501 & 1,417 & 688 & 1,926 & 1,893 & 33 & 56 & 125 & 8,733 & 20,917 & 6,947 & 1,648 & 857 & 1,834 & 1,814 & 20 & 60 & 209 & 9,362 \\
\hline 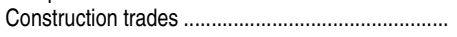 & & & 0 & 0 & 0 & 0 & 0 & 0 & 0 & 0 & & & 0 & 0 & 0 & 0 & 0 & 0 & 0 & 4 \\
\hline 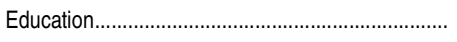 & 185,009 & 139,909 & 19,816 & 12,925 & 5,002 & 4,679 & 323 & 1,088 & 1,507 & 4,762 & 178,062 & 132,477 & 19,486 & 13,442 & 5,094 & 4,722 & 372 & 929 & 2,124 & 4,510 \\
\hline $\begin{array}{l}\text { Engine } \\
\text { Engine }\end{array}$ & 38,719 & 14,807 & 1,139 & 1,547 & 4,102 & 4, & 21 & 73 & 298 & 16,753 & 40,323 & 15,980 & 1,185 & 1,735 & 3,961 & 3,926 & 35 & 82 & 392 & 16,988 \\
\hline & 4,515 & 2,190 & 372 & 220 & 373 & 372 & 1 & 29 & 46 & 1,285 & 4,769 & 2,313 & 372 & 286 & 328 & 318 & 10 & 32 & 51 & 1,387 \\
\hline gglish & 9,476 & 7,529 & 462 & 566 & 347 & 334 & 13 & 69 & 148 & 355 & 9,939 & 7,824 & 598 & 59 & 34 & 329 & 14 & 61 & 185 & 337 \\
\hline Family & 2,918 & 2,056 & 412 & 152 & 77 & 76 & 1 & 17 & 22 & 182 & 3,157 & 2,204 & 440 & 16 & 10 & 101 & 5 & 19 & 38 & 184 \\
\hline Foreign la & 3,727 & 2,114 & 79 & 592 & 166 & 163 & 3 & 21 & 36 & 719 & 3,827 & 2,133 & 101 & 637 & 148 & 137 & 11 & 9 & 59 & 740 \\
\hline Health $p$ & 75,579 & 52,288 & 8,452 & 4,547 & 5,823 & 5,689 & 134 & 481 & 545 & 3,443 & 83,893 & 57,582 & 9,684 & 5,105 & 6,500 & 6,255 & 245 & 464 & 988 & 3,570 \\
\hline Home & & & & & & & & & & & & & & & & & & & & \\
\hline & 7,433 & 4,664 & 1,715 & 640 & 197 & 176 & 21 & 56 & 50 & 111 & 8,402 & 5,184 & 1,853 & 824 & 204 & 185 & 19 & 72 & 106 & 159 \\
\hline Legal $p$ & 6,300 & 2,185 & 386 & 287 & 365 & 361 & 4 & 21 & 42 & 3,014 & 6,614 & 2,081 & 489 & 291 & 217 & 211 & 6 & 35 & 45 & 3,456 \\
\hline bera & & & & & & & & & & & & & & & & & & & & \\
\hline Library & $\begin{array}{l}3,971 \\
7,727\end{array}$ & $\begin{array}{l}2,859 \\
6,474\end{array}$ & $\begin{array}{l}378 \\
381\end{array}$ & $\begin{array}{l}206 \\
372\end{array}$ & $\begin{array}{l}187 \\
284\end{array}$ & $\begin{array}{l}181 \\
280\end{array}$ & $\begin{array}{l}6 \\
4\end{array}$ & $\begin{array}{l}24 \\
45\end{array}$ & $\begin{array}{l}56 \\
48\end{array}$ & $\begin{array}{l}261 \\
123\end{array}$ & $\begin{array}{l}3,791 \\
7,441\end{array}$ & $\begin{array}{l}2,667 \\
6,068\end{array}$ & $\begin{array}{l}412 \\
326\end{array}$ & $\begin{array}{l}237 \\
501\end{array}$ & $\begin{array}{l}151 \\
285\end{array}$ & $\begin{array}{l}150 \\
271\end{array}$ & $\begin{array}{r}1 \\
14\end{array}$ & $\begin{array}{l}28 \\
32\end{array}$ & $\begin{array}{r}81 \\
110\end{array}$ & $\begin{array}{l}215 \\
119\end{array}$ \\
\hline & 5,843 & 2,636 & 171 & 220 & 521 & 517 & 4 & 16 & 37 & 2,242 & 6,245 & 2,757 & 190 & 23 & 50 & 495 & 6 & 11 & 62 & 2,492 \\
\hline & 0 & . & 0 & 0 & 0 & 0 & 0 & 0 & 0 & 0 & 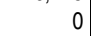 & . & 0 & 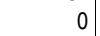 & 0 & 0 & 0 & 0 & 0 & 0 \\
\hline & 0 & 0 & 0 & 0 & 0 & 0 & 0 & 0 & 0 & 0 & 29 & 23 & 1 & 3 & 0 & 0 & 0 & 0 & 1 & 1 \\
\hline & 6,748 & 4,576 & 543 & 495 & 374 & 356 & 18 & 39 & 84 & 637 & 7,745 & 5,305 & 603 & 561 & 407 & 395 & 12 & 42 & 133 & 694 \\
\hline fitness studies .... & 6,553 & 4,882 & 631 & 334 & 174 & 156 & 18 & 38 & 73 & 421 & 7,047 & 5,208 & 749 & 347 & 166 & 151 & 15 & 34 & 116 & 427 \\
\hline $\mathrm{Pl}$ & 1,833 & 1,400 & 121 & 78 & 5 & $\sqrt{4}$ & 2 & 10 & 30 & 138 & 2 , & 1, & 19 & $1 c$ & 91 & 9 & 2 & & 31 & 130 \\
\hline e technologies... & 6,386 & 3,707 & 185 & 268 & 404 & 394 & 10 & 28 & 46 & 1,748 & 6,910 & 4,005 & 230 & 245 & 330 & 325 & 5 & 30 & 90 & 1,980 \\
\hline & & & 0 & 0 & 0 & 0 & 0 & 0 & 0 & 1 & 11 & 10 & 0 & 0 & 1 & 1 & 0 & 0 & 0 & 0 \\
\hline & 25,051 & 17,066 & 3,425 & 2,255 & 979 & 928 & 51 & 151 & 292 & 883 & 26,834 & 18,063 & 3,726 & 2,378 & 1,146 & 1,084 & 62 & 139 & 495 & 887 \\
\hline Public administration and social services......... & 38,634 & 22,912 & 7,344 & 3,696 & 1,654 & 1,561 & 93 & 340 & 618 & 2,070 & 41,680 & 24,700 & 7,986 & 4,183 & 1,743 & 1,657 & 86 & 298 & 797 & 1,973 \\
\hline 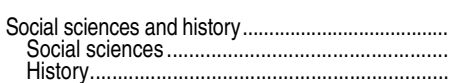 & $\begin{array}{r}21,084 \\
17,081 \\
4,003\end{array}$ & $\begin{array}{r}13,469 \\
10,096 \\
3,373\end{array}$ & $\begin{array}{l}1,404 \\
1,278 \\
126\end{array}$ & $\begin{array}{l}1,362 \\
1,129 \\
233\end{array}$ & $\begin{array}{r}1,020 \\
935 \\
85\end{array}$ & $\begin{array}{r}997 \\
915 \\
82\end{array}$ & $\begin{array}{r}23 \\
20 \\
3\end{array}$ & $\begin{array}{r}108 \\
84 \\
24\end{array}$ & $\begin{array}{r}301 \\
252 \\
49\end{array}$ & $\begin{array}{l}3,420 \\
3,307 \\
113\end{array}$ & $\begin{array}{r}21,889 \\
17,734 \\
4,155\end{array}$ & $\begin{array}{r}13,750 \\
10,311 \\
3,439\end{array}$ & $\begin{array}{l}1,488 \\
1,341 \\
147\end{array}$ & $\begin{array}{l}1,541 \\
1,287 \\
254\end{array}$ & $\begin{array}{r}1,053 \\
973 \\
80\end{array}$ & $\begin{array}{r}1,025 \\
950 \\
75\end{array}$ & $\begin{array}{r}28 \\
23 \\
5\end{array}$ & $\begin{array}{r}105 \\
77 \\
28\end{array}$ & $\begin{array}{r}402 \\
340 \\
62\end{array}$ & $\begin{array}{r}3,550 \\
3,405 \\
145\end{array}$ \\
\hline Theology and religious vocat & 13,191 & 9,088 & 1,817 & 507 & 648 & 618 & 30 & 60 & 83 & 988 & 13,396 & 9,119 & 2,007 & 480 & 635 & 612 & 23 & 41 & 139 & 975 \\
\hline & 1,390 & 1,105 & 92 & 85 & 41 & 39 & 2 & 8 & 18 & 41 & 1,702 & 1,340 & 124 & 114 & 66 & 61 & 5 & 9 & 8 & 41 \\
\hline Visual and $\mathrm{p}$ & 16,277 & 10,897 & 880 & 904 & 879 & 869 & 10 & 62 & 183 & 2,472 & 17,331 & 11,397 & 837 & 1,053 & 911 & 885 & 26 & 58 & 299 & 2,776 \\
\hline Other and not classified...................................... & & & 0 & 0 & 0 & 0 & 0 & 0 & 0 & & & & 0 & & 0 & 0 & 0 & 0 & 0 & 0 \\
\hline
\end{tabular}

"Excludes "Construction trades" and "Mechanic and repair technologies/technicians," which are listed separately.

NOTE: Data are for postsecondary institutions participating in Title IV federal financial aid programs. Race categories exclude persons of Hispanic ethnichy. Reported racial/ethnic distributions of students by level of degree, field of degree, and sex were used to

and natural resources" includes Agriculture, agriculture operations, and related sciences and Natural resources and conservation have been made of the degree fields as reported in the Integrated Postsecondary Education Data System (IPEDS): "Agriculture 


\begin{tabular}{|c|c|c|c|c|c|c|c|c|c|c|c|c|c|c|c|c|c|c|c|c|}
\hline \multirow[b]{3}{*}{ Field of study } & \multicolumn{10}{|c|}{$2010-11$} & \multicolumn{10}{|c|}{ 2011-12 } \\
\hline & \multirow[b]{2}{*}{ Total } & \multirow[b]{2}{*}{ White } & \multirow[b]{2}{*}{ Black } & \multirow[b]{2}{*}{ Hispanic } & \multicolumn{3}{|c|}{ Asian/Pacific Islander } & \multirow{2}{*}{\begin{tabular}{|r|} 
American \\
Indian/ \\
Alaska \\
Native \\
\end{tabular}} & \multirow{2}{*}{$\begin{array}{r}\text { Two or } \\
\text { more } \\
\text { races }\end{array}$} & \multirow{2}{*}{$\begin{array}{r}\text { Non- } \\
\text { resident } \\
\text { alien } \\
\end{array}$} & \multirow[b]{2}{*}{ Total } & \multirow[b]{2}{*}{ White } & \multirow[b]{2}{*}{ Black } & \multirow[b]{2}{*}{ Hispanic } & \multicolumn{3}{|c|}{ Asian/Pacific Islander } & \multirow{2}{*}{\begin{tabular}{|r|} 
American \\
Indian/ \\
Alaska \\
Native \\
\end{tabular}} & \multirow[b]{2}{*}{$\begin{array}{r}\text { Two or } \\
\text { more } \\
\text { races }\end{array}$} & \\
\hline & & & & & Total & Asian & $\begin{array}{r}\text { Pacific } \\
\text { Islander }\end{array}$ & & & & & & & & Total & Asian & $\begin{array}{r}\text { Pacific } \\
\text { Islander }\end{array}$ & & & $\begin{array}{c}\text { resident } \\
\text { alien }\end{array}$ \\
\hline 1 & 2 & 3 & 4 & 5 & 6 & 7 & 8 & 9 & 10 & 11 & 12 & 13 & 14 & 15 & 16 & 17 & 18 & 19 & 20 & 21 \\
\hline All fields, total. & 291,551 & 177,780 & 23,741 & 17,213 & 20,050 & 9,508 & 542 & 1,409 & 2,594 & 48,764 & 302,191 & 182,960 & 5,143 & 18,849 & 20,774 & 20,157 & 617 & 1,297 & 3,512 & 49,656 \\
\hline Agriculture and $n$ & 2,750 & 1,994 & 95 & 103 & $\begin{array}{l}90 \\
90\end{array}$ & 88 & 2 & 14 & 20 & 434 & 3,026 & 2,248 & 80 & 122 & 103 & 97 & 6 & 18 & 41 & 414 \\
\hline ed services & 4,265 & 2,926 & 182 & 284 & 230 & 226 & 4 & 16 & 38 & 589 & 4,504 & 3,054 & 195 & 344 & 225 & 221 & 4 & 15 & 63 & 608 \\
\hline group studies ... & 723 & 420 & 58 & 76 & 52 & 50 & 2 & 9 & 12 & 96 & 717 & 419 & 47 & 90 & 41 & 37 & 4 & 11 & 17 & 92 \\
\hline iologic & 4,871 & 2,832 & 238 & 241 & 670 & 658 & 12 & 20 & 61 & 809 & 5,378 & 3,128 & 234 & 271 & 707 & 697 & 10 & 18 & 74 & 946 \\
\hline Business.... & 101,450 & 61,000 & 9,767 & 6,082 & 8,676 & 8,432 & 244 & 445 & 888 & 14,592 & 103,253 & 61,327 & 10,286 & 6,667 & 9,140 & 8,867 & 273 & 427 & 1,109 & 14,297 \\
\hline Communication, journalism, and related programs. & 2,520 & 1,684 & 206 & 163 & 109 & 106 & 3 & 18 & 33 & 307 & 2,760 & 1,843 & 233 & 193 & 93 & 90 & 3 & 13 & 41 & 344 \\
\hline $\mathrm{mm}$ & 300 & 139 & 24 & 11 & 13 & 13 & 0 & 0 & 0 & 113 & 305 & 143 & 18 & 23 & 10 & 10 & 0 & 4 & 1 & 106 \\
\hline sciences...... & 13,956 & 5,042 & 856 & 499 & 1,281 & 1,256 & 25 & 43 & 82 & 6,153 & 15,129 & 5,495 & 972 & 637 & 1,247 & 1,235 & 12 & 39 & 154 & 6,585 \\
\hline onstru & & & 0 & 0 & 0 & 0 & 0 & 0 & 0 & 0 & & 1 & 0 & 0 & 0 & 0 & 0 & 0 & 0 & \\
\hline Education...... & 42,022 & 31,972 & 4,178 & 2,924 & 1,125 & 1,043 & 82 & 253 & 345 & 1,225 & 41,180 & 31,141 & 4,096 & 2,991 & 1,128 & 1,046 & 82 & 220 & 482 & 1,122 \\
\hline ngin & 30,090 & 12,024 & 804 & 1,178 & 2,92 & 2,905 & 18 & 59 & 239 & 12,863 & 31,190 & 13,007 & 842 & 1,290 & 2,915 & 2,889 & 26 & 58 & 268 & 12,810 \\
\hline & 3,328 & 1,689 & 231 & 168 & 250 & 249 & 1 & 25 & 36 & 929 & 3,504 & 1,819 & 224 & 202 & 228 & 219 & 9 & 20 & 32 & 979 \\
\hline nglish : & 3,137 & 2,598 & 97 & 184 & 87 & 85 & 2 & 30 & 47 & 94 & 3,403 & 2,777 & 141 & 225 & 81 & 74 & 7 & 23 & 55 & 101 \\
\hline Family & 395 & 263 & 44 & 21 & 16 & 16 & 0 & 4 & 1 & 46 & 413 & 282 & 47 & 29 & 14 & 13 & 1 & 3 & 4 & 34 \\
\hline Foreign languages, literatures, and linguistics... & 1,256 & 762 & 24 & 185 & 43 & 42 & 1 & 11 & 11 & 220 & 1,280 & 762 & 39 & 189 & 40 & 33 & 7 & 3 & 23 & 224 \\
\hline Tealth professions and related programs.. & 14,041 & 8,855 & 1,287 & 931 & 1,472 & 1,455 & 17 & 100 & 119 & 1,277 & 15,625 & 9,904 & 1,526 & 1,006 & 1,646 & 1,593 & 53 & 78 & 203 & 1,262 \\
\hline omel & & & & & & & & & & & & & & & & & & & & \\
\hline & 3,416 & 2,370 & 588 & 273 & 80 & 72 & 8 & 25 & 21 & 59 & 3,947 & 2,697 & 637 & 389 & 78 & 70 & 8 & 38 & 36 & 72 \\
\hline Legal profe & 3,054 & 1,116 & 141 & 126 & 192 & 189 & 3 & 7 & 13 & 1,459 & 3,209 & 1,044 & 165 & 126 & 134 & 131 & 3 & 15 & 13 & 1,712 \\
\hline $\begin{array}{l}\text { Liberal arts } \\
\text { and hum }\end{array}$ & 1.619 & 1.165 & 115 & 84 & 97 & 96 & 1 & 14 & 18 & 126 & 1,490 & 1.066 & 131 & 95 & 76 & 76 & 0 & 13 & 25 & 84 \\
\hline 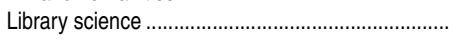 & 1,483 & 1,257 & 61 & 63 & 47 & 47 & 0 & 8 & 9 & 38 & 1,425 & 1,160 & 43 & 106 & 60 & 58 & 2 & 5 & 25 & 26 \\
\hline Mathematics and statistics ......... & 3,453 & 1,642 & 96 & 146 & 300 & 298 & 2 & 8 & 23 & 1,238 & 3,694 & 1,727 & 111 & 148 & 268 & 264 & 4 & 9 & 40 & 1,391 \\
\hline Mech & 0 & & 0 & 0 & 0 & 0 & 0 & 0 & 0 & 0 & 0 & 0 & 0 & 0 & 0 & 0 & 0 & 0 & 0 & 0 \\
\hline & 0 & & 0 & 0 & 0 & 0 & 0 & 0 & 0 & 0 & 21 & 17 & 1 & 2 & 0 & 0 & 0 & 0 & 0 & 1 \\
\hline & 2,561 & 1,712 & 186 & 189 & 136 & 129 & 7 & 14 & 29 & 295 & 2,988 & 2,039 & 210 & 209 & 156 & 148 & 8 & 18 & 40 & 316 \\
\hline Parks, recreation, leisure, and fitness studies ... & 3,585 & 2,686 & 348 & 185 & 93 & 81 & 12 & 23 & 39 & 211 & 3,938 & 2,947 & 417 & 198 & 78 & 74 & 4 & 18 & 64 & 216 \\
\hline . & 16 & 9 & 55 & 5 & 28 & 26 & 2 & 4 & 19 & 9 & 1,2 & 945 & 91 & 5 & $\mathrm{~J}$ & 53 & 1 & 6 & 18 & 81 \\
\hline . & 3,907 & 2,292 & 96 & 166 & 224 & 220 & 4 & 21 & 26 & 1,082 & 4,299 & 2,520 & 124 & 144 & 194 & 192 & 2 & 16 & 47 & 1,254 \\
\hline & 3 & 3 & 0 & 0 & 0 & 0 & 0 & 0 & 0 & 0 & 9 & 9 & 0 & 0 & 0 & 0 & 0 & 0 & 0 & 0 \\
\hline (1) & 5,118 & 3,601 & 545 & 469 & 214 & 204 & 10 & 36 & 56 & 197 & 5,435 & 3,792 & 624 & 434 & 277 & 260 & 17 & 25 & 93 & 190 \\
\hline Public administration and social services ................ & 9,793 & 5,826 & 1,514 & 889 & 418 & 381 & 37 & 76 & 134 & 936 & 10,475 & 6,279 & 1,587 & 1,011 & 464 & 444 & 20 & 78 & 164 & 892 \\
\hline 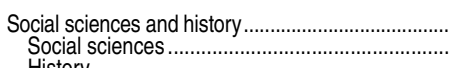 & $\begin{array}{r}10,578 \\
8,351\end{array}$ & $\begin{array}{l}7,115 \\
5,209\end{array}$ & $\begin{array}{l}550 \\
489\end{array}$ & $\begin{array}{r}657 \\
532 \\
125\end{array}$ & $\begin{array}{r}406 \\
373 \\
23\end{array}$ & $\begin{array}{r}394 \\
362 \\
32\end{array}$ & $\begin{array}{l}12 \\
11\end{array}$ & $\begin{array}{l}53 \\
37 \\
16\end{array}$ & $\begin{array}{l}140 \\
116\end{array}$ & $\begin{array}{l}1,657 \\
1,595\end{array}$ & $\begin{array}{r}10,983 \\
8,741\end{array}$ & $\begin{array}{l}7,219 \\
5,325 \\
1,894\end{array}$ & $\begin{array}{l}549 \\
495\end{array}$ & $\begin{array}{l}727 \\
586\end{array}$ & $\begin{array}{l}476 \\
442\end{array}$ & $\begin{array}{l}466 \\
433 \\
32\end{array}$ & $\begin{array}{r}10 \\
9 \\
1\end{array}$ & $\begin{array}{l}47 \\
36 \\
11\end{array}$ & $\begin{array}{l}183 \\
142\end{array}$ & $\begin{array}{l}1,782 \\
1,715\end{array}$ \\
\hline & 2,227 & 1,906 & & 125 & 33 & 32 & 1 & 16 & 24 & 62 & 2,242 & 1,894 & 54 & 141 & & 33 & 1 & 11 & 41 & 67 \\
\hline Theolog & 8,668 & 6,174 & 907 & 339 & 449 & 424 & 25 & 40 & 42 & 717 & 8,582 & 6,013 & 1,013 & 309 & 456 & 438 & 18 & 26 & 69 & 696 \\
\hline Irans & 1,161 & 924 & 76 & 73 & 30 & 29 & 1 & 5 & 16 & 37 & 1,441 & 1,139 & 97 & 109 & 54 & 49 & 5 & 7 & 7 & 28 \\
\hline Visual and performing arts .. & 6,882 & 4,781 & 372 & 451 & 299 & 294 & 5 & 28 & 77 & 874 & 7,331 & 4,997 & 363 & 505 & 331 & 313 & 18 & 26 & 121 & 988 \\
\hline Other and not classified.......................................... & & & 0 & 0 & 0 & 0 & 0 & 0 & 0 & 0 & & & 0 & 0 & 0 & 0 & 0 & 0 & 0 & \\
\hline
\end{tabular}

"Excludes "Construction trades" and "Mechanic and repair technologies/technicians," which are listed separately.

NOTE: Data are for postsecondary institutions participating in Titte IV federal financial aid programs. Race categories exclude persons of Hispanic eithicity. Reported racial/ethnic distributilins of students by level of degree, field of degree, and sex were used to have been made of the degree fields as reported in the Integrated Postsecondary Education Data System (IPEDS): "Agriculture and natural resources" includes Agriculture, agriculture operations, and related sciences and Natural resources and conservation and "Business" includes Business management, marketing, and related support services and Personal and culinary services.

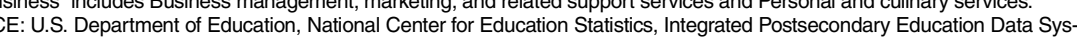
tem (IPEDS), Fall 2011 and Fall 2012, Completions component. (This table was prepared July 2013.) 
Table 323.50. Master's degrees conferred to females by postsecondary institutions, by race/ethnicity and field of study: 2010-11 and 2011-12

\begin{tabular}{|c|c|c|c|c|c|c|c|c|c|c|c|c|c|c|c|c|c|c|c|c|}
\hline \multirow[b]{3}{*}{ Field of study } & \multicolumn{10}{|c|}{$2010-11$} & \multicolumn{10}{|c|}{ 2011-12 } \\
\hline & \multirow[b]{2}{*}{ Total } & \multirow[b]{2}{*}{ White } & \multirow[b]{2}{*}{ Black } & \multirow[b]{2}{*}{ Hispanic } & \multicolumn{3}{|c|}{ Asian/Pacific Islander } & \multirow{2}{*}{\begin{tabular}{|r|} 
American \\
Indian/ \\
Alaska \\
Native
\end{tabular}} & \multirow{2}{*}{$\begin{array}{r}\text { Two or } \\
\text { more } \\
\text { races }\end{array}$} & \multirow{2}{*}{$\begin{array}{l}\text { Non- } \\
\text { resident } \\
\text { alien }\end{array}$} & \multirow[b]{2}{*}{ Total } & \multirow[b]{2}{*}{ White } & \multirow[b]{2}{*}{ Black } & \multirow[b]{2}{*}{ Hispanic } & \multicolumn{3}{|c|}{ Asian/Pacific Islander } & \multirow{2}{*}{$\begin{array}{r}\text { American } \\
\text { Indian/ } \\
\text { Alaska } \\
\text { Native }\end{array}$} & \multirow{2}{*}{$\begin{array}{r}\text { Two or } \\
\text { more } \\
\text { races }\end{array}$} & \\
\hline & & & & & Total & Asian & $\begin{array}{r}\text { Pacific } \\
\text { Islander }\end{array}$ & & & & & & & & Total & Asian & $\begin{array}{r}\text { Pacific } \\
\text { Islander }\end{array}$ & & & $\begin{array}{r}\text { resident } \\
\text { alien }\end{array}$ \\
\hline 1 & 2 & 3 & 4 & 5 & 6 & 7 & 8 & 9 & 10 & 11 & 12 & 13 & 14 & 15 & 16 & 17 & 18 & 19 & 20 & 21 \\
\hline All fields, total ............................... & 439,084 & 285,123 & 56,965 & 29,574 & 23,678 & 22,873 & 805 & 2,539 & 4,106 & 37,099 & 452,038 & 286,679 & 60,172 & 32,415 & 24,626 & 23,616 & 1,010 & 2,377 & 6,268 & 39,501 \\
\hline ural resources.... & 3,023 & 2,172 & 123 & 119 & 143 & 141 & 2 & 24 & 33 & 409 & 3,364 & 2,451 & 114 & 133 & 158 & 156 & 2 & 19 & 38 & 451 \\
\hline Architectur & 3,523 & 2,091 & 154 & 254 & 3 & 316 & 3 & 21 & 34 & 650 & 3,944 & 2,341 & 166 & 301 & 33 & 331 & 6 & 14 & 42 & 743 \\
\hline ural, gender, and group studies ... & 1,191 & 651 & 155 & 124 & 63 & 59 & 4 & 17 & 22 & 159 & 1,230 & 638 & 134 & 155 & 78 & 67 & 11 & 21 & 43 & 161 \\
\hline Biologic & 6,456 & 3,629 & 453 & 359 & 794 & 779 & 15 & 26 & 68 & 1,127 & 7,037 & 3,851 & 516 & 394 & 927 & 908 & 19 & 37 & 111 & 1,201 \\
\hline Business. & 85,763 & 44,520 & 16,945 & 5,598 & 6,702 & 6,474 & 228 & 476 & 730 & 10,792 & 88,318 & 43,941 & 17,800 & 6,198 & 7,056 & 6,800 & 256 & 455 & 1,113 & 11,755 \\
\hline Communication, journalism, and related programs.. & 5,783 & 3,452 & 662 & 414 & 256 & 253 & 3 & 20 & 73 & 906 & 6,245 & 3,601 & 749 & 448 & 295 & 284 & 11 & 22 & 125 & 1,005 \\
\hline Comm & 202 & 75 & 22 & 12 & 14 & 14 & 0 & 2 & 0 & 77 & 186 & 68 & 17 & 13 & 9 & 9 & 0 & 1 & 1 & 77 \\
\hline iation sciences ............. & 5,490 & 1,459 & 561 & 189 & 645 & 637 & 8 & 13 & 43 & 2,580 & 5,788 & 1,452 & 676 & 220 & 587 & 579 & 8 & 21 & 55 & 2,777 \\
\hline 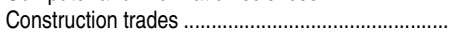 & & 0 & 0 & 0 & 0 & 0 & 0 & 0 & 0 & 0 & & & 0 & 0 & 0 & 0 & 0 & 0 & 0 & 1 \\
\hline 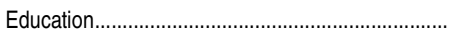 & 142,987 & 107,937 & 15,638 & 10,001 & 3,877 & 3,636 & 241 & 835 & 1,162 & 3,537 & 136,882 & 101,336 & 15,390 & 10,451 & 3,966 & 3,676 & 290 & 709 & 1,642 & 3,388 \\
\hline $\begin{array}{l}\text { Engine } \\
\text { Engine }\end{array}$ & 8,629 & 2,783 & 335 & 369 & 1,179 & 1,176 & 3 & 14 & 59 & 3,890 & 9,133 & 2,973 & 343 & 445 & 1,046 & 1,037 & 9 & 24 & 124 & 4,178 \\
\hline & 1,187 & 501 & 141 & 52 & 123 & 123 & 0 & 4 & 10 & 356 & 1,265 & 494 & 148 & 84 & 100 & 99 & 1 & 12 & 19 & 408 \\
\hline English & 6,339 & 4,931 & 365 & 382 & 260 & 249 & 11 & 39 & 101 & 261 & 6,536 & 5,047 & 457 & 366 & 262 & 255 & 7 & 38 & 130 & 236 \\
\hline Family & 2,523 & 1,793 & 368 & 131 & 61 & 60 & 1 & 13 & 21 & 136 & 2,744 & 1,922 & 393 & 137 & 92 & 88 & 4 & 16 & 34 & 150 \\
\hline Foreign lang & 2,471 & 1,352 & 55 & 407 & 123 & 121 & 2 & 10 & 25 & 499 & 2,547 & 1,371 & 62 & 448 & 108 & 104 & 4 & 6 & 36 & 516 \\
\hline Health pr & 61,538 & 43,433 & 7,165 & 3,616 & 4,351 & 4,234 & 117 & 381 & 426 & 2,166 & 68,268 & 47,678 & 8,158 & 4,099 & 4,854 & 4,662 & 192 & 386 & 785 & 2,308 \\
\hline Homela & & & & & & & & & & & & & & & & & & & & \\
\hline firefigl & $\begin{array}{l}4,017 \\
3246\end{array}$ & 2,294 & $\begin{array}{r}1,127 \\
245\end{array}$ & $\begin{array}{l}367 \\
161\end{array}$ & $\begin{array}{l}117 \\
173\end{array}$ & 104 & $\begin{array}{r}13 \\
1\end{array}$ & 31 & 29 & $\begin{array}{r}52 \\
1555\end{array}$ & 4,455 & 2,487 & $\begin{array}{l}1,216 \\
-224\end{array}$ & $\begin{array}{r}435 \\
165\end{array}$ & $\begin{array}{r}126 \\
83\end{array}$ & $\begin{array}{r}115 \\
80\end{array}$ & $\begin{array}{r}11 \\
3\end{array}$ & 34 & $\begin{array}{r}70 \\
70\end{array}$ & $\begin{array}{r}87 \\
1744\end{array}$ \\
\hline $\begin{array}{l}\text { Legal pr } \\
\text { Liberal a }\end{array}$ & 3,246 & 1,069 & 245 & 161 & 173 & 172 & 1 & 14 & 29 & 1,555 & 3,405 & 1,037 & 324 & 165 & 83 & 80 & 3 & 20 & 32 & 1,744 \\
\hline & 2,352 & 1,694 & 263 & 122 & 90 & 85 & 5 & 10 & 38 & 135 & 2,301 & 1,601 & 281 & 142 & 75 & 74 & 1 & 15 & 56 & 131 \\
\hline Library scienc & 6,244 & 5,217 & 320 & 309 & 237 & 233 & 4 & 37 & 39 & 85 & 6,016 & 4,908 & 283 & 395 & 225 & 213 & 12 & 27 & 85 & 93 \\
\hline Mathematics and statistics. & 2,390 & 994 & 75 & 74 & 221 & 219 & 2 & 8 & 14 & 1,004 & 2,551 & 1,030 & 79 & 84 & 233 & 231 & 2 & 2 & 22 & 1,101 \\
\hline Mecha & 0 & 0 & 0 & 0 & 0 & 0 & 0 & 0 & 0 & 0 & 0 & 0 & 0 & 0 & 0 & 0 & 0 & 0 & 0 & 0 \\
\hline & 0 & 0 & 0 & 0 & 0 & 0 & 0 & 0 & 0 & 0 & 8 & 6 & 0 & 1 & 0 & 0 & 0 & 0 & 1 & 0 \\
\hline IVIult & 4,187 & 2,864 & 357 & 306 & 238 & 227 & 11 & 25 & 55 & 342 & 4,757 & 3,266 & 393 & 352 & 251 & 247 & 4 & 24 & 93 & 378 \\
\hline d fitness studies ...... & 2,968 & 2,196 & 283 & 149 & 81 & 75 & 6 & 15 & 34 & 210 & 3,109 & 2,261 & 332 & 149 & 88 & 77 & 11 & 16 & 52 & 211 \\
\hline & 6 & 484 & 66 & 26 & 2 & 26 & 0 & 6 & 11 & 48 & 750 & 56 & 100 & 45 & 37 & 6 & 1 & 3 & 13 & 49 \\
\hline ce technologies.... & 2,479 & 1,415 & 89 & 102 & 180 & 174 & 6 & 7 & 20 & 666 & 2,611 & 1,485 & 106 & 101 & 136 & 133 & 3 & 14 & 43 & 726 \\
\hline in & & & 0 & 0 & 0 & 0 & 0 & 0 & 0 & 1 & & & 0 & 0 & 1 & 1 & 0 & 0 & 0 & 0 \\
\hline (n) & 19,933 & 13,465 & 2,880 & 1,786 & 765 & 724 & 41 & 115 & 236 & 686 & 21,399 & 14,271 & 3,102 & 1,944 & 869 & 824 & 45 & 114 & 402 & 697 \\
\hline Public administration and social services .......... & 28,841 & 17,086 & 5,830 & 2,807 & 1,236 & 1,180 & 56 & 264 & 484 & 1,134 & 31,205 & 18,421 & 6,399 & 3,172 & 1,279 & 1,213 & 66 & 220 & 633 & 1,081 \\
\hline 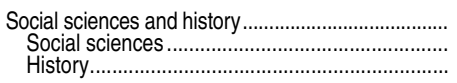 & $\begin{array}{r}10,506 \\
8,730 \\
1,776\end{array}$ & $\begin{array}{l}6,354 \\
4,887 \\
1,467\end{array}$ & $\begin{array}{r}854 \\
789 \\
65\end{array}$ & $\begin{array}{l}705 \\
597 \\
108\end{array}$ & $\begin{array}{r}614 \\
562 \\
52\end{array}$ & $\begin{array}{r}603 \\
553 \\
50\end{array}$ & $\begin{array}{r}11 \\
9 \\
2\end{array}$ & $\begin{array}{r}55 \\
47 \\
8\end{array}$ & $\begin{array}{r}161 \\
136 \\
25\end{array}$ & $\begin{array}{r}1,763 \\
1,712 \\
51\end{array}$ & $\begin{array}{r}10,906 \\
8,993 \\
1,913\end{array}$ & $\begin{array}{l}6,531 \\
4,986 \\
1,545\end{array}$ & $\begin{array}{r}939 \\
846 \\
93\end{array}$ & $\begin{array}{l}814 \\
701 \\
113\end{array}$ & $\begin{array}{r}577 \\
531 \\
46\end{array}$ & $\begin{array}{r}559 \\
517 \\
42\end{array}$ & $\begin{array}{r}18 \\
14 \\
4\end{array}$ & $\begin{array}{l}58 \\
41 \\
17\end{array}$ & $\begin{array}{r}219 \\
198 \\
21\end{array}$ & $\begin{array}{l}1,768 \\
1,690 \\
78\end{array}$ \\
\hline Theology and religious vocati & 4,523 & 2,914 & 910 & 168 & 199 & 194 & 5 & 20 & 41 & 271 & 4,814 & 3,106 & 994 & 171 & 179 & 174 & 5 & 15 & 70 & 279 \\
\hline & 229 & 181 & 16 & 12 & 11 & 10 & 1 & 3 & 2 & 4 & 261 & 201 & 27 & 5 & 12 & 12 & 0 & 2 & 1 & 13 \\
\hline 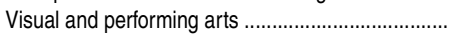 & 9,395 & 6,116 & 508 & 453 & 580 & 575 & 5 & 34 & 106 & 1,598 & 10,000 & 6,400 & 474 & 548 & 580 & 572 & 8 & 32 & 178 & 1,788 \\
\hline Other and not classified...................................... & & & 0 & 0 & 0 & 0 & 0 & 0 & 0 & & & & 0 & 0 & 0 & 0 & 0 & 0 & 0 & 0 \\
\hline
\end{tabular}

'Excludes "Construction trades" and "Mechanic and repair technologies/technicians," which are listed separately.

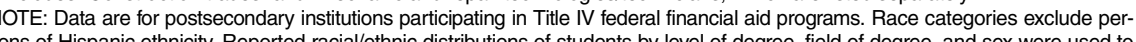
sonstimate race/ethnicity for students whose race/ethnicity was not reported. To facilitate trend comparisons, certain were used to

and natural resources" includes Agriculture, agriculture operations, and related sciences and Natural resources and conservation estimate race/ethnicity for students whose race/ethnicity was not reported. To facilitate trend comparisons, certain aggregations 
Table 324.10. Doctor's degrees conferred by postsecondary institutions, by field of study: Selected years, 1970-71 through 2011-12

\begin{tabular}{|c|c|c|c|c|c|c|c|c|c|c|c|c|c|c|c|c|c|c|}
\hline Field of study & $1970-71$ & $1975-76$ & $1980-81$ & $1985-86$ & $1990-91$ & $1995-96$ & $2000-01$ & 2001-02 & $2002-03$ & $2003-04$ & $2004-05$ & $2005-06$ & $2006-07$ & $2007-08$ & $2008-09$ & $2009-10$ & $2010-11$ & $2011-12$ \\
\hline 1 & 2 & 3 & 4 & 5 & 6 & 7 & 8 & 9 & 10 & 11 & 12 & 13 & 14 & 15 & 16 & 17 & 18 & 19 \\
\hline Total ... & 64,998 & 91,007 & 98,016 & 100,280 & 105,547 & 115,507 & 119,585 & 119,663 & 121,579 & 126,087 & 134,387 & 138,056 & 144,690 & 149,378 & 154,425 & 158,558 & 163,765 & 170,062 \\
\hline Agriculture and natural resources .............................. & 1,086 & 928 & 1,067 & 1,158 & 1,185 & 1,259 & 1,127 & 1,148 & 1,229 & 1,185 & 1,173 & 1,194 & 1,272 & 1,257 & 1,328 & 1,147 & 1,246 & 1,333 \\
\hline rchitecture and related services............................ & 36 & 82 & 93 & 73 & 135 & 141 & 153 & 183 & 152 & 173 & 179 & 201 & 178 & 199 & 212 & 210 & 205 & 255 \\
\hline Area, ethnic, cultural, gender, and group studies........ & 143 & 186 & 161 & 156 & 159 & 183 & 216 & 212 & 186 & 209 & 189 & 226 & 233 & 270 & 239 & 253 & 278 & 302 \\
\hline ………………..... & 3,603 & 3,347 & 3,640 & 3,405 & 4,152 & 5,250 & 5,225 & 5,104 & 5,268 & 5,538 & 5,935 & 6,162 & 6,764 & 7,400 & 7,499 & 7,666 & 7,693 & 7,935 \\
\hline Business & 774 & 906 & 808 & 923 & 1,185 & 1,366 & 1,180 & 1,156 & 1,252 & 1,481 & 1,498 & 1,711 & 2,029 & 2,084 & 2,123 & 2,245 & 2,286 & 2,531 \\
\hline ommunication, journalism, and related programs.... & 145 & 196 & 171 & 212 & 259 & 338 & 368 & 374 & 394 & 418 & 465 & 461 & 479 & 489 & 533 & 570 & 577 & 563 \\
\hline ommunic & 0 & 8 & 11 & 6 & 13 & 7 & 2 & 9 & 4 & 8 & 3 & 3 & 1 & 7 & 2 & 3 & 1 & 4 \\
\hline Computer & 128 & 244 & 252 & 344 & 676 & 869 & 768 & 752 & 816 & 909 & 1,119 & 1,416 & 1,595 & 1,698 & 1,580 & 1,599 & 1,588 & 1,698 \\
\hline ........ & 6,041 & 7,202 & 7,279 & 6,610 & 6,189 & 6,246 & 6,284 & 6,549 & 6,832 & 7,088 & 7,681 & 7,584 & 8,261 & 8,491 & 9,028 & 9,233 & ,623 & 9,990 \\
\hline Engineering & 3,687 & 2,872 & 2,598 & 3,444 & 5,316 & 6,304 & 5,485 & 5,123 & 5,195 & 5,801 & 6,413 & 7,243 & 7,867 & 7,922 & 7,742 & 7,704 & 8,369 & 8,722 \\
\hline echnologies & 1 & 2 & 10 & 12 & 14 & 50 & 62 & 58 & 57 & 58 & 54 & 75 & 61 & 55 & 59 & 67 & 56 & 134 \\
\hline rature/letters..... & 1,554 & 1,514 & 1,040 & 895 & 1,056 & 1,395 & 1,330 & 1,291 & 1,246 & 1,207 & 1,212 & 1,254 & 1,178 & 1,262 & 1,271 & 1,332 & 1,344 & 1,427 \\
\hline Family a & 123 & 178 & 247 & 307 & 229 & 375 & 354 & 311 & 376 & 329 & 331 & 340 & 337 & 323 & 333 & 296 & 320 & 325 \\
\hline Fore & 1,084 & 1,245 & 931 & 768 & 889 & 1,020 & 1,078 & 1,003 & 1,042 & 1,031 & 1,027 & 1,074 & 1,059 & 1,078 & 1,111 & 1,091 & 1,158 & 1,231 \\
\hline Health professions and related $p$ & 15,988 & 25,267 & 29,595 & 31,922 & 29,842 & 32,678 & 39,019 & 39,435 & 39,799 & 41,861 & 44,201 & 45,677 & 48,943 & 51,675 & 54,709 & 57,746 & 60,153 & 62,090 \\
\hline Homeland security, law enforcement, and firefighting. & & 9 & 21 & 21 & 28 & 38 & 44 & 49 & 72 & 54 & 94 & 80 & 85 & 88 & 97 & 106 & 131 & 117 \\
\hline s.................................... & 17,441 & 32,369 & 36,391 & 35,898 & 38,035 & 39,919 & 38,190 & 39,060 & 39,172 & 40,328 & 43,521 & 43,569 & 43,629 & 43,880 & 44,304 & 44,626 & 44,877 & 46,836 \\
\hline $\begin{array}{l}\text { Liberal art } \\
\text { and } \mathrm{h}\end{array}$ & 32 & 162 & 121 & 90 & 70 & 75 & 102 & 113 & 78 & 95 & 109 & 84 & 77 & 76 & 67 & 96 & 95 & 93 \\
\hline brary science .......................... & 39 & 71 & 71 & 62 & 56 & 53 & 58 & 45 & 62 & 47 & 42 & 44 & 52 & 64 & 35 & 64 & 50 & 60 \\
\hline Mathematics & 1,199 & 856 & 728 & 742 & 978 & 1,158 & 997 & 923 & 1,007 & 1,060 & 1,176 & 1,293 & 1,351 & 1,360 & 1,535 & 1,592 & 1,586 & 1,669 \\
\hline & 101 & 156 & 236 & 352 & 306 & 549 & 512 & 484 & 634 & 580 & 626 & 600 & 683 & 660 & 731 & 631 & 660 & 727 \\
\hline ation, leisure, and fitness studies............. & 2 & 15 & 42 & 39 & 28 & 104 & 177 & 151 & 199 & 222 & 207 & 194 & 218 & 228 & 285 & 266 & 257 & 288 \\
\hline Philosophy and religious studies.... & 555 & 556 & 411 & 480 & 464 & 550 & 600 & 610 & 662 & 595 & 586 & 578 & 637 & 635 & 686 & 667 & 805 & 778 \\
\hline & 4,324 & 3,388 & 3,105 & 3,521 & 4,248 & 4,589 & 3,968 & 3,824 & 3,939 & 3,937 & 4,248 & 4,642 & 5,041 & 4,994 & 5,237 & 5,063 &, 295 & 5,370 \\
\hline Psychold & 2,144 & 3,157 & 3,576 & 3,593 & 3,932 & 4,141 & 5,091 & 4,759 & 4,835 & 4,827 & 5,106 & 4,921 & 5,153 & 5,296 & 5,477 & 5,540 & 5,851 & 5,928 \\
\hline Public & 174 & 292 & 362 & 382 & 430 & 499 & 574 & 571 & 599 & 649 & 673 & 704 & 726 & 760 & 812 & 838 & 851 & 884 \\
\hline Social sciences and history................................ & 3,660 & 4,157 & 3,122 & 2,955 & 3,012 & 3,760 & 3,930 & 3,902 & 3,850 & 3,811 & 3,819 & 3,914 & 3,844 & 4,059 & 4,234 & 4,238 & 4,390 & 4,597 \\
\hline Theology and religious voca & 312 & 1,022 & 1,273 & 1,185 & 1,076 & 1,517 & 1,461 & 1,350 & 1,329 & 1,304 & 1,422 & 1,429 & 1,573 & 1,615 & 1,587 & 2,070 & 2,374 & 2,447 \\
\hline & 0 & 0 & 0 & 3 & 0 & 0 & 0 & 0 & 0 & 0 & 0 & ( & 0 & 0 & 0 & 0 & 0 & 0 \\
\hline & 621 & 620 & 654 & 722 & 838 & 1,067 & 1,167 & 1,114 & 1,293 & 1,282 & 1,278 & 1,383 & 1,364 & 1,453 & 1,569 & 1,599 & 1,646 & 1,728 \\
\hline 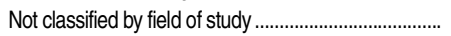 & 0 & 0 & 0 & 0 & 747 & 7 & 63 & 0 & 0 & 0 & 0 & 0 & 0 & 0 & . & 0 & 0 & 0 \\
\hline
\end{tabular}

NOTE: Data through 1990-91 are for institutions of higher education, while later data are for postsecondary institutions that participate in Title IV federal financial aid programs. The new Classification of Instructional Programs was initiated in law degrees that were formerly classified as first-professional degrees. The figures for earlier years have been reclassified when necessary to make them conform to the new taxonomy. To facilitate trend comparisons, certain aggregations have been made of the degree fields as reported in the Integrated Postsecondary Education Data System (IPEDS): "Agriculture and nat-

"Business" includes Business, management, marketing, and related support services and Personal and culinary services;

SOURCE: U.S. Department of Education, National Center for Education Statistics, Higher Education General Information ary Education Data System (IPEDS), "Completions Survey” (IPEDS-C:91-99); and IPEDS Fall 2000 through Fall 2012, Comural resources" includes Agriculture, agriculture operations, and related sciences and Natural resources and conservation; 
Table 324.20. Doctor's degrees conferred by postsecondary institutions, by race/ethnicity and sex of student: Selected years, 1976-77 through 2011-12

\begin{tabular}{|c|c|c|c|c|c|c|c|c|c|c|c|c|c|c|c|}
\hline \multirow[b]{2}{*}{ Year and sex } & \multicolumn{8}{|c|}{ Number of degrees conferred to U.S. citizens and nonresident aliens } & \multicolumn{7}{|c|}{ Percentage distribution of degrees conferred' to U.S. citizens } \\
\hline & Total & White & Black & Hispanic & $\begin{array}{r}\text { Asian/ } \\
\text { Pacific } \\
\text { Islander }\end{array}$ & $\begin{array}{r}\text { American } \\
\text { Indian/ } \\
\text { Alaska } \\
\text { Native }\end{array}$ & $\begin{array}{r}\text { Two or } \\
\text { more } \\
\text { races }\end{array}$ & $\begin{array}{r}\text { Non- } \\
\text { resident } \\
\text { alien }\end{array}$ & Total & White & Black & Hispanic & $\begin{array}{r}\text { Asian/ } \\
\text { Pacific } \\
\text { Islander }\end{array}$ & $\begin{array}{r}\text { American } \\
\text { Indian/ } \\
\text { Alaska } \\
\text { Native }\end{array}$ & $\begin{array}{l}\text { Two or } \\
\text { more } \\
\text { races }\end{array}$ \\
\hline 1 & 2 & 3 & 4 & 5 & 6 & 7 & 8 & 9 & 10 & 11 & 12 & 13 & 14 & 15 & 16 \\
\hline $\begin{array}{l}\text { Total } \\
1976-77^{2} \\
1980-81^{3} \\
1990-91 \ldots \ldots \ldots \ldots \ldots \ldots \ldots \ldots \ldots \ldots \\
1995-96\end{array}$ & $\begin{array}{r}91,218 \\
97,281 \\
105,547 \\
115,507 \\
118,747\end{array}$ & $\begin{array}{l}79,932 \\
84,200 \\
81,791 \\
82,641 \\
84,244\end{array}$ & $\begin{array}{l}3,575 \\
3,893 \\
4,429 \\
6,153 \\
6,694\end{array}$ & $\begin{array}{l}1,533 \\
1,924 \\
3,210 \\
4,361 \\
4,615\end{array}$ & $\begin{array}{l}1,674 \\
2,267 \\
5,120 \\
8,979 \\
9,730\end{array}$ & $\begin{array}{l}240 \\
312 \\
356 \\
607 \\
675\end{array}$ & $\begin{array}{l}- \\
- \\
- \\
-\end{array}$ & $\begin{array}{r}4,264 \\
4,685 \\
10,641 \\
12,766 \\
12,789\end{array}$ & $\begin{array}{l}100.0 \\
100.0 \\
100.0 \\
100.0 \\
100.0\end{array}$ & $\begin{array}{l}91.9 \\
90.9 \\
86.2 \\
80.4 \\
79.5\end{array}$ & $\begin{array}{l}4.1 \\
4.2 \\
4.7 \\
6.0 \\
6.3\end{array}$ & $\begin{array}{l}1.8 \\
2.1 \\
3.4 \\
4.2 \\
4.4\end{array}$ & $\begin{array}{l}1.9 \\
2.4 \\
5.4 \\
8.7 \\
9.2\end{array}$ & $\begin{array}{l}0.3 \\
0.3 \\
0.4 \\
0.6 \\
0.6\end{array}$ & $\begin{array}{l}- \\
- \\
\overline{-} \\
-\end{array}$ \\
\hline $\begin{array}{l}1997-98 . \ldots . \\
1998-99 \ldots \ldots \ldots \ldots \ldots \ldots . . \\
1999-2000 \\
2000-01 \ldots \ldots \ldots \ldots \ldots \ldots \ldots \ldots \ldots \ldots \\
2001-02 \ldots \ldots \ldots \ldots \ldots \ldots \ldots\end{array}$ & $\begin{array}{l}118,735 \\
116,700 \\
118,736 \\
119,585 \\
119,663\end{array}$ & $\begin{array}{l}83,690 \\
82,066 \\
82,984 \\
82,321 \\
81,995\end{array}$ & $\begin{array}{l}7,018 \\
7,004 \\
7,078 \\
7,035 \\
7,570\end{array}$ & $\begin{array}{l}4,705 \\
4,959 \\
5,042 \\
5,204 \\
5,267\end{array}$ & $\begin{array}{r}9,814 \\
10,025 \\
10,682 \\
11,587 \\
11,633\end{array}$ & $\begin{array}{l}732 \\
774 \\
708 \\
705 \\
753\end{array}$ & $\begin{array}{l}- \\
- \\
- \\
-\end{array}$ & $\begin{array}{l}12,776 \\
11,872 \\
12,242 \\
12,733 \\
12,445\end{array}$ & $\begin{array}{l}100.0 \\
100.0 \\
100.0 \\
100.0 \\
100.0\end{array}$ & $\begin{array}{l}79.0 \\
78.3 \\
77.9 \\
77.0 \\
76.5\end{array}$ & $\begin{array}{l}6.6 \\
6.7 \\
6.6 \\
6.6 \\
7.1\end{array}$ & $\begin{array}{l}4.4 \\
4.7 \\
4.7 \\
4.9 \\
4.9\end{array}$ & \begin{tabular}{r|}
9.3 \\
9.6 \\
10.0 \\
10.8 \\
10.8
\end{tabular} & $\begin{array}{l}0.7 \\
0.7 \\
0.7 \\
0.7 \\
0.7\end{array}$ & $\begin{array}{l}- \\
- \\
- \\
-\end{array}$ \\
\hline 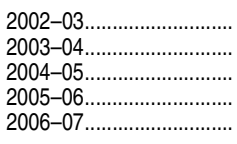 & $\begin{array}{l}121,579 \\
126,087 \\
134,387 \\
138,056 \\
144,690\end{array}$ & $\begin{array}{l}82,549 \\
84,695 \\
89,763 \\
91,050 \\
94,248\end{array}$ & $\begin{array}{l}7,537 \\
8,089 \\
8,527 \\
8,523 \\
9,377\end{array}$ & $\begin{array}{l}5,503 \\
5,795 \\
6,115 \\
6,202 \\
6,593\end{array}$ & $\begin{array}{l}12,008 \\
12,371 \\
13,176 \\
13,686 \\
14,924\end{array}$ & $\begin{array}{l}759 \\
771 \\
788 \\
929 \\
918\end{array}$ & $\begin{array}{l}- \\
- \\
- \\
-\end{array}$ & $\begin{array}{l}13,223 \\
14,366 \\
16,018 \\
17,666 \\
18,630\end{array}$ & $\begin{array}{l}100.0 \\
100.0 \\
100.0 \\
100.0 \\
100.0\end{array}$ & $\begin{array}{l}76.2 \\
75.8 \\
75.8 \\
75.6 \\
74.8\end{array}$ & $\begin{array}{l}7.0 \\
7.2 \\
7.2 \\
7.1 \\
7.4\end{array}$ & $\begin{array}{l}5.1 \\
5.2 \\
5.2 \\
5.2 \\
5.2\end{array}$ & $\begin{array}{l}11.1 \\
11.1 \\
11.1 \\
11.4 \\
11.8\end{array}$ & $\begin{array}{l}0.7 \\
0.7 \\
0.7 \\
0.8 \\
0.7\end{array}$ & $\begin{array}{l}- \\
- \\
- \\
-\end{array}$ \\
\hline $\begin{array}{l}2007-08 \\
2008-09 \\
2009-10 \\
2010-11 \\
2011-12\end{array}$ & $\begin{array}{l}149,378 \\
154,425 \\
158,558 \\
163,765 \\
170,062\end{array}$ & $\begin{array}{r}97,839 \\
101,303 \\
104,426 \\
105,932 \\
109,270\end{array}$ & $\begin{array}{r}9,463 \\
10,183 \\
10,417 \\
10,925 \\
11,740\end{array}$ & $\begin{array}{l}6,949 \\
7,490 \\
8,085 \\
8,650 \\
9,215\end{array}$ & $\begin{array}{l}15,203 \\
15,809 \\
16,625 \\
17,078 \\
17,893\end{array}$ & $\begin{array}{l}932 \\
978 \\
952 \\
947 \\
913\end{array}$ & $\begin{array}{r}- \\
\overline{-} \\
1,271 \\
1,569\end{array}$ & $\begin{array}{l}18,992 \\
18,662 \\
18,053 \\
18,962 \\
19,462\end{array}$ & $\begin{array}{l}100.0 \\
100.0 \\
100.0 \\
100.0 \\
100.0\end{array}$ & $\begin{array}{l}75.0 \\
74.6 \\
74.3 \\
73.2 \\
72.6\end{array}$ & $\begin{array}{l}7.3 \\
7.5 \\
7.4 \\
7.5 \\
7.8\end{array}$ & $\begin{array}{l}5.3 \\
5.5 \\
5.8 \\
6.0 \\
6.1\end{array}$ & $\begin{array}{l}11.7 \\
11.6 \\
11.8 \\
11.8 \\
11.9\end{array}$ & $\begin{array}{l}0.7 \\
0.7 \\
0.7 \\
0.7 \\
0.6\end{array}$ & $\begin{array}{l}\overline{-} \\
\overline{-} \\
0.9 \\
1.0\end{array}$ \\
\hline $\begin{array}{l}\text { Males } \\
1976-77^{2} \\
1980-81^{3} \ldots \ldots \ldots \ldots \ldots \ldots \ldots \ldots \\
1990-91 \ldots \ldots \ldots \ldots \ldots \ldots \ldots \ldots \\
1995-96 \ldots \ldots \ldots \ldots \ldots \ldots \ldots \ldots \ldots \\
1996-97\end{array}$ & $\begin{array}{l}71,709 \\
68,853 \\
64,242 \\
67,189 \\
68,387\end{array}$ & $\begin{array}{l}62,977 \\
59,574 \\
48,812 \\
47,420 \\
48,113\end{array}$ & $\begin{array}{l}2,338 \\
2,206 \\
1,991 \\
2,526 \\
2,704\end{array}$ & $\begin{array}{l}1,216 \\
1,338 \\
1,835 \\
2,364 \\
2,481\end{array}$ & $\begin{array}{l}1,311 \\
1,589 \\
3,038 \\
4,987 \\
5,334\end{array}$ & $\begin{array}{l}182 \\
223 \\
196 \\
328 \\
368\end{array}$ & $\begin{array}{l}- \\
- \\
- \\
-\end{array}$ & $\begin{array}{l}3,685 \\
3,923 \\
8,370 \\
9,564 \\
9,387\end{array}$ & $\begin{array}{l}100.0 \\
100.0 \\
100.0 \\
100.0 \\
100.0\end{array}$ & $\begin{array}{l}92.6 \\
91.8 \\
87.4 \\
82.3 \\
81.5\end{array}$ & $\begin{array}{l}3.4 \\
3.4 \\
3.6 \\
4.4 \\
4.6\end{array}$ & $\begin{array}{l}1.8 \\
2.1 \\
3.3 \\
4.1 \\
4.2\end{array}$ & $\begin{array}{l}1.9 \\
2.4 \\
5.4 \\
8.7 \\
9.0\end{array}$ & $\begin{array}{l}0.3 \\
0.3 \\
0.4 \\
0.6 \\
0.6\end{array}$ & $\begin{array}{l}- \\
- \\
- \\
-\end{array}$ \\
\hline $\begin{array}{l}1997-98 \\
1998-99 \\
1999-2000 \\
2000-01\end{array}$ & $\begin{array}{l}67,232 \\
65,340 \\
64,930 \\
64,171 \\
62,731\end{array}$ & $\begin{array}{l}47,189 \\
45,802 \\
45,308 \\
44,131 \\
43,014\end{array}$ & $\begin{array}{l}2,808 \\
2,793 \\
2,762 \\
2,655 \\
2,821\end{array}$ & $\begin{array}{l}2,525 \\
2,533 \\
2,602 \\
2,564 \\
2,586\end{array}$ & $\begin{array}{l}5,171 \\
5,382 \\
5,467 \\
5,759 \\
5,645\end{array}$ & $\begin{array}{l}364 \\
402 \\
333 \\
346 \\
357\end{array}$ & $\begin{array}{l}- \\
- \\
- \\
-\end{array}$ & $\begin{array}{l}9,175 \\
8,428 \\
8,458 \\
8,716 \\
8,308\end{array}$ & $\begin{array}{l}100.0 \\
100.0 \\
100.0 \\
100.0 \\
100.0\end{array}$ & $\begin{array}{l}81.3 \\
80.5 \\
80.2 \\
79.6 \\
79.0\end{array}$ & $\begin{array}{l}4.8 \\
4.9 \\
4.9 \\
4.8 \\
5.2\end{array}$ & $\begin{array}{l}4.3 \\
4.5 \\
4.6 \\
4.6 \\
4.8\end{array}$ & $\begin{array}{r}8.9 \\
9.5 \\
9.7 \\
10.4 \\
10.4\end{array}$ & $\begin{array}{l}0.6 \\
0.7 \\
0.6 \\
0.6 \\
0.7\end{array}$ & $\begin{array}{l}- \\
- \\
- \\
-\end{array}$ \\
\hline $\begin{array}{l}2002-03 \\
2003-04 \\
2004-05 \\
2005-06 \\
2006-07\end{array}$ & $\begin{array}{l}62,730 \\
63,981 \\
67,257 \\
68,912 \\
71,308\end{array}$ & $\begin{array}{l}42,569 \\
43,014 \\
44,749 \\
45,476 \\
46,228\end{array}$ & $\begin{array}{l}2,735 \\
2,888 \\
2,904 \\
2,949 \\
3,225\end{array}$ & $\begin{array}{l}2,671 \\
2,731 \\
2,863 \\
2,850 \\
3,049\end{array}$ & $\begin{array}{l}5,683 \\
5,620 \\
5,913 \\
5,977 \\
6,597\end{array}$ & $\begin{array}{l}358 \\
357 \\
370 \\
429 \\
421\end{array}$ & $\begin{array}{l}- \\
- \\
- \\
-\end{array}$ & $\begin{array}{r}8,714 \\
9,371 \\
10,458 \\
11,231 \\
11,788\end{array}$ & $\begin{array}{l}100.0 \\
100.0 \\
100.0 \\
100.0 \\
100.0\end{array}$ & $\begin{array}{l}78.8 \\
78.8 \\
78.8 \\
78.8 \\
77.7\end{array}$ & $\begin{array}{l}5.1 \\
5.3 \\
5.1 \\
5.1 \\
5.4\end{array}$ & $\begin{array}{l}4.9 \\
5.0 \\
5.0 \\
4.9 \\
5.1\end{array}$ & $\begin{array}{r}10.5 \\
10.3 \\
10.4 \\
10.4 \\
11.1\end{array}$ & $\begin{array}{l}0.7 \\
0.7 \\
0.7 \\
0.7 \\
0.7\end{array}$ & $\begin{array}{l}- \\
- \\
- \\
-\end{array}$ \\
\hline $\begin{array}{l}2008-09 . \ldots \\
2009-10 \ldots \ldots \\
2010-11 \ldots \ldots \ldots \\
2011-12 \ldots \ldots \ldots \ldots \ldots \ldots\end{array}$ & $\begin{array}{l}73,453 \\
75,639 \\
76,605 \\
79,654 \\
82,611\end{array}$ & $\begin{array}{l}48,203 \\
49,861 \\
50,705 \\
51,666 \\
53,444\end{array}$ & $\begin{array}{l}3,296 \\
3,528 \\
3,622 \\
3,836 \\
4,108\end{array}$ & $\begin{array}{l}3,146 \\
3,385 \\
3,641 \\
3,985 \\
4,215\end{array}$ & $\begin{array}{l}6,535 \\
6,904 \\
7,230 \\
7,545 \\
7,792\end{array}$ & $\begin{array}{l}447 \\
460 \\
430 \\
454 \\
418\end{array}$ & $\begin{array}{r}- \\
- \\
571 \\
701\end{array}$ & $\begin{array}{l}11,826 \\
11,501 \\
10,977 \\
11,597 \\
11,933\end{array}$ & $\begin{array}{l}100.0 \\
100.0 \\
100.0 \\
100.0 \\
100.0\end{array}$ & $\begin{array}{l}78.2 \\
77.7 \\
77.3 \\
75.9 \\
75.6\end{array}$ & $\begin{array}{l}5.3 \\
5.5 \\
5.5 \\
5.6 \\
5.8\end{array}$ & $\begin{array}{l}5.1 \\
5.3 \\
5.5 \\
5.9 \\
6.0\end{array}$ & $\begin{array}{l}10.6 \\
10.8 \\
11.0 \\
11.1 \\
11.0\end{array}$ & $\begin{array}{l}0.7 \\
0.7 \\
0.7 \\
0.7 \\
0.6\end{array}$ & $\begin{array}{l}\overline{-} \\
\overline{-} \\
0.8 \\
1.0\end{array}$ \\
\hline $\begin{array}{l}1976-77^{2} \ldots \\
1980-81^{3} \ldots \\
1990-91 \ldots \ldots \\
1995-96 \ldots \ldots \\
1996-97 \ldots \ldots\end{array}$ & $\begin{array}{l}19,509 \\
28,428 \\
41,305 \\
48,318 \\
50,360\end{array}$ & $\begin{array}{l}16,955 \\
24,626 \\
32,979 \\
35,221 \\
36,131\end{array}$ & $\begin{array}{l}1,237 \\
1,687 \\
2,438 \\
3,627 \\
3,990\end{array}$ & $\begin{array}{r}317 \\
586 \\
1,375 \\
1,997 \\
2,134\end{array}$ & $\begin{array}{r}363 \\
678 \\
2,082 \\
3,992 \\
4,396\end{array}$ & $\begin{array}{r}58 \\
89 \\
160 \\
279 \\
307\end{array}$ & $\begin{array}{l}- \\
- \\
- \\
-\end{array}$ & $\begin{array}{r}579 \\
762 \\
2,271 \\
3,202 \\
3,402\end{array}$ & $\begin{array}{l}100.0 \\
100.0 \\
100.0 \\
100.0 \\
100.0\end{array}$ & $\begin{array}{l}89.6 \\
89.0 \\
84.5 \\
78.1 \\
76.9\end{array}$ & $\begin{array}{l}6.5 \\
6.1 \\
6.2 \\
8.0 \\
8.5\end{array}$ & $\begin{array}{l}1.7 \\
2.1 \\
3.5 \\
4.4 \\
4.5\end{array}$ & $\begin{array}{l}1.9 \\
2.5 \\
5.3 \\
8.8 \\
9.4\end{array}$ & $\begin{array}{l}0.3 \\
0.3 \\
0.4 \\
0.6 \\
0.7\end{array}$ & $\begin{array}{l}- \\
\overline{-} \\
\overline{-}\end{array}$ \\
\hline $\begin{array}{l}1997-98 . \\
1998-99 \ldots \ldots \\
1999-2000 \\
2000-01 \ldots \ldots \\
2001-02\end{array}$ & $\begin{array}{l}51,503 \\
51,360 \\
53,806 \\
55,414 \\
56,932\end{array}$ & $\begin{array}{l}36,501 \\
36,264 \\
37,676 \\
38,190 \\
38,981\end{array}$ & $\begin{array}{l}4,210 \\
4,211 \\
4,316 \\
4,380 \\
4,749\end{array}$ & $\begin{array}{l}2,180 \\
2,426 \\
2,440 \\
2,640 \\
2,681\end{array}$ & $\begin{array}{l}4,643 \\
4,643 \\
5,215 \\
5,828 \\
5,988\end{array}$ & $\begin{array}{l}368 \\
372 \\
375 \\
359 \\
396\end{array}$ & $\begin{array}{l}- \\
- \\
- \\
-\end{array}$ & $\begin{array}{l}3,601 \\
3,444 \\
3,784 \\
4,017 \\
4,137\end{array}$ & $\begin{array}{l}100.0 \\
100.0 \\
100.0 \\
100.0 \\
100.0\end{array}$ & $\begin{array}{l}76.2 \\
75.7 \\
75.3 \\
74.3 \\
73.8\end{array}$ & $\begin{array}{l}8.8 \\
8.8 \\
8.6 \\
8.5 \\
9.0\end{array}$ & $\begin{array}{l}4.6 \\
5.1 \\
4.9 \\
5.1 \\
5.1\end{array}$ & \begin{tabular}{r|}
9.7 \\
9.7 \\
10.4 \\
11.3 \\
11.3
\end{tabular} & $\begin{array}{l}0.8 \\
0.8 \\
0.7 \\
0.7 \\
0.8\end{array}$ & $\begin{array}{l}- \\
- \\
- \\
-\end{array}$ \\
\hline $\begin{array}{l}2002-03 \\
2003-04 \\
2004-05 \\
2005-06 \\
2006-07\end{array}$ & $\begin{array}{l}58,849 \\
62,106 \\
67,130 \\
69,144 \\
73,382\end{array}$ & $\begin{array}{l}39,980 \\
41,681 \\
45,014 \\
45,574 \\
48,020\end{array}$ & $\begin{array}{l}4,802 \\
5,201 \\
5,623 \\
5,574 \\
6,152\end{array}$ & $\begin{array}{l}2,832 \\
3,064 \\
3,252 \\
3,352 \\
3,544\end{array}$ & $\begin{array}{l}6,325 \\
6,751 \\
7,263 \\
7,709 \\
8,327\end{array}$ & $\begin{array}{l}401 \\
414 \\
418 \\
500 \\
497\end{array}$ & $\begin{array}{l}- \\
- \\
- \\
-\end{array}$ & $\begin{array}{l}4,509 \\
4,995 \\
5,560 \\
6,435 \\
6,842\end{array}$ & $\begin{array}{l}100.0 \\
100.0 \\
100.0 \\
100.0 \\
100.0\end{array}$ & $\begin{array}{l}73.6 \\
73.0 \\
73.1 \\
72.7 \\
72.2\end{array}$ & $\begin{array}{l}8.8 \\
9.1 \\
9.1 \\
8.9 \\
9.2\end{array}$ & $\begin{array}{l}5.2 \\
5.4 \\
5.3 \\
5.3 \\
5.3\end{array}$ & $\begin{array}{l}11.6 \\
11.8 \\
11.8 \\
12.3 \\
12.5\end{array}$ & $\begin{array}{l}0.7 \\
0.7 \\
0.7 \\
0.8 \\
0.7\end{array}$ & $\begin{array}{l}- \\
- \\
- \\
-\end{array}$ \\
\hline 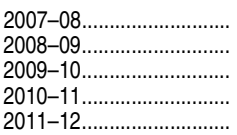 & $\begin{array}{l}75,925 \\
78,786 \\
81,953 \\
84,111 \\
87,451\end{array}$ & $\begin{array}{l}49,636 \\
51,442 \\
53,721 \\
54,266 \\
55,826\end{array}$ & $\begin{array}{l}6,167 \\
6,655 \\
6,795 \\
7,089 \\
7,632\end{array}$ & $\begin{array}{l}3,803 \\
4,105 \\
4,444 \\
4,665 \\
5,000\end{array}$ & $\begin{array}{r}8,668 \\
8,905 \\
9,395 \\
9,533 \\
10,101\end{array}$ & $\begin{array}{l}485 \\
518 \\
522 \\
493 \\
495\end{array}$ & $\begin{array}{r}- \\
\overline{-} \\
700 \\
868\end{array}$ & $\begin{array}{l}7,166 \\
7,161 \\
7,076 \\
7,365 \\
7,529\end{array}$ & $\begin{array}{l}100.0 \\
100.0 \\
100.0 \\
100.0 \\
100.0\end{array}$ & $\begin{array}{l}72.2 \\
71.8 \\
71.7 \\
70.7 \\
69.9\end{array}$ & $\begin{array}{l}9.0 \\
9.3 \\
9.1 \\
9.2 \\
9.5\end{array}$ & $\begin{array}{l}5.5 \\
5.7 \\
5.9 \\
6.1 \\
6.3\end{array}$ & $\begin{array}{l}12.6 \\
12.4 \\
12.5 \\
12.4 \\
12.6\end{array}$ & $\begin{array}{l}0.7 \\
0.7 \\
0.7 \\
0.6 \\
0.6\end{array}$ & $\begin{array}{l}- \\
- \\
0.9 \\
1.1\end{array}$ \\
\hline
\end{tabular}

-Not available.

IIncludes Ph.D., Ed.D., and comparable degrees at the doctoral level, as well as such degrees as M.D., D.D.S., and law degrees that were formerly classified as first-professional degrees. 'Excludes 500 males and 12 females whose racial/ethnic group was not available. ${ }^{3}$ Excludes 714 males and 21 females whose racial/ethnic group was not available. NOTE: Data through 1990-91 are for institutions of higher education, while later data are for postsecondary institutions participating in Title IV federal financial aid programs. Race catego- distributions of students by level of degree, field of degree, and sex were used to estimate race/ ethnicity for students whose race/ethnicity was not reported. Detail may not sum to totals because of rounding.

SOURCE: U.S. Department of Education, National Center for Education Statistics, Higher Education General Information Survey (HEGIS), "Degrees and Other Formal Awards Conferred" surveys, 1976-77 and 1980-81; Integrated Postsecondary Education Data System (IPEDS), "Completions Survey" (IPEDS-C:90-99); and IPEDS Fall 2000 through Fall 2012, Completions component. (This table was prepared July 2013.) 
Table 324.25. Doctor's degrees conferred by postsecondary institutions, by race/ethnicity and field of study: 2010-11 and 2011-12

Communication, journalism, and related programs Communications technologies...

Computer and information sciences .......................

\section{Engineering}

Engineering technologies and engineering-related

English language and literature/letters

Family and consumer sciences/human sciences ...

.

Health professions and related programs.

Homeland security, law enforcement, and firefighting..

Legal professions and studies.

Liberal arts and sciences, general studies, and

humanities.

Library science

Mathematics and statistics .

Mechanics and repair technologies/technicians

Military technologies and applied sciences ...

Mutti/nterdisciplinary studies ....................................
Parks, recreation, leisure, and fitness studies .......

Philosophy and religious studies

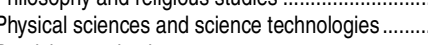
Precision production

Public administration and social services

Social sciences and history .

$$
\text { Social sciences.... }
$$

Theology and religious vocations

Transportation and materials movin ...

Visual and performing arts ...

2010-11

Other and not classified.

\begin{tabular}{|c|c|c|c|c|c|}
\hline 2 & 3 & 4 & 5 & 6 & \\
\hline 63,765 & 105,932 & 10,925 & 8,650 & 17,078 & 16,7 \\
\hline 1,246 & 610 & 25 & 48 & 40 & \\
\hline 205 & 68 & 8 & 9 & 41 & \\
\hline 278 & 141 & 38 & 16 & 27 & \\
\hline 7,693 & 4,214 & 285 & 342 & 688 & \\
\hline 2,286 & 1,089 & 338 & 96 & 148 & \\
\hline 577 & 358 & 36 & 14 & 17 & \\
\hline 1 & 0 & 0 & 0 & 0 & \\
\hline 1,588 & 581 & 41 & 21 & 146 & \\
\hline 0 & 0 & 0 & 0 & 0 & \\
\hline 9,623 & 6,172 & 1,743 & 593 & 326 & \\
\hline 8,369 & 2,599 & 155 & 200 & 644 & \\
\hline 56 & 32 & 1 & 1 & 3 & \\
\hline 1,344 & 1,044 & 59 & 54 & 50 & \\
\hline 320 & 189 & 30 & 7 & 11 & \\
\hline 1,158 & 625 & 23 & 84 & 48 & \\
\hline 60,153 & 41,177 & 3,480 & 2,875 & 9,933 & \\
\hline 131 & 89 & 16 & 4 & 5 & \\
\hline 44,877 & 32,762 & 3,207 & 3,290 & 3,686 & \\
\hline 95 & 73 & 4 & 1 & 5 & \\
\hline 50 & 26 & 1 & 1 & 1 & \\
\hline 1,586 & 685 & 25 & 31 & 98 & \\
\hline 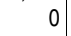 & 0 & 0 & 0 & 0 & \\
\hline $\operatorname{con}$ & 0 & 0 & 0 & 0 & \\
\hline 660 & 372 & 71 & 34 & 38 & \\
\hline 257 & 163 & 19 & 5 & 6 & \\
\hline 805 & 550 & 54 & 25 & 23 & \\
\hline 5,295 & 2,579 & 100 & 144 & 272 & \\
\hline 0 & 0 & 0 & 0 & 0 & \\
\hline 5,851 & 4,303 & 430 & 376 & 300 & \\
\hline 851 & 458 & 145 & 50 & 45 & \\
\hline 4,390 & 2,509 & 194 & 194 & 202 & \\
\hline 3.482 & 1,846 & 148 & 152 & 175 & \\
\hline 908 & 663 & 46 & 42 & 27 & \\
\hline 2,374 & 1,417 & 362 & 74 & 167 & \\
\hline & 0 & 0 & 0 & 0 & \\
\hline 1,646 & 1,047 & 35 & 61 & 108 & \\
\hline & & & & & \\
\hline
\end{tabular}

'Excludes "Construction trades" and "Mechanic and repair technologies/technicians," which are listed separately. NOTE: Data are for postsecondary institutions participating in Titie IV federal financial aid programs. Race categories exclude per-

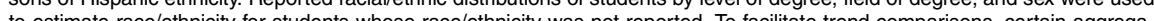

tions have been made of the degree fields as reported in the Integrated Postsecondary Education Data System (IPEDS): "Agricul-

ture and natural resources" includes Agriculture, agriculture operations, and related sciences and Natural resources and

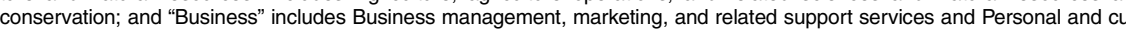
nary services.

Fon System (IPEDS), Fall 2011 and Fall 2012, Completions component. (This table was prepared July 2013.) 
Table 324.30. Doctor's degrees conferred to males by postsecondary institutions, by race/ethnicity and field of study: 2010-11 and 2011-12

\begin{tabular}{|c|c|c|c|c|c|c|c|c|c|c|c|c|c|c|c|c|c|c|c|c|}
\hline \multirow[b]{3}{*}{ Field of study } & \multicolumn{10}{|c|}{$2010-11$} & \multicolumn{10}{|c|}{ 2011-12 } \\
\hline & \multirow[b]{2}{*}{ Total } & \multirow[b]{2}{*}{ White } & \multirow[b]{2}{*}{ Black } & \multirow[b]{2}{*}{ Hispanic } & \multicolumn{3}{|c|}{ Asian/Pacific Islander } & \multirow{2}{*}{$\begin{array}{r}\text { American } \\
\text { Indian/ } \\
\text { Alaska } \\
\text { Native } \\
\end{array}$} & \multirow{2}{*}{$\begin{array}{r}\text { Two or } \\
\text { more } \\
\text { races }\end{array}$} & \multirow{2}{*}{$\begin{array}{l}\text { Non- } \\
\text { resident } \\
\text { alien }\end{array}$} & \multirow[b]{2}{*}{ Total } & \multirow[b]{2}{*}{ White } & \multirow[b]{2}{*}{ Black } & \multirow[b]{2}{*}{ Hispanic } & \multicolumn{3}{|c|}{ Asian/Pacific Islander } & \multirow{2}{*}{\begin{tabular}{|r|} 
American \\
Indian/ \\
Alaska \\
Native \\
\end{tabular}} & & \\
\hline & & & & & Total & Asian & $\begin{array}{r}\text { Pacific } \\
\text { Islander }\end{array}$ & & & & & & & & Total & Asian & $\begin{array}{r}\text { Pacific } \\
\text { Islander }\end{array}$ & & $\begin{array}{c}\text { more } \\
\text { races }\end{array}$ & $\begin{array}{r}\text { resident } \\
\text { alien }\end{array}$ \\
\hline 1 & 2 & 3 & 4 & 5 & 6 & 7 & 8 & 9 & 10 & 11 & 12 & 13 & 14 & 15 & 16 & 17 & 18 & 19 & 20 & 21 \\
\hline All fields, total & 79,654 & 51,666 & 3,836 & 3,985 & 7,545 & 7,379 & 166 & 454 & 571 & 11,597 & 82,611 & 53,444 & 4,108 & 4,215 & 7,792 & 7,631 & 161 & 418 & 701 & 11,933 \\
\hline Agriculture and natural resources......................... & 675 & 327 & 16 & 23 & 17 & 16 & 1 & 3 & 2 & 287 & 721 & 355 & 15 & 26 & 14 & 14 & 0 & 5 & 4 & 302 \\
\hline Architecture and related services ........................... & 110 & 40 & 4 & 2 & 19 & 19 & 0 & 0 & 1 & 44 & 147 & 52 & 6 & 4 & 14 & 14 & 0 & 1 & 4 & 66 \\
\hline Area, ethnic, cultural, gender, and group studies ... & 116 & 68 & 9 & 4 & 10 & 9 & 1 & 2 & 0 & 23 & 112 & 46 & 19 & 10 & 8 & 8 & 0 & 5 & 1 & 23 \\
\hline Biological and biomedical sciences ........................... & 3,648 & 2,015 & 105 & 162 & 312 & 306 & 6 & 15 & 21 & 1,018 & 3,708 & 2,039 & 115 & 156 & 287 & 283 & 4 & 16 & 25 & 1,070 \\
\hline 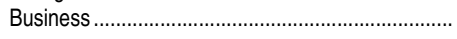 & 1,357 & 676 & 175 & 53 & 84 & 83 & 1 & 8 & 5 & 356 & 1,460 & 731 & 177 & 51 & 101 & 99 & 2 & 8 & 7 & 385 \\
\hline Communication, journalism, and related programs.. & 207 & 127 & 12 & 6 & 5 & 5 & 0 & 0 & 1 & 56 & 239 & 153 & 14 & 8 & 7 & 7 & 0 & 1 & 2 & 54 \\
\hline 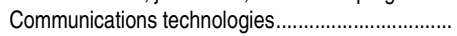 & 0 & 0 & 0 & 0 & 0 & 0 & 0 & 0 & 0 & 0 & 3 & 3 & 0 & 0 & 0 & 0 & 0 & 0 & 0 & 0 \\
\hline Computer and information sciences ....................... & 1,267 & 482 & 24 & 21 & 107 & 105 & 2 & 2 & 2 & 629 & 1,332 & 497 & 26 & 24 & 105 & 105 & 0 & 1 & 5 & 674 \\
\hline 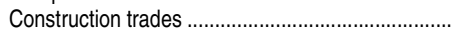 & 0 & 0 & 0 & 0 & 0 & 0 & 0 & 0 & 0 & 0 & 0 & 0 & 0 & 0 & 0 & 0 & 0 & 0 & 0 & 0 \\
\hline Education ........................................................ & 3,064 & 2,059 & 460 & 199 & 77 & 73 & 4 & 28 & 20 & 221 & 3,215 & 2,147 & 505 & 223 & 104 & 100 & 4 & 21 & 25 & 190 \\
\hline Engineering ... & 6,510 & 2,019 & 94 & 149 & 449 & 447 & 2 & 14 & 26 & 3,759 & 6,770 & 2,139 & 114 & 139 & 437 & 436 & 1 & 9 & 29 & 3,903 \\
\hline Engineering technologies and engineering- & & & & & & & & & & & & & & & & & & & & \\
\hline 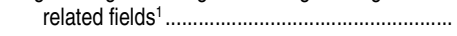 & 38 & 23 & 1 & 1 & 3 & 3 & 0 & 0 & 0 & 10 & 68 & 28 & 3 & 1 & 3 & 3 & 0 & 1 & 2 & 30 \\
\hline English language and literature/letters .................. & 529 & 421 & 17 & 24 & 9 & 9 & 0 & 2 & 8 & 48 & 548 & 436 & 18 & 26 & 19 & 19 & 0 & 3 & 3 & 43 \\
\hline Family and consumer sciences/human sciences ... & 59 & 34 & 5 & 0 & 0 & 0 & 0 & 1 & 0 & 19 & 59 & 32 & 6 & 0 & 2 & 2 & 0 & 0 & 0 & 19 \\
\hline Foreign languages, literatures, and linguistics........ & 477 & 271 & 7 & 26 & 14 & 14 & 0 & 1 & 1 & 157 & 497 & 272 & 7 & 36 & 19 & 18 & 1 & 0 & 3 & 160 \\
\hline Health professions and related programs ................. & 25,361 & 17,512 & 1,138 & 1,264 & 4,234 & 4,176 & 58 & 155 & 181 & 877 & 26,074 & 17,840 & 1,227 & 1,252 & 4,482 & 4,420 & 62 & 148 & 234 & 891 \\
\hline Homeland security, law enforcement, and firefighting. & 62 & 42 & 6 & 1 & & 4 & 0 & 0 & 0 & 9 & 63 & 41 & 3 & 7 & 0 & 0 & 0 & 1 & 1 & 10 \\
\hline Legal professions and studies ............................... & 23,720 & 18,321 & 1,202 & 1,607 & 1,654 & 1,574 & 80 & 192 & 223 & 521 & 24,764 & 19,202 & 1,248 & 1,767 & 1,628 & 1,555 & 73 & 172 & 258 & 489 \\
\hline Liberal arts and sciences, general studies, and & & & & & & & & & & & & & & & & & & & & \\
\hline 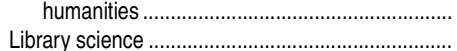 & $\begin{array}{r}40 \\
18\end{array}$ & $\begin{array}{r}31 \\
11\end{array}$ & 4 & $\begin{array}{c}1 \\
1\end{array}$ & $\begin{array}{l}0 \\
0 \\
0\end{array}$ & $\begin{array}{l}0 \\
0 \\
0\end{array}$ & 0 & 0 & 0 & 4 & 32 & $\begin{array}{r}21 \\
21\end{array}$ & 4 & 1 & 0 & 0 & 0 & 0 & 0 & 6 \\
\hline Lividy scierice .................................... & & 而 & | & 1 & ( & & ( & & 0 & & & & & & & & 0 & 0 & 1 & $T$ \\
\hline Mathematics and statistics... & 1,132 & 517 & 15 & 21 & 57 & 56 & 1 & 5 & 1 & 516 & 1,198 & 522 & 12 & 32 & 55 & 53 & 2 & 0 & 6 & 571 \\
\hline Mechanic and repair technologies/technicians....... & 0 & 0 & 0 & 0 & 0 & 0 & 0 & 0 & 0 & 0 & 0 & 0 & 0 & 0 & 0 & 0 & 0 & 0 & 0 & 0 \\
\hline Military technologies and applied sciences ............ & 0 & 0 & 0 & 0 & 0 & 0 & 0 & 0 & 0 & 0 & 0 & 0 & 0 & 0 & 0 & 0 & 0 & 0 & 0 & 0 \\
\hline 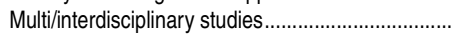 & 276 & 161 & 19 & 14 & 12 & 12 & 0 & 1 & 4 & 65 & 297 & 172 & 22 & 16 & 12 & 11 & 1 & 2 & 1 & 72 \\
\hline Parks, recreation, leisure, and fitness studies ........ & 140 & 90 & 6 & 1 & 4 & 4 & 0 & 1 & 1 & 37 & 161 & 106 & 9 & 6 & 2 & 2 & 0 & 0 & 3 & 35 \\
\hline Philos & 530 & 367 & 31 & 17 & 15 & 15 & 0 & 0 & 6 & 94 & 542 & 394 & 18 & 17 & 20 & 20 & 0 & 1 & 6 & 86 \\
\hline Physical sciences and science technologies.......... & 3,608 & 1,763 & 49 & 97 & 157 & 151 & 6 & 6 & 21 & 1,515 & 3,609 & 1,797 & 61 & 100 & 149 & 147 & 2 & 6 & 32 & 1,464 \\
\hline 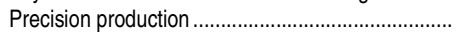 & 0 & 0 & 0 & 0 & 0 & 0 & 0 & 0 & 0 & 0 & 0 & 0 & 0 & 0 & 0 & 0 & 0 & 0 & 0 & 0 \\
\hline 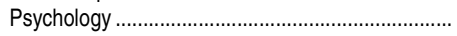 & 1,481 & 1,133 & 82 & 93 & 64 & 64 & 0 & 5 & 14 & 90 & 1,519 & 1,152 & 81 & 109 & 69 & 68 & 1 & 9 & 16 & 83 \\
\hline Public administration and social services............... & 327 & 177 & 53 & 16 & 13 & 13 & 0 & 1 & 2 & 65 & 338 & 174 & 51 & 20 & 19 & 18 & 1 & 0 & 0 & 74 \\
\hline Social sciences and history.... & 2,331 & 1,320 & 74 & 94 & 72 & 71 & 1 & 6 & 20 & 745 & 2,464 & 1,379 & 86 & 97 & 89 & 87 & 2 & 4 & 16 & 793 \\
\hline Social sciences & 1,834 & 940 & 57 & 69 & 64 & 63 & 1 & 3 & 12 & 689 & 1,931 & 996 & 57 & 73 & 75 & 74 & 1 & 4 & 12 & 714 \\
\hline History & 497 & 380 & 17 & 25 & 8 & 8 & 0 & 3 & 8 & 56 & 533 & 383 & 29 & 24 & 14 & 13 & 1 & 0 & 4 & 79 \\
\hline Theology and religious vocations ............................ & 1,801 & 1,102 & 211 & 59 & 128 & 126 & 2 & 1 & 5 & 295 & 1,857 & 1,131 & 241 & 51 & 122 & 117 & 5 & 4 & 14 & 294 \\
\hline Transportation and materials moving...................... & 0 & 0 & 0 & 0 & 0 & 0 & 0 & 0 & 0 & 0 & 0 & 0 & 0 & 0 & 0 & 0 & 0 & 0 & 0 & 0 \\
\hline Visual and performing arts ..................................... & 770 & 557 & 17 & 29 & 25 & 24 & 1 & 5 & 6 & 131 & 790 & 571 & 20 & 35 & 22 & 22 & 0 & 0 & 3 & 139 \\
\hline Other and not classified .......................................... & 0 & 0 & 0 & 0 & 0 & 0 & 0 & 0 & 0 & 0 & 0 & 0 & 0 & 0 & 0 & 0 & 0 & 0 & 0 & 0 \\
\hline
\end{tabular}

'Excludes "Construction trades" and "Mechanic and repair technologies/technicians," which are listed separately.

(IPEDS): "Agriculture and natural resources" includes Agriculture, agriculture operations, and related sciences and Natura resources and conservation; and "Business" includes Business management, marketing, and related support services and SOURCE: U.S. Department of Education, National Center for Education Statistics, Integrated Postsecondary Education Data System (IPEDS), Fall 2011 and Fall 2012, Completions component. (This table was prepared July 2013.) 
Table 324.35. Doctor's degrees conferred to females by postsecondary institutions, by race/ethnicity and field of study: 2010-11 and 2011-12

Communication, journalism, and related programs. Communications technologies..........

Construction trades

Education..........

\section{Engineering technologies and engineering-}

related fields

English language and literature/letters

Family and consumer sciences/human sciences ...

Foreign languages, literatures, and linguistics.......

Health professions and related program

Homeland security, law enforcement, and firefighting.

Legal professions and studies

Liberal arts and sciences, general studies, and

humanities..

Library science

Mathematics and statistics

Mechanic and repair technologies/technicians....

Miltary technologies and applied sciences...

Multi/nterdisciplinary studies.................................

Philosophy and religious studies.

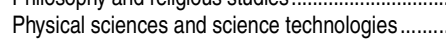
Precision production

Public administration and social services

Social sciences and history...

Social sciences.......

History

Theology and religious vocations

Transportation and materials moving

Visual and performing arts

2010-11

Other and not classified.

\begin{tabular}{|c|c|c|c|c|c|}
\hline \multirow[b]{2}{*}{ Total } & \multirow[b]{2}{*}{ White } & \multirow[b]{2}{*}{ Black } & \multirow[b]{2}{*}{ Hispanic } & \multicolumn{2}{|c|}{ Asian/Pacific } \\
\hline & & & & Total & A \\
\hline 2 & 3 & 4 & 5 & 6 & \\
\hline 84,111 & 54,266 & 7,089 & 4,665 & 9.533 & \\
\hline 571 & 283 & 9 & 25 & 23 & \\
\hline 95 & 28 & 4 & 7 & 22 & \\
\hline 162 & 73 & 29 & 12 & 17 & \\
\hline 4,045 & 2,199 & 180 & 180 & 376 & \\
\hline 929 & 413 & 163 & 43 & 64 & \\
\hline 370 & 231 & 24 & 8 & 12 & \\
\hline 1 & 0 & 0 & 0 & 0 & \\
\hline 321 & 99 & 17 & 0 & 39 & \\
\hline 0 & 0 & 0 & 0 & 0 & \\
\hline 6,559 & 4,113 & 1,283 & 394 & 249 & \\
\hline 1,859 & 580 & 61 & 51 & 195 & \\
\hline 18 & 9 & 0 & 0 & 0 & \\
\hline 815 & 623 & 42 & 30 & 41 & \\
\hline 261 & 155 & 25 & 7 & 11 & \\
\hline 681 & 354 & 16 & 58 & 34 & \\
\hline 34,792 & 23,665 & 2,342 & 1,611 & 5,699 & \\
\hline 69 & 47 & 10 & 3 & 1 & \\
\hline 21,157 & 14,441 & 2,005 & 1,683 & 2,032 & \\
\hline 55 & 42 & 0 & 0 & 5 & \\
\hline 32 & 15 & 1 & 0 & 1 & \\
\hline 454 & 168 & 10 & 10 & 41 & \\
\hline 0 & 0 & 0 & 0 & 0 & \\
\hline 0 & 0 & 0 & 0 & 0 & \\
\hline 384 & 211 & 52 & 20 & 26 & \\
\hline 117 & 73 & 13 & 4 & 2 & \\
\hline 275 & 183 & 23 & 8 & 8 & \\
\hline 1,687 & 816 & 51 & 47 & 115 & \\
\hline & 0 & 0 & 0 & 0 & \\
\hline 4,370 & 3,170 & 348 & 283 & 236 & \\
\hline 524 & 281 & 92 & 34 & 32 & \\
\hline 2,059 & 1,189 & 120 & 100 & 130 & \\
\hline 1,648 & 906 & 91 & 83 & 111 & \\
\hline 411 & 283 & 29 & 17 & 19 & \\
\hline 573 & 315 & 151 & 15 & 39 & \\
\hline 0 & 0 & 0 & 0 & 0 & \\
\hline 876 & 490 & 18 & 32 & 83 & \\
\hline 0 & 0 & 0 & 0 & 0 & \\
\hline
\end{tabular}

1Excludes "Construction trades" and "Mechanic and repair technologies/technicians," which are listed separately. NOTE: Data are for postsecondary institutions participating in Title IV federal financial aid programs. Race categories exclude used to estimpte rac/ethnicity for students whose racelethnicty was not reportel To failtite trend comparisons, certain aggregations have been made of the degree fields as reported in the Integrated Postsecondary Education Data System

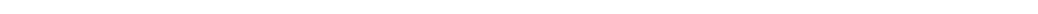
resources and conservation; and "Business" includes Business management, marketing, and related support services and Peronal and culnary services.

(T) System (IPEDS), Fall 2011 and Fall 2012, Completions component. (This table was prepared July 2013.) 
Table 324.40. Number of postsecondary institutions conferring doctor's degrees in dentistry, medicine, and law, and number of such degrees conferred, by sex of student: Selected years, 1949-50 through 2011-12

\begin{tabular}{|c|c|c|c|c|c|c|c|c|c|c|c|c|}
\hline \multirow[b]{3}{*}{ Year } & \multicolumn{4}{|c|}{ Dentistry (D.D.S. or D.M.D.) } & \multicolumn{4}{|c|}{ Medicine (M.D.) } & \multicolumn{4}{|c|}{ Law (LL.B. or J.D.) } \\
\hline & \multirow{2}{*}{$\begin{array}{r}\text { Number of } \\
\text { institutions } \\
\text { conferring } \\
\text { degrees }\end{array}$} & \multicolumn{3}{|c|}{ Number of degrees conferred } & \multirow{2}{*}{$\begin{array}{r}\text { Number of } \\
\text { institutions } \\
\text { conferring } \\
\text { degrees }\end{array}$} & \multicolumn{3}{|c|}{ Number of degrees conferred } & \multirow{2}{*}{$\begin{array}{r}\text { Number of } \\
\text { institutions } \\
\text { conferring } \\
\text { degrees }\end{array}$} & \multicolumn{3}{|c|}{ Number of degrees conferred } \\
\hline & & Total & Males & Females & & Total & Males & Females & & Total & Males & Females \\
\hline 1 & 2 & 3 & 4 & 5 & 6 & 7 & 8 & 9 & 10 & 11 & 12 & 13 \\
\hline 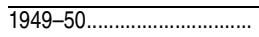 & 40 & 2,579 & 2,561 & 18 & 72 & 5,612 & 5,028 & 584 & - & - & - & - \\
\hline $1951-52 \ldots \ldots \ldots \ldots \ldots \ldots \ldots \ldots \ldots \ldots$ & 41 & 2,918 & 2,895 & 23 & 72 & 6,201 & 5,871 & 330 & - & - & - & - \\
\hline $1953-54 \ldots \ldots \ldots$ & 42 & 3,102 & 3,063 & 39 & 73 & 6,712 & 6,377 & 335 & - & - & - & - \\
\hline $1955-56$ & 42 & 3,009 & 2,975 & 34 & 73 & 6,810 & 6,464 & 346 & 131 & 8,262 & 7,974 & 288 \\
\hline $1957-58 \ldots \ldots \ldots \ldots \ldots \ldots \ldots \ldots$ & 43 & 3,065 & 3,031 & 34 & 75 & 6,816 & 6,469 & 347 & 131 & 9,394 & 9,122 & 272 \\
\hline $1959-60$ & 45 & 3,247 & 3,221 & 26 & 79 & 7,032 & 6,645 & 387 & 134 & 9,240 & 9,010 & 230 \\
\hline $1961-62 \ldots \ldots \ldots \ldots$ & 46 & 3,183 & 3,166 & 17 & 81 & 7,138 & 6,749 & 389 & 134 & 9,364 & 9,091 & 273 \\
\hline $1963-64 \ldots \ldots \ldots$ & 46 & 3,180 & 3,168 & 12 & 82 & 7,303 & 6,878 & 425 & 133 & 10,679 & 10,372 & 307 \\
\hline 1964-65............................ & 46 & 3,108 & 3,086 & 22 & 81 & 7,304 & 6,832 & 472 & 137 & 11,583 & 11,216 & 367 \\
\hline 1965-66............................. & 47 & 3,178 & 3,146 & 32 & 84 & 7,673 & 7,170 & 503 & 136 & 13,246 & 12,776 & 470 \\
\hline 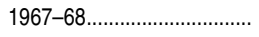 & 48 & 3,422 & 3,375 & 47 & 85 & 7,944 & 7,318 & 626 & 138 & 16,454 & 15,805 & 649 \\
\hline $1968-69 \ldots \ldots \ldots \ldots \ldots$ & - & 3,408 & 3,376 & 32 & - & 8,025 & 7,415 & 610 & - & 17,053 & 16,373 & 680 \\
\hline $1969-70 \ldots$ & 48 & 3,718 & 3,684 & 34 & 86 & 8,314 & 7,615 & 699 & 145 & 14,916 & 14,115 & 801 \\
\hline $1970-71 \ldots \ldots$ & 48 & 3,745 & 3,703 & 42 & 89 & 8,919 & 8,110 & 809 & 147 & 17,421 & 16,181 & 1,240 \\
\hline $1971-72 \ldots \ldots \ldots \ldots \ldots \ldots \ldots$ & 48 & 3,862 & 3,819 & 43 & 92 & 9,253 & 8,423 & 830 & 147 & 21,764 & 20,266 & 1,498 \\
\hline $1972-73 \ldots \ldots$ & 51 & 4,047 & 3,992 & 55 & 97 & 10,307 & 9,388 & 919 & 152 & 27,205 & 25,037 & 2,168 \\
\hline $1973-74 \ldots \ldots \ldots \ldots \ldots \ldots \ldots \ldots$ & 52 & 4,440 & 4,355 & 85 & 99 & 11,356 & 10,093 & 1,263 & 151 & 29,326 & 25,986 & 3,340 \\
\hline $1974-75 \ldots$ & 52 & 4,773 & 4,627 & 146 & 104 & 12,447 & 10,818 & 1,629 & 154 & 29,296 & 24,881 & 4,415 \\
\hline $1975-76 \ldots \ldots \ldots$ & 56 & 5,425 & 5,187 & 238 & 107 & 13,426 & 11,252 & 2,174 & 166 & 32,293 & 26,085 & 6,208 \\
\hline $1976-77 \ldots \ldots \ldots \ldots \ldots \ldots \ldots \ldots \ldots$ & 57 & 5,138 & 4,764 & 374 & 109 & 13,461 & 10,891 & 2,570 & 169 & 34,104 & 26,447 & 7,657 \\
\hline $1977-78 \ldots \ldots \ldots \ldots \ldots \ldots \ldots \ldots \ldots \ldots$ & 57 & 5,189 & 4,623 & 566 & 109 & 14,279 & 11,210 & 3,069 & 169 & 34,402 & 25,457 & 8,945 \\
\hline 1978-79.............................. & 58 & 5,434 & 4,794 & 640 & 109 & 14,786 & 11,381 & 3,405 & 175 & 35,206 & 25,180 & 10,026 \\
\hline $1979-80 \ldots \ldots \ldots$ & 58 & 5,258 & 4,558 & 700 & 112 & 14,902 & 11,416 & 3,486 & 179 & 35,647 & 24,893 & 10,754 \\
\hline $1980-81 \ldots \ldots \ldots$ & 58 & 5,460 & 4,672 & 788 & 116 & 15,505 & 11,672 & 3,833 & 176 & 36,331 & 24,563 & 11,768 \\
\hline $1981-82 \ldots \ldots$ & 59 & 5,282 & 4,467 & 815 & 119 & 15,814 & 11,867 & 3,947 & 180 & 35,991 & 23,965 & 12,026 \\
\hline 1982-83............................ & 59 & 5,585 & 4,631 & 954 & 118 & 15,484 & 11,350 & 4,134 & 177 & 36,853 & 23,550 & 13,303 \\
\hline 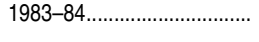 & 60 & 5,353 & 4,302 & 1,051 & 119 & 15,813 & 11,359 & 4,454 & 179 & 37,012 & 23,382 & 13,630 \\
\hline $1984-85 \ldots \ldots \ldots$ & 59 & 5,339 & 4,233 & 1,106 & 120 & 16,041 & 11,167 & 4,874 & 181 & 37,491 & 23,070 & 14,421 \\
\hline $1985-86 \ldots \ldots \ldots$ & 59 & 5,046 & 3,907 & 1,139 & 120 & 15,938 & 11,022 & 4,916 & 181 & 35,844 & 21,874 & 13,970 \\
\hline $1986-87 \ldots \ldots \ldots \ldots \ldots \ldots$ & 58 & 4,741 & 3,603 & 1,138 & 121 & 15,428 & 10,431 & 4,997 & 179 & 36,056 & 21,561 & 14,495 \\
\hline $1987-88 \ldots \ldots \ldots \ldots \ldots \ldots \ldots \ldots \ldots$ & 57 & 4,477 & 3,300 & 1,177 & 122 & 15,358 & 10,278 & 5,080 & 180 & 35,397 & 21,067 & 14,330 \\
\hline $1988-89 \ldots \ldots \ldots \ldots$ & 58 & 4,265 & 3,124 & 1,141 & 124 & 15,460 & 10,310 & 5,150 & 182 & 35,634 & 21,069 & 14,565 \\
\hline $1989-90 \ldots \ldots \ldots$ & 57 & 4,100 & 2,834 & 1,266 & 124 & 15,075 & 9,923 & 5,152 & 182 & 36,485 & 21,079 & 15,406 \\
\hline 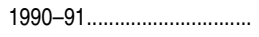 & 55 & 3,699 & 2,510 & 1,189 & 121 & 15,043 & 9,629 & 5,414 & 179 & 37,945 & 21,643 & 16,302 \\
\hline 1991-92...................... & 52 & 3,593 & 2,431 & 1,162 & 120 & 15,243 & 9,796 & 5,447 & 177 & 38,848 & 22,260 & 16,588 \\
\hline 1992-93...................... & 55 & 3,605 & 2,383 & 1,222 & 122 & 15,531 & 9,679 & 5,852 & 184 & 40,302 & 23,182 & 17,120 \\
\hline $1993-94 \ldots \ldots \ldots \ldots \ldots \ldots$ & 53 & 3,787 & 2,330 & 1,457 & 121 & 15,368 & 9,544 & 5,824 & 185 & 40,044 & 22,826 & 17,218 \\
\hline 1994-95......................... & 53 & 3,897 & 2,480 & 1,417 & 119 & 15,537 & 9,507 & 6,030 & 183 & 39,349 & 22,592 & 16,757 \\
\hline 1995-96............................. & 53 & 3,697 & 2,374 & 1,323 & 119 & 15,341 & 9,061 & 6,280 & 183 & 39,828 & 22,508 & 17,320 \\
\hline 1996-97...................... & 52 & 3,784 & 2,387 & 1,397 & 118 & 15,571 & 9,121 & 6,450 & 184 & 40,079 & 22,548 & 17,531 \\
\hline 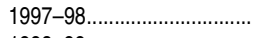 & 53 & 4,032 & 2,490 & 1,542 & 117 & 15,424 & 9,006 & 6,418 & 185 & 39,331 & 21,876 & 17,455 \\
\hline 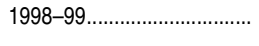 & 53 & 4,143 & 2,673 & 1,470 & 118 & 15,566 & 8,972 & 6,594 & 185 & 38,297 & 21,102 & 17,195 \\
\hline 1999-2000 & 54 & 4,250 & 2,547 & 1,703 & 118 & 15,286 & 8,761 & 6,525 & 190 & 38,152 & 20,638 & 17,514 \\
\hline 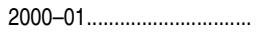 & 54 & 4,391 & 2,696 & 1,695 & 118 & 15,403 & 8,728 & 6,675 & 192 & 37,904 & 19,981 & 17,923 \\
\hline $2001-02 \ldots \ldots \ldots \ldots \ldots \ldots \ldots$ & 53 & 4,239 & 2,608 & 1,631 & 118 & 15,237 & 8,469 & 6,768 & 192 & 38,981 & 20,254 & 18,727 \\
\hline $2002-03 \ldots \ldots \ldots \ldots \ldots \ldots \ldots \ldots \ldots$ & 53 & 4,345 & 2,654 & 1,691 & 118 & 15,034 & 8,221 & 6,813 & 194 & 39,067 & 19,916 & 19,151 \\
\hline $2003-04 \ldots \ldots \ldots \ldots \ldots \ldots \ldots$ & 53 & 4,335 & 2,532 & 1,803 & 118 & 15,442 & 8,273 & 7,169 & 195 & 40,209 & 20,332 & 19,877 \\
\hline $2004-05 \ldots \ldots \ldots \ldots \ldots \ldots \ldots \ldots$ & 53 & 4,454 & 2,505 & 1,949 & 120 & 15,461 & 8,151 & 7,310 & 198 & 43,423 & 22,297 & 21,126 \\
\hline $2005-06 \ldots \ldots \ldots$ & 54 & 4,389 & 2,435 & 1,954 & 119 & 15,455 & 7,900 & 7,555 & 197 & 43,440 & 22,597 & 20,843 \\
\hline 2006-07 & 55 & 4,596 & 2,548 & 2,048 & 120 & 15,730 & 7,987 & 7,743 & 200 & 43,486 & 22,777 & 20,709 \\
\hline $2007-08 \ldots \ldots \ldots$ & 55 & 4,795 & 2,661 & 2,134 & 120 & 15,646 & 7,935 & 7,711 & 201 & 43,769 & 23,197 & 20,572 \\
\hline $2008-09 \ldots \ldots \ldots \ldots \ldots \ldots \ldots$ & 55 & 4,918 & 2,637 & 2,281 & 120 & 15,987 & 8,164 & 7,823 & 203 & 44,045 & 23,860 & 20,185 \\
\hline 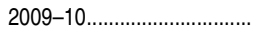 & 55 & 5,062 & 2,745 & 2,317 & 120 & 16,356 & 8,468 & 7,888 & 205 & 44,345 & 23,394 & 20,951 \\
\hline $2010-11 \ldots \ldots \ldots \ldots \ldots \ldots \ldots \ldots \ldots \ldots$ & 55 & 5,071 & 2,764 & 2,307 & 120 & 16,863 & 8,701 & 8,162 & 206 & 44,445 & 23,493 & 20,952 \\
\hline 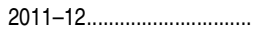 & 55 & 5,109 & 2,748 & 2,361 & 120 & 16,927 & 8,809 & 8,118 & 207 & 46,445 & 24,576 & 21,869 \\
\hline
\end{tabular}

-Not available.

NOTE: Data are for postsecondary institutions participating in Title IV federal financial aid programs.

SOURCE: U.S. Department of Education, National Center for Education Statistics, Earned Degrees Conferred, 1949-50 through 1964-65; Higher Education General Information Sur- vey (HEGIS), "Degrees and Other Formal Awards Conferred" surveys, 1965-66 through 1985-86; Integrated Postsecondary Education Data System (IPEDS), "Completions Survey" (IPEDS-C:87-99); and IPEDS Fall 2000 through Fall 2012, Completions component. (This table was prepared July 2013.) 


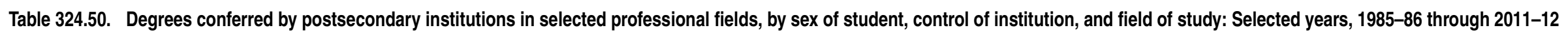

\begin{tabular}{|c|c|c|c|c|c|c|c|c|c|c|c|c|c|c|c|c|c|c|c|c|c|}
\hline \multirow[b]{2}{*}{ Control of institution and field of study } & \multirow[b]{2}{*}{$1985-86$} & \multirow[b]{2}{*}{ 1990-91 } & \multirow[b]{2}{*}{$1995-96$} & \multirow[b]{2}{*}{$2000-01$} & \multirow[b]{2}{*}{$2001-02$} & \multirow[b]{2}{*}{$2002-03$} & \multirow[b]{2}{*}{ 2003-04 } & \multirow[b]{2}{*}{ 2004-05 } & \multirow[b]{2}{*}{$2005-06$} & \multirow[b]{2}{*}{ 2006-07 } & \multirow[b]{2}{*}{$2007-08$} & \multirow[b]{2}{*}{ 2008-09 } & \multicolumn{3}{|c|}{$2009-10$} & \multicolumn{3}{|c|}{$2010-11$} & \multicolumn{3}{|c|}{$2011-12$} \\
\hline & & & & & & & & & & & & & Total & Males & Females & Total & Males & Females & Total & Males & Females \\
\hline 1 & 2 & 3 & 4 & 5 & 6 & 7 & 8 & 9 & 10 & 11 & 12 & 13 & 14 & 15 & 16 & 17 & 18 & 19 & 20 & 21 & 22 \\
\hline Total, all institutions & 73,910 & 71,948 & 76,734 & 79,707 & 80,698 & 80,897 & 83,041 & 87,289 & 87,655 & 90,064 & 91,309 & 92,004 & 94,103 & 47,538 & 46,565 & 95,749 & 48,801 & 46,948 & 98,710 & 50,334 & 48,376 \\
\hline entistry (D.D.S. or D.M.D.) ........ & 5,046 & 699 & 3,697 & ,391 & ,239 & 4,345 & 4,335 & 4,454 & 4,389 & 4,596 & 4,795 & 4,918 & 5,062 & 2,745 & 2,317 & 5,071 & 2,764 & 2,307 & 5,109 & 2,748 & 2,361 \\
\hline Medicine (M.D.). & 15,938 & 15,043 & 15,341 & 15,403 & 15,237 & 15,034 & 15,442 & 15,461 & 15,455 & 15,730 & 15,646 & 15,987 & 16,356 & 8,468 & 7,888 & 16,863 & 8,701 & 8,162 & 16,927 & 8,809 & 8,118 \\
\hline ptometry (O.D.) .. & 1,029 & 1,115 & 1,231 & 1,289 & 1,280 & 1,281 & 1,275 & 1,252 & 1,198 & 1,311 & 1,304 & 1,338 & 1,335 & 457 & 878 & 1,322 & 475 & 847 & 1,361 & 476 & 885 \\
\hline steopathic & 1,547 & 459 & 1,895 & 2,450 & 2,416 & 2,596 & 2,722 & 2,762 & 2,718 & 2,992 & 3,232 & 3,665 & 3,890 & 1,979 & 1,911 & 4,141 & 2,121 & 2,020 & 4,336 & 2,283 & 2,053 \\
\hline Pharmacy (Pharm & 903 & 1,244 & 2,555 & 6,324 & 7,076 & 7,474 & 8,221 & 8,885 & 9,292 & 10,439 & 10,932 & 11,291 & 11,873 & 4,297 & 7,576 & 12,274 & 4,694 & 7,580 & 12,943 & 4,971 & 7,972 \\
\hline $\begin{array}{l}\text { Podiatry (Pod.D. or D.P.) or podiatric medicine } \\
\text { (D.P.M.) }\end{array}$ & 612 & 589 & 650 & 528 & 474 & 439 & 382 & 343 & 347 & 331 & 555 & 431 & 491 & 276 & 215 & 543 & 318 & 225 & 535 & 342 & 193 \\
\hline Veterinary medicine (D.V.M.) & 2,270 & 2,032 & 2,109 & 2,248 & 2,289 & 2,354 & 2,228 & 2,354 & 2,370 & 2,443 & 2,504 & 2,377 & 2,478 & 555 & 1,923 & 2,564 & 580 & 1,984 & 2,616 & 588 & 2,028 \\
\hline hiropra & 3,395 & 2,640 & 3,379 & 3,796 & 3,284 & 2,718 & 2,730 & 2,560 & 2,564 & 2,525 & 2,639 & 2,512 & 2,601 & 1,610 & 991 & 2,694 & 1,666 & 1,028 & 2,496 & 1,538 & 958 \\
\hline Law (LL.B. 0 & 35,844 & 37,945 & 39,828 & 37,904 & 38,981 & 39,067 & 40,209 & 43,423 & 43,440 & 43,486 & 43,769 & 44,045 & 44,345 & 23,394 & 20,951 & 44,445 & 23,493 & 20,952 & 46,445 & 24,576 & 21,869 \\
\hline $\begin{array}{l}\text { Theology (M. Div., M.H.L., B.D., or Ord. and } \\
\text { M.H.L.R.Rav., B.D., or Ord.) }\end{array}$ & 7,283 & 5,695 & 5,879 & 5,026 & 5,195 & 5,360 & 5,332 & 5,533 & 5,666 & 5,990 & 5,751 & 5,362 & 5,672 & 3,757 & 1,915 & 5,832 &, 989 & ,843 & 942 & 4,003 & 939 \\
\hline 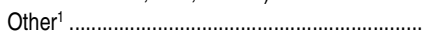 & 43 & 487 & 170 & 348 & 227 & 229 & 165 & 262 & 216 & 221 & 182 & 78 & 0 & 0 & 0 & 0 & 0 & 0 & 0 & 0 & 0 \\
\hline Total, public $\mathrm{i}$ & 29,568 & 29,554 & 29,882 & 32,633 & 33,439 & 33,549 & 34,499 & 35,768 & 36,269 & 36,855 & 37,278 & 37,357 & 38,132 & 18,432 & 19,700 & 39,071 & 19,027 & 20,044 & 39,776 & 19,589 & 20,187 \\
\hline$\ldots$ & 2,827 & 2,308 & 2,198 & 2,477 & 2,525 & 2,493 & 2,498 & 2,577 & 2,669 & 2,769 & 2,760 & 2,870 & 2,984 & 1,694 & 1,290 & 3,008 & 1,687 & 1,321 & 3,053 & 1,708 & 1,345 \\
\hline edl & 9,991 & 9,364 & 9,370 & 9,408 & 9,390 & 9,276 & 9,418 & 9,536 & 9,650 & 9,733 & 9,646 & 9,795 & 10,043 & 5,208 & 4,835 & 10,577 & 5,522 & 5,055 & 10,626 & 5,591 & 5,035 \\
\hline 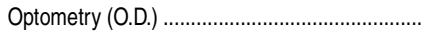 & 441 & 477 & 499 & 497 & 503 & 481 & 476 & 477 & 462 & 518 & 492 & 517 & 507 & 158 & 349 & 515 & 180 & 335 & 508 & 178 & 330 \\
\hline steop & 486 & 493 & 528 & 562 & 538 & 571 & 586 & 568 & 585 & 637 & 634 & 679 & 817 & 384 & 433 & 856 & 429 & 427 & 841 & 442 & 399 \\
\hline Pharmacy & 473 & 808 & 1,557 & 3,876 & 4,382 & 4,558 & 4,930 & 5,352 & 5,523 & 5,903 & 6,218 & 6,395 & 6,587 & 2,416 & 4,171 & 6,888 & 2,643 & 4,245 & 6,919 & 2,679 & 4,240 \\
\hline $\begin{array}{l}\text { Podiatry (Pod.D. or D.P.) or podiatric medicine } \\
\text { (D.P.M.) }\end{array}$ & 0 & 0 & 0 & 84 & 75 & 81 & 64 & 64 & 65 & 66 & 73 & 68 & 85 & 45 & 40 & 87 & 41 & 46 & 204 & 128 & 76 \\
\hline 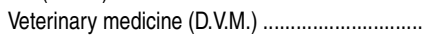 & 1,931 & 1,814 & 1,889 & 2,017 & 2,052 & 2,023 & 1,912 & 2,033 & 2,048 & 2,116 & 2,123 & 1,968 & 2,048 & 465 & 1,583 & 2,134 & 485 & 1,649 & 2,168 & 493 & 1,675 \\
\hline & & & & & & & 0 & & & & & & & 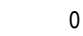 & 0 & & 0 & 0 & & 0 & 0 \\
\hline$\ldots \ldots \ldots \ldots . .$. & 13,419 & 14,290 & 13,841 & 13,712 & 13,974 & 14,066 & 14,615 & 15,161 & 15,267 & 15,113 & 15,332 & 15,065 & 15,061 & 8,062 & 6,999 & 15,006 & 8,040 & 6,966 & 15,457 & 8,370 & 7,087 \\
\hline 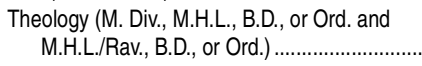 & 0 & 0 & 0 & 0 & 0 & 0 & 0 & 0 & 0 & 0 & 0 & 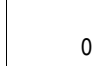 & 0 & 0 & 0 & 0 & 0 & 0 & 0 & 0 & 0 \\
\hline Other ${ }^{1}$.......... & 0 & 0 & 0 & 0 & 0 & 0 & 0 & 0 & 0 & 0 & 0 & 0 & 0 & 0 & 0 & 0 & 0 & 0 & 0 & 0 & 0 \\
\hline Total, & 44,342 & 42,394 & 46,852 & 47,074 & 47,259 & 47,348 & 48,542 & 51,521 & 51,386 & 53,209 & 54,031 & 54,647 & 55,971 & 29,106 & 26,865 & 56,678 & 29,774 & 6,904 & 58,934 & 30,745 & 28,189 \\
\hline entistry (D.D.S. & 219 & 91 & 99 & & 14 & 52 & 337 & 77 & 1,720 & 1,827 & 2,035 & 2,048 & 2,078 & 1,051 & 1,0 & 2,063 & 1,077 & 986 & 2,056 & 1,040 & 1,016 \\
\hline & 5,947 & 99 & 1 & & 7 & 5,758 & 6,024 & 5,925 & 5,805 & 5,997 & 6,000 & 6,192 & 6,313 & 3,260 & 3,0 & 6,286 & 3,179 & 3,107 & 6,301 & 3,218 & 3,083 \\
\hline Optom & 588 & 638 & 732 & 792 & 777 & 800 & 799 & 775 & 736 & 793 & 812 & 821 & 828 & 299 & 529 & 807 & 295 & 512 & 853 & 298 & 555 \\
\hline Osteopathic medicine (D.O.) & 1,061 & 966 & 1,367 & 1,888 & 1,878 & 2,025 & 2,136 & 2,194 & 2,133 & 2,355 & 2,598 & 2,986 & 3,073 & 1,595 & 1,478 & 3,285 & 1,692 & 1,593 & 3,495 & 1,841 & 1,654 \\
\hline Pharma & 430 & 436 & 998 & 2,448 & 2,694 & 2,916 & 3,291 & 3,533 & 3,769 & 4,536 & 4,714 & 4,896 & 5,286 & 1,881 & 3,405 & 5,386 & 2,051 & 3,335 & 6,024 & 2,292 & 3,732 \\
\hline & & & & & & & & & & & & & & & & & & & & & \\
\hline & $\begin{array}{l}012 \\
339\end{array}$ & $\begin{array}{l}589 \\
218\end{array}$ & $\begin{array}{l}650 \\
220\end{array}$ & $\begin{array}{l}444 \\
231\end{array}$ & $\begin{array}{l}399 \\
237\end{array}$ & $\begin{array}{l}358 \\
331\end{array}$ & $\begin{array}{l}318 \\
316\end{array}$ & $\begin{array}{l}279 \\
321\end{array}$ & $\begin{array}{l}282 \\
322\end{array}$ & $\begin{array}{l}265 \\
327\end{array}$ & $\begin{array}{l}482 \\
381\end{array}$ & $\begin{array}{l}363 \\
409\end{array}$ & 406 & $\begin{array}{r}231 \\
90\end{array}$ & 17 & $\begin{array}{l}456 \\
430\end{array}$ & $\begin{array}{r}27 / \\
95\end{array}$ & $\begin{array}{l}179 \\
335\end{array}$ & $\begin{array}{l}331 \\
448\end{array}$ & $\begin{array}{r}214 \\
95\end{array}$ & $\begin{array}{l}117 \\
353\end{array}$ \\
\hline Chiropra & 3,395 & 2,640 & 3,379 & 3,796 & 3,284 & 2,718 & 2,730 & 2,560 & 2,564 & 2,525 & 2,639 & 2,512 & 2,601 & 1,610 & 991 & 2,694 & 1,666 & 1,028 & 2,496 & 1,538 & 958 \\
\hline Law (LL & 22,425 & 23,655 & 25,987 & 24,192 & 25,007 & 25,001 & 25,594 & 28,262 & 28,173 & 28,373 & 28,437 & 28,980 & 29,284 & 15,332 & 13,952 & 29,439 & 15,453 & 13,986 & 30,988 & 16,206 & 14,782 \\
\hline & & & & & & & & & & & & & & & & & & & & & \\
\hline & 7,283 & 5,695 & 5,879 & 5,026 & 5,195 & 5,360 & 5,332 & 5,533 & 5,666 & 5,990 & 5,751 & 5,362 & 5,672 & 3,757 & 1,915 & 5,832 & 3,989 & 1,843 & 5,942 & 4,003 & ,939 \\
\hline Other ${ }^{1} \ldots . .$. & 43 & 487 & 170 & 348 & 227 & 229 & 165 & 262 & 216 & 221 & 182 & 78 & & & & & & & & & \\
\hline
\end{tabular}

'Includes naturopathic medicine and degrees that were not classified by field by the reporting institution.

NOTE: Data are for postsecondary institutions participating in Title IV federal financial aid programs. Includes degrees that require at least 6 years of college work for completion (including at least 2 years of preprofessional training).
SOURCE: U.S. Department of Education, National Center for Education Statistics, Higher Education General Information Survey (HEGIS), "Degrees and Other Formal Awards Conferred," 1985-86; Integrated Postsecondary Education Data Sys-
tem (IPEDS), "Completions Survey" (IPEDS-C:91-99); and IPEDS Fall 2000 through Fall 2012, Completions component. (This table was prepared July 2013.) 
Table 324.55. Degrees conferred by postsecondary institutions in selected professional fields, by race/ethnicity and field of study: 2010-11 and 2011-12

\begin{tabular}{|c|c|c|c|c|c|c|c|c|c|c|c|c|c|c|c|c|c|c|c|c|}
\hline \multirow[b]{3}{*}{ Field of study } & \multicolumn{10}{|c|}{$2010-11$} & \multicolumn{10}{|c|}{ 2011-12 } \\
\hline & \multirow[b]{2}{*}{ Total } & \multirow[b]{2}{*}{ White } & \multirow[b]{2}{*}{ Black } & \multirow[b]{2}{*}{ Hispanic } & \multicolumn{3}{|c|}{ Asian/Pacific Islander } & \multirow{2}{*}{$\begin{array}{r}\text { American } \\
\text { Indian/ } \\
\text { Alaska } \\
\text { Native }\end{array}$} & \multirow[b]{2}{*}{$\begin{array}{r}\text { Two or } \\
\text { more races }\end{array}$} & \multirow{2}{*}{$\begin{array}{r}\text { Non- } \\
\text { resident } \\
\text { alien }\end{array}$} & \multirow[b]{2}{*}{ Total } & \multirow[b]{2}{*}{ White } & \multirow[b]{2}{*}{ Black } & \multirow[b]{2}{*}{ Hispanic } & \multicolumn{3}{|c|}{ Asian/Pacific Islander } & \multirow{2}{*}{$\begin{array}{r}\text { American } \\
\text { Indian/ } \\
\text { Alaska } \\
\text { Native }\end{array}$} & \multirow[b]{2}{*}{$\begin{array}{r}\text { Two or } \\
\text { more races }\end{array}$} & \multirow{2}{*}{$\begin{array}{r}\text { Non- } \\
\text { resident } \\
\text { alien }\end{array}$} \\
\hline & & & & & Total & Asian & $\begin{array}{r}\text { Pacific } \\
\text { Islander }\end{array}$ & & & & & & & & Total & Asian & $\begin{array}{r}\text { Pacific } \\
\text { Islander }\end{array}$ & & & \\
\hline 1 & 2 & 3 & 4 & 5 & 6 & 7 & 8 & 9 & 10 & 11 & 12 & 13 & 14 & 15 & 16 & 17 & 18 & 19 & 20 & 21 \\
\hline All fields, total... & 95,749 & 66,211 & 6,915 & 5,800 & 12,843 & 12,561 & 282 & 662 & 842 & 2,476 & 98,710 & 68,003 & 7,255 & 6,042 & 13,318 & 13,054 & 264 & 618 & 1,076 & 2,398 \\
\hline 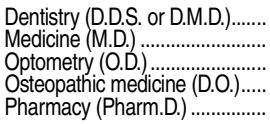 & $\begin{array}{r}5,071 \\
16,863 \\
1,322 \\
4,41 \\
12,274\end{array}$ & $\begin{array}{r}3,094 \\
10,713 \\
785 \\
2,986 \\
7,598\end{array}$ & $\begin{array}{r}278 \\
1,129 \\
32 \\
137 \\
849\end{array}$ & $\begin{array}{r}323 \\
967 \\
49 \\
159 \\
540\end{array}$ & $\begin{array}{r}934 \\
3,570 \\
348 \\
804 \\
2,786\end{array}$ & $\begin{array}{r}915 \\
3,557 \\
346 \\
783 \\
2,747\end{array}$ & \begin{tabular}{r|}
19 \\
23 \\
2 \\
21 \\
39
\end{tabular} & $\begin{array}{r}25 \\
100 \\
6 \\
25 \\
56\end{array}$ & \begin{tabular}{r|}
37 \\
161 \\
3 \\
15 \\
76
\end{tabular} & $\begin{array}{r}380 \\
223 \\
99 \\
15 \\
369 \\
\end{array}$ & $\begin{array}{r}5,109 \\
16,927 \\
1,361 \\
4,336 \\
12,943\end{array}$ & $\begin{array}{r}3,039 \\
10,683 \\
802 \\
3,131 \\
7,829\end{array}$ & $\begin{array}{r}262 \\
1,190 \\
37 \\
135 \\
897\end{array}$ & $\begin{array}{r}276 \\
935 \\
41 \\
186 \\
534\end{array}$ & $\begin{array}{r}1,038 \\
3,557 \\
370 \\
790 \\
3,167\end{array}$ & $\begin{array}{r}1,028 \\
3,528 \\
364 \\
768 \\
3,133\end{array}$ & \begin{tabular}{r|}
10 \\
29 \\
6 \\
22 \\
34
\end{tabular} & \begin{tabular}{r|}
35 \\
114 \\
1 \\
28 \\
64
\end{tabular} & \begin{tabular}{r|r}
37 \\
229 \\
7 \\
32 \\
104
\end{tabular} & $\begin{array}{r}422 \\
219 \\
103 \\
34 \\
348\end{array}$ \\
\hline $\begin{array}{l}\text { Podiatry (Pod.D. or D.P.) or } \\
\text { podiatric medicine (D.P.M.). } \\
\text { Veterinary medicine (D.V.M.).... } \\
\text { Chiropractic (D.C. or D.C.M.)..... } \\
\text { Law (LL.B. or J.D.) } \\
\text { Theology (M.Div. M.H.L..Rav.. }\end{array}$ & $\begin{array}{r}543 \\
2,564 \\
2,694 \\
44,445\end{array}$ & $\begin{array}{r}372 \\
2,233 \\
2,114 \\
32,599\end{array}$ & $\begin{array}{r}55 \\
59 \\
139 \\
3,186\end{array}$ & $\begin{array}{r}21 \\
117 \\
129 \\
3,271\end{array}$ & $\begin{array}{r}71 \\
99 \\
190 \\
3,664\end{array}$ & $\begin{array}{r}71 \\
96 \\
179 \\
3,512\end{array}$ & $\begin{array}{r}0 \\
3 \\
11 \\
152\end{array}$ & $\begin{array}{r}12 \\
21 \\
23 \\
360\end{array}$ & $\begin{array}{r}0 \\
24 \\
17 \\
476\end{array}$ & $\begin{array}{r}12 \\
11 \\
82 \\
889\end{array}$ & $\begin{array}{r}535 \\
2,616 \\
2,496 \\
46,445\end{array}$ & $\begin{array}{r}366 \\
2,247 \\
1,959 \\
34,192\end{array}$ & $\begin{array}{r}41 \\
70 \\
130 \\
3,377\end{array}$ & $\begin{array}{r}32 \\
141 \\
136 \\
3,545\end{array}$ & $\begin{array}{r}68 \\
106 \\
182 \\
3,659\end{array}$ & $\begin{array}{r}68 \\
106 \\
172 \\
3,525\end{array}$ & $\begin{array}{r}0 \\
0 \\
10 \\
134\end{array}$ & $\begin{array}{r}3 \\
19 \\
8 \\
328\end{array}$ & $\begin{array}{r}4 \\
21 \\
20 \\
557\end{array}$ & $\begin{array}{r}21 \\
12 \\
61 \\
787\end{array}$ \\
\hline B.D., or Ord.) & 5,832 & 3,717 & 1,051 & 224 & 377 & 365 & 12 & 34 & 33 & 396 & 5,942 & 3,755 & 1,116 & 216 & 381 & 362 & 19 & 18 & 65 & 391 \\
\hline
\end{tabular}

NOTE: Data are for postsecondary institutions participating in Tittle IV federal financial aid programs. Includes degrees that require at least 6 years of college work for completion (including at least 2 years of preprofessional training). Race categories
exclude persons of Hispanic ethnicity. Reported racial/ethnic distributions of students by level of degree, field of degree, and sex

SOURCE: U.S. Department of Education, National Center for Education Statistics, Integrated Postsecondary Education Data were used to estimate race/ethnicity for students whose race/ethnicity was not reported.

\section{Table 324.60. Degrees conferred to males by postsecondary institutions in selected professional fields, by race/ethnicity and field of study: 2010-11 and 2011-12}

\begin{tabular}{|c|c|c|c|c|c|c|c|c|c|c|c|c|c|c|c|c|c|c|c|c|}
\hline \multirow[b]{3}{*}{ Field of study } & \multicolumn{10}{|c|}{$2010-11$} & \multicolumn{10}{|c|}{$2011-12$} \\
\hline & \multirow[b]{2}{*}{ Total } & \multirow[b]{2}{*}{ White } & \multirow[b]{2}{*}{ Black } & \multirow[b]{2}{*}{ Hispanic } & \multicolumn{3}{|c|}{ Asian/Pacific Islander } & \multirow{2}{*}{$\begin{array}{r}\text { American } \\
\text { Indian/ } \\
\text { Alaska } \\
\text { Native } \\
\end{array}$} & \multirow[b]{2}{*}{$\begin{array}{r}\text { Two or } \\
\text { more races }\end{array}$} & \multirow[b]{2}{*}{$\begin{array}{r}\text { Non- } \\
\text { resident } \\
\text { alien }\end{array}$} & \multirow[b]{2}{*}{ Total } & \multirow[b]{2}{*}{ White } & \multirow[b]{2}{*}{ Black } & \multirow[b]{2}{*}{ Hispanic } & \multicolumn{3}{|c|}{ Asian/Pacific Islander } & \multirow{2}{*}{$\begin{array}{r}\text { American } \\
\text { Indian/ } \\
\text { Alaska } \\
\text { Native }\end{array}$} & \multirow[b]{2}{*}{$\begin{array}{r}\text { Two or } \\
\text { more races }\end{array}$} & \multirow[b]{2}{*}{$\begin{array}{r}\text { Non- } \\
\text { resident } \\
\text { alien }\end{array}$} \\
\hline & & & & & Total & Asian & $\begin{array}{r}\text { Pacific } \\
\text { Islander }\end{array}$ & & & & & & & & Total & Asian & $\begin{array}{r}\text { Pacific } \\
\text { Islander }\end{array}$ & & & \\
\hline 1 & 2 & 3 & 4 & 5 & 6 & 7 & 8 & 9 & 10 & 11 & 12 & 13 & 14 & 15 & 16 & 17 & 18 & 19 & 20 & 21 \\
\hline All fields, tota & 48,801 & 35,456 & 2,719 & 2,835 & 5,772 & 5,630 & 142 & 349 & 393 & 1,277 & 50,334 & 36,584 & 2,807 & 2,971 & 5,914 & 5,777 & 137 & 313 & 494 & 1,251 \\
\hline 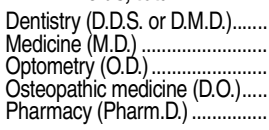 & $\begin{array}{l}2,764 \\
8,701 \\
475 \\
2,121 \\
4,694\end{array}$ & \begin{tabular}{r|}
1,868 \\
5,833 \\
334 \\
1,552 \\
2,967
\end{tabular} & $\begin{array}{r}102 \\
399 \\
7 \\
37 \\
305\end{array}$ & \begin{tabular}{r|}
144 \\
495 \\
13 \\
83 \\
213
\end{tabular} & $\begin{array}{r}426 \\
1,731 \\
93 \\
416 \\
984\end{array}$ & $\begin{array}{r}416 \\
1,719 \\
93 \\
405 \\
971\end{array}$ & \begin{tabular}{r|}
10 \\
12 \\
0 \\
11 \\
13
\end{tabular} & \begin{tabular}{r|}
13 \\
55 \\
1 \\
16 \\
27
\end{tabular} & \begin{tabular}{r|}
22 \\
71 \\
1 \\
8 \\
36
\end{tabular} & $\begin{array}{r}189 \\
117 \\
26 \\
9 \\
162\end{array}$ & $\begin{array}{l}2,748 \\
8,809 \\
476 \\
2,283 \\
4,971\end{array}$ & $\begin{array}{r}1,830 \\
5,893 \\
324 \\
1,715 \\
3,064\end{array}$ & $\begin{array}{r}101 \\
419 \\
7 \\
46 \\
343\end{array}$ & $\begin{array}{r}124 \\
491 \\
14 \\
86 \\
207\end{array}$ & $\begin{array}{r}449 \\
1,751 \\
92 \\
388 \\
1,138\end{array}$ & $\begin{array}{r}443 \\
1,739 \\
89 \\
376 \\
1,125\end{array}$ & \begin{tabular}{r|}
6 \\
12 \\
3 \\
12 \\
13
\end{tabular} & $\begin{array}{r}21 \\
58 \\
0 \\
13 \\
25\end{array}$ & $\begin{array}{r}22 \\
95 \\
4 \\
21 \\
43\end{array}$ & $\begin{array}{r}201 \\
102 \\
35 \\
14 \\
151\end{array}$ \\
\hline $\begin{array}{l}\text { Podiatry (Pod.D. or D.P.) or } \\
\text { podiatric medicine (D.P.M.). } \\
\text { Veterinary medicine (D.V.M.). } \\
\text { Chiropractic (D.C. or D.C.M.)..... } \\
\text { Law (LL.B. or J.D.) } \\
\text { Theology (M.Di.., M.H.L........... }\end{array}$ & $\begin{array}{r}318 \\
580 \\
1,666 \\
23,493\end{array}$ & $\begin{array}{r}243 \\
505 \\
1,318 \\
18,236\end{array}$ & $\begin{array}{r}23 \\
12 \\
69 \\
1,191\end{array}$ & $\begin{array}{r}10 \\
28 \\
87 \\
1,598\end{array}$ & $\begin{array}{r}31 \\
26 \\
125 \\
1,645\end{array}$ & $\begin{array}{r}31 \\
26 \\
118 \\
1,566\end{array}$ & $\begin{array}{r}0 \\
0 \\
7 \\
79\end{array}$ & $\begin{array}{r}5 \\
2 \\
13 \\
192\end{array}$ & $\begin{array}{r}0 \\
3 \\
11 \\
221\end{array}$ & $\begin{array}{r}6 \\
4 \\
43 \\
410\end{array}$ & $\begin{array}{r}342 \\
558 \\
1,538 \\
24,576\end{array}$ & $\begin{array}{r}256 \\
502 \\
1,234 \\
19,137\end{array}$ & $\begin{array}{r}17 \\
18 \\
64 \\
1,239\end{array}$ & $\begin{array}{r}16 \\
37 \\
86 \\
1,759\end{array}$ & $\begin{array}{r}37 \\
16 \\
108 \\
1,620\end{array}$ & $\begin{array}{r}37 \\
16 \\
106 \\
1,547\end{array}$ & $\begin{array}{r}0 \\
0 \\
2 \\
73\end{array}$ & $\begin{array}{r}1 \\
7 \\
6 \\
171\end{array}$ & $\begin{array}{r}4 \\
5 \\
7 \\
256\end{array}$ & $\begin{array}{r}11 \\
3 \\
33 \\
394\end{array}$ \\
\hline 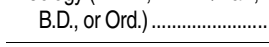 & 3,989 & 2,600 & 574 & 164 & 295 & 285 & 10 & 25 & 20 & 311 & 4,003 & 2,629 & 553 & 151 & 315 & 299 & 16 & 11 & 37 & 307 \\
\hline
\end{tabular}

NOTE: Data are for postsecondary institutions participating in Title IV federal financial aid programs. Includes degrees that SOURCE: U.S. Department of Education, National Center for Education Statistics, Integrated Postsecondary Education Data require at least 6 years of college work for completion (including at least 2 years of preprofessional training). Race categories System (IPEDS), Fall 2011 and Fall 2012, Completions component. (This table was prepared July 2013.) 
Table 324.70. Degrees conferred to females by postsecondary institutions in selected professional fields, by race/ethnicity and field of study: 2010-11 and 2011-12

\begin{tabular}{|c|c|c|c|c|c|c|c|c|c|c|c|c|c|c|c|c|c|c|c|c|}
\hline \multirow[b]{3}{*}{ Field of study } & \multicolumn{10}{|c|}{$2010-11$} & \multicolumn{10}{|c|}{ 2011-12 } \\
\hline & \multirow[b]{2}{*}{ Total } & \multirow[b]{2}{*}{ White } & \multirow[b]{2}{*}{ Black } & \multirow[b]{2}{*}{ Hispanic } & \multicolumn{3}{|c|}{ Asian/Pacific Islander } & \multirow{2}{*}{$\begin{array}{r}\text { American } \\
\text { Indian/ } \\
\text { Alaska } \\
\text { Native } \\
\end{array}$} & \multirow[b]{2}{*}{$\begin{array}{r}\text { Two or } \\
\text { more races }\end{array}$} & \multirow{2}{*}{$\begin{array}{r}\text { Non- } \\
\text { resident } \\
\text { alien }\end{array}$} & \multirow[b]{2}{*}{ Total } & \multirow[b]{2}{*}{ White } & \multirow[b]{2}{*}{ Black } & \multirow[b]{2}{*}{ Hispanic } & \multicolumn{3}{|c|}{ Asian/Pacific Islander } & \multirow{2}{*}{$\begin{array}{r}\text { American } \\
\text { Indian/ } \\
\text { Alaska } \\
\text { Native } \\
\end{array}$} & \multirow[b]{2}{*}{$\begin{array}{r}\text { Two or } \\
\text { more races }\end{array}$} & \multirow{2}{*}{$\begin{array}{r}\text { Non- } \\
\text { resident } \\
\text { alien } \\
\end{array}$} \\
\hline & & & & & Total & Asian & $\begin{array}{r}\text { Pacific } \\
\text { Islander }\end{array}$ & & & & & & & & Total & Asian & $\begin{array}{r}\text { Pacific } \\
\text { Islander }\end{array}$ & & & \\
\hline 1 & 2 & 3 & 4 & 5 & 6 & 7 & 8 & 9 & 10 & 11 & 12 & 13 & 14 & 15 & 16 & 17 & 18 & 19 & 20 & 21 \\
\hline All fields, total ................. & 46,948 & 30,755 & 4,196 & 2,965 & 7,071 & 6,931 & 140 & 313 & 449 & 1,199 & 48,376 & 31,419 & 4,448 & 3,071 & 7,404 & 7,277 & 127 & 305 & 582 & 1,147 \\
\hline Dentistry (D.D.S. or D.M.D.)....... & 2,307 & 1,226 & 176 & 179 & 508 & 499 & 9 & 12 & 15 & 191 & 2,361 & 1,209 & 161 & 152 & 589 & 585 & 4 & 14 & 15 & 221 \\
\hline Medicine (M.D.) ...................... & 8,162 & 4,880 & 730 & 472 & 1,839 & 1,828 & 11 & 45 & 90 & 106 & 8,118 & 4,790 & 771 & 444 & 1,806 & 1,789 & 17 & 56 & 134 & 117 \\
\hline Optometry (O.D.) ....................... & 847 & 451 & 25 & 36 & 255 & 253 & 2 & 5 & 2 & 73 & 885 & 478 & 30 & 27 & 278 & 275 & 3 & 1 & 3 & 68 \\
\hline Osteopathic medicine (D.O.)..... & 2,020 & 1,434 & 100 & 76 & 388 & 378 & 10 & 9 & 7 & 6 & 2,053 & 1,416 & 89 & 100 & 402 & 392 & 10 & 15 & 11 & 20 \\
\hline Pharmacy (Pharm.D.) ................ & 7,580 & 4,631 & 544 & 327 & 1,802 & 1,776 & 26 & 29 & 40 & 207 & 7,972 & 4,765 & 554 & 327 & 2,029 & 2,008 & 21 & 39 & 61 & 197 \\
\hline $\begin{array}{l}\text { Podiatry (Pod.D. or D.P.) or } \\
\text { podiatric medicine (D.P.M.). }\end{array}$ & 225 & 129 & 32 & 11 & 40 & 40 & 0 & 7 & 0 & 6 & 193 & 110 & 24 & 16 & 31 & 31 & 0 & 2 & 0 & 10 \\
\hline Veterinary medicine (D.V.M.)..... & 1,984 & 1,728 & 47 & 89 & 73 & 70 & 3 & 19 & 21 & 7 & 2,028 & 1,745 & 52 & 104 & 90 & 90 & 0 & 12 & 16 & 9 \\
\hline Chiropractic (D.C. or D.C.M.)..... & 1,028 & 796 & 70 & 42 & 65 & 61 & 4 & 10 & 6 & 39 & 958 & 725 & 66 & 50 & 74 & 66 & 8 & 2 & 13 & 28 \\
\hline Law (LL.B. or J.D.) .................... & 20,952 & 14,363 & 1,995 & 1,673 & 2,019 & 1,946 & 73 & 168 & 255 & 479 & 21,869 & 15,055 & 2,138 & 1,786 & 2,039 & 1,978 & 61 & 157 & 301 & 393 \\
\hline $\begin{array}{l}\text { Theology (M.Div., M.H.L./Rav., } \\
\text { B.D., or Ord.).................... }\end{array}$ & 1,843 & 1,117 & 477 & 60 & 82 & 80 & 2 & 9 & 13 & 85 & 1,939 & 1,126 & 563 & 65 & 66 & 63 & 3 & 7 & 28 & 84 \\
\hline
\end{tabular}

NOTE: Data are for postsecondary institutions participating in Title IV federal financial aid programs. Includes degrees that require at least 6 years of college work for completion (including at least 2 years of preprofessional training). Race categories

SOURCE: U.S. Department of Education, National Center for Education Statistics, Integrated Postsecondary Education Data exclude persons of Hispanic ethnicity. Reported racial/ethnic distributions of students by level of degree, field of degree, and sex 
Table 324.80. Statistical profile of persons receiving doctor's degrees, by field of study and selected characteristics: 2009-10 and 2010-11

\begin{tabular}{|c|c|c|c|c|c|c|c|c|c|c|}
\hline \multirow[b]{3}{*}{ Selected characteristic } & \multirow{3}{*}{$\begin{array}{l}\text { All fields, } \\
2009-10\end{array}$} & \multicolumn{9}{|c|}{ Field of study, 2010-11 } \\
\hline & & \multirow[b]{2}{*}{ All fields } & \multirow[b]{2}{*}{ Education } & \multirow[b]{2}{*}{ Engineering } & \multirow[b]{2}{*}{ Humanities } & \multirow[b]{2}{*}{ Life sciences } & \multicolumn{2}{|c|}{$\begin{array}{l}\text { Physical sciences, } \\
\text { mathematics, and } \\
\text { computer science }^{1}\end{array}$} & \multirow{2}{*}{$\begin{array}{r}\text { Social } \\
\text { sciences and } \\
\text { psychology }\end{array}$} & \multirow[b]{2}{*}{ Other fields } \\
\hline & & & & & & & Total & Mathematics & & \\
\hline 1 & 2 & 3 & 4 & 5 & 6 & 7 & 8 & 9 & 10 & 11 \\
\hline Number of doctor's degrees conferred ..................... & 48,069 & 49,010 & 4,691 & 8,004 & 5,214 & 11,467 & 8,678 & 1,607 & 8,120 & 2,836 \\
\hline \multicolumn{11}{|l|}{ Sex (percent) $)^{2}$} \\
\hline 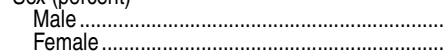 & $\begin{array}{l}53.1 \\
46.8\end{array}$ & $\begin{array}{l}53.5 \\
46.4\end{array}$ & $\begin{array}{l}30.6 \\
69.3\end{array}$ & $\begin{array}{l}77.7 \\
22.2\end{array}$ & $\begin{array}{l}48.5 \\
51.5\end{array}$ & $\begin{array}{l}45.2 \\
54.7\end{array}$ & $\begin{array}{l}71.4 \\
28.6\end{array}$ & $\begin{array}{l}71.3 \\
28.6\end{array}$ & $\begin{array}{l}40.5 \\
59.5\end{array}$ & $\begin{array}{l}48.9 \\
51.1\end{array}$ \\
\hline \multicolumn{11}{|l|}{ Race/ethnicity (percent) ${ }^{3}$} \\
\hline White.................. & 74.5 & 74.1 & 71.7 & 69.1 & 80.0 & 73.4 & 77.3 & 78.7 & 73.5 & 71.2 \\
\hline 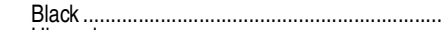 & 6.3 & 6.1 & 13.0 & 4.0 & 3.9 & 5.7 & 3.0 & 2.9 & 6.6 & 9.3 \\
\hline Hispanic .............................................. & 5.9 & 6.3 & 6.0 & 5.8 & 6.9 & 6.0 & 4.5 & 3.2 & 8.4 & 6.0 \\
\hline 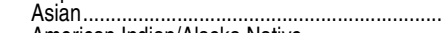 & 9.0 & 9.0 & 4.8 & 16.9 & 4.7 & 10.8 & 10.7 & 10.3 & 6.7 & 9.3 \\
\hline American Indian/Alaska Native ............................ & 0.4 & 0.4 & 0.8 & 0.2 & 0.4 & 0.3 & 0.3 & 0.4 & 0.6 & 0.3 \\
\hline 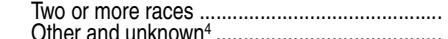 & $\begin{array}{l}2.1 \\
1.9\end{array}$ & 2.3 & 2.2 & 2.2 & 2.2 & 2.3 & 2.4 & 2.3 & 2.5 & 2.1 \\
\hline 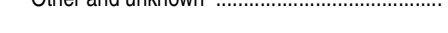 & 1.9 & & 1.0 & 1.0 & & 1.5 & 1.9 & 2.1 & & \\
\hline \multicolumn{11}{|l|}{ Citizenship (percent) } \\
\hline U.S. citizen and permanent resident .................... & 65.7 & 64.9 & 83.0 & 41.5 & 80.4 & 68.5 & 54.5 & 50.7 & 73.7 & 63.9 \\
\hline 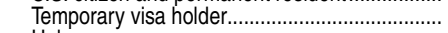 & 28.3 & 29.1 & 10.6 & 52.0 & 14.4 & 26.2 & 39.6 & 42.9 & 19.5 & 28.6 \\
\hline Unknown & 6.0 & 6.1 & 6.3 & 6.5 & 5.2 & 5.3 & 5.9 & 6.4 & 6.9 & 7.5 \\
\hline 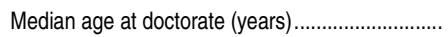 & 32.2 & 32.0 & 39.3 & 30.4 & 34.2 & 31.3 & 30.2 & 29.5 & 32.5 & 35.7 \\
\hline Percent with bachelor's degree in same field as & & & & & & & & & & \\
\hline 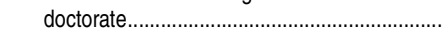 & 53.5 & 55.0 & 26.2 & 77.4 & 52.2 & 50.5 & 66.4 & 70.8 & 52.2 & 35.5 \\
\hline \multicolumn{11}{|l|}{ Median time lapse to doctorate (years) } \\
\hline Since bachelor's degree completion ................... & 9.3 & 9.1 & 15.0 & 7.8 & 11.0 & 8.5 & 7.6 & 7.0 & 9.5 & 12.2 \\
\hline 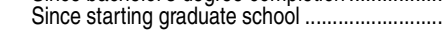 & 7.7 & 7.7 & 11.7 & 6.8 & 8.3 & 6.9 & 6.7 & 6.3 & 7.7 & 9.7 \\
\hline \multicolumn{11}{|l|}{ Postdoctoral plans (percent) ${ }^{5}$} \\
\hline 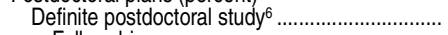 & 29.1 & 27.4 & 5.3 & 25.7 & 9.5 & 42.5 & 39.9 & 37.0 & 25.3 & 5.3 \\
\hline 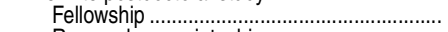 & 15.2 & 14.1 & 2.5 & 8.3 & 7.8 & 24.5 & 15.8 & 19.0 & 17.5 & 3.2 \\
\hline Research associateship .................................. & 12.9 & 12.2 & 2.4 & 16.5 & 1.4 & 16.7 & 23.0 & 16.8 & 5.8 & 2.0 \\
\hline 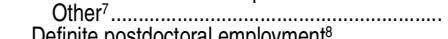 & 1.0 & 1.1 & 0.4 & 0.9 & 0.2 & 1.4 & 1.1 & 1.2 & 2.0 & 0.2 \\
\hline Definite postdoctoral employment ${ }^{8}$....................... & 38.1 & 36.8 & 61.4 & 37.0 & 45.5 & 18.8 & 28.6 & 33.1 & 43.0 & 63.8 \\
\hline Postsecondary educational institution ${ }^{9} . . . . . . . . .$. & 20.4 & 19.5 & 36.5 & 6.3 & 38.0 & 9.3 & 9.3 & 18.0 & 26.6 & 50.4 \\
\hline 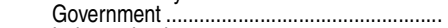 & 3.5 & 3.1 & 2.1 & 4.3 & 1.2 & 2.7 & 2.7 & 2.8 & 5.1 & 2.6 \\
\hline Industry, business ........................................ & 8.6 & 9.6 & 2.6 & 24.8 & 1.9 & 4.8 & 15.1 & 10.6 & 5.5 & 5.9 \\
\hline Nonprofit organization ...................................... & 2.0 & 2.1 & 3.2 & 1.0 & 2.3 & 1.7 & 1.0 & 1.2 & 3.8 & 3.1 \\
\hline 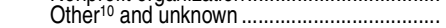 & 3.5 & 2.6 & 17.1 & 0.7 & 2.0 & 0.5 & 0.6 & 0.5 & 2.1 & 1.8 \\
\hline 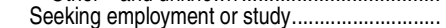 & 28.9 & 31.9 & 30.4 & 34.3 & 41.1 & 31.9 & 28.9 & 28.0 & 29.1 & 28.0 \\
\hline 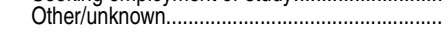 & 3.8 & 3.9 & 2.9 & 3.0 & 3.9 & 6.8 & 2.6 & 2.0 & 2.7 & 2.9 \\
\hline Primary work activity after doctorate (percent) ${ }^{11}$ & & & & & & & & & & \\
\hline 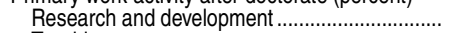 & 36.8 & 40.2 & 13.0 & 75.5 & 12.0 & 44.4 & 61.9 & 43.5 & 36.9 & 33.0 \\
\hline 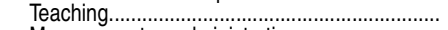 & 38.5 & 37.1 & 43.5 & 8.5 & 75.1 & 30.0 & 23.6 & 45.3 & 38.5 & 49.1 \\
\hline Management or administration ................................ & 13.6 & 11.1 & 31.5 & 5.2 & 7.0 & 11.4 & 4.3 & 2.2 & 7.6 & 10.1 \\
\hline Professional services ………………………......... & 9.8 & 9.6 & 10.8 & 8.0 & 4.1 & 12.2 & 7.6 & 7.9 & 15.7 & 6.0 \\
\hline 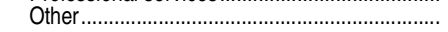 & 1.3 & 1.9 & 1.2 & 2.9 & 1.9 & 2.0 & 2.6 & 1.1 & 1.3 & 1.8 \\
\hline Employment location after doctorate (percent) ${ }^{12}$ & & & & & & & & & & \\
\hline 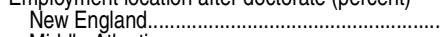 & 8.2 & 8.6 & 4.7 & 7.9 & 8.8 & 10.8 & 8.5 & 7.6 & 9.5 & 6.0 \\
\hline 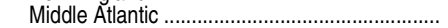 & 13.0 & 13.1 & 11.8 & 12.0 & 16.0 & 12.6 & 13.4 & 17.1 & 13.8 & 13.2 \\
\hline 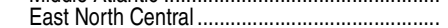 & 12.3 & 11.9 & 14.0 & 11.2 & 13.8 & 11.0 & 11.1 & 12.8 & 11.3 & 14.8 \\
\hline 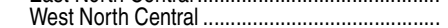 & 5.3 & 5.4 & 7.5 & 3.7 & 6.8 & 6.5 & 3.7 & 4.6 & 4.8 & 7.1 \\
\hline South Atlantic........... & 16.9 & 16.9 & 21.9 & 13.7 & 15.6 & 18.2 & 14.2 & 16.3 & 19.0 & 16.5 \\
\hline East South Central......................... & 3.7 & 4.1 & 7.8 & 3.0 & 5.5 & 4.4 & 2.4 & 2.0 & 3.3 & 5.4 \\
\hline West South Central........................................ & 7.5 & 6.9 & 9.6 & 6.7 & 7.6 & 6.3 & 6.2 & 5.6 & 6.7 & 7.7 \\
\hline Mountain & 5.1 & 5.1 & 7.2 & 6.2 & 4.4 & 4.3 & 5.7 & 4.1 & 4.0 & 4.6 \\
\hline 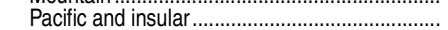 & 16.0 & 16.5 & 9.5 & 22.1 & 11.4 & 17.3 & 20.7 & 13.5 & 14.7 & 9.5 \\
\hline 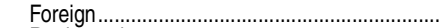 & 10.9 & 10.8 & 5.7 & 12.5 & 9.6 & 7.9 & 13.4 & 15.8 & 12.2 & 14.8 \\
\hline Region unknown & 0.1 & 0.1 & 0.1 & 0.2 & 0.1 & 0.1 & 0.1 & 0.2 & 0.1 & 0.1 \\
\hline
\end{tabular}

1'Includes mathematics, computer science, physics and astronomy, chemistry, and earth, atmospheric, and marine sciences.

2Distribution based on respondents reporting sex data.

${ }^{3}$ Distribution based on U.S. citizens and permanent residents.

${ }^{4}$ Includes Native Hawaiians and other Pacific Islanders.

${ }^{5}$ Percentages are based on only those doctorate recipients who responded to questions about postdoctoral plans.

${ }^{6}$ Percentages are based on only those doctorate recipients who indicated definite postdoctoral plans for study and who indicated the type of study.

${ }^{7}$ Includes respondents who indicated definite postgraduation study plans for traineeship, internship/clinical residency, or other study.

${ }^{8}$ Percentages are based on only those doctorate recipients who indicated definite postdoctoral plans for employment and who indicated the sector of employment.

Includes 2-year, 4-year, and foreign colleges and universities, and medical schools.

10 Other is mainly composed of elementary and secondary schools.

${ }^{11}$ Percentages are based on only those doctorate recipients who indicated definite postdoctoral plans for employment and who indicated their primary work activity.

${ }^{12}$ Percentages are based on only those doctorate recipients who indicated definite postdoctoral plans and type of plans.
NOTE: The above classification of degrees by field differs somewhat from that in most publications of the National Center for Education Statistics (NCES). One major difference is that history is included under humanities rather than social sciences. Includes Ph.D., Ed.D., and comparable degrees at the doctoral level. Includes only graduates of research programs, which typically require the preparation and defense of a dissertation based on original research, or the planning and execution of an original project demonstrating substantial artistic or scholarly achievement. Excludes nonresearch professional practice doctor's degrees (e.g., M.D., D.D.S., and J.D.) that are conferred upon completion of a program providing the knowledge and skills for the recognition, credential, or license required for professional practice in such fields as health and theology. The number of doctor's degrees in this table differs from that reported in the NCES Integrated Postsecondary Education Data System (IPEDS), which includes both the research and nonresearch degrees. Race categories exclude persons of Hispanic ethnicity. Detail may not sum to totals because of rounding.

SOURCE: Doctorate Recipients From U.S. Universities: 2010 and 2011, Survey of Earned Doctorates, National Science Foundation, National Institutes of Health, U.S. Department of Education, National Endowment for the Humanities, U.S. Department of Agriculture, and the National Aeronautics and Space Administration. (This table was prepared April 2013.) 
Table 324.90. Doctor's degrees conferred by the 60 institutions conferring the most doctor's degrees, by rank order: 2002-03 through 2011-12

\begin{tabular}{|c|c|c|c|c|c|c|c|c|c|c|c|c|}
\hline Institution & $\begin{array}{c}\text { Rank } \\
\text { order }^{1}\end{array}$ & $\begin{array}{r}\text { Total, } \\
2002-03 \\
\text { to } \\
2011-12 \\
\end{array}$ & $2002-03$ & 2003-04 & $2004-05$ & $2005-06$ & $2006-07$ & $2007-08$ & 2008-09 & $2009-10$ & 2010-11 & $2011-12$ \\
\hline 1 & 2 & 3 & 4 & 5 & 6 & 7 & 8 & 9 & 10 & 11 & 12 & 13 \\
\hline 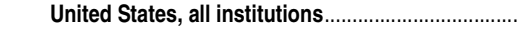 & $t$ & $1,460,987$ & 121,579 & 126,087 & 134,387 & 138,056 & 144,690 & 149,378 & 154,425 & 158,558 & 163,765 & 170,062 \\
\hline Total, 60 institutions conferring most doctorates.. & $t$ & 566,380 & 49,452 & 51,191 & 53,202 & 54,588 & 57,214 & 58,255 & 59,387 & 59,742 & 61,257 & 62,092 \\
\hline 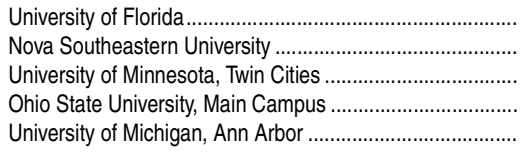 & $\begin{array}{l}1 \\
2 \\
3 \\
4 \\
5\end{array}$ & $\begin{array}{l}18,887 \\
16,936 \\
15,391 \\
15,248 \\
14,750\end{array}$ & $\begin{array}{l}1,532 \\
1,524 \\
1,279 \\
1,314 \\
1,260\end{array}$ & $\begin{array}{l}1,658 \\
1,540 \\
1,307 \\
1,342 \\
1,365\end{array}$ & $\begin{array}{l}1,665 \\
1,629 \\
1,455 \\
1,432 \\
1,406\end{array}$ & $\begin{array}{l}1,732 \\
1,521 \\
1,536 \\
1,549 \\
1,514\end{array}$ & $\begin{array}{l}1,957 \\
1,913 \\
1,667 \\
1,501 \\
1,496\end{array}$ & $\begin{array}{l}2,107 \\
1,772 \\
1,563 \\
1,611 \\
1,483\end{array}$ & $\begin{array}{l}2,028 \\
1,732 \\
1,594 \\
1,617 \\
1,576\end{array}$ & $\begin{array}{l}2,127 \\
1,806 \\
1,618 \\
1,596 \\
1,534\end{array}$ & $\begin{array}{l}2,127 \\
1,699 \\
1,692 \\
1,658 \\
1,550\end{array}$ & $\begin{array}{l}1,954 \\
1,800 \\
1,680 \\
1,628 \\
1,566\end{array}$ \\
\hline 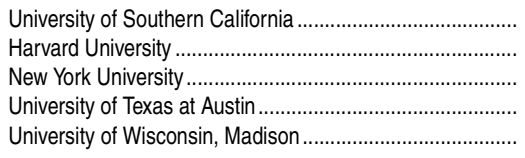 & $\begin{array}{r}6 \\
7 \\
8 \\
9 \\
10\end{array}$ & $\begin{array}{l}14,257 \\
14,025 \\
13,907 \\
13,654 \\
13,610\end{array}$ & $\begin{array}{l}1,392 \\
1,324 \\
1,361 \\
1,269 \\
1,274\end{array}$ & $\begin{array}{l}1,269 \\
1,333 \\
1,339 \\
1,299 \\
1,213\end{array}$ & $\begin{array}{l}1,361 \\
1,288 \\
1,385 \\
1,404 \\
1,314\end{array}$ & $\begin{array}{l}1,312 \\
1,393 \\
1,321 \\
1,443 \\
1,261\end{array}$ & $\begin{array}{l}1,378 \\
1,476 \\
1,331 \\
1,358 \\
1,425\end{array}$ & $\begin{array}{l}1,523 \\
1,468 \\
1,413 \\
1,439 \\
1,407\end{array}$ & $\begin{array}{l}1,571 \\
1,418 \\
1,419 \\
1,379 \\
1,430\end{array}$ & $\begin{array}{l}1,459 \\
1,401 \\
1,444 \\
1,382 \\
1,355\end{array}$ & $\begin{array}{l}1,474 \\
1,450 \\
1,413 \\
1,309 \\
1,417\end{array}$ & $\begin{array}{l}1,518 \\
1,474 \\
1,481 \\
1,372 \\
1,514\end{array}$ \\
\hline 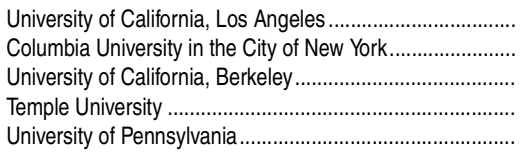 & $\begin{array}{l}11 \\
12 \\
13 \\
14 \\
15\end{array}$ & $\begin{array}{l}12,985 \\
12,347 \\
12,040 \\
11,577 \\
11,435\end{array}$ & $\begin{array}{r}1,174 \\
1,083 \\
1,095 \\
985 \\
1,027\end{array}$ & $\begin{array}{l}1,251 \\
1,116 \\
1,169 \\
1,141 \\
1,032\end{array}$ & $\begin{array}{l}1,225 \\
1,231 \\
1,151 \\
1,119 \\
1,170\end{array}$ & $\begin{array}{l}1,271 \\
1,300 \\
1,110 \\
1,205 \\
1,162\end{array}$ & $\begin{array}{l}1,307 \\
1,203 \\
1,280 \\
1,194 \\
1,136\end{array}$ & $\begin{array}{l}1,361 \\
1,218 \\
1,218 \\
1,220 \\
1,105\end{array}$ & $\begin{array}{l}1,382 \\
1,281 \\
1,216 \\
1,169 \\
1,190\end{array}$ & $\begin{array}{l}1,358 \\
1,295 \\
1,245 \\
1,144 \\
1,212\end{array}$ & $\begin{array}{l}1,330 \\
1,291 \\
1,292 \\
1,246 \\
1,212\end{array}$ & $\begin{array}{l}1,326 \\
1,329 \\
1,264 \\
1,154 \\
1,189\end{array}$ \\
\hline 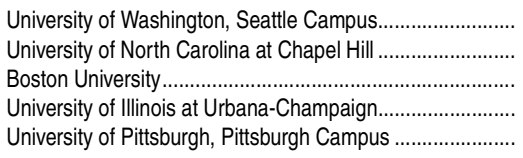 & $\begin{array}{l}16 \\
17 \\
18 \\
19 \\
20\end{array}$ & $\begin{array}{r}11,259 \\
11,201 \\
10,570 \\
10,317 \\
9,889\end{array}$ & $\begin{array}{r}962 \\
1,084 \\
771 \\
918 \\
887\end{array}$ & $\begin{array}{r}991 \\
1,026 \\
876 \\
882 \\
980\end{array}$ & $\begin{array}{r}1,003 \\
1,069 \\
926 \\
971 \\
936\end{array}$ & $\begin{array}{r}1,124 \\
1,098 \\
1,062 \\
998 \\
926\end{array}$ & $\begin{array}{r}1,130 \\
1,113 \\
1,210 \\
1,018 \\
996\end{array}$ & $\begin{array}{l}1,125 \\
1,204 \\
1,161 \\
1,067 \\
1,026\end{array}$ & $\begin{array}{l}1,176 \\
1,101 \\
1,179 \\
1,081 \\
1,022\end{array}$ & $\begin{array}{r}1,224 \\
1,155 \\
1,097 \\
1,066 \\
944\end{array}$ & $\begin{array}{l}1,251 \\
1,172 \\
1,111 \\
1,106 \\
1,113\end{array}$ & $\begin{array}{l}1,273 \\
1,179 \\
1,177 \\
1,210 \\
1,059\end{array}$ \\
\hline 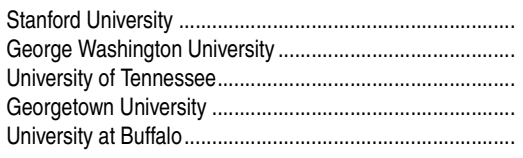 & $\begin{array}{l}21 \\
22 \\
23 \\
24 \\
25\end{array}$ & $\begin{array}{l}9,527 \\
9,451 \\
9,223 \\
9,219 \\
9,147\end{array}$ & $\begin{array}{l}895 \\
815 \\
810 \\
915 \\
801\end{array}$ & $\begin{array}{l}891 \\
875 \\
813 \\
934 \\
856\end{array}$ & $\begin{array}{l}904 \\
879 \\
790 \\
890 \\
933\end{array}$ & $\begin{array}{l}954 \\
937 \\
873 \\
844 \\
905\end{array}$ & $\begin{array}{l}969 \\
949 \\
895 \\
923 \\
970\end{array}$ & $\begin{array}{l}944 \\
956 \\
912 \\
926 \\
938\end{array}$ & $\begin{array}{r}920 \\
1,011 \\
994 \\
967 \\
964\end{array}$ & $\begin{array}{r}978 \\
1,005 \\
1,024 \\
950 \\
919\end{array}$ & $\begin{array}{r}1,053 \\
974 \\
1,002 \\
936 \\
948\end{array}$ & $\begin{array}{r}1,019 \\
1,050 \\
1,110 \\
934 \\
913\end{array}$ \\
\hline 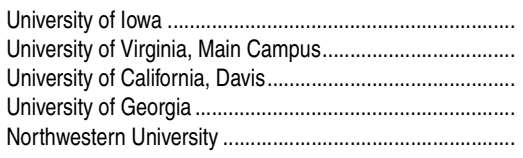 & $\begin{array}{l}26 \\
27 \\
28 \\
29 \\
30\end{array}$ & $\begin{array}{l}9,065 \\
8,716 \\
8,613 \\
8,512 \\
8,503\end{array}$ & $\begin{array}{l}801 \\
817 \\
750 \\
800 \\
765\end{array}$ & $\begin{array}{l}847 \\
851 \\
770 \\
833 \\
761\end{array}$ & $\begin{array}{l}924 \\
826 \\
791 \\
818 \\
798\end{array}$ & $\begin{array}{l}887 \\
840 \\
812 \\
828 \\
837\end{array}$ & $\begin{array}{l}926 \\
852 \\
876 \\
858 \\
878\end{array}$ & $\begin{array}{l}926 \\
925 \\
900 \\
832 \\
876\end{array}$ & $\begin{array}{l}937 \\
907 \\
894 \\
897 \\
872\end{array}$ & $\begin{array}{l}920 \\
861 \\
891 \\
854 \\
891\end{array}$ & $\begin{array}{l}949 \\
933 \\
927 \\
889 \\
927\end{array}$ & $\begin{array}{r}948 \\
904 \\
1,002 \\
903 \\
898\end{array}$ \\
\hline 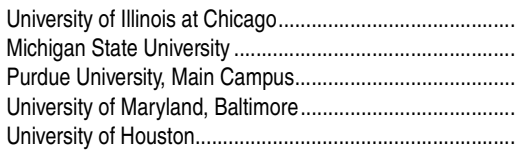 & $\begin{array}{l}31 \\
32 \\
33 \\
34 \\
35\end{array}$ & $\begin{array}{l}8,422 \\
8,396 \\
8,084 \\
7,944 \\
7,739\end{array}$ & $\begin{array}{l}701 \\
745 \\
666 \\
667 \\
687\end{array}$ & $\begin{array}{l}748 \\
774 \\
662 \\
787 \\
697\end{array}$ & $\begin{array}{l}789 \\
774 \\
763 \\
750 \\
824\end{array}$ & $\begin{array}{l}807 \\
768 \\
785 \\
813 \\
772\end{array}$ & $\begin{array}{l}862 \\
855 \\
837 \\
767 \\
778\end{array}$ & $\begin{array}{l}873 \\
770 \\
840 \\
775 \\
809\end{array}$ & $\begin{array}{l}851 \\
876 \\
882 \\
775 \\
786\end{array}$ & $\begin{array}{l}965 \\
921 \\
845 \\
835 \\
757\end{array}$ & $\begin{array}{l}914 \\
951 \\
924 \\
875 \\
831\end{array}$ & $\begin{array}{l}912 \\
962 \\
880 \\
900 \\
798\end{array}$ \\
\hline $\begin{array}{l}\text { University of Arizona } \\
\text { Thomas M. Cooley Law School } \\
\text { Cornell University } 2\end{array}$ & $\begin{array}{l}36 \\
37 \\
38 \\
39 \\
40\end{array}$ & $\begin{array}{l}7,672 \\
7,637 \\
7,462 \\
7,405 \\
7,316\end{array}$ & $\begin{array}{l}673 \\
438 \\
665 \\
623 \\
632\end{array}$ & $\begin{array}{l}702 \\
405 \\
678 \\
682 \\
701\end{array}$ & $\begin{array}{l}696 \\
524 \\
740 \\
685 \\
682\end{array}$ & $\begin{array}{l}698 \\
614 \\
754 \\
673 \\
703\end{array}$ & $\begin{array}{l}814 \\
756 \\
752 \\
707 \\
688\end{array}$ & $\begin{array}{l}778 \\
845 \\
752 \\
703 \\
758\end{array}$ & $\begin{array}{l}824 \\
981 \\
785 \\
758 \\
772\end{array}$ & $\begin{array}{l}824 \\
955 \\
779 \\
860 \\
717\end{array}$ & $\begin{array}{r}813 \\
1,039 \\
782 \\
803 \\
856\end{array}$ & $\begin{array}{r}850 \\
1,080 \\
775 \\
911 \\
807\end{array}$ \\
\hline 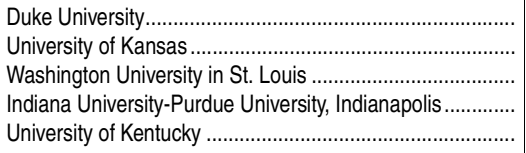 & $\begin{array}{l}41 \\
42 \\
43 \\
44 \\
45\end{array}$ & $\begin{array}{l}7,217 \\
7,036 \\
7,026 \\
6,989 \\
6,974\end{array}$ & $\begin{array}{l}573 \\
500 \\
566 \\
622 \\
571\end{array}$ & $\begin{array}{l}662 \\
557 \\
599 \\
640 \\
605\end{array}$ & $\begin{array}{l}615 \\
562 \\
641 \\
655 \\
670\end{array}$ & $\begin{array}{l}570 \\
585 \\
678 \\
669 \\
634\end{array}$ & $\begin{array}{l}680 \\
789 \\
727 \\
719 \\
653\end{array}$ & $\begin{array}{l}682 \\
781 \\
730 \\
720 \\
717\end{array}$ & $\begin{array}{l}718 \\
766 \\
760 \\
687 \\
719\end{array}$ & $\begin{array}{l}820 \\
819 \\
737 \\
751 \\
734\end{array}$ & $\begin{array}{l}887 \\
856 \\
805 \\
755 \\
783\end{array}$ & $\begin{array}{r}1,010 \\
821 \\
783 \\
771 \\
888\end{array}$ \\
\hline 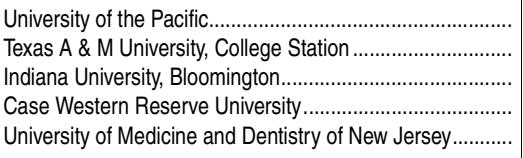 & $\begin{array}{l}46 \\
47 \\
48 \\
49 \\
50\end{array}$ & $\begin{array}{l}6,964 \\
6,904 \\
6,890 \\
6,812 \\
6,803\end{array}$ & $\begin{array}{l}631 \\
561 \\
659 \\
566 \\
587\end{array}$ & $\begin{array}{l}642 \\
633 \\
647 \\
638 \\
642\end{array}$ & $\begin{array}{l}733 \\
651 \\
683 \\
636 \\
609\end{array}$ & $\begin{array}{l}684 \\
660 \\
667 \\
681 \\
623\end{array}$ & $\begin{array}{l}691 \\
727 \\
651 \\
654 \\
621\end{array}$ & $\begin{array}{l}708 \\
723 \\
695 \\
718 \\
662\end{array}$ & $\begin{array}{l}681 \\
717 \\
729 \\
750 \\
715\end{array}$ & $\begin{array}{l}713 \\
703 \\
718 \\
781 \\
759\end{array}$ & $\begin{array}{l}749 \\
739 \\
693 \\
730 \\
787\end{array}$ & $\begin{array}{l}732 \\
790 \\
748 \\
658 \\
798\end{array}$ \\
\hline $\begin{array}{l}\text { University of Chicago } \\
\text { Yale University } \\
\text { Florida State University } \\
\text { Yeshiva University } \\
\text { Pennsylvania State University, Main Campus }\end{array}$ & $\begin{array}{l}51 \\
52 \\
53 \\
54 \\
55\end{array}$ & $\begin{array}{l}6,739 \\
6,649 \\
6,581 \\
6,489 \\
6,478\end{array}$ & $\begin{array}{l}635 \\
631 \\
532 \\
587 \\
503\end{array}$ & $\begin{array}{l}624 \\
625 \\
479 \\
621 \\
539\end{array}$ & $\begin{array}{l}638 \\
625 \\
577 \\
659 \\
571\end{array}$ & $\begin{array}{l}695 \\
622 \\
601 \\
627 \\
646\end{array}$ & $\begin{array}{l}653 \\
640 \\
631 \\
635 \\
664\end{array}$ & $\begin{array}{l}704 \\
671 \\
730 \\
649 \\
643\end{array}$ & $\begin{array}{l}682 \\
685 \\
680 \\
657 \\
703\end{array}$ & $\begin{array}{l}682 \\
752 \\
683 \\
680 \\
718\end{array}$ & $\begin{array}{l}711 \\
686 \\
818 \\
690 \\
736\end{array}$ & $\begin{array}{l}715 \\
712 \\
850 \\
684 \\
755\end{array}$ \\
\hline $\begin{array}{l}\text { University of South Carolina, Columbia } \\
\text { A.T. Still University of Health Sciences } \\
\text { Arizona State University } \\
\text { University of Connecticut } \\
\text { Creighton University }\end{array}$ & $\begin{array}{l}56 \\
57 \\
58 \\
59 \\
60\end{array}$ & $\begin{array}{l}6,476 \\
6,298 \\
6,292 \\
6,269 \\
6,156\end{array}$ & $\begin{array}{l}574 \\
410 \\
495 \\
465 \\
603\end{array}$ & $\begin{array}{l}621 \\
412 \\
524 \\
510 \\
575\end{array}$ & $\begin{array}{l}636 \\
477 \\
478 \\
554 \\
612\end{array}$ & $\begin{array}{l}642 \\
551 \\
569 \\
629 \\
613\end{array}$ & $\begin{array}{l}641 \\
644 \\
574 \\
609 \\
610\end{array}$ & $\begin{array}{l}639 \\
694 \\
656 \\
576 \\
628\end{array}$ & $\begin{array}{l}703 \\
730 \\
766 \\
687 \\
638\end{array}$ & $\begin{array}{l}643 \\
815 \\
656 \\
746 \\
619\end{array}$ & $\begin{array}{l}703 \\
810 \\
746 \\
720 \\
614\end{array}$ & $\begin{array}{l}674 \\
755 \\
828 \\
773 \\
644\end{array}$ \\
\hline
\end{tabular}

†Not applicable.

'Institutions are ranked by the total number of doctor's degrees conferred during the 10 year period ending June 30, 2012.

Includes degrees conferred by the Endowed and Statutory Colleges.

NOTE: Includes Ph.D., Ed.D., and comparable degrees at the doctoral level, as well as such degrees as M.D., D.D.S., and law degrees that were formerly classified as firstprofessional degrees.

SOURCE: U.S. Department of Education, National Center for Education Statistics, Integrated Postsecondary Education Data System (IPEDS), Fall 2003 through Fall 2012 Completions component. (This table was prepared August 2013.) 
Table 325.10. Degrees in agriculture and natural resources conferred by postsecondary institutions, by level of degree and sex of student: 1970-71 through 2011-12

\begin{tabular}{|c|c|c|c|c|c|c|c|c|c|c|c|}
\hline \multirow[b]{3}{*}{ Year } & \multicolumn{5}{|c|}{ Bachelor's degrees } & \multicolumn{3}{|c|}{ Master's degrees } & \multicolumn{3}{|c|}{ Doctor's degrees } \\
\hline & \multicolumn{2}{|c|}{ Total } & \multirow[b]{2}{*}{ Males } & \multirow[b]{2}{*}{ Females } & \multirow{2}{*}{$\begin{array}{r}\text { Females } \\
\text { as a } \\
\text { percent } \\
\text { of total }\end{array}$} & \multirow[b]{2}{*}{ Total } & \multirow[b]{2}{*}{ Males } & \multirow[b]{2}{*}{ Females } & \multirow[b]{2}{*}{ Total } & \multirow[b]{2}{*}{ Males } & \multirow[b]{2}{*}{ Females } \\
\hline & Number & $\begin{array}{l}\text { Annual } \\
\text { percent } \\
\text { change }\end{array}$ & & & & & & & & & \\
\hline 1 & 2 & 3 & 4 & 5 & 6 & 7 & 8 & 9 & 10 & 11 & 12 \\
\hline $\begin{array}{l}970-71 \ldots \\
\end{array}$ & 12,672 & $t$ & 12,136 & 536 & 4.2 & 2,457 & 2,313 & 144 & 1,086 & 1,055 & 31 \\
\hline $1971-72 \ldots \ldots \ldots$ & 13,516 & 6.7 & 12,779 & 737 & 5.5 & 2,680 & 2,490 & 190 & 971 & 945 & 26 \\
\hline $1972-73 \ldots$ & 14,756 & 9.2 & 13,661 & 1,095 & 7.4 & 2,807 & 2,588 & 219 & 1,059 & 1,031 & 28 \\
\hline 1973-74_............. & 16,253 & 10.1 & 14,684 & 1,569 & 9.7 & 2,928 & 2,640 & 288 & 930 & 897 & 33 \\
\hline $1974-75 \ldots \ldots \ldots \ldots \ldots \ldots \ldots \ldots \ldots$ & 17,528 & 7.8 & 15,061 & 2,467 & 14.1 & 3,067 & 2,703 & 364 & 991 & 958 & 33 \\
\hline $1975-76 \ldots \ldots \ldots \ldots$ & 19,402 & 10.7 & 15,845 & 3,557 & 18.3 & 3,340 & 2,862 & 478 & 928 & 867 & 61 \\
\hline $1976-77 \ldots \ldots \ldots \ldots$ & 21,467 & 10.6 & 16,690 & 4,777 & 22.3 & 3,724 & 3,177 & 547 & 893 & 831 & 62 \\
\hline $1977-78 \ldots \ldots$. & 22,650 & 5.5 & 17,069 & 5,581 & 24.6 & 4,023 & 3,268 & 755 & 971 & 909 & 62 \\
\hline $1978-79 \ldots \ldots \ldots . . . .$. & 23,134 & 2.1 & 16,854 & 6,280 & 27.1 & 3,994 & 3,187 & 807 & 950 & 877 & 73 \\
\hline 1979-80................................... & 22,802 & -1.4 & 16,045 & 6,757 & 29.6 & 3,976 & 3,082 & 894 & 991 & 879 & 112 \\
\hline $1980-81 \ldots \ldots .$. & 21,886 & -4.0 & 15,154 & 6,732 & 30.8 & 4,003 & 3,061 & 942 & 1,067 & 940 & 127 \\
\hline $1981-82 \ldots \ldots \ldots$ & 21,029 & -3.9 & 14,443 & 6,586 & 31.3 & 4,163 & 3,114 & 1,049 & 1,079 & 925 & 154 \\
\hline $1982-83 \ldots \ldots \ldots \ldots$ & 20,909 & -0.6 & 14,085 & 6,824 & 32.6 & 4,254 & 3,129 & 1,125 & 1,149 & 1,004 & 145 \\
\hline $1983-84 \ldots \ldots \ldots \ldots . . . .$. & 19,317 & -7.6 & 13,206 & 6,111 & 31.6 & 4,178 & 2,989 & 1,189 & 1,172 & 1,001 & 171 \\
\hline $1984-85 \ldots . .$. & 18,107 & -6.3 & 12,477 & 5,630 & 31.1 & 3,928 & 2,846 & 1,082 & 1,213 & 1,036 & 177 \\
\hline $1985-86 \ldots \ldots$. & 16,823 & -7.1 & 11,544 & 5,279 & 31.4 & 3,801 & 2,701 & 1,100 & 1,158 & 966 & 192 \\
\hline $1986-87 \ldots \ldots \ldots . . .$. & 14,991 & -10.9 & 10,314 & 4,677 & 31.2 & 3,522 & 2,460 & 1,062 & 1,049 & 871 & 178 \\
\hline $1987-88 \ldots \ldots \ldots \ldots . . .$. & 14,222 & -5.1 & 9,744 & 4,478 & 31.5 & 3,479 & 2,427 & 1,052 & 1,142 & 926 & 216 \\
\hline 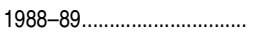 & 13,492 & -5.1 & 9,298 & 4,194 & 31.1 & 3,245 & 2,231 & 1,014 & 1,183 & 950 & 233 \\
\hline $1989-90 \ldots \ldots \ldots \ldots \ldots \ldots \ldots \ldots \ldots . .$. & 12,900 & -4.4 & 8,822 & 4,078 & 31.6 & 3,382 & 2,239 & 1,143 & 1,295 & 1,038 & 257 \\
\hline 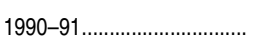 & 13,124 & 1.7 & 8,832 & 4,292 & 32.7 & 3,295 & 2,160 & 1,135 & 1,185 & 953 & 232 \\
\hline $1991-92 \ldots \ldots$ & 15,113 & 15.2 & 9,867 & 5,246 & 34.7 & 3,730 & 2,409 & 1,321 & 1,205 & 955 & 250 \\
\hline $1992-93 \ldots \ldots \ldots \ldots$ & 16,769 & 11.0 & 11,079 & 5,690 & 33.9 & 3,959 & 2,474 & 1,485 & 1,159 & 869 & 290 \\
\hline $1993-94 \ldots \ldots \ldots \ldots$ & 18,056 & 7.7 & 11,746 & 6,310 & 34.9 & 4,110 & 2,512 & 1,598 & 1,262 & 969 & 293 \\
\hline $1994-95 \ldots \ldots \ldots \ldots \ldots \ldots \ldots \ldots \ldots \ldots$ & 19,832 & 9.8 & 12,686 & 7,146 & 36.0 & 4,234 & 2,541 & 1,693 & 1,256 & 955 & 301 \\
\hline $1995-96 \ldots \ldots \ldots . .$. & 21,425 & 8.0 & 13,531 & 7,894 & 36.8 & 4,551 & 2,642 & 1,909 & 1,259 & 926 & 333 \\
\hline $1996-97 \ldots \ldots \ldots$ & 22,597 & 5.5 & 13,791 & 8,806 & 39.0 & 4,505 & 2,601 & 1,904 & 1,202 & 875 & 327 \\
\hline $1997-98 \ldots \ldots \ldots \ldots . .$. & 23,276 & 3.0 & 13,806 & 9,470 & 40.7 & 4,464 & 2,545 & 1,919 & 1,290 & 924 & 366 \\
\hline 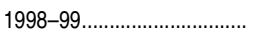 & 24,179 & 3.9 & 14,045 & 10,134 & 41.9 & 4,376 & 2,360 & 2,016 & 1,249 & 869 & 380 \\
\hline $1999-2000 \ldots \ldots \ldots \ldots \ldots \ldots \ldots \ldots$ & 24,238 & 0.2 & 13,843 & 10,395 & 42.9 & 4,360 & 2,356 & 2,004 & 1,168 & 803 & 365 \\
\hline $2000-01 \ldots \ldots \ldots . .$. & 23,370 & -3.6 & 12,840 & 10,530 & 45.1 & 4,272 & 2,251 & 2,021 & 1,127 & 741 & 386 \\
\hline $2001-02 \ldots \ldots \ldots \ldots . . . .$. & 23,331 & -0.2 & 12,630 & 10,701 & 45.9 & 4,503 & 2,340 & 2,163 & 1,148 & 760 & 388 \\
\hline $2002-03 \ldots \ldots$ & 23,348 & 0.1 & 12,343 & 11,005 & 47.1 & 4,492 & 2,232 & 2,260 & 1,229 & 790 & 439 \\
\hline 2003-04 & 22,835 & -2.2 & 11,889 & 10,946 & 47.9 & 4,783 & 2,306 & 2,477 & 1,185 & 758 & 427 \\
\hline $2004-05 \ldots \ldots \ldots \ldots \ldots \ldots$ & 23,002 & 0.7 & 11,987 & 11,015 & 47.9 & 4,746 & 2,288 & 2,458 & 1,173 & 763 & 410 \\
\hline $2005-06 \ldots \ldots \ldots \ldots . . .$. & 23,053 & 0.2 & 12,063 & 10,990 & 47.7 & 4,640 & 2,280 & 2,360 & 1,194 & 710 & 484 \\
\hline $2006-07 \ldots$. & 23,133 & 0.3 & 12,309 & 10,824 & 46.8 & 4,623 & 2,174 & 2,449 & 1,272 & 768 & 504 \\
\hline $2007-08 \ldots .$. & 24,113 & 4.2 & 12,634 & 11,479 & 47.6 & 4,684 & 2,180 & 2,504 & 1,257 & 742 & 515 \\
\hline $2008-09 \ldots \ldots \ldots$ & 24,988 & 3.6 & 13,101 & 11,887 & 47.6 & 4,877 & 2,328 & 2,549 & 1,328 & 741 & 587 \\
\hline $2009-10 \ldots \ldots \ldots \ldots \ldots \ldots \ldots \ldots \ldots$ & 26,336 & 5.4 & 13,519 & 12,817 & 48.7 & 5,211 & 2,509 & 2,702 & 1,147 & 625 & 522 \\
\hline $2010-11 \ldots \ldots \ldots \ldots . . . .$. & 28,623 & 8.7 & 14,675 & 13,948 & 48.7 & 5,773 & 2,750 & 3,023 & 1,246 & 675 & 571 \\
\hline $2011-12 \ldots . .$. & 30,929 & 8.1 & 15,453 & 15,476 & 50.0 & 6,390 & 3,026 & 3,364 & 1,333 & 721 & 612 \\
\hline Percent change & & & & & & & & & & & \\
\hline $\begin{array}{l}2001-02 \text { to } 2006-07 \ldots \ldots . . . \\
2006-07 \text { to } 2011-12 \ldots \ldots \ldots\end{array}$ & $\begin{array}{r}-0.8 \\
33.7\end{array}$ & $\begin{array}{l}t \\
t\end{array}$ & $\begin{array}{r}-2.5 \\
25.5\end{array}$ & $\begin{array}{r}1.1 \\
43.0\end{array}$ & $\begin{array}{l}\dagger \\
t\end{array}$ & $\begin{array}{r}2.7 \\
38.2\end{array}$ & $\begin{array}{r}-7.1 \\
39.2\end{array}$ & $\begin{array}{l}13.2 \\
37.4\end{array}$ & $\begin{array}{r}10.8 \\
4.8\end{array}$ & $\begin{array}{r}1.1 \\
-6.1\end{array}$ & $\begin{array}{l}29.9 \\
21.4\end{array}$ \\
\hline
\end{tabular}

†Not applicable.

NOTE: Data are for postsecondary institutions participating in Title IV federal financial aid programs. Includes degrees in agriculture, agriculture operations, and related sciences and in natural resources and conservation.

SOURCE: U.S. Department of Education, National Center for Education Statistics, Higher
Education General Information Survey (HEGIS), "Degrees and Other Formal Awards Conferred" surveys, 1970-71 through 1985-86; Integrated Postsecondary Education Data System (IPEDS), "Completions Survey" (IPEDS-C:87-99); and IPEDS Fall 2000 through Fall 2012, Completions component. (This table was prepared August 2013.) 
Table 325.15. Degrees in architecture and related services conferred by postsecondary institutions, by level of degree and sex of student: Selected years, 1949-50 through 2011-12

\begin{tabular}{|c|c|c|c|c|c|c|c|c|c|c|c|}
\hline \multirow[b]{3}{*}{ Year } & \multicolumn{5}{|c|}{ Bachelor's degrees } & \multicolumn{3}{|c|}{ Master's degrees } & \multicolumn{3}{|c|}{ Doctor's degrees } \\
\hline & \multicolumn{2}{|c|}{ Total } & \multirow[b]{2}{*}{ Males } & \multirow[b]{2}{*}{ Females } & \multirow[b]{2}{*}{$\begin{array}{r}\text { Females } \\
\text { as a } \\
\text { percent } \\
\text { of total }\end{array}$} & \multirow[b]{2}{*}{ Total } & \multirow[b]{2}{*}{ Males } & \multirow[b]{2}{*}{ Females } & \multirow[b]{2}{*}{ Total } & \multirow[b]{2}{*}{ Males } & \multirow[b]{2}{*}{ Females } \\
\hline & Number & $\begin{array}{l}\text { Annual } \\
\text { percent } \\
\text { change }\end{array}$ & & & & & & & & & \\
\hline 1 & 2 & 3 & 4 & 5 & 6 & 7 & 8 & 9 & 10 & 11 & 12 \\
\hline 1949-50_.............................. & 2,563 & $\dagger$ & 2,441 & 122 & 4.8 & 166 & 159 & 7 & 1 & 1 & 0 \\
\hline $1959-60 \ldots \ldots \ldots \ldots \ldots \ldots \ldots \ldots . .$. & 1,801 & $\dagger$ & 1,744 & 57 & 3.2 & 319 & 305 & 14 & 17 & 17 & 0 \\
\hline $1967-68$ & 3,057 & $\dagger$ & 2,931 & 126 & 4.1 & 1,021 & 953 & 68 & 15 & 15 & 0 \\
\hline $1969-70 \ldots \ldots \ldots \ldots \ldots \ldots \ldots$ & 4,105 & $\dagger$ & 3,888 & 217 & 5.3 & 1,427 & 1,260 & 167 & 35 & 33 & 2 \\
\hline 1970-71_........................... & 5,570 & 35.7 & 4,906 & 664 & 11.9 & 1,705 & 1,469 & 236 & 36 & 33 & 3 \\
\hline $1971-72 \ldots \ldots \ldots \ldots \ldots \ldots \ldots \ldots \ldots$ & 6,440 & 15.6 & 5,667 & 773 & 12.0 & 1,899 & 1,626 & 273 & 50 & 43 & 7 \\
\hline $1972-73 \ldots \ldots \ldots \ldots$ & 6,962 & 8.1 & 6,042 & 920 & 13.2 & 2,307 & 1,943 & 364 & 58 & 54 & 4 \\
\hline $1973-74$ & 7,822 & 12.4 & 6,665 & 1,157 & 14.8 & 2,702 & 2,208 & 494 & 69 & 65 & 4 \\
\hline $1974-75 \ldots \ldots \ldots$ & 8,226 & 5.2 & 6,791 & 1,435 & 17.4 & 2,938 & 2,343 & 595 & 69 & 58 & 11 \\
\hline $1975-76 \ldots \ldots \ldots \ldots \ldots \ldots$ & 9,146 & 11.2 & 7,396 & 1,750 & 19.1 & 3,215 & 2,545 & 670 & 82 & 69 & 13 \\
\hline $1976-77 \ldots \ldots \ldots$ & 9,222 & 0.8 & 7,249 & 1,973 & 21.4 & 3,213 & 2,489 & 724 & 73 & 62 & 11 \\
\hline 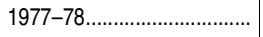 & 9,250 & 0.3 & 7,054 & 2,196 & 23.7 & 3,115 & 2,304 & 811 & 73 & 57 & 16 \\
\hline $1978-79 \ldots \ldots \ldots \ldots \ldots \ldots \ldots \ldots$ & 9,273 & 0.2 & 6,876 & 2,397 & 25.8 & 3,113 & 2,226 & 887 & 96 & 74 & 22 \\
\hline $1979-80 \ldots \ldots \ldots$ & 9,132 & -1.5 & 6,596 & 2,536 & 27.8 & 3,139 & 2,245 & 894 & 79 & 66 & 13 \\
\hline $1980-81 \ldots \ldots \ldots \ldots \ldots \ldots$ & 9,455 & 3.5 & 6,800 & 2,655 & 28.1 & 3,153 & 2,234 & 919 & 93 & 73 & 20 \\
\hline $1981-82 \ldots \ldots$ & 9,728 & 2.9 & 6,825 & 2,903 & 29.8 & 3,327 & 2,242 & 1,085 & 80 & 58 & 22 \\
\hline 1982-83.............................. & 9,823 & 1.0 & 6,403 & 3,420 & 34.8 & 3,357 & 2,224 & 1,133 & 97 & 74 & 23 \\
\hline $1983-84 \ldots \ldots \ldots \ldots \ldots \ldots \ldots \ldots$ & 9,186 & -6.5 & 5,895 & 3,291 & 35.8 & 3,223 & 2,197 & 1,026 & 84 & 62 & 22 \\
\hline $1984-85 \ldots \ldots \ldots \ldots$ & 9,325 & 1.5 & 6,019 & 3,306 & 35.5 & 3,275 & 2,148 & 1,127 & 89 & 66 & 23 \\
\hline $1985-86 \ldots \ldots \ldots \ldots \ldots \ldots \ldots \ldots$ & 9,119 & -2.2 & 5,824 & 3,295 & 36.1 & 3,260 & 2,129 & 1,131 & 73 & 56 & 17 \\
\hline $1986-87 \ldots \ldots \ldots \ldots \ldots \ldots$ & 8,950 & -1.9 & 5,617 & 3,333 & 37.2 & 3,163 & 2,086 & 1,077 & 92 & 66 & 26 \\
\hline 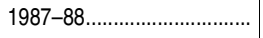 & 8,603 & -3.9 & 5,271 & 3,332 & 38.7 & 3,159 & 2,042 & 1,117 & 98 & 66 & 32 \\
\hline $1988-89$ & 9,150 & 6.4 & 5,545 & 3,605 & 39.4 & 3,383 & 2,192 & 1,191 & 86 & 63 & 23 \\
\hline $1989-90 \ldots \ldots \ldots \ldots$ & 9,364 & 2.3 & 5,703 & 3,661 & 39.1 & 3,499 & 2,228 & 1,271 & 103 & 73 & 30 \\
\hline $1990-91 \ldots \ldots \ldots \ldots \ldots \ldots \ldots \ldots$ & 9,781 & 4.5 & 5,788 & 3,993 & 40.8 & 3,490 & 2,244 & 1,246 & 135 & 101 & 34 \\
\hline $1991-92 \ldots \ldots \ldots \ldots$ & 8,753 & -10.5 & 5,805 & 2,948 & 33.7 & 3,640 & 2,271 & 1,369 & 132 & 93 & 39 \\
\hline 1992-93............................. & 9,167 & 4.7 & 5,940 & 3,227 & 35.2 & 3,808 & 2,376 & 1,432 & 148 & 105 & 43 \\
\hline $1993-94 \ldots \ldots \ldots$ & 8,975 & -2.1 & 5,764 & 3,211 & 35.8 & 3,943 & 2,428 & 1,515 & 161 & 111 & 50 \\
\hline 1994-95 .............................. & 8,756 & -2.4 & 5,741 & 3,015 & 34.4 & 3,923 & 2,310 & 1,613 & 141 & 95 & 46 \\
\hline $1995-96 \ldots \ldots \ldots$ & 8,352 & -4.6 & 5,340 & 3,012 & 36.1 & 3,993 & 2,361 & 1,632 & 141 & 96 & 45 \\
\hline 1996-97................................ & 7,944 & -4.9 & 5,090 & 2,854 & 35.9 & 4,034 & 2,336 & 1,698 & 135 & 93 & 42 \\
\hline 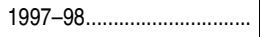 & 7,652 & -3.7 & 4,966 & 2,686 & 35.1 & 4,347 & 2,537 & 1,810 & 131 & 80 & 51 \\
\hline $1998-99$ & 8,245 & 7.7 & 5,145 & 3,100 & 37.6 & 4,235 & 2,435 & 1,800 & 119 & 76 & 43 \\
\hline $1999-2000 \ldots \ldots \ldots \ldots \ldots \ldots \ldots$ & 8,462 & 2.6 & 5,193 & 3,269 & 38.6 & 4,268 & 2,508 & 1,760 & 129 & 85 & 44 \\
\hline $2000-01 \ldots \ldots \ldots \ldots \ldots \ldots \ldots \ldots$ & 8,480 & 0.2 & 5,086 & 3,394 & 40.0 & 4,302 & 2,515 & 1,787 & 153 & 83 & 70 \\
\hline $2001-02 \ldots \ldots \ldots \ldots \ldots \ldots \ldots$ & 8,808 & 3.9 & 5,224 & 3,584 & 40.7 & 4,566 & 2,606 & 1,960 & 183 & 117 & 66 \\
\hline $2002-03 \ldots \ldots \ldots \ldots$ & 9,056 & 2.8 & 5,331 & 3,725 & 41.1 & 4,925 & 2,832 & 2,093 & 152 & 83 & 69 \\
\hline $2003-04 \ldots \ldots \ldots \ldots \ldots$ & 8,838 & -2.4 & 5,059 & 3,779 & 42.8 & 5,424 & 3,049 & 2,375 & 173 & 94 & 79 \\
\hline $2004-05 \ldots \ldots \ldots \ldots \ldots \ldots \ldots \ldots$ & 9,237 & 4.5 & 5,222 & 4,015 & 43.5 & 5,674 & 3,180 & 2,494 & 179 & 110 & 69 \\
\hline $2005-06 \ldots \ldots \ldots \ldots \ldots \ldots \ldots$ & 9,515 & 3.0 & 5,414 & 4,101 & 43.1 & 5,743 & 3,165 & 2,578 & 201 & 108 & 93 \\
\hline $2006-07 \ldots \ldots \ldots \ldots \ldots \ldots \ldots \ldots$ & 9,717 & 2.1 & 5,393 & 4,324 & 44.5 & 5,951 & 3,304 & 2,647 & 178 & 104 & 74 \\
\hline $2007-08 \ldots \ldots \ldots \ldots \ldots \ldots$ & 9,805 & 0.9 & 5,579 & 4,226 & 43.1 & 6,065 & 3,252 & 2,813 & 199 & 103 & 96 \\
\hline $2008-09 \ldots \ldots \ldots \ldots \ldots \ldots \ldots \ldots$ & 10,119 & 3.2 & 5,797 & 4,322 & 42.7 & 6,587 & 3,657 & 2,930 & 212 & 113 & 99 \\
\hline $2009-10 \ldots \ldots \ldots \ldots \ldots \ldots$ & 10,051 & -0.7 & 5,694 & 4,357 & 43.3 & 7,280 & 4,012 & 3,268 & 210 & 116 & 94 \\
\hline $2010-11 \ldots \ldots \ldots \ldots \ldots \ldots \ldots \ldots \ldots$ & 9,832 & -2.2 & 5,696 & 4,136 & 42.1 & 7,788 & 4,265 & 3,523 & 205 & 110 & 95 \\
\hline $2011-12 \ldots \ldots \ldots \ldots$ & 9,728 & -1.1 & 5,567 & 4,161 & 42.8 & 8,448 & 4,504 & 3,944 & 255 & 147 & 108 \\
\hline Percent change & & & & & & & & & & & \\
\hline $2001-02$ to $2006-07 \ldots \ldots$ & 10.3 & $\dagger$ & 3.2 & 20.6 & $\dagger$ & 30.3 & 26.8 & 35.1 & -2.7 & -11.1 & 12.1 \\
\hline $2006-07$ to $2011-12 \ldots \ldots$ & 0.1 & $\dagger$ & 3.2 & -3.8 & $\dagger$ & 42.0 & 36.3 & 49.0 & 43.3 & 41.3 & 45.9 \\
\hline
\end{tabular}

†Not applicable.

NOTE: Data are for postsecondary institutions participating in Title IV federal financial aid programs.

SOURCE: U.S. Department of Education, National Center for Education Statistics, Earned Degrees Conferred, 1949-50 and 1959-60; Higher Education General Information Survey
(HEGIS), "Degrees and Other Formal Awards Conferred" surveys, 1967-68 through 1985-86; Integrated Postsecondary Education Data System (IPEDS), "Completions Survey" (IPEDS-C:87-99); and IPEDS Fall 2000 through Fall 2012, Completions component. (This table was prepared August 2013.) 
Table 325.20. Degrees in the biological and biomedical sciences conferred by postsecondary institutions, by level of degree and sex of student: Selected years, 1951-52 through 2011-12

\begin{tabular}{|c|c|c|c|c|c|c|c|c|c|c|c|}
\hline \multirow[b]{3}{*}{ Year } & \multicolumn{5}{|c|}{ Bachelor's degrees } & \multicolumn{3}{|c|}{ Master's degrees } & \multicolumn{3}{|c|}{ Doctor's degrees } \\
\hline & \multicolumn{2}{|c|}{ Total } & \multirow[b]{2}{*}{ Males } & \multirow[b]{2}{*}{ Females } & \multirow[b]{2}{*}{$\begin{array}{r}\text { Females } \\
\text { as a } \\
\text { percent } \\
\text { of total }\end{array}$} & \multirow[b]{2}{*}{ Total } & \multirow[b]{2}{*}{ Males } & \multirow[b]{2}{*}{ Females } & \multirow[b]{2}{*}{ Total } & \multirow[b]{2}{*}{ Males } & \multirow[b]{2}{*}{ Females } \\
\hline & Number & $\begin{array}{l}\text { Annual } \\
\text { percent } \\
\text { change }\end{array}$ & & & & & & & & & \\
\hline 1 & 2 & 3 & 4 & 5 & 6 & 7 & 8 & 9 & 10 & 11 & 12 \\
\hline 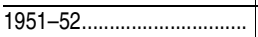 & 11,094 & $\dagger$ & 8,212 & 2,882 & 26.0 & 2,307 & 1,908 & 399 & 764 & 680 & $\overline{84}$ \\
\hline $1953-54$ & 9,279 & $\dagger$ & 6,710 & 2,569 & 27.7 & 1,610 & 1,287 & 323 & 1,077 & 977 & 100 \\
\hline $1955-56$ & 12,423 & $\dagger$ & 9,515 & 2,908 & 23.4 & 1,759 & 1,379 & 380 & 1,025 & 908 & 117 \\
\hline $1957-58 \ldots \ldots \ldots$ & 14,308 & $\dagger$ & 11,159 & 3,149 & 22.0 & 1,852 & 1,448 & 404 & 1,125 & 987 & 138 \\
\hline $1959-60$ & 15,576 & $\dagger$ & 11,654 & 3,922 & 25.2 & 2,154 & 1,668 & 486 & 1,205 & 1,086 & 119 \\
\hline $1961-62$ & 16,915 & $\dagger$ & 12,136 & 4,779 & 28.3 & 2,642 & 1,982 & 660 & 1,338 & 1,179 & 159 \\
\hline $1963-64$ & 22,723 & $\dagger$ & 16,321 & 6,402 & 28.2 & 3,296 & 2,348 & 948 & 1,625 & 1,432 & 193 \\
\hline $1965-66 \ldots \ldots$ & 26,916 & $\dagger$ & 19,368 & 7,548 & 28.0 & 4,232 & 3,085 & 1,147 & 2,097 & 1,792 & 305 \\
\hline $1967-68 \ldots \ldots \ldots \ldots \ldots \ldots \ldots$ & 31,826 & $\dagger$ & 22,986 & 8,840 & 27.8 & 5,506 & 3,959 & 1,547 & 2,784 & 2,345 & 439 \\
\hline $1969-70$ & 34,034 & $\dagger$ & 23,919 & 10,115 & 29.7 & 5,800 & 3,975 & 1,825 & 3,289 & 2,820 & 469 \\
\hline $1970-71 \ldots \ldots \ldots \ldots \ldots \ldots$ & 35,705 & 4.9 & 25,319 & 10,386 & 29.1 & 5,625 & 3,782 & 1,843 & 3,603 & 3,018 & 585 \\
\hline $1971-72 \ldots \ldots \ldots \ldots \ldots \ldots \ldots \ldots$ & 37,269 & 4.4 & 26,314 & 10,955 & 29.4 & 5,989 & 4,056 & 1,933 & 3,587 & 2,981 & 606 \\
\hline 1972-73 & 42,207 & 13.2 & 29,625 & 12,582 & 29.8 & 6,156 & 4,317 & 1,839 & 3,583 & 2,892 & 691 \\
\hline $1973-74$ & 48,244 & 14.3 & 33,217 & 15,027 & 31.1 & 6,408 & 4,512 & 1,896 & 3,358 & 2,684 & 674 \\
\hline $1974-75 \ldots \ldots \ldots \ldots \ldots \ldots \ldots \ldots \ldots$ & 51,609 & 7.0 & 34,580 & 17,029 & 33.0 & 6,429 & 4,554 & 1,875 & 3,334 & 2,612 & 722 \\
\hline $1975-76$ & 54,154 & 4.9 & 35,498 & 18,656 & 34.4 & 6,457 & 4,466 & 1,991 & 3,347 & 2,631 & 716 \\
\hline $1976-77 \ldots \ldots \ldots$ & 53,464 & -1.3 & 34,178 & 19,286 & 36.1 & 6,953 & 4,670 & 2,283 & 3,335 & 2,627 & 708 \\
\hline $1977-78$ & 51,360 & -3.9 & 31,673 & 19,687 & 38.3 & 6,651 & 4,353 & 2,298 & 3,255 & 2,481 & 774 \\
\hline $1978-79$ & 48,713 & -5.2 & 29,173 & 19,540 & 40.1 & 6,638 & 4,198 & 2,440 & 3,459 & 2,593 & 866 \\
\hline $1979-80 \ldots \ldots \ldots \ldots \ldots \ldots \ldots \ldots . .$. & 46,254 & -5.0 & 26,797 & 19,457 & 42.1 & 6,339 & 4,042 & 2,297 & 3,568 & 2,651 & 917 \\
\hline $1980-81 \ldots \ldots \ldots \ldots$ & 43,078 & -6.9 & 24,124 & 18,954 & 44.0 & 5,766 & 3,602 & 2,164 & 3,640 & 2,620 & 1,020 \\
\hline $1981-82$ & 41,501 & -3.7 & 22,722 & 18,779 & 45.2 & 5,679 & 3,384 & 2,295 & 3,662 & 2,611 & 1,051 \\
\hline $1982-83 \ldots \ldots \ldots$ & 39,924 & -3.8 & 21,572 & 18,352 & 46.0 & 5,711 & 3,298 & 2,413 & 3,386 & 2,306 & 1,080 \\
\hline $1983-84$ & 38,593 & -3.3 & 20,565 & 18,028 & 46.7 & 5,489 & 3,123 & 2,366 & 3,496 & 2,416 & 1,080 \\
\hline $1984-85 \ldots \ldots \ldots \ldots \ldots \ldots \ldots$ & 38,354 & -0.6 & 20,071 & 18,283 & 47.7 & 5,109 & 2,775 & 2,334 & 3,465 & 2,335 & 1,130 \\
\hline $1985-86 \ldots \ldots \ldots$ & 38,395 & 0.1 & 20,000 & 18,395 & 47.9 & 5,064 & 2,733 & 2,331 & 3,405 & 2,273 & 1,132 \\
\hline $1986-87 \ldots \ldots \ldots$ & 38,074 & -0.8 & 19,684 & 18,390 & 48.3 & 4,995 & 2,646 & 2,349 & 3,469 & 2,268 & 1,201 \\
\hline 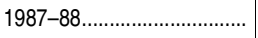 & 36,688 & -3.6 & 18,267 & 18,421 & 50.2 & 4,871 & 2,530 & 2,341 & 3,688 & 2,389 & 1,299 \\
\hline $1988-89$ & 36,068 & -1.7 & 17,998 & 18,070 & 50.1 & 5,034 & 2,598 & 2,436 & 3,617 & 2,299 & 1,318 \\
\hline $1989-90 \ldots \ldots \ldots \ldots$ & 37,304 & 3.4 & 18,363 & 18,941 & 50.8 & 4,941 & 2,509 & 2,432 & 3,922 & 2,478 & 1,444 \\
\hline $1990-91 \ldots \ldots \ldots \ldots$ & 39,482 & 5.8 & 19,418 & 20,064 & 50.8 & 4,834 & 2,417 & 2,417 & 4,152 & 2,618 & 1,534 \\
\hline $1991-92$ & 42,892 & 8.6 & 20,816 & 22,076 & 51.5 & 4,862 & 2,437 & 2,425 & 4,442 & 2,749 & 1,693 \\
\hline $1992-93 \ldots \ldots$ & 47,009 & 9.6 & 22,870 & 24,139 & 51.3 & 5,026 & 2,540 & 2,486 & 4,749 & 2,866 & 1,883 \\
\hline $1993-94 \ldots \ldots$ & 51,296 & 9.1 & 25,071 & 26,225 & 51.1 & 5,462 & 2,681 & 2,781 & 4,891 & 2,910 & 1,981 \\
\hline $1994-95 \ldots \ldots \ldots \ldots \ldots \ldots \ldots \ldots \ldots \ldots$ & 55,983 & 9.1 & 26,734 & 29,249 & 52.2 & 5,873 & 2,920 & 2,953 & 5,069 & 3,012 & 2,057 \\
\hline $1995-96 \ldots \ldots \ldots \ldots \ldots \ldots$ & 61,014 & 9.0 & 28,921 & 32,093 & 52.6 & 6,593 & 3,212 & 3,381 & 5,250 & 3,062 & 2,188 \\
\hline $1996-97$ & 63,973 & 4.8 & 29,562 & 34,411 & 53.8 & 6,986 & 3,419 & 3,567 & 5,313 & 3,014 & 2,299 \\
\hline $1997-98$ & 65,917 & 3.0 & 29,663 & 36,254 & 55.0 & 6,848 & 3,336 & 3,512 & 5,474 & 3,123 & 2,351 \\
\hline $1998-99$ & 65,310 & -0.9 & 28,507 & 36,803 & 56.4 & 6,966 & 3,279 & 3,687 & 5,250 & 3,010 & 2,240 \\
\hline $1999-2000$ & 63,630 & -2.6 & 26,579 & 37,051 & 58.2 & 6,850 & 3,171 & 3,679 & 5,463 & 3,068 & 2,395 \\
\hline $2000-01 \ldots \ldots$ & 60,576 & -4.8 & 24,600 & 35,976 & 59.4 & 7,017 & 3,075 & 3,942 & 5,225 & 2,923 & 2,302 \\
\hline $2001-02$ & 60,309 & -0.4 & 23,694 & 36,615 & 60.7 & 7,011 & 3,033 & 3,978 & 5,104 & 2,836 & 2,268 \\
\hline $2002-03 \ldots \ldots \ldots$ & 61,294 & 1.6 & 23,356 & 37,938 & 61.9 & 7,050 & 3,015 & 4,035 & 5,268 & 2,866 & 2,402 \\
\hline $2003-04 \ldots \ldots \ldots \ldots \ldots \ldots \ldots$ & 62,624 & 2.2 & 23,691 & 38,933 & 62.2 & 7,732 & 3,271 & 4,461 & 5,538 & 2,975 & 2,563 \\
\hline $2004-05 \ldots \ldots \ldots \ldots \ldots \ldots \ldots \ldots$ & 65,915 & 5.3 & 25,104 & 40,811 & 61.9 & 8,284 & 3,361 & 4,923 & 5,935 & 3,025 & 2,910 \\
\hline $2005-06 \ldots \ldots \ldots \ldots$ & 70,607 & 7.1 & 27,183 & 43,424 & 61.5 & 8,781 & 3,709 & 5,072 & 6,162 & 3,138 & 3,024 \\
\hline $2006-07 \ldots \ldots \ldots \ldots \ldots \ldots \ldots$ & 76,832 & 8.8 & 30,600 & 46,232 & 60.2 & 8,898 & 3,639 & 5,259 & 6,764 & 3,440 & 3,324 \\
\hline $2007-08$ & 79,829 & 3.9 & 32,401 & 47,428 & 59.4 & 9,689 & 4,094 & 5,595 & 7,400 & 3,645 & 3,755 \\
\hline $2008-09$ & 82,825 & 3.8 & 33,705 & 49,120 & 59.3 & 10,017 & 4,250 & 5,767 & 7,499 & 3,549 & 3,950 \\
\hline 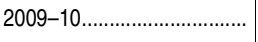 & 86,400 & 4.3 & 35,865 & 50,535 & 58.5 & 10,725 & 4,611 & 6,114 & 7,666 & 3,600 & 4,066 \\
\hline $2010-11 \ldots \ldots \ldots \ldots \ldots$ & 90,003 & 4.2 & 36,892 & 53,111 & 59.0 & 11,327 & 4,871 & 6,456 & 7,693 & 3,648 & 4,045 \\
\hline $2011-12 \ldots \ldots \ldots \ldots \ldots \ldots \ldots \ldots \ldots \ldots$ & 95,849 & 6.5 & 39,545 & 56,304 & 58.7 & 12,415 & 5,378 & 7,037 & 7,935 & 3,708 & 4,227 \\
\hline $\begin{array}{l}\text { Percent change } \\
2001-02 \text { to } 2006-07 \ldots \ldots . . \\
2006-07 \text { to } 2011-12 \ldots \ldots .\end{array}$ & $\begin{array}{l}27.4 \\
24.8\end{array}$ & 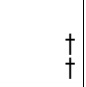 & $\begin{array}{l}29.1 \\
29.2\end{array}$ & $\begin{array}{l}26.3 \\
21.8\end{array}$ & $t$ & $\begin{array}{l}26.9 \\
39.5\end{array}$ & $\begin{array}{l}20.0 \\
47.8\end{array}$ & $\begin{array}{l}32.2 \\
33.8\end{array}$ & $\begin{array}{l}32.5 \\
17.3\end{array}$ & $\begin{array}{r}21.3 \\
7.8\end{array}$ & $\begin{array}{l}46.6 \\
27.2\end{array}$ \\
\hline
\end{tabular}

†Not applicable.

NOTE: Data are for postsecondary institutions participating in Title IV federal financial aid programs.

SOURCE: U.S. Department of Education, National Center for Education Statistics, Earned Degrees Conferred, 1951-52 through 1963-64; Higher Education General Information Sur- vey (HEGIS), "Degrees and Other Formal Awards Conferred" surveys, 1965-66 through 1985-86; Integrated Postsecondary Education Data System (IPEDS), "Completions Survey" (IPEDS-C:87-99); and IPEDS Fall 2000 through Fall 2012, Completions component. (This table was prepared August 2013.) 
588 CHAPTER 3: Postsecondary Education

Trends in Degrees by Field

Table 325.22. Degrees in biology, microbiology, and zoology conferred by postsecondary institutions, by level of degree: 1970-71 through 2011-12

\begin{tabular}{|c|c|c|c|c|c|c|c|c|c|}
\hline \multirow[b]{2}{*}{ Year } & \multicolumn{3}{|c|}{ Biology, general } & \multicolumn{3}{|c|}{ Microbiology ${ }^{1}$} & \multicolumn{3}{|c|}{ Zoology $y^{2}$} \\
\hline & Bachelor's & Master's & Doctor's & Bachelor's & Master's & Doctor's & Bachelor's & Master's & Doctor's \\
\hline 1 & 2 & 3 & 4 & 5 & 6 & 7 & 8 & 9 & 10 \\
\hline $1970-71 \ldots \ldots \ldots \ldots \ldots \ldots \ldots \ldots \ldots . . .1$. & 26,294 & 2,665 & 536 & 1,475 & 456 & 365 & 5,721 & 1,027 & 878 \\
\hline $1971-72 \ldots \ldots$ & 27,473 & 2,943 & 580 & 1,548 & 470 & 351 & 5,518 & 1,040 & 836 \\
\hline $1972-73 \ldots \ldots \ldots .$. & 31,185 & 2,959 & 627 & 1,940 & 517 & 344 & 5,763 & 1,042 & 803 \\
\hline $1973-74 \ldots \ldots \ldots \ldots \ldots \ldots \ldots \ldots \ldots . .$. & 36,188 & 3,186 & 657 & 2,311 & 505 & 384 & 6,128 & 1,091 & 677 \\
\hline $1974-75 \ldots \ldots \ldots \ldots \ldots \ldots \ldots \ldots$ & 38,748 & 3,109 & 637 & 2,767 & 552 & 345 & 6,110 & 1,039 & 697 \\
\hline $1975-76 \ldots \ldots \ldots$ & 40,163 & 3,177 & 624 & 2,927 & 585 & 364 & 6,077 & 976 & 645 \\
\hline $1976-77 \ldots \ldots \ldots \ldots \ldots \ldots \ldots \ldots .$. & 39,530 & 3,322 & 608 & 2,884 & 659 & 325 & 5,574 & 985 & 696 \\
\hline 1977-78_...................... & 37,598 & 3,094 & 664 & 2,695 & 615 & 353 & 5,096 & 958 & 624 \\
\hline $1978-79 \ldots \ldots \ldots \ldots \ldots \ldots \ldots \ldots$ & 35,962 & 3,093 & 663 & 2,670 & 597 & 395 & 4,738 & 946 & 669 \\
\hline $1979-80 \ldots \ldots \ldots \ldots \ldots \ldots \ldots \ldots \ldots . .$. & 33,523 & 2,911 & 718 & 2,631 & 596 & 376 & 4,301 & 922 & 639 \\
\hline $1980-81 \ldots \ldots \ldots . .$. & 31,323 & 2,598 & 734 & 2,414 & 482 & 370 & 3,873 & 881 & 613 \\
\hline $1981-82 \ldots \ldots \ldots \ldots \ldots \ldots \ldots \ldots \ldots \ldots$ & 29,651 & 2,579 & 678 & 2,377 & 470 & 350 & 3,615 & 868 & 625 \\
\hline $1982-83 \ldots \ldots \ldots \ldots \ldots \ldots \ldots \ldots \ldots . .$. & 28,022 & 2,354 & 521 & 2,324 & 499 & 358 & 3,407 & 738 & 533 \\
\hline $1983-84 \ldots \ldots \ldots$. & 27,379 & 2,313 & 617 & 2,349 & 505 & 388 & 3,231 & 700 & 521 \\
\hline $1984-85 \ldots \ldots \ldots \ldots \ldots \ldots \ldots \ldots$ & 27,593 & 2,130 & 658 & 2,207 & 471 & 319 & 3,069 & 664 & 508 \\
\hline $1985-86 \ldots$ & 27,618 & 2,173 & 574 & 2,257 & 392 & 362 & 2,894 & 618 & 548 \\
\hline $1986-87 \ldots \ldots$ & 27,465 & 2,022 & 537 & 2,159 & 451 & 380 & 2,791 & 623 & 464 \\
\hline $1987-88 \ldots \ldots \ldots \ldots \ldots \ldots \ldots \ldots \ldots . .$. & 26,838 & 1,981 & 576 & 2,061 & 404 & 442 & 2,537 & 629 & 492 \\
\hline $1988-89 \ldots \ldots \ldots \ldots \ldots \ldots \ldots \ldots . .$. & 26,229 & 2,097 & 527 & 1,833 & 449 & 423 & 2,549 & 634 & 466 \\
\hline $1989-90 \ldots \ldots \ldots \ldots \ldots \ldots \ldots$ & 27,213 & 1,998 & 551 & 1,973 & 403 & 441 & 2,473 & 548 & 545 \\
\hline $1990-91 \ldots \ldots \ldots \ldots$ & 29,285 & 1,956 & 632 & 1,788 & 343 & 443 & 2,641 & 551 & 516 \\
\hline $1991-92 \ldots \ldots$. & 31,909 & 1,995 & 657 & 1,750 & 372 & 532 & 2,811 & 530 & 494 \\
\hline $1992-93 \ldots . .$. & 34,932 & 2,000 & 671 & 1,798 & 367 & 621 & 3,036 & 559 & 465 \\
\hline 1993-94_......................... & 38,103 & 2,178 & 665 & 1,872 & 359 & 591 & 3,162 & 658 & 503 \\
\hline $1994-95 \ldots \ldots \ldots \ldots \ldots \ldots \ldots \ldots \ldots$ & 41,658 & 2,350 & 729 & 1,992 & 326 & 572 & 3,149 & 586 & 487 \\
\hline $1995-96 \ldots \ldots \ldots \ldots \ldots \ldots$ & 44,818 & 2,606 & 768 & 2,220 & 364 & 606 & 3,463 & 677 & 501 \\
\hline $1996-97 \ldots \ldots \ldots \ldots \ldots \ldots \ldots \ldots$ & 46,632 & 2,742 & 693 & 2,530 & 363 & 612 & 3,438 & 720 & 474 \\
\hline $1997-98 \ldots \ldots$. & 47,054 & 2,617 & 809 & 2,926 & 401 & 585 & 3,653 & 685 & 465 \\
\hline $1998-99 \ldots$. & 46,172 & 2,616 & 718 & 2,885 & 406 & 544 & 3,508 & 606 & 462 \\
\hline $1999-2000 \ldots$ & 44,982 & 2,599 & 727 & 3,049 & 383 & 551 & 3,226 & 616 & 481 \\
\hline $2000-01 \ldots \ldots . .$. & 42,310 & 2,582 & 780 & 2,779 & 334 & 553 & 3,045 & 560 & 380 \\
\hline $2001-02 \ldots \ldots \ldots \ldots \ldots \ldots$ & 42,281 & 2,424 & 689 & 2,622 & 325 & 538 & 2,979 & 578 & 413 \\
\hline $2002-03 \ldots \ldots \ldots \ldots . . .$. & 42,699 & 2,340 & 680 & 2,455 & 297 & 507 & 2,488 & 379 & 355 \\
\hline $2003-04 \ldots \ldots$. & 43,465 & 2,529 & 681 & 2,365 & 350 & 599 & 2,454 & 367 & 245 \\
\hline $2004-05 \ldots \ldots \ldots . .$. & 45,540 & 2,564 & 712 & 2,318 & 390 & 610 & 2,159 & 384 & 268 \\
\hline $2005-06 \ldots \ldots . .$. & 48,855 & 2,719 & 776 & 2,243 & 372 & 612 & 2,140 & 384 & 254 \\
\hline $2006-07 \ldots \ldots \ldots \ldots \ldots \ldots \ldots$ & 52,527 & 2,679 & 788 & 2,347 & 369 & 667 & 2,223 & 416 & 263 \\
\hline $2007-08 \ldots \ldots \ldots \ldots \ldots \ldots$ & 54,384 & 2,935 & 866 & 2,458 & 353 & 734 & 2,235 & 381 & 281 \\
\hline $2008-09 \ldots \ldots \ldots . . .$. & 55,856 & 2,986 & 896 & 2,480 & 291 & 716 & 2,141 & 347 & 297 \\
\hline 2009-10................................ & 58,732 & 3,156 & 914 & 2,449 & 303 & 767 & 2,147 & 360 & 243 \\
\hline $2010-11 \ldots \ldots \ldots . . .$. & 61,247 & 3,283 & 935 & 2,466 & 337 & 739 & 2,062 & 338 & 230 \\
\hline $2011-12 \ldots \ldots \ldots \ldots \ldots \ldots \ldots \ldots \ldots$ & 64,611 & 3,490 & 964 & 2,532 & 395 & 687 & 2,174 & 346 & 258 \\
\hline Percent change & & & & & & & & & \\
\hline $\begin{array}{l}2001-02 \text { to } 2006-07 \ldots \ldots . \\
2006-07 \text { to } 2011-12 \ldots \ldots . .\end{array}$ & $\begin{array}{l}24.2 \\
23.0\end{array}$ & $\begin{array}{l}10.5 \\
30.3\end{array}$ & $\begin{array}{l}14.4 \\
22.3\end{array}$ & $\begin{array}{r}-10.5 \\
7.9\end{array}$ & $\begin{array}{r}13.5 \\
7.0\end{array}$ & $\begin{array}{r}24.0 \\
3.0\end{array}$ & $\begin{array}{r}-25.4 \\
-2.2\end{array}$ & $\begin{array}{l}-28.0 \\
-16.8\end{array}$ & $\begin{array}{r}-36.3 \\
-1.9\end{array}$ \\
\hline
\end{tabular}

IIncludes microbiology, general; medical microbiology and bacteriology; virology; parasitology: immunology; and microbiological sciences and immunology, other.

Includes zoology/animal biology; entomology; animal physiology; animal behavior and ethology; wildlife biology; and zoology/animal biology, other.

NOTE: Data are for postsecondary institutions participating in Title IV federal financial aid programs.
SOURCE: US. Department of Education, National Center for Education Statistics, Higher Education General Information Survey (HEGIS), "Degrees and Other Formal Awards Conferred" surveys, 1970-71 through 1985-86; Integrated Postsecondary Education Data System (IPEDS), "Completions Survey" (IPEDS-C:87-99); and IPEDS Fall 2000 through Fall 2012, Completions component. (This table was prepared August 2013.) 
Table 325.25. Degrees in business conferred by postsecondary institutions, by level of degree and sex of student: Selected years, 1955-56 through 2011-12

\begin{tabular}{|c|c|c|c|c|c|c|c|c|c|c|c|}
\hline \multirow[b]{3}{*}{ Year } & \multicolumn{5}{|c|}{ Bachelor's degrees } & \multicolumn{3}{|c|}{ Master's degrees } & \multicolumn{3}{|c|}{ Doctor's degrees } \\
\hline & \multicolumn{2}{|c|}{ Total } & \multirow[b]{2}{*}{ Males } & \multirow[b]{2}{*}{ Females } & \multirow{2}{*}{$\begin{array}{r}\text { Females } \\
\text { as a } \\
\text { percent } \\
\text { of total }\end{array}$} & \multirow[b]{2}{*}{ Total } & \multirow[b]{2}{*}{ Males } & \multirow[b]{2}{*}{ Females } & \multirow[b]{2}{*}{ Total } & \multirow[b]{2}{*}{ Males } & \multirow[b]{2}{*}{ Females } \\
\hline & Number & $\begin{array}{l}\text { Annual } \\
\text { percent } \\
\text { change }\end{array}$ & & & & & & & & & \\
\hline 1 & 2 & 3 & 4 & 5 & 6 & 7 & 8 & 9 & 10 & 11 & 12 \\
\hline$\overline{1955-56 \ldots \ldots \ldots \ldots \ldots \ldots \ldots \ldots}$ & 42,813 & $t$ & 38,706 & 4,107 & 9.6 & 3,280 & 3,118 & 162 & 129 & 127 & 2 \\
\hline $1957-58 \ldots \ldots \ldots \ldots \ldots \ldots$ & 51,991 & $\dagger$ & 48,063 & 3,928 & 7.6 & 4,223 & 4,072 & 151 & 110 & 105 & 5 \\
\hline $1959-60 \ldots \ldots \ldots \ldots \ldots$ & 51,076 & $\dagger$ & 47,262 & 3,814 & 7.5 & 4,643 & 4,476 & 167 & 135 & 133 & 2 \\
\hline $1961-62 \ldots \ldots \ldots \ldots \ldots \ldots \ldots$ & 49,017 & $\dagger$ & 45,184 & 3,833 & 7.8 & 7,691 & 7,484 & 207 & 226 & 221 & 5 \\
\hline $1963-64 \ldots \ldots \ldots \ldots \ldots \ldots \ldots$ & 55,474 & $\dagger$ & 51,056 & 4,418 & 8.0 & 9,251 & 9,008 & 243 & 275 & 268 & 7 \\
\hline 1965-66 .................... & 62,721 & $\dagger$ & 57,516 & 5,205 & 8.3 & 12,959 & 12,628 & 331 & 387 & 370 & 17 \\
\hline 1967-68.................... & 79,074 & $\dagger$ & 72,126 & 6,948 & 8.8 & 17,795 & 17,186 & 609 & 441 & 427 & 14 \\
\hline 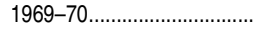 & 105,580 & $\dagger$ & 96,346 & 9,234 & 8.7 & 21,561 & 20,792 & 769 & 620 & 610 & 10 \\
\hline $1970-71 \ldots \ldots \ldots \ldots \ldots \ldots$ & 115,396 & 9.3 & 104,936 & 10,460 & 9.1 & 26,490 & 25,458 & 1,032 & 774 & 753 & 21 \\
\hline $1971-72 \ldots \ldots \ldots \ldots \ldots \ldots \ldots \ldots$ & 121,917 & 5.7 & 110,331 & 11,586 & 9.5 & 30,509 & 29,317 & 1,192 & 876 & 857 & 19 \\
\hline $1972-73 \ldots \ldots \ldots \ldots \ldots$ & 126,717 & 3.9 & 113,337 & 13,380 & 10.6 & 31,208 & 29,689 & 1,519 & 917 & 864 & 53 \\
\hline 1973-74_..................... & 132,304 & 4.4 & 115,363 & 16,941 & 12.8 & 32,691 & 30,557 & 2,134 & 922 & 873 & 49 \\
\hline 1974-75 ....................... & 133,639 & 1.0 & 111,983 & 21,656 & 16.2 & 36,315 & 33,274 & 3,041 & 939 & 900 & 39 \\
\hline 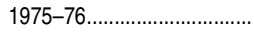 & 143,171 & 7.1 & 114,986 & 28,185 & 19.7 & 42,592 & 37,654 & 4,938 & 906 & 856 & 50 \\
\hline $1976-77 \ldots \ldots \ldots \ldots \ldots \ldots$ & 152,010 & 6.2 & 116,394 & 35,616 & 23.4 & 46,505 & 39,852 & 6,653 & 839 & 785 & 54 \\
\hline $1977-78 \ldots \ldots \ldots$ & 160,775 & 5.8 & 117,103 & 43,672 & 27.2 & 48,347 & 40,224 & 8,123 & 834 & 760 & 74 \\
\hline $1978-79 \ldots \ldots \ldots \ldots \ldots$ & 172,392 & 7.2 & 119,765 & 52,627 & 30.5 & 50,397 & 40,766 & 9,631 & 852 & 752 & 100 \\
\hline 1979-80........................ & 186,264 & 8.0 & 123,639 & 62,625 & 33.6 & 55,008 & 42,744 & 12,264 & 767 & 650 & 117 \\
\hline 1980-81........................ & 200,521 & 7.7 & 126,798 & 73,723 & 36.8 & 57,888 & 43,411 & 14,477 & 808 & 686 & 122 \\
\hline $1981-82 \ldots$ & 215,190 & 7.3 & 130,693 & 84,497 & 39.3 & 61,251 & 44,230 & 17,021 & 826 & 676 & 150 \\
\hline $1982-83 \ldots \ldots \ldots \ldots . .$. & 226,442 & 5.2 & 131,451 & 94,991 & 41.9 & 64,741 & 45,987 & 18,754 & 770 & 638 & 132 \\
\hline 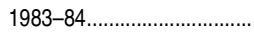 & 229,013 & 1.1 & 129,296 & 99,717 & 43.5 & 66,129 & 46,167 & 19,962 & 926 & 727 & 199 \\
\hline $1984-85 \ldots \ldots$. & 232,282 & 1.4 & 127,467 & 104,815 & 45.1 & 66,981 & 46,199 & 20,782 & 827 & 685 & 142 \\
\hline $1985-86 \ldots \ldots \ldots \ldots \ldots \ldots \ldots$ & 236,700 & 1.9 & 128,415 & 108,285 & 45.7 & 66,676 & 45,927 & 20,749 & 923 & 720 & 203 \\
\hline $1986-87 \ldots \ldots \ldots \ldots \ldots \ldots$ & 240,346 & 1.5 & 128,506 & 111,840 & 46.5 & 67,093 & 44,913 & 22,180 & 1,062 & 808 & 254 \\
\hline $1987-88 \ldots$ & 242,859 & 1.0 & 129,467 & 113,392 & 46.7 & 69,230 & 45,980 & 23,250 & 1,063 & 810 & 253 \\
\hline 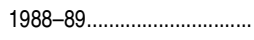 & 246,262 & 1.4 & 131,098 & 115,164 & 46.8 & 73,065 & 48,540 & 24,525 & 1,100 & 800 & 300 \\
\hline 1989-90...................... & 248,568 & 0.9 & 132,284 & 116,284 & 46.8 & 76,676 & 50,585 & 26,091 & 1,093 & 818 & 275 \\
\hline $1990-91 \ldots \ldots \ldots \ldots \ldots \ldots$ & 249,165 & 0.2 & 131,557 & 117,608 & 47.2 & 78,255 & 50,883 & 27,372 & 1,185 & 876 & 309 \\
\hline $1991-92 \ldots \ldots \ldots \ldots \ldots \ldots$ & 256,298 & 2.9 & 135,263 & 121,035 & 47.2 & 84,517 & 54,609 & 29,908 & 1,242 & 953 & 289 \\
\hline $1992-93 \ldots \ldots . .$. & 256,473 & 0.1 & 135,368 & 121,105 & 47.2 & 89,425 & 57,504 & 31,921 & 1,346 & 969 & 377 \\
\hline 1993-94_.................. & 246,265 & -4.0 & 128,946 & 117,319 & 47.6 & 93,285 & 59,223 & 34,062 & 1,364 & 980 & 384 \\
\hline 1994-95.................... & 233,895 & -5.0 & 121,663 & 112,232 & 48.0 & 93,540 & 58,931 & 34,609 & 1,391 & 1,011 & 380 \\
\hline $1995-96 \ldots \ldots \ldots \ldots \ldots \ldots$ & 226,623 & -3.1 & 116,545 & 110,078 & 48.6 & 93,554 & 58,400 & 35,154 & 1,366 & 972 & 394 \\
\hline 1996-97 ..................... & 225,934 & -0.3 & 116,023 & 109,911 & 48.6 & 97,204 & 59,333 & 37,871 & 1,336 & 947 & 389 \\
\hline 1997-98................ & 232,079 & 2.7 & 119,379 & 112,700 & 48.6 & 101,652 & 62,357 & 39,295 & 1,290 & 885 & 405 \\
\hline 1998-99................... & 239,924 & 3.4 & 121,741 & 118,183 & 49.3 & 106,830 & 64,271 & 42,559 & 1,216 & 848 & 368 \\
\hline 1999-2000 ................. & 256,070 & 6.7 & 128,521 & 127,549 & 49.8 & 111,532 & 67,078 & 44,454 & 1,194 & 812 & 382 \\
\hline $2000-01 \ldots \ldots \ldots \ldots \ldots . . . . . . .$. & 263,515 & 2.9 & 132,275 & 131,240 & 49.8 & 115,602 & 68,471 & 47,131 & 1,180 & 783 & 397 \\
\hline $2001-02 \ldots \ldots \ldots \ldots \ldots \ldots \ldots$ & 278,217 & 5.6 & 138,343 & 139,874 & 50.3 & 119,725 & 70,463 & 49,262 & 1,156 & 746 & 410 \\
\hline 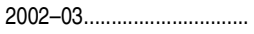 & 293,391 & 5.5 & 145,075 & 148,316 & 50.6 & 127,685 & 75,239 & 52,446 & 1,252 & 820 & 432 \\
\hline $2003-04 \ldots \ldots \ldots . .$. & 307,149 & 4.7 & 152,513 & 154,636 & 50.3 & 139,347 & 80,858 & 58,489 & 1,481 & 960 & 521 \\
\hline 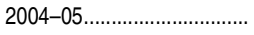 & 311,574 & 1.4 & 155,940 & 155,634 & 50.0 & 142,617 & 82,151 & 60,466 & 1,498 & 901 & 597 \\
\hline 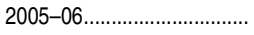 & 318,042 & 2.1 & 159,683 & 158,359 & 49.8 & 146,406 & 83,550 & 62,856 & 1,711 & 1,049 & 662 \\
\hline 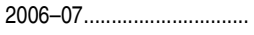 & 327,531 & 3.0 & 166,350 & 161,181 & 49.2 & 150,211 & 84,115 & 66,096 & 2,029 & 1,188 & 841 \\
\hline $2007-08 \ldots \ldots \ldots \ldots . . .$. & 335,254 & 2.4 & 170,978 & 164,276 & 49.0 & 155,637 & 86,258 & 69,379 & 2,084 & 1,250 & 834 \\
\hline 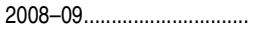 & 347,985 & 3.8 & 177,862 & 170,123 & 48.9 & 168,375 & 91,981 & 76,394 & 2,123 & 1,302 & 821 \\
\hline $2009-10 \ldots \ldots \ldots \ldots \ldots . . . .$. & 358,293 & 3.0 & 183,301 & 174,992 & 48.8 & 177,684 & 96,709 & 80,975 & 2,245 & 1,335 & 910 \\
\hline 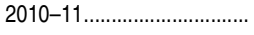 & 365,093 & 1.9 & 187,081 & 178,012 & 48.8 & 187,213 & 101,450 & 85,763 & 2,286 & 1,357 & 929 \\
\hline $2011-12 .$. & 366,815 & 0.5 & 190,082 & 176,733 & 48.2 & 191,571 & 103,253 & 88,318 & 2,531 & 1,460 & 1,071 \\
\hline $\begin{array}{l}\text { Percent change } \\
2001-02 \text { to } 2006-07 \ldots \ldots . . \\
2006-07 \text { to } 2011-12 \ldots \ldots .\end{array}$ & $\begin{array}{l}17.7 \\
12.0\end{array}$ & $\stackrel{t}{\dagger}$ & $\begin{array}{l}20.2 \\
14.3\end{array}$ & $\begin{array}{r}15.2 \\
9.6\end{array}$ & $\dagger$ & $\begin{array}{l}25.5 \\
27.5\end{array}$ & $\begin{array}{r}19.4 \\
22.8\end{array}$ & $\begin{array}{l}34.2 \\
33.6\end{array}$ & $\begin{array}{l}75.5 \\
24.7\end{array}$ & $\begin{array}{l}59.2 \\
22.9\end{array}$ & $\begin{array}{r}105.1 \\
27.3\end{array}$ \\
\hline
\end{tabular}

†Not applicable.

NOTE: Data are for postsecondary institutions participating in Title IV federal financial aid programs. Includes degrees in business, management, marketing, and related support services and in personal and culinary services.

SOURCE: U.S. Department of Education, National Center for Education Statistics, Earned
Degrees Conferred, 1955-56 through 1963-64; Higher Education General Information Survey (HEGIS), "Degrees and Other Formal Awards Conferred" surveys, 1965-66 through 1985-86; Integrated Postsecondary Education Data System (IPEDS), "Completions Survey" (IPEDS-C:87-99); and IPEDS Fall 2000 through Fall 2012, Completions component. (This table was prepared July 2013.) 
Table 325.30. Degrees in communication, journalism, and related programs and in communications technologies conferred by postsecondary institutions, by level of degree and sex of student: 1970-71 through 2011-12

\begin{tabular}{|c|c|c|c|c|c|c|c|c|c|c|c|}
\hline \multirow[b]{3}{*}{ Year } & \multicolumn{5}{|c|}{ Bachelor's degrees } & \multicolumn{3}{|c|}{ Master's degrees } & \multicolumn{3}{|c|}{ Doctor's degrees } \\
\hline & \multicolumn{2}{|c|}{ Total } & \multirow[b]{2}{*}{ Males } & \multirow[b]{2}{*}{ Females } & \multirow[b]{2}{*}{$\begin{array}{r}\text { Females } \\
\text { as a } \\
\text { percent } \\
\text { of total }\end{array}$} & \multirow[b]{2}{*}{ Total } & \multirow[b]{2}{*}{ Males } & \multirow[b]{2}{*}{ Females } & \multirow[b]{2}{*}{ Total } & \multirow[b]{2}{*}{ Males } & \multirow[b]{2}{*}{ Females } \\
\hline & Number & $\begin{array}{l}\text { Annual } \\
\text { percent } \\
\text { change }\end{array}$ & & & & & & & & & \\
\hline 1 & 2 & 3 & 4 & 5 & 6 & 7 & 8 & 9 & 10 & 11 & 12 \\
\hline 1970-71_............................. & 10,802 & $\dagger$ & 6,989 & 3,813 & 35.3 & 1,856 & 1,214 & 642 & 145 & 126 & 19 \\
\hline $1971-72 \ldots \ldots \ldots \ldots \ldots \ldots \ldots \ldots \ldots$ & 12,340 & 14.2 & 7,964 & 4,376 & 35.5 & 2,200 & 1,443 & 757 & 111 & 96 & 15 \\
\hline $1972-73 \ldots \ldots \ldots$ & 14,317 & 16.0 & 9,074 & 5,243 & 36.6 & 2,406 & 1,546 & 860 & 139 & 114 & 25 \\
\hline $1973-74$ & 17,096 & 19.4 & 10,536 & 6,560 & 38.4 & 2,640 & 1,668 & 972 & 175 & 146 & 29 \\
\hline 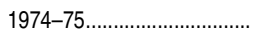 & 19,248 & 12.6 & 11,455 & 7,793 & 40.5 & 2,794 & 1,618 & 1,176 & 165 & 119 & 46 \\
\hline $1975-76$ & 21,282 & 10.6 & 12,458 & 8,824 & 41.5 & 3,126 & 1,818 & 1,308 & 204 & 154 & 50 \\
\hline $1976-77 \ldots \ldots \ldots$ & 23,214 & 9.1 & 12,932 & 10,282 & 44.3 & 3,091 & 1,719 & 1,372 & 171 & 130 & 41 \\
\hline $1977-78$ & 25,400 & 9.4 & 13,480 & 11,920 & 46.9 & 3,296 & 1,673 & 1,623 & 191 & 138 & 53 \\
\hline $1978-79 \ldots \ldots \ldots$ & 26,457 & 4.2 & 13,266 & 13,191 & 49.9 & 2,882 & 1,483 & 1,399 & 192 & 138 & 54 \\
\hline $1979-80 \ldots \ldots \ldots \ldots$ & 28,616 & 8.2 & 13,656 & 14,960 & 52.3 & 3,082 & 1,527 & 1,555 & 193 & 121 & 72 \\
\hline 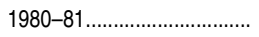 & 31,282 & 9.3 & 14,179 & 17,103 & 54.7 & 3,105 & 1,448 & 1,657 & 182 & 107 & 75 \\
\hline $1981-82$ & 34,222 & 9.4 & 14,917 & 19,305 & 56.4 & 3,327 & 1,578 & 1,749 & 200 & 136 & 64 \\
\hline $1982-83 \ldots \ldots \ldots \ldots \ldots \ldots$ & 38,647 & 12.9 & 16,213 & 22,434 & 58.0 & 3,600 & 1,660 & 1,940 & 208 & 123 & 85 \\
\hline 1983-84 ....................... & 40,203 & 4.0 & 16,662 & 23,541 & 58.6 & 3,620 & 1,578 & 2,042 & 216 & 129 & 87 \\
\hline 1984-85.............................. & 42,102 & 4.7 & 17,233 & 24,869 & 59.1 & 3,657 & 1,574 & 2,083 & 232 & 141 & 91 \\
\hline $1985-86 \ldots \ldots \ldots$ & 43,145 & 2.5 & 17,681 & 25,464 & 59.0 & 3,808 & 1,603 & 2,205 & 218 & 116 & 102 \\
\hline $1986-87 \ldots \ldots \ldots \ldots$ & 45,521 & 5.5 & 18,201 & 27,320 & 60.0 & 3,881 & 1,584 & 2,297 & 275 & 158 & 117 \\
\hline 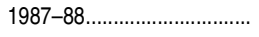 & 46,916 & 3.1 & 18,672 & 28,244 & 60.2 & 3,916 & 1,568 & 2,348 & 233 & 133 & 100 \\
\hline $1988-89 \ldots \ldots \ldots$ & 48,889 & 4.2 & 19,357 & 29,532 & 60.4 & 4,249 & 1,734 & 2,515 & 248 & 137 & 111 \\
\hline 1989-90_............................ & 51,572 & 5.5 & 20,374 & 31,198 & 60.5 & 4,353 & 1,705 & 2,648 & 272 & 145 & 127 \\
\hline 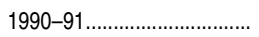 & 53,047 & 2.9 & 20,806 & 32,241 & 60.8 & 4,327 & 1,711 & 2,616 & 272 & 150 & 122 \\
\hline $1991-92 \ldots \ldots \ldots \ldots$ & 55,144 & 4.0 & 21,601 & 33,543 & 60.8 & 4,463 & 1,692 & 2,771 & 255 & 132 & 123 \\
\hline 1992-93........................ & 54,907 & -0.4 & 22,154 & 32,753 & 59.7 & 5,179 & 1,969 & 3,210 & 301 & 146 & 155 \\
\hline $1993-94 \ldots \ldots \ldots \ldots$ & 52,033 & -5.2 & 21,484 & 30,549 & 58.7 & 5,388 & 2,088 & 3,300 & 345 & 174 & 171 \\
\hline 1994-95 ........................... & 48,969 & -5.9 & 20,501 & 28,468 & 58.1 & 5,559 & 2,086 & 3,473 & 321 & 162 & 159 \\
\hline 1995-96............................. & 48,173 & -1.6 & 19,868 & 28,305 & 58.8 & 5,561 & 2,153 & 3,408 & 345 & 190 & 155 \\
\hline 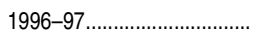 & 47,894 & -0.6 & 19,771 & 28,123 & 58.7 & 5,552 & 1,989 & 3,563 & 300 & 155 & 145 \\
\hline 1997-98......................... & 50,263 & 4.9 & 20,103 & 30,160 & 60.0 & 6,097 & 2,369 & 3,728 & 359 & 171 & 188 \\
\hline $1998-99$ & 52,397 & 4.2 & 20,943 & 31,454 & 60.0 & 5,582 & 2,001 & 3,581 & 348 & 182 & 166 \\
\hline $1999-2000 \ldots \ldots \ldots \ldots \ldots \ldots$ & 57,058 & 8.9 & 22,152 & 34,906 & 61.2 & 5,525 & 2,030 & 3,495 & 357 & 168 & 189 \\
\hline $2000-01 \ldots \ldots \ldots \ldots \ldots$ & 59,191 & 3.7 & 22,542 & 36,649 & 61.9 & 5,645 & 1,964 & 3,681 & 370 & 190 & 180 \\
\hline $2001-02 \ldots \ldots$ & 64,036 & 8.2 & 23,692 & 40,344 & 63.0 & 5,980 & 2,169 & 3,811 & 383 & 168 & 215 \\
\hline $2002-03 \ldots \ldots \ldots$ & 69,828 & 9.0 & 25,338 & 44,490 & 63.7 & 6,495 & 2,301 & 4,194 & 398 & 179 & 219 \\
\hline 2003-04 & 73,002 & 4.5 & 25,813 & 47,189 & 64.6 & 6,900 & 2,329 & 4,571 & 426 & 186 & 240 \\
\hline 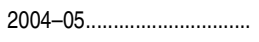 & 75,238 & 3.1 & 26,926 & 48,312 & 64.2 & 7,195 & 2,535 & 4,660 & 468 & 195 & 273 \\
\hline 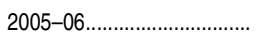 & 76,936 & 2.3 & 28,142 & 48,794 & 63.4 & 7,745 & 2,611 & 5,134 & 464 & 207 & 257 \\
\hline $2006-07 \ldots \ldots \ldots \ldots$ & 78,420 & 1.9 & 29,009 & 49,411 & 63.0 & 7,272 & 2,485 & 4,787 & 480 & 188 & 292 \\
\hline $2007-08 \ldots \ldots \ldots \ldots$ & 81,048 & 3.4 & 30,384 & 50,664 & 62.5 & 7,546 & 2,580 & 4,966 & 496 & 209 & 287 \\
\hline 2008-09............................. & 83,109 & 2.5 & 31,218 & 51,891 & 62.4 & 7,567 & 2,459 & 5,108 & 535 & 225 & 310 \\
\hline 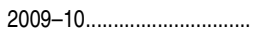 & 86,048 & 3.5 & 32,040 & 54,008 & 62.8 & 8,099 & 2,659 & 5,440 & 573 & 225 & 348 \\
\hline 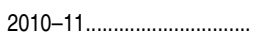 & 88,132 & 2.4 & 33,023 & 55,109 & 62.5 & 8,805 & 2,820 & 5,985 & 578 & 207 & 371 \\
\hline $2011-12 \ldots \ldots \ldots \ldots$ & 88,752 & 0.7 & 33,525 & 55,227 & 62.2 & 9,496 & 3,065 & 6,431 & 567 & 242 & 325 \\
\hline $\begin{array}{l}\text { Percent change } \\
2001-02 \text { to } 2006-07 \ldots \ldots . \\
2006-07 \text { to } 2011-12 \ldots \ldots .\end{array}$ & $\begin{array}{l}22.5 \\
13.2\end{array}$ & $\begin{array}{l}t \\
t\end{array}$ & $\begin{array}{l}22.4 \\
15.6\end{array}$ & $\begin{array}{l}22.5 \\
11.8\end{array}$ & $\begin{array}{l}\dagger \\
\dagger\end{array}$ & $\begin{array}{l}21.6 \\
30.6\end{array}$ & $\begin{array}{l}14.6 \\
23.3\end{array}$ & $\begin{array}{l}25.6 \\
34.3\end{array}$ & $\begin{array}{l}25.3 \\
18.1\end{array}$ & $\begin{array}{l}11.9 \\
28.7\end{array}$ & $\begin{array}{l}35.8 \\
11.3\end{array}$ \\
\hline
\end{tabular}

†Not applicable.

NOTE: Data are for postsecondary institutions participating in Title IV federal financial aid programs.

SOURCE: U.S. Department of Education, National Center for Education Statistics, Higher
Education General Information Survey (HEGIS), "Degrees and Other Formal Awards Conferred" surveys, 1970-71 through 1985-86; Integrated Postsecondary Education Data System (IPEDS), "Completions Survey" (IPEDS-C:87-99); and IPEDS Fall 2000 through Fall 2012, Completions component. (This table was prepared July 2013.) 
Table 325.35. Degrees in computer and information sciences conferred by postsecondary institutions, by level of degree and sex of student: 1970-71 through 2011-12

\begin{tabular}{|c|c|c|c|c|c|c|c|c|c|c|c|}
\hline \multirow[b]{3}{*}{ Year } & \multicolumn{5}{|c|}{ Bachelor's degrees } & \multicolumn{3}{|c|}{ Master's degrees } & \multicolumn{3}{|c|}{ Doctor's degrees } \\
\hline & \multicolumn{2}{|c|}{ Total } & \multirow[b]{2}{*}{ Males } & \multirow[b]{2}{*}{ Females } & \multirow{2}{*}{$\begin{array}{r}\text { Females } \\
\text { as a } \\
\text { percent } \\
\text { of total }\end{array}$} & \multirow[b]{2}{*}{ Total } & \multirow[b]{2}{*}{ Males } & \multirow[b]{2}{*}{ Females } & \multirow[b]{2}{*}{ Total } & \multirow[b]{2}{*}{ Males } & \multirow[b]{2}{*}{ Females } \\
\hline & Number & $\begin{array}{c}\text { Annual } \\
\text { percent } \\
\text { change }\end{array}$ & & & & & & & & & \\
\hline 1 & 2 & 3 & 4 & 5 & 6 & 7 & 8 & 9 & 10 & 11 & 12 \\
\hline 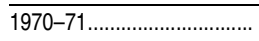 & 2,388 & $\dagger$ & 2,064 & 324 & 13.6 & 1,588 & 1,424 & 164 & 128 & 125 & 3 \\
\hline $1971-72 \ldots \ldots$. & 3,402 & 42.5 & 2,941 & 461 & 13.6 & 1,977 & 1,752 & 225 & 167 & 155 & 12 \\
\hline $1972-73 \ldots \ldots$ & 4,304 & 26.5 & 3,664 & 640 & 14.9 & 2,113 & 1,888 & 225 & 196 & 181 & 15 \\
\hline $1973-74 \ldots \ldots \ldots$. & 4,756 & 10.5 & 3,976 & 780 & 16.4 & 2,276 & 1,983 & 293 & 198 & 189 & 9 \\
\hline $1974-75 \ldots \ldots \ldots \ldots \ldots \ldots \ldots \ldots \ldots$ & 5,033 & 5.8 & 4,080 & 953 & 18.9 & 2,299 & 1,961 & 338 & 213 & 199 & 14 \\
\hline $1975-76 \ldots \ldots$ & 5,652 & 12.3 & 4,534 & 1,118 & 19.8 & 2,603 & 2,226 & 377 & 244 & 221 & 23 \\
\hline $1976-77 \ldots \ldots$ & 6,407 & 13.4 & 4,876 & 1,531 & 23.9 & 2,798 & 2,332 & 466 & 216 & 197 & 19 \\
\hline $1977-78 \ldots \ldots \ldots \ldots$ & 7,201 & 12.4 & 5,349 & 1,852 & 25.7 & 3,038 & 2,471 & 567 & 196 & 181 & 15 \\
\hline $1978-79 \ldots \ldots \ldots$ & 8,719 & 21.1 & 6,272 & 2,447 & 28.1 & 3,055 & 2,480 & 575 & 236 & 206 & 30 \\
\hline $1979-80 \ldots \ldots \ldots \ldots \ldots \ldots \ldots$ & 11,154 & 27.9 & 7,782 & 3,372 & 30.2 & 3,647 & 2,883 & 764 & 240 & 213 & 27 \\
\hline $1980-81 \ldots$. & 15,121 & 35.6 & 10,202 & 4,919 & 32.5 & 4,218 & 3,247 & 971 & 252 & 227 & 25 \\
\hline $1981-82 \ldots$ & 20,267 & 34.0 & 13,218 & 7,049 & 34.8 & 4,935 & 3,625 & 1,310 & 251 & 230 & 21 \\
\hline $1982-83 \ldots \ldots \ldots . .$. & 24,565 & 21.2 & 15,641 & 8,924 & 36.3 & 5,321 & 3,813 & 1,508 & 262 & 228 & 34 \\
\hline $1983-84 \ldots \ldots \ldots . .$. & 32,439 & 32.1 & 20,416 & 12,023 & 37.1 & 6,190 & 4,379 & 1,811 & 251 & 225 & 26 \\
\hline $1984-85 \ldots \ldots \ldots . .$. & 39,121 & 20.6 & 24,737 & 14,384 & 36.8 & 7,101 & 5,064 & 2,037 & 248 & 223 & 25 \\
\hline $1985-86 \ldots \ldots \ldots \ldots \ldots \ldots \ldots$ & 42,337 & 8.2 & 27,208 & 15,129 & 35.7 & 8,070 & 5,658 & 2,412 & 344 & 299 & 45 \\
\hline $1986-87 \ldots \ldots \ldots \ldots \ldots$ & 39,767 & -6.1 & 25,962 & 13,805 & 34.7 & 8,481 & 5,985 & 2,496 & 374 & 322 & 52 \\
\hline $1987-88 \ldots \ldots$ & 34,651 & -12.9 & 23,414 & 11,237 & 32.4 & 9,197 & 6,726 & 2,471 & 428 & 380 & 48 \\
\hline $1988-89 \ldots .$. & 30,560 & -11.8 & 21,143 & 9,417 & 30.8 & 9,414 & 6,775 & 2,639 & 551 & 466 & 85 \\
\hline $1989-90 \ldots \ldots \ldots \ldots \ldots \ldots \ldots \ldots \ldots$ & 27,347 & -10.5 & 19,159 & 8,188 & 29.9 & 9,677 & 6,960 & 2,717 & 627 & 534 & 93 \\
\hline $1990-91 \ldots \ldots \ldots$ & 25,159 & -8.0 & 17,771 & 7,388 & 29.4 & 9,324 & 6,563 & 2,761 & 676 & 584 & 92 \\
\hline $1991-92 \ldots \ldots$ & 24,821 & -1.3 & 17,685 & 7,136 & 28.7 & 9,655 & 6,980 & 2,675 & 772 & 669 & 103 \\
\hline $1992-93 \ldots \ldots \ldots \ldots \ldots$ & 24,519 & -1.2 & 17,606 & 6,913 & 28.2 & 10,353 & 7,557 & 2,796 & 805 & 689 & 116 \\
\hline $1993-94 \ldots \ldots$. & 24,527 & $\#$ & 17,528 & 6,999 & 28.5 & 10,568 & 7,836 & 2,732 & 810 & 685 & 125 \\
\hline $1994-95 \ldots \ldots \ldots$ & 24,737 & 0.9 & 17,684 & 7,053 & 28.5 & 10,595 & 7,805 & 2,790 & 887 & 726 & 161 \\
\hline $1995-96 \ldots \ldots$. & 24,506 & -0.9 & 17,757 & 6,749 & 27.5 & 10,579 & 7,729 & 2,850 & 869 & 743 & 126 \\
\hline $1996-97 \ldots \ldots \ldots$ & 25,422 & 3.7 & 18,527 & 6,895 & 27.1 & 10,513 & 7,526 & 2,987 & 857 & 721 & 136 \\
\hline $1997-98 \ldots \ldots \ldots . .$. & 27,829 & 9.5 & 20,372 & 7,457 & 26.8 & 11,765 & 8,343 & 3,422 & 858 & 718 & 140 \\
\hline $1998-99 \ldots$ & 30,552 & 9.8 & 22,289 & 8,263 & 27.0 & 12,843 & 8,866 & 3,977 & 806 & 656 & 150 \\
\hline $1999-2000 \ldots$ & 37,788 & 23.7 & 27,185 & 10,603 & 28.1 & 14,990 & 9,978 & 5,012 & 779 & 648 & 131 \\
\hline $2000-01 \ldots \ldots$. & 44,142 & 16.8 & 31,923 & 12,219 & 27.7 & 16,911 & 11,195 & 5,716 & 768 & 632 & 136 \\
\hline $2001-02 \ldots \ldots \ldots . . .$. & 50,365 & 14.1 & 36,462 & 13,903 & 27.6 & 17,173 & 11,447 & 5,726 & 752 & 581 & 171 \\
\hline $2002-03$ & 57,433 & 14.0 & 41,950 & 15,483 & 27.0 & 19,509 & 13,267 & 6,242 & 816 & 648 & 168 \\
\hline 2003-04.................... & 59,488 & 3.6 & 44,585 & 14,903 & 25.1 & 20,143 & 13,868 & 6,275 & 909 & 709 & 200 \\
\hline $2004-05 \ldots \ldots \ldots \ldots \ldots \ldots$ & 54,111 & -9.0 & 42,125 & 11,986 & 22.2 & 18,416 & 13,136 & 5,280 & 1,119 & 905 & 214 \\
\hline $2005-06 \ldots$ & 47,480 & -12.3 & 37,705 & 9,775 & 20.6 & 17,055 & 12,470 & 4,585 & 1,416 & 1,109 & 307 \\
\hline $2006-07 \ldots \ldots \ldots \ldots . . . .$. & 42,170 & -11.2 & 34,342 & 7,828 & 18.6 & 16,232 & 11,985 & 4,247 & 1,595 & 1,267 & 328 \\
\hline $2007-08 \ldots \ldots . .$. & 38,476 & -8.8 & 31,694 & 6,782 & 17.6 & 17,087 & 12,513 & 4,574 & 1,698 & 1,323 & 375 \\
\hline $2008-09 \ldots \ldots \ldots \ldots \ldots \ldots$ & 37,994 & -1.3 & 31,215 & 6,779 & 17.8 & 17,907 & 13,063 & 4,844 & 1,580 & 1,226 & 354 \\
\hline $2009-10 \ldots \ldots \ldots \ldots \ldots \ldots$ & 39,589 & 4.2 & 32,410 & 7,179 & 18.1 & 17,953 & 13,017 & 4,936 & 1,599 & 1,250 & 349 \\
\hline 2010-11 & 43,072 & 8.8 & 35,478 & 7,594 & 17.6 & 19,446 & 13,956 & 5,490 & 1,588 & 1,267 & 321 \\
\hline $2011-12 \ldots \ldots \ldots \ldots \ldots \ldots \ldots$ & 47,384 & 10.0 & 38,773 & 8,611 & 18.2 & 20,917 & 15,129 & 5,788 & 1,698 & 1,332 & 366 \\
\hline & & & & & & & & & & & \\
\hline $2001-02$ to $2006-07 \ldots \ldots$ & -16.3 & $\dagger$ & -5.8 & -43.7 & $\dagger$ & -5.5 & 4.7 & -25.8 & 112.1 & 118.1 & 91.8 \\
\hline $2006-07$ to $2011-12 \ldots \ldots$. & 12.4 & $t$ & 12.9 & 10.0 & $t$ & 28.9 & 26.2 & 36.3 & 6.5 & 5.1 & 11.6 \\
\hline
\end{tabular}

†Not applicable.

\#Rounds to zero.

NOTE: Data are for postsecondary institutions participating in Title IV federal financial aid programs.

SOURCE: U.S. Department of Education, National Center for Education Statistics, Higher
Education General Information Survey (HEGIS), "Degrees and Other Formal Awards Conferred" surveys, 1970-71 through 1985-86; Integrated Postsecondary Education Data System (IPEDS), "Completions Survey" (IPEDS-C:87-99); and IPEDS Fall 2000 through Fall 2012, Completions component. (This table was prepared July 2013.) 
Table 325.40. Degrees in education conferred by postsecondary institutions, by level of degree and sex of student: Selected years, 1949-50 through 2011-12

\begin{tabular}{|c|c|c|c|c|c|c|c|c|c|c|c|}
\hline \multirow[b]{3}{*}{ Year } & \multicolumn{5}{|c|}{ Bachelor's degrees } & \multicolumn{3}{|c|}{ Master's degrees } & \multicolumn{3}{|c|}{ Doctor's degrees } \\
\hline & \multicolumn{2}{|c|}{ Total } & \multirow[b]{2}{*}{ Males } & \multirow[b]{2}{*}{ Females } & \multirow[b]{2}{*}{$\begin{array}{r}\text { Females as } \\
\text { a percent } \\
\text { of total }\end{array}$} & \multirow[b]{2}{*}{ Total } & \multirow[b]{2}{*}{ Males } & \multirow[b]{2}{*}{ Females } & \multirow[b]{2}{*}{ Total } & \multirow[b]{2}{*}{ Males } & \multirow[b]{2}{*}{ Females } \\
\hline & Number & $\begin{array}{l}\text { Annual } \\
\text { percent } \\
\text { change }\end{array}$ & & & & & & & & & \\
\hline 1 & 2 & 3 & 4 & 5 & 6 & 7 & 8 & 9 & 10 & 11 & 12 \\
\hline 1949-50............................. & 61,472 & $\dagger$ & 31,398 & 30,074 & 48.9 & 20,069 & 12,025 & 8,044 & 953 & 797 & 156 \\
\hline $1959-60 \ldots \ldots \ldots \ldots \ldots \ldots \ldots \ldots$ & 89,002 & $\dagger$ & 25,556 & 63,446 & 71.3 & 33,433 & 18,057 & 15,376 & 1,591 & 1,279 & 312 \\
\hline 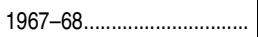 & 133,965 & $\dagger$ & 31,926 & 102,039 & 76.2 & 63,399 & 30,672 & 32,727 & 4,078 & 3,250 & 828 \\
\hline 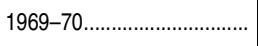 & 163,964 & $\dagger$ & 40,420 & 123,544 & 75.3 & 78,020 & 34,832 & 43,188 & 5,588 & 4,479 & 1,109 \\
\hline 1970-71 ............................ & 176,307 & 7.5 & 44,896 & 131,411 & 74.5 & 87,666 & 38,365 & 49,301 & 6,041 & 4,771 & 1,270 \\
\hline 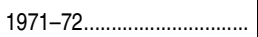 & 190,880 & 8.3 & 49,344 & 141,536 & 74.1 & 96,668 & 41,141 & 55,527 & 6,648 & 5,104 & 1,544 \\
\hline $1972-73 \ldots \ldots$ & 193,984 & 1.6 & 51,300 & 142,684 & 73.6 & 103,777 & 43,298 & 60,479 & 6,857 & 5,191 & 1,666 \\
\hline $1973-74 \ldots \ldots \ldots \ldots$ & 184,907 & -4.7 & 48,997 & 135,910 & 73.5 & 110,402 & 44,112 & 66,290 & 6,757 & 4,974 & 1,783 \\
\hline $1974-75 \ldots \ldots \ldots \ldots \ldots \ldots \ldots \ldots \ldots$ & 166,758 & -9.8 & 44,463 & 122,295 & 73.3 & 117,841 & 44,430 & 73,411 & 6,975 & 4,856 & 2,119 \\
\hline $1975-76 \ldots \ldots \ldots \ldots \ldots \ldots \ldots \ldots$ & 154,437 & -7.4 & 42,004 & 112,433 & 72.8 & 126,061 & 44,831 & 81,230 & 7,202 & 4,826 & 2,376 \\
\hline $1976-77 \ldots \ldots \ldots \ldots \ldots \ldots \ldots \ldots \ldots$ & 143,234 & -7.3 & 39,867 & 103,367 & 72.2 & 124,267 & 42,308 & 81,959 & 7,338 & 4,832 & 2,506 \\
\hline $1977-78$ & 135,821 & -5.2 & 37,410 & 98,411 & 72.5 & 116,916 & 37,662 & 79,254 & 7,018 & 4,281 & 2,737 \\
\hline $1978-79 \ldots \ldots \ldots \ldots \ldots \ldots \ldots$ & 125,873 & -7.3 & 33,743 & 92,130 & 73.2 & 109,866 & 34,410 & 75,456 & 7,170 & 4,174 & 2,996 \\
\hline $1979-80 \ldots \ldots \ldots \ldots \ldots \ldots \ldots \ldots$ & 118,038 & -6.2 & 30,901 & 87,137 & 73.8 & 101,819 & 30,300 & 71,519 & 7,314 & 4,100 & 3,214 \\
\hline $1980-81 \ldots \ldots \ldots \ldots \ldots \ldots \ldots \ldots \ldots$ & 108,074 & -8.4 & 27,039 & 81,035 & 75.0 & 96,713 & 27,548 & 69,165 & 7,279 & 3,843 & 3,436 \\
\hline $1981-82$ & 100,932 & -6.6 & 24,380 & 76,552 & 75.8 & 91,601 & 25,339 & 66,262 & 6,999 & 3,612 & 3,387 \\
\hline $1982-83 \ldots \ldots \ldots \ldots \ldots$ & 97,908 & -3.0 & 23,651 & 74,257 & 75.8 & 83,254 & 22,824 & 60,430 & 7,063 & 3,550 & 3,513 \\
\hline 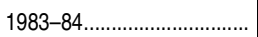 & 92,310 & -5.7 & 22,200 & 70,110 & 76.0 & 75,700 & 21,164 & 54,536 & 6,914 & 3,448 & 3,466 \\
\hline $1984-85 \ldots \ldots \ldots$ & 88,078 & -4.6 & 21,254 & 66,824 & 75.9 & 74,667 & 20,539 & 54,128 & 6,614 & 3,174 & 3,440 \\
\hline $1985-86 \ldots \ldots \ldots \ldots \ldots \ldots \ldots$ & 87,147 & -1.1 & 20,982 & 66,165 & 75.9 & 74,816 & 20,302 & 54,514 & 6,610 & 3,088 & 3,522 \\
\hline $1986-87 \ldots \ldots \ldots$ & 86,788 & -0.4 & 20,705 & 66,083 & 76.1 & 72,619 & 18,955 & 53,664 & 5,905 & 2,745 & 3,160 \\
\hline 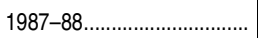 & 90,928 & 4.8 & 20,947 & 69,981 & 77.0 & 75,270 & 18,777 & 56,493 & 5,568 & 2,530 & 3,038 \\
\hline $1988-89 \ldots \ldots \ldots \ldots$ & 96,740 & 6.4 & 21,643 & 75,097 & 77.6 & 79,793 & 19,616 & 60,177 & 5,884 & 2,522 & 3,362 \\
\hline $1989-90 \ldots \ldots \ldots \ldots$ & 105,112 & 8.7 & 23,007 & 82,105 & 78.1 & 84,890 & 20,469 & 64,421 & 6,503 & 2,776 & 3,727 \\
\hline $1990-91 \ldots \ldots \ldots \ldots \ldots \ldots \ldots \ldots \ldots$ & 110,807 & 5.4 & 23,417 & 87,390 & 78.9 & 87,352 & 20,448 & 66,904 & 6,189 & 2,614 & 3,575 \\
\hline $1991-92 \ldots \ldots \ldots \ldots \ldots \ldots \ldots \ldots$ & 107,836 & -2.7 & 22,655 & 85,181 & 79.0 & 91,225 & 20,897 & 70,328 & 6,423 & 2,652 & 3,771 \\
\hline 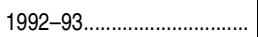 & 107,578 & -0.2 & 23,199 & 84,379 & 78.4 & 94,497 & 21,857 & 72,640 & 6,581 & 2,712 & 3,869 \\
\hline $1993-94$ & 107,440 & -0.1 & 24,424 & 83,016 & 77.3 & 97,427 & 22,656 & 74,771 & 6,450 & 2,555 & 3,895 \\
\hline $1994-95 \ldots \ldots \ldots$ & 105,929 & -1.4 & 25,619 & 80,310 & 75.8 & 99,835 & 23,511 & 76,324 & 6,475 & 2,490 & 3,985 \\
\hline $1995-96 \ldots \ldots \ldots \ldots \ldots \ldots \ldots \ldots \ldots$ & 105,384 & -0.5 & 26,214 & 79,170 & 75.1 & 104,936 & 24,955 & 79,981 & 6,246 & 2,404 & 3,842 \\
\hline $1996-97 \ldots \ldots \ldots \ldots \ldots \ldots \ldots \ldots$ & 105,116 & -0.3 & 26,242 & 78,874 & 75.0 & 108,720 & 25,518 & 83,202 & 6,297 & 2,367 & 3,930 \\
\hline $1997-98$ & 105,833 & 0.7 & 26,285 & 79,548 & 75.2 & 113,374 & 26,814 & 86,560 & 6,261 & 2,334 & 3,927 \\
\hline $1998-99$ & 107,372 & 1.5 & 26,321 & 81,051 & 75.5 & 118,226 & 28,077 & 90,149 & 6,471 & 2,297 & 4,174 \\
\hline 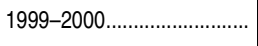 & 108,034 & 0.6 & 26,103 & 81,931 & 75.8 & 123,045 & 29,081 & 93,964 & 6,409 & 2,295 & 4,114 \\
\hline $2000-01 \ldots \ldots \ldots \ldots \ldots \ldots \ldots \ldots \ldots$ & 105,458 & -2.4 & 24,580 & 80,878 & 76.7 & 127,829 & 29,997 & 97,832 & 6,284 & 2,237 & 4,047 \\
\hline $2001-02 \ldots \ldots \ldots \ldots \ldots \ldots \ldots \ldots$ & 106,295 & 0.8 & 24,049 & 82,246 & 77.4 & 135,189 & 31,907 & 103,282 & 6,549 & 2,211 & 4,338 \\
\hline $2002-03 \ldots \ldots \ldots \ldots \ldots \ldots \ldots \ldots$ & 105,845 & -0.4 & 22,604 & 83,241 & 78.6 & 147,883 & 34,033 & 113,850 & 6,832 & 2,314 & 4,518 \\
\hline $2003-04 \ldots \ldots \ldots \ldots \ldots \ldots$ & 106,278 & 0.4 & 22,802 & 83,476 & 78.5 & 162,345 & 37,843 & 124,502 & 7,088 & 2,403 & 4,685 \\
\hline $2004-05 \ldots \ldots \ldots \ldots \ldots \ldots \ldots \ldots$ & 105,451 & -0.8 & 22,513 & 82,938 & 78.7 & 167,490 & 38,863 & 128,627 & 7,681 & 2,557 & 5,124 \\
\hline $2005-06 \ldots \ldots \ldots \ldots \ldots \ldots \ldots$ & 107,238 & 1.7 & 22,448 & 84,790 & 79.1 & 174,620 & 40,700 & 133,920 & 7,584 & 2,664 & 4,920 \\
\hline $2006-07 \ldots \ldots \ldots \ldots$ & 105,641 & -1.5 & 22,516 & 83,125 & 78.7 & 176,572 & 40,164 & 136,408 & 8,261 & 2,681 & 5,580 \\
\hline $2007-08$ & 102,582 & -2.9 & 21,828 & 80,754 & 78.7 & 175,880 & 40,055 & 135,825 & 8,491 & 2,773 & 5,718 \\
\hline $2008-09 \ldots \ldots \ldots \ldots \ldots \ldots$ & 101,708 & -0.9 & 21,159 & 80,549 & 79.2 & 178,564 & 40,324 & 138,240 & 9,028 & 2,956 & 6,072 \\
\hline 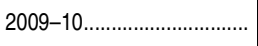 & 101,265 & -0.4 & 20,726 & 80,539 & 79.5 & 182,139 & 41,296 & 140,843 & 9,233 & 3,023 & 6,210 \\
\hline 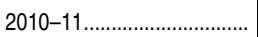 & 103,992 & 2.7 & 21,195 & 82,797 & 79.6 & 185,009 & 42,022 & 142,987 & 9,623 & 3,064 & 6,559 \\
\hline $2011-12 \ldots \ldots \ldots \ldots \ldots \ldots \ldots \ldots$ & 105,785 & 1.7 & 21,757 & 84,028 & 79.4 & 178,062 & 41,180 & 136,882 & 9,990 & 3,215 & 6,775 \\
\hline $\begin{array}{l}\text { Percent change } \\
2001-02 \text { to } 2006-07 \ldots \ldots . \\
2006-07 \text { to } 2011-12 \ldots \ldots .\end{array}$ & $\begin{array}{r}-0.6 \\
0.1\end{array}$ & $\begin{array}{l}t \\
t\end{array}$ & $\begin{array}{l}-6.4 \\
-3.4\end{array}$ & $\begin{array}{l}1.1 \\
1.1\end{array}$ & $\begin{array}{l}\dagger \\
\dagger\end{array}$ & $\begin{array}{r}30.6 \\
0.8\end{array}$ & $\begin{array}{r}25.9 \\
2.5\end{array}$ & $\begin{array}{r}32.1 \\
0.3\end{array}$ & $\begin{array}{l}26.1 \\
20.9\end{array}$ & $\begin{array}{l}21.3 \\
19.9\end{array}$ & $\begin{array}{l}28.6 \\
21.4\end{array}$ \\
\hline
\end{tabular}

†Not applicable.

NOTE: Data are for postsecondary institutions participating in Title IV federal financial aid programs.

SOURCE: U.S. Department of Education, National Center for Education Statistics, Earned Degrees Conferred, 1949-50 and 1959-60; Higher Education General Information Survey
(HEGIS), "Degrees and Other Formal Awards Conferred" surveys, 1967-68 through 1985-86; Integrated Postsecondary Education Data System (IPEDS), "Completions Survey" (IPEDS-C:87-99); and Fall 2000 through Fall 2012, Completions component. (This table was prepared July 2013.) 
Table 325.45. Degrees in engineering and engineering technologies conferred by postsecondary institutions, by level of degree and sex of student: Selected years, 1949-50 through 2011-12

\begin{tabular}{|c|c|c|c|c|c|c|c|c|c|c|c|}
\hline \multirow[b]{3}{*}{ Year } & \multicolumn{5}{|c|}{ Bachelor's degrees } & \multicolumn{3}{|c|}{ Master's degrees } & \multicolumn{3}{|c|}{ Doctor's degrees } \\
\hline & \multicolumn{2}{|c|}{ Total } & \multirow[b]{2}{*}{ Males } & \multirow[b]{2}{*}{ Females } & \multirow[b]{2}{*}{$\begin{array}{r}\text { Females as } \\
\text { a percent } \\
\text { of total }\end{array}$} & \multirow[b]{2}{*}{ Total } & \multirow[b]{2}{*}{ Males } & \multirow[b]{2}{*}{ Females } & \multirow[b]{2}{*}{ Total } & \multirow[b]{2}{*}{ Males } & \multirow[b]{2}{*}{ Females } \\
\hline & Number & $\begin{array}{l}\text { Annual } \\
\text { percent } \\
\text { change }\end{array}$ & & & & & & & & & \\
\hline 1 & 2 & 3 & 4 & 5 & 6 & 7 & 8 & 9 & 10 & 11 & 12 \\
\hline $1949-50 \ldots \ldots \ldots . . .$. & 52,246 & $t$ & 52,071 & 175 & 0.3 & 4,496 & 4,481 & 15 & 417 & 416 & 1 \\
\hline $1959-60 \ldots \ldots \ldots \ldots \ldots \ldots \ldots$ & 37,679 & $\dagger$ & 37,537 & 142 & 0.4 & 7,159 & 7,133 & 26 & 786 & 783 & 3 \\
\hline $1969-70 \ldots \ldots \ldots \ldots \ldots \ldots \ldots \ldots \ldots$ & 44,479 & $\dagger$ & 44,149 & 330 & 0.7 & 15,593 & 15,421 & 172 & 3,681 & 3,657 & 24 \\
\hline $1970-71 \ldots .$. & 50,182 & 12.8 & 49,775 & 407 & 0.8 & 16,947 & 16,734 & 213 & 3,688 & 3,663 & 25 \\
\hline $1971-72 \ldots \ldots \ldots$ & 51,258 & 2.1 & 50,726 & 532 & 1.0 & 17,299 & 17,009 & 290 & 3,708 & 3,685 & 23 \\
\hline $1972-73 \ldots \ldots$ & 51,384 & 0.2 & 50,766 & 618 & 1.2 & 16,988 & 16,694 & 294 & 3,513 & 3,459 & 54 \\
\hline 1973-74....................... & 50,412 & -1.9 & 49,611 & 801 & 1.6 & 15,851 & 15,470 & 381 & 3,374 & 3,318 & 56 \\
\hline $1974-75 \ldots \ldots \ldots \ldots \ldots \ldots \ldots$ & 47,131 & -6.5 & 46,105 & 1,026 & 2.2 & 15,837 & 15,426 & 411 & 3,181 & 3,113 & 68 \\
\hline $1975-76 \ldots$ & 46,676 & -1.0 & 45,184 & 1,492 & 3.2 & 16,800 & 16,174 & 626 & 2,874 & 2,805 & 69 \\
\hline $1976-77 \ldots \ldots \ldots . .$. & 49,482 & 6.0 & 47,238 & 2,244 & 4.5 & 16,659 & 15,891 & 768 & 2,622 & 2,547 & 75 \\
\hline $1977-78 \ldots \ldots \ldots$ & 56,150 & 13.5 & 52,353 & 3,797 & 6.8 & 16,887 & 15,940 & 947 & 2,483 & 2,424 & 59 \\
\hline 1978-79...................... & 62,898 & 12.0 & 57,603 & 5,295 & 8.4 & 16,012 & 14,971 & 1,041 & 2,545 & 2,459 & 86 \\
\hline $1979-80 \ldots \ldots \ldots \ldots . .$. & 69,387 & 10.3 & 62,877 & 6,510 & 9.4 & 16,765 & 15,535 & 1,230 & 2,546 & 2,447 & 99 \\
\hline $1980-81 \ldots \ldots \ldots . . .$. & 75,355 & 8.6 & 67,573 & 7,782 & 10.3 & 17,216 & 15,761 & 1,455 & 2,608 & 2,499 & 109 \\
\hline $1981-82 \ldots$ & 80,632 & 7.0 & 71,305 & 9,327 & 11.6 & 18,475 & 16,747 & 1,728 & 2,676 & 2,532 & 144 \\
\hline $1982-83 \ldots$. & 89,811 & 11.4 & 78,673 & 11,138 & 12.4 & 19,949 & 18,038 & 1,911 & 2,871 & 2,742 & 129 \\
\hline $1983-84 \ldots \ldots \ldots . .$. & 95,295 & 6.1 & 82,841 & 12,454 & 13.1 & 21,197 & 18,916 & 2,281 & 3,032 & 2,864 & 168 \\
\hline $1984-85 \ldots \ldots \ldots . .$. & 97,099 & 1.9 & 83,991 & 13,108 & 13.5 & 22,124 & 19,688 & 2,436 & 3,269 & 3,055 & 214 \\
\hline $1985-86 \ldots \ldots \ldots$ & 97,122 & \# & 84,050 & 13,072 & 13.5 & 22,146 & 19,545 & 2,601 & 3,456 & 3,220 & 236 \\
\hline $1986-87 \ldots \ldots \ldots$ & 93,560 & -3.7 & 80,543 & 13,017 & 13.9 & 23,101 & 20,137 & 2,964 & 3,854 & 3,585 & 269 \\
\hline $1987-88 \ldots .$. & 89,406 & -4.4 & 76,886 & 12,520 & 14.0 & 23,839 & 20,815 & 3,024 & 4,237 & 3,941 & 296 \\
\hline $1988-89 \ldots$ & 85,982 & -3.8 & 74,020 & 11,962 & 13.9 & 25,066 & 21,731 & 3,335 & 4,572 & 4,160 & 412 \\
\hline $1989-90 \ldots \ldots \ldots \ldots . . .$. & 82,480 & -4.1 & 70,859 & 11,621 & 14.1 & 25,294 & 21,753 & 3,541 & 5,030 & 4,576 & 454 \\
\hline $1990-91 \ldots \ldots \ldots \ldots \ldots \ldots \ldots \ldots$ & 79,751 & -3.3 & 68,482 & 11,269 & 14.1 & 25,450 & 21,780 & 3,670 & 5,330 & 4,834 & 496 \\
\hline $1991-92 \ldots \ldots \ldots \ldots$ & 78,036 & -2.2 & 67,086 & 10,950 & 14.0 & 26,373 & 22,397 & 3,976 & 5,499 & 4,967 & 532 \\
\hline 1992-93......................... & 78,619 & 0.7 & 67,214 & 11,405 & 14.5 & 29,103 & 24,721 & 4,382 & 5,870 & 5,300 & 570 \\
\hline $1993-94 \ldots \ldots \ldots . .$. & 78,580 & $\#$ & 66,867 & 11,713 & 14.9 & 30,102 & 25,394 & 4,708 & 5,954 & 5,288 & 666 \\
\hline $1994-95 \ldots \ldots \ldots$. & 78,483 & -0.1 & 66,157 & 12,326 & 15.7 & 29,949 & 25,028 & 4,921 & 6,108 & 5,378 & 730 \\
\hline $1995-96 \ldots \ldots$. & 77,997 & -0.6 & 65,362 & 12,635 & 16.2 & 28,843 & 23,840 & 5,003 & 6,354 & 5,559 & 795 \\
\hline $1996-97 \ldots \ldots \ldots \ldots$ & 75,659 & -3.0 & 62,994 & 12,665 & 16.7 & 27,016 & 22,047 & 4,969 & 6,166 & 5,408 & 758 \\
\hline $1997-98 \ldots \ldots \ldots \ldots$ & 74,557 & -1.5 & 61,880 & 12,677 & 17.0 & 27,244 & 21,800 & 5,444 & 5,966 & 5,230 & 736 \\
\hline 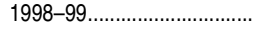 & 72,796 & -2.4 & 59,859 & 12,937 & 17.8 & 26,689 & 21,348 & 5,341 & 5,413 & 4,643 & 770 \\
\hline $1999-2000 \ldots . . .$. & 73,323 & 0.7 & 59,668 & 13,655 & 18.6 & 26,648 & 21,047 & 5,601 & 5,367 & 4,539 & 828 \\
\hline $2000-01 \ldots \ldots \ldots . . .$. & 72,869 & -0.6 & 59,489 & 13,380 & 18.4 & 27,187 & 21,341 & 5,846 & 5,547 & 4,630 & 917 \\
\hline $2001-02 \ldots \ldots \ldots \ldots \ldots \ldots \ldots$ & 74,588 & 2.4 & 60,417 & 14,171 & 19.0 & 26,987 & 21,212 & 5,775 & 5,181 & 4,285 & 896 \\
\hline $2002-03 \ldots \ldots \ldots \ldots \ldots$ & 77,231 & 3.5 & 62,821 & 14,410 & 18.7 & 30,583 & 24,097 & 6,486 & 5,252 & 4,353 & 899 \\
\hline $2003-04 \ldots \ldots \ldots \ldots \ldots \ldots$ & 78,079 & 1.1 & 63,401 & 14,678 & 18.8 & 35,053 & 27,561 & 7,492 & 5,859 & 4,821 & 1,038 \\
\hline $2004-05 \ldots \ldots \ldots$ & 79,544 & 1.9 & 65,033 & 14,511 & 18.2 & 34,988 & 27,049 & 7,939 & 6,467 & 5,263 & 1,204 \\
\hline $2005-06 \ldots \ldots$. & 81,406 & 2.3 & 66,866 & 14,540 & 17.9 & 33,389 & 25,568 & 7,821 & 7,318 & 5,848 & 1,470 \\
\hline $2006-07 \ldots \ldots \ldots \ldots \ldots \ldots \ldots \ldots \ldots$ & 81,854 & 0.6 & 68,081 & 13,773 & 16.8 & 31,989 & 24,746 & 7,243 & 7,928 & 6,285 & 1,643 \\
\hline $2007-08 \ldots \ldots \ldots$. & 83,608 & 2.1 & 69,540 & 14,068 & 16.8 & 34,430 & 26,461 & 7,969 & 7,977 & 6,263 & 1,714 \\
\hline $2008-09 \ldots . .$. & 84,414 & 1.0 & 70,511 & 13,903 & 16.5 & 38,001 & 29,452 & 8,549 & 7,801 & 6,121 & 1,680 \\
\hline $2009-10 \ldots .$. & 88,729 & 5.1 & 73,833 & 14,896 & 16.8 & 39,346 & 30,521 & 8,825 & 7,771 & 5,984 & 1,787 \\
\hline 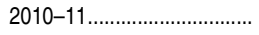 & 93,117 & 4.9 & 77,100 & 16,017 & 17.2 & 43,234 & 33,418 & 9,816 & 8,425 & 6,548 & 1,877 \\
\hline $2011-12 \ldots \ldots \ldots \ldots \ldots \ldots \ldots \ldots$ & 98,540 & 5.8 & 81,270 & 17,270 & 17.5 & 45,097 & 34,698 & 10,399 & 8,856 & 6,838 & 2,018 \\
\hline Percent change & & & & & & & & & & & \\
\hline $2001-02$ to $2006-07 \ldots \ldots$ & 9.7 & $t$ & 12.7 & -2.8 & $\dagger$ & 18.5 & 16.7 & 25.4 & 53.0 & 46.7 & 83.4 \\
\hline $2006-07$ to $2011-12 \ldots \ldots$. & 20.4 & $\dagger$ & 19.4 & 25.4 & $\dagger$ & 41.0 & 40.2 & 43.6 & 11.7 & 8.8 & 22.8 \\
\hline
\end{tabular}

†Not applicable.

\#Rounds to zero.

NOTE: Data are for postsecondary institutions participating in Title IV federal financial aid programs. Includes degrees in engineering, engineering-related technologies, mechanic and repair technologies, and construction trades for 1969-70 and later years. Degrees in engineering include degrees in all areas of engineering-for example, chemical, civil, electrical, and mechanical engineering — as well as degrees in general engineering.
SOURCE: US. Department of Education, National Center for Education Statistics, Earned Degrees Conferred, 1949-50 and 1959-60; Higher Education General Information Survey (HEGIS), "Degrees and Other Formal Awards Conferred" surveys, 1969-70 through 1985-86; Integrated Postsecondary Education Data System (IPEDS), "Completions Survey" (IPEDS-C:87-99); and IPEDS Fall 2000 through Fall 2012, Completions component. (This table was prepared July 2013.) 
Table 325.47. Degrees in chemical, civil, electrical, and mechanical engineering conferred by postsecondary institutions, by level of degree: 1970-71 through 2011-12

\begin{tabular}{|c|c|c|c|c|c|c|c|c|c|c|c|c|}
\hline \multirow[b]{2}{*}{ Year } & \multicolumn{3}{|c|}{ Chemical engineering } & \multicolumn{3}{|c|}{ Civil engineering } & \multicolumn{3}{|c|}{$\begin{array}{l}\text { Electrical, electronics, } \\
\text { and communications engineering }\end{array}$} & \multicolumn{3}{|c|}{ Mechanical engineering } \\
\hline & Bachelor's & Master's & Doctor's & Bachelor's & Master's & Doctor's & Bachelor's & Master's & Doctor's & Bachelor's & Master's & Doctor's \\
\hline 1 & 2 & 3 & 4 & 5 & 6 & 7 & 8 & 9 & 10 & 11 & 12 & 13 \\
\hline 1970-71_.......................... & 3,579 & 1,100 & 406 & 6,526 & 2,425 & 446 & \begin{tabular}{l|l}
12,198 \\
\end{tabular} & 4,282 & 879 & 8,858 & 2,237 & 438 \\
\hline $1971-72 \ldots \ldots \ldots \ldots$ & 3,625 & 1,154 & 394 & 6,803 & 2,487 & 415 & 12,101 & 4,206 & 824 & 8,530 & 2,282 & 411 \\
\hline 1972-73...................... & 3,578 & 1,051 & 397 & 7,390 & 2,627 & 397 & 12,313 & 3,895 & 791 & 8,523 & 2,141 & 370 \\
\hline $1973-74 \ldots .$. & 3,399 & 1,044 & 400 & 8,017 & 2,652 & 368 & 11,316 & 3,499 & 705 & 7,677 & 1,843 & 385 \\
\hline $1974-75 \ldots$. & 3,070 & 990 & 346 & 7,651 & 2,769 & 356 & 10,161 & 3,469 & 701 & 6,890 & 1,858 & 340 \\
\hline $1975-76 \ldots \ldots .$. & 3,140 & 1,031 & 308 & 7,923 & 2,999 & 370 & 9,791 & 3,774 & 649 & 6,800 & 1,907 & 305 \\
\hline $1976-77 \ldots \ldots \ldots \ldots$ & 3,524 & 1,086 & 291 & 8,228 & 2,964 & 309 & 9,936 & 3,788 & 566 & 7,703 & 1,952 & 283 \\
\hline 1977-78_....................... & 4,569 & 1,235 & 259 & 9,135 & 2,685 & 277 & 11,133 & 3,740 & 503 & 8,875 & 1,942 & 279 \\
\hline 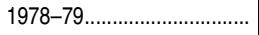 & 5,568 & 1,149 & 304 & 9,809 & 2,646 & 253 & 12,338 & 3,591 & 586 & 10,107 & 1,877 & 271 \\
\hline $1979-80 \ldots \ldots \ldots \ldots \ldots \ldots \ldots \ldots$ & 6,320 & 1,270 & 284 & 10,326 & 2,683 & 270 & 13,821 & 3,836 & 525 & 11,808 & 2,060 & 281 \\
\hline $1980-81 \ldots \ldots .$. & 6,527 & 1,267 & 300 & 10,678 & 2,891 & 325 & 14,938 & 3,901 & 535 & 13,329 & 2,291 & 276 \\
\hline $1981-82 \ldots \ldots \ldots . . .$. & 6,740 & 1,285 & 311 & 10,524 & 2,995 & 329 & 16,455 & 4,462 & 526 & 13,922 & 2,399 & 333 \\
\hline 1982-83 ……………...... & 7,185 & 1,368 & 319 & 9,989 & 3,074 & 340 & 18,049 & 4,531 & 550 & 15,675 & 2,511 & 299 \\
\hline 1983-84_....................... & 7,475 & 1,514 & 330 & 9,693 & 3,146 & 369 & 19,943 & 5,078 & 585 & 16,629 & 2,797 & 319 \\
\hline $1984-85 \ldots \ldots \ldots \ldots \ldots \ldots \ldots \ldots \ldots$ & 7,146 & 1,544 & 418 & 9,162 & 3,172 & 377 & 21,691 & 5,153 & 660 & 16,794 & 3,053 & 409 \\
\hline $1985-86 \ldots \ldots \ldots \ldots$ & 5,877 & 1,361 & 446 & 8,679 & 2,926 & 395 & 23,742 & 5,534 & 722 & 16,194 & 3,075 & 426 \\
\hline $1986-87 \ldots \ldots \ldots \ldots$ & 4,991 & 1,184 & 497 & 8,147 & 2,901 & 451 & 24,547 & 6,183 & 724 & 15,450 & 3,198 & 528 \\
\hline $1987-88 \ldots \ldots \ldots$ & 3,917 & 1,088 & 579 & 7,488 & 2,836 & 481 & 23,597 & 6,688 & 860 & 14,900 & 3,329 & 596 \\
\hline $1988-89 \ldots \ldots \ldots . . .$. & 3,663 & 1,093 & 602 & 7,312 & 2,903 & 505 & 21,908 & 7,028 & 998 & 14,843 & 3,498 & 633 \\
\hline 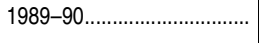 & 3,430 & 1,035 & 562 & 7,252 & 2,812 & 516 & 20,711 & 7,225 & 1,162 & 14,336 & 3,424 & 742 \\
\hline $1990-91 \ldots$. & 3,444 & 903 & 611 & 7,314 & 2,927 & 536 & 19,320 & 7,095 & 1,220 & 13,977 & 3,516 & 757 \\
\hline $1991-92 \ldots \ldots$. & 3,754 & 956 & 590 & 8,034 & 3,113 & 540 & 17,958 & 7,360 & 1,282 & 14,067 & 3,653 & 851 \\
\hline $1992-93 \ldots \ldots \ldots \ldots$ & 4,459 & 990 & 595 & 8,868 & 3,610 & 577 & 17,281 & 7,870 & 1,413 & 14,464 & 3,982 & 871 \\
\hline 1993-94........... & 5,163 & 1,032 & 604 & 9,479 & 3,873 & 651 & 15,823 & 7,791 & 1,470 & 15,030 & 4,099 & 887 \\
\hline $1994-95 \ldots \ldots \ldots . . .$. & 5,901 & 1,085 & 571 & 9,927 & 4,077 & 625 & 14,929 & 7,693 & 1,543 & 14,794 & 4,213 & 890 \\
\hline $1995-96 \ldots . .$. & 6,319 & 1,176 & 670 & 10,607 & 3,905 & 616 & 13,900 & 7,103 & 1,591 & 14,177 & 3,881 & 940 \\
\hline $1996-97 \ldots .$. & 6,564 & 1,131 & 650 & 10,437 & 3,833 & 640 & 13,336 & 6,393 & 1,512 & 13,493 & 3,608 & 913 \\
\hline $1997-98 \ldots \ldots . .$. & 6,319 & 1,128 & 652 & 9,926 & 3,795 & 610 & 12,995 & 6,737 & 1,458 & 13,071 & 3,441 & 933 \\
\hline 1998-99............. & 6,038 & 1,130 & 575 & 9,178 & 3,656 & 534 & 12,606 & 6,708 & 1,309 & 12,753 & 3,268 & 788 \\
\hline $1999-2000 \ldots \ldots \ldots \ldots \ldots \ldots \ldots$ & 5,807 & 1,078 & 590 & 8,136 & 3,433 & 543 & 12,930 & 6,926 & 1,392 & 12,807 & 3,273 & 776 \\
\hline $2000-01 \ldots \ldots$. & 5,611 & 1,083 & 610 & 7,588 & 3,310 & 571 & 13,091 & 6,815 & 1,417 & 12,817 & 3,371 & 849 \\
\hline $2001-02 \ldots$ & 5,462 & 973 & 605 & 7,665 & 3,295 & 574 & 13,056 & 6,587 & 1,235 & 13,058 & 3,391 & 772 \\
\hline $2002-03 \ldots \ldots . .$. & 5,109 & 1,065 & 542 & 7,836 & 3,596 & 599 & 13,627 & 7,621 & 1,256 & 13,693 & 3,695 & 747 \\
\hline $2003-04 \ldots \ldots \ldots \ldots \ldots \ldots \ldots \ldots . . .$. & 4,742 & 1,165 & 623 & 7,827 & 3,790 & 636 & 14,123 & 9,511 & 1,440 & 14,050 & 4,420 & 787 \\
\hline 2004-05 ................................ & 4,397 & 1,183 & 773 & 8,186 & 3,834 & 713 & 14,171 & 9,054 & 1,566 & 14,609 & 4,637 & 915 \\
\hline 2005-06 & 4,326 & 1,116 & 819 & 9,090 & 3,768 & 750 & 13,966 & 8,123 & 1,860 & 15,850 & 4,443 & 1,096 \\
\hline 2006-07 & 4,492 & 957 & 835 & 9,671 & 3,482 & 805 & 13,089 & 7,777 & 2,042 & 16,601 & 4,294 & 1,106 \\
\hline $2007-08 \ldots$ & 4,795 & 933 & 853 & 10,455 & 3,595 & 752 & 12,375 & 8,631 & 1,996 & 17,367 & 4,497 & 1,109 \\
\hline $2008-09 \ldots .$. & 5,036 & 994 & 789 & 10,785 & 3,794 & 762 & 11,619 & 9,178 & 1,811 & 17,352 & 4,620 & 1,142 \\
\hline $2009-10 \ldots \ldots \ldots \ldots \ldots \ldots \ldots . .$. & 5,740 & 1,042 & 830 & 11,333 & 4,076 & 717 & 11,450 & 9,050 & 1,869 & 18,498 & 4,816 & 996 \\
\hline 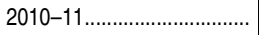 & 6,311 & 1,283 & 831 & 12,557 & 4,860 & 751 & 11,573 & 9,691 & 2,037 & 19,165 & 5,801 & 1,106 \\
\hline $2011-12 \ldots \ldots \ldots \ldots \ldots \ldots \ldots \ldots$ & 7,028 & 1,389 & 823 & 12,746 & 5,341 & 787 & 12,113 & 9,696 & 2,119 & 20,541 & 5,841 & 1,213 \\
\hline Percent change & & & & & & & & & & & & \\
\hline $\begin{array}{l}2001-02 \text { to } 2006-07 \ldots \ldots . \\
2006-07 \text { to } 2011-12 \ldots \ldots .\end{array}$ & $\begin{array}{r}-17.8 \\
56.5\end{array}$ & $\begin{array}{r}-1.6 \\
45.1\end{array}$ & $\begin{array}{r}38.0 \\
-1.4\end{array}$ & $\begin{array}{l}26.2 \\
31.8\end{array}$ & $\begin{array}{r}5.7 \\
53.4\end{array}$ & $\begin{array}{r}40.2 \\
-2.2\end{array}$ & $\begin{array}{r}0.3 \\
-7.5\end{array}$ & $\begin{array}{l}18.1 \\
24.7\end{array}$ & $\begin{array}{r}65.3 \\
3.8\end{array}$ & $\begin{array}{l}27.1 \\
23.7\end{array}$ & $\begin{array}{l}26.6 \\
36.0\end{array}$ & $\begin{array}{r}43.3 \\
9.7\end{array}$ \\
\hline 2000 & & & -1.4 & 01.0 & 0.4 & -2.4 & & & 0.0 & 20.1 & 30.0 & \\
\hline
\end{tabular}

NOTE: Data are for postsecondary institutions participating in Title IV federal financial aid programs. From 1970-71 through 1981-82, civil engineering includes construction and transportation engineering. From 1991-92, civil engineering includes geotechnical, structural, transportation, and water resources engineering. Degrees in engineering technologies are not included in this table.
SOURCE: U.S. Department of Education, National Center for Education Statistics, Higher Education General Information Survey (HEGIS), "Degrees and Other Formal Awards Con ferred" surveys, 1970-71 through 1985-86; Integrated Postsecondary Education Data System (IPEDS), "Completions Survey" (IPEDS-C:87-99); and IPEDS Fall 2000 through Fal 2012, Completions component. (This table was prepared July 2013.) 
Table 325.50. Degrees in English language and literature/letters conferred by postsecondary institutions, by level of degree and sex of student: Selected years, 1949-50 through 2011-12

\begin{tabular}{|c|c|c|c|c|c|c|c|c|c|c|c|}
\hline \multirow[b]{3}{*}{ Year } & \multicolumn{5}{|c|}{ Bachelor's degrees } & \multicolumn{3}{|c|}{ Master's degrees } & \multicolumn{3}{|c|}{ Doctor's degrees } \\
\hline & \multicolumn{2}{|c|}{ Total } & \multirow[b]{2}{*}{ Males } & \multirow[b]{2}{*}{ Females } & \multirow[b]{2}{*}{$\begin{array}{r}\text { Females as } \\
\text { a percent } \\
\text { of total }\end{array}$} & \multirow[b]{2}{*}{ Total } & \multirow[b]{2}{*}{ Males } & \multirow[b]{2}{*}{ Females } & \multirow[b]{2}{*}{ Total } & \multirow[b]{2}{*}{ Males } & \multirow[b]{2}{*}{ Females } \\
\hline & Number & $\begin{array}{c}\text { Annual } \\
\text { percent } \\
\text { change }\end{array}$ & & & & & & & & & \\
\hline 1 & 2 & 3 & 4 & 5 & 6 & 7 & 8 & 9 & 10 & 11 & 12 \\
\hline 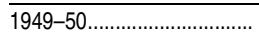 & 17,240 & $t$ & 8,221 & 9,019 & 52.3 & 2,259 & 1,320 & 939 & 230 & 181 & 49 \\
\hline $1959-60 \ldots \ldots \ldots \ldots$ & 20,128 & $\dagger$ & 7,580 & 12,548 & 62.3 & 2,931 & 1,458 & 1,473 & 397 & 314 & 83 \\
\hline $1967-68 \ldots \ldots$. & 47,977 & $\dagger$ & 15,700 & 32,277 & 67.3 & 7,916 & 3,434 & 4,482 & 977 & 717 & 260 \\
\hline $1969-70 \ldots$ & 56,410 & $\dagger$ & 18,650 & 37,760 & 66.9 & 8,517 & 3,326 & 5,191 & 1,213 & 837 & 376 \\
\hline $1970-71 \ldots \ldots \ldots$ & 63,914 & 13.3 & 22,005 & 41,909 & 65.6 & 10,441 & 4,126 & 6,315 & 1,554 & 1,107 & 447 \\
\hline $1971-72 \ldots \ldots \ldots$ & 63,707 & -0.3 & 22,580 & 41,127 & 64.6 & 10,412 & 4,066 & 6,346 & 1,734 & 1,173 & 561 \\
\hline $1972-73 \ldots$ & 60,607 & -4.9 & 22,022 & 38,585 & 63.7 & 10,035 & 3,988 & 6,047 & 1,817 & 1,189 & 628 \\
\hline $1973-74 \ldots .$. & 54,190 & -10.6 & 20,082 & 34,108 & 62.9 & 9,573 & 3,824 & 5,749 & 1,755 & 1,142 & 613 \\
\hline $1974-75 \ldots$ & 47,062 & -13.2 & 17,689 & 29,373 & 62.4 & 9,178 & 3,463 & 5,715 & 1,595 & 974 & 621 \\
\hline $1975-76 \ldots \ldots \ldots$ & 41,452 & -11.9 & 15,898 & 25,554 & 61.6 & 8,599 & 3,290 & 5,309 & 1,514 & 895 & 619 \\
\hline 1976-77.......................... & 37,343 & -9.9 & 14,135 & 23,208 & 62.1 & 7,824 & 2,907 & 4,917 & 1,373 & 768 & 605 \\
\hline 1977-78 & 34,799 & -6.8 & 12,972 & 21,827 & 62.7 & 7,444 & 2,623 & 4,821 & 1,272 & 698 & 574 \\
\hline $1978-79 \ldots .$. & 33,218 & -4.5 & 12,085 & 21,133 & 63.6 & 6,503 & 2,307 & 4,196 & 1,186 & 639 & 547 \\
\hline $1979-80 \ldots .$. & 32,187 & -3.1 & 11,237 & 20,950 & 65.1 & 6,026 & 2,181 & 3,845 & 1,196 & 635 & 561 \\
\hline $1980-81 \ldots \ldots$. & 31,922 & -0.8 & 11,082 & 20,840 & 65.3 & 5,742 & 2,026 & 3,716 & 1,040 & 497 & 543 \\
\hline $1981-82 \ldots \ldots \ldots \ldots \ldots \ldots$ & 33,078 & 3.6 & 11,300 & 21,778 & 65.8 & 5,593 & 1,916 & 3,677 & 986 & 467 & 519 \\
\hline 1982-83........................... & 31,327 & -5.3 & 10,699 & 20,628 & 65.8 & 4,866 & 1,653 & 3,213 & 877 & 419 & 458 \\
\hline 1983-84........................... & 32,296 & 3.1 & 11,007 & 21,289 & 65.9 & 4,814 & 1,681 & 3,133 & 899 & 413 & 486 \\
\hline $1984-85 \ldots \ldots \ldots \ldots \ldots \ldots \ldots \ldots \ldots$ & 32,686 & 1.2 & 11,195 & 21,491 & 65.7 & 4,987 & 1,723 & 3,264 & 915 & 414 & 501 \\
\hline $1985-86 \ldots \ldots \ldots \ldots \ldots \ldots \ldots \ldots \ldots$ & 34,083 & 4.3 & 11,657 & 22,426 & 65.8 & 5,335 & 1,811 & 3,524 & 895 & 390 & 505 \\
\hline $1986-87 \ldots \ldots \ldots \ldots \ldots \ldots \ldots \ldots \ldots$ & 35,667 & 4.6 & 12,133 & 23,534 & 66.0 & 5,298 & 1,819 & 3,479 & 853 & 367 & 486 \\
\hline $1987-88 \ldots \ldots \ldots$. & 38,106 & 6.8 & 12,687 & 25,419 & 66.7 & 5,366 & 1,796 & 3,570 & 858 & 380 & 478 \\
\hline $1988-89 \ldots \ldots \ldots$. & 41,786 & 9.7 & 13,729 & 28,057 & 67.1 & 5,716 & 1,930 & 3,786 & 929 & 405 & 524 \\
\hline $1989-90 \ldots \ldots \ldots \ldots \ldots \ldots \ldots \ldots \ldots$ & 46,803 & 12.0 & 15,437 & 31,366 & 67.0 & 6,317 & 2,125 & 4,192 & 986 & 444 & 542 \\
\hline $1990-91 \ldots \ldots \ldots$ & 51,064 & 9.1 & 16,891 & 34,173 & 66.9 & 6,784 & 2,203 & 4,581 & 1,056 & 469 & 587 \\
\hline $1991-92 \ldots \ldots \ldots \ldots$ & 54,250 & 6.2 & 18,314 & 35,936 & 66.2 & 7,215 & 2,441 & 4,774 & 1,142 & 484 & 658 \\
\hline $1992-93 \ldots \ldots \ldots \ldots$ & 55,289 & 1.9 & 19,007 & 36,282 & 65.6 & 7,537 & 2,570 & 4,967 & 1,201 & 495 & 706 \\
\hline 1993-94............................ & 53,150 & -3.9 & 18,214 & 34,936 & 65.7 & 7,611 & 2,620 & 4,991 & 1,205 & 512 & 693 \\
\hline 1994-95........................... & 51,170 & -3.7 & 17,581 & 33,589 & 65.6 & 7,612 & 2,672 & 4,940 & 1,393 & 589 & 804 \\
\hline $1995-96 \ldots$ & 49,928 & -2.4 & 17,007 & 32,921 & 65.9 & 7,657 & 2,727 & 4,930 & 1,395 & 535 & 860 \\
\hline 1996-97.......................... & 48,641 & -2.6 & 16,325 & 32,316 & 66.4 & 7,487 & 2,650 & 4,837 & 1,431 & 610 & 821 \\
\hline 1997-98....................... & 49,016 & 0.8 & 16,280 & 32,736 & 66.8 & 7,587 & 2,568 & 5,019 & 1,489 & 611 & 878 \\
\hline 1998-99........................ & 49,877 & 1.8 & 16,332 & 33,545 & 67.3 & 7,326 & 2,452 & 4,874 & 1,412 & 554 & 858 \\
\hline $1999-2000 \ldots \ldots \ldots \ldots \ldots \ldots$ & 50,106 & 0.5 & 16,124 & 33,982 & 67.8 & 7,022 & 2,315 & 4,707 & 1,470 & 611 & 859 \\
\hline $2000-01 \ldots \ldots \ldots . .$. & 50,569 & 0.9 & 15,997 & 34,572 & 68.4 & 6,763 & 2,160 & 4,603 & 1,330 & 533 & 797 \\
\hline $2001-02 \ldots$ & 52,375 & 3.6 & 16,457 & 35,918 & 68.6 & 7,097 & 2,270 & 4,827 & 1,291 & 532 & 759 \\
\hline $2002-03 \ldots \ldots$. & 53,699 & 2.5 & 16,738 & 36,961 & 68.8 & 7,428 & 2,433 & 4,995 & 1,246 & 492 & 754 \\
\hline $2003-04 \ldots \ldots \ldots \ldots$ & 53,984 & 0.5 & 16,792 & 37,192 & 68.9 & 7,956 & 2,459 & 5,497 & 1,207 & 479 & 728 \\
\hline $2004-05 \ldots \ldots \ldots \ldots \ldots \ldots \ldots \ldots$ & 54,379 & 0.7 & 17,154 & 37,225 & 68.5 & 8,468 & 2,615 & 5,853 & 1,212 & 494 & 718 \\
\hline $2005-06 \ldots \ldots \ldots \ldots \ldots \ldots \ldots \ldots$ & 55,096 & 1.3 & 17,316 & 37,780 & 68.6 & 8,845 & 2,860 & 5,985 & 1,254 & 510 & 744 \\
\hline 2006-07........................ & 55,122 & \# & 17,475 & 37,647 & 68.3 & 8,742 & 2,867 & 5,875 & 1,178 & 478 & 700 \\
\hline $2007-08 \ldots$ & 55,038 & \# & 17,681 & 37,357 & 67.9 & 9,161 & 3,027 & 6,134 & 1,262 & 453 & 809 \\
\hline $2008-09 \ldots \ldots .$. & 55,462 & 0.8 & 17,973 & 37,489 & 67.6 & 9,261 & 3,001 & 6,260 & 1,271 & 464 & 807 \\
\hline $2009-10 \ldots \ldots \ldots \ldots$ & 53,231 & -4.0 & 17,050 & 36,181 & 68.0 & 9,201 & 3,006 & 6,195 & 1,332 & 522 & 810 \\
\hline $2010-11 \ldots \ldots \ldots \ldots \ldots$ & 52,744 & -0.9 & 16,916 & 35,828 & 67.9 & 9,476 & 3,137 & 6,339 & 1,344 & 529 & 815 \\
\hline $2011-12 \ldots \ldots \ldots \ldots \ldots \ldots \ldots \ldots \ldots$ & 53,767 & 1.9 & 16,976 & 36,791 & 68.4 & 9,939 & 3,403 & 6,536 & 1,427 & 548 & 879 \\
\hline Percent change & & & & & & & & & & & \\
\hline $\begin{array}{l}2001-02 \text { to } 2006-07 \ldots \ldots \\
2006-07 \text { to } 2011-12 \ldots \ldots\end{array}$ & $\begin{array}{r}5.2 \\
-2.5\end{array}$ & $\begin{array}{c}\dagger \\
t\end{array}$ & $\begin{array}{r}6.2 \\
-2.9\end{array}$ & $\begin{array}{r}4.8 \\
-2.3\end{array}$ & $\begin{array}{c}t \\
t\end{array}$ & $\begin{array}{l}23.2 \\
137\end{array}$ & $\begin{array}{l}26.3 \\
18.7\end{array}$ & $\begin{array}{l}21.7 \\
11.3\end{array}$ & $\begin{array}{l}-8.8 \\
211\end{array}$ & $\begin{array}{r}-10.2 \\
146\end{array}$ & $\begin{array}{l}-7.8 \\
256\end{array}$ \\
\hline $2006-07$ to $2011-12 \ldots \ldots$ & -2.5 & $\uparrow$ & -2.9 & -2.3 & 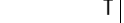 & 13.1 & 18.7 & 11.3 & 21.1 & 74.6 & \\
\hline
\end{tabular}

†Not applicable.

\#Rounds to zero.

NOTE: Data are for postsecondary institutions participating in Title IV federal financial aid pro-

grams.

SOURCE: U.S. Department of Education, National Center for Education Statistics, Earned Degrees Conferred, 1949-50 and 1959-60; Higher Education General Information Survey
(HEGIS), "Degrees and Other Formal Awards Conferred" surveys, 1967-68 through 1985-86; Integrated Postsecondary Education Data System (IPEDS), "Completions Survey" (IPEDSC:87-99); and IPEDS Fall 2000 through Fall 2012, Completions component. (This table was prepared July 2013.) 
Table 325.55. Degrees in foreign languages and literatures conferred by postsecondary institutions, by level of degree and sex of student: Selected years, 1959-60 through 2011-12

\begin{tabular}{|c|c|c|c|c|c|c|c|c|c|c|c|}
\hline \multirow[b]{3}{*}{ Year } & \multicolumn{5}{|c|}{ Bachelor's degrees } & \multicolumn{3}{|c|}{ Master's degrees } & \multicolumn{3}{|c|}{ Doctor's degrees } \\
\hline & \multicolumn{2}{|c|}{ Total } & \multirow[b]{2}{*}{ Males } & \multirow[b]{2}{*}{ Females } & \multirow[b]{2}{*}{$\begin{array}{r}\text { Females as } \\
\text { a percent } \\
\text { of total }\end{array}$} & \multirow[b]{2}{*}{ Total } & \multirow[b]{2}{*}{ Males } & \multirow[b]{2}{*}{ Females } & \multirow[b]{2}{*}{ Total } & \multirow[b]{2}{*}{ Males } & \multirow[b]{2}{*}{ Females } \\
\hline & Number & $\begin{array}{l}\text { Annual } \\
\text { percent } \\
\text { change }\end{array}$ & & & & & & & & & \\
\hline 1 & 2 & 3 & 4 & 5 & 6 & 7 & 8 & 9 & 10 & 11 & 12 \\
\hline 1959-60.................................. & 5,462 & $\dagger$ & 2,090 & 3,372 & 61.7 & 1,125 & 590 & 535 & 229 & 166 & 63 \\
\hline 1967-68............................ & 19,254 & $\dagger$ & 5,253 & 14,001 & 72.7 & 4,849 & 2,068 & 2,781 & 707 & 503 & 204 \\
\hline $1969-70 \ldots \ldots \ldots \ldots \ldots$ & 21,109 & $\dagger$ & 5,613 & 15,496 & 73.4 & 5,137 & 1,917 & 3,220 & 869 & 579 & 290 \\
\hline $1970-71 \ldots \ldots \ldots$ & 20,988 & -0.6 & 5,508 & 15,480 & 73.8 & 5,480 & 1,961 & 3,519 & 1,084 & 714 & 370 \\
\hline $1971-72 \ldots \ldots \ldots \ldots \ldots \ldots \ldots \ldots \ldots$ & 19,890 & -5.2 & 5,196 & 14,694 & 73.9 & 5,283 & 1,919 & 3,364 & 1,134 & 742 & 392 \\
\hline 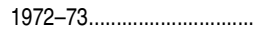 & 20,170 & 1.4 & 5,119 & 15,051 & 74.6 & 5,068 & 1,909 & 3,159 & 1,347 & 829 & 518 \\
\hline $1973-74 \ldots \ldots$ & 20,197 & 0.1 & 5,063 & 15,134 & 74.9 & 4,851 & 1,788 & 3,063 & 1,248 & 703 & 545 \\
\hline $1974-75 \ldots \ldots \ldots \ldots$ & 19,103 & -5.4 & 4,723 & 14,380 & 75.3 & 4,721 & 1,672 & 3,049 & 1,220 & 665 & 555 \\
\hline $1975-76 \ldots \ldots \ldots \ldots$ & 17,068 & -10.7 & 4,270 & 12,798 & 75.0 & 4,432 & 1,581 & 2,851 & 1,245 & 643 & 602 \\
\hline $1976-77 \ldots \ldots$ & 15,496 & -9.2 & 3,965 & 11,531 & 74.4 & 4,056 & 1,365 & 2,691 & 1,103 & 574 & 529 \\
\hline $1977-78 \ldots \ldots \ldots$ & 14,334 & -7.5 & 3,684 & 10,650 & 74.3 & 3,624 & 1,194 & 2,430 & 1,002 & 490 & 512 \\
\hline 1978-79 & 13,211 & -7.8 & 3,391 & 9,820 & 74.3 & 3,248 & 1,092 & 2,156 & 960 & 471 & 489 \\
\hline $1979-80 \ldots \ldots \ldots \ldots \ldots \ldots \ldots$ & 12,480 & -5.5 & 3,226 & 9,254 & 74.2 & 3,067 & 1,026 & 2,041 & 857 & 412 & 445 \\
\hline $1980-81 \ldots \ldots \ldots$ & 11,638 & -6.7 & 3,013 & 8,625 & 74.1 & 2,934 & 1,039 & 1,895 & 931 & 460 & 471 \\
\hline 1981-82 .......................... & 11,175 & -4.0 & 2,919 & 8,256 & 73.9 & 2,892 & 997 & 1,895 & 869 & 407 & 462 \\
\hline 1982-83................................. & 11,170 & $\#$ & 3,048 & 8,122 & 72.7 & 2,706 & 1,001 & 1,705 & 790 & 362 & 428 \\
\hline $1983-84 \ldots \ldots \ldots$ & 10,985 & -1.7 & 3,098 & 7,887 & 71.8 & 2,814 & 984 & 1,830 & 779 & 353 & 426 \\
\hline $1984-85 \ldots \ldots \ldots \ldots \ldots \ldots \ldots \ldots$ & 11,436 & 4.1 & 3,186 & 8,250 & 72.1 & 2,708 & 932 & 1,776 & 761 & 342 & 419 \\
\hline $1985-86 \ldots \ldots \ldots \ldots \ldots$ & 11,550 & 1.0 & 3,374 & 8,176 & 70.8 & 2,690 & 878 & 1,812 & 768 & 338 & 430 \\
\hline 1986-87.......................... & 11,706 & 1.4 & 3,374 & 8,332 & 71.2 & 2,574 & 847 & 1,727 & 769 & 332 & 437 \\
\hline $1987-88 \ldots \ldots \ldots$ & 11,515 & -1.6 & 3,223 & 8,292 & 72.0 & 2,680 & 931 & 1,749 & 725 & 330 & 395 \\
\hline $1988-89 \ldots \ldots$ & 12,403 & 7.7 & 3,432 & 8,971 & 72.3 & 2,837 & 955 & 1,882 & 727 & 317 & 410 \\
\hline $1989-90 \ldots \ldots \ldots \ldots \ldots \ldots \ldots$ & 13,133 & 5.9 & 3,625 & 9,508 & 72.4 & 3,018 & 987 & 2,031 & 816 & 348 & 468 \\
\hline $1990-91 \ldots \ldots$ & 13,937 & 6.1 & 4,008 & 9,929 & 71.2 & 3,049 & 1,018 & 2,031 & 889 & 396 & 493 \\
\hline $1991-92 \ldots \ldots \ldots$ & 14,634 & 5.0 & 4,225 & 10,409 & 71.1 & 3,229 & 1,074 & 2,155 & 984 & 434 & 550 \\
\hline 1992-93.......................... & 15,305 & 4.6 & 4,435 & 10,870 & 71.0 & 3,513 & 1,182 & 2,331 & 977 & 417 & 560 \\
\hline $1993-94 \ldots \ldots \ldots$ & 15,242 & -0.4 & 4,573 & 10,669 & 70.0 & 3,612 & 1,199 & 2,413 & 1,033 & 418 & 615 \\
\hline 1994-95....................... & 14,558 & -4.5 & 4,496 & 10,062 & 69.1 & 3,439 & 1,124 & 2,315 & 1,081 & 479 & 602 \\
\hline 1995-96............................. & 14,832 & 1.9 & 4,514 & 10,318 & 69.6 & 3,443 & 1,141 & 2,302 & 1,020 & 446 & 574 \\
\hline 1996-97................................ & 14,487 & -2.3 & 4,388 & 10,099 & 69.7 & 3,361 & 1,104 & 2,257 & 1,064 & 450 & 614 \\
\hline $1997-98 \ldots \ldots \ldots \ldots \ldots \ldots \ldots \ldots \ldots \ldots \ldots \ldots$ & 15,279 & 5.5 & 4,585 & 10,694 & 70.0 & 3,181 & 1,033 & 2,148 & 1,118 & 473 & 645 \\
\hline 1998-99 ............................ & 15,835 & 3.6 & 4,738 & 11,097 & 70.1 & 3,109 & 976 & 2,133 & 1,049 & 443 & 606 \\
\hline $1999-2000 \ldots \ldots \ldots \ldots \ldots \ldots \ldots \ldots$ & 15,886 & 0.3 & 4,616 & 11,270 & 70.9 & 3,037 & 944 & 2,093 & 1,086 & 446 & 640 \\
\hline $2000-01 \ldots \ldots \ldots$ & 16,128 & 1.5 & 4,695 & 11,433 & 70.9 & 3,035 & 969 & 2,066 & 1,078 & 420 & 658 \\
\hline $2001-02 \ldots \ldots \ldots$ & 16,258 & 0.8 & 4,685 & 11,573 & 71.2 & 3,075 & 958 & 2,117 & 1,003 & 418 & 585 \\
\hline $2002-03 \ldots \ldots$ & 16,912 & 4.0 & 4,996 & 11,916 & 70.5 & 3,049 & 874 & 2,175 & 1,042 & 424 & 618 \\
\hline $2003-04 \ldots \ldots \ldots$ & 17,754 & 5.0 & 5,215 & 12,539 & 70.6 & 3,124 & 957 & 2,167 & 1,031 & 410 & 621 \\
\hline $2004-05 \ldots \ldots \ldots \ldots \ldots \ldots \ldots$ & 18,386 & 3.6 & 5,370 & 13,016 & 70.8 & 3,407 & 1,056 & 2,351 & 1,027 & 410 & 617 \\
\hline $2005-06 \ldots \ldots$ & 19,410 & 5.6 & 5,842 & 13,568 & 69.9 & 3,539 & 1,049 & 2,490 & 1,074 & 436 & 638 \\
\hline $2006-07 \ldots \ldots \ldots$ & 20,275 & 4.5 & 6,173 & 14,102 & 69.6 & 3,443 & 1,058 & 2,385 & 1,059 & 437 & 622 \\
\hline $2007-08 \ldots \ldots \ldots \ldots \ldots \ldots$ & 20,977 & 3.5 & 6,254 & 14,723 & 70.2 & 3,565 & 1,128 & 2,437 & 1,078 & 431 & 647 \\
\hline $2008-09 \ldots \ldots$ & 21,158 & 0.9 & 6,302 & 14,856 & 70.2 & 3,592 & 1,211 & 2,381 & 1,111 & 426 & 685 \\
\hline $2009-10 \ldots \ldots \ldots \ldots \ldots \ldots \ldots$ & 21,516 & 1.7 & 6,610 & 14,906 & 69.3 & 3,755 & 1,254 & 2,501 & 1,091 & 446 & 645 \\
\hline $2010-11 \ldots \ldots \ldots \ldots$ & 21,706 & 0.9 & 6,720 & 14,986 & 69.0 & 3,727 & 1,256 & 2,471 & 1,158 & 477 & 681 \\
\hline $2011-12 \ldots \ldots \ldots \ldots \ldots \ldots \ldots \ldots$ & 21,764 & 0.3 & 6,630 & 15,134 & 69.5 & 3,827 & 1,280 & 2,547 & 1,231 & 497 & 734 \\
\hline Percent change & & & & & & & & & & & \\
\hline $2001-02$ to $2006-07 \ldots \ldots$ & 24.7 & $\dagger$ & 31.8 & 21.9 & $t$ & 12.0 & 10.4 & 12.7 & 5.6 & 4.5 & 6.3 \\
\hline $2006-07$ to $2011-12 \ldots \ldots$. & 7.3 & $\dagger$ & 7.4 & 7.3 & $\dagger$ & 11.2 & 21.0 & 6.8 & 16.2 & 13.7 & 18.0 \\
\hline
\end{tabular}

†Not applicable.

\#Rounds to zero.

NOTE: Data are for postsecondary institutions participating in Title IV federal financial aid programs.

SOURCE: U.S. Department of Education, National Center for Education Statistics, Earned
Degrees Conferred, 1949-50 and 1959-60; Higher Education General Information Survey (HEGIS), "Degrees and Other Formal Awards Conferred" surveys, 1967-68 through 1985-86; Integrated Postsecondary Education Data System (IPEDS), "Completions Survey" (IPEDS-C:87-99); and IPEDS Fall 2000 through Fall 2012, Completions component. (This table was prepared August 2013.) 
Table 325.57. Degrees in French, German, Italian, and Spanish language and literature conferred by postsecondary institutions, by level of degree: Selected years, 1949-50 through 2011-12

\begin{tabular}{|c|c|c|c|c|c|c|c|c|c|c|c|c|}
\hline \multirow[b]{2}{*}{ Year } & \multicolumn{3}{|c|}{ French } & \multicolumn{3}{|c|}{ German } & \multicolumn{3}{|c|}{ Italian } & \multicolumn{3}{|c|}{ Spanish } \\
\hline & Bachelor's & Master's & Doctor's & Bachelor's & Master's & Doctor's & Bachelor's & Master's & Doctor's & Bachelor's & Master's & Doctor's \\
\hline 1 & 2 & 3 & 4 & 5 & 6 & 7 & 8 & 9 & 10 & 11 & 12 & 13 \\
\hline 1949-50_............................ & 1,471 & 299 & 53 & 540 & 121 & 40 & - & - & - & 2,122 & 373 & 34 \\
\hline $1959-60 \ldots \ldots \ldots$ & 1,927 & 316 & 58 & 659 & 126 & 21 & - & - & - & 1,610 & 261 & 31 \\
\hline $1967-68 \ldots$. & 7,068 & 1,301 & 152 & 2,368 & 771 & 117 & - & - & - & 6,381 & 1,188 & 123 \\
\hline $1969-70 \ldots \ldots \ldots \ldots \ldots \ldots \ldots \ldots . .$. & 7,624 & 1,409 & 181 & 2,652 & 669 & 118 & 242 & 71 & 14 & 7,226 & 1,372 & 139 \\
\hline $1970-71 \ldots \ldots$. & 7,306 & 1,437 & 192 & 2,601 & 690 & 144 & 201 & 87 & 10 & 7,068 & 1,456 & 168 \\
\hline $1971-72 \ldots .$. & 6,822 & 1,421 & 193 & 2,477 & 608 & 167 & 287 & 104 & 19 & 6,847 & 1,421 & 152 \\
\hline $1972-73 \ldots . .$. & 6,705 & 1,277 & 203 & 2,520 & 598 & 176 & 313 & 78 & 27 & 7,209 & 1,298 & 206 \\
\hline $1973-74$ & 6,263 & 1,195 & 213 & 2,425 & 550 & 149 & 292 & 81 & 19 & 7,250 & 1,217 & 203 \\
\hline $1974-75 \ldots \ldots \ldots \ldots \ldots \ldots \ldots \ldots \ldots$ & 5,745 & 1,077 & 200 & 2,289 & 480 & 147 & 329 & 100 & 13 & 6,719 & 1,228 & 202 \\
\hline $1975-76 \ldots .$. & 4,783 & 914 & 190 & 1,983 & 471 & 164 & 342 & 85 & 19 & 5,984 & 1,080 & 176 \\
\hline $1976-77 \ldots \ldots$ & 4,228 & 875 & 177 & 1,820 & 394 & 126 & 325 & 89 & 16 & 5,359 & 930 & 153 \\
\hline $1977-78 \ldots \ldots$ & 3,708 & 692 & 155 & 1,647 & 357 & 101 & 301 & 58 & 19 & 4,832 & 822 & 113 \\
\hline $1978-79 \ldots \ldots$ & 3,558 & 576 & 143 & 1,524 & 344 & 106 & 236 & 60 & 14 & 4,563 & 720 & 118 \\
\hline $1979-80 \ldots \ldots \ldots \ldots \ldots \ldots \ldots \ldots \ldots . .$. & 3,285 & 513 & 128 & 1,466 & 309 & 94 & 272 & 49 & 9 & 4,331 & 685 & 103 \\
\hline $1980-81 \ldots \ldots \ldots \ldots \ldots$ & 3,178 & 460 & 115 & 1,286 & 294 & 79 & 205 & 65 & 13 & 3,870 & 592 & 131 \\
\hline $1981-82 \ldots \ldots$ & 3,054 & 485 & 92 & 1,327 & 324 & 76 & 208 & 55 & 14 & 3,633 & 568 & 140 \\
\hline $1982-83 \ldots \ldots$ & 2,871 & 360 & 106 & 1,367 & 281 & 68 & 224 & 45 & 18 & 3,349 & 506 & 129 \\
\hline $1983-84 \ldots . .$. & 2,876 & 418 & 86 & 1,292 & 241 & 63 & 206 & 41 & 13 & 3,254 & 537 & 102 \\
\hline $1984-85 \ldots \ldots \ldots \ldots \ldots \ldots \ldots \ldots \ldots$ & 2,991 & 385 & 74 & 1,411 & 240 & 58 & 190 & 44 & 9 & 3,415 & 505 & 115 \\
\hline $1985-86 \ldots$ & 3,015 & 409 & 86 & 1,396 & 249 & 73 & 240 & 42 & 10 & 3,385 & 521 & 95 \\
\hline $1986-87 \ldots \ldots \ldots \ldots$ & 3,062 & 421 & 85 & 1,366 & 234 & 70 & 219 & 53 & 17 & 3,450 & 504 & 104 \\
\hline $1987-88 \ldots \ldots$ & 3,082 & 437 & 89 & 1,350 & 244 & 71 & 224 & 45 & 7 & 3,416 & 553 & 93 \\
\hline ...................... & 3,297 & 444 & 83 & 1,428 & 263 & 59 & 239 & 45 & 17 & 3,748 & 552 & 101 \\
\hline $1989-90 \ldots \ldots$. & 3,259 & 478 & 115 & 1,437 & 253 & 67 & 247 & 38 & 19 & 4,176 & 573 & 108 \\
\hline $1990-91 \ldots . .$. & 3,355 & 480 & 98 & 1,543 & 242 & 58 & 253 & 36 & 21 & 4,480 & 609 & 125 \\
\hline $1991-92 \ldots \ldots \ldots \ldots \ldots$ & 3,371 & 465 & 112 & 1,616 & 273 & 85 & 238 & 55 & 18 & 4,768 & 647 & 143 \\
\hline $1992-93 \ldots \ldots$ & 3,280 & 513 & 98 & 1,572 & 317 & 86 & 274 & 50 & 13 & 5,233 & 667 & 145 \\
\hline $1993-94$ & 3,094 & 479 & 104 & 1,580 & 298 & 61 & 264 & 47 & 24 & 5,505 & 691 & 160 \\
\hline $1994-95 \ldots \ldots \ldots \ldots \ldots \ldots \ldots \ldots \ldots$ & 2,764 & 470 & 118 & 1,352 & 278 & 83 & 271 & 69 & 31 & 5,602 & 709 & 161 \\
\hline $1995-96 \ldots \ldots \ldots \ldots$ & 2,655 & 446 & 113 & 1,290 & 305 & 75 & 232 & 44 & 22 & 5,995 & 769 & 151 \\
\hline $1996-97 \ldots \ldots \ldots \ldots \ldots \ldots \ldots$ & 2,468 & 414 & 119 & 1,214 & 281 & 80 & 234 & 49 & 18 & 6,161 & 677 & 175 \\
\hline $1997-98 \ldots \ldots \ldots \ldots \ldots \ldots$ & 2,530 & 389 & 104 & 1,181 & 209 & 94 & 252 & 60 & 25 & 6,595 & 781 & 160 \\
\hline $1998-99$ & 2,565 & 365 & 115 & 1,237 & 242 & 78 & 257 & 41 & 12 & 6,992 & 697 & 153 \\
\hline $1999-2000 \ldots \ldots \ldots \ldots \ldots \ldots \ldots . .$. & 2,514 & 343 & 129 & 1,125 & 184 & 76 & 237 & 48 & 13 & 7,031 & 718 & 175 \\
\hline $2000-01 \ldots .$. & 2,371 & 376 & 115 & 1,143 & 242 & 73 & 286 & 42 & 11 & 7,164 & 716 & 185 \\
\hline $2001-02 \ldots \ldots \ldots \ldots \ldots$ & 2,396 & 356 & 89 & 1,092 & 208 & 64 & 263 & 46 & 15 & 7,243 & 792 & 193 \\
\hline ….................... & 2,294 & 348 & 75 & 1,097 & 188 & 77 & 307 & 54 & 20 & 7,619 & 791 & 190 \\
\hline $2003-04 \ldots \ldots \ldots \ldots \ldots \ldots \ldots$ & 2,362 & 361 & 85 & 1,031 & 153 & 30 & 279 & 49 & 31 & 7,991 & 833 & 199 \\
\hline $2004-05 \ldots \ldots \ldots \ldots \ldots \ldots \ldots \ldots \ldots . . .$. & 2,394 & 356 & 80 & 1,103 & 180 & 56 & 277 & 70 & 12 & 8,304 & 919 & 190 \\
\hline 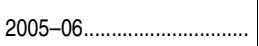 & 2,410 & 395 & 84 & 1,106 & 172 & 48 & 321 & 94 & 17 & 8,690 & 981 & 192 \\
\hline $2006-07 \ldots \ldots \ldots$ & 2,462 & 364 & 95 & 1,055 & 158 & 56 & 280 & 97 & 20 & 9,013 & 982 & 195 \\
\hline $2007-08 \ldots \ldots$ & 2,432 & 359 & 102 & 1,085 & 173 & 51 & 359 & 88 & 25 & 9,278 & 990 & 193 \\
\hline $2008-09 \ldots \ldots \ldots \ldots \ldots$ & 2,450 & 386 & 86 & 1,058 & 163 & 47 & 341 & 76 & 34 & 9,331 & 878 & 218 \\
\hline $2009-10 \ldots \ldots \ldots \ldots \ldots \ldots \ldots \ldots . .$. & 2,488 & 391 & 87 & 1,028 & 143 & 46 & 336 & 73 & 23 & 9,138 & 961 & 199 \\
\hline $2010-11 \ldots \ldots \ldots \ldots \ldots \ldots$ & 2,492 & 366 & 81 & 1,019 & 156 & 43 & 313 & 83 & 28 & 8,918 & 955 & 179 \\
\hline $2011-12 \ldots \ldots \ldots \ldots \ldots \ldots$ & 2,362 & 341 & 96 & 1,001 & 130 & 67 & 332 & 72 & 35 & 8,718 & 991 & 189 \\
\hline Percent change & & & & & & & & & & & & \\
\hline $\begin{array}{l}2001-02 \text { to } 2006-07 \ldots \ldots . . \\
2006-07 \text { to } 2011-12\end{array}$ & $\begin{array}{r}2.8 \\
-4.1\end{array}$ & $\begin{array}{r}2.2 \\
-6.3\end{array}$ & $\begin{array}{l}6.7 \\
11\end{array}$ & $\begin{array}{l}-3.4 \\
-5.1\end{array}$ & $\begin{array}{r}-24.0 \\
\end{array}$ & -12.5 & 6.5 & 110.9 & 33.3 & 24.4 & 24.0 & 1.0 \\
\hline $2006-07$ to $2011-12 \ldots \ldots$ & -4.1 & -6.3 & 1.1 & -5.1 & -17.7 & 19.6 & 18.6 & -25.8 & 75.0 & -3.3 & 0.9 & -3.1 \\
\hline
\end{tabular}

-Not available.

NOTE: Data are for postsecondary institutions participating in Title IV federal financial aid programs.

SOURCE: U.S. Department of Education, National Center for Education Statistics, Earned Degrees Conferred, 1949-50 and 1959-60; Higher Education General Information Survey
(HEGIS), "Degrees and Other Formal Awards Conferred" surveys, 1967-68 through 1985-86; Integrated Postsecondary Education Data System (IPEDS), "Completions Survey" (IPEDS-C:87-99); and IPEDS Fall 2000 through Fall 2012, Completions component. (This table was prepared August 2013.) 
598 CHAPTER 3: Postsecondary Education

Trends in Degrees by Field

Table 325.59. Degrees in Arabic, Chinese, Korean, and Russian language and literature conferred by postsecondary institutions, by level of degree: 1969-70 through 2011-12

\begin{tabular}{|c|c|c|c|c|c|c|c|c|c|c|c|c|}
\hline \multirow[b]{2}{*}{ Year } & \multicolumn{3}{|c|}{ Arabic } & \multicolumn{3}{|c|}{ Chinese } & \multicolumn{3}{|c|}{ Korean } & \multicolumn{3}{|c|}{ Russian } \\
\hline & Bachelor's & Master's & Doctor's & Bachelor's & Master's & Doctor's & Bachelor's & Master's & Doctor's & Bachelor's & Master's & Doctor's \\
\hline 1 & 2 & 3 & 4 & 5 & 6 & 7 & 8 & 9 & 10 & 11 & 12 & 13 \\
\hline 1969-70_.......................... & - & - & - & 81 & 34 & 0 & - & - & - & 768 & 172 & 24 \\
\hline $1970-71 \ldots \ldots \ldots \ldots$ & 15 & 6 & 4 & 89 & 22 & 8 & - & - & - & 715 & 110 & 14 \\
\hline $1971-72 \ldots \ldots$ & 10 & 4 & 0 & 103 & 20 & 11 & - & - & - & 658 & 150 & 15 \\
\hline $1972-73 \ldots \ldots \ldots . . .$. & 12 & 3 & 1 & 98 & 29 & 13 & - & - & - & 622 & 120 & 27 \\
\hline $1973-74 \ldots \ldots \ldots \ldots$ & 20 & 5 & 1 & 121 & 37 & 5 & - & - & - & 624 & 100 & 27 \\
\hline $1974-75 \ldots \ldots \ldots \ldots \ldots \ldots \ldots \ldots$ & 13 & 11 & 2 & 141 & 26 & 12 & - & - & - & 598 & 106 & 20 \\
\hline 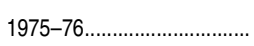 & 10 & 7 & 2 & 150 & 23 & 6 & - & - & - & 531 & 81 & 13 \\
\hline $1976-77 \ldots \ldots$ & 7 & 15 & 1 & 112 & 32 & 6 & - & - & - & 528 & 66 & 19 \\
\hline $1977-78 \ldots \ldots \ldots \ldots \ldots \ldots \ldots$ & 8 & 3 & 1 & 116 & 23 & 4 & - & - & - & 442 & 50 & 12 \\
\hline $1978-79 \ldots \ldots \ldots \ldots \ldots \ldots$ & 4 & 4 & 5 & 91 & 22 & 12 & - & - & - & 465 & 51 & 9 \\
\hline $1979-80 \ldots \ldots \ldots \ldots \ldots \ldots \ldots \ldots$ & 13 & 2 & 5 & 79 & 33 & 7 & - & - & - & 402 & 60 & 6 \\
\hline $1980-81 \ldots \ldots \ldots$ & 6 & 7 & 0 & 73 & 20 & 6 & - & - & - & 409 & 68 & 8 \\
\hline $1981-82 \ldots \ldots \ldots$ & 15 & 4 & 4 & 68 & 14 & 10 & - & - & - & 324 & 49 & 7 \\
\hline $1982-83 \ldots \ldots \ldots \ldots \ldots \ldots \ldots$ & 12 & 4 & 1 & 92 & 15 & 7 & - & - & - & 342 & 33 & 5 \\
\hline 1983-84........................... & 6 & 2 & 0 & 115 & 14 & 10 & - & - & - & 340 & 39 & 3 \\
\hline $1984-85 \ldots \ldots \ldots \ldots \ldots \ldots \ldots$ & 9 & 4 & 0 & 97 & 21 & 3 & - & - & - & 432 & 47 & 6 \\
\hline $1985-86 \ldots$ & 5 & 4 & 0 & 87 & 23 & 11 & - & - & - & 493 & 33 & 3 \\
\hline $1986-87 \ldots \ldots \ldots \ldots$ & 8 & 1 & 1 & 110 & 16 & 10 & - & - & - & 502 & 54 & 8 \\
\hline $1987-88$ & 9 & 4 & 0 & 103 & 31 & 9 & - & - & - & 472 & 54 & 8 \\
\hline $1988-89 \ldots \ldots \ldots \ldots \ldots$ & 6 & 2 & 1 & 138 & 27 & 8 & - & - & - & 469 & 55 & 6 \\
\hline $1989-90 \ldots \ldots$ & 4 & 0 & 1 & 144 & 33 & 8 & - & - & - & 549 & 52 & 5 \\
\hline $1990-91 \ldots \ldots$. & 9 & 0 & 1 & 150 & 24 & 9 & - & - & - & 593 & 70 & 6 \\
\hline $1991-92 \ldots \ldots .$. & 13 & 0 & 0 & 183 & 36 & 14 & - & - & - & 629 & 68 & 7 \\
\hline $1992-93 \ldots \ldots \ldots . . .$. & 8 & 3 & 2 & 129 & 54 & 8 & - & - & - & 612 & 68 & 4 \\
\hline $1993-94 \ldots \ldots \ldots \ldots \ldots$ & 8 & 2 & 0 & 112 & 48 & 18 & - & - & - & 611 & 71 & 3 \\
\hline $1994-95 \ldots \ldots \ldots \ldots \ldots \ldots \ldots$ & 10 & 1 & 1 & 107 & 63 & 16 & - & - & - & 572 & 66 & 3 \\
\hline $1995-96 \ldots \ldots \ldots \ldots . . . .$. & 8 & 3 & 2 & 136 & 42 & 19 & - & - & - & 494 & 58 & 7 \\
\hline $1996-97 \ldots \ldots \ldots \ldots . .$. & 9 & 3 & 0 & 152 & 31 & 15 & - & - & - & 455 & 46 & 9 \\
\hline $1997-98 \ldots . .$. & 16 & 2 & 1 & 161 & 21 & 13 & - & - & - & 383 & 49 & 9 \\
\hline $1998-99 \ldots \ldots$ & 13 & 3 & 1 & 178 & 20 & 14 & - & - & - & 398 & 29 & 4 \\
\hline $1999-2000 \ldots \ldots \ldots \ldots \ldots \ldots \ldots \ldots$ & 6 & 4 & 5 & 183 & 18 & 15 & - & - & - & 340 & 33 & 10 \\
\hline $2000-01 \ldots \ldots \ldots$. & 7 & 2 & 3 & 183 & 13 & 7 & - & - & - & 335 & 24 & 7 \\
\hline $2001-02 \ldots .$. & 13 & 2 & 2 & 189 & 16 & 12 & - & - & - & 277 & 34 & 5 \\
\hline $2002-03 \ldots \ldots .$. & 13 & 3 & 0 & 190 & 12 & 9 & 5 & 0 & 0 & 271 & 16 & 6 \\
\hline $2003-04 \ldots \ldots \ldots \ldots$ & 13 & 3 & 1 & 186 & 15 & 5 & 9 & 2 & 1 & 301 & 21 & 3 \\
\hline $2004-05 \ldots \ldots \ldots .$. & 21 & 5 & 0 & 208 & 21 & 8 & 8 & 0 & 0 & 298 & 18 & 0 \\
\hline 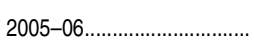 & 26 & 4 & 2 & 241 & 20 & 10 & 17 & 4 & 3 & 279 & 28 & 7 \\
\hline $2006-07 \ldots \ldots \ldots \ldots \ldots \ldots \ldots$ & 68 & 2 & 0 & 261 & 30 & 2 & 13 & 0 & 0 & 311 & 18 & 4 \\
\hline $2007-08 \ldots \ldots \ldots$ & 57 & 8 & 1 & 289 & 35 & 5 & 15 & 4 & 1 & 294 & 20 & 1 \\
\hline $2008-09 \ldots \ldots$. & 85 & 14 & 1 & 384 & 45 & 11 & 24 & 2 & 1 & 325 & 21 & 1 \\
\hline $2009-10 \ldots \ldots$. & 121 & 10 & 6 & 456 & 51 & 12 & 27 & 19 & 1 & 356 & 19 & 1 \\
\hline $2010-11 \ldots \ldots \ldots$ & 141 & 5 & 1 & 449 & 51 & 8 & 28 & 10 & 3 & 340 & 11 & 3 \\
\hline $2011-12 \ldots \ldots \ldots \ldots \ldots \ldots \ldots$ & 143 & 8 & 7 & 496 & 46 & 9 & 38 & 8 & 3 & 392 & 17 & 2 \\
\hline Percent change & & & & & & & & & & & & \\
\hline $2001-02$ to $2006-07 \ldots \ldots$. & 423.1 & 0.0 & -100.0 & 38.1 & 87.5 & -83.3 & $\dagger$ & $\dagger$ & $\dagger$ & 12.3 & -47.1 & -20.0 \\
\hline $2006-07$ to $2011-12 \ldots \ldots$ & 110.3 & 300.0 & $\dagger$ & 90.0 & 53.3 & 350.0 & 192.3 & $\dagger$ & $\dagger$ & 26.0 & -5.6 & -50.0 \\
\hline
\end{tabular}

-Not available.

†Not applicable.

NOTE: Data are for postsecondary institutions participating in Title IV federal financial aid programs. SOURCE: U.S. Department of Education, National Center for Education Statis- tics, Higher Education General Information Survey (HEGIS), "Degrees and Other Forma Awards Conferred" surveys, 1969-70 through 1985-86; Integrated Postsecondary Education Data System (IPEDS), "Completions Survey" (IPEDS-C:87-99); and IPEDS Fall 2000 through Fall 2012, Completions component. (This table was prepared August 2013.) 
Table 325.60. Degrees in the health professions and related programs conferred by postsecondary institutions, by level of degree and sex of student: 1970-71 through 2011-12

\begin{tabular}{|c|c|c|c|c|c|c|c|c|c|c|c|}
\hline \multirow[b]{3}{*}{ Year } & \multicolumn{5}{|c|}{ Bachelor's degrees } & \multicolumn{3}{|c|}{ Master's degrees } & \multicolumn{3}{|c|}{ Doctor's degrees } \\
\hline & \multicolumn{2}{|c|}{ Total } & \multirow[b]{2}{*}{ Males } & \multirow[b]{2}{*}{ Females } & \multirow[b]{2}{*}{$\begin{array}{r}\text { Females as } \\
\text { a percent } \\
\text { of total }\end{array}$} & \multirow[b]{2}{*}{ Total } & \multirow[b]{2}{*}{ Males } & \multirow[b]{2}{*}{ Females } & \multirow[b]{2}{*}{ Total } & \multirow[b]{2}{*}{ Males } & \multirow[b]{2}{*}{ Females } \\
\hline & Number & $\begin{array}{c}\text { Annual } \\
\text { percent } \\
\text { change }\end{array}$ & & & & & & & & & \\
\hline 1 & 2 & 3 & 4 & 5 & 6 & 7 & 8 & 9 & 10 & 11 & 12 \\
\hline 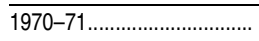 & 25,223 & $\dagger$ & 5,785 & 19,438 & 77.1 & 5,330 & 2,165 & 3,165 & 15,988 & 14,863 & 1,125 \\
\hline $1971-72 \ldots \ldots$. & 28,611 & 13.4 & 7,005 & 21,606 & 75.5 & 6,811 & 2,749 & 4,062 & 16,538 & 15,373 & 1,165 \\
\hline $1972-73 \ldots \ldots$ & 33,562 & 17.3 & 7,752 & 25,810 & 76.9 & 7,978 & 3,189 & 4,789 & 18,215 & 16,870 & 1,345 \\
\hline $1973-74 \ldots \ldots$. & 41,421 & 23.4 & 9,347 & 32,074 & 77.4 & 9,232 & 3,444 & 5,788 & 20,094 & 18,287 & 1,807 \\
\hline $1974-75 \ldots \ldots \ldots$ & 49,002 & 18.3 & 10,844 & 38,158 & 77.9 & 10,277 & 3,686 & 6,591 & 22,191 & 19,808 & 2,383 \\
\hline $1975-76 \ldots \ldots$ & 53,885 & 10.0 & 11,386 & 42,499 & 78.9 & 12,164 & 3,837 & 8,327 & 25,267 & 21,980 & 3,287 \\
\hline $1976-77 \ldots \ldots$ & 57,222 & 6.2 & 11,896 & 45,326 & 79.2 & 12,627 & 3,865 & 8,762 & 24,972 & 21,022 & 3,950 \\
\hline $1977-78 \ldots \ldots \ldots \ldots \ldots$ & 59,445 & 3.9 & 11,600 & 47,845 & 80.5 & 14,027 & 3,972 & 10,055 & 26,516 & 21,622 & 4,894 \\
\hline $1978-79 \ldots \ldots \ldots$ & 62,095 & 4.5 & 11,214 & 50,881 & 81.9 & 15,110 & 4,155 & 10,955 & 27,766 & 22,194 & 5,572 \\
\hline $1979-80 \ldots \ldots \ldots \ldots \ldots \ldots \ldots$ & 63,848 & 2.8 & 11,330 & 52,518 & 82.3 & 15,374 & 4,060 & 11,314 & 28,190 & 22,157 & 6,033 \\
\hline $1980-81 \ldots$. & 63,665 & -0.3 & 10,531 & 53,134 & 83.5 & 16,176 & 4,024 & 12,152 & 29,595 & 22,792 & 6,803 \\
\hline $1981-82 \ldots$ & 63,660 & \# & 10,110 & 53,550 & 84.1 & 16,212 & 3,743 & 12,469 & 30,096 & 22,968 & 7,128 \\
\hline $1982-83 \ldots \ldots$ & 65,642 & 3.1 & 10,247 & 55,395 & 84.4 & 16,941 & 4,138 & 12,803 & 30,800 & 22,920 & 7,880 \\
\hline $1983-84 \ldots \ldots .$. & 65,305 & -0.5 & 10,068 & 55,237 & 84.6 & 17,351 & 4,124 & 13,227 & 31,655 & 22,851 & 8,804 \\
\hline $1984-85 \ldots \ldots \ldots$ & 65,331 & $\#$ & 9,741 & 55,590 & 85.1 & 17,442 & 4,046 & 13,396 & 31,493 & 22,045 & 9,448 \\
\hline $1985-86 \ldots \ldots \ldots . .$. & 65,309 & $\#$ & 9,629 & 55,680 & 85.3 & 18,603 & 4,355 & 14,248 & 31,922 & 22,069 & 9,853 \\
\hline $1986-87 \ldots \ldots \ldots$ & 63,963 & -2.1 & 9,137 & 54,826 & 85.7 & 18,442 & 3,818 & 14,624 & 29,500 & 19,686 & 9,814 \\
\hline $1987-88 \ldots .$. & 61,614 & -3.7 & 8,955 & 52,659 & 85.5 & 18,774 & 4,004 & 14,770 & 30,060 & 19,853 & 10,207 \\
\hline $1988-89 \ldots$ & 59,850 & -2.9 & 8,878 & 50,972 & 85.2 & 19,493 & 4,197 & 15,296 & 30,546 & 19,893 & 10,653 \\
\hline $1989-90 \ldots \ldots \ldots \ldots$ & 58,983 & -1.4 & 9,075 & 49,908 & 84.6 & 20,406 & 4,486 & 15,920 & 30,101 & 19,118 & 10,983 \\
\hline $1990-91 \ldots \ldots .$. & 59,875 & 1.5 & 9,619 & 50,256 & 83.9 & 21,354 & 4,423 & 16,931 & 29,842 & 18,492 & 11,350 \\
\hline $1991-92 \ldots \ldots$ & 62,779 & 4.9 & 10,330 & 52,449 & 83.5 & 23,671 & 4,794 & 18,877 & 31,479 & 19,362 & 12,117 \\
\hline $1992-93 \ldots \ldots$ & 68,434 & 9.0 & 11,605 & 56,829 & 83.0 & 26,190 & 5,249 & 20,941 & 31,089 & 18,446 & 12,643 \\
\hline $1993-94 \ldots$ & 75,890 & 10.9 & 13,377 & 62,513 & 82.4 & 28,442 & 5,813 & 22,629 & 30,959 & 17,988 & 12,971 \\
\hline $1994-95 \ldots$. & 81,596 & 7.5 & 14,812 & 66,784 & 81.8 & 31,770 & 6,718 & 25,052 & 32,124 & 18,463 & 13,661 \\
\hline $1995-96 \ldots .$. & 86,087 & 5.5 & 15,942 & 70,145 & 81.5 & 33,920 & 7,017 & 26,903 & 32,678 & 18,495 & 14,183 \\
\hline $1996-97 \ldots \ldots$. & 87,997 & 2.2 & 16,440 & 71,557 & 81.3 & 36,162 & 7,536 & 28,626 & 34,971 & 19,619 & 15,352 \\
\hline $1997-98 \ldots \ldots \ldots$ & 86,843 & -1.3 & 15,700 & 71,143 & 81.9 & 39,567 & 8,644 & 30,923 & 35,369 & 19,370 & 15,999 \\
\hline $1998-99 \ldots$ & 84,989 & -2.1 & 15,191 & 69,798 & 82.1 & 40,628 & 9,152 & 31,476 & 35,939 & 19,673 & 16,266 \\
\hline $1999-2000 \ldots$ & 80,863 & -4.9 & 13,342 & 67,521 & 83.5 & 42,593 & 9,500 & 33,093 & 37,829 & 19,984 & 17,845 \\
\hline $2000-01 \ldots \ldots$. & 75,933 & -6.1 & 12,514 & 63,419 & 83.5 & 43,623 & 9,711 & 33,912 & 39,019 & 20,260 & 18,759 \\
\hline $2001-02 \ldots \ldots$. & 72,887 & -4.0 & 10,869 & 62,018 & 85.1 & 43,560 & 9,588 & 33,972 & 39,435 & 19,760 & 19,675 \\
\hline $2002-03 \ldots \ldots$ & 71,261 & -2.2 & 10,096 & 61,165 & 85.8 & 42,748 & 9,280 & 33,468 & 39,799 & 19,493 & 20,306 \\
\hline 2003-04.................... & 73,934 & 3.8 & 10,017 & 63,917 & 86.5 & 44,939 & 9,670 & 35,269 & 41,861 & 19,587 & 22,274 \\
\hline $2004-05 \ldots \ldots \ldots \ldots \ldots \ldots$ & 80,685 & 9.1 & 10,858 & 69,827 & 86.5 & 46,703 & 9,816 & 36,887 & 44,201 & 19,697 & 24,504 \\
\hline $2005-06$ & 91,973 & 14.0 & 12,914 & 79,059 & 86.0 & 51,380 & 10,630 & 40,750 & 45,677 & 19,640 & 26,037 \\
\hline $2006-07 \ldots \ldots \ldots \ldots$ & 101,810 & 10.7 & 14,325 & 87,485 & 85.9 & 54,531 & 10,636 & 43,895 & 48,943 & 20,522 & 28,421 \\
\hline $2007-08 \ldots \ldots$. & 111,478 & 9.5 & 16,286 & 95,192 & 85.4 & 58,120 & 11,010 & 47,110 & 51,675 & 21,616 & 30,059 \\
\hline $2008-09 \ldots \ldots \ldots \ldots \ldots \ldots \ldots \ldots \ldots$ & 120,488 & 8.1 & 17,792 & 102,696 & 85.2 & 62,620 & 11,869 & 50,751 & 54,709 & 22,645 & 32,064 \\
\hline $2009-10$ & 129,634 & 7.6 & 19,306 & 110,328 & 85.1 & 69,084 & 12,871 & 56,213 & 57,746 & 23,946 & 33,800 \\
\hline $2010-11 \ldots \ldots \ldots . . .$. & 143,430 & 10.6 & 21,536 & 121,894 & 85.0 & 75,579 & 14,041 & 61,538 & 60,153 & 25,361 & 34,792 \\
\hline $2011-12 \ldots \ldots \ldots \ldots \ldots \ldots \ldots \ldots$ & 163,440 & 14.0 & 24,868 & 138,572 & 84.8 & 83,893 & 15,625 & 68,268 & 62,090 & 26,074 & 36,016 \\
\hline & & & & & & & & & & & \\
\hline $2001-02$ to $2006-07 \ldots \ldots$. & 39.7 & $\dagger$ & 31.8 & 41.1 & $\dagger$ & 25.2 & 10.9 & 29.2 & 24.1 & 3.9 & 44.5 \\
\hline $2006-07$ to $2011-12 \ldots \ldots$. & 60.5 & $t$ & 73.6 & 58.4 & $\dagger$ & 53.8 & 46.9 & 55.5 & 26.9 & 27.1 & 26.7 \\
\hline
\end{tabular}

†Not applicable.

\#Rounds to zero.

NOTE: Data are for postsecondary institutions participating in Title IV federal financial aid programs. Doctor's degrees include medicine (M.D.), dentistry (D.D.S. and D.M.D), and other medical specialty degrees that were formerly classified as first-professional.
SOURCE: U.S. Department of Education, National Center for Education Statistics, Higher Education General Information Survey (HEGIS), "Degrees and Other Formal Awards Conferred" surveys, 1970-71 through 1985-86; Integrated Postsecondary Education Data System (IPEDS), "Completions Survey" (IPEDS-C:87-99); and IPEDS Fall 2000 through Fall 2012, Completions component. (This table was prepared August 2013.) 
Table 325.65. Degrees in mathematics and statistics conferred by degree-granting institutions, by level of degree and sex of student: Selected years, 1949-50 through 2011-12

\begin{tabular}{|c|c|c|c|c|c|c|c|c|c|c|c|}
\hline \multirow[b]{3}{*}{ Year } & \multicolumn{5}{|c|}{ Bachelor's degrees } & \multicolumn{3}{|c|}{ Master's degrees } & \multicolumn{3}{|c|}{ Doctor's degrees } \\
\hline & \multicolumn{2}{|c|}{ Total } & \multirow[b]{2}{*}{ Males } & \multirow[b]{2}{*}{ Females } & \multirow[b]{2}{*}{$\begin{array}{r}\text { Females as } \\
\text { a percent } \\
\text { of total }\end{array}$} & \multirow[b]{2}{*}{ Total } & \multirow[b]{2}{*}{ Males } & \multirow[b]{2}{*}{ Females } & \multirow[b]{2}{*}{ Total } & \multirow[b]{2}{*}{ Males } & \multirow[b]{2}{*}{ Females } \\
\hline & Number & $\begin{array}{l}\text { Annual } \\
\text { percent } \\
\text { change }\end{array}$ & & & & & & & & & \\
\hline 1 & 2 & 3 & 4 & 5 & 6 & 7 & 8 & 9 & 10 & 11 & 12 \\
\hline 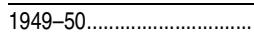 & 6,382 & $\dagger$ & 4,942 & 1,440 & 22.6 & 974 & 784 & 190 & 160 & 151 & 9 \\
\hline $1959-60 \ldots \ldots$ & 11,399 & $\dagger$ & 8,293 & 3,106 & 27.2 & 1,757 & 1,422 & 335 & 303 & 285 & 18 \\
\hline $1967-68 \ldots \ldots \ldots \ldots \ldots$ & 23,513 & $\dagger$ & 14,782 & 8,731 & 37.1 & 5,527 & 4,199 & 1,328 & 947 & 895 & 52 \\
\hline $1969-70$ & 27,442 & $\dagger$ & 17,177 & 10,265 & 37.4 & 5,636 & 3,966 & 1,670 & 1,236 & 1,140 & 96 \\
\hline 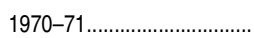 & 24,801 & -9.6 & 15,369 & 9,432 & 38.0 & 5,191 & 3,673 & 1,518 & 1,199 & 1,106 & 93 \\
\hline $1971-72 \ldots \ldots \ldots \ldots$ & 23,713 & -4.4 & 14,454 & 9,259 & 39.0 & 5,198 & 3,655 & 1,543 & 1,128 & 1,039 & 89 \\
\hline 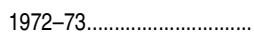 & 23,067 & -2.7 & 13,796 & 9,271 & 40.2 & 5,028 & 3,525 & 1,503 & 1,068 & 966 & 102 \\
\hline $1973-74 \ldots \ldots \ldots \ldots$ & 21,635 & -6.2 & 12,791 & 8,844 & 40.9 & 4,834 & 3,337 & 1,497 & 1,031 & 931 & 100 \\
\hline $1974-75 \ldots \ldots \ldots \ldots \ldots \ldots \ldots \ldots \ldots$ & 18,181 & -16.0 & 10,586 & 7,595 & 41.8 & 4,327 & 2,905 & 1,422 & 975 & 865 & 110 \\
\hline 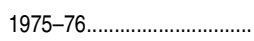 & 15,984 & -12.1 & 9,475 & 6,509 & 40.7 & 3,857 & 2,547 & 1,310 & 856 & 762 & 94 \\
\hline $1976-77 \ldots \ldots \ldots \ldots$ & 14,196 & -11.2 & 8,303 & 5,893 & 41.5 & 3,695 & 2,396 & 1,299 & 823 & 714 & 109 \\
\hline 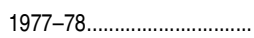 & 12,569 & -11.5 & 7,398 & 5,171 & 41.1 & 3,373 & 2,228 & 1,145 & 805 & 681 & 124 \\
\hline $1978-79 \ldots \ldots$ & 11,806 & -6.1 & 6,899 & 4,907 & 41.6 & 3,036 & 1,985 & 1,051 & 730 & 608 & 122 \\
\hline 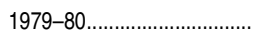 & 11,378 & -3.6 & 6,562 & 4,816 & 42.3 & 2,860 & 1,828 & 1,032 & 724 & 624 & 100 \\
\hline $1980-81 \ldots \ldots \ldots \ldots$ & 11,078 & -2.6 & 6,342 & 4,736 & 42.8 & 2,567 & 1,692 & 875 & 728 & 614 & 114 \\
\hline 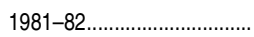 & 11,599 & 4.7 & 6,593 & 5,006 & 43.2 & 2,727 & 1,821 & 906 & 681 & 587 & 94 \\
\hline 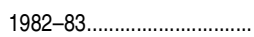 & 12,294 & 6.0 & 6,888 & 5,406 & 44.0 & 2,810 & 1,838 & 972 & 697 & 581 & 116 \\
\hline $1983-84 \ldots \ldots \ldots \ldots$ & 13,087 & 6.5 & 7,290 & 5,797 & 44.3 & 2,723 & 1,773 & 950 & 695 & 569 & 126 \\
\hline 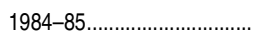 & 15,009 & 14.7 & 8,080 & 6,929 & 46.2 & 2,859 & 1,858 & 1,001 & 699 & 590 & 109 \\
\hline $1985-86 \ldots \ldots \ldots \ldots \ldots \ldots \ldots \ldots \ldots \ldots \ldots \ldots \ldots$ & 16,122 & 7.4 & 8,623 & 7,499 & 46.5 & 3,131 & 2,028 & 1,103 & 742 & 618 & 124 \\
\hline 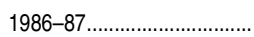 & 16,257 & 0.8 & 8,673 & 7,584 & 46.7 & 3,283 & 1,995 & 1,288 & 723 & 598 & 125 \\
\hline $1987-88 \ldots \ldots \ldots$ & 15,712 & -3.4 & 8,408 & 7,304 & 46.5 & 3,413 & 2,052 & 1,361 & 750 & 625 & 125 \\
\hline $1988-89 \ldots \ldots \ldots \ldots \ldots \ldots \ldots$ & 15,017 & -4.4 & 8,081 & 6,936 & 46.2 & 3,405 & 2,061 & 1,344 & 866 & 700 & 166 \\
\hline 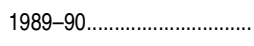 & 14,276 & -4.9 & 7,674 & 6,602 & 46.2 & 3,624 & 2,172 & 1,452 & 917 & 754 & 163 \\
\hline 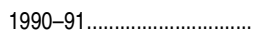 & 14,393 & 0.8 & 7,580 & 6,813 & 47.3 & 3,549 & 2,096 & 1,453 & 978 & 790 & 188 \\
\hline $1991-92 \ldots \ldots$ & 14,468 & 0.5 & 7,668 & 6,800 & 47.0 & 3,558 & 2,151 & 1,407 & 1,048 & 825 & 223 \\
\hline $1992-93 \ldots \ldots \ldots \ldots$ & 14,384 & -0.6 & 7,566 & 6,818 & 47.4 & 3,644 & 2,151 & 1,493 & 1,138 & 867 & 271 \\
\hline $1993-94 \ldots \ldots \ldots \ldots \ldots \ldots \ldots$ & 14,171 & -1.5 & 7,594 & 6,577 & 46.4 & 3,682 & 2,237 & 1,445 & 1,125 & 880 & 245 \\
\hline 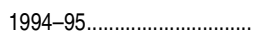 & 13,494 & -4.8 & 7,154 & 6,340 & 47.0 & 3,820 & 2,289 & 1,531 & 1,181 & 919 & 262 \\
\hline 1995-96.................................. & 12,713 & -5.8 & 6,847 & 5,866 & 46.1 & 3,651 & 2,178 & 1,473 & 1,158 & 919 & 239 \\
\hline $1996-97 \ldots \ldots \ldots$ & 12,401 & -2.5 & 6,649 & 5,752 & 46.4 & 3,504 & 2,055 & 1,449 & 1,134 & 861 & 273 \\
\hline $1997-98 \ldots \ldots \ldots$ & 11,795 & -4.9 & 6,247 & 5,548 & 47.0 & 3,409 & 1,985 & 1,424 & 1,215 & 903 & 312 \\
\hline 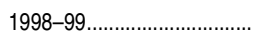 & 12,011 & 1.8 & 6,206 & 5,805 & 48.3 & 3,304 & 1,912 & 1,392 & 1,107 & 812 & 295 \\
\hline 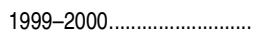 & 11,418 & -4.9 & 5,955 & 5,463 & 47.8 & 3,208 & 1,749 & 1,459 & 1,075 & 803 & 272 \\
\hline $2000-01 \ldots \ldots \ldots \ldots \ldots \ldots \ldots \ldots \ldots \ldots \ldots$ & 11,171 & -2.2 & 5,791 & 5,380 & 48.2 & 3,209 & 1,857 & 1,352 & 997 & 715 & 282 \\
\hline $2001-02 \ldots \ldots \ldots$ & 11,950 & 7.0 & 6,333 & 5,617 & 47.0 & 3,350 & 1,913 & 1,437 & 923 & 658 & 265 \\
\hline $2002-03 \ldots \ldots \ldots \ldots \ldots \ldots \ldots$ & 12,505 & 4.6 & 6,784 & 5,721 & 45.7 & 3,620 & 1,996 & 1,624 & 1,007 & 734 & 273 \\
\hline 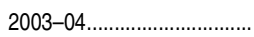 & 13,327 & 6.6 & 7,203 & 6,124 & 46.0 & 4,191 & 2,302 & 1,889 & 1,060 & 762 & 298 \\
\hline $2004-05 \ldots \ldots$ & 14,351 & 7.7 & 7,937 & 6,414 & 44.7 & 4,477 & 2,525 & 1,952 & 1,176 & 841 & 335 \\
\hline 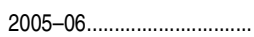 & 14,770 & 2.9 & 8,115 & 6,655 & 45.1 & 4,730 & 2,712 & 2,018 & 1,293 & 911 & 382 \\
\hline $2006-07 \ldots \ldots \ldots \ldots$ & 14,954 & 1.2 & 8,360 & 6,594 & 44.1 & 4,884 & 2,859 & 2,025 & 1,351 & 949 & 402 \\
\hline 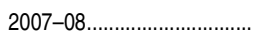 & 15,192 & 1.6 & 8,490 & 6,702 & 44.1 & 4,980 & 2,860 & 2,120 & 1,360 & 938 & 422 \\
\hline 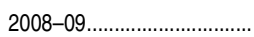 & 15,496 & 2.0 & 8,793 & 6,703 & 43.3 & 5,211 & 3,064 & 2,147 & 1,535 & 1,059 & 476 \\
\hline 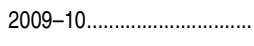 & 16,030 & 3.4 & 9,087 & 6,943 & 43.3 & 5,634 & 3,376 & 2,258 & 1,592 & 1,116 & 476 \\
\hline 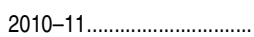 & 17,182 & 7.2 & 9,783 & 7,399 & 43.1 & 5,843 & 3,453 & 2,390 & 1,586 & 1,132 & 454 \\
\hline $2011-12 \ldots \ldots \ldots \ldots$ & 18,842 & 26.0 & 10,723 & 8,119 & 43.1 & 6,245 & 3,694 & 2,551 & 1,669 & 1,198 & 471 \\
\hline Percent change & & & & & & & & & & & \\
\hline $2001-02$ to $2006-07 \ldots \ldots$ & 25.1 & $\dagger$ & 32.0 & 17.4 & $\dagger$ & 45.8 & 49.5 & 40.9 & 46.4 & 44.2 & 51.7 \\
\hline $2006-07$ to $2011-12 \ldots \ldots$ & 26.0 & $\dagger$ & 28.3 & 23.1 & $t$ & 27.9 & 29.2 & 26.0 & 23.5 & 26.2 & 17.2 \\
\hline
\end{tabular}

†Not applicable.

NOTE: Data are for postsecondary institutions participating in Title IV federal financial aid programs.

SOURCE: U.S. Department of Education, National Center for Education Statistics, Earned Degrees Conferred, 1949-50 and 1959-60; Higher Education General Information Survey
(HEGIS), "Degrees and Other Formal Awards Conferred" surveys, 1967-68 through 1985-86; Integrated Postsecondary Education Data System (IPEDS), "Completions Survey" (IPEDS-C:87-99); and IPEDS Fall 2000 through Fall 2012, Completions component. (This table was prepared August 2013.) 
Table 325.70. Degrees in the physical sciences and science technologies conferred by postsecondary institutions, by level of degree and sex of student: Selected years, 1959-60 through 2011-12

\begin{tabular}{|c|c|c|c|c|c|c|c|c|c|c|c|}
\hline \multirow[b]{3}{*}{ Year } & \multicolumn{5}{|c|}{ Bachelor's degrees } & \multicolumn{3}{|c|}{ Master's degrees } & \multicolumn{3}{|c|}{ Doctor's degrees } \\
\hline & \multicolumn{2}{|c|}{ Total } & \multirow[b]{2}{*}{ Males } & \multirow[b]{2}{*}{ Females } & \multirow[b]{2}{*}{$\begin{array}{r}\text { Females as } \\
\text { a percent } \\
\text { of total }\end{array}$} & \multirow[b]{2}{*}{ Total } & \multirow[b]{2}{*}{ Males } & \multirow[b]{2}{*}{ Females } & \multirow[b]{2}{*}{ Total } & \multirow[b]{2}{*}{ Males } & \multirow[b]{2}{*}{ Females } \\
\hline & Number & $\begin{array}{c}\text { Annual } \\
\text { percent } \\
\text { change }\end{array}$ & & & & & & & & & \\
\hline 1 & 2 & 3 & 4 & 5 & 6 & 7 & 8 & 9 & 10 & 11 & 12 \\
\hline 1959-60_............................. & 16,007 & $\dagger$ & 14,013 & 1,994 & 12.5 & 3,376 & 3,049 & 327 & 1,838 & 1,776 & 62 \\
\hline 1967-68 .......................... & 19,380 & $\dagger$ & 16,739 & 2,641 & 13.6 & 5,499 & 4,869 & 630 & 3,593 & 3,405 & 188 \\
\hline 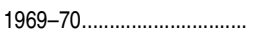 & 21,439 & $\dagger$ & 18,522 & 2,917 & 13.6 & 5,908 & 5,069 & 839 & 4,271 & 4,038 & 233 \\
\hline 1970-71 ....................... & 21,410 & -0.1 & 18,457 & 2,953 & 13.8 & 6,336 & 5,495 & 841 & 4,324 & 4,082 & 242 \\
\hline $1971-72$ & 20,743 & -3.1 & 17,661 & 3,082 & 14.9 & 6,268 & 5,390 & 878 & 4,075 & 3,805 & 270 \\
\hline 1972-73............................. & 20,692 & -0.2 & 17,622 & 3,070 & 14.8 & 6,230 & 5,388 & 842 & 3,961 & 3,698 & 263 \\
\hline $1973-74 \ldots \ldots \ldots$ & 21,170 & 2.3 & 17,669 & 3,501 & 16.5 & 6,019 & 5,157 & 862 & 3,558 & 3,312 & 246 \\
\hline $1974-75 \ldots \ldots \ldots \ldots \ldots \ldots$ & 20,770 & -1.9 & 16,986 & 3,784 & 18.2 & 5,782 & 4,949 & 833 & 3,577 & 3,284 & 293 \\
\hline $1975-76 \ldots \ldots \ldots \ldots$ & 21,458 & 3.3 & 17,349 & 4,109 & 19.1 & 5,428 & 4,622 & 806 & 3,388 & 3,097 & 291 \\
\hline $1976-77 \ldots \ldots$ & 22,482 & 4.8 & 17,985 & 4,497 & 20.0 & 5,281 & 4,411 & 870 & 3,295 & 2,981 & 314 \\
\hline $1977-78$ & 22,975 & 2.2 & 18,083 & 4,892 & 21.3 & 5,507 & 4,583 & 924 & 3,073 & 2,763 & 310 \\
\hline 1978-79 ........................... & 23,197 & 1.0 & 17,976 & 5,221 & 22.5 & 5,418 & 4,438 & 980 & 3,061 & 2,717 & 344 \\
\hline 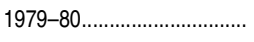 & 23,407 & 0.9 & 17,861 & 5,546 & 23.7 & 5,167 & 4,210 & 957 & 3,044 & 2,669 & 375 \\
\hline $1980-81 \ldots \ldots$ & 23,936 & 2.3 & 18,052 & 5,884 & 24.6 & 5,246 & 4,172 & 1,074 & 3,105 & 2,733 & 372 \\
\hline $1981-82 \ldots \ldots$ & 24,045 & 0.5 & 17,861 & 6,184 & 25.7 & 5,446 & 4,274 & 1,172 & 3,246 & 2,804 & 442 \\
\hline 1982-83...................... & 23,374 & -2.8 & 16,988 & 6,386 & 27.3 & 5,250 & 4,131 & 1,119 & 3,214 & 2,767 & 447 \\
\hline 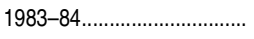 & 23,645 & 1.2 & 17,112 & 6,533 & 27.6 & 5,541 & 4,249 & 1,292 & 3,269 & 2,789 & 480 \\
\hline 1984-85 ............................ & 23,694 & 0.2 & 17,065 & 6,629 & 28.0 & 5,752 & 4,425 & 1,327 & 3,349 & 2,808 & 541 \\
\hline $1985-86 \ldots \ldots \ldots \ldots \ldots \ldots$ & 21,711 & -8.4 & 15,750 & 5,961 & 27.5 & 5,860 & 4,443 & 1,417 & 3,521 & 2,946 & 575 \\
\hline $1986-87 \ldots \ldots \ldots \ldots \ldots \ldots \ldots \ldots \ldots$ & 20,060 & -7.6 & 14,365 & 5,695 & 28.4 & 5,586 & 4,193 & 1,393 & 3,629 & 3,004 & 625 \\
\hline $1987-88$ & 17,797 & -11.3 & 12,385 & 5,412 & 30.4 & 5,696 & 4,300 & 1,396 & 3,758 & 3,085 & 673 \\
\hline $1988-89$ & 17,179 & -3.5 & 12,071 & 5,108 & 29.7 & 5,691 & 4,180 & 1,511 & 3,795 & 3,046 & 749 \\
\hline 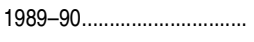 & 16,056 & -6.5 & 11,026 & 5,030 & 31.3 & 5,410 & 3,996 & 1,414 & 4,116 & 3,328 & 788 \\
\hline $1990-91 \ldots \ldots$ & 16,334 & 1.7 & 11,170 & 5,164 & 31.6 & 5,281 & 3,823 & 1,458 & 4,248 & 3,417 & 831 \\
\hline 1991-92 & 16,970 & 3.9 & 11,443 & 5,527 & 32.6 & 5,397 & 3,935 & 1,462 & 4,378 & 3,433 & 945 \\
\hline 1992-93....................... & 17,577 & 3.6 & 11,853 & 5,724 & 32.6 & 5,392 & 3,840 & 1,552 & 4,372 & 3,426 & 946 \\
\hline 1993-94 ............................. & 18,474 & 5.1 & 12,271 & 6,203 & 33.6 & 5,718 & 4,069 & 1,649 & 4,652 & 3,657 & 995 \\
\hline 1994-95 ....................... & 19,247 & 4.2 & 12,556 & 6,691 & 34.8 & 5,798 & 4,058 & 1,740 & 4,486 & 3,443 & 1,043 \\
\hline $1995-96 \ldots \ldots \ldots \ldots \ldots \ldots \ldots \ldots \ldots \ldots$ & 19,716 & 2.4 & 12,634 & 7,082 & 35.9 & 5,910 & 4,031 & 1,879 & 4,589 & 3,543 & 1,046 \\
\hline 1996-97............................ & 19,594 & -0.6 & 12,285 & 7,309 & 37.3 & 5,616 & 3,799 & 1,817 & 4,501 & 3,479 & 1,022 \\
\hline 1997-98........................ & 19,454 & -0.7 & 11,999 & 7,455 & 38.3 & 5,411 & 3,484 & 1,927 & 4,592 & 3,451 & 1,141 \\
\hline 1998-99........................... & 18,448 & -5.2 & 11,119 & 7,329 & 39.7 & 5,241 & 3,454 & 1,787 & 4,229 & 3,206 & 1,023 \\
\hline 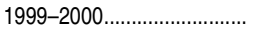 & 18,427 & -0.1 & 11,019 & 7,408 & 40.2 & 4,888 & 3,167 & 1,721 & 4,017 & 3,002 & 1,015 \\
\hline $2000-01 \ldots \ldots \ldots \ldots \ldots$ & 18,025 & -2.2 & 10,628 & 7,397 & 41.0 & 5,134 & 3,276 & 1,858 & 3,968 & 2,914 & 1,054 \\
\hline $2001-02 \ldots \ldots \ldots$ & 17,890 & -0.7 & 10,349 & 7,541 & 42.2 & 5,082 & 3,186 & 1,896 & 3,824 & 2,766 & 1,058 \\
\hline $2002-03$ & 18,038 & 0.8 & 10,625 & 7,413 & 41.1 & 5,196 & 3,284 & 1,912 & 3,939 & 2,854 & 1,085 \\
\hline 2003-04...................... & 18,131 & 0.5 & 10,577 & 7,554 & 41.7 & 5,714 & 3,470 & 2,244 & 3,937 & 2,855 & 1,082 \\
\hline $2004-05 \ldots \ldots \ldots \ldots \ldots \ldots \ldots \ldots$ & 19,104 & 5.4 & 11,065 & 8,039 & 42.1 & 5,823 & 3,569 & 2,254 & 4,248 & 3,071 & 1,177 \\
\hline $2005-06$ & 20,522 & 7.4 & 11,978 & 8,544 & 41.6 & 6,063 & 3,666 & 2,397 & 4,642 & 3,258 & 1,384 \\
\hline $2006-07 \ldots \ldots \ldots$ & 21,291 & 3.7 & 12,604 & 8,687 & 40.8 & 6,012 & 3,675 & 2,337 & 5,041 & 3,454 & 1,587 \\
\hline 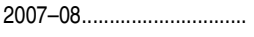 & 22,179 & 4.2 & 13,143 & 9,036 & 40.7 & 6,061 & 3,762 & 2,299 & 4,994 & 3,513 & 1,481 \\
\hline $2008-09$ & 22,688 & 2.3 & 13,463 & 9,225 & 40.7 & 5,862 & 3,576 & 2,286 & 5,237 & 3,554 & 1,683 \\
\hline 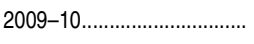 & 23,379 & 3.0 & 13,862 & 9,517 & 40.7 & 6,063 & 3,652 & 2,411 & 5,063 & 3,404 & 1,659 \\
\hline $2010-11 \ldots \ldots \ldots \ldots$ & 24,712 & 5.7 & 14,782 & 9,930 & 40.2 & 6,386 & 3,907 & 2,479 & 5,295 & 3,608 & 1,687 \\
\hline 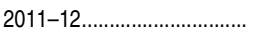 & 26,663 & 7.9 & 15,972 & 10,691 & 40.1 & 6,910 & 4,299 & 2,611 & 5,370 & 3,609 & 1,761 \\
\hline Percent change & & & & & & & & & & & \\
\hline $2001-02$ to $2006-07 \ldots \ldots$ & 19.0 & $\dagger$ & 21.8 & 15.2 & $t$ & 18.3 & 15.3 & 23.3 & 31.8 & 24.9 & 50.0 \\
\hline $2006-07$ to $2011-12 \ldots \ldots$. & 25.2 & $\dagger$ & 26.7 & 23.1 & $t$ & 14.9 & 17.0 & 11.7 & 6.5 & 4.5 & 11.0 \\
\hline
\end{tabular}

$\dagger$ Not applicable.

NOTE: Data are for postsecondary institutions participating in Title IV federal financial aid programs.

SOURCE: U.S. Department of Education, National Center for Education Statistics, Earned Degrees Conferred, 1959-60; Higher Education General Information Survey (HEGIS)
"Degrees and Other Formal Awards Conferred" surveys, 1967-68 through 1985-86; Integrated Postsecondary Education Data System (IPEDS), "Completions Survey" (IPEDSC:87-99); and IPEDS Fall 2000 through Fall 2012, Completions component. (This table was prepared August 2013.) 
602 CHAPTER 3: Postsecondary Education

Trends in Degrees by Field

Table 325.72. Degrees in chemistry, geology and earth science, and physics conferred by postsecondary institutions, by level of degree: 1970-71 through 2011-12

\begin{tabular}{|c|c|c|c|c|c|c|c|c|c|}
\hline \multirow[b]{2}{*}{ Year } & \multicolumn{3}{|c|}{ Chemistry } & \multicolumn{3}{|c|}{ Geology and earth science ${ }^{1}$} & \multicolumn{3}{|c|}{ Physics $^{2}$} \\
\hline & Bachelor's & Master's & Doctor's & Bachelor's & Master's & Doctor's & Bachelor's & Master's & Doctor's \\
\hline 1 & 2 & 3 & 4 & 5 & 6 & 7 & 8 & 9 & 10 \\
\hline $1970-71 \ldots \ldots \ldots \ldots \ldots \ldots$ & 11,061 & 2,244 & 2,093 & 3,312 & 1,074 & 408 & 5,071 & 2,188 & 1,482 \\
\hline $1971-72 \ldots$ & 10,588 & 2,229 & 1,943 & 3,766 & 1,233 & 433 & 4,634 & 2,033 & 1,344 \\
\hline $1972-73 \ldots$. & 10,124 & 2,198 & 1,827 & 4,117 & 1,296 & 430 & 4,259 & 1,747 & 1,338 \\
\hline 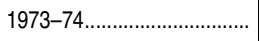 & 10,430 & 2,082 & 1,755 & 4,526 & 1,479 & 416 & 3,952 & 1,655 & 1,115 \\
\hline $1974-75 \ldots \ldots \ldots \ldots \ldots \ldots \ldots \ldots \ldots . .$. & 10,541 & 1,961 & 1,773 & 4,566 & 1,320 & 433 & 3,706 & 1,574 & 1,080 \\
\hline $1975-76 \ldots \ldots \ldots$ & 11,015 & 1,745 & 1,578 & 4,677 & 1,384 & 445 & 3,544 & 1,451 & 997 \\
\hline $1976-77 \ldots \ldots \ldots \ldots \ldots \ldots$ & 11,200 & 1,717 & 1,522 & 5,280 & 1,446 & 480 & 3,420 & 1,319 & 945 \\
\hline $1977-78 \ldots \ldots \ldots \ldots \ldots$ & 11,304 & 1,832 & 1,461 & 5,648 & 1,633 & 419 & 3,330 & 1,294 & 873 \\
\hline $1978-79 \ldots \ldots \ldots$ & 11,499 & 1,724 & 1,475 & 5,753 & 1,596 & 414 & 3,337 & 1,319 & 918 \\
\hline $1979-80 \ldots \ldots$ & 11,229 & 1,671 & 1,500 & 5,785 & 1,623 & 440 & 3,396 & 1,192 & 830 \\
\hline $1980-81 \ldots \ldots \ldots \ldots$ & 11,331 & 1,616 & 1,586 & 6,332 & 1,702 & 404 & 3,441 & 1,294 & 866 \\
\hline $1981-82 \ldots \ldots \ldots \ldots \ldots \ldots \ldots \ldots$ & 11,058 & 1,683 & 1,682 & 6,650 & 1,848 & 452 & 3,472 & 1,284 & 873 \\
\hline $1982-83 \ldots \ldots \ldots \ldots \ldots \ldots \ldots$ & 10,789 & 1,582 & 1,691 & 6,981 & 1,784 & 406 & 3,793 & 1,369 & 873 \\
\hline $1983-84 \ldots \ldots \ldots \ldots \ldots \ldots$ & 10,698 & 1,632 & 1,707 & 7,524 & 1,747 & 408 & 3,907 & 1,532 & 953 \\
\hline 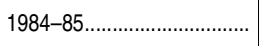 & 10,472 & 1,675 & 1,735 & 7,194 & 1,927 & 401 & 4,097 & 1,523 & 951 \\
\hline $1985-86 \ldots \ldots \ldots . .$. & 10,110 & 1,712 & 1,878 & 5,760 & 2,036 & 395 & 4,180 & 1,501 & 1,010 \\
\hline $1986-87 \ldots \ldots \ldots$ & 9,660 & 1,695 & 1,932 & 3,943 & 1,835 & 399 & 4,318 & 1,543 & 1,074 \\
\hline $1987-88 \ldots \ldots \ldots \ldots \ldots \ldots \ldots \ldots \ldots . .$. & 9,043 & 1,671 & 1,944 & 3,204 & 1,722 & 462 & 4,100 & 1,675 & 1,093 \\
\hline $1988-89 \ldots \ldots \ldots \ldots \ldots$ & 8,618 & 1,742 & 1,974 & 2,847 & 1,609 & 492 & 4,352 & 1,736 & 1,112 \\
\hline $1989-90 \ldots \ldots . .$. & 8,122 & 1,643 & 2,135 & 2,372 & 1,399 & 562 & 4,155 & 1,831 & 1,192 \\
\hline $1990-91 \ldots \ldots \ldots \ldots \ldots$ & 8,311 & 1,637 & 2,196 & 2,367 & 1,336 & 600 & 4,236 & 1,725 & 1,209 \\
\hline $1991-92 \ldots \ldots$ & 8,629 & 1,746 & 2,233 & 2,784 & 1,245 & 549 & 4,098 & 1,834 & 1,337 \\
\hline $1992-93 \ldots \ldots \ldots \ldots \ldots$ & 8,903 & 1,822 & 2,216 & 3,123 & 1,195 & 626 & 4,063 & 1,777 & 1,277 \\
\hline $1993-94 \ldots \ldots \ldots \ldots$ & 9,417 & 1,968 & 2,298 & 3,456 & 1,221 & 577 & 4,001 & 1,945 & 1,465 \\
\hline $1994-95 \ldots \ldots \ldots \ldots \ldots \ldots \ldots \ldots \ldots . .$. & 9,706 & 2,062 & 2,211 & 4,032 & 1,280 & 539 & 3,823 & 1,817 & 1,424 \\
\hline 1995-96 & 10,395 & 2,214 & 2,228 & 4,019 & 1,288 & 555 & 3,679 & 1,678 & 1,462 \\
\hline $1996-97 \ldots \ldots \ldots \ldots \ldots \ldots \ldots \ldots$ & 10,609 & 2,203 & 2,202 & 4,023 & 1,258 & 564 & 3,376 & 1,496 & 1,410 \\
\hline $1997-98 \ldots \ldots$ & 10,528 & 2,108 & 2,291 & 3,866 & 1,227 & 588 & 3,441 & 1,371 & 1,393 \\
\hline $1998-99 \ldots \ldots$ & 10,109 & 2,019 & 2,175 & 3,570 & 1,196 & 533 & 3,200 & 1,326 & 1,257 \\
\hline $1999-2000 \ldots \ldots \ldots \ldots \ldots$ & 9,989 & 1,857 & 2,028 & 3,516 & 1,186 & 492 & 3,342 & 1,232 & 1,208 \\
\hline $2000-01 \ldots \ldots \ldots$ & 9,466 & 1,952 & 2,056 & 3,495 & 1,220 & 472 & 3,418 & 1,365 & 1,169 \\
\hline $2001-02 \ldots \ldots \ldots \ldots \ldots$ & 9,084 & 1,823 & 1,984 & 3,449 & 1,263 & 494 & 3,627 & 1,344 & 1,096 \\
\hline $2002-03 \ldots \ldots \ldots . .$. & 9,013 & 1,777 & 2,092 & 3,381 & 1,323 & 466 & 3,900 & 1,438 & 1,089 \\
\hline 2003-04 & 9,016 & 2,009 & 2,033 & 3,312 & 1,389 & 463 & 4,118 & 1,625 & 1,119 \\
\hline $2004-05 \ldots \ldots \ldots \ldots \ldots \ldots \ldots \ldots$ & 9,664 & 1,879 & 2,148 & 3,276 & 1,420 & 476 & 4,182 & 1,785 & 1,254 \\
\hline $2005-06 \ldots \ldots .$. & 10,606 & 2,044 & 2,403 & 3,322 & 1,476 & 505 & 4,541 & 1,846 & 1,341 \\
\hline $2006-07 \ldots \ldots \ldots \ldots \ldots \ldots$ & 10,994 & 2,097 & 2,514 & 3,319 & 1,437 & 640 & 4,843 & 1,777 & 1,442 \\
\hline 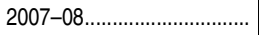 & 11,568 & 2,194 & 2,410 & 3,561 & 1,350 & 577 & 4,862 & 1,791 & 1,507 \\
\hline $2008-09 \ldots \ldots \ldots \ldots \ldots \ldots$ & 11,851 & 2,085 & 2,556 & 3,809 & 1,352 & 614 & 4,822 & 1,653 & 1,580 \\
\hline $2009-10 \ldots \ldots \ldots \ldots \ldots \ldots \ldots . .$. & 12,107 & 2,122 & 2,469 & 4,093 & 1,446 & 613 & 4,982 & 1,792 & 1,570 \\
\hline 2010-11 . & 12,655 & 2,272 & 2,599 & 4,617 & 1,568 & 567 & 5,201 & 1,769 & 1,670 \\
\hline $2011-12 \ldots \ldots \ldots . .$. & 13,472 & 2,435 & 2,537 & 5,111 & 1,807 & 612 & 5,531 & 1,872 & 1,752 \\
\hline Percent change & & & & & & & & & \\
\hline $2001-02$ to $2006-07 \ldots \ldots$ & 21.0 & 15.0 & 26.7 & -3.8 & 13.8 & 29.6 & 33.5 & 32.2 & 31.6 \\
\hline $2006-07$ to $2011-12 \ldots \ldots$ & 22.5 & 16.1 & 0.9 & 54.0 & 25.7 & -4.4 & 14.2 & 5.3 & 21.5 \\
\hline
\end{tabular}

1'Includes geology/earth science, general; geochemistry; geophysics; paleontology; hydrology; oceanography; and geological and earth sciences, other.

Includes physics, general; atomic/molecular physics; elementary particle physics; nuclear physics; optics; acoustics; theoretical physics; and physics, other.

NOTE: Data are for postsecondary institutions participating in Title IV federal financial aid programs.
SOURCE: U.S. Department of Education, National Center for Education Statistics, Higher Education General Information Survey (HEGIS), "Degrees and Other Formal Awards Conferred" surveys, 1970-71 through 1985-86; Integrated Postsecondary Education Data System (IPEDS), "Completions Survey" (IPEDS-C:87-99); and IPEDS Fall 2000 through Fall 2012, Completions component. (This table was prepared August 2013.) 
Table 325.80. Degrees in psychology conferred by postsecondary institutions, by level of degree and sex of student: Selected years, 1949-50 through 2011-12

\begin{tabular}{|c|c|c|c|c|c|c|c|c|c|c|c|}
\hline \multirow[b]{3}{*}{ Year } & \multicolumn{5}{|c|}{ Bachelor's degrees } & \multicolumn{3}{|c|}{ Master's degrees } & \multicolumn{3}{|c|}{ Doctor's degrees } \\
\hline & \multicolumn{2}{|c|}{ Total } & \multirow[b]{2}{*}{ Males } & \multirow[b]{2}{*}{ Females } & \multirow[b]{2}{*}{$\begin{array}{r}\text { Females as } \\
\text { a percent } \\
\text { of total }\end{array}$} & \multirow[b]{2}{*}{ Total } & \multirow[b]{2}{*}{ Males } & \multirow[b]{2}{*}{ Females } & \multirow[b]{2}{*}{ Total } & \multirow[b]{2}{*}{ Males } & \multirow[b]{2}{*}{ Females } \\
\hline & Number & $\begin{array}{l}\text { Annual } \\
\text { percent } \\
\text { change }\end{array}$ & & & & & & & & & \\
\hline 1 & 2 & 3 & 4 & 5 & 6 & 7 & 8 & 9 & 10 & 11 & 12 \\
\hline 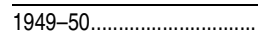 & 9,569 & $\dagger$ & 6,055 & 3,514 & 36.7 & 1,316 & 948 & 368 & 283 & 241 & 42 \\
\hline $1959-60 \ldots \ldots \ldots$ & 8,061 & $\dagger$ & 4,773 & 3,288 & 40.8 & 1,406 & 981 & 425 & 641 & 544 & 97 \\
\hline $1967-68 \ldots \ldots \ldots$ & 23,819 & $\dagger$ & 13,792 & 10,027 & 42.1 & 3,479 & 2,321 & 1,158 & 1,268 & 982 & 286 \\
\hline $1969-70 \ldots \ldots$ & 33,679 & $\dagger$ & 19,077 & 14,602 & 43.4 & 5,158 & 2,975 & 2,183 & 1,962 & 1,505 & 457 \\
\hline $1970-71 \ldots \ldots \ldots$ & 38,187 & 13.4 & 21,227 & 16,960 & 44.4 & 5,717 & 3,395 & 2,322 & 2,144 & 1,629 & 515 \\
\hline $1971-72 \ldots \ldots \ldots$ & 43,433 & 13.7 & 23,352 & 20,081 & 46.2 & 6,764 & 3,934 & 2,830 & 2,277 & 1,694 & 583 \\
\hline $1972-73 \ldots \ldots$ & 47,940 & 10.4 & 25,117 & 22,823 & 47.6 & 7,619 & 4,325 & 3,294 & 2,550 & 1,797 & 753 \\
\hline $1973-74$ & 52,139 & 8.8 & 25,868 & 26,271 & 50.4 & 8,796 & 4,983 & 3,813 & 2,872 & 1,987 & 885 \\
\hline $1974-75 \ldots \ldots \ldots$ & 51,245 & -1.7 & 24,284 & 26,961 & 52.6 & 9,394 & 5,035 & 4,359 & 2,913 & 1,979 & 934 \\
\hline $1975-76 \ldots \ldots$ & 50,278 & -1.9 & 22,898 & 27,380 & 54.5 & 10,167 & 5,136 & 5,031 & 3,157 & 2,115 & 1,042 \\
\hline $1976-77 \ldots \ldots \ldots$ & 47,861 & -4.8 & 20,627 & 27,234 & 56.9 & 10,859 & 5,293 & 5,566 & 3,386 & 2,127 & 1,259 \\
\hline $1977-78 \ldots \ldots$ & 44,879 & -6.2 & 18,422 & 26,457 & 59.0 & 10,282 & 4,670 & 5,612 & 3,164 & 1,974 & 1,190 \\
\hline $1978-79 \ldots \ldots \ldots \ldots$ & 42,697 & -4.9 & 16,540 & 26,157 & 61.3 & 10,132 & 4,405 & 5,727 & 3,228 & 1,895 & 1,333 \\
\hline $1979-80 \ldots \ldots \ldots \ldots \ldots \ldots \ldots \ldots \ldots \ldots \ldots$ & 42,093 & -1.4 & 15,440 & 26,653 & 63.3 & 9,938 & 4,096 & 5,842 & 3,395 & 1,921 & 1,474 \\
\hline $1980-81 \ldots \ldots \ldots$ & 41,068 & -2.4 & 14,332 & 26,736 & 65.1 & 10,223 & 4,066 & 6,157 & 3,576 & 2,002 & 1,574 \\
\hline $1981-82 \ldots \ldots \ldots$ & 41,212 & 0.4 & 13,645 & 27,567 & 66.9 & 9,947 & 3,823 & 6,124 & 3,461 & 1,856 & 1,605 \\
\hline $1982-83 \ldots \ldots \ldots$ & 40,460 & -1.8 & 13,131 & 27,329 & 67.5 & 9,981 & 3,647 & 6,334 & 3,602 & 1,838 & 1,764 \\
\hline $1983-84 \ldots \ldots$ & 39,955 & -1.2 & 12,812 & 27,143 & 67.9 & 9,525 & 3,400 & 6,125 & 3,535 & 1,774 & 1,761 \\
\hline 1984-85.............................. & 39,900 & -0.1 & 12,706 & 27,194 & 68.2 & 9,891 & 3,452 & 6,439 & 3,447 & 1,739 & 1,708 \\
\hline $1985-86 \ldots \ldots \ldots \ldots$ & 40,628 & 1.8 & 12,605 & 28,023 & 69.0 & 9,845 & 3,347 & 6,498 & 3,593 & 1,724 & 1,869 \\
\hline $1986-87 \ldots \ldots \ldots$ & 43,152 & 6.2 & 13,395 & 29,757 & 69.0 & 11,000 & 3,516 & 7,484 & 4,062 & 1,801 & 2,261 \\
\hline $1987-88 \ldots \ldots$ & 45,371 & 5.1 & 13,579 & 31,792 & 70.1 & 10,488 & 3,256 & 7,232 & 3,973 & 1,783 & 2,190 \\
\hline $1988-89 \ldots \ldots \ldots \ldots$ & 49,083 & 8.2 & 14,265 & 34,818 & 70.9 & 11,329 & 3,465 & 7,864 & 4,143 & 1,773 & 2,370 \\
\hline $1989-90 \ldots \ldots$ & 53,952 & 9.9 & 15,336 & 38,616 & 71.6 & 10,730 & 3,377 & 7,353 & 3,811 & 1,566 & 2,245 \\
\hline $1990-91 \ldots \ldots \ldots$ & 58,655 & 8.7 & 16,067 & 42,588 & 72.6 & 11,349 & 3,329 & 8,020 & 3,932 & 1,520 & 2,412 \\
\hline 1991-92...................... & 63,683 & 8.6 & 17,062 & 46,621 & 73.2 & 11,659 & 3,335 & 8,324 & 3,814 & 1,490 & 2,324 \\
\hline 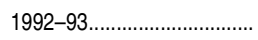 & 66,931 & 5.1 & 17,942 & 48,989 & 73.2 & 12,518 & 3,380 & 9,138 & 4,100 & 1,570 & 2,530 \\
\hline $1993-94 \ldots \ldots \ldots \ldots$ & 69,419 & 3.7 & 18,668 & 50,751 & 73.1 & 13,723 & 3,763 & 9,960 & 4,021 & 1,497 & 2,524 \\
\hline $1994-95 \ldots \ldots$ & 72,233 & 4.1 & 19,570 & 52,663 & 72.9 & 15,378 & 4,210 & 11,168 & 4,252 & 1,562 & 2,690 \\
\hline $1995-96 \ldots \ldots$ & 73,416 & 1.6 & 19,836 & 53,580 & 73.0 & 15,152 & 4,090 & 11,062 & 4,141 & 1,380 & 2,761 \\
\hline $1996-97 \ldots \ldots \ldots$ & 74,308 & 1.2 & 19,408 & 54,900 & 73.9 & 15,769 & 4,155 & 11,614 & 4,507 & 1,495 & 3,012 \\
\hline $1997-98 \ldots \ldots$ & 74,107 & -0.3 & 18,976 & 55,131 & 74.4 & 15,142 & 3,978 & 11,164 & 4,541 & 1,470 & 3,071 \\
\hline 1998-99 & 73,747 & -0.5 & 18,376 & 55,371 & 75.1 & 15,560 & 3,959 & 11,601 & 4,678 & 1,528 & 3,150 \\
\hline $1999-2000 \ldots \ldots \ldots$ & 74,194 & 0.6 & 17,451 & 56,743 & 76.5 & 15,740 & 3,821 & 11,919 & 4,731 & 1,529 & 3,202 \\
\hline $2000-01 \ldots \ldots \ldots \ldots$ & 73,645 & -0.7 & 16,585 & 57,060 & 77.5 & 16,539 & 3,892 & 12,647 & 5,091 & 1,598 & 3,493 \\
\hline $2001-02 \ldots \ldots$ & 76,775 & 4.3 & 17,284 & 59,491 & 77.5 & 16,357 & 3,814 & 12,543 & 4,759 & 1,503 & 3,256 \\
\hline $2002-03 \ldots \ldots \ldots$ & 78,650 & 2.4 & 17,514 & 61,136 & 77.7 & 17,161 & 3,839 & 13,322 & 4,835 & 1,483 & 3,352 \\
\hline 2003-04.................... & 82,098 & 4.4 & 18,193 & 63,905 & 77.8 & 17,898 & 3,789 & 14,109 & 4,827 & 1,496 & 3,331 \\
\hline $2004-05 \ldots \ldots \ldots \ldots \ldots \ldots \ldots \ldots$ & 85,614 & 4.3 & 19,000 & 66,614 & 77.8 & 18,830 & 3,900 & 14,930 & 5,106 & 1,466 & 3,640 \\
\hline $2005-06 \ldots \ldots \ldots$ & 88,134 & 2.9 & 19,865 & 68,269 & 77.5 & 19,770 & 4,079 & 15,691 & 4,921 & 1,347 & 3,574 \\
\hline $2006-07 \ldots \ldots$ & 90,039 & 2.2 & 20,343 & 69,696 & 77.4 & 21,037 & 4,265 & 16,772 & 5,153 & 1,382 & 3,771 \\
\hline $2007-08 \ldots \ldots \ldots \ldots$ & 92,587 & 2.8 & 21,202 & 71,385 & 77.1 & 21,431 & 4,356 & 17,075 & 5,296 & 1,440 & 3,856 \\
\hline $2008-09 \ldots \ldots \ldots$ & 94,271 & 1.8 & 21,488 & 72,783 & 77.2 & 23,415 & 4,789 & 18,626 & 5,477 & 1,478 & 3,999 \\
\hline $2009-10 \ldots \ldots \ldots \ldots \ldots \ldots \ldots \ldots$ & 97,216 & 3.1 & 22,275 & 74,941 & 77.1 & 23,752 & 4,797 & 18,955 & 5,540 & 1,478 & 4,062 \\
\hline $2010-11 \ldots \ldots \ldots \ldots$ & 100,893 & 3.8 & 23,229 & 77,664 & 77.0 & 25,051 & 5,118 & 19,933 & 5,851 & 1,481 & 4,370 \\
\hline 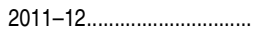 & 108,986 & 8.0 & 25,406 & 83,580 & 76.7 & 26,834 & 5,435 & 21,399 & 5,928 & 1,519 & 4,409 \\
\hline Percent change & & & & & & & & & & & \\
\hline $2001-02$ to $2006-07 \ldots \ldots$. & 17.3 & $\dagger$ & 17.7 & 17.2 & $t$ & 28.6 & 11.8 & 33.7 & 8.3 & -8.1 & 15.8 \\
\hline $2006-07$ to $2011-12 \ldots \ldots$. & 21.0 & $\dagger$ & 24.9 & 19.9 & $\dagger$ & 27.6 & 27.4 & 27.6 & 15.0 & 9.9 & 16.9 \\
\hline
\end{tabular}

†Not applicable.

NOTE: Data are for postsecondary institutions participating in Title IV federal financial aid programs.

SOURCE: U.S. Department of Education, National Center for Education Statistics, Earned Degrees Conferred, 1949-50 and 1959-60; Higher Education General Information Survey
(HEGIS), "Degrees and Other Formal Awards Conferred" surveys, 1967-68 through 1985-86; Integrated Postsecondary Education Data System (IPEDS), "Completions Survey" (IPEDS-C:87-99); and IPEDS Fall 2000 through Fall 2012, Completions component. (This table was prepared August 2013.) 
604 CHAPTER 3: Postsecondary Education

Trends in Degrees by Field

Table 325.85. Degrees in public administration and social services conferred by postsecondary institutions, by level of degree and sex of student: 1970-71 through 2011-12

\begin{tabular}{|c|c|c|c|c|c|c|c|c|c|c|c|}
\hline \multirow[b]{3}{*}{ Year } & \multicolumn{5}{|c|}{ Bachelor's degrees } & \multicolumn{3}{|c|}{ Master's degrees } & \multicolumn{3}{|c|}{ Doctor's degrees } \\
\hline & \multicolumn{2}{|c|}{ Total } & \multirow[b]{2}{*}{ Males } & \multirow[b]{2}{*}{ Females } & \multirow[b]{2}{*}{$\begin{array}{r}\text { Females as } \\
\text { a percent } \\
\text { of total }\end{array}$} & \multirow[b]{2}{*}{ Total } & \multirow[b]{2}{*}{ Males } & \multirow[b]{2}{*}{ Females } & \multirow[b]{2}{*}{ Total } & \multirow[b]{2}{*}{ Males } & \multirow[b]{2}{*}{ Females } \\
\hline & Number & $\begin{array}{l}\text { Annual } \\
\text { percent } \\
\text { change }\end{array}$ & & & & & & & & & \\
\hline 1 & 2 & 3 & 4 & 5 & 6 & 7 & 8 & 9 & 10 & 11 & 12 \\
\hline 1970-71_............................. & 5,466 & $\dagger$ & 1,726 & 3,740 & 68.4 & 7,785 & 3,893 & 3,892 & 174 & 132 & 42 \\
\hline $1971-72 \ldots \ldots \ldots$ & 7,508 & 37.4 & 2,588 & 4,920 & 65.5 & 8,756 & 4,537 & 4,219 & 193 & 150 & 43 \\
\hline 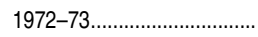 & 10,690 & 42.4 & 3,998 & 6,692 & 62.6 & 10,068 & 5,271 & 4,797 & 198 & 160 & 38 \\
\hline $1973-74$ & 11,966 & 11.9 & 4,266 & 7,700 & 64.3 & 11,415 & 6,028 & 5,387 & 201 & 154 & 47 \\
\hline $1974-75 \ldots \ldots \ldots \ldots \ldots$ & 13,661 & 14.2 & 4,630 & 9,031 & 66.1 & 13,617 & 7,200 & 6,417 & 257 & 192 & 65 \\
\hline $1975-76 \ldots \ldots \ldots \ldots$ & 15,440 & 13.0 & 5,706 & 9,734 & 63.0 & 15,209 & 7,969 & 7,240 & 292 & 192 & 100 \\
\hline $1976-77 \ldots \ldots$ & 16,136 & 4.5 & 5,544 & 10,592 & 65.6 & 17,026 & 8,810 & 8,216 & 292 & 197 & 95 \\
\hline $1977-78 \ldots \ldots \ldots$ & 16,607 & 2.9 & 5,096 & 11,511 & 69.3 & 17,337 & 8,513 & 8,824 & 357 & 237 & 120 \\
\hline $1978-79 \ldots \ldots \ldots$ & 17,328 & 4.3 & 4,938 & 12,390 & 71.5 & 17,306 & 8,051 & 9,255 & 315 & 215 & 100 \\
\hline $1979-80 \ldots \ldots \ldots$ & 16,644 & -3.9 & 4,451 & 12,193 & 73.3 & 17,560 & 7,866 & 9,694 & 342 & 216 & 126 \\
\hline $1980-81 \ldots \ldots \ldots$ & 16,707 & 0.4 & 4,248 & 12,459 & 74.6 & 17,803 & 7,460 & 10,343 & 362 & 212 & 150 \\
\hline $1981-82 \ldots \ldots \ldots \ldots \ldots \ldots$ & 16,495 & -1.3 & 4,176 & 12,319 & 74.7 & 17,416 & 6,975 & 10,441 & 372 & 205 & 167 \\
\hline 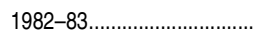 & 14,414 & -12.6 & 3,343 & 11,071 & 76.8 & 16,046 & 5,961 & 10,085 & 347 & 184 & 163 \\
\hline $1983-84 \ldots \ldots \ldots$ & 12,570 & -12.8 & 2,998 & 9,572 & 76.1 & 15,060 & 5,634 & 9,426 & 420 & 230 & 190 \\
\hline 1984-85................................. & 11,754 & -6.5 & 2,829 & 8,925 & 75.9 & 15,575 & 5,573 & 10,002 & 431 & 213 & 218 \\
\hline $1985-86 \ldots \ldots$ & 11,887 & 1.1 & 2,966 & 8,921 & 75.0 & 15,692 & 5,594 & 10,098 & 382 & 171 & 211 \\
\hline $1986-87 \ldots \ldots \ldots$ & 12,328 & 3.7 & 2,993 & 9,335 & 75.7 & 16,432 & 5,673 & 10,759 & 398 & 216 & 182 \\
\hline $1987-88 \ldots \ldots$ & 12,385 & 0.5 & 2,923 & 9,462 & 76.4 & 16,424 & 5,631 & 10,793 & 470 & 238 & 232 \\
\hline $1988-89 \ldots \ldots \ldots$ & 13,162 & 6.3 & 3,214 & 9,948 & 75.6 & 17,020 & 5,615 & 11,405 & 428 & 210 & 218 \\
\hline $1989-90 \ldots \ldots \ldots$ & 13,908 & 5.7 & 3,334 & 10,574 & 76.0 & 17,399 & 5,634 & 11,765 & 508 & 235 & 273 \\
\hline $1990-91 \ldots \ldots \ldots$ & 14,350 & 3.2 & 3,215 & 11,135 & 77.6 & 17,905 & 5,679 & 12,226 & 430 & 190 & 240 \\
\hline $1991-92 \ldots \ldots$ & 15,987 & 11.4 & 3,479 & 12,508 & 78.2 & 19,243 & 5,769 & 13,474 & 432 & 204 & 228 \\
\hline 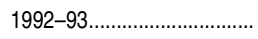 & 16,775 & 4.9 & 3,801 & 12,974 & 77.3 & 20,634 & 6,105 & 14,529 & 459 & 215 & 244 \\
\hline $1993-94 \ldots \ldots$ & 17,815 & 6.2 & 3,919 & 13,896 & 78.0 & 21,833 & 6,406 & 15,427 & 519 & 238 & 281 \\
\hline 1994-95 & 18,586 & 4.3 & 3,935 & 14,651 & 78.8 & 23,501 & 6,870 & 16,631 & 556 & 274 & 282 \\
\hline $1995-96 \ldots \ldots \ldots \ldots$ & 19,849 & 6.8 & 4,205 & 15,644 & 78.8 & 24,229 & 6,927 & 17,302 & 499 & 220 & 279 \\
\hline $1996-97 \ldots \ldots$ & 20,649 & 4.0 & 4,177 & 16,472 & 79.8 & 24,781 & 6,957 & 17,824 & 518 & 243 & 275 \\
\hline $1997-98 \ldots \ldots \ldots$ & 20,408 & -1.2 & 3,881 & 16,527 & 81.0 & 25,144 & 7,025 & 18,119 & 499 & 223 & 276 \\
\hline 1998-99 ........................... & 20,323 & -0.4 & 3,799 & 16,524 & 81.3 & 25,038 & 6,621 & 18,417 & 534 & 240 & 294 \\
\hline 1999-2000 ........................ & 20,185 & -0.7 & 3,816 & 16,369 & 81.1 & 25,594 & 6,808 & 18,786 & 537 & 227 & 310 \\
\hline $2000-01 \ldots \ldots \ldots \ldots$ & 19,447 & -3.7 & 3,670 & 15,777 & 81.1 & 25,268 & 6,544 & 18,724 & 574 & 263 & 311 \\
\hline $2001-02 \ldots \ldots \ldots \ldots \ldots \ldots$ & 19,392 & -0.3 & 3,706 & 15,686 & 80.9 & 25,448 & 6,505 & 18,943 & 571 & 250 & 321 \\
\hline $2002-03$ & 19,900 & 2.6 & 3,726 & 16,174 & 81.3 & 25,903 & 6,391 & 19,512 & 599 & 265 & 334 \\
\hline $2003-04 \ldots \ldots \ldots$ & 20,552 & 3.3 & 3,793 & 16,759 & 81.5 & 28,250 & 7,001 & 21,249 & 649 & 275 & 374 \\
\hline $2004-05 \ldots \ldots \ldots \ldots \ldots \ldots \ldots \ldots . . . . . \ldots \ldots$ & 21,769 & 5.9 & 4,209 & 17,560 & 80.7 & 29,552 & 7,370 & 22,182 & 673 & 272 & 401 \\
\hline $2005-06 \ldots \ldots \ldots \ldots$ & 21,986 & 1.0 & 4,126 & 17,860 & 81.2 & 30,510 & 7,572 & 22,938 & 704 & 285 & 419 \\
\hline $2006-07 \ldots \ldots \ldots$ & 23,147 & 5.3 & 4,354 & 18,793 & 81.2 & 31,131 & 7,758 & 23,373 & 726 & 253 & 473 \\
\hline 2007-08....................... & 23,493 & 1.5 & 4,202 & 19,291 & 82.1 & 33,029 & 8,140 & 24,889 & 760 & 269 & 491 \\
\hline $2008-09 \ldots \ldots$ & 23,851 & 1.5 & 4,374 & 19,477 & 81.7 & 33,933 & 8,346 & 25,587 & 812 & 306 & 506 \\
\hline 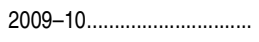 & 25,414 & 6.6 & 4,578 & 20,836 & 82.0 & 35,729 & 8,865 & 26,864 & 838 & 323 & 515 \\
\hline $2010-11 \ldots \ldots$ & 26,774 & 5.4 & 4,908 & 21,866 & 81.7 & 38,634 & 9,793 & 28,841 & 851 & 327 & 524 \\
\hline 2011-12................... & 29,695 & 10.9 & 5,385 & 24,310 & 81.9 & 41,680 & 10,475 & 31,205 & 884 & 338 & 546 \\
\hline Percent change & & & & & & & & & & & \\
\hline $2001-02$ to $2006-07 \ldots \ldots$. & 19.4 & $\dagger$ & 17.5 & 19.8 & $\dagger$ & 22.3 & 19.3 & 23.4 & 27.1 & 1.2 & 47.4 \\
\hline $2006-07$ to $2011-12 \ldots \ldots$. & 28.3 & $\dagger$ & 23.7 & 29.4 & $\dagger$ & 33.9 & 35.0 & 33.5 & 21.8 & 33.6 & 15.4 \\
\hline
\end{tabular}

†Not applicable.

NOTE: Data are for postsecondary institutions participating in Title IV federal financial aid programs.

SOURCE: U.S. Department of Education, National Center for Education Statistics, Higher
Education General Information Survey (HEGIS), "Degrees and Other Formal Awards Conferred" surveys, 1970-71 through 1985-86; Integrated Postsecondary Education Data System (IPEDS), "Completions Survey" (IPEDS-C:87-99); and IPEDS Fall 2000 through Fall 2012, Completions component. (This table was prepared August 2013.) 
Table 325.90. Degrees in the social sciences and history conferred by postsecondary institutions, by level of degree and sex of student: 1970-71 through 2011-12

\begin{tabular}{|c|c|c|c|c|c|c|c|c|c|c|c|}
\hline \multirow[b]{3}{*}{ Year } & \multicolumn{5}{|c|}{ Bachelor's degrees } & \multicolumn{3}{|c|}{ Master's degrees } & \multicolumn{3}{|c|}{ Doctor's degrees } \\
\hline & \multicolumn{2}{|c|}{ Total } & \multirow[b]{2}{*}{ Males } & \multirow[b]{2}{*}{ Females } & \multirow[b]{2}{*}{$\begin{array}{r}\text { Females as } \\
\text { a percent } \\
\text { of total }\end{array}$} & \multirow[b]{2}{*}{ Total } & \multirow[b]{2}{*}{ Males } & \multirow[b]{2}{*}{ Females } & \multirow[b]{2}{*}{ Total } & \multirow[b]{2}{*}{ Males } & \multirow[b]{2}{*}{ Females } \\
\hline & Number & $\begin{array}{c}\text { Annual } \\
\text { percent } \\
\text { change }\end{array}$ & & & & & & & & & \\
\hline 1 & 2 & 3 & 4 & 5 & 6 & 7 & 8 & 9 & 10 & 11 & 12 \\
\hline 1970-71_............................. & 155,324 & $\dagger$ & 98,173 & 57,151 & 36.8 & 16,539 & 11,833 & 4,706 & 3,660 & 3,153 & 507 \\
\hline $1971-72 \ldots \ldots$. & 158,060 & 1.8 & 100,895 & 57,165 & 36.2 & 17,445 & 12,540 & 4,905 & 4,081 & 3,483 & 598 \\
\hline $1972-73 \ldots \ldots$ & 155,970 & -1.3 & 99,735 & 56,235 & 36.1 & 17,477 & 12,605 & 4,872 & 4,234 & 3,573 & 661 \\
\hline $1973-74 \ldots \ldots \ldots$. & 150,320 & -3.6 & 95,650 & 54,670 & 36.4 & 17,293 & 12,321 & 4,972 & 4,124 & 3,383 & 741 \\
\hline $1974-75 \ldots \ldots \ldots \ldots \ldots \ldots \ldots \ldots$ & 135,190 & -10.1 & 84,826 & 50,364 & 37.3 & 16,977 & 11,875 & 5,102 & 4,212 & 3,334 & 878 \\
\hline $1975-76 \ldots \ldots$ & 126,396 & -6.5 & 78,691 & 47,705 & 37.7 & 15,953 & 10,918 & 5,035 & 4,157 & 3,262 & 895 \\
\hline $1976-77 \ldots \ldots$ & 117,040 & -7.4 & 71,128 & 45,912 & 39.2 & 15,533 & 10,413 & 5,120 & 3,802 & 2,957 & 845 \\
\hline $1977-78 \ldots \ldots \ldots \ldots \ldots \ldots$ & 112,952 & -3.5 & 67,217 & 45,735 & 40.5 & 14,718 & 9,845 & 4,873 & 3,594 & 2,722 & 872 \\
\hline $1978-79 \ldots \ldots \ldots . . .$. & 108,059 & -4.3 & 62,852 & 45,207 & 41.8 & 12,963 & 8,395 & 4,568 & 3,371 & 2,501 & 870 \\
\hline $1979-80 \ldots \ldots \ldots \ldots \ldots \ldots \ldots \ldots$ & 103,662 & -4.1 & 58,511 & 45,151 & 43.6 & 12,176 & 7,794 & 4,382 & 3,230 & 2,357 & 873 \\
\hline $1980-81 \ldots$. & 100,513 & -3.0 & 56,131 & 44,382 & 44.2 & 11,945 & 7,457 & 4,488 & 3,122 & 2,274 & 848 \\
\hline $1981-82 \ldots$ & 99,705 & -0.8 & 55,196 & 44,509 & 44.6 & 12,002 & 7,468 & 4,534 & 3,061 & 2,237 & 824 \\
\hline $1982-83 \ldots \ldots$ & 95,228 & -4.5 & 52,771 & 42,457 & 44.6 & 11,205 & 6,974 & 4,231 & 2,931 & 2,042 & 889 \\
\hline $1983-84 \ldots \ldots .$. & 93,323 & -2.0 & 52,154 & 41,169 & 44.1 & 10,577 & 6,551 & 4,026 & 2,911 & 2,030 & 881 \\
\hline $1984-85 \ldots \ldots .$. & 91,570 & -1.9 & 51,226 & 40,344 & 44.1 & 10,503 & 6,475 & 4,028 & 2,851 & 1,933 & 918 \\
\hline $1985-86 \ldots \ldots \ldots \ldots \ldots \ldots \ldots$ & 93,840 & 2.5 & 52,724 & 41,116 & 43.8 & 10,564 & 6,419 & 4,145 & 2,955 & 1,970 & 985 \\
\hline $1986-87 \ldots \ldots \ldots$ & 96,342 & 2.7 & 53,949 & 42,393 & 44.0 & 10,506 & 6,373 & 4,133 & 2,916 & 2,026 & 890 \\
\hline $1987-88 \ldots . .$. & 100,460 & 4.3 & 56,377 & 44,083 & 43.9 & 10,412 & 6,310 & 4,102 & 2,781 & 1,849 & 932 \\
\hline $1988-89 \ldots$. & 108,151 & 7.7 & 60,121 & 48,030 & 44.4 & 11,023 & 6,599 & 4,424 & 2,885 & 1,949 & 936 \\
\hline $1989-90 \ldots \ldots \ldots \ldots$ & 118,083 & 9.2 & 65,887 & 52,196 & 44.2 & 11,634 & 6,898 & 4,736 & 3,010 & 2,019 & 991 \\
\hline $1990-91 \ldots \ldots$. & 125,107 & 5.9 & 68,701 & 56,406 & 45.1 & 12,233 & 7,016 & 5,217 & 3,012 & 1,956 & 1,056 \\
\hline $1991-92 \ldots \ldots$ & 133,974 & 7.1 & 73,001 & 60,973 & 45.5 & 12,702 & 7,237 & 5,465 & 3,218 & 2,126 & 1,092 \\
\hline $1992-93 \ldots \ldots \ldots \ldots$ & 135,703 & 1.3 & 73,589 & 62,114 & 45.8 & 13,471 & 7,671 & 5,800 & 3,460 & 2,203 & 1,257 \\
\hline $1993-94 \ldots . .$. & 133,680 & -1.5 & 72,006 & 61,674 & 46.1 & 14,561 & 8,152 & 6,409 & 3,627 & 2,317 & 1,310 \\
\hline $1994-95 \ldots \ldots \ldots . . .$. & 128,154 & -4.1 & 68,139 & 60,015 & 46.8 & 14,845 & 8,207 & 6,638 & 3,725 & 2,319 & 1,406 \\
\hline $1995-96 \ldots \ldots$. & 126,479 & -1.3 & 65,872 & 60,607 & 47.9 & 15,012 & 8,093 & 6,919 & 3,760 & 2,339 & 1,421 \\
\hline $1996-97 \ldots \ldots .$. & 124,891 & -1.3 & 64,115 & 60,776 & 48.7 & 14,787 & 7,830 & 6,957 & 3,989 & 2,479 & 1,510 \\
\hline $1997-98 \ldots \ldots . .$. & 125,040 & 0.1 & 63,537 & 61,503 & 49.2 & 14,938 & 7,960 & 6,978 & 4,127 & 2,445 & 1,682 \\
\hline $1998-99 \ldots$ & 124,815 & -0.2 & 61,843 & 62,972 & 50.5 & 14,396 & 7,440 & 6,956 & 3,873 & 2,290 & 1,583 \\
\hline $1999-2000 \ldots$ & 127,101 & 1.8 & 62,062 & 65,039 & 51.2 & 14,066 & 7,024 & 7,042 & 4,095 & 2,407 & 1,688 \\
\hline $2000-01 \ldots . .$. & 128,036 & 0.7 & 61,749 & 66,287 & 51.8 & 13,791 & 6,816 & 6,975 & 3,930 & 2,302 & 1,628 \\
\hline $2001-02 \ldots \ldots . .$. & 132,874 & 3.8 & 64,170 & 68,704 & 51.7 & 14,112 & 6,941 & 7,171 & 3,902 & 2,219 & 1,683 \\
\hline $2002-03 \ldots \ldots \ldots \ldots \ldots \ldots \ldots \ldots$ & 143,256 & 7.8 & 69,517 & 73,739 & 51.5 & 14,630 & 7,202 & 7,428 & 3,850 & 2,196 & 1,654 \\
\hline 2003-04..................... & 150,357 & 5.0 & 73,834 & 76,523 & 50.9 & 16,110 & 7,810 & 8,300 & 3,811 & 2,188 & 1,623 \\
\hline $2004-05 \ldots \ldots \ldots \ldots \ldots \ldots \ldots \ldots \ldots$ & 156,892 & 4.3 & 77,702 & 79,190 & 50.5 & 16,952 & 8,256 & 8,696 & 3,819 & 2,184 & 1,635 \\
\hline $2005-06 \ldots \ldots \ldots \ldots \ldots \ldots \ldots \ldots \ldots$ & 161,485 & 2.9 & 80,799 & 80,686 & 50.0 & 17,369 & 8,415 & 8,954 & 3,914 & 2,218 & 1,696 \\
\hline $2006-07 \ldots \ldots \ldots . . .$. & 164,183 & 1.7 & 82,417 & 81,766 & 49.8 & 17,665 & 8,577 & 9,088 & 3,844 & 2,110 & 1,734 \\
\hline $2007-08 \ldots \ldots$. & 167,363 & 1.9 & 84,868 & 82,495 & 49.3 & 18,495 & 9,349 & 9,146 & 4,059 & 2,194 & 1,865 \\
\hline $2008-09 \ldots \ldots \ldots . .$. & 168,500 & 0.7 & 85,197 & 83,303 & 49.4 & 19,240 & 9,605 & 9,635 & 4,234 & 2,353 & 1,881 \\
\hline $2009-10$ & 172,780 & 2.5 & 87,406 & 85,374 & 49.4 & 20,222 & 9,963 & 10,259 & 4,238 & 2,292 & 1,946 \\
\hline $2010-11 \ldots \ldots \ldots \ldots \ldots$ & 177,144 & 2.5 & 89,814 & 87,330 & 49.3 & 21,084 & 10,578 & 10,506 & 4,390 & 2,331 & 2,059 \\
\hline 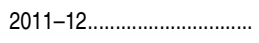 & 178,543 & 0.8 & 90,634 & 87,909 & 49.2 & 21,889 & 10,983 & 10,906 & 4,597 & 2,464 & 2,133 \\
\hline Percent change & & & & & & & & & & & \\
\hline $\begin{array}{l}2001-02 \text { to } 2006-07 \ldots \ldots . . \\
2006-07 \text { to } 2011-12 \ldots \ldots\end{array}$ & $\begin{array}{r}23.6 \\
8.7\end{array}$ & $\begin{array}{l}\dagger \\
t\end{array}$ & $\begin{array}{l}28.4 \\
10.0\end{array}$ & $\begin{array}{r}19.0 \\
7.5\end{array}$ & $\begin{array}{c}t \\
t\end{array}$ & $\begin{array}{l}25.2 \\
23.9\end{array}$ & $\begin{array}{l}23.6 \\
28.1\end{array}$ & $\begin{array}{l}26.7 \\
20.0\end{array}$ & $\begin{array}{r}-1.5 \\
196\end{array}$ & $\begin{array}{r}-4.9 \\
16.8\end{array}$ & $\begin{array}{r}3.0 \\
23.0\end{array}$ \\
\hline $2006-07$ to $2011-12 \ldots \ldots$ & 8.7 & $\dagger$ & 10.0 & 7.5 & & 23.9 & 28.1 & 20.0 & 19.6 & 16.8 & 23.0 \\
\hline
\end{tabular}

†Not applicable.

NOTE: Data are for postsecondary institutions participating in Title IV federal financial aid programs.

SOURCE: U.S. Department of Education, National Center for Education Statistics, Higher
Education General Information Survey (HEGIS), "Degrees and Other Formal Awards Conferred" surveys, 1970-71 through 1985-86; Integrated Postsecondary Education Data System (IPEDS), "Completions Survey" (IPEDS-C:87-99); and IPEDS Fall 2000 through Fall 2012, Completions component. (This table was prepared August 2013.) 
Table 325.92. Degrees in economics, history, political science and government, and sociology conferred by postsecondary institutions, by level of degree: Selected years, 1949-50 through 2011-12

\begin{tabular}{|c|c|c|c|c|c|c|c|c|c|c|c|c|}
\hline \multirow[b]{2}{*}{ Year } & \multicolumn{3}{|c|}{ Economics } & \multicolumn{3}{|c|}{ History } & \multicolumn{3}{|c|}{ Political science and government } & \multicolumn{3}{|c|}{ Sociology } \\
\hline & Bachelor's & Master's & Doctor's & Bachelor's & Master's & Doctor's & Bachelor's & Master's & Doctor's & Bachelor's & Master's & Doctor's \\
\hline 1 & 2 & 3 & 4 & 5 & 6 & 7 & 8 & 9 & 10 & 11 & 12 & 13 \\
\hline 1949-50........................... & 14,568 & 921 & 200 & 13,542 & 1,801 & 275 & 6,336 & 710 & 127 & 7,870 & 552 & 98 \\
\hline $1951-52 \ldots \ldots \ldots \ldots \ldots \ldots$ & 8,593 & 695 & 239 & 10,187 & 1,445 & 317 & 4,911 & 525 & 147 & 6,648 & 517 & 141 \\
\hline $1953-54 \ldots \ldots \ldots \ldots$ & 6,719 & 609 & 245 & 9,363 & 1,220 & 355 & 5,314 & 534 & 153 & 5,692 & 440 & 184 \\
\hline 1955-56........................ & 6,555 & 581 & 232 & 10,510 & 1,114 & 259 & 5,633 & 509 & 203 & 5,878 & 402 & 170 \\
\hline 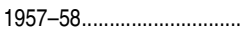 & 7,457 & 669 & 239 & 12,840 & 1,397 & 297 & 6,116 & 665 & 170 & 6,568 & 397 & 150 \\
\hline 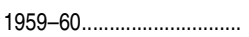 & 7,453 & 708 & 237 & 14,737 & 1,794 & 342 & 6,596 & 722 & 201 & 7,147 & 440 & 161 \\
\hline $1961-62 \ldots \ldots \ldots \ldots$ & 8,366 & 853 & 268 & 17,340 & 2,163 & 343 & 8,326 & 839 & 214 & 8,120 & 578 & 173 \\
\hline 1963-64 ........................... & 10,583 & 1,104 & 385 & 23,668 & 2,705 & 507 & 12,126 & 1,163 & 263 & 10,943 & 646 & 198 \\
\hline $1965-66$ & 11,555 & 1,522 & 458 & 28,612 & 3,883 & 599 & 15,242 & 1,429 & 336 & 15,038 & 981 & 244 \\
\hline 1967-68........................... & 15,193 & 1,916 & 600 & 35,291 & 4,845 & 688 & 20,387 & 1,937 & 457 & 21,710 & 1,193 & 367 \\
\hline 1969-70...................... & 17,197 & 1,988 & 794 & 43,386 & 5,049 & 1,038 & 25,713 & 2,105 & 525 & 30,436 & 1,813 & 534 \\
\hline 1970-71 ........................ & 15,758 & 1,995 & 721 & 44,663 & 5,157 & 991 & 27,482 & 2,318 & 700 & 33,263 & 1,808 & 574 \\
\hline $1971-72 \ldots \ldots \ldots \ldots \ldots$ & 15,231 & 2,224 & 794 & 43,695 & 5,217 & 1,133 & 28,135 & 2,451 & 758 & 35,216 & 1,944 & 636 \\
\hline 1972-73......................... & 14,770 & 2,225 & 845 & 40,943 & 5,030 & 1,140 & 30,100 & 2,398 & 747 & 35,436 & 1,923 & 583 \\
\hline $1973-74 \ldots \ldots \ldots \ldots \ldots \ldots \ldots \ldots \ldots$ & 14,285 & 2,141 & 788 & 37,049 & 4,533 & 1,114 & 30,744 & 2,448 & 766 & 35,491 & 2,196 & 632 \\
\hline 1974-75 ........................... & 14,046 & 2,127 & 815 & 31,470 & 4,226 & 1,117 & 29,126 & 2,333 & 680 & 31,488 & 2,112 & 693 \\
\hline $1975-76 \ldots \ldots \ldots \ldots$ & 14,741 & 2,087 & 763 & 28,400 & 3,658 & 1,014 & 28,302 & 2,191 & 723 & 27,634 & 2,009 & 729 \\
\hline $1976-77 \ldots \ldots \ldots$ & 15,296 & 2,158 & 758 & 25,433 & 3,393 & 921 & 26,411 & 2,222 & 641 & 24,713 & 1,830 & 714 \\
\hline 1977-78......................... & 15,661 & 1,995 & 706 & 23,004 & 3,033 & 813 & 26,069 & 2,069 & 636 & 22,750 & 1,611 & 599 \\
\hline 1978-79............................... & 16,409 & 1,955 & 712 & 21,019 & 2,536 & 756 & 25,628 & 2,037 & 563 & 20,285 & 1,415 & 612 \\
\hline 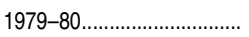 & 17,863 & 1,821 & 677 & 19,301 & 2,367 & 712 & 25,457 & 1,938 & 535 & 18,881 & 1,341 & 583 \\
\hline 1980-81 ............................ & 18,753 & 1,911 & 727 & 18,301 & 2,237 & 643 & 24,977 & 1,875 & 484 & 17,272 & 1,240 & 610 \\
\hline 1981-82..................... & 19,876 & 1,964 & 677 & 17,146 & 2,210 & 636 & 25,658 & 1,954 & 513 & 16,042 & 1,145 & 558 \\
\hline 1982-83....................... & 20,517 & 1,972 & 734 & 16,467 & 2,041 & 575 & 25,791 & 1,829 & 435 & 14,105 & 1,112 & 522 \\
\hline 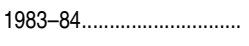 & 20,719 & 1,891 & 729 & 16,643 & 1,940 & 561 & 25,719 & 1,769 & 457 & 13,145 & 1,008 & 520 \\
\hline 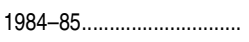 & 20,711 & 1,992 & 749 & 16,049 & 1,921 & 468 & 25,834 & 1,500 & 441 & 11,968 & 1,022 & 480 \\
\hline 1985-86............................. & 21,602 & 1,937 & 789 & 16,415 & 1,961 & 497 & 26,439 & 1,704 & 439 & 12,271 & 965 & 504 \\
\hline 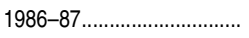 & 22,378 & 1,855 & 750 & 16,997 & 2,021 & 534 & 26,817 & 1,618 & 435 & 12,239 & 950 & 451 \\
\hline 1987-88............................. & 22,911 & 1,847 & 770 & 18,207 & 2,093 & 517 & 27,207 & 1,579 & 391 & 13,024 & 984 & 452 \\
\hline 1988-89 & 23,454 & 1,886 & 827 & 20,159 & 2,121 & 487 & 30,450 & 1,598 & 452 & 14,435 & 1,135 & 451 \\
\hline 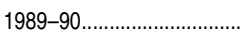 & 23,923 & 1,950 & 806 & 22,476 & 2,369 & 570 & 33,560 & 1,580 & 480 & 16,035 & 1,198 & 432 \\
\hline 1990-91 ........................ & 23,488 & 1,951 & 802 & 24,541 & 2,591 & 606 & 35,737 & 1,772 & 468 & 17,550 & 1,260 & 465 \\
\hline 1991-92............................. & 23,423 & 2,106 & 866 & 26,966 & 2,754 & 644 & 37,805 & 1,908 & 535 & 19,568 & 1,347 & 501 \\
\hline 1992-93............................. & 21,321 & 2,292 & 879 & 27,774 & 2,952 & 690 & 37,931 & 1,943 & 529 & 20,896 & 1,521 & 536 \\
\hline $1993-94 \ldots \ldots \ldots \ldots \ldots . .$. & 19,496 & 2,521 & 869 & 27,503 & 3,009 & 752 & 36,097 & 2,147 & 616 & 22,368 & 1,639 & 530 \\
\hline $1994-95 \ldots \ldots \ldots \ldots \ldots \ldots \ldots \ldots$ & 17,673 & 2,400 & 910 & 26,598 & 3,091 & 816 & 33,013 & 2,019 & 637 & 22,886 & 1,748 & 546 \\
\hline 1995-96........................ & 16,674 & 2,533 & 916 & 26,005 & 2,898 & 805 & 30,775 & 2,024 & 634 & 24,071 & 1,772 & 527 \\
\hline 1996-97........................ & 16,539 & 2,433 & 968 & 25,214 & 2,901 & 873 & 28,969 & 1,909 & 686 & 24,672 & 1,731 & 591 \\
\hline 1997-98......................... & 17,074 & 2,435 & 928 & 25,726 & 2,895 & 937 & 28,044 & 1,957 & 705 & 24,806 & 1,737 & 596 \\
\hline $1998-99 \ldots \ldots \ldots \ldots$ & 17,577 & 2,332 & 819 & 24,742 & 2,618 & 931 & 27,476 & 1,667 & 694 & 24,979 & 1,940 & 521 \\
\hline 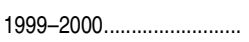 & 18,441 & 2,168 & 851 & 25,247 & 2,573 & 984 & 27,635 & 1,627 & 693 & 25,598 & 1,996 & 595 \\
\hline $2000-01 \ldots \ldots \ldots \ldots$ & 19,437 & 2,139 & 851 & 25,090 & 2,365 & 931 & 27,792 & 1,596 & 688 & 25,268 & 1,845 & 546 \\
\hline $2001-02 \ldots \ldots \ldots \ldots \ldots \ldots \ldots$ & 20,927 & 2,330 & 826 & 26,001 & 2,420 & 924 & 29,354 & 1,641 & 625 & 25,202 & 1,928 & 534 \\
\hline $2002-03 \ldots \ldots \ldots$ & 23,007 & 2,582 & 836 & 27,757 & 2,521 & 861 & 33,205 & 1,664 & 671 & 26,095 & 1,897 & 591 \\
\hline 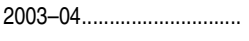 & 24,069 & 2,824 & 849 & 29,808 & 2,522 & 855 & 35,581 & 1,869 & 618 & 26,939 & 2,009 & 558 \\
\hline 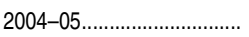 & 24,217 & 3,092 & 973 & 31,398 & 2,893 & 819 & 38,107 & 1,983 & 636 & 28,473 & 1,499 & 527 \\
\hline $2005-06 \ldots \ldots \ldots \ldots \ldots \ldots \ldots \ldots \ldots \ldots \ldots$ & 23,807 & 2,941 & 930 & 33,153 & 2,992 & 852 & 39,409 & 2,054 & 649 & 28,467 & 1,547 & 562 \\
\hline $2006-07 \ldots \ldots \ldots \ldots \ldots \ldots \ldots \ldots \ldots$ & 23,916 & 2,962 & 941 & 34,446 & 3,144 & 807 & 39,899 & 2,102 & 614 & 28,960 & 1,545 & 569 \\
\hline 2007-08 & 25,278 & 3,187 & 1,025 & 34,441 & 3,403 & 860 & 40,259 & 2,156 & 639 & 28,815 & 1,560 & 585 \\
\hline $2008-09 \ldots \ldots \ldots \ldots \ldots \ldots$ & 26,299 & 3,233 & 1,015 & 34,711 & 3,542 & 918 & 39,198 & 2,171 & 709 & 28,732 & 1,580 & 628 \\
\hline 2009-10 & 27,624 & 3,356 & 983 & 35,198 & 3,854 & 888 & 39,467 & 2,251 & 745 & 28,637 & 1,427 & 603 \\
\hline $2010-11 \ldots \ldots \ldots \ldots \ldots \ldots \ldots \ldots . .$. & 28,528 & 3,731 & 1,018 & 34,999 & 4,003 & 908 & 40,150 & 2,487 & 722 & 29,271 & 1,559 & 656 \\
\hline 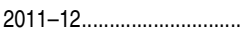 & 27,995 & 3,890 & 1,130 & 35,121 & 4,155 & 969 & 39,800 & 2,508 & 746 & 30,132 & 1,696 & 626 \\
\hline $\begin{array}{l}\text { Percent change } \\
2001-02 \text { to } 2006-07 \ldots \ldots \\
2006-07 \text { to } 2011-12 \ldots \ldots .\end{array}$ & $\begin{array}{l}14.3 \\
17.1\end{array}$ & $\begin{array}{l}27.1 \\
31.3\end{array}$ & $\begin{array}{l}13.9 \\
20.1\end{array}$ & $\begin{array}{r}32.5 \\
2.0\end{array}$ & $\begin{array}{l}29.9 \\
32.2\end{array}$ & $\begin{array}{r}-12.7 \\
20.1\end{array}$ & $\begin{array}{r}35.9 \\
-0.2\end{array}$ & $\begin{array}{l}28.1 \\
19.3\end{array}$ & $\begin{array}{r}-1.8 \\
21.5\end{array}$ & $\begin{array}{r}14.9 \\
4.0\end{array}$ & $\begin{array}{r}-19.9 \\
9.8\end{array}$ & $\begin{array}{r}6.6 \\
10.0\end{array}$ \\
\hline
\end{tabular}

NOTE: Data are for postsecondary institutions participating in Title IV federal financial aid programs.

SOURCE: U.S. Department of Education, National Center for Education Statistics, Earned Degrees Conferred, 1949-50 through 1963-64; Higher Education General Information Sur- vey (HEGIS), "Degrees and Other Formal Awards Conferred" surveys, 1965-66 through 1985-86; Integrated Postsecondary Education Data System (IPEDS), "Completions Survey" (IPEDS-C:87-99); and IPEDS Fall 2000 through Fall 2012, Completions component. (This table was prepared August 2013.) 
Table 325.95. Degrees in visual and performing arts conferred by postsecondary institutions, by level of degree and sex of student: 1970-71 through 2011-12

\begin{tabular}{|c|c|c|c|c|c|c|c|c|c|c|c|}
\hline \multirow[b]{3}{*}{ Year } & \multicolumn{5}{|c|}{ Bachelor's degrees } & \multicolumn{3}{|c|}{ Master's degrees } & \multicolumn{3}{|c|}{ Doctor's degrees } \\
\hline & \multicolumn{2}{|c|}{ Total } & \multirow[b]{2}{*}{ Males } & \multirow[b]{2}{*}{ Females } & \multirow[b]{2}{*}{$\begin{array}{r}\text { Females as } \\
\text { a percent } \\
\text { of total }\end{array}$} & \multirow[b]{2}{*}{ Total } & \multirow[b]{2}{*}{ Males } & \multirow[b]{2}{*}{ Females } & \multirow[b]{2}{*}{ Total } & \multirow[b]{2}{*}{ Males } & \multirow[b]{2}{*}{ Females } \\
\hline & Number & $\begin{array}{c}\text { Annual } \\
\text { percent } \\
\text { change }\end{array}$ & & & & & & & & & \\
\hline 1 & 2 & 3 & 4 & 5 & 6 & 7 & 8 & 9 & 10 & 11 & 12 \\
\hline 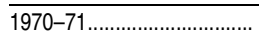 & 30,394 & $\dagger$ & 12,256 & 18,138 & 59.7 & 6,675 & 3,510 & 3,165 & 621 & 483 & 138 \\
\hline $1971-72 \ldots \ldots$. & 33,831 & 11.3 & 13,580 & 20,251 & 59.9 & 7,537 & 4,049 & 3,488 & 572 & 428 & 144 \\
\hline $1972-73 \ldots \ldots$ & 36,017 & 6.5 & 14,267 & 21,750 & 60.4 & 7,254 & 4,005 & 3,249 & 616 & 449 & 167 \\
\hline $1973-74 \ldots \ldots$. & 39,730 & 10.3 & 15,821 & 23,909 & 60.2 & 8,001 & 4,325 & 3,676 & 585 & 440 & 145 \\
\hline $1974-75 \ldots \ldots \ldots$ & 40,782 & 2.6 & 15,532 & 25,250 & 61.9 & 8,362 & 4,448 & 3,914 & 649 & 446 & 203 \\
\hline $1975-76 \ldots \ldots$. & 42,138 & 3.3 & 16,491 & 25,647 & 60.9 & 8,817 & 4,507 & 4,310 & 620 & 447 & 173 \\
\hline $1976-77 \ldots \ldots$ & 41,793 & -0.8 & 16,166 & 25,627 & 61.3 & 8,636 & 4,211 & 4,425 & 662 & 447 & 215 \\
\hline $1977-78 \ldots \ldots \ldots \ldots \ldots$ & 40,951 & 2.0 & 15,572 & 25,379 & 62.0 & 9,036 & 4,327 & 4,709 & 708 & 448 & 260 \\
\hline $1978-79 \ldots \ldots \ldots \ldots$ & 40,969 & $\#$ & 15,380 & 25,589 & 62.5 & 8,524 & 3,933 & 4,591 & 700 & 454 & 246 \\
\hline $1979-80 \ldots \ldots \ldots \ldots \ldots \ldots \ldots \ldots$ & 40,892 & -0.2 & 15,065 & 25,827 & 63.2 & 8,708 & 4,067 & 4,641 & 655 & 413 & 242 \\
\hline $1980-81 \ldots$. & 40,479 & -1.0 & 14,798 & 25,681 & 63.4 & 8,629 & 4,056 & 4,573 & 654 & 396 & 258 \\
\hline $1981-82 \ldots$ & 40,422 & -0.1 & 14,819 & 25,603 & 63.3 & 8,746 & 3,866 & 4,880 & 670 & 380 & 290 \\
\hline $1982-83 \ldots \ldots \ldots . .$. & 39,804 & -1.5 & 14,695 & 25,109 & 63.1 & 8,763 & 4,013 & 4,750 & 692 & 404 & 288 \\
\hline $1983-84 \ldots \ldots \ldots$. & 40,131 & 0.8 & 15,089 & 25,042 & 62.4 & 8,526 & 3,897 & 4,629 & 730 & 406 & 324 \\
\hline $1984-85 \ldots \ldots \ldots . .$. & 38,285 & -4.6 & 14,518 & 23,767 & 62.1 & 8,720 & 3,896 & 4,824 & 696 & 407 & 289 \\
\hline $1985-86 \ldots \ldots \ldots \ldots \ldots \ldots \ldots$ & 37,241 & -2.7 & 14,236 & 23,005 & 61.8 & 8,420 & 3,775 & 4,645 & 722 & 396 & 326 \\
\hline $1986-87 \ldots \ldots \ldots \ldots \ldots \ldots$ & 36,873 & -1.0 & 13,980 & 22,893 & 62.1 & 8,508 & 3,756 & 4,752 & 793 & 447 & 346 \\
\hline $1987-88 \ldots \ldots$ & 37,150 & 0.8 & 14,225 & 22,925 & 61.7 & 7,939 & 3,442 & 4,497 & 727 & 424 & 303 \\
\hline $1988-89 \ldots .$. & 38,420 & 3.4 & 14,698 & 23,722 & 61.7 & 8,267 & 3,611 & 4,656 & 753 & 446 & 307 \\
\hline $1989-90 \ldots \ldots \ldots \ldots \ldots \ldots \ldots \ldots$ & 39,934 & 3.9 & 15,189 & 24,745 & 62.0 & 8,481 & 3,706 & 4,775 & 849 & 472 & 377 \\
\hline $1990-91 \ldots \ldots \ldots$ & 42,186 & 5.6 & 15,761 & 26,425 & 62.6 & 8,657 & 3,830 & 4,827 & 838 & 466 & 372 \\
\hline $1991-92 \ldots \ldots$ & 46,522 & 10.3 & 17,616 & 28,906 & 62.1 & 9,353 & 4,078 & 5,275 & 906 & 504 & 402 \\
\hline $1992-93 \ldots \ldots$ & 47,761 & 2.7 & 18,610 & 29,151 & 61.0 & 9,440 & 4,099 & 5,341 & 882 & 478 & 404 \\
\hline $1993-94 \ldots$ & 49,053 & 2.7 & 19,538 & 29,515 & 60.2 & 9,925 & 4,229 & 5,696 & 1,054 & 585 & 469 \\
\hline $1994-95 \ldots .$. & 48,690 & -0.7 & 19,781 & 28,909 & 59.4 & 10,277 & 4,374 & 5,903 & 1,080 & 545 & 535 \\
\hline $1995-96 \ldots \ldots .$. & 49,296 & 1.2 & 20,126 & 29,170 & 59.2 & 10,280 & 4,361 & 5,919 & 1,067 & 524 & 543 \\
\hline $1996-97 \ldots \ldots \ldots$ & 50,083 & 1.6 & 20,729 & 29,354 & 58.6 & 10,627 & 4,470 & 6,157 & 1,060 & 525 & 535 \\
\hline $1997-98 \ldots \ldots \ldots . .$. & 52,077 & 4.0 & 21,483 & 30,594 & 58.7 & 11,145 & 4,596 & 6,549 & 1,163 & 566 & 597 \\
\hline $1998-99 \ldots$ & 54,446 & 4.5 & 22,270 & 32,176 & 59.1 & 10,762 & 4,544 & 6,218 & 1,117 & 567 & 550 \\
\hline $1999-2000 \ldots$ & 58,791 & 8.0 & 24,003 & 34,788 & 59.2 & 10,918 & 4,672 & 6,246 & 1,127 & 537 & 590 \\
\hline $2000-01 \ldots \ldots$. & 61,148 & 4.0 & 24,967 & 36,181 & 59.2 & 11,404 & 4,788 & 6,616 & 1,167 & 568 & 599 \\
\hline $2001-02 \ldots \ldots \ldots . . .$. & 66,773 & 9.2 & 27,130 & 39,643 & 59.4 & 11,595 & 4,912 & 6,683 & 1,114 & 490 & 624 \\
\hline $2002-03 \ldots \ldots$ & 71,482 & 7.1 & 27,922 & 43,560 & 60.9 & 11,982 & 4,975 & 7,007 & 1,293 & 613 & 680 \\
\hline 2003-04.................... & 77,181 & 8.0 & 30,037 & 47,144 & 61.1 & 12,906 & 5,531 & 7,375 & 1,282 & 572 & 710 \\
\hline $2004-05 \ldots \ldots \ldots \ldots \ldots \ldots \ldots$ & 80,955 & 4.9 & 31,355 & 49,600 & 61.3 & 13,183 & 5,646 & 7,537 & 1,278 & 594 & 684 \\
\hline $2005-06$ & 83,297 & 2.9 & 32,117 & 51,180 & 61.4 & 13,530 & 5,801 & 7,729 & 1,383 & 639 & 744 \\
\hline $2006-07 \ldots \ldots \ldots \ldots$ & 85,186 & 2.3 & 32,729 & 52,457 & 61.6 & 13,767 & 5,910 & 7,857 & 1,364 & 625 & 739 \\
\hline $2007-08 \ldots \ldots . .$. & 87,703 & 3.0 & 33,862 & 53,841 & 61.4 & 14,164 & 5,998 & 8,166 & 1,453 & 675 & 778 \\
\hline $2008-09 \ldots \ldots \ldots \ldots \ldots \ldots \ldots \ldots$ & 89,140 & 1.6 & 35,051 & 54,089 & 60.7 & 14,918 & 6,325 & 8,593 & 1,569 & 726 & 843 \\
\hline $2009-10 \ldots \ldots \ldots \ldots \ldots \ldots \ldots$ & 91,802 & 3.0 & 35,768 & 56,034 & 61.0 & 15,552 & 6,525 & 9,027 & 1,599 & 700 & 899 \\
\hline $2010-11 \ldots \ldots \ldots . . .$. & 93,956 & 2.3 & 36,341 & 57,615 & 61.3 & 16,277 & 6,882 & 9,395 & 1,646 & 770 & 876 \\
\hline $2011-12 \ldots \ldots \ldots \ldots \ldots \ldots \ldots$ & 95,797 & 2.0 & 37,158 & 58,639 & 61.2 & 17,331 & 7,331 & 10,000 & 1,728 & 790 & 938 \\
\hline & & & & & & & & & & & \\
\hline $2001-02$ to $2006-07 \ldots \ldots$ & 27.6 & $t$ & 20.6 & 32.3 & $\dagger$ & 18.7 & 20.3 & 17.6 & 22.4 & 27.6 & 18.4 \\
\hline $2006-07$ to $2011-12 \ldots \ldots$. & 12.5 & $\dagger$ & 13.5 & 11.8 & $\dagger$ & 25.9 & 24.0 & 27.3 & 26.7 & 26.4 & 26.9 \\
\hline
\end{tabular}

†Not applicable.

\#Rounds to zero.

NOTE: Data are for postsecondary institutions participating in Title IV federal financial aid programs.
SOURCE: U.S. Department of Education, National Center for Education Statistics, Higher Education General Information Survey (HEGIS), "Degrees and Other Formal Awards Conferred" surveys, 1970-71 through 1985-86; Integrated Postsecondary Education Data System (IPEDS), "Completions Survey" (IPEDS-C:87-99); and IPEDS Fall 2000 through Fall 2012, Completions component. (This table was prepared August 2013.) 
Table 326.10. Graduation rates of first-time, full-time bachelor's degree-seeking students at 4-year postsecondary institutions, by race/ethnicity, time to completion, sex, and control of institution: Selected cohort entry years, 1996 through 2006

\begin{tabular}{|c|c|c|c|c|c|c|c|c|c|c|}
\hline \multirow{2}{*}{$\begin{array}{l}\text { Time to completion, sex, } \\
\text { control of institution, and } \\
\text { cohort entry year }\end{array}$} & \multirow[b]{2}{*}{ Total } & \multirow[b]{2}{*}{ White } & \multirow[b]{2}{*}{ Black } & \multirow[b]{2}{*}{ Hispanic } & \multicolumn{3}{|c|}{ Asian/Pacific Islander } & \multirow{2}{*}{$\begin{array}{r}\text { American } \\
\text { Indian/ } \\
\text { Alaska } \\
\text { Native }\end{array}$} & \multirow[b]{2}{*}{$\begin{array}{r}\text { Two or } \\
\text { more races }\end{array}$} & \multirow[b]{2}{*}{$\begin{array}{r}\text { Nonresident } \\
\text { alien }\end{array}$} \\
\hline & & & & & Total & Asian & $\begin{array}{r}\text { Pacific } \\
\text { Islander }\end{array}$ & & & \\
\hline 1 & 2 & 3 & 4 & 5 & 6 & 7 & 8 & 9 & 10 & 11 \\
\hline \multicolumn{11}{|l|}{$\begin{array}{l}\text { Graduating within } 4 \text { years after start, } \\
\text { males and females }\end{array}$} \\
\hline 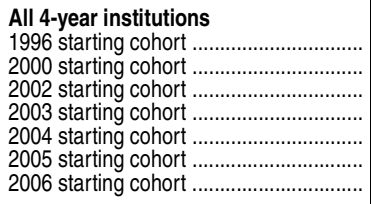 & $\begin{array}{l}33.7 \\
36.1 \\
36.4 \\
36.7 \\
37.9 \\
38.6 \\
39.0\end{array}$ & $\begin{array}{l}36.3 \\
38.9 \\
39.3 \\
40.0 \\
41.1 \\
41.9 \\
42.6\end{array}$ & $\begin{array}{l}19.5 \\
21.3 \\
20.4 \\
19.9 \\
20.4 \\
20.8 \\
20.5\end{array}$ & $\begin{array}{l}22.8 \\
25.9 \\
26.4 \\
26.5 \\
27.9 \\
28.6 \\
29.2\end{array}$ & $\begin{array}{l}37.5 \\
41.0 \\
42.8 \\
43.8 \\
45.0 \\
45.1 \\
45.8\end{array}$ & $\begin{array}{r}\overline{-} \\
\overline{-} \\
\overline{-} \\
45.5 \\
46.3\end{array}$ & $\begin{array}{r}\overline{-} \\
\overline{-} \\
\overline{-} \\
22.7 \\
24.2\end{array}$ & $\begin{array}{l}18.8 \\
21.0 \\
20.5 \\
20.4 \\
21.8 \\
22.5 \\
21.9\end{array}$ & $\begin{array}{r}\overline{-} \\
\overline{-} \\
\overline{-} \\
\overline{4} .0 \\
46.5\end{array}$ & $\begin{array}{l}41.7 \\
41.9 \\
38.7 \\
37.3 \\
43.7 \\
44.0 \\
44.1\end{array}$ \\
\hline 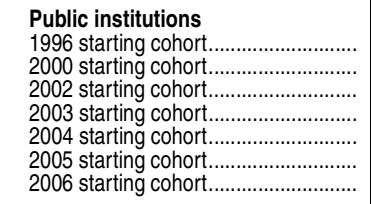 & $\begin{array}{l}26.0 \\
29.0 \\
29.9 \\
30.7 \\
31.3 \\
32.0 \\
32.8\end{array}$ & $\begin{array}{l}28.3 \\
31.4 \\
32.3 \\
33.4 \\
34.2 \\
35.2 \\
36.0\end{array}$ & $\begin{array}{l}15.0 \\
17.9 \\
16.9 \\
16.5 \\
16.4 \\
16.6 \\
17.0\end{array}$ & $\begin{array}{l}15.8 \\
18.9 \\
20.1 \\
20.6 \\
21.5 \\
22.5 \\
23.1\end{array}$ & $\begin{array}{l}28.5 \\
33.7 \\
35.8 \\
37.5 \\
37.9 \\
38.8 \\
39.8\end{array}$ & $\begin{array}{r}\overline{-} \\
\overline{-} \\
\overline{-} \\
39.1 \\
40.2\end{array}$ & $\begin{array}{r}\overline{-} \\
\overline{-} \\
\overline{-} \\
16 . \overline{9} \\
18.6\end{array}$ & $\begin{array}{l}14.5 \\
16.4 \\
16.0 \\
17.0 \\
17.2 \\
17.9 \\
17.9\end{array}$ & $\begin{array}{r}\overline{-} \\
\overline{-} \\
\overline{-} \\
28.8 \\
30.5\end{array}$ & $\begin{array}{l}30.9 \\
32.7 \\
33.4 \\
33.7 \\
34.4 \\
33.5 \\
33.8\end{array}$ \\
\hline 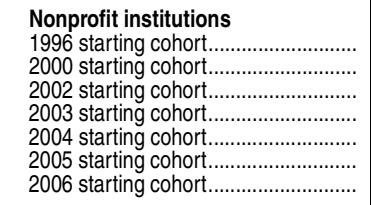 & $\begin{array}{l}48.6 \\
50.3 \\
51.0 \\
51.5 \\
52.4 \\
51.9 \\
52.9\end{array}$ & $\begin{array}{l}51.3 \\
53.5 \\
54.0 \\
54.6 \\
55.3 \\
55.0 \\
56.2\end{array}$ & $\begin{array}{l}29.3 \\
28.2 \\
29.4 \\
29.7 \\
30.5 \\
29.2 \\
29.7\end{array}$ & $\begin{array}{l}39.9 \\
42.9 \\
44.1 \\
43.9 \\
46.1 \\
44.9 \\
47.4\end{array}$ & $\begin{array}{l}57.9 \\
58.8 \\
61.0 \\
61.4 \\
62.8 \\
62.0 \\
62.8\end{array}$ & $\begin{array}{r}\bar{Z} \\
\overline{-} \\
\overline{-} \\
62.5 \\
63.5\end{array}$ & $\begin{array}{r}\overline{-} \\
\overline{-} \\
\overline{-} \\
35.1 \\
37.2\end{array}$ & $\begin{array}{l}33.7 \\
36.0 \\
36.6 \\
34.3 \\
39.0 \\
35.1 \\
38.2\end{array}$ & $\begin{array}{r}\overline{-} \\
\overline{-} \\
\overline{-} \\
59.7 \\
61.9\end{array}$ & $\begin{array}{l}50.4 \\
50.3 \\
54.8 \\
55.1 \\
57.4 \\
57.3 \\
56.8\end{array}$ \\
\hline 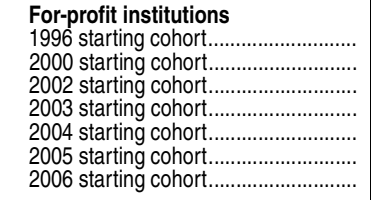 & $\begin{array}{l}21.8 \\
25.7 \\
14.2 \\
12.7 \\
20.4 \\
35.4 \\
22.8\end{array}$ & $\begin{array}{l}26.3 \\
30.3 \\
17.5 \\
16.0 \\
27.0 \\
38.9 \\
32.6\end{array}$ & $\begin{array}{r}14.8 \\
22.5 \\
10.0 \\
8.9 \\
13.2 \\
27.7 \\
12.7\end{array}$ & $\begin{array}{l}20.1 \\
27.4 \\
19.1 \\
17.9 \\
20.6 \\
27.6 \\
23.0\end{array}$ & $\begin{array}{l}24.6 \\
42.7 \\
29.4 \\
24.1 \\
31.5 \\
40.8 \\
30.1\end{array}$ & $\begin{array}{r}\overline{-} \\
\overline{-} \\
\overline{-} \\
43.0 \\
32.4\end{array}$ & $\begin{array}{r}\overline{-} \\
\overline{-} \\
\overline{-} \\
20.0 \\
9.4\end{array}$ & $\begin{array}{r}16.5 \\
28.0 \\
11.2 \\
6.8 \\
9.3 \\
33.6 \\
13.0\end{array}$ & $\begin{array}{r}\overline{-} \\
\overline{-} \\
\overline{-} \\
24.1 \\
27.6\end{array}$ & $\begin{array}{r}33.8 \\
36.5 \\
3.4 \\
3.6 \\
10.5 \\
15.3 \\
22.4\end{array}$ \\
\hline \multicolumn{11}{|l|}{$\begin{array}{l}\text { Graduating within } 4 \text { years after } \\
\text { start, males }\end{array}$} \\
\hline 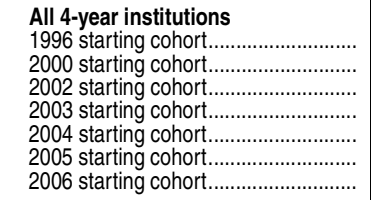 & $\begin{array}{l}28.5 \\
31.1 \\
31.3 \\
31.9 \\
32.9 \\
34.1 \\
34.2\end{array}$ & $\begin{array}{l}30.6 \\
33.4 \\
33.8 \\
34.6 \\
35.6 \\
36.6 \\
37.1\end{array}$ & $\begin{array}{l}13.9 \\
15.5 \\
14.7 \\
14.6 \\
15.0 \\
16.3 \\
15.6\end{array}$ & $\begin{array}{l}19.0 \\
21.8 \\
21.8 \\
22.3 \\
23.2 \\
24.8 \\
24.9\end{array}$ & $\begin{array}{l}32.2 \\
35.7 \\
37.4 \\
38.9 \\
39.9 \\
40.0 \\
41.1\end{array}$ & $\begin{array}{r}\bar{Z} \\
\overline{-} \\
\overline{\overline{ }} \\
40.3 \\
41.5\end{array}$ & $\begin{array}{r}\overline{-} \\
\overline{-} \\
\overline{-} \\
20.8 \\
21.6\end{array}$ & $\begin{array}{l}15.1 \\
17.1 \\
17.2 \\
17.5 \\
18.9 \\
20.1 \\
17.6\end{array}$ & $\begin{array}{r}\overline{-} \\
\overline{-} \\
\overline{-} \\
40.1 \\
43.1\end{array}$ & $\begin{array}{l}38.6 \\
39.3 \\
36.6 \\
36.1 \\
39.7 \\
40.2 \\
39.6\end{array}$ \\
\hline 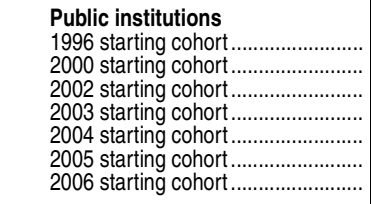 & $\begin{array}{l}20.8 \\
23.6 \\
24.5 \\
25.6 \\
26.1 \\
27.1 \\
27.8\end{array}$ & $\begin{array}{l}22.6 \\
25.5 \\
26.6 \\
27.8 \\
28.4 \\
29.7 \\
30.3\end{array}$ & $\begin{array}{r}9.9 \\
11.7 \\
11.0 \\
10.9 \\
11.2 \\
11.5 \\
11.9\end{array}$ & $\begin{array}{l}12.5 \\
14.5 \\
15.8 \\
16.4 \\
16.9 \\
18.4 \\
18.7\end{array}$ & $\begin{array}{l}23.4 \\
27.8 \\
30.4 \\
32.5 \\
32.8 \\
33.5 \\
34.8\end{array}$ & $\begin{array}{r}\overline{-} \\
\overline{-} \\
\overline{-} \\
33.8 \\
35.1\end{array}$ & $\begin{array}{r}\overline{-} \\
\overline{-} \\
\overline{-} \\
\overline{\overline{1}} \overline{14.0} \\
15.4\end{array}$ & $\begin{array}{l}10.9 \\
11.9 \\
12.7 \\
14.1 \\
14.5 \\
15.0 \\
13.7\end{array}$ & $\begin{array}{r}\overline{-} \\
\overline{-} \\
\overline{-} \\
26.5 \\
29.2\end{array}$ & $\begin{array}{l}28.6 \\
30.2 \\
30.3 \\
30.6 \\
30.1 \\
29.9 \\
29.5\end{array}$ \\
\hline $\begin{array}{l}\text { Nonprofit institutions } \\
1996 \text { starting cohort ........................ } \\
2000 \text { starting cohort.................... } \\
2002 \text { starting cohort..................... } \\
2003 \text { starting cohort..................... } \\
2004 \text { starting cohort.................... } \\
2005 \text { starting cohort ...................... } \\
2006 \text { starting cohort ..................... }\end{array}$ & $\begin{array}{l}43.6 \\
46.0 \\
46.3 \\
46.9 \\
47.7 \\
47.2 \\
48.2\end{array}$ & $\begin{array}{l}46.2 \\
48.9 \\
49.1 \\
49.7 \\
50.5 \\
50.2 \\
51.2\end{array}$ & $\begin{array}{l}22.1 \\
22.3 \\
22.9 \\
23.1 \\
23.2 \\
22.6 \\
23.5\end{array}$ & $\begin{array}{l}35.0 \\
38.2 \\
38.8 \\
39.8 \\
41.1 \\
40.5 \\
42.4\end{array}$ & $\begin{array}{l}53.5 \\
56.1 \\
57.6 \\
58.4 \\
59.1 \\
58.4 \\
60.2\end{array}$ & $\begin{array}{r}\overline{-} \\
\overline{-} \\
\overline{-} \\
58.9 \\
60.9\end{array}$ & $\begin{array}{r}- \\
- \\
- \\
29.9 \\
34.6\end{array}$ & $\begin{array}{l}28.9 \\
33.2 \\
32.1 \\
30.6 \\
35.4 \\
30.7 \\
34.3\end{array}$ & $\begin{array}{r}\overline{-} \\
\overline{-} \\
\overline{-} \\
55.5 \\
58.2\end{array}$ & $\begin{array}{l}47.0 \\
48.0 \\
50.6 \\
51.1 \\
53.2 \\
52.6 \\
52.2\end{array}$ \\
\hline 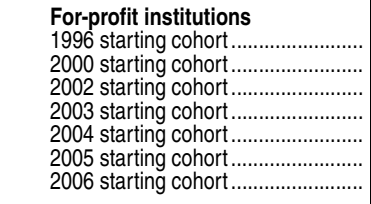 & $\begin{array}{l}22.3 \\
30.1 \\
17.0 \\
15.3 \\
23.3 \\
42.1 \\
27.8\end{array}$ & $\begin{array}{l}25.5 \\
34.3 \\
20.9 \\
18.9 \\
30.2 \\
44.6 \\
37.3\end{array}$ & $\begin{array}{l}16.1 \\
23.7 \\
11.8 \\
10.6 \\
14.8 \\
36.0 \\
16.6\end{array}$ & $\begin{array}{l}23.0 \\
30.9 \\
20.1 \\
19.4 \\
21.6 \\
32.5 \\
26.0\end{array}$ & $\begin{array}{l}27.7 \\
44.5 \\
33.3 \\
27.0 \\
36.6 \\
42.6 \\
33.7\end{array}$ & $\begin{array}{r}\overline{-} \\
\overline{-} \\
\overline{-} \\
43.6 \\
35.2\end{array}$ & $\begin{array}{r}\overline{-} \\
\overline{-} \\
\overline{-} \\
31.0 \\
17.2\end{array}$ & $\begin{array}{r}25.6 \\
28.7 \\
17.6 \\
9.4 \\
12.3 \\
47.6 \\
14.7\end{array}$ & $\begin{array}{r}\overline{-} \\
\overline{-} \\
\overline{-} \\
24.2 \\
30.1\end{array}$ & $\begin{array}{r}33.1 \\
36.7 \\
4.0 \\
4.8 \\
10.7 \\
16.5 \\
23.7\end{array}$ \\
\hline \multicolumn{11}{|l|}{$\begin{array}{l}\text { Graduating within } 4 \text { years after } \\
\text { start, females }\end{array}$} \\
\hline 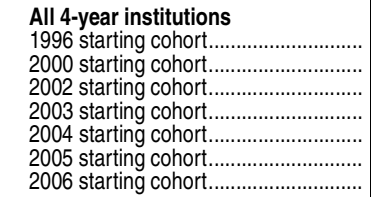 & $\begin{array}{l}38.0 \\
40.2 \\
40.5 \\
40.6 \\
42.1 \\
42.3 \\
43.0\end{array}$ & $\begin{array}{l}41.1 \\
43.5 \\
43.9 \\
44.4 \\
45.8 \\
46.3 \\
47.3\end{array}$ & $\begin{array}{l}23.2 \\
25.2 \\
24.3 \\
23.6 \\
24.1 \\
23.9 \\
23.7\end{array}$ & $\begin{array}{l}25.8 \\
29.0 \\
29.9 \\
29.5 \\
31.3 \\
31.4 \\
32.5\end{array}$ & $\begin{array}{l}42.2 \\
45.7 \\
47.4 \\
48.0 \\
49.4 \\
49.6 \\
50.1\end{array}$ & $\begin{array}{r}\bar{Z} \\
\overline{-} \\
\overline{-} \\
50.1 \\
50.6\end{array}$ & $\begin{array}{r}\overline{-} \\
\overline{-} \\
\overline{-} \\
24.2 \\
26.1\end{array}$ & $\begin{array}{l}21.7 \\
24.0 \\
23.0 \\
22.5 \\
23.9 \\
24.4 \\
25.1\end{array}$ & $\begin{array}{r}\bar{Z} \\
\overline{-} \\
\overline{-} \\
47.3 \\
49.0\end{array}$ & $\begin{array}{l}45.8 \\
45.3 \\
41.0 \\
38.4 \\
48.1 \\
48.4 \\
49.3\end{array}$ \\
\hline
\end{tabular}

See notes at end of table. 
Table 326.10. Graduation rates of first-time, full-time bachelor's degree-seeking students at 4-year postsecondary institutions, by race/ethnicity, time to completion, sex, and control of institution: Selected cohort entry years, 1996 through 2006-Continued

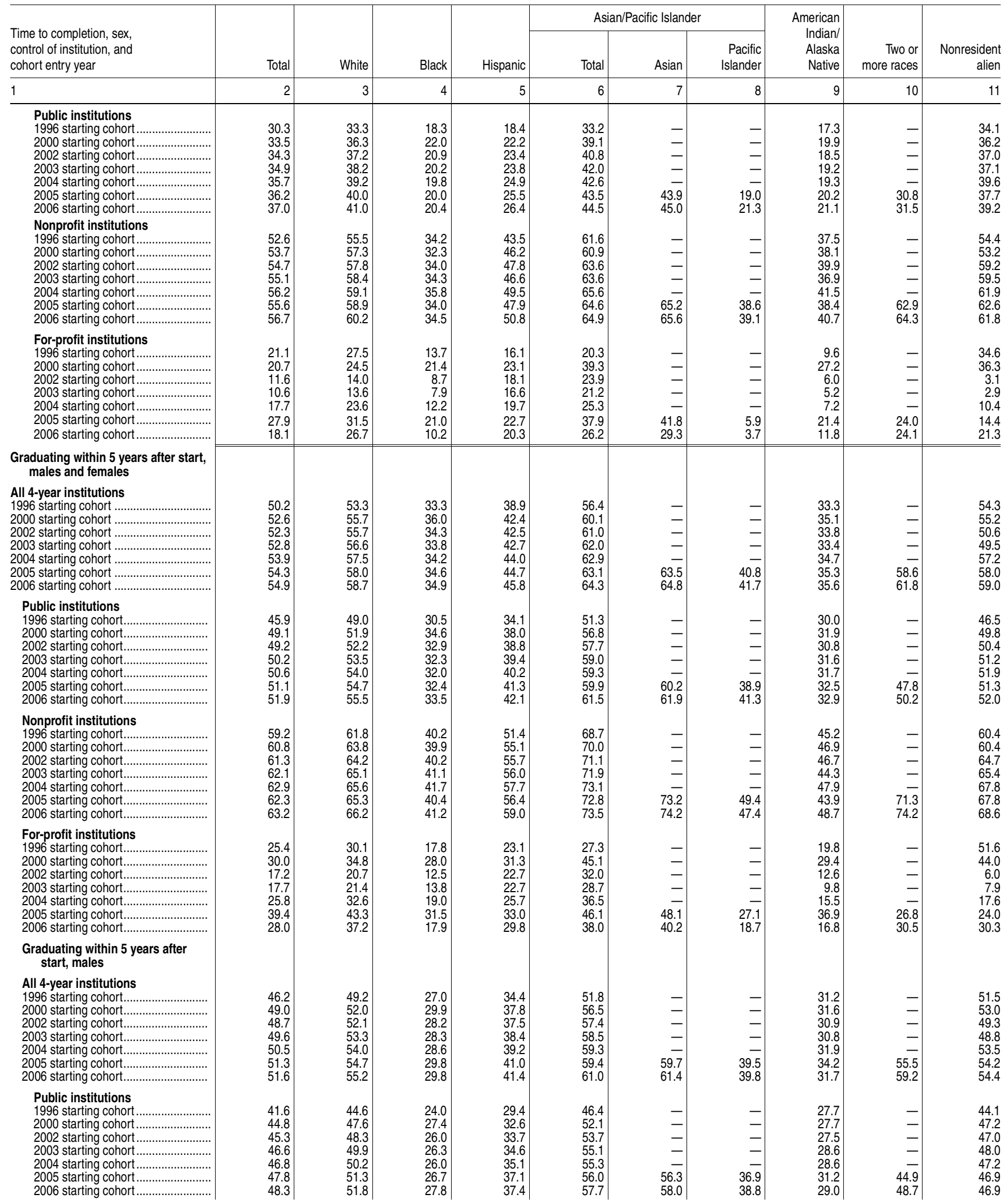

See notes at end of table. 
Table 326.10. Graduation rates of first-time, full-time bachelor's degree-seeking students at 4-year postsecondary institutions, by race/ethnicity, time to completion, sex, and control of institution: Selected cohort entry years, 1996 through 2006-Continued

\begin{tabular}{|c|c|c|c|c|c|c|c|c|c|c|}
\hline \multirow{2}{*}{$\begin{array}{l}\text { Time to completion, sex, } \\
\text { control of institution, and } \\
\text { cohort entry year }\end{array}$} & \multirow[b]{2}{*}{ Total } & \multirow[b]{2}{*}{ White } & \multirow[b]{2}{*}{ Black } & \multirow[b]{2}{*}{ Hispanic } & \multicolumn{3}{|c|}{ Asian/Pacific Islander } & \multirow{2}{*}{$\begin{array}{r}\text { American } \\
\text { Indian/ } \\
\text { Alaska } \\
\text { Native }\end{array}$} & \multirow[b]{2}{*}{$\begin{array}{r}\text { Two or } \\
\text { more races }\end{array}$} & \multirow[b]{2}{*}{$\begin{array}{r}\text { Nonresident } \\
\text { alien }\end{array}$} \\
\hline & & & & & Total & Asian & $\begin{array}{r}\text { Pacific } \\
\text { Islander }\end{array}$ & & & \\
\hline 1 & 2 & 3 & 4 & 5 & 6 & 7 & 8 & 9 & 10 & 11 \\
\hline 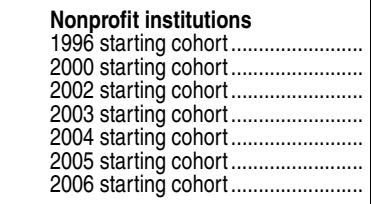 & $\begin{array}{l}55.8 \\
58.5 \\
58.5 \\
59.3 \\
60.0 \\
59.2 \\
60.1\end{array}$ & $\begin{array}{l}58.5 \\
61.3 \\
61.5 \\
62.3 \\
62.8 \\
62.2 \\
63.2\end{array}$ & $\begin{array}{l}34.0 \\
35.1 \\
34.7 \\
35.0 \\
35.5 \\
34.7 \\
35.6\end{array}$ & $\begin{array}{l}47.4 \\
51.7 \\
51.4 \\
53.1 \\
53.9 \\
53.2 \\
55.4\end{array}$ & $\begin{array}{l}65.9 \\
69.9 \\
70.0 \\
70.6 \\
71.1 \\
70.2 \\
72.2\end{array}$ & $\begin{array}{r}\overline{-} \\
\overline{-} \\
\overline{-} \\
70.6 \\
72.9\end{array}$ & $\begin{array}{r}- \\
\overline{-} \\
- \\
\overline{-} \\
45.2 \\
44.7\end{array}$ & $\begin{array}{l}42.9 \\
45.9 \\
44.0 \\
41.5 \\
45.9 \\
40.3 \\
45.7\end{array}$ & $\begin{array}{r}- \\
- \\
- \\
-\overline{-} \\
69.1 \\
72.5\end{array}$ & $\begin{array}{l}57.7 \\
58.9 \\
61.9 \\
62.1 \\
64.4 \\
63.8 \\
64.4\end{array}$ \\
\hline 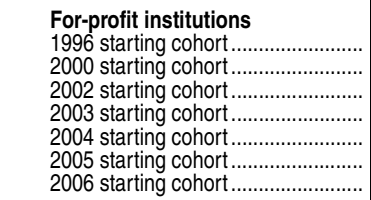 & $\begin{array}{l}25.6 \\
33.6 \\
19.9 \\
20.0 \\
27.6 \\
45.6 \\
32.5\end{array}$ & $\begin{array}{l}29.2 \\
38.1 \\
24.1 \\
24.1 \\
34.8 \\
48.5 \\
41.5\end{array}$ & $\begin{array}{l}18.1 \\
27.6 \\
14.3 \\
14.5 \\
18.9 \\
38.8 \\
20.9\end{array}$ & $\begin{array}{l}25.4 \\
34.4 \\
23.6 \\
23.4 \\
26.0 \\
36.7 \\
32.0\end{array}$ & $\begin{array}{l}29.9 \\
46.4 \\
35.4 \\
30.7 \\
41.5 \\
47.3 \\
40.8\end{array}$ & $\begin{array}{r}- \\
\overline{-} \\
\overline{-} \\
48.1 \\
42.1\end{array}$ & $\begin{array}{r}- \\
- \\
- \\
- \\
39.1 \\
25.9\end{array}$ & $\begin{array}{l}30.8 \\
28.7 \\
18.5 \\
13.3 \\
15.1 \\
50.9 \\
18.2\end{array}$ & $\begin{array}{r}- \\
- \\
- \\
- \\
27.5 \\
34.0\end{array}$ & $\begin{array}{r}51.0 \\
43.1 \\
6.3 \\
7.8 \\
16.8 \\
24.8 \\
32.4\end{array}$ \\
\hline \multicolumn{11}{|l|}{$\begin{array}{l}\text { Graduating within } 5 \text { years after } \\
\text { start, females }\end{array}$} \\
\hline 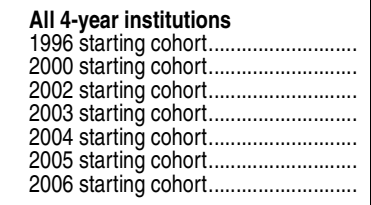 & $\begin{array}{l}53.6 \\
55.6 \\
55.2 \\
55.4 \\
56.8 \\
56.8 \\
57.6\end{array}$ & $\begin{array}{l}56.8 \\
58.8 \\
58.6 \\
59.4 \\
60.5 \\
60.8 \\
61.7\end{array}$ & $\begin{array}{l}37.5 \\
40.2 \\
38.4 \\
37.6 \\
38.1 \\
37.9 \\
38.4\end{array}$ & $\begin{array}{l}42.4 \\
45.9 \\
46.2 \\
45.8 \\
47.5 \\
47.4 \\
49.0\end{array}$ & $\begin{array}{l}60.5 \\
63.4 \\
64.1 \\
64.9 \\
66.0 \\
66.4 \\
67.3\end{array}$ & $\begin{array}{r}\overline{-} \\
\overline{-} \\
\overline{-} \\
66.9 \\
67.9\end{array}$ & $\begin{array}{r}\overline{-} \\
\overline{-} \\
\overline{-} \\
41.8 \\
43.2\end{array}$ & $\begin{array}{l}34.9 \\
37.8 \\
36.0 \\
35.3 \\
36.8 \\
36.1 \\
38.5\end{array}$ & $\begin{array}{r}- \\
\overline{-} \\
\overline{-} \\
61.2 \\
63.6\end{array}$ & $\begin{array}{l}57.9 \\
58.0 \\
52.0 \\
50.1 \\
61.3 \\
62.4 \\
64.2\end{array}$ \\
\hline 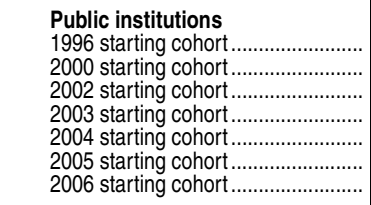 & $\begin{array}{l}49.5 \\
52.7 \\
52.5 \\
53.2 \\
53.7 \\
53.9 \\
54.9\end{array}$ & $\begin{array}{l}52.7 \\
55.5 \\
55.4 \\
56.6 \\
57.3 \\
57.7 \\
58.7\end{array}$ & $\begin{array}{l}34.8 \\
39.3 \\
37.6 \\
36.4 \\
35.9 \\
36.1 \\
37.2\end{array}$ & $\begin{array}{l}37.8 \\
42.1 \\
42.6 \\
43.1 \\
44.0 \\
44.4 \\
45.7\end{array}$ & $\begin{array}{l}56.0 \\
61.0 \\
61.5 \\
62.5 \\
62.9 \\
63.3 \\
65.1\end{array}$ & $\begin{array}{r}\overline{-} \\
\overline{-} \\
\overline{-} \\
63.7 \\
65.5\end{array}$ & $\begin{array}{r}- \\
\overline{-} \\
\overline{-} \\
40.4 \\
43.3\end{array}$ & $\begin{array}{l}31.8 \\
35.1 \\
33.2 \\
33.8 \\
34.0 \\
33.5 \\
36.0\end{array}$ & $\begin{array}{r}- \\
\overline{-} \\
\overline{-} \\
50.3 \\
51.4\end{array}$ & $\begin{array}{l}50.0 \\
53.5 \\
54.4 \\
54.8 \\
57.5 \\
56.5 \\
58.2\end{array}$ \\
\hline 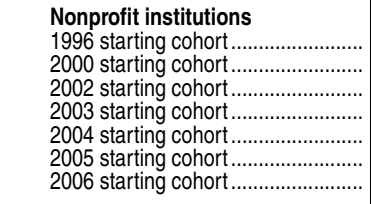 & $\begin{array}{l}61.8 \\
62.7 \\
63.5 \\
64.4 \\
65.2 \\
64.8 \\
65.7\end{array}$ & $\begin{array}{l}64.5 \\
65.8 \\
66.4 \\
67.3 \\
67.8 \\
67.7 \\
68.5\end{array}$ & $\begin{array}{l}44.5 \\
43.2 \\
44.0 \\
45.4 \\
46.2 \\
44.6 \\
45.5\end{array}$ & $\begin{array}{l}54.3 \\
57.4 \\
58.7 \\
57.9 \\
60.3 \\
58.6 \\
61.5\end{array}$ & $\begin{array}{l}71.0 \\
70.0 \\
71.9 \\
72.9 \\
74.6 \\
74.7 \\
74.5\end{array}$ & $\begin{array}{r}\overline{-} \\
\overline{-} \\
\overline{-} \\
75.2 \\
75.2\end{array}$ & $\begin{array}{r}- \\
\overline{-} \\
\overline{-} \\
52.3 \\
49.3\end{array}$ & $\begin{array}{l}47.0 \\
47.7 \\
48.6 \\
46.3 \\
49.2 \\
46.6 \\
50.6\end{array}$ & $\begin{array}{r}- \\
\overline{-} \\
\overline{-} \\
72.9 \\
75.3\end{array}$ & $\begin{array}{l}63.7 \\
62.3 \\
67.7 \\
69.1 \\
71.5 \\
72.3 \\
73.2\end{array}$ \\
\hline 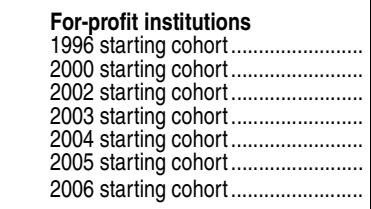 & $\begin{array}{l}25.1 \\
25.9 \\
14.7 \\
15.9 \\
24.1 \\
32.5 \\
23.8\end{array}$ & $\begin{array}{l}31.4 \\
30.0 \\
17.3 \\
19.1 \\
30.3 \\
36.5 \\
31.8 \\
\end{array}$ & $\begin{array}{l}17.6 \\
28.4 \\
11.2 \\
13.4 \\
19.1 \\
25.5 \\
15.8\end{array}$ & $\begin{array}{l}20.0 \\
27.5 \\
21.7 \\
22.1 \\
25.4 \\
29.3 \\
27.8\end{array}$ & $\begin{array}{l}23.7 \\
42.6 \\
27.1 \\
26.7 \\
30.5 \\
44.1 \\
35.1 \\
\end{array}$ & $\begin{array}{r}- \\
\overline{-} \\
\overline{-} \\
\overline{-} \\
48.0 \\
38.1\end{array}$ & $\begin{array}{r}\overline{-} \\
\overline{-} \\
\overline{-} \\
\overline{11.8} \\
13.6\end{array}$ & $\begin{array}{r}11.5 \\
30.4 \\
8.0 \\
7.6 \\
15.8 \\
24.7 \\
15.8 \\
\end{array}$ & $\begin{array}{r}- \\
- \\
- \\
- \\
26.0 \\
25.9\end{array}$ & $\begin{array}{r}52.2 \\
45.1 \\
5.8 \\
8.0 \\
18.2 \\
23.5 \\
28.5 \\
\end{array}$ \\
\hline \multicolumn{11}{|l|}{$\begin{array}{l}\text { Graduating within } 6 \text { years after start, } \\
\text { males and females }\end{array}$} \\
\hline 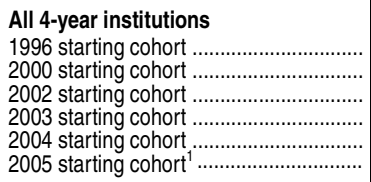 & $\begin{array}{l}55.4 \\
57.5 \\
57.2 \\
57.4 \\
58.3 \\
58.7\end{array}$ & $\begin{array}{l}58.1 \\
60.2 \\
60.2 \\
60.8 \\
61.5 \\
62.1\end{array}$ & $\begin{array}{l}38.9 \\
42.1 \\
40.1 \\
39.1 \\
39.5 \\
39.9\end{array}$ & $\begin{array}{l}45.7 \\
49.1 \\
48.9 \\
48.7 \\
50.1 \\
51.0\end{array}$ & $\begin{array}{l}63.4 \\
66.7 \\
67.1 \\
68.0 \\
68.7 \\
69.2\end{array}$ & $\begin{array}{r}- \\
\overline{-} \\
\overline{-} \\
69.6\end{array}$ & $\begin{array}{r}- \\
- \\
- \\
48 \overline{5}\end{array}$ & $\begin{array}{l}38.0 \\
40.2 \\
38.3 \\
38.3 \\
39.4 \\
39.8\end{array}$ & $\begin{array}{r}- \\
- \\
- \\
64.3\end{array}$ & $\begin{array}{l}58.0 \\
59.6 \\
55.3 \\
53.3 \\
61.5 \\
62.6\end{array}$ \\
\hline 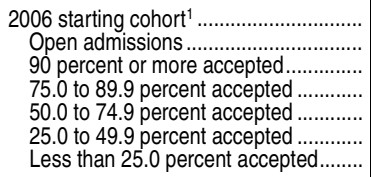 & $\begin{array}{l}59.2 \\
32.8 \\
47.6 \\
55.9 \\
60.5 \\
72.4 \\
85.6\end{array}$ & $\begin{array}{l}62.5 \\
41.3 \\
50.2 \\
58.8 \\
63.9 \\
76.6 \\
88.9\end{array}$ & $\begin{array}{l}40.2 \\
19.3 \\
32.7 \\
38.3 \\
43.2 \\
51.6 \\
58.7\end{array}$ & $\begin{array}{l}51.9 \\
30.3 \\
40.1 \\
47.4 \\
51.9 \\
65.1 \\
85.0\end{array}$ & $\begin{array}{l}70.1 \\
37.8 \\
49.5 \\
61.2 \\
67.8 \\
80.2 \\
91.8\end{array}$ & $\begin{array}{l}70.6 \\
40.1 \\
49.8 \\
61.3 \\
68.2 \\
80.5 \\
92.3\end{array}$ & $\begin{array}{l}48.5 \\
21.3 \\
38.2 \\
54.5 \\
49.6 \\
57.5 \\
68.1\end{array}$ & $\begin{array}{l}40.2 \\
17.6 \\
29.2 \\
40.9 \\
42.2 \\
55.0 \\
79.4\end{array}$ & $\begin{array}{l}66.6 \\
36.8 \\
46.5 \\
59.8 \\
60.4 \\
79.1 \\
91.6\end{array}$ & $\begin{array}{l}63.6 \\
38.1 \\
48.0 \\
59.6 \\
62.3 \\
73.5 \\
88.5\end{array}$ \\
\hline 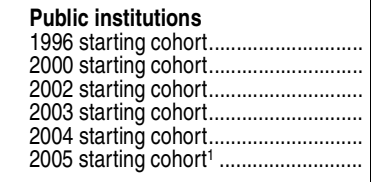 & $\begin{array}{l}51.7 \\
54.8 \\
54.9 \\
55.7 \\
56.0 \\
56.5\end{array}$ & $\begin{array}{l}54.3 \\
57.1 \\
57.4 \\
58.6 \\
58.9 \\
59.6\end{array}$ & $\begin{array}{l}36.8 \\
40.8 \\
39.4 \\
38.6 \\
38.3 \\
38.6\end{array}$ & $\begin{array}{l}42.1 \\
46.0 \\
46.3 \\
46.9 \\
47.8 \\
48.7\end{array}$ & $\begin{array}{l}59.5 \\
64.1 \\
64.7 \\
65.8 \\
66.2 \\
67.0\end{array}$ & $\begin{array}{c}\overline{-} \\
\overline{-} \\
\overline{-} \\
67.2\end{array}$ & $\begin{array}{c}- \\
- \\
- \\
\overline{-} \\
49.5\end{array}$ & $\begin{array}{l}35.3 \\
37.5 \\
35.7 \\
37.1 \\
37.0 \\
37.8\end{array}$ & $\begin{array}{r}- \\
\overline{-} \\
\overline{-} \\
55.9\end{array}$ & $\begin{array}{l}51.3 \\
54.6 \\
55.5 \\
56.2 \\
57.2 \\
57.3\end{array}$ \\
\hline 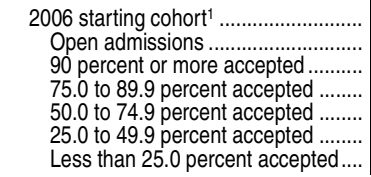 & $\begin{array}{l}57.2 \\
32.2 \\
47.9 \\
54.0 \\
60.0 \\
70.0 \\
70.4\end{array}$ & $\begin{array}{l}60.2 \\
38.5 \\
50.3 \\
56.9 \\
63.3 \\
73.5 \\
80.4\end{array}$ & $\begin{array}{l}39.7 \\
18.2 \\
32.4 \\
37.4 \\
44.3 \\
50.2 \\
34.6\end{array}$ & $\begin{array}{l}49.5 \\
29.0 \\
40.1 \\
46.0 \\
50.8 \\
61.6 \\
70.1\end{array}$ & $\begin{array}{l}68.2 \\
34.8 \\
50.3 \\
60.9 \\
67.5 \\
78.6 \\
69.6\end{array}$ & $\begin{array}{l}68.5 \\
36.0 \\
50.5 \\
61.0 \\
67.9 \\
78.8 \\
70.0\end{array}$ & $\begin{array}{l}49.1 \\
10.0 \\
25.0 \\
52.1 \\
49.0 \\
55.8 \\
63.2\end{array}$ & $\begin{array}{l}38.2 \\
13.7 \\
29.6 \\
40.3 \\
41.0 \\
50.7 \\
70.2\end{array}$ & $\begin{array}{l}57.0 \\
31.4 \\
57.1 \\
50.8 \\
54.6 \\
76.5 \\
79.7\end{array}$ & $\begin{array}{l}57.7 \\
44.4 \\
45.8 \\
58.2 \\
59.7 \\
64.5 \\
74.8\end{array}$ \\
\hline
\end{tabular}

See notes at end of table. 
Table 326.10. Graduation rates of first-time, full-time bachelor's degree-seeking students at 4-year postsecondary institutions, by race/ethnicity, time to completion, sex, and control of institution: Selected cohort entry years, 1996 through 2006-Continued

\begin{tabular}{|c|c|c|c|c|c|c|c|c|c|c|}
\hline \multirow{2}{*}{$\begin{array}{l}\text { Time to completion, sex, } \\
\text { control of institution, and } \\
\text { cohort entry year }\end{array}$} & \multirow[b]{2}{*}{ Total } & \multirow[b]{2}{*}{ White } & \multirow[b]{2}{*}{ Black } & \multirow[b]{2}{*}{ Hispanic } & \multicolumn{3}{|c|}{ Asian/Pacific Islander } & \multirow{2}{*}{$\begin{array}{r}\text { American } \\
\text { Indian/ } \\
\text { Alaska } \\
\text { Native }\end{array}$} & \multirow[b]{2}{*}{$\begin{array}{r}\text { Two or } \\
\text { more races }\end{array}$} & \multirow[b]{2}{*}{$\begin{array}{r}\text { Nonresident } \\
\text { alien }\end{array}$} \\
\hline & & & & & Total & Asian & $\begin{array}{r}\text { Pacific } \\
\text { Islander }\end{array}$ & & & \\
\hline 1 & 2 & 3 & 4 & 5 & 6 & 7 & 8 & 9 & 10 & 11 \\
\hline $\begin{array}{l}\text { Nonprofit institutions } \\
1996 \text { starting cohort........................... } \\
2000 \text { starting cohort....................... } \\
2002 \text { starting cohort......................... } \\
2003 \text { starting cohort........................ } \\
2004 \text { starting cohort........................ } \\
2005 \text { starting cohort }{ }^{1}\end{array}$ & $\begin{array}{l}63.1 \\
64.5 \\
64.6 \\
65.1 \\
65.4 \\
65.1\end{array}$ & $\begin{array}{l}65.7 \\
67.0 \\
67.2 \\
67.7 \\
67.9 \\
67.8\end{array}$ & $\begin{array}{l}44.6 \\
45.9 \\
44.9 \\
45.0 \\
44.9 \\
43.8\end{array}$ & $\begin{array}{l}55.7 \\
59.0 \\
59.5 \\
59.4 \\
60.5 \\
60.4\end{array}$ & $\begin{array}{l}73.5 \\
75.2 \\
75.3 \\
75.9 \\
76.2 \\
76.4\end{array}$ & $\begin{array}{r}\overline{-} \\
\overline{-} \\
\overline{-} \\
76.9\end{array}$ & $\begin{array}{r}- \\
- \\
- \\
- \\
52.6\end{array}$ & $\begin{array}{l}48.1 \\
50.9 \\
49.8 \\
47.6 \\
50.7 \\
46.4\end{array}$ & $\begin{array}{r}- \\
- \\
- \\
- \\
75.2\end{array}$ & $\begin{array}{l}63.4 \\
64.5 \\
68.3 \\
69.1 \\
71.2 \\
71.0\end{array}$ \\
\hline $\begin{array}{r}2006 \text { starting cohort }{ }^{1} . . . \ldots \ldots \ldots . . . . . . . . . . . . . . \\
\text { Open admissions .......................... } \\
90 \text { percent or more accepted .......... } \\
75.0 \text { to } 89.9 \text { percent accepted ........ } \\
50.0 \text { to } 74.9 \text { percent accepted ......... } \\
25.0 \text { to } 49.9 \text { percent accepted ........ } \\
\text { Less than } 25.0 \text { percent accepted.... }\end{array}$ & $\begin{array}{l}65.5 \\
38.1 \\
48.5 \\
61.1 \\
62.3 \\
77.5 \\
90.6\end{array}$ & $\begin{array}{l}68.1 \\
44.8 \\
51.2 \\
63.8 \\
65.8 \\
81.0 \\
92.2\end{array}$ & $\begin{array}{l}44.5 \\
22.4 \\
38.5 \\
42.5 \\
41.3 \\
55.0 \\
73.7\end{array}$ & $\begin{array}{l}62.0 \\
34.4 \\
42.9 \\
53.0 \\
56.5 \\
76.2 \\
90.0\end{array}$ & $\begin{array}{l}76.8 \\
43.4 \\
43.5 \\
63.0 \\
69.4 \\
84.9 \\
95.3\end{array}$ & $\begin{array}{l}77.5 \\
44.7 \\
44.3 \\
63.2 \\
70.0 \\
85.1 \\
95.6\end{array}$ & $\begin{array}{l}52.6 \\
36.5 \\
40.3 \\
56.4 \\
51.3 \\
62.1 \\
71.4\end{array}$ & $\begin{array}{l}51.3 \\
28.6 \\
28.9 \\
45.7 \\
48.1 \\
66.3 \\
82.1\end{array}$ & $\begin{array}{l}77.5 \\
45.1 \\
37.9 \\
73.6 \\
69.3 \\
84.7 \\
94.4\end{array}$ & $\begin{array}{l}71.9 \\
47.2 \\
56.0 \\
61.8 \\
65.6 \\
79.6 \\
89.3\end{array}$ \\
\hline 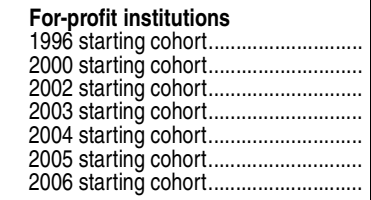 & $\begin{array}{l}28.0 \\
32.6 \\
22.0 \\
20.4 \\
28.4 \\
42.0 \\
31.5\end{array}$ & $\begin{array}{l}33.2 \\
38.1 \\
25.5 \\
24.5 \\
35.3 \\
45.5 \\
40.3\end{array}$ & $\begin{array}{l}19.2 \\
29.7 \\
16.3 \\
16.1 \\
21.3 \\
34.4 \\
21.1\end{array}$ & $\begin{array}{l}24.6 \\
33.8 \\
27.5 \\
24.9 \\
28.9 \\
36.5 \\
33.7\end{array}$ & $\begin{array}{l}28.9 \\
47.3 \\
35.5 \\
31.3 \\
38.9 \\
49.2 \\
42.5\end{array}$ & $\begin{array}{r}\overline{-} \\
\overline{-} \\
\overline{-} \\
51.1 \\
44.4\end{array}$ & $\begin{array}{r}\overline{-} \\
\overline{-} \\
\overline{-} \\
31.0 \\
25.2\end{array}$ & $\begin{array}{l}23.1 \\
30.4 \\
17.1 \\
11.9 \\
19.2 \\
39.3 \\
18.8\end{array}$ & $\begin{array}{r}- \\
\overline{-} \\
\overline{-} \\
27.2 \\
32.4\end{array}$ & $\begin{array}{r}54.0 \\
47.5 \\
12.5 \\
9.3 \\
21.7 \\
28.3 \\
35.5\end{array}$ \\
\hline $\begin{array}{l}\text { Graduating within } 6 \text { years after } \\
\text { start, males }\end{array}$ & & & & & & & & & & \\
\hline 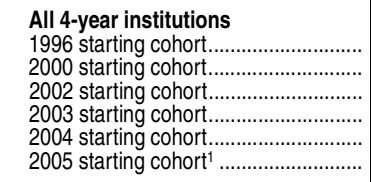 & $\begin{array}{l}52.0 \\
54.3 \\
54.1 \\
54.8 \\
55.5 \\
56.3\end{array}$ & $\begin{array}{l}54.8 \\
57.1 \\
57.3 \\
58.2 \\
58.8 \\
59.5\end{array}$ & $\begin{array}{l}32.8 \\
35.6 \\
34.0 \\
33.9 \\
34.2 \\
35.1\end{array}$ & $\begin{array}{l}41.3 \\
44.6 \\
44.1 \\
44.6 \\
45.6 \\
47.4\end{array}$ & $\begin{array}{l}59.5 \\
62.9 \\
64.0 \\
65.0 \\
65.7 \\
66.3\end{array}$ & $\begin{array}{r}- \\
\overline{-} \\
\overline{-} \\
66.6\end{array}$ & $\begin{array}{r}- \\
- \\
- \\
\overline{-} \\
49.0\end{array}$ & $\begin{array}{l}36.2 \\
37.1 \\
35.1 \\
36.4 \\
37.5 \\
38.9\end{array}$ & $\begin{array}{r}- \\
- \\
- \\
\overline{-} \\
61.3\end{array}$ & $\begin{array}{l}55.4 \\
56.8 \\
53.9 \\
52.8 \\
58.5 \\
59.2\end{array}$ \\
\hline 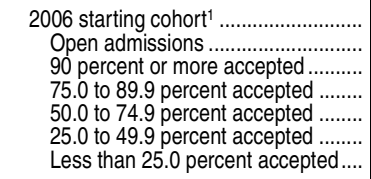 & $\begin{array}{l}56.5 \\
33.1 \\
44.8 \\
53.1 \\
57.3 \\
70.1 \\
84.2\end{array}$ & $\begin{array}{l}59.8 \\
41.3 \\
47.4 \\
56.0 \\
60.7 \\
74.5 \\
87.7\end{array}$ & $\begin{array}{l}35.2 \\
17.8 \\
29.1 \\
33.6 \\
38.1 \\
44.7 \\
53.9\end{array}$ & $\begin{array}{l}47.7 \\
28.6 \\
36.3 \\
43.6 \\
47.2 \\
61.0 \\
81.6\end{array}$ & $\begin{array}{l}67.4 \\
36.7 \\
47.0 \\
58.2 \\
65.0 \\
78.0 \\
89.8\end{array}$ & $\begin{array}{l}67.8 \\
39.1 \\
47.4 \\
58.2 \\
65.4 \\
78.2 \\
90.1\end{array}$ & $\begin{array}{l}46.5 \\
18.9 \\
25.8 \\
56.2 \\
47.2 \\
51.4 \\
70.5\end{array}$ & $\begin{array}{l}37.2 \\
19.4 \\
26.9 \\
36.6 \\
39.5 \\
48.5 \\
77.0\end{array}$ & $\begin{array}{l}64.5 \\
34.9 \\
46.1 \\
57.8 \\
56.9 \\
74.3 \\
90.3\end{array}$ & $\begin{array}{l}60.1 \\
38.4 \\
42.9 \\
57.1 \\
57.4 \\
71.4 \\
86.8\end{array}$ \\
\hline 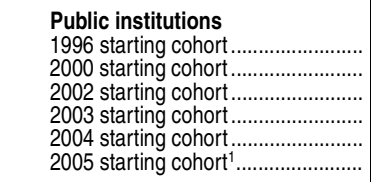 & $\begin{array}{l}48.1 \\
51.3 \\
51.7 \\
52.9 \\
53.0 \\
53.9\end{array}$ & $\begin{array}{l}50.8 \\
53.8 \\
54.4 \\
55.9 \\
56.0 \\
57.1\end{array}$ & $\begin{array}{l}30.3 \\
34.1 \\
32.9 \\
32.9 \\
32.7 \\
33.2\end{array}$ & $\begin{array}{l}37.5 \\
41.1 \\
41.4 \\
42.3 \\
43.0 \\
44.8\end{array}$ & $\begin{array}{l}55.2 \\
60.0 \\
61.3 \\
62.7 \\
62.9 \\
64.0\end{array}$ & $\begin{array}{r}\overline{-} \\
\overline{-} \\
\overline{-} \\
64.2\end{array}$ & $\begin{array}{r}- \\
- \\
- \\
\overline{-} \\
50.7\end{array}$ & $\begin{array}{l}33.1 \\
33.6 \\
32.2 \\
34.9 \\
34.9 \\
36.8\end{array}$ & $\begin{array}{r}- \\
- \\
- \\
\overline{-} \\
52.7\end{array}$ & $\begin{array}{l}48.8 \\
52.1 \\
52.5 \\
53.3 \\
53.0 \\
53.3\end{array}$ \\
\hline 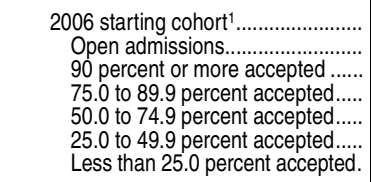 & $\begin{array}{r}54.4 \\
29.5 \\
0.0 \\
51.7 \\
56.9 \\
66.9 \\
71.3\end{array}$ & $\begin{array}{l}57.4 \\
35.6 \\
47.9 \\
54.5 \\
60.2 \\
70.4 \\
80.3\end{array}$ & $\begin{array}{l}34.2 \\
15.3 \\
29.4 \\
32.5 \\
38.9 \\
43.3 \\
32.2\end{array}$ & $\begin{array}{l}45.0 \\
24.9 \\
36.2 \\
42.7 \\
45.7 \\
58.0 \\
68.1\end{array}$ & $\begin{array}{l}65.1 \\
28.9 \\
47.9 \\
57.8 \\
64.5 \\
76.0 \\
65.6\end{array}$ & $\begin{array}{l}65.4 \\
30.2 \\
48.0 \\
57.9 \\
64.9 \\
76.3 \\
65.8\end{array}$ & $\begin{array}{r}47.2 \\
9.5 \\
25.0 \\
52.3 \\
47.2 \\
50.6 \\
62.5\end{array}$ & $\begin{array}{l}35.2 \\
15.2 \\
27.9 \\
36.1 \\
38.9 \\
43.7 \\
57.1\end{array}$ & $\begin{array}{l}56.1 \\
27.8 \\
57.6 \\
53.8 \\
48.9 \\
74.0 \\
79.7\end{array}$ & $\begin{array}{l}53.7 \\
38.7 \\
41.1 \\
55.7 \\
54.8 \\
62.7 \\
77.8\end{array}$ \\
\hline 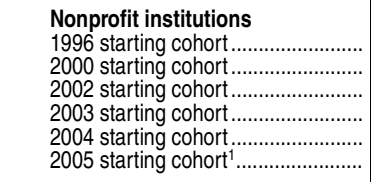 & $\begin{array}{l}60.4 \\
61.7 \\
61.9 \\
62.4 \\
63.0 \\
62.4\end{array}$ & $\begin{array}{l}63.0 \\
64.4 \\
64.8 \\
65.2 \\
65.7 \\
65.2\end{array}$ & $\begin{array}{l}38.9 \\
39.3 \\
38.6 \\
38.9 \\
39.2 \\
38.1\end{array}$ & $\begin{array}{l}52.1 \\
55.3 \\
55.4 \\
56.6 \\
57.0 \\
57.2\end{array}$ & $\begin{array}{l}71.5 \\
73.1 \\
73.8 \\
74.2 \\
74.4 \\
74.6\end{array}$ & $\begin{array}{r}- \\
\overline{-} \\
\overline{-} \\
75.0\end{array}$ & $\begin{array}{r}- \\
- \\
- \\
\overline{-} \\
49.2\end{array}$ & $\begin{array}{l}46.7 \\
50.1 \\
46.6 \\
45.4 \\
49.3 \\
42.7\end{array}$ & $\begin{array}{r}- \\
- \\
- \\
\overline{-} \\
73.5\end{array}$ & $\begin{array}{l}60.9 \\
61.7 \\
65.4 \\
65.6 \\
68.2 \\
67.4\end{array}$ \\
\hline 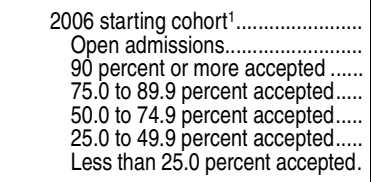 & $\begin{array}{l}62.9 \\
36.6 \\
43.4 \\
57.5 \\
58.9 \\
76.4 \\
89.7\end{array}$ & $\begin{array}{l}65.6 \\
44.1 \\
46.1 \\
60.4 \\
62.5 \\
80.2 \\
91.5\end{array}$ & $\begin{array}{l}39.2 \\
19.2 \\
31.8 \\
38.1 \\
37.2 \\
48.7 \\
68.8\end{array}$ & $\begin{array}{l}58.7 \\
32.4 \\
38.7 \\
48.5 \\
52.9 \\
72.1 \\
88.1\end{array}$ & $\begin{array}{l}75.7 \\
41.4 \\
39.7 \\
61.2 \\
67.3 \\
83.8 \\
95.2\end{array}$ & $\begin{array}{l}76.3 \\
43.1 \\
42.2 \\
61.3 \\
67.9 \\
84.1 \\
95.4\end{array}$ & $\begin{array}{l}49.2 \\
34.5 \\
26.1 \\
60.5 \\
47.8 \\
52.9 \\
80.0\end{array}$ & $\begin{array}{l}48.6 \\
27.1 \\
14.3 \\
42.8 \\
44.0 \\
61.9 \\
84.7\end{array}$ & $\begin{array}{l}76.2 \\
38.5 \\
27.6 \\
64.3 \\
70.0 \\
82.0 \\
94.8\end{array}$ & $\begin{array}{l}68.8 \\
51.2 \\
50.2 \\
59.4 \\
60.9 \\
77.3 \\
87.4\end{array}$ \\
\hline 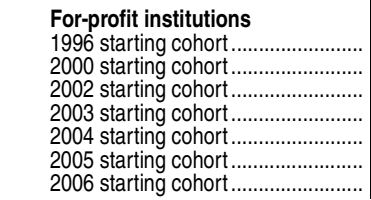 & $\begin{array}{l}28.0 \\
35.5 \\
23.6 \\
22.7 \\
30.2 \\
47.4 \\
35.4\end{array}$ & $\begin{array}{l}32.3 \\
40.2 \\
27.8 \\
26.7 \\
37.0 \\
50.2 \\
43.9\end{array}$ & $\begin{array}{l}19.4 \\
29.8 \\
16.6 \\
16.6 \\
21.2 \\
40.8 \\
23.5\end{array}$ & $\begin{array}{l}26.7 \\
36.2 \\
26.7 \\
25.2 \\
29.1 \\
39.1 \\
35.3\end{array}$ & $\begin{array}{l}31.7 \\
48.4 \\
38.4 \\
33.6 \\
43.5 \\
50.4 \\
44.0\end{array}$ & $\begin{array}{r}\overline{-} \\
\overline{-} \\
\overline{-} \\
51.2 \\
45.5\end{array}$ & $\begin{array}{r}- \\
\overline{-} \\
\overline{-} \\
41.4 \\
27.6\end{array}$ & $\begin{array}{l}30.8 \\
30.3 \\
23.5 \\
16.0 \\
18.5 \\
53.3 \\
19.6\end{array}$ & $\begin{array}{r}- \\
\overline{-} \\
\overline{-} \\
27.5 \\
34.6\end{array}$ & $\begin{array}{r}53.0 \\
46.3 \\
11.7 \\
9.3 \\
23.6 \\
29.2 \\
37.4\end{array}$ \\
\hline
\end{tabular}

See notes at end of table. 
612 CHAPTER 3: Postsecondary Education

Completion Rates

Table 326.10. Graduation rates of first-time, full-time bachelor's degree-seeking students at 4-year postsecondary institutions, by race/ethnicity, time to completion, sex, and control of institution: Selected cohort entry years, 1996 through 2006-Continued

\begin{tabular}{|c|c|c|c|c|c|c|c|c|c|c|}
\hline \multirow{2}{*}{$\begin{array}{l}\text { Time to completion, sex, } \\
\text { control of institution, and } \\
\text { cohort entry year }\end{array}$} & \multirow[b]{2}{*}{ Total } & \multirow[b]{2}{*}{ White } & \multirow[b]{2}{*}{ Black } & \multirow[b]{2}{*}{ Hispanic } & \multicolumn{3}{|c|}{ Asian/Pacific Islander } & \multirow{2}{*}{$\begin{array}{r}\text { American } \\
\text { Indian/ } \\
\text { Alaska } \\
\text { Native }\end{array}$} & \multirow[b]{2}{*}{$\begin{array}{r}\text { Two or } \\
\text { more races }\end{array}$} & \multirow[b]{2}{*}{$\begin{array}{r}\text { Nonresiden } \\
\text { alier }\end{array}$} \\
\hline & & & & & Total & Asian & $\begin{array}{r}\text { Pacific } \\
\text { Islander }\end{array}$ & & & \\
\hline 1 & 2 & 3 & 4 & 5 & 6 & 7 & 8 & 9 & 10 & 11 \\
\hline \multicolumn{11}{|l|}{$\begin{array}{l}\text { Graduating within } 6 \text { years after } \\
\text { start, females }\end{array}$} \\
\hline 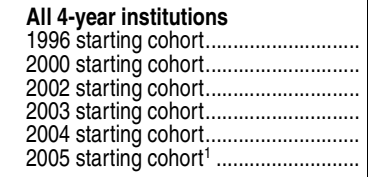 & $\begin{array}{l}58.2 \\
60.2 \\
59.7 \\
59.5 \\
60.6 \\
60.8\end{array}$ & $\begin{array}{l}60.9 \\
62.8 \\
62.5 \\
63.0 \\
63.8 \\
64.2\end{array}$ & $\begin{array}{l}43.0 \\
46.4 \\
44.2 \\
42.7 \\
43.1 \\
43.1\end{array}$ & $\begin{array}{l}49.1 \\
52.4 \\
52.5 \\
51.8 \\
53.4 \\
53.7\end{array}$ & $\begin{array}{l}66.8 \\
70.1 \\
69.8 \\
70.5 \\
71.3 \\
71.7\end{array}$ & $\begin{array}{r}- \\
- \\
- \\
72.2\end{array}$ & $\begin{array}{l}- \\
- \\
- \\
48.1\end{array}$ & $\begin{array}{l}39.5 \\
42.7 \\
40.7 \\
39.7 \\
40.9 \\
40.5\end{array}$ & $\begin{array}{c}- \\
- \\
- \\
- \\
66.8\end{array}$ & $\begin{array}{l}61.5 \\
63.1 \\
56.7 \\
53.8 \\
64.9 \\
66.5\end{array}$ \\
\hline 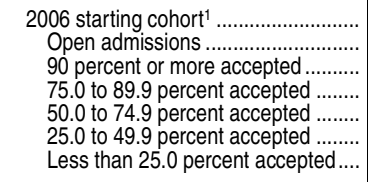 & $\begin{array}{l}61.4 \\
32.5 \\
50.2 \\
58.2 \\
63.0 \\
74.3 \\
87.2\end{array}$ & $\begin{array}{l}64.9 \\
41.4 \\
52.8 \\
61.2 \\
66.6 \\
78.3 \\
90.5\end{array}$ & $\begin{array}{l}43.6 \\
20.5 \\
35.5 \\
41.5 \\
46.5 \\
56.0 \\
62.6\end{array}$ & $\begin{array}{l}54.9 \\
31.7 \\
43.2 \\
50.1 \\
55.3 \\
67.9 \\
88.9\end{array}$ & $\begin{array}{l}72.6 \\
38.8 \\
51.9 \\
64.0 \\
70.3 \\
82.1 \\
93.9\end{array}$ & $\begin{array}{l}73.1 \\
41.1 \\
52.2 \\
64.2 \\
70.8 \\
82.3 \\
94.5\end{array}$ & $\begin{array}{l}50.1 \\
23.4 \\
44.8 \\
52.8 \\
51.4 \\
62.5 \\
66.0\end{array}$ & $\begin{array}{l}42.4 \\
16.3 \\
31.1 \\
44.4 \\
44.1 \\
59.5 \\
81.7\end{array}$ & $\begin{array}{l}68.1 \\
38.5 \\
46.8 \\
61.4 \\
62.6 \\
82.3 \\
92.8\end{array}$ & $\begin{array}{l}67.6 \\
37.8 \\
55.6 \\
63.1 \\
67.8 \\
75.4 \\
90.6\end{array}$ \\
\hline 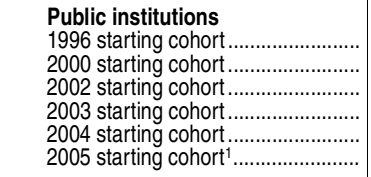 & $\begin{array}{l}54.7 \\
57.7 \\
57.5 \\
58.1 \\
58.5 \\
58.8\end{array}$ & $\begin{array}{l}57.4 \\
59.9 \\
59.9 \\
61.0 \\
61.4 \\
61.9\end{array}$ & $\begin{array}{l}41.0 \\
45.2 \\
43.7 \\
42.4 \\
42.1 \\
42.2\end{array}$ & $\begin{array}{l}45.7 \\
49.7 \\
50.0 \\
50.4 \\
51.4 \\
51.7\end{array}$ & $\begin{array}{l}63.5 \\
67.8 \\
67.7 \\
68.7 \\
69.2 \\
69.7\end{array}$ & $\begin{array}{c}\overline{-} \\
\overline{-} \\
\overline{-} \\
70.0\end{array}$ & $\begin{array}{r}\overline{-} \\
\overline{-} \\
\overline{\bar{z}}\end{array}$ & $\begin{array}{l}37.0 \\
40.5 \\
38.3 \\
38.8 \\
38.5 \\
38.6\end{array}$ & $\begin{array}{c}- \\
- \\
- \\
\overline{-} \\
58.7\end{array}$ & $\begin{array}{l}54.9 \\
58.1 \\
59.0 \\
59.5 \\
62.2 \\
61.9\end{array}$ \\
\hline $\begin{array}{l}2006 \text { starting cohort }{ }^{1} . . . . . . . . . . . . . . . . . . . \\
\text { Open admissions........................ } \\
90 \text { percent or more accepted...... } \\
75.0 \text { to } 89.9 \text { percent accepted..... } \\
50.0 \text { to } 74.9 \text { percent accepted..... } \\
25.0 \text { to } 49.9 \text { percent accepted..... } \\
\text { Less than } 25.0 \text { percent accepted. }\end{array}$ & $\begin{array}{l}59.6 \\
34.6 \\
50.1 \\
55.9 \\
62.6 \\
72.3 \\
68.7\end{array}$ & $\begin{array}{l}62.7 \\
41.3 \\
52.5 \\
58.9 \\
66.0 \\
76.0 \\
80.6\end{array}$ & $\begin{array}{l}43.3 \\
20.6 \\
34.6 \\
40.6 \\
47.7 \\
54.7 \\
36.8\end{array}$ & $\begin{array}{l}52.9 \\
32.7 \\
43.2 \\
48.4 \\
54.6 \\
64.0 \\
74.5\end{array}$ & $\begin{array}{l}71.1 \\
41.9 \\
52.8 \\
64.0 \\
70.3 \\
80.7 \\
78.3\end{array}$ & $\begin{array}{l}71.5 \\
42.9 \\
53.0 \\
64.1 \\
70.8 \\
80.9 \\
79.4\end{array}$ & $\begin{array}{l}50.7 \\
11.1 \\
25.0 \\
51.8 \\
50.5 \\
59.6 \\
64.3\end{array}$ & $\begin{array}{l}40.5 \\
12.4 \\
30.9 \\
43.9 \\
42.5 \\
55.2 \\
89.5\end{array}$ & $\begin{array}{l}57.8 \\
34.4 \\
56.8 \\
48.4 \\
58.3 \\
78.4 \\
79.5\end{array}$ & $\begin{array}{l}62.6 \\
50.9 \\
53.0 \\
61.9 \\
65.6 \\
66.2 \\
68.4\end{array}$ \\
\hline 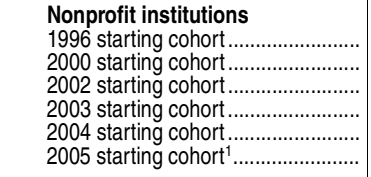 & $\begin{array}{l}65.4 \\
66.7 \\
66.7 \\
67.1 \\
67.3 \\
67.2\end{array}$ & $\begin{array}{l}67.9 \\
69.1 \\
69.1 \\
69.7 \\
69.6 \\
69.7\end{array}$ & $\begin{array}{l}48.4 \\
50.4 \\
49.4 \\
49.2 \\
49.1 \\
48.0\end{array}$ & $\begin{array}{l}58.3 \\
61.7 \\
62.2 \\
61.2 \\
62.8 \\
62.6\end{array}$ & $\begin{array}{l}75.0 \\
76.7 \\
76.3 \\
77.2 \\
77.6 \\
77.8\end{array}$ & $\begin{array}{c}- \\
\overline{-} \\
\overline{-} \\
78.3\end{array}$ & $\begin{array}{l}\overline{-} \\
\overline{-} \\
\overline{\bar{L}} \\
54.9\end{array}$ & $\begin{array}{l}49.2 \\
51.5 \\
52.1 \\
49.2 \\
51.6 \\
49.2\end{array}$ & $\begin{array}{c}- \\
- \\
- \\
\overline{7} \\
76.5\end{array}$ & $\begin{array}{l}66.4 \\
67.9 \\
71.5 \\
73.0 \\
74.4 \\
75.0\end{array}$ \\
\hline 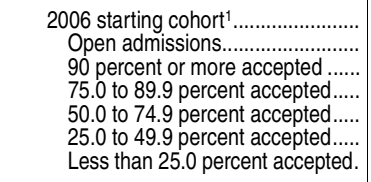 & $\begin{array}{l}67.6 \\
39.6 \\
53.1 \\
63.7 \\
64.8 \\
78.4 \\
91.4\end{array}$ & $\begin{array}{l}70.1 \\
45.4 \\
55.9 \\
66.3 \\
68.3 \\
81.7 \\
92.9\end{array}$ & $\begin{array}{l}48.5 \\
25.7 \\
43.9 \\
45.8 \\
44.5 \\
58.8 \\
77.3\end{array}$ & $\begin{array}{l}64.2 \\
36.4 \\
46.1 \\
55.9 \\
58.8 \\
79.0 \\
91.7\end{array}$ & $\begin{array}{l}77.7 \\
45.1 \\
46.2 \\
64.3 \\
71.0 \\
85.8 \\
95.3\end{array}$ & $\begin{array}{l}78.4 \\
46.0 \\
46.0 \\
64.7 \\
71.6 \\
85.9 \\
95.8\end{array}$ & $\begin{array}{l}55.0 \\
39.1 \\
46.9 \\
53.7 \\
53.8 \\
71.9 \\
66.7\end{array}$ & $\begin{array}{l}52.9 \\
29.5 \\
37.5 \\
47.4 \\
50.6 \\
69.3 \\
80.0\end{array}$ & $\begin{array}{l}78.3 \\
52.0 \\
41.1 \\
80.8 \\
68.9 \\
86.2 \\
94.1\end{array}$ & $\begin{array}{l}75.4 \\
40.0 \\
64.0 \\
65.0 \\
70.3 \\
81.8 \\
91.5\end{array}$ \\
\hline 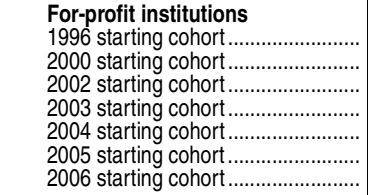 & $\begin{array}{l}27.9 \\
29.1 \\
20.5 \\
18.7 \\
26.8 \\
35.9 \\
28.0\end{array}$ & $\begin{array}{l}34.5 \\
35.1 \\
23.1 \\
22.7 \\
33.4 \\
39.4 \\
35.8\end{array}$ & $\begin{array}{l}19.0 \\
29.7 \\
16.1 \\
15.8 \\
21.3 \\
29.1 \\
19.5\end{array}$ & $\begin{array}{l}21.9 \\
30.9 \\
28.3 \\
24.7 \\
28.7 \\
34.0 \\
32.1\end{array}$ & $\begin{array}{l}24.9 \\
45.2 \\
31.3 \\
29.1 \\
33.3 \\
47.3 \\
40.8\end{array}$ & $\begin{array}{r}\overline{-} \\
\overline{-} \\
\overline{-} \\
50.9 \\
43.3\end{array}$ & $\begin{array}{r}- \\
\overline{-} \\
\overline{-} \\
17.6 \\
23.5\end{array}$ & $\begin{array}{r}17.3 \\
30.4 \\
12.0 \\
9.3 \\
19.6 \\
27.2 \\
18.2\end{array}$ & $\begin{array}{r}- \\
\overline{-} \\
\overline{-} \\
\overline{-} \\
26.9 \\
29.3\end{array}$ & $\begin{array}{r}55.1 \\
48.9 \\
13.0 \\
9.4 \\
20.3 \\
27.7 \\
33.9\end{array}$ \\
\hline
\end{tabular}

-Not available.

1 Includes data for institutions not reporting admissions data, which are not separately shown NOTE: Data are for 4-year degree-granting postsecondary institutions participating in Title IV federal financial aid programs. Graduation rates refer to students receiving bachelor's degrees from their initial institutions of attendance only. Totals include data for persons whose race/ethnicity was not reported. Race categories exclude persons of Hispanic ethnicity. Some data have been revised from previously published figures.

SOURCE: U.S. Department of Education, National Center for Education Statistics, Integrated Postsecondary Education Data System (IPEDS), Fall 2001 and Spring 2007 through Spring 2013, Graduation Rates component. (This table was prepared January 2014.) 
Table 326.20. Graduation rates of first-time, full-time degree/certificate-seeking students at 2-year postsecondary institutions who completed a credential within 150 percent of normal time, by race/ethnicity, sex, and control of institution: Selected cohort entry years, 2000 through 2009

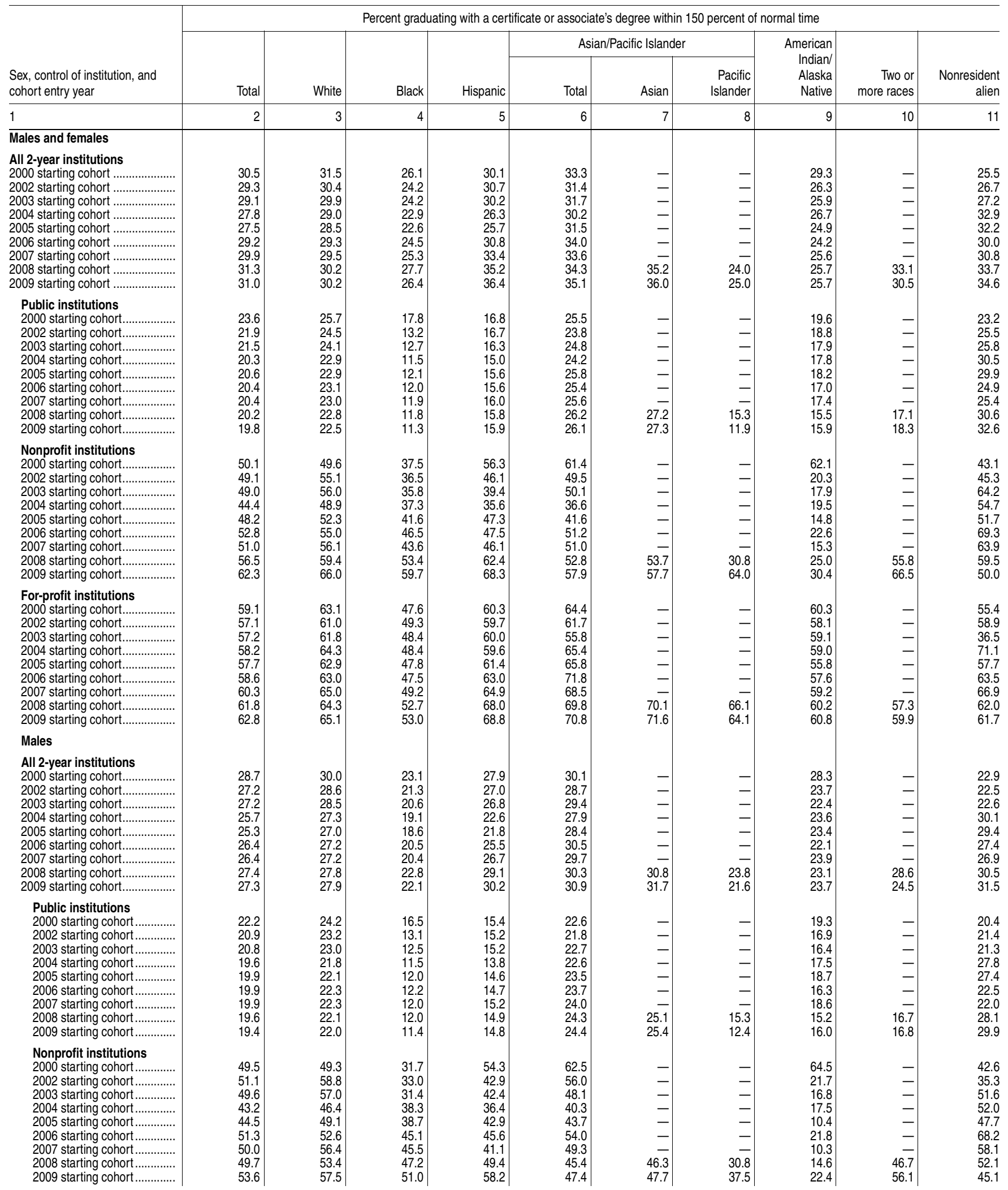


Table 326.20. Graduation rates of first-time, full-time degree/certificate-seeking students at 2-year postsecondary institutions who completed a credential within 150 percent of normal time, by race/ethnicity, sex, and control of institution: Selected cohort entry years, 2000 through 2009-Continued

\begin{tabular}{|c|c|c|c|c|c|c|c|c|c|c|}
\hline \multirow[b]{3}{*}{$\begin{array}{l}\text { Sex, control of institution, and } \\
\text { cohort entry year }\end{array}$} & \multicolumn{10}{|c|}{ Percent graduating with a certificate or associate's degree within 150 percent of normal time } \\
\hline & \multirow[b]{2}{*}{ Total } & \multirow[b]{2}{*}{ White } & \multirow[b]{2}{*}{ Black } & \multirow[b]{2}{*}{ Hispanic } & \multicolumn{3}{|c|}{ Asian/Pacific Islander } & \multirow{2}{*}{$\begin{array}{r}\text { American } \\
\text { Indian/ } \\
\text { Alaska } \\
\text { Native }\end{array}$} & \multirow[b]{2}{*}{$\begin{array}{r}\text { Two or } \\
\text { more races }\end{array}$} & \multirow[b]{2}{*}{$\begin{array}{r}\text { Nonresiden } \\
\text { alier }\end{array}$} \\
\hline & & & & & Total & Asian & $\begin{array}{r}\text { Pacific } \\
\text { Islander }\end{array}$ & & & \\
\hline 1 & 2 & 3 & 4 & 5 & 6 & 7 & 8 & 9 & 10 & 11 \\
\hline $\begin{array}{l}\text { For-profit institutions } \\
2000 \text { starting cohort............. } \\
2002 \text { starting cohort............. } \\
2003 \text { starting cohort............ } \\
2004 \text { starting cohort............ } \\
2005 \text { starting cohort............ } \\
2006 \text { starting cohort ............. } \\
2007 \text { starting cohort............ } \\
2008 \text { starting cohort ............. } \\
2009 \text { starting cohort.............. }\end{array}$ & $\begin{array}{l}59.3 \\
56.6 \\
58.0 \\
58.1 \\
57.7 \\
56.8 \\
58.3 \\
59.1 \\
59.8\end{array}$ & $\begin{array}{l}63.7 \\
62.0 \\
63.7 \\
65.4 \\
64.8 \\
62.3 \\
65.3 \\
64.4 \\
63.7\end{array}$ & $\begin{array}{l}45.6 \\
45.9 \\
45.7 \\
44.6 \\
43.1 \\
43.0 \\
44.6 \\
48.2 \\
49.3\end{array}$ & $\begin{array}{l}58.2 \\
56.1 \\
56.9 \\
55.4 \\
57.5 \\
58.3 \\
59.3 \\
63.0 \\
64.6\end{array}$ & $\begin{array}{l}63.1 \\
59.7 \\
62.0 \\
64.3 \\
65.7 \\
69.4 \\
66.3 \\
67.7 \\
67.7\end{array}$ & $\begin{array}{r}- \\
- \\
- \\
- \\
- \\
- \\
68.0 \\
68.7\end{array}$ & $\begin{array}{r}- \\
- \\
- \\
- \\
- \\
65.1 \\
59.2\end{array}$ & $\begin{array}{l}55.9 \\
58.4 \\
59.5 \\
59.6 \\
56.3 \\
57.2 \\
56.9 \\
54.9 \\
59.4\end{array}$ & $\begin{array}{r}- \\
- \\
- \\
- \\
- \\
58.3 \\
55.2\end{array}$ & $\begin{array}{l}55.0 \\
61.9 \\
36.7 \\
69.4 \\
56.3 \\
61.6 \\
66.7 \\
54.6 \\
59.9\end{array}$ \\
\hline \multicolumn{11}{|l|}{ Female } \\
\hline $\begin{array}{l}\text { All 2-year institutions } \\
2000 \text { starting cohort................. } \\
2002 \text { starting cohort............... } \\
2003 \text { starting cohort................. } \\
2004 \text { starting cohort............... } \\
2005 \text { starting cohort................ } \\
2006 \text { starting cohort............... } \\
2007 \text { starting cohort............... } \\
2008 \text { starting cohort.............. } \\
2009 \text { starting cohort................ }\end{array}$ & $\begin{array}{l}32.1 \\
30.9 \\
30.7 \\
29.6 \\
29.3 \\
31.6 \\
32.7 \\
34.4 \\
34.1\end{array}$ & $\begin{array}{l}33.0 \\
32.0 \\
31.2 \\
30.5 \\
29.9 \\
31.2 \\
31.6 \\
32.3 \\
32.3\end{array}$ & $\begin{array}{l}28.1 \\
26.1 \\
26.3 \\
25.2 \\
25.2 \\
27.1 \\
28.4 \\
31.0 \\
29.4\end{array}$ & $\begin{array}{l}31.8 \\
33.4 \\
32.7 \\
29.0 \\
28.6 \\
34.5 \\
37.9 \\
39.5 \\
40.9\end{array}$ & $\begin{array}{l}36.3 \\
33.9 \\
33.9 \\
32.6 \\
34.6 \\
37.5 \\
37.4 \\
38.3 \\
39.3\end{array}$ & $\begin{array}{r}- \\
- \\
- \\
- \\
- \\
\overline{-} \\
39.5 \\
40.4\end{array}$ & $\begin{array}{r}- \\
- \\
- \\
- \\
- \\
-\overline{1} \\
24.1 \\
28.0\end{array}$ & $\begin{array}{l}30.0 \\
28.2 \\
28.4 \\
28.8 \\
25.9 \\
25.8 \\
26.8 \\
27.8 \\
27.3\end{array}$ & $\begin{array}{r}- \\
- \\
- \\
- \\
- \\
- \\
36.1 \\
34.9\end{array}$ & $\begin{array}{l}28.3 \\
30.4 \\
31.5 \\
35.3 \\
34.8 \\
32.4 \\
34.4 \\
36.8 \\
37.6\end{array}$ \\
\hline $\begin{array}{l}\text { Public institutions } \\
2000 \text { starting cohort............. } \\
2002 \text { starting cohort............ } \\
2003 \text { starting cohort............ } \\
2004 \text { starting cohort............ } \\
2005 \text { starting cohort ............. } \\
2006 \text { starting cohort ............. } \\
2007 \text { starting cohort............ } \\
2008 \text { starting cohort............. } \\
2009 \text { starting cohort .............. }\end{array}$ & $\begin{array}{l}24.8 \\
22.8 \\
22.2 \\
21.0 \\
21.2 \\
21.0 \\
20.8 \\
20.7 \\
20.2\end{array}$ & $\begin{array}{l}27.1 \\
25.8 \\
25.1 \\
24.0 \\
23.8 \\
23.9 \\
23.7 \\
23.5 \\
23.1\end{array}$ & $\begin{array}{l}18.8 \\
13.2 \\
12.8 \\
11.5 \\
12.1 \\
11.8 \\
11.8 \\
11.7 \\
11.2\end{array}$ & $\begin{array}{l}17.9 \\
17.8 \\
17.3 \\
16.0 \\
16.4 \\
16.3 \\
16.8 \\
16.5 \\
16.8\end{array}$ & $\begin{array}{l}28.4 \\
25.9 \\
27.1 \\
26.1 \\
28.2 \\
27.3 \\
27.5 \\
28.3 \\
28.1\end{array}$ & $\begin{array}{r}- \\
- \\
- \\
- \\
- \\
29.6 \\
29.6\end{array}$ & $\begin{array}{r}- \\
- \\
- \\
- \\
- \\
- \\
15.3 \\
11.4\end{array}$ & $\begin{array}{l}19.9 \\
20.2 \\
19.0 \\
17.9 \\
17.8 \\
17.5 \\
16.5 \\
15.7 \\
15.8\end{array}$ & $\begin{array}{r}- \\
- \\
- \\
- \\
- \\
17.4 \\
19.8\end{array}$ & $\begin{array}{l}26.2 \\
29.2 \\
30.0 \\
32.8 \\
32.2 \\
27.3 \\
28.7 \\
33.0 \\
35.3\end{array}$ \\
\hline $\begin{array}{l}\text { Nonprofit institutions } \\
2000 \text { starting cohort............. } \\
2002 \text { starting cohort............ } \\
2003 \text { starting cohort............ } \\
2004 \text { starting cohort............ } \\
2005 \text { starting cohort............. } \\
2006 \text { starting cohort............. } \\
2007 \text { starting cohort............ } \\
2008 \text { starting cohort............ } \\
2009 \text { starting cohort .............. }\end{array}$ & $\begin{array}{l}50.7 \\
47.3 \\
48.5 \\
45.4 \\
51.3 \\
54.0 \\
51.8 \\
59.7 \\
66.6\end{array}$ & $\begin{array}{l}50.0 \\
51.4 \\
55.0 \\
51.1 \\
54.9 \\
56.7 \\
55.8 \\
63.0 \\
70.8\end{array}$ & $\begin{array}{l}43.1 \\
39.2 \\
38.8 \\
36.3 \\
44.9 \\
47.7 \\
41.6 \\
55.7 \\
63.4\end{array}$ & $\begin{array}{l}58.3 \\
48.9 \\
37.5 \\
35.1 \\
49.6 \\
48.5 \\
49.5 \\
67.6 \\
72.5\end{array}$ & $\begin{array}{l}60.1 \\
44.3 \\
51.4 \\
34.3 \\
40.1 \\
48.8 \\
52.2 \\
56.6 \\
63.2\end{array}$ & $\begin{array}{r}- \\
- \\
- \\
- \\
- \\
- \\
57.4 \\
62.7\end{array}$ & $\begin{array}{r}- \\
- \\
- \\
- \\
- \\
30.8 \\
76.5\end{array}$ & $\begin{array}{l}60.2 \\
19.3 \\
18.7 \\
21.0 \\
18.0 \\
23.2 \\
18.9 \\
31.5 \\
34.5\end{array}$ & $\begin{array}{r}- \\
- \\
- \\
- \\
- \\
58.3 \\
70.3\end{array}$ & $\begin{array}{l}43.8 \\
55.0 \\
75.4 \\
57.4 \\
55.2 \\
70.4 \\
69.9 \\
66.8 \\
54.5\end{array}$ \\
\hline $\begin{array}{l}\text { For-profit institutions } \\
2000 \text { starting cohort............. } \\
2002 \text { starting cohort............ } \\
2003 \text { starting cohort............ } \\
2004 \text { starting cohort............ } \\
2005 \text { starting cohort............. } \\
2006 \text { starting cohort............. } \\
2007 \text { starting cohort............ } \\
2008 \text { starting cohort ............. } \\
2009 \text { starting cohort............ }\end{array}$ & $\begin{array}{l}58.9 \\
57.4 \\
56.8 \\
58.3 \\
57.7 \\
59.6 \\
61.3 \\
63.2 \\
64.5\end{array}$ & $\begin{array}{l}62.6 \\
60.3 \\
60.4 \\
63.4 \\
61.6 \\
63.4 \\
64.8 \\
64.3 \\
66.0\end{array}$ & $\begin{array}{l}48.6 \\
50.8 \\
49.4 \\
49.9 \\
49.4 \\
49.3 \\
50.8 \\
54.7 \\
54.7\end{array}$ & $\begin{array}{l}61.8 \\
61.7 \\
61.9 \\
61.9 \\
63.3 \\
65.2 \\
67.3 \\
70.5 \\
70.9\end{array}$ & $\begin{array}{l}65.3 \\
63.3 \\
52.1 \\
66.2 \\
65.8 \\
73.4 \\
69.8 \\
71.0 \\
72.7\end{array}$ & $\begin{array}{r}- \\
- \\
- \\
- \\
- \\
\overline{-} \\
71.2 \\
73.4\end{array}$ & $\begin{array}{r}- \\
- \\
- \\
- \\
- \\
- \\
67.1 \\
67.0\end{array}$ & $\begin{array}{l}63.8 \\
58.0 \\
59.0 \\
58.7 \\
55.7 \\
57.9 \\
60.2 \\
63.6 \\
61.5\end{array}$ & $\begin{array}{r}- \\
- \\
- \\
- \\
- \\
- \\
56.9 \\
61.9\end{array}$ & $\begin{array}{l}55.7 \\
56.7 \\
36.4 \\
72.3 \\
58.6 \\
65.1 \\
67.1 \\
67.7 \\
62.8\end{array}$ \\
\hline
\end{tabular}

-Not available.

NOTE: Data are for 2-year degree-granting postsecondary institutions participating in Title IV federal financial aid programs. Graduation rates refer to students receiving associate's degrees or certificates from their initial institutions of attendance only. Totals include data for persons whose race/ethnicity was not reported. Race categories exclude persons of Hispanic ethnicity. Some data have been revised from previously published figures.
SOURCE: U.S. Department of Education, National Center for Education Statistics, Integrated Postsecondary Education Data System (IPEDS), Fall 2001 and Spring 2002 through Spring 2013, Graduation Rates component. (This table was prepared January 2014.) 
Table 326.30. Retention of first-time degree-seeking undergraduates at degree-granting postsecondary institutions, by attendance status, level and control of institution, and percentage of applications accepted: 2006 to 2012

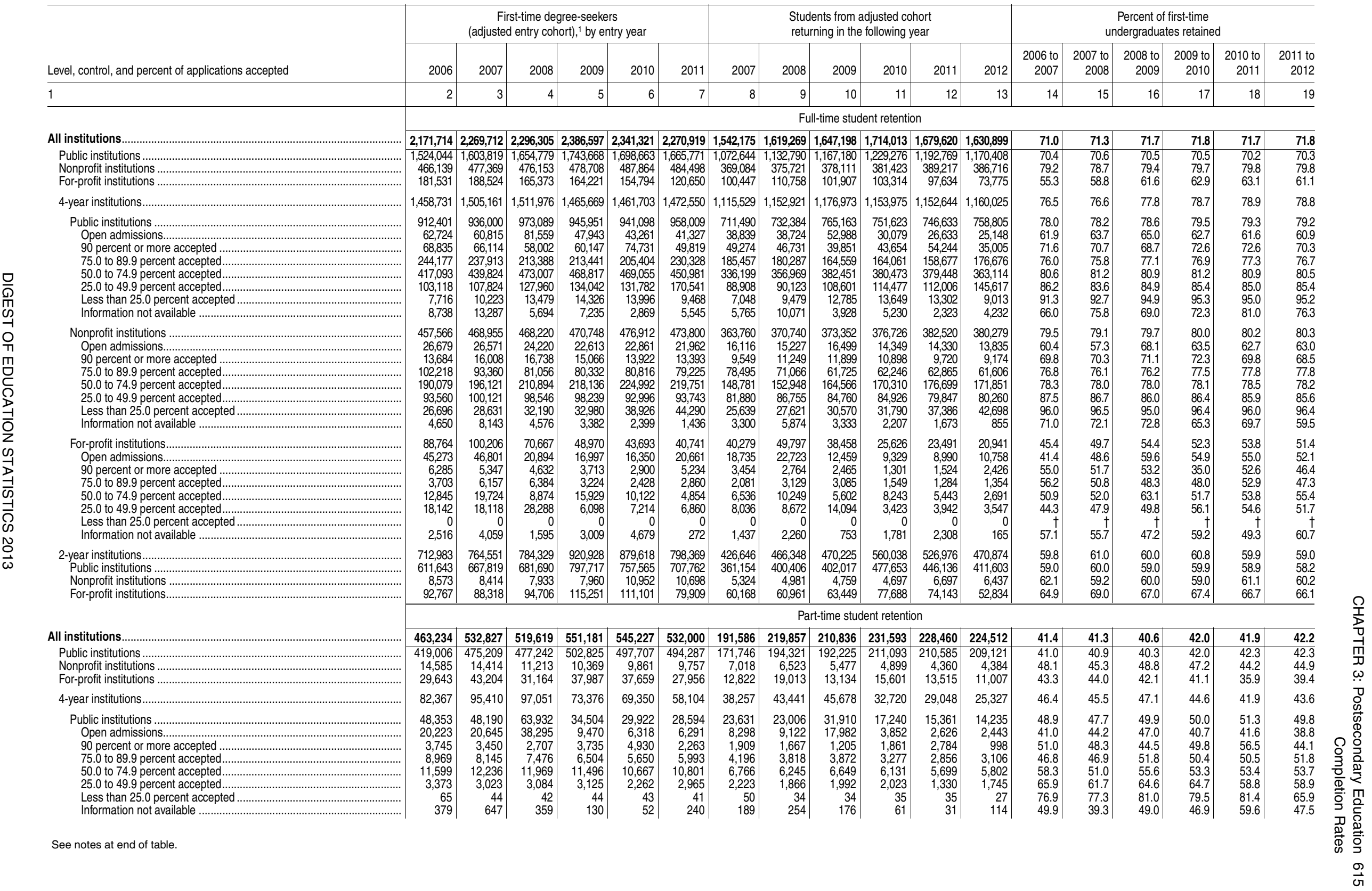




\begin{tabular}{|c|c|c|c|c|c|c|c|c|c|c|c|c|c|c|c|c|c|c|}
\hline \multirow[b]{2}{*}{ Level, control, and percent of applications accepted } & \multicolumn{6}{|c|}{$\begin{array}{c}\text { First-time degree-seekers } \\
\text { (adjusted entry cohort), }{ }^{1} \text { by entry year }\end{array}$} & \multicolumn{6}{|c|}{$\begin{array}{l}\text { Students from adjusted cohort } \\
\text { returning in the following year }\end{array}$} & \multicolumn{6}{|c|}{$\begin{array}{c}\text { Percent of first-time } \\
\text { undergraduates retained }\end{array}$} \\
\hline & 2006 & 2007 & 2008 & 2009 & 2010 & 2011 & 2007 & 2008 & 2009 & 2010 & 2011 & 2012 & $\begin{array}{r}2006 \text { to } \\
2007\end{array}$ & $\begin{array}{r}2007 \text { to } \\
2008\end{array}$ & $\begin{array}{r}2008 \text { to } \\
2009\end{array}$ & $\begin{array}{r}2009 \text { to } \\
2010\end{array}$ & $\begin{array}{r}2010 \text { to } \\
2011\end{array}$ & $\begin{array}{r}2011 \text { to } \\
2012\end{array}$ \\
\hline 1 & 2 & 3 & 4 & 5 & 6 & 7 & 8 & 9 & 10 & 11 & 12 & 13 & 14 & 15 & 16 & 17 & 18 & 19 \\
\hline 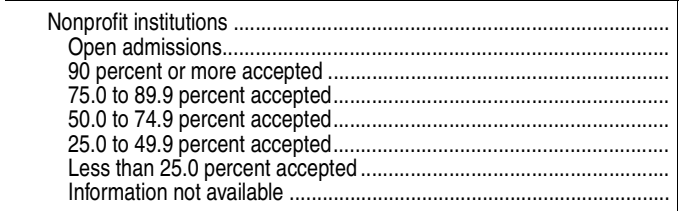 & $\begin{array}{r}12,828 \\
5,446 \\
523 \\
2,459 \\
3,131 \\
853 \\
112 \\
304\end{array}$ & $\begin{array}{r}12,886 \\
5,330 \\
1,272 \\
2,132 \\
2,899 \\
917 \\
94 \\
242\end{array}$ & $\begin{array}{r}9,883 \\
3,369 \\
971 \\
1,307 \\
2,016 \\
1,963 \\
78 \\
179\end{array}$ & $\begin{array}{r}9,609 \\
3,821 \\
393 \\
1,177 \\
3,256 \\
712 \\
93 \\
157\end{array}$ & $\begin{array}{r}9,110 \\
3,949 \\
478 \\
951 \\
2,955 \\
647 \\
84 \\
46\end{array}$ & $\begin{array}{r}8,802 \\
4,220 \\
843 \\
1,254 \\
1,868 \\
466 \\
116 \\
35\end{array}$ & $\begin{array}{r}6,045 \\
2,579 \\
237 \\
1,047 \\
1,406 \\
452 \\
86 \\
238\end{array}$ & $\begin{array}{r}5,614 \\
2,306 \\
434 \\
895 \\
1,307 \\
478 \\
84 \\
110\end{array}$ & $\begin{array}{r}4,772 \\
1,504 \\
421 \\
633 \\
1,029 \\
1,016 \\
70 \\
99\end{array}$ & $\begin{array}{r}4,499 \\
1,693 \\
199 \\
558 \\
1,531 \\
366 \\
78 \\
74\end{array}$ & $\begin{array}{r}3,992 \\
1,614 \\
180 \\
456 \\
1,333 \\
319 \\
67 \\
23\end{array}$ & $\begin{array}{r}3,870 \\
1,636 \\
357 \\
671 \\
844 \\
240 \\
104 \\
18\end{array}$ & $\begin{array}{l}47.1 \\
47.4 \\
45.3 \\
42.6 \\
44.9 \\
53.0 \\
76.8 \\
78.3\end{array}$ & $\begin{array}{l}43.6 \\
43.3 \\
34.1 \\
42.0 \\
45.1 \\
52.1 \\
89.4 \\
45.5\end{array}$ & $\begin{array}{l}48.3 \\
44.6 \\
43.4 \\
48.4 \\
51.0 \\
51.8 \\
89.7 \\
55.3\end{array}$ & $\begin{array}{l}46.8 \\
44.3 \\
50.6 \\
47.4 \\
47.0 \\
51.4 \\
83.9 \\
47.1\end{array}$ & $\begin{array}{l}43.8 \\
40.9 \\
37.7 \\
47.9 \\
45.1 \\
49.3 \\
79.8 \\
50.0\end{array}$ & $\begin{array}{l}44.0 \\
38.8 \\
42.3 \\
53.5 \\
45.2 \\
51.5 \\
89.7 \\
51.4\end{array}$ \\
\hline 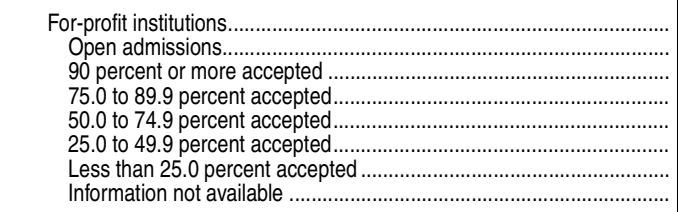 & $\begin{array}{r}21,186 \\
10,515 \\
2,212 \\
2,838 \\
2,774 \\
2,033 \\
0 \\
814\end{array}$ & $\begin{array}{r}34,334 \\
20,602 \\
1,616 \\
2,702 \\
4,360 \\
3,185 \\
170 \\
1,699\end{array}$ & $\begin{array}{r}23,236 \\
10,933 \\
3,518 \\
2,057 \\
3,686 \\
2,584 \\
48 \\
410\end{array}$ & $\begin{array}{r}29,263 \\
10,996 \\
1,375 \\
3,151 \\
4,661 \\
1,099 \\
0 \\
7,981\end{array}$ & $\begin{array}{r}30,318 \\
13,052 \\
2,549 \\
2,407 \\
6,237 \\
1,826 \\
0 \\
4,247\end{array}$ & $\begin{array}{r}20,708 \\
10,632 \\
2,246 \\
4,145 \\
525 \\
2,933 \\
0 \\
227\end{array}$ & $\begin{array}{r}8,581 \\
4,105 \\
639 \\
1,342 \\
1,134 \\
627 \\
0 \\
734\end{array}$ & $\begin{array}{r}14,821 \\
9,896 \\
735 \\
959 \\
1,399 \\
951 \\
67 \\
814\end{array}$ & $\begin{array}{r}8,996 \\
4,296 \\
1,037 \\
697 \\
1,707 \\
1,116 \\
22 \\
121\end{array}$ & $\begin{array}{r}10,981 \\
4,333 \\
339 \\
1,093 \\
2,283 \\
342 \\
0 \\
2,551\end{array}$ & $\begin{array}{r}9,695 \\
4,767 \\
569 \\
527 \\
1,996 \\
583 \\
0 \\
1,253\end{array}$ & $\begin{array}{r}7,222 \\
4,251 \\
643 \\
1,106 \\
221 \\
936 \\
0 \\
65\end{array}$ & $\begin{array}{r}40.5 \\
39.0 \\
28.9 \\
47.3 \\
40.9 \\
30.8 \\
\dagger \\
90.2\end{array}$ & $\begin{array}{l}43.2 \\
48.0 \\
455.5 \\
35.5 \\
32.1 \\
29.9 \\
39.4 \\
47.9\end{array}$ & $\begin{array}{l}38.7 \\
39.3 \\
29.5 \\
33.9 \\
46.3 \\
43.2 \\
45.8 \\
29.5\end{array}$ & $\begin{array}{r}37.5 \\
39.4 \\
27.6 \\
34.7 \\
49.0 \\
31.1 \\
\dagger \\
32.0\end{array}$ & $\begin{array}{r}32.0 \\
36.5 \\
22.3 \\
21.9 \\
32.0 \\
31.9 \\
\dagger \\
29.5\end{array}$ & $\begin{array}{r}34.9 \\
40.0 \\
28.6 \\
26.7 \\
42.1 \\
31.9 \\
\dagger \\
28.6\end{array}$ \\
\hline 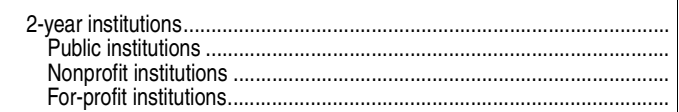 & $\begin{array}{r}380,867 \\
370,653 \\
1,757 \\
8,457\end{array}$ & $\begin{array}{r}437,417 \\
427,019 \\
1,528 \\
8,870\end{array}$ & $\begin{array}{r}422,568 \\
413,310 \\
1,330 \\
7,928\end{array}$ & $\begin{array}{r}477,805 \\
468,321 \\
760 \\
8,724\end{array}$ & $\begin{array}{r}475,877 \\
467,785 \\
751 \\
7,341\end{array}$ & $\begin{array}{r}473,896 \\
465,693 \\
955 \\
7,248\end{array}$ & $\begin{array}{r}153,329 \\
148,115 \\
973 \\
4,241\end{array}$ & $\begin{array}{r}176,416 \\
171,315 \\
909 \\
4,192\end{array}$ & $\begin{array}{r}165,158 \\
160,315 \\
705 \\
4,138\end{array}$ & $\begin{array}{r}198,873 \\
193,853 \\
400 \\
4,620\end{array}$ & $\begin{array}{r}199,412 \\
195,224 \\
368 \\
3,820\end{array}$ & $\begin{array}{r}199,185 \\
194,886 \\
514 \\
3,785\end{array}$ & $\begin{array}{l}40.3 \\
40.0 \\
55.4 \\
50.1\end{array}$ & $\begin{array}{l}40.3 \\
40.1 \\
59.5 \\
47.3\end{array}$ & $\begin{array}{l}39.1 \\
38.8 \\
53.0 \\
52.2\end{array}$ & $\begin{array}{l}41.6 \\
41.4 \\
52.6 \\
53.0\end{array}$ & $\begin{array}{l}41.9 \\
41.7 \\
49.0 \\
52.0\end{array}$ & $\begin{array}{l}42.0 \\
41.8 \\
53.8 \\
52.2\end{array}$ \\
\hline
\end{tabular}

Nonporfitinistitutions

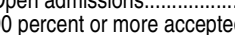

75.0 to 89.9 percent accepted.
50.0 to 74.9 percent accepted

5.0 to 499 percent accepted

SOURCE: U.S. Department of Education, National Center for Education Statistics, Integrated Postsecondary Education Data Sys-

'Adjusted student counts exclude students who died or were totally and permanently disabled, served in the armed forces (includtem (IPEDS), Spring 2008 through 2013, Enrollment component; and IPEDS Fall 2006 through Fall 2011, Institutional Characterising those called to active duty), served with a foreign aid service of the federal government (e.g., Peace Corps), or served on official tics component. (This table was prepared January 2014.) 


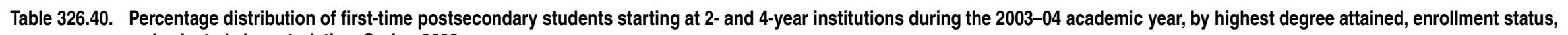
and selected characteristics: Spring 2009

[Standard errors appear in parentheses]

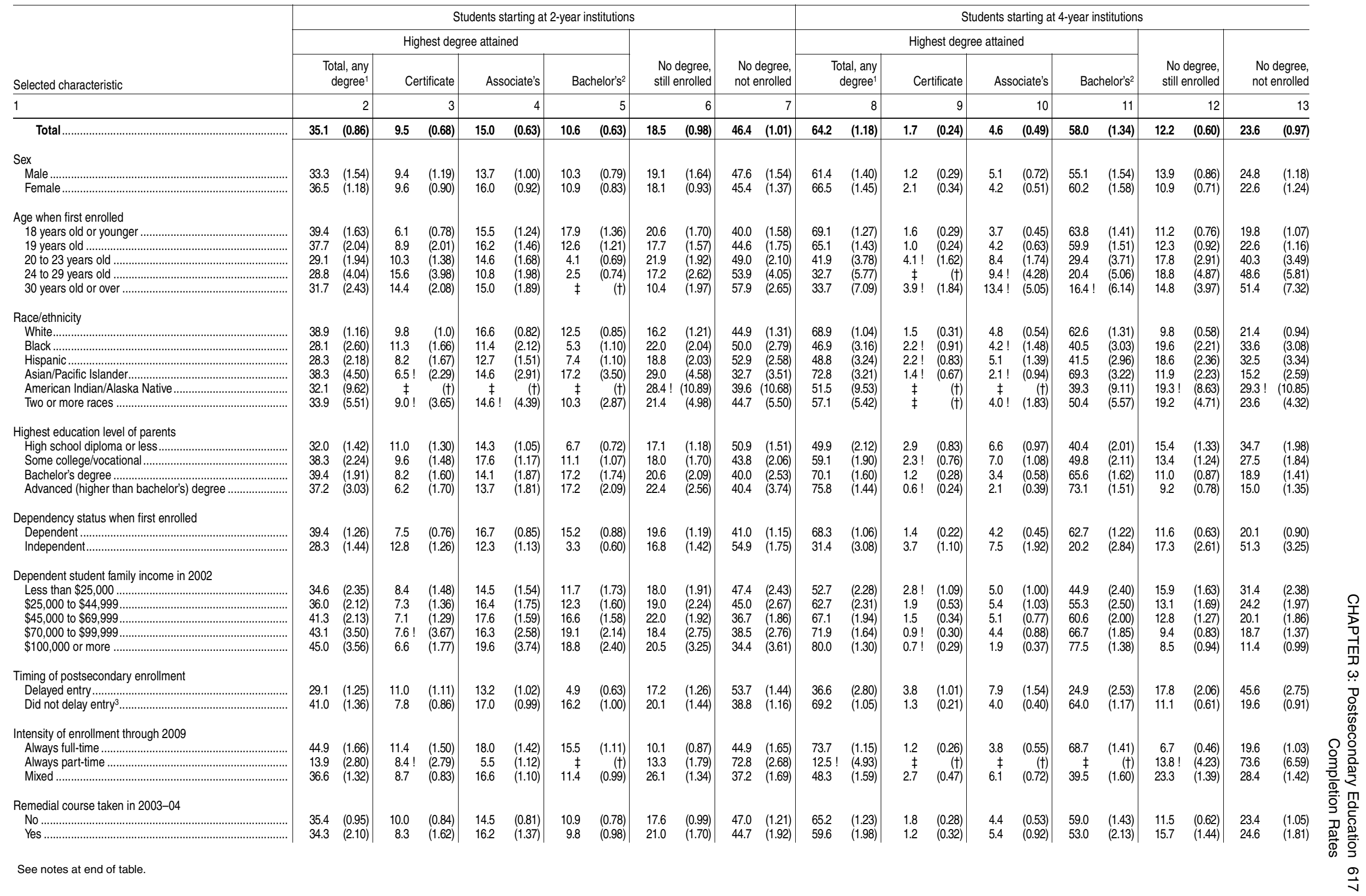




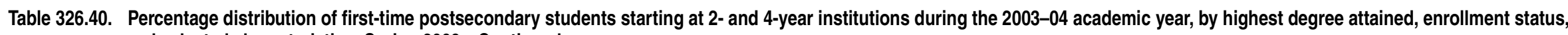
and selected characteristics: Spring 2009-Continued

[Standard errors appear in parentheses]

\begin{tabular}{|c|c|c|c|c|c|c|c|c|c|c|c|c|c|c|c|c|c|c|c|c|c|c|c|c|}
\hline \multirow[b]{3}{*}{ Selected characteristic } & \multicolumn{12}{|c|}{ Students starting at 2-year institutions } & \multicolumn{12}{|c|}{ Students starting at 4-year institutions } \\
\hline & \multicolumn{8}{|c|}{ Highest degree attained } & \multirow{2}{*}{\multicolumn{2}{|c|}{$\begin{array}{l}\text { No degree, } \\
\text { still enrolled }\end{array}$}} & \multirow{2}{*}{\multicolumn{2}{|c|}{$\begin{array}{l}\text { No degree, } \\
\text { not enrolled }\end{array}$}} & \multicolumn{8}{|c|}{ Highest degree attained } & \multirow{2}{*}{\multicolumn{2}{|c|}{$\begin{array}{r}\text { No degree, } \\
\text { still enrolled }\end{array}$}} & \multirow{2}{*}{\multicolumn{2}{|c|}{$\begin{array}{l}\text { No degree, } \\
\text { not enrolled }\end{array}$}} \\
\hline & \multicolumn{2}{|c|}{$\begin{array}{r}\text { Total, any } \\
\text { degree }^{1}\end{array}$} & \multicolumn{2}{|c|}{ Certificate } & \multicolumn{2}{|c|}{ Associate's } & \multicolumn{2}{|c|}{ Bachelor's $^{2}$} & & & & & \multicolumn{2}{|c|}{$\begin{array}{r}\text { Total, any } \\
\text { degree }^{1}\end{array}$} & \multicolumn{2}{|c|}{ Certificate } & \multicolumn{2}{|c|}{ Associate's } & \multicolumn{2}{|c|}{ Bachelor's $^{2}$} & & & & \\
\hline 1 & & 2 & & 3 & & 4 & & 5 & & 6 & & 7 & & 8 & & 9 & & 10 & & 11 & & 12 & & 13 \\
\hline \multirow{2}{*}{\multicolumn{25}{|c|}{ Highest degree expected in 2003-04 }} \\
\hline & & & & & & & & & $\ddagger$ & $(+)$ & 87.3 & (4.75) & $\ddagger$ & $(+)$ & $\ddagger$ & $(+)$ & $\ddagger$ & $(+)$ & $\ddagger$ & (†) & $\ddagger$ & (†) & $\ddagger$ & $(\dagger)$ \\
\hline Certi & 44.8 & $(5.47)$ & 42.8 & $(5.28)$ & $\ddagger$ & $(t)$ & 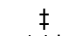 & $(t)$ & 6.9 & (2.02) & 48.3 & $(5.60)$ & $41.2 !$ & $(18.43)$ & $\ddagger$ & $(\dagger)$ & $\ddagger$ & $(\dagger)$ & $\ddagger$ & $(\dagger)$ & $\ddagger$ & $(\dagger)$ & $\ddagger$ & $(\dagger)$ \\
\hline Assoc & 34.6 & (2.38) & 13.9 & $(2.05)$ & 19.3 & $(1.86)$ & 1.4 ! & $(0.49)$ & 12.3 & $(1.69)$ & 53.1 & $(2.80)$ & 43.7 & $(8.43)$ & $16.2 !$ & $(5.50)$ & $21.3 !$ & $(7.06)$ & $6.1 !$ & (2.93) & $12.8 !$ & $(5.09)$ & 43.5 & $(7.70)$ \\
\hline Bachel & 32.7 & $(1.81)$ & 8.0 & (1.49) & 15.4 & (1.02) & 9.3 & $(1.03)$ & 18.1 & $(1.50)$ & 49.3 & $(1.60)$ & 55.2 & (2.02) & 2.2 & $(0.52)$ & 6.8 & $(1.02)$ & 46.2 & (2.07) & 15.1 & (1.37) & 29.7 & (1.59) \\
\hline Maste & 38.2 & (1.72) & 7.0 & (1.32) & 14.8 & (1.21) & 16.4 & $(1.19)$ & 22.7 & $(1.63)$ & 39.1 & $(1.66)$ & 66.7 & (1.42) & 1.0 & $(0.25)$ & 4.1 & $(0.62)$ & 61.7 & $(1.42)$ & 11.2 & $(0.77)$ & 22.1 & $(1.32)$ \\
\hline Doctoral/first-professional degree ${ }^{4}$ & 34.7 & $(2.30$ & 4.8 & $(0.93)$ & 13.8 & (2.02) & 16.0 & $(1.65)$ & 22.4 & $(2.54)$ & 42.9 & (3.25) & 70.6 & (1.57) & 1.3 & $(0.36)$ & 1.9 & $(0.36)$ & 67.4 & (1.69) & 11.0 & $(0.95)$ & 18.3 & $(1.35)$ \\
\hline \multicolumn{25}{|l|}{ Work intensity (including work-study) in 2003-04 } \\
\hline Did not work. & 34.7 & (1.79) & 11.2 & (1.57) & 15.8 & $(1.20)$ & 7.7 & $(0,85)$ & 19.9 & $(1.80)$ & 45.3 & (2.16) & 69.9 & $(1.35)$ & 0.8 & (0.18) & 3.4 & $(0.55)$ & 65.8 & $(1.47)$ & 10.9 & $(0.92)$ & 19.1 & $(1.08)$ \\
\hline Workec & 39.9 & 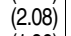 & 7.9 & $(1.2$ & 17.4 & (1) & 14.6 & $(1.0$ & 17. & & 42.8 & $(1.7$ & 66.2 & $(1$. & 1.7 & $(0)$. & 5.2 & ine & 59.3 & & 12.1 & $(0.85)$ & 21.7 & (1.21) \\
\hline Worked full time & 28.6 & (1.96) & 10.6 & (1.63) & 10.9 & (1.08) & 7.2 & $(0.94)$ & 19.3 & $(1.53)$ & 52.1 & $(2.10)$ & 40.1 & (2.93) & 4.1 & $(1.22)$ & 5.9 & $(1.20)$ & 30.1 & $(2.60)$ & 16.5 & $(1.77)$ & 43.4 & $(2.86)$ \\
\hline \multicolumn{25}{|l|}{ Control of first institution } \\
\hline Public .... & 34.4 & $(0.95)$ & 8.5 & $(0.68)$ & 14.4 & $(0.61)$ & 11.6 & $(0.68)$ & 19.6 & (1.03) & 46.0 & $(1.00)$ & 64.8 & (1.22) & 1.6 & $(0.23)$ & 3.8 & $(0.45)$ & 59.5 & (1.32) & 12.9 & $(0.73)$ & 22.2 & $(0.98)$ \\
\hline Private, & 46.2 & (8.52) & $13.3 !$ & (6.56) & $21.5 !$ & (6.76) & $11.3 !$ & $(4.99)$ & $10.4 !$ & (3.32) & 43.4 & (8.28) & 69.9 & $(1.45)$ & 1.5 & $(0.37)$ & 3.8 & $(0.95)$ & 64.6 & $(1.89)$ & 11.1 & $(1.02)$ & 19.0 & $(1.18)$ \\
\hline Private, for pro & 39.5 & (3.70) & 19.6 & (4.78) & 19.5 & (3.51) & $\ddagger$ & $(t)$ & 9.6 & (2.61) & 50.9 & $(4.64)$ & 33.9 & $(4.37)$ & $\ddagger$ & $(t)$ & 14.6 & $(3.45)$ & 15.7 & (3.78) & 11.3 & $(2.44)$ & 54.8 & (3.82) \\
\hline \multicolumn{25}{|l|}{ Income q } \\
\hline & 30.6 & (1.45) & 9.4 & $(1.2$ & 13.0 & (1.14) & 8.3 & $(0.84)$ & 18.4 & (1.46) & 51.0 & $(1)$. & 49.5 & $(1.8$ & 2.7 & (0.73) & 4.6 & $(0.74)$ & 42.2 & $(2$. & 16.2 & $(1.37)$ & 34.3 & (1.75) \\
\hline & 37.1 & (1.58) & 10.5 & (1. & 15.8 & (1.26) & 10.8 & & 19.7 & $(1.58)$ & 43.2 & $(1.86)$ & 60.5 & $(2.04)$ & 2.4 & $(0.51)$ & 6.5 & $(1.10)$ & 51.6 & $(2$. & 13.5 & $(1.16)$ & 26.0 & (1.82) \\
\hline & 36.3 & (2.51) & 9.6 & (1.71) & 15.0 & (1.35) & 11.6 & (1.53) & 18.7 & $(1.64)$ & 45.0 & (2.18) & 67.2 & $(1.58)$ & 1.3 & $(0.31)$ & 4.9 & $(0.80)$ & 61.0 & $(1.85)$ & 11.2 & $(0.88)$ & 21.6 & $(1.55)$ \\
\hline Highest quartile.... & 38.6 & (2.51) & 8.1 & (1.49) & 17.3 & $(1.96)$ & 13.2 & $(1.65)$ & 16.5 & (2.30) & 45.0 & $(3.20)$ & 76.8 & $(1.37)$ & $0.6 !$ & $(0.25)$ & 2.4 & $(0.46)$ & 73.8 & (1.42) & 8.7 & $(0.80)$ & 14.4 & (1.18) \\
\hline
\end{tabular}

\section{†Not applicable.}

IInterpret tota with caution. The coefficient of variation (CV) for this estimate is between 30 and 50 percent ‡Reporting standards not met. Either there are too few cases for a reliable estimate or the coefficient of variation (CV) is 50 percent or greater. -Includes a small percentage of students who had attained a degree and were still enrolled. Includes recipients of degrees not shown separately.
2Includes a small
3Includes students with a standard high school diploma who enrolled in postsecondary education in the same year as their graduation.
${ }_{4}$ Students
G

IIndicates the income quartile of the student, based on the student's total income in 2002 for independent students or the parents' total income in 2002 for dependent students. Income quartiles were determined separately for dependent and independent students based on percentile rankings and then combined into one variable.

SOURCE: U.S. Department of Education, National Center for Education Statistics, 2004/09 Beginning Postsecondary Students Longitudinal Study (BPS:04/09). (This table was prepared November 2011.) 
Table 327.10. Average scores and standard deviations on Graduate Record Examination (GRE) general and subject tests: 1965 through 2012

[Standard deviations appear in square brackets]

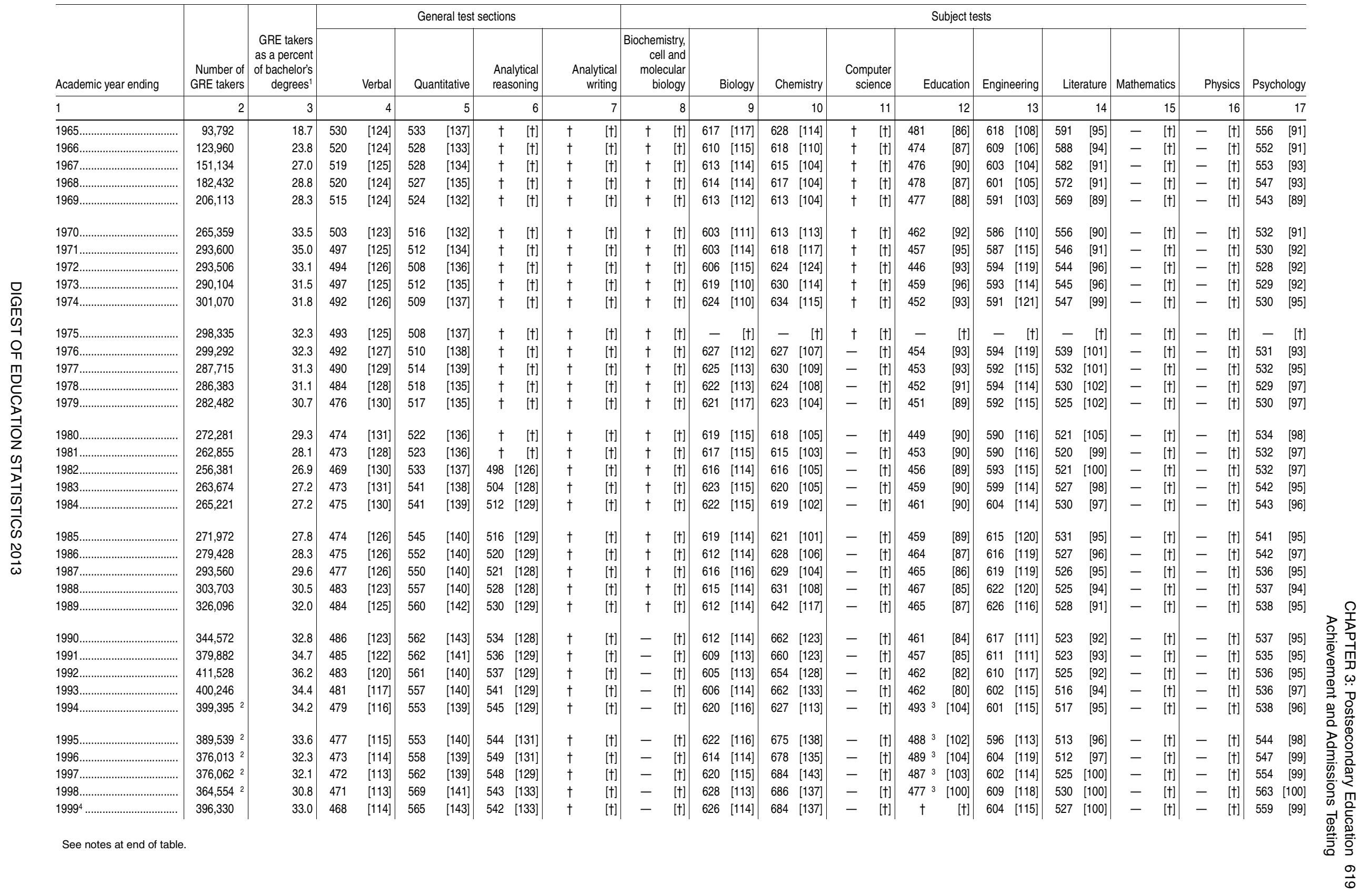


Table 327.10. Average scores and standard deviations on Graduate Record Examination (GRE) general and subject tests: 1965 through 2012-Continued

[Standard deviations appear in square brackets]

\begin{tabular}{|c|c|c|c|c|c|c|c|c|c|c|c|c|c|c|c|c|c|c|c|c|c|c|c|c|c|c|c|c|c|c|c|}
\hline \multirow[b]{2}{*}{ Academic year ending } & \multirow[b]{2}{*}{$\begin{array}{r}\text { Number of } \\
\text { GRE takers }\end{array}$} & \multirow[b]{2}{*}{$\begin{array}{r}\text { GRE takers } \\
\text { as a percent } \\
\text { of bachelor's } \\
\text { degrees } 1\end{array}$} & \multicolumn{8}{|c|}{ General test sections } & \multicolumn{21}{|c|}{ Subject tests } \\
\hline & & & & Verbal & Quan & titative & & sonical & & $\begin{array}{l}\text { Alytical } \\
\text { vriting }\end{array}$ & $\begin{array}{r}\text { Bioche } \\
\mathrm{c} \\
\mathrm{mo} \\
\mathrm{b}\end{array}$ & $\begin{array}{l}\text { mistry, } \\
\text { ell and } \\
\text { ecular } \\
\text { iology }\end{array}$ & & Biology & & emistry & & $\begin{array}{l}\text { mput } \\
\text { scien }\end{array}$ & & & ation & Engine & ering & & rature & Mathe & ematics & & Physics & Psyct & chology \\
\hline 1 & 2 & 3 & & 4 & & 5 & & 6 & & 7 & & 8 & & 9 & & 10 & & & 11 & & 12 & & 13 & & 14 & & 15 & & 16 & & 17 \\
\hline $2000^{4} \ldots \ldots \ldots \ldots \ldots \ldots \ldots \ldots \ldots$ & 387,422 & 31.3 & 465 & [116] & 578 & [147] & 562 & [141] & $\dagger$ & [t] & - & [t] & 629 & [114] & 686 & {$[133$} & - & & [†] & $\dagger$ & {$[\dagger]$} & - & {$[t]$} & 530 & [99] & - & [t] & - & [t] & 563 & {$[98$} \\
\hline 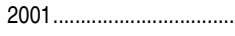 & 433,109 & 34.8 & - & [t] & - & [t] & - & [t] & $\dagger$ & [t] & - & [t] & - & [t] & - & [t] & - & & [†] & $\dagger$ & {$[t]$} & - & [t] & - & [t] & - & [t] & - & [t] & - & [t] \\
\hline $2002 .$. & 536,523 & 41.5 & 473 & [123] & 597 & [151] & 571 & [139] & $\dagger$ & [t] & - & [†] & - & [t] & - & [t] & - & & [t] ] & $\dagger$ & {$[t]$} & $\dagger$ & [t] & - & [t] & - & [t] & - & [†] & - & [t] \\
\hline $2003^{3,6}$. & 440,982 & 32.7 & 470 & [121] & 598 & [148] & $\dagger$ & [t] & 4.2 & {$[1.0]$} & 517 & [100] & 635 & [114] & 682 & {$[125$} & 71 & {$[9$} & 97] & $\dagger$ & {$[t]$} & $\dagger$ & [t] & 538 & [98] & 620 & [131] & 669 & 9 [151] & 580 & {$[101$} \\
\hline $2004^{5,6,7} \ldots \ldots \ldots \ldots \ldots \ldots \ldots$ & 446,661 & 31.9 & 469 & {$[120]$} & 597 & [148] & $\dagger$ & {$[t]$} & 4.2 & {$[1.0]$} & 517 & [101] & 643 & [115] & 675 & {$[120]$} & 71 & {$[9$} & 93] & $\dagger$ & {$[t]$} & $\dagger$ & {$[\dagger]$} & 537 & [97] & 621 & [130] & 665 & 5 [148] & 586 & {$[101]$} \\
\hline $2005^{5,6,7} \ldots$ & 474,594 & 33.0 & 467 & {$[118]$} & 591 & [148] & $\dagger$ & {$[\dagger]$} & 4.2 & {$[0.9]$} & 518 & [100] & 647 & [117] & 675 & {$[117]$} & 71 & & 91] & $\dagger$ & {$[\dagger]$} & $\dagger$ & {$[\dagger]$} & 540 & [97] & 623 & [130] & 672 & 2 [151] & 592 & {$[101$} \\
\hline $2006^{5,7,8} \ldots \ldots \ldots \ldots \ldots \ldots \ldots \ldots$ & 506,633 & 34.1 & 465 & [117] & 584 & [149] & $\dagger$ & [t] & 4.1 & {$[0.9]$} & 519 & [99] & 650 & [118] & 677 & {$[116$} & 71 & & 92] & $\dagger$ & [t] & $\dagger$ & [t] & 541 & [97] & 627 & [129] & 678 & 8 [153] & 598 & {$[101]$} \\
\hline $2007^{5,7,8} \ldots$ & 556,729 & 36.5 & 462 & [119] & 584 & [151] & $\dagger$ & [†] & 4.0 & {$[0.9]$} & 521 & [97] & 650 & [120] & 689 & {$[115$} & 71 & & 91] & $\dagger$ & [t] & $\dagger$ & [t] & 542 & [98] & 636 & [130] & 686 & 6 [155] & 600 & {$[101]$} \\
\hline $2008^{5,7,8} \ldots \ldots \ldots \ldots \ldots$ & 540,441 & 34.6 & 457 & [121] & 586 & [152] & $\dagger$ & [t] & 3.9 & {$[0.9]$} & 525 & [97] & 651 & [120] & 694 & {$[116$} & 71 & & 92] & $\dagger$ & [t] & $\dagger$ & {$[+]$} & 541 & [98] & 640 & [131] & 692 & 2 [156] & 603 & {$[101$} \\
\hline $20095,7,8 \ldots \ldots \ldots \ldots \ldots \ldots \ldots \ldots$ & 597,171 & 37.3 & 456 & [120] & 590 & [150] & $\dagger$ & {$[t]$} & 3.8 & {$[0.9]$} & 523 & [97] & 650 & [120] & 699 & {$[115$} & 70 & & 91] & $\dagger$ & [t] & $\dagger$ & [t] & 541 & [97] & 648 & [134] & 692 & 2 [156] & 605 & {$[103$} \\
\hline $2010^{5} \ldots \ldots \ldots \ldots \ldots \ldots \ldots \ldots$ & 630,212 & 38.2 & - & {$[t]$} & - & [t] & $\dagger$ & [t] & - & [t] & 525 & [97] & 651 & [121] & 700 & {$[115$} & 70 & & 96] & $\dagger$ & [t] & $\dagger$ & [t] & 542 & [98] & 650 & [134] & 692 & 2 [157] & 609 & {$[103$} \\
\hline $2011^{5} \ldots \ldots \ldots \ldots \ldots \ldots \ldots \ldots \ldots$ & 700,713 & 40.8 & $151^{9}$ & [8.5] & $151^{9}$ & [8.7] & $\dagger$ & [t] & $3.7^{9}$ & {$[0.9]$} & 525 & [97] & 651 & [122] & 703 & {$[114$} & 69 & {$[9$} & 99] & $\dagger$ & [t] & $\dagger$ & [t] & 547 & [98] & 655 & [135] & 689 & 9 [156] & 612 & {$[103$} \\
\hline $2012^{5} \ldots \ldots \ldots \ldots \ldots \ldots \ldots \ldots$ & 585,959 & 32.7 & $151^{9}$ & [8.4] & $152^{9}$ & [8.8] & $\dagger$ & [t] & $3.61^{9}$ & {$[0.9]$} & 526 & [95] & 658 & [123] & 703 & {$[115$} & 69 & {$[10$} & & $\dagger$ & {$[t]$} & $\dagger$ & {$[\dagger]$} & 549 & [99] & 657 & [136] & 696 & $\begin{array}{ll}6 \\
6\end{array}$ & 616 & [102 \\
\hline
\end{tabular}

\section{- Not available.}

'GRE takers include examinees from inside and outside of the United States, while the bachelor's degrees include only those conferred by U.S. institutions.

reived no score on one or more general test measures.

reported test year and September 30 of the reported test year. These data are not directly comparable with data for most other years.

${ }^{5}$ Subject test score data reflect the 3-year average for all examinees who tested between July 1 three years prior to the reported test year and June 30 of the reported test year. These data are not directly comparable with previous years, except Ar

the reported test year.

tVerbal and quantitative test score data reflect the 3-year average for all examinees who tested between July 1 three years
prior to the reported test year and June 30 of the reported test year. These data are not directly comparable with previous

years.
8 Analytical writing test score data reflect the 3 -year average for all examinees who tested between July 1 three years prior to the reported test year and June 30 of the reported test year.
${ }^{9}$ On August 1, 2011, the GRE revised general test was introduced. Scores for the revised verbal reasoning and quantitative reasoning sections range from 130 to 170 , in 1-point increments. Scores for the revised analytical writing section continue to range from 0 to 6, in half-point increments. For all three sections of the revised general test, 2011 scores are based on the performance of all examinees who tested between August 1, 2011, and April 30, 2012, and 2012 scores are based on the
performance of all examinees who tested between August 1, 2011, and April 30, 2013. These scores are not comparable with scores from previous years. NOTE: GRE data include test takers from both within and outside of the United States. Prior to 2011, GRE scores for the verbal, quantitative, and analytical reasoning sections range from 200 to 800 . Scores for the analytical writing section range from 0 to 6 , in half-point increments. The range of scores is different for the various subject tests, from as low as 200 to as high a 990. The analytical reasoning section of the GRE, a multiple-choice test, was discontinued in September 2002 and replaced
by the analytical writing section, an essay-based test. The education subject test was administered for the final time in April by the analytical writing section, an essay-based test. The education subject test was administered for the final time in Apr
1998 . The engineering subject test was administered for the final time in April 2001 . SOURCE: Graduate Record Examination Board, Examinee and Score Trends for the GRE General Test, 1964-65 through 1985-86: A Summary of Data Collected From Graduate Record Examinations Tost-Takers During 1986-87: Guide to the Ut of Scores, 1987-88 through 2013-14; GRE Volumes by Country, 2000-2012; and Interpreting Your GRE Scores, 2005-06 through 2011-12. U.S. Department of Education, National Center for Education Statistics, Higher Education General Information Survey (HEGIS), Degrees and Other Formal Awards Conferred" surveys, 1964-65 through 1985-86; Integrated Postsecondary Education Data System (IPEDS), "Completions Survey" (IPEDS-C:87-99); and IPEDS Fall 2000 through Fall 
Table 329.10. On-campus crimes, arrests, and referrals for disciplinary action at degree-granting postsecondary institutions, by location of incident, control and level of institution, and type of incident: 2001 through 2011

\begin{tabular}{|c|c|c|c|c|c|c|c|c|c|c|c|c|c|}
\hline \multirow[b]{3}{*}{ Control and level of institution and type of incident } & \multicolumn{13}{|c|}{ Number of incidents } \\
\hline & \multirow[b]{2}{*}{2001} & \multirow[b]{2}{*}{2002} & \multirow[b]{2}{*}{2003} & \multirow[b]{2}{*}{2004} & \multirow[b]{2}{*}{2005} & \multirow[b]{2}{*}{2006} & \multirow[b]{2}{*}{2007} & \multirow[b]{2}{*}{2008} & \multirow[b]{2}{*}{2009} & \multirow[b]{2}{*}{2010} & \multicolumn{3}{|c|}{2011} \\
\hline & & & & & & & & & & & Total & $\begin{array}{r}\text { In } \\
\text { residence } \\
\text { hall }\end{array}$ & $\begin{array}{l}\text { At other } \\
\text { locations }\end{array}$ \\
\hline 1 & 2 & 3 & 4 & 5 & 6 & 7 & 8 & 9 & 10 & 11 & 12 & 13 & 14 \\
\hline 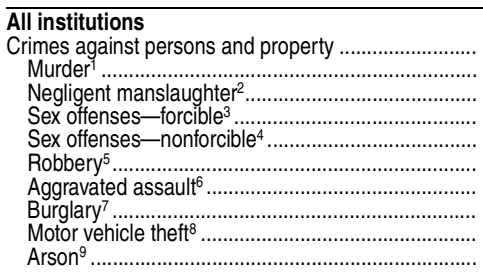 & $\begin{array}{r}41,596 \\
17 \\
2 \\
2,201 \\
461 \\
1,663 \\
2,947 \\
26,904 \\
6,221 \\
1,180\end{array}$ & $\begin{array}{r}42,521 \\
20 \\
0 \\
2,327 \\
261 \\
1,802 \\
2,804 \\
28,038 \\
6,181 \\
1,088\end{array}$ & $\begin{array}{r}43,064 \\
9 \\
1 \\
2,595 \\
60 \\
1,625 \\
2,832 \\
28,639 \\
6,285 \\
1,018\end{array}$ & $\begin{array}{r}43,555 \\
15 \\
0 \\
2,667 \\
27 \\
1,550 \\
2,721 \\
29,480 \\
6,062 \\
1,033\end{array}$ & $\begin{array}{r}42,710 \\
11 \\
2 \\
2,674 \\
42 \\
1,551 \\
2,656 \\
29,256 \\
5,531 \\
987\end{array}$ & $\begin{array}{r}44,492 \\
8 \\
0 \\
2,670 \\
43 \\
1,547 \\
2,817 \\
31,260 \\
5,231 \\
916\end{array}$ & $\begin{array}{r}41,829 \\
44 \\
3 \\
2,694 \\
40 \\
1,561 \\
2,604 \\
29,488 \\
4,619 \\
776\end{array}$ & $\begin{array}{r}40,296 \\
12 \\
3 \\
2,639 \\
35 \\
1,576 \\
2,495 \\
28,737 \\
4,104 \\
695\end{array}$ & $\begin{array}{r}34,054 \\
16 \\
0 \\
2,544 \\
65 \\
1,409 \\
2,327 \\
23,083 \\
3,977 \\
633\end{array}$ & $\begin{array}{r}31,919 \\
15 \\
1 \\
2,919 \\
33 \\
1,391 \\
2,224 \\
21,190 \\
3,418 \\
728\end{array}$ & $\begin{array}{r}30,401 \\
15 \\
1 \\
3,344 \\
45 \\
1,292 \\
2,211 \\
19,488 \\
3,373 \\
632\end{array}$ & $\begin{array}{r}14,698 \\
4 \\
1 \\
2,378 \\
16 \\
225 \\
805 \\
10,913 \\
5 \\
351\end{array}$ & $\begin{array}{r}15,703 \\
11 \\
0 \\
966 \\
29 \\
1,067 \\
1,406 \\
8,575 \\
3,368 \\
281\end{array}$ \\
\hline 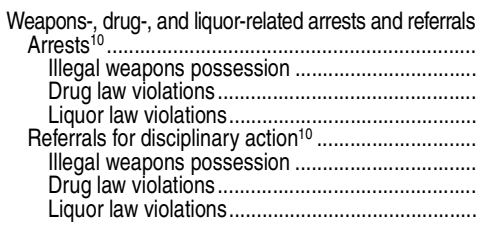 & $\begin{array}{r}40,348 \\
1,073 \\
11,854 \\
27,421 \\
155,201 \\
1,277 \\
23,900 \\
130,024\end{array}$ & \begin{tabular}{|r|}
43,407 \\
1,142 \\
12,041 \\
30,224 \\
167,319 \\
1,287 \\
26,038 \\
139,994 \\
\end{tabular} & $\begin{array}{r}44,581 \\
1,094 \\
12,467 \\
31,020 \\
184,915 \\
1,566 \\
25,753 \\
157,596\end{array}$ & $\begin{array}{r}47,939 \\
1,263 \\
12,775 \\
33,901 \\
196,775 \\
1,799 \\
25,762 \\
169,214\end{array}$ & $\begin{array}{r}49,024 \\
1,316 \\
13,707 \\
34,001 \\
202,816 \\
1,882 \\
25,356 \\
175,578\end{array}$ & $\begin{array}{r}50,187 \\
1,316 \\
13,952 \\
34,919 \\
218,040 \\
1,871 \\
27,251 \\
188,918\end{array}$ & $\begin{array}{r}50,558 \\
1,318 \\
14,135 \\
35,105 \\
216,600 \\
1,658 \\
28,476 \\
186,466\end{array}$ & $\begin{array}{r}50,639 \\
1,190 \\
15,146 \\
34,303 \\
217,526 \\
1,455 \\
32,469 \\
183,602\end{array}$ & $\begin{array}{r}50,066 \\
1,077 \\
15,871 \\
33,118 \\
220,987 \\
1,275 \\
36,344 \\
183,368\end{array}$ & $\begin{array}{r}51,423 \\
1,103 \\
18,510 \\
31,810 \\
229,630 \\
1,308 \\
41,970 \\
186,352\end{array}$ & $\begin{array}{r}54,612 \\
1,028 \\
20,729 \\
32,855 \\
250,557 \\
1,310 \\
52,014 \\
197,233\end{array}$ & $\begin{array}{r}27,760 \\
248 \\
11,438 \\
16,074 \\
222,912 \\
869 \\
43,367 \\
178,676\end{array}$ & $\begin{array}{r}26,852 \\
780 \\
9,291 \\
16,781 \\
27,645 \\
441 \\
8,647 \\
18,557\end{array}$ \\
\hline 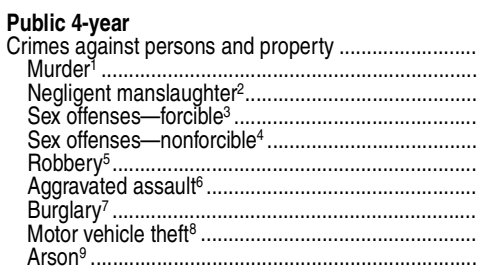 & $\begin{array}{r}18,710 \\
9 \\
2 \\
1,245 \\
207 \\
584 \\
1,434 \\
11,520 \\
3,072 \\
637\end{array}$ & $\begin{array}{r}19,563 \\
9 \\
0 \\
1,278 \\
113 \\
659 \\
1,39 \\
12,523 \\
3,092 \\
569\end{array}$ & $\begin{array}{r}19,789 \\
5 \\
1 \\
1,358 \\
28 \\
669 \\
1,381 \\
12,634 \\
3,116 \\
597\end{array}$ & $\begin{array}{r}19,984 \\
8 \\
0 \\
1,482 \\
16 \\
612 \\
1,269 \\
13,026 \\
2,964 \\
607\end{array}$ & $\begin{array}{r}19,582 \\
4 \\
1 \\
1,398 \\
25 \\
696 \\
1,260 \\
12,935 \\
2,667 \\
576\end{array}$ & $\begin{array}{r}20,648 \\
5 \\
0 \\
1,400 \\
15 \\
680 \\
1,338 \\
14,027 \\
2,662 \\
521\end{array}$ & $\begin{array}{r}19,579 \\
42 \\
2 \\
1,425 \\
23 \\
722 \\
1,258 \\
13,371 \\
2,266 \\
470\end{array}$ & $\begin{array}{r}18,695 \\
9 \\
1 \\
1,317 \\
12 \\
750 \\
1,182 \\
12,970 \\
2,027 \\
427\end{array}$ & $\begin{array}{r}15,975 \\
8 \\
0 \\
1,214 \\
40 \\
647 \\
1,134 \\
10,708 \\
1,824 \\
400\end{array}$ & $\begin{array}{r}15,429 \\
9 \\
0 \\
1,460 \\
15 \\
655 \\
1,072 \\
10,170 \\
1,593 \\
455\end{array}$ & $\begin{array}{r}14,679 \\
9 \\
1 \\
1,630 \\
17 \\
616 \\
1,081 \\
9,363 \\
1,610 \\
352\end{array}$ & $\begin{array}{r}7,189 \\
3 \\
1 \\
1,151 \\
7 \\
138 \\
426 \\
5,244 \\
5 \\
214\end{array}$ & $\begin{array}{r}7,490 \\
6 \\
0 \\
479 \\
10 \\
478 \\
655 \\
4,119 \\
1,605 \\
138\end{array}$ \\
\hline 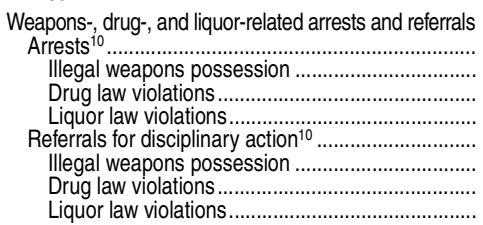 & $\begin{array}{r}31,077 \\
692 \\
9,125 \\
21,260 \\
79,152 \\
678 \\
13,179 \\
65,295\end{array}$ & $\begin{array}{r}33,831 \\
745 \\
9,338 \\
23,848 \\
84,636 \\
675 \\
13,943 \\
70,018\end{array}$ & $\begin{array}{r}34,657 \\
697 \\
9,389 \\
24,571 \\
94,365 \\
847 \\
13,811 \\
79,707\end{array}$ & $\begin{array}{r}36,746 \\
811 \\
9,620 \\
26,315 \\
100,588 \\
1,001 \\
13,658 \\
85,929\end{array}$ & $\begin{array}{r}38,051 \\
878 \\
10,606 \\
26,567 \\
100,211 \\
1,097 \\
13,020 \\
86,094\end{array}$ & $\begin{array}{r}39,900 \\
859 \\
10,850 \\
28,191 \\
107,289 \\
972 \\
13,798 \\
92,519\end{array}$ & $\begin{array}{r}39,570 \\
825 \\
10,693 \\
28,052 \\
106,148 \\
867 \\
14,458 \\
90,823\end{array}$ & $\begin{array}{r}40,607 \\
759 \\
11,714 \\
28,134 \\
104,585 \\
792 \\
16,656 \\
87,137\end{array}$ & $\begin{array}{r}40,780 \\
659 \\
12,186 \\
27,935 \\
108,756 \\
669 \\
18,260 \\
89,827\end{array}$ & $\begin{array}{r}41,940 \\
664 \\
14,318 \\
26,958 \\
115,743 \\
659 \\
21,375 \\
93,709\end{array}$ & $\begin{array}{r}45,094 \\
631 \\
16,329 \\
28,134 \\
129,822 \\
613 \\
27,377 \\
101,832\end{array}$ & $\begin{array}{r}22,910 \\
188 \\
9,286 \\
13,436 \\
116,244 \\
448 \\
22,809 \\
92,987\end{array}$ & $\begin{array}{r}22,184 \\
443 \\
7,043 \\
14,698 \\
13,578 \\
165 \\
4,568 \\
8,845\end{array}$ \\
\hline 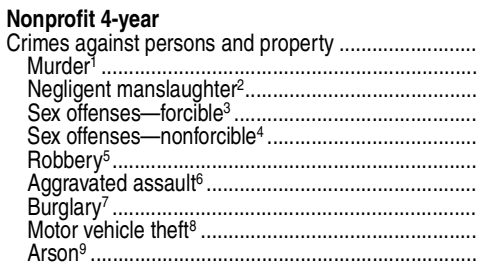 & $\begin{array}{r}14,844 \\
5 \\
0 \\
820 \\
113 \\
649 \\
882 \\
10,471 \\
1,471 \\
433\end{array}$ & $\begin{array}{r}14,859 \\
9 \\
0 \\
914 \\
81 \\
735 \\
900 \\
10,561 \\
1,273 \\
386\end{array}$ & $\begin{array}{r}15,179 \\
2 \\
0 \\
1,048 \\
14 \\
538 \\
773 \\
11,066 \\
1,385 \\
353\end{array}$ & $\begin{array}{r}15,523 \\
4 \\
0 \\
1,026 \\
5 \\
577 \\
838 \\
11,426 \\
1,316 \\
331\end{array}$ & $\begin{array}{r}15,574 \\
5 \\
1 \\
1,088 \\
6 \\
500 \\
744 \\
11,657 \\
1,248 \\
325\end{array}$ & $\begin{array}{r}16,864 \\
3 \\
0 \\
1,080 \\
10 \\
502 \\
834 \\
13,051 \\
1,077 \\
307\end{array}$ & $\begin{array}{r}15,452 \\
2 \\
1 \\
1,065 \\
8 \\
460 \\
768 \\
11,941 \\
984 \\
223\end{array}$ & $\begin{array}{r}14,892 \\
1 \\
0 \\
1,083 \\
16 \\
437 \\
754 \\
11,551 \\
859 \\
191\end{array}$ & $\begin{array}{r}11,964 \\
6 \\
0 \\
1,102 \\
11 \\
366 \\
661 \\
8,810 \\
834 \\
174\end{array}$ & $\begin{array}{r}11,128 \\
5 \\
0 \\
1,220 \\
8 \\
317 \\
641 \\
8,077 \\
637 \\
223\end{array}$ & \begin{tabular}{r|r}
10,742 \\
3 \\
0 \\
1,406 \\
13 \\
325 \\
633 \\
7,444 \\
702 \\
216
\end{tabular} & $\begin{array}{r}6,538 \\
1 \\
0 \\
1,132 \\
6 \\
75 \\
291 \\
4,900 \\
0 \\
133\end{array}$ & $\begin{array}{r}4,204 \\
2 \\
0 \\
274 \\
7 \\
250 \\
342 \\
2,544 \\
702 \\
83\end{array}$ \\
\hline 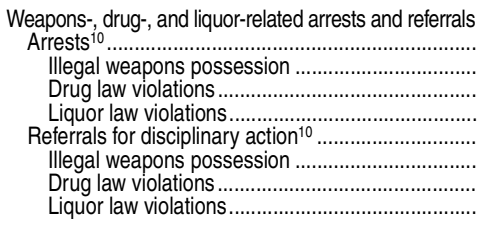 & $\begin{array}{r}6,329 \\
167 \\
1,628 \\
4,534 \\
71,293 \\
443 \\
9,688 \\
61,162\end{array}$ & $\begin{array}{r}6,548 \\
162 \\
1,723 \\
4,663 \\
77,641 \\
424 \\
11,100 \\
66,117\end{array}$ & $\begin{array}{r}6,856 \\
166 \\
1,869 \\
4,821 \\
85,184 \\
537 \\
10,885 \\
73,762\end{array}$ & $\begin{array}{r}7,722 \\
184 \\
1,751 \\
5,787 \\
90,749 \\
608 \\
10,903 \\
79,238\end{array}$ & $\begin{array}{r}7,406 \\
150 \\
1,691 \\
5,565 \\
96,646 \\
590 \\
11,208 \\
84,848\end{array}$ & $\begin{array}{r}6,134 \\
146 \\
1,650 \\
4,338 \\
103,484 \\
622 \\
12,114 \\
90,748\end{array}$ & $\begin{array}{r}6,732 \\
178 \\
1,804 \\
4,750 \\
103,254 \\
545 \\
12,685 \\
90,024\end{array}$ & $\begin{array}{r}6,112 \\
158 \\
1,883 \\
4,071 \\
105,289 \\
457 \\
14,157 \\
90,675\end{array}$ & $\begin{array}{r}5,777 \\
148 \\
2,080 \\
3,549 \\
103,457 \\
358 \\
15,845 \\
87,254\end{array}$ & $\begin{array}{r}5,417 \\
137 \\
2,221 \\
3,059 \\
104,512 \\
391 \\
17,814 \\
86,307\end{array}$ & $\begin{array}{r}5,470 \\
128 \\
2,270 \\
2,972 \\
110,925 \\
433 \\
21,478 \\
89,014\end{array}$ & $\begin{array}{r}1,574 \\
99,218 \\
335 \\
18,518 \\
80,365\end{array}$ & $\begin{array}{r}2,317 \\
98 \\
821 \\
1,398 \\
11,707 \\
98 \\
2,960 \\
8,649\end{array}$ \\
\hline 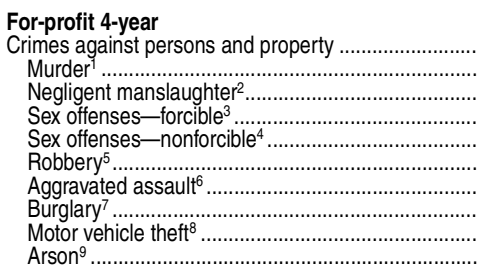 & \begin{tabular}{r|r}
505 \\
0 \\
0 \\
4 \\
13 \\
64 \\
23 \\
347 \\
52 \\
2
\end{tabular} & $\begin{array}{r}592 \\
0 \\
0 \\
4 \\
1 \\
71 \\
45 \\
376 \\
94 \\
1\end{array}$ & $\begin{array}{r}720 \\
0 \\
0 \\
8 \\
2 \\
43 \\
41 \\
542 \\
80 \\
4\end{array}$ & $\begin{array}{r}718 \\
0 \\
0 \\
5 \\
0 \\
46 \\
38 \\
524 \\
100 \\
5\end{array}$ & $\begin{array}{r}829 \\
0 \\
0 \\
4 \\
1 \\
43 \\
59 \\
607 \\
110 \\
5\end{array}$ & $\begin{array}{r}641 \\
0 \\
0 \\
12 \\
0 \\
25 \\
31 \\
489 \\
78 \\
6\end{array}$ & $\begin{array}{r}612 \\
0 \\
0 \\
12 \\
2 \\
31 \\
31 \\
446 \\
89 \\
1\end{array}$ & $\begin{array}{r}574 \\
0 \\
0 \\
9 \\
0 \\
38 \\
63 \\
385 \\
79 \\
0\end{array}$ & $\begin{array}{r}525 \\
0 \\
0 \\
9 \\
1 \\
86 \\
43 \\
299 \\
85 \\
2\end{array}$ & $\begin{array}{r}548 \\
0 \\
0 \\
22 \\
1 \\
70 \\
50 \\
339 \\
64 \\
2\end{array}$ & $\begin{array}{r}502 \\
1 \\
0 \\
29 \\
0 \\
64 \\
47 \\
282 \\
77 \\
2\end{array}$ & $\begin{array}{r}0 \\
13 \\
0 \\
0 \\
15 \\
65\end{array}$ & $\begin{array}{r}409 \\
1 \\
0 \\
16 \\
0 \\
64 \\
32 \\
217 \\
77\end{array}$ \\
\hline 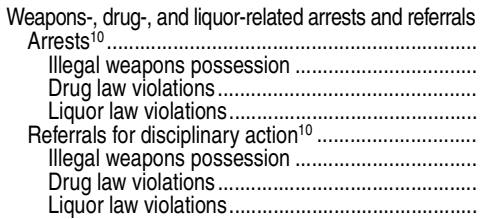 & \begin{tabular}{r|r}
11 \\
2 \\
4 \\
5 \\
316 \\
11 \\
92 \\
213
\end{tabular} & $\begin{array}{r}17 \\
3 \\
9 \\
5 \\
399 \\
25 \\
133 \\
241\end{array}$ & $\begin{array}{r}11 \\
2 \\
4 \\
5 \\
465 \\
24 \\
130 \\
311\end{array}$ & \begin{tabular}{r|r}
41 \\
5 \\
12 \\
24 \\
298 \\
11 \\
99 \\
188
\end{tabular} & $\begin{array}{r}28 \\
2 \\
16 \\
10 \\
529 \\
42 \\
128 \\
359\end{array}$ & $\begin{array}{r}52 \\
5 \\
14 \\
33 \\
513 \\
13 \\
138 \\
362\end{array}$ & $\begin{array}{r}28 \\
3 \\
16 \\
9 \\
519 \\
11 \\
132 \\
376\end{array}$ & $\begin{array}{r}40 \\
8 \\
14 \\
18 \\
566 \\
13 \\
159 \\
394\end{array}$ & $\begin{array}{r}54 \\
6 \\
22 \\
26 \\
882 \\
23 \\
231 \\
628\end{array}$ & $\begin{array}{r}165 \\
13 \\
66 \\
86 \\
760 \\
9 \\
221 \\
530\end{array}$ & \begin{tabular}{r|r}
204 \\
13 \\
62 \\
129 \\
987 \\
22 \\
352 \\
613
\end{tabular} & $\begin{array}{r}144 \\
6 \\
44 \\
94 \\
889 \\
15 \\
307 \\
567\end{array}$ & $\begin{array}{r}60 \\
7 \\
18 \\
35 \\
98 \\
7 \\
45 \\
46\end{array}$ \\
\hline
\end{tabular}

See notes at end of table. 
Table 329.10. On-campus crimes, arrests, and referrals for disciplinary action at degree-granting postsecondary institutions, by location of incident, control and level of institution, and type of incident: 2001 through 2011-Continued

\begin{tabular}{|c|c|c|c|c|c|c|c|c|c|c|c|c|c|}
\hline \multirow[b]{3}{*}{ Control and level of institution and type of incident } & \multicolumn{13}{|c|}{ Number of incidents } \\
\hline & \multirow[b]{2}{*}{2001} & \multirow[b]{2}{*}{2002} & \multirow[b]{2}{*}{2003} & \multirow[b]{2}{*}{2004} & \multirow[b]{2}{*}{2005} & \multirow[b]{2}{*}{2006} & \multirow[b]{2}{*}{2007} & \multirow[b]{2}{*}{2008} & \multirow[b]{2}{*}{2009} & \multirow[b]{2}{*}{2010} & \multicolumn{3}{|c|}{2011} \\
\hline & & & & & & & & & & & Total & $\begin{array}{r}\text { In } \\
\text { residence } \\
\text { hall }\end{array}$ & $\begin{array}{l}\text { At other } \\
\text { locations }\end{array}$ \\
\hline 1 & 2 & 3 & 4 & 5 & 6 & 7 & 8 & 9 & 10 & 11 & 12 & 13 & 14 \\
\hline $\begin{array}{l}\text { Public 2-year } \\
\text { Crimes against persons and property }^{\text {Murder }}{ }^{1} \ldots \ldots \\
\text { Negligent manslaughter }^{2} \\
\text { Sex offenses-forcible } \\
\text { Sex offenses-nonforcible } \\
\text { Robbery } \\
\text { Aggravated assault } \\
\text { Burglary }\end{array}$ & $\begin{array}{r}6,817 \\
2 \\
0 \\
118 \\
119 \\
245 \\
545 \\
4,132 \\
1,552 \\
104\end{array}$ & $\begin{array}{r}6,860 \\
1 \\
0 \\
118 \\
61 \\
234 \\
503 \\
4,158 \\
1,661 \\
124\end{array}$ & $\begin{array}{r}6,637 \\
2 \\
0 \\
160 \\
14 \\
230 \\
589 \\
3,973 \\
1,607 \\
62\end{array}$ & $\begin{array}{r}6,637 \\
3 \\
0 \\
142 \\
6 \\
213 \\
497 \\
4,068 \\
1,620 \\
88\end{array}$ & $\begin{array}{r}5,981 \\
2 \\
0 \\
175 \\
10 \\
248 \\
501 \\
3,541 \\
1,428 \\
76\end{array}$ & $\begin{array}{r}5,669 \\
0 \\
0 \\
167 \\
16 \\
284 \\
546 \\
3,261 \\
1,319 \\
76\end{array}$ & $\begin{array}{r}5,381 \\
0 \\
0 \\
181 \\
7 \\
279 \\
462 \\
3,202 \\
1,174 \\
76\end{array}$ & $\begin{array}{r}5,464 \\
2 \\
0 \\
210 \\
7 \\
285 \\
401 \\
3,430 \\
1,059 \\
70\end{array}$ & $\begin{array}{r}4,984 \\
2 \\
0 \\
205 \\
12 \\
251 \\
431 \\
2,920 \\
1,109 \\
54\end{array}$ & $\begin{array}{r}4,365 \\
1 \\
1 \\
208 \\
8 \\
300 \\
415 \\
2,371 \\
1,018 \\
43\end{array}$ & $\begin{array}{r}4,098 \\
2 \\
0 \\
261 \\
15 \\
262 \\
404 \\
2,200 \\
895 \\
59\end{array}$ & $\begin{array}{r}826 \\
0 \\
0 \\
72 \\
3 \\
12 \\
73 \\
662 \\
0 \\
4\end{array}$ & $\begin{array}{r}3,272 \\
2 \\
0 \\
189 \\
12 \\
250 \\
331 \\
1,538 \\
895 \\
55\end{array}$ \\
\hline 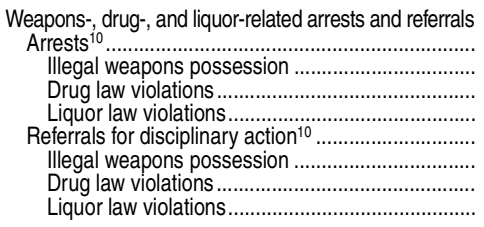 & $\begin{array}{r}2,660 \\
198 \\
989 \\
1,473 \\
3,529 \\
127 \\
761 \\
2,641\end{array}$ & $\begin{array}{r}2,844 \\
221 \\
996 \\
1,627 \\
3,744 \\
146 \\
692 \\
2,906\end{array}$ & $\begin{array}{r}2,950 \\
220 \\
1,141 \\
1,589 \\
4,036 \\
145 \\
679 \\
3,212\end{array}$ & $\begin{array}{r}3,270 \\
255 \\
1,312 \\
1,703 \\
4,371 \\
167 \\
858 \\
3,346\end{array}$ & $\begin{array}{r}3,416 \\
278 \\
1,326 \\
1,812 \\
4,688 \\
133 \\
819 \\
3,736\end{array}$ & $\begin{array}{r}3,993 \\
300 \\
1,378 \\
2,315 \\
5,897 \\
238 \\
908 \\
4,751\end{array}$ & $\begin{array}{r}4,124 \\
304 \\
1,563 \\
2,257 \\
5,987 \\
218 \\
1,006 \\
4,763\end{array}$ & $\begin{array}{r}3,764 \\
258 \\
1,490 \\
2,016 \\
6,425 \\
183 \\
1,302 \\
4,940\end{array}$ & $\begin{array}{r}3,335 \\
256 \\
1,507 \\
1,572 \\
7,241 \\
210 \\
1,745 \\
5,286\end{array}$ & $\begin{array}{r}3,806 \\
278 \\
1,858 \\
1,670 \\
7,945 \\
241 \\
2,332 \\
5,372\end{array}$ & $\begin{array}{r}3,768 \\
251 \\
1,919 \\
1,598 \\
8,225 \\
230 \\
2,587 \\
5,408\end{array}$ & $\begin{array}{r}1,527 \\
24 \\
545 \\
958 \\
6,079 \\
70 \\
1,540 \\
4,469\end{array}$ & $\begin{array}{r}2,241 \\
227 \\
1,374 \\
640 \\
2,146 \\
160 \\
1,047 \\
939\end{array}$ \\
\hline 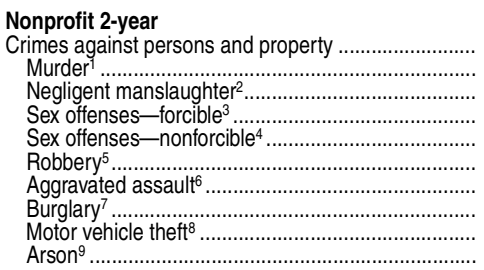 & \begin{tabular}{r|r}
248 \\
1 \\
0 \\
2 \\
2 \\
54 \\
23 \\
142 \\
23 \\
1
\end{tabular} & $\begin{array}{r}230 \\
0 \\
0 \\
7 \\
2 \\
56 \\
17 \\
123 \\
21 \\
4\end{array}$ & $\begin{array}{r}189 \\
0 \\
0 \\
6 \\
0 \\
64 \\
12 \\
83 \\
23 \\
1\end{array}$ & \begin{tabular}{r|r}
166 \\
0 \\
0 \\
3 \\
0 \\
22 \\
17 \\
111 \\
13 \\
0
\end{tabular} & $\begin{array}{r}314 \\
0 \\
0 \\
8 \\
0 \\
9 \\
22 \\
266 \\
7 \\
2\end{array}$ & \begin{tabular}{r|r}
250 \\
0 \\
0 \\
3 \\
1 \\
7 \\
35 \\
187 \\
14 \\
3
\end{tabular} & $\begin{array}{r}258 \\
0 \\
0 \\
9 \\
0 \\
2 \\
52 \\
178 \\
14 \\
3\end{array}$ & $\begin{array}{r}272 \\
0 \\
1 \\
16 \\
0 \\
13 \\
66 \\
160 \\
9 \\
7\end{array}$ & $\begin{array}{r}147 \\
0 \\
0 \\
8 \\
0 \\
9 \\
5 \\
120 \\
4 \\
1\end{array}$ & $\begin{array}{r}120 \\
0 \\
0 \\
7 \\
0 \\
5 \\
9 \\
95 \\
2 \\
2\end{array}$ & $\begin{array}{r}95 \\
0 \\
0 \\
11 \\
0 \\
1 \\
6 \\
72 \\
5 \\
0\end{array}$ & $\begin{array}{r}42 \\
0 \\
0 \\
8 \\
0 \\
0 \\
0 \\
34 \\
0 \\
0\end{array}$ & $\begin{array}{r}53 \\
0 \\
0 \\
3 \\
0 \\
1 \\
6 \\
38 \\
5 \\
0\end{array}$ \\
\hline 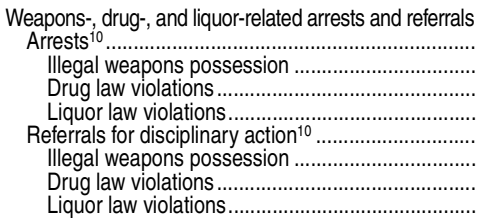 & \begin{tabular}{r|r}
108 \\
1 \\
21 \\
86 \\
624 \\
2 \\
91 \\
531
\end{tabular} & $\begin{array}{r}39 \\
2 \\
10 \\
27 \\
569 \\
3 \\
65 \\
501\end{array}$ & $\begin{array}{r}23 \\
3 \\
16 \\
4 \\
552 \\
6 \\
52 \\
494\end{array}$ & \begin{tabular}{r|r}
48 \\
2 \\
16 \\
30 \\
447 \\
5 \\
58 \\
384
\end{tabular} & $\begin{array}{r}76 \\
5 \\
32 \\
39 \\
514 \\
12 \\
47 \\
455\end{array}$ & \begin{tabular}{r|r}
67 \\
3 \\
34 \\
30 \\
537 \\
19 \\
74 \\
444
\end{tabular} & $\begin{array}{r}59 \\
4 \\
27 \\
28 \\
519 \\
10 \\
73 \\
436\end{array}$ & $\begin{array}{r}93 \\
3 \\
33 \\
57 \\
413 \\
6 \\
85 \\
322\end{array}$ & $\begin{array}{r}58 \\
4 \\
35 \\
19 \\
348 \\
7 \\
100 \\
241\end{array}$ & $\begin{array}{r}49 \\
6 \\
18 \\
25 \\
377 \\
4 \\
105 \\
268\end{array}$ & \begin{tabular}{r|}
52 \\
5 \\
34 \\
13 \\
309 \\
1 \\
101 \\
207
\end{tabular} & \begin{tabular}{r|r}
23 \\
0 \\
13 \\
10 \\
263 \\
0 \\
98 \\
165
\end{tabular} & $\begin{array}{r}29 \\
5 \\
21 \\
3 \\
46 \\
1 \\
3 \\
42\end{array}$ \\
\hline $\begin{array}{l}\text { For-profit 2-year } \\
\text { Crimes against persons and property } \\
\text { Murder }^{1} \ldots \\
\text { Negligent manslaughter }^{2} \\
\text { Sex offenses-forcible } \\
\text { Sex offenses-nonforcible } \\
\text { Robbery } \\
\text { Aggravated assault } \\
\text { Burglary }\end{array}$ & \begin{tabular}{r|r}
472 \\
0 \\
0 \\
12 \\
7 \\
67 \\
40 \\
292 \\
51 \\
3
\end{tabular} & $\begin{array}{r}417 \\
1 \\
0 \\
6 \\
3 \\
47 \\
19 \\
297 \\
40 \\
4\end{array}$ & $\begin{array}{r}550 \\
0 \\
0 \\
15 \\
2 \\
81 \\
36 \\
341 \\
74 \\
1\end{array}$ & \begin{tabular}{r|r}
527 \\
0 \\
0 \\
9 \\
0 \\
80 \\
62 \\
325 \\
49 \\
2
\end{tabular} & $\begin{array}{r}430 \\
0 \\
0 \\
1 \\
0 \\
55 \\
50 \\
250 \\
71 \\
3\end{array}$ & \begin{tabular}{r|}
420 \\
0 \\
0 \\
8 \\
1 \\
49 \\
33 \\
245 \\
81 \\
3
\end{tabular} & $\begin{array}{r}547 \\
0 \\
0 \\
2 \\
0 \\
67 \\
33 \\
350 \\
92 \\
3\end{array}$ & $\begin{array}{r}399 \\
0 \\
1 \\
4 \\
0 \\
53 \\
29 \\
241 \\
71 \\
0\end{array}$ & $\begin{array}{r}459 \\
0 \\
0 \\
6 \\
1 \\
50 \\
53 \\
226 \\
121 \\
2\end{array}$ & $\begin{array}{r}329 \\
0 \\
0 \\
2 \\
1 \\
44 \\
37 \\
138 \\
104 \\
3\end{array}$ & $\begin{array}{r}285 \\
0 \\
0 \\
7 \\
0 \\
24 \\
40 \\
127 \\
84 \\
3\end{array}$ & $\begin{array}{r}10 \\
0 \\
0 \\
2 \\
0 \\
0 \\
0 \\
8 \\
0 \\
0\end{array}$ & $\begin{array}{r}275 \\
0 \\
0 \\
5 \\
0 \\
24 \\
40 \\
119 \\
84 \\
3\end{array}$ \\
\hline 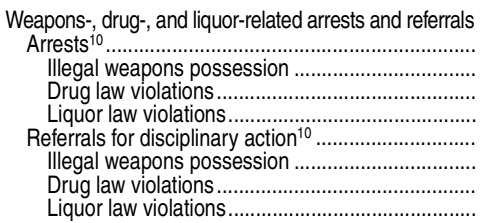 & $\begin{array}{r}163 \\
13 \\
87 \\
63 \\
287 \\
16 \\
89 \\
182\end{array}$ & $\begin{array}{r}128 \\
9 \\
65 \\
54 \\
330 \\
14 \\
105 \\
211\end{array}$ & $\begin{array}{r}84 \\
6 \\
48 \\
30 \\
313 \\
7 \\
196 \\
110\end{array}$ & $\begin{array}{r}112 \\
6 \\
64 \\
42 \\
322 \\
7 \\
186 \\
129\end{array}$ & $\begin{array}{r}47 \\
3 \\
36 \\
8 \\
228 \\
8 \\
134 \\
86\end{array}$ & $\begin{array}{r}41 \\
3 \\
26 \\
12 \\
320 \\
7 \\
219 \\
94\end{array}$ & $\begin{array}{r}45 \\
4 \\
32 \\
9 \\
173 \\
7 \\
122 \\
44\end{array}$ & $\begin{array}{r}23 \\
4 \\
12 \\
7 \\
248 \\
4 \\
110 \\
134\end{array}$ & $\begin{array}{r}62 \\
4 \\
41 \\
17 \\
303 \\
8 \\
163 \\
132\end{array}$ & $\begin{array}{r}46 \\
5 \\
29 \\
12 \\
293 \\
4 \\
123 \\
166\end{array}$ & $\begin{array}{r}24 \\
0 \\
15 \\
9 \\
289 \\
11 \\
119 \\
159\end{array}$ & $\begin{array}{r}3 \\
0 \\
1 \\
2 \\
219 \\
1 \\
95 \\
123\end{array}$ & $\begin{array}{r}21 \\
0 \\
14 \\
7 \\
70 \\
10 \\
24 \\
36\end{array}$ \\
\hline
\end{tabular}

${ }^{1}$ Excludes suicides, fetal deaths, traffic fatalities, accidental deaths, and justifiable homicide (such as the killing of a felon by a law enforcement officer in the line of duty). ${ }^{2}$ Killing of another person through gross negligence (excludes traffic fatalities).

${ }^{3}$ Any sexual act directed against another person forcibly and/or against that person's will. ${ }^{4}$ Includes only statutory rape or incest.

${ }^{5}$ Taking or attempting to take anything of value using actual or threatened force or violence. ${ }^{6}$ Attack upon a person for the purpose of inflicting severe or aggravated bodily injury.

7 Unlawful entry of a structure to commit a felony or theft.

${ }^{8}$ Theft or attempted theft of a motor vehicle.

${ }^{9}$ Willful or malicious burning or attempt to burn a dwelling house, public building, motor vehicle, or personal property of another. 10lf an individual is both arrested and referred to college officials for disciplinary action for a single offense, only the arrest is counted.

NOTE: Degree-granting institutions grant associate's or higher degrees and participate in Title IV federal financial aid programs. Crimes, arrests, and referrals include incidents involving students, staff, and on-campus guests. Excludes off-campus crimes and arrests even if they involve college students or staff.

SOURCE: U.S. Department of Education, Office of Postsecondary Education, Campus Safety and Security Reporting System, 2001 through 2011; and National Center for Education Statistics, Integrated Postsecondary Education Data System (IPEDS), Spring 2002 through Spring 2012, Enrollment component. (This table was prepared November 2013.) 
Table 329.20. On-campus crimes, arrests, and referrals for disciplinary action per 10,000 full-time-equivalent (FTE) students at degree-granting postsecondary institutions, by whether institution has residence halls, control and level of institution, and type of incident: 2001 through 2011

\begin{tabular}{|c|c|c|c|c|c|c|c|c|c|c|c|c|c|}
\hline \multirow[b]{3}{*}{ Control and level of institution and type of incident } & \multicolumn{13}{|c|}{ Number of incidents per 10,000 full-time-equivalent (FTE) students ${ }^{1}$} \\
\hline & \multicolumn{10}{|c|}{ Total, institutions with and without residence halls } & \multicolumn{3}{|c|}{2011} \\
\hline & 2001 & 2002 & 2003 & 2004 & 2005 & 2006 & 2007 & 2008 & 2009 & 2010 & Total & $\begin{array}{r}\text { Institutions } \\
\text { with } \\
\text { residence } \\
\text { halls }\end{array}$ & $\begin{array}{r}\text { Institutions } \\
\text { without } \\
\text { residence } \\
\text { halls }\end{array}$ \\
\hline 1 & 2 & 3 & 4 & 5 & & & 8 & & 1 & 11 & 12 & 1 & 14 \\
\hline 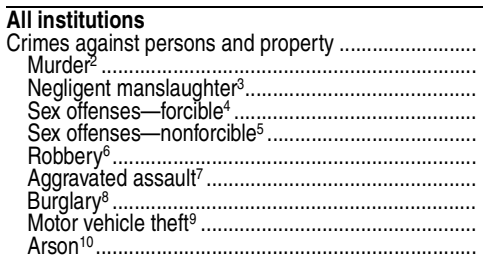 & $\begin{array}{r}35.619 \\
0.015 \\
0.002 \\
1.885 \\
0.395 \\
1.424 \\
2.524 \\
23.038 \\
5.327 \\
1.010\end{array}$ & $\begin{array}{r}34.649 \\
0.016 \\
0.000 \\
1.896 \\
0.213 \\
1.468 \\
2.285 \\
22.847 \\
5.037 \\
0.887\end{array}$ & $\begin{array}{r}34.040 \\
0.007 \\
0.001 \\
2.051 \\
0.047 \\
1.284 \\
2.239 \\
22.638 \\
4.968 \\
0.805\end{array}$ & $\begin{array}{r}33.580 \\
0.012 \\
0.000 \\
2.056 \\
0.021 \\
1.195 \\
2.098 \\
22.728 \\
4.674 \\
0.796\end{array}$ & $\begin{array}{r}32.864 \\
0.008 \\
0.002 \\
2.058 \\
0.032 \\
1.193 \\
2.044 \\
22.511 \\
4.256 \\
0.759\end{array}$ & $\begin{array}{r}33.347 \\
0.006 \\
0.000 \\
2.001 \\
0.032 \\
1.159 \\
2.111 \\
23.429 \\
3.921 \\
0.687\end{array}$ & $\begin{array}{r}30.568 \\
0.032 \\
0.002 \\
1.969 \\
0.029 \\
1.141 \\
1.903 \\
21.549 \\
3.375 \\
0.567\end{array}$ & $\begin{array}{r}28.987 \\
0.009 \\
0.002 \\
1.898 \\
0.025 \\
1.134 \\
1.795 \\
20.672 \\
2.952 \\
0.500\end{array}$ & $\begin{array}{r}22.922 \\
0.011 \\
0.000 \\
1.712 \\
0.044 \\
0.948 \\
1.566 \\
15.538 \\
2.677 \\
0.426\end{array}$ & $\begin{array}{r}20.782 \\
0.010 \\
0.001 \\
1.901 \\
0.021 \\
0.906 \\
1.448 \\
13.797 \\
2.225 \\
0.474\end{array}$ & $\begin{array}{r}19.738 \\
0.010 \\
0.001 \\
2.171 \\
0.029 \\
0.839 \\
1.436 \\
12.653 \\
2.190 \\
0.410\end{array}$ & $\begin{array}{r}26.105 \\
0.012 \\
0.001 \\
3.099 \\
0.030 \\
0.952 \\
1.799 \\
17.387 \\
2.256 \\
0.570\end{array}$ & $\begin{array}{l}7.625 \\
0.006 \\
0.000 \\
0.405 \\
0.028 \\
0.624 \\
0.744 \\
3.646 \\
2.064 \\
0.107\end{array}$ \\
\hline 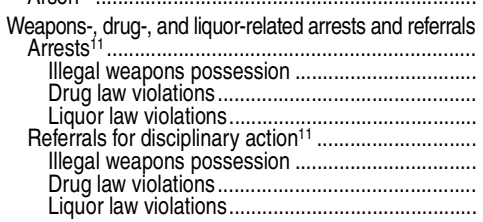 & $\begin{array}{r}34.550 \\
0.919 \\
10.151 \\
23.481 \\
132.899 \\
1.093 \\
20.466 \\
111.340\end{array}$ & $\begin{array}{r}35.371 \\
0.931 \\
9.812 \\
24.629 \\
136.344 \\
1.049 \\
21.218 \\
114.077\end{array}$ & $\begin{array}{r}35.239 \\
0.865 \\
9.854 \\
24.520 \\
146.165 \\
1.238 \\
20.356 \\
124.571\end{array}$ & $\begin{array}{r}36.960 \\
0.974 \\
9.849 \\
26.137 \\
151.708 \\
1.387 \\
19.862 \\
130.459\end{array}$ & $\begin{array}{r}37.722 \\
1.013 \\
10.547 \\
26.163 \\
156.060 \\
1.448 \\
19.511 \\
135.101\end{array}$ & $\begin{array}{r}37.615 \\
0.986 \\
10.457 \\
26.172 \\
163.421 \\
1.402 \\
20.425 \\
141.594\end{array}$ & $\begin{array}{r}36.947 \\
0.963 \\
10.330 \\
25.654 \\
158.288 \\
1.212 \\
20.810 \\
136.267\end{array}$ & $\begin{array}{r}36.428 \\
0.856 \\
10.895 \\
24.676 \\
156.479 \\
1.047 \\
23.357 \\
132.076\end{array}$ & $\begin{array}{r}0.4<0 \\
33.700 \\
0.725 \\
10.683 \\
22.292 \\
148.751 \\
0.858 \\
24.464\end{array}$ & $\begin{array}{r}0.414 \\
33.481 \\
0.718 \\
12.052 \\
20.711 \\
149.511 \\
0.82 \\
27.326 \\
121.333\end{array}$ & $\begin{array}{r}35.457 \\
0.667 \\
13.459 \\
21.331 \\
162.677 \\
0.851 \\
33.771 \\
128.056\end{array}$ & $\begin{array}{r}52.244 \\
0.824 \\
19.342 \\
32.078 \\
246.400 \\
1.168 \\
50.645 \\
194.587\end{array}$ & $\begin{array}{l}3.520 \\
0.369 \\
2.265 \\
0.886 \\
3.394 \\
0.247 \\
1.668 \\
1.479\end{array}$ \\
\hline 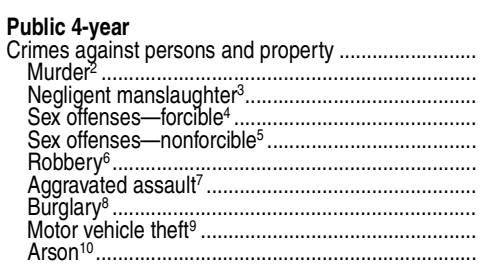 & $\begin{array}{r}36.191 \\
0.017 \\
0.004 \\
2.408 \\
0.400 \\
1.130 \\
2.774 \\
22.283 \\
5.942 \\
1.232\end{array}$ & $\begin{array}{r}36.334 \\
0.017 \\
0.000 \\
2.374 \\
0.210 \\
1.224 \\
2.452 \\
23.259 \\
5.743 \\
1.057\end{array}$ & $\begin{array}{r}35.725 \\
0.009 \\
0.002 \\
2.452 \\
0.051 \\
1.208 \\
2.493 \\
22.808 \\
5.625 \\
1.078\end{array}$ & $\begin{array}{r}35.522 \\
0.014 \\
0.000 \\
2.634 \\
0.028 \\
1.088 \\
2.256 \\
23.154 \\
5.269 \\
1.079\end{array}$ & $\begin{array}{r}34.295 \\
0.007 \\
0.002 \\
2.448 \\
0.044 \\
1.219 \\
2.242 \\
22.654 \\
4.671 \\
1.009\end{array}$ & $\begin{array}{r}35.532 \\
0.009 \\
0.000 \\
2.409 \\
0.026 \\
1.170 \\
2.302 \\
24.138 \\
4.581 \\
0.897\end{array}$ & $\begin{array}{r}32.837 \\
0.070 \\
0.003 \\
2.390 \\
0.039 \\
1.211 \\
2.110 \\
22.425 \\
3.800\end{array}$ & $\begin{array}{r}30.531 \\
0.015 \\
0.002 \\
2.151 \\
0.020 \\
1.225 \\
1.930 \\
21.181 \\
3.310 \\
0.697\end{array}$ & $\begin{array}{r}24.898 \\
0.012 \\
0.000 \\
1.892 \\
0.062 \\
1.008 \\
1.767 \\
16.689 \\
2.843 \\
0.623\end{array}$ & $\begin{array}{r}23.426 \\
0.014 \\
0.000 \\
2.217 \\
0.023 \\
0.994 \\
1.628 \\
15.441 \\
2.419 \\
0.691\end{array}$ & $\begin{array}{r}21.853 \\
0.013 \\
0.001 \\
2.427 \\
0.025 \\
0.917 \\
1.609 \\
13.939 \\
2.397 \\
0.524\end{array}$ & $\begin{array}{r}23.266 \\
0.015 \\
0.002 \\
2.633 \\
0.026 \\
0.969 \\
1.711 \\
14.906\end{array}$ & $\begin{array}{l}7.973 \\
0.000 \\
0.000 \\
0.403 \\
0.016 \\
0.403 \\
0.612 \\
4.446 \\
2.046 \\
0.048\end{array}$ \\
\hline $\begin{array}{l}\text { Weapons-, drug-, an } \\
\text { Arrests }{ }^{11} \text {.................. } \\
\text { lllegal weapons } \\
\text { Drug law violat } \\
\text { Liquor law viola } \\
\text { Referrals for disci } \\
\text { lllegal weapons } \\
\text { Drug law violat } \\
\text { Liquor law viola }\end{array}$ & $\begin{array}{r}60.113 \\
1.339 \\
17.651 \\
41.123 \\
153.104 \\
1.311 \\
25.492 \\
126.301\end{array}$ & $\begin{array}{r}62.833 \\
1.384 \\
17.158 \\
44.292 \\
157.192 \\
1.254 \\
25.896 \\
130.043\end{array}$ & $\begin{array}{r}62.566 \\
1.258 \\
16.950 \\
44.358 \\
170.355 \\
1.529 \\
24.933 \\
143.893\end{array}$ & $\begin{array}{r}65.318 \\
1.442 \\
17.100 \\
46.776 \\
178.800 \\
1.779 \\
24.278 \\
152.743\end{array}$ & $\begin{array}{r}66.641 \\
1.538 \\
18.575 \\
46.529 \\
175.506 \\
1.921 \\
22.803 \\
150.782\end{array}$ & $\begin{array}{r}68.662 \\
1.478 \\
18.671 \\
48.513 \\
184.628 \\
1.673 \\
23.744 \\
159.211\end{array}$ & $\begin{array}{r}66.366 \\
1.384 \\
17.934 \\
47.048 \\
178.029 \\
1.454 \\
24.249 \\
152.326\end{array}$ & \begin{tabular}{|r|}
170.797 \\
1.293 \\
27.201 \\
142.303
\end{tabular} & $\begin{array}{r}63.558 \\
1.027 \\
10.02\end{array}$ & $\begin{array}{r}63.677 \\
1.008 \\
21.739 \\
40.930 \\
175.732 \\
1.001 \\
32.454 \\
142.278\end{array}$ & $\begin{array}{r}67.132 \\
0.939 \\
24.309 \\
41.883 \\
193.268 \\
0.913 \\
40.756 \\
151.598\end{array}$ & $\begin{array}{r}73.573 \\
1.017 \\
26.542 \\
46.014 \\
212.708\end{array}$ & $\begin{array}{l}3.882 \\
0.177 \\
2.384 \\
1.321 \\
2.368 \\
0.097 \\
1.337 \\
0.934\end{array}$ \\
\hline $\begin{array}{l}\text { Murd } \\
\text { Negl } \\
\text { Sex } \\
\text { Sex } \\
\text { Robb } \\
\text { Aggr } \\
\text { Burg } \\
\text { Moto } \\
\text { Arsol }\end{array}$ & $\begin{array}{r}57.358 \\
0.019 \\
0.000 \\
3.169 \\
0.437 \\
2.508 \\
3.408 \\
40.460 \\
5.684 \\
1.673\end{array}$ & $\begin{array}{r}55.445 \\
0.034 \\
0.000 \\
3.410 \\
0.302 \\
2.743 \\
3.358 \\
39.407 \\
4.750 \\
1.440\end{array}$ & $\begin{array}{r}54.8 \\
0.0 \\
0.0 \\
3.7 \\
0.0 \\
1.9 \\
2.7 \\
40.0 \\
5.0 \\
1.2\end{array}$ & $\begin{array}{r}54 . \\
0 . \\
0 . \\
3 . \\
0 . \\
2 . \\
2 . \\
40 . \\
4 . \\
1 .\end{array}$ & $\begin{aligned} 54 . & \\
0 . & \\
0 . & \\
3 . & \\
0 . & \\
1 . & \\
2 . & \\
40 . & \\
4 . & \\
1 . & \end{aligned}$ & $\begin{array}{r}57.6 \\
0.0 \\
0.0 \\
3.6 \\
0.0 \\
1.7 \\
2.8 \\
44.6 \\
3.6 \\
1.0\end{array}$ & $\begin{array}{l}0 . \\
0 . \\
3 . \\
0 . \\
1 . \\
2 .\end{array}$ & & $\begin{array}{r}38 . \\
0 . \\
0 . \\
3 . \\
0 . \\
1 . \\
2 .\end{array}$ & $\begin{array}{r}34.977 \\
0.016 \\
0.000 \\
3.835 \\
0.025 \\
0.996 \\
2.015 \\
25.387 \\
2.002 \\
0.701\end{array}$ & $\begin{array}{r}33.041 \\
0.009 \\
0.000 \\
4.325 \\
0.040 \\
1.000 \\
1.947 \\
22.897 \\
2.159 \\
0.664\end{array}$ & $\begin{array}{l}0 \\
0 \\
4 \\
0 \\
1 \\
1\end{array}$ & $\begin{array}{r}10.546 \\
0.039 \\
0.000 \\
0.748 \\
0.118 \\
0.708 \\
1.338 \\
6.335 \\
1.141 \\
0.118\end{array}$ \\
\hline $\begin{array}{l}\text { Weapons } \\
\text { Arrests } \\
\text { Illege } \\
\text { Drug } \\
\text { Liqu } \\
\text { Referra } \\
\text { lleg } \\
\text { Drug } \\
\text { Liqu }\end{array}$ & $\begin{array}{r}24.456 \\
0.645 \\
6.291 \\
17.520 \\
275.480 \\
1.712 \\
37.435\end{array}$ & $\begin{array}{r}24.433 \\
0.604 \\
6.429 \\
17.399 \\
289.709 \\
11.582 \\
41.418\end{array}$ & $\begin{array}{l}3 \\
0 \\
59 \\
34 \\
4 \\
12\end{array}$ & $\begin{array}{r}27.225 \\
0.649 \\
6.173 \\
20.403 \\
319.945 \\
2.144 \\
38.440\end{array}$ & $\begin{array}{r}25 \\
0 \\
5 \\
19 \\
336 \\
2\end{array}$ & $\begin{array}{r}31 \\
79 \\
44 \\
38 \\
54 \\
27 \\
34\end{array}$ & & & $\begin{array}{r}18 . \\
0 \\
6\end{array}$ & $\begin{array}{r}17.026 \\
0.431 \\
6.981 \\
9.615 \\
328.494 \\
1.229 \\
55.992\end{array}$ & $\begin{array}{r}325 \\
394 \\
290 \\
141 \\
188 \\
332 \\
663\end{array}$ & & $\begin{array}{r}3.069 \\
0.354 \\
2.204 \\
0.512 \\
23.609 \\
0.236 \\
3.148\end{array}$ \\
\hline ciblete $^{4}{ }^{4}$ & $\begin{array}{r}19.109 \\
0.000 \\
0.000 \\
0.151 \\
0.492 \\
2.422 \\
0.870 \\
13.130 \\
1.968 \\
0.076\end{array}$ & $\begin{array}{r}17.840 \\
0.000 \\
0.000 \\
0.121 \\
0.030 \\
2.140 \\
1.356 \\
11.331 \\
2.833 \\
0.030\end{array}$ & $\begin{array}{r}17.6 \\
0.0 \\
0.0 \\
0.1\end{array}$ & $\begin{array}{l}1.000 \\
0.000 \\
0.095\end{array}$ & $\begin{array}{r}17.049 \\
0.000 \\
0.000 \\
0.082 \\
0.021 \\
0.884 \\
1.213 \\
12.484 \\
2.262 \\
0.103\end{array}$ & $\begin{array}{l}0.002 \\
0.000 \\
0.000 \\
0.179 \\
0.000 \\
0.373 \\
0.462 \\
7.287 \\
1.162 \\
0.089\end{array}$ & $\begin{array}{l}.177 \\
.013\end{array}$ & $\begin{array}{l}0.00 \\
0.00 \\
0.16 \\
0.00 \\
0.68 \\
1.13 \\
6.92 \\
1.42 \\
0.00\end{array}$ & $\begin{array}{l}7.288 \\
0.000 \\
0.000 \\
0.125 \\
0.014 \\
1.194 \\
0.597 \\
4.151 \\
1.180 \\
0.028\end{array}$ & $\begin{array}{l}6.596 \\
0.000 \\
0.000 \\
0.265 \\
0.012 \\
0.842 \\
0.602 \\
4.080 \\
0.770 \\
0.024\end{array}$ & $\begin{array}{l}6.128 \\
0.012 \\
0.000 \\
0.354 \\
0.000 \\
0.781 \\
0.574 \\
3.442 \\
0.940 \\
0.024\end{array}$ & $\begin{array}{r}10.354 \\
0.000 \\
0.000 \\
1.544 \\
0.000 \\
0.129 \\
1.286 \\
6.431 \\
0.836 \\
0.129\end{array}$ & $\begin{array}{l}5.138 \\
0.015 \\
0.000 \\
0.075 \\
0.000 \\
0.934 \\
0.407 \\
2.742 \\
0.964 \\
0.000\end{array}$ \\
\hline 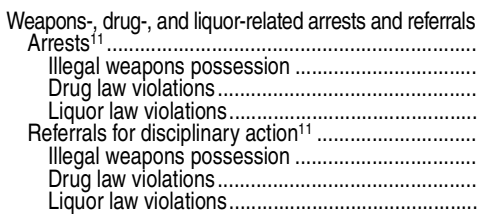 & $\begin{array}{r}0.416 \\
0.076 \\
0.151 \\
0.189 \\
11.957 \\
0.416 \\
3.481 \\
8.060\end{array}$ & $\begin{array}{r}0.090 \\
0.271 \\
0.151 \\
12.024 \\
0.753 \\
4.008 \\
7.263\end{array}$ & $\begin{array}{r}0.209 \\
0.049 \\
0.098 \\
0.122 \\
11.370 \\
0.587 \\
3.179 \\
7.605\end{array}$ & $\begin{array}{l}0.095 \\
0.228 \\
0.456 \\
5.665 \\
0.209 \\
1.882 \\
3.574\end{array}$ & $\begin{array}{r}0 . \\
0 \\
0 \\
10 . \\
0 .\end{array}$ & $\begin{array}{l}7.645 \\
0.194 \\
2.057 \\
5.395\end{array}$ & $\begin{array}{l}0.119 \\
0.865 \\
0.145 \\
1.746 \\
4.973\end{array}$ & $\begin{array}{l}0.234 \\
2.859 \\
7.084\end{array}$ & $\begin{array}{r}0.083 \\
0.305 \\
0.361 \\
12.244 \\
0.319 \\
3.207 \\
8.718\end{array}$ & $\begin{array}{l}0.156 \\
0.794 \\
1.035 \\
9.147 \\
0.108 \\
2.660 \\
6.379\end{array}$ & $\begin{array}{r}2.490 \\
0.159 \\
0.757 \\
1.575 \\
12.048 \\
0.269 \\
4.297 \\
7.483\end{array}$ & $\begin{array}{r}0.041 \\
0.643 \\
3.280 \\
6.624 \\
59.361 \\
1.029 \\
20.709 \\
37.623\end{array}$ & $\begin{array}{l}0.166 \\
0.392 \\
0.964 \\
0.090 \\
0.452 \\
0.422\end{array}$ \\
\hline
\end{tabular}


Table 329.20. On-campus crimes, arrests, and referrals for disciplinary action per 10,000 full-time-equivalent (FTE) students at degree-granting postsecondary institutions, by whether institution has residence halls, control and level of institution, and type of incident: 2001 through 2011-Continued

\begin{tabular}{|c|c|c|c|c|c|c|c|c|c|c|c|c|c|}
\hline \multirow[b]{3}{*}{ Control and level of institution and type of incident } & \multicolumn{13}{|c|}{ Number of incidents per 10,000 full-time-equivalent (FTE) students ${ }^{1}$} \\
\hline & \multicolumn{10}{|c|}{ Total, institutions with and without residence halls } & \multicolumn{3}{|c|}{2011} \\
\hline & 2001 & 2002 & 2003 & 2004 & 2005 & 2006 & 2007 & 2008 & 2009 & 2010 & Total & $\begin{array}{r}\text { Institutions } \\
\text { with } \\
\text { residence } \\
\text { halls }\end{array}$ & $\begin{array}{l}\text { Institutions } \\
\text { without } \\
\text { residence } \\
\text { halls }\end{array}$ \\
\hline 1 & 2 & 3 & 4 & 5 & 6 & 7 & 8 & 9 & 1 & 11 & 12 & 13 & 14 \\
\hline 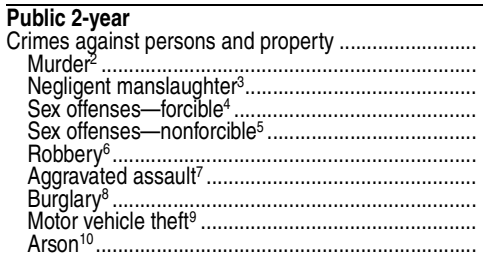 & $\begin{array}{r}19.867 \\
0.006 \\
0.000 \\
0.344 \\
0.347 \\
0.714 \\
1.588 \\
12.042 \\
4.523 \\
0.303\end{array}$ & $\begin{array}{r}18.834 \\
0.003 \\
0.000 \\
0.324 \\
0.167 \\
0.642 \\
11.381 \\
11.416 \\
4.560 \\
0.340\end{array}$ & $\begin{array}{r}18.044 \\
0.005 \\
0.000 \\
0.435 \\
0.038 \\
0.625 \\
1.601 \\
10.801 \\
4.369 \\
0.169\end{array}$ & $\begin{array}{r}17.903 \\
0.008 \\
0.000 \\
0.383 \\
0.016 \\
0.575 \\
1.341 \\
10.974 \\
4.370 \\
0.237\end{array}$ & $\begin{array}{r}16.389 \\
0.005 \\
0.000 \\
0.480 \\
0.027 \\
0.680 \\
1.373 \\
9.703 \\
3.913 \\
0.208\end{array}$ & $\begin{array}{r}15.423 \\
0.000 \\
0.000 \\
0.454 \\
0.044 \\
0.773 \\
1.485 \\
8.872 \\
3.588 \\
0.207\end{array}$ & $\begin{array}{r}14.388 \\
0.000 \\
0.000 \\
0.084 \\
0.019 \\
0.746 \\
1.235 \\
8.561 \\
3.139 \\
0.203\end{array}$ & $\begin{array}{r}13.991 \\
0.005 \\
0.000 \\
0.538 \\
0.018 \\
0.730 \\
1.027 \\
8.783 \\
2.712 \\
0.179\end{array}$ & $\begin{array}{r}11.735 \\
0.005 \\
0.000 \\
0.483 \\
0.028 \\
0.591 \\
1.015 \\
6.875 \\
2.611 \\
0.127\end{array}$ & $\begin{array}{r}10.042 \\
0.002 \\
0.002 \\
0.479 \\
0.018 \\
0.690 \\
0.955 \\
5.454 \\
2.342 \\
0.099\end{array}$ & $\begin{array}{l}9.721 \\
0.005 \\
0.000 \\
0.619 \\
0.036 \\
0.621 \\
0.958 \\
5.219 \\
2.123 \\
0.140\end{array}$ & $\begin{array}{r}17.583 \\
0.012 \\
0.000 \\
1.234 \\
0.048 \\
0.726 \\
1.803 \\
12.355 \\
1.271 \\
0.133\end{array}$ & $\begin{array}{l}7.804 \\
0.003 \\
0.000 \\
0.469 \\
0.032 \\
0.596 \\
0.752 \\
3.479 \\
2.331 \\
0.142\end{array}$ \\
\hline d arrests and referrals & $\begin{array}{r}7.752 \\
0.577 \\
2.882 \\
4.293 \\
10.284 \\
0.370 \\
2.218 \\
7.697\end{array}$ & $\begin{array}{r}7.808 \\
0.607 \\
2.735 \\
4.467 \\
10.279 \\
0.401 \\
1.900 \\
7.978\end{array}$ & $\begin{array}{r}8.020 \\
0.598 \\
3.102 \\
4.320 \\
10.973 \\
0.394 \\
1.846 \\
8.732\end{array}$ & $\begin{array}{r}8.821 \\
0.688 \\
3.539 \\
4.594 \\
11.791 \\
0.450 \\
2.314 \\
9.026\end{array}$ & $\begin{array}{r}9.360 \\
0.762 \\
3.633 \\
4.965 \\
12.846 \\
0.364 \\
2.244 \\
10.237\end{array}$ & $\begin{array}{r}10.863 \\
0.816 \\
3.749 \\
6.298 \\
16.043 \\
0.648 \\
2.470 \\
12.926\end{array}$ & $\begin{array}{r}11.027 \\
0.813 \\
4.179 \\
6.035 \\
16.008 \\
0.583 \\
2.690 \\
12.735\end{array}$ & $\begin{array}{r}9.638 \\
0.661 \\
3.815 \\
5.162 \\
16.451 \\
0.469 \\
3.334 \\
12.649\end{array}$ & $\begin{array}{r}7.852 \\
0.6003 \\
3.548 \\
3.701 \\
17.049 \\
0.494 \\
4.109 \\
12.446\end{array}$ & $\begin{array}{r}8.756 \\
0.640 \\
4.274 \\
3.842 \\
18.277 \\
0.554 \\
5.365 \\
12.358\end{array}$ & $\begin{array}{r}8.938 \\
0.595 \\
4.552 \\
3.791 \\
19.511 \\
0.546 \\
6.137 \\
12.829\end{array}$ & $\begin{array}{r}27.639 \\
0.956 \\
11.472 \\
15.211 \\
17.444 \\
1.488 \\
3.101 \\
3.254\end{array}$ & $\begin{array}{l}2.000 \\
1.006 \\
2.850 \\
0.316 \\
2.000 \\
0.534\end{array}$ \\
\hline 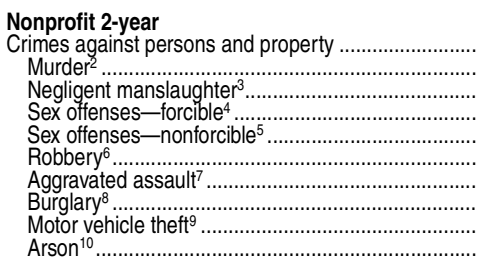 & $\begin{array}{r}63.955 \\
0.258 \\
0.000 \\
0.516 \\
0.516 \\
13.926 \\
5.931 \\
36.620 \\
5.931 \\
0.258\end{array}$ & $\begin{array}{r}58.903 \\
0.000 \\
0.000 \\
1.793 \\
0.512 \\
14.342 \\
41.354 \\
31.500 \\
5.378 \\
1.024\end{array}$ & $\begin{array}{r}51.594 \\
0.000 \\
0.000 \\
1.638 \\
0.000 \\
17.471 \\
3.276 \\
22.658 \\
6.279 \\
0.273\end{array}$ & $\begin{array}{r}48.535 \\
0.000 \\
0.000 \\
0.877 \\
0.000 \\
6.432 \\
4.970 \\
32.454 \\
3.801 \\
0.000\end{array}$ & $\begin{array}{r}91.263 \\
0.000 \\
0.000 \\
2.325 \\
0.000 \\
2.616 \\
6.394 \\
77.312 \\
2.035 \\
0.581\end{array}$ & $\begin{array}{r}81.948 \\
0.000 \\
0.000 \\
0.983 \\
0.328 \\
2.295 \\
11.473 \\
61.297 \\
4.589 \\
0.983\end{array}$ & $\begin{array}{r}103.819 \\
0.000 \\
0.000 \\
3.622 \\
0.000 \\
0.805 \\
20.925 \\
71.627 \\
5.634 \\
1.207\end{array}$ & $\begin{array}{r}0.00 \\
0.36 \\
5.84 \\
0.00 \\
4.74 \\
24.9 \\
58.41 \\
3.28 \\
2.55\end{array}$ & $\begin{array}{r}55.894 \\
0.000 \\
0.000 \\
3.042 \\
0.000 \\
3.422 \\
1.901 \\
45.627 \\
1.521 \\
0.380\end{array}$ & $\begin{array}{r}47.971 \\
0.000 \\
0.000 \\
2.798 \\
0.000 \\
1.999 \\
3.598 \\
37.977 \\
0.800 \\
0.800\end{array}$ & $\begin{array}{r}28.673 \\
0.000 \\
0.000 \\
3.320 \\
0.000 \\
0.302 \\
1.811 \\
21.731 \\
1.509 \\
0.000\end{array}$ & $\begin{array}{r}73.101 \\
0.000 \\
0.000 \\
10.280 \\
0.000 \\
1.142 \\
4.569 \\
54.826 \\
2.284 \\
0.000\end{array}$ & $\begin{array}{r}12.717 \\
0.000 \\
0.000 \\
0.820 \\
0.000 \\
0.000 \\
0.820 \\
9.845 \\
1.231 \\
0.000\end{array}$ \\
\hline $\begin{array}{l}\text { Weapons-, drug-, and } \\
\text { Arrests'1 } 1 \text {........... } \\
\text { Illegal weapons } \\
\text { Drug law volatati } \\
\text { Liquor law violat } \\
\text { Referrals for discip } \\
\text { Illegal weapons } \\
\text { Drug law violatic } \\
\text { Liquor law violat }\end{array}$ & $\begin{array}{r}27.852 \\
0.258 \\
5.416 \\
22.178 \\
160.920 \\
0.516 \\
23.468 \\
136.937\end{array}$ & $\begin{array}{r}9.988 \\
0.512 \\
2.561 \\
6.915 \\
145.722 \\
0.768 \\
16.647 \\
128.307\end{array}$ & $\begin{array}{l}6.279 \\
0.819 \\
4.368 \\
1.092\end{array}$ & $\begin{array}{r}14.034 \\
0.585 \\
4.678 \\
8.771 \\
130.694 \\
1.462 \\
16.958 \\
112.274\end{array}$ & $\begin{array}{r}22.089 \\
1.453 \\
9.301 \\
11.335 \\
149.393 \\
3.488 \\
13.660 \\
132.244\end{array}$ & $\begin{array}{r}21.962 \\
0.983 \\
11.145 \\
9.834 \\
176.025 \\
6.228 \\
24.257 \\
145.540\end{array}$ & $\begin{array}{r}23.741 \\
1.610 \\
10.865 \\
11.267 \\
208.845 \\
4.024 \\
29.375 \\
175.446\end{array}$ & $\begin{array}{r}33.952 \\
1.095 \\
12.047 \\
20.809 \\
150.774 \\
2.190 \\
31.031 \\
117.553\end{array}$ & $\begin{array}{r}22.053 \\
1.521 \\
13.308 \\
7.224 \\
132.319\end{array}$ & \begin{tabular}{r|r|r|}
19.588 \\
2.399 \\
7.196 \\
9.994 \\
150.710 \\
1.599 \\
41.975 \\
107.136
\end{tabular} & $\begin{array}{r}15.695 \\
1.509 \\
10.262 \\
3.924 \\
93.263 \\
0.302 \\
30.484 \\
62.477\end{array}$ & $\begin{array}{r}51.399 \\
4.569 \\
33.124 \\
13.706 \\
352.941 \\
1.142 \\
115.363 \\
236.436 \\
\end{array}$ & 2.872 \\
\hline $\begin{array}{c}\text { Crimes against } \\
\text { Murder } \\
\text { Negligent ma } \\
\text { Sex offenses- } \\
\text { Sex offenses- } \\
\text { Robbery } \\
\text { Aggravated a } \\
\text { Burglary } \\
\text { Motor vehicle } \\
\text { Arson }^{10} \ldots \ldots . . . . .\end{array}$ & $\begin{array}{r}25.385 \\
0.000 \\
0.000 \\
0.645 \\
0.376 \\
3.603 \\
2.151 \\
15.704 \\
2.743 \\
0.161\end{array}$ & $\begin{array}{r}21.447 \\
0.051 \\
0.000 \\
0.309 \\
0.154 \\
2.417 \\
0.977 \\
15.275 \\
2.057 \\
0.206\end{array}$ & $\begin{array}{r}0.00 \\
0.00 \\
0.67 \\
0.00 \\
3.67 \\
1.61 \\
15.31 \\
3.32 \\
0.04\end{array}$ & $\begin{array}{r}21.845 \\
0.000 \\
0.000 \\
0.373 \\
0.000 \\
3.316 \\
2.570 \\
13.472 \\
2.031 \\
0.083\end{array}$ & $\begin{array}{r}17.851 \\
0.000 \\
0.000 \\
0.002 \\
0.000 \\
2.283 \\
2.076 \\
10.378 \\
2.947 \\
0.125\end{array}$ & \begin{tabular}{r|}
18.237 \\
0.000 \\
0.000 \\
0.347 \\
0.043 \\
2.128 \\
1.433 \\
10.638 \\
3.517 \\
0.130
\end{tabular} & $\begin{array}{r}23.658 \\
0.000 \\
0.000 \\
0.087 \\
0.000 \\
2.898 \\
1.427 \\
15.138 \\
3.979 \\
0.130\end{array}$ & $\begin{array}{r}14.826 \\
0.000 \\
0.037 \\
0.149 \\
0.000 \\
1.969 \\
1.078 \\
8.955 \\
2.638 \\
0.000\end{array}$ & \begin{tabular}{r|}
13.060 \\
0.000 \\
0.000 \\
0.171 \\
0.028 \\
1.423 \\
1.508 \\
6.430 \\
3.443 \\
0.057
\end{tabular} & $\begin{array}{l}8.477 \\
0.000 \\
0.000 \\
0.052 \\
0.026 \\
1.134 \\
0.953 \\
3.556 \\
2.680 \\
0.077\end{array}$ & $\begin{array}{l}7.791 \\
0.000 \\
0.000 \\
0.191 \\
0.000 \\
0.656 \\
1.093 \\
3.472 \\
2.296 \\
0.082\end{array}$ & $\begin{array}{r}16.319 \\
0.000 \\
0.000 \\
1.718 \\
0.000 \\
0.000 \\
0.859 \\
12.024 \\
1.718 \\
0.000\end{array}$ & $\begin{array}{l}7.511 \\
0.000 \\
0.000 \\
0.141 \\
0.000 \\
0.678 \\
1.101 \\
3.191 \\
2.315 \\
0.085\end{array}$ \\
\hline 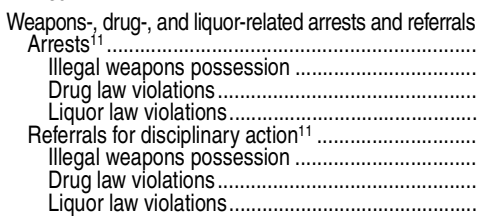 & $\begin{array}{r}8.766 \\
0.699 \\
4.679 \\
3.388 \\
15.435 \\
0.861 \\
4.787 \\
9.788\end{array}$ & $\begin{array}{r}6.583 \\
0.463 \\
3.343 \\
2.777 \\
16.972 \\
0.720 \\
5.400 \\
10.852\end{array}$ & $\begin{array}{r}3.7 \\
0.2 \\
2.1 \\
1.3 \\
14.0 \\
0.3 \\
8.8 \\
4.9\end{array}$ & $\begin{array}{r}0.043 \\
2.653 \\
1.741 \\
13.348 \\
0.290 \\
7.710 \\
5.347\end{array}$ & $\begin{array}{l}0.125 \\
1.495 \\
0.332 \\
9.465 \\
0.332 \\
5.563 \\
3.570\end{array}$ & $\begin{array}{r}1.780 \\
0.130 \\
1.129 \\
0.521 \\
13.895 \\
0.304 \\
9.509 \\
4.082\end{array}$ & & $\begin{array}{l}0.440 \\
0.260 \\
9.215 \\
0.149 \\
4.087 \\
4.979\end{array}$ & & $\begin{array}{l}1.185 \\
0.129 \\
0.747 \\
0.309 \\
7.550 \\
0.103 \\
3.169 \\
4.277\end{array}$ & $\begin{array}{l}0.050 \\
0.000 \\
0.410 \\
0.246 \\
7.900 \\
0.301 \\
3.253 \\
4.347\end{array}$ & $\begin{array}{r}0.000 \\
3.436 \\
1.718 \\
227.605 \\
4.294 \\
90.183 \\
133.127\end{array}$ & $\begin{array}{l}0.395 \\
0.113\end{array}$ \\
\hline
\end{tabular}

${ }^{1}$ Although crimes, arrests, and referrals include incidents involving students, staff, and campus guests, they are expressed as a ratio to FTE students because comprehensive FTE counts of all these groups are not available.

${ }^{2}$ Excludes suicides, fetal deaths, traffic fatalities, accidental deaths, and justifiable homicide (such as the killing of a felon by a law enforcement officer in the line of duty). Killing of another person through gross negligence (excludes traffic fatalities).

Any sexual act directed against another person forcibly and/or against that person's will. Includes only statutory rape or incest.

'Taking or attempting to take anything of value using actual or threatened force or violence. ${ }^{7}$ Attack upon a person for the purpose of inflicting severe or aggravated bodily injury.

¿Unlawful entry of a structure to commit a felony or theft.

${ }^{9}$ Theft or attempted theft of a motor vehicle.
${ }^{10}$ Willful or malicious burning or attempt to burn a dwelling house, public building, motor vehicle, or personal property of another.

${ }^{11} \mathrm{If}$ an individual is both arrested and referred to college officials for disciplinary action for a single offense, only the arrest is counted.

NOTE: Degree-granting institutions grant associate's or higher degrees and participate in Title IV federal financial aid programs. Crimes, arrests, and referrals include incidents involving students, staff, and on-campus guests. Excludes off-campus crimes and arrests even if they involve college students or staff. Detail may not sum to totals because of rounding. SOURCE: U.S. Department of Education, Office of Postsecondary Education, Campus Safety and Security Reporting System, 2001 through 2011; and National Center for Education Statistics, Integrated Postsecondary Education Data System (IPEDS), Spring 2002 through Spring 2012, Enrollment component. (This table was prepared November 2013.) 


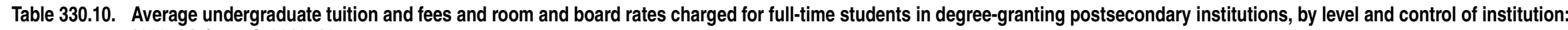
1963-64 through 2012-13

\begin{tabular}{|c|c|c|c|c|c|c|c|c|c|c|c|c|c|c|c|c|c|c|c|c|c|c|c|c|c|}
\hline \multirow[b]{3}{*}{$\begin{array}{l}\text { Year and control } \\
\text { of institution }\end{array}$} & \multicolumn{12}{|c|}{ Constant 2012-13 dollars 1} & \multicolumn{12}{|c|}{ Current dollars } & \\
\hline & \multicolumn{3}{|c|}{$\begin{array}{l}\text { Total tuition, fees, } \\
\text { room, and board }\end{array}$} & \multicolumn{3}{|c|}{ Tuition and required fees ${ }^{2}$} & \multicolumn{3}{|c|}{ Dormitory rooms } & \multicolumn{3}{|c|}{ Board $^{3}$} & \multicolumn{3}{|c|}{$\begin{array}{l}\text { Total tuition, fees, } \\
\text { room, and board }\end{array}$} & \multicolumn{3}{|c|}{ Tuition and required fees ${ }^{2}$} & \multicolumn{3}{|c|}{ Dormitory rooms } & \multicolumn{3}{|c|}{ Board $^{3}$} & \\
\hline & $\begin{array}{r}\text { All } \\
\text { institu- } \\
\text { tions }\end{array}$ & 4-year & 2-year & $\begin{array}{r}\text { All } \\
\text { institu- } \\
\text { tions }\end{array}$ & 4-year & 2-year & $\begin{array}{r}\text { All } \\
\text { institu- } \\
\text { tions }\end{array}$ & 4-year & 2-year & \begin{tabular}{r|} 
All \\
institu- \\
tions
\end{tabular} & 4-year & 2-year & $\begin{array}{r}\text { All } \\
\text { institu- } \\
\text { tions }\end{array}$ & 4-year & 2-year & \begin{tabular}{r|} 
All \\
institu- \\
tions
\end{tabular} & 4-year & 2-year & $\begin{array}{r}\text { All } \\
\text { institu- } \\
\text { tions }\end{array}$ & 4-year & 2-year & $\begin{array}{r}\text { All } \\
\text { institu- } \\
\text { tions }\end{array}$ & 4-year & 2-year & \\
\hline 1 & 2 & 3 & 4 & 5 & 6 & 7 & 8 & 9 & 10 & 11 & 12 & 13 & 14 & 15 & 16 & 17 & 18 & 19 & 20 & 21 & 22 & 23 & 24 & 25 & \\
\hline $\begin{array}{l}\text { All institutions } \\
1963-64 \ldots \ldots \ldots \ldots \\
1964-65 \ldots \ldots \ldots \ldots \\
1965-66 \ldots \ldots \ldots \ldots \\
1966-67 \ldots \ldots \ldots \ldots \\
1967-68 \ldots \ldots \ldots \ldots \ldots \\
1968-69 \ldots \ldots \ldots \ldots . . .\end{array}$ & $\begin{array}{r}\$ 9,361 \\
9,503 \\
9,598 \\
9,685 \\
9,627 \\
9,461\end{array}$ & $\begin{array}{r}\$ 9,647 \\
9,818 \\
9,971 \\
10,116 \\
10,118 \\
10,023\end{array}$ & $\begin{array}{r}\$ 5,817 \\
6,231 \\
6,412 \\
6,506 \\
6,693 \\
6,830\end{array}$ & $\begin{array}{r}\$ 3,812 \\
3,926 \\
3,977 \\
4,034 \\
3,997 \\
3,868\end{array}$ & $\begin{array}{r}\$ 4,145 \\
4,297 \\
4,398 \\
4,500 \\
4,508 \\
4,432\end{array}$ & $\begin{array}{r}\$ 1,285 \\
1,387 \\
1,471 \\
1,506 \\
1,579 \\
1,624\end{array}$ & $\begin{array}{r}\$ 2,118 \\
2,190 \\
2,252 \\
2,309 \\
2,327 \\
2,337\end{array}$ & $\begin{array}{r}\$ 2,090 \\
2,157 \\
2,230 \\
2,299 \\
2,321 \\
2,336\end{array}$ & $\begin{array}{r}\$ 1,569 \\
1,760 \\
1,874 \\
1,968 \\
2,050 \\
2,120\end{array}$ & $\begin{array}{r}\$ 3,431 \\
3,388 \\
3,369 \\
3,342 \\
3,304 \\
3,256\end{array}$ & $\begin{array}{r}\$ 3,413 \\
3,363 \\
3,343 \\
3,317 \\
3,289 \\
3,255\end{array}$ & $\begin{array}{r}\$ 2,963 \\
3,084 \\
3,067 \\
3,033 \\
3,064 \\
3,085\end{array}$ & $\begin{array}{r}\$ 1,248 \\
1,283 \\
1,324 \\
1,378 \\
1,415 \\
1,459\end{array}$ & $\begin{array}{r}\$ 1,286 \\
1,325 \\
1,375 \\
1,49 \\
1,487 \\
1,545\end{array}$ & $\begin{array}{r}\$ 775 \\
841 \\
884 \\
926 \\
984 \\
1,053\end{array}$ & $\begin{array}{r}\$ 508 \\
530 \\
549 \\
574 \\
588 \\
596\end{array}$ & $\begin{array}{r}\$ 553 \\
580 \\
607 \\
640 \\
663 \\
683\end{array}$ & $\begin{array}{r}\$ 171 \\
187 \\
203 \\
214 \\
232 \\
250\end{array}$ & $\begin{array}{r}\$ 282 \\
296 \\
311 \\
328 \\
342 \\
360\end{array}$ & $\begin{array}{r}\$ 279 \\
291 \\
308 \\
327 \\
341 \\
360\end{array}$ & $\begin{array}{r}\$ 209 \\
238 \\
258 \\
280 \\
301 \\
327\end{array}$ & $\begin{array}{r}\$ 457 \\
457 \\
465 \\
476 \\
486 \\
502\end{array}$ & $\begin{array}{r}\$ 455 \\
454 \\
461 \\
472 \\
483 \\
502\end{array}$ & $\begin{array}{r}\$ 395 \\
416 \\
423 \\
431 \\
450 \\
476\end{array}$ & \\
\hline $\begin{array}{l}1969-70 \ldots \ldots \ldots \ldots . . . \\
1970-71 \ldots \ldots \ldots \ldots . . \\
1971-72 \ldots \ldots \ldots \ldots . . \\
1972-73 \ldots \ldots \ldots \ldots \ldots . . \\
1973-74 \ldots \ldots \ldots \ldots \ldots .\end{array}$ & $\begin{array}{l}9,554 \\
9,625 \\
9,729 \\
9,914 \\
9,443\end{array}$ & $\begin{array}{l}10,255 \\
10,392 \\
10,556 \\
10,975 \\
10,406\end{array}$ & $\begin{array}{l}6,672 \\
6,525 \\
6,588 \\
6,896 \\
6,740\end{array}$ & $\begin{array}{l}3,951 \\
4,007 \\
4,069 \\
4,104 \\
3,948\end{array}$ & $\begin{array}{l}4,624 \\
4,739 \\
4,865 \\
5,136 \\
4,885\end{array}$ & $\begin{array}{l}1,515 \\
1,453 \\
1,410 \\
1,550 \\
1,630\end{array}$ & $\begin{array}{l}2,384 \\
2,439 \\
2,501 \\
2,636 \\
2,458\end{array}$ & $\begin{array}{l}2,400 \\
2,457 \\
2,521 \\
2,661 \\
2,480\end{array}$ & $\begin{array}{l}2,125 \\
2,152 \\
2,198 \\
2,242 \\
2,132\end{array}$ & $\begin{array}{l}3,219 \\
3,179 \\
3,158 \\
3,173 \\
3,037\end{array}$ & $\begin{array}{l}3,231 \\
3,195 \\
3,170 \\
3,178 \\
3,041\end{array}$ & $\begin{array}{l}3,032 \\
2,921 \\
2,980 \\
3,104 \\
2,978\end{array}$ & $\begin{array}{l}1,560 \\
1,653 \\
1,730 \\
1,834 \\
1,903\end{array}$ & $\begin{array}{l}1,674 \\
1,784 \\
1,878 \\
2,031 \\
2,097\end{array}$ & $\begin{array}{l}1,089 \\
1,120 \\
1,172 \\
1,276 \\
1,358\end{array}$ & $\begin{array}{l}645 \\
688 \\
724 \\
759 \\
796\end{array}$ & $\begin{array}{l}755 \\
814 \\
865 \\
950 \\
985\end{array}$ & \begin{tabular}{l|}
247 \\
249 \\
251 \\
287 \\
328
\end{tabular} & $\begin{array}{l}389 \\
419 \\
445 \\
488 \\
495\end{array}$ & $\begin{array}{l}392 \\
422 \\
448 \\
492 \\
500\end{array}$ & $\begin{array}{l}347 \\
369 \\
391 \\
415 \\
430\end{array}$ & $\begin{array}{l}526 \\
546 \\
562 \\
587 \\
612\end{array}$ & $\begin{array}{l}528 \\
549 \\
564 \\
588 \\
613\end{array}$ & $\begin{array}{l}495 \\
501 \\
530 \\
574 \\
600\end{array}$ & \\
\hline $\begin{array}{l}1974-75 . \ldots \ldots \ldots \ldots . . . \\
1975-76 \ldots \ldots \ldots \ldots \ldots . . \\
1976-77 \ldots \ldots \ldots \ldots \ldots . . \\
1977-78 \ldots \ldots \ldots \ldots \ldots . . \\
1978-79 \ldots \ldots \ldots \ldots \ldots .\end{array}$ & $\begin{array}{l}8,858 \\
8,774 \\
8,968 \\
8,905 \\
8,736\end{array}$ & $\begin{array}{r}9,767 \\
9,823 \\
10,157 \\
10,065 \\
9,853\end{array}$ & $\begin{array}{l}6,394 \\
6,146 \\
6,298 \\
6,292 \\
6,174\end{array}$ & $\begin{array}{l}3,615 \\
3,459 \\
3,642 \\
3,636 \\
3,623\end{array}$ & $\begin{array}{l}4,503 \\
4,477 \\
4,803 \\
4,770 \\
4,717\end{array}$ & $\begin{array}{l}1,463 \\
1,40 \\
1,362 \\
1,397 \\
1,388\end{array}$ & $\begin{array}{l}2,359 \\
2,373 \\
2,378 \\
2,383 \\
2,323\end{array}$ & $\begin{array}{l}2,379 \\
2,403 \\
2,408 \\
2,415 \\
2,349\end{array}$ & $\begin{array}{l}2,056 \\
1,977 \\
1,982 \\
1,938 \\
1,942\end{array}$ & $\begin{array}{l}2,884 \\
2,942 \\
2,948 \\
2,885 \\
2,790\end{array}$ & $\begin{array}{l}2,885 \\
2,943 \\
2,947 \\
2,880 \\
2,786\end{array}$ & $\begin{array}{l}2,875 \\
2,929 \\
2,955 \\
2,957 \\
2,844\end{array}$ & $\begin{array}{l}1,983 \\
2,103 \\
2,275 \\
2,411 \\
2,587\end{array}$ & $\begin{array}{l}2,187 \\
2,355 \\
2,577 \\
2,725 \\
2,917\end{array}$ & $\begin{array}{l}1,432 \\
1,473 \\
1,598 \\
1,703 \\
1,828\end{array}$ & $\begin{array}{r}809 \\
829 \\
924 \\
984 \\
1,073\end{array}$ & $\begin{array}{l}1,008 \\
1,073 \\
1,218 \\
1,291 \\
1,397\end{array}$ & $\begin{array}{l}328 \\
297 \\
346 \\
338 \\
411\end{array}$ & $\begin{array}{l}528 \\
569 \\
603 \\
645 \\
688\end{array}$ & $\begin{array}{l}533 \\
576 \\
611 \\
654 \\
696\end{array}$ & $\begin{array}{l}460 \\
474 \\
503 \\
525 \\
575\end{array}$ & $\begin{array}{l}646 \\
705 \\
748 \\
781 \\
826\end{array}$ & $\begin{array}{l}646 \\
706 \\
748 \\
780 \\
825\end{array}$ & $\begin{array}{l}644 \\
702 \\
750 \\
801 \\
842\end{array}$ & \\
\hline $\begin{array}{l}1979-80 \ldots \ldots \ldots \ldots . . . \\
1980-81 \ldots \ldots \ldots \ldots \ldots . . \\
1981-82 \ldots \ldots \ldots \ldots \ldots . . \\
1982-83 \ldots \ldots \ldots \ldots \ldots . . \\
1983-84 \ldots \ldots \ldots \ldots \ldots .\end{array}$ & $\begin{array}{l}8,371 \\
8,283 \\
8,578 \\
9,138 \\
9,472\end{array}$ & $\begin{array}{r}9,438 \\
9,346 \\
9,713 \\
10,385 \\
10,790\end{array}$ & $\begin{array}{l}5,899 \\
5,956 \\
6,086 \\
6,396 \\
6,488\end{array}$ & $\begin{array}{l}3,465 \\
3,442 \\
3,581 \\
3,832 \\
4,052\end{array}$ & $\begin{array}{l}4,509 \\
4,483 \\
4,689 \\
5,043 \\
5,327\end{array}$ & \begin{tabular}{r|}
1,344 \\
1,405 \\
1,449 \\
1,590 \\
1,660
\end{tabular} & $\begin{array}{l}2,238 \\
2,233 \\
2,335 \\
2,507 \\
2,603\end{array}$ & $\begin{array}{l}2,263 \\
2,259 \\
2,364 \\
2,541 \\
2,641\end{array}$ & $\begin{array}{l}1,871 \\
1,882 \\
1,948 \\
2,059 \\
2,082\end{array}$ & $\begin{array}{l}2,668 \\
2,608 \\
2,662 \\
2,798 \\
2,817\end{array}$ & $\begin{array}{l}2,667 \\
2,604 \\
2,660 \\
2,802 \\
2,822\end{array}$ & $\begin{array}{l}2,683 \\
2,670 \\
2,688 \\
2,747 \\
2,746\end{array}$ & $\begin{array}{l}2,809 \\
3,101 \\
3,489 \\
3,877 \\
4,167\end{array}$ & $\begin{array}{l}3,167 \\
3,49 \\
3,951 \\
4,406 \\
4,747\end{array}$ & $\begin{array}{l}1,979 \\
2,230 \\
2,476 \\
2,713 \\
2,854\end{array}$ & $\begin{array}{l}1,163 \\
1,289 \\
1,457 \\
1,626 \\
1,783\end{array}$ & $\begin{array}{l}1,513 \\
1,679 \\
1,907 \\
2,139 \\
2,344\end{array}$ & $\begin{array}{l}451 \\
526 \\
590 \\
675 \\
730\end{array}$ & $\begin{array}{r}751 \\
836 \\
950 \\
1,064 \\
1,145\end{array}$ & $\begin{array}{r}759 \\
846 \\
961 \\
1,078 \\
1,162\end{array}$ & $\begin{array}{l}628 \\
705 \\
793 \\
873 \\
916\end{array}$ & $\begin{array}{r}895 \\
976 \\
1,083 \\
1,187 \\
1,239\end{array}$ & $\begin{array}{r}895 \\
975 \\
1,082 \\
1,189 \\
1,242\end{array}$ & $\begin{array}{r}900 \\
1,000 \\
1,094 \\
1,165 \\
1,208\end{array}$ & \\
\hline $\begin{array}{l}1984-85 \ldots \ldots \ldots \ldots . . \\
1985-864 \ldots \ldots \ldots . . \\
1986-87 \ldots \ldots \ldots \ldots . . . \\
1987-88 \ldots \ldots \ldots \ldots . . \\
1988-89 \ldots \ldots \ldots \ldots . . .\end{array}$ & $\begin{array}{r}9,980 \\
10,385 \\
10,827 \\
10,973 \\
11,203\end{array}$ & $\begin{array}{l}11,288 \\
11,702 \\
12,405 \\
12,527 \\
12,839\end{array}$ & $\begin{array}{l}6,955 \\
7,158 \\
6,854 \\
6,517 \\
6,821\end{array}$ & $\begin{array}{l}4,343 \\
4,637 \\
4,809 \\
4,909 \\
5,073\end{array}$ & $\begin{array}{l}5,616 \\
5,920 \\
6,327 \\
6,393 \\
6,628\end{array}$ & \begin{tabular}{r|}
1,796 \\
1,889 \\
1,866 \\
1,66 \\
1,870
\end{tabular} & $\begin{array}{l}2,772 \\
2,845 \\
2,922 \\
2,971 \\
3,006\end{array}$ & $\begin{array}{l}2,804 \\
2,880 \\
2,967 \\
3,028 \\
3,071\end{array}$ & $\begin{array}{l}2,313 \\
2,353 \\
2,151 \\
2,031 \\
2,071\end{array}$ & $\begin{array}{l}2,866 \\
2,903 \\
3,097 \\
3,093 \\
3,124\end{array}$ & $\begin{array}{l}2,867 \\
2,902 \\
3,110 \\
3,106 \\
3,139\end{array}$ & $\begin{array}{l}2,845 \\
2,916 \\
2,837 \\
2,869 \\
2,880\end{array}$ & $\begin{array}{l}4,563 \\
4,885 \\
5,206 \\
5,494 \\
5,869\end{array}$ & $\begin{array}{l}5,160 \\
5,504 \\
5,964 \\
6,272 \\
6,725\end{array}$ & $\begin{array}{l}3,179 \\
3,367 \\
3,295 \\
3,263 \\
3,573\end{array}$ & $\begin{array}{l}1,985 \\
2,181 \\
2,312 \\
2,458 \\
2,658\end{array}$ & $\begin{array}{l}2,567 \\
2,784 \\
3,042 \\
3,201 \\
3,472\end{array}$ & $\begin{array}{l}821 \\
888 \\
897 \\
809 \\
979\end{array}$ & $\begin{array}{r}1,267 \\
1,338 \\
1,405 \\
1,488 \\
1,575\end{array}$ & $\begin{array}{l}1,282 \\
1,355 \\
1,427 \\
1,516 \\
1,609\end{array}$ & $\begin{array}{l}1,058 \\
1,107 \\
1,034 \\
1,017 \\
1,085\end{array}$ & $\begin{array}{l}1,310 \\
1,365 \\
1,489 \\
1,549 \\
1,636\end{array}$ & $\begin{array}{l}1,311 \\
1,365 \\
1,495 \\
1,555 \\
1,644\end{array}$ & $\begin{array}{l}1,301 \\
1,372 \\
1,364 \\
1,437 \\
1,509\end{array}$ & \\
\hline $\begin{array}{l}1989-90 \ldots \ldots \ldots \ldots . . . \\
1990-91 \ldots \ldots \ldots \ldots \ldots . \\
1991-92 \ldots \ldots \ldots \ldots . . \\
1992-93 \ldots \ldots \ldots \ldots . . \\
1993-94 \ldots \ldots \ldots \ldots . .\end{array}$ & $\begin{array}{l}11,310 \\
11,336 \\
11,847 \\
12,097 \\
12,549\end{array}$ & $\begin{array}{l}13,140 \\
13,132 \\
13,789 \\
14,216 \\
14,709\end{array}$ & $\begin{array}{l}6,751 \\
6,790 \\
6,850 \\
6,830 \\
7,039\end{array}$ & $\begin{array}{l}5,173 \\
5,211 \\
5,500 \\
5,709 \\
6,056\end{array}$ & $\begin{array}{l}6,924 \\
6,926 \\
7,341 \\
7,714 \\
8,100\end{array}$ & $\begin{array}{l}1,782 \\
1,879 \\
1,991 \\
2,201 \\
2,213\end{array}$ & $\begin{array}{l}2,984 \\
3,012 \\
3,137 \\
3,147 \\
3,255\end{array}$ & $\begin{array}{l}3,051 \\
3,078 \\
3,216 \\
3,232 \\
3,340\end{array}$ & $\begin{array}{l}2,013 \\
2,043 \\
2,026 \\
2,013 \\
2,108\end{array}$ & $\begin{array}{l}3,152 \\
3,113 \\
3,210 \\
3,241 \\
3,239\end{array}$ & $\begin{array}{l}3,164 \\
3,128 \\
3,233 \\
3,270 \\
3,270\end{array}$ & $\begin{array}{l}2,956 \\
2,869 \\
2,833 \\
2,746 \\
2,718\end{array}$ & $\begin{array}{l}6,207 \\
6,562 \\
7,077 \\
7,452 \\
7,931\end{array}$ & $\begin{array}{l}7,212 \\
7,602 \\
8,238 \\
8,758 \\
9,296\end{array}$ & $\begin{array}{l}3,705 \\
3,930 \\
4,092 \\
4,207 \\
4,449\end{array}$ & $\begin{array}{l}2,839 \\
3,016 \\
3,286 \\
3,517 \\
3,827\end{array}$ & $\begin{array}{l}3,800 \\
4,009 \\
4,385 \\
4,752 \\
5,119\end{array}$ & $\begin{array}{r}978 \\
1,087 \\
1,189 \\
1,276 \\
1,399\end{array}$ & $\begin{array}{r}1,638 \\
1,743 \\
1,874 \\
1,939 \\
2,057\end{array}$ & $\begin{array}{l}1,675 \\
1,782 \\
1,921 \\
1,991 \\
2,111\end{array}$ & $\begin{array}{l}1,105 \\
1,182 \\
1,210 \\
1,240 \\
1,332\end{array}$ & $\begin{array}{l}1,730 \\
1,802 \\
1,918 \\
1,996 \\
2,047\end{array}$ & $\begin{array}{l}1,737 \\
1,811 \\
1,931 \\
2,015 \\
2,067\end{array}$ & $\begin{array}{l}1,622 \\
1,660 \\
1,692 \\
1,692 \\
1,718\end{array}$ & \\
\hline $\begin{array}{l}1994-95 \ldots \ldots \ldots \ldots . . . \\
1995-96 \ldots \ldots \ldots \ldots \ldots . . \\
1996-97 . \ldots \ldots \ldots \ldots . . \\
1997-98 \ldots \ldots \ldots \ldots . . \\
1998-99 \ldots \ldots \ldots \ldots \ldots . .\end{array}$ & $\begin{array}{l}12,775 \\
13,178 \\
13,403 \\
13,714 \\
14,167\end{array}$ & $\begin{array}{l}14,963 \\
15,468 \\
15,783 \\
16,131 \\
16,716\end{array}$ & $\begin{array}{l}7,127 \\
7,075 \\
7,127 \\
7,427 \\
7,439\end{array}$ & $\begin{array}{l}6,221 \\
6,496 \\
6,645 \\
6,801 \\
7,048\end{array}$ & $\begin{array}{l}8,292 \\
8,664 \\
8,908 \\
9,084 \\
9,452\end{array}$ & \begin{tabular}{l|}
2,288 \\
2,279 \\
2,246 \\
2,424 \\
2,426
\end{tabular} & $\begin{array}{l}3,300 \\
3,390 \\
3,444 \\
3,496 \\
3,596\end{array}$ & $\begin{array}{l}3,383 \\
3,471 \\
3,526 \\
3,586 \\
3,692\end{array}$ & $\begin{array}{l}2,147 \\
2,205 \\
2,217 \\
2,285 \\
2,272\end{array}$ & $\begin{array}{l}3,254 \\
3,292 \\
3,314 \\
3,417 \\
3,523\end{array}$ & $\begin{array}{l}3,288 \\
3,333 \\
3,349 \\
3,461 \\
3,572\end{array}$ & $\begin{array}{l}2,691 \\
2,590 \\
2,664 \\
2,717 \\
2,741\end{array}$ & $\begin{array}{r}8,306 \\
8,800 \\
9,206 \\
9,588 \\
10,076\end{array}$ & $\begin{array}{r}9,728 \\
10,30 \\
10,841 \\
11,27 \\
11,888\end{array}$ & $\begin{array}{l}4,633 \\
4,725 \\
4,895 \\
5,192 \\
5,291\end{array}$ & $\begin{array}{l}4,044 \\
4,338 \\
4,564 \\
4,755 \\
5,013\end{array}$ & $\begin{array}{l}5,391 \\
5,786 \\
6,118 \\
6,351 \\
6,723\end{array}$ & $\begin{array}{l}1,488 \\
1,522 \\
1,543 \\
1,695 \\
1,725\end{array}$ & $\begin{array}{l}2,145 \\
2,264 \\
2,365 \\
2,444 \\
2,557\end{array}$ & $\begin{array}{l}2,200 \\
2,318 \\
2,422 \\
2,507 \\
2,626\end{array}$ & $\begin{array}{l}1,396 \\
1,473 \\
1,522 \\
1,598 \\
1,616\end{array}$ & $\begin{array}{l}2,116 \\
2,199 \\
2,276 \\
2,389 \\
2,506\end{array}$ & $\begin{array}{l}2,138 \\
2,226 \\
2,301 \\
2,419 \\
2,540\end{array}$ & $\begin{array}{l}1,750 \\
1,730 \\
1,830 \\
1,900 \\
1,950\end{array}$ & $\frac{O}{T}$ \\
\hline $\begin{array}{l}1999-2000 \ldots \ldots \ldots . . . \\
2000-01 \ldots \ldots \ldots \ldots . . \\
2001-02 \ldots \ldots \ldots \ldots . . \\
2002-03 \ldots \ldots \ldots \ldots . . \\
2003-04 \ldots \ldots \ldots \ldots . .\end{array}$ & $\begin{array}{l}14,254 \\
14,296 \\
14,775 \\
15,262 \\
16,104\end{array}$ & $\begin{array}{l}16,876 \\
17,075 \\
17,708 \\
18,344 \\
19,276\end{array}$ & $\begin{array}{l}7,406 \\
7,223 \\
7,424 \\
7,943 \\
8,336\end{array}$ & $\begin{array}{l}7,136 \\
7,105 \\
7,331 \\
7,625 \\
8,215\end{array}$ & $\begin{array}{r}9,621 \\
9,740 \\
10,109 \\
10,555 \\
11,225\end{array}$ & $\begin{array}{l}2,361 \\
2,244 \\
2,337 \\
2,418 \\
2,703\end{array}$ & $\begin{array}{l}3,671 \\
3,728 \\
3,870 \\
4,039 \\
4,176\end{array}$ & $\begin{array}{l}3,759 \\
3,822 \\
3,973 \\
4,146 \\
4,287\end{array}$ & $\begin{array}{l}2,421 \\
2,353 \\
2,399 \\
2,639 \\
2,745\end{array}$ & $\begin{array}{l}3,447 \\
3,463 \\
3,574 \\
3,598 \\
3,712\end{array}$ & $\begin{array}{l}3,496 \\
3,512 \\
3,626 \\
3,643 \\
3,765\end{array}$ & $\begin{array}{l}2,624 \\
2,626 \\
2,688 \\
2,886 \\
2,887\end{array}$ & $\begin{array}{l}10,430 \\
10,820 \\
11,380 \\
12,014 \\
12,953\end{array}$ & $\begin{array}{l}12,349 \\
12,922 \\
13,639 \\
14,49 \\
15,505\end{array}$ & $\begin{array}{l}5,420 \\
5,466 \\
5,718 \\
6,252 \\
6,705\end{array}$ & $\begin{array}{l}5,222 \\
5,377 \\
5,646 \\
6,002 \\
6,608\end{array}$ & $\begin{array}{r}7,040 \\
7,372 \\
7,786 \\
8,309 \\
9,029\end{array}$ & $\begin{array}{l}1,728 \\
1,698 \\
1,800 \\
1,903 \\
2,174\end{array}$ & $\begin{array}{l}2,686 \\
2,821 \\
2,981 \\
3,179 \\
3,359\end{array}$ & $\begin{array}{l}2,751 \\
2,893 \\
3,060 \\
3,263 \\
3,448\end{array}$ & $\begin{array}{l}1,771 \\
1,781 \\
1,848 \\
2,077 \\
2,208\end{array}$ & $\begin{array}{l}2,523 \\
2,621 \\
2,753 \\
2,832 \\
2,986\end{array}$ & $\begin{array}{l}2,558 \\
2,658 \\
2,793 \\
2,867 \\
3,028\end{array}$ & $\begin{array}{l}1,920 \\
1,987 \\
2,070 \\
2,272 \\
2,322\end{array}$ & wِ \\
\hline $\begin{array}{l}2004-05 \ldots \ldots \ldots \ldots . . . \\
2005-06 \ldots \ldots \ldots \ldots . . \\
2006-07 \ldots \ldots \ldots \ldots . . \\
2007-08 \ldots \ldots \ldots \ldots . . \\
2008-09 \ldots \ldots \ldots \ldots . .\end{array}$ & $\begin{array}{l}16,647 \\
17,014 \\
17,547 \\
17,737 \\
18,421\end{array}$ & $\begin{array}{l}19,925 \\
20,289 \\
20,934 \\
21,160 \\
21,996\end{array}$ & $\begin{array}{l}8,563 \\
8,412 \\
8,461 \\
8,346 \\
8,879\end{array}$ & $\begin{array}{l}8,596 \\
8,838 \\
9,171 \\
9,271 \\
9,584\end{array}$ & $\begin{array}{l}11,714 \\
11,950 \\
12,388 \\
12,517 \\
12,982\end{array}$ & $\begin{array}{l}2,822 \\
2,810 \\
2,828 \\
2,753 \\
2,822\end{array}$ & $\begin{array}{l}4,310 \\
4,430 \\
4,554 \\
4,605 \\
4,792\end{array}$ & $\begin{array}{l}4,420 \\
4,540 \\
4,665 \\
4,717 \\
4,911\end{array}$ & $\begin{array}{l}2,841 \\
2,803 \\
2,864 \\
2,880 \\
2,996\end{array}$ & $\begin{array}{l}3,741 \\
3,746 \\
3,822 \\
3,862 \\
4,045\end{array}$ & $\begin{array}{l}3,792 \\
3,799 \\
3,881 \\
3,926 \\
4,103\end{array}$ & $\begin{array}{l}2,901 \\
2,800 \\
2,768 \\
2,713 \\
3,060\end{array}$ & $\begin{array}{l}13,793 \\
14,634 \\
15,483 \\
16,231 \\
17,092\end{array}$ & $\begin{array}{l}16,510 \\
17,41 \\
18,471 \\
19,363 \\
20,409\end{array}$ & $\begin{array}{l}7,095 \\
7,236 \\
7,466 \\
7,637 \\
8,238\end{array}$ & $\begin{array}{l}7,122 \\
7,601 \\
8,092 \\
8,483 \\
8,893\end{array}$ & $\begin{array}{r}9,706 \\
10,279 \\
10,931 \\
11,454 \\
12,045\end{array}$ & $\begin{array}{l}2,338 \\
2,417 \\
2,496 \\
2,519 \\
2,618\end{array}$ & $\begin{array}{l}3,572 \\
3,810 \\
4,019 \\
4,214 \\
4,446\end{array}$ & $\begin{array}{l}3,662 \\
3,905 \\
4,116 \\
4,317 \\
4,557\end{array}$ & $\begin{array}{l}2,354 \\
2,411 \\
2,527 \\
2,635 \\
2,780\end{array}$ & $\begin{array}{l}3,100 \\
3,222 \\
3,372 \\
3,534 \\
3,754\end{array}$ & $\begin{array}{l}3,142 \\
3,268 \\
3,424 \\
3,592 \\
3,807\end{array}$ & $\begin{array}{l}2,404 \\
2,408 \\
2,443 \\
2,483 \\
2,839\end{array}$ & \\
\hline 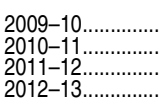 & $\begin{array}{l}18,839 \\
19,355 \\
19,741 \\
20,234\end{array}$ & $\begin{array}{l}22,515 \\
23,118 \\
23,409 \\
23,872\end{array}$ & $\begin{array}{l}9,109 \\
9,323 \\
9,461 \\
9,574\end{array}$ & $\begin{array}{r}9,752 \\
10,044 \\
10,349 \\
10,683\end{array}$ & $\begin{array}{l}13,205 \\
13,569 \\
13,793 \\
14,101\end{array}$ & $\begin{array}{l}3,120 \\
3,238 \\
3,302 \\
3,322\end{array}$ & $\begin{array}{l}4,971 \\
5,100 \\
5,180 \\
5,296\end{array}$ & $\begin{array}{l}5,108 \\
5,248 \\
5,322 \\
5,433\end{array}$ & $\begin{array}{l}3,186 \\
3,220 \\
3,244 \\
3,340\end{array}$ & $\begin{array}{l}4,116 \\
4,212 \\
4,213 \\
4,256\end{array}$ & $\begin{array}{l}4,202 \\
4,302 \\
4,293 \\
4,338\end{array}$ & $\begin{array}{l}2,803 \\
2,864 \\
2,915 \\
2,912\end{array}$ & $\begin{array}{l}17,649 \\
18,497 \\
19,418 \\
20,234\end{array}$ & $\begin{array}{l}21,093 \\
22,092 \\
23,025 \\
23,872\end{array}$ & $\begin{array}{l}8,533 \\
8,909 \\
9,306 \\
9,574\end{array}$ & $\begin{array}{r}9,136 \\
9,598 \\
10,180 \\
10,683\end{array}$ & $\begin{array}{l}12,370 \\
12,, 667 \\
13,567 \\
14,101\end{array}$ & $\begin{array}{l}2,923 \\
3,095 \\
3,248 \\
3,322\end{array}$ & $\begin{array}{l}4,657 \\
4,874 \\
5,095 \\
5,296\end{array}$ & $\begin{array}{l}4,785 \\
5,015 \\
5,235 \\
5,433\end{array}$ & $\begin{array}{l}2,985 \\
3,077 \\
3,191 \\
3,340\end{array}$ & $\begin{array}{l}3,856 \\
4,025 \\
4,144 \\
4,256\end{array}$ & $\begin{array}{l}3,937 \\
4,111 \\
4,223 \\
4,338\end{array}$ & $\begin{array}{l}2,626 \\
2,737 \\
2,867 \\
2,912\end{array}$ & 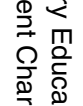 \\
\hline
\end{tabular}




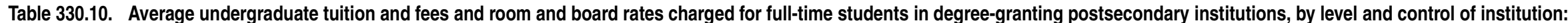
1963-64 through 2012-13-Continued

\begin{tabular}{|c|c|c|c|c|c|c|c|c|c|c|c|c|c|c|c|c|c|c|c|c|c|c|c|c|}
\hline \multirow[b]{3}{*}{$\begin{array}{l}\text { Year and control } \\
\text { of institution }\end{array}$} & \multicolumn{12}{|c|}{ Constant 2012-13 dollars 1} & \multicolumn{12}{|c|}{ Current dollars } \\
\hline & \multicolumn{3}{|c|}{$\begin{array}{l}\text { Total tuition, fees, } \\
\text { room, and board }\end{array}$} & \multicolumn{3}{|c|}{ Tuition and required fees ${ }^{2}$} & \multicolumn{3}{|c|}{ Dormitory rooms } & \multicolumn{3}{|c|}{ Board $^{3}$} & \multicolumn{3}{|c|}{$\begin{array}{l}\text { Total tuition, fees, } \\
\text { room, and board }\end{array}$} & \multicolumn{3}{|c|}{ Tuition and required fees ${ }^{2}$} & \multicolumn{3}{|c|}{ Dormitory rooms } & \multicolumn{3}{|c|}{ Board $^{3}$} \\
\hline & $\begin{array}{r}\text { All } \\
\text { institu- } \\
\text { tions }\end{array}$ & 4-year & 2-year & $\begin{array}{r}\text { All } \\
\text { institu- } \\
\text { tions }\end{array}$ & 4-year & 2-year & $\begin{array}{r}\text { All } \\
\text { institu- } \\
\text { tions }\end{array}$ & 4-year & 2-year & $\begin{array}{r}\text { All } \\
\text { institu- } \\
\text { tions }\end{array}$ & 4-year & 2-year & $\begin{array}{r}\text { All } \\
\text { institu- } \\
\text { tions }\end{array}$ & 4-year & 2-year & $\begin{array}{r}\text { All } \\
\text { institu- } \\
\text { tions }\end{array}$ & 4-year & 2-year & $\begin{array}{r}\text { All } \\
\text { institu- } \\
\text { tions }\end{array}$ & 4-year & 2-year & $\begin{array}{r}\text { All } \\
\text { institu- } \\
\text { tions }\end{array}$ & 4-year & 2-year \\
\hline 1 & 2 & 3 & 4 & 5 & 6 & 7 & 8 & 9 & 10 & 11 & 12 & 13 & 14 & 15 & 16 & 17 & 18 & 19 & 20 & 21 & 22 & 23 & 24 & 25 \\
\hline $\begin{array}{l}\text { Public institutions } \\
1963-64 \ldots \ldots \ldots \ldots \ldots . . \\
1964-65 \ldots \ldots \ldots \ldots . . . \\
1965-66 \ldots \ldots \ldots \ldots . . \\
1966-67 \ldots \ldots \ldots \ldots . . . \\
1967-68 \ldots \ldots \ldots \ldots . . . \\
1968-69 \ldots \ldots \ldots \ldots . .\end{array}$ & $\begin{array}{l}6,845 \\
6,901 \\
7,018 \\
7,131 \\
7,180 \\
7,210\end{array}$ & $\begin{array}{l}6,966 \\
7,045 \\
7,219 \\
7,372 \\
7,406 \\
7,414\end{array}$ & $\begin{array}{l}4,726 \\
4,726 \\
4,858 \\
4,990 \\
5,367 \\
5,728\end{array}$ & $\begin{array}{l}1,755 \\
1,800 \\
1,863 \\
1,933 \\
1,925 \\
1,914\end{array}$ & $\begin{array}{l}1,825 \\
1,895 \\
2,015 \\
2,125 \\
2,109 \\
2,082\end{array}$ & $\begin{array}{r}728 \\
733 \\
790 \\
850 \\
980 \\
1,103\end{array}$ & $\begin{array}{l}1,874 \\
1,934 \\
1,991 \\
2,047 \\
2,111 \\
2,167\end{array}$ & $\begin{array}{l}1,901 \\
1,961 \\
2,018 \\
2,072 \\
2,132 \\
2,186\end{array}$ & $\begin{array}{l}1,290 \\
1,318 \\
1,407 \\
1,497 \\
1,653 \\
1,803\end{array}$ & $\begin{array}{l}3,216 \\
3,167 \\
3,163 \\
3,152 \\
3,145 \\
3,129\end{array}$ & $\begin{array}{l}3,239 \\
3,189 \\
3,186 \\
3,175 \\
3,164 \\
3,145\end{array}$ & $\begin{array}{l}2,708 \\
2,674 \\
2,661 \\
2,643 \\
2,735 \\
2,822\end{array}$ & $\begin{array}{r}912 \\
932 \\
968 \\
1,015 \\
1,055 \\
1,112\end{array}$ & $\begin{array}{r}929 \\
951 \\
996 \\
1,049 \\
1,089 \\
1,143\end{array}$ & $\begin{array}{l}630 \\
638 \\
670 \\
710 \\
789 \\
883\end{array}$ & $\begin{array}{l}234 \\
243 \\
257 \\
275 \\
283 \\
295\end{array}$ & $\begin{array}{l}243 \\
256 \\
278 \\
302 \\
310 \\
321\end{array}$ & $\begin{array}{r}97 \\
99 \\
109 \\
121 \\
144 \\
170\end{array}$ & $\begin{array}{l}250 \\
261 \\
275 \\
291 \\
310 \\
334\end{array}$ & $\begin{array}{l}253 \\
265 \\
278 \\
295 \\
313 \\
337\end{array}$ & $\begin{array}{l}172 \\
178 \\
194 \\
213 \\
243 \\
278\end{array}$ & $\begin{array}{l}429 \\
428 \\
436 \\
448 \\
462 \\
482\end{array}$ & $\begin{array}{l}432 \\
431 \\
439 \\
452 \\
465 \\
485\end{array}$ & $\begin{array}{l}361 \\
361 \\
367 \\
376 \\
402 \\
435\end{array}$ \\
\hline $\begin{array}{l}1969-70 \ldots \ldots \ldots \ldots . . . \\
1970-71 \ldots \ldots \ldots \ldots . . . \\
1971-72 \ldots \ldots \ldots \ldots . . . \\
1972-73 \ldots \ldots \ldots \ldots . . \\
1973-74 \ldots \ldots \ldots \ldots . . .\end{array}$ & $\begin{array}{l}7,328 \\
7,431 \\
7,573 \\
7,849 \\
7,517\end{array}$ & $\begin{array}{l}7,582 \\
7,722 \\
7,898 \\
8,395 \\
7,920\end{array}$ & $\begin{array}{l}5,824 \\
5,812 \\
6,033 \\
6,469 \\
6,322\end{array}$ & $\begin{array}{l}1,978 \\
2,044 \\
2,114 \\
2,200 \\
2,173\end{array}$ & $\begin{array}{l}2,195 \\
2,293 \\
2,405 \\
2,716 \\
2,548\end{array}$ & $\begin{array}{l}1,090 \\
1,089 \\
1,079 \\
1,259 \\
1,360\end{array}$ & $\begin{array}{l}2,241 \\
2,314 \\
2,394 \\
2,547 \\
2,374\end{array}$ & $\begin{array}{l}2,262 \\
2,336 \\
2,416 \\
2,574 \\
2,399\end{array}$ & $\begin{array}{l}1,886 \\
1,968 \\
2,058 \\
2,151 \\
2,029\end{array}$ & $\begin{array}{l}3,109 \\
3,073 \\
3,065 \\
3,102 \\
2,969\end{array}$ & $\begin{array}{l}3,125 \\
3,093 \\
3,077 \\
3,105 \\
2,972\end{array}$ & $\begin{array}{l}2,848 \\
2,755 \\
2,895 \\
3,059 \\
2,933\end{array}$ & $\begin{array}{l}1,197 \\
1,276 \\
1,347 \\
1,452 \\
1,515\end{array}$ & \begin{tabular}{r|}
1,238 \\
1,326 \\
1,405 \\
1,553 \\
1,596
\end{tabular} & $\begin{array}{r}951 \\
998 \\
1,073 \\
1,197 \\
1,274\end{array}$ & $\begin{array}{l}323 \\
351 \\
376 \\
407 \\
438\end{array}$ & $\begin{array}{l}358 \\
394 \\
428 \\
503 \\
514\end{array}$ & $\begin{array}{l}178 \\
187 \\
192 \\
233 \\
274\end{array}$ & $\begin{array}{l}366 \\
397 \\
426 \\
471 \\
479\end{array}$ & $\begin{array}{l}369 \\
401 \\
430 \\
476 \\
483\end{array}$ & $\begin{array}{l}308 \\
338 \\
366 \\
398 \\
409\end{array}$ & $\begin{array}{l}508 \\
528 \\
545 \\
574 \\
598\end{array}$ & $\begin{array}{l}510 \\
531 \\
547 \\
575 \\
599\end{array}$ & $\begin{array}{l}465 \\
473 \\
515 \\
566 \\
591\end{array}$ \\
\hline $\begin{array}{r}1974-75 \ldots \ldots \ldots \ldots . . . \\
1975-76 \ldots \ldots \ldots \ldots . . . \\
1976-77 \ldots \ldots \ldots \ldots . . . \\
1977-78 \ldots \ldots \ldots \ldots . . . \\
1978-79 \ldots \ldots \ldots \ldots . . .\end{array}$ & $\begin{array}{l}6,974 \\
6,937 \\
7,052 \\
6,972 \\
6,733\end{array}$ & $\begin{array}{l}7,355 \\
7,424 \\
7,628 \\
7,527 \\
7,244\end{array}$ & $\begin{array}{l}5,981 \\
5,782 \\
5,876 \\
5,872 \\
5,711\end{array}$ & $\begin{array}{l}1,930 \\
1,806 \\
1,887 \\
1,890 \\
1,833\end{array}$ & $\begin{array}{l}2,289 \\
2,262 \\
2,430 \\
2,418 \\
2,323\end{array}$ & $\begin{array}{l}1,237 \\
1,022 \\
1,117 \\
1,132 \\
1,105\end{array}$ & $\begin{array}{l}2,257 \\
2,267 \\
2,296 \\
2,293 \\
2,212\end{array}$ & $\begin{array}{l}2,284 \\
2,302 \\
2,333 \\
2,332 \\
2,243\end{array}$ & $\begin{array}{l}1,894 \\
1,844 \\
1,832 \\
1,795 \\
1,779\end{array}$ & $\begin{array}{l}2,787 \\
2,864 \\
2,869 \\
2,789 \\
2,688\end{array}$ & $\begin{array}{l}2,783 \\
2,860 \\
2,864 \\
2,777 \\
2,678\end{array}$ & $\begin{array}{l}2,850 \\
2,916 \\
2,926 \\
2,945 \\
2,826\end{array}$ & $\begin{array}{l}1,561 \\
1,663 \\
1,789 \\
1,888 \\
1,994\end{array}$ & $\begin{array}{l}1,647 \\
1,70 \\
1,935 \\
2,038 \\
2,145\end{array}$ & $\begin{array}{l}1,339 \\
1,386 \\
1,491 \\
1,590 \\
1,691\end{array}$ & $\begin{array}{l}432 \\
433 \\
479 \\
512 \\
543\end{array}$ & $\begin{array}{l}512 \\
542 \\
617 \\
655 \\
688\end{array}$ & $\begin{array}{l}277 \\
245 \\
283 \\
306 \\
327\end{array}$ & $\begin{array}{l}505 \\
543 \\
582 \\
621 \\
655\end{array}$ & $\begin{array}{l}511 \\
552 \\
592 \\
631 \\
664\end{array}$ & $\begin{array}{l}424 \\
442 \\
465 \\
486 \\
527\end{array}$ & $\begin{array}{l}624 \\
687 \\
728 \\
755 \\
796\end{array}$ & $\begin{array}{l}623 \\
686 \\
727 \\
752 \\
793\end{array}$ & $\begin{array}{l}638 \\
699 \\
742 \\
797 \\
837\end{array}$ \\
\hline $\begin{array}{c}1979-80 \ldots \ldots \ldots \ldots . . \\
1980-81 \ldots \ldots \ldots \ldots . . . \\
1981-82 \ldots \ldots \ldots \ldots \ldots . . \\
1982-83 \ldots \ldots \ldots \ldots . . . \\
1983-84 \ldots \ldots \ldots \ldots . . .\end{array}$ & $\begin{array}{l}6,452 \\
6,339 \\
6,546 \\
6,941 \\
7,173\end{array}$ & $\begin{array}{l}6,936 \\
6,811 \\
7,058 \\
7,534 \\
7,803\end{array}$ & $\begin{array}{l}5,428 \\
5,414 \\
5,467 \\
5,632 \\
5,759\end{array}$ & $\begin{array}{l}1,739 \\
1,696 \\
1,755 \\
1,881 \\
2,026\end{array}$ & $\begin{array}{l}2,198 \\
2,147 \\
2,236 \\
2,431 \\
2,609\end{array}$ & $\begin{array}{l}1,057 \\
1,045 \\
1,068 \\
1,115 \\
1,200\end{array}$ & $\begin{array}{l}2,131 \\
2,133 \\
2,236 \\
2,381 \\
2,471\end{array}$ & $\begin{array}{l}2,161 \\
2,166 \\
2,275 \\
2,429 \\
2,522\end{array}$ & $\begin{array}{l}1,710 \\
1,714 \\
1,729 \\
1,780 \\
1,820\end{array}$ & $\begin{array}{l}2,582 \\
2,510 \\
2,555 \\
2,678 \\
2,677\end{array}$ & $\begin{array}{l}2,577 \\
2,499 \\
2,547 \\
2,674 \\
2,672\end{array}$ & $\begin{array}{l}2,661 \\
2,655 \\
2,670 \\
2,738 \\
2,739\end{array}$ & $\begin{array}{l}2,165 \\
2,373 \\
2,663 \\
2,945 \\
3,156\end{array}$ & $\begin{array}{l}2,327 \\
2,550 \\
2,871 \\
3,196 \\
3,433\end{array}$ & $\begin{array}{l}1,822 \\
2,027 \\
2,224 \\
2,390 \\
2,534\end{array}$ & $\begin{array}{l}583 \\
635 \\
714 \\
798 \\
891\end{array}$ & $\begin{array}{r}738 \\
804 \\
909 \\
1,031 \\
1,148\end{array}$ & $\begin{array}{l}355 \\
391 \\
434 \\
473 \\
528\end{array}$ & $\begin{array}{r}715 \\
799 \\
909 \\
1,010 \\
1,087\end{array}$ & $\begin{array}{r}725 \\
811 \\
925 \\
1,030 \\
1,110\end{array}$ & $\begin{array}{l}574 \\
642 \\
703 \\
755 \\
801\end{array}$ & $\begin{array}{r}867 \\
940 \\
1,039 \\
1,136 \\
1,178\end{array}$ & $\begin{array}{r}865 \\
936 \\
1,036 \\
1,134 \\
1,175\end{array}$ & $\begin{array}{r}893 \\
994 \\
1,086 \\
1,162 \\
1,205\end{array}$ \\
\hline $\begin{array}{r}1984-85 \ldots \ldots \ldots \ldots . . . \\
1985-86^{4} \ldots \ldots \ldots \ldots . . . \\
1986-87 \ldots \ldots \ldots \ldots . . . \\
1987-88 \ldots \ldots \ldots \ldots . . . \\
1988-89 \ldots \ldots \ldots \ldots . . .\end{array}$ & $\begin{array}{l}7,455 \\
7,593 \\
7,914 \\
8,088 \\
8,159\end{array}$ & $\begin{array}{l}8,053 \\
8,203 \\
8,606 \\
8,794 \\
8,931\end{array}$ & $\begin{array}{l}6,140 \\
6,338 \\
6,216 \\
6,122 \\
6,076\end{array}$ & $\begin{array}{l}2,123 \\
2,221 \\
2,301 \\
2,433 \\
2,452\end{array}$ & $\begin{array}{l}2,686 \\
2,801 \\
2,940 \\
3,070 \\
3,143\end{array}$ & $\begin{array}{l}1,277 \\
1,363 \\
1,374 \\
1,410 \\
1,394\end{array}$ & $\begin{array}{l}2,616 \\
2,640 \\
2,706 \\
2,752 \\
2,781\end{array}$ & $\begin{array}{l}2,661 \\
2,685 \\
2,751 \\
2,815 \\
2,855\end{array}$ & $\begin{array}{l}2,014 \\
2,041 \\
2,036 \\
1,883 \\
1,841\end{array}$ & $\begin{array}{l}2,715 \\
2,732 \\
2,908 \\
2,903 \\
2,926\end{array}$ & $\begin{array}{l}2,706 \\
2,717 \\
2,915 \\
2,908 \\
2,933\end{array}$ & $\begin{array}{l}2,849 \\
2,934 \\
2,807 \\
2,830 \\
2,841\end{array}$ & $\begin{array}{l}3,408 \\
3,571 \\
3,805 \\
4,050 \\
4,274\end{array}$ & $\begin{array}{l}3,682 \\
3,859 \\
4,138 \\
4,403 \\
4,678\end{array}$ & $\begin{array}{l}2,807 \\
2,981 \\
2,989 \\
3,066 \\
3,183\end{array}$ & $\begin{array}{r}971 \\
1,045 \\
1,106 \\
1,218 \\
1,285\end{array}$ & $\begin{array}{l}1,228 \\
1,318 \\
1,414 \\
1,537 \\
1,646\end{array}$ & $\begin{array}{l}584 \\
641 \\
660 \\
706 \\
730\end{array}$ & $\begin{array}{l}1,196 \\
1,242 \\
1,301 \\
1,378 \\
1,457\end{array}$ & $\begin{array}{l}1,217 \\
1,263 \\
1,323 \\
1,410 \\
1,496\end{array}$ & $\begin{array}{l}921 \\
960 \\
979 \\
943 \\
965\end{array}$ & $\begin{array}{r}1,241 \\
1,285 \\
1,398 \\
1,454 \\
1,533\end{array}$ & $\begin{array}{l}1,237 \\
1,278 \\
1,401 \\
1,456 \\
1,536\end{array}$ & $\begin{array}{l}1,302 \\
1,380 \\
1,349 \\
1,417 \\
1,488\end{array}$ \\
\hline $\begin{array}{l}1989-90 \ldots \ldots \ldots \ldots . . . \\
1990-91 \ldots \ldots \ldots \ldots \ldots . \\
1991-92 \ldots \ldots \ldots \ldots \ldots . \\
1992-93 \ldots \ldots \ldots \ldots . . \\
1993-94 \ldots \ldots \ldots \ldots . .\end{array}$ & $\begin{array}{l}8,206 \\
8,218 \\
8,601 \\
8,731 \\
9,010\end{array}$ & $\begin{array}{r}9,065 \\
9,057 \\
9,530 \\
9,772 \\
10,071\end{array}$ & $\begin{array}{l}6,011 \\
5,990 \\
6,064 \\
6,166 \\
6,322\end{array}$ & $\begin{array}{l}2,471 \\
2,512 \\
2,725 \\
2,892 \\
3,073\end{array}$ & $\begin{array}{l}3,242 \\
3,262 \\
3,544 \\
3,813 \\
4,014\end{array}$ & $\begin{array}{l}1,378 \\
1,424 \\
1,567 \\
1,664 \\
1,779\end{array}$ & $\begin{array}{l}2,757 \\
2,785 \\
2,897 \\
2,851 \\
2,963\end{array}$ & $\begin{array}{l}2,837 \\
2,862 \\
2,987 \\
2,948 \\
3,060\end{array}$ & $\begin{array}{l}1,753 \\
1,813 \\
1,798 \\
1,795 \\
1,883\end{array}$ & $\begin{array}{l}2,978 \\
2,921 \\
2,979 \\
2,988 \\
2,974\end{array}$ & $\begin{array}{l}2,985 \\
2,933 \\
2,999 \\
3,010 \\
2,998\end{array}$ & $\begin{array}{l}2,881 \\
2,753 \\
2,699 \\
2,707 \\
2,660\end{array}$ & $\begin{array}{l}4,504 \\
4,757 \\
5,138 \\
5,379 \\
5,694\end{array}$ & $\begin{array}{l}4,975 \\
5,243 \\
5,693 \\
6,020 \\
6,365\end{array}$ & $\begin{array}{l}3,299 \\
3,467 \\
3,623 \\
3,799 \\
3,996\end{array}$ & $\begin{array}{l}1,356 \\
1,454 \\
1,628 \\
1,782 \\
1,942\end{array}$ & $\begin{array}{l}1,780 \\
1,888 \\
2,117 \\
2,349 \\
2,537\end{array}$ & $\begin{array}{r}756 \\
824 \\
936 \\
1,025 \\
1,125\end{array}$ & $\begin{array}{l}1,513 \\
1,612 \\
1,731 \\
1,756 \\
1,873\end{array}$ & $\begin{array}{l}1,557 \\
1,657 \\
1,785 \\
1,816 \\
1,934\end{array}$ & $\begin{array}{r}962 \\
1,050 \\
1,074 \\
1,106 \\
1,190\end{array}$ & $\begin{array}{l}1,635 \\
1,691 \\
1,780 \\
1,841 \\
1,880\end{array}$ & $\begin{array}{l}1,638 \\
1,698 \\
1,792 \\
1,854 \\
1,895\end{array}$ & $\begin{array}{l}1,581 \\
1,594 \\
1,612 \\
1,668 \\
1,681\end{array}$ \\
\hline $\begin{array}{r}1994-95 \ldots \ldots \ldots \ldots . . . \\
1995-96 \ldots \ldots \ldots \ldots . . . \\
1996-97 \ldots \ldots \ldots \ldots . . . \\
1997-98 \ldots \ldots \ldots \ldots . . . \\
1998-99 \ldots \ldots \ldots \ldots . . .\end{array}$ & $\begin{array}{l}9,175 \\
9,368 \\
9,507 \\
9,746 \\
9,992\end{array}$ & $\begin{array}{l}10,260 \\
10,503 \\
10,678 \\
10,976 \\
11,286\end{array}$ & $\begin{array}{l}6,363 \\
6,314 \\
6,411 \\
6,450 \\
6,474\end{array}$ & $\begin{array}{l}3,164 \\
3,262 \\
3,307 \\
3,376 \\
3,417\end{array}$ & $\begin{array}{l}4,123 \\
4,264 \\
4,349 \\
4,448 \\
4,540\end{array}$ & $\begin{array}{l}1,834 \\
1,856 \\
1,858 \\
1,880 \\
1,865\end{array}$ & $\begin{array}{l}3,014 \\
3,081 \\
3,127 \\
3,183 \\
3,275\end{array}$ & $\begin{array}{l}3,111 \\
3,176 \\
3,223 \\
3,291 \\
3,387\end{array}$ & $\begin{array}{l}1,895 \\
1,941 \\
1,950 \\
2,004 \\
2,039\end{array}$ & $\begin{array}{l}2,998 \\
3,024 \\
3,073 \\
3,187 \\
3,300\end{array}$ & $\begin{array}{l}3,025 \\
3,063 \\
3,106 \\
3,237 \\
3,359\end{array}$ & $\begin{array}{l}2,634 \\
2,517 \\
2,604 \\
2,567 \\
2,570\end{array}$ & $\begin{array}{l}5,965 \\
6,256 \\
6,530 \\
6,813 \\
7,107\end{array}$ & $\begin{array}{r}6,670 \\
7,014 \\
7,334 \\
7,673 \\
8,027\end{array}$ & $\begin{array}{l}4,137 \\
4,217 \\
4,404 \\
4,509 \\
4,604\end{array}$ & $\begin{array}{l}2,057 \\
2,179 \\
2,271 \\
2,360 \\
2,430\end{array}$ & $\begin{array}{l}2,681 \\
2,848 \\
2,987 \\
3,110 \\
3,229\end{array}$ & $\begin{array}{l}1,192 \\
1,239 \\
1,276 \\
1,314 \\
1,327\end{array}$ & $\begin{array}{l}1,959 \\
2,057 \\
2,148 \\
2,225 \\
2,330\end{array}$ & $\begin{array}{l}2,023 \\
2,121 \\
2,214 \\
2,301 \\
2,409\end{array}$ & $\begin{array}{l}1,232 \\
1,297 \\
1,339 \\
1,401 \\
1,450\end{array}$ & $\begin{array}{l}1,949 \\
2,020 \\
2,111 \\
2,228 \\
2,347\end{array}$ & $\begin{array}{l}1,967 \\
2,045 \\
2,133 \\
2,263 \\
2,389\end{array}$ & $\begin{array}{l}1,712 \\
1,681 \\
1,789 \\
1,795 \\
1,828\end{array}$ \\
\hline $\begin{array}{l}1999-2000 \ldots \ldots \ldots . . \\
2000-01 \ldots \ldots \ldots \ldots . . \\
2001-02 \ldots \ldots \ldots \ldots . . . \\
2002-03 \ldots \ldots \ldots \ldots . . . \\
2003-04 \ldots \ldots \ldots \ldots \ldots . .\end{array}$ & $\begin{array}{r}9,987 \\
10,024 \\
10,415 \\
10,800 \\
11,496\end{array}$ & $\begin{array}{l}11,307 \\
11,434 \\
11,940 \\
12,434 \\
13,270\end{array}$ & $\begin{array}{l}6,464 \\
6,394 \\
6,670 \\
7,116 \\
7,474\end{array}$ & $\begin{array}{l}3,421 \\
3,385 \\
3,506 \\
3,688 \\
4,126\end{array}$ & $\begin{array}{l}4,576 \\
4,625 \\
4,850 \\
5,140 \\
5,702\end{array}$ & $\begin{array}{l}1,842 \\
1,761 \\
1,791 \\
1,884 \\
2,116\end{array}$ & $\begin{array}{l}3,334 \\
3,394 \\
3,535 \\
3,722 \\
3,861\end{array}$ & $\begin{array}{l}3,443 \\
3,507 \\
3,657 \\
3,848 \\
3,993\end{array}$ & $\begin{array}{l}2,117 \\
2,115 \\
2,236 \\
2,482 \\
2,597\end{array}$ & $\begin{array}{l}3,231 \\
3,244 \\
3,374 \\
3,391 \\
3,509\end{array}$ & $\begin{array}{l}3,288 \\
3,302 \\
3,433 \\
3,446 \\
3,575\end{array}$ & $\begin{array}{l}2,506 \\
2,518 \\
2,643 \\
2,750 \\
2,761\end{array}$ & $\begin{array}{l}7,308 \\
7,586 \\
8,022 \\
8,502 \\
9,247\end{array}$ & $\begin{array}{r}8,274 \\
8,653 \\
9,196 \\
9,787 \\
10,674\end{array}$ & $\begin{array}{l}4,730 \\
4,839 \\
5,137 \\
5,601 \\
6,012\end{array}$ & $\begin{array}{l}2,504 \\
2,562 \\
2,700 \\
2,903 \\
3,319\end{array}$ & $\begin{array}{l}3,349 \\
3,501 \\
3,735 \\
4,046 \\
4,587\end{array}$ & $\begin{array}{l}1,348 \\
1,333 \\
1,380 \\
1,483 \\
1,702\end{array}$ & $\begin{array}{l}2,440 \\
2,569 \\
2,723 \\
2,930 \\
3,106\end{array}$ & $\begin{array}{l}2,519 \\
2,654 \\
2,816 \\
3,029 \\
3,212\end{array}$ & $\begin{array}{l}1,549 \\
1,600 \\
1,722 \\
1,954 \\
2,089\end{array}$ & $\begin{array}{l}2,364 \\
2,455 \\
2,598 \\
2,669 \\
2,822\end{array}$ & $\begin{array}{l}2,406 \\
2,499 \\
2,645 \\
2,712 \\
2,876\end{array}$ & $\begin{array}{l}1,834 \\
1,906 \\
2,036 \\
2,164 \\
2,221\end{array}$ \\
\hline $\begin{array}{l}2004-05 \ldots \ldots \ldots \ldots . . . \\
2005-06 \ldots \ldots \ldots \ldots . . . \\
2006-07 \ldots \ldots \ldots \ldots . . . \\
2007-08 \ldots \ldots \ldots \ldots . . . \\
2008-09 \ldots \ldots \ldots \ldots . . .\end{array}$ & $\begin{array}{l}11,905 \\
12,154 \\
12,522 \\
12,647 \\
13,209\end{array}$ & $\begin{array}{l}13,790 \\
14,077 \\
14,503 \\
14,675 \\
15,371\end{array}$ & $\begin{array}{l}7,694 \\
7,547 \\
7,723 \\
7,623 \\
8,156\end{array}$ & $\begin{array}{l}4,380 \\
4,503 \\
4,649 \\
4,689 \\
4,863\end{array}$ & $\begin{array}{l}6,067 \\
6,221 \\
6,422 \\
6,495 \\
6,803\end{array}$ & $\begin{array}{l}2,231 \\
2,250 \\
2,287 \\
2,252 \\
2,302\end{array}$ & $\begin{array}{l}3,988 \\
4,122 \\
4,258 \\
4,318 \\
4,516\end{array}$ & $\begin{array}{l}4,126 \\
4,260 \\
4,395 \\
4,461 \\
4,668\end{array}$ & $\begin{array}{l}2,624 \\
2,617 \\
2,728 \\
2,738 \\
2,871\end{array}$ & $\begin{array}{l}3,537 \\
3,529 \\
3,616 \\
3,640 \\
3,831\end{array}$ & $\begin{array}{l}3,597 \\
3,596 \\
3,686 \\
3,720 \\
3,901\end{array}$ & $\begin{array}{l}2,839 \\
2,681 \\
2,708 \\
2,633 \\
2,984\end{array}$ & $\begin{array}{r}9,864 \\
10,454 \\
11,049 \\
11,573 \\
12,256\end{array}$ & $\begin{array}{l}11,426 \\
12,108 \\
12,797 \\
13,429 \\
14,262\end{array}$ & $\begin{array}{l}6,375 \\
6,492 \\
6,815 \\
6,975 \\
7,568\end{array}$ & $\begin{array}{l}3,629 \\
3,874 \\
4,102 \\
4,291 \\
4,512\end{array}$ & $\begin{array}{l}5,027 \\
5,351 \\
5,666 \\
5,943 \\
6,312\end{array}$ & $\begin{array}{l}1,849 \\
1,935 \\
2,018 \\
2,061 \\
2,136\end{array}$ & $\begin{array}{l}3,304 \\
3,545 \\
3,757 \\
3,952 \\
4,190\end{array}$ & $\begin{array}{l}3,418 \\
3,664 \\
3,878 \\
4,082 \\
4,331\end{array}$ & $\begin{array}{l}2,174 \\
2,251 \\
2,407 \\
2,506 \\
2,664\end{array}$ & $\begin{array}{l}2,931 \\
3,035 \\
3,191 \\
3,331 \\
3,554\end{array}$ & $\begin{array}{l}2,981 \\
3,093 \\
3,253 \\
3,404 \\
3,619\end{array}$ & $\begin{array}{l}2,353 \\
2,306 \\
2,390 \\
2,409 \\
2,769\end{array}$ \\
\hline $\begin{array}{l}2009-10 \ldots \ldots \ldots \ldots . . \\
2010-11 \ldots \ldots \ldots \ldots . . . \\
2011-12 \ldots \ldots \ldots \ldots . . . \\
2012-13 \ldots \ldots \ldots \ldots . . .\end{array}$ & $\begin{array}{l}13,667 \\
14,194 \\
14,616 \\
15,022\end{array}$ & $\begin{array}{l}16,027 \\
16,657 \\
17,084 \\
17,474\end{array}$ & $\begin{array}{l}8,223 \\
8,460 \\
8,715 \\
8,928\end{array}$ & $\begin{array}{l}5,071 \\
5,312 \\
5,652 \\
5,899\end{array}$ & $\begin{array}{l}7,147 \\
7,467 \\
7,832 \\
8,070\end{array}$ & $\begin{array}{l}2,439 \\
2,553 \\
2,696 \\
2,792\end{array}$ & $\begin{array}{l}4,696 \\
4,855 \\
4,943 \\
5,062\end{array}$ & $\begin{array}{l}4,873 \\
5,048 \\
5,130 \\
5,241\end{array}$ & $\begin{array}{l}3,037 \\
3,097 \\
3,141 \\
3,247\end{array}$ & $\begin{array}{l}3,900 \\
4,026 \\
4,021 \\
4,061\end{array}$ & $\begin{array}{l}4,007 \\
4,142 \\
4,123 \\
4,163\end{array}$ & $\begin{array}{l}2,747 \\
2,810 \\
2,878 \\
2,889\end{array}$ & $\begin{array}{l}12,804 \\
13,564 \\
14,377 \\
15,022\end{array} \mid$ & $\begin{array}{l}15,014 \\
15,918 \\
16,805 \\
17,474\end{array}$ & $\begin{array}{l}7,703 \\
8,085 \\
8,572 \\
8,928\end{array}$ & $\begin{array}{l}4,751 \\
5,076 \\
5,559 \\
5,899\end{array}$ & $\begin{array}{l}6,695 \\
7,136 \\
7,703 \\
8,070\end{array}$ & $\begin{array}{l}2,285 \\
2,439 \\
2,652 \\
2,792\end{array}$ & $\begin{array}{l}4,399 \\
4,640 \\
4,862 \\
5,062\end{array}$ & $\begin{array}{l}4,565 \\
4,824 \\
5,046 \\
5,241\end{array}$ & $\begin{array}{l}2,845 \\
2,960 \\
3,090 \\
3,247\end{array}$ & $\begin{array}{l}3,653 \\
3,848 \\
3,955 \\
4,061\end{array}$ & $\begin{array}{l}3,754 \\
3,958 \\
4,055 \\
4,163\end{array}$ & $\begin{array}{l}2,574 \\
2,685 \\
2,831 \\
2,889\end{array}$ \\
\hline
\end{tabular}




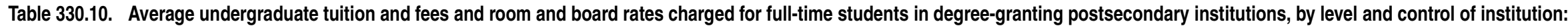
1963-64 through 2012-13-Continued

\begin{tabular}{|c|c|c|c|c|c|c|c|c|c|c|c|c|c|c|c|c|c|c|c|c|c|c|c|c|c|}
\hline \multirow[b]{3}{*}{$\begin{array}{l}\text { Year and control } \\
\text { of institution }\end{array}$} & \multicolumn{12}{|c|}{ Constant 2012-13 dollars ${ }^{1}$} & \multicolumn{12}{|c|}{ Current dollars } & \\
\hline & \multicolumn{3}{|c|}{$\begin{array}{l}\text { Total tuition, fees, } \\
\text { room, and board }\end{array}$} & \multicolumn{3}{|c|}{ Tuition and required fees ${ }^{2}$} & \multicolumn{3}{|c|}{ Dormitory rooms } & \multicolumn{3}{|c|}{ Board $^{3}$} & \multicolumn{3}{|c|}{$\begin{array}{l}\text { Total tuition, fees, } \\
\text { room, and board }\end{array}$} & \multicolumn{3}{|c|}{ Tuition and required fees ${ }^{2}$} & \multicolumn{3}{|c|}{ Dormitory rooms } & \multicolumn{3}{|c|}{ Board $^{3}$} & \\
\hline & $\begin{array}{r}\text { All } \\
\text { institu- } \\
\text { tions }\end{array}$ & 4-year & 2-year & $\begin{array}{r}\text { All } \\
\text { institu- } \\
\text { tions }\end{array}$ & 4-year & 2-year & $\begin{array}{r}\text { All } \\
\text { institu- } \\
\text { tions }\end{array}$ & 4-year & 2-year & $\begin{array}{r}\text { All } \\
\text { institu- } \\
\text { tions }\end{array}$ & 4-year & 2-year & $\begin{array}{r}\text { All } \\
\text { institu- } \\
\text { tions }\end{array}$ & 4-year & 2-year & $\begin{array}{r}\text { All } \\
\text { institu- } \\
\text { tions }\end{array}$ & 4-year & 2-year & $\begin{array}{r}\text { All } \\
\text { institu- } \\
\text { tions }\end{array}$ & 4-year & 2-year & $\begin{array}{r}\text { All } \\
\text { institu- } \\
\text { tions }\end{array}$ & 4-year & 2-year & \\
\hline 1 & 2 & 3 & 4 & 5 & 6 & 7 & 8 & 9 & 10 & 11 & 12 & 13 & 14 & 15 & 16 & 17 & 18 & 19 & 20 & 21 & 22 & 23 & 24 & 25 & \\
\hline 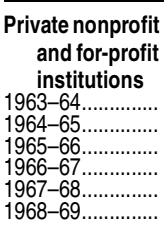 & $\begin{array}{l}13,615 \\
14,126 \\
14,537 \\
14,928 \\
15,000 \\
15,055\end{array}$ & $\begin{array}{l}13,575 \\
14,194 \\
14,588 \\
14,961 \\
15,126 \\
15,283\end{array}$ & $\begin{array}{r}9,849 \\
10,778 \\
11,289 \\
11,801 \\
11,987 \\
12,169\end{array}$ & $\begin{array}{l}7,591 \\
8,059 \\
8,367 \\
8,666 \\
8,823 \\
8,971\end{array}$ & $\begin{array}{l}7,582 \\
8,125 \\
8,428 \\
8,724 \\
8,960 \\
9,192\end{array}$ & $\begin{array}{l}4,816 \\
5,200 \\
5,568 \\
5,939 \\
6,068 \\
6,201\end{array}$ & $\begin{array}{l}2,370 \\
2,452 \\
2,581 \\
2,706 \\
2,667 \\
2,621\end{array}$ & $\begin{array}{l}2,346 \\
2,448 \\
2,567 \\
2,682 \\
2,655 \\
2,624\end{array}$ & $\begin{array}{l}1,830 \\
2,41 \\
2,291 \\
2,439 \\
2,490 \\
2,536\end{array}$ & $\begin{array}{l}3,653 \\
3,615 \\
3,589 \\
3,556 \\
3,510 \\
3,464\end{array}$ & $\begin{array}{l}3,647 \\
3,621 \\
3,593 \\
3,555 \\
3,511 \\
3,467\end{array}$ & $\begin{array}{l}3,203 \\
3,437 \\
3,430 \\
3,423 \\
3,429 \\
3,431\end{array}$ & $\begin{array}{l}1,815 \\
1,907 \\
2,005 \\
2,124 \\
2,205 \\
2,321\end{array}$ & $\begin{array}{l}1,810 \\
1,916 \\
2,012 \\
2,129 \\
2,223 \\
2,356\end{array}$ & $\begin{array}{l}1,313 \\
1,455 \\
1,557 \\
1,679 \\
1,762 \\
1,876\end{array}$ & $\begin{array}{l}1,012 \\
1,088 \\
1,154 \\
1,233 \\
1,297 \\
1,383\end{array}$ & $\begin{array}{l}1,011 \\
1,097 \\
1,162 \\
1,241 \\
1,317 \\
1,417\end{array}$ & $\begin{array}{l}642 \\
702 \\
768 \\
845 \\
892 \\
956\end{array}$ & $\begin{array}{l}316 \\
331 \\
356 \\
385 \\
392 \\
404\end{array}$ & $\begin{array}{l}313 \\
330 \\
354 \\
382 \\
390 \\
405\end{array}$ & $\begin{array}{l}244 \\
289 \\
316 \\
347 \\
366 \\
391\end{array}$ & $\begin{array}{l}487 \\
488 \\
495 \\
506 \\
516 \\
534\end{array}$ & $\begin{array}{l}486 \\
489 \\
496 \\
506 \\
516 \\
534\end{array}$ & $\begin{array}{l}427 \\
464 \\
473 \\
487 \\
504 \\
529\end{array}$ & \\
\hline $\begin{array}{l}1969-70 \ldots \ldots \ldots \ldots . . . \\
1970-71 \ldots \ldots \ldots \ldots \ldots . . \\
1971-72 \ldots \ldots \ldots \ldots . . \\
1972-73 \ldots \ldots \ldots \ldots . . \\
1973-74 \ldots \ldots \ldots \ldots . .\end{array}$ & $\begin{array}{l}15,479 \\
15,893 \\
16,317 \\
16,408 \\
15,691\end{array}$ & $\begin{array}{l}15,671 \\
16,042 \\
16,409 \\
16,706 \\
15,986\end{array}$ & $\begin{array}{l}12,206 \\
12,248 \\
12,290 \\
12,284 \\
11,958\end{array}$ & $\begin{array}{r}9,389 \\
9,807 \\
10,232 \\
10,257 \\
9,869\end{array}$ & $\begin{array}{r}9,566 \\
9,937 \\
10,301 \\
10,529 \\
10,145\end{array}$ & $\begin{array}{l}6,333 \\
6,459 \\
6,589 \\
6,599 \\
6,465\end{array}$ & $\begin{array}{l}2,659 \\
2,693 \\
2,730 \\
2,826 \\
2,640\end{array}$ & $\begin{array}{l}2,667 \\
2,703 \\
2,742 \\
2,846 \\
2,654\end{array}$ & $\begin{array}{l}2,529 \\
2,528 \\
2,524 \\
2,470 \\
2,397\end{array}$ & $\begin{array}{l}3,432 \\
3,393 \\
3,355 \\
3,325 \\
3,182\end{array}$ & $\begin{array}{l}3,438 \\
3,401 \\
3,366 \\
3,331 \\
3,187\end{array}$ & $\begin{array}{l}3,344 \\
3,261 \\
3,177 \\
3,216 \\
3,096\end{array}$ & $\begin{array}{l}2,527 \\
2,729 \\
2,902 \\
3,036 \\
3,162\end{array}$ & $\begin{array}{l}2,559 \\
2,754 \\
2,919 \\
3,091 \\
3,222\end{array}$ & $\begin{array}{l}1,993 \\
2,103 \\
2,186 \\
2,273 \\
2,410\end{array}$ & $\begin{array}{l}1,533 \\
1,684 \\
1,820 \\
1,898 \\
1,989\end{array}$ & $\begin{array}{l}1,562 \\
1,706 \\
1,832 \\
1,948 \\
2,045\end{array}$ & $\begin{array}{l}1,034 \\
1,109 \\
1,172 \\
1,221 \\
1,303\end{array}$ & $\begin{array}{l}434 \\
462 \\
486 \\
523 \\
532\end{array}$ & $\begin{array}{l}436 \\
464 \\
488 \\
527 \\
535\end{array}$ & $\begin{array}{l}413 \\
434 \\
449 \\
457 \\
483\end{array}$ & $\begin{array}{l}560 \\
583 \\
597 \\
615 \\
641\end{array}$ & $\begin{array}{l}561 \\
584 \\
599 \\
616 \\
642\end{array}$ & $\begin{array}{l}546 \\
560 \\
565 \\
595 \\
624\end{array}$ & \\
\hline $\begin{array}{l}1974-75 \ldots \ldots \ldots \ldots . . . \\
1975-76 \ldots \ldots \ldots \ldots . . . \\
1976-77 \ldots \ldots \ldots \ldots . . \\
1977-78 \ldots \ldots \ldots \ldots . . . \\
1978-79 \ldots \ldots \ldots \ldots \ldots . .\end{array}$ & $\begin{array}{l}15,135 \\
15,203 \\
15,397 \\
15,360 \\
15,246\end{array}$ & $\begin{array}{l}15,206 \\
15,305 \\
15,676 \\
15,662 \\
15,568\end{array}$ & $\begin{array}{l}11,574 \\
11,309 \\
11,711 \\
11,627 \\
11,447\end{array}$ & $\begin{array}{l}9,457 \\
9,478 \\
9,723 \\
9,691 \\
9,685\end{array}$ & $\begin{array}{l}9,516 \\
9,558 \\
9,989 \\
9,974 \\
9,990\end{array}$ & $\begin{array}{l}6,106 \\
5,953 \\
6,275 \\
6,300 \\
6,183\end{array}$ & $\begin{array}{l}2,582 \\
2,609 \\
2,558 \\
2,579 \\
2,559\end{array}$ & $\begin{array}{l}2,585 \\
2,622 \\
2,568 \\
2,593 \\
2,570\end{array}$ & $\begin{array}{l}2,519 \\
2,386 \\
2,394 \\
2,333 \\
2,365\end{array}$ & $\begin{array}{l}3,096 \\
3,115 \\
3,116 \\
3,090 \\
3,002\end{array}$ & $\begin{array}{l}3,104 \\
3,124 \\
3,120 \\
3,094 \\
3,007\end{array}$ & $\begin{array}{l}2,948 \\
2,970 \\
3,041 \\
2,995 \\
2,899\end{array}$ & $\begin{array}{l}3,388 \\
3,644 \\
3,906 \\
4,158 \\
4,514\end{array}$ & $\begin{array}{l}3,404 \\
3,669 \\
3,977 \\
4,240 \\
4,609\end{array}$ & $\begin{array}{l}2,591 \\
2,711 \\
2,971 \\
3,148 \\
3,389\end{array}$ & $\begin{array}{l}2,117 \\
2,272 \\
2,467 \\
2,624 \\
2,867\end{array}$ & $\begin{array}{l}2,130 \\
2,291 \\
2,534 \\
2,700 \\
2,958\end{array}$ & $\begin{array}{l}1,367 \\
1,427 \\
1,592 \\
1,706 \\
1,831\end{array}$ & $\begin{array}{l}578 \\
625 \\
649 \\
698 \\
758\end{array}$ & $\begin{array}{l}579 \\
629 \\
651 \\
702 \\
761\end{array}$ & $\begin{array}{l}564 \\
572 \\
607 \\
631 \\
700\end{array}$ & $\begin{array}{l}693 \\
747 \\
790 \\
836 \\
889\end{array}$ & $\begin{array}{l}695 \\
749 \\
791 \\
838 \\
890\end{array}$ & $\begin{array}{l}660 \\
712 \\
772 \\
811 \\
858\end{array}$ & \\
\hline $\begin{array}{l}1979-80 \ldots \ldots \ldots \ldots . . . \\
1980-81 \ldots \ldots \ldots \ldots \ldots . . \\
1981-82 \ldots \ldots \ldots \ldots \ldots . \\
1982-83 \ldots \ldots \ldots \ldots \ldots . . \\
1983-84 \ldots \ldots \ldots \ldots . .\end{array}$ & $\begin{array}{l}14,639 \\
14,609 \\
15,157 \\
16,311 \\
17,067\end{array}$ & $\begin{array}{l}14,938 \\
14,939 \\
15,561 \\
16,797 \\
17,637\end{array}$ & $\begin{array}{l}11,179 \\
11,492 \\
11,668 \\
12,644 \\
12,663\end{array}$ & $\begin{array}{r}9,328 \\
9,342 \\
9,717 \\
10,463 \\
11,025\end{array}$ & $\begin{array}{r}9,611 \\
9,660 \\
10,112 \\
1,935 \\
11,576\end{array}$ & $\begin{array}{l}6,144 \\
6,444 \\
6,403 \\
7,000 \\
7,044\end{array}$ & $\begin{array}{l}2,465 \\
2,451 \\
2,551 \\
2,784 \\
2,904\end{array}$ & $\begin{array}{l}2,476 \\
2,459 \\
2,553 \\
2,785 \\
2,908\end{array}$ & $\begin{array}{l}2,284 \\
2,327 \\
2,514 \\
2,775 \\
2,848\end{array}$ & $\begin{array}{l}2,846 \\
2,816 \\
2,889 \\
3,064 \\
3,137\end{array}$ & $\begin{array}{l}2,851 \\
2,821 \\
2,896 \\
3,078 \\
3,153\end{array}$ & $\begin{array}{l}2,751 \\
2,720 \\
2,751 \\
2,779 \\
2,771\end{array}$ & $\begin{array}{l}4,912 \\
5,470 \\
6,166 \\
6,920 \\
7,508\end{array}$ & $\begin{array}{l}5,013 \\
5,594 \\
6,330 \\
7,126 \\
7,759\end{array}$ & $\begin{array}{l}3,751 \\
4,303 \\
4,746 \\
5,364 \\
5,571\end{array}$ & $\begin{array}{l}3,130 \\
3,498 \\
3,953 \\
4,439 \\
4,851\end{array}$ & $\begin{array}{l}3,225 \\
3,617 \\
4,113 \\
4,639 \\
5,093\end{array}$ & $\begin{array}{l}2,062 \\
2,413 \\
2,605 \\
3,008 \\
3,099\end{array}$ & $\begin{array}{r}827 \\
918 \\
1,038 \\
1,181 \\
1,278\end{array}$ & $\begin{array}{r}831 \\
921 \\
1,039 \\
1,181 \\
1,279\end{array}$ & $\begin{array}{r}766 \\
871 \\
1,022 \\
1,177 \\
1,253\end{array}$ & $\begin{array}{r}955 \\
1,054 \\
1,175 \\
1,300 \\
1,380\end{array}$ & $\begin{array}{r}957 \\
1,056 \\
1,178 \\
1,306 \\
1,387\end{array}$ & $\begin{array}{r}923 \\
1,019 \\
1,19 \\
1,179 \\
1,219\end{array}$ & \\
\hline $\begin{array}{l}1984-85 \ldots \ldots \ldots \ldots . . . \\
1985-86^{4} \ldots \ldots \ldots \ldots . . \\
1986-87 \ldots \ldots \ldots \ldots . . \\
1987-88 \ldots \ldots \ldots \ldots . . \\
1988-89 \ldots \ldots \ldots \ldots \ldots .\end{array}$ & $\begin{array}{l}17,941 \\
18,889 \\
20,125 \\
20,993 \\
21,360\end{array}$ & $\begin{array}{l}18,485 \\
19,620 \\
20,881 \\
21,288 \\
21,904\end{array}$ & $\begin{array}{l}13,569 \\
13,845 \\
13,277 \\
14,135 \\
15,209\end{array}$ & $\begin{array}{l}11,625 \\
12,307 \\
13,136 \\
13,957 \\
14,243\end{array}$ & $\begin{array}{l}12,153 \\
13,013 \\
13,849 \\
14,212 \\
14,740\end{array}$ & $\begin{array}{l}7,623 \\
7,807 \\
7,662 \\
8,310 \\
9,196\end{array}$ & $\begin{array}{l}3,119 \\
3,303 \\
3,449 \\
3,491 \\
3,529\end{array}$ & $\begin{array}{l}3,119 \\
3,310 \\
3,481 \\
3,515 \\
3,557\end{array}$ & $\begin{array}{l}3,115 \\
3,189 \\
2,633 \\
2,757 \\
2,940\end{array}$ & $\begin{array}{l}3,197 \\
3,279 \\
3,540 \\
3,546 \\
3,588\end{array}$ & $\begin{array}{l}3,213 \\
3,297 \\
3,551 \\
3,561 \\
3,606\end{array}$ & $\begin{array}{l}2,831 \\
2,849 \\
2,983 \\
3,069 \\
3,072\end{array}$ & $\begin{array}{r}8,202 \\
8,885 \\
9,676 \\
10,512 \\
11,189\end{array}$ & $\begin{array}{r}8,451 \\
9,228 \\
10,039 \\
10,659 \\
11,474\end{array}$ & $\begin{array}{l}6,203 \\
6,512 \\
6,384 \\
7,078 \\
7,967\end{array}$ & $\begin{array}{l}5,315 \\
5,789 \\
6,316 \\
6,988 \\
7,461\end{array}$ & $\begin{array}{l}5,556 \\
6,121 \\
6,658 \\
7,116 \\
7,722\end{array}$ & $\begin{array}{l}3,485 \\
3,672 \\
3,684 \\
4,161 \\
4,817\end{array}$ & $\begin{array}{r}1,426 \\
1,553 \\
1,658 \\
1,748 \\
1,849\end{array}$ & $\begin{array}{l}1,426 \\
1,557 \\
1,673 \\
1,760 \\
1,863\end{array}$ & $\begin{array}{l}1,424 \\
1,500 \\
1,266 \\
1,380 \\
1,540\end{array}$ & $\begin{array}{l}1,462 \\
1,542 \\
1,702 \\
1,775 \\
1,880\end{array}$ & $\begin{array}{l}1,469 \\
1,551 \\
1,708 \\
1,783 \\
1,889\end{array}$ & $\begin{array}{l}1,294 \\
1,340 \\
1,434 \\
1,537 \\
1,609\end{array}$ & \\
\hline $\begin{array}{l}1989-90 \ldots \ldots \ldots \ldots . . . \\
1990-91 \ldots \ldots \ldots \ldots \ldots . . \\
1991-92 \ldots \ldots \ldots \ldots \ldots . . \\
1992-93 \ldots \ldots \ldots \ldots . . \\
1993-94 \ldots \ldots \ldots \ldots . .\end{array}$ & $\begin{array}{l}21,898 \\
22,303 \\
23,255 \\
23,754 \\
24,518\end{array}$ & $\begin{array}{l}22,382 \\
22,868 \\
23,866 \\
24,364 \\
25,164\end{array}$ & $\begin{array}{l}15,797 \\
16,070 \\
16,124 \\
16,076 \\
16,465\end{array}$ & $\begin{array}{l}14,844 \\
15,155 \\
15,768 \\
16,138 \\
16,727\end{array}$ & $\begin{array}{l}15,298 \\
15,691 \\
16,337 \\
16,709 \\
17,329\end{array}$ & $\begin{array}{r}9,468 \\
9,623 \\
9,632 \\
9,835 \\
10,079\end{array}$ & $\begin{array}{l}3,504 \\
3,565 \\
3,718 \\
3,811 \\
3,940\end{array}$ & $\begin{array}{l}3,525 \\
3,589 \\
3,751 \\
3,834 \\
3,966\end{array}$ & $\begin{array}{l}3,030 \\
3,012 \\
2,994 \\
3,198 \\
3,270\end{array}$ & $\begin{array}{l}3,549 \\
3,583 \\
3,769 \\
3,805 \\
3,851\end{array}$ & $\begin{array}{l}3,558 \\
3,588 \\
3,778 \\
3,821 \\
3,869\end{array}$ & $\begin{array}{l}3,299 \\
3,435 \\
3,498 \\
3,043 \\
3,117\end{array}$ & $\begin{array}{l}12,018 \\
12,910 \\
13,892 \\
14,634 \\
15,496\end{array}$ & $\begin{array}{l}12,284 \\
13,23 \\
14,258 \\
15,009 \\
15,904\end{array}$ & $\begin{array}{r}8,670 \\
9,302 \\
9,632 \\
9,903 \\
10,406\end{array}$ & $\begin{array}{r}8,147 \\
8,772 \\
9,419 \\
9,942 \\
10,572\end{array}$ & $\begin{array}{r}8,396 \\
9,083 \\
9,759 \\
10,294 \\
10,952\end{array}$ & $\begin{array}{l}5,196 \\
5,570 \\
5,754 \\
6,059 \\
6,370\end{array}$ & $\begin{array}{l}1,923 \\
2,063 \\
2,221 \\
2,348 \\
2,490\end{array}$ & $\begin{array}{l}1,935 \\
2,077 \\
2,241 \\
2,362 \\
2,506\end{array}$ & $\begin{array}{l}1,663 \\
1,744 \\
1,788 \\
1,970 \\
2,067\end{array}$ & $\begin{array}{l}1,948 \\
2,074 \\
2,252 \\
2,344 \\
2,434\end{array}$ & $\begin{array}{l}1,953 \\
2,077 \\
2,257 \\
2,354 \\
2,445\end{array}$ & $\begin{array}{l}1,811 \\
1,989 \\
2,090 \\
1,875 \\
1,970\end{array}$ & \\
\hline $\begin{array}{l}1994-95 . \ldots \ldots \ldots \ldots . . . \\
1995-96 \ldots \ldots \ldots \ldots \ldots . . \\
1996-97 \ldots \ldots \ldots \ldots . . \\
1997-98 \ldots \ldots \ldots \ldots \ldots . . \\
1998-99 \ldots \ldots \ldots \ldots \ldots .\end{array}$ & $\begin{array}{l}24,929 \\
25,768 \\
26,262 \\
26,485 \\
27,232\end{array}$ & $\begin{array}{l}25,537 \\
26,372 \\
26,850 \\
27,277 \\
28,021\end{array}$ & $\begin{array}{l}17,182 \\
17,315 \\
17,404 \\
18,482 \\
18,727\end{array}$ & $\begin{array}{l}17,090 \\
17,766 \\
18,195 \\
18,310 \\
18,881\end{array}$ & $\begin{array}{l}17,660 \\
18,333 \\
18,754 \\
19,087 \\
19,646\end{array}$ & $\begin{array}{l}10,635 \\
10,623 \\
10,535 \\
10,677 \\
11,042\end{array}$ & $\begin{array}{l}3,980 \\
4,100 \\
4,189 \\
4,225 \\
4,323\end{array}$ & $\begin{array}{l}4,001 \\
4,120 \\
4,206 \\
4,240 \\
4,346\end{array}$ & $\begin{array}{l}3,435 \\
3,550 \\
3,694 \\
3,822 \\
3,629\end{array}$ & $\begin{array}{l}3,859 \\
3,903 \\
3,877 \\
3,951 \\
4,029\end{array}$ & $\begin{array}{l}3,876 \\
3,919 \\
3,890 \\
3,950 \\
4,028\end{array}$ & $\begin{array}{l}3,111 \\
3,141 \\
3,175 \\
3,983 \\
4,055\end{array}$ & $\begin{array}{l}16,207 \\
17,208 \\
18,039 \\
18,516 \\
19,368\end{array}$ & $\begin{array}{l}16,602 \\
17,612 \\
18,442 \\
19,007 \\
19,929\end{array}$ & $\begin{array}{l}11,170 \\
11,563 \\
11,954 \\
12,921 \\
13,319\end{array}$ & $\begin{array}{l}11,111 \\
11,864 \\
12,498 \\
12,801 \\
13,428\end{array}$ & $\begin{array}{l}11,481 \\
12,243 \\
12,881 \\
13,344 \\
13,973\end{array}$ & $\begin{array}{l}6,914 \\
7,094 \\
7,236 \\
7,464 \\
7,854\end{array}$ & $\begin{array}{l}2,587 \\
2,738 \\
2,878 \\
2,954 \\
3,075\end{array}$ & $\begin{array}{l}2,601 \\
2,751 \\
2,889 \\
2,964 \\
3,091\end{array}$ & $\begin{array}{l}2,233 \\
2,371 \\
2,537 \\
2,672 \\
2,581\end{array}$ & $\begin{array}{l}2,509 \\
2,606 \\
2,663 \\
2,762 \\
2,865\end{array}$ & $\begin{array}{l}2,520 \\
2,617 \\
2,672 \\
2,761 \\
2,865\end{array}$ & $\begin{array}{l}2,023 \\
2,098 \\
2,181 \\
2,785 \\
2,884\end{array}$ & $\frac{1}{D}$ \\
\hline $\begin{array}{l}1999-2000 \ldots \ldots . . . . \\
2000-01 \ldots \ldots \ldots \ldots . . \\
2001-02 \ldots \ldots \ldots \ldots . . \\
2002-03 \ldots \ldots \ldots \ldots . . \\
2003-04 \ldots \ldots \ldots \ldots . .\end{array}$ & $\begin{array}{l}27,623 \\
28,241 \\
29,100 \\
29,652 \\
30,613\end{array}$ & $\begin{array}{l}28,339 \\
28,879 \\
29,727 \\
30,220 \\
31,167\end{array}$ & $\begin{array}{l}19,194 \\
19,697 \\
20,547 \\
22,554 \\
24,315\end{array}$ & $\begin{array}{l}19,269 \\
19,820 \\
20,439 \\
20,813 \\
21,526\end{array}$ & $\begin{array}{l}19,974 \\
20,441 \\
21,047 \\
21,37 \\
22,083\end{array}$ & $\begin{array}{l}11,240 \\
11,980 \\
13,082 \\
13,531 \\
14,354\end{array}$ & $\begin{array}{l}4,422 \\
4,469 \\
4,632 \\
4,767 \\
4,905\end{array}$ & $\begin{array}{l}4,430 \\
4,482 \\
4,643 \\
4,782 \\
4,914\end{array}$ & $\begin{array}{l}4,192 \\
3,972 \\
4,046 \\
4,106 \\
4,452\end{array}$ & $\begin{array}{l}3,932 \\
3,952 \\
4,030 \\
4,072 \\
4,182\end{array}$ & $\begin{array}{l}3,935 \\
3,955 \\
4,036 \\
4,062 \\
4,170\end{array}$ & $\begin{array}{l}3,762 \\
3,745 \\
3,419 \\
4,917 \\
5,510\end{array}$ & $\begin{array}{l}20,213 \\
21,373 \\
22,413 \\
23,340 \\
24,624\end{array}$ & $\begin{array}{l}20,737 \\
21,856 \\
22,896 \\
23,787 \\
25,070\end{array}$ & $\begin{array}{l}14,045 \\
14,907 \\
15,825 \\
17,753 \\
19,558\end{array}$ & $\begin{array}{l}14,100 \\
15,000 \\
15,742 \\
16,383 \\
17,315\end{array}$ & $\begin{array}{l}14,616 \\
15,470 \\
16,211 \\
16,826 \\
17,763\end{array}$ & $\begin{array}{r}8,225 \\
9,067 \\
10,076 \\
10,651 \\
11,545\end{array}$ & $\begin{array}{l}3,236 \\
3,382 \\
3,567 \\
3,752 \\
3,945\end{array}$ & $\begin{array}{l}3,242 \\
3,392 \\
3,576 \\
3,764 \\
3,952\end{array}$ & $\begin{array}{l}3,067 \\
3,006 \\
3,116 \\
3,232 \\
3,581\end{array}$ & $\begin{array}{l}2,877 \\
2,991 \\
3,104 \\
3,206 \\
3,364\end{array}$ & $\begin{array}{l}2,879 \\
2,993 \\
3,109 \\
3,197 \\
3,354\end{array}$ & $\begin{array}{l}2,753 \\
2,834 \\
2,633 \\
3,870 \\
4,432\end{array}$ & 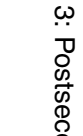 \\
\hline $\begin{array}{l}2004-05 \ldots \ldots \ldots \ldots . . . \\
2005-06 \ldots \ldots \ldots \ldots . . \\
2006-07 \ldots \ldots \ldots \ldots . . \\
2007-08 \ldots \ldots \ldots \ldots . . \\
2008-09 \ldots \ldots \ldots \ldots . .\end{array}$ & $\begin{array}{l}31,158 \\
31,284 \\
32,231 \\
32,530 \\
33,199\end{array}$ & $\begin{array}{l}31,693 \\
31,778 \\
32,774 \\
33,032 \\
33,706\end{array}$ & $\begin{array}{l}24,497 \\
24,885 \\
22,988 \\
23,698 \\
24,494\end{array}$ & $\begin{array}{l}21,910 \\
21,930 \\
22,720 \\
22,918 \\
23,248\end{array}$ & $\begin{array}{l}22,453 \\
22,429 \\
23,253 \\
23,416 \\
23,750\end{array}$ & \begin{tabular}{r|}
14,630 \\
14,444 \\
14,402 \\
14,345 \\
14,617
\end{tabular} & $\begin{array}{l}5,042 \\
5,116 \\
5,221 \\
5,249 \\
5,416\end{array}$ & $\begin{array}{l}5,036 \\
5,120 \\
5,228 \\
5,254 \\
5,423\end{array}$ & $\begin{array}{l}5,401 \\
4,852 \\
4,700 \\
4,900 \\
4,890\end{array}$ & $\begin{array}{l}4,206 \\
4,238 \\
4,290 \\
4,363 \\
4,536\end{array}$ & $\begin{array}{l}4,204 \\
4,229 \\
4,293 \\
4,362 \\
4,533\end{array}$ & $\begin{array}{l}4,465 \\
5,558 \\
3,886 \\
4,452 \\
4,987\end{array}$ & $\begin{array}{l}25,817 \\
26,908 \\
28,439 \\
29,767 \\
30,804\end{array}$ & $\begin{array}{l}26,260 \\
27,33 \\
28,919 \\
30,26 \\
31,273\end{array}$ & $\begin{array}{l}20,297 \\
21,404 \\
20,284 \\
21,685 \\
22,726\end{array}$ & $\begin{array}{l}18,154 \\
18,862 \\
20,048 \\
20,972 \\
21,570\end{array}$ & $\begin{array}{l}18,604 \\
19,292 \\
20,517 \\
21,427 \\
22,036\end{array}$ & $\begin{array}{l}12,122 \\
12,450 \\
12,708 \\
13,126 \\
13,562\end{array}$ & $\begin{array}{l}4,178 \\
4,400 \\
4,606 \\
4,804 \\
5,025\end{array}$ & $\begin{array}{l}4,173 \\
4,404 \\
4,613 \\
4,808 \\
5,032\end{array}$ & $\begin{array}{l}4,475 \\
4,173 \\
4,147 \\
4,484 \\
4,537\end{array}$ & $\begin{array}{l}3,485 \\
3,645 \\
3,785 \\
3,992 \\
4,209\end{array}$ & $\begin{array}{l}3,483 \\
3,637 \\
3,788 \\
3,991 \\
4,206\end{array}$ & $\begin{array}{l}3,700 \\
4,781 \\
3,429 \\
4,074 \\
4,627\end{array}$ & 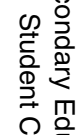 \\
\hline $\begin{array}{l}2009-10 \ldots \ldots \ldots . . . . \\
2010-11 \ldots \ldots \ldots \ldots . . \\
2011-12 \ldots \ldots \ldots \ldots . . \\
2012-13 \ldots \ldots \ldots \ldots \ldots . .\end{array}$ & $\begin{array}{l}33,116 \\
33,513 \\
33,608 \\
34,483\end{array}$ & $\begin{array}{l}33,612 \\
34,131 \\
34,234 \\
35,074\end{array}$ & $\begin{array}{l}26,134 \\
24,979 \\
24,049 \\
23,328\end{array}$ & $\begin{array}{l}22,890 \\
23,217 \\
23,230 \\
23,943\end{array}$ & $\begin{array}{l}23,386 \\
23,828 \\
23,851 \\
24,525\end{array}$ & $\begin{array}{l}15,880 \\
15,139 \\
14,236 \\
14,129\end{array}$ & $\begin{array}{l}5,603 \\
5,657 \\
5,718 \\
5,831\end{array}$ & $\begin{array}{l}5,603 \\
5,664 \\
5,723 \\
5,837\end{array}$ & $\begin{array}{l}5,568 \\
5,157 \\
5,254 \\
5,222\end{array}$ & $\begin{array}{l}4,623 \\
4,639 \\
4,660 \\
4,709\end{array}$ & $\begin{array}{l}4,623 \\
4,639 \\
4,660 \\
4,712\end{array}$ & $\begin{array}{l}4,686 \\
4,683 \\
4,558 \\
3,977\end{array}$ & $\begin{array}{l}31,023 \\
32,026 \\
33,058 \\
34,483\end{array}$ & $\begin{array}{l}31,488 \\
32,617 \\
33,674 \\
35,074\end{array}$ & $\begin{array}{l}24,483 \\
23,871 \\
23,655 \\
23,328\end{array}$ & $\begin{array}{l}21,444 \\
22,186 \\
22,850 \\
23,943\end{array} \mid$ & $\begin{array}{l}21,908 \\
22,771 \\
23,460 \\
24,525\end{array}$ & $\begin{array}{l}14,876 \\
14,46 \\
14,003 \\
14,129\end{array}$ & $\begin{array}{l}5,249 \\
5,406 \\
5,624 \\
5,831\end{array}$ & $\begin{array}{l}5,249 \\
5,413 \\
5,629 \\
5,837\end{array}$ & $\begin{array}{l}5,217 \\
4,928 \\
5,168 \\
5,222\end{array}$ & $\begin{array}{l}4,331 \\
4,434 \\
4,584 \\
4,709\end{array}$ & $\begin{array}{l}4,331 \\
4,433 \\
4,584 \\
4,712\end{array}$ & $\begin{array}{l}4,390 \\
4,475 \\
4,483 \\
3,977\end{array}$ & 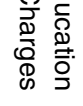 \\
\hline
\end{tabular}




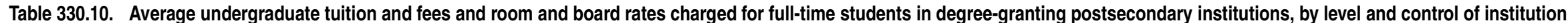
1963-64 through 2012-13-Continued

\begin{tabular}{|c|c|c|c|c|c|c|c|c|c|c|c|c|c|c|c|c|c|c|c|c|c|c|c|c|}
\hline \multirow[b]{3}{*}{$\begin{array}{l}\text { Year and control } \\
\text { of institution }\end{array}$} & \multicolumn{12}{|c|}{ Constant 2012-13 dollars ${ }^{1}$} & \multicolumn{12}{|c|}{ Current dollars } \\
\hline & \multicolumn{3}{|c|}{$\begin{array}{l}\text { Total tuition, fees, } \\
\text { room, and board }\end{array}$} & \multicolumn{3}{|c|}{ Tuition and required fees ${ }^{2}$} & \multicolumn{3}{|c|}{ Dormitory rooms } & \multicolumn{3}{|c|}{ Board $^{3}$} & \multicolumn{3}{|c|}{$\begin{array}{l}\text { Total tuition, fees, } \\
\text { room, and board }\end{array}$} & \multicolumn{3}{|c|}{ Tuition and required fees ${ }^{2}$} & \multicolumn{3}{|c|}{ Dormitory rooms } & \multicolumn{3}{|c|}{ Board $^{3}$} \\
\hline & $\begin{array}{r}\text { All } \\
\text { institu- } \\
\text { tions }\end{array}$ & 4-year & 2-year & $\begin{array}{r}\text { All } \\
\text { institu- } \\
\text { tions }\end{array}$ & 4-year & 2-year & $\begin{array}{r}\text { All } \\
\text { institu- } \\
\text { tions }\end{array}$ & 4-year & 2-year & $\begin{array}{r}\text { All } \\
\text { institu- } \\
\text { tions }\end{array}$ & 4-year & 2-year & $\begin{array}{r}\text { All } \\
\text { institu- } \\
\text { tions }\end{array}$ & 4-year & 2-year & $\begin{array}{r}\text { All } \\
\text { institu- } \\
\text { tions }\end{array}$ & 4-year & 2-year & $\begin{array}{r}\text { All } \\
\text { institu- } \\
\text { tions }\end{array}$ & 4-year & 2-year & $\begin{array}{r}\text { All } \\
\text { institu- } \\
\text { tions }\end{array}$ & 4-year & 2-year \\
\hline 1 & 2 & 3 & 4 & 5 & 6 & 7 & 8 & 9 & 10 & 11 & 12 & 13 & 14 & 15 & 16 & 17 & 18 & 19 & 20 & 21 & 2 & 23 & 24 & 25 \\
\hline $\begin{array}{r}\text { Nonprofit } \\
1999-2000 . . \\
2000-01 \ldots . . \\
2001-02 \ldots . . . \\
2002-03 \ldots . . \\
2003-04 \ldots . .\end{array}$ & $\begin{array}{l}28,683 \\
28,982 \\
29,965 \\
30,841 \\
31,932\end{array}$ & $\begin{array}{l}29,014 \\
29,293 \\
30,195 \\
31,056 \\
32,141\end{array}$ & $\begin{array}{l}15,973 \\
15,481 \\
16,839 \\
18,347 \\
19,356\end{array}$ & $\begin{array}{l}20,377 \\
20,607 \\
21,345 \\
22,053 \\
22,911\end{array}$ & $\begin{array}{l}20,678 \\
20,892 \\
21,557 \\
22,254 \\
23,104\end{array}$ & $\begin{array}{r}9,419 \\
9,207 \\
10,551 \\
11,315 \\
11,918\end{array}$ & $\begin{array}{l}4,378 \\
4,423 \\
4,590 \\
4,729 \\
4,857\end{array}$ & $\begin{array}{l}4,401 \\
4,446 \\
4,602 \\
4,740 \\
4,867\end{array}$ & $\begin{array}{l}2,890 \\
2,653 \\
2,991 \\
3,362 \\
3,547\end{array}$ & $\begin{array}{l}3,929 \\
3,952 \\
4,030 \\
4,059 \\
4,164\end{array}$ & $\begin{array}{l}3,935 \\
3,955 \\
4,036 \\
4,062 \\
4,170\end{array}$ & $\begin{array}{l}3,663 \\
3,621 \\
3,297 \\
3,670 \\
3,890\end{array}$ & $\begin{array}{l}20,989 \\
21,934 \\
23,080 \\
24,276 \\
25,685\end{array}$ & $\begin{array}{l}21,231 \\
22,170 \\
23,257 \\
24,446 \\
25,853\end{array}$ & $\begin{array}{l}11,688 \\
11,717 \\
12,970 \\
14,442 \\
15,569\end{array}$ & $\begin{array}{l}14,911 \\
15,596 \\
16,440 \\
17,359 \\
18,429\end{array}$ & $\begin{array}{l}15,131 \\
15,811 \\
16,004 \\
17,517 \\
18,584\end{array}$ & $\begin{array}{l}6,893 \\
6,968 \\
8,26 \\
8,907 \\
9,587\end{array}$ & $\begin{array}{l}3,204 \\
3,347 \\
3,536 \\
3,723 \\
3,907\end{array}$ & $\begin{array}{l}3,221 \\
3,365 \\
3,544 \\
3,731 \\
3,915\end{array}$ & $\begin{array}{l}2,115 \\
2,008 \\
2,304 \\
2,646\end{array}$ & $\begin{array}{l}2,875 \\
2,991 \\
3,104 \\
3,195 \\
3,349\end{array}$ & $\begin{array}{l}2,879 \\
2,993 \\
3,109 \\
3,197 \\
3,354\end{array}$ & $\begin{array}{l}2,680 \\
2,740 \\
2,540 \\
2,889 \\
3,129\end{array}$ \\
\hline $\begin{array}{l}2004-05 \ldots . . . \\
2005-06 \ldots . . . \\
2006-07 \ldots . . . \\
2007-08 \ldots . . . \\
2008-09 \ldots . . .\end{array}$ & $\begin{array}{l}32,687 \\
33,158 \\
34,186 \\
34,884 \\
36,298\end{array}$ & $\begin{array}{l}32,894 \\
33,358 \\
34,362 \\
35,025 \\
36,433\end{array}$ & $\begin{array}{l}19,197 \\
18,984 \\
20,038 \\
20,607 \\
21,847\end{array}$ & $\begin{array}{l}23,533 \\
23,913 \\
24,753 \\
25,355 \\
26,407\end{array}$ & $\begin{array}{l}23,718 \\
24,103 \\
24,927 \\
25,494 \\
26,552\end{array}$ & $\begin{array}{l}11,960 \\
11,996 \\
12,394 \\
12,883 \\
13,583\end{array}$ & $\begin{array}{l}4,964 \\
5,017 \\
5,137 \\
5,164 \\
5,342\end{array}$ & $\begin{array}{l}4,972 \\
5,026 \\
5,142 \\
5,169 \\
5,348\end{array}$ & $\begin{array}{l}3,535 \\
3,507 \\
4,053 \\
4,148 \\
4,191\end{array}$ & $\begin{array}{l}4,191 \\
4,228 \\
4,296 \\
4,365 \\
4,549\end{array}$ & $\begin{array}{l}4,204 \\
4,229 \\
4,293 \\
4,362 \\
4,533\end{array}$ & $\begin{array}{l}3,702 \\
3,481 \\
3,592 \\
3,576 \\
4,073\end{array}$ & $\begin{array}{l}27,083 \\
28,520 \\
30,165 \\
31,921 \\
33,679\end{array}$ & $\begin{array}{l}27,255 \\
28,692 \\
30,320 \\
32,050 \\
33,804\end{array}$ & $\begin{array}{l}15,906 \\
16,329 \\
17,681 \\
18,857 \\
20,271\end{array}$ & $\begin{array}{l}19,498 \\
20,568 \\
21,841 \\
23,201 \\
24,502\end{array}$ & $\begin{array}{l}19,652 \\
20,732 \\
21,994 \\
23,328 \\
24,636\end{array}$ & & $\begin{array}{l}4,113 \\
4,315 \\
4,532 \\
4,725 \\
4,957\end{array}$ & $\begin{array}{l}4,119 \\
4,323 \\
4,537 \\
4,730 \\
4,962\end{array}$ & $\begin{array}{l}2,929 \\
3,017 \\
3,576 \\
3,796\end{array}$ & $\begin{array}{l}3,472 \\
3,637 \\
3,791 \\
3,994 \\
4,221\end{array}$ & $\begin{array}{l}3,483 \\
3,637 \\
3,788 \\
3,991 \\
4,206\end{array}$ & $\begin{array}{l}2,994 \\
3,169 \\
3,270\end{array}$ \\
\hline $\begin{array}{l}2009-10 \ldots . . . \\
2010-11 \ldots . . \\
2011-12 \ldots . . \\
2012-13 \ldots . . .\end{array}$ & $\begin{array}{l}37,295 \\
37,935 \\
38,332 \\
39,173\end{array}$ & $\begin{array}{l}37,426 \\
38,053 \\
38,464 \\
39,302\end{array}$ & $\begin{array}{l}22,177 \\
21,027 \\
23,307 \\
22,110\end{array}$ & $\begin{array}{r}27,127 \\
27,608 \\
27,899 \\
28,569\end{array}$ & $\begin{array}{l}27,275 \\
27,755 \\
28,075 \\
28,746\end{array}$ & $\begin{array}{l}13,510 \\
13,257 \\
14,312 \\
13,747\end{array}$ & $\begin{array}{l}5,523 \\
5,652 \\
5,724 \\
5,839\end{array}$ & $\begin{array}{l}5,528 \\
5,659 \\
5,729 \\
5,844\end{array}$ & $\begin{array}{l}4,394 \\
4,166 \\
4,352 \\
4,405\end{array}$ & $\begin{array}{l}4,646 \\
4,676 \\
4,709 \\
4,766\end{array}$ & $\begin{array}{l}4,623 \\
4,639 \\
4,660 \\
4,712\end{array}$ & $\begin{array}{l}4,274 \\
3,604 \\
4,643 \\
3,958\end{array}$ & $\begin{array}{l}34,939 \\
36,252 \\
37,705 \\
39,173\end{array}$ & $\begin{array}{l}35,061 \\
36,364 \\
37,835 \\
39,302\end{array}$ & $\begin{array}{l}20,776 \\
20,094 \\
22,925 \\
22,110\end{array}$ & $\begin{array}{r}25,413 \\
26,383 \\
27,443 \\
28,569\end{array}$ & $\begin{array}{l}25,552 \\
26,523 \\
27,615 \\
28,746\end{array}$ & $\begin{array}{l}12,656 \\
12,669 \\
14,077 \\
13,747\end{array}$ & $\begin{array}{l}5,174 \\
5,401 \\
5,630 \\
5,839\end{array}$ & $\begin{array}{l}5,178 \\
5,408 \\
5,635 \\
5,844\end{array}$ & $\begin{array}{l}4,116 \\
3,981 \\
4,281 \\
4,405\end{array}$ & $\begin{array}{l}4,353 \\
4,468 \\
4,632 \\
4,766\end{array}$ & $\begin{array}{l}4,331 \\
4,433 \\
4,584 \\
4,712\end{array}$ & $\begin{array}{l}3,444 \\
4,567 \\
3,958\end{array}$ \\
\hline $\begin{array}{r}\text { For-profit } \\
199-2000 . . \\
2000-01 \ldots . . \\
2001-02 \ldots . . \\
2002-03 \ldots . . \\
2003-04 \ldots . .\end{array}$ & $\begin{array}{l}22,035 \\
23,371 \\
24,118 \\
25,019 \\
27,129\end{array}$ & $\begin{array}{l}22,613 \\
24,075 \\
25,671 \\
25,458 \\
27,205\end{array}$ & $\begin{array}{l}21,501 \\
22,543 \\
22,015 \\
24,651 \\
27,812\end{array}$ & $\begin{array}{l}11,899 \\
13,467 \\
14,100 \\
14,368 \\
15,265\end{array}$ & $\begin{array}{l}11,836 \\
13,756 \\
14,371 \\
14,491 \\
15,414\end{array}$ & $\begin{array}{r}11,979 \\
13,141 \\
13,800 \\
14,138 \\
14,948\end{array}$ & $\begin{array}{l}5,803 \\
5,955 \\
6,010 \\
5,816 \\
6,330\end{array}$ & $\begin{array}{l}6,329 \\
6,554 \\
7,006 \\
6,839 \\
7,154\end{array}$ & $\begin{array}{l}5,346 \\
5,225 \\
4,647 \\
4,484 \\
4,962\end{array}$ & $\begin{array}{l}4,333 \\
3,949 \\
4,008 \\
4,835 \\
5,534\end{array}$ & $\begin{array}{l}4,449 \\
3,765 \\
4,293 \\
4,127 \\
4,638\end{array}$ & $\begin{array}{l}4,177 \\
4,177 \\
3,567 \\
6,029 \\
7,901\end{array}$ & $\begin{array}{l}16,124 \\
17,688 \\
18,576 \\
19,694 \\
21,822\end{array}$ & $\begin{array}{l}16,547 \\
18,220 \\
19,772 \\
20,039 \\
21,883\end{array}$ & $\begin{array}{l}15,734 \\
17,061 \\
16,956 \\
19,404 \\
22,371\end{array}$ & $\begin{array}{r}8,707 \\
10,192 \\
10,860 \\
11,310 \\
12,278\end{array}$ & $\begin{array}{r}8,661 \\
10,411 \\
11,069 \\
11,407 \\
12,398\end{array}$ & $\begin{array}{r}8,766 \\
9,945 \\
10,629 \\
11,129 \\
12,024\end{array}$ & $\begin{array}{l}4,247 \\
4,507 \\
4,629 \\
4,578 \\
5,092\end{array}$ & $\begin{array}{l}4,631 \\
4,960 \\
5,396 \\
5,384 \\
5,754\end{array}$ & $\begin{array}{l}3,912 \\
3,955 \\
3,579 \\
3,530 \\
3,992\end{array}$ & $\begin{array}{l}3,171 \\
2,988 \\
3,087 \\
3,806 \\
4,451\end{array}$ & $\begin{array}{l}3,255 \\
2,849 \\
3,307 \\
3,249 \\
3,730\end{array}$ & $\begin{array}{l}3,056 \\
3,161 \\
2,748 \\
4,746 \\
6,355\end{array}$ \\
\hline $\begin{array}{l}2004-05 \ldots . . . \\
2005-06 \ldots . . \\
2006-07 \ldots . . . \\
2007-08 \ldots . . . \\
2008-09 \ldots . . .\end{array}$ & $\begin{array}{l}27,877 \\
27,388 \\
27,205 \\
27,042 \\
26,214\end{array}$ & $\begin{array}{l}28,260 \\
27,002 \\
28,004 \\
27,411 \\
26,348\end{array}$ & $\begin{array}{l}26,977 \\
29,845 \\
24,083 \\
25,705 \\
26,587\end{array}$ & $\begin{array}{l}15,733 \\
15,390 \\
16,181 \\
15,746 \\
15,422\end{array}$ & $\begin{array}{l}15,928 \\
15,480 \\
16,538 \\
16,004 \\
15,545\end{array}$ & $\begin{array}{l}15,216 \\
15,066 \\
14,829 \\
14,603 \\
14,793\end{array}$ & $\begin{array}{l}6,825 \\
7,075 \\
7,032 \\
7,044 \\
6,695\end{array}$ & $\begin{array}{l}7,076 \\
7,539 \\
7,522 \\
7,410 \\
6,942\end{array}$ & $\begin{array}{l}6,215 \\
5,553 \\
5,061 \\
5,356 \\
5,280\end{array}$ & $\begin{array}{l}5,319 \\
4,924 \\
3,993 \\
4,253 \\
4,098\end{array}$ & $\begin{array}{l}5,256 \\
3,983 \\
3,943 \\
3,998 \\
3,861\end{array}$ & $\begin{array}{l}5,547 \\
9,226 \\
4,193 \\
5,746 \\
6,514\end{array}$ & $\begin{array}{l}23,098 \\
23,557 \\
24,005 \\
24,745 \\
24,322\end{array}$ & $\begin{array}{l}23,415 \\
23,225 \\
24,710 \\
25,083 \\
24,447\end{array}$ & $\begin{array}{l}22,353 \\
25,670 \\
21,250 \\
23,522 \\
24,669\end{array}$ & \begin{tabular}{r|}
13,036 \\
13,237 \\
14,277 \\
14,409 \\
14,309
\end{tabular} & $\begin{array}{l}13,197 \\
13,315 \\
14,593 \\
14,644 \\
14,423\end{array}$ & $\begin{array}{r}12,607 \\
12,959 \\
13,085 \\
13,363 \\
13,725\end{array}$ & $\begin{array}{l}5,655 \\
6,085 \\
6,205 \\
6,445 \\
6,212\end{array}$ & $\begin{array}{l}5,863 \\
6,485 \\
6,638 \\
6,781 \\
6,441\end{array}$ & $\begin{array}{l}5,149 \\
4,776 \\
4,466 \\
4,901 \\
4,899\end{array}$ & $\begin{array}{l}4,407 \\
4,235 \\
3,523 \\
3,892 \\
3,802\end{array}$ & $\begin{array}{l}4,355 \\
3,426 \\
3,479 \\
3,658 \\
3,583\end{array}$ & $\begin{array}{l}4,596 \\
7,935 \\
3,700 \\
5,258 \\
6,044\end{array}$ \\
\hline $\begin{array}{l}2009-10 \ldots . . . \\
2010-11 \ldots . . \\
2011-12 \ldots . . \\
2012-13 \ldots \ldots .\end{array}$ & $\begin{array}{l}25,433 \\
24,585 \\
23,364 \\
23,158\end{array}$ & $\begin{array}{l}25,144 \\
24,393 \\
23,306 \\
23,083\end{array}$ & $\begin{array}{l}27,746 \\
27,784 \\
23,989 \\
23,991\end{array}$ & $\begin{array}{l}14,659 \\
14,914 \\
13,989 \\
13,766\end{array}$ & $\begin{array}{l}14,343 \\
14,819 \\
13,941 \\
13,689\end{array}$ & $\begin{array}{r}16,167 \\
15,334 \\
14,225 \\
14,193\end{array}$ & $\begin{array}{l}6,669 \\
5,712 \\
5,650 \\
5,738\end{array}$ & $\begin{array}{l}6,766 \\
5,733 \\
5,643 \\
5,745\end{array}$ & $\begin{array}{l}6,073 \\
5,563 \\
5,721 \\
5,663\end{array}$ & $\begin{array}{l}4,104 \\
3,959 \\
3,725 \\
3,653\end{array}$ & $\begin{array}{l}4,036 \\
3,840 \\
3,721 \\
3,649\end{array}$ & $\begin{array}{l}5,506 \\
6,977 \\
4,042 \\
4,135\end{array}$ & $\begin{array}{l}23,826 \\
23,495 \\
22,982 \\
23,158\end{array}$ & $\begin{array}{l}23,556 \\
23,310 \\
22,924 \\
23,083\end{array}$ & $\begin{array}{l}25,993 \\
26,637 \\
23,596 \\
23,991\end{array}$ & $\begin{array}{l}13,733 \\
14,53 \\
13,760 \\
13,766\end{array}$ & $\begin{array}{r}13,437 \\
14,62 \\
13,713 \\
13,689\end{array}$ & $\begin{array}{l}15,146 \\
14,654 \\
13,992 \\
14,193\end{array}$ & $\begin{array}{l}6,248 \\
5,459 \\
5,558 \\
5,738\end{array}$ & $\begin{array}{l}6,338 \\
5,479 \\
5,551 \\
5,745\end{array}$ & $\begin{array}{l}5,689 \\
5,316 \\
5,628 \\
5,663\end{array}$ & $\begin{array}{l}3,845 \\
3,783 \\
3,664 \\
3,653\end{array}$ & $\begin{array}{l}3,781 \\
3,669 \\
3,660 \\
3,649\end{array}$ & $\begin{array}{l}5,158 \\
6,667 \\
3,976 \\
4,135\end{array}$ \\
\hline
\end{tabular}

'Constant dollars based on the Consumer Price Index, prepared by the Bureau of Labor Statistics, U.S. Department of Labor, adjusted to a school-year basis.

${ }^{2}$ For public institutions, in-state tuition and required fees are used.

${ }^{3}$ Data for 1986-87 and later years reflect a basis of 20 meals per week, while data for earlier years are for meals served 7 days a week (the number of meals per day was not specified). Because of this revision in data collection and tabulation procedures, data
are not entirely comparable with figures for previous years. In particular, data on board rates are somewhat higher than in earlier years because they reflect the basis of 20 meals per week rather than meals served 7 days a week. Since many institutions serve fewer than 3 meals each day, the 1986-87 and later data reflect a more accurate accounting of total board costs.

${ }^{4}$ Room and board data are estimated.

NOTE: Data are for the entire academic year and are average charges for full-time students. Tuition and fees were weighted by the full-time students. Data through 1995-96 are for institutions of higher education, while later data are for degree-granting institutions.

Degree-granting institutions grant associate's or higher degrees and participate in Title IV federal financial aid programs. The degree-granting classification is very similar to the earlier higher education classification, but it includes more 2-year colleges and
excludes a few higher education institutions that did not grant degrees. Because of their low response rate, data for private 2-year colleges must be interpreted with caution. Some data have been revised from previously published figures. Detail may not sum to totals because of rounding.

SOURCE: U.S. Department of Education, National Center for Education Statistics, Projections of Education Statistics to 1986-87; Higher Education General Information Survey (HEGIS), "Institutional Characteristics of Colleges and Universities" surveys, (O) ondary Education Data System (IPEDS), "Fall Enrollment Survey" (IPEDS-EF:86-99) and "Institutitional Characteristics Survey"
(IPEDS-IC:86-99); IPEDS Spring 2001 through Spring 2013, Enrollment component; and IPEDS Fall 2000 through Fall 2012, Institutional Characteristics component. (This table was prepared March 2014.) 
Table 330.20. Average undergraduate tuition and fees and room and board rates charged for full-time students in degree-granting postsecondary institutions, by control and level of institution and state or jurisdiction: 2011-12 and 2012-13 [In current dollars]

\begin{tabular}{|c|c|c|c|c|c|c|c|c|c|c|c|c|c|c|c|c|}
\hline \multirow[b]{3}{*}{ State or jurisdiction } & \multicolumn{7}{|c|}{ Public 4-year } & \multicolumn{6}{|c|}{ Private 4-year } & \multirow{2}{*}{\multicolumn{3}{|c|}{$\begin{array}{l}\text { Public 2-year, } \\
\text { on and required fees }\end{array}$}} \\
\hline & \multicolumn{2}{|c|}{$\begin{array}{l}\text { In-state, } \\
2011-12\end{array}$} & \multicolumn{4}{|c|}{$\begin{array}{l}\text { In-state, } \\
\text { 2012-13 }\end{array}$} & \multirow{2}{*}{$\begin{array}{r}\text { Out-of- } \\
\text { state } \\
\text { tuition } \\
\text { and } \\
\text { required } \\
\text { fees, } \\
2012-13\end{array}$} & \multicolumn{2}{|c|}{ 2011-12 } & \multicolumn{4}{|c|}{$2012-13$} & & & \\
\hline & Total & $\begin{array}{r}\text { Tuition } \\
\text { and } \\
\text { required } \\
\text { fees }\end{array}$ & Total & $\begin{array}{r}\text { Tuition } \\
\text { and } \\
\text { required } \\
\text { fees }\end{array}$ & Room & Board & & Total & $\begin{array}{r}\text { Tuition } \\
\text { and } \\
\text { required } \\
\text { fees }\end{array}$ & Total & $\begin{array}{r}\text { Tuition } \\
\text { and } \\
\text { required } \\
\text { fees }\end{array}$ & Room & Board & $\begin{array}{r}\text { In-state, } \\
2011-12\end{array}$ & $\begin{array}{r}\text { In-state, } \\
2012-13\end{array}$ & $\begin{array}{r}\text { Out-of- } \\
\text { state, } \\
2012-13\end{array}$ \\
\hline 1 & 2 & 3 & 4 & 5 & 6 & 7 & 8 & 9 & 10 & 11 & 12 & 13 & 14 & 15 & 16 & 17 \\
\hline United States ........... & $\$ 16,805$ & $\$ 7,703$ & $\$ 17,474$ & $\$ 8,070$ & $\$ 5,241$ & 4,163 & $\$ 21,847$ & $\$ 33,674$ & $\$ 23,460$ & $\$ 35,074$ & $\$ 24,525$ & $\$ 5,837$ & $\$ 4,712$ & $\$ 2,652$ & $\$ 2,792$ & $\$ 6,767$ \\
\hline 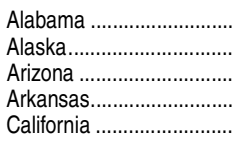 & $\begin{array}{l}15,550 \\
14,541 \\
19,274 \\
13,100 \\
20,670\end{array}$ & $\begin{array}{l}7,528 \\
5,956 \\
9,030 \\
6,377 \\
8,830\end{array}$ & $\begin{array}{l}16,546 \\
15,415 \\
19,064 \\
13,936 \\
21,029\end{array}$ & $\begin{array}{l}8,073 \\
6,317 \\
9,694 \\
6,604 \\
8,892\end{array}$ & $\begin{array}{l}4,695 \\
5,265 \\
5,948 \\
4,113 \\
6,474\end{array}$ & $\begin{array}{l}3,777 \\
3,833 \\
3,421 \\
3,219 \\
5,663\end{array}$ & $\begin{array}{l}20,380 \\
18,790 \\
21,201 \\
15,669 \\
30,765\end{array}$ & $\begin{array}{l}21,037 \\
28,270 \\
20,391 \\
23,939 \\
39,177\end{array}$ & $\begin{array}{l}13,041 \\
19,211 \\
11,865 \\
16,888 \\
27,379\end{array}$ & $\begin{array}{l}22,486 \\
30,418 \\
20,394 \\
25,267 \\
40,599\end{array}$ & $\begin{array}{l}13,983 \\
21,496 \\
11,650 \\
18,004 \\
28,345\end{array}$ & $\begin{array}{l}4,378 \\
4,123 \\
4,979 \\
3,690 \\
6,990\end{array}$ & $\begin{array}{l}4,124 \\
4,799 \\
3,765 \\
3,573 \\
5,264\end{array}$ & $\begin{array}{r}3,864 \\
3,883 \\
1,802 \\
2,435 \\
977\end{array}$ & $\begin{array}{l}4,048 \\
3,972 \\
1,842 \\
2,633 \\
1,225\end{array}$ & $\begin{array}{l}7,736 \\
4,150 \\
7,870 \\
4,605 \\
6,267\end{array}$ \\
\hline 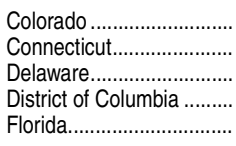 & $\begin{array}{r}17,161 \\
19,842 \\
20,926 \\
\dagger \\
13,622\end{array}$ & $\begin{array}{r}7,177 \\
9,087 \\
10,470 \\
7,000 \\
4,042\end{array}$ & $\begin{array}{r}18,052 \\
20,655 \\
21,940 \\
\dagger \\
14,170\end{array}$ & $\begin{array}{r}7,656 \\
9,517 \\
10,929 \\
7,244 \\
4,377\end{array}$ & $\begin{array}{r}5,153 \\
5,999 \\
6,595 \\
\dagger \\
5,813\end{array}$ & $\begin{array}{r}5,243 \\
5,139 \\
4,416 \\
\dagger \\
3,980\end{array}$ & $\begin{array}{l}25,470 \\
26,688 \\
26,228 \\
14,540 \\
17,050\end{array}$ & $\begin{array}{l}29,860 \\
46,642 \\
23,521 \\
47,365 \\
29,598\end{array}$ & $\begin{array}{l}19,093 \\
34,208 \\
13,182 \\
33,774 \\
19,925\end{array}$ & $\begin{array}{l}30,907 \\
48,262 \\
23,701 \\
48,440 \\
30,123\end{array}$ & $\begin{array}{l}19,967 \\
35,336 \\
12,943 \\
35,524 \\
20,155\end{array}$ & $\begin{array}{l}6,078 \\
7,229 \\
5,135 \\
8,557 \\
5,522\end{array}$ & $\begin{array}{l}4,861 \\
5,697 \\
5,623 \\
4,358 \\
4,446\end{array}$ & $\begin{array}{r}3,484 \\
3,490 \\
3,086 \\
\dagger \\
2,485\end{array}$ & $\begin{array}{r}3,004 \\
3,596 \\
3,242 \\
\dagger \\
2,486\end{array}$ & $\begin{array}{r}8,882 \\
10,512 \\
7,562 \\
\dagger \\
6,889\end{array}$ \\
\hline 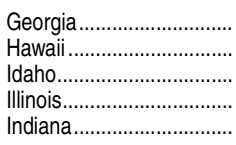 & $\begin{array}{l}14,828 \\
16,397 \\
12,347 \\
21,178 \\
17,034\end{array}$ & $\begin{array}{r}6,029 \\
7,450 \\
5,673 \\
11,290 \\
7,937\end{array}$ & $\begin{array}{l}15,331 \\
16,987 \\
13,476 \\
22,222 \\
17,758\end{array}$ & $\begin{array}{r}6,325 \\
7,731 \\
5,980 \\
11,882 \\
8,269\end{array}$ & $\begin{array}{l}5,397 \\
4,720 \\
3,368 \\
5,671 \\
4,956\end{array}$ & $\begin{array}{l}3,608 \\
4,536 \\
4,128 \\
4,668 \\
4,533\end{array}$ & $\begin{array}{l}22,393 \\
23,614 \\
17,736 \\
26,873 \\
26,538\end{array}$ & $\begin{array}{l}30,737 \\
24,719 \\
13,916 \\
35,645 \\
34,380\end{array}$ & $\begin{array}{r}20,447 \\
13,408 \\
7,118 \\
25,091 \\
25,259\end{array}$ & $\begin{array}{l}33,177 \\
25,808 \\
11,544 \\
37,097 \\
36,368\end{array}$ & $\begin{array}{r}22,456 \\
14,287 \\
6,752 \\
26,299 \\
26,794\end{array}$ & $\begin{array}{l}5,915 \\
4,969 \\
2,356 \\
6,274 \\
4,901\end{array}$ & $\begin{array}{l}4,807 \\
6,552 \\
2,436 \\
4,524 \\
4,672\end{array}$ & $\begin{array}{l}2,645 \\
2,388 \\
2,672 \\
3,086 \\
3,354\end{array}$ & $\begin{array}{l}2,652 \\
2,484 \\
2,915 \\
3,192 \\
3,455\end{array}$ & $\begin{array}{l}7,554 \\
7,166 \\
7,276 \\
9,034 \\
7,302\end{array}$ \\
\hline 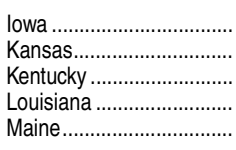 & $\begin{array}{l}15,663 \\
13,432 \\
15,921 \\
12,596 \\
18,631\end{array}$ & $\begin{array}{l}7,563 \\
6,660 \\
7,942 \\
5,205 \\
9,294\end{array}$ & $\begin{array}{l}16,358 \\
13,901 \\
16,581 \\
14,245 \\
18,676\end{array}$ & $\begin{array}{l}7,832 \\
6,970 \\
8,416 \\
5,817 \\
9,295\end{array}$ & $\begin{array}{l}4,149 \\
3,426 \\
4,150 \\
4,991 \\
4,450\end{array}$ & $\begin{array}{l}4,376 \\
3,505 \\
4,015 \\
3,437 \\
4,930\end{array}$ & $\begin{array}{l}23,019 \\
17,646 \\
19,040 \\
17,405 \\
24,397\end{array}$ & $\begin{array}{l}22,563 \\
27,425 \\
26,450 \\
36,998 \\
41,456\end{array}$ & $\begin{array}{l}15,819 \\
20,023 \\
18,658 \\
27,163 \\
30,765\end{array}$ & $\begin{array}{l}22,258 \\
28,525 \\
28,654 \\
39,088 \\
42,745\end{array}$ & $\begin{array}{l}15,426 \\
20,852 \\
20,639 \\
28,691 \\
31,558\end{array}$ & $\begin{array}{l}3,017 \\
3,635 \\
4,056 \\
5,783 \\
5,635\end{array}$ & $\begin{array}{l}3,815 \\
4,039 \\
3,959 \\
4,614 \\
5,552\end{array}$ & $\begin{array}{l}3,998 \\
2,601 \\
3,268 \\
2,584 \\
3,409\end{array}$ & $\begin{array}{l}4,099 \\
2,621 \\
3,391 \\
2,837 \\
3,409\end{array}$ & $\begin{array}{r}5,190 \\
4,023 \\
11,789 \\
5,781 \\
6,053\end{array}$ \\
\hline 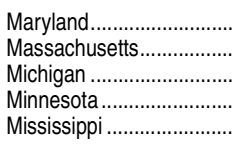 & $\begin{array}{l}17,420 \\
20,328 \\
19,240 \\
17,354 \\
12,831\end{array}$ & $\begin{array}{r}7,801 \\
10,094 \\
10,533 \\
9,908 \\
5,678\end{array}$ & $\begin{array}{l}18,094 \\
21,094 \\
19,865 \\
17,998 \\
13,583\end{array}$ & $\begin{array}{r}8,051 \\
10,632 \\
11,027 \\
10,291 \\
6,147\end{array}$ & $\begin{array}{l}5,680 \\
6,378 \\
4,523 \\
4,175 \\
4,200\end{array}$ & $\begin{array}{l}4,362 \\
4,084 \\
4,315 \\
3,533 \\
3,236\end{array}$ & $\begin{array}{l}20,199 \\
24,399 \\
31,047 \\
16,313 \\
15,055\end{array}$ & $\begin{array}{l}43,406 \\
48,159 \\
25,038 \\
33,864 \\
20,594\end{array}$ & $\begin{array}{l}30,989 \\
35,586 \\
17,043 \\
25,191 \\
14,506\end{array}$ & $\begin{array}{l}44,819 \\
49,871 \\
26,381 \\
35,409 \\
20,881\end{array}$ & $\begin{array}{l}32,580 \\
36,795 \\
18,135 \\
26,499 \\
14,592\end{array}$ & $\begin{array}{l}6,896 \\
7,457 \\
4,076 \\
4,708 \\
3,201\end{array}$ & $\begin{array}{l}5,342 \\
5,619 \\
4,170 \\
4,201 \\
3,089\end{array}$ & $\begin{array}{l}3,356 \\
4,006 \\
2,595 \\
5,195 \\
2,212\end{array}$ & $\begin{array}{l}3,500 \\
4,186 \\
2,736 \\
5,362 \\
2,276\end{array}$ & $\begin{array}{l}8,355 \\
9,516 \\
5,651 \\
6,197 \\
4,284\end{array}$ \\
\hline 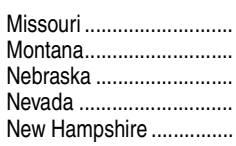 & $\begin{array}{l}15,665 \\
13,074 \\
14,577 \\
15,141 \\
23,314\end{array}$ & $\begin{array}{r}7,609 \\
5,995 \\
6,749 \\
4,624 \\
13,339\end{array}$ & $\begin{array}{l}16,236 \\
13,572 \\
15,291 \\
15,944 \\
24,705\end{array}$ & $\begin{array}{r}7,815 \\
6,267 \\
7,023 \\
4,953 \\
14,435\end{array}$ & $\begin{array}{l}4,804 \\
3,463 \\
4,371 \\
5,288 \\
6,098\end{array}$ & $\begin{array}{l}3,617 \\
3,843 \\
3,897 \\
5,703 \\
4,172\end{array}$ & $\begin{array}{l}18,885 \\
20,164 \\
16,702 \\
19,156 \\
24,945\end{array}$ & $\begin{array}{l}26,788 \\
25,590 \\
25,956 \\
28,861 \\
41,411\end{array}$ & $\begin{array}{l}18,186 \\
18,468 \\
18,485 \\
15,797 \\
29,805\end{array}$ & $\begin{array}{l}27,615 \\
27,320 \\
27,212 \\
37,710 \\
42,310\end{array}$ & $\begin{array}{l}19,020 \\
19,737 \\
19,478 \\
16,108 \\
30,202\end{array}$ & $\begin{array}{l}4,717 \\
3,547 \\
4,006 \\
7,622 \\
7,118\end{array}$ & $\begin{array}{r}3,878 \\
4,037 \\
3,727 \\
13,980 \\
4,990\end{array}$ & $\begin{array}{l}2,600 \\
3,120 \\
2,470 \\
2,513 \\
7,194\end{array}$ & $\begin{array}{l}2,716 \\
3,151 \\
2,594 \\
2,700 \\
7,218\end{array}$ & $\begin{array}{r}5,384 \\
8,351 \\
3,415 \\
9,345 \\
15,697\end{array}$ \\
\hline 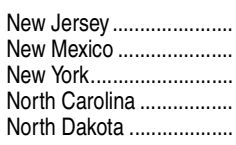 & $\begin{array}{l}23,151 \\
12,877 \\
17,559 \\
13,692 \\
12,846\end{array}$ & $\begin{array}{r}11,580 \\
5,275 \\
6,183 \\
5,708 \\
6,437\end{array}$ & $\begin{array}{l}23,773 \\
13,225 \\
18,397 \\
14,514 \\
13,210\end{array}$ & $\begin{array}{r}11,955 \\
5,483 \\
6,556 \\
6,223 \\
6,572\end{array}$ & $\begin{array}{l}7,590 \\
4,134 \\
7,446 \\
4,673 \\
2,897\end{array}$ & $\begin{array}{l}4,229 \\
3,608 \\
4,394 \\
3,618 \\
3,741\end{array}$ & $\begin{array}{l}24,447 \\
14,327 \\
15,751 \\
19,733 \\
16,170\end{array}$ & $\begin{array}{l}41,201 \\
24,128 \\
43,605 \\
34,781 \\
16,641\end{array}$ & $\begin{array}{l}29,700 \\
15,417 \\
31,225 \\
25,271 \\
11,582\end{array}$ & $\begin{array}{l}42,831 \\
25,144 \\
45,338 \\
36,194 \\
17,743\end{array}$ & $\begin{array}{l}31,195 \\
16,256 \\
32,438 \\
26,336 \\
12,318\end{array}$ & $\begin{array}{l}6,779 \\
4,727 \\
7,731 \\
5,217 \\
2,422\end{array}$ & $\begin{array}{l}4,857 \\
4,161 \\
5,169 \\
4,640 \\
3,002\end{array}$ & $\begin{array}{l}3,682 \\
1,372 \\
4,143 \\
2,138 \\
3,994\end{array}$ & $\begin{array}{l}3,782 \\
1,399 \\
4,331 \\
2,212 \\
4,048\end{array}$ & $\begin{array}{l}6,591 \\
4,558 \\
7,827 \\
8,171 \\
8,216\end{array}$ \\
\hline 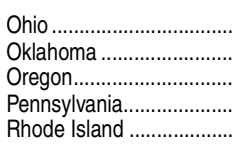 & $\begin{array}{l}18,737 \\
12,662 \\
17,601 \\
20,978 \\
20,649\end{array}$ & $\begin{array}{r}8,860 \\
5,573 \\
7,978 \\
11,817 \\
9,936\end{array}$ & $\begin{array}{l}19,453 \\
13,005 \\
18,526 \\
21,637 \\
21,582\end{array}$ & $\begin{array}{r}9,301 \\
5,882 \\
8,294 \\
12,184 \\
10,817\end{array}$ & $\begin{array}{l}5,607 \\
3,933 \\
5,684 \\
5,604 \\
6,715\end{array}$ & $\begin{array}{l}4,545 \\
3,190 \\
4,549 \\
3,850 \\
4,050\end{array}$ & $\begin{array}{l}21,683 \\
16,543 \\
25,067 \\
22,891 \\
26,762\end{array}$ & $\begin{array}{l}34,832 \\
28,113 \\
38,411 \\
42,432 \\
44,511\end{array}$ & $\begin{array}{l}25,568 \\
19,692 \\
28,555 \\
31,402 \\
32,685\end{array}$ & $\begin{array}{l}35,367 \\
29,230 \\
40,655 \\
44,407 \\
46,114\end{array}$ & $\begin{array}{l}25,756 \\
20,572 \\
30,195 \\
32,949 \\
33,940\end{array}$ & $\begin{array}{l}4,884 \\
4,353 \\
5,411 \\
6,286 \\
6,680\end{array}$ & $\begin{array}{l}4,728 \\
4,305 \\
5,049 \\
5,173 \\
5,494\end{array}$ & $\begin{array}{l}3,349 \\
2,732 \\
3,561 \\
3,936 \\
3,676\end{array}$ & $\begin{array}{l}3,480 \\
2,904 \\
3,752 \\
4,133 \\
3,950\end{array}$ & $\begin{array}{r}7,421 \\
7,101 \\
7,689 \\
11,009 \\
10,582\end{array}$ \\
\hline 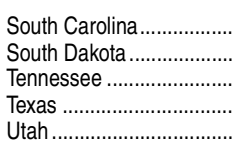 & $\begin{array}{l}18,073 \\
13,327 \\
14,612 \\
15,364 \\
11,297\end{array}$ & $\begin{array}{r}10,366 \\
6,948 \\
7,005 \\
7,124 \\
5,166\end{array}$ & $\begin{array}{l}18,655 \\
13,858 \\
15,416 \\
15,940 \\
12,076\end{array}$ & $\begin{array}{r}10,691 \\
7,413 \\
7,472 \\
7,402 \\
5,375\end{array}$ & $\begin{array}{l}4,841 \\
2,983 \\
4,337 \\
4,556 \\
2,938\end{array}$ & $\begin{array}{l}3,122 \\
3,462 \\
3,607 \\
3,983 \\
3,763\end{array}$ & $\begin{array}{r}26,042 \\
9,654 \\
22,412 \\
20,044 \\
16,631\end{array}$ & $\begin{array}{l}27,927 \\
25,121 \\
29,941 \\
33,308 \\
15,224\end{array}$ & $\begin{array}{r}20,038 \\
18,035 \\
21,215 \\
24,051 \\
7,677\end{array}$ & $\begin{array}{l}29,165 \\
25,796 \\
31,135 \\
34,861 \\
15,330\end{array}$ & $\begin{array}{r}20,990 \\
18,843 \\
22,046 \\
25,174 \\
7,758\end{array}$ & $\begin{array}{l}4,092 \\
3,260 \\
5,067 \\
5,363 \\
3,844\end{array}$ & $\begin{array}{l}4,084 \\
3,693 \\
4,023 \\
4,323 \\
3,728\end{array}$ & $\begin{array}{l}3,710 \\
4,802 \\
3,380 \\
1,750 \\
3,021\end{array}$ & $\begin{array}{l}3,820 \\
5,066 \\
3,526 \\
1,815 \\
3,170\end{array}$ & $\begin{array}{r}7,910 \\
5,261 \\
13,682 \\
5,075 \\
10,012\end{array}$ \\
\hline 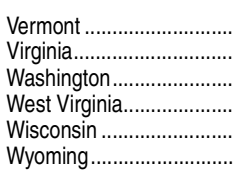 & $\begin{array}{l}22,504 \\
17,963 \\
17,690 \\
13,476 \\
14,718 \\
12,022\end{array}$ & $\begin{array}{r}13,084 \\
9,366 \\
7,789 \\
5,261 \\
7,864 \\
3,501\end{array}$ & $\begin{array}{l}23,290 \\
18,843 \\
18,925 \\
14,126 \\
15,446 \\
12,479\end{array}$ & $\begin{array}{r}13,524 \\
9,866 \\
8,856 \\
5,599 \\
8,339 \\
3,642\end{array}$ & $\begin{array}{l}6,160 \\
5,033 \\
5,319 \\
4,508 \\
4,166 \\
3,901\end{array}$ & $\begin{array}{l}3,607 \\
3,944 \\
4,750 \\
4,018 \\
2,940 \\
4,936\end{array}$ & $\begin{array}{l}32,650 \\
27,079 \\
26,314 \\
16,582 \\
20,146 \\
10,962\end{array}$ & $\begin{array}{r}43,752 \\
29,050 \\
38,443 \\
18,124 \\
32,830 \\
\dagger\end{array}$ & $\begin{array}{l}33,174 \\
20,641 \\
28,572 \\
10,229 \\
24,303 \\
14,177\end{array}$ & $\begin{array}{r}46,255 \\
30,483 \\
40,293 \\
19,120 \\
34,199 \\
\dagger\end{array}$ & $\begin{array}{l}35,130 \\
21,524 \\
30,133 \\
10,721 \\
25,500 \\
13,562\end{array}$ & $\begin{array}{r}5,983 \\
4,468 \\
5,409 \\
3,997 \\
4,689 \\
\dagger\end{array}$ & $\begin{array}{r}5,142 \\
4,491 \\
4,752 \\
4,402 \\
4,010 \\
\dagger\end{array}$ & $\begin{array}{l}5,236 \\
3,749 \\
3,713 \\
3,011 \\
3,874 \\
2,305\end{array}$ & $\begin{array}{l}5,452 \\
3,910 \\
3,957 \\
3,135 \\
4,073 \\
2,420\end{array}$ & $\begin{array}{r}10,804 \\
8,592 \\
6,983 \\
7,798 \\
6,824 \\
5,998\end{array}$ \\
\hline
\end{tabular}

†Not applicable.

NOTE: Data are for the entire academic year and are average charges for full-time students. In-state tuition and fees were weighted by the number of full-time-equivalent undergraduates, but were not adjusted to reflect the number of students who were state residents. Out-of-state tuition and fees were weighted by the number of first-time freshmen attending the institution of full-time students. Degree-granting institutions grant associate's or higher degrees and par- ticipate in Title IV federal financial aid programs. Some data have been revised from previously published figures. Detail may not sum to totals because of rounding.

SOURCE: U.S. Department of Education, National Center for Education Statistics, Integrated Postsecondary Education Data System (IPEDS), Fall 2011 and Fall 2012, Institutional Characteristics component; and Spring 2012 and Spring 2013, Enrollment component. (This table was prepared December 2013.) 
630 CHAPTER 3: Postsecondary Education

Student Charges

Table 330.30. Average undergraduate tuition, fees, room, and board rates for full-time students in degree-granting postsecondary institutions, by percentile, control, and level of institution: Selected years, 2000-01 through 2012-13

[In current dollars]

\begin{tabular}{|c|c|c|c|c|c|c|c|c|c|c|}
\hline \multirow[b]{2}{*}{$\begin{array}{l}\text { Control and level of } \\
\text { institution, and year }\end{array}$} & \multicolumn{5}{|c|}{ Tuition, fees, room, and board } & \multicolumn{5}{|c|}{ Tuition and required fees } \\
\hline & $\begin{array}{r}10 \text { th } \\
\text { percentile }\end{array}$ & $\begin{array}{r}25 \text { th } \\
\text { percentile }\end{array}$ & $\begin{array}{r}\text { Median (50th } \\
\text { percentile) }\end{array}$ & $\begin{array}{r}75 \text { th } \\
\text { percentile }\end{array}$ & $\begin{array}{r}\text { 90th } \\
\text { percentile }\end{array}$ & $\begin{array}{r}10 \text { th } \\
\text { percentile }\end{array}$ & $\begin{array}{r}25 \text { th } \\
\text { percentile }\end{array}$ & $\begin{array}{r}\text { Median (50th } \\
\text { percentile) }\end{array}$ & $\begin{array}{r}75 \text { th } \\
\text { percentile }\end{array}$ & $\begin{array}{r}\text { 90th } \\
\text { percentile }\end{array}$ \\
\hline 1 & 2 & 3 & 4 & 5 & 6 & 7 & 8 & 9 & 10 & 11 \\
\hline $\begin{array}{l}\text { All public institutions }{ }^{1} \\
2000-01 \ldots \\
2005-06 \\
2009-10 \\
2010-11\end{array}$ & $\begin{array}{r}\$ 5,741 \\
7,700 \\
9,433 \\
9,889 \\
10,730 \\
11,283\end{array}$ & $\begin{array}{r}\$ 6,880 \\
9,623 \\
12,069 \\
12,856 \\
13,650 \\
14,426\end{array}$ & $\begin{array}{l}\$ 8,279 \\
11,348 \\
14,446 \\
15,234 \\
16,274 \\
17,012\end{array}$ & $\begin{array}{l}\$ 9,617 \\
13,543 \\
17,146 \\
17,860 \\
18,801 \\
19,481\end{array}$ & $\begin{array}{r}\$ 11,384 \\
16,264 \\
19,898 \\
21,593 \\
22,697 \\
23,298\end{array}$ & $\begin{array}{r}\$ 612 \\
990 \\
1,200 \\
1,230 \\
1,408 \\
1,536\end{array}$ & $\begin{array}{r}\$ 1,480 \\
2,070 \\
2,492 \\
2,628 \\
2,907 \\
3,048\end{array}$ & $\begin{array}{r}\$ 2,403 \\
3,329 \\
4,370 \\
4,632 \\
5,187 \\
5,576\end{array}$ & $\begin{array}{r}\$ 3,444 \\
5,322 \\
6,726 \\
7,127 \\
7,653 \\
8,132\end{array}$ & $\begin{array}{r}\$ 4,583 \\
6,972 \\
8,726 \\
9,420 \\
10,164 \\
10,514\end{array}$ \\
\hline 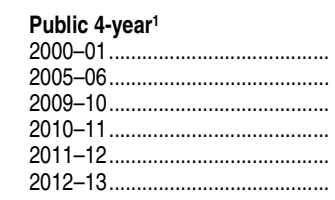 & $\begin{array}{r}6,503 \\
8,863 \\
11,158 \\
11,952 \\
12,693 \\
13,324\end{array}$ & $\begin{array}{r}7,347 \\
10,219 \\
12,793 \\
13,604 \\
14,478 \\
15,102\end{array}$ & $\begin{array}{r}8,468 \\
11,596 \\
15,040 \\
15,788 \\
16,860 \\
17,561\end{array}$ & $\begin{array}{r}9,816 \\
13,830 \\
17,661 \\
18,419 \\
19,137 \\
19,713\end{array}$ & $\begin{array}{l}11,611 \\
16,443 \\
20,253 \\
22,191 \\
23,024 \\
23,686\end{array}$ & $\begin{array}{l}2,118 \\
3,094 \\
4,044 \\
4,336 \\
4,703 \\
4,982\end{array}$ & $\begin{array}{l}2,520 \\
3,822 \\
4,900 \\
5,105 \\
5,765 \\
6,180\end{array}$ & $\begin{array}{l}3,314 \\
5,084 \\
6,458 \\
6,780 \\
7,175 \\
7,554\end{array}$ & $\begin{array}{l}4,094 \\
6,458 \\
8,266 \\
8,689 \\
9,367 \\
9,769\end{array}$ & $\begin{array}{r}5,085 \\
8,097 \\
9,886 \\
11,029 \\
12,612 \\
12,692\end{array}$ \\
\hline 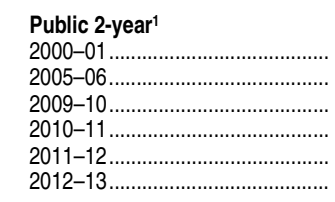 & $\begin{array}{l}3,321 \\
4,380 \\
5,114 \\
5,347 \\
5,770 \\
5,812\end{array}$ & $\begin{array}{l}3,804 \\
4,822 \\
6,008 \\
6,327 \\
6,703 \\
6,536\end{array}$ & $\begin{array}{l}4,627 \\
6,234 \\
7,048 \\
7,340 \\
7,831 \\
8,291\end{array}$ & $\begin{array}{r}5,750 \\
7,567 \\
8,981 \\
9,370 \\
9,674 \\
10,282\end{array}$ & $\begin{array}{r}6,871 \\
8,993 \\
10,977 \\
11,312 \\
11,567 \\
12,464\end{array}$ & $\begin{array}{r}310 \\
691 \\
704 \\
700 \\
960 \\
1,183\end{array}$ & $\begin{array}{r}724 \\
1,109 \\
1,316 \\
1,412 \\
1,600 \\
1,627\end{array}$ & $\begin{array}{l}1,387 \\
1,920 \\
2,380 \\
2,537 \\
2,704 \\
2,804\end{array}$ & $\begin{array}{l}1,799 \\
2,589 \\
3,090 \\
3,315 \\
3,542 \\
3,717\end{array}$ & $\begin{array}{l}2,460 \\
3,100 \\
3,650 \\
3,840 \\
4,132 \\
4,352\end{array}$ \\
\hline 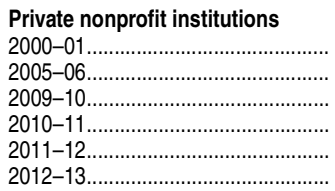 & $\begin{array}{l}13,514 \\
18,243 \\
22,334 \\
23,125 \\
24,471 \\
24,955\end{array}$ & $\begin{array}{l}17,552 \\
23,258 \\
28,699 \\
29,865 \\
31,398 \\
32,582\end{array}$ & $\begin{array}{l}22,493 \\
29,497 \\
36,550 \\
38,063 \\
39,540 \\
41,412\end{array}$ & $\begin{array}{l}27,430 \\
35,918 \\
44,895 \\
46,737 \\
49,146 \\
51,744\end{array}$ & $\begin{array}{l}32,659 \\
41,707 \\
50,297 \\
52,229 \\
54,258 \\
56,419\end{array}$ & $\begin{array}{r}7,800 \\
9,981 \\
11,696 \\
11,794 \\
11,986 \\
12,048\end{array}$ & $\begin{array}{l}11,730 \\
15,375 \\
18,970 \\
19,610 \\
20,230 \\
21,152\end{array}$ & $\begin{array}{l}15,540 \\
21,070 \\
25,890 \\
26,920 \\
28,128 \\
29,312\end{array}$ & $\begin{array}{l}19,600 \\
26,265 \\
32,816 \\
34,250 \\
35,992 \\
37,830\end{array}$ & $\begin{array}{l}24,532 \\
31,690 \\
38,690 \\
40,082 \\
41,576 \\
43,204\end{array}$ \\
\hline 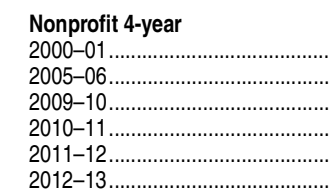 & $\begin{array}{l}13,972 \\
18,350 \\
22,356 \\
23,548 \\
24,608 \\
25,183\end{array}$ & $\begin{array}{l}17,714 \\
23,322 \\
28,840 \\
29,884 \\
31,460 \\
32,668\end{array}$ & $\begin{array}{l}22,554 \\
29,598 \\
36,665 \\
38,129 \\
39,596 \\
41,476\end{array}$ & $\begin{array}{l}27,476 \\
36,028 \\
44,895 \\
46,737 \\
49,146 \\
51,750\end{array}$ & $\begin{array}{l}32,659 \\
41,774 \\
50,298 \\
52,229 \\
54,258 \\
56,419\end{array}$ & $\begin{array}{r}8,450 \\
10,300 \\
12,240 \\
12,220 \\
12,338 \\
12,464\end{array}$ & $\begin{array}{l}11,920 \\
15,560 \\
19,200 \\
19,854 \\
20,640 \\
21,496\end{array}$ & $\begin{array}{l}15,746 \\
21,190 \\
26,180 \\
27,100 \\
28,310 \\
29,460\end{array}$ & $\begin{array}{l}19,730 \\
26,500 \\
32,910 \\
34,417 \\
36,130 \\
38,000\end{array}$ & $\begin{array}{l}24,532 \\
31,690 \\
38,690 \\
40,082 \\
41,576 \\
43,204\end{array}$ \\
\hline 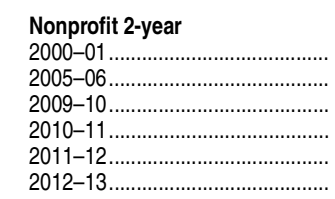 & $\begin{array}{r}6,850 \\
8,030 \\
13,105 \\
10,393 \\
19,325 \\
20,135\end{array}$ & $\begin{array}{r}6,850 \\
15,680 \\
18,316 \\
19,718 \\
20,300 \\
22,399\end{array}$ & $\begin{array}{r}9,995 \\
16,830 \\
20,369 \\
21,186 \\
22,303 \\
24,480\end{array}$ & $\begin{array}{l}14,209 \\
20,829 \\
26,455 \\
27,386 \\
28,506 \\
28,882\end{array}$ & $\begin{array}{l}20,240 \\
28,643 \\
40,733 \\
30,758 \\
32,679 \\
30,114\end{array}$ & $\begin{array}{l}2,430 \\
4,218 \\
3,530 \\
3,840 \\
7,036 \\
7,124\end{array}$ & $\begin{array}{r}4,825 \\
8,640 \\
8,950 \\
9,730 \\
10,904 \\
11,640\end{array}$ & $\begin{array}{r}7,250 \\
9,940 \\
12,292 \\
12,000 \\
14,531 \\
14,944\end{array}$ & $\begin{array}{r}8,266 \\
12,270 \\
15,177 \\
14,640 \\
16,131 \\
16,162\end{array}$ & $\begin{array}{l}11,100 \\
14,472 \\
19,000 \\
18,965 \\
19,880 \\
19,220\end{array}$ \\
\hline 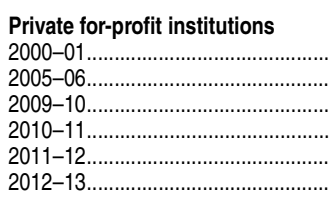 & $\begin{array}{l}13,396 \\
17,278 \\
17,789 \\
16,097 \\
15,827 \\
16,115\end{array}$ & $\begin{array}{l}15,778 \\
19,098 \\
17,789 \\
16,097 \\
15,827 \\
16,115\end{array}$ & $\begin{array}{l}19,403 \\
25,589 \\
21,321 \\
17,484 \\
15,827 \\
16,115\end{array}$ & $\begin{array}{l}21,400 \\
26,499 \\
31,433 \\
26,175 \\
25,518 \\
22,612\end{array}$ & $\begin{array}{l}21,845 \\
31,903 \\
32,000 \\
31,639 \\
31,639 \\
32,239\end{array}$ & $\begin{array}{r}6,900 \\
7,632 \\
9,792 \\
10,200 \\
9,763 \\
9,936\end{array}$ & $\begin{array}{r}8,202 \\
10,011 \\
9,792 \\
11,520 \\
11,415 \\
11,202\end{array}$ & $\begin{array}{r}9,644 \\
12,450 \\
12,392 \\
13,700 \\
12,800 \\
12,685\end{array}$ & $\begin{array}{l}12,090 \\
14,335 \\
15,450 \\
16,440 \\
15,605 \\
16,156\end{array}$ & $\begin{array}{l}14,600 \\
17,740 \\
19,950 \\
18,209 \\
18,048 \\
18,650\end{array}$ \\
\hline 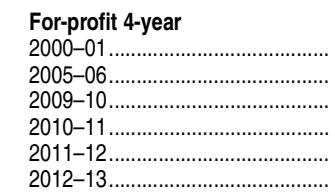 & $\begin{array}{l}13,396 \\
17,383 \\
17,789 \\
16,097 \\
15,827 \\
16,115\end{array}$ & $\begin{array}{l}15,818 \\
19,098 \\
17,789 \\
16,097 \\
15,827 \\
16,115\end{array}$ & $\begin{array}{l}20,417 \\
25,589 \\
21,321 \\
17,484 \\
15,827 \\
16,115\end{array}$ & $\begin{array}{l}21,400 \\
26,499 \\
31,433 \\
26,175 \\
25,518 \\
21,697\end{array}$ & $\begin{array}{l}21,400 \\
31,903 \\
32,000 \\
31,639 \\
31,639 \\
32,239\end{array}$ & $\begin{array}{r}7,206 \\
7,632 \\
9,792 \\
10,200 \\
9,648 \\
9,936\end{array}$ & $\begin{array}{r}8,305 \\
10,418 \\
9,792 \\
11,520 \\
11,415 \\
11,202\end{array}$ & $\begin{array}{r}9,675 \\
12,900 \\
11,920 \\
14,085 \\
12,682 \\
12,110\end{array}$ & $\begin{array}{l}12,800 \\
14,450 \\
15,071 \\
16,500 \\
15,660 \\
16,156\end{array}$ & $\begin{array}{l}15,090 \\
17,735 \\
19,080 \\
18,050 \\
18,050 \\
18,650\end{array}$ \\
\hline $\begin{array}{l}\text { For-profit 2-year } \\
2000-01 \ldots \ldots \ldots \\
2005-06 \ldots \ldots \ldots \ldots \\
2009-10 \ldots \ldots \ldots \ldots \ldots \ldots \ldots \ldots \ldots\end{array}$ & $\begin{array}{l}15,778 \\
13,010 \\
22,857 \\
23,687 \\
24,366 \\
23,600\end{array}$ & $\begin{array}{l}15,778 \\
18,281 \\
22,857 \\
23,687 \\
24,366 \\
23,600\end{array}$ & $\begin{array}{l}19,403 \\
43,425 \\
26,696 \\
25,161 \\
25,172 \\
23,600\end{array}$ & $\begin{array}{l}21,845 \\
43,425 \\
26,696 \\
25,161 \\
25,172 \\
25,866\end{array}$ & $\begin{array}{l}21,845 \\
43,425 \\
26,696 \\
25,161 \\
25,172 \\
25,866\end{array}$ & $\begin{array}{r}6,025 \\
7,870 \\
10,116 \\
9,940 \\
10,620 \\
10,425\end{array}$ & $\begin{array}{r}7,365 \\
9,285 \\
11,735 \\
12,094 \\
12,094 \\
12,314\end{array}$ & $\begin{array}{r}9,644 \\
11,550 \\
13,548 \\
13,599 \\
13,500 \\
13,240\end{array}$ & $\begin{array}{l}12,000 \\
14,196 \\
17,148 \\
15,960 \\
15,064 \\
15,552\end{array}$ & $\begin{array}{l}14,255 \\
19,425 \\
21,245 \\
20,533 \\
17,762 \\
18,048\end{array}$ \\
\hline
\end{tabular}

${ }^{1}$ Average undergraduate tuition and fees are based on in-state students only.

NOTE: Data are for the entire academic year and are average charges for full-time students. Student charges were weighted by the number of full-time-equivalent undergraduates, but were not adjusted to reflect student residency. The data have not been adjusted for changes in the purchasing power of the dollar. Degree-granting institutions grant associate's or higher degrees and participate in Title IV federal financial aid programs.
SOURCE: US. Department of Education, National Center for Education Statistics, Integrated Postsecondary Education Data System (IPEDS), Fall 2000 through Fall 2012, Institutional Characteristics component; and Spring 2001 through Spring 2013, Enrollment component. (This table was prepared December 2013.) 


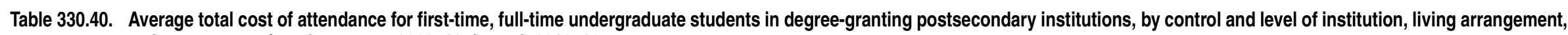
and component of student costs: 2009-10 through 2012-13

[In current dollars]

\begin{tabular}{|c|c|c|c|c|c|c|c|c|c|c|c|c|c|c|c|c|}
\hline \multirow{3}{*}{$\begin{array}{l}\text { Level of institution, living arrangement, and } \\
\text { component of student costs }\end{array}$} & \multicolumn{4}{|c|}{ 2009-10 } & \multicolumn{4}{|c|}{$2010-11$} & \multicolumn{4}{|c|}{ 2011-12 } & \multicolumn{4}{|c|}{ 2012-13 } \\
\hline & \multirow{2}{*}{$\begin{array}{r}\text { All } \\
\text { institutions }\end{array}$} & \multirow{2}{*}{$\begin{array}{r}\text { Public, } \\
\text { in-state }\end{array}$} & \multicolumn{2}{|c|}{ Private } & \multirow{2}{*}{$\begin{array}{r}\text { All } \\
\text { institutions }\end{array}$} & \multirow{2}{*}{$\begin{array}{r}\text { Public, } \\
\text { in-state }\end{array}$} & \multicolumn{2}{|c|}{ Private } & \multirow{2}{*}{$\begin{array}{r}\text { All } \\
\text { institutions } \\
\end{array}$} & \multirow{2}{*}{$\begin{array}{r}\text { Public, } \\
\text { in-state }\end{array}$} & \multicolumn{2}{|c|}{ Private } & \multirow{2}{*}{$\begin{array}{r}\text { All } \\
\text { institutions } \\
\end{array}$} & \multirow{2}{*}{$\begin{array}{r}\text { Public, } \\
\text { in-state }\end{array}$} & \multicolumn{2}{|c|}{ Private } \\
\hline & & & Nonprofit & For-profit & & & Nonprofit & For-profit & & & Nonprofit & For-profit & & & Nonprofit & For-profit \\
\hline 1 & 2 & 3 & 4 & 5 & 6 & 7 & 8 & 9 & 10 & 11 & 12 & 13 & 14 & 15 & 16 & 17 \\
\hline \multicolumn{17}{|l|}{ 4-year institutions } \\
\hline 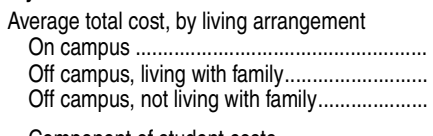 & $\begin{array}{r}\$ 26,380 \\
19,491 \\
28,312\end{array}$ & $\begin{array}{r}\$ 19,312 \\
12,103 \\
20,952\end{array}$ & $\begin{array}{r}\$ 38,240 \\
30,456 \\
38,753\end{array}$ & $\begin{array}{r}\$ 28,555 \\
18,969 \\
27,412\end{array}$ & $\begin{array}{r}\$ 27,435 \\
19,940 \\
29,390\end{array}$ & $\begin{array}{r}\$ 20,114 \\
12,561 \\
21,665\end{array}$ & $\begin{array}{r}\$ 39,772 \\
31,630 \\
40,148\end{array}$ & $\begin{array}{r}\$ 30,130 \\
20,226 \\
29,114\end{array}$ & $\begin{array}{r}\$ 28,739 \\
20,989 \\
29,736\end{array}$ & $\begin{array}{r}\$ 20,997 \\
13,328 \\
22,364\end{array}$ & $\begin{array}{r}\$ 41,418 \\
32,939 \\
41,582\end{array}$ & $\begin{array}{r}\$ 30,840 \\
22,595 \\
30,121\end{array}$ & $\begin{array}{r}\$ 29,408 \\
21,272 \\
29,818\end{array}$ & $\begin{array}{r}\$ 21,683 \\
13,648 \\
22,763\end{array}$ & $\begin{array}{r}\$ 42,962 \\
34,136 \\
42,516\end{array}$ & $\begin{array}{r}\$ 30,187 \\
21,902 \\
28,774\end{array}$ \\
\hline 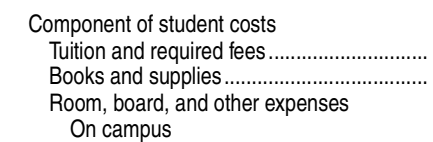 & $\begin{array}{r}13,994 \\
1,055\end{array}$ & $\begin{array}{l}6,893 \\
1,166\end{array}$ & $\begin{array}{r}25,702 \\
1,179\end{array}$ & $\begin{array}{r}13,242 \\
523\end{array}$ & $\begin{array}{r}14,551 \\
1,134\end{array}$ & $\begin{array}{l}7,249 \\
1,194\end{array}$ & $\begin{array}{r}26,769 \\
1,217\end{array}$ & $\begin{array}{r}14,236 \\
799\end{array}$ & $\begin{array}{r}15,359 \\
1,245\end{array}$ & $\begin{array}{l}7,731 \\
1,232\end{array}$ & $\begin{array}{r}27,949 \\
1,238\end{array}$ & $\begin{array}{r}15,643 \\
1,416\end{array}$ & $\begin{array}{r}15,639 \\
1,250\end{array}$ & $\begin{array}{l}8,005 \\
1,243\end{array}$ & $\begin{array}{r}29,115 \\
1,243\end{array}$ & $\begin{array}{r}14,914 \\
1,393\end{array}$ \\
\hline 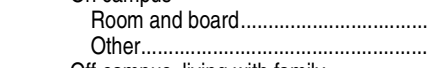 & $\begin{array}{l}8,561 \\
2,770\end{array}$ & $\begin{array}{l}8,134 \\
3,118\end{array}$ & $\begin{array}{l}9,071 \\
2,288\end{array}$ & $\begin{array}{r}10,420 \\
4,370\end{array}$ & $\begin{array}{l}8,921 \\
2,829\end{array}$ & $\begin{array}{l}8,502 \\
3,169\end{array}$ & $\begin{array}{l}9,464 \\
2,323\end{array}$ & $\begin{array}{l}9,370 \\
5,726\end{array}$ & $\begin{array}{l}9,271 \\
2,864\end{array}$ & $\begin{array}{l}8,831 \\
3,203\end{array}$ & $\begin{array}{l}9,853 \\
2,378\end{array}$ & $\begin{array}{l}9,533 \\
4,249\end{array}$ & $\begin{array}{l}9,600 \\
2,920\end{array}$ & $\begin{array}{l}9,183 \\
3,253\end{array}$ & $\begin{array}{r}10,181 \\
2,423\end{array}$ & $\begin{array}{l}9,608 \\
4,271\end{array}$ \\
\hline $\begin{array}{l}\text { Off campus, living with family } \\
\text { Other.................................... } \\
\text { Off campus, not living with family }\end{array}$ & 4,442 & 4,044 & 3,575 & 5,204 & 4,256 & 4,118 & 3,645 & 5,191 & 4,385 & 4,365 & 3,752 & 5,537 & 4,383 & 4,401 & 3,778 & 5,594 \\
\hline 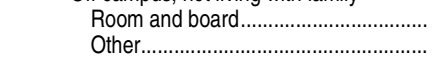 & $\begin{array}{l}8,584 \\
4,680 \\
\end{array}$ & $\begin{array}{l}8,924 \\
3,968 \\
\end{array}$ & $\begin{array}{l}8,140 \\
3,732 \\
\end{array}$ & $\begin{array}{l}8,472 \\
5,175 \\
\end{array}$ & $\begin{array}{l}8,679 \\
5,026 \\
\end{array}$ & $\begin{array}{l}9,085 \\
4,137 \\
\end{array}$ & $\begin{array}{l}8,391 \\
3,772 \\
\end{array}$ & $\begin{array}{l}8,543 \\
5,536 \\
\end{array}$ & $\begin{array}{l}8,759 \\
4,372 \\
\end{array}$ & $\begin{array}{l}9,263 \\
4,138 \\
\end{array}$ & $\begin{array}{l}8,421 \\
3,974 \\
\end{array}$ & $\begin{array}{l}8,256 \\
4,807 \\
\end{array}$ & $\begin{array}{l}8,485 \\
4,443 \\
\end{array}$ & $\begin{array}{l}9,297 \\
4,218 \\
\end{array}$ & $\begin{array}{l}8,267 \\
3,891 \\
\end{array}$ & $\begin{array}{l}7,584 \\
4,883 \\
\end{array}$ \\
\hline 2-year institutions & & & & & & & & & & & & & & & & \\
\hline 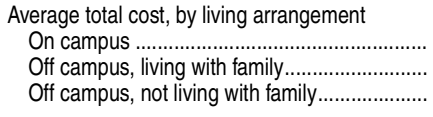 & $\begin{array}{r}\$ 14,398 \\
9,822 \\
17,294\end{array}$ & $\begin{array}{r}\$ 11,815 \\
7,579 \\
14,873\end{array}$ & $\begin{array}{r}\$ 23,553 \\
17,311 \\
25,754\end{array}$ & $\begin{array}{r}\$ 29,352 \\
20,477 \\
28,201\end{array}$ & $\begin{array}{r}\$ 15,267 \\
10,451 \\
17,934\end{array}$ & $\begin{array}{r}\$ 12,398 \\
7,933 \\
15,278\end{array}$ & $\begin{array}{r}\$ 24,654 \\
17,334 \\
25,773\end{array}$ & $\begin{array}{r}\$ 29,587 \\
21,143 \\
28,805\end{array}$ & $\begin{array}{r}\$ 14,383 \\
9,421 \\
16,882\end{array}$ & $\begin{array}{r}\$ 12,823 \\
8,150 \\
15,526\end{array}$ & $\begin{array}{r}\$ 26,840 \\
20,324 \\
29,301\end{array}$ & $\begin{array}{r}\$ 27,713 \\
19,692 \\
27,362\end{array}$ & $\begin{array}{r}\$ 14,608 \\
9,385 \\
16,980\end{array}$ & $\begin{array}{r}\$ 13,277 \\
8,339 \\
15,896\end{array}$ & $\begin{array}{r}\$ 27,478 \\
19,921 \\
28,647\end{array}$ & $\begin{array}{r}\$ 28,246 \\
20,086 \\
27,591\end{array}$ \\
\hline $\begin{array}{l}\text { Component of student costs } \\
\text { Tuition and required fees................... } \\
\text { Books and supplies................... } \\
\text { Room, board, and other expenses } \\
\text { On campus }\end{array}$ & $\begin{array}{l}4,816 \\
1,255\end{array}$ & $\begin{array}{l}2,640 \\
1,235\end{array}$ & $\begin{array}{r}12,698 \\
1,229\end{array}$ & $\begin{array}{r}14,918 \\
1,392\end{array}$ & $\begin{array}{l}5,230 \\
1,324\end{array}$ & $\begin{array}{l}2,794 \\
1,292\end{array}$ & $\begin{array}{r}12,839 \\
1,276\end{array}$ & $\begin{array}{r}15,373 \\
1,514\end{array}$ & $\begin{array}{l}4,222 \\
1,314\end{array}$ & $\begin{array}{l}2,970 \\
1,314\end{array}$ & $\begin{array}{r}14,335 \\
1,413\end{array}$ & $\begin{array}{r}14,343 \\
1,301\end{array}$ & $\begin{array}{l}4,109 \\
1,339\end{array}$ & $\begin{array}{l}3,080 \\
1,341\end{array}$ & $\begin{array}{r}14,496 \\
1,373\end{array}$ & $\begin{array}{r}14,511 \\
1,300\end{array}$ \\
\hline 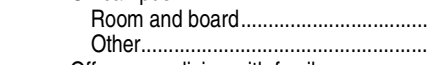 & $\begin{array}{l}5,518 \\
2,809\end{array}$ & $\begin{array}{l}5,186 \\
2,754\end{array}$ & $\begin{array}{l}7,061 \\
2,565\end{array}$ & $\begin{array}{l}8,979 \\
4,063\end{array}$ & $\begin{array}{l}5,719 \\
2,994\end{array}$ & $\begin{array}{l}5,384 \\
2,928\end{array}$ & $\begin{array}{l}7,460 \\
3,079\end{array}$ & $\begin{array}{l}8,628 \\
4,071\end{array}$ & $\begin{array}{l}5,829 \\
3,018\end{array}$ & $\begin{array}{l}5,552 \\
2,988\end{array}$ & $\begin{array}{l}7,880 \\
3,212\end{array}$ & $\begin{array}{l}8,655 \\
3,414\end{array}$ & $\begin{array}{l}6,093 \\
3,068\end{array}$ & $\begin{array}{l}5,817 \\
3,040\end{array}$ & $\begin{array}{l}8,443 \\
3,167\end{array}$ & $\begin{array}{l}8,753 \\
3,682\end{array}$ \\
\hline $\begin{array}{l}\text { Off campus, living with family } \\
\text { Other........................................... } \\
\text { Off campus, not living with family }\end{array}$ & 3,751 & 3,704 & 3,384 & 4,167 & 3,897 & 3,847 & 3,219 & 4,256 & 3,884 & 3,866 & 4,576 & 4,048 & 3,937 & 3,919 & 4,052 & 4,274 \\
\hline 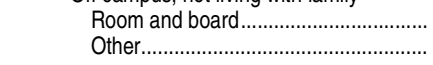 & $\begin{array}{l}7,494 \\
3,729\end{array}$ & $\begin{array}{l}7,344 \\
3,654\end{array}$ & $\begin{array}{l}8,105 \\
3,721\end{array}$ & $\begin{array}{l}7,933 \\
3,958\end{array}$ & $\begin{array}{l}7,539 \\
3,841\end{array}$ & $\begin{array}{l}7,428 \\
3,763\end{array}$ & $\begin{array}{l}8,267 \\
3,391\end{array}$ & $\begin{array}{l}7,836 \\
4,082\end{array}$ & $\begin{array}{l}7,507 \\
3,839\end{array}$ & $\begin{array}{l}7,466 \\
3,776\end{array}$ & $\begin{array}{l}8,270 \\
5,283\end{array}$ & $\begin{array}{l}7,670 \\
4,048\end{array}$ & $\begin{array}{l}7,662 \\
3,870\end{array}$ & $\begin{array}{l}7,645 \\
3,830\end{array}$ & $\begin{array}{l}8,045 \\
4,734\end{array}$ & $\begin{array}{l}7,737 \\
4,043\end{array}$ \\
\hline
\end{tabular}

NOTE: Excludes students who previously attended another postsecondary institution or who began their studies on a parttime basis. Tuition and fees at public institutions are the lower of either in-district or in-state tuition and fees. Data illustrating
the average total cost of attendance for all students are weighted by the number of students at the institution receiving Title IV

SOURCE: U.S. Department of Education, National Center for Education Statistics, Integrated Postsecondary Education Data System (IPEDS), Spring 2010 through Spring 2013, Student Financial Aid component; and Fall 2009 through Fall 2012, Instiaid. Detail may not sum to totals because of rounding.
a ding tutional Characteristics component. (This table was prepared November 2013.) 
Table 330.50. Average graduate tuition and required fees in degree-granting postsecondary institutions, by control of institution and percentile: 1989-90 through 2012-13

\begin{tabular}{|c|c|c|c|c|c|c|c|c|c|c|c|}
\hline \multirow[b]{2}{*}{ Year } & \multirow[b]{2}{*}{ Total } & \multirow[b]{2}{*}{$\begin{array}{r}\text { Public } \\
\text { institutions }^{1}\end{array}$} & \multicolumn{3}{|c|}{ Private institutions } & \multicolumn{3}{|c|}{ Public institutions, ${ }^{1}$ by percentile } & \multicolumn{3}{|c|}{ Nonprofit institutions, by percentile } \\
\hline & & & Total & Nonprofit & For-profit & $\begin{array}{r}25 \text { th } \\
\text { percentile }\end{array}$ & $\begin{array}{r}\text { Median (50th } \\
\text { percentile) }\end{array}$ & $\begin{array}{r}\text { 75th } \\
\text { percentile }\end{array}$ & $\begin{array}{r}25 \text { th } \\
\text { percentile }\end{array}$ & $\begin{array}{r}\text { Median (50th } \\
\text { percentile) }\end{array}$ & $\begin{array}{r}\text { 75th } \\
\text { percentile }\end{array}$ \\
\hline \multirow[t]{2}{*}{1} & 2 & 3 & 4 & 5 & 6 & 7 & 8 & 9 & 10 & 11 & 12 \\
\hline & \multicolumn{11}{|c|}{ Current dollars } \\
\hline $\begin{array}{l}1989-90 \ldots \ldots \ldots \ldots \ldots \ldots \\
1990-91 \ldots \ldots \ldots \ldots \ldots \ldots \ldots \ldots \\
1991-92 \ldots \ldots \ldots \ldots \ldots \ldots \ldots \ldots . . . \\
1992-93 \ldots \ldots \ldots \ldots \ldots \ldots \ldots \ldots . . \\
1993-94 \ldots \ldots \ldots \ldots \ldots \ldots \ldots \ldots . .\end{array}$ & $\begin{array}{r}\$ 4,135 \\
4,488 \\
5,116 \\
5,475 \\
5,973\end{array}$ & $\begin{array}{r}\$ 1,999 \\
2,206 \\
2,524 \\
2,791 \\
3,050\end{array}$ & $\begin{array}{r}\$ 7,881 \\
8,507 \\
9,592 \\
10,008 \\
10,790\end{array}$ & $\begin{array}{l}- \\
- \\
- \\
-\end{array}$ & $\begin{array}{l}- \\
- \\
- \\
-\end{array}$ & $\begin{array}{l}- \\
- \\
- \\
-\end{array}$ & $\begin{array}{l}- \\
- \\
- \\
-\end{array}$ & $\begin{array}{l}- \\
- \\
- \\
-\end{array}$ & $\begin{array}{l}- \\
- \\
- \\
-\end{array}$ & $\begin{array}{l}- \\
- \\
- \\
-\end{array}$ & $\begin{array}{l}- \\
- \\
- \\
-\end{array}$ \\
\hline 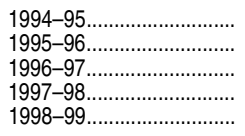 & $\begin{array}{l}6,247 \\
6,741 \\
7,111 \\
7,246 \\
7,685\end{array}$ & $\begin{array}{l}3,250 \\
3,449 \\
3,607 \\
3,744 \\
3,897\end{array}$ & $\begin{array}{l}11,338 \\
12,083 \\
12,537 \\
12,774 \\
13,299\end{array}$ & $\begin{array}{l}- \\
- \\
- \\
-\end{array}$ & $\begin{array}{l}- \\
- \\
- \\
-\end{array}$ & $\begin{array}{l}- \\
- \\
- \\
-\end{array}$ & $\begin{array}{l}- \\
- \\
- \\
-\end{array}$ & $\begin{array}{l}- \\
- \\
- \\
-\end{array}$ & $\begin{array}{l}- \\
- \\
- \\
-\end{array}$ & $\begin{array}{l}- \\
- \\
- \\
-\end{array}$ & $\begin{array}{l}- \\
- \\
- \\
-\end{array}$ \\
\hline $\begin{array}{l}1999-2000 \ldots \ldots \ldots \ldots \ldots \ldots \\
2000-01 \ldots \ldots \ldots \ldots \ldots \ldots \ldots \ldots \\
2001-02 \ldots \ldots \ldots \ldots \ldots \ldots \ldots \ldots \\
2002-03 \ldots \ldots \ldots \ldots \ldots \ldots \ldots \ldots . . . \\
2003-04 \ldots \ldots \ldots \ldots \ldots \ldots \ldots \ldots \ldots\end{array}$ & $\begin{array}{r}8,069 \\
8,429 \\
8,857 \\
9,226 \\
10,312\end{array}$ & $\begin{array}{l}4,042 \\
4,243 \\
4,496 \\
4,842 \\
5,544\end{array}$ & $\begin{array}{l}13,821 \\
14,420 \\
15,165 \\
14,983 \\
16,209\end{array}$ & $\begin{array}{r}\$ 14,123 \\
14,457 \\
15,232 \\
15,676 \\
16,807\end{array}$ & $\begin{array}{r}\$ 9,611 \\
13,229 \\
13,414 \\
9,644 \\
12,542\end{array}$ & $\begin{array}{r}\$ 2,640 \\
2,931 \\
3,226 \\
3,395 \\
3,795\end{array}$ & $\begin{array}{r}\$ 3,637 \\
3,822 \\
4,119 \\
4,452 \\
5,103\end{array}$ & $\begin{array}{r}\$ 5,163 \\
5,347 \\
5,596 \\
5,927 \\
7,063\end{array}$ & $\begin{array}{r}\$ 7,998 \\
8,276 \\
8,583 \\
8,690 \\
9,072\end{array}$ & $\begin{array}{r}\$ 12,870 \\
13,200 \\
14,157 \\
14,140 \\
15,030\end{array}$ & $\begin{array}{r}\$ 20,487 \\
21,369 \\
22,054 \\
22,700 \\
25,600\end{array}$ \\
\hline $\begin{array}{l}2004-05 \ldots \ldots \ldots \ldots \ldots \ldots \ldots \\
2005-06 \ldots \ldots \ldots \ldots \ldots \ldots \ldots \ldots \\
2006-07 \ldots \ldots \ldots \ldots \ldots \ldots \ldots \ldots \ldots \\
2007-08 \ldots \ldots \ldots \ldots \ldots \ldots \ldots \ldots . . . \\
2008-09 \ldots \ldots \ldots \ldots \ldots \ldots \ldots \ldots . . .\end{array}$ & $\begin{array}{l}11,004 \\
11,621 \\
12,312 \\
13,002 \\
13,647\end{array}$ & $\begin{array}{l}6,080 \\
6,493 \\
6,894 \\
7,415 \\
7,999\end{array}$ & $\begin{array}{l}16,751 \\
17,244 \\
18,108 \\
18,878 \\
19,230\end{array}$ & $\begin{array}{l}17,551 \\
18,171 \\
19,033 \\
19,896 \\
20,485\end{array}$ & $\begin{array}{l}13,133 \\
13,432 \\
14,421 \\
14,713 \\
14,418\end{array}$ & $\begin{array}{l}4,236 \\
4,608 \\
4,909 \\
5,176 \\
5,612\end{array}$ & $\begin{array}{l}5,663 \\
6,209 \\
6,594 \\
6,990 \\
7,376\end{array}$ & $\begin{array}{l}7,616 \\
7,977 \\
8,341 \\
9,288 \\
9,912\end{array}$ & $\begin{array}{r}9,300 \\
9,745 \\
10,346 \\
10,705 \\
11,290\end{array}$ & $\begin{array}{l}16,060 \\
16,222 \\
17,057 \\
17,647 \\
18,270\end{array}$ & $\begin{array}{l}26,140 \\
26,958 \\
29,118 \\
30,247 \\
30,514\end{array}$ \\
\hline $\begin{array}{l}2009-10 \ldots \ldots \ldots \ldots \ldots \ldots \\
2010-11 \ldots \ldots \ldots \ldots \ldots \ldots \ldots \ldots \ldots \\
2011-12 \ldots \ldots \ldots \ldots \ldots \ldots \ldots \ldots \\
2012-13 \ldots \ldots \ldots \ldots \ldots \ldots \ldots \ldots . . .\end{array}$ & $\begin{array}{l}14,537 \\
14,993 \\
15,787 \\
16,435 \\
\end{array}$ & $\begin{array}{r}8,763 \\
9,247 \\
9,980 \\
10,408 \\
\end{array}$ & $\begin{array}{l}20,368 \\
20,335 \\
21,105 \\
21,955\end{array}$ & $\begin{array}{l}21,307 \\
21,996 \\
22,872 \\
23,698 \\
\end{array}$ & $\begin{array}{l}14,550 \\
13,506 \\
13,823 \\
14,418 \\
\end{array}$ & $\begin{array}{l}6,084 \\
6,550 \\
7,506 \\
7,706\end{array}$ & $\begin{array}{l}7,983 \\
8,788 \\
9,445 \\
9,900\end{array}$ & $\begin{array}{l}10,658 \\
10,933 \\
11,954 \\
12,590\end{array}$ & $\begin{array}{l}12,285 \\
12,510 \\
12,936 \\
13,030\end{array}$ & $\begin{array}{l}19,350 \\
19,586 \\
20,625 \\
21,352 \\
\end{array}$ & $\begin{array}{l}31,730 \\
33,215 \\
34,680 \\
36,820\end{array}$ \\
\hline & \multicolumn{11}{|c|}{ Constant $2012-13$ dollars } \\
\hline 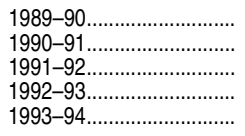 & $\begin{array}{r}\$ 7,534 \\
7,753 \\
8,564 \\
8,887 \\
9,451\end{array}$ & $\begin{array}{r}\$ 3,642 \\
3,811 \\
4,225 \\
4,530 \\
4,826\end{array}$ & $\begin{array}{r}\$ 14,359 \\
14,697 \\
16,056 \\
16,245 \\
17,072\end{array}$ & $\begin{array}{l}- \\
- \\
- \\
-\end{array}$ & $\begin{array}{l}- \\
- \\
- \\
-\end{array}$ & $\begin{array}{l}- \\
- \\
- \\
-\end{array}$ & $\begin{array}{l}- \\
- \\
- \\
-\end{array}$ & $\begin{array}{l}\overline{-} \\
\overline{-} \\
-\end{array}$ & $\begin{array}{l}- \\
- \\
- \\
-\end{array}$ & $\begin{array}{l}- \\
- \\
- \\
-\end{array}$ & $\begin{array}{l}- \\
- \\
- \\
-\end{array}$ \\
\hline $\begin{array}{l}1994-95 \ldots \ldots \ldots \ldots \ldots \ldots \ldots \\
1995-96 \ldots \ldots \ldots \ldots \ldots \ldots \ldots \ldots . . . \\
1996-97 \ldots \ldots \ldots \ldots \ldots \ldots \ldots \ldots . . . \\
1997-98 \ldots \ldots \ldots \ldots \ldots \ldots \ldots \ldots . . . \\
1998-99\end{array}$ & $\begin{array}{r}9,609 \\
10,094 \\
10,353 \\
10,364 \\
10,805\end{array}$ & $\begin{array}{l}4,999 \\
5,165 \\
5,251 \\
5,355 \\
5,479\end{array}$ & $\begin{array}{l}17,440 \\
18,093 \\
18,253 \\
18,272 \\
18,699\end{array}$ & $\begin{array}{l}- \\
- \\
- \\
-\end{array}$ & $\begin{array}{l}- \\
- \\
- \\
-\end{array}$ & $\begin{array}{l}- \\
- \\
- \\
-\end{array}$ & $\begin{array}{l}- \\
- \\
- \\
-\end{array}$ & $\begin{array}{l}- \\
- \\
- \\
-\end{array}$ & $\begin{array}{l}- \\
- \\
- \\
-\end{array}$ & $\begin{array}{l}- \\
- \\
- \\
-\end{array}$ & $\begin{array}{l}- \\
- \\
- \\
-\end{array}$ \\
\hline $\begin{array}{l}1999-2000 \ldots \ldots \ldots \ldots \ldots \ldots \\
2000-01 \ldots \ldots \ldots \ldots \ldots \ldots \ldots \ldots \\
2001-02 \ldots \ldots \ldots \ldots \ldots \ldots \ldots \ldots \\
2002-03 \ldots \ldots \ldots \ldots \ldots \ldots \ldots \ldots \\
2003-04 \ldots \ldots \ldots \ldots \ldots \ldots \ldots \ldots\end{array}$ & $\begin{array}{l}11,027 \\
11,138 \\
11,500 \\
11,720 \\
12,820\end{array}$ & $\begin{array}{l}5,524 \\
5,607 \\
5,837 \\
6,151 \\
6,892\end{array}$ & $\begin{array}{l}18,887 \\
19,053 \\
19,689 \\
19,034 \\
20,151\end{array}$ & $\begin{array}{r}\$ 19,301 \\
19,102 \\
19,777 \\
19,915 \\
20,895\end{array}$ & $\begin{array}{r}\$ 13,134 \\
17,479 \\
17,415 \\
12,252 \\
15,593\end{array}$ & $\begin{array}{r}\$ 3,608 \\
3,873 \\
4,188 \\
4,313 \\
4,718\end{array}$ & $\begin{array}{r}\$ 4,970 \\
5,050 \\
5,348 \\
5,656 \\
6,344\end{array}$ & $\begin{array}{r}\$ 7,056 \\
7,065 \\
7,265 \\
7,530 \\
8,781\end{array}$ & $\begin{array}{r}\$ 10,930 \\
10,935 \\
11,144 \\
11,040 \\
11,278\end{array}$ & $\begin{array}{r}\$ 17,588 \\
17,441 \\
18,380 \\
17,964 \\
18,685\end{array}$ & $\begin{array}{r}\$ 27,997 \\
28,235 \\
28,633 \\
28,838 \\
31,826\end{array}$ \\
\hline $\begin{array}{l}2004-05 \ldots \ldots \ldots \ldots \ldots \ldots \\
2005-06 \ldots \ldots \ldots \ldots \ldots \ldots \ldots \ldots \\
2006-07 \ldots \ldots \ldots \ldots \ldots \ldots \ldots \ldots \ldots \\
2007-08 \ldots \ldots \ldots \ldots \ldots \ldots \ldots \ldots . . . \\
2008-09 \ldots \ldots \ldots \ldots \ldots \ldots \ldots \ldots\end{array}$ & $\begin{array}{l}13,281 \\
13,511 \\
13,953 \\
14,209 \\
14,708\end{array}$ & $\begin{array}{l}7,338 \\
7,549 \\
7,813 \\
8,104 \\
8,621\end{array}$ & $\begin{array}{l}20,217 \\
20,048 \\
20,522 \\
20,630 \\
20,725\end{array}$ & $\begin{array}{l}21,183 \\
21,126 \\
21,571 \\
21,743 \\
22,079\end{array}$ & $\begin{array}{l}15,851 \\
15,616 \\
16,344 \\
16,079 \\
15,539\end{array}$ & $\begin{array}{l}5,112 \\
5,357 \\
5,563 \\
5,656 \\
6,048\end{array}$ & $\begin{array}{l}6,835 \\
7,219 \\
7,473 \\
7,639 \\
7,950\end{array}$ & $\begin{array}{r}9,192 \\
9,274 \\
9,453 \\
10,150 \\
10,683\end{array}$ & $\begin{array}{l}11,224 \\
11,330 \\
11,725 \\
11,699 \\
12,168\end{array}$ & $\begin{array}{l}19,383 \\
18,860 \\
19,331 \\
19,285 \\
19,691\end{array}$ & $\begin{array}{l}31,548 \\
31,342 \\
33,000 \\
33,055 \\
32,887\end{array}$ \\
\hline $\begin{array}{l}2009-10 \ldots \ldots \ldots \ldots \ldots \\
2010-11 \ldots \ldots \ldots \ldots \ldots \ldots \ldots \ldots \\
2011-12 \ldots \ldots \ldots \ldots \ldots \ldots \ldots \ldots . . . \\
2012-13 \ldots \ldots \ldots \ldots \ldots \ldots \ldots \ldots . . .\end{array}$ & $\begin{array}{l}15,518 \\
15,689 \\
16,050 \\
16,435\end{array}$ & $\begin{array}{r}9,355 \\
9,677 \\
10,146 \\
10,408\end{array}$ & $\begin{array}{l}21,741 \\
21,279 \\
21,456 \\
21,955\end{array}$ & $\begin{array}{l}22,743 \\
23,017 \\
23,252 \\
23,698\end{array}$ & $\begin{array}{l}15,532 \\
14,133 \\
14,053 \\
14,418\end{array}$ & $\begin{array}{l}6,494 \\
6,854 \\
7,631 \\
7,706\end{array}$ & $\begin{array}{l}8,521 \\
9,196 \\
9,602 \\
9,900\end{array}$ & $\begin{array}{l}11,377 \\
11,441 \\
12,153 \\
12,590\end{array}$ & $\begin{array}{l}13,114 \\
13,091 \\
13,151 \\
13,030\end{array}$ & $\begin{array}{l}20,655 \\
20,495 \\
20,968 \\
21,352\end{array}$ & $\begin{array}{l}33,870 \\
34,757 \\
35,257 \\
36,820\end{array}$ \\
\hline
\end{tabular}

-Not available.

'Data are based on in-state tuition only.

NOTE: Average graduate student tuition weighted by fall full-time-equivalent graduate enrollment. Data through 1995-96 are for institutions of higher education, while later data are for degree-granting institutions. Degree-granting institutions grant associate's or higher degrees and participate in Title IV federal financial aid programs. The degree-granting classification is very similar to the earlier higher education classification, but it includes more 2-year colleges and excludes a few higher education institutions that did not grant degrees. Some data have been revised from previously published figures.

SOURCE: U.S. Department of Education, National Center for Education Statistics, Integrated Postsecondary Education Data System (IPEDS), "Fall Enrollment Survey" (IPEDS-EF:89-99); "Completions Survey" (IPEDS-C:90-99); "Institutional Characteristics Survey" (IPEDS-IC:89-99); IPEDS Fall 2000 through Fall 2012, Institutional Characteristics component; and IPEDS Spring 2001 through Spring 2013, Enrollment component. (This table was prepared December 2013.) 
Table 331.10. Percentage of undergraduates receiving financial aid, by type and source of aid and selected student characteristics: 2011-12

[Standard errors appear in parentheses]

\begin{tabular}{|c|c|c|c|c|c|c|c|c|c|c|c|c|c|c|c|c|c|c|c|c|c|}
\hline \multirow[b]{2}{*}{ Selected student characteristic } & \multirow{2}{*}{$\begin{array}{r}\text { Number of } \\
\text { undergraduates } \\
\text { (in thousands) } \\
\end{array}$} & \multicolumn{6}{|c|}{ Any aid } & \multicolumn{6}{|c|}{ Grants } & \multicolumn{6}{|c|}{ Loans } & \multicolumn{2}{|c|}{ Work study } \\
\hline & & & Total $^{2}$ & & Federal $\left.\right|^{3}$ & & ifederal & & Total & & Federal & & federal & & Total $^{4}$ & & Federal ${ }^{4}$ & & ffederal & & Total $^{5}$ \\
\hline 1 & 2 & & 3 & & 4 & & 5 & & 6 & & 7 & & 8 & & 9 & & 10 & & 11 & & 12 \\
\hline All undergraduates ..................................... & 23,055 & 70.7 & $(0.56)$ & 59.4 & $(0.51)$ & 40.4 & $(0.44)$ & 59.1 & $(0.45)$ & 41.5 & (0.36) & 36.3 & (0.42) & 41.9 & (0.14) & 40.3 & (0.10) & 6.5 & (0.14) & 5.9 & 1 \\
\hline 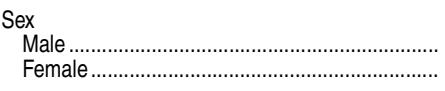 & $\begin{array}{r}9,921 \\
13,135\end{array}$ & $\begin{array}{l}68.4 \\
72.5\end{array}$ & $\begin{array}{l}(0.72) \\
(0.53)\end{array}$ & $\begin{array}{l}56.7 \\
61.5\end{array}$ & $\begin{array}{l}(0.73) \\
(0.46)\end{array}$ & $\begin{array}{l}39.8 \\
40.9\end{array}$ & $\begin{array}{l}(0.55) \\
(0.47)\end{array}$ & $\begin{array}{l}55.1 \\
62.1\end{array}$ & $\begin{array}{l}(0.57) \\
(0.46)\end{array}$ & $\begin{array}{l}36.7 \\
45.1\end{array}$ & $\begin{array}{l}(0.55) \\
(0.36)\end{array}$ & $\begin{array}{l}35.6 \\
36.7\end{array}$ & $\begin{array}{l}(0.53) \\
(0.45)\end{array}$ & $\begin{array}{l}39.0 \\
44.1\end{array}$ & $\begin{array}{l}(0.35) \\
(0.22)\end{array}$ & $\begin{array}{l}37.3 \\
42.6\end{array}$ & $\begin{array}{l}(0.35) \\
(0.22)\end{array}$ & $\begin{array}{l}6.4 \\
6.5\end{array}$ & $\begin{array}{l}(0.18) \\
(0.17)\end{array}$ & $\begin{array}{l}6.0 \\
5.9\end{array}$ & 0.1 \\
\hline 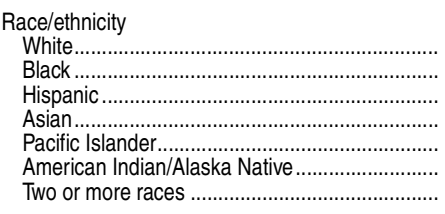 & $\begin{array}{r}13,345 \\
3,709 \\
3,696 \\
1,292 \\
119 \\
209 \\
686\end{array}$ & $\begin{array}{l}68.1 \\
81.0 \\
72.3 \\
60.8 \\
68.3 \\
76.3 \\
74.8\end{array}$ & $\begin{array}{l}(0.59) \\
(0.81) \\
(0.85) \\
(1.64) \\
(3.58) \\
(3.13) \\
(1.48)\end{array}$ & $\begin{array}{l}55.3 \\
75.2 \\
61.9 \\
46.3 \\
56.7 \\
69.0 \\
63.6\end{array}$ & $\begin{array}{l}(0.53) \\
(0.87) \\
(0.91) \\
(1.45) \\
(3.66) \\
(3.23) \\
(1.43)\end{array}$ & $\begin{array}{l}40.0 \\
36.8 \\
43.0 \\
44.2 \\
37.4 \\
40.9 \\
46.7\end{array}$ & $\begin{array}{l}(0.49) \\
(0.78) \\
(0.89) \\
(1.46) \\
(3.15) \\
(3.05) \\
(1.76)\end{array}$ & $\begin{array}{l}54.5 \\
71.4 \\
64.0 \\
53.0 \\
55.1 \\
67.6 \\
63.9\end{array}$ & $\begin{array}{l}(0.47) \\
(0.72) \\
(0.81) \\
(1.49) \\
(3.32) \\
(3.18) \\
(1.59)\end{array}$ & $\begin{array}{l}33.7 \\
62.1 \\
50.1 \\
33.4 \\
39.3 \\
55.3 \\
45.7\end{array}$ & $\begin{array}{l}(0.38) \\
(0.80 \\
(0.81) \\
(1.22) \\
(3.23) \\
(3.10) \\
(1.45)\end{array}$ & $\begin{array}{l}35.9 \\
32.2 \\
38.9 \\
41.2 \\
34.9 \\
37.6 \\
41.9\end{array}$ & $\begin{array}{l}(0.48) \\
(0.72) \\
(0.90) \\
(1.36) \\
(3.14) \\
(3.02) \\
(1.75)\end{array}$ & $\begin{array}{l}41.9 \\
52.3 \\
35.6 \\
28.4 \\
37.9 \\
43.0 \\
46.1\end{array}$ & $\begin{array}{l}(0.34) \\
(0.84) \\
(0.83) \\
(1.12) \\
(3.28) \\
(3.17) \\
(1.46)\end{array}$ & $\begin{array}{l}40.2 \\
51.0 \\
34.2 \\
27.0 \\
37.3 \\
41.9 \\
44.1\end{array}$ & $\begin{array}{l}(0.32) \\
(0.82) \\
(0.84) \\
(1.06) \\
(3.22) \\
(3.12) \\
(1.40)\end{array}$ & $\begin{array}{l}6.8 \\
6.5 \\
5.6 \\
5.0 \\
4.6 \\
5.1 \\
8.4\end{array}$ & $\begin{array}{l}(0.19) \\
(0.34) \\
(0.27) \\
(0.49) \\
(1.02) \\
(0.91) \\
(0.84)\end{array}$ & $\begin{array}{l}6.0 \\
5.1 \\
5.3 \\
9.0 \\
4.5 ! \\
4.7 \\
7.2\end{array}$ & $\begin{array}{l}0.6 \\
(1.4 \\
(1.1 \\
(0.6\end{array}$ \\
\hline 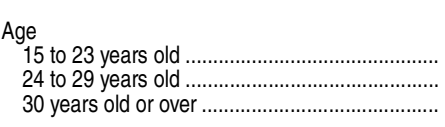 & $\begin{array}{r}12,956 \\
4,253 \\
5,846\end{array}$ & $\begin{array}{l}72.1 \\
70.4 \\
67.9\end{array}$ & $\begin{array}{l}(0.49) \\
(1.05) \\
(0.89)\end{array}$ & $\begin{array}{l}59.2 \\
61.9 \\
58.2\end{array}$ & $\begin{array}{l}(0.41) \\
(1.09) \\
(0.92)\end{array}$ & $\begin{array}{l}48.2 \\
31.8 \\
29.5\end{array}$ & $\begin{array}{l}(0.47) \\
(0.76) \\
(0.64)\end{array}$ & $\begin{array}{l}60.9 \\
59.0 \\
55.1\end{array}$ & $\begin{array}{l}(0.42) \\
(0.89) \\
(0.76)\end{array}$ & $\begin{array}{l}38.0 \\
49.1 \\
43.7\end{array}$ & $\begin{array}{l}(0.29) \\
(0.83) \\
(0.77)\end{array}$ & $\begin{array}{l}44.4 \\
27.1 \\
25.0\end{array}$ & $\begin{array}{l}(0.47) \\
(0.70) \\
(0.60)\end{array}$ & $\begin{array}{l}42.8 \\
41.6 \\
40.4\end{array}$ & $\begin{array}{l}(0.28) \\
(0.68) \\
(0.52)\end{array}$ & $\begin{array}{l}41.1 \\
39.9 \\
39.1\end{array}$ & $\begin{array}{l}(0.25) \\
(0.64) \\
(0.51)\end{array}$ & $\begin{array}{l}7.4 \\
5.8 \\
4.9\end{array}$ & $\begin{array}{l}(0.15) \\
(0.30) \\
(0.25)\end{array}$ & $\begin{array}{l}9.0 \\
2.4 \\
1.6\end{array}$ & $(0.1$ \\
\hline 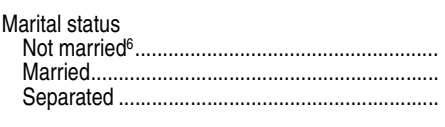 & $\begin{array}{r}18,507 \\
4,087 \\
461\end{array}$ & $\begin{array}{l}71.9 \\
63.9 \\
82.0\end{array}$ & $\begin{array}{l}(0.50) \\
(1.21) \\
(1.72)\end{array}$ & $\begin{array}{l}60.6 \\
52.2 \\
76.6\end{array}$ & $\begin{array}{l}(0.41) \\
(1.28) \\
(1.91)\end{array}$ & $\begin{array}{l}43.0 \\
30.0 \\
30.8\end{array}$ & $\begin{array}{l}(0.46) \\
(0.71) \\
(1.62)\end{array}$ & $\begin{array}{l}60.9 \\
49.4 \\
74.2\end{array}$ & $\begin{array}{l}(0.43) \\
(0.92) \\
(1.92)\end{array}$ & $\begin{array}{l}42.2 \\
35.5 \\
67.1\end{array}$ & $\begin{array}{l}(0.30) \\
(1.00) \\
(2.07)\end{array}$ & $\begin{array}{l}38.8 \\
26.0 \\
26.3\end{array}$ & $\begin{array}{l}(0.44) \\
(0.68) \\
(1.72)\end{array}$ & $\begin{array}{l}43.5 \\
33.8 \\
50.8\end{array}$ & $\begin{array}{l}(0.17) \\
(0.75) \\
(2.09)\end{array}$ & $\begin{array}{l}41.9 \\
32.4 \\
50.0\end{array}$ & $\begin{array}{l}(0.15) \\
(0.70) \\
(2.07)\end{array}$ & $\begin{array}{l}7.0 \\
4.3 \\
5.3\end{array}$ & $\begin{array}{l}(0.14) \\
(0.32) \\
(0.88)\end{array}$ & $\begin{array}{l}7.0 \\
1.4 \\
1.6\end{array}$ & $\begin{array}{l}0.1 \\
(0.4\end{array}$ \\
\hline 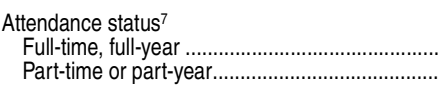 & $\begin{array}{r}8,864 \\
14,192\end{array}$ & $\begin{array}{l}84.4 \\
62.1\end{array}$ & $\begin{array}{l}(0.36) \\
(1.05)\end{array}$ & $\begin{array}{l}72.8 \\
51.1\end{array}$ & $\begin{array}{l}(0.51) \\
(1.10)\end{array}$ & $\begin{array}{l}56.9 \\
30.1\end{array}$ & $\begin{array}{l}(0.46) \\
(0.60)\end{array}$ & $\begin{array}{l}72.4 \\
50.8\end{array}$ & $\begin{array}{l}(0.41) \\
(0.87)\end{array}$ & $\begin{array}{l}47.4 \\
37.8\end{array}$ & $\begin{array}{l}(0.50) \\
(0.85)\end{array}$ & $\begin{array}{l}52.6 \\
26.1\end{array}$ & $\begin{array}{l}(0.45) \\
(0.56)\end{array}$ & $\begin{array}{l}56.7 \\
32.7\end{array}$ & $\begin{array}{l}(0.53) \\
(0.48)\end{array}$ & $\begin{array}{l}55.5 \\
30.9\end{array}$ & $\begin{array}{l}(0.54) \\
(0.45)\end{array}$ & $\begin{array}{l}9.2 \\
4.8\end{array}$ & $\begin{array}{l}(0.22) \\
(0.17)\end{array}$ & $\begin{array}{r}11.9 \\
2.2\end{array}$ & \\
\hline 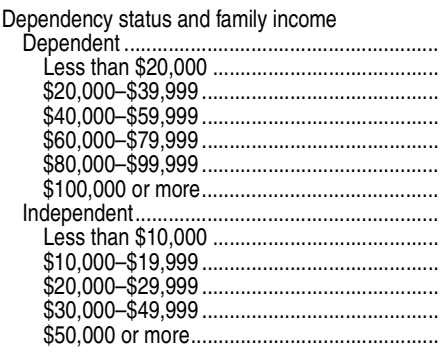 & $\begin{array}{r}11,231 \\
1,775 \\
2,011 \\
1,389 \\
1,535 \\
1,339 \\
3,183 \\
11,1825 \\
3,561 \\
2,349 \\
1,702 \\
1,895 \\
2,318\end{array}$ & $\begin{array}{l}71.6 \\
88.3 \\
81.5 \\
79.7 \\
65.7 \\
61.6 \\
59.5 \\
69.9 \\
78.6 \\
77.0 \\
71.4 \\
65.5 \\
51.8\end{array}$ & $\begin{array}{l}(0.49) \\
(0.68) \\
(0.88) \\
(0.89) \\
(1.06) \\
(1.29) \\
(0.79) \\
(0.81) \\
(0.72) \\
(1.09) \\
(1.14) \\
(1.23) \\
(1.73)\end{array}$ & $\begin{array}{l}58.2 \\
83.5 \\
74.1 \\
70.0 \\
49.6 \\
45.0 \\
38.7 \\
60.6 \\
71.6 \\
71.1 \\
62.9 \\
53.6 \\
37.1\end{array}$ & $\begin{array}{l}(0.40) \\
(0.79) \\
(0.92) \\
(0.96) \\
(1.07) \\
(0.95) \\
(0.64) \\
(0.85) \\
(0.74) \\
(1.05) \\
(1.41) \\
(1.36) \\
(1.54)\end{array}$ & $\begin{array}{l}49.9 \\
53.2 \\
54.7 \\
57.5 \\
49.0 \\
44.5 \\
44.5 \\
31.4 \\
35.2 \\
32.1 \\
30.4 \\
30.2 \\
26.6\end{array}$ & $\begin{array}{l}(0.50) \\
(1.01) \\
(0.99) \\
(1.06) \\
(0.97) \\
(1.22) \\
(0.74) \\
(0.55) \\
(0.75) \\
(0.93) \\
(1.06) \\
(1.11) \\
(0.94)\end{array}$ & $\begin{array}{l}59.6 \\
87.0 \\
79.1 \\
72.1 \\
48.3 \\
40.4 \\
40.2 \\
58.6 \\
73.5 \\
71.2 \\
56.6 \\
48.7 \\
32.3\end{array}$ & $\begin{array}{l}(0.44) \\
(0.67) \\
(0.92) \\
(0.97) \\
(1.00) \\
(1.17) \\
(0.74) \\
(0.67) \\
(0.76) \\
(1.14) \\
(1.14) \\
(1.17) \\
(1.08)\end{array}$ & $\begin{array}{r}34.9 \\
82.1 \\
70.9 \\
54.7 \\
14.2 \\
2.7 \\
0.7 \\
47.7 \\
66.5 \\
65.5 \\
45.7 \\
34.0 \\
13.7\end{array}$ & $\begin{array}{l}(0.30) \\
(0.78) \\
(0.92) \\
(0.91) \\
(0.62) \\
(0.28) \\
(0.09) \\
(0.68) \\
(0.76) \\
(1.12) \\
(1.20) \\
(0.98) \\
(0.75)\end{array}$ & $\begin{array}{l}46.1 \\
50.8 \\
52.0 \\
54.3 \\
44.3 \\
39.6 \\
39.9 \\
26.9 \\
30.3 \\
27.0 \\
25.7 \\
25.8 \\
23.2\end{array}$ & $\begin{array}{l}(0.50) \\
(1.00) \\
(1.03) \\
(1.07) \\
(1.01) \\
(1.17) \\
(0.74) \\
(0.52) \\
(0.76) \\
(0.83) \\
(1.04) \\
(1.13) \\
(0.88)\end{array}$ & $\begin{array}{l}43.4 \\
45.5 \\
42.8 \\
51.0 \\
46.0 \\
43.9 \\
38.0 \\
40.5 \\
46.7 \\
46.9 \\
42.3 \\
36.8 \\
26.2\end{array}$ & $\begin{array}{l}(0.31) \\
(0.84) \\
(0.80) \\
(0.96) \\
(1.02) \\
(0.91) \\
(0.63) \\
(0.33) \\
(0.72) \\
(0.86) \\
(0.90) \\
(0.91) \\
(1.25)\end{array}$ & $\begin{array}{l}41.7 \\
44.3 \\
41.6 \\
49.9 \\
43.9 \\
41.4 \\
35.9 \\
39.0 \\
45.1 \\
45.6 \\
40.6 \\
35.1 \\
25.2\end{array}$ & $\begin{array}{l}(0.29) \\
(0.84) \\
(0.82) \\
(0.99) \\
(0.97) \\
(0.89) \\
(0.59) \\
(0.30) \\
(0.73) \\
(0.87) \\
(0.91) \\
(0.92) \\
(1.14)\end{array}$ & $\begin{array}{r}7.8 \\
4.9 \\
5.6 \\
8.5 \\
9.8 \\
1.2 \\
8.5 \\
5.2 \\
5.8 \\
5.7 \\
5.7 \\
5.1 \\
3.7\end{array}$ & $\begin{array}{l}(0.17) \\
(0.35) \\
(0.35) \\
(0.50) \\
(0.62) \\
(0.62) \\
(0.34) \\
(0.20) \\
(0.30) \\
(0.35) \\
(0.41) \\
(0.34) \\
(0.37)\end{array}$ & $\begin{array}{r}9.8 \\
10.7 \\
11.6 \\
11.2 \\
9.9 \\
9.3 \\
7.6 \\
2.3 \\
4.4 \\
2.3 \\
1.8 \\
0.8 \\
0.6\end{array}$ & $\begin{array}{c}(0.54) \\
(0.53) \\
(0.59) \\
(0.65) \\
(0.37) \\
(0.10) \\
(0.25) \\
(0.23) \\
(0.24) \\
(0.13) \\
(0.12)\end{array}$ \\
\hline 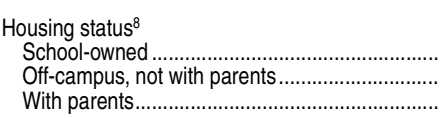 & $\begin{array}{r}2,800 \\
10,619 \\
7,734\end{array}$ & $\begin{array}{l}85.3 \\
68.1 \\
68.3\end{array}$ & $\begin{array}{l}(0.52) \\
(0.88) \\
(0.74)\end{array}$ & $\begin{array}{l}69.6 \\
57.4 \\
57.8\end{array}$ & $\begin{array}{l}(0.59) \\
(0.87) \\
(0.69)\end{array}$ & $\begin{array}{l}71.8 \\
34.4 \\
36.9\end{array}$ & $\begin{array}{l}(0.63) \\
(0.59) \\
(0.69)\end{array}$ & $\begin{array}{l}74.5 \\
56.1 \\
57.7\end{array}$ & $\begin{array}{l}(0.59) \\
(0.69) \\
(0.69)\end{array}$ & $\begin{array}{l}35.5 \\
42.1 \\
43.2\end{array}$ & $\left.\begin{array}{l}(0.60) \\
(0.67) \\
(0.65)\end{array}\right)$ & $\begin{array}{l}68.1 \\
30.0 \\
33.1\end{array}$ & $\begin{array}{l}(0.64) \\
(0.54) \\
(0.67)\end{array}$ & $\begin{array}{l}63.0 \\
39.1 \\
36.5\end{array}$ & $\begin{array}{l}(0.64) \\
(0.41) \\
(0.53)\end{array}$ & $\begin{array}{l}61.4 \\
37.5 \\
35.0\end{array}$ & $\begin{array}{l}(0.62) \\
(0.39) \\
(0.53)\end{array}$ & $\begin{array}{r}11.6 \\
5.8 \\
5.2\end{array}$ & $\begin{array}{l}(0.39) \\
(0.19) \\
(0.24)\end{array}$ & $\begin{array}{r}23.0 \\
3.1 \\
3.6\end{array}$ & $\begin{array}{l}(0.15) \\
(0.19)\end{array}$ \\
\hline
\end{tabular}

!Interpret data with caution. The coefficient of variation (CV) for this estimate is between 30 and 50 percent. Numbers of undergraduates may not equal figures reported in other tables, since these data are based on a sample survey of students who enrolled at any time during the school year. Includes all postsecondary institutions.

Includes students who reported they were awarded aid, but did not specity the source or type of aid.

4 Includes Parent Loans for Undergraduate Students (PLUS).

${ }^{6}$ Includes students who were single, divorced, or widowed.
'Full-time, full-year includes students enrolled full time for 9 or more months. Part-time or part-year includes students enrolled part time for 9 or more months and students enrolled less than 9 months either part time or full time.

NOTE: Detail may not sum to totals because of rounding and because some students receive multiple types of aid and aid from Rico. Race categries exclude persons of Hispanic ethnicity In 2012 no students wer reported in the "O ther" race category. SOURCE: U.S. Department of Education, National Center for Education Statistics, 2011-12 National Postsecondary Studen Aid Study (NPSAS:12). (This table was prepared January 2014.) 
Table 331.20. Full-time, first-time degree/certificate-seeking undergraduate students enrolled in degree-granting postsecondary institutions, by participation and average amount awarded in financial aid programs, and control and level of institution: 2000-01 through 2011-12

\begin{tabular}{|c|c|c|c|c|c|c|c|c|c|c|c|c|c|c|c|}
\hline \multirow[b]{3}{*}{ Control and level of institution, and year } & \multirow[b]{3}{*}{$\begin{array}{l}\text { Number } \\
\text { enrolled }\end{array}$} & \multirow{3}{*}{$\begin{array}{r}\text { Number } \\
\text { receiving } \\
\text { financial aid }\end{array}$} & \multirow[b]{3}{*}{$\begin{array}{r}\text { Percent } \\
\text { receiving aid }\end{array}$} & \multirow{2}{*}{\multicolumn{4}{|c|}{ Percent of enrolled students in student aid programs }} & \multicolumn{8}{|c|}{ Average award for students in aid programs ${ }^{1}$} \\
\hline & & & & & & & & \multicolumn{4}{|c|}{ Current dollars } & \multicolumn{4}{|c|}{ Constant 2012-13 dollars } \\
\hline & & & & $\begin{array}{r}\text { Federal } \\
\text { grants }\end{array}$ & $\begin{array}{r}\text { State/local } \\
\text { grants }\end{array}$ & $\begin{array}{r}\text { Institutional } \\
\text { grants }\end{array}$ & $\begin{array}{r}\text { Student } \\
\text { loans }{ }^{2}\end{array}$ & $\begin{array}{r}\text { Federal } \\
\text { grants }\end{array}$ & $\begin{array}{r}\text { State/local } \\
\text { grants }\end{array}$ & $\begin{array}{r}\text { Institutional } \\
\text { grants }\end{array}$ & $\begin{array}{r}\text { Student } \\
\text { loans }{ }^{2}\end{array}$ & $\begin{array}{r}\text { Federal } \\
\text { grants }\end{array}$ & $\begin{array}{r}\text { State/local } \\
\text { grants }\end{array}$ & $\begin{array}{r}\text { Institutional } \\
\text { grants }\end{array}$ & $\begin{array}{r}\text { Student } \\
\text { loans }^{2}\end{array}$ \\
\hline 1 & 2 & 3 & 4 & 5 & 6 & 7 & 8 & 9 & 10 & 11 & 12 & 13 & 14 & 15 & $\overline{16}$ \\
\hline 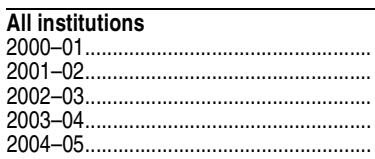 & $\begin{array}{l}1,976,600 \\
2,050,0016 \\
2,135,613 \\
2,178,517 \\
2,260,590\end{array}$ & $\begin{array}{l}1,390,527 \\
1,481,592 \\
1,553,024 \\
1,610,967 \\
1,689,910\end{array}$ & $\begin{array}{l}70.3 \\
72.3 \\
72.7 \\
73.9 \\
74.8\end{array}$ & $\begin{array}{l}31.6 \\
33.3 \\
34.1 \\
34.6 \\
35.2\end{array}$ & $\begin{array}{l}31.2 \\
32.5 \\
30.9 \\
31.2 \\
31.3\end{array}$ & $\begin{array}{l}31.1 \\
31.5 \\
31.5 \\
31.9 \\
31.7\end{array}$ & $\begin{array}{l}40.1 \\
40.7 \\
41.4 \\
43.1 \\
44.0\end{array}$ & $\begin{array}{r}\$ 2,486 \\
2,739 \\
2,947 \\
2,934 \\
2,939\end{array}$ & $\begin{array}{r}\$ 2,039 \\
2,057 \\
2,189 \\
2,226 \\
2,343\end{array}$ & $\begin{array}{r}\$ 4,740 \\
4,918 \\
5,267 \\
5,648 \\
5,958\end{array}$ & $\begin{array}{r}\$ 3,764 \\
3,970 \\
4,331 \\
4,193 \\
4,463\end{array}$ & $\begin{array}{r}\$ 3,285 \\
3,556 \\
3,744 \\
3,647 \\
3,547\end{array}$ & $\begin{array}{r}\$ 2,694 \\
2,671 \\
2,781 \\
2,768 \\
2,828\end{array}$ & $\begin{array}{r}\$ 6,263 \\
6,385 \\
6,691 \\
7,022 \\
7,191\end{array}$ & $\begin{array}{r}\$ 4,974 \\
5,154 \\
5,502 \\
5,213 \\
5,386\end{array}$ \\
\hline 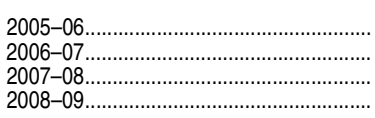 & $\begin{array}{l}2,309,543 \\
2,427,7043 \\
2,532,955 \\
2,675,974\end{array}$ & $\begin{array}{l}1,731,315 \\
1,766,257 \\
1,914,567 \\
2,089,288\end{array}$ & $\begin{array}{l}75.0 \\
72.8 \\
75.6 \\
78.1\end{array}$ & $\begin{array}{l}33.7 \\
32.1 \\
35.4 \\
38.0\end{array}$ & $\begin{array}{l}30.8 \\
30.0 \\
30.6 \\
30.2\end{array}$ & $\begin{array}{l}32.7 \\
32.2 \\
33.6 \\
34.1\end{array}$ & $\begin{array}{l}44.6 \\
43.5 \\
45.6 \\
48.6\end{array}$ & $\begin{array}{l}2,959 \\
3,125 \\
3,376 \\
3,915\end{array}$ & $\begin{array}{l}2,441 \\
2,526 \\
2,580 \\
2,705\end{array}$ & $\begin{array}{l}6,213 \\
6,593 \\
6,791 \\
7,250\end{array}$ & $\begin{array}{l}4,831 \\
5,014 \\
6,009 \\
6,974\end{array}$ & $\begin{array}{l}3,440 \\
3,542 \\
3,690 \\
4,220\end{array}$ & $\begin{array}{l}2,838 \\
2,862 \\
2,820 \\
2,915\end{array}$ & $\begin{array}{l}7,223 \\
7,472 \\
7,422 \\
7,814\end{array}$ & $\begin{array}{l}5,617 \\
5,683 \\
6,567 \\
7,517\end{array}$ \\
\hline $\begin{array}{c}2009-10 \\
2010-11 \ldots \\
2011-12\end{array}$ & $\begin{array}{l}2,857,363 \\
2,654,501 \\
2,571,801\end{array}$ & $\begin{array}{l}2,323,660 \\
2,184,367 \\
2,140,298\end{array}$ & $\begin{array}{l}81.3 \\
82.3 \\
83.2\end{array}$ & $\begin{array}{l}46.1 \\
47.8 \\
47.6\end{array}$ & $\begin{array}{l}28.6 \\
30.9 \\
30.8\end{array}$ & $\begin{array}{l}33.2 \\
35.7 \\
37.9\end{array}$ & $\begin{array}{l}51.1 \\
50.1 \\
51.2\end{array}$ & $\begin{array}{l}4,688 \\
4,755 \\
4,419\end{array}$ & $\begin{array}{l}2,766 \\
2,844 \\
2,910\end{array}$ & $\begin{array}{l}7,679 \\
8,386 \\
8,762\end{array}$ & $\begin{array}{l}7,013 \\
6,618 \\
6,654\end{array}$ & $\begin{array}{l}5,005 \\
4,976 \\
4,493\end{array}$ & $\begin{array}{l}2,953 \\
2,976 \\
2,959\end{array}$ & $\begin{array}{l}8,197 \\
8,775 \\
8,908\end{array}$ & $\begin{array}{l}7,486 \\
6,926 \\
6,765\end{array}$ \\
\hline 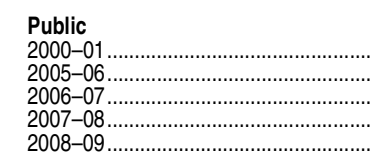 & $\begin{array}{l}1,333,236 \\
1,510,268 \\
1,568,395 \\
1,648,583 \\
1,700,907\end{array}$ & $\begin{array}{r}872,109 \\
1,06,6041 \\
1,096,808 \\
1,173,222 \\
1,246,670\end{array}$ & $\begin{array}{l}65.4 \\
70.6 \\
69.9 \\
71.2 \\
73.3\end{array}$ & $\begin{array}{l}30.0 \\
31.1 \\
30.9 \\
32.6 \\
33.7\end{array}$ & $\begin{array}{l}33.5 \\
34.8 \\
34.9 \\
35.8 \\
36.9\end{array}$ & $\begin{array}{l}22.7 \\
25.1 \\
25.2 \\
25.9 \\
26.5\end{array}$ & $\begin{array}{l}30.7 \\
34.2 \\
34.2 \\
34.7 \\
36.3\end{array}$ & $\begin{array}{l}2,408 \\
2,926 \\
3,099 \\
3,368 \\
3,869\end{array}$ & $\begin{array}{l}1,707 \\
2,226 \\
2,318 \\
2,351 \\
2,486\end{array}$ & $\begin{array}{l}2,275 \\
3,162 \\
3,316 \\
3,530 \\
3,755\end{array}$ & $\begin{array}{l}3,050 \\
3,866 \\
4,081 \\
4,803 \\
5,542\end{array}$ & $\begin{array}{l}3,181 \\
3,402 \\
3,512 \\
3,681 \\
4,170\end{array}$ & $\begin{array}{l}2,255 \\
2,588 \\
2,627 \\
2,569 \\
2,679\end{array}$ & $\begin{array}{l}3,005 \\
3,676 \\
3,758 \\
3,858 \\
4,047\end{array}$ & $\begin{array}{l}4,030 \\
4,495 \\
4,625 \\
5,249 \\
5,973\end{array}$ \\
\hline 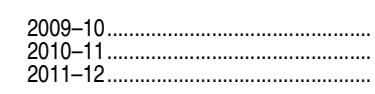 & $\begin{array}{l}1,804,811 \\
1,802,565 \\
1,766,681\end{array}$ & $\begin{array}{l}1,383,069 \\
1,421,056 \\
1,417,798\end{array}$ & $\begin{array}{l}76.6 \\
78.8 \\
80.3\end{array}$ & $\begin{array}{l}41.1 \\
46.0 \\
46.7\end{array}$ & $\begin{array}{l}35.6 \\
35.9 \\
35.6\end{array}$ & $\begin{array}{l}26.3 \\
27.2 \\
29.6\end{array}$ & $\begin{array}{l}38.6 \\
40.2 \\
42.5\end{array}$ & $\begin{array}{l}4,696 \\
4,768 \\
4,395\end{array}$ & $\begin{array}{l}2,553 \\
2,680 \\
2,770\end{array}$ & $\begin{array}{l}3,897 \\
4,157 \\
4,429\end{array}$ & $\begin{array}{l}5,680 \\
5,782 \\
5,936\end{array}$ & $\begin{array}{l}5,012 \\
4,989 \\
4,468\end{array}$ & $\begin{array}{l}2,725 \\
2,805 \\
2,816\end{array}$ & $\begin{array}{l}4,160 \\
4,350 \\
4,503\end{array}$ & $\begin{array}{l}6,063 \\
6,050 \\
6,034\end{array}$ \\
\hline 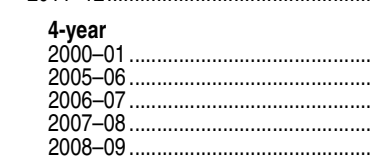 & $\begin{array}{r}804,793 \\
906,948 \\
949,162 \\
976,830 \\
1,007,609\end{array}$ & $\begin{array}{l}573,430 \\
695,017 \\
716,323 \\
753,643 \\
792,028\end{array}$ & $\begin{array}{l}71.3 \\
76.6 \\
75.5 \\
77.2 \\
78.6\end{array}$ & $\begin{array}{l}26.6 \\
26.6 \\
26.6 \\
28.0 \\
28.4\end{array}$ & $\begin{array}{l}36.5 \\
36.8 \\
36.7 \\
37.4 \\
37.9\end{array}$ & $\begin{array}{l}29.6 \\
34.2 \\
34.2 \\
36.2 \\
37.2\end{array}$ & $\begin{array}{l}40.7 \\
44.4 \\
43.8 \\
45.2 \\
46.9\end{array}$ & $\begin{array}{l}2,569 \\
3,071 \\
3,365 \\
3,675 \\
4,157\end{array}$ & $\begin{array}{l}2,068 \\
2,752 \\
2,848 \\
2,963 \\
3,152\end{array}$ & $\begin{array}{l}2,616 \\
3,573 \\
3,759 \\
3,956 \\
4,186\end{array}$ & $\begin{array}{l}3,212 \\
4,166 \\
4,433 \\
5,190 \\
5,972\end{array}$ & $\begin{array}{l}3,395 \\
3,570 \\
3,813 \\
4,016 \\
4,480\end{array}$ & $\begin{array}{l}2,732 \\
3,200 \\
3,228 \\
3,238 \\
3,397\end{array}$ & $\begin{array}{l}3,457 \\
4,154 \\
4,260 \\
4,323 \\
4,511\end{array}$ & $\begin{array}{l}4,244 \\
4,843 \\
5,024 \\
5,672 \\
6,436\end{array}$ \\
\hline 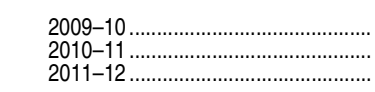 & $\begin{array}{l}1,021,259 \\
1,039,170 \\
1,059,832\end{array}$ & $\begin{array}{l}832,561 \\
858,433 \\
878,851\end{array}$ & $\begin{array}{l}81.5 \\
82.6 \\
82.9\end{array}$ & $\begin{array}{l}34.4 \\
38.9 \\
39.1\end{array}$ & $\begin{array}{l}37.4 \\
38.3 \\
37.1\end{array}$ & $\begin{array}{l}38.8 \\
39.6 \\
42.1\end{array}$ & $\begin{array}{l}50.0 \\
51.5 \\
52.6\end{array}$ & $\begin{array}{l}4,965 \\
4,988 \\
4,466\end{array}$ & $\begin{array}{l}3,300 \\
3,474 \\
3,525\end{array}$ & $\begin{array}{l}4,339 \\
4,630 \\
4,884\end{array}$ & $\begin{array}{l}6,063 \\
6,130 \\
6,348\end{array}$ & $\begin{array}{l}5,300 \\
5,220 \\
4,540\end{array}$ & $\begin{array}{l}3,522 \\
3,635 \\
3,584\end{array}$ & $\begin{array}{l}4,632 \\
4,845 \\
4,965\end{array}$ & $\begin{array}{l}6,472 \\
6,415 \\
6,454\end{array}$ \\
\hline 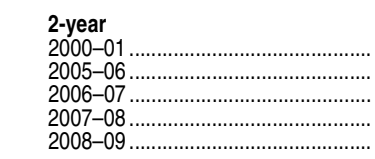 & $\begin{array}{l}528,443 \\
603,320 \\
619,233 \\
671,753 \\
693,298\end{array}$ & $\begin{array}{l}298,679 \\
371,024 \\
380,485 \\
419,579 \\
454,642\end{array}$ & $\begin{array}{l}56.5 \\
61.5 \\
61.4 \\
62.5 \\
65.6\end{array}$ & $\begin{array}{l}35.2 \\
38.0 \\
37.5 \\
39.1 \\
41.5\end{array}$ & $\begin{array}{l}28.8 \\
31.9 \\
32.2 \\
33.4 \\
35.4\end{array}$ & $\begin{array}{l}12.1 \\
11.3 \\
11.6 \\
10.8 \\
11.0\end{array}$ & $\begin{array}{l}15.3 \\
19.0 \\
19.6 \\
19.4 \\
21.1\end{array}$ & $\begin{array}{l}2,222 \\
2,774 \\
2,810 \\
3,048 \\
3,584\end{array}$ & $\begin{array}{l}1,009 \\
1,314 \\
1,393 \\
1,354 \\
1,451\end{array}$ & $\begin{array}{l}1,004 \\
1,297 \\
1,311 \\
1,458 \\
1,637\end{array}$ & $\begin{array}{l}2,396 \\
2,812 \\
2,877 \\
3,488 \\
4,152\end{array}$ & $\begin{array}{l}2,936 \\
3,225 \\
3,184 \\
3,331 \\
3,862\end{array}$ & $\begin{array}{l}1,334 \\
1,528 \\
1,579 \\
1,480 \\
1,564\end{array}$ & $\begin{array}{l}1,326 \\
1,508 \\
1,486 \\
1,594 \\
1,764\end{array}$ & $\begin{array}{l}3,166 \\
3,270 \\
3,261 \\
3,812 \\
4,475\end{array}$ \\
\hline 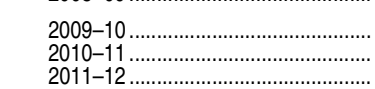 & $\begin{array}{l}783,552 \\
763,395 \\
706,849\end{array}$ & $\begin{array}{l}550,508 \\
562,623 \\
538,947\end{array}$ & $\begin{array}{l}70.3 \\
73.7 \\
76.2\end{array}$ & $\begin{array}{l}49.7 \\
55.6 \\
58.1\end{array}$ & $\begin{array}{l}33.2 \\
32.7 \\
33.4\end{array}$ & $\begin{array}{r}9.9 \\
10.3 \\
10.9\end{array}$ & $\begin{array}{l}23.7 \\
24.8 \\
27.4\end{array}$ & $\begin{array}{l}4,453 \\
4,558 \\
4,324\end{array}$ & $\begin{array}{l}1,460 \\
1,418 \\
1,509\end{array}$ & $\begin{array}{l}1,646 \\
1,681 \\
1,789\end{array}$ & $\begin{array}{l}4,627 \\
4,800 \\
4,747\end{array}$ & $\begin{array}{l}4,753 \\
4,770 \\
4,396\end{array}$ & $\begin{array}{l}1,558 \\
1,484 \\
1,534\end{array}$ & $\begin{array}{l}1,757 \\
1,759 \\
1,819\end{array}$ & $\begin{array}{l}4,939 \\
5,023 \\
4,826\end{array}$ \\
\hline 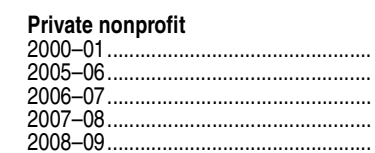 & $\begin{array}{l}439,369 \\
471,069 \\
477,698 \\
494,088 \\
496,638\end{array}$ & $\begin{array}{l}363,044 \\
401,908 \\
407,247 \\
424,943 \\
433,208\end{array}$ & $\begin{array}{l}82.6 \\
85.3 \\
85.3 \\
86.0 \\
87.2\end{array}$ & $\begin{array}{l}28.4 \\
26.5 \\
26.2 \\
27.3 \\
27.4\end{array}$ & $\begin{array}{l}31.8 \\
31.3 \\
30.5 \\
30.0 \\
30.2\end{array}$ & $\begin{array}{l}68.1 \\
73.8 \\
73.9 \\
74.4 \\
76.6\end{array}$ & $\begin{array}{l}57.7 \\
59.8 \\
59.3 \\
60.2 \\
60.6\end{array}$ & $\begin{array}{l}2,879 \\
3,426 \\
3,704 \\
3,928 \\
4,450\end{array}$ & $\begin{array}{l}2,998 \\
3,117 \\
3,321 \\
3,386 \\
3,523\end{array}$ & $\begin{array}{r}7,368 \\
9,932 \\
10,724 \\
11,465 \\
12,699\end{array}$ & $\begin{array}{l}4,019 \\
5,270 \\
5,544 \\
6,415 \\
7,609\end{array}$ & $\begin{array}{l}3,804 \\
3,984 \\
4,198 \\
4,293 \\
4,796\end{array}$ & $\begin{array}{l}3,961 \\
3,624 \\
3,764 \\
3,700 \\
3,797\end{array}$ & $\begin{array}{r}9,735 \\
11,547 \\
12,154 \\
12,529 \\
13,687\end{array}$ & $\begin{array}{l}5,311 \\
6,127 \\
6,284 \\
7,010 \\
8,201\end{array}$ \\
\hline 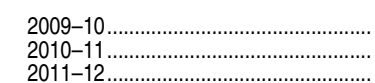 & $\begin{array}{l}501,223 \\
518,433 \\
512,814\end{array}$ & $\begin{array}{l}445,309 \\
463,163 \\
457,300\end{array}$ & $\begin{array}{l}88.8 \\
89.3 \\
89.2\end{array}$ & $\begin{array}{l}33.0 \\
36.4 \\
35.0\end{array}$ & $\begin{array}{l}27.8 \\
27.7 \\
27.0\end{array}$ & $\begin{array}{l}78.2 \\
78.2 \\
79.3\end{array}$ & $\begin{array}{l}62.9 \\
64.3 \\
63.5\end{array}$ & $\begin{array}{l}5,067 \\
5,065 \\
4,646\end{array}$ & $\begin{array}{l}3,644 \\
3,544 \\
3,534\end{array}$ & $\begin{array}{l}13,638 \\
14,316 \\
15,064\end{array}$ & $\begin{array}{l}7,440 \\
7,302 \\
7,473\end{array}$ & $\begin{array}{l}5,408 \\
5,300 \\
4,724\end{array}$ & $\begin{array}{l}3,890 \\
3,709 \\
3,593\end{array}$ & $\begin{array}{l}14,558 \\
14,981 \\
15,314\end{array}$ & $\begin{array}{l}7,942 \\
7,641 \\
7,598\end{array}$ \\
\hline
\end{tabular}


Table 331.20. Full-time, first-time degree/certificate-seeking undergraduate students enrolled in degree-granting postsecondary institutions, by participation and average amount awarded in financial aid programs, and control and level of institution: 2000-01 through 2011-12-Continued

\begin{tabular}{|c|c|c|c|c|c|c|c|c|c|c|c|c|c|c|c|}
\hline \multirow[b]{3}{*}{ Control and level of institution, and year } & \multirow[b]{3}{*}{$\begin{array}{l}\text { Number } \\
\text { enrolled }\end{array}$} & \multirow{3}{*}{$\begin{array}{r}\text { Number } \\
\text { receiving } \\
\text { financial aid }\end{array}$} & \multirow[b]{3}{*}{$\begin{array}{r}\text { Percent } \\
\text { receiving aid }\end{array}$} & \multirow{2}{*}{\multicolumn{4}{|c|}{ Percent of enrolled students in student aid programs }} & \multicolumn{8}{|c|}{ Average award for students in aid programs ${ }^{1}$} \\
\hline & & & & & & & & \multicolumn{4}{|c|}{ Current dollars } & \multicolumn{4}{|c|}{ Constant 2012-13 dollars } \\
\hline & & & & \begin{tabular}{r|} 
Federal \\
grants
\end{tabular} & $\begin{array}{r}\text { State/local } \\
\text { grants }\end{array}$ & $\begin{array}{r}\text { Institutional } \\
\text { grants }\end{array}$ & $\begin{array}{r}\text { Student } \\
\text { loans }^{2}\end{array}$ & $\begin{aligned} \text { Federal } \\
\text { grants }\end{aligned}$ & $\begin{array}{r}\text { State/local } \\
\text { grants }\end{array}$ & $\begin{array}{r}\text { Institutional } \\
\text { grants }\end{array}$ & $\begin{array}{r}\text { Student } \\
\text { loans }^{2}\end{array}$ & \begin{tabular}{r|} 
Federal \\
grants
\end{tabular} & $\begin{array}{r}\text { State/local } \\
\text { grants }\end{array}$ & $\begin{array}{r}\text { Institutional } \\
\text { grants }\end{array}$ & $\begin{array}{r}\text { Student } \\
\text { loans }^{2}\end{array}$ \\
\hline 1 & 2 & 3 & 4 & 5 & 6 & 7 & 8 & 9 & 10 & 11 & 12 & 13 & 14 & 15 & 16 \\
\hline 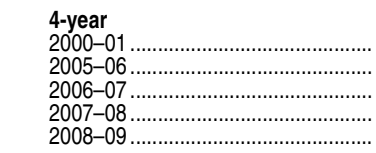 & $\begin{array}{l}419,499 \\
460,832 \\
468,969 \\
484,021 \\
487,050\end{array}$ & $\begin{array}{l}347,638 \\
393,429 \\
400,044 \\
416,405 \\
424,881\end{array}$ & $\begin{array}{l}82.9 \\
85.4 \\
85.3 \\
86.0 \\
87.2\end{array}$ & $\begin{array}{l}27.4 \\
26.0 \\
25.8 \\
26.7 \\
26.8\end{array}$ & $\begin{array}{l}32.2 \\
31.2 \\
30.4 \\
30.0 \\
30.1\end{array}$ & $\begin{array}{l}70.1 \\
74.6 \\
74.4 \\
75.1 \\
77.4\end{array}$ & $\begin{array}{l}58.1 \\
59.8 \\
59.4 \\
60.3 \\
60.6\end{array}$ & $\begin{array}{l}2,930 \\
3,437 \\
3,729 \\
3,960 \\
4,488\end{array}$ & $\begin{array}{l}3,001 \\
3,121 \\
3,329 \\
3,391 \\
3,523\end{array}$ & $\begin{array}{r}7,458 \\
10,002 \\
10,797 \\
11,539 \\
12,780\end{array}$ & $\begin{array}{l}4,000 \\
5,264 \\
5,558 \\
6,435 \\
7,638\end{array}$ & $\begin{array}{l}3,872 \\
3,996 \\
4,226 \\
4,328 \\
4,837\end{array}$ & $\begin{array}{l}3,966 \\
3,628 \\
3,773 \\
3,706 \\
3,796\end{array}$ & $\begin{array}{r}9,854 \\
11,629 \\
12,236 \\
12,610 \\
13,774\end{array}$ & $\begin{array}{l}5,285 \\
6,120 \\
6,299 \\
7,033 \\
8,232\end{array}$ \\
\hline 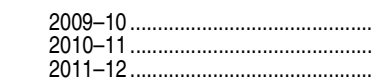 & $\begin{array}{l}491,136 \\
504,874 \\
499,961\end{array}$ & $\begin{array}{l}436,294 \\
450,906 \\
445,217\end{array}$ & $\begin{array}{l}88.8 \\
89.3 \\
89.1\end{array}$ & $\begin{array}{l}32.3 \\
35.4 \\
33.9\end{array}$ & $\begin{array}{l}27.7 \\
27.7 \\
27.1\end{array}$ & $\begin{array}{l}79.0 \\
79.6 \\
80.5\end{array}$ & $\begin{array}{l}63.0 \\
64.3 \\
63.4\end{array}$ & $\begin{array}{l}5,099 \\
5,098 \\
4,673\end{array}$ & $\begin{array}{l}3,658 \\
3,567 \\
3,551\end{array}$ & $\begin{array}{l}13,733 \\
14,404 \\
15,175\end{array}$ & $\begin{array}{l}7,466 \\
7,314 \\
7,486\end{array}$ & $\begin{array}{l}5,443 \\
5,335 \\
4,751\end{array}$ & $\begin{array}{l}3,905 \\
3,732 \\
3,610\end{array}$ & $\begin{array}{l}14,660 \\
15,073 \\
15,428\end{array}$ & $\begin{array}{l}7,970 \\
7,654 \\
7,610\end{array}$ \\
\hline 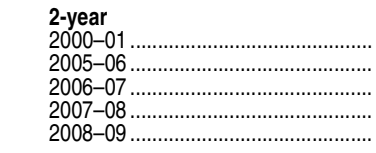 & $\begin{array}{r}19,870 \\
10,237 \\
8,729 \\
10,067 \\
9,588\end{array}$ & $\begin{array}{r}15,406 \\
8,479 \\
7,203 \\
8,538 \\
8,327\end{array}$ & $\begin{array}{l}77.5 \\
82.8 \\
82.5 \\
84.8 \\
86.8\end{array}$ & $\begin{array}{l}49.2 \\
51.6 \\
47.6 \\
53.3 \\
59.2\end{array}$ & $\begin{array}{l}23.9 \\
36.1 \\
37.2 \\
31.6 \\
32.0\end{array}$ & $\begin{array}{r}25.7 \\
38.5 \\
44.0 \\
37.7 \\
37.5\end{array}$ & $\begin{array}{l}49.5 \\
55.9 \\
53.5 \\
54.1 \\
58.1\end{array}$ & $\begin{array}{l}2,269 \\
3,176 \\
2,992 \\
3,161 \\
3,563\end{array}$ & $\begin{array}{l}2,892 \\
2,974 \\
2,963 \\
3,138 \\
3,550\end{array}$ & $\begin{array}{l}2,168 \\
3,799 \\
4,122 \\
4,364 \\
4,194\end{array}$ & $\begin{array}{l}4,509 \\
5,531 \\
4,715 \\
5,323 \\
6,089\end{array}$ & $\begin{array}{l}2,999 \\
3,693 \\
3,391 \\
3,455 \\
3,840\end{array}$ & $\begin{array}{l}3,821 \\
3,457 \\
3,358 \\
3,430 \\
3,826\end{array}$ & $\begin{array}{l}2,864 \\
4,417 \\
4,672 \\
4,769 \\
4,520\end{array}$ & $\begin{array}{l}5,958 \\
6,430 \\
5,344 \\
5,817 \\
6,562\end{array}$ \\
\hline 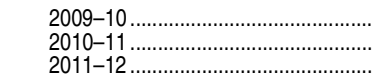 & $\begin{array}{l}10,087 \\
13,559 \\
12,853\end{array}$ & $\begin{array}{r}9,015 \\
12,257 \\
12,083\end{array}$ & $\begin{array}{l}89.4 \\
90.4 \\
94.0\end{array}$ & $\begin{array}{l}66.9 \\
73.5 \\
76.3\end{array}$ & $\begin{array}{l}29.1 \\
27.4 \\
24.3\end{array}$ & $\begin{array}{l}41.5 \\
28.4 \\
31.8\end{array}$ & $\begin{array}{l}58.6 \\
65.2 \\
65.5\end{array}$ & $\begin{array}{l}4,294 \\
4,470 \\
4,180\end{array}$ & $\begin{array}{l}3,000 \\
2,696 \\
2,830\end{array}$ & $\begin{array}{l}4,798 \\
5,138 \\
4,075\end{array}$ & $\begin{array}{l}6,078 \\
6,844 \\
7,014\end{array}$ & $\begin{array}{l}4,584 \\
4,678 \\
4,250\end{array}$ & $\begin{array}{l}3,202 \\
2,821 \\
2,877\end{array}$ & $\begin{array}{l}5,121 \\
5,377 \\
4,143\end{array}$ & $\begin{array}{l}6,488 \\
7,162 \\
7,130\end{array}$ \\
\hline $\begin{array}{l}\text { Private for-profit } \\
2000-01 \ldots \ldots \\
2005-06 \ldots \ldots \\
2006-07 \ldots \ldots \ldots \ldots \\
2007\end{array}$ & $\begin{array}{l}203,995 \\
328,206 \\
380,950 \\
390,284 \\
478,429\end{array}$ & $\begin{array}{l}155,374 \\
263,366 \\
262,202 \\
316,402 \\
409,410\end{array}$ & $\begin{array}{l}76.2 \\
80.2 \\
68.8 \\
81.1 \\
85.6\end{array}$ & $\begin{array}{l}49.3 \\
55.6 \\
44.8 \\
57.8 \\
64.5\end{array}$ & $\begin{array}{r}15.2 \\
11.4 \\
9.3 \\
9.5 \\
6.6\end{array}$ & $\begin{array}{r}6.2 \\
8.8 \\
8.4 \\
14.9 \\
17.2\end{array}$ & $\begin{array}{l}63.5 \\
70.4 \\
61.7 \\
72.9 \\
79.6\end{array}$ & $\begin{array}{l}2,312 \\
2,725 \\
2,776 \\
3,066 \\
3,766\end{array}$ & $\begin{array}{l}2,494 \\
2,796 \\
2,474 \\
2,996 \\
3,167\end{array}$ & $\begin{array}{l}1,540 \\
1,423 \\
1,545 \\
1,154 \\
1,184\end{array}$ & $\begin{array}{l}5,517 \\
6,454 \\
6,506 \\
8,010 \\
8,798\end{array}$ & $\begin{array}{l}3,055 \\
3,168 \\
3,146 \\
3,351 \\
4,058\end{array}$ & $\begin{array}{l}3,295 \\
3,250 \\
2,803 \\
3,274 \\
3,413\end{array}$ & $\begin{array}{l}2,034 \\
1,655 \\
1,751 \\
1,261 \\
1,276\end{array}$ & $\begin{array}{l}7,290 \\
7,503 \\
7,373 \\
8,753 \\
9,482\end{array}$ \\
\hline 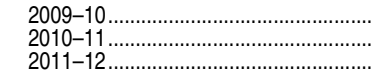 & $\begin{array}{l}551,329 \\
333,503 \\
292,306\end{array}$ & $\begin{array}{l}495,282 \\
300,148 \\
265,200\end{array}$ & $\begin{array}{l}89.8 \\
90.0 \\
90.7\end{array}$ & $\begin{array}{l}74.5 \\
75.2 \\
75.4\end{array}$ & $\begin{array}{l}6.3 \\
8.9 \\
8.4\end{array}$ & $\begin{array}{l}15.1 \\
15.3 \\
15.2\end{array}$ & $\begin{array}{l}81.3 \\
82.0 \\
82.3\end{array}$ & $\begin{array}{l}4,523 \\
4,479 \\
4,324\end{array}$ & $\begin{array}{l}3,190 \\
3,020 \\
2,993\end{array}$ & $\begin{array}{l}1,171 \\
1,881 \\
2,120\end{array}$ & $\begin{array}{l}8,786 \\
8,003 \\
7,789\end{array}$ & $\begin{array}{l}4,828 \\
4,687 \\
4,396\end{array}$ & $\begin{array}{l}3,405 \\
3,160 \\
3,043\end{array}$ & $\begin{array}{l}1,250 \\
1,968 \\
2,155\end{array}$ & $\begin{array}{l}9,378 \\
8,374 \\
7,918\end{array}$ \\
\hline 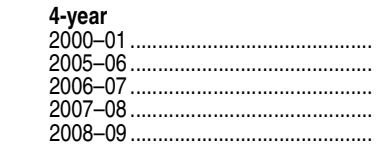 & $\begin{array}{r}81,075 \\
157,705 \\
229,746 \\
210,468 \\
258,498\end{array}$ & $\begin{array}{r}51,739 \\
116,237 \\
127,215 \\
159,991 \\
221,487\end{array}$ & $\begin{array}{l}63.8 \\
73.7 \\
55.4 \\
76.0 \\
85.7\end{array}$ & $\begin{array}{l}36.1 \\
46.8 \\
32.5 \\
51.5 \\
62.7\end{array}$ & $\begin{array}{r}11.9 \\
8.9 \\
5.7 \\
7.2 \\
5.8\end{array}$ & $\begin{array}{r}8.3 \\
10.9 \\
8.4 \\
20.4 \\
23.5\end{array}$ & $\begin{array}{l}57.7 \\
67.2 \\
52.0 \\
68.7 \\
81.4\end{array}$ & $\begin{array}{l}2,295 \\
2,490 \\
2,608 \\
3,030 \\
3,745\end{array}$ & $\begin{array}{l}2,889 \\
2,945 \\
2,622 \\
2,922 \\
3,139\end{array}$ & $\begin{array}{l}1,616 \\
1,641 \\
1,878 \\
1,235 \\
1,296\end{array}$ & $\begin{array}{l}5,749 \\
7,046 \\
6,989 \\
8,799 \\
9,660\end{array}$ & $\begin{array}{l}3,033 \\
2,895 \\
2,955 \\
3,311 \\
4,036\end{array}$ & $\begin{array}{l}3,817 \\
3,424 \\
2,972 \\
3,193 \\
3,384\end{array}$ & $\begin{array}{l}2,135 \\
1,908 \\
2,129 \\
1,350 \\
1,397\end{array}$ & $\begin{array}{r}7,596 \\
8,192 \\
7,920 \\
9,616 \\
10,411\end{array}$ \\
\hline $\begin{array}{l}2009-10 \\
2010-11 \\
2011-12 \ldots-1\end{array}$ & $\begin{array}{l}243,429 \\
113,482 \\
112,917\end{array}$ & $\begin{array}{l}223,526 \\
102,643 \\
102,422\end{array}$ & $\begin{array}{l}91.8 \\
90.4 \\
90.7\end{array}$ & $\begin{array}{l}75.3 \\
73.5 \\
75.7\end{array}$ & $\begin{array}{r}6.6 \\
11.3 \\
10.8\end{array}$ & $\begin{array}{l}23.5 \\
23.6 \\
22.3\end{array}$ & $\begin{array}{l}86.1 \\
82.8 \\
82.8\end{array}$ & $\begin{array}{l}4,547 \\
4,736 \\
4,686\end{array}$ & $\begin{array}{l}2,715 \\
2,950 \\
3,000\end{array}$ & $\begin{array}{l}1,311 \\
2,790 \\
2,896\end{array}$ & $\begin{array}{l}9,641 \\
8,484 \\
8,223\end{array}$ & $\begin{array}{l}4,854 \\
4,956 \\
4,764\end{array}$ & $\begin{array}{l}2,898 \\
3,086 \\
3,050\end{array}$ & $\begin{array}{l}1,400 \\
2,919 \\
2,945\end{array}$ & $\begin{array}{r}10,291 \\
8,878 \\
8,360\end{array}$ \\
\hline 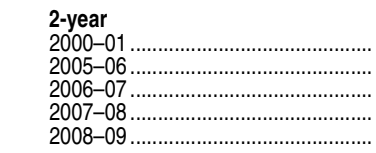 & $\begin{array}{l}122,920 \\
170,501 \\
151,204 \\
179,816 \\
219,931\end{array}$ & $\begin{array}{l}103,635 \\
147,129 \\
134,987 \\
156,411 \\
187,923\end{array}$ & $\begin{array}{l}84.3 \\
86.3 \\
89.3 \\
87.0 \\
85.4\end{array}$ & $\begin{array}{l}58.0 \\
63.6 \\
63.4 \\
65.0 \\
66.6\end{array}$ & $\begin{array}{r}17.3 \\
13.7 \\
14.7 \\
12.3 \\
7.6\end{array}$ & $\begin{array}{l}4.8 \\
6.8 \\
8.3 \\
8.4 \\
9.8\end{array}$ & $\begin{array}{l}67.3 \\
73.4 \\
76.4 \\
77.9 \\
77.5\end{array}$ & $\begin{array}{l}2,319 \\
2,885 \\
2,906 \\
3,100 \\
3,788\end{array}$ & $\begin{array}{l}2,314 \\
2,706 \\
2,386 \\
3,047 \\
3,191\end{array}$ & $\begin{array}{r}1,453 \\
1,098 \\
1,029 \\
924 \\
869\end{array}$ & $\begin{array}{l}5,387 \\
5,951 \\
6,007 \\
7,195 \\
7,734\end{array}$ & $\begin{array}{l}3,064 \\
3,354 \\
3,294 \\
3,388 \\
4,083\end{array}$ & $\begin{array}{l}3,057 \\
3,146 \\
2,704 \\
3,330 \\
3,439\end{array}$ & $\begin{array}{r}1,919 \\
1,277 \\
1,166 \\
1,009 \\
936\end{array}$ & $\begin{array}{l}7,117 \\
6,919 \\
6,808 \\
7,863 \\
8,335\end{array}$ \\
\hline $\begin{array}{l}2009-10 \\
2010-11 \\
2011-12\end{array}$ & $\begin{array}{l}307,900 \\
220,021 \\
179,389\end{array}$ & $\begin{array}{l}271,756 \\
197,505 \\
162,778\end{array}$ & $\begin{array}{l}88.3 \\
89.8 \\
90.7\end{array}$ & $\begin{array}{l}74.0 \\
76.1 \\
75.2\end{array}$ & $\begin{array}{l}6.1 \\
7.6 \\
6.9\end{array}$ & $\begin{array}{r}8.5 \\
11.0 \\
10.8\end{array}$ & $\begin{array}{l}77.5 \\
81.5 \\
82.0\end{array}$ & $\begin{array}{l}4,503 \\
4,350 \\
4,094\end{array}$ & $\begin{array}{l}3,597 \\
3,074 \\
2,986\end{array}$ & $\begin{array}{r}865 \\
876 \\
1,107\end{array}$ & $\begin{array}{l}8,035 \\
7,751 \\
7,513\end{array}$ & $\begin{array}{l}4,807 \\
4,552 \\
4,162\end{array}$ & $\begin{array}{l}3,840 \\
3,216 \\
3,036\end{array}$ & $\begin{array}{r}923 \\
917 \\
1,126\end{array}$ & $\begin{array}{l}8,577 \\
8,111 \\
7,638\end{array}$ \\
\hline
\end{tabular}

${ }^{1}$ Average amounts for students participating in indicated programs. 'Includes only loans made directly to students. Does not include Parent Loans for Undergraduate Students (PLUS) and other loans made directly to parents.
NOTE: Degree-granting institutions grant associate's or higher degrees and participate in Title IV federal financial aid programs. SOURCE: U.S. Department of Education, National Center for Education Statistics, Integrated Postsecondary Education Data Sys-
tem (IPEDS). Spring 2002 through Spring 2013, Student Financial Aid component. (This table was prepared November 2013.) 
Table 331.30. Average amount of grant and scholarship aid and average net price for first-time, full-time students receiving Title IV aid, and percentage distribution of students, by control and level of institution and income level: 2009-10, 2010-11 and 2011-12

\begin{tabular}{|c|c|c|c|c|c|c|c|c|c|c|c|c|}
\hline \multirow[b]{3}{*}{ Selected characteristic } & \multicolumn{4}{|c|}{$2009-10$} & \multicolumn{4}{|c|}{$2010-11$} & \multicolumn{4}{|c|}{$2011-12$} \\
\hline & \multirow{2}{*}{$\begin{array}{r}\text { All } \\
\text { institutions }\end{array}$} & \multirow[b]{2}{*}{ Public } & \multicolumn{2}{|c|}{ Private } & \multirow{2}{*}{$\begin{array}{r}\text { All } \\
\text { institutions }\end{array}$} & \multirow[b]{2}{*}{ Public } & \multicolumn{2}{|c|}{ Private } & \multirow{2}{*}{$\begin{array}{r}\text { All } \\
\text { institutions }\end{array}$} & \multirow[b]{2}{*}{ Public } & \multicolumn{2}{|c|}{ Private } \\
\hline & & & Non-profit & For-profit & & & Non-profit & For-profit & & & Non-profit & For-profit \\
\hline 1 & 2 & 3 & 4 & 5 & 6 & 7 & 8 & 9 & 10 & 11 & 12 & 13 \\
\hline 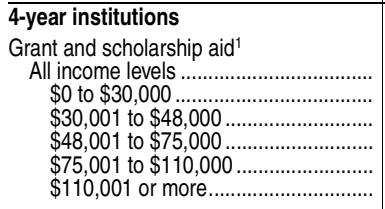 & $\begin{array}{r}\$ 9,050 \\
10,290 \\
11,170 \\
9,140 \\
7,150 \\
6,300\end{array}$ & $\begin{array}{r}\$ 5,980 \\
9,080 \\
8,330 \\
4,910 \\
2,270 \\
1,590\end{array}$ & $\begin{array}{r}\$ 15,560 \\
17,460 \\
18,710 \\
16,810 \\
14,650 \\
11,560\end{array}$ & $\begin{array}{r}\$ 4,420 \\
5,110 \\
4,530 \\
2,430 \\
1,220 \\
1,020\end{array}$ & $\begin{array}{r}\$ 9,630 \\
10,820 \\
11,750 \\
9,700 \\
7,660 \\
6,910\end{array}$ & $\begin{array}{r}\$ 6,420 \\
9,500 \\
8,790 \\
5,400 \\
2,470 \\
1,640\end{array}$ & $\begin{array}{r}\$ 16,310 \\
17,800 \\
19,390 \\
17,640 \\
15,590 \\
12,440\end{array}$ & $\begin{array}{r}\$ 4,800 \\
5,360 \\
5,000 \\
3,150 \\
1,580 \\
1,390\end{array}$ & $\begin{array}{r}\$ 9,740 \\
10,750 \\
11,870 \\
9,850 \\
7,980 \\
7,270\end{array}$ & $\begin{array}{r}\$ 6,270 \\
9,240 \\
8,560 \\
5,240 \\
2,490 \\
1,680\end{array}$ & $\begin{array}{r}\$ 17,040 \\
18,450 \\
20,350 \\
18,560 \\
16,440 \\
13,220\end{array}$ & $\begin{array}{r}\$ 4,990 \\
5,410 \\
5,190 \\
3,330 \\
1,990 \\
2,190\end{array}$ \\
\hline 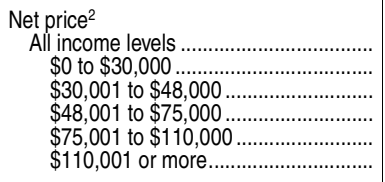 & $\begin{array}{l}15,900 \\
12,570 \\
13,110 \\
16,610 \\
19,860 \\
24,080\end{array}$ & $\begin{array}{r}11,070 \\
7,720 \\
9,260 \\
13,290 \\
16,410 \\
17,880\end{array}$ & $\begin{array}{l}21,780 \\
15,970 \\
17,200 \\
20,270 \\
23,900 \\
30,210\end{array}$ & $\begin{array}{l}22,590 \\
21,770 \\
23,590 \\
26,710 \\
29,830 \\
32,910\end{array}$ & $\begin{array}{l}16,360 \\
12,980 \\
13,480 \\
16,890 \\
20,410 \\
24,980\end{array}$ & $\begin{array}{r}11,570 \\
8,190 \\
9,710 \\
13,640 \\
17,100 \\
18,730\end{array}$ & $\begin{array}{l}22,570 \\
17,080 \\
18,120 \\
21,030 \\
24,610 \\
31,050\end{array}$ & $\begin{array}{l}22,710 \\
22,270 \\
23,330 \\
26,230 \\
28,790 \\
31,150\end{array}$ & $\begin{array}{l}16,910 \\
13,340 \\
14,100 \\
17,570 \\
21,000 \\
25,570\end{array}$ & $\begin{array}{r}12,410 \\
9,260 \\
10,900 \\
14,680 \\
17,910 \\
19,500\end{array}$ & $\begin{array}{l}23,540 \\
17,840 \\
18,730 \\
21,650 \\
25,160 \\
31,720\end{array}$ & $\begin{array}{l}21,330 \\
20,680 \\
22,260 \\
25,120 \\
27,690 \\
30,010\end{array}$ \\
\hline $\begin{array}{l}\text { 2-year institutions } \\
\text { Grant and scholarship aid }\end{array}$ & & & & & & & & & & & & \\
\hline 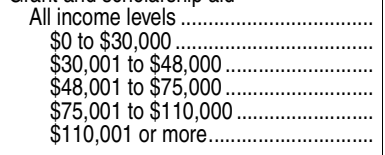 & $\begin{array}{r}4,460 \\
5,250 \\
4,380 \\
2,240 \\
800 \\
610\end{array}$ & $\begin{array}{r}4,540 \\
5,450 \\
4,520 \\
2,250 \\
750 \\
600\end{array}$ & $\begin{array}{l}5,180 \\
5,540 \\
5,080 \\
4,150 \\
3,240 \\
2,940\end{array}$ & $\begin{array}{r}4,090 \\
4,590 \\
3,670 \\
1,960 \\
830 \\
470\end{array}$ & $\begin{array}{r}4,620 \\
5,370 \\
4,600 \\
2,470 \\
890 \\
690\end{array}$ & $\begin{array}{r}4,680 \\
5,510 \\
4,730 \\
2,480 \\
850 \\
650\end{array}$ & $\begin{array}{l}5,740 \\
5,870 \\
5,680 \\
5,330 \\
5,060 \\
5,350\end{array}$ & $\begin{array}{r}4,260 \\
4,810 \\
3,900 \\
2,100 \\
590 \\
310\end{array}$ & $\begin{array}{r}4,480 \\
5,240 \\
4,350 \\
2,400 \\
790 \\
550\end{array}$ & $\begin{array}{r}4,530 \\
5,350 \\
4,510 \\
2,390 \\
740 \\
500\end{array}$ & $\begin{array}{l}5,630 \\
5,840 \\
5,580 \\
5,360 \\
4,280 \\
3,940\end{array}$ & $\begin{array}{r}4,110 \\
4,680 \\
3,550 \\
2,030 \\
560 \\
440\end{array}$ \\
\hline 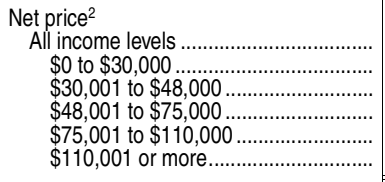 & $\begin{array}{r}8,930 \\
8,560 \\
8,720 \\
10,690 \\
12,230 \\
12,760 \\
\end{array}$ & $\begin{array}{r}6,290 \\
5,380 \\
6,330 \\
8,810 \\
10,630 \\
10,820 \\
\end{array}$ & $\begin{array}{l}16,270 \\
16,500 \\
16,620 \\
18,650 \\
20,760 \\
20,930 \\
\end{array}$ & $\begin{array}{l}18,360 \\
18,240 \\
19,070 \\
21,290 \\
23,020 \\
24,620 \\
\end{array}$ & $\begin{array}{r}9,030 \\
8,610 \\
9,000 \\
10,750 \\
12,500 \\
12,970 \\
\end{array}$ & $\begin{array}{r}6,550 \\
5,690 \\
6,520 \\
8,910 \\
10,780 \\
11,010 \\
\end{array}$ & $\begin{array}{l}17,170 \\
16,760 \\
18,090 \\
19,680 \\
20,830 \\
21,900 \\
\end{array}$ & $\begin{array}{l}18,770 \\
18,800 \\
19,650 \\
21,850 \\
24,040 \\
24,670 \\
\end{array}$ & $\begin{array}{r}9,160 \\
8,640 \\
9,690 \\
10,860 \\
12,570 \\
12,860 \\
\end{array}$ & $\begin{array}{r}6,980 \\
6,210 \\
7,050 \\
9,270 \\
11,150 \\
11,350 \\
\end{array}$ & $\begin{array}{l}17,610 \\
17,240 \\
18,140 \\
20,400 \\
21,100 \\
21,480 \\
\end{array}$ & $\begin{array}{l}19,300 \\
19,130 \\
20,380 \\
22,310 \\
24,250 \\
25,080 \\
\end{array}$ \\
\hline & & & & rel & age distri & stue & who rece & any Title & $V$ aid & & & \\
\hline 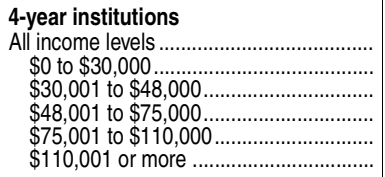 & $\begin{array}{r}100.0 \\
35.0 \\
15.4 \\
16.6 \\
15.6 \\
17.5\end{array}$ & $\begin{array}{r}100.0 \\
34.8 \\
16.3 \\
17.1 \\
15.9 \\
15.8\end{array}$ & $\begin{array}{r}100.0 \\
25.1 \\
14.0 \\
18.0 \\
18.4 \\
24.5\end{array}$ & $\begin{array}{r}100.0 \\
67.6 \\
14.3 \\
8.9 \\
5.2 \\
4.0\end{array}$ & $\begin{array}{r}100.0 \\
35.5 \\
15.5 \\
16.9 \\
15.3 \\
16.8\end{array}$ & $\begin{array}{r}100.0 \\
35.7 \\
16.5 \\
17.7 \\
15.5 \\
14.6\end{array}$ & $\begin{array}{r}100.0 \\
26.0 \\
14.1 \\
17.9 \\
17.8 \\
24.1\end{array}$ & $\begin{array}{r}100.0 \\
69.1 \\
14.2 \\
8.6 \\
4.7 \\
3.4\end{array}$ & $\begin{array}{r}100.0 \\
36.4 \\
14.6 \\
16.3 \\
15.3 \\
17.4\end{array}$ & $\begin{array}{r}100.0 \\
36.7 \\
15.8 \\
17.1 \\
15.4 \\
15.1\end{array}$ & $\begin{array}{r}100.0 \\
26.1 \\
13.3 \\
17.2 \\
18.1 \\
25.3\end{array}$ & $\begin{array}{r}100.0 \\
73.2 \\
12.2 \\
7.7 \\
4.1 \\
2.9\end{array}$ \\
\hline 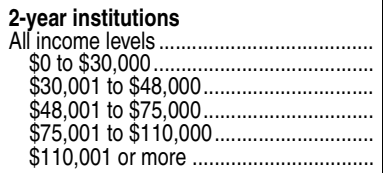 & $\begin{array}{r}100.0 \\
66.4 \\
15.7 \\
10.0 \\
5.2 \\
2.6\end{array}$ & $\begin{array}{r}100.0 \\
64.0 \\
16.4 \\
10.9 \\
5.8 \\
2.9\end{array}$ & $\begin{array}{r}100.0 \\
68.3 \\
16.1 \\
9.0 \\
4.5 \\
2.2\end{array}$ & $\begin{array}{r}100.0 \\
75.2 \\
13.4 \\
6.8 \\
3.0 \\
1.6\end{array}$ & $\begin{array}{r}100.0 \\
67.1 \\
15.4 \\
10.3 \\
4.9 \\
2.3\end{array}$ & $\begin{array}{r}100.0 \\
65.4 \\
15.7 \\
11.1 \\
5.4 \\
2.5\end{array}$ & $\begin{array}{r}100.0 \\
66.9 \\
17.2 \\
8.7 \\
4.7 \\
2.6\end{array}$ & $\begin{array}{r}100.0 \\
74.0 \\
14.2 \\
7.1 \\
3.1 \\
1.6\end{array}$ & $\begin{array}{r}100.0 \\
67.9 \\
14.6 \\
9.9 \\
5.1 \\
2.4\end{array}$ & $\begin{array}{r}100.0 \\
67.0 \\
14.3 \\
10.6 \\
5.5 \\
2.6\end{array}$ & $\begin{array}{r}100.0 \\
67.5 \\
16.0 \\
9.1 \\
5.0 \\
2.4\end{array}$ & $\begin{array}{r}100.0 \\
72.7 \\
16.3 \\
6.6 \\
2.9 \\
1.5\end{array}$ \\
\hline
\end{tabular}

${ }^{1}$ Grant and scholarship aid consists of federal Title IV grants, as well as other grant or scholarship aid from the federal government, state or local governments, or institutional sources Title IV grants include Federal Pell Grants, Federal Supplemental Educational Opportunity Grants (FSEOGs), Academic Competitiveness Grants (ACGs), National Science and Mathematics Access to Retain Talent Grants (National SMART Grants), and Teacher Education Assistance for College and Higher Education (TEACH) Grants. The average amount of grant and scholarship aid by income level was calculated based on all students who received any type of Title IV aid, even those students who received zero Title IV aid in the form of grants and received Title IV aid only in the form of work-study aid or loan aid.

${ }^{2}$ Net price is the total cost of attendance minus grant and scholarship aid from the federal government, state or local governments, or institutional sources. However, average net price by income level was calculated based on all students who received any type of Title IV aid, even those who received zero Title IV aid in the form of grants and received Title IV aid only in the form of work-study aid or loan aid.

NOTE: Excludes students who previously attended another postsecondary institution or who began their studies on a part-time basis. Includes only first-time, full-time students who paid the in-state or in-district tuition rate (if they attended public institutions) and who received Title IV aid. Excludes the 18 percent of students who did not receive any Title IV aid. Title IV aid includes grant aid, work-study aid, and loan aid. Data are weighted by the number of students at the institution receiving Title IV aid. Some data have been revised from previously published figures.

SOURCE: U.S. Department of Education, National Center for Education Statistics, Integrated Postsecondary Education Data System (IPEDS), Spring 2013, Student Financial Aid component. (This table was prepared December 2013.) 
Table 331.40. Average amount of financial aid awarded to full-time, full-year undergraduates, by type and source of aid and selected student characteristics: 2011-12

[In current dollars. Standard errors appear in parentheses]

\begin{tabular}{|c|c|c|c|c|c|c|c|c|c|c|c|c|c|c|c|c|c|c|c|c|}
\hline \multirow[b]{2}{*}{ Selected student characteristic } & \multicolumn{6}{|c|}{ Any aid } & \multicolumn{6}{|c|}{ Grants } & \multicolumn{6}{|c|}{ Loans } & \multicolumn{2}{|c|}{ Work study } \\
\hline & \multicolumn{2}{|c|}{ Total' } & \multicolumn{2}{|r|}{ Federal $^{2}$} & \multicolumn{2}{|c|}{ Nonfederal } & \multirow{2}{*}{\multicolumn{2}{|c|}{ Total }} & \multicolumn{2}{|r|}{ Federal } & \multicolumn{2}{|c|}{ Nonfederal } & \multicolumn{2}{|r|}{ Total $^{3}$} & \multicolumn{2}{|r|}{ Federal $^{3}$} & \multicolumn{2}{|c|}{ Nonfederal } & \multicolumn{2}{|r|}{ Total $^{4}$} \\
\hline 1 & & 2 & & 3 & & 4 & & & & 6 & & 7 & & 8 & & 9 & & 10 & & 11 \\
\hline $\begin{array}{l}\text { All full-time, full-year } \\
\text { undergraduates..... }\end{array}$ & $\$ 15,510$ & (106) & $\$ 10,820$ & (75) & $\$ 9,160$ & $(110)$ & $\$ 9,230$ & (92) & $\$ 4,580$ & (20) & $\$ 8,590$ & (115) & $\$ 10,090$ & (75) & $\$ 9,160$ & (69) & $\$ 6,980$ & (187) & $\$ 2,250$ & \\
\hline \multicolumn{21}{|l|}{ Sex } \\
\hline 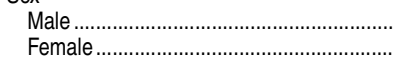 & $\begin{array}{l}15,710 \\
15,360\end{array}$ & $\begin{array}{l}(168) \\
(134)\end{array}$ & $\begin{array}{l}11,000 \\
10,690\end{array}$ & $\begin{array}{r}(109) \\
(88)\end{array}$ & $\begin{array}{l}9,300 \\
9,060\end{array}$ & $\begin{array}{l}(174) \\
(141)\end{array}$ & $\begin{array}{l}9,420 \\
9,100\end{array}$ & $\begin{array}{l}(149) \\
(109)\end{array}$ & $\begin{array}{l}4,550 \\
4,590\end{array}$ & $\begin{array}{l}(27) \\
(26)\end{array}$ & $\begin{array}{l}8,750 \\
8,480\end{array}$ & $\begin{array}{l}(178) \\
(140)\end{array}$ & $\begin{array}{l}10,180 \\
10,030\end{array}$ & $\begin{array}{r}(112) \\
(94)\end{array}$ & $\begin{array}{l}9,240 \\
9,100\end{array}$ & $\begin{array}{l}(98) \\
(91)\end{array}$ & $\begin{array}{l}6,910 \\
7,040\end{array}$ & $\begin{array}{l}(255) \\
(275)\end{array}$ & $\begin{array}{l}2,300 \\
2,200\end{array}$ & \\
\hline \multicolumn{21}{|l|}{ Race/ethnicity } \\
\hline White... & 15,380 & (146) & 10,760 & (101) & 9,370 & (138) & 9,060 & (115) & 4,370 & (27) & 8,670 & (144) & 10,280 & (99) & 9,250 & (97) & 7,230 & (181) & 2,200 & \\
\hline Black... & 16,120 & (257) & 11,890 & (157) & 8,270 & (300) & 8,600 & (191) & 4,780 & (30) & 7,850 & (313) & 9,990 & (167) & 9,320 & (157) & 6,360 & (406) & 2,320 & \\
\hline Hispanic.. & 14,730 & (310) & 10,190 & (157) & 8,200 & (319) & 9,280 & (267) & 4,750 & (40) & 7,920 & (340) & 9,450 & (180) & 8,670 & (163) & 6,330 & (338) & 2,350 & \\
\hline Asian.... & 16,230 & (536) & 9,520 & (248) & 10,690 & (512) & 11,740 & (444) & 4,780 & (82) & 10,310 & (498) & 9,480 & (400) & 8,500 & (303) & 7,500 & $(1,734)$ & 2,350 & \\
\hline Pacific Islander.... & 17,820 & $(1,659)$ & 11,910 & (872) & 11,100 & $(1,870)$ & 11,960 & $(1,704)$ & 4,990 & (164) & 11,100 & $(1,983)$ & 10,750 & $(1,171)$ & 10,240 & $(1,057)$ & $\ddagger$ & $(t)$ & $\ddagger$ & \\
\hline laska Native... & 14,760 & (992) & 9,980 & (514) & 8,930 & $(1,129)$ & 9,350 & (785) & 4,970 & (260) & 8,490 & $(1,048)$ & 8,000 & (607) & 7,300 & (487) & $6,620 !$ & $(2,584)$ & $\ddagger$ & \\
\hline Two or more races & 17,060 & $(544)$ & 11,490 & (295) & 9,840 & (573) & 10,070 & (416) & 4,750 & $(94)$ & 9,110 & $(536)$ & 10,890 & (353) & 9,750 & $(300)$ & 6,710 & (955) & $2,120^{+}$ & \\
\hline \multicolumn{21}{|l|}{ Age } \\
\hline 15 to 2 & 16,190 & (126) & 10,460 & (90) & 9,960 & (124) & 10,340 & (112) & 4,570 & (22) & 9,380 & (124) & 10,300 & (99) & 9,320 & (94) & 6,900 & (215) & 2,220 & \\
\hline 24 to 29 years old ........ & 14,120 & (240) & 11,770 & (165) & 5,950 & (355) & 6,550 & (202) & 4,600 & (39) & 5,000 & (389) & 9,700 & (123) & 8,770 & (82) & 7,790 & (482) & 2,530 & \\
\hline 30 years old or over ................................... & 13,160 & (210) & 11,620 & (145) & 4,910 & (234) & 5,800 & (125) & 4,570 & (39) & 4,000 & (266) & 9,460 & (122) & 8,760 & (86) & 6,750 & (367) & 2,550 & $(15$ \\
\hline Marital sta & & & & & & & & & & & & & & & & & & & & \\
\hline Not mar & 15,890 & (111) & 10,810 & (79) & 9,460 & (115) & 9,620 & (97) & 4,600 & (20) & 8,880 & (117) & 10,200 & $(81)$ & 9,230 & (75) & 6,980 & (197) & 2,240 & \\
\hline Marrie & 12,390 & (254) & 10,790 & (178) & 5,380 & (335) & 5,990 & (187) & 4,400 & (50) & 4,680 & (380) & 9,270 & (168) & 8,610 & (114) & 6,800 & $(619)$ & 2,630 & \\
\hline 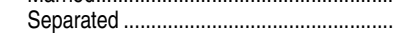 & 13,130 & (517) & 11,360 & (358) & 4,970 & $(817)$ & 6,010 & (303) & 4,750 & (80) & 4,070 & (857) & 8,950 & (314) & 8,260 & (222) & 8,150 & $(1,369)$ & $\ddagger$ & \\
\hline Depen & & & & & & & & & & & & & & & & & & & & \\
\hline Depende & 16,460 & (132) & 10,500 & & 10,150 & (125) & 10,580 & (117) & 4,520 & (24) & 9,570 & (128) & 10,440 & (105) & 9,450 & (101) & 6,840 & (219) & 2,210 & \\
\hline Le & 16,380 & (272) & 10,530 & (137) & 8,800 & (328) & 11,150 & (255) & 5,460 & (28) & 8,560 & (330) & 8,010 & (149) & 7,590 & (143) & 5,180 & (426) & 2,140 & \\
\hline 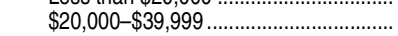 & 17,000 & (284) & 10,440 & (134) & 9,450 & (278) & 11,530 & (239) & 5,010 & (31) & 9,250 & (284) & 8,350 & (148) & 7,880 & (145) & 4,610 & (347) & 2,250 & \\
\hline 9 & 16,700 & (313) & 9,770 & (161) & 9,930 & (293) & 10,030 & (265) & 2,980 & (50) & 9,380 & (278) & 9,700 & (215) & 8,930 & (185) & 5,330 & (397) & 2,250 & \\
\hline$\$ 60,000-\$ 7$ & 16,080 & (387) & 9,870 & (221) & 10,330 & (353) & 9,6 & (356) & 2,0 & (70) & 9,680 & (378) & 10,660 & (245) & 9,460 & (216) & 6,680 & (373) & & \\
\hline$\ldots \ldots \ldots$ & 16,180 & (398) & 10,460 & (277) & 10,690 & (388) & 9,8 & (382) & 2,3 & (184) & 9,880 & (387) & 11,620 & (267) & 10,360 & (268) & 6,0 & (425) & 2,110 & \\
\hline 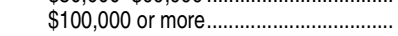 & 16,310 & (276) & 11,380 & (241) & 11,160 & (253) & 10,300 & (243) & 2,900 & (327) & 10,300 & (244) & 12,810 & (240) & 11,360 & (229) & 8,530 & (517) & 2,280 & \\
\hline ……………..... & 13,540 & (166) & 11,390 & (104) & 5,820 & (222) & 6,520 & (118) & 4,640 & (28) & 5,010 & (239) & 9,410 & (89) & 8,600 & $(60)$ & 7,350 & (299) & 2,480 & \\
\hline Less than $\$ 10,000$ & 14,400 & (255) & 11,600 & (148) & 6,210 & (333) & 7,510 & (185) & 5,070 & (31) & 5,490 & (340) & 9,180 & (134) & 8,360 & (96) & 7,560 & (552) & 2,330 & \\
\hline$\$ 10,000-\$ 19,999 \ldots \ldots$ & 13,700 & (282) & 11,590 & (195) & 5,580 & (369) & 6,160 & (188) & 4,440 & (53) & 4,760 & (404) & 9,440 & (137) & 8,650 & (104) & 7,170 & (388) & 2,700 & \\
\hline 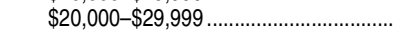 & 12,670 & (295) & 11,120 & (210) & 4,840 & (380) & 5,550 & (189) & 4,450 & (69) & 3,920 & (412) & 9,080 & (207) & 8,440 & (159) & 6,550 & (489) & 3,230 & $(38$ \\
\hline$\$ 30,000-\$ 49,999 \ldots \ldots \ldots \ldots \ldots \ldots \ldots \ldots \ldots \ldots \ldots$. & 12,920 & (409) & 11,390 & (262) & 5,820 & (743) & 5,750 & (374) & 4,320 & (65) & 4,940 & (798) & 9,650 & (217) & 8,810 & (134) & 7,440 & (837) & 1,920 & \\
\hline 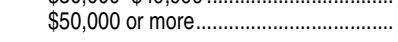 & 11,770 & (359) & 10,420 & (240) & 5,940 & (534) & 4,690 & (363) & 2,750 & (97) & 4,820 & (573) & 10,410 & (292) & 9,330 & (166) & 7,890 & $(1,159)$ & $\ddagger$ & \\
\hline Housi & & & & & & & & & & & & & & & & & & & & \\
\hline School & 22,220 & (251) & 12,340 & (160) & 13,880 & (249) & 14,390 & (257) & 4,690 & (44) & 13,060 & (259) & 11,410 & (140) & 10,190 & (145) & 7,690 & (269) & 2,140 & \\
\hline 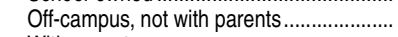 & 13,480 & (169) & 10,780 & (113) & 6,820 & (172) & 7,190 & (123) & 4,550 & (28) & 6,230 & (191) & 9,830 & (124) & 8,990 & (1) & 6,580 & (268) & 2,410 & \\
\hline With par & 12,380 & (167) & 9,550 & (98) & 6,460 & (193) & 7,340 & (141) & 4,580 & (36) & 5,900 & (197) & 9,170 & (132) & 8,360 & (100) & 6,900 & $(439)$ & 2,490 & \\
\hline Attended more than one institution ............ & 13,960 & (224) & 10,670 & (143) & 7,530 & (237) & 7,810 & (182) & 4,430 & (45) & 7,010 & (237) & 9,500 & (146) & 8,750 & (122) & 6,170 & (339) & 2,050 & \\
\hline
\end{tabular}

†Not applicable.

!nterpret data with caution. The coefficient of variation (CV) for this estimate is between 30 and 50 percent fReporting standards not met (too few cases for a reliable estimate).

2Includes Department of Veterans Affairs and Department of Defen specify the source or type of aid. Includes Parent Loans for Undergraduate Students (PLUS).

${ }^{4}$ Details on federal and nonfederal work-study participants are not available.
5 Includes students who were single, divorced, or widowed.

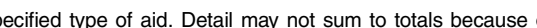
rounding and because and non-degree-granting institutions. Data exclude Puerto Rico. Race categories exclude persons of Hispanic ethnicity. SOURCE: U.S. Department of Education, National Center for Education Statistics, 2011-12 National Postsecondary Studen Aid Study (NPSAS: 12). (This table was prepared January 2014.) 
Table 331.45. Average amount of financial aid awarded to part-time or part-year undergraduates, by type and source of aid and selected student characteristics: 2011-12

[In current dollars] [Standard errors appear in parentheses]

\begin{tabular}{|c|c|c|c|c|c|c|c|c|c|c|c|c|c|c|c|c|c|c|c|c|}
\hline \multirow[b]{2}{*}{ Selected student characteristic } & \multicolumn{6}{|c|}{ Any aid } & \multicolumn{6}{|c|}{ Grants } & \multicolumn{6}{|c|}{ Loans } & \multicolumn{2}{|c|}{ Work study } \\
\hline & & Total $^{1}$ & & Federal $^{2}$ & & federal & & Total & & Federal & & federal & & Total $^{3}$ & & Federal $^{3}$ & & federal & & Total $^{4}$ \\
\hline 1 & & 2 & & 3 & & 4 & & 5 & & 6 & & 7 & & 8 & & 9 & & 10 & & 11 \\
\hline $\begin{array}{l}\text { All part-time or part-year } \\
\text { undergraduates............ }\end{array}$ & $\$ 6,760$ & (70) & $\$ 6,340$ & (63) & $\$ 3,190$ & $(86)$ & $\$ 3,430$ & (45) & $\$ 2,680$ & (22) & $\$ 2,790$ & (86) & $\$ 6,560$ & (55) & $\$ 6,270$ & (47) & $\$ 4,420$ & (131) & $\$ 2,350$ & (82) \\
\hline 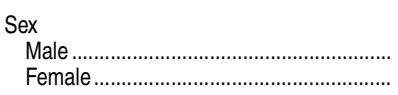 & $\begin{array}{l}6,760 \\
6,760\end{array}$ & $\begin{array}{r}(105) \\
(84)\end{array}$ & $\begin{array}{l}6,400 \\
6,300\end{array}$ & $\begin{array}{l}(86) \\
(73)\end{array}$ & $\begin{array}{l}3,200 \\
3,190\end{array}$ & $\begin{array}{l}(104) \\
(107)\end{array}$ & $\begin{array}{l}3,360 \\
3,470\end{array}$ & $\begin{array}{l}(64) \\
(57)\end{array}$ & $\begin{array}{l}2,620 \\
2,710\end{array}$ & $\begin{array}{l}(28) \\
(27)\end{array}$ & $\begin{array}{l}2,770 \\
2,810\end{array}$ & $\begin{array}{l}(107) \\
(111)\end{array}$ & $\begin{array}{l}6,550 \\
6,570\end{array}$ & $\begin{array}{l}(86) \\
(66)\end{array}$ & $\begin{array}{l}6,240 \\
6,280\end{array}$ & $\begin{array}{l}(76) \\
(56)\end{array}$ & $\begin{array}{l}4,480 \\
4,370\end{array}$ & $\begin{array}{l}(191) \\
(163)\end{array}$ & $\begin{array}{l}2,600 \\
2,160\end{array}$ & $\begin{array}{l}(157) \\
(107)\end{array}$ \\
\hline 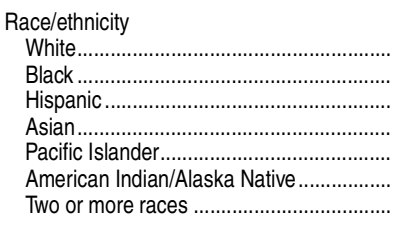 & $\begin{array}{l}6,880 \\
7,040 \\
6,040 \\
6,750 \\
6,350 \\
6,610 \\
7,020\end{array}$ & $\begin{array}{r}(95) \\
(121) \\
(140) \\
(352) \\
(528) \\
(537) \\
(276)\end{array}$ & $\begin{array}{l}6,490 \\
6,440 \\
5,790 \\
6,260 \\
6,470 \\
6,110 \\
6,430\end{array}$ & $\begin{array}{r}(77) \\
(126) \\
(130) \\
(323) \\
(469) \\
(417) \\
(237)\end{array}$ & $\begin{array}{l}3,470 \\
3,130 \\
2,370 \\
3,720 \\
2,560 \\
2,410 \\
3,290\end{array}$ & $\begin{array}{l}(111) \\
(164) \\
(114) \\
(358) \\
(447) \\
(384) \\
(296)\end{array}$ & $\begin{array}{l}3,460 \\
3,400 \\
3,200 \\
4,200 \\
3,440 \\
3,370 \\
3,570\end{array}$ & $\begin{array}{r}(64) \\
(81) \\
(71) \\
(274) \\
(309) \\
(305) \\
(170)\end{array}$ & $\begin{array}{l}2,630 \\
2,690 \\
2,740 \\
2,920 \\
2,740 \\
2,720 \\
2,610\end{array}$ & $\begin{array}{r}(25) \\
(38) \\
(39) \\
(107) \\
(185) \\
(154) \\
(83)\end{array}$ & $\begin{array}{l}3,030 \\
2,810 \\
1,970 \\
3,480 \\
2,060 \\
2,240 \\
2,880\end{array}$ & $\begin{array}{l}(113) \\
(189) \\
(104) \\
(356) \\
(457) \\
(359) \\
(285)\end{array}$ & $\begin{array}{l}6,590 \\
6,470 \\
6,510 \\
7,210 \\
7,140 \\
6,230 \\
6,410\end{array}$ & $\begin{array}{r}(76) \\
(106) \\
(123) \\
(514) \\
(623) \\
(399) \\
(277)\end{array}$ & $\begin{array}{l}6,280 \\
6,210 \\
6,200 \\
7,000 \\
6,840 \\
6,030 \\
6,140\end{array}$ & $\begin{array}{r}(65) \\
(103) \\
(107) \\
(514) \\
(586) \\
(375) \\
(238)\end{array}$ & $\begin{array}{r}4,740 \\
3,850 \\
4,150 \\
3,980 \\
\ddagger \\
\ddagger \\
4,400\end{array}$ & $\begin{array}{r}(190) \\
(202) \\
(238) \\
(516) \\
(\dagger) \\
(\dagger) \\
(758)\end{array}$ & $\begin{array}{r}2,310 \\
2,210 \\
2,910 \\
2,040 \\
\ddagger \\
\ddagger \\
1,870\end{array}$ & $\begin{array}{r}(112) \\
(254) \\
(246) \\
(205) \\
(\dagger) \\
(\dagger) \\
(309)\end{array}$ \\
\hline 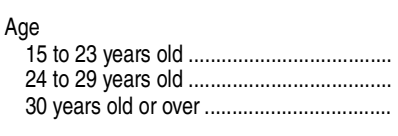 & $\begin{array}{l}6,920 \\
6,540 \\
6,710\end{array}$ & $\begin{array}{r}(116) \\
(110) \\
(85)\end{array}$ & $\begin{array}{l}5,950 \\
6,430 \\
6,780\end{array}$ & $\begin{array}{l}(83) \\
(98) \\
(98)\end{array}$ & $\begin{array}{l}3,860 \\
2,500 \\
2,590\end{array}$ & $\begin{array}{l}(136) \\
(113) \\
(102)\end{array}$ & $\begin{array}{l}4,020 \\
2,930 \\
2,990\end{array}$ & $\begin{array}{l}(84) \\
(58) \\
(60)\end{array}$ & $\begin{array}{l}2,760 \\
2,580 \\
2,650\end{array}$ & $\begin{array}{l}(27) \\
(32) \\
(31)\end{array}$ & $\begin{array}{l}3,540 \\
1,950 \\
2,140\end{array}$ & $\begin{array}{r}(135) \\
(98) \\
(112)\end{array}$ & $\begin{array}{l}6,420 \\
6,450 \\
6,820\end{array}$ & $\begin{array}{r}(107) \\
(82) \\
(76)\end{array}$ & $\begin{array}{l}6,110 \\
6,110 \\
6,570\end{array}$ & $\begin{array}{r}(101) \\
(73) \\
(67)\end{array}$ & $\begin{array}{l}4,370 \\
4,670 \\
4,310\end{array}$ & $\begin{array}{l}(173) \\
(223) \\
(270)\end{array}$ & $\begin{array}{l}2,290 \\
2,640 \\
2,300\end{array}$ & $\begin{array}{l}(101) \\
(239) \\
(198)\end{array}$ \\
\hline 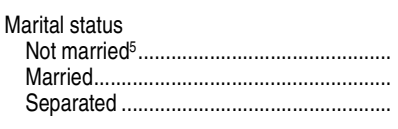 & $\begin{array}{l}6,860 \\
6,380 \\
7,010\end{array}$ & $\begin{array}{r}(85) \\
(129) \\
(248)\end{array}$ & $\begin{array}{l}6,240 \\
6,660 \\
6,630\end{array}$ & $\begin{array}{r}(66) \\
(133) \\
(248)\end{array}$ & $\begin{array}{l}3,390 \\
2,550 \\
2,610\end{array}$ & $\begin{array}{l}(101) \\
(129) \\
(265)\end{array}$ & $\begin{array}{l}3,580 \\
2,910 \\
3,150\end{array}$ & $\begin{array}{r}(52) \\
(79) \\
(110)\end{array}$ & $\begin{array}{l}2,700 \\
2,550 \\
2,800\end{array}$ & $\begin{array}{l}(21) \\
(44) \\
(87)\end{array}$ & $\begin{array}{l}2,970 \\
2,240 \\
1,950\end{array}$ & $\begin{array}{l}(100) \\
(132) \\
(251)\end{array}$ & $\begin{array}{l}6,520 \\
6,730 \\
6,490\end{array}$ & $\begin{array}{r}(66) \\
(97) \\
(211)\end{array}$ & $\begin{array}{l}6,200 \\
6,560 \\
6,110\end{array}$ & $\begin{array}{r}(57) \\
(87) \\
(200)\end{array}$ & $\begin{array}{l}4,520 \\
3,930 \\
4,570\end{array}$ & $\begin{array}{l}(150) \\
(248) \\
(585)\end{array}$ & $\begin{array}{r}2,300 \\
2,820 \\
\ddagger\end{array}$ & $\begin{array}{r}(80) \\
(404) \\
(\dagger)\end{array}$ \\
\hline $\begin{array}{l}\text { ependency status and family income } \\
\text { Dependent } \\
\text { Less than } \$ 20,000 \\
\$ 20,000-\$ 39,999 \\
\$ 40,000-\$ 59,999\end{array}$ & $\begin{array}{l}7,050 \\
6,530 \\
6,690 \\
6,990 \\
7,070 \\
7,260 \\
8,280 \\
6,610 \\
6,800 \\
6,990 \\
6,610 \\
6,370 \\
6,000\end{array}$ & $\begin{array}{r}(135) \\
(171) \\
(215) \\
(260) \\
(344) \\
(352) \\
(374) \\
(69) \\
(110) \\
(131) \\
(143) \\
(152) \\
(172)\end{array}$ & $\begin{array}{l}5,900 \\
5,420 \\
5,360 \\
5,740 \\
6,210 \\
6,280 \\
7,810 \\
6,560 \\
6,430 \\
6,590 \\
6,520 \\
6,610 \\
6,770\end{array}$ & $\begin{array}{r}(98) \\
(131) \\
(124) \\
(194) \\
(258) \\
(272) \\
(344) \\
(80) \\
(101) \\
(137) \\
(160) \\
(135) \\
(192)\end{array}$ & $\begin{array}{l}4,070 \\
3,140 \\
3,640 \\
3,530 \\
4,270 \\
4,960 \\
5,440 \\
2,600 \\
2,710 \\
2,580 \\
2,500 \\
2,470 \\
2,650\end{array}$ & $\begin{array}{l}(149) \\
(180) \\
(334) \\
(220) \\
(299) \\
(328) \\
(392) \\
(85) \\
(135) \\
(137) \\
(161) \\
(150) \\
(137)\end{array}$ & $\begin{array}{l}4,240 \\
4,190 \\
4,340 \\
3,560 \\
3,910 \\
4,310 \\
5,220 \\
3,030 \\
3,330 \\
3,090 \\
2,910 \\
2,820 \\
2,420\end{array}$ & $\begin{array}{r}(96) \\
(106) \\
(188) \\
(156) \\
(262) \\
(324) \\
(425) \\
(42) \\
(59) \\
(68) \\
(80) \\
(97) \\
(108)\end{array}$ & $\begin{array}{l}2,770 \\
3,080 \\
2,930 \\
2,020 \\
1,620 \\
1,760 \\
4,390 \\
2,640 \\
2,860 \\
2,580 \\
2,560 \\
2,610 \\
1,700\end{array}$ & $\begin{array}{r}(30) \\
(45) \\
(45) \\
(53) \\
(118) \\
(244) \\
(605) \\
(25) \\
(31) \\
(40) \\
(51) \\
(51) \\
(63)\end{array}$ & $\begin{array}{l}3,730 \\
2,930 \\
3,380 \\
3,230 \\
3,930 \\
4,310 \\
5,160 \\
2,140 \\
2,200 \\
2,050 \\
1,970 \\
1,970 \\
2,400\end{array}$ & $\begin{array}{r}(146) \\
(190) \\
(340) \\
(211) \\
(289) \\
(343) \\
(433) \\
(88) \\
(139) \\
(152) \\
(147) \\
(140) \\
(138)\end{array}$ & $\begin{array}{l}6,600 \\
5,270 \\
5,660 \\
6,790 \\
6,760 \\
7,060 \\
8,380 \\
6,540 \\
6,010 \\
6,490 \\
6,580 \\
6,950 \\
7,350\end{array}$ & $\begin{array}{r}(127) \\
(136) \\
(166) \\
(252) \\
(288) \\
(298) \\
(345) \\
(51) \\
(75) \\
(95) \\
(131) \\
(128) \\
(135)\end{array}$ & $\begin{array}{l}6,270 \\
5,080 \\
5,410 \\
6,440 \\
6,480 \\
6,420 \\
8,070 \\
6,260 \\
5,690 \\
6,190 \\
6,300 \\
6,720 \\
7,180\end{array}$ & $\begin{array}{r}(118) \\
(136) \\
(158) \\
(254) \\
(257) \\
(271) \\
(351) \\
(42) \\
(66) \\
(91) \\
(111) \\
(118) \\
(132)\end{array}$ & $\begin{array}{l}4,430 \\
3,640 \\
3,880 \\
3,650 \\
4,110 \\
5,770 \\
5,310 \\
4,410 \\
4,620 \\
4,480 \\
4,250 \\
4,540 \\
3,940\end{array}$ & $\begin{array}{l}(198) \\
(255) \\
(418) \\
(388) \\
(405) \\
(554) \\
(551) \\
(169) \\
(235) \\
(218) \\
(372) \\
(548) \\
(318)\end{array}$ & $\begin{array}{l}2,230 \\
2,050 \\
1,910 \\
2,160 \\
2,290 \\
2,170 \\
2,830 \\
2,530 \\
2,280 \\
2,710 \\
2,490 \\
3,600 \\
2,750\end{array}$ & $\begin{array}{l}(105) \\
(343) \\
(177) \\
(261) \\
(280) \\
(248) \\
(268) \\
(145) \\
(177) \\
(319) \\
(613) \\
(530) \\
(709)\end{array}$ \\
\hline 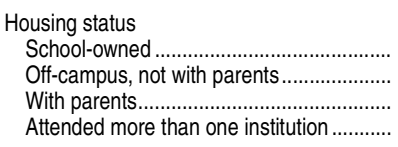 & $\begin{array}{r}12,620 \\
6,460 \\
6,170 \\
7,830\end{array}$ & $\begin{array}{r}(468) \\
(76) \\
(120) \\
(167)\end{array}$ & $\begin{array}{l}8,940 \\
6,320 \\
5,850 \\
7,290\end{array}$ & $\begin{array}{r}(383) \\
(79) \\
(94) \\
(161)\end{array}$ & $\begin{array}{l}7,910 \\
2,790 \\
2,730 \\
3,390\end{array}$ & $\begin{array}{r}(397) \\
(91) \\
(155) \\
(152)\end{array}$ & $\begin{array}{l}7,540 \\
3,140 \\
3,220 \\
3,740\end{array}$ & $\begin{array}{r}(382) \\
(48) \\
(80) \\
(108)\end{array}$ & $\begin{array}{l}2,870 \\
2,650 \\
2,660 \\
2,900\end{array}$ & $\begin{array}{l}(81) \\
(26) \\
(36) \\
(53)\end{array}$ & $\begin{array}{l}7,420 \\
2,340 \\
2,380 \\
2,960\end{array}$ & $\begin{array}{r}(428) \\
(98) \\
(149) \\
(163)\end{array}$ & $\begin{array}{l}8,560 \\
6,450 \\
6,200 \\
7,110\end{array}$ & $\begin{array}{r}(368) \\
(67) \\
(93) \\
(133)\end{array}$ & $\begin{array}{l}7,880 \\
6,180 \\
5,960 \\
6,760\end{array}$ & $\begin{array}{r}(353) \\
(59) \\
(76) \\
(129)\end{array}$ & $\begin{array}{l}6,350 \\
4,430 \\
4,010 \\
4,220\end{array}$ & $\begin{array}{l}(709) \\
(188) \\
(200) \\
(255)\end{array}$ & $\begin{array}{l}1,700 \\
2,550 \\
2,610 \\
2,180\end{array}$ & $\begin{array}{l}(143) \\
(165) \\
(156) \\
(223)\end{array}$ \\
\hline
\end{tabular}

†Not applicable.

fReporting standards not met (too few cases for a reliable estimate)

Includes students who reported they were awarded aid, but did not specify the source or type of aid.

2heludes Department or velerans Afrairs and Department of Defense benefils.

${ }^{4}$ Details on federal and nonfederal work-study participants.

5 Includes students who were single, divorced, or widowed.
NOTE: Aid averages are for those students who received the specified type of aid. Detail may not sum to totals because of rounding and because some students receive multiple types of aid and aid from different sources. Part-time or part-year undergraduates include students enrolled part time tor 9 or more monhs and students enrolled less han 9 months either part Rico. Race categories exclude persons of Hispanic ethnicity. Aid Study (NPSAS:12). (This table was prepared January 2014.) 
Table 331.50. Amount borrowed, aid status, and sources of aid for full-time and part-time undergraduates, by control and level of institution: 2007-08 and 2011-12

[Standard errors appear in parentheses]

\begin{tabular}{|c|c|c|c|c|c|c|c|c|c|c|c|c|c|c|c|c|c|c|}
\hline \multirow[b]{3}{*}{ Control and level of institution } & \multirow{3}{*}{\multicolumn{2}{|c|}{$\begin{array}{r}\text { Number of } \\
\text { undergraduates } \\
\text { (in thousands) }\end{array}$}} & \multicolumn{4}{|c|}{$\begin{array}{c}\text { Cumulative amount borrowed for } \\
\text { undergraduate education }{ }^{2}\end{array}$} & \multicolumn{12}{|c|}{ Aid status (percent of students) } \\
\hline & & & \multirow{2}{*}{\multicolumn{2}{|c|}{$\begin{array}{r}\text { In current } \\
\text { dollars }\end{array}$}} & \multirow{2}{*}{\multicolumn{2}{|c|}{$\begin{array}{r}\text { In constant } \\
2012-13 \\
\text { dollars }^{3}\end{array}$}} & \multirow{2}{*}{\multicolumn{2}{|c|}{ Nonaided }} & \multicolumn{10}{|c|}{ Source of aid } \\
\hline & & & & & & & & & \multicolumn{2}{|c|}{ Any aid 4,5} & \multicolumn{2}{|c|}{ Federal $^{5}$} & & State & \multicolumn{2}{|c|}{ Institutional } & \multicolumn{2}{|r|}{ Other ${ }^{4}$} \\
\hline \multirow[t]{2}{*}{1} & & 2 & & 3 & & 4 & & 5 & & 6 & & 7 & & 8 & & & & 10 \\
\hline & \multicolumn{18}{|c|}{$2007-08$} \\
\hline $\begin{array}{l}\text { ull-time, full-year students } \\
\text { All institutions........................ }\end{array}$ & 7,650 & $(-)$ & $\$ 15,170$ & (127) & $\$ 16,580$ & (138) & 19.7 & (0.28) & 80.3 & $(0.28)$ & 64.3 & (0.32) & 28.5 & (0.38) & 34.1 & $(0.47)$ & 32.7 & $(0.32)$ \\
\hline 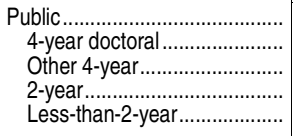 & $\begin{array}{r}5,189 \\
2,531 \\
1,051 \\
1,584 \\
22\end{array}$ & $\begin{array}{l}(-) \\
(-) \\
(-) \\
(-) \\
(-)\end{array}$ & $\begin{array}{r}13,150 \\
14,710 \\
13,430 \\
8,710 \\
10,000\end{array}$ & $\begin{array}{l}(117) \\
(169) \\
(202) \\
(176) \\
(996)\end{array}$ & $\begin{array}{r}14,370 \\
16,080 \\
14,680 \\
9,520 \\
10,930\end{array}$ & $\begin{array}{r}(127) \\
(185) \\
(220) \\
(193) \\
(1,089)\end{array}$ & $\begin{array}{l}24.6 \\
22.2 \\
17.5 \\
33.1 \\
30.9\end{array}$ & $\begin{array}{l}(0.33) \\
(0.40) \\
(0.58) \\
(0.69) \\
(3.87)\end{array}$ & $\begin{array}{l}75.4 \\
77.8 \\
82.5\end{array}$ & $\begin{array}{l}(0.33) \\
(0.40) \\
(0.58) \\
(0.69) \\
(3.87)\end{array}$ & $\begin{array}{l}58.8 \\
59.6 \\
67.9 \\
51.4 \\
58.6\end{array}$ & $\begin{array}{l}(0.35) \\
(0.48) \\
(0.67) \\
(0.73) \\
(3.84)\end{array}$ & $\begin{array}{l}29.8 \\
30.6 \\
34.5 \\
25.8 \\
17.1\end{array}$ & $\begin{array}{l}(0.42) \\
(0.60) \\
(0.94) \\
(0.76) \\
(4.00)\end{array}$ & $\begin{array}{r}27.0 \\
33.6 \\
25.0 \\
18.1 \\
\ddagger\end{array}$ & $\begin{array}{r}(0.39) \\
(0.59) \\
(0.89) \\
(0.71) \\
(\dagger)\end{array}$ & $\begin{array}{l}26.4 \\
30.8 \\
29.2 \\
17.6 \\
21.6\end{array}$ & $\begin{array}{l}(0.32) \\
(0.43) \\
(0.67) \\
(0.56) \\
(3.23)\end{array}$ \\
\hline 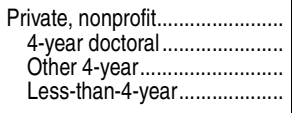 & $\begin{array}{r}1,737 \\
861 \\
854 \\
22\end{array}$ & $\begin{array}{l}(-) \\
(-) \\
(-) \\
(-)\end{array}$ & $\begin{array}{l}19,300 \\
20,730 \\
18,100 \\
12,740\end{array}$ & $\begin{array}{r}(325) \\
(499) \\
(439) \\
(1,267)\end{array}$ & $\begin{array}{l}21,090 \\
22,650 \\
19,780 \\
13,920\end{array}$ & $\begin{array}{r}(355) \\
(545) \\
(480) \\
(1,385)\end{array}$ & $\begin{array}{c}10.2 \\
14.2 \\
6.1 \\
6.2 !\end{array}$ & $\begin{array}{l}(0.56) \\
(0.93) \\
(0.71) \\
(2.01)\end{array}$ & $\begin{array}{l}89.8 \\
85.8 \\
93.9 \\
93.8\end{array}$ & $\begin{array}{l}(0.56) \\
(0.93) \\
(0.71) \\
(2.01)\end{array}$ & $\begin{array}{l}72.2 \\
67.8 \\
76.2 \\
88.8\end{array}$ & $\begin{array}{l}(0.64) \\
(1.20) \\
(1.09) \\
(2.95)\end{array}$ & $\begin{array}{l}32.3 \\
27.9 \\
36.6 \\
40.1\end{array}$ & $\begin{array}{l}(1.01) \\
(0.96) \\
(1.90) \\
(7.04)\end{array}$ & $\begin{array}{l}66.6 \\
65.0 \\
69.4 \\
15.4 !\end{array}$ & $\begin{array}{l}(1.54) \\
(2.09) \\
(2.31) \\
(7.51)\end{array}$ & 42.9 & $\begin{array}{l}(0.68) \\
(1.04) \\
(1.04) \\
(4.97)\end{array}$ \\
\hline 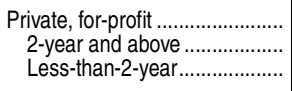 & $\begin{array}{l}724 \\
610 \\
115\end{array}$ & $\begin{array}{l}(-) \\
(-) \\
(-)\end{array}$ & $\begin{array}{r}15,960 \\
17,030 \\
9,570\end{array}$ & $\begin{array}{l}(382) \\
(453) \\
(215)\end{array}$ & $\begin{array}{l}17,440 \\
18,610 \\
10,460\end{array}$ & $\begin{array}{l}(418) \\
(495) \\
(235)\end{array}$ & $\begin{array}{l}7.2 \\
7.5 \\
5.7\end{array}$ & $\begin{array}{l}(0.67) \\
(0.79) \\
(0.85)\end{array}$ & $\begin{array}{l}92.8 \\
92.5 \\
94.3\end{array}$ & $\begin{array}{l}(0.67) \\
(0.79) \\
(0.85)\end{array}$ & $\begin{array}{l}85.1 \\
84.4 \\
88.9\end{array}$ & $\begin{array}{l}(1.21) \\
(1.41) \\
(1.71)\end{array}$ & $\begin{array}{r}9.4 \\
8.9 \\
12.3\end{array}$ & $\begin{array}{l}(1.06) \\
(1.18) \\
(2.45)\end{array}$ & $\begin{array}{l}7.6 \\
7.7 \\
6.9\end{array}$ & $\begin{array}{l}(1.54) \\
(1.83) \\
(1.48)\end{array}$ & $\begin{array}{l}53.8 \\
56.7 \\
38.5\end{array}$ & $\begin{array}{l}(1.24) \\
(1.41) \\
(1.30)\end{array}$ \\
\hline $\begin{array}{l}\text { Part-time or part-year students } \\
\text { All institutions }\end{array}$ & 13,112 & $(-)$ & $\$ 12,770$ & (117) & $\$ 13,960$ & (127) & 43.1 & 1.45) & 56.9 & $(0.45)$ & 39.3 & (0.30) & .6 & (0.23) & 1.9 & .36) & 24.0 & $(0.35)$ \\
\hline 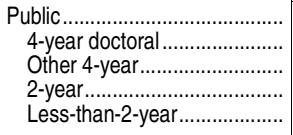 & $\begin{array}{r}10,402 \\
1,685 \\
1,164 \\
7,477 \\
76\end{array}$ & $\begin{array}{l}(-) \\
(-) \\
(-) \\
(-) \\
(-)\end{array}$ & $\begin{array}{r}11,800 \\
16,390 \\
13,670 \\
9,360 \\
8,140\end{array}$ & $\begin{array}{l}(114) \\
(249) \\
(284) \\
(152) \\
(574)\end{array}$ & $\begin{array}{r}12,900 \\
17,910 \\
14,940 \\
10,230 \\
8,900\end{array}$ & \begin{tabular}{l|}
$(125)$ \\
$(272)$ \\
$(311)$ \\
$(166)$ \\
$(628)$
\end{tabular} & $\begin{array}{l}50.7 \\
35.8 \\
39.9 \\
55.8 \\
53.3\end{array}$ & $\begin{array}{l}(0.54) \\
(0.73) \\
(1.02) \\
(0.68) \\
(2.17)\end{array}$ & 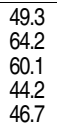 & $\begin{array}{l}(1.02) \\
(0.68) \\
(2.17)\end{array}$ & 30.3 & $\begin{array}{l}(0.36) \\
(0.74) \\
(0.97) \\
(0.42) \\
(1.91)\end{array}$ & $\begin{array}{c}10.6 \\
15.9 \\
11.4 \\
9.4 \\
9.9 !\end{array}$ & $\begin{array}{l}(0.25) \\
(0.57) \\
(0.57) \\
(0.32) \\
(3.86)\end{array}$ & $\begin{array}{l}10.5 \\
16.6 \\
7.4 \\
9.8 \\
4.0 !\end{array}$ & $42)$ & $\begin{array}{l}5.1 \\
6.4 \\
5.5\end{array}$ & $\begin{array}{l}(0.31) \\
(0.78) \\
(0.95) \\
(0.36) \\
(1.43)\end{array}$ \\
\hline 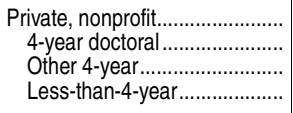 & $\begin{array}{r}1,168 \\
465 \\
637 \\
66\end{array}$ & $\begin{array}{l}(-) \\
(-) \\
(-) \\
(-)\end{array}$ & $\begin{array}{l}18,480 \\
20,420 \\
17,690 \\
12,380\end{array}$ & $\begin{array}{r}(349) \\
(595) \\
(463) \\
(1,756)\end{array}$ & $\begin{array}{l}20,200 \\
22,320 \\
19,330 \\
13,530\end{array}$ & $\begin{array}{r}(381) \\
(651) \\
(506) \\
(1,919)\end{array}$ & $\begin{array}{l}22.7 \\
24.5 \\
21.2 \\
24.7\end{array}$ & $\begin{array}{l}(0.90) \\
(1.37) \\
(1.29) \\
(4.14)\end{array}$ & 77.3 & $\begin{array}{l}(0.90) \\
(1.37) \\
(1.29) \\
(4.14)\end{array}$ & $\begin{array}{l}55.4 \\
49.7\end{array}$ & $\begin{array}{l}(0.87) \\
(1.87) \\
(1.43) \\
(3.94)\end{array}$ & $\begin{array}{l}15.6 \\
12.7\end{array}$ & $\begin{array}{l}(0.80) \\
(1.00) \\
(1.21) \\
(5.28)\end{array}$ & $\begin{array}{c}27.9 \\
30.9 \\
27.7 \\
8.1 !\end{array}$ & 1.18) & $\begin{array}{l}40.8 \\
43.2 \\
40.8 \\
24.1\end{array}$ & $\begin{array}{l}(0.95) \\
(1.49) \\
(1.42) \\
(2.18)\end{array}$ \\
\hline 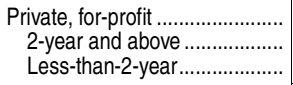 & $\begin{array}{r}1,542 \\
1,205 \\
337\end{array}$ & $\begin{array}{l}(-) \\
(-) \\
(-)\end{array}$ & $\begin{array}{r}12,470 \\
13,410 \\
8,840\end{array}$ & & $\begin{array}{r}13,630 \\
14,650 \\
9,660\end{array}$ & & $\begin{array}{r}6.8 \\
5.5 \\
11.4\end{array}$ & $(0.56)$ & & & 87.7 & & $\begin{array}{l}6.6 \\
7.0 \\
5.3\end{array}$ & $\begin{array}{l}(0.68) \\
(0.80) \\
(1.07)\end{array}$ & $\begin{array}{l}8.7 \\
9.0\end{array}$ & 1.74) & $\begin{array}{l}4.5 \\
6.7\end{array}$ & $\begin{array}{l}(1.62) \\
(2.01) \\
(1.40)\end{array}$ \\
\hline Less-than-2-year.......................... & \multicolumn{18}{|c|}{ 2011-1 } \\
\hline $\begin{array}{l}\text { Full-time, full-y } \\
\text { All institutic }\end{array}$ & 8,864 & $(-)$ & $\$ 18,960$ & (146) & $\$ 19,280$ & (148) & 15.6 & $(0.36)$ & 84.4 & $(0.36)$ & 72.8 & 51) & 0 & (0.43) & 33.9 & 1.48) & 28.1 & .36) \\
\hline 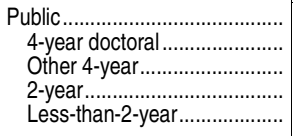 & $\begin{array}{r}5,997 \\
2,893 \\
969 \\
2,104 \\
31\end{array}$ & \begin{tabular}{l|}
$(-)$ \\
$(-)$ \\
$(-)$ \\
$(-)$ \\
$(-)$
\end{tabular} & $\begin{array}{l}16,550 \\
18,080 \\
16,980 \\
12,740 \\
12,740\end{array}$ & $\begin{array}{r}(165) \\
(196) \\
(347) \\
(416) \\
(3,005)\end{array}$ & $\begin{array}{l}16,830 \\
18,380 \\
17,260 \\
12,950 \\
12,950\end{array}$ & $\begin{array}{r}(167) \\
(199) \\
(353) \\
(423) \\
(3,055)\end{array}$ & $\begin{array}{l}19.6 \\
16.1 \\
16.5 \\
25.5 \\
28.4\end{array}$ & (4.50) & 804 & $\begin{array}{l}(0.47) \\
(0.46) \\
(0.93) \\
(1.03) \\
(4.50)\end{array}$ & $\begin{array}{l}68.4 \\
70.9 \\
72.7\end{array}$ & $\begin{array}{l}(0.61) \\
(0.47) \\
(1.34) \\
(1.24) \\
(4.72)\end{array}$ & $\begin{array}{l}26.5 \\
30.6 \\
30.2 \\
19.3 \\
18.2 !\end{array}$ & $\begin{array}{l}(0.58) \\
(0.68) \\
(1.36) \\
(0.98) \\
(6.85)\end{array}$ & $\begin{array}{r}26.2 \\
33.2 \\
22.9 \\
18.5 \\
\ddagger\end{array}$ & $\begin{array}{r}(0.97) \\
(t)\end{array}$ & $\begin{array}{l}7.5 \\
7.8 \\
8.9\end{array}$ & $\begin{array}{l}(0.36) \\
(0.49) \\
(0.90) \\
(0.57) \\
(4.08)\end{array}$ \\
\hline 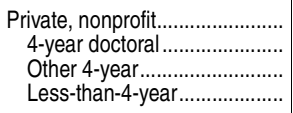 & $\begin{array}{r}1,875 \\
990 \\
849 \\
36\end{array}$ & $\begin{array}{l}(-) \\
(-) \\
(-) \\
(-)\end{array}$ & $\begin{array}{l}21,780 \\
22,190 \\
21,500 \\
17,230\end{array}$ & $\begin{array}{r}(425) \\
(756) \\
(466) \\
(1,985)\end{array}$ & $\begin{array}{l}22,140 \\
22,560 \\
21,860 \\
17,520\end{array}$ & $\begin{array}{r}(432) \\
(769) \\
(473) \\
(2,018)\end{array}$ & $\begin{array}{l}8.4 \\
9.6 \\
6.9 \\
9.8 !\end{array}$ & $(0.55)$ & & & 76.1 & $\begin{array}{l}(0.75) \\
(0.94) \\
(1.20) \\
(5.04)\end{array}$ & $\begin{array}{l}25.3 \\
23.3 \\
28.0 \\
19.5 !\end{array}$ & $\begin{array}{l}(0.87) \\
(1.29) \\
(1.24) \\
(7.60)\end{array}$ & $\begin{array}{l}73.7 \\
74.5 \\
74.3 \\
34.5 !\end{array}$ & $\begin{array}{r}(0.97) \\
(1.29) \\
(1.38) \\
(11.90)\end{array}$ & $\begin{array}{r}39.6 \\
88.9 \\
10.5\end{array}$ & $\begin{array}{l}(0.96) \\
(1.50) \\
(1.08) \\
(4.24)\end{array}$ \\
\hline $\begin{array}{l}\text { Private, for-profit ............................ } \\
\text { 2-year and above ................... } \\
\text { Less-than-2-year.................. }\end{array}$ & $\begin{array}{l}992 \\
859 \\
133\end{array}$ & $\begin{array}{l}(-) \\
(-) \\
(-)\end{array}$ & $\begin{array}{l}23,830 \\
25,440 \\
13,080\end{array}$ & $\begin{array}{l}(303) \\
(351) \\
(356)\end{array}$ & $\begin{array}{l}24,230 \\
25,860 \\
13,300\end{array}$ & $\begin{array}{l}(308) \\
(357) \\
(361)\end{array}$ & $\begin{array}{l}5.2 \\
5.4 \\
4.1\end{array}$ & $\begin{array}{l}(0.46) \\
(0.53) \\
(0.75)\end{array}$ & & $\begin{array}{l}(0.46) \\
(0.53) \\
(0.75)\end{array}$ & $\begin{array}{l}93.1 \\
92.8 \\
95.2\end{array}$ & $\begin{array}{l}(0.51) \\
(0.59) \\
(0.79)\end{array}$ & $\begin{array}{r}6.9 \\
7.5 \\
\ddagger\end{array}$ & $\begin{array}{r}(0.70) \\
(0.78) \\
(\dagger)\end{array}$ & $\begin{array}{r}4.8 \\
5.4 \\
\ddagger\end{array}$ & $\begin{array}{r}(0.72) \\
(0.83) \\
(\dagger)\end{array}$ & $\begin{array}{l}29.2 \\
30.7 \\
19.3\end{array}$ & $\begin{array}{l}(0.89) \\
(0.96) \\
(2.30)\end{array}$ \\
\hline $\begin{array}{l}\text { Part-time or part-year students } \\
\text { All institutions }\end{array}$ & 14,192 & $(-)$ & $\$ 16,350$ & (186) & $\$ 16,620$ & (189) & & & & & . 10 & 10) & & $(0.36)$ & 12.1 & 1.52) & 16.4 & $(0.34)$ \\
\hline 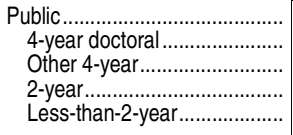 & $\begin{array}{r}10,929 \\
1,875 \\
1,477 \\
7,521 \\
56\end{array}$ & $\begin{array}{l}(-) \\
(-) \\
(-) \\
(-) \\
(-)\end{array}$ & $\begin{array}{l}14,870 \\
20,940 \\
15,890 \\
12,080 \\
11,420\end{array}$ & $\begin{array}{r}(202) \\
(368) \\
(452) \\
(248) \\
(2,303)\end{array}$ & $\begin{array}{l}15,120 \\
21,290 \\
16,150 \\
12,280 \\
11,610\end{array}$ & $\begin{array}{r}(205) \\
(374) \\
(460) \\
(252) \\
(2,341)\end{array}$ & $\begin{array}{l}44.0 \\
33.9 \\
40.5 \\
47.3 \\
29.8\end{array}$ & \begin{tabular}{l|}
$(1.18)$ \\
$(1.04)$ \\
$(1.46)$ \\
$(1.36)$ \\
$(4.21)$
\end{tabular} & 6.0 & & 60.3 & $\begin{array}{l}(1.22) \\
(0.81) \\
(1.66) \\
(1.39) \\
(4.47)\end{array}$ & $\begin{array}{r}11.7 \\
9.6 \\
19.7\end{array}$ & $\begin{array}{l}(0.41) \\
(0.60) \\
(0.75) \\
(0.53) \\
(5.84)\end{array}$ & $\begin{array}{c}11.8 \\
13.9 \\
7.0 \\
12.3 \\
3.1 !\end{array}$ & $(1.37)$ & $\begin{array}{r}13.4 \\
20.7 \\
16.9 \\
10.9 \\
9.2\end{array}$ & $\begin{array}{l}(0.36) \\
(0.73) \\
(0.94) \\
(0.39) \\
(2.44)\end{array}$ \\
\hline 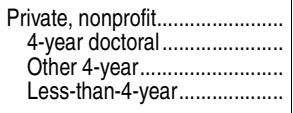 & $\begin{array}{r}1,135 \\
557 \\
527 \\
51\end{array}$ & $\begin{array}{l}(-) \\
(-) \\
(-) \\
(-)\end{array}$ & $\begin{array}{l}23,120 \\
24,890 \\
22,300 \\
12,630\end{array}$ & $\begin{array}{r}(850) \\
(1,518) \\
(946) \\
(1,266)\end{array}$ & $\begin{array}{l}23,500 \\
25,300 \\
22,670 \\
12,840\end{array}$ & $\begin{array}{r}(864) \\
(1,543) \\
(962) \\
(1,287)\end{array}$ & $\begin{array}{l}22.6 \\
24.0 \\
20.8 \\
25.7\end{array}$ & $\begin{array}{l}(1.47) \\
(1.87) \\
(2.42) \\
(4.47)\end{array}$ & 77.4 & $\begin{array}{l}(1.47) \\
(1.87) \\
(2.42) \\
(4.47)\end{array}$ & $\begin{array}{l}61.0 \\
57.9 \\
64.0 \\
64.3\end{array}$ & $\begin{array}{l}(1.61) \\
(2.12) \\
(2.54) \\
(3.22)\end{array}$ & $\begin{array}{r}13.5 \\
9.5 \\
18.6 \\
\ddagger\end{array}$ & $\begin{array}{r}(1.28) \\
(1.49) \\
(2.12) \\
(\dagger)\end{array}$ & $\begin{array}{r}30.2 \\
30.1 \\
32.3 \\
\ddagger\end{array}$ & $\begin{array}{r}(1.95) \\
(2.15) \\
(3.36) \\
(\dagger)\end{array}$ & $\begin{array}{l}28.7 \\
28.1 \\
30.2 \\
18.2\end{array}$ & $\begin{array}{l}(1.58) \\
(2.61) \\
(2.14) \\
(4.18)\end{array}$ \\
\hline 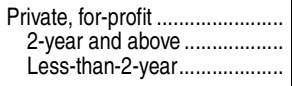 & $\begin{array}{r}2,128 \\
1,790 \\
337\end{array}$ & $\begin{array}{l}(-) \\
(-) \\
(-)\end{array}$ & $\begin{array}{r}17,450 \\
18,680 \\
11,170\end{array}$ & $\begin{array}{l}(245) \\
(281) \\
(344)\end{array}$ & $\begin{array}{l}17,740 \\
18,990 \\
11,360\end{array}$ & $\begin{array}{l}(249) \\
(286) \\
(350)\end{array}$ & $\begin{array}{l}14.6 \\
14.7 \\
14.1\end{array}$ & $\begin{array}{l}(1.02) \\
(1.20) \\
(1.39)\end{array}$ & & $\begin{array}{l}(1.02) \\
(1.20) \\
(1.39)\end{array}$ & $\begin{array}{l}79.7 \\
78.8 \\
84.6\end{array}$ & $\begin{array}{l}(0.83) \\
(0.97) \\
(1.40)\end{array}$ & $\begin{array}{r}4.2 \\
4.2 \\
\ddagger\end{array}$ & $\begin{array}{r}(0.52) \\
(0.49) \\
(\dagger)\end{array}$ & $\begin{array}{r}3.7 \\
3.6 \\
\ddagger\end{array}$ & $\begin{array}{r}(0.71) \\
(0.68) \\
(\dagger)\end{array}$ & $\begin{array}{l}25.3 \\
27.0 \\
16.3\end{array}$ & $\begin{array}{l}(1.09) \\
(1.22) \\
(1.71)\end{array}$ \\
\hline
\end{tabular}

-Not available.

†Not applicable.

!Interpret data with caution. The coefficient of variation (CV) for this estimate is between

30 and 50 percent.

‡Reporting standards not met. The coefficient of variation (CV) for this estimate is 50 percent or greater.

${ }^{1}$ Numbers of undergraduates may not equal figures reported in other tables, since these data are based on a sample survey of students who enrolled at any time during the academic year.

Includes only those students who borrowed to finance their undergraduate education Excludes loans from family sources.
${ }^{3}$ Constant dollars based on the Consumer Price Index, prepared by the Bureau of Labor Statistics, U.S. Department of Labor, adjusted to a school-year basis.

${ }^{4}$ Includes students who reported that they were awarded aid, but did not specify the source of the aid.

5 Includes Department of Veterans Affairs and Department of Defense benefits.

NOTE: Excludes students whose attendance status was not reported. Detail may not sum to totals because of rounding and because some students receive multiple types of aid and aid from different sources. Data for 2007-08 include Puerto Rico, which is excluded from the 2011-12 data.

SOURCE: U.S. Department of Education, National Center for Education Statistics, 2007-08 and 2011-12 National Postsecondary Student Aid Study (NPSAS:08 and NPSAS:12). (This table was prepared January 2014.) 
Table 331.60. Percentage of full-time, full-year undergraduates receiving financial aid, by type and source of aid and control and level of institution: Selected years, 1992-93 through 2011-12

[Standard errors appear in parentheses]

\begin{tabular}{|c|c|c|c|c|c|c|c|c|c|c|c|c|c|c|c|c|c|c|c|c|c|c|}
\hline \multirow{2}{*}{ Control and level of institution } & \multicolumn{6}{|c|}{ Any aid } & \multicolumn{6}{|c|}{ Grants } & \multicolumn{6}{|c|}{ Loans } & \multicolumn{4}{|c|}{ Work study ${ }^{1}$} \\
\hline & & Total $^{2}$ & & Federa $^{3}$ & & federal & & Total & & Federal & & federal & & Total $^{4}$ & & Federa $^{4}$ & & fifederal & & Total & & Federal \\
\hline 1 & & 2 & & 3 & & 4 & & 5 & & 6 & & 7 & & 8 & & 9 & & 10 & & 11 & & 12 \\
\hline 1992-93, all institutions............. & 58.7 & $(0.81)$ & 45.6 & $(0.80)$ & 37.9 & (0.76) & 48.9 & $(0.75)$ & 29.4 & $(0.76)$ & 34.0 & $(0.71)$ & 32.3 & $(0.78)$ & 31.3 & $(0.77)$ & 2.7 & $(0.20)$ & 10.2 & $(0.48)$ & 6.8 & $(0.39)$ \\
\hline 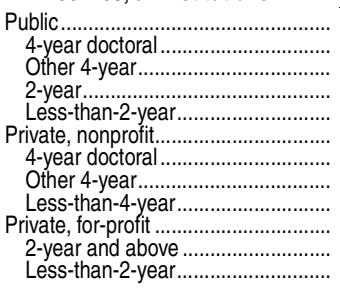 & $\begin{array}{l}52.6 \\
54.1 \\
57.1 \\
47.2 \\
35.4 \\
70.2 \\
63.6 \\
76.2 \\
73.9 \\
77.3 \\
82.7 \\
73.2 \\
\end{array}$ & $\begin{array}{l}1.03 \\
1.18 \\
1.56 \\
2.35 \\
7.28 \\
1.52 \\
1.80 \\
2.07 \\
4.01 \\
2.53 \\
3.43 \\
(3.27) \\
\end{array}$ & $\begin{array}{l}40.0 \\
39.3 \\
46.1 \\
36.0 \\
31.6 \\
53.4 \\
44.5 \\
60.8 \\
63.9 \\
72.4 \\
77.4 \\
68.6 \\
\end{array}$ & $\begin{array}{l}(0.98) \\
1.17 \\
1.61 \\
2.09 \\
(7.27 \\
1.43 \\
1.57 \\
(2.07) \\
5.69 \\
(2.76) \\
4.27 \\
(3.26) \\
\end{array}$ & $\begin{array}{l}33.0 \\
34.8 \\
37.4 \\
27.0 \\
15.7 ! \\
58.0 \\
54.8 \\
62.7 \\
42.0 \\
16.4 \\
22.7 \\
11.5 \\
\end{array}$ & $\begin{array}{l}(0.88) \\
0.81 \\
1.69 \\
1.96 \\
6.50 \\
1.60 \\
1.78 \\
2.66 \\
5.38 \\
2.97 \\
5.67 \\
(2.43) \\
\end{array}$ & $\begin{array}{l}43.1 \\
42.4 \\
46.1 \\
41.9 \\
30.3 \\
62.9 \\
56.1 \\
69.4 \\
61.3 \\
57.0 \\
52.5 \\
60.4 \\
\end{array}$ & $\begin{array}{l}(0.94) \\
1.02 \\
1.65 \\
2.19 \\
5.52 \\
1.50 \\
1.79 \\
2.07 \\
4.73 \\
(2.67) \\
4.19 \\
(3.57) \\
\end{array}$ & $\begin{array}{l}27.8 \\
23.8 \\
32.1 \\
29.9 \\
26.6 \\
27.7 \\
17.3 \\
35.6 \\
47.3 \\
50.9 \\
43.4 \\
56.7 \\
\end{array}$ & $\begin{array}{l}(0.83) \\
0.96 \\
(1.63) \\
1.81 \\
(5.70) \\
1.78) \\
1.29 \\
(2.77) \\
7.16 \\
(2.69) \\
4.13 \\
(3.75) \\
\end{array}$ & $\begin{array}{l}29.1 \\
30.8 \\
32.4 \\
24.3 \\
12.8 ! \\
54.1 \\
51.8 \\
58.1 \\
35.4 \\
11.4 \\
16.4 ! \\
7.5 ! \\
\end{array}$ & $\begin{array}{l}(0.79) \\
0.74 \\
1.55 \\
1.87 \\
5.75 \\
1.64 \\
1.70 \\
2.81 \\
6.71 \\
2.75 \\
5.15 \\
2.47 \\
\end{array}$ & $\begin{array}{r}25.5 \\
31.2 \\
32.2 \\
12.1 \\
\neq \\
45.4 \\
40.5 \\
50.6 \\
39.7 \\
52.9 \\
63.3 \\
45.0 \\
\end{array}$ & $\begin{array}{r}(0.89) \\
1.05 \\
1.38 \\
1.40 \\
(+) \\
(1.33) \\
1.37 \\
2.17 \\
5.73 \\
3.87 \\
4.16 \\
(5.12) \\
\end{array}$ & $\begin{array}{r}24.8 \\
30.4 \\
31.1 \\
11.7 \\
\ddagger \\
43.6 \\
38.5 \\
49.0 \\
38.1 \\
52.4 \\
63.0 \\
44.3 \\
\end{array}$ & $\begin{array}{r}(0.88) \\
1.04 \\
1.34 \\
1.38 \\
(+) \\
(1.31 \\
1.31 \\
2.20 \\
5.51 \\
3.87 \\
4.18 \\
(5.09) \\
\end{array}$ & $\begin{array}{l}2.0 \\
2.4 \\
2.8 \\
0.7 ! \\
\ddagger \\
5.0 \\
6.1 \\
4.1 \\
2.5 ! \\
2.1 ! \\
3.0 ! \\
1.5 \\
\end{array}$ & $\begin{array}{l}(0.22) \\
0.26 \\
0.59 \\
0.24 \\
(+) \\
(0.48) \\
0.65) \\
0.77) \\
0.97 \\
0.66 \\
1.41 \\
(0.40) \\
\end{array}$ & $\begin{array}{r}6.8 \\
7.1 \\
9.5 \\
4.1 \\
\ddagger \\
\neq 2.2 \\
18.9 \\
27.0 \\
4.6 \\
\ddagger \\
\ddagger \\
\ddagger \\
\end{array}$ & \begin{tabular}{r|}
$(0.43)$ \\
0.55 \\
0.76 \\
0.75 \\
$(\dagger)$ \\
$(1.11$ \\
1.24 \\
$1.61)$ \\
1.36 \\
$(+)$ \\
$(\dagger)$ \\
$+t$ \\
\end{tabular} & $\begin{array}{r}4.2 \\
4.3 \\
5.4 \\
3.0 \\
\ddagger \\
15.9 \\
13.2 \\
19.7 \\
3.0 ! \\
0.8 ! \\
\ddagger \\
0.2 ! \\
\end{array}$ & $\begin{array}{r}(0.30) \\
0.37 \\
0.57 \\
0.58 \\
(\dagger) \\
0.99 \\
1.38 \\
1.47 \\
1.01 \\
0.36 \\
(\dagger) \\
(0.09) \\
\end{array}$ \\
\hline 1999-2000, all institutions....... & 72.5 & $(0.51)$ & 57.7 & $(0.56)$ & 51.8 & $(0.64)$ & 58.7 & (0.59) & 30.3 & $(0.59)$ & 48.3 & $(0.65)$ & 45.4 & $(0.62)$ & 44.3 & $(0.63)$ & 6.8 & $(0.25)$ & 11.2 & $(0.38)$ & 8.5 & $(0.31)$ \\
\hline 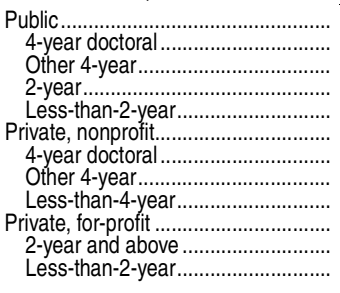 & $\begin{array}{l}67.5 \\
71.0 \\
75.0 \\
58.2 \\
60.7 \\
84.0 \\
78.8 \\
88.3 \\
81.1 \\
89.2 \\
88.3 \\
91.7 \\
\end{array}$ & $\begin{array}{l}(0.64) \\
0.65 \\
1.24 \\
1.34 \\
5.94 \\
0.77 \\
1.13 \\
1.12 \\
3.64 \\
1.25 \\
1.60 \\
1.27) \\
\end{array}$ & $\begin{array}{l}52.6 \\
54.7 \\
62.2 \\
43.8 \\
48.1 \\
67.6 \\
62.3 \\
72.2 \\
62.6 \\
86.0 \\
85.3 \\
88.3 \\
\end{array}$ & \begin{tabular}{|}
$(0.68)$ \\
0.70 \\
1.48 \\
1.28 \\
6.42 \\
1.02 \\
1.41 \\
1.53 \\
3.94 \\
1.50 \\
1.90 \\
$(1.92)$ \\
\end{tabular} & $\begin{array}{l}46.0 \\
48.7 \\
50.0 \\
40.0 \\
33.6 \\
71.6 \\
69.4 \\
74.1 \\
61.5 \\
35.3 \\
38.3 \\
26.1 \\
\end{array}$ & $\begin{array}{l}(0.72) \\
0.74 \\
1.61) \\
1.56 \\
4.81 \\
1.27 \\
1.29 \\
2.29 \\
4.76 \\
3.45 \\
4.46 \\
(3.49) \\
\end{array}$ & $\begin{array}{l}53.0 \\
53.1 \\
57.7 \\
49.9 \\
49.2 \\
74.7 \\
69.7 \\
78.7 \\
73.9 \\
61.8 \\
58.5 \\
71.9 \\
\end{array}$ & $\begin{array}{l}(0.70) \\
0.70 \\
1.74 \\
1.42 \\
6.35 \\
1.12 \\
1.24 \\
1.81 \\
3.59 \\
2.49 \\
2.99 \\
(3.47) \\
\end{array}$ & $\begin{array}{l}25.7 \\
34.5 \\
32.1 \\
40.8 \\
27.7 \\
22.4 \\
30.9 \\
40.0 \\
52.0 \\
46.3 \\
69.9 \\
\end{array}$ & $\begin{array}{r}(0.69) \\
0.72 \\
(2.11) \\
1.17 \\
66.85 \\
1.23 \\
(0.95) \\
2.13 \\
3.66 \\
(2.95) \\
3.47 \\
(3.52) \\
\end{array}$ & $\begin{array}{l}42.5 \\
44.6 \\
46.2 \\
37.7 \\
25.0 \\
68.9 \\
66.4 \\
71.6 \\
59.4 \\
28.8 \\
33.1 \\
15.6 \\
\end{array}$ & $\begin{array}{l}(0.72) \\
0.71 \\
1.60 \\
1.60 \\
5.05 \\
1.36 \\
1.36 \\
2.27 \\
5.18 \\
3.14 \\
4.01 \\
(3.83) \\
\end{array}$ & $\begin{array}{l}38.9 \\
48.3 \\
49.1 \\
20.5 \\
11.0 ! \\
59.3 \\
57.3 \\
62.2 \\
40.3 \\
75.0 \\
79.5 \\
61.0 \\
\end{array}$ & $\begin{array}{l}(0.74) \\
0.76 \\
1.75 \\
1.26 \\
4.14 \\
1.14 \\
1.42 \\
1.79 \\
5.18 \\
2.87 \\
2.77 \\
(7.08) \\
\end{array}$ & $\begin{array}{l}37.9 \\
47.2 \\
48.2 \\
19.6 \\
11.0 ! \\
57.7 \\
55.5 \\
60.6 \\
40.2 \\
74.1 \\
78.7 \\
59.9 \\
\end{array}$ & $\begin{array}{r}(0.75) \\
0.78 \\
1.78 \\
1.24 \\
4.14 \\
1.18 \\
1.43 \\
1.87 \\
5.19 \\
2.93 \\
2.80 \\
(7.28) \\
\end{array}$ & $\begin{array}{r}4.4 \\
5.5 \\
4.5 \\
3.1 \\
\neq \\
13.4 \\
15.1 \\
12.8 \\
5.0 \\
7.3 \\
6.8 ! \\
8.9 \\
\end{array}$ & $\begin{array}{r}(0.24) \\
0.36 \\
0.46 \\
0.47 \\
(t) \\
(0.65) \\
0.86 \\
1.01) \\
0.80 \\
(1.69 \\
2.15 \\
(1.89) \\
\end{array}$ & $\begin{array}{r}7.2 \\
8.3 \\
10.4 \\
3.8 \\
\neq \\
24.4 \\
24.7 \\
24.8 \\
15.1 \\
2.3 ! \\
2.6 ! \\
\ddagger \\
\end{array}$ & $\begin{array}{r}(0.36 \\
0.46 \\
1.05 \\
0.53 \\
(\dagger) \\
(1.07) \\
1.17 \\
1.75 \\
2.91) \\
0.84 \\
1.03 \\
(\dagger) \\
\end{array}$ & $\begin{array}{r}5.4 \\
5.8 \\
7.7 \\
3.4 \\
\# \\
18.8 \\
20.9 \\
17.7 \\
10.9 \\
2.0 ! \\
2.1 ! \\
\ddagger \\
\end{array}$ & $\begin{array}{r}(0.30) \\
0.38 \\
0.83 \\
0.50 \\
(\dagger \\
0.82 \\
1.06 \\
1.26 \\
2.54 \\
0.83 \\
1.00 \\
(\dagger) \\
\end{array}$ \\
\hline 2007-08, all institutions ........... & 80.3 & $(0.28)$ & 64.3 & $(0.32)$ & 63.7 & $(0.36)$ & 65.1 & $(0.36)$ & 34.0 & $(0.27)$ & 53.5 & $(0.40)$ & 54.4 & $(0.32)$ & 50.6 & $(0.31)$ & 20.4 & $(0.31)$ & 13.7 & $(0.28)$ & 10.6 & $(0.22)$ \\
\hline 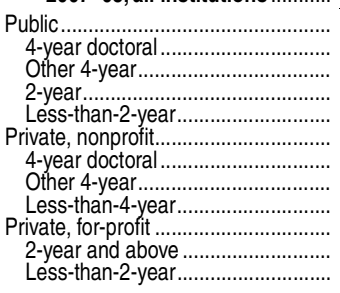 & $\begin{array}{l}75.4 \\
77.8 \\
82.5 \\
66.9 \\
69.1 \\
89.8 \\
85.8 \\
93.9 \\
93.8 \\
92.8 \\
92.5 \\
94.3 \\
\end{array}$ & $\begin{array}{l}(0.33) \\
0.40 \\
0.58 \\
0.69 \\
3.87 \\
0.56 \\
0.93 \\
0.71 \\
2.01 \\
0.67) \\
(0.79) \\
(0.85) \\
\end{array}$ & $\begin{array}{l}58.8 \\
59.6 \\
67.9 \\
51.4 \\
58.6 \\
72.2 \\
67.8 \\
76.2 \\
88.8 \\
85.1 \\
84.4 \\
88.9 \\
\end{array}$ & \begin{tabular}{|c|}
$(0.35)$ \\
0.48 \\
0.67 \\
0.73 \\
3.84 \\
$0.64)$ \\
1.20 \\
$(1.09)$ \\
2.95 \\
1.21 \\
1.41 \\
$(1.71)$ \\
\end{tabular} & $\begin{array}{l}57.9 \\
62.8 \\
62.3 \\
47.5 \\
33.0 \\
82.5 \\
79.1 \\
86.5 \\
58.7 \\
59.7 \\
61.5 \\
50.2 \\
\end{array}$ & $\begin{array}{l}(0.39 \\
0.49 \\
0.79 \\
0.79 \\
4.74 \\
0.80 \\
1.14 \\
1.07 \\
7.48 \\
1.55 \\
(1.78) \\
(2.53) \\
\end{array}$ & $\begin{array}{l}59.3 \\
59.9 \\
63.5 \\
55.5 \\
56.6 \\
81.5 \\
76.9 \\
86.4 \\
73.6 \\
66.8 \\
65.3 \\
75.1 \\
\end{array}$ & $\begin{array}{l}(0.38) \\
0.54 \\
0.80 \\
0.63) \\
3.58) \\
0.82 \\
1.17 \\
1.06 \\
(5.18) \\
1.42 \\
1.64) \\
(1.87) \\
\end{array}$ & $\begin{array}{l}32.5 \\
27.9 \\
36.0 \\
37.3 \\
50.0 \\
30.0 \\
25.1 \\
34.1 \\
63.0 \\
54.8 \\
51.5 \\
72.3 \\
\end{array}$ & $\begin{array}{l}(0.29) \\
0.38 \\
0.65 \\
0.65 \\
3.97 \\
0.44 \\
1.05 \\
1.19 \\
6.84 \\
1.41 \\
(1.63) \\
(1.88) \\
\end{array}$ & $\begin{array}{l}49.6 \\
53.9 \\
52.3 \\
41.3 \\
16.1 \\
76.6 \\
73.2 \\
80.8 \\
46.8 \\
26.3 \\
27.9 \\
17.9 \\
\end{array}$ & $\begin{array}{l}0.40 \\
0.53 \\
0.83 \\
0.76 \\
2.88 \\
1.01 \\
1.42 \\
1.37 \\
6.64 \\
1.60 \\
1.87 \\
(2.11) \\
\end{array}$ & $\begin{array}{l}46.0 \\
54.6 \\
56.7 \\
25.5 \\
26.5 \\
67.1 \\
63.9 \\
70.9 \\
44.6 \\
84.4 \\
85.6 \\
78.0 \\
\end{array}$ & $\begin{array}{l}(0.33) \\
0.50) \\
0.71 \\
0.59 \\
4.79 \\
0.63) \\
1.19 \\
1.14 \\
6.148 \\
1.11 \\
1.27) \\
(1.79) \\
\end{array}$ & $\begin{array}{l}42.5 \\
50.7 \\
53.5 \\
22.3 \\
23.6 \\
63.3 \\
59.7 \\
67.6 \\
41.4 \\
78.2 \\
80.2 \\
67.7 \\
\end{array}$ & $\begin{array}{l}(0.33) \\
0.50 \\
0.71 \\
0.57) \\
4.33 \\
0.58 \\
1.21 \\
1.17 \\
6.20 \\
1.23 \\
1.34) \\
(3.00) \\
\end{array}$ & $\begin{array}{r}14.2 \\
17.4 \\
16.2 \\
7.8 \\
10.7 \\
29.9 \\
29.5 \\
30.6 \\
19.2 \\
42.5 \\
43.7 \\
35.8 \\
\end{array}$ & $\begin{array}{l}(0.24) \\
0.37) \\
0.60 \\
0.37 \\
(.75) \\
0.71) \\
1.01 \\
1.03 \\
(5.61) \\
1.58 \\
(1.87) \\
(1.43) \\
\end{array}$ & $\begin{array}{r}9.5 \\
10.2 \\
11.5 \\
7.1 \\
\# \\
31.4 \\
29.8 \\
33.7 \\
4.9 \\
1.9 \\
2.1 \\
0.8 ! \\
\end{array}$ & $\begin{array}{r}(0.25) \\
0.35 \\
0.59 \\
(0.36) \\
(+) \\
(1.03 \\
1.13 \\
1.77 \\
1.07 \\
0.29 \\
(0.34) \\
(0.28) \\
\end{array}$ & $\begin{array}{r}7.1 \\
7.6 \\
8.7 \\
5.5 \\
\# \\
24.5 \\
24.2 \\
25.3 \\
4.2 \\
1.6 \\
1.8 \\
0.6 ! \\
\end{array}$ & 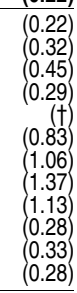 \\
\hline 2011-12, all institutions............ & 84.4 & $(0.36)$ & $\begin{array}{llll}72.8 & & & \\
\end{array}$ & $(0.51$ & 56.9 & $(0.46$ & 72.4 & $(0.41)$ & 47.4 & $(0.50$ & 52.6 & $(0.4$ & 56. & $(0.53)$ & 55.5 & $(0.54)$ & 9.2 & $(0.22$ & 11.9 & $(0.25)$ & 10.5 & $(0.24)$ \\
\hline 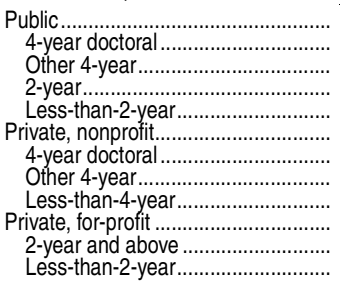 & $\begin{array}{l}80.4 \\
83.9 \\
83.5 \\
74.5 \\
71.6 \\
91.6 \\
90.4 \\
93.1 \\
90.2 \\
94.8 \\
94.6 \\
95.9\end{array}$ & $\begin{array}{l}(0.47) \\
0.46 \\
0.93 \\
1.03 \\
4.50 \\
0.55 \\
0.84 \\
0.68 \\
4.12 \\
0.46 \\
0.53 \\
0.75)\end{array}$ & $\begin{array}{l}68.4 \\
70.9 \\
72.7 \\
63.0 \\
67.8 \\
76.1 \\
74.3 \\
78.0 \\
78.1 \\
93.1 \\
92.8 \\
95.2\end{array}$ & $\begin{array}{l}(0.61) \\
0.47 \\
1.34 \\
1.24 \\
4.72 \\
(0.75) \\
(0.94) \\
(1.20) \\
5.04 \\
0.51 \\
(0.59) \\
(0.79)\end{array}$ & $\begin{array}{l}53.3 \\
61.2 \\
54.1 \\
42.5 \\
33.5 \\
83.1 \\
82.9 \\
84.2 \\
60.2 \\
29.3 \\
30.7 \\
20.3\end{array}$ & $\left.\begin{array}{l}(0.58) \\
0.63 \\
1.23 \\
1.14 \\
5.54 \\
0.77 \\
1.13 \\
0.98 \\
7.07 \\
1.05 \\
1.16 \\
2.64\end{array}\right)$ & $\begin{array}{l}67.3 \\
67.8 \\
69.2 \\
65.7 \\
68.6 \\
85.4 \\
84.2 \\
87.2 \\
77.8 \\
78.6 \\
77.4 \\
86.2\end{array}$ & $\begin{array}{l}(0.49) \\
0.51 \\
0.99 \\
1.09 \\
4.05 \\
0.77 \\
1.17 \\
0.92 \\
6.09 \\
0.76 \\
0.86 \\
1.54)\end{array}$ & $\begin{array}{l}46.1 \\
41.1 \\
48.3 \\
51.6 \\
63.7 \\
37.6 \\
34.9 \\
40.3 \\
48.5 \\
73.9 \\
72.2 \\
85.4\end{array}$ & $\begin{array}{l}(0.59) \\
0.40 \\
11.10 \\
1.30 \\
4.54 \\
0.65 \\
0.80 \\
(1.10 \\
6.54 \\
0.82 \\
0.92 \\
(1.63)\end{array}$ & $\begin{array}{r}49.7 \\
56.8 \\
50.1 \\
40.2 \\
27.2 \\
80.3 \\
80.4 \\
81.3 \\
51.1 \\
17.4 \\
18.9 \\
7.5\end{array}$ & $\begin{array}{l}(0.56) \\
0.61 \\
1.32 \\
1.15 \\
3.90 \\
0.85 \\
1.21 \\
1.15 \\
8.78 \\
0.94 \\
1.05 \\
1.82\end{array}$ & $\begin{array}{l}48.5 \\
61.6 \\
55.5 \\
27.5 \\
20.5 \\
68.4 \\
66.7 \\
70.7 \\
61.2 \\
84.1 \\
84.2 \\
83.8\end{array}$ & $\begin{array}{l}(0.57) \\
0.44 \\
1.49 \\
0.99 \\
5.20 \\
0.90 \\
1.08 \\
1.41 \\
5.71 \\
0.85 \\
0.85 \\
(3.56)\end{array}$ & $\begin{array}{l}47.4 \\
60.4 \\
54.3 \\
26.6 \\
20.2 \\
66.7 \\
65.3 \\
68.7 \\
59.0 \\
83.4 \\
83.4 \\
83.0\end{array}$ & $\begin{array}{l}(0.57) \\
0.43 \\
1.51 \\
1.00 \\
5.20 \\
0.88 \\
1.05 \\
1.44 \\
7.42 \\
0.89 \\
(0.89 \\
(3.52)\end{array}$ & $\begin{array}{r}6.3 \\
8.6 \\
7.4 \\
2.7 \\
\neq \\
15.3 \\
15.0 \\
15.8 \\
12.2 \\
14.8 \\
15.0 \\
13.5\end{array}$ & $\begin{array}{l}(0.19) \\
0.31 \\
(0.60) \\
0.24 \\
(t) \\
(0.65) \\
(0.92) \\
(.091) \\
2.62 \\
(.75) \\
(0.82) \\
(1.58)\end{array}$ & $\begin{array}{r}6.9 \\
8.3 \\
9.3 \\
3.9 \\
1.0 ! \\
33.1 \\
33.2 \\
33.9 \\
\ddagger \\
1.9 \\
2.2 \\
\ddagger\end{array}$ & 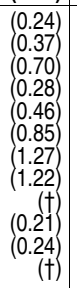 & $\begin{array}{r}6.2 \\
7.4 \\
8.6 \\
3.4 \\
\ddagger \\
29.2 \\
30.0 \\
29.1 \\
\ddagger \\
1.8 \\
2.1 \\
\ddagger\end{array}$ & 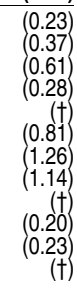 \\
\hline
\end{tabular}

\section{†Not applicable.}

\#Rounds to zero. ₹Reporting standards not met. The coefficient of variation (CV) for this estimate is 50 percent or greater. 1Details on nonfederal work-study participants are not available.

Includes Department of Veterans Affairs and Department of Defense benefits.
4The 2007-08 and 2011-12 data include Parent Loans for Undergraduate Students (PLUS). NOTE: Excludes students whose attendance status was not reported. Detail may not sum to totals because of rounding and Puerto Rico, which is excluded rom the 2011-12 data SOURCE: U.S. Department of Education, National Center for Education Statistics, 1992-93, 1999-2000, 2007-08, and
2011-12 National Postsecondary Student Aid Study (NPSAS:93, NPSAS:2000, NPSAS:08, and NPSAS:12). (This table was prepared January 2014.) 
Table 331.70. Average amount of financial aid awarded to full-time, full-year undergraduates, by type and source of aid and control and level of institution: Selected years, 1992-93 through 2011-12

[Standard errors appear in parentheses]

\begin{tabular}{|c|c|c|c|c|c|c|c|c|c|c|c|c|c|c|c|c|c|c|c|c|c|c|}
\hline \multirow[b]{2}{*}{ Control and level of institution } & \multicolumn{6}{|c|}{ Any aid } & \multicolumn{6}{|c|}{ Grants } & \multicolumn{6}{|c|}{ Loans } & \multicolumn{4}{|c|}{ Work study ${ }^{1}$} \\
\hline & \multirow{2}{*}{\multicolumn{2}{|c|}{\begin{tabular}{r|} 
Total $^{2}$ \\
2
\end{tabular}}} & \multirow{2}{*}{\multicolumn{2}{|c|}{\begin{tabular}{r|} 
Federal $^{3}$ \\
3
\end{tabular}}} & \multicolumn{2}{|r|}{ Nonfederal } & \multirow{2}{*}{\multicolumn{2}{|c|}{$\begin{array}{r}\text { Total }^{4} \\
5\end{array}$}} & \multirow{2}{*}{\multicolumn{2}{|c|}{$\begin{array}{r}\text { Federal } \\
6\end{array}$}} & \multicolumn{2}{|r|}{ Nonfederal } & \multirow{2}{*}{\multicolumn{2}{|c|}{$\begin{array}{r}\text { Total }^{5} \\
8\end{array}$}} & \multirow{2}{*}{\multicolumn{2}{|c|}{$\begin{array}{r}\text { Federal }^{5} \\
9\end{array}$}} & \multicolumn{2}{|c|}{ Nonfederal } & \multicolumn{2}{|r|}{ Total } & \multicolumn{2}{|r|}{ Federal } \\
\hline 1 & & & & & & 4 & & & & & & 7 & & & & & & 10 & & 11 & & 12 \\
\hline & \multicolumn{22}{|c|}{ Current dollars } \\
\hline 1992-93, all institutions... & $\$ 5,730$ & $(1,344)$ & $\$ 4,300$ & (334) & $\$ 3,480$ & (915) & $\$ 3,550$ & (643) & $\$ 1,980$ & (32) & $\$ 3,320$ & (807) & $\$ 3,880$ & (293) & $\$ 3,760$ & (198) & $\$ 2,730$ & (664) & $\$ 1,380$ & (103) & $\$ 1,290$ & (93) \\
\hline 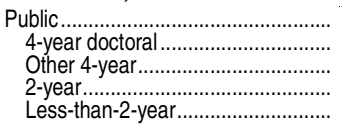 & $\begin{array}{l}4,070 \\
4,750 \\
4,240 \\
2,760 \\
2,300\end{array}$ & $\begin{array}{l}(314) \\
349 \\
302 \\
189 \\
(322)\end{array}$ & $\begin{array}{l}3,700 \\
4,360 \\
3,780 \\
2,620 \\
1,950\end{array}$ & $\begin{array}{r}(45) \\
(55) \\
(71) \\
(100) \\
(217)\end{array}$ & $\begin{array}{l}1,800 \\
2,280 \\
1,660 \\
1,090 ! \\
1,140 !\end{array}$ & $\begin{array}{l}(262) \\
(235) \\
(85) \\
(461) \\
(503)\end{array}$ & $\begin{array}{l}2,400 \\
2,710 \\
2,420 \\
1,930 \\
1,970\end{array}$ & $\begin{array}{r}(60) \\
(106) \\
(49) \\
(76) \\
(305)\end{array}$ & $\begin{array}{l}1,880 \\
1,970 \\
1,940 \\
1,720 \\
1,760\end{array}$ & $\left(\begin{array}{l}21 \\
25 \\
29 \\
61 \\
44\end{array}\right)$ & $\begin{array}{r}1,660 \\
2,140 \\
1,450 \\
\ddagger \\
880\end{array}$ & $\begin{array}{r}(325) \\
278 \\
(123) \\
(+) \\
(163)\end{array}$ & $\begin{array}{l}3,330 \\
3,440 \\
3,200 \\
2,30 \\
3,140\end{array}$ & $\begin{array}{r}(41) \\
(60) \\
(64) \\
(163) \\
(801)\end{array}$ & $\begin{array}{l}3,270 \\
3,560 \\
3,120 \\
2,560 \\
2,970\end{array}$ & $\begin{array}{r}(46) \\
(68) \\
(66) \\
(152) \\
(885)\end{array}$ & $\begin{array}{r}2,020 \\
2,110 \\
2,150 \\
\ddagger \\
\ddagger\end{array}$ & 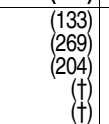 & $\begin{array}{r}1,370 \\
1,430 \\
1,240 \\
1,470 \\
\ddagger\end{array}$ & $\begin{array}{r}(84) \\
(116) \\
(61) \\
(165) \\
(\dagger)\end{array}$ & $\begin{array}{r}1,350 \\
1,360 \\
1,270 \\
1,470 \\
\ddagger\end{array}$ & $\begin{array}{r}(65) \\
(102) \\
(69) \\
(156) \\
(\dagger)\end{array}$ \\
\hline 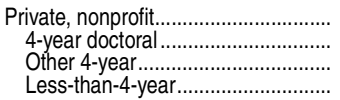 & $\begin{array}{c}9,220 ! \\
10,240 \\
8,280 \\
7,670\end{array}$ & $\begin{array}{r}(3,036) \\
(932,403 \\
(920)\end{array}$ & $\begin{array}{l}5,250 \\
5,630 \\
4,920 \\
4,750\end{array}$ & $\left.\begin{array}{l}(949) \\
341 \\
363 \\
(225)\end{array}\right)$ & $\begin{array}{l}6,050 ! \\
6,920 \\
5,160 \\
4,580\end{array}$ & $\begin{array}{r}(1,869) \\
(326) \\
(315) \\
(434)\end{array}$ & $\begin{array}{l}6,030 \\
6,810 \\
5,370 \\
4,860\end{array}$ & $\begin{array}{r}(1,564) \\
2411 \\
359 \\
(405)\end{array}$ & $\begin{array}{l}2,310 \\
2,410 \\
2,260 \\
2,230\end{array}$ & $\begin{array}{r}(124) \\
(59) \\
71 \\
25)\end{array}$ & $\begin{array}{l}5,740 \\
6,390 \\
4,790 \\
4,620\end{array}$ & $\left.\begin{array}{r}(1,651) \\
(422) \\
316 \\
(389)\end{array}\right)$ & $\begin{array}{l}4,430 \\
4,880 \\
4,170 \\
3,730\end{array}$ & $\left.\begin{array}{l}8099 \\
142 \\
175 \\
124\end{array}\right)$ & $\begin{array}{l}4,190 \\
4,540 \\
4,020 \\
3,640\end{array}$ & $\left.\begin{array}{l}600) \\
121 \\
155 \\
111\end{array}\right)$ & $\begin{array}{l}3,440 \\
3,690 \\
2,910 \\
2,670\end{array}$ & $\left.\begin{array}{l}(772) \\
468 \\
318 \\
(405)\end{array}\right)$ & $\begin{array}{l}1,360 \\
1,520 \\
1,280 \\
1,120\end{array}$ & $\left.\begin{array}{r}(268) \\
(63) \\
74 \\
(68)\end{array}\right)$ & $\begin{array}{l}1,250 \\
1,370 \\
1,180 \\
1,100\end{array}$ & $\left.\begin{array}{r}(194) \\
(80) \\
62 \\
66\end{array}\right)$ \\
\hline 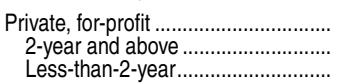 & $\begin{array}{l}5,210 \\
6,010 \\
4,510\end{array}$ & $\left.\begin{array}{l}(294) \\
(328) \\
434\end{array}\right)$ & $\begin{array}{l}4,920 \\
5,530 \\
4,390\end{array}$ & $\left(\begin{array}{l}2844 \\
(285) \\
430\end{array}\right)$ & $\begin{aligned} 2,350 ! \\
\vdots \\
\ddagger\end{aligned}$ & $\left.\begin{array}{r}(1,168) \\
(+) \\
+\end{array}\right)$ & $\begin{array}{l}2,120 \\
2,410 \\
1,920\end{array}$ & $\left.\begin{array}{l}307 \\
(528) \\
158\end{array}\right)$ & $\begin{array}{l}1,900 \\
1,970 \\
1,860\end{array}$ & $\begin{array}{r}(71) \\
(142) \\
(70)\end{array}$ & 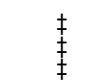 & $\left(\begin{array}{c}+ \\
+ \\
(\dagger)\end{array}\right)$ & $\begin{array}{l}4,740 \\
5,190 \\
4,240\end{array}$ & $\left(\begin{array}{l}2877 \\
417 \\
420\end{array}\right)$ & $\begin{array}{l}4,680 \\
5,110 \\
4,210\end{array}$ & $\left.\begin{array}{l}(286) \\
381 \\
(384)\end{array}\right)$ & $\begin{aligned} 2,360 \\
\ddagger \\
\ddagger\end{aligned}$ & 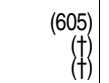 & $\begin{aligned} 2,420 \\
\ddagger \\
\ddagger\end{aligned}$ & $\begin{aligned}(593) \\
\left(\begin{array}{l}0 \\
+\end{array}\right)\end{aligned}$ & $\begin{array}{l}\ddagger \\
\ddagger \\
\ddagger\end{array}$ & $\left(\begin{array}{l}(+) \\
(十) \\
(t)\end{array}\right.$ \\
\hline 1995-96, all institutions..... & $\$ 6,860$ & (240) & $\$ 5,370$ & (115) & $\$ 3,800$ & (253) & $\$ 3,900$ & (212) & $\$ 2,010$ & (22) & $\$ 3,610$ & (253) & $\$ 5,020$ & (95) & $\$ 4,970$ & (94) & $\$ 2,750$ & (363) & $\$ 1,370$ & (75) & $\$ 1,300$ & (66) \\
\hline 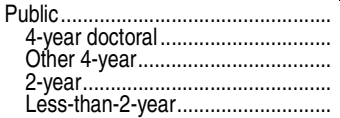 & $\begin{array}{r}5,230 \\
6,290 \\
5,420 \\
3,420 \\
\ddagger\end{array}$ & $\begin{array}{r}(148) \\
165 \\
229 \\
232 \\
(\dagger)\end{array}$ & $\begin{array}{l}4,820 \\
5,670 \\
4,850 \\
3,460 \\
2,660 !\end{array}$ & $\begin{array}{r}(136) \\
(248) \\
197 \\
(206) \\
(1,040)\end{array}$ & $\begin{array}{l}2,210 \\
2,860 \\
1,980 \\
1,270 \\
2,410\end{array}$ & $\begin{array}{r}(74) \\
(104) \\
(63) \\
(112) \\
(471)\end{array}$ & $\begin{array}{l}2,700 \\
3,190 \\
2,700 \\
2,010 \\
2,370\end{array}$ & $\begin{array}{r}(76) \\
(142) \\
(68) \\
(75) \\
(113)\end{array}$ & $\begin{array}{l}1,930 \\
1,910 \\
1,950 \\
1,940 \\
1,740\end{array}$ & \begin{tabular}{r|}
$(26)$ \\
24 \\
$(73$ \\
$(185$ \\
$(328)$
\end{tabular} & $\begin{array}{l}2,080 \\
2,730 \\
1,850 \\
1,090 \\
2,550\end{array}$ & $\begin{array}{r}(72) \\
(106) \\
(53) \\
(91) \\
(282)\end{array}$ & $\begin{array}{l}4,620 \\
5,180 \\
4,310 \\
3,620 \\
3,600\end{array}$ & $\begin{array}{l}(138) \\
233 \\
135 \\
303 \\
564) \\
(564)\end{array}$ & $\begin{array}{l}4,610 \\
5,130 \\
4,300 \\
3,680 \\
3,600\end{array}$ & $\begin{array}{l}(139) \\
(232) \\
133 \\
319 \\
(564)\end{array}$ & $\begin{array}{r}2,350 \\
2,690 \\
\ddagger \\
\neq \\
\neq\end{array}$ & $\left.\begin{array}{r}(564) \\
(715 \\
(+) \\
(+) \\
+\end{array}\right)$ & $\begin{array}{r}1,350 \\
1,310 \\
1,440 \\
1,270 \\
\ddagger\end{array}$ & 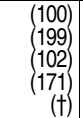 & $\begin{array}{l}1,290 \\
1,280 \\
1,370 \\
1,220\end{array}$ & $\begin{array}{r}(77) \\
(147) \\
(70) \\
(175) \\
(\dagger)\end{array}$ \\
\hline 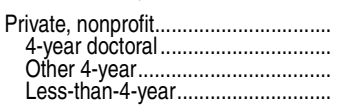 & $\begin{array}{r}10,540 \\
13,040 \\
9,810 \\
6,190\end{array}$ & $\begin{array}{r}(660) \\
(1,635) \\
(240 \\
(296)\end{array}$ & $\begin{array}{l}6,500 \\
7,310 \\
6,270 \\
5,100\end{array}$ & $\left.\begin{array}{l}2366 \\
433 \\
237 \\
(183)\end{array}\right)$ & $\begin{array}{l}6,390 \\
8,450 \\
5,700 \\
2,850\end{array}$ & $\begin{array}{r}(586) \\
(1,494) \\
(133) \\
(303)\end{array}$ & $\begin{array}{l}6,360 \\
8,240 \\
5,790 \\
3,190\end{array}$ & $\begin{array}{r}(576) \\
(1,549 \\
(120) \\
(622)\end{array}$ & $\begin{array}{l}2,270 \\
2,350 \\
2,270 \\
2,030\end{array}$ & $\left.\begin{array}{r}(60) \\
(61) \\
(101 \\
(32)\end{array}\right]$ & $\begin{array}{l}5,990 \\
7,870 \\
5,330 \\
2,760\end{array}$ & $\left.\begin{array}{r}(567) \\
(1,465) \\
(126) \\
(619)\end{array}\right)$ & $\begin{array}{l}5,700 \\
6,450 \\
5,420 \\
5,000\end{array}$ & $\left.\begin{array}{l}(137) \\
276 \\
161 \\
(349)\end{array}\right)$ & $\begin{array}{l}5,580 \\
6,320 \\
5,310 \\
4,870\end{array}$ & $\begin{array}{l}(130) \\
(217) \\
148 \\
(236)\end{array}$ & $\begin{array}{l}3,110 \\
3,560 ! \\
3,340 \\
1,280\end{array}$ & $\left.\begin{array}{r}(620) \\
(1,564) \\
(329) \\
(90)\end{array}\right]$ & $\begin{array}{l}1,390 \\
1,650 \\
1,280 \\
1,190\end{array}$ & $\begin{array}{r}(109) \\
(239) \\
(69) \\
(55)\end{array}$ & $\begin{array}{l}1,310 \\
1,540 \\
1,210 \\
1,090\end{array}$ & $\begin{array}{l}(100) \\
(204) \\
(62) \\
(213)\end{array}$ \\
\hline 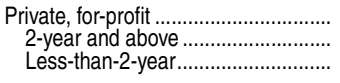 & $\begin{array}{l}6,400 \\
7,040 \\
5,650 \\
\end{array}$ & $\begin{array}{l}(158) \\
389 \\
(525)\end{array}$ & $\begin{array}{l}5,870 \\
6,370 \\
5,270 \\
\end{array}$ & $\left.\begin{array}{l}(114) \\
328 \\
(461)\end{array}\right)$ & $\begin{array}{l}2,700 \\
2,950 \\
2,370 \\
\end{array}$ & $\left.\begin{array}{l}273) \\
1977 \\
527\end{array}\right)$ & $\begin{array}{l}2,510 \\
2,830 \\
2,140 \\
\end{array}$ & $\begin{array}{r}(97) \\
(193) \\
(102)\end{array}$ & $\begin{array}{l}1,950 \\
2,000 \\
1,900 \\
\end{array}$ & $\begin{array}{l}33 \\
33 \\
(88)\end{array}$ & $\begin{array}{l}2,360 \\
2,690 \\
1,620 \\
\end{array}$ & $\begin{array}{l}(253) \\
149 \\
407)\end{array}$ & $\begin{array}{l}5,280 \\
5,670 \\
4,770 \\
\end{array}$ & $\begin{array}{l}(245) \\
(220) \\
(713)\end{array}$ & $\begin{array}{l}5,210 \\
5,620 \\
4,680 \\
\end{array}$ & $\left.\begin{array}{l}(230) \\
2244 \\
(678)\end{array}\right)$ & $\begin{array}{r}2,350 \\
\ddagger \\
2,070 \\
\end{array}$ & $\begin{array}{r}(255) \\
(+) \\
(404)\end{array}$ & 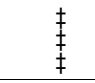 & $\left(\begin{array}{c}t \\
+ \\
+\end{array}\right)$ & $\begin{array}{l}\ddagger \\
\neq \\
\ddagger\end{array}$ & $\left(\begin{array}{l}(t) \\
(t) \\
(t)\end{array}\right.$ \\
\hline 1999-2000, all institutions....... & $\$ 8,520$ & (78) & $\$ 6,160$ & (57) & $\$ 5,030$ & (97) & $\$ 4,980$ & (69) & $\$ 2,520$ & (17) & $\$ 4,460$ & (90) & $\$ 6,280$ & (72) & $\$ 5,690$ & (69) & $\$ 4,940$ & (128) & $\$ 1,670$ & (33) & $\$ 1,560$ & (26) \\
\hline 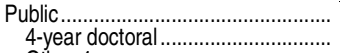 & $\begin{array}{l}6,340 \\
7,560\end{array}$ & $\begin{array}{l}(74) \\
85\end{array}$ & $\begin{array}{l}5,500 \\
6,420\end{array}$ & $\left.\begin{array}{l}60 \\
68\end{array}\right)$ & $\begin{array}{l}3,000 \\
3,800\end{array}$ & $(57)$ & $\begin{array}{l}3,490 \\
4,110\end{array}$ & $\left(\begin{array}{l}38) \\
(57)\end{array}\right.$ & $\begin{array}{l}2,460 \\
2,510\end{array}$ & $\left(\begin{array}{l}13 \\
38\end{array}\right)$ & $\begin{array}{l}2,620 \\
3,440\end{array}$ & $(42)$ & $\begin{array}{l}5,450 \\
5,950\end{array}$ & $\left(\begin{array}{l}65) \\
(74)\end{array}\right.$ & $\begin{array}{l}5,130 \\
5,620\end{array}$ & $\begin{array}{l}688 \\
599\end{array}$ & $\begin{array}{l}3,930 \\
3,950\end{array}$ & $\left(\begin{array}{l}212 \\
204\end{array}\right)$ & $\begin{array}{l}1,730 \\
1,790\end{array}$ & $\left.\begin{array}{l}(38) \\
(54)\end{array}\right)$ & $\begin{array}{l}1,640 \\
1,690\end{array}$ & $\begin{array}{l}(53) \\
(31)\end{array}$ \\
\hline Other 4- & 6,310 & $\left(\begin{array}{l}193 \\
109\end{array}\right.$ & 5,480 & (149) & 2,630 & (141) & 3,240 & $(104)$ & 2,410 & $(26)$ & 2,240 & $\left(\begin{array}{l}99 \\
49\end{array}\right)$ & $\begin{array}{l}5,12 \\
443\end{array}$ & $(197)$ & $\begin{array}{l}4,880 \\
3,990\end{array}$ & (197) & 3,630 & $\left(\begin{array}{l}477 \\
454\end{array}\right)$ & 1,660 & $\left(\begin{array}{c}103 \\
135\end{array}\right)$ & 1,570 & (171) \\
\hline Less-than-2-year. & $\begin{array}{l}4,400 \\
4,480\end{array}$ & $(947)$ & $\begin{array}{l}4,000 \\
4,100\end{array}$ & $(1,163)$ & 2,040 & $(391)$ & 2,850 & $(210)$ & $\begin{array}{l}2,450 \\
2,380\end{array}$ & $\left(\begin{array}{l}154 \\
(308)\end{array}\right.$ & 1,770 & $(430)$ & $\begin{array}{l}4,430 \\
5,540\end{array}$ & $(1,081)$ & 5,490 & $(1,157)$ & $\begin{aligned} 4,100 \\
\ddagger\end{aligned}$ & $\begin{aligned}(454) \\
(t)\end{aligned}$ & $\begin{array}{l}1,090 \\
\ddagger\end{array}$ & $\begin{aligned}(t 35) \\
(t)\end{aligned}$ & $\begin{aligned} 1,010 \\
\ddagger\end{aligned}$ & $\begin{array}{r}(14) \\
(\dagger)\end{array}$ \\
\hline 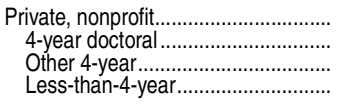 & $\begin{array}{r}13,490 \\
15,670 \\
12,280 \\
8,520\end{array}$ & $\left.\begin{array}{l}(218) \\
268 \\
259 \\
(981)\end{array}\right)$ & $\begin{array}{l}7,260 \\
7,960 \\
6,860 \\
6,110\end{array}$ & $\begin{array}{r}(78) \\
(169) \\
(964) \\
(464)\end{array}$ & $\begin{array}{r}8,920 \\
10,610 \\
7,920 \\
4,940\end{array}$ & $\left.\begin{array}{l}258 \\
325 \\
257 \\
(618)\end{array}\right)$ & $\begin{array}{l}8,270 \\
9,850 \\
7,380 \\
5,040\end{array}$ & $\begin{array}{l}(276) \\
290 \\
290 \\
(637)\end{array}$ & $\begin{array}{l}2,700 \\
2,610 \\
2,620 \\
2,510\end{array}$ & $\begin{array}{r}(70) \\
(66) \\
(136) \\
(22)\end{array}$ & $\begin{array}{l}7,870 \\
9,370 \\
6,980 \\
4,460\end{array}$ & $\left.\begin{array}{l}(233) \\
261 \\
2555 \\
(710)\end{array}\right)$ & $\begin{array}{l}7,610 \\
8,350 \\
7,140 \\
6,100\end{array}$ & $\begin{array}{r}(83) \\
(146) \\
(966) \\
(326)\end{array}$ & $\begin{array}{l}6,480 \\
6,870 \\
6,250 \\
5,440\end{array}$ & $\begin{array}{r}(84) \\
(178) \\
(67) \\
(268)\end{array}$ & $\begin{array}{l}5,790 \\
6,500 \\
5,150 \\
5,520\end{array}$ & $\left.\begin{array}{r}(160) \\
310 \\
(196) \\
(1,439)\end{array}\right)$ & $\begin{array}{r}1,610 \\
1,820 \\
1,470 \\
960\end{array}$ & $\begin{array}{r}(52) \\
52 \\
(63) \\
(119)\end{array}$ & $\begin{array}{r}1,480 \\
1,700 \\
1,290 \\
870\end{array}$ & $\begin{array}{l}(30) \\
59 \\
37 \\
(80)\end{array}$ \\
\hline 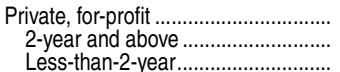 & $\begin{array}{l}9,300 \\
9,980 \\
6,930\end{array}$ & $\left(\begin{array}{l}345 \\
441 \\
390\end{array}\right)$ & $\begin{array}{l}8,030 \\
8,520 \\
6,290\end{array}$ & $\left.\begin{array}{l}(233) \\
308 \\
374\end{array}\right)$ & $\begin{array}{l}3,880 \\
3,980 \\
3,310\end{array}$ & $\left.\begin{array}{l}3444 \\
377 \\
597\end{array}\right)$ & $\begin{array}{l}3,500 \\
3,780 \\
2,610\end{array}$ & $\left.\begin{array}{r}(190) \\
(247) \\
(72)\end{array}\right)$ & $\begin{array}{l}2,570 \\
2,460 \\
2,880\end{array}$ & $\left.\begin{array}{l}87 \\
96 \\
78\end{array}\right)$ & $\begin{array}{l}2,850 \\
3,010 \\
1,270 !\end{array}$ & $\left.\begin{array}{l}331) \\
350 \\
411\end{array}\right)$ & $\begin{array}{l}7,460 \\
7,840 \\
5,940\end{array}$ & $\left.\begin{array}{l}256) \\
311 \\
357\end{array}\right)$ & $\begin{array}{l}6,930 \\
7,320 \\
5,330\end{array}$ & $\left.\begin{array}{l}232 \\
281 \\
339\end{array}\right)$ & $\begin{array}{l}6,210 \\
6,820 \\
4,680\end{array}$ & $\left.\begin{array}{l}(478) \\
659 \\
617\end{array}\right)$ & $\begin{array}{l}\text { 䒠 } \\
\neq \\
\neq\end{array}$ & $\left(\begin{array}{c}t \\
+ \\
(t\end{array}\right)$ & $\begin{array}{l}\ddagger \\
\ddagger \\
\ddagger\end{array}$ & $\left(\begin{array}{l}+ \\
+ \\
+ \\
+\end{array}\right)$ \\
\hline 2003-04, all institutions........... & $\$ 99,670$ & (100) & $\$ 6,950$ & (50) & $\$ 5,640$ & (126) & $\$ 5,630$ & (107) & $\$ 3,240$ & (23) & $\$ 4,890$ & (132) & $\$ 6,970$ & (67) & $\$ 6,040$ & (52) & $\$ 6,080$ & \begin{tabular}{ll|l}
$(137)$ \\
\end{tabular} & $\$ 1,930$ & (35) & $\$ 1,780$ & $\overline{(37)}$ \\
\hline 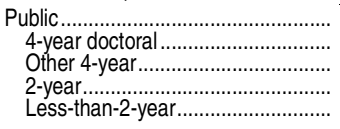 & $\begin{array}{l}7,380 \\
8,930 \\
7,820 \\
4,690 \\
4,770\end{array}$ & $\begin{array}{r}(93) \\
(106 \\
190 \\
130 \\
(388)\end{array}$ & $\begin{array}{l}6,240 \\
7,330 \\
6,400 \\
4,410 \\
4,490\end{array}$ & $\begin{array}{r}(89) \\
(96) \\
(152) \\
(366)\end{array}$ & $\begin{array}{l}3,610 \\
4,480 \\
3,530 \\
2,140 \\
2,920\end{array}$ & $\begin{array}{r}(45) \\
72 \\
(87 \\
(84) \\
(250)\end{array}$ & $\begin{array}{l}4,230 \\
4,880 \\
4,220 \\
3,330 \\
3,180\end{array}$ & $\begin{array}{r}(45) \\
(65) \\
(116) \\
(64) \\
(205)\end{array}$ & $\begin{array}{l}3,200 \\
3,230 \\
3,170 \\
3,180 \\
2,800\end{array}$ & $\begin{array}{r}(31) \\
60 \\
(45) \\
(157 \\
(297)\end{array}$ & $\begin{array}{l}3,090 \\
3,910 \\
2,880 \\
1,810 \\
2,500\end{array}$ & $\begin{array}{r}(45) \\
666 \\
(55 \\
(243) \\
(243)\end{array}$ & $\begin{array}{l}6,060 \\
6,750 \\
5,870 \\
4,170 \\
5,260\end{array}$ & $\begin{array}{r}(729) \\
(127) \\
146 \\
621)\end{array}$ & $\begin{array}{l}5,520 \\
6,150 \\
5,280 \\
3,850 \\
4,740\end{array}$ & $\begin{array}{r}(64) \\
(111) \\
(147) \\
402)\end{array}$ & $\begin{array}{l}5,090 \\
5,500 \\
5,250 \\
3,700 \\
4,230\end{array}$ & $\begin{array}{l}(114) \\
160) \\
226 \\
207 \\
(802)\end{array}$ & $\begin{array}{l}2,010 \\
2,070 \\
1,930 \\
2,000 \\
2,430 !\end{array}$ & $\begin{array}{r}(45) \\
(64) \\
(85) \\
(99 \\
(1,160)\end{array}$ & $\begin{array}{r}1,850 \\
1,900 \\
1,810 \\
1,820 \\
\ddagger\end{array}$ & $\begin{array}{r}(51) \\
(65) \\
(100) \\
108 \\
(\dagger)\end{array}$ \\
\hline 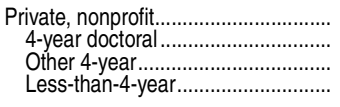 & $\begin{array}{r}15,700 \\
17,230 \\
15,040 \\
8,580\end{array}$ & $\left.\begin{array}{l}(359) \\
529 \\
513 \\
641\end{array}\right)$ & $\begin{array}{l}8,270 \\
8,830 \\
8,030 \\
6,040\end{array}$ & $\begin{array}{l}(114) \\
244) \\
1734 \\
(334)\end{array}$ & $\begin{array}{r}10,080 \\
11,390 \\
9,400 \\
4,960\end{array}$ & $\begin{array}{l}(266) \\
4301 \\
331 \\
(543)\end{array}$ & $\begin{array}{r}9,330 \\
10,410 \\
8,800 \\
5,590\end{array}$ & $\begin{array}{l}(328) \\
510 \\
389 \\
(536)\end{array}$ & $\begin{array}{l}3,410 \\
3,510 \\
3,350 \\
3,580\end{array}$ & $\begin{array}{r}(477) \\
55 \\
(264) \\
(40)\end{array}$ & $\begin{array}{l}8,690 \\
9,770 \\
8,130 \\
4,400\end{array}$ & $\begin{array}{l}(275) \\
4879 \\
3099 \\
(635)\end{array}$ & $\begin{array}{l}8,680 \\
9,640 \\
8,170 \\
6,160\end{array}$ & $\left.\begin{array}{l}(157) \\
2906 \\
(206) \\
572)\end{array}\right)$ & $\begin{array}{l}6,960 \\
7,500 \\
6,660 \\
5,580\end{array}$ & $\left(\begin{array}{c}113 \\
192 \\
144 \\
456\end{array}\right)$ & $\begin{array}{l}7,390 \\
8,200 \\
6,870 \\
4,460\end{array}$ & $\left.\begin{array}{l}269) \\
3358 \\
388 \\
763\end{array}\right)$ & $\begin{array}{l}1,810 \\
2,100 \\
1,630 \\
1,540\end{array}$ & $\begin{array}{r}(53) \\
778 \\
(58) \\
(456)\end{array}$ & $\begin{array}{l}1,670 \\
1,960 \\
1,480 \\
1,540\end{array}$ & $\begin{array}{r}(51) \\
74 \\
(53 \\
(449)\end{array}$ \\
\hline 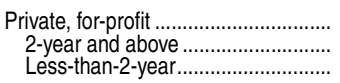 & $\begin{array}{r}10,380 \\
11,330 \\
7,650\end{array}$ & $\left.\begin{array}{l}(335) \\
435 \\
(128)\end{array}\right)$ & $\begin{array}{l}8,460 \\
9,050 \\
6,740\end{array}$ & $\begin{array}{r}(228) \\
(297) \\
(85)\end{array}$ & $\begin{array}{l}5,000 \\
5,300 \\
3,780\end{array}$ & $\begin{array}{l}(286) \\
(349) \\
(130)\end{array}$ & $\begin{array}{l}4,280 \\
4,650 \\
3,240\end{array}$ & $\left(\begin{array}{l}1655 \\
221 \\
(111)\end{array}\right)$ & $\begin{array}{l}3,240 \\
3,370 \\
2,880\end{array}$ & $\begin{array}{r}(69) \\
(67) \\
(104)\end{array}$ & $\begin{array}{l}3,800 \\
4,000 \\
2,770\end{array}$ & $\left.\begin{array}{l}(319) \\
366 \\
(145)\end{array}\right)$ & $\begin{array}{l}7,640 \\
8,140 \\
6,050\end{array}$ & $\left.\begin{array}{l}(267) \\
(351) \\
139\end{array}\right)$ & $\begin{array}{l}6,580 \\
6,950 \\
5,340\end{array}$ & $\left(\begin{array}{l}190) \\
253 \\
112\end{array}\right)$ & $\begin{array}{l}5,720 \\
6,050 \\
4,540\end{array}$ & $\left.\begin{array}{l}(524) \\
657 \\
203\end{array}\right)$ & $\begin{array}{l}2,650 \\
2,780 \\
1,730\end{array}$ & $\left.\begin{array}{l}(274) \\
308 \\
(116)\end{array}\right)$ & $\begin{array}{l}2,720 \\
2,890 \\
1,550\end{array}$ & $\left.\begin{array}{l}326 \\
361 \\
101\end{array}\right)$ \\
\hline
\end{tabular}

See notes at end of table. 
Table 331.70. Average amount of financial aid awarded to full-time, full-year undergraduates, by type and source of aid and control and level of institution: Selected years, 1992-93 through 2011-12-Continued

[Standard errors appear in parentheses]

\begin{tabular}{|c|c|c|c|c|c|c|c|c|c|c|c|c|c|c|c|c|c|c|c|c|c|c|}
\hline \multirow[b]{2}{*}{ Control and level of institution } & \multicolumn{6}{|c|}{ Any aid } & \multicolumn{6}{|c|}{ Grants } & \multicolumn{6}{|c|}{ Loans } & \multicolumn{4}{|c|}{ Work study ${ }^{1}$} \\
\hline & & Total $^{2}$ & & Federal $^{3}$ & \multicolumn{2}{|c|}{ Nonfederal } & & Total $^{4}$ & & Federal & \multicolumn{2}{|c|}{ Nonfederal } & \multicolumn{4}{|r|}{ Federal $^{5}$} & \multicolumn{2}{|c|}{ Nonfederal } & \multicolumn{2}{|r|}{ Total } & \multicolumn{2}{|r|}{ Federal } \\
\hline 1 & & 2 & & 3 & & 4 & & 5 & & 6 & & 7 & & 8 & & 9 & & 10 & & 11 & & 12 \\
\hline $2007-08$, all institutions.... & $\$ 12,860$ & (98) & $\$ 8,100$ & (51) & $\$ 8,040$ & (89) & , 190 & (72) & $\$ 3,690$ & (18) & $\$ 6,390$ & $(80)$ & $\$ 9,470$ & (76) & $\$ 7,050$ & (55) & 7,760 & (111) & $\$ 2,260$ & (26) & $\$ 2,150$ & (30) \\
\hline 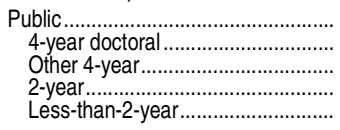 & $\begin{array}{r}9,650 \\
11,640 \\
9,950 \\
5,750 \\
6,210\end{array}$ & $\begin{array}{r}(62) \\
(135) \\
(628) \\
(528)\end{array}$ & $\begin{array}{l}7,240 \\
8,310 \\
7,370 \\
5,160 \\
5,200\end{array}$ & $\begin{array}{r}(51) \\
(82) \\
(107) \\
(441)\end{array}$ & $\begin{array}{l}5,220 \\
6,530 \\
5,150 \\
2,510 \\
3,750\end{array}$ & $\begin{array}{r}(50 \\
83 \\
95 \\
45 \\
(477)\end{array}$ & $\begin{array}{l}6,390 \\
5,390 \\
3,750 \\
3,610\end{array}$ & $\begin{array}{r}(40 \\
71 \\
86 \\
(44) \\
(212)\end{array}$ & $\begin{array}{l}3,670 \\
3,780 \\
3,710 \\
3,530 \\
3,320\end{array}$ & $\begin{array}{r}(18 \\
33 \\
32 \\
(29) \\
(153)\end{array}$ & $\begin{array}{l}4,060 \\
5,150 \\
4,000 \\
1,860 \\
2,390\end{array}$ & $\begin{array}{r}(42 \\
67 \\
99 \\
(35) \\
(351)\end{array}$ & $\begin{array}{l}7,980 \\
8,860 \\
7,670 \\
5,450 \\
6,910\end{array}$ & $\begin{array}{r}(60) \\
(90) \\
(123) \\
(500) \\
(500)\end{array}$ & $\begin{array}{l}1,100 \\
6,230 \\
4,600 \\
5,550\end{array}$ & $\begin{array}{r}(58) \\
83 \\
94) \\
(73) \\
(388)\end{array}$ & $\begin{array}{l}7,130 \\
6,270 \\
4,670 \\
4,920\end{array}$ & $\left.\begin{array}{l}(108) \\
155 \\
206 \\
150 \\
284\end{array}\right)$ & $\begin{array}{r}2,440 \\
2,270 \\
2,560 \\
\ddagger\end{array}$ & $\begin{array}{r}(36) \\
(42) \\
(68) \\
(107) \\
(\dagger)\end{array}$ & $\begin{array}{r}2,360 \\
2,300 \\
2,110 \\
2,760 \\
\ddagger\end{array}$ & $\begin{array}{r}(44) \\
(46) \\
(80) \\
(122) \\
(\dagger)\end{array}$ \\
\hline 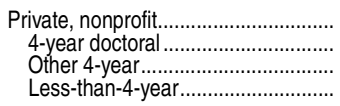 & $\begin{array}{r}21,030 \\
22,500 \\
19,960 \\
9,890\end{array}$ & $\begin{array}{r}(311) \\
(480) \\
(421) \\
(1,546)\end{array}$ & $\begin{array}{r}9,790 \\
10,230 \\
9,480 \\
6,890\end{array}$ & $\left.\begin{array}{l}156 \\
214 \\
211 \\
(879)\end{array}\right)$ & $\begin{array}{r}14,340 \\
15,620 \\
13,310 \\
5,390\end{array}$ & $\begin{array}{r}(220) \\
(335) \\
(324) \\
(1,352)\end{array} \mid$ & $\begin{array}{r}12,120 \\
12,950 \\
11,510 \\
5,730\end{array}$ & $\begin{array}{r}(200) \\
(314) \\
(247) \\
(1,362)\end{array}$ & $\begin{array}{l}4,090 \\
4,260 \\
3,950 \\
4,360\end{array}$ & $\begin{array}{r}(48) \\
82 \\
(54 \\
(663)\end{array}$ & $\begin{array}{r}11,300 \\
12,150 \\
10,640 \\
3,130 !\end{array}$ & $\begin{array}{r}(180) \\
(267) \\
(252) \\
(1,131)\end{array}$ & $\begin{array}{l}12,150 \\
13,270 \\
11,160 \\
10,570\end{array}$ & $\left.\begin{array}{l}(198) \\
263 \\
(302 \\
684\end{array}\right)$ & $\begin{array}{l}8,240 \\
8,750 \\
7,800 \\
7,530\end{array}$ & $\begin{array}{r}(158) \\
(213) \\
(214) \\
(1,074)\end{array}$ & $\begin{array}{r}9,820 \\
11,050 \\
8,640 \\
8,350\end{array}$ & $\begin{array}{r}(222) \\
(358) \\
(260) \\
(1,060)\end{array}$ & & $\begin{array}{r}(35) \\
(53) \\
(40) \\
(264)\end{array}$ & $\begin{array}{l}1,920 \\
2,070 \\
1,770 \\
2,200\end{array}$ & $\begin{array}{r}(36) \\
(57) \\
(433) \\
(323)\end{array}$ \\
\hline 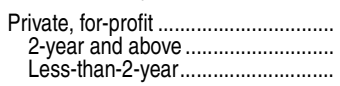 & $\begin{array}{r}12,570 \\
13,120 \\
9,680 \\
\end{array}$ & $\begin{array}{l}(279) \\
332 \\
(245)\end{array}$ & $\begin{array}{l}8,930 \\
9,170 \\
7,700\end{array}$ & $\left.\begin{array}{l}177) \\
204 \\
241\end{array}\right)$ & $\begin{array}{l}6,810 \\
7,150 \\
4,560\end{array}$ & $\left.\begin{array}{l}(260) \\
300 \\
223\end{array}\right)$ & $\begin{array}{l}4,050 \\
4,130 \\
3,680\end{array}$ & $\begin{array}{r}(91) \\
(109) \\
(89)\end{array}$ & $\begin{array}{l}3,250 \\
3,210 \\
3,400 \\
\end{array}$ & $\begin{array}{l}(58) \\
70 \\
(78) \\
\end{array}$ & & $\begin{array}{l}(188) \\
214 \\
(225)\end{array}$ & $\begin{array}{r}10,170 \\
10,550 \\
7,930 \\
\end{array}$ & $\left.\begin{array}{l}(228) \\
266 \\
207\end{array}\right)$ & $\begin{array}{l}7,020 \\
7,120 \\
6,370 \\
\end{array}$ & $\begin{array}{l}(133) \\
152 \\
166)\end{array}$ & & $\begin{array}{l}(300) \\
347 \\
(188)\end{array}$ & $\begin{array}{r}3,540 \\
3,680 \\
\ddagger \\
\end{array}$ & $\begin{array}{r}(384) \\
393 \\
(\dagger\end{array}$ & $\begin{array}{r}3,700 \\
3,840 \\
\ddagger \\
\end{array}$ & $\begin{array}{r}(379) \\
(377) \\
(t) \\
\end{array}$ \\
\hline 2011-12, all institutions ............ & $\$ \$ 15,510$ & (106) & $\$ 10,820$ & (75) & $\$ 9,160$ & (110) & $\$ 9,230$ & \begin{tabular}{l|l}
$(92)$ \\
\end{tabular} & $\$ 4,580$ & (20) & $\$ 8,590$ & $\begin{array}{ll}(115) \$ \\
\$\end{array}$ & $\$ 10,090$ & (75) & $\$ 9,160$ & (69) & $\$ 6,980$ & (187) & $\$ 2,250$ & (48) & $\$ 2,180$ & $(37)$ \\
\hline 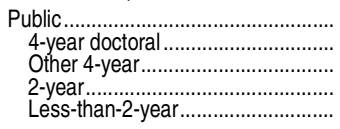 & $\begin{array}{r}14,130 \\
11,730 \\
7,120 \\
7,300\end{array}$ & $\begin{array}{r}(933) \\
(1229) \\
(117) \\
(989)\end{array}$ & $\begin{array}{r}9,400 \\
11,000 \\
9,800 \\
6,740 \\
6,360\end{array}$ & $\begin{array}{r}(71) \\
(106) \\
(150) \\
(91) \\
(1,018)\end{array}$ & $\begin{array}{l}5,170 \\
6,610 \\
4,920 \\
2,480 \\
2,740\end{array}$ & $\begin{array}{r}(75) \\
(108) \\
(170) \\
(86 \\
(813)\end{array}$ & $\begin{array}{l}6,610 \\
7,880 \\
6,440 \\
4,910 \\
5,050\end{array}$ & $\begin{array}{r}(62) \\
(101) \\
(73) \\
(458)\end{array}$ & $\begin{array}{l}4,560 \\
4,610 \\
4,650 \\
4,460 \\
4,510\end{array}$ & $\begin{array}{r}(22) \\
27 \\
49 \\
(41) \\
(464)\end{array}$ & $\begin{array}{l}4,730 \\
6,70 \\
4,410 \\
2,320 \\
2,170 !\end{array}$ & $\begin{array}{r}(75) \\
(112) \\
155 \\
(74) \\
(676)\end{array}$ & $\begin{array}{l}8,860 \\
9,750 \\
8,790 \\
6,200 \\
7,260\end{array}$ & $\begin{array}{r}(87) \\
(112) \\
(186) \\
(78) \\
(950)\end{array}$ & $\begin{array}{l}8,300 \\
9,040 \\
8,210 \\
6,060 \\
7,060\end{array}$ & $\begin{array}{r}(81) \\
(109) \\
152 \\
(79) \\
(939)\end{array}$ & $\begin{array}{r}5,790 \\
6,400 \\
5,630 \\
3,380 \\
\ddagger\end{array}$ & $\begin{array}{r}237 \\
289 \\
483 \\
208 \\
(\dagger)\end{array}$ & $\begin{array}{r}2,330 \\
2,410 \\
2,020 \\
2,460 \\
\ddagger\end{array}$ & $\begin{array}{r}(60) \\
(80 \\
(106) \\
130 \\
(\dagger)\end{array}$ & $\begin{array}{r}2,290 \\
2,320 \\
2,050 \\
2,460 \\
\ddagger\end{array}$ & $\begin{array}{r}(60) \\
(79) \\
(112) \\
146 \\
(\dagger)\end{array}$ \\
\hline 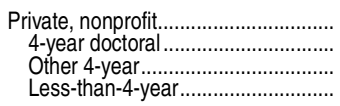 & $\begin{array}{l}27,250 \\
29,080 \\
25,630 \\
16,190\end{array}$ & $\begin{array}{r}(300) \\
(456) \\
(384) \\
(2,359)\end{array}$ & $\begin{array}{l}13,300 \\
13,700 \\
12,870 \\
12,830\end{array}$ & $\begin{array}{r}(217) \\
(355) \\
(216) \\
(1,038)\end{array}$ & $\begin{array}{l}17,870 \\
19,410 \\
16,400 \\
7,610 !\end{array}$ & $\begin{array}{r}(265) \\
(383 \\
(355) \\
(2,474)\end{array} \mid$ & $\begin{array}{r}17,780 \\
19,380 \\
16,370 \\
7,410\end{array}$ & $\begin{array}{r}(264) \\
(410) \\
(1366 \\
(1,336)\end{array}$ & $\begin{array}{l}4,710 \\
4,690 \\
4,720 \\
4,870\end{array}$ & $\begin{array}{r}(46) \\
81 \\
(46 \\
(140)\end{array}$ & $\begin{array}{c}16,720 \\
18,260 \\
15,210 \\
6,670 !\end{array}$ & $\begin{array}{r}(266) \\
(396) \\
(348) \\
(2,156)\end{array}$ & $\begin{array}{l}12,550 \\
13,120 \\
11,960 \\
11,600\end{array}$ & $\begin{array}{r}(200) \\
(356) \\
(167) \\
(1,621)\end{array} \mid$ & $\begin{array}{l}10,930 \\
11,420 \\
10,430 \\
10,330\end{array}$ & $\begin{array}{r}(190) \\
(330) \\
(172) \\
(1,239)\end{array}$ & $\begin{array}{l}8,460 \\
8,700 \\
8,200 \\
8,170 !\end{array}$ & $\begin{array}{r}(437) \\
(728) \\
(385) \\
(3,055)\end{array}$ & $\begin{array}{l}2,150 \\
2,280 \\
1,980 \\
2,750\end{array}$ & $\begin{array}{r}(67) \\
(65) \\
(130) \\
(478)\end{array}$ & $\begin{array}{l}2,050 \\
2,220 \\
1,830 \\
2,790\end{array}$ & $\begin{array}{r}(44) \\
60 \\
69 \\
(508)\end{array}$ \\
\hline \multirow[t]{2}{*}{ 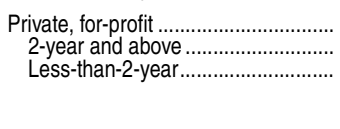 } & $\begin{array}{l}15,070 \\
15,520 \\
12,170\end{array}$ & $\left.\begin{array}{l}(214) \\
219 \\
633\end{array}\right)$ & $\begin{array}{l}13,300 \\
13,660 \\
10,990\end{array}$ & $\left.\begin{array}{l}173) \\
181 \\
483\end{array}\right)$ & $\begin{array}{l}6,480 \\
6,530 \\
5,960\end{array}$ & $\left.\begin{array}{l}(205) \\
218 \\
(551)\end{array}\right)$ & $\begin{array}{l}5,270 \\
5,310 \\
5,050\end{array}$ & $\begin{array}{r}(85) \\
(85) \\
(268)\end{array}$ & $\begin{array}{l}4,520 \\
4,500 \\
4,670 \\
\end{array}$ & $\begin{array}{r}(49) \\
40 \\
(230)\end{array}$ & $\begin{array}{l}4,600 \\
4,580 \\
4,880 \\
\end{array}$ & $\begin{array}{l}(257) \\
267 \\
(532)\end{array}$ & $\begin{array}{r}10,610 \\
10,960 \\
8,370 \\
\end{array}$ & $\left.\begin{array}{l}(139) \\
151 \\
(313)\end{array}\right)$ & $\begin{array}{l}9,440 \\
9,740 \\
7,510 \\
\end{array}$ & $\left.\begin{array}{l}107) \\
1177 \\
(211)\end{array}\right)$ & $\begin{array}{l}7,170 \\
7,350 \\
5,810 \\
\end{array}$ & $\left.\begin{array}{l}(211) \\
222 \\
(675)\end{array}\right)$ & $\begin{array}{r}3,690 \\
3,750 \\
\ddagger \\
\end{array}$ & $\begin{array}{r}(272) \\
(281) \\
(\dagger)\end{array}$ & $\begin{array}{r}3,760 \\
3,830 \\
\quad \neq \\
\end{array}$ & $\begin{array}{r}(291) \\
299 \\
(t)\end{array}$ \\
\hline & \multicolumn{22}{|c|}{ Constant 2012-13 dollars 6} \\
\hline 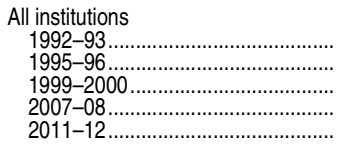 & $\begin{array}{r}9,300 \\
10,270 \\
11,640 \\
14,050 \\
15,770\end{array}$ & $\begin{array}{r}(2,182) \\
(360) \\
107 \\
(107) \\
(108)\end{array}$ & $\begin{array}{r}6,970 \\
8,050 \\
8,420 \\
81,850 \\
11,000\end{array}$ & $\begin{array}{r}(542) \\
(172) \\
(78) \\
55 \\
(76)\end{array}$ & $\begin{array}{l}5,650 \\
5,690 \\
6,870 \\
8,790 \\
9,310\end{array}$ & $\left.\begin{array}{r}(1,485) \\
(379) \\
(132) \\
(97) \\
(112)\end{array}\right)$ & $\begin{array}{l}5,750 \\
5,840 \\
6,800 \\
7,850 \\
9,390\end{array}$ & $\begin{array}{r}1,044 \\
(317) \\
(94) \\
(78 \\
(94)\end{array}$ & $\begin{array}{l}3,220 \\
3,010 \\
3,450 \\
4,040 \\
4,650\end{array}$ & $\begin{array}{l}(51) \\
34 \\
23 \\
20 \\
(20)\end{array}$ & $\begin{array}{l}5,410 \\
6,090 \\
6,980 \\
8,740\end{array}$ & $\begin{array}{r}(1,310) \\
(379) \\
123 \\
(87) \\
(117)\end{array}$ & $\begin{array}{r}6,300 \\
7,520 \\
8,580 \\
10,350 \\
10,260\end{array}$ & $\left.\begin{array}{r}(476) \\
142 \\
(98 \\
83 \\
(76)\end{array}\right)$ & $\begin{array}{l}7,440 \\
7,770 \\
7,710 \\
9,310\end{array}$ & $\begin{array}{c}(322) \\
(141) \\
(94) \\
(60) \\
(70)\end{array}$ & $\begin{array}{l}4,430 \\
4,120 \\
6,750 \\
8,480 \\
7,220\end{array}$ & $\left.\begin{array}{r}(1,077) \\
(544) \\
175) \\
121 \\
(193)\end{array}\right)$ & $\begin{array}{l}2,230 \\
2,050 \\
2,290 \\
2,470 \\
2,280\end{array}$ & $\left.\begin{array}{r}(167) \\
113 \\
(45) \\
28 \\
(48)\end{array}\right)$ & $\begin{array}{l}2,090 \\
1,950 \\
2,130 \\
2,350 \\
2,210\end{array}$ & $\begin{array}{r}(150) \\
(99 \\
35 \\
32 \\
(37)\end{array}$ \\
\hline
\end{tabular}

†Not applicable

!Interpret data with caution. The coefficient of variation (CV) for this estimate is between 30 and 50 percent. ₹Reporting standards not met. Either there are too few cases for a reliable estimate or the coefficient of variation (CV) is 50 percent or greater.

Details on nonfederal work-study participants are not available.

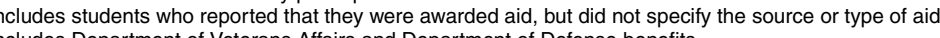

employers.

${ }^{5}$ The 2003-04, 2007--08, and 2011-12 data include Parent Loans for Undergraduate Students (PLUS). ${ }^{6}$ Constant dollars based on the Consumer Price Index, prepared by the Bureau of Labor Statistics, U.S. Department of Labor,

NOTE: Aid averages are for those students who received the specified type of aid. Full-time, full-year students were enrolled 1 through June 30. Data for 2007-08 and pior SOURCE: U.S. Department of Education, National Center for Education Statistics, 1992-93, 1995-96, 1999-2000, 2003-04, 2007-08, and 2011-12 National Postsecondary Student Aid Study (NPSAS:93, NPSAS:96, NPSAS:2000, NPSAS:04 NPSAS:08, and NPSAS:12). (This table was prepared January 2014.) 


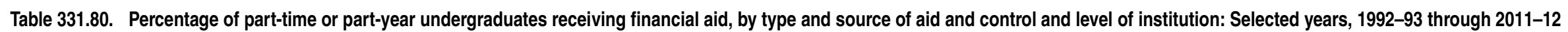
[Standard errors appear in parentheses]

\begin{tabular}{|c|c|c|c|c|c|c|c|c|c|c|c|c|c|c|c|c|c|c|c|c|c|c|}
\hline \multirow{3}{*}{$\frac{\text { Control and level of institution }}{1}$} & \multicolumn{6}{|c|}{ Any aid } & \multicolumn{6}{|c|}{ Grants } & \multicolumn{6}{|c|}{ Loans } & \multicolumn{4}{|c|}{ Work study ${ }^{1}$} \\
\hline & & Total $^{2}$ & & Federal $^{3}$ & & nfederal & & Total & & Federal & & federal & & Total $^{4}$ & & Federal $^{4}$ & & ffederal & & Total & & Federal \\
\hline & & 2 & & 3 & & 4 & & 5 & & 6 & & 7 & & 8 & & 9 & & 10 & & 11 & & 12 \\
\hline 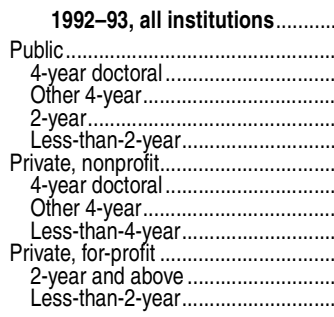 & $\begin{array}{l}37.6 \\
31.7 \\
40.5 \\
39.5 \\
28.6 \\
21.2 \\
56.4 \\
51.4 \\
59.4 \\
53.9 \\
71.0 \\
64.4 \\
75.5\end{array}$ & $\begin{array}{l}(0.80) \\
(0.71) \\
1.02 \\
1.24 \\
0.91 \\
3.11 \\
1.96 \\
1.91 \\
2.83 \\
5.17 \\
3.08 \\
5.75 \\
(2.78)\end{array}$ & $\begin{array}{l}\mathbf{2 5 . 0} \\
19.8 \\
27.5 \\
28.4 \\
16.5 \\
15.1 \\
35.1 \\
28.3 \\
38.1 \\
35.8 \\
64.4 \\
54.9 \\
70.8\end{array}$ & $\begin{array}{l}(0.83) \\
(0.67) \\
0.95 \\
(1.25) \\
(0.83 \\
3.55 \\
(2.65) \\
1.49 \\
(4.18 \\
4.98 \\
(3.44) \\
(5.93 \\
(3.36) \\
\end{array}$ & $\begin{array}{r}16.5 \\
14.5 \\
19.5 \\
19.2 \\
12.7 \\
6.9 \\
33.7 \\
33.0 \\
35.6 \\
28.4 \\
11.8 \\
14.3 \\
10.2\end{array}$ & $\begin{array}{l}(0.44) \\
(0.46) \\
0.66 \\
1.00 \\
0.61 \\
1.47 \\
1.54 \\
1.91 \\
2.25 \\
(4.07) \\
1.58 \\
2.75 \\
1.74)\end{array}$ & $\begin{array}{l}32.4 \\
27.6 \\
31.3 \\
33.8 \\
25.9 \\
19.4 \\
50.2 \\
44.4 \\
53.8 \\
47.3 \\
55.3 \\
46.2 \\
61.5\end{array}$ & $\begin{array}{l}(0.76) \\
(0.66) \\
0.85 \\
1.17 \\
0.87 \\
3.43 \\
2.12 \\
1.90 \\
3.14 \\
4.83 \\
3.30 \\
4.25 \\
(4.15)\end{array}$ & $\begin{array}{l}18.8 \\
15.3 \\
17.1 \\
22.0 \\
13.7 \\
13.8 \\
23.2 \\
12.8 \\
26.8 \\
28.3 \\
48.8 \\
35.0 \\
58.1\end{array}$ & $\begin{array}{l}(0.77) \\
(0.60) \\
0.68 \\
1.17) \\
0.76 \\
3.90 \\
2.96 \\
0.98 \\
4.73 \\
4.56 \\
3.61 \\
4.19 \\
4.52)\end{array}$ & $\begin{array}{r}14.5 \\
12.6 \\
16.6 \\
16.1 \\
11.2 \\
6.0 ! \\
31.7 \\
31.7 \\
33.6 \\
24.4 \\
8.6 \\
12.1 \\
6.3\end{array}$ & $\begin{array}{l}(0.39) \\
(0.40) \\
0.61 \\
0.88 \\
0.52 \\
1.41 \\
1.49 \\
1.91 \\
2.19 \\
4.05 \\
1.34 \\
2.45 \\
1.27) \\
\end{array}$ & $\begin{array}{r}13.5 \\
9.3 \\
20.9 \\
16.2 \\
5.6 \\
0.7 ! \\
23.7 \\
24.2 \\
24.4 \\
20.7 \\
42.3 \\
45.7 \\
40.0\end{array}$ & $\begin{array}{l}(0.50) \\
(0.41) \\
0.83 \\
0.99 \\
0.44 \\
0.32 \\
1.38 \\
1.42 \\
2.08 \\
3.59 \\
3.54 \\
5.59 \\
(4.50)\end{array}$ & $\begin{array}{c}13.1 \\
8.9 \\
20.4 \\
15.6 \\
5.3 \\
0.7 ! \\
23.2 \\
23.3 \\
23.9 \\
20.3 \\
41.9 \\
45.5 \\
39.4\end{array}$ & $\begin{array}{l}(0.49) \\
(0.39) \\
(0.82) \\
0.93 \\
0.43 \\
(0.32 \\
1.34) \\
1.39 \\
(2.02) \\
3.58) \\
(3.51) \\
5.58 \\
(4.42) \\
\end{array}$ & $\begin{array}{r}0.8 \\
0.6 \\
1.1 \\
1.3 \\
0.4 \\
\# \\
1.8 \\
2.7 \\
1.5 \\
1.2 ! \\
1.5 ! \\
\ddagger \\
1.8 !\end{array}$ & \begin{tabular}{r|}
$(0.09)$ \\
$(0.09)$ \\
0.18 \\
0.32 \\
0.11 \\
$(t)$ \\
$(0.23)$ \\
0.47 \\
0.32 \\
$0.44)$ \\
$(0.46)$ \\
$(+)$ \\
$(0.63)$ \\
\end{tabular} & $\begin{array}{r}2.1 \\
1.7 \\
3.6 \\
3.1 \\
1.1 \\
\ddagger \\
5.9 \\
5.4 \\
7.3 \\
\ddagger \\
0.9 ! \\
1.4 ! \\
\ddagger\end{array}$ & $\begin{array}{r}(0.13) \\
(0.12) \\
0.32 \\
0.42 \\
(0.11 \\
(t) \\
(0.71) \\
0.88 \\
(1.14 \\
(t) \\
(0.29) \\
0.58 \\
(+)\end{array}$ & $\begin{array}{l}1.2 \\
0.9 \\
2.1 \\
1.6 \\
0.6 \\
\ddagger \\
3.8 \\
3.1 \\
4.8 \\
\ddagger \\
0.4 \\
0.6 ! \\
0.3 !\end{array}$ & 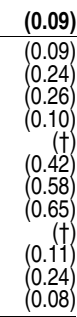 \\
\hline 1999-2000, all institutions............ & 44.6 & $(0.81)$ & 29.8 & $(0.64)$ & 27.4 & $(0.75)$ & 35.4 & $(0.70)$ & 18.6 & $(0.52)$ & 25.0 & (0.73) & 18.4 & $(0.56)$ & 17.7 & $(0.55)$ & 2.1 & $(0.12)$ & 1.9 & $(0.11)$ & 1.4 & \\
\hline 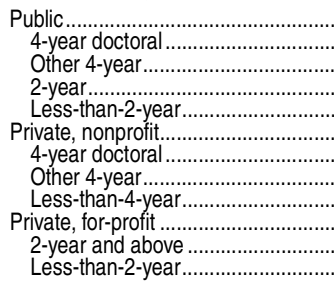 & $\begin{array}{l}39.7 \\
51.0 \\
51.2 \\
34.9 \\
38.6 \\
64.8 \\
60.2 \\
66.2 \\
71.2 \\
83.1 \\
81.8 \\
84.7\end{array}$ & $\begin{array}{l}(0.85) \\
0.93 \\
1.33 \\
1.14 \\
3.11 \\
1.02 \\
1.59 \\
1.33 \\
4.24 \\
1.78 \\
2.03 \\
2.75\end{array}$ & $\begin{array}{l}24.8 \\
36.8 \\
37.0 \\
19.8 \\
21.9 \\
44.5 \\
40.9 \\
44.6 \\
57.3 \\
78.5 \\
77.9 \\
79.1\end{array}$ & $\begin{array}{l}(0.57) \\
0.93 \\
1.36 \\
0.69 \\
3.93 \\
1.56 \\
1.74 \\
(2.23 \\
5.11 \\
11.53 \\
2.24 \\
1.97)\end{array}$ & $\begin{array}{l}25.3 \\
30.0 \\
29.9 \\
23.5 \\
22.2 \\
47.2 \\
46.8 \\
48.5 \\
37.2 \\
22.3 \\
25.4 \\
18.7\end{array}$ & $\left.\begin{array}{l}(0.86) \\
0.83 \\
1.10 \\
1.20 \\
1.77 \\
1.32 \\
1.64 \\
1.78 \\
6.39 \\
1.82 \\
2.77 \\
2.41\end{array}\right)$ & $\begin{array}{l}31.7 \\
35.7 \\
39.1 \\
29.5 \\
29.6 \\
53.9 \\
49.9 \\
54.9 \\
61.0 \\
58.9 \\
54.0 \\
64.5\end{array}$ & $\begin{array}{l}(0.78) \\
0.79 \\
1.24 \\
1.08 \\
3.16 \\
1.15 \\
1.54 \\
1.58 \\
4.36 \\
2.03 \\
2.92 \\
2.44\end{array}$ & $\begin{array}{l}15.9 \\
17.9 \\
21.5 \\
14.4 \\
18.2 \\
22.1 \\
17.0 \\
22.2 \\
41.7 \\
53.3 \\
45.6 \\
62.2\end{array}$ & $\begin{array}{l}(0.48) \\
0.70 \\
1.33 \\
0.62 \\
3.53 \\
1.33 \\
1.15 \\
1.94 \\
4.22 \\
2.19 \\
2.94 \\
(2.45)\end{array}$ & $\begin{array}{r}23.3 \\
26.7 \\
27.9 \\
21.9 \\
14.4 \\
44.8 \\
44.2 \\
46.3 \\
34.4 \\
14.6 \\
19.3 \\
9.1\end{array}$ & $\begin{array}{l}(0.83) \\
0.70 \\
1.10 \\
1.16 \\
2.46 \\
1.44 \\
1.48 \\
2.02 \\
6.66 \\
1.69 \\
2.16 \\
1.83\end{array}$ & $\begin{array}{r}13.5 \\
31.5 \\
27.4 \\
6.9 \\
\ddagger \\
34.8 \\
35.1 \\
34.4 \\
36.4 \\
62.7 \\
69.5 \\
54.8\end{array}$ & $\begin{array}{l}(0.41) \\
0.96 \\
1.04 \\
0.42 \\
(+) \\
(1.48 \\
1.76 \\
(2.11 \\
5.14 \\
3.06 \\
3.09 \\
6.25)\end{array}$ & $\begin{array}{r}13.0 \\
30.3 \\
26.6 \\
6.5 \\
\ddagger \\
33.4 \\
34.1 \\
32.8 \\
35.9 \\
61.2 \\
68.5 \\
52.9\end{array}$ & $\begin{array}{r}(0.39) \\
0.87 \\
1.02 \\
(0.40) \\
(t) \\
(1.39) \\
1.74 \\
1.95 \\
5.04 \\
3.07 \\
3.12 \\
6.32)\end{array}$ & $\begin{array}{l}1.3 \\
3.3 \\
2.4 \\
0.6 \\
\ddagger \\
6.0 \\
7.6 \\
5.7 \\
2.9 \\
6.1 \\
6.0 \\
6.3\end{array}$ & $\begin{array}{r}(0.11) \\
0.42 \\
0.34 \\
0.10 \\
(t) \\
0.50 \\
1.01 \\
0.03 \\
0.62 \\
(0.86 \\
(.28) \\
(1.11)\end{array}$ & $\begin{array}{c}1.5 \\
3.0 \\
3.1 \\
0.8 \\
1.6 \\
5.9 \\
6.5 \\
5.8 \\
4.6 ! \\
0.3 ! \\
\ddagger \\
\ddagger\end{array}$ & $\left.\begin{array}{r}(0.11) \\
0.28 \\
0.48 \\
0.12 \\
0.47 \\
0.52 \\
0.93 \\
0.08 \\
1.49 \\
0.16 \\
(+) \\
+\end{array}\right)$ & $\begin{array}{l}1.1 \\
1.9 \\
2.5 \\
0.7 \\
0.9 ! \\
4.0 \\
4.7 \\
3.7 \\
3.5 ! \\
0.3 ! \\
\ddagger \\
\neq\end{array}$ & $\begin{array}{l}0.44 \\
0.11 \\
0.33 \\
0.41 \\
0.80 \\
0.52 \\
1.12 \\
0.15 \\
\end{array}$ \\
\hline 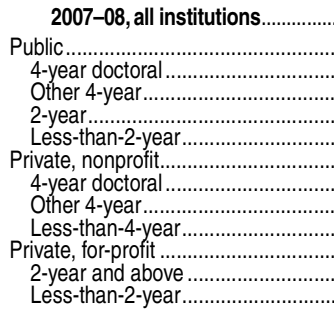 & $\begin{array}{l}56.9 \\
49.3 \\
64.2 \\
60.1 \\
44.2 \\
46.7 \\
77.3 \\
75.5 \\
78.8 \\
75.3 \\
93.2 \\
94.5 \\
88.6 \\
\end{array}$ & $\begin{array}{l}(0.45) \\
(0.54) \\
0.73 \\
1.02 \\
0.68 \\
(2.17) \\
0.90 \\
1.37 \\
1.29 \\
4.14 \\
0.56 \\
(0.70) \\
(0.81) \\
\end{array}$ & $\begin{array}{l}39.3 \\
30.3 \\
44.0 \\
43.2 \\
25.2 \\
31.4 \\
55.4 \\
49.7 \\
58.2 \\
67.4 \\
87.7 \\
89.6 \\
80.7 \\
\end{array}$ & $\begin{array}{l}(0.30) \\
(0.36) \\
0.74) \\
(0.97) \\
0.42 \\
11.91 \\
0.87 \\
11.87 \\
(1.43 \\
(3.94) \\
(0.73) \\
(0.90) \\
(1.24) \\
\end{array}$ & $\begin{array}{l}37.8 \\
33.3 \\
44.9 \\
35.9 \\
30.4 \\
26.5 \\
59.7 \\
62.1 \\
59.8 \\
42.3 \\
51.2 \\
53.0 \\
44.8 \\
\end{array}$ & $\begin{array}{l}(0.46) \\
(0.46) \\
0.72 \\
1.08 \\
0.58 \\
4.22 \\
1.04 \\
1.69 \\
1.33 \\
5.29 \\
1.72 \\
(2.16) \\
(1.91) \\
\end{array}$ & $\begin{array}{l}43.4 \\
38.0 \\
43.1 \\
42.5 \\
36.2 \\
38.5 \\
60.5 \\
59.0 \\
62.0 \\
55.8 \\
66.7 \\
67.0 \\
65.8 \\
\end{array}$ & $\begin{array}{l}(0.46) \\
(0.53) \\
0.611 \\
0.79 \\
0.69 \\
1.87 \\
1.00 \\
1.68 \\
1.39 \\
3.11 \\
1.02 \\
1.28 \\
(1.15) \\
\end{array}$ & $\begin{array}{l}24.5 \\
19.2 \\
19.7 \\
25.5 \\
18.0 \\
27.6 \\
25.3 \\
20.1 \\
26.9 \\
45.9 \\
59.7 \\
58.9 \\
62.4 \\
\end{array}$ & $\begin{array}{l}(0.29) \\
(0.31) \\
0.57 \\
0.80 \\
0.38 \\
1.43 \\
0.76 \\
1.38 \\
1.29 \\
3.45 \\
1.18 \\
1.48 \\
(1.05) \\
\end{array}$ & $\begin{array}{l}\mathbf{2 8 . 4} \\
27.7 \\
34.3 \\
26.9 \\
26.4 \\
15.8 \\
49.5 \\
51.6 \\
50.4 \\
25.6 \\
17.6 \\
18.7 \\
13.8 \\
\end{array}$ & $\begin{array}{l}(0.45) \\
(0.46 \\
0.62 \\
0.85 \\
0.60 \\
2.14 \\
1.10 \\
1.86 \\
1.39 \\
3.85 \\
1.73 \\
2.16 \\
(2.11) \\
\end{array}$ & $\begin{array}{l}30.1 \\
19.6 \\
42.5 \\
34.7 \\
12.1 \\
14.6 \\
50.9 \\
49.7 \\
52.3 \\
45.5 \\
85.6 \\
88.0 \\
76.8 \\
\end{array}$ & $\begin{array}{l}(\mathbf{0 . 2 2}) \\
(0.21) \\
0.81 \\
0.96 \\
(0.20) \\
1.79 \\
0.77 \\
1.58 \\
1.34 \\
1.97) \\
0.71 \\
(0.79 \\
(1.43) \\
\end{array}$ & $\begin{array}{r}\mathbf{2 6 . 1} \\
15.9 \\
36.8 \\
29.5 \\
9.1 \\
11.3 \\
46.2 \\
43.5 \\
48.6 \\
42.0 \\
79.8 \\
83.6 \\
66.5 \\
\end{array}$ & $\begin{array}{l}(0.19) \\
(0.17) \\
0.76 \\
0.82 \\
0.13 \\
1.91 \\
0.79 \\
1.90 \\
1.37 \\
2.21 \\
0.66 \\
(0.76) \\
(1.23) \\
\end{array}$ & $\begin{array}{r}11.6 \\
6.6 \\
14.0 \\
10.6 \\
4.3 \\
5.7 \\
19.9 \\
21.4 \\
19.0 \\
18.2 \\
39.4 \\
40.9 \\
34.1 \\
\end{array}$ & $\begin{array}{l}(0.28) \\
(0.17) \\
0.56 \\
0.64) \\
(0.18) \\
(.24) \\
0.74) \\
(1.23 \\
1.12 \\
(2.47) \\
(1.65) \\
(2.04) \\
(1.58) \\
\end{array}$ & $\begin{array}{r}3.4 \\
2.9 \\
4.5 \\
3.3 \\
2.5 \\
\# \\
9.3 \\
11.0 \\
8.8 \\
1.9 ! \\
2.0 \\
2.5 \\
0.1 ! \\
\end{array}$ & $\begin{array}{r}(0.16) \\
(0.17) \\
0.30 \\
0.30 \\
0.22 \\
(4) \\
(0.72) \\
1.42 \\
0.80 \\
0.59 \\
0.34 \\
0.43 \\
(0.07) \\
\end{array}$ & $\begin{array}{r}2.6 \\
2.2 \\
3.3 \\
2.5 \\
2.0 \\
\# \\
7.0 \\
8.2 \\
6.7 \\
1.6 \\
1.7 \\
2.1 \\
\ddagger \\
\end{array}$ & $\begin{array}{r}(\mathbf{0 . 1 1}) \\
(0.10) \\
0.26 \\
0.28 \\
0.13 \\
(\dagger) \\
(0.63 \\
1.19 \\
0.73 \\
0.42 \\
0.34 \\
0.43 \\
(\dagger) \\
\end{array}$ \\
\hline 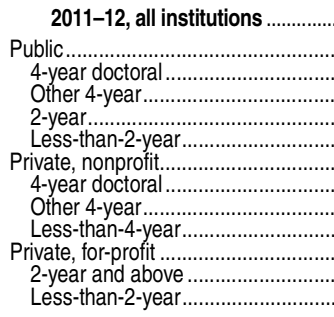 & $\begin{array}{l}62.1 \\
56.0 \\
66.1 \\
59.5 \\
52.7 \\
70.2 \\
77.4 \\
76.0 \\
79.2 \\
74.3 \\
85.4 \\
85.3 \\
85.9\end{array}$ & $\begin{array}{l}(1.05) \\
(1.18) \\
1.04 \\
1.46 \\
1.36 \\
4.21 \\
1.47 \\
1.87 \\
2.42 \\
4.47 \\
1.02 \\
1.20 \\
1.39\end{array}$ & $\begin{array}{l}51.1 \\
44.5 \\
53.4 \\
49.7 \\
41.2 \\
60.3 \\
61.0 \\
57.9 \\
64.0 \\
64.3 \\
79.7 \\
78.8 \\
84.6\end{array}$ & $\begin{array}{l}(1.10) \\
(1.22) \\
0.81 \\
1.66 \\
1.39 \\
4.47 \\
1.61 \\
2.12 \\
(2.54) \\
3.22 \\
(0.83 \\
0.97 \\
(1.40)\end{array}$ & $\begin{array}{l}30.1 \\
28.9 \\
36.8 \\
27.0 \\
27.4 \\
28.4 \\
51.5 \\
49.0 \\
56.6 \\
26.6 \\
24.7 \\
25.5 \\
20.7\end{array}$ & $\begin{array}{l}(0.60) \\
(0.67) \\
1.02 \\
1.13 \\
0.86 \\
(5.72) \\
2.10 \\
2.65 \\
3.34 \\
6.12 \\
1.17 \\
1.30 \\
(3.40)\end{array}$ & $\begin{array}{l}50.8 \\
46.5 \\
47.7 \\
46.2 \\
46.1 \\
63.7 \\
60.8 \\
57.4 \\
63.9 \\
67.7 \\
67.2 \\
65.9 \\
74.2\end{array}$ & $\begin{array}{l}(0.87) \\
(0.93) \\
1.05 \\
1.23 \\
1.08 \\
4.42 \\
1.91 \\
2.68 \\
2.81 \\
4.68 \\
1.33 \\
1.56 \\
(1.66)\end{array}$ & $\begin{array}{l}37.8 \\
33.6 \\
30.9 \\
35.7 \\
33.7 \\
54.0 \\
34.9 \\
29.3 \\
38.7 \\
57.9 \\
60.8 \\
58.6 \\
72.3\end{array}$ & $\begin{array}{l}(0.85) \\
(0.90) \\
0.65 \\
1.21 \\
1.09 \\
4.12 \\
1.51 \\
1.78 \\
2.60 \\
2.94 \\
1.08 \\
1.24 \\
(1.58)\end{array}$ & $\begin{array}{r}26.1 \\
26.3 \\
31.2 \\
23.1 \\
25.8 \\
19.4 \\
45.6 \\
43.2 \\
50.8 \\
18.3 ! \\
14.5 \\
15.6 \\
8.6\end{array}$ & $\begin{array}{l}(0.56) \\
0.64) \\
1.02 \\
0.98 \\
0.83 \\
4.26 \\
2.13 \\
2.63 \\
3.36 \\
6.47 \\
1.26 \\
1.45 \\
2.47\end{array}$ & $\begin{array}{l}32.7 \\
23.6 \\
47.3 \\
30.8 \\
16.4 \\
22.9 \\
53.6 \\
52.6 \\
55.6 \\
45.0 \\
68.2 \\
67.3 \\
73.3\end{array}$ & $\begin{array}{l}(0.48) \\
(0.45) \\
0.60 \\
1.17 \\
0.47 \\
(3.99 \\
1.60) \\
2.12 \\
2.61 \\
4.55 \\
0.69 \\
0.78 \\
(1.16)\end{array}$ & $\begin{array}{l}30.9 \\
22.2 \\
44.3 \\
28.5 \\
15.4 \\
20.8 \\
49.8 \\
48.5 \\
52.0 \\
40.8 \\
65.7 \\
64.5 \\
71.6\end{array}$ & $\begin{array}{l}(0.45) \\
(0.43) \\
0.611 \\
1.16 \\
0.42 \\
4.28 \\
1.59 \\
(1.99 \\
2.45 \\
(3.99) \\
0.51) \\
0.56 \\
(1.35)\end{array}$ & $\begin{array}{r}4.8 \\
2.9 \\
7.0 \\
4.5 \\
1.6 \\
2.3 ! \\
10.5 \\
10.2 \\
11.0 \\
8.5 ! \\
11.5 \\
11.3 \\
12.5\end{array}$ & $\begin{array}{l}(0.17) \\
(0.13) \\
0.411 \\
0.53 \\
0.13 \\
(1.16 \\
1.01 \\
(1.62) \\
1.52 \\
2.85 \\
0.64) \\
0.68 \\
(1.71)\end{array}$ & $\begin{array}{l}2.2 \\
1.7 \\
2.7 \\
2.5 \\
1.3 \\
\neq \\
8.9 \\
9.7 \\
8.9 \\
\neq \\
1.0 \\
1.2 \\
0.2 !\end{array}$ & $\begin{array}{r}(0.12) \\
(0.11) \\
0.26 \\
0.36 \\
0.14 \\
(t) \\
(0.86 \\
1.21 \\
1.26 \\
(+) \\
(0.13) \\
0.15 \\
0.08)\end{array}$ & $\begin{array}{l}\mathbf{2 . 0} \\
1.6 \\
2.5 \\
2.4 \\
1.3 \\
\# \\
7.1 \\
6.9 \\
7.8 \\
\neq \\
0.9 \\
1.1 \\
0.2 !\end{array}$ & $\left.\begin{array}{r}0.33 \\
0.14 \\
+ \\
(0.76 \\
0.96 \\
1.15 \\
(t \\
0.14 \\
0.16 \\
0.07\end{array}\right)$ \\
\hline
\end{tabular}

†Not applicable.

!Interpret data with caution. The coefficient of variation (CV) for this estimate is between 30 and 50 percent.

†Reporting standards not met. Either there are too few cases for a reliable estimate or the coefficient of variation (CV) is 50 percent or greater.

tederal work-study participants are not available.

Includes students who reported they were awarded aid, but did not specify the source of aid.

${ }_{3}^{3}$ Includes Department of Veterans Affairs and Department of Defense benefits.
4The 2007-08 and 2011-12 data include Parent Loans for Undergraduate Students (PLUS). NOT Ex to tounding and

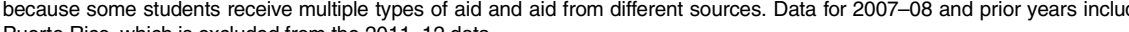
SOURCE: U.S. Department of Education, National Center for Education Statistics, 1992-93, 1999-2000, 2007-08, and 2011-12 National Postsecondary Student Aid Study (NPSAS:93, NPSAS:2000, NPSAS:08, and NPSAS:12). (This table was prepared January 2014.) 
Table 331.90. Percentage of full-time and part-time undergraduates receiving federal aid, by aid program and control and level of institution: 2007-08 and 2011-12

[Standard errors appear in parentheses]

\begin{tabular}{|c|c|c|c|c|c|c|c|c|c|c|c|c|c|c|c|c|c|c|}
\hline \multirow[b]{3}{*}{ Control and level of institution } & \multirow{3}{*}{\multicolumn{2}{|c|}{$\begin{array}{r}\text { Number of } \\
\text { undergraduates } \\
\text { (in thousands) }\end{array}$}} & \multicolumn{16}{|c|}{ Percent receiving federal aid } \\
\hline & & & \multirow{2}{*}{\multicolumn{2}{|c|}{ Any federal aid }} & \multicolumn{14}{|c|}{ Selected Title IV programs² } \\
\hline & & & & & Any Tit & e IV aid & & Pell & & $\mathrm{SEOG}^{3}$ & & CWS $^{4}$ & & Perkins ${ }^{5}$ & & tafford ${ }^{6}$ & & PLUS \\
\hline 1 & & 2 & & 3 & & 4 & & 5 & & 6 & & 7 & & 8 & & 9 & & 10 \\
\hline \multicolumn{19}{|l|}{ 2007-08 } \\
\hline $\begin{array}{l}\text { Full-time, full-year students } \\
\text { All institutions ................... }\end{array}$ & 7,650 & $(-)$ & 64.3 & $(0.32)$ & 63.3 & $(0.32)$ & 33.6 & $(0.28)$ & 9.1 & $(0.20)$ & 10.6 & $(0.22)$ & 5.9 & $(0.17)$ & 49.8 & $(0.31)$ & 7.4 & $(0.20)$ \\
\hline Public.. & 5,189 & $(-)$ & 58.8 & $(0.35)$ & 57.7 & $(0.36)$ & 32.2 & $(0.29)$ & 6.8 & $(0.18)$ & 7.1 & $(0.22)$ & 4.1 & $(0.15)$ & 41.8 & $(0.33)$ & 6.1 & $(0.21)$ \\
\hline 4-year doctor & 2,531 & $(-)$ & 59.6 & $(0.48)$ & 58.7 & $(0.48)$ & 27.4 & $(0.37)$ & 6.5 & $(0.23)$ & 7.6 & $(0.32)$ & 6.1 & $(0.27)$ & 9.6 & $(0.49)$ & 9.2 & \\
\hline Other $4-y$ & 1,051 & $(-)$ & 67.9 & $(0.67)$ & 66.9 & $(0.70)$ & 35.8 & $(0.65)$ & 9 & $(0.37)$ & 8.7 & $(0$ & 4.9 & $(0.41)$ & 3.0 & 1) & 6.3 & \\
\hline 2-year... & 1,584 & $(-)$ & 51.4 & $(0.73)$ & 49.9 & $(0.75)$ & 37.2 & $(0.65)$ & 6.6 & $(0.36)$ & 5.5 & $(0.29)$ & 0.4 & $(0.08)$ & 2.1 & (0.58) & 1.1 & $(0.12)$ \\
\hline Less-than-2-year....... & 22 & $(-)$ & 58.6 & (3.84) & 57.1 & $(4.15)$ & 49.7 & (4.14) & $\ddagger$ & $(\dagger)$ & \# & $(\dagger)$ & \# & $(\dagger)$ & 23.6 & (4.33) & $\ddagger$ & $(\dagger)$ \\
\hline Private, nonprofit... & 1,737 & $(-)$ & 72.2 & $(0.64)$ & 71.5 & $(0.64)$ & 29.1 & $(0.43)$ & 13.5 & $(0.47)$ & 24.5 & $(0.83)$ & 13.4 & $(0.61)$ & 62.0 & $(0.61)$ & 11.8 & $(0.57)$ \\
\hline 4-year & 861 & $(-)$ & 67.8 & $(1.20)$ & 66.8 & (1.23) & 23.7 & $(1.06)$ & 12.0 & 5) & 24.2 & b) & 16.0 & $(1.03)$ & 3.1 & $(1.26)$ & 2.0 & 67) \\
\hline Other & 854 & $(-)$ & 76.2 & $(1.09)$ & & 9) & 33.8 & 0) & 14.9 & & .3 & & 1.0 & 5) & 4 & & .6 & 39) \\
\hline Less-than-4-y & 22 & $(-)$ & 88.8 & (2.95) & 87.8 & (3.42) & 61.7 & (7.02) & 23.3 & (5.78) & 4.2 & (1.13) & $\ddagger$ & $(t)$ & 40.7 & (6.36) & $\ddagger$ & $(t)$ \\
\hline Private, for-profit & 724 & $(-)$ & 85.1 & (1.21) & 84.4 & (1.32) & 54.6 & (1.39) & 14.3 & $(1.23)$ & 1.6 & $(0.28)$ & 0.9 & $(0.18)$ & 78.1 & (1.23) & 5.6 & $(0.61)$ \\
\hline 2-yea & 610 & $(-)$ & 84.4 & (141) & & $(155)$ & 51.3 & (1.61) & 12.7 & & 18 & & 1.0 & $(0.21)$ & 0.1 & & 4.9 & \\
\hline Less-than-2-y & 115 & $(-)$ & 88.9 & $(1.71)$ & 88.7 & (1.79) & 72.2 & $(1.90)$ & 22.6 & $(2.06)$ & $0.6 !$ & $(0.28)$ & $\ddagger$ & $(\dagger)$ & 67.0 & (2.92) & 9.5 & (1.06) \\
\hline \multirow{2}{*}{ Part-time or part-year students } & & & & & & & & & & & & & & & & & & \\
\hline & 13,112 & $(-)$ & 39.3 & $(0.30)$ & 37.7 & $(0.29)$ & 24.4 & $(0.28)$ & 4.4 & $(0.23)$ & 2.6 & $(0.11)$ & 0.9 & $(0.05)$ & 25.9 & (0.19) & 1.6 & $(0.10)$ \\
\hline Sublic. & 10,402 & $(-)$ & 30.3 & $(0.36)$ & 28.6 & $(0.34)$ & 19.1 & $(0.30)$ & 2.1 & $(011)$ & 2.2 & 10 & 0.6 & $(0.04$ & 5.7 & (n) 1 & 0.9 & $.06)$ \\
\hline Private & 1,168 & $(-)$ & 55.4 & $(0.87)$ & & $(0.87)$ & 25 & $(0$. & 6.5 & & 7.0 & & 3 & & & & - & \\
\hline 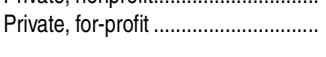 & 1,542 & $(-)$ & 87.7 & $(0.73)$ & 87.2 & $(0.73)$ & 59.5 & $(1.17)$ & 18.4 & $(1.6$ & 1.7 & $(0.3$ & 0.9 & $(0.13)$ & 79.6 & $(0.6$ & 5.1 & . \\
\hline \multicolumn{19}{|l|}{ 2011-12 } \\
\hline $\begin{array}{l}\text { Eull-time, full-year students } \\
\text { All institutions ....................... }\end{array}$ & 8,864 & $(-)$ & 72.8 & $(0.51)$ & 71.4 & $(0.54)$ & 47.1 & (0.50) & 9.0 & $(0.24)$ & 10.5 & $(0.24)$ & 4.2 & $(0.18)$ & 55.1 & (0.54) & 9.1 & $(0.23)$ \\
\hline olic & 5,997 & $(-)$ & 68.4 & $(0.61)$ & 1 & $(0.64)$ & 45.8 & 0 & 6. & 6) & 6.2 & 3) & 2.7 & $(0.15)$ & 7.1 & & 7.1 & 28) \\
\hline 4-year & 2,893 & $(-)$ & 7 & & & & 3 & it & 7.1 & & & & 4.3 & & 0 & & 11.4 & \\
\hline Other 4 & 969 & $(-)$ & 72.7 & (1.34) & & (1.43) & 48.1 & $(1.07)$ & 6.5 & $(0.5$ & & & 2.8 & 5) & 1.0 & 3) & 8.1 & \\
\hline 2-year.................. & 2,104 & $(-)$ & 63.0 & (1.24) & 61.0 & (1.29) & 51.4 & (1.30) & 5.9 & $(0.40)$ & 4 & (0. & 0.3 & $(0.06)$ & 6.5 & $(0.99)$ & 1.0 & 11) \\
\hline Less-the & 31 & $(-)$ & 67.8 & $(4.72)$ & 66.4 & $(5.20)$ & 62.4 & $(5.04)$ & $\ddagger$ & $(\dagger)$ & $\ddagger$ & $(\dagger)$ & \# & $(\dagger)$ & 19.7 & $(4.83)$ & $\ddagger$ & $(†)$ \\
\hline Private, & 1,875 & $(-)$ & 76.1 & $(0.75)$ & 74.9 & $(0.75)$ & 37.2 & $(0.64)$ & 12.2 & .60) & 29.2 & .81) & 10.6 & $(0.61)$ & 66.0 & $(0.90)$ & 16.5 & $.67)$ \\
\hline & 990 & $(-)$ & & & & & 3 & & 11.0 & & 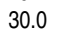 & & 3 & & & & & \\
\hline & 849 & $(-)$ & 78.0 & $(1$. & 76 & (1. & 39.8 & (1. & 13.6 & 14 & 29.1 & $(1.14)$ & 8.0 & .69) & 2 & 8) & 16.2 & \\
\hline Less-than & 36 & $(-)$ & 78.1 & (5.04) & 74.6 & (5.35) & 48.5 & (6.54) & $13.1 !$ & (5.38) & $\ddagger$ & & $\ddagger$ & $(t)$ & 9.0 & (7.42) & 13.9 & $36)$ \\
\hline vate for-pro & 992 & $(-)$ & 93.1 & (051) & 90.4 & $(0,52)$ & 73.8 & $(081)$ & 17.8 & $(0.87)$ & 18 & ) & 1.4 & $(0.23)$ & 3.2 & $(0.90)$ & 7.1 & 4) \\
\hline & 859 & $(-)$ & & & & & 72.1 & & 15.7 & & 2.1 & & 1.6 & & 3.3 & & 7.3 & 18) \\
\hline Less-than-2-y & 133 & $(-)$ & 95.2 & $(0.79)$ & 95.1 & $(0.80)$ & 85.0 & (1.46) & 31.4 & $(4.40)$ & $\ddagger$ & $(\dagger)$ & $\ddagger$ & $(\mathrm{t})$ & 82.9 & (3.51) & 5.9 & $(0.77)$ \\
\hline $\begin{array}{l}\text { Part-time or part-year students } \\
\text { All institutions }\end{array}$ & 14,192 & $(-)$ & 51.1 & (1.10) & 48.4 & (1.09) & 37.6 & $(0.85)$ & 4.4 & $(0.19)$ & 2.0 & $(0.12)$ & 0.9 & $(0.08)$ & 30.7 & (0.44) & 1.6 & $(0.10)$ \\
\hline Public.. & 10,929 & $(-)$ & 44.5 & $(1.22)$ & 4 & 3) & 33.4 & $(0.8$ & 2.6 & $(0.14)$ & 1.6 & $(0.11)$ & 0.5 & $(0.05)$ & 2.1 & $(0.43)$ & 1.0 & $0.08)$ \\
\hline & & $(-)$ & & & & & & & & & & & & & & & & \\
\hline & 1,47 & $(-)$ & & & & (1. & 3 & (1. & 2 & $(0$. & 2.4 & & 0.9 & $(0$ & 3 & (1 & .7 & \\
\hline & 521 & $(-)$ & 41.2 & (1.39) & 39 & (1.31) & 33.6 & $(1.08)$ & 2.5 & $(0.17)$ & 1.3 & $(0.14)$ & 0.1 & $(0.02)$ & 5.4 & & 0.1 & $(0.02)$ \\
\hline Less-than-2-y & 56 & $(-)$ & 60.3 & (4.47) & 59.6 & (4.47) & 53.9 & (4.11) & $\ddagger$ & $(\dagger)$ & $\#$ & $(\dagger)$ & \# & $(t)$ & 20.7 & (4.33) & $\ddagger$ & $(\dagger)$ \\
\hline Private, $n$ & 1,135 & $(-)$ & 61.0 & (1.61) & 5 & (1.99) & 34.8 & (1.51) & 6.8 & 6) & 7.1 & $(0.76)$ & 1.9 & $(0.30)$ & 49.5 & (1.57) & 4.3 & $0.51)$ \\
\hline & 557 & $(-)$ & & & & & & (1.77) & 4.2 & & & & 2.4 & & 3 & & 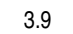 & \\
\hline & 527 & $(-)$ & 64.0 & $(2.5$ & & $(2.9$ & 38.6 & (2.59) & 82 & . & 7.8 & (1.15) & 1.6 & $(0.41)$ & 1.6 & & 4.9 & $(0.96)$ \\
\hline Less-than-4-year.... & & $(-)$ & 64.3 & (3.22) & 64.2 & (3.18) & 57.9 & (2.94) & 21.0 & (5.35) & $\ddagger$ & $(\dagger)$ & $\ddagger$ & $(\dagger)$ & 40.6 & (3.92) & $2.0 !$ & $(0.81)$ \\
\hline Private & 2,128 & $(-)$ & 79.7 & $(0.83)$ & 75.2 & $(1.16)$ & 60.5 & $(1.09)$ & 12.8 & (0. & & & 2.0 & $(0.47)$ & 65.3 & 7) & 3.4 & \\
\hline & 1,790 & $(-)$ & 78.8 & $(0$. & 73.6 & $(1.5)$ & 58.4 & $(1.25)$ & 11.8 & $(0$. & 1.1 & $(0.16)$ & 2.4 & $(0.56)$ & 64.1 & & 3.2 & $(0.33)$ \\
\hline Less-than-2-year..... & 337 & $(-)$ & 84.6 & $(1.40)$ & 83.6 & (1.33) & 71.9 & $(1.60)$ & 18.1 & $(2.38)$ & 0.2 ! & $(0.07)$ & $\ddagger$ & $(t)$ & 71.5 & $(1.36)$ & 4.2 & $(0.84)$ \\
\hline
\end{tabular}

-Not available.

†Not applicable.

\#Rounds to zero.

!nterpret data with caution. The coefficient of variation (CV) for this estimate is between 30 and 50 percent.

ҒReporting standards not met. The coefficient of variation (CV) for this estimate is 50 percent or greater.

${ }^{1}$ Numbers of undergraduates may not equal figures reported in other tables, since these data are based on a sample survey of students who enrolled at any point during the year. 2Title IV of the Higher Education Act.

${ }^{3}$ Supplemental Educational Opportunity Grants.
${ }^{4}$ College Work Study. Prior to October 17,1986 , private for-profit institutions were prohibited by law from spending CWS funds for on-campus work. Includes persons who participated in the program but had no earnings.

${ }^{5}$ Formerly National Direct Student Loans (NDSL).

${ }^{6}$ Formerly Guaranteed Student Loans (GSL).

'Parent Loans for Undergraduate Students.

NOTE: Excludes students whose attendance status was not reported. Detail may not sum to totals because of rounding and because some students receive multiple types of aid and aid from different sources. Data for 2007-08 include Puerto Rico, which is excluded from the 2011-12 data.

SOURCE: U.S. Department of Education, National Center for Education Statistics, 2007-08 and 2011-12 National Postsecondary Student Aid Study (NPSAS:08 and NPSAS:12). (This table was prepared January 2014.) 


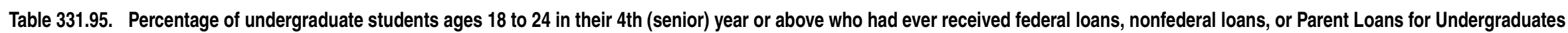
(PLUS), and the average cumulative amount borrowed, by selected student characteristics and control and level of institution: 1989-90, 1999-2000, and 2011-12 [Standard errors appear in parentheses]

\begin{tabular}{|c|c|c|c|c|c|c|c|c|c|c|c|c|c|c|c|c|c|c|c|c|c|c|}
\hline \multirow[b]{3}{*}{$\begin{array}{l}\text { Selected student characteristic } \\
\text { or control and level of institution }\end{array}$} & \multicolumn{8}{|c|}{$1989-90$} & \multicolumn{6}{|c|}{$1999-2000$} & \multicolumn{8}{|c|}{$2011-12$} \\
\hline & \multirow{2}{*}{\multicolumn{2}{|c|}{ Total $^{1}$}} & \multicolumn{4}{|c|}{ Federal loans to students ${ }^{2}$} & \multirow{2}{*}{\multicolumn{2}{|c|}{$\begin{array}{r}\text { Parent } \\
\text { PLUS loans }\end{array}$}} & \multirow{2}{*}{\multicolumn{2}{|c|}{ Total $^{1}$}} & \multirow{2}{*}{\multicolumn{2}{|c|}{$\begin{array}{l}\text { Federal loans } \\
\text { to students }{ }^{2}\end{array}$}} & \multirow{2}{*}{\multicolumn{2}{|c|}{$\begin{array}{r}\text { Parent } \\
\text { PLUS loans }\end{array}$}} & \multirow{2}{*}{\multicolumn{2}{|c|}{ Total $^{1}$}} & \multirow{2}{*}{\multicolumn{2}{|c|}{$\begin{array}{r}\text { Federal loans } \\
\text { to students }{ }^{2}\end{array}$}} & \multirow{2}{*}{\multicolumn{2}{|c|}{$\begin{array}{r}\text { Nonfederal } \\
\text { loans }\end{array}$}} & \multirow{2}{*}{\multicolumn{2}{|c|}{$\begin{array}{r}\text { Parent } \\
\text { PLUS loans }\end{array}$}} \\
\hline & & & & $\begin{array}{r}\text { Stafford } \\
\text { loans }^{3}\end{array}$ & & $\begin{array}{r}\text { Perkins } \\
\text { loans }\end{array}$ & & & & & & & & & & & & & & & & \\
\hline 1 & & 2 & & 3 & & 4 & & 5 & & 6 & & 7 & & 8 & & 9 & & 10 & & 11 & & 12 \\
\hline & & & & & & & & & & Perc & ent of stud & lents with & loans & & & & & & & & & \\
\hline Total... & 50.4 & \begin{tabular}{ll|}
$(0.82)$ \\
\end{tabular} & 37.8 & (0.75) & 13.0 & (0.64) & 4.1 & (0.22) & 60.0 & $\begin{array}{l}(0.66) \\
\end{array}$ & 57.8 & (0.69) & 12.1 & (0.50) & 67.7 & $(0.74)$ & 64.3 & (0.71) & 29.0 & (0.73) & 19.9 & $(0.70)$ \\
\hline 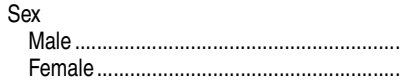 & $\begin{array}{l}51.6 \\
49.2\end{array}$ & $\begin{array}{l}(1.24) \\
(0.90)\end{array}$ & $\begin{array}{l}37.8 \\
37.7\end{array}$ & $\begin{array}{l}(1.17) \\
(0.87)\end{array}$ & $\begin{array}{l}12.6 \\
13.2\end{array}$ & $\begin{array}{l}(0.75) \\
(0.72)\end{array}$ & $\begin{array}{l}3.7 \\
4.3\end{array}$ & $\begin{array}{l}(0.29) \\
(0.29)\end{array}$ & $\begin{array}{l}58.2 \\
61.3\end{array}$ & $\begin{array}{l}(0.90) \\
(0.91)\end{array}$ & $\begin{array}{l}55.6 \\
59.5\end{array}$ & $\begin{array}{l}(0.92) \\
(0.92)\end{array}$ & $\begin{array}{l}12.2 \\
12.1\end{array}$ & $\begin{array}{l}(0.54) \\
(0.68)\end{array}$ & $\begin{array}{l}67.2 \\
68.0\end{array}$ & $\begin{array}{l}(1.14) \\
(1.01)\end{array}$ & $\begin{array}{l}63.4 \\
65.1\end{array}$ & $\begin{array}{l}(1.10) \\
(1.05)\end{array}$ & $\begin{array}{l}29.2 \\
28.9\end{array}$ & $\begin{array}{l}(1.09) \\
(0.96)\end{array}$ & $\begin{array}{l}19.9 \\
19.9\end{array}$ & $\begin{array}{l}(1.07) \\
(0.91)\end{array}$ \\
\hline Race/ethnicity & & & & & & & & & & & & & & & & & & & & & & \\
\hline White.............. & 49.5 & $(0.97)$ & 36.8 & $(0.92)$ & 11.9 & $(0.64)$ & 4.2 & $(0.27)$ & 58.9 & $(0.79)$ & 56.9 & $(0.82)$ & 12.4 & $(0.57)$ & 65.5 & $(0.87)$ & 62.1 & $(0.81)$ & 29.6 & $(0.92)$ & 19.9 & $(0.88)$ \\
\hline Black ... & 68.9 & (2.24) & 57.1 & (2.16) & 23.2 & (2.42) & 7.0 & $(1.06)$ & 76.8 & $(2.53)$ & 74.5 & (2.49) & 15.5 & (1.47) & 90.3 & (1.34) & 88.1 & $(1.74)$ & 31.3 & (3.03) & 30.4 & (2.25) \\
\hline Hispani & 53.5 & (3.52) & 37.9 & $(3.00)$ & 15.7 & $(1.68)$ & 3.3 & $(0.78)$ & 63.1 & $(3.21)$ & 59.1 & (2.66) & 11.1 & (1.56) & 72.3 & (1.93) & 70.2 & $(1.98)$ & 28.4 & (2.19) & 19.3 & (2.06) \\
\hline Asian ${ }^{5} .$. & 40.6 & $(1.76)$ & 27.4 & $(2.30)$ & 13.5 & $(2.67)$ & $\ddagger$ & $(t)$ & 50.6 & (2.16) & 49.5 & (2.22) & 7.5 & $(1.29)$ & 50.8 & $(2.88)$ & 45.2 & (2.72) & 21.4 & (2.76) & 9.9 & (1.58) \\
\hline 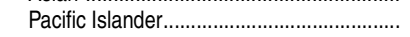 & - & $(t)$ & - & $(t)$ & - & $(t)$ & - & $(\dagger)$ & 55.3 & $(9.93)$ & 55.3 & $(9.93)$ & $14.2 !$ & $(5.01)$ & $\ddagger$ & $(t)$ & $\ddagger$ & $(\dagger)$ & $\ddagger$ & $(\dagger)$ & $\ddagger$ & $(\dagger)$ \\
\hline American Indian/Alaska Native... & $\ddagger$ & $(t)$ & $\ddagger$ & $(t)$ & $\ddagger$ & $(t)$ & $\ddagger$ & $(t)$ & 46.9 & $(9.93)$ & 38.7 & $(9.01)$ & $\ddagger$ & $(t)$ & $\ddagger$ & $(\dagger)$ & $\ddagger$ & $(t)$ & $\ddagger$ & $(\dagger)$ & $\ddagger$ & $(\dagger)$ \\
\hline 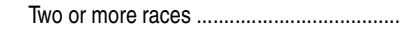 & - & $(\dagger)$ & - & $(\dagger)$ & - & $(t)$ & - & $(t)$ & 52.1 & $(4.84)$ & 50.6 & $(5.09)$ & $8.1 !$ & (2.52) & 77.9 & $(3.68)$ & 76.4 & $(3.84)$ & 36.1 & $(4.68)$ & 20.2 & (4.44) \\
\hline Dependency status & & & & & & & & & & & & & & & & & & & & & & \\
\hline Depend & 47.3 & $(0.97)$ & 35.5 & $(0.91)$ & 11.7 & $(0.56)$ & 4.3 & $(0.25)$ & 59.3 & $(0.74)$ & 57.0 & $(0.76)$ & 13.4 & $(0.58)$ & 66.5 & $(0.79)$ & 63.4 & $(0.78)$ & 29.2 & $(0.79)$ & 21.0 & $(0.80)$ \\
\hline Independent. & 59.4 & $(1.46)$ & 44.7 & $(1.28)$ & 16.7 & $(1.26)$ & 3.4 & $(0.35)$ & 62.3 & $(1.29)$ & 60.5 & $(1.25)$ & 7.2 & $(0.57)$ & 73.1 & $(1.82)$ & 69.0 & $(1.85)$ & 28.3 & $(1.99)$ & 14.7 & (1.50) \\
\hline Public institutions & & & & & & & & & & & & & & & & & & & & & & \\
\hline 4-yес & 49.3 & (1.41) & 36.2 & (1.31) & 11.7 & $(1.06)$ & 3.5 & $(0.30)$ & 57.2 & (1.13) & 55.0 & $(1.15)$ & 10.8 & $(0.62)$ & 64.6 & $(0.89)$ & 61.9 & $(0.88)$ & 25.0 & $(0.87)$ & 16.5 & $(0.83)$ \\
\hline 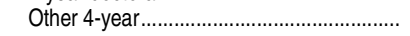 & 49.4 & (2.05) & 34.3 & $(1.93)$ & 11.3 & $(0.76)$ & 3.5 & $(0.52)$ & 57.3 & $(1.75)$ & 55.9 & $(1.77)$ & 8.7 & (1.32) & 64.9 & $(2.05)$ & 60.1 & $(1.96)$ & 27.1 & (1.94) & 16.5 & (1.55) \\
\hline 2-year... & $\ddagger$ & $(\mathrm{t})$ & $\ddagger$ & $(t)$ & $\ddagger$ & $(\mathrm{t})$ & $\ddagger$ & $(\mathrm{t})$ & 42.9 & $(6.05)$ & 40.0 & (5.42) & $\ddagger$ & $(t)$ & $\ddagger$ & $(t)$ & $\ddagger$ & $(t)$ & $\ddagger$ & $(\mathrm{t})$ & $\ddagger$ & $(t)$ \\
\hline Private nonprofit institutions & & & & & & & & & & & & & & & & & & & & & & \\
\hline 4-year doctoral ..................... & 50.4 & (1.76) & 42.0 & $(1.92)$ & 20.8 & (1.23) & 5.1 & (0.46) & 63.6 & $(1.70)$ & 61.7 & $(1.67)$ & 17.2 & (1.24) & 74.1 & $(2.82)$ & 69.2 & (2.69) & 36.9 & (2.87) & 29.0 & (3.14) \\
\hline 2-ye & & (t) & & & & & & (t) & 852 & 130 & 838 & (4.1) & 29.5 & $(6.01)$ & 85. & $(3.16)$ & 843 & $(3,43)$ & 380 & $(3.73)$ & 38.6 & $(4.07)$ \\
\hline Other and attended multiple institutions ......... & $41.3^{\top}$ & $(2.28)$ & $28.8^{+}$ & (2.13) & 10.9 & (1.10) & 3.8 & $(0.67)$ & 59.9 & $(2.95)$ & 56.1 & $(2.80)$ & 13.5 & (1.76) & 71.0 & $(1.93)$ & 67.7 & (1.93) & 30.7 & (2.06) & 20.3 & $(1.96)$ \\
\hline & & & & & & & & erage cu & mulative I & an amour & nt for stude & ints with lc & ans (const & ant 2012- & 13 dollars) & & & & & & & \\
\hline Total .............. & 14,900 & (320) & 11,600 & (200) & 4,400 & (150) & 8,900 & (260) & 21,500 & (200) & 18,900 & (140) & 19,000 & (750) & 25,900 & (400) & 20,600 & (220) & 14,700 & (730) & 27,700 & $(1,230)$ \\
\hline Sex & & & & & & & & & & & & & & & & & & & & & & \\
\hline $\mathrm{Ma}$ & 15,400 & $(350)$ & 11,900 & (250) & 4,200 & (210) & 9,500 & $(400)$ & 21,400 & (290) & 19,000 & (180) & 19,700 & (970) & 26,200 & (650) & 20,300 & (310) & 16,200 & $(1,240)$ & 29,000 & $(2,090)$ \\
\hline 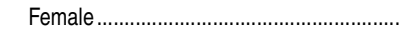 & 14,400 & $(400)$ & 11,300 & (220) & 4,500 & (160) & 8,500 & $(430)$ & 21,600 & (290) & 18,800 & (220) & 18,400 & $(1,000)$ & 25,600 & (480) & 20,800 & (300) & 13,400 & $(790)$ & 26,600 & $(1,430)$ \\
\hline Race/ethnicity & & & & & & & & & & & & & & & & & & & & & & \\
\hline White................. & 15,600 & (320) & 11,900 & (250) & 4,300 & (130) & 9,300 & (240) & 21,600 & (260) & 18,800 & (170) & 19,700 & (900) & 25,800 & (480) & 20,000 & (270) & 15,200 & (770) & 28,100 & $(1,580)$ \\
\hline Black ......... & 11,900 & $(710)$ & 11,900 & (490) & 5,500 & $(610)$ & $\ddagger$ & $(t)$ & 25,000 & $(760)$ & 22,600 & $(660)$ & 14,900 & $(1,360)$ & 30,400 & $(1,160)$ & 26,000 & $(660)$ & 14,700 & $(2,180)$ & 25,800 & $(3,260)$ \\
\hline Hispanic... & 9,900 & (920) & 9,300 & $(500)$ & 3,600 & (280) & $\ddagger$ & $(\dagger)$ & 19,000 & $(800)$ & 16,900 & (620) & 17,800 & $(1,760)$ & 24,700 & $(1,080)$ & 19,900 & (690) & 13,700 & $(2,210)$ & 24,300 & $(3,410)$ \\
\hline Asian $\ldots$ & 13,000 & (830) & 9,400 & (540) & 4,300 & (710) & $\ddagger$ & $(t)$ & 19,200 & (560) & 17,700 & (540) & 15,300 & $(3,350)$ & 20,300 & $(1,180)$ & 18,000 & (750) & 10,100 & $(1,940)$ & 28,600 & $(3,590)$ \\
\hline Pacific Islander....... & - & $(t)$ & - & $(t)$ & - & $(t)$ & - & $(t)$ & 18,400 & $(2,650)$ & 16,200 & $(1,770)$ & $\ddagger$ & $(t)$ & $\ddagger$ & $(t)$ & $\ddagger$ & $(t)$ & $\neq$ & $(t)$ & $\ddagger$ & $(t)$ \\
\hline dian/Alaska Native .... & $\ddagger$ & $(\dagger)$ & $\ddagger$ & $(\dagger)$ & $\ddagger$ & $(t)$ & $\ddagger$ & $(\dagger)$ & 22,300 & $(3,740)$ & 21,800 & $(2,910)$ & $\ddagger$ & $(\dagger)$ & & $(\dagger)$ & & $(\dagger)$ & & $(\dagger)$ & $\ddagger$ & $(\dagger)$ \\
\hline Two or more races ..................................... & - & $(\dagger)$ & - & $(\dagger)$ & - & $(t)$ & - & $(\dagger)$ & 20,500 & $(1,570)$ & 18,000 & $(1,410)$ & $\ddagger$ & $(+)$ & 25,900 & $(2,920)$ & 19,100 & $(1,180)$ & $15,500 !$ & $(5,180)$ & $\ddagger$ & $(\dagger)$ \\
\hline Dependency status & & & & & & & & & & & & & & & & & & & & & & \\
\hline Dependent ........... & 15,300 & $(320)$ & 11,400 & (200) & 4,400 & (170) & 9,100 & $(290)$ & 21,400 & (220) & 18,500 & (150) & 19,700 & (820) & 25,600 & (440) & 20,000 & (230) & 14,900 & $(780)$ & 27,700 & $(1,090)$ \\
\hline Independent........ & 14,100 & $(540)$ & 12,100 & (340) & 4,200 & (180) & 8,000 & $(510)$ & 22,000 & (520) & 20,200 & $(460)$ & 14,600 & $(1,220)$ & 27,000 & (910) & 23,000 & (710) & 13,700 & $(1,690)$ & 28,100 & $(6,180)$ \\
\hline Public institutions & & & & & & & & & & & & & & & & & & & & & & \\
\hline 4-year doctoral.... & 13,400 & $(520)$ & 10,900 & (290) & 3,900 & (240) & 9,000 & $(410)$ & 20,500 & (280) & 18,600 & (220) & 16,200 & (840) & 23,600 & (440) & 19,800 & (310) & 12,000 & (670) & 22,600 & $(1,080)$ \\
\hline Other 4-yea & 10,000 & $(400)$ & 9,200 & $(600)$ & 3,600 & (240) & 7,600 & $(570)$ & 19,400 & (570) & 17,500 & (480) & 12,200 & $(700)$ & 21,300 & (830) & 18,200 & (600) & 10,500 & $(1,190)$ & 19,800 & $(1,750)$ \\
\hline 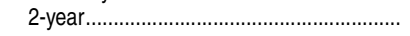 & & $(t)$ & $\ddagger$ & $(\mathrm{t})$ & $\ddagger$ & $(\dagger)$ & $\ddagger$ & $(t)$ & $\ddagger$ & $(\mathrm{t})$ & $\ddagger$ & $(t)$ & $\ddagger$ & $(\dagger)$ & $\ddagger$ & $(\dagger)$ & $\ddagger$ & $(t)$ & $\ddagger$ & & & $(t)$ \\
\hline
\end{tabular}




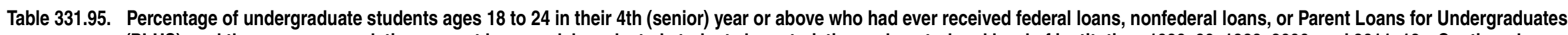
(PLUS), and the average cumulative amount borrowed, by selected student characteristics and control and level of institution: 1989-90, 1999-2000, and 2011-12-Continued [Standard errors appear in parentheses]

\begin{tabular}{|c|c|c|c|c|c|c|c|c|c|c|c|c|c|c|c|c|c|c|c|c|c|c|}
\hline \multirow[b]{3}{*}{$\begin{array}{l}\text { Selected student characteristic } \\
\text { or control and level of institution }\end{array}$} & \multicolumn{8}{|c|}{$1989-90$} & \multicolumn{6}{|c|}{$1999-2000$} & \multicolumn{8}{|c|}{$2011-12$} \\
\hline & \multirow{2}{*}{\multicolumn{2}{|c|}{ Total $^{1}$}} & \multicolumn{4}{|c|}{ Federal loans to students ${ }^{2}$} & \multirow{2}{*}{\multicolumn{2}{|c|}{$\begin{array}{r}\text { Parent } \\
\text { PLUS loans }\end{array}$}} & \multirow{2}{*}{\multicolumn{2}{|c|}{ Total $^{1}$}} & \multirow{2}{*}{\multicolumn{2}{|c|}{$\begin{array}{l}\text { Federal loans } \\
\text { to students }\end{array}$}} & \multirow{2}{*}{\multicolumn{2}{|c|}{$\begin{array}{r}\text { Parent } \\
\text { PLUS loans }\end{array}$}} & \multirow{2}{*}{\multicolumn{2}{|c|}{ Total $^{1}$}} & \multirow{2}{*}{\multicolumn{2}{|c|}{$\begin{array}{r}\text { Federal loans } \\
\text { to students }{ }^{2}\end{array}$}} & \multirow{2}{*}{\multicolumn{2}{|c|}{$\begin{array}{r}\begin{array}{r}\text { Nonfederal } \\
\text { loans }\end{array} \\
\end{array}$}} & \multirow{2}{*}{\multicolumn{2}{|c|}{$\begin{array}{r}\text { Parent } \\
\text { PLUS loans }\end{array}$}} \\
\hline & & & & $\begin{aligned} & \begin{array}{c}\text { Stafford } \\
\text { loans }\end{array} \\
&\end{aligned}$ & & $\begin{array}{r}\text { Perkins } \\
\text { loans }\end{array}$ & & & & & & & & & & & & & & & & \\
\hline 1 & & 2 & & 3 & & 4 & & 5 & & 6 & & 7 & & 8 & & 9 & & 10 & & 11 & & 12 \\
\hline $\begin{array}{l}\text { Private nonprofit institutions } \\
4 \text {-year doctoral }\end{array}$ & 23,100 & (440) & 14,000 & (320) & 5,600 & (290) & 9.600 & (540) & 26,500 & $(740)$ & 21.400 & (540) & 27.400 & $(1,730)$ & 30,800 & $(1,860)$ & 22,700 & $(700)$ & 19,500 & $(3,130)$ & 41,700 & $(4,870)$ \\
\hline Other 4-year............................. & 19,500 & (960) & 13,400 & (420) & 5,500 & (450) & 9,100 & (680) & 24,700 & (630) & 20,700 & (410) & 23,600 & $(2,190)$ & 32,000 & $(1,300)$ & 22,300 & (590) & 20,100 & $(2,320)$ & 30,200 & $(2,110)$ \\
\hline 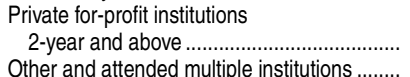 & $\begin{array}{r}\ddagger \\
17,500\end{array}$ & $\begin{array}{r}(t) \\
(1,130)\end{array}$ & $\begin{array}{r}\ddagger \\
12.000\end{array}$ & $\begin{array}{r}(t) \\
(500)\end{array}$ & $\begin{array}{r}\ddagger \\
\vdots \\
4,200\end{array}$ & $\begin{array}{r}(t) \\
(310)\end{array}$ & $\begin{array}{l}\ddagger \\
\ddagger\end{array}$ & $\begin{array}{l}(+) \\
(+)\end{array}$ & $\begin{array}{l}23,600 \\
20,000\end{array}$ & $\begin{array}{r}(1,940) \\
(930)\end{array}$ & $\begin{array}{l}19,400 \\
17,700\end{array}$ & $\begin{array}{r}(1,950) \\
(710)\end{array}$ & $\begin{array}{r}\ddagger \\
17,100\end{array}$ & $\begin{array}{r}(\dagger) \\
(1.460)\end{array}$ & $\begin{array}{l}39,600 \\
26,000\end{array}$ & $\begin{array}{r}(2,020) \\
(940)\end{array}$ & $\begin{array}{l}31,700 \\
20,100\end{array}$ & $\begin{array}{r}(1,250) \\
(740)\end{array}$ & $\begin{array}{l}18,600 \\
15,900\end{array}$ & $\left.\begin{array}{l}(3,440) \\
(1,460)\end{array}\right)$ & $\begin{array}{l}33,600 \\
27,300\end{array}$ & $\begin{array}{l}(4,070) \\
(3,650)\end{array}$ \\
\hline
\end{tabular}

\section{-Not available.}

Not applicable.

Interpret data with caution. The coefficient of variation (CV) for this estimate is between 30 and 50 percen

Reporting standards not met. Either there are too few cases for a reliable estimate or the coefficient of variation (CV) is 50 per'For $1989-90$

excludes loans from family and friends.

${ }^{2}$ Includes Stafford loans and Perkins loans only.

Cumulative Stafford loan amounts shown in the table include federal subsidized and unsubsidized Stafford loans as well as any Supplemental Loans for Students (SLS) received in prior years. The SLS program was an unsubsidized student loan program

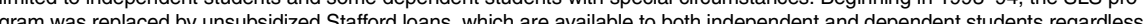
of need. Subsidized Stafford loans are only available to students with demonstrated financial need. Stafford Loans were avail-

able through both the William D. Ford Federal Direct Loan Program and the Federal Family Education Loan Program (FFELP) until FFELP was discontinued in 2010. Since then, Stafford Loans have been referred to as Direct Loans

'Parent PLUS loans are taken out by parents of dependent students and are used towards the students' undergraduate educaEducation Lan Program (FFELP) until FFELP was discontinued in 2010. Since then, Parent PLUS Loans have been referred to as Direct PLUS Loans.

5 Includes Pacific Islanders in 1989-90.

-Average loan amounts were calculated only for students who took out a loan (or whose parents took out a PLUS loan on their behalf). Constant dollars based on the Consumer Price Index, prepared by the Bureau of Labor Statistics, U.S. Department of Labor, adjusted to a school-year basis.

(1989-90, 1990-2000, and 2011-12 Nation I 
CHAPTER 3: Postsecondary Education 647

Financial Aid for Postbaccalaureate Students

Table 332.10. Amount borrowed, aid status, and sources of aid for full-time, full-year postbaccalaureate students, by level of study and control and level of institution: Selected years, 1992-93 through 2011-12

[Standard errors appear in parentheses]

\begin{tabular}{|c|c|c|c|c|c|c|c|c|c|c|c|c|c|c|c|c|c|c|}
\hline \multirow[b]{4}{*}{$\begin{array}{l}\text { Level of study, control } \\
\text { and level of institution }\end{array}$} & \multirow{2}{*}{\multicolumn{6}{|c|}{$\begin{array}{l}\text { Cumulative borrowing for } \\
\text { undergraduate and graduate education }\end{array}$}} & \multicolumn{12}{|c|}{ Aid status (percent of students) } \\
\hline & & & & & & & \multirow{3}{*}{\multicolumn{2}{|c|}{ Nonaided }} & \multicolumn{10}{|c|}{ Source of aid } \\
\hline & \multirow{2}{*}{\multicolumn{2}{|c|}{$\begin{array}{r}\text { Percent } \\
\text { who borrowed }\end{array}$}} & \multicolumn{4}{|c|}{$\begin{array}{l}\text { Average amount for } \\
\text { those who borrowed }\end{array}$} & & & \multirow{2}{*}{\multicolumn{2}{|c|}{ Any aid ${ }^{2}$}} & \multirow{2}{*}{\multicolumn{2}{|c|}{ Federal $^{3}$}} & \multirow{2}{*}{\multicolumn{2}{|c|}{ State }} & \multirow{2}{*}{\multicolumn{2}{|c|}{ Institutional }} & \multirow{2}{*}{\multicolumn{2}{|c|}{ Employer }} \\
\hline & & & \multicolumn{2}{|c|}{ Current dollars } & \multicolumn{2}{|c|}{$\begin{array}{r}\text { Constant } \\
2012-13 \\
\text { dollars }^{4}\end{array}$} & & & & & & & & & & & & \\
\hline 1 & & 2 & & 3 & & 4 & & 5 & & 6 & & 7 & & 8 & & 9 & & 10 \\
\hline 1992-93, all institutions. & - & $(\dagger)$ & - & $(\dagger)$ & - & $(+)$ & 30.7 & (1.43) & 69.3 & (1.43) & 4.4 & (1.42) & 6.9 & $(0.64)$ & 40.6 & (2.02) & 5.3 & $(0.59)$ \\
\hline 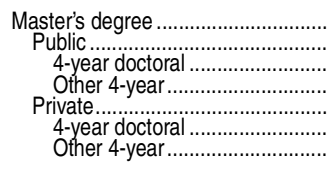 & $\begin{array}{l}= \\
= \\
= \\
= \\
=\end{array}$ & $\left(\begin{array}{l}(+) \\
+ \\
+ \\
+ \\
) \\
+ \\
+ \\
+\end{array}\right)$ & $\begin{array}{l}= \\
\bar{z} \\
= \\
\bar{z}\end{array}$ & $\begin{array}{l}(+) \\
+ \\
(+) \\
(+) \\
(f)\end{array}$ & $\begin{array}{l}z \\
z \\
= \\
=\end{array}$ & $\left(\begin{array}{c}(t) \\
(t) \\
(f) \\
(f)\end{array}\right.$ & $\begin{array}{l}35.5 \\
32.8 \\
32.5 \\
34.6 \\
39.2 \\
37.4 \\
50.5\end{array}$ & \begin{tabular}{r|}
$(2.54)$ \\
2.39 \\
2.58 \\
4.37 \\
4.74 \\
$(4.70)$ \\
$(10.60)$
\end{tabular} & $\begin{array}{l}64.5 \\
67.2 \\
67.5 \\
65.4 \\
60.8 \\
62.6 \\
49.5\end{array}$ & $\begin{array}{r}(2.54) \\
2.39 \\
(2.58) \\
4.37 \\
4.74) \\
(4.70) \\
(10.60)\end{array}$ & $\begin{array}{l}33.8 \\
33.9 \\
32.4 \\
42.5 \\
33.7 \\
34.2 \\
30.5\end{array}$ & $\begin{array}{l}(1.91) \\
2.04 \\
(2.24) \\
5.30 \\
3.62 \\
(4.09) \\
(7.06)\end{array}$ & $\begin{array}{c}5.8 \\
7.8 \\
6.7 \\
14.4 \\
3.2 \\
2.9 ! \\
\ddagger\end{array}$ & $\begin{array}{r}(0.79) \\
1.09 \\
0.96 \\
4.13 \\
0.89 \\
1.00 \\
(\dagger)\end{array}$ & $\begin{array}{l}42.4 \\
44.0 \\
46.3 \\
30.4 \\
40.2 \\
42.9 \\
22.8 !\end{array}$ & $\begin{array}{l}(2.97) \\
2.68) \\
3.19 \\
3.67 \\
6.34 \\
6.75) \\
(9.39)\end{array}$ & $\begin{array}{l}8.3 \\
7.6 \\
7.7 \\
6.8 ! \\
9.4 \\
8.9 \\
\ddagger\end{array}$ & $\begin{array}{r}(1.01) \\
1.24 \\
1.27 \\
2.66 \\
1.88 \\
(1.88) \\
(\dagger)\end{array}$ \\
\hline 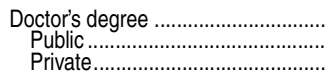 & $\bar{z} \quad$ & $(†)$ & $\bar{z}$ & $(+)$ & $\bar{z}$ & $(t)$ & $\begin{array}{l}30.1 \\
29.9 \\
30.4\end{array}$ & $\left.\begin{array}{l}(2.32) \\
(2.99 \\
(3.27)\end{array}\right)$ & $\begin{array}{l}69.9 \\
70.1 \\
69.6\end{array}$ & $\left(\begin{array}{l}2.32 \\
2.99 \\
(3.27)\end{array}\right)$ & $\begin{array}{l}28.3 \\
22.3 \\
37.8\end{array}$ & $\begin{array}{l}(2.14) \\
(2.26) \\
(3.54)\end{array}$ & $\begin{array}{r}4.4 \\
6.5 \\
\ddagger\end{array}$ & $\left.\begin{array}{r}(0.71) \\
(1.14) \\
(\dagger)\end{array}\right)$ & $\begin{array}{l}51.6 \\
55.5 \\
45.5\end{array}$ & $\left.\begin{array}{l}(2.70) \\
(3.01 \\
(3.52)\end{array}\right)$ & $\begin{array}{r}3.0 \\
3.9 \\
\ddagger\end{array}$ & $\left.\begin{array}{c}(0.79) \\
(1.00) \\
(\dagger)\end{array}\right)$ \\
\hline 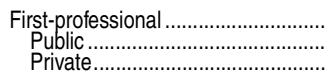 & $\bar{z}$ & $(†)$ & z & $(+)$ & 二 & $(\$)$ & $\begin{array}{l}22.6 \\
20.4 \\
24.5\end{array}$ & $\left.\begin{array}{l}(0.96) \\
(1.02 \\
(1.65)\end{array}\right)$ & $\begin{array}{l}77.4 \\
79.6 \\
75.5\end{array}$ & $\left.\begin{array}{l}(0.96 \\
1.02 \\
1.65\end{array}\right)$ & $\begin{array}{l}68.2 \\
72.4 \\
64.3\end{array}$ & $\left(\begin{array}{l}1.544 \\
1.29 \\
(2.42\end{array}\right)$ & $\begin{array}{r}10.0 \\
13.4 \\
6.8\end{array}$ & $\left(\begin{array}{l}1.33 \\
1.75 \\
1.19\end{array}\right)$ & $\begin{array}{l}37.0 \\
37.7 \\
36.4\end{array}$ & $\left.\begin{array}{l}(1.80) \\
(1.66) \\
(3.29)\end{array}\right)$ & $\begin{array}{l}2.3 \\
2.3 \\
2.3 !\end{array}$ & $\left.\begin{array}{l}(0.52) \\
0.59 \\
0.70\end{array}\right)$ \\
\hline Other graduate.... & - & $(\dagger)$ & - & $(\dagger)$ & - & $(\dagger)$ & 38.2 & (6.81) & 61.8 & (6.81) & 42.3 & $(4.27)$ & 6.7 & $(1.81)$ & 22.9 & $(4.02)$ & $6.0 !$ & (2.97) \\
\hline 1999-2000, all institutions..... & 69.4 & (0.74) & $\$ 41,720$ & (859) & $\$ 57,010$ & $(1,174)$ & 18.3 & $(0.66)$ & 81.7 & $(0.66)$ & 52.6 & $(0.76)$ & 6.1 & $(0.59)$ & 49.7 & $(1.03$ & 6.0 & $(0.57)$ \\
\hline 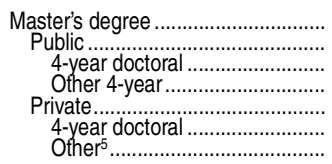 & $\begin{array}{l}68.4 \\
63.4 \\
62.7 \\
70.9 \\
74.5 \\
73.4 \\
76.8\end{array}$ & $\left.\begin{array}{l}(1.10) \\
1.58 \\
1.53 \\
6.04 \\
1.54 \\
1.75 \\
3.75\end{array}\right)$ & $\left\{\begin{array}{l}31,730 \\
27,910 \\
27,320 \\
31,920 \\
35,650 \\
38,280 \\
30,380\end{array}\right.$ & $\left.\begin{array}{l}(1,083) \\
1,069 \\
1,220 \\
2,822 \\
1,850 \\
2,483 \\
1,946\end{array}\right)$ & $\begin{array}{l}43,360 \\
38,140 \\
37,340 \\
43,620 \\
48,720 \\
52,310 \\
41,520\end{array}$ & $\begin{array}{l}(1,479) \\
1,461 \\
1,66 \\
(3,857 \\
2,558 \\
(3,394 \\
(2,660)\end{array}$ & $\begin{array}{l}20.7 \\
22.1 \\
20.0 \\
29.9 \\
18.9 \\
17.2 \\
22.5\end{array}$ & $\begin{array}{l}(1.15) \\
1.52 \\
1.46 \\
5.08 \\
1.63 \\
1.94 \\
(2.74)\end{array}$ & $\begin{array}{l}79.3 \\
77.9 \\
80.0 \\
70.1 \\
81.1 \\
82.8 \\
77.5\end{array}$ & $\begin{array}{l}(1.15) \\
1.52 \\
1.46 \\
5.08 \\
1.63 \\
1.94 \\
(2.74)\end{array}$ & $\begin{array}{l}50.5 \\
44.6 \\
43.2 \\
54.7 \\
57.6 \\
58.3 \\
56.1\end{array}$ & $\begin{array}{l}(1.22) \\
(1.84 \\
1.74 \\
6.88 \\
(1.85) \\
2.34 \\
(4.31)\end{array}$ & $\begin{array}{c}5.2 \\
7.5 \\
7.1 \\
10.2 ! \\
2.5 \\
2.9 ! \\
\ddagger\end{array}$ & $\begin{array}{r}(0.66) \\
1.13 \\
(1.30 \\
3.32 \\
0.63 \\
(0.09) \\
(\dagger)\end{array}$ & $\begin{array}{l}45.4 \\
50.0 \\
54.5 \\
27.4 \\
39.9 \\
50.3 \\
17.9\end{array}$ & $\begin{array}{l}(2.18 \\
(2.06) \\
6.85 \\
(2.62) \\
(3.23 \\
(3.91)\end{array}$ & $\begin{array}{l}9.1 \\
6.9 \\
7.3 \\
5.1 ! \\
11.7 \\
8.3 \\
18.9\end{array}$ & $\begin{array}{l}(1.02) \\
1.04 \\
1.19 \\
1.79 \\
1.87 \\
1.31 \\
(5.14)\end{array}$ \\
\hline 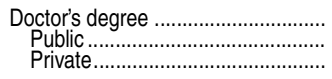 & $\begin{array}{l}56.8 \\
54.5 \\
60.6\end{array}$ & $\left.\begin{array}{l}(1.95) \\
1.92 \\
(3.62)\end{array}\right)$ & $\left\{\begin{array}{l}38,940 \\
33,600 \\
46,530\end{array}\right.$ & $\begin{array}{l}(3,417) \\
1,564) \\
(7,267)\end{array}$ & $\begin{array}{l}53,220 \\
45,920 \\
63,590\end{array}$ & $\left\{\begin{array}{l}4,669) \\
2,138 \\
(9,931)\end{array}\right.$ & $\begin{array}{l}12.1 \\
11.4 \\
13.0\end{array}$ & $\left.\begin{array}{l}(1.38) \\
(1.38 \\
(2.79\end{array}\right)$ & $\begin{array}{l}87.9 \\
88.6 \\
87.0\end{array}$ & $\left.\begin{array}{l}(1.38) \\
1.38 \\
(2.79\end{array}\right)$ & $\begin{array}{l}29.6 \\
26.1 \\
35.2\end{array}$ & $\left.\begin{array}{l}(2.80) \\
(1.86) \\
(6.25)\end{array}\right)$ & $\begin{array}{r}2.6 \\
3.2 \\
\ddagger\end{array}$ & $\left.\begin{array}{r}(0.54) \\
0.75 \\
(\dagger\end{array}\right)$ & & & $\begin{array}{l}5.4 \\
7.3 \\
2.3\end{array}$ & \\
\hline $\begin{array}{l}\text { First-professional } \\
\text { Public . } \\
\text { Private }\end{array}$ & $\begin{array}{l}85.1 \\
86.9 \\
83.7\end{array}$ & $\begin{array}{l}(1.14) \\
1.70 \\
(1.60)\end{array}$ & $\left\{\begin{array}{l}60,620 \\
52,660 \\
67,450\end{array}\right.$ & $\left.\begin{array}{l}(1,666) \\
1,963 \\
3,136\end{array}\right)$ & $\begin{array}{l}82,840 \\
71,960 \\
92,180\end{array}$ & $\left\{\begin{array}{l}(2,277) \\
(2,683 \\
(4,285)\end{array}\right.$ & $\begin{array}{l}13.4 \\
13.7 \\
13.1\end{array}$ & $\left(\begin{array}{l}1.177 \\
(1.82 \\
(1.49\end{array}\right)$ & $\begin{array}{l}86.6 \\
86.3 \\
86.9\end{array}$ & $\left.\begin{array}{l}(1.17) \\
(1.82 \\
(1.49\end{array}\right)$ & $\begin{array}{l}77.2 \\
78.4 \\
76.2\end{array}$ & $\left.\begin{array}{l}(1.29) \\
2.12 \\
(1.83)\end{array}\right)$ & $\begin{array}{r}9.8 \\
12.7 \\
7.5\end{array}$ & $\left(\begin{array}{l}1.63 \\
2.56 \\
2.10\end{array}\right)$ & & & $\begin{array}{l}1.7 ! \\
1.7 ! \\
1.7 !\end{array}$ & \\
\hline Other graduate.... & 57.4 & (3.88) & 27,620 & $(2,028)$ & 37,750 & $(2,771)$ & 38.9 & (3.64) & 61.1 & (3.64) & 45.4 & $(3.64)$ & 8.6 & $(2.41)$ & 25.6 & (3.32) & $2.8 !$ & (1.19) \\
\hline 2007-08, all institutions.......... & 71.3 & (1.04) & $\$ 54,980$ & (992) & $\$ 60,080$ & $(1,084)$ & 13.1 & $(0.80)$ & 86.9 & $(0.80)$ & 56.5 & $(1.18$ & 3.9 & $(0.29$ & 43.9 & (1) & 11.6 & $(0.92)$ \\
\hline 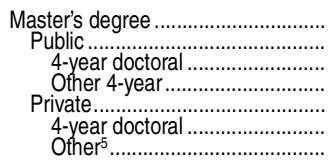 & $\begin{array}{l}71.8 \\
66.5 \\
65.1 \\
77.1 \\
75.5 \\
71.5 \\
80.7\end{array}$ & $\begin{array}{l}(1.76) \\
1.77 \\
1.92 \\
4.81 \\
2.57 \\
1.85 \\
(5.13)\end{array}$ & $\begin{array}{l}43,140 \\
37,640 \\
38,290 \\
33,440 \\
46,490 \\
46,370 \\
46,630\end{array}$ & $\begin{array}{l}(1,370) \\
1,466 \\
1,636) \\
2,285 \\
1,969 \\
1,644) \\
(3,671)\end{array}$ & $\begin{array}{l}47,140 \\
41,130 \\
41,840 \\
36,540 \\
50,810 \\
50,670 \\
50,960\end{array}$ & $\left\{\begin{array}{l}1,498) \\
1,602 \\
1,787 \\
2,497 \\
2,152 \\
1,797 \\
4,011)\end{array}\right.$ & $\begin{array}{l}15.6 \\
13.3 \\
12.0 \\
22.7 \\
17.2 \\
19.1 \\
14.9\end{array}$ & 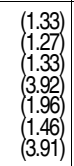 & $\begin{array}{l}84.4 \\
86.7 \\
88.0 \\
77.3 \\
82.8 \\
80.9 \\
85.1\end{array}$ & $\begin{array}{l}(1.33) \\
1.27 \\
1.33 \\
3.92 \\
1.96 \\
1.46 \\
(3.91)\end{array}$ & $\begin{array}{l}55.4 \\
50.5 \\
49.8 \\
55.6 \\
58.9 \\
55.3 \\
63.5\end{array}$ & $\begin{array}{l}(1.93) \\
1.89 \\
2.05 \\
5.96) \\
2.81 \\
1.51 \\
(5.95)\end{array}$ & $\begin{array}{l}3.0 \\
4.2 \\
4.3 \\
27 \\
2.2 \\
2.6 \\
1.6\end{array}$ & $\begin{array}{l}(0.43) \\
0.85 \\
0.95 \\
(\dagger) \\
(0.40) \\
0.59 \\
0.43)\end{array}$ & $\begin{array}{r}35.6 \\
52.4 \\
56.2 \\
23.5 \\
23.9 \\
35.9 \\
8.4\end{array}$ & $\begin{array}{l}(1.47 \\
2.38 \\
(2.60) \\
4.89 \\
1.58 \\
(2.46) \\
(1.44)\end{array}$ & $\begin{array}{l}16.3 \\
13.5 \\
14.6 \\
5.1 ! \\
18.3 \\
14.4 \\
23.3\end{array}$ & $\begin{array}{l}(1.75) \\
1.50 \\
1.68 \\
1.92 \\
2.78 \\
1.17 \\
(6.22)\end{array}$ \\
\hline 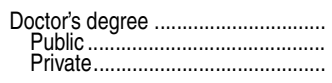 & $\begin{array}{l}59.8 \\
52.1 \\
67.8\end{array}$ & $\left.\begin{array}{l}(1.73) \\
(2.16 \\
(2.41)\end{array}\right)$ & $\begin{array}{l}55,170 \\
44,190 \\
64,060\end{array}$ & $\left.\begin{array}{l}(2,106) \\
(1,604) \\
(3,121)\end{array}\right)$ & $\begin{array}{l}60,290 \\
48,290 \\
70,010\end{array}$ & $\left(\begin{array}{l}2,301) \\
1,753) \\
(3,410)\end{array}\right.$ & $\begin{array}{l}7.1 \\
7.9 \\
6.2\end{array}$ & $\left.\begin{array}{l}(0.87) \\
1.48 \\
(1.08)\end{array}\right)$ & $\begin{array}{l}92.9 \\
92.1 \\
93.8\end{array}$ & $\left.\begin{array}{l}(0.87) \\
1.48 \\
(1.08)\end{array}\right)$ & $\begin{array}{l}38.4 \\
29.6 \\
47.7\end{array}$ & $\begin{array}{l}(2.18) \\
(1.80) \\
(3.42)\end{array}$ & $\begin{array}{l}2.9 \\
3.6 \\
2.2 !\end{array}$ & $\left.\begin{array}{l}(0.41) \\
0.65 \\
0.65)\end{array}\right)$ & & & $\begin{array}{r}7.9 \\
7.9 \\
8.0\end{array}$ & \\
\hline $\begin{array}{l}\text { First-professional } \\
\text { Public . } \\
\text { Private }\end{array}$ & $\begin{array}{l}85.0 \\
84.5 \\
85.4\end{array}$ & $\left(\begin{array}{l}1.28) \\
(1.94) \\
(1.57)\end{array}\right)$ & $\left\{\begin{array}{l}81,140 \\
72,750 \\
87,760\end{array}\right.$ & $\begin{array}{l}(1,776) \\
(2,697) \\
2,185)\end{array}$ & $\begin{array}{l}88,670 \\
79,500 \\
95,910\end{array}$ & $\left\{\begin{array}{l}1,941) \\
2,948 \\
(2,388\end{array}\right)$ & $\begin{array}{l}11.6 \\
11.7 \\
11.5\end{array}$ & $\left.\begin{array}{l}(1.15) \\
(1.69 \\
(1.46)\end{array}\right)$ & $\begin{array}{l}88.4 \\
88.3 \\
88.5\end{array}$ & $\left.\begin{array}{l}(1.15) \\
(1.69 \\
(1.46)\end{array}\right)$ & $\begin{array}{l}81.6 \\
81.6 \\
81.5\end{array}$ & $\left.\begin{array}{l}(1.37) \\
(2.14) \\
(1.67)\end{array}\right)$ & $\begin{array}{r}7.7 \\
10.9 \\
5.2\end{array}$ & $\begin{array}{l}(0.85) \\
(1.51 \\
(0.86)\end{array} \mid$ & & & $\begin{array}{l}4.6 \\
4.9 \\
4.4\end{array}$ & $\begin{array}{l}(0.75) \\
1.43 \\
(0.71)\end{array}$ \\
\hline Other graduate... & 62.5 & (6.48) & 43,700 & $(3,904)$ & 47,760 & $(4,267)$ & 30.8 & (6.54) & 69.2 & (6.54) & 51.0 & (6.62) & $\ddagger$ & $(\mathrm{t})$ & 25.4 & (5.77) & $6.2 !$ & (2.33) \\
\hline stitutions.......... & 73.3 & $(0.90)$ & $\$ 74,710$ & (996) & $\$ 75,950$ & $(1,013)$ & 13.9 & $(0.77)$ & 86.1 & $(0.77)$ & 62.3 & $(0.9$ & 2.4 & $(0.34)$ & 42.2 & (1. & 10.2 & $(0.48)$ \\
\hline 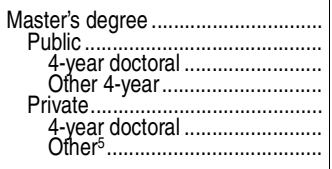 & $\begin{array}{l}73.5 \\
71.8 \\
70.7 \\
82.2 \\
74.8 \\
70.1 \\
81.8\end{array}$ & $\begin{array}{l}(1.45) \\
2.24 \\
2.41 \\
3.71 \\
1.95 \\
2.41 \\
(3.20)\end{array}$ & $\begin{array}{l}58,590 \\
50,200 \\
50,620 \\
46,900 \\
64,510 \\
67,130 \\
61,140\end{array}$ & $\begin{array}{l}(1,142) \\
1,816 \\
2,015) \\
2,538) \\
1,456) \\
2,165 \\
(1,816)\end{array}$ & $\begin{array}{l}59,570 \\
51,040 \\
51,460 \\
47,680 \\
65,580 \\
68,250 \\
62,160\end{array}$ & $\begin{array}{l}(1,161) \\
1,846) \\
(2,048) \\
2,581 \\
1,480 \\
(2,201) \\
(1,846)\end{array}$ & $\begin{array}{l}17.4 \\
16.2 \\
16.3 \\
15.4 \\
18.2 \\
19.6 \\
16.1\end{array}$ & $\begin{array}{l}(1.28) \\
(1.84 \\
2.03 \\
4.13 \\
11.80 \\
2.06 \\
(3.09)\end{array}$ & $\begin{array}{l}82.6 \\
83.8 \\
83.7 \\
84.6 \\
81.8 \\
80.4 \\
83.9\end{array}$ & $\left.\begin{array}{l}(1.28) \\
1.84 \\
2.03 \\
4.13 \\
1.80 \\
2.06 \\
3.09\end{array}\right)$ & $\begin{array}{l}63.0 \\
58.2 \\
57.0 \\
69.5 \\
66.5 \\
59.5 \\
77.0\end{array}$ & $\begin{array}{l}(1.44) \\
(2.41) \\
2.60) \\
(5.18 \\
2.13 \\
2.45 \\
(3.66)\end{array}$ & $\begin{array}{c}1.8 \\
3.7 \\
4.0 \\
\ddagger \\
0.4 ! \\
\ddagger \\
\ddagger\end{array}$ & $\begin{array}{r}(0.35) \\
0.80 \\
(0.89) \\
(+) \\
(0.19 \\
(t) \\
(t)\end{array}$ & $\begin{array}{l}35.1 \\
45.6 \\
47.1 \\
31.2 \\
27.5 \\
35.2 \\
15.9\end{array}$ & $\begin{array}{l}(1.53) \\
(2.35) \\
2.56 \\
(3.46 \\
2.09 \\
2.96) \\
(2.70)\end{array}$ & $\begin{array}{r}8.8 \\
10.3 \\
10.8 \\
5.9 \\
7.8 \\
7.8 \\
7.6\end{array}$ & $\begin{array}{l}(0.70) \\
1.17 \\
1.28 \\
1.68 \\
0.88 \\
1.23 \\
(1.04)\end{array}$ \\
\hline $\begin{array}{l}\text { Doctor's des } \\
\text { scholars } \\
\text { Public ..... } \\
\text { Private.... }\end{array}$ & $\begin{array}{l}50.5 \\
47.9 \\
54.0\end{array}$ & $\begin{array}{l}(1.42) \\
(2.23 \\
(1.86)\end{array}$ & $\left\{\begin{array}{l}65,090 \\
55,500 \\
76,180\end{array}\right.$ & $\left(\begin{array}{l}(2,343) \\
2,291 \\
(4,351)\end{array}\right)$ & $\begin{array}{l}66,170 \\
56,420 \\
77,450\end{array}$ & $\left(\begin{array}{l}2,382 \\
2,30 \\
(4,424)\end{array}\right.$ & $\begin{array}{l}6.6 \\
5.9 \\
7.5\end{array}$ & $\begin{array}{l}(0.73) \\
(1.04) \\
(1.07)\end{array}$ & $\begin{array}{l}93.4 \\
94.1 \\
92.5\end{array}$ & $\left(\begin{array}{l}0.73 \\
1.04 \\
(1.07)\end{array}\right)$ & $\begin{array}{l}27.8 \\
24.2 \\
32.3\end{array}$ & $\left.\begin{array}{l}1.19 \\
(1.41) \\
(2.30)\end{array}\right)$ & $\begin{array}{c}1.5 ! \\
2.1 ! \\
\ddagger\end{array}$ & $\begin{array}{r}(0.49) \\
(0.78 \\
(\dagger)\end{array}$ & $\begin{array}{l}79.8 \\
87.2 \\
70.1\end{array}$ & $\left.\begin{array}{l}(1.27) \\
(2.59) \\
2.28\end{array}\right)$ & $\begin{array}{l}24.0 \\
27.0 \\
20.1\end{array}$ & $\begin{array}{l}(1.25) \\
(1.93 \\
(1.06)\end{array}$ \\
\hline $\begin{array}{r}\text { Doctor's degree } \\
\text { practice and } \\
\text { Public........... } \\
\text { Private.......... }\end{array}$ & $\begin{array}{l}88.3 \\
88.3 \\
88.3\end{array}$ & $\begin{array}{l}(0.90) \\
(1.00) \\
(1.28)\end{array}$ & $\left\{\begin{array}{l}110,570 \\
102,220 \\
116,000\end{array}\right.$ & $\left.\begin{array}{l}(1,848) \\
(2,726) \\
2,490\end{array}\right)$ & $\begin{array}{l}112,410 \\
103,920 \\
117,930\end{array}$ & $\begin{array}{l}1,878) \\
(2,72) \\
(2,531)\end{array}$ & $\begin{array}{l}9.3 \\
8.9 \\
9.6\end{array}$ & $\begin{array}{l}(0.88) \\
1.09 \\
(1.22)\end{array}$ & $\begin{array}{l}90.7 \\
91.1 \\
90.4\end{array}$ & $\left.\begin{array}{l}(0.88) \\
1.09 \\
(1.22\end{array}\right)$ & $\begin{array}{l}84.4 \\
84.4 \\
84.4\end{array}$ & $\left(\begin{array}{l}1.03 \\
1.31 \\
(1.50)\end{array}\right)$ & $\begin{array}{l}4.5 \\
8.1 \\
2.2\end{array}$ & $\begin{array}{l}(0.96) \\
2.27 \\
(0.53)\end{array}$ & $\begin{array}{l}35.1 \\
40.6 \\
31.5\end{array}$ & $\begin{array}{l}(1.66) \\
(2.51) \\
(2.19)\end{array}$ & $\begin{array}{l}4.4 \\
5.4 \\
3.7\end{array}$ & $\left.\begin{array}{l}(0.51) \\
0.82 \\
0.62\end{array}\right)$ \\
\hline 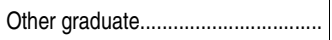 & 74.9 & $(6.28)$ & 57,540 & $(5,456)$ & 58,500 & $(5,546)$ & 29.1 & (6.46) & 70.9 & (6.46) & 61.4 & $(7.24)$ & $\ddagger$ & $(†)$ & 16.9 & (4.78) & $5.5 !$ & (2.47) \\
\hline
\end{tabular}

-Not available.

†Not applicable.

!Interpret data with caution. The coefficient of variation (CV) for this estimate is between 30 and 50 percent.

†Reporting standards not met. Either there are too few cases for a reliable estimate or the coefficient of variation (CV) is 50 percent or greater.

${ }^{1}$ Includes all loans ever taken out for both graduate and undergraduate education. Does not include Parent Loans for Undergraduate Students (PLUS) or loans from families and friends. Includes students who reported they were awarded aid, but did not specify the source of aid. ${ }^{3}$ Includes Department of Veterans Affairs and Department of Defense benefits.

${ }^{4}$ Constant dollars based on the Consumer Price Index, prepared by the Bureau of Labor Statistics, U.S. Department of Labor, adjusted to a school-year basis.
${ }^{5}$ Includes nonprofit 4-year nondoctoral institutions and for-profit 2-year-and-above institutions. ${ }^{6}$ Professional practice doctor's degrees include most degrees formerly classified as firstprofessional (such as M.D., D.D.S., and J.D.). "Other" doctor's degrees are those that are neither research/scholarship degrees nor professional practice degrees.

NOTE: Excludes students whose attendance status was not reported. Total includes some students whose level of study or control of institution was unknown. Detail may not sum to totals because of rounding and because some students receive multiple types of aid and aid from different sources. Data for 2007-08 and prior years include Puerto Rico, which is excluded from the 2011-12 data.

SOURCE: U.S. Department of Education, National Center for Education Statistics, 1992-93, 1999-2000, 2007-08, and 2011-12 National Postsecondary Student Aid Study (NPSAS:93, NPSAS:2000, NPSAS:08, and NPSAS:12). (This table was prepared March 2014.) 
Table 332.20. Amount borrowed, aid status, and sources of aid for part-time or part-year postbaccalaureate students, by level of study and control and level of institution: Selected years, 1992-93 through 2011-12

[Standard errors appear in parentheses]

\begin{tabular}{|c|c|c|c|c|c|c|c|c|c|c|c|c|c|c|c|c|c|}
\hline \multirow[b]{3}{*}{$\begin{array}{l}\text { Level of study, } \\
\text { control and level of institution }\end{array}$} & \multicolumn{5}{|c|}{$\begin{array}{l}\text { Cumulative borrowing for } \\
\text { undergraduate and graduate education }\end{array}$} & \multicolumn{12}{|c|}{ Aid status (percent of students) } \\
\hline & \multirow{2}{*}{\multicolumn{2}{|c|}{$\begin{array}{r}\text { Percent } \\
\text { who borrowed }\end{array}$}} & \multicolumn{3}{|c|}{$\begin{array}{l}\text { Average amount for } \\
\text { those who borrowed }\end{array}$} & \multirow{2}{*}{\multicolumn{2}{|c|}{ Nonaided }} & \multicolumn{10}{|c|}{ Source of aid } \\
\hline & & & Curre & nt dollars & $\begin{array}{r}\text { Constant } \\
2012-13 \text { dollars }\end{array}$ & & & \multicolumn{2}{|r|}{ Any aid² } & \multicolumn{2}{|r|}{ Federal $^{3}$} & \multicolumn{2}{|r|}{ State } & \multicolumn{2}{|c|}{ Institutional } & \multicolumn{2}{|c|}{ Employer } \\
\hline 1 & & 2 & & 3 & 4 & & 5 & & 6 & & 7 & & 8 & & 9 & & 10 \\
\hline 1992-93, all institutions... & - & $(t)$ & - & $(\dagger)$ & $(t)$ & 63.2 & $(0.81)$ & 36.8 & $(0.81)$ & 10.8 & $(0.53)$ & 1.9 & (0.14) & 12.7 & $(0.53)$ & 16.7 & $(0.70)$ \\
\hline 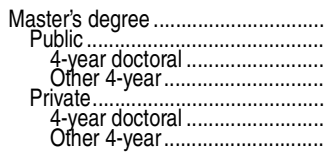 & $\begin{array}{l}\bar{z} \\
\bar{z} \\
=\end{array}$ & (f) & $\begin{array}{l}\text { z } \\
\text { = } \\
\text { z }\end{array}$ & $(f)$ & $\begin{array}{l}= \\
= \\
= \\
=\end{array}$ & $\begin{array}{l}62.5 \\
66.4 \\
62.2 \\
73.7 \\
57.0 \\
55.2 \\
60.4\end{array}$ & $\begin{array}{l}(0.85) \\
1.00 \\
(1.25 \\
(1.39 \\
(1.55) \\
1.91 \\
(2.82)\end{array}$ & $\begin{array}{l}37.5 \\
33.6 \\
37.8 \\
26.3 \\
43.0 \\
44.8 \\
39.6\end{array}$ & $\begin{array}{l}(0.85) \\
(1.00 \\
(1.25 \\
(1.39 \\
(1.55) \\
1.91 \\
(2.82)\end{array}$ & $\begin{array}{r}10.5 \\
10.1 \\
11.9 \\
6.9 \\
11.1 \\
12.1 \\
9.3\end{array}$ & $\begin{array}{l}(0.61) \\
0.58 \\
(0.81 \\
0.76 \\
(1.66 \\
1.15 \\
1.70)\end{array}$ & $\begin{array}{l}1.6 \\
2.5 \\
2.5 \\
2.4 \\
0.4 ! \\
\vdots ! \\
0.6 !\end{array}$ & $\begin{array}{l}(0.18) \\
0.30 \\
(0.48 \\
(0.55) \\
0.12 \\
(0.27)\end{array}$ & $\begin{array}{r}11.1 \\
11.7 \\
15.3 \\
5.5 \\
10.3 \\
12.1 \\
6.9\end{array}$ & $\begin{array}{l}(0.69) \\
(0.77) \\
(1.10 \\
(1.11 \\
1.04 \\
1.57 \\
1.33\end{array}$ & $\begin{array}{l}18.6 \\
14.6 \\
14.6 \\
14.4 \\
24.4 \\
25.1 \\
23.1\end{array}$ & $\begin{array}{l}(0.90) \\
(0.82 \\
(1.05) \\
(1.09 \\
(1.45) \\
(.71) \\
(2.31)\end{array}$ \\
\hline 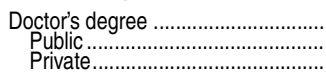 & $\bar{z}$ & $(+千)$ & - & & $\bar{z}$ & $\begin{array}{l}51.5 \\
51.4 \\
51.8\end{array}$ & $\begin{array}{l}(2.56) \\
3.10 \\
(5.53)\end{array}$ & $\begin{array}{l}48.5 \\
48.6 \\
48.2\end{array}$ & $\left.\begin{array}{l}(2.56) \\
3.10 \\
(5.53)\end{array}\right)$ & $\begin{array}{l}8.6 \\
8.5 \\
8.9\end{array}$ & $\left.\begin{array}{l}(1.18) \\
(1.38 \\
(2.49\end{array}\right)$ & $\begin{array}{l}3.5 \\
4.4 \\
1.6 !\end{array}$ & $\begin{array}{l}(0.78) \\
(1.24) \\
(0.68)\end{array}$ & $\begin{array}{l}33.1 \\
33.3 \\
32.6\end{array}$ & $\left.\begin{array}{l}(2.44) \\
3.02 \\
(4.51)\end{array}\right)$ & $\begin{array}{l}12.0 \\
12.9 \\
10.2\end{array}$ & $\left.\begin{array}{l}(1.49) \\
(1.89\end{array}\right)$ \\
\hline 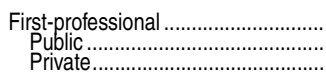 & $\bar{z}$ & $(f)$ & ב & & $\bar{z}$ & $\begin{array}{l}41.4 \\
48.3 \\
37.4\end{array}$ & $\begin{array}{l}(3.04) \\
(4.43 \\
(3.43)\end{array}$ & $\begin{array}{l}58.6 \\
51.7 \\
62.6\end{array}$ & $\begin{array}{l}(3.04) \\
(4.43) \\
(3.43)\end{array}$ & $\begin{array}{l}44.9 \\
42.8 \\
46.1\end{array}$ & 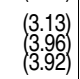 & $\begin{array}{l}3.3 \\
3.6 ! \\
3.2\end{array}$ & $\left.\begin{array}{l}(0.71) \\
(1.11 \\
0.91)\end{array}\right)$ & $\begin{array}{l}25.7 \\
22.2 \\
27.8\end{array}$ & $\left.\begin{array}{l}(2.07) \\
3.35 \\
2.44\end{array}\right)$ & $\begin{array}{l}6.1 \\
5.0 ! \\
6.7\end{array}$ & $\begin{array}{l}(1.34) \\
(1.61) \\
(1.81)\end{array}$ \\
\hline Other graduate.. & - & (t) & - & $(t)$ & (t) & 73.0 & (1.42) & 27.0 & (1.42) & 7.7 & $(0.77)$ & 1.7 & (0.42) & 8.4 & $(0.85)$ & 13.4 & $(1.00)$ \\
\hline 1999-2000, all institutions.. & 55.8 & $(0.78)$ & $\$ 21,970$ & (402) & $\$ 30,020 \quad(550)$ & 51.3 & $(0.72)$ & 48.7 & $(0.72)$ & 19.4 & $(0.50)$ & 1.7 & $(0.21)$ & 16.0 & $(0.51)$ & 20.1 & $(0.66)$ \\
\hline 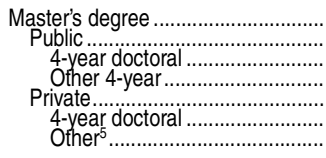 & $\begin{array}{l}57.0 \\
55.8 \\
56.2 \\
54.5 \\
58.6 \\
57.9 \\
59.8\end{array}$ & $\begin{array}{l}(0.91) \\
(1.20 \\
1.51 \\
2.19 \\
1.27 \\
1.62 \\
(2.23)\end{array}$ & $\begin{array}{l}20,720 \\
18,020 \\
18,630 \\
16,320 \\
23,960 \\
25,430 \\
21,330\end{array}$ & $\begin{array}{r}(397) \\
498 \\
684 \\
649 \\
670 \\
(898) \\
(1,132)\end{array}$ & \begin{tabular}{rr|}
28,320 & $(540)$ \\
24,630 & $(680)$ \\
25,460 & $(940)$ \\
22,300 & $(890)$ \\
32,740 & $(920)$ \\
34,750 & $(1,230)$ \\
29,150 & $(1,550)$
\end{tabular} & $\begin{array}{l}48.8 \\
53.0 \\
49.7 \\
60.8 \\
43.5 \\
42.3 \\
45.9\end{array}$ & $\begin{array}{l}(0.84) \\
1.18 \\
(1.55 \\
1.96 \\
(1.29) \\
1.46 \\
(2.31)\end{array}$ & $\begin{array}{l}51.2 \\
47.0 \\
50.3 \\
39.2 \\
56.5 \\
57.7 \\
54.1\end{array}$ & $\begin{array}{l}(0.84) \\
(1.18 \\
(1.55 \\
(1.96 \\
(1.29 \\
1.46 \\
(2.31)\end{array}$ & $\begin{array}{l}20.7 \\
16.9 \\
18.2 \\
14.2 \\
25.5 \\
25.4 \\
25.5\end{array}$ & $\begin{array}{l}(0.66) \\
0.81 \\
(1.20 \\
1.45 \\
(1.06 \\
(.37 \\
(1.98)\end{array}$ & $\begin{array}{l}1.4 \\
2.0 \\
2.0 \\
2.0 \\
0.6 ! \\
0.9 ! \\
\ddagger\end{array}$ & $\begin{array}{r}(0.25) \\
0.38 \\
0.51 \\
0.50 \\
0.22 \\
0.33 \\
(\dagger)\end{array}$ & $\begin{array}{r}14.1 \\
15.3 \\
18.0 \\
9.5 \\
12.7 \\
15.0 \\
8.5\end{array}$ & $\begin{array}{l}(0.58) \\
(0.95) \\
1.21 \\
1.52 \\
0.95 \\
1.10 \\
1.65)\end{array}$ & $\begin{array}{l}23.1 \\
20.6 \\
21.4 \\
18.5 \\
26.2 \\
25.3 \\
28.0\end{array}$ & $\begin{array}{l}(0.82) \\
1.32 \\
1.61 \\
(2.28) \\
1.12 \\
1.22 \\
(2.13)\end{array}$ \\
\hline 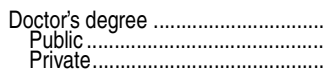 & $\begin{array}{l}53.1 \\
48.4 \\
62.9\end{array}$ & $\left.\begin{array}{l}(1.71) \\
(1.84) \\
(3.80)\end{array}\right)$ & $\begin{array}{l}27,930 \\
25,030 \\
32,560\end{array}$ & $\begin{array}{l}(1,939) \\
(1,476)\end{array}$ & $\begin{array}{ll}38,170 & (2,650) \\
34,210 & (2,020) \\
44,500 & (5,390)\end{array}$ & $\begin{array}{l}45.5 \\
46.9 \\
42.4\end{array}$ & $\left.\begin{array}{l}(1.78) \\
(2.32 \\
(2.82)\end{array}\right)$ & $\begin{array}{l}54.5 \\
53.1 \\
57.6\end{array}$ & $\begin{array}{l}(1.78) \\
(2.32 \\
(2.82)\end{array}$ & $\begin{array}{l}15.4 \\
13.0 \\
20.4\end{array}$ & $\left.\begin{array}{l}(1.42) \\
(1.16 \\
(3.49)\end{array}\right)$ & $\begin{array}{r}0.9 \\
1.4 \\
\#\end{array}$ & $\left.\begin{array}{r}(0.17) \\
0.25 \\
(\dagger\end{array}\right)$ & $\begin{array}{l}36.9 \\
40.3 \\
29.9\end{array}$ & $\left.\begin{array}{l}(1.64) \\
(2.03 \\
2.63\end{array}\right)$ & $\begin{array}{l}14.0 \\
12.1 \\
18.0\end{array}$ & $\left.\begin{array}{l}(1.35) \\
1.45 \\
(3.10\end{array}\right)$ \\
\hline $\begin{array}{l}\text { First-profe } \\
\text { Public.. } \\
\text { Private. }\end{array}$ & $\begin{array}{l}77.7 \\
79.0 \\
77.1\end{array}$ & $\left.\begin{array}{l}(4.00) \\
(6.85) \\
(4.72)\end{array}\right)$ & $\begin{array}{l}47,030 \\
39,910 \\
50,220\end{array}$ & $\begin{array}{l}(3,743) \\
(3,571) \\
(5,124)\end{array}$ & $\begin{array}{l}64,270 \\
54,54,120) \\
68,630 \\
6,8800)\end{array}$ & $\begin{array}{l}24.3 \\
27.7 \\
22.8\end{array}$ & $\begin{array}{l}(3.13) \\
(6.92) \\
(3.05)\end{array}$ & $\begin{array}{l}75.7 \\
72.3 \\
77.2\end{array}$ & $\begin{array}{l}(3.13) \\
6.92 \\
(3.05)\end{array}$ & $\begin{array}{l}55.6 \\
53.2 \\
56.6\end{array}$ & $\left.\begin{array}{l}(4.83) \\
(7.99 \\
6.24)\end{array}\right)$ & $\begin{array}{l}4.9 ! \\
4.7 ! \\
4.9 !\end{array}$ & $\left(\begin{array}{l}1.76 \\
2.25 \\
(2.41)\end{array}\right)$ & $\begin{array}{l}28.0 \\
21.2 \\
31.0\end{array}$ & $\begin{array}{l}(3.09) \\
(6.22) \\
(3.03)\end{array}$ & $\begin{array}{c}10.8 \\
7.9 ! \\
12.1\end{array}$ & $\begin{array}{l}(2.04) \\
(3.76 \\
(2.78)\end{array}$ \\
\hline Other graduate... & 48.9 & $(2.01)$ & 15,700 & (713) & $21,460 \quad(970)$ & 67.1 & (1.79) & 32.9 & $(1.79)$ & 9.9 & $(1.25)$ & 2.2 & $(0.47)$ & 10.1 & $(1.07)$ & 15.2 & $(1.31)$ \\
\hline 2007 & 66.8 & $(0.76)$ & $\$ 36,230$ & (840) & $\$ 39,590 \quad(918)$ & 33.1 & $(0.84)$ & 66.9 & $(0.84)$ & 32.0 & $(0.71)$ & 2.0 & $(0.50)$ & 18.8 & $(0.65)$ & 27.2 & (0.93) \\
\hline 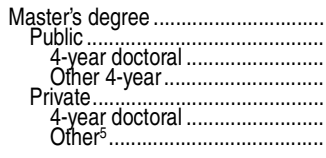 & $\begin{array}{l}67.2 \\
65.1 \\
65.2 \\
64.7 \\
69.4 \\
66.7 \\
73.8\end{array}$ & $\begin{array}{l}(1.08) \\
(1.30 \\
1.38 \\
(3.08 \\
1.56 \\
1.36 \\
(3.28)\end{array}$ & $\begin{array}{l}34,030 \\
30,860 \\
31,420 \\
29,080 \\
37,010 \\
37,220 \\
36,710\end{array}$ & $\begin{array}{r}(906) \\
702 \\
(815) \\
(1,639) \\
(1,513 \\
(395) \\
(3,266)\end{array}$ & $\begin{array}{rr}37,190 & (990) \\
33,720 & (767 \\
34,340 & (890) \\
31,780 & (1,791 \\
40,450 & (1,653) \\
40,670 & (989) \\
40,120 & (3,569)\end{array}$ & $\begin{array}{l}30.9 \\
34.2 \\
32.2 \\
40.6 \\
27.6 \\
28.9 \\
25.3\end{array}$ & $\begin{array}{l}(1.09) \\
(1.38 \\
(1.59 \\
2.99 \\
1.58 \\
1.51 \\
(3.20)\end{array}$ & $\begin{array}{l}69.1 \\
65.8 \\
67.8 \\
59.4 \\
72.4 \\
71.1 \\
74.7\end{array}$ & $\begin{array}{l}(1.09) \\
(1.38 \\
(1.59 \\
2.99 \\
(1.58) \\
(1.51 \\
(3.20)\end{array}$ & $\begin{array}{l}34.4 \\
29.7 \\
29.6 \\
29.7 \\
39.1 \\
34.2 \\
46.9\end{array}$ & $\begin{array}{l}(0.98) \\
0.94 \\
(1.17 \\
2.67 \\
(1.49 \\
1.52 \\
(2.93)\end{array}$ & $\begin{array}{l}2.2 ! \\
1.7 \\
1.9 \\
1.2 \\
2.7 ! \\
1.5 \\
\ddagger\end{array}$ & $\begin{array}{r}(0.68) \\
0.37 \\
0.47 \\
0.48 \\
(1.32 \\
0.40 \\
(\dagger)\end{array}$ & $\begin{array}{l}16.0 \\
18.1 \\
20.5 \\
10.4 \\
13.8 \\
16.0 \\
10.2\end{array}$ & $\begin{array}{l}(0.71) \\
(0.91 \\
(1.14 \\
1.40 \\
(1.11 \\
(1.28) \\
(1.64)\end{array}$ & $\begin{array}{l}29.8 \\
27.8 \\
29.3 \\
22.7 \\
31.8 \\
32.8 \\
30.1\end{array}$ & $\begin{array}{l}(1.22) \\
(1.42 \\
(1.56) \\
1.85 \\
1.20 \\
(4.48)\end{array}$ \\
\hline 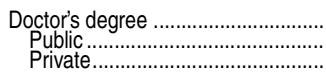 & $\begin{array}{l}64.7 \\
54.8 \\
77.9\end{array}$ & $\left.\begin{array}{l}(3.45) \\
(1.93 \\
(5.54)\end{array}\right)$ & $\begin{array}{l}52,060 \\
36,730 \\
66,300\end{array}$ & $\begin{array}{l}(5,370) \\
(1,352) \\
(9,050)\end{array}$ & $\begin{array}{l}56,890 \\
45,140 \\
42,469) \\
72,450 \\
(9,891)\end{array}$ & $\begin{array}{l}20.2 \\
23.4 \\
15.9\end{array}$ & $\left.\begin{array}{l}(1.91) \\
1.55 \\
3.88\end{array}\right)$ & $\begin{array}{l}79.8 \\
76.6 \\
84.1\end{array}$ & $\begin{array}{l}(1.91) \\
(1.55) \\
(3.88)\end{array}$ & $\begin{array}{l}32.1 \\
18.0 \\
50.7\end{array}$ & $\left(\begin{array}{l}4.93 \\
1.20 \\
(9.05)\end{array}\right)$ & $\begin{array}{r}1.6 \\
2.2 \\
\ddagger\end{array}$ & $\left.\begin{array}{r}(0.33 \\
0.41) \\
(\dagger\end{array}\right)$ & $\begin{array}{l}48.2 \\
60.1 \\
32.6\end{array}$ & $\begin{array}{l}(3.15) \\
(1.76 \\
(5.14)\end{array} \mid$ & $\begin{array}{l}19.2 \\
19.6 \\
18.6\end{array}$ & $\left.\begin{array}{l}(1.71) \\
1.42 \\
4.05\end{array}\right)$ \\
\hline 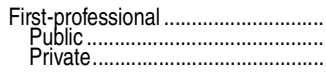 & $\begin{array}{l}82.2 \\
76.7 \\
85.2\end{array}$ & $\left.\begin{array}{l}(2.40) \\
(5.12 \\
(2.49)\end{array}\right)$ & $\begin{array}{l}64,430 \\
63,520 \\
64,860\end{array}$ & $\left.\begin{array}{l}(3,817) \\
(5,656) \\
(5,310)\end{array}\right)$ & $\begin{array}{ll}70,410 & (4,171) \\
69,420 & (6,181 \\
70,880 & (5,803)\end{array}$ & $\begin{array}{l}14.2 \\
11.4 \\
15.7\end{array}$ & $\begin{array}{l}(2.50) \\
(4.88 \\
(3.06)\end{array}$ & $\begin{array}{l}85.8 \\
88.6 \\
84.3\end{array}$ & $\begin{array}{l}(2.50) \\
(4.88) \\
(3.06)\end{array}$ & $\begin{array}{l}63.8 \\
64.1 \\
63.6\end{array}$ & $\begin{array}{l}(4.51) \\
(7.15) \\
6.06)\end{array}$ & $\begin{array}{c}3.8 ! \\
8.1 !\end{array}$ & $\left.\begin{array}{c}(1.49 \\
3.15 \\
(\dagger\end{array}\right)$ & $\begin{array}{l}31.3 \\
32.3 \\
30.8\end{array}$ & $\left.\begin{array}{l}(3.37) \\
5.88 \\
(4.56)\end{array}\right)$ & $\begin{array}{l}16.3 \\
16.0 \\
16.5\end{array}$ & $\begin{array}{l}(2.17) \\
3.67 \\
(2.81)\end{array}$ \\
\hline 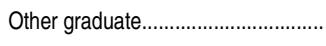 & 63.9 & $(2.68)$ & 28,950 & $(1,970)$ & $31,640 \quad(2,153)$ & 56.1 & $(3.06)$ & 43.9 & (3.06) & 16.1 & (1.59) & 1.2 & $(0.32)$ & 7.5 & $(1.09)$ & 23.4 & (2.79) \\
\hline 2011 & 63.6 & $(0.90)$ & $\$ 49,410$ & (968) & $\$ 50,230$ & 39.1 & $(0.99)$ & 60.9 & $(0.99)$ & 35.8 & $(0.66)$ & 1.0 & $(0.14)$ & 18.0 & (0.76) & 17.0 & $(0.88)$ \\
\hline 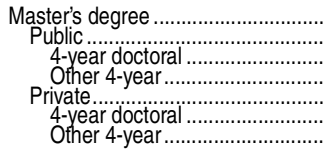 & $\begin{array}{l}65.1 \\
61.5 \\
60.2 \\
68.2 \\
68.3 \\
63.6 \\
74.4\end{array}$ & $\begin{array}{l}(1.13) \\
(1.63 \\
(1.87 \\
(2.74) \\
(2.73) \\
(1.45)\end{array}$ & $\begin{array}{l}45,860 \\
40,340 \\
40,870 \\
38,070 \\
50,210 \\
49,510 \\
51,000\end{array}$ & $\begin{array}{l}(1,055) \\
1,064 \\
1,584 \\
2,079 \\
1,1,536 \\
1,979 \\
(2,306)\end{array}$ & $\begin{array}{ll}46,620 & (1,073) \\
41,010 & (1,387 \\
41,550 & (1,611 \\
38,700 & (2,113 \\
51,1,000 & (1,561) \\
50,330 & (2,012) \\
51,750 & (2,345)\end{array}$ & $\begin{array}{l}37.5 \\
42.9 \\
41.5 \\
49.8 \\
32.7 \\
34.3 \\
30.6\end{array}$ & $\begin{array}{l}(1.29) \\
1.51 \\
(1.74 \\
2.32 \\
1.94 \\
2.07 \\
(3.63)\end{array}$ & $\begin{array}{l}62.5 \\
57.1 \\
58.5 \\
50.2 \\
67.3 \\
65.7 \\
69.4\end{array}$ & $\begin{array}{l}(1.29) \\
1.51 \\
1.74 \\
2.32 \\
1.94 \\
2.07 \\
(3.63)\end{array}$ & $\begin{array}{l}39.4 \\
34.3 \\
34.1 \\
35.4 \\
43.9 \\
37.9 \\
51.7\end{array}$ & $\begin{array}{l}(0.88) \\
(.28 \\
(1.47 \\
2.04 \\
(1.31 \\
(1.65) \\
(2.22)\end{array}$ & 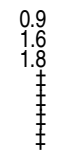 & $\begin{array}{r}(0.18) \\
(0.33 \\
0.39 \\
(+) \\
(+) \\
(+)\end{array}$ & $\begin{array}{r}16.1 \\
17.0 \\
18.6 \\
9.0 \\
15.3 \\
15.9 \\
14.4\end{array}$ & $\begin{array}{l}(0.89) \\
(1.17 \\
(1.38 \\
1.31 \\
(1.31 \\
1.77 \\
(2.05)\end{array}$ & $\begin{array}{l}17.3 \\
14.7 \\
15.6 \\
10.3 \\
19.5 \\
21.2 \\
17.3\end{array}$ & $\begin{array}{l}(1.13) \\
(1.02 \\
1.15 \\
1.66 \\
(1.91 \\
2.02 \\
(3.39)\end{array}$ \\
\hline $\begin{array}{r}\text { Doctor's deg } \\
\text { scholars } \\
\text { Public...... } \\
\text { Private..... }\end{array}$ & $\begin{array}{l}57.7 \\
50.2 \\
72.8\end{array}$ & $\left.\begin{array}{l}(1.52) \\
(1.96 \\
(1.72)\end{array}\right)$ & $\begin{array}{l}66,220 \\
51,810 \\
86,290\end{array}$ & $\left.\begin{array}{l}(2,390) \\
2,2,94 \\
(3,951)\end{array}\right)$ & $\begin{array}{ll}67,320 & (2,430) \\
52,670 & (2,332 \\
87,730 & (4,017)\end{array}$ & $\begin{array}{l}29.1 \\
30.1 \\
26.9\end{array}$ & $\begin{array}{l}(1.67) \\
2.12 \\
(2.56)\end{array}$ & $\begin{array}{l}70.9 \\
69.9 \\
73.1\end{array}$ & $\left.\begin{array}{l}(1.67) \\
2.12 \\
(2.56)\end{array}\right)$ & $\begin{array}{l}25.6 \\
16.6 \\
43.7\end{array}$ & $\left.\begin{array}{l}(1.54) \\
(1.62) \\
2.76\end{array}\right)$ & $\begin{array}{l}1.2 \\
1.3 \\
0.8 !\end{array}$ & $\begin{array}{l}(0.21) \\
(0.258 \\
0.38)\end{array}$ & $\begin{array}{l}43.4 \\
51.6 \\
26.9\end{array}$ & $\begin{array}{l}(2.01) \\
(2.40) \\
(2.44)\end{array}$ & $\begin{array}{l}20.9 \\
23.6 \\
15.5\end{array}$ & $\begin{array}{l}(1.35) \\
(1.77) \\
(1.78)\end{array}$ \\
\hline 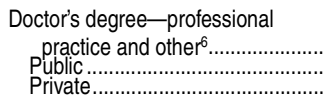 & $\begin{array}{l}69.4 \\
61.6 \\
74.7\end{array}$ & $\left.\begin{array}{l}(3.45) \\
4.88 \\
(4.23)\end{array}\right)$ & $\begin{array}{l}100,780 \\
79,230 \\
112,960\end{array}$ & $\begin{array}{l}(4,860) \\
5,498 \\
(6,242)\end{array}$ & $\begin{array}{rr}102,460 & (4,941) \\
80,550 & 5,590 \\
114,840 & 6,346)\end{array}$ & $\begin{array}{l}31.5 \\
41.7 \\
24.5\end{array}$ & $\begin{array}{l}(3.09) \\
4.51 \\
(3.48)\end{array}$ & $\begin{array}{l}68.5 \\
58.3 \\
75.5\end{array}$ & $\left.\begin{array}{l}(3.09) \\
4.51 \\
(3.48)\end{array}\right)$ & $\begin{array}{l}48.7 \\
38.1 \\
56.0\end{array}$ & $\begin{array}{l}3.68 \\
4.14 \\
(5.04)\end{array}$ & $\stackrel{2.0}{3.6 !} \underset{\ddagger}{\ddagger}$ & $\left.\begin{array}{r}(0.59) \\
(1.32 \\
(t)\end{array}\right)$ & $\begin{array}{l}19.3 \\
23.3 \\
16.6\end{array}$ & $\begin{array}{l}(2.20) \\
(3.59 \\
(2.60)\end{array}$ & $\begin{array}{l}12.1 \\
12.6 \\
11.8\end{array}$ & $\begin{array}{l}(1.83) \\
(2.94) \\
(2.64)\end{array}$ \\
\hline Other graduate... & 56.0 & (2.72) & 39,690 & $(2,498)$ & $40,350 \quad(2,539)$ & 59.4 & (2.66) & 40.6 & (2.66) & 16.5 & (1.63) & $1.1 !$ & $(0.33)$ & 11.5 & (2.13) & 14.6 & (1.91) \\
\hline
\end{tabular}

-Not available

†Not applicable.

\#Rounds to zero.

!nterpret data with caution. The coefficient of variation (CV) for this estimate is between 30 and 50 percent.

‡Reporting standards not met. The coefficient of variation (CV) for this estimate is 50 percent or greater.

${ }^{1}$ Includes all loans ever taken out for both graduate and undergraduate education. Does not include Parent Loans for Undergraduate Students (PLUS) or loans from families or friends. Includes students who reported they were awarded aid, but did not specify the source of aid Includes Department of Veterans Affairs and Department of Defense benefits.

${ }^{4}$ Constant dollars based on the Consumer Price Index, prepared by the Bureau of Labor Statistics, U.S. Department of Labor, adjusted to a school-year basis.
${ }^{5}$ Includes nonprofit 4-year nondoctoral institutions and for-profit 2-year-and-above institutions ${ }^{6}$ Professional practice doctor's degrees include most degrees formerly classified as first-professional (such as M.D., D.D.S., and J.D). "Other" doctor's degrees are those that are neither research/scholarship degrees nor professional practice degrees.

NOTE: Excludes students whose attendance status was not reported. Total includes some students whose level of study or control of institution was unknown. Detail may not sum to totals because of rounding and because some students receive multiple types of aid and aid from different sources. Data for 2007-08 and prior years include Puerto Rico, which is excluded from the 2011-12 data.

SOURCE: U.S. Department of Education, National Center for Education Statistics, 1992-93, 1999-2000, 2007-08, and 2011-12 National Postsecondary Student Aid Study (NPSAS:93, NPSAS:2000, NPSAS:08, and NPSAS:12). (This table was prepared March 2014.) 
CHAPTER 3: Postsecondary Education 649

Financial Aid for Postbaccalaureate Students

Table 332.30. Percentage of full-time, full-year postbaccalaureate students receiving financial aid, by type of aid, level of study, and control and level of institution: Selected years, 1992-93 through 2011-12

[Standard errors appear in parentheses]

\begin{tabular}{|c|c|c|c|c|c|c|c|c|c|c|c|c|c|c|c|c|c|c|}
\hline \multirow{3}{*}{$\begin{array}{l}\text { Level of study, control and level } \\
\text { of institution }\end{array}$} & \multirow{3}{*}{\multicolumn{2}{|c|}{$\begin{array}{r}\text { Number of } \\
\text { students } \\
\text { (in thousands) }\end{array}$}} & \multicolumn{16}{|c|}{ Percent receiving aid } \\
\hline & & & \multirow{2}{*}{\multicolumn{2}{|c|}{ Any aid $^{2}$}} & \multirow{2}{*}{\multicolumn{2}{|c|}{$\begin{array}{r}\text { Fellowship } \\
\text { grants }\end{array}$}} & \multirow{2}{*}{\multicolumn{2}{|c|}{ Tuition waivers }} & \multirow{2}{*}{\multicolumn{2}{|c|}{ Assistantships $^{3}$}} & \multirow{2}{*}{\multicolumn{2}{|c|}{$\begin{array}{r}\text { Employer } \\
\text { (includes } \\
\text { college staff) }\end{array}$}} & \multicolumn{6}{|c|}{ Loans } \\
\hline & & & & & & & & & & & & & \multicolumn{2}{|c|}{ Any loans } & \multicolumn{2}{|c|}{ Stafford 4} & \multicolumn{2}{|r|}{ Perkins 5} \\
\hline 1 & & 2 & & 3 & & 4 & & 5 & & 6 & & 7 & & 8 & & 9 & & 10 \\
\hline 1992-93, all institutions .... & 673 & $(-)$ & 69.3 & $(1.43)$ & {$\left[{ }^{6}\right]$} & $(t)$ & 12.4 & $(0.99)$ & 14.3 & $(1.32)$ & 5.3 & $(0.59)$ & 43.3 & $(1.36)$ & 41.1 & $(1.40)$ & 9.0 & $(0.89)$ \\
\hline 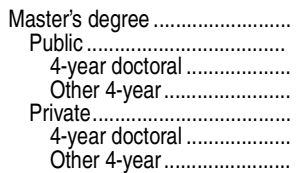 & $\begin{array}{r}281 \\
163 \\
139 \\
24 \\
118 \\
103 \\
16\end{array}$ & $\begin{array}{l}(Z) \\
(-) \\
(-) \\
(-)\end{array}$ & $\begin{array}{l}64.5 \\
67.2 \\
67.5 \\
65.4 \\
60.8 \\
62.6 \\
49.5\end{array}$ & $\begin{array}{r}(2.54) \\
(2.39) \\
(2.58) \\
4.37) \\
(4.74) \\
(4.70) \\
(10.60)\end{array}$ & $\begin{array}{l}{[6]} \\
{[6]} \\
{[6]} \\
66] \\
{[6]} \\
{[6]} \\
{[6]}\end{array}$ & $\begin{array}{c}(t) \\
(t) \\
(t) \\
+ \\
(t) \\
(t) \\
(t)\end{array}$ & $\begin{array}{l}15.6 \\
20.5 \\
23.3 \\
4.4 ! \\
8.9 \\
9.5 \\
\ddagger\end{array}$ & $\begin{array}{r}(1.53) \\
(2.39) \\
(2.76) \\
(2.11) \\
(1.74) \\
1.92 \\
(\dagger)\end{array}$ & $\begin{array}{l}18.1 \\
22.4 \\
23.5 \\
15.8 \\
12.2 ! \\
13.6 ! \\
\ddagger\end{array}$ & $\begin{array}{r}(2.01) \\
1.83) \\
(2.24) \\
(3.11) \\
(4.44) \\
4.86 \\
(\dagger)\end{array}$ & $\begin{array}{l}8.3 \\
7.6 \\
7.7 \\
6.8 ! \\
9.4 \\
8.9 \\
\ddagger\end{array}$ & $\left.\begin{array}{r}(1.01) \\
1.24) \\
(1.27) \\
(2.66) \\
(1.88) \\
1.88 \\
(\dagger)\end{array}\right)$ & $\begin{array}{l}32.3 \\
32.1 \\
30.6 \\
40.4 \\
32.7 \\
33.3 \\
28.7\end{array}$ & $\begin{array}{l}(1.80) \\
1.96) \\
(2.16) \\
(5.65) \\
(3.39) \\
3.97 \\
(5.35)\end{array}$ & $\begin{array}{l}30.5 \\
30.8 \\
29.6 \\
38.4 \\
29.9 \\
30.8 \\
24.6\end{array}$ & $\begin{array}{l}(1.84) \\
1.99) \\
(2.16) \\
(5.72) \\
(3.42) \\
(4.04) \\
(5.32)\end{array}$ & $\begin{array}{l}5.0 \\
4.0 \\
3.3 \\
8.3 ! \\
6.4 \\
6.7 \\
\quad \ddagger\end{array}$ & $\begin{array}{r}(0.89) \\
(0.87) \\
0.84) \\
(3.50) \\
1.50 \\
1.66) \\
(\dagger)\end{array}$ \\
\hline 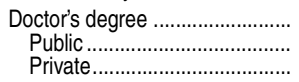 & $\begin{array}{r}120 \\
74 \\
46\end{array}$ & $\begin{array}{l}(-) \\
(-)\end{array}$ & $\begin{array}{l}69.9 \\
70.1 \\
69.6\end{array}$ & $\begin{array}{l}(2.32) \\
(2.99) \\
(3.27)\end{array}$ & $\begin{array}{l}{[6]} \\
66 \\
{[6]}\end{array}$ & $\left(\begin{array}{c}(t) \\
(t \\
+\end{array}\right)$ & $\begin{array}{l}19.4 \\
23.1 \\
13.6\end{array}$ & $\begin{array}{l}(1.91) \\
(2.78) \\
(2.50)\end{array}$ & $\begin{array}{l}27.0 \\
31.6 \\
19.9\end{array}$ & $\begin{array}{l}(2.36) \\
(2.31) \\
(3.74)\end{array}$ & $\begin{array}{r}3.0 \\
3.9 \\
\ddagger\end{array}$ & $\begin{array}{r}(0.79) \\
1.00) \\
(\dagger)\end{array}$ & $\begin{array}{l}25.8 \\
20.6 \\
34.1\end{array}$ & $\left.\begin{array}{l}(2.33) \\
(2.04) \\
4.20\end{array}\right)$ & $\begin{array}{l}23.9 \\
18.9 \\
31.9\end{array}$ & $\begin{array}{l}(2.16) \\
(2.07) \\
(3.67)\end{array}$ & $\begin{array}{l}3.5 \\
2.9 \\
4.3\end{array}$ & $\begin{array}{l}(0.71) \\
(0.85) \\
1.16)\end{array}$ \\
\hline 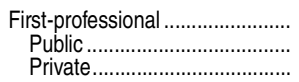 & $\begin{array}{l}211 \\
101 \\
110\end{array}$ & $\begin{array}{l}(-) \\
(-)\end{array}$ & $\begin{array}{l}77.4 \\
79.6 \\
75.5\end{array}$ & $\left.\begin{array}{l}(0.96) \\
1.02 \\
(1.65)\end{array}\right)$ & $\begin{array}{l}{[6]} \\
6] \\
66\end{array}$ & $\begin{array}{c}(t) \\
(t) \\
(t)\end{array}$ & $\begin{array}{l}5.6 \\
5.4 \\
5.8\end{array}$ & $\begin{array}{l}(0.98) \\
1.11) \\
(1.40)\end{array}$ & $\begin{array}{l}4.4 \\
4.2 \\
4.5\end{array}$ & $\begin{array}{l}(0.69) \\
0.53) \\
(1.24)\end{array}$ & $\begin{array}{l}2.3 \\
2.3 \\
2.3 !\end{array}$ & $\begin{array}{l}(0.52) \\
0.59) \\
(0.70)\end{array}$ & $\begin{array}{l}67.8 \\
71.8 \\
64.1\end{array}$ & $\left.\begin{array}{l}(1.49) \\
1.31 \\
(2.32)\end{array}\right)$ & $\begin{array}{l}65.5 \\
69.8 \\
61.6\end{array}$ & $\begin{array}{l}(1.47) \\
(1.20) \\
(2.34)\end{array}$ & $\begin{array}{l}19.3 \\
23.2 \\
15.7\end{array}$ & $\begin{array}{l}(1.65) \\
(2.25) \\
(1.92)\end{array}$ \\
\hline 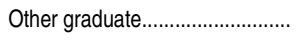 & 61 & $(-)$ & 61.8 & $(6.81)$ & {$[6]$} & $(\dagger)$ & 7.5 & $(1.64)$ & 6.1 & $(1.61)$ & $6.0 !$ & $(2.97)$ & 43.5 & $(4.26)$ & 39.5 & $(4.04)$ & $2.7 !$ & $(0.88)$ \\
\hline 1999-2000, all institutions. & 878 & $(-)$ & 81.7 & $(0.66)$ & 20.5 & $(0.97)$ & 11.9 & $(0.48)$ & 24.0 & $(0.93)$ & 6.0 & $(0.57)$ & 52.3 & $(0.76)$ & 50.5 & $(0.80)$ & 8.3 & $(0.63)$ \\
\hline 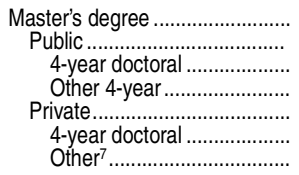 & $\begin{array}{r}409 \\
224 \\
181 \\
37 \\
185 \\
126 \\
59\end{array}$ & $\begin{array}{l}(Z) \\
(Z) \\
(Z) \\
(-)\end{array}$ & $\begin{array}{l}79.3 \\
77.9 \\
80.0 \\
70.1 \\
81.1 \\
82.8 \\
77.5\end{array}$ & $\begin{array}{l}(1.15) \\
1.52) \\
1.46) \\
(5.08) \\
1.63) \\
(1.94) \\
(2.74)\end{array}$ & $\begin{array}{l}16.8 \\
15.7 \\
16.6 \\
11.2 \\
18.1 \\
23.8 \\
6.2 !\end{array}$ & $\begin{array}{l}(1.09) \\
1.43 \\
1.61) \\
(3.31) \\
1.76) \\
(2.30) \\
(2.10)\end{array}$ & $\begin{array}{l}11.4 \\
18.2 \\
19.4 \\
14.6 ! \\
3.2 \\
4.0 \\
1.4 !\end{array}$ & $\begin{array}{l}(0.86) \\
1.46) \\
1.59) \\
(4.91) \\
0.74) \\
1.04 \\
0.52)\end{array}$ & $\begin{array}{l}21.9 \\
30.5 \\
34.0 \\
14.1 ! \\
11.5 \\
13.8 \\
\ddagger\end{array}$ & $\begin{array}{r}(1.42) \\
1.97) \\
(2.15) \\
4.31) \\
(1.65) \\
1.69) \\
(\dagger)\end{array}$ & $\begin{array}{c}9.1 \\
6.9 \\
7.3 \\
5.1 ! \\
11.7 \\
8.3 \\
18.9\end{array}$ & 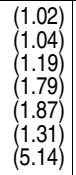 & $\begin{array}{l}50.3 \\
43.3 \\
41.5 \\
54.4 \\
58.8 \\
60.7 \\
54.7\end{array}$ & $\begin{array}{l}(1.25) \\
1.85) \\
(1.74) \\
6.55) \\
(1.78) \\
(2.13) \\
(4.38)\end{array}$ & $\begin{array}{l}48.6 \\
42.1 \\
40.9 \\
53.1 \\
56.5 \\
57.3 \\
54.7\end{array}$ & $\begin{array}{l}(1.33) \\
(1.93) \\
(1.72) \\
(6.84) \\
(2.05) \\
(2.59) \\
(4.38)\end{array}$ & $\begin{array}{c}5.8 \\
2.8 \\
3.0 \\
\ddagger \\
9.4 \\
11.9 \\
4.3 !\end{array}$ & $\begin{array}{r}(0.54) \\
0.57) \\
(0.67) \\
(\dagger) \\
(1.17) \\
1.62) \\
(1.51)\end{array}$ \\
\hline 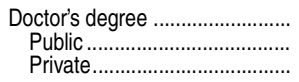 & $\begin{array}{r}184 \\
113 \\
71\end{array}$ & $(-)$ & $\begin{array}{l}87.9 \\
88.6 \\
87.0\end{array}$ & $\left.\begin{array}{l}(1.38) \\
(1.38) \\
(2.79\end{array}\right)$ & $\begin{array}{l}37.6 \\
30.0 \\
49.7\end{array}$ & $\begin{array}{l}(1.43) \\
(1.28) \\
(3.30)\end{array}$ & $\begin{array}{r}23.3 \\
34.9 \\
5.1\end{array}$ & $\begin{array}{l}(1.40) \\
(1.66) \\
(1.10)\end{array}$ & $\begin{array}{l}54.8 \\
62.8 \\
42.0\end{array}$ & $\begin{array}{l}(3.12) \\
1.80) \\
(6.83)\end{array}$ & $\begin{array}{l}5.4 \\
7.3 \\
2.3\end{array}$ & $\begin{array}{l}(0.63) \\
0.88) \\
(0.55)\end{array}$ & $\begin{array}{l}28.9 \\
25.8 \\
33.8\end{array}$ & $\begin{array}{l}(2.89) \\
1.96) \\
(6.35)\end{array}$ & $\begin{array}{l}27.3 \\
24.0 \\
32.5\end{array}$ & $\begin{array}{l}(2.83) \\
1.89) \\
(6.30)\end{array}$ & $\underset{1.0 !}{\ddagger}$ & $\begin{array}{r}(t) \\
(0.37) \\
(\dagger)\end{array}$ \\
\hline 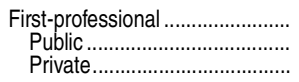 & $\begin{array}{l}223 \\
101 \\
122\end{array}$ & $(-)$ & $\begin{array}{l}86.6 \\
86.3 \\
86.9\end{array}$ & $\left(\begin{array}{l}1.17) \\
1.82 \\
1.49\end{array}\right)$ & $\begin{array}{l}17.2 \\
12.2 \\
21.3\end{array}$ & $\left.\begin{array}{l}(2.24) \\
1.72 \\
(3.76)\end{array}\right)$ & $\begin{array}{l}4.3 \\
7.5 \\
1.6 !\end{array}$ & $\begin{array}{l}(0.79) \\
1.52 \\
(0.60)\end{array}$ & $\begin{array}{l}7.1 \\
7.0 \\
7.3\end{array}$ & $\begin{array}{l}(1.06) \\
1.51) \\
(1.63)\end{array}$ & $\begin{array}{l}1.7 ! \\
1.7 ! \\
1.7 !\end{array}$ & $\begin{array}{l}(0.53) \\
(0.87) \\
(0.65)\end{array}$ & $\begin{array}{l}77.9 \\
78.6 \\
77.4\end{array}$ & $\begin{array}{l}(1.34) \\
(2.16) \\
(1.83)\end{array}$ & $\begin{array}{l}75.6 \\
77.1 \\
74.3\end{array}$ & $\begin{array}{l}(1.37) \\
(2.15) \\
(1.95)\end{array}$ & $\begin{array}{l}17.4 \\
18.6 \\
16.4\end{array}$ & $\begin{array}{l}(1.84) \\
(2.22) \\
(2.86)\end{array}$ \\
\hline 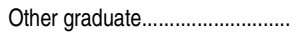 & 62 & $(-)$ & 61.1 & $(3.64)$ & 5.5 & $(1.55)$ & 8.5 & $(1.91)$ & 7.0 & $(1.92)$ & $2.8 !$ & $(1.19)$ & 42.7 & $(3.75)$ & 42.1 & $(3.71)$ & $3.8 !$ & $(1.51)$ \\
\hline $2007-08$, all institutions .... & 1,143 & $(-)$ & 86.9 & $(0.80)$ & 23.5 & $(0.87)$ & 12.3 & $(0.61)$ & 25.2 & $(0.87)$ & 11.6 & $(0.92)$ & 58.3 & $(1.20)$ & 55.1 & $(1.17)$ & 6.1 & $(0.38)$ \\
\hline 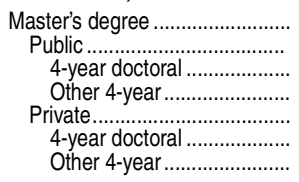 & $\begin{array}{r}594 \\
243 \\
215 \\
28 \\
351 \\
198 \\
153\end{array}$ & $\begin{array}{l}(-) \\
(-) \\
(-) \\
(-)\end{array}$ & $\begin{array}{l}84.4 \\
86.7 \\
88.0 \\
77.3 \\
82.8 \\
80.9 \\
85.1\end{array}$ & $\begin{array}{l}(1.33) \\
1.27) \\
(1.33) \\
(3.92) \\
1.96) \\
(1.46) \\
(3.91)\end{array}$ & $\begin{array}{r}17.7 \\
19.9 \\
21.8 \\
5.2 ! \\
16.2 \\
25.5 \\
4.1\end{array}$ & $\begin{array}{l}(1.03) \\
(1.82) \\
(2.01) \\
(2.19) \\
1.32 \\
(2.18) \\
(0.85)\end{array}$ & $\begin{array}{l}10.8 \\
21.3 \\
23.4 \\
6.0 ! \\
3.5 \\
3.8 \\
3.2 !\end{array}$ & $\begin{array}{l}(0.89) \\
(1.96) \\
(2.15) \\
(2.38) \\
0.61) \\
0.63) \\
(1.14)\end{array}$ & $\begin{array}{r}19.4 \\
35.7 \\
37.8 \\
19.8 \\
8.2 \\
12.9 \\
2.0\end{array}$ & $\begin{array}{l}(1.01) \\
(1.77) \\
1.97) \\
(4.57) \\
0.74) \\
(1.17) \\
(0.51)\end{array}$ & $\begin{array}{c}16.3 \\
13.5 \\
14.6 \\
5.1 ! \\
18.3 \\
14.4 \\
23.3\end{array}$ & $\begin{array}{l}(1.75) \\
(1.50) \\
(1.68) \\
1.92 \\
(2.78) \\
(1.17) \\
(6.22)\end{array}$ & $\begin{array}{l}59.4 \\
53.1 \\
52.1 \\
61.1 \\
63.7 \\
58.1 \\
71.0\end{array}$ & $\begin{array}{l}(2.02) \\
(1.85) \\
(2.00) \\
5.94) \\
(2.88) \\
(1.51) \\
6.08)\end{array}$ & $\begin{array}{l}54.8 \\
49.9 \\
49.2 \\
55.6 \\
58.2 \\
54.1 \\
63.4\end{array}$ & $\begin{array}{l}(1.92) \\
1.86) \\
(2.02) \\
(5.96) \\
(2.79) \\
(1.50) \\
(5.95)\end{array}$ & $\begin{array}{l}4.4 \\
4.7 \\
4.5 \\
6.2 ! \\
4.2 \\
7.1 \\
\ddagger\end{array}$ & $\begin{array}{r}(0.50) \\
0.96) \\
(1.00) \\
2.87 \\
0.54) \\
(0.95) \\
(\dagger)\end{array}$ \\
\hline 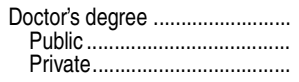 & $\begin{array}{l}280 \\
144 \\
136\end{array}$ & $(-)$ & $\begin{array}{l}92.9 \\
92.1 \\
93.8\end{array}$ & $\begin{array}{l}(0.87) \\
(1.48) \\
(1.08)\end{array}$ & $\begin{array}{l}35.1 \\
30.7 \\
39.8\end{array}$ & $\begin{array}{l}(1.90) \\
(2.39) \\
(3.41)\end{array}$ & $\begin{array}{l}25.5 \\
39.4 \\
10.8\end{array}$ & $\begin{array}{l}(1.69) \\
(2.32) \\
(1.90)\end{array}$ & $\begin{array}{l}53.1 \\
66.5 \\
39.1\end{array}$ & $\begin{array}{l}(2.55) \\
(2.70) \\
(3.41)\end{array}$ & $\begin{array}{l}7.9 \\
7.9 \\
8.0\end{array}$ & $\left.\begin{array}{l}(0.80) \\
0.94 \\
(1.35)\end{array}\right)$ & $\begin{array}{l}37.3 \\
29.0 \\
46.1\end{array}$ & $\left.\begin{array}{l}(2.31) \\
1.70 \\
(3.84)\end{array}\right)$ & $\begin{array}{l}35.4 \\
27.7 \\
43.5\end{array}$ & $\left.\begin{array}{l}(2.23) \\
1.70 \\
(3.73\end{array}\right)$ & $\begin{array}{l}2.6 \\
2.5 \\
2.8\end{array}$ & $\left.\begin{array}{l}(0.46) \\
0.60 \\
0.69\end{array}\right)$ \\
\hline 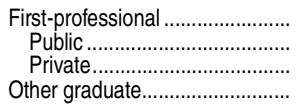 & $\begin{array}{r}236 \\
105 \\
131 \\
33 \\
\end{array}$ & $\begin{array}{l}(-) \\
(-) \\
(-)\end{array}$ & $\begin{array}{l}88.4 \\
88.3 \\
88.5 \\
69.2 \\
\end{array}$ & $\begin{array}{l}(1.15) \\
(1.69) \\
(1.46) \\
(6.54)\end{array}$ & $\begin{array}{l}26.1 \\
22.0 \\
29.4 \\
10.4 !\end{array}$ & $\begin{array}{l}(1.78) \\
(2.15) \\
(2.56) \\
(3.70)\end{array}$ & $\begin{array}{l}1.7 \\
3.2 \\
0.5 ! \\
3.2 !\end{array}$ & $\begin{array}{l}(0.41) \\
(0.89) \\
(0.18) \\
(1.26)\end{array}$ & $\begin{array}{c}7.9 \\
9.4 \\
6.7 \\
16.0 ! \\
\end{array}$ & $\begin{array}{l}(0.78) \\
(1.38) \\
0.92) \\
(5.07)\end{array}$ & $\begin{array}{l}4.6 \\
4.9 \\
4.4 \\
6.2 !\end{array}$ & $\begin{array}{l}(0.75) \\
(1.43) \\
(0.71) \\
(2.33)\end{array}$ & $\begin{array}{l}81.7 \\
81.4 \\
82.0 \\
49.3\end{array}$ & $\begin{array}{l}(1.40) \\
(2.25) \\
(1.62) \\
(6.72)\end{array}$ & $\begin{array}{l}80.3 \\
80.4 \\
80.2 \\
47.4 \\
\end{array}$ & $\begin{array}{l}(1.43) \\
(2.25) \\
(1.70) \\
(6.58)\end{array}$ & $\begin{array}{c}14.5 \\
14.5 \\
14.5 \\
4.7 !\end{array}$ & $\begin{array}{l}(1.26) \\
(2.03) \\
(1.66) \\
(2.12) \\
\end{array}$ \\
\hline 2011-12, all institutions .... & 1,391 & $(-)$ & 86.1 & $(0.77)$ & 26.3 & $(1.06)$ & 10.0 & $(0.60)$ & 20.7 & $(0.79)$ & 10.2 & $(0.48)$ & 61.6 & $(0.90)$ & 60.0 & $(0.91)$ & 3.9 & $(0.39)$ \\
\hline 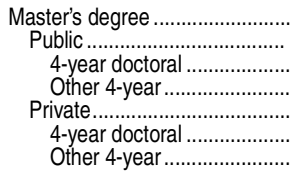 & $\begin{array}{r}777 \\
329 \\
297 \\
32 \\
448 \\
269 \\
180\end{array}$ & $\begin{array}{l}(-) \\
(-) \\
(-) \\
(-)\end{array}$ & $\begin{array}{l}82.6 \\
83.8 \\
83.7 \\
84.6 \\
81.8 \\
80.4 \\
83.9\end{array}$ & $\begin{array}{l}(1.28) \\
1.84) \\
(2.03) \\
(4.13) \\
(1.80) \\
(2.06) \\
(3.09)\end{array}$ & $\begin{array}{l}21.5 \\
24.0 \\
25.5 \\
10.1 \\
19.6 \\
25.3 \\
11.0\end{array}$ & $\begin{array}{l}(1.36) \\
(2.28) \\
(2.49) \\
(2.79) \\
1.76) \\
(2.64) \\
(2.25)\end{array}$ & $\begin{array}{r}7.4 \\
12.1 \\
12.5 \\
7.5 \\
4.0 \\
5.2 \\
2.1 !\end{array}$ & $\begin{array}{l}(0.73) \\
(1.40) \\
(1.57) \\
(2.05) \\
0.71) \\
(1.04) \\
(0.76)\end{array}$ & $\begin{array}{r}15.9 \\
24.6 \\
25.0 \\
21.1 \\
9.6 \\
13.1 \\
4.3 !\end{array}$ & $\begin{array}{l}(1.13) \\
(1.98) \\
(2.17) \\
(2.80) \\
1.33) \\
(1.69) \\
(1.88)\end{array}$ & $\begin{array}{r}8.8 \\
10.3 \\
10.8 \\
5.9 \\
7.8 \\
7.8 \\
7.6\end{array}$ & $\begin{array}{l}(0.70) \\
(1.17) \\
(1.28) \\
1.68) \\
(0.88) \\
(1.23) \\
(1.04)\end{array}$ & $\begin{array}{l}62.6 \\
57.5 \\
56.2 \\
69.5 \\
66.4 \\
61.0 \\
74.5\end{array}$ & $\begin{array}{l}(1.43) \\
(2.27) \\
(2.43) \\
5.14) \\
(1.99) \\
(2.15) \\
(3.59)\end{array}$ & $\begin{array}{l}60.8 \\
56.2 \\
54.8 \\
69.0 \\
64.3 \\
57.9 \\
73.8\end{array}$ & $\begin{array}{l}(1.40) \\
(2.31) \\
(2.48) \\
5.14) \\
(2.00) \\
(2.35) \\
(3.45)\end{array}$ & $\begin{array}{l}3.1 \\
3.8 \\
4.0 \\
1.5 ! \\
2.7 \\
4.3 \\
\ddagger\end{array}$ & $\begin{array}{r}(0.47) \\
0.83) \\
(0.91) \\
0.65) \\
0.47) \\
0.76) \\
(\mathrm{t})\end{array}$ \\
\hline 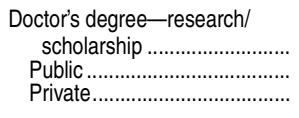 & $\begin{array}{l}235 \\
133 \\
102\end{array}$ & $(Z)$ & $\begin{array}{l}93.4 \\
94.1 \\
92.5\end{array}$ & $\begin{array}{l}(0.73) \\
1.04) \\
(1.07)\end{array}$ & $\begin{array}{l}42.6 \\
39.8 \\
46.3\end{array}$ & $\begin{array}{l}(1.58) \\
(2.10) \\
(2.46)\end{array}$ & $\begin{array}{l}28.1 \\
33.3 \\
21.3\end{array}$ & $\begin{array}{l}(1.56) \\
(2.32) \\
(2.16)\end{array}$ & $\begin{array}{l}62.2 \\
72.7 \\
48.5\end{array}$ & $\begin{array}{l}(1.29) \\
(1.65) \\
1.96)\end{array}$ & $\begin{array}{l}24.0 \\
27.0 \\
20.1\end{array}$ & $\begin{array}{l}(1.25) \\
(1.93) \\
(1.06)\end{array}$ & $\begin{array}{l}25.4 \\
22.2 \\
29.5\end{array}$ & $\begin{array}{l}(1.20) \\
(1.49) \\
(2.23)\end{array}$ & $\begin{array}{l}23.9 \\
20.9 \\
27.8\end{array}$ & $\left(\begin{array}{l}1.13 \\
1.46 \\
2.06\end{array}\right)$ & $\begin{array}{l}1.2 ! \\
1.1 ! \\
1.3 !\end{array}$ & $\left.\begin{array}{l}0.38 \\
0.46 \\
0.58\end{array}\right)$ \\
\hline 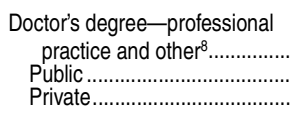 & $\begin{array}{l}342 \\
135 \\
207\end{array}$ & $\begin{array}{l}(-) \\
(-)\end{array}$ & $\begin{array}{l}90.7 \\
91.1 \\
90.4\end{array}$ & $\begin{array}{l}(0.88) \\
1.09) \\
(1.22)\end{array}$ & $\begin{array}{l}28.5 \\
32.3 \\
25.9\end{array}$ & $\begin{array}{l}(1.55) \\
(2.24) \\
(2.11)\end{array}$ & $\begin{array}{l}4.7 \\
7.5 \\
2.8\end{array}$ & $\begin{array}{l}(0.70) \\
(1.38) \\
(0.73)\end{array}$ & $\begin{array}{l}4.0 \\
5.5 \\
3.0\end{array}$ & $\begin{array}{l}(0.48) \\
(0.92) \\
0.53)\end{array}$ & $\begin{array}{l}4.4 \\
5.4 \\
3.7\end{array}$ & $\begin{array}{l}(0.51) \\
(0.82) \\
(0.62)\end{array}$ & $\begin{array}{l}84.2 \\
83.9 \\
84.4\end{array}$ & $\left(\begin{array}{l}1.05 \\
1.23 \\
1.51\end{array}\right)$ & $\begin{array}{l}82.9 \\
83.3 \\
82.7\end{array}$ & $\left(\begin{array}{l}1.00 \\
1.25 \\
1.45\end{array}\right)$ & $\begin{array}{l}7.6 \\
7.5 \\
7.7\end{array}$ & $\begin{array}{l}(1.10) \\
(1.17) \\
(1.64)\end{array}$ \\
\hline 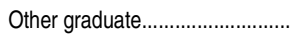 & 37 & $(-)$ & 70.9 & $(6.46)$ & $6.6 !$ & $(2.45)$ & $\ddagger$ & $(t)$ & $10.7 !$ & $(3.85)$ & $5.5 !$ & $(2.47)$ & 61.7 & $(7.20)$ & 58.9 & $(7.45)$ & $2.3 !$ & (1.10) \\
\hline
\end{tabular}

-Not available.

INot applicable. !nterpret data

and 50 percent. coefficient of variation (CV) is 50 percent or greater.

${ }^{1}$ Numbers of full-time, full-year postbaccalaureate students may not equal figures reported in other tables, since these data are based on a sample survey of all postbaccalaureate students who enrolled at any time during the school year.

Includes students who reported they were awarded aid, but did not specify the source of aid. ${ }^{3}$ Includes students who received teaching or research assistantships and/or participated in work-study programs.

${ }^{4}$ Formerly Guaranteed Student Loans (GSL).

${ }^{5}$ Formerly National Direct Student Loans (NDSL). Includes subsidized amounts only.
${ }^{6}$ Fellowship estimates for 1992-93 were based primarily on information provided by institutions and are not comparable to data for 1999-2000 and later years, which were based on information provided by both students and institutions.

IIncludes nonprofit 4-year nondoctoral institutions and for-profit 2-year-and-above institutions. ${ }^{8}$ Professional practice doctor's degrees include most degrees formerly classified as first-professional (such as M.D., D.D.S., and J.D). "Other" doctor's degrees are those that are neither research/scholarship degrees nor professional practice degrees.

NOTE: Excludes students whose attendance status was not reported. Total includes some students whose level of study or control of institution was unknown. Detail may not sum to totals because of rounding and because some students receive aid from multiple sources. Data for 2007-08 and prior years include Puerto Rico, which is excluded from the 2011-12 data.

SOURCE: U.S. Department of Education, National Center for Education Statistics, 1992-93, 1999-2000, 2007-08, and 2011-12 National Postsecondary Student Aid Study (NPSAS:93, NPSAS:2000, NPSAS:08, and NPSAS:12). (This table was prepared March 2014.) 
Table 332.40. Percentage of part-time or part-year postbaccalaureate students receiving financial aid, by type of aid, level of study, and control and level of institution: Selected years, 1992-93 through 2011-12

[Standard errors appear in parentheses]

\begin{tabular}{|c|c|c|c|c|c|c|c|c|c|c|c|c|c|c|c|c|c|c|}
\hline \multirow{3}{*}{$\begin{array}{l}\text { Level of study, control and level } \\
\text { of institution }\end{array}$} & \multirow{3}{*}{\multicolumn{2}{|c|}{$\begin{array}{r}\text { Number of } \\
\text { students } \\
\text { (in thousands) }\end{array}$}} & \multicolumn{16}{|c|}{ Percent receiving aid } \\
\hline & & & \multirow{2}{*}{\multicolumn{2}{|c|}{ Any aid ${ }^{2}$}} & \multirow{2}{*}{\multicolumn{2}{|c|}{$\begin{array}{r}\text { Fellowship } \\
\text { grants }\end{array}$}} & \multirow{2}{*}{\multicolumn{2}{|c|}{ Tuition waivers }} & \multirow{2}{*}{\multicolumn{2}{|c|}{ Assistantships $^{3}$}} & \multirow{2}{*}{\multicolumn{2}{|c|}{$\begin{array}{r}\text { Employer } \\
\text { (includes } \\
\text { college staff) }\end{array}$}} & \multicolumn{6}{|c|}{ Loans } \\
\hline & & & & & & & & & & & & & \multicolumn{2}{|c|}{ Any loans } & \multicolumn{2}{|r|}{ Stafford 4} & \multicolumn{2}{|r|}{ Perkins $^{5}$} \\
\hline 1 & & 2 & & 3 & & 4 & & 5 & & 6 & & 7 & & 8 & & 9 & & 10 \\
\hline 1992-93, all institutions .... & 1,980 & $(-)$ & 36.8 & $(0.81)$ & {$\left[{ }^{6}\right]$} & $(t)$ & 5.0 & $(0.38)$ & 4.3 & $(0.28)$ & 16.7 & $(0.70)$ & 10.5 & $(0.52)$ & 9.4 & $(0.48)$ & 1.0 & $(0.13)$ \\
\hline 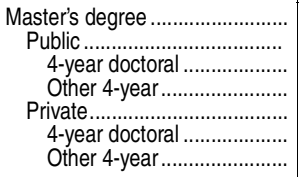 & $\begin{array}{r}1,322 \\
773 \\
489 \\
284 \\
549 \\
357 \\
192\end{array}$ & $\begin{array}{l}(-) \\
(-) \\
(-) \\
(-)\end{array}$ & $\begin{array}{l}37.5 \\
33.6 \\
37.8 \\
26.3 \\
43.0 \\
44.8 \\
39.6\end{array}$ & $\begin{array}{l}(0.85) \\
1.00) \\
(1.25) \\
1.39) \\
(1.55) \\
1.91) \\
(2.82)\end{array}$ & $\begin{array}{l}{[6]} \\
66] \\
{[6]} \\
66] \\
{[6]} \\
66] \\
{[6]}\end{array}$ & $\begin{array}{l}(\dagger) \\
+ \\
(t) \\
(t) \\
(\dagger) \\
(\dagger) \\
(\dagger)\end{array}$ & $\begin{array}{l}4.6 \\
4.9 \\
6.5 \\
2.2 \\
4.2 \\
4.4 \\
3.8\end{array}$ & $\begin{array}{l}(0.48) \\
(0.49) \\
(0.66) \\
0.59) \\
(0.68) \\
0.89) \\
(1.10)\end{array}$ & $\begin{array}{l}3.8 \\
5.2 \\
6.7 \\
2.6 \\
1.8 ! \\
2.5 ! \\
0.7 !\end{array}$ & $\begin{array}{l}(0.37) \\
0.46) \\
(0.70) \\
0.62) \\
(0.60) \\
0.81) \\
(0.30)\end{array}$ & $\begin{array}{l}18.6 \\
14.6 \\
14.6 \\
14.4 \\
24.4 \\
25.1 \\
23.1\end{array}$ & $\begin{array}{l}(0.90) \\
(0.82) \\
(1.05) \\
1.09) \\
(1.45) \\
1.71) \\
(2.31)\end{array}$ & $\begin{array}{r}10.3 \\
9.9 \\
11.8 \\
6.5 \\
11.0 \\
11.9 \\
9.3\end{array}$ & $\begin{array}{l}(0.62) \\
0.65) \\
(0.90) \\
0.76) \\
(1.02) \\
1.16) \\
(1.57)\end{array}$ & $\begin{array}{r}9.3 \\
9.0 \\
10.7 \\
6.0 \\
9.7 \\
10.5 \\
8.1\end{array}$ & $\begin{array}{l}(0.53) \\
0.55) \\
(0.74) \\
0.76) \\
0.88) \\
(0.99) \\
(1.31)\end{array}$ & $\begin{array}{l}0.9 \\
1.2 \\
1.5 \\
0.6 ! \\
0.5 ! \\
0.6 ! \\
\ddagger\end{array}$ & $\begin{array}{r}(0.15) \\
(0.23) \\
0.33 \\
(0.21) \\
0.18 \\
0.26 \\
(\dagger)\end{array}$ \\
\hline 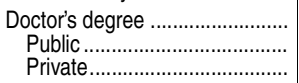 & $\begin{array}{r}149 \\
97 \\
51\end{array}$ & $\begin{array}{l}(-) \\
(-)\end{array}$ & $\begin{array}{l}48.5 \\
48.6 \\
48.2\end{array}$ & $\begin{array}{l}(2.56) \\
3.10) \\
(5.53)\end{array}$ & {$\left[\begin{array}{l}6 \\
6 \\
6 \\
66\end{array}\right]$} & $\left(\begin{array}{l}+ \\
+ \\
(\dagger\end{array}\right)$ & $\begin{array}{r}12.7 \\
15.0 \\
8.3\end{array}$ & $\begin{array}{l}(2.19) \\
(2.91) \\
(2.05)\end{array}$ & $\begin{array}{l}17.0 \\
17.0 \\
17.0\end{array}$ & $\begin{array}{l}(1.78) \\
(2.16) \\
(4.31)\end{array}$ & $\begin{array}{l}12.0 \\
12.9 \\
10.2\end{array}$ & $\begin{array}{l}(1.49) \\
1.89 \\
(2.47)\end{array}$ & $\begin{array}{l}7.3 \\
7.0 \\
7.6 !\end{array}$ & $\begin{array}{l}(1.16) \\
(1.19) \\
2.76)\end{array}$ & $\begin{array}{l}6.9 \\
6.5 \\
7.5 !\end{array}$ & $\begin{array}{l}(1.19) \\
(1.20) \\
2.79)\end{array}$ & $\begin{array}{c}0.8 ! \\
\ddagger \\
\ddagger\end{array}$ & $\begin{array}{r}(0.35) \\
(\dagger) \\
(\dagger)\end{array}$ \\
\hline 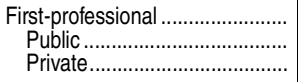 & $\begin{array}{l}64 \\
24 \\
40\end{array}$ & $\left(\begin{array}{l}(-) \\
(-)\end{array}\right.$ & $\begin{array}{l}58.6 \\
51.7 \\
62.6\end{array}$ & $\begin{array}{l}(3.04) \\
4.43) \\
(3.43)\end{array}$ & {$\left[\begin{array}{l}6 \\
66 \\
66 \\
66\end{array}\right]$} & $\begin{array}{l}(t) \\
(\dagger) \\
(\dagger)\end{array}$ & $\begin{array}{l}5.9 \\
6.8 \\
5.4 !\end{array}$ & $\left.\begin{array}{l}(1.41) \\
1.65) \\
(1.77)\end{array}\right)$ & $\begin{array}{l}3.1 \\
6.1 ! \\
1.4 !\end{array}$ & $\begin{array}{l}(0.92) \\
(2.23) \\
(0.50)\end{array}$ & $\begin{array}{l}6.1 \\
5.0 ! \\
6.7\end{array}$ & $\begin{array}{l}(1.34) \\
1.61) \\
(1.81)\end{array}$ & $\begin{array}{l}45.6 \\
42.4 \\
47.5\end{array}$ & $\begin{array}{l}(3.35) \\
(3.99) \\
(4.28)\end{array}$ & $\begin{array}{l}42.0 \\
41.4 \\
42.3\end{array}$ & $\begin{array}{l}(3.20) \\
(3.86) \\
(3.94)\end{array}$ & $\begin{array}{l}6.2 \\
8.5 \\
4.9\end{array}$ & $\begin{array}{l}(0.84) \\
(1.77) \\
0.96)\end{array}$ \\
\hline 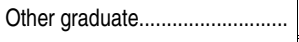 & 415 & $(-)$ & 27.0 & $(1.42)$ & {$\left[{ }^{6}\right]$} & $(\mathrm{t})$ & 3.4 & $(0.55)$ & 1.6 & $(0.32)$ & 13.4 & $(1.00)$ & 7.1 & $(0.68)$ & 6.0 & $(0.59)$ & $\ddagger$ & $(\mathrm{t})$ \\
\hline 1999-2000, all institutions. & 1,739 & $(-)$ & 48.7 & $(0.72)$ & 4.9 & $(0.27)$ & 5.8 & $(0.32)$ & 5.4 & $(0.34)$ & 20.1 & $(0.66)$ & 19.3 & $(0.51)$ & 18.2 & $(0.47)$ & 1.0 & $(0.13)$ \\
\hline 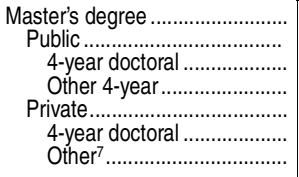 & $\begin{array}{r}1,140 \\
635 \\
438 \\
188 \\
505 \\
326 \\
178\end{array}$ & $\begin{array}{l}(\bar{Z}) \\
(-) \\
(-) \\
(-)\end{array}$ & $\begin{array}{l}51.2 \\
47.0 \\
50.3 \\
39.2 \\
56.5 \\
57.7 \\
54.1\end{array}$ & $\begin{array}{l}(0.84) \\
1.18 \\
1.55) \\
(1.96) \\
1.29) \\
(1.46) \\
(2.31)\end{array}$ & $\begin{array}{l}4.4 \\
3.8 \\
4.2 \\
3.2 ! \\
5.2 \\
6.4 \\
3.1 !\end{array}$ & $\begin{array}{l}(0.36) \\
0.51 \\
0.47) \\
(1.41) \\
0.54) \\
(0.68) \\
(0.92)\end{array}$ & $\begin{array}{l}5.0 \\
6.3 \\
7.4 \\
4.2 \\
3.3 \\
3.6 \\
2.5\end{array}$ & $\begin{array}{l}(0.32) \\
0.55) \\
0.71) \\
(0.93) \\
(0.41) \\
0.56 \\
(0.61)\end{array}$ & $\begin{array}{l}4.7 \\
6.2 \\
7.9 \\
2.3 \\
2.8 \\
3.3 \\
1.9 !\end{array}$ & $\begin{array}{l}(0.35) \\
0.56) \\
(0.78) \\
0.46) \\
(0.50) \\
0.51) \\
0.92)\end{array}$ & $\begin{array}{l}23.1 \\
20.6 \\
21.4 \\
18.5 \\
26.2 \\
25.3 \\
28.0\end{array}$ & $\begin{array}{l}(0.82) \\
1.32) \\
(1.61) \\
(2.28) \\
1.12 \\
1.22 \\
(2.13)\end{array}$ & $\begin{array}{l}20.6 \\
16.8 \\
17.8 \\
14.4 \\
25.3 \\
25.0 \\
25.7\end{array}$ & $\begin{array}{l}(0.69) \\
0.84) \\
(1.23) \\
1.47) \\
(1.06) \\
1.24) \\
(2.02)\end{array}$ & $\begin{array}{l}19.4 \\
15.7 \\
16.7 \\
13.6 \\
24.0 \\
23.8 \\
24.4\end{array}$ & $\begin{array}{l}(0.64) \\
0.78) \\
(1.17) \\
1.49) \\
(1.05) \\
1.25) \\
(2.06)\end{array}$ & $\begin{array}{l}0.8 \\
0.7 \\
0.5 ! \\
1.2 ! \\
0.9 ! \\
0.9 ! \\
\ddagger\end{array}$ & $\begin{array}{r}(0.14) \\
0.16) \\
(0.17) \\
0.41) \\
(0.30) \\
0.34) \\
(\dagger)\end{array}$ \\
\hline 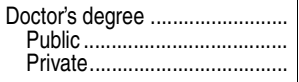 & $\begin{array}{r}161 \\
109 \\
52\end{array}$ & $\left(\begin{array}{l}(-) \\
(-)\end{array}\right.$ & $\begin{array}{l}54.5 \\
53.1 \\
57.6\end{array}$ & $\left.\begin{array}{l}(1.78) \\
(2.32 \\
(2.82)\end{array}\right)$ & $\begin{array}{r}10.7 \\
8.8 \\
14.7\end{array}$ & $\begin{array}{l}(0.93) \\
(0.84) \\
(2.43)\end{array}$ & $\begin{array}{r}14.8 \\
19.4 \\
5.3\end{array}$ & $\begin{array}{l}(1.22) \\
(1.34) \\
(1.55)\end{array}$ & $\begin{array}{l}20.7 \\
25.6 \\
10.5\end{array}$ & $\begin{array}{l}(1.57) \\
1.97) \\
(1.77)\end{array}$ & $\begin{array}{l}14.0 \\
12.1 \\
18.0\end{array}$ & $\begin{array}{l}(1.35) \\
1.45) \\
(3.10)\end{array}$ & $\begin{array}{l}14.8 \\
12.5 \\
19.6\end{array}$ & & $\begin{array}{l}14.2 \\
11.9 \\
19.0\end{array}$ & $\left.\begin{array}{l}(1.36) \\
1.12 \\
(3.22)\end{array}\right)$ & $\begin{array}{l}\ddagger \\
\ddagger \\
\ddagger\end{array}$ & $\begin{array}{l}(t) \\
(\dagger) \\
(\dagger)\end{array}$ \\
\hline 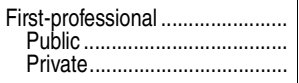 & $\begin{array}{l}73 \\
22 \\
51\end{array}$ & $(Z)$ & $\begin{array}{l}75.7 \\
72.3 \\
77.2\end{array}$ & $\left.\begin{array}{l}(3.13) \\
6.92 \\
3.05\end{array}\right)$ & $\begin{array}{l}10.0 \\
8.3 ! \\
10.8 !\end{array}$ & $\left.\begin{array}{l}(2.66) \\
3.63 \\
3.60\end{array}\right)$ & $\begin{array}{l}5.2 ! \\
\ddagger \\
5.9 !\end{array}$ & $\begin{array}{r}(1.58) \\
(\dagger \\
(2.11)\end{array}$ & $\begin{array}{c}\ddagger \\
\ddagger \\
2.7 !\end{array}$ & $\begin{array}{r}(t) \\
+ \\
(1.31)\end{array}$ & $\begin{array}{c}10.8 \\
7.9 ! \\
12.1\end{array}$ & $\begin{array}{l}(2.04) \\
(3.76) \\
(2.78)\end{array}$ & $\begin{array}{l}58.2 \\
57.3 \\
58.5\end{array}$ & $\begin{array}{l}(4.36) \\
8.38) \\
(5.31)\end{array}$ & $\begin{array}{l}54.9 \\
53.2 \\
55.7\end{array}$ & $\begin{array}{l}(4.99) \\
(7.99) \\
(6.49)\end{array}$ & $\begin{array}{l}6.7 ! \\
4.6 ! \\
7.6 !\end{array}$ & $\left.\begin{array}{l}(2.64) \\
(1.88) \\
3.65\end{array}\right)$ \\
\hline 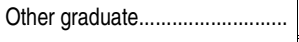 & 365 & $(-)$ & 32.9 & $(1.79)$ & 2.6 & $(0.44)$ & 4.4 & $(0.79)$ & 1.3 & $(0.33)$ & 15.2 & $(1.31)$ & 9.5 & $(1.09)$ & 8.9 & $(1.10)$ & $0.4 !$ & $(0.17)$ \\
\hline $2007-08$, all institutions .... & 2,349 & $(-)$ & 66.9 & $(0.84)$ & 6.6 & $(0.50)$ & 6.8 & $(0.33)$ & 9.7 & $(0.37)$ & 27.2 & $(0.93)$ & 34.6 & $(0.70)$ & 30.5 & $(0.64)$ & 0.9 & $(0.09)$ \\
\hline 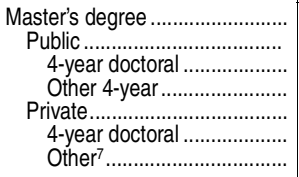 & $\begin{array}{r}1,656 \\
831 \\
633 \\
198 \\
825 \\
510 \\
315\end{array}$ & $\begin{array}{l}(-) \\
(-) \\
(-) \\
(-)\end{array}$ & $\begin{array}{l}69.1 \\
65.8 \\
67.8 \\
59.4 \\
72.4 \\
71.1 \\
74.7\end{array}$ & $\begin{array}{l}(1.09) \\
1.38) \\
(1.59) \\
(2.99) \\
1.58) \\
1.51) \\
(3.20)\end{array}$ & $\begin{array}{l}5.5 \\
4.6 \\
5.0 \\
3.0 ! \\
6.4 \\
8.0 \\
3.9\end{array}$ & $\begin{array}{l}(0.45) \\
0.53) \\
(0.64) \\
0.97 \\
0.73 \\
0.95 \\
(0.77)\end{array}$ & $\begin{array}{l}5.6 \\
7.2 \\
8.4 \\
3.6 ! \\
4.0 \\
3.8 \\
4.3\end{array}$ & $\begin{array}{l}(0.39) \\
(0.68) \\
0.80) \\
(1.18) \\
0.50) \\
0.52 \\
(0.97)\end{array}$ & $\begin{array}{r}7.5 \\
10.7 \\
12.2 \\
6.0 \\
4.3 \\
5.6 \\
2.3\end{array}$ & $\begin{array}{l}(0.39) \\
0.72) \\
0.94) \\
(1.17) \\
0.44) \\
0.59) \\
(0.56)\end{array}$ & $\begin{array}{l}29.8 \\
27.8 \\
29.3 \\
22.7 \\
31.8 \\
32.8 \\
30.1\end{array}$ & $\begin{array}{l}(1.22) \\
(1.42) \\
1.70) \\
(2.56) \\
1.85 \\
1.20) \\
(4.48)\end{array}$ & $\begin{array}{l}36.8 \\
32.7 \\
32.2 \\
34.5 \\
40.9 \\
36.6 \\
48.0\end{array}$ & $\begin{array}{l}(0.98) \\
(1.16) \\
1.35) \\
(2.98) \\
1.41) \\
(1.32) \\
(2.91)\end{array}$ & $\begin{array}{l}32.7 \\
27.8 \\
27.9 \\
27.2 \\
37.6 \\
32.8 \\
45.3\end{array}$ & $\begin{array}{l}(0.93) \\
(0.90) \\
1.16) \\
(2.63) \\
(1.40) \\
(1.23) \\
(2.88)\end{array}$ & $\begin{array}{l}0.9 \\
1.0 \\
0.9 \\
1.2 ! \\
0.8 \\
1.1 \\
0.2 !\end{array}$ & $\begin{array}{l}(0.12) \\
(0.16) \\
(0.18) \\
0.37) \\
0.18) \\
(0.29) \\
0.11)\end{array}$ \\
\hline 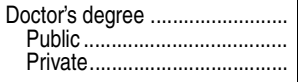 & $\begin{array}{l}272 \\
155 \\
117\end{array}$ & $(-)$ & $\begin{array}{l}79.8 \\
76.6 \\
84.1\end{array}$ & $\begin{array}{l}(1.91) \\
(1.55) \\
3.88)\end{array}$ & $\begin{array}{l}17.1 \\
16.8 \\
17.4\end{array}$ & $\begin{array}{l}(2.08) \\
(1.67) \\
(4.56)\end{array}$ & $\begin{array}{r}16.3 \\
24.2 \\
6.0 !\end{array}$ & $\begin{array}{l}(1.76) \\
(1.51) \\
(2.00)\end{array}$ & $\begin{array}{l}33.9 \\
47.1 \\
16.4\end{array}$ & $\begin{array}{l}(3.38) \\
(2.01) \\
4.25)\end{array}$ & $\begin{array}{l}19.2 \\
19.6 \\
18.6\end{array}$ & $\begin{array}{l}(1.71) \\
(1.42) \\
(4.05)\end{array}$ & $\begin{array}{l}33.3 \\
18.8 \\
52.6\end{array}$ & $\begin{array}{l}(4.77) \\
(1.25) \\
(8.57)\end{array}$ & $\begin{array}{l}30.4 \\
15.8 \\
49.8\end{array}$ & $\left.\begin{array}{l}(5.04) \\
1.15 \\
(9.24)\end{array}\right)$ & $\begin{array}{c}0.5 ! \\
\ddagger \\
\ddagger\end{array}$ & $\begin{array}{r}(0.25) \\
(\dagger) \\
(\dagger)\end{array}$ \\
\hline 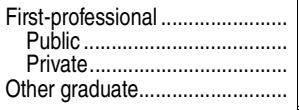 & $\begin{array}{r}59 \\
20 \\
38 \\
363 \\
\end{array}$ & $\begin{array}{l}(-) \\
(-) \\
(-) \\
\end{array}$ & $\begin{array}{l}85.8 \\
88.6 \\
84.3 \\
43.9 \\
\end{array}$ & $\begin{array}{l}(2.50) \\
(4.88) \\
(3.06) \\
(3.06) \\
\end{array}$ & $\begin{array}{r}20.2 \\
13.5 \\
23.8 \\
1.5 \\
\end{array}$ & $\begin{array}{l}(3.96) \\
(3.95) \\
(5.42) \\
(0.37) \\
\end{array}$ & $\begin{array}{r}6.4 ! \\
10.8 ! \\
\ddagger \\
4.8 \\
\end{array}$ & $\begin{array}{r}(2.49) \\
(4.22) \\
(\dagger) \\
(0.97) \\
\end{array}$ & $\begin{array}{r}10.2 \\
18.1 \\
5.9 \\
1.5 \\
\end{array}$ & $\begin{array}{l}(1.99) \\
(4.66) \\
1.68) \\
(0.41)\end{array}$ & $\begin{array}{l}16.3 \\
16.0 \\
16.5 \\
23.4 \\
\end{array}$ & $\begin{array}{l}(2.17) \\
(3.67) \\
(2.81) \\
(2.79)\end{array}$ & $\begin{array}{l}68.3 \\
67.1 \\
68.9 \\
20.0 \\
\end{array}$ & $\begin{array}{l}(3.91) \\
(5.83) \\
(5.37) \\
(2.10) \\
\end{array}$ & $\begin{array}{l}62.7 \\
61.5 \\
63.3 \\
15.5 \\
\end{array}$ & $\begin{array}{l}(4.59) \\
(7.03) \\
(6.07) \\
(1.58) \\
\end{array}$ & $\begin{array}{c}4.0 ! \\
7.8 ! \\
\ddagger \\
0.5 !\end{array}$ & $\begin{array}{r}(1.46) \\
(3.19) \\
(\dagger) \\
(0.25) \\
\end{array}$ \\
\hline 2011-12, all institutions .... & 2,291 & $(-)$ & 60.9 & $(0.99)$ & 8.6 & $(0.55)$ & 6.7 & $(0.56)$ & 6.4 & $(0.43)$ & 17.0 & $(0.88)$ & 35.0 & $(0.61)$ & 32.7 & $(0.60)$ & 0.8 & $(0.17)$ \\
\hline 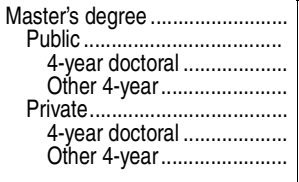 & $\begin{array}{r}1,715 \\
800 \\
664 \\
136 \\
914 \\
515 \\
399\end{array}$ & $\begin{array}{l}(-) \\
(-) \\
(-) \\
(-) \\
(-)\end{array}$ & $\begin{array}{l}62.5 \\
57.1 \\
58.5 \\
50.2 \\
67.3 \\
65.7 \\
69.4\end{array}$ & $\begin{array}{l}(1.29) \\
1.51) \\
(1.74) \\
(2.32) \\
(1.94) \\
(2.07) \\
(3.63)\end{array}$ & $\begin{array}{r}7.6 \\
7.2 \\
8.1 \\
2.7 \\
8.0 \\
10.1 \\
5.2\end{array}$ & $\begin{array}{l}(0.61) \\
0.83) \\
(1.00) \\
0.76) \\
(0.92) \\
(1.49) \\
(0.93)\end{array}$ & $\begin{array}{l}5.6 \\
5.8 \\
6.2 \\
3.8 \\
5.5 \\
3.7 \\
7.8\end{array}$ & $\begin{array}{l}(0.62) \\
(0.72) \\
(0.84) \\
(1.07) \\
(0.91) \\
0.91) \\
(1.71)\end{array}$ & $\begin{array}{l}4.8 \\
7.5 \\
7.9 \\
5.3 \\
2.5 \\
2.7 \\
2.1 !\end{array}$ & $\begin{array}{l}(0.47) \\
0.85) \\
(1.02) \\
1.06) \\
(0.55) \\
0.72) \\
(0.95)\end{array}$ & $\begin{array}{l}17.3 \\
14.7 \\
15.6 \\
10.3 \\
19.5 \\
21.2 \\
17.3\end{array}$ & $\begin{array}{l}(1.13) \\
1.02) \\
(1.15) \\
(1.66) \\
1.91) \\
(2.02) \\
(3.39)\end{array}$ & $\begin{array}{l}38.1 \\
33.7 \\
33.4 \\
35.0 \\
41.9 \\
37.9 \\
47.2\end{array}$ & $\begin{array}{l}(0.83) \\
(1.19) \\
1.36) \\
(2.15) \\
1.32) \\
1.67) \\
(2.03)\end{array}$ & $\begin{array}{l}36.0 \\
31.2 \\
31.1 \\
31.7 \\
40.1 \\
35.4 \\
46.1\end{array}$ & $\begin{array}{l}(0.83) \\
(1.12) \\
(1.29) \\
(2.10) \\
1.30) \\
(1.72) \\
(1.92)\end{array}$ & $\begin{array}{c}0.7 \\
1.2 ! \\
1.2 ! \\
\ddagger \\
0.2 ! \\
\ddagger \\
\ddagger\end{array}$ & $\begin{array}{r}(0.17) \\
(0.37) \\
(0.43) \\
(\dagger) \\
(0.08) \\
(t) \\
(t)\end{array}$ \\
\hline 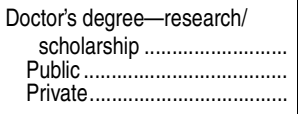 & $\begin{array}{r}198 \\
133 \\
66\end{array}$ & $(Z)$ & $\begin{array}{l}70.9 \\
69.9 \\
73.1\end{array}$ & $\left(\begin{array}{l}1.67) \\
2.12 \\
2.56)\end{array}\right)$ & $\begin{array}{l}18.1 \\
20.0 \\
14.2\end{array}$ & $\left(\begin{array}{l}1.31 \\
1.76 \\
1.34\end{array}\right)$ & $\begin{array}{r}20.0 \\
25.2 \\
9.6\end{array}$ & $\begin{array}{l}(1.27) \\
1.78) \\
(1.24)\end{array}$ & $\begin{array}{l}30.4 \\
39.4 \\
12.2\end{array}$ & $\begin{array}{l}(1.98) \\
(2.56) \\
(1.77)\end{array}$ & $\begin{array}{l}20.9 \\
23.6 \\
15.5\end{array}$ & $\begin{array}{l}(1.35) \\
1.77) \\
(1.78)\end{array}$ & $\begin{array}{l}24.4 \\
14.7 \\
44.0\end{array}$ & $\begin{array}{l}(1.46) \\
1.34) \\
(2.68)\end{array}$ & $\begin{array}{l}22.4 \\
13.5 \\
40.5\end{array}$ & $\begin{array}{l}(1.44) \\
(1.28) \\
(2.75)\end{array}$ & $\begin{array}{c}0.3 ! \\
0.4 ! \\
\ddagger\end{array}$ & $\begin{array}{r}(0.10) \\
(0.15) \\
(\dagger)\end{array}$ \\
\hline 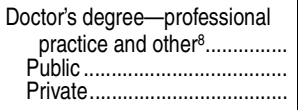 & $\begin{array}{r}100 \\
41 \\
59\end{array}$ & $($ Z) & $\begin{array}{l}68.5 \\
58.3 \\
75.5\end{array}$ & $\begin{array}{l}(3.09) \\
4.51 \\
3.48)\end{array}$ & $\begin{array}{l}13.8 \\
16.0 \\
12.3\end{array}$ & $\begin{array}{l}(1.88) \\
(2.83) \\
(2.41)\end{array}$ & $\begin{array}{l}4.6 \\
7.3 \\
2.7 !\end{array}$ & $\begin{array}{l}(0.98) \\
(1.96) \\
(1.02)\end{array}$ & $\begin{array}{l}2.3 ! \\
3.8 ! \\
1.3 !\end{array}$ & $\begin{array}{l}(0.79) \\
1.75) \\
(0.50)\end{array}$ & $\begin{array}{l}12.1 \\
12.6 \\
11.8\end{array}$ & $\begin{array}{l}(1.83) \\
(2.94) \\
(2.64)\end{array}$ & $\begin{array}{l}51.5 \\
40.3 \\
59.1\end{array}$ & $\begin{array}{l}(3.52) \\
(4.01) \\
4.83)\end{array}$ & $\begin{array}{l}47.3 \\
37.4 \\
54.1\end{array}$ & $\begin{array}{l}(3.67) \\
(4.10) \\
(5.03)\end{array}$ & $\begin{array}{c}4.7 ! \\
3.0 ! \\
\ddagger\end{array}$ & $\begin{array}{r}(2.12) \\
(1.32) \\
(t)\end{array}$ \\
\hline Other graduate ................................ & 278 & $(-)$ & 40.6 & $(2.66)$ & 6.5 & $(1.57)$ & $4.6 !$ & $(1.47)$ & $0.7 !$ & $(0.34)$ & 14.6 & $(1.91)$ & 17.9 & $(1.76)$ & 14.9 & $(1.64)$ & $\ddagger$ & $(t)$ \\
\hline
\end{tabular}

\section{-Not available.}

†Not applicable. !nterpret data and 50 percent.

¥Reporting standards not met. The coefficient of variation (CV) for this estimate is 50 percen or greater.

Numbers of part-time or part-year postbaccalaureate students may not equal figures reported in other tables, since these data are based on a sample survey of all postbaccalaureate students enrolled at any time during the school year.

Includes students who reported they were awarded aid, but did not specify the source of aid. ${ }^{3}$ Includes students who received teaching or research assistantships and/or participated in work-study programs.

${ }^{4}$ Formerly Guaranteed Student Loans (GSL)

${ }^{5}$ Formerly National Direct Student Loans (NDSL). Includes subsidized amounts only.
${ }^{6}$ Fellowship estimates for 1992-93 were based primarily on information provided by institutions and are not comparable to data for 1999-2000 and later years, which were based on information provided by both students and institutions.

${ }^{7}$ Includes nonprofit 4-year nondoctoral institutions and for-profit 2-year-and-above institutions. ${ }^{8}$ Professional practice doctor's degrees include most degrees formerly classified as first-professional (such as M.D., D.D.S., and J.D). "Other" doctor's degrees are those that are neither research/scholarship degrees nor professional practice degrees.

NOTE: Excludes students whose attendance status was not reported. Total includes some students whose level of study or control of institution was unknown. Detail may not sum to totals because of rounding and because some students receive aid from multiple sources. Data for 2007-08 and prior years include Puerto Rico, which is excluded from the 2011-12 data.

SOURCE: U.S. Department of Education, National Center for Education Statistics, 1992-93, 1999-2000, 2007-08, and 2011-12 National Postsecondary Student Aid Study (NPSAS:93 NPSAS:2000, NPSAS:08, and NPSAS:12). (This table was prepared March 2014.) 
CHAPTER 3: Postsecondary Education 651 Financial Aid for Postbaccalaureate Students

Table 332.50. Number of postsecondary students who entered the student loan repayment phase, number of students who defaulted, and student loan cohort default rates, by 2-year or 3-year default period and level and control of institution: Fiscal years 2009 through 2011

\begin{tabular}{|c|c|c|c|c|c|c|}
\hline \multirow[b]{2}{*}{ Fiscal year and level and control of institution } & \multicolumn{3}{|c|}{ For student loan cohorts over a 2-year period } & \multicolumn{3}{|c|}{ For student loan cohorts over a 3-year period } \\
\hline & $\begin{array}{l}\text { Number entering } \\
\text { repayment phase in } \\
\text { given fiscal year }^{-1}\end{array}$ & $\begin{array}{l}\text { Number defaulting by } \\
\text { end of next fiscal year }\end{array}$ & 2-year default rate ${ }^{3,4}$ & $\begin{array}{r}\text { Number entering } \\
\text { repayment phase in } \\
\text { given fiscal year }^{1}\end{array}$ & $\begin{array}{r}\text { Number defaulting } \\
\text { by end of second } \\
\text { following fiscal year }{ }^{2}\end{array}$ & 3-year default rate $e^{4,5}$ \\
\hline 1 & 2 & 3 & 4 & 5 & 6 & 7 \\
\hline $\begin{array}{l}\text { Fiscal year } 2009 \\
\quad \text { All institutions } 6\end{array}$ & $3,628,846$ & 320,194 & 8.8 & $3,629,109$ & 489,040 & 13.4 \\
\hline 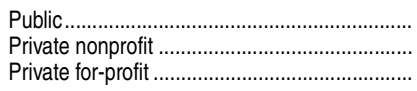 & $\begin{array}{r}1,778,903 \\
825,221 \\
1,015,855\end{array}$ & $\begin{array}{r}128,121 \\
38,718 \\
152,862\end{array}$ & $\begin{array}{r}7.2 \\
4.6 \\
15.0\end{array}$ & $\begin{array}{r}1,778,645 \\
835,492 \\
1,006,190\end{array}$ & $\begin{array}{r}196,032 \\
63,047 \\
229,315\end{array}$ & $\begin{array}{r}11.0 \\
7.5 \\
22.7\end{array}$ \\
\hline 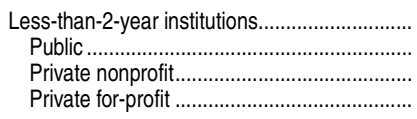 & $\begin{array}{r}142,632 \\
7,548 \\
4,148 \\
130,936\end{array}$ & $\begin{array}{r}19,385 \\
749 \\
605 \\
18,031\end{array}$ & $\begin{array}{r}13.6 \\
9.9 \\
14.5 \\
13.7\end{array}$ & $\begin{array}{r}140,742 \\
7,401 \\
4,106 \\
129,235\end{array}$ & $\begin{array}{r}29,940 \\
1,202 \\
950 \\
27,788\end{array}$ & $\begin{array}{l}21.3 \\
16.2 \\
23.1 \\
21.5\end{array}$ \\
\hline 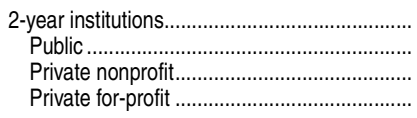 & $\begin{array}{r}824,841 \\
520,256 \\
15,039 \\
289,546\end{array}$ & $\begin{array}{r}106,634 \\
62,234 \\
1,507 \\
42,893\end{array}$ & $\begin{array}{l}12.9 \\
11.9 \\
10.0 \\
14.8\end{array}$ & $\begin{array}{r}814,256 \\
518,299 \\
16,244 \\
279,713\end{array}$ & $\begin{array}{r}161,448 \\
94,945 \\
2,357 \\
64,146\end{array}$ & $\begin{array}{l}19.8 \\
18.3 \\
14.5 \\
22.9\end{array}$ \\
\hline 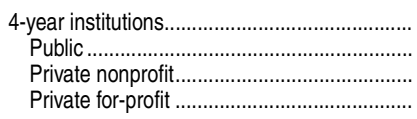 & $\begin{array}{r}2,652,506 \\
1,251,099 \\
806,034 \\
595,373\end{array}$ & $\begin{array}{r}193,682 \\
65,138 \\
36,606 \\
91,938\end{array}$ & $\begin{array}{r}7.3 \\
5.2 \\
4.5 \\
15.4\end{array}$ & $\begin{array}{r}2,665,329 \\
1,252,945 \\
815,142 \\
597,242\end{array}$ & $\begin{array}{r}297,006 \\
99,885 \\
59,740 \\
137,381\end{array}$ & $\begin{array}{r}11.1 \\
7.9 \\
7.3 \\
23.0\end{array}$ \\
\hline Fiscal year 2010 & & & & & & \\
\hline All institutions 6 & $4,100,778$ & 374,940 & 9.1 & $4,082,570$ & 600,545 & 14.7 \\
\hline 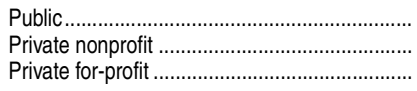 & $\begin{array}{r}1,928,054 \\
882,005 \\
1,281,215\end{array}$ & $\begin{array}{r}161,815 \\
46,481 \\
166,364\end{array}$ & $\begin{array}{r}8.3 \\
5.2 \\
12.9\end{array}$ & $\begin{array}{r}1,922,773 \\
879,269 \\
1,270,965\end{array}$ & $\begin{array}{r}250,661 \\
72,347 \\
277,088\end{array}$ & $\begin{array}{r}13.0 \\
8.2 \\
21.8\end{array}$ \\
\hline 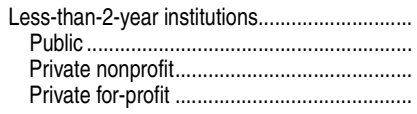 & $\begin{array}{r}179,650 \\
8,261 \\
4,953 \\
166,436\end{array}$ & $\begin{array}{r}21,274 \\
831 \\
676 \\
19,767\end{array}$ & $\begin{array}{l}11.8 \\
10.0 \\
13.6 \\
11.8\end{array}$ & $\begin{array}{r}178,904 \\
7,963 \\
5,020 \\
165,921\end{array}$ & $\begin{array}{r}37,223 \\
1,315 \\
1,097 \\
34,811\end{array}$ & $\begin{array}{l}20.8 \\
16.5 \\
21.8 \\
20.9\end{array}$ \\
\hline 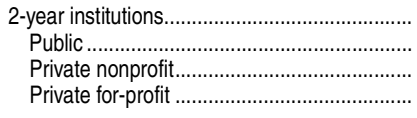 & $\begin{array}{r}966,842 \\
604,872 \\
18,384 \\
343,586\end{array}$ & $\begin{array}{r}124,136 \\
81,120 \\
1,573 \\
41,443\end{array}$ & $\begin{array}{r}12.8 \\
13.4 \\
8.5 \\
12.0\end{array}$ & $\begin{array}{r}950,143 \\
599,467 \\
16,217 \\
334,459\end{array}$ & $\begin{array}{r}199,922 \\
125,764 \\
2,305 \\
71,853\end{array}$ & $\begin{array}{l}21.0 \\
20.9 \\
14.2 \\
21.4\end{array}$ \\
\hline 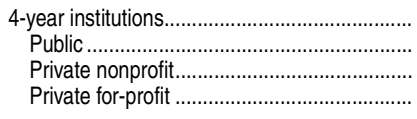 & $\begin{array}{r}2,944,782 \\
1,314,921 \\
858,668 \\
771,193 \\
\end{array}$ & $\begin{array}{r}229,250 \\
79,864 \\
44,232 \\
105,154 \\
\end{array}$ & $\begin{array}{r}7.8 \\
6.0 \\
5.1 \\
13.6 \\
\end{array}$ & $\begin{array}{r}2,943,960 \\
1,315,343 \\
858,032 \\
770,585 \\
\end{array}$ & $\begin{array}{r}362,951 \\
123,582 \\
68,945 \\
170,424 \\
\end{array}$ & $\begin{array}{r}12.3 \\
9.3 \\
8.0 \\
22.1 \\
\end{array}$ \\
\hline $\begin{array}{l}\text { Fiscal year } 2011 \\
\quad \text { All institutions }{ }^{6} . .\end{array}$ & $4,739,481$ & 475,538 & 10.0 & - & - & - \\
\hline 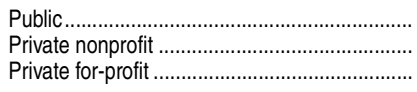 & $\begin{array}{r}2,253,463 \\
967,956 \\
1,507,562\end{array}$ & $\begin{array}{r}218,418 \\
51,153 \\
205,681\end{array}$ & $\begin{array}{r}9.6 \\
5.2 \\
13.6\end{array}$ & $\begin{array}{l}- \\
- \\
-\end{array}$ & $\begin{array}{l}- \\
-\end{array}$ & - \\
\hline 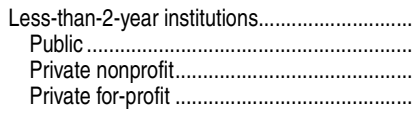 & $\begin{array}{r}211,988 \\
8,779 \\
5,219 \\
197,990\end{array}$ & $\begin{array}{r}29,576 \\
824 \\
734 \\
28,018\end{array}$ & $\begin{array}{r}14.0 \\
9.3 \\
14.0 \\
14.1\end{array}$ & $\begin{array}{l}- \\
- \\
-\end{array}$ & $\begin{array}{l}- \\
- \\
-\end{array}$ & - \\
\hline 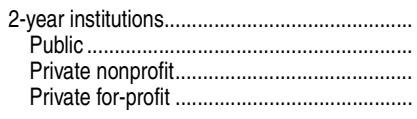 & $\begin{array}{r}1,179,508 \\
774,772 \\
17,458 \\
387,278\end{array}$ & $\begin{array}{r}172,265 \\
116,966 \\
1,445 \\
53,854\end{array}$ & $\begin{array}{r}14.6 \\
15.0 \\
8.2 \\
13.9\end{array}$ & $\begin{array}{l}- \\
- \\
-\end{array}$ & $\begin{array}{l}- \\
- \\
-\end{array}$ & - \\
\hline 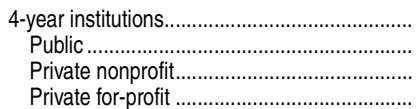 & $\begin{array}{r}3,337,485 \\
1,469,912 \\
945,279 \\
922,294\end{array}$ & $\begin{array}{r}273,411 \\
100,628 \\
48,974 \\
123,809\end{array}$ & $\begin{array}{r}8.2 \\
6.8 \\
5.1 \\
13.4\end{array}$ & $\begin{array}{l}- \\
- \\
-\end{array}$ & $\begin{array}{l}- \\
- \\
-\end{array}$ & - \\
\hline
\end{tabular}

-Not available.

The repayment phase is the period when student loans must be repaid; it generally begins 6 months after a student leaves an institution. Students who enter the repayment phase during a particular federal fiscal year (October 1 through September 30) make up the cohort for that fiscal year. For example, members of the fiscal year (FY) 2009 cohort entered the repayment phase any time from October 1, 2008, through September 30, 2009.

2Default occurs when a borrower fails to make a payment for 270 days.

${ }^{3}$ The 2-year cohort default rate is the percentage of borrowers entering repayment during one fiscal year and defaulting by the end of the next fiscal year. For example, the 2-year cohort default rate for FY 2009 is the percentage of borrowers who entered repayment during FY 2009 (any time from October 1, 2008, through September 30,2009) and who defaulted by the end of FY 2010 (September 30, 2010).

${ }^{4}$ For purposes of computing default rates, if an individual or entity affiliated with the institution makes a payment to prevent a borrower's default on a loan, the borrower is still considered in default.

${ }^{5}$ The 3-year cohort default rate is the percentage of borrowers entering repayment during the specified fiscal year and defaulting by the end of the second fiscal year that follows. For exam- ple, the 3-year cohort default rate for FY 2009 is the percentage of borrowers who entered repayment during FY 2009 (any time from October 1, 2008, through September 30, 2009) and who defaulted by the end of FY 2011 (September 30, 2011).

${ }^{6}$ Includes borrowers from foreign and unclassified schools, which account for less than 1 percent of borrowers and are not included elsewhere.

NOTE: Data are for certain loans under the Federal Family Education Loan (FFEL) Program and the William D. Ford Federal Direct Loan Program (commonly referred to as the Direct Loan Program). Includes Federal Stafford Loans. Does not include PLUS loans, Federal Insured Student Loans (FISLs), or Federal Perkins Loans. For more details, see http://ifap.ed.gov/Default Management/guide/attachments/CDRGuideCh2Pt1CDRCalculation.pdf.

SOURCE: U.S. Department of Education, Office of Federal Student Aid, Direct Loan and Federal Family Education Loan Programs, Cohort Default Rate Database; retrieved December 3 , eral Family Education Loan Programs, Cohort Default Rate Database; retrieved December 3,
2013, from http://www2.ed.gov/offices/OSFAP/defaultmanagement/cdrschooltype2yr.pdf and http://www2.ed.gov/offices/OSFAP/defaultmanagement/cdrschooltype3yr.pdf. (This table was prepared December 2013.) 
652 CHAPTER 3: Postsecondary Education

Revenues

Table 333.10. Revenues of public degree-granting postsecondary institutions, by source of revenue and level of institution: 2005-06 through 2011-12

\begin{tabular}{|c|c|c|c|c|c|c|c|c|c|}
\hline \multirow[b]{3}{*}{$\begin{array}{l}\text { Level of institution } \\
\text { and year }\end{array}$} & \multirow[b]{3}{*}{ Total revenues } & \multicolumn{8}{|c|}{ Operating revenue } \\
\hline & & \multirow[b]{2}{*}{$\begin{array}{r}\text { Tuition } \\
\text { and fees }\end{array}$} & \multicolumn{3}{|c|}{ Grants and contracts } & \multirow{2}{*}{$\begin{array}{r}\text { Sales and } \\
\text { services of } \\
\text { auxiliary } \\
\text { enterprises }^{1}\end{array}$} & \multirow{2}{*}{$\begin{array}{r}\text { Sales and } \\
\text { services of } \\
\text { hospitals }\end{array}$} & \multirow[b]{2}{*}{$\begin{array}{r}\text { Independent } \\
\text { operations }\end{array}$} & \multirow{2}{*}{$\begin{array}{r}\text { Other } \\
\text { operating } \\
\text { revenues }^{2}\end{array}$} \\
\hline & & & Federal & State & $\begin{array}{r}\text { Local and } \\
\text { private }\end{array}$ & & & & \\
\hline 1 & 2 & 3 & 4 & 5 & 6 & 7 & 8 & 9 & $\overline{10}$ \\
\hline \multirow[b]{2}{*}{$\begin{array}{l}\text { All levels } \\
2005-06 \ldots \ldots \ldots \ldots . . . \\
2006-07 \ldots \ldots \ldots \ldots . . \\
2007-08 \ldots \ldots \ldots \ldots . . \\
2008-09 \ldots \ldots \ldots \ldots . . . \\
2009-10 \ldots \ldots \ldots \ldots . . \\
2010-11 \ldots \ldots \ldots \ldots . . \\
2011-12 \ldots \ldots \ldots \ldots . .\end{array}$} & \multicolumn{9}{|c|}{ In thousands of current dollars } \\
\hline & $\begin{array}{r}\$ 246,164,836 \\
268,556,045 \\
273,109,306 \\
267,385,180 \\
303,329,538 \\
323,817,821 \\
317,306,882\end{array}$ & $\begin{array}{r}\$ 41,770,600 \\
44,773,470 \\
48,070,012 \\
51,840,367 \\
55,930,482 \\
60,240,671 \\
65,386,643\end{array}$ & $\begin{array}{r}\$ 30,333,948 \\
30,779,946 \\
25,522,915 \\
26,092,100 \\
28,397,667 \\
29,808,728 \\
29,170,906\end{array}$ & $\begin{array}{r}\$ 7,207,813 \\
7,613,614 \\
7,831,530 \\
7,403,141 \\
6,904,221 \\
7,020,373 \\
6,830,610\end{array}$ & $\begin{array}{r}\$ 7,606,076 \\
8,176,011 \\
8,699,329 \\
9,600,416 \\
9,620,133 \\
10,062,621 \\
10,143,900\end{array}$ & $\begin{array}{r}\$ 18,786,806 \\
20,398,261 \\
20,488,319 \\
21,358,319 \\
22,173,700 \\
23,606,433 \\
24,275,773\end{array}$ & $\begin{array}{r}\$ 22,100,555 \\
22,575,459 \\
25,183,379 \\
27,301,883 \\
29,236,931 \\
31,105,677 \\
33,508,840\end{array}$ & $\begin{array}{r}\$ 635,607 \\
688,024 \\
1,174,836 \\
1,036,660 \\
1,343,230 \\
1,330,334 \\
1,356,396\end{array}$ & $\begin{array}{r}\$ 14,483,979 \\
13,765,596 \\
14,108,986 \\
14,165,654 \\
14,814,344 \\
15,804,536 \\
16,287,670\end{array}$ \\
\hline $\begin{array}{l}\text { 4-year } \\
2005-06 \ldots \ldots \ldots \ldots . . \\
2006-07 \ldots \ldots \ldots \ldots . . \\
2007-08 . \ldots \ldots \ldots \ldots . . \\
2008-09 \ldots \ldots \ldots \ldots . \\
2009-10 \ldots \ldots \ldots \ldots . . \\
2010-11 \ldots \ldots \ldots \ldots . . \\
2011-12 \ldots \ldots \ldots \ldots . .\end{array}$ & $\begin{array}{l}202,511,496 \\
221,882,332 \\
223,566,529 \\
216,432,317 \\
248,104,870 \\
265,941,566 \\
261,153,808\end{array}$ & $\begin{array}{l}34,506,560 \\
37,205,630 \\
40,083,063 \\
43,478,018 \\
46,943,248 \\
51,018,362 \\
55,979,010\end{array}$ & $\begin{array}{l}25,583,341 \\
26,027,591 \\
23,518,933 \\
24,178,064 \\
26,272,013 \\
27,643,131 \\
27,238,924\end{array}$ & $\begin{array}{l}5,383,780 \\
5,530,987 \\
5,715,188 \\
5,526,583 \\
5,301,243 \\
5,480,388 \\
5,352,808\end{array}$ & $\begin{array}{l}7,024,078 \\
7,586,434 \\
8,106,887 \\
9,031,844 \\
9,062,160 \\
9,495,263 \\
9,573,172\end{array}$ & $\begin{array}{l}16,945,544 \\
18,520,922 \\
18,507,934 \\
19,391,219 \\
20,099,137 \\
21,507,520 \\
22,239,682\end{array}$ & $\begin{array}{l}22,100,555 \\
22,575,459 \\
25,183,379 \\
27,301,883 \\
29,236,931 \\
31,105,677 \\
33,508,840\end{array}$ & $\begin{array}{r}635,607 \\
688,024 \\
1,174,836 \\
1,036,660 \\
1,343,230 \\
1,330,334 \\
1,356,396\end{array}$ & $\begin{array}{l}13,753,422 \\
13,057,589 \\
13,135,633 \\
13,291,611 \\
13,894,006 \\
14,876,568 \\
15,337,305\end{array}$ \\
\hline \multirow[t]{2}{*}{$\begin{array}{l}\text { 2-year } \\
2005-06 \ldots \ldots \ldots \ldots . . . \\
2006-07 \ldots \ldots \ldots \ldots . . \\
2007-08 \ldots \ldots \ldots \ldots . . \\
2008-09 \ldots \ldots \ldots \ldots . . \\
2009-10 \ldots \ldots \ldots \ldots . . \\
2010-11 \ldots \ldots \ldots \ldots . . \\
2011-12 \ldots \ldots \ldots \ldots . .\end{array}$} & $\begin{array}{l}43,653,340 \\
46,673,713 \\
49,542,777 \\
50,952,862 \\
55,224,668 \\
57,876,255 \\
56,153,074\end{array}$ & $\begin{array}{l}7,264,040 \\
7,567,840 \\
7,986,949 \\
8,362,349 \\
8,987,234 \\
9,222,309 \\
9,407,634 \\
\end{array}$ & $\begin{array}{l}4,750,607 \\
4,752,356 \\
2,003,982 \\
1,914,036 \\
2,125,654 \\
2,165,597 \\
1,931,982 \\
\end{array}$ & $\begin{array}{l}1,824,034 \\
2,082,627 \\
2,116,343 \\
1,876,558 \\
1,602,978 \\
1,539,985 \\
1,477,802 \\
\end{array}$ & $\begin{array}{l}581,998 \\
589,578 \\
592,442 \\
568,572 \\
557,973 \\
567,358 \\
570,728 \\
\end{array}$ & $\begin{array}{l}1,841,262 \\
1,877,338 \\
1,980,385 \\
1,967,100 \\
2,074,563 \\
2,098,913 \\
2,036,091\end{array}$ & $\begin{array}{l}0 \\
0 \\
0 \\
0 \\
0 \\
0 \\
0 \\
\end{array}$ & $\begin{array}{l}0 \\
0 \\
0 \\
0 \\
0 \\
0 \\
0 \\
0\end{array}$ & $\begin{array}{l}730,557 \\
708,007 \\
973,353 \\
874,043 \\
920,338 \\
927,968 \\
950,365 \\
\end{array}$ \\
\hline & \multicolumn{9}{|c|}{ Percentage distribution } \\
\hline $\begin{array}{l}\text { All levels } \\
2005-06 \ldots \ldots \ldots \ldots . . . \\
2006-07 \ldots \ldots \ldots \ldots . . . \\
2007-08 \ldots \ldots \ldots \ldots . . . \\
2008-09 . \ldots \ldots \ldots \ldots . . \\
2009-10 \ldots \ldots \ldots \ldots . . \\
2010-11 \ldots \ldots \ldots \ldots . . . \\
2011-12 \ldots \ldots \ldots \ldots . .\end{array}$ & $\begin{array}{l}100.00 \\
100.00 \\
100.00 \\
100.00 \\
100.00 \\
100.00 \\
100.00\end{array}$ & $\begin{array}{l}16.97 \\
16.67 \\
17.60 \\
19.39 \\
18.44 \\
18.60 \\
20.61\end{array}$ & $\begin{array}{r}12.32 \\
11.46 \\
9.35 \\
9.76 \\
9.36 \\
9.21 \\
9.19\end{array}$ & $\begin{array}{l}2.93 \\
2.84 \\
2.87 \\
2.77 \\
2.28 \\
2.17 \\
2.15\end{array}$ & $\begin{array}{l}3.09 \\
3.04 \\
3.19 \\
3.59 \\
3.17 \\
3.11 \\
3.20\end{array}$ & $\begin{array}{l}7.63 \\
7.60 \\
7.50 \\
7.99 \\
7.31 \\
7.29 \\
7.65\end{array}$ & $\begin{array}{r}8.98 \\
8.41 \\
9.22 \\
10.21 \\
9.64 \\
9.61 \\
10.56\end{array}$ & $\begin{array}{l}0.26 \\
0.26 \\
0.43 \\
0.39 \\
0.44 \\
0.41 \\
0.43\end{array}$ & $\begin{array}{l}5.88 \\
5.13 \\
5.17 \\
5.30 \\
4.88 \\
4.88 \\
5.13\end{array}$ \\
\hline $\begin{array}{l}\text { 4-year } \\
2005-06 \ldots \ldots \ldots \ldots . . \\
2006-07 \ldots \ldots \ldots \ldots . . \\
2007-08 . \ldots \ldots \ldots \ldots . . \\
2008-09 \ldots \ldots \ldots \ldots . \\
2009-10 \ldots \ldots \ldots \ldots . . \\
2010-11 \ldots \ldots \ldots \ldots . . \\
2011-12 \ldots \ldots \ldots \ldots . .\end{array}$ & $\begin{array}{l}100.00 \\
100.00 \\
100.00 \\
100.00 \\
100.00 \\
100.00 \\
100.00\end{array}$ & $\begin{array}{l}17.04 \\
16.77 \\
17.93 \\
20.09 \\
18.92 \\
19.18 \\
21.44\end{array}$ & $\begin{array}{l}12.63 \\
11.73 \\
10.52 \\
11.17 \\
10.59 \\
10.39 \\
10.43\end{array}$ & $\begin{array}{l}2.66 \\
2.49 \\
2.56 \\
2.55 \\
2.14 \\
2.06 \\
2.05\end{array}$ & $\begin{array}{l}3.47 \\
3.42 \\
3.63 \\
4.17 \\
3.65 \\
3.57 \\
3.67\end{array}$ & $\begin{array}{l}8.37 \\
8.35 \\
8.28 \\
8.96 \\
8.10 \\
8.09 \\
8.52\end{array}$ & $\begin{array}{l}10.91 \\
10.17 \\
11.26 \\
12.61 \\
11.78 \\
11.70 \\
12.83\end{array}$ & $\begin{array}{l}0.31 \\
0.31 \\
0.53 \\
0.48 \\
0.54 \\
0.50 \\
0.52\end{array}$ & $\begin{array}{l}6.79 \\
5.88 \\
5.88 \\
6.14 \\
5.60 \\
5.59 \\
5.87\end{array}$ \\
\hline \multirow[t]{2}{*}{$\begin{array}{l}\text { 2-year } \\
2005-06 \ldots \ldots \ldots \ldots . . \\
2006-07 \ldots \ldots \ldots \ldots . . \\
2007-08 \ldots \ldots \ldots \ldots . . \\
2008-09 \ldots \ldots \ldots \ldots . . \\
2009-10 \ldots \ldots \ldots \ldots . . \\
2010-11 \ldots \ldots \ldots \ldots . . \\
2011-12 \ldots \ldots \ldots \ldots . .\end{array}$} & $\begin{array}{l}100.00 \\
100.00 \\
100.00 \\
100.00 \\
100.00 \\
100.00 \\
100.00 \\
\end{array}$ & $\begin{array}{l}16.64 \\
16.21 \\
16.12 \\
16.41 \\
16.27 \\
15.93 \\
16.75 \\
\end{array}$ & $\begin{array}{r}10.88 \\
10.18 \\
4.04 \\
3.76 \\
3.85 \\
3.74 \\
3.44 \\
\end{array}$ & $\begin{array}{l}4.18 \\
4.46 \\
4.27 \\
3.68 \\
2.90 \\
2.66 \\
2.63 \\
\end{array}$ & $\begin{array}{l}1.33 \\
1.26 \\
1.20 \\
1.12 \\
1.01 \\
0.98 \\
1.02 \\
\end{array}$ & $\begin{array}{l}4.22 \\
4.02 \\
4.00 \\
3.86 \\
3.76 \\
3.63 \\
3.63 \\
\end{array}$ & $\begin{array}{l}0.00 \\
0.00 \\
0.00 \\
0.00 \\
0.00 \\
0.00 \\
0.00 \\
\end{array}$ & $\begin{array}{l}0.00 \\
0.00 \\
0.00 \\
0.00 \\
0.00 \\
0.00 \\
0.00 \\
\end{array}$ & $\begin{array}{l}1.67 \\
1.52 \\
1.96 \\
1.72 \\
1.67 \\
1.60 \\
1.69 \\
\end{array}$ \\
\hline & \multicolumn{9}{|c|}{ Revenue per full-time-equivalent student in constant 2012-13 dollars 3} \\
\hline $\begin{array}{l}\text { All levels } \\
2005-06 \ldots \ldots \ldots \ldots . . \\
2006-07 \ldots \ldots \ldots \ldots . . \\
2007-08 \ldots \ldots \ldots \ldots . . \\
2008-09 \ldots \ldots \ldots \ldots . . \\
2009-10 \ldots \ldots \ldots \ldots . . \\
2010-11 \ldots \ldots \ldots \ldots . . \\
2011-12 \ldots \ldots \ldots \ldots . .\end{array}$ & $\begin{array}{r}\$ 30,478 \\
32,026 \\
30,644 \\
28,641 \\
30,119 \\
30,747 \\
29,464\end{array}$ & $\begin{array}{r}\$ 5,172 \\
5,339 \\
5,394 \\
5,553 \\
5,554 \\
5,720 \\
6,072\end{array}$ & $\begin{array}{r}\$ 3,756 \\
3,671 \\
2,864 \\
2,795 \\
2,820 \\
2,830 \\
2,709\end{array}$ & $\begin{array}{r}\$ 892 \\
908 \\
879 \\
793 \\
686 \\
667 \\
634\end{array}$ & $\begin{array}{r}\$ 942 \\
975 \\
976 \\
1,028 \\
955 \\
955 \\
942\end{array}$ & $\begin{array}{r}\$ 2,326 \\
2,433 \\
2,299 \\
2,288 \\
2,202 \\
2,241 \\
2,254\end{array}$ & $\begin{array}{r}\$ 2,736 \\
2,692 \\
2,826 \\
2,924 \\
2,903 \\
2,954 \\
3,112\end{array}$ & $\begin{array}{r}\$ 79 \\
82 \\
132 \\
111 \\
133 \\
126 \\
126\end{array}$ & $\begin{array}{r}\$ 1,793 \\
1,642 \\
1,583 \\
1,517 \\
1,471 \\
1,501 \\
1,512\end{array}$ \\
\hline $\begin{array}{l}\text { 4-year } \\
2005-06 \ldots \ldots \ldots \ldots . . \\
2006-07 \ldots \ldots \ldots \ldots . . \\
2007-08 \ldots \ldots \ldots \ldots . . \\
2008-09 \ldots \ldots \ldots \ldots . . \\
2009-10 \ldots \ldots \ldots \ldots . . \\
2010-11 \ldots \ldots \ldots \ldots . . \\
2011-12 \ldots \ldots \ldots \ldots . .\end{array}$ & $\begin{array}{l}41,102 \\
43,171 \\
40,759 \\
37,994 \\
41,045 \\
41,935 \\
39,433\end{array}$ & $\begin{array}{l}7,003 \\
7,239 \\
7,308 \\
7,632 \\
7,766 \\
8,045 \\
8,453\end{array}$ & $\begin{array}{l}5,192 \\
5,064 \\
4,288 \\
4,244 \\
4,346 \\
4,359 \\
4,113\end{array}$ & $\begin{array}{r}1,093 \\
1,076 \\
1,042 \\
970 \\
877 \\
864 \\
808\end{array}$ & $\begin{array}{l}1,426 \\
1,476 \\
1,478 \\
1,586 \\
1,499 \\
1,497 \\
1,446\end{array}$ & $\begin{array}{l}3,439 \\
3,604 \\
3,374 \\
3,404 \\
3,325 \\
3,391 \\
3,358\end{array}$ & $\begin{array}{l}4,486 \\
4,392 \\
4,591 \\
4,793 \\
4,837 \\
4,905 \\
5,060\end{array}$ & $\begin{array}{l}129 \\
134 \\
214 \\
182 \\
222 \\
210 \\
205\end{array}$ & $\begin{array}{l}2,791 \\
2,541 \\
2,395 \\
2,333 \\
2,299 \\
2,346 \\
2,316\end{array}$ \\
\hline $\begin{array}{l}\text { 2-year } \\
2005-06 \ldots \ldots \ldots \ldots . . \\
2006-07 \ldots \ldots \ldots \ldots . . \\
2007-08 . \ldots \ldots \ldots \ldots . . \\
2008-09 \ldots \ldots \ldots \ldots . \\
2009-10 \ldots \ldots \ldots \ldots . . \\
2010-11 \ldots \ldots \ldots \ldots . . \\
2011-12 \ldots \ldots \ldots \ldots . .\end{array}$ & $\begin{array}{l}13,860 \\
14,379 \\
14,455 \\
14,001 \\
13,716 \\
13,813 \\
13,542\end{array}$ & $\begin{array}{l}2,306 \\
2,331 \\
2,330 \\
2,298 \\
2,232 \\
2,201 \\
2,269\end{array}$ & $\begin{array}{r}1,508 \\
1,464 \\
585 \\
526 \\
528 \\
517 \\
466\end{array}$ & $\begin{array}{l}579 \\
642 \\
617 \\
516 \\
398 \\
368 \\
356\end{array}$ & $\begin{array}{l}185 \\
182 \\
173 \\
156 \\
139 \\
135 \\
138\end{array}$ & $\begin{array}{l}585 \\
578 \\
578 \\
541 \\
515 \\
501 \\
491\end{array}$ & $\begin{array}{l}0 \\
0 \\
0 \\
0 \\
0 \\
0 \\
0\end{array}$ & $\begin{array}{l}0 \\
0 \\
0 \\
0 \\
0 \\
0 \\
0\end{array}$ & $\begin{array}{l}232 \\
218 \\
284 \\
240 \\
229 \\
221 \\
229\end{array}$ \\
\hline
\end{tabular}

See notes at end of table. 
Table 333.10. Revenues of public degree-granting postsecondary institutions, by source of revenue and level of institution: 2005-06 through 2011-12-Continued

\begin{tabular}{|c|c|c|c|c|c|c|c|c|c|c|c|c|c|}
\hline \multirow{3}{*}{$\begin{array}{l}\text { Level of institution } \\
\text { and year }\end{array}$} & \multicolumn{9}{|c|}{ Nonoperating revenue } & \multicolumn{4}{|c|}{ Other revenues and additions } \\
\hline & \multicolumn{3}{|c|}{ Appropriations } & \multicolumn{3}{|c|}{ Nonoperating grants } & \multirow[b]{2}{*}{ Gifts } & \multirow{2}{*}{$\begin{array}{r}\text { Investment } \\
\text { income }\end{array}$} & \multirow[b]{2}{*}{ Other } & \multirow{2}{*}{$\begin{array}{r}\text { Capital } \\
\text { appro- } \\
\text { priations }\end{array}$} & \multirow{2}{*}{$\begin{array}{r}\text { Capital } \\
\text { grants } \\
\text { and gifts }\end{array}$} & \multirow{2}{*}{$\begin{array}{r}\text { Additions to } \\
\text { permanent } \\
\text { endowments }\end{array}$} & \multirow[b]{2}{*}{ Other } \\
\hline & Federal & State & Local & Federal & State & Local & & & & & & & \\
\hline 1 & 11 & 12 & 13 & 14 & 15 & 16 & 17 & 18 & 19 & 20 & 21 & 22 & 23 \\
\hline \multirow[b]{2}{*}{$\begin{array}{l}\text { All levels } \\
2005-06 \ldots \ldots \ldots \ldots . . \\
2006-07 \ldots \ldots \ldots \ldots \ldots \\
2007-08 \ldots \ldots \ldots \ldots . . \\
2008-09 \ldots \ldots \ldots \ldots . . \\
2009-10 \ldots \ldots \ldots \ldots . . \\
2010-11 \ldots \ldots \ldots \ldots . . \\
2011-12 \ldots \ldots \ldots \ldots . . .\end{array}$} & \multicolumn{13}{|c|}{ In thousands of current dollars } \\
\hline & $\begin{array}{r}\$ 1,858,625 \\
1,910,169 \\
1,849,775 \\
2,010,843 \\
2,152,228 \\
1,946,965 \\
1,835,767\end{array}$ & $\begin{array}{r}\$ 58,720,088 \\
63,204,939 \\
68,375,062 \\
65,486,232 \\
62,456,235 \\
63,015,552 \\
58,789,643\end{array}$ & $\begin{array}{r}\$ 8,249,690 \\
8,818,685 \\
9,319,219 \\
9,787,019 \\
9,954,504 \\
10,023,205 \\
10,214,576\end{array}$ & $\begin{array}{r}\$ 2,811,434 \\
2,859,223 \\
10,022,315 \\
12,760,716 \\
20,740,102 \\
24,366,180 \\
23,205,569\end{array}$ & $\begin{array}{r}\$ 1,177,322 \\
1,291,896 \\
1,909,570 \\
2,720,449 \\
3,123,358 \\
3,404,970 \\
3,559,749\end{array}$ & $\begin{array}{r}\$ 102,497 \\
129,138 \\
177,555 \\
265,789 \\
231,104 \\
228,045 \\
232,167\end{array}$ & $\begin{array}{r}\$ 4,975,616 \\
5,589,156 \\
6,070,499 \\
5,893,912 \\
5,876,450 \\
6,286,802 \\
6,540,837\end{array}$ & $\begin{array}{r}\$ 9,597,624 \\
15,588,573 \\
5,278,643 \\
-9,487,915 \\
10,046,610 \\
14,185,059 \\
6,171,056\end{array}$ & $\begin{array}{r}\$ 2,705,351 \\
3,950,191 \\
2,251,324 \\
3,011,240 \\
5,210,022 \\
5,623,707 \\
4,191,861\end{array}$ & $\begin{array}{r}\$ 5,421,660 \\
7,332,387 \\
7,578,049 \\
7,038,658 \\
6,041,010 \\
5,640,026 \\
5,544,504\end{array}$ & $\begin{array}{r}\$ 2,568,688 \\
3,509,682 \\
3,090,589 \\
2,938,605 \\
3,780,012 \\
3,744,845 \\
3,724,320\end{array}$ & \begin{tabular}{|r|}
$\$ 1,004,691$ \\
$1,039,425$ \\
$1,133,783$ \\
843,528 \\
869,950 \\
965,007 \\
825,587
\end{tabular} & $\begin{array}{r}\$ 4,046,166 \\
4,562,199 \\
4,973,618 \\
5,317,562 \\
4,427,245 \\
5,408,083 \\
5,510,507\end{array}$ \\
\hline $\begin{array}{l}\text { 4-year } \\
2005-06 \ldots \ldots \ldots \ldots . . \\
2006-07 \ldots \ldots \ldots \ldots . . \\
2007-08 \ldots \ldots \ldots \ldots . . \\
2008-09 \ldots \ldots \ldots \ldots . . \\
2009-10 \ldots \ldots \ldots \ldots . . \\
2010-11 \ldots \ldots \ldots \ldots . . \\
2011-12 \ldots \ldots \ldots \ldots . .\end{array}$ & $\begin{array}{l}1,720,108 \\
1,786,143 \\
1,776,452 \\
1,934,958 \\
2,006,623 \\
1,853,109 \\
1,715,489\end{array}$ & $\begin{array}{l}45,591,539 \\
49,216,667 \\
53,268,648 \\
50,863,465 \\
48,721,670 \\
48,977,437 \\
45,755,610\end{array}$ & $\begin{array}{l}336,424 \\
446,923 \\
453,280 \\
484,689 \\
431,615 \\
507,010 \\
517,219\end{array}$ & $\begin{array}{r}1,546,322 \\
1,625,932 \\
5,177,569 \\
6,425,434 \\
10,318,977 \\
11,849,748 \\
11,264,322\end{array}$ & $\begin{array}{r}613,928 \\
705,405 \\
1,201,394 \\
1,729,985 \\
2,088,155 \\
2,320,005 \\
2,398,688\end{array}$ & $\begin{array}{r}33,269 \\
71,908 \\
103,824 \\
131,427 \\
134,608 \\
130,451 \\
130,598\end{array}$ & $\begin{array}{l}4,713,701 \\
5,332,020 \\
5,798,732 \\
5,635,304 \\
5,646,279 \\
6,061,073 \\
6,274,473\end{array}$ & $\begin{array}{r}8,927,767 \\
14,616,593 \\
4,430,479 \\
-9,958,068 \\
9,666,292 \\
13,771,423 \\
5,994,816\end{array}$ & $\begin{array}{l}2,330,293 \\
3,365,017 \\
1,770,108 \\
2,601,770 \\
4,595,894 \\
4,783,422 \\
3,491,418\end{array}$ & $\begin{array}{l}3,680,390 \\
5,064,705 \\
5,637,968 \\
4,987,773 \\
4,003,617 \\
3,880,567 \\
3,884,832\end{array}$ & $\begin{array}{l}2,250,167 \\
3,161,015 \\
2,762,277 \\
2,554,107 \\
3,312,753 \\
3,249,730 \\
3,357,088\end{array}$ & $\begin{array}{r}986,771 \\
1,016,329 \\
1,120,806 \\
830,264 \\
853,705 \\
943,748 \\
815,973\end{array}$ & $\begin{array}{l}3,847,930 \\
4,281,040 \\
4,639,141 \\
4,975,326 \\
4,172,713 \\
5,156,596 \\
4,967,146\end{array}$ \\
\hline $\begin{array}{l}\text { 2-year } \\
2005-06 \ldots \ldots \ldots \ldots . . . \\
2006-07 \ldots \ldots \ldots \ldots . . . \\
2007-08 \ldots \ldots \ldots \ldots . . . \\
2008-09 . \ldots \ldots \ldots \ldots . . \\
2009-10 \ldots \ldots \ldots \ldots . . \\
2010-11 \ldots \ldots \ldots \ldots . . \\
2011-12 \ldots \ldots \ldots \ldots . . .\end{array}$ & $\begin{array}{r}138,517 \\
124,026 \\
73,324 \\
75,885 \\
145,606 \\
93,856 \\
120,279 \\
\end{array}$ & $\begin{array}{l}13,128,549 \\
13,988,272 \\
15,106,414 \\
14,622,766 \\
13,734,565 \\
14,038,114 \\
13,034,033 \\
\end{array}$ & $\begin{array}{l}7,913,266 \\
8,371,762 \\
8,865,938 \\
9,302,330 \\
9,522,890 \\
9,516,195 \\
9,697,357 \\
\end{array}$ & $\begin{array}{r}1,265,113 \\
1,233,292 \\
4,844,746 \\
6,335,282 \\
10,421,125 \\
12,516,431 \\
11,941,246 \\
\end{array}$ & $\begin{array}{r}563,394 \\
586,491 \\
708,176 \\
990,464 \\
1,035,203 \\
1,084,965 \\
1,161,061 \\
\end{array}$ & $\begin{array}{r}69,228 \\
57,230 \\
73,731 \\
134,362 \\
96,496 \\
97,594 \\
101,569 \\
\end{array}$ & $\begin{array}{l}261,914 \\
257,136 \\
271,766 \\
258,608 \\
230,170 \\
225,730 \\
266,364 \\
\end{array}$ & $\begin{array}{l}669,858 \\
971,979 \\
848,164 \\
470,153 \\
380,318 \\
413,636 \\
176,240 \\
\end{array}$ & $\begin{array}{l}375,058 \\
585,175 \\
481,216 \\
409,470 \\
614,128 \\
840,284 \\
700,443 \\
\end{array}$ & $\begin{array}{l}1,741,270 \\
2,267,682 \\
1,940,082 \\
2,050,885 \\
2,037,393 \\
1,759,459 \\
1,659,672 \\
\end{array}$ & $\begin{array}{l}318,521 \\
348,667 \\
328,312 \\
384,498 \\
467,258 \\
495,115 \\
367,232 \\
\end{array}$ & $\begin{array}{r}17,920 \\
23,096 \\
12,978 \\
13,263 \\
16,245 \\
21,258 \\
9,614 \\
\end{array}$ & $\begin{array}{l}198,236 \\
281,159 \\
334,477 \\
342,236 \\
254,532 \\
251,487 \\
543,362 \\
\end{array}$ \\
\hline \multirow[b]{2}{*}{ 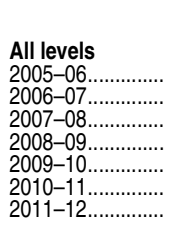 } & \multicolumn{13}{|c|}{ Percentage distribution } \\
\hline & $\begin{array}{l}0.76 \\
0.71 \\
0.68 \\
0.75 \\
0.71 \\
0.60 \\
0.58\end{array}$ & $\begin{array}{l}23.85 \\
23.54 \\
25.04 \\
24.49 \\
20.59 \\
19.46 \\
18.53\end{array}$ & $\begin{array}{l}3.35 \\
3.28 \\
3.41 \\
3.66 \\
3.28 \\
3.10 \\
3.22\end{array}$ & $\begin{array}{l}1.14 \\
1.06 \\
3.67 \\
4.77 \\
6.84 \\
7.52 \\
7.31\end{array}$ & $\begin{array}{l}0.48 \\
0.48 \\
0.70 \\
1.02 \\
1.03 \\
1.05 \\
1.12\end{array}$ & $\begin{array}{l}0.04 \\
0.05 \\
0.07 \\
0.10 \\
0.08 \\
0.07 \\
0.07\end{array}$ & $\begin{array}{l}2.02 \\
2.08 \\
2.22 \\
2.20 \\
1.94 \\
1.94 \\
2.06\end{array}$ & $\begin{array}{r}3.90 \\
5.80 \\
1.93 \\
-3.55 \\
3.31 \\
4.38 \\
1.94\end{array}$ & $\begin{array}{l}1.10 \\
1.47 \\
0.82 \\
1.13 \\
1.72 \\
1.74 \\
1.32\end{array}$ & $\begin{array}{l}2.20 \\
2.73 \\
2.77 \\
2.63 \\
1.99 \\
1.74 \\
1.75\end{array}$ & $\begin{array}{l}1.04 \\
1.31 \\
1.13 \\
1.10 \\
1.25 \\
1.16 \\
1.17\end{array}$ & $\begin{array}{l}0.41 \\
0.39 \\
0.42 \\
0.32 \\
0.29 \\
0.30 \\
0.26\end{array}$ & $\begin{array}{l}1.64 \\
1.70 \\
1.82 \\
1.99 \\
1.46 \\
1.67 \\
1.74\end{array}$ \\
\hline $\begin{array}{l}\text { 4-year } \\
2005-06 \ldots \ldots \ldots \ldots . \\
2006-07 \ldots \ldots \ldots \ldots . \\
2007-08 \ldots \ldots \ldots \ldots . . \\
2008-09 \ldots \ldots \ldots \ldots . . \\
2009-10 \ldots \ldots \ldots \ldots . . \\
2010-11 \ldots \ldots \ldots \ldots . . \\
2011-12 \ldots \ldots \ldots \ldots . .\end{array}$ & $\begin{array}{l}0.85 \\
0.80 \\
0.79 \\
0.89 \\
0.81 \\
0.70 \\
0.66\end{array}$ & $\begin{array}{l}22.51 \\
22.18 \\
23.83 \\
23.50 \\
19.64 \\
18.42 \\
17.52\end{array}$ & $\begin{array}{l}0.17 \\
0.20 \\
0.20 \\
0.22 \\
0.17 \\
0.19 \\
0.20\end{array}$ & $\begin{array}{l}0.76 \\
0.73 \\
2.32 \\
2.97 \\
4.16 \\
4.46 \\
4.31\end{array}$ & $\begin{array}{l}0.30 \\
0.32 \\
0.54 \\
0.80 \\
0.84 \\
0.87 \\
0.92\end{array}$ & $\begin{array}{l}0.02 \\
0.03 \\
0.05 \\
0.06 \\
0.05 \\
0.05 \\
0.05\end{array}$ & $\begin{array}{l}2.33 \\
2.40 \\
2.59 \\
2.60 \\
2.28 \\
2.28 \\
2.40\end{array}$ & $\begin{array}{r}4.41 \\
6.59 \\
1.98 \\
-4.60 \\
3.90 \\
5.18 \\
2.30\end{array}$ & $\begin{array}{l}1.15 \\
1.52 \\
0.79 \\
1.20 \\
1.85 \\
1.80 \\
1.34\end{array}$ & $\begin{array}{l}1.82 \\
2.28 \\
2.52 \\
2.30 \\
1.61 \\
1.46 \\
1.49\end{array}$ & $\begin{array}{l}1.11 \\
1.42 \\
1.24 \\
1.18 \\
1.34 \\
1.22 \\
1.29\end{array}$ & $\begin{array}{l}0.49 \\
0.46 \\
0.50 \\
0.38 \\
0.34 \\
0.35 \\
0.31\end{array}$ & $\begin{array}{l}1.90 \\
1.93 \\
2.08 \\
2.30 \\
1.68 \\
1.94 \\
1.90\end{array}$ \\
\hline \multirow[t]{2}{*}{$\begin{array}{l}\text { 2-year } \\
2005-06 \ldots \ldots \ldots \ldots . . \\
2006-07 \ldots \ldots \ldots \ldots \ldots \\
2007-08 \ldots \ldots \ldots \ldots . . . \\
2008-09 \ldots \ldots \ldots \ldots . . . \\
2009-10 \ldots \ldots \ldots \ldots . . . \\
2010-11 \ldots \ldots \ldots \ldots . . . \\
2011-12 \ldots \ldots \ldots \ldots \ldots\end{array}$} & $\begin{array}{l}0.32 \\
0.27 \\
0.15 \\
0.15 \\
0.26 \\
0.16 \\
0.21 \\
\end{array}$ & $\begin{array}{l}30.07 \\
29.97 \\
30.49 \\
28.70 \\
24.87 \\
24.26 \\
23.21 \\
\end{array}$ & $\begin{array}{l}18.13 \\
17.94 \\
17.90 \\
18.26 \\
17.24 \\
16.44 \\
17.27 \\
\end{array}$ & $\begin{array}{r}2.90 \\
2.64 \\
9.78 \\
12.43 \\
18.87 \\
21.63 \\
21.27 \\
\end{array}$ & $\begin{array}{l}1.29 \\
1.26 \\
1.43 \\
1.94 \\
1.87 \\
1.87 \\
2.07 \\
\end{array}$ & $\begin{array}{l}0.16 \\
0.12 \\
0.15 \\
0.26 \\
0.17 \\
0.17 \\
0.18 \\
\end{array}$ & $\begin{array}{l}0.60 \\
0.55 \\
0.55 \\
0.51 \\
0.42 \\
0.39 \\
0.47 \\
\end{array}$ & $\begin{array}{l}1.53 \\
2.08 \\
1.71 \\
0.92 \\
0.69 \\
0.71 \\
0.31 \\
\end{array}$ & $\begin{array}{l}0.86 \\
1.25 \\
0.97 \\
0.80 \\
1.11 \\
1.45 \\
1.25 \\
\end{array}$ & $\begin{array}{l}3.99 \\
4.86 \\
3.92 \\
4.03 \\
3.69 \\
3.04 \\
2.96 \\
\end{array}$ & $\begin{array}{l}0.73 \\
0.75 \\
0.66 \\
0.75 \\
0.85 \\
0.86 \\
0.65 \\
\end{array}$ & $\begin{array}{l}0.04 \\
0.05 \\
0.03 \\
0.03 \\
0.03 \\
0.04 \\
0.02 \\
\end{array}$ & $\begin{array}{l}0.45 \\
0.60 \\
0.68 \\
0.67 \\
0.46 \\
0.43 \\
0.97 \\
\end{array}$ \\
\hline & \multicolumn{13}{|c|}{ Revenue per full-time-equivalent student in constant 2012-13 dollars ${ }^{3}$} \\
\hline 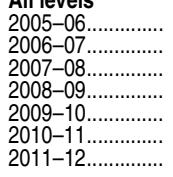 & $\begin{array}{r}\$ 230 \\
228 \\
208 \\
215 \\
214 \\
185 \\
170\end{array}$ & $\begin{array}{r}\$ 7,270 \\
7,537 \\
7,672 \\
7,015 \\
6,202 \\
5,983 \\
5,459\end{array}$ & $\begin{array}{r}\$ 1,021 \\
1,052 \\
1,046 \\
1,048 \\
988 \\
952 \\
948\end{array}$ & $\begin{array}{r}\$ 348 \\
341 \\
1,125 \\
1,367 \\
2,059 \\
2,314 \\
2,155\end{array}$ & $\begin{array}{r}\$ 146 \\
154 \\
214 \\
291 \\
310 \\
323 \\
331\end{array}$ & $\begin{array}{r}\$ 13 \\
15 \\
20 \\
28 \\
23 \\
22 \\
22\end{array}$ & $\begin{array}{r}\$ 616 \\
667 \\
681 \\
631 \\
584 \\
597 \\
607\end{array}$ & $\begin{array}{r}\$ 1,188 \\
1,859 \\
592 \\
-1,016 \\
998 \\
1,347 \\
573\end{array}$ & $\begin{array}{r}\$ 335 \\
471 \\
253 \\
323 \\
517 \\
534 \\
389\end{array}$ & $\begin{array}{r}\$ 671 \\
874 \\
850 \\
754 \\
600 \\
536 \\
515\end{array}$ & $\begin{array}{r}\$ 318 \\
419 \\
347 \\
315 \\
375 \\
356 \\
346\end{array}$ & $\begin{array}{r}\$ 124 \\
124 \\
127 \\
90 \\
86 \\
92 \\
77\end{array}$ & $\begin{array}{r}\$ 501 \\
544 \\
558 \\
570 \\
440 \\
514 \\
512\end{array}$ \\
\hline $\begin{array}{l}\text { 4-year } \\
2005-06 \ldots \ldots \ldots \ldots . . \\
2006-07 \ldots \ldots \ldots \ldots . . \\
2007-08 \ldots \ldots \ldots \ldots . . \\
2008-09 \ldots \ldots \ldots \ldots . . \\
2009-10 \ldots \ldots \ldots \ldots . . \\
2010-11 \ldots \ldots \ldots \ldots . . \\
2011-12 \ldots \ldots \ldots \ldots . . .\end{array}$ & $\begin{array}{l}349 \\
348 \\
324 \\
340 \\
332 \\
292 \\
259\end{array}$ & $\begin{array}{l}9,253 \\
9,576 \\
9,712 \\
8,929 \\
8,060 \\
7,723 \\
6,909\end{array}$ & $\begin{array}{l}68 \\
87 \\
83 \\
85 \\
71 \\
80 \\
78\end{array}$ & $\begin{array}{r}314 \\
316 \\
944 \\
1,128 \\
1,707 \\
1,869 \\
1,701\end{array}$ & $\begin{array}{l}125 \\
137 \\
219 \\
304 \\
345 \\
366 \\
362\end{array}$ & $\begin{array}{r}7 \\
14 \\
19 \\
23 \\
22 \\
21 \\
20\end{array}$ & $\begin{array}{r}957 \\
1,037 \\
1,057 \\
989 \\
934 \\
956 \\
947\end{array}$ & $\begin{array}{r}1,812 \\
2,844 \\
808 \\
-1,748 \\
1,599 \\
2,172 \\
905\end{array}$ & $\begin{array}{l}473 \\
655 \\
323 \\
457 \\
760 \\
754 \\
527\end{array}$ & $\begin{array}{r}747 \\
985 \\
1,028 \\
876 \\
662 \\
612 \\
587\end{array}$ & $\begin{array}{l}457 \\
615 \\
504 \\
448 \\
548 \\
512 \\
507\end{array}$ & $\begin{array}{l}200 \\
198 \\
204 \\
146 \\
141 \\
149 \\
123\end{array}$ & $\begin{array}{l}781 \\
833 \\
846 \\
873 \\
690 \\
813 \\
750\end{array}$ \\
\hline $\begin{array}{l}\text { 2-year } \\
2005-06 \ldots \ldots \ldots \ldots . . \\
2006-07 \ldots \ldots \ldots \ldots . . \\
2007-08 \ldots \ldots \ldots \ldots . . \\
2008-09 \ldots \ldots \ldots \ldots . . \\
2009-10 \ldots \ldots \ldots \ldots . . \\
2010-11 \ldots \ldots \ldots \ldots . . \\
2011-12 \ldots \ldots \ldots \ldots . .\end{array}$ & $\begin{array}{l}44 \\
38 \\
21 \\
21 \\
36 \\
22 \\
29\end{array}$ & $\begin{array}{l}4,168 \\
4,309 \\
4,408 \\
4,018 \\
3,411 \\
3,350 \\
3,143\end{array}$ & $\begin{array}{l}2,512 \\
2,579 \\
2,587 \\
2,556 \\
2,365 \\
2,271 \\
2,339\end{array}$ & $\begin{array}{r}402 \\
380 \\
1,414 \\
1,741 \\
2,588 \\
2,987 \\
2,880\end{array}$ & $\begin{array}{l}179 \\
181 \\
207 \\
272 \\
257 \\
259 \\
280\end{array}$ & $\begin{array}{l}22 \\
18 \\
22 \\
37 \\
24 \\
23 \\
24\end{array}$ & $\begin{array}{l}83 \\
79 \\
79 \\
71 \\
57 \\
54 \\
64\end{array}$ & $\begin{array}{r}213 \\
299 \\
247 \\
129 \\
94 \\
99 \\
43\end{array}$ & $\begin{array}{l}119 \\
180 \\
140 \\
113 \\
153 \\
201 \\
169\end{array}$ & $\begin{array}{l}553 \\
699 \\
566 \\
564 \\
506 \\
420 \\
400\end{array}$ & $\begin{array}{r}101 \\
107 \\
96 \\
106 \\
116 \\
118 \\
89\end{array}$ & $\begin{array}{l}6 \\
7 \\
4 \\
4 \\
4 \\
5 \\
2\end{array}$ & $\begin{array}{r}63 \\
87 \\
98 \\
94 \\
63 \\
60 \\
131\end{array}$ \\
\hline
\end{tabular}

1 After deducting discounts and allowances.

Includes sales and services of educational activities.

${ }^{3}$ Constant dollars based on the Consumer Price Index, prepared by the Bureau of Labor Statistics, U.S. Department of Labor, adjusted to a school-year basis.

NOTE: Degree-granting institutions grant associate's or higher degrees and participate in Title IV federal financial aid programs. Includes data for public institutions reporting data according to either the Governmental Accounting Standards Board (GASB) or the Financial Accounting Standards Board (FASB) questionnaire. Detail may not sum to totals because of rounding. SOURCE: U.S. Department of Education, National Center for Education Statistics, Integrated Postsecondary Education Data System (IPEDS), Spring 2006 through Spring 2013, Finance and Enrollment components. (This table was prepared January 2014.) 
Table 333.20. Revenues of public degree-granting postsecondary institutions, by source of revenue and state or jurisdiction: 2011-12 [In thousands of current dollars]

\begin{tabular}{|c|c|c|c|c|c|c|c|c|c|c|c|c|}
\hline \multirow[b]{2}{*}{ State or jurisdiction } & \multirow[b]{2}{*}{$\begin{array}{r}\text { Total } \\
\text { revenues }\end{array}$} & \multicolumn{7}{|c|}{ Operating revenue } & \multicolumn{3}{|c|}{ Nonoperating revenue ${ }^{1}$} & \multirow[b]{2}{*}{$\begin{array}{r}\text { Other } \\
\text { revenues } \\
\text { and additions }\end{array}$} \\
\hline & & Total & $\begin{array}{r}\text { Tuition } \\
\text { and fees }\end{array}$ & $\begin{array}{r}\text { Federal } \\
\text { grants and } \\
\text { contracts }\end{array}$ & $\begin{array}{r}\text { State, local, } \\
\text { and private } \\
\text { grants and } \\
\text { contracts }\end{array}$ & $\begin{array}{r}\text { Sales and } \\
\text { services } \\
\text { of auxiliary } \\
\text { enterprises }^{2}\end{array}$ & $\begin{array}{r}\text { Sales and } \\
\text { services } \\
\text { of hospitals }\end{array}$ & $\begin{array}{r}\text { Independent } \\
\text { operations } \\
\text { and other }{ }^{3}\end{array}$ & Total & $\begin{array}{r}\text { State } \\
\text { appro- } \\
\text { priations }\end{array}$ & $\begin{array}{r}\text { Local } \\
\text { appro- } \\
\text { priations }\end{array}$ & \\
\hline 1 & 2 & 3 & 4 & 5 & 6 & 7 & 8 & & 10 & 11 & 12 & 13 \\
\hline United States....... & $7,306,882$ & $86,960,737$ & $5,386,643$ & $9,170,906$ & $5,974,510$ & $4,275,773$ & $3,508,840$ & $7,644,066$ & $\$ 114,741,226$ & $58,789,643$ & $0,214,576$ & $\overline{15,604,918}$ \\
\hline 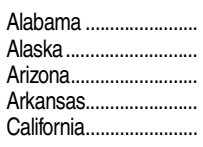 & $\begin{array}{r}6,898,551 \\
984,645 \\
5,417,482 \\
3,746,046 \\
43,273,373\end{array}$ & $\begin{array}{r}4,470,826 \\
323,106 \\
2,794,932 \\
2,299,638 \\
25,008,634\end{array}$ & $\begin{array}{r}1,445,641 \\
124,504 \\
1,548,148 \\
441,167 \\
6,064,944\end{array}$ & $\begin{array}{r}638,664 \\
63,452 \\
577,593 \\
298,138 \\
3,799,698\end{array}$ & $\begin{array}{r}234,802 \\
75,364 \\
174,917 \\
187,638 \\
2,422,968\end{array}$ & $\begin{array}{r}377,327 \\
40,611 \\
338,428 \\
246,418 \\
1,892,987\end{array}$ & $\begin{array}{r}1,430,697 \\
0 \\
0 \\
876,544 \\
6,817,495\end{array}$ & $\begin{array}{r}343,695 \\
19,175 \\
155,846 \\
249,734 \\
4,010,541\end{array}$ & \begin{tabular}{r|}
$2,266,648$ \\
494,218 \\
$2,524,426$ \\
$1,338,735$ \\
$15,543,874$
\end{tabular} & $\begin{array}{r}1,332,025 \\
358,441 \\
783,210 \\
755,308 \\
7,397,375\end{array}$ & $\begin{array}{r}1,277 \\
10,031 \\
749,180 \\
31,131 \\
2,561,870\end{array}$ & $\begin{array}{r}161,078 \\
167,322 \\
98,124 \\
107,673 \\
2,720,866\end{array}$ \\
\hline 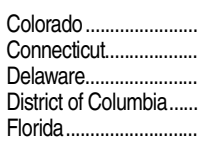 & $\begin{array}{r}5,481,511 \\
3,112,449 \\
1,133,613 \\
167,230 \\
10,622,365\end{array}$ & $\begin{array}{r}4,543,086 \\
1,705,133 \\
784,390 \\
56,749 \\
5,055,543\end{array}$ & $\begin{array}{r}1,708,897 \\
590,081 \\
423,082 \\
27,050 \\
2,097,380\end{array}$ & $\begin{array}{r}949,988 \\
173,699 \\
145,096 \\
13,854 \\
1,084,379\end{array}$ & $\begin{array}{r}558,591 \\
98,321 \\
40,460 \\
12,207 \\
940,208\end{array}$ & $\begin{array}{r}490,576 \\
270,590 \\
128,887 \\
377 \\
771,409\end{array}$ & $\begin{array}{r}8,461 \\
9,388 \\
0 \\
0 \\
0\end{array}$ & $\begin{array}{r}356,573 \\
283,054 \\
46,863 \\
3,260 \\
162,165\end{array}$ & $\begin{array}{r}748,878 \\
1,117,577 \\
320,566 \\
84,445 \\
5,205,271\end{array}$ & $\begin{array}{r}30,648 \\
892,046 \\
222,253 \\
67,362 \\
3,037,050\end{array}$ & $\begin{array}{r}3,374 \\
0 \\
0 \\
0 \\
0\end{array}$ & $\begin{array}{r}189,547 \\
289,739 \\
28,658 \\
26,036 \\
361,551\end{array}$ \\
\hline 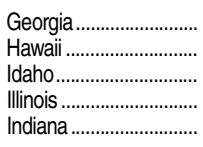 & $\begin{array}{r}7,664,812 \\
1,584,602 \\
1,282,864 \\
11,780,728 \\
6,604,271\end{array}$ & $\begin{array}{r}4,299,845 \\
780,940 \\
660,724 \\
5,996,283 \\
4,142,356\end{array}$ & $\begin{array}{r}1,780,346 \\
238,172 \\
322,712 \\
2,393,531 \\
2,141,648\end{array}$ & $\begin{array}{l}776,296 \\
346,662 \\
120,035 \\
888,551 \\
609,029\end{array}$ & $\begin{array}{r}529,480 \\
60,956 \\
51,578 \\
394,977 \\
262,448\end{array}$ & $\begin{array}{r}800,241 \\
87,631 \\
121,301 \\
910,618 \\
724,944\end{array}$ & $\begin{array}{r}196,911 \\
0 \\
0 \\
655,563 \\
0\end{array}$ & $\begin{array}{r}216,571 \\
47,518 \\
45,097 \\
753,043 \\
404,288\end{array}$ & $\begin{array}{r}2,979,565 \\
616,659 \\
581,949 \\
5,582,666 \\
2,376,556\end{array}$ & $\begin{array}{r}1,847,730 \\
375,754 \\
308,986 \\
1,815,619 \\
1,415,835\end{array}$ & $\begin{array}{r}44 \\
0 \\
20,559 \\
015,855 \\
9,012\end{array}$ & $\begin{array}{r}385,401 \\
187,003 \\
40,191 \\
201,779 \\
85,359\end{array}$ \\
\hline 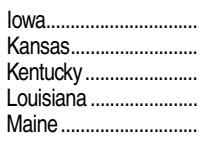 & $\begin{array}{r}5,034,055 \\
3,320,431 \\
5,148,333 \\
4,000,467 \\
919,695\end{array}$ & $\begin{array}{r}3,699,260 \\
1,898,469 \\
3,425,174 \\
2,386,961 \\
493,225\end{array}$ & $\begin{array}{l}843,756 \\
758,127 \\
954,277 \\
791,720 \\
216,316\end{array}$ & $\begin{array}{r}577,340 \\
370,136 \\
438,238 \\
333,795 \\
67,108\end{array}$ & $\begin{array}{r}143,341 \\
188,492 \\
245,000 \\
442,797 \\
68,063\end{array}$ & & $\begin{array}{r}1,319,642 \\
0 \\
1,084,839 \\
287,764 \\
0\end{array}$ & & $\begin{array}{r}1,250,437 \\
1,323,151 \\
1,623,158 \\
1,463,053 \\
374,279\end{array}$ & & $\begin{array}{r}114,880 \\
233,851 \\
17,501 \\
0 \\
0\end{array}$ & $\begin{array}{r}84,357 \\
98,812 \\
100,000 \\
150,453 \\
52,191\end{array}$ \\
\hline moland & $\begin{array}{r}6,381,736 \\
4,648,600 \\
13,321,669 \\
5,053,633 \\
4,008,102\end{array}$ & & & $\begin{array}{r}784,837 \\
407,861 \\
1,469,930 \\
513,955 \\
384,546\end{array}$ & & $\begin{array}{r}649,640 \\
428,542 \\
1,072,373 \\
597,554 \\
267,205\end{array}$ & $\begin{array}{r}0 \\
0 \\
2,601,803 \\
0 \\
704,269\end{array}$ & & & & $\begin{array}{r}310,463 \\
0 \\
523,771 \\
0 \\
59,716\end{array}$ & $\begin{array}{l}407,383 \\
290,364 \\
305,471 \\
197,354 \\
157,771\end{array}$ \\
\hline 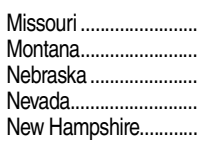 & $\begin{array}{r}4,736,828 \\
1,018,626 \\
2,351,516 \\
1,362,281 \\
939,405\end{array}$ & $\begin{array}{r}3,021,550 \\
661,181 \\
1,248,587 \\
694,960 \\
724,302\end{array}$ & $\begin{array}{r}1,023,031 \\
279,324 \\
404,450 \\
335,187 \\
371,385\end{array}$ & $\begin{array}{r}265,314 \\
173,977 \\
245,921 \\
141,148 \\
65,790\end{array}$ & $\begin{array}{r}187,060 \\
34,181 \\
175,016 \\
65,159 \\
64,294\end{array}$ & $\begin{array}{r}734,490 \\
86,022 \\
286,557 \\
91,760 \\
198,475\end{array}$ & $\begin{array}{r}656,903 \\
15,484 \\
25,752 \\
0 \\
0\end{array}$ & $\begin{array}{r}154,752 \\
72,191 \\
110,892 \\
61,706 \\
24,358\end{array}$ & $\begin{array}{r}1,623,104 \\
325,884 \\
1,008,319 \\
643,010 \\
174,129\end{array}$ & & $\begin{array}{r}146,266 \\
8,404 \\
127,737 \\
0 \\
0\end{array}$ & $\begin{array}{l}92,174 \\
31,562 \\
94,609 \\
24,312 \\
40,975\end{array}$ \\
\hline & $\begin{array}{r}7,319,457 \\
3,203,410 \\
15,687,238 \\
10,263,991 \\
1,115,052\end{array}$ & $\begin{array}{r}4,631,023 \\
1,822,786 \\
7,840,647 \\
4,289,664 \\
691,468\end{array}$ & $\begin{array}{r}2,025,314 \\
273,385 \\
2,410,166 \\
1,539,459 \\
275,366\end{array}$ & $\begin{array}{l}497,186 \\
385,027 \\
795,823 \\
823,784 \\
164,278\end{array}$ & $\begin{array}{r}410,975 \\
157,246 \\
1,048,339 \\
309,500 \\
58,833\end{array}$ & $\begin{array}{r}585,610 \\
120,755 \\
927,283 \\
1,427,382 \\
113,007\end{array}$ & $\begin{array}{r}920,868 \\
624,117 \\
2,459,479 \\
974 \\
0\end{array}$ & & & & $\begin{array}{r}194,452 \\
126,890 \\
797,232 \\
200,980 \\
2,686\end{array}$ & $\begin{array}{r}156,965 \\
79,143 \\
726,171 \\
643,372 \\
57,960\end{array}$ \\
\hline 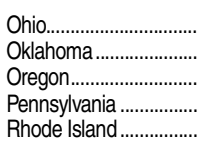 & $\begin{array}{r}12,202,046 \\
4,042,219 \\
5,722,757 \\
12,076,791 \\
780,754\end{array}$ & $\begin{array}{r}8,689,965 \\
2,363,087 \\
4,105,013 \\
9,495,751 \\
522,339\end{array}$ & $\begin{array}{r}3,427,072 \\
771,736 \\
1,122,000 \\
3,841,626 \\
264,236\end{array}$ & $\begin{array}{r}791,674 \\
269,595 \\
675,695 \\
1,300,138 \\
87,381\end{array}$ & $\begin{array}{r}502,995 \\
292,237 \\
172,101 \\
330,584 \\
38,536\end{array}$ & $\begin{array}{r}1,116,246 \\
456,635 \\
459,727 \\
984,355 \\
102,825\end{array}$ & $\begin{array}{r}2,550,550 \\
67,631 \\
1,442,402 \\
2,412,708 \\
0\end{array}$ & $\begin{array}{r}301,429 \\
505,254 \\
233,088 \\
626,339 \\
29,361\end{array}$ & $\begin{array}{r}3,278,851 \\
1,533,106 \\
1,493,524 \\
2,480,199 \\
209,791\end{array}$ & $\begin{array}{r}1,861,830 \\
898,544 \\
583,336 \\
1,189,943 \\
141,208\end{array}$ & $\begin{array}{r}158,190 \\
50,986 \\
210,454 \\
111,524 \\
0\end{array}$ & $\begin{array}{r}233,230 \\
146,025 \\
124,220 \\
100,840 \\
48,624\end{array}$ \\
\hline$\ldots$ & $\begin{array}{r}4,063,314 \\
800,354 \\
4,297,676 \\
30,178,634 \\
5,016,569\end{array}$ & $\begin{array}{r}2,755,593 \\
512,259 \\
2,151,942 \\
13,571,633 \\
3,455,190\end{array}$ & $\begin{array}{r}1,304,733 \\
214,192 \\
992,372 \\
4,655,347 \\
674,688\end{array}$ & $\begin{array}{r}416,150 \\
125,186 \\
332,362 \\
2,082,244 \\
433,497\end{array}$ & $\begin{array}{r}360,754 \\
43,018 \\
257,387 \\
2,023,194 \\
141,904\end{array}$ & $\begin{array}{r}398,300 \\
66,209 \\
299,677 \\
1,259,078 \\
195,995\end{array}$ & $\begin{array}{r}0 \\
0 \\
0 \\
1,922,484 \\
1,267,170\end{array}$ & $\begin{array}{r}275,654 \\
63,654 \\
270,145 \\
1,629,287 \\
741,935\end{array}$ & & & $\begin{array}{r}62,126 \\
0 \\
5,655 \\
1,452,266 \\
0\end{array}$ & $\begin{array}{r}151,828 \\
40,843 \\
241,901 \\
3,652,272 \\
453,610\end{array}$ \\
\hline 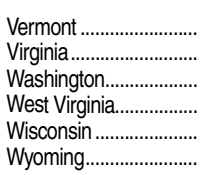 & $\begin{array}{r}760,959 \\
9,215,536 \\
7,678,762 \\
1,922,218 \\
6,404,192 \\
804,486\end{array}$ & $\begin{array}{r}645,422 \\
6,003,793 \\
5,557,323 \\
1,128,696 \\
3,558,863 \\
281,495\end{array}$ & $\begin{array}{r}348,332 \\
2,302,342 \\
1,615,340 \\
517,199 \\
1,294,046 \\
78,962\end{array}$ & $\begin{array}{r}127,751 \\
850,969 \\
1,289,869 \\
146,773 \\
712,773 \\
45,014\end{array}$ & & $\begin{array}{r}102,133 \\
1,171,606 \\
522,263 \\
221,689 \\
482,556 \\
59,262\end{array}$ & $\begin{array}{r}0 \\
1,173,193 \\
1,097,525 \\
0 \\
0 \\
0\end{array}$ & $\begin{array}{r}23,398 \\
305,829 \\
408,867 \\
57,811 \\
616,764 \\
35,405\end{array}$ & $\begin{array}{r}105,702 \\
2,562,990 \\
1,881,491 \\
625,209 \\
2,393,871 \\
494,402\end{array}$ & $\begin{array}{r}67,894 \\
1,441,710 \\
1,074,462 \\
429,716 \\
943,010 \\
333,566\end{array}$ & $\begin{array}{r}0 \\
5,141 \\
0 \\
874 \\
769,923 \\
45,274\end{array}$ & $\begin{array}{r}9,835 \\
648,753 \\
239,948 \\
168,313 \\
451,458 \\
28,589\end{array}$ \\
\hline Academies........ & $1,750,547$ & 304,344 & 1,480 & 92,709 & 338 & 77,093 & 128,223 & 0 & 3,303 & 0 & 0 & 22,900 \\
\hline $\begin{array}{l}\text { Other } \\
\text { jurisdictions. }\end{array}$ & $1,833,704$ & 585,614 & 22,708 & 239,686 & 116 & 14,326 & 86,819 & ;,959 & 240,687 & 891,770 & 40,258 & 7,403 \\
\hline American Samoa .......... & 25,002 & 14,919 & 4,208 & 10,036 & & 669 & 0 & 6 & 10,083 & 1,948 & 0 & 0 \\
\hline & 9 & $\begin{array}{r}6,283 \\
68,274\end{array}$ & $\begin{array}{l}612 \\
6,693\end{array}$ & $\begin{array}{r}2,180 \\
34,233\end{array}$ & $\begin{array}{l}1,206 \\
3,322\end{array}$ & & $\begin{array}{l}0 \\
0\end{array}$ & $\begin{array}{l}412 \\
467\end{array}$ & & & & \\
\hline & & & & & 0 & & & 302 & & & & \\
\hline & $\begin{array}{l}19,824 \\
11,310\end{array}$ & $\begin{array}{r}13,279 \\
4,528\end{array}$ & $\begin{array}{l}2,527 \\
3092\end{array}$ & 1 & $\begin{array}{l}0 \\
0 \\
0\end{array}$ & $\begin{array}{r}1,265 \\
139\end{array}$ & $\begin{array}{l}0 \\
0 \\
0\end{array}$ & $\begin{array}{r}16 \\
216\end{array}$ & $\begin{array}{l}6,545 \\
6781\end{array}$ & $\begin{array}{l}3,749 \\
2,654\end{array}$ & $\begin{array}{l}0 \\
0\end{array}$ & \\
\hline & 11, & 40 & & & & 3,216 & 19 & & & $\begin{array}{r}2,654 \\
846,348\end{array}$ & & 2,307 \\
\hline & 81, & 11,854 & 14,76 & 20,223 & 2,9 & 3,593 & & 354 & 35,267 & & 25,687 &, 992 \\
\hline
\end{tabular}

IIncludes other categories not separately shown. ${ }^{2}$ After deducting discounts and allowances.

Includes sales and services of educational activities.

NOTE: Degree-granting institutions grant associate's or higher degrees and participate in Title IV federal financial aid programs. Includes data for public institutions reporting data according to either the Governmental Accounting Standards Board (GASB) or the Financial
Accounting Standards Board (FASB) questionnaire. Detail may not sum to totals because of rounding.

SOURCE: U.S. Department of Education, National Center for Education Statistics, Integrated Postsecondary Education Data System (IPEDS), Spring 2013, Finance component. (This table was prepared January 2014.) 
Table 333.25. Revenues of public degree-granting postsecondary institutions, by source of revenue and state or jurisdiction: 2010-11 [In thousands of current dollars]

\begin{tabular}{|c|c|c|c|c|c|c|c|c|c|c|c|c|}
\hline \multirow[b]{2}{*}{ State or jurisdiction } & \multirow[b]{2}{*}{$\begin{array}{r}\text { Total } \\
\text { revenues }\end{array}$} & \multicolumn{7}{|c|}{ Operating revenue } & \multicolumn{3}{|c|}{ Nonoperating revenue ${ }^{1}$} & \multirow[b]{2}{*}{$\begin{array}{r}\text { Other } \\
\text { revenues } \\
\text { and additions } \\
\end{array}$} \\
\hline & & Total & $\begin{array}{r}\text { Tuition } \\
\text { and fees }{ }^{2}\end{array}$ & $\begin{array}{r}\text { Federal } \\
\text { grants and } \\
\text { contracts }\end{array}$ & $\begin{array}{r}\text { State, local, } \\
\text { and private } \\
\text { grants and } \\
\text { contracts }\end{array}$ & $\begin{array}{r}\text { Sales and } \\
\text { services } \\
\text { of auxiliary } \\
\text { enterprises }^{2}\end{array}$ & $\begin{array}{r}\text { Sales and } \\
\text { services } \\
\text { of hospitals }\end{array}$ & $\begin{array}{r}\text { Independent } \\
\text { operations } \\
\text { and other }{ }^{3}\end{array}$ & Total & $\begin{array}{r}\text { State } \\
\text { appro- } \\
\text { priations }\end{array}$ & $\begin{array}{r}\text { Local } \\
\text { appro- } \\
\text { priations }\end{array}$ & \\
\hline 1 & 2 & 3 & 4 & 5 & 6 & 7 & 8 & 9 & 10 & 11 & 12 & 13 \\
\hline United States .... & $\$ 323,817,821$ & $\$ 178,979,374$ & $\$ 60,240,671$ & $\$ 29,808,728$ & $\$ 17,082,994$ & $\$ 23,606,433$ & $\$ 31,105,677$ & $\$ 17,134,870$ & $\$ 129,080,485$ & $\$ 63,015,552$ & $\$ 10,023,205$ & $\$ 15,757,961$ \\
\hline 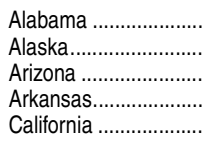 & $\begin{array}{r}7,061,371 \\
933,674 \\
5,406,400 \\
3,627,870 \\
43,771,386\end{array}$ & $\begin{array}{r}4,775,199 \\
360,889 \\
2,601,499 \\
2,186,376 \\
23,730,000\end{array}$ & $\begin{array}{r}1,315,917 \\
116,803 \\
1,382,320 \\
396,452 \\
5,294,304\end{array}$ & $\begin{array}{r}768,169 \\
110,787 \\
558,816 \\
256,466 \\
3,909,349\end{array}$ & $\begin{array}{r}273,882 \\
66,519 \\
162,053 \\
181,764 \\
2,442,031\end{array}$ & $\begin{array}{r}755,423 \\
39,868 \\
372,390 \\
238,500 \\
1,787,495\end{array}$ & $\begin{array}{r}1,328,100 \\
0 \\
0 \\
868,685 \\
6,523,699\end{array}$ & $\begin{array}{r}333,709 \\
26,911 \\
125,919 \\
244,509 \\
3,773,123\end{array}$ & $\begin{array}{r}2,092,590 \\
455,576 \\
2,739,629 \\
1,370,586 \\
17,436,153\end{array}$ & $\begin{array}{r}1,281,923 \\
346,644 \\
1,006,196 \\
753,573 \\
9,338,728\end{array}$ & $\begin{array}{r}1,204 \\
9,681 \\
746,962 \\
30,375 \\
2,490,105\end{array}$ & $\begin{array}{r}193,583 \\
117,209 \\
65,271 \\
70,908 \\
2,605,232\end{array}$ \\
\hline 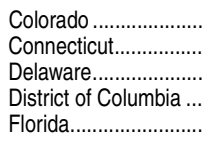 & $\begin{array}{r}5,340,674 \\
2,957,975 \\
1,346,612 \\
179,633 \\
11,275,449\end{array}$ & $\begin{array}{r}4,364,646 \\
1,660,790 \\
772,242 \\
68,450 \\
4,816,147\end{array}$ & $\begin{array}{r}1,559,832 \\
573,935 \\
387,647 \\
28,756 \\
1,843,934\end{array}$ & $\begin{array}{r}961,621 \\
184,121 \\
134,137 \\
16,958 \\
1,064,483\end{array}$ & $\begin{array}{r}595,820 \\
99,013 \\
48,281 \\
10,440 \\
996,156\end{array}$ & $\begin{array}{r}464,434 \\
261,333 \\
115,576 \\
436 \\
758,547\end{array}$ & $\begin{array}{r}422,491 \\
266,254 \\
0 \\
0 \\
0\end{array}$ & $\begin{array}{r}360,447 \\
276,135 \\
86,601 \\
11,859 \\
153,027\end{array}$ & $\begin{array}{r}804,059 \\
1,241,688 \\
561,675 \\
96,691 \\
5,683,339\end{array}$ & $\begin{array}{r}33,667 \\
1,018,015 \\
214,445 \\
66,420 \\
3,243,232\end{array}$ & $\begin{array}{r}82,141 \\
0 \\
0 \\
0 \\
0\end{array}$ & $\begin{array}{r}171,969 \\
55,496 \\
12,695 \\
14,493 \\
775,962\end{array}$ \\
\hline 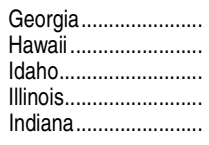 & $\begin{array}{r}7,517,554 \\
1,631,285 \\
1,240,745 \\
11,179,395 \\
6,770,464\end{array}$ & $\begin{array}{r}3,977,505 \\
796,195 \\
589,797 \\
5,735,567 \\
3,997,530\end{array}$ & $\begin{array}{r}1,637,750 \\
225,027 \\
263,014 \\
2,253,166 \\
2,037,133\end{array}$ & $\begin{array}{l}692,327 \\
368,061 \\
126,456 \\
858,332 \\
615,320\end{array}$ & $\begin{array}{r}476,858 \\
62,722 \\
47,066 \\
390,339 \\
271,830\end{array}$ & $\begin{array}{r}752,393 \\
91,060 \\
114,642 \\
909,162 \\
713,708\end{array}$ & $\begin{array}{r}196,852 \\
0 \\
0 \\
601,791 \\
0\end{array}$ & $\begin{array}{r}221,324 \\
49,325 \\
38,618 \\
722,776 \\
359,539\end{array}$ & $\begin{array}{r}3,063,048 \\
602,728 \\
580,065 \\
5,347,017 \\
2,680,943\end{array}$ & $\begin{array}{r}1,938,523 \\
359,077 \\
312,809 \\
1,789,707 \\
1,431,488\end{array}$ & $\begin{array}{r}23 \\
0 \\
13,398 \\
1,001,566 \\
7,951\end{array}$ & $\begin{array}{r}477,002 \\
232,362 \\
70,883 \\
96,812 \\
91,991\end{array}$ \\
\hline 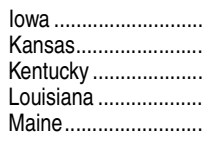 & $\begin{array}{r}4,752,473 \\
3,259,553 \\
5,383,272 \\
4,342,000 \\
928,947\end{array}$ & $\begin{array}{r}3,334,182 \\
1,830,006 \\
3,305,914 \\
2,340,759 \\
504,454\end{array}$ & $\begin{array}{l}754,875 \\
720,719 \\
899,179 \\
697,479 \\
210,601\end{array}$ & $\begin{array}{r}603,914 \\
387,655 \\
478,461 \\
335,569 \\
74,973\end{array}$ & $\begin{array}{r}156,006 \\
172,533 \\
260,276 \\
456,237 \\
67,081\end{array}$ & $\begin{array}{r}444,447 \\
298,804 \\
282,659 \\
326,521 \\
96,664\end{array}$ & $\begin{array}{r}1,065,744 \\
0 \\
1,005,561 \\
315,557 \\
0\end{array}$ & $\begin{array}{r}309,195 \\
250,295 \\
379,778 \\
209,395 \\
55,135\end{array}$ & $\begin{array}{r}1,337,176 \\
1,353,566 \\
1,848,856 \\
1,830,724 \\
391,852\end{array}$ & $\begin{array}{r}731,485 \\
741,285 \\
971,263 \\
1,018,696 \\
252,786\end{array}$ & $\begin{array}{r}107,022 \\
228,630 \\
18,261 \\
0 \\
0\end{array}$ & $\begin{array}{r}81,116 \\
75,981 \\
228,502 \\
170,518 \\
32,641\end{array}$ \\
\hline $\begin{array}{l}\text { Maryland............... } \\
\text { Massachusetts.......... } \\
\text { Michigan ..................... } \\
\text { Minnesota ............... } \\
\text { Mississippi ................ }\end{array}$ & $\begin{array}{r}6,248,811 \\
4,550,848 \\
15,038,480 \\
5,297,262 \\
4,023,249\end{array}$ & $\begin{array}{l}3,615,614 \\
2,866,493 \\
9,096,292 \\
2,766,245 \\
2,166,463\end{array}$ & $\begin{array}{r}1,460,145 \\
1,098,581 \\
3,321,279 \\
1,205,536 \\
493,031\end{array}$ & $\begin{array}{r}833,396 \\
442,698 \\
1,422,055 \\
491,723 \\
452,730\end{array}$ & $\begin{array}{l}393,155 \\
237,243 \\
428,004 \\
325,321 \\
167,889\end{array}$ & $\begin{array}{r}605,746 \\
394,611 \\
1,034,544 \\
590,713 \\
261,884\end{array}$ & $\begin{array}{r}0 \\
0 \\
2,411,131 \\
0 \\
668,734\end{array}$ & $\begin{array}{l}323,172 \\
693,360 \\
479,280 \\
152,952 \\
122,195\end{array}$ & $\begin{array}{l}2,243,809 \\
1,545,246 \\
5,695,248 \\
2,279,356 \\
1,653,408\end{array}$ & $\begin{array}{r}1,392,864 \\
1,034,211 \\
1,713,747 \\
1,206,301 \\
868,311\end{array}$ & $\begin{array}{r}319,337 \\
0 \\
551,945 \\
0 \\
58,179\end{array}$ & $\begin{array}{l}389,387 \\
139,109 \\
246,939 \\
251,661 \\
203,378\end{array}$ \\
\hline $\begin{array}{l}\text { Missouri ..................... } \\
\text { Montana..................... } \\
\text { Nebraska ................... } \\
\text { Nevada .................. } \\
\text { New Hampshire ......... }\end{array}$ & $\begin{array}{l}4,842,364 \\
1,008,519 \\
2,372,403 \\
1,549,690 \\
1,011,894\end{array}$ & $\begin{array}{r}2,875,331 \\
647,425 \\
1,219,057 \\
709,208 \\
686,123\end{array}$ & $\begin{array}{l}942,673 \\
269,752 \\
372,097 \\
328,805 \\
332,173\end{array}$ & $\begin{array}{r}275,157 \\
176,881 \\
249,955 \\
147,151 \\
61,969\end{array}$ & $\begin{array}{r}178,810 \\
35,384 \\
175,371 \\
78,117 \\
70,101\end{array}$ & $\begin{array}{r}732,499 \\
84,977 \\
276,429 \\
93,802 \\
195,452\end{array}$ & $\begin{array}{r}616,483 \\
0 \\
27,653 \\
0 \\
0\end{array}$ & $\begin{array}{r}129,709 \\
80,430 \\
117,552 \\
61,332 \\
26,427\end{array}$ & $\begin{array}{r}1,886,933 \\
325,044 \\
1,075,305 \\
826,969 \\
234,187\end{array}$ & $\begin{array}{l}904,594 \\
173,250 \\
621,957 \\
539,712 \\
131,878\end{array}$ & $\begin{array}{r}148,970 \\
8,151 \\
120,979 \\
0 \\
7\end{array}$ & $\begin{array}{l}80,100 \\
36,051 \\
78,041 \\
13,512 \\
91,585\end{array}$ \\
\hline $\begin{array}{l}\text { New Jersey ................. } \\
\text { New Mexico .............. } \\
\text { New York................. } \\
\text { North Carolina .......... } \\
\text { North Dakota ............ }\end{array}$ & $\begin{array}{r}7,169,289 \\
3,437,062 \\
15,088,288 \\
10,649,043 \\
1,085,482\end{array}$ & $\begin{array}{r}4,450,655 \\
1,861,856 \\
7,176,619 \\
4,080,044 \\
655,231\end{array}$ & $\begin{array}{r}1,921,021 \\
259,413 \\
2,287,135 \\
1,397,544 \\
258,447\end{array}$ & $\begin{array}{l}461,771 \\
418,514 \\
831,872 \\
824,967 \\
169,998\end{array}$ & $\begin{array}{r}450,959 \\
192,667 \\
978,224 \\
333,739 \\
49,400\end{array}$ & $\begin{array}{r}539,213 \\
121,193 \\
889,985 \\
1,322,074 \\
105,442\end{array}$ & $\begin{array}{r}888,477 \\
628,888 \\
2,011,711 \\
0 \\
0\end{array}$ & $\begin{array}{r}189,215 \\
241,182 \\
177,693 \\
201,719 \\
71,945\end{array}$ & $\begin{array}{r}2,607,003 \\
1,456,312 \\
7,207,602 \\
5,854,554 \\
367,638\end{array}$ & $\begin{array}{r}1,495,505 \\
724,046 \\
4,247,113 \\
3,434,423 \\
268,488\end{array}$ & $\begin{array}{r}211,638 \\
120,930 \\
762,484 \\
196,168 \\
2,459\end{array}$ & $\begin{array}{r}111,631 \\
118,895 \\
704,067 \\
714,445 \\
62,613\end{array}$ \\
\hline 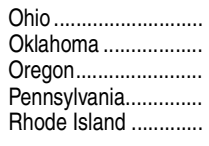 & $\begin{array}{r}13,019,806 \\
3,979,507 \\
5,723,038 \\
12,951,463 \\
744,569\end{array}$ & $\begin{array}{r}8,354,140 \\
2,229,746 \\
3,865,483 \\
9,097,027 \\
503,189\end{array}$ & $\begin{array}{r}3,213,442 \\
711,322 \\
1,041,237 \\
3,609,914 \\
261,165\end{array}$ & $\begin{array}{r}796,495 \\
268,961 \\
640,641 \\
1,313,534 \\
78,031\end{array}$ & $\begin{array}{r}546,609 \\
305,813 \\
129,786 \\
325,974 \\
33,863\end{array}$ & $\begin{array}{l}982,746 \\
419,810 \\
441,711 \\
955,300 \\
101,030\end{array}$ & $\begin{array}{r}2,349,051 \\
69,036 \\
1,316,947 \\
2,311,243 \\
0\end{array}$ & $\begin{array}{r}465,798 \\
454,804 \\
295,161 \\
581,062 \\
29,100\end{array}$ & $\begin{array}{r}4,354,212 \\
1,598,069 \\
1,717,902 \\
3,760,824 \\
200,280\end{array}$ & $\begin{array}{r}1,888,347 \\
924,623 \\
537,918 \\
1,401,316 \\
137,071\end{array}$ & $\begin{array}{r}163,891 \\
49,857 \\
206,762 \\
117,967 \\
0\end{array}$ & $\begin{array}{r}311,454 \\
151,692 \\
139,653 \\
93,612 \\
41,099\end{array}$ \\
\hline 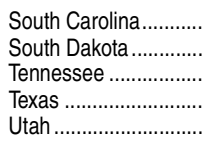 & $\begin{array}{r}4,110,622 \\
825,968 \\
4,532,732 \\
31,676,209 \\
4,640,993\end{array}$ & $\begin{array}{r}2,626,052 \\
490,290 \\
2,028,657 \\
13,143,332 \\
3,250,856\end{array}$ & $\begin{array}{r}1,212,011 \\
195,540 \\
887,065 \\
4,271,691 \\
597,444\end{array}$ & $\begin{array}{r}434,041 \\
141,597 \\
345,884 \\
2,244,736 \\
418,062\end{array}$ & $\begin{array}{r}337,224 \\
38,724 \\
302,878 \\
2,046,450 \\
144,611\end{array}$ & $\begin{array}{r}369,569 \\
60,921 \\
291,506 \\
1,177,768 \\
200,976\end{array}$ & $\begin{array}{r}0 \\
0 \\
0 \\
1,774,837 \\
1,178,146\end{array}$ & $\begin{array}{r}273,207 \\
53,507 \\
201,325 \\
1,627,851 \\
711,617\end{array}$ & $\begin{array}{r}1,311,920 \\
255,629 \\
2,311,854 \\
14,353,611 \\
1,276,343\end{array}$ & $\begin{array}{r}480,329 \\
157,444 \\
1,250,509 \\
5,179,075 \\
661,823\end{array}$ & $\begin{array}{r}62,799 \\
0 \\
5,327 \\
1,377,390 \\
0\end{array}$ & $\begin{array}{r}172,650 \\
80,048 \\
192,221 \\
4,179,265 \\
113,794\end{array}$ \\
\hline 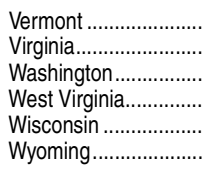 & $\begin{array}{r}842,124 \\
9,483,831 \\
8,203,665 \\
1,810,683 \\
6,453,819 \\
809,196\end{array}$ & $\begin{array}{r}636,439 \\
5,571,497 \\
5,304,335 \\
1,097,945 \\
3,518,077 \\
308,663\end{array}$ & $\begin{array}{r}330,652 \\
2,092,672 \\
1,449,758 \\
489,514 \\
1,257,677 \\
71,806\end{array}$ & $\begin{array}{r}141,310 \\
859,035 \\
1,304,952 \\
171,503 \\
692,624 \\
88,484\end{array}$ & $\begin{array}{r}40,046 \\
184,406 \\
619,367 \\
174,510 \\
453,930 \\
63,638\end{array}$ & $\begin{array}{r}101,704 \\
1,091,172 \\
507,411 \\
206,768 \\
476,635 \\
53,024\end{array}$ & $\begin{array}{r}0 \\
1,064,876 \\
1,063,827 \\
0 \\
0 \\
0\end{array}$ & $\begin{array}{r}22,727 \\
279,336 \\
359,021 \\
55,649 \\
637,212 \\
31,712\end{array}$ & $\begin{array}{r}193,556 \\
3,361,706 \\
2,476,011 \\
623,520 \\
2,647,595 \\
482,199\end{array}$ & $\begin{array}{r}72,466 \\
1,516,128 \\
1,329,108 \\
395,050 \\
1,151,462 \\
326,523\end{array}$ & $\begin{array}{r}0 \\
3,737 \\
0 \\
316 \\
757,773 \\
38,818\end{array}$ & $\begin{array}{r}12,130 \\
550,629 \\
423,319 \\
89,219 \\
288,147 \\
18,334\end{array}$ \\
\hline $\begin{array}{l}\text { U.S. Service } \\
\quad \text { Academies............ }\end{array}$ & $1,730,181$ & 332,846 & 1,284 & 102,029 & 3,872 & 95,757 & 129,904 & 0 & $1,378,678$ & 0 & 0 & 18,657 \\
\hline $\begin{array}{l}\text { Other } \\
\text { jurisdictions. }\end{array}$ & $1,794,951$ & 513,557 & 113,603 & 219,516 & 55,049 & 15,244 & 71,466 & 38,680 & $1,258,708$ & 883,692 & 46,944 & 22,686 \\
\hline $\begin{array}{l}\text { American Samoa ....... } \\
\text { Federated States }\end{array}$ & 28,586 & 18,398 & 3,400 & 14,284 & 0 & 714 & 0 & 0 & 10,188 & 0 & 0 & 0 \\
\hline 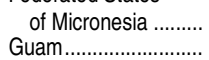 & $\begin{array}{r}21,751 \\
138,602\end{array}$ & $\begin{array}{r}5,432 \\
61,337\end{array}$ & $\begin{array}{r}998 \\
12,480\end{array}$ & $\begin{array}{r}1,324 \\
35,754\end{array}$ & $\begin{array}{l}1,149 \\
3,902\end{array}$ & $\begin{array}{l}1,799 \\
2,683\end{array}$ & $\begin{array}{l}0 \\
0\end{array}$ & $\begin{array}{r}162 \\
6,518\end{array}$ & $\begin{array}{l}16,319 \\
75,649\end{array}$ & $\begin{array}{r}0 \\
31,936\end{array}$ & $\begin{array}{r}0 \\
15,700\end{array}$ & $\begin{array}{r}0 \\
1,616\end{array}$ \\
\hline Marshall Islands.......... & 16,984 & 1,635 & 335 & 0 & 250 & 721 & 0 & 329 & 15,350 & 2,000 & 0 & \\
\hline Northern Marianas .... & 23,626 & 15,686 & 2,144 & 12,305 & 0 & 1,223 & 0 & 13 & 7,940 & 4,385 & 0 & 0 \\
\hline Palau........................ & 14,019 & 7,107 & 2,539 & 3,649 & 200 & 291 & 0 & 429 & 6,483 & 2,039 & 0 & 429 \\
\hline Puerto Rico.................... & $1,469,623$ & 365,594 & 78,166 & 135,017 & 47,091 & 3,069 & 66 & 30,786 & $1,087,380$ & 843,332 & 1,824 & 16,649 \\
\hline U.S. Virgin Islands ..... & 81,759 & 38,367 & 13,541 & 17,183 & 2,457 & 4,745 & & 442 & 39,399 & 0 & 29,420 & 3,992 \\
\hline
\end{tabular}

IIncludes other categories not separately shown. ${ }^{2}$ After deducting discounts and allowances.

${ }^{3}$ Includes sales and services of educational activities.

NOTE: Degree-granting institutions grant associate's or higher degrees and participate in Title IV federal financial aid programs. Includes data for public institutions reporting data according to either the Governmental Accounting Standards Board (GASB) or the Financial
Accounting Standards Board (FASB) questionnaire. Detail may not sum to totals because of rounding.

SOURCE: U.S. Department of Education, National Center for Education Statistics, Integrated Postsecondary Education Data System (IPEDS), Spring 2012, Finance component. (This table was prepared November 2012.) 
Table 333.30. Appropriations from state and local governments for public degree-granting postsecondary institutions, by state or jurisdiction: Selected years, 1990-91 through 2011-12

[In thousands of current dollars]

\begin{tabular}{|c|c|c|c|c|c|c|c|c|c|c|c|c|}
\hline \multirow[b]{2}{*}{ State or jurisdiction } & \multicolumn{6}{|c|}{ State appropriations } & \multicolumn{6}{|c|}{ Local appropriations } \\
\hline & $1990-91$ & $2000-01$ & 2005-06 & $2009-10$ & $2010-11$ & $2011-12$ & $1990-91$ & $2000-01$ & $2005-06$ & $2009-10$ & $2010-11$ & $2011-12$ \\
\hline 1 & 2 & 3 & 4 & 5 & 6 & 7 & 8 & 9 & 10 & 11 & 12 & 13 \\
\hline United States .... & $\$ 35,898,653$ & $\$ 56,268,990$ & $\$ 58,720,088$ & $\$ 62,456,235$ & $\$ 63,015,552$ & $\$ 58,789,643$ & $\$ 3,159,789$ & $\$ 5,582,287$ & $\$ 8,249,690$ & $\$ 9,954,504$ & $\$ 10,023,205$ & $\$ 10,214,576$ \\
\hline 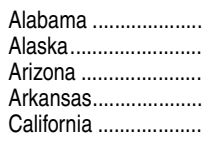 & $\begin{array}{r}708,191 \\
168,395 \\
591,656 \\
315,372 \\
5,313,052\end{array}$ & $\begin{array}{r}991,302 \\
190,650 \\
903,196 \\
583,794 \\
7,891,669\end{array}$ & $\begin{array}{r}1,302,342 \\
252,512 \\
1,015,117 \\
639,745 \\
8,275,470\end{array}$ & $\begin{array}{r}1,289,317 \\
334,826 \\
1,011,599 \\
753,337 \\
8,849,101\end{array}$ & $\begin{array}{r}1,281,923 \\
346,644 \\
1,006,196 \\
753,573 \\
9,338,728\end{array}$ & $\begin{array}{r}1,332,025 \\
358,441 \\
783,210 \\
755,308 \\
7,397,375\end{array}$ & $\begin{array}{r}6,796 \\
260 \\
149,337 \\
216 \\
771,160\end{array}$ & $\begin{array}{r}4,829 \\
10,340 \\
310,762 \\
9,496 \\
1,764,717\end{array}$ & $\begin{array}{r}733 \\
0 \\
062,474 \\
23,269 \\
2,218,323\end{array}$ & $\begin{array}{r}1,124 \\
8,993 \\
734,888 \\
30,776 \\
2,447,042 \\
\end{array}$ & $\begin{array}{r}1,204 \\
9,681 \\
746,962 \\
30,375 \\
2,490,105\end{array}$ & $\begin{array}{r}1,277 \\
10,031 \\
749,180 \\
31,131 \\
2,561,870\end{array}$ \\
\hline 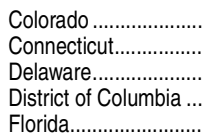 & $\begin{array}{r}423,710 \\
363,427 \\
115,729 \\
0 \\
1,638,218\end{array}$ & $\begin{array}{r}655,037 \\
664,356 \\
193,695 \\
3,019 \\
2,656,376\end{array}$ & $\begin{array}{r}15,436 \\
814,255 \\
218,634 \\
6,554 \\
3,186,756\end{array}$ & $\begin{array}{r}31,950 \\
992,343 \\
219,409 \\
62,070 \\
3,075,209\end{array}$ & $\begin{array}{r}33,667 \\
1,018,015 \\
214,445 \\
66,420 \\
3,243,232\end{array}$ & $\begin{array}{r}30,648 \\
892,046 \\
222,253 \\
67,362 \\
3,037,050\end{array}$ & $\begin{array}{r}22,400 \\
0 \\
0 \\
73,495 \\
1,850\end{array}$ & $\begin{array}{r}36,840 \\
0 \\
0 \\
46,933 \\
2\end{array}$ & $\begin{array}{r}54,422 \\
0 \\
0 \\
61,266 \\
0\end{array}$ & $\begin{array}{r}96,324 \\
0 \\
0 \\
0 \\
0\end{array}$ & $\begin{array}{r}82,141 \\
0 \\
0 \\
0 \\
0\end{array}$ & $\begin{array}{r}78,374 \\
0 \\
0 \\
0 \\
0\end{array}$ \\
\hline 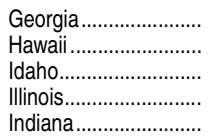 & $\begin{array}{r}915,303 \\
304,131 \\
177,918 \\
1,296,895 \\
886,124\end{array}$ & $\begin{array}{r}1,826,961 \\
395,884 \\
290,746 \\
1,760,300 \\
1,257,919\end{array}$ & $\begin{array}{r}1,959,504 \\
430,451 \\
338,143 \\
1,602,641 \\
1,338,901\end{array}$ & $\begin{array}{r}1,770,643 \\
366,836 \\
324,563 \\
1,779,108 \\
1,435,079\end{array}$ & $\begin{array}{r}1,938,523 \\
359,077 \\
312,809 \\
1,789,707 \\
1,431,488\end{array}$ & $\begin{array}{r}1,847,730 \\
375,754 \\
308,986 \\
1,815,619 \\
1,415,835\end{array}$ & $\begin{array}{r}25,705 \\
0 \\
6,161 \\
284,635 \\
1,507\end{array}$ & $\begin{array}{r}21,615 \\
0 \\
11,148 \\
520,136 \\
6,190\end{array}$ & $\begin{array}{r}0 \\
0 \\
7,633 \\
768,509 \\
7,379\end{array}$ & \begin{tabular}{r|r|}
0 \\
0 \\
12,900 \\
967,455 \\
6,932 \\
\end{tabular} & $\begin{array}{r}23 \\
0 \\
13,398 \\
1,001,566 \\
7,951\end{array}$ & $\begin{array}{r}44 \\
0 \\
20,559 \\
1,015,855 \\
9,012\end{array}$ \\
\hline 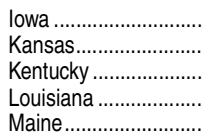 & $\begin{array}{l}544,945 \\
437,413 \\
617,915 \\
566,798 \\
174,737\end{array}$ & $\begin{array}{l}813,805 \\
664,201 \\
939,047 \\
834,643 \\
212,144\end{array}$ & $\begin{array}{r}798,961 \\
725,777 \\
1,014,939 \\
1,084,984 \\
231,890\end{array}$ & $\begin{array}{r}781,895 \\
731,725 \\
967,970 \\
1,030,152 \\
245,705\end{array}$ & $\begin{array}{r}731,485 \\
741,285 \\
971,263 \\
1,018,696 \\
252,786\end{array}$ & $\begin{array}{l}709,408 \\
719,033 \\
969,989 \\
944,649 \\
255,518\end{array}$ & $\begin{array}{r}21,624 \\
87,026 \\
4,682 \\
1,462 \\
0\end{array}$ & $\begin{array}{r}36,129 \\
160,873 \\
14,930 \\
517 \\
0\end{array}$ & $\begin{array}{r}73,502 \\
211,593 \\
12,035 \\
0 \\
0\end{array}$ & $\begin{array}{r}99,099 \\
229,963 \\
16,437 \\
0 \\
0\end{array}$ & $\begin{array}{r}107,022 \\
228,630 \\
18,261 \\
0 \\
0\end{array}$ & $\begin{array}{r}114,880 \\
233,851 \\
17,501 \\
0 \\
0\end{array}$ \\
\hline $\begin{array}{l}\text { Maryland................... } \\
\text { Massachusetts........... } \\
\text { Michigan ................... } \\
\text { Minnesota ................. } \\
\text { Mississippi ................. }\end{array}$ & $\begin{array}{r}724,223 \\
471,368 \\
1,326,884 \\
744,381 \\
365,574\end{array}$ & $\begin{array}{r}999,723 \\
1,038,998 \\
1,991,098 \\
1,174,797 \\
758,242\end{array}$ & $\begin{array}{r}1,078,966 \\
1,039,187 \\
1,771,921 \\
1,194,106 \\
774,001\end{array}$ & $\begin{array}{r}1,276,246 \\
899,748 \\
1,786,389 \\
1,242,407 \\
895,859\end{array}$ & $\begin{array}{r}1,392,864 \\
1,034,211 \\
1,713,747 \\
1,206,301 \\
868,311\end{array}$ & $\begin{array}{r}1,411,746 \\
1,046,090 \\
1,490,701 \\
1,095,626 \\
939,075\end{array}$ & $\begin{array}{r}117,913 \\
0 \\
159,202 \\
2,040 \\
25,670\end{array}$ & $\begin{array}{r}185,034 \\
0 \\
288,112 \\
0 \\
38,167\end{array}$ & $\begin{array}{r}253,486 \\
0 \\
535,401 \\
0 \\
57,539\end{array}$ & $\begin{array}{r}328,704 \\
0 \\
596,436 \\
0 \\
57,730\end{array}$ & $\begin{array}{r}319,337 \\
0 \\
551,945 \\
0 \\
58,179\end{array}$ & $\begin{array}{r}310,463 \\
0 \\
523,771 \\
0 \\
59,716\end{array}$ \\
\hline $\begin{array}{l}\text { Missouri ...................... } \\
\text { Montana................... } \\
\text { Nebraska .................. } \\
\text { Nevada .................... } \\
\text { New Hampshire ......... }\end{array}$ & $\begin{array}{r}563,430 \\
110,199 \\
318,482 \\
161,581 \\
71,226\end{array}$ & $\begin{array}{r}945,746 \\
137,341 \\
514,235 \\
333,117 \\
96,157\end{array}$ & $\begin{array}{l}868,899 \\
154,770 \\
532,258 \\
524,701 \\
114,557\end{array}$ & $\begin{array}{l}992,722 \\
174,784 \\
629,652 \\
388,082 \\
130,868\end{array}$ & $\begin{array}{l}904,594 \\
173,250 \\
621,957 \\
539,712 \\
131,878\end{array}$ & $\begin{array}{r}836,519 \\
192,386 \\
616,412 \\
466,961 \\
80,192\end{array}$ & $\begin{array}{r}38,097 \\
3,310 \\
36,569 \\
0 \\
6\end{array}$ & $\begin{array}{r}101,562 \\
4,069 \\
19,892 \\
0 \\
0\end{array}$ & $\begin{array}{r}128,638 \\
6,283 \\
78,470 \\
0 \\
0\end{array}$ & $\begin{array}{r}146,283 \\
8,105 \\
122,263 \\
0 \\
0\end{array}$ & $\begin{array}{r}148,970 \\
8,151 \\
120,979 \\
0 \\
7\end{array}$ & $\begin{array}{r}146,266 \\
8,404 \\
127,737 \\
0 \\
0\end{array}$ \\
\hline $\begin{array}{l}\text { New Jersey ................ } \\
\text { New Mexico ............... } \\
\text { New York.................. } \\
\text { North Carolina ........... } \\
\text { North Dakota ............. }\end{array}$ & $\begin{array}{r}854,989 \\
307,083 \\
2,313,128 \\
1,351,111 \\
129,986\end{array}$ & $\begin{array}{r}1,246,554 \\
538,822 \\
4,461,671 \\
2,221,600 \\
188,047\end{array}$ & $\begin{array}{r}1,644,413 \\
679,588 \\
3,500,566 \\
2,815,090 \\
195,040\end{array}$ & $\begin{array}{r}1,549,086 \\
773,235 \\
4,350,324 \\
3,375,984 \\
267,744\end{array}$ & $\begin{array}{r}1,495,505 \\
724,046 \\
4,247,113 \\
3,434,423 \\
268,488\end{array}$ & $\begin{array}{r}1,495,920 \\
675,069 \\
4,248,791 \\
3,387,420 \\
276,228\end{array}$ & $\begin{array}{r}145,010 \\
34,364 \\
372,650 \\
62,785 \\
9\end{array}$ & $\begin{array}{r}172,667 \\
60,183 \\
431,415 \\
113,448 \\
21\end{array}$ & $\begin{array}{r}195,502 \\
92,644 \\
622,550 \\
156,171 \\
1,786\end{array}$ & $\begin{array}{r}211,947 \\
119,340 \\
757,504 \\
194,949 \\
185\end{array}$ & $\begin{array}{r}211,638 \\
120,930 \\
762,484 \\
196,168 \\
2,459\end{array}$ & $\begin{array}{r}194,452 \\
126,890 \\
797,232 \\
200,980 \\
2,686\end{array}$ \\
\hline 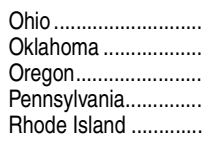 & $\begin{array}{r}1,360,141 \\
473,898 \\
377,476 \\
962,121 \\
113,614\end{array}$ & $\begin{array}{r}1,922,571 \\
754,540 \\
640,347 \\
1,331,544 \\
157,137\end{array}$ & $\begin{array}{r}1,848,717 \\
782,847 \\
657,011 \\
1,371,792 \\
172,703\end{array}$ & $\begin{array}{r}1,884,232 \\
928,324 \\
666,799 \\
1,420,760 \\
137,159\end{array}$ & $\begin{array}{r}1,888,347 \\
924,623 \\
537,918 \\
1,401,316 \\
137,071\end{array}$ & $\begin{array}{r}1,861,830 \\
898,544 \\
583,336 \\
1,189,943 \\
141,208\end{array}$ & $\begin{array}{r}63,899 \\
12,822 \\
118,499 \\
62,794 \\
0\end{array}$ & $\begin{array}{r}101,647 \\
28,367 \\
106,436 \\
94,338 \\
0\end{array}$ & $\begin{array}{r}126,530 \\
38,081 \\
161,438 \\
111,721 \\
0\end{array}$ & $\begin{array}{r}145,807 \\
48,197 \\
203,681 \\
118,747 \\
0\end{array}$ & $\begin{array}{r}163,891 \\
49,857 \\
206,762 \\
117,967 \\
0\end{array}$ & $\begin{array}{r}158,190 \\
50,986 \\
210,454 \\
111,524 \\
0\end{array}$ \\
\hline 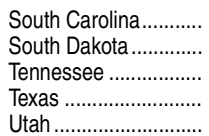 & $\begin{array}{r}578,794 \\
81,859 \\
663,536 \\
2,627,916 \\
304,738\end{array}$ & $\begin{array}{r}853,139 \\
129,680 \\
969,316 \\
4,236,852 \\
531,975\end{array}$ & $\begin{array}{r}715,967 \\
153,928 \\
1,081,753 \\
4,658,611 \\
669,271\end{array}$ & $\begin{array}{r}604,283 \\
163,817 \\
1,089,782 \\
5,445,771 \\
658,038\end{array}$ & $\begin{array}{r}480,329 \\
157,444 \\
1,250,509 \\
5,179,075 \\
661,823\end{array}$ & $\begin{array}{r}465,402 \\
159,652 \\
1,002,136 \\
5,022,641 \\
677,217\end{array}$ & $\begin{array}{r}18,670 \\
0 \\
1,779 \\
210,934 \\
0\end{array}$ & $\begin{array}{r}36,060 \\
0 \\
3,824 \\
439,342 \\
0\end{array}$ & $\begin{array}{r}50,592 \\
0 \\
4,326 \\
971,351 \\
0\end{array}$ & $\begin{array}{r}61,419 \\
0 \\
5,184 \\
1,384,512 \\
0\end{array}$ & $\begin{array}{r}62,799 \\
0 \\
5,327 \\
1,377,390 \\
0\end{array}$ & $\begin{array}{r}62,126 \\
0 \\
5,655 \\
1,452,266 \\
0\end{array}$ \\
\hline 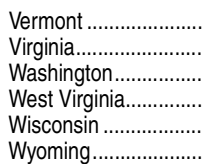 & $\begin{array}{r}40,997 \\
886,208 \\
828,700 \\
263,269 \\
841,192 \\
120,623\end{array}$ & $\begin{array}{r}53,605 \\
1,395,308 \\
1,200,392 \\
382,269 \\
1,186,415 \\
149,009\end{array}$ & $\begin{array}{r}63,740 \\
1,482,002 \\
1,315,804 \\
355,870 \\
1,019,374 \\
229,620\end{array}$ & $\begin{array}{r}76,575 \\
1,433,589 \\
1,367,777 \\
393,821 \\
1,099,243 \\
300,301\end{array}$ & $\begin{array}{r}72,466 \\
1,516,128 \\
1,329,108 \\
395,050 \\
1,151,462 \\
326,523\end{array}$ & $\begin{array}{r}67,894 \\
1,441,710 \\
1,074,462 \\
429,716 \\
943,010 \\
333,566\end{array}$ & $\begin{array}{r}4 \\
973 \\
2,470 \\
574 \\
197,712 \\
12,721\end{array}$ & $\begin{array}{r}0 \\
1,570 \\
0 \\
503 \\
379,648 \\
20,525\end{array}$ & $\begin{array}{r}0 \\
1,934 \\
33 \\
0 \\
621,514 \\
32,562\end{array}$ & $\begin{array}{r}0 \\
2,289 \\
0 \\
451 \\
739,123 \\
49,716\end{array}$ & $\begin{array}{r}0 \\
3,737 \\
0 \\
316 \\
757,773 \\
38,818\end{array}$ & $\begin{array}{r}0 \\
5,141 \\
0 \\
874 \\
769,923 \\
45,274\end{array}$ \\
\hline $\begin{array}{l}\text { U.S. Service } \\
\quad \text { Academies......... }\end{array}$ & 0 & 0 & 0 & 0 & 0 & 0 & 0 & 0 & 0 & 0 & 0 & 0 \\
\hline $\begin{array}{l}\text { Other } \\
\text { jurisdictions. }\end{array}$ & 337,393 & 709,473 & 913,597 & 901,837 & 883,692 & 891,770 & 12,724 & 20,612 & 45,878 & 50,593 & 46,944 & 40,258 \\
\hline $\begin{array}{l}\text { American Samoa ........ } \\
\text { Federated States }\end{array}$ & 0 & & 0 & 0 & 0 & 1,948 & 0 & 0 & 0 & 0 & 0 & 0 \\
\hline & 0 & 40 & 0 & 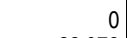 & 0 & 0 & 0 & $0,0<1$ & 0 & 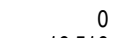 & 0 & 0 \\
\hline ............. & 28,283 & & 29,684 & 33,072 & 31,936 & 34,197 & 10,028 & 12,826 & 13,827 & 16,516 & 15,700 & 14,569 \\
\hline $\begin{array}{l}\text { Marshall Islands......... } \\
\text { Northern Marianas .... }\end{array}$ & 0 & $\begin{array}{l}1,924 \\
9,055\end{array}$ & $\begin{array}{r}0 \\
7,270\end{array}$ & $\begin{array}{l}2,000 \\
5,323\end{array}$ & $\begin{array}{l}2,000 \\
4,385\end{array}$ & $\begin{array}{l}2,875 \\
3,749\end{array}$ & 0 & $\begin{array}{l}0 \\
0\end{array}$ & $\begin{array}{r}2,000 \\
0\end{array}$ & $\begin{array}{l}0 \\
0\end{array}$ & $\begin{array}{l}0 \\
0\end{array}$ & $\begin{array}{l}0 \\
0\end{array}$ \\
\hline Palau.................................... & 644 & 2,345 & 2,385 & 2,310 & 2,039 & 2,654 & 0 & 0 & 0 & 0 & 0 & 0 \\
\hline Puerto & 277,295 & 647,623 & 874,258 & 859,133 & 843,332 & 846,348 & 2,375 & 4,459 & 2,996 & 2,651 & & \\
\hline U.S. Virgin Islands ..... & 31,170 & 19,365 & 0 & & 0 & 0 & 320 & & 27,055 & 31,427 & 29,420 & 25,687 \\
\hline
\end{tabular}

NOTE: Data for 1990-91 are for institutions of higher education, while later data are for degree-granting institutions. Degree-granting institutions grant associate's or higher degrees and participate in Title IV federal financial aid programs. The degree-granting classification is very similar to the earlier higher education classification, but it includes more 2-year colleges and excludes a few higher education institutions that did not grant degrees. Includes data for public institutions reporting data according to either the Govern- mental Accounting Standards Board (GASB) or the Financial Accounting Standards Board (FASB) questionnaire. Detail may not sum to totals because of rounding

SOURCE: U.S. Department of Education, National Center for Education Statistics, Integrated Postsecondary Education Data System (IPEDS), "Finance Survey" (IPEDSF:FY91); and Spring 2001 through Spring 2013, Finance component. (This table was prepared January 2014.) 
Table 333.40. Total revenue of private nonprofit degree-granting postsecondary institutions, by source of funds and level of institution: 1999-2000 through 2011-12

\begin{tabular}{|c|c|c|c|c|c|c|c|c|c|c|c|c|}
\hline \multirow[b]{2}{*}{$\begin{array}{l}\text { Level of institution } \\
\text { and year }\end{array}$} & \multirow[b]{2}{*}{ Total } & \multirow[b]{2}{*}{$\begin{array}{r}\text { Student } \\
\text { tuition and } \\
\text { fees (net of } \\
\text { allowances) }\end{array}$} & \multirow[b]{2}{*}{$\begin{array}{r}\text { Federal } \\
\text { appro- } \\
\text { priations, } \\
\text { grants, and } \\
\text { contracts }^{1}\end{array}$} & \multirow[b]{2}{*}{$\begin{array}{r}\text { State and } \\
\text { local appro- } \\
\text { priations, } \\
\text { grants, and } \\
\text { contracts }\end{array}$} & \multicolumn{3}{|c|}{ Private gifts, grants, and contracts } & \multirow[b]{2}{*}{$\begin{array}{r}\text { Investment } \\
\text { return (gain } \\
\text { or loss) }\end{array}$} & \multirow[b]{2}{*}{$\begin{array}{r}\text { Educational } \\
\text { activities }\end{array}$} & \multirow[b]{2}{*}{$\begin{array}{r}\text { Auxiliary } \\
\text { enterprises } \\
\text { (net of } \\
\text { allowances) }\end{array}$} & \multirow[b]{2}{*}{ Hospitals } & \multirow[b]{2}{*}{ Other } \\
\hline & & & & & Total & $\begin{array}{r}\text { Private } \\
\text { grants and } \\
\text { contracts }\end{array}$ & \begin{tabular}{|r|} 
Private gifts \\
and contri- \\
butions from \\
affiliated \\
entities
\end{tabular} & & & & & \\
\hline 1 & 2 & 3 & 4 & 5 & 6 & 7 & 8 & 9 & 10 & 11 & 12 & 13 \\
\hline \multicolumn{13}{|c|}{ In thousands of current dollars } \\
\hline 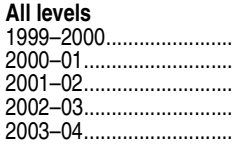 & \begin{tabular}{|r}
$\$ 120,625,806$ \\
$82,174,492$ \\
$84,346,652$ \\
$105,672,753$ \\
$134,230,762$
\end{tabular} & $\begin{array}{r}\$ 29,651,812 \\
31,318,106 \\
33,499,121 \\
36,019,267 \\
38,505,631\end{array}$ & $\begin{array}{r}\$ 12,191,827 \\
13,378,019 \\
14,790,235 \\
16,625,072 \\
18,335,784\end{array}$ & $\begin{array}{r}\$ 1,697,979 \\
1,684,425 \\
1,796,930 \\
1,988,977 \\
1,941,273\end{array}$ & $\begin{array}{r}\$ 16,488,984 \\
15,859,313 \\
15,394,353 \\
14,380,351 \\
15,847,571\end{array}$ & $\begin{array}{l}- \\
- \\
- \\
-\end{array}$ & \multirow{2}{*}{$\begin{array}{l}- \\
- \\
- \\
- \\
- \\
- \\
- \\
-\end{array}$} & $\begin{array}{r}\$ 37,763,518 \\
-3,602,326 \\
-6,545,330 \\
9,340,400 \\
30,896,917\end{array}$ & $\begin{array}{r}\$ 2,865,606 \\
3,468,680 \\
3,220,868 \\
3,056,259 \\
3,290,420\end{array}$ & $\begin{array}{r}\$ 8,317,607 \\
8,742,610 \\
9,317,922 \\
9,833,972 \\
10,325,606\end{array}$ & $\begin{array}{r}\$ 7,208,600 \\
7,126,343 \\
8,083,935 \\
8,942,047 \\
9,657,753\end{array}$ & $\begin{array}{r}\$ 4,439,874 \\
4,199,323 \\
4,788,618 \\
5,486,409 \\
5,429,805\end{array}$ \\
\hline $\begin{array}{l}2004-05 \ldots \ldots \ldots \ldots \ldots \\
2005-06 \ldots \ldots \ldots \ldots \ldots \ldots \ldots \ldots \\
2006-07 \ldots \ldots \ldots \ldots \ldots \ldots \ldots \ldots \\
2007-08 \ldots \ldots \ldots \ldots \ldots \ldots \ldots \ldots \ldots \\
2008-09 \ldots \ldots \ldots \ldots \ldots \ldots \ldots \ldots \ldots\end{array}$ & $\begin{array}{r}140,150,716 \\
152,744,665 \\
182,381,275 \\
139,250,857 \\
69,064,329\end{array}$ & $\begin{array}{l}41,394,424 \\
44,263,227 \\
47,481,431 \\
50,736,003 \\
53,707,913\end{array}$ & $\begin{array}{l}19,699,204 \\
19,683,291 \\
20,193,637 \\
20,204,523 \\
21,023,733\end{array}$ & $\begin{array}{l}1,957,921 \\
2,075,850 \\
2,165,371 \\
2,385,888 \\
2,391,285\end{array}$ & $\begin{array}{l}16,738,916 \\
18,346,525 \\
20,193,231 \\
20,991,936 \\
17,671,730\end{array}$ & $\begin{array}{l}- \\
- \\
-\end{array}$ & & $\begin{array}{r}30,431,521 \\
35,634,520 \\
55,907,662 \\
6,446,982 \\
-64,205,252\end{array}$ & $\begin{array}{l}3,595,559 \\
3,716,409 \\
4,105,289 \\
4,849,728 \\
4,791,466\end{array}$ & $\begin{array}{l}10,823,963 \\
11,610,762 \\
12,291,973 \\
12,928,521 \\
13,559,084\end{array}$ & $\begin{array}{l}10,377,808 \\
11,536,658 \\
12,636,904 \\
13,299,928 \\
14,802,999\end{array}$ & $\begin{array}{l}5,131,401 \\
5,877,423 \\
7,405,779 \\
7,407,348 \\
5,321,371\end{array}$ \\
\hline $\begin{array}{l}2009-10 \\
2010-11 \ldots \ldots \ldots \ldots \ldots \ldots . . \\
2011-12 \ldots \ldots \ldots \ldots \ldots \ldots . .\end{array}$ & $\begin{array}{l}168,689,242 \\
207,236,345 \\
161,868,611\end{array}$ & $\begin{array}{l}56,355,862 \\
60,047,027 \\
63,021,108\end{array}$ & $\begin{array}{l}22,913,792 \\
24,334,677 \\
24,147,119\end{array}$ & $\begin{array}{l}2,193,084 \\
2,165,996 \\
1,964,938\end{array}$ & $\begin{array}{l}18,017,260 \\
22,100,617 \\
21,617,966\end{array}$ & $\begin{array}{r}\$ 4,189,573 \\
4,379,206 \\
4,446,490\end{array}$ & $\begin{array}{r}\$ 13,827,687 \\
17,721,411 \\
17,171,476\end{array}$ & $\begin{array}{r}28,425,581 \\
53,571,921 \\
4,544,786\end{array}$ & $\begin{array}{l}4,821,825 \\
4,992,000 \\
5,082,882\end{array}$ & $\begin{array}{l}14,080,329 \\
14,797,598 \\
15,499,433\end{array}$ & $\begin{array}{l}16,541,461 \\
17,521,091 \\
18,667,425\end{array}$ & $\begin{array}{l}5,340,047 \\
7,705,419 \\
7,322,955\end{array}$ \\
\hline 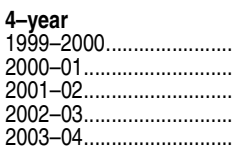 & $\begin{array}{r}119,708,625 \\
81,568,928 \\
83,764,907 \\
105,064,157 \\
133,594,668\end{array}$ & $\begin{array}{l}29,257,523 \\
30,996,381 \\
33,165,965 \\
35,676,736 \\
38,181,648\end{array}$ & $\begin{array}{l}12,133,829 \\
13,318,572 \\
14,708,582 \\
16,515,854 \\
18,236,313\end{array}$ & $\begin{array}{l}1,673,707 \\
1,659,505 \\
1,771,383 \\
1,957,729 \\
1,903,374\end{array}$ & $\begin{array}{l}16,346,616 \\
15,788,869 \\
15,328,974 \\
14,319,622 \\
15,789,672\end{array}$ & $\begin{array}{l}- \\
- \\
- \\
-\end{array}$ & $\begin{array}{l}- \\
- \\
- \\
-\end{array}$ & $\begin{array}{r}37,698,219 \\
-3,623,323 \\
-6,547,915 \\
9,338,684 \\
30,854,091\end{array}$ & $\begin{array}{l}2,837,784 \\
3,452,731 \\
3,206,440 \\
3,041,307 \\
3,277,767\end{array}$ & $\begin{array}{r}8,261,507 \\
8,703,316 \\
9,263,171 \\
9,779,275 \\
10,287,215\end{array}$ & $\begin{array}{l}7,208,600 \\
7,125,648 \\
8,083,935 \\
8,942,047 \\
9,657,753\end{array}$ & $\begin{array}{l}4,290,841 \\
4,147,227 \\
4,784,371 \\
5,492,904 \\
5,406,836\end{array}$ \\
\hline $\begin{array}{l}2004-05 \ldots \ldots \ldots \ldots \ldots \ldots \\
2005-06 \ldots \ldots \ldots \ldots \ldots \ldots \ldots \ldots \\
2006-07 \ldots \ldots \ldots \ldots \ldots \ldots \ldots \ldots \ldots \\
2007-08 \ldots \ldots \ldots \ldots \ldots \ldots \ldots \ldots . . . \\
2008-09 \ldots \ldots \ldots \ldots \ldots \ldots \ldots \ldots\end{array}$ & $\begin{array}{r}139,528,763 \\
152,150,193 \\
181,853,949 \\
138,749,560 \\
68,617,694\end{array}$ & $\begin{array}{l}41,045,608 \\
43,944,766 \\
47,211,041 \\
50,431,352 \\
53,408,932\end{array}$ & $\begin{array}{l}19,622,002 \\
19,607,858 \\
20,137,112 \\
20,143,833 \\
20,964,805\end{array}$ & $\begin{array}{l}1,931,021 \\
2,045,814 \\
2,144,350 \\
2,361,511 \\
2,370,216\end{array}$ & $\begin{array}{l}16,671,017 \\
18,288,085 \\
20,143,850 \\
20,938,774 \\
17,625,407\end{array}$ & $\begin{array}{l}- \\
- \\
- \\
-\end{array}$ & $\begin{array}{l}- \\
- \\
- \\
-\end{array}$ & $\begin{array}{r}30,408,545 \\
35,603,805 \\
55,857,220 \\
6,459,197 \\
-64,173,065\end{array}$ & $\begin{array}{l}3,581,869 \\
3,699,630 \\
4,097,001 \\
4,838,649 \\
4,785,951\end{array}$ & $\begin{array}{l}10,784,161 \\
11,573,115 \\
12,253,297 \\
12,890,431 \\
13,522,267\end{array}$ & $\begin{array}{l}10,377,808 \\
11,536,658 \\
12,636,904 \\
13,299,928 \\
14,802,999\end{array}$ & $\begin{array}{l}5,106,733 \\
5,850,463 \\
7,373,173 \\
7,385,886 \\
5,310,181\end{array}$ \\
\hline $\begin{array}{l}2009-10 \\
2010-11 \ldots \ldots \ldots \ldots \\
2011-12 \ldots \ldots \ldots \ldots\end{array}$ & $\begin{array}{l}168,169,978 \\
206,577,102 \\
161,272,285\end{array}$ & $\begin{array}{l}56,056,932 \\
59,582,471 \\
62,582,114\end{array}$ & $\begin{array}{l}22,843,558 \\
24,274,070 \\
24,098,850\end{array}$ & $\begin{array}{l}2,179,072 \\
2,150,455 \\
1,953,324\end{array}$ & $\begin{array}{l}17,966,413 \\
22,061,064 \\
21,579,107\end{array}$ & $\begin{array}{l}4,185,606 \\
4,376,380 \\
4,443,977\end{array}$ & $\begin{array}{l}13,780,807 \\
17,684,684 \\
17,135,131\end{array}$ & $\begin{array}{r}28,404,786 \\
53,555,533 \\
4,539,625\end{array}$ & $\begin{array}{l}4,814,426 \\
4,987,562 \\
5,079,876\end{array}$ & $\begin{array}{l}14,044,652 \\
14,762,886 \\
15,471,108\end{array}$ & $\begin{array}{l}16,541,461 \\
17,521,091 \\
18,667,425\end{array}$ & $\begin{array}{l}5,318,679 \\
7,681,969 \\
7,300,856\end{array}$ \\
\hline 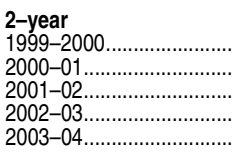 & $\begin{array}{l}917,181 \\
605,564 \\
581,745 \\
608,596 \\
636,094\end{array}$ & $\begin{array}{l}394,289 \\
321,724 \\
333,156 \\
342,531 \\
323,983\end{array}$ & $\begin{array}{r}57,998 \\
59,446 \\
81,653 \\
109,217 \\
99,471\end{array}$ & $\begin{array}{l}24,272 \\
24,920 \\
25,547 \\
31,247 \\
37,900\end{array}$ & $\begin{array}{r}142,368 \\
70,444 \\
65,379 \\
60,729 \\
57,900\end{array}$ & $\begin{array}{l}- \\
- \\
- \\
-\end{array}$ & $\begin{array}{l}z \\
z \\
- \\
-\end{array}$ & $\begin{array}{r}65,299 \\
20,996 \\
2,585 \\
1,716 \\
42,826\end{array}$ & $\begin{array}{l}27,822 \\
15,949 \\
14,429 \\
14,953 \\
12,653\end{array}$ & $\begin{array}{l}56,100 \\
39,294 \\
54,750 \\
54,697 \\
38,391\end{array}$ & $\begin{array}{r}0 \\
694 \\
0 \\
0 \\
0\end{array}$ & $\begin{array}{r}149,033 \\
52,096 \\
4,246 \\
-6,495 \\
22,969\end{array}$ \\
\hline 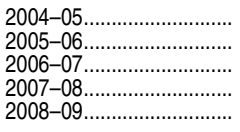 & $\begin{array}{l}621,953 \\
594,473 \\
527,327 \\
501,297 \\
446,635\end{array}$ & $\begin{array}{l}348,815 \\
318,460 \\
270,389 \\
304,651 \\
298,981\end{array}$ & $\begin{array}{l}77,202 \\
75,433 \\
56,525 \\
60,689 \\
58,927\end{array}$ & $\begin{array}{l}26,900 \\
30,036 \\
21,021 \\
24,377 \\
21,069\end{array}$ & $\begin{array}{l}67,899 \\
58,441 \\
49,381 \\
53,162 \\
46,323\end{array}$ & $\begin{array}{l}- \\
- \\
- \\
-\end{array}$ & $\begin{array}{l}- \\
\overline{-} \\
- \\
-\end{array}$ & $\begin{array}{r}22,976 \\
30,716 \\
50,442 \\
-12,214 \\
-32,187\end{array}$ & $\begin{array}{r}13,690 \\
16,778 \\
8,288 \\
11,080 \\
5,515\end{array}$ & $\begin{array}{l}39,802 \\
37,648 \\
38,675 \\
38,091 \\
36,816\end{array}$ & $\begin{array}{l}0 \\
0 \\
0 \\
0 \\
0\end{array}$ & $\begin{array}{l}24,668 \\
26,960 \\
32,606 \\
21,462 \\
11,191\end{array}$ \\
\hline \multirow[t]{2}{*}{ 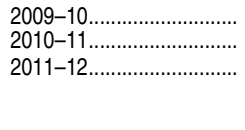 } & $\begin{array}{l}519,264 \\
659,244 \\
596,326 \\
\end{array}$ & $\begin{array}{l}298,930 \\
464,556 \\
438,994 \\
\end{array}$ & $\begin{array}{l}70,235 \\
60,607 \\
48,269 \\
\end{array}$ & $\begin{array}{l}14,012 \\
15,541 \\
11,614 \\
\end{array}$ & $\begin{array}{l}50,847 \\
39,553 \\
38,858 \\
\end{array}$ & $\begin{array}{l}3,967 \\
2,825 \\
2,513 \\
\end{array}$ & $\begin{array}{l}46,880 \\
36,727 \\
36,345 \\
\end{array}$ & $\begin{array}{r}20,795 \\
16,388 \\
5,161 \\
\end{array}$ & $\begin{array}{l}7,400 \\
4,437 \\
3,007 \\
\end{array}$ & $\begin{array}{l}35,677 \\
34,712 \\
28,325 \\
\end{array}$ & $\begin{array}{l}0 \\
0 \\
0 \\
\end{array}$ & $\begin{array}{l}21,368 \\
23,450 \\
22,099 \\
\end{array}$ \\
\hline & \multicolumn{12}{|c|}{ Percentage distribution } \\
\hline 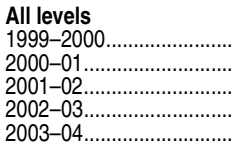 & $\begin{array}{l}100.00 \\
100.00 \\
100.00 \\
100.00 \\
100.00\end{array}$ & $\begin{array}{l}24.58 \\
38.11 \\
39.72 \\
34.09 \\
28.69\end{array}$ & $\begin{array}{l}10.11 \\
16.28 \\
17.54 \\
15.73 \\
13.66\end{array}$ & $\begin{array}{l}1.41 \\
2.05 \\
2.13 \\
1.88 \\
1.45\end{array}$ & $\begin{array}{l}13.67 \\
19.30 \\
18.25 \\
13.61 \\
11.81\end{array}$ & $\begin{array}{l}- \\
- \\
- \\
-\end{array}$ & $\begin{array}{l}- \\
z \\
- \\
-\end{array}$ & $\begin{array}{r}31.31 \\
-4.38 \\
-7.76 \\
8.84 \\
23.02\end{array}$ & $\begin{array}{l}2.38 \\
4.22 \\
3.82 \\
2.89 \\
2.45\end{array}$ & $\begin{array}{r}6.90 \\
10.64 \\
11.05 \\
9.31 \\
7.69\end{array}$ & $\begin{array}{l}5.98 \\
8.67 \\
9.58 \\
8.46 \\
7.19\end{array}$ & $\begin{array}{l}3.68 \\
5.11 \\
5.68 \\
5.19 \\
4.05\end{array}$ \\
\hline 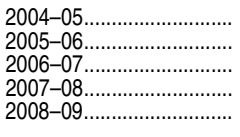 & $\begin{array}{l}100.00 \\
100.00 \\
100.00 \\
100.00 \\
100.00\end{array}$ & $\begin{array}{l}29.54 \\
28.98 \\
26.03 \\
36.43 \\
77.77\end{array}$ & $\begin{array}{l}14.06 \\
12.89 \\
11.07 \\
14.51 \\
30.44\end{array}$ & $\begin{array}{l}1.40 \\
1.36 \\
1.19 \\
1.71 \\
3.46\end{array}$ & $\begin{array}{l}11.94 \\
12.01 \\
11.07 \\
15.07 \\
25.59\end{array}$ & $\begin{array}{l}- \\
- \\
- \\
-\end{array}$ & $\begin{array}{l}- \\
- \\
- \\
-\end{array}$ & $\begin{array}{r}21.71 \\
23.33 \\
30.65 \\
4.63 \\
-92.96\end{array}$ & $\begin{array}{l}2.57 \\
2.43 \\
2.25 \\
3.48 \\
6.94\end{array}$ & $\begin{array}{r}7.72 \\
7.60 \\
6.74 \\
9.28 \\
19.63\end{array}$ & $\begin{array}{r}7.40 \\
7.55 \\
6.93 \\
9.55 \\
21.43\end{array}$ & $\begin{array}{l}3.66 \\
3.85 \\
4.06 \\
5.32 \\
7.70\end{array}$ \\
\hline $\begin{array}{l}2009-10 \\
2010-11 \\
2011-12\end{array}$ & $\begin{array}{l}100.00 \\
100.00 \\
100.00\end{array}$ & $\begin{array}{l}33.41 \\
28.98 \\
38.93\end{array}$ & $\begin{array}{l}13.58 \\
11.74 \\
14.92\end{array}$ & $\begin{array}{l}1.30 \\
1.05 \\
1.21\end{array}$ & $\begin{array}{l}10.68 \\
10.66 \\
13.36\end{array}$ & $\begin{array}{l}2.48 \\
2.11 \\
2.75\end{array}$ & $\begin{array}{r}8.20 \\
8.55 \\
10.61\end{array}$ & $\begin{array}{r}16.85 \\
25.85 \\
2.81\end{array}$ & $\begin{array}{l}2.86 \\
2.41 \\
3.14\end{array}$ & $\begin{array}{l}8.35 \\
7.14 \\
9.58\end{array}$ & $\begin{array}{r}9.81 \\
8.45 \\
11.53\end{array}$ & $\begin{array}{l}3.17 \\
3.72 \\
4.52\end{array}$ \\
\hline 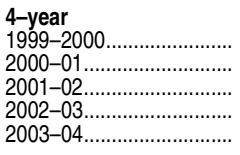 & $\begin{array}{l}100.00 \\
100.00 \\
100.00 \\
100.00 \\
100.00\end{array}$ & $\begin{array}{l}24.44 \\
38.00 \\
39.59 \\
33.96 \\
28.58\end{array}$ & $\begin{array}{l}10.14 \\
16.33 \\
17.56 \\
15.72 \\
13.65\end{array}$ & $\begin{array}{l}1.40 \\
2.03 \\
2.11 \\
1.86 \\
1.42\end{array}$ & $\begin{array}{l}13.66 \\
19.36 \\
18.30 \\
13.63 \\
11.82\end{array}$ & $\begin{array}{l}- \\
- \\
- \\
-\end{array}$ & $\begin{array}{l}\bar{z} \\
\overline{-} \\
-\end{array}$ & $\begin{array}{r}31.49 \\
-4.44 \\
-7.82 \\
8.89 \\
23.10\end{array}$ & $\begin{array}{l}2.37 \\
4.23 \\
3.83 \\
2.89 \\
2.45\end{array}$ & $\begin{array}{r}6.90 \\
10.67 \\
11.06 \\
9.31 \\
7.70\end{array}$ & $\begin{array}{l}6.02 \\
8.74 \\
9.65 \\
8.51 \\
7.23\end{array}$ & $\begin{array}{l}3.58 \\
5.08 \\
5.71 \\
5.23 \\
4.05\end{array}$ \\
\hline 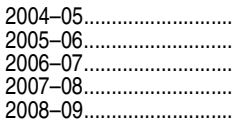 & $\begin{array}{l}100.00 \\
100.00 \\
100.00 \\
100.00 \\
100.00\end{array}$ & $\begin{array}{l}29.42 \\
28.88 \\
25.96 \\
36.35 \\
77.84\end{array}$ & $\begin{array}{l}14.06 \\
12.89 \\
11.07 \\
14.52 \\
30.55\end{array}$ & $\begin{array}{l}1.38 \\
1.34 \\
1.18 \\
1.70 \\
3.45\end{array}$ & $\begin{array}{l}11.95 \\
12.02 \\
11.08 \\
15.09 \\
25.69\end{array}$ & $\begin{array}{l}- \\
z \\
z \\
-\end{array}$ & $\begin{array}{l}z \\
\overline{-} \\
\overline{-}\end{array}$ & $\begin{array}{r}21.79 \\
23.40 \\
30.72 \\
4.66 \\
-93.52\end{array}$ & $\begin{array}{l}2.57 \\
2.43 \\
2.25 \\
3.49 \\
6.97\end{array}$ & $\begin{array}{r}7.73 \\
7.61 \\
6.74 \\
9.29 \\
19.71\end{array}$ & $\begin{array}{r}7.44 \\
7.58 \\
6.95 \\
9.59 \\
21.57\end{array}$ & $\begin{array}{l}3.66 \\
3.85 \\
4.05 \\
5.32 \\
7.74\end{array}$ \\
\hline $\begin{array}{l}2009-10 \\
2010-11 \ldots \ldots \ldots \\
2011-12\end{array}$ & $\begin{array}{l}100.00 \\
100.00 \\
100.00\end{array}$ & $\begin{array}{l}33.33 \\
28.84 \\
38.81\end{array}$ & $\begin{array}{l}13.58 \\
11.75 \\
14.94\end{array}$ & $\begin{array}{l}1.30 \\
1.04 \\
1.21\end{array}$ & $\begin{array}{l}10.68 \\
10.68 \\
13.38\end{array}$ & $\begin{array}{l}2.49 \\
2.12 \\
2.76\end{array}$ & $\begin{array}{r}8.19 \\
8.56 \\
10.62\end{array}$ & $\begin{array}{r}16.89 \\
25.93 \\
2.81\end{array}$ & $\begin{array}{l}2.86 \\
2.41 \\
3.15\end{array}$ & $\begin{array}{l}8.35 \\
7.15 \\
9.59\end{array}$ & $\begin{array}{r}9.84 \\
8.48 \\
11.58\end{array}$ & $\begin{array}{l}3.16 \\
3.72 \\
4.53\end{array}$ \\
\hline
\end{tabular}

See notes at end of table. 
Table 333.40. Total revenue of private nonprofit degree-granting postsecondary institutions, by source of funds and level of institution: 1999-2000 through 2011-12-Continued

\begin{tabular}{|c|c|c|c|c|c|c|c|c|c|c|c|c|}
\hline \multirow[b]{2}{*}{$\begin{array}{l}\text { Level of institution } \\
\text { and year }\end{array}$} & \multirow[b]{2}{*}{ Total } & \multirow[b]{2}{*}{$\begin{array}{r}\text { Student } \\
\text { tuition and } \\
\text { fees (net of } \\
\text { allowances) }\end{array}$} & \multirow[b]{2}{*}{$\begin{array}{r}\text { Federal } \\
\text { appro- } \\
\text { priations, } \\
\text { grants, and } \\
\text { contracts }^{1}\end{array}$} & \multirow[b]{2}{*}{$\begin{array}{r}\text { State and } \\
\text { local appro- } \\
\text { priations, } \\
\text { grants, and } \\
\text { contracts }\end{array}$} & \multicolumn{3}{|c|}{ Private gifts, grants, and contracts } & \multirow[b]{2}{*}{$\begin{array}{r}\text { Investment } \\
\text { return (gain } \\
\text { or loss) }\end{array}$} & \multirow[b]{2}{*}{$\begin{array}{r}\text { Educational } \\
\text { activities }\end{array}$} & \multirow[b]{2}{*}{$\begin{array}{r}\text { Auxiliary } \\
\text { enterprises } \\
\text { (net of } \\
\text { allowances) }\end{array}$} & \multirow[b]{2}{*}{ Hospitals } & \multirow[b]{2}{*}{ Other } \\
\hline & & & & & Total & $\begin{array}{r}\text { Private } \\
\text { grants and } \\
\text { contracts }\end{array}$ & $\begin{array}{r}\text { Private gifts } \\
\text { and contri- } \\
\text { butions from } \\
\text { affiliated } \\
\text { entities }\end{array}$ & & & & & \\
\hline 1 & 2 & 3 & 4 & 5 & 6 & 7 & 8 & 9 & 10 & 11 & 12 & 13 \\
\hline $\begin{array}{l}2-y e a r \\
1999-2000 \ldots \ldots \ldots \ldots \ldots \ldots \\
2000-01 \ldots \ldots \ldots \ldots \ldots \ldots \ldots \ldots \\
2001-02 \ldots \ldots \ldots \ldots \ldots \ldots \ldots \ldots \ldots \\
2002-03 \ldots \ldots \ldots \ldots \ldots \ldots \ldots \ldots \ldots \\
2003-04 \ldots \ldots \ldots \ldots \ldots \ldots \ldots \ldots \ldots\end{array}$ & $\begin{array}{l}100.00 \\
100.00 \\
100.00 \\
100.00 \\
100.00\end{array}$ & $\begin{array}{l}42.99 \\
53.13 \\
57.27 \\
56.28 \\
50.93\end{array}$ & $\begin{array}{r}6.32 \\
9.82 \\
14.04 \\
17.95 \\
15.64\end{array}$ & $\begin{array}{l}2.65 \\
4.12 \\
4.39 \\
5.13 \\
5.96\end{array}$ & $\begin{array}{r}15.52 \\
11.63 \\
11.24 \\
9.98 \\
9.10\end{array}$ & $\begin{array}{l}- \\
- \\
- \\
-\end{array}$ & $\begin{array}{l}- \\
\overline{-} \\
- \\
-\end{array}$ & $\begin{array}{l}7.12 \\
3.47 \\
0.44 \\
0.28 \\
6.73\end{array}$ & $\begin{array}{l}3.03 \\
2.63 \\
2.48 \\
2.46 \\
1.99\end{array}$ & $\begin{array}{l}6.12 \\
6.49 \\
9.41 \\
8.99 \\
6.04\end{array}$ & $\begin{array}{l}0.00 \\
0.11 \\
0.00 \\
0.00 \\
0.00\end{array}$ & $\begin{array}{r}16.25 \\
8.60 \\
0.73 \\
-1.07 \\
3.61\end{array}$ \\
\hline $\begin{array}{l}2004-05 \ldots \ldots \ldots \ldots \\
2005-06 \ldots \ldots \ldots \ldots \ldots \ldots \ldots \\
2006-07 \ldots \ldots \ldots \ldots \ldots \ldots \ldots \ldots \ldots \\
2007-08 \ldots \ldots \ldots \ldots \ldots \ldots \ldots \ldots \ldots \\
2008-09 \ldots \ldots \ldots \ldots \ldots \ldots \ldots . .\end{array}$ & $\begin{array}{l}100.00 \\
100.00 \\
100.00 \\
100.00 \\
100.00\end{array}$ & $\begin{array}{l}56.08 \\
53.57 \\
51.28 \\
60.77 \\
66.94\end{array}$ & $\begin{array}{l}12.41 \\
12.69 \\
10.72 \\
12.11 \\
13.19\end{array}$ & $\begin{array}{l}4.33 \\
5.05 \\
3.99 \\
4.86 \\
4.72\end{array}$ & $\begin{array}{r}10.92 \\
9.83 \\
9.36 \\
10.60 \\
10.37\end{array}$ & $\begin{array}{l}- \\
- \\
- \\
-\end{array}$ & $\begin{array}{l}- \\
\overline{-} \\
\overline{-}\end{array}$ & $\begin{array}{r}3.69 \\
5.17 \\
9.57 \\
-2.44 \\
-7.21\end{array}$ & $\begin{array}{l}2.20 \\
2.82 \\
1.57 \\
2.21 \\
1.23\end{array}$ & $\begin{array}{l}6.40 \\
6.33 \\
7.33 \\
7.60 \\
8.24\end{array}$ & $\begin{array}{l}0.00 \\
0.00 \\
0.00 \\
0.00 \\
0.00\end{array}$ & $\begin{array}{l}3.97 \\
4.54 \\
6.18 \\
4.28 \\
2.51\end{array}$ \\
\hline $\begin{array}{l}2009-10 \ldots \ldots \ldots \ldots \ldots \ldots \\
2010-11 \ldots \ldots \ldots \ldots \ldots \ldots \ldots \\
2011-12 \ldots \ldots \ldots \ldots \ldots \ldots . . .\end{array}$ & $\begin{array}{l}100.00 \\
100.00 \\
100.00\end{array}$ & $\begin{array}{l}57.57 \\
70.47 \\
73.62\end{array}$ & $\begin{array}{r}13.53 \\
9.19 \\
8.09 \\
\end{array}$ & $\begin{array}{l}2.70 \\
2.36 \\
1.95\end{array}$ & $\begin{array}{l}9.79 \\
6.00 \\
6.52\end{array}$ & $\begin{array}{l}0.76 \\
0.43 \\
0.42\end{array}$ & $\begin{array}{l}9.03 \\
5.57 \\
6.09\end{array}$ & $\begin{array}{l}4.00 \\
2.49 \\
0.87\end{array}$ & $\begin{array}{l}1.43 \\
0.67 \\
0.50\end{array}$ & $\begin{array}{l}6.87 \\
5.27 \\
4.75\end{array}$ & $\begin{array}{l}0.00 \\
0.00 \\
0.00\end{array}$ & $\begin{array}{l}4.12 \\
3.56 \\
3.71 \\
\end{array}$ \\
\hline & \multicolumn{12}{|c|}{ Revenue per full-time-equivalent student in constant $2012-13$ dollars ${ }^{2}$} \\
\hline 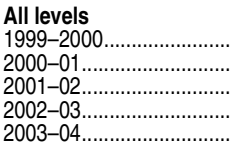 & $\begin{array}{r}\$ 64,927 \\
41,934 \\
41,386 \\
49,095 \\
59,571\end{array}$ & $\begin{array}{r}\$ 15,960 \\
15,982 \\
16,437 \\
16,735 \\
17,089\end{array}$ & $\begin{array}{r}\$ 6,562 \\
6,827 \\
7,257 \\
7,724 \\
8,137\end{array}$ & $\begin{array}{r}\$ 914 \\
860 \\
882 \\
924 \\
862\end{array}$ & $\begin{array}{r}\$ 8,875 \\
8,093 \\
7,553 \\
6,681 \\
7,033\end{array}$ & $\begin{array}{l}z \\
- \\
- \\
-\end{array}$ & $\begin{array}{l}- \\
- \\
- \\
-\end{array}$ & $\begin{array}{r}\$ 20,326 \\
-1,838 \\
-3,212 \\
4,340 \\
13,712\end{array}$ & $\begin{array}{r}\$ 1,542 \\
1,770 \\
1,580 \\
1,420 \\
1,460\end{array}$ & $\begin{array}{r}\$ 4,477 \\
4,461 \\
4,572 \\
4,569 \\
4,582\end{array}$ & $\begin{array}{r}\$ 3,880 \\
3,637 \\
3,966 \\
4,154 \\
4,286\end{array}$ & $\begin{array}{r}\$ 2,390 \\
2,143 \\
2,350 \\
2,549 \\
2,410\end{array}$ \\
\hline 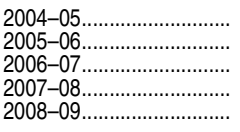 & $\begin{array}{l}58,947 \\
61,044 \\
69,796 \\
50,129 \\
24,146\end{array}$ & $\begin{array}{l}17,410 \\
17,690 \\
18,171 \\
18,264 \\
18,777\end{array}$ & $\begin{array}{l}8,285 \\
7,866 \\
7,728 \\
7,273 \\
7,350\end{array}$ & $\begin{array}{l}823 \\
830 \\
829 \\
859 \\
836\end{array}$ & $\begin{array}{l}7,040 \\
7,332 \\
7,728 \\
7,557 \\
6,178\end{array}$ & $\begin{array}{l}- \\
- \\
- \\
-\end{array}$ & $\begin{array}{l}\overline{-} \\
\overline{-} \\
-\end{array}$ & $\begin{array}{r}12,799 \\
14,241 \\
21,395 \\
2,321 \\
-22,447\end{array}$ & $\begin{array}{l}1,512 \\
1,485 \\
1,571 \\
1,746 \\
1,675\end{array}$ & $\begin{array}{l}4,553 \\
4,640 \\
4,704 \\
4,654 \\
4,741\end{array}$ & $\begin{array}{l}4,365 \\
4,611 \\
4,836 \\
4,788 \\
5,175\end{array}$ & $\begin{array}{l}2,158 \\
2,349 \\
2,834 \\
2,667 \\
1,860\end{array}$ \\
\hline $\begin{array}{l}2009-10 \\
2010-11 \ldots \ldots \ldots \ldots . . . \\
2011-12 \ldots \ldots \ldots \ldots \ldots \ldots \ldots . .\end{array}$ & $\begin{array}{l}56,956 \\
66,005 \\
49,648\end{array}$ & $\begin{array}{l}19,028 \\
19,125 \\
19,330\end{array}$ & $\begin{array}{l}7,737 \\
7,751 \\
7,406\end{array}$ & $\begin{array}{l}740 \\
690 \\
603\end{array}$ & $\begin{array}{l}6,083 \\
7,039 \\
6,631\end{array}$ & $\begin{array}{r}\$ 1,415 \\
1,395 \\
1,364\end{array}$ & $\begin{array}{r}\$ 4,669 \\
5,644 \\
5,267\end{array}$ & $\begin{array}{r}9,598 \\
17,063 \\
1,394\end{array}$ & $\begin{array}{l}1,628 \\
1,590 \\
1,559\end{array}$ & $\begin{array}{l}4,754 \\
4,713 \\
4,754\end{array}$ & $\begin{array}{l}5,585 \\
5,580 \\
5,726\end{array}$ & $\begin{array}{l}1,803 \\
2,454 \\
2,246\end{array}$ \\
\hline 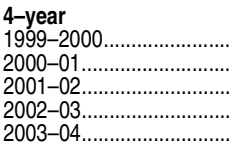 & $\begin{array}{l}65,814 \\
42,275 \\
41,714 \\
49,469 \\
60,046\end{array}$ & $\begin{array}{l}16,085 \\
16,065 \\
16,516 \\
16,798 \\
17,161\end{array}$ & $\begin{array}{l}6,671 \\
6,903 \\
7,325 \\
7,776 \\
8,197\end{array}$ & $\begin{array}{l}920 \\
860 \\
882 \\
922 \\
855\end{array}$ & $\begin{array}{l}8,987 \\
8,183 \\
7,634 \\
6,742 \\
7,097\end{array}$ & $\begin{array}{l}- \\
- \\
- \\
-\end{array}$ & $\begin{array}{l}- \\
- \\
- \\
-\end{array}$ & $\begin{array}{r}20,726 \\
-1,878 \\
-3,261 \\
4,397 \\
13,868\end{array}$ & $\begin{array}{l}1,560 \\
1,789 \\
1,597 \\
1,432 \\
1,473\end{array}$ & $\begin{array}{l}4,542 \\
4,511 \\
4,613 \\
4,604 \\
4,624\end{array}$ & $\begin{array}{l}3,963 \\
3,693 \\
4,026 \\
4,210 \\
4,341\end{array}$ & $\begin{array}{l}2,359 \\
2,149 \\
2,383 \\
2,586 \\
2,430\end{array}$ \\
\hline 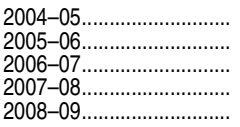 & $\begin{array}{l}59,398 \\
61,467 \\
70,197 \\
50,396 \\
24,194\end{array}$ & $\begin{array}{l}17,473 \\
17,753 \\
18,224 \\
18,317 \\
18,831\end{array}$ & $\begin{array}{l}8,353 \\
7,921 \\
7,773 \\
7,317 \\
7,392\end{array}$ & $\begin{array}{l}822 \\
826 \\
828 \\
858 \\
836\end{array}$ & $\begin{array}{l}7,097 \\
7,388 \\
7,776 \\
7,605 \\
6,215\end{array}$ & $\begin{array}{l}- \\
- \\
- \\
-\end{array}$ & $\begin{array}{l}- \\
- \\
- \\
-\end{array}$ & $\begin{array}{r}12,945 \\
14,384 \\
21,561 \\
2,346 \\
-22,627\end{array}$ & $\begin{array}{l}1,525 \\
1,495 \\
1,581 \\
1,757 \\
1,687\end{array}$ & $\begin{array}{l}4,591 \\
4,675 \\
4,730 \\
4,682 \\
4,768\end{array}$ & $\begin{array}{l}4,418 \\
4,661 \\
4,878 \\
4,831 \\
5,219\end{array}$ & $\begin{array}{l}2,174 \\
2,364 \\
2,846 \\
2,683 \\
1,872\end{array}$ \\
\hline $\begin{array}{l}2009-10 \ldots \ldots \ldots \ldots \ldots \ldots \\
2010-11 \ldots \ldots \ldots \ldots \ldots \ldots \ldots \\
2011-12 \ldots \ldots \ldots \ldots \ldots \ldots \ldots . .\end{array}$ & $\begin{array}{l}57,248 \\
66,500 \\
49,955\end{array}$ & $\begin{array}{l}19,083 \\
19,181 \\
19,385\end{array}$ & $\begin{array}{l}7,776 \\
7,814 \\
7,465\end{array}$ & $\begin{array}{l}742 \\
692 \\
605\end{array}$ & $\begin{array}{l}6,116 \\
7,102 \\
6,684\end{array}$ & $\begin{array}{l}1,425 \\
1,409 \\
1,377\end{array}$ & $\begin{array}{l}4,691 \\
5,693 \\
5,308\end{array}$ & $\begin{array}{r}9,669 \\
17,240 \\
1,406\end{array}$ & $\begin{array}{l}1,639 \\
1,606 \\
1,574\end{array}$ & $\begin{array}{l}4,781 \\
4,752 \\
4,792\end{array}$ & $\begin{array}{l}5,631 \\
5,640 \\
5,782\end{array}$ & $\begin{array}{l}1,811 \\
2,473 \\
2,261\end{array}$ \\
\hline 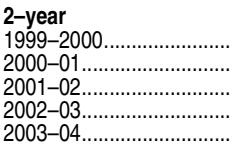 & $\begin{array}{l}23,532 \\
20,103 \\
19,391 \\
21,322 \\
22,393\end{array}$ & $\begin{array}{l}10,116 \\
10,680 \\
11,105 \\
12,001 \\
11,406\end{array}$ & $\begin{array}{l}1,488 \\
1,973 \\
2,722 \\
3,826 \\
3,502\end{array}$ & $\begin{array}{r}623 \\
827 \\
852 \\
1,095 \\
1,334\end{array}$ & $\begin{array}{l}3,653 \\
2,338 \\
2,179 \\
2,128 \\
2,038\end{array}$ & $\begin{array}{l}- \\
z \\
- \\
-\end{array}$ & $\begin{array}{l}- \\
\overline{-} \\
- \\
-\end{array}$ & $\begin{array}{r}1,675 \\
697 \\
86 \\
60 \\
1,508\end{array}$ & $\begin{array}{l}714 \\
529 \\
481 \\
524 \\
445\end{array}$ & $\begin{array}{l}1,439 \\
1,304 \\
1,825 \\
1,916 \\
1,352\end{array}$ & $\begin{array}{r}0 \\
23 \\
0 \\
0 \\
0\end{array}$ & $\begin{array}{r}3,824 \\
1,729 \\
142 \\
-228 \\
809\end{array}$ \\
\hline $\begin{array}{l}2004-05 \ldots \ldots \ldots \ldots \ldots \ldots \ldots \\
2005-06 \ldots \ldots \ldots \ldots \ldots \ldots \ldots \ldots \ldots \ldots \\
2006-07 \ldots \ldots \ldots \ldots \ldots \ldots \ldots \ldots \ldots \\
2007-08 \ldots \ldots \ldots \ldots \ldots \ldots \ldots \ldots \ldots \ldots\end{array}$ & $\begin{array}{l}21,799 \\
22,095 \\
23,481 \\
20,298 \\
18,541\end{array}$ & $\begin{array}{l}12,226 \\
11,836 \\
12,040 \\
12,336 \\
12,412\end{array}$ & $\begin{array}{l}2,706 \\
2,804 \\
2,517 \\
2,457 \\
2,446\end{array}$ & $\begin{array}{r}943 \\
1,116 \\
936 \\
987 \\
875\end{array}$ & $\begin{array}{l}2,380 \\
2,172 \\
2,199 \\
2,153 \\
1,923\end{array}$ & $\begin{array}{l}- \\
- \\
- \\
-\end{array}$ & $\begin{array}{l}- \\
\overline{-} \\
- \\
-\end{array}$ & $\begin{array}{r}805 \\
1,142 \\
2,246 \\
-495 \\
-1,336\end{array}$ & $\begin{array}{l}480 \\
624 \\
369 \\
449 \\
229\end{array}$ & $\begin{array}{l}1,395 \\
1,399 \\
1,722 \\
1,542 \\
1,528\end{array}$ & $\begin{array}{l}0 \\
0 \\
0 \\
0 \\
0\end{array}$ & $\begin{array}{r}865 \\
1,002 \\
1,452 \\
869 \\
465\end{array}$ \\
\hline $\begin{array}{l}2009-10 \ldots \ldots \ldots \ldots \ldots . . \\
2010-11 \ldots \ldots \ldots \ldots \ldots \ldots . . \\
2011-12 \ldots \ldots \ldots \ldots \ldots \ldots \ldots . .\end{array}$ & $\begin{array}{l}21,499 \\
19,791 \\
18,635\end{array}$ & $\begin{array}{l}12,376 \\
13,947 \\
13,718\end{array}$ & $\begin{array}{l}2,908 \\
1,820 \\
1,508\end{array}$ & $\begin{array}{l}580 \\
467 \\
363\end{array}$ & $\begin{array}{l}2,105 \\
1,187 \\
1,214\end{array}$ & $\begin{array}{r}164 \\
85 \\
79\end{array}$ & $\begin{array}{l}1,941 \\
1,103 \\
1,136\end{array}$ & $\begin{array}{l}861 \\
492 \\
161\end{array}$ & $\begin{array}{r}306 \\
133 \\
94\end{array}$ & $\begin{array}{r}1,477 \\
1,042 \\
885\end{array}$ & $\begin{array}{l}0 \\
0 \\
0\end{array}$ & $\begin{array}{l}885 \\
704 \\
691\end{array}$ \\
\hline
\end{tabular}

IIncludes independent operations

${ }^{2}$ Constant dollars based on the Consumer Price Index, prepared by the Bureau of Labor Statistics, U.S. Department of Labor, adjusted to a school-year basis.

NOTE: Degree-granting institutions grant associate's or higher degrees and participate in Title IV federal financial aid programs. Detail may not sum to totals because of rounding.
SOURCE: U.S. Department of Education, National Center for Education Statistics, Integrated Postsecondary Education Data System (IPEDS), "Fall Enrollment Survey" (IPEDSEF:99) and "Finance Survey" (IPEDS-F:FY99); and Spring 2002 through Spring 2013, Enrollment and Finance components. (This table was prepared January 2014.) 
Table 333.50. Total revenue of private nonprofit degree-granting postsecondary institutions, by source of funds and classification of institution: $2011-12$

\begin{tabular}{|c|c|c|c|c|c|c|c|c|c|c|c|}
\hline Classification of institution & Total & $\begin{array}{r}\text { Student } \\
\text { tuition and } \\
\text { fees (net of } \\
\text { allowances) }\end{array}$ & $\begin{array}{r}\text { Federal } \\
\text { appro- } \\
\text { priations, } \\
\text { grants, and } \\
\text { contracts }^{1}\end{array}$ & $\begin{array}{r}\text { State and } \\
\text { local appro- } \\
\text { priations, } \\
\text { grants, and } \\
\text { contracts }\end{array}$ & $\begin{array}{r}\text { Private } \\
\text { grants and } \\
\text { contracts }\end{array}$ & $\begin{array}{r}\text { Private gifts } \\
\text { and contri- } \\
\text { butions from } \\
\text { affiliated } \\
\text { entities }\end{array}$ & $\begin{array}{r}\text { Investment } \\
\text { return } \\
\text { (gain or loss) }\end{array}$ & $\begin{array}{r}\text { Educational } \\
\text { activities }\end{array}$ & $\begin{array}{r}\text { Auxiliary } \\
\text { enterprises } \\
\text { (net of } \\
\text { allowances) }\end{array}$ & Hospitals & Other \\
\hline \multirow[t]{2}{*}{1} & 2 & 3 & 4 & 5 & 6 & 7 & 8 & 9 & 10 & 11 & 12 \\
\hline & \multicolumn{11}{|c|}{ In thousands of current dollars } \\
\hline Total.. & $\$ 161,868,611$ & $\$ 63,021,108$ & $\$ 24,147,119$ & $\$ 1,964,938$ & $\$ 4,446,490$ & $\$ 17,171,476$ & $\$ 4,544,786$ & $\$ 5,082,882$ & $\$ 15,499,433$ & $\$ 18,667,425$ & $\$ 7,322,955$ \\
\hline 4-year.... & $161,272,285$ & $62,582,114$ & $24,098,850$ & $1,953,324$ & $4,443,977$ & $17,135,131$ & $4,539,625$ & $5,079,876$ & $15,471,108$ & $18,667,425$ & $7,300,856$ \\
\hline Research university, very high ${ }^{2} \ldots$ & $76,342,910$ & $13,431,966$ & $18,475,129$ & 895,993 & $3,051,095$ & $8,298,019$ & $5,149,262$ & $3,683,611$ & $4,174,539$ & $14,700,173$ & $4,483,122$ \\
\hline Research university, high ${ }^{3} \ldots \ldots \ldots \ldots . . .$. & $11,891,098$ & $5,987,967$ & $1,244,375$ & 149,466 & 220,769 & $1,448,322$ & $-216,520$ & 606,728 & $1,455,487$ & 477,960 & 516,546 \\
\hline Doctoral/research 4 ........................... & $7,692,801$ & $5,659,408$ & 225,429 & 86,739 & 99,707 & 533,660 & $-126,428$ & 63,563 & 931,918 & 0 & 218,806 \\
\hline 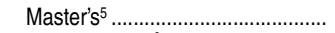 & $27,873,765$ & $19,974,763$ & $1,059,629$ & 293,701 & 136,931 & $1,916,039$ & $-422,314$ & 155,971 & $3,991,113$ & 136,649 & 631,282 \\
\hline Baccalaureate $^{6} \ldots \ldots \ldots \ldots \ldots \ldots \ldots \ldots \ldots$ & $20,798,498$ & $11,378,775$ & 805,767 & 157,819 & 196,651 & $3,307,008$ & 141,292 & 143,561 & $4,112,906$ & 715 & 554,004 \\
\hline Special-focus institutions ${ }^{7} \ldots \ldots \ldots \ldots . . .$. & $16,673,213$ & $6,149,234$ & $2,288,521$ & 369,607 & 738,823 & $1,632,083$ & 14,334 & 426,443 & 805,146 & $3,351,927$ & 897,097 \\
\hline 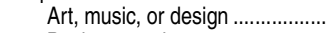 & $2,081,948$ & $1,494,505$ & 53,096 & 16,358 & 19,519 & 239,519 & $-35,478$ & 21,341 & 227,276 & 0 & 45,812 \\
\hline Business and management ....... & 601,675 & 426,889 & 20,904 & 7,776 & 856 & 55,800 & $-2,705$ & 5,638 & 69,295 & 0 & 17,222 \\
\hline Engineering or technology ......... & 131,844 & 82,412 & 4,884 & 901 & 190 & 43,510 & $-24,830$ & 513 & 20,109 & 0 & 4,154 \\
\hline 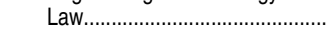 & 654,865 & 585,291 & 11,945 & 3,753 & 3,238 & 28,767 & $-2,041$ & 854 & 15,982 & 0 & 7,077 \\
\hline Medical or other health ............... & $11,128,667$ & $2,762,896$ & $2,056,313$ & 327,402 & 670,334 & 553,644 & 88,820 & 374,551 & 237,090 & $3,351,927$ & 705,689 \\
\hline Theological........................... & $1,660,753$ & 591,466 & 39,415 & 3,739 & 40,535 & 675,278 & $-10,289$ & 12,315 & 207,415 & 0 & 100,879 \\
\hline Tribal $^{8} \ldots \ldots$ & 116,843 & 9,989 & 88,584 & 3,260 & 2,980 & 610 & 479 & 469 & 2,885 & 0 & 7,587 \\
\hline Other special focus ........................ & 296,618 & 195,783 & 13,380 & 6,417 & 1,170 & 34,955 & 379 & 10,763 & 25,094 & 0 & 8,677 \\
\hline (n) & 596,326 & 438,994 & 48,269 & 11,614 & 2,513 & 36,345 & 5,161 & 3,007 & 28,325 & 0 & 22,099 \\
\hline Associate's of arts................................. & 578,184 & 438,290 & 35,826 & 11,102 & 1,918 & 35,692 & 5,146 & 3,007 & 28,224 & 0 & 18,981 \\
\hline \multirow[t]{2}{*}{ Triba| $^{8}$} & 18,142 & 705 & 12,443 & 512 & 596 & 653 & 14 & 0 & 101 & 0 & 3,118 \\
\hline & \multicolumn{11}{|c|}{ Percentage distribution } \\
\hline 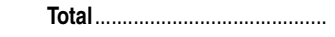 & 100.00 & 38.93 & 14.92 & 1.21 & 2.75 & 10.61 & 2.81 & 3.14 & 9.58 & 11.53 & 4.52 \\
\hline 4 -year............. & 100.00 & 38.81 & 14.94 & 1.21 & 2.76 & 10.62 & 2.81 & 3.15 & 9.59 & 11.58 & 4.53 \\
\hline Research university, very high².. & 100.00 & 17.59 & 24.20 & 1.17 & 4.00 & 10.87 & 6.74 & 4.83 & 5.47 & 19.26 & 5.87 \\
\hline Research university, high $\mathrm{h}^{3} \ldots \ldots \ldots \ldots . . .$. & 100.00 & 50.36 & 10.46 & 1.26 & 1.86 & 12.18 & -1.82 & 5.10 & 12.24 & 4.02 & 4.34 \\
\hline 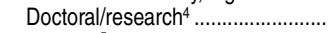 & 100.00 & 73.57 & 2.93 & 1.13 & 1.30 & 6.94 & -1.64 & 0.83 & 12.11 & 0.00 & 2.84 \\
\hline 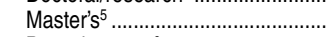 & 100.00 & 71.66 & 3.80 & 1.05 & 0.49 & 6.87 & -1.52 & 0.56 & 14.32 & 0.49 & 2.26 \\
\hline Baccalaureate ${ }^{6} .$. & 100.00 & 54.71 & 3.87 & 0.76 & 0.95 & 15.90 & 0.68 & 0.69 & 19.78 & 0.00 & 2.66 \\
\hline Special-focus institutions ${ }^{7} \ldots \ldots \ldots \ldots$ & 100.00 & 36.88 & 13.73 & 2.22 & 4.43 & 9.79 & 0.09 & 2.56 & 4.83 & 20.10 & 5.38 \\
\hline 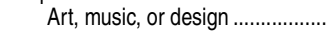 & 100.00 & 71.78 & 2.55 & 0.79 & 0.94 & 11.50 & -1.70 & 1.03 & 10.92 & 0.00 & 2.20 \\
\hline Business and management ...... & 100.00 & 70.95 & 3.47 & 1.29 & 0.14 & 9.27 & -0.45 & 0.94 & 11.52 & 0.00 & 2.86 \\
\hline Engineering or technology ......... & 100.00 & 62.51 & 3.70 & 0.68 & 0.14 & 33.00 & -18.83 & 0.39 & 15.25 & 0.00 & 3.15 \\
\hline 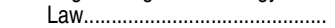 & 100.00 & 89.38 & 1.82 & 0.57 & 0.49 & 4.39 & -0.31 & 0.13 & 2.44 & 0.00 & 1.08 \\
\hline Medical or other health ............... & 100.00 & 24.83 & 18.48 & 2.94 & 6.02 & 4.97 & 0.80 & 3.37 & 2.13 & 30.12 & 6.34 \\
\hline Theological.............................. & 100.00 & 35.61 & 2.37 & 0.23 & 2.44 & 40.66 & -0.62 & 0.74 & 12.49 & 0.00 & 6.07 \\
\hline 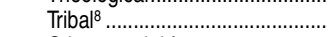 & 100.00 & 8.55 & 75.81 & 2.79 & 2.55 & 0.52 & 0.41 & 0.40 & 2.47 & 0.00 & 6.49 \\
\hline Other special focus ........................ & 100.00 & 66.01 & 4.51 & 2.16 & 0.39 & 11.78 & 0.13 & 3.63 & 8.46 & 0.00 & 2.93 \\
\hline 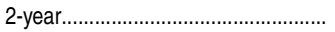 & 100.00 & 73.62 & 8.09 & 1.95 & 0.42 & 6.09 & 0.87 & 0.50 & 4.75 & 0.00 & 3.71 \\
\hline Associate's of arts.............. & 100.00 & 75.80 & 6.20 & 1.92 & 0.33 & 6.17 & 0.89 & 0.52 & 4.88 & 0.00 & 3.28 \\
\hline \multirow{2}{*}{ 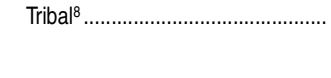 } & 100.00 & 3.88 & 68.59 & 2.82 & 3.28 & 3.60 & 0.08 & 0.00 & 0.56 & 0.00 & 17.19 \\
\hline & \multicolumn{11}{|c|}{ Revenue per full-time-equivalent student in current dollars } \\
\hline 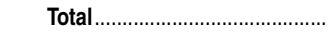 & $\$ 48,835$ & $\$ 19,013$ & $\$ 7,285$ & $\$ 593$ & $\$ 1,341$ & $\$ 5,181$ & $\$ 1,371$ & $\$ 1,533$ & $\$ 4,676$ & $\$ 5,632$ & $\$ 2,209$ \\
\hline 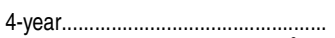 & 49,138 & 19,068 & 7,343 & 595 & 1,354 & 5,221 & 1,383 & 1,548 & 4,714 & 5,688 & 2,224 \\
\hline Research university, very high ${ }^{2} \ldots . .$. & 154,499 & 27,183 & 37,389 & 1,813 & 6,175 & 16,793 & 10,421 & 7,455 & 8,448 & 29,750 & 9,073 \\
\hline Research university, high ${ }^{3} \ldots \ldots \ldots \ldots . . . .$. & 42,764 & 21,534 & 4,475 & 538 & 794 & 5,209 & -779 & 2,182 & 5,234 & 1,719 & 1,858 \\
\hline Doctoral/research ${ }^{4} \ldots \ldots \ldots \ldots$ & 28,900 & 21,261 & 847 & 326 & 375 & 2,005 & -475 & 239 & 3,501 & 0 & 822 \\
\hline 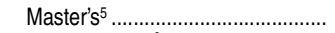 & 22,846 & 16,372 & 869 & 241 & 112 & 1,570 & -346 & 128 & 3,271 & 112 & 517 \\
\hline Baccalaureate $^{6} \ldots \ldots \ldots \ldots \ldots \ldots$ & 28,545 & 15,617 & 1,106 & 217 & 270 & 4,539 & 194 & 197 & 5,645 & 1 & 760 \\
\hline Special-focus institutions ${ }^{7} \ldots \ldots \ldots \ldots . . . .$. & 56,519 & 20,845 & 7,758 & 1,253 & 2,504 & 5,532 & 49 & 1,446 & 2,729 & 11,362 & 3,041 \\
\hline 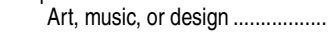 & 36,103 & 25,916 & 921 & 284 & 338 & 4,153 & -615 & 370 & 3,941 & 0 & 794 \\
\hline Business and management ....... & 25,167 & 17,856 & 874 & 325 & 36 & 2,334 & -113 & 236 & 2,899 & 0 & 720 \\
\hline Engineering or technology ........ & 9,559 & 5,975 & 354 & 65 & 14 & 3,155 & $-1,800$ & 37 & 1,458 & 0 & 301 \\
\hline 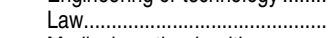 & 36,131 & 32,292 & 659 & 207 & 179 & 1,587 & -113 & 47 & 882 & 0 & 390 \\
\hline Medical or other health ............... & 111,026 & 27,564 & 20,515 & 3,266 & 6,688 & 5,523 & 886 & 3,737 & 2,365 & 33,441 & 7,040 \\
\hline 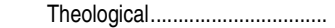 & 23,430 & 8,344 & 556 & 53 & 572 & 9,527 & -145 & 174 & 2,926 & 0 & 1,423 \\
\hline 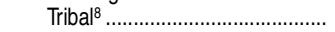 & 37,283 & 3,187 & 28,265 & 1,040 & 951 & 195 & 153 & 150 & 921 & 0 & 2,421 \\
\hline Other special focus ....................... & 40,873 & 26,979 & 1,844 & 884 & 161 & 4,817 & 52 & 1,483 & 3,458 & 0 & 1,196 \\
\hline 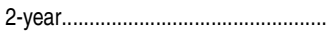 & 18,330 & 13,494 & 1,484 & 357 & 77 & 1,117 & 159 & 92 & 871 & 0 & 679 \\
\hline 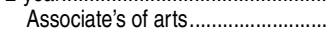 & 18,111 & 13,729 & 1,122 & 348 & 60 & 1,118 & 161 & 94 & 884 & 0 & 595 \\
\hline Tribal8 & 29,790 & 1,157 & 20,432 & 841 & 978 & 1,072 & 24 & 0 & 166 & 0 & 5,120 \\
\hline
\end{tabular}

${ }^{1}$ Includes independent operations.

${ }^{2}$ Research universities with a very high level of research activity.

${ }^{3}$ Research universities with a high level of research activity.

${ }^{4}$ Includes institutions that award at least 20 doctor's degrees per year, but did not have high levels of research activity.

${ }^{5}$ Master's institutions award at least 50 master's degrees per year.

${ }^{6}$ Baccalaureate institutions primarily emphasize undergraduate education. Also includes institutions classified as 4-year under the IPEDS system, which had been classified as 2-year in the Carnegie classification system because they primarily award associate's degrees.

${ }^{7}$ Special-focus 4-year institutions award degrees primarily in single fields of study, such as medicine, business, fine arts, theology, and engineering.
${ }^{8}$ Tribally controlled colleges are located on reservations and are members of the American Indian Higher Education Consortium.

NOTE: Relative levels of research activity for research universities were determined by an analysis of research and development expenditures, science and engineering research staffing, and doctoral degrees conferred, by field. Further information on the Carnegie 2005 classification system used in this table may be obtained from http://classifications.carnegiefoundation.org/ resources/. Degree-granting institutions grant associate's or higher degrees and participate in Title IV federal financial aid programs. Detail may not sum to totals because of rounding. SOURCE: U.S. Department of Education, National Center for Education Statistics, Integrated Postsecondary Education Data System (IPEDS), Spring 2012, Enrollment component; and Spring 2013, Finance component. (This table was prepared January 2014.) 
Table 333.55. Total revenue of private for-profit degree-granting postsecondary institutions, by source of funds and level of institution: Selected years, 1999-2000 through 2011-12

\begin{tabular}{|c|c|c|c|c|c|c|c|c|c|}
\hline Level of institution and year & Total & $\begin{array}{r}\text { Student tuition } \\
\text { and fees } \\
\text { (net of } \\
\text { allowances) }\end{array}$ & $\begin{array}{r}\text { Federal } \\
\text { appropriations, } \\
\text { grants, and } \\
\text { contracts }\end{array}$ & $\begin{array}{r}\text { State and local } \\
\text { appropriations, } \\
\text { grants, and } \\
\text { contracts }\end{array}$ & $\begin{array}{r}\text { Private } \\
\text { gifts, grants, } \\
\text { and contracts }\end{array}$ & $\begin{array}{r}\text { Investment } \\
\text { income and } \\
\text { gains (losses) }\end{array}$ & $\begin{array}{r}\text { Educational } \\
\text { activities }\end{array}$ & $\begin{array}{r}\text { Auxiliary } \\
\text { enterprises } \\
\text { (net of } \\
\text { allowances) }\end{array}$ & Other \\
\hline 1 & 2 & 3 & 4 & 5 & 6 & 7 & 8 & 9 & 10 \\
\hline & \multicolumn{9}{|c|}{ In thousands of current dollars } \\
\hline 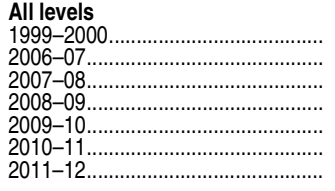 & $\begin{array}{l}\$ 4,321,985 \\
13,978,218 \\
16,083,784 \\
19,373,779 \\
24,684,829 \\
28,221,419 \\
26,922,879\end{array}$ & $\begin{array}{l}\$ 3,721,032 \\
12,329,854 \\
14,029,958 \\
16,740,041 \\
22,374,050 \\
25,155,815 \\
24,035,276\end{array}$ & $\begin{array}{r}\$ 198,923 \\
726,002 \\
959,684 \\
1,407,615 \\
1,951,202 \\
1,583,146 \\
1,527,947\end{array}$ & $\begin{array}{r}\$ 71,904 \\
69,944 \\
67,926 \\
130,378 \\
114,075 \\
157,269 \\
102,568\end{array}$ & $\begin{array}{r}\$ 2,151 \\
3,715 \\
4,755 \\
80,345 \\
38,299 \\
31,272 \\
9,386\end{array}$ & $\begin{array}{r}\$ 18,537 \\
48,802 \\
64,848 \\
38,707 \\
40,115 \\
32,859 \\
36,726\end{array}$ & $\begin{array}{l}\$ 70,672 \\
245,526 \\
289,640 \\
368,034 \\
435,519 \\
402,384 \\
352,468\end{array}$ & $\begin{array}{r}\$ 156,613 \\
312,301 \\
351,900 \\
395,728 \\
485,216 \\
542,589 \\
511,364\end{array}$ & $\begin{array}{r}\$ 82,153 \\
242,073 \\
315,073 \\
212,930 \\
-753,647 \\
316,084 \\
347,145\end{array}$ \\
\hline 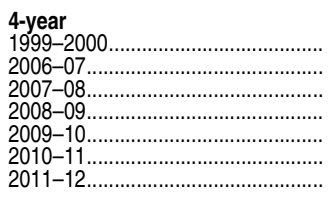 & $\begin{array}{r}2,381,042 \\
10,307,793 \\
12,174,363 \\
14,766,008 \\
18,983,250 \\
21,689,815 \\
21,204,816\end{array}$ & $\begin{array}{r}2,050,136 \\
9,227,102 \\
10,751,121 \\
12,954,629 \\
17,321,210 \\
19,480,318 \\
18,942,669\end{array}$ & $\begin{array}{r}103,865 \\
446,632 \\
644,062 \\
897,503 \\
1,226,115 \\
1,113,185 \\
1,143,845\end{array}$ & $\begin{array}{r}39,460 \\
35,145 \\
30,688 \\
80,021 \\
69,168 \\
118,033 \\
70,872\end{array}$ & $\begin{array}{r}1,109 \\
2,426 \\
2,638 \\
71,601 \\
35,634 \\
29,118 \\
7,298\end{array}$ & $\begin{array}{l}10,340 \\
37,052 \\
50,771 \\
35,461 \\
35,949 \\
28,976 \\
30,546\end{array}$ & $\begin{array}{r}33,764 \\
211,132 \\
246,419 \\
327,474 \\
376,427 \\
346,786 \\
308,909\end{array}$ & $\begin{array}{l}102,103 \\
217,725 \\
269,771 \\
297,764 \\
372,285 \\
405,572 \\
404,301\end{array}$ & $\begin{array}{r}40,266 \\
130,579 \\
178,894 \\
101,555 \\
-453,538 \\
167,828 \\
296,375\end{array}$ \\
\hline \multirow[t]{2}{*}{ 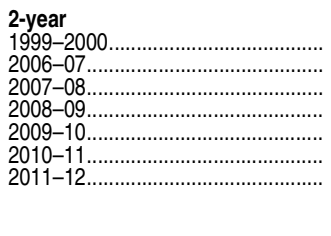 } & $\begin{array}{l}1,940,943 \\
3,670,424 \\
3,909,421 \\
4,607,770 \\
5,701,579 \\
6,531,603 \\
5,718,063 \\
\end{array}$ & $\begin{array}{l}1,670,896 \\
3,102,752 \\
3,278,837 \\
3,785,412 \\
5,052,841 \\
5,675,497 \\
5,092,607 \\
\end{array}$ & $\begin{array}{r}95,058 \\
279,370 \\
315,622 \\
510,112 \\
725,087 \\
469,961 \\
384,102 \\
\end{array}$ & $\begin{array}{l}32,444 \\
34,799 \\
37,238 \\
50,358 \\
44,907 \\
39,236 \\
31,696 \\
\end{array}$ & $\begin{array}{l}1,042 \\
1,289 \\
2,117 \\
8,745 \\
2,664 \\
2,154 \\
2,087 \\
\end{array}$ & $\begin{array}{r}8,197 \\
11,750 \\
14,077 \\
3,246 \\
4,166 \\
3,882 \\
6,180 \\
\end{array}$ & $\begin{array}{l}36,908 \\
34,394 \\
43,222 \\
40,560 \\
59,092 \\
55,599 \\
43,558 \\
\end{array}$ & $\begin{array}{r}54,510 \\
94,576 \\
82,129 \\
97,964 \\
112,930 \\
137,018 \\
107,063 \\
\end{array}$ & $\begin{array}{r}41,888 \\
111,494 \\
136,178 \\
111,374 \\
-300,108 \\
148,256 \\
50,770 \\
\end{array}$ \\
\hline & \multicolumn{9}{|c|}{ Percentage distribution } \\
\hline 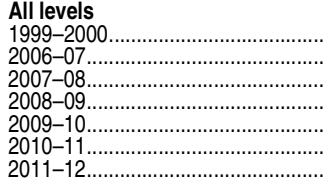 & $\begin{array}{l}100.00 \\
100.00 \\
100.00 \\
100.00 \\
100.00 \\
100.00 \\
100.00\end{array}$ & $\begin{array}{l}86.10 \\
88.21 \\
87.23 \\
86.41 \\
90.64 \\
89.14 \\
89.27\end{array}$ & $\begin{array}{l}4.60 \\
5.19 \\
5.97 \\
7.27 \\
7.90 \\
5.61 \\
5.68\end{array}$ & $\begin{array}{l}1.66 \\
0.50 \\
0.42 \\
0.67 \\
0.46 \\
0.56 \\
0.38\end{array}$ & $\begin{array}{l}0.05 \\
0.03 \\
0.03 \\
0.41 \\
0.16 \\
0.11 \\
0.03\end{array}$ & $\begin{array}{l}0.43 \\
0.35 \\
0.40 \\
0.20 \\
0.16 \\
0.12 \\
0.14\end{array}$ & $\begin{array}{l}1.64 \\
1.76 \\
1.80 \\
1.90 \\
1.76 \\
1.43 \\
1.31\end{array}$ & $\begin{array}{l}3.62 \\
2.23 \\
2.19 \\
2.04 \\
1.97 \\
1.92 \\
1.90\end{array}$ & $\begin{array}{r}1.90 \\
1.73 \\
1.96 \\
1.10 \\
-3.05 \\
1.12 \\
1.29\end{array}$ \\
\hline 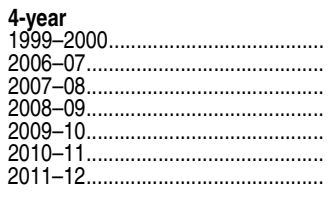 & $\begin{array}{l}100.00 \\
100.00 \\
100.00 \\
100.00 \\
100.00 \\
100.00 \\
100.00\end{array}$ & $\begin{array}{l}86.10 \\
89.52 \\
88.31 \\
87.73 \\
91.24 \\
89.81 \\
89.33\end{array}$ & $\begin{array}{l}4.36 \\
4.33 \\
5.29 \\
6.08 \\
6.46 \\
5.13 \\
5.39\end{array}$ & $\begin{array}{l}1.66 \\
0.34 \\
0.25 \\
0.54 \\
0.36 \\
0.54 \\
0.33\end{array}$ & $\begin{array}{l}0.05 \\
0.02 \\
0.02 \\
0.48 \\
0.19 \\
0.13 \\
0.03\end{array}$ & $\begin{array}{l}0.43 \\
0.36 \\
0.42 \\
0.24 \\
0.19 \\
0.13 \\
0.14\end{array}$ & $\begin{array}{l}1.42 \\
2.05 \\
2.02 \\
2.22 \\
1.98 \\
1.60 \\
1.46\end{array}$ & $\begin{array}{l}4.29 \\
2.11 \\
2.22 \\
2.02 \\
1.96 \\
1.87 \\
1.91\end{array}$ & $\begin{array}{r}1.69 \\
1.27 \\
1.47 \\
0.69 \\
-2.39 \\
0.77 \\
1.40\end{array}$ \\
\hline \multirow[t]{2}{*}{ 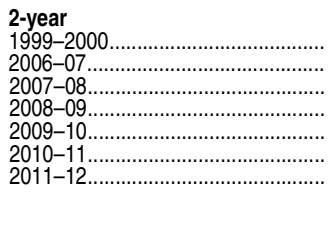 } & $\begin{array}{l}100.00 \\
100.00 \\
100.00 \\
100.00 \\
100.00 \\
100.00 \\
100.00 \\
\end{array}$ & $\begin{array}{l}86.09 \\
84.53 \\
83.87 \\
82.15 \\
88.62 \\
86.89 \\
89.06 \\
\end{array}$ & $\begin{array}{r}4.90 \\
7.61 \\
8.07 \\
11.07 \\
12.72 \\
7.20 \\
6.72 \\
\end{array}$ & $\begin{array}{l}1.67 \\
0.95 \\
0.95 \\
1.09 \\
0.79 \\
0.60 \\
0.55 \\
\end{array}$ & $\begin{array}{l}0.05 \\
0.04 \\
0.05 \\
0.19 \\
0.05 \\
0.03 \\
0.04 \\
\end{array}$ & $\begin{array}{l}0.42 \\
0.32 \\
0.36 \\
0.07 \\
0.07 \\
0.06 \\
0.11 \\
\end{array}$ & $\begin{array}{l}1.90 \\
0.94 \\
1.11 \\
0.88 \\
1.04 \\
0.85 \\
0.76 \\
\end{array}$ & $\begin{array}{l}2.81 \\
2.58 \\
2.10 \\
2.13 \\
1.98 \\
2.10 \\
1.87 \\
\end{array}$ & $\begin{array}{r}2.16 \\
3.04 \\
3.48 \\
2.42 \\
-5.26 \\
2.27 \\
0.89 \\
\end{array}$ \\
\hline & \multicolumn{9}{|c|}{ Revenue per full-time-equivalent student in constant $2012-13$ dollars 1} \\
\hline 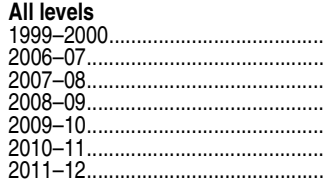 & $\begin{array}{r}\$ 15,356 \\
16,790 \\
17,055 \\
16,394 \\
16,404 \\
17,925 \\
16,999\end{array}$ & $\begin{array}{r}\$ 13,221 \\
14,810 \\
14,877 \\
14,165 \\
14,868 \\
15,978 \\
15,176\end{array}$ & $\begin{array}{r}\$ 707 \\
872 \\
1,018 \\
1,191 \\
1,297 \\
1,006 \\
965\end{array}$ & $\begin{array}{r}\$ 255 \\
84 \\
72 \\
110 \\
76 \\
100 \\
65\end{array}$ & $\begin{array}{r}\$ 8 \\
4 \\
5 \\
68 \\
25 \\
20 \\
6\end{array}$ & $\begin{array}{r}\$ 66 \\
59 \\
69 \\
33 \\
27 \\
21 \\
23\end{array}$ & $\begin{array}{r}\$ 251 \\
295 \\
307 \\
311 \\
289 \\
256 \\
223\end{array}$ & $\begin{array}{r}\$ 556 \\
375 \\
373 \\
335 \\
322 \\
345 \\
323\end{array}$ & $\begin{array}{r}\$ 292 \\
291 \\
334 \\
180 \\
-501 \\
201 \\
219\end{array}$ \\
\hline 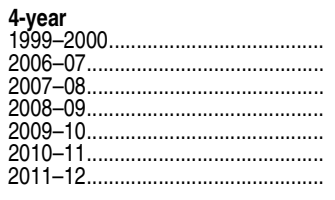 & $\begin{array}{l}15,586 \\
16,591 \\
16,862 \\
16,241 \\
16,409 \\
18,097 \\
17,156\end{array}$ & $\begin{array}{l}13,420 \\
14,851 \\
14,891 \\
14,249 \\
14,972 \\
16,253 \\
15,326\end{array}$ & $\begin{array}{r}680 \\
719 \\
892 \\
987 \\
1,060 \\
929 \\
925\end{array}$ & $\begin{array}{r}258 \\
57 \\
43 \\
88 \\
60 \\
98 \\
57\end{array}$ & $\begin{array}{r}7 \\
4 \\
4 \\
79 \\
31 \\
24 \\
6\end{array}$ & $\begin{array}{l}68 \\
60 \\
70 \\
39 \\
31 \\
24 \\
25\end{array}$ & $\begin{array}{l}221 \\
340 \\
341 \\
360 \\
325 \\
289 \\
250\end{array}$ & $\begin{array}{l}668 \\
350 \\
374 \\
328 \\
322 \\
338 \\
327\end{array}$ & $\begin{array}{r}264 \\
210 \\
248 \\
112 \\
-392 \\
140 \\
240\end{array}$ \\
\hline 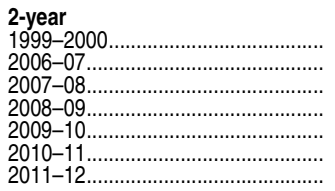 & $\begin{array}{l}15,084 \\
17,378 \\
17,686 \\
16,905 \\
16,387 \\
17,379 \\
16,440\end{array}$ & $\begin{array}{l}12,985 \\
14,690 \\
14,833 \\
13,888 \\
14,523 \\
15,101 \\
14,641\end{array}$ & $\begin{array}{r}739 \\
1,323 \\
1,428 \\
1,872 \\
2,084 \\
1,250 \\
1,104\end{array}$ & $\begin{array}{r}252 \\
165 \\
168 \\
185 \\
129 \\
104 \\
91\end{array}$ & $\begin{array}{r}8 \\
6 \\
10 \\
32 \\
8 \\
6 \\
6\end{array}$ & $\begin{array}{l}64 \\
56 \\
64 \\
12 \\
12 \\
10 \\
18\end{array}$ & $\begin{array}{l}287 \\
163 \\
196 \\
149 \\
170 \\
148 \\
125\end{array}$ & $\begin{array}{l}424 \\
448 \\
372 \\
359 \\
325 \\
365 \\
308\end{array}$ & $\begin{array}{r}326 \\
528 \\
616 \\
409 \\
-863 \\
394 \\
146\end{array}$ \\
\hline
\end{tabular}

${ }^{1}$ Constant dollars based on the Consumer Price Index, prepared by the Bureau of Labor Statistics, U.S. Department of Labor, adjusted to a school-year basis.

NOTE: Degree-granting institutions grant associate's or higher degrees and participate in Title IV federal financial aid programs. Detail may not sum to totals because of rounding.
SOURCE: US. Department of Education, National Center for Education Statistics, Integrated Postsecondary Education Data System (IPEDS), "Fall Enrollment Survey" (IPEDS-EF:99); and Spring 2002 through Spring 2013, Enrollment and Finance components. (This table was prepared January 2014.) 
Table 333.60. Total revenue of private for-profit degree-granting postsecondary institutions, by source of funds and classification of institution: 2011-12

\begin{tabular}{|c|c|c|c|c|c|c|c|c|c|}
\hline Classification of institution & Total & $\begin{array}{r}\text { Student tuition } \\
\text { and fees (net of } \\
\text { allowances) }\end{array}$ & $\begin{array}{r}\text { Federal } \\
\text { appropriations, } \\
\text { grants, and } \\
\text { contracts }\end{array}$ & $\begin{array}{r}\text { State and local } \\
\text { appropriations, } \\
\text { grants, and } \\
\text { contracts }\end{array}$ & $\begin{array}{r}\text { Private gifts, } \\
\text { grants, and } \\
\text { contracts }\end{array}$ & $\begin{array}{r}\text { Investment } \\
\text { income and } \\
\text { gains (losses) }\end{array}$ & $\begin{array}{r}\text { Educational } \\
\text { activities }\end{array}$ & $\begin{array}{r}\text { Auxiliary } \\
\text { enterprises } \\
\text { (net of } \\
\text { allowances) }\end{array}$ & Other \\
\hline \multirow[t]{2}{*}{1} & 2 & 3 & 4 & 5 & 6 & 7 & 8 & 9 & 10 \\
\hline & \multicolumn{9}{|c|}{ In thousands of current dollars } \\
\hline Total... & $\$ 26,922,879$ & $\$ 24,035,276$ & $\$ 1,527,947$ & $\$ 102,568$ & $\$ 9,386$ & $\$ 36,726$ & $\$ 352,468$ & $\$ 511,364$ & $\$ 347,145$ \\
\hline 4-year......................... & $21,204,816$ & $18,942,669$ & $1,143,845$ & 70,872 & 7,298 & 30,546 & 308,909 & 404,301 & 296,375 \\
\hline Doctoral/research 1 ............................ & $4,079,699$ & $3,843,128$ & 5,565 & 271 & 0 & 15,219 & 181,003 & 3,662 & 30,851 \\
\hline 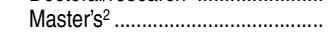 & $6,170,398$ & $5,608,299$ & 329,205 & 2,700 & 5 & 2,312 & 55,558 & 95,133 & 77,187 \\
\hline Baccalaureate $^{3} \ldots \ldots \ldots \ldots . . . . . .$. & $2,607,351$ & $2,278,914$ & 183,076 & 11,030 & 5,863 & 2,759 & 23,935 & 53,575 & 48,198 \\
\hline Special-focus institutions ${ }^{4} .$. & $8,347,369$ & $7,212,329$ & 625,999 & 56,870 & 1,430 & 10,257 & 48,412 & 251,931 & 140,140 \\
\hline 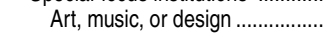 & $2,759,444$ & $2,138,032$ & 353,106 & 42,067 & 97 & 3,334 & 5,458 & 168,350 & 48,999 \\
\hline Business and management ..... & $2,834,872$ & $2,539,297$ & 201,153 & 8,400 & 661 & 1,389 & 26,913 & 42,860 & 14,199 \\
\hline Engineering or technology ........ & $1,667,086$ & $1,591,461$ & 44,286 & 5,765 & 125 & 4,880 & 4,702 & 14,908 & 958 \\
\hline 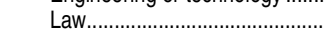 & 213,107 & 207,706 & 4,629 & 0 & 220 & 9 & 347 & 61 & 134 \\
\hline Medical or other health ............. & 701,765 & 650,983 & 22,824 & 614 & 327 & 499 & 6,998 & 5,254 & 14,267 \\
\hline 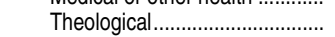 & 116,744 & 36,870 & & 25 & 0 & 114 & 195 & 18,101 & 61,439 \\
\hline 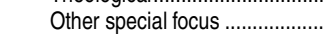 & 54,352 & 47,979 & 0 & 0 & 0 & 32 & 3,798 & 2,398 & 145 \\
\hline \multirow[t]{2}{*}{ 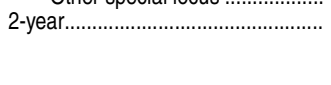 } & $5,718,063$ & $5,092,607$ & 384,102 & 31,696 & 2,087 & 6,180 & 43,558 & 107,063 & 50,770 \\
\hline & \multicolumn{9}{|c|}{ Percentage distribution } \\
\hline Total.. & 100.00 & 89.27 & 5.68 & 0.38 & 0.03 & 0.14 & 1.31 & 1.90 & 1.29 \\
\hline 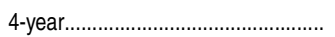 & 100.00 & 89.33 & 5.39 & 0.33 & 0.03 & 0.14 & 1.46 & 1.91 & 1.40 \\
\hline Doctoral/research' & 100.00 & 94.20 & 0.14 & 0.01 & 0.00 & 0.37 & 4.44 & 0.09 & 0.76 \\
\hline Master's ${ }^{2}$ & 100.00 & 90.89 & 5.34 & 0.04 & \# & 0.04 & 0.90 & 1.54 & 1.25 \\
\hline Baccalaureate 3 & 100.00 & 87.40 & 7.02 & 0.42 & 0.22 & 0.11 & 0.92 & 2.05 & 1.85 \\
\hline 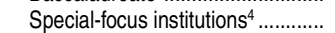 & 100.00 & 86.40 & 7.50 & 0.68 & 0.02 & 0.12 & 0.58 & 3.02 & 1.68 \\
\hline Art, music, or design .................... & 100.00 & 77.48 & 12.80 & 1.52 & \# & 0.12 & 0.20 & 6.10 & 1.78 \\
\hline Business and management ..... & 100.00 & 89.57 & 7.10 & 0.30 & 0.02 & 0.05 & 0.95 & 1.51 & 0.50 \\
\hline Engineering or technology ........ & 100.00 & 95.46 & 2.66 & 0.35 & 0.01 & 0.29 & 0.28 & 0.89 & 0.06 \\
\hline 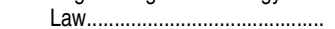 & 100.00 & 97.47 & 2.17 & 0.00 & 0.10 & \# & 0.16 & 0.03 & 0.06 \\
\hline Medical or other health .............. & 100.00 & 92.76 & 3.25 & 0.09 & 0.05 & 0.07 & 1.00 & 0.75 & 2.03 \\
\hline 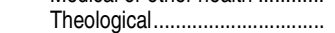 & 100.00 & 31.58 & 0.00 & 0.02 & 0.00 & 0.10 & 0.17 & 15.50 & 52.63 \\
\hline 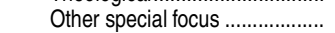 & 100.00 & 88.27 & 0.00 & 0.00 & 0.00 & 0.06 & 6.99 & 4.41 & 0.27 \\
\hline \multirow{2}{*}{ 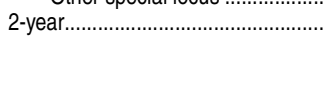 } & 100.00 & 89.06 & 6.72 & 0.55 & 0.04 & 0.11 & 0.76 & 1.87 & 0.89 \\
\hline & \multicolumn{9}{|c|}{ Revenue per full-time-equivalent student in current dollars } \\
\hline .................... & $\$ 16,721$ & $\$ 14,927$ & $\$ 949$ & $\$ 64$ & $\$ 6$ & $\$ 23$ & $\$ 219$ & $\$ 318$ & $\$ 216$ \\
\hline 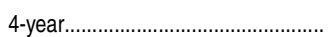 & 16,875 & 15,075 & 910 & 56 & 6 & 24 & 246 & 322 & 236 \\
\hline 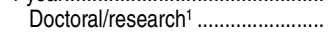 & 10,783 & 10,157 & 15 & 1 & 0 & 40 & 478 & 10 & 82 \\
\hline 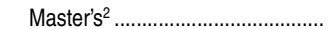 & 17,455 & 15,865 & 931 & 8 & \# & 7 & 157 & 269 & 218 \\
\hline Baccalaureate ${ }^{3} . \ldots \ldots \ldots \ldots \ldots \ldots \ldots \ldots \ldots$ & 19,821 & 17,324 & 1,392 & 84 & 45 & 21 & 182 & 407 & 366 \\
\hline 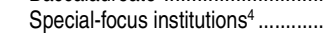 & 21,232 & 18,345 & 1,592 & 145 & 4 & 26 & 123 & 641 & 356 \\
\hline 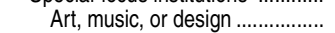 & 28,033 & 21,720 & 3,587 & 427 & 1 & 34 & 55 & 1,710 & 498 \\
\hline Business and management ...... & 15,772 & 14,127 & 1,119 & 47 & 4 & 8 & 150 & 238 & 79 \\
\hline Engineering or technology ........ & 22,987 & 21,945 & 611 & 79 & 2 & 67 & 65 & 206 & 13 \\
\hline Law.................. & 33,492 & 32,643 & 728 & 0 & 35 & 1 & 55 & 10 & 21 \\
\hline Medical or other health ............. & 23,324 & 21,636 & 759 & 20 & 11 & 17 & 233 & 175 & 474 \\
\hline 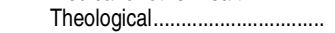 & 34,316 & 10,838 & 0 & 7 & 0 & 33 & 57 & 5,321 & 18,060 \\
\hline Other special focus ..................... & 20,888 & 18,439 & 0 & 0 & 0 & 12 & 1,460 & 921 & 56 \\
\hline \multirow[t]{2}{*}{2 -year......................................... } & 16,171 & 14,402 & 1,086 & 90 & 6 & 17 & 123 & 303 & 144 \\
\hline & \multicolumn{9}{|c|}{ Revenue per full-time-equivalent student in constant $2012-13$ dollars 5} \\
\hline 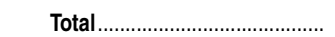 & $\$ 16,999$ & $\$ 15,176$ & $\$ 965$ & $\$ 65$ & $\$ 6$ & $\$ 23$ & $\$ 223$ & $\$ 323$ & $\$ 219$ \\
\hline 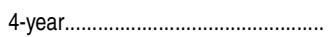 & 17,156 & 15,326 & 925 & 57 & 6 & 25 & 250 & 327 & 240 \\
\hline 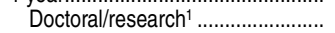 & 10,962 & 10,326 & 15 & 1 & 0 & 41 & 486 & 10 & 83 \\
\hline Master's ${ }^{2}$ & 17,745 & 16,129 & 947 & 8 & $\#$ & 7 & 160 & 274 & 222 \\
\hline 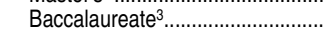 & 20,151 & 17,613 & 1,415 & 85 & 45 & 21 & 185 & 414 & 373 \\
\hline Special-focus institutions ${ }^{4} \ldots \ldots \ldots \ldots . . . . .$. & 21,585 & 18,650 & 1,619 & 147 & 4 & 27 & 125 & 651 & 362 \\
\hline Art, music, or design .................... & 28,500 & 22,082 & 3,647 & 434 & 1 & 34 & 56 & 1,739 & 506 \\
\hline Business and management ..... & 16,034 & 14,362 & 1,138 & 48 & 4 & 8 & 152 & 242 & 80 \\
\hline Engineering or technology ......... & 23,370 & 22,310 & 621 & 81 & 2 & 68 & 66 & 209 & 13 \\
\hline Law............................................... & 34,049 & 33,186 & 740 & 0 & 35 & 1 & 56 & 10 & 21 \\
\hline Medical or other health ............. & 23,712 & 21,996 & 771 & 21 & 11 & 17 & 236 & 178 & 482 \\
\hline 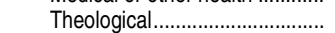 & 34,887 & 11,018 & 0 & 7 & 0 & 34 & 58 & 5,409 & 18,360 \\
\hline 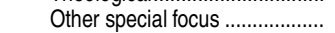 & 21,236 & 18,746 & 0 & 0 & 0 & 12 & 1,484 & 937 & 57 \\
\hline 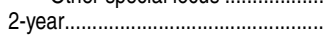 & 16,440 & 14,641 & 1,104 & 91 & 6 & 18 & 125 & 308 & 146 \\
\hline
\end{tabular}

\#Rounds to zero.

${ }^{1}$ Includes institutions that award at least 20 doctor's degrees per year, but did not have high levels of research activity.

${ }^{2}$ Master's institutions award at least 50 master's degrees per year.

${ }^{3}$ Baccalaureate institutions primarily emphasize undergraduate education. Also includes institutions classified as 4-year under the IPEDS system, which had been classified as 2-year in the Carnegie classification system because they primarily award associate's degrees.

${ }^{4}$ Special-focus 4-year institutions award degrees primarily in single fields of study, such as medicine, business, fine arts, theology, and engineering.
${ }^{5}$ Constant dollars based on the Consumer Price Index, prepared by the Bureau of Labor Statistics, U.S. Department of Labor, adjusted to a school-year basis.

NOTE: Degree-granting institutions grant associate's or higher degrees and participate in Title IV federal financial aid. Further information on the Carnegie 2005 classification system used in this table may be obtained from http://classifications.carnegiefoundation.org/resources/. Detail may not sum to totals because of rounding.

SOURCE: U.S. Department of Education, National Center for Education Statistics, Integrated Postsecondary Education Data System (IPEDS), Spring 2012, Enrollment component; and Spring 2013, Finance component. (This table was prepared January 2014.) 
Table 333.70. Revenue received from the federal government by the 120 degree-granting postsecondary institutions receiving the largest amounts, by control and rank order: 2011-12

\begin{tabular}{|c|c|c|c|c|c|c|c|}
\hline Institution & Control $^{1}$ & $\begin{array}{l}\text { Rank } \\
\text { order }\end{array}$ & $\begin{array}{r}\text { Revenue } \\
\text { from the } \\
\text { federal } \\
\text { govern- } \\
\text { ment }^{2} \text { (in } \\
\text { thousands) }\end{array}$ & Institution & Control $^{1}$ & $\begin{array}{l}\text { Rank } \\
\text { order }\end{array}$ & $\begin{array}{r}\text { Revenue } \\
\text { from the } \\
\text { federal } \\
\text { govern- } \\
\text { ment }{ }^{2} \text { (in } \\
\text { thousands) }\end{array}$ \\
\hline 1 & 2 & 3 & 4 & 1 & 2 & 3 & 4 \\
\hline 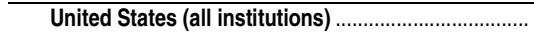 & $t$ & $t$ & $\$ 81,243,703$ & & & & \\
\hline 120 institutions receiving the largest amounts........ & $+t$ & $+t$ & $47,084,539$ & & & & \\
\hline 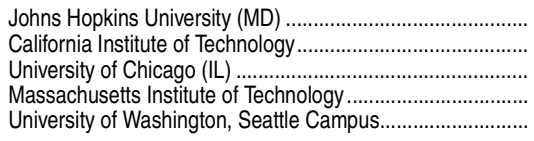 & $\begin{array}{l}2 \\
2 \\
2 \\
2 \\
1\end{array}$ & \begin{tabular}{l|l}
1 \\
2 \\
3 \\
4 \\
5
\end{tabular} & $\begin{array}{l}2,239,657 \\
1,882,168 \\
1,576,508 \\
1,302,872 \\
1,118,287\end{array}$ & 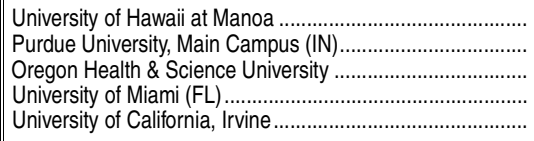 & \begin{tabular}{l|l}
1 & \\
1 & \\
1 & \\
2 & \\
1 &
\end{tabular} & $\begin{array}{l}61 \\
62 \\
63 \\
64 \\
65\end{array}$ & $\begin{array}{l}299,389 \\
288,263 \\
279,874 \\
279,051 \\
271,562\end{array}$ \\
\hline 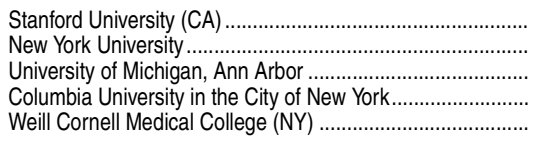 & \begin{tabular}{l|}
2 \\
2 \\
1 \\
2 \\
2
\end{tabular} & $\begin{array}{r}6 \\
7 \\
8 \\
9 \\
10\end{array}$ & $\begin{array}{r}1,035,600 \\
923,527 \\
854,787 \\
839,572 \\
829,144\end{array}$ & 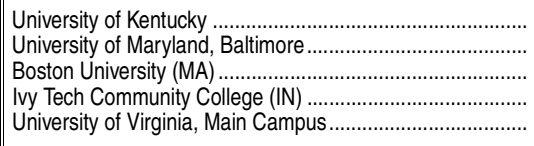 & \begin{tabular}{l|l}
1 & \\
1 & \\
2 & \\
1 & \\
1
\end{tabular} & $\begin{array}{l}66 \\
67 \\
68 \\
69 \\
70\end{array}$ & $\begin{array}{l}265,610 \\
265,542 \\
257,090 \\
253,591 \\
253,391\end{array}$ \\
\hline 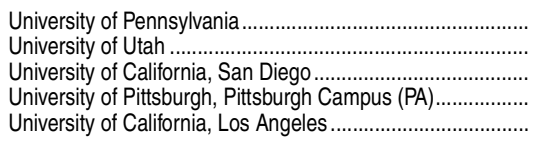 & \begin{tabular}{l|}
2 \\
1 \\
1 \\
1 \\
1
\end{tabular} & $\begin{array}{l}11 \\
12 \\
13 \\
14 \\
15\end{array}$ & $\begin{array}{l}807,040 \\
795,862 \\
747,029 \\
696,832 \\
684,531\end{array}$ & 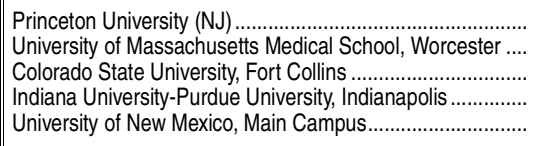 & \begin{tabular}{l|l}
2 \\
1 \\
1 \\
1 \\
1
\end{tabular} & $\begin{array}{l}71 \\
72 \\
73 \\
74 \\
75\end{array}$ & $\begin{array}{l}248,641 \\
245,974 \\
244,886 \\
242,340 \\
228,087\end{array}$ \\
\hline 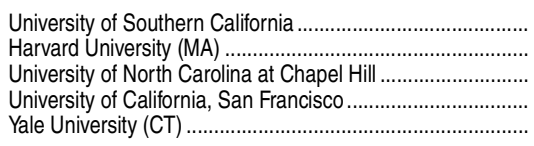 & \begin{tabular}{l|}
2 \\
2 \\
1 \\
1 \\
2
\end{tabular} & $\begin{array}{l}16 \\
17 \\
18 \\
19 \\
20\end{array}$ & $\begin{array}{l}676,333 \\
669,563 \\
653,936 \\
641,612 \\
562,613\end{array}$ & 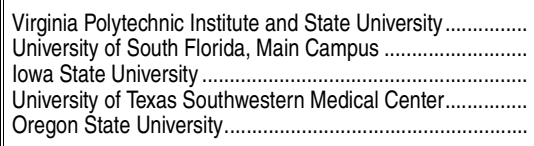 & $\begin{array}{l}1 \\
1 \\
1 \\
1 \\
1\end{array}$ & $\begin{array}{l}76 \\
77 \\
78 \\
79 \\
80\end{array}$ & $\begin{array}{l}224,462 \\
223,455 \\
223,035 \\
211,828 \\
202,736\end{array}$ \\
\hline 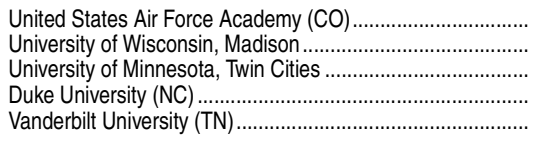 & \begin{tabular}{l|}
1 \\
1 \\
1 \\
2 \\
2
\end{tabular} & $\begin{array}{l}21 \\
22 \\
23 \\
24 \\
25\end{array}$ & $\begin{array}{l}561,836 \\
557,501 \\
553,385 \\
548,668 \\
524,564\end{array}$ & 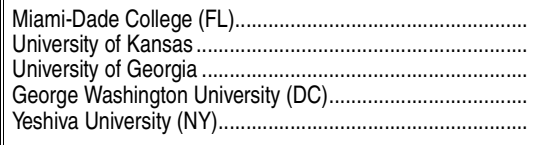 & \begin{tabular}{l|l}
1 & \\
1 & \\
1 & \\
2 & \\
2 &
\end{tabular} & $\begin{array}{l}81 \\
82 \\
83 \\
84 \\
85\end{array}$ & $\begin{array}{l}198,293 \\
197,295 \\
196,327 \\
192,967 \\
189,738\end{array}$ \\
\hline 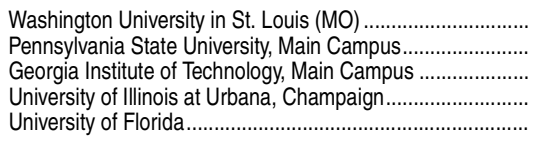 & $\begin{array}{l}2 \\
1 \\
1 \\
1 \\
1\end{array}$ & $\begin{array}{l}26 \\
27 \\
28 \\
29 \\
30\end{array}$ & $\begin{array}{l}514,776 \\
500,784 \\
485,326 \\
462,020 \\
457,156\end{array}$ & 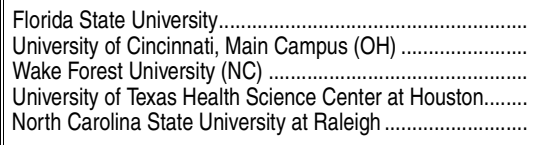 & \begin{tabular}{l|l}
1 & \\
1 & \\
2 & \\
1 & 1
\end{tabular} & $\begin{array}{l}86 \\
87 \\
88 \\
89 \\
90\end{array}$ & $\begin{array}{l}189,149 \\
182,601 \\
180,417 \\
179,265 \\
177,423\end{array}$ \\
\hline 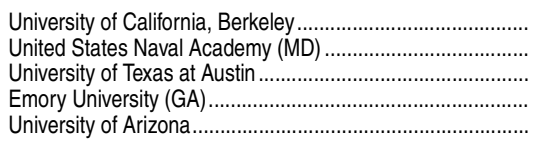 & \begin{tabular}{l|}
1 \\
1 \\
1 \\
2 \\
1
\end{tabular} & $\begin{array}{l}31 \\
32 \\
33 \\
34 \\
35\end{array}$ & $\begin{array}{l}447,883 \\
447,271 \\
445,865 \\
444,884 \\
439,754\end{array}$ & 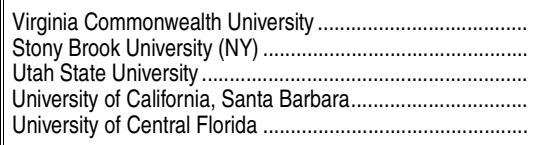 & $\begin{array}{l}1 \\
1 \\
1 \\
1 \\
1\end{array}$ & $\begin{array}{l}91 \\
92 \\
93 \\
94 \\
95\end{array}$ & $\begin{array}{l}176,891 \\
176,056 \\
174,025 \\
172,065 \\
171,107\end{array}$ \\
\hline 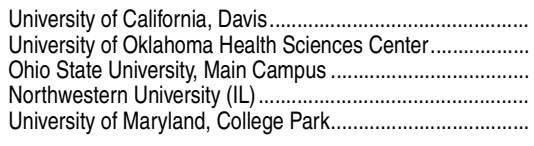 & \begin{tabular}{l|}
1 \\
1 \\
1 \\
2 \\
1
\end{tabular} & $\begin{array}{l}36 \\
37 \\
38 \\
39 \\
40\end{array}$ & $\begin{array}{l}434,672 \\
426,952 \\
422,103 \\
406,375 \\
379,316\end{array}$ & 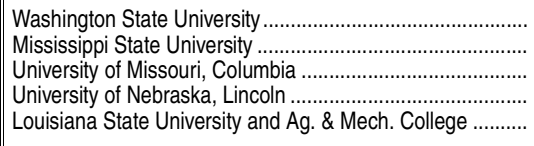 & \begin{tabular}{l|}
1 \\
1 \\
1 \\
1 \\
1
\end{tabular} & $\begin{array}{r}96 \\
97 \\
98 \\
99 \\
100\end{array}$ & $\begin{array}{l}170,588 \\
169,690 \\
167,507 \\
161,038 \\
154,451\end{array}$ \\
\hline 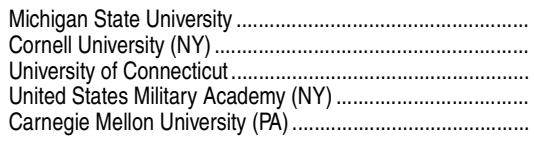 & \begin{tabular}{l|}
1 \\
2 \\
1 \\
1 \\
2
\end{tabular} & $\begin{array}{l}41 \\
42 \\
43 \\
44 \\
45\end{array}$ & $\begin{array}{l}368,818 \\
363,794 \\
355,804 \\
352,791 \\
351,563\end{array}$ & 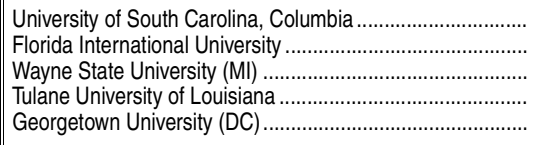 & \begin{tabular}{l|l}
1 & \\
1 & \\
1 & \\
2 & \\
2 &
\end{tabular} & $\begin{array}{l}101 \\
102 \\
103 \\
104 \\
105\end{array}$ & $\begin{array}{l}154,337 \\
153,281 \\
153,020 \\
152,373 \\
149,954\end{array}$ \\
\hline $\begin{array}{l}\text { University of Illinois at Chicago } \\
\text { Case Western Reserve University }(\mathrm{OH}) \\
\text { University of lowa } \\
\text { Arizona State University } \\
\text { University of Colorado, Boulder }\end{array}$ & \begin{tabular}{l|}
1 \\
2 \\
1 \\
1 \\
1
\end{tabular} & $\begin{array}{l}46 \\
47 \\
48 \\
49 \\
50\end{array}$ & $\begin{array}{l}347,119 \\
346,590 \\
341,181 \\
340,525 \\
338,515\end{array}$ & 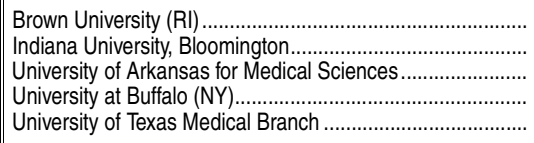 & \begin{tabular}{l|l}
2 \\
1 \\
1 \\
1 \\
1
\end{tabular} & $\begin{array}{l}106 \\
107 \\
108 \\
109 \\
110\end{array}$ & $\begin{array}{l}148,002 \\
147,290 \\
146,664 \\
145,952 \\
145,879\end{array}$ \\
\hline 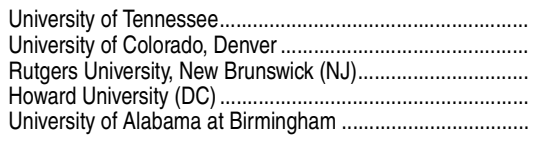 & \begin{tabular}{l|}
1 \\
1 \\
1 \\
2 \\
1
\end{tabular} & $\begin{array}{l}51 \\
52 \\
53 \\
54 \\
55\end{array}$ & $\begin{array}{l}332,035 \\
330,091 \\
329,285 \\
325,797 \\
321,207\end{array}$ & 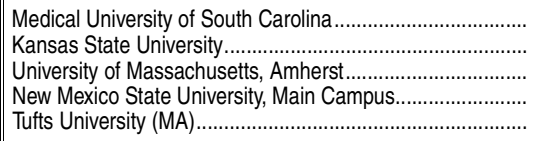 & \begin{tabular}{l|l}
1 & \\
1 & \\
1 & 1 \\
2 &
\end{tabular} & $\begin{array}{l}111 \\
112 \\
113 \\
114 \\
115\end{array}$ & $\begin{array}{l}136,071 \\
135,735 \\
135,082 \\
134,921 \\
134,744\end{array}$ \\
\hline 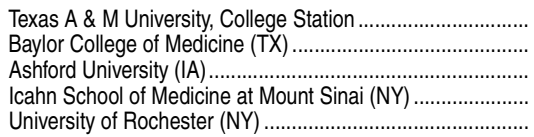 & $\begin{array}{l}1 \\
2 \\
3 \\
2 \\
2\end{array}$ & $\begin{array}{l}56 \\
57 \\
58 \\
59 \\
60\end{array}$ & $\begin{array}{l}314,888 \\
309,703 \\
307,104 \\
304,492 \\
304,282\end{array}$ & 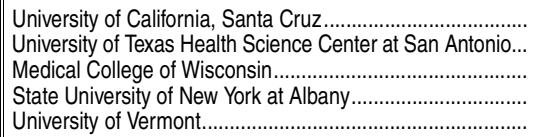 & \begin{tabular}{l|l}
1 & \\
1 & \\
2 & \\
1 & 1
\end{tabular} & $\begin{array}{l}116 \\
117 \\
118 \\
119 \\
120\end{array}$ & $\begin{array}{l}130,381 \\
129,371 \\
128,228 \\
127,405 \\
125,996\end{array}$ \\
\hline
\end{tabular}

†Not applicable.

'Publicly controlled institutions are identified by a "1"; private nonprofit, by a "2"; and private for-profit, by a "3."

Includes federal appropriations; operating, nonoperating, unrestricted, and restricted federal contracts and grants; and revenue for independent operations. Independent operations generally include only the revenues associated with major federally funded research and development centers. Pell grants are included for public institutions and may also be included for private nonprofit institutions that do not treat Pell grants as pass-through trans- actions. American Recovery and Reinvestment Act (ARRA) funds are not included. Data for public, private nonprofit, and private for-profit institutions are only roughly comparable because they were collected using different survey instruments.

NOTE: Degree-granting institutions grant associate's or higher degrees and participate in Title IV federal financial aid programs.

SOURCE: U.S. Department of Education, National Center for Education Statistics, Integrated Postsecondary Education Data System (IPEDS), Spring 2013, Finance component. (This table was prepared January 2014.) 
Table 333.80. Voluntary support for degree-granting postsecondary institutions, by source and purpose of support: Selected years, 1949-50 through 2011-12

\begin{tabular}{|c|c|c|c|c|c|c|c|c|c|c|c|}
\hline \multirow[b]{3}{*}{ Year } & \multirow{3}{*}{$\begin{array}{r}\text { Total } \\
\text { voluntary } \\
\text { support, in } \\
\text { millions of } \\
\text { constant } \\
2012-13 \\
\text { dollars }^{1}\end{array}$} & \multicolumn{9}{|c|}{ In millions of current dollars } & \multirow{3}{*}{$\begin{array}{r}\text { Voluntary } \\
\text { support } \\
\text { as a percent } \\
\text { of total } \\
\text { expenditures }^{2}\end{array}$} \\
\hline & & \multirow[b]{2}{*}{$\begin{array}{r}\text { Total } \\
\text { voluntary } \\
\text { support }\end{array}$} & \multicolumn{6}{|c|}{ Sources } & \multicolumn{2}{|c|}{ Purpose } & \\
\hline & & & Alumni & $\begin{array}{l}\text { Nonalumni } \\
\text { individuals }\end{array}$ & Corporations & Foundations & $\begin{array}{r}\text { Religious } \\
\text { organizations }\end{array}$ & Other & $\begin{array}{r}\text { Current } \\
\text { operations }\end{array}$ & $\begin{array}{r}\text { Capital } \\
\text { purposes }\end{array}$ & \\
\hline 1 & 2 & 3 & 4 & 5 & 6 & 7 & 8 & 9 & 10 & 11 & 12 \\
\hline 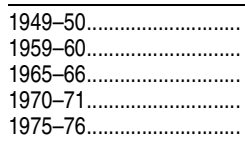 & \begin{tabular}{r|}
$\$ 2,344$ \\
6,417 \\
10,441 \\
10,832 \\
10,054
\end{tabular} & $\begin{array}{r}\$ 240 \\
815 \\
1,440 \\
1,860 \\
2,410\end{array}$ & $\begin{array}{l}\$ 60 \\
191 \\
310 \\
458 \\
588\end{array}$ & $\begin{array}{l}\$ 60 \\
194 \\
350 \\
495 \\
569\end{array}$ & $\begin{array}{l}\$ 28 \\
130 \\
230 \\
259 \\
379\end{array}$ & $\begin{array}{l}\$ 60 \\
163 \\
357 \\
418 \\
549\end{array}$ & $\begin{array}{r}16 \\
80 \\
108 \\
104 \\
130\end{array}$ & $\begin{array}{r}16 \\
57 \\
85 \\
126 \\
195\end{array}$ & $\begin{array}{r}\$ 101 \\
385 \\
675 \\
1,050 \\
1,480\end{array}$ & $\begin{array}{r}139 \\
430 \\
765 \\
810 \\
930\end{array}$ & $\begin{array}{r}10.7 \\
14.6 \\
11.5 \\
8.0 \\
6.2\end{array}$ \\
\hline $\begin{array}{l}1980-81 \ldots \ldots \ldots \\
1985-86 \ldots \ldots \ldots \ldots \ldots \\
1989-90 \ldots \ldots \ldots \ldots \ldots \ldots \\
1990-91 \ldots \ldots \ldots \ldots \ldots \ldots \ldots \ldots \\
1993-94\end{array}$ & $\begin{array}{l}11,297 \\
15,733 \\
17,856 \\
17,621 \\
19,541\end{array}$ & $\begin{array}{r}4,230 \\
7,400 \\
9,800 \\
10,200 \\
12,350\end{array}$ & $\begin{array}{l}1,049 \\
1,825 \\
2,540 \\
2,680 \\
3,410\end{array}$ & $\begin{array}{l}1,007 \\
1,781 \\
2,230 \\
2,310 \\
2,800\end{array}$ & $\begin{array}{r}778 \\
1,702 \\
2,170 \\
2,230 \\
2,510\end{array}$ & $\begin{array}{r}922 \\
1,363 \\
1,920 \\
2,030 \\
2,540\end{array}$ & $\begin{array}{l}140 \\
211 \\
240 \\
240 \\
240\end{array}$ & $\begin{array}{l}334 \\
518 \\
700 \\
710 \\
850\end{array}$ & $\begin{array}{l}2,590 \\
4,022 \\
5,440 \\
5,830 \\
6,710\end{array}$ & $\begin{array}{l}1,640 \\
3,378 \\
4,360 \\
4,370 \\
5,640\end{array}$ & $\begin{array}{l}6.6 \\
7.6 \\
7.3 \\
7.0 \\
7.1\end{array}$ \\
\hline $\begin{array}{l}1994-95 \\
1995-96 \ldots \ldots \ldots \ldots \\
1996-97 \ldots \ldots \ldots \ldots \ldots \ldots \\
1997-98 \ldots \ldots \ldots \ldots \ldots \ldots \ldots \ldots \\
1998-99\end{array}$ & $\begin{array}{l}19,612 \\
21,338 \\
23,294 \\
26,319 \\
28,683\end{array}$ & $\begin{array}{l}12,750 \\
14,250 \\
16,000 \\
18,400 \\
20,400\end{array}$ & $\begin{array}{l}3,600 \\
4,040 \\
4,650 \\
5,500 \\
5,930\end{array}$ & $\begin{array}{l}2,940 \\
3,400 \\
3,850 \\
4,500 \\
4,810\end{array}$ & $\begin{array}{l}2,560 \\
2,800 \\
3,050 \\
3,250 \\
3,610\end{array}$ & $\begin{array}{l}2,460 \\
2,815 \\
3,200 \\
3,800 \\
4,530\end{array}$ & $\begin{array}{l}250 \\
255 \\
250 \\
300 \\
330\end{array}$ & $\begin{array}{r}940 \\
940 \\
1,000 \\
1,050 \\
1,190\end{array}$ & $\begin{array}{l}7,230 \\
7,850 \\
8,500 \\
9,000 \\
9,900\end{array}$ & $\begin{array}{r}5,520 \\
6,400 \\
7,500 \\
9,400 \\
10,500\end{array}$ & $\begin{array}{l}7.0 \\
7.5 \\
8.0 \\
8.8 \\
9.3\end{array}$ \\
\hline $\begin{array}{l}1999-2000 \ldots \ldots \ldots \ldots \\
2000-01 \ldots \ldots \ldots \ldots \ldots \ldots \ldots \ldots \\
2001-02 \ldots \ldots \ldots \ldots \ldots \ldots \ldots \ldots \ldots \\
2002-03 \ldots \ldots \ldots \ldots \ldots \ldots \ldots \ldots \\
2003-04 \ldots \ldots \ldots \ldots \ldots \ldots \ldots . . .\end{array}$ & $\begin{array}{l}31,705 \\
31,976 \\
31,030 \\
29,982 \\
30,334\end{array}$ & $\begin{array}{l}23,200 \\
24,200 \\
23,900 \\
23,600 \\
24,400\end{array}$ & $\begin{array}{l}6,800 \\
6,830 \\
5,900 \\
6,570 \\
6,700\end{array}$ & $\begin{array}{l}5,420 \\
5,200 \\
5,400 \\
4,280 \\
5,200\end{array}$ & $\begin{array}{l}4,150 \\
4,350 \\
4,370 \\
4,250 \\
4,400\end{array}$ & $\begin{array}{l}5,080 \\
6,000 \\
6,300 \\
6,600 \\
6,200\end{array}$ & $\begin{array}{l}370 \\
370 \\
360 \\
360 \\
350\end{array}$ & $\begin{array}{l}1,380 \\
1,450 \\
1,570 \\
1,540 \\
1,550\end{array}$ & $\begin{array}{l}11,270 \\
12,200 \\
12,400 \\
12,900 \\
13,600\end{array}$ & $\begin{array}{l}11,930 \\
12,000 \\
11,500 \\
10,700 \\
10,800\end{array}$ & $\begin{array}{l}9.8 \\
9.3 \\
8.5 \\
7.8 \\
7.7\end{array}$ \\
\hline 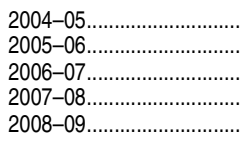 & $\begin{array}{l}30,897 \\
32,553 \\
33,716 \\
34,533 \\
30,016\end{array}$ & $\begin{array}{l}25,600 \\
28,000 \\
29,750 \\
31,600 \\
27,850\end{array}$ & $\begin{array}{l}7,100 \\
8,400 \\
8,270 \\
8,700 \\
7,130\end{array}$ & $\begin{array}{l}5,000 \\
5,700 \\
5,650 \\
6,120 \\
4,995\end{array}$ & $\begin{array}{l}4,400 \\
4,600 \\
4,800 \\
4,900 \\
4,620\end{array}$ & $\begin{array}{l}7,000 \\
7,100 \\
8,500 \\
9,100 \\
8,235\end{array}$ & $\begin{array}{l}370 \\
375 \\
380 \\
380 \\
325\end{array}$ & $\begin{array}{l}1,730 \\
1,825 \\
2,150 \\
2,400 \\
2,545\end{array}$ & $\begin{array}{l}14,200 \\
15,000 \\
16,100 \\
17,070 \\
16,955\end{array}$ & $\begin{array}{l}11,400 \\
13,000 \\
13,650 \\
14,530 \\
10,895\end{array}$ & $\begin{array}{l}7.6 \\
7.9 \\
7.9 \\
7.7 \\
6.5\end{array}$ \\
\hline 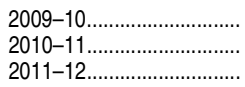 & $\begin{array}{l}29,888 \\
31,707 \\
31,516\end{array}$ & $\begin{array}{l}28,000 \\
30,300 \\
31,000\end{array}$ & $\begin{array}{l}7,100 \\
7,800 \\
7,700\end{array}$ & $\begin{array}{l}4,920 \\
5,650 \\
5,825\end{array}$ & $\begin{array}{l}4,730 \\
5,020 \\
5,250\end{array}$ & $\begin{array}{l}8,400 \\
8,675 \\
9,150\end{array}$ & $\begin{array}{l}305 \\
305 \\
275\end{array}$ & $\begin{array}{l}2,545 \\
2,850 \\
2,800\end{array}$ & $\begin{array}{l}17,000 \\
17,800 \\
18,900\end{array}$ & $\begin{array}{l}11,000 \\
12,500 \\
12,100\end{array}$ & $\begin{array}{l}6.3 \\
6.4 \\
6.3\end{array}$ \\
\hline
\end{tabular}

${ }^{1}$ Constant dollars based on the Consumer Price Index, prepared by the Bureau of Labor statistics, U.S. Department of Labor, adjusted to a school-year basis.

${ }^{2}$ Total expenditures include current-fund expenditures and additions to plant value through 1995-96.

NOTE: Data rounding is consistent with the original source material. Voluntary support data are from the Council for Aid to Education, while the percentage of total expenditures is based on total expenditures reported through the Integrated Postsecondary Education Data System.
SOURCE: Council for Aid to Education, Voluntary Support of Education, selected years, 1949-50 through 2011-12. U.S. Department of Education, National Center for Education Statistics, Higher Education General Information Survey (HEGIS), 1965-66 through 1985-86; Financial Statistics of Institutions of Higher Education, 1949-50 and 1959-60; Integrated Postsecondary Education Data System (IPEDS), "Finance Survey" (IPEDS-F:FY87-99); and IPEDS Spring 2001 through Spring 2013, Finance component. (This table was prepared March 2014.) 
Table 333.90. Endowment funds of the 120 degree-granting postsecondary institutions with the largest endowments, by rank order: Fiscal year 2012

\begin{tabular}{|c|c|c|c|c|c|c|c|c|c|}
\hline \multirow[b]{3}{*}{ Institution } & \multicolumn{4}{|c|}{ Fiscal year (FY) 2012} & \multirow[b]{3}{*}{ Institution } & \multicolumn{4}{|c|}{ Fiscal year (FY) 2012} \\
\hline & \multirow[b]{2}{*}{\begin{tabular}{|r|} 
Rank \\
order, \\
end of \\
$\mathrm{FY}^{1}$ \\
\end{tabular}} & \multicolumn{3}{|c|}{ Market value of endowment } & & \multirow{2}{*}{$\begin{array}{r}\text { Rank } \\
\text { order, } \\
\text { end of } \\
F^{1}\end{array}$} & \multicolumn{3}{|c|}{ Market value of endowment } \\
\hline & & $\begin{array}{r}\text { Beginning } \\
\text { of } F Y \\
\text { (in thousands) }\end{array}$ & $\begin{array}{r}\text { End of FY } \\
\text { (in thousands) }\end{array}$ & $\begin{array}{c}\text { Percent } \\
\text { change }^{2}\end{array}$ & & & $\begin{array}{r}\text { Beginning } \\
\text { of } F Y \\
\text { (in thousands) }\end{array}$ & $\begin{array}{r}\text { End of FY } \\
\text { (in thousands) }\end{array}$ & $\begin{array}{l}\text { Percent } \\
\text { change }{ }^{2}\end{array}$ \\
\hline 1 & 2 & 3 & 4 & 5 & 1 & 2 & 3 & 4 & 5 \\
\hline \multirow{2}{*}{$\begin{array}{l}\text { United States (all institutions).......................... } \\
120 \text { institutions with the largest amounts...... }\end{array}$} & t & $\$ 420,785,545$ & $\$ 424,587,666$ & 0.9 & & & \multirow{7}{*}{$\begin{array}{l}1,099,347 \\
1,138,203 \\
1,077,430 \\
1,062,627 \\
1,058,250\end{array}$} & & \\
\hline & $t$ & $312,707,855$ & $315,950,083$ & 1.0 & & & & & \\
\hline Harvard University (MA) & 1 & $32,012,729$ & $30,745,534$ & -4.0 & Weill Cornell Medical College (NY)...... & & & $1,096,528$ & -0.3 \\
\hline 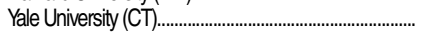 & 2 & $19,174,387$ & $19,264,289$ & 0.5 & University of Delaware...... & \multirow{4}{*}{$\begin{array}{l}62 \\
63 \\
64 \\
65\end{array}$} & & $1,087,873$ & -4.4 \\
\hline Princeton University (NJ) ................................................ & 3 & $17,162,603$ & $17,404,002$ & 1.4 & Lehigh University (PA) ............... & & & $1,035,593$ & -3.9 \\
\hline 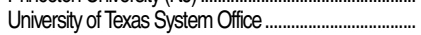 & 4 & $14,635,240$ & $17,070,515$ & 16.6 & Soka University of America (CA)... & & & $1,035,512$ & -2.6 \\
\hline 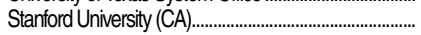 & 5 & $16,502,606$ & $17,035,804$ & 3.2 & Wake Forest University (NC).... & & & $1,025,069$ & -3.1 \\
\hline $\begin{array}{l}\text { Massachusetts Institute of Technology..................... } \\
\text { Columbia University in the City of New York (NY) }\end{array}$ & $\begin{array}{l}6 \\
7\end{array}$ & $\begin{array}{l}9,712,628 \\
7,789,578\end{array}$ & $\begin{array}{r}10,149,564 \\
7654,152\end{array}$ & $\begin{array}{r}4.5 \\
-1.7\end{array}$ & $\begin{array}{l}\text { University of llinois at Urbana-Champaign...... } \\
\text { University of lowa }\end{array}$ & $\begin{array}{l}66 \\
67\end{array}$ & $\begin{array}{l}1,006,556 \\
1,044,097\end{array}$ & $\begin{array}{l}996,226 \\
981,104\end{array}$ & $\begin{array}{l}-1.0 \\
-6.0\end{array}$ \\
\hline University of Michigan, Ann Arbor ............................. & 8 & $7,725,307$ & $\begin{array}{l}1,004,102 \\
7,586,547\end{array}$ & $\begin{array}{l}-1.7 \\
-1.8\end{array}$ & Carnegie Mellon University (PA)............. & 68 & $1,009,219$ & $\begin{array}{l}901,104 \\
979,230\end{array}$ & -3.0 \\
\hline Texas A \& M University, College Station ................................. & 9 & $6,362,369$ & $7,032,204$ & 10.5 & Baylor University (TX).... & 69 & $1,003,929$ & 964,161 & -4.0 \\
\hline University of Pennsylvania. & 10 & $6,582,030$ & $6,754,658$ & 2.6 & Brigham Young University, Provo (UT)......... & 70 & 920,149 & 957,010 & 4.0 \\
\hline University of Notre Dame (IN) & 11 & $6,383,344$ & $6,444,599$ & 1.0 & University of Kentucky.. & 71 & 952,248 & 947,383 & -0.5 \\
\hline Jniversity of California Sy & 12 & $5,441,225$ & $6,342,217$ & 16.6 & Tulane University of Louisiana. & 72 & $1,004,738$ & 946,176 & -5.8 \\
\hline Emory University $(\mathrm{GA}) \ldots . . . . . . . . . . . . . . . .$. & 13 & $5,443,397$ & $5,774,500$ & 6.1 & Berea College $(\mathrm{KY}) \ldots$. & 73 & 978,735 & 942,618 & -3.7 \\
\hline University of Ch & 14 & $5,691,013$ & $5,701,419$ & 0.2 & Syracuse University (NY). & 74 & 913,662 & 940,056 & 2.9 \\
\hline Northwestern University (LL)..... & 15 & $5,474,935$ & $5,574,319$ & 1.8 & Yeshiva University (NY)... & 75 & 945,790 & 931,914 & -1.5 \\
\hline Duke University (NC).. & 16 & $5,747,377$ & $5,555,196$ & -3.3 & Trinity University (TX)... & 76 & 974,935 & 915,918 & -6.1 \\
\hline Nashington Uni & 17 & $5,348,871$ & $5,303,196$ & -0.9 & Bowdoin Colle & 77 & 904,215 & 902,364 & -0.2 \\
\hline University & 18 & $4,707,593$ & $4,734,895$ & 0.6 & Middlebury College (VT).... & 78 & 907,668 & 879,690 & -3.1 \\
\hline Rice Universit & 19 & $4,498,951$ & $4,448,069$ & -1.1 & Princeton Theological Seminary (NJ)... & 79 & 913,945 & 866,930 & -5.1 \\
\hline Comell University (NY)...... & 20 & $3,960,057$ & $3,850,426$ & -2.8 & Saint Louis University, Main Campus (MO)..... & 80 & 880,251 & 852,842 & -3.1 \\
\hline University of Southern Califormia. & 21 & $3,517,173$ & $3,488,933$ & -0.8 & University of Texas Southwestern Medical Cente & 81 & 838,838 & 836,413 & -0.3 \\
\hline Dartmouth Colle & 22 & $3,413,407$ & $3,486,383$ & 2.1 & University of Cincinnati, & 82 & $1,024,525$ & 834,929 & -18.5 \\
\hline Vanderbilt & 23 & $3,375,153$ & $3,360,036$ & -0.4 & Berry College (GA)...... & 83 & 761,534 & 821,977 & 7.9 \\
\hline University of Texas at Austin. & 24 & $2,852,960$ & $2,861,389$ & 0.3 & Vassar College (NY) & 84 & 814,130 & 804,912 & -1.1 \\
\hline New York University............ & 25 & $2,724,134$ & $2,800,399$ & 2.8 & University of Tulsa (OK)... & 85 & 817,324 & 802,455 & -1.8 \\
\hline University of Pittsburgh, Pittsburgh Campus (PA)..... & 26 & $2,511,816$ & $2,600,314$ & 3.5 & Juilliard School (NY)........ & 86 & 814,005 & 787,698 & -3.2 \\
\hline (MD) ……............................ & 27 & $2,598,467$ & $2,593,316$ & -0.2 & University of OK & 87 & 804,886 & 784,834 & -2.5 \\
\hline 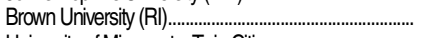 & 28 & $2,525,662$ & $2,525,091$ & \# & Indiana & 88 & 807,627 & 772,185 & -4.4 \\
\hline Univers & 29 & $2,441,712$ & $2,424,734$ & -0.7 & Universit & 89 & 788,668 & & -2.3 \\
\hline Ohio State University, & 30 & $2,104,611$ & $2,348,193$ & 11.6 & Baylor College of Medicine (TX) & 90 & 797,474 & 751,378 & -5.8 \\
\hline University of Washington, Seattle Campus.. & 31 & $2,248,770$ & $2,206,040$ & -1.9 & Washington State University.... & 91 & 722,735 & 737,428 & 2.0 \\
\hline Unive & 32 & $2,239,239$ & $2,157,237$ & -3.7 & University of Louisville (KY). & 92 & 769,337 & 721,104 & -6.3 \\
\hline University of Wis & 33 & $2,171,258$ & $2,068,495$ & -4.7 & Oberlin College $(\mathrm{OH})$ & 93 & 738,357 & 708,238 & -4.1 \\
\hline Uni & 34 & $1,878,169$ & 1,868 & -0.5 & Hamilton Co & 94 & 721,287 & 693 & -3.8 \\
\hline Purdue University, Main Campus (IN).... & 35 & $1,944,305$ & $1,861,079$ & -4.3 & Santa Clara University (CA) & 95 & 716,821 & 688,118 & -4.0 \\
\hline California Institute of Technology.... & 36 & $1,624,331$ & $1,811,497$ & 11.5 & Colgate University (NY)...... & 96 & 700,994 & 687,474 & -1.9 \\
\hline Pans & 37 & $1,737,843$ & $1,772,921$ & 2.0 & University of Mis & 97 & 719,852 & 678,694 & -5.7 \\
\hline Michican & 38 & $1,758,505$ & $1,760,708$ & 0.1 & Brandeis University (MA).... & 98 & 703,666 & 674,522 & -4.1 \\
\hline & 39 & $1,755,418$ & $1,728,549$ & -1.5 & University of Alabama.... & 99 & 616,925 & 673,606 & 9.2 \\
\hline Pomona College (C & 40 & $1,700,454$ & $1,679,640$ & -1.2 & University of Tennessee... & 100 & 674,434 & 665,833 & -1.3 \\
\hline Amherst College (MA)... & 41 & $1,641,511$ & $1,640,666$ & -0.1 & Carleton College (MN)... & 101 & 653,465 & 645,654 & -1.2 \\
\hline the & 42 & & $1,632,635$ & -7.0 & Rutgers Univer & 102 & & & \\
\hline Main Campus..... & 43 & $1,619,718$ & $1,608,248$ & -0.7 & College of William and Mary (VA).... & 103 & 624,726 & 644,233 & 3.1 \\
\hline Case Western Reserve & 44 & $1,703,164$ & $1,600,013$ & -6.1 & Denison University $(\mathrm{OH}) .$. & 104 & 671,523 & 644,201 & -4.1 \\
\hline University of Rochester (NY & 45 & $1,622,812$ & $1,581,773$ & -2.5 & Bryn Mawr College (PA).... & 105 & 677,307 & 641,173 & -5.3 \\
\hline George Washington University (DC)........ & 46 & $1,581,800$ & $1,556,592$ & -1.6 & Lafayette College (PA). & 106 & 649,588 & 640,769 & -1.4 \\
\hline Swarthmore College (PA & 47 & $1,508,483$ & $1,498,775$ & -0.6 & 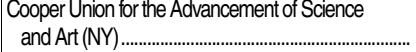 & 107 & 609,056 & 640,536 & 5.2 \\
\hline Wellesley C & 48 & $1,523,683$ & $1,468,582$ & -3.6 & North Carolina State University at Raleigh. & 108 & 617,632 & & 2.9 \\
\hline & 49 & $1,429,527$ & $1,409,755$ & -1.4 & Indiana University, Purdue University, Indianapolis. & 109 & 632,004 & 634,979 & 0.5 \\
\hline Grinnell College (IA)........ & 50 & $1,500,220$ & $1,383,856$ & -7.8 & Rochester Institute of Technology (NY)................... & 110 & 640,762 & 628,128 & -2.0 \\
\hline & & $1,403,883$ & $1,351,166$ & & Macalester College (MN).... & 111 & & & \\
\hline University of California, Los Angeles..... & 52 & $1,110,981$ & $1,317,905$ & 18.6 & University of Missouri, Columbia. & 112 & 586,413 & 624,382 & 6.5 \\
\hline Washing & 53 & $1,218,132$ & $1,261,553$ & 3.6 & University of California, San Francisco... & 113 & 492,755 & 623,548 & 26.5 \\
\hline University & 54 & 945,318 & $1,218,592$ & 28.9 & Wesleyan University (CT) ... & 114 & 601,478 & 616,195 & 2.4 \\
\hline University of Kansas & 55 & $1,270,511$ & $1,202,585$ & -5.3 & Pepperdine University (CA)..... & 115 & 622,580 & 607,953 & -2.3 \\
\hline Boston University (MA).......... & 56 & $1,194,164$ & $1,190,512$ & & Colby College (ME) .... & 116 & 611,441 & 599,557 & -1.9 \\
\hline Southem Methodist University (TX)... & 57 & $1,190,709$ & $1,162,415$ & $-2.4 \|$ & Bucknell University (PA) . & 117 & 575,367 & 599,216 & 4.1 \\
\hline Georget & 58 & $1,162,239$ & $1,140,486$ & -1.9 & Icahn School of Medicine at Mount Sinai (NY).... & 118 & 607,498 & 594,968 & -2.1 \\
\hline Universit & 59 & $1,085,600$ & $1,127,419$ & 3.9 & Mount Holyoke College (MA)...... & 119 & 617,284 & 594,045 & -3.8 \\
\hline Texas Christian University................................................... & 60 & $1,191,900$ & $1,110,868$ & -6.8 & College of the Holy Cross (MA).... & 120 & 607,713 & 589,769 & -3.0 \\
\hline
\end{tabular}

†Not applicable.

\#Rounds to zero.

1 Institutions ranked by size of endowment at end of 2012 fiscal year.

${ }^{2}$ Change in market value of endowment. Includes growth from gifts and returns on investments, as well as reductions from expenditures and withdrawals.
NOTE: Degree-granting institutions grant associate's or higher degrees and participate in Title IV federal financial aid programs.

SOURCE: U.S. Department of Education, National Center for Education Statistics, Integrated Postsecondary Education Data System (IPEDS), Spring 2013, Finance component. (This table was prepared January 2014.) 
Table 334.10. Expenditures of public degree-granting postsecondary institutions, by purpose of expenditure and level of institution: 2005-06 through 2011-12

\begin{tabular}{|c|c|c|c|c|c|c|c|c|c|c|c|c|c|c|c|c|}
\hline \multirow[b]{2}{*}{$\begin{array}{l}\text { Level of institution } \\
\text { and year }\end{array}$} & \multirow[b]{2}{*}{$\begin{array}{r}\text { Total } \\
\text { expenditures }\end{array}$} & \multicolumn{2}{|c|}{ Instruction } & \multirow[b]{2}{*}{ Research } & \multirow[b]{2}{*}{ Public service } & \multirow[b]{2}{*}{$\begin{array}{r}\text { Academic } \\
\text { support }\end{array}$} & \multirow[b]{2}{*}{$\begin{array}{l}\text { Student } \\
\text { services }\end{array}$} & \multirow[b]{2}{*}{$\begin{array}{r}\text { Institutional } \\
\text { support }\end{array}$} & \multirow{2}{*}{$\begin{array}{r}\text { Operation and } \\
\text { maintenance } \\
\text { of plant }\end{array}$} & \multirow[b]{2}{*}{ Depreciation } & \multirow{2}{*}{$\begin{array}{r}\text { Scholarships } \\
\text { and } \\
\text { fellowships }{ }^{2} \\
\end{array}$} & \multirow[b]{2}{*}{$\begin{array}{r}\text { Auxiliary } \\
\text { enterprises }\end{array}$} & \multirow[b]{2}{*}{ Hospitals } & \multirow[b]{2}{*}{$\begin{array}{r}\text { Independent } \\
\text { operations }\end{array}$} & \multirow[b]{2}{*}{ Interest } & \multirow[b]{2}{*}{ Other } \\
\hline & & Total" & $\begin{array}{r}\text { Salaries } \\
\text { and wages }\end{array}$ & & & & & & & & & & & & & \\
\hline 1 & 2 & 3 & 4 & 5 & 6 & 7 & 8 & 9 & 10 & 11 & 12 & 13 & 14 & 15 & 16 & 17 \\
\hline \multirow[b]{2}{*}{ 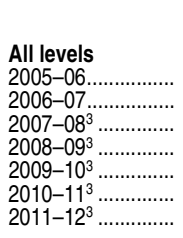 } & \multicolumn{16}{|c|}{ In thousands of current dollars } \\
\hline & $\begin{array}{r}\$ 226,549,889 \\
238,828,801 \\
261,045,829 \\
273,030,301 \\
281,368,314 \\
296,114,046 \\
305,534,191\end{array}$ & $\begin{array}{r}\$ 62,988,407 \\
67,188,249 \\
71,807,253 \\
75,078,714 \\
76,292,102 \\
79,37,704 \\
80,898,6039\end{array}$ & $\begin{array}{r}\$ 43,202,237 \\
45,998,524 \\
48,691,508 \\
51,151,501 \\
51,812,151 \\
53,573,417 \\
54,360,626\end{array}$ & $\begin{array}{r}\$ 23,056,406 \\
23,893,564 \\
25,331,167 \\
26,651,018 \\
28,077,991 \\
29,357,793 \\
29,655,988\end{array}$ & \begin{tabular}{l|}
$\$ 9,746,753$ \\
$10,148,312$ \\
$10,800,588$ \\
$11,244,501$ \\
$11,506,354$ \\
$11,865,709$ \\
$11,943,858$
\end{tabular} & $\begin{array}{r}\$ 15,299,823 \\
16,306,542 \\
17,871,280 \\
18,805,325 \\
18,878,483 \\
19,338,463 \\
20,301,350\end{array}$ & $\begin{array}{r}\$ 10,634,906 \\
11,377,541 \\
12,205,110 \\
12,939,434 \\
13,137,932 \\
13,566,425 \\
14,160,344\end{array}$ & $\begin{array}{r}\$ 18,528,338 \\
19,962,037 \\
22,145,030 \\
23,078,908 \\
22,685,634 \\
23,863,660 \\
24,154,135\end{array}$ & $\begin{array}{r}\$ 15,117,844 \\
15,806,925 \\
17,032,966 \\
17,839,601 \\
18,052,279 \\
18,847,081 \\
19,180,861\end{array}$ & $\begin{array}{r}\$ 10,071,291 \\
10,772,442 \\
12,814,049 \\
13,719,465 \\
14,306,697 \\
15,413,378 \\
16,469,939\end{array}$ & $\begin{array}{r}\$ 8,616,689 \\
8,956,265 \\
9,664,173 \\
11,104,773 \\
15,435,492 \\
17,604,651 \\
16,620,812\end{array}$ & $\begin{array}{r}\$ 17,314,237 \\
18,501,797 \\
19,533,181 \\
20,588,239 \\
20,457,106 \\
21,715,258 \\
22,190,775\end{array}$ & $\begin{array}{r}\$ 20,689,224 \\
22,111,404 \\
23,974,721 \\
25,944,900 \\
26,674,882 \\
27,894,885 \\
30,899,227\end{array}$ & $\begin{array}{r}\$ 744,028 \\
784,684 \\
931,838 \\
1,177,848 \\
1,236,092 \\
1,153,975 \\
1,204,016\end{array}$ & $\begin{array}{r}\$ 3,404,166 \\
3,819,104 \\
4,301,708 \\
2,972,642 \\
5,061,939 \\
5,628,124 \\
6,136,311\end{array}$ & $\begin{array}{r}\$ 10,337,778 \\
9,199,935 \\
12,632,765 \\
11,884,935 \\
9,565,330 \\
10,490,939 \\
11,717,934\end{array}$ \\
\hline $\begin{array}{l}\text { 4-year } \\
2005-06 \ldots \ldots \ldots \ldots \ldots \\
2006-07 \ldots \ldots \ldots \ldots \ldots \\
2007-08^{3} \ldots \ldots \ldots \ldots \ldots \\
2008-09^{3} \ldots \ldots \ldots \ldots . . \\
2009-10^{3} \ldots \ldots \ldots \ldots \ldots \\
2010-11^{1} \ldots \ldots \ldots \ldots \\
2011-12^{3} \ldots \ldots \ldots \ldots .\end{array}$ & $\begin{array}{l}186,074,213 \\
196,121,062 \\
215,474,080 \\
225,363,128 \\
230,216,045 \\
241,754,071 \\
251,503,636\end{array}$ & $\begin{array}{l}47,286,043 \\
50,755,304 \\
54,371,328 \\
57,265,615 \\
58,268,076 \\
60,607,823 \\
62,238,557\end{array}$ & $\begin{array}{l}32,206,726 \\
34,541,885 \\
36,618,879 \\
38,666,432 \\
39,035,682 \\
40,407,972 \\
41,349,288\end{array}$ & $\begin{array}{l}23,031,885 \\
23,875,451 \\
25,312,279 \\
26,629,400 \\
28,057,280 \\
29,336,607 \\
29,635,707\end{array}$ & $\begin{array}{r}9,054,397 \\
9,455,605 \\
10,055,606 \\
10,499,031 \\
10,752,578 \\
11,099,605 \\
11,184,077\end{array}$ & $\begin{array}{l}12,290,114 \\
13,151,359 \\
14,471,795 \\
15,300,115 \\
15,355,204 \\
15,720,410 \\
16,652,094\end{array}$ & $\begin{array}{l}6,906,675 \\
7,430,739 \\
8,051,799 \\
8,612,795 \\
8,755,313 \\
9,112,980 \\
9,634,329\end{array}$ & $\begin{array}{l}12,915,660 \\
14,046,030 \\
15,812,151 \\
16,505,969 \\
16,348,654 \\
17,294,034 \\
17,439,517\end{array}$ & $\begin{array}{l}11,508,008 \\
12,031,682 \\
13,047,228 \\
13,805,143 \\
13,675,766 \\
14,260,755 \\
14,705,781\end{array}$ & $\begin{array}{r}8,517,539 \\
9,140,557 \\
10,959,500 \\
11,719,734 \\
12,311,891 \\
13,184,265 \\
14,105,698\end{array}$ & $\begin{array}{r}5,697,202 \\
6,031,919 \\
6,467,362 \\
7,156,258 \\
9,092,603 \\
10,103,136 \\
9,739,168\end{array}$ & $\begin{array}{l}15,158,273 \\
16,308,351 \\
17,296,774 \\
18,293,456 \\
18,120,806 \\
19,321,726 \\
19,819,696\end{array}$ & $\begin{array}{l}20,689,224 \\
22,111,404 \\
23,974,721 \\
25,944,900 \\
26,674,882 \\
27,894,885 \\
30,899,227\end{array}$ & $\begin{array}{r}744,028 \\
784,684 \\
931,838 \\
1,177,848 \\
1,236,092 \\
1,153,975 \\
1,204,016\end{array}$ & $\begin{array}{l}2,856,931 \\
3,129,141 \\
3,523,683 \\
2,354,694 \\
4,091,219 \\
4,502,944 \\
4,777,487\end{array}$ & $\begin{array}{r}9,418,234 \\
7,868,836 \\
11,198,015 \\
10,098,170 \\
7,475,682 \\
8,160,925 \\
9,468,280\end{array}$ \\
\hline 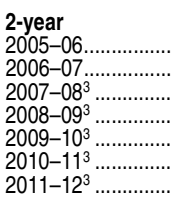 & $\begin{array}{l}40,475,676 \\
42,707,739 \\
45,571,749 \\
47,667,173 \\
51,152,269 \\
54,359,975 \\
54,030,554 \\
\end{array}$ & $\begin{array}{l}15,702,364 \\
16,432,945 \\
17,435,926 \\
17,813,099 \\
18,024,027 \\
18,765,881 \\
18,660,082 \\
\end{array}$ & $\begin{array}{l}10,995,511 \\
11,456,639 \\
12,072,630 \\
12,485,070 \\
12,776,469 \\
13,165,446 \\
13,011,338 \\
\end{array}$ & $\begin{array}{l}24,520 \\
18,113 \\
18,887 \\
21,617 \\
20,711 \\
21,187 \\
20,281 \\
\end{array}$ & $\begin{array}{l}692,356 \\
692,707 \\
744,982 \\
745,470 \\
753,776 \\
766,104 \\
759,781 \\
\end{array}$ & $\begin{array}{l}3,009,709 \\
3,115,, 183 \\
3,399,485 \\
3,505,209 \\
3,523,280 \\
3,618,052 \\
3,649,257 \\
\end{array}$ & $\begin{array}{l}3,728,231 \\
3,496,803 \\
4,153,311 \\
4,326,639 \\
4,382,619 \\
4,453,445 \\
4,526,015 \\
\end{array}$ & $\begin{array}{l}5,612,677 \\
5,916,6007 \\
6,332,879 \\
6,572,940 \\
6,336,980 \\
6,569,626 \\
6,714,618 \\
\end{array}$ & $\begin{array}{l}3,609,836 \\
3,775,2343 \\
3,985,738 \\
4,034,457 \\
4,376,513 \\
4,586,326 \\
4,475,080 \\
\end{array}$ & $\begin{array}{l}1,553,752 \\
1,631,885 \\
1,854,549 \\
1,999,732 \\
1,994,806 \\
2,229,112 \\
2,364,242 \\
\end{array}$ & $\begin{array}{l}2,919,487 \\
2,924,346 \\
3,196,811 \\
3,948,515 \\
6,342,889 \\
7,501,515 \\
6,881,643 \\
\end{array}$ & $\begin{array}{l}2,155,964 \\
2,193,446 \\
2,236,407 \\
2,294,783 \\
2,336,300 \\
2,393,532 \\
2,371,079 \\
\end{array}$ & $\begin{array}{l}0 \\
0 \\
0 \\
0 \\
0 \\
0 \\
0 \\
\end{array}$ & $\begin{array}{l}0 \\
0 \\
0 \\
0 \\
0 \\
0 \\
0 \\
\end{array}$ & $\begin{array}{r}547,234 \\
689,963 \\
778,025 \\
617,948 \\
970,721 \\
1,125,180 \\
1,358,824 \\
\end{array}$ & $\begin{array}{r}919,544 \\
1,331,099 \\
1,434,749 \\
1,786,764 \\
2,089,648 \\
2,330,014 \\
2,249,654 \\
\end{array}$ \\
\hline & \multicolumn{16}{|c|}{ Percentage distribution } \\
\hline 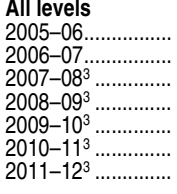 & $\begin{array}{l}100.00 \\
100.00 \\
100.00 \\
100.00 \\
100.00 \\
100.00 \\
100.00\end{array}$ & $\begin{array}{l}27.80 \\
28.13 \\
27.51 \\
27.50 \\
27.11 \\
26.81 \\
26.48\end{array}$ & $\begin{array}{l}19.07 \\
19.26 \\
18.65 \\
18.73 \\
18.41 \\
18.09 \\
17.79\end{array}$ & \begin{tabular}{r|}
10.18 \\
10.00 \\
9.70 \\
9.76 \\
9.98 \\
9.91 \\
9.71
\end{tabular} & $\begin{array}{l}4.30 \\
4.25 \\
4.14 \\
4.12 \\
4.09 \\
4.01 \\
3.91\end{array}$ & $\begin{array}{l}6.75 \\
6.83 \\
6.85 \\
6.89 \\
6.71 \\
6.53 \\
6.64\end{array}$ & $\begin{array}{l}4.69 \\
4.76 \\
4.68 \\
4.74 \\
4.67 \\
4.58 \\
4.63\end{array}$ & $\begin{array}{l}8.18 \\
8.36 \\
8.48 \\
8.45 \\
8.06 \\
8.06 \\
7.91\end{array}$ & $\begin{array}{l}6.67 \\
6.62 \\
6.52 \\
6.53 \\
6.42 \\
6.36 \\
6.28\end{array}$ & $\begin{array}{l}4.45 \\
4.51 \\
4.91 \\
5.02 \\
5.08 \\
5.21 \\
5.39\end{array}$ & $\begin{array}{l}3.80 \\
3.75 \\
3.70 \\
4.07 \\
5.49 \\
5.95 \\
5.44\end{array}$ & $\begin{array}{l}7.64 \\
7.75 \\
7.48 \\
7.54 \\
7.27 \\
7.33 \\
7.26\end{array}$ & $\begin{array}{r}9.13 \\
9.26 \\
9.18 \\
9.50 \\
9.48 \\
9.42 \\
10.11\end{array}$ & $\begin{array}{l}0.33 \\
0.33 \\
0.36 \\
0.43 \\
0.44 \\
0.39 \\
0.39\end{array}$ & $\begin{array}{l}1.50 \\
1.60 \\
1.65 \\
1.09 \\
1.80 \\
1.90 \\
2.01\end{array}$ & $\begin{array}{l}4.56 \\
3.85 \\
4.84 \\
4.35 \\
3.40 \\
3.54 \\
3.84\end{array}$ \\
\hline 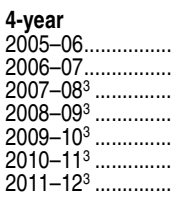 & $\begin{array}{l}100.00 \\
100.00 \\
100.00 \\
100.00 \\
100.00 \\
100.00 \\
100.00\end{array}$ & $\begin{array}{l}25.41 \\
25.88 \\
25.23 \\
25.41 \\
25.31 \\
25.07 \\
24.75\end{array}$ & $\begin{array}{l}17.31 \\
17.61 \\
16.99 \\
17.16 \\
16.96 \\
16.71 \\
16.44\end{array}$ & \begin{tabular}{r|}
12.38 \\
12.17 \\
11.75 \\
11.82 \\
12.19 \\
12.13 \\
11.78
\end{tabular} & $\begin{array}{l}4.87 \\
4.82 \\
4.67 \\
4.66 \\
4.67 \\
4.59 \\
4.45\end{array}$ & $\begin{array}{l}6.60 \\
6.71 \\
6.72 \\
6.79 \\
6.67 \\
6.50 \\
6.62\end{array}$ & $\begin{array}{l}3.71 \\
3.79 \\
3.74 \\
3.82 \\
3.80 \\
3.77 \\
3.83\end{array}$ & $\begin{array}{l}6.94 \\
7.16 \\
7.34 \\
7.32 \\
7.10 \\
7.15 \\
6.93\end{array}$ & $\begin{array}{l}6.18 \\
6.13 \\
6.06 \\
6.13 \\
5.94 \\
5.90 \\
5.85\end{array}$ & $\begin{array}{l}4.58 \\
4.66 \\
5.09 \\
5.20 \\
5.35 \\
5.45 \\
5.61\end{array}$ & $\begin{array}{l}3.06 \\
3.08 \\
3.00 \\
3.18 \\
3.95 \\
4.18 \\
3.87\end{array}$ & $\begin{array}{l}8.15 \\
8.32 \\
8.03 \\
8.12 \\
7.87 \\
7.99 \\
7.88\end{array}$ & $\begin{array}{l}11.12 \\
11.27 \\
11.13 \\
11.51 \\
11.59 \\
11.54 \\
12.29\end{array}$ & $\begin{array}{l}0.40 \\
0.40 \\
0.43 \\
0.52 \\
0.54 \\
0.48 \\
0.48\end{array}$ & $\begin{array}{l}1.54 \\
1.60 \\
1.64 \\
1.04 \\
1.78 \\
1.86 \\
1.90\end{array}$ & $\begin{array}{l}5.06 \\
4.01 \\
5.20 \\
4.48 \\
3.25 \\
3.38 \\
3.76\end{array}$ \\
\hline 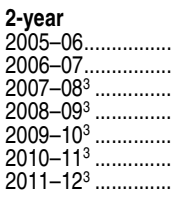 & $\begin{array}{l}100.00 \\
100.00 \\
100.00 \\
100.00 \\
100.00 \\
100.00 \\
100.00 \\
\end{array}$ & $\begin{array}{l}38.79 \\
38.48 \\
38.26 \\
37.37 \\
35.24 \\
34.52 \\
34.54 \\
\end{array}$ & $\begin{array}{l}27.17 \\
26.83 \\
26.49 \\
26.19 \\
24.98 \\
24.22 \\
24.08 \\
\end{array}$ & $\begin{array}{l}0.06 \\
0.04 \\
0.04 \\
0.05 \\
0.04 \\
0.04 \\
0.04\end{array}$ & $\begin{array}{l}1.71 \\
1.62 \\
1.63 \\
1.56 \\
1.47 \\
1.41 \\
1.41 \\
\end{array}$ & $\begin{array}{l}7.44 \\
7.39 \\
7.46 \\
7.35 \\
6.89 \\
6.66 \\
6.75 \\
\end{array}$ & $\begin{array}{l}9.21 \\
9.24 \\
9.11 \\
9.08 \\
8.57 \\
8.19 \\
8.38 \\
\end{array}$ & $\begin{array}{l}13.87 \\
13.85 \\
13.90 \\
13.79 \\
12.39 \\
12.09 \\
12.43 \\
\end{array}$ & $\begin{array}{l}8.92 \\
8.84 \\
8.75 \\
8.46 \\
8.56 \\
8.44 \\
8.28 \\
\end{array}$ & $\begin{array}{l}3.84 \\
3.82 \\
4.07 \\
4.20 \\
3.90 \\
4.10 \\
4.38 \\
\end{array}$ & $\begin{array}{r}7.21 \\
6.85 \\
7.01 \\
8.28 \\
12.40 \\
13.80 \\
12.74 \\
\end{array}$ & $\begin{array}{l}5.33 \\
5.14 \\
4.91 \\
4.81 \\
4.57 \\
4.40 \\
4.39 \\
\end{array}$ & $\begin{array}{l}0.00 \\
0.00 \\
0.00 \\
0.00 \\
0.00 \\
0.00 \\
0.00 \\
\end{array}$ & $\begin{array}{l}0.00 \\
0.00 \\
0.00 \\
0.00 \\
0.00 \\
0.00 \\
0.00\end{array}$ & $\begin{array}{l}1.35 \\
1.62 \\
1.71 \\
1.30 \\
1.90 \\
2.07 \\
2.51 \\
\end{array}$ & $\begin{array}{l}2.27 \\
3.12 \\
3.15 \\
3.75 \\
4.09 \\
4.29 \\
4.16 \\
\end{array}$ \\
\hline
\end{tabular}

See notes at end of table. 
Table 334.10. Expenditures of public degree-granting postsecondary institutions, by purpose of expenditure and level of institution: 2005-06 through 2011-12-Continued

\begin{tabular}{|c|c|c|c|c|c|c|c|c|c|c|c|c|c|c|c|c|}
\hline \multirow[b]{2}{*}{$\begin{array}{l}\text { Level of institution } \\
\text { and year }\end{array}$} & \multirow[b]{2}{*}{$\begin{array}{r}\text { Total } \\
\text { expenditures }\end{array}$} & \multicolumn{2}{|c|}{ Instruction } & \multirow[b]{2}{*}{ Research } & \multirow[b]{2}{*}{ Public service } & \multirow[b]{2}{*}{$\begin{array}{r}\text { Academic } \\
\text { support }\end{array}$} & \multirow[b]{2}{*}{$\begin{array}{l}\text { Student } \\
\text { services }\end{array}$} & \multirow[b]{2}{*}{$\begin{array}{r}\text { Institutional } \\
\text { support }\end{array}$} & \multirow{2}{*}{$\begin{array}{r}\text { Operation and } \\
\text { maintenance } \\
\text { of plant }\end{array}$} & \multirow[b]{2}{*}{ Depreciation } & \multirow{2}{*}{$\begin{array}{r}\text { Scholarships } \\
\text { and } \\
\text { fellowships } \\
\end{array}$} & \multirow[b]{2}{*}{$\begin{array}{r}\text { Auxiliary } \\
\text { enterprises }\end{array}$} & \multirow[b]{2}{*}{ Hospitals } & \multirow[b]{2}{*}{$\begin{array}{r}\text { Independent } \\
\text { operations }\end{array}$} & \multirow[b]{2}{*}{ Interest } & \multirow[b]{2}{*}{ Other } \\
\hline & & Total $^{1}$ & $\begin{array}{r}\text { Salaries } \\
\text { and wages }\end{array}$ & & & & & & & & & & & & & \\
\hline 1 & 2 & 3 & 4 & 5 & 6 & 7 & 8 & 9 & 10 & 11 & 12 & 13 & 14 & 15 & 16 & 17 \\
\hline & \multicolumn{16}{|c|}{ Expenditures per full-time-equivalent student in current dollars } \\
\hline $\begin{array}{l}\text { All levels } \\
205-06 \ldots \ldots \ldots \ldots . . . \\
2006-07 \ldots \ldots \ldots \ldots . . \\
2007-08^{3} \ldots \ldots \ldots \ldots . . . \\
2008-09^{3} \ldots \ldots \ldots \ldots . . \\
2009-10^{3} \ldots \ldots \ldots \ldots . . \\
2010-11^{3} \ldots \ldots \ldots \ldots . . \\
2011-12^{3} \ldots \ldots \ldots \ldots . .\end{array}$ & $\begin{array}{l}24,126 \\
25,130 \\
26,802 \\
27,735 \\
26,173 \\
26,869 \\
27,906\end{array}$ & $\begin{array}{l}6,708 \\
7,070 \\
7,373 \\
7,462 \\
7,097 \\
7,202 \\
7,389\end{array}$ & $\begin{array}{l}4,601 \\
4,840 \\
4,999 \\
5,084 \\
4,820 \\
4,861 \\
4,965\end{array}$ & $\begin{array}{l}2,455 \\
2,514 \\
2,601 \\
2,649 \\
2,612 \\
2,664 \\
2,709\end{array}$ & $\begin{array}{l}1,038 \\
1,068 \\
1,109 \\
1,118 \\
1,070 \\
1,077 \\
1,091\end{array}$ & $\begin{array}{l}1,629 \\
1,716 \\
1,835 \\
1,869 \\
1,756 \\
1,755 \\
1,854\end{array}$ & $\begin{array}{l}1,133 \\
1,197 \\
1,253 \\
1,286 \\
1,222 \\
1,231 \\
1,293\end{array}$ & $\begin{array}{l}1,973 \\
2,100 \\
2,274 \\
2,294 \\
2,110 \\
2,165 \\
2,206\end{array}$ & $\begin{array}{l}1,610 \\
1,663 \\
1,749 \\
1,773 \\
1,679 \\
1,710 \\
1,752\end{array}$ & $\begin{array}{l}1,073 \\
1,134 \\
1,316 \\
1,364 \\
1,331 \\
1,399 \\
1,504\end{array}$ & $\begin{array}{r}918 \\
942 \\
992 \\
1,104 \\
1,436 \\
1,597 \\
1,518\end{array}$ & $\begin{array}{l}1,844 \\
1,947 \\
2,006 \\
2,046 \\
1,903 \\
1,970 \\
2,027\end{array}$ & $\begin{array}{l}2,203 \\
2,327 \\
2,462 \\
2,579 \\
2,481 \\
2,531 \\
2,822\end{array}$ & $\begin{array}{r}79 \\
83 \\
96 \\
117 \\
115 \\
105 \\
110\end{array}$ & $\begin{array}{l}363 \\
402 \\
442 \\
295 \\
471 \\
511 \\
560\end{array}$ & $\begin{array}{r}1,101 \\
968 \\
1,297 \\
1,181 \\
890 \\
952 \\
1,070\end{array}$ \\
\hline 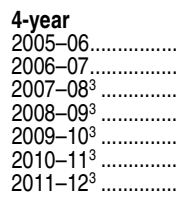 & $\begin{array}{l}32,483 \\
33,670 \\
35,947 \\
36,707 \\
35,679 \\
36,430 \\
37,354\end{array}$ & $\begin{array}{l}8,255 \\
8,714 \\
9,071 \\
9,327 \\
9,030 \\
9,133 \\
9,244\end{array}$ & $\begin{array}{l}5,622 \\
5,930 \\
6,109 \\
6,298 \\
6,050 \\
6,089 \\
6,141\end{array}$ & $\begin{array}{l}4,021 \\
4,099 \\
4,223 \\
4,337 \\
4,348 \\
4,421 \\
4,402\end{array}$ & $\begin{array}{l}1,581 \\
1,623 \\
1,678 \\
1,710 \\
1,666 \\
1,673 \\
1,661\end{array}$ & $\begin{array}{l}2,145 \\
2,258 \\
2,414 \\
2,492 \\
2,380 \\
2,369 \\
2,473\end{array}$ & $\begin{array}{l}1,206 \\
1,276 \\
1,343 \\
1,403 \\
1,357 \\
1,373 \\
1,431\end{array}$ & $\begin{array}{l}2,255 \\
2,411 \\
2,638 \\
2,688 \\
2,534 \\
2,606 \\
2,590\end{array}$ & $\begin{array}{l}2,009 \\
2,066 \\
2,177 \\
2,249 \\
2,119 \\
2,149 \\
2,184\end{array}$ & $\begin{array}{l}1,487 \\
1,569 \\
1,828 \\
1,909 \\
1,908 \\
1,987 \\
2,095\end{array}$ & $\begin{array}{r}995 \\
1,036 \\
1,079 \\
1,166 \\
1,409 \\
1,522 \\
1,446\end{array}$ & $\begin{array}{l}2,646 \\
2,800 \\
2,886 \\
2,980 \\
2,808 \\
2,912 \\
2,944\end{array}$ & $\begin{array}{l}3,612 \\
3,796 \\
4,000 \\
4,226 \\
4,234 \\
4,203 \\
4,589\end{array}$ & $\begin{array}{l}130 \\
135 \\
155 \\
192 \\
192 \\
174 \\
179\end{array}$ & $\begin{array}{l}499 \\
537 \\
588 \\
384 \\
634 \\
679 \\
710\end{array}$ & $\begin{array}{l}1,644 \\
1,351 \\
1,868 \\
1,645 \\
1,159 \\
1,230 \\
1,406\end{array}$ \\
\hline $\begin{array}{l}\text { 2-year } \\
2005-06 \ldots \ldots \ldots \ldots . . . \\
2006-07 \ldots \ldots \ldots \ldots . . . \\
2007-08^{3} \ldots \ldots \ldots \ldots . . . \\
2008-09^{3} \ldots \ldots \ldots \ldots . . \\
2009-10^{3} \ldots \ldots \ldots \ldots . . \\
2010-11^{3} \ldots \ldots \ldots \ldots . . \\
2011-12^{3} \ldots \ldots \ldots \ldots . .\end{array}$ & $\begin{array}{r}11,053 \\
11,609 \\
12,167 \\
12,153 \\
11,902 \\
12,398 \\
12,817 \\
\end{array}$ & $\begin{array}{l}4,288 \\
4,467 \\
4,655 \\
4,542 \\
4,194 \\
4,280 \\
4,426 \\
\end{array}$ & $\begin{array}{l}3,003 \\
3,114 \\
3,223 \\
3,183 \\
2,973 \\
3,003 \\
3,086 \\
\end{array}$ & $\begin{array}{l}7 \\
5 \\
5 \\
6 \\
5 \\
5 \\
5 \\
\end{array}$ & $\begin{array}{l}189 \\
188 \\
199 \\
190 \\
175 \\
175 \\
180 \\
\end{array}$ & $\begin{array}{l}822 \\
858 \\
908 \\
894 \\
820 \\
825 \\
866 \\
\end{array}$ & $\begin{array}{l}1,018 \\
1,073 \\
1,109 \\
1,103 \\
1,020 \\
1,016 \\
1,074 \\
\end{array}$ & $\begin{array}{l}1,533 \\
1,608 \\
1,691 \\
1,676 \\
1,474 \\
1,498 \\
1,593 \\
\end{array}$ & $\begin{array}{r}986 \\
1,026 \\
1,064 \\
1,029 \\
1,018 \\
1,046 \\
1,062 \\
\end{array}$ & $\begin{array}{l}424 \\
444 \\
495 \\
510 \\
464 \\
508 \\
561 \\
\end{array}$ & $\begin{array}{r}797 \\
795 \\
854 \\
1,007 \\
1,476 \\
1,711 \\
1,632 \\
\end{array}$ & $\begin{array}{l}589 \\
596 \\
597 \\
585 \\
544 \\
546 \\
562 \\
\end{array}$ & $\begin{array}{l}0 \\
0 \\
0 \\
0 \\
0 \\
0 \\
0 \\
\end{array}$ & $\begin{array}{l}0 \\
0 \\
0 \\
0 \\
0 \\
0 \\
0 \\
\end{array}$ & $\begin{array}{l}149 \\
188 \\
208 \\
158 \\
226 \\
257 \\
322 \\
\end{array}$ & $\begin{array}{l}251 \\
362 \\
383 \\
456 \\
486 \\
531 \\
534 \\
\end{array}$ \\
\hline & \multicolumn{16}{|c|}{ Expenditures per full-time-equivalent student in constant 2012-13 dollars ${ }^{4}$} \\
\hline $\begin{array}{l}\text { All levels } \\
2005-06 \ldots \ldots \ldots \ldots . . . \\
2006-07 \ldots \ldots \ldots \ldots . . . \\
2007-08^{3} \ldots \ldots \ldots \ldots . . . \\
2008-09^{3} \ldots \ldots \ldots \ldots . . . \\
2009-10^{3} \ldots \ldots \ldots \ldots . . . \\
2010-11^{3} \ldots \ldots \ldots \ldots . . . \\
2011-12^{3} \ldots \ldots \ldots \ldots . .\end{array}$ & $\begin{array}{l}28,050 \\
28,481 \\
29,290 \\
29,246 \\
27,939 \\
28,116 \\
28,371\end{array}$ & $\begin{array}{l}7,799 \\
8,012 \\
8,057 \\
8,042 \\
7,575 \\
7,537 \\
7,512\end{array}$ & $\begin{array}{l}5,349 \\
5,485 \\
5,463 \\
5,479 \\
5,145 \\
5,087 \\
5,048\end{array}$ & $\begin{array}{l}2,855 \\
2,849 \\
2,842 \\
2,855 \\
2,788 \\
2,788 \\
2,754\end{array}$ & $\begin{array}{l}1,207 \\
1,210 \\
1,212 \\
1,204 \\
1,143 \\
1,127 \\
1,109\end{array}$ & $\begin{array}{l}1,894 \\
1,945 \\
2,005 \\
2,014 \\
1,875 \\
1,836 \\
1,885\end{array}$ & $\begin{array}{l}1,317 \\
1,357 \\
1,369 \\
1,386 \\
1,305 \\
1,288 \\
1,315\end{array}$ & $\begin{array}{l}2,294 \\
2,380 \\
2,485 \\
2,472 \\
2,253 \\
2,266 \\
2,243\end{array}$ & $\begin{array}{l}1,872 \\
1,885 \\
1,911 \\
1,911 \\
1,793 \\
1,790 \\
1,781\end{array}$ & $\begin{array}{l}1,247 \\
1,285 \\
1,438 \\
1,470 \\
1,421 \\
1,464 \\
1,529\end{array}$ & $\begin{array}{l}1,067 \\
1,068 \\
1,084 \\
1,189 \\
1,533 \\
1,672 \\
1,543\end{array}$ & $\begin{array}{l}2,144 \\
2,206 \\
2,192 \\
2,205 \\
2,031 \\
2,062 \\
2,061\end{array}$ & $\begin{array}{l}2,562 \\
2,637 \\
2,690 \\
2,779 \\
2,649 \\
2,649 \\
2,869\end{array}$ & $\begin{array}{r}92 \\
94 \\
105 \\
126 \\
123 \\
110 \\
112\end{array}$ & $\begin{array}{l}421 \\
455 \\
483 \\
318 \\
503 \\
534 \\
570\end{array}$ & $\begin{array}{r}1,280 \\
1,097 \\
1,417 \\
1,273 \\
950 \\
996 \\
1,088\end{array}$ \\
\hline 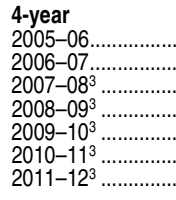 & $\begin{array}{l}37,766 \\
33,159 \\
39,283 \\
39,562 \\
38,085 \\
38,121 \\
37,976\end{array}$ & $\begin{array}{r}9,597 \\
9,875 \\
9,913 \\
10,053 \\
9,639 \\
9,557 \\
9,398\end{array}$ & $\begin{array}{l}6,537 \\
6,721 \\
6,676 \\
6,788 \\
6,458 \\
6,372 \\
6,244\end{array}$ & $\begin{array}{l}4,675 \\
4,645 \\
4,615 \\
4,675 \\
4,642 \\
4,626 \\
4,475\end{array}$ & $\begin{array}{r}1,838 \\
1,840 \\
1,833 \\
1,843 \\
1,779 \\
1,750 \\
1,689\end{array}$ & $\begin{array}{l}2,494 \\
2,559 \\
2,638 \\
2,686 \\
2,540 \\
2,479 \\
2,514\end{array}$ & $\begin{array}{l}1,402 \\
1,446 \\
1,468 \\
1,512 \\
1,448 \\
1,437 \\
1,455\end{array}$ & $\begin{array}{l}2,621 \\
2,733 \\
2,883 \\
2,898 \\
2,705 \\
2,727 \\
2,633\end{array}$ & $\begin{array}{l}2,336 \\
2,341 \\
2,379 \\
2,423 \\
2,262 \\
2,249 \\
2,221\end{array}$ & $\begin{array}{l}1,729 \\
1,778 \\
1,998 \\
2,057 \\
2,037 \\
2,079 \\
2,130\end{array}$ & $\begin{array}{l}1,156 \\
1,174 \\
1,179 \\
1,256 \\
1,504 \\
1,593 \\
1,471\end{array}$ & $\begin{array}{l}3,077 \\
3,173 \\
3,153 \\
3,211 \\
2,998 \\
3,047 \\
2,993\end{array}$ & $\begin{array}{l}4,199 \\
4,302 \\
4,371 \\
4,555 \\
4,413 \\
4,399 \\
4,666\end{array}$ & $\begin{array}{l}151 \\
153 \\
170 \\
207 \\
204 \\
182 \\
182\end{array}$ & $\begin{array}{l}580 \\
609 \\
642 \\
413 \\
677 \\
710 \\
721\end{array}$ & $\begin{array}{l}1,912 \\
1,531 \\
2,042 \\
1,773 \\
1,237 \\
1,287 \\
1,430\end{array}$ \\
\hline $\begin{array}{l}\text { 2-year } \\
2005-06 \ldots \ldots \ldots \ldots . . . \\
2006-07 \ldots \ldots \ldots \ldots . . . \\
2007-08^{3} \ldots \ldots \ldots \ldots . . . \\
2008-09^{3} \ldots \ldots \ldots \ldots . . \\
2009-10^{3} \ldots \ldots \ldots \ldots . . \\
2010-11^{3} \ldots \ldots \ldots \ldots . . \\
2011-12^{3} \ldots \ldots \ldots \ldots . .\end{array}$ & $\begin{array}{l}12,851 \\
13,157 \\
13,296 \\
13,098 \\
12,705 \\
12,974 \\
13,030\end{array}$ & $\begin{array}{l}4,985 \\
5,062 \\
5,087 \\
4,895 \\
4,477 \\
4,479 \\
4,500\end{array}$ & $\begin{array}{l}3,491 \\
3,529 \\
3,522 \\
3,431 \\
3,173 \\
3,142 \\
3,138\end{array}$ & $\begin{array}{l}8 \\
6 \\
6 \\
6 \\
5 \\
5 \\
5\end{array}$ & $\begin{array}{l}220 \\
213 \\
217 \\
205 \\
187 \\
183 \\
183\end{array}$ & $\begin{array}{l}956 \\
972 \\
992 \\
963 \\
875 \\
863 \\
880\end{array}$ & $\begin{array}{l}1,184 \\
1,216 \\
1,212 \\
1,189 \\
1,089 \\
1,063 \\
1,091\end{array}$ & $\begin{array}{l}1,782 \\
1,823 \\
1,848 \\
1,806 \\
1,574 \\
1,568 \\
1,619\end{array}$ & $\begin{array}{l}1,146 \\
1,163 \\
1,163 \\
1,109 \\
1,087 \\
1,095 \\
1,079\end{array}$ & $\begin{array}{l}493 \\
503 \\
541 \\
549 \\
495 \\
532 \\
570\end{array}$ & $\begin{array}{r}927 \\
901 \\
933 \\
1,085 \\
1,575 \\
1,790 \\
1,660\end{array}$ & $\begin{array}{l}685 \\
676 \\
653 \\
631 \\
580 \\
571 \\
572\end{array}$ & $\begin{array}{l}0 \\
0 \\
0 \\
0 \\
0 \\
0 \\
0\end{array}$ & $\begin{array}{l}0 \\
0 \\
0 \\
0 \\
0 \\
0 \\
0\end{array}$ & $\begin{array}{l}174 \\
213 \\
227 \\
170 \\
241 \\
269 \\
328\end{array}$ & $\begin{array}{l}292 \\
410 \\
419 \\
491 \\
519 \\
556 \\
543\end{array}$ \\
\hline
\end{tabular}

IIncludes other categories not separately shown

${ }^{3}$ All expenditures reported by institutions for operation and maintenance of plant have been aggregated in the operation and maintenance of plant category, even in cases where they originally were reported by purpose. Similarly, all expenditures reported by by purpose. In addition, all expenditures reported by institutions for interest have been aggregated in the interest category, even in cases where they originally were reported by purpose.
${ }^{4}$ Constant dollars based on the Consumer Price Index, prepared by the Bureau of Labor Statistics, U.S. Department of Labor adjusted to a school-year basis

Includes data for public institutions grant associate's or higher degrees and participate in Title IV federal financial aid programs. Financial Accounting Standards Board (FASB) questionnaire. Detail may not sum to totals because of rounding.

SOURCE: U.S. Department or Education, National Center for Education Statistics, Integrated Postsecondary Education Data System (IPEDS), Spring 2006 through Spring 2013, Finance and Enrollment components. (This table was prepared January 2014.) 
Table 334.20. Expenditures of public degree-granting postsecondary institutions, by level of institution, purpose of expenditure, and state or jurisdiction: 2008-09 through 2011-12

[In thousands of current dollars]

\begin{tabular}{|c|c|c|c|c|c|c|c|c|c|c|c|}
\hline \multirow[b]{3}{*}{ State or jurisdiction } & \multirow{3}{*}{$\begin{array}{r}\text { Total } \\
\text { expenditures, } \\
2008-09\end{array}$} & \multirow{3}{*}{$\begin{array}{r}\text { Total } \\
\text { expenditures, } \\
2009-10\end{array}$} & \multicolumn{3}{|c|}{ Total expenditures, 2010-11 } & \multicolumn{6}{|c|}{$2011-12$} \\
\hline & & & \multirow[b]{2}{*}{ All institutions } & \multirow{2}{*}{$\begin{array}{r}\text { 4-year } \\
\text { institutions }\end{array}$} & \multirow{2}{*}{$\begin{array}{r}2 \text {-year } \\
\text { institutions }\end{array}$} & \multicolumn{2}{|c|}{ All institutions } & \multicolumn{2}{|c|}{ 4-year institutions } & \multicolumn{2}{|c|}{ 2-year institutions } \\
\hline & & & & & & Total $^{1}$ & Instruction $^{2}$ & Total $^{1}$ & Instruction $^{2}$ & Total $^{1}$ & Instruction² \\
\hline 1 & 2 & 3 & 4 & 5 & 6 & 7 & 8 & 9 & 10 & 11 & 12 \\
\hline United States ..................... & $\$ 273,030,301$ & $\$ 281,368,314$ & $\$ 296,114,046$ & $\$ 241,754,071$ & $\$ 54,359,975$ & $\$ 305,534,191$ & $\$ 80,898,639$ & $\$ 251,503,636$ & $\$ 62,238,557$ & $\$ 54,030,554$ & $\$ 18,660,082$ \\
\hline 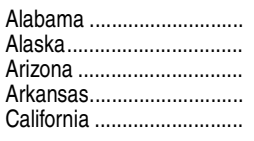 & $\begin{array}{r}5,964,685 \\
750,308 \\
4,523,629 \\
3,109,431 \\
39,706,162\end{array}$ & \begin{tabular}{r|}
$6,324,853$ \\
780,028 \\
$4,721,129$ \\
$3,268,738$ \\
$39,702,048$ \\
\end{tabular} & \begin{tabular}{r|}
$6,649,467$ \\
800,218 \\
$4,968,606$ \\
$3,454,422$ \\
$42,790,625$
\end{tabular} & $\begin{array}{r}5,839,064 \\
779,239 \\
3,612,788 \\
2,941,157 \\
31,296,311\end{array}$ & $\begin{array}{r}810,403 \\
20,978 \\
1,355,818 \\
513,265 \\
11,494,314\end{array}$ & $\begin{array}{r}6,249,322 \\
829,978 \\
5,126,746 \\
3,592,033 \\
45,496,484\end{array}$ & $\begin{array}{r}1,457,529 \\
217,370 \\
1,494,971 \\
727,714 \\
10,588,055\end{array}$ & $\begin{array}{r}5,505,628 \\
806,882 \\
3,711,078 \\
3,079,753 \\
34,205,136\end{array}$ & $\begin{array}{r}1,185,672 \\
210,855 \\
1,042,863 \\
561,865 \\
7,282,151\end{array}$ & \begin{tabular}{r|}
743,694 \\
23,096 \\
$1,415,668$ \\
512,279 \\
$11,291,348$
\end{tabular} & $\begin{array}{r}271,857 \\
6,515 \\
452,107 \\
165,849 \\
3,305,905\end{array}$ \\
\hline 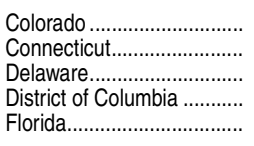 & $\begin{array}{r}4,424,140 \\
2,833,427 \\
937,997 \\
138,348 \\
9,220,508\end{array}$ & $\begin{array}{r}4,516,268 \\
2,814,866 \\
967,381 \\
109,469 \\
9,721,394\end{array}$ & $\begin{array}{r}4,837,724 \\
2,974,554 \\
1,032,228 \\
152,640 \\
10,413,803\end{array}$ & $\begin{array}{r}4,315,611 \\
2,515,522 \\
887,780 \\
152,640 \\
9,810,395\end{array}$ & $\begin{array}{r}522,114 \\
459,032 \\
144,448 \\
0 \\
603,408\end{array}$ & $\begin{array}{r}5,149,199 \\
2,931,898 \\
1,128,190 \\
147,034 \\
10,559,827\end{array}$ & $\begin{array}{r}1,461,843 \\
805,500 \\
410,987 \\
54,628 \\
3,066,934\end{array}$ & $\begin{array}{r}4,593,560 \\
2,476,931 \\
976,509 \\
147,034 \\
10,047,373\end{array}$ & $\begin{array}{r}1,258,133 \\
629,957 \\
343,048 \\
54,628 \\
2,927,676\end{array}$ & $\begin{array}{r}555,639 \\
454,966 \\
151,681 \\
0 \\
512,454\end{array}$ & $\begin{array}{r}203,709 \\
175,543 \\
67,939 \\
0 \\
139,258\end{array}$ \\
\hline 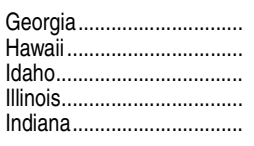 & $\begin{array}{l}6,063,773 \\
1,531,975 \\
1,024,541 \\
9,350,383 \\
5,487,959\end{array}$ & $\begin{array}{l}6,426,195 \\
1,406,821 \\
1,070,934 \\
9,954,173 \\
5,739,211\end{array}$ & $\begin{array}{r}7,028,610 \\
1,523,301 \\
1,116,296 \\
10,302,240 \\
5,959,191\end{array}$ & $\begin{array}{r}5,748,748 \\
1,290,065 \\
911,158 \\
7,460,195 \\
5,316,900\end{array}$ & $\begin{array}{r}1,279,862 \\
233,236 \\
205,138 \\
2,842,045 \\
642,291\end{array}$ & $\begin{array}{r}7,293,926 \\
1,609,315 \\
1,216,909 \\
10,888,678 \\
6,098,731\end{array}$ & $\begin{array}{r}1,902,757 \\
427,437 \\
328,272 \\
3,088,692 \\
2,125,765\end{array}$ & $\begin{array}{r}6,090,473 \\
1,364,952 \\
951,754 \\
7,958,821 \\
5,438,638\end{array}$ & $\begin{array}{r}1,505,704 \\
323,112 \\
269,697 \\
2,178,967 \\
1,909,123\end{array}$ & $\begin{array}{r}1,203,453 \\
244,363 \\
265,155 \\
2,929,857 \\
660,093\end{array}$ & $\begin{array}{r}397,053 \\
104,325 \\
58,574 \\
909,725 \\
216,643\end{array}$ \\
\hline 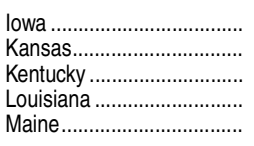 & $\begin{array}{r}4,193,485 \\
2,821,376 \\
4,513,299 \\
4,303,137 \\
809,983\end{array}$ & $\begin{array}{r}4,169,366 \\
2,916,446 \\
4,723,961 \\
4,143,613 \\
807,827\end{array}$ & $\begin{array}{r}4,332,274 \\
3,053,391 \\
4,889,725 \\
4,163,519 \\
837,119\end{array}$ & $\begin{array}{r}3,464,024 \\
2,342,731 \\
4,193,994 \\
3,649,282 \\
715,786\end{array}$ & $\begin{array}{l}868,250 \\
710,660 \\
695,731 \\
514,237 \\
121,333\end{array}$ & $\begin{array}{r}4,726,859 \\
3,214,748 \\
5,136,705 \\
4,204,018 \\
844,272\end{array}$ & $\begin{array}{r}967,311 \\
940,794 \\
1,166,682 \\
1,119,549 \\
235,727\end{array}$ & $\begin{array}{r}3,842,076 \\
2,490,979 \\
4,423,207 \\
3,688,602 \\
722,060\end{array}$ & $\begin{array}{l}634,650 \\
707,310 \\
923,563 \\
930,091 \\
186,090\end{array}$ & $\begin{array}{l}884,783 \\
723,769 \\
713,498 \\
515,416 \\
122,212\end{array}$ & $\begin{array}{r}332,661 \\
233,484 \\
243,119 \\
189,458 \\
49,638\end{array}$ \\
\hline 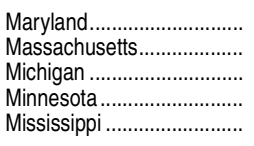 & $\begin{array}{r}5,282,745 \\
3,731,294 \\
11,928,733 \\
4,679,338 \\
3,445,846\end{array}$ & $\begin{array}{r}5,489,313 \\
3,941,641 \\
12,411,095 \\
4,782,817 \\
3,591,772\end{array}$ & $\begin{array}{r}5,627,221 \\
4,224,820 \\
12,793,640 \\
4,841,837 \\
3,717,313\end{array}$ & $\begin{array}{r}4,300,679 \\
3,443,382 \\
10,841,022 \\
3,785,610 \\
2,809,641\end{array}$ & $\begin{array}{r}1,326,541 \\
781,438 \\
1,952,618 \\
1,056,227 \\
907,672\end{array}$ & $\begin{array}{r}5,829,195 \\
4,297,014 \\
13,384,789 \\
4,810,022 \\
3,815,187\end{array}$ & $\begin{array}{r}1,623,747 \\
1,195,062 \\
3,345,058 \\
1,364,177 \\
866,062\end{array}$ & $\begin{array}{r}4,472,795 \\
3,490,312 \\
11,447,703 \\
3,798,676 \\
2,909,603\end{array}$ & $\begin{array}{r}1,125,279 \\
892,924 \\
2,675,348 \\
953,626 \\
564,587\end{array}$ & $\begin{array}{r}1,356,400 \\
806,702 \\
1,937,086 \\
1,011,346 \\
905,584\end{array}$ & $\begin{array}{l}498,468 \\
302,138 \\
669,710 \\
410,551 \\
301,474\end{array}$ \\
\hline 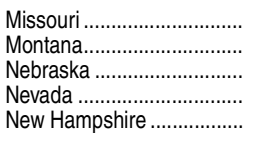 & $\begin{array}{r}4,067,585 \\
936,000 \\
1,893,340 \\
1,417,355 \\
803,946\end{array}$ & $\begin{array}{r}4,220,808 \\
933,785 \\
2,005,277 \\
1,423,657 \\
837,543\end{array}$ & $\begin{array}{r}4,370,406 \\
961,380 \\
2,119,516 \\
1,452,203 \\
916,009\end{array}$ & $\begin{array}{r}3,593,302 \\
839,058 \\
1,745,447 \\
1,382,958 \\
770,735\end{array}$ & $\begin{array}{r}777,104 \\
122,321 \\
374,069 \\
69,245 \\
145,274\end{array}$ & $\begin{array}{r}4,563,353 \\
980,626 \\
2,176,505 \\
1,374,536 \\
894,369\end{array}$ & $\begin{array}{r}1,222,197 \\
243,570 \\
628,518 \\
476,935 \\
266,551\end{array}$ & $\begin{array}{r}3,777,389 \\
852,199 \\
1,788,005 \\
1,307,944 \\
764,722\end{array}$ & $\begin{array}{l}943,879 \\
212,017 \\
483,171 \\
450,449 \\
220,208\end{array}$ & $\begin{array}{r}785,964 \\
128,427 \\
388,500 \\
66,592 \\
129,647\end{array}$ & $\begin{array}{r}278,318 \\
31,553 \\
145,347 \\
26,486 \\
46,343\end{array}$ \\
\hline $\begin{array}{l}\text { New Jersey ..................... } \\
\text { New Mexico ........................ } \\
\text { New York.......................... } \\
\text { North Carolina .................. } \\
\text { North Dakota }\end{array}$ & $\begin{array}{r}6,487,776 \\
3,033,621 \\
14,393,529 \\
8,648,614 \\
900,709\end{array}$ & $\begin{array}{r}6,679,185 \\
3,094,887 \\
14,564,719 \\
9,061,392 \\
960,204\end{array}$ & $\begin{array}{r}6,818,023 \\
3,195,659 \\
15,481,165 \\
9,639,567 \\
993,822\end{array}$ & $\begin{array}{r}5,509,244 \\
2,584,062 \\
12,371,236 \\
7,462,272 \\
914,830\end{array}$ & $\begin{array}{r}1,308,780 \\
611,597 \\
3,109,929 \\
2,177,296 \\
78,992\end{array}$ & $\begin{array}{r}7,080,758 \\
3,150,710 \\
16,037,336 \\
9,556,563 \\
1,041,219\end{array}$ & $\begin{array}{r}1,996,534 \\
595,333 \\
4,526,656 \\
3,069,125 \\
351,006\end{array}$ & $\begin{array}{r}5,766,819 \\
2,545,009 \\
12,848,763 \\
7,417,647 \\
950,491\end{array}$ & $\begin{array}{r}1,551,648 \\
397,190 \\
3,250,053 \\
2,195,716 \\
317,064\end{array}$ & $\begin{array}{r}1,313,939 \\
605,701 \\
3,188,573 \\
2,138,916 \\
90,728\end{array}$ & $\begin{array}{r}444,885 \\
198,144 \\
1,276,602 \\
873,410 \\
33,942\end{array}$ \\
\hline 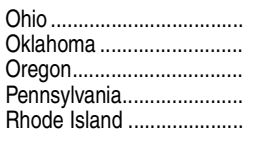 & $\begin{array}{r}10,690,988 \\
3,424,475 \\
4,705,101 \\
10,424,097 \\
639,371\end{array}$ & $\begin{array}{r}11,191,776 \\
3,565,946 \\
4,989,706 \\
10,880,853 \\
663,552\end{array}$ & $\begin{array}{r}11,618,185 \\
3,722,869 \\
5,312,294 \\
11,287,473 \\
683,831\end{array}$ & $\begin{array}{r}9,997,413 \\
3,238,832 \\
4,078,285 \\
10,099,710 \\
571,947\end{array}$ & $\begin{array}{r}1,620,772 \\
484,037 \\
1,234,009 \\
1,187,763 \\
111,884\end{array}$ & $\begin{array}{r}11,808,439 \\
3,859,699 \\
5,531,213 \\
11,823,354 \\
717,329\end{array}$ & $\begin{array}{r}3,139,947 \\
1,088,350 \\
1,190,991 \\
2,993,974 \\
193,230\end{array}$ & $\begin{array}{r}10,182,544 \\
3,377,425 \\
4,341,196 \\
10,615,217 \\
600,406\end{array}$ & $\begin{array}{r}2,562,406 \\
906,703 \\
802,885 \\
2,568,704 \\
143,121\end{array}$ & $\begin{array}{r}1,625,895 \\
482,275 \\
1,190,017 \\
1,208,137 \\
116,924\end{array}$ & $\begin{array}{r}577,541 \\
181,647 \\
388,106 \\
425,271 \\
50,109\end{array}$ \\
\hline 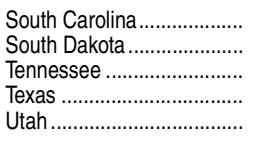 & $\begin{array}{r}3,415,654 \\
626,176 \\
3,607,113 \\
24,222,080 \\
3,797,090\end{array}$ & $\begin{array}{r}3,537,943 \\
686,412 \\
3,781,861 \\
25,080,639 \\
3,940,464\end{array}$ & $\begin{array}{r}3,715,311 \\
707,073 \\
3,980,862 \\
26,346,922 \\
4,248,983\end{array}$ & $\begin{array}{r}2,907,953 \\
628,178 \\
3,323,326 \\
21,582,546 \\
3,945,043\end{array}$ & $\begin{array}{r}807,358 \\
78,895 \\
657,537 \\
4,764,376 \\
303,940\end{array}$ & $\begin{array}{r}3,827,663 \\
739,971 \\
4,156,217 \\
26,413,997 \\
4,461,853\end{array}$ & $\begin{array}{r}1,224,213 \\
213,929 \\
1,376,912 \\
6,722,163 \\
740,774\end{array}$ & $\begin{array}{r}3,010,114 \\
663,378 \\
3,492,606 \\
21,789,774 \\
4,260,114\end{array}$ & $\begin{array}{r}940,090 \\
188,562 \\
1,130,233 \\
5,171,887 \\
661,828\end{array}$ & $\begin{array}{r}817,549 \\
76,594 \\
663,611 \\
4,624,223 \\
201,739\end{array}$ & $\begin{array}{r}284,123 \\
25,367 \\
246,679 \\
1,550,276 \\
78,946\end{array}$ \\
\hline 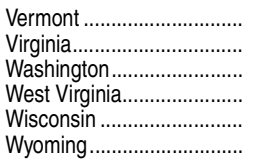 & $\begin{array}{r}718,762 \\
7,183,108 \\
6,714,962 \\
1,518,943 \\
5,499,072 \\
639,509\end{array}$ & $\begin{array}{r}761,182 \\
7,329,410 \\
6,874,560 \\
1,672,009 \\
5,757,793 \\
671,896\end{array}$ & $\begin{array}{r}793,941 \\
7,878,109 \\
7,312,805 \\
1,738,447 \\
5,974,368 \\
706,750\end{array}$ & $\begin{array}{r}757,661 \\
6,835,495 \\
5,871,046 \\
1,579,411 \\
4,635,981 \\
451,090\end{array}$ & $\begin{array}{r}36,280 \\
1,042,614 \\
1,441,759 \\
159,036 \\
1,338,387 \\
255,661\end{array}$ & $\begin{array}{r}799,662 \\
8,367,116 \\
7,402,548 \\
1,813,682 \\
5,942,717 \\
752,127\end{array}$ & $\begin{array}{r}210,880 \\
2,231,456 \\
2,139,459 \\
528,639 \\
1,806,595 \\
225,402\end{array}$ & $\begin{array}{r}762,660 \\
7,254,946 \\
6,055,036 \\
1,651,111 \\
4,629,546 \\
478,492\end{array}$ & $\begin{array}{r}200,699 \\
1,773,188 \\
1,580,896 \\
479,796 \\
1,179,633 \\
136,934\end{array}$ & $\begin{array}{r}37,002 \\
1,112,170 \\
1,347,512 \\
162,572 \\
1,313,171 \\
273,635\end{array}$ & $\begin{array}{r}10,182 \\
458,268 \\
558,563 \\
48,842 \\
626,962 \\
88,468\end{array}$ \\
\hline U.S. Service Academies.... & $1,844,822$ & $1,699,493$ & $1,653,288$ & $1,653,288$ & 0 & $1,679,549$ & 512,678 & $1,679,549$ & 512,678 & 0 & 0 \\
\hline Other jurisdictions....... & $1,721,830$ & $1,1,776,740$ & $1,1,698,347$ & $1,595,433$ & 102,914 & $1,727,062$ & 4886,963 & $1,625,469$ & $4 \quad 453,524$ & 101,592 & 33,439 \\
\hline $\begin{array}{l}\text { American Samoa ............... } \\
\text { Federated States of }\end{array}$ & 12,910 & 13,243 & 15,942 & 0 & 15,942 & 15,097 & 6,506 & 15,097 & 6,506 & 0 & ( \\
\hline $\begin{array}{l}\text { Micronesia } \\
\text { Guam }\end{array}$ & $\begin{array}{r}22,380 \\
106,784\end{array}$ & $\begin{array}{r}23,128 \\
115,262\end{array}$ & $\begin{array}{r}21,048 \\
125,565\end{array}$ & $\begin{array}{r}0 \\
93,324\end{array}$ & $\begin{array}{l}21,048 \\
32,242\end{array}$ & $\begin{array}{r}23,134 \\
136,515\end{array}$ & $\begin{array}{r}8,692 \\
31,051\end{array}$ & $\begin{array}{r}0 \\
99,800\end{array}$ & $\begin{array}{r}0 \\
20,099\end{array}$ & $\begin{array}{l}23,134 \\
36,715\end{array}$ & $\begin{array}{r}8,692 \\
10,952\end{array}$ \\
\hline Marshall Islands.... & 8,503 & 12,681 & 17,259 & & 17,259 & 18,381 & 3,441 & & & 18,381 & 3,441 \\
\hline Northern Marianas . & 13,945 & 14,619 & 20,214 & 20,214 & & 18,085 & 8,005 & 18,085 & 8,005 & 0 & \\
\hline 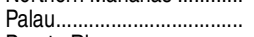 & 5,858 & 5,416 & 4,856 & 0 & 4,856 & 9,023 & 3,982 & 0 & 0 & 9,023 & \\
\hline $\begin{array}{l}\text { Puerto Rico.......................... } \\
\text { US. Virgin Islands }\end{array}$ & $\begin{array}{r}1,477,913 \\
73,536\end{array}$ & $\begin{array}{r}1,506,865 \\
85,525\end{array}$ & $\begin{array}{r}1,406,063 \\
87,400\end{array}$ & $1,394,495$ & 11,568 & $\begin{array}{r}1,418,143 \\
88,683\end{array}$ & 411,183 & $\begin{array}{r}1,403,804 \\
88,683\end{array}$ & 404,811 & 14,339 & 6 \\
\hline & & & & & & 88,683 & 14,104 & 88,683 & 14,104 & 0 & \\
\hline
\end{tabular}

${ }^{1}$ Includes other categories not separately shown.

${ }^{2}$ Excludes expenditures for operations and maintenance, interest, and depreciation, which are included in the total.

NOTE: Degree-granting institutions grant associate's or higher degrees and participate in Title IV federal financial aid programs. Includes data for public institutions reporting data according to either the Governmental Accounting Standards Board (GASB) or the Financial Accounting Standards Board (FASB) questionnaire. All expenditures reported by institutions for operation and maintenance of plant have been aggregated in the operation and maintenance of plant category, even in cases where they originally were reported by pur- pose. Similarly, all expenditures reported by institutions for depreciation have been aggregated in the depreciation category, even in cases where they originally were reported by purpose. In addition, all expenditures reported by institutions for interest have been aggregated in the interest category, even in cases where they originally were reported by purpose. Detail may not sum to totals because of rounding.

SOURCE: U.S. Department of Education, National Center for Education Statistics, Integrated Postsecondary Education Data System (IPEDS), Spring 2010 through Spring 2013, Finance component. (This table was prepared January 2014.) 
Table 334.30. Total expenditures of private nonprofit degree-granting postsecondary institutions, by purpose and level of institution: 1999-2000 through 2011-12

\begin{tabular}{|c|c|c|c|c|c|c|c|c|c|c|c|c|}
\hline Level of institution and year & Total & Instruction & Research & $\begin{array}{r}\text { Public } \\
\text { service }\end{array}$ & $\begin{array}{r}\text { Academic } \\
\text { support }\end{array}$ & $\begin{array}{c}\text { Student } \\
\text { services }\end{array}$ & $\begin{array}{r}\text { Institutional } \\
\text { support }\end{array}$ & $\begin{array}{r}\text { Auxiliary } \\
\text { enterprises }\end{array}$ & $\begin{array}{r}\text { Net grant } \\
\text { aid to } \\
\text { students }^{2}\end{array}$ & Hospitals & $\begin{array}{r}\text { Independent } \\
\text { operations }\end{array}$ & Other \\
\hline 1 & 2 & 3 & 4 & 5 & 6 & 7 & 8 & 9 & 10 & 11 & 12 & 13 \\
\hline & \multicolumn{12}{|c|}{ In thousands of current dollars } \\
\hline $\begin{array}{l}\text { All levels } \\
1999-2000 \\
2000-01 \\
2001-02 \ldots \\
2002-03 \\
2003-04\end{array}$ & $\begin{array}{r}\$ 80,613,037 \\
85,625,016 \\
92,192,297 \\
99,748,076 \\
104,317,870\end{array}$ & \begin{tabular}{|r|}
$\$ 26,012,599$ \\
$27,607,324$ \\
$29,689,041$ \\
$32,062,218$ \\
$33,909,179$
\end{tabular} & $\begin{array}{r}\$ 8,381,926 \\
9,025,739 \\
10,035,480 \\
11,079,532 \\
12,039,531\end{array}$ & $\begin{array}{r}\$ 1,446,958 \\
1,473,292 \\
1,665,884 \\
1,878,380 \\
1,972,351\end{array}$ & \begin{tabular}{|r|}
$\$ 6,510,951$ \\
$7,368,263$ \\
$7,802,637$ \\
$8,156,688$ \\
$8,759,743$
\end{tabular} & $\begin{array}{r}\$ 5,688,499 \\
6,117,195 \\
6,573,185 \\
7,096,223 \\
7,544,021\end{array}$ & \begin{tabular}{|r|}
$\$ 10,585,850$ \\
$11,434,074$ \\
$12,068,120$ \\
$13,157,744$ \\
$13,951,408$
\end{tabular} & \begin{tabular}{|r|}
$\$ 8,300,021$ \\
$9,010,853$ \\
$9,515,829$ \\
$9,936,478$ \\
$10,508,719$
\end{tabular} & $\begin{array}{r}\$ 1,180,882 \\
1,176,160 \\
1,188,690 \\
1,173,845 \\
1,101,738\end{array}$ & $\begin{array}{r}\$ 7,355,110 \\
7,255,376 \\
7,633,043 \\
7,586,208 \\
8,374,128\end{array}$ & \begin{tabular}{|r|}
$\$ 2,753,679$ \\
$3,134,609$ \\
$3,397,979$ \\
$3,879,736$ \\
$4,222,980$
\end{tabular} & $\begin{array}{r}\$ 2,396,563 \\
2,022,132 \\
2,622,409 \\
3,741,024 \\
1,934,070\end{array}$ \\
\hline 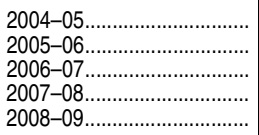 & $\begin{array}{l}110,394,127 \\
116,817,913 \\
124,557,725 \\
133,503,539 \\
141,349,229\end{array}$ & \begin{tabular}{|l|}
$36,258,473$ \\
$38,465,058$ \\
$41,223,483$ \\
$44,226,329$ \\
$46,452,942$
\end{tabular} & $\begin{array}{l}12,812,857 \\
13,242,343 \\
13,704,450 \\
14,474,367 \\
15,262,667\end{array}$ & $\begin{array}{l}2,000,437 \\
1,941,519 \\
2,036,588 \\
2,182,676 \\
2,298,526\end{array}$ & $\begin{array}{r}9,342,064 \\
10,217,274 \\
10,882,028 \\
11,884,345 \\
12,579,759\end{array}$ & $\begin{array}{r}8,191,737 \\
8,965,704 \\
9,591,334 \\
10,363,476 \\
11,012,204\end{array}$ & $\begin{array}{l}14,690,328 \\
15,667,101 \\
16,831,353 \\
18,364,513 \\
19,400,981\end{array}$ & \begin{tabular}{|l|}
$10,944,342$ \\
$11,741,258$ \\
$12,451,087$ \\
$13,319,602$ \\
$13,707,921$
\end{tabular} & $\begin{array}{r}1,069,591 \\
708,158 \\
728,139 \\
721,487 \\
757,852\end{array}$ & $\begin{array}{r}9,180,775 \\
9,645,428 \\
10,400,055 \\
10,754,966 \\
11,930,840\end{array}$ & $\begin{array}{l}4,223,779 \\
4,203,523 \\
4,680,393 \\
4,887,609 \\
5,158,480\end{array}$ & $\begin{array}{l}1,679,741 \\
2,020,548 \\
2,028,816 \\
2,324,170 \\
2,787,056\end{array}$ \\
\hline $\begin{array}{l}2009-10 \ldots \ldots \ldots \\
2010-11 \ldots \ldots \ldots \ldots \\
2011-12 \ldots \ldots \ldots \ldots \ldots \ldots \ldots . . \\
.\end{array}$ & $\begin{array}{l}145,141,785 \\
152,509,741 \\
159,873,305\end{array}$ & $\begin{array}{l}47,486,299 \\
49,692,506 \\
52,214,210\end{array}$ & $\begin{array}{l}16,155,474 \\
17,378,300 \\
17,430,156\end{array}$ & $\begin{array}{l}2,089,745 \\
2,255,102 \\
2,334,489\end{array}$ & \begin{tabular}{|l|}
$12,939,489$ \\
$13,609,316$ \\
$14,186,675$
\end{tabular} & $\begin{array}{l}11,416,177 \\
12,239,151 \\
12,881,771\end{array}$ & $\begin{array}{l}19,433,113 \\
20,234,530 \\
21,153,637\end{array}$ & \begin{tabular}{|l|}
$13,887,042$ \\
$14,457,573$ \\
$14,948,085$
\end{tabular} & $\begin{array}{l}832,078 \\
772,177 \\
845,319\end{array}$ & $\begin{array}{l}13,174,405 \\
14,239,347 \\
15,483,513\end{array}$ & $\begin{array}{l}5,154,851 \\
5,376,016 \\
5,450,073\end{array}$ & $\begin{array}{l}2,573,113 \\
2,255,722 \\
2,945,376\end{array}$ \\
\hline 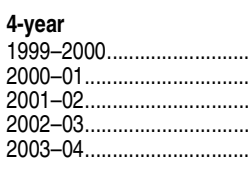 & $\begin{array}{r}79,699,659 \\
85,048,123 \\
91,612,337 \\
99,137,236 \\
103,733,257\end{array}$ & \begin{tabular}{|l|}
$25,744,199$ \\
$27,413,897$ \\
$29,492,583$ \\
$31,866,310$ \\
$33,712,542$
\end{tabular} & $\begin{array}{r}8,376,568 \\
9,019,966 \\
10,035,394 \\
11,079,332 \\
12,039,080\end{array}$ & $\begin{array}{l}1,438,544 \\
1,467,325 \\
1,658,781 \\
1,871,274 \\
1,964,898\end{array}$ & $\begin{array}{l}6,476,338 \\
7,333,851 \\
7,768,870 \\
8,122,181 \\
8,726,505\end{array}$ & $\begin{array}{l}5,590,978 \\
6,036,478 \\
6,497,127 \\
7,014,149 \\
7,466,472\end{array}$ & $\begin{array}{l}10,398,914 \\
11,292,310 \\
11,914,149 \\
12,996,836 \\
13,774,084\end{array}$ & \begin{tabular}{|r|}
$8,228,409$ \\
$8,957,973$ \\
$9,470,557$ \\
$9,876,937$ \\
$10,464,984$
\end{tabular} & $\begin{array}{l}1,162,570 \\
1,160,660 \\
1,173,725 \\
1,161,441 \\
1,084,880\end{array}$ & $\begin{array}{l}7,355,110 \\
7,253,479 \\
7,632,942 \\
7,586,208 \\
8,374,128\end{array}$ & $\begin{array}{l}2,752,019 \\
3,133,099 \\
3,396,831 \\
3,854,471 \\
4,221,611\end{array}$ & $\begin{array}{l}2,176,011 \\
1,979,086 \\
2,571,376 \\
3,708,098 \\
1,904,075\end{array}$ \\
\hline 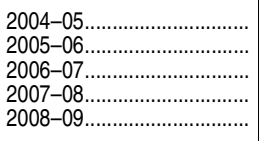 & $\begin{array}{l}109,789,731 \\
116,247,359 \\
124,061,478 \\
132,967,352 \\
140,852,609\end{array}$ & $\begin{array}{l}36,051,084 \\
38,249,125 \\
41,056,590 \\
44,041,162 \\
46,286,662\end{array}$ & $\begin{array}{l}12,812,326 \\
13,241,769 \\
13,703,502 \\
14,473,394 \\
15,262,322\end{array}$ & $\begin{array}{l}1,993,767 \\
1,931,804 \\
2,028,364 \\
2,176,695 \\
2,294,914\end{array}$ & \begin{tabular}{|r|}
$9,307,600$ \\
$10,177,381$ \\
$10,850,270$ \\
$11,847,922$ \\
$12,538,248$
\end{tabular} & $\begin{array}{r}8,101,214 \\
8,894,330 \\
9,522,535 \\
10,286,780 \\
10,943,745\end{array}$ & $\begin{array}{l}14,516,197 \\
15,524,004 \\
16,693,987 \\
18,216,170 \\
19,258,651\end{array}$ & \begin{tabular}{|l|}
$10,899,456$ \\
$11,696,510$ \\
$12,414,609$ \\
$13,281,694$ \\
$13,670,550$
\end{tabular} & $\begin{array}{r}1,051,216 \\
699,462 \\
714,398 \\
711,903 \\
750,687\end{array}$ & $\begin{array}{r}9,180,775 \\
9,645,428 \\
10,400,055 \\
10,754,966 \\
11,930,840\end{array}$ & $\begin{array}{l}4,223,779 \\
4,203,523 \\
4,680,393 \\
4,887,609 \\
5,158,480\end{array}$ & $\begin{array}{l}1,652,317 \\
1,984,024 \\
1,996,775 \\
2,289,058 \\
2,757,510\end{array}$ \\
\hline 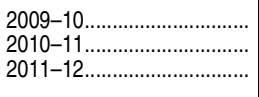 & $\begin{array}{l}144,651,140 \\
151,886,926 \\
159,287,851\end{array}$ & \begin{tabular}{|l|}
$47,320,761$ \\
$49,483,331$ \\
$52,010,324$
\end{tabular} & $\begin{array}{l}16,154,889 \\
17,378,015 \\
17,429,483\end{array}$ & $\begin{array}{l}2,084,704 \\
2,252,753 \\
2,332,440\end{array}$ & $\begin{array}{l}12,896,579 \\
13,555,980 \\
14,135,313\end{array}$ & $\begin{array}{l}11,347,049 \\
12,152,861 \\
12,796,288\end{array}$ & $\begin{array}{l}19,297,756 \\
20,068,168 \\
21,003,182\end{array}$ & \begin{tabular}{|l|}
$13,852,640$ \\
$14,427,590$ \\
$14,924,473$
\end{tabular} & $\begin{array}{l}824,895 \\
770,812 \\
843,247\end{array}$ & $\begin{array}{l}13,174,405 \\
14,239,347 \\
15,483,513\end{array}$ & $\begin{array}{l}5,154,851 \\
5,376,016 \\
5,450,073\end{array}$ & $\begin{array}{l}2,542,611 \\
2,182,053 \\
2,879,516\end{array}$ \\
\hline 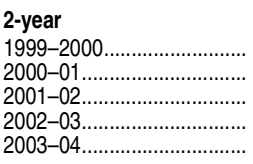 & $\begin{array}{l}913,378 \\
576,893 \\
579,960 \\
610,840 \\
584,612\end{array}$ & $\begin{array}{l}268,400 \\
193,428 \\
196,459 \\
195,909 \\
196,637\end{array}$ & $\begin{array}{r}5,358 \\
5,772 \\
86 \\
200 \\
451\end{array}$ & $\begin{array}{l}8,415 \\
5,967 \\
7,102 \\
7,106 \\
7,453\end{array}$ & $\begin{array}{l}34,612 \\
34,412 \\
33,767 \\
34,506 \\
33,238\end{array}$ & $\begin{array}{l}97,521 \\
80,717 \\
76,058 \\
82,074 \\
77,549\end{array}$ & $\begin{array}{l}186,936 \\
141,764 \\
153,971 \\
160,908 \\
177,324\end{array}$ & $\begin{array}{l}71,612 \\
52,880 \\
45,271 \\
59,541 \\
43,735\end{array}$ & $\begin{array}{l}18,311 \\
15,500 \\
14,965 \\
12,404 \\
16,859\end{array}$ & $\begin{array}{r}0 \\
1,896 \\
100 \\
0 \\
0\end{array}$ & $\begin{array}{r}1,660 \\
1,510 \\
1,147 \\
25,265 \\
1,369\end{array}$ & $\begin{array}{r}220,553 \\
43,046 \\
51,033 \\
32,926 \\
29,995\end{array}$ \\
\hline 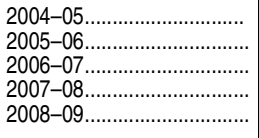 & $\begin{array}{l}604,395 \\
570,554 \\
496,247 \\
536,187 \\
496,620\end{array}$ & $\begin{array}{l}207,389 \\
215,934 \\
166,893 \\
185,167 \\
166,280\end{array}$ & $\begin{array}{l}532 \\
574 \\
947 \\
973 \\
345\end{array}$ & $\begin{array}{l}6,670 \\
9,715 \\
8,224 \\
5,982 \\
3,612\end{array}$ & $\begin{array}{l}34,464 \\
39,893 \\
31,758 \\
36,423 \\
41,511\end{array}$ & $\begin{array}{l}90,523 \\
71,374 \\
68,799 \\
76,696 \\
68,459\end{array}$ & $\begin{array}{l}174,131 \\
143,096 \\
137,366 \\
148,343 \\
142,330\end{array}$ & $\begin{array}{l}44,886 \\
44,748 \\
36,478 \\
37,908 \\
37,372\end{array}$ & $\begin{array}{r}18,375 \\
8,696 \\
13,741 \\
9,584 \\
7,165\end{array}$ & $\begin{array}{l}0 \\
0 \\
0 \\
0 \\
0\end{array}$ & $\begin{array}{l}0 \\
0 \\
0 \\
0 \\
0\end{array}$ & $\begin{array}{l}27,425 \\
36,524 \\
32,041 \\
35,112 \\
29,546\end{array}$ \\
\hline \multirow[t]{2}{*}{$\begin{array}{l}2009-10 \\
2010-11 \ldots \ldots \\
2011-12 \ldots \ldots \ldots \ldots \ldots \ldots\end{array}$} & $\begin{array}{l}490,645 \\
622,815 \\
585,454 \\
\end{array}$ & $\begin{array}{l}165,538 \\
209,176 \\
203,885 \\
\end{array}$ & $\begin{array}{l}585 \\
285 \\
673 \\
\end{array}$ & $\begin{array}{l}5,041 \\
2,349 \\
2,049 \\
\end{array}$ & $\begin{array}{l}42,909 \\
53,336 \\
51,363 \\
\end{array}$ & $\begin{array}{l}69,129 \\
86,290 \\
85,483 \\
\end{array}$ & $\begin{array}{l}135,357 \\
166,362 \\
150,455 \\
\end{array}$ & $\begin{array}{l}34,402 \\
29,983 \\
23,613\end{array}$ & $\begin{array}{l}7,183 \\
1,365 \\
2,072 \\
\end{array}$ & $\begin{array}{l}0 \\
0 \\
0 \\
\end{array}$ & $\begin{array}{l}0 \\
0 \\
0 \\
\end{array}$ & $\begin{array}{l}30,502 \\
73,669 \\
65,861 \\
\end{array}$ \\
\hline & \multicolumn{12}{|c|}{ Percentage distribution } \\
\hline 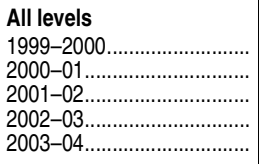 & $\begin{array}{l}100.00 \\
100.00 \\
100.00 \\
100.00 \\
100.00\end{array}$ & $\begin{array}{l}32.27 \\
32.24 \\
32.20 \\
32.14 \\
32.51\end{array}$ & $\begin{array}{l}10.40 \\
10.54 \\
10.89 \\
11.11 \\
11.54\end{array}$ & $\begin{array}{l}1.79 \\
1.72 \\
1.81 \\
1.88 \\
1.89\end{array}$ & $\begin{array}{l}8.08 \\
8.61 \\
8.46 \\
8.18 \\
8.40\end{array}$ & $\begin{array}{l}7.06 \\
7.14 \\
7.13 \\
7.11 \\
7.23\end{array}$ & $\begin{array}{l}13.13 \\
13.35 \\
13.09 \\
13.19 \\
13.37\end{array}$ & \begin{tabular}{r|}
10.30 \\
10.52 \\
10.32 \\
9.96 \\
10.07
\end{tabular} & $\begin{array}{l}1.46 \\
1.37 \\
1.29 \\
1.18 \\
1.06\end{array}$ & $\begin{array}{l}9.12 \\
8.47 \\
8.28 \\
7.61 \\
8.03\end{array}$ & $\begin{array}{l}3.42 \\
3.66 \\
3.69 \\
3.89 \\
4.05\end{array}$ & $\begin{array}{l}2.97 \\
2.36 \\
2.84 \\
3.75 \\
1.85\end{array}$ \\
\hline 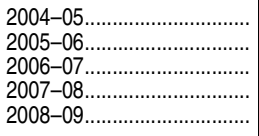 & $\begin{array}{l}100.00 \\
100.00 \\
100.00 \\
100.00 \\
100.00\end{array}$ & $\begin{array}{l}32.84 \\
32.93 \\
33.10 \\
33.13 \\
32.86\end{array}$ & $\begin{array}{l}11.61 \\
11.34 \\
11.00 \\
10.84 \\
10.80\end{array}$ & $\begin{array}{l}1.81 \\
1.66 \\
1.64 \\
1.63 \\
1.63\end{array}$ & $\begin{array}{l}8.46 \\
8.75 \\
8.74 \\
8.90 \\
8.90\end{array}$ & $\begin{array}{l}7.42 \\
7.67 \\
7.70 \\
7.76 \\
7.79\end{array}$ & $\begin{array}{l}13.31 \\
13.41 \\
13.51 \\
13.76 \\
13.73\end{array}$ & $\begin{array}{r}9.91 \\
10.05 \\
10.00 \\
9.98 \\
9.70\end{array}$ & $\begin{array}{l}0.97 \\
0.61 \\
0.58 \\
0.54 \\
0.54\end{array}$ & $\begin{array}{l}8.32 \\
8.26 \\
8.35 \\
8.06 \\
8.44\end{array}$ & $\begin{array}{l}3.83 \\
3.60 \\
3.76 \\
3.66 \\
3.65\end{array}$ & $\begin{array}{l}1.52 \\
1.73 \\
1.63 \\
1.74 \\
1.97\end{array}$ \\
\hline 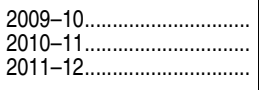 & $\begin{array}{l}100.00 \\
100.00 \\
100.00\end{array}$ & $\begin{array}{l}32.72 \\
32.58 \\
32.66\end{array}$ & $\begin{array}{l}11.13 \\
11.39 \\
10.90\end{array}$ & $\begin{array}{l}1.44 \\
1.48 \\
1.46\end{array}$ & $\begin{array}{l}8.92 \\
8.92 \\
8.87\end{array}$ & $\begin{array}{l}7.87 \\
8.03 \\
8.06\end{array}$ & $\begin{array}{l}13.39 \\
13.27 \\
13.23\end{array}$ & $\begin{array}{l}9.57 \\
9.48 \\
9.35\end{array}$ & $\begin{array}{l}0.57 \\
0.51 \\
0.53\end{array}$ & $\begin{array}{l}9.08 \\
9.34 \\
9.68\end{array}$ & $\begin{array}{l}3.55 \\
3.53 \\
3.41\end{array}$ & $\begin{array}{l}1.77 \\
1.48 \\
1.84\end{array}$ \\
\hline 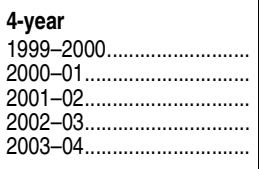 & $\begin{array}{l}100.00 \\
100.00 \\
100.00 \\
100.00 \\
100.00\end{array}$ & $\begin{array}{l}32.30 \\
32.23 \\
32.19 \\
32.14 \\
32.50\end{array}$ & $\begin{array}{l}10.51 \\
10.61 \\
10.95 \\
11.18 \\
11.61\end{array}$ & $\begin{array}{l}1.80 \\
1.73 \\
1.81 \\
1.89 \\
1.89\end{array}$ & $\begin{array}{l}8.13 \\
8.62 \\
8.48 \\
8.19 \\
8.41\end{array}$ & $\begin{array}{l}7.02 \\
7.10 \\
7.09 \\
7.08 \\
7.20\end{array}$ & $\begin{array}{l}13.05 \\
13.28 \\
13.00 \\
13.11 \\
13.28\end{array}$ & $\begin{array}{r}10.32 \\
10.53 \\
10.34 \\
9.96 \\
10.09\end{array}$ & $\begin{array}{l}1.46 \\
1.36 \\
1.28 \\
1.17 \\
1.05\end{array}$ & $\begin{array}{l}9.23 \\
8.53 \\
8.33 \\
7.65 \\
8.07\end{array}$ & $\begin{array}{l}3.45 \\
3.68 \\
3.71 \\
3.89 \\
4.07\end{array}$ & $\begin{array}{l}2.73 \\
2.33 \\
2.81 \\
3.74 \\
1.84\end{array}$ \\
\hline 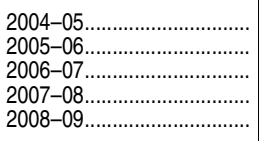 & $\begin{array}{l}100.00 \\
100.00 \\
100.00 \\
100.00 \\
100.00\end{array}$ & $\begin{array}{l}32.84 \\
32.90 \\
33.09 \\
33.12 \\
32.86\end{array}$ & $\begin{array}{l}11.67 \\
11.39 \\
11.05 \\
10.88 \\
10.84\end{array}$ & $\begin{array}{l}1.82 \\
1.66 \\
1.63 \\
1.64 \\
1.63\end{array}$ & $\begin{array}{l}8.48 \\
8.75 \\
8.75 \\
8.91 \\
8.90\end{array}$ & $\begin{array}{l}7.38 \\
7.65 \\
7.68 \\
7.74 \\
7.77\end{array}$ & $\begin{array}{l}13.22 \\
13.35 \\
13.46 \\
13.70 \\
13.67\end{array}$ & $\begin{array}{r}9.93 \\
10.06 \\
10.01 \\
9.99 \\
9.71\end{array}$ & $\begin{array}{l}0.96 \\
0.60 \\
0.58 \\
0.54 \\
0.53\end{array}$ & $\begin{array}{l}8.36 \\
8.30 \\
8.38 \\
8.09 \\
8.47\end{array}$ & $\begin{array}{l}3.85 \\
3.62 \\
3.77 \\
3.68 \\
3.66\end{array}$ & $\begin{array}{l}1.50 \\
1.71 \\
1.61 \\
1.72 \\
1.96\end{array}$ \\
\hline 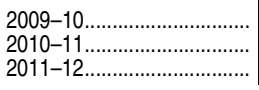 & $\begin{array}{l}100.00 \\
100.00 \\
100.00\end{array}$ & $\begin{array}{l}32.71 \\
32.58 \\
32.65\end{array}$ & $\begin{array}{l}11.17 \\
11.44 \\
10.94\end{array}$ & $\begin{array}{l}1.44 \\
1.48 \\
1.46\end{array}$ & $\begin{array}{l}8.92 \\
8.93 \\
8.87\end{array}$ & $\begin{array}{l}7.84 \\
8.00 \\
8.03\end{array}$ & $\begin{array}{l}13.34 \\
13.21 \\
13.19\end{array}$ & $\begin{array}{l}9.58 \\
9.50 \\
9.37\end{array}$ & $\begin{array}{l}0.57 \\
0.51 \\
0.53\end{array}$ & $\begin{array}{l}9.11 \\
9.37 \\
9.72\end{array}$ & $\begin{array}{l}3.56 \\
3.54 \\
3.42\end{array}$ & $\begin{array}{l}1.76 \\
1.44 \\
1.81\end{array}$ \\
\hline
\end{tabular}


Table 334.30. Total expenditures of private nonprofit degree-granting postsecondary institutions, by purpose and level of institution: 1999-2000 through 2011-12-Continued

\begin{tabular}{|c|c|c|c|c|c|c|c|c|c|c|c|c|}
\hline Level of institution and year & Total & Instruction & Research & $\begin{array}{r}\text { Public } \\
\text { service }\end{array}$ & $\begin{array}{r}\text { Academic } \\
\text { support }\end{array}$ & $\begin{array}{r}\text { Student } \\
\text { services }\end{array}$ & $\begin{array}{r}\text { Institutional } \\
\text { support }\end{array}$ & $\begin{array}{r}\text { Auxiliary } \\
\text { enterprises }^{1}\end{array}$ & $\begin{array}{r}\text { Net grant } \\
\text { aid to } \\
\text { students }^{2}\end{array}$ & Hospitals & $\begin{array}{r}\text { Independent } \\
\text { operations }\end{array}$ & Other \\
\hline 1 & 2 & 3 & 4 & 5 & 6 & 7 & 8 & 9 & 10 & 11 & 12 & 13 \\
\hline 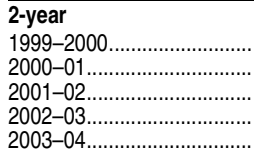 & $\begin{array}{l}100.00 \\
100.00 \\
100.00 \\
100.00 \\
100.00\end{array}$ & $\begin{array}{l}29.39 \\
33.53 \\
33.87 \\
32.07 \\
33.64\end{array}$ & $\begin{array}{l}0.59 \\
1.00 \\
0.01 \\
0.03 \\
0.08\end{array}$ & $\begin{array}{l}0.92 \\
1.03 \\
1.22 \\
1.16 \\
1.27\end{array}$ & $\begin{array}{l}3.79 \\
5.96 \\
5.82 \\
5.65 \\
5.69\end{array}$ & $\begin{array}{l}10.68 \\
13.99 \\
13.11 \\
13.44 \\
13.27\end{array}$ & $\begin{array}{l}20.47 \\
24.57 \\
26.55 \\
26.34 \\
30.33\end{array}$ & $\begin{array}{l}7.84 \\
9.17 \\
7.81 \\
9.75 \\
7.48\end{array}$ & $\begin{array}{l}2.00 \\
2.69 \\
2.58 \\
2.03 \\
2.88\end{array}$ & $\begin{array}{l}0.00 \\
0.33 \\
0.02 \\
0.00 \\
0.00\end{array}$ & $\begin{array}{l}0.18 \\
0.26 \\
0.20 \\
4.14 \\
0.23\end{array}$ & $\begin{array}{r}24.15 \\
7.46 \\
8.80 \\
5.39 \\
5.13\end{array}$ \\
\hline $\begin{array}{l}2004-05 \\
2005-06 \\
2006-07 \\
2007-08 \ldots \ldots \ldots \ldots \ldots \ldots \ldots \ldots \\
2008-09 \ldots \ldots \ldots\end{array}$ & $\begin{array}{l}100.00 \\
100.00 \\
100.00 \\
100.00 \\
100.00\end{array}$ & $\begin{array}{l}34.31 \\
37.85 \\
33.63 \\
34.53 \\
33.48\end{array}$ & $\begin{array}{l}0.09 \\
0.10 \\
0.19 \\
0.18 \\
0.07\end{array}$ & $\begin{array}{l}1.10 \\
1.70 \\
1.66 \\
1.12 \\
0.73\end{array}$ & $\begin{array}{l}5.70 \\
6.99 \\
6.40 \\
6.79 \\
8.36\end{array}$ & $\begin{array}{l}14.98 \\
12.51 \\
13.86 \\
14.30 \\
13.78\end{array}$ & $\begin{array}{l}28.81 \\
25.08 \\
27.68 \\
27.67 \\
28.66\end{array}$ & $\begin{array}{l}7.43 \\
7.84 \\
7.35 \\
7.07 \\
7.53\end{array}$ & $\begin{array}{l}3.04 \\
1.52 \\
2.77 \\
1.79 \\
1.44\end{array}$ & $\begin{array}{l}0.00 \\
0.00 \\
0.00 \\
0.00 \\
0.00\end{array}$ & $\begin{array}{l}0.00 \\
0.00 \\
0.00 \\
0.00 \\
0.00\end{array}$ & $\begin{array}{l}4.54 \\
6.40 \\
6.46 \\
6.55 \\
5.95\end{array}$ \\
\hline 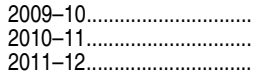 & $\begin{array}{l}100.00 \\
100.00 \\
100.00 \\
\end{array}$ & $\begin{array}{l}33.74 \\
33.59 \\
34.83 \\
\end{array}$ & $\begin{array}{l}0.12 \\
0.05 \\
0.11 \\
\end{array}$ & $\begin{array}{l}1.03 \\
0.38 \\
0.35 \\
\end{array}$ & $\begin{array}{l}8.75 \\
8.56 \\
8.77 \\
\end{array}$ & $\begin{array}{l}14.09 \\
13.85 \\
14.60 \\
\end{array}$ & $\begin{array}{l}27.59 \\
26.71 \\
25.70 \\
\end{array}$ & $\begin{array}{l}7.01 \\
4.81 \\
4.03\end{array}$ & $\begin{array}{l}1.46 \\
0.22 \\
0.35 \\
\end{array}$ & $\begin{array}{l}0.00 \\
0.00 \\
0.00\end{array}$ & $\begin{array}{l}0.00 \\
0.00 \\
0.00 \\
\end{array}$ & $\begin{array}{r}6.22 \\
11.83 \\
11.25 \\
\end{array}$ \\
\hline & \multicolumn{12}{|c|}{ Expenditure per full-time-equivalent student in constant 2012-13 dollars ${ }^{3}$} \\
\hline 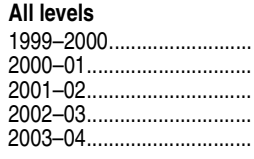 & $\begin{array}{r}\$ 43,390 \\
43,695 \\
45,235 \\
46,343 \\
46,297\end{array}$ & $\begin{array}{r}\$ 14,001 \\
14,088 \\
14,567 \\
14,896 \\
15,049\end{array}$ & $\begin{array}{r}\$ 4,512 \\
4,606 \\
4,924 \\
5,148 \\
5,343\end{array}$ & $\begin{array}{r}\$ 779 \\
752 \\
817 \\
873 \\
875\end{array}$ & $\begin{array}{r}\$ 3,505 \\
3,760 \\
3,828 \\
3,790 \\
3,888\end{array}$ & $\begin{array}{r}\$ 3,062 \\
3,122 \\
3,225 \\
3,297 \\
3,348\end{array}$ & $\begin{array}{r}\$ 5,698 \\
5,835 \\
5,921 \\
6,113 \\
6,192\end{array}$ & $\begin{array}{r}\$ 4,468 \\
4,598 \\
4,669 \\
4,616 \\
4,664\end{array}$ & $\begin{array}{r}\$ 636 \\
600 \\
583 \\
545 \\
489\end{array}$ & $\begin{array}{r}\$ 3,959 \\
3,702 \\
3,745 \\
3,525 \\
3,717\end{array}$ & $\begin{array}{r}\$ 1,482 \\
1,600 \\
1,667 \\
1,803 \\
1,874\end{array}$ & $\begin{array}{r}\$ 1,290 \\
1,032 \\
1,287 \\
1,738 \\
858\end{array}$ \\
\hline 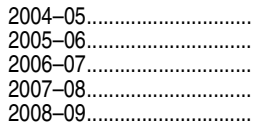 & $\begin{array}{l}46,432 \\
46,686 \\
47,667 \\
48,060 \\
49,419\end{array}$ & $\begin{array}{l}15,250 \\
15,372 \\
15,776 \\
15,921 \\
16,241\end{array}$ & $\begin{array}{l}5,389 \\
5,292 \\
5,245 \\
5,211 \\
5,336\end{array}$ & $\begin{array}{l}841 \\
776 \\
779 \\
786 \\
804\end{array}$ & $\begin{array}{l}3,929 \\
4,083 \\
4,164 \\
4,278 \\
4,398\end{array}$ & $\begin{array}{l}3,445 \\
3,583 \\
3,671 \\
3,731 \\
3,850\end{array}$ & $\begin{array}{l}6,179 \\
6,261 \\
6,441 \\
6,611 \\
6,783\end{array}$ & $\begin{array}{l}4,603 \\
4,692 \\
4,765 \\
4,795 \\
4,793\end{array}$ & $\begin{array}{l}450 \\
283 \\
279 \\
260 \\
265\end{array}$ & $\begin{array}{l}3,861 \\
3,855 \\
3,980 \\
3,872 \\
4,171\end{array}$ & $\begin{array}{l}1,777 \\
1,680 \\
1,791 \\
1,759 \\
1,804\end{array}$ & $\begin{array}{l}706 \\
808 \\
776 \\
837 \\
974\end{array}$ \\
\hline $\begin{array}{l}2009-10 \\
2010-11 \\
2011-12\end{array}$ & $\begin{array}{l}49,006 \\
48,574 \\
49,036\end{array}$ & $\begin{array}{l}16,033 \\
15,827 \\
16,015\end{array}$ & $\begin{array}{l}5,455 \\
5,535 \\
5,346\end{array}$ & $\begin{array}{l}706 \\
718 \\
716\end{array}$ & $\begin{array}{l}4,369 \\
4,335 \\
4,351\end{array}$ & $\begin{array}{l}3,855 \\
3,898 \\
3,951\end{array}$ & $\begin{array}{l}6,561 \\
6,445 \\
6,488\end{array}$ & $\begin{array}{l}4,689 \\
4,605 \\
4,585\end{array}$ & $\begin{array}{l}281 \\
246 \\
259\end{array}$ & $\begin{array}{l}4,448 \\
4,535 \\
4,749\end{array}$ & $\begin{array}{l}1,740 \\
1,712 \\
1,672\end{array}$ & $\begin{array}{l}869 \\
718 \\
903\end{array}$ \\
\hline 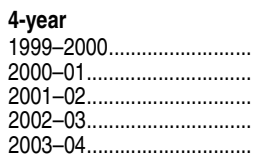 & $\begin{array}{l}43,818 \\
44,078 \\
45,622 \\
46,678 \\
46,625\end{array}$ & $\begin{array}{l}14,154 \\
14,208 \\
14,687 \\
15,004 \\
15,153\end{array}$ & $\begin{array}{l}4,605 \\
4,675 \\
4,998 \\
5,217 \\
5,411\end{array}$ & $\begin{array}{l}791 \\
760 \\
826 \\
881 \\
883\end{array}$ & $\begin{array}{l}3,561 \\
3,801 \\
3,869 \\
3,824 \\
3,922\end{array}$ & $\begin{array}{l}3,074 \\
3,129 \\
3,236 \\
3,303 \\
3,356\end{array}$ & $\begin{array}{l}5,717 \\
5,853 \\
5,933 \\
6,119 \\
6,191\end{array}$ & $\begin{array}{l}4,524 \\
4,643 \\
4,716 \\
4,650 \\
4,704\end{array}$ & $\begin{array}{l}639 \\
602 \\
585 \\
547 \\
488\end{array}$ & $\begin{array}{l}4,044 \\
3,759 \\
3,801 \\
3,572 \\
3,764\end{array}$ & $\begin{array}{l}1,513 \\
1,624 \\
1,692 \\
1,815 \\
1,898\end{array}$ & $\begin{array}{r}1,196 \\
1,026 \\
1,281 \\
1,746 \\
856\end{array}$ \\
\hline 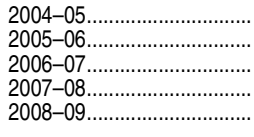 & $\begin{array}{l}46,738 \\
46,963 \\
47,889 \\
48,296 \\
49,663\end{array}$ & $\begin{array}{l}15,347 \\
15,452 \\
15,848 \\
15,996 \\
16,320\end{array}$ & $\begin{array}{l}5,454 \\
5,350 \\
5,290 \\
5,257 \\
5,381\end{array}$ & $\begin{array}{l}849 \\
780 \\
783 \\
791 \\
809\end{array}$ & $\begin{array}{l}3,962 \\
4,112 \\
4,188 \\
4,303 \\
4,421\end{array}$ & $\begin{array}{l}3,449 \\
3,593 \\
3,676 \\
3,736 \\
3,859\end{array}$ & $\begin{array}{l}6,180 \\
6,272 \\
6,444 \\
6,616 \\
6,790\end{array}$ & $\begin{array}{l}4,640 \\
4,725 \\
4,792 \\
4,824 \\
4,820\end{array}$ & $\begin{array}{l}448 \\
283 \\
276 \\
259 \\
265\end{array}$ & $\begin{array}{l}3,908 \\
3,897 \\
4,015 \\
3,906 \\
4,207\end{array}$ & $\begin{array}{l}1,798 \\
1,698 \\
1,807 \\
1,775 \\
1,819\end{array}$ & $\begin{array}{l}703 \\
802 \\
771 \\
831 \\
972\end{array}$ \\
\hline $\begin{array}{l}2009-10 \\
2010-11 \ldots \ldots \ldots \ldots \ldots \ldots \ldots \ldots \ldots \\
2011-12 \ldots \ldots \ldots \ldots \ldots \ldots \ldots \ldots \ldots . .\end{array}$ & $\begin{array}{l}49,241 \\
48,895 \\
49,341\end{array}$ & $\begin{array}{l}16,109 \\
15,929 \\
16,111\end{array}$ & $\begin{array}{l}5,499 \\
5,594 \\
5,399\end{array}$ & $\begin{array}{l}710 \\
725 \\
722\end{array}$ & $\begin{array}{l}4,390 \\
4,364 \\
4,379\end{array}$ & $\begin{array}{l}3,863 \\
3,912 \\
3,964\end{array}$ & $\begin{array}{l}6,569 \\
6,460 \\
6,506\end{array}$ & $\begin{array}{l}4,716 \\
4,644 \\
4,623\end{array}$ & $\begin{array}{l}281 \\
248 \\
261\end{array}$ & $\begin{array}{l}4,485 \\
4,584 \\
4,796\end{array}$ & $\begin{array}{l}1,755 \\
1,731 \\
1,688\end{array}$ & $\begin{array}{l}866 \\
702 \\
892\end{array}$ \\
\hline 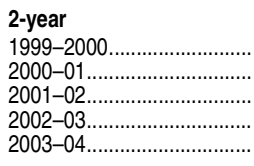 & $\begin{array}{l}23,435 \\
19,151 \\
19,332 \\
21,401 \\
20,589\end{array}$ & $\begin{array}{l}6,886 \\
6,421 \\
6,549 \\
6,864 \\
6,925\end{array}$ & $\begin{array}{r}137 \\
192 \\
3 \\
7 \\
16\end{array}$ & $\begin{array}{l}216 \\
198 \\
237 \\
249 \\
262\end{array}$ & $\begin{array}{r}888 \\
1,142 \\
1,126 \\
1,209 \\
1,171\end{array}$ & $\begin{array}{l}2,502 \\
2,680 \\
2,535 \\
2,875 \\
2,731\end{array}$ & $\begin{array}{l}4,796 \\
4,706 \\
5,132 \\
5,637 \\
6,245\end{array}$ & $\begin{array}{l}1,837 \\
1,755 \\
1,509 \\
2,086 \\
1,540\end{array}$ & $\begin{array}{l}470 \\
515 \\
499 \\
435 \\
594\end{array}$ & $\begin{array}{r}0 \\
63 \\
3 \\
0 \\
0\end{array}$ & $\begin{array}{r}43 \\
50 \\
38 \\
885 \\
48\end{array}$ & $\begin{array}{l}5,659 \\
1,429 \\
1,701 \\
1,154 \\
1,056\end{array}$ \\
\hline 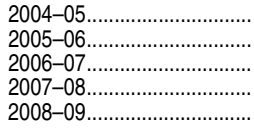 & $\begin{array}{l}21,184 \\
21,206 \\
22,097 \\
21,711 \\
20,616\end{array}$ & $\begin{array}{l}7,269 \\
8,026 \\
7,432 \\
7,498 \\
6,903\end{array}$ & $\begin{array}{l}19 \\
21 \\
42 \\
39 \\
14\end{array}$ & $\begin{array}{l}234 \\
361 \\
366 \\
242 \\
150\end{array}$ & $\begin{array}{l}1,208 \\
1,483 \\
1,414 \\
1,475 \\
1,723\end{array}$ & $\begin{array}{l}3,173 \\
2,653 \\
3,064 \\
3,106 \\
2,842\end{array}$ & $\begin{array}{l}6,103 \\
5,318 \\
6,117 \\
6,007 \\
5,909\end{array}$ & $\begin{array}{l}1,573 \\
1,663 \\
1,624 \\
1,535 \\
1,551\end{array}$ & $\begin{array}{l}644 \\
323 \\
612 \\
388 \\
297\end{array}$ & $\begin{array}{l}0 \\
0 \\
0 \\
0 \\
0\end{array}$ & $\begin{array}{l}0 \\
0 \\
0 \\
0 \\
0\end{array}$ & $\begin{array}{r}961 \\
1,357 \\
1,427 \\
1,422 \\
1,227\end{array}$ \\
\hline $\begin{array}{l}2009-10 \\
2010-11 \\
2011-12 \ldots \ldots \ldots \ldots\end{array}$ & $\begin{array}{l}20,314 \\
18,698 \\
18,295\end{array}$ & $\begin{array}{l}6,854 \\
6,280 \\
6,371\end{array}$ & $\begin{array}{r}24 \\
9 \\
21\end{array}$ & $\begin{array}{r}209 \\
71 \\
64\end{array}$ & $\begin{array}{l}1,777 \\
1,601 \\
1,605\end{array}$ & $\begin{array}{l}2,862 \\
2,591 \\
2,671\end{array}$ & $\begin{array}{l}5,604 \\
4,994 \\
4,702\end{array}$ & $\begin{array}{r}1,424 \\
900 \\
738\end{array}$ & $\begin{array}{r}297 \\
41 \\
65\end{array}$ & $\begin{array}{l}0 \\
0 \\
0\end{array}$ & $\begin{array}{l}0 \\
0 \\
0\end{array}$ & $\begin{array}{l}1,263 \\
2,212 \\
2,058\end{array}$ \\
\hline
\end{tabular}

${ }^{1}$ Essentially self-supporting operations of institutions that furnish a service to students, faculty, or staff, such as residence halls and food services.

Excludes tuition, fee, and auxiliary enterprise allowances and agency transactions, such as student awards made from contributed funds or grant funds. These exclusions accoun for the majority of total student grants.

${ }^{3}$ Constant dollars based on the Consumer Price Index, prepared by the Bureau of Labor Statistics, U.S. Department of Labor, adjusted to a school-year basis.
NOTE: Degree-granting institutions grant associate's or higher degrees and participate in Title IV federal financial aid programs. Detail may not sum to totals because of rounding. SOURCE: U.S. Department of Education, National Center for Education Statistics, Integrated Postsecondary Education Data System (IPEDS), Spring 2001 through Spring 2012, Enrollment component; and Spring 2002 through Spring 2013, Finance component. (This table was prepared January 2014.) 
Table 334.40. Total expenditures of private nonprofit degree-granting postsecondary institutions, by purpose and classification of institution: 2011-12

\begin{tabular}{|c|c|c|c|c|c|c|c|c|c|c|c|c|}
\hline Classification of institution & Total & Instruction & Research & $\begin{array}{l}\text { Public } \\
\text { service }\end{array}$ & $\begin{array}{r}\text { Academic } \\
\text { support }\end{array}$ & $\begin{array}{l}\text { Student } \\
\text { services }\end{array}$ & $\begin{array}{r}\text { Institutional } \\
\text { support }\end{array}$ & $\begin{array}{r}\text { Auxiliary } \\
\text { enterprises }^{1}\end{array}$ & $\begin{array}{r}\text { Net grant } \\
\text { aid to } \\
\text { students }^{2}\end{array}$ & Hospitals & $\begin{array}{r}\text { Independent } \\
\text { operations }\end{array}$ & Other \\
\hline 1 & 2 & 3 & 4 & 5 & 6 & 7 & 8 & 9 & 10 & 11 & 12 & 13 \\
\hline & \multicolumn{12}{|c|}{ In thousands of current dollars } \\
\hline Total...... & $\$ 159,873,305$ & $\$ 52,214,210$ & $\$ 17,430,156$ & $\$ 2,334,489$ & $\$ 14,186,675$ & $\$ 12,881,771$ & $\$ 21,153,637$ & $\$ 14,948,085$ & $\$ 845,319$ & $\$ 15,483,513$ & $\$ 5,450,073$ & $\$ 2,945,376$ \\
\hline 4-year..... & $159,287,851$ & $52,010,324$ & $17,429,483$ & $2,332,440$ & $14,135,313$ & $12,796,288$ & $21,003,182$ & $14,924,473$ & 843,247 & $15,483,513$ & $5,450,073$ & $2,879,516$ \\
\hline Research university, very high ${ }^{3} . .$. & $75,062,746$ & $22,578,702$ & $14,048,235$ & 915,700 & $5,319,337$ & $2,682,330$ & $6,390,965$ & $4,694,616$ & 534,660 & $12,024,449$ & $4,356,661$ & $1,517,092$ \\
\hline 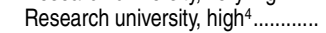 & $11,663,973$ & $4,246,545$ & $1,050,017$ & 186,635 & $1,703,822$ & 858,221 & $1,581,765$ & $1,474,453$ & 26,359 & 480,140 & 53,068 & 2,948 \\
\hline Doctoral/research ${ }^{5} \ldots \ldots \ldots \ldots \ldots \ldots$ & $7,539,964$ & $3,049,254$ & 231,254 & 117,883 & 869,434 & 921,486 & $1,333,863$ & 967,124 & 7,824 & 0 & 20,473 & 21,370 \\
\hline 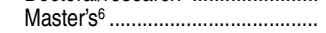 & $27,087,760$ & $10,405,904$ & 286,883 & 288,665 & $2,725,249$ & $4,073,331$ & $5,169,105$ & $3,556,934$ & 100,565 & 100,865 & 117,302 & 262,958 \\
\hline Baccalaureate $^{7} \ldots \ldots \ldots \ldots \ldots \ldots \ldots$ & $21,668,985$ & $7,682,396$ & 253,565 & 204,064 & $1,869,038$ & $3,382,887$ & $4,170,596$ & $3,529,050$ & 117,313 & 6,028 & 63,215 & 390,833 \\
\hline Special-focus institutions ${ }^{8}$. & $16,264,423$ & $4,047,523$ & $1,559,530$ & 619,494 & $1,648,433$ & 878,033 & $2,356,889$ & 702,295 & 56,526 & $2,872,031$ & 839,354 & 684,314 \\
\hline 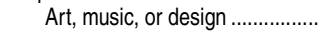 & $2,069,096$ & 858,339 & 910 & 22,193 & 225,618 & 208,902 & 436,958 & 219,052 & 7,450 & 0 & 26,177 & 63,498 \\
\hline Business and management ..... & 581,438 & 205,372 & 5,505 & 791 & 59,094 & 80,320 & 135,493 & 66,408 & 58 & 0 & 0 & 28,396 \\
\hline Engineering or technology ....... & 172,296 & 73,027 & 3,175 & 4 & 12,702 & 28,891 & 36,478 & 13,823 & 2,167 & 0 & 57 & 1,972 \\
\hline 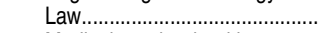 & 631,450 & 275,187 & 7,222 & 13,963 & 92,938 & 79,172 & 138,730 & 16,040 & 1,870 & 0 & 1,850 & 4,478 \\
\hline Medical or other health ............... & $10,671,447$ & $1,937,718$ & $1,536,413$ & 499,375 & $1,063,237$ & 285,418 & $1,038,862$ & 188,349 & 10,650 & $2,872,031$ & 799,101 & 440,293 \\
\hline 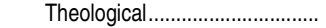 & $1,757,432$ & 547,210 & 3,610 & 56,735 & 166,605 & 158,454 & 475,076 & 173,720 & 30,716 & 0 & 10,712 & 134,593 \\
\hline Tribal $^{9}$ & 107,116 & 35,322 & 428 & 8,925 & 5,287 & 16,520 & 24,829 & 2,379 & 2,981 & 0 & 1,457 & 8,988 \\
\hline Other special focus ....................... & 274,148 & 115,348 & 2,267 & 17,508 & 22,952 & 20,356 & 70,463 & 22,525 & 633 & 0 & 0 & 2,096 \\
\hline 2 -year......... & 585,454 & 203,885 & 673 & 2,049 & 51,363 & 85,483 & 150,455 & 23,613 & 2,072 & 0 & 0 & 65,861 \\
\hline Associate's of arts... & 569,564 & 201,498 & 433 & 1,730 & 50,451 & 84,070 & 146,143 & 23,264 & 641 & 0 & 0 & 61,335 \\
\hline \multirow[t]{2}{*}{ 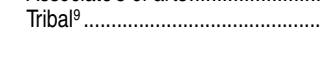 } & 15,890 & 2,388 & 240 & 320 & 912 & 1,413 & 4,312 & 348 & 1,431 & 0 & 0 & 4,526 \\
\hline & \multicolumn{12}{|c|}{ Percentage distribution } \\
\hline 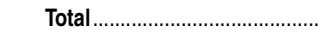 & 100.00 & 32.66 & 10.90 & 1.46 & 8.87 & 8.06 & 13.23 & 9.35 & 0.53 & 9.68 & 3.41 & 1.84 \\
\hline 4-year... & 100.00 & 32.65 & 10.94 & 1.46 & 8.87 & 8.03 & 13.19 & 9.37 & 0.53 & 9.72 & 3.42 & 1.81 \\
\hline Research university, very high ${ }^{3} \ldots$ & 100.00 & 30.08 & 18.72 & 1.22 & 7.09 & 3.57 & 8.51 & 6.25 & 0.71 & 16.02 & 5.80 & 2.02 \\
\hline Research university, high ${ }^{4} \ldots \ldots \ldots \ldots . . . . .$. & 100.00 & 36.41 & 9.00 & 1.60 & 14.61 & 7.36 & 13.56 & 12.64 & 0.23 & 4.12 & 0.45 & 0.03 \\
\hline Doctoral//research ${ }^{5} \ldots \ldots \ldots \ldots$ & 100.00 & 40.44 & 3.07 & 1.56 & 11.53 & 12.22 & 17.69 & 12.83 & 0.10 & 0.00 & 0.27 & 0.28 \\
\hline Master's 6 & 100.00 & 38.42 & 1.06 & 1.07 & 10.06 & 15.04 & 19.08 & 13.13 & 0.37 & 0.37 & 0.43 & 0.97 \\
\hline Baccalaureate ${ }^{7}$. & 100.00 & 35.45 & 1.17 & 0.94 & 8.63 & 15.61 & 19.25 & 16.29 & 0.54 & 0.03 & 0.29 & 1.80 \\
\hline Special-focus institutions ${ }^{8} \ldots$ & 100.00 & 24.89 & 9.59 & 3.81 & 10.14 & 5.40 & 14.49 & 4.32 & 0.35 & 17.66 & 5.16 & 4.21 \\
\hline 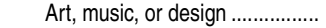 & 100.00 & 41.48 & 0.04 & 1.07 & 10.90 & 10.10 & 21.12 & 10.59 & 0.36 & 0.00 & 1.27 & 3.07 \\
\hline Business and management ..... & 100.00 & 35.32 & 0.95 & 0.14 & 10.16 & 13.81 & 23.30 & 11.42 & 0.01 & 0.00 & 0.00 & 4.88 \\
\hline Engineering or technology ........ & 100.00 & 42.38 & 1.84 & \# & 7.37 & 16.77 & 21.17 & 8.02 & 1.26 & 0.00 & 0.03 & 1.14 \\
\hline 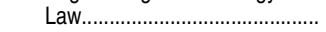 & 100.00 & 43.58 & 1.14 & 2.21 & 14.72 & 12.54 & 21.97 & 2.54 & 0.30 & 0.00 & 0.29 & 0.71 \\
\hline Medical or other health .............. & 100.00 & 18.16 & 14.40 & 4.68 & 9.96 & 2.67 & 9.73 & 1.76 & 0.10 & 26.91 & 7.49 & 4.13 \\
\hline 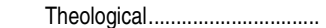 & 100.00 & 31.14 & 0.21 & 3.23 & 9.48 & 9.02 & 27.03 & 9.88 & 1.75 & 0.00 & 0.61 & 7.66 \\
\hline Tribal $^{9}$. & 100.00 & 32.98 & 0.40 & 8.33 & 4.94 & 15.42 & 23.18 & 2.22 & 2.78 & 0.00 & 1.36 & 8.39 \\
\hline 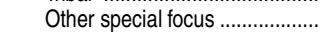 & 100.00 & 42.08 & 0.83 & 6.39 & 8.37 & 7.43 & 25.70 & 8.22 & 0.23 & 0.00 & 0.00 & 0.76 \\
\hline 2-year............ & 100.00 & 34.83 & 0.11 & 0.35 & 8.77 & 14.60 & 25.70 & 4.03 & 0.35 & 0.00 & 0.00 & 11.25 \\
\hline Associate's of arts..... & 100.00 & 35.38 & 0.08 & 0.30 & 8.86 & 14.76 & 25.66 & 4.08 & 0.11 & 0.00 & 0.00 & 10.77 \\
\hline \multirow[t]{2}{*}{ 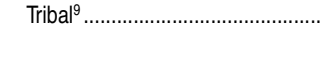 } & 100.00 & 15.03 & 1.51 & 2.01 & 5.74 & 8.89 & 27.13 & 2.19 & 9.00 & 0.00 & 0.00 & 28.49 \\
\hline & \multicolumn{12}{|c|}{ Expenditure per full-time-equivalent student in current dollars } \\
\hline 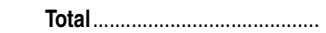 & $\$ 48,233$ & $\$ 15,753$ & $\$ 5,259$ & $\$ 704$ & $\$ 4,280$ & $\$ 3,886$ & $\$ 6,382$ & $\$ 4,510$ & $\$ 255$ & $\$ 4,671$ & $\$ 1,644$ & $\$ 889$ \\
\hline 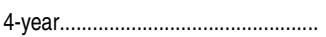 & 48,533 & 15,847 & 5,311 & 711 & 4,307 & 3,899 & 6,399 & 4,547 & 257 & 4,718 & 1,661 & 877 \\
\hline Research university, very high ${ }^{3} \ldots$. & 151,909 & 45,694 & 28,430 & 1,853 & 10,765 & 5,428 & 12,934 & 9,501 & 1,082 & 24,335 & 8,817 & 3,070 \\
\hline Research university, high ${ }^{4} \ldots \ldots \ldots \ldots . . . . .$. & 41,947 & 15,272 & 3,776 & 671 & 6,127 & 3,086 & 5,688 & 5,303 & 95 & 1,727 & 191 & 11 \\
\hline 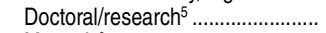 & 28,326 & 11,455 & 869 & 443 & 3,266 & 3,462 & 5,011 & 3,633 & 29 & 0 & 77 & 80 \\
\hline Master's ${ }^{6} \ldots \ldots \ldots \ldots \ldots$ & 22,202 & 8,529 & 235 & 237 & 2,234 & 3,339 & 4,237 & 2,915 & 82 & 83 & 96 & 216 \\
\hline 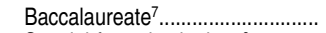 & 29,739 & 10,544 & 348 & 280 & 2,565 & 4,643 & 5,724 & 4,843 & 161 & 8 & 87 & 536 \\
\hline Special-focus institutions ${ }^{8}$.. & 55,134 & 13,720 & 5,287 & 2,100 & 5,588 & 2,976 & 7,989 & 2,381 & 192 & 9,736 & 2,845 & 2,320 \\
\hline Art, music, or design .... & 35,880 & 14,884 & 16 & 385 & 3,912 & 3,623 & 7,577 & 3,799 & 129 & 0 & 454 & 1,101 \\
\hline Business and management ...... & 24,321 & 8,590 & 230 & 33 & 2,472 & 3,360 & 5,668 & 2,778 & 2 & 0 & 0 & 1,188 \\
\hline Engineering or technology ........ & 12,491 & 5,294 & 230 & \# & 921 & 2,095 & 2,645 & 1,002 & 157 & 0 & 4 & 143 \\
\hline Law. & 34,839 & 15,183 & 398 & 770 & 5,128 & 4,368 & 7,654 & 885 & 103 & 0 & 102 & 247 \\
\hline Medical or other health .............. & 106,464 & 19,332 & 15,328 & 4,982 & 10,607 & 2,847 & 10,364 & 1,879 & 106 & 28,653 & 7,972 & 4,393 \\
\hline Theological.................................... & 24,794 & 7,720 & 51 & 800 & 2,350 & 2,235 & 6,702 & 2,451 & 433 & 0 & 151 & 1,899 \\
\hline Tribal $^{9}$.. & 34,179 & 11,271 & 137 & 2,848 & 1,687 & 5,271 & 7,922 & 759 & 951 & 0 & 465 & 2,868 \\
\hline Other special focus ....... & 37,777 & 15,895 & 312 & 2,413 & 3,163 & 2,805 & 9,710 & 3,104 & 87 & 0 & 0 & 289 \\
\hline 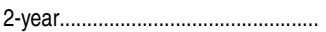 & 17,996 & 6,267 & 21 & 63 & 1,579 & 2,628 & 4,625 & 726 & 64 & 0 & 0 & 2,024 \\
\hline 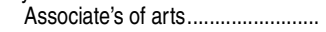 & 17,841 & 6,312 & 14 & 54 & 1,580 & 2,633 & 4,578 & 729 & 20 & 0 & 0 & 1,921 \\
\hline Tribal $^{9}$ & 26,091 & 3,921 & 395 & 525 & 1,498 & 2,320 & 7,080 & 572 & 2,349 & 0 & 0 & 7,432 \\
\hline
\end{tabular}

\section{\#Rounds to zero.}

${ }^{1}$ Essentially self-supporting operations of institutions that furnish a service to students, faculty, or staff, such as residence halls and food services.

2Excludes tuition, fee, and auxiliary enterprise allowances and agency transactions, such as student awards made from contributed funds or grant funds. These exclusions account for the majority of total student grants.

${ }^{3}$ Research universities with a very high level of research activity.

${ }^{4}$ Research universities with a high level of research activity.

5 Includes institutions that award at least 20 doctor's degrees per year, but did not have high levels of research activity.

'Master's institutions award at least 50 master's degrees per year.

Baccalaureate institutions primarily emphasize undergraduate education. Also includes institutions classified as 4-year under the IPEDS system, which had been classified as 2-year in the Carnegie classification system because they primarily award associate's degrees.
${ }^{8}$ Special-focus 4-year institutions award degrees primarily in single fields of study, such as medicine, business, fine arts, theology, and engineering

${ }^{9}$ Tribally controlled colleges are located on reservations and are members of the American Indian Higher Education Consortium.

NOTE: Relative levels of research activity for research universities were determined by an analysis of research and development expenditures, science and engineering research staffing, and doctoral degrees conferred, by field. Further information on the Carnegie 2005 classification system used in this table may be obtained from http://classifications.carnegiefoundation.org/ resources/. Degree-granting institutions grant associate's or higher degrees and participate in Title IV federal financial aid programs. Detail may not sum to totals because of rounding.

SOURCE: U.S. Department of Education, National Center for Education Statistics, Integrated Postsecondary Education Data System (IPEDS), Spring 2012, Enrollment component; and Spring 2013, Finance component. (This table was prepared January 2014.) 
Table 334.50. Total expenditures of private for-profit degree-granting postsecondary institutions, by purpose and level of institution: 1999-2000 through 2011-12

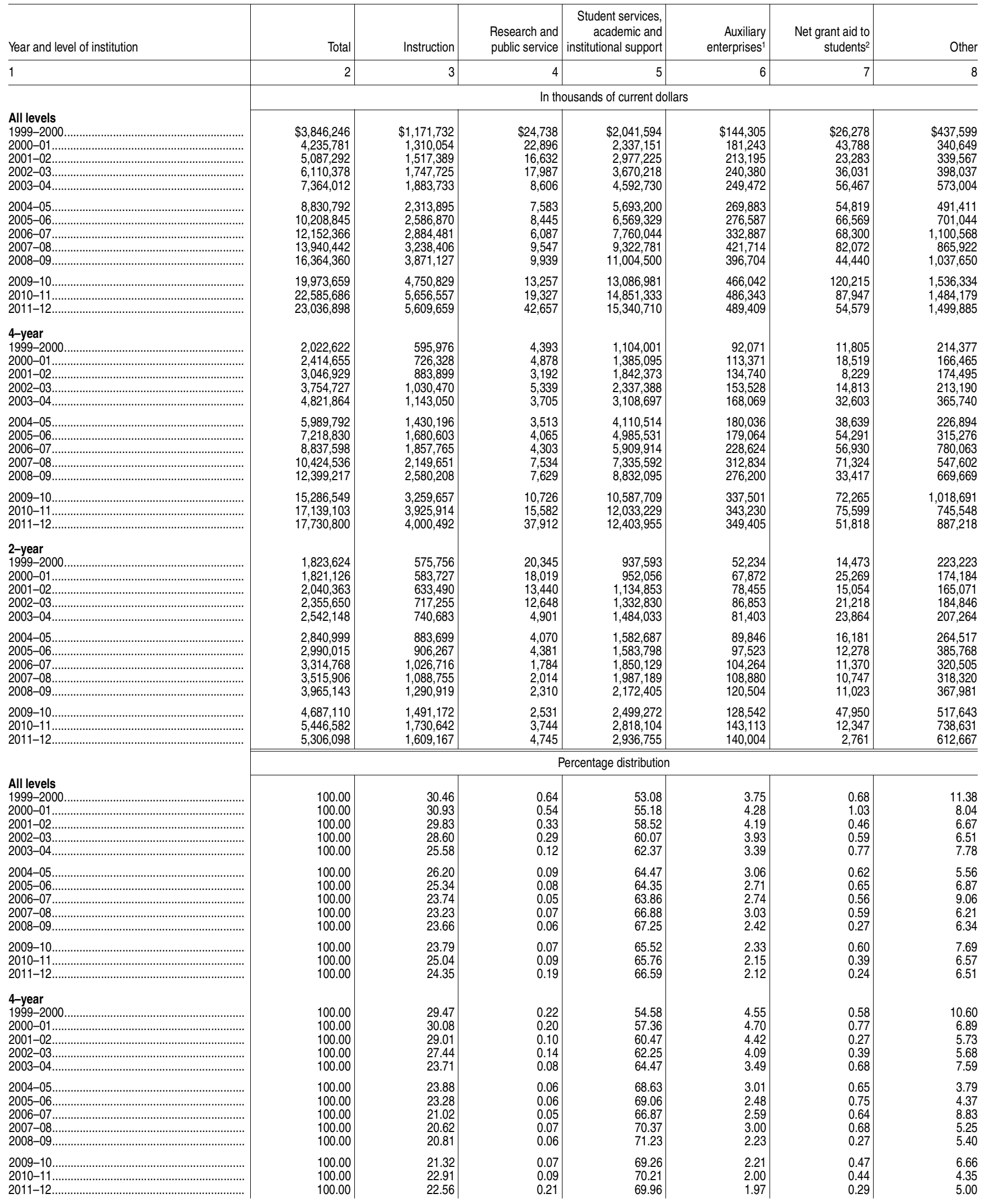

See notes at end of table. 
672 CHAPTER 3: Postsecondary Education

Expenditures

Table 334.50. Total expenditures of private for-profit degree-granting postsecondary institutions, by purpose and level of institution: 1999-2000 through 2011-12-Continued

\begin{tabular}{|c|c|c|c|c|c|c|c|}
\hline Year and level of institution & Total & Instruction & $\begin{array}{l}\text { Research and } \\
\text { public service }\end{array}$ & $\begin{array}{r}\text { Student services, } \\
\text { academic and } \\
\text { institutional support }\end{array}$ & $\begin{array}{r}\text { Auxiliary } \\
\text { enterprises }^{1}\end{array}$ & $\begin{array}{r}\text { Net grant aid to } \\
\text { students }^{2}\end{array}$ & Other \\
\hline 1 & 2 & 3 & 4 & 5 & 6 & 7 & 8 \\
\hline 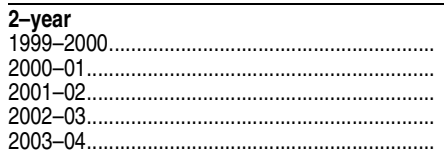 & $\begin{array}{l}100.00 \\
100.00 \\
100.00 \\
100.00 \\
100.00\end{array}$ & $\begin{array}{l}31.57 \\
32.05 \\
31.05 \\
30.45 \\
29.14\end{array}$ & $\begin{array}{l}1.12 \\
0.99 \\
0.66 \\
0.54 \\
0.19\end{array}$ & $\begin{array}{l}51.41 \\
52.28 \\
55.62 \\
56.58 \\
58.38\end{array}$ & $\begin{array}{l}2.86 \\
3.73 \\
3.85 \\
3.69 \\
3.20\end{array}$ & $\begin{array}{l}0.79 \\
1.39 \\
0.74 \\
0.90 \\
0.94\end{array}$ & $\begin{array}{r}12.24 \\
9.56 \\
8.09 \\
7.85 \\
8.15\end{array}$ \\
\hline $2006-07$ & $\begin{array}{l}100.00 \\
100.00 \\
100.00 \\
100.00 \\
100.00\end{array}$ & $\begin{array}{l}31.11 \\
30.31 \\
30.97 \\
30.97 \\
32.56\end{array}$ & $\begin{array}{l}0.14 \\
0.15 \\
0.05 \\
0.06 \\
0.06\end{array}$ & $\begin{array}{l}55.71 \\
52.97 \\
55.81 \\
56.52 \\
54.79\end{array}$ & $\begin{array}{l}3.16 \\
3.26 \\
3.15 \\
3.10 \\
3.04\end{array}$ & $\begin{array}{l}0.57 \\
0.41 \\
0.34 \\
0.31 \\
0.28\end{array}$ & $\begin{array}{r}9.31 \\
12.90 \\
9.67 \\
9.05 \\
9.28\end{array}$ \\
\hline \multirow[t]{2}{*}{ 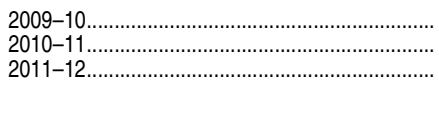 } & $\begin{array}{l}100.00 \\
100.00 \\
100.00\end{array}$ & $\begin{array}{l}31.81 \\
31.77 \\
30.33\end{array}$ & $\begin{array}{l}0.05 \\
0.07 \\
0.09\end{array}$ & $\begin{array}{l}53.32 \\
51.74 \\
55.35\end{array}$ & $\begin{array}{l}2.74 \\
2.63 \\
2.64\end{array}$ & $\begin{array}{l}1.02 \\
0.23 \\
0.05\end{array}$ & $\begin{array}{l}11.04 \\
13.56 \\
11.55\end{array}$ \\
\hline & \multicolumn{7}{|c|}{ Total expenditures per full-time-equivalent student in constant 2012-13 dollars ${ }^{3}$} \\
\hline $\begin{array}{l}\text { All levels } \\
1999-2000 \\
2000-01 \ldots \ldots \ldots \\
2001-02 \\
2002-03 \ldots \ldots \ldots \ldots \ldots\end{array}$ & $\begin{array}{r}\$ 13,666 \\
14,246 \\
14,468 \\
14,357 \\
14,149\end{array}$ & $\begin{array}{r}\$ 4,163 \\
4,406 \\
4,315 \\
4,107 \\
3,619\end{array}$ & $\begin{array}{r}\$ 88 \\
77 \\
47 \\
42 \\
17\end{array}$ & $\begin{array}{r}\$ 7,254 \\
7,860 \\
8,467 \\
8,624 \\
8,825\end{array}$ & $\begin{array}{r}\$ 513 \\
610 \\
606 \\
565 \\
479\end{array}$ & $\begin{array}{r}\$ 93 \\
147 \\
66 \\
85 \\
108\end{array}$ & $\begin{array}{r}\$ 1,555 \\
1,146 \\
966 \\
935 \\
1,101\end{array}$ \\
\hline 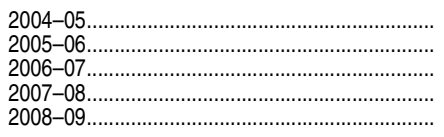 & $\begin{array}{l}13,524 \\
13,180 \\
14,597 \\
14,782 \\
13,847\end{array}$ & $\begin{array}{l}3,544 \\
3,340 \\
3,465 \\
3,434 \\
3,276\end{array}$ & $\begin{array}{r}12 \\
11 \\
7 \\
10 \\
8\end{array}$ & $\begin{array}{l}8,719 \\
8,481 \\
9,321 \\
9,886 \\
9,312\end{array}$ & $\begin{array}{l}413 \\
357 \\
400 \\
447 \\
336\end{array}$ & $\begin{array}{l}84 \\
86 \\
82 \\
87 \\
38\end{array}$ & $\begin{array}{r}753 \\
905 \\
1,322 \\
918 \\
878\end{array}$ \\
\hline 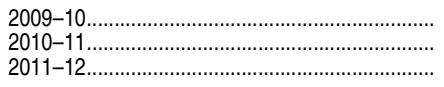 & $\begin{array}{l}13,273 \\
14,346 \\
14,545\end{array}$ & $\begin{array}{l}3,157 \\
3,593 \\
3,542\end{array}$ & $\begin{array}{r}9 \\
12 \\
27\end{array}$ & $\begin{array}{l}8,697 \\
9,433 \\
9,686\end{array}$ & $\begin{array}{l}310 \\
309 \\
309\end{array}$ & $\begin{array}{l}80 \\
56 \\
34\end{array}$ & $\begin{array}{r}1,021 \\
943 \\
947\end{array}$ \\
\hline 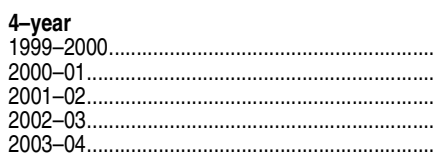 & $\begin{array}{l}13,240 \\
13,991 \\
14,308 \\
13,799 \\
14,037\end{array}$ & $\begin{array}{l}3,901 \\
4,208 \\
4,151 \\
3,787 \\
3,328\end{array}$ & $\begin{array}{l}29 \\
28 \\
15 \\
20 \\
11\end{array}$ & $\begin{array}{l}7,227 \\
8,025 \\
8,652 \\
8,590 \\
9,050\end{array}$ & $\begin{array}{l}603 \\
657 \\
633 \\
564 \\
489\end{array}$ & $\begin{array}{r}77 \\
107 \\
39 \\
54 \\
95\end{array}$ & $\begin{array}{r}1,403 \\
965 \\
819 \\
783 \\
1,065\end{array}$ \\
\hline $2004-05$ & $\begin{array}{l}13,056 \\
12,669 \\
14,224 \\
14,439 \\
13,638\end{array}$ & $\begin{array}{l}3,117 \\
2,950 \\
2,990 \\
2,977 \\
2,838\end{array}$ & $\begin{array}{r}8 \\
7 \\
7 \\
10 \\
8\end{array}$ & $\begin{array}{r}8,960 \\
8,750 \\
9,512 \\
10,160 \\
9,714\end{array}$ & $\begin{array}{l}392 \\
314 \\
368 \\
433 \\
304\end{array}$ & $\begin{array}{l}84 \\
95 \\
92 \\
99 \\
37\end{array}$ & $\begin{array}{r}495 \\
553 \\
1,256 \\
758 \\
737\end{array}$ \\
\hline $\begin{array}{l}2009-10 \\
2010-11 \\
2011-12\end{array}$ & $\begin{array}{l}13,213 \\
14,300 \\
14,345\end{array}$ & $\begin{array}{l}2,818 \\
3,276 \\
3,237\end{array}$ & $\begin{array}{r}9 \\
13 \\
31\end{array}$ & $\begin{array}{r}9,152 \\
10,040 \\
10,036\end{array}$ & $\begin{array}{l}292 \\
286 \\
283\end{array}$ & $\begin{array}{l}62 \\
63 \\
42\end{array}$ & $\begin{array}{l}881 \\
622 \\
718\end{array}$ \\
\hline 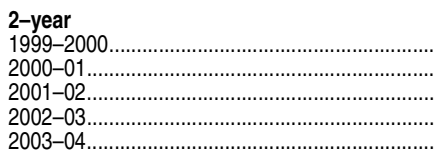 & $\begin{array}{l}14,172 \\
14,598 \\
14,714 \\
15,348 \\
14,368\end{array}$ & $\begin{array}{l}4,474 \\
4,679 \\
4,568 \\
4,673 \\
4,186\end{array}$ & $\begin{array}{r}158 \\
144 \\
97 \\
82 \\
28\end{array}$ & $\begin{array}{l}7,286 \\
7,632 \\
8,184 \\
8,684 \\
8,387\end{array}$ & $\begin{array}{l}406 \\
544 \\
566 \\
566 \\
460\end{array}$ & $\begin{array}{l}112 \\
203 \\
109 \\
138 \\
135\end{array}$ & $\begin{array}{l}1,735 \\
1,396 \\
1,190 \\
1,204 \\
1,171\end{array}$ \\
\hline $2007-08$ & $\begin{array}{l}14,628 \\
14,601 \\
15,694 \\
15,906 \\
14,547\end{array}$ & $\begin{array}{l}4,550 \\
4,425 \\
4,861 \\
4,925 \\
4,736\end{array}$ & $\begin{array}{r}21 \\
21 \\
8 \\
9 \\
8\end{array}$ & $\begin{array}{l}8,149 \\
7,734 \\
8,759 \\
8,990 \\
7,970\end{array}$ & $\begin{array}{l}463 \\
476 \\
494 \\
493 \\
442\end{array}$ & $\begin{array}{l}83 \\
60 \\
54 \\
49 \\
40\end{array}$ & $\begin{array}{l}1,362 \\
1,884 \\
1,517 \\
1,440 \\
1,350\end{array}$ \\
\hline $\begin{array}{l}2009-10 \\
2010-11 \\
2011-12\end{array}$ & $\begin{array}{l}13,471 \\
14,492 \\
15,255\end{array}$ & $\begin{array}{l}4,286 \\
4,605 \\
4,626\end{array}$ & $\begin{array}{r}7 \\
10 \\
14\end{array}$ & $\begin{array}{l}7,183 \\
7,498 \\
8,443\end{array}$ & $\begin{array}{l}369 \\
381 \\
403\end{array}$ & $\begin{array}{r}138 \\
33 \\
8\end{array}$ & $\begin{array}{l}1,488 \\
1,965 \\
1,761\end{array}$ \\
\hline
\end{tabular}

'Essentially self-supporting operations of institutions that furnish a service to students, faculty, or staff, such as residence halls and food services.

${ }^{2}$ Excludes tuition and fee allowances and agency transactions, such as student awards made from contributed funds or grant funds.

${ }^{3}$ Constant dollars based on the Consumer Price Index, prepared by the Bureau of Labor Statistics, U.S. Department of Labor, adjusted to a school-year basis.
NOTE: Degree-granting institutions grant associate's or higher degrees and participate in Title IV federal financial aid programs. Detail may not sum to totals because of rounding.

SOURCE: U.S. Department of Education, National Center for Education Statistics, Integrated Postsecondary Education Data System (IPEDS), "Fall Enrollment Survey" (IPEDS-EF:99), and Spring 2001 through Spring 2013, Enrollment and Finance components. (This table was prepared January 2014.) 
Table 334.60. Total expenditures of private for-profit degree-granting postsecondary institutions, by purpose and classification of institution: 2011-12

\begin{tabular}{|c|c|c|c|c|c|c|c|}
\hline Classification of institution & Total & Instruction & $\begin{array}{r}\text { Research and public } \\
\text { service }\end{array}$ & $\begin{array}{r}\text { Student services, } \\
\text { academic and } \\
\text { institutional support }\end{array}$ & $\begin{array}{r}\text { Auxiliary } \\
\text { enterprises }\end{array}$ & $\begin{array}{r}\text { Net grant aid } \\
\text { to students }\end{array}$ & Other \\
\hline \multirow[t]{2}{*}{1} & 2 & 3 & 4 & 5 & 6 & 7 & 8 \\
\hline & \multicolumn{7}{|c|}{ In thousands of current dollars } \\
\hline 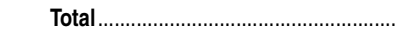 & $\$ 23,036,898$ & $\$ 5,609,659$ & $\$ 42,657$ & $\$ 15,340,710$ & $\$ 489,409$ & $\$ 54,579$ & $\$ 1,499,885$ \\
\hline 4-year........................ & $17,730,800$ & $4,000,492$ & 37,912 & $12,403,955$ & 349,405 & 51,818 & 887,218 \\
\hline Doctoral/research ${ }^{3}$. & $3,283,878$ & 556,241 & 15,685 & $2,534,679$ & 4,698 & 0 & 172,575 \\
\hline Master's ${ }^{4} \ldots \ldots \ldots \ldots$ & $4,541,576$ & $1,059,238$ & 4,931 & $3,244,611$ & 72,375 & 823 & 159,597 \\
\hline Baccalaureate ${ }^{5} \ldots \ldots \ldots \ldots \ldots \ldots \ldots \ldots \ldots \ldots \ldots \ldots$ & $2,206,008$ & 686,131 & 2,851 & $1,335,726$ & 40,020 & 917 & 140,362 \\
\hline 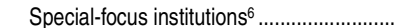 & $7,699,338$ & $1,698,881$ & 14,445 & $5,288,939$ & 232,311 & 50,079 & 414,683 \\
\hline Art, music, or design & $2,362,325$ & 583,499 & 3,969 & $1,488,191$ & 157,028 & 2,481 & 127,158 \\
\hline 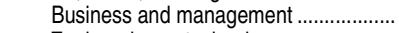 & $2,984,942$ & 524,195 & 7,536 & $2,272,687$ & 40,059 & 32,550 & 107,916 \\
\hline Engineering or technology ......................... & $1,409,720$ & 326,774 & 2 & $1,040,504$ & 13,725 & 908 & 27,807 \\
\hline 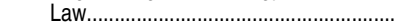 & 177,123 & 44,796 & 1,350 & 82,282 & 379 & 14,047 & 34,269 \\
\hline Medical or other health ........................... & 588,191 & 179,223 & 435 & 354,845 & 3,328 & 93 & 50,266 \\
\hline 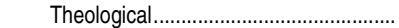 & 116,688 & 22,215 & 1,154 & 20,016 & 16,046 & 0 & 57,257 \\
\hline 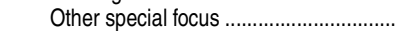 & 60,350 & 18,180 & & 30,413 & 1,746 & 0 & 10,011 \\
\hline \multirow[t]{2}{*}{ 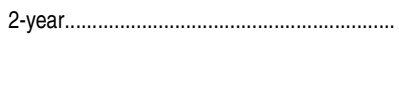 } & $5,306,098$ & $1,609,167$ & 4,745 & $2,936,755$ & 140,004 & 2,761 & 612,667 \\
\hline & \multicolumn{7}{|c|}{ Percentage distribution } \\
\hline$\ldots \ldots \ldots \ldots \ldots \ldots$ & 100.00 & 24.35 & 0.19 & 66.59 & 2.12 & 0.24 & 6.51 \\
\hline 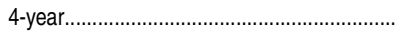 & 100.00 & 22.56 & 0.21 & 69.96 & 1.97 & 0.29 & 5.00 \\
\hline Doctoral/research ${ }^{3}$ & 100.00 & 16.94 & 0.48 & 77.19 & 0.14 & 0.00 & 5.26 \\
\hline Master's ${ }^{4} \ldots \ldots \ldots \ldots \ldots \ldots$ & 100.00 & 23.32 & 0.11 & 71.44 & 1.59 & 0.02 & 3.51 \\
\hline Baccalaureate ${ }^{5} \ldots \ldots \ldots \ldots \ldots$ & 100.00 & 31.10 & 0.13 & 60.55 & 1.81 & 0.04 & 6.36 \\
\hline Special-focus institutions ${ }^{6} \ldots \ldots \ldots \ldots \ldots \ldots \ldots \ldots \ldots$ & 100.00 & 22.07 & 0.19 & 68.69 & 3.02 & 0.65 & 5.39 \\
\hline Art, music, or design & 100.00 & 24.70 & 0.17 & 63.00 & 6.65 & 0.11 & 5.38 \\
\hline Business and management ....................... & 100.00 & 17.56 & 0.25 & 76.14 & 1.34 & 1.09 & 3.62 \\
\hline Engineering or technology ......................... & 100.00 & 23.18 & $\#$ & 73.81 & 0.97 & 0.06 & 1.97 \\
\hline 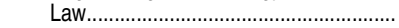 & 100.00 & 25.29 & 0.76 & 46.45 & 0.21 & 7.93 & 19.35 \\
\hline Medical or other health .............................. & 100.00 & 30.47 & 0.07 & 60.33 & 0.57 & 0.02 & 8.55 \\
\hline 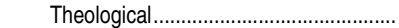 & 100.00 & 19.04 & 0.99 & 17.15 & 13.75 & 0.00 & 49.07 \\
\hline 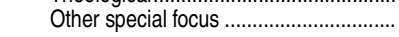 & 100.00 & 30.12 & 0.00 & 50.39 & 2.89 & 0.00 & 16.59 \\
\hline \multirow[t]{2}{*}{2 -year. } & 100.00 & 30.33 & 0.09 & 55.35 & 2.64 & 0.05 & 11.55 \\
\hline & \multicolumn{7}{|c|}{ Expenditure per full-time-equivalent student in current dollars } \\
\hline Total. & $\$ 14,307$ & $\$ 3,484$ & $\$ 26$ & $\$ 9,527$ & $\$ 304$ & $\$ 34$ & $\$ 932$ \\
\hline 4 -year.......... & 14,111 & 3,184 & 30 & 9,871 & 278 & 41 & 706 \\
\hline 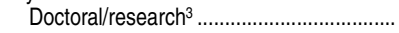 & 8,679 & 1,470 & 41 & 6,699 & 12 & 0 & 456 \\
\hline 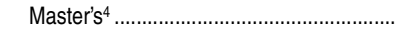 & 12,847 & 2,996 & 14 & 9,178 & 205 & 2 & 451 \\
\hline Baccalaureate 5 & 16,770 & 5,216 & 22 & 10,154 & 304 & 7 & 1,067 \\
\hline Special-focus institutions ${ }^{6} \ldots \ldots \ldots \ldots \ldots \ldots \ldots \ldots \ldots$ & 19,583 & 4,321 & 37 & 13,453 & 591 & 127 & 1,055 \\
\hline 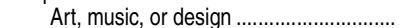 & 23,999 & 5,928 & 40 & 15,119 & 1,595 & 25 & 1,292 \\
\hline 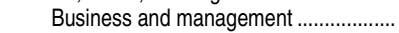 & 16,607 & 2,916 & 42 & 12,644 & 223 & 181 & 600 \\
\hline Engineering or technology ........................... & 19,439 & 4,506 & $\#$ & 14,347 & 189 & 13 & 383 \\
\hline 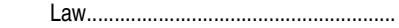 & 27,836 & 7,040 & 212 & 12,931 & 59 & 2,208 & 5,386 \\
\hline 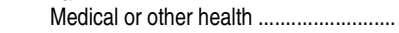 & 19,549 & 5,957 & 14 & 11,794 & 111 & 3 & 1,671 \\
\hline 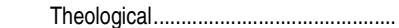 & 34,300 & 6,530 & 339 & 5,884 & 4,717 & 0 & 16,830 \\
\hline 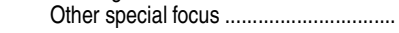 & 23,194 & 6,987 & 0 & 11,688 & 671 & 0 & 3,848 \\
\hline \multirow[t]{2}{*}{ 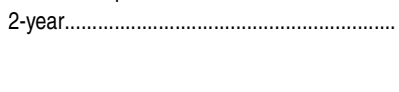 } & 15,006 & 4,551 & 13 & 8,305 & 396 & 8 & 1,733 \\
\hline & \multicolumn{7}{|c|}{ Expenditure full-time-equivalent student in constant 2012-13 dollars ${ }^{7}$} \\
\hline Total & $\$ 14,545$ & $\$ 3,542$ & $\$ 27$ & $\$ 9,686$ & $\$ 309$ & $\$ 34$ & $\$ 947$ \\
\hline 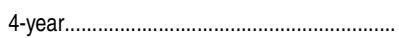 & 14,345 & 3,237 & 31 & 10,036 & 283 & 42 & 718 \\
\hline 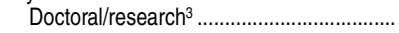 & 8,824 & 1,495 & 42 & 6,811 & 13 & 0 & 464 \\
\hline 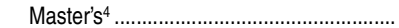 & 13,061 & 3,046 & 14 & 9,331 & 208 & 2 & 459 \\
\hline Baccalaureate $^{5}$ & 17,049 & 5,303 & 22 & 10,323 & 309 & 7 & 1,085 \\
\hline Special-focus institutions ${ }^{6} \ldots \ldots \ldots \ldots \ldots \ldots \ldots \ldots$ & 19,909 & 4,393 & 37 & 13,676 & 601 & 129 & 1,072 \\
\hline 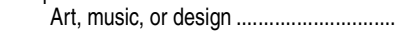 & 24,398 & 6,026 & 41 & 15,370 & 1,622 & 26 & 1,313 \\
\hline 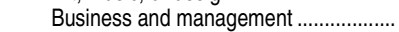 & 16,883 & 2,965 & 43 & 12,854 & 227 & 184 & 610 \\
\hline Engineering or technology ......................... & 19,762 & 4,581 & $\#$ & 14,586 & 192 & 13 & 390 \\
\hline 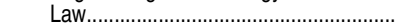 & 28,300 & 7,157 & 216 & 13,147 & 60 & 2,244 & 5,475 \\
\hline 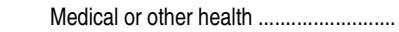 & 19,874 & 6,056 & 15 & 11,990 & 112 & 3 & 1,698 \\
\hline 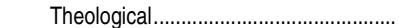 & 34,871 & 6,639 & 345 & 5,982 & 4,795 & 0 & 17,110 \\
\hline 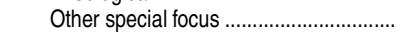 & 23,580 & 7,103 & 0 & 11,883 & 682 & 0 & 3,912 \\
\hline 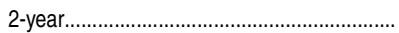 & 15,255 & 4,626 & 14 & 8,443 & 403 & 8 & 1,761 \\
\hline
\end{tabular}

\#Rounds to zero

'Essentially self-supporting operations of institutions that furnish a service to students, faculty, or staff, such as residence halls and food services.

${ }^{2}$ Excludes tuition, fee, and auxiliary enterprise allowances and agency transactions, such as student awards made from contributed funds or grant funds.

IIncludes institutions that award at least 20 doctor's degrees per year, but did not have high levels of research activity.

${ }^{4}$ Master's institutions award at least 50 master's degrees per year.

${ }^{5}$ Baccalaureate institutions primarily emphasize undergraduate education. Also includes institutions classified as 4-year under the IPEDS system, which had been classified as 2-year in the Carnegie classification system because they primarily award associate's degrees.
${ }^{6}$ Special focus 4-year institutions award degrees primarily in single fields of study, such as medicine, business, fine arts, theology, and engineering.

${ }^{7}$ Constant dollars based on the Consumer Price Index, prepared by the Bureau of Labor Statistics, U.S. Department of Labor, adjusted to a school-year basis.

NOTE: Degree-granting institutions grant associate's or higher degrees and participate in Title IV federal financial aid programs. Further information on the Carnegie 2005 classification system used in this table may be obtained from http://classifications.carnegiefoundation.org/ resources/. Detail may not sum to totals because of rounding.

SOURCE: U.S. Department of Education, National Center for Education Statistics, Integrated Postsecondary Education Data System (IPEDS), Spring 2012, Enrollment component; and Spring 2013, Finance component. (This table was prepared January 2014.) 
Table 334.70. Total expenditures of private nonprofit and for-profit degree-granting postsecondary institutions, by state or jurisdiction: Selected years, 1999-2000 through 2011-12

[In thousands of current dollars]

\begin{tabular}{|c|c|c|c|c|c|c|c|c|c|c|c|c|}
\hline \multirow[b]{2}{*}{ State or jurisdiction } & \multicolumn{6}{|c|}{ Nonprofit institutions } & \multicolumn{6}{|c|}{ For-profit institutions } \\
\hline & 1999-2000 & 2004-05 & 2008-09 & $2009-10$ & $2010-11$ & 2011-12 & 1999-2000 & 2004-05 & $2008-09$ & $2009-10$ & $2010-11$ & $2011-12$ \\
\hline 1 & 2 & 3 & 4 & 5 & 6 & 7 & 8 & 9 & 10 & 11 & 12 & 13 \\
\hline United States ... & $\$ 80,613,037$ & $\$ 110,394,127$ & $\$ 141,349,229$ & $\$ 145,141,785$ & $\$ 152,509,741$ & $\$ 159,873,305$ & $\$ 3,846,246$ & $\$ 8,830,792$ & $\$ 16,364,360$ & $\$ 19,973,659$ & $\$ 22,585,686$ & $\$ 23,036,898$ \\
\hline 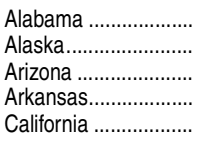 & $\begin{array}{r}393,465 \\
19,042 \\
143,698 \\
230,860 \\
7,871,651\end{array}$ & $\begin{array}{r}459,250 \\
21,076 \\
147,825 \\
239,357 \\
10,728,872\end{array}$ & $\begin{array}{r}546,535 \\
17,211 \\
165,960 \\
287,259 \\
13,421,736\end{array}$ & $\begin{array}{r}561,968 \\
16,249 \\
176,443 \\
289,868 \\
13,925,287\end{array}$ & $\begin{array}{r}583,205 \\
18,319 \\
212,911 \\
322,896 \\
14,557,205\end{array}$ & $\begin{array}{r}604,992 \\
17,245 \\
237,638 \\
341,827 \\
15,355,141\end{array}$ & $\begin{array}{r}88,190 \\
3,559 \\
278,286 \\
5,828 \\
666,020\end{array}$ & $\begin{array}{r}60,629 \\
3,986 \\
1,095,783 \\
11,574 \\
1,243,346\end{array}$ & $\begin{array}{r}98,444 \\
9,109 \\
2,722,216 \\
26,615 \\
2,047,729\end{array}$ & $\begin{array}{r}139,366 \\
19,302 \\
3,412,261 \\
31,263 \\
2,552,449\end{array}$ & $\begin{array}{r}244,943 \\
41,245 \\
3,623,551 \\
27,834 \\
2,952,470\end{array}$ & $\begin{array}{r}218,687 \\
53,164 \\
3,419,611 \\
29,152 \\
3,016,592\end{array}$ \\
\hline $\begin{array}{l}\text { Colorado ................... } \\
\text { Connecticut................ } \\
\text { Delaware................. } \\
\text { District of Columbia .. } \\
\text { Florida....................... }\end{array}$ & $\begin{array}{r}376,887 \\
2,094,981 \\
52,533 \\
2,267,409 \\
2,031,623\end{array}$ & $\begin{array}{r}524,349 \\
2,882,963 \\
87,617 \\
2,824,081 \\
3,067,443\end{array}$ & $\begin{array}{r}632,322 \\
3,858,956 \\
124,757 \\
3,715,850 \\
4,523,485\end{array}$ & $\begin{array}{r}627,123 \\
3,975,262 \\
132,851 \\
3,687,042 \\
4,592,898\end{array}$ & $\begin{array}{r}659,716 \\
4,127,051 \\
141,186 \\
3,724,430 \\
5,071,442\end{array}$ & $\begin{array}{r}692,467 \\
4,337,333 \\
150,054 \\
3,929,951 \\
5,356,148\end{array}$ & $\begin{array}{r}154,801 \\
18,110 \\
\dagger \\
59,375 \\
315,721\end{array}$ & $\begin{array}{r}320,550 \\
41,931 \\
\dagger \\
127,859 \\
781,280\end{array}$ & $\begin{array}{r}611,882 \\
52,340 \\
\dagger \\
328,919 \\
1,379,974\end{array}$ & $\begin{array}{r}661,384 \\
59,726 \\
4,042 \\
66,677 \\
1,825,704\end{array}$ & $\begin{array}{r}736,387 \\
80,628 \\
4,957 \\
77,469 \\
1,982,163\end{array}$ & $\begin{array}{r}739,248 \\
95,498 \\
5,191 \\
68,746 \\
2,038,395\end{array}$ \\
\hline 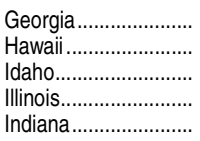 & $\begin{array}{r}2,635,438 \\
209,135 \\
118,150 \\
5,668,566 \\
1,343,315\end{array}$ & $\begin{array}{r}3,442,374 \\
195,152 \\
164,694 \\
7,113,842 \\
1,796,767\end{array}$ & $\begin{array}{r}4,340,833 \\
214,383 \\
219,607 \\
9,088,501 \\
2,185,735\end{array}$ & $\begin{array}{r}4,497,299 \\
210,680 \\
228,589 \\
9,512,165 \\
2,251,554\end{array}$ & $\begin{array}{r}4,796,550 \\
231,683 \\
242,764 \\
10,095,051 \\
2,360,297\end{array}$ & $\begin{array}{r}5,346,024 \\
251,071 \\
261,954 \\
10,532,731 \\
2,502,296\end{array}$ & $\begin{array}{r}106,794 \\
9,422 \\
5,932 \\
166,956 \\
89,932\end{array}$ & $\begin{array}{r}261,219 \\
24,996 \\
13,073 \\
620,678 \\
211,310\end{array}$ & $\begin{array}{r}509,600 \\
37,439 \\
23,649 \\
988,986 \\
433,600\end{array}$ & $\begin{array}{r}675,496 \\
34,299 \\
32,602 \\
1,100,032 \\
591,600\end{array}$ & $\begin{array}{r}783,834 \\
41,754 \\
51,944 \\
1,054,104 \\
726,450\end{array}$ & $\begin{array}{r}811,908 \\
46,358 \\
50,751 \\
1,542,922 \\
730,138\end{array}$ \\
\hline 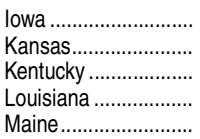 & $\begin{array}{l}740,760 \\
208,729 \\
400,513 \\
746,629 \\
316,114\end{array}$ & $\begin{array}{l}921,320 \\
265,476 \\
470,392 \\
940,075 \\
422,938\end{array}$ & $\begin{array}{r}1,143,991 \\
357,557 \\
589,525 \\
1,032,490 \\
530,015\end{array}$ & $\begin{array}{r}1,156,393 \\
364,286 \\
597,495 \\
1,089,736 \\
552,463\end{array}$ & $\begin{array}{r}1,188,889 \\
381,327 \\
637,466 \\
1,137,685 \\
592,174\end{array}$ & $\begin{array}{r}1,248,348 \\
414,219 \\
683,702 \\
1,192,748 \\
619,223\end{array}$ & $\begin{array}{r}34,311 \\
9,156 \\
55,010 \\
31,675 \\
7,137\end{array}$ & $\begin{array}{r}146,688 \\
11,213 \\
114,564 \\
70,241 \\
5,648\end{array}$ & $\begin{array}{r}758,054 \\
35,743 \\
187,046 \\
89,353 \\
11,192\end{array}$ & $\begin{array}{r}1,002,405 \\
47,645 \\
242,672 \\
111,844 \\
12,409\end{array}$ & $\begin{array}{r}1,269,406 \\
57,986 \\
285,217 \\
104,007 \\
14,411\end{array}$ & $\begin{array}{r}1,189,547 \\
58,226 \\
288,146 \\
110,097 \\
13,111\end{array}$ \\
\hline $\begin{array}{l}\text { Maryland.................. } \\
\text { Massachusetts........... } \\
\text { Michigan ................... } \\
\text { Minnesota ................ } \\
\text { Mississippi ................ }\end{array}$ & $\begin{array}{r}2,205,880 \\
7,591,344 \\
995,384 \\
1,004,427 \\
150,123\end{array}$ & $\begin{array}{r}3,497,182 \\
10,799,206 \\
1,327,051 \\
1,297,457 \\
178,142\end{array}$ & $\begin{array}{r}4,547,357 \\
13,916,336 \\
1,563,761 \\
1,626,949 \\
221,582\end{array}$ & $\begin{array}{r}4,792,089 \\
13,862,598 \\
1,638,367 \\
1,622,869 \\
225,484\end{array}$ & $\begin{array}{r}5,069,546 \\
14,533,360 \\
1,680,792 \\
1,664,254 \\
234,795\end{array}$ & $\begin{array}{r}5,278,869 \\
15,252,538 \\
1,751,050 \\
1,729,682 \\
248,970\end{array}$ & $\begin{array}{r}5,354 \\
34,893 \\
25,340 \\
123,571 \\
\dagger\end{array}$ & $\begin{array}{r}41,717 \\
64,126 \\
55,391 \\
325,758 \\
8,369\end{array}$ & $\begin{array}{r}70,854 \\
103,384 \\
100,224 \\
784,964 \\
16,466\end{array}$ & $\begin{array}{r}115,071 \\
118,526 \\
120,070 \\
928,396 \\
21,061\end{array}$ & $\begin{array}{r}118,794 \\
130,488 \\
142,261 \\
1,092,542 \\
26,002\end{array}$ & $\begin{array}{r}107,983 \\
127,099 \\
151,906 \\
1,179,028 \\
29,899\end{array}$ \\
\hline $\begin{array}{l}\text { Missouri ...................... } \\
\text { Montana................... } \\
\text { Nebraska .................. } \\
\text { Nevada .................... } \\
\text { New Hampshire ......... }\end{array}$ & $\begin{array}{r}2,144,299 \\
69,426 \\
387,569 \\
7,006 \\
589,823\end{array}$ & $\begin{array}{r}3,128,635 \\
91,446 \\
557,724 \\
9,637 \\
883,914\end{array}$ & $\begin{array}{r}3,864,444 \\
104,336 \\
699,561 \\
43,433 \\
1,073,128\end{array}$ & $\begin{array}{r}3,958,548 \\
116,161 \\
709,182 \\
73,701 \\
1,085,570\end{array}$ & $\begin{array}{r}4,203,742 \\
132,829 \\
731,588 \\
85,024 \\
1,115,169\end{array}$ & $\begin{array}{r}4,377,146 \\
107,390 \\
744,788 \\
98,835 \\
1,179,386\end{array}$ & $\begin{array}{r}100,307 \\
\dagger \\
12,051 \\
29,278 \\
21,831\end{array}$ & $\begin{array}{r}196,447 \\
\dagger \\
25,524 \\
104,949 \\
41,599\end{array}$ & $\begin{array}{r}277,715 \\
\dagger \\
34,999 \\
118,434 \\
47,523\end{array}$ & $\begin{array}{r}331,391 \\
\dagger \\
42,559 \\
143,358 \\
36,737\end{array}$ & $\begin{array}{r}426,479 \\
\dagger \\
42,926 \\
156,577 \\
47,598\end{array}$ & $\begin{array}{r}432,200 \\
\dagger \\
43,275 \\
152,954 \\
44,532\end{array}$ \\
\hline $\begin{array}{l}\text { New Jersey ................ } \\
\text { New Mexico .............. } \\
\text { New York................. } \\
\text { North Carolina ........... } \\
\text { North Dakota ............ }\end{array}$ & $\begin{array}{r}1,362,090 \\
54,280 \\
12,519,671 \\
3,530,337 \\
56,000\end{array}$ & $\begin{array}{r}1,873,156 \\
54,076 \\
17,680,799 \\
4,808,306 \\
88,860\end{array}$ & $\begin{array}{r}2,472,048 \\
31,149 \\
22,892,724 \\
6,272,149 \\
94,477\end{array}$ & $\begin{array}{r}2,591,234 \\
30,447 \\
23,511,385 \\
6,452,783 \\
87,938\end{array}$ & $\begin{array}{r}2,681,051 \\
31,564 \\
24,664,171 \\
6,890,504 \\
93,751\end{array}$ & $\begin{array}{r}2,747,352 \\
32,930 \\
25,903,697 \\
7,001,839 \\
114,109\end{array}$ & $\begin{array}{r}61,109 \\
25,806 \\
326,329 \\
4,041 \\
1,145\end{array}$ & $\begin{array}{r}85,429 \\
35,073 \\
624,764 \\
38,078 \\
7,885\end{array}$ & $\begin{array}{r}115,467 \\
111,888 \\
718,608 \\
116,192 \\
14,835\end{array}$ & \begin{tabular}{r|r|}
126,833 \\
83,708 \\
762,214 \\
186,514 \\
20,198
\end{tabular} & $\begin{array}{r}137,408 \\
104,193 \\
876,944 \\
242,098 \\
18,456\end{array}$ & $\begin{array}{r}125,946 \\
111,639 \\
871,255 \\
261,901 \\
15,292\end{array}$ \\
\hline $\begin{array}{l}\text { Ohio ..................... } \\
\text { Oklahoma .................. } \\
\text { Oregon................... } \\
\text { Pennsylvania............ } \\
\text { Rhode Island ............. }\end{array}$ & $\begin{array}{r}2,211,035 \\
338,276 \\
456,683 \\
7,590,629 \\
828,715\end{array}$ & $\begin{array}{r}3,017,764 \\
392,427 \\
550,322 \\
9,960,675 \\
1,237,106\end{array}$ & $\begin{array}{r}3,551,098 \\
515,934 \\
706,683 \\
12,681,659 \\
1,554,627\end{array}$ & $\begin{array}{r}3,582,655 \\
523,630 \\
734,883 \\
13,154,197 \\
1,564,624\end{array}$ & $\begin{array}{r}3,732,414 \\
550,897 \\
790,331 \\
13,800,521 \\
1,596,480\end{array}$ & $\begin{array}{r}3,803,772 \\
583,898 \\
832,852 \\
14,460,608 \\
1,702,209\end{array}$ & $\begin{array}{r}122,531 \\
32,527 \\
23,175 \\
306,135 \\
4,519\end{array}$ & $\begin{array}{r}232,685 \\
72,537 \\
86,156 \\
530,515 \\
10,073\end{array}$ & $\begin{array}{r}437,588 \\
103,780 \\
118,604 \\
706,505 \\
7,084\end{array}$ & $\begin{array}{r}564,498 \\
110,336 \\
120,490 \\
842,052 \\
+\end{array}$ & $\begin{array}{r}636,245 \\
129,544 \\
131,966 \\
935,748 \\
+\end{array}$ & $\begin{array}{r}658,160 \\
145,509 \\
134,421 \\
861,247 \\
\dagger\end{array}$ \\
\hline 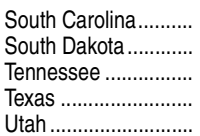 & $\begin{array}{r}408,127 \\
69,555 \\
1,971,564 \\
2,490,597 \\
648,035\end{array}$ & $\begin{array}{r}563,952 \\
99,575 \\
3,140,336 \\
3,379,710 \\
867,956\end{array}$ & $\begin{array}{r}786,592 \\
117,711 \\
4,262,494 \\
4,283,965 \\
962,042\end{array}$ & $\begin{array}{r}680,369 \\
119,974 \\
4,500,016 \\
4,376,280 \\
1,012,997\end{array}$ & $\begin{array}{r}717,448 \\
125,637 \\
4,801,285 \\
4,665,642 \\
1,061,194\end{array}$ & $\begin{array}{r}739,911 \\
125,509 \\
4,918,450 \\
4,806,456 \\
1,177,439\end{array}$ & $\begin{array}{r}6,627 \\
18,061 \\
50,921 \\
172,327 \\
36,348\end{array}$ & $\begin{array}{r}18,374 \\
23,477 \\
142,256 \\
343,221 \\
62,880\end{array}$ & $\begin{array}{r}69,377 \\
30,354 \\
245,140 \\
677,625 \\
115,801\end{array}$ & $\begin{array}{r}226,848 \\
41,594 \\
331,287 \\
803,401 \\
144,226\end{array}$ & $\begin{array}{r}273,395 \\
47,972 \\
346,050 \\
851,581 \\
206,186\end{array}$ & $\begin{array}{r}289,770 \\
51,505 \\
340,537 \\
847,702 \\
211,978\end{array}$ \\
\hline 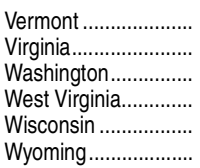 & $\begin{array}{r}347,293 \\
944,905 \\
600,315 \\
170,653 \\
999,502 \\
\dagger\end{array}$ & $\begin{array}{r}510,623 \\
1,311,743 \\
778,678 \\
181,181 \\
1,410,625 \\
+\end{array}$ & $\begin{array}{r}762,710 \\
1,686,972 \\
964,938 \\
201,699 \\
1,889,964 \\
\dagger\end{array}$ & $\begin{array}{r}717,199 \\
1,841,075 \\
988,571 \\
211,877 \\
1,929,430 \\
\dagger\end{array}$ & $\begin{array}{r}754,383 \\
1,737,579 \\
1,034,761 \\
222,031 \\
2,024,751 \\
\dagger\end{array}$ & $\begin{array}{r}782,385 \\
1,923,966 \\
1,073,689 \\
179,112 \\
2,119,356 \\
\dagger\end{array}$ & $\begin{array}{l}24,841 \\
65,804 \\
51,134 \\
17,926 \\
16,333 \\
19,766\end{array}$ & $\begin{array}{r}24,914 \\
258,642 \\
104,107 \\
28,634 \\
36,044 \\
34,596\end{array}$ & $\begin{array}{r}24,079 \\
443,621 \\
140,546 \\
121,720 \\
102,556 \\
36,535\end{array}$ & \begin{tabular}{r|r}
17,126 \\
614,287 \\
161,645 \\
165,043 \\
131,140 \\
39,869
\end{tabular} & $\begin{array}{r}16,242 \\
678,326 \\
178,364 \\
214,223 \\
170,376 \\
45,942\end{array}$ & $\begin{array}{r}16,288 \\
663,162 \\
163,426 \\
259,876 \\
172,703 \\
40,220\end{array}$ \\
\hline $\begin{array}{l}\text { Other } \\
\text { jurisdictions.. }\end{array}$ & 431,216 & 615,990 & 727,264 & 742,820 & 793,439 & 855,651 & 56,116 & 70,535 & 116,452 & 116,452 & 260,512 & 258,693 \\
\hline 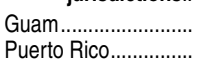 & $\begin{array}{r}\dagger \\
431,216\end{array}$ & $\begin{array}{r}1,535 \\
614,455\end{array}$ & $\begin{array}{r}3,680 \\
723,583\end{array}$ & $\begin{array}{r}2,551 \\
740,269\end{array}$ & $\begin{array}{r}2,215 \\
791,224\end{array}$ & $\begin{array}{r}1,756 \\
853,895\end{array}$ & $\begin{array}{r}\dagger \\
56,116\end{array}$ & $\begin{array}{r}\dagger \\
70,535\end{array}$ & $\begin{array}{r}\dagger \\
116,452\end{array}$ & $\begin{array}{r}\dagger \\
116,452\end{array}$ & $\begin{array}{r}\dagger \\
260,512\end{array}$ & $\begin{array}{r}\dagger \\
258,693\end{array}$ \\
\hline
\end{tabular}

†Not applicable.

NOTE: Degree-granting institutions grant associate's or higher degrees and participate in Title IV federal financial aid programs. Detail may not sum to totals because of rounding.
SOURCE: U.S. Department of Education, National Center for Education Statistics, Integrated Postsecondary Education Data System (IPEDS), Spring 2001 through Spring 2013, Finance component. (This table was prepared January 2014.) 


\section{CHAPTER 4 \\ Federal Funds for Education and Related Activities}

This chapter provides information on federal support for education. The tables include detailed data on funding by specific federal agencies, funding for different levels of education and types of education-related activities, and funding for specific programs. Preceding the tables is a brief chronology of federal education legislation enacted since 1787, which provides historical context for the education funding data.

The data in this chapter primarily reflect outlays and appropriations of federal agencies. The data are compiled from budget information prepared by federal agencies. In contrast, most of the federal revenue data reported in other chapters are compiled by educational institutions or state education agencies and reported to the federal government through standardized survey forms. Tabulations based on institution- or statereported revenue data differ substantially from federal budget reports because of numerous variations in methodology and definitions. Federal dollars are not necessarily spent by recipient institutions in the same year in which they are appropriated. In some cases, institutions cannot identify the source of federal revenues because they flow through state agencies. Some types of revenues, such as tuition and fees, are reported as revenues from students even though they may be supported by federal student aid programs. Some institutions that receive federal education funds are not included in regular surveys, censuses, and administrative data collections conducted by the National Center for Education Statistics (NCES). Thus, the federal programs data tabulated in this chapter are not comparable with figures reported in other chapters. Readers should also be careful about comparing the data on obligations shown in table 402.10 with the data on outlays and appropriations appearing in other tables in this chapter.

\section{Federal Education Funding}

Federal on-budget funding (federal appropriations) for education increased 427 percent from fiscal year (FY) 1965 to FY 2012, after adjustment for inflation (table D, table 401.10, and figure 20). From FY 1965 to FY 1975, federal on-budget funding for education increased by 151 percent. From FY 1975 to FY 1985, there was a decrease of 15 percent. Thereafter, federal on-budget funding for education generally increased. From FY 1990 to FY 2000, after adjustment for inflation, federal on-budget funding for education increased by 30 percent. From FY 2000 to FY 2012, it increased by 68 percent.
Table D. Federal on-budget funding for education, by category: Selected fiscal years, 1965 through 2012 [In billions of constant fiscal year (FY) 2013 dollars]

\begin{tabular}{|c|c|c|c|c|c|}
\hline Year & Total & $\begin{array}{r}\text { Elementary/ } \\
\text { secondary }\end{array}$ & $\begin{array}{r}\text { Post- } \\
\text { secondary }\end{array}$ & $\begin{array}{r}\text { Other } \\
\text { education }\end{array}$ & $\begin{array}{r}\text { Research at } \\
\text { educational } \\
\text { institutions }\end{array}$ \\
\hline $1965 \ldots \ldots \ldots . . . .$. & $\$ 36.7$ & $\$ 13.4$ & $\$ 8.3$ & $\$ 2.6$ & $\$ 12.5$ \\
\hline $1975 \ldots \ldots \ldots \ldots$ & 92.3 & 42.1 & 30.3 & 6.4 & 13.6 \\
\hline $1980 \ldots \ldots \ldots \ldots$ & 93.3 & 43.4 & 30.1 & 4.2 & 15.7 \\
\hline $1985 \ldots \ldots \ldots \ldots$ & 78.2 & 33.8 & 22.4 & 4.2 & 17.7 \\
\hline $1990 \ldots \ldots \ldots \ldots$ & 88.6 & 37.7 & 23.4 & 5.8 & 21.6 \\
\hline $1995 \ldots \ldots \ldots \ldots$ & 104.9 & 49.2 & 25.8 & 6.9 & 23.0 \\
\hline $2000 \ldots \ldots \ldots \ldots$ & 115.3 & 58.8 & 20.1 & 7.4 & 29.1 \\
\hline $2005 \ldots \ldots \ldots \ldots$ & 172.0 & 81.1 & 45.4 & 8.1 & 37.4 \\
\hline $2012 \ldots \ldots \ldots \ldots$ & 193.6 & 79.4 & 71.2 & 9.5 & 33.5 \\
\hline
\end{tabular}

NOTE: Detail may not sum to totals because of rounding.

SOURCE: U.S. Department of Education, Budget Service and National Center for Education Statistics, unpublished tabulations. U.S. Office of Management and Budget, Budget of the U.S. Government, Appendix, various FYs. National Science Foundation, Federal Funds for Research and Development, various FYs.

Between FY 1990 and FY 2000, after adjustment for inflation, federal on-budget funding increased for three of the four major categories reported: elementary and secondary education (by 56 percent), other education (by 27 percent), and research at educational institutions (by 34 percent) (table $\mathrm{D}$, table 401.10, and figure 20). During the same period, funding for postsecondary education decreased by 14 percent. From FY 2000 to FY 2012, after adjustment for inflation, federal on-budget funding showed a net increase of 35 percent for elementary and secondary education, 254 percent for postsecondary education, 30 percent for other education, and 15 percent for research at educational institutions. In FY 2009, federal on-budget funding for elementary and secondary education was at a record-high level (\$184.4 billion in FY 2013 dollars) due to funds from the American Recovery and Reinvestment Act of 2009 (ARRA) (table 401.10). ${ }^{1}$ For FY 2013, federal program funds were estimated to be $\$ 80.4$ billion for elementary and secondary education, $\$ 62.4$ billion for postsecondary education, and $\$ 9.7$ billion for other education programs (table 401.30). (FY 2013 data on research at educational institutions were not available at the time this publication was prepared.)

\footnotetext{
${ }^{1}$ Throughout this chapter, all education funds from ARRA are included in FY 2009. Most of these funds had a 2-year availability, meaning that they were available for the Department of Education to obligate during FY 2009 and FY 2010.
} 
After adjustment for inflation, off-budget support (federal support for education not tied to appropriations) and nonfederal funds generated by federal legislation (e.g., private loans, grants, and aid) showed an increase of 135 percent between FY 1990 (\$19.2 billion in FY 2013 dollars) and FY 2000 (\$45.1 billion in FY 2013 dollars) (table 401.10). In FY 2012, these same funds totaled $\$ 107.5$ billion in FY 2013 dollars, an increase of 138 percent over FY 2000. In FY 2013, these funds were an estimated $\$ 106.9$ billion.

In FY 2012, federal on-budget funds for education totaled $\$ 190.5$ billion in current dollars (figure 21 and table 401.20). The U.S. Department of Education provided 52 percent ( $\$ 99.1$ billion) of this total. Funds exceeding $\$ 3$ billion also came from the U.S. Department of Health and Human Services (\$29.7 billion), the U.S. Department of Agriculture (\$22.2 billion), the U.S. Department of Veterans Affairs (\$10.6 billion), the U.S. Department of Defense (\$7.3 billion), the U.S. Department of Labor ( $\$ 5.7$ billion), the National Science Foundation ( $\$ 5.5$ billion), and the U.S. Department of Energy (\$3.2 billion).

\section{Chronology of Federal Education Legislation}

A capsule view of the history of federal education activities is provided in the following list of selected legislation:

1787 Northwest Ordinance authorized land grants for the establishment of educational institutions.

1802 An Act Fixing the Military Peace Establishment of the United States established the U.S. Military Academy. (The U.S. Naval Academy was established in 1845 by the Secretary of the Navy.)

1862 First Morrill Act authorized public land grants to the states for the establishment and maintenance of agricultural and mechanical colleges.

1867 Department of Education Act authorized the establishment of the U.S. Department of Education. ${ }^{2}$

1876 Appropriation Act, U.S. Department of the Treasury, established the U.S. Coast Guard Academy.

1890 Second Morrill Act provided for money grants for support of instruction in the agricultural and mechanical colleges.

1911 State Marine School Act authorized federal funds to be used for the benefit of any nautical school in any of 11 specified state seaport cities.

\footnotetext{
${ }^{2}$ The U.S. Department of Education as established in 1867 was later known as the Office of Education. In 1980, under Public Law 96-88, it became a cabinet-level department. Therefore, for purposes of consistency, it is referred to as the "U.S. Department of Education" even in those tables covering years when it was officially the Office of Education.
}

1917 Smith-Hughes Act provided for grants to states for support of vocational education.

1918 Vocational Rehabilitation Act provided for grants for rehabilitation through training of World War I veterans.

1920 Smith-Bankhead Act authorized grants to states for vocational rehabilitation programs.

1935 Bankhead-Jones Act (Public Law 74-182) authorized grants to states for agricultural experiment stations.

Agricultural Adjustment Act (Public Law 74-320) authorized 30 percent of the annual customs receipts to be used to encourage the exportation and domestic consumption of agricultural commodities. Commodities purchased under this authorization began to be used in school lunch programs in 1936. The National School Lunch Act of 1946 continued and expanded this assistance.

1936 An Act to Further the Development and Maintenance of an Adequate and Well-Balanced American Merchant Marine (Public Law 74-415) established the U.S. Merchant Marine Academy.

1937 National Cancer Institute Act established the Public Health Service fellowship program.

1941 Amendment to Lanham Act of 1940 authorized federal aid for construction, maintenance, and operation of schools in federally impacted areas. Such assistance was continued under Public Law 815 and Public Law 874, 81st Congress, in 1950.

1943 Vocational Rehabilitation Act (Public Law 78-16) provided assistance to veterans with disabilities.

School Lunch Indemnity Plan (Public Law 78-129) provided funds for local lunch food purchases.

1944 Servicemen's Readjustment Act (Public Law 78-346), known as the GI Bill, provided assistance for the education of veterans.

Surplus Property Act (Public Law 78-457) authorized transfer of surplus property to educational institutions.

1946 National School Lunch Act (Public Law 79-396) authorized assistance through grants-in-aid and other means to states to assist in providing adequate foods and facilities for the establishment, maintenance, operation, and expansion of nonprofit school lunch programs.

George-Barden Act (Public Law 80-402) expanded federal support of vocational education.

1948 United States Information and Educational Exchange Act (Public Law 80-402) provided for the interchange of persons, knowledge, and skills between the United States and other countries. 
1949 Federal Property and Administrative Services Act (Public Law 81-152) provided for donation of surplus property to educational institutions and for other public purposes.

1950 Financial Assistance for Local Educational Agencies Affected by Federal Activities (Public Law 81-815 and Public Law 81-874) provided assistance for construction (Public Law 815) and operation (Public Law 874) of schools in federally affected areas.

Housing Act (Public Law 81-475) authorized loans for construction of college housing facilities.

1954 An Act for the Establishment of the United States Air Force Academy and Other Purposes (Public Law 83325) established the U.S. Air Force Academy.

Educational Research Act (Public Law 83-531) authorized cooperative arrangements with universities, colleges, and state educational agencies for educational research.

School Milk Program Act (Public Law 83-597) provided funds for purchase of milk for school lunch programs.

1956 Library Services Act (Public Law 84-597) provided grants to states for extension and improvement of rural public library services.

1957 Practical Nurse Training Act (Public Law 84-911) provided grants to states for practical nurse training.

1958 National Defense Education Act (Public Law 85-864) provided assistance to state and local school systems for instruction in science, mathematics, modern foreign languages, and other critical subjects; state statistical services; guidance, counseling, and testing services and training institutes; higher education student loans and fellowships as well as foreign language study and training; experimentation and dissemination of information on more effective use of television, motion pictures, and related media for educational purposes; and vocational education for technical occupations necessary to the national defense.

Education of Mentally Retarded Children Act (Public Law 85-926) authorized federal assistance for training teachers of the disabled.

Captioned Films for the Deaf Act (Public Law 85-905) authorized a loan service of captioned films for the deaf.

1961 Area Redevelopment Act (Public Law 87-27) included provisions for training or retraining of persons in redevelopment areas.

1962 Manpower Development and Training Act (Public Law 87-415) provided training in new and improved skills for the unemployed and underemployed.

Migration and Refugee Assistance Act of 1962 (Public Law 87-510) authorized loans, advances, and grants for education and training of refugees.
1963 Health Professions Educational Assistance Act of 1963 (Public Law 88-129) provided funds to expand teaching facilities and for loans to students in the health professions.

Vocational Education Act of 1963 (Part of Public Law 88-210) increased federal support of vocational education schools; vocational work-study programs; and research, training, and demonstrations in vocational education.

Higher Education Facilities Act of 1963 (Public Law 88-204) authorized grants and loans for classrooms, libraries, and laboratories in public community colleges and technical institutes, as well as undergraduate and graduate facilities in other institutions of higher education.

1964 Civil Rights Act of 1964 (Public Law 88-352) authorized the Commissioner of Education to arrange for support for institutions of higher education and school districts to provide inservice programs for assisting instructional staff in dealing with problems caused by desegregation.

Economic Opportunity Act of 1964 (Public Law 88452) authorized grants for college work-study programs for students from low-income families; established a Job Corps program and authorized support for work-training programs to provide education and vocational training and work experience opportunities in welfare programs; authorized support of education and training activities and of community action programs, including Head Start, Follow Through, and Upward Bound; and authorized the establishment of Volunteers in Service to America (VISTA).

1965 Elementary and Secondary Education Act of 1965 (Public Law 89-10) authorized grants for elementary and secondary school programs for children of lowincome families; school library resources, textbooks, and other instructional materials for school children; supplementary educational centers and services; strengthening state education agencies; and educational research and research training.

Health Professions Educational Assistance Amendments of 1965 (Public Law 89-290) authorized scholarships to aid needy students in the health professions.

Higher Education Act of 1965 (Public Law 89-329) provided grants for university community service programs, college library assistance, library training and research, strengthening developing institutions, teacher training programs, and undergraduate instructional equipment. Authorized insured student loans, established a National Teacher Corps, and provided for graduate teacher training fellowships.

National Foundation on the Arts and the Humanities Act (Public Law 89-209) authorized grants and loans for projects in the creative and performing arts and for research, training, and scholarly publications in the humanities. 
National Technical Institute for the Deaf Act (Public Law 89-36) provided for the establishment, construction, equipping, and operation of a residential school for postsecondary education and technical training of the deaf.

School Assistance in Disaster Areas Act (Public Law 89-313) provided for assistance to local education agencies to help meet exceptional costs resulting from a major disaster.

1966 International Education Act (Public Law 89-698) provided grants to institutions of higher education for the establishment, strengthening, and operation of centers for research and training in international studies and the international aspects of other fields of study.

National Sea Grant College and Program Act (Public Law 89-688) authorized the establishment and operation of Sea Grant Colleges and programs by initiating and supporting programs of education and research in the various fields relating to the development of marine resources.

Adult Education Act (Public Law 89-750) authorized grants to states for the encouragement and expansion of educational programs for adults, including training of teachers of adults and demonstrations in adult education (previously part of Economic Opportunity Act of 1964).

Model Secondary School for the Deaf Act (Public Law 89-694) authorized the establishment and operation, by Gallaudet College, of a model secondary school for the deaf.

1967 Education Professions Development Act (Public Law 90-35) amended the Higher Education Act of 1965 for the purpose of improving the quality of teaching and to help meet critical shortages of adequately trained educational personnel.

Public Broadcasting Act of 1967 (Public Law 90-129) established a Corporation for Public Broadcasting to assume major responsibility in channeling federal funds to noncommercial radio and television stations, program production groups, and educational television networks; conduct research, demonstration, or training in matters related to noncommercial broadcasting; and award grants for construction of educational radio and television facilities.

1968 Elementary and Secondary Education Amendments of 1968 (Public Law 90-247) modified existing programs and authorized support of regional centers for education of children with disabilities, model centers and services for deaf-blind children, recruitment of personnel and dissemination of information on education of children with disabilities; technical assistance in education to rural areas; support of dropout prevention projects; and support of bilingual education programs.
Handicapped Children's Early Education Assistance Act (Public Law 90-538) authorized preschool and early education programs for children with disabilities.

Vocational Education Amendments of 1968 (Public Law 90-576) modified existing programs and provided for a National Advisory Council on Vocational Education and collection and dissemination of information for programs administered by the Commissioner of Education.

1970 Elementary and Secondary Education Assistance Programs, Extension (Public Law 91-230) authorized comprehensive planning and evaluation grants to state and local education agencies; provided for the establishment of a National Commission on School Finance.

National Commission on Libraries and Information Services Act (Public Law 91-345) established a National Commission on Libraries and Information Science to effectively utilize the nation's educational resources.

Office of Education Appropriation Act (Public Law 91-380) provided emergency school assistance to desegregating local education agencies.

Environmental Education Act (Public Law 91-516) established an Office of Environmental Education to develop curriculum and initiate and maintain environmental education programs at the elementary/secondary levels; disseminate information; provide training programs for teachers and other educational, public, community, labor, and industrial leaders and employees; provide community education programs; and distribute material dealing with the environment and ecology.

Drug Abuse Education Act of 1970 (Public Law 91527) provided for development, demonstration, and evaluation of curricula on the problems of drug abuse.

1971 Comprehensive Health Manpower Training Act of 1971 (Public Law 92-257) amended Title VII of the Public Health Service Act, increasing and expanding provisions for health manpower training and training facilities.

1972 Drug Abuse Office and Treatment Act of 1972 (Public Law 92-255) established a Special Action Office for Drug Abuse Prevention to provide overall planning and policy for all federal drug-abuse prevention functions; a National Advisory Council for Drug Abuse Prevention; community assistance grants for community mental health centers for treatment and rehabilitation of people with drug-abuse problems; and, in December 1974, a National Institute on Drug Abuse.

Education Amendments of 1972 (Public Law 92-318) established the Education Division in the U.S. Department of Health, Education, and Welfare and the National Institute of Education; general aid for institutions of higher education; federal matching grants for state Student Incentive Grants; a National 
Commission on Financing Postsecondary Education; State Advisory Councils on Community Colleges; a Bureau of Occupational and Adult Education and State Grants for the design, establishment, and conduct of postsecondary occupational education; and a bureau-level Office of Indian Education. Amended current U.S. Department of Education programs to increase their effectiveness and better meet special needs. Prohibited sex bias in admission to vocational, professional, and graduate schools, and public institutions of undergraduate higher education.

1973 Older Americans Comprehensive Services Amendment of 1973 (Public Law 93-29) made available to older citizens comprehensive programs of health, education, and social services.

Comprehensive Employment and Training Act of 1973 (Public Law 93-203) provided for opportunities for employment and training to unemployed and underemployed people. Extended and expanded provisions in the Manpower Development and Training Act of 1962, Title I of the Economic Opportunity Act of 1962, Title I of the Economic Opportunity Act of 1964, and the Emergency Employment Act of 1971 as in effect prior to June 30, 1973.

1974 Education Amendments of 1974 (Public Law 93-380) provided for the consolidation of certain programs; and established a National Center for Education Statistics.

Juvenile Justice and Delinquency Prevention Act of 1974 (Public Law 93-415) provided for technical assistance, staff training, centralized research, and resources to develop and implement programs to keep students in elementary and secondary schools; and established, in the U.S. Department of Justice, a National Institute for Juvenile Justice and Delinquency Prevention.

1975 Indian Self-Determination and Education Assistance Act (Public Law 93-638) provided for increased participation of Indians in the establishment and conduct of their education programs and services.

Harry S Truman Memorial Scholarship Act (Public Law 93-642) established the Harry S Truman Scholarship Foundation and created a perpetual education scholarship fund for young Americans to prepare for and pursue careers in public service.

Education for All Handicapped Children Act (Public Law 94-142) provided that all children with disabilities have available to them a free appropriate education designed to meet their unique needs.

1976 Educational Broadcasting Facilities and Telecommunications Demonstration Act of 1976 (Public Law 94309) established a telecommunications demonstration program to promote the development of nonbroadcast telecommunications facilities and services for the transmission, distribution, and delivery of health, education, and public or social service information.
1977 Youth Employment and Demonstration Projects Act of 1977 (Public Law 95-93) established a youth employment training program including, among other activities, promoting education-to-work transition, literacy training and bilingual training, and attainment of certificates of high school equivalency.

Career Education Incentive Act (Public Law 95-207) authorized the establishment of a career education program for elementary and secondary schools.

1978 Tribally Controlled Community College Assistance Act of 1978 (Public Law 95-471) provided federal funds for the operation and improvement of tribally controlled community colleges for Indian students.

Middle Income Student Assistance Act (Public Law 95-566) modified the provisions for student financial assistance programs to allow middle-income as well as low-income students attending college or other postsecondary institutions to qualify for federal education assistance.

1979 Department of Education Organization Act (Public Law 96-88) established a U.S. Department of Education containing functions from the Education Division of the U.S. Department of Health, Education, and Welfare (HEW) along with other selected education programs from HEW, the U.S. Department of Justice, U.S. Department of Labor, and the National Science Foundation.

1980 Asbestos School Hazard Detection and Control Act of 1980 (Public Law 96-270) established a program for inspection of schools for detection of hazardous asbestos materials and provided loans to assist educational agencies to contain or remove and replace such materials.

1981 Education Consolidation and Improvement Act of 1981 (Part of Public Law 97-35) consolidated 42 programs into 7 programs to be funded under the elementary and secondary block grant authority.

1983 Student Loan Consolidation and Technical Amendments Act of 1983 (Public Law 98-79) established an 8 percent interest rate for Guaranteed Student Loans and an extended Family Contribution Schedule.

Challenge Grant Amendments of 1983 (Public Law 98-95) amended Title III, Higher Education Act, and added authorization of the Challenge Grant program. The Challenge Grant program provides funds to eligible institutions on a matching basis as an incentive to seek alternative sources of funding.

Education of the Handicapped Act Amendments of 1983 (Public Law 98-199) added the Architectural Barrier amendment and clarified participation of children with disabilities in private schools.

1984 Education for Economic Security Act (Public Law 98377) added new science and mathematics programs 
for elementary, secondary, and postsecondary education. The new programs included magnet schools, excellence in education, and equal access.

Carl D. Perkins Vocational Education Act (Public Law 98-524) continued federal assistance for vocational education through FY 1989. The act replaced the Vocational Education Act of 1963. It provided aid to the states to make vocational education programs accessible to all people, including disabled and disadvantaged, single parents and homemakers, and the incarcerated.

Human Services Reauthorization Act (Public Law 98558) created a Carl D. Perkins scholarship program, a National Talented Teachers Fellowship program, a Federal Merit Scholarships program, and a Leadership in Educational Administration program.

1985 Montgomery GI Bill-Active Duty (Public Law 98525), brought about a new GI Bill for individuals who initially entered active military duty on or after July $1,1985$.

Montgomery GI Bill-Selected Reserve (Public Law 98-525), established an education program for members of the Selected Reserve (which includes the National Guard) who enlist, reenlist, or extend an enlistment after June 30, 1985, for a 6-year period.

1986 Handicapped Children's Protection Act of 1986 (Public Law 99-372) allowed parents of children with disabilities to collect attorneys' fees in cases brought under the Education of the Handicapped Act and provided that the Education of the Handicapped Act does not preempt other laws, such as Section 504 of the Rehabilitation Act.

Drug-Free Schools and Communities Act of 1986 (Part of Public Law 99-570) established programs for drug abuse education and prevention, coordinated with related community efforts and resources, through the use of federal financial assistance.

1988 Augustus F. Hawkins-Robert T. Stafford Elementary and Secondary School Improvement Amendments of 1988 (Public Law 100-297) reauthorized through 1993 major elementary and secondary education programs, including Chapter 1, Chapter 2, Bilingual Education, Math-Science Education, Magnet Schools, Impact Aid, Indian Education, Adult Education, and other smaller education programs.

Stewart B. McKinney Homeless Assistance Amendments Act of 1988 (Public Law 100-628) extended for 2 additional years programs providing assistance to the homeless, including literacy training for homeless adults and education for homeless youths.

Tax Reform Technical Amendments (Public Law 100647) authorized an Education Savings Bond for the purpose of postsecondary educational expenses. The bill grants tax exclusion for interest earned on regular series EE savings bonds.

1989 Childhood Education and Development Act of 1989 (Part of Public Law 101-239) authorized the appropriations to expand Head Start programs and programs carried out under the Elementary and Secondary Education Act of 1965 to include child care services.

1990 Excellence in Mathematics, Science and Engineering Education Act of 1990 (Public Law 101-589) created a national mathematics and science clearinghouse and created several other mathematics, science, and engineering education programs.

Student Right-To-Know and Campus Security Act (Public Law 101-542) required institutions of higher education receiving federal financial assistance to provide certain information with respect to the graduation rates of student-athletes at such institutions.

Americans with Disabilities Act of 1990 (Public Law 101-336) prohibited discrimination against persons with disabilities.

National and Community Service Act of 1990 (Public Law 101-610) increased school and college-based community service opportunities and authorized the President's Points of Light Foundation.

1991 National Literacy Act of 1991 (Public Law 102-73) established the National Institute for Literacy, the National Institute Board, and the Interagency Task Force on Literacy. Amended various federal laws to establish and extend various literacy programs.

High-Performance Computing Act of 1991 (Public Law 102-194) directed the President to implement a National High-Performance Computing Program. Provided for (1) establishment of a National Research and Education Network; (2) standards and guidelines for high-performance networks; and (3) the responsibility of certain federal departments and agencies with regard to the Network.

Veterans' Educational Assistance Amendments of 1991 (Public Law 102-127) restored certain educational benefits available to reserve and active-duty personnel under the Montgomery GI Bill to students whose courses of studies were interrupted by the Persian Gulf War.

Civil Rights Act of 1991 (Public Law 102-166) amended the Civil Rights Act of 1964, the Age Discrimination in Employment Act of 1967, and the Americans with Disabilities Act of 1990, with regard to employment discrimination. Established the Technical Assistance Training Institute.

1992 Ready-To-Learn Act (Public Law 102-545) amended the General Education Provisions Act to establish Ready-To-Learn Television programs to support educational programming and support materials for 
preschool and elementary school children and their parents, child care providers, and educators.

1993 Student Loan Reform Act (Public Law 103-66) reformed the student aid process by phasing in a system of direct lending designed to provide savings for taxpayers and students. Allows students to choose among a variety of repayment options, including income contingency.

National Service Trust Act (Public Law 103-82) amended the National and Community Service Act of 1990 to establish a Corporation for National Service. In addition, provided education grants up to $\$ 4,725$ per year for 2 years to people age 17 or older who perform community service before, during, or after postsecondary education.

NAEP Assessment Authorization (Public Law 103-33) authorized use of the National Assessment of Educational Progress (NAEP) for state-by-state comparisons.

1994 Goals 2000: Educate America Act (Public Law 103227) established a new federal partnership through a system of grants to states and local communities to reform the nation's education system. The Act formalized the national education goals and established the National Education Goals Panel.

School-To-Work Opportunities Act of 1994 (Public Law 103-239) established a national framework within which states and communities can develop School-To-Work Opportunities systems to prepare young people for first jobs and continuing education. The Act also provided money to states and communities to develop a system of programs that include work-based learning, school-based learning, and connecting activities components.

Safe Schools Act of 1994 (Part of Public Law 103-227) authorized the award of competitive grants to local educational agencies with serious crime to implement violence prevention activities such as conflict resolution and peer mediation.

1996 Contract With America: Unfunded Mandates (Public Law 104-4) ended the imposition, in the absence of full consideration by Congress, of federal mandates on state, local, and tribal governments without adequate funding, in a manner that may displace other essential governmental priorities; and ensured that the federal government pays the costs incurred by those governments in complying with certain requirements under federal statutes and regulations.

1997 The Taxpayer Relief Act of 1997 (Public Law 10534) enacted the Hope Scholarship and Life-Long Learning Tax Credit provisions into law.

Emergency Student Loan Consolidation Act of 1997 (Public Law 105-78) amended the Higher Education Act to provide for improved student loan consolidation services.
1998 Workforce Investment Act of 1998 (Public Law 105220) enacted the Adult Education and Family Literacy Act, and substantially revised and extended, through FY 2003, the Rehabilitation Act of 1973.

Omnibus Consolidated and Emergency Supplemental Appropriations Act, 1999 (Public Law 105-277) enacted the Reading Excellence Act, to promote the ability of children to read independently by the third grade; and earmarked funds to help states and school districts reduce class sizes in the early grades.

Charter School Expansion Act (Public Law 105-278) amended the charter school program, enacted in 1994 as Title X, Part C of the Elementary and Secondary Education Act of 1965.

Carl D. Perkins Vocational and Applied Technology Education Amendments of 1998 (Public Law 105332) revised, in its entirety, the Carl D. Perkins Vocational and Applied Technology Education Act, and reauthorized the Act through FY 2003

Assistive Technology Act of 1998 (Public Law 105394) replaced the Technology-Related Assistance for Individuals with Disabilities Act of 1988 with a new Act, authorized through FY 2004, to address the assistive-technology needs of individuals with disabilities.

1999 Education Flexibility Partnership Act of 1999 (Public Law 106-25) authorized the Secretary of Education to allow all states to participate in the Education Flexibility Partnership program.

District of Columbia College Access Act of 1999 (Public Law 106-98) established a program to afford high school graduates from the District of Columbia the benefits of in-state tuition at state colleges and universities outside the District of Columbia.

2000 The National Defense Authorization Act for Fiscal Year 2001 (Public Law 106-398) included, as Title XVIII, the Impact Aid Reauthorization Act of 2000, which extended the Impact Aid programs through FY 2003.

College Scholarship Fraud Prevention Act of 2000 (Public Law 106-420) enhanced federal penalties for offenses involving scholarship fraud; required an annual scholarship fraud report by the Attorney General, the Secretary of Education, and the Federal Trade Commission (FTC); and required the Secretary of Education, in conjunction with the FTC, to maintain a scholarship fraud awareness website.

Consolidated Appropriations Act 2001 (Public Law 106-554) created a new program of assistance for school repair and renovation, and amended the Elementary and Secondary Education Act of 1965 to authorize credit enhancement initiatives to help charter schools obtain, construct, or repair facilities; reauthorized the Even Start program; and enacted the "Children's Internet Protection Act."

2001 50th Anniversary of Brown v. the Board of Education (Public Law 107-41) established a commission for the purpose of encouraging and providing for the com- 
memoration of the 50th anniversary of the 1954 Supreme Court decision Brown v. Board of Education.

2002 No Child Left Behind Act of 2001 (Public Law 107110) provided for the comprehensive reauthorization of the Elementary and Secondary Education Act of 1965, incorporating specific proposals in such areas as testing, accountability, parental choice, and early reading.

Reauthorization of the National Center for Education Statistics and the Creating of the Institute of Education Sciences of 2002 (Public Law 107-279) established the Institute of Education Sciences within the U.S. Department of Education to carry out a coordinated, focused agenda of high-quality research, statistics, and evaluation that is relevant to the educational challenges of the nation.

The Higher Education Relief Opportunities for Students Act of 2001 (Public Law 107-122) provided the Secretary of Education with waiver authority over student financial aid programs under Title IV of the Higher Education Act of 1965, to deal with student and family situations resulting from the September 11, 2001, terrorist attacks.

Established fixed interest rates for student and parent borrowers (Public Law 107-139) under Title IV of the Higher Education Act of 1965.

2003 The Higher Education Relief Opportunities for Students Act of 2003 (Public Law 108-76) provided the Secretary of Education with waiver authority over student financial aid programs under Title IV of the Higher Education Act of 1965, to deal with student and family situations resulting from wars or national emergencies.

2004 Assistive Technology Act of 2004 (Public Law 108364) reauthorized the Assistive Technology program, administered by the Department of Education.

Taxpayer-Teacher Protection Act of 2004 (Public Law 108-409) temporarily stopped excessive special allowance payments to certain lenders under the Federal Family Education Loan (FFEL) Program and increased the amount of loans that can be forgiven for certain borrowers who are highly qualified mathematics, science, and special education teachers who serve in high-poverty schools for 5 years.

Individuals with Disabilities Education Improvement Act of 2004 (Public Law 108-446) provided a comprehensive reauthorization of the Individuals with Disabilities Education Act.

2005 Student Grant Hurricane and Disaster Relief Act (Public Law 109-67) authorized the Secretary of Education to waive certain repayment requirements for students receiving campus-based federal grant assistance if they were residing in, employed in, or attending an institution of higher education located in a major disaster area, or their attendance was interrupted because of the disaster.

Natural Disaster Student Aid Fairness Act (Public Law 109-86) authorized the Secretary of Education during FY 2006 to reallocate campus-based student aid funds to institutions of higher learning in Louisiana, Mississippi, Alabama, and Texas, or institutions that had accepted students displaced by Hurricane Katrina or Rita. The law also waived requirements for matching funds that are normally imposed on institutions and students.

Hurricane Education Recovery Act (HERA) (Public Law 109-148, provision in the Defense Department Appropriations Act for FY 2006) provided funds for states affected by Hurricane Katrina to restart school operations, provide temporary emergency aid for displaced students, and assist homeless youth. The law also permitted the Secretary of Education to extend deadlines under the Individuals with Disabilities Education Act for those affected by Katrina or Rita.

2006 Higher Education Reconciliation Act of 2005 (Public Law 109-171) made various amendments to programs of student financial assistance under Title IV of the Higher Education Act of 1965.

Public Law 109-211 reauthorized the "ED-FLEX" program (under the Education Flexibility Partnership Act of 1999), under which the Secretary of Education permits states to waive certain requirements of federal statutes and regulations if they meet certain conditions.

Carl D. Perkins Career and Technical Education Improvement Act of 2006 (Public Law 109-270) reauthorized the vocational and technical education programs under the Perkins Act through 2012.

2007 Public Law 110-15 designated the Department of Education Headquarters Building as the "Lyndon Baines Johnson Department of Education Building."

America COMPETES Act (or "America Creating Opportunities to Meaningfully Promote Excellence in Technology, Education, and Science Act") (Public Law 110-69) created new STEM (science, technology, engineering, and mathematics) education programs in various agencies, including the Department of Education.

College Cost Reduction and Access Act of 2007 (Public Law 110-84) reduced interest rates on student loans and made other amendments to the Higher Education Act of 1965 to make college more accessible and affordable.

Permanent extension of the Higher Education Relief Opportunities for Students Act of 2003 (HEROES Act) (Public Law 110-93) gave the Secretary of Education authority to waive or modify any statutory or regulatory provision applicable to the student financial assistance programs under Title IV of the Higher Education Act of 1965 as deemed necessary in connection with a war or other military operation or national emergency.

2008 Ensuring Continued Access to Student Loans Act of 2008 (Public Law 110-227) provided various author- 
ities to the Department of Education, among other provisions, to help ensure that college students and their parents continue to have access to loans in the tight credit market.

Higher Education Opportunity Act (Public Law 110315) provided a comprehensive reauthorization of the Higher Education Act of 1965.

2009 American Recovery and Reinvestment Act of 2009 (Public Law 111-5) provided about $\$ 100$ billion to state education systems and supplemental appropriations for several Department of Education programs.

Public Law 111-39 made miscellaneous and technical amendments to the Higher Education Act of 1965.

2010 Health Care and Education Reconciliation Act of 2010 (Public Law 111-152) included, as Title II, the "SAFRA Act" (also known as the "Student Aid and Fiscal Responsibility Act"). The SAFRA Act ended the federal government's role in subsidizing financial institutions that make student loans through the Federal Family Education Loan (FFEL) Program under
Part B of Title IV of the Higher Education Act of 1965 (HEA), and correspondingly expanded the Federal Direct Student Loan Program administered by the Department of Education under Part D of Title IV of the HEA.

Public Law 111-226 provided an additional \$10 billion to states and school districts, through an "Education Jobs Fund" modeled closely on the State Fiscal Stabilization Fund created by the 2009 Recovery Act, to hire (or avoid laying off) teachers and other educators.

2013 The Health Bipartisan Student Loan Certainty Act of 2013 (Public Law 113-28) amended the Higher Education Act of 1965 (HEA) to govern the interest rates on the various categories of student loans under Title IV of the HEA.

Violence Against Women Reauthorization Act of 2013 (Public Law 113-4) includes important amendments to the Clery Act (a provision in the HEA relating to campus crime).

Figure 20. Federal on-budget funds for education, by level or other educational purpose: Selected years, 1965 through 2013 Billions of constant fiscal year 2013 dollars

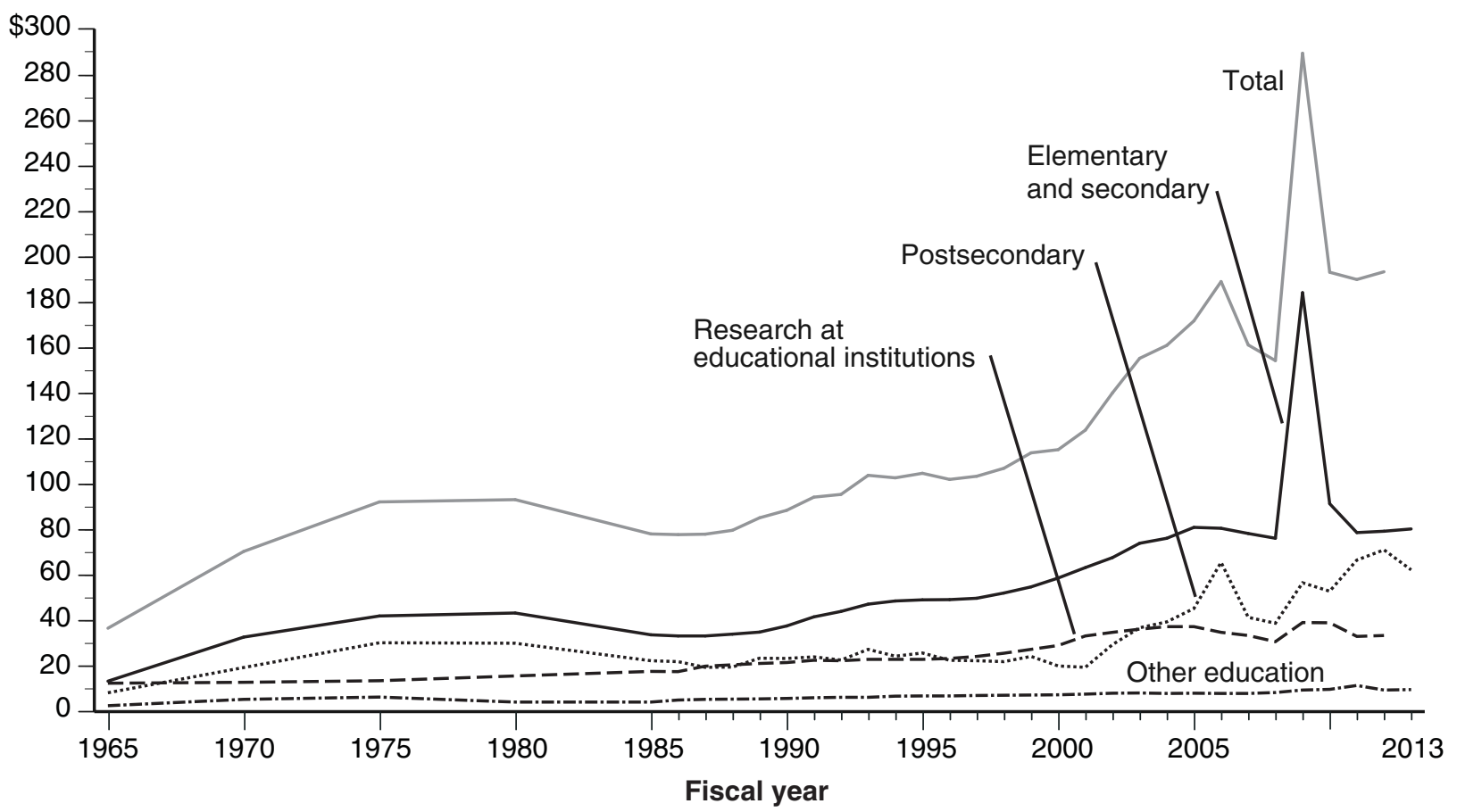

NOTE: The increase in postsecondary expenditures in 2006 resulted primarily from an accounting adjustment. Amounts for 2009 include funds from the American Recovery and Reinvestment Act of 2009 (ARRA). Data for research at educational institutions are estimated for 2011 and 2012 and are not available for 2013. Data for elementary and secondary, postsecondary, and other education are estimated for 2013.

SOURCE: U.S. Department of Education, Budget Service, unpublished tabulations. U.S. Department of Education, National Center for Education Statistics, unpublished tabulations. U.S. Office of Management and Budget, Budget of the U.S. Government, Appendix, fiscal years 1967 through 2014. National Science Foundation, Federal Funds for Research and Development, fiscal years 1967 through 2012. 
Figure 21. Percentage of federal on-budget funds for education, by agency: Fiscal year 2012

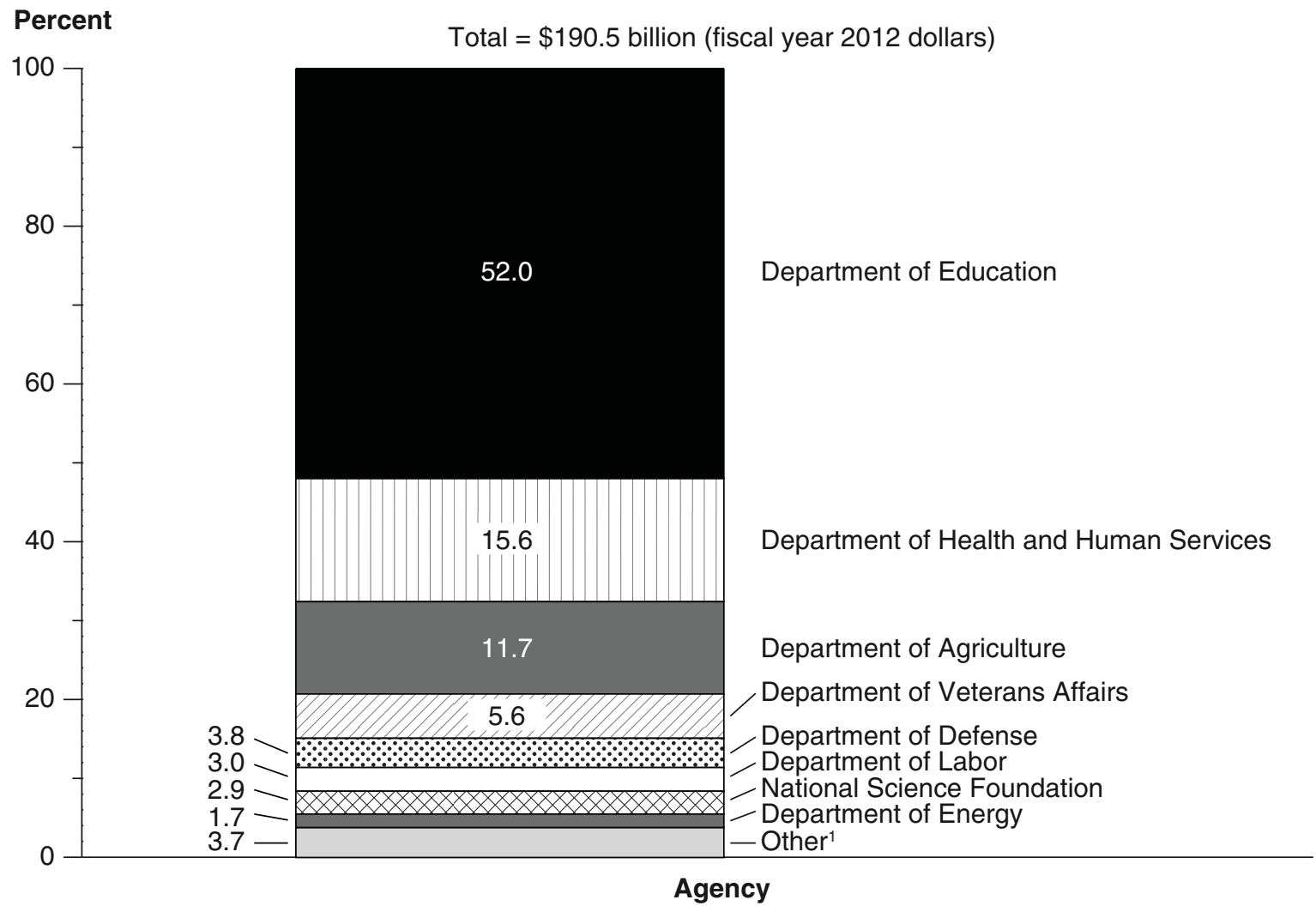

${ }^{1}$ In addition to the eight agencies shown in this figure, other agencies provide smaller amounts of funding for education.

NOTE: On-budget funds are tied to federal appropriations for education programs. Detail may not sum to totals because of rounding.

SOURCE: U.S. Department of Education, National Center for Education Statistics, unpublished tabulations. U.S. Office of Management and Budget, Budget of the U.S. Government, Appendix, fiscal year 2014. National Science Foundation, Federal Funds for Research and Development, fiscal year 2012. 
Table 401.10. Federal support and estimated federal tax expenditures for education, by category: Selected fiscal years, 1965 through 2013

[In millions of dollars]

\begin{tabular}{|c|c|c|c|c|c|c|c|c|c|c|c|c|c|c|c|c|}
\hline \multirow[b]{3}{*}{ Fiscal year } & \multirow{3}{*}{\begin{tabular}{|} 
Total on-budget \\
support, \\
off-budget \\
support, and \\
nonfederal \\
funds \\
generated \\
by federal \\
legislation
\end{tabular}} & \multicolumn{5}{|c|}{ On-budget support ${ }^{1}$} & \multicolumn{8}{|c|}{ Off-budget support and nonfederal funds generated by federal legislation } & \multirow[b]{3}{*}{$\begin{array}{r}\text { Estimated } \\
\text { federal tax } \\
\text { expenditures } \\
\text { for education }{ }^{2}\end{array}$} & \\
\hline & & \multirow[b]{2}{*}{ Total } & \multirow[b]{2}{*}{$\begin{array}{r}\text { Elementary } \\
\text { and } \\
\text { secondary }\end{array}$} & \multirow[b]{2}{*}{$\begin{array}{r}\text { Post- } \\
\text { secondary }\end{array}$} & \multirow[b]{2}{*}{$\begin{array}{r}\text { Other } \\
\text { education }\end{array}$} & \multirow[b]{2}{*}{$\begin{array}{r}\text { Research at } \\
\text { educational } \\
\text { institutions }\end{array}$} & & $\begin{array}{c}\text { Off-budget } \\
\text { support }\end{array}$ & \multicolumn{6}{|c|}{ Nonfederal funds } & & \\
\hline & & & & & & & Total & $\begin{array}{r}\text { Direct Loan } \\
\text { Program }^{4}\end{array}$ & $\begin{array}{r}\text { Federal } \\
\text { Family } \\
\text { Education } \\
\text { Loan } \\
\text { Program } \\
\end{array}$ & $\begin{array}{l}\text { Perkins } \\
\text { Loans }^{6}\end{array}$ & $\begin{array}{r}\text { Income } \\
\text { Contingent } \\
\text { Loans }{ }^{7}\end{array}$ & $\begin{array}{r}\text { Leveraging } \\
\text { Educational } \\
\text { Assistance }^{\text {Partnerships }}{ }^{8}\end{array}$ & $\begin{array}{r}\text { Supplemental } \\
\text { Educational } \\
\text { Opportunity } \\
\text { Grants }^{9}\end{array}$ & $\begin{array}{r}\text { Work-Study } \\
\text { Aid }^{10}\end{array}$ & & \\
\hline 1 & 2 & 3 & 4 & 5 & 6 & 7 & 8 & 9 & 10 & 11 & 12 & 13 & 14 & 15 & 16 & \\
\hline & \multicolumn{16}{|c|}{ Current dollars } \\
\hline 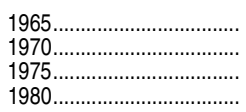 & $\begin{array}{l}\$ 5,354.7 \\
13,359.1 \\
24,691.5 \\
39,349.5\end{array}$ & $\begin{array}{l}\$ 5,331.0 \\
12,526.5 \\
23,288.1 \\
34,493.5\end{array}$ & $\begin{array}{r}\$ 1,942.6 \\
5,830.4 \\
10,617.2 \\
16,027.7\end{array}$ & $\begin{array}{r}\$ 1,197.5 \\
3,447.7 \\
7,644.0 \\
11,115.9\end{array}$ & $\begin{array}{r}\$ 374.7 \\
964.7 \\
1,608.5 \\
1,548.7\end{array}$ & $\begin{array}{r}\$ 1,816.3 \\
2,283.6 \\
3,418.4 \\
5,801.2\end{array}$ & $\begin{array}{r}\$ 23.7 \\
832.6 \\
1,403.4 \\
4,856.0\end{array}$ & $\begin{array}{l}+ \\
+ \\
\dagger \\
+ \\
\dagger\end{array}$ & $\begin{array}{r}\dagger \\
\$ 770.0 \\
1,233.0 \\
4,598.0\end{array}$ & $\begin{array}{r}\$ 16.1 \\
21.0 \\
35.7 \\
31.8\end{array}$ & $\begin{array}{l}t \\
t \\
t \\
t\end{array}$ & $\begin{array}{r}\dagger \\
\dagger \\
\$ 20.0 \\
76.8\end{array}$ & $\begin{array}{l}\dagger \\
t \\
t \\
\dagger\end{array}$ & $\begin{array}{r}\$ 7.6 \\
41.6 \\
114.7 \\
149.4\end{array}$ & $\begin{array}{r}\overline{-} \\
\$ 8,605.0 \\
13,320.0\end{array}$ & \\
\hline 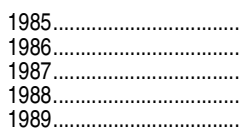 & $\begin{array}{l}47,753.4 \\
48,357.3 \\
50,724.6 \\
54,078.7 \\
59,537.4\end{array}$ & $\begin{array}{l}39,027.9 \\
39,962.9 \\
41,194.7 \\
43,454.4 \\
48,269.6\end{array}$ & $\begin{array}{l}16,901.3 \\
17,049.9 \\
17,535.7 \\
18,564.9 \\
19,809.5\end{array}$ & $\begin{array}{l}11,174.4 \\
11,283.6 \\
10,300.0 \\
10,657.5 \\
13,269.9\end{array}$ & $\begin{array}{l}2,107.6 \\
2,620.0 \\
2,820.4 \\
2,981.6 \\
3,180.3\end{array}$ & $\begin{array}{r}8,844.6 \\
9,009.4 \\
10,538.6 \\
11,250.5 \\
12,009.8\end{array}$ & $\begin{array}{r}8,725.5 \\
8,394.4 \\
9,529.8 \\
10,624.3 \\
11,267.8\end{array}$ & $\begin{array}{l}t \\
t \\
t \\
t \\
t\end{array}$ & $\begin{array}{r}8,467.0 \\
8,42.0 \\
9,272.0 \\
10,380.0 \\
10,938.0\end{array}$ & $\begin{array}{l}21.4 \\
20.2 \\
20.9 \\
20.6 \\
20.4\end{array}$ & $\begin{array}{r}\dagger \\
\dagger \\
\$ 0.6 \\
0.5 \\
0.5\end{array}$ & $\begin{array}{l}76.0 \\
72.7 \\
76.0 \\
72.8 \\
71.9\end{array}$ & $\begin{array}{r}t \\
t \\
t \\
t \\
\$ 22.0\end{array}$ & $\begin{array}{l}161.1 \\
159.5 \\
160.4 \\
150.4 \\
215.0\end{array}$ & $\begin{array}{l}19,105.0 \\
20,425.0 \\
20,830.0 \\
17,025.0 \\
17,755.0\end{array}$ & \\
\hline $\begin{array}{l}1990 . \\
1991 \ldots \\
1992 \\
1993 \\
1994\end{array}$ & $\begin{array}{l}62,811.5 \\
70,375.6 \\
74,481.1 \\
84,741.5 \\
92,781.5\end{array}$ & $\begin{array}{l}51,624.3 \\
57,599.5 \\
60,483.1 \\
67,740.6 \\
68,254.2\end{array}$ & $\begin{array}{l}21,984.4 \\
25,418.0 \\
27,926.9 \\
30,834.3 \\
32,304.4\end{array}$ & $\begin{array}{l}13,650.9 \\
14,707.4 \\
14,387.4 \\
17,844.0 \\
16,177.1\end{array}$ & $\begin{array}{l}3,383.0 \\
3,698.6 \\
3,992.0 \\
4,107.2 \\
4,483.7\end{array}$ & $\begin{array}{l}12,606.0 \\
13,775.4 \\
14,176.9 \\
14,955.1 \\
15,289.1\end{array}$ & $\begin{array}{l}11,187.2 \\
12,776.1 \\
13,998.0 \\
17,000.8 \\
24,527.3\end{array}$ & $\begin{array}{r}t \\
t \\
t \\
t \\
\$ 813.0\end{array}$ & $\begin{array}{l}10,826.0 \\
12,372.0 \\
13,568.0 \\
16,524.0 \\
23,214.0\end{array}$ & $\begin{array}{l}15.0 \\
17.3 \\
17.3 \\
29.3 \\
52.7\end{array}$ & $\begin{array}{r}0.5 \\
0.5 \\
0.5 \\
\dagger \\
\dagger\end{array}$ & $\begin{array}{l}59.2 \\
63.5 \\
72.0 \\
72.4 \\
72.4\end{array}$ & $\begin{array}{r}48.8 \\
87.7 \\
97.2 \\
184.6 \\
184.6\end{array}$ & $\begin{array}{l}237.7 \\
235.0 \\
242.9 \\
190.5 \\
190.5\end{array}$ & $\begin{array}{l}19,040.0 \\
18,995.0 \\
19,950.0 \\
21,010.0 \\
22,630.0\end{array}$ & \\
\hline $\begin{array}{l}1995 . \\
1996 \\
1997 \\
1998 \\
1999\end{array}$ & \begin{tabular}{r|}
$95,810.8$ \\
$96,833.0$ \\
$103,259.8$ \\
$107,810.5$ \\
$113,417.2$
\end{tabular} & $\begin{array}{l}71,639.5 \\
71,327.4 \\
73,731.8 \\
76,909.2 \\
82,863.6\end{array}$ & $\begin{array}{l}33,623.8 \\
34,391.5 \\
35,478.9 \\
37,486.2 \\
39,937.9\end{array}$ & $\begin{array}{l}17,618.1 \\
15,775.5 \\
15,959.4 \\
15,799.6 \\
17,651.2\end{array}$ & $\begin{array}{l}4,719.7 \\
4,828.0 \\
5,021.2 \\
5,148.5 \\
5,318.0\end{array}$ & $\begin{array}{l}15,677.9 \\
16,332.3 \\
17,272.4 \\
18,475.0 \\
19,956.5\end{array}$ & $\begin{array}{l}24,171.2 \\
25,505.6 \\
29,528.0 \\
30,901.3 \\
30,553.6\end{array}$ & $\begin{array}{r}5,161.0 \\
8,357.0 \\
9,838.0 \\
10,400.1 \\
9,953.0\end{array}$ & $\begin{array}{l}18,519.0 \\
16,711.0 \\
19,163.0 \\
20,002.5 \\
20,107.0\end{array}$ & $\begin{array}{l}52.7 \\
31.1 \\
52.7 \\
45.0 \\
33.3\end{array}$ & $\begin{array}{l}\dagger \\
\dagger \\
\dagger \\
\dagger \\
\dagger\end{array}$ & $\begin{array}{l}63.4 \\
31.4 \\
50.0 \\
25.0 \\
25.0\end{array}$ & $\begin{array}{l}184.6 \\
184.6 \\
184.6 \\
194.3 \\
195.9\end{array}$ & $\begin{array}{l}190.5 \\
190.5 \\
239.7 \\
234.4 \\
239.4\end{array}$ & $\begin{array}{l}24,600.0 \\
26,340.0 \\
28,125.0 \\
29,540.0 \\
37,360.0\end{array}$ & $\frac{O}{1}$ \\
\hline $\begin{array}{l}2000 \text {. } \\
2001 \ldots \\
2002 \ldots \\
2003 \ldots \\
2004 \ldots\end{array}$ & $\begin{array}{l}119,541.6 \\
130,668.5 \\
150,034.5 \\
170,671.5 \\
185,176.7\end{array}$ & $\begin{array}{r}85,944.2 \\
94,846.5 \\
109,211.5 \\
124,374.5 \\
132,420.7\end{array}$ & $\begin{array}{l}43,790.8 \\
48,530.1 \\
52,754.1 \\
59,274.2 \\
62,653.2\end{array}$ & $\begin{array}{l}15,008.7 \\
14,938.3 \\
22,964.2 \\
29,499.7 \\
32,433.0\end{array}$ & $\begin{array}{l}5,484.6 \\
5,880.0 \\
6,297.7 \\
6,532.5 \\
6,576.8\end{array}$ & $\begin{array}{l}21,660.1 \\
25,498.1 \\
27,195.5 \\
29,068.1 \\
30,757.7\end{array}$ & $\begin{array}{l}33,597.4 \\
35,822.0 \\
40,823.0 \\
46,297.0 \\
52,756.0\end{array}$ & $\begin{array}{l}10,347.0 \\
10,635.0 \\
11,689.0 \\
11,969.0 \\
12,840.0\end{array}$ & $\begin{array}{l}22,711.0 \\
24,694.0 \\
28,606.0 \\
33,791.0 \\
39,266.0\end{array}$ & $\begin{array}{l}33.3 \\
25.0 \\
25.0 \\
33.0 \\
33.0\end{array}$ & $\begin{array}{l}\dagger \\
+ \\
\dagger \\
\dagger \\
\dagger\end{array}$ & $\begin{array}{r}50.0 \\
80.0 \\
104.0 \\
103.0 \\
102.0\end{array}$ & $\begin{array}{l}199.7 \\
184.0 \\
192.0 \\
202.0 \\
244.0\end{array}$ & $\begin{array}{l}256.4 \\
204.0 \\
207.0 \\
199.0 \\
271.0\end{array}$ & $\begin{array}{r}39,475.0 \\
41,460.0 \\
= \\
-\end{array}$ & 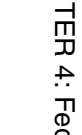 \\
\hline 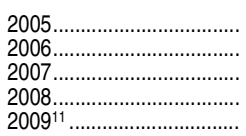 & $\begin{array}{l}203,036.0 \\
226,978.7 \\
210,536.0 \\
220,336.9 \\
368,349.6\end{array}$ & $\begin{array}{l}146,207.0 \\
166,495.7 \\
145,698.0 \\
144,338.9 \\
271,297.6\end{array}$ & $\begin{array}{r}68,957.7 \\
70,948.2 \\
70,735.9 \\
71,272.6 \\
172,660.8\end{array}$ & $\begin{array}{l}38,587.3 \\
57,757.7 \\
37,465.3 \\
36,386.3 \\
53,085.4\end{array}$ & $\begin{array}{l}6,908.5 \\
7,074.5 \\
7,214.9 \\
7,882.2 \\
8,853.7\end{array}$ & $\begin{array}{l}31,753.5 \\
30,715.2 \\
30,281.9 \\
28,797.8 \\
36,697.7\end{array}$ & $\begin{array}{l}56,829.0 \\
60,483.0 \\
64,838.0 \\
75,998.0 \\
97,052.0\end{array}$ & $\begin{array}{l}12,930.0 \\
12,677.0 \\
13,022.0 \\
18,213.0 \\
29,738.0\end{array}$ & $\begin{array}{l}43,284.0 \\
47,307.0 \\
51,320.0 \\
57,296.0 \\
66,778.0\end{array}$ & $\begin{array}{l}0.0 \\
0.0 \\
0.0 \\
0.0 \\
0.0\end{array}$ & $\begin{array}{l}+ \\
+ \\
\dagger \\
\dagger \\
\dagger\end{array}$ & $\begin{array}{r}101.0 \\
100.0 \\
100.0 \\
98.0 \\
98.0\end{array}$ & $\begin{array}{l}246.0 \\
205.0 \\
205.0 \\
201.0 \\
201.0\end{array}$ & $\begin{array}{l}268.0 \\
194.0 \\
191.0 \\
190.0 \\
237.0\end{array}$ & $\begin{array}{l}- \\
\overline{-} \\
- \\
-\end{array}$ & $\begin{array}{l}\frac{0}{0} \\
\frac{D}{0} \\
\frac{1}{5} \\
\frac{0}{0}\end{array}$ \\
\hline \multirow[t]{2}{*}{$\begin{array}{l}2010 \ldots \ldots \\
2011 \ldots \ldots \ldots \ldots \\
2012 \\
2013^{12}\end{array}$} & $\begin{array}{l}288,009.7 \\
292,962.0 \\
296,199.5\end{array}$ & $\begin{array}{r}183,199.7 \\
183,655.7 \\
190,468.5 \\
-\end{array}$ & $\begin{array}{l}86,681.8 \\
76,118.9 \\
78,087.1 \\
80,444.4\end{array}$ & $\begin{array}{l}50,197.8 \\
64,400.2 \\
70,054.2 \\
62,448.9\end{array}$ & $\begin{array}{r}9,326.7 \\
11,133.7 \\
9,395.3 \\
9,659.5\end{array}$ & $\begin{array}{c}36,993.3 \\
32,002.9^{12} \\
32,931.8^{12} \\
-\end{array}$ & $\begin{array}{l}104,810.0 \\
109,306.3 \\
105,731.0 \\
106,932.7\end{array}$ & $\begin{array}{r}84,703.0 \\
108,926.3 \\
105,351.0 \\
106,434.0\end{array}$ & $\begin{array}{r}19,618.0 \\
0.0 \\
0.0 \\
0.0\end{array}$ & $\begin{array}{l}0.0 \\
0.0 \\
0.0 \\
0.0\end{array}$ & $\begin{array}{l}\dagger \\
t \\
\dagger \\
\dagger\end{array}$ & $\begin{array}{r}98.0 \\
0.0 \\
0.0 \\
0.0\end{array}$ & $\begin{array}{l}201.0 \\
195.0 \\
195.0 \\
188.2\end{array}$ & $\begin{array}{l}190.0 \\
185.0 \\
185.0 \\
310.5\end{array}$ & $\begin{array}{l}- \\
\bar{z} \\
-\end{array}$ & 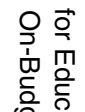 \\
\hline & \multicolumn{15}{|c|}{ Constant fiscal year 2013 dollars ${ }^{13}$} & \\
\hline 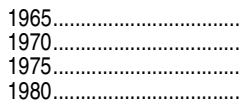 & $\begin{array}{r}\$ 36,902.7 \\
75,224.9 \\
97,904.4 \\
106,439.9\end{array}$ & $\begin{array}{r}\$ 36,739.3 \\
70,536.7 \\
92,339.9 \\
93,304.5\end{array}$ & $\begin{array}{r}\$ 13,387.5 \\
32,831.2 \\
42,098.3 \\
43,354.7\end{array}$ & $\begin{array}{l}\$ 8,252.8 \\
1,414.0 \\
30,309.4 \\
30,068.3\end{array}$ & $\begin{array}{r}\$ 2,582.0 \\
5,432.3 \\
6,377.8 \\
4,189.3\end{array}$ & $\begin{array}{r}\$ 12,517.1 \\
12,859.2 \\
13,554.4 \\
15,692.2\end{array}$ & $\begin{array}{r}\$ 163.4 \\
4,688.2 \\
5,564.5 \\
13,135.4\end{array}$ & $\begin{array}{l}\dagger \\
\dagger \\
\dagger \\
\dagger\end{array}$ & $\begin{array}{r}\dagger \\
\$ 4,335.9 \\
4,889.0 \\
12,437.5\end{array}$ & $\begin{array}{r}\$ 111.0 \\
118.1 \\
141.4 \\
86.0\end{array}$ & $\begin{array}{l}t \\
t \\
t \\
\dagger\end{array}$ & $\begin{array}{r}t \\
\dagger \\
\$ 79.3 \\
207.7\end{array}$ & $\begin{array}{l}t \\
t \\
t \\
\dagger\end{array}$ & $\begin{array}{l}\$ 52.4 \\
234.2 \\
454.8 \\
404.1\end{array}$ & $\begin{array}{r}- \\
\$ 34,119.8 \\
36,030.4\end{array}$ & 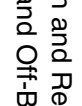 \\
\hline $\begin{array}{l}1985 . \\
1986 \ldots \\
1987 \\
1988 \\
1989\end{array}$ & $\begin{array}{r}95,632.1 \\
94,313.1 \\
96,224.4 \\
99,255.9 \\
105,242.2\end{array}$ & $\begin{array}{l}78,158.2 \\
77,941.2 \\
78,146.3 \\
79,756.0 \\
85,324.4\end{array}$ & $\begin{array}{l}33,847.0 \\
33,253.1 \\
33,265.2 \\
34,073.9 \\
35,016.6\end{array}$ & $\begin{array}{l}22,378.1 \\
22,006.8 \\
19,539.1 \\
19,560.8 \\
23,456.7\end{array}$ & $\begin{array}{l}4,220.7 \\
5,109.9 \\
5,350.3 \\
5,472.4 \\
5,621.8\end{array}$ & $\begin{array}{l}17,712.4 \\
17,571.3 \\
19,991.7 \\
20,649.0 \\
21,229.3\end{array}$ & $\begin{array}{l}17,473.9 \\
16,371.9 \\
18,078.1 \\
19,499.8 \\
19,917.8\end{array}$ & $\begin{array}{l}t \\
t \\
t \\
t \\
t\end{array}$ & $\begin{array}{l}16,956.2 \\
15,879.7 \\
17,589.0 \\
19,051.4 \\
19,334.7\end{array}$ & $\begin{array}{l}42.8 \\
39.4 \\
39.6 \\
37.9 \\
36.0\end{array}$ & $\begin{array}{r}\dagger \\
\dagger \\
\$ 1.05 \\
0.9 \\
1.0\end{array}$ & $\begin{array}{l}152.2 \\
141.8 \\
144.2 \\
133.6 \\
127.1\end{array}$ & $\begin{array}{r}t \\
t \\
\dagger \\
\dagger \\
\$ 38.9\end{array}$ & $\begin{array}{l}322.6 \\
311.1 \\
304.3 \\
276.0 \\
380.0\end{array}$ & $\begin{array}{l}38,260.1 \\
39,835.6 \\
39,514.5 \\
31,247.6 \\
31,384.9\end{array}$ & 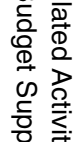 \\
\hline
\end{tabular}




\begin{tabular}{|c|c|c|c|c|c|c|c|c|c|c|c|c|c|c|c|}
\hline \multirow[b]{3}{*}{ Fiscal year } & \multirow{3}{*}{$\begin{array}{r}\text { Total on-budget } \\
\text { support, } \\
\text { off-budget } \\
\text { support, and } \\
\text { nonfederal } \\
\text { funds } \\
\text { generated } \\
\text { by federal } \\
\text { legislation }\end{array}$} & \multicolumn{5}{|c|}{ On-budget support ${ }^{1}$} & \multicolumn{8}{|c|}{ Off-budget support and nonfederal funds generated by federal legislation } & \multirow[b]{3}{*}{$\begin{array}{r}\text { Estimated } \\
\text { federal tax } \\
\text { expenditures } \\
\text { for education }\end{array}$} \\
\hline & & & & & & & & $\begin{array}{l}\text { Off-budget } \\
\text { support }\end{array}$ & \multicolumn{6}{|c|}{ Nonfederal funds } & \\
\hline & & Total & $\begin{array}{r}\text { Elementary } \\
\text { and } \\
\text { secondary }\end{array}$ & $\begin{array}{r}\begin{array}{r}\text { Post- } \\
\text { secondary }\end{array} \\
\end{array}$ & $\begin{array}{r}\text { Other } \\
\text { education }{ }^{3}\end{array}$ & $\begin{array}{r}\text { Research at } \\
\text { educational } \\
\text { institutions }\end{array}$ & Total & $\begin{array}{r}\text { Direct Loan } \\
\text { Program }^{4}\end{array}$ & $\begin{array}{r}\text { Federal } \\
\text { Family } \\
\text { Education } \\
\text { Loan } \\
\text { Program }\end{array}$ & $\begin{array}{l}\text { Perkins } \\
\text { Loans }\end{array}$ & $\begin{array}{r}\text { Income } \\
\text { Contingent } \\
\text { Loans }^{7}\end{array}$ & $\begin{array}{r}\text { Leveraging } \\
\text { Educational } \\
\text { Assistance } \\
\text { Partnerships } \\
\end{array}$ & $\begin{array}{r}\text { Supplemental } \\
\text { Educational } \\
\text { Opportunity } \\
\text { Grants }^{9}\end{array}$ & $\begin{array}{r}\text { Work-Study } \\
\text { Aid } 10\end{array}$ & \\
\hline 1 & 2 & 3 & 4 & 5 & 6 & 7 & 8 & 9 & 10 & 11 & 12 & 13 & 14 & 15 & 16 \\
\hline 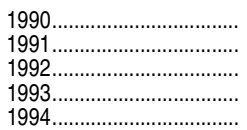 & $\begin{array}{l}107,766.3 \\
115,387.8 \\
117,728.2 \\
130,096.1 \\
139,846.4\end{array}$ & $\begin{array}{r}88,572.3 \\
94,440.2 \\
95,602.3 \\
103,996.2 \\
102,877.3\end{array}$ & $\begin{array}{l}37,718.8 \\
41,675.4 \\
44,142.5 \\
47,337.2 \\
48,691.3\end{array}$ & $\begin{array}{l}23,421.0 \\
24,114.3 \\
22,741.4 \\
27,394.3 \\
24,383.1\end{array}$ & $\begin{array}{l}5,804.3 \\
6,064.3 \\
6,309.9 \\
6,305.4 \\
6,758.1\end{array}$ & $\begin{array}{l}21,628.3 \\
22,586.2 \\
22,408.6 \\
22,959.2 \\
23,044.7\end{array}$ & $\begin{array}{l}19,194.0 \\
20,947.7 \\
22,125.9 \\
26,099.9 \\
36,969.1\end{array}$ & $\begin{array}{r}t \\
t \\
t \\
t \\
\$ 1,225.4\end{array}$ & $\begin{array}{l}18,574.3 \\
20,285.1 \\
21,446.2 \\
25,367.8 \\
34,989.7\end{array}$ & $\begin{array}{l}25.8 \\
28.4 \\
27.4 \\
44.9 \\
79.4\end{array}$ & $\begin{array}{r}0.9 \\
0.8 \\
0.9 \\
\dagger \\
+\end{array}$ & \begin{tabular}{r|}
101.5 \\
104.2 \\
113.8 \\
111.2 \\
109.2
\end{tabular} & $\begin{array}{r}83.7 \\
143.8 \\
153.7 \\
283.4 \\
278.3\end{array}$ & $\begin{array}{l}407.8 \\
385.3 \\
384.0 \\
292.5 \\
287.2\end{array}$ & $\begin{array}{l}32,667.1 \\
31,144.2 \\
31,533.9 \\
32,254.8 \\
34,109.4\end{array}$ \\
\hline 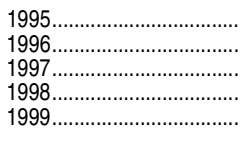 & $\begin{array}{l}140,314.0 \\
138,804.3 \\
145,096.2 \\
150,147.6 \\
155,963.2\end{array}$ & $\begin{array}{l}104,915.5 \\
102,243.5 \\
103,604.8 \\
107,111.4 \\
113,948.1\end{array}$ & $\begin{array}{l}49,241.8 \\
49,298.2 \\
49,853.4 \\
52,206.9 \\
54,919.8\end{array}$ & $\begin{array}{l}25,801 \cdot 6 \\
22,613.3 \\
22,425.5 \\
22,000.0 \\
24,272.7\end{array}$ & $\begin{array}{l}6,911.9 \\
6,920.7 \\
7,055.5 \\
7,170.3 \\
7,313.0\end{array}$ & $\begin{array}{l}22,960.2 \\
23,411.4 \\
24,270.4 \\
25,730.1 \\
27,442.7\end{array}$ & $\begin{array}{l}35,398.6 \\
36,560.8 \\
41,491.5 \\
43,036.2 \\
42,2015.1\end{array}$ & $\begin{array}{r}7,558.2 \\
11,979.3 \\
13,823.9 \\
14,484.2 \\
13,686.7\end{array}$ & $\begin{array}{l}27,120.9 \\
23,954.2 \\
26,927.0 \\
27,857.5 \\
27,649.7\end{array}$ & $\begin{array}{l}77.1 \\
44.6 \\
74.1 \\
62.7 \\
45.8\end{array}$ & $\begin{array}{l}\dagger \\
t \\
\dagger \\
\dagger\end{array}$ & $\begin{array}{l}92.8 \\
45.0 \\
70.3 \\
34.8 \\
34.4\end{array}$ & $\begin{array}{l}270.4 \\
264.6 \\
259.4 \\
270.6 \\
269.4\end{array}$ & $\begin{array}{l}279.0 \\
273.1 \\
336.8 \\
326.4 \\
329.2\end{array}$ & $\begin{array}{l}36,026.5 \\
37,756.8 \\
39,520.0 \\
41,140.3 \\
51,374.8\end{array}$ \\
\hline $\begin{array}{l}2000 \ldots \\
2001 \ldots \\
2002 \ldots \\
2003 \ldots \ldots \\
2004 \ldots \ldots\end{array}$ & $\begin{array}{l}160,379.7 \\
170,740.1 \\
192,790.6 \\
213,379.3 \\
225,445.4\end{array}$ & $\begin{array}{l}115,304.7 \\
123,932.7 \\
140,334.1 \\
155,497.2 \\
161,217.0\end{array}$ & $\begin{array}{l}58,750.7 \\
63,412.6 \\
67,787.7 \\
74,106.6 \\
76,277.8\end{array}$ & $\begin{array}{l}20,136.0 \\
19,519.3 \\
29,508.4 \\
36,881.5 \\
39,485.9\end{array}$ & $\begin{array}{l}7,358.2 \\
7,683.2 \\
8,092.4 \\
8,167.2 \\
8,007.0\end{array}$ & $\begin{array}{l}29,059.7 \\
33,317.6 \\
34,945.5 \\
36,341.9 \\
37,446.3\end{array}$ & $\begin{array}{l}45,075.0 \\
46,807.4 \\
52,456.5 \\
57,882.1 \\
64,228.4\end{array}$ & $\begin{array}{l}13,881.8 \\
13,896.4 \\
15,020.1 \\
14,964.1 \\
15,632.2\end{array}$ & $\begin{array}{l}30,469.6 \\
32,266.8 \\
36,758.0 \\
42,246.7 \\
47,804.8\end{array}$ & $\begin{array}{l}44.7 \\
32.7 \\
32.1 \\
41.3 \\
40.2\end{array}$ & $\begin{array}{l}t \\
t \\
t \\
t \\
t\end{array}$ & $\begin{array}{r}67.1 \\
104.5 \\
133.6 \\
128.8 \\
124.2\end{array}$ & $\begin{array}{l}267.9 \\
240.4 \\
246.7 \\
252.5 \\
297.1\end{array}$ & $\begin{array}{l}344.0 \\
266.6 \\
266.0 \\
248.8 \\
329.9\end{array}$ & $\begin{array}{r}52,960.6 \\
54,174.4 \\
- \\
-\end{array}$ \\
\hline $\begin{array}{l}2005 \ldots \\
2006 \ldots \\
2007 \ldots \ldots \\
2008 \ldots \ldots \\
200911\end{array}$ & $\begin{array}{l}238,858.0 \\
258,099.4 \\
233,220.5 \\
235,835.5 \\
393,471.0\end{array}$ & $\begin{array}{l}172,002.6 \\
189,323.7 \\
161,396.4 \\
154,491.8 \\
289,800.1\end{array}$ & $\begin{array}{r}81,124.0 \\
80,675.9 \\
78,357.4 \\
76,285.9 \\
184,436.2\end{array}$ & $\begin{array}{l}45,395.3 \\
65,676.8 \\
41,502.0 \\
38,945.7 \\
56,705.8\end{array}$ & $\begin{array}{l}8,127.4 \\
8,044.5 \\
7,992.3 \\
8,436.7 \\
9,457.5\end{array}$ & $\begin{array}{l}37,355.8 \\
34,926.5 \\
33,544.7 \\
30,823.5 \\
39,200.5\end{array}$ & $\begin{array}{r}66,855.4 \\
68,775.8 \\
71,824.1 \\
81,343.8 \\
103,670.9\end{array}$ & $\begin{array}{l}15,211.3 \\
14,415.1 \\
14,425.1 \\
19,494.1 \\
31,766.1\end{array}$ & $\begin{array}{l}50,920.7 \\
53,793.2 \\
56,849.6 \\
61,326.2 \\
71,332.3\end{array}$ & $\begin{array}{l}0.0 \\
0.0 \\
0.0 \\
0.0 \\
0.0\end{array}$ & $\begin{array}{l}t \\
t \\
t \\
t \\
t\end{array}$ & $\begin{array}{l}118.8 \\
113.7 \\
110.8 \\
104.9 \\
104.7\end{array}$ & $\begin{array}{l}289.4 \\
233.1 \\
227.1 \\
215.1 \\
214.7\end{array}$ & $\begin{array}{l}315.3 \\
220.6 \\
211.6 \\
203.4 \\
253.2\end{array}$ & $\begin{array}{l}- \\
- \\
- \\
-\end{array}$ \\
\hline 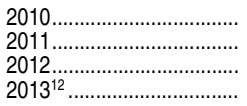 & $\begin{array}{l}304,064.0 \\
303,326.5 \\
301,018.2\end{array}$ & $\begin{array}{r}193,411.6 \\
190,153.2 \\
193,567.1 \\
-\end{array}$ & $\begin{array}{l}91,513.6 \\
78,811.8 \\
79,357.5 \\
80,444.4\end{array}$ & $\begin{array}{l}52,996.0 \\
66,678.6 \\
71,193.9 \\
62,448.9\end{array}$ & $\begin{array}{r}9,846.6 \\
11,527.6 \\
9,548.1 \\
9,659.5\end{array}$ & 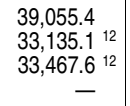 & $\begin{array}{l}110,652.3 \\
113,173.4 \\
107,451.1 \\
106,932.7\end{array}$ & $\begin{array}{r}89,424.5 \\
112,779.9 \\
107,064.9 \\
106,434.0\end{array}$ & $\begin{array}{r}20,711.6 \\
0.0 \\
0.0 \\
0.0\end{array}$ & $\begin{array}{l}0.0 \\
0.0 \\
0.0 \\
0.0\end{array}$ & $\begin{array}{l}\dagger \\
\dagger \\
\dagger \\
\dagger\end{array}$ & $\begin{array}{r}103.5 \\
0.0 \\
0.0 \\
0.0\end{array}$ & $\begin{array}{l}212.2 \\
201.9 \\
198.2 \\
188.2\end{array}$ & $\begin{array}{l}200.6 \\
191.5 \\
188.0 \\
310.5\end{array}$ & $\begin{array}{l}\bar{z} \\
\bar{z}\end{array}$ \\
\hline
\end{tabular}

$-17,728.2$
$-130,096.1$

$6,309.9$

-1
$-12,586.2$

(2,099.

$36,969.1$

$1,225.4$

$25,367.8$

\section{- Not available.}

On-budget support includes federal funds for education programs tied to appropriations. Excludes federal support for medi-

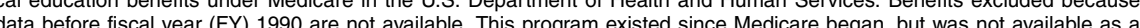
separate budget item until FY 1990. Excluded amounts range from $\$ 4,440,000,000$ in FY 1990 to an estimated $\$ 10,000,000,000$ in $\mathrm{FY} 2013$

Losses of tax revenue attributable to provisions of the federal income tax laws that allow a special exclusion, exemption, or deduction from gross income or provide a special credit, preferential rate of tax, or a deferral of tax liability affecting individual or corporate income tax liabilities.

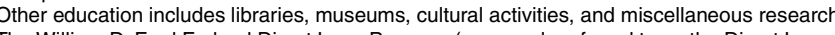

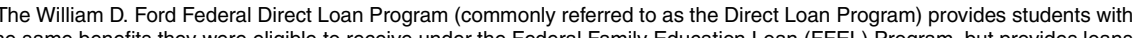
(FFEL) Program, but provides loans ${ }^{5}$ The Federal Family Education Loan (FFEL) Program, formerly known as the Guaranteed Student Loan Program, provided student loans guaranteed by the federal government and disbursed to borrowers. After June 30, 2010, no new FFEL loans

have been originated; all new loans are originated through the Direct Loan Program.
6 Student loans created from institutional matching funds (since 1993 one-third of federal capital contributions). Excludes Student loans created from instilutic

(This was a demonstration

${ }^{8}$ Formerly the State Student Incentive Grant Program. Starting in fiscal year 2000, amounts under $\$ 30.0$ million have required dollar-for-dollar state matching contributions, while amounts over $\$ 30.0$ million have required two-to-one state matching contributions.

s to undergraduate students, and the federal share of such grants may not exceed 75 percent of the total grant

${ }^{11}$ All education funds from the American Recovery and Reinvestment Act of 2009 (ARRA) are included in the FY 2009 row of this table. Most of these funds had a 2-year availability, meaning that they were available for the Department of Education to obligate during FY 2009 and FY 2010.

${ }^{13}$ Data adjusted by the federal funds composite deflator reported in the U.S. Office of Management and Budget, Budget of the U.S. Government, Historical Tables, Fiscal Year 2014.

revised from previously puble, federal education funds data represent outlays rather than obligations. Some data have been expenditures in 2006 resulted primarily from an accounting adjustment.

SOURCE: U.S. Department of Education, Budget Service, unpublished tabulations. U.S. Department of Education, National Center for Education Statistics, unpublished tabulations. U.S. Office of Management and Budget, Budget of the U.S. Government, Appendix, fiscal years 1967 through 2014. National Science Foundation, Federal Funds for Research and Develop-

project that involved only 10 institutions and had unsubsidized interest rates. Program repealed in fiscal year 1992. 
Table 401.20. Federal on-budget funds for education, by agency: Selected fiscal years, 1970 through 2012

[In thousands]

\begin{tabular}{|c|c|c|c|c|c|c|c|c|c|c|}
\hline Agency & 1970 & 1980 & $1990^{1}$ & $2000^{1}$ & $2005^{1}$ & $2008^{1}$ & $2009^{1,2}$ & $2010^{1}$ & $2011^{1,3}$ & $2012^{1,3}$ \\
\hline 1 & 2 & 3 & 4 & 5 & 6 & 7 & 8 & 9 & 10 & 11 \\
\hline Total $\ldots 1 \cdots+11$ & $\$ 12,526,499$ & $\$ 34,493,502$ & $\$ 51,624,342$ & $\$ 85,944,203$ & $\$ 146,206,999$ & $\$ 144,338,888$ & $\$ 271,297,567$ & $\$ 183,199,676$ & $\$ 183,655,692$ & $\$ 190,468,459$ \\
\hline Department of Education ${ }^{2}$. & $4,625,224$ & $13,137,785$ & $23,198,575$ & $34,106,697$ & $72,893,301$ & $72,177,819$ & $187,733,247$ & $91,893,199$ & $93,777,295$ & $99,128,616$ \\
\hline 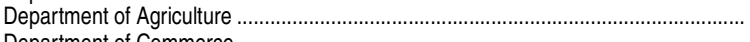 & 960,910 & $4,562,467$ & $6,260,843$ & $11,080,031$ & $13,817,553$ & $16,588,529$ & $16,603,791$ & $19,260,881$ & $20,396,195$ & $22,212,582$ \\
\hline 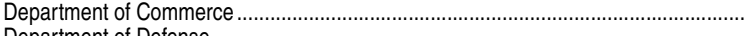 & 13,990 & 135,561 & 53,835 & 114,575 & 243,948 & 193,612 & 263,000 & 303,000 & 296,489 & 307,919 \\
\hline Department of Defense .......... & 821,388 & $1,560,301$ & $3,605,509$ & $4,525,080$ & $6,320,454$ & $6,578,416$ & $6,894,895$ & $7,686,288$ & $7,234,113$ & $7,328,795$ \\
\hline Department of Energy ........ & 551,527 & $1,605,558$ & $2,561,950$ & $3,577,004$ & $4,339,879$ & $2,469,637$ & $3,747,800$ & $3,402,600$ & $2,807,045$ & $3,219,690$ \\
\hline Department of Health and Human Services............................................................. & $1,796,854$ & $5,613,930$ & $7,956,011$ & $17,670,867$ & $26,107,860$ & $26,470,379$ & $31,860,858$ & $31,962,136$ & $28,932,720$ & $29,706,125$ \\
\hline 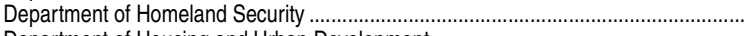 & & & & & 624,860 & 410,580 & 508,920 & 540,229 & $2,081,111$ & 426,821 \\
\hline Department of Housing and Urban Development... & 114,709 & 5,314 & 118 & 1,400 & 1,100 & 400 & 200 & 400 & 1,300 & 1,400 \\
\hline 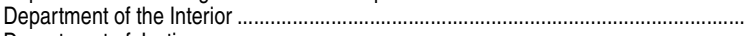 & 190,975 & 440,547 & 630,537 & 959,802 & $1,254,533$ & $1,066,457$ & $1,010,559$ & $1,039,367$ & $1,000,447$ & 981,255 \\
\hline 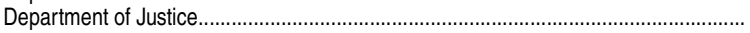 & 15,728 & 60,721 & 99,775 & 278,927 & 608,148 & 168,776 & 186,215 & 205,692 & 203,488 & 196,150 \\
\hline 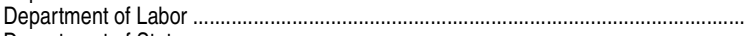 & 424,494 & $1,862,738$ & $2,511,380$ & $4,696,100$ & $5,764,500$ & $5,070,500$ & $6,073,300$ & $6,826,000$ & $6,121,000$ & $5,662,000$ \\
\hline 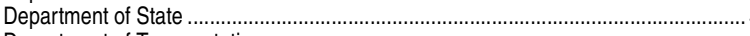 & 59,742 & 25,188 & 51,225 & 388,349 & 533,309 & 636,627 & 676,520 & 778,180 & 741,670 & 725,222 \\
\hline 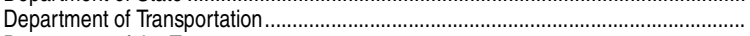 & 27,534 & 54,712 & 76,186 & 117,054 & 126,900 & 143,378 & 138,433 & 165,246 & 154,035 & 212,120 \\
\hline Departn & & $1,247,463$ & 41,715 & 83,000 & & 100 & & & 100 & 100 \\
\hline Department of Veterans Affairs... & $1,032,918$ & $2,351,233$ & 757,476 & $1,577,374$ & $4,293,624$ & $4,527,232$ & $4,763,479$ & $8,802,944$ & $10,293,752$ & $10,603,821$ \\
\hline \multicolumn{11}{|l|}{ Other agencies and programs } \\
\hline ACTION... & & 2,8 & 8,472 & & & & & & & \\
\hline ......... & 88,034 & 176,770 & 249,786 & 332,500 & 602,100 & 635,320 & 642,225 & 557,900 & 614,900 & 613,400 \\
\hline Appalachian & 37,838 & $19,032+$ & 93 & 7,243 & 8,542 & 7,176 & 6,106 & 5,070 & 11,902 & 11,124 \\
\hline in Education Foundation.... & & & 1,033 & 3,000 & 3,000 & 3,000 & 3,000 & 4,000 & 3,000 & 4,000 \\
\hline Corporation & & & & 386,000 & 472,000 & 333,000 & 401,000 & 965,000 & 983,000 & 757,000 \\
\hline Environmental Protection A & 19,446 & 41,083 & 87,481 & 98,900 & 83,400 & 44,500 & 52,900 & 54,700 & 53,600 & 53,800 \\
\hline 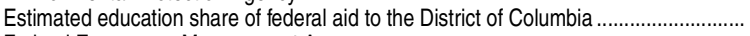 & 33,019 & 81,847 & 104,940 & 127,127 & 154,962 & 149,722 & 157,465 & 159,670 & 155,643 & 151,381 \\
\hline Federal Eme & 290 & 1,946 & 215 & 14,894 & & & & & & \\
\hline General Sen & 14,775 & 34,800 & & & & & & & & \\
\hline Harry S Trum & & $-1,895$ & 2,883 & 3,000 & 3,000 & 3,000 & 2,000 & 2,000 & 1,000 & 1,200 \\
\hline d Alaska Native Culture and Arts Development............ & & & 4,305 & 2,000 & 6,000 & 7,000 & 8,000 & 8,000 & 8,284 & 8,500 \\
\hline Institute of N & & & & 166,000 & 250,000 & 253,000 & 265,000 & 265,000 & 274,000 & 243,000 \\
\hline James Madi & & & 191 & 7,000 & 2,000 & 2,000 & 2,000 & 2,000 & 2,000 & 2,000 \\
\hline Friendsh & & 2,294 & 2,299 & 3,000 & 3,000 & 2,0 & 2,000 & 2,000 & 3,700 & 3,700 \\
\hline Library of Congress... & 29,478 & 151,871 & 189,827 & 299,000 & 430,000 & 434,000 & 468,000 & 516,000 & 521,000 & 521,000 \\
\hline National Aeronautics and Space Admi & 258,366 & 255,511 & $1,093,303$ & $2,077,830$ & $2,763,120$ & $1,154,900$ & $1,754,100$ & $1,585,500$ & $1,430,761$ & $1,277,997$ \\
\hline National Arc & t & & 77,397 & 121,879 & 276,000 & 279,000 & 329,000 & 339,000 & 349,000 & 339,000 \\
\hline National Commission on Libraries ar & & 2,090 & 3,281 & 2,000 & 1,000 & 1,000 & & & & \\
\hline National Endo & 340 & 5,220 & 5,577 & 10,048 & 10,976 & 12,808 & 12,918 & 14,413 & 13,495 & 16,595 \\
\hline National Endowment for the Humanities ................... & 8,459 & 142,586 & $141,048+$ & 100,014 & 117,825 & 124,162 & 134,533 & 142,654 & 131,135 & 136,100 \\
\hline National Science Foundation & 295,628 & 808,392 & $1,588,891$ & $2,955,244$ & $3,993,216$ & $4,298,290$ & $6,464,300$ & $5,560,700$ & $4,918,290$ & $5,484,138$ \\
\hline Nuclear Regulatory Commission ................................................................ & & 32,590 & 42,328 & 12,200 & 15,100 & 2,200 & 8,200 & 14,500 & 14,200 & 14,900 \\
\hline 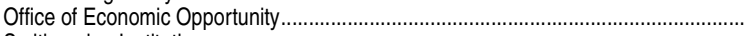 & $1,092,410$ & & & & & & & & & \\
\hline 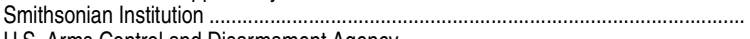 & 2,461 & 5,153 & 5,779 & 25,764 & $\begin{array}{r}45,890 \\
+\end{array}$ & 64,768 & 61,104 & 63,107 & $\begin{array}{r}67,322 \\
+\end{array}$ & 65,109 \\
\hline 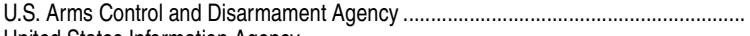 & 100 & 661 & & & & & & & & \\
\hline 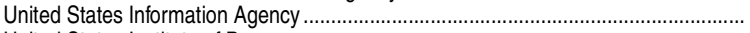 & 8,423 & 66,210 & 201,547 & & & & & & & \\
\hline United States Institute & & & 7,621 & 13,000 & 28,000 & 17,000 & 49,000 & 58,000 & 47,000 & 44,000 \\
\hline Other agencies & 1,421 & 990 & 885 & 300 & 7,900 & 8,600 & 13,500 & 14,300 & 11,700 & 7,900 \\
\hline
\end{tabular}

See notes at end of table. 
[In thousands]

\begin{tabular}{|c|c|c|c|c|c|c|c|c|c|c|}
\hline Agency & 1970 & 1980 & $1990^{1}$ & $2000^{1}$ & $2005^{1}$ & $2008^{1}$ & $2009^{1,2}$ & $2010^{1}$ & $2011^{1,3}$ & $2012^{1,3}$ \\
\hline \multirow[b]{3}{*}{ Total. } & 2 & 3 & 4 & 5 & 6 & 7 & 8 & 9 & 10 & $\overline{11}$ \\
\hline & \multicolumn{10}{|c|}{ Constant fiscal year 2013 dollars ${ }^{4}$} \\
\hline & $\$ 70,536,670$ & $\$ 93,304,530$ & $\$ 88,572,313$ & $\$ 115,304,694$ & $\$ 172,002,551$ & $\$ 154,491,784$ & $\$ 289,800,061$ & $\$ 193,411,636$ & $\$ 190,153,155$ & $\$ 193,567,128$ \\
\hline Department of Education ${ }^{2}$ & $26,044,619$ & $35,537,559$ & $39,801,988$ & $45,758,319$ & $85,753,991$ & $77,254,856$ & $200,536,654$ & $97,015,532$ & $97,094,995$ & $100,741,307$ \\
\hline 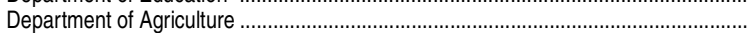 & $5,410,881$ & $12,341,421$ & $10,741,780$ & $14,865,221$ & $16,255,408$ & $17,755,377$ & $\begin{array}{r}17,736,169 \\
\end{array}$ & $20,334,526$ & $21,117,782$ & $22,573,951$ \\
\hline Department of Commerce... & 78,778 & 366,691 & 92,365 & 153,716 & 286,988 & 207,231 & 280,937 & 319,890 & 306,978 & 312,928 \\
\hline 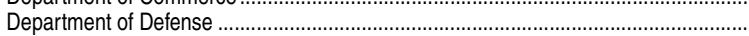 & $4,625,233$ & $4,220,596$ & $6,186,002$ & $6,070,950$ & $7,435,583$ & $7,041,146$ & $7,365,127$ & $8,114,739$ & $7,490,045$ & $7,448,024$ \\
\hline 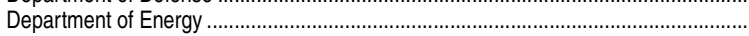 & $3,105,647$ & $4,343,016$ & $4,395,559$ & $4,798,990$ & $5,105,571$ & $2,643,353$ & $4,003,400$ & $3,592,269$ & $2,906,354$ & $3,272,070$ \\
\hline Department of Health and Human Services............ & $10,118,078$ & $15,185,617$ & $13,650,194$ & $23,707,636$ & $30,714,115$ & $28,332,323$ & $34,033,769$ & $33,743,777$ & $29,956,316$ & $30,189,404$ \\
\hline Department of Homeland Security .................. & & & & & 735,105 & 439,460 & 543,628 & 570,343 & $2,154,737$ & 433,765 \\
\hline 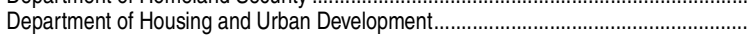 & 645,926 & 14,374 & 202 & 1,878 & 1,294 & 428 & 214 & 422 & 1,346 & 1,423 \\
\hline 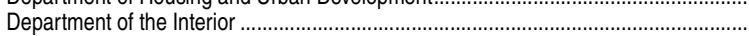 & $1,075,380$ & $1,191,675$ & $1,081,818$ & $1,287,692$ & $1,475,872$ & $1,141,472$ & $1,079,479$ & $1,097,304$ & $1,035,841$ & 997,219 \\
\hline 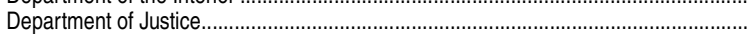 & 88,564 & 164,250 & 171,185 & 374,215 & 715,445 & 180,648 & 198,915 & 217,158 & 210,687 & 199,341 \\
\hline 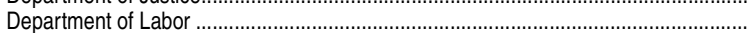 & $2,390,324$ & $5,038,685$ & $4,308,796$ & $6,300,394$ & $6,781,541$ & $5,427,162$ & $6.487,499$ & $7,206,497$ & $6,337,552$ & $5,754,113$ \\
\hline Department of State & $\begin{array}{r}2,05,0,40 \\
336,407\end{array}$ & 68,133 & 87,887 & 521,018 & 627,402 & 681,408 & 722,659 & 821,557 & 767,909 & 737,020 \\
\hline Department of Transportation & 155,044 & 147,995 & 130,713 & 157,042 & 149,289 & 153,463 & 147,874 & 174,457 & 159,485 & 215,571 \\
\hline 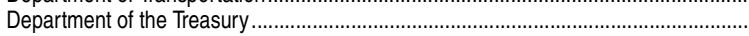 & 101 & $3,374,373$ & 71,571 & 111,355 & & 107 & & & 104 & 102 \\
\hline 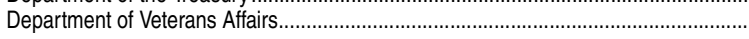 & $5,816,357$ & $6,360,058$ & $1,299,608$ & $2,116,241$ & $5,051,155$ & $4,845,681$ & $5,088,348$ & $9,293,640$ & $10,657,930$ & $10,776,331$ \\
\hline \multicolumn{11}{|l|}{ Other agencies and programs } \\
\hline 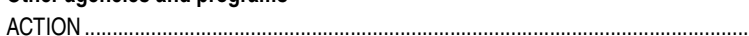 & & 7,663 & 14,535 & & & & & & & \\
\hline Agency for Int & 495,719 & 478,161 & 428,560 & 446,090 & 708,330 & 680,009 & 686,025 & 588,999 & 636,654 & 623,379 \\
\hline pals & 213,066 & 51,481 & 160 & 9,717 & 10,049 & 7,681 & 6,522 & 5,353 & 12,323 & 11,305 \\
\hline 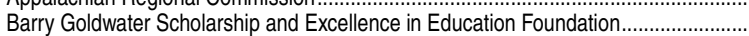 & & & 1,772 & 4,025 & 3,529 & 3,211 & 3,205 & 4,223 & 3,106 & 4,065 \\
\hline 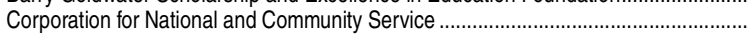 & & & & 517,866 & 555,276 & 356,423 & 428,348 & $1,018,791$ & $1,017,777$ & 769,315 \\
\hline Environmental Protectio & 109,500 & 111,129 & 150,092 & 132,686 & 98,114 & 47,630 & 56,508 & 57,749 & 55,496 & 54,675 \\
\hline deral aid to the District of Columbia.. & 185,930 & 221,395 & 180,046 & 170,556 & 182,302 & 160,254 & 168,204 & 168,570 & 161,149 & 153,844 \\
\hline Management Agency ...................................... & 1,633 & 5,264 & 369 & 19,982 & & & & & & \\
\hline 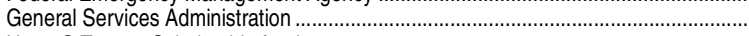 & 83,198 & 94,134 & $t$ & & & & & & $t$ & \\
\hline Harry S Truman & & $-5,126$ & 4,946 & 4,025 & 3,529 & 3,211 & 2,136 & 2,111 & 1,035 & 1,220 \\
\hline Alaska Native Culture and Arts Development.......... & & & 7,386 & 2,683 & 7,059 & 7,492 & 8,546 & 8,446 & 8,577 & 8,638 \\
\hline Institute of M & & & | & 222,709 & 294,108 & 270,796 & 283,073 & 279,772 & 283,694 & 246,953 \\
\hline 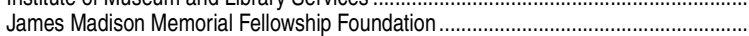 & & $t$ & 328 & 9,391 & 2,353 & 2,141 & 2,136 & 2,111 & 2,071 & 2,033 \\
\hline 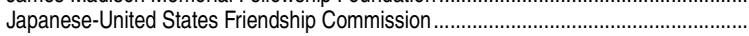 & & 6,205 & 3,944 & 4,025 & 3,529 & 2,141 & 2,136 & 2,111 & 3,831 & 3,760 \\
\hline Library of Congress ...... & 165,991 & 410,809 & 325,688 & 401,145 & 505,866 & 464,528 & 499,918 & 544,763 & 539,432 & 529,476 \\
\hline utics and Space Administration ... & $1,454,858$ & 691,154 & $1,875,789$ & $2,787,664$ & $3,250,622$ & $1,236,136$ & $1,873,730$ & $1,673,879$ & $1,481,379$ & $1,298,788$ \\
\hline 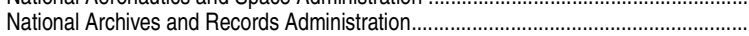 & & & 132,791 & 163,516 & 324,695 & 298,625 & 351,438 & 357,897 & 361,347 & 344,515 \\
\hline 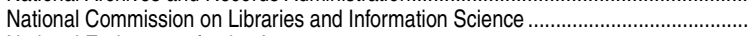 & & 5,653 & 5,629 & 2,683 & 1,176 & 1,070 & & & & \\
\hline National Endowment for the Arts.. & 1,915 & 14,120 & 9,569 & 13,480 & 12,913 & 13,709 & 13,799 & 15,216 & 13,972 & 16,865 \\
\hline National Endowment for the Humanities ... & 47,633 & 385,694 & 241,997 & $\begin{array}{r}134,182 \\
\end{array}$ & 138,613 & 132,896 & 143,708 & 150,605 & 135,774 & 138,314 \\
\hline 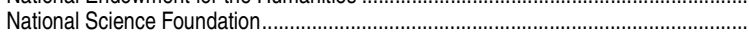 & $1,664,680$ & $2,186,691$ & $2,726,074$ & $3,964,822$ & $4,697,746$ & $4,600,635$ & $6,905,165$ & $5,870,666$ & $5,092,292$ & $5,573,357$ \\
\hline 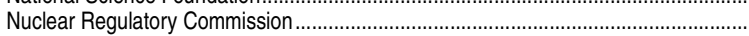 & & 88,156 & 72,623 & 16,368 & 17,764 & 2,355 & 8,759 & 15,308 & 14,702 & 15,142 \\
\hline 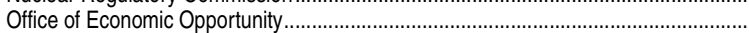 & $6,151,357$ & & t & $t$ & & & & & & \\
\hline 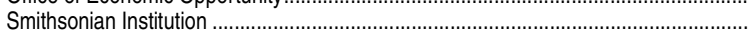 & 13,858 & 13,939 & 9,915 & 34,566 & 53,986 & 69,324 & 65,271 & 66,625 & 69,704 & 66,168 \\
\hline 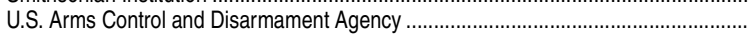 & 563 & 1,788 & 43 & & & & $\dagger$ & & & \\
\hline United States Information Agency …………………………………………………. & 47,430 & 179,097 & 345,796 & $t$ & & & & & & \\
\hline 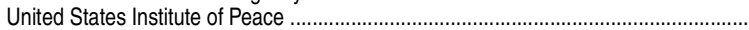 & 1 & $\dagger$ & 13,075 & 17,441 & 32,940 & 18,196 & 52,342 & 61,233 & 48,663 & 44,716 \\
\hline Other agencies ............. & 8,002 & 2,678 & 1,518 & 402 & 9,294 & 9,205 & 14,421 & 15,097 & 12,114 & 8,029 \\
\hline
\end{tabular}

†Not applicable.

${ }^{1}$ Excludes federal support for medical education benefits under Medicare in the U.S. Department of Health and Human Services. Benefits excluded from total because data before fiscal year ( FY) 1990 are not available. This program existed since Medicare began, but was not available as a separate budget item until $F Y$ 1 1990. Excluded amounts are as follows: $\$ 4,440,000,000$ in $F Y 1990$, $\mathrm{FY} 2010, \$ 9,200,000,000$ in $\mathrm{FY} 2011$, and $\$ 9,800,000,000$ in $\mathrm{FY} 2012$.

${ }^{2}$ All education funds from the American Recovery and Reinvestment Act of 2009 (ARRA) are included in the Department of Education amount for FY 2009. Most of these funds had a 2-year availability, meaning that they were available for the Department of Education to obligate during FY 2009 and FY 2010.
${ }^{3}$ Estimated.

${ }^{4}$ Data adjusted by the federal budget composite deflator reported in U.S. Office of Management and Budget, Budget of the U.S. Government, Historical Tables, Fiscal Year 2014

Geste the extent possible, amounts reported represent outlays rather than obligations. Negative amounts occur when program S. Department of Education are appropriations, no SOURCE: U.S. Department of Education, National Center for Eduy not sum to totals because of rounding

ment and Budget, Budget of the U.S. Government, Appendix, fiscal years 1972 through 2014. National Science Foundation, Federal Funds for Research and Development, fiscal years 1970 to 2012. (This table was prepared April 2014.) 
Table 401.30. Federal on-budget funds for education, by level/educational purpose, agency, and program: Selected fiscal years, 1970 through 2013

[In thousands of current dollars]

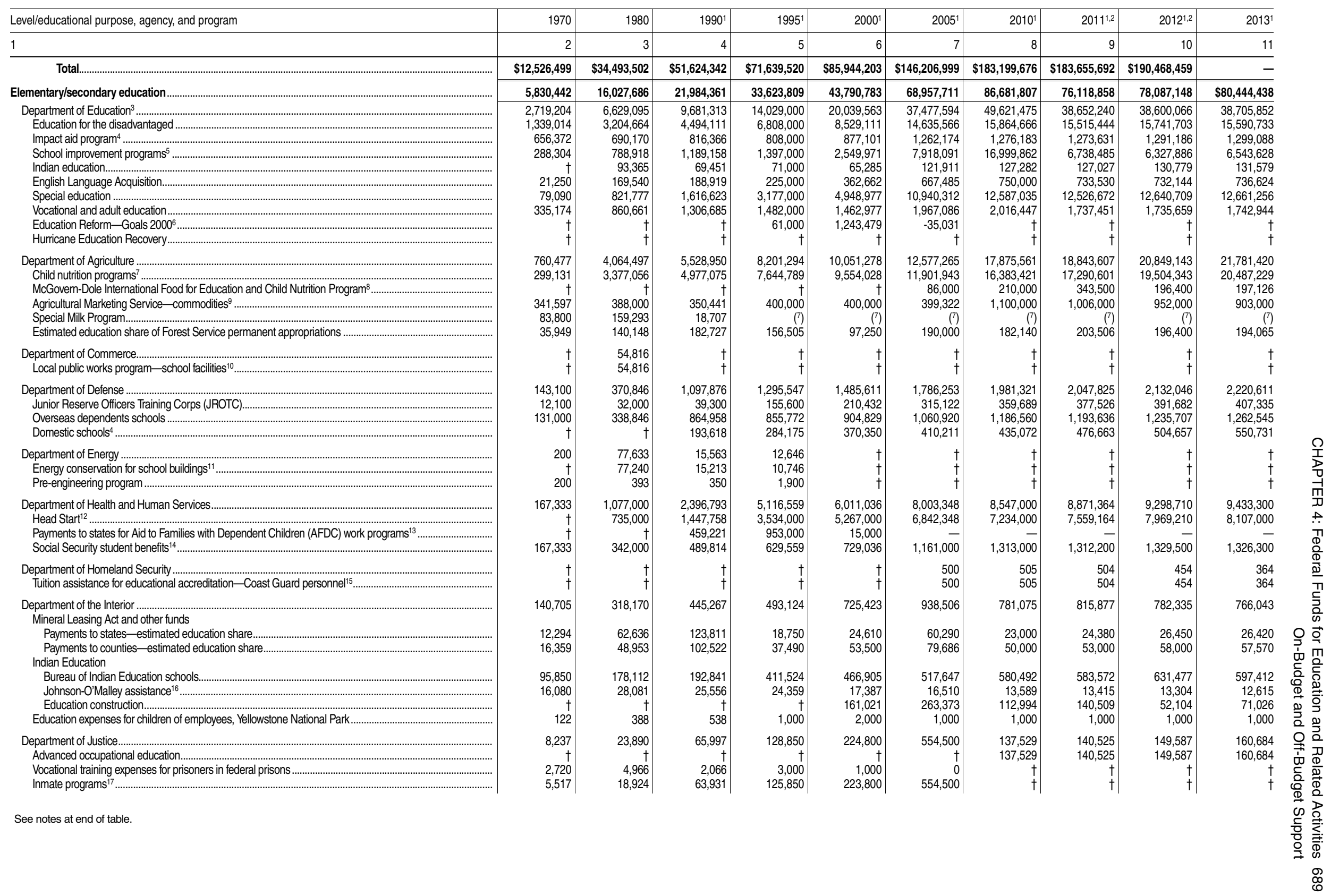



[In thousands of current dollars]

\begin{tabular}{|c|c|c|c|c|c|c|c|c|c|c|}
\hline Level/educational purpose, agency, and program & 1970 & 1980 & $1990^{1}$ & $1995^{1}$ & $2000^{1}$ & $2005^{1}$ & $2010^{1}$ & $2011^{1,2}$ & $2012^{1,2}$ & $2013^{1}$ \\
\hline 1 & 2 & 3 & 4 & 5 & 6 & 7 & 8 & 9 & 10 & 11 \\
\hline 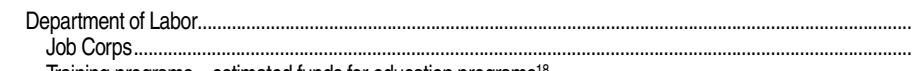 & 420,927 & $\begin{array}{r}1,849,800 \\
469,800\end{array}$ & $\begin{array}{r}2,505,487 \\
739,376\end{array}$ & $\begin{array}{l}3,957,800 \\
1,029,000\end{array}$ & $\begin{array}{r}4,683,200 \\
1,256,000\end{array}$ & $\begin{array}{l}5,654,000 \\
1,521,000\end{array}$ & $\begin{array}{r}6,826,000 \\
1,850,000\end{array}$ & $\begin{array}{l}6,121,000 \\
1,660,000\end{array}$ & $\begin{array}{r}5,662,000 \\
1,789,000\end{array}$ & $\begin{array}{l}6,650,000 \\
1,650,000\end{array}$ \\
\hline 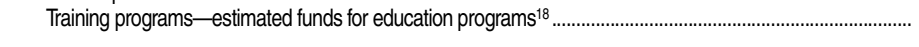 & 420,927 & $1,380,000$ & $1,766,111$ & $2,928,800$ & $3,427,200$ & $4,133,000$ & $4,976,000$ & $4,461,000$ & $3,873,000$ & $5,000,000$ \\
\hline 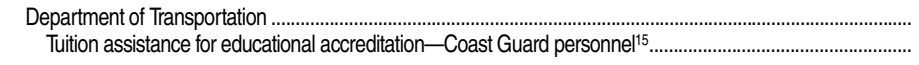 & $\begin{array}{l}45 \\
45\end{array}$ & $\begin{array}{l}60 \\
60\end{array}$ & $\begin{array}{l}46 \\
46\end{array}$ & $\begin{array}{l}62 \\
62\end{array}$ & $\begin{array}{l}188 \\
188\end{array}$ & $\begin{array}{l}\dagger \\
\dagger\end{array}$ & $\begin{array}{l}\dagger \\
\dagger\end{array}$ & $\begin{array}{l}\dagger \\
\dagger\end{array}$ & $\stackrel{\dagger}{\dagger}$ & $\dagger$ \\
\hline Department of the Treasury.................................................... & $\dagger$ & 935,903 & $\dagger$ & $\dagger$ & $\dagger$ & $\dagger$ & $\dagger$ & $\dagger$ & $\dagger$ & $\dagger$ \\
\hline $\begin{array}{l}\text { Estimated education share of general revenue sharing } \\
\text { State }{ }^{20}\end{array}$ & & 525,019 & $\dagger$ & + & $\dagger$ & $\dagger$ & $\dagger$ & $\dagger$ & $\dagger$ & $t$ \\
\hline Local............................................................... & $\dagger$ & 410,884 & $\dagger$ & $\dagger$ & $\dagger$ & $\dagger$ & $\dagger$ & $\dagger$ & $\dagger$ & $\dagger$ \\
\hline Department of Veterans Affairs .......................... & 338,910 & 545,786 & 155,351 & 311,768 & 445,052 & $1,815,000$ & 760,500 & 472,000 & 488,769 & 534,796 \\
\hline Noncollegiate and job training programs $\mathrm{s}^{21} \ldots . .$. & 281,640 & 439,993 & 12,848 & & & & & & $\dagger$ & $\dagger$ \\
\hline Vocational rehabilitation for disabled veteran $\mathrm{s}^{22} \ldots \ldots \ldots \ldots \ldots \ldots \ldots \ldots \ldots \ldots \ldots \ldots$ & 41,700 & 87,980 & 136,780 & 298,132 & 438,635 & $1,815,000$ & 760,500 & 472,000 & 488,769 & 534,796 \\
\hline $\begin{array}{l}\text { Dependents' education }{ }^{23} \\
\text { Service members occupational conversion training act of } 1992 \ldots \ldots \ldots\end{array}$ & $\begin{array}{r}15,570 \\
t\end{array}$ & \begin{tabular}{r|r}
17,813 \\
$t$
\end{tabular} & 5,723 & 5,961 & 6,417 & - & - & - & - & - \\
\hline Other agencies & & & & & 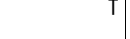 & $\mathrm{T}$ & $T$ & $\uparrow$ & 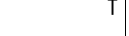 & $\dagger$ \\
\hline Appalachian Regional Commission........... & 33,161 & 9,157 & 93 & 2,173 & 2,588 & 2.962 & 986 & 2,290 & 962 & 1,689 \\
\hline National Endowment for the Arts......... & & 4,989 & 4,641 & 7,117 & 6,002 & 8,470 & 11,530 & 12,125 & 10,450 & 10,427 \\
\hline Arts in education......................... & $\dagger$ & 4,989 & 4,641 & 7,117 & 6,002 & 8,470 & 11,530 & 12,125 & 10,450 & 10,427 \\
\hline National Endowment for the Humanities & 20 & 330 & 404 & 997 & 812 & 603 & 125 & 75 & 100 & 333 \\
\hline 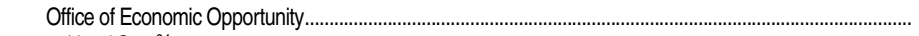 & $1,072,375$ & $\dagger$ & $t$ & $t$ & $t$ & $\dagger$ & $\dagger$ & $t$ & $\dagger$ & $\dagger$ \\
\hline Head Start $2^{2}, \ldots \ldots \ldots \ldots$ & 325,700 & $\dagger$ & $\dagger$ & $\dagger$ & $\dagger$ & $\dagger$ & $\dagger$ & $\dagger$ & $\dagger$ & $\dagger$ \\
\hline Other elementary and secondary program ${ }^{25} \ldots \ldots \ldots$ & 42,809 & 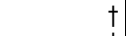 & 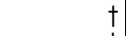 & $\dot{t}$ & $\dagger$ & $\dagger$ & $\dagger$ & $\dagger$ & $\dagger$ & $\dagger$ \\
\hline 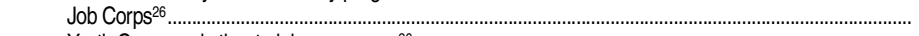 & 144,000 & & & & $\dagger$ & & $t$ & $\dagger$ & $\dagger$ & $\dagger$ \\
\hline Youth Corps and other training programs $\mathrm{s}^{26} \ldots \ldots \ldots \ldots \ldots \ldots$ & 553,368 & $\dagger$ & $\dagger$ & $\dagger$ & $\dagger$ & $\dagger$ & $\dagger$ & $\dagger$ & $\dagger$ & $\dagger$ \\
\hline 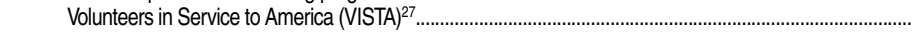 & 6,498 & $\dagger$ & & $\dagger$ & $\dagger$ & $\dagger$ & $\dagger$ & $\dagger$ & $\dagger$ & $\dagger$ \\
\hline Other programs & & & & & & & & & & \\
\hline Estimated education share of federal aid to the District of Columbia.... & 25,748 & 65,714 & 86,579 & 66,871 & 115,230 & 138,710 & 138,200 & 139,426 & 112,526 & 178,919 \\
\hline Postsecondary education..... & $\$ 3,447,697$ & $\$ 11,115,882$ & $\$ 13,650,915$ & $\$ 17,618,137$ & $\$ 15,008,715$ & $\$ 38,587,287$ & $\$ 50,197,838$ & $\$ 64,400,219$ & $\$ 70,054,237$ & $\$ 62,448,915$ \\
\hline Department of Education ${ }^{3} \ldots . .$. & $1,187,962$ & $5,682,242$ & $11,175,978$ & $14,234,000$ & $10,727,315$ & $31,420,023$ & $36,539,655$ & $49,260,330$ & $54,470,178$ & $45,942,515$ \\
\hline Student financial assistance. & & $3,682,789$ & $5,920,328$ & $7,047,000$ & $9,060,317$ & $15,209,515$ & $25,959,478$ & $43,753,247$ & $43,324,872$ & $37,130,405$ \\
\hline Direct Loan Program ${ }^{28} \ldots . . . . . . . . .$. & & & & 840,000 & $-2,862,240$ & $3,020,992$ & $3,481,859$ & $2,781,709$ & $6,917,373$ & $3,273,880$ \\
\hline Federal Family Education Loan Programm ${ }^{29} \ldots$ & 2,323 & $1,407,977$ & $4,372,446$ & $5,190,000$ & $2,707,473$ & $10,777,470$ & 3,932,994 & $-91,796$ & $1,498,353$ & $2,787,755$ \\
\hline Higher education & $1,029,131$ & 399,787 & 659,492 & 871,000 & $1,530,779$ & $2,053,288$ & $2,740,665$ & $2,388,946$ & $2,297,656$ & $2,302,753$ \\
\hline 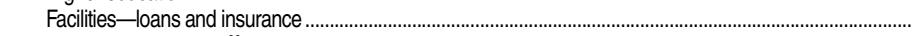 & 114,199 & $-19,031$ & 19,219 & $-6,000$ & $-2,174$ & $-1,464$ & $-8,360$ & $-4,607$ & $-8,513$ & -129 \\
\hline College housing loans ${ }^{30}$ & & 14,082 & $-57,167$ & $-46,000$ & $-41,886$ & $-33,521$ & $-16,725$ & $-13,265$ & $-16,725$ & $-1,176$ \\
\hline 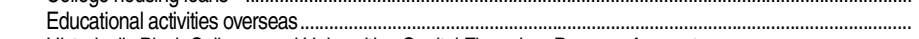 & 774 & 3,561 & 82 & & $t$ & $\dagger$ & & & & $\dagger$ \\
\hline Historically Black Colleges and Universities Capital Financing, Program Account................................................ & & & & & 150 & 169 & 23,330 & 23,289 & 32,160 & 21,424 \\
\hline 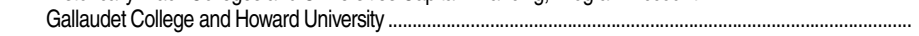 & 38,559 & 176,829 & 230,327 & 292,000 & 291,060 & 339,823 & 357,977 & 357,261 & 359,580 & 361,781 \\
\hline 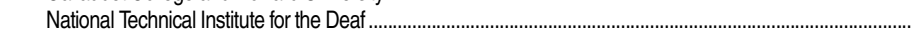 & 2,976 & 16,248 & 31,251 & 46,000 & 43,836 & 53,751 & 68,437 & 65,546 & 65,422 & 65,822 \\
\hline 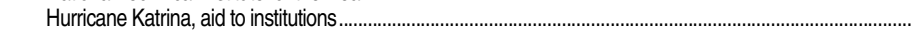 & & & & t & $\dagger$ & $\dagger$ & t & $\dagger$ & $\dagger$ & $\dagger$ \\
\hline 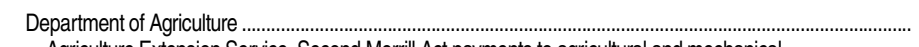 & $\dagger$ & 10,453 & 31,273 & 33,373 & 30,676 & 61,957 & 80,697 & 81,658 & 81,658 & 79,089 \\
\hline $\begin{array}{l}\text { Agriculture Extension Service, Second Morrill Act payments to agricultural and mechanical } \\
\text { colleges and Tuskegee Institute............................................................................. }\end{array}$ & $\dagger$ & 10,453 & 31,273 & 33,373 & 30,676 & 61,957 & 80,697 & 81,658 & 81,658 & 79,089 \\
\hline 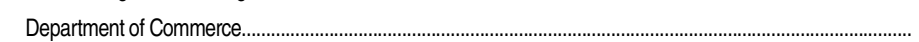 & 8,277 & 29,971 & 3,312 & 3,487 & 3,800 & - & - & - & - & - \\
\hline 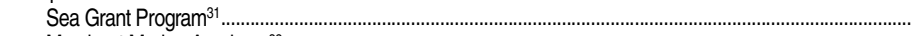 & & 3,123 & 3,312 & 3,487 & 3,800 & - & - & - & - & - \\
\hline Merchant Marine Academy32..... & 6,160 & 14,809 & $\dagger$ & $t$ & $t$ & $\dagger$ & $t$ & $t$ & $\dagger$ & $\dagger$ \\
\hline 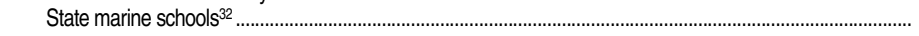 & 2,117 & 12,039 & $\dagger$ & $\dagger$ & $\dagger$ & $\dagger$ & $\dagger$ & $\dagger$ & $\dagger$ & $t$ \\
\hline
\end{tabular}


Table 401.30. Federal on-budget funds for education, by level/educational purpose, agency, and program: Selected fiscal years, 1970 through $2013-$ Continued [In thousands of current dollars]

\begin{tabular}{|c|c|c|c|c|c|c|c|c|c|c|c|}
\hline Level/educational purpose, agency, and program & 1970 & 1980 & $1990^{1}$ & $1995^{1}$ & $2000^{1}$ & $2005^{1}$ & $2010^{1}$ & $2011^{1,2}$ & $2012^{1,2}$ & $2013^{1}$ & \\
\hline 1 & 2 & 3 & 4 & 5 & 6 & 7 & 8 & 9 & 10 & 11 & \\
\hline 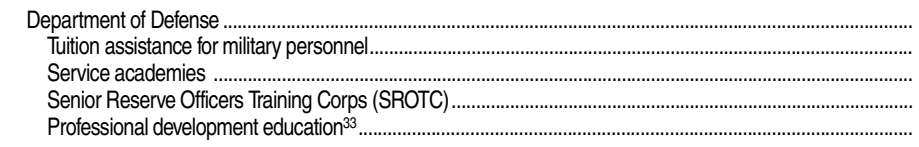 & $\begin{array}{r}322,100 \\
57,500 \\
78,700 \\
108,100 \\
77,800\end{array}$ & $\begin{array}{r}545,000 \\
-106,100 \\
- \\
-\end{array}$ & $\begin{array}{r}635,769 \\
95,300 \\
120,613 \\
193,056 \\
226,800\end{array}$ & $\begin{array}{l}729,500 \\
127,000 \\
163,300 \\
219,400 \\
219,800\end{array}$ & $\begin{array}{r}1,147,759 \\
263,303 \\
212,678 \\
363,461 \\
308,317\end{array}$ & $\begin{array}{r}1,858,301 \\
608,109 \\
300,760 \\
537,525 \\
411,907\end{array}$ & $\begin{array}{r}2,550,667 \\
669,892 \\
402,640 \\
885,500 \\
592,635\end{array}$ & $\begin{array}{r}2,297,234 \\
567,412 \\
348,836 \\
851,910 \\
529,076\end{array}$ & $\begin{array}{r}2,407,629 \\
590,626 \\
375,250 \\
844,498 \\
597,255\end{array}$ & $\begin{array}{r}2,272,909 \\
564,604 \\
224,677 \\
843,018 \\
640,610\end{array}$ & \\
\hline 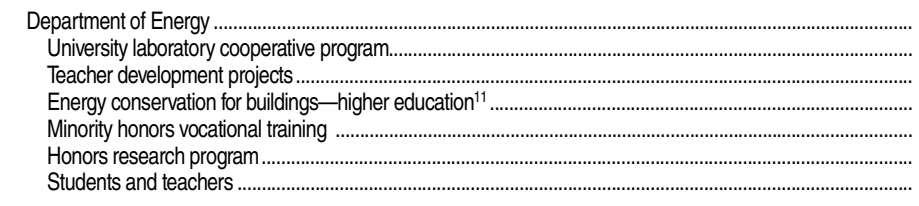 & $\begin{array}{r}3,000 \\
3,000 \\
\dagger \\
\dagger \\
\dagger \\
\dagger \\
\dagger\end{array}$ & $\begin{array}{r}57,701 \\
2,800 \\
1,400 \\
53,501 \\
\dagger \\
+ \\
\dagger\end{array}$ & $\begin{array}{r}25,502 \\
9,402 \\
\dagger \\
7,459 \\
\dagger \\
6,472 \\
2,169\end{array}$ & \begin{tabular}{r|r}
28,027 \\
8,552 \\
$\dagger$ \\
7,381 \\
$\dagger$ \\
2,221 \\
9,873
\end{tabular} & $\begin{array}{l}\dagger \\
+ \\
+ \\
+ \\
\dagger \\
\dagger \\
\dagger\end{array}$ & 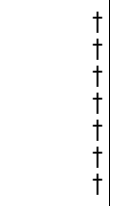 & $\begin{array}{l}\dagger \\
+ \\
+ \\
+ \\
\dagger \\
\dagger \\
\dagger\end{array}$ & 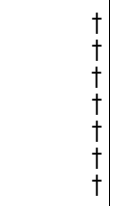 & 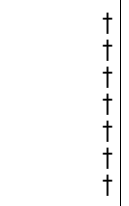 & $\begin{array}{l}\dagger \\
\dagger \\
\dagger \\
\dagger \\
\dagger \\
\dagger \\
\dagger\end{array}$ & \\
\hline 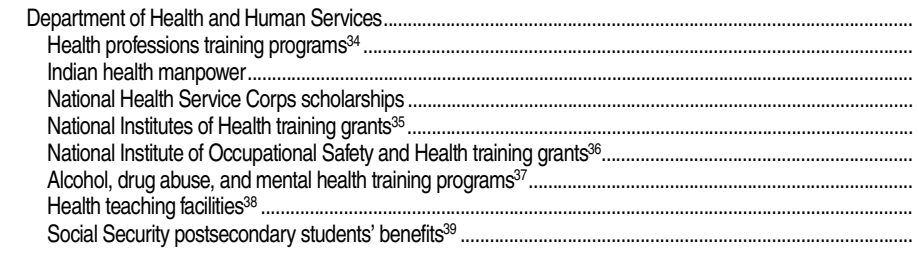 & $\begin{array}{r}981,483 \\
353,029 \\
\dagger \\
\dagger \\
\dagger \\
8,088 \\
118,366 \\
\dagger \\
502,000\end{array}$ & $\begin{array}{r}2,412,058 \\
460,736 \\
7,187 \\
70,667 \\
176,388 \\
12,899 \\
122,103 \\
3,078 \\
1,559,000\end{array}$ & $\begin{array}{r}578,542 \\
230,600 \\
9,508 \\
4,759 \\
241,356 \\
10,461 \\
81,353 \\
505 \\
\dagger\end{array}$ & $\begin{array}{r}796,035 \\
298,302 \\
27,000 \\
78,206 \\
380,502 \\
11,660 \\
\dagger \\
365 \\
\dagger\end{array}$ & $\begin{array}{r}954,190 \\
340,361 \\
16,000 \\
33,300 \\
550,220 \\
14,198 \\
\dagger \\
110 \\
+\end{array}$ & $\begin{array}{r}1,433,516 \\
581,661 \\
27,000 \\
45,000 \\
756,014 \\
23,841 \\
\dagger \\
\dagger \\
\dagger\end{array}$ & $\begin{array}{r}1,278,936 \\
406,000 \\
46,000 \\
41,000 \\
775,186 \\
10,750 \\
\dagger \\
\dagger \\
\dagger\end{array}$ & $\begin{array}{r}1,367,895 \\
498,000 \\
41,000 \\
46,400 \\
771,766 \\
10,729 \\
\dagger \\
\dagger \\
\dagger\end{array}$ & $\begin{array}{r}1,331,410 \\
459,000 \\
41,000 \\
42,940 \\
777,761 \\
10,709 \\
\dagger \\
\dagger \\
\dagger\end{array}$ & $\begin{array}{r}1,295,616 \\
438,039 \\
41,000 \\
39,868 \\
766,000 \\
10,709 \\
\dagger \\
\dagger \\
\dagger\end{array}$ & \\
\hline 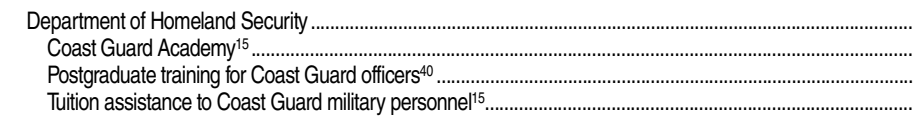 & $\begin{array}{l}\dagger \\
\dagger \\
\dagger \\
\dagger\end{array}$ & $\begin{array}{l}\dagger \\
\dagger \\
\dagger \\
\dagger\end{array}$ & $\begin{array}{l}\dagger \\
\dagger \\
\dagger \\
\dagger\end{array}$ & $\begin{array}{l}\dagger \\
\vdots \\
\dagger \\
\dagger\end{array}$ & $\begin{array}{l}\dagger \\
\dagger \\
\dagger \\
\dagger\end{array}$ & $\begin{array}{r}36,400 \\
16,400 \\
8,700 \\
11,300\end{array}$ & $\begin{array}{r}45,824 \\
26,326 \\
4,645 \\
14,853\end{array}$ & $\begin{array}{r}49,604 \\
27,581 \\
4,883 \\
17,140\end{array}$ & $\begin{array}{r}48,592 \\
26,803 \\
5,891 \\
15,898\end{array}$ & $\begin{array}{r}43,468 \\
24,359 \\
6,198 \\
12,911\end{array}$ & \\
\hline 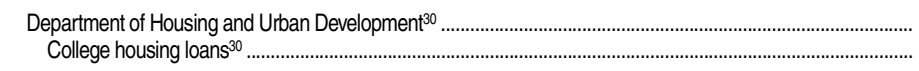 & $\begin{array}{l}114,199 \\
114,199\end{array}$ & $\begin{array}{c}\dagger \\
\dagger\end{array}$ & $\begin{array}{c}\dagger \\
\dagger\end{array}$ & 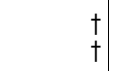 & $\begin{array}{l}\dagger \\
\dagger\end{array}$ & $\begin{array}{l}\dagger \\
\dagger\end{array}$ & $\begin{array}{l}\dagger \\
\dagger\end{array}$ & 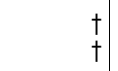 & $\begin{array}{l}\dagger \\
\dagger\end{array}$ & $\dagger$ & $\frac{100}{T}$ \\
\hline 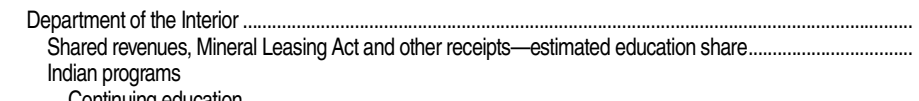 & $\begin{array}{r}31,749 \\
6,949 \\
\end{array}$ & $\begin{array}{r}80,202 \\
35,403 \\
\end{array}$ & $\begin{array}{r}135,480 \\
69,980\end{array}$ & $\begin{array}{r}159,054 \\
82,810\end{array}$ & $\begin{array}{r}187,179 \\
98,740\end{array}$ & $\begin{array}{l}249,227 \\
146,235\end{array}$ & $\begin{array}{r}174,092 \\
16,250\end{array}$ & $\begin{array}{r}112,970 \\
20,430\end{array}$ & $\begin{array}{r}120,720 \\
29,900\end{array}$ & $\begin{array}{r}108,837 \\
21,670\end{array}$ & 盄 \\
\hline Continuing education. & $\begin{array}{r}9,380 \\
15,420\end{array}$ & $\begin{array}{l}16,909 \\
27,890\end{array}$ & $\begin{array}{l}34,911 \\
30,589\end{array}$ & $\begin{array}{l}43,907 \\
32,337\end{array}$ & $\begin{array}{l}57,576 \\
30,863\end{array}$ & $\begin{array}{l}76,271 \\
26,721\end{array}$ & $\begin{array}{r}126,791 \\
31,051\end{array}$ & $\begin{array}{l}61,603 \\
30,937\end{array}$ & $\begin{array}{l}61,435 \\
29,385\end{array}$ & $\begin{array}{l}58,832 \\
28,335\end{array}$ & 范 \\
\hline 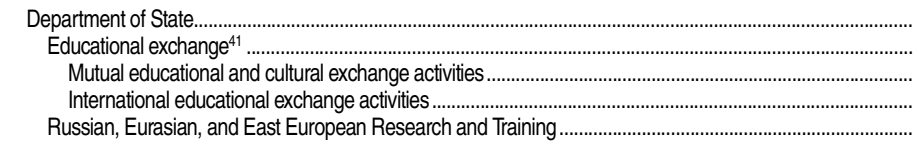 & $\begin{array}{r}30,850 \\
30,850 \\
30,454 \\
396 \\
\dagger\end{array}$ & $\begin{array}{l}\dagger \\
\dagger \\
\dagger \\
\dagger \\
\dagger\end{array}$ & $\begin{array}{r}2,167 \\
\dagger \\
\dagger \\
\dagger \\
\quad, 167\end{array}$ & \begin{tabular}{r|r}
3,000 \\
$t$ \\
$t$ \\
$\dagger$ \\
3,000
\end{tabular} & $\begin{array}{r}319,000 \\
319,000 \\
303,000 \\
16,000 \\
\dagger\end{array}$ & $\begin{array}{r}424,000 \\
424,000 \\
402,000 \\
22,000 \\
\dagger\end{array}$ & $\begin{array}{r}657,660 \\
657,660 \\
635,000 \\
22,660 \\
\dagger\end{array}$ & $\begin{array}{r}620,050 \\
620,050 \\
599,550 \\
20,500 \\
\dagger\end{array}$ & $\begin{array}{r}601,770 \\
601,770 \\
583,200 \\
18,570 \\
\dagger\end{array}$ & $\begin{array}{r}605,641 \\
605,641 \\
586,957 \\
18,684 \\
\dagger\end{array}$ & $\begin{array}{l}\frac{10}{D} \\
\frac{T}{5} \\
\frac{0}{\infty}\end{array}$ \\
\hline 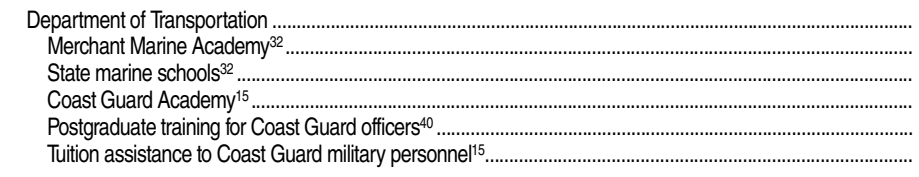 & $\begin{array}{r}11,197 \\
\dagger \\
\dagger \\
9,342 \\
1,655 \\
200\end{array}$ & $\begin{array}{r}12,530 \\
\dagger \\
\dagger \\
10,000 \\
2,230 \\
300\end{array}$ & $\begin{array}{r}46,025 \\
20,926 \\
8,269 \\
12,074 \\
4,173 \\
582\end{array}$ & $\begin{array}{r}59,257 \\
30,850 \\
8,980 \\
13,500 \\
5,513 \\
414\end{array}$ & $\begin{array}{r}60,300 \\
34,000 \\
7,000 \\
15,500 \\
2,500 \\
1,300\end{array}$ & $\begin{array}{r}73,000 \\
61,000 \\
12,000 \\
\dagger \\
\dagger \\
\dagger\end{array}$ & $\begin{array}{r}95,000 \\
79,000 \\
16,000 \\
\dagger \\
\dagger \\
\dagger\end{array}$ & $\begin{array}{r}77,000 \\
61,000 \\
16,000 \\
\dagger \\
\dagger \\
\dagger\end{array}$ & $\begin{array}{r}118,000 \\
101,000 \\
17,000 \\
\dagger \\
\dagger \\
\dagger\end{array}$ & $\begin{array}{r}130,000 \\
109,000 \\
21,000 \\
\dagger \\
\dagger \\
\dagger\end{array}$ & 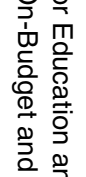 \\
\hline 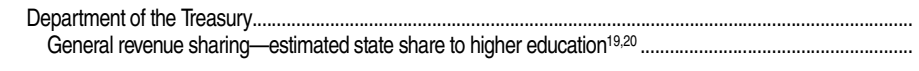 & $\begin{array}{l}\dagger \\
\dagger\end{array}$ & $\begin{array}{l}296,750 \\
296,750\end{array}$ & $\begin{array}{l}\dagger \\
\dagger\end{array}$ & $\begin{array}{l}\dagger \\
\dagger\end{array}$ & $\begin{array}{l}\dagger \\
\dagger\end{array}$ & $\begin{array}{l}\dagger \\
\dagger\end{array}$ & $\begin{array}{l}\dagger \\
\dagger\end{array}$ & $\begin{array}{l}t \\
t\end{array}$ & $\begin{array}{l}\dagger \\
\dagger\end{array}$ & $\begin{array}{l}\dagger \\
\dagger\end{array}$ & \\
\hline 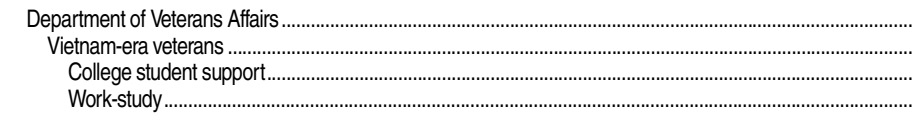 & $\begin{array}{r}693,490 \\
638,260 \\
\dagger \\
\dagger\end{array}$ & $\begin{array}{r}1,803,847 \\
1,579,974 \\
1,560,081 \\
19,893\end{array}$ & $\begin{array}{r}599,825 \\
46,998 \\
39,458 \\
7,540\end{array}$ & $\begin{array}{r}1,010,114 \\
\dagger \\
\dagger \\
\dagger\end{array}$ & $\begin{array}{r}1,132,322 \\
\dagger \\
\dagger \\
\dagger\end{array}$ & $\begin{array}{r}2,478,624 \\
\dagger \\
\dagger \\
\dagger\end{array}$ & $\begin{array}{r}8,042,444 \\
\dagger \\
\dagger \\
\dagger\end{array}$ & $\begin{array}{r}9,821,752 \\
\dagger \\
\dagger \\
\dagger\end{array}$ & $\begin{array}{r}10,115,052 \\
t \\
t \\
\dagger\end{array}$ & $\begin{array}{r}11,162,755 \\
\dagger \\
\dagger \\
\dagger\end{array}$ & 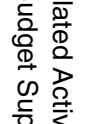 \\
\hline
\end{tabular}


[In thousands of current dollars]

\begin{tabular}{|c|c|c|c|c|c|c|c|c|c|c|}
\hline Level/educational purpose, agency, and program & 1970 & 1980 & $1990^{1}$ & $1995^{1}$ & $2000^{1}$ & $2005^{1}$ & $2010^{1}$ & $2011^{1,2}$ & $2012^{1,2}$ & $2013^{1}$ \\
\hline 1 & 2 & 3 & 4 & 5 & 6 & 7 & 8 & 9 & 10 & $\overline{11}$ \\
\hline 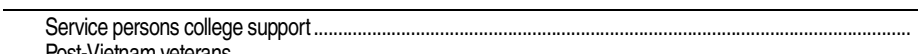 & 18,900 & 46,617 & 8,911 & $\dagger$ & $\dagger$ & $\dagger$ & $\dagger$ & $\dagger$ & $\dagger$ & $\bar{\dagger}$ \\
\hline Post-Vietnam veterans & & 922 & 161,475 & 33,596 & 3,958 & 1,136 & 894 & 1,343 & 932 & 848 \\
\hline All-volunteer-force educational assistance & $\dagger$ & $\dagger$ & 269,947 & 868,394 & 984,068 & $2,070,996$ & $1,854,917$ & $1,587,376$ & $1,086,585$ & 885,715 \\
\hline Veterans ………………………………………………………..... & & & 183,765 & 760,390 & 876,434 & $1,887,239$ & $1,659,694$ & $1,385,943$ & 931,756 & 726,697 \\
\hline Reservists........ & & $t$ & 86,182 & 108,004 & 107,634 & 183,757 & 195,223 & 201,433 & 154,829 & 159,018 \\
\hline 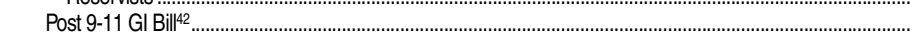 & & & & & & & $5,542,843$ & $7,656,490$ & $8,476,227$ & $9,716,174$ \\
\hline Veteran dependents' education & 36,330 & 176,334 & 100,494 & 95,124 & 131,296 & 388,719 & 507,294 & 462,877 & 455,318 & 486,705 \\
\hline Payments to state education agencies. & & & 12,000 & 13,000 & 13,000 & 17,773 & & 18,342 & 19,000 & 19,000 \\
\hline Reserve Education Assistance Program (REAP) $)^{43}$ & $\dagger$ & $\dagger$ & & & & & 136,496 & 95,324 & 76,990 & 54,313 \\
\hline \multirow{11}{*}{ 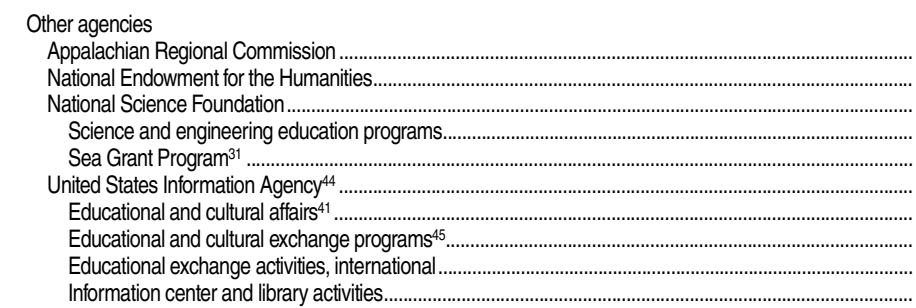 } & & & & & & & & & & \\
\hline & 4,105 & 1,751 & - & 2,741 & 2,286 & 4,407 & 2,464 & 6,098 & 6,653 & 4,443 \\
\hline & 3,349 & 56,451 & 50,938 & 56,481 & 28,395 & 29,253 & 47,949 & 40,168 & 45,000 & 39,399 \\
\hline & 42,000 & 64,583 & 161,884 & 211,800 & 389,000 & 490,000 & 646,000 & 636,060 & 654,000 & 710,000 \\
\hline & 37,000 & 64,583 & 161,884 & 211,800 & 389,000 & 490,000 & 646,000 & 636,060 & 654,000 & 710,000 \\
\hline & 5,000 & & & & & & & & & \\
\hline & 8,423 & 51,095 & 181,172 & 260,800 & $\dagger$ & $\dagger$ & $\dagger$ & $\dagger$ & $\dagger$ & $\dagger$ \\
\hline & & 49,546 & 35,862 & 13,600 & & $\dagger$ & & $\dagger$ & & \\
\hline & & $\dagger$ & 145,307 & 247,200 & & & & & & $\dagger$ \\
\hline & & 1,549 & & & $\dagger$ & $\dagger$ & & & & $\dagger$ \\
\hline & 8,423 & $\dagger$ & $\dagger$ & $\dagger$ & $\dagger$ & $\dagger$ & $\dagger$ & $\dagger$ & $\dagger$ & \\
\hline \multicolumn{11}{|l|}{ Other programs } \\
\hline Barry Goldwater Schol & $\dagger$ & $\dagger$ & 1,033 & 3,000 & 3,000 & 3,000 & 4,000 & 3,000 & 4,000 & 4,000 \\
\hline 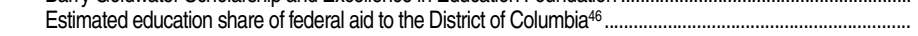 & 5,513 & 13,143 & 14,637 & 9,468 & 11,493 & 14,578 & 20,450 & 15,115 & 37,875 & 37,193 \\
\hline 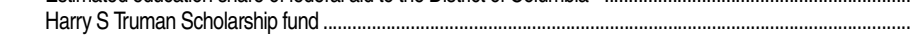 & t & $-1,895$ & 2,883 & 3,000 & 3,000 & 3,000 & 2,000 & 1,000 & 1,200 & 1,500 \\
\hline Institute of American Indian and Alaska Native Culture and Arts Development.... & $\dagger$ & t & 4,305 & 13,000 & 2,000 & 6,000 & 8,000 & 8,284 & 8,500 & 9,550 \\
\hline James Madison Memorial Fellowship Foundation ..... & $\dagger$ & $\dagger$ & 191 & 2,000 & 7,000 & 2,000 & 2,000 & 2,000 & 2,000 & 2,000 \\
\hline Other education.... & $\$ 964,719$ & $\$ 1,548,730$ & $\$ 3,383,031$ & $\$ 4,719,655$ & $\$ 5,484,571$ & $\$ 6,908,504$ & $\$ 9,326,725$ & $\$ 11,133,686$ & $\$ 9,395,279$ & $\$ 9,659,535$ \\
\hline $\begin{array}{c}\text { Department of Education }{ }^{3} \ldots \ldots \ldots \ldots \ldots \ldots \ldots \ldots \ldots \ldots \ldots \ldots \ldots \ldots \ldots \ldots \\
\text { Administration }\end{array}$ & $\begin{array}{r}630,235 \\
\end{array}$ & $\begin{array}{l}747,706 \\
187,31\end{array}$ & $\begin{array}{r}2,251,801 \\
328,293\end{array}$ & $2,861,000$ & $3,223,355$ & $3,538,862$ & $5,073,063$ & $5,255,939$ & $5,464,708$ & $5,641,061$ \\
\hline Administration & $\begin{array}{r}47,456 \\
108,284\end{array}$ & $\begin{array}{l}187,317 \\
129,127\end{array}$ & $\begin{array}{l}328,293 \\
137,264\end{array}$ & $\begin{array}{l}404,000 \\
117,000\end{array}$ & $\begin{array}{r}458,054 \\
\dagger\end{array}$ & $\begin{array}{r}548,842 \\
\dagger\end{array}$ & & & $\begin{array}{r}1,928,821 \\
+\end{array}$ & $\begin{aligned} 2,048,098 \\
+\end{aligned}$ \\
\hline Rehabilitative services and disability research & 473,091 & 426,886 & $1,780,360$ & $2,333,000$ & $2,755,468$ & $2,973,346$ & $3,506,861$ & $3,474,718$ & $3,511,281$ & $3,622,925$ \\
\hline 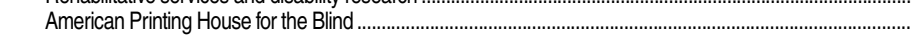 & 1,404 & 4,349 & 5,736 & 7,000 & 9,368 & $\begin{array}{r}16,538 \\
\end{array}$ & 24,600 & 24,551 & 24,505 & 24,655 \\
\hline 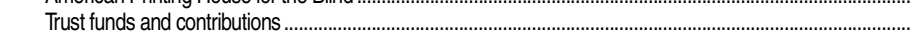 & & 27 & 148 & & 465 & 136 & 10,370 & 1,286 & & $-54,617$ \\
\hline \multirow{3}{*}{ 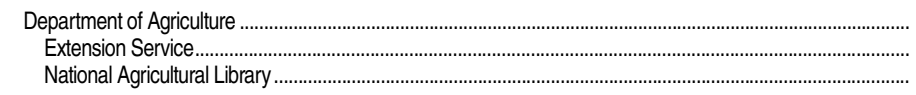 } & 135,637 & 271,112 & 352,511 & 422,878 & 444,477 & 468,631 & 567,423 & 552,030 & 547,081 & 534,371 \\
\hline & $\begin{array}{l}131,734 \\
\end{array}$ & 263,584 & 337,907 & 405,371 & 424,174 & 445,631 & 543,423 & 530,030 & 526,081 & 513,371 \\
\hline & 3,903 & 7,528 & 14,604 & 17,507 & 20,303 & 23,000 & 24,000 & 22,000 & 21,000 & 21,000 \\
\hline \multirow{3}{*}{ 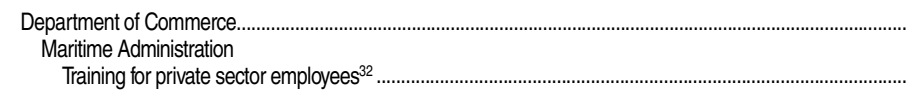 } & 1,226 & 2,479 & $\dagger$ & $\dagger$ & $\dagger$ & $\dagger$ & $\dagger$ & $\dagger$ & $\dagger$ & $\dagger$ \\
\hline & & & & & & & & & & \\
\hline & 1,226 & 2,479 & $\dagger$ & $\dagger$ & $\dagger$ & $\dagger$ & $\dagger$ & $\dagger$ & $\dagger$ & $\dagger$ \\
\hline 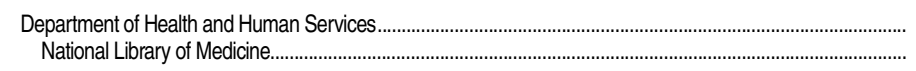 & $\begin{array}{l}24,273 \\
24,273\end{array}$ & $\begin{array}{l}37,819 \\
37819\end{array}$ & 77,962 & $\begin{array}{l}138,000 \\
138,000\end{array}$ & $\begin{array}{l}214,000 \\
214,000\end{array}$ & 313,000 & 340,000 & 337,000 & $\begin{array}{l}337,639 \\
337,639\end{array}$ & $\begin{array}{l}339,705 \\
339705\end{array}$ \\
\hline \multirow{3}{*}{ 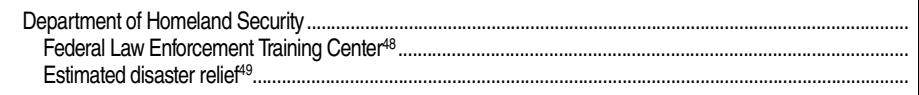 } & & & + & & + & 278,243 & 341,100 & $1.892,000$ & 215,471 & 258,000 \\
\hline & $t$ & $\dagger$ & $t$ & $t$ & $t$ & 159,000 & 323,000 & $\begin{array}{r},, 00 z, 000 \\
311,000\end{array}$ & 271,000 & 258,000 \\
\hline & $\dagger$ & $\dagger$ & $\dagger$ & $\dagger$ & $\dagger$ & 119,243 & 18,100 & $1,581,000$ & $-55,529$ & - \\
\hline \multirow{2}{*}{ 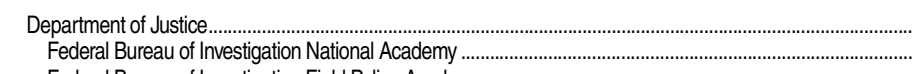 } & 5,546 & 27,642 & 26,920 & 36,296 & 34,727 & 26,148 & 33,563 & 33,563 & 33,563 & 33,563 \\
\hline & 2,066 & 7,234 & 6,028 & 12,831 & 22,479 & 15,619 & 19,443 & 19,443 & 19,443 & 19,443 \\
\hline 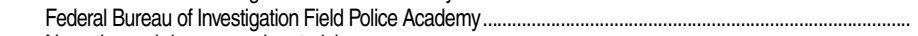 & 2,500 & 7,715 & 10,548 & 11,140 & 11,962 & 10,456 & 14,120 & 14,120 & 14,120 & 14,120 \\
\hline … & 980 & 2,416 & 850 & 325 & 286 & 73 & & & & $\dagger$ \\
\hline 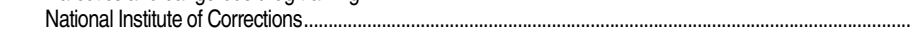 & & 10,277 & 9,494 & 12,000 & $\dagger$ & & & & & $\dagger$ \\
\hline
\end{tabular}

See notes at end of table. 
Table 401.30. Federal on-budget funds for education, by level/educational purpose, agency, and program: Selected fiscal years, 1970 through $2013-$ Continued [In thousands of current dollars]

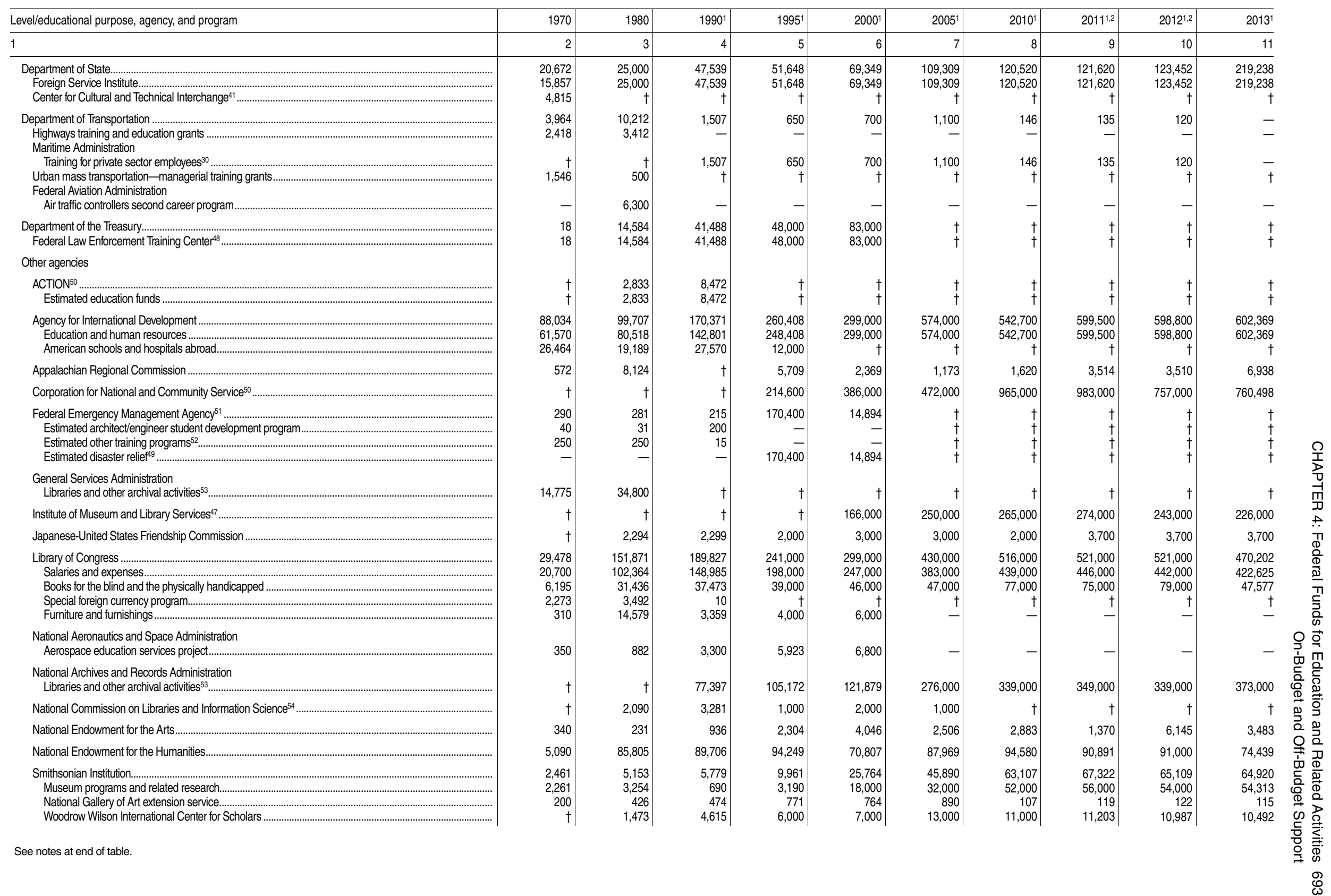


Table 401.30. Federal on-budget funds for education, by level/educational purpose, agency, and program: Selected fiscal years, 1970 through $2013-$ Continued

\begin{tabular}{|c|c|c|c|c|c|c|c|c|c|c|}
\hline Level/educational purpose, agency, and program & 1970 & 1980 & $1990^{1}$ & $1995^{1}$ & $2000^{1}$ & $2005^{1}$ & $2010^{1}$ & $2011^{1,2}$ & $2012^{1,2}$ & $2013^{1}$ \\
\hline 1 & 2 & 3 & 4 & 5 & 6 & 7 & 8 & 9 & 10 & 11 \\
\hline U.S. Information Agency-Center for Cultural and Technical Interchange $e^{41} \ldots$. & \multirow{3}{*}{$\begin{array}{l}\dagger \\
\dagger\end{array}$} & \multirow{3}{*}{$\begin{array}{r}15,115 \\
\dagger\end{array}$} & \multirow{3}{*}{$\begin{array}{r}20,375 \\
7,621\end{array}$} & \multirow{2}{*}{$\begin{array}{l}34,000 \\
12,000\end{array}$} & \multirow{2}{*}{$\begin{array}{r}\dagger \\
13,000\end{array}$} & \multirow{2}{*}{$\begin{array}{r}\dagger \\
28,000\end{array}$} & \multirow{2}{*}{$\begin{array}{r}\dagger \\
58,000\end{array}$} & \multirow{2}{*}{$\begin{array}{r}\dagger \\
47,000\end{array}$} & \multirow{2}{*}{$\begin{array}{r}\dagger \\
44,000\end{array}$} & \multirow{2}{*}{47,000} \\
\hline 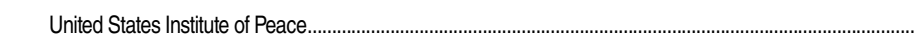 & & & & & & & & & & \\
\hline $\begin{array}{l}\text { Other programs } \\
\text { Estimated education share of federal aid for the District of Columbia..... }\end{array}$ & & & & 2,457 & 404 & 1,674 & 1,020 & 1,102 & 980 & 1,048 \\
\hline Research programs at universities and related institutions ${ }^{55} .$. & $\$ 2,283,641$ & $\$ 5,801,204$ & $\$ 12,606,035$ & $\$ 15,677,919$ & $\$ 21,660,134$ & $\$ 31,753,498$ & $\$ 36,993,306$ & $\$ 32,002,929$ & $\$ 32,931,796$ & - \\
\hline $\begin{array}{l}\text { Department of Education }{ }^{56} \ldots \ldots \ldots \ldots \ldots \ldots \ldots \ldots \\
\text { Department of Agriculture }\end{array}$ & $\begin{array}{r}87,823 \\
64,796\end{array}$ & $\begin{array}{r}78,742 \\
216,405\end{array}$ & $\begin{array}{r}89,483 \\
348,109 \\
\end{array}$ & $\begin{array}{l}279,000 \\
434,544\end{array}$ & $\begin{array}{l}116,464 \\
553,600\end{array}$ & $\begin{array}{l}456,822 \\
709,700\end{array}$ & $\begin{array}{r}659,006 \\
737,200\end{array}$ & $\begin{array}{r}608,786 \\
918,900\end{array}$ & $\begin{array}{r}593,664 \\
734,700\end{array}$ & $\$ 597,297$ \\
\hline Department of Commerce................................................. & $\begin{array}{r}4,487 \\
\end{array}$ & 48,295 & $\begin{array}{r}348,109 \\
50,523\end{array}$ & $\begin{array}{r}434,544 \\
85,442\end{array}$ & $\begin{array}{l}553,000 \\
110,775\end{array}$ & 243,948 & 303,000 & 296,489 & 307,919 & - \\
\hline Department of Defense & 356,188 & 644,455 & $1,871,864$ & $1,853,955$ & $1,891,710$ & $2,675,900$ & $3,154,300$ & $2,889,054$ & $2,789,120$ & \\
\hline Department of Energy ................................................. & 548,327 & $1,470,224$ & $2,520,885$ & $2,651,641$ & $3,577,004$ & $4,339,879$ & $3,402,600$ & $2,807,045$ & $3,219,690$ & \\
\hline Department of Health and Human Services... & 623,765 & $2,087,053$ & $4,902,714$ & $6,418,969$ & $10,491,641$ & $16,357,996$ & $21,796,200$ & $18,356,461$ & $18,738,366$ & - \\
\hline 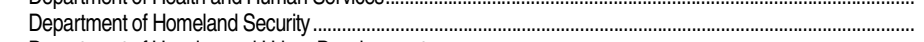 & & & & & & 309,717 & 152,800 & 139,003 & 162,304 & - \\
\hline 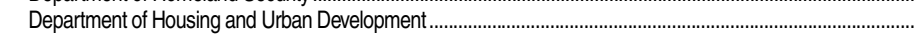 & 510 & 5,314 & 118 & 1,613 & 1,400 & 1,100 & 400 & 1,300 & 1,400 & - \\
\hline 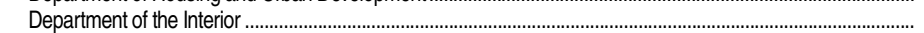 & 18,521 & 42,175 & 49,790 & 50,618 & 47,200 & 66,800 & 84,200 & 71,600 & 78,200 & - \\
\hline Department of Justice & 1,945 & 9,189 & 6,858 & 7,204 & 19,400 & 27,500 & 34,600 & 29,400 & 13,000 & - \\
\hline 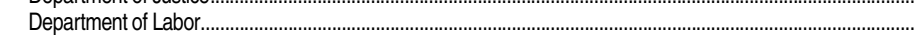 & 3,567 & 12,938 & 5,893 & 10,114 & 12,900 & 110,500 & $t$ & $\dagger$ & $t$ & $\dagger$ \\
\hline Department of State............. & 8,220 & 188 & 1,519 & 23 & & & & & & $\dagger$ \\
\hline Department of Transportation .... & 12,328 & 31,910 & 28,608 & 75,847 & 55,866 & 52,800 & 70,100 & 76,900 & 94,000 & - \\
\hline Department of the Treasury. & & 226 & 227 & 1,496 & & & & 100 & 100 & - \\
\hline 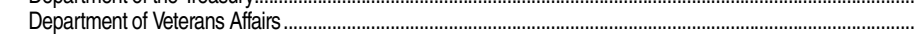 & 518 & 1,600 & 2,300 & 2,500 & $\dagger$ & $\dagger$ & $\dagger$ & $\dagger$ & $\dagger$ & $\dagger$ \\
\hline Agency for International Development $\ldots \ldots \ldots \ldots$ & & 77,063 & 79,415 & $\begin{array}{r}30,172 \\
105\end{array}$ & 33,500 & 28,100 & 15,200 & 15,400 & 14,600 & - \\
\hline 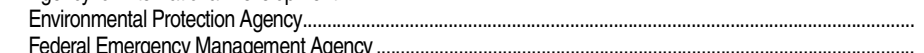 & $\begin{array}{r}19,446 \\
+\end{array}$ & $\begin{array}{r}41,083 \\
1,665\end{array}$ & 87,481 & 125,721 & 98,900 & 83,400 & 54,700 & 53,600 & $\begin{aligned} 53,800 \\
t\end{aligned}$ & $\bar{t}$ \\
\hline 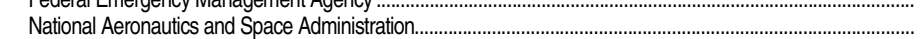 & 258,016 & 254,629 & $1,090,003$ & $1,751,977$ & $2,071,030$ & $2,763,120$ & $1,585,500$ & $1,430,761$ & $1,277,997$ & 1 \\
\hline 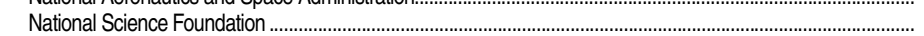 & 253,628 & 743,809 & $1,427,007$ & $1,874,395$ & $2,566,244$ & $3,503,216$ & $4,914,700$ & $4,282,230$ & $4,830,138$ & - \\
\hline 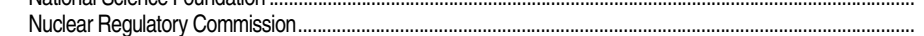 & $20,0,0$ & 32,590 & $\begin{array}{r}1,42,328 \\
42,328\end{array}$ & 22,188 & $\begin{aligned} 2,200 \\
12,200\end{aligned}$ & 15,100 & 14,500 & 14,200 & 14,900 & - \\
\hline Office of Economic Opportunity ............................................................................................ & 20,035 & & & $\dagger$ & $t$ & & $t$ & $\dagger$ & $\dagger$ & $\dagger$ \\
\hline U.S. Arms Control and Disarmament Agency .............................................................. & 100 & 661 & 25 & $\dagger$ & $\dagger$ & $\dagger$ & $\dagger$ & $\dagger$ & $\dagger$ & $\dagger$ \\
\hline Other agencies & 1,421 & 990 & 885 & 500 & 300 & 7,900 & 14,300 & 11,700 & 7,900 & - \\
\hline
\end{tabular}

\footnotetext{
See notes at end of table.
} 


\section{-Not available.}

Excludes federal support for medical education benefits under Medicare in the U.S. Department of Health and Human Services. Benefits excluded from total because data before fiscal year (FY) 1990 are not available. This program existed since Medicare began, but was not available as a separate budget item until FY 1990. Excluded amounts are as follows: $\$ 4,440,000,000$ in $\mathrm{FY} 1990, \$ 7,510,000,000$ in $\mathrm{FY} 1995, \$ 8,020,000,000$ in $\mathrm{FY} 2000, \$ 8,290,000,000$ in $\mathrm{FY} 2005$, $\$ 9,080,000,000$ in $\mathrm{FY} 2010, \$ 9,200,000,000$ in FY 2011, $\$ 9,800,000,000$ in FY 2012, and an estimated $\$ 10,000,000,000$ in FY 2013.

Data for research programs at universities and related institutions are estimated.

The U.S. Department of Education was created in May 1980. It formerly was the Office of Education in the U.S. Department Health, Education, and Welfare.

"Arranges for the education of children who reside on federal property when no suitable local school district can or will provide for the education of these children.

Includes many programs, such as No Child Left Behind, 21st Century Community Learning Centers, Class Size Reduction, Charter Schools, Safe and Drug-Free Schools, and Innovative programs.

Included the School-To-Work Opportunities program, which initiated a national system to be administered jointly by the U.S. Dearments of Educalion and Labor. Progras pro in FY Educalion Reform program were transtened to he school improvement proIStarting in FY 1994, the Special Milk Program has been included in the child nutrition programs.
F

${ }^{8}$ The Farm Security and Rural Investment Act of 2002 (Public Law 107-171) carries out preschool and school feeding program in foreign countries to help reduce the incidence of hunger and malnutrition, and improve literacy and primary education.

These commodities are purchased under Section 32 of the Act of August 24, 1935, for use in the child nutrition programs. ${ }^{10}$ Assisted in the construction of public facilities, such as vocational schools, through grants or loans. No funds have been appropriated for this program since FY 1977, and it was completely phased out in FY 1984

'2Formerly in the Office of Economic Opportunity. In FY 1972, funds were transferred to the U.S. Department of Health, Education, and Welfare, Office of Child Development.

Created by the Family Support Act of 1988 to provide funds for the Job Opportunities and Basic Skills Training program. Later incorporated into the Temporary Assistance for Needy Families program.

${ }^{14}$ After age 18 , benefits terminate at the end of the school term or in 3 months, whichever comes first.

Transterred from the U.S. Department of Transportation to the U.S. Department of Homeland Security in March 2003

17Finanes funding tor supplen

${ }^{18} \mathrm{Some}$ of the work and training programs were in the Office of Economic Opportunity and were transferred to the U.S Department of Labor in FYs 1971 and 1972. From FY 1994 through FY 2001, included the School-to-Work Opportunities program, which was administered jointly by the U.S. Departments of Education and Labor.

19Established in FY 1972 and closed in FY 1986.

${ }^{20}$ The states' share of revenue-sharing funds could not be spent on education in FYs 1981 through 1986.

Provided educational assistance allowances in order to restore lost educational opportunities to those individuals whose 22This program is in "Readjustment Benefits" program, Chapter 31, and covers the costs of subsistence tuition, books, plies, and equipment for disabled veterans requiring vocational rehabilitation.

${ }^{23}$ This program is in "Readjustment Benefits" program. Chapter 35 , and provides benefits to children and spouses of veterans. ${ }^{24} \mathrm{Head}$ Start program funds were transferred to the U.S. Department of Health, Education, and Welfare, Office of Child Development, in FY 1972

${ }^{25}$ Most of these programs were transferred to the U.S. Department of Health, Education, and Welfare, Office of Education, in

Transferred to the U.S. Department of Labor in FYs 1971 and 1972

${ }^{27}$ Transferred to the ACTION Agency in FY 1972

Under the William D. Ford Federal Direct Loan Program (commonly referred to as the Direct Loan Program), the federal govenment uses Treasury funds to provide loan capital directly to schools, which then disburse loan funds to students. The Federal Family Education Loan (FFEL) Program eliminated the authorization to originate new FFEL loans after June 30 ,

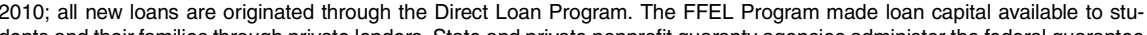
protecting FFEL lenders against losses other services to lenders.
${ }^{30}$ Transferred from the U.S. Department of Housing and Urban Development to the U.S. Department of Health, Education, an

32Transferred from the U.S. Department of Commerce to the U.S. Department of Transportation in FY 1981.

${ }^{33}$ Includes special education programs (military and civilian); legal education program; flight training; advanced degree program; college degree program (officers); and "Armed Forces Health Professions Scholarship" program.

Jaoes not include higher education assistance loans.

${ }^{35} \mathrm{Alcohol}$, drug abuse, and mental health training programs are included starting in FY 1992.

${ }_{36}^{36}$ From 2008 onward, funding came from "Harwood Training Grants."

Health training grants program.

39Postsecondary student benefits were ended by the Omnibus Budget Reconciliation Act of 1981 (Public Law 97-35) and were completely phased out by August 1985

${ }^{40 I n c l u d e s ~ f l i g h t ~ t r a i n i n g . ~ T r a n s f e r r e d ~ t o ~ t h e ~ U . ~}$

${ }^{41}$ Transferred from the U.S. Department of State to the United States Information Agency in 1977, then transferred back to the U.S. Department of State in FY 1998.

"Chapter 33 was enacted in the "Post 9-11 Veterans Educational Assistance Act of 2008" (Public Law 110-252).

23Part of the Ronald W. Reagan National Defense Authorization Act for FY 2005 (Public Law 108-375), enacted October 28 Guard and Reserves who serve on active duty in support of a contingency operation under federal authority on or after September 11, 2001.

${ }^{44} \mathrm{Abolished} \mathrm{in} \mathrm{FY} \mathrm{1998,} \mathrm{with} \mathrm{functions} \mathrm{transferred} \mathrm{to} \mathrm{the} \mathrm{U.S.} \mathrm{Department} \mathrm{of} \mathrm{State} \mathrm{and} \mathrm{the} \mathrm{newly} \mathrm{created} \mathrm{Broadcasting} \mathrm{Board}$ of Governors.

"45Included in the "Educational and Cultural Affairs" program in FYs 1980 through 1983, and became an independent program

作 Eanors Scholarship Program, United States Senate Youth Prant, and the College Access Challenge Grant

${ }^{47}$ Transferred from U.S. Department of Education to the Institute of Museum and Library Services in FY 1997.

${ }^{48}$ Transferred to the U.S. Department of Homeland Security in FY 2003

${ }^{49}$ The disaster relief program repairs and replaces damaged and destroyed school buildings. This program was transferred

列 ${ }_{51}$ The Federal Emergency Management Agency was created in 1979, representing a combination of five existing agencies. The funds for the Federal Emergency Management Agency in FY 1970 to FY 1975 were in other agencies. This agency was

transferred to the U.S. Department of Homeland Security in March 2003.
${ }_{52}$ These programs include the Fall-Out Shelter Analysis, Blast Protection Design through FY 1992. Starting in FY 1993, earthquake training and safety for teachers and administrators for grades 1 through 12 are included.

Administration in April 1985. Science to the Institute of Museum

${ }^{55}$ Includes federal obligations for research and development centers and $\mathrm{R} \& \mathrm{D}$ plant administered by colleges and univers: ties. FY 2011 and FY 2012 data are estimated, except the U.S Department of Education data, which are actual numbers. ${ }^{56} \mathrm{FY} 1970$ includes outlays for the "Research and Training" program. FY 1980 includes outlays for the "National Institute Education "program. $\mathrm{FY}$ 1990 through $\mathrm{FY} 2000$ anounts are oullays for the Onice of Educational Research and Improve prior to FY 2010 and appropriations for later years. NOTE: To the extent possible, amounts reported represent outlays rather than obligations. Negative amounts occur when program receipts exceed outlays. Starting in FY 2010, amounts for the U.S. Department of Education are appropriations, not ou lays. Some data have been revised from previously published figures. Detail may not sum to totals because of rounding. SOURCE: U.S. Department of Education, Budget Service, unpublished tabulations. U.S. Office of Management and Budget,
Budget of the U.S. Government, Appendix, fiscal years 1972 through 2014. National Science Foundation, Federal Funds for Budget of the U.S. Government, Appendix, fiscal years 1972 through 2014. National Science Foun 
696 CHAPTER 4: Federal Funds for Education and Related Activities

On-Budget and Off-Budget Support

Table 401.60. U.S. Department of Education appropriations for major programs, by state or jurisdiction: Fiscal year 2012

[In thousands of current dollars]

\begin{tabular}{|c|c|c|c|c|c|c|c|c|c|c|}
\hline State or jurisdiction & Total & $\begin{array}{r}\text { Grants } \\
\text { for the } \\
\text { disadvantaged }^{1}\end{array}$ & $\begin{array}{r}\text { Block grants to } \\
\text { states for } \\
\text { school } \\
\text { improvement }{ }^{2}\end{array}$ & $\begin{array}{r}\text { School } \\
\text { assistance } \\
\text { in federally } \\
\text { affected areas } \\
\end{array}$ & $\begin{array}{r}\text { Career/ } \\
\text { technical } \\
\text { and adult } \\
\text { education }{ }^{4}\end{array}$ & $\begin{array}{r}\text { Special } \\
\text { education }{ }^{5}\end{array}$ & $\begin{array}{r}\text { Language } \\
\text { assistance }\end{array}$ & $\begin{array}{r}\text { American } \\
\text { Indian } \\
\text { education }\end{array}$ & $\begin{array}{r}\text { Student } \\
\text { financial } \\
\text { assistance }^{7}\end{array}$ & $\begin{array}{r}\text { Rehabilitation } \\
\text { services }^{8}\end{array}$ \\
\hline 1 & 2 & 3 & 4 & 5 & 6 & 7 & 8 & 9 & 10 & 11 \\
\hline Total, 50 states and D.C. ${ }^{9} \ldots$ & $72,528,405$ & $\$ 14,805,310$ & $\$ 4,159,353$ & $\$ 1,200,579$ & $\$ 1,656,054$ & $\$ 12,103,118$ & $\$ 672,514$ & $\$ 105,921$ & $\$ 34,698,008$ & $\$ 3,127,548$ \\
\hline $\begin{array}{l}\text { Total, } 50 \text { states, D.C., other } \\
\text { activities, and other } \\
\text { jurisdictions................... }\end{array}$ & $75,175,878$ & $15,493,477$ & $4,401,536$ & $1,219,394$ & $1,718,024$ & $12,393,210$ & 729,654 & 105,921 & $35,766,437$ & $3,348,225$ \\
\hline 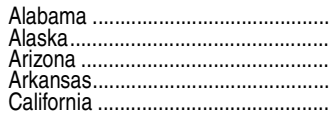 & $\begin{array}{l}1,229,656 \\
332,407 \\
2,749,652 \\
733,907 \\
8,489,412\end{array}$ & $\begin{array}{r}242,268 \\
46,221 \\
335,274 \\
167,121 \\
1,852,037\end{array}$ & $\begin{array}{r}70,561 \\
21,820 \\
78,443 \\
47,358 \\
458,794\end{array}$ & $\begin{array}{r}2,859 \\
143,650 \\
179,851 \\
493 \\
67,010\end{array}$ & $\begin{array}{r}28,995 \\
5,253 \\
36,218 \\
17,289 \\
214,447\end{array}$ & $\begin{array}{r}193,241 \\
39,884 \\
203,668 \\
121,266 \\
1,316,596\end{array}$ & $\begin{array}{r}3,882 \\
1,057 \\
18,303 \\
3,112 \\
161,603\end{array}$ & $\begin{array}{r}1,673 \\
12,043 \\
11,267 \\
309 \\
6,070\end{array}$ & $\begin{array}{r}628,187 \\
48,535 \\
1,820,058 \\
329,489 \\
4,097,299\end{array}$ & $\begin{array}{r}57,990 \\
13,944 \\
66,870 \\
47,469 \\
315,556\end{array}$ \\
\hline 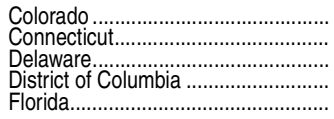 & $\begin{array}{r}1,059,344 \\
655,6,679 \\
196,104 \\
303,627 \\
4,245,103\end{array}$ & $\begin{array}{r}160,854 \\
111,438 \\
45,705 \\
48,386 \\
787,624\end{array}$ & $\begin{array}{r}50,175 \\
38,613 \\
21,814 \\
21,357 \\
196,933\end{array}$ & $\begin{array}{r}20,205 \\
4,436 \\
48 \\
928 \\
7,127\end{array}$ & $\begin{array}{r}22,375 \\
14,966 \\
6,349 \\
5,514 \\
100,426\end{array}$ & $\begin{array}{r}166,213 \\
141,654 \\
37,854 \\
19,733 \\
672,126\end{array}$ & $\begin{array}{r}9,901 \\
5,765 \\
1,231 \\
779 \\
43,011\end{array}$ & $\begin{array}{r}708 \\
0 \\
0 \\
0 \\
94\end{array}$ & $\begin{array}{r}585,213 \\
303,918 \\
69,875 \\
191,665 \\
2,287,165\end{array}$ & $\begin{array}{r}43,700 \\
34,889 \\
13,228 \\
15,265 \\
150,596\end{array}$ \\
\hline 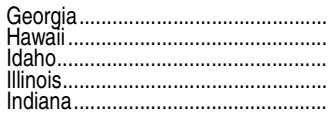 & $\begin{array}{r}2,442,012 \\
286,756 \\
375,232 \\
3,102,934 \\
1,552,154\end{array}$ & $\begin{array}{r}530,703 \\
48,562 \\
61,650 \\
674,596 \\
279,553\end{array}$ & $\begin{array}{r}129,001 \\
21,960 \\
23,955 \\
176,196 \\
75,018\end{array}$ & $\begin{array}{r}22,617 \\
51,620 \\
6,099 \\
14,187 \\
115\end{array}$ & $\begin{array}{r}56,151 \\
7,647 \\
8,757 \\
62,599 \\
35,573\end{array}$ & $\begin{array}{r}352,372 \\
43,004 \\
59,835 \\
540,519 \\
275,037\end{array}$ & $\begin{array}{r}15,211 \\
3,499 \\
1,948 \\
28,373 \\
8,310\end{array}$ & $\begin{array}{r}0 \\
0 \\
412 \\
170 \\
0\end{array}$ & $\begin{array}{r}1,231,515 \\
95,097 \\
193,856 \\
1,487,216 \\
812,408\end{array}$ & $\begin{array}{r}104,442 \\
15,367 \\
18,719 \\
119,078 \\
66,141\end{array}$ \\
\hline 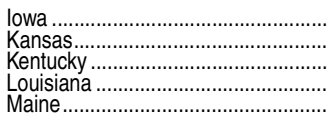 & $\begin{array}{r}1,082,778 \\
648,937 \\
1,055,935 \\
1,124,940 \\
292,600\end{array}$ & $\begin{array}{r}89,474 \\
122,519 \\
237,372 \\
302,720 \\
54,984\end{array}$ & $\begin{array}{l}35,952 \\
38,871 \\
69,602 \\
89,168 \\
24,735\end{array}$ & $\begin{array}{r}192 \\
27,537 \\
975 \\
8,752 \\
2,111\end{array}$ & $\begin{array}{r}15,644 \\
14,008 \\
27,012 \\
30,360 \\
7,369\end{array}$ & $\begin{array}{r}129,841 \\
112,810 \\
173,551 \\
201,807 \\
59,284\end{array}$ & $\begin{array}{l}3,216 \\
4,095 \\
3,712 \\
3,057 \\
720\end{array}$ & $\begin{array}{r}271 \\
1,299 \\
0 \\
955 \\
152\end{array}$ & $\begin{array}{l}779,966 \\
296,816 \\
494,677 \\
449,605 \\
124,141\end{array}$ & $\begin{array}{l}28,221 \\
30,982 \\
49,033 \\
38,515 \\
19,103\end{array}$ \\
\hline 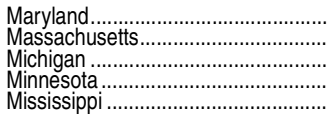 & $\begin{array}{r}1,046,363 \\
1,271,597 \\
2,502,887 \\
1,220,169 \\
859,440\end{array}$ & $\begin{array}{l}198,900 \\
222,219 \\
565,606 \\
165,421 \\
196,857\end{array}$ & $\begin{array}{r}58,628 \\
71,248 \\
159,423 \\
58,344 \\
63,415\end{array}$ & $\begin{array}{r}6,593 \\
259 \\
4,355 \\
20,774 \\
2,284\end{array}$ & $\begin{array}{l}25,135 \\
28,103 \\
52,673 \\
22,783 \\
19,744\end{array}$ & $\begin{array}{l}213,960 \\
300,719 \\
424,224 \\
203,985 \\
128,559\end{array}$ & $\begin{array}{r}10,001 \\
13,035 \\
10,570 \\
8,590 \\
1,642\end{array}$ & $\begin{array}{r}75 \\
79 \\
2,681 \\
4,035 \\
456\end{array}$ & $\begin{array}{r}482,234 \\
569,080 \\
1,172,816 \\
684,639 \\
399,470\end{array}$ & $\begin{array}{r}50,837 \\
66,854 \\
110,539 \\
51,598 \\
47,013\end{array}$ \\
\hline 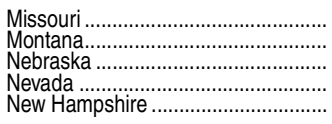 & $\begin{array}{r}1,397,389 \\
278,398 \\
419,559 \\
412,299 \\
242,643\end{array}$ & $\begin{array}{r}244,057 \\
47,860 \\
78,342 \\
111,017 \\
41,227\end{array}$ & $\begin{array}{l}79,183 \\
27,7179 \\
26,948 \\
26,814 \\
24,240\end{array}$ & $\begin{array}{r}20,988 \\
44,285 \\
18,254 \\
3,565 \\
6\end{array}$ & $\begin{array}{r}30,903 \\
6,506 \\
9,242 \\
14,938 \\
7,226\end{array}$ & $\begin{array}{r}240,655 \\
40,556 \\
79,448 \\
76,890 \\
51,095\end{array}$ & $\begin{array}{r}5,066 \\
511 \\
2,667 \\
8,799 \\
931\end{array}$ & $\begin{array}{r}88 \\
3,363 \\
858 \\
755 \\
0\end{array}$ & $\begin{array}{r}707,139 \\
92,183 \\
181,439 \\
154,605 \\
103,575\end{array}$ & $\begin{array}{l}69,310 \\
15,955 \\
22,360 \\
14,915 \\
14,343\end{array}$ \\
\hline 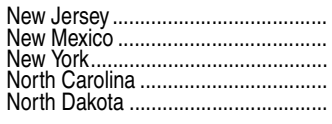 & $\begin{array}{r}1,605,369 \\
658,954 \\
4,795,922 \\
2,002,790 \\
203,814\end{array}$ & $\begin{array}{r}317,358 \\
124,990 \\
1,182,857 \\
422,198 \\
37,099\end{array}$ & $\begin{array}{r}92,716 \\
36,076 \\
315,524 \\
107,323 \\
22,457\end{array}$ & $\begin{array}{l}11,582 \\
98,094 \\
34,490 \\
16,990 \\
27,120\end{array}$ & $\begin{array}{r}38,388 \\
12,416 \\
94,947 \\
53,163 \\
5,235\end{array}$ & $\begin{array}{r}382,975 \\
97,119 \\
815,307 \\
350,250 \\
30,935\end{array}$ & $\begin{array}{r}21,706 \\
4,047 \\
55,533 \\
15,381 \\
507\end{array}$ & $\begin{array}{r}55 \\
8,914 \\
1,934 \\
3,688 \\
1,888\end{array}$ & $\begin{array}{r}678,007 \\
250,871 \\
2,136,538 \\
921,956 \\
64,043\end{array}$ & $\begin{array}{r}62,581 \\
26,428 \\
158,792 \\
111,842 \\
14,531\end{array}$ \\
\hline 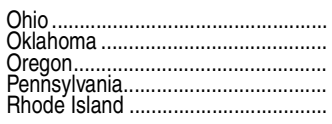 & $\begin{array}{r}2,632,547 \\
906,988 \\
886,723 \\
2,597,888 \\
284,594\end{array}$ & $\begin{array}{r}612,269 \\
168,971 \\
163,469 \\
605,092 \\
51,328\end{array}$ & $\begin{array}{r}160,555 \\
58,392 \\
45,976 \\
160,016 \\
21,934\end{array}$ & $\begin{array}{r}1,599 \\
37,914 \\
3,569 \\
858 \\
1,581\end{array}$ & $\begin{array}{r}59,041 \\
21,293 \\
19,042 \\
60,959 \\
7,841\end{array}$ & $\begin{array}{r}463,737 \\
156,615 \\
137,424 \\
454,732 \\
47,485\end{array}$ & $\begin{array}{r}9,599 \\
4,499 \\
7,668 \\
14,209 \\
2,437\end{array}$ & $\begin{array}{r}0 \\
25,541 \\
2,167 \\
0 \\
0\end{array}$ & $\begin{array}{r}1,222,011 \\
386,874 \\
465,376 \\
1,172,771 \\
136,565\end{array}$ & $\begin{array}{r}103,736 \\
46,890 \\
42,032 \\
129,251 \\
15,422\end{array}$ \\
\hline 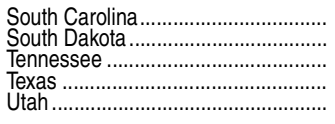 & $\begin{array}{r}1,041,816 \\
299,540 \\
1,404,514 \\
6,022,685 \\
759,759\end{array}$ & $\begin{array}{r}224,458 \\
46,116 \\
291,669 \\
1,999,509 \\
99,508\end{array}$ & $\begin{array}{r}60,285 \\
22,834 \\
79,982 \\
363,983 \\
30,310\end{array}$ & $\begin{array}{r}1,855 \\
52,678 \\
4,016 \\
103,314 \\
8,636\end{array}$ & $\begin{array}{r}27,367 \\
5,423 \\
35,770 \\
148,174 \\
15,216\end{array}$ & $\begin{array}{r}189,959 \\
36,933 \\
251,628 \\
1,043,536 \\
118,396\end{array}$ & $\begin{array}{r}4,469 \\
738 \\
5,670 \\
101,415 \\
4,813\end{array}$ & $\begin{array}{r}20 \\
4,132 \\
0 \\
399 \\
1,347\end{array}$ & $\begin{array}{r}474,316 \\
117,640 \\
665,991 \\
2,510,206 \\
442,173\end{array}$ & $\begin{array}{r}59,088 \\
13,045 \\
69,788 \\
252,148 \\
39,360\end{array}$ \\
\hline 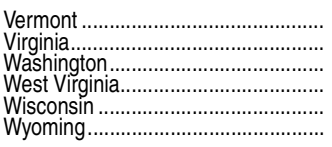 & $\begin{array}{r}173,880 \\
1,549,671 \\
1,219,371 \\
536,981 \\
1,162,2854 \\
171,835\end{array}$ & $\begin{array}{r}36,999 \\
240,392 \\
237,616 \\
99,026 \\
238,115 \\
35,699\end{array}$ & $\begin{array}{l}21,438 \\
75,757 \\
70,101 \\
35,74 \\
70,756 \\
21,441\end{array}$ & $\begin{array}{r}40,359 \\
45,422 \\
15 \\
13,338 \\
14,969\end{array}$ & $\begin{array}{r}5,150 \\
37,744 \\
30,203 \\
12,320 \\
27,129 \\
5,026\end{array}$ & $\begin{array}{r}29,983 \\
300,918 \\
237,842 \\
81,436 \\
224,319 \\
31,500\end{array}$ & $\begin{array}{r}504 \\
11,625 \\
17,374 \\
610 \\
6,612 \\
500\end{array}$ & $\begin{array}{r}237 \\
15 \\
4,415 \\
0 \\
2,529 \\
828\end{array}$ & $\begin{array}{r}61,041 \\
766,559 \\
518,037 \\
262,073 \\
520,862 \\
50,219\end{array}$ & $\begin{array}{l}18,521 \\
76,301 \\
58,360 \\
45,753 \\
59,193 \\
11,652\end{array}$ \\
\hline $\begin{array}{l}\text { Other activities/jurisdictions } \\
\text { Indian Tribe (Set-Aside)......... } \\
\text { Other nonstate allocations...... }\end{array}$ & $\begin{array}{l}280,521 \\
319,299\end{array}$ & $\begin{array}{r}101,541 \\
47,040\end{array}$ & $\begin{array}{l}23,687 \\
72,601\end{array}$ & $\begin{array}{r}17,441 \\
\end{array}$ & $\begin{array}{l}14,038 \\
13,313\end{array}$ & $\begin{array}{l}98,252 \\
25,000\end{array}$ & $\begin{array}{r}5,000 \\
45,100\end{array}$ & $\begin{array}{l}0 \\
0\end{array}$ & $\begin{array}{l}0 \\
0\end{array}$ & $\begin{array}{l}38,003 \\
98,805\end{array}$ \\
\hline 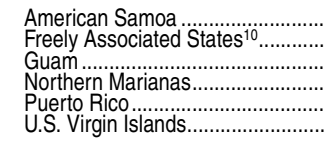 & $\begin{array}{r}33,482 \\
26,526 \\
57,718 \\
20,304 \\
1,867,682 \\
41,940\end{array}$ & $\begin{array}{r}11,518 \\
0 \\
12,158 \\
4,184 \\
496,248 \\
15,477\end{array}$ & $\begin{array}{r}4,835 \\
0 \\
7,052 \\
2,719 \\
125,132 \\
6,159\end{array}$ & $\begin{array}{r}0 \\
0 \\
0 \\
0 \\
1,239 \\
135\end{array}$ & $\begin{array}{r}583 \\
177 \\
1,068 \\
696 \\
31,006 \\
1,089\end{array}$ & $\begin{array}{r}6,951 \\
6,579 \\
15,548 \\
5,286 \\
122,743 \\
9,733\end{array}$ & $\begin{array}{r}959 \\
0 \\
1,436 \\
1,203 \\
3,379 \\
63\end{array}$ & $\begin{array}{l}0 \\
0 \\
0 \\
0\end{array}$ & $\begin{array}{r}7,119 \\
19,771 \\
17,055 \\
4,964 \\
1,012,866 \\
6,654\end{array}$ & $\begin{array}{r}1,517 \\
0 \\
3,401 \\
1,253 \\
75,069 \\
2,630\end{array}$ \\
\hline
\end{tabular}

${ }^{1}$ Title I includes Grants to Local Education Agencies (Basic, Concentration, Targeted, and Education Finance Incentive Grants); School Turnaround Grants; Migrant Education Grants; and Neglected and Delinquent Children Grants.

${ }^{2}$ Title VI includes Improving Teacher Quality State Grants; Mathematics and Science Partnerships; Educational Technology State Grants; 21st Century Community Learning Centers; Assessing Achievement, including No Child Left Behind; Education for the Homeless Children and Youth; Rural and Low-Income Schools Program; and Small, Rural School Achievement Program.

Includes Impact Aid-Basic Support Payments; Impact Aid—Payments for Children with Disabilities; and Impact Aid-Construction.

${ }^{4}$ Includes Career and Technical Education State Grants; English Literacy and Civics Education State Grants; and Adult Basic and Literacy Education State Grants.

Includes Special Education-Grants to States; Preschool Grants; and Grants for Infants and Families.
${ }^{6}$ Includes English Learner Education.

${ }^{7}$ Includes Pell Grants; Federal Supplemental Educational Opportunity Grants; Federal WorkStudy; College Access Challenge Grant; and Student Loan Program interest subsidies. ${ }^{8}$ Includes Vocational Rehabilitation State Grants; Supported Employment State Grants; Client Assistance State Grants; Independent Living State Grants; Services for Older Blind Individuals; Centers for Independent Living; Protection and Advocacy for Assistive Technology; Assistive Technology State Grant Program; and Protection and Advocacy of Individual Rights. ${ }^{9}$ Total excludes other activities and other jurisdictions.

10Includes the Marshall Islands, the Federated States of Micronesia, and Palau.

NOTE: Data reflect revisions to figures in the Budget of the United States Government, Fiscal Year 2014. Detail may not sum to totals because of rounding.

SOURCE: U.S. Department of Education, Budget Service, retrieved December 6, 2013 from http://www2.ed.gov/about/overview/budget/statetables/14stbyprogram.pdf; and unpublished tabulations. (This table was prepared January 2014.) 
Table 401.70. Appropriations for Title I and selected other programs under the No Child Left Behind Act of 2001, by program and state or jurisdiction: Fiscal years 2012 and 2013

[In thousands of current dollars]

\begin{tabular}{|c|c|c|c|c|c|c|c|c|}
\hline \multirow[b]{3}{*}{ State or jurisdiction } & \multirow[b]{3}{*}{$\begin{array}{r}\text { Title I } \\
\text { total, } 2012 \\
\end{array}$} & \multicolumn{5}{|c|}{ Title I, 2013} & \multirow{3}{*}{$\begin{array}{r}\text { Assessing } \\
\text { Achievement, } \\
2013\end{array}$} & \multirow{3}{*}{$\begin{array}{r}\text { Improving } \\
\text { Teacher } \\
\text { Quality State } \\
\text { Grants, } 2013\end{array}$} \\
\hline & & \multirow[b]{2}{*}{ Total } & \multirow{2}{*}{$\begin{array}{r}\text { Grants to local } \\
\text { education } \\
\text { agencies }^{1}\end{array}$} & \multicolumn{2}{|c|}{ State agency programs } & \multirow{2}{*}{$\begin{array}{r}\text { Turn- } \\
\text { around } \\
\text { Grants }\end{array}$} & & \\
\hline & & & & $\begin{array}{r}\text { Neglected and } \\
\text { Delinquent }\end{array}$ & Migrant & & & \\
\hline 1 & 2 & 3 & 4 & 5 & 6 & 7 & 8 & 9 \\
\hline Total, 50 states and D.C. ${ }^{2} \ldots \ldots \ldots \ldots \ldots \ldots \ldots \ldots \ldots \ldots \ldots \ldots$ & $\$ 14,805,310$ & $\$ 14,036,475$ & $\$ 13,164,974$ & $\$ 45,763$ & $\$ 362,751$ & $\$ 462,988$ & $\$ 351,136$ & $\$ 2,196,936$ \\
\hline $\begin{array}{l}\text { Total, } 50 \text { states, D.C., other activities, } \\
\text { and other jurisdictions }\end{array}$ & $15,493,477$ & $14,686,340$ & $13,760,219$ & 47,614 & 372,751 & 505,756 & 368,900 & $2,337,830$ \\
\hline 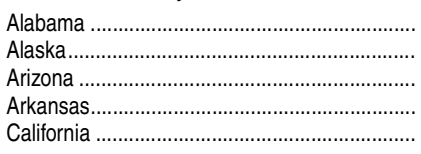 & \begin{tabular}{r|}
242,268 \\
46,221 \\
335,274 \\
167,121 \\
$1,852,037$
\end{tabular} & $\begin{array}{r}225,523 \\
46,332 \\
329,654 \\
157,652 \\
1,726,778\end{array}$ & \begin{tabular}{r|}
215,160 \\
37,767 \\
311,045 \\
147,089 \\
$1,540,847$
\end{tabular} & $\begin{array}{r}951 \\
210 \\
1,342 \\
374 \\
1,348\end{array}$ & $\begin{array}{r}2,021 \\
6,836 \\
6,450 \\
5,173 \\
127,557\end{array}$ & $\begin{array}{r}7,391 \\
1,520 \\
10,817 \\
5,015 \\
57,026\end{array}$ & \begin{tabular}{r|}
6,033 \\
3,493 \\
7,329 \\
4,894 \\
27,810 \\
\end{tabular} & $\begin{array}{r}36,446 \\
10,869 \\
35,693 \\
22,067 \\
254,874\end{array}$ \\
\hline 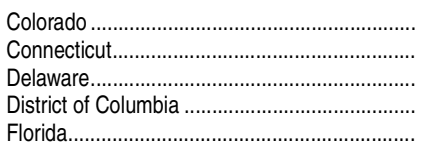 & $\begin{array}{r}160,854 \\
111,438 \\
45,705 \\
48,386 \\
787,624\end{array}$ & $\begin{array}{r}152,033 \\
113,713 \\
44,782 \\
45,653 \\
750,985\end{array}$ & $\begin{array}{r}139,574 \\
107,665 \\
42,595 \\
44,013 \\
701,541\end{array}$ & $\begin{array}{r}529 \\
1,192 \\
446 \\
216 \\
1,172\end{array}$ & $\begin{array}{r}6,905 \\
976 \\
286 \\
0 \\
22,302\end{array}$ & $\begin{array}{r}5,024 \\
3,881 \\
1,455 \\
1,424 \\
25,970\end{array}$ & $\begin{array}{r}6,272 \\
5,234 \\
3,549 \\
3,255 \\
13,758\end{array}$ & $\begin{array}{r}25,502 \\
21,661 \\
10,869 \\
10,869 \\
103,193\end{array}$ \\
\hline 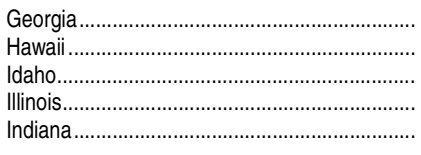 & $\begin{array}{r}530,703 \\
48,562 \\
61,650 \\
674,596 \\
279,553\end{array}$ & $\begin{array}{r}506,837 \\
50,526 \\
59,635 \\
653,514 \\
262,746\end{array}$ & $\begin{array}{r}481,413 \\
47,598 \\
53,679 \\
627,985 \\
248,168\end{array}$ & $\begin{array}{r}1,206 \\
357 \\
438 \\
1,598 \\
544\end{array}$ & $\begin{array}{r}7,742 \\
788 \\
3,502 \\
1,871 \\
5,390\end{array}$ & $\begin{array}{r}16,477 \\
1,783 \\
2,016 \\
22,060 \\
8,644\end{array}$ & $\begin{array}{r}9,656 \\
3,796 \\
4,138 \\
11,364 \\
7,303\end{array}$ & $\begin{array}{l}60,014 \\
10,869 \\
10,886 \\
94,180 \\
39,054\end{array}$ \\
\hline 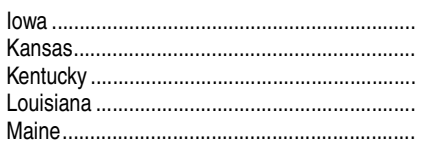 & $\begin{array}{r}89,474 \\
122,519 \\
237,372 \\
302,720 \\
54,984\end{array}$ & $\begin{array}{r}88,444 \\
111,823 \\
226,111 \\
293,028 \\
51,867\end{array}$ & $\begin{array}{r}83,471 \\
96,510 \\
210,475 \\
279,286 \\
48,799\end{array}$ & $\begin{array}{r}367 \\
327 \\
926 \\
1,746 \\
217\end{array}$ & $\begin{array}{r}1,577 \\
11,315 \\
7,247 \\
2,422 \\
1,146\end{array}$ & $\begin{array}{l}3,029 \\
3,671 \\
7,463 \\
9,573 \\
1,704\end{array}$ & $\begin{array}{l}4,935 \\
4,917 \\
5,726 \\
5,953 \\
3,743\end{array}$ & $\begin{array}{l}17,933 \\
18,274 \\
36,017 \\
52,216 \\
10,869\end{array}$ \\
\hline 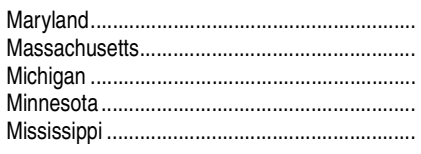 & $\begin{array}{l}198,900 \\
222,219 \\
565,606 \\
165,421 \\
196,857\end{array}$ & $\begin{array}{l}190,388 \\
215,355 \\
537,497 \\
152,790 \\
184,133\end{array}$ & $\begin{array}{l}181,688 \\
204,213 \\
511,731 \\
145,454 \\
176,722\end{array}$ & $\begin{array}{r}1,585 \\
2,336 \\
621 \\
321 \\
750\end{array}$ & $\begin{array}{r}495 \\
1,577 \\
8,387 \\
2,029 \\
1,015\end{array}$ & $\begin{array}{r}6,620 \\
7,229 \\
16,758 \\
4,987 \\
5,646\end{array}$ & $\begin{array}{l}6,613 \\
6,830 \\
9,306 \\
6,409 \\
4,993\end{array}$ & $\begin{array}{l}33,309 \\
41,975 \\
91,628 \\
31,352 \\
34,059\end{array}$ \\
\hline $\begin{array}{l}\text { Missouri } \\
\text { Montana. } \\
\text { Nebraska } \\
\text { Nevada } \\
\text { New Hampshire }\end{array}$ & $\begin{array}{r}244,057 \\
47,860 \\
78,342 \\
111,017 \\
41,227\end{array}$ & $\begin{array}{r}235,146 \\
45,559 \\
73,006 \\
105,776 \\
41,800\end{array}$ & $\begin{array}{r}224,772 \\
42,989 \\
65,230 \\
101,368 \\
39,809\end{array}$ & $\begin{array}{r}1,356 \\
97 \\
335 \\
451 \\
476\end{array}$ & $\begin{array}{r}1,486 \\
986 \\
4,989 \\
232 \\
143\end{array}$ & $\begin{array}{l}7,532 \\
1,486 \\
2,454 \\
3,726 \\
1,372\end{array}$ & $\begin{array}{l}6,787 \\
3,592 \\
4,211 \\
4,759 \\
3,782\end{array}$ & $\begin{array}{l}39,562 \\
10,869 \\
11,146 \\
11,441 \\
10,869\end{array}$ \\
\hline $\begin{array}{l}\text { New Jersey } \\
\text { New Mexico } \\
\text { New York } \\
\text { North Carolina } \\
\text { North Dakota }\end{array}$ & $\begin{array}{r}317,358 \\
124,990 \\
1,182,857 \\
422,198 \\
37,099\end{array}$ & $\begin{array}{r}290,960 \\
117,059 \\
1,126,996 \\
400,309 \\
33,886\end{array}$ & $\begin{array}{r}278,123 \\
112,088 \\
1,078,369 \\
379,295 \\
32,448\end{array}$ & $\begin{array}{r}1,429 \\
314 \\
2,900 \\
1,885 \\
99\end{array}$ & $\begin{array}{r}1,922 \\
902 \\
9,680 \\
5,519 \\
229\end{array}$ & $\begin{array}{r}9,486 \\
3,754 \\
36,046 \\
13,611 \\
1,110\end{array}$ & $\begin{array}{r}8,553 \\
4,377 \\
14,505 \\
9,109 \\
3,391\end{array}$ & $\begin{array}{r}52,275 \\
18,128 \\
188,660 \\
49,941 \\
10,869\end{array}$ \\
\hline 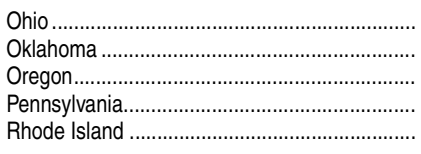 & $\begin{array}{r}612,269 \\
168,971 \\
163,469 \\
605,092 \\
51,328\end{array}$ & $\begin{array}{r}578,176 \\
154,908 \\
162,632 \\
560,176 \\
49,365\end{array}$ & $\begin{array}{r}555,292 \\
148,120 \\
145,927 \\
532,380 \\
47,193\end{array}$ & $\begin{array}{r}1,128 \\
335 \\
1,139 \\
570 \\
495\end{array}$ & $\begin{array}{r}2,599 \\
1,503 \\
10,035 \\
8,870 \\
65\end{array}$ & $\begin{array}{r}19,158 \\
4,951 \\
5,531 \\
18,355 \\
1,612\end{array}$ & $\begin{array}{r}10,306 \\
5,468 \\
5,311 \\
10,507 \\
3,602 \\
\end{array}$ & $\begin{array}{l}86,229 \\
26,278 \\
22,277 \\
93,850 \\
10,869\end{array}$ \\
\hline $\begin{array}{l}\text { South Carolina } \\
\text { South Dakota } \\
\text { Tennessee } \\
\text { Texas }\end{array}$ & $\begin{array}{r}224,458 \\
46,116 \\
291,669 \\
1,499,509 \\
99,508\end{array}$ & $\begin{array}{r}214,794 \\
43,885 \\
274,364 \\
1,417,633 \\
90,695\end{array}$ & $\begin{array}{r}205,586 \\
41,482 \\
264,087 \\
1,311,223 \\
84,915\end{array}$ & $\begin{array}{r}1,464 \\
143 \\
500 \\
1,916 \\
853\end{array}$ & $\begin{array}{r}550 \\
819 \\
563 \\
57,720 \\
1,807\end{array}$ & $\begin{array}{r}7,195 \\
1,440 \\
9,214 \\
46,774 \\
3,120\end{array}$ & $\begin{array}{r}5,866 \\
3,529 \\
7,006 \\
21,428 \\
5,278\end{array}$ & $\begin{array}{r}28,646 \\
10,869 \\
38,983 \\
187,803 \\
15,003\end{array}$ \\
\hline 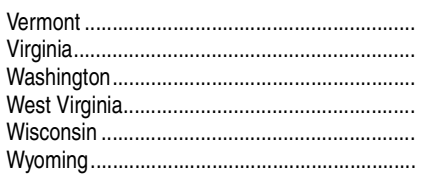 & $\begin{array}{r}36,999 \\
240,392 \\
237,616 \\
99,026 \\
238,115 \\
35,699\end{array}$ & $\begin{array}{r}34,284 \\
230,229 \\
227,536 \\
94,217 \\
220,871 \\
34,415\end{array}$ & $\begin{array}{r}31,925 \\
220,136 \\
203,756 \\
89,837 \\
211,698 \\
32,439\end{array}$ & $\begin{array}{r}613 \\
1,722 \\
1,382 \\
1,125 \\
1,301 \\
618\end{array}$ & $\begin{array}{r}621 \\
777 \\
14,793 \\
79 \\
622 \\
228\end{array}$ & $\begin{array}{l}1,125 \\
7,593 \\
7,605 \\
3,177 \\
7,250 \\
1,129\end{array}$ & $\begin{array}{l}3,349 \\
7,950 \\
7,194 \\
4,037 \\
6,580 \\
3,351\end{array}$ & $\begin{array}{l}10,869 \\
40,865 \\
37,530 \\
19,728 \\
37,830 \\
10,869\end{array}$ \\
\hline 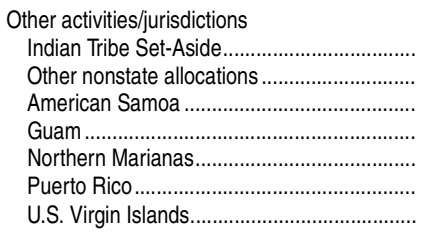 & $\begin{array}{r}101,541 \\
47,040 \\
11,518 \\
12,158 \\
4,184 \\
496,248 \\
15,477\end{array}$ & $\begin{array}{r}96,451 \\
45,255 \\
10,939 \\
11,632 \\
4,289 \\
467,547 \\
13,751\end{array}$ & $\begin{array}{r}93,299 \\
8,777 \\
10,583 \\
11,171 \\
4,039 \\
453,904 \\
13,473\end{array}$ & $\begin{array}{r}0 \\
1,190 \\
0 \\
0 \\
0 \\
661 \\
0\end{array}$ & $\begin{array}{r}0 \\
10,000 \\
0 \\
0 \\
0 \\
0 \\
0\end{array}$ & $\begin{array}{r}3,152 \\
25,288 \\
356 \\
460 \\
250 \\
12,983 \\
279\end{array}$ & $\begin{array}{r}1,801 \\
8,733 \\
350 \\
790 \\
256 \\
5,429 \\
405\end{array}$ & $\begin{array}{r}11,631 \\
46,757 \\
2,657 \\
4,474 \\
1,634 \\
70,876 \\
2,867\end{array}$ \\
\hline
\end{tabular}

IIncludes Basic, Concentration, Targeted, and Education Finance Incentive Grants. ${ }^{2}$ Total excludes other activities and other jurisdictions.

NOTE: Detail may not sum to totals because of rounding. Estimates for fiscal year 2013 are preliminary.
SOURCE: U.S. Department of Education, Budget Service, Elementary, Secondary, and Vocational Education Analysis Division, retrieved December 6, 2013, from http:// www2.ed.gov/about/overview/budget/statetables/14stbyprogram.pdf. (This table was prepared December 2013.) 
698 CHAPTER 4: Federal Funds for Education and Related Activities

Federal Obligations for Research and Development

Table 402.10. Federal obligations for research, development, and R\&D plant, by category of obligation, performers, and fields of science: Fiscal years 2005 through 2013

[In millions]

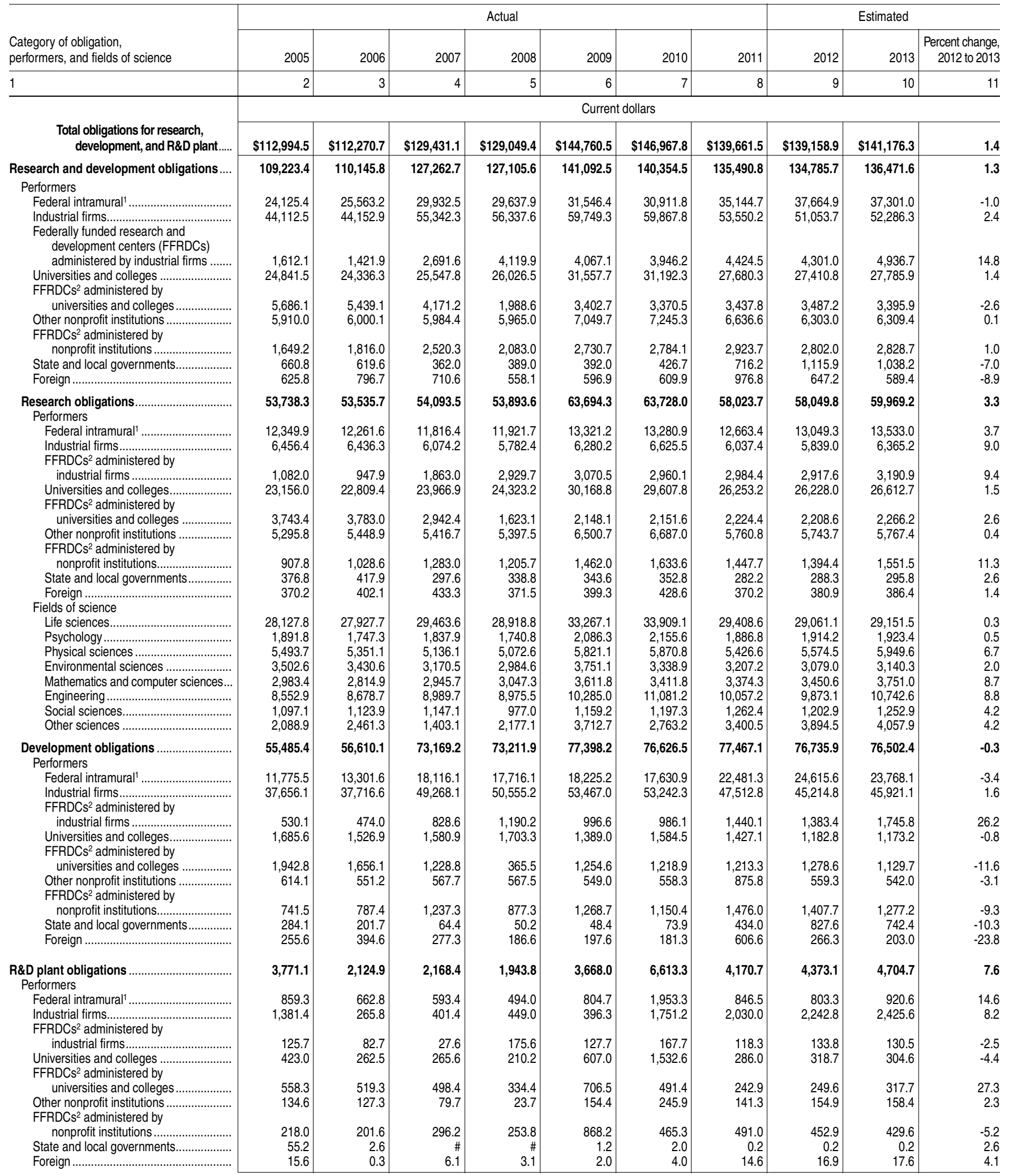

See notes at end of table. 
CHAPTER 4: Federal Funds for Education and Related Activities 699 Federal Obligations for Research and Development

Table 402.10. Federal obligations for research, development, and R\&D plant, by category of obligation, performers, and fields of science: Fiscal years 2005 through 2013-Continued

[In millions]

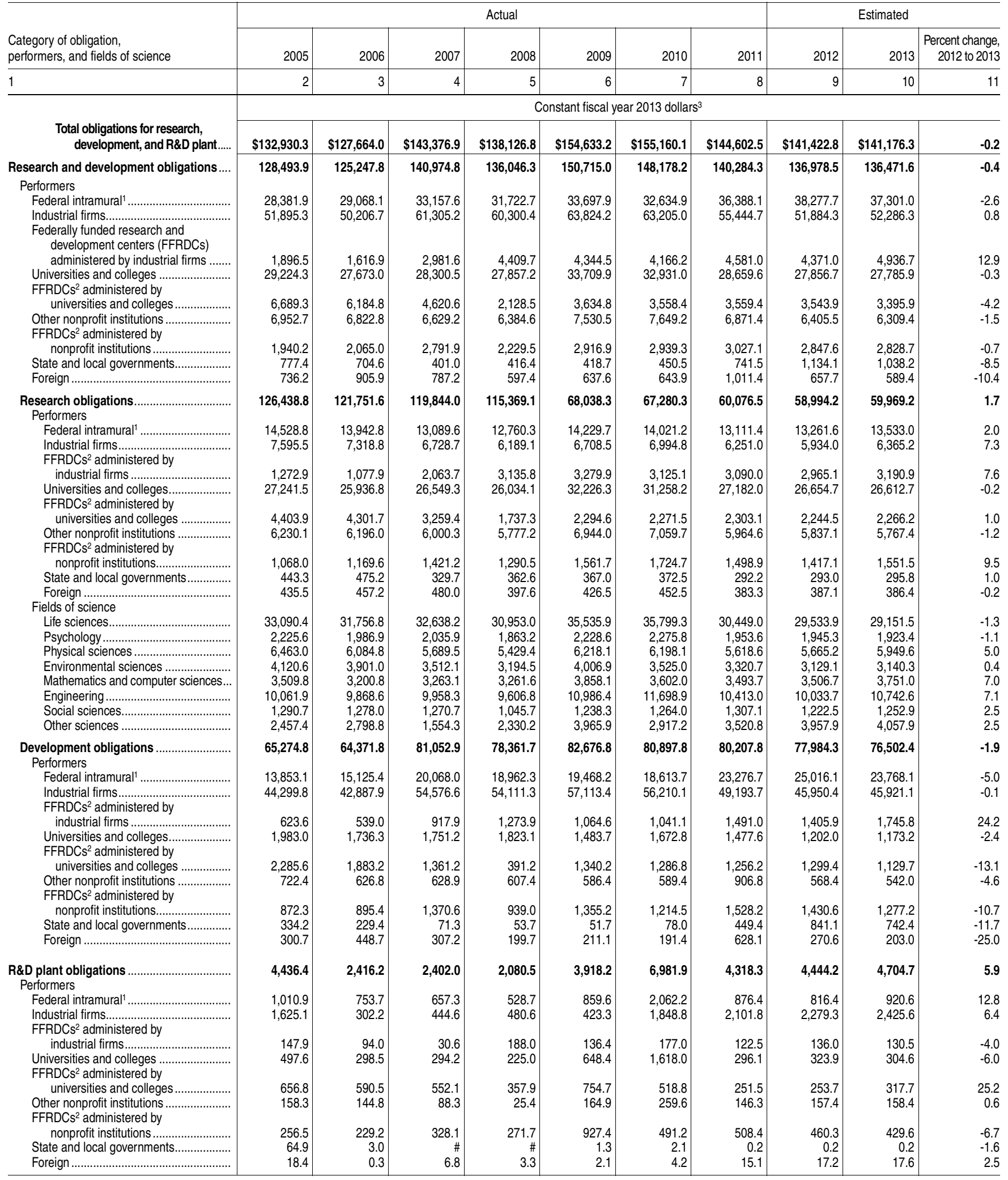

\#Rounds to zero.

IIncludes costs associated with the administration of intramural and extramural programs by federal personnel as well as actual intramural performance.

${ }^{2}$ Federally funded research and development centers.

${ }^{3}$ Data adjusted by the federal budget composite deflator reported in U.S. Office of Management and Budget, Budget of the U.S. Government, Historical Tables, Fiscal Year 2014.
NOTE: Some data have been revised from previously published figures. Detail may not sum to totals because of rounding. Totals do not include the U.S. Department of Homeland Security. SOURCE: National Science Foundation, National Center for Science and Engineering Statistics, Survey of Federal Funds for Research and Development, 2005 through 2013, retrieved July 30, 2014, from http://www.nsf.gov/statistics/nsf14312/content.cfm?pub id=4408\&id=2. (This table was prepared March 2014. 



\section{CHAPTER 5 Outcomes of Education}

This chapter contains tables comparing educational attainment and workforce characteristics. The data show labor force status, income levels, and occupations of high school dropouts and high school and college graduates. Most of these tables are based on data from the U.S. Census Bureau and the U.S. Bureau of Labor Statistics. Population characteristics are provided for many of the measures to allow for comparisons among various demographic groups. While most of the tables in this chapter focus on labor market outcomes, the chapter ends with a few tables on adults' attitudes, skills, and participation in continuing education.

Statistics related to outcomes of education appear in other sections of the Digest. For example, statistics on educational attainment of the entire population are in chapter 1. More detailed data on the numbers of high school and college graduates can be found in chapters 2 and 3. Chapter 3 contains trend data on the percentage of high school completers going to college. Chapter 6 includes international comparisons of employment rates by educational attainment. Additional data on earnings by educational attainment may be obtained from the U.S. Census Bureau's Current Population Reports, Series P-60. The U.S. Bureau of Labor Statistics has a series of publications dealing with the educational characteristics of the labor force. Further information on survey methodologies can be found in Appendix A: Guide to Sources and in the publications cited in the table source notes.

\section{Labor Force}

The labor force participation rate - that is, the percentage of people either employed or actively seeking employment-was generally higher for adults with higher levels of educational attainment than for those with less education. Among 25- to 64-year-old adults, 86 percent of those with a bachelor's or higher degree participated in the labor force in 2012, compared with 73 percent of those who had completed only high school and 61 percent of those who had not completed high school (table 501.10). Within each education level, the labor force participation rate also varied by race/ ethnicity. For 25- to 64-year-olds who had completed only high school, the 2012 labor force participation rate was highest for Hispanics (77 percent), followed by Asians (74 percent) and Whites (73 percent), then Blacks ( 68 percent), and then American Indians/Alaska Natives (65 percent). For 25- to 64-year-olds with a bachelor's or higher degree in 2012, the labor force participation rate was highest for Blacks (88 percent), followed by Hispanics (87 percent), then Whites (86 percent), and then Asians (83 percent). The labor force participation rate for American Indians/Alaska Natives with a bachelor's or higher degree (84 percent) was lower than the rates for Blacks and Hispanics, but not measurably different from the rates for Whites and Asians.

The unemployment rate - that is, the percentage of people in the labor force who are not employed and who have made specific efforts to find employment sometime during the prior 4 weeks - was generally higher for people with lower levels of educational attainment than for those with more education. In 2013, the unemployment rate for 25- to 64-year-old adults who had not completed high school was 13 percent, compared with 9 percent for those who had completed high school and 4 percent for those with a bachelor's or higher degree (table 501.80). Within each education level, the unemployment rates for 16- to 19-year-olds and 20- to 24-year-olds tended to be higher than the unemployment rate for 25- to 64-year-olds. For example, among 20- to 24-year-olds who had not completed high school and were not enrolled in school, the 2013 unemployment rate was 29 percent, compared with 13 percent for 25- to 64-year-olds with the same level of educational attainment. Among adults in the 25- to 34-year-old age group, the 2013 unemployment rate was 15 percent for those who had not completed high school, 12 percent for high school completers, and 4 percent for those with a bachelor's or higher degree (table 501.80 and figure 22).

The employment to population ratio - that is, the percentage of the population that is employed-was generally higher for people with higher levels of educational attainment than for those with less education. Among 25- to 34-year-olds, for example, 84 percent of those with a bachelor's or higher degree were employed in 2013, compared with 68 percent of those who had completed only high school and 57 percent of those who had not completed high school (table 501.50 and figure 23).

The relative difficulties that high school dropouts encounter in entering the job market are highlighted by comparing the labor force participation and employment rates of recent high school dropouts with those of recent high school completers. In October 2012, about 47 percent of 2011-12 dropouts participated in the labor force (i.e., were either employed or looking for work), with 24 percent employed and 23 percent looking for work (table 504.20 and figure 24). In con- 
trast, the labor force participation rate was 70 percent for 2011-12 high school completers who were not enrolled in college, with 46 percent employed and 24 percent looking for work (table 504.10 and figure 24).

\section{Earnings}

Median annual earnings were generally higher for adults with higher levels of educational attainment than for those with lower levels of educational attainment. Among fulltime year-round workers age 25 and over, both males and females who had more education generally earned more than people of the same sex who had less education. In 2012, for example, males whose highest level of educational attainment was a bachelor's degree earned 64 percent more than males whose highest level of attainment was high school completion, and females who had attained a bachelor's degree earned 65 percent more than females who had only completed high school (table E, table 502.20, and figure 25).

Among full-time year-round workers age 25 and over, the earnings of females were lower than the earnings of males overall, as well as by education level. For example, median 2012 earnings for full-time year-round workers with a bachelor's degree were 32 percent higher for males than for females. Among those who had only completed high school, median 2012 earnings were 33 percent higher for males than for females.

From 1995 to 2012, net percentage changes in earnings (after adjustment for inflation) varied by highest level of educational attainment and sex. After adjusting for inflation, the median annual earnings of male full-time year-round workers age 25 and over who had not completed high school decreased 10 percent from $1995(\$ 33,680)$ to 2012 $(\$ 30,330)$, and the median earnings of those who had completed high school also decreased 10 percent from 1995 $(\$ 44,800)$ to $2012(\$ 40,350)$. For males with a bachelor's degree, median annual earnings in constant 2012 dollars decreased 4 percent from $1995(\$ 68,720)$ to $2012(\$ 66,150)$. The median annual earnings of female full-time year-round workers who had not completed high school decreased 11 percent from $1995(\$ 24,020)$ to $2012(\$ 21,390)$, and the median earnings of those who had completed high school decreased 2 percent from $1995(\$ 31,060)$ to $2012(\$ 30,410)$. For females with a bachelor's degree, median annual earnings in constant 2012 dollars increased 3 percent from 1995 $(\$ 48,660)$ to $2012(\$ 50,170)$.
Table E. Median annual earnings of full-time year-round workers 25 years old and over, by selected levels of educational attainment and sex: Selected years, 1995 through 2012 [In constant 2012 dollars]

\begin{tabular}{|c|c|c|c|}
\hline Sex and year & $\begin{array}{l}\text { Some high } \\
\text { school, no } \\
\text { completion }\end{array}$ & $\begin{array}{r}\text { High school } \\
\text { completion }\end{array}$ & $\begin{array}{r}\text { Bachelor's } \\
\text { degree }\end{array}$ \\
\hline \multicolumn{4}{|l|}{ Males } \\
\hline $1995 \ldots$ & $\$ 33,680$ & $\$ 44,800$ & $\$ 68,720$ \\
\hline $2000 \ldots$ & 33,720 & 46,090 & 75,690 \\
\hline 2005 & 32,210 & 43,000 & 71,100 \\
\hline $2012 .$. & 30,330 & 40,350 & 66,150 \\
\hline \multicolumn{4}{|l|}{ Females } \\
\hline 1995 & 24,020 & 31,060 & 48,660 \\
\hline 2000. & 24,070 & 33,550 & 54,300 \\
\hline 2005 & 23,840 & 31,140 & 49,960 \\
\hline 2012 & 21,390 & 30,410 & 50,170 \\
\hline
\end{tabular}

SOURCE: U.S. Department of Commerce, Census Bureau, Current Population Reports, Series P-60, Money Income in the United States, 1995 and 2000; and Current Population Survey (CPS), 2005 and 2012 Annual Social and Economic Supplement.

In 2009, the median annual salary of bachelor's degree recipients employed full time 1 year after graduation was $\$ 38,500$ in constant 2012 dollars (table 505.50 and figure 26). Full-time median annual salaries varied by degree field, however. In 2009, graduates employed full time 1 year after receiving bachelor's degrees in engineering had the highest median annual salary ( $\$ 57,800$ in constant 2012 dollars), followed by those with degrees in the health professions $(\$ 49,200)$ and mathematics/computer science $(\$ 48,100)$, and then those with degrees in business/management $(\$ 42,800)$. Among the lowest full-time median annual salaries were those earned by graduates with degrees in the humanities $(\$ 31,000)$ and psychology $(\$ 31,400)$.

Overall, the inflation-adjusted median annual salary of graduates employed full time 1 year after receiving their bachelor's degree was 7 percent lower in 2009 than in 2001. However, the change in median annual salary from 2001 to 2009 varied by degree field, ranging from an increase of 7 percent for graduates with degrees in the health professions to a decrease of 19 percent for those with degrees in mathematics/computer science and a decrease of 16 percent for those with degrees in the humanities. Although the overall median annual salary of graduates employed full time 1 year after graduation decreased from 2001 to 2009, it had previously increased 13 percent from 1991 to 2001. From 1991 to 2009 , there was a net increase of 5 percent in the overall median salary. 
Figure 22. Unemployment rates of persons 25 to 34 years old, by highest level of educational attainment: 1990 through 2013

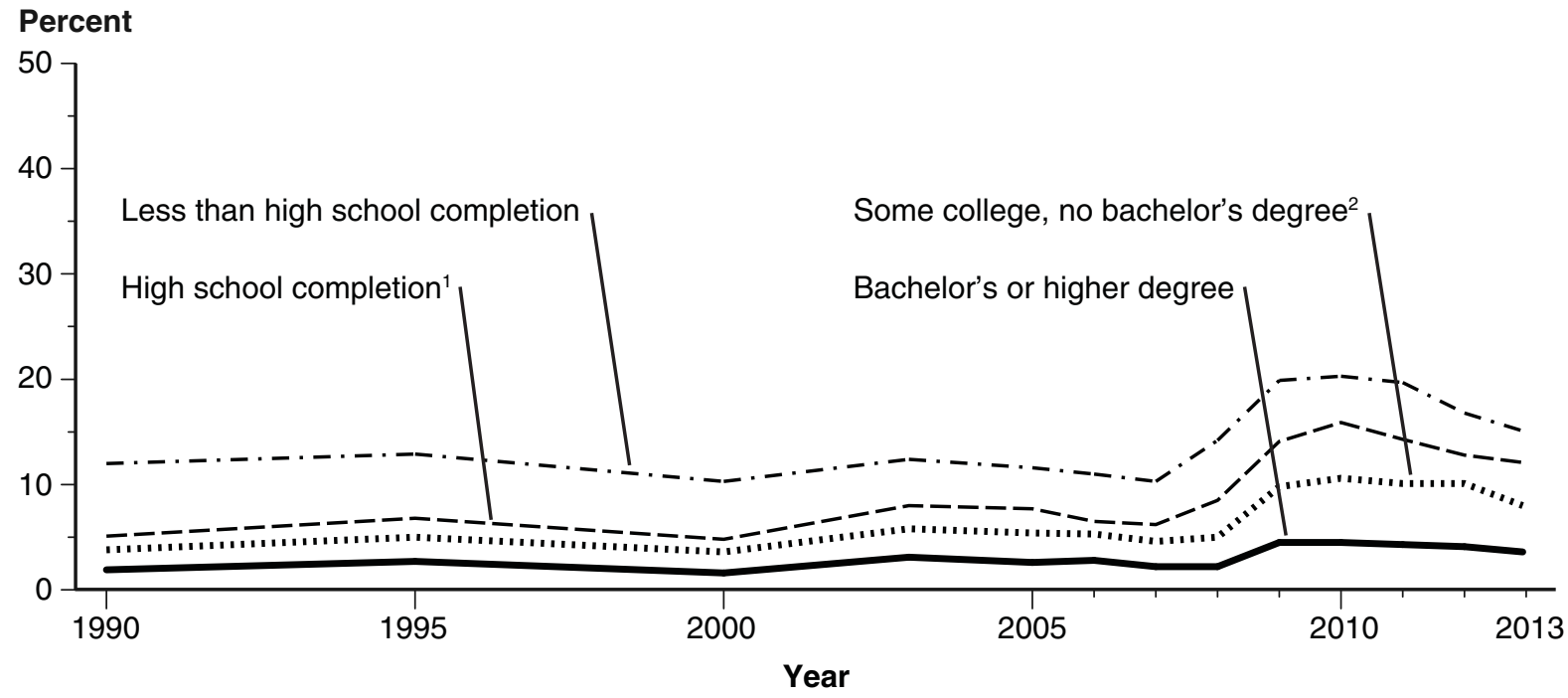

${ }^{1}$ Includes equivalency credentials, such as the General Educational Development (GED) credential.

2Includes persons with no college degree as well as those with an associate's degree.

NOTE: The unemployment rate is the percentage of persons in the civilian labor force who are not working and who made specific efforts to find employment sometime during the prior 4 weeks. The civilian labor force consists of all civilians who are employed or seeking employment.

SOURCE: U.S. Department of Labor, Bureau of Labor Statistics, Office of Employment and Unemployment Statistics, unpublished annual average data from the Current Population Survey (CPS), selected years, 1990 through 2013.

Figure 23. Employment to population ratios of persons 25 to 34 years old, by highest level of educational attainment: 1990 through 2013

\section{Percent}

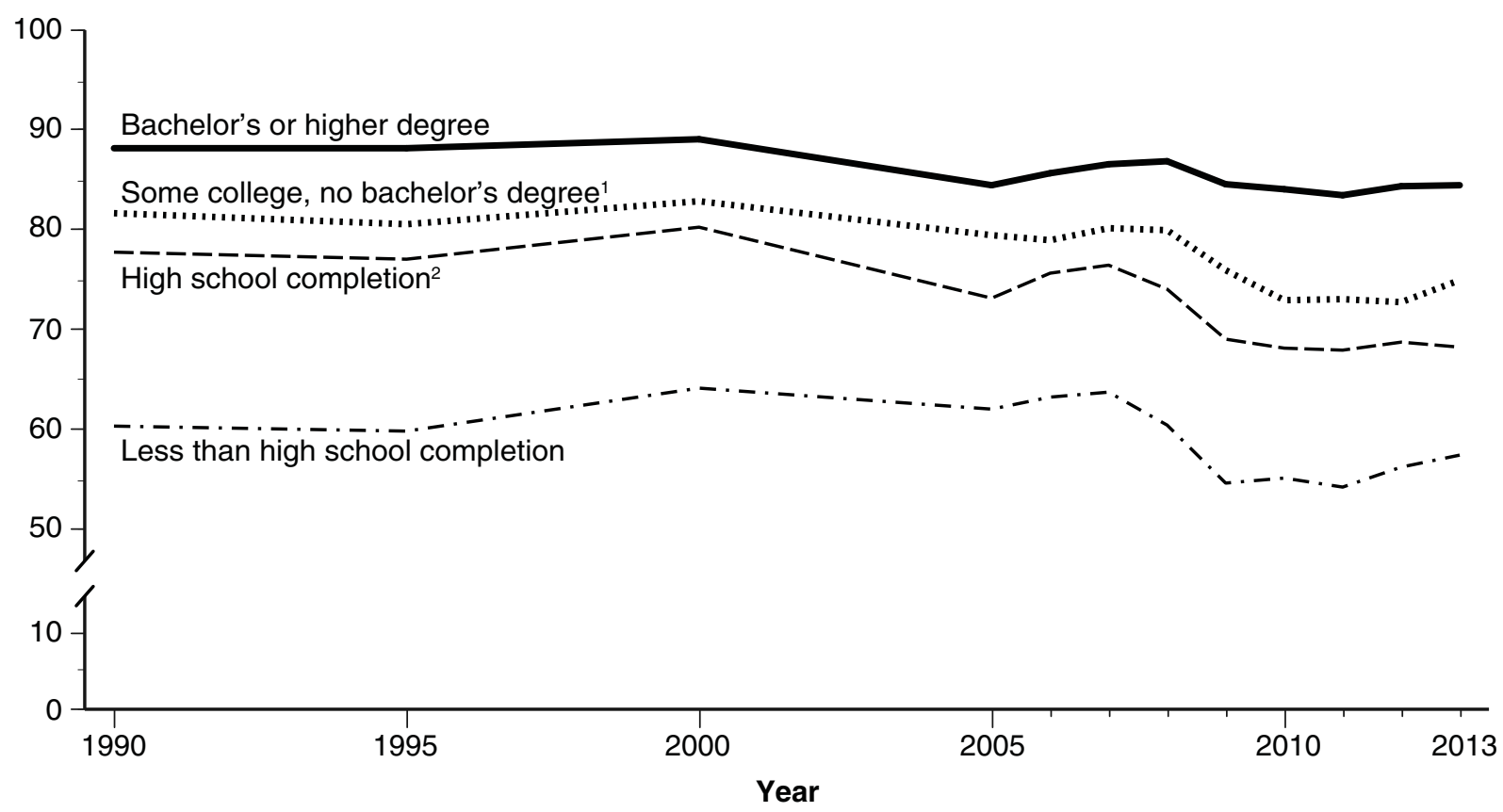

1Includes persons with no college degree as well as those with an associate's degree.

Includes equivalency credentials, such as the General Educational Development (GED) credential.

NOTE: The employment to population ratio is the number of persons employed as a percentage of the civilian population.

SOURCE: U.S. Department of Labor, Bureau of Labor Statistics, Office of Employment and Unemployment Statistics, unpublished annual average data from the Current Population Survey (CPS), selected years, 1990 through 2013. 
Figure 24. Percentage distribution of 2011-12 high school dropouts and high school completers not enrolled in college, by labor force status: October 2012

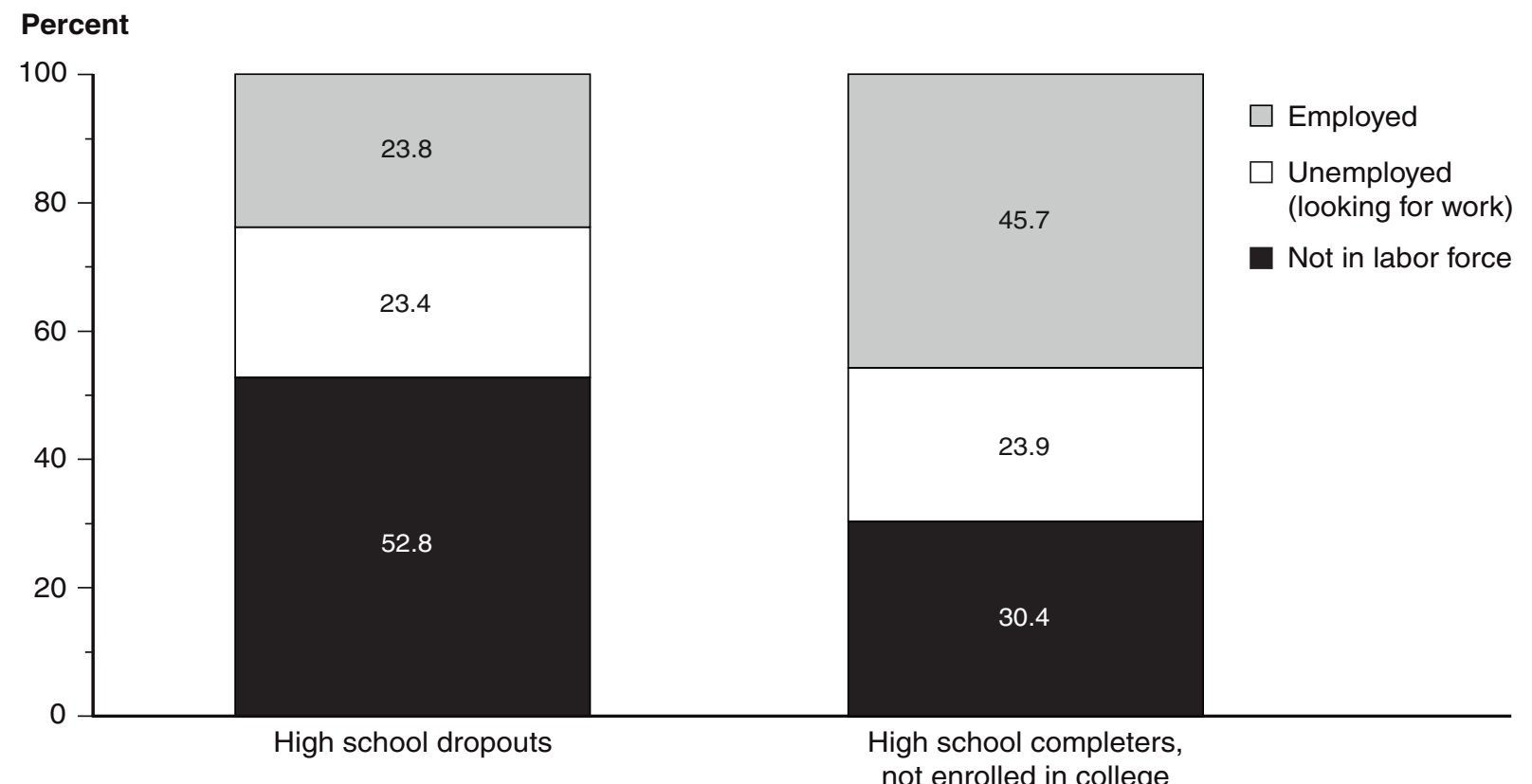

High school completion status

NOTE: Dropouts are persons who have not completed high school and are not enrolled in school. High school completers include recipients of equivalency credentials as well as diploma recipients. Detail may not sum to totals because of rounding.

SOURCE: U.S. Department of Commerce, Census Bureau, Current Population Survey (CPS), October 2012.

Figure 25. Median annual earnings of full-time year-round workers 25 years old and over, by highest level of educational attainment and sex: 2012

[In current dollars]

\section{Earnings}

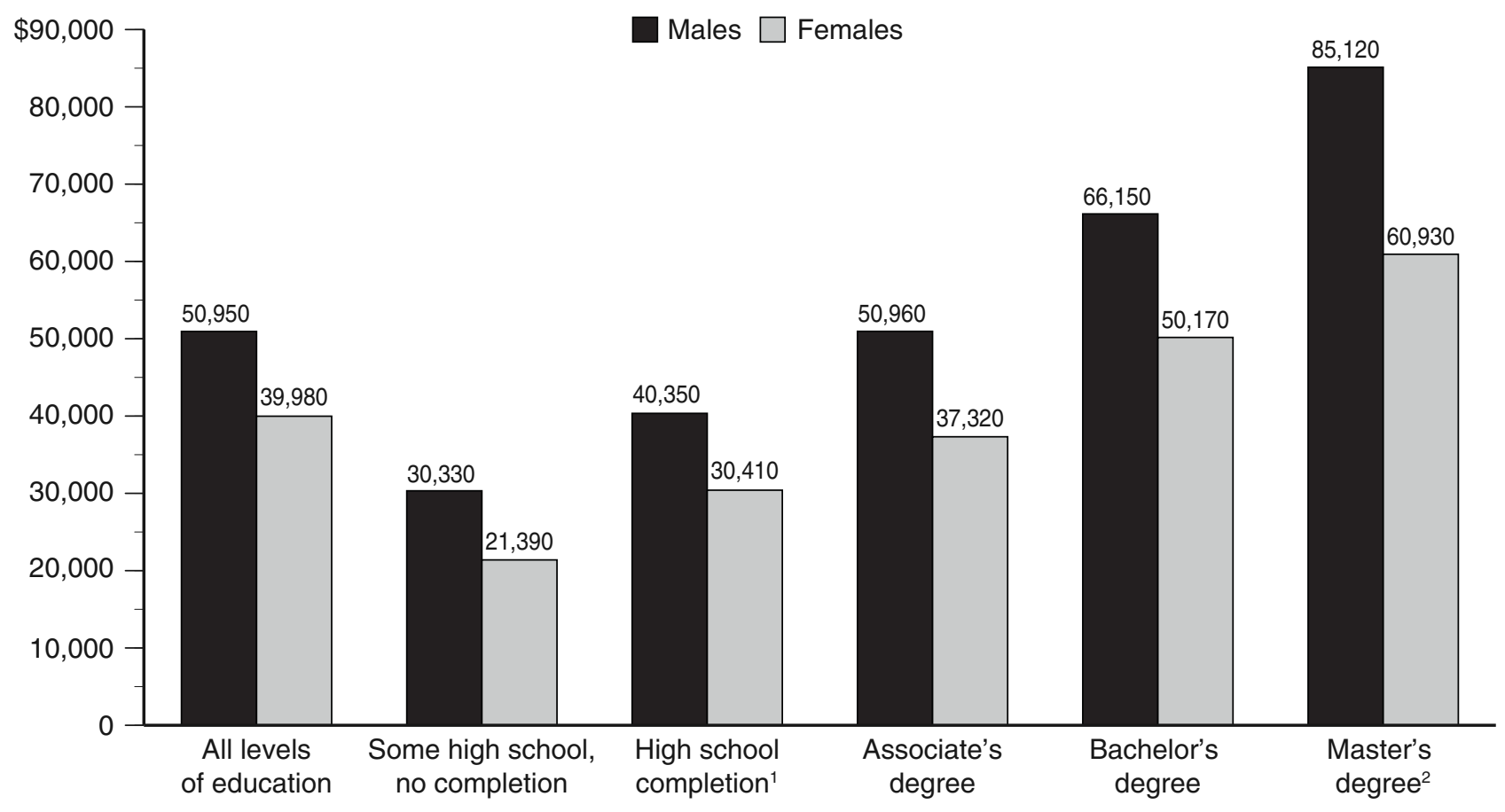

Highest level of educational attainment

${ }^{1}$ Includes equivalency credentials, such as the General Educational Development (GED) credential.

2Includes only persons whose highest level of education is a master's degree. Doctor's degree recipients are not included.

SOURCE: U.S. Department of Commerce, Census Bureau, Current Population Survey (CPS), 2013 Annual Social and Economic Supplement, retrieved December 26, 2013, from http://www.census.gov/hhes/www/cpstables/032013/perinc/pinc03 000.htm. 
Figure 26. Median annual salaries of bachelor's degree recipients employed full time 1 year after graduation, by field of study: 1991, 2001, and 2009

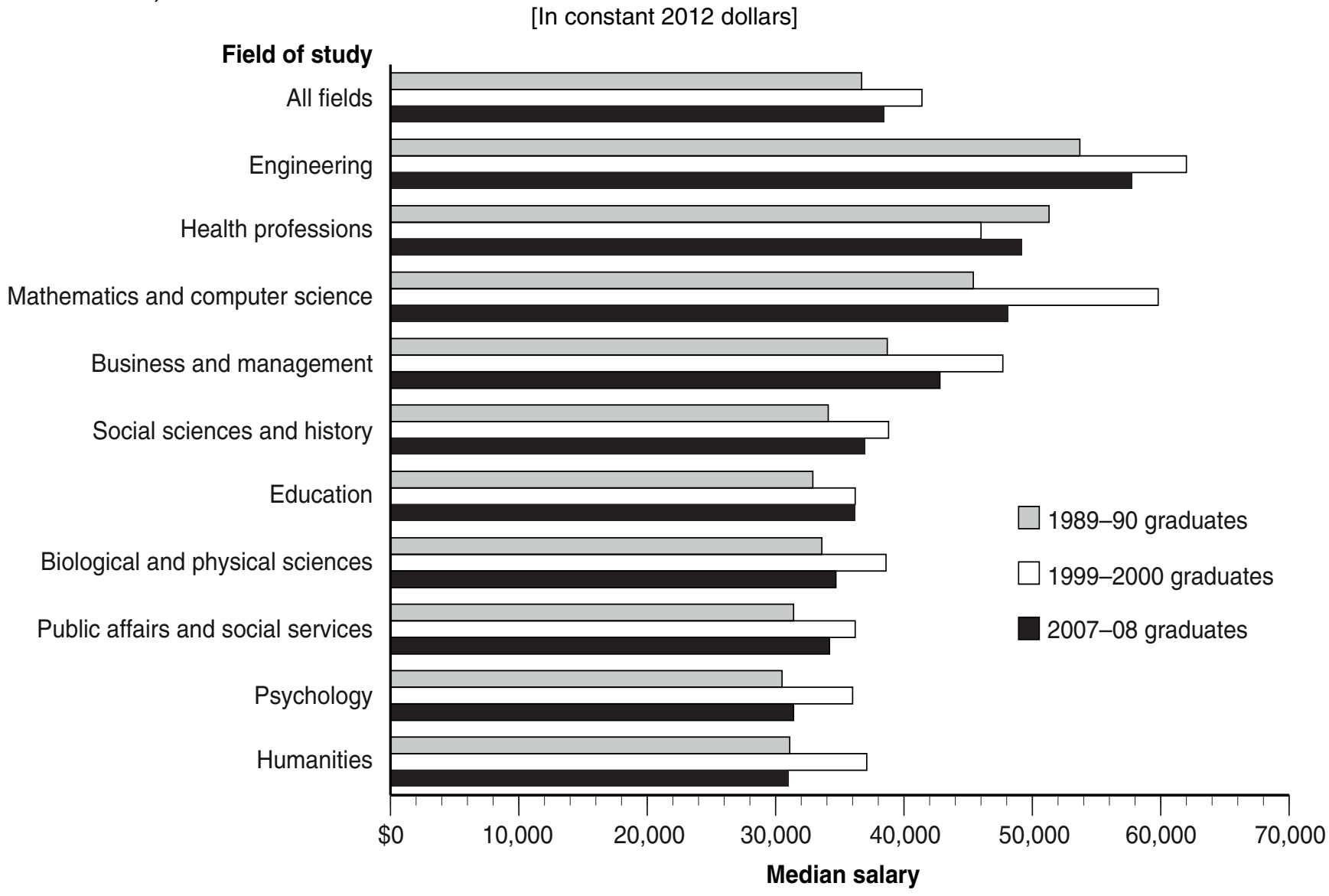

SOURCE: U.S. Department of Education, National Center for Education Statistics, "Recent College Graduates" survey, 1991; and 2000/01 and 2008/09 Baccalaureate and Beyond Longitudinal Study (B\&B:2000/01 and B\&B:08/09). 
[Standard errors appear in parentheses]

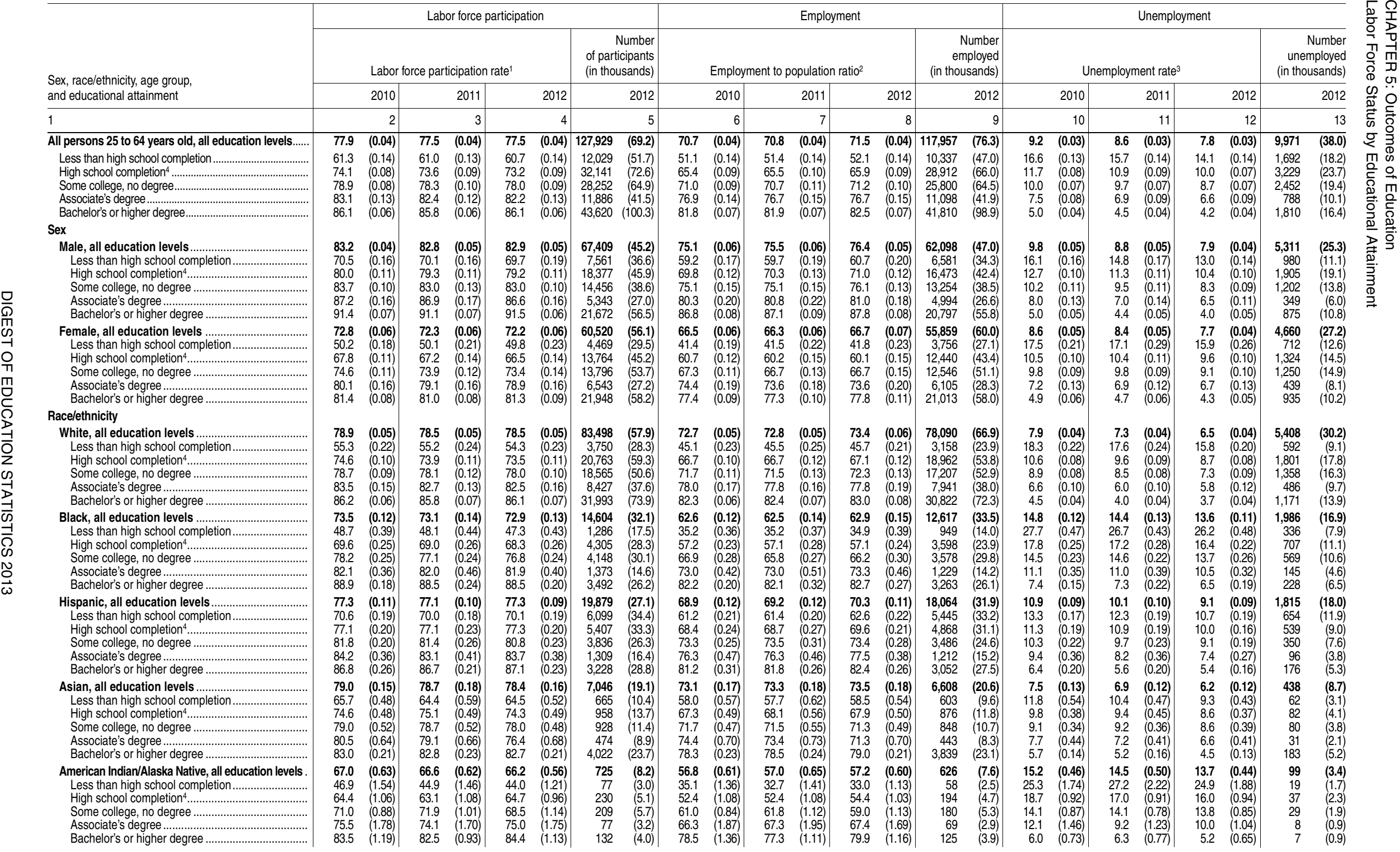

See notes at end of table. 


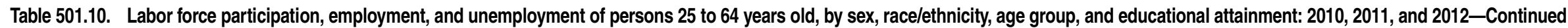
[Standard errors appear in parentheses]

\begin{tabular}{|c|c|c|c|c|c|c|c|c|c|c|c|c|c|c|c|c|c|c|c|c|c|c|c|c|}
\hline \multirow{3}{*}{$\begin{array}{l}\text { Sex, race/ethnicity, age group, } \\
\text { and educational attainment }\end{array}$} & \multicolumn{8}{|c|}{ Labor force participation } & \multicolumn{8}{|c|}{ Employment } & \multicolumn{8}{|c|}{ Unemployment } \\
\hline & \multicolumn{6}{|c|}{ Labor force participation rate $^{1}$} & \multicolumn{2}{|c|}{$\begin{array}{r}\text { Number } \\
\text { of participants } \\
\text { (in thousands) }\end{array}$} & \multicolumn{6}{|c|}{ Employment to population ratio ${ }^{2}$} & \multicolumn{2}{|c|}{$\begin{array}{r}\text { Number } \\
\text { employed } \\
\text { (in thousands) }\end{array}$} & \multicolumn{6}{|c|}{ Unemployment rate ${ }^{3}$} & \multicolumn{2}{|c|}{$\begin{array}{r}\text { Number } \\
\text { unemployed } \\
\text { (in thousands) }\end{array}$} \\
\hline & & 2010 & & 2011 & & 2012 & & 2012 & & 2010 & & 2011 & & 2012 & & 2012 & & 2010 & & 2011 & & 2012 & & 2012 \\
\hline 1 & & 2 & & 3 & & 4 & & 5 & & 6 & & 7 & & 8 & & 9 & & 10 & & 11 & & 12 & & 13 \\
\hline Age group & & & & & & & & & & & & & & & & & & & & & & & & \\
\hline 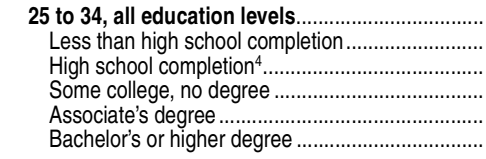 & $\begin{array}{l}82.1 \\
66.8 \\
78.5 \\
82.8 \\
87.4 \\
89.5\end{array}$ & $\begin{array}{l}(0.09) \\
(0.29) \\
(0.16) \\
(0.16) \\
(0.24) \\
(0.11)\end{array}$ & $\begin{array}{l}81.8 \\
66.0 \\
78.1 \\
82.2 \\
86.3 \\
89.3\end{array}$ & $\begin{array}{l}(0.08) \\
(0.31) \\
(0.19) \\
(0.17) \\
(0.25) \\
(0.11)\end{array}$ & $\begin{array}{l}82.0 \\
65.5 \\
78.0 \\
82.1 \\
86.7 \\
89.7\end{array}$ & $\begin{array}{l}(0.06) \\
(0.29) \\
(0.17) \\
(0.17) \\
(0.22) \\
(0.10)\end{array}$ & $\begin{array}{r}34,149 \\
3,200 \\
7,767 \\
7,952 \\
3,127 \\
12,103\end{array}$ & $\begin{array}{l}(37.7) \\
(27.1) \\
(35.2) \\
(41.0) \\
(22.6) \\
(47.0)\end{array}$ & $\begin{array}{l}73.1 \\
53.4 \\
66.3 \\
72.9 \\
80.3 \\
84.9\end{array}$ & $\begin{array}{l}(0.11) \\
(0.28) \\
(0.20) \\
(0.18) \\
(0.28) \\
(0.14)\end{array}$ & $\begin{array}{l}73.2 \\
53.2 \\
66.8 \\
72.1 \\
79.4 \\
84.9\end{array}$ & $\begin{array}{l}(0.08) \\
(0.32) \\
(0.20) \\
(0.20) \\
(0.28) \\
(0.13)\end{array}$ & $\begin{array}{l}74.1 \\
53.7 \\
67.2 \\
72.9 \\
80.1 \\
85.8\end{array}$ & $\begin{array}{l}(0.07) \\
(0.32) \\
(0.17) \\
(0.20) \\
(0.26) \\
(0.11)\end{array}$ & $\begin{array}{r}30,845 \\
2,624 \\
6,690 \\
7,063 \\
2,887 \\
11,580\end{array}$ & $\begin{array}{l}(36.7) \\
(24.0) \\
(32.6) \\
(40.5) \\
(21.1) \\
(47.3)\end{array}$ & $\begin{array}{r}11.0 \\
20.1 \\
15.5 \\
12.0 \\
8.1 \\
5.1\end{array}$ & $\begin{array}{l}(0.08) \\
(0.28) \\
(0.17) \\
(0.17) \\
(0.20) \\
(0.09)\end{array}$ & $\begin{array}{r}10.6 \\
19.5 \\
14.5 \\
12.3 \\
8.0 \\
4.9\end{array}$ & $\begin{array}{l}(0.08) \\
(0.28) \\
(0.20) \\
(0.17) \\
(0.20) \\
(0.10)\end{array}$ & $\begin{array}{r}9.7 \\
18.0 \\
13.9 \\
11.2 \\
7.7 \\
4.3\end{array}$ & $\begin{array}{l}(0.06) \\
(0.31) \\
(0.15) \\
(0.15) \\
(0.22) \\
(0.08)\end{array}$ & $\begin{array}{r}3,304 \\
575 \\
1,077 \\
889 \\
240 \\
522\end{array}$ & $\begin{array}{r}(21.3) \\
(11.0) \\
(12.3) \\
(11.9) \\
(7.3) \\
(9.8)\end{array}$ \\
\hline 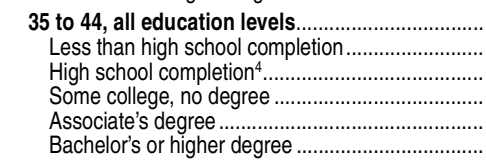 & $\begin{array}{l}82.7 \\
68.1 \\
79.7 \\
84.1 \\
87.0 \\
88.9\end{array}$ & $\begin{array}{l}(0.06) \\
(0.23) \\
(0.16) \\
(0.15) \\
(0.22) \\
(0.09)\end{array}$ & $\begin{array}{l}82.5 \\
68.5 \\
79.3 \\
83.6 \\
86.9 \\
88.7\end{array}$ & $\begin{array}{l}(0.08) \\
(0.29) \\
(0.18) \\
(0.15) \\
(0.23) \\
(0.10)\end{array}$ & $\begin{array}{l}82.5 \\
68.4 \\
79.0 \\
83.1 \\
86.5 \\
89.1\end{array}$ & $\begin{array}{l}(0.08) \\
(0.024) \\
(0.18) \\
(0.18) \\
(0.24) \\
(0.11)\end{array}$ & $\begin{array}{r}33,611 \\
3,454 \\
7,953 \\
7,214 \\
3,172 \\
11,818\end{array}$ & $\begin{array}{l}(37.1) \\
(24.4) \\
(36.1) \\
(31.6) \\
(19.3) \\
(33.8)\end{array}$ & $\begin{array}{l}75.3 \\
57.1 \\
70.2 \\
75.9 \\
80.7 \\
85.0\end{array}$ & $\begin{array}{l}(0.07) \\
(0.30) \\
(0.17) \\
(0.17) \\
(0.24) \\
(0.12)\end{array}$ & $\begin{array}{l}75.7 \\
58.2 \\
70.4 \\
76.0 \\
81.1 \\
85.3\end{array}$ & $\begin{array}{l}(0.09) \\
(0.29) \\
(0.20) \\
(0.19) \\
(0.27) \\
(0.12)\end{array}$ & $\begin{array}{l}76.3 \\
59.3 \\
70.9 \\
76.1 \\
80.8 \\
85.8\end{array}$ & $\begin{array}{l}(0.09) \\
(0.26) \\
(0.18) \\
(0.23) \\
(0.27) \\
(0.12)\end{array}$ & $\begin{array}{r}31,075 \\
2,992 \\
7,135 \\
6,602 \\
2,963 \\
11,383\end{array}$ & $\begin{array}{l}(38.5) \\
(21.8) \\
(32.0) \\
(32.3) \\
(20.5) \\
(35.2)\end{array}$ & $\begin{array}{r}9.0 \\
16.1 \\
12.0 \\
9.7 \\
7.3 \\
4.4\end{array}$ & $\begin{array}{l}(0.07) \\
(0.29) \\
(0.15) \\
(0.13) \\
(0.18) \\
(0.08)\end{array}$ & $\begin{array}{r}8.2 \\
15.1 \\
11.2 \\
9.2 \\
6.7 \\
3.8\end{array}$ & $\begin{array}{l}(0.07) \\
(0.27) \\
(0.15) \\
(0.15) \\
(0.19) \\
(0.08)\end{array}$ & $\begin{array}{r}7.5 \\
13.4 \\
10.3 \\
8.5 \\
6.6 \\
3.7\end{array}$ & $\begin{array}{l}(0.06) \\
(0.22) \\
(0.16) \\
(0.15) \\
(0.22) \\
(0.08)\end{array}$ & $\begin{array}{r}2,537 \\
463 \\
818 \\
612 \\
209 \\
435\end{array}$ & $\begin{array}{r}(21.4) \\
(8.4) \\
(13.8) \\
(10.4) \\
(6.7) \\
(8.9)\end{array}$ \\
\hline 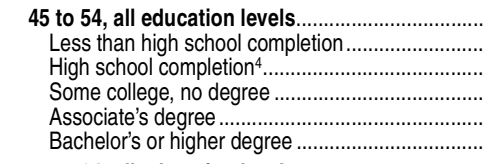 & $\begin{array}{l}80.9 \\
62.8 \\
78.1 \\
81.9 \\
85.7 \\
89.6\end{array}$ & $\begin{array}{l}(0.07) \\
(0.25) \\
(0.14) \\
(0.15) \\
(0.21) \\
(0.11)\end{array}$ & $\begin{array}{l}80.4 \\
62.1 \\
77.4 \\
81.4 \\
85.4 \\
89.3\end{array}$ & $\begin{array}{l}(0.07) \\
(0.26) \\
(0.14) \\
(0.17) \\
(0.21) \\
(0.10)\end{array}$ & $\begin{array}{l}80.3 \\
61.9 \\
76.9 \\
81.3 \\
84.6 \\
89.4\end{array}$ & $\begin{array}{l}(0.07) \\
(0.26) \\
(0.16) \\
(0.13) \\
(0.21) \\
(0.12)\end{array}$ & $\begin{array}{r}35,434 \\
3,312 \\
9,905 \\
7,657 \\
3,346 \\
11,212\end{array}$ & $\begin{array}{l}(41.2) \\
(19.5) \\
(34.7) \\
(27.6) \\
(21.1) \\
(43.2)\end{array}$ & $\begin{array}{l}74.0 \\
53.1 \\
70.1 \\
74.5 \\
79.6 \\
85.2\end{array}$ & $\begin{array}{l}(0.08) \\
(0.27) \\
(0.14) \\
(0.17) \\
(0.23) \\
(0.12)\end{array}$ & $\begin{array}{l}74.0 \\
53.2 \\
69.9 \\
74.6 \\
79.9 \\
85.4\end{array}$ & $\begin{array}{l}(0.08) \\
(0.29) \\
(0.15) \\
(0.18) \\
(0.26) \\
(0.11)\end{array}$ & $\begin{array}{l}74.6 \\
53.8 \\
70.3 \\
75.3 \\
79.5 \\
85.9\end{array}$ & $\begin{array}{l}(0.08) \\
(0.27) \\
(0.17) \\
(0.16) \\
(0.27) \\
(0.14)\end{array}$ & $\begin{array}{r}32,941 \\
2,881 \\
9,054 \\
7,095 \\
3,146 \\
10,765\end{array}$ & $\begin{array}{l}(45.6) \\
(18.7) \\
(34.1) \\
(29.5) \\
(22.3) \\
(42.9)\end{array}$ & $\begin{array}{r}8.5 \\
15.5 \\
10.2 \\
9.0 \\
7.1 \\
4.8\end{array}$ & $\begin{array}{l}(0.05) \\
(0.25) \\
(0.12) \\
(0.13) \\
(0.15) \\
(0.07)\end{array}$ & $\begin{array}{r}7.9 \\
14.4 \\
9.7 \\
8.4 \\
6.4 \\
4.4\end{array}$ & $\begin{array}{l}(0.06) \\
(0.25) \\
(0.13) \\
(0.11) \\
(0.16) \\
(0.07)\end{array}$ & $\begin{array}{r}7.0 \\
13.0 \\
8.6 \\
7.3 \\
6.0 \\
4.0\end{array}$ & $\begin{array}{l}(0.05) \\
(0.22) \\
(0.10) \\
(0.11) \\
(0.17) \\
(0.07)\end{array}$ & $\begin{array}{r}2,493 \\
431 \\
851 \\
562 \\
201 \\
448\end{array}$ & $\begin{array}{r}(17.4) \\
(7.8) \\
(9.9) \\
(8.2) \\
(5.2) \\
(8.1)\end{array}$ \\
\hline 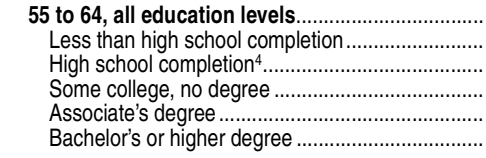 & $\begin{array}{l}64.3 \\
45.1 \\
59.2 \\
65.0 \\
70.2 \\
74.9\end{array}$ & $\begin{array}{l}(0.09) \\
(0.25) \\
(0.16) \\
(0.18) \\
(0.28) \\
(0.14)\end{array}$ & $\begin{array}{l}64.0 \\
45.4 \\
59.2 \\
64.7 \\
69.1 \\
74.4\end{array}$ & $\begin{array}{l}(0.09) \\
(0.28) \\
(0.16) \\
(0.23) \\
(0.29) \\
(0.14)\end{array}$ & $\begin{array}{l}64.1 \\
45.5 \\
59.3 \\
64.4 \\
69.2 \\
74.5\end{array}$ & $\begin{array}{l}(0.08) \\
(0.26) \\
(0.15) \\
(0.19) \\
(0.31) \\
(0.15)\end{array}$ & $\begin{array}{r}24,735 \\
2,063 \\
6,516 \\
5,429 \\
2,241 \\
8,487\end{array}$ & $\begin{array}{l}(31.4) \\
(16.1) \\
(25.7) \\
(26.6) \\
(16.5) \\
(29.3)\end{array}$ & $\begin{array}{l}59.1 \\
39.1 \\
53.7 \\
59.1 \\
64.7 \\
70.7\end{array}$ & $\begin{array}{l}(0.08) \\
(0.26) \\
(0.16) \\
(0.18) \\
(0.27) \\
(0.13)\end{array}$ & $\begin{array}{l}59.3 \\
39.7 \\
54.3 \\
59.2 \\
64.4 \\
70.5\end{array}$ & $\begin{array}{l}(0.09) \\
(0.29) \\
(0.16) \\
(0.22) \\
(0.32) \\
(0.15)\end{array}$ & $\begin{array}{l}59.9 \\
40.5 \\
54.9 \\
59.8 \\
65.0 \\
71.0\end{array}$ & $\begin{array}{l}(0.08) \\
(0.26) \\
(0.15) \\
(0.20) \\
(0.34) \\
(0.16)\end{array}$ & $\begin{array}{r}23,097 \\
1,839 \\
6,033 \\
5,040 \\
2,102 \\
8,082\end{array}$ & $\begin{array}{l}(33.7) \\
(15.2) \\
(24.4) \\
(25.7) \\
(15.3) \\
(28.9)\end{array}$ & $\begin{array}{r}8.2 \\
13.3 \\
9.2 \\
9.1 \\
7.8 \\
5.7\end{array}$ & $\begin{array}{l}(0.07) \\
(0.31) \\
(0.13) \\
(0.13) \\
(0.19) \\
(0.10)\end{array}$ & $\begin{array}{r}7.5 \\
12.7 \\
8.2 \\
8.4 \\
6.7 \\
5.2\end{array}$ & $\begin{array}{l}(0.06) \\
(0.30) \\
(0.14) \\
(0.14) \\
(0.20) \\
(0.08)\end{array}$ & $\begin{array}{r}6.6 \\
10.8 \\
7.4 \\
7.2 \\
6.2 \\
4.8\end{array}$ & $\begin{array}{l}(0.06) \\
(0.24) \\
(0.11) \\
(0.12) \\
(0.19) \\
(0.08)\end{array}$ & $\begin{array}{r}1,639 \\
223 \\
483 \\
389 \\
138 \\
405\end{array}$ & $\begin{array}{r}(13.8) \\
(5.1) \\
(7.8) \\
(7.0) \\
(4.5) \\
(7.2)\end{array}$ \\
\hline
\end{tabular}

'Percentage of the civilian population who are employed or seeking employment.

${ }^{2}$ Number of persons employed as a percentage of the civilian population.

${ }^{3}$ The percentage of persons in the civilian labor force who are not working and who made specific efforts to find employment

${ }^{4}$ Includes equivalency credentials, such as the General Educational Development (GED) credential.
NOTE: Race categories exclude persons of Hispanic ethnicity. Totals include racial/ethnic groups not separately shown. Standard errors were computed using replicate weights.

SOURCE: U.S. Department of Commerce, Census Bureau, American Community Survey, 2010, 2011, and 2012, unpublished tabulations. (This table was prepared January 2014.) 


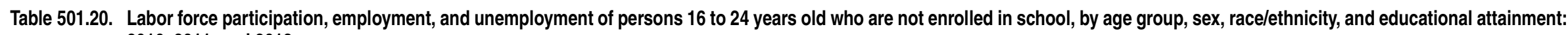
2010, 2011, and 2012

[Standard errors appear in parentheses]

\begin{tabular}{|c|c|c|c|c|c|c|c|c|c|c|c|c|c|c|c|c|c|c|c|c|c|c|c|c|}
\hline \multirow{3}{*}{$\begin{array}{l}\text { Age group, sex, race/ethnicity, } \\
\text { and educational attainment }\end{array}$} & \multicolumn{8}{|c|}{ Labor force participation } & \multicolumn{8}{|c|}{ Employment } & \multicolumn{8}{|c|}{ Unemployment } \\
\hline & \multicolumn{6}{|c|}{ Labor force participation rate $^{1}$} & \multicolumn{2}{|c|}{$\begin{array}{r}\text { Number of } \\
\text { participants } \\
\text { (in thousands) }\end{array}$} & \multicolumn{6}{|c|}{ Employment to population ratio ${ }^{2}$} & \multicolumn{2}{|c|}{$\begin{array}{r}\text { Number } \\
\text { employed } \\
\text { (in thousands) }\end{array}$} & \multicolumn{6}{|c|}{ Unemployment rate $^{3}$} & \multicolumn{2}{|c|}{$\begin{array}{r}\text { Number } \\
\text { unemployed } \\
\text { (in thousands) }\end{array}$} \\
\hline & & 2010 & & 2011 & & 2012 & & 2012 & & 2010 & & 2011 & & 2012 & & 2012 & & 2010 & & 2011 & & 2012 & & 2012 \\
\hline 1 & & 2 & & 3 & & 4 & & 5 & & 6 & & 7 & & 8 & & 9 & & 10 & & 11 & & 12 & & 13 \\
\hline 16 to 19 years old & & & & & & & & & & & & & & & & & & & & & & & & \\
\hline $\begin{array}{l}\text { All persons, all educatio } \\
\text { Less than high school c } \\
\text { High school completion } \\
\text { At least some college.. }\end{array}$ & $\begin{array}{l}62.7 \\
48.6 \\
70.2 \\
75.1\end{array}$ & $\begin{array}{l}(0.36) \\
(0.62) \\
(0.49) \\
(0.99)\end{array}$ & $\begin{array}{l}62.7 \\
47.2 \\
70.0 \\
74.7\end{array}$ & $\begin{array}{l}.43) \\
.75) \\
.47) \\
.13)\end{array}$ & $\begin{array}{l}64.1 \\
47.9 \\
70.3 \\
77.1\end{array}$ & $\begin{array}{l}(0.39) \\
(0.72) \\
(0.53) \\
(1.03)\end{array}$ & $\begin{array}{r}1,571 \\
366 \\
986 \\
219\end{array}$ & $\begin{array}{r}(17.2) \\
(8.1) \\
(14.2) \\
(5.4)\end{array}$ & $\begin{array}{l}41.7 \\
29.1 \\
47.5 \\
58.1\end{array}$ & $\begin{array}{l}(0.34) \\
(0.51) \\
(0.53) \\
(1.12)\end{array}$ & $\begin{array}{l}41.7 \\
26.6 \\
47.9 \\
57.9\end{array}$ & $\begin{array}{l}(0.42) \\
(0.71) \\
(0.53) \\
(1.22)\end{array}$ & $\begin{array}{l}43.5 \\
27.6 \\
48.6 \\
61.1\end{array}$ & $\begin{array}{l}(0.41) \\
(0.63) \\
(0.54) \\
(1.22)\end{array}$ & $\begin{array}{r}1,066 \\
211 \\
682 \\
173\end{array}$ & $\begin{array}{r}(13.9) \\
(6.2) \\
(11.1) \\
(4.9)\end{array}$ & $\begin{array}{l}33.4 \\
40.2 \\
32.4 \\
22.6\end{array}$ & $\begin{array}{l}. .49) \\
.799) \\
.08)\end{array}$ & $\begin{array}{l}33.5 \\
43.6 \\
31.6 \\
22.5\end{array}$ & \begin{tabular}{l|}
$0.52)$ \\
$1.12)$ \\
0.61 \\
$1.35)$
\end{tabular} & $\begin{array}{l}32.1 \\
42.5 \\
30.8 \\
20.8\end{array}$ & $\begin{array}{l}(0.50) \\
(1.06) \\
(0.61) \\
(1.12)\end{array}$ & $\begin{array}{r}505 \\
156 \\
304 \\
46\end{array}$ & $\begin{array}{l}(9.7) \\
(5.1) \\
(7.8) \\
(2.7)\end{array}$ \\
\hline $\begin{array}{l}\text { Male, all } \\
\text { Less th } \\
\text { High sc } \\
\text { At least }\end{array}$ & $\begin{array}{l}65.2 \\
53.0 \\
73.1 \\
74.3\end{array}$ & $\begin{array}{l}(0.49) \\
(0.86) \\
(0.65) \\
(1.51)\end{array}$ & $\begin{array}{l}64.4 \\
50.9 \\
71.6 \\
75.9\end{array}$ & $\begin{array}{l}(0.58) \\
(1.04) \\
(0.59) \\
(1.54)\end{array}$ & $\begin{array}{l}66.0 \\
51.2 \\
72.5 \\
77.2\end{array}$ & $\begin{array}{l}(0.52) \\
(1.09) \\
(0.63) \\
(1.43)\end{array}$ & $\begin{array}{l}924 \\
234 \\
582 \\
108\end{array}$ & $\begin{array}{r}(12.3) \\
(6.7) \\
(9.7) \\
(4.1)\end{array}$ & $\begin{array}{l}42.5 \\
32.3 \\
48.1 \\
55.9\end{array}$ & $\begin{array}{l}(0.48) \\
(0.82) \\
(0.61) \\
(1.59)\end{array}$ & $\begin{array}{l}47.9 \\
59.0\end{array}$ & $\begin{array}{l}(0.55) \\
(0.97) \\
(0.71) \\
(1.79)\end{array}$ & $\begin{array}{l}44.9 \\
30.1 \\
50.7 \\
60.2\end{array}$ & $\begin{array}{l}(0.49) \\
(0.90) \\
(0.65) \\
(1.58)\end{array}$ & $\begin{array}{r}628 \\
138 \\
407 \\
84\end{array}$ & $\begin{array}{l}(9.4) \\
(5.0) \\
(7.9) \\
(3.6)\end{array}$ & & $\begin{array}{l}(0.62) \\
(1.12) \\
(0.80) \\
(1.51)\end{array}$ & $\begin{array}{l}34.9 \\
43.2 \\
33.1 \\
22.3\end{array}$ & $\begin{array}{l}.60) \\
.36) \\
.789 \\
1.79)\end{array}$ & $\begin{array}{l}32.0 \\
41.2 \\
30.1 \\
22.1\end{array}$ & $\begin{array}{l}(0.59) \\
(1.30) \\
(0.75) \\
(1.75)\end{array}$ & $\begin{array}{r}296 \\
97 \\
175 \\
24\end{array}$ & $\begin{array}{l}(7.0) \\
(4.2) \\
(5.4) \\
(2.2)\end{array}$ \\
\hline 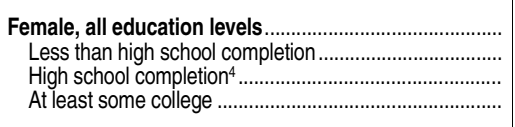 & $\begin{array}{l}59.5 \\
41.8 \\
66.7 \\
75.7\end{array}$ & $\begin{array}{l}(\mathbf{0 . 5 2 )} \\
(0.91) \\
(0.69) \\
(1.25)\end{array}$ & $\begin{array}{l}60.4 \\
41.4 \\
68.0 \\
73.6\end{array}$ & $\begin{array}{l}(0.65) \\
(1.04) \\
(0.77) \\
(1.59)\end{array}$ & $\begin{array}{l}61.5 \\
43.0 \\
67.2 \\
77.0\end{array}$ & $\begin{array}{l}(0.66) \\
(1.05) \\
(0.78) \\
(1.34)\end{array}$ & $\begin{array}{l}647 \\
132 \\
404 \\
111\end{array}$ & $\begin{array}{r}(10.7) \\
(4.4) \\
(9.1) \\
(4.0)\end{array}$ & $\begin{array}{l}40.8 \\
24.0 \\
46.7 \\
60.1\end{array}$ & $\begin{array}{l}(0.56) \\
(0.84) \\
(0.83) \\
(1.52)\end{array}$ & $\begin{array}{l}41.3 \\
23.1 \\
48.0 \\
57.0\end{array}$ & $\begin{array}{l}(0.62) \\
(0.90) \\
(0.78) \\
(1.91)\end{array}$ & $\begin{array}{l}41.6 \\
23.8 \\
45.9 \\
62.0\end{array}$ & $\begin{array}{l}(0.65) \\
(0.89) \\
(0.92) \\
(1.56)\end{array}$ & $\begin{array}{r}438 \\
73 \\
275 \\
90\end{array}$ & $\begin{array}{l}(9.1) \\
(3.3) \\
(7.7) \\
(3.6)\end{array}$ & & $\begin{array}{l}(0.72) \\
(1.46) \\
(0.99) \\
(1.56)\end{array}$ & $\begin{array}{l}31.6 \\
44.3 \\
29.4 \\
22.6\end{array}$ & & $\begin{array}{l}32.3 \\
44.7 \\
31.8 \\
19.5\end{array}$ & $\begin{array}{c}(0.82) \\
(1.70) \\
(1.03) \\
(1.57)\end{array}$ & $\begin{array}{r}209 \\
59 \\
128 \\
22\end{array}$ & $\begin{array}{l}(6.3) \\
(2.9) \\
(4.8) \\
(2.0)\end{array}$ \\
\hline 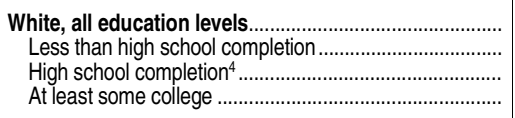 & $\begin{array}{l}67.5 \\
49.4 \\
74.8 \\
81.2\end{array}$ & $\begin{array}{l}(0.45) \\
(0.88) \\
(0.52) \\
(1.06)\end{array}$ & $\begin{array}{l}67.4 \\
47.5 \\
74.9 \\
79.8\end{array}$ & $\begin{array}{l}(0.55) \\
(1.24) \\
(0.63) \\
(1.30)\end{array}$ & $\begin{array}{l}68.8 \\
49.6 \\
74.8 \\
81.8\end{array}$ & $\begin{array}{l}(0.51) \\
(1.07) \\
(0.64) \\
(1.20)\end{array}$ & $\begin{array}{l}819 \\
162 \\
533 \\
124\end{array}$ & $\begin{array}{r}(11.1) \\
(5.4) \\
(8.9) \\
(4.3)\end{array}$ & $\begin{array}{l}46.2 \\
29.1 \\
52.2 \\
64.7\end{array}$ & $\begin{array}{l}(0.51) \\
(0.72) \\
(0.73) \\
(1.56)\end{array}$ & $\begin{array}{l}47.4 \\
28.3 \\
53.4 \\
65.0\end{array}$ & $\begin{array}{l}(0.55) \\
(1.00) \\
(0.67) \\
(1.50)\end{array}$ & $\begin{array}{l}50.4 \\
29.1 \\
56.3 \\
68.5\end{array}$ & $\begin{array}{l}(0.58) \\
(1.01) \\
(0.71) \\
(1.36)\end{array}$ & $\begin{array}{r}600 \\
95 \\
401 \\
104\end{array}$ & $\begin{array}{l}(9.9) \\
(4.3) \\
(8.1) \\
(3.9)\end{array}$ & $\begin{array}{l}31.5 \\
41.0 \\
30.3 \\
20.4\end{array}$ & $\begin{array}{l}(0.62) \\
(1.16) \\
(0.86) \\
(1.51)\end{array}$ & $\begin{array}{l}29.7 \\
40.5 \\
28.7 \\
18.6\end{array}$ & $\begin{array}{l}(0.66) \\
(1.52) \\
(0.73) \\
(1.66)\end{array}$ & $\begin{array}{l}26.7 \\
41.3 \\
24.8 \\
16.2\end{array}$ & $\begin{array}{l}(0.57) \\
(1.47) \\
(0.70) \\
(1.27)\end{array}$ & $\begin{array}{r}219 \\
67 \\
132 \\
20\end{array}$ & $\begin{array}{l}(5.1) \\
(3.0) \\
(4.1) \\
(1.7)\end{array}$ \\
\hline 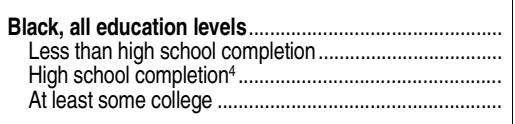 & $\begin{array}{l}52.6 \\
37.1 \\
62.6 \\
65.9\end{array}$ & $\begin{array}{l}(0.97) \\
(1.48) \\
(1.39) \\
(2.86)\end{array}$ & $\begin{array}{l}51.4 \\
35.4 \\
60.5 \\
63.3\end{array}$ & (3.03) & $\begin{array}{l}63.2 \\
75.8\end{array}$ & $\begin{array}{l}(1.36) \\
(2.88)\end{array}$ & $\begin{array}{r}242 \\
50 \\
155 \\
37\end{array}$ & $\left.\begin{array}{l}(2.9) \\
(5.9) \\
(3.1)\end{array}\right]$ & & & $\begin{array}{l}33.0 \\
42.9\end{array}$ & & $\begin{array}{l}27.6 \\
12.6 \\
31.8 \\
50.1\end{array}$ & $\begin{array}{l}(1.25) \\
(1.47) \\
(2.69)\end{array}$ & $\begin{array}{r}120 \\
18 \\
78 \\
24\end{array}$ & $\begin{array}{l}(4.8) \\
(1.8) \\
(4.5) \\
(2.3)\end{array}$ & $\begin{array}{l}46.7 \\
33.2\end{array}$ & $\begin{array}{l}(1.32) \\
(2.27) \\
(1.68) \\
(3.64)\end{array}$ & & & $\begin{array}{l}50.3 \\
64.4 \\
49.6 \\
33.9\end{array}$ & $\begin{array}{l}(1.39) \\
(2.97) \\
(1.85) \\
(2.90)\end{array}$ & $\begin{array}{r}122 \\
32 \\
77 \\
13\end{array}$ & $\begin{array}{l}(2.3) \\
(3.7) \\
(1.5)\end{array}$ \\
\hline & $\begin{array}{l}61.8 \\
55.2 \\
66.9 \\
70.2\end{array}$ & $\begin{array}{l}(0.76) \\
(1.19) \\
(1.21) \\
(2.49)\end{array}$ & $\begin{array}{l}63.4 \\
54.4 \\
68.9 \\
73.6\end{array}$ & $\begin{array}{l}(0.71) \\
(1.09) \\
(1.11) \\
(2.12)\end{array}$ & $\begin{array}{l}61.9 \\
52.8 \\
66.6 \\
71.2\end{array}$ & $\begin{array}{l}(0.72) \\
(1.48) \\
(1.05) \\
(2.70)\end{array}$ & $\begin{array}{r}407 \\
128 \\
235 \\
44\end{array}$ & $\begin{array}{l}(7.4) \\
(4.9) \\
(5.7) \\
(2.7)\end{array}$ & $\begin{array}{l}44.2 \\
38.3 \\
48.0 \\
55.6\end{array}$ & $\begin{array}{l}(1.13) \\
(2.79)\end{array}$ & $\begin{array}{l}49.4 \\
54.7\end{array}$ & & $\begin{array}{l}42.1 \\
34.7 \\
44.8 \\
56.1\end{array}$ & $\begin{array}{l}(1.27) \\
(1.11) \\
(2.83)\end{array}$ & $\begin{array}{r}277 \\
84 \\
158 \\
34\end{array}$ & $\begin{array}{l}(6.0) \\
(3.8) \\
(4.9) \\
(2.4)\end{array}$ & $\begin{array}{l}28.6 \\
30.7 \\
28.2 \\
20.7\end{array}$ & & & (2.85) & $\begin{array}{l}32.0 \\
34.2 \\
32.7 \\
21.2\end{array}$ & $\begin{array}{l}(0.96) \\
(1.79) \\
(1.33) \\
(2.42)\end{array}$ & $\begin{array}{r}130 \\
44 \\
77 \\
9\end{array}$ & $\begin{array}{l}(4.8) \\
(2.9) \\
(3.7) \\
(1.2)\end{array}$ \\
\hline & $\begin{array}{l}55.3 \\
38.5 \\
60.2 \\
64.5\end{array}$ & $\begin{array}{l}(\mathbf{2 . 9 2}) \\
(5.13) \\
(3.81) \\
(5.61)\end{array}$ & $\begin{array}{l}55.1 \\
36.7 \\
61.0 \\
61.7\end{array}$ & $\begin{array}{l}(5.19) \\
(3.85) \\
(8.02)\end{array}$ & $\begin{array}{l}65.3 \\
61.8\end{array}$ & $\begin{array}{l}(5.69) \\
(4.12) \\
(7.32)\end{array}$ & $\begin{array}{r}24 \\
3 \\
17 \\
4\end{array}$ & $\begin{array}{l}(1.9) \\
(0.7) \\
(1.5) \\
(0.8)\end{array}$ & $\begin{array}{l}39.5 \\
26.2 \\
40.6 \\
53.9\end{array}$ & $\begin{array}{l}(3.101) \\
(6.52) \\
(6.16)\end{array}$ & 49.9 & $\begin{array}{l}(4.16) \\
(3.76) \\
(6.86)\end{array}$ & $\begin{array}{l}48.3 \\
27.5 \\
56.0 \\
49.6\end{array}$ & $\begin{array}{l}(5.25) \\
(4.27) \\
(8.50)\end{array}$ & $\begin{array}{r}20 \\
\ddagger \\
15 \\
\ddagger\end{array}$ & $\begin{array}{r}(t) \\
(1.4) \\
(t)\end{array}$ & $\begin{array}{l}28.5 \\
31.8 \\
32.5 \\
16.5 !\end{array}$ & $\begin{array}{l}(7.67) \\
(4.35) \\
(5.23)\end{array}$ & $\begin{array}{l}30.6 \\
41.9 \\
31.1 \\
19.1 !\end{array}$ & $(6.74)$ & $\begin{array}{l}16.0 \\
20.5 \\
14.3 \\
19.8 !\end{array}$ & $\begin{array}{l}(2.76) \\
(5.60) \\
(3.29) \\
(8.49)\end{array}$ & $\begin{array}{l}4 \\
\ddagger\end{array}$ & $\begin{array}{r}(0.6) \\
(+) \\
(+) \\
(\dagger)\end{array}$ \\
\hline $\begin{array}{l}\text { American Indian/Alaska } \\
\text { Less than high school cc } \\
\text { High school completion } \\
\text { At least some college .... }\end{array}$ & $\begin{array}{r}44.0 \\
30.4 \\
55.6 \\
\ddagger \\
\end{array}$ & $\begin{array}{r}(3.34) \\
(4.50) \\
(4.89) \\
(\mathrm{t}) \\
\end{array}$ & $\begin{array}{l}47.8 \\
37.8 \\
55.3 \\
49.3 \\
\end{array}$ & $\begin{array}{l}(4.83) \\
(4.38) \\
(9.42) \\
\end{array}$ & $\begin{array}{l}56.1 \\
45.7 \\
63.6 \\
66.7 \\
\end{array}$ & $\begin{array}{l}(3.26) \\
(5.02) \\
(4.40) \\
(7.65)\end{array}$ & $\begin{array}{r}20 \\
7 \\
11 \\
2 \\
\end{array}$ & $\begin{array}{l}(1.8) \\
(1.2) \\
(1.2) \\
(0.5) \\
\end{array}$ & $\begin{array}{l}28.5 \\
15.7 \\
38.4 \\
44.8 \\
\end{array}$ & $\begin{array}{r}(2.87) \\
(3.21) \\
(4.64) \\
(10.11) \\
\end{array}$ & $\begin{array}{l}27.3 \\
27.6 !\end{array}$ & $\begin{array}{l}(2.78) \\
(3.90) \\
(4.55) \\
(8.42) \\
\end{array}$ & $\begin{array}{l}28.3 \\
17.3 \\
36.4 \\
38.3 \\
\end{array}$ & $\begin{array}{l}(3.43) \\
(3.98) \\
(4.67) \\
(8.74) \\
\end{array}$ & $\begin{array}{r}10 \\
\ddagger \\
6 \\
\ddagger \\
\end{array}$ & $\begin{array}{r}(1.4) \\
(t) \\
(1.1) \\
(t) \\
\end{array}$ & $\begin{array}{r}48.3 \\
30.9 \\
\ddagger \\
\end{array}$ & $\begin{array}{r}(7.43) \\
(5.48) \\
(t) \\
\end{array}$ & $\begin{array}{r}54.3 \\
50.6 \\
\ddagger \\
\end{array}$ & $\begin{array}{r}(6.87) \\
(\dagger) \\
\end{array}$ & $\begin{array}{l}62.1 \\
42.7 \\
42.6 \\
\end{array}$ & $\begin{array}{r}(5.04) \\
(8.22) \\
(5.70) \\
(11.01) \\
\end{array}$ & $\begin{array}{l}10 \\
4 \\
5 \\
\ddagger \\
\end{array}$ & $\begin{array}{r}(1.2) \\
(1.0) \\
(0.7) \\
(\dagger) \\
\end{array}$ \\
\hline & & & & & & & & & & & & & & & & & & & & & & & & \\
\hline 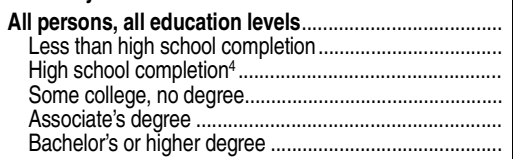 & $\begin{array}{l}80.2 \\
65.5 \\
78.8 \\
85.0 \\
90.6 \\
93.3\end{array}$ & $\begin{array}{l}(0.14) \\
(0.38) \\
(0.20) \\
(0.30) \\
(0.47) \\
(0.26)\end{array}$ & $\begin{array}{l}79.9 \\
64.5 \\
77.9 \\
85.1 \\
90.1 \\
93.4\end{array}$ & $\begin{array}{l}(0.13) \\
(0.42) \\
(0.23) \\
(0.30) \\
(0.54) \\
(0.25)\end{array}$ & $\begin{array}{l}80.5 \\
64.2 \\
78.4 \\
85.3 \\
89.4 \\
93.8\end{array}$ & $\begin{array}{l}(0.13) \\
(0.47) \\
(0.24) \\
(0.27) \\
(0.60) \\
(0.25)\end{array}$ & $\begin{array}{r}10,170 \\
1,295 \\
4,013 \\
2,663 \\
544 \\
1,654\end{array}$ & $\begin{array}{l}(33.4) \\
(17.6) \\
(23.1) \\
(20.3) \\
(10.4) \\
(17.8)\end{array}$ & $\begin{array}{l}65.3 \\
46.3 \\
61.6 \\
72.1 \\
82.3 \\
86.0\end{array}$ & $\begin{array}{l}(0.18) \\
(0.041) \\
(0.28) \\
(0.39) \\
(0.00) \\
(0.34)\end{array} \mid$ & $\begin{array}{l}65.1 \\
45.5 \\
61.0 \\
71.6 \\
81.6 \\
86.2\end{array}$ & $\begin{array}{l}(0.17) \\
(0.46) \\
(0.28) \\
(0.44) \\
(0.79) \\
(0.40)\end{array}$ & $\begin{array}{l}66.6 \\
45.3 \\
62.4 \\
72.7 \\
81.2 \\
87.0\end{array}$ & $\begin{array}{l}(0.18) \\
(0.44) \\
(0.30) \\
(0.36) \\
(0.72) \\
(0.35)\end{array} \mid$ & $\begin{array}{r}8,407 \\
913 \\
3,193 \\
2,272 \\
494 \\
1,535\end{array}$ & $\begin{array}{l}(32.1) \\
(14.0) \\
(20.3) \\
(19.2) \\
(9.7) \\
(17.2)\end{array}$ & $\begin{array}{r}18.6 \\
29.3 \\
21.8 \\
15.2 \\
9.2 \\
7.9\end{array}$ & $\begin{array}{l}(0.17) \\
(0.53) \\
(0.30) \\
(0.31) \\
(0.55) \\
(0.28)\end{array} \mid$ & $\begin{array}{r}18.6 \\
29.5 \\
21.8 \\
15.8 \\
9.4 \\
7.8\end{array}$ & $\begin{array}{l}(0.18) \\
(0.57) \\
(0.30) \\
(0.38) \\
(0.71) \\
(0.31)\end{array}$ & $\begin{array}{r}17.3 \\
29.5 \\
20.4 \\
14.7 \\
9.2 \\
7.2\end{array}$ & $\begin{array}{l}(0.18) \\
(0.58) \\
(0.30) \\
(0.33) \\
(0.53) \\
(0.27)\end{array}$ & $\begin{array}{r}1,763 \\
382 \\
820 \\
391 \\
50 \\
120\end{array}$ & $\begin{array}{r}(19.1) \\
(9.5) \\
(13.8) \\
(9.2) \\
(3.1) \\
(4.7)\end{array}$ \\
\hline
\end{tabular}

See notes at end of table. 


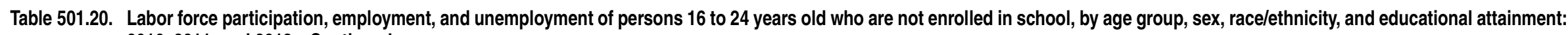
2010, 2011, and 2012-Continued

[Standard errors appear in parentheses]

\begin{tabular}{|c|c|c|c|c|c|c|c|c|c|c|c|c|c|c|c|c|c|c|c|c|c|c|c|c|}
\hline \multirow{3}{*}{$\begin{array}{l}\text { Age group, sex, race/ethnicity, } \\
\text { and educational attainment }\end{array}$} & \multicolumn{8}{|c|}{ Labor force participation } & \multicolumn{8}{|c|}{ Employment } & \multicolumn{8}{|c|}{ Unemployment } \\
\hline & \multicolumn{6}{|c|}{ Labor force participation rate ${ }^{1}$} & \multicolumn{2}{|c|}{$\begin{array}{r}\text { Number of } \\
\text { participants } \\
\text { (in thousands) }\end{array}$} & \multicolumn{6}{|c|}{ Employment to population ratio ${ }^{2}$} & \multicolumn{2}{|c|}{$\begin{array}{r}\text { Number } \\
\text { employed } \\
\text { (in thousands) }\end{array}$} & \multicolumn{6}{|c|}{ Unemployment rate ${ }^{3}$} & \multicolumn{2}{|c|}{$\begin{array}{r}\text { Number } \\
\text { unemployed } \\
\text { (in thousands) }\end{array}$} \\
\hline & & 2010 & & 2011 & & 2012 & & 2012 & & 2010 & & 2011 & & 2012 & & 2012 & & 2010 & & 2011 & & 2012 & & 2012 \\
\hline 1 & & 2 & & 3 & & 4 & & 5 & & 6 & & 7 & & 8 & & 9 & & 10 & & 11 & & 12 & & 13 \\
\hline 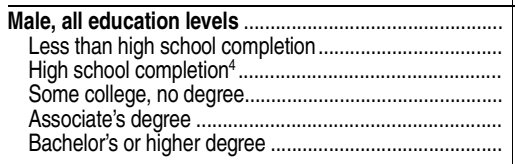 & $\begin{array}{l}83.0 \\
71.8 \\
82.6 \\
87.4 \\
92.9 \\
95.3\end{array}$ & $\begin{array}{l}(0.19) \\
(0.47) \\
(0.30) \\
(0.41) \\
(0.66) \\
(0.34)\end{array}$ & $\begin{array}{l}82.6 \\
71.0 \\
81.9 \\
87.6 \\
92.3 \\
93.8\end{array}$ & $\begin{array}{l}(0.19) \\
(0.47) \\
(0.27) \\
(0.42) \\
(0.68) \\
(0.44)\end{array}$ & $\begin{array}{l}83.0 \\
69.7 \\
81.9 \\
88.2 \\
92.2 \\
94.9\end{array}$ & $\begin{array}{l}(0.17) \\
(0.57) \\
(0.27) \\
(0.31) \\
(0.70) \\
(0.30)\end{array}$ & $\begin{array}{r}, 624 \\
843 \\
2,448 \\
1,390 \\
263 \\
680\end{array}$ & $\begin{array}{l}(25.8) \\
(13.0) \\
(16.7) \\
(16.2) \\
(6.7) \\
(11.9)\end{array}$ & $\begin{array}{l}66.3 \\
51.8 \\
63.9 \\
73.4 \\
83.4 \\
86.5\end{array}$ & $\begin{array}{l}(0.23) \\
(0.55) \\
(0.36) \\
(0.54) \\
(0.83) \\
(0.56)\end{array}$ & $\begin{array}{l}66.6 \\
52.1 \\
63.6 \\
73.4 \\
83.9 \\
85.7\end{array}$ & $\begin{array}{l}(0.25) \\
(0.53) \\
(0.36) \\
(0.60) \\
(0.95) \\
(0.62)\end{array}$ & $\begin{array}{l}67.8 \\
50.7 \\
65.1 \\
74.7 \\
82.8 \\
87.0\end{array}$ & $\begin{array}{l}(0.24) \\
(0.65) \\
(0.39) \\
(0.45) \\
(1.02) \\
(0.50)\end{array}$ & \begin{tabular}{r|}
4,598 \\
614 \\
1,947 \\
1,178 \\
236 \\
623
\end{tabular} & $\begin{array}{l}(25.0) \\
(10.6) \\
(15.5) \\
(15.2) \\
(6.3) \\
(11.4)\end{array}$ & $\begin{array}{r}20.1 \\
27.8 \\
22.7 \\
16.1 \\
10.3 \\
9.3\end{array}$ & $\begin{array}{l}(0.22) \\
(0.63) \\
(0.35) \\
(0.43) \\
(0.83) \\
(0.50)\end{array}$ & $\begin{array}{r}19.4 \\
26.6 \\
22.3 \\
16.2 \\
9.1 \\
8.6\end{array}$ & $\begin{array}{l}(0.23) \\
(0.62) \\
(0.39) \\
(0.52) \\
(0.81) \\
(0.48)\end{array}$ & $\begin{array}{r}18.2 \\
27.1 \\
20.5 \\
15.2 \\
10.2 \\
8.4\end{array}$ & $\begin{array}{l}(0.23) \\
(0.74) \\
(0.38) \\
(0.41) \\
(0.85)\end{array}$ & $\begin{array}{r}1,026 \\
229 \\
502 \\
212 \\
27 \\
57\end{array}$ & $\begin{array}{r}(13.7) \\
(7.6) \\
(10.3) \\
(6.0) \\
(2.4) \\
(2.8)\end{array}$ \\
\hline 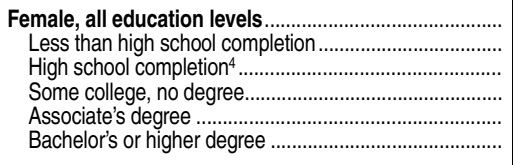 & $\begin{array}{l}76.9 \\
55.5 \\
73.6 \\
82.7 \\
88.6 \\
92.0\end{array}$ & $\begin{array}{l}(0.23) \\
(0.73) \\
(0.33) \\
(0.44) \\
(0.73) \\
(0.35)\end{array}$ & $\begin{array}{l}76.7 \\
54.8 \\
72.5 \\
82.6 \\
88.4 \\
93.1\end{array}$ & $\begin{array}{l}(0.21) \\
(0.71) \\
(0.46) \\
(0.43) \\
(0.78) \\
(0.34)\end{array}$ & $\begin{array}{l}77.7 \\
56.0 \\
73.6 \\
82.3 \\
87.0 \\
93.0\end{array}$ & $\begin{array}{l}(0.21) \\
(0.81) \\
(0.39) \\
(0.42) \\
(0.89) \\
(0.32)\end{array}$ & $\begin{array}{r}4,545 \\
452 \\
1,565 \\
1,273 \\
282 \\
974\end{array}$ & $\begin{array}{l}(21.8) \\
(10.4) \\
(12.8) \\
(14.5) \\
(7.9) \\
(11.8)\end{array}$ & $\begin{array}{l}64.0 \\
37.6 \\
58.5 \\
70.9 \\
81.3 \\
85.6\end{array}$ & $\begin{array}{l}(0.29) \\
(0.79) \\
(0.43) \\
(0.52) \\
(0.92) \\
(0.44)\end{array}$ & $\begin{array}{l}3.3 \\
5.5 \\
7.3 \\
9.8\end{array}$ & $\begin{array}{l}(0.26) \\
(0.73) \\
(0.48) \\
(0.53) \\
(1.11) \\
(0.47)\end{array}$ & $\begin{array}{l}65.1 \\
37.0 \\
58.6 \\
70.7 \\
79.7 \\
87.0\end{array}$ & $\begin{array}{l}(0.27) \\
(0.74) \\
(0.48) \\
(0.54) \\
(1.01) \\
(0.41)\end{array}$ & $\begin{array}{r}3,809 \\
299 \\
1,246 \\
1,094 \\
258 \\
911\end{array}$ & $\begin{array}{r}(21.7) \\
(8.2) \\
(12.6) \\
(13.6) \\
(7.3) \\
(11.7)\end{array}$ & $\begin{array}{r}16.7 \\
32.3 \\
20.6 \\
14.2 \\
8.3 \\
6.9\end{array}$ & $\begin{array}{l}.25) \\
.96) \\
.39)\end{array}$ & $\begin{array}{r}17.5 \\
35.2 \\
21.0 \\
15.4 \\
9.7 \\
7.2\end{array}$ & $\begin{array}{l}.26) \\
.44) \\
.48)\end{array}$ & $\begin{array}{r}16.2 \\
33.9 \\
20.4 \\
14.0 \\
8.3 \\
6.4\end{array}$ & $\begin{array}{l}0.24) \\
1.07) \\
0.46 \\
0.47\end{array}$ & $\begin{array}{r}737 \\
153 \\
319 \\
179 \\
23 \\
63\end{array}$ & $\begin{array}{r}(11.2) \\
(6.2) \\
(7.7) \\
(6.4) \\
(2.0) \\
(3.3)\end{array}$ \\
\hline 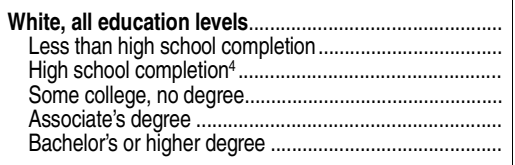 & $\begin{array}{l}84.0 \\
65.2 \\
81.5 \\
86.8 \\
92.5 \\
95.4\end{array}$ & $\begin{array}{l}(0.19) \\
(0.67) \\
(0.27) \\
(0.36) \\
(0.49) \\
(0.23)\end{array}$ & $\begin{array}{l}83.4 \\
63.6 \\
80.4 \\
86.9 \\
91.7 \\
94.9\end{array}$ & $\begin{array}{l}(0.22) \\
(0.83) \\
(0.36) \\
(0.33) \\
(0.59) \\
(0.30)\end{array}$ & $\begin{array}{l}84.1 \\
64.6 \\
81.1 \\
86.7 \\
91.5 \\
95.6\end{array}$ & $\begin{array}{l}(0.17) \\
(0.80) \\
(0.34) \\
(0.35) \\
(0.61) \\
(0.24)\end{array}$ & $\begin{array}{r}5,777 \\
462 \\
2,175 \\
1,537 \\
382 \\
1,220\end{array}$ & $\begin{array}{l}(25.1) \\
(9.3) \\
(17.6) \\
(15.9) \\
(9.6) \\
(15.4)\end{array}$ & $\begin{array}{l}70.9 \\
44.9 \\
65.3 \\
75.5 \\
86.2 \\
89.1\end{array}$ & $\begin{array}{l}(0.22) \\
(0.70) \\
(0.38) \\
(0.48) \\
(0.59) \\
(0.33)\end{array}$ & $\begin{array}{l}.5 \\
.4 \\
.1 \\
.7\end{array}$ & $\begin{array}{l}(0.26) \\
(0.67) \\
(0.37) \\
(0.49) \\
(0.79) \\
(0.48)\end{array}$ & $\begin{array}{l}72.4 \\
45.0 \\
66.6 \\
76.7 \\
84.5 \\
89.9\end{array}$ & $\begin{array}{l}(0.20) \\
(0.70) \\
(0.39) \\
(0.45) \\
(0.78) \\
(0.31)\end{array}$ & $\begin{array}{r}4,970 \\
322 \\
1,788 \\
1,359 \\
353 \\
1,148\end{array}$ & $\begin{array}{r}(22.4) \\
(7.6) \\
(15.7) \\
(15.2) \\
(8.8) \\
(15.1)\end{array}$ & $\begin{array}{r}15.6 \\
31.1 \\
19.8 \\
13.0 \\
6.9 \\
6.6\end{array}$ & & $\begin{array}{r}15.4 \\
33.4 \\
19.0 \\
12.9 \\
7.5 \\
6.6\end{array}$ & $\begin{array}{l}\text { 21) } \\
77) \\
350 \\
40\end{array}$ & $\begin{array}{r}14.0 \\
30.2 \\
17.8 \\
11.6 \\
7.7 \\
6.0\end{array}$ & $\begin{array}{l}(0.20) \\
(1.00) \\
(0.35) \\
(0.38) \\
(0.59) \\
(0.27)\end{array}$ & $\begin{array}{r}806 \\
140 \\
387 \\
177 \\
29 \\
73\end{array}$ & $\begin{array}{r}(12.4) \\
(5.7) \\
(8.4) \\
(6.1) \\
(2.5) \\
(3.4)\end{array}$ \\
\hline gree & $\begin{array}{l}71.4 \\
50.2 \\
71.8 \\
83.4 \\
85.5 \\
91.1\end{array}$ & $\begin{array}{l}(0.44) \\
(1.14) \\
(0.63) \\
(0.71) \\
(2.18) \\
(1.30)\end{array}$ & $\begin{array}{l}71.9 \\
51.3 \\
71.4 \\
81.8 \\
88.9 \\
94.7\end{array}$ & $\begin{array}{l}(0.43) \\
(1.08) \\
(0.64) \\
(0.81) \\
(1.79) \\
(0.93)\end{array}$ & $\begin{array}{l}73.0 \\
53.3 \\
71.1 \\
84.0 \\
86.3 \\
92.9\end{array}$ & $\begin{array}{l}(0.45) \\
(1.09) \\
(0.61) \\
(0.72) \\
(1.98) \\
(1.03)\end{array}$ & $\begin{array}{r}1,451 \\
203 \\
637 \\
442 \\
50 \\
119\end{array}$ & $\begin{array}{r}(15.1) \\
(7.0) \\
(11.4) \\
(8.4) \\
(3.0) \\
(4.3)\end{array}$ & $\begin{array}{l}63.7 \\
68.9 \\
77.1\end{array}$ & $\begin{array}{l}(0.48) \\
(0.82) \\
(0.75) \\
(0.90) \\
(2.68) \\
(1.72)\end{array}$ & & $\begin{array}{l}0.96 \\
(2.46 \\
(1.38\end{array}$ & $\begin{array}{l}50.4 \\
25.6 \\
47.7 \\
63.0 \\
73.0 \\
81.1\end{array}$ & $\begin{array}{l}(0.61) \\
(0.95) \\
(0.76) \\
(1.08) \\
(2.75) \\
(1.46)\end{array}$ & $\begin{array}{r}1,003 \\
97 \\
428 \\
332 \\
42 \\
104\end{array}$ & $\begin{array}{r}(15.1) \\
(4.5) \\
(8.9) \\
(8.5) \\
(3.0) \\
(3.8)\end{array}$ & 15.4 & $\begin{array}{l}(0.94) \\
(2.66) \\
(1.43)\end{array}$ & $\begin{array}{l}23.3 \\
16.6 \\
13.3\end{array}$ & $\begin{array}{l}(2.59) \\
(1.41)\end{array}$ & 12.7 & $(1.37)$ & $\begin{array}{r}449 \\
106 \\
210 \\
110 \\
8 \\
15\end{array}$ & $\begin{array}{l}(9.1) \\
(5.1) \\
(6.6) \\
(4.5) \\
(1.3) \\
(1.8)\end{array}$ \\
\hline r degree .............................. & $\begin{array}{l}77.8 \\
72.2 \\
78.4 \\
82.7 \\
87.7 \\
87.7\end{array}$ & $\begin{array}{l}(0.28) \\
(0.53) \\
(0.46) \\
(0.77) \\
(1.44) \\
(1.03)\end{array}$ & $\begin{array}{l}77.9 \\
71.6 \\
77.8 \\
84.1 \\
84.9 \\
90.3\end{array}$ & $\begin{array}{l}(1.69) \\
(1.06)\end{array}$ & $\begin{array}{l}77.8 \\
69.4 \\
78.3 \\
83.4 \\
84.0 \\
91.2\end{array}$ & $\begin{array}{l}(0.72) \\
(0.51) \\
(0.54) \\
(1.80) \\
(0.85)\end{array}$ & $\begin{array}{r}2,293 \\
564 \\
977 \\
523 \\
84 \\
144\end{array}$ & $\begin{array}{r}(17.6) \\
(11.8) \\
(12.6) \\
(9.5) \\
(3.9) \\
(5.6)\end{array}$ & & & & $\begin{array}{l}(0.93) \\
(2.36) \\
(1.51)\end{array}$ & $\begin{array}{l}64.5 \\
55.0 \\
64.3 \\
71.2 \\
74.5 \\
81.7\end{array}$ & $\begin{array}{l}(0.00) \\
(0.60) \\
(1.73) \\
(1.90) \\
(1.31)\end{array}$ & $\begin{array}{r}1,900 \\
447 \\
803 \\
446 \\
75 \\
129\end{array}$ & $\begin{array}{r}(17.8) \\
(10.7) \\
(12.3) \\
(8.6) \\
(3.6) \\
(4.9)\end{array}$ & $\begin{array}{r}13.4 \\
9.0\end{array}$ & & 9.8 & $(1.07)$ & & & $\begin{array}{r}117 \\
175 \\
77 \\
10 \\
15\end{array}$ & $\begin{array}{l}(5.0) \\
(5.0) \\
(5.7) \\
(3.8) \\
(1.3) \\
(2.1)\end{array}$ \\
\hline igher degree ...................................... & $\begin{array}{l}79.1 \\
66.5 \\
78.2 \\
79.2 \\
84.7 \\
82.6\end{array}$ & $\begin{array}{l}(1.00) \\
(3.14) \\
(1.93) \\
(1.87) \\
(3.31) \\
(1.28)\end{array}$ & $\begin{array}{l}80.3 \\
72.1 \\
78.1 \\
80.3 \\
86.3 \\
83.3\end{array}$ & $\begin{array}{l}(2.63) \\
(2.03) \\
(1.68) \\
(3.13) \\
(1.50)\end{array}$ & $\begin{array}{l}78.9 \\
61.2 \\
78.9 \\
80.0 \\
81.2 \\
82.7\end{array}$ & $\begin{array}{l}(3.18) \\
(1.75) \\
(2.00) \\
(3.87) \\
(1.23)\end{array}$ & $\begin{array}{r}291 \\
24 \\
70 \\
57 \\
15 \\
125\end{array}$ & $\begin{array}{l}(1.9) \\
(3.1) \\
(3.5) \\
(1.5) \\
(4.2)\end{array}$ & $\begin{array}{l}67.4 \\
48.8 \\
64.6 \\
70.4 \\
70.4 \\
72.7\end{array}$ & $\begin{array}{l}(3.41) \\
(2.19) \\
(2.03) \\
(3.70) \\
(1.49)\end{array}$ & 73.4 & $\begin{array}{l}(2.36) \\
(2.23) \\
(3.48) \\
(1.85)\end{array} \mid$ & $\begin{array}{l}49.3 \\
65.6 \\
68.2 \\
71.8 \\
74.5\end{array}$ & $\begin{array}{l}(3.69) \\
(2.13) \\
(2.29) \\
(4.44) \\
(1.42)\end{array}$ & $\begin{array}{r}252 \\
19 \\
59 \\
49 \\
13 \\
112\end{array}$ & $\begin{array}{l}(6.8) \\
(1.8) \\
(3.1) \\
(3.1) \\
(1.5) \\
(4.0)\end{array}$ & $\begin{array}{l}17.4 \\
11.2 \\
16.8 \\
12.0\end{array}$ & $\begin{array}{l}(3.69) \\
(2.01) \\
(1.20) \\
(3.26) \\
(0.99)\end{array}$ & $\begin{array}{c}24.3 \\
16.7 \\
13.4 \\
6.8 ! \\
11.9\end{array}$ & $\begin{array}{l}(1.99 \\
(2.02 \\
(2.38 \\
(1.30\end{array}$ & $\begin{array}{l}16.9 \\
14.8 \\
11.5 \\
10.0\end{array}$ & $\begin{array}{l}(1.40) \\
(1.93) \\
(1.70) \\
(3.42) \\
(1.07)\end{array}$ & $\begin{array}{r}39 \\
5 \\
12 \\
8 \\
7 \\
13\end{array}$ & $\begin{array}{r}(0.9) \\
(1.4) \\
(1.1) \\
(+) \\
(1.4)\end{array}$ \\
\hline 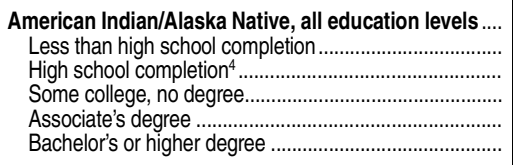 & $\begin{array}{l}67.7 \\
54.0 \\
69.6 \\
74.4 \\
80.3 \\
99.5\end{array}$ & $\begin{array}{l}(1.96) \\
(4.60) \\
(2.20) \\
(4.82) \\
(8.90) \\
(0.53)\end{array}$ & $\begin{array}{l}51.6 \\
68.3 \\
71.9 \\
84.0 \\
82.0\end{array}$ & $\begin{array}{l}(6.15) \\
(8.14)\end{array}$ & $\begin{array}{l}71.8 \\
55.9 \\
73.0 \\
79.0 \\
86.3 \\
89.7\end{array}$ & $\begin{array}{l}(1.39) \\
(3.41) \\
(1.68) \\
(2.84) \\
(5.12) \\
(4.84)\end{array}$ & $\begin{array}{r}83 \\
13 \\
41 \\
23 \\
3 \\
\ddagger\end{array}$ & $\begin{array}{r}(1.2) \\
(2.4) \\
(2.2) \\
(0.5) \\
(t)\end{array}$ & $\begin{array}{l}45.1 \\
24.0 \\
47.4 \\
56.0 \\
70.4 \\
96.2\end{array}$ & $\begin{array}{l}(1.71) \\
(3.00) \\
(2.57) \\
(3.63) \\
(9.36) \\
(3.64)\end{array}$ & & $\begin{array}{l}(1.93) \\
(3.27) \\
(3.02) \\
(4.15) \\
(8.45) \\
(8.00)\end{array}$ & $\begin{array}{l}50.6 \\
32.1 \\
50.3 \\
61.2 \\
76.3 \\
72.4\end{array}$ & $\begin{array}{r}(1.72) \\
(3.53) \\
(2.25) \\
(3.13) \\
(7.99) \\
(10.74)\end{array}$ & $\begin{array}{r}58 \\
8 \\
29 \\
18 \\
2 \\
\ddagger\end{array}$ & $\begin{array}{r}(1.0) \\
(2.0) \\
(1.9) \\
(0.5) \\
(\dagger)\end{array}$ & $\begin{array}{r}55.7 \\
32.0 \\
24.7 \\
\ddagger \\
\ddagger\end{array}$ & $\begin{array}{r}(2.12) \\
(5.32) \\
(3.00) \\
(4.22) \\
(\dagger) \\
(\dagger)\end{array}$ & $\begin{array}{r}40.7 \\
24.7 \\
26.6 \\
\ddagger \\
\ddagger\end{array}$ & $\begin{array}{r}(4.85) \\
(3.23) \\
(3.94) \\
(\dagger) \\
(\dagger)\end{array}$ & $\begin{array}{r}2.5 \\
1.0 \\
2.5 \\
\ddagger \\
\ddagger\end{array}$ & $\begin{array}{r}(4.49) \\
(2.44) \\
(2.76) \\
(\dagger) \\
(\dagger)\end{array}$ & $\begin{array}{r}24 \\
6 \\
13 \\
5 \\
\ddagger \\
\ddagger\end{array}$ & $\begin{array}{r}(1.7) \\
(0.7) \\
(1.2) \\
(0.7) \\
(\dagger)\end{array}$ \\
\hline
\end{tabular}

†Not applicable.

. mards not met. Either there are too few cases for a reliable estimate or the coefficient of variation (CV) is 50 percent or greater.

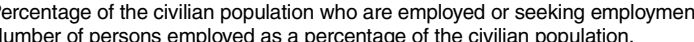

${ }^{3}$ The percentage of persons in the civilian labor force who are not working and who made specific efforts to find employmen sometime during the prior 4 weeks.

(GED) credential.

NOTE: Table excludes persons enrolled in school. Race categories exclude persons of Hispanic ethnicity. Totals include racial ethnic groups not separately shown. Standard errors were computed using replicate weights.
SOURCE: U.S. Department of Commerce, Census Bureau, American Community Survey, 2010, 2011, and 2012, unpublished tabulations. (This table was prepared January 2014.) 
710 CHAPTER 5: Outcomes of Education

Labor Force Status by Educational Attainment

Table 501.30. Number and percentage of persons 16 to 24 years old who were neither enrolled in school nor working, by educational attainment, age group, family poverty status, and race/ethnicity: 2013

[Standard errors appear in parentheses]

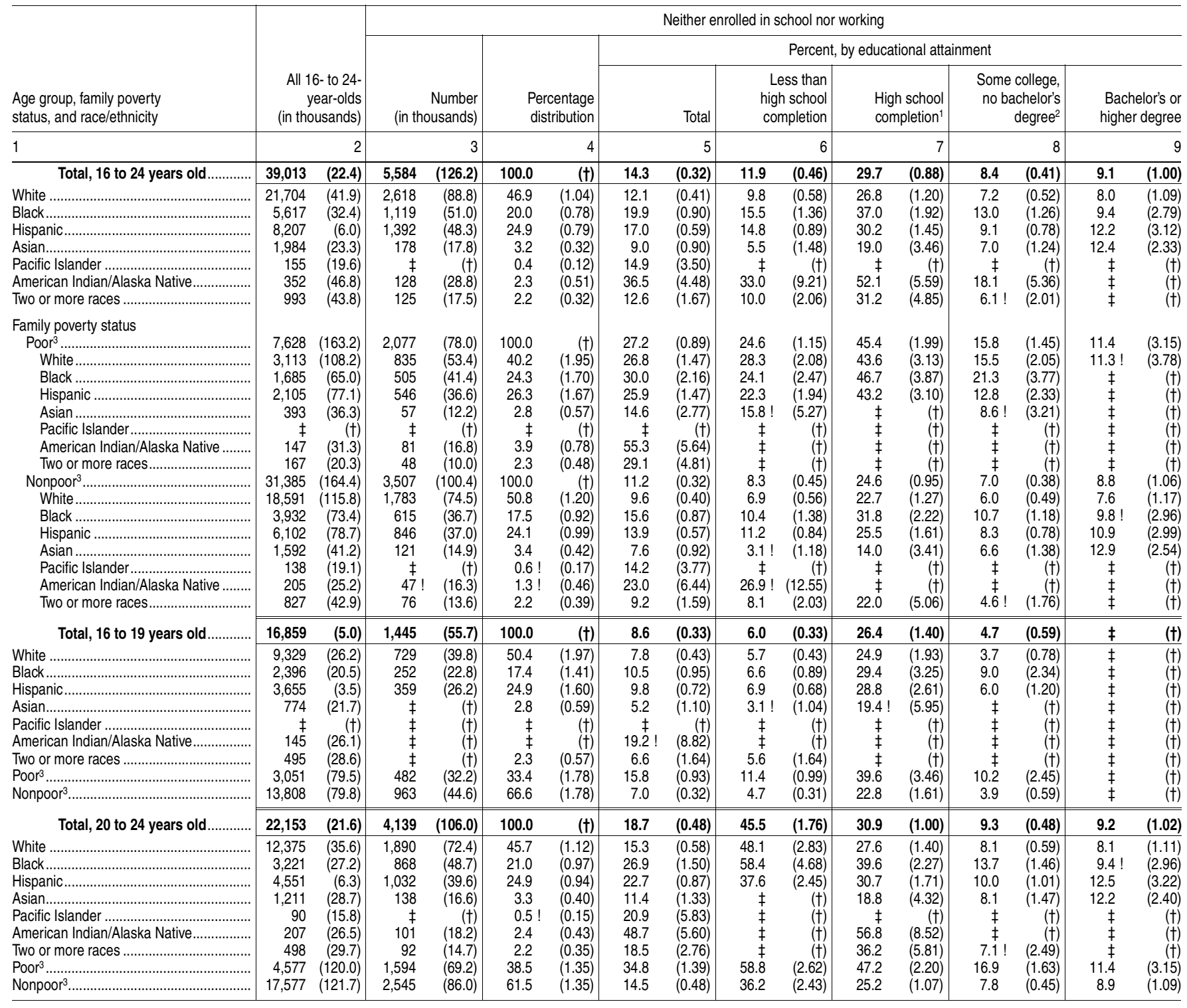

†Not applicable.

!nterpret data with caution. The coefficient of variation (CV) for this estimate is between 30 and 50 percent.

†Reporting standards not met. Either there are too few cases for a reliable estimate or the coefficient of variation (CV) is 50 percent or greater.

${ }^{1}$ Includes equivalency credentials, such as the General Educational Development (GED) credential.

'Includes persons with no college degree as well as those with an associate's degree.
${ }^{3}$ Poor is defined to include families with incomes below the poverty threshold. Nonpoor is defined to include families with incomes at or above the poverty threshold. For information about how the Census Bureau determines who is in poverty, see http://www.census.gov/ hhes/www/poverty/about/overview/measure.html.

NOTE: Race categories exclude persons of Hispanic ethnicity. Standard errors were computed using replicate weights. Detail may not sum to totals because of rounding. SOURCE: U.S. Department of Commerce, Census Bureau, Current Population Survey (CPS), March 2013, unpublished data. (This table was prepared October 2013.) 
Table 501.40. Percentage distribution of 25- to 34-year-olds with various levels of educational attainment, by labor force status, sex, race/ethnicity, and U.S. nativity and citizenship status: 2012

[Standard errors appear in parentheses]

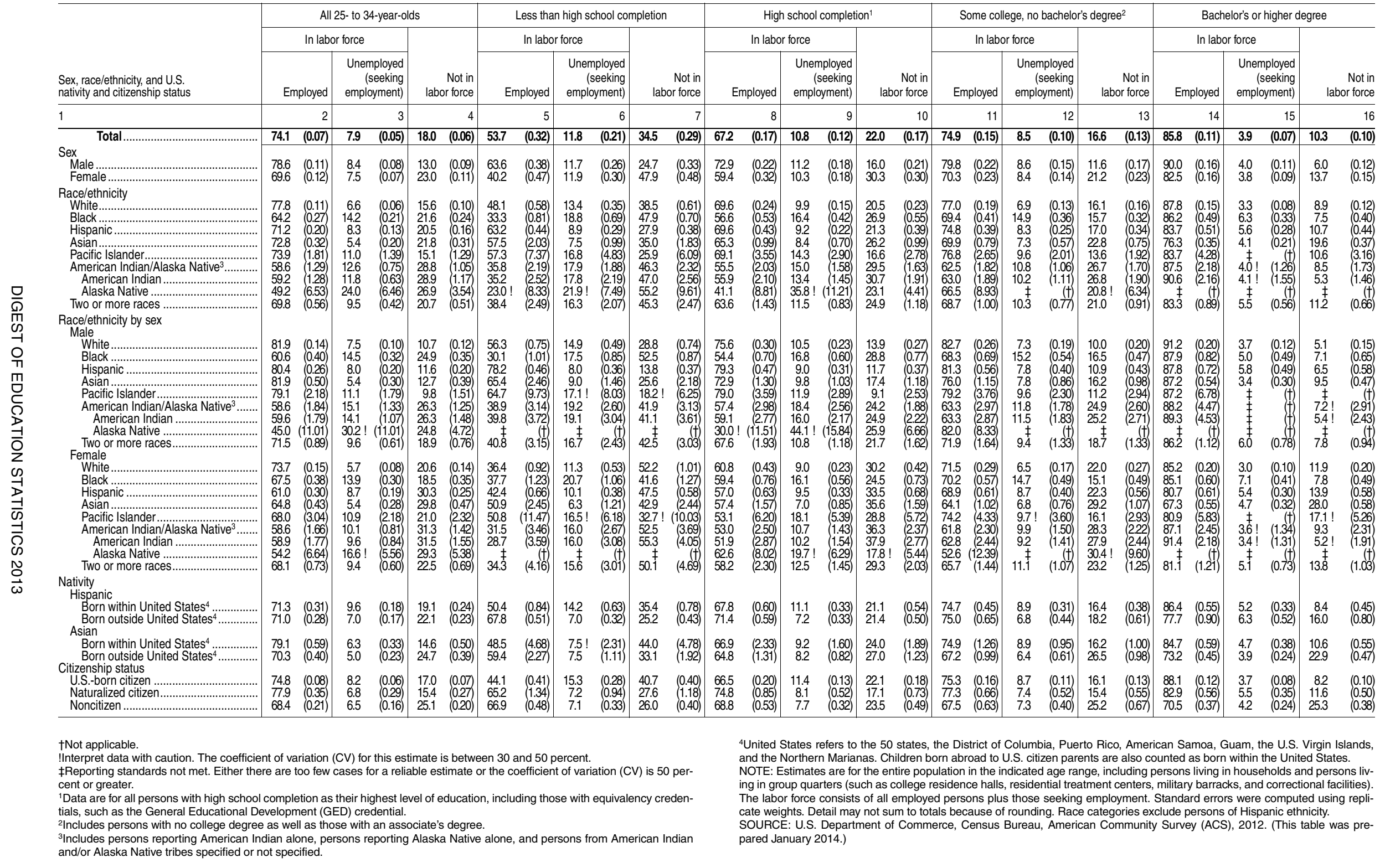


Table 501.50. Employment to population ratios of persons 16 to 64 years old, by age group and educational attainment: Selected years, 1975 through 2013

[Standard errors appear in parentheses]

\begin{tabular}{|c|c|c|c|c|c|c|c|c|c|c|c|c|c|c|c|c|c|c|c|c|c|c|c|c|c|c|c|c|}
\hline \multirow{2}{*}{ Age group and educational attainment } & \multicolumn{2}{|r|}{1975} & \multicolumn{2}{|r|}{1980} & \multicolumn{2}{|r|}{1985} & \multicolumn{2}{|r|}{1990} & \multicolumn{2}{|r|}{1995} & \multicolumn{2}{|r|}{2000} & \multicolumn{2}{|r|}{2005} & \multicolumn{2}{|r|}{2007} & \multicolumn{2}{|r|}{2008} & \multicolumn{2}{|r|}{2009} & \multicolumn{2}{|r|}{2010} & \multicolumn{2}{|r|}{2011} & \multicolumn{2}{|r|}{2012} & \multicolumn{2}{|r|}{2013} \\
\hline & & 2 & & 3 & & 4 & & 5 & & 6 & & 7 & & 8 & & 9 & & 10 & & 11 & & 12 & & 13 & & 14 & & 15 \\
\hline 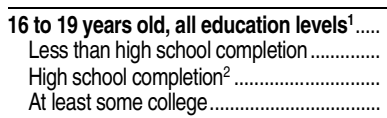 & $\begin{array}{l}- \\
\overline{-} \\
-\end{array}$ & $\begin{array}{l}(t) \\
(\dagger) \\
(\dagger) \\
(\dagger)\end{array}$ & $\begin{array}{l}- \\
\overline{-} \\
-\end{array}$ & $\begin{array}{l}(+) \\
(+) \\
(+) \\
(t)\end{array}$ & $\begin{array}{l}- \\
- \\
-\end{array}$ & $\begin{array}{l}(t) \\
(t) \\
(t) \\
(t)\end{array}$ & $\begin{array}{l}60.8 \\
44.2 \\
74.2 \\
76.8\end{array}$ & \begin{tabular}{l|}
$(2.03)$ \\
$(3.08)$ \\
$(2.54)$ \\
$(9.32)$
\end{tabular} & $\begin{array}{l}58.0 \\
44.0 \\
70.1 \\
71.6\end{array}$ & \begin{tabular}{l|}
$(2.13)$ \\
$(3.13)$ \\
$(2.99)$ \\
$(6.38)$
\end{tabular} & $\begin{array}{l}62.6 \\
52.2 \\
70.1 \\
78.2\end{array}$ & $\begin{array}{l}(2.09) \\
(3.19) \\
(2.92) \\
(6.22)\end{array}$ & $\begin{array}{l}53.7 \\
39.4 \\
65.0 \\
66.6\end{array}$ & $\begin{array}{l}(1.40) \\
(2.01) \\
(2.04) \\
(4.54)\end{array}$ & $\begin{array}{l}56.7 \\
42.7 \\
67.2 \\
71.9\end{array}$ & & $\begin{array}{l}53.5 \\
37.5 \\
64.3 \\
65.3\end{array}$ & & $\begin{array}{l}46.6 \\
31.1 \\
53.6 \\
65.4\end{array}$ & \begin{tabular}{l|}
$(1.36)$ \\
$(1.89)$ \\
$(1.72)$ \\
$(3.70)$
\end{tabular} & $\begin{array}{l}43.2 \\
29.4 \\
51.1 \\
57.5\end{array}$ & $\begin{array}{l}(1.30) \\
(1.83) \\
(1.84) \\
(3.99)\end{array}$ & $\begin{array}{l}44.8 \\
31.1 \\
50.3 \\
61.5\end{array}$ & $\begin{array}{l}(1.40) \\
(2.21) \\
(2.01) \\
(3.63)\end{array}$ & $\begin{array}{l}45.8 \\
28.5 \\
53.6 \\
64.3\end{array}$ & $\begin{array}{l}(1.43) \\
(2.05) \\
(1.90) \\
(4.07)\end{array}$ & $\begin{array}{l}46.3 \\
32.6 \\
52.7 \\
63.5\end{array}$ & $\begin{array}{l}(1.40) \\
(2.03) \\
(2.15) \\
(3.96)\end{array}$ \\
\hline 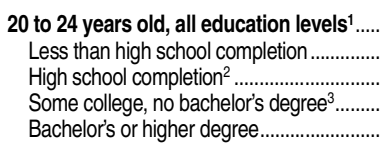 & $\begin{array}{l}- \\
- \\
- \\
-\end{array}$ & $\begin{array}{l}(t) \\
(+) \\
(t) \\
(t) \\
(t)\end{array}$ & $\begin{array}{l}- \\
\overline{-} \\
\overline{-} \\
-\end{array}$ & $\begin{array}{l}(t) \\
(+) \\
(t) \\
(+) \\
(t)\end{array}$ & $\begin{array}{l}- \\
\overline{-} \\
- \\
-\end{array}$ & $\begin{array}{l}(t) \\
(+) \\
(+) \\
(+) \\
(t)\end{array}$ & $\begin{array}{l}75.6 \\
54.4 \\
76.6 \\
85.6 \\
93.3\end{array}$ & $\begin{array}{l}(0.90) \\
(2.29) \\
(1.26) \\
(1.69) \\
(1.57)\end{array}$ & $\begin{array}{l}73.7 \\
52.7 \\
72.2 \\
83.6 \\
90.9\end{array}$ & $\begin{array}{l}(0.93) \\
(2.41) \\
(1.46) \\
(1.52) \\
(1.76)\end{array}$ & $\begin{array}{l}77.4 \\
60.8 \\
76.5 \\
86.6 \\
87.8\end{array}$ & $\begin{array}{l}(0.93) \\
(2.43) \\
(1.46) \\
(1.49) \\
(2.07)\end{array}$ & $\begin{array}{l}73.2 \\
55.7 \\
72.3 \\
80.3 \\
89.3\end{array}$ & $\begin{array}{l}(0.66) \\
(1.27) \\
(0.91) \\
(1.19) \\
(1.16)\end{array}$ & $\begin{array}{l}74.9 \\
57.9 \\
72.3 \\
82.1 \\
92.3\end{array}$ & & $\begin{array}{l}73.4 \\
55.1 \\
69.8 \\
81.8 \\
89.6\end{array}$ & & $\begin{array}{l}68.3 \\
50.6 \\
63.9 \\
74.9 \\
87.2\end{array}$ & $\begin{array}{l}(0.66) \\
(1.60) \\
(1.03) \\
(1.32) \\
(1.26)\end{array}$ & $\begin{array}{l}65.5 \\
44.4 \\
61.5 \\
72.9 \\
86.5\end{array}$ & $\begin{array}{l}(0.72) \\
(1.58) \\
(1.01) \\
(1.27) \\
(1.37)\end{array}$ & $\begin{array}{l}67.0 \\
46.8 \\
62.9 \\
73.2 \\
85.2\end{array}$ & $\begin{array}{l}(0.59) \\
(1.71) \\
(1.07) \\
(1.01) \\
(1.41)\end{array}$ & $\begin{array}{l}68.7 \\
47.7 \\
64.2 \\
75.3 \\
87.3\end{array}$ & $\begin{array}{l}(0.67) \\
(1.95) \\
(0.99) \\
(1.19) \\
(1.16)\end{array}$ & $\begin{array}{l}68.5 \\
46.8 \\
63.5 \\
75.3 \\
86.6\end{array}$ & $\begin{array}{l}(0.72) \\
(1.88) \\
(1.16) \\
(1.15) \\
(1.46)\end{array}$ \\
\hline 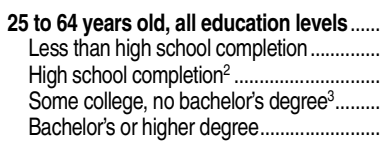 & $\begin{array}{l}65.8 \\
55.3 \\
65.7 \\
71.7 \\
82.5\end{array}$ & $\begin{array}{l}(0.33) \\
(0.62) \\
(0.53) \\
(0.86) \\
(0.68)\end{array}$ & $\begin{array}{l}70.2 \\
55.5 \\
70.4 \\
76.1 \\
84.5\end{array}$ & $\begin{array}{l}(0.30) \\
(0.66) \\
(0.48) \\
(0.70) \\
(0.55)\end{array}$ & $\begin{array}{l}71.6 \\
53.1 \\
70.7 \\
77.8 \\
85.6\end{array}$ & $\begin{array}{l}(0.30) \\
(0.74) \\
(0.48) \\
(0.66) \\
(0.51)\end{array}$ & $\begin{array}{l}75.0 \\
54.9 \\
74.4 \\
80.2 \\
86.7\end{array}$ & \begin{tabular}{l|}
$(0.29)$ \\
$(0.80)$ \\
$(0.46)$ \\
$(0.60)$ \\
$(0.47)$
\end{tabular} & $\begin{array}{l}75.5 \\
53.8 \\
73.3 \\
79.5 \\
86.5\end{array}$ & $\begin{array}{l}(0.28) \\
(0.85) \\
(0.49) \\
(0.51) \\
(0.44)\end{array}$ & $\begin{array}{l}77.7 \\
57.8 \\
75.5 \\
80.7 \\
86.4\end{array}$ & $\begin{array}{l}(0.27) \\
(0.91) \\
(0.49) \\
(0.50) \\
(0.42)\end{array}$ & $\begin{array}{l}75.0 \\
57.2 \\
71.5 \\
77.7 \\
83.7\end{array}$ & $\begin{array}{l}(0.19) \\
(0.51) \\
(0.34) \\
(0.33) \\
(0.26)\end{array}$ & $\begin{array}{l}76.0 \\
58.3 \\
72.7 \\
78.1 \\
84.3\end{array}$ & $\begin{array}{l}(0.17) \\
(0.58) \\
(0.32) \\
(0.29) \\
(0.24)\end{array}$ & $\begin{array}{l}75.5 \\
56.2 \\
71.6 \\
77.5 \\
84.4\end{array}$ & & $\begin{array}{l}72.2 \\
52.5 \\
67.8 \\
73.9 \\
82.2\end{array}$ & \begin{tabular}{l|}
$(0.19)$ \\
$(0.57)$ \\
$(0.33)$ \\
$(0.33)$ \\
$(0.25)$
\end{tabular} & $\begin{array}{l}71.5 \\
52.1 \\
67.0 \\
72.7 \\
81.6\end{array}$ & $\begin{array}{l}(0.19) \\
(0.60) \\
(0.36) \\
(0.30) \\
(0.24)\end{array}$ & $\begin{array}{l}71.2 \\
51.1 \\
66.2 \\
72.2 \\
81.5\end{array}$ & & $\begin{array}{l}71.7 \\
52.9 \\
66.5 \\
72.2 \\
82.1\end{array}$ & $\begin{array}{l}(0.18) \\
(0.60) \\
(0.35) \\
(0.30) \\
(0.24)\end{array}$ & $\begin{array}{l}72.1 \\
53.2 \\
66.7 \\
73.1 \\
81.9\end{array}$ & $\begin{array}{l}(0.19) \\
(0.60) \\
(0.38) \\
(0.31) \\
(0.26)\end{array}$ \\
\hline 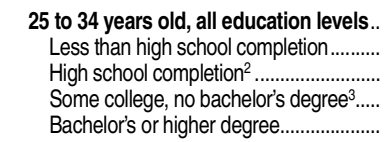 & $\begin{array}{l}67.7 \\
52.9 \\
65.5 \\
71.7 \\
82.0\end{array}$ & $\begin{array}{l}(0.59) \\
(1.43) \\
(0.92) \\
(1.33) \\
(1.04)\end{array}$ & $\begin{array}{l}74.5 \\
58.3 \\
72.0 \\
77.8 \\
85.4\end{array}$ & $\begin{array}{l}(0.49) \\
(1.46) \\
(0.81) \\
(1.01) \\
(0.82)\end{array}$ & $\begin{array}{l}76.2 \\
57.0 \\
74.3 \\
80.1 \\
86.6\end{array}$ & $\begin{array}{l}(0.48) \\
(1.54) \\
(0.78) \\
(0.97) \\
(0.79)\end{array}$ & $\begin{array}{l}78.6 \\
60.3 \\
77.7 \\
81.6 \\
88.1\end{array}$ & $\begin{array}{l}(0.47) \\
(1.50) \\
(0.74) \\
(0.96) \\
(0.76)\end{array}$ & $\begin{array}{l}78.5 \\
59.8 \\
77.0 \\
80.5 \\
88.1\end{array}$ & $\begin{array}{l}(0.48) \\
(1.59) \\
(0.84) \\
(0.87) \\
(0.75)\end{array}$ & $\begin{array}{l}81.6 \\
64.1 \\
80.2 \\
82.8 \\
89.0\end{array}$ & $\begin{array}{l}(0.49) \\
(1.76) \\
(0.91) \\
(0.90) \\
(0.73)\end{array}$ & $\begin{array}{l}76.8 \\
62.0 \\
73.1 \\
79.4 \\
84.4\end{array}$ & $\begin{array}{l}(0.31) \\
(0.95) \\
(0.60) \\
(0.54) \\
(0.52)\end{array}$ & $\begin{array}{l}78.9 \\
63.7 \\
76.4 \\
80.1 \\
86.5\end{array}$ & & $\begin{array}{l}78.1 \\
60.4 \\
74.0 \\
79.9 \\
86.8\end{array}$ & & $\begin{array}{l}74.2 \\
54.6 \\
69.0 \\
75.9 \\
84.5\end{array}$ & $\begin{array}{l}(0.36) \\
(1.07) \\
(0.66) \\
(0.60) \\
(0.49)\end{array}$ & $\begin{array}{l}73.2 \\
55.1 \\
68.1 \\
72.9 \\
84.0\end{array}$ & $\begin{array}{l}(0.34) \\
(0.95) \\
(0.72) \\
(0.57) \\
(0.49)\end{array}$ & $\begin{array}{l}73.0 \\
54.2 \\
67.9 \\
73.0 \\
83.4\end{array}$ & $\begin{array}{l}(0.35) \\
(1.17) \\
(0.67) \\
(0.62) \\
(0.45)\end{array}$ & $\begin{array}{l}73.8 \\
56.2 \\
68.7 \\
72.7 \\
84.3\end{array}$ & $\begin{array}{l}(0.31) \\
(1.14) \\
(0.75) \\
(0.68) \\
(0.45)\end{array}$ & $\begin{array}{l}74.6 \\
57.4 \\
68.2 \\
74.9 \\
84.4\end{array}$ & $\begin{array}{l}(0.33) \\
(1.03) \\
(0.68) \\
(0.65)\end{array}$ \\
\hline $\begin{array}{l}35 \text { to } 44 \text { years old, all education levels.. } \\
\text { Less than high school completion.......... } \\
\text { High school completion }{ }^{2} \ldots \ldots \ldots \ldots \ldots \ldots \ldots . . \\
\text { Some college, no bachelor's degree }{ }^{3} . . . . \\
\text { Bachelor's or higher degree................... }\end{array}$ & $\begin{array}{l}70.3 \\
61.4 \\
69.6 \\
74.5 \\
84.5\end{array}$ & $\begin{array}{l}(0.66) \\
(1.31) \\
(1.02) \\
(1.74) \\
(1.31)\end{array}$ & $\begin{array}{l}76.5 \\
63.4 \\
76.6 \\
80.9 \\
87.1\end{array}$ & $\begin{array}{l}(0.58) \\
(1.39) \\
(0.90) \\
(1.33) \\
(1.00)\end{array}$ & $\begin{array}{l}78.1 \\
60.0 \\
76.6 \\
81.6 \\
88.8\end{array}$ & $\begin{array}{l}(0.54) \\
(1.58) \\
(0.88) \\
(1.15) \\
(0.80)\end{array}$ & $\begin{array}{l}81.6 \\
62.5 \\
80.0 \\
85.0 \\
89.5\end{array}$ & $\begin{array}{l}(0.48) \\
(1.69) \\
(0.80) \\
(0.93) \\
(0.72)\end{array}$ & $\begin{array}{l}80.2 \\
58.6 \\
78.6 \\
83.3 \\
88.5\end{array}$ & $\begin{array}{l}(0.46) \\
(1.66) \\
(0.82) \\
(0.81) \\
(0.71)\end{array}$ & $\begin{array}{l}81.8 \\
64.8 \\
81.0 \\
84.4 \\
87.6\end{array}$ & $\begin{array}{l}(0.45) \\
(1.64) \\
(0.79) \\
(0.80) \\
(0.74)\end{array}$ & $\begin{array}{l}79.9 \\
64.9 \\
78.0 \\
82.0 \\
85.9\end{array}$ & $\begin{array}{l}(0.26) \\
(0.93) \\
(0.52) \\
(0.48) \\
(0.41)\end{array}$ & $\begin{array}{l}80.7 \\
65.0 \\
78.6 \\
83.6 \\
86.0\end{array}$ & $\begin{array}{l}(0.26) \\
(1.00) \\
(0.50) \\
(0.50) \\
(0.40)\end{array}$ & $\begin{array}{l}80.1 \\
64.3 \\
76.9 \\
82.4 \\
86.4\end{array}$ & $\begin{array}{l}(0.30) \\
(1.05) \\
(0.57) \\
(0.58) \\
(0.40)\end{array}$ & $\begin{array}{l}76.7 \\
60.2 \\
72.6 \\
78.5 \\
84.8\end{array}$ & $\begin{array}{l}(0.29) \\
(1.01) \\
(0.63) \\
(0.53) \\
(0.42)\end{array}$ & $\begin{array}{l}76.0 \\
58.2 \\
72.4 \\
76.9 \\
84.7\end{array}$ & $\begin{array}{l}(0.30) \\
(1.13) \\
(0.64) \\
(0.53) \\
(0.39)\end{array}$ & $\begin{array}{l}76.0 \\
57.5 \\
71.8 \\
76.9 \\
84.8\end{array}$ & $\begin{array}{l}(0.35) \\
(1.04) \\
(0.64) \\
(0.62) \\
(0.43)\end{array}$ & $\begin{array}{l}76.9 \\
59.6 \\
72.1 \\
78.2 \\
85.0\end{array}$ & $\begin{array}{l}(0.35) \\
(1.13) \\
(0.68) \\
(0.61) \\
(0.41)\end{array}$ & $\begin{array}{l}7.0 \\
1.6 \\
2.6\end{array}$ & $\begin{array}{l}(0.35) \\
(1.03)\end{array}$ \\
\hline 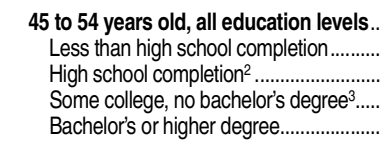 & $\begin{array}{l}68.4 \\
59.8 \\
68.8 \\
74.7 \\
87.1\end{array}$ & $\begin{array}{l}(0.65) \\
(1.14) \\
(1.03) \\
(1.81) \\
(1.36)\end{array}$ & $\begin{array}{l}71.7 \\
61.8 \\
72.0 \\
76.5 \\
87.3\end{array}$ & $\begin{array}{l}(0.65) \\
(1.24) \\
(1.02) \\
(1.72) \\
(1.21)\end{array}$ & $\begin{array}{l}73.5 \\
58.7 \\
74.0 \\
79.2 \\
87.9\end{array}$ & $\begin{array}{l}(0.67) \\
(1.52) \\
(1.03) \\
(1.63) \\
(1.16)\end{array}$ & $\begin{array}{l}77.6 \\
60.7 \\
77.5 \\
81.9 \\
89.4\end{array}$ & $\begin{array}{l}(0.62) \\
(1.63) \\
(0.97) \\
(1.38) \\
(0.97)\end{array}$ & $\begin{array}{l}78.8 \\
58.4 \\
75.9 \\
81.7 \\
89.5\end{array}$ & $\begin{array}{l}(0.55) \\
(1.79) \\
(1.01) \\
(1.03) \\
(0.78)\end{array}$ & $\begin{array}{l}81.2 \\
60.3 \\
78.2 \\
83.4 \\
89.7\end{array}$ & $\begin{array}{l}(0.50) \\
(1.89) \\
(0.95) \\
(0.91) \\
(0.71)\end{array}$ & $\begin{array}{l}78.4 \\
59.0 \\
75.1 \\
80.4 \\
87.5\end{array}$ & $\begin{array}{l}(0.32) \\
(1.04) \\
(0.64) \\
(0.57) \\
(0.45)\end{array}$ & $\begin{array}{l}78.9 \\
58.5 \\
76.2 \\
81.0 \\
87.7\end{array}$ & $\begin{array}{l}(0.33) \\
(1.05) \\
(0.58) \\
(0.58) \\
(0.42)\end{array}$ & $\begin{array}{l}78.4 \\
56.0 \\
75.4 \\
80.2 \\
88.1\end{array}$ & $\begin{array}{l}(0.33) \\
(1.02) \\
(0.57) \\
(0.51) \\
(0.45)\end{array}$ & $\begin{array}{l}75.2 \\
54.0 \\
71.6 \\
77.3 \\
85.2\end{array}$ & $\begin{array}{l}(0.34) \\
(1.13) \\
(0.53) \\
(0.58) \\
(0.45)\end{array}$ & $\begin{array}{l}74.7 \\
52.5 \\
71.0 \\
77.3 \\
84.4\end{array}$ & $\begin{array}{l}(0.35) \\
(1.05) \\
(0.65) \\
(0.54) \\
(0.45)\end{array}$ & $\begin{array}{l}74.3 \\
51.7 \\
70.1 \\
76.6 \\
84.9\end{array}$ & $\begin{array}{l}(0.32) \\
(0.84) \\
(0.58) \\
(0.53) \\
(0.45)\end{array}$ & $\begin{array}{l}74.6 \\
54.7 \\
70.4 \\
76.2 \\
84.7\end{array}$ & $\begin{array}{l}(0.30) \\
(1.06) \\
(0.62) \\
(0.53) \\
(0.48)\end{array}$ & $\begin{array}{l}74.9 \\
53.3 \\
70.1 \\
77.4 \\
84.7\end{array}$ & $(0.30)$ \\
\hline $\begin{array}{l}55 \text { to } 64 \text { years old, all education levels.. } \\
\text { Less than high school completion.......... } \\
\text { High school completion' }{ }^{2} . \ldots \ldots \ldots \ldots \ldots \ldots \ldots . . . \\
\text { Some college, no bachelor's degree }{ }^{3} \ldots . . . \\
\text { Bachelor's or higher degree.................. }\end{array}$ & $\begin{array}{l}\mathbf{5 4 . 6} \\
48.5 \\
56.5 \\
62.6 \\
72.6\end{array}$ & $\begin{array}{l}(0.77) \\
(1.11) \\
(1.32) \\
(2.48) \\
(2.34)\end{array}$ & $\begin{array}{l}54.1 \\
43.2 \\
57.5 \\
62.5 \\
71.9\end{array}$ & $\begin{array}{l}(0.73) \\
(1.16) \\
(1.19) \\
(2.08) \\
(1.96)\end{array}$ & $\begin{array}{l}52.1 \\
41.8 \\
52.1 \\
58.9 \\
71.3\end{array}$ & $\begin{array}{l}(0.77) \\
(1.29) \\
(1.22) \\
(2.21) \\
(1.83)\end{array}$ & $\begin{array}{l}53.4 \\
39.5 \\
54.0 \\
60.4 \\
70.5\end{array}$ & $\begin{array}{l}(0.81) \\
(1.46) \\
(1.29) \\
(2.12) \\
(1.79)\end{array}$ & $\begin{array}{l}55.0 \\
38.1 \\
53.7 \\
62.0 \\
70.0\end{array}$ & $\begin{array}{l}(0.82) \\
(1.67) \\
(1.34) \\
(1.74) \\
(1.72)\end{array}$ & $\begin{array}{l}58.1 \\
40.4 \\
55.4 \\
62.4 \\
71.9\end{array}$ & $\begin{array}{l}(0.79) \\
(1.84) \\
(1.34) \\
(1.64) \\
(1.49)\end{array}$ & $\begin{array}{l}60.8 \\
39.4 \\
55.3 \\
64.8 \\
73.5\end{array}$ & $\begin{array}{l}(0.48) \\
(1.13) \\
(0.79) \\
(0.90) \\
(0.74)\end{array}$ & $\begin{array}{l}\mathbf{6 2 . 2} \\
43.3 \\
55.9 \\
64.6 \\
74.5\end{array}$ & $\begin{array}{l}(0.46) \\
(1.19) \\
(0.85) \\
(0.73) \\
(0.75)\end{array}$ & $\begin{array}{l}\mathbf{6 2 . 8} \\
41.0 \\
57.8 \\
64.8 \\
74.0\end{array}$ & $\begin{array}{l}(0.41) \\
(1.24) \\
(0.69) \\
(0.80) \\
(0.68)\end{array}$ & $\begin{array}{l}60.8 \\
38.2 \\
55.8 \\
61.6 \\
72.7\end{array}$ & $\begin{array}{l}(0.42) \\
(1.19) \\
(0.73) \\
(0.74) \\
(0.63)\end{array}$ & $\begin{array}{l}60.6 \\
40.0 \\
55.1 \\
61.8 \\
72.0\end{array}$ & $\begin{array}{l}(0.41) \\
(1.19) \\
(0.71) \\
(0.76) \\
(0.65)\end{array}$ & $\begin{array}{l}60.2 \\
39.4 \\
54.4 \\
61.2 \\
71.8\end{array}$ & $\begin{array}{l}(0.43) \\
(1.15) \\
(0.81) \\
(0.78) \\
(0.71)\end{array}$ & $\begin{array}{l}\mathbf{6 0 . 6} \\
39.1 \\
54.6 \\
61.2 \\
73.1\end{array}$ & $\begin{array}{l}(0.41) \\
(1.08) \\
(0.75) \\
(0.70) \\
(0.66)\end{array}$ & $\begin{array}{l}1.3 \\
8.5 \\
6.3\end{array}$ & $\begin{array}{l}(0.43) \\
(1.32) \\
(0.74) \\
(0.72) \\
(0.67)\end{array}$ \\
\hline
\end{tabular}

\section{-Not available.}

†Not applicable.
'Data for 16 - to 19 -year-olds and 20- to 24 -year-olds exclude persons enrolled in school. 2Includes equivalency credentials, such as the General Educational Development (GED) credential. IIncludes persons with no college degree as well as those with an associate's degree.
NOTE: For each age group, the employment to population ratio is the number of persons in that age group who are employed as a percentage of the civilian population in that age group.

ished annual average data from the Current Population Survey (CPS), selected years, 1975 through 2013. (This table was prepared June 2014.) 
Table 501.60. Employment to population ratios of males 16 to 64 years old, by age group and educational attainment: Selected years, 1975 through 2013

[Standard errors appear in parentheses]

\begin{tabular}{|c|c|c|c|c|c|c|c|c|c|c|c|c|c|c|c|c|c|c|c|c|c|c|c|c|c|c|c|c|}
\hline$p$ and educational attainment & & 1975 & & 1980 & & 1985 & & 1990 & & 1995 & & 2000 & & 2005 & & 2007 & & 2008 & & 2009 & & 2010 & & 2011 & & 2012 & & 2013 \\
\hline 1 & & 2 & & 3 & & 4 & & 5 & & 6 & & 7 & & 8 & & & & 10 & & 11 & & 12 & & 13 & & 14 & & 15 \\
\hline 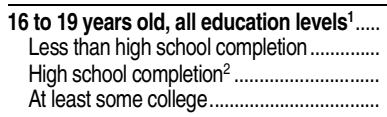 & $\begin{array}{l}- \\
- \\
-\end{array}$ & $\begin{array}{l}(+) \\
(+) \\
(+) \\
(\dagger)\end{array}$ & $\begin{array}{l}- \\
- \\
-\end{array}$ & $\begin{array}{l}(+) \\
(+) \\
(+) \\
(\dagger)\end{array}$ & $\begin{array}{l}- \\
- \\
-\end{array}$ & $\begin{array}{l}(\dagger) \\
(\dagger) \\
(\dagger) \\
(\dagger)\end{array}$ & $\begin{array}{l}65.3 \\
51.5 \\
78.7 \\
83.1\end{array}$ & $\begin{array}{r}(2.82) \\
(4.20) \\
(3.51) \\
(13.41)\end{array}$ & $\begin{array}{l}6 \\
1 \\
9\end{array}$ & $\begin{array}{l}877) \\
26)\end{array}$ & $\begin{array}{l}69.2 \\
63.1 \\
74.4 \\
77.0\end{array}$ & $\begin{array}{l}(2.70) \\
(4.09) \\
(3.77) \\
(9.81)\end{array}$ & $\begin{array}{l}6.2 \\
7.0 \\
3.1 \\
0.4\end{array}$ & $\begin{array}{l}\mathbf{( 2 . 1 0 )} \\
(3.07) \\
(2.88) \\
(5.98)\end{array}$ & $\begin{array}{l}59.6 \\
48.0 \\
69.1 \\
71.0\end{array}$ & $\begin{array}{l}(1.57) \\
(2.48) \\
(2.46) \\
(6.02)\end{array}$ & $\begin{array}{l}58.7 \\
45.8 \\
67.1 \\
74.3\end{array}$ & $\begin{array}{l}(1.72) \\
(2.44) \\
(2.47) \\
(4.67)\end{array}$ & $\begin{array}{l}45.8 \\
34.0 \\
51.1 \\
62.9\end{array}$ & $\begin{array}{l}(1.77) \\
(2.70) \\
(2.35) \\
(5.37)\end{array}$ & $\begin{array}{l}44.0 \\
31.5 \\
51.0 \\
61.4\end{array}$ & $\begin{array}{l}(1.72) \\
(2.64) \\
(2.37) \\
(6.00)\end{array}$ & $\begin{array}{l}47.0 \\
37.4 \\
51.2 \\
60.2\end{array}$ & $\begin{array}{l}(1.94) \\
(3.03) \\
(2.84) \\
(5.67)\end{array}$ & $\begin{array}{l}48.1 \\
34.7 \\
52.5 \\
64.2\end{array}$ & $\begin{array}{l}(2.00) \\
(3.25) \\
(2.51) \\
(5.72)\end{array}$ & $\begin{array}{l}48.1 \\
33.9 \\
55.8 \\
65.9\end{array}$ & $\begin{array}{l}(1.92) \\
(2.63) \\
(2.86) \\
(5.64)\end{array}$ \\
\hline 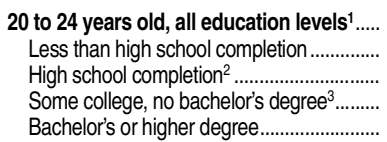 & $\begin{array}{l}- \\
- \\
- \\
-\end{array}$ & $\begin{array}{l}(+) \\
(+) \\
(+) \\
(+) \\
(t)\end{array}$ & $\begin{array}{l}- \\
- \\
- \\
-\end{array}$ & $\begin{array}{c}(t) \\
(t) \\
(t) \\
(t) \\
(t)\end{array}$ & $\begin{array}{l}- \\
- \\
- \\
-\end{array}$ & $\begin{array}{l}(t) \\
(+) \\
(t) \\
(+) \\
(t)\end{array}$ & $\begin{array}{l}83.5 \\
70.0 \\
84.6 \\
91.8 \\
94.9\end{array}$ & $\begin{array}{l}(1.10) \\
(2.84) \\
(1.50) \\
(1.98) \\
(2.07)\end{array}$ & $\begin{array}{l}81.2 \\
69.3 \\
81.1\end{array}$ & & 83.3 & $\begin{array}{l}(1.16) \\
(2.93) \\
(1.78) \\
(1.65) \\
(3.07)\end{array}$ & & $\begin{array}{l}(0.86) \\
(1.80) \\
(1.21) \\
(1.43) \\
(1.82)\end{array}$ & $\begin{array}{l}80.8 \\
67.9 \\
79.7 \\
87.3 \\
94.1\end{array}$ & $\begin{array}{l}(0.72) \\
(1.97) \\
(1.11) \\
(1.25) \\
(1.38)\end{array}$ & $\begin{array}{l}79.1 \\
68.2 \\
76.9 \\
85.2 \\
92.4\end{array}$ & $\begin{array}{l}(0.68) \\
(2.11) \\
(1.05) \\
(1.38) \\
(1.51)\end{array}$ & $\begin{array}{l}70.6 \\
59.2 \\
66.9 \\
77.7 \\
86.4\end{array}$ & $\begin{array}{l}(0.86) \\
(2.28) \\
(1.38) \\
(1.69) \\
(1.94)\end{array}$ & $\begin{array}{l}68.4 \\
52.9 \\
66.0 \\
74.8 \\
86.3\end{array}$ & $\begin{array}{l}(0.97) \\
(2.06) \\
(1.31) \\
(1.71) \\
(2.04)\end{array}$ & $\begin{array}{l}69.5 \\
57.3 \\
66.2 \\
75.2 \\
84.7\end{array}$ & $\begin{array}{l}(0.84) \\
(2.43) \\
(1.31) \\
(1.66) \\
(2.16)\end{array}$ & $\begin{array}{l}72.1 \\
56.6 \\
68.0 \\
80.5 \\
88.7\end{array}$ & $\begin{array}{l}(0.96) \\
(2.42) \\
(1.43) \\
(1.59) \\
(1.77)\end{array}$ & $\begin{array}{l}71.4 \\
57.0 \\
67.3 \\
77.9 \\
86.1\end{array}$ & $\begin{array}{l}(0.95) \\
(2.54) \\
(1.47) \\
(1.51) \\
(2.11)\end{array}$ \\
\hline 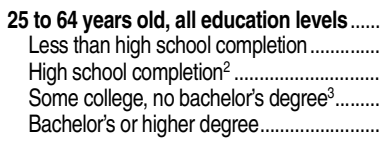 & $\begin{array}{l}84.6 \\
74.3 \\
87.2 \\
88.8 \\
93.8\end{array}$ & $\begin{array}{l}(0.36) \\
(0.77) \\
(0.56) \\
(0.83) \\
(0.55)\end{array}$ & $\begin{array}{l}85.0 \\
72.4 \\
87.0 \\
88.3 \\
93.6\end{array}$ & $\begin{array}{l}(0.34) \\
(0.84) \\
(0.54) \\
(0.73) \\
(0.48)\end{array}$ & $\begin{array}{l}83.1 \\
67.6 \\
83.5 \\
87.1 \\
92.4\end{array}$ & $\begin{array}{l}(0.36) \\
(0.98) \\
(0.58) \\
(0.75) \\
(0.50)\end{array}$ & $\begin{array}{l}84.5 \\
67.9 \\
85.1 \\
87.9 \\
92.5\end{array}$ & $\begin{array}{l}(0.34) \\
(1.04) \\
(0.55) \\
(0.70) \\
(0.48)\end{array}$ & 91.4 & & 91.8 & $\begin{array}{l}(0.33) \\
(1.17) \\
(0.61) \\
(0.63) \\
(0.47)\end{array}$ & & $\begin{array}{l}(0.25) \\
(0.70)\end{array}$ & $\begin{array}{l}82.5 \\
69.3 \\
79.3 \\
83.8 \\
90.7\end{array}$ & $\begin{array}{l}(0.22) \\
(0.79) \\
(0.45) \\
(0.42) \\
(0.28)\end{array}$ & $\begin{array}{l}81.6 \\
66.6 \\
78.3 \\
82.9 \\
90.0\end{array}$ & $\begin{array}{l}(0.22) \\
(0.78) \\
(0.42) \\
(0.42) \\
(0.31)\end{array}$ & $\begin{array}{l}77.0 \\
61.6 \\
72.1 \\
78.1 \\
87.6\end{array}$ & $\begin{array}{l}(0.25) \\
(0.80) \\
(0.49) \\
(0.41) \\
(0.34)\end{array}$ & $\begin{array}{l}76.3 \\
61.2 \\
71.7 \\
76.6 \\
86.9\end{array}$ & $\begin{array}{l}(0.27) \\
(0.93) \\
(0.50) \\
(0.42) \\
(0.33)\end{array}$ & $\begin{array}{l}76.3 \\
61.0 \\
71.8 \\
75.9 \\
86.9\end{array}$ & $\begin{array}{l}(0.27) \\
(0.81) \\
(0.50) \\
(0.45) \\
(0.35)\end{array}$ & $\begin{array}{l}77.4 \\
63.0 \\
72.6 \\
77.3 \\
87.5\end{array}$ & $\begin{array}{l}(0.25) \\
(0.77) \\
(0.45) \\
(0.43) \\
(0.33)\end{array}$ & $\begin{array}{l}78.2 \\
64.0 \\
73.1 \\
78.3 \\
88.0\end{array}$ & $\begin{array}{l}(0.27) \\
(0.75) \\
(0.51) \\
(0.46) \\
(0.33)\end{array}$ \\
\hline 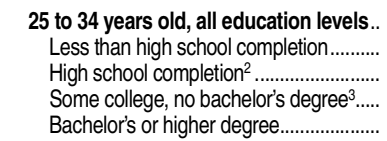 & $\begin{array}{l}87.4 \\
76.2 \\
88.4 \\
87.7 \\
93.5\end{array}$ & $\begin{array}{l}(0.59) \\
(1.78) \\
(0.93) \\
(1.31) \\
(0.87)\end{array}$ & $\begin{array}{l}88.1 \\
76.3 \\
88.4 \\
88.5 \\
93.4\end{array}$ & $\begin{array}{l}(0.52) \\
(1.80) \\
(0.86) \\
(1.06) \\
(0.76)\end{array}$ & $\begin{array}{l}86.9 \\
75.1 \\
86.1 \\
89.7 \\
92.2\end{array}$ & $\begin{array}{l}(0.54) \\
(1.87) \\
(0.88) \\
(1.04) \\
(0.85)\end{array}$ & $\begin{array}{l}89.7 \\
93.1\end{array}$ & $\begin{array}{l}(0.52) \\
(1.77) \\
(0.80) \\
(1.08) \\
(0.83)\end{array}$ & 871 & $(0.55)$ & $\begin{array}{l}89.1 \\
90.7 \\
93.6\end{array}$ & $\begin{array}{l}(0.55) \\
(2.04) \\
(0.98) \\
(1.02) \\
(0.82)\end{array}$ & & & $\begin{array}{l}86.7 \\
77.1 \\
84.4 \\
87.7 \\
93.5\end{array}$ & & $\begin{array}{l}84.6 \\
73.5 \\
81.7 \\
86.3 \\
91.7\end{array}$ & $\begin{array}{l}(0.41) \\
(1.40) \\
(0.83) \\
(0.73) \\
(0.62)\end{array}$ & $\begin{array}{l}79.1 \\
66.2 \\
73.4 \\
81.4 \\
89.5\end{array}$ & & & & & $\begin{array}{l}(0.51) \\
(1.47) \\
(0.91) \\
(0.90) \\
(0.70)\end{array}$ & $\begin{array}{l}80.1 \\
70.1 \\
76.5 \\
78.2 \\
89.3\end{array}$ & $\begin{array}{l}(0.48) \\
(1.51) \\
(0.90) \\
(0.97) \\
(0.67)\end{array}$ & & $\begin{array}{l}(0.46) \\
(1.32) \\
(0.82) \\
(0.95) \\
(0.57)\end{array}$ \\
\hline 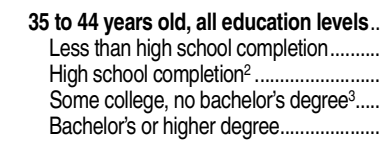 & $\begin{array}{l}90.1 \\
81.6 \\
91.3 \\
93.8 \\
97.0\end{array}$ & $\begin{array}{l}(0.61) \\
(1.48) \\
(0.95) \\
(1.34) \\
(0.77)\end{array}$ & $\begin{array}{l}91.1 \\
80.1 \\
92.3 \\
93.8 \\
97.1\end{array}$ & $\begin{array}{l}(0.55) \\
(1.65) \\
(0.85) \\
(1.13) \\
(0.65)\end{array}$ & $\begin{array}{l}89.1 \\
74.6 \\
88.6 \\
90.2 \\
96.3\end{array}$ & $\begin{array}{l}(0.57) \\
(1.99) \\
(1.00) \\
(1.25) \\
(0.62)\end{array}$ & $\begin{array}{l}90.2 \\
73.9 \\
89.1 \\
92.6 \\
96.3\end{array}$ & $\begin{array}{l}(0.52) \\
(2.13) \\
(0.91) \\
(0.97) \\
(0.59)\end{array}$ & 95.1 & $\begin{array}{l}(0.98) \\
(0.99) \\
(0.66)\end{array}$ & 95.1 & $\begin{array}{l}(0.52) \\
(2.00) \\
(0.93) \\
(0.95) \\
(0.67)\end{array}$ & & $\begin{array}{l}(0.37) \\
(1.26) \\
(0.71) \\
(0.60) \\
(0.45)\end{array}$ & $\begin{array}{l}88.2 \\
76.0 \\
85.0 \\
90.2 \\
95.3\end{array}$ & $\begin{array}{l}(0.32) \\
(1.16) \\
(0.63) \\
(0.66) \\
(0.41)\end{array}$ & $\begin{array}{l}87.1 \\
73.3 \\
83.3 \\
89.0 \\
94.9\end{array}$ & $\begin{array}{l}(0.41) \\
(1.51) \\
(0.76) \\
(0.71) \\
(0.41)\end{array}$ & $\begin{array}{l}82.7 \\
69.4 \\
77.6 \\
83.9 \\
92.3\end{array}$ & & $\begin{array}{l}82.3 \\
69.5 \\
77.6 \\
82.7 \\
91.9\end{array}$ & $\begin{array}{l}(0.42) \\
(1.61) \\
(0.92) \\
(0.73) \\
(0.55)\end{array}$ & $\begin{array}{l}\mathbf{8 2 . 4} \\
70.9 \\
76.8 \\
83.1 \\
91.4\end{array}$ & $\begin{array}{l}(0.43) \\
(1.59) \\
(0.83) \\
(0.86) \\
(0.51)\end{array}$ & $\begin{array}{l}83.3 \\
70.6 \\
78.2 \\
83.9 \\
92.2\end{array}$ & $\begin{array}{l}(0.43) \\
(1.47) \\
(0.97) \\
(0.76) \\
(0.51)\end{array}$ & $\begin{array}{l}84.7 \\
74.8 \\
79.4 \\
84.6 \\
92.9\end{array}$ & $\begin{array}{l}(0.47) \\
(1.38) \\
(0.88) \\
(0.78) \\
(0.48)\end{array}$ \\
\hline $\begin{array}{l}45 \text { to } 54 \text { yee } \\
\text { Less than } \\
\text { High scho } \\
\text { Some coll } \\
\text { Bachelor's }\end{array}$ & $\begin{array}{l}86.6 \\
78.2 \\
90.3 \\
91.0 \\
95.6\end{array}$ & $\begin{array}{l}(0.68) \\
(1.34) \\
(1.01) \\
(1.66) \\
(1.02)\end{array}$ & $\begin{array}{l}87.4 \\
79.6 \\
89.3 \\
89.4 \\
96.0\end{array}$ & $\begin{array}{l}(1.78) \\
(0.88)\end{array}$ & $\begin{array}{l}85.8 \\
73.2 \\
87.3 \\
89.3 \\
94.8\end{array}$ & $\begin{array}{l}(1.76) \\
(1.00)\end{array}$ & $\begin{array}{l}87.1 \\
74.3 \\
87.5 \\
88.9 \\
95.2\end{array}$ & $\begin{array}{l}\mathbf{( 0 . 7 0 )} \\
(2.05) \\
(1.15) \\
(1.58) \\
(0.88)\end{array}$ & 93.8 & $(0.68)$ & $\begin{array}{l}86.4 \\
94.6\end{array}$ & $\begin{array}{l}(0.62) \\
(2.52) \\
(1.21) \\
(1.18) \\
(0.72)\end{array}$ & & $\begin{array}{l}(0.84) \\
(0.53)\end{array}$ & $\begin{array}{l}84.0 \\
67.7 \\
80.5 \\
85.9 \\
92.9\end{array}$ & $\begin{array}{l}(0.43) \\
(1.34) \\
(0.78) \\
(0.82) \\
(0.56)\end{array}$ & $\begin{array}{l}83.7 \\
65.5 \\
80.4 \\
85.6 \\
93.5\end{array}$ & $\begin{array}{l}(0.43) \\
(1.49) \\
(0.81) \\
(0.64) \\
(0.46)\end{array}$ & $\begin{array}{l}78.8 \\
61.4 \\
74.2 \\
80.1 \\
90.2\end{array}$ & $\begin{array}{l}(0.44) \\
(1.50) \\
(0.80) \\
(0.84) \\
(0.58)\end{array}$ & $\begin{array}{l}78.3 \\
58.8 \\
74.6 \\
79.4 \\
89.4\end{array}$ & $\begin{array}{l}(0.50) \\
(1.48) \\
(0.91) \\
(0.80) \\
(0.58)\end{array}$ & $\begin{array}{l}78.9 \\
58.6 \\
75.4 \\
79.2 \\
90.5\end{array}$ & $\begin{array}{l}(0.45) \\
(1.25) \\
(0.78) \\
(0.81) \\
(0.53)\end{array}$ & $\begin{array}{l}79.9 \\
62.5 \\
75.2 \\
81.9 \\
90.2\end{array}$ & $\begin{array}{l}(0.44) \\
(1.45) \\
(0.88) \\
(0.74) \\
(0.60)\end{array}$ & $\begin{array}{l}79.7 \\
61.1 \\
74.2 \\
82.1 \\
90.7\end{array}$ & $\begin{array}{l}(0.38) \\
(1.33) \\
(0.78) \\
(0.69) \\
(0.51)\end{array}$ \\
\hline 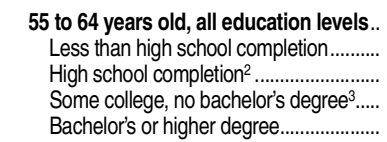 & $\begin{array}{l}71.3 \\
64.5 \\
74.9 \\
80.8 \\
84.1\end{array}$ & $\begin{array}{l}(1.00) \\
(1.51) \\
(1.73) \\
(2.87) \\
(2.52)\end{array}$ & $\begin{array}{l}69.7 \\
58.3 \\
74.6 \\
77.2 \\
83.8\end{array}$ & $\begin{array}{l}(0.98) \\
(1.65) \\
(1.61) \\
(2.53) \\
(2.04)\end{array}$ & $\begin{array}{l}53.4 \\
66.1 \\
67.5 \\
80.7\end{array}$ & $\begin{array}{l}(1.05) \\
(1.85) \\
(1.80) \\
(3.01) \\
(1.98)\end{array}$ & $\begin{array}{l}49.6 \\
66.0 \\
67.7 \\
77.9\end{array}$ & $\begin{array}{l}(1.89) \\
(2.93) \\
(2.03)\end{array}$ & $\begin{array}{l}67.1 \\
74.9\end{array}$ & $\begin{array}{l}(1.99) \\
(2.41) \\
(2.04)\end{array}$ & $\begin{array}{l}61.0 \\
66.6 \\
77.0\end{array}$ & $\begin{array}{l}(1.09) \\
(2.71) \\
(1.97) \\
(2.31) \\
(1.82)\end{array}$ & $\begin{array}{l}61.8 \\
69.6 \\
78.6\end{array}$ & $\begin{array}{l}(1.70) \\
(1.15) \\
(1.31) \\
(0.89)\end{array}$ & $\begin{array}{l}67.5 \\
50.8 \\
61.1 \\
67.8 \\
79.2\end{array}$ & $\begin{array}{l}(0.62) \\
(1.78) \\
(1.23) \\
(1.03) \\
(0.93)\end{array}$ & $\begin{array}{l}68.0 \\
48.3 \\
62.9 \\
67.9 \\
78.6\end{array}$ & $\begin{array}{l}(0.54) \\
(1.60) \\
(1.10) \\
(1.10) \\
(0.81)\end{array}$ & $\begin{array}{l}65.2 \\
44.3 \\
59.3 \\
64.5 \\
77.4\end{array}$ & $\begin{array}{l}(0.59) \\
(1.75) \\
(1.19) \\
(1.06) \\
(0.83)\end{array}$ & $\begin{array}{l}64.4 \\
45.0 \\
58.5 \\
63.9 \\
76.2\end{array}$ & $\begin{array}{l}(0.61) \\
(1.81) \\
(1.12) \\
(1.10) \\
(0.82)\end{array}$ & $\begin{array}{l}64.1 \\
45.2 \\
58.2 \\
63.0 \\
76.3\end{array}$ & $\begin{array}{l}(0.61) \\
(1.68) \\
(1.12) \\
(1.08) \\
(0.84)\end{array}$ & $\begin{array}{l}65.1 \\
44.6 \\
59.1 \\
64.3 \\
77.7\end{array}$ & $\begin{array}{l}(0.58) \\
(1.48) \\
(1.05) \\
(1.11) \\
(0.85)\end{array}$ & $\begin{array}{l}66.0 \\
45.5 \\
61.1 \\
64.9 \\
77.8\end{array}$ & $\begin{array}{l}(0.54) \\
(1.73) \\
(1.04) \\
(1.02) \\
(0.91)\end{array}$ \\
\hline
\end{tabular}

\section{-Not available.}

†Not applicable.
'Data for 16 - to 19 -year-olds and 20- to 24 -year-olds exclude persons enrolled in school.

2Includes equivalency credentials, such as the General Educational Development (GED) credential. Includes persons with no college degree as well as those with an associate's degree.
NOTE: For each age group, the employment to population ratio of males is the number of males in that age group who are employed as a percentage of the male civilian population in that age group. lished annual average data from the Current Population Survey (CPS), selected years, 1975 thmployment Statistics, unpubprepared June 2014.) 
Table 501.70. Employment to population ratios of females 16 to 64 years old, by age group and educational attainment: Selected years, 1975 through 2013

[Standard errors appear in parentheses]

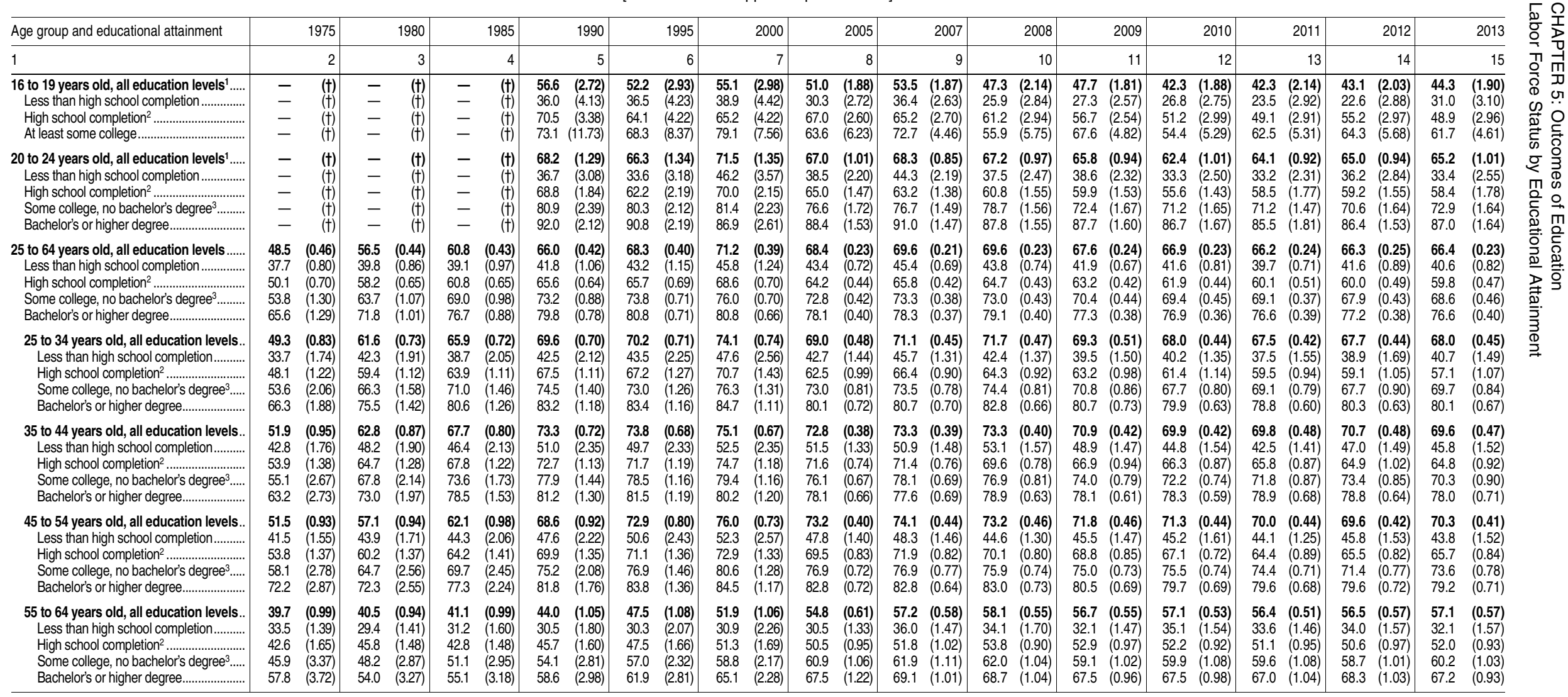

\section{-Not available.}

†Not applicable.
'Data for 16 - to 19 -year-olds and 20 - to 24 -year-olds exclude persons enrolled in school. 2Includes equivalency credentials, such as the General Educational Development (GED) credential. Includes persons with no college degree as well as those with an associate's degree.
NOTE: For each age group, the employment to population ratio of females is the number of females who are employed as a percentage of the female civilian population in that age group.

lished annual average data from the Current Population Survey (CPS), Employment and Unemployment Statistics, unpubprepared June 2014.) 
Table 501.80. Unemployment rates of persons 16 to 64 years old, by age group and educational attainment: Selected years, 1975 through 2013

[Standard errors appear in parentheses]

\begin{tabular}{|c|c|c|c|c|c|c|c|c|c|c|c|c|c|c|c|c|c|c|c|c|c|c|c|c|c|c|c|c|c|c|c|c|}
\hline ge group and educational attainment & & 1975 & & 1980 & & 1985 & & 1990 & & 1995 & & 2000 & & 2003 & & 2005 & & 2006 & & 2007 & & 2008 & & 2009 & & 2010 & & 2011 & & 2012 & & 2013 \\
\hline 1 & & 2 & & 3 & & 4 & & 5 & & & & 7 & & 8 & & $\mathrm{~s}$ & & 10 & & 11 & & 12 & & 13 & & 14 & & 15 & & 16 & & 17 \\
\hline 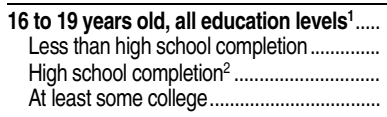 & - & $\begin{array}{c}(+) \\
(+) \\
(+) \\
(t)\end{array}$ & $\begin{array}{l}- \\
- \\
-\end{array}$ & $\begin{array}{l}(+) \\
(+) \\
(+) \\
(t)\end{array}$ & $\begin{array}{l}- \\
- \\
-\end{array}$ & $\begin{array}{l}(t) \\
(+) \\
(t) \\
(t)\end{array}$ & $\begin{array}{l}17.0 \\
26.2 \\
11.7 \\
\ddagger !\end{array}$ & $\begin{array}{r}(1.83) \\
(3.54) \\
(2.05) \\
(+)\end{array}$ & $\begin{array}{l}21.0 \\
30.3 \\
15.1 \\
12.4 !\end{array}$ & $\begin{array}{l}(2.06) \\
(3.67) \\
(2.59) \\
!(5.19)\end{array}$ & $\begin{array}{c}7.2 \\
1.4 \\
5.3 \\
\ddagger !\end{array}$ & $\begin{array}{r}(1.89) \\
(3.23) \\
(2.54) \\
!(t)\end{array}$ & $\begin{array}{l}27.0 \\
34.6 \\
22.4 \\
20.9\end{array}$ & & $\begin{array}{l}22.8 \\
30.3 \\
19.1 \\
15.8\end{array}$ & & $\begin{array}{l}20.6 \\
25.8 \\
17.6 \\
17.7\end{array}$ & & $\begin{array}{r}19.5 \\
28.6 \\
15.1 \\
8.9\end{array}$ & $\begin{array}{l}(1.23) \\
(2.42) \\
(1.59) \\
(2.44)\end{array}$ & $\begin{array}{l}20.9 \\
30.8 \\
17.2 \\
11.3\end{array}$ & & $\begin{array}{l}30.3 \\
38.9 \\
29.1 \\
18.1\end{array}$ & \begin{tabular}{l|}
$(1.58)$ \\
$(3.05)$ \\
$(1.80)$ \\
$(3.68)$
\end{tabular} & $\begin{array}{l}31.9 \\
41.7 \\
29.6 \\
18.1\end{array}$ & & $\begin{array}{l}28.8 \\
35.1 \\
28.9 \\
16.2\end{array}$ & & $\begin{array}{l}28.7 \\
19.6\end{array}$ & & $\begin{array}{r}29.4 \\
36.3 \\
29.2 \\
16.2\end{array}$ & $\begin{array}{l}(1.57) \\
(2.70) \\
(2.12) \\
(3.32)\end{array}$ \\
\hline 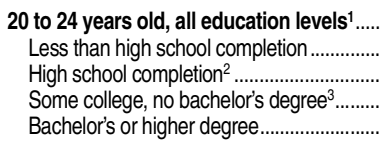 & - & $\begin{array}{c}(t) \\
(t) \\
(t) \\
(t) \\
(t)\end{array}$ & $\begin{array}{l}- \\
- \\
- \\
-\end{array}$ & $\begin{array}{l}(t) \\
(+) \\
(+) \\
(+) \\
(t)\end{array}$ & $\begin{array}{l}- \\
- \\
- \\
-\end{array}$ & $\begin{array}{l}(t) \\
(+) \\
(t) \\
(+) \\
(t)\end{array}$ & $\begin{array}{r}8.2 \\
17.4 \\
7.8 \\
4.8 \\
3.1 !\end{array}$ & $\begin{array}{l}(0.63) \\
(2.15) \\
(0.88) \\
(1.09) \\
!(1.12)\end{array}$ & $\begin{array}{c}10.7 \\
19.5 \\
12.0 \\
7.3 \\
4.1 !\end{array}$ & $\begin{array}{l}(0.72) \\
(2.37) \\
(1.18) \\
(1.13) \\
!(1.26)\end{array}$ & $\begin{array}{r}9.2 \\
16.6 \\
10.0 \\
5.2 \\
5.0\end{array}$ & $\begin{array}{l}(0.70) \\
(2.18) \\
(1.12) \\
(1.02) \\
(1.43)\end{array}$ & $\begin{array}{l}11.4 \\
17.6 \\
11.7\end{array}$ & $\begin{array}{l}(0.55) \\
(1.55) \\
(0.86) \\
(0.97) \\
(1.09)\end{array}$ & $\begin{array}{r}10.9 \\
18.9 \\
12.0 \\
7.3 \\
5.4\end{array}$ & & $\begin{array}{r}9.3 \\
15.7 \\
10.4 \\
7.1 \\
3.9\end{array}$ & & $\begin{array}{r}9.3 \\
18.6 \\
9.4 \\
7.2 \\
3.4\end{array}$ & & $\begin{array}{r}10.7 \\
19.2 \\
13.0 \\
6.8 \\
4.5\end{array}$ & & $\begin{array}{r}17.0 \\
29.0 \\
20.3 \\
12.1 \\
7.9\end{array}$ & & $\begin{array}{r}18.8 \\
32.3 \\
22.3 \\
14.2 \\
7.9\end{array}$ & & $\begin{array}{r}18.1 \\
30.1 \\
21.6 \\
14.0 \\
8.7\end{array}$ & & $\begin{array}{r}15.5 \\
27.6 \\
18.3 \\
12.7 \\
6.0\end{array}$ & & $\begin{array}{r}15.2 \\
29.2 \\
17.5 \\
12.2 \\
7.0\end{array}$ & $\begin{array}{l}(0.62) \\
(2.27) \\
(0.91) \\
(1.02) \\
(1.09)\end{array}$ \\
\hline 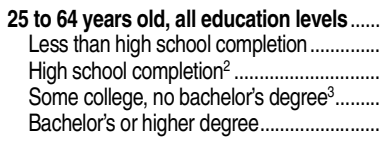 & 6.8 & $\begin{array}{l}(0.21) \\
(0.49) \\
(0.34) \\
(0.50) \\
(0.30)\end{array}$ & $\begin{array}{l}5.0 \\
8.4 \\
5.1 \\
4.3 \\
1.9\end{array}$ & $\begin{array}{l}(0.17) \\
(0.48) \\
(0.27) \\
(0.38) \\
(0.23)\end{array}$ & $\begin{array}{r}6.1 \\
11.4 \\
6.9 \\
4.7 \\
2.4\end{array}$ & $\begin{array}{l}(0.18) \\
(0.61) \\
(0.31) \\
(0.37) \\
(0.24)\end{array}$ & $\begin{array}{l}3.6 \\
7.7 \\
3.8 \\
3.1 \\
1.7\end{array}$ & $\begin{array}{l}(0.14) \\
(0.55) \\
(0.23) \\
(0.29) \\
(0.19)\end{array}$ & $\begin{array}{l}5.2 \\
4.5 \\
2.5\end{array}$ & & $\begin{array}{l}3.3 \\
7.9 \\
3.8 \\
3.0 \\
1.5\end{array}$ & \begin{tabular}{l|}
$(0.13)$ \\
$(0.63)$ \\
$(0.25)$ \\
$(0.24)$ \\
$(0.16)$
\end{tabular} & $\begin{array}{l}5.3 \\
9.9 \\
6.4 \\
5.2 \\
3.0\end{array}$ & $\begin{array}{l}(0.11) \\
(0.48) \\
(0.23) \\
(0.21) \\
(0.15)\end{array}$ & $\begin{array}{l}4.4 \\
9.0 \\
5.5 \\
4.2 \\
2.3\end{array}$ & & $\begin{array}{l}4.1 \\
8.3 \\
4.7 \\
3.9 \\
2.3\end{array}$ & & $\begin{array}{l}3.9 \\
8.5 \\
4.7 \\
3.7 \\
1.8\end{array}$ & & $\begin{array}{r}4.4 \\
10.1 \\
5.8 \\
4.2 \\
2.1\end{array}$ & & $\begin{array}{r}8.1 \\
15.8 \\
10.4 \\
8.0 \\
4.3\end{array}$ & & $\begin{array}{r}9.1 \\
16.8 \\
12.1 \\
8.8 \\
4.7\end{array}$ & & $\begin{array}{r}8.3 \\
16.2 \\
10.9 \\
8.1 \\
4.4\end{array}$ & & $\left.\begin{array}{r}7.4 \\
14.3 \\
9.2 \\
7.9 \\
4.1\end{array}\right\}$ & & $\begin{array}{r}6.6 \\
12.7 \\
8.7 \\
6.5 \\
3.8\end{array}$ & $\begin{array}{l}(0.12) \\
(0.46) \\
(0.27) \\
(0.21) \\
(0.13)\end{array}$ \\
\hline $\begin{array}{c}25 \text { to } 34 \\
\text { Less } \\
\text { High } \\
\text { Some } \\
\text { Bache }\end{array}$ & 8.6 & $\begin{array}{l}(0.41) \\
(1.36) \\
(0.67) \\
(0.85) \\
(0.50)\end{array}$ & $\begin{array}{r}6.8 \\
13.7 \\
7.9 \\
6.0 \\
2.5\end{array}$ & $\begin{array}{l}(0.32) \\
(1.24) \\
(0.55) \\
(0.64) \\
(0.39)\end{array}$ & $\begin{array}{r}7.3 \\
15.5 \\
9.1 \\
5.4 \\
2.8\end{array}$ & $\begin{array}{l}(0.33) \\
(1.38) \\
(0.57) \\
(0.60) \\
(0.41)\end{array}$ & $\begin{array}{r}4.8 \\
12.0 \\
5.1 \\
3.8 \\
1.9\end{array}$ & $\begin{array}{l}(0.27) \\
(1.21) \\
(0.44) \\
(0.51) \\
(0.34)\end{array}$ & $\begin{array}{r}5.8 \\
12.9 \\
6.8 \\
5.0 \\
2.7\end{array}$ & & $\begin{array}{r}4.0 \\
10.3 \\
4.8 \\
3.6 \\
1.6\end{array}$ & $\begin{array}{l}(0.27) \\
(1.33) \\
(0.54) \\
(0.49) \\
(0.31)\end{array}$ & $\begin{array}{r}6.3 \\
12.4 \\
8.0 \\
5.8 \\
3.1\end{array}$ & $\begin{array}{l}(0.24) \\
(0.96) \\
(0.50) \\
(0.43) \\
(0.30)\end{array}$ & $\begin{array}{r}5.8 \\
11.6 \\
7.7 \\
5.4 \\
2.6\end{array}$ & & $\begin{array}{r}5.5 \\
11.0 \\
6.5 \\
5.3 \\
2.8\end{array}$ & & $\begin{array}{r}4.9 \\
10.3 \\
6.2 \\
4.6 \\
2.2\end{array}$ & & $\begin{array}{r}5.9 \\
14.2 \\
8.5 \\
5.0 \\
2.2\end{array}$ & & $\begin{array}{r}10.1 \\
19.9 \\
14.1 \\
9.8 \\
4.5\end{array}$ & & $\begin{array}{r}10.8 \\
20.3 \\
15.9 \\
10.6 \\
4.5\end{array}$ & & $\begin{array}{r}10.0 \\
19.7 \\
14.3 \\
10.1 \\
4.3\end{array}$ & & $\begin{array}{r}9.2 \\
16.8 \\
12.8 \\
10.1 \\
4.1\end{array}$ & & $\begin{array}{r}8.0 \\
15.1 \\
12.1 \\
8.0 \\
3.6\end{array}$ & $\begin{array}{l}(0.23) \\
(0.97) \\
(0.57) \\
(0.42)\end{array}$ \\
\hline $\begin{array}{l}35 \text { to } 44 \text { ye } \\
\text { Less thar } \\
\text { High sch } \\
\text { Some co } \\
\text { Bachelor }\end{array}$ & $\begin{array}{r}6.4 \\
11.2\end{array}$ & $\begin{array}{l}(0.41) \\
(1.02) \\
(0.60) \\
(0.95) \\
(0.59)\end{array}$ & $\begin{array}{l}4.3 \\
9.0 \\
4.2 \\
3.1 \\
1.6\end{array}$ & $\begin{array}{l}(0.31) \\
(1.00) \\
(0.48) \\
(0.64) \\
(0.41)\end{array}$ & $\begin{array}{r}5.6 \\
12.4 \\
6.1 \\
4.8 \\
2.2\end{array}$ & $\begin{array}{l}(0.33) \\
(1.29) \\
(0.55) \\
(0.69) \\
(0.39)\end{array}$ & $\begin{array}{l}3.3 \\
8.3 \\
3.7 \\
2.8 \\
1.6\end{array}$ & $\begin{array}{l}(0.24) \\
(1.17) \\
(0.41) \\
(0.47) \\
(0.31)\end{array}$ & $\begin{array}{r}4.6 \\
10.5 \\
5.1 \\
4.7 \\
2.2\end{array}$ & $\begin{array}{l}(0.27) \\
(1.28) \\
(0.48) \\
(0.49) \\
(0.34)\end{array}$ & $\begin{array}{l}3.5 \\
8.4 \\
3.9 \\
3.1 \\
1.8\end{array}$ & $\begin{array}{l}(0.23) \\
(1.14) \\
(0.43) \\
(0.41) \\
(0.31)\end{array}$ & $\begin{array}{r}10.2 \\
67\end{array}$ & $\begin{array}{l}(0.86) \\
(0.41) \\
(0.38) \\
(0.28)\end{array}$ & $\begin{array}{l}4.2 \\
8.7 \\
5.2 \\
3.9 \\
2.0\end{array}$ & & & & $\begin{array}{l}9.3 \\
4.8 \\
3.0 \\
1.5\end{array}$ & & $\begin{array}{l}9.1 \\
6.0 \\
3.8 \\
1.9\end{array}$ & & $\begin{array}{r}7.9 \\
15.3 \\
10.6 \\
7.2 \\
4.2\end{array}$ & & $\begin{array}{r}9.2 \\
17.8 \\
11.9 \\
9.2 \\
4.6\end{array}$ & & $\begin{array}{r}8.2 \\
15.9 \\
11.3 \\
7.5 \\
4.6\end{array}$ & & $\left.\begin{array}{r}7.1 \\
14.1 \\
9.1 \\
7.4 \\
3.6\end{array}\right\}$ & $\begin{array}{l}(0.22) \\
(0.88) \\
(0.48) \\
(0.44) \\
(0.26)\end{array}$ & $\begin{array}{r}6.4 \\
11.5 \\
8.5 \\
6.7 \\
3.6\end{array}$ & $\begin{array}{l}(0.40) \\
(0.23)\end{array}$ \\
\hline $\begin{array}{l}45 \text { to } 54 \text { years old, } \\
\text { Less than high scl } \\
\text { High school comp } \\
\text { Some college, no } \\
\text { Bachelor's or high }\end{array}$ & & $\begin{array}{r}(0.39) \\
(0.81) \\
(0.60) \\
(1.00) \\
!(0.61)\end{array}$ & $\begin{array}{l}3.9 \\
6.6 \\
3.4 \\
3.0 \\
1.3 !\end{array}$ & $\begin{array}{l}(0.32) \\
(0.78) \\
(0.48) \\
(0.78) \\
(0.44)\end{array}$ & $\begin{array}{r}5.4 \\
10.2 \\
5.4 \\
3.2 \\
2.1\end{array}$ & $\begin{array}{l}(0.39) \\
(1.16) \\
(0.60) \\
(0.79) \\
(0.54)\end{array}$ & $\begin{array}{l}2.5 \\
4.7 \\
2.3 \\
2.6 \\
1.4\end{array}$ & $\begin{array}{l}(0.26) \\
(0.89) \\
(0.39) \\
(0.62) \\
(0.38)\end{array}$ & $\begin{array}{l}3.9 \\
7.9 \\
4.0 \\
3.9 \\
2.4\end{array}$ & $\begin{array}{l}(0.29) \\
(1.24) \\
(0.53) \\
(0.56) \\
(0.41)\end{array}$ & $\begin{array}{l}2.4 \\
6.1 \\
2.7 \\
2.4 \\
1.3\end{array}$ & $\begin{array}{l}(0.22) \\
(1.16) \\
(0.42) \\
(0.40) \\
(0.28)\end{array}$ & $\begin{array}{l}4.8 \\
8.4 \\
5.6 \\
5.1 \\
2.9\end{array}$ & $\begin{array}{l}(0.21) \\
(0.93) \\
(0.41) \\
(0.40) \\
(0.28)\end{array}$ & $\begin{array}{l}3.9 \\
7.0 \\
4.6 \\
3.7 \\
2.5\end{array}$ & $\begin{array}{l}(0.16) \\
(0.66) \\
(0.33) \\
(0.30) \\
(0.26)\end{array}$ & & & $\begin{array}{l}3.5 \\
7.3 \\
4.0 \\
3.7 \\
1.8\end{array}$ & $\begin{array}{l}(0.17) \\
(0.71) \\
(0.31) \\
(0.33) \\
(0.18)\end{array}$ & $\begin{array}{l}3.9 \\
8.9 \\
4.7 \\
4.0 \\
1.9\end{array}$ & & $\begin{array}{r}7.4 \\
13.6 \\
8.8 \\
7.5 \\
4.3\end{array}$ & & $\begin{array}{r}8.4 \\
15.6 \\
11.0 \\
7.6 \\
4.8\end{array}$ & & $\begin{array}{r}7.5 \\
16.3 \\
9.3 \\
7.1 \\
4.0\end{array}$ & & $\begin{array}{r}6.8 \\
13.5 \\
7.8 \\
6.9 \\
3.9\end{array}$ & $\begin{array}{l}(0.18) \\
(0.92) \\
(0.36) \\
(0.36) \\
(0.27)\end{array}$ & $\begin{array}{r}6.0 \\
12.3 \\
7.8\end{array}$ & $(0.18)$ \\
\hline 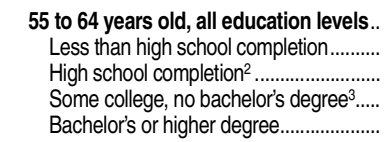 & & $\begin{array}{r}(0.46) \\
(0.79) \\
(0.76) \\
!(1.26) \\
!(0.75)\end{array}$ & $\begin{array}{l}5.2 \\
2.7 \\
2.0 ! \\
\ddagger !\end{array}$ & $\begin{array}{r}(0.35) \\
(0.77) \\
(0.51) \\
(0.77) \\
(\dagger)\end{array}$ & $\begin{array}{l}4.6 \\
7.1 \\
4.5 \\
3.0 ! \\
2.2 !\end{array}$ & $\begin{array}{l}(0.44) \\
(1.01) \\
(0.69) \\
(1.00) \\
(0.70)\end{array}$ & $\begin{array}{l}2.8 \\
3.9 \\
3.0 \\
2.2 ! \\
1.8 !\end{array}$ & $\begin{array}{l}(0.36) \\
(0.90) \\
(0.59) \\
(0.82) \\
(0.62)\end{array}$ & $\begin{array}{l}3.9 \\
6.7 \\
3.4 \\
3.2 \\
3.3\end{array}$ & $\begin{array}{l}(0.65) \\
(0.80) \\
(0.79)\end{array}$ & $\begin{array}{l}5.2 \\
3.1 \\
2.8 \\
1.4 !\end{array}$ & $\left.\begin{array}{r}(1.28) \\
(0.62) \\
(0.70) \\
!(0.46)\end{array}\right]$ & $\begin{array}{l}6.5 \\
4.5 \\
4.4 \\
3.1\end{array}$ & $\begin{array}{l}(0.27) \\
(1.02) \\
(0.50) \\
(0.54) \\
(0.41)\end{array}$ & $\begin{array}{l}7.5 \\
4.3 \\
3.5 \\
2.3\end{array}$ & & $\begin{array}{l}6.0 \\
2.9 \\
3.1 \\
2.0\end{array}$ & $\begin{array}{l}(0.82) \\
(0.35) \\
(0.34) \\
(0.22)\end{array}$ & $\begin{array}{l}5.3 \\
3.7 \\
3.5 \\
1.8\end{array}$ & $\begin{array}{l}(0.72) \\
(0.38) \\
(0.39) \\
(0.22)\end{array}$ & $\begin{array}{l}3.3 \\
5.6 \\
3.4 \\
3.7 \\
2.4\end{array}$ & & $\begin{array}{r}6.7 \\
12.7 \\
7.8 \\
7.0 \\
4.3\end{array}$ & $\begin{array}{l}(0.25) \\
(1.25) \\
(0.50) \\
(0.50) \\
(0.33)\end{array}$ & $\begin{array}{r}7.3 \\
10.1 \\
9.3 \\
7.7 \\
5.0\end{array}$ & & $\begin{array}{r}10.0 \\
8.4 \\
7.3 \\
4.9\end{array}$ & $\begin{array}{l}(1.02) \\
(0.58) \\
(0.45) \\
(0.35)\end{array}$ & $\begin{array}{r}11.5 \\
7.1 \\
7.1 \\
4.8\end{array}$ & $\begin{array}{l}(0.23) \\
(1.05) \\
(0.50) \\
(0.44) \\
(0.38)\end{array}$ & $\begin{array}{l}.2 \\
4\end{array}$ & $\begin{array}{l}(1.19) \\
(0.47) \\
(0.40) \\
(0.29)\end{array}$ \\
\hline
\end{tabular}

\section{-Not available.}

TNot applicable.
!nterpret data with caution. The coefficient of variation (CV) for this estimate is between 30 and 50 percent. †Reporting standards not met. The coefficient of variation (CV) for this estimate is 50 percent or greater. 'Data for 16- to 19-year-olds and 20- to 24-year-olds exclude persons enrolled in school. ${ }^{2}$ Includes equivalency credentials, such as the General Educational Development (GED) credential. 3Includes persons with no college degree as well as those with an associate's degree.
NOTE: The unemployment rate is the percentage of persons in the civilian labor force who are not working and who made specific efforts to find employment sometime during the prior 4 weeks. The civilian labor force consists of all civilians who are employed or seeking employment. Some data have been revised from previously published figures.

lished annual average data from the Current Population Survey (CPS), selected years, 1975 through 2013 . (This thenpubprepared November 2013.) 
Table 501.85. Unemployment rates of males 16 to 64 years old, by age group and educational attainment: Selected years, 1975 through 2013

[Standard errors appear in parentheses]

\begin{tabular}{|c|c|c|c|c|c|c|c|c|c|c|c|c|c|c|c|c|c|c|c|c|c|c|c|c|c|c|c|c|c|c|c|c|}
\hline e group and educational attainment & & 1975 & & 1980 & & 1985 & & 1990 & & 1995 & & 2000 & & 2003 & & 2005 & & 2006 & & 2007 & & 2008 & & 2009 & & 2010 & & 2011 & & 2012 & & 2013 \\
\hline 1 & & 2 & & 3 & & 4 & & 5 & & 6 & & 7 & & 8 & & 9 & & 10 & & 11 & & 12 & & 13 & & 14 & & 15 & & 16 & & 17 \\
\hline 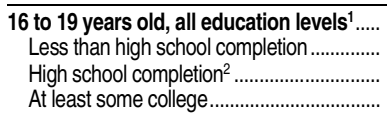 & $\begin{array}{l}- \\
- \\
- \\
-\end{array}$ & $\begin{array}{l}(t) \\
(+) \\
(+) \\
(t)\end{array}$ & $\begin{array}{l}- \\
- \\
-\end{array}$ & $\begin{array}{l}(\dagger) \\
(\dagger) \\
(\dagger) \\
(\dagger)\end{array}$ & $\begin{array}{l}- \\
- \\
-\end{array}$ & $\begin{array}{l}(\dagger) \\
(\dagger) \\
(\dagger) \\
(\dagger)\end{array}$ & $\begin{array}{c}18.9 \\
27.9 \\
12.1 \\
\ddagger !\end{array}$ & $\begin{array}{r}(2.58) \\
(4.45) \\
(2.96) \\
! \quad(\dagger)\end{array}$ & $\begin{array}{r}21.3 \\
30.6 \\
14.4 \\
\ddagger !\end{array}$ & $\begin{array}{r}(2.71) \\
(4.60) \\
(3.38) \\
! \quad(+)\end{array}$ & $\begin{array}{c}16.0 \\
17.6 \\
15.0 \\
\ddagger !\end{array}$ & $\begin{array}{r}(2.36) \\
(3.69) \\
(3.30) \\
!(\dagger)\end{array}$ & $\begin{array}{l}30.0 \\
36.3 \\
26.2 \\
18.9 !\end{array}$ & $\begin{array}{l}(2.31) \\
(3.72) \\
(3.13) \\
(7.39)\end{array}$ & $\begin{array}{l}25.2 \\
29.9 \\
23.4 \\
12.7 !\end{array}$ & $\begin{array}{l}(1.83) \\
(2.88) \\
(2.77) \\
(4.34)\end{array}$ & $\begin{array}{l}22.0 \\
26.1 \\
19.8 \\
15.4 !\end{array}$ & $\begin{array}{l}(1.63) \\
(2.92) \\
(2.08) \\
(5.16)\end{array}$ & $\begin{array}{l}20.7 \\
25.6 \\
18.9 \\
10.2 !\end{array}$ & $\begin{array}{l}(1.62) \\
(2.92) \\
(2.28) \\
!(3.57)\end{array}$ & $\begin{array}{c}22.3 \\
30.7 \\
18.9 \\
9.1 !\end{array}$ & $\begin{array}{l}(1.79) \\
(2.87) \\
(2.43) \\
!(3.09)\end{array}$ & $\begin{array}{l}35.1 \\
41.2 \\
34.4 \\
22.4\end{array}$ & $\begin{array}{l}(2.08) \\
(3.89) \\
(2.46) \\
(5.43)\end{array}$ & $\begin{array}{l}35.6 \\
44.7 \\
33.0 \\
19.0\end{array}$ & $\begin{array}{l}(2.07) \\
(4.07) \\
(2.59) \\
(5.64)\end{array}$ & $\begin{array}{l}31.2 \\
32.0 \\
32.7 \\
21.4\end{array}$ & $\begin{array}{l}(2.10) \\
(4.05) \\
(2.96) \\
(5.91)\end{array}$ & $\begin{array}{l}31.4 \\
37.1 \\
31.8 \\
20.2\end{array}$ & $\begin{array}{l}(2.05) \\
(3.82) \\
(2.68) \\
(5.03)\end{array}$ & $\begin{array}{l}29.7 \\
36.1 \\
28.8 \\
17.5\end{array}$ & $\begin{array}{l}(2.00) \\
(3.57) \\
(2.70) \\
(4.79)\end{array}$ \\
\hline $\begin{array}{l}\text { l education levels }{ }^{1} \ldots . . . \\
\text { ol completion } \\
\text { tion }\end{array}$ & $\begin{array}{l}- \\
\overline{-} \\
- \\
-\end{array}$ & $\begin{array}{l}(t) \\
(t) \\
(t) \\
(t) \\
(t)\end{array}$ & $\begin{array}{l}- \\
- \\
- \\
-\end{array}$ & $\begin{array}{l}(t) \\
(\dagger) \\
(t) \\
(t) \\
(t)\end{array}$ & $\begin{array}{l}- \\
- \\
- \\
-\end{array}$ & $\begin{array}{l}(t) \\
(\dagger) \\
(t) \\
(t) \\
(t)\end{array}$ & $\begin{array}{r}8.4 \\
16.9 \\
7.4 \\
4.6 ! \\
\ddagger !\end{array}$ & $\begin{array}{r}(0.86) \\
(2.53) \\
(1.15) \\
!(1.54) \\
! \quad(\dagger)\end{array}$ & \begin{tabular}{|l}
11.1 \\
17.4 \\
11.6 \\
8.0 \\
$5.6 !$
\end{tabular} & $\begin{array}{l}(0.97) \\
(2.68) \\
(1.48) \\
(1.65) \\
!(2.22)\end{array}$ & $\begin{array}{r}9.4 \\
16.5 \\
9.6 \\
4.8 \\
5.5 !\end{array}$ & $\begin{array}{l}(0.94) \\
(2.61) \\
(1.45) \\
(1.36) \\
!(2.32)\end{array}$ & $\begin{array}{r}11.8 \\
15.6 \\
11.9 \\
9.7 \\
9.1\end{array}$ & $\begin{array}{l}(0.73) \\
(1.78) \\
(1.09) \\
(1.33) \\
(2.10)\end{array}$ & $\begin{array}{r}11.4 \\
16.1 \\
12.4 \\
7.8 \\
6.8\end{array}$ & $\begin{array}{l}(0.61) \\
(1.37) \\
(0.97) \\
(1.04) \\
(1.54)\end{array}$ & $\begin{array}{c}9.9 \\
14.5 \\
10.7 \\
7.5 \\
4.0 !\end{array}$ & $\begin{array}{l}(0.60) \\
(1.61) \\
(0.98) \\
(0.96) \\
(1.23)\end{array}$ & $\begin{array}{c}9.8 \\
17.6 \\
10.0 \\
7.3 \\
2.7 !\end{array}$ & & $\begin{array}{r}11.5 \\
18.2 \\
13.3 \\
7.1 \\
4.7\end{array}$ & $\begin{array}{l}(0.58) \\
(1.89) \\
(0.85) \\
(0.97) \\
(1.19)\end{array}$ & $\begin{array}{l}19.8 \\
29.2 \\
22.7 \\
13.7 \\
10.1\end{array}$ & & $\begin{array}{r}21.4 \\
32.4 \\
23.7 \\
16.4 \\
9.8\end{array}$ & $\begin{array}{l}(0.88) \\
(2.20) \\
(1.25) \\
(1.58) \\
(1.82)\end{array}$ & $\begin{array}{l}19.7 \\
27.0 \\
22.9 \\
15.2 \\
10.8\end{array}$ & $\begin{array}{l}(0.81) \\
(2.23) \\
(1.31) \\
(1.46) \\
(1.82)\end{array}$ & $\begin{array}{r}16.6 \\
27.8 \\
19.0 \\
12.0 \\
6.6\end{array}$ & & $\begin{array}{r}16.5 \\
26.4 \\
19.0 \\
12.8 \\
8.5\end{array}$ & $\begin{array}{l}(0.80) \\
(2.72) \\
(1.24) \\
(1.36) \\
(1.89)\end{array}$ \\
\hline 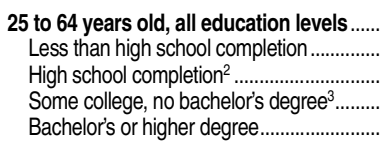 & $\begin{array}{r}6.5 \\
10.3 \\
6.6 \\
5.0 \\
2.1\end{array}$ & $\begin{array}{l}(0.26) \\
(0.59) \\
(0.43) \\
(0.59) \\
(0.34)\end{array}$ & $\left.\begin{array}{l}4.9 \\
8.2 \\
5.3 \\
4.4 \\
1.7\end{array}\right\}$ & $\begin{array}{l}(0.22) \\
(0.58) \\
(0.37) \\
(0.49) \\
(0.26)\end{array}$ & $\begin{array}{r}6.1 \\
11.2 \\
7.2 \\
4.5 \\
2.4\end{array}$ & $\begin{array}{l}(0.24) \\
(0.76) \\
(0.43) \\
(0.49) \\
(0.30)\end{array}$ & $\begin{array}{l}3.6 \\
7.3 \\
3.8 \\
3.0 \\
1.8\end{array}$ & $\begin{array}{l}(0.19) \\
(0.68) \\
(0.32) \\
(0.38) \\
(0.25)\end{array}$ & $\begin{array}{r}5.1 \\
10.9 \\
5.7 \\
4.4 \\
2.6\end{array}$ & $\begin{array}{l}(0.21) \\
(0.86) \\
(0.40) \\
(0.39) \\
(0.28)\end{array}$ & $\begin{array}{l}3.3 \\
7.1 \\
3.9 \\
3.1 \\
1.6\end{array}$ & $\begin{array}{l}(0.18) \\
(0.75) \\
(0.34) \\
(0.34) \\
(0.22)\end{array}$ & $\begin{array}{l}5.8 \\
9.5 \\
6.9 \\
6.0 \\
3.2\end{array}$ & $\begin{array}{l}(0.16) \\
(0.58) \\
(0.32) \\
(0.32) \\
(0.21)\end{array}$ & $\begin{array}{l}4.7 \\
7.9 \\
6.0 \\
4.3 \\
2.5\end{array}$ & & $\begin{array}{l}4.3 \\
7.6 \\
5.0 \\
4.2 \\
2.4\end{array}$ & $\begin{array}{l}(0.12) \\
(0.51) \\
(0.23) \\
(0.25) \\
(0.15)\end{array}$ & $\begin{array}{l}4.3 \\
8.4 \\
5.5 \\
3.9 \\
1.9\end{array}$ & & $\begin{array}{r}4.9 \\
10.9 \\
6.3 \\
4.2 \\
2.0\end{array}$ & & $\begin{array}{r}9.5 \\
16.5 \\
12.4 \\
9.3 \\
4.7\end{array}$ & & $\begin{array}{r}10.5 \\
17.8 \\
13.8 \\
10.2 \\
5.1\end{array}$ & & $\begin{array}{r}9.2 \\
16.7 \\
12.2 \\
8.7 \\
4.6\end{array}$ & $\begin{array}{l}(0.18) \\
(0.70) \\
(0.38) \\
(0.33) \\
(0.20)\end{array}$ & $\begin{array}{r}8.0 \\
13.6 \\
10.1\end{array}$ & & $\begin{array}{r}6.9 \\
11.9 \\
9.2 \\
6.5 \\
3.7\end{array}$ & $\begin{array}{l}(0.16) \\
(0.58) \\
(0.37) \\
(0.30) \\
(0.18)\end{array}$ \\
\hline $\begin{array}{c}25 \text { to } 34 \\
\text { Less th } \\
\text { High s } \\
\text { Some } \\
\text { Bachel }\end{array}$ & $\begin{array}{r}8.3 \\
17.3 \\
9.0 \\
6.6 \\
2.6\end{array}$ & $\begin{array}{l}(0.50) \\
(1.65) \\
(0.85) \\
(1.03) \\
(0.57)\end{array}$ & $\left.\begin{array}{r}6.8 \\
13.4 \\
8.2 \\
6.0 \\
2.4\end{array}\right\}$ & $\begin{array}{l}(0.41) \\
(1.53) \\
(0.75) \\
(0.81) \\
(0.48)\end{array}$ & $\begin{array}{r}7.3 \\
13.9 \\
9.5 \\
4.9 \\
2.8\end{array}$ & $\begin{array}{l}\mathbf{( 0 . 4 3 )} \\
(1.60) \\
(0.77) \\
(0.76) \\
(0.54)\end{array}$ & $\begin{array}{r}4.5 \\
10.3 \\
4.6 \\
3.6 \\
1.9\end{array}$ & $\begin{array}{l}(0.35) \\
(1.36) \\
(0.55) \\
(0.68) \\
(0.46)\end{array}$ & $\begin{array}{r}5.9 \\
12.5 \\
6.6 \\
4.6 \\
2.8\end{array}$ & $\begin{array}{l}(0.40) \\
(1.57) \\
(0.72) \\
(0.70) \\
(0.55)\end{array}$ & $\begin{array}{l}4.2 \\
8.8 \\
4.9 \\
3.8 \\
1.8\end{array}$ & $\begin{array}{l}(0.37) \\
(1.51) \\
(0.70) \\
(0.69) \\
(0.46)\end{array}$ & $\begin{array}{r}6.5 \\
10.7 \\
7.8 \\
6.3 \\
3.3\end{array}$ & & $\begin{array}{l}6.0 \\
9.7 \\
7.8 \\
5.6 \\
2.7\end{array}$ & $\begin{array}{l}(0.27) \\
(0.84) \\
(0.52) \\
(0.57) \\
(0.36)\end{array}$ & $\begin{array}{l}5.5 \\
8.7 \\
6.4 \\
5.6 \\
2.8\end{array}$ & & $\begin{array}{l}5.3 \\
9.9 \\
6.4 \\
4.9 \\
2.4\end{array}$ & & $\begin{array}{r}6.5 \\
14.8 \\
8.5 \\
5.0 \\
2.1\end{array}$ & & $\begin{array}{r}11.9 \\
19.2 \\
16.1 \\
11.3 \\
5.1\end{array}$ & & \begin{tabular}{r|}
12.6 \\
20.7 \\
17.8 \\
11.8 \\
4.8
\end{tabular} & & $\begin{array}{r}11.3 \\
19.2 \\
15.2 \\
11.2 \\
4.5\end{array}$ & $\begin{array}{l}(0.38) \\
(1.30) \\
(0.74)\end{array}$ & $\begin{array}{r}10.0 \\
14.3 \\
13.5 \\
11.1 \\
4.2\end{array}$ & & $\begin{array}{r}8.4 \\
13.2 \\
11.8 \\
8.5 \\
3.9\end{array}$ & $\begin{array}{l}(0.31) \\
(1.19) \\
(0.69) \\
(0.63) \\
(0.40)\end{array}$ \\
\hline $\begin{array}{l}35 \text { to } 44 \text { years old, all education levels.. } \\
\text { Less than high school completion.......... } \\
\text { High school completion }{ }^{2} \ldots \ldots \ldots \ldots \ldots \ldots \ldots . \\
\text { Some college, no bachelor's degree }{ }^{3} . . . . \\
\text { Bachelor's or higher degree..................... }\end{array}$ & $\begin{array}{c}6.0 \\
10.8 \\
5.8 \\
3.3 ! \\
1.9 !\end{array}$ & $\begin{array}{l}(0.50) \\
(1.24) \\
(0.80) \\
(1.01) \\
(0.61)\end{array}$ & $\left.\begin{array}{l}4.1 \\
8.4 \\
4.2 \\
2.9 \\
1.3 !\end{array}\right\}$ & $\begin{array}{l}(0.39) \\
(1.22) \\
(0.65) \\
(0.81) \\
(0.44)\end{array}$ & $\begin{array}{r}5.7 \\
12.3 \\
6.5 \\
5.3 \\
2.2\end{array}$ & $\begin{array}{l}(0.44) \\
(1.63) \\
(0.79) \\
(0.96) \\
(0.49)\end{array}$ & $\begin{array}{l}3.2 \\
7.9 \\
3.4 \\
2.8 \\
1.7\end{array}$ & $\begin{array}{l}(0.32) \\
(1.46) \\
(0.56) \\
(0.63) \\
(0.41)\end{array}$ & $\begin{array}{r}4.9 \\
11.8 \\
5.6 \\
4.8 \\
2.0\end{array}$ & $\begin{array}{l}(0.37) \\
(1.69) \\
(0.68) \\
(0.69) \\
(0.43)\end{array}$ & $\begin{array}{l}3.4 \\
6.3 \\
4.2 \\
2.9 \\
1.7\end{array}$ & $\begin{array}{l}(0.31) \\
(1.27) \\
(0.58) \\
(0.56) \\
(0.42)\end{array}$ & $\begin{array}{l}6.0 \\
9.7 \\
7.3 \\
5.7 \\
3.3\end{array}$ & $\begin{array}{l}(0.29) \\
(1.04) \\
(0.56) \\
(0.57) \\
(0.40)\end{array}$ & $\begin{array}{l}4.4 \\
7.8 \\
5.7 \\
4.1 \\
2.1\end{array}$ & $\begin{array}{l}(0.20) \\
(0.76) \\
(0.46) \\
(0.38) \\
(0.27)\end{array}$ & $\begin{array}{l}4.2 \\
8.5 \\
5.0 \\
3.8 \\
1.9\end{array}$ & $\begin{array}{l}(0.25) \\
(0.97) \\
(0.43) \\
(0.43) \\
(0.27)\end{array}$ & $\begin{array}{l}4.0 \\
8.8 \\
5.5 \\
3.1 \\
1.4\end{array}$ & $\begin{array}{l}(0.21) \\
(0.93) \\
(0.41) \\
(0.42) \\
(0.20)\end{array}$ & $\begin{array}{l}4.7 \\
9.9 \\
6.4 \\
4.1 \\
1.7\end{array}$ & $\begin{array}{l}(0.24) \\
(1.05) \\
(0.45) \\
(0.43) \\
(0.24)\end{array}$ & $\begin{array}{r}9.2 \\
16.5 \\
12.2 \\
8.3 \\
4.6\end{array}$ & & $\begin{array}{r}10.1 \\
18.4 \\
12.9 \\
9.9 \\
4.6\end{array}$ & $\begin{array}{l}(0.33) \\
(1.42) \\
(0.71) \\
(0.63) \\
(0.38)\end{array}$ & $\begin{array}{r}8.9 \\
15.8 \\
12.4 \\
7.4 \\
4.7\end{array}$ & $\begin{array}{l}(0.32) \\
(1.34) \\
(0.66) \\
(0.60) \\
(0.39)\end{array}$ & $\left.\begin{array}{r}7.6 \\
13.5 \\
9.7 \\
7.4 \\
4.1\end{array}\right\}$ & & $\begin{array}{r}6.3 \\
10.3 \\
8.8 \\
6.1 \\
3.1\end{array}$ & $\begin{array}{l}(0.29) \\
(0.97) \\
(0.63) \\
(0.58) \\
(0.33)\end{array}$ \\
\hline $\begin{array}{l}45 \text { to } 54 \text { years old, all education levels.. } \\
\text { Less than high school completion......... } \\
\text { High school completion }{ }^{2} . \ldots \ldots \ldots \ldots \ldots \ldots \ldots . . . \\
\text { Some college, no bachelor's degree }{ }^{3} \text {..... } \\
\text { Bachelor's or higher degree.................. }\end{array}$ & & $\begin{array}{l}(0.48) \\
(0.97) \\
(0.76) \\
(1.21) \\
(0.67)\end{array}$ & $\left.\begin{array}{l}3.7 \\
6.1 \\
3.3 \\
3.5 ! \\
1.1 !\end{array}\right\}$ & $\begin{array}{l}(0.40) \\
(0.92) \\
(0.64)\end{array}$ & $\begin{array}{r}5.4 \\
10.9 \\
5.5 \\
2.6 ! \\
2.0 !\end{array}$ & $\begin{array}{l}(0.51) \\
(1.48) \\
(0.84) \\
!(0.94) \\
!(0.63)\end{array}$ & $\begin{array}{l}2.7 \\
4.7 \\
2.8 \\
2.5 ! \\
1.4 !\end{array}$ & $\begin{array}{l}(0.36) \\
(1.12) \\
(0.61) \\
!(0.82) \\
!(0.49)\end{array}$ & $\begin{array}{l}4.6 \\
9.4 \\
5.5 \\
4.0 \\
2.7\end{array}$ & $\begin{array}{l}(0.42) \\
(1.74) \\
(0.87) \\
(0.79) \\
(0.55)\end{array}$ & $\begin{array}{l}2.5 \\
6.9 \\
2.4 \\
2.6 \\
1.3\end{array}$ & $\begin{array}{l}(0.30) \\
(1.60) \\
(0.55) \\
(0.58) \\
(0.38)\end{array}$ & $\begin{array}{l}5.1 \\
7.8 \\
6.2 \\
5.7 \\
3.1\end{array}$ & $\begin{array}{l}(0.29) \\
(1.13) \\
(0.59) \\
(0.59) \\
(0.39)\end{array}$ & $\begin{array}{l}4.1 \\
6.3 \\
5.1 \\
3.8 \\
2.7\end{array}$ & $\begin{array}{l}(0.25) \\
(0.81) \\
(0.51) \\
(0.47) \\
(0.38)\end{array}$ & $\begin{array}{l}3.8 \\
5.9 \\
4.4 \\
3.7 \\
2.7\end{array}$ & $\begin{array}{l}(0.21) \\
(0.97) \\
(0.42) \\
(0.39) \\
(0.31)\end{array}$ & $\begin{array}{l}3.9 \\
7.9 \\
4.9 \\
3.7 \\
1.9\end{array}$ & $\begin{array}{l}(0.26) \\
(0.95) \\
(0.47) \\
(0.52) \\
(0.28)\end{array}$ & $\begin{array}{l}4.3 \\
9.7 \\
5.4 \\
3.9 \\
1.9\end{array}$ & $\begin{array}{l}(0.23) \\
(0.97) \\
(0.47) \\
(0.45) \\
(0.28)\end{array}$ & $\begin{array}{r}8.6 \\
14.1 \\
10.7 \\
8.6 \\
4.8\end{array}$ & $\begin{array}{l}(0.31) \\
(1.24) \\
(0.59) \\
(0.64) \\
(0.43)\end{array}$ & $\begin{array}{r}9.9 \\
16.8 \\
12.6 \\
9.5 \\
5.3\end{array}$ & $\begin{array}{l}(0.32) \\
(1.29) \\
(0.67) \\
(0.63) \\
(0.42)\end{array}$ & $\begin{array}{r}8.2 \\
16.6 \\
10.3 \\
8.1 \\
3.9\end{array}$ & $\begin{array}{l}(0.30) \\
(1.15) \\
(0.56) \\
(0.56) \\
(0.37)\end{array}$ & $\left.\begin{array}{r}7.0 \\
13.7 \\
8.7 \\
6.3 \\
3.8\end{array}\right\}$ & & $\begin{array}{r}6.5 \\
12.3 \\
8.9 \\
5.0 \\
3.7\end{array}$ & $\begin{array}{l}(0.26) \\
(1.23) \\
(0.58) \\
(0.47) \\
(0.33)\end{array}$ \\
\hline $\begin{array}{l}55 \text { to } 64 \text { years old, all education levels.. } \\
\text { Less than high school completion.......... } \\
\text { High school completion }{ }^{2} . \ldots \ldots \ldots \ldots \ldots \ldots \ldots \\
\text { Some college, no bachelor's degree }{ }^{3} . . . \\
\text { Bachelor's or higher degree................... }\end{array}$ & $\begin{array}{r}5.5 \\
6.9 \\
5.5 \\
3.1 ! \\
\ddagger !\end{array}$ & $\begin{array}{r}(0.58) \\
(0.96) \\
(1.02) \\
(1.39) \\
(\dagger)\end{array}$ & $\left.\begin{array}{r}3.6 \\
5.9 \\
2.8 \\
2.5 ! \\
\ddagger !\end{array}\right\}$ & $\begin{array}{r}(0.46) \\
(1.01) \\
(0.70) \\
(1.06) \\
(\dagger)\end{array}$ & $\begin{array}{l}4.7 \\
7.4 \\
4.6 \\
3.6 ! \\
2.2 !\end{array}$ & $\begin{array}{r}(0.57) \\
(1.28) \\
(0.96) \\
!(1.43) \\
!(0.80)\end{array}$ & $\begin{array}{r}3.3 \\
4.6 \\
3.7 \\
\ddagger ! \\
2.1 !\end{array}$ & $\begin{array}{r}(0.51) \\
(1.24) \\
(0.91) \\
(+) \\
!(0.78)\end{array}$ & $\begin{array}{l}4.3 \\
7.7 \\
3.6 \\
3.7 ! \\
3.6\end{array}$ & $\begin{array}{r}(0.59) \\
(1.84) \\
(0.95) \\
!(1.16) \\
(1.00)\end{array}$ & $\begin{array}{l}3.2 \\
5.5 ! \\
3.5 \\
3.4 ! \\
1.7 !\end{array}$ & $\begin{array}{r}(0.49) \\
!(1.67) \\
(0.93) \\
!(1.06) \\
!(0.63)\end{array}$ & $\begin{array}{l}5.2 \\
8.8 \\
5.2 \\
6.2 \\
3.2\end{array}$ & $\begin{array}{l}(0.40) \\
(1.49) \\
(0.77) \\
(0.89) \\
(0.53)\end{array}$ & $\begin{array}{l}3.9 \\
6.7 \\
5.2 \\
3.3 \\
2.6\end{array}$ & $\begin{array}{l}(0.30) \\
(1.01) \\
(0.63) \\
(0.52) \\
(0.41)\end{array}$ & $\begin{array}{l}3.2 \\
6.4 \\
3.6 \\
2.9 \\
2.4\end{array}$ & $\begin{array}{l}(0.28) \\
(1.25) \\
(0.54) \\
(0.43) \\
(0.33)\end{array}$ & $\begin{array}{l}3.6 \\
5.2 \\
4.8 \\
4.1 \\
2.0\end{array}$ & $\left.\begin{array}{l}(0.25) \\
(0.99) \\
(0.59) \\
(0.54) \\
(0.30)\end{array}\right]$ & $\begin{array}{l}3.4 \\
5.7 \\
4.0 \\
3.5 \\
2.4\end{array}$ & $\begin{array}{l}(0.25) \\
(1.06) \\
(0.48) \\
(0.51) \\
(0.34)\end{array}$ & $\begin{array}{r}7.6 \\
14.8 \\
9.4 \\
8.5 \\
4.3\end{array}$ & $\begin{array}{l}(0.36) \\
(1.75) \\
(0.78) \\
(0.80) \\
(0.47)\end{array}$ & $\begin{array}{r}8.6 \\
11.6 \\
11.1 \\
9.2 \\
5.8\end{array}$ & $\begin{array}{l}(0.37) \\
(1.48) \\
(0.88) \\
(0.77) \\
(0.48)\end{array}$ & $\begin{array}{r}7.9 \\
13.4 \\
10.2 \\
7.5 \\
5.3\end{array}$ & $\begin{array}{l}(0.34) \\
(1.53) \\
(0.88) \\
(0.65) \\
(0.47)\end{array}$ & $\begin{array}{r}7.1 \\
12.1 \\
7.7 \\
8.0 \\
5.2\end{array}$ & $(0.55)$ & $\begin{array}{r}6.1 \\
11.7 \\
6.7 \\
6.2 \\
4.4\end{array}$ & $\begin{array}{l}(0.32) \\
(1.56) \\
(0.64) \\
(0.62) \\
(0.42)\end{array}$ \\
\hline
\end{tabular}

\section{-Not available.}

!Interpret data with caution. The coefficient of variation (CV) for this estimate is between 30 and 50 percent. Reporting standards not met. The coefficient of variation (CV) for this estimate is 50 percent or greater. Data for 16- to 19-year-olds and 20- to 24-year-olds exclude persons enrolled in school.

2Includes equivalency credentials, such as the General Educational Development (GED) credential.
Includes persons with no college degree as well as those with an associate's degree.
NOTE. The unemployment rate is the percentage of persons in the civilian labor force who are not working and who made specific efforts to find employment sometime during the prior 4 weeks. The civilian labor force consists of all civilians who are

Department of Labor, Bureau of Labor Statistics, Office of Employment and Unemployment Statistics, unpubprepared October 2013.) 
Table 501.90. Unemployment rates of females 16 to 64 years old, by age group and educational attainment: Selected years, 1975 through 2013

[Standard errors appear in parentheses]

\begin{tabular}{|c|c|c|c|c|c|c|c|c|c|c|c|c|c|c|c|c|c|c|c|c|c|c|c|c|c|c|c|c|c|c|c|c|}
\hline and educa & & 1975 & & 1980 & & 1985 & & 1990 & & 1995 & & 2000 & & 2003 & & 2005 & & 2006 & & 2007 & & 2008 & & 2009 & & 2010 & & 2011 & & 12 & & 013 \\
\hline 1 & & 2 & & 3 & & 4 & & 5 & & 6 & & 7 & & 8 & & & & 10 & & 11 & & 12 & & 13 & & 14 & & 15 & & 16 & & 17 \\
\hline (1) & $\begin{array}{l}- \\
\overline{-} \\
-\end{array}$ & \begin{tabular}{l|}
$(t)$ \\
$(t)$ \\
$(t)$ \\
$(t)$
\end{tabular} & $\begin{array}{l}- \\
\overline{-} \\
-\end{array}$ & \begin{tabular}{l|}
$(t)$ \\
$(t)$ \\
$(t)$ \\
$(t)$
\end{tabular} & $\begin{array}{l}\overline{-} \\
\overline{-} \\
-\end{array}$ & \begin{tabular}{l|}
$(t)$ \\
$(t)$ \\
$(t)$ \\
$(t)$
\end{tabular} & $\begin{array}{r}14.7 \\
23.4 \\
11.3 \\
\ddagger\end{array}$ & $\begin{array}{l}(2.39) \\
(5311)\end{array}$ & $\begin{array}{c}9.6 \\
9.7 \\
6.0 \\
\ddagger\end{array}$ & $\begin{array}{r}(2.93) \\
(5.57) \\
(3.69) \\
(\dagger)\end{array}$ & $\begin{array}{l}8.9 \\
7.9 \\
5.7 \\
\ddagger\end{array}$ & $\begin{array}{r}(2.85) \\
(5.53) \\
(3.66) \\
(\dagger)\end{array}$ & & & & & \begin{tabular}{|l|}
15.0 \\
19.7
\end{tabular} & & $\begin{array}{c}18.0 \\
32.8 \\
10.2 \\
7.8 !\end{array}$ & & & & $\begin{array}{l}23.8 \\
34.9 \\
22.2 \\
14.0\end{array}$ & & & & $\begin{array}{l}25.5 \\
40.4 \\
23.8 \\
11.8 !\end{array}$ & & $\begin{array}{l}29.6 \\
46.2 \\
24.5 \\
18.7 !\end{array}$ & & $\begin{array}{l}29.6 \\
15.2\end{array}$ & $\begin{array}{l}\mathbf{( 2 . 3 1 )} \\
(4.27) \\
(3.16) \\
(3.92)\end{array}$ \\
\hline \begin{tabular}{c} 
els ${ }^{1} \ldots . .$. \\
\hdashline$\ldots \ldots \ldots \ldots$ \\
$\ldots \ldots \ldots \ldots .$.
\end{tabular} & $\begin{array}{l}- \\
- \\
- \\
-\end{array}$ & 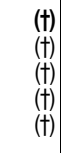 & $\begin{array}{l}- \\
- \\
- \\
-\end{array}$ & $\begin{array}{l}(t) \\
(t) \\
(t) \\
(t) \\
(t)\end{array}$ & $\begin{array}{l}- \\
- \\
- \\
-\end{array}$ & 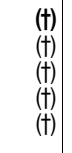 & $\begin{array}{r}7.8 \\
18.6 \\
8.1 \\
4.9 \\
3.5 !\end{array}$ & $\begin{array}{l}(0.86) \\
(3.70) \\
(1.26) \\
(1.43) \\
(1.47)\end{array}$ & $\begin{array}{c}10.2 \\
24.3 \\
12.7 \\
6.7 \\
3.1 !\end{array}$ & $\begin{array}{r}(1.00) \\
(4.34) \\
(1.78) \\
(1.43) \\
!(1.35)\end{array}$ & $\begin{array}{r}8.9 \\
17.0 \\
10.6 \\
5.7 \\
4.6 !\end{array}$ & $\begin{array}{r}(0.96) \\
(3.60) \\
(1.63) \\
(1.42) \\
!(1.70)\end{array}$ & $\begin{array}{r}10.9 \\
21.6 \\
11.5 \\
9.9 \\
3.7\end{array}$ & & $\begin{array}{ll}3 & 0 \\
5 & 0 \\
5 & 2 \\
5 & 1 \\
8 & 1 \\
4 & 1 \\
4 & 1\end{array}$ & $\begin{array}{l}(0.73) \\
(2.79) \\
(1.14)\end{array}$ & $\begin{array}{l}3.6 \\
3.3 \\
.8 \\
.6 \\
3.9\end{array}$ & $\begin{array}{l}(0.66) \\
(2.36) \\
(0.99) \\
(1.04) \\
(0.92)\end{array}$ & $\begin{array}{r}8.6 \\
20.6 \\
8.4 \\
7.2 \\
3.9\end{array}$ & & $\begin{array}{r}9.7 \\
21.6 \\
12.5 \\
6.5 \\
4.4\end{array}$ & & $\begin{array}{r}13.5 \\
28.4 \\
16.6 \\
10.5 \\
6.1\end{array}$ & & & & & & 14.1 & & $\begin{array}{r}13.4 \\
34.9 \\
15.1 \\
11.5 \\
5.6\end{array}$ & $\begin{array}{l}(0.85) \\
(3.85) \\
(1.44) \\
(1.36) \\
(1.01)\end{array}$ \\
\hline$\ldots \ldots \ldots$ & $\begin{array}{r}7.3 \\
10.8 \\
7.1 \\
6.3 \\
3.1\end{array}$ & $\begin{array}{l}(0.33) \\
(0.79) \\
(0.49) \\
(0.84) \\
(0.57)\end{array}$ & $\begin{array}{l}5.0 \\
8.9 \\
5.0 \\
4.1 \\
2.2\end{array}$ & $\begin{array}{l}(0.25) \\
(0.76) \\
(0.37) \\
(0.54) \\
(0.39)\end{array}$ & $\begin{array}{r}6.0 \\
11.7 \\
6.5 \\
4.8 \\
2.5\end{array}$ & & $\begin{array}{l}3.7 \\
8.3 \\
3.9 \\
3.2 \\
1.6\end{array}$ & $\begin{array}{l}(0.20) \\
(0.88) \\
(0.32) \\
(0.40) \\
(0.27)\end{array}$ & $\begin{array}{l}4.4 \\
8.6 \\
4.6 \\
4.5 \\
2.4\end{array}$ & & $\begin{array}{l}3.2 \\
9.1 \\
3.6 \\
2.9 \\
1.4\end{array}$ & $\begin{array}{l}(0.18) \\
(1.00) \\
(0.33) \\
(0.31) \\
(0.22)\end{array}$ & $\begin{array}{r}4.8 \\
10.6 \\
5.9 \\
4.4 \\
2.8\end{array}$ & & $\begin{array}{l}4.2(0 \\
0.9(0 \\
4.8<0\end{array}$ & & & & $\begin{array}{l}3.4 \\
8.5 \\
3.8 \\
3.6 \\
1.8\end{array}$ & & & & $\begin{array}{r}6.6 \\
14.5 \\
7.9\end{array}$ & & $\begin{array}{r}7.5 \\
15.0 \\
9.8 \\
7.5 \\
4.3\end{array}$ & & 7.2 & & & & $\begin{array}{l}6.3 \\
14.1 \\
8.1 \\
6.4 \\
3.8\end{array}$ & $\begin{array}{l}(0.15) \\
(0.84) \\
(0.35) \\
(0.26) \\
(0.19)\end{array}$ \\
\hline $\begin{array}{c}25 \text { to } 3 \\
\text { Less } \\
\text { High } \\
\text { Som } \\
\text { Bac }\end{array}$ & $\begin{array}{r}9.1 \\
17.0 \\
10.0 \\
6.9 \\
3.5\end{array}$ & $\begin{array}{l}(2.18) \\
(1.01) \\
(1.38) \\
(0.88)\end{array}$ & $\begin{array}{r}6.8 \\
14.2 \\
7.6 \\
5.9 \\
2.6\end{array}$ & $\begin{array}{l}(0.47) \\
(1.93) \\
(0.76) \\
(0.94) \\
(0.60)\end{array}$ & $\begin{array}{r}7.3 \\
18.5 \\
8.6 \\
6.0 \\
2.7\end{array}$ & & $\begin{array}{r}5.1 \\
15.1 \\
5.7 \\
4.0 \\
2.0\end{array}$ & & $\begin{array}{r}5.7 \\
13.7 \\
6.9 \\
5.4 \\
2.6\end{array}$ & & $\begin{array}{r}3.9 \\
12.9 \\
4.8 \\
3.5 \\
1.4\end{array}$ & $\begin{array}{l}(0.37) \\
(2.33) \\
(0.78) \\
(0.63) \\
(0.39)\end{array}$ & $\begin{array}{c}6.1 \\
15.7 \\
8.4 \\
5.3 \\
3.0\end{array}$ & & 2.510 & & $\begin{array}{l}5.4 \\
16.0 \\
6.6 \\
4.9 \\
2.7\end{array}$ & & $\begin{array}{r}4.4 \\
11.0 \\
5.9 \\
4.3 \\
2.1\end{array}$ & & & & 8.0 & & & & & & & & $\begin{array}{r}7.5 \\
19.3 \\
12.5 \\
7.4 \\
3.3\end{array}$ & $\begin{array}{l}(0.32) \\
(1.65) \\
(0.88) \\
(0.57) \\
(0.33)\end{array}$ \\
\hline $\begin{array}{c}35 \text { to } 44 \\
\text { Less } \\
\text { High } \\
\text { Some } \\
\text { Bache }\end{array}$ & $\begin{array}{r}7.1 \\
11.9 \\
5.7 \\
6.8 \\
3.5 !\end{array}$ & $\begin{array}{l}(0.66) \\
(1.65) \\
(0.85) \\
(1.76) \\
(1.29)\end{array}$ & $\begin{array}{c}4.7 \\
10.0 \\
4.1 \\
3.3 \\
2.3 !\end{array}$ & $\begin{array}{r}(0.47) \\
(1.56) \\
(0.65) \\
(0.97) \\
(0.76)\end{array}$ & $\begin{array}{r}5.4 \\
12.7 \\
5.7 \\
4.3 \\
2.2\end{array}$ & & $\begin{array}{l}3.5 \\
8.9 \\
4.0 \\
2.8 \\
1.4 !\end{array}$ & $\begin{array}{l}(0.34) \\
(1.79) \\
(0.57) \\
(0.64) \\
(0.42)\end{array}$ & $\begin{array}{l}4.3 \\
8.4 \\
4.5 \\
4.7 \\
2.4\end{array}$ & & $\begin{array}{r}3.7 \\
11.3 \\
3.6 \\
3.3 \\
1.8\end{array}$ & $\begin{array}{l}(0.33) \\
(1.94) \\
(0.58) \\
(0.57) \\
(0.44)\end{array}$ & $\begin{array}{r}4.9 \\
11.1 \\
6.0 \\
4.2 \\
2.7\end{array}$ & $\begin{array}{l}(0.27) \\
(1.39) \\
(0.55) \\
(0.46) \\
(0.37)\end{array}$ & $\begin{array}{l}3.7 \\
1.9\end{array}$ & & & & $\begin{array}{r}3.3 \\
10.3 \\
3.9 \\
3.0 \\
1.6\end{array}$ & & & & $\begin{array}{r}6.4 \\
13.0 \\
8.4 \\
6.2 \\
3.7\end{array}$ & & $\begin{array}{r}8.2 \\
16.7 \\
10.5 \\
8.5 \\
4.5\end{array}$ & & 7.4 & & & & $\begin{array}{r}6.6 \\
13.6 \\
8.1 \\
7.3 \\
4.0\end{array}$ & $\begin{array}{l}(0.27) \\
(1.57) \\
(0.70) \\
(0.53) \\
(0.35)\end{array}$ \\
\hline $\begin{array}{l}45 \text { to } 54 \\
\text { Less th } \\
\text { High s } \\
\text { Some } \\
\text { Bache }\end{array}$ & & $\begin{array}{l}0 . \\
1 . \\
0 . \\
0 .\end{array}$ & $\begin{array}{l}4.1 \\
7.6 \\
3.6 \\
2.3 ! \\
1.9 !\end{array}$ & $\begin{array}{l}(0.49) \\
(1.32) \\
(0.66) \\
(0.99) \\
(0.90)\end{array}$ & $\begin{array}{l}5.3 \\
9.2 \\
5.4 \\
4.1\end{array}$ & $\begin{array}{l}(0 . \\
1 . \\
(0.8 \\
1 . \\
1 . \\
0 .\end{array}$ & $\begin{array}{l}2.3 \\
4.7 \\
1.8 \\
2.7 ! \\
1.3 !\end{array}$ & $\begin{array}{l}(0 . \\
(1 \\
(0 . \\
10 \\
(0 .\end{array}$ & $\begin{array}{l}3.1 \\
5.8 \\
2.7 \\
3.7 \\
2.1\end{array}$ & $\begin{array}{l}(0.36) \\
(1.55) \\
(0.57) \\
(0.73) \\
(0.57)\end{array}$ & $\begin{array}{l}2.4 \\
5.1 ! \\
3.0 \\
2.2 \\
1.3 !\end{array}$ & $\begin{array}{l}(0 \\
! \\
1 \\
10 \\
(0 \\
!\end{array}$ & $\begin{array}{l}4.4 \\
9.3 \\
5.0 \\
4.5 \\
2.7\end{array}$ & & $\begin{array}{l}3.6 \\
8.2 \\
4.0 \\
3.6 \\
2.2\end{array}$ & $\begin{array}{l}(0.39) \\
(0.41) \\
(0.33)\end{array}$ & & & $\begin{array}{l}3.1 \\
6.4 \\
3.0 \\
3.7 \\
1.8\end{array}$ & & $\begin{array}{l}.5 \\
.3 \\
.7 \\
.2 \\
.9\end{array}$ & & $\begin{array}{r}6.1 \\
12.7 \\
6.6\end{array}$ & & $\begin{array}{r}6.8 \\
13.6 \\
9.0 \\
5.9 \\
4.3\end{array}$ & & ... & & 4.1 & & $\begin{array}{r}5.6 \\
12.1 \\
6.4 \\
5.4 \\
3.9\end{array}$ & () \\
\hline $\begin{array}{l}55 \text { to } 64 \text { years old, all education levels.. } \\
\text { Less than high school completion.......... } \\
\text { High school completion' }{ }^{2} . \ldots \ldots \ldots \ldots \ldots \ldots \ldots \ldots . . . \\
\text { Some college, no bachelor's degree }{ }^{3} \ldots . . . \\
\text { Bachelor's or higher degree.................. }\end{array}$ & $\begin{array}{c}5.4 \\
7.3 \\
4.6 \\
5.6 ! \\
\ddagger\end{array}$ & $\begin{array}{l}(0.7 \\
(1.2 \\
(1.0 \\
(2.2 \\
\end{array}$ & $\begin{array}{r}2.5 \\
3.7 \\
2.6 \\
\ddagger \\
\ddagger\end{array}$ & $\begin{array}{r}(0.47) \\
(1.06) \\
(0.69) \\
(\dagger) \\
(\dagger)\end{array}$ & $\begin{array}{r}4.5 \\
6.7 \\
4.5 \\
\ddagger \\
\ddagger\end{array}$ & $(t)$ & $\begin{array}{l}2.2 \\
2.9 ! \\
2.2 ! \\
2.4 ! \\
\ddagger\end{array}$ & $\begin{array}{l}(0.4 \\
1.1 \\
0.6 \\
1.1\end{array}$ & & & $\begin{array}{l}2.4 \\
4.8 ! \\
2.8 \\
2.2 ! \\
\ddagger\end{array}$ & $\begin{array}{l}(0.4 \\
! \\
(0.7 \\
! \\
!\end{array}$ & $\begin{array}{l}3.2 \\
3.4 ! \\
3.8 \\
2.6 \\
3.0\end{array}$ & $\begin{array}{l}(0.33) \\
(1.10) \\
(0.60) \\
(0.57) \\
(0.60)\end{array}$ & 1.9 & & & & $\begin{array}{l}2.6 \\
5.3 \\
2.8 \\
2.9 \\
1.6 \\
\end{array}$ & & & & 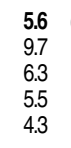 & & 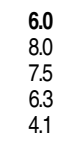 & $\begin{array}{l}(0.32 \\
(1.36 \\
(0.68 \\
(0.65 \\
(0.49\end{array}$ & & & 4.4 & & $\begin{array}{r}5.4 \\
10.5 \\
6.0 \\
5.5 \\
4.0 \\
\end{array}$ & $(0.44)$ \\
\hline
\end{tabular}

\section{-Not available.}

†Not applicable.
!nterpret data with caution. The coefficient of variation (CV) for this estimate is between 30 and 50 percent. †Reporting standards not met. The coefficient of variation (CV) for this estimate is 50 percent or greater. 'Data for 16- to 19-year-olds and 20- to 24-year-olds exclude persons enrolled in school.

2Includes equivalency credentials, such as the General Educational Development (GED) credential.
3Includes persons with no college degree as well as those with an associate's degree.
NOTE. The unemployment rate is the percentage of persons in the civilian labor force who are not working and who made specific efforts to find employment sometime during the prior 4 weeks. The civilian labor force consists of all civilians who are employed or seeking employment. Some data have been revised from previously published figures.

lished annual averare prepared November 2013.) 


\begin{tabular}{|c|c|c|c|c|c|c|c|c|c|c|c|c|c|c|c|}
\hline \multirow[b]{3}{*}{ Sex and occupation } & & & \multicolumn{13}{|c|}{ Percentage distribution, by highest level of educational attainment } \\
\hline & \multirow{2}{*}{\multicolumn{2}{|c|}{$\begin{array}{l}\text { Total employed } \\
\text { (in thousands) }\end{array}$}} & \multirow[b]{2}{*}{ Total } & \multirow{2}{*}{\multicolumn{2}{|c|}{$\begin{array}{r}\text { Less than high } \\
\text { school completion }\end{array}$}} & \multirow{2}{*}{\multicolumn{2}{|c|}{$\begin{array}{r}\text { High school completion } \\
\text { (includes equivalency) }\end{array}$}} & \multicolumn{8}{|c|}{ College } \\
\hline & & & & & & & & \multicolumn{2}{|c|}{ Some college, no degree } & \multicolumn{2}{|c|}{ Associate's degree } & \multicolumn{2}{|c|}{ Bachelor's degree } & \multicolumn{2}{|c|}{ Master's or higher degree } \\
\hline 1 & & 2 & 3 & & 4 & & 5 & & 6 & & 7 & & 8 & & 9 \\
\hline All persons ............ & 124,635 & (231.4) & 100.0 & 8.0 & $(0.09)$ & 27.1 & $(0.15)$ & 16.8 & (0.12) & 11.0 & (0.10) & 23.6 & (0.14) & 13.6 & $(0.11)$ \\
\hline 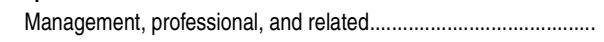 & 51,013 & (221.9) & 100.0 & 1.3 & $(0.06)$ & 11.1 & $(0.16)$ & 11.4 & $(0.16)$ & 10.7 & $(0.16)$ & 36.8 & $(0.25)$ & 28.8 & $(0.23)$ \\
\hline Management, business, and financial operations ....................... & 21,794 & (160.2) & 100.0 & 2.2 & $(0.12)$ & 16.6 & $(0.29)$ & 14.6 & $(0.28)$ & 9.2 & $(0.23)$ & 38.2 & $(0.38)$ & 19.3 & $(0.31)$ \\
\hline Professional and related & 29,219 & (181.2) & 100.0 & 0.7 & $(0.06)$ & 7.0 & $(0.17)$ & 9.0 & $(0.19)$ & 11.8 & $(0.22)$ & 35.7 & $(0.32)$ & 35.8 & $(0.32)$ \\
\hline Education, training, and library ................................................... & 7,828 & (100.1) & 100.0 & 0.6 & $(0.10)$ & 6.5 & $(0.32)$ & 7.0 & $(0.33)$ & 5.4 & $(0.30)$ & 34.9 & (0.62) & 45.6 & $(0.65)$ \\
\hline Preschool and kindergarten teachers..................................... & 593 & $(28.1)$ & 100.0 & $1.2 !$ & $(0.51)$ & 14.2 & $(1.66)$ & 17.4 & $(1.80)$ & 13.2 & (1.60) & 38.1 & (2.31) & 15.9 & (1.73) \\
\hline 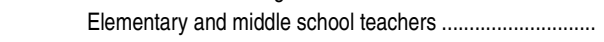 & 2,713 & $(59.8)$ & 100.0 & $0.2 !$ & $(0.10)$ & 2.3 & $(0.33)$ & 2.7 & $(0.36)$ & 2.2 & (0.33) & 44.7 & (1.10) & 47.8 & (1.11) \\
\hline 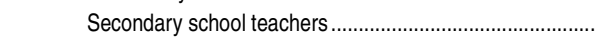 & 1,071 & $(37.7)$ & 100.0 & $\ddagger$ & $(\dagger)$ & $1.2 !$ & $(0.39)$ & 1.7 & $(0.45)$ & 1.6 & $(0.44)$ & 42.7 & $(1.75)$ & 52.8 & $(1.76)$ \\
\hline Special education teachers .............................................. & 351 & $(21.6)$ & 100.0 & \# & $(\dagger)$ & $3.1 !$ & $(1.08)$ & 3.4 ! & (1.12) & $3.7 !$ & $(1.17)$ & 34.5 & (2.93) & 55.3 & $(3.07)$ \\
\hline Postsecondary teachers........................................................ & 1,249 & $(40.7)$ & 100.0 & $\ddagger$ & $(\dagger)$ & 1.4 & $(0.38)$ & 2.0 & $(0.46)$ & 2.5 & $(0.51)$ & 13.9 & (1.13) & 80.0 & $(1.31)$ \\
\hline Other education, training, and library workers..................... & 675 & $(30.0)$ & 100.0 & 2.2 & $(0.66)$ & 10.7 & $(1.37)$ & 14.2 & $(1.55)$ & 8.7 & (1.26) & 39.0 & $(2.17)$ & 25.3 & $(1.94)$ \\
\hline 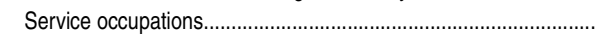 & 19,730 & (153.4) & 100.0 & 16.3 & $(0.30)$ & 37.4 & $(0.40)$ & 19.8 & $(0.33)$ & 11.9 & $(0.27)$ & 12.1 & $(0.27)$ & 2.5 & $(0.13)$ \\
\hline Sales and office occupations & 27,462 & (176.7) & 100.0 & 4.6 & $(0.15)$ & 31.4 & $(0.32)$ & 24.1 & $(0.30)$ & 12.4 & $(0.23)$ & 22.6 & $(0.29)$ & 4.8 & $(0.15)$ \\
\hline 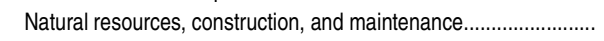 & 11,458 & (119.8) & 100.0 & 19.5 & $(0.43)$ & 42.9 & $(0.53)$ & 17.4 & $(0.41)$ & 11.7 & $(0.35)$ & 7.2 & $(0.28)$ & 1.4 & $(0.12)$ \\
\hline Production, transportation, and material moving ............................... & 14,972 & (135.6) & 100.0 & 16.9 & $(0.35)$ & 47.8 & $(0.47)$ & 17.5 & $(0.36)$ & 8.1 & (0.26) & 7.9 & $(0.25)$ & 1.8 & $(0.12)$ \\
\hline Males.... & 66,455 & (155.7) & 100.0 & 9.5 & $(0.13)$ & 28.9 & $(0.20)$ & 16.3 & $(0.16)$ & 9.6 & (0.13) & 22.6 & (0.18) & 13.1 & $(0.15)$ \\
\hline 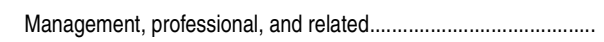 & 24,884 & (153.4) & 100.0 & 1.7 & $(0.09)$ & 11.5 & $(0.23)$ & 11.4 & $(0.23)$ & 8.3 & $(0.20)$ & 37.1 & $(0.35)$ & 30.0 & $(0.33)$ \\
\hline Management, business, and financial operations ....................... & 12,334 & (117.6) & 100.0 & 2.7 & $(0.17)$ & 17.1 & $(0.39)$ & 14.0 & $(0.36)$ & 8.0 & $(0.28)$ & 38.2 & $(0.50)$ & 20.0 & $(0.41)$ \\
\hline Professional and related & 12,551 & (118.5) & 100.0 & 0.7 & $(0.09)$ & 6.0 & $(0.24)$ & 8.9 & $(0.29)$ & 8.7 & $(0.29)$ & 35.9 & (0.49) & 39.8 & $(0.50)$ \\
\hline 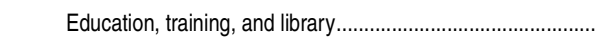 & 2,054 & $(51.0)$ & 100.0 & $0.5 !$ & $(0.17)$ & 3.2 & $(0.44)$ & 4.2 & $(0.51)$ & 3.0 & $(0.43)$ & 33.5 & $(1.18)$ & 55.6 & $(1.25)$ \\
\hline Service occupations. & 8,541 & (100.2) & 100.0 & 16.5 & $(0.46)$ & 35.8 & (0.59) & 20.1 & $(0.49)$ & 10.9 & $(0.38)$ & 13.8 & $(0.43)$ & 2.9 & $(0.21)$ \\
\hline Sales and office occupations & 10,398 & (109.3) & 100.0 & 4.7 & $(0.24)$ & 28.3 & $(0.50)$ & 22.3 & $(0.46)$ & 10.3 & $(0.34)$ & 28.2 & $(0.50)$ & 6.3 & $(0.27)$ \\
\hline Natural resources, construction, and maintenance.......................... & 10,984 & (111.9) & 100.0 & 19.4 & $(0.43)$ & 43.4 & $(0.54)$ & 17.3 & $(0.41)$ & 11.7 & $(0.35)$ & 6.9 & $(0.28)$ & 1.3 & $(0.12)$ \\
\hline 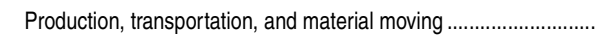 & 11,648 & (114.8) & 100.0 & 16.1 & $(0.39)$ & 47.9 & $(0.53)$ & 17.8 & $(0.40)$ & 8.5 & $(0.29)$ & 7.9 & $(0.29)$ & 1.7 & $(0.14)$ \\
\hline 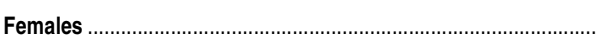 & 58,180 & (160.3) & 100.0 & 6.2 & (0.11) & 25.0 & $(0.20)$ & 17.3 & $(0.17)$ & 12.7 & $(0.15)$ & 24.7 & $(0.20)$ & 14.1 & $(0.16)$ \\
\hline Management, professional, and related........................................ & 26,129 & (150.4) & 100.0 & 1.0 & $(0.07)$ & 10.7 & $(0.21)$ & 11.3 & $(0.22)$ & 12.9 & $(0.23)$ & 36.5 & (0.33) & 27.6 & $(0.30)$ \\
\hline Management, business, and financial operations .......................... & 9,461 & (101.4) & 100.0 & 1.6 & $(0.14)$ & 15.9 & $(0.41)$ & 15.3 & $(0.41)$ & 10.7 & $(0.35)$ & 38.2 & $(0.55)$ & 18.4 & $(0.44)$ \\
\hline 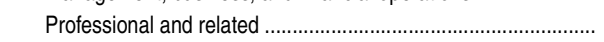 & 16,668 & $(128.5)$ & 100.0 & 0.7 & $(0.07)$ & 7.7 & $(0.23)$ & 9.1 & $(0.24)$ & 14.2 & $(0.30)$ & 35.5 & $(0.41)$ & 32.8 & $(0.40)$ \\
\hline 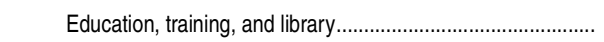 & 5,774 & $(81.0)$ & 100.0 & 0.6 & $(0.11)$ & 7.7 & $(0.39)$ & 8.0 & $(0.39)$ & 6.3 & $(0.35)$ & 35.4 & $(0.69)$ & 42.0 & $(0.72)$ \\
\hline 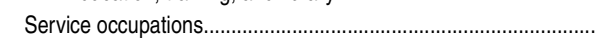 & 11,189 & (109.1) & 100.0 & 16.1 & $(0.38)$ & 38.6 & $(0.51)$ & 19.6 & $(0.41)$ & 12.6 & $(0.35)$ & 10.8 & $(0.32)$ & 2.2 & $(0.15)$ \\
\hline Sales and office occupations & 17,063 & (129.7) & 100.0 & 4.6 & $(0.18)$ & 33.4 & (0.40) & 25.2 & $(0.37)$ & 13.7 & $(0.29)$ & 19.3 & $(0.33)$ & 3.9 & $(0.16)$ \\
\hline Natural resources, construction, and maintenance....................... & 474 & (23.9) & 100.0 & 22.6 & $(2.11)$ & 31.2 & $(2.34)$ & 18.8 & $(1.97)$ & 10.5 & (1.55) & 14.1 & (1.76) & 3.0 & $(0.86)$ \\
\hline 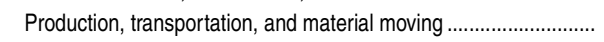 & 3,324 & $(62.3)$ & 100.0 & 19.8 & (0.76) & 47.5 & $(0.95)$ & 16.2 & $(0.70)$ & 6.7 & $(0.48)$ & 7.8 & $(0.51)$ & 2.0 & $(0.27)$ \\
\hline
\end{tabular}


Table 502.20. Median annual earnings of full-time year-round workers 25 years old and over, by highest level of educational attainment and sex: 1990 through 2012

[Standard errors appear in parentheses]

\begin{tabular}{|c|c|c|c|c|c|c|c|c|c|c|c|c|c|c|c|c|c|c|c|c|c|c|}
\hline \multirow[b]{3}{*}{ Sex and year } & \multirow{3}{*}{\multicolumn{2}{|c|}{ Total }} & \multicolumn{6}{|c|}{ Elementary/secondary } & \multicolumn{14}{|c|}{ College } \\
\hline & & & \multirow{2}{*}{\multicolumn{2}{|c|}{ Less than 9th grade }} & \multirow{2}{*}{\multicolumn{2}{|c|}{$\begin{array}{l}\text { Some high school, } \\
\text { no completion }\end{array}$}} & \multirow{2}{*}{\multicolumn{2}{|c|}{$\begin{array}{r}\text { High school } \\
\text { completion (includes } \\
\text { equivalency) }\end{array}$}} & \multirow{2}{*}{\multicolumn{2}{|c|}{$\begin{array}{r}\text { Some college, } \\
\text { no degree }{ }^{3}\end{array}$}} & \multirow{2}{*}{\multicolumn{2}{|c|}{ Associate's degree }} & \multicolumn{10}{|c|}{ Bachelor's or higher degree ${ }^{4}$} \\
\hline & & & & & & & & & & & & & & Total & Bachelor's & legree $^{5}$ & Maste & 's degree & Profession & hal degree & Doctor & 's degree \\
\hline \multirow[t]{2}{*}{1} & & 2 & & 3 & & 4 & & 5 & & 6 & & 7 & & 8 & & 9 & & 10 & & 11 & & 12 \\
\hline & \multicolumn{22}{|c|}{ Current dollars } \\
\hline 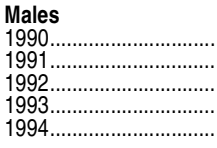 & $\begin{array}{r}\$ 30,730 \\
31,610 \\
32,060 \\
32,360 \\
33,440\end{array}$ & $\left.\begin{array}{r}(-) \\
(120) \\
(124) \\
(246)\end{array}\right)$ & $\begin{array}{r}\$ 17,390 \\
17,620 \\
17,290 \\
16,860 \\
17,530\end{array}$ & $\left.\begin{array}{c}(Z \\
Z \\
(-) \\
(453)\end{array}\right)$ & $\begin{array}{r}\$ 20,900 \\
21,400 \\
21,700 \\
21,750 \\
22,050\end{array}$ & $\left(\begin{array}{c}(Z \\
- \\
(-) \\
(319)\end{array}\right.$ & $\begin{array}{r}\$ 26,650 \\
26,780 \\
27,280 \\
27,370 \\
28,040\end{array}$ & $\left.\begin{array}{c}(-) \\
(-) \\
(175) \\
(204) \\
322\end{array}\right)$ & $\begin{array}{r}\$ 31,730 \\
31,660 \\
32,100 \\
32,080 \\
32,280\end{array}$ & $\left(\begin{array}{c}(Z \\
Z \\
(Z) \\
(300)\end{array}\right.$ & $\begin{array}{r}{[6]} \\
\$ 33,820 \\
33,430 \\
33,690 \\
35,790\end{array}$ & $\left(\begin{array}{c}(+) \\
(-) \\
(430)\end{array}\right)$ & $\begin{array}{r}\$ 42,670 \\
45,140 \\
45,800 \\
47,740 \\
49,230\end{array}$ & $\left(\begin{array}{c}(Z \\
- \\
- \\
(707)\end{array}\right.$ & $\begin{array}{r}\$ 39,240 \\
40,910 \\
41,360 \\
42,760 \\
43,660\end{array}$ & $\left.\begin{array}{c}(-) \\
(- \\
304 \\
536 \\
633\end{array}\right)$ & $\begin{array}{r}{ }^{[6]} \\
\$ 49,730 \\
49,970 \\
51,870 \\
53,500\end{array}$ & $\left(\begin{array}{c}(+) \\
- \\
- \\
(854)\end{array}\right)$ & $\begin{array}{r}{[6]} \\
\$ 74,000 \\
76,220 \\
80,550 \\
75,010\end{array}$ & $\begin{array}{r}(t+) \\
(-) \\
(3,040)\end{array}$ & $\begin{array}{r}{[6]} \\
\$ 57,190 \\
57,420 \\
63,150 \\
61,920\end{array}$ & $\left(\begin{array}{c}(+) \\
- \\
(-) \\
(1,619)\end{array}\right)$ \\
\hline 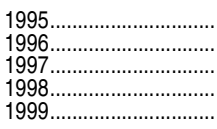 & $\begin{array}{l}34,550 \\
35,6620 \\
36,680 \\
37,910 \\
40,330\end{array}$ & $\left.\begin{array}{l}(275) \\
150 \\
149 \\
291 \\
144)\end{array}\right)$ & $\begin{array}{l}18,350 \\
17,960 \\
19,290 \\
19,380 \\
20,430\end{array}$ & $\left.\begin{array}{l}(545) \\
594 \\
629 \\
600 \\
444\end{array}\right)$ & $\begin{array}{l}22,190 \\
22,720 \\
24,730 \\
23,960 \\
25,040\end{array}$ & $\left.\begin{array}{l}(342) \\
414 \\
466 \\
547 \\
(535)\end{array}\right)$ & $\begin{array}{l}29,510 \\
30,710 \\
31,220 \\
31,480 \\
33,180\end{array}$ & $\left.\begin{array}{c}(358) \\
(184) \\
171 \\
169 \\
(388)\end{array}\right)$ & $\begin{array}{l}33,880 \\
34,850 \\
35,950 \\
36,930 \\
39,220\end{array}$ & $\begin{array}{l}(517) \\
456 \\
293 \\
291 \\
581)\end{array}$ & $\begin{array}{l}35,200 \\
37,130 \\
38,020 \\
40,270 \\
41,640\end{array}$ & $\left.\begin{array}{l}(535) \\
435 \\
774 \\
539 \\
459\end{array}\right)$ & $\begin{array}{l}50,480 \\
51,440 \\
53,450\end{array}$ & $\left.\begin{array}{l}(312) \\
303 \\
755 \\
421 \\
(439)\end{array}\right)$ & & $\left.\begin{array}{l}(510) \\
458 \\
851 \\
349 \\
722\end{array}\right)$ & $\begin{array}{l}55,220 \\
60,510 \\
61,690 \\
62,20 \\
66,240\end{array}$ & $\left.\begin{array}{l}(973) \\
945 \\
771 \\
847 \\
690\end{array}\right)$ & $\begin{array}{c}79,670 \\
85,960 \\
85,010 \\
94,740 \\
100,000 !\end{array}$ & $\left.\begin{array}{r}(2,582) \\
3,317 \\
(4,253) \\
(12,105 \\
(37,836)\end{array}\right)$ & $\begin{array}{l}65,340 \\
71,230 \\
76,230 \\
75,080 \\
81,690\end{array}$ & $\begin{array}{l}(2,188) \\
(3,362) \\
3,611) \\
2,507) \\
(3,953)\end{array}$ \\
\hline 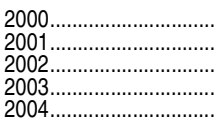 & $\begin{array}{l}41,060 \\
41,620 \\
41,150 \\
41,940 \\
42,090\end{array}$ & $\left.\begin{array}{r}(156) \\
104 \\
100 \\
(90) \\
89\end{array}\right)$ & $\begin{array}{l}20,790 \\
21,360 \\
20,920 \\
21,220 \\
21,660\end{array}$ & 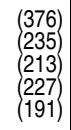 & $\begin{array}{l}25,100 \\
26,210 \\
25,900 \\
26,470 \\
26,280\end{array}$ & $\begin{array}{l}(436) \\
251 \\
2077 \\
(280) \\
(234)\end{array}$ & $\begin{array}{l}34,300 \\
34,720 \\
33,210 \\
35,410 \\
35,730\end{array}$ & $\left.\begin{array}{c}(457) \\
(299) \\
311 \\
168 \\
148\end{array}\right)$ & $\begin{array}{l}40,340 \\
41,050 \\
40,850 \\
41,350 \\
41,900\end{array}$ & $\left.\begin{array}{c}(312) \\
214 \\
195 \\
182 \\
175\end{array}\right)$ & $\begin{array}{l}41,950 \\
42,780 \\
42,860 \\
42,870 \\
44,400\end{array}$ & $\begin{array}{l}(460) \\
561 \\
673 \\
719 \\
(931)\end{array}$ & $\begin{array}{l}61,870 \\
62,220 \\
61,700\end{array}$ & $\begin{array}{l}(303) \\
279 \\
201 \\
187 \\
798)\end{array}$ & $\begin{array}{l}56,330 \\
55,930 \\
56,080 \\
56,500 \\
57,220\end{array}$ & $\left.\begin{array}{l}(573) \\
335 \\
385 \\
365 \\
393\end{array}\right)$ & $\begin{array}{l}68,320 \\
70,900 \\
67,280 \\
70,640 \\
71,530\end{array}$ & $\begin{array}{r}(1,506) \\
(687) \\
(1,294) \\
(562) \\
(490)\end{array}$ & $\begin{array}{r}99,410 \\
100,000 \\
100,000 \\
100,000 \\
100,000\end{array}$ & $\begin{array}{r}(20,832) \\
(Z) \\
- \\
-)\end{array}$ & $\begin{array}{l}80,250 \\
86,970 \\
83,310 \\
87,130 \\
82,400\end{array}$ & $\begin{array}{l}(2,446) \\
3,013 \\
2,076 \\
2,528 \\
(2,423)\end{array}$ \\
\hline 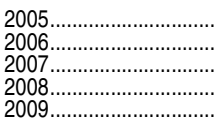 & $\begin{array}{l}43,320 \\
45,760 \\
47,000 \\
49,000 \\
49,990\end{array}$ & $\left.\begin{array}{l}(367) \\
134 \\
130 \\
339 \\
(201)\end{array}\right)$ & $\begin{array}{l}22,330 \\
22,710 \\
23,380 \\
24,260 \\
23,950\end{array}$ & $\left.\begin{array}{l}(220) \\
398 \\
544 \\
631 \\
394\end{array}\right)$ & $\begin{array}{l}27,190 \\
27,650 \\
29,320 \\
29,680 \\
28,020\end{array}$ & $\begin{array}{l}(237) \\
573 \\
590 \\
(458) \\
542)\end{array}$ & $\begin{array}{l}36,300 \\
37,030 \\
37,860 \\
39,010 \\
39,480\end{array}$ & $\left.\begin{array}{l}(141) \\
164 \\
406 \\
339 \\
379\end{array}\right)$ & $\begin{array}{l}42,420 \\
43,830 \\
44,900 \\
45,820 \\
47,100\end{array}$ & $\left.\begin{array}{l}(323) \\
812 \\
585 \\
276 \\
(347)\end{array}\right)$ & $\begin{array}{l}47,180 \\
47,070 \\
49,040 \\
50,150 \\
50,300\end{array}$ & $\begin{array}{l}\left(\begin{array}{l}367) \\
390 \\
801 \\
344 \\
238\end{array}\right) \\
\end{array}$ & $\begin{array}{l}66,170 \\
66,930 \\
70,400 \\
72,220 \\
71,470\end{array}$ & $\begin{array}{l}(356) \\
346 \\
241 \\
236 \\
(239)\end{array} \mid$ & $\begin{array}{l}60,020 \\
60,910 \\
62,090 \\
65,800 \\
62,440\end{array}$ & $\left.\begin{array}{l}(653) \\
235 \\
236 \\
388 \\
707\end{array}\right)$ & $\begin{array}{l}75,030 \\
75,430 \\
76,280 \\
80,960 \\
79,340\end{array}$ & $\begin{array}{r}(1,229) \\
(859) \\
416 \\
468 \\
(1,568)\end{array} \mid$ & & $\begin{array}{r}(Z) \\
(Z) \\
(2,539)\end{array}$ & $\begin{array}{r}85,860 \\
100,000 \\
92,090 \\
100,000 \\
100,740\end{array}$ & $\begin{array}{c}(3,061) \\
(-) \\
(1,894) \\
(-) \\
(519)\end{array}$ \\
\hline 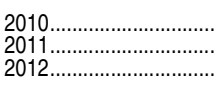 & $\begin{array}{l}50,360 \\
50,660 \\
50,950\end{array}$ & $\left.\begin{array}{r}(93) \\
(25) \\
(144)\end{array}\right)$ & $\begin{array}{l}24,450 \\
25,220 \\
25,130\end{array}$ & $\begin{array}{r}(597) \\
(23) \\
(440)\end{array}$ & $\begin{array}{l}29,440 \\
30,420 \\
30,330\end{array}$ & $\left.\begin{array}{l}(684) \\
300 \\
(430)\end{array}\right)$ & $\begin{array}{l}40,060 \\
40,450 \\
40,350\end{array}$ & $\begin{array}{r}(237) \\
(87) \\
(194)\end{array}$ & $\begin{array}{l}46,430 \\
47,070 \\
47,190\end{array}$ & $\begin{array}{r}(348) \\
(78) \\
(407)\end{array}$ & $\begin{array}{l}50,280 \\
50,930 \\
50,960\end{array}$ & $\left.\begin{array}{l}(245) \\
212 \\
329\end{array}\right)$ & $\begin{array}{l}71,780 \\
73,850 \\
75,320\end{array}$ & $\left.\begin{array}{l}(267) \\
490 \\
(565)\end{array}\right)$ & $\begin{array}{l}63,740 \\
66,200 \\
66,150\end{array}$ & $\begin{array}{r}(1,115) \\
(25) \\
(570)\end{array}$ & $\begin{array}{l}80,960 \\
83,030 \\
85,120\end{array}$ & $\begin{array}{r}(453) \\
(755) \\
(1,412)\end{array}$ & & $\begin{array}{l}(4,891) \\
1,917) \\
(5,632)\end{array}$ & $\begin{array}{l}101,220 \\
100,770 \\
106,470\end{array}$ & $\begin{array}{r}(653) \\
(192) \\
(4,656)\end{array}$ \\
\hline 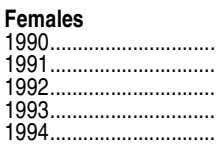 & $\begin{array}{l}21,370 \\
22,040 \\
23,140 \\
23,630 \\
24,400\end{array}$ & $\left.\begin{array}{r}(-) \\
(159) \\
(166) \\
165\end{array}\right)$ & $\begin{array}{l}12,250 \\
12,070 \\
12,960 \\
12,420 \\
12,430\end{array}$ & $\left.\begin{array}{c}(Z \\
(Z) \\
(427)\end{array}\right)$ & $\begin{array}{l}14,430 \\
14,460 \\
14,560 \\
15,390 \\
15,130\end{array}$ & $\left(\begin{array}{c}(Z \\
- \\
- \\
(328)\end{array}\right.$ & $\begin{array}{l}18,320 \\
18,840 \\
19,430 \\
19,960 \\
20,370\end{array}$ & $\left.\begin{array}{c}(-) \\
(-) \\
(176 \\
158\end{array}\right)$ & $\begin{array}{l}22,230 \\
22,140 \\
23,160 \\
23,060 \\
23,510\end{array}$ & $\begin{array}{c}(Z \\
- \\
(-) \\
(327)\end{array}$ & $\begin{array}{l}{ }^{[6]} \\
25,000 \\
25,620 \\
25,880 \\
25,940\end{array}$ & $\left(\begin{array}{c}(+) \\
\text { (一) } \\
(295)\end{array}\right)$ & $\begin{array}{l}30,380 \\
31,310 \\
32,300 \\
34,310 \\
35,380\end{array}$ & $\left(\begin{array}{c}(Z \\
Z \\
(-) \\
(280)\end{array}\right.$ & $\begin{array}{l}28,020 \\
29,080 \\
30,330\end{array}$ & $\left.\begin{array}{c}(-) \\
(-) \\
294 \\
310 \\
314\end{array}\right)$ & $\begin{array}{l}\quad[6] \\
34,950 \\
36,040 \\
38,610 \\
39,460\end{array}$ & $\left(\begin{array}{c}(t) \\
- \\
- \\
(606)\end{array}\right)$ & $\begin{array}{l}{ }^{[6]} \\
46,740 \\
46,260 \\
50,210 \\
50,620\end{array}$ & $\left.\begin{array}{r}(t) \\
(-) \\
(2,154)\end{array}\right)$ & $\begin{array}{l}{ }^{[6]} \\
43,300 \\
45,790 \\
47,250 \\
51,120\end{array}$ & $\left(\begin{array}{c}(+) \\
(-) \\
(-) \\
(2,888)\end{array}\right.$ \\
\hline 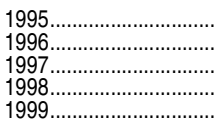 & $\begin{array}{l}24,880 \\
25,810 \\
26,970 \\
27,960 \\
28,840\end{array}$ & $\left.\begin{array}{c}(160) \\
131 \\
134 \\
199 \\
(216)\end{array}\right)$ & $\begin{array}{l}13,580 \\
14,410 \\
14,160 \\
14,470 \\
15,100\end{array}$ & $\left.\begin{array}{l}(490) \\
559 \\
492 \\
429 \\
492\end{array}\right)$ & $\begin{array}{l}15,830 \\
16,950 \\
16,700 \\
16,480 \\
17,020\end{array}$ & $\begin{array}{l}(293) \\
333 \\
335 \\
322 \\
(298)\end{array}$ & $\begin{array}{l}20,460 \\
21,180 \\
22,070 \\
22,780 \\
23,060\end{array}$ & $\left.\begin{array}{l}162 \\
143 \\
148 \\
(254) \\
279\end{array}\right)$ & $\begin{array}{l}24,000 \\
25,170 \\
26,340 \\
27,420 \\
27,760\end{array}$ & $\begin{array}{l}(274) \\
267 \\
291 \\
271 \\
(369)\end{array}$ & $\begin{array}{l}27,310 \\
28,080 \\
28,810 \\
29,920 \\
30,920\end{array}$ & $\begin{array}{l}(428) \\
526 \\
660 \\
513 \\
(318)\end{array}$ & $\begin{array}{l}35,260 \\
36,460 \\
38,040 \\
39,790 \\
41,750\end{array}$ & $\left.\begin{array}{l}(313) \\
296 \\
481 \\
408 \\
(275)\end{array}\right)$ & 32.050 & $\left.\begin{array}{l}(273) \\
437 \\
295 \\
305 \\
614\end{array}\right)$ & $\begin{array}{l}40,260 \\
41,1900 \\
44,950 \\
45,280 \\
48,100\end{array}$ & $\left.\begin{array}{l}(556) \\
564 \\
837 \\
760 \\
862\end{array}\right)$ & $\begin{array}{l}50,000 \\
57,620 \\
61,050 \\
57,570 \\
59,900\end{array}$ & $\left.\begin{array}{l}(2,532) \\
3,635 \\
4,737 \\
1,705 \\
4,479\end{array}\right)$ & $\begin{array}{l}48,140 \\
56,270 \\
53,040 \\
57,800 \\
60,080\end{array}$ & $\begin{array}{l}(2,373) \\
3,300 \\
3,626 \\
1,881 \\
3,130)\end{array}$ \\
\hline 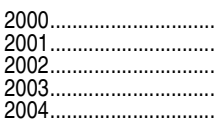 & $\begin{array}{l}30,330 \\
31,360 \\
31,010 \\
31,570 \\
31,990\end{array}$ & $\begin{array}{r}(138) \\
(91) \\
83 \\
85 \\
(80)\end{array}$ & $\begin{array}{l}15,800 \\
16,690 \\
16,510 \\
16,910 \\
17,020\end{array}$ & $\left.\begin{array}{l}(327) \\
255 \\
297 \\
256 \\
241\end{array}\right)$ & $\begin{array}{l}17,920 \\
19,160 \\
19,310 \\
18,940 \\
19,160\end{array}$ & $\begin{array}{l}(434) \\
359 \\
360 \\
327 \\
(319)\end{array}$ & $\begin{array}{l}24,970 \\
25,300 \\
25,180 \\
26,070 \\
26,030\end{array}$ & $\left.\begin{array}{l}(236) \\
132 \\
121 \\
118 \\
116\end{array}\right)$ & $\begin{array}{l}28,700 \\
30,420 \\
29,400 \\
30,140 \\
30,820\end{array}$ & $\left.\begin{array}{l}(364) \\
186 \\
299 \\
176 \\
(135)\end{array}\right)$ & $\begin{array}{l}31,070 \\
32,150 \\
31,630 \\
32,250 \\
33,480\end{array}$ & $\left.\begin{array}{l}(307) \\
231 \\
211 \\
241 \\
489\end{array}\right)$ & $\begin{array}{l}42,710 \\
44,780 \\
43,250 \\
45,120 \\
45,910\end{array}$ & $\begin{array}{l}(439) \\
367 \\
568 \\
291 \\
(229)\end{array}$ & $\begin{array}{l}40,420 \\
40,990 \\
40,850 \\
41,330 \\
41,680\end{array}$ & $\left.\begin{array}{l}284) \\
231 \\
173 \\
204 \\
172\end{array}\right)$ & $\begin{array}{l}50,140 \\
50,670 \\
48,890 \\
50,160 \\
51,320\end{array}$ & $\left.\begin{array}{l}735) \\
328 \\
595 \\
454 \\
263\end{array}\right)$ & $\begin{array}{l}58,960 \\
61,750 \\
57,020 \\
66,490 \\
75,040\end{array}$ & $\left.\begin{array}{l}(3,552) \\
3,976 \\
2,421 \\
3,469 \\
(2,436)\end{array}\right)$ & & $\begin{array}{l}(2,999) \\
2,228 \\
2,268 \\
2,462) \\
(2,450)\end{array}$ \\
\hline 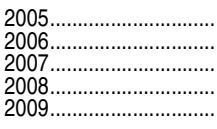 & $\begin{array}{l}33,080 \\
35,100 \\
36,090 \\
36,700 \\
37,260\end{array}$ & $\left.\begin{array}{c}(242) \\
113 \\
105 \\
109 \\
(107)\end{array}\right)$ & $\begin{array}{l}16,140 \\
18,130 \\
18,260 \\
18,630 \\
18,480\end{array}$ & $\left.\begin{array}{l}(250) \\
408 \\
461 \\
494 \\
451)\end{array}\right)$ & $\begin{array}{l}20,130 \\
20,130 \\
20,400 \\
20,410 \\
21,230\end{array}$ & $\begin{array}{l}(274) \\
270 \\
292 \\
295 \\
(301)\end{array}$ & $\begin{array}{l}26,290 \\
26,740 \\
27,240 \\
28,380 \\
29,150\end{array}$ & $\left.\begin{array}{l}(134) \\
136 \\
(133) \\
(283 \\
273\end{array}\right)$ & $\begin{array}{l}31,400 \\
31,950 \\
32,840 \\
32,630 \\
34,090\end{array}$ & $\begin{array}{l}(165) \\
165 \\
415 \\
(555) \\
483)\end{array}$ & $\begin{array}{l}33,940 \\
35,160 \\
36,330 \\
36,760 \\
37,270\end{array}$ & $\begin{array}{l}(497) \\
376 \\
283 \\
243 \\
(310)\end{array}$ & $\begin{array}{l}46,950 \\
49,570 \\
50,400 \\
51,410 \\
51,880\end{array}$ & $\begin{array}{c}(232) \\
441 \\
(158) \\
(45) \\
(169)\end{array}$ & $\begin{array}{l}42,170 \\
45,410 \\
45,770 \\
47,030 \\
46,830\end{array}$ & $\left.\begin{array}{l}(179) \\
259 \\
262 \\
237 \\
260\end{array}\right)$ & $\begin{array}{l}51,410 \\
52,440 \\
55,430 \\
57,510 \\
61,070\end{array}$ & $\left.\begin{array}{l}(283) \\
561 \\
412 \\
745 \\
304\end{array}\right)$ & $\begin{array}{l}80,460 \\
76,240 \\
71,100 \\
71,300 \\
83,910\end{array}$ & $\begin{array}{r}(2,774) \\
(2,488) \\
(910) \\
(2,859) \\
(3,210)\end{array}$ & $\begin{array}{l}66,850 \\
70,520 \\
68,990 \\
74,030 \\
76,580\end{array}$ & $\begin{array}{r}(2,490) \\
1,779 \\
2,155 \\
2,144) \\
(912)\end{array}$ \\
\hline 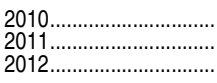 & $\begin{array}{l}38,290 \\
38,910 \\
39,980\end{array}$ & $\left(\begin{array}{l}272 \\
216 \\
294\end{array}\right)$ & $\begin{array}{l}18,240 \\
20,100 \\
20,060\end{array}$ & $\left.\begin{array}{l}(592) \\
250 \\
(514)\end{array}\right)$ & $\begin{array}{l}20,880 \\
21,110 \\
21,390\end{array}$ & $\left.\begin{array}{l}(334) \\
131 \\
285\end{array}\right) \mid$ & $\begin{array}{l}29,860 \\
30,010 \\
30,410\end{array}$ & $\left(\begin{array}{l}260) \\
145 \\
(165)\end{array}\right)$ & $\begin{array}{l}33,400 \\
34,590 \\
35,060\end{array}$ & & $\begin{array}{l}37,770 \\
39,290 \\
37,320\end{array}$ & $\begin{array}{r}(588) \\
(40) \\
(455)\end{array} \mid$ & $\begin{array}{l}51,940 \\
52,140 \\
53,690\end{array}$ & $\begin{array}{r}(159) \\
(88) \\
(888)\end{array} \mid$ & $\begin{array}{l}47,440 \\
49,110 \\
50,170\end{array}$ & $\left.\begin{array}{l}336 \\
103 \\
290\end{array}\right)$ & $\begin{array}{l}59,100 \\
60,300 \\
60,930\end{array}$ & $\begin{array}{r}(1,021) \\
(533) \\
(464)\end{array} \mid$ & $\begin{array}{l}76,740 \\
80,720 \\
94,470\end{array}$ & $\left.\begin{array}{l}(2,723) \\
(135) \\
(6,655)\end{array}\right)$ & $\begin{array}{l}77,390 \\
77,460 \\
77,900\end{array}$ & $\begin{array}{l}(2,174) \\
(21) \\
(3,616)\end{array}$ \\
\hline
\end{tabular}


[Standard errors appear in parentheses]

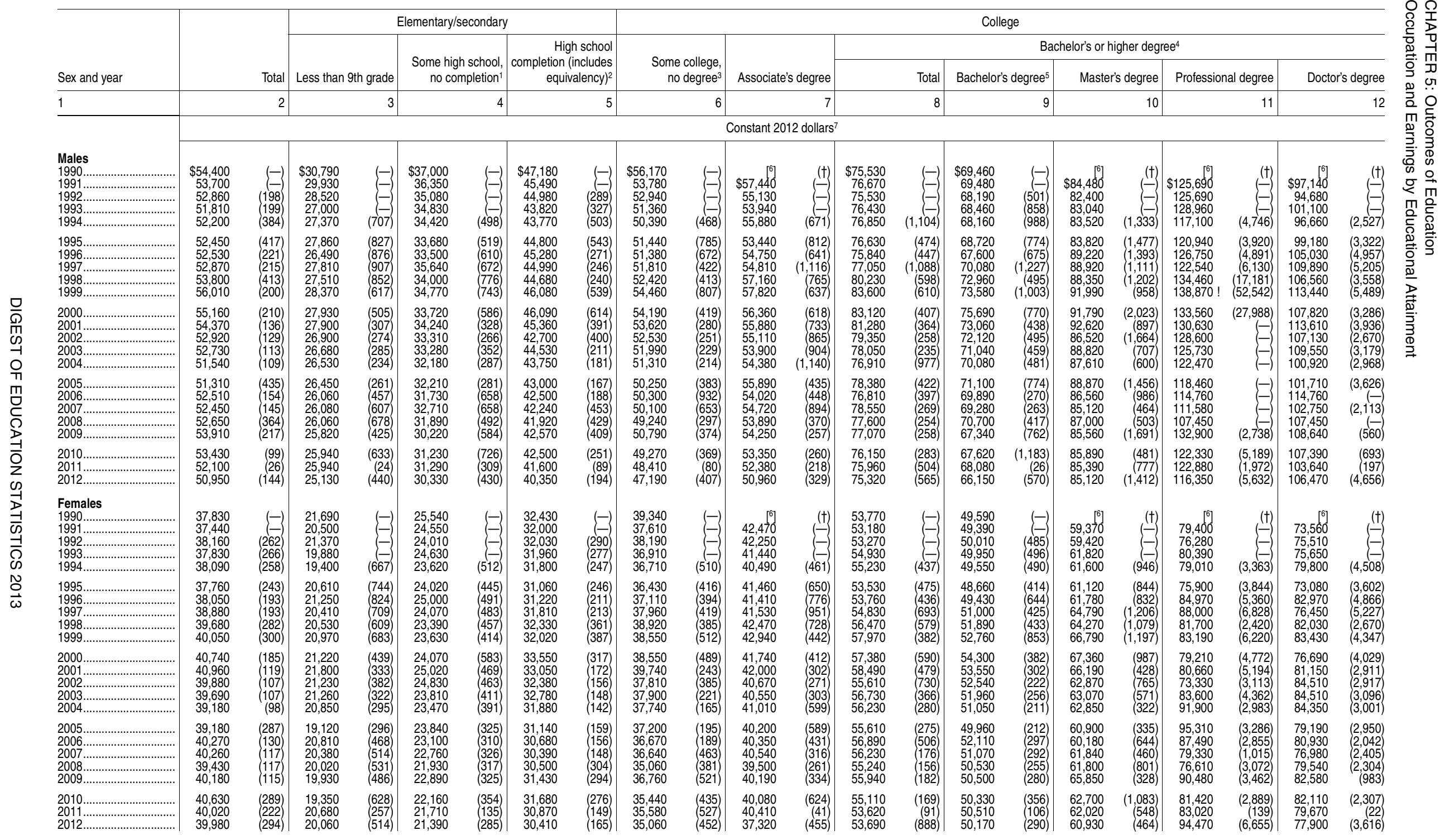

See notes at end of table. 
Table 502.20. Median annual earnings of full-time year-round workers 25 years old and over, by highest level of educational attainment and sex: 1990 through $2012-$ Continued

[Standard errors appear in parentheses]

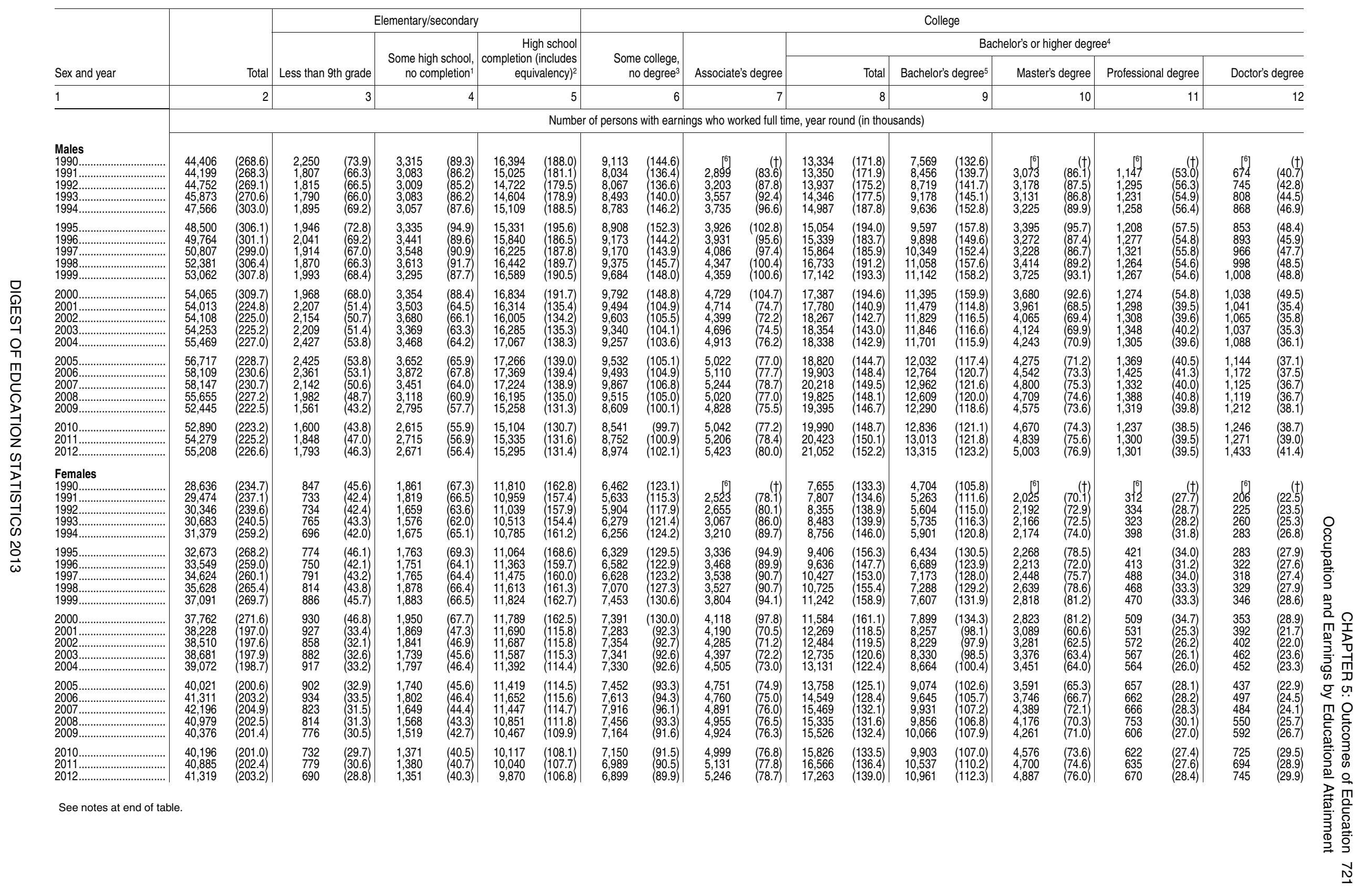


[Standard errors appear in parentheses]

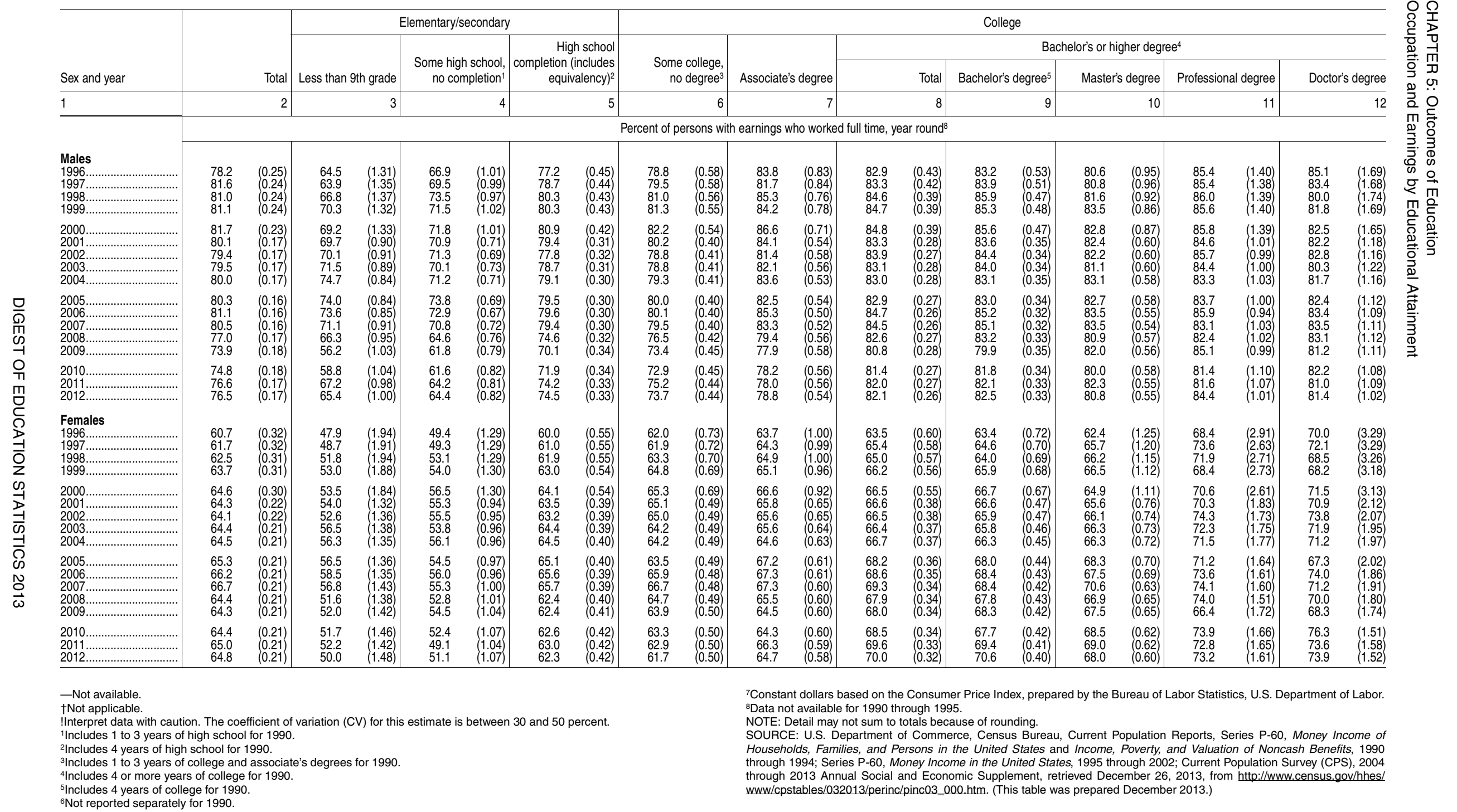




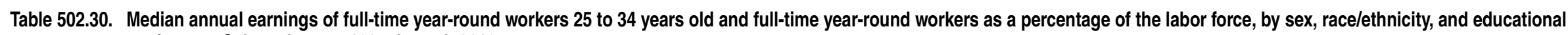
attainment: Selected years, 1995 through 2012

[Amounts in constant 2012 dollars. Standard errors appear in parentheses]

\begin{tabular}{|c|c|c|c|c|c|c|c|c|c|c|c|c|c|c|c|c|c|c|c|c|c|c|c|}
\hline Sex, race/ethnicity, and educational attainment & & 1995 & & 2000 & & 2002 & & 2005 & & 2006 & & 2007 & & 2008 & & 2009 & & 2010 & & 2011 & & 2012 & \\
\hline 1 & & 2 & & 3 & & 4 & & 5 & & 6 & & 7 & & 8 & & 9 & & 10 & & 11 & & 12 & \\
\hline \multicolumn{24}{|l|}{$\begin{array}{l}\text { Total, all full-time year-round workers } \\
25 \text { to } 34 \text { years old }\end{array}$} \\
\hline 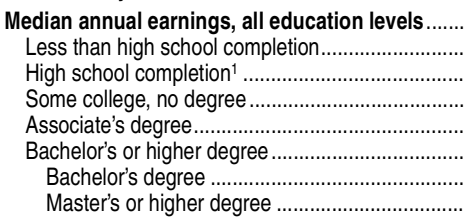 & $\begin{array}{r}\$ 37,670 \\
23,880 \\
31,320 \\
35,020 \\
37,390 \\
49,680 \\
46,650 \\
59,730\end{array}$ & $\begin{array}{r}(209) \\
(379) \\
(299) \\
(652) \\
(613) \\
(848) \\
(379) \\
(1,098)\end{array}$ & $\begin{array}{r}\$ 40,000 \\
24,130 \\
33,330 \\
38,460 \\
39,990 \\
53,320 \\
53,210 \\
63,880\end{array}$ & $\begin{array}{l}(127) \\
(524) \\
(234) \\
(501) \\
(378) \\
(276) \\
(394) \\
(1,973)\end{array}$ & $\begin{array}{r}\$ 39,800 \\
25,530 \\
3,180 \\
38,270 \\
40,670 \\
54,020 \\
51,050 \\
63,820\end{array}$ & $\begin{array}{l}(132) \\
(274) \\
(207) \\
(264) \\
(545) \\
(559) \\
(291) \\
(1,128)\end{array}$ & $\begin{array}{r}\$ 38,770 \\
24,150 \\
32,790 \\
36,890 \\
39,930 \\
51,570 \\
47,970 \\
58,710\end{array}$ & $\begin{array}{r}(1,059) \\
(754) \\
(1,102) \\
(754) \\
(1,012) \\
(1,044) \\
(1,296) \\
(53)\end{array}$ & $\begin{array}{r}\$ 38,930 \\
22,780 \\
32,960 \\
35,750 \\
38,500 \\
51,090 \\
49,530 \\
56,950\end{array}$ & $\begin{array}{r}(1,042) \\
(778) \\
(1,121) \\
(924) \\
(1,248) \\
(146) \\
(1,183) \\
(2,494)\end{array}$ & $\begin{array}{r}\$ 38,760 \\
24,270 \\
32,070 \\
36,400 \\
38,530 \\
52,990 \\
49,630 \\
61,640\end{array}$ & $\begin{array}{r}(\#) \\
(685) \\
(694) \\
(854) \\
(152) \\
(1,423) \\
(877) \\
(2,176)\end{array}$ & $\begin{array}{r}\$ 38,380 \\
22,790 \\
31,960 \\
34,080 \\
38,320 \\
53,260 \\
49,050 \\
58,590\end{array}$ & $\begin{array}{r}(819) \\
(745) \\
(5) \\
(462) \\
(775) \\
(15) \\
(923) \\
(733)\end{array}$ & $\begin{array}{r}\$ 40,630 \\
22,300 \\
32,020 \\
35,500 \\
38,420 \\
53,340 \\
48,140 \\
63,370\end{array}$ & $\begin{array}{r}(1,057) \\
(773) \\
(16) \\
(1,225) \\
(1,031) \\
(34) \\
(290) \\
(2,164)\end{array}$ & $\begin{array}{r}\$ 39,360 \\
22,110 \\
31,490 \\
34,650 \\
38,940 \\
51,310 \\
47,380 \\
57,540\end{array}$ & $\begin{array}{r}(815) \\
(828) \\
(32) \\
(909) \\
(1,085) \\
(1,057) \\
(654) \\
(1,043)\end{array}$ & $\begin{array}{r}\$ 38,740 \\
23,340 \\
30,570 \\
32,660 \\
37,800 \\
51,030 \\
45,900 \\
60,450\end{array}$ & $\begin{array}{r}(96) \\
(842) \\
(24) \\
(510) \\
(1,479) \\
(348) \\
(641) \\
(1,533)\end{array}$ & $\begin{array}{r}\$ 38,000 \\
22,910 \\
29,960 \\
32,850 \\
35,720 \\
49,950 \\
46,900 \\
59,620\end{array}$ & $\begin{array}{r}(874) \\
(814) \\
(15) \\
(718) \\
(1,450) \\
(16) \\
(1893) \\
(1,133)\end{array}$ & \\
\hline 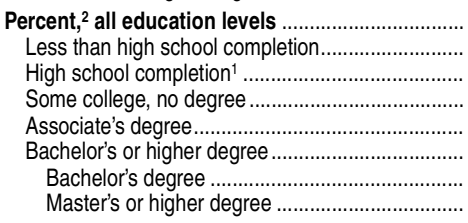 & $\begin{array}{l}63.6 \\
49.6 \\
62.8 \\
61.5 \\
67.4 \\
70.4 \\
70.5 \\
69.8\end{array}$ & $\begin{array}{l}(0.44) \\
(1.37) \\
(0.79) \\
(0.99) \\
(1.41) \\
(0.79) \\
(0.90) \\
(1.65)\end{array}$ & $\begin{array}{l}68.4 \\
59.4 \\
67.2 \\
67.8 \\
70.9 \\
72.3 \\
73.1 \\
69.6\end{array}$ & $\begin{array}{l}(0.32) \\
(1.02) \\
(0.59) \\
(0.71) \\
(1.01) \\
(0.55) \\
(0.62) \\
(1.18)\end{array}$ & $\begin{array}{l}66.3 \\
60.0 \\
64.2 \\
64.9 \\
67.4 \\
70.9 \\
71.2 \\
70.1\end{array}$ & $\begin{array}{l}(0.32) \\
(1.01) \\
(0.62) \\
(0.74) \\
(1.07) \\
(0.56) \\
(0.64) \\
(1.12)\end{array}$ & $\begin{array}{l}66.6 \\
60.0 \\
66.9 \\
63.5 \\
67.8 \\
70.2 \\
70.9 \\
68.2\end{array}$ & $\begin{array}{l}(0.37) \\
(1.32) \\
(0.75) \\
(0.83) \\
(1.16) \\
(0.67) \\
(0.16) \\
(1.27)\end{array}$ & $\begin{array}{l}68.0 \\
61.7 \\
66.2 \\
64.8 \\
69.8 \\
72.9 \\
73.0 \\
72.4\end{array}$ & $\begin{array}{l}(0.41) \\
(1.13) \\
(0.72) \\
(0.90) \\
(1.16) \\
(0.65) \\
(0.73) \\
(1.11)\end{array}$ & $\begin{array}{l}67.8 \\
56.5 \\
67.0 \\
64.8 \\
67.8 \\
73.5 \\
73.2 \\
74.4\end{array}$ & $\begin{array}{l}(0.36) \\
(1.26) \\
(0.71) \\
(0.92) \\
(1.23) \\
(0.59) \\
(0.70) \\
(1.21)\end{array}$ & $\begin{array}{l}64.6 \\
50.2 \\
61.7 \\
62.9 \\
66.3 \\
71.6 \\
71.6 \\
71.5 \\
\end{array}$ & $\begin{array}{l}(0.41) \\
(1.32) \\
(0.75) \\
(0.79) \\
(1.30) \\
(0.56) \\
(0.70) \\
(1.05)\end{array}$ & $\begin{array}{l}61.0 \\
47.0 \\
55.3 \\
58.7 \\
65.1 \\
69.4 \\
69.1 \\
70.0\end{array}$ & $\begin{array}{l}(0.41) \\
(1.25) \\
(0.74) \\
(0.91) \\
(1.18) \\
(0.63) \\
(0.77) \\
(1.10)\end{array}$ & $\begin{array}{l}61.9 \\
44.9 \\
57.0 \\
58.1 \\
63.6 \\
71.4 \\
771.2 \\
71.7\end{array}$ & $\begin{array}{l}(0.42) \\
(1.52) \\
(0.80) \\
(0.92) \\
(1.29) \\
(0.59) \\
(0.71) \\
(1.23)\end{array}$ & $\begin{array}{l}63.3 \\
48.1 \\
59.1 \\
59.0 \\
65.4 \\
71.4 \\
71.1 \\
72.2\end{array}$ & $\begin{array}{l}(0.41) \\
(1.43) \\
(0.78) \\
(0.99) \\
(1.17) \\
(0.62) \\
(0.12) \\
(1.25)\end{array}$ & $\begin{array}{l}64.2 \\
48.6 \\
60.3 \\
59.2 \\
64.8 \\
72.8 \\
72.9 \\
72.5\end{array}$ & $\begin{array}{l}(0.44) \\
(1.38) \\
(0.80) \\
(1.00) \\
(1.18) \\
(0.62) \\
(0.75) \\
(1.20)\end{array}$ & \\
\hline \multicolumn{24}{|l|}{ Male } \\
\hline 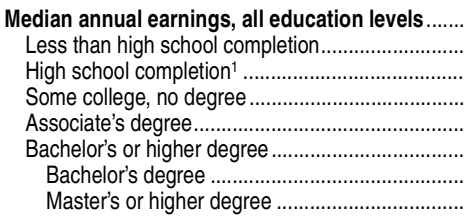 & $\begin{array}{l}40,580 \\
26,750 \\
36,070 \\
39,090 \\
38,860 \\
56,010 \\
52,690 \\
66,690\end{array}$ & $\begin{array}{r}(277) \\
(706) \\
(592) \\
(539) \\
(998) \\
(868) \\
(697) \\
(2,138)\end{array}$ & $\begin{array}{l}42,660 \\
26,560 \\
38,420 \\
42,400 \\
46,630 \\
61,220 \\
59,690 \\
73,180\end{array}$ & $\begin{array}{r}(204) \\
(332) \\
(630) \\
(357) \\
(729) \\
(552) \\
(799) \\
(1,981)\end{array}$ & $\begin{array}{l}43,360 \\
26,610 \\
36,940 \\
43,000 \\
47,020 \\
61,250 \\
57,400 \\
75,650\end{array}$ & $\begin{array}{r}(529) \\
(307) \\
(577) \\
(1,316) \\
(1,370) \\
(1,154) \\
(640) \\
(1,490)\end{array}$ & $\begin{array}{l}41,150 \\
25,760 \\
35,130 \\
41,040 \\
45,700 \\
58,750 \\
52,860 \\
64,650\end{array}$ & $\begin{array}{r}(\#) \\
(1,023) \\
(48) \\
(309) \\
(1,823) \\
(1,875) \\
(1,264) \\
(3,922)\end{array}$ & $\begin{array}{l}39,860 \\
24,980 \\
34,150 \\
39,560 \\
42,880 \\
56,590 \\
56,150 \\
65,940\end{array}$ & $\begin{array}{r}(696) \\
(449) \\
(446) \\
(186) \\
(1,832) \\
(188) \\
(1,737) \\
(3,256)\end{array}$ & $\begin{array}{l}42,010 \\
254,460 \\
34,140 \\
40,620 \\
43,990 \\
57,110 \\
55,240 \\
68,310\end{array}$ & $\begin{array}{r}(97) \\
(555) \\
(1,034) \\
(1,519) \\
(368) \\
(1,085) \\
(51) \\
(3,330)\end{array}$ & $\begin{array}{l}42,650 \\
25,570 \\
34,080 \\
38,620 \\
42,940 \\
58,490 \\
56,420 \\
68,590\end{array}$ & $\begin{array}{r}(1) \\
(834) \\
(705) \\
(1,408) \\
(1,696) \\
(408) \\
(1,731) \\
(1,875)\end{array}$ & $\begin{array}{l}42,810 \\
24,250 \\
35,200 \\
41,390 \\
44,610 \\
58,250 \\
54,020 \\
74,100\end{array}$ & $\begin{array}{r}(\#) \\
(1,042) \\
(1,207) \\
(952) \\
(1,646) \\
(588) \\
(1,374) \\
(3,106)\end{array}$ & $\begin{array}{l}41,990 \\
25,270 \\
34,530 \\
39,880 \\
42,020 \\
55,550 \\
52,420 \\
67,560\end{array}$ & $\begin{array}{r}(31) \\
(816) \\
(881) \\
(969) \\
(453) \\
(1,873) \\
(160) \\
(1,475)\end{array} \mid$ & $\begin{array}{l}40,750 \\
25,480 \\
3,120 \\
37,450 \\
42,710 \\
55,490 \\
50,790 \\
69,400\end{array}$ & $\begin{array}{r}(33) \\
(1,081) \\
(844) \\
(1,219) \\
(1,767) \\
(1,056) \\
(124) \\
(2,399)\end{array}$ & $\begin{array}{l}40,000 \\
24,600 \\
32,830 \\
37,670 \\
43,640 \\
54,840 \\
49,970 \\
65,000\end{array}$ & $\begin{array}{r}(1) \\
(978) \\
(720) \\
(842) \\
(2,742) \\
(513) \\
(584) \\
(2,361)\end{array}$ & \\
\hline 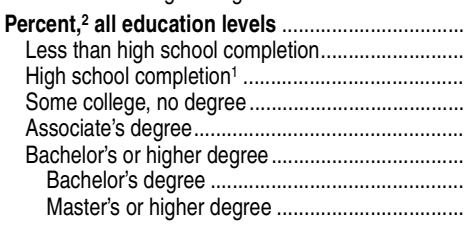 & $\begin{array}{l}69.7 \\
54.3 \\
69.3 \\
68.5 \\
78.6 \\
75.9 \\
76.4 \\
74.6\end{array}$ & $\begin{array}{l}(0.57) \\
(1.71) \\
(1.00) \\
(1.31) \\
(1.81) \\
(1.04) \\
(1.19) \\
(2.11)\end{array}$ & $\begin{array}{l}75.1 \\
67.8 \\
73.6 \\
76.1 \\
80.9 \\
78.0 \\
78.8 \\
75.3\end{array}$ & $\left.\begin{array}{l}(0.40) \\
(1.22) \\
(0.73) \\
(0.91) \\
(1.31) \\
(0.72) \\
(0.81) \\
(1.58)\end{array}\right)$ & $\begin{array}{l}72.1 \\
66.8 \\
70.3 \\
71.1 \\
74.7 \\
76.3 \\
76.6 \\
75.4\end{array}$ & $\begin{array}{l}(0.42) \\
(1.19) \\
(0.77) \\
(0.97) \\
(1.44) \\
(0.74) \\
(0.85) \\
(1.53)\end{array}$ & $\begin{array}{l}72.5 \\
66.7 \\
73.5 \\
70.7 \\
75.1 \\
74.6 \\
74.5 \\
75.1\end{array}$ & $\begin{array}{l}(0.48) \\
(1.54) \\
(0.91) \\
(1.13) \\
(1.67) \\
(0.93) \\
(1.01) \\
(2.00)\end{array}$ & $\begin{array}{l}72.9 \\
67.8 \\
71.1 \\
71.3 \\
78.4 \\
76.7 \\
77.1 \\
75.5\end{array}$ & $\begin{array}{l}(0.54) \\
(1.34) \\
(0.88) \\
(1.21) \\
(1.61) \\
(0.82) \\
(0.97) \\
(1.58)\end{array}$ & $\begin{array}{l}72.2 \\
61.1 \\
71.9 \\
71.1 \\
73.4 \\
77.7 \\
78.0 \\
76.8\end{array}$ & $\begin{array}{l}(0.51) \\
(1.51) \\
(0.94) \\
(1.31) \\
(1.70) \\
(0.94) \\
(1.07) \\
(1.93)\end{array}$ & $\begin{array}{l}68.5 \\
55.7 \\
64.8 \\
68.2 \\
73.2 \\
76.6 \\
76.3 \\
77.2\end{array}$ & $\begin{array}{l}(0.57) \\
(1.54) \\
(0.95) \\
(1.12) \\
(1.82) \\
(0.90) \\
(1.10) \\
(1.50)\end{array}$ & $\begin{array}{l}62.8 \\
49.2 \\
57.4 \\
62.7 \\
70.1 \\
71.8 \\
70.6 \\
75.6\end{array}$ & $\begin{array}{l}(0.58) \\
(1.71) \\
(1.01) \\
(1.31) \\
(1.65) \\
(0.94) \\
(1.15) \\
(1.61)\end{array}$ & $\begin{array}{l}64.5 \\
47.4 \\
60.6 \\
62.0 \\
68.6 \\
75.0 \\
75.4 \\
74.0\end{array}$ & $\begin{array}{l}(0.56) \\
(1.81) \\
(1.01) \\
(1.17) \\
(1.77) \\
(0.80) \\
(0.91) \\
(1.88)\end{array}$ & $\begin{array}{l}67.4 \\
55.5 \\
63.8 \\
64.2 \\
71.6 \\
75.3 \\
74.7 \\
77.3\end{array}$ & $\begin{array}{l}(0.57) \\
(1.74) \\
(1.00) \\
(1.33) \\
(1.61) \\
(0.84) \\
(0.98) \\
(1.63)\end{array}$ & $\begin{array}{l}68.4 \\
54.1 \\
65.5 \\
64.3 \\
71.8 \\
77.1 \\
77.3 \\
76.4\end{array}$ & $\begin{array}{l}(0.53) \\
(1.88) \\
(1.00) \\
(1.41) \\
(1.70) \\
(0.87) \\
(0.94) \\
(1.82)\end{array}$ & 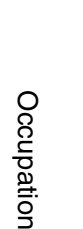 \\
\hline \multicolumn{24}{|l|}{ Female } \\
\hline 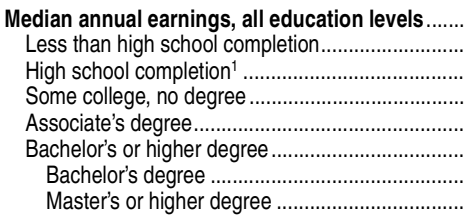 & $\begin{array}{l}32,850 \\
1,490 \\
26,530 \\
30,120 \\
36,080 \\
44,850 \\
42,040 \\
52,040\end{array}$ & $\begin{array}{r}(270) \\
(760) \\
(448) \\
(435) \\
(1,344) \\
(634) \\
(911) \\
(1,437)\end{array}$ & $\begin{array}{l}36,950 \\
1,970 \\
29,220 \\
33,300 \\
35,520 \\
48,000 \\
46,520 \\
55,440\end{array}$ & $\begin{array}{l}(318) \\
(558) \\
(319) \\
(326) \\
(478) \\
(332) \\
(371) \\
(1,116)\end{array} \mid$ & $\begin{array}{l}37,390 \\
21,110 \\
29,600 \\
32,830 \\
35,600 \\
50,530 \\
48,280 \\
55,260\end{array}$ & $\begin{array}{r}(327) \\
(600) \\
(515) \\
(349) \\
(931) \\
(439) \\
(708) \\
(1,469)\end{array}$ & $\begin{array}{l}35,220 \\
1,750 \\
28,100 \\
32,820 \\
34,470 \\
46,750 \\
44,090 \\
55,190\end{array}$ & $\begin{array}{r}(34) \\
(751) \\
(192) \\
(467) \\
(420) \\
(123) \\
(1,076) \\
(2,162)\end{array}$ & $\begin{array}{l}35,300 \\
20,300 \\
26,810 \\
31,830 \\
34,120 \\
46,590 \\
45,400 \\
54,490\end{array}$ & $\begin{array}{r}(440) \\
(489) \\
(695) \\
(596) \\
(838) \\
(1,031) \\
(482) \\
(2,164)\end{array}$ & $\begin{array}{l}36,480 \\
19,730 \\
26,610 \\
33,120 \\
34,320 \\
47,510 \\
44,120 \\
55,570\end{array}$ & $\begin{array}{r}(429) \\
(894) \\
(1,070) \\
(795) \\
(1,151) \\
(1,060) \\
(103) \\
(1,672)\end{array}$ & $\begin{array}{l}36,230 \\
17,610 \\
26,560 \\
30,860 \\
34,650 \\
47,920 \\
44,400 \\
54,170\end{array}$ & $\begin{array}{r}(508) \\
(746) \\
(128) \\
(931) \\
(1,049) \\
(28) \\
(580) \\
(1,554)\end{array}$ & $\begin{array}{l}37,370 \\
20,290 \\
26,700 \\
31,250 \\
33,060 \\
48,110 \\
42,910 \\
57,790\end{array}$ & $\begin{array}{r}(223) \\
(620) \\
(27) \\
(1,048) \\
(1,291) \\
(26) \\
(1,245) \\
(2,261)\end{array}$ & $\begin{array}{l}36,730 \\
18,710 \\
26,300 \\
31,070 \\
36,500 \\
46,320 \\
42,100 \\
52,470\end{array}$ & $\begin{array}{r}(36) \\
(694) \\
(66) \\
(1,069) \\
(899) \\
(1,237) \\
(1,190) \\
(94)\end{array}$ & $\begin{array}{l}35,680 \\
19,320 \\
26,440 \\
29,540 \\
32,740 \\
45,830 \\
41,800 \\
52,530\end{array}$ & $\begin{array}{r}(20) \\
(480) \\
(748) \\
(1,117) \\
(1,363) \\
(58) \\
(1,361) \\
(1,585)\end{array}$ & $\begin{array}{l}35,000 \\
17,9000 \\
24,980 \\
29,350 \\
31,610 \\
46,840 \\
42,2950 \\
53,520\end{array}$ & $\begin{array}{r}(786) \\
(773) \\
(9) \\
(627) \\
(969) \\
(694) \\
(1,236) \\
(1,458)\end{array}$ & 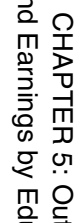 \\
\hline 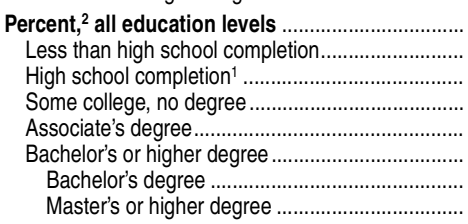 & $\begin{array}{l}56.6 \\
41.3 \\
54.4 \\
53.9 \\
57.6 \\
64.7 \\
64.9 \\
63.9\end{array}$ & $\begin{array}{l}(0.67) \\
(2.24) \\
(1.23) \\
(1.46) \\
(2.05) \\
(1.17) \\
(1.32) \\
(2.57)\end{array}$ & $\begin{array}{l}60.7 \\
45.3 \\
58.5 \\
59.2 \\
62.7 \\
66.8 \\
67.6 \\
64.2\end{array}$ & $\begin{array}{l}(0.49) \\
(1.68) \\
(0.96) \\
(1.08) \\
(1.45) \\
(0.82) \\
(0.93) \\
(1.71)\end{array}$ & $\begin{array}{l}59.5 \\
46.4 \\
55.7 \\
58.1 \\
60.8 \\
65.7 \\
65.9 \\
65.3\end{array}$ & $\begin{array}{l}(0.50) \\
(1.77) \\
(0.98) \\
(1.10) \\
(1.54) \\
(0.82) \\
(0.95) \\
(1.60)\end{array}$ & $\begin{array}{l}59.6 \\
45.9 \\
57.0 \\
55.7 \\
60.8 \\
66.0 \\
67.4 \\
62.6\end{array}$ & $\begin{array}{l}(0.57) \\
(1.83) \\
(1.11) \\
(1.19) \\
(1.57) \\
(0.99) \\
(1.18) \\
(1.76)\end{array}$ & $\begin{array}{l}62.1 \\
48.5 \\
58.8 \\
57.6 \\
62.1 \\
69.3 \\
69.2 \\
69.8\end{array}$ & $\begin{array}{l}(0.60) \\
(2.01) \\
(1.28) \\
(1.31) \\
(1.64) \\
(0.90) \\
(1.06) \\
(1.62)\end{array}$ & $\begin{array}{l}62.7 \\
45.9 \\
59.4 \\
57.9 \\
62.7 \\
69.9 \\
68.7 \\
72.6\end{array}$ & $\begin{array}{l}(0.57) \\
(2.22) \\
(1.13) \\
(1.22) \\
(1.75) \\
(0.76) \\
(0.92) \\
(1.52)\end{array}$ & $\begin{array}{l}60.0 \\
38.6 \\
56.6 \\
56.6 \\
60.1 \\
67.2 \\
67.3 \\
67.1\end{array}$ & $\begin{array}{l}(0.51) \\
(1.91) \\
(1.11) \\
(1.26) \\
(1.68) \\
(0.71) \\
(0.88) \\
(1.44)\end{array}$ & $\begin{array}{l}58.9 \\
42.7 \\
51.8 \\
54.1 \\
60.8 \\
67.2 \\
67.9 \\
65.7\end{array}$ & $\begin{array}{l}(0.53) \\
(2.03) \\
(1.12) \\
(1.28) \\
(1.65) \\
(0.82) \\
(1.03) \\
(1.58)\end{array}$ & $\begin{array}{l}58.7 \\
39.4 \\
51.1 \\
53.6 \\
59.1 \\
68.0 \\
67.2 \\
70.0\end{array}$ & $\begin{array}{l}(0.53) \\
(2.22) \\
(1.19) \\
(1.29) \\
(1.67) \\
(0.77) \\
(0.94) \\
(1.63)\end{array}$ & $\begin{array}{l}\mathbf{5 8 . 6} \\
34.1 \\
51.6 \\
53.3 \\
59.5 \\
68.0 \\
67.8 \\
68.6\end{array}$ & $\begin{array}{l}(0.52) \\
(2.03) \\
(1.19) \\
(1.33) \\
(1.75) \\
(0.84) \\
(1.06) \\
(1.76)\end{array}$ & $\begin{array}{l}59.3 \\
37.8 \\
51.9 \\
53.3 \\
58.8 \\
68.9 \\
68.5 \\
69.7\end{array}$ & $\begin{array}{l}(0.63) \\
(1.96) \\
(1.24) \\
(1.22) \\
(1.69) \\
(0.90) \\
(1.13) \\
(1.71)\end{array}$ & 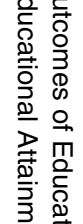 \\
\hline
\end{tabular}




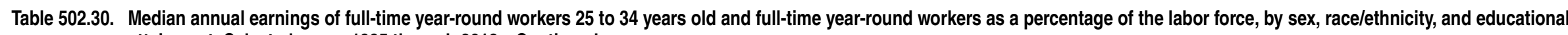
attainment: Selected years, 1995 through 2012-Continued

[Amounts in constant 2012 dollars. Standard errors appear in parentheses]

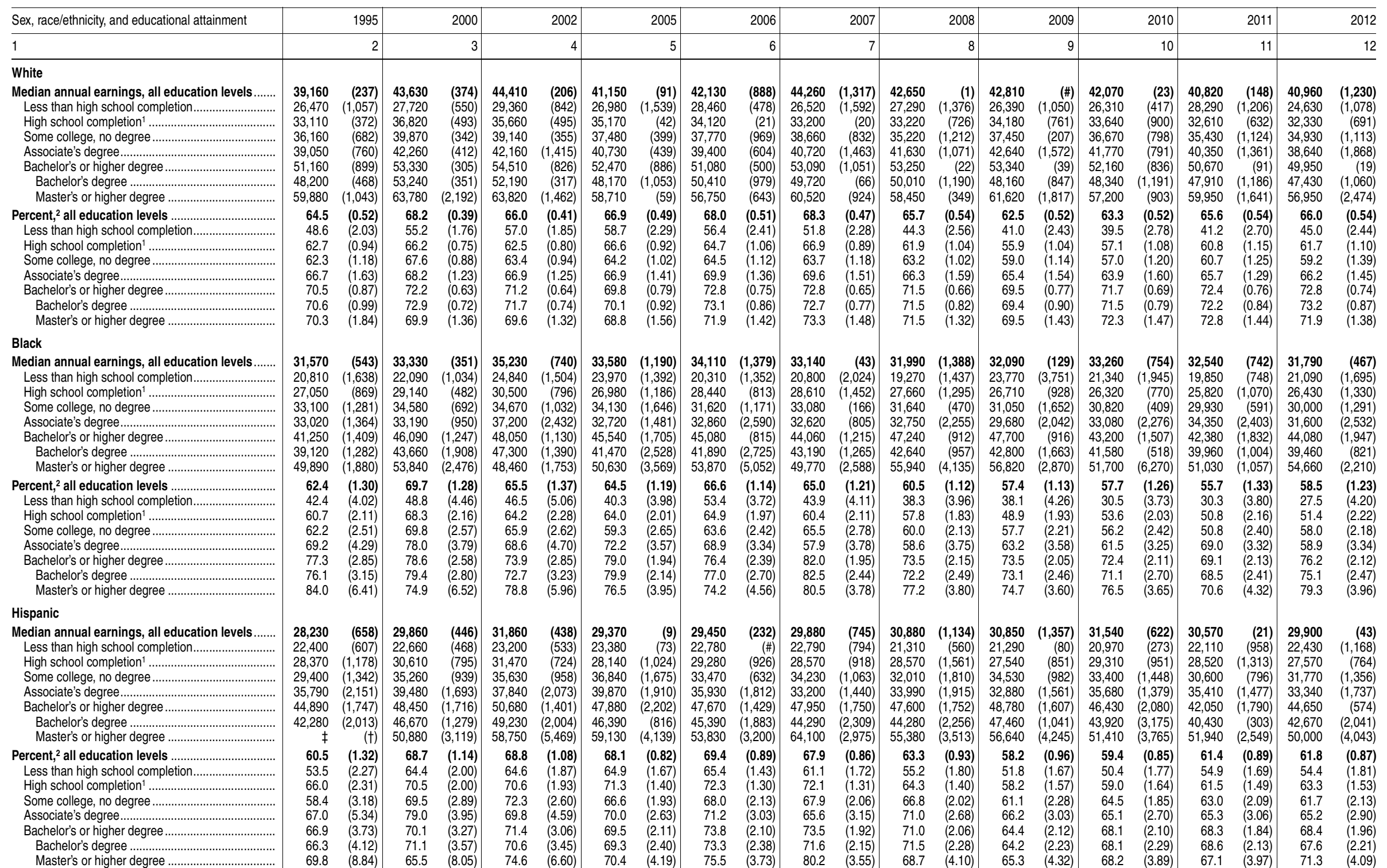




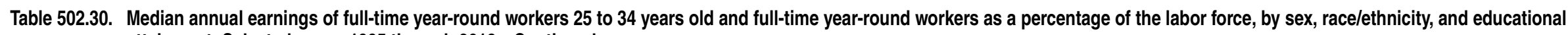
attainment: Selected years, 1995 through 2012-Continued

[Amounts in constant 2012 dollars. Standard errors appear in parentheses]

\begin{tabular}{|c|c|c|c|c|c|c|c|c|c|c|c|c|c|c|c|c|c|c|c|c|c|c|}
\hline thnicity, and educational attainment & & 1995 & & 2000 & & 2002 & & 2005 & & 2006 & & 2007 & & 2008 & & 2009 & & 2010 & & 2011 & & 2012 \\
\hline 1 & & 2 & & 3 & & 4 & & 5 & & ( & & 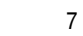 & & $\varepsilon$ & & g & & 10 & & 11 & & 12 \\
\hline \multicolumn{23}{|l|}{ Asian $^{3}$} \\
\hline 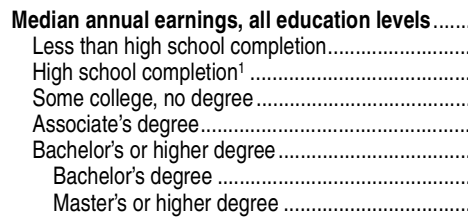 & $\begin{array}{r}38,100 \\
\ddagger \\
29,900 \\
27,900 \\
30,130\end{array}$ & $\begin{array}{r}(1,061) \\
(+) \\
(2,188) \\
(2,624) \\
(1,847) \\
(2,135) \\
(958) \\
(5,473)\end{array}$ & $\begin{array}{r}\mathbf{4 7 , 8 1 0} \\
\ddagger \\
33,320 \\
38,350 \\
39,330 \\
65,750 \\
59,790 \\
76,270\end{array}$ & $\begin{array}{r}(\mathbf{8 1 1}) \\
(\dagger) \\
(1,206) \\
(1,985) \\
(1,965) \\
(1,360) \\
(2,408) \\
(5,852)\end{array}$ & $\begin{array}{r}\mathbf{5 0 , 3 3 0} \\
\neq \\
31,160 \\
34,540 \\
\neq \\
7 \\
63,370 \\
57,000 \\
75,750\end{array}$ & $\begin{array}{r}(+, 281) \\
(+462) \\
1,735) \\
(\dagger) \\
1,167)\end{array}$ & $\begin{array}{r}46,850 \\
\ddagger \\
\exists 11,620 \\
34,870 \\
40,000 \\
58,770 \\
58,760 \\
63,980\end{array}$ & $\begin{array}{r}1,907) \\
(+) \\
1,660) \\
2,448) \\
4,961) \\
1,070) \\
3,821) \\
4,692)\end{array}$ & $\begin{array}{r}\mathbf{5 0 , 9 8 0} \\
\neq \\
31,170 \\
36,000 \\
40,580 \\
61,560 \\
56,360 \\
68,140\end{array}$ & $\begin{array}{r}(1,319) \\
(+) \\
(2,892) \\
(2,771) \\
(5,146) \\
(3,077) \\
(908) \\
(2,035)\end{array}$ & $\begin{array}{r}49,540 \\
\neq \\
\vdots 0,870 \\
38,550 \\
38,890 \\
60,850 \\
54,580 \\
71,710\end{array}$ & $\begin{array}{r}(2,025) \\
(+) \\
(2,827) \\
(2,665) \\
(5,042) \\
(5,043) \\
(1,896) \\
(2,408)\end{array}$ & $\begin{array}{r}52,860 \\
\ddagger \\
29,820 \\
35,120 \\
33,690 \\
63,500 \\
58,260 \\
73,860\end{array}$ & $\begin{array}{r}(744) \\
(+) \\
(2,633) \\
(4,560) \\
(2,682) \\
(898) \\
(2,230) \\
(2,998)\end{array}$ & $\begin{array}{r}52,650 \\
\ddagger \\
27,690 \\
40,650 \\
38,830 \\
63,440 \\
53,300 \\
74,910\end{array}$ & $\begin{array}{r}(790) \\
(+) \\
(2,165) \\
(3,513) \\
(4,093) \\
(1,500) \\
(1,202) \\
(3,219)\end{array}$ & $\begin{array}{r}48,150 \\
\neq \\
30,750 \\
36,580 \\
37,780 \\
63,020 \\
56,870 \\
71,900\end{array}$ & $\begin{array}{r}(2,697) \\
(+) \\
(1,813) \\
(1,503) \\
(2,826) \\
(1,137) \\
(4,176) \\
(5,165)\end{array}$ & $\begin{array}{r}50,240 \\
\ddagger \\
75,460 \\
31,520 \\
35,300 \\
62,370 \\
52,350 \\
74,740\end{array}$ & $\begin{array}{r}(2,679) \\
(\dagger) \\
(1,313) \\
(1,835) \\
(6,650) \\
(2,413) \\
(3,384) \\
(4,556)\end{array}$ & $\begin{array}{r}53,830 \\
\ddagger \\
29,530 \\
3,210 \\
43,100 \\
64,220 \\
59,280 \\
69,720\end{array}$ & $\begin{array}{r}(2,499) \\
(+) \\
(816) \\
(2,634) \\
(3,162) \\
(1,674) \\
(1,925) \\
(1,963)\end{array}$ \\
\hline $\begin{array}{l}\text { High school } \\
\text { Some colled } \\
\text { Associate's } \\
\text { Bachelor's } \\
\text { Bachelor' } \\
\text { Master's }\end{array}$ & $\begin{array}{l}63.4 \\
46.6 \\
66.9 \\
51.8 \\
77.1 \\
65.6 \\
68.0 \\
62.0\end{array}$ & $\begin{array}{l}(2.98) \\
(9.98) \\
(7.05) \\
(8.46) \\
(8.01) \\
(4.18) \\
(5.27) \\
(6.80)\end{array}$ & $\begin{array}{l}68.5 \\
61.6 \\
68.9 \\
63.4 \\
72.2 \\
69.9 \\
70.8 \\
67.9\end{array}$ & $\begin{array}{l}(1.78) \\
(8.31) \\
(4.59) \\
(4.59) \\
(5.92) \\
(2.35) \\
(2.87) \\
(4.11)\end{array}$ & $\begin{array}{r}65.8 \\
\ddagger \\
67.2 \\
63.8 \\
67.3 \\
67.4 \\
66.8 \\
68.4\end{array}$ & $\begin{array}{r}(1.91) \\
(+) \\
(4.64) \\
(5.54) \\
(8.22) \\
(2.40) \\
(3.05) \\
(3.91)\end{array}$ & $\begin{array}{l}64.8 \\
49.4 \\
62.5 \\
66.5 \\
66.3 \\
66.0 \\
68.7 \\
61.3\end{array}$ & $\begin{array}{l}(1.57) \\
(7.62) \\
(4.82) \\
(4.65) \\
(5.93) \\
(2.07) \\
(2.69) \\
(3.08)\end{array}$ & $\begin{array}{r}69.3 \\
\neq \\
63.3 \\
64.7 \\
74.1 \\
71.0 \\
69.5 \\
73.3\end{array}$ & $\begin{array}{r}(1.75) \\
(\dagger) \\
(4.18) \\
(4.97) \\
(5.81) \\
(2.17) \\
(2.78) \\
(3.23)\end{array}$ & $\begin{array}{r}71.2 \\
\ddagger \\
68.5 \\
73.4 \\
70.6 \\
72.4 \\
71.6 \\
73.6\end{array}$ & $\begin{array}{r}(1.63) \\
(\dagger) \\
(4.09) \\
(4.48) \\
(5.49) \\
(2.04) \\
(2.40) \\
(3.25)\end{array}$ & $\begin{array}{r}68.8 \\
\ddagger \\
63.0 \\
63.8 \\
78.4 \\
71.9 \\
72.7 \\
70.9\end{array}$ & $\begin{array}{r}(1.72) \\
(\dagger) \\
(4.17) \\
(4.70) \\
(5.36) \\
(1.93) \\
(2.48) \\
(2.79)\end{array}$ & $\begin{array}{r}66.7 \\
\ddagger \\
59.3 \\
57.4 \\
70.3 \\
70.5 \\
69.7 \\
71.6\end{array}$ & $\begin{array}{r}(1.51) \\
(+) \\
(4.15) \\
(5.03) \\
(4.25) \\
(1.84) \\
(2.46) \\
(3.17)\end{array}$ & $\begin{array}{r}65.1 \\
\neq \\
55.9 \\
58.2 \\
56.5 \\
71.1 \\
72.2 \\
69.4\end{array}$ & $\begin{array}{r}(1.46) \\
(+) \\
(3.97) \\
(4.93) \\
(5.57) \\
(1.89) \\
(2.22) \\
(3.15)\end{array}$ & 65.1 & $\begin{array}{l}(1.73) \\
(6.80) \\
(4.47) \\
(4.37) \\
(5.88) \\
(2.08) \\
(2.59) \\
(3.20)\end{array}$ & $\begin{array}{l}67.9 \\
50.9 \\
64.6 \\
51.7 \\
60.6 \\
72.9 \\
73.7 \\
71.7\end{array}$ & $\begin{array}{l}(1.57) \\
(7.17) \\
(3.35) \\
(4.31) \\
(5.79) \\
(1.80) \\
(2.31) \\
(2.85)\end{array}$ \\
\hline $\begin{array}{l}\text { Median annual earnings for other race groups, } \\
\text { all leducation levels } \\
\text { Pacific Islander }{ }^{4}\end{array}$ & $\begin{array}{r}{ }^{[3]} \\
29,880\end{array}$ & $\begin{array}{r}(+) \\
(372) \\
(\dagger)\end{array}$ & $\begin{array}{r}{\left[{ }^{[3]}\right]} \\
33,310\end{array}$ & $\begin{array}{r}(\dagger) \\
(493) \\
(\dagger)\end{array}$ & $\begin{array}{r}\ddagger \\
31,620 \\
41,760\end{array}$ & $\begin{array}{r}(\dagger) \\
(2,332) \\
(2,265)\end{array}$ & $\begin{array}{r}\ddagger \\
34,680 \\
39,970\end{array}$ & $\begin{array}{r}(\dagger) \\
(2,002) \\
(1,676)\end{array}$ & $\begin{array}{l}33,140 \\
29,550 \\
39,050\end{array}$ & $\begin{array}{l}(3,052) \\
(2,782) \\
(1,364)\end{array}$ & $\begin{array}{l}38,060 \\
33,980 \\
35,900\end{array}$ & $\begin{array}{l}(3,583) \\
(1,932) \\
(3,411)\end{array}$ & $\begin{array}{r}\ddagger \\
30,710 \\
35,750\end{array}$ & $\begin{array}{r}(\dagger) \\
(2,447) \\
(3,003)\end{array}$ & $\begin{array}{r}\ddagger \\
32,110 \\
35,960\end{array}$ & $\begin{array}{r}\left(\begin{array}{r}(\dagger) \\
(4,220) \\
(2,881)\end{array}\right.\end{array}$ & $\begin{array}{r}\ddagger \\
33,160 \\
36,640\end{array}$ & $\begin{array}{r}(\dagger) \\
(3,330) \\
(1,466)\end{array}$ & $\begin{array}{l}34,950 \\
29,900 \\
37,460\end{array}$ & $\begin{array}{l}(2,623) \\
(1,710) \\
(1,680)\end{array}$ & $\begin{array}{l}32,090 \\
32,890 \\
35,570\end{array}$ & $\begin{array}{l}(4,904) \\
(2,715) \\
(1,515)\end{array}$ \\
\hline 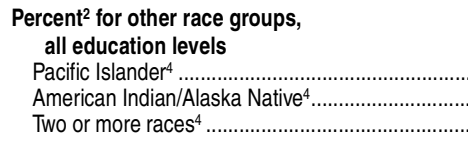 & $\begin{array}{r}{[3]} \\
46.9 \\
\end{array}$ & $\begin{array}{r}(\dagger) \\
(8.10) \\
(\dagger)\end{array}$ & $\begin{array}{r}\left.{ }^{[3]}\right] \\
57.6 \\
-\end{array}$ & $\begin{array}{r}(t) \\
(4.94) \\
(\dagger)\end{array}$ & $\begin{array}{l}66.2 \\
50.3 \\
56.1\end{array}$ & $\begin{array}{l}(7.71) \\
(6.16) \\
(4.599\end{array}$ & $\begin{array}{l}53.7 \\
60.2 \\
61.9\end{array}$ & $\begin{array}{l}(6.81) \\
(4.01) \\
(3.46)\end{array}$ & $\begin{array}{l}68.1 \\
56.2 \\
60.9\end{array}$ & $\begin{array}{r}(4.86) \\
(3.18)\end{array}$ & $\begin{array}{l}70.2 \\
64.3 \\
59.5\end{array}$ & $\begin{array}{l}(0.58) \\
(3.21)\end{array}$ & 59.5 & $\begin{array}{l}(4.76) \\
(4.28) \\
(2.89)\end{array}$ & $\begin{array}{l}59.8 \\
50.2\end{array}$ & $\begin{array}{l}(7.15) \\
(4.30) \\
(2.95)\end{array}$ & $\begin{array}{l}62.2 \\
52.9 \\
60.2\end{array}$ & $\begin{array}{l}(4.14) \\
(2.87)\end{array}$ & $\begin{array}{l}56.9 \\
52.2 \\
58.1\end{array}$ & $\begin{array}{l}(4.58) \\
(2.93)\end{array}$ & & $\begin{array}{l}(6.03) \\
(5.05) \\
(2.94)\end{array}$ \\
\hline
\end{tabular}

\section{-Not available.}

†Not applicable.
\#Rounds to zero.

\#Reporting standards not met (too few cases for a reliable estimate).

IIncludes equivatency credentials, such as the General Eductional Development (GED) credential

${ }^{2}$ Full-time year-round workers as a percentage of the population ages 25 through 34 who reported working or looking for work in the given year.

${ }^{3}$ For 1995 and 2000, data for Asians and Pacific Islanders were not reported separately; therefore, Pacific Islanders are included with Asians for 1995 and 2000.
${ }^{4}$ For Pacific Islanders, American Indians/Alaska Natives, and persons of two or more races, data by educational attainment are omitted because these data did not meet reporting standards. All data shown for these three race categories are for perNOTE: Begining in levels.

dard errors were computed using replicate weights, which produced more precise values than the methodology used in prior years. Race categories exclude persons of Hispanic ethnicity. Constant dollars based on the SOURCE: U.S. Department of Commerce, Census Bureau, Current Population Survey (CPS), March 1996 through March 2013. (This table was prepared October 2013.) 
Table 502.40. Distribution of earnings and median earnings of persons 25 years old and over, by highest level of educational attainment and sex: 2012

[Standard errors appear in parentheses]

\begin{tabular}{|c|c|c|c|c|c|c|c|c|c|c|c|c|c|c|c|c|c|c|c|c|c|c|}
\hline \multirow[b]{3}{*}{ Sex and earnings } & \multirow{3}{*}{\multicolumn{2}{|c|}{ Total }} & \multicolumn{6}{|c|}{ Elementary/secondary } & \multicolumn{14}{|c|}{ College } \\
\hline & & & \multirow{2}{*}{\multicolumn{2}{|c|}{ Less than 9 th grade }} & \multirow{2}{*}{\multicolumn{2}{|c|}{$\begin{array}{r}\text { Some high school, } \\
\text { no completion }\end{array}$}} & \multirow{2}{*}{\multicolumn{2}{|c|}{$\begin{array}{r}\text { High school } \\
\text { completion } \\
\text { (includes } \\
\text { equivalency) }\end{array}$}} & \multirow{2}{*}{\multicolumn{2}{|c|}{$\begin{array}{r}\text { Some college, } \\
\text { no degree }\end{array}$}} & \multirow{2}{*}{\multicolumn{2}{|c|}{ Associate's degree }} & \multicolumn{10}{|c|}{ Bachelor's or higher degree } \\
\hline & & & & & & & & & & & & & & Total & Bachelor & degree & Master & degree & Profession & I degree & Docto & degree \\
\hline 1 & & 2 & & 3 & & 4 & & 5 & & 6 & & 7 & & 8 & & 9 & & 10 & & 11 & & 12 \\
\hline \multirow{2}{*}{$\begin{array}{l}\text { Number of persons } \\
\text { (in thousands).... }\end{array}$} & 206,899 & (210.7) & 9,922 & (109.1) & 14,595 & $(131.0)$ & 61,704 & (240.9) & 34,805 & (193.4) & 20,367 & (152.9) & 65,506 & (245.7) & 41,575 & (208.0) & 17,395 & (142.2) & 3,066 & (61.5) & 3,470 & (65.4) \\
\hline & 135,931 & (278.2) & 4,123 & $\begin{array}{r}(71.2) \\
(71)\end{array}$ & 6,795 & (90.9) & 36,375 & $(197.0)$ & 23,359 & $(162.6)$ & 14,990 & $(132.7)$ & 50,289 & (224.0) & 31,682 & $(185.9)$ & 13,384 & $(125.8)$ & 2,456 & $(55.1)$ & 2,768 & $(58.5)$ \\
\hline 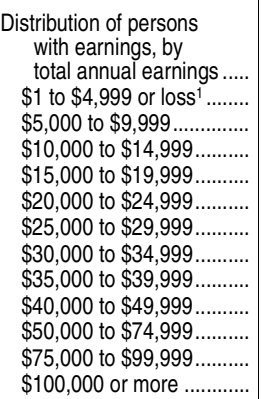 & $\begin{array}{r}100.0 \\
5.2 \\
5.3 \\
6.8 \\
6.8 \\
7.8 \\
7.2 \\
7.8 \\
6.6 \\
11.1 \\
18.0 \\
7.7 \\
9.7\end{array}$ & $\begin{array}{r}(t) \\
(0.07) \\
(0.07) \\
(0.08) \\
(0.08) \\
(0.08) \\
(0.08) \\
(0.08) \\
(0.08) \\
(0.08) \\
(0.12) \\
(0.08) \\
(0.09)\end{array}$ & $\begin{array}{r}100.0 \\
7.6 \\
10.0 \\
16.3 \\
18.6 \\
15.7 \\
11.0 \\
6.7 \\
3.6 \\
4.8 \\
4.0 \\
0.9 \\
0.8\end{array}$ & $\begin{array}{r}(t) \\
(0.46) \\
(0.52) \\
(0.64) \\
(0.68) \\
(0.63) \\
(0.55) \\
(0.44) \\
(0.33) \\
(0.37) \\
(0.34) \\
(0.16) \\
(0.16)\end{array}$ & $\begin{array}{r}100.0 \\
10.2 \\
10.8 \\
14.2 \\
14.2 \\
13.6 \\
8.7 \\
7.3 \\
5.5 \\
6.5 \\
6.5 \\
1.5 \\
1.1\end{array}$ & $\begin{array}{r}(\dagger) \\
(0.41) \\
(0.42) \\
(0.47) \\
(0.07) \\
(0.46) \\
(0.38) \\
(0.35) \\
(0.31) \\
(0.34) \\
(0.33) \\
(0.16) \\
(0.14)\end{array}$ & $\begin{array}{r}100.0 \\
5.9 \\
6.8 \\
8.5 \\
9.0 \\
10.5 \\
9.6 \\
10.0 \\
8.0 \\
11.2 \\
13.9 \\
3.9 \\
2.7\end{array}$ & $\begin{array}{r}(\dagger) \\
(0.14) \\
(0.15) \\
(0.16) \\
(0.17) \\
(0.18) \\
(0.17) \\
(0.18) \\
(0.16) \\
(0.18) \\
(0.20) \\
(0.11) \\
(0.10)\end{array}$ & $\begin{array}{r}100.0 \\
6.4 \\
5.8 \\
7.3 \\
7.2 \\
8.9 \\
8.6 \\
8.9 \\
7.8 \\
11.7 \\
16.8 \\
5.9 \\
4.7\end{array}$ & $\begin{array}{r}(\dagger) \\
(0.18) \\
(0.17) \\
(0.19) \\
(0.19) \\
(0.21) \\
(0.20) \\
(0.21) \\
(0.20) \\
(0.24) \\
(0.27) \\
(0.17) \\
(0.15)\end{array}$ & $\begin{array}{r}100.0 \\
5.1 \\
4.4 \\
6.5 \\
6.1 \\
7.9 \\
8.0 \\
9.3 \\
7.3 \\
13.4 \\
20.3 \\
7.3 \\
4.4\end{array}$ & $\begin{array}{r}(\dagger) \\
(0.20) \\
(0.19) \\
(0.22) \\
(0.22) \\
(0.25) \\
(0.25) \\
(0.26) \\
(0.24) \\
(0.31) \\
(0.37) \\
(0.24) \\
(0.19)\end{array}$ & $\begin{array}{r}100.0 \\
3.4 \\
3.2 \\
3.6 \\
3.3 \\
4.0 \\
4.0 \\
5.3 \\
5.2 \\
11.3 \\
23.4 \\
12.7 \\
20.6\end{array}$ & $\begin{array}{r}(\dagger) \\
(0.09) \\
(0.09) \\
(0.09) \\
(0.09) \\
(0.10) \\
(0.10) \\
(0.11) \\
(0.11) \\
(0.16) \\
(0.21) \\
(0.17) \\
(0.20)\end{array}$ & $\begin{array}{r}100.0 \\
3.6 \\
3.5 \\
3.9 \\
3.8 \\
4.9 \\
4.7 \\
6.3 \\
6.2 \\
12.5 \\
23.2 \\
12.0 \\
15.4\end{array}$ & \begin{tabular}{r|}
$(t)$ \\
$(0.12)$ \\
$(0.12)$ \\
$(0.12)$ \\
$(0.12)$ \\
$(0.14)$ \\
$(0.13)$ \\
$(0.15)$ \\
$(0.15)$ \\
$(0.21)$ \\
$(0.27)$ \\
$(0.20)$ \\
$(0.23)$
\end{tabular} & $\begin{array}{r}100.0 \\
3.2 \\
3.0 \\
3.2 \\
2.6 \\
2.8 \\
3.2 \\
4.1 \\
4.2 \\
10.7 \\
25.6 \\
14.4 \\
22.9\end{array}$ & 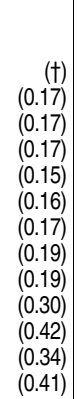 & $\begin{array}{r}100.0 \\
2.3 \\
1.2 \\
2.3 \\
1.5 \\
1.9 \\
1.9 \\
2.8 \\
2.1 \\
4.7 \\
17.4 \\
12.7 \\
49.2\end{array}$ & $\begin{array}{r}(\mathrm{t}) \\
(0.34) \\
(0.25) \\
(0.34) \\
(0.27) \\
(0.31) \\
(0.31) \\
(0.37) \\
(0.32) \\
(0.48) \\
(0.85) \\
(0.75) \\
(1.13)\end{array}$ & $\begin{array}{r}100.0 \\
2.4 \\
1.9 \\
2.3 \\
2.1 \\
2.0 \\
2.3 \\
2.4 \\
1.4 \\
7.2 \\
20.2 \\
13.6 \\
42.3\end{array}$ & $\begin{array}{r}(\dagger) \\
(0.32) \\
(0.29) \\
(0.32) \\
(0.31) \\
(0.29) \\
(0.32) \\
(0.33) \\
(0.25) \\
(0.55) \\
(0.85) \\
(0.73) \\
(1.05)\end{array}$ \\
\hline Median earnings ${ }^{2} \ldots \ldots \ldots \ldots \ldots \ldots$ & $\$ 36,630$ & (121) & $\$ 19,210$ & (372) & $\$ 20,150$ & (241) & $\$ 29,770$ & (314) & $\$ 32,030$ & (185) & $\$ 36,360$ & (342) & $\$ 55,140$ & (386) & $\$ 50,280$ & (192) & $\$ 61,040$ & (345) & $\$ 97,200$ & $(3,645)$ & $\$ 82,880$ & $(3,072)$ \\
\hline $\begin{array}{l}\text { Number of males } \\
\text { (in thousands)............. } \\
\text { With earnings....................... }\end{array}$ & 99,305 & (124.7) & 4,963 & (77.0) & 7,314 & (92.4) & 30,014 & (166.1) & 16,508 & (132.7) & 8,775 & $(100.6)$ & 31,731 & (169.0) & 19,860 & (143.1) & 7,804 & (95.3) & 1,876 & (48.0) & 2,192 & $(51.8)$ \\
\hline $\begin{array}{l}\text { Distribution of males with } \\
\text { earnings, by total annual } \\
\text { earnings...... }\end{array}$ & 72,128 & (181.3) & 2,742 & $(57.8)$ & 4,150 & (70.7) & 20,533 & (144.9) & 12,181 & (116.5) & 6,879 & (89.8) & 25,642 & (157.5) & 16,146 & (131.5) & 6,196 & (85.5) & 1,540 & (43.6) & 1,760 & $(46.5)$ \\
\hline 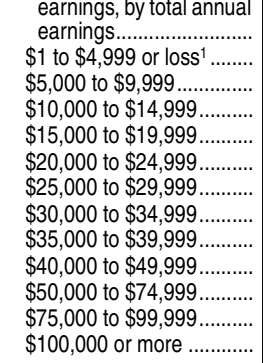 & $\begin{array}{r}100.0 \\
3.9 \\
3.9 \\
5.2 \\
5.7 \\
6.6 \\
6.6 \\
7.2 \\
6.2 \\
11.4 \\
20.1 \\
9.7 \\
13.6\end{array}$ & $\begin{array}{r}(t) \\
(0.08) \\
(0.08) \\
(0.09) \\
(0.0) \\
(0.10) \\
(0.10) \\
(0.11) \\
(0.0) \\
(0.13) \\
(0.17) \\
(0.12) \\
(0.14)\end{array}$ & $\begin{array}{r}100.0 \\
4.5 \\
7.6 \\
13.5 \\
18.5 \\
16.3 \\
12.7 \\
8.3 \\
4.6 \\
6.5 \\
5.3 \\
1.2 \\
0.9\end{array}$ & 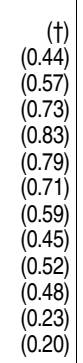 & $\begin{array}{r}100.0 \\
7.6 \\
8.2 \\
10.5 \\
13.3 \\
13.4 \\
8.9 \\
9.2 \\
7.1 \\
8.7 \\
9.5 \\
2.3 \\
1.4\end{array}$ & $\begin{array}{r}(\dagger) \\
(0.46) \\
(0.48) \\
(0.53) \\
(0.59) \\
(0.59) \\
(0.49) \\
(0.50) \\
(0.44) \\
(0.49) \\
(0.51) \\
(0.26) \\
(0.20)\end{array}$ & $\begin{array}{r}100.0 \\
4.5 \\
4.8 \\
6.2 \\
7.2 \\
8.8 \\
8.6 \\
10.0 \\
8.4 \\
13.1 \\
18.6 \\
5.9 \\
4.0\end{array}$ & $\begin{array}{r}(\dagger) \\
(0.16) \\
(0.17) \\
(0.19) \\
(0.20) \\
(0.22) \\
(0.22) \\
(0.23) \\
(0.22) \\
(0.26) \\
(0.30) \\
(0.18) \\
(0.15)\end{array}$ & $\begin{array}{r}100.0 \\
4.3 \\
4.5 \\
5.1 \\
5.2 \\
7.1 \\
8.0 \\
7.7 \\
7.1 \\
13.1 \\
21.8 \\
8.9 \\
7.2\end{array}$ & $\begin{array}{r}(t) \\
(0.21) \\
(0.21) \\
(0.22) \\
(0.23) \\
(0.26) \\
(0.27) \\
(0.27) \\
(0.26) \\
(0.34) \\
(0.42) \\
(0.29) \\
(0.26)\end{array}$ & $\begin{array}{r}100.0 \\
3.9 \\
2.8 \\
4.7 \\
3.8 \\
5.3 \\
6.5 \\
7.8 \\
6.7 \\
14.1 \\
26.3 \\
11.0 \\
7.2\end{array}$ & $\begin{array}{r}(\dagger) \\
(0.26) \\
(0.22) \\
(0.28) \\
(0.26) \\
(0.30) \\
(0.33) \\
(0.36) \\
(0.34) \\
(0.47) \\
(0.59) \\
(0.42) \\
(0.35)\end{array}$ & $\begin{array}{r}100.0 \\
2.4 \\
2.0 \\
2.8 \\
2.6 \\
3.0 \\
3.3 \\
4.3 \\
3.8 \\
9.4 \\
22.2 \\
14.9 \\
29.4\end{array}$ & $\begin{array}{r}(\dagger) \\
(0.11) \\
(0.10) \\
(0.12) \\
(0.11) \\
(0.12) \\
(0.12) \\
(0.14) \\
(0.13) \\
(0.20) \\
(0.29) \\
(0.25) \\
(0.32)\end{array}$ & $\begin{array}{r}100.0 \\
2.7 \\
2.1 \\
2.9 \\
3.0 \\
3.7 \\
3.6 \\
5.1 \\
41.8 \\
11.2 \\
23.4 \\
14.7 \\
22.7\end{array}$ & \begin{tabular}{r|}
$(\dagger)$ \\
$(0.14)$ \\
$(0.13)$ \\
$(0.15)$ \\
$(0.15)$ \\
$(0.17)$ \\
$(0.16)$ \\
$(0.19)$ \\
$(0.19)$ \\
$(0.28)$ \\
$(0.37)$ \\
$(0.31)$ \\
$(0.37)$
\end{tabular} & $\begin{array}{r}100.0 \\
2.1 \\
2.0 \\
2.9 \\
2.2 \\
2.0 \\
3.2 \\
3.0 \\
2.3 \\
7.0 \\
21.9 \\
16.5 \\
34.8\end{array}$ & $\begin{array}{r}(+) \\
(0.20) \\
(0.20) \\
(0.24) \\
(0.21) \\
(0.20) \\
(0.25) \\
(0.24) \\
(0.21) \\
(0.36) \\
(0.59) \\
(0.53) \\
(0.68)\end{array}$ & $\begin{array}{c}100.0 \\
1.3 \\
0.5 ! \\
1.9 \\
1.1 \\
1.4 \\
1.7 \\
2.6 \\
2.1 \\
4.3 \\
15.0 \\
12.8 \\
55.3\end{array}$ & $\begin{array}{r}(\dagger) \\
(0.33) \\
(0.21) \\
(0.39) \\
(0.29) \\
(0.33) \\
(0.36) \\
(0.46) \\
(0.41) \\
(0.58) \\
(1.02) \\
(0.95) \\
(1.42)\end{array}$ & $\begin{array}{r}100.0 \\
2.3 \\
2.0 \\
2.0 \\
1.6 \\
1.6 \\
2.1 \\
2.2 \\
0.9 \\
6.2 \\
17.6 \\
12.2 \\
49.4\end{array}$ & $\begin{array}{r}(\dagger) \\
(0.40) \\
(0.38) \\
(0.37) \\
(0.33) \\
(0.33) \\
(0.38) \\
(0.39) \\
(0.25) \\
(0.64) \\
(1.02) \\
(0.87) \\
(1.33)\end{array}$ \\
\hline Median earnings ${ }^{2} \ldots \ldots \ldots \ldots \ldots$ & $\$ 42,310$ & (142) & $\$ 21,320$ & (280) & $\$ 23,280$ & (664) & $\$ 34,960$ & (529) & $\$ 40,470$ & (311) & $\$ 45,590$ & (608) & $\$ 66,870$ & (508) & $\$ 60,300$ & (406) & $\$ 76,020$ & (843) & $\$ 101,890$ & $(1,766)$ & $\$ 96,910$ & $(5,001)$ \\
\hline
\end{tabular}

See notes at end of table. 
Table 502.40. Distribution of earnings and median earnings of persons 25 years old and over, by highest level of educational attainment and sex: $2012-$ Continued [Standard errors appear in parentheses]

\begin{tabular}{|c|c|c|c|c|c|c|c|c|c|c|c|c|c|c|c|c|c|c|c|c|c|c|}
\hline \multirow[b]{3}{*}{ Sex and earnings } & & \multirow[b]{3}{*}{ Total } & \multicolumn{6}{|c|}{ Elementary/secondary } & \multicolumn{14}{|c|}{ College } \\
\hline & & & \multirow{2}{*}{\multicolumn{2}{|c|}{ Less than 9th grade }} & \multirow{2}{*}{\multicolumn{2}{|c|}{$\begin{array}{r}\text { Some high school, } \\
\text { no completion }\end{array}$}} & \multirow{2}{*}{\multicolumn{2}{|c|}{$\begin{array}{r}\text { High school } \\
\text { completion } \\
\text { (includes } \\
\text { equivalency) }\end{array}$}} & \multirow{2}{*}{\multicolumn{2}{|c|}{$\begin{array}{l}\text { Some college } \\
\text { no degre }\end{array}$}} & \multirow{2}{*}{\multicolumn{2}{|c|}{ Associate's degree }} & \multicolumn{10}{|c|}{ Bachelor's or higher degree } \\
\hline & & & & & & & & & & & & & & & \multicolumn{2}{|c|}{ Bachelor's degree } & \multicolumn{2}{|c|}{ Master's degree } & \multicolumn{2}{|c|}{ Professional degree } & \multicolumn{2}{|c|}{ Doctor's degree } \\
\hline 1 & & 2 & & 3 & \multicolumn{2}{|r|}{4} & \multicolumn{2}{|r|}{5} & \multicolumn{2}{|c|}{6} & \multicolumn{2}{|c|}{7} & \multicolumn{2}{|r|}{$\begin{array}{r}\text { Total } \\
8\end{array}$} & & 9 & & 10 & & 11 & & 12 \\
\hline $\begin{array}{l}\text { Number of females } \\
\text { (in thousands)... }\end{array}$ & 107,594 & (136.5) & 4,958 & (77.1) & 7,282 & (92.5) & 31,690 & (171.9) & 18,298 & $(139.7$ & 11,592 & $(114.6)$ & 33,775 & (175.4) & 21,715 & (149.7) & 9,591 & (105.2) & 1,191 & (38.4) & 1,278 & (39.7) \\
\hline With earnings...................... & 63,802 & (197.4) & 1,380 & $(41.3)$ & 2,644 & $(56.9)$ & 15,842 & (131.4) & 11,178 & $(112.7$ & 8,111 & $(97.3)$ & 24,647 & (157.2) & 15,536 & (130.3) & 7,188 & (92.0) & 915 & (33.7) & 1,008 & $(35.3)$ \\
\hline 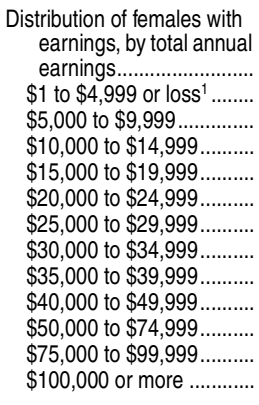 & $\begin{array}{r}100.0 \\
6.8 \\
6.9 \\
8.6 \\
8.1 \\
9.2 \\
7.8 \\
8.4 \\
7.1 \\
10.9 \\
15.5 \\
5.4 \\
5.3\end{array}$ & $\begin{array}{r}(\dagger) \\
(0.11) \\
(0.11) \\
(0.12) \\
(0.12) \\
(0.13) \\
(0.12) \\
(0.12) \\
(0.11) \\
(0.14) \\
(0.16) \\
(0.10) \\
(0.10)\end{array}$ & $\begin{array}{r}100.0 \\
13.8 \\
14.7 \\
21.7 \\
18.6 \\
14.5 \\
7.7 \\
3.5 \\
1.7 \\
1.5 \\
1.4 \\
\neq \\
0.7 !\end{array}$ & $\begin{array}{r}(\dagger) \\
(1.04) \\
(1.07) \\
(1.24) \\
(1.17) \\
(1.06) \\
(0.80) \\
(0.55) \\
(0.39) \\
(0.37) \\
(0.35) \\
(\dagger) \\
(0.25)\end{array}$ & $\begin{array}{r}100.0 \\
14.4 \\
15.0 \\
20.0 \\
15.6 \\
13.8 \\
8.4 \\
4.4 \\
3.0 \\
3.1 \\
1.6 \\
0.3 ! \\
0.5 !\end{array}$ & $\begin{array}{r}(\dagger) \\
(0.76) \\
(0.78) \\
(0.87) \\
(0.79) \\
(0.75) \\
(0.60) \\
(0.44) \\
(0.37) \\
(0.38) \\
(0.28) \\
(0.11) \\
(0.16)\end{array}$ & $\begin{array}{r}100.0 \\
7.8 \\
9.3 \\
11.5 \\
11.4 \\
12.7 \\
10.8 \\
10.0 \\
7.6 \\
8.8 \\
7.8 \\
1.3 \\
1.0\end{array}$ & $\begin{array}{l}(t) \\
(0.24) \\
(0.26) \\
(0.28) \\
(0.28) \\
(0.30) \\
(0.28) \\
(0.27) \\
(0.23) \\
(0.25) \\
(0.24) \\
(0.10) \\
(0.09)\end{array}$ & $\begin{array}{r}100.0 \\
8.7 \\
7.2 \\
9.7 \\
9.4 \\
10.9 \\
9.3 \\
10.2 \\
8.5 \\
10.2 \\
11.2 \\
2.7 \\
1.9\end{array}$ & $\begin{array}{l}(\dagger \\
(0.30 \\
(0.27 \\
(0.31 \\
(0.31 \\
0.33 \\
(0.31 \\
(0.32 \\
(0.29 \\
(0.32 \\
(0.33 \\
0.17 \\
0.15\end{array}$ & $\begin{array}{r}100.0 \\
6.2 \\
5.7 \\
8.0 \\
8.0 \\
10.1 \\
9.2 \\
10.6 \\
7.8 \\
12.8 \\
15.3 \\
4.2 \\
2.1\end{array}$ & $\begin{array}{l}(\dagger) \\
(0.30) \\
(0.29) \\
(0.34) \\
(0.34) \\
(0.37) \\
(0.36) \\
(0.38) \\
(0.33) \\
(0.41) \\
(0.45) \\
(0.25) \\
(0.18)\end{array}$ & $\begin{array}{r}100.0 \\
4.4 \\
4.4 \\
4.3 \\
4.1 \\
5.1 \\
4.7 \\
6.4 \\
6.7 \\
13.3 \\
24.7 \\
10.5 \\
11.3\end{array}$ & $\begin{array}{r}(\dagger) \\
(0.15) \\
(0.15) \\
(0.15) \\
(0.14) \\
(0.16) \\
(0.15) \\
(0.17) \\
(0.18) \\
(0.24) \\
(0.31) \\
(0.22) \\
(0.23)\end{array}$ & $\begin{array}{r}100.0 \\
4.6 \\
4.9 \\
4.9 \\
4.7 \\
6.1 \\
5.7 \\
7.5 \\
7.7 \\
13.8 \\
23.0 \\
9.1 \\
7.9\end{array}$ & $\begin{array}{r}(\dagger) \\
(0.19) \\
(0.19) \\
(0.19) \\
(0.19) \\
(0.21) \\
(0.21) \\
(0.24) \\
(0.24) \\
(0.31) \\
(0.38) \\
(0.26) \\
(0.24)\end{array}$ & $\begin{array}{r}100.0 \\
4.2 \\
3.9 \\
3.4 \\
3.0 \\
3.5 \\
3.1 \\
5.0 \\
5.8 \\
13.9 \\
28.8 \\
12.6 \\
12.7\end{array}$ & $\begin{array}{r}(t) \\
(0.27) \\
(0.25) \\
(0.24) \\
(0.22) \\
(0.24) \\
(0.23) \\
(0.29) \\
(0.31) \\
(0.46) \\
(0.60) \\
(0.44) \\
(0.44)\end{array}$ & $\begin{array}{r}100.0 \\
3.8 \\
2.3 \\
3.1 \\
2.2 \\
2.9 \\
2.4 \\
3.1 \\
2.1 \\
5.3 \\
21.4 \\
12.5 \\
39.0\end{array}$ & 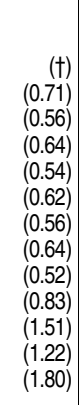 & $\begin{array}{r}100.0 \\
2.5 \\
1.6 \\
2.8 \\
3.2 \\
2.7 \\
2.5 \\
2.7 \\
2.4 \\
9.1 \\
24.5 \\
16.0 \\
29.9\end{array}$ & 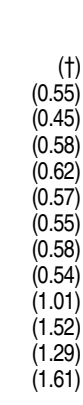 \\
\hline Median earnings ${ }^{2} \ldots \ldots \ldots \ldots \ldots \ldots . . . . . . . .$. & $\$ 30,990$ & (119) & $\$ 14,930$ & $(566)$ & $\$ 15,150$ & (301) & $\$ 23,500$ & (324) & $\$ 26,620$ & $(274$ & $\$ 30,890$ & (272) & $\$ 46,710$ & (269) & $\$ 41,570$ & (237) & $\$ 51,570$ & (330) & $\$ 76,050$ & $(2,191)$ & $\$ 70,810$ & $(1,925)$ \\
\hline
\end{tabular}

†Not applicable.

!Interpret data with caution. The coefficient of variation (CV) for this estimate is between 30 and 50 percent. fReporting slandards not mel. The coenticht of variation (CV) for this estimate is 50 percent or greater.

${ }^{2}$ Excludes persons wintout earnings.
NOTE: Detail may not sum to totals because of rounding

SOURCE: U.S. Department of Commerce, Census Bureau, Current Population Survey (CPS), 2013 Annual Social and Economic Supplement, retrieved December 26, 2013, from http://www.census.gov/hhes/www/cpstables/032013/perinc/pinc03 000.htm. (Th 


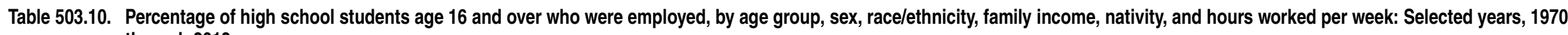
through 2012

[Standard errors appear in parentheses]

\begin{tabular}{|c|c|c|c|c|c|c|c|c|c|c|c|c|c|c|c|c|c|c|c|c|c|c|c|c|c|c|}
\hline \multirow[b]{2}{*}{ Year } & \multirow{2}{*}{\multicolumn{2}{|c|}{ Total }} & \multicolumn{4}{|c|}{ Age group } & \multicolumn{4}{|c|}{ Sex } & \multicolumn{6}{|c|}{ Race/ethnicity } & \multicolumn{6}{|c|}{ Family income $^{1}$} & \multicolumn{4}{|c|}{ Nativity } \\
\hline & & & \multicolumn{2}{|c|}{$\begin{array}{l}16 \text { and } 17 \\
\text { years old }\end{array}$} & \multicolumn{2}{|c|}{$\begin{array}{l}18 \text { years } \\
\text { old and over }\end{array}$} & \multicolumn{2}{|r|}{ le } & \multicolumn{2}{|r|}{ Female } & \multicolumn{2}{|r|}{ White } & \multicolumn{2}{|r|}{ Black } & \multicolumn{2}{|r|}{ Hispanic } & \multicolumn{2}{|c|}{ Low income } & \multicolumn{2}{|c|}{ Middle income } & \multicolumn{2}{|c|}{ High income } & \multicolumn{2}{|r|}{ U.S.-born } & \multicolumn{2}{|c|}{ Foreign-born } \\
\hline 1 & & 2 & & 3 & & 4 & & 5 & & 6 & & 7 & & 8 & & 9 & & 10 & & 11 & & 12 & & 13 & & 14 \\
\hline & \multicolumn{26}{|c|}{ ercent employed² } \\
\hline 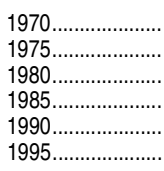 & $\begin{array}{l}31.9 \\
33.2 \\
35.6 \\
31.6 \\
32.3 \\
33.6\end{array}$ & $\begin{array}{l}(0.88) \\
(0.85) \\
(0.87) \\
(0.93) \\
(0.98) \\
(0.92)\end{array}$ & $\begin{array}{l}30.8 \\
32.9 \\
34.9 \\
30.8 \\
31.2 \\
32.7\end{array}$ & $\begin{array}{l}(0.93) \\
(0.91) \\
(0.94) \\
(1.00) \\
(1.08) \\
(1.02)\end{array}$ & $\begin{array}{l}39.7 \\
34.9 \\
39.6 \\
36.1 \\
37.1 \\
37.5\end{array}$ & $\begin{array}{l}(2.55) \\
(2.40) \\
(2.28) \\
(2.47) \\
(2.33) \\
(2.19)\end{array}$ & & $\begin{array}{l}(1.24) \\
(1.19) \\
(1.22) \\
(1.29) \\
(1.37) \\
(1.26)\end{array}$ & $\begin{array}{l}28.3 \\
31.2 \\
34.2 \\
31.0 \\
31.3 \\
34.2\end{array}$ & $\begin{array}{l}(1.22) \\
(1.22) \\
(1.24) \\
(1.33) \\
(1.39) \\
(1.35)\end{array}$ & $\begin{array}{l}38.0 \\
41.2 \\
37.9 \\
37.8 \\
40.8\end{array}$ & $\begin{array}{r}(\dagger) \\
(1.00) \\
(1.03) \\
(1.15) \\
(1.24) \\
(1.18)\end{array}$ & $\begin{array}{l}\overline{-} \\
13.9 \\
15.0 \\
15.0 \\
17.3 \\
18.0\end{array}$ & $\begin{array}{r}(+) \\
(1.63) \\
(1.64) \\
(1.85) \\
(2.05) \\
(1.91)\end{array}$ & $\begin{array}{l}-\overline{21.8} \\
24.1 \\
17.6 \\
26.4 \\
22.2\end{array}$ & 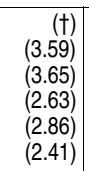 & $\begin{array}{l}14.7 \\
21.4 \\
17.4\end{array}$ & $\begin{array}{l}(2.51) \\
(2.22) \\
(2.10) \\
(1.85) \\
(2.16) \\
(1.82)\end{array}$ & $\begin{array}{l}31.5 \\
31.8 \\
35.2 \\
31.0 \\
33.1 \\
34.4\end{array}$ & $\begin{array}{l}1.12) \\
10)\end{array}$ & $\begin{array}{l}35.9 \\
40.4 \\
42.3 \\
41.1 \\
36.8 \\
42.1\end{array}$ & $\begin{array}{l}(1.64) \\
(1.59) \\
(1.59) \\
(1.81) \\
(1.97) \\
(1.88)\end{array}$ & $\begin{array}{l}- \\
- \\
- \\
\overline{-} \\
34.9\end{array}$ & $\begin{array}{r}(+) \\
(+) \\
(t) \\
(\dagger) \\
(+) \\
(0.97)\end{array}$ & $\begin{array}{l}\overline{-} \\
= \\
= \\
\overline{-} \\
20 . \overline{1}\end{array}$ & $\begin{array}{r}(+) \\
(+) \\
(+) \\
(+) \\
(+) \\
(2.65)\end{array}$ \\
\hline 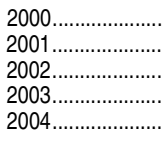 & $\begin{array}{l}34.1 \\
32.4 \\
30.6 \\
27.0 \\
27.2\end{array}$ & $\begin{array}{l}(0.93) \\
(0.86) \\
(0.84) \\
(0.79) \\
(0.80)\end{array}$ & $\begin{array}{l}33.3 \\
31.1 \\
29.2 \\
25.3 \\
25.6\end{array}$ & $\begin{array}{l}(1.03) \\
(0.95) \\
(0.93) \\
(0.86) \\
(0.87)\end{array}$ & $\begin{array}{l}37.7 \\
37.8 \\
35.9 \\
34.6 \\
34.7\end{array}$ & $\begin{array}{l}(2.15) \\
(1.99) \\
(1.92) \\
(1.97) \\
(2.03)\end{array}$ & & $\begin{array}{l}(1.28) \\
(1.17) \\
(1.13) \\
(1.09) \\
(1.09)\end{array}$ & $\begin{array}{l}35.1 \\
34.5 \\
33.4 \\
27.3 \\
28.3\end{array}$ & $\begin{array}{l}(1.36) \\
(1.27) \\
(1.24) \\
(1.15) \\
(1.17)\end{array}$ & $\begin{array}{l}41.3 \\
38.9 \\
37.5 \\
33.3 \\
32.9\end{array}$ & $\begin{array}{l}(1.20) \\
(1.11) \\
(1.11) \\
(1.07) \\
(1.08)\end{array}$ & $\begin{array}{l}21.3 \\
18.7 \\
16.9 \\
15.2 \\
15.1\end{array}$ & $\begin{array}{l}(2.14) \\
(1.85) \\
(1.81) \\
(1.68) \\
(1.71)\end{array}$ & $\begin{array}{l}20.9 \\
23.6 \\
21.1 \\
18.8 \\
21.2\end{array}$ & $\begin{array}{l}(2.18) \\
(2.23) \\
(1.94)\end{array}$ & $\begin{array}{l}22.0 \\
21.4 \\
18.4\end{array}$ & $\begin{array}{l}(2.11) \\
(2.04) \\
(1.83) \\
(1.64) \\
(1.55)\end{array}$ & $\begin{array}{l}34.1 \\
33.3\end{array}$ & & $\begin{array}{l}40.7 \\
36.1 \\
35.3 \\
31.8 \\
34.4\end{array}$ & & $\begin{array}{l}35.1 \\
33.3 \\
31.6 \\
28.0 \\
27.8\end{array}$ & $\begin{array}{l}(0.99) \\
(0.90) \\
(0.89) \\
(0.84) \\
(0.85)\end{array}$ & $\begin{array}{l}24.4 \\
23.0 \\
21.3 \\
17.7 \\
20.8\end{array}$ & $\begin{array}{l}(2.74) \\
(2.64) \\
(2.34) \\
(2.17) \\
(2.43)\end{array}$ \\
\hline 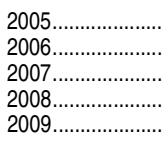 & $\begin{array}{l}26.4 \\
27.6 \\
26.2 \\
22.6 \\
17.0\end{array}$ & $\begin{array}{l}(0.77) \\
(0.79) \\
(0.78) \\
(0.74) \\
(0.67)\end{array}$ & $\begin{array}{l}25.2 \\
26.0 \\
24.8 \\
21.0 \\
15.2\end{array}$ & $\begin{array}{l}(0.84) \\
(0.86) \\
(0.85) \\
(0.80) \\
(0.72)\end{array}$ & $\begin{array}{l}32.2 \\
34.1 \\
32.2 \\
29.5 \\
23.8\end{array}$ & $\begin{array}{l}(1.95) \\
(1.87) \\
(1.87) \\
(1.83) \\
(1.65)\end{array}$ & & $\begin{array}{l}(1.05) \\
(1.08) \\
(1.06) \\
(0.99) \\
(0.91)\end{array}$ & $\begin{array}{l}27.6 \\
28.8 \\
27.6 \\
25.4 \\
18.1\end{array}$ & $\begin{array}{l}(1.14) \\
(1.16) \\
(1.14) \\
(1.10) \\
(0.98)\end{array}$ & $\begin{array}{l}31.8 \\
33.6 \\
31.3 \\
27.7 \\
21.5\end{array}$ & $\begin{array}{l}(1.05) \\
(1.08) \\
(1.06) \\
(1.04) \\
(0.96)\end{array}$ & $\begin{array}{l}13.7 \\
20.1 \\
15.1 \\
15.5 \\
10.5\end{array}$ & & $\begin{array}{l}19.4 \\
17.5 \\
21.1 \\
15.1 \\
11.9\end{array}$ & $\begin{array}{l}(1.78) \\
(1.72) \\
(1.83) \\
(1.54) \\
(1.39)\end{array}$ & $\begin{array}{l}14.8 \\
178\end{array}$ & $\begin{array}{l}(1.61) \\
(1.72) \\
(1.74) \\
(1.54) \\
(1.33)\end{array}$ & & & $\begin{array}{l}31.7 \\
33.5\end{array}$ & & $\begin{array}{l}26.8 \\
27.9 \\
26.0 \\
23.1 \\
17.0\end{array}$ & $\begin{array}{l}(0.81) \\
(0.82) \\
(0.81) \\
(0.78) \\
(0.70)\end{array}$ & $\begin{array}{l}21.7 \\
23.9 \\
28.5 \\
18.0 \\
16.9\end{array}$ & $\begin{array}{l}(2.49) \\
(2.64) \\
(2.64) \\
(2.35) \\
(2.32)\end{array}$ \\
\hline $\begin{array}{l}2010^{3} \ldots \ldots \ldots \ldots \ldots . . . \\
2011^{3} \ldots \ldots \ldots \ldots \ldots . . . \\
2012^{3} \ldots \ldots \ldots \ldots \ldots \ldots . .\end{array}$ & $\begin{array}{l}16.2 \\
16.9 \\
18.0 \\
\end{array}$ & $\begin{array}{l}(0.55) \\
(0.67) \\
(0.71)\end{array}$ & $\begin{array}{l}15.0 \\
16.4 \\
16.0 \\
\end{array}$ & & $\begin{array}{l}20.8 \\
18.7 \\
24.5 \\
\end{array}$ & & & & $\begin{array}{l}18.5 \\
19.4 \\
19.4 \\
\end{array}$ & & $\begin{array}{l}20.9 \\
22.2 \\
23.2 \\
\end{array}$ & $\begin{array}{l}(0.86) \\
(1.07) \\
(0.97) \\
\end{array}$ & $\begin{array}{r}9.6 \\
10.2 \\
12.7 \\
\end{array}$ & & $\begin{array}{l}10.4 \\
11.3 \\
11.4 \\
\end{array}$ & & $\begin{array}{r}8.5 \\
10.2 \\
13.0 \\
\end{array}$ & $\begin{array}{l}(1.01) \\
(1.29) \\
(1.42)\end{array}$ & & & 20.9 & & $\begin{array}{l}16.4 \\
17.3 \\
18.6 \\
\end{array}$ & & $\begin{array}{l}13.4 \\
12.4 \\
12.0 \\
\end{array}$ & $\begin{array}{l}(2.20) \\
(1.91) \\
(2.01) \\
\end{array}$ \\
\hline $2012^{3} \ldots \ldots \ldots \ldots \ldots \ldots$ & \multicolumn{26}{|c|}{ Percent working less than 15 hours per week ${ }^{4}$} \\
\hline $\begin{array}{l}1990 \ldots . . \\
1995 \ldots .\end{array}$ & $\begin{array}{l}13.6 \\
13.4 \\
14.0 \\
12.3 \\
11.7 \\
11.9\end{array}$ & $\begin{array}{l}(0.64) \\
(0.62) \\
(0.63) \\
(0.65) \\
(0.67) \\
(0.63)\end{array}$ & $\begin{array}{l}14.5 \\
14.0 \\
14.9 \\
12.8 \\
12.9 \\
13.1\end{array}$ & $\begin{array}{l}(0.71) \\
(0.67) \\
(0.70)\end{array}$ & $\begin{array}{l}7.5 \\
8.8 \\
8.9 \\
9.5 \\
6.8 \\
6.8\end{array}$ & $\begin{array}{l}(1.51) \\
(1.21) \\
(1.14)\end{array}$ & & $\begin{array}{l}(0.85) \\
(0.82) \\
(0.87) \\
(0.89) \\
(0.92) \\
(0.84)\end{array}$ & $\begin{array}{l}14.9 \\
14.3 \\
14.2 \\
12.9 \\
12.2 \\
12.9\end{array}$ & $\begin{array}{l}(0.91) \\
(0.96) \\
(0.98) \\
(0.96)\end{array}$ & $\begin{array}{r}15.5 \\
16.4 \\
15.2 \\
14.7 \\
14.8\end{array}$ & $\begin{array}{r}(\dagger) \\
(0.75) \\
(0.77) \\
(0.85) \\
(0.90) \\
(0.85)\end{array}$ & $\begin{array}{l}-\overline{-} \\
5.3 \\
4.6 \\
6.2 \\
6.0 \\
6.5\end{array}$ & $\begin{array}{r}(\dagger) \\
(1.05) \\
(0.96) \\
(1.25) \\
(1.28) \\
(1.22)\end{array}$ & $\begin{array}{l}-\overline{6} \\
6.6 ! \\
9.4 \\
3.0 ! \\
4.8 \\
6.5\end{array}$ & $\begin{array}{r}(\dagger) \\
(2.15)\end{array}$ & $\begin{array}{l}9.9 \\
6.8 \\
7.7 \\
3.6 \\
5.9 \\
4.4\end{array}$ & $\begin{array}{l}(1.81) \\
(1.44) \\
(1.41) \\
(0.97) \\
(1.24) \\
(0.98)\end{array}$ & $\begin{array}{l}12.6 \\
12.3 \\
13.2\end{array}$ & & $\begin{array}{l}16.8 \\
17.4 \\
17.7 \\
17.5 \\
15.6 \\
18.1\end{array}$ & & $\begin{array}{r}- \\
- \\
- \\
- \\
12.6\end{array}$ & $\begin{array}{r}(+) \\
(+) \\
(+) \\
(+) \\
(+) \\
(0.68)\end{array}$ & $\begin{array}{l}- \\
- \\
- \\
- \\
5.1\end{array}$ & $\begin{array}{r}(+) \\
(+) \\
(+) \\
(+) \\
(+) \\
(1.46)\end{array}$ \\
\hline $2004 \ldots \ldots$. & $\begin{array}{r}11.9 \\
11.6 \\
11.1 \\
9.6 \\
10.4\end{array}$ & $\begin{array}{l}(0.64) \\
(0.59) \\
(0.57) \\
(0.52) \\
(0.55)\end{array}$ & $\begin{array}{l}12.9 \\
12.6 \\
12.1 \\
10.0 \\
10.9\end{array}$ & $\begin{array}{l}(0.73) \\
(0.68) \\
(0.66) \\
(0.59) \\
(0.62)\end{array}$ & $\begin{array}{l}7.8 \\
7.7 \\
7.2 \\
7.8 \\
8.4\end{array}$ & $\begin{array}{l}(1.19) \\
(1.10) \\
(1.04) \\
(1.11) \\
(1.18)\end{array}$ & $\begin{array}{r}11.2 \\
9.8 \\
9.7 \\
9.0 \\
9.9\end{array}$ & $\begin{array}{l}(0.86) \\
(0.75) \\
(0.74) \\
(0.70) \\
(0.74)\end{array}$ & $\begin{array}{l}12.6 \\
13.7 \\
12.7 \\
10.2 \\
11.0\end{array}$ & & $\begin{array}{l}15.4 \\
15.0 \\
15.0 \\
12.4 \\
14.0\end{array}$ & $\begin{array}{l}(0.88) \\
(0.82) \\
(0.82) \\
(0.75) \\
(0.80)\end{array}$ & $\begin{array}{l}6.3 \\
4.3 \\
4.5 \\
4.5 \\
4.9\end{array}$ & $\begin{array}{l}(1.27) \\
(0.96) \\
(1.00) \\
(0.96) \\
(1.03)\end{array}$ & $\begin{array}{l}3.7 \\
6.1 \\
3.6 \\
5.5 \\
4.4\end{array}$ & & 3.5 & $\begin{array}{l}(1.15) \\
(1.15) \\
(1.12) \\
(1.00) \\
(0.87)\end{array}$ & $\begin{array}{l}11.3 \\
10.8\end{array}$ & & $\begin{array}{l}16.5 \\
16.4 \\
16.1\end{array}$ & & $\begin{array}{l}12.6 \\
12.2 \\
11.9 \\
10.2 \\
11.0\end{array}$ & $\begin{array}{l}(0.68) \\
(0.63) \\
(0.62) \\
(0.57) \\
(0.59)\end{array}$ & $\begin{array}{l}5.2 \\
5.5 \\
4.1 \\
3.7 \\
5.2\end{array}$ & $\begin{array}{l}(1.42) \\
(1.43) \\
(1.13) \\
(1.07) \\
(1.33)\end{array}$ \\
\hline $\begin{array}{l}2005 \ldots \ldots \ldots \ldots \ldots . . . \\
2006 \ldots \ldots \ldots \ldots \ldots . . . \\
2007 \ldots \ldots \ldots \ldots \ldots \ldots . . .\end{array}$ & $\begin{array}{r}10.1 \\
9.9 \\
10.6 \\
9.2 \\
7.6\end{array}$ & $\begin{array}{l}(0.53) \\
(0.53) \\
(0.54) \\
(0.51) \\
(0.47)\end{array}$ & $\begin{array}{r}10.7 \\
10.7 \\
11.4 \\
9.9 \\
8.0\end{array}$ & $\begin{array}{l}(0.60) \\
(0.61) \\
(0.63) \\
(0.59) \\
(0.54)\end{array}$ & $\begin{array}{l}7.2 \\
6.4 \\
7.0 \\
6.1 \\
6.2\end{array}$ & $\begin{array}{l}(1.08) \\
(0.97) \\
(1.02) \\
(0.96) \\
(0.94)\end{array}$ & $\begin{array}{l}8.9 \\
8.8 \\
9.5 \\
8.1 \\
6.8\end{array}$ & $\begin{array}{l}(0.69) \\
(0.69) \\
(0.72) \\
(0.68) \\
(0.62)\end{array}$ & $\begin{array}{r}11.4 \\
11.0 \\
11.7 \\
10.3 \\
8.4\end{array}$ & & $\begin{array}{l}13.4 \\
12.8 \\
14.2 \\
12.4 \\
10.1\end{array}$ & $\begin{array}{l}(0.77) \\
(0.76) \\
(0.80) \\
(0.77) \\
(0.71)\end{array}$ & $\begin{array}{l}3.7 \\
5.2 \\
3.0 \\
3.2 \\
3.6\end{array}$ & $\begin{array}{l}(0.89) \\
(1.03) \\
(0.80) \\
(0.82) \\
(0.86)\end{array}$ & $\begin{array}{l}5.0 \\
4.2 \\
6.0 \\
4.1 \\
4.7\end{array}$ & & $\begin{array}{l}3.7 \\
3.7 \\
6.1 \\
3.1 \\
3.6\end{array}$ & $\begin{array}{l}(0.85) \\
(0.85) \\
(1.10) \\
(0.78) \\
(0.83)\end{array}$ & $\begin{array}{l}9.9 \\
9.2 \\
9.6 \\
9.1 \\
6.9\end{array}$ & & $\begin{array}{l}13.9 \\
14.7 \\
15.3\end{array}$ & & $\begin{array}{r}10.6 \\
10.5 \\
11.1 \\
9.6 \\
7.8\end{array}$ & $\begin{array}{l}(0.56) \\
(0.56) \\
(0.58) \\
(0.54) \\
(0.50)\end{array}$ & $\begin{array}{l}4.6 \\
3.0 ! \\
5.7 \\
4.6 \\
5.2\end{array}$ & $\begin{array}{l}(1.26) \\
(1.06) \\
(1.36) \\
(1.28) \\
(1.38)\end{array}$ \\
\hline $\begin{array}{l}2010^{3} \ldots \ldots \ldots \ldots . . . \\
2011^{3} \ldots \ldots \ldots \ldots \ldots . . . \\
2012^{3} \ldots \ldots \ldots \ldots \ldots . . .\end{array}$ & $\begin{array}{l}7.3 \\
7.3 \\
8.2\end{array}$ & $\begin{array}{l}(0.42) \\
(0.40) \\
(0.46)\end{array}$ & $\begin{array}{l}7.5 \\
8.1 \\
8.5\end{array}$ & $\begin{array}{l}(0.49) \\
(0.50) \\
(0.53)\end{array}$ & $\begin{array}{l}6.8 \\
4.4 \\
7.3\end{array}$ & $\begin{array}{l}(0.94) \\
(0.71) \\
(0.95)\end{array}$ & $\begin{array}{l}6.3 \\
5.8 \\
7.1\end{array}$ & $\begin{array}{l}(0.50) \\
(0.51) \\
(0.57)\end{array}$ & $\begin{array}{l}8.4 \\
9.0 \\
9.4\end{array}$ & $\begin{array}{l}(0.69) \\
(0.66) \\
(0.73)\end{array}$ & $\begin{array}{r}9.5 \\
11.0 \\
12.2\end{array}$ & $\begin{array}{l}(0.65) \\
(0.66) \\
(0.73)\end{array}$ & $\begin{array}{l}4.1 \\
2.2 \\
3.7\end{array}$ & $\begin{array}{l}(0.82) \\
(0.60) \\
(0.92)\end{array}$ & $\begin{array}{l}4.5 \\
2.7 \\
2.4\end{array}$ & & $\begin{array}{l}3.0 \\
3.7 \\
4.2\end{array}$ & & & & $\begin{array}{l}10.9 \\
10.2 \\
13.3\end{array}$ & & $\begin{array}{l}7.7 \\
7.7 \\
8.8\end{array}$ & & $\begin{array}{l}3.4 ! \\
2.8 ! \\
2.4 !\end{array}$ & $\begin{array}{l}(1.21) \\
(0.98) \\
(0.75)\end{array}$ \\
\hline $2012^{3} \ldots \ldots \ldots \ldots \ldots \ldots$ & \multicolumn{26}{|c|}{ Percent working 15 or more hours per week ${ }^{4}$} \\
\hline & & & & & & & & & & & & & - & & & & & & & & & & & & - & \\
\hline & & & & & & & & & & & & & & & & & & & & & & & & & - & \\
\hline & & & & & & & & & & & & & 10.1 & & & & & & & & & & & & - & \\
\hline & & & & & & & & & & & & & & & & & & & & & & & 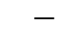 & & - & $(\dagger)$ \\
\hline & & & 17 & & & & 21 & & & & & & & & & & & & & & & & & & & \\
\hline & 20.5 & $(0.79)$ & 18.4 & 0.84 & 29.7 & $(2.07)$ & 20.8 & $(1.09)$ & 20.2 & $(1.14)$ & 24.5 & $(1.03)$ & 10.9 & $(1.5$ & 15.1 & $(2.07)]$ & 12.7 & $(1.60)$ & 21.9 & $(1.07)$ & 22.5 & (1.59) & 1.1 & $.83)$ & 14.9 & $.35)$ \\
\hline
\end{tabular}




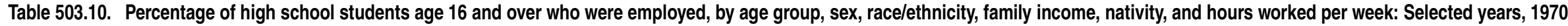
through 2012-Continued

[Standard errors appear in parentheses]

\begin{tabular}{|c|c|c|c|c|c|c|c|c|c|c|c|c|c|c|c|c|c|c|c|c|c|c|c|c|c|c|}
\hline \multirow[b]{2}{*}{ Year } & \multirow{2}{*}{\multicolumn{2}{|c|}{ Total }} & \multicolumn{4}{|c|}{ Age group } & \multicolumn{4}{|c|}{ Sex } & \multicolumn{6}{|c|}{ Race/ethnicity } & \multicolumn{6}{|c|}{ Family income $^{1}$} & \multicolumn{4}{|c|}{ Nativity } \\
\hline & & & \multicolumn{2}{|c|}{$\begin{array}{c}16 \text { and } 17 \\
\text { years old }\end{array}$} & \multicolumn{2}{|c|}{$\begin{array}{r}18 \text { years } \\
\text { old and over }\end{array}$} & \multicolumn{2}{|r|}{ Male } & \multicolumn{2}{|r|}{ Female } & \multicolumn{2}{|r|}{ White } & \multicolumn{2}{|r|}{ Black } & \multicolumn{2}{|r|}{ Hispanic } & \multicolumn{2}{|c|}{ Low income } & \multicolumn{2}{|c|}{ Middle income } & \multicolumn{2}{|c|}{ High income } & \multicolumn{2}{|c|}{ U.S.-born } & \multicolumn{2}{|c|}{ Foreign-born } \\
\hline 1 & & 2 & & 3 & & 4 & & 5 & & 6 & & 7 & & 8 & & 9 & & 10 & & 11 & & 12 & & 13 & & 14 \\
\hline 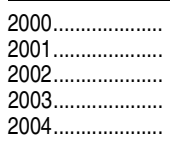 & $\begin{array}{l}21.1 \\
19.4 \\
18.5 \\
16.4 \\
16.0\end{array}$ & $\begin{array}{l}(0.80) \\
(0.73) \\
(0.71) \\
(0.66) \\
(0.66)\end{array}$ & $\begin{array}{l}19.2 \\
17.1 \\
16.1 \\
14.3 \\
13.8\end{array}$ & $\begin{array}{l}(0.86) \\
(0.77) \\
(0.75) \\
(0.69) \\
(0.68)\end{array}$ & $\begin{array}{l}28.8 \\
28.3 \\
27.9 \\
25.9 \\
26.2\end{array}$ & $\begin{array}{l}(2.01) \\
(1.85) \\
(1.80) \\
(1.82) \\
(1.88)\end{array}$ & $\begin{array}{l}21.1 \\
19.6 \\
17.5 \\
16.8 \\
15.5\end{array}$ & \begin{tabular}{l|}
$(1.11)$ \\
$(1.01)$ \\
$(0.95)$ \\
$(0.92)$ \\
$(0.90)$
\end{tabular} & $\begin{array}{l}21.0 \\
19.1 \\
19.7 \\
16.0 \\
16.6\end{array}$ & $\begin{array}{l}(1.16) \\
(1.05) \\
(1.04) \\
(0.94) \\
(0.97)\end{array}$ & $\begin{array}{l}24.6 \\
22.2 \\
21.4 \\
19.5 \\
17.8\end{array}$ & $\begin{array}{l}(1.05) \\
(0.95) \\
(0.94) \\
(0.90) \\
(0.88)\end{array}$ & $\begin{array}{l}10.0 \\
13.4 \\
11.9 \\
10.4 \\
10.2\end{array}$ & $\begin{array}{l}(1.80) \\
(1.62) \\
(1.57) \\
(1.42) \\
(1.45)\end{array}$ & $\begin{array}{l}16.3 \\
17.0 \\
16.8 \\
13.1 \\
16.6\end{array}$ & \begin{tabular}{l|}
$(1.98)$ \\
$(1.97)$ \\
$(1.78)$ \\
$(1.57)$ \\
$(1.75)$
\end{tabular} & $\begin{array}{r}15.6 \\
14.6 \\
12.3 \\
9.1 \\
8.1\end{array}$ & $\begin{array}{l}(1.85) \\
(1.76) \\
(1.55) \\
(1.35) \\
(1.30)\end{array}$ & $\begin{array}{l}21.5 \\
20.9 \\
20.7 \\
17.6 \\
18.3\end{array}$ & $\begin{array}{l}(1.06) \\
(0.97) \\
(0.97) \\
(0.89) \\
(0.91)\end{array}$ & $\begin{array}{l}23.1 \\
18.4 \\
17.4 \\
17.7 \\
15.2\end{array}$ & $\begin{array}{l}(1.59) \\
(1.37) \\
(1.30) \\
(1.29) \\
(1.24)\end{array}$ & $\begin{array}{l}21.3 \\
19.6 \\
18.7 \\
16.7 \\
16.1\end{array}$ & $\begin{array}{l}(0.84) \\
(0.76) \\
(0.75) \\
(0.70) \\
(0.69)\end{array}$ & $\begin{array}{l}19.0 \\
16.9 \\
16.5 \\
13.6 \\
15.2\end{array}$ & $\begin{array}{l}(2.50) \\
(2.35) \\
(2.12) \\
(1.95) \\
(2.15)\end{array}$ \\
\hline 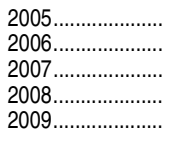 & $\begin{array}{r}15.2 \\
17.0 \\
15.0 \\
12.8 \\
8.7\end{array}$ & $\begin{array}{l}(0.63) \\
(0.66) \\
(0.63) \\
(0.59) \\
(0.50)\end{array}$ & $\begin{array}{r}13.4 \\
14.4 \\
12.8 \\
10.3 \\
6.4\end{array}$ & $\begin{array}{l}(0.66) \\
(0.69) \\
(0.66) \\
(0.60) \\
(0.49)\end{array}$ & $\begin{array}{l}23.5 \\
27.0 \\
24.2 \\
22.7 \\
17.3\end{array}$ & $\begin{array}{l}(1.77) \\
(1.75) \\
(1.72) \\
(1.68) \\
(1.47)\end{array}$ & $\begin{array}{r}15.5 \\
16.8 \\
14.8 \\
11.4 \\
8.4\end{array}$ & $\begin{array}{l}(0.88) \\
(0.91) \\
(0.87) \\
(0.79) \\
(0.69)\end{array}$ & $\begin{array}{r}14.8 \\
17.1 \\
15.2 \\
14.1 \\
9.1\end{array}$ & $\begin{array}{l}(0.90) \\
(0.96) \\
(0.92) \\
(0.88) \\
(0.73)\end{array}$ & $\begin{array}{l}17.0 \\
19.5 \\
16.2 \\
14.3 \\
10.4\end{array}$ & $\begin{array}{l}(0.84) \\
(0.90) \\
(0.85) \\
(0.82) \\
(0.71)\end{array}$ & $\begin{array}{r}9.6 \\
14.5 \\
11.4 \\
11.9 \\
6.5\end{array}$ & $\begin{array}{l}(1.40) \\
(1.63) \\
(1.49) \\
(1.51) \\
(1.15)\end{array}$ & $\begin{array}{r}13.6 \\
13.3 \\
14.9 \\
10.6 \\
7.2\end{array}$ & $\begin{array}{l}(1.55) \\
(1.54) \\
(1.59) \\
(1.32) \\
(1.11)\end{array}$ & $\begin{array}{r}10.8 \\
13.8 \\
10.9 \\
9.9 \\
5.9\end{array}$ & $\begin{array}{l}(1.40) \\
(1.55) \\
(1.44) \\
(1.34) \\
(1.06)\end{array}$ & $\begin{array}{r}15.9 \\
17.7 \\
15.6 \\
12.8 \\
8.9\end{array}$ & $\begin{array}{l}(0.85) \\
(0.89) \\
(0.83) \\
(0.77) \\
(0.66)\end{array}$ & $\begin{array}{r}16.1 \\
17.3 \\
15.8 \\
14.4 \\
9.9\end{array}$ & $\begin{array}{l}(1.23) \\
(1.27) \\
(1.27)\end{array}$ & $\begin{array}{r}15.1 \\
16.6 \\
14.3 \\
12.7 \\
8.4\end{array}$ & $\begin{array}{l}(0.66) \\
(0.68) \\
(0.65) \\
(0.62) \\
(0.52)\end{array}$ & $\begin{array}{l}16.5 \\
20.8 \\
22.2 \\
13.0 \\
11.7\end{array}$ & $\begin{array}{l}(2.24) \\
(2.51) \\
(2.43) \\
(2.06) \\
(1.99)\end{array}$ \\
\hline 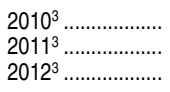 & $\begin{array}{l}8.3 \\
9.0 \\
8.9\end{array}$ & $\begin{array}{l}(0.45) \\
(0.52) \\
(0.55)\end{array}$ & $\begin{array}{l}6.9 \\
7.7 \\
6.7\end{array}$ & $\begin{array}{l}(0.47) \\
(0.56) \\
(0.51)\end{array}$ & $\begin{array}{l}13.4 \\
13.6 \\
16.5\end{array}$ & $\begin{array}{l}(1.24) \\
(1.10) \\
(1.62)\end{array}$ & $\begin{array}{l}7.2 \\
8.4 \\
8.4\end{array}$ & $\begin{array}{l}(0.62) \\
(0.63) \\
(0.62)\end{array}$ & $\begin{array}{l}9.4 \\
9.8 \\
9.5\end{array}$ & $\begin{array}{l}(0.70) \\
(0.78) \\
(0.84)\end{array}$ & $\begin{array}{l}10.5 \\
10.5 \\
10.0\end{array}$ & $\begin{array}{l}(0.67) \\
(0.77) \\
(0.69)\end{array}$ & $\begin{array}{l}5.3 \\
7.4 \\
8.2\end{array}$ & $\begin{array}{l}(1.01) \\
(1.30) \\
(1.97)\end{array}$ & $\begin{array}{l}5.6 \\
8.4 \\
8.4\end{array}$ & $\begin{array}{l}(0.84) \\
(1.06) \\
(1.04)\end{array}$ & $\begin{array}{l}5.3 \\
6.3 \\
8.3\end{array}$ & $\begin{array}{l}(0.88) \\
(1.10) \\
(1.22)\end{array}$ & $\begin{array}{r}9.0 \\
10.0 \\
8.7\end{array}$ & $\begin{array}{l}(0.58) \\
(0.69) \\
(0.68)\end{array}$ & $\begin{array}{l}8.7 \\
8.5 \\
9.9\end{array}$ & $\begin{array}{l}(1.16) \\
(0.94) \\
(1.30)\end{array}$ & $\begin{array}{l}8.1 \\
9.0 \\
8.9\end{array}$ & $\begin{array}{l}(0.46) \\
(0.55) \\
(0.59)\end{array}$ & $\begin{array}{l}9.6 \\
9.6 \\
9.6\end{array}$ & $\begin{array}{l}(1.83) \\
(1.84) \\
(1.76)\end{array}$ \\
\hline
\end{tabular}

†Not available.

with caution. The coefficient of variation (CV) for this estimate is between 30 and 50 percent.

Low income refers to the bottom 20 percent of all family incomes; high income refers to the top 20 percent of all family Percent amploct includes those who were employed but not at wor

in 2010, standard errors were computed using replicate weights, which produced more precise values than the

${ }^{4}$ Hours worked per week refers to the number of hours the respondent worked at all jobs during the survey week. The estimates of the percentage of high school students age 16 and over who worked less than 15 hours per week or 15 or more hours per week exclude those who were employed but not at work during the survey week. Therefore, detail may not sum to total percentage employed.

.

Census Bureau, Current Population Survey (CPS), October, 1970 through 2012 This table was prepared June 2013.) 
Table 503.20. Percentage of college students 16 to 24 years old who were employed, by attendance status, hours worked per week, and control and level of institution: Selected years, October 1970 through 2012

[Standard errors appear in parentheses]

\begin{tabular}{|c|c|c|c|c|c|c|c|c|c|c|c|c|c|c|c|c|}
\hline \multirow{4}{*}{ Control and level of institution and year } & \multicolumn{8}{|c|}{ Full-time students } & \multicolumn{8}{|c|}{ Part-time students } \\
\hline & \multirow{2}{*}{\multicolumn{2}{|c|}{$\begin{array}{r}\text { Percent } \\
\text { employed }^{2}\end{array}$}} & \multicolumn{6}{|c|}{ Hours worked per week ${ }^{1}$} & \multirow{2}{*}{\multicolumn{2}{|c|}{$\begin{array}{r}\text { Percent } \\
\text { employed }^{2}\end{array}$}} & \multicolumn{6}{|c|}{ Hours worked per week ${ }^{1}$} \\
\hline & & & \multicolumn{2}{|c|}{$\begin{array}{l}\text { Less than } \\
20 \text { hours }\end{array}$} & \multicolumn{2}{|c|}{20 to 34 hours } & \multicolumn{2}{|c|}{35 or more hours } & & & \multicolumn{2}{|c|}{$\begin{array}{r}\text { Less than } \\
20 \text { hours }\end{array}$} & \multicolumn{2}{|c|}{20 to 34 hours } & \multicolumn{2}{|c|}{35 or more hours } \\
\hline & & 2 & & 3 & & 4 & & 5 & & 6 & & 7 & & 8 & & 9 \\
\hline 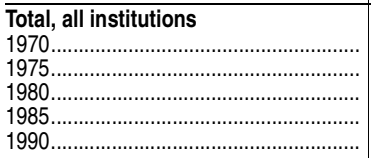 & $\begin{array}{l}33.8 \\
35.3 \\
40.0 \\
44.2 \\
45.7\end{array}$ & $\begin{array}{l}(0.88) \\
(0.83) \\
(0.84) \\
(0.88) \\
(0.89)\end{array}$ & $\begin{array}{l}19.0 \\
18.0 \\
21.3 \\
21.7 \\
20.6\end{array}$ & $\begin{array}{l}(0.73) \\
(0.67) \\
(0.70) \\
(0.73) \\
(0.73)\end{array}$ & $\begin{array}{l}10.4 \\
12.0 \\
14.0 \\
17.3 \\
19.3\end{array}$ & $\begin{array}{l}(0.57) \\
(0.56) \\
(0.59) \\
(0.67) \\
(0.71)\end{array}$ & $\begin{array}{l}3.7 \\
4.6 \\
3.9 \\
4.3 \\
4.8\end{array}$ & $\begin{array}{l}(0.35) \\
(0.36) \\
(0.33) \\
(0.36) \\
(0.38)\end{array}$ & $\begin{array}{l}82.1 \\
80.8 \\
84.7 \\
85.9 \\
83.7\end{array}$ & $\begin{array}{l}(1.81) \\
(1.55) \\
(1.38) \\
(1.41) \\
(1.50)\end{array}$ & $\begin{array}{l}5.0 \\
6.0 \\
7.9 \\
5.7 \\
4.0\end{array}$ & $\begin{array}{l}(1.03) \\
(0.94) \\
(1.04) \\
(0.94) \\
(0.80)\end{array}$ & $\begin{array}{l}15.9 \\
19.4 \\
22.5 \\
26.9 \\
26.0\end{array}$ & $\begin{array}{l}(1.72) \\
(1.56) \\
(1.60) \\
(1.80) \\
(1.78)\end{array}$ & $\begin{array}{l}60.1 \\
52.6 \\
52.7 \\
52.2 \\
52.7\end{array}$ & $\begin{array}{l}(2.31) \\
(1.97) \\
(1.91) \\
(2.03) \\
(2.03)\end{array}$ \\
\hline 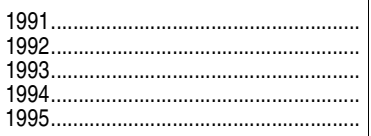 & $\begin{array}{l}47.2 \\
47.2 \\
46.3 \\
48.6 \\
47.2\end{array}$ & $\begin{array}{l}(0.88) \\
(0.87) \\
(0.89) \\
(0.87) \\
(0.87)\end{array}$ & $\begin{array}{l}20.9 \\
20.3 \\
20.8 \\
20.1 \\
19.1\end{array}$ & $\begin{array}{l}(0.72) \\
(0.70) \\
(0.72) \\
(0.70) \\
(0.69)\end{array}$ & $\begin{array}{l}19.8 \\
20.3 \\
19.5 \\
21.7 \\
20.3\end{array}$ & $\begin{array}{l}(0.70) \\
(0.70) \\
(0.71) \\
(0.72) \\
(0.70)\end{array}$ & $\begin{array}{l}5.6 \\
5.5 \\
5.1 \\
5.8 \\
6.5\end{array}$ & $\begin{array}{l}(0.41) \\
(0.40) \\
(0.39) \\
(0.41) \\
(0.43)\end{array}$ & $\begin{array}{l}85.9 \\
83.4 \\
84.6 \\
86.3 \\
82.9\end{array}$ & $\begin{array}{l}(1.45) \\
(1.50) \\
(1.43) \\
(1.28) \\
(1.45)\end{array}$ & $\begin{array}{l}8.2 \\
7.5 \\
8.5 \\
9.8 \\
8.6\end{array}$ & $\begin{array}{l}(1.15) \\
(1.06) \\
(1.10) \\
(1.10) \\
(1.08)\end{array}$ & $\begin{array}{l}25.4 \\
27.2 \\
31.4 \\
31.1 \\
30.4\end{array}$ & $\begin{array}{l}(1.82) \\
(1.79) \\
(1.84) \\
(1.72) \\
(1.77)\end{array}$ & $\begin{array}{l}51.0 \\
47.8 \\
43.7 \\
43.8 \\
42.3\end{array}$ & $\begin{array}{l}(2.09) \\
(2.01) \\
(1.96) \\
(1.84) \\
(1.90)\end{array}$ \\
\hline 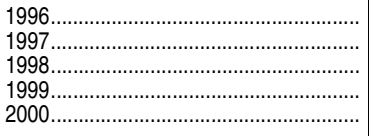 & $\begin{array}{l}49.2 \\
47.8 \\
50.2 \\
50.4 \\
52.0\end{array}$ & $\begin{array}{l}(0.88) \\
(0.86) \\
(0.86) \\
(0.86) \\
(0.86)\end{array}$ & $\begin{array}{l}18.2 \\
18.3 \\
20.2 \\
19.0 \\
20.1\end{array}$ & $\begin{array}{l}(0.68) \\
(0.67) \\
(0.69) \\
(0.68) \\
(0.69)\end{array}$ & $\begin{array}{l}22.3 \\
21.4 \\
20.6 \\
22.3 \\
21.7\end{array}$ & $\begin{array}{l}(0.74) \\
(0.71) \\
(0.70) \\
(0.72) \\
(0.71)\end{array}$ & $\begin{array}{l}7.0 \\
7.4 \\
8.0 \\
7.8 \\
8.9\end{array}$ & $\begin{array}{l}(0.45) \\
(0.45) \\
(0.47) \\
(0.46) \\
(0.49)\end{array}$ & $\begin{array}{l}84.8 \\
84.4 \\
84.1 \\
82.3 \\
84.9\end{array}$ & $\begin{array}{l}(1.47) \\
(1.46) \\
(1.45) \\
(1.55) \\
(1.38)\end{array}$ & $\begin{array}{l}8.3 \\
9.4 \\
7.0 \\
6.2 \\
8.6\end{array}$ & $\begin{array}{l}(1.13) \\
(1.17) \\
(1.01) \\
(0.98) \\
(1.08)\end{array}$ & $\begin{array}{l}27.5 \\
26.2 \\
26.8 \\
28.8 \\
27.8\end{array}$ & $\begin{array}{l}(1.83) \\
(1.77) \\
(1.76) \\
(1.85) \\
(1.73)\end{array}$ & $\begin{array}{l}48.0 \\
47.7 \\
49.3 \\
45.9 \\
47.5\end{array}$ & $\begin{array}{l}(2.05) \\
(2.01) \\
(1.98) \\
(2.03) \\
(1.93)\end{array}$ \\
\hline 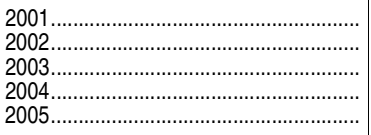 & $\begin{array}{l}47.1 \\
47.8 \\
47.7 \\
49.0 \\
49.1\end{array}$ & $\begin{array}{l}(0.80) \\
(0.78) \\
(0.78) \\
(0.76) \\
(0.75)\end{array}$ & $\begin{array}{l}17.4 \\
17.3 \\
17.1 \\
17.7 \\
17.8\end{array}$ & $\begin{array}{l}(0.61) \\
(0.59) \\
(0.59) \\
(0.58) \\
(0.58)\end{array}$ & $\begin{array}{l}20.6 \\
20.9 \\
20.7 \\
21.6 \\
21.1\end{array}$ & $\begin{array}{l}(0.65) \\
(0.64) \\
(0.63) \\
(0.62) \\
(0.61)\end{array}$ & $\begin{array}{l}7.9 \\
8.5 \\
8.8 \\
8.6 \\
9.0\end{array}$ & $\begin{array}{l}(0.43) \\
(0.44) \\
(0.44) \\
(0.43) \\
(0.43)\end{array}$ & $\begin{array}{l}84.4 \\
78.9 \\
79.0 \\
81.5 \\
85.0\end{array}$ & $\begin{array}{l}(1.29) \\
(1.51) \\
(1.44) \\
(1.44) \\
(1.30)\end{array}$ & $\begin{array}{r}8.0 \\
8.7 \\
7.8 \\
8.5 \\
10.2\end{array}$ & $\begin{array}{l}(0.97) \\
(1.04) \\
(0.95)\end{array}$ & $\begin{array}{l}25.8 \\
25.3 \\
27.2 \\
27.4 \\
27.1\end{array}$ & $\begin{array}{l}(1.56) \\
(1.61) \\
(1.58) \\
(1.66) \\
(1.62)\end{array}$ & $\begin{array}{l}.9 \\
4 \\
8 \\
1\end{array}$ & $\begin{array}{l}(1.78) \\
(1.84) \\
(1.75) \\
(1.84) \\
(1.82)\end{array}$ \\
\hline 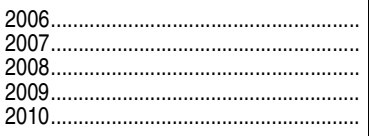 & $\begin{array}{l}46.5 \\
45.5 \\
45.3 \\
40.6 \\
39.8\end{array}$ & $\begin{array}{l}(0.76) \\
(0.74) \\
(0.72) \\
(0.69) \\
(1.01)\end{array}$ & $\begin{array}{l}15.1 \\
15.4 \\
15.6 \\
15.6 \\
14.9\end{array}$ & $\begin{array}{l}(0.55) \\
(0.54) \\
(0.53) \\
(0.51) \\
(0.57)\end{array}$ & $\begin{array}{l}22.0 \\
20.7 \\
20.1 \\
17.6 \\
17.2\end{array}$ & $\begin{array}{l}(0.63) \\
(0.60) \\
(0.58) \\
(0.54) \\
(0.77)\end{array}$ & $\begin{array}{l}8.1 \\
8.7 \\
8.7 \\
6.2 \\
6.6\end{array}$ & $\begin{array}{l}(0.42) \\
(0.42) \\
(0.41) \\
(0.34) \\
(0.46)\end{array}$ & $\begin{array}{l}81.0 \\
81.2 \\
79.4 \\
76.2 \\
73.4\end{array}$ & $\begin{array}{l}(1.41) \\
(1.39) \\
(1.51) \\
(1.57) \\
(2.03)\end{array}$ & $\begin{array}{r}7.3 \\
6.8 \\
9.3 \\
10.1 \\
10.7\end{array}$ & $\begin{array}{l}(0.94) \\
(0.90) \\
(1.09) \\
(1.11) \\
(1.24)\end{array}$ & $\begin{array}{l}27.6 \\
27.2 \\
24.7 \\
27.5 \\
28.3\end{array}$ & $\begin{array}{l}(1.61) \\
(1.59) \\
(1.61) \\
(1.65) \\
(1.92)\end{array}$ & $\begin{array}{l}45.5 \\
45.9 \\
44.4 \\
36.9 \\
32.8\end{array}$ & $\begin{array}{l}(1.80) \\
(1.78) \\
(1.86) \\
(1.78) \\
(2.19)\end{array}$ \\
\hline 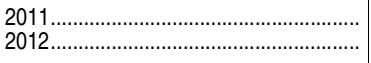 & $\begin{array}{l}41.3 \\
41.0\end{array}$ & $\begin{array}{l}(0.94) \\
(0.83)\end{array}$ & $\begin{array}{l}15.8 \\
15.1\end{array}$ & $\begin{array}{l}(0.67) \\
(0.72)\end{array}$ & $\begin{array}{l}17.4 \\
17.8\end{array}$ & $\begin{array}{l}(0.66) \\
(0.71)\end{array}$ & $\begin{array}{l}7.0 \\
7.2\end{array}$ & $\begin{array}{l}(0.44) \\
(0.44)\end{array}$ & $\begin{array}{l}75.5 \\
71.7\end{array}$ & $\begin{array}{l}(1.93) \\
(2.07)\end{array}$ & $\begin{array}{l}9.7 \\
9.0\end{array}$ & $\begin{array}{l}(1.21) \\
(1.27)\end{array}$ & $\begin{array}{l}28.4 \\
29.5\end{array}$ & $\begin{array}{l}(1.99) \\
(2.09)\end{array}$ & 35.5 & $\begin{array}{l}(2.16) \\
(2.07)\end{array}$ \\
\hline $\begin{array}{l}\text { Public 4-year institutions } \\
1990 \ldots \ldots \\
1995 \ldots \ldots \\
2000 \ldots\end{array}$ & $\begin{array}{l}43.0 \\
48.8 \\
50.5 \\
49.6\end{array}$ & $\begin{array}{l}(1.18) \\
(1.16) \\
(1.15) \\
(0.99)\end{array}$ & $\begin{array}{l}19.8 \\
19.4 \\
19.1 \\
17.8\end{array}$ & $\begin{array}{l}(0.95) \\
(0.92) \\
(0.90) \\
(0.76)\end{array}$ & $\begin{array}{l}18.6 \\
22.6 \\
21.5 \\
22.7\end{array}$ & $\begin{array}{l}(0.93) \\
(0.97) \\
(0.94) \\
(0.83)\end{array}$ & $\begin{array}{l}3.7 \\
5.6 \\
9.0 \\
8.0\end{array}$ & $\begin{array}{l}(0.45) \\
(0.53) \\
(0.66) \\
(0.54)\end{array}$ & $\begin{array}{l}87.4 \\
86.7 \\
87.3 \\
86.3\end{array}$ & $\begin{array}{l}(2.25) \\
(2.08) \\
(1.91) \\
(1.90)\end{array}$ & $\begin{array}{l}4.2 ! \\
9.6 \\
8.5 \\
9.0\end{array}$ & $\begin{array}{l}(1.37) \\
(1.80) \\
(1.60) \\
(1.58)\end{array}$ & $\begin{array}{l}27.9 \\
30.8 \\
26.4 \\
26.8\end{array}$ & $\begin{array}{l}(3.05) \\
(2.83) \\
(2.53) \\
(2.45)\end{array}$ & $\begin{array}{l}54.7 \\
45.0 \\
50.9 \\
49.7\end{array}$ & $\begin{array}{l}(3.39) \\
(3.05) \\
(2.87) \\
(2.76)\end{array}$ \\
\hline 2006 & $\begin{array}{l}46.6 \\
44.7 \\
44.1 \\
40.6 \\
40.8\end{array}$ & $\begin{array}{l}(1.00) \\
(0.98) \\
(0.96) \\
(0.91) \\
(1.27)\end{array}$ & $\begin{array}{l}13.9 \\
14.9 \\
15.1 \\
14.7 \\
15.2\end{array}$ & $\begin{array}{l}(0.69) \\
(0.70) \\
(0.70) \\
(0.66) \\
(0.88)\end{array}$ & $\begin{array}{l}22.9 \\
20.1 \\
19.2 \\
18.7 \\
18.0\end{array}$ & $\begin{array}{l}(0.84) \\
(0.79) \\
(0.76) \\
(0.73) \\
(0.93)\end{array}$ & $\begin{array}{l}8.6 \\
8.9 \\
8.8 \\
5.8 \\
6.6\end{array}$ & $\begin{array}{l}(0.56) \\
(0.56) \\
(0.55) \\
(0.44) \\
(0.64)\end{array}$ & $\begin{array}{l}80.5 \\
78.3 \\
83.9 \\
78.7 \\
70.4\end{array}$ & $\begin{array}{l}(2.06) \\
(2.26) \\
(2.25) \\
(2.45) \\
(3.58)\end{array}$ & $\begin{array}{r}7.1 \\
6.4 \\
9.3 \\
11.1 \\
10.5\end{array}$ & $\begin{array}{l}(1.33) \\
(1.34) \\
(1.78) \\
(1.88) \\
(2.04)\end{array}$ & $\begin{array}{l}26.4 \\
23.1 \\
24.7 \\
25.7 \\
26.9\end{array}$ & $\begin{array}{l}(2.29) \\
(2.31) \\
(2.64) \\
(2.61) \\
(2.82)\end{array}$ & $\begin{array}{l}9.5 \\
9.8 \\
2.1\end{array}$ & $\begin{array}{l}(2.59) \\
(2.74) \\
(3.06) \\
(2.92) \\
(3.59)\end{array}$ \\
\hline 2011 & $\begin{array}{l}41.0 \\
41.0\end{array}$ & $\begin{array}{l}(1.20) \\
(1.13)\end{array}$ & $\begin{array}{l}15.0 \\
14.9\end{array}$ & $\begin{array}{l}(0.91) \\
(0.95)\end{array}$ & $\begin{array}{l}17.6 \\
18.6\end{array}$ & $\begin{array}{l}(0.85) \\
(0.99)\end{array}$ & $\begin{array}{l}7.4 \\
6.7\end{array}$ & $\begin{array}{l}(0.63) \\
(0.57)\end{array}$ & $\begin{array}{l}77.5 \\
77.6\end{array}$ & $\begin{array}{l}(3.27) \\
(3.20)\end{array}$ & $\begin{array}{l}7.8 \\
9.9\end{array}$ & $(1.65)$ & $\begin{array}{l}28.4 \\
28.0\end{array}$ & $\begin{array}{l}(3.18) \\
(3.44)\end{array}$ & $\begin{array}{l}9.7 \\
8.8\end{array}$ & $\begin{array}{l}(3.29) \\
(3.36)\end{array}$ \\
\hline 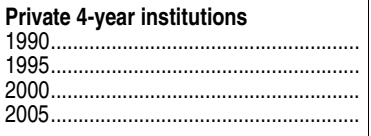 & $\begin{array}{l}38.1 \\
38.6 \\
44.8 \\
42.3\end{array}$ & $\begin{array}{l}(1.89) \\
(1.78) \\
(1.88) \\
(1.64)\end{array}$ & $\begin{array}{l}24.0 \\
21.6 \\
23.6 \\
20.1\end{array}$ & $\begin{array}{l}(1.66) \\
(1.51) \\
(1.60) \\
(1.33)\end{array}$ & $\begin{array}{r}9.9 \\
10.7 \\
14.9 \\
13.8\end{array}$ & $\begin{array}{l}(1.17) \\
(1.13) \\
(1.34) \\
(1.15)\end{array}$ & $\begin{array}{l}3.5 \\
4.6 \\
5.4 \\
7.0\end{array}$ & $\begin{array}{l}(0.72) \\
(0.77) \\
(0.85) \\
(0.85)\end{array}$ & $\begin{array}{l}89.9 \\
80.1 \\
78.0 \\
88.5\end{array}$ & $\begin{array}{l}(4.27) \\
(4.85) \\
(5.36) \\
(3.32)\end{array}$ & $\begin{array}{r}\ddagger \\
14 \\
14.9 \\
\ddagger \\
10.6 !\end{array}$ & $\begin{array}{r}(t) \\
(4.32) \\
(t) \\
(3.20)\end{array}$ & $\begin{array}{l}31.9 \\
26.8 \\
18.5 \\
34.5\end{array}$ & $\begin{array}{l}(6.62) \\
(5.38) \\
(5.02) \\
(4.94)\end{array}$ & & $\begin{array}{l}(7.09) \\
(5.84) \\
(6.46) \\
(5.15)\end{array}$ \\
\hline 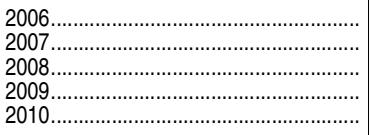 & $\begin{array}{l}36.9 \\
38.7 \\
38.0 \\
35.2 \\
35.6\end{array}$ & $\begin{array}{l}(1.71) \\
(1.70) \\
(1.68) \\
(1.64) \\
(2.37)\end{array}$ & $\begin{array}{l}18.1 \\
18.0 \\
18.5 \\
18.6 \\
15.7\end{array}$ & $\begin{array}{l}(1.36) \\
(1.34) \\
(1.35) \\
(1.33) \\
(1.63)\end{array}$ & $\begin{array}{l}12.4 \\
13.0 \\
12.4 \\
10.7 \\
12.2\end{array}$ & $\begin{array}{l}(1.17) \\
(1.18) \\
(1.14) \\
(1.06) \\
(1.52)\end{array}$ & $\begin{array}{l}5.1 \\
6.7 \\
5.6 \\
5.1 \\
6.0\end{array}$ & $\begin{array}{l}(0.78) \\
(0.87) \\
(0.80) \\
(0.76) \\
(1.08)\end{array}$ & $\begin{array}{l}83.0 \\
83.9 \\
84.4 \\
93.9 \\
78.6\end{array}$ & $\begin{array}{l}(4.31) \\
(4.55) \\
(4.44) \\
(2.89) \\
(7.00)\end{array}$ & $\begin{array}{c}6.1 ! \\
\ddagger \\
\ddagger \\
7.5 ! \\
\ddagger\end{array}$ & $\begin{array}{r}(2.75) \\
(\dagger) \\
(\dagger) \\
(3.17) \\
(\dagger)\end{array}$ & $\begin{array}{l}21.0 \\
14.3 ! \\
21.4 \\
22.1 \\
23.4 !\end{array}$ & $\begin{array}{l}(4.67) \\
(4.34) \\
(5.01) \\
(5.00) \\
(7.49)\end{array}$ & $\begin{array}{l}55.3 \\
62.4 \\
45.6\end{array}$ & $\begin{array}{l}(5.70) \\
(6.04) \\
(6.08) \\
(5.84) \\
(9.01)\end{array}$ \\
\hline 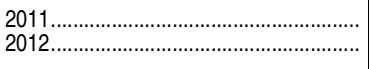 & $\begin{array}{l}36.3 \\
40.4\end{array}$ & $\begin{array}{l}(2.07) \\
(2.39)\end{array}$ & $\begin{array}{l}20.0 \\
19.9\end{array}$ & $\begin{array}{l}(1.61) \\
(1.80)\end{array}$ & $\begin{array}{l}10.1 \\
12.2\end{array}$ & $\begin{array}{l}(1.34) \\
(1.40)\end{array}$ & $\begin{array}{l}4.5 \\
6.7\end{array}$ & $\begin{array}{l}(0.82) \\
(1.13)\end{array}$ & $\begin{array}{l}79.4 \\
84.4\end{array}$ & $\begin{array}{l}(6.01) \\
(5.35)\end{array}$ & $\stackrel{\ddagger}{\ddagger}$ & $\begin{array}{r}(\dagger) \\
(4.53)\end{array}$ & $\begin{array}{l}34.2 \\
33.9\end{array}$ & $\begin{array}{l}(7.03) \\
(6.58)\end{array}$ & $\begin{array}{l}38.2 \\
36.9\end{array}$ & $(7.67)$ \\
\hline $\begin{array}{l}\text { Public 2-year inst } \\
1990 \ldots \ldots \ldots \ldots \ldots \ldots \\
1995 \ldots \ldots \ldots \ldots \ldots \ldots \ldots \\
2000 \ldots \ldots \ldots \ldots \ldots \ldots \ldots \\
2005 \ldots \ldots \ldots \ldots \ldots \ldots \ldots\end{array}$ & $\begin{array}{l}61.2 \\
52.9 \\
63.9 \\
54.2\end{array}$ & $\begin{array}{l}(1.94) \\
(1.97) \\
(1.79) \\
(1.69)\end{array}$ & $\begin{array}{l}19.1 \\
15.6 \\
20.6 \\
15.6\end{array}$ & $\begin{array}{l}(1.43) \\
(1.51) \\
(1.23)\end{array}$ & $\begin{array}{l}31.2 \\
25.3 \\
29.9 \\
24.2\end{array}$ & $\begin{array}{l}(1.85) \\
(1.72) \\
(1.71) \\
(1.46)\end{array}$ & $\begin{array}{r}9.2 \\
10.9 \\
11.9 \\
13.4\end{array}$ & $\begin{array}{l}(1.23) \\
(1.21) \\
(1.16)\end{array}$ & $\begin{array}{l}81.5 \\
81.1 \\
85.5 \\
82.0\end{array}$ & $\begin{array}{l}(2.17) \\
(2.21) \\
(2.09) \\
(2.20)\end{array}$ & $\begin{array}{r}4.1 \\
6.1 \\
9.9 \\
10.8\end{array}$ & $\begin{array}{l}(1.12) \\
(1.35) \\
(1.77) \\
(1.77)\end{array}$ & $\begin{array}{l}24.9 \\
32.5 \\
30.0 \\
25.8\end{array}$ & $\begin{array}{l}(2.42) \\
(2.64) \\
(2.72) \\
(2.50)\end{array}$ & $\begin{array}{l}51.1 \\
40.5 \\
44.9 \\
44.8\end{array}$ & $\begin{array}{l}(2.80) \\
(2.77) \\
(2.95) \\
(2.84)\end{array}$ \\
\hline 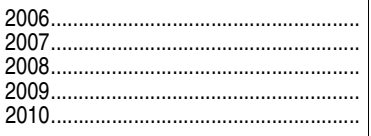 & $\begin{array}{l}55.3 \\
54.0 \\
52.9 \\
45.4 \\
40.6\end{array}$ & $\begin{array}{l}(1.66) \\
(1.55) \\
(1.43) \\
(1.45) \\
(1.90)\end{array}$ & $\begin{array}{l}15.8 \\
15.2 \\
14.6 \\
16.0 \\
14.0\end{array}$ & $\begin{array}{l}(1.22) \\
(1.11) \\
(1.01) \\
(1.07) \\
(1.20)\end{array}$ & $\begin{array}{l}28.8 \\
28.7 \\
26.9 \\
20.5 \\
19.1\end{array}$ & $\begin{array}{l}(1.52) \\
(1.41) \\
(1.27) \\
(1.18) \\
(1.50)\end{array}$ & $\begin{array}{r}9.2 \\
9.6 \\
10.7 \\
7.8 \\
6.8\end{array}$ & $\begin{array}{l}(0.97) \\
(0.91) \\
(0.89) \\
(0.78) \\
(0.78)\end{array}$ & $\begin{array}{l}80.7 \\
83.4 \\
74.8 \\
71.8 \\
74.7\end{array}$ & $\begin{array}{l}(2.26) \\
(1.98) \\
(2.29) \\
(2.36) \\
(2.51)\end{array}$ & $\begin{array}{r}8.2 \\
7.1 \\
9.7 \\
10.3 \\
11.6\end{array}$ & $\begin{array}{l}(1.57) \\
(1.36) \\
(1.56) \\
(1.60) \\
(1.93)\end{array}$ & $\begin{array}{l}30.0 \\
33.7 \\
25.9 \\
30.6 \\
30.1\end{array}$ & $\begin{array}{l}(2.62) \\
(2.51) \\
(2.31) \\
(2.42) \\
(2.86)\end{array}$ & $\begin{array}{l}42.2 \\
40.9 \\
37.8 \\
29.4 \\
31.0\end{array}$ & $\begin{array}{l}(2.82) \\
(2.61) \\
(2.56) \\
(2.39) \\
(3.08)\end{array}$ \\
\hline 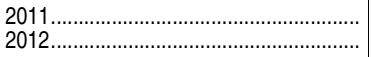 & $\begin{array}{l}45.6 \\
41.2\end{array}$ & $\begin{array}{l}(2.00) \\
(1.76)\end{array}$ & $\begin{array}{l}14.7 \\
12.0\end{array}$ & $\begin{array}{l}(1.45) \\
(1.17)\end{array}$ & $\begin{array}{l}22.1 \\
19.8\end{array}$ & $\begin{array}{l}(1.47) \\
(1.44)\end{array}$ & $\begin{array}{l}8.1 \\
8.4\end{array}$ & $\begin{array}{l}(1.01) \\
(0.95)\end{array}$ & $\begin{array}{l}73.6 \\
66.1\end{array}$ & $\begin{array}{l}(2.58) \\
(2.98)\end{array}$ & $\begin{array}{r}11.3 \\
8.3\end{array}$ & $\left.\begin{array}{l}(1.73) \\
(1.60)\end{array}\right)$ & $\begin{array}{l}27.5 \\
30.0\end{array}$ & $\begin{array}{l}(3.12) \\
(2.70)\end{array}$ & $\begin{array}{l}32.4 \\
26.9\end{array}$ & $\begin{array}{l}(3.21) \\
(2.79)\end{array}$ \\
\hline
\end{tabular}

†Not applicable.

!Interpret data with caution. The coefficient of variation (CV) for this estimate is between 30 and 50 percent.

‡Reporting standards not met. Either there are too few cases for a reliable estimate or the coefficient of variation $(\mathrm{CV})$ is 50 percent or greater.

${ }^{1}$ Excludes those who were employed but not at work during the survey week; therefore, detal may not sum to total percentage employed. "Hours worked per week" refers to the number of hours worked at all jobs during the survey week.
2Includes those who were employed but not at work during the survey week.

NOTE: Students were classified as full time if they were taking at least 12 hours of classes (or at least 9 hours of graduate classes) during an average school week and as part time if they were taking fewer hours. Some data have been revised from previously published figures. SOURCE: U.S. Department of Commerce, Census Bureau, Current Population Survey (CPS), October, selected years, 1970 through 2012. (This table was prepared July 2013.) 
Table 503.30. Percentage of college students 16 to 24 years old who were employed, by attendance status, hours worked per week, and selected characteristics: October 2010 through 2012

[Standard errors appear in parentheses]

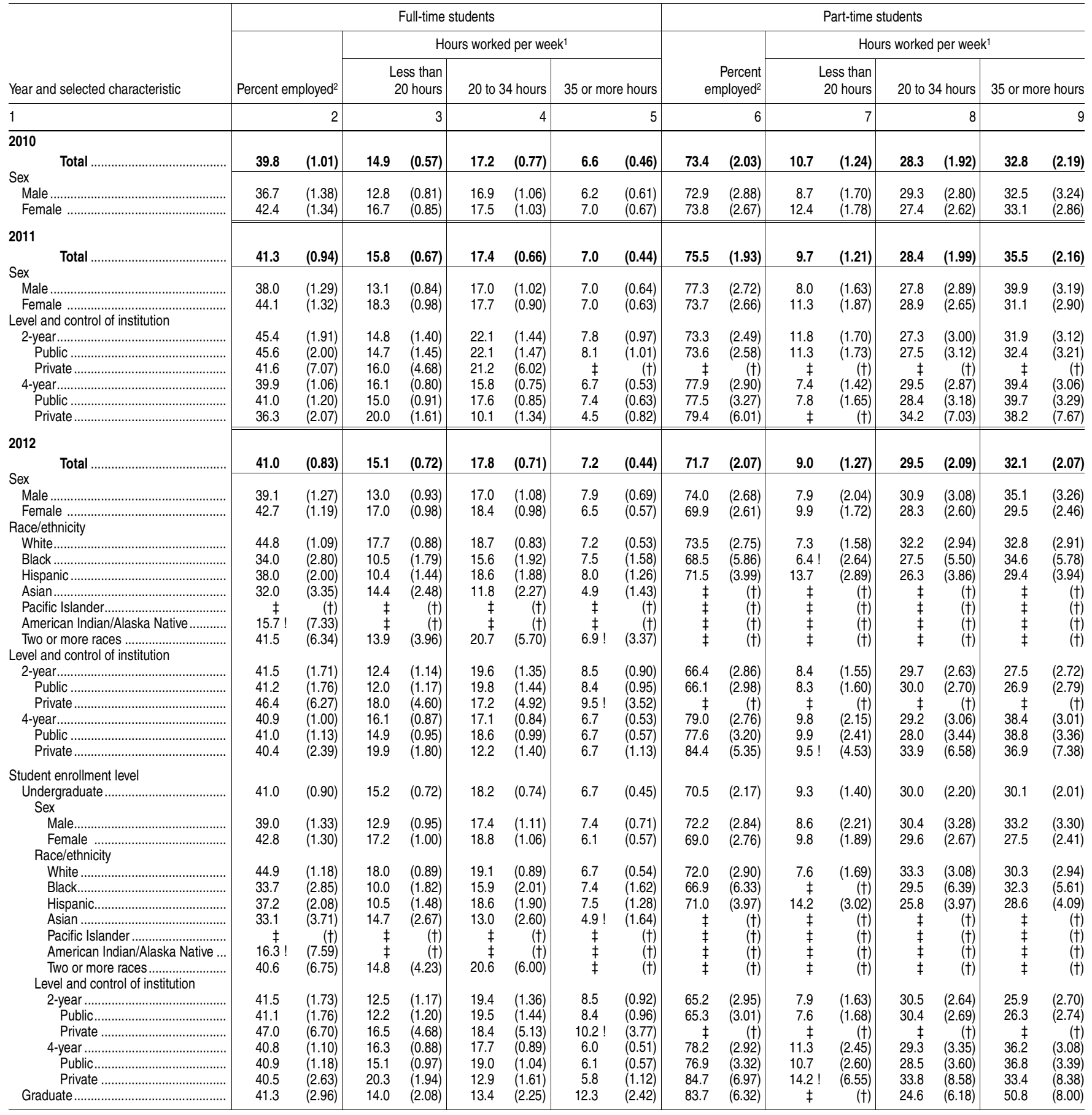

†Not applicable.

!Interpret data with caution. The coefficient of variation (CV) for this estimate is between 30 and 50 percent.

†Reporting standards not met. Either there are too few cases for a reliable estimate or the coefficient of variation $(\mathrm{CV})$ is 50 percent or greater.

${ }^{1}$ Excludes those who were employed but not at work during the survey week; therefore, detail may not sum to total percentage employed. "Hours worked per week" refers to the number of hours worked at all jobs during the survey week.
2Includes those who were employed but not at work during the survey week.

NOTE: Students were classified as full time if they were taking at least 12 hours of classes (or at least 9 hours of graduate classes) during an average school week and as part time if they were taking fewer hours. Race categories exclude persons of Hispanic ethnicity. SOURCE: U.S. Department of Commerce, Census Bureau, Current Population Survey (CPS), October, 2010 through 2012. (This table was prepared June 2013.) 


\begin{tabular}{|c|c|c|c|c|c|c|c|c|c|c|c|c|c|c|c|c|c|c|c|c|c|c|c|c|}
\hline \multirow[b]{3}{*}{ Selected characteristic } & \multirow{3}{*}{\multicolumn{2}{|c|}{$\begin{array}{r}\text { Total number of } \\
\text { high school } \\
\text { completers } \\
\text { (in thousands) }\end{array}$}} & \multicolumn{4}{|c|}{ Percent of high school completers } & \multicolumn{6}{|c|}{ Percentage distribution of all high school completers } & \multirow{3}{*}{\multicolumn{2}{|c|}{$\begin{array}{r}\text { Labor force } \\
\text { participation } \\
\text { rate of all } \\
\text { high school } \\
\text { completers }\end{array}$}} & \multicolumn{8}{|c|}{ High school completers in civilian labor force ${ }^{2}$} & \multirow{3}{*}{\multicolumn{2}{|c|}{$\begin{array}{r}\text { High school } \\
\text { completers not } \\
\text { in labor force } \\
\text { (in thousands) }\end{array}$}} \\
\hline & & & \multirow{2}{*}{\multicolumn{2}{|c|}{$\begin{array}{r}\text { Separately for } \\
\text { those enrolled in } \\
\text { college vs. those } \\
\text { not enrolled }\end{array}$}} & \multirow{2}{*}{\multicolumn{2}{|c|}{$\begin{array}{r}\text { For all high } \\
\text { school } \\
\text { completers }\end{array}$}} & \multirow{2}{*}{\multicolumn{2}{|c|}{ Employed }} & \multirow{2}{*}{\multicolumn{2}{|c|}{$\begin{array}{r}\text { Unemployed } \\
\text { (seeking } \\
\text { employment) }\end{array}$}} & \multirow{2}{*}{\multicolumn{2}{|c|}{$\begin{array}{r}\text { Not in } \\
\text { labor force }\end{array}$}} & & & \multicolumn{6}{|c|}{ Number (in thousands) } & \multirow{2}{*}{\multicolumn{2}{|c|}{$\begin{array}{l}\text { Unemployment } \\
\text { rate }\end{array}$}} & & \\
\hline & & & & & & & & & & & & & & & \multicolumn{2}{|c|}{$\begin{array}{r}\text { Total, all } \\
\text { completers in } \\
\text { labor force }\end{array}$} & \multicolumn{2}{|c|}{ Employed } & \multicolumn{2}{|c|}{$\begin{array}{r}\text { Unemployed } \\
\text { (seeking } \\
\text { employment) }\end{array}$} & & & & \\
\hline 1 & & 2 & & 3 & & 4 & & 5 & & 6 & & 7 & & 8 & & 9 & & 10 & & 11 & & 12 & & $\overline{13}$ \\
\hline $\begin{array}{l}2010 \text { high school completers } \\
\text { Total }\end{array}$ & 3,160 & (91.8) & $t$ & $(t)$ & 100.0 & $(t)$ & 37.3 & (1.73) & 14.4 & (1.18) & 48.3 & (1.77) & 51.7 & (1.77) & 1,633 & (70.7) & 1,179 & (64.9) & 454 & (38.1) & 27.8 & $(2.14)$ & 1,528 & (74.0) \\
\hline 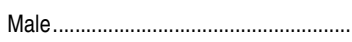 & 1,679 & $(64.6)$ & $t$ & $(+)$ & 53.1 & $(1.30)$ & 39.3 & $(2.31)$ & 15.9 & $(1.71)$ & 44.8 & $(2.26)$ & 55.2 & $(2.26)$ & 926 & $(51.5)$ & 659 & $(49.2)$ & 267 & $(28.2)$ & 28.9 & $(2.91)$ & 752 & $(48.0)$ \\
\hline Female ........................... & 1,482 & $(58.4)$ & $t$ & $(\mathrm{t})$ & 46.9 & $(1.30)$ & 35.1 & $(2.32)$ & 12.6 & $(1.50)$ & 52.3 & (2.52) & 47.7 & (2.52) & 706 & (45.2) & 520 & $(38.0)$ & 187 & $(23.9)$ & 26.4 & $(2.85)$ & 775 & (49.5) \\
\hline White... & 1,937 & (68.7) & $t$ & $(\dagger)$ & 61.3 & $(1.41)$ & 40.9 & (2.18) & 12.9 & (1.34) & 46.2 & (2.10) & 53.8 & (2.10) & 1,041 & (55.1) & 792 & (52.1) & 249 & (26.7) & 23.9 & (2.43) & 896 & (51.7) \\
\hline Black.... & 461 & (36.9) & $t$ & $(t)$ & 14.6 & (1.11) & 24.5 & (3.74) & 23.3 & (4.22) & 52.2 & (4.50) & 47.8 & (4.50) & 220 & (27.2) & 113 & (19.8) & 107 & (20.9) & 48.7 & $(6.96)$ & 241 & (28.3) \\
\hline 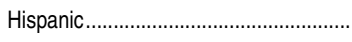 & 507 & (37.3) & $t$ & $(t)$ & 16.0 & $(1.05)$ & 42.5 & $(4.60)$ & 12.3 & (2.68) & 45.1 & $(4.60)$ & 54.9 & $(4.60)$ & 278 & $(30.6)$ & 215 & (27.9) & $\ddagger$ & $(t)$ & 22.5 & $(4.71)$ & 229 & (29.1) \\
\hline Enrolled in college, 2010. & 2,152 & (78.8) & 100.0 & $(t)$ & 68.1 & (1.49) & 30.9 & (1.94) & 9.1 & (1.22) & 60.0 & (2.13) & 40.0 & (2.13) & 860 & $(51.9)$ & 664 & (46.9) & 196 & (26.4) & 22.8 & $(2.77)$ & 1,292 & (70.3) \\
\hline Male..... & 1,055 & $(50.5)$ & 49.0 & (1.64) & 33.4 & $(1.24)$ & 30.1 & $(2.67)$ & 11.0 & $(1.81)$ & 58.9 & (3.05) & 41.1 & (3.05) & 433 & (37.4) & 317 & (31.7) & 116 & (19.6) & 26.8 & $(3.87)$ & 621 & (44.8) \\
\hline Female.... & 1,097 & $(55.2)$ & 51.0 & $(1.64)$ & 34.7 & $(1.44)$ & 31.6 & (2.68) & 7.3 & (1.52) & 61.1 & (2.84) & 38.9 & $(2.84)$ & 427 & $(37.4)$ & 347 & $(34.0)$ & $\ddagger$ & $(t)$ & 18.7 & $(3.66)$ & 670 & (46.3) \\
\hline 2-year.... & 842 & (55.9) & 39.2 & $(2.02)$ & 39.2 & (2.02) & 42.6 & (3.21) & 9.8 & (1.93) & 47.6 & (3.43) & 52.4 & (3.43) & 441 & $(39.3)$ & 359 & (36.1) & $\ddagger$ & (†) & 18.7 & (3.39) & 401 & (41.0) \\
\hline 4 -year................................. & 1,309 & $(61.1)$ & 60.9 & $(2.02)$ & 60.9 & $(2.02)$ & 23.3 & $(2.14)$ & 8.7 & (1.50) & 68.0 & $(2.33)$ & 32.0 & $(2.33)$ & 419 & (35.5) & 305 & $(30.9)$ & 114 & (20.4) & 27.1 & $(4.25)$ & 890 & (52.5) \\
\hline Full-tim & 1,946 & $(76.2)$ & 90.4 & $(1.11)$ & 90.4 & $(1.11)$ & 27.6 & $(1$. & 9.1 & $(1.24)$ & 63.3 & (2.16) & 36.7 & (2.16) & 714 & (48.1) & 537 & (41.6) & 176 & (24.7) & 24.7 & (3.01) & 1,233 & (67.2) \\
\hline White.. & 1,365 & (56.9) & 63.5 & $(1.81)$ & 43.2 & $(1.40)$ & 34.3 & $(2.41)$ & 9.1 & (1.39) & 56.7 & (2.51) & 43.3 & $(2.51)$ & 592 & $(41.0)$ & 468 & (37.6) & 124 & (19.4) & 21.0 & (3.03) & 774 & (48.7) \\
\hline 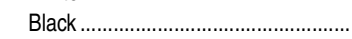 & 286 & (33.4) & 13.3 & (1.42) & 9.1 & $(1.01)$ & 22.4 & (4.79) & $13.3 !$ & (4.58) & 64.2 & (5.48) & 35.8 & (5.48) & $\ddagger$ & $(t)$ & $\ddagger$ & $(t)$ & $\ddagger$ & $(t)$ & $\ddagger$ & $(\dagger)$ & 184 & (26.3) \\
\hline Hispanic ................. & 302 & (31.5) & 14.1 & $(1.30)$ & 9.6 & $(0.96)$ & 30.8 & (5.59) & $6.8 !$ & (2.60) & 62.4 & $(5.72)$ & 37.6 & (5.72) & 114 & (20.6) & 93 & $(19.1)$ & $\ddagger$ & $(t)$ & $18.1 !$ & $(6.83)$ & 189 & (26.8) \\
\hline Not enrolled in college, $2010 \ldots$ & 1,009 & $(54.9)$ & 100.0 & $(\dagger)$ & 31.9 & (1.49) & 51.0 & $(2.98)$ & 25.6 & (2.38) & 23.4 & (2.29) & 76.6 & (2.29) & 773 & (49.7) & 515 & (42.9) & 258 & (27.4) & 33.4 & $(3.07)$ & 236 & (25.4) \\
\hline Male ..................... & 624 & $(40.4)$ & 61.9 & $(2.77)$ & 19.7 & $(1.15)$ & 54.8 & $(3.66)$ & 24.2 & (2.99) & 21.0 & $(2.67)$ & 79.0 & $(2.67)$ & 493 & (38.9) & 342 & $(35.6)$ & 151 & $(19.9)$ & 30.7 & $(3.75)$ & 131 & $(17.0)$ \\
\hline 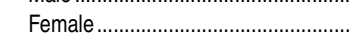 & 385 & (37.4) & 38.1 & $(2.77)$ & 12.2 & $(1.13)$ & 45.0 & $(4.64)$ & 27.8 & (3.95) & 27.3 & $(4.11)$ & 72.7 & $(4.11)$ & 280 & (30.8) & 173 & (24.6) & 107 & $(17.8)$ & 38.2 & $(5.13)$ & 105 & (19.2) \\
\hline White.. & 571 & $(39.3)$ & 56.7 & (2.72) & 18.1 & (1.13) & 56.8 & (3.94) & 21.9 & $(3.0$ & 21.4 & (3.15) & 78.6 & (3.15) & 449 & $(36$. & 324 & (33.6) & 125 & (18.1) & 27.8 & (3.79) & 122 & (19.7) \\
\hline Black.. & 175 & $(24.9)$ & 17.3 & $(2.11)$ & 5.5 & $(0.80)$ & 27.8 & $(6.61)$ & 39.6 & $(6.95)$ & 32.6 & $(6.23)$ & 67.4 & $(6.23)$ & 118 & $(21.7)$ & $\ddagger$ & $(t)$ & $\ddagger$ & $(\dagger)$ & 58.7 & $(9.00)$ & $\ddagger$ & $(\dagger)$ \\
\hline Hispanic .... & 204 & (25.4) & 20.3 & $(2.34)$ & 6.5 & $(0.76)$ & 59.9 & $(5.86)$ & 20.5 & $(5.10)$ & 19.6 & $(5.11)$ & 80.4 & $(5.11)$ & 164 & $(23.9)$ & 122 & $(19.9)$ & $\ddagger$ & $(\dagger)$ & 25.5 & $(6.01)$ & $\ddagger$ & $(\dagger)$ \\
\hline $\begin{array}{l}2011 \text { high school completers } \\
\text { Total.... }\end{array}$ & 3,079 & (88.3) & $\dagger$ & $(t)$ & 100.0 & $(t)$ & 35.2 & $(1.40)$ & 12.9 & (1.12) & 51.9 & $(1.60)$ & 48.1 & $(1.60)$ & 1,482 & (58.7) & 1,084 & $(50.0)$ & 398 & $(34.8)$ & 26.8 & $(2.01)$ & 1,597 & (73.3) \\
\hline 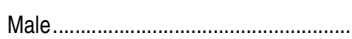 & 1,611 & $(60.6)$ & $\dagger$ & $(\mathrm{t})$ & 52.3 & $(1.30)$ & 34.2 & $(2.00)$ & 16.0 & $(1.62)$ & 49.8 & $(2.40)$ & 50.2 & $(2.40)$ & 808 & $(46.2)$ & 551 & $(36.3)$ & 258 & (27.3) & 31.9 & $(2.67)$ & 802 & $(51.6)$ \\
\hline Female & 1,468 & (58.4) & $t$ & $(t)$ & 47.7 & $(1.30)$ & 36.3 & (2.22) & 9.5 & (1.32) & 54.1 & $(2.28)$ & 45.9 & $(2.28)$ & 674 & (40.4) & 534 & (37.3) & 140 & (19.7) & 20.8 & $(2.69)$ & 795 & $(48.6)$ \\
\hline White .... & 1,747 & $(60.6)$ & $\dagger$ & $(t)$ & 56.7 & $(1.38)$ & 42.7 & $(1.85)$ & 10.2 & $(1.25)$ & 47.1 & (2.15) & 52.9 & $(2.15)$ & 925 & (46.9) & 746 & (39. & 179 & (22.4) & 19.3 & $(2.08)$ & 822 & (49.5) \\
\hline Black.... & 464 & $(36.1)$ & $\dagger$ & $(t)$ & 15.1 & $(1.08)$ & 23.1 & $(3.76)$ & 17.5 & (3.65) & 59.4 & (4.49) & 40.6 & $(4.49)$ & 189 & $(25.6)$ & 107 & (20.8) & $\ddagger$ & $(t)$ & 43.2 & $(7.23)$ & 275 & (29.2) \\
\hline Hispanic................................... & 623 & (42.0) & $t$ & $(t)$ & 20.2 & $(1.20)$ & 28.4 & (3.25) & 15.9 & (2.72) & 55.7 & $(3.60)$ & 44.3 & $(3.60)$ & 276 & (29.2) & 177 & (23.6) & 99 & $(18.0)$ & 35.9 & $(5.33)$ & 347 & (32.0) \\
\hline Enrolled in college, $2011 \ldots . .$. & 2,101 & (77.2) & 100.0 & $(\dagger)$ & 68.2 & $(1.45)$ & 30.4 & (1.69) & 8.2 & $(1.17)$ & 61.4 & (1.92) & 38.6 & (1.92) & 810 & (49.2) & 638 & (42.1) & 172 & $(25.1)$ & 21.2 & $(2.68)$ & 1,291 & (63.1) \\
\hline & 1,041 & $(55.6)$ & 49.6 & $(1.70)$ & 33.8 & $(1.44)$ & 26.2 & $(2.33)$ & 10.1 & $(1.96)$ & 63.7 & (2.86) & 36.3 & $(2.86)$ & 378 & $(35.7)$ & 273 & $(27.2)$ & 106 & $(21.6)$ & 27.9 & $(4.47)$ & 663 & (46.2) \\
\hline Female & 1,060 & (49.1) & 50.4 & $(1.70)$ & 34.4 & $(1.29)$ & 34.5 & $(2.57)$ & 6.3 & (1.15) & 59.2 & (2.62) & 40.8 & (2.62) & 432 & (34.3) & 365 & (32.4) & $\ddagger$ & $(t)$ & 15.3 & $(2.73)$ & 628 & (40.0) \\
\hline Full-time students ........... & 1,930 & (74.2) & 91.9 & $(1.11)$ & 62.7 & (1.42) & 27.0 & (1.71) & 7.9 & $(1.20)$ & 65.1 & (1.95) & 34.9 & $(1.95)$ & 674 & (44.0) & 522 & $(36.8)$ & 152 & $(24.0)$ & 22.6 & (3.02) & 1,256 & (63.0) \\
\hline Part-time students. ............................. & 170 & (24.1) & 8.1 & $(1.11)$ & 5.5 & $(0.78)$ & 68.3 & (6.42) & 11.4 ! & $(4.38)$ & 20.3 & $(4.97)$ & 79.7 & (4.97) & 136 & $(20.8)$ & 116 & $(18.8)$ & $\ddagger$ & $(t)$ & $14.3 !$ & (5.53) & $\ddagger$ & $(\dagger)$ \\
\hline
\end{tabular}

See notes at end of table. 
Table 504.10. Labor force status of 2010, 2011, and 2012 high school completers, by college enrollment status, sex, and race/ethnicity: October 2010, 2011, and 2012-Continued

[Standard errors appear in parentheses]

\begin{tabular}{|c|c|c|c|c|c|c|c|c|c|c|c|c|c|c|c|c|c|c|c|c|c|c|c|c|}
\hline \multirow[b]{3}{*}{ Selected characteristic } & \multirow{3}{*}{\multicolumn{2}{|c|}{$\begin{array}{r}\text { Total number of } \\
\text { high school } \\
\text { completers } \\
\text { (in thousands) }\end{array}$}} & \multicolumn{4}{|c|}{ Percent of high school completers } & \multicolumn{6}{|c|}{ Percentage distribution of all high school completers } & \multirow{3}{*}{\multicolumn{2}{|c|}{$\begin{array}{r}\text { Labor force } \\
\text { participation } \\
\text { rate of all } \\
\text { high school } \\
\text { completers }^{1}\end{array}$}} & \multicolumn{8}{|c|}{ High school completers in civilian labor force ${ }^{2}$} & \multirow{3}{*}{\multicolumn{2}{|c|}{$\begin{array}{r}\text { High school } \\
\text { completers not } \\
\text { in labor force } \\
\text { (in thousands) }\end{array}$}} \\
\hline & & & & & & & & \multicolumn{6}{|c|}{ Number (in thousands) } & & & & \\
\hline & & & \multicolumn{2}{|c|}{$\begin{array}{r}\text { Separately for } \\
\text { those enrolled in } \\
\text { college vs. those } \\
\text { not enrolled }\end{array}$} & \multicolumn{2}{|c|}{$\begin{array}{r}\text { For all high } \\
\text { school } \\
\text { completers }\end{array}$} & \multicolumn{2}{|c|}{ Employed } & \multicolumn{2}{|c|}{$\begin{array}{r}\text { Unemployed } \\
\text { (seeking } \\
\text { employment) }\end{array}$} & & & & & $\begin{array}{r}\text { comp } \\
\text { lab }\end{array}$ & $\begin{array}{l}\text { otal, all } \\
\text { eters in } \\
\text { or force }\end{array}$ & & iployed & $\begin{array}{r}\text { Uner } \\
\text { empl }\end{array}$ & $\begin{array}{l}\text { ployed } \\
\text { eeking } \\
\text { yment) }\end{array}$ & Unemp & $\begin{array}{r}\begin{array}{r}\text { loyment } \\
\text { rate }\end{array} \\
-\end{array}$ & & \\
\hline 1 & & 2 & & 3 & & 4 & & 5 & & 6 & & 7 & & 8 & & 9 & & 10 & & 11 & & 12 & & \\
\hline White.... & 1,193 & (52.9) & 56.8 & (1.73) & 38.7 & (1.43) & 37.4 & (2.27) & 6.4 & $(1.33)$ & 56.2 & (2.69) & 43.8 & (2.69) & 522 & $(40.1)$ & 446 & (33.1) & $\ddagger$ & $(\mathrm{t})$ & 14.6 & (2.66) & 670 & \\
\hline Black .... & 312 & (31.6) & 14.8 & $(1.44)$ & 10.1 & $(0.96)$ & 19.9 & $(4.50)$ & $7.7 !$ & (3.02) & 72.4 & $(4.76)$ & 27.6 & $(4.76)$ & 86 & $(17.2)$ & $\ddagger$ & $(\dagger)$ & $\ddagger$ & $(\dagger)$ & $28.0 !$ & (10.19) & 226 & \\
\hline Hispanic ........................... & 415 & (33.9) & 19.7 & $(1.39)$ & 13.5 & $(1.02)$ & 24.9 & (3.96) & 12.5 & (3.31) & 62.6 & $(4.45)$ & 37.4 & (4.45) & 155 & (22.3) & 103 & (18.5) & $\ddagger$ & $(\mathrm{t})$ & 33.5 & $(7.70)$ & 260 & \\
\hline Not enrolled in college, $2011 \ldots$. & 978 & (51.1) & 100.0 & (†) & 31.8 & (1.45) & 45.6 & (2.88) & 23.1 & (2.58) & 31.3 & (2.74) & 68.7 & (2.74) & 672 & (42.5) & 446 & (34.7) & 226 & (27.9) & 33.6 & (3.40) & 306 & \\
\hline Male... & 569 & (38.2) & 58.2 & (2.65) & 18.5 & $(1.20)$ & 48.8 & (3.94) & 26.7 & (3.33) & 24.5 & (3.42) & 75.5 & (3.42) & 430 & $(34.3)$ & 278 & (27.4) & 152 & (22.5) & 35.4 & $(4.17)$ & 139 & \\
\hline Female .... & 409 & (34.4) & 41.8 & (2.65) & 13.3 & $(1.03)$ & 41.1 & (4.39) & 18.0 & (3.43) & 40.8 & $(4.77)$ & 59.2 & (4.77) & 242 & $(24.5)$ & 168 & $(21.8)$ & 74 & (13.9) & 30.5 & (5.11) & 167 & \\
\hline White.... & 554 & (37.4) & 56.7 & (2.58) & 18.0 & $(1.14)$ & 54.1 & (3.72) & 18.5 & (2.97) & 27.4 & (3.32) & 72.6 & (3.32) & 402 & $(31.6)$ & 300 & (26.6) & 103 & (18.4) & 25.5 & (3.89) & 152 & \\
\hline Black ... & 152 & (21.3) & 15.6 & (2.01) & 5.0 & $(0.69)$ & 29.7 & 6 & 37.6 & (7) & 32.6 & $(7.91)$ & 67.4 & (7.91) & 103 & $(19.8)$ & $\ddagger$ & $(\dagger)$ & $\ddagger$ & $(\dagger)$ & 55.9 & (8.44) & $\ddagger$ & \\
\hline Hispanic.... & 208 & (26.8) & 21.3 & (2.38) & 6.8 & $(0.84)$ & 35.4 & $(6.04)$ & 22.6 & (5.12) & 42.0 & (6.75) & 58.0 & (6.75) & 121 & (19.4) & 74 & (15.0) & $\ddagger$ & $(\mathrm{t})$ & 39.0 & (7.47) & $\ddagger$ & \\
\hline $\begin{array}{l}2012 \text { high school completers } \\
\text { Total }\end{array}$ & 3,203 & (96.2) & $\dagger$ & $(t)$ & 100.0 & (†) & 36.3 & (1.53) & 12.6 & (1.15) & 51.2 & $(1.61)$ & 48.8 & (1.61) & 1,563 & (67.9) & 1,161 & (57.7) & 402 & (38.9) & 25.7 & $(2.13)$ & 1,639 & \\
\hline Male....................................... & 1,622 & $(70.1)$ & $t$ & $(\dagger)$ & 50.6 & $(1.25)$ & 33.7 & $(2.21)$ & 14.5 & $(1.75)$ & 51.8 & (2.29) & 48.2 & $(2.29)$ & 783 & $(49.3)$ & 547 & $(42.8)$ & 235 & (29.5) & 30.0 & (3.29) & 840 & \\
\hline Female... & 1,581 & (54.0) & $t$ & $(\dagger)$ & 49.4 & (1.25) & 38.8 & (1.92) & 10.6 & (1.29) & 50.6 & (2.16) & 49.4 & (2.16) & 781 & (42.2) & 614 & $(36.0)$ & 167 & (21.1) & 21.4 & (2.31) & 800 & \\
\hline White & 1,820 & (62.8) & $\dagger$ & (†) & 56.8 & $(1.52)$ & 42.5 & (2.07) & 10.9 & $(1.31)$ & 46.6 & (2.02) & 53.4 & (2.02) & 971 & $(49.9)$ & 774 & (46 & 198 & (24.8) & 20.3 & (2.35) & 849 & \\
\hline Black... & 413 & (33.9) & $\dagger$ & $(t)$ & 12.9 & $(0.98)$ & 26.4 & $(4.5$ & 23 & (4. & 50.4 & $(4.88)$ & 49.6 & $(4.88)$ & 205 & (26. & 109 & (19 & 96 & (19.3) & 46 & $(7.23)$ & 208 & \\
\hline 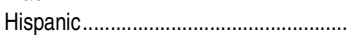 & 697 & (54.9) & $\dagger$ & $(\dagger)$ & 21.8 & (1.41) & 32.1 & (3.10) & 10.2 & (2.13) & 57.6 & (3.29) & 42.4 & (3.29) & 296 & (28.7) & 224 & (25.2) & $\ddagger$ & $(\dagger)$ & 24.2 & (4.60) & 402 & \\
\hline Enrollec & 2,121 & (76.4) & 100.0 & (†) & 66.2 & (1.59) & 31.5 & $(1.6$ & 6. & $(0$. & 61.8 & $(1.8$ & 38.2 & (1.84) & 811 & (46.7) & 667 & $(41$ & 143 & (20.0) & 17.7 & (2.18) & 1,310 & \\
\hline Male ... & 994 & (53.3) & 46.9 & $(1.66)$ & 31.0 & $(1.31)$ & 27.4 & $(2.3$ & 7. & & 65.6 & $(2.5$ & $31+2+2$ & (2.58) & 342 & (29. & 272 & $(27.0)$ & $\ddagger$ & $(t)$ & 20. & (3.65) & 652 & \\
\hline Female ............. & 1,127 & (49.9) & 53.1 & (1.66) & 35.2 & (1.41) & 35.1 & (2.19) & 6.5 & (1.20) & 58.4 & (2.43) & 41.6 & (2.43) & 469 & (32.6) & 395 & (29.0) & $\ddagger$ & $(\mathrm{t})$ & 15.7 & (2.60) & 658 & \\
\hline 2 & 921 & (57.7) & 43.4 & (2.07) & 28.8 & (1.57) & 39.9 & (3.1 & 8.0 & $(1.5$ & 52.1 & (3.22 & 47.9 & (3.22) & 441 & (35.2) & 367 & (32. & $\ddagger$ & $(t)$ & 16.7 & (3.09) & 480 & \\
\hline 4-year............................. & 1,200 & (58.3) & 56.6 & $(2.07)$ & 37.5 & $(1.60)$ & 25.0 & (1.92) & 5.8 & $(1.1$ & 69.2 & $(2.17$ & 30.8 & (2.17) & 370 & $(31.8)$ & 300 & (27.6) & $\ddagger$ & $(t)$ & 18.8 & (3.32) & 830 & \\
\hline Full-tin & 1,863 & (71.3) & 87.8 & $(1.31)$ & 58.2 & $(1.61)$ & 28.1 & (1.74) & 5.8 & (0. & 66.1 & $(1.89)$ & 33.9 & $(1.89)$ & 632 & $(41.6$ & 523 & (36.6) & 109 & (16.8) & 17.2 & (2.34) & 1,231 & \\
\hline Part-time students........ & 258 & (29.7) & 12.2 & (1.31) & 8.1 & $(0.90)$ & 55.9 & (5.63) & 13.4 & (3.98) & 30.8 & $(5.73)$ & 69.2 & (5.73) & 179 & (25.8) & 144 & (22.3) & $\ddagger$ & $(\dagger)$ & 19.3 & (5.36) & $\ddagger$ & \\
\hline 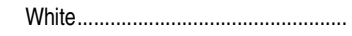 & 1,196 & (52.7) & 56.4 & (1.88) & 37.3 & $(1.50)$ & 35.0 & (2.32) $>->$ & 6.6 & (1.16) & 58.3 & (2.46) & 41.7 & (2.46) & 498 & (35.5) & 419 & $(32.1)$ & 79 & (14.3) & 15.9 & (2.61) & 698 & \\
\hline & 233 & (30.4) & 11.0 & $(1.38)$ & 7.3 & $(0.93)$ & 24.4 & $(5.7$ & $10.8 !$ & $(4.25)$ & 64.7 & $(6.27)$ & 35.3 & $(6.27)$ & $\ddagger$ & $(\dagger)$ & $\ddagger$ & $(t)$ & $\ddagger$ & $(t)$ & $\ddagger$ & $(t)$ & 151 & \\
\hline Hispanic ........ & 490 & $(43.3)$ & 23.1 & (1.71) & 15.3 & (1.16) & 31.7 & (3.98) & $4.7 !$ & $(1.83)$ & 63.6 & $(4.00)$ & 36.4 & $(4.00)$ & 178 & (22.7) & 155 & (22.0) & $\ddagger$ & $(\dagger)$ & $12.9 !$ & (4.91) & 312 & \\
\hline Not enrolled in college, $2012 \ldots \ldots \ldots . .$. & 1,082 & (63.3) & 100.0 & $(\dagger)$ & 33.8 & $(1.59)$ & 45.7 & $(2.5$ & 23.9 & (2. & 30.4 & (2 & 69.6 & $(2.6$ & 753 & (53. & 494 & (40.9) & 259 & 1.4) & 34.4 & (3.24) & 329 & \\
\hline Male & 628 & (45.9) & 58.1 & (2.47) & 19.6 & $(1.22)$ & 43.8 & (3. & 26 & & 29.8 & $(3.64)$ & 70.2 & (3.64) & 441 & $(39.1)$ & 275 & $(31.1)$ & 166 & (25.0) & 37.5 & (4.55) & 187 & \\
\hline Female & 454 & (37.3) & 41.9 & (2.47) & 14.2 & $(1.09)$ & 48.2 & (3.92) & 20.5 & (3.35) & 31.3 & (3.78) & 68.7 & (3.78) & 312 & (29.8) & 219 & $(25.1)$ & 93 & (16.5) & 29.9 & $(4.50)$ & 142 & \\
\hline White & 624 & (42.3) & 57.7 & $(2.63)$ & 19.5 & $(1.21)$ & 56.9 & (3.29) & 18.9 & (2.6) & 24.2 & (3.1 & 75.8 & (3.11) & 473 & (39. & 355 & $(34.3)$ & 118 & (17.9) & 25.0 & (3.32) & 151 & \\
\hline Black... & 180 & (22.0) & 16.6 & $(1.84)$ & 5.6 & $(0.66)$ & 28.8 & $(6.8$ & 39 & (7.43) & 31.9 & $(7.23)$ & 68.1 & $(7.23)$ & 122 & (19.9) & $\ddagger$ & $(t)$ & $\ddagger$ & $(t)$ & 57.6 & $(9.06)$ & $\ddagger$ & \\
\hline 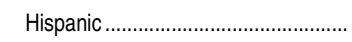 & 207 & (28.4) & 19.1 & $(2.25)$ & 6.5 & $(0.85)$ & 33.2 & (6.32) & 23.4 & (5.69) & 43.4 & $(5.64)$ & 56.6 & (5.64) & 117 & $(18.0)$ & $\ddagger$ & $(\dagger)$ & $\ddagger$ & $(\dagger)$ & 41.4 & $(9.35)$ & 90 & \\
\hline
\end{tabular}

†Not applicable.

!nterpret data with caution. The coefficient of variation (CV) for this estimate is between 30 and 50 percent fReporting standards not met (too few cases for a reliable estimate).

${ }^{2}$ The employment.
3Includes 16- to 24-year-olds who completed high school between October of the previous year and October of the given year. Includes recipients of equivalency credentials as well as diploma recipients.

are only hown when the ries not separately shown. Rase categories exclude persons of Hispanic ethnicity Detail may not sum to totals because of reunding SOURCE: U.S. Department of Commerce, Census Bureau, Current Population Survey (CPS), October 2010, 2011, and 2012. (This 
Table 504.20. Labor force status of high school dropouts, by sex and race/ethnicity: October, selected years, 1980 through 2012 [Standard errors appear in parentheses]

\begin{tabular}{|c|c|c|c|c|c|c|c|c|c|c|c|c|c|c|c|c|c|c|c|c|}
\hline \multirow[b]{3}{*}{$\begin{array}{l}\text { Year, sex, and } \\
\text { race/ethnicity }\end{array}$} & \multirow{3}{*}{\multicolumn{2}{|c|}{$\begin{array}{r}\text { Number of } \\
\text { dropouts } \\
\text { (in thousands) }\end{array}$}} & \multirow{3}{*}{\multicolumn{2}{|c|}{$\begin{array}{r}\text { Percent of all } \\
\text { dropouts }\end{array}$}} & \multirow{2}{*}{\multicolumn{6}{|c|}{ Percentage distribution of dropouts }} & \multirow{3}{*}{\multicolumn{2}{|c|}{$\begin{array}{r}\text { Labor force } \\
\text { participation } \\
\text { rate of } \\
\text { dropouts }^{1}\end{array}$}} & \multicolumn{6}{|c|}{ Dropouts in civilian labor force ${ }^{2}$} & & \\
\hline & & & & & & & & & & & & & \multicolumn{4}{|c|}{ Number (in thousands) } & & & & \\
\hline & & & & & & mployed & $\begin{array}{l}\text { Uner } \\
\text { empl }\end{array}$ & $\begin{array}{l}\text { nployed } \\
\text { seeking } \\
\text { byment) }\end{array}$ & & $\begin{array}{r}\text { Not in } \\
\text { or force }\end{array}$ & & & & Total & $\begin{array}{r}\text { Unem } \\
(s \\
\text { emplo }\end{array}$ & $\begin{array}{l}\text { nployed } \\
\text { seeking } \\
\text { yyment) }\end{array}$ & Unempl & $\begin{array}{r}\text { loyment } \\
\text { rate } \\
\end{array}$ & & $\begin{array}{l}\text { ir force } \\
\text { sands) } \\
\end{array}$ \\
\hline 1 & & 2 & & 3 & & 4 & & 5 & & 6 & & 7 & & 8 & & 9 & & 10 & & 11 \\
\hline All dropouts & & & & & & & & & & & & & & & & & & & & \\
\hline 80 & 738 & $(44.0)$ & 100.0 & $(t)$ & 43.8 & $(2.97)$ & 20.0 & $(2.37)$ & 36.2 & $(2.87)$ & 63.8 & $(2.87)$ & 471 & (35.2) & 148 & (19.5) & 31.4 & (3.44) & 267 & (26.5) \\
\hline $85 .$. & 610 & $(42.3)$ & 100.0 & $(t)$ & 43.5 & $(3.45)$ & 4.0 & 2.94) & & $(3.25)$ & 67.5 & $(3.25)$ & 412 & 4.8) & 147 & 20.6) & 5.6 & $(4.01)$ & 198 & (24.1) \\
\hline $90 .$. & 412 & $(36.0)$ & 100.0 & $(t)$ & 46.3 & $(4.37)$ & 21.6 & (3.57) & .6 & $(4.09)$ & 67.8 & $(4.09)$ & 279 & 9.7) & 89 & (16.6) & 1.8 & $(4.90)$ & 132 & (20.4) \\
\hline 95 & 604 & $(43.6)$ & 100.0 & $(t)$ & 47.7 & 1) & 20.0 & $(2.86)$ & 2.3 & .38) & 67.7 & (3.38) & 409 & 5.9) & 121 & 9.3) & 9.6 & (3.97) & 195 & (24.8) \\
\hline bo.. & 515 & $(28.5)$ & 100.0 & $(t)$ & 48.7 & $(2.77)$ & 19.2 & $(3.01)$ & 10 & (2.59) & 68.0 & $(2.59)$ & 350 & 3.5) & 99 & 7.2) & 8.1 & 16) & 165 & (16.2) \\
\hline & 407 & $(35.3)$ & 100.0 & $(t)$ & & $(4,22)$ & 18.9 & (3.42) & & (3.32) & 57.2 & $(4.30)$ & 233 & 6.7) & 77 & 5.4) & 2.9 & & 174 & (17.9) \\
\hline & 340 & $(29.0)$ & 100.0 & $(\dagger)$ & .9 & $(4.24)$ & 23.0 & $(4.29)$ & 46.1 & (4.78) & 53.9 & $(4.78)$ & 183 & 1.5) & 78 & .0) & 2.7 & 3.67) & 157 & $(21.9)$ \\
\hline & 372 & $(33.4)$ & 100.0 & $(t)$ & 33.9 & $(4$ & .1 & (4.18) & 1.9 & $(4.78)$ & 55.1 & $(4.78)$ & 2045 & 4.2) & 79 & 9) & 8.4 & (6.26) & 167 & (24.5) \\
\hline $2012^{\circ}$ & 370 & $(37.1)$ & 100.0 & $(t)$ & 23.8 & $(4.56)$ & 23.4 & $(4.69)$ & 52.8 & $(5.64)$ & 47.2 & $(5.64)$ & 174 & $(27.0)$ & $\ddagger$ & (t) & 49.6 & $(7.82)$ & 195 & (28.8) \\
\hline Male & & & & & & & & & & & & & & & & & & & & \\
\hline 880. & 422 & (32.5) & 57.2 & .89) & 50.3 & 386 & 0 & 3.20) & 27.7 & (3.45) & 2.3 & (3.45) & 305 & 7) & 93 & 15.3) & .5 & 4.18) & 117 & (17.1) \\
\hline & 319 & $(29.9)$ & 52.3 & (3.39) & 50.8 & $(4.69)$ & 30.6 & (4.32) & 18 & (3.) & 81.4 & $(3.65)$ & 260 & a) & 98 & & & $(5$ & 59 & (12.9) \\
\hline & 217 & (25.6) & 52.8 & $(4.27)$ & 51.3 & $(5.8$ & 28 & (5. & 20. & $(4.7$ & 79.3 & $(4.77)$ & 172 & (22.8) & 61 & & & & 45 & (11.6) \\
\hline & 39 & $(31.5)$ & 56.2 & (3.45) & 2.8 & $(4.64)$ & 21. & $(3.80)$ & 26. & $(4.07)$ & 74.0 & $(4.07)$ & 251 & (27.1) & 72 & 14.5) & .7 & (4. & 88 & (16.1) \\
\hline & 5 & (29.3) & 57.3 & (3.73) & & $(4$. & & 13 & 25 & (4.) & 74.4 & $(4.35)$ & 220 & 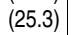 & $\ddagger$ & $(t)$ & & & 76 & (14.9) \\
\hline & 227 & (25.9) & 55.8 & $(4.24)$ & 59.9 & $(5.6$ & 21.6 & (4. & 40. & $(5.61)$ & 59.7 & $(5.61)$ & 136 & 1) & $\ddagger$ & $(t)$ & 9 & 9) & 91 & (16.4) \\
\hline & 179 & $(21.3)$ & 52.7 & $(4.17)$ & & $(4.9$ & 17.2 & (4. & 56 & $(5.7$ & 43.1 & $(5.70)$ & 77 & (12 & $\ddagger$ & $(t)$ & .8 & & 102 & (17.2) \\
\hline & 204 & (24.5) & 54.7 & $(4.00)$ & 42.1 & $(5.9$ & $16.0 !$ & $(4.85)$ & 41.8 & $(6.25)$ & 58.2 & $(6.25)$ & 118 & 1) & $\ddagger$ & $(t)$ & 7.5 & $(7.53)$ & 85 & $(17.4)$ \\
\hline$\angle 01$ & 192 & $(27.1)$ & 51.9 & (5.42) & 31.1 & $(6.5$ & 26.8 & $(6$. & 42. & $(6.64)$ & 57.9 & $(6.64)$ & 11 & 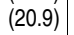 & $\ddagger$ & $(+1)$ & 46.3 & 19.5 & $\ddagger$ & $(t)$ \\
\hline Femle & & & & & & & & & & & & & & & & & & & & \\
\hline 30 & 16 & $(27.0)$ & 42.8 & .77) & 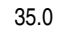 & $(4.0$ & 17. & (3.2) & 47. & $(4.2$ & 52.4 & $(4.28)$ & 165 & (19.6) & 55 & (11.3) & 2 & (5.57) & 150 & (18.7) \\
\hline & 291 & $(27.4)$ & 47.7 & $(3.25)$ & & $(4$. & 16 & & & $(4)$ & 2 & $(4.71)$ & 152 & & 49 & 2) & & & 139 & 18.9) \\
\hline & 44 & (23.2) & 47.2 & $(4.10)$ & & & 14.4 & (4 & & $(5.94)$ & 5.0 & $(5.94)$ & 107 & 2) & $\ddagger$ & †) & & & 87 & $(15.6)$ \\
\hline & 265 & $(26.6)$ & 43.8 & (3.31) & & i & 184 & 6 & & $(4.95)$ & 9.5 & $(4.95)$ & 157 & & $\ddagger$ & & .9 & & 107 & $(17.0)$ \\
\hline & 0 & (24.3) & 42.7 & (3.58) & & & & & & & .4 & $(5.43)$ & 131 & & $\ddagger$ & & & & 90 & $(15.6)$ \\
\hline & 0 & (22.4) & 44.2 & $(4.11)$ & & & & 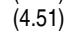 & & & 0 & $(6$. & 97 & & $\ddagger$ & & & & 83 & (15.2) \\
\hline & 1 & (19.3) & 47.3 & $(4.17)$ & & & & & & (6. & 66.0 & (6.8 & 106 & & $\ddagger$ & $(t)$ & & & $\ddagger$ & $(t)$ \\
\hline & 69 & $(20.4)$ & 45.3 & (4) & & & & & 48 & (7) & 51.3 & $(7$. & 87 & ( & $\ddagger$ & $(\dagger$ & 3.1 & $(9.84)$ & 82 & (17.0) \\
\hline $2012^{3}$. & 178 & $(27.1)$ & 48.1 & (5.42) & $15.9 !$ & $(5.41)$ & 19.7 ! & $(6.66)$ & 64.5 & $(8.03)$ & 35.5 & $(8.03)$ & $\ddagger$ & $(\dagger)$ & $\ddagger$ & $(t)$ & $\ddagger$ & $(t)$ & 115 & (24.8) \\
\hline & & & & & & & & & & & & & & & & & & & & \\
\hline & 39 & (35.9) & 66 & 8 & $0-8$ & 136 & 8 & (2. & 31 & (3. & 68 & (3. & 33 & $(29$. & 88 & $(15.1)$ & 263 & & 155 & (20.2) \\
\hline & & (32.3) & & & & & & & & & & (4. & 25 & & 83 & 15.4) & & & 98 & (16.9) \\
\hline & & $(27.6)$ & & & & & & & & & & & & & $\ddagger$ & $(+)$ & & & 60 & (13.8) \\
\hline & & (31. & & & & & & & & & .9 & $(4.5$ & 22 & 4) & $\ddagger$ & & & & 95 & (17.3) \\
\hline & & (21.4) & 5 & (2 & & & & & 23.4 & & 76 & (3. & 221 & & $\ddagger$ & & & & $\ddagger$ & $(t)$ \\
\hline & 4 & (24. & 47 & $(4.3$ & & & 20. & (5. & 39.7 & (6. & 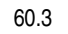 & (6. & 117 & & $\ddagger$ & & & & 77 & (15.4) \\
\hline & 8 & (18.9) & & & & & & & & & & & 77 & & $\ddagger$ & & & & 71 & (14.1) \\
\hline & 181 & $(25.3)$ & 48.5 & $(4.76)$ & 32.8 & (5.7 & 18.2 & $(5.0$ & 49. & $(6.21)$ & 51.0 & $(6.21)$ & 92 & (15.9) & $\ddagger$ & $(t)$ & 5.7 & (8.57) & 88 & $(17.6)$ \\
\hline 2012 & 86 & $(15.3)$ & 23.2 & $(4.16)$ & $24.7 !$ & $(7.85)$ & $11.6 !$ & $(5.44)$ & 63.7 & $(8.29)$ & 36.3 & $(8.29)$ & $\ddagger$ & $(t)$ & $\ddagger$ & $(t)$ & $\ddagger$ & $(t)$ & $\ddagger$ & $\left(t^{\prime}\right)$ \\
\hline & & & & & & & & & & & & & & & & & & & & \\
\hline & 1 & (19.9) & 10 & & & & & & & & & II. & 69 & $(14.0)$ & $\ddagger$ & & $\ddagger$ & $\sigma_{-1}$ & 71 & (14.2) \\
\hline & 30 & & & & & & & & & & & & 68 & i) & $\ddagger$ & & $\ddagger$ & & 62 & (14.0) \\
\hline & 82 & (16.6) & 19.9 & & & & & (9. & & (9. & 66.1 & $(9.64)$ & $\ddagger$ & (t) & $\ddagger$ & & $\ddagger$ & (T) & $\ddagger$ & $(t)$ \\
\hline & 104 & (18.5) & & & & & & & & & & & $\ddagger$ & $(+)$ & $\ddagger$ & & $\ddagger$ & & & $(t)$ \\
\hline & 106 & (18.7) & 20.6 & (3.) & & (8. & $25.5 !$ & (7.68) & 47.8 & (8. & 52.2 & $(8.80)$ & $\ddagger$ & (I) & $\ddagger$ & & $\ddagger$ & $(t)$ & $\ddagger$ & $(t)$ \\
\hline & 108 & (19.3) & & & 26.5 & & $16.0 !$ & (6 & 5 & (8. & 42.5 & $(88$ & $\ddagger$ & t & $\ddagger$ & & $\ddagger$ & & $\ddagger$ & $(t)$ \\
\hline & $\ddagger$ & $(t)$ & 18.7 & (3.9) & $\ddagger$ & $(t)$ & $\ddagger$ & $(t)$ & $\ddagger$ & $(t)$ & $\ddagger$ & $(t)$ & $\ddagger$ & (t) & $\ddagger$ & 11 & $\ddagger$ & $(t)$ & $\ddagger$ & $(t)$ \\
\hline & $\ddagger$ & $(\mathrm{t})$ & & $(3.7$ & $\ddagger$ & $(t)$ & $\ddagger$ & & $\ddagger$ & & $\ddagger$ & & $\ddagger$ & $(\dagger$ & $\ddagger$ & $f(t$ & $\ddagger$ & (t) & $\ddagger$ & $(t)$ \\
\hline $2012^{3}$. & 114 & (22.9) & 30.8 & $(5.01)$ & $\ddagger$ & $(t)$ & 35.6 & $(9.75)$ & 57.3 & (10.21) & 42.7 & (10.21) & $\ddagger$ & (t) & $\ddagger$ & (t) & $\ddagger$ & $(t)$ & $\ddagger$ & $(\dagger)$ \\
\hline & & & & & & & & & & & & & & & & & & & & \\
\hline & 9 & (18.9) & . & & & & 179 & & & & & 190 & 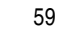 & & $\ddagger$ & & + & & & (1) \\
\hline & 105 & & 1 & & 09.9 & & $0<.0$ & 4 & 00.1 & & 69.9 & (7.) & 74 & (15.2) & $\ddagger$ & & $\ddagger$ & & 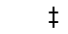 & (t) \\
\hline & 72 & (15.6) & & & 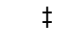 & & $t$ & & & & & & $\ddagger$ & & $\ddagger$ & & $\ddagger$ & & $\ddagger$ & (†) \\
\hline & 174 & $(23.8)$ & 28.8 & & & & & (5.) & & (6. & 68.6 & $(6.40)$ & 119 & (19.7) & $\ddagger$ & $(t)$ & 29.3 & $(7.57)$ & $\ddagger$ & $(t)$ \\
\hline & 101 & (18.2) & 19.6 & & & & & & & & 61.1 & $(8.82)$ & $\ddagger$ & $(+)$ & $\ddagger$ & & $\ddagger$ & $(t)$ & $\ddagger$ & $(t)$ \\
\hline & 86 & (17.2) & 21.1 & (3.) & & & 66 & & & (9. & 33.9 & (9. & 66 & (5.0) & $\ddagger$ & (T) & $\ddagger$ & $(t)$ & $\ddagger$ & $(t)$ \\
\hline & 93 & (15.8) & 27.3 & & & & 52 & & 25.5 ! & (7. & 47.8 & (8. & 52 & (8.8) & $\ddagger$ & $(\dagger$ & $\ddagger$ & $(t)$ & $\ddagger$ & $(t)$ \\
\hline & 99 & (17.4) & 26.6 & (4.1 & 28. & $(7.3$ & $20.1 !$ & (6. & 51.6 & (8. & 48.4 & $(8.76)$ & $\ddagger$ & $(t)$ & $\ddagger$ & 11 & $\ddagger$ & $(t)$ & $\ddagger$ & $(t)$ \\
\hline $2012^{3}$. & 134 & (24.2) & 36.3 & $(5.08)$ & 33.9 & $(8.08)$ & $21.0 !$ & (7.47) & 45.1 & (10.42) & 54.9 & (10.42) & $\ddagger$ & $(t)$ & $\ddagger$ & (T) & $\ddagger$ & $(t)$ & $\ddagger$ & \\
\hline
\end{tabular}

†Not applicable.

!Interpret data with caution. The coefficient of variation (CV) for this estimate is between 30 and 50 percent

ҒReporting standards not met. Either there are too few cases for a reliable estimate or the coefficient of variation $(\mathrm{CV})$ is 50 percent or greater.

${ }^{1} T$ The labor force participation rate is the percentage of persons who are either employed or seeking employment.

2The labor force includes all employed persons plus those seeking employment. The unemployment rate is the percentage of persons in the labor force who are not working and who made specific efforts to find employment sometime during the prior 4 weeks.
${ }^{3}$ Beginning in 2010, standard errors were computed using replicate weights, which produced more precise values than the generalized variance function methodology used in prior years.

NOTE: Data are based on sample surveys of the civilian noninstitutional population. Data are for October of a given year. Dropouts are considered persons 16 to 24 years old who dropped out of school in the 12-month period ending in October of years shown. Includes dropouts from any grade, including a small number from elementary and middle schools. Percentages are only shown when the base is 75,000 or greater. Totals include race categories not separately shown. Race categories exclude persons of Hispanic ethnicity. Detail may not sum to totals because of rounding

SOURCE: U.S. Department of Commerce, Census Bureau, Current Population Survey (CPS), October, selected years, 1980 through 2012. (This table was prepared April 2014.) 


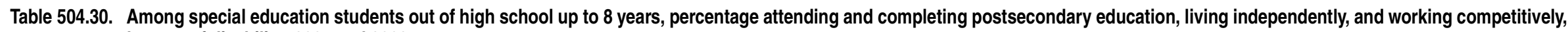
by type of disability: 2007 and 2009

[Standard errors appear in parentheses]

\begin{tabular}{|c|c|c|c|c|c|c|c|c|c|c|c|c|c|c|c|c|c|c|c|c|c|c|c|c|c|c|}
\hline \multirow{2}{*}{$\begin{array}{l}\text { Year, postsecondary status and } \\
\text { institution type, and living and } \\
\text { employment status } \\
1\end{array}$} & \multicolumn{2}{|c|}{ All disabilities $^{1}$} & \multicolumn{2}{|c|}{$\begin{array}{r}\text { Specific } \\
\text { learning } \\
\text { disabilities }\end{array}$} & \multicolumn{2}{|c|}{$\begin{array}{r}\text { Speech or } \\
\text { language } \\
\text { impairments }\end{array}$} & \multicolumn{2}{|c|}{$\begin{array}{r}\text { Intellectual } \\
\text { disability }\end{array}$} & \multicolumn{2}{|c|}{$\begin{array}{r}\text { Emotional } \\
\text { disturbance }\end{array}$} & \multicolumn{2}{|c|}{$\begin{array}{r}\text { Hearing } \\
\text { impairments }\end{array}$} & \multicolumn{2}{|c|}{$\begin{array}{r}\text { Orthopedic } \\
\text { impairments }\end{array}$} & \multicolumn{2}{|c|}{$\begin{array}{l}\text { Other health } \\
\text { impairments }\end{array}$} & \multicolumn{2}{|c|}{$\begin{array}{r}\text { Visual } \\
\text { impairments }\end{array}$} & \multicolumn{2}{|c|}{$\begin{array}{r}\text { Multiple } \\
\text { disabilities }\end{array}$} & \multicolumn{2}{|c|}{ Deaf-blindness } & \multicolumn{2}{|r|}{ Autism } & \multicolumn{2}{|c|}{$\begin{array}{l}\text { Traumatic } \\
\text { brain injury }\end{array}$} \\
\hline & & 2 & & 3 & & 4 & & 5 & & 6 & & 7 & & 8 & & 9 & & 10 & & 11 & & 12 & & 13 & & 14 \\
\hline $\begin{array}{l}2007 \text { (out of high school up to } \\
6 \text { years) }\end{array}$ & & & & & & & & & & & & & & & & & & & & & & & & & & \\
\hline 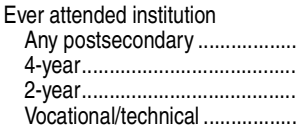 & $\begin{array}{l}55.0 \\
14.7 \\
37.3 \\
28.3\end{array}$ & $\begin{array}{l}(2.62) \\
(1.87) \\
(2.55) \\
(2.37)\end{array}$ & $\begin{array}{l}60.9 \\
15.6 \\
40.8 \\
31.4\end{array}$ & $\begin{array}{l}(3.88) \\
(2.89) \\
(3.91) \\
(3.69)\end{array}$ & $\begin{array}{l}63.0 \\
29.8 \\
41.0 \\
20.3\end{array}$ & $\begin{array}{l}(3.77) \\
(3.57) \\
(3.84) \\
(3.14)\end{array}$ & $\begin{array}{c}28.2 \\
6.2 ! \\
21.2 \\
16.0\end{array}$ & $\begin{array}{l}(3.65) \\
(1.96) \\
(3.32) \\
(2.97)\end{array}$ & $\begin{array}{l}44.6 \\
7.7 ! \\
30.0 \\
27.5\end{array}$ & $\begin{array}{l}(4.36) \\
(2.34) \\
(4.02) \\
(3.92)\end{array}$ & $\begin{array}{l}70.9 \\
31.4 \\
44.9 \\
37.8\end{array}$ & $\begin{array}{l}(4.61) \\
(4.71) \\
(5.05) \\
(4.92)\end{array}$ & $\begin{array}{l}59.8 \\
22.5 \\
45.5 \\
21.5\end{array}$ & $\begin{array}{l}(4.59) \\
(3.91) \\
(4.66) \\
(3.84)\end{array}$ & $\begin{array}{l}56.9 \\
19.5 \\
44.6 \\
28.1\end{array}$ & $\begin{array}{l}(4.14) \\
(3.31) \\
(4.16) \\
(3.76)\end{array}$ & $\begin{array}{l}70.8 \\
42.8 \\
47.0 \\
21.2\end{array}$ & $\begin{array}{l}(5.23) \\
(5.70) \\
(5.74) \\
(4.71)\end{array}$ & $\begin{array}{l}31.3 \\
8.0 ! \\
17.2 \\
14.8\end{array}$ & $\begin{array}{l}(5.28) \\
(3.08) \\
(4.29) \\
(4.04)\end{array}$ & $\begin{array}{l}48.8 \\
18.2 \\
29.1 \\
18.9\end{array}$ & $\begin{array}{l}(6.83) \\
(5.28) \\
(6.21) \\
(5.35)\end{array}$ & $\begin{array}{l}46.6 \\
15.7 \\
32.6 \\
21.8\end{array}$ & $\begin{array}{l}(5.25) \\
(3.82) \\
(4.93) \\
(4.35)\end{array}$ & $\begin{array}{l}56.2 \\
15.7 ! \\
33.5 \\
33.2\end{array}$ & $\begin{array}{l}(7.49) \\
(5.49) \\
(7.12) \\
(7.11)\end{array}$ \\
\hline 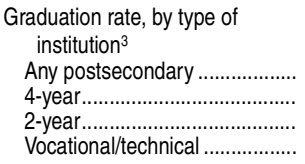 & $\begin{array}{l}38.4 \\
29.4 \\
29.7 \\
54.6\end{array}$ & $\begin{array}{l}(4.41) \\
(8.30) \\
(4.83) \\
(7.22)\end{array}$ & $\begin{array}{r}37.5 \\
\ddagger \\
29.4 \\
55.1\end{array}$ & $\begin{array}{r}(6.13) \\
(\dagger) \\
(6.81) \\
(9.66)\end{array}$ & $\begin{array}{l}48.4 \\
39.8 ! \\
40.2 \\
69.8\end{array}$ & $\begin{array}{r}(6.64) \\
(12.46) \\
(7.79) \\
(10.43)\end{array}$ & $\begin{array}{c}40.0 \\
\ddagger \\
28.1 ! \\
50.3 !\end{array}$ & $\left.\begin{array}{r}(10.17) \\
(\dagger) \\
(11.70) \\
(15.09)\end{array}\right)$ & $\begin{array}{c}41.1 \\
\ddagger \\
26.7 ! \\
56.5\end{array}$ & $\begin{array}{r}(7.55) \\
(\dagger) \\
(8.47) \\
(11.38)\end{array}$ & $\begin{array}{l}38.9 \\
37.2 ! \\
30.6 ! \\
33.0 !\end{array}$ & $\begin{array}{r}(8.80) \\
(13.80) \\
(10.78) \\
(14.56)\end{array}$ & $\begin{array}{l}35.7 \\
35.7 ! \\
23.1 ! \\
44.4\end{array}$ & $\begin{array}{r}(7.55) \\
(16.18) \\
(8.41) \\
(11.95)\end{array}$ & $\begin{array}{r}33.8 \\
\ddagger \\
32.6 \\
47.1\end{array}$ & $\begin{array}{r}(6.09) \\
(\dagger) \\
(6.63) \\
(11.65)\end{array}$ & $\begin{array}{l}49.7 \\
58.7 \\
42.9 \\
50.9 !\end{array}$ & $\begin{array}{r}(9.35) \\
(13.84) \\
(11.33) \\
(19.67)\end{array}$ & $\begin{array}{c}32.1 ! \\
\ddagger \\
\ddagger \\
\ddagger\end{array}$ & $\left.\begin{array}{r}(10.55) \\
(\dagger \\
(\dagger) \\
(\dagger)\end{array}\right)$ & $\begin{array}{l}\ddagger \\
\ddagger \\
\ddagger \\
\ddagger\end{array}$ & 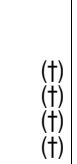 & $\begin{array}{c}35.3 \\
\ddagger \\
33.0 ! \\
49.2 !\end{array}$ & $\begin{array}{r}(10.36) \\
(\dagger) \\
(13.39) \\
(15.05)\end{array}$ & $\begin{array}{r}50.4 \\
\ddagger \\
24.8 ! \\
\ddagger\end{array}$ & $\begin{array}{r}(12.59) \\
(+) \\
(12.11) \\
(\dagger)\end{array}$ \\
\hline 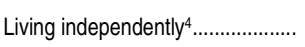 & 35.7 & (2.53) & 40.6 & (3.91) & 30.4 & (3.60) & 21.2 & (3.32) & 34.4 & $(4.17)$ & 28.5 & $(4.60)$ & 14.0 & (3.26) & 30.8 & (3.86) & 31.3 & (5.35) & $10.6 !$ & $(3.51)$ & $13.7 !$ & (4.69) & 11.8 & (3.39) & 24.8 & (6.52) \\
\hline $\begin{array}{l}\text { Competitively employed } \\
\text { Currently ..................................................... }\end{array}$ & $\begin{array}{l}61.1 \\
78.6 \\
\end{array}$ & $\begin{array}{l}(2.86) \\
(2.27) \\
\end{array}$ & $\begin{array}{l}70.4 \\
85.9 \\
\end{array}$ & $\begin{array}{l}(4.12) \\
(2.92) \\
\end{array}$ & $\begin{array}{l}61.4 \\
78.8 \\
\end{array}$ & $\begin{array}{l}(4.17) \\
(3.30) \\
\end{array}$ & $\begin{array}{l}31.6 \\
49.8 \\
\end{array}$ & $\begin{array}{l}(4.22) \\
(4.32) \\
\end{array}$ & $\begin{array}{l}53.2 \\
78.9 \\
\end{array}$ & $\begin{array}{l}(4.94) \\
(3.77) \\
\end{array}$ & $\begin{array}{l}49.4 \\
70.3 \\
\end{array}$ & $\begin{array}{l}(5.85) \\
(4.93) \\
\end{array}$ & $\begin{array}{l}26.2 \\
42.8 \\
\end{array}$ & $\begin{array}{l}(4.36) \\
(4.62) \\
\end{array}$ & $\begin{array}{l}60.3 \\
78.8 \\
\end{array}$ & $\begin{array}{l}(4.51) \\
(3.54) \\
\end{array}$ & $\begin{array}{l}34.4 \\
54.6 \\
\end{array}$ & $\begin{array}{l}(5.98) \\
(5.97) \\
\end{array}$ & $\begin{array}{l}31.6 \\
41.0 \\
\end{array}$ & $\begin{array}{l}(6.13) \\
(5.99) \\
\end{array}$ & $\begin{array}{l}15.0 ! \\
26.4 \\
\end{array}$ & $\begin{array}{l}(5.46) \\
(6.17) \\
\end{array}$ & $\begin{array}{l}32.7 \\
44.1 \\
\end{array}$ & $\begin{array}{l}(5.63) \\
(5.40) \\
\end{array}$ & $\begin{array}{l}32.6 \\
63.6 \\
\end{array}$ & $\begin{array}{l}(7.47) \\
(7.50) \\
\end{array}$ \\
\hline $\begin{array}{l}2009 \text { (out } \\
8 \text { years }\end{array}$ & & & & & & & & & & & & & & & & & & & & & & & & & & \\
\hline 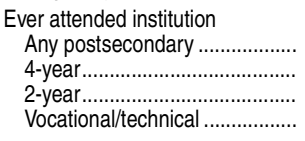 & $\begin{array}{l}59.2 \\
18.4 \\
44.4 \\
31.3\end{array}$ & $\begin{array}{l}(2.64) \\
(2.08) \\
(2.67) \\
(2.49)\end{array}$ & $\begin{array}{l}65.3 \\
20.9 \\
49.7 \\
34.1\end{array}$ & $\begin{array}{l}(3.93) \\
(3.36) \\
(4.13) \\
(3.92)\end{array}$ & $\begin{array}{l}67.0 \\
30.9 \\
46.5 \\
28.5\end{array}$ & $\begin{array}{l}(3.62) \\
(3.56) \\
(3.86) \\
(3.48)\end{array}$ & $\begin{array}{c}29.5 \\
6.2 ! \\
19.7 \\
17.2\end{array}$ & $\begin{array}{l}(3.62) \\
(1.92) \\
(3.16) \\
(2.99)\end{array}$ & $\begin{array}{l}53.0 \\
11.0 \\
38.0 \\
33.0\end{array}$ & $\begin{array}{l}(4.53) \\
(2.84) \\
(4.40) \\
(4.27)\end{array}$ & $\begin{array}{l}74.8 \\
34.7 \\
53.4 \\
40.3\end{array}$ & $\begin{array}{l}(4.24) \\
(4.66) \\
(4.88) \\
(4.79)\end{array}$ & $\begin{array}{l}62.0 \\
23.5 \\
50.9 \\
26.5\end{array}$ & $\begin{array}{l}(4.42) \\
(3.87) \\
(4.57) \\
(4.03)\end{array}$ & $\begin{array}{l}65.2 \\
19.1 \\
53.2 \\
33.1\end{array}$ & $\left.\begin{array}{l}(4.05) \\
(3.34) \\
(4.25) \\
(4.00)\end{array}\right]$ & $\begin{array}{l}70.7 \\
41.5 \\
51.2 \\
25.6\end{array}$ & $\left.\begin{array}{l}(5.01) \\
(5.43) \\
(5.51) \\
(4.81)\end{array}\right]$ & $\begin{array}{c}33.2 \\
7.3 ! \\
21.7 \\
17.6\end{array}$ & $\left.\begin{array}{l}(5.09) \\
(2.82) \\
(4.45) \\
(4.11)\end{array}\right)$ & $\begin{array}{l}56.8 \\
23.7 \\
36.9 \\
21.6\end{array}$ & $\begin{array}{l}(7.09) \\
(6.09) \\
(6.911) \\
(5.89)\end{array}$ & $\begin{array}{l}44.2 \\
17.4 \\
32.2 \\
22.1\end{array}$ & $\begin{array}{l}(4.66) \\
(3.56) \\
(4.39) \\
(3.90)\end{array}$ & $\begin{array}{l}60.4 \\
18.5 ! \\
42.1 \\
34.5\end{array}$ & $\begin{array}{l}(7.40) \\
(5.87) \\
(7.47) \\
(7.20)\end{array}$ \\
\hline 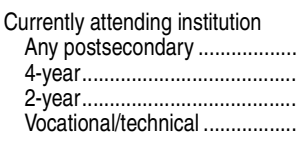 & $\begin{array}{l}15.1 \\
5.2 \\
9.0 \\
2.2 !\end{array}$ & $\begin{array}{l}(1.93) \\
(1.20) \\
(1.54) \\
(0.79)\end{array}$ & $\begin{array}{c}17.3 \\
5.9 ! \\
10.3 \\
\ddagger\end{array}$ & $\begin{aligned}(3.13) \\
(1.95) \\
(2.52) \\
(\dagger)\end{aligned}$ & $\begin{array}{c}20.1 \\
10.6 \\
8.3 \\
2.7 !\end{array}$ & $\begin{array}{l}(3.09) \\
(2.38) \\
(2.14) \\
(1.24)\end{array}$ & $\begin{array}{l}\ddagger \\
\ddagger \\
\ddagger \\
\ddagger\end{array}$ & $\begin{array}{l}(t) \\
(t) \\
(t) \\
(t)\end{array}$ & $\begin{array}{l}12.9 \\
3.9 ! \\
8.6 \\
\ddagger\end{array}$ & $\begin{array}{r}(3.04) \\
(1.76) \\
(2.56) \\
(\dagger)\end{array}$ & $\begin{array}{r}25.0 \\
15.0 \\
11.6 \\
\ddagger\end{array}$ & $\begin{array}{r}(4.23) \\
(3.51) \\
(3.15) \\
(\dagger)\end{array}$ & $\begin{array}{c}23.3 \\
8.0 ! \\
13.2 \\
5.5 !\end{array}$ & $\begin{array}{l}(3.87) \\
(2.47) \\
(3.10) \\
(2.09)\end{array}$ & $\begin{array}{l}16.1 \\
3.1 ! \\
10.9 \\
2.9 !\end{array}$ & $\begin{array}{l}(3.13) \\
(1.48) \\
(2.67) \\
(1.43)\end{array}$ & $\begin{array}{l}25.0 \\
15.1 \\
8.9 ! \\
\ddagger\end{array}$ & $\begin{array}{r}(4.79) \\
(3.94) \\
(3.16) \\
(\dagger)\end{array}$ & $\begin{array}{c}8.2 ! \\
\ddagger \\
\ddagger \\
\ddagger\end{array}$ & $\begin{array}{r}(2.99) \\
(\dagger) \\
(t) \\
(\dagger)\end{array}$ & $\begin{array}{l}24.5 \\
9.1 ! \\
16.7 ! \\
\ddagger\end{array}$ & $\begin{array}{r}(6.19) \\
(4.11) \\
(5.34) \\
(\dagger)\end{array}$ & $\begin{array}{l}14.0 \\
5.3 ! \\
8.2 ! \\
\ddagger\end{array}$ & $\begin{array}{r}(3.26) \\
(2.12) \\
(2.59) \\
(\dagger)\end{array}$ & $\begin{aligned} & 14.6 ! \vdots \\
& \ddagger \\
& 9.2 ! \\
& \ddagger\end{aligned}$ & $\begin{aligned}(5.34) \\
(\dagger) \\
(4.38) \\
(\dagger)\end{aligned}$ \\
\hline 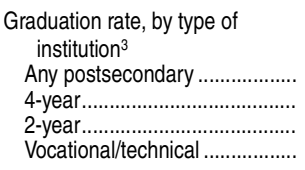 & $\begin{array}{l}47.6 \\
45.3 \\
37.2 \\
54.6\end{array}$ & $\begin{array}{l}(3.92) \\
(7.28) \\
(4.46) \\
(5.96)\end{array}$ & $\begin{array}{l}47.8 \\
47.7 \\
38.2 \\
52.7\end{array}$ & $\begin{aligned}(5.49) \\
(10.07) \\
(6.16) \\
(8.29)\end{aligned}$ & $\begin{array}{l}53.5 \\
60.1 \\
39.2 \\
64.3\end{array}$ & $\begin{array}{l}(5.35) \\
(8.80) \\
(6.35) \\
(8.39)\end{array}$ & $\begin{array}{l}39.8 \\
\ddagger \\
28.2 ! \\
51.2\end{array}$ & $\begin{array}{r}(8.45) \\
(\dagger) \\
(9.90) \\
(12.94)\end{array}$ & $\begin{array}{r}45.9 \\
\ddagger \\
33.3 \\
62.5\end{array}$ & $\begin{array}{r}(6.45) \\
(+) \\
(7.61) \\
(8.67)\end{array}$ & $\begin{array}{l}58.7 \\
49.5 \\
42.5 \\
63.8\end{array}$ & $\begin{array}{r}(6.67) \\
(9.93) \\
(8.53) \\
(10.75)\end{array}$ & $\begin{array}{l}45.3 \\
48.8 \\
32.9 \\
50.7\end{array}$ & $\begin{array}{r}(6.40) \\
(11.86) \\
(7.24) \\
(10.12)\end{array}$ & $\begin{array}{l}44.8 \\
30.6 ! \\
35.1 \\
58.7\end{array}$ & $\left.\begin{array}{l}(5.64) \\
(9.72) \\
(6.12) \\
(8.28)\end{array}\right]$ & $\begin{array}{l}58.4 \\
63.1 \\
45.9 \\
47.3\end{array}$ & $\begin{array}{r}(7.24) \\
(10.01) \\
(9.06) \\
(12.97)\end{array}$ & $\begin{array}{r}58.9 \\
\ddagger \\
44.3 \\
46.5\end{array}$ & $\begin{array}{r}(9.71) \\
(\dagger) \\
(12.86) \\
(12.73)\end{array}$ & $\begin{array}{l}\ddagger \\
\ddagger \\
\ddagger \\
\ddagger\end{array}$ & 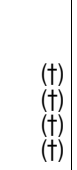 & $\begin{array}{l}50.7 \\
59.0 \\
43.3 \\
53.2\end{array}$ & $\left.\begin{array}{rl}(8.15) \\
(12.15) \\
(10.61) \\
(12.43)\end{array}\right)$ & $\begin{array}{r}61.8 \\
\ddagger \\
35.7 ! \\
73.9\end{array}$ & $\begin{array}{r}(10.33) \\
(\dagger) \\
(11.88) \\
(14.00)\end{array}$ \\
\hline Living independently ${ }^{4} \ldots \ldots \ldots \ldots \ldots$ & 44.7 & (2.68) & 51.0 & (4.15) & 38.7 & (3.75) & 25.7 & (3.48) & 44.3 & $(4.52)$ & 40.3 & $(4.79)$ & 24.9 & (3.95) & 39.2 & $(4.17)$ & 41.4 & (5.43) & $11.2 !$ & $(3.41)$ & 20.5 & $(5.79)$ & $7.1 !$ & (2.42) & 24.0 & (6.48) \\
\hline 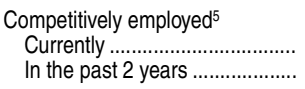 & $\begin{array}{l}53.1 \\
70.1\end{array}$ & $\begin{array}{l}(2.82) \\
(2.52)\end{array}$ & $\begin{array}{l}62.4 \\
78.1\end{array}$ & $\begin{array}{l}(4.27) \\
(3.51)\end{array}$ & $\begin{array}{l}58.5 \\
77.2\end{array}$ & $\begin{array}{l}(3.93) \\
(3.28)\end{array}$ & $\begin{array}{l}25.7 \\
38.7\end{array}$ & $\begin{array}{l}(3.60) \\
(3.98)\end{array}$ & $\begin{array}{l}40.9 \\
68.6\end{array}$ & $\begin{array}{l}(4.65) \\
(4.31)\end{array}$ & $\begin{array}{l}47.4 \\
65.0\end{array}$ & $\begin{array}{l}(5.14) \\
(4.81)\end{array}$ & $\begin{array}{l}26.4 \\
40.2\end{array}$ & $\begin{array}{l}(4.03) \\
(4.53)\end{array}$ & $\begin{array}{l}53.8 \\
72.2\end{array}$ & $\begin{array}{l}(4.48) \\
(3.92)\end{array}$ & $\begin{array}{l}34.1 \\
47.2\end{array}$ & $\begin{array}{l}(5.36) \\
(5.61)\end{array}$ & $\begin{array}{l}21.5 \\
32.1\end{array}$ & $\begin{array}{l}(4.63) \\
(5.15)\end{array}$ & $\begin{array}{l}23.1 \\
34.9\end{array}$ & $\begin{array}{l}(6.19) \\
(6.96)\end{array}$ & $\begin{array}{l}24.2 \\
33.9\end{array}$ & $\begin{array}{l}(4.07) \\
(4.54)\end{array}$ & $\begin{array}{l}41.7 \\
53.3\end{array}$ & $\begin{array}{l}(7.52) \\
(7.64)\end{array}$ \\
\hline
\end{tabular}

†Not applicable

data with caution. The coefficient of variation (CV) for this estimate is between 30 and 50 percent. orting standards not met. The coefficient of variation (CV) for this estimate is 50 percent or greater.

'Other health impairments include having limited strength, vitality, or alertness that is due to chronic or acute health problems (such as a heart condition, rheumatic fever, asthma, hemophilia, and leukemia) and that adversely affects edu-

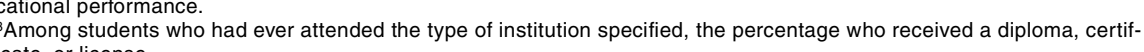
icate, or license.

indes living alone, with a spouse or roommate, in a college dormitory, in Job Corps housing, or in military housing as a service member.
${ }^{5}$ Competitively employed refers to those receiving more than minimum wage and working in an environment where the majority or workers are not disabled.

attended special or regular schools in the been out of high school up to 6 years in 2007 and up to 8 years in 2009 and had graduation percentages between 2007 and 2009 may be due to inconsistent reporting by respondents and smaller numbers of respondents for the 2009 survey wave. Some data have been revised from previously published figures.

SOURCE: U.S. Department of Education, Institute of Education Sciences, National Center for Special Education Research, National Longitudinal Transition Study-2 (NLTS2), Waves 4 and 5, 2007 and 2009, unpublished tabulations. (This table was prepared July 2010.) 


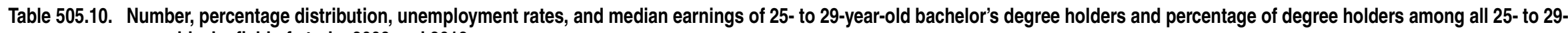
year-olds, by field of study: 2009 and 2012

[Standard errors appear in parentheses]

\begin{tabular}{|c|c|c|c|c|c|c|c|c|c|c|c|c|c|c|c|c|c|c|c|c|}
\hline \multirow[b]{3}{*}{ Field of study } & \multicolumn{10}{|c|}{2009} & \multicolumn{10}{|c|}{2012} \\
\hline & \multicolumn{8}{|c|}{ 25- to 29 -year-old bachelor's degree holders } & \multirow{2}{*}{\multicolumn{2}{|c|}{$\begin{array}{r}\text { Percent of all } \\
25-\text { to } 29 \text {-year-olds } \\
\text { with degree in } \\
\text { specific field }\end{array}$}} & \multicolumn{8}{|c|}{ 25- to 29-year-old bachelor's degree holders } & \multirow{2}{*}{\multicolumn{2}{|c|}{$\begin{array}{r}\text { Percent of all } \\
25 \text { - to } 29 \text {-year-olds } \\
\text { with degree in } \\
\text { specific field }\end{array}$}} \\
\hline & \multicolumn{2}{|c|}{$\begin{array}{l}\text { Number, in } \\
\text { thousands }\end{array}$} & \multicolumn{2}{|c|}{$\begin{array}{c}\text { Percentage } \\
\text { distribution }\end{array}$} & \multicolumn{2}{|c|}{ Unemployment rate } & \multicolumn{2}{|c|}{$\begin{array}{r}\text { Median } \\
\text { annual earnings } \\
\text { (in current dollars) }\end{array}$} & & & \multicolumn{2}{|c|}{$\begin{array}{l}\text { Number, in } \\
\text { thousands }\end{array}$} & \multicolumn{2}{|c|}{$\begin{array}{r}\text { Percentage } \\
\text { distribution }\end{array}$} & \multicolumn{2}{|c|}{ Unemployment rate } & \multicolumn{2}{|c|}{$\begin{array}{r}\text { Median } \\
\text { annual earnings } \\
\text { (in current dollars) }\end{array}$} & & \\
\hline 1 & & 2 & & 3 & & 4 & & 5 & & 6 & & 7 & & 8 & & 9 & & 10 & & 11 \\
\hline Total, all bachelor's degrees. & 6,418 & $(30.8)$ & 100.0 & $(\dagger)$ & 5.2 & $(0.12)$ & $\$ 44,880$ & (547) & 29.9 & $(0.14)$ & 6,738 & $(37.0$ & 100.0 & $(\dagger)$ & 4.8 & $(0.13)$ & $\$ 44,530$ & (760) & 31.8 & $(0.17)$ \\
\hline 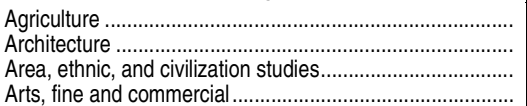 & $\begin{array}{l}59 \\
45 \\
27\end{array}$ & $\begin{array}{l}(2.9) \\
(2.3) \\
(2.1)\end{array}$ & $\begin{array}{l}0.9 \\
0.7 \\
0.4\end{array}$ & $\begin{array}{l}(0.04) \\
(0.04) \\
(0.03)\end{array}$ & $\begin{array}{l}2.2 ! \\
9.6 \\
7.3\end{array}$ & $\begin{array}{l}(0.85) \\
(1.58) \\
(2.10)\end{array}$ & $\begin{array}{l}38,970 \\
45,950 \\
39,930\end{array}$ & $\begin{array}{r}(995) \\
(1,186) \\
(1,495)\end{array}$ & $\begin{array}{l}0.3 \\
0.2 \\
0.1\end{array}$ & $\begin{array}{l}(0.01) \\
(0.01) \\
(0.01)\end{array}$ & $\begin{array}{l}62 \\
53 \\
28\end{array}$ & $\begin{array}{l}(2.6 \\
(3.3 \\
(2.2\end{array}$ & $\begin{array}{l}0.9 \\
0.8 \\
0.4\end{array}$ & $\begin{array}{l}(0.04) \\
(0.05) \\
(0.03)\end{array}$ & $\begin{array}{l}1.8 ! \\
6.0 \\
5.4\end{array}$ & $\begin{array}{l}(0.61) \\
(1.51) \\
(1.54)\end{array}$ & $\begin{array}{l}42,570 \\
44,930 \\
36,940\end{array}$ & $\begin{array}{l}(1,333) \\
(1,394) \\
(2,323)\end{array}$ & $\begin{array}{l}0.3 \\
0.2 \\
0.1\end{array}$ & $\begin{array}{l}(0.01) \\
(0.02) \\
(0.01)\end{array}$ \\
\hline 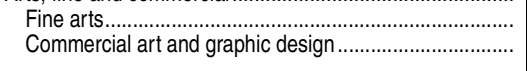 & $\begin{array}{r}250 \\
96\end{array}$ & $\begin{array}{l}(6.5) \\
(4.9)\end{array}$ & $\begin{array}{l}3.9 \\
1.5\end{array}$ & $\begin{array}{l}(0.10) \\
(0.08)\end{array}$ & $\begin{array}{l}8.8 \\
9.2\end{array}$ & $\begin{array}{l}(0.79) \\
(1.22)\end{array}$ & $\begin{array}{l}35,870 \\
39,940\end{array}$ & $\begin{array}{l}(889) \\
(535)\end{array}$ & $\begin{array}{l}1.2 \\
0.4\end{array}$ & $\begin{array}{l}(0.03) \\
(0.02)\end{array}$ & $\begin{array}{l}273 \\
108\end{array}$ & $(4.9$ & $\begin{array}{l}4.1 \\
1.6\end{array}$ & $\begin{array}{l}(0.12) \\
(0.07)\end{array}$ & $\begin{array}{l}6.6 \\
5.6\end{array}$ & $\begin{array}{l}(0.69) \\
(1.07)\end{array}$ & $\begin{array}{l}36,190 \\
38,300\end{array}$ & $\begin{array}{l}(1,170) \\
(1,686)\end{array}$ & $\begin{array}{l}1.3 \\
0.5\end{array}$ & $\begin{array}{l}(0.04) \\
(0.02)\end{array}$ \\
\hline 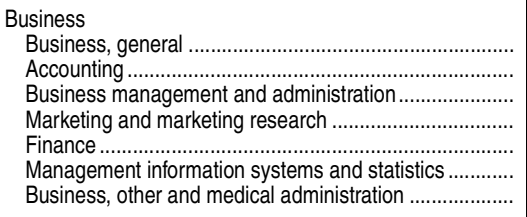 & $\begin{array}{r}224 \\
184 \\
372 \\
196 \\
168 \\
27 \\
121\end{array}$ & $\begin{array}{l}(6.6) \\
(5.9) \\
(8.7) \\
(6.3) \\
(5.2) \\
(2.0) \\
(5.2)\end{array}$ & $\begin{array}{l}3.5 \\
2.9 \\
5.8 \\
3.0 \\
2.6 \\
0.4 \\
1.9\end{array}$ & $\begin{array}{l}(0.10) \\
(0.09) \\
(0.13) \\
(0.10) \\
(0.08) \\
(0.03) \\
(0.08)\end{array}$ & $\begin{array}{l}5.2 \\
4.4 \\
5.9 \\
5.7 \\
4.8 \\
5.8 \\
4.9\end{array}$ & $\begin{array}{l}(0.63) \\
(0.63) \\
(0.46) \\
(0.67) \\
(0.74) \\
(1.66) \\
(0.88)\end{array}$ & $\begin{array}{l}45,910 \\
52,840 \\
43,900 \\
44,740 \\
51,390 \\
55,350 \\
45,040\end{array}$ & $\begin{array}{r}(1,110) \\
(1,428) \\
(1,237) \\
(134) \\
(891) \\
(2,569) \\
(1,434)\end{array}$ & $\begin{array}{l}1.0 \\
0.9 \\
1.7 \\
0.9 \\
0.8 \\
0.1 \\
0.6\end{array}$ & $\begin{array}{l}(0.03) \\
(0.03) \\
(0.04) \\
(0.03) \\
(0.02) \\
(0.01) \\
(0.02)\end{array}$ & $\begin{array}{r}245 \\
201 \\
349 \\
201 \\
167 \\
21 \\
135\end{array}$ & $\begin{array}{l}(8.0 \\
6.5 \\
(7.9 \\
(5.4 \\
6.0 \\
(1.8 \\
(4.9\end{array}$ & $\begin{array}{l}3.6 \\
3.0 \\
5.2 \\
3.0 \\
2.5 \\
0.3 \\
2.0\end{array}$ & $\begin{array}{l}(0.12) \\
(0.10) \\
(0.12) \\
(0.08) \\
(0.09) \\
(0.03) \\
(0.07)\end{array}$ & $\begin{array}{r}4.1 \\
4.6 \\
4.5 \\
5.0 \\
4.3 \\
\ddagger \\
4.2\end{array}$ & $\begin{array}{r}(0.61) \\
(0.67) \\
(0.47) \\
(0.64) \\
(0.76) \\
(t) \\
(0.67)\end{array}$ & $\begin{array}{l}45,230 \\
52,190 \\
44,370 \\
44,570 \\
54,940 \\
50,920 \\
45,000\end{array}$ & $\begin{array}{r}(155) \\
(829) \\
(1,176) \\
(854) \\
(1,092) \\
(5,066) \\
(899)\end{array}$ & $\begin{array}{l}1.2 \\
0.9 \\
1.6 \\
1.0 \\
0.8 \\
0.1 \\
0.6\end{array}$ & $\begin{array}{l}(0.04) \\
(0.03) \\
(0.04) \\
(0.03) \\
(0.03) \\
(0.01) \\
(0.02)\end{array}$ \\
\hline $\begin{array}{l}\text { Communications and communications technologies........... } \\
\text { Computer and information systems ........................... } \\
\text { Construction/electrical/transportation technologies.......... } \\
\text { Criminal justice and fire protection .................................... }\end{array}$ & $\begin{array}{r}384 \\
259 \\
34 \\
133\end{array}$ & $\begin{array}{l}(8.8) \\
(6.2) \\
(2.2) \\
(4.5)\end{array}$ & $\begin{array}{l}6.0 \\
4.0 \\
0.5 \\
2.1\end{array}$ & $\begin{array}{l}(0.13) \\
(0.09) \\
(0.03) \\
(0.07)\end{array}$ & $\begin{array}{l}5.4 \\
5.2 \\
4.1 \\
4.2\end{array}$ & $\begin{array}{l}(0.51) \\
(0.64) \\
(1.19) \\
(0.72)\end{array}$ & $\begin{array}{l}39,900 \\
59,030 \\
49,950 \\
39,900\end{array}$ & $\begin{array}{r}(62) \\
(947) \\
(2,248) \\
(453)\end{array}$ & $\begin{array}{l}1.8 \\
1.2 \\
0.2 \\
0.6\end{array}$ & $\begin{array}{l}(0.04) \\
(0.03) \\
(0.01) \\
(0.02)\end{array}$ & $\begin{array}{r}375 \\
227 \\
39 \\
157\end{array}$ & $\left.\begin{array}{l}7.8 \\
7.9 \\
(2.5 \\
(5.3\end{array}\right)$ & $\begin{array}{l}5.6 \\
3.4 \\
0.6 \\
2.3\end{array}$ & $\begin{array}{l}(0.12) \\
(0.11) \\
(0.04) \\
(0.08)\end{array}$ & $\begin{array}{l}4.8 \\
4.5 \\
4.7 ! \\
6.2\end{array}$ & $\begin{array}{l}(0.48) \\
(0.72) \\
(1.41) \\
(0.84)\end{array}$ & $\begin{array}{l}40,180 \\
58,330 \\
49,700 \\
39,140\end{array}$ & $\begin{array}{r}(88) \\
(1,662) \\
(1,829) \\
(1,450)\end{array}$ & $\begin{array}{l}1.8 \\
1.1 \\
0.2 \\
0.7\end{array}$ & $\begin{array}{l}(0.04) \\
(0.04) \\
(0.01) \\
(0.03)\end{array}$ \\
\hline 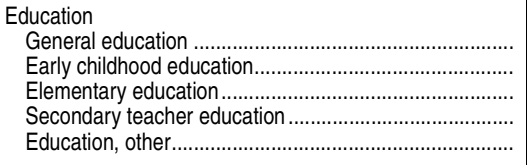 & $\begin{array}{r}143 \\
41 \\
192 \\
21 \\
180\end{array}$ & $\begin{array}{l}(4.8) \\
(2.5) \\
(5.2) \\
(1.5) \\
(5.0)\end{array}$ & $\begin{array}{l}2.2 \\
0.6 \\
3.0 \\
0.3 \\
2.8\end{array}$ & $\begin{array}{l}(0.08) \\
(0.04) \\
(0.08) \\
(0.02) \\
(0.08)\end{array}$ & $\begin{array}{l}3.3 \\
2.8 ! \\
3.2 \\
3.8 ! \\
3.2\end{array}$ & $\begin{array}{l}(0.63) \\
(1.00) \\
(0.49) \\
(1.86) \\
(0.59)\end{array}$ & $\begin{array}{l}39,180 \\
35,230 \\
35,980 \\
38,480 \\
37,970\end{array}$ & $\begin{array}{l}(537) \\
(889) \\
(896) \\
(958) \\
(824)\end{array}$ & $\begin{array}{l}0.7 \\
0.2 \\
0.9 \\
0.1 \\
0.8\end{array}$ & $\begin{array}{l}(0.02) \\
(0.01) \\
(0.02) \\
(0.01) \\
(0.02)\end{array}$ & $\begin{array}{r}156 \\
41 \\
172 \\
19 \\
193\end{array}$ & $\begin{array}{l}(6.0 \\
(2.6 \\
(4.9 \\
(1.6 \\
(6.1\end{array}$ & $\begin{array}{l}2.3 \\
0.6 \\
2.6 \\
0.3 \\
2.9\end{array}$ & $\begin{array}{l}(0.09) \\
(0.04) \\
(0.07) \\
(0.02) \\
(0.09)\end{array}$ & $\begin{array}{l}3.3 \\
3.2 ! \\
2.9 \\
4.5 ! \\
3.3\end{array}$ & $\begin{array}{l}(0.71) \\
(1.26) \\
(0.55) \\
(1.74) \\
(0.58)\end{array}$ & $\begin{array}{l}38,290 \\
35,210 \\
37,320 \\
37,970 \\
39,270\end{array}$ & $\begin{array}{r}(1,335) \\
(976) \\
(584) \\
(2,214) \\
(1,022)\end{array}$ & $\begin{array}{l}0.7 \\
0.2 \\
0.8 \\
0.1 \\
0.9\end{array}$ & $\begin{array}{l}(0.03) \\
(0.01) \\
(0.02) \\
(0.01) \\
(0.03)\end{array}$ \\
\hline 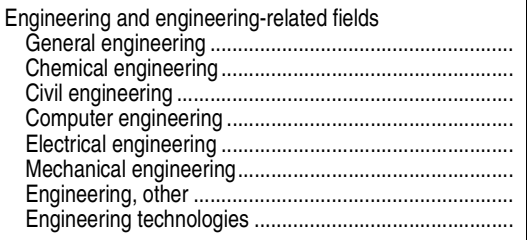 & $\begin{array}{l}55 \\
30 \\
42 \\
55 \\
95 \\
84 \\
74 \\
38\end{array}$ & $\begin{array}{l}(3.2) \\
(2.1) \\
(2.3) \\
(2.5) \\
(3.3) \\
(3.7) \\
(3.7) \\
(2.8)\end{array}$ & $\begin{array}{l}0.9 \\
0.5 \\
0.7 \\
0.9 \\
1.5 \\
1.3 \\
1.2 \\
0.6\end{array}$ & $\begin{array}{l}(0.05) \\
(0.03) \\
(0.03) \\
(0.04) \\
(0.05) \\
(0.06) \\
(0.06) \\
(0.04)\end{array}$ & $\begin{array}{l}6.0 \\
3.6 ! \\
4.2 \\
4.9 \\
4.3 \\
5.0 \\
4.3 \\
7.0\end{array}$ & $\begin{array}{l}(1.25) \\
(1.65) \\
(1.13) \\
(1.19) \\
(0.90) \\
(0.92) \\
(0.93) \\
(1.59)\end{array}$ & $\begin{array}{l}59,780 \\
64,930 \\
57,840 \\
59,900 \\
63,580 \\
61,590 \\
58,870 \\
54,240\end{array}$ & $\begin{array}{r}(1,395) \\
(3,706) \\
(1,793) \\
(1,524) \\
(1,522) \\
(1,699) \\
(931) \\
(1,871)\end{array}$ & $\begin{array}{l}0.3 \\
0.1 \\
0.2 \\
0.3 \\
0.4 \\
0.4 \\
0.3 \\
0.2\end{array}$ & $\begin{array}{l}(0.01) \\
(0.01) \\
(0.01) \\
(0.01) \\
(0.02) \\
(0.02) \\
(0.02) \\
(0.01)\end{array}$ & $\begin{array}{l}72 \\
26 \\
53 \\
52 \\
88 \\
90 \\
85 \\
41\end{array}$ & $\begin{array}{l}(4.1 \\
1.9 \\
(2.9 \\
(3.0 \\
3.8 \\
4.0 \\
4.0 \\
3.9 \\
3.0\end{array}$ & $\begin{array}{l}1.1 \\
0.4 \\
0.8 \\
0.8 \\
1.3 \\
1.3 \\
1.3 \\
0.6\end{array}$ & $\begin{array}{l}(0.06) \\
(0.03) \\
(0.04) \\
(0.05) \\
(0.06) \\
(0.06) \\
(0.06) \\
(0.04)\end{array}$ & $\begin{array}{l}4.4 ! \\
0.9 ! \\
6.3 \\
6.1 \\
3.7 \\
2.7 \\
3.6 \\
5.7\end{array}$ & $\begin{array}{l}(1.36) \\
(0.60) \\
(1.56) \\
(1.63) \\
(0.88) \\
(0.60) \\
(0.94) \\
(1.70)\end{array}$ & $\begin{array}{l}59,830 \\
70,210 \\
59,650 \\
69,790 \\
69,080 \\
65,150 \\
64,710 \\
52,360\end{array}$ & $\begin{array}{l}(610) \\
(1,422) \\
(2,110) \\
(2,362) \\
(2,330) \\
(1,589) \\
(3,193) \\
(2,039)\end{array}$ & $\begin{array}{l}0.3 \\
0.1 \\
0.3 \\
0.2 \\
0.4 \\
0.4 \\
0.4 \\
0.2\end{array}$ & $\begin{array}{l}(0.02) \\
(0.01) \\
(0.01) \\
(0.01) \\
(0.02) \\
(0.02) \\
(0.02) \\
(0.01)\end{array}$ \\
\hline 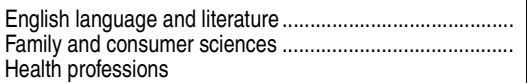 & $\begin{array}{r}200 \\
62\end{array}$ & $\begin{array}{l}(5.3) \\
(2.8)\end{array}$ & $\begin{array}{l}3.1 \\
1.0\end{array}$ & $\begin{array}{l}(0.08) \\
(0.05)\end{array}$ & $\begin{array}{l}5.7 \\
2.4\end{array}$ & $\begin{array}{l}(0.77) \\
(0.65)\end{array}$ & $\begin{array}{l}37,960 \\
35,920\end{array}$ & $\begin{array}{l}(1,050) \\
(2,415)\end{array}$ & $\begin{array}{l}0.9 \\
0.3\end{array}$ & $\begin{array}{l}(0.02) \\
(0.01)\end{array}$ & $\begin{array}{r}203 \\
59\end{array}$ & $\begin{array}{l}(5.8 \\
(2.9\end{array}$ & $\begin{array}{l}3.0 \\
0.9\end{array}$ & $\begin{array}{l}(0.09) \\
(0.04)\end{array}$ & $\begin{array}{l}5.9 \\
4.9\end{array}$ & $\begin{array}{l}(0.68) \\
(1.19)\end{array}$ & $\begin{array}{l}39,510 \\
36,220\end{array}$ & $\begin{array}{l}(1,017) \\
(1,582)\end{array}$ & $\begin{array}{l}1.0 \\
0.3\end{array}$ & $\begin{array}{l}(0.03) \\
(0.01)\end{array}$ \\
\hline $\begin{array}{l}\text { General medical and health services................................ } \\
\text { Nursing }\end{array}$ & $\begin{array}{l}183 \\
164\end{array}$ & $\begin{array}{l}(5.2) \\
(5.2)\end{array}$ & $\begin{array}{l}2.9 \\
2.6\end{array}$ & $\begin{array}{l}(0.08) \\
(0.08)\end{array}$ & $\begin{array}{l}3.3 \\
1.5\end{array}$ & $\begin{array}{l}(0.60) \\
(0.34)\end{array}$ & $\begin{array}{l}49,880 \\
52,890\end{array}$ & $\begin{array}{l}(1,305) \\
(1,753)\end{array}$ & $\begin{array}{l}0.9 \\
0.8\end{array}$ & $\begin{array}{l}(0.02) \\
(0.02)\end{array}$ & $\begin{array}{l}224 \\
221\end{array}$ & 6.2 & $\begin{array}{l}3.3 \\
3.3\end{array}$ & $\begin{array}{l}(0.09) \\
(0.09)\end{array}$ & $\begin{array}{l}3.6 \\
3.2\end{array}$ & $\begin{array}{l}(0.48) \\
(0.52)\end{array}$ & $\begin{array}{l}49,480 \\
50,830\end{array}$ & $\begin{array}{l}(1,364) \\
(1,220)\end{array}$ & $\begin{array}{l}1.1 \\
1.0\end{array}$ & $\begin{array}{l}(0.03) \\
(0.03)\end{array}$ \\
\hline 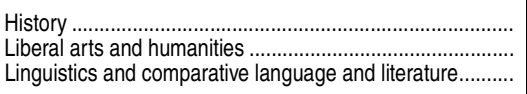 & $\begin{array}{r}133 \\
117 \\
68\end{array}$ & $\begin{array}{l}(4.3) \\
(4.4) \\
(3.3)\end{array}$ & $\begin{array}{l}2.1 \\
1.8 \\
1.1\end{array}$ & $\begin{array}{l}(0.07) \\
(0.07) \\
(0.05)\end{array}$ & $\begin{array}{l}7.4 \\
7.1 \\
5.6\end{array}$ & $\begin{array}{l}(0.90) \\
(0.88) \\
(1.18)\end{array}$ & $\begin{array}{l}39,640 \\
38,890 \\
39,910\end{array}$ & $\begin{array}{r}(737) \\
(1,374) \\
(795)\end{array}$ & $\begin{array}{l}0.6 \\
0.5 \\
0.3\end{array}$ & $\begin{array}{l}(0.02) \\
(0.02) \\
(0.02)\end{array}$ & $\begin{array}{r}141 \\
84 \\
74\end{array}$ & $\begin{array}{l}(5.0 \\
(4.5 \\
(3.6\end{array}$ & $\begin{array}{l}2.1 \\
1.2 \\
1.1\end{array}$ & $\begin{array}{l}(0.07) \\
(0.07) \\
(0.05)\end{array}$ & $\begin{array}{l}5.8 \\
5.7 \\
5.6\end{array}$ & $\begin{array}{l}(0.80) \\
(1.20) \\
(1.09)\end{array}$ & $\begin{array}{l}40,900 \\
35,280 \\
42,050\end{array}$ & $\begin{array}{l}(1,706) \\
(1,162) \\
(1,251)\end{array}$ & $\begin{array}{l}0.7 \\
0.4 \\
0.4\end{array}$ & $\begin{array}{l}(0.02) \\
(0.02) \\
(0.02)\end{array}$ \\
\hline 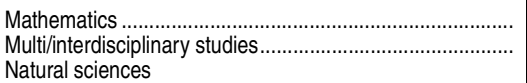 & $\begin{array}{r}70 \\
121\end{array}$ & $\begin{array}{l}(3.2) \\
(4.3)\end{array}$ & $\begin{array}{l}1.1 \\
1.9\end{array}$ & $\begin{array}{l}(0.05) \\
(0.07)\end{array}$ & $\begin{array}{l}4.7 \\
5.8\end{array}$ & $\begin{array}{l}(1.33) \\
(0.92)\end{array}$ & $\begin{array}{l}49,540 \\
42,980\end{array}$ & $\begin{array}{r}(909) \\
(1,946)\end{array}$ & $\begin{array}{l}0.3 \\
0.6\end{array}$ & $\begin{array}{l}(0.01) \\
(0.02)\end{array}$ & $\begin{array}{l}87 \\
71\end{array}$ & $\begin{array}{l}3.6 \\
4.3\end{array}$ & $\begin{array}{l}1.3 \\
1.1\end{array}$ & $\begin{array}{l}(0.05) \\
(0.06)\end{array}$ & $\begin{array}{l}2.7 \\
5.6\end{array}$ & $\begin{array}{l}(0.63) \\
(1.08)\end{array}$ & $\begin{array}{l}48,180 \\
40,030\end{array}$ & $\begin{array}{r}(1,957) \\
(803)\end{array}$ & $\begin{array}{l}0.4 \\
0.3\end{array}$ & $\begin{array}{l}(0.02) \\
(0.02)\end{array}$ \\
\hline 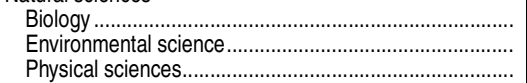 & $\begin{array}{r}354 \\
42 \\
104\end{array}$ & $\begin{array}{l}(6.8) \\
(2.5) \\
(4.2)\end{array}$ & $\begin{array}{l}5.5 \\
0.7 \\
1.6\end{array}$ & $\begin{array}{l}(0.10) \\
(0.04) \\
(0.06)\end{array}$ & $\begin{array}{l}4.5 \\
3.0 ! \\
4.2\end{array}$ & $\begin{array}{l}(0.52) \\
(1.15) \\
(0.81)\end{array}$ & $\begin{array}{l}42,300 \\
39,220 \\
44,170\end{array}$ & $\begin{array}{l}(879) \\
(603) \\
(433)\end{array}$ & $\begin{array}{l}1.6 \\
0.2 \\
0.5\end{array}$ & $\begin{array}{l}(0.03) \\
(0.01) \\
(0.02)\end{array}$ & $\begin{array}{r}394 \\
37 \\
183\end{array}$ & & $\begin{array}{l}5.8 \\
0.6 \\
2.7\end{array}$ & $\begin{array}{l}(0.11) \\
(0.03) \\
(0.09)\end{array}$ & $\begin{array}{l}4.1 \\
2.9 ! \\
4.4\end{array}$ & $\begin{array}{l}(0.41) \\
(0.99) \\
(0.63)\end{array}$ & $\begin{array}{l}42,530 \\
39,500 \\
45,030\end{array}$ & $\begin{array}{l}(1,279) \\
(1,621) \\
(1,150)\end{array}$ & $\begin{array}{l}1.9 \\
0.2 \\
0.9\end{array}$ & $\begin{array}{l}(0.04) \\
(0.01) \\
(0.03)\end{array}$ \\
\hline
\end{tabular}

\section{Agriculture}

Commercial art and graphic design..

Business

See notes at end of table.

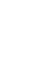

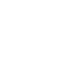




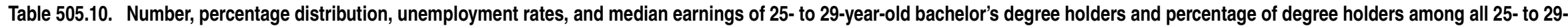
year-olds, by field of study: 2009 and 2012-Continued

[Standard errors appear in parentheses]

\begin{tabular}{|c|c|c|c|c|c|c|c|c|c|c|c|c|c|c|c|c|c|c|c|c|}
\hline \multirow{3}{*}{ Field of study } & \multicolumn{10}{|c|}{2009} & \multicolumn{10}{|c|}{2012} \\
\hline & \multicolumn{8}{|c|}{ 25- to 29-year-old bachelor's degree holders } & \multirow{2}{*}{\multicolumn{2}{|c|}{$\begin{array}{r}\text { Percent of all } \\
25 \text { - to } 29 \text {-year-olds } \\
\text { with degree in } \\
\text { specific field }\end{array}$}} & \multicolumn{8}{|c|}{ 25- to 29-year-old bachelor's degree holders } & \multirow{2}{*}{\multicolumn{2}{|c|}{$\begin{array}{l}\text { Percent of all } \\
25 \text { - to } 29 \text {-year-olds } \\
\text { with degree in } \\
\text { specific field }\end{array}$}} \\
\hline & \multicolumn{2}{|c|}{$\begin{array}{l}\text { Number, in } \\
\text { thousands }\end{array}$} & \multicolumn{2}{|c|}{$\begin{array}{c}\text { Percentage } \\
\text { distribution }\end{array}$} & \multicolumn{2}{|c|}{ Unemployment rate } & \multicolumn{2}{|c|}{$\begin{array}{r}\text { Median } \\
\text { annual earnings } \\
\text { (in current dollars) }\end{array}$} & & & \multicolumn{2}{|c|}{$\begin{array}{l}\text { Number, in } \\
\text { thousands }\end{array}$} & \multicolumn{2}{|c|}{$\begin{array}{r}\text { Percentage } \\
\text { distribution }\end{array}$} & \multicolumn{2}{|c|}{ Unemployment rate } & \multicolumn{2}{|c|}{$\begin{array}{r}\text { Median } \\
\text { annual earnings } \\
\text { (in current dollars) }\end{array}$} & & \\
\hline 1 & & 2 & & 3 & & 4 & & 5 & & 6 & & 7 & & 8 & & 9 & & 10 & & 11 \\
\hline 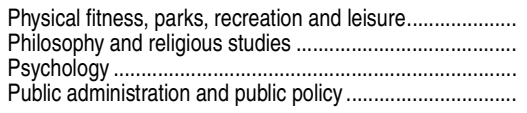 & $\begin{array}{r}96 \\
57 \\
371 \\
14\end{array}$ & $\begin{array}{l}(3.9) \\
(3.0) \\
(7.6) \\
(1.7)\end{array}$ & $\begin{array}{l}1.5 \\
0.9 \\
5.8 \\
0.2\end{array}$ & $\begin{array}{l}(0.06) \\
(0.05) \\
(0.12) \\
(0.03)\end{array}$ & $\begin{array}{l}5.9 \\
8.1 \\
5.0 \\
\ddagger !\end{array}$ & $\begin{array}{r}(0.93) \\
(1.51) \\
(0.50) \\
(\dagger)\end{array}$ & $\begin{array}{l}39,380 \\
40,970 \\
39,890 \\
52,150\end{array}$ & $\begin{array}{r}(350) \\
(1,387) \\
(765) \\
(4,290)\end{array}$ & $\begin{array}{l}0.4 \\
0.3 \\
1.7 \\
0.1\end{array}$ & $\begin{array}{l}(0.02) \\
(0.01) \\
(0.04) \\
(0.01)\end{array}$ & $\begin{array}{r}109 \\
53 \\
394 \\
13\end{array}$ & $\begin{array}{l}(3.9) \\
(2.9) \\
(8.5) \\
(1.4)\end{array}$ & $\begin{array}{l}1.6 \\
0.8 \\
5.8 \\
0.2\end{array}$ & $\begin{array}{l}(0.06) \\
(0.04) \\
(0.12) \\
(0.02)\end{array}$ & $\begin{array}{l}4.1 \\
6.6 \\
5.8 \\
7.3 !\end{array}$ & $\begin{array}{l}(0.70) \\
(1.52) \\
(0.53) \\
(3.48)\end{array}$ & $\begin{array}{l}40,380 \\
39,710 \\
38,350 \\
58,080\end{array}$ & $\left.\begin{array}{r}(1,487) \\
(1,977) \\
(662) \\
(2,186)\end{array}\right)$ & $\begin{array}{l}0.5 \\
0.3 \\
1.9 \\
0.1\end{array}$ & $\begin{array}{l}(0.02) \\
(0.01) \\
(0.04) \\
(0.01)\end{array}$ \\
\hline 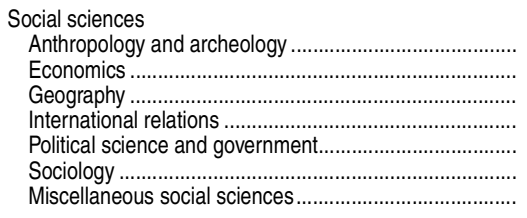 & $\begin{array}{r}33 \\
126 \\
21 \\
20 \\
167 \\
113 \\
32\end{array}$ & $\begin{array}{l}(2.1) \\
(4.5) \\
(1.7) \\
(1.6) \\
(5.2) \\
(3.9) \\
(2.4)\end{array}$ & $\begin{array}{l}0.5 \\
2.0 \\
0.3 \\
0.3 \\
2.6 \\
1.8 \\
0.5\end{array}$ & $\begin{array}{l}(0.03) \\
(0.07) \\
(0.03) \\
(0.02) \\
(0.08) \\
(0.06) \\
(0.04)\end{array}$ & $\begin{array}{l}5.6 ! \\
5.1 \\
5.8 ! \\
7.4 \\
6.6 \\
5.3 \\
6.6 !\end{array}$ & $\begin{array}{l}(1.91) \\
(0.80) \\
(2.11) \\
(2.18) \\
(0.85) \\
(0.94) \\
(2.21)\end{array}$ & $\begin{array}{l}33,260 \\
58,980 \\
40,170 \\
45,320 \\
47,480 \\
38,620 \\
39,900\end{array}$ & $\begin{array}{r}(2,555) \\
(3,144) \\
(1,216) \\
(2,964) \\
(1,034) \\
(1,585) \\
(526)\end{array}$ & $\begin{array}{l}0.2 \\
0.6 \\
0.1 \\
0.1 \\
0.8 \\
0.5 \\
0.2\end{array}$ & $\begin{array}{l}(0.01) \\
(0.02) \\
(0.01) \\
(0.01) \\
(0.02) \\
(0.02) \\
(0.01)\end{array}$ & $\begin{array}{r}40 \\
126 \\
24 \\
28 \\
172 \\
109 \\
33\end{array}$ & $\begin{array}{l}(2.7) \\
(4.7) \\
(2.3) \\
(2.1) \\
(5.4) \\
(4.1) \\
(2.3)\end{array}$ & $\begin{array}{l}0.6 \\
1.9 \\
0.4 \\
0.4 \\
2.6 \\
1.6 \\
0.5\end{array}$ & $\begin{array}{l}(0.04) \\
(0.07) \\
(0.03) \\
(0.03) \\
(0.08) \\
(0.06) \\
(0.03)\end{array}$ & $\begin{array}{l}8.6 \\
4.8 \\
9.1 ! \\
7.5 ! \\
8.2 \\
5.1 \\
6.6 !\end{array}$ & $\begin{array}{l}(1.92) \\
(0.82) \\
(3.23) \\
(2.28) \\
(0.96) \\
(0.81) \\
(2.13)\end{array}$ & $\begin{array}{l}34,410 \\
54,250 \\
40,400 \\
50,110 \\
46,980 \\
40,300 \\
40,230\end{array}$ & $\begin{array}{r}(2,232) \\
(1,456) \\
(2,675) \\
(2,051) \\
(2,495) \\
(205) \\
(2,561)\end{array}$ & $\begin{array}{l}0.2 \\
0.6 \\
0.1 \\
0.1 \\
0.8 \\
0.5 \\
0.2\end{array}$ & $\begin{array}{l}(0.01) \\
(0.02) \\
(0.01) \\
(0.01) \\
(0.03) \\
(0.02) \\
(0.01)\end{array}$ \\
\hline 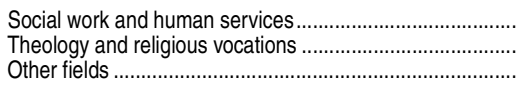 & $\begin{array}{l}67 \\
32 \\
22\end{array}$ & $\begin{array}{l}(3.9) \\
(2.4) \\
(2.2)\end{array}$ & $\begin{array}{l}1.0 \\
0.5 \\
0.3\end{array}$ & $\begin{array}{l}(0.06) \\
(0.04) \\
(0.03)\end{array}$ & $\begin{array}{l}4.0 \\
3.7 ! \\
7.2 !\end{array}$ & $\begin{array}{l}(0.92) \\
(1.20) \\
(2.59)\end{array}$ & $\begin{array}{l}34,950 \\
35,300 \\
42,760\end{array}$ & $\begin{array}{r}(1,081) \\
(962) \\
(3,817)\end{array}$ & $\begin{array}{l}0.3 \\
0.1 \\
0.1\end{array}$ & $\begin{array}{l}(0.02) \\
(0.01) \\
(0.01)\end{array}$ & $\begin{array}{l}68 \\
33 \\
26\end{array}$ & $\begin{array}{l}(3.4) \\
(2.5) \\
(2.3)\end{array}$ & $\begin{array}{l}1.0 \\
0.5 \\
0.4\end{array}$ & $\begin{array}{l}(0.05) \\
(0.04) \\
(0.03)\end{array}$ & $\begin{array}{c}4.3 \\
\ddagger ! \\
8.6 !\end{array}$ & $\begin{array}{r}(1.00) \\
(\dagger) \\
(2.99)\end{array}$ & $\begin{array}{l}34,240 \\
35,140 \\
39,640\end{array}$ & $\begin{array}{l}(1,594) \\
(2,456) \\
(1,473)\end{array}$ & $\begin{array}{l}0.3 \\
0.2 \\
0.1 \\
\end{array}$ & $\begin{array}{l}(0.02) \\
(0.01) \\
(0.01) \\
\end{array}$ \\
\hline
\end{tabular}

†Not applicable.

!Interpret data with caution. The coefficient of variation (CV) for this estimate is between 30 and 50 percent.

₹Reporting standards not met. Either there are too few cases for a reliable estimate or the coefficient of variation (CV) is 50 percent or greater.
NOTE: Detail may not sum to totals because of rounding. Some data have been revised from previously published figures. SOURCE: U.S. Department of Commerce, Census Bureau, 2009 and 2012 American Community Survey (ACS) Public Use Microdata Sample (PUMS) data. (This table was prepared April 2014.) 


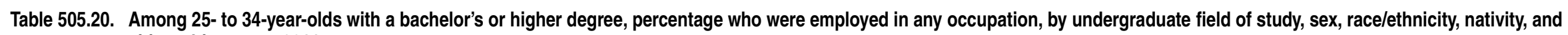
citizenship status: 2011

[Standard errors appear in parentheses]

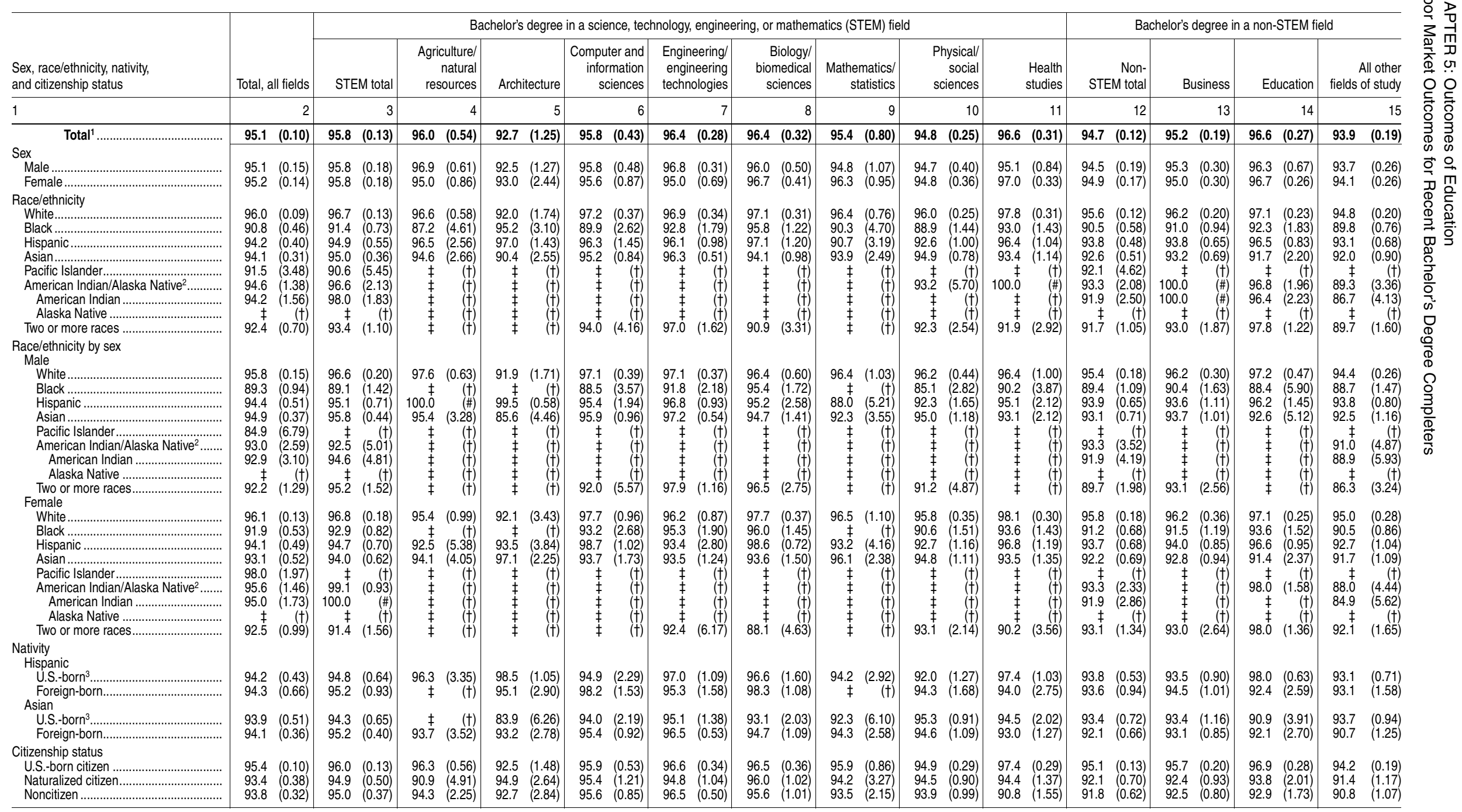

†Not applicable.

fReporting standards not met (too few cases for a reliable estimate)

Total includes other racial/ethnic groups not shown separately.

reporting Alaska Native alone, and persons from American

Includes those born in the 50 states, the District of Cociem

Puerto Rico, American Samoa, Guam, the U.S. Virgin Islands,
NOTE: Estimates are for the entire population of bachelor's degree holders in the indicated age range, including persons living in households and persons living in group quarters (such as college residence halls, residential treatment centers, military barracks, and correctional facilities). The first bachelor's degree major reported by respondents was used to classify their field of study, even though they were able to report a second bachelor's degree major and may possess advanced degrees in other major field aggregations, except that management of STEM activities was counted as a STEM field instead of a business field. Race categories exclude persons of Hispanic ethnicity. pared February 2013.) 


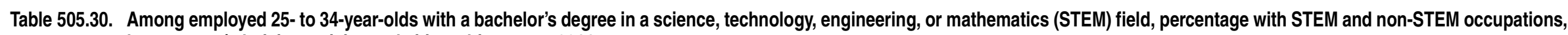
by sex, race/ethnicity, nativity, and citizenship status: 2011

[Standard errors appear in parentheses]

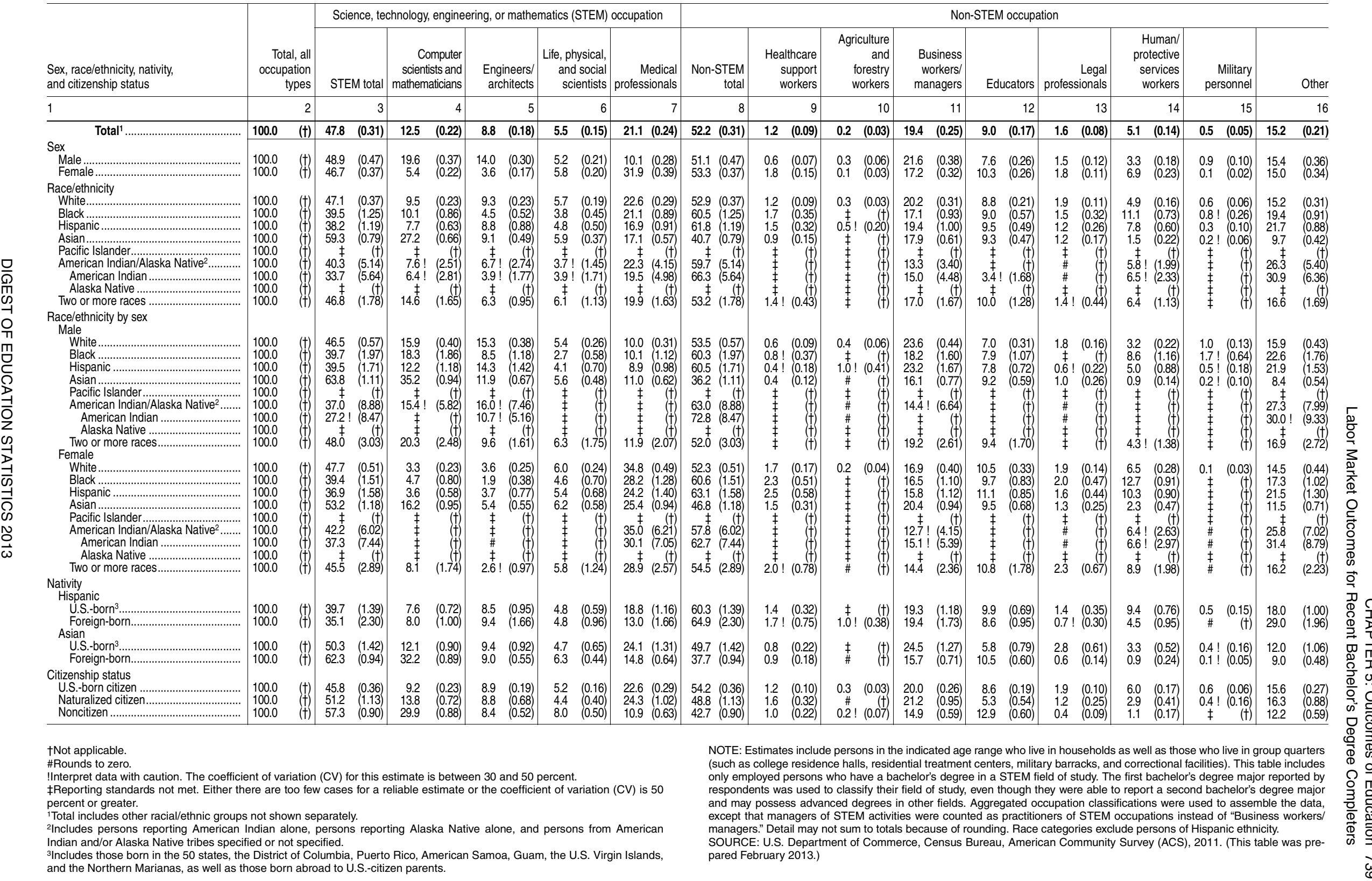


Table 505.40. Percentage distribution of recipients of bachelor's degrees in various fields of study 1 year after graduation, by time to completion, enrollment and employment status, and occupation: 2001 and 2009

[Standard errors appear in parentheses]

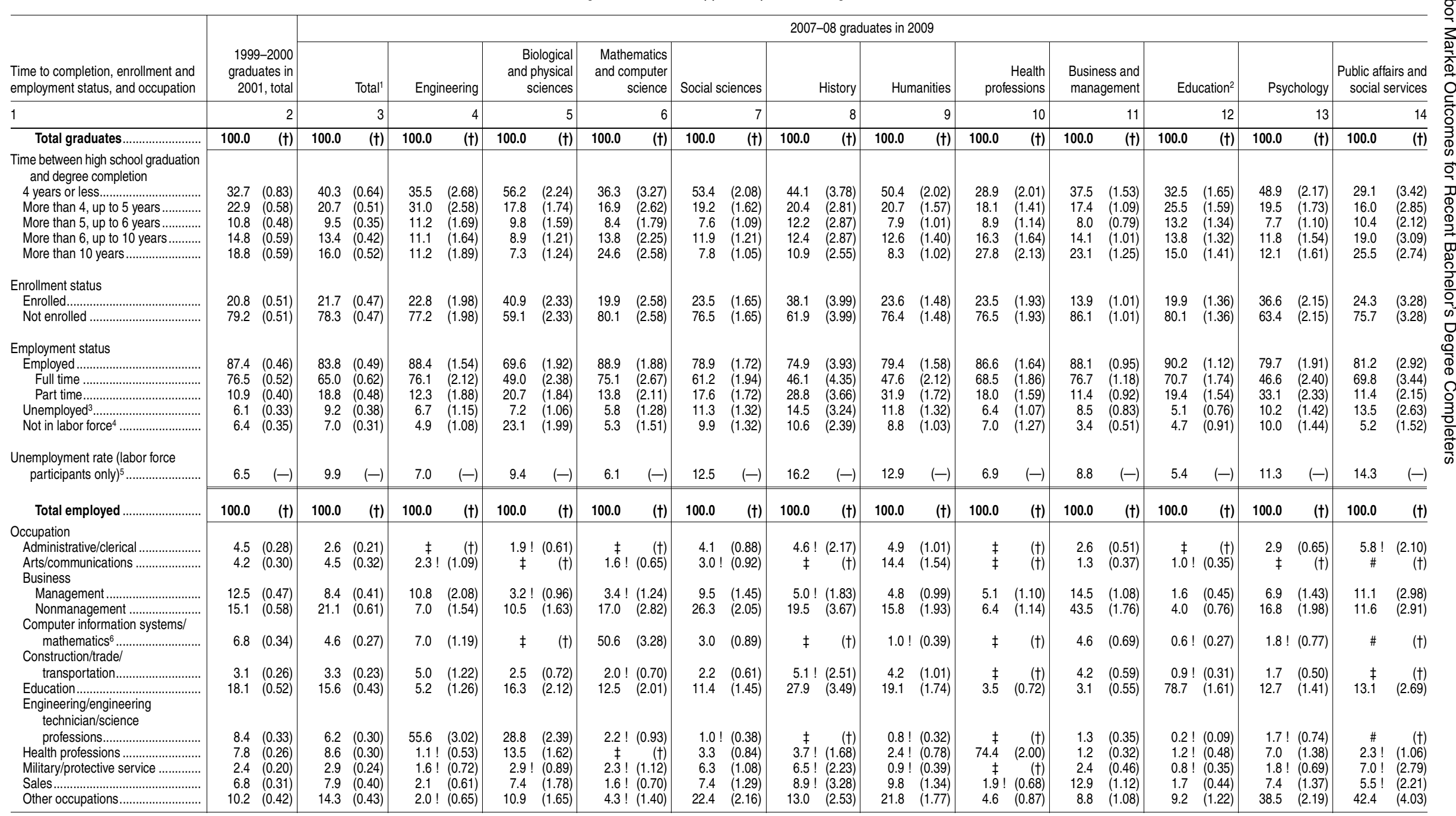

\section{- Not available.}

†Not applicable.

!Interpret data with caution. The coefficient of variation (CV) for this estimate is between 30 and 50 percent. FReporting standards not met. The coefficient of variation (CV) for this estimate is 50 percent or greater.

2Includes graduates who have not finished all requirements for teaching certification or were previously qualified to teach. 3Percentage of all graduates who are not employed, but are looking for work.
${ }^{5}$ The labor force is made up of persons who are employed and persons who are not employed but are looking for work. (It does not include those who are neither employed nor looking for work.) The unemployment rate is the percentage of labor force participants who are not employed but are actively seeking work.

${ }^{6}$ For 2001, does not include mathematics professions.

NOTE: Data exclude bachelor's degree recipients from U.S. Service Academies, deceased graduates, and graduates living at foreign addresses at the time of the survey. Detail may not sum to totals because of rounding. 
Table 505.50. Percentage, selected employment characteristics, and annual salaries of bachelor's degree recipients employed full time 1 year after graduation, by field of study: 1991, 2001, and 2009 [Standard errors appear in parentheses]

\begin{tabular}{|c|c|c|c|c|c|c|c|c|c|c|c|c|c|c|c|c|c|c|c|c|c|c|}
\hline \multirow{2}{*}{ Selected employment characteristic and annual salary } & \multicolumn{2}{|c|}{$\begin{array}{l}\text { All fields } \\
\text { of study }{ }^{1}\end{array}$} & \multicolumn{2}{|c|}{ Engineering } & \multicolumn{2}{|c|}{$\begin{array}{r}\text { Biological } \\
\text { and physical } \\
\text { sciences }^{2}\end{array}$} & \multicolumn{2}{|c|}{$\begin{array}{r}\text { Mathematics } \\
\text { and computer } \\
\text { science }^{2}\end{array}$} & \multicolumn{2}{|c|}{$\begin{array}{l}\text { Social sciences } \\
\text { and history }\end{array}$} & \multicolumn{2}{|c|}{ Humanities } & \multicolumn{2}{|c|}{$\begin{array}{r}\text { Health } \\
\text { professions }\end{array}$} & \multicolumn{2}{|c|}{$\begin{array}{l}\text { Business and } \\
\text { management }\end{array}$} & \multicolumn{2}{|c|}{ Education $^{3}$} & \multicolumn{2}{|c|}{ Psychology } & \multicolumn{2}{|c|}{$\begin{array}{l}\text { Public affairs and } \\
\text { social services }\end{array}$} \\
\hline & & 2 & & 3 & & 4 & & 5 & & 6 & & 7 & & 8 & & 0 & & 10 & & 11 & & 12 \\
\hline \multicolumn{23}{|l|}{ Employment characteristics } \\
\hline 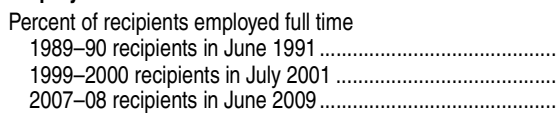 & & $\begin{array}{l}(0.36) \\
(0.52) \\
(0.62)\end{array}$ & $\begin{array}{l}85.2 \\
86.0 \\
76.1\end{array}$ & $\begin{array}{l}(0.95) \\
(1.77) \\
(2.12)\end{array}$ & $\begin{array}{l}50.6 \\
58.6 \\
49.0\end{array}$ & $\begin{array}{l}(1.72) \\
(2.04) \\
(2.38)\end{array}$ & $\begin{array}{l}71.2 \\
83.7 \\
75.1\end{array}$ & $\begin{array}{l}(1.30) \\
(2.06) \\
(2.67)\end{array}$ & & $\begin{array}{l}(0.94) \\
(1.88) \\
(1.81)\end{array}$ & $\begin{array}{l}59.2 \\
67.5 \\
50.4\end{array}$ & $\begin{array}{l}(1.32) \\
(1.65) \\
(1.82)\end{array}$ & $\begin{array}{l}80.9 \\
74.8 \\
68.5\end{array}$ & $\begin{array}{l}(1.35) \\
(1.50) \\
(1.86)\end{array}$ & $\begin{array}{l}83.2 \\
85.5 \\
77.2\end{array}$ & $\begin{array}{l}(0.57) \\
(1.27) \\
(1.20)\end{array}$ & $\begin{array}{l}77.0 \\
84.0 \\
70.6\end{array}$ & $\begin{array}{l}(0.74) \\
(1.29) \\
(1.75)\end{array}$ & & $\begin{array}{l}(1.64) \\
(2.64) \\
(2.40)\end{array}$ & $\begin{array}{l}77.0 \\
85.1 \\
69.8\end{array}$ & $\begin{array}{l}(2.06) \\
(2.25) \\
(3.44)\end{array}$ \\
\hline different job ${ }^{4}$ & $\begin{array}{l}21.5 \\
24.6 \\
31.2\end{array}$ & $\begin{array}{l}(0.35) \\
(0.66) \\
(0.74)\end{array}$ & $\begin{array}{l}12.9 \\
19.2 \\
20.2\end{array}$ & $\begin{array}{l}(1.05) \\
(2.30) \\
(2.53)\end{array}$ & $\begin{array}{l}21.0 \\
22.9 \\
28.5\end{array}$ & $\begin{array}{l}(1.95) \\
(2.64) \\
(3.47)\end{array}$ & $\begin{array}{l}16.6 \\
18.3 \\
27.7\end{array}$ & $\begin{array}{l}(1.08) \\
(2.36) \\
(3.37)\end{array}$ & $\begin{array}{l}24.5 \\
27.1 \\
35.3\end{array}$ & $\begin{array}{l}(1.20) \\
(2.06) \\
(2.47)\end{array}$ & $\begin{array}{l}25.8 \\
28.3 \\
39.2\end{array}$ & $\begin{array}{l}(1.44) \\
(2.13) \\
(2.56)\end{array}$ & $\begin{array}{r}9.2 \\
20.9 \\
21.8\end{array}$ & $\begin{array}{l}(1.10) \\
(1.93) \\
(2.40)\end{array}$ & $\begin{array}{l}20.7 \\
24.4 \\
32.0\end{array}$ & $\begin{array}{l}(0.78) \\
(1.51) \\
(1.61)\end{array}$ & $\begin{array}{l}25.5 \\
17.4 \\
23.6\end{array}$ & $\begin{array}{l}(0.92) \\
(1.45) \\
(1.78)\end{array}$ & $\begin{array}{l}21.8 \\
23.9 \\
37.3\end{array}$ & $\begin{array}{l}(1.57) \\
(2.54) \\
(2.99)\end{array}$ & 26.8 & $\begin{array}{l}(2.36) \\
(2.80) \\
(4.86)\end{array}$ \\
\hline $\begin{array}{r}\text { Percent } \\
\text { field } \\
1989- \\
1999- \\
2007-\end{array}$ & & $\begin{array}{l}(0.55) \\
(0.65) \\
(0.78) \\
\end{array}$ & $\begin{array}{l}57.5 \\
70.0 \\
61.3 \\
\end{array}$ & $\begin{array}{l}(1.24) \\
(3.35) \\
(2.86) \\
\end{array}$ & $\begin{array}{l}49.4 \\
48.6 \\
49.0 \\
\end{array}$ & $\begin{array}{l}(2.31) \\
(3.00) \\
(3.36) \\
\end{array}$ & & & & $\begin{array}{l}(1.12) \\
(2.03) \\
(2.07) \\
\end{array}$ & & $\begin{array}{l}(2.07) \\
(2.16) \\
(2.56) \\
\end{array}$ & $\begin{array}{l}88.2 \\
77.5 \\
81.7 \\
\end{array}$ & $\begin{array}{l}(2.10) \\
(2.45) \\
(2.10) \\
\end{array}$ & $\begin{array}{l}49.8 \\
58.7 \\
49.3 \\
\end{array}$ & $\begin{array}{l}(0.79) \\
(1.67) \\
(1.76) \\
\end{array}$ & & $\begin{array}{l}(0.89) \\
(1.68) \\
(1.68) \\
\end{array}$ & 26.6 & $\begin{array}{l}(2.13) \\
(3.65) \\
(3.04) \\
\end{array}$ & $\begin{array}{l}57.6 \\
61.2 \\
57.2 \\
\end{array}$ & $\begin{array}{l}(2.56) \\
(3.11) \\
(4.93) \\
\end{array}$ \\
\hline no & & & & & & & & & & & & & & & & & & & & & & \\
\hline $\begin{array}{l}1999-\mathrm{y} \\
2007-C\end{array}$ & $\begin{array}{r}\$ 23,600 \\
35,400 \\
40,100\end{array}$ & $\begin{array}{l}(180) \\
(300) \\
(340)\end{array}$ & $\begin{array}{r}\$ 30,900 \\
47,900 \\
53,900\end{array}$ & $\begin{array}{r}(390) \\
(840) \\
(1,080)\end{array}$ & $\begin{array}{r}\$ 21,100 \\
31,000 \\
34,600\end{array}$ & $\begin{array}{r}(410) \\
(710) \\
(1,220)\end{array}$ & $\begin{array}{r}\$ 27,200 \\
47,400 \\
48,800\end{array}$ & $\begin{array}{r}(400) \\
(1,080) \\
(1,570)\end{array}$ & $\begin{array}{r}\$ 22,100 \\
33,000 \\
36,600\end{array}$ & $\begin{array}{l}(330) \\
(700) \\
(980)\end{array}$ & $\begin{array}{r}\$ 19,100 \\
30,100 \\
31,100\end{array}$ & $\begin{array}{l}(350) \\
(690) \\
(780)\end{array}$ & $\left\{\begin{array}{r}\$ 31,500 \\
39,400 \\
49,100\end{array}\right.$ & $\begin{array}{r}(860) \\
(1,110) \\
(1,290)\end{array}$ & $\begin{array}{r}\$ 24,700 \\
41,000 \\
44,200\end{array}$ & $\begin{array}{l}(330) \\
(860) \\
(890)\end{array}$ & & $\begin{array}{l}(140) \\
(370) \\
(490)\end{array}$ & $\begin{array}{r}\$ 19,200 \\
28,800 \\
30,600\end{array}$ & $\begin{array}{l}(310) \\
(990) \\
(910)\end{array}$ & $\begin{array}{r}\$ 20,900 \\
30,400 \\
35,000\end{array}$ & $\begin{array}{r}(470) \\
(1,030) \\
(1,700)\end{array}$ \\
\hline $\begin{array}{r}\text { Average sa } \\
1989-90\end{array}$ & $\begin{array}{r}\$ 39,900 \\
45,900 \\
42,900\end{array}$ & $\begin{array}{l}(300) \\
(380) \\
(360)\end{array}$ & $\begin{array}{r}\$ 52,100 \\
62,200 \\
57,700\end{array}$ & $\begin{array}{r}(660) \\
(1,090) \\
(1,160)\end{array}$ & $\begin{array}{r}\$ 35,500 \\
40,200 \\
37,100\end{array}$ & $\begin{array}{r}(700) \\
(930) \\
(1,300)\end{array}$ & $\begin{array}{r}\$ 45,800 \\
61,500 \\
52,300\end{array}$ & $\begin{array}{r}(670) \\
(1,400) \\
(1,680)\end{array}$ & $\begin{array}{r}\$ 37,200 \\
42,700 \\
39,100\end{array}$ & $\begin{array}{r}(560) \\
(910) \\
(1,050)\end{array}$ & $\begin{array}{r}\$ 32,200 \\
39,000 \\
33,300\end{array}$ & $\begin{array}{l}(600) \\
(900) \\
(830)\end{array}$ & $\left\{\begin{array}{r}\$ 53,000 \\
51,100 \\
52,600\end{array}\right.$ & $\begin{array}{l}(1,450) \\
(1,440) \\
(1,380)\end{array}$ & $\begin{array}{r}\$ 41,700 \\
53,200 \\
47,300\end{array}$ & $\begin{array}{r}(550) \\
(1,120) \\
(950)\end{array}$ & $\begin{array}{r}\$ 32,200 \\
35,800 \\
35,300\end{array}$ & $\begin{array}{l}(230) \\
(470) \\
(530)\end{array}$ & $\begin{array}{r}\$ 32,300 \\
37,400 \\
32,800\end{array}$ & $\begin{array}{r}(530) \\
(1,280) \\
(980)\end{array}$ & $\begin{array}{r}\$ 35,200 \\
39,400 \\
37,500\end{array}$ & $\begin{array}{r}(790) \\
(1,340) \\
(1,820)\end{array}$ \\
\hline … & $\begin{array}{r}7.6 \\
15.2 \\
-6.6\end{array}$ & $\begin{array}{l}(-) \\
(-) \\
(-)\end{array}$ & $\begin{array}{l}10.6 \\
19.2 \\
-7.2\end{array}$ & $\begin{array}{l}(-) \\
(-) \\
(-)\end{array}$ & $\begin{array}{r}4.4 \\
13.2 \\
-7.7\end{array}$ & $\begin{array}{l}(-) \\
(-) \\
(-)\end{array}$ & $\begin{array}{r}14.1 \\
34.3 \\
-15.0\end{array}$ & $\begin{array}{l}(-) \\
(-) \\
(-)\end{array}$ & $\begin{array}{r}5.1 \\
14.7 \\
-8.4\end{array}$ & $\begin{array}{l}(-) \\
(-) \\
(-)\end{array}$ & $\begin{array}{r}3.5 \\
21.4 \\
-14.7\end{array}$ & $\begin{array}{l}(-) \\
(-) \\
(-)\end{array}$ & $\begin{array}{r}-0.8 \\
-3.6 \\
2.8\end{array}$ & $\begin{array}{l}(-) \\
(-) \\
(-)\end{array}$ & $\begin{array}{r}13.2 \\
27.4 \\
-11.1\end{array}$ & $\begin{array}{l}(-) \\
(-) \\
(-)\end{array}$ & $\begin{array}{r}9.5 \\
11.2 \\
-1.5\end{array}$ & $\begin{array}{l}(-) \\
(-) \\
(-)\end{array}$ & $\begin{array}{r}1.5 \\
15.8 \\
-12.4\end{array}$ & $\begin{array}{l}(-) \\
(-) \\
(-)\end{array}$ & $\begin{array}{r}6.6 \\
12.1 \\
-4.9\end{array}$ & $\begin{array}{l}(-) \\
(-) \\
(-)\end{array}$ \\
\hline $\begin{array}{l}\text { Median salary, in current dollars } \\
1989-90 \text { recipients in June } 1991 \ldots . . . . . \\
1999-2000 \text { recipients in July } 2001 \ldots . . . \\
2007-08 \text { recipients in June } 2009 . . . . . .\end{array}$ & $\begin{array}{r}\$ 21,800 \\
32,000 \\
36,000\end{array}$ & $\begin{array}{r}(210) \\
(90) \\
(220)\end{array}$ & $\begin{array}{r}\$ 31,900 \\
47,800 \\
54,000\end{array}$ & $\begin{array}{l}(470) \\
(880) \\
(900)\end{array}$ & $\begin{array}{r}\$ 20,000 \\
29,800 \\
32,500\end{array}$ & $\begin{array}{r}(430) \\
(470) \\
(1,570)\end{array}$ & $\begin{array}{r}\$ 27,000 \\
46,100 \\
45,000\end{array}$ & $\begin{array}{r}(510) \\
(1,990) \\
(1,830)\end{array}$ & $\begin{array}{r}\$ 20,300 \\
29,900 \\
34,600\end{array}$ & $\begin{array}{l}(250) \\
(360) \\
(920)\end{array}$ & $\begin{array}{r}\$ 18,500 \\
28,600 \\
29,000\end{array}$ & $\begin{array}{r}(360) \\
(700) \\
(1,060)\end{array}$ & $\left\{\begin{array}{r}\$ 30,400 \\
35,500 \\
45,900\end{array}\right.$ & $\begin{array}{l}(760) \\
(770) \\
(920)\end{array}$ & $\begin{array}{r}\$ 23,000 \\
36,800 \\
40,000\end{array}$ & $\begin{array}{l}(300) \\
(700) \\
(300)\end{array}$ & $\begin{array}{r}\$ 19,500 \\
27,900 \\
33,800\end{array}$ & $\begin{array}{l}(220) \\
(410) \\
(570)\end{array}$ & $\begin{array}{r}\$ 18,100 \\
27,700 \\
29,300\end{array}$ & $\begin{array}{r}(320) \\
(1,180) \\
(1,040)\end{array}$ & $\begin{array}{r}\$ 18,600 \\
27,900 \\
32,000\end{array}$ & $\begin{array}{r}(410) \\
(710) \\
(1,430)\end{array}$ \\
\hline $\begin{array}{l}\text { Median salary, in constant } 2012 \text { dollars } \\
1989-90 \text { recipients in June } 1991 \ldots \ldots . . . \\
1999-2000 \text { recipients in July } 2001 . . . . \\
2007-08 \text { recipients in June } 2009 . \ldots . . .\end{array}$ & $\begin{array}{r}\$ 36,700 \\
41,400 \\
38,500\end{array}$ & $\begin{array}{l}(350) \\
(120) \\
(230)\end{array}$ & $\begin{array}{r}\$ 53,700 \\
62,000 \\
57,800\end{array}$ & $\begin{array}{r}(800) \\
(1,140) \\
(960)\end{array}$ & $\begin{array}{r}\$ 33,600 \\
38,600 \\
34,700\end{array}$ & $\begin{array}{r}(720) \\
(610) \\
(1,680)\end{array}$ & $\begin{array}{r}\$ 45,400 \\
59,800 \\
48,100\end{array}$ & $\begin{array}{r}(870) \\
(2,580) \\
(1,960)\end{array} \mid$ & $\begin{array}{r}\$ 34,100 \\
38,800 \\
37,000\end{array}$ & $\begin{array}{l}(420) \\
(460) \\
(980)\end{array}$ & $\begin{array}{r}\$ 31,100 \\
37,100 \\
31,000\end{array}$ & $\begin{array}{r}(600) \\
(910) \\
(1,130)\end{array}$ & $\left\{\begin{array}{r}\$ 51,300 \\
46,000 \\
49,200\end{array}\right.$ & $\begin{array}{r}(1,280) \\
(1,000) \\
(990)\end{array}$ & $\begin{array}{r}\$ 38,700 \\
47,700 \\
42,800\end{array}$ & $\begin{array}{l}(500) \\
(910) \\
(320)\end{array}$ & $\begin{array}{r}\$ 32,900 \\
36,200 \\
36,200\end{array}$ & $\begin{array}{l}(370) \\
(540) \\
(610)\end{array}$ & $\begin{array}{r}\$ 30,500 \\
36,000 \\
31,400\end{array}$ & $\begin{array}{r}(540) \\
(1,530) \\
(1,120)\end{array}$ & $\begin{array}{r}\$ 31,400 \\
36,200 \\
34,200\end{array}$ & $\begin{array}{r}(690) \\
(920) \\
(1,530)\end{array}$ \\
\hline 2001 to 2009 & $\begin{array}{r}4.9 \\
12.8 \\
-7.0\end{array}$ & $\begin{array}{l}(-) \\
(-) \\
(-)\end{array}$ & $\begin{array}{r}7.5 \\
15.4 \\
-6.8\end{array}$ & $\begin{array}{l}(-) \\
(-) \\
(-)\end{array}$ & $\begin{array}{r}3.2 \\
14.9 \\
-10.1\end{array}$ & $\begin{array}{l}1-1 \\
(-)\end{array}$ & $\begin{array}{r}31.5 \\
-19.4\end{array}$ & $\begin{array}{l}1 \\
(-) \\
(-)\end{array}$ & $\begin{array}{l}13.5 \\
-4.5\end{array}$ & $\begin{array}{l}(-1 \\
(-)\end{array}$ & $\begin{array}{r}-0.0 \\
19.1 \\
-16.3\end{array}$ & $\begin{array}{l}1-1 \\
(-) \\
(-)\end{array}$ & $\begin{array}{r}-4.1 \\
-10.2 \\
6.9\end{array}$ & $\begin{array}{l}(-) \\
(-) \\
(-)\end{array}$ & $\begin{array}{r}23.2 \\
-10.3\end{array}$ & $\begin{array}{l}(-) \\
(-) \\
(-)\end{array}$ & $\begin{array}{l}10.1 \\
-0.1\end{array}$ & $\begin{array}{l}(-) \\
(-) \\
(-)\end{array}$ & $\begin{array}{r}2.0 \\
17.9 \\
-12.7\end{array}$ & $\begin{array}{l}(-) \\
(-) \\
(-)\end{array}$ & -5.4 & $\begin{array}{l}(-) \\
(-) \\
(-)\end{array}$ \\
\hline
\end{tabular}

\section{-Not available.}

2For 1991, physical sciences not included in column 4 with biological sciences; instead, they are included in column 5 with mathematics and computer science.

3Most educators work 9- to 10 -month contracts.

${ }^{4}$ In 1991, respondents were asked whether they were "looking for a different principal job." In 2001 and 2009, they were asked

IIn all years, reported salaries of full-time workers under $\$ 1,000$ were excluded from the tabulations. In addition, salaries reported as above $\$ 500,000$ were set to $\$ 500,000$ in 2001 , and salaries reported as above $\$ 250,000$ were set to
2009 . In all years, only a tiny fraction of reported full-time salaries were either below $\$ 1,000$ or above $\$ 250,000$.

NOTE: Data exclude bachelor's degree recipients from U.S. Service Academies, deceased graduates, and graduates living at foreign addresses at the time of the survey. Constant dollars based on the Consumer Price Index, prepared by the Bureau Labor Statistics, U.S. Department of Labor. Data for 2001 have been revised from previously published figures. and 2000/01 and 2008/09 Baccalaureate and Beyond Longitudinal Study (B\&B-2000/01 and B\&B.08/09). (This tabvey, 199 pared June 2014.) 


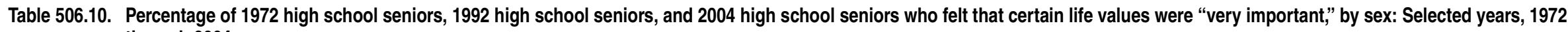
through 2004

[Standard errors appear in parentheses]

\begin{tabular}{|c|c|c|c|c|c|c|c|c|c|c|c|c|c|c|c|c|c|c|c|c|c|c|c|c|c|c|}
\hline \multirow{2}{*}{$\frac{\text { Year and sex }}{1}$} & \multicolumn{2}{|c|}{$\begin{array}{r}\text { Being successful } \\
\text { in work }\end{array}$} & \multicolumn{2}{|c|}{$\begin{array}{r}\text { Finding } \\
\text { steady work }\end{array}$} & \multicolumn{2}{|c|}{$\begin{array}{r}\text { Having lots } \\
\text { of money }\end{array}$} & \multicolumn{2}{|c|}{$\begin{array}{l}\text { Being a leader } \\
\text { in the community }\end{array}$} & \multicolumn{2}{|c|}{$\begin{array}{l}\text { Helping others } \\
\text { in the community }\end{array}$} & \multicolumn{2}{|c|}{$\begin{array}{c}\text { Correcting } \\
\text { inequalities }\end{array}$} & \multicolumn{2}{|c|}{ Having children } & \multicolumn{2}{|c|}{$\begin{array}{r}\text { Having a } \\
\text { happy family life }\end{array}$} & \multicolumn{2}{|c|}{$\begin{array}{r}\text { Giving my } \\
\text { children better } \\
\text { opportunities }\end{array}$} & \multicolumn{2}{|c|}{$\begin{array}{r}\text { Living close } \\
\text { to parents } \\
\text { or relatives }\end{array}$} & \multicolumn{2}{|c|}{$\begin{array}{r}\text { Moving } \\
\text { from area }\end{array}$} & \multicolumn{2}{|c|}{$\begin{array}{r}\text { Having strong } \\
\text { friendships }\end{array}$} & \multicolumn{2}{|c|}{$\begin{array}{r}\text { Having } \\
\text { leisure time }\end{array}$} \\
\hline & & 2 & & 3 & & 4 & & 5 & & 6 & & 7 & & 8 & & 9 & & 10 & & 11 & & 12 & & 13 & & 14 \\
\hline \multicolumn{27}{|l|}{1972 seniors } \\
\hline Total... & 84.5 & $(0.35)$ & 78.2 & $(0.39)$ & 17.9 & $(0.36)$ & 11.4 & $(0.29)$ & - & (t) & 27.1 & $(0.41)$ & - & $(t)$ & 82.1 & $(0.36)$ & 67.7 & $(0.44)$ & 8.0 & $(0.25)$ & 14.3 & $(0.33)$ & 79.1 & $(0.37)$ & - & $(\dagger)$ \\
\hline Male.................... & 86.4 & $(0.47)$ & 82.3 & $(0.52)$ & 25.8 & $(0.58)$ & 14.9 & $(0.47)$ & - & $(t)$ & 23.0 & $(0.55)$ & - & $(t)$ & 79.0 & $(0.55)$ & 67.4 & $(0.62)$ & 7.4 & $(0.34)$ & 14.0 & $(0.46)$ & 80.5 & $(0.52)$ & - & $(\dagger)$ \\
\hline Female .................. & 82.6 & $(0.51)$ & 74.1 & $(0.58)$ & 10.1 & $(0.38)$ & 7.9 & $(0.34)$ & - & $(t)$ & 31.2 & $(0.60)$ & - & $(t)$ & 85.2 & $(0.47)$ & 67.9 & $(0.61)$ & 8.7 & $(0.37)$ & 14.7 & $(0.47)$ & 77.6 & $(0.53)$ & - & $(\dagger)$ \\
\hline \multicolumn{27}{|l|}{ In 1974} \\
\hline Total.... & 77.2 & $(0.40)$ & 66.9 & $(0.44)$ & 13.1 & $(0.31)$ & 6.1 & $(0.21)$ & - & $(\dagger)$ & 16.6 & $(0.34)$ & - & $(t)$ & 84.8 & $(0.34)$ & 59.4 & $(0.45)$ & 9.9 & $(0.28)$ & 7.6 & $(0.25)$ & 75.4 & $(0.40)$ & 57.9 & $(0.46)$ \\
\hline Male...................... & 80.3 & $(0.54)$ & 74.4 & $(0.59)$ & 17.6 & $(0.51)$ & 8.2 & $(0.35)$ & - & $(\dagger)$ & 15.8 & $(0.47)$ & - & $(\dagger)$ & 82.7 & $(0.51)$ & 58.8 & $(0.65)$ & 8.0 & $(0.36)$ & 7.9 & $(0.36)$ & 76.2 & $(0.57)$ & 60.6 & $(0.65)$ \\
\hline Female .................. & 74.2 & $(0.58)$ & 59.7 & (0.64) & 8.6 & $(0.36)$ & 4.1 & $(0.25)$ & - & $(t)$ & 17.3 & $(0.48)$ & - & $(t)$ & 86.9 & $(0.44)$ & 60.0 & $(0.63)$ & 11.8 & $(0.42)$ & 7.3 & $(0.34)$ & 74.7 & $(0.56)$ & 55.4 & $(0.65)$ \\
\hline \multicolumn{27}{|l|}{ In 1976} \\
\hline Total..... & 74.5 & $(0.41)$ & 70.4 & $(0.43)$ & 13.0 & $(0.31)$ & 6.2 & $(0.22)$ & - & (†) & 16.1 & $(0.34)$ & - & $(\dagger)$ & 85.1 & $(0.34)$ & 57.9 & $(0.46)$ & 9.3 & $(0.27)$ & 6.4 & $(0.23)$ & 74.3 & $(0.41)$ & 62.6 & $(0.45)$ \\
\hline Male...................... & 79.8 & $(0.55)$ & 79.3 & $(0.55)$ & 17.1 & $(0.50)$ & 8.7 & $(0.36)$ & - & (t) & 15.6 & $(0.48)$ & - & $(\dagger)$ & 84.2 & $(0.50)$ & 58.8 & $(0.65)$ & 7.2 & $(0.34)$ & 6.6 & $(0.33)$ & 76.4 & $(0.57)$ & 65.1 & $(0.64)$ \\
\hline Female .. & 69.3 & $(0.61)$ & 61.6 & $(0.64)$ & 9.0 & $(0.37)$ & 3.8 & $(0.24)$ & - & $(t)$ & 16.5 & $(0.48)$ & - & $(t)$ & 85.9 & $(0.46)$ & 57.1 & $(0.64)$ & 11.4 & $(0.42)$ & 6.3 & $(0.32)$ & 72.3 & $(0.58)$ & 60.0 & (0.64) \\
\hline \multicolumn{27}{|l|}{1992 seniors } \\
\hline \multicolumn{27}{|l|}{ In 1992} \\
\hline Total... & 88.8 & $(0.44)$ & 88.5 & $(0.41)$ & 37.1 & $(0.63)$ & - & $(\dagger)$ & 33.8 & $(0.63)$ & 20.2 & $(0.55)$ & 44.6 & $(0.65)$ & 79.0 & $(0.57)$ & 76.0 & $(0.56)$ & 16.6 & $(0.46)$ & 20.6 & $(0.55)$ & 80.0 & (0.52) & 64.0 & $(0.64)$ \\
\hline Male..................... & 88.3 & $(0.69)$ & 87.8 & $(0.59)$ & 45.6 & $(0.98)$ & - & $(\dagger)$ & 27.9 & $(0.93)$ & 17.1 & $(0.72)$ & 39.5 & $(0.96)$ & 75.8 & $(0.89)$ & 74.6 & $(0.83)$ & 14.9 & $(0.60)$ & 20.9 & $(0.83)$ & 79.8 & $(0.70)$ & 66.3 & $(0.95)$ \\
\hline Female .... & 89.3 & $(0.53)$ & 89.2 & $(0.56)$ & 28.6 & $(0.79)$ & - & $(\dagger)$ & 39.7 & $(0.86)$ & 23.3 & $(0.83)$ & 49.7 & $(0.87)$ & 82.1 & $(0.72)$ & 77.3 & $(0.75)$ & 18.2 & $(0.68)$ & 20.3 & $(0.71)$ & 80.3 & $(0.77)$ & 61.7 & $(0.84)$ \\
\hline \multicolumn{27}{|l|}{ In 1994} \\
\hline Total..... & 89.7 & $(0.38)$ & 89.7 & $(0.40)$ & 36.9 & $(0.63)$ & - & $(\dagger)$ & - & $(\dagger)$ & - & $(\dagger)$ & - & $(t)$ & - & $(t)$ & 91.3 & $(0.34)$ & - & $(\dagger)$ & - & $(t)$ & 86.2 & $(0.44)$ & - & $(\dagger)$ \\
\hline Male.................. & 89.6 & $(0.55)$ & 89.1 & (0.61) & 41.3 & $(0.94)$ & - & $(\dagger)$ & - & $(t)$ & - & $(\dagger)$ & - & $(t)$ & - & $(t)$ & 91.1 & $(0.52)$ & - & $(t)$ & - & $(t)$ & 87.2 & $(0.58)$ & - & $(t)$ \\
\hline Female ................... & 89.7 & $(0.52)$ & 90.3 & (0.52) & 32.5 & $(0.86)$ & - & $(\dagger)$ & - & $(t)$ & - & $(t)$ & - & $(t)$ & - & $(t)$ & 91.5 & $(0.43)$ & - & $(t)$ & - & $(t)$ & 85.1 & $(0.65)$ & - & $(\dagger)$ \\
\hline \multicolumn{27}{|l|}{2004 seniors } \\
\hline In 2004 & & & & & & & & & & & & & & & & & & & & & & & & & & \\
\hline Total........................... & 91.3 & $(0.33)$ & 87.3 & $(0.40)$ & 35.1 & $(0.58)$ & - & $(\dagger)$ & 41.7 & $(0.57)$ & 19.7 & $(0.46)$ & 49.3 & $(0.55)$ & 81.0 & $(0.46)$ & 82.5 & $(0.45)$ & 24.5 & $(0.50)$ & 18.3 & $(0.45)$ & 85.5 & $(0.41)$ & 69.0 & $(0.55)$ \\
\hline Male.......... & 89.7 & $(0.49)$ & 85.6 & $(0.55)$ & 42.7 & $(0.80)$ & - & $(\dagger)$ & 35.2 & $(0.77)$ & 18.1 & $(0.60)$ & 45.4 & $(0.75)$ & 80.1 & $(0.63)$ & 82.1 & $(0.64)$ & 22.3 & $(0.65)$ & 18.6 & $(0.63)$ & 84.9 & $(0.56)$ & 70.2 & $(0.69)$ \\
\hline Female .............. & 92.9 & $(0.40)$ & 89.0 & $(0.49)$ & 27.6 & (0.69) & - & $(\dagger)$ & 48.1 & $(0.74)$ & 21.2 & $(0.67)$ & 53.2 & $(0.78)$ & 81.9 & $(0.64)$ & 82.9 & (0.58) & 26.6 & $(0.74)$ & 17.9 & $(0.59)$ & 86.1 & $(0.57)$ & 67.8 & $(0.74)$ \\
\hline
\end{tabular}

-Not available.

TNot applicable.

SOURCE: U.S. Department of Education, National Center for Education Statistics, National Longitudinal Study of the High School Class of 1972, "Base Year" (NLS:72), "Second Follow-up" (NLS:72/74), and "Third Follow-up" (NLS:72/76); National
Education Longitudinal Study of 1988, "Second Follow-up, Student Survey, 1992" (NELS:88/92) and "Third Follow-up. 1994 " (NELS:88/94); and Education Longitudinal Study of 2002, "First Follow-up" (ELS: 02/04). (This table was prepared
October 2011.) 
Table 507.10. Literacy skills of adults, by type of literacy, proficiency levels, and selected characteristics: 1992 and 2003

[Standard errors appear in parentheses]

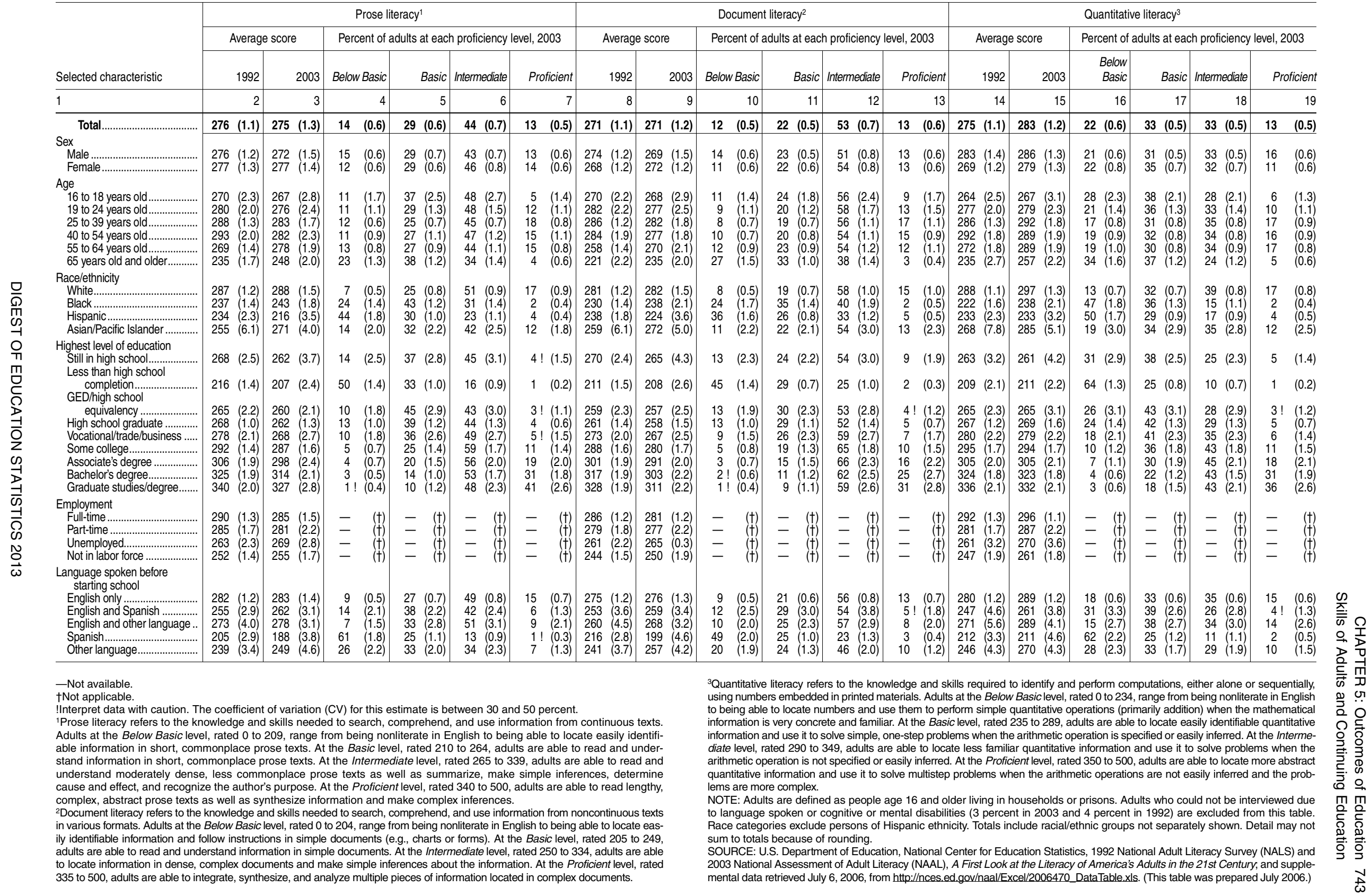


Table 507.20. Participants in state-administered adult basic education, secondary education, and English as a second language programs, by type of program and state or jurisdiction: Selected fiscal years, 2000 through 2011

\begin{tabular}{|c|c|c|c|c|c|c|c|c|c|c|c|}
\hline \multirow[b]{2}{*}{ State or jurisdiction } & \multicolumn{3}{|c|}{ Total } & \multicolumn{4}{|c|}{2010} & \multicolumn{4}{|c|}{2011} \\
\hline & 2000 & 2005 & 2009 & Total & $\begin{array}{r}\text { Adult basic } \\
\text { education }\end{array}$ & $\begin{array}{r}\text { Adult } \\
\text { secondary } \\
\text { education }\end{array}$ & $\begin{array}{r}\text { English } \\
\text { as a second } \\
\text { language }\end{array}$ & Total & $\begin{array}{r}\text { Adult basic } \\
\text { education }\end{array}$ & $\begin{array}{r}\text { Adult } \\
\text { secondary } \\
\text { education }\end{array}$ & $\begin{array}{r}\text { English } \\
\text { as a second } \\
\text { language }\end{array}$ \\
\hline 1 & 2 & 3 & 4 & 5 & 6 & 7 & 8 & 9 & 10 & 11 & 12 \\
\hline United States .............. & $2,629,643$ & $2,543,953$ & $2,157,155$ & $1,990,118$ & 921,374 & 230,163 & 838,581 & $1,792,527$ & 847,792 & 212,390 & 732,345 \\
\hline 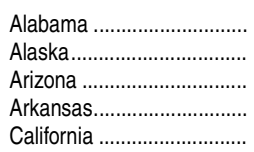 & $\begin{array}{r}23,666 \\
5,312 \\
31,136 \\
38,867 \\
473,050\end{array}$ & $\begin{array}{r}19,827 \\
3,791 \\
26,881 \\
37,102 \\
591,893\end{array}$ & $\begin{array}{r}25,153 \\
3,326 \\
19,789 \\
31,551 \\
434,428\end{array}$ & $\begin{array}{r}24,339 \\
3,176 \\
18,552 \\
27,603 \\
392,918\end{array}$ & \begin{tabular}{r|}
17,725 \\
2,010 \\
11,296 \\
17,410 \\
98,721
\end{tabular} & $\begin{array}{r}4,560 \\
360 \\
1,391 \\
5,702 \\
33,013\end{array}$ & $\begin{array}{r}2,054 \\
806 \\
5,865 \\
4,491 \\
261,184\end{array}$ & \begin{tabular}{r|}
23,338 \\
2,928 \\
17,719 \\
25,406 \\
354,066
\end{tabular} & \begin{tabular}{r|}
17,628 \\
1,875 \\
10,540 \\
16,104 \\
95,891
\end{tabular} & \begin{tabular}{r|r|}
4,199 \\
278 \\
1,251 \\
5,028 \\
32,266
\end{tabular} & $\begin{array}{r}1,511 \\
775 \\
5,928 \\
4,274 \\
225,909\end{array}$ \\
\hline 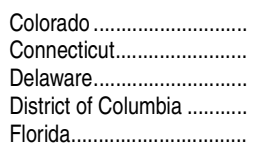 & $\begin{array}{r}13,818 \\
30,844 \\
4,342 \\
3,667 \\
404,912\end{array}$ & $\begin{array}{r}15,011 \\
31,958 \\
6,329 \\
3,646 \\
348,119\end{array}$ & $\begin{array}{r}14,298 \\
28,255 \\
5,059 \\
4,247 \\
256,498\end{array}$ & $\begin{array}{r}12,873 \\
25,924 \\
4,961 \\
3,808 \\
239,653\end{array}$ & $\begin{array}{r}3,836 \\
7,234 \\
3,077 \\
2,064 \\
105,307\end{array}$ & $\begin{array}{r}1,240 \\
6,618 \\
516 \\
189 \\
25,475\end{array}$ & $\begin{array}{r}7,797 \\
12,072 \\
1,368 \\
1,555 \\
108,871\end{array}$ & $\begin{array}{r}10,812 \\
24,120 \\
4,922 \\
3,145 \\
168,664\end{array}$ & $\begin{array}{r}3,661 \\
7,030 \\
3,068 \\
1,546 \\
74,624\end{array}$ & $\begin{array}{r}1,087 \\
5,836 \\
592 \\
171 \\
21,400\end{array}$ & $\begin{array}{r}6,064 \\
11,254 \\
1,262 \\
1,428 \\
72,640\end{array}$ \\
\hline 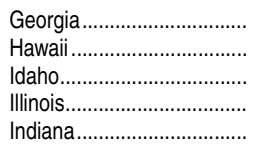 & $\begin{array}{r}108,004 \\
10,525 \\
10,506 \\
122,043 \\
42,135\end{array}$ & $\begin{array}{r}95,434 \\
7,461 \\
7,744 \\
118,296 \\
43,498\end{array}$ & $\begin{array}{r}72,657 \\
9,196 \\
7,429 \\
108,383 \\
35,995\end{array}$ & $\begin{array}{r}64,668 \\
9,058 \\
6,675 \\
96,620 \\
28,571\end{array}$ & $\begin{array}{r}46,149 \\
3,849 \\
4,066 \\
26,175 \\
19,815\end{array}$ & $\begin{array}{r}5,949 \\
2,099 \\
484 \\
14,086 \\
3,945\end{array}$ & $\begin{array}{r}12,570 \\
3,110 \\
2,125 \\
56,359 \\
4,811\end{array}$ & $\begin{array}{r}60,235 \\
8,654 \\
6,329 \\
91,697 \\
28,791\end{array}$ & $\begin{array}{r}41,878 \\
3,746 \\
3,897 \\
26,456 \\
19,687\end{array}$ & $\begin{array}{r}5,267 \\
2,283 \\
489 \\
13,715 \\
4,647\end{array}$ & $\begin{array}{r}13,090 \\
2,625 \\
1,943 \\
51,526 \\
4,457\end{array}$ \\
\hline 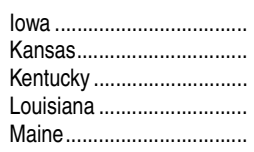 & $\begin{array}{l}20,161 \\
11,248 \\
31,050 \\
30,929 \\
12,430\end{array}$ & $\begin{array}{r}11,989 \\
9,475 \\
30,931 \\
29,367 \\
8,151\end{array}$ & $\begin{array}{r}10,752 \\
9,024 \\
39,218 \\
30,559 \\
8,604\end{array}$ & $\begin{array}{r}11,167 \\
8,100 \\
38,654 \\
27,270 \\
6,776\end{array}$ & $\begin{array}{r}5,254 \\
3,873 \\
26,410 \\
22,340 \\
3,800\end{array}$ & $\begin{array}{r}1,931 \\
863 \\
8,468 \\
3,142 \\
1,611\end{array}$ & $\begin{array}{l}3,982 \\
3,364 \\
3,776 \\
1,788 \\
1,365\end{array}$ & $\begin{array}{r}10,921 \\
7,642 \\
39,487 \\
26,747 \\
6,433\end{array}$ & $\begin{array}{r}4,948 \\
3,864 \\
26,640 \\
21,730 \\
3,682\end{array}$ & $\begin{array}{r}1,926 \\
898 \\
9,070 \\
3,279 \\
1,481\end{array}$ & $\begin{array}{l}4,047 \\
2,880 \\
3,777 \\
1,738 \\
1,270\end{array}$ \\
\hline 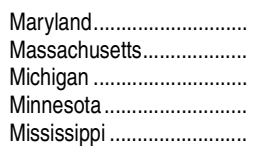 & $\begin{array}{l}22,702 \\
24,053 \\
56,096 \\
42,039 \\
37,947\end{array}$ & $\begin{array}{l}27,055 \\
21,448 \\
34,768 \\
47,174 \\
25,675\end{array}$ & $\begin{array}{l}33,942 \\
20,372 \\
31,106 \\
47,612 \\
17,782\end{array}$ & $\begin{array}{l}32,833 \\
20,314 \\
25,745 \\
46,009 \\
16,854\end{array}$ & $\begin{array}{r}15,174 \\
4,888 \\
14,359 \\
17,948 \\
13,877\end{array}$ & $\begin{array}{l}3,953 \\
3,473 \\
2,994 \\
5,720 \\
2,750\end{array}$ & $\begin{array}{r}13,706 \\
11,953 \\
8,392 \\
22,341 \\
227\end{array}$ & $\begin{array}{l}31,094 \\
21,369 \\
28,614 \\
43,449 \\
16,403\end{array}$ & $\begin{array}{r}14,102 \\
4,800 \\
17,335 \\
18,052 \\
13,900\end{array}$ & $\begin{array}{l}3,899 \\
3,668 \\
2,697 \\
5,806 \\
2,252\end{array}$ & $\begin{array}{r}13,093 \\
12,901 \\
8,582 \\
19,591 \\
251\end{array}$ \\
\hline 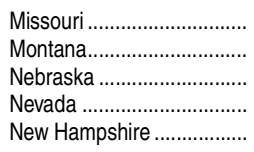 & $\begin{array}{r}41,089 \\
4,892 \\
7,917 \\
22,992 \\
5,962\end{array}$ & $\begin{array}{r}37,052 \\
3,291 \\
10,226 \\
9,981 \\
5,804\end{array}$ & $\begin{array}{r}35,542 \\
3,735 \\
8,588 \\
9,193 \\
5,589\end{array}$ & $\begin{array}{r}31,397 \\
3,494 \\
8,485 \\
8,673 \\
5,740\end{array}$ & $\begin{array}{r}21,612 \\
2,581 \\
4,108 \\
1,508 \\
1,676\end{array}$ & $\begin{array}{r}3,655 \\
720 \\
893 \\
447 \\
1,737\end{array}$ & $\begin{array}{r}6,130 \\
193 \\
3,484 \\
6,718 \\
2,327\end{array}$ & $\begin{array}{r}28,307 \\
3,353 \\
7,946 \\
7,358 \\
5,389\end{array}$ & $\begin{array}{r}19,289 \\
2,442 \\
4,017 \\
1,163 \\
1,560\end{array}$ & $\begin{array}{r}3,261 \\
734 \\
788 \\
316 \\
1,614\end{array}$ & $\begin{array}{r}5,757 \\
177 \\
3,141 \\
5,879 \\
2,215\end{array}$ \\
\hline 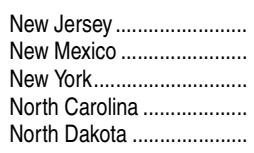 & $\begin{array}{r}44,317 \\
23,243 \\
176,239 \\
107,504 \\
2,124\end{array}$ & $\begin{array}{r}40,889 \\
24,132 \\
157,486 \\
109,047 \\
2,063\end{array}$ & $\begin{array}{r}33,901 \\
23,248 \\
129,636 \\
123,030 \\
1,783\end{array}$ & $\begin{array}{r}30,976 \\
21,466 \\
122,833 \\
115,312 \\
1,581\end{array}$ & $\begin{array}{r}12,152 \\
12,154 \\
48,118 \\
66,377 \\
773\end{array}$ & $\begin{array}{r}1,325 \\
1,725 \\
7,544 \\
23,294 \\
415\end{array}$ & $\begin{array}{r}17,499 \\
7,587 \\
67,171 \\
25,641 \\
393\end{array}$ & $\begin{array}{r}27,263 \\
18,854 \\
115,699 \\
105,080 \\
1,653\end{array}$ & $\begin{array}{r}9,819 \\
10,466 \\
44,938 \\
61,911 \\
832\end{array}$ & $\begin{array}{r}1,015 \\
1,588 \\
7,011 \\
19,769 \\
369\end{array}$ & $\begin{array}{r}16,429 \\
6,800 \\
63,750 \\
23,400 \\
452\end{array}$ \\
\hline 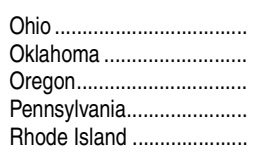 & $\begin{array}{r}65,579 \\
20,101 \\
25,228 \\
49,369 \\
5,592\end{array}$ & $\begin{array}{r}50,869 \\
20,447 \\
21,668 \\
54,274 \\
6,697\end{array}$ & $\begin{array}{r}46,042 \\
19,711 \\
22,976 \\
34,975 \\
6,497\end{array}$ & $\begin{array}{r}41,692 \\
18,329 \\
20,851 \\
30,577 \\
6,012\end{array}$ & $\begin{array}{r}30,093 \\
12,539 \\
9,914 \\
17,957 \\
2,484\end{array}$ & $\begin{array}{r}5,341 \\
1,809 \\
2,592 \\
4,037 \\
561\end{array}$ & $\begin{array}{l}6,258 \\
3,981 \\
8,345 \\
8,583 \\
2,967\end{array}$ & $\begin{array}{r}39,877 \\
16,241 \\
18,848 \\
24,310 \\
6,345\end{array}$ & $\begin{array}{r}28,624 \\
11,024 \\
9,018 \\
14,294 \\
2,715\end{array}$ & $\begin{array}{r}4,935 \\
1,737 \\
2,218 \\
3,050 \\
447\end{array}$ & $\begin{array}{l}6,318 \\
3,480 \\
7,612 \\
6,966 \\
3,183\end{array}$ \\
\hline $\begin{array}{l}\text { South Carolina } \\
\text { South Dakota } \\
\text { Tennessee } \\
\text { Texas } \\
\text { Utah. }\end{array}$ & $\begin{array}{r}94,452 \\
5,637 \\
40,615 \\
111,585 \\
30,714\end{array}$ & $\begin{array}{r}65,901 \\
3,517 \\
48,924 \\
119,867 \\
29,320\end{array}$ & $\begin{array}{r}53,645 \\
2,773 \\
32,177 \\
98,063 \\
26,337\end{array}$ & $\begin{array}{r}49,484 \\
2,423 \\
28,170 \\
99,333 \\
24,686\end{array}$ & $\begin{array}{r}37,205 \\
1,398 \\
21,254 \\
45,638 \\
15,048\end{array}$ & $\begin{array}{r}7,500 \\
558 \\
3,409 \\
3,553 \\
2,659\end{array}$ & $\begin{array}{r}4,779 \\
467 \\
3,507 \\
50,142 \\
6,979\end{array}$ & $\begin{array}{r}47,237 \\
2,395 \\
27,694 \\
91,710 \\
21,005\end{array}$ & $\begin{array}{r}35,716 \\
1,374 \\
21,242 \\
41,624 \\
13,121\end{array}$ & $\begin{array}{r}6,982 \\
471 \\
3,187 \\
3,211 \\
2,202\end{array}$ & $\begin{array}{r}4,539 \\
550 \\
3,265 \\
46,875 \\
5,682\end{array}$ \\
\hline 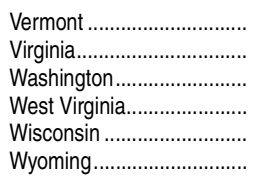 & $\begin{array}{r}1,146 \\
35,261 \\
53,460 \\
13,072 \\
27,304 \\
2,767\end{array}$ & $\begin{array}{r}2,015 \\
29,222 \\
50,386 \\
9,444 \\
26,029 \\
2,379\end{array}$ & $\begin{array}{r}2,461 \\
29,802 \\
65,606 \\
9,780 \\
23,694 \\
3,136\end{array}$ & $\begin{array}{r}1,590 \\
28,220 \\
61,392 \\
9,785 \\
21,523 \\
2,973\end{array}$ & $\begin{array}{r}1,019 \\
11,481 \\
26,324 \\
7,679 \\
11,964 \\
1,661\end{array}$ & $\begin{array}{r}277 \\
4,336 \\
4,264 \\
1,871 \\
4,334 \\
775 \\
\end{array}$ & $\begin{array}{r}294 \\
12,403 \\
30,804 \\
235 \\
5,225 \\
537 \\
\end{array}$ & $\begin{array}{r}2,188 \\
24,898 \\
55,176 \\
9,199 \\
18,829 \\
2,688\end{array}$ & $\begin{array}{r}1,406 \\
10,507 \\
24,585 \\
7,091 \\
10,815 \\
1,515\end{array}$ & $\begin{array}{r}404 \\
3,721 \\
4,041 \\
1,802 \\
3,396 \\
636\end{array}$ & $\begin{array}{r}378 \\
10,670 \\
26,550 \\
306 \\
4,618 \\
537 \\
\end{array}$ \\
\hline Other jurisdictions ... & 44,785 & 37,328 & 24,098 & 22,045 & 4,791 & 16,436 & 818 & 25,914 & 5,421 & 19,579 & 1,276 \\
\hline 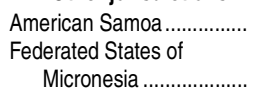 & 662 & 838 & 169 & 225 & 38 & 52 & 135 & 132 & 0 & 34 & 98 \\
\hline 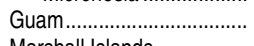 & 1,092 & $\begin{array}{r}1,062 \\
0\end{array}$ & $\begin{array}{r}633 \\
0\end{array}$ & $\begin{array}{r}539 \\
0\end{array}$ & 364 & $\begin{array}{r}59 \\
0\end{array}$ & 116 & $\begin{array}{r}873 \\
0\end{array}$ & $\begin{array}{r}713 \\
0\end{array}$ & 58 & $\begin{array}{r}102 \\
0\end{array}$ \\
\hline 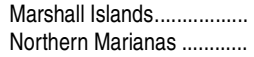 & $\begin{array}{l}335 \\
680\end{array}$ & $\begin{array}{r}0 \\
740\end{array}$ & $\begin{array}{r}0 \\
607\end{array}$ & $\begin{array}{r}0 \\
607\end{array}$ & $\begin{array}{r}0 \\
369\end{array}$ & $\begin{array}{r}0 \\
90\end{array}$ & $\begin{array}{r}0 \\
148\end{array}$ & $\begin{array}{r}0 \\
455\end{array}$ & $\begin{array}{r}0 \\
93\end{array}$ & $\begin{array}{r}0 \\
305\end{array}$ & $\begin{array}{r}0 \\
57\end{array}$ \\
\hline 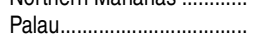 & 132 & 206 & 63 & 56 & 0 & 56 & $\begin{array}{r}140 \\
0\end{array}$ & 76 & 0 & 76 & 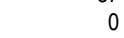 \\
\hline Puerto Rico........................... & 41,043 & 33,463 & 22,626 & 20,464 & 3,873 & 16,172 & 419 & 24,378 & 4,261 & 19,098 & 1,019 \\
\hline U.S. Virgin Islands ................... & 841 & 1,019 & 0 & 154 & 147 & 7 & 0 & - & 354 & 8 & - \\
\hline
\end{tabular}

-Not available.

NOTE: Adult basic education provides instruction in basic skills for adults 16 and over functioning at literacy levels below the secondary level. Adult secondary education provides instruction at the high school level for adults who are seeking to pass the GED or obtain an adult high school credential. English as a second language instruction is for adults who lack proficiency in English and who seek to improve their literacy and competence in English.

SOURCE: U.S. Department of Education, Office of Vocational and Adult Education (OVAE) OVAE National Reporting System, retrieved August 30, 2013, from http://wdcrobcolp01.ed.gov/ CFAPPS/OVAE/NRS/reports/index.cfm. (This table was prepared August 2013.) 


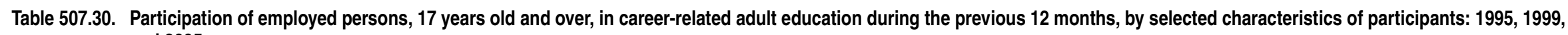
and 2005

[Standard errors appear in parentheses]

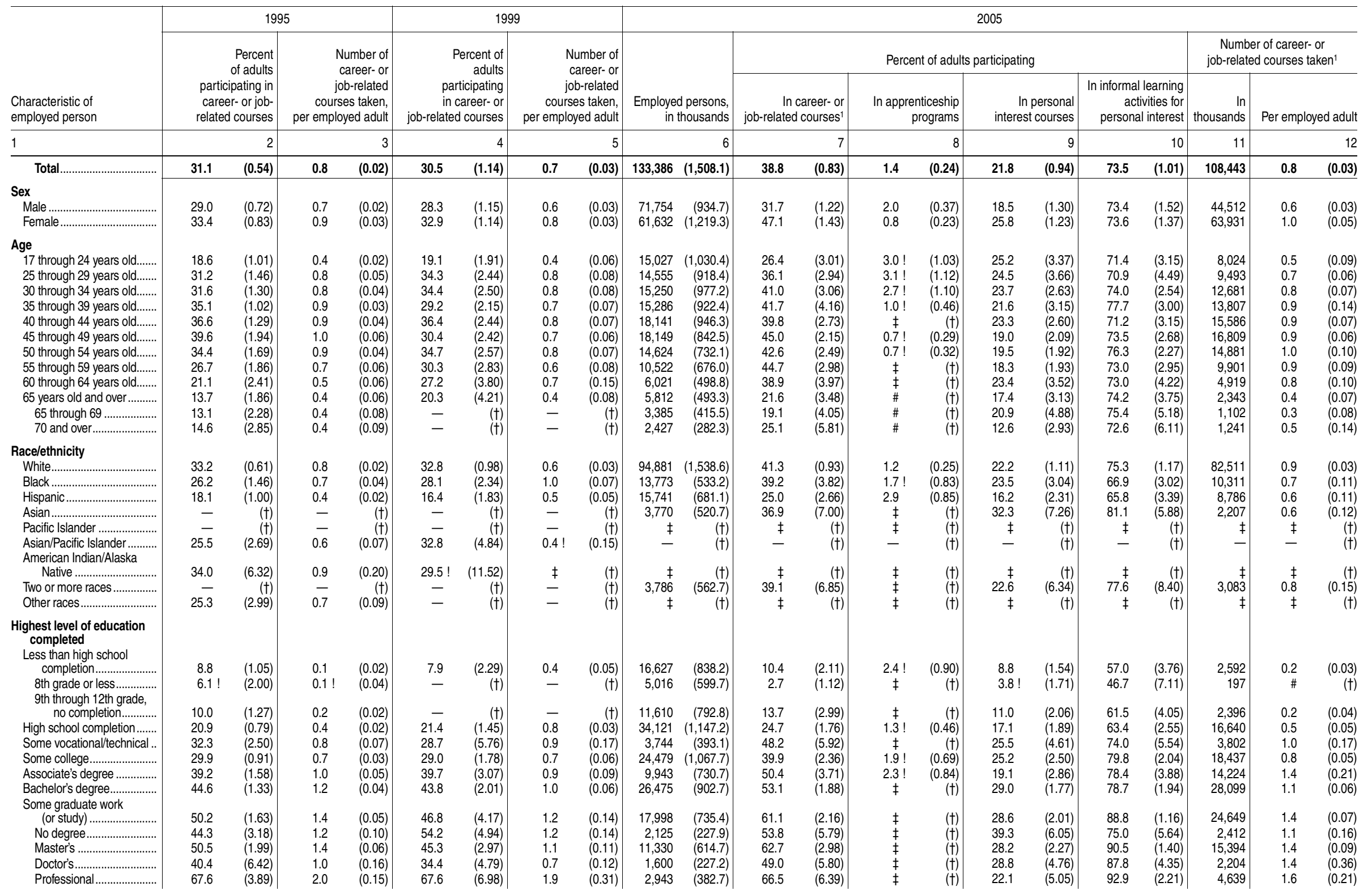

See notes at end of table. 


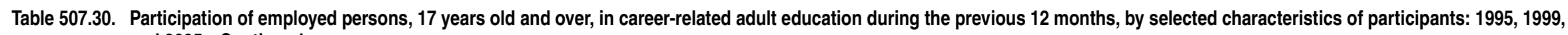
and 2005-Continued

[Standard errors appear in parentheses]

\begin{tabular}{|c|c|c|c|c|c|c|c|c|c|c|c|c|c|c|c|c|c|c|c|c|c|}
\hline \multirow[b]{3}{*}{$\begin{array}{l}\text { Characteristic of } \\
\text { employed person }\end{array}$} & \multicolumn{4}{|c|}{1995} & \multicolumn{4}{|c|}{1999} & \multicolumn{13}{|c|}{2005} \\
\hline & \multirow{2}{*}{\multicolumn{2}{|c|}{$\begin{array}{r}\text { Percent } \\
\text { of adults } \\
\text { participating in } \\
\text { career- or job- } \\
\text { related courses }\end{array}$}} & \multirow{2}{*}{\multicolumn{2}{|c|}{$\begin{array}{r}\text { Number of } \\
\text { career- or } \\
\text { job-related } \\
\text { courses taken, } \\
\text { per employed adult }\end{array}$}} & \multirow{2}{*}{\multicolumn{2}{|c|}{$\begin{array}{r}\text { Percent of } \\
\text { adults } \\
\text { participating } \\
\text { in career- or } \\
\text { job-related courses }\end{array}$}} & \multirow{2}{*}{\multicolumn{2}{|c|}{$\begin{array}{r}\text { Number of } \\
\text { career- or } \\
\text { job-related } \\
\text { courses taken, } \\
\text { per employed adult }\end{array}$}} & \multirow{2}{*}{\multicolumn{2}{|c|}{$\begin{array}{r}\text { Employed persons, } \\
\text { in thousands }\end{array}$}} & \multicolumn{8}{|c|}{ Percent of adults participating } & \multicolumn{3}{|c|}{$\begin{array}{l}\text { Number of career- or } \\
\text { job-related courses taken }\end{array}$} \\
\hline & & & & & & & & & & & $\begin{aligned} \ln c \\
\text { job-related }\end{aligned}$ & $\begin{array}{l}\text { er- or } \\
\text { urses }^{1}\end{array}$ & $\begin{array}{r}\text { In apprer } \\
\mathrm{p}\end{array}$ & iceship & $\begin{array}{r}\ln \\
\text { interest }\end{array}$ & $\begin{array}{l}\text { rsonal } \\
\text { Durses }\end{array}$ & $\begin{array}{r}\text { In informa } \\
\text { ac } \\
\text { person }\end{array}$ & $\begin{array}{l}\text { learning } \\
\text { ivities for } \\
\text { I interest }\end{array}$ & $\begin{array}{r}\ln \\
\text { thousands }\end{array}$ & Per emplo & ed adult \\
\hline 1 & & 2 & & 3 & & 4 & & 5 & & 6 & & 7 & & 8 & & 9 & & 10 & 11 & & 12 \\
\hline 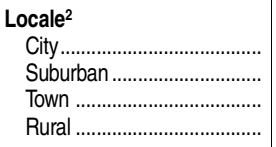 & $\begin{array}{l}- \\
- \\
- \\
-\end{array}$ & $\begin{array}{l}(+) \\
(\dagger) \\
(\dagger) \\
(\dagger)\end{array}$ & $\begin{array}{l}- \\
- \\
- \\
-\end{array}$ & $\begin{array}{l}(t) \\
(+) \\
(+) \\
(t)\end{array}$ & $\begin{array}{l}- \\
- \\
-\end{array}$ & $\begin{array}{l}(t) \\
(t) \\
(t) \\
(t)\end{array}$ & $\begin{array}{l}- \\
\overline{-} \\
-\end{array}$ & $\begin{array}{l}(t) \\
(t) \\
(t) \\
(t)\end{array}$ & $\begin{array}{l}39,283 \\
48,452 \\
17,616 \\
27,847\end{array}$ & $\begin{array}{r}(1,391.3) \\
(1,555.0) \\
(1,060.7) \\
(885.2)\end{array}$ & $\begin{array}{l}39.6 \\
41.1 \\
36.0 \\
35.4\end{array}$ & $\begin{array}{l}(1.67) \\
(1.87) \\
(2.64) \\
(2.14)\end{array}$ & $\begin{array}{c}2.2 \\
1.2 \\
\ddagger \\
1.4 !\end{array}$ & $\left.\begin{array}{r}(0.60) \\
(0.32) \\
(t) \\
(0.58)\end{array}\right]$ & $\begin{array}{l}23.1 \\
23.3 \\
19.6 \\
19.0\end{array}$ & $\begin{array}{l}(1.43) \\
(1.38) \\
(2.83) \\
(2.19)\end{array}$ & $\begin{array}{l}74.0 \\
74.2 \\
71.7 \\
72.7\end{array}$ & $\begin{array}{l}(1.77) \\
(1.49) \\
(3.02) \\
(2.22)\end{array}$ & $\begin{array}{l}34,327 \\
39,802 \\
12,947 \\
21,135\end{array}$ & $\begin{array}{l}0.9 \\
0.8 \\
0.7 \\
0.8\end{array}$ & $\begin{array}{l}(0.05) \\
(0.04) \\
(0.07) \\
(0.06)\end{array}$ \\
\hline $\begin{array}{l}\text { Occupation } \\
\text { Executive, administrative, or }\end{array}$ & & & & & & & & & & & & & & & & & & & & & \\
\hline $\begin{array}{l}\text { managerial occupations. } \\
\text { Engineers, surveyors, and } \\
\text { architects................... }\end{array}$ & $\begin{array}{l}42.9 \\
44.2\end{array}$ & $\begin{array}{l}(1.49) \\
(4.46)\end{array}$ & $\begin{array}{l}1.2 \\
1.1\end{array}$ & $\begin{array}{l}(0.05) \\
(0.12)\end{array}$ & $\begin{array}{l}40.6 \\
52.1\end{array}$ & $\begin{array}{l}(2.06) \\
(6.96)\end{array}$ & $\begin{array}{l}1.0 \\
1.0\end{array}$ & $\begin{array}{l}(0.07) \\
(0.16)\end{array}$ & $\begin{array}{r}14,596 \\
1,987\end{array}$ & $\begin{array}{l}(707.6) \\
(244.9)\end{array}$ & $\begin{array}{l}53.6 \\
56.3\end{array}$ & $\begin{array}{l}(2.79) \\
(5.68)\end{array}$ & $\begin{array}{l}\ddagger \\
\ddagger\end{array}$ & $\begin{array}{l}(t) \\
(\dagger)\end{array}$ & $\begin{array}{l}29.5 \\
30.5\end{array}$ & $\begin{array}{l}(2.89) \\
(6.36)\end{array}$ & $\begin{array}{l}77.7 \\
81.0\end{array}$ & $\begin{array}{l}(2.87) \\
(4.73)\end{array}$ & $\begin{array}{r}16,567 \\
2,323\end{array}$ & $\begin{array}{l}1.1 \\
1.2\end{array}$ & $\begin{array}{l}(0.09) \\
(0.16)\end{array}$ \\
\hline $\begin{array}{l}\text { Natural scientists and } \\
\text { mathematicians............. }\end{array}$ & 59.7 & $(3.97)$ & 1.7 & $(0.15)$ & 46.0 & $(6.61)$ & 0.8 & $(0.14)$ & 4,130 & $(445.4)$ & 51.5 & $(5.64)$ & $\ddagger$ & $(\dagger)$ & 31.2 & $(4.83)$ & 85.3 & $(5.44)$ & 3,693 & 0.9 & $(0.11)$ \\
\hline $\begin{array}{l}\text { Social scientists and } \\
\quad \text { workers, religious } \\
\quad \text { workers, and lawyers .... } \\
\text { Teachers elementary/ }\end{array}$ & 59.5 & (2.61) & 1.8 & $(0.11)$ & 56.9 & (5.66) & 1.7 & $(0.24)$ & 4,697 & (480.9) & 66.8 & (4.48) & $\ddagger$ & (t) & 28.3 & $(3.81)$ & 88.6 & (2.95) & 7,822 & 1.7 & $(0.29)$ \\
\hline $\begin{array}{l}\text { secondary...................... } \\
\text { Teachers, postsecondary }\end{array}$ & 53.9 & $(2.23)$ & 1.5 & $(0.08)$ & 52.1 & (3.53) & 1.2 & $(0.11)$ & 7,085 & $(568.5)$ & 67.7 & $(4.16)$ & $\ddagger$ & $(\dagger)$ & 31.5 & $(3.93)$ & 83.0 & (2.79) & 12,233 & 1.7 & $(0.13)$ \\
\hline $\begin{array}{l}\text { and counselors, } \\
\text { librarians, and archivists. } \\
\text { Health diagnosing and }\end{array}$ & 41.6 & $(4.57)$ & 1.0 & $(0.15)$ & 35.6 & (5.85) & 0.7 & $(0.14)$ & 2,393 & (420.9) & 53.1 & (8.63) & $\ddagger$ & (†) & 17.7 & (4.91) & 90.9 & (3.97) & 2,122 & 0.9 & $(0.09)$ \\
\hline $\begin{array}{l}\text { treating practitioners...... } \\
\text { Registered nurses, } \\
\text { pharmacists, dieticians, }\end{array}$ & 68.6 & $(5.85)$ & 2.0 & $(0.23)$ & 65.2 & (11.99) & $1.5 !$ & (0.50) & 978 & $(208.8)$ & 78.9 & (7.10) & $\ddagger$ & $(t)$ & $27.4 !$ & $(9.60)$ & 86.6 & (5.37) & 1,951 & 2.0 & $(0.25)$ \\
\hline $\begin{array}{l}\text { therapists, and } \\
\text { physician's assistants.... } \\
\text { Writers, artists, entertainers. }\end{array}$ & 72.8 & (3.02) & 2.2 & $(0.14)$ & 72.2 & $(5.04)$ & 1.8 & $(0.21)$ & 2,794 & (238.8) & 79.7 & $(4.60)$ & $\ddagger$ & $(\dagger)$ & 29.4 & $(4.17)$ & 84.3 & (3.70) & 4,984 & 1.8 & $(0.15)$ \\
\hline $\begin{array}{l}\text { and ath } \\
\text { Heathtech }\end{array}$ & 23.4 & $(2.89)$ & 0.5 & $(0.07)$ & 30.6 & $(6.21)$ & 0.6 & $(0.18)$ & 2,969 & (405.2) & 29.9 & $(5.69)$ & $\ddagger$ & $(\mathrm{t})$ & 31.8 & $(6.15)$ & 88.9 & (4.39) & 1,865 & 0.6 & $(0.15)$ \\
\hline technicians .............. & 50.0 & $(4.08)$ & 1.4 & $(0.12)$ & 41.8 & $(6.00)$ & 1.0 & $(0.19)$ & 3,060 & $(436.7)$ & 70.6 & $(7.31)$ & $\ddagger$ & $(\mathrm{t})$ & 27.8 & $(6.48)$ & 77.5 & (6.40) & 4,473 & 1.5 & $(0.18)$ \\
\hline $\begin{array}{l}\text { Technologists and } \\
\text { technicians, except } \\
\text { health............................... }\end{array}$ & 43.8 & (2.67) & 1.1 & $(0.10)$ & 37.6 & (4.87) & 1.0 & $(0.15)$ & 1,774 & (336.5) & 29.4 & (8.10) & $\ddagger$ & (t) & $5.3 !$ & $(2.02)$ & 75.2 & (8.98) & 1,015 & 0.6 & $(0.17)$ \\
\hline $\begin{array}{l}\text { Marketing and sales } \\
\quad \text { occupations }\end{array}$ & 25.2 & (1.26) & 0.6 & $(0.03)$ & 21.1 & $(2.27)$ & 0.4 & $(0.06)$ & 14,845 & (971.9) & 32.3 & $(3.17)$ & $\ddagger$ & $(\dagger)$ & 20.8 & $(2.64)$ & 70.5 & (3.53) & 7,724 & 0.5 & $(0.05)$ \\
\hline $\begin{array}{l}\text { Administrative support } \\
\text { occupations, including }\end{array}$ & & & & & & & & & & & & & & & & & & & & & \\
\hline & 30.8 & (1.15) & 0.7 & $(0.03)$ & 27.4 & (2.02) & 0.6 & $(0.05)$ & 21,167 & $(1,179.4)$ & 36. & (2.95) & $0.8 !$ & $(0.40)$ & 28. & $(2.28)$ & 72.9 & (2.37) & 15,443 & 0.7 & $(0.10)$ \\
\hline $\begin{array}{l}\text { Service occupations............ } \\
\text { Agriculture, forestry, and }\end{array}$ & 22.6 & $(1.25)$ & 足 & 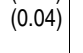 & 21.0 & $(2.15)$ & 0.5 & $(0.07)$ & 17,180 & $(1,033.7)$ & 33.7 & $(3.13)$ & $1.1 !$ & $(0.36)$ & 16.2 & $(2.31)$ & 69.0 & $(2.74)$ & 13,029 & 0.8 & $(0.10)$ \\
\hline 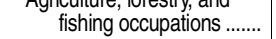 & 12. & (2.47) & 0.3 & $(0.07)$ & $12.2 !$ & $(4.09)$ & $0.2 !$ & $(0.07)$ & 2,522 & (423.8) & $22.4 !$ & $(7.61)$ & $\ddagger$ & $(\dagger)$ & $23.0 !$ & (11.03) & 62.9 & $(11.04)$ & 960 & $0.4 !$ & $(0.12)$ \\
\hline $\begin{array}{l}\text { Mechanics and repairers..... } \\
\text { Construction and extractive }\end{array}$ & 29.1 & (2.62) & 0.7 & (2006 & 15.0 & (3.40) & 0.3 & $(0.09)$ & 5,241 & 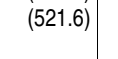 & 28.3 & $(4.47)$ & $4.0 !$ & $(1.44)$ & 12.6 & $(3.24)$ & 69.3 & $(4.36)$ & 2,669 & 0.5 & $(0.09)$ \\
\hline $\begin{array}{l}\text { occupations .................. } \\
\text { Precision production }\end{array}$ & $\begin{array}{l}18.6 \\
256\end{array}$ & $\begin{array}{l}(2.33) \\
(4.04)\end{array}$ & $\begin{array}{l}0.3 \\
0.6\end{array}$ & $\begin{array}{l}(0.04) \\
(0.12)\end{array}$ & $\begin{array}{l}13.2 \\
18.31\end{array}$ & $\begin{array}{l}(3.16) \\
(6.52)\end{array}$ & $\begin{array}{l}0.2 \\
0.4 !\end{array}$ & $\begin{array}{l}(0.06) \\
(0.12)\end{array}$ & $\begin{array}{r}6,827 \\
10,483\end{array}$ & $\begin{array}{l}(647.1) \\
(839.3)\end{array} \mid$ & $\begin{array}{l}12.4 \\
23.5\end{array}$ & $\begin{array}{l}(3.04) \\
(3.79)\end{array}$ & $5.3 !$ & $\begin{array}{l}(2.26) \\
(+)\end{array}$ & $\begin{array}{r}7.8 \\
140\end{array}$ & $\begin{array}{l}(1.88) \\
(3.34)\end{array}$ & $\begin{array}{l}69.0 \\
64.9\end{array}$ & $\begin{array}{l}(5.25) \\
(3.74)\end{array}$ & $\begin{array}{l}2,323 \\
4,904\end{array}$ & $0.3 !$ & $\begin{array}{l}(0.13) \\
(0.07)\end{array}$ \\
\hline Production workers............ & 14.8 & (1.13) & 0.3 & (0.02) & 23.0 & $(3.17)$ & 0.5 & $(0.08)$ & - & $(t)$ & - & $(t)$ & \pm & $(+)$ & - & $\left.\begin{array}{rl}(t) & -1\end{array}\right)$ & - & $(t)$ & - & - & $(t)$ \\
\hline
\end{tabular}




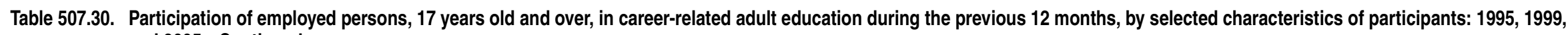
and 2005-Continued

[Standard errors appear in parentheses]

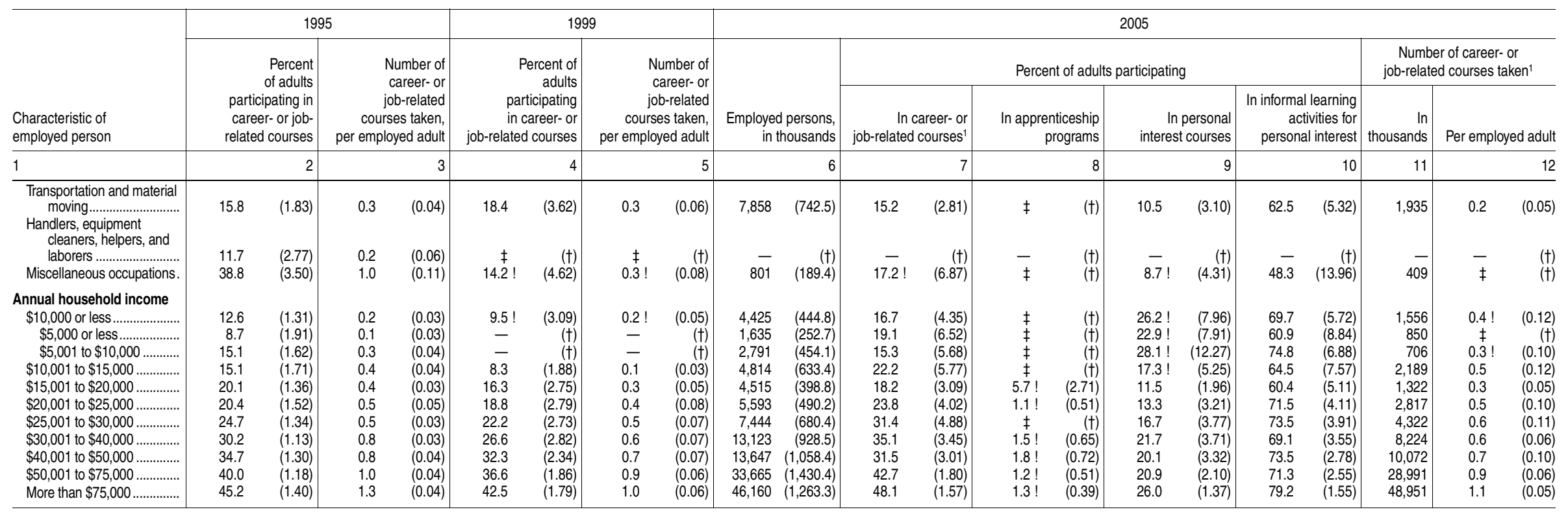

\section{-Not available.}

Not applicable.

Interpret data with caution. The coefficient of variation (CV) for this estimate is between 30 and 50 percent. Reporting standards not met. The coefficient of variation (CV) for this estimate is 50 percent or greater.

'The 2005 estimates on participation in career- or job-related courses were based on responses to multiple questions. Speciically, respondents were first asked what courses they had taken, and then whether each course was career-or job-related. In contrast, 1995 and 1999 respondents were asked a single, general question about whether they had participated in any
career- or job-related courses. Therefore, 2005 results may not be comparable to results from the earlier years.

2Detail may not sum to totals due to missing locale information.

NOTE: Data do not include persons enrolled in high school or below. Race categories exclude persons of Hispanic ethnicity. Detail may not sum to totals because of rounding. SOURCE: U.S. Department of Education, National Center Household Education Surveys Program. (This table was prepared AE-NHES:1999, and AE-NHES:2005) of the National Household Education Surveys Program. (This table was prepared
October 2010.) 
Table 507.40. Participation rate of persons, 17 years old and over, in adult education during the previous 12 months, by selected characteristics of participants: Selected years, 1991 through 2005

[Standard errors appear in parentheses]

\begin{tabular}{|c|c|c|c|c|c|c|c|c|c|c|c|c|c|c|c|c|c|c|c|c|c|c|c|c|}
\hline & \multicolumn{10}{|c|}{ Percent taking any program, class, or course } & \multicolumn{12}{|c|}{ Percent taking specific programs, classes, or courses, 2005} & \multirow{2}{*}{\multicolumn{2}{|c|}{$\begin{array}{r}\text { Percent doing } \\
\text { informal learning } \\
\text { activities for } \\
\text { persona } \\
\text { interest, } 2005\end{array}$}} \\
\hline & & 1991 & & 1995 & & 1999 & & 2001 & & 2005 & $\begin{array}{r}\text { Ba } \\
\text { Edi } \\
\text { Deve } \\
(\text { GED }\end{array}$ & $\begin{array}{l}\text { ic skills/ } \\
\text { General } \\
\text { cational } \\
\text { opment } \\
\text { classes }\end{array}$ & \multicolumn{2}{|c|}{$\begin{array}{r}\text { English as a } \\
\text { second language } \\
\text { (ESL) classes }\end{array}$} & \multicolumn{2}{|c|}{$\begin{array}{r}\text { Part-time post- } \\
\text { secondary } \\
\text { education }{ }^{1}\end{array}$} & \multicolumn{2}{|c|}{$\begin{array}{r}\text { Career- or job- } \\
\text { related courses }\end{array}$} & \multicolumn{2}{|c|}{$\begin{array}{r}\text { Apprenticeship } \\
\text { programs }\end{array}$} & \multicolumn{2}{|c|}{$\begin{array}{r}\text { Personal-interest } \\
\text { courses }\end{array}$} & & \\
\hline Characteristic of participant & & 2 & & 3 & & 4 & & 5 & & 6 & & 7 & & 8 & & 9 & & 10 & & 11 & & 12 & & 13 \\
\hline Total .............................................. & 33.0 & $(0.68)$ & 40.2 & $(0.48)$ & 44.5 & $(0.77)$ & 46.4 & $(0.55)$ & 44.4 & $(0.74)$ & 1.3 & $(0.22)$ & 0.9 & $(0.17)$ & 5.0 & $(0.29)$ & 27.0 & $(0.63)$ & 1.2 & $(0.18)$ & 21.4 & $(0.71)$ & 70.5 & $(0.79)$ \\
\hline 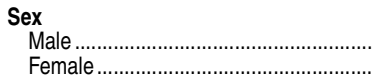 & $\begin{array}{l}32.6 \\
33.2\end{array}$ & $\begin{array}{l}(1.09) \\
(0.97)\end{array}$ & $\begin{array}{l}38.2 \\
42.1\end{array}$ & $\begin{array}{l}(0.65) \\
(0.59)\end{array}$ & $\begin{array}{l}41.7 \\
47.1\end{array}$ & $\begin{array}{l}(1.15) \\
(1.02)\end{array}$ & $\begin{array}{l}43.1 \\
49.5\end{array}$ & $\begin{array}{l}(0.83) \\
(0.78)\end{array}$ & $\begin{array}{l}41.0 \\
47.5\end{array}$ & $\begin{array}{l}(1.20) \\
(1.01)\end{array}$ & $\begin{array}{l}1.4 \\
1.2\end{array}$ & $\begin{array}{l}(0.41) \\
(0.19)\end{array}$ & $\begin{array}{l}0.9 ! \\
0.9\end{array}$ & $\begin{array}{l}(0.29) \\
(0.15)\end{array}$ & $\begin{array}{l}5.0 \\
5.1\end{array}$ & $\begin{array}{l}(0.44) \\
(0.37)\end{array}$ & $\begin{array}{l}24.5 \\
29.2\end{array}$ & $\begin{array}{l}(0.99) \\
(0.95)\end{array}$ & $\begin{array}{l}1.7 \\
0.7\end{array}$ & $\begin{array}{l}(0.31) \\
(0.15)\end{array}$ & $\begin{array}{l}18.3 \\
24.2\end{array}$ & $\begin{array}{l}(1.08) \\
(0.88)\end{array}$ & $\begin{array}{l}70.8 \\
70.2\end{array}$ & $\begin{array}{l}(1.10) \\
(1.03)\end{array}$ \\
\hline 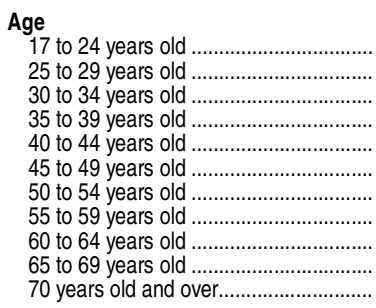 & $\begin{array}{r}37.8 \\
40.0 \\
37.6 \\
42.1 \\
49.2 \\
40.0 \\
26.8 \\
29.0 \\
17.4 \\
14.2 \\
8.6\end{array}$ & $\begin{array}{l}(1.46) \\
(2.33) \\
(2.88) \\
(2.71) \\
(3.28) \\
(2.43) \\
(3.31 \\
(3.74) \\
(1.90) \\
(2.97) \\
(1.25)\end{array}$ & $\begin{array}{l}47.0 \\
49.6 \\
47.3 \\
47.7 \\
50.9 \\
48.7 \\
42.5 \\
32.2 \\
23.7 \\
18.1 \\
13.8\end{array}$ & $\begin{array}{l}(1.12) \\
(1.31) \\
(1.41) \\
(1.15) \\
(1.15) \\
(1.66) \\
(1.38) \\
(1.66) \\
(1.89) \\
(1.46) \\
(1.09)\end{array}$ & $\begin{array}{l}49.9 \\
56.5 \\
56.2 \\
50.1 \\
50.5 \\
49.8 \\
47.2 \\
38.0 \\
31.4 \\
25.4 \\
15.0\end{array}$ & $\begin{array}{l}(2.34) \\
(2.53) \\
(2.57) \\
(2.43) \\
(2.43) \\
(2.69) \\
(2.51) \\
(2.60) \\
(2.83) \\
(2.54) \\
(1.38)\end{array}$ & $\begin{array}{l}52.8 \\
52.9 \\
53.7 \\
54.0 \\
53.5 \\
55.4 \\
51.1 \\
44.1 \\
30.8 \\
20.5 \\
21.7\end{array}$ & $\begin{array}{l}(2.04) \\
(2.60) \\
(2.18) \\
(1.71) \\
(1.88) \\
(2.02) \\
(2.22) \\
(1.98) \\
(2.18) \\
(1.74) \\
(1.37)\end{array}$ & $\begin{array}{l}52.8 \\
51.6 \\
52.7 \\
48.6 \\
48.9 \\
49.0 \\
46.6 \\
42.2 \\
37.9 \\
26.2 \\
21.5\end{array}$ & $\begin{array}{l}(2.79) \\
(3.82) \\
(2.52) \\
(3.21) \\
(2.43) \\
(2.09) \\
(2.36) \\
(2.78) \\
(3.00) \\
(2.67) \\
(1.44)\end{array}$ & $\begin{array}{l}6.0 \\
1.8 \\
1.9 ! \\
0.4 ! \\
0.8 ! \\
\ddagger \\
\ddagger \\
\ddagger \\
\neq \\
\neq \\
\neq \\
\ddagger\end{array}$ & $\begin{array}{r}(1.48) \\
(0.48) \\
(0.66) \\
(0.16) \\
(0.31) \\
(+) \\
(+) \\
(+) \\
(+) \\
(+) \\
(+)\end{array}$ & $\begin{array}{c}1.7 ! \\
3.3 ! \\
1.6 ! \\
0.7 ! \\
0.6 ! \\
0.6 ! \\
0.3 ! \\
\ddagger \\
\ddagger \\
\ddagger \\
\ddagger\end{array}$ & $\begin{array}{r}(0.61) \\
(1.48) \\
(0.64) \\
(0.26) \\
(0.23) \\
(0.25) \\
(0.15) \\
(+) \\
(+) \\
(+) \\
(+)\end{array}$ & $\begin{array}{c}11.5 \\
9.1 \\
8.4 \\
6.1 \\
4.7 \\
3.2 \\
4.5 \\
1.9 \\
0.9 ! \\
0.5 ! \\
\ddagger\end{array}$ & $\begin{array}{r}(1.34) \\
(1.50) \\
(1.28) \\
(0.90) \\
(0.77) \\
(0.48) \\
(0.75) \\
(0.43) \\
(0.36) \\
(0.22) \\
(\dagger)\end{array}$ & $\begin{array}{r}21.3 \\
29.5 \\
33.8 \\
32.6 \\
34.8 \\
37.7 \\
35.2 \\
31.9 \\
20.9 \\
8.1 \\
4.0\end{array}$ & $\begin{array}{l}(2.22) \\
(2.48) \\
(2.71) \\
(3.29) \\
(2.30) \\
(1.83) \\
(2.25) \\
(2.39) \\
(2.07) \\
(1.36) \\
(0.78)\end{array}$ & $\begin{array}{l}2.7 \\
3.2 ! \\
2.5 ! \\
0.9 ! \\
0.9 ! \\
0.5 ! \\
0.6 ! \\
\neq \\
\neq \\
\neq \\
\ddagger \\
\ddagger\end{array}$ & $\begin{array}{r}(0.76) \\
(1.06) \\
(0.89) \\
(0.36) \\
(0.42) \\
(0.23) \\
(0.28) \\
(\dagger) \\
(\dagger) \\
(\dagger) \\
(\dagger)\end{array}$ & $\begin{array}{l}26.3 \\
20.9 \\
23.2 \\
20.7 \\
23.4 \\
19.3 \\
20.3 \\
18.0 \\
24.1 \\
20.9 \\
17.9\end{array}$ & $\begin{array}{l}(2.60) \\
(2.78) \\
(2.23) \\
(2.67) \\
(2.29) \\
(1.88) \\
(1.64) \\
(1.63) \\
(2.40) \\
(2.41) \\
(1.33)\end{array}$ & $\begin{array}{l}69.2 \\
6.8 \\
73.8 \\
75.5 \\
71.5 \\
71.6 \\
75.6 \\
69.5 \\
71.4 \\
67.6 \\
62.9\end{array}$ & $\begin{array}{l}(2.54) \\
(3.75) \\
(2.22) \\
(2.69) \\
(2.62) \\
(2.52) \\
(1.89) \\
(2.56) \\
(3.04) \\
(2.52) \\
(1.82)\end{array}$ \\
\hline 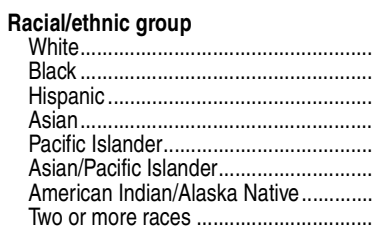 & $\begin{array}{r}34.1 \\
25.9 \\
31.4 \\
- \\
-\overline{-} \\
35.9 \\
29.3 ! \\
-\end{array}$ & \begin{tabular}{r|}
$(0.82)$ \\
$(2.23)$ \\
$(2.63)$ \\
$(\dagger)$ \\
$(\dagger)$ \\
$(5.55)$ \\
$(11.55)$ \\
$(\dagger)$
\end{tabular} & $\begin{array}{r}41.5 \\
37.0 \\
33.7 \\
- \\
- \\
39.7 \\
38.8 \\
-\end{array}$ & $\begin{array}{r}(0.54) \\
(1.45) \\
(1.18) \\
(\dagger) \\
(\dagger) \\
(2.92) \\
(4.85) \\
(\dagger)\end{array}$ & $\begin{array}{r}44.4 \\
46.3 \\
41.3 \\
- \\
- \\
51.1 \\
36.3 \\
-\end{array}$ & 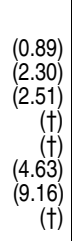 & $\begin{array}{r}47.4 \\
43.3 \\
41.7 \\
- \\
- \\
49.5 \\
50.2 \\
-\end{array}$ & $\begin{array}{r}(0.59) \\
(1.50) \\
(2.28) \\
(\dagger) \\
(t) \\
(3.81) \\
(8.28) \\
(\dagger)\end{array}$ & $\begin{array}{r}45.6 \\
46.4 \\
37.8 \\
48.3 \\
\ddagger \\
\neq \\
\\
36.3 \\
39.4\end{array}$ & $\begin{array}{r}(0.84) \\
(2.81 \\
(2.43) \\
(5.39) \\
(\dagger) \\
(\dagger) \\
(10.17) \\
(4.94)\end{array}$ & $\begin{array}{r}0.9 \\
1.9 \\
2.6 \\
\ddagger \\
\ddagger \\
\neq \\
\neq \\
\neq \\
5.1 !\end{array}$ & $\begin{array}{r}(0.23) \\
(0.49) \\
(0.72) \\
(+) \\
(+) \\
(+) \\
(+) \\
(2.17)\end{array}$ & $\begin{array}{c}0.2 ! \\
\ddagger \\
5.6 \\
2.6 ! \\
\ddagger \\
\neq \\
\ddagger \\
\ddagger \\
\ddagger\end{array}$ & $\begin{array}{r}(0.08) \\
(+) \\
(1.22) \\
(1.03) \\
(+) \\
(\dagger) \\
(\dagger) \\
(\dagger)\end{array}$ & $\begin{array}{c}4.9 \\
5.4 \\
5.7 \\
7.6 ! \\
\ddagger \\
\neq \\
4.4 ! \\
3.2 !\end{array}$ & $\begin{array}{r}(0.35) \\
(0.97) \\
(1.55) \\
(2.62) \\
(\dagger) \\
(\dagger) \\
(1.82) \\
(1.07)\end{array}$ & $\begin{array}{r}29.1 \\
27.0 \\
16.9 \\
27.2 \\
\neq \\
\neq \\
\neq \\
23.0 ! \\
23.8\end{array}$ & $\begin{array}{r}(0.70) \\
(2.53) \\
(1.72) \\
(4.70) \\
(+) \\
(+) \\
(8.51) \\
(4.06)\end{array}$ & $\begin{aligned} 0.9 \\
1.5 ! \\
2.2 \\
\neq \\
\neq \\
\neq \\
\neq \\
\neq \\
1.3 !\end{aligned}$ & $\begin{array}{r}(0.17) \\
(0.73) \\
(0.63) \\
(\dagger) \\
(\dagger) \\
(\dagger) \\
(\dagger) \\
(0.59)\end{array}$ & $\begin{array}{r}22.1 \\
23.7 \\
15.4 \\
26.5 \\
\neq \\
\neq \\
\neq \\
13.0 ! \\
21.0\end{array}$ & $\begin{array}{r}(0.87) \\
(2.11) \\
(1.75) \\
(5.06) \\
(\dagger) \\
(\dagger) \\
(6.16) \\
(4.13)\end{array}$ & $\begin{array}{r}73.0 \\
65.3 \\
57.5 \\
81.1 \\
\neq \\
\neq \\
70.6 \\
77.6\end{array}$ & $\begin{array}{r}(0.92) \\
(2.02) \\
(2.86) \\
(4.10) \\
(+) \\
(+) \\
(9.18) \\
(5.28)\end{array}$ \\
\hline 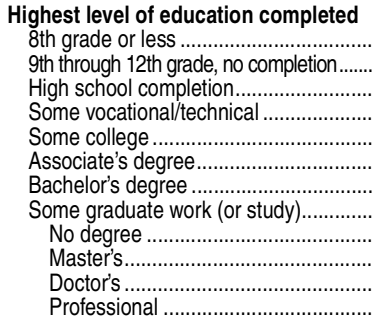 & $\begin{array}{r}7.7 \\
15.8 \\
24.1 \\
34.2 \\
41.4 \\
49.2 \\
51.1 \\
55.1 \\
= \\
= \\
-\end{array}$ & $\begin{array}{r}(1.44) \\
(2.25) \\
(1.10) \\
(3.80) \\
(1.67) \\
(5.82) \\
(2.46) \\
(2.90) \\
(\dagger) \\
(\dagger) \\
(\dagger) \\
(\dagger)\end{array}$ & $\begin{array}{l}10.0 \\
20.2 \\
30.7 \\
41.9 \\
49.3 \\
56.1 \\
56.9 \\
59.9 \\
62.2 \\
59.1 \\
54.0 \\
65.9\end{array}$ & $\begin{array}{l}(1.10) \\
(1.38) \\
(0.84) \\
(2.16) \\
(0.92) \\
(1.85) \\
(1.20) \\
(1.55) \\
(2.67) \\
(1.88) \\
(6.99) \\
(3.91)\end{array}$ & $\begin{array}{l}14.7 \\
25.6 \\
34.8 \\
41.1 \\
51.1 \\
56.6 \\
60.3 \\
63.6 \\
64.7 \\
65.7 \\
53.1 \\
72.5\end{array}$ & $\begin{array}{l}(2.92) \\
(2.55) \\
(1.37) \\
(3.97) \\
(1.76) \\
(2.93) \\
(1.84) \\
(1.96) \\
(4.39) \\
(2.64) \\
(4.73) \\
(5.75)\end{array}$ & $\begin{array}{l}19.7 \\
25.5 \\
33.9 \\
50.7 \\
57.4 \\
62.5 \\
64.5 \\
68.9 \\
64.2 \\
70.7 \\
63.7 \\
72.8\end{array}$ & $\begin{array}{l}(2.84) \\
(1.53) \\
(1.07) \\
(3.51) \\
(1.29) \\
(2.15) \\
(1.39) \\
(1.64) \\
(3.54) \\
(2.10) \\
(3.98) \\
(3.79)\end{array}$ & $\begin{array}{l}15.5 \\
27.2 \\
33.0 \\
43.3 \\
51.1 \\
56.5 \\
59.8 \\
66.3 \\
65.3 \\
67.5 \\
58.0 \\
68.2\end{array}$ & $\begin{array}{l}(2.47) \\
(2.40) \\
(1.62) \\
(4.30) \\
(1.79) \\
(3.64) \\
(1.56) \\
(1.99) \\
(4.84) \\
(2.59) \\
(4.94) \\
(5.77)\end{array}$ & $\begin{array}{c}1.9 \\
7.9 \\
0.5 ! \\
\ddagger \\
\neq \\
\neq \\
\neq \\
\neq \\
\neq \\
\neq \\
\neq \\
\neq \\
\ddagger\end{array}$ & $\begin{array}{r}(0.57) \\
(1.69) \\
(0.24) \\
(\dagger) \\
(\dagger) \\
(\dagger) \\
(\dagger) \\
(\dagger) \\
(\dagger) \\
(\dagger) \\
(\dagger) \\
(\dagger)\end{array}$ & $\begin{array}{c}4.3 ! \\
1.1 ! \\
0.7 ! \\
\ddagger \\
\ddagger \\
1.1 ! \\
0.4 ! \\
\ddagger \\
\ddagger \\
\neq \\
\neq \\
\neq \\
\ddagger\end{array}$ & $\begin{array}{r}(1.70) \\
(0.41) \\
(0.24) \\
(\dagger) \\
(\dagger) \\
(0.51) \\
(0.17) \\
(\dagger) \\
(\dagger) \\
(\dagger) \\
(\dagger) \\
(\dagger)\end{array}$ & $\begin{array}{r}\ddagger \\
2.1 \\
2.5 \\
4.5 ! \\
8.6 \\
6.6 \\
6.3 \\
8.7 \\
14.5 \\
8.9 \\
10.1 ! \\
\ddagger\end{array}$ & $\begin{array}{r}(\dagger) \\
(0.57) \\
(0.36) \\
(1.42) \\
(1.06) \\
(1.42) \\
(0.82) \\
(0.86) \\
(2.55) \\
(1.31) \\
(3.14) \\
(\mathrm{t})\end{array}$ & $\begin{array}{c}1.7 ! \\
7.6 \\
17.2 \\
28.3 \\
28.8 \\
40.8 \\
44.1 \\
49.3 \\
40.5 \\
51.4 \\
34.0 \\
59.0\end{array}$ & $\begin{array}{l}(0.55) \\
(1.44) \\
(1.18) \\
(3.71) \\
(1.54) \\
(3.27) \\
(1.61) \\
(2.15) \\
(4.68) \\
(2.81) \\
(4.53) \\
(6.35)\end{array}$ & $\begin{array}{r}\ddagger \\
1.5 ! \\
1.1 ! \\
\ddagger \\
1.4 ! \\
1.9 ! \\
0.4 ! \\
\ddagger \\
\neq \\
\neq \\
\neq \\
\ddagger \\
\ddagger\end{array}$ & $\begin{array}{r}(\dagger) \\
(0.61) \\
(0.35) \\
(+) \\
(0.47) \\
(0.66) \\
(0.17) \\
(\dagger) \\
(+) \\
(\dagger) \\
(\dagger) \\
(\dagger)\end{array}$ & $\begin{array}{r}7.3 \\
12.5 \\
16.8 \\
23.2 \\
26.8 \\
20.1 \\
28.6 \\
30.7 \\
38.7 \\
30.6 \\
31.4 \\
23.9\end{array}$ & $\begin{array}{l}(1.24) \\
(1.53) \\
(1.27) \\
(3.09) \\
(1.80) \\
(2.48) \\
(1.55) \\
(1.77) \\
(4.81) \\
(2.04) \\
(3.95) \\
(4.35)\end{array}$ & $\begin{array}{l}38.1 \\
55.7 \\
63.6 \\
77.6 \\
79.8 \\
75.9 \\
79.3 \\
88.0 \\
78.2 \\
88.8 \\
90.3 \\
91.6\end{array}$ & $\begin{array}{l}(3.27) \\
(2.52) \\
(1.93) \\
(3.98) \\
(1.52) \\
(3.70) \\
(1.72) \\
(1.06) \\
(4.34) \\
(1.33) \\
(3.26) \\
(2.15)\end{array}$ \\
\hline 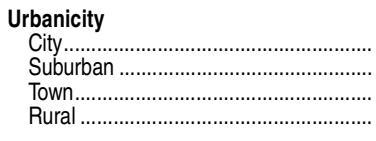 & $\begin{array}{l}- \\
- \\
-\end{array}$ & $\begin{array}{l}(t) \\
(t) \\
(t) \\
(t)\end{array}$ & $\begin{array}{l}- \\
\overline{-} \\
-\end{array}$ & $\begin{array}{l}(\dagger) \\
(\dagger) \\
(\dagger) \\
(\dagger)\end{array}$ & $\begin{array}{l}- \\
\overline{-} \\
-\end{array}$ & $\begin{array}{l}(+) \\
(+) \\
(+) \\
(+)\end{array}$ & $\begin{array}{l}- \\
\overline{-} \\
-\end{array}$ & \begin{tabular}{l|l}
$(\dagger)$ \\
$(\dagger)$ \\
$(\dagger)$ \\
$(\dagger)$
\end{tabular} & $\begin{array}{l}45.8 \\
46.9 \\
41.8 \\
39.5\end{array}$ & $\begin{array}{l}(1.46) \\
(1.33) \\
(2.33) \\
(2.04)\end{array}$ & $\begin{array}{l}1.4 \\
0.9 \\
2.7 ! \\
0.8\end{array}$ & $\begin{array}{l}(0.31) \\
(0.23) \\
(1.16) \\
(0.22)\end{array}$ & $\begin{array}{l}1.6 \\
0.9 ! \\
0.4 ! \\
\ddagger\end{array}$ & $\begin{array}{r}(0.38) \\
(0.36) \\
(0.14) \\
(t)\end{array}$ & $\begin{array}{l}5.7 \\
5.8 \\
4.2 \\
3.3\end{array}$ & $\begin{array}{l}(0.59) \\
(0.55) \\
(0.87) \\
(0.59)\end{array}$ & $\begin{array}{l}26.3 \\
29.7 \\
25.6 \\
24.2\end{array}$ & $\begin{array}{l}(1.24) \\
(1.26) \\
(1.74) \\
(1.38)\end{array}$ & $\begin{array}{l}1.8 \\
0.9 \\
0.5 ! \\
1.2 !\end{array}$ & $\begin{array}{l}(0.43) \\
(0.22) \\
(0.21) \\
(0.40)\end{array}$ & $\begin{array}{l}22.5 \\
23.4 \\
18.5 \\
18.3\end{array}$ & $\begin{array}{l}(1.10) \\
(1.16) \\
(1.96) \\
(1.76)\end{array}$ & $\begin{array}{l}69.2 \\
73.4 \\
70.5 \\
67.6\end{array}$ & $\begin{array}{l}(1.39) \\
(1.28) \\
(2.43) \\
(1.76)\end{array}$ \\
\hline 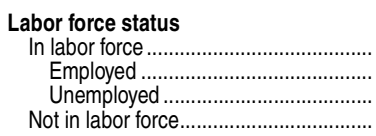 & $\begin{array}{l}40.7 \\
42.0 \\
26.0 \\
15.7\end{array}$ & $\begin{array}{l}(0.96) \\
(1.00) \\
(3.24) \\
(0.91)\end{array} \mid$ & $\begin{array}{l}49.8 \\
50.7 \\
36.6 \\
21.3\end{array}$ & $\begin{array}{l}(0.69) \\
(0.53) \\
(1.91) \\
(0.69)\end{array}$ & $\begin{array}{l}52.1 \\
52.5 \\
44.9 \\
24.9\end{array}$ & $\begin{array}{l}(0.94) \\
(0.96) \\
(4.60) \\
(1.17)\end{array}$ & $\begin{array}{l}\overline{-} \\
\bar{z}\end{array}$ & $\begin{array}{c}(+) \\
(+) \\
(+) \\
(t)\end{array} \mid$ & $\begin{array}{l}52.3 \\
53.4 \\
37.8 \\
27.6\end{array}$ & $\begin{array}{l}(0.93) \\
(0.94) \\
(4.26) \\
(1.18)\end{array}$ & $\begin{array}{l}1.4 \\
1.1 \\
5.8 \\
1.1\end{array}$ & $\begin{array}{l}(0.32) \\
(0.31) \\
(1.60) \\
(0.24)\end{array}$ & $\begin{array}{l}0.8 \\
0.7 \\
1.9 ! \\
1.3\end{array}$ & $\begin{array}{l}(0.19) \\
(0.20) \\
(0.79) \\
(0.36)\end{array}$ & $\begin{array}{l}6.4 \\
6.5 \\
5.2 \\
2.3\end{array}$ & $\begin{array}{l}(0.39) \\
(0.39) \\
(1.37) \\
(0.45)\end{array}$ & $\begin{array}{r}37.1 \\
38.8 \\
13.5 \\
5.7\end{array}$ & $\begin{array}{l}(0.83) \\
(2.16) \\
(0.55)\end{array} \mid$ & $\begin{array}{c}1.4 \\
\ddagger \\
\vdots \\
0.6 !\end{array}$ & $\begin{array}{r}(0.24) \\
(0.24) \\
(0.22)\end{array} \mid$ & $\begin{array}{l}21.9 \\
21.8 \\
22.1 \\
20.5\end{array}$ & $\begin{array}{l}(0.94) \\
(3.99) \\
(0.97)\end{array} \mid$ & $\begin{array}{l}73.0 \\
73.5 \\
66.7 \\
65.2\end{array}$ & $\begin{array}{l}(0.94) \\
(1.01) \\
(3.80) \\
(1.27)\end{array}$ \\
\hline
\end{tabular}

See notes at end of table. 


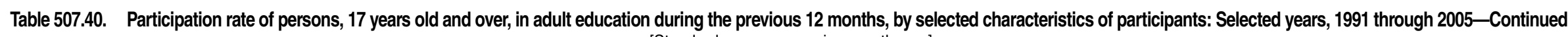
[Standard errors appear in parentheses]

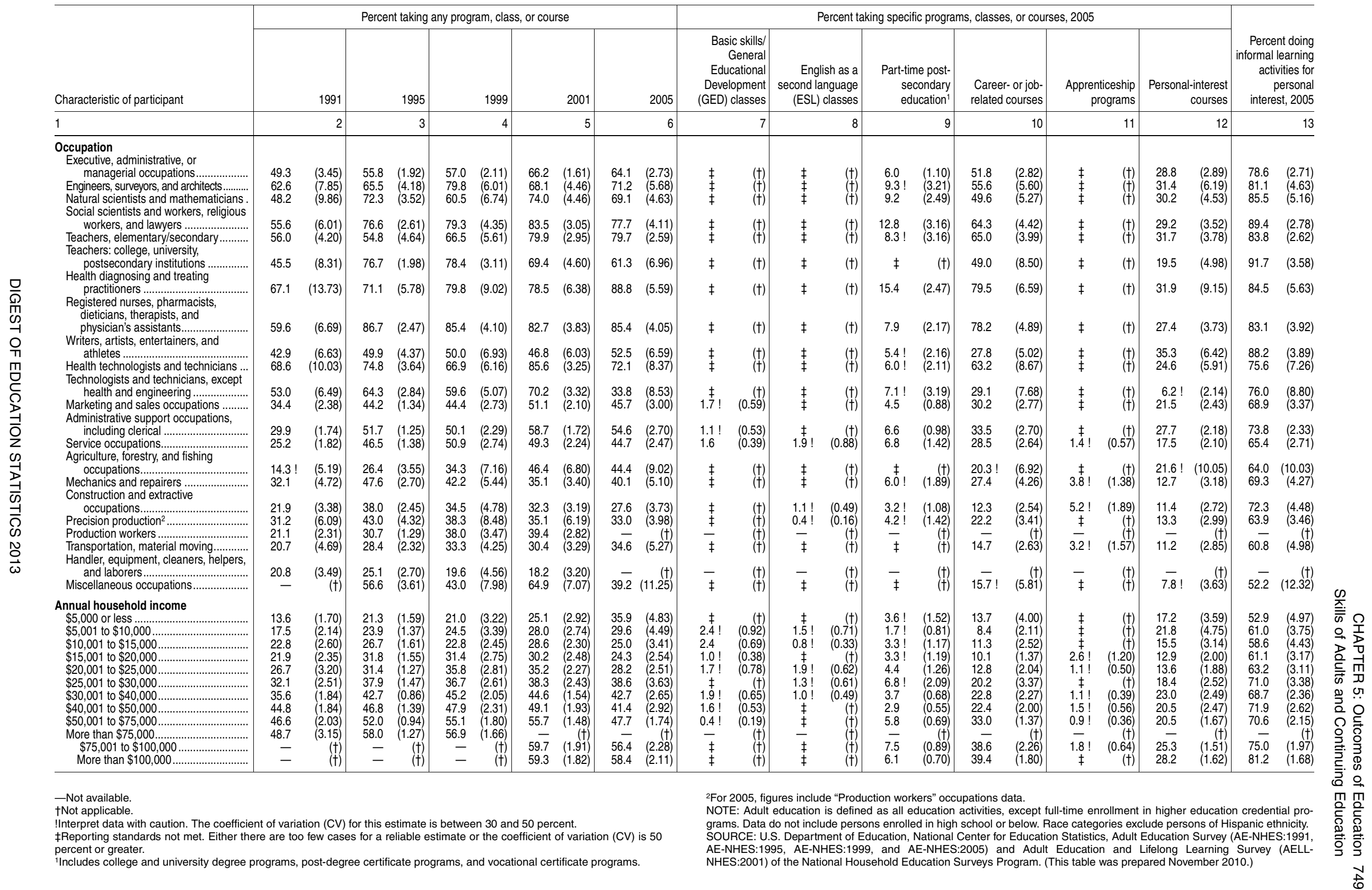





\section{CHAPTER 6 International Comparisons of Education}

This chapter offers a broad perspective on education across the nations of the world. It also provides an international context for examining the condition of education in the United States. Insights into the educational practices and outcomes of the United States are obtained by comparing them with those of other education systems. Most of the education systems represent countries; however, some of the tables in this chapter also include data for subnational entities with separate education systems, such as Hong Kong. The National Center for Education Statistics (NCES) carries out a variety of activities in order to provide statistical data for international comparisons of education.

This chapter presents data drawn from materials prepared by the United Nations Educational, Scientific, and Cultural Organization (UNESCO); the Organization for Economic Cooperation and Development (OECD); and the International Association for the Evaluation of Educational Achievement (IEA). Basic summary data on enrollments and enrollment ratios, teachers, educational attainment, and finances were synthesized from data published by OECD in the Online Education Database and the annual Education at a Glance report, as well as from data collected by UNESCO. Even though their tabulations are carefully prepared, international data users should be cautioned about the many problems of definition and reporting involved in the collection of data about the education systems of the world (see the OECD and UNESCO entries in Appendix A: Guide to Sources).

Also presented in this chapter are data from two international assessments of student achievement that are carried out under the aegis of IEA and supported by NCES. The Trends in International Mathematics and Science Study (TIMSS), formerly known as the Third International Mathematics and Science Study, assesses the mathematics and science knowledge and skills of fourth- and eighth-graders every 4 years. The Progress in International Reading Literacy Study (PIRLS) measures the reading knowledge and skills of fourth-graders every 5 years.

This chapter includes additional information from the Program for International Student Assessment (PISA), an OECD assessment supported by NCES. PISA provides performance scores of 15-year-olds in the areas of reading, mathematics, and science literacy; it also measures general, or cross-curricular, competencies such as learning strategies. While PISA focuses on OECD countries, data from some non-OECD education systems are also provided.
Further information on survey methodologies is in Appendix A: Guide to Sources and in the publications cited in the table source notes.

\section{Population}

Among the reporting OECD countries, Mexico had the largest percentage of its population made up of young people ages 5 to 14 (20 percent) in 2010, followed by Israel and Turkey (both at 18 percent) (table 601.30). OECD countries with small percentages of people in this age group included the Czech Republic, Estonia, Germany, Greece, Italy, Japan, and Slovenia (all at 9 percent), and Austria, Hungary, Poland, Portugal, the Slovak Republic, Spain, and Switzerland (all at 10 percent). In the United States, the proportion of 5- to 14-year-olds was 13 percent, which was higher than in most of the other OECD countries.

\section{Enrollments}

In 2011, about 1.4 billion students were enrolled in schools around the world (table 601.10). Of these students, 699 million were in elementary-level programs, 544 million were in secondary programs, and 183 million were in postsecondary programs.

From 2000 to 2011, enrollment changes varied from region to region. Changes in elementary enrollment ranged from increases of 49 percent in Africa, 8 percent in Oceania, and less than 1 percent in Asia to decreases of 12 percent in Europe, 6 percent in Central and South America (including Latin America and the Caribbean), and 1 percent in Northern America (including Bermuda, Canada, Greenland, St. Pierre and Miquelon, and the United States) (table F, table 601.10, and figure 27). Over the same period, secondary enrollment increased by 68 percent in Africa, 29 percent in Asia, 11 percent in Central and South America, and 5 percent in Northern America, but decreased by 20 percent in Europe and 4 percent in Oceania. At the postsecondary level, enrollments increased in all major areas of the world from 2000 to 2011. Postsecondary enrollment rose by 126 percent in Asia, 96 percent in Central and South America, 80 percent in Africa, 54 percent in Oceania, 51 percent in Northern America, and 31 percent in Europe. These increases are due to both growth in the percentages of people attending postsecondary institutions and population increases. 
Table F. Population and enrollment at different levels in major areas of the world: 2000 and 2011

[In millions]

\begin{tabular}{|c|c|c|c|c|}
\hline \multirow[b]{2}{*}{ Area of the world } & \multirow[b]{2}{*}{ Population } & \multicolumn{3}{|c|}{ Enrollment } \\
\hline & & Elementary & Secondary & Postsecondary \\
\hline \multicolumn{5}{|l|}{ World total } \\
\hline $2000 \ldots \ldots \ldots \ldots \ldots \ldots$ & $6,090.3$ & 654.7 & 450.4 & 99.5 \\
\hline $2011 \ldots \ldots \ldots \ldots \ldots \ldots$ & $6,943.4$ & 699.3 & 544.0 & 183.0 \\
\hline \multicolumn{5}{|l|}{ Africa } \\
\hline $2000 \ldots \ldots \ldots \ldots \ldots \ldots$ & 803.5 & 108.3 & 38.3 & 6.1 \\
\hline $2011 \ldots \ldots \ldots \ldots$ & $1,048.3$ & 161.5 & 64.2 & 10.9 \\
\hline \multicolumn{5}{|l|}{ Asia } \\
\hline 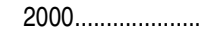 & 3,694.6 & 404.0 & 258.5 & 41.0 \\
\hline $2011 \ldots \ldots \ldots \ldots \ldots$ & $4,181.6$ & 404.7 & 332.9 & 92.8 \\
\hline \multicolumn{5}{|l|}{ Europe } \\
\hline $2000 \ldots \ldots \ldots \ldots \ldots$ & 730.6 & 41.7 & 70.4 & 25.6 \\
\hline $2011 \ldots \ldots \ldots \ldots \ldots$ & 740.3 & 36.8 & 56.5 & 33.5 \\
\hline \multicolumn{5}{|l|}{$\begin{array}{l}\text { Central and South } \\
\text { America }\end{array}$} \\
\hline 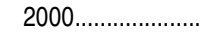 & 517.8 & 70.0 & 54.7 & 11.4 \\
\hline $2011 \ldots \ldots \ldots \ldots \ldots$ & 592.2 & 65.9 & 60.8 & 22.4 \\
\hline \multicolumn{5}{|l|}{ Northern America } \\
\hline $2000 \ldots \ldots \ldots \ldots \ldots \ldots$ & 313.4 & 27.4 & 25.1 & 14.4 \\
\hline $2011 \ldots \ldots \ldots \ldots$ & 345.8 & 27.0 & 26.4 & 21.8 \\
\hline \multicolumn{5}{|l|}{ Oceania } \\
\hline 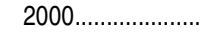 & 30.4 & 3.1 & 3.4 & 1.0 \\
\hline $2011 \ldots \ldots \ldots \ldots \ldots \ldots$ & 35.4 & 3.4 & 3.2 & 1.6 \\
\hline
\end{tabular}

SOURCE: United Nations Educational, Scientific, and Cultural Organization, unpublished tabulations, and U.S. Department of Commerce, Census Bureau, International Data Base.

In 2011, the reporting OECD country with the highest proportion of 18- to 21-year-olds enrolled in postsecondary education was the Republic of Korea (68 percent), followed by the United States (50 percent), Greece (48 percent), Belgium (46 percent), and Slovenia (44 percent) (table 601.40). Also in 2011, the reporting OECD country with the highest proportion of 22- to 25-year-olds enrolled in postsecondary education was Slovenia (39 percent), followed by Finland and the Republic of Korea (both at 38 percent) and Denmark (37 percent). The United States' proportion of enrolled 22- to 25-year-olds was 27 percent. Postsecondary enrollment varied among countries due partially to differences in how postsecondary education is defined and the age at which postsecondary education begins. For example, programs classified as postsecondary education in some countries may be classified as longduration secondary education in other countries.

\section{Achievement}

\section{Mathematics and Science at Grades $\mathbf{4}$ and 8}

The 2011 TIMSS assessed students' mathematics and science performance at grade 4 in 45 countries and at grade 8 in 38 countries. A number of subnational entities also participated in TIMSS as separate education systems. Examples of subnational participants include the cities of Hong Kong and Taipei, several U.S. states and Canadian provinces, Northern Ireland and England within the United Kingdom, and the Flemish community in Belgium. Results for individual U.S. states are based on public school students only, while U.S. national results are based on both public and private school students. TIMSS assessments are curriculum based and measure what students have actually learned against the subject matter that is expected to be taught in the participating education systems by the end of grades 4 and 8 . At both grades, TIMSS scores are reported on a scale of 0 to 1,000 , with the scale average set at 500 .

In 2011, the average mathematics scores of U.S. fourthgraders (541) and eighth-graders (509) were higher than the TIMSS scale average of 500 (tables 602.20 and 602.30). The average U.S. fourth-grade mathematics score was higher than the average score in 37 of the 44 other countries participating at grade 4 , lower than the average score in 3 countries, and not measurably different from the average score in the remaining 4 countries (table 602.20). The 3 countries that outperformed the United States in fourth-grade mathematics were Singapore, the Republic of Korea, and Japan. At grade 8 , the average U.S. mathematics score was higher than the average score in 27 of the 37 other participating countries in 2011, lower than the average score in 4 countries, and not measurably different from the average score in the remaining 6 countries (table 602.30). The 4 countries that outperformed the United States in eighth-grade mathematics were the Republic of Korea, Singapore, Japan, and the Russian Federation.

Of the two U.S. states that participated in the 2011 TIMSS as separate education systems at grade 4, one state-North Carolina—had an average score for public schools that was higher than both the TIMSS scale average and the U.S. national average in mathematics (table 602.20). Public schools in the other state, Florida, had an average fourth-grade mathematics score that was higher than the TIMSS scale average but not measurably different from the U.S. national average. Of the nine U.S. states that participated separately at grade 8 , four states-Massachusetts, Minnesota, North Carolina, and Indiana—had public school average scores that were higher than both the TIMSS scale average and the U.S. national average in mathematics (table 602.30). The public schools in three states-Colorado, Connecticut, and Florida-had average eighth-grade mathematics scores that were higher than the TIMSS scale average but not measurably different from the U.S. national average. The average eighth-grade score for public schools in California was not measurably different from the TIMSS scale average but was lower than the U.S. national average, while Alabama's public school average was lower than both the TIMSS scale average and the U.S. national average in mathematics.

The average science scores of both U.S. fourth-graders (544) and U.S. eighth-graders (525) were higher than the TIMSS scale average of 500 in 2011 (tables 602.20 and 602.30). The average U.S. fourth-grade science score was higher than the average score in 39 of the 44 other countries participating at grade 4 and lower than the average score in 5 countries (table 602.20). The 5 countries that outperformed the United States in fourth-grade science were the Republic of Korea, Singapore, Finland, Japan, and the Rus- 
sian Federation. At grade 8, the average U.S. science score was higher than the average score in 28 of the 37 other participating countries in 2011, lower than the average score in 6 countries, and not measurably different from the average score in the remaining 3 countries (table 602.30). The 6 countries that outperformed the United States in eighthgrade science were Singapore, the Republic of Korea, Japan, Finland, Slovenia, and the Russian Federation.

Public schools in both Florida and North Carolina, which were the two U.S. states participating in the 2011 TIMSS at grade 4, had average fourth-grade science scores that were higher than the TIMSS scale average but not measurably different from the U.S. national average (table 602.20). Of the nine U.S. states that participated at grade 8, three states-Massachusetts, Minnesota, and Coloradohad public school average scores that were higher than both the TIMSS scale average and the U.S. national average in science (table 602.30). Public schools in four states-Indiana, Connecticut, North Carolina, and Florida-had average eighth-grade science scores that were higher than the TIMSS scale average but not measurably different from the U.S. national average. The average eighth-grade score for public schools in California was not measurably different from the TIMSS scale average but was lower than the U.S. national average, while Alabama's public school average was lower than both the TIMSS scale average and the U.S. national average in science.

\section{Reading Literacy at Grade 4}

PIRLS has conducted international assessments of fourth-grade reading literacy in 2001, 2006, and 2011. In 2011, PIRLS participants consisted of 40 countries as well as a number of subnational education systems. Examples of subnational participants include the cities of Hong Kong and Taipei, the public school system of the U.S. state of Florida, several Canadian provinces, Northern Ireland and England within the United Kingdom, and the Flemish community in Belgium. PIRLS scores are reported on a scale from 0 to 1,000 , with the scale average set at 500 .

On the 2011 PIRLS, U.S. fourth-graders had an average reading literacy score of 556 (table 602.10). The U.S. average score in 2011 was 14 points higher than in 2001 and 16 points higher than in 2006. In all 3 assessment years, the U.S. average score was higher than the PIRLS scale average.

In 2011, the average reading literacy score of fourthgraders in the United States was higher than the average score in 33 of the 39 other participating countries, lower than the average score in 3 countries, and not measurably different from the average in the remaining 3 countries. The 3 countries that outperformed the United States on the 2011 PIRLS were the Russian Federation, Finland, and Singapore. Public school students in Florida scored higher than both the PIRLS scale average and the U.S. national average.

In the United States, the 2011 average reading literacy score for females (562) was higher than the average score for males (551). In 34 of the 39 other participating countries, the average score for females was also higher than the average score for males, while there was no measurable difference between females' and males' average scores in the remaining 5 countries.

\section{Reading, Mathematics, and Science Literacy at Age 15}

PISA assesses 15-year-old students' application of reading, mathematics, and science literacy to problems within a real-life context. In 2012, PISA assessed students in the 34 OECD countries as well as in a number of other education systems. Some subnational entities participated as separate education systems, including the U.S. states of Connecticut, Florida, and Massachusetts. Results for individual U.S. states are based on public school students only, while U.S. national results are based on both public and private school students. PISA scores are reported on a scale of 0 to 1,000 .

On the 2012 PISA assessment, U.S. 15-year-olds' average score in reading literacy was 498 , which was not measurably different from the OECD average of 496 (table 602.50). The average reading literacy score in the United States was lower than the average score in 13 of the 33 other OECD countries, higher than the average score in 10 of the other OECD countries, and not measurably different from the average score in 10 of the OECD countries. The average reading literacy scores of public school students in Massachusetts (527) and Connecticut (521) were higher than both the U.S. average and the OECD average, while the average score in Florida (492) was not measurably different from either the U.S. average or the OECD average. In all participating education systems, females outperformed males in reading (table 602.40). The U.S. gender gap in reading (31 points) was smaller than the OECD average gap (38 points) and smaller than the gaps in 14 of the OECD countries.

In mathematics literacy, U.S. 15-year-olds' average score of 481 on the 2012 PISA assessment was lower than the OECD average score of 494 (table 602.60). The average mathematics literacy score in the United States was lower than the average in 21 of the 33 other OECD countries, higher than the average in 5 OECD countries, and not measurably different from the average in 7 OECD countries. The average mathematics literacy score of public school students in Massachusetts (514) was higher than both the U.S. average and the OECD average, while the average score in Connecticut (506) was higher than the U.S. average but not measurably different from the OECD average. The average score in Florida (467) was lower than both the U.S. average and the OECD average. In 25 of the OECD countries, males outperformed females in mathematics literacy (table 602.40). In the United States, however, the average score of males (484) was not measurably different from that of females (479).

In science literacy, U.S. 15-year-olds' average score of 497 was not measurably different from the OECD average score of 501 (table 602.70). The average science literacy score in the United States was lower than the average in 15 
OECD countries, higher than the average in 8 OECD countries, and not measurably different from the average in 10 OECD countries. The average science literacy scores of public school students in Massachusetts (527) and Connecticut (521) were higher than both the U.S. average and the OECD average. The average score in Florida (485) was not measurably different from the U.S. average but was lower than the OECD average.

\section{Educational Attainment}

In 2011, the percentage of 25- to 64-year-olds who had completed high school varied among reporting OECD countries (table 603.10). Countries with high percentages included the Czech Republic (92 percent); the Slovak Republic (91 percent); and the United States, Poland, Estonia, and Canada (all at 89 percent). Ten additional countries had percentages between 80 and 87 percent. Countries with relatively low percentages of 25- to 64-year-olds who had completed high school included Turkey (32 percent), Portugal (35 percent), and Mexico (36 percent).

In 2011, the OECD country reporting the highest percentage of 25- to 64-year-olds with a bachelor's or higher degree was Norway (36 percent), followed by the United States (32 percent); Israel (31 percent); and Iceland, the United Kingdom, and the Netherlands (all at 30 percent) (table 603.20). The countries with the lowest percentages of 25- to 64-yearolds who had attained a bachelor's or higher degree were Austria (12 percent), Slovenia and Turkey (both at 14 percent), and Italy (15 percent). The percentage of younger adults (25 to 34 years old) with a bachelor's or higher degree also varied in 2011 (table 603.20 and figure 28). The OECD country reporting the highest percentage of 25- to 34-year-olds at this level of educational attainment was Norway (46 percent), followed by the United Kingdom, Poland, and the Republic of Korea (all at 39 percent); Finland and the Netherlands (both at 38 percent); and Iceland (37 percent). Eleven additional countries reported that at least 30 percent of their 25- to 34-yearolds had a bachelor's or higher degree. In the United States, 33 percent of adults in this age group had a bachelor's or higher degree. The lowest percentages among OECD countries were reported by Austria (16 percent), Germany (18 percent), and Turkey (19 percent).

\section{Degrees}

In 29 of the 32 reporting OECD countries, more than half of all bachelor's and higher degrees were awarded to women in 2011 (table 603.60). However, the proportion of degrees awarded to women varied by field. For example, 30 of the 32 countries reported that more than 70 percent of education degrees at the bachelor's or higher level were awarded to women. In contrast, women received less than 24 percent of the computer science degrees in 24 of the 31 countries reporting data on degrees awarded in this field.
The percentages of bachelor's degrees that were awarded in mathematics and science fields-including natural sciences, mathematics and computer science, and engineeringvaried across the 32 OECD countries that reported these data in 2010 (table 603.70). Only one of the reporting OECD countries awarded more than 30 percent of its bachelor's degrees in mathematics and science fields: the Republic of Korea (34 percent). Two countries awarded 15 percent or less of their bachelor's degrees in mathematics and science fields: the Netherlands (13 percent) and Norway (15 percent). In 2010, the United States awarded 16 percent of its bachelor's degrees in mathematics and science fields, a lower percentage than most other reporting countries.

The percentages of graduate degrees awarded in mathematics and science fields ranged widely across the 31 OECD countries that reported these data in 2010 (table 603.80). Seven of the reporting OECD countries awarded 30 percent or more of their graduate degrees in mathematics and science fields: Japan (46 percent), Sweden and Finland (both at 40 percent), Germany (33 percent), Austria and Greece (both at 32 percent), and Portugal (31 percent). Six OECD countries awarded less than 15 percent of their graduate degrees in mathematics and science fields: Hungary (10 percent), Chile and Poland (both at 11 percent), Mexico and the United States (both at 13 percent), and Iceland (14 percent).

\section{Finances}

In 2010, expenditures per full-time-equivalent (FTE) student at the combined elementary and secondary level of education were over $\$ 11,000$ (in current U.S. dollars) in 6 of the 31 OECD countries that reported finance data for this level of education (table 605.10). Specifically, Luxembourg spent $\$ 19,000$ per elementary/secondary student; Switzerland spent $\$ 13,500$; Norway spent $\$ 13,100$; the United States spent \$11,800; Austria spent \$11,700; and Denmark spent $\$ 11,400$. At the higher education level, 6 of 29 reporting countries had expenditures of over $\$ 17,000$ per FTE student in 2010: the United States $(\$ 25,600)$, Switzerland $(\$ 21,900)$, Sweden $(\$ 19,600)$, Denmark $(\$ 19,000)$, Norway $(\$ 18,500)$, and the Netherlands $(\$ 17,200)$. These expenditures were adjusted to U.S. dollars using the purchasing-power-parity (PPP) index. This index is considered more stable and comparable than indexes using currency exchange rates.

A comparison of public direct expenditures on education as a percentage of gross domestic product (GDP) in reporting OECD countries shows that public investment in education in 2010 ranged from 3.6 percent in Japan to 7.5 percent in Norway and 7.6 percent in Denmark (table 605.20 and figure 29). Among reporting OECD countries, the average public direct expenditure on education in 2010 was 5.4 percent of GDP. In the United States, the public direct expenditure on education as a percentage of GDP was 5.1 percent. 
Figure 27. Percentage change in enrollment, by major areas of the world and level of education: 2000 to 2011

\section{Percent change}

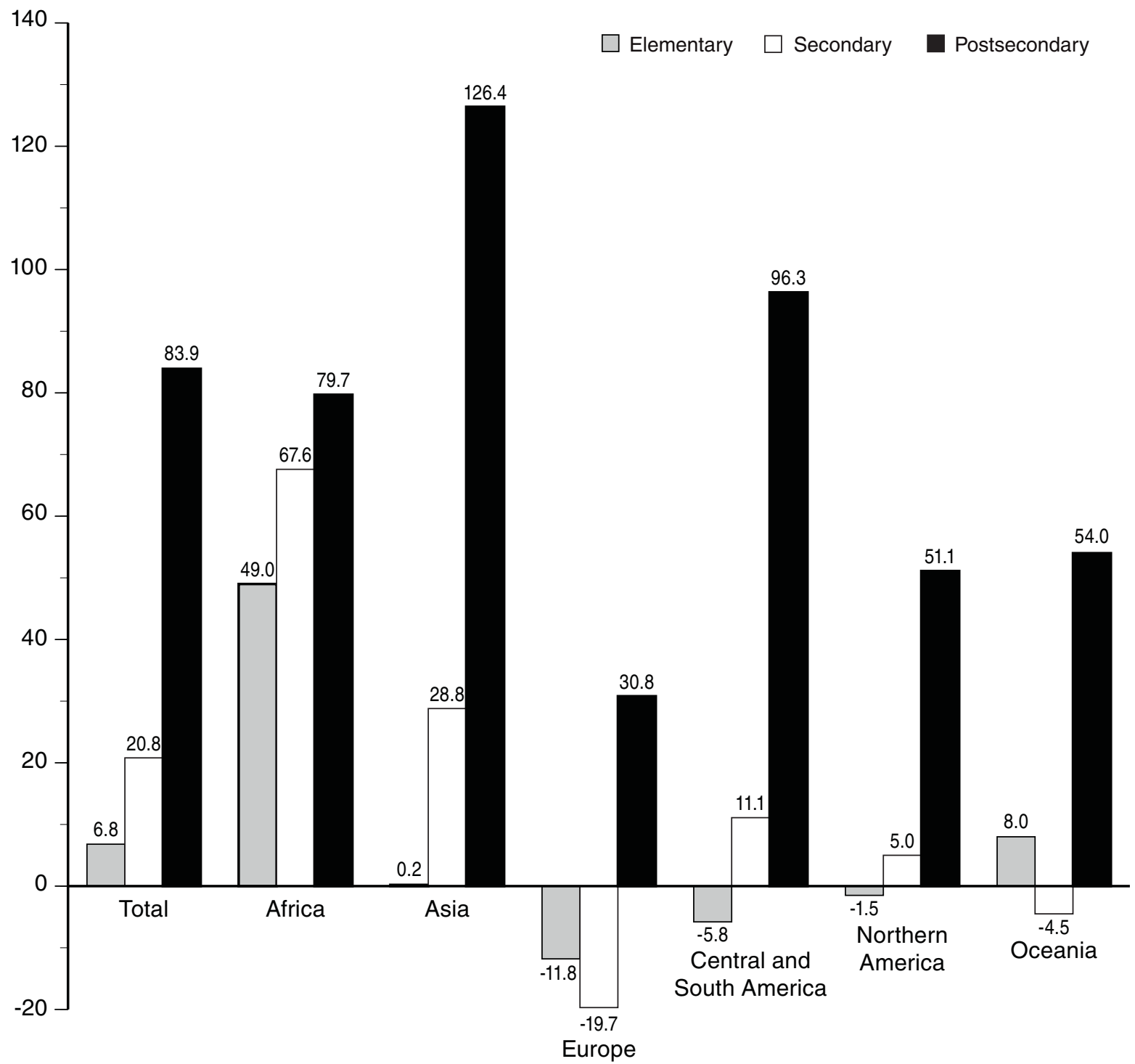

Area of the world

NOTE: Europe includes all countries of the former Union of Soviet Socialist Republics (U.S.S.R.) except Armenia, Azerbaijan, Georgia, Kazakhstan, Kyrgyzstan, Tajikistan, Turkmenistan, and Uzbekistan, which are included in Asia. Turkey, the Arab states, and Israel are also included in Asia. Central and South America includes Latin America and the Caribbean. Northern America includes Bermuda, Canada, Greenland, St. Pierre and Miquelon, and the United States of America. Data include imputed values for nonrespondent countries.

SOURCE: United Nations Educational, Scientific, and Cultural Organization (UNESCO), previously unpublished tabulations (January 2014). 
Figure 28. Percentage of the population 25 to 34 years old with a bachelor's or higher degree, by OECD country: 2011 OECD country

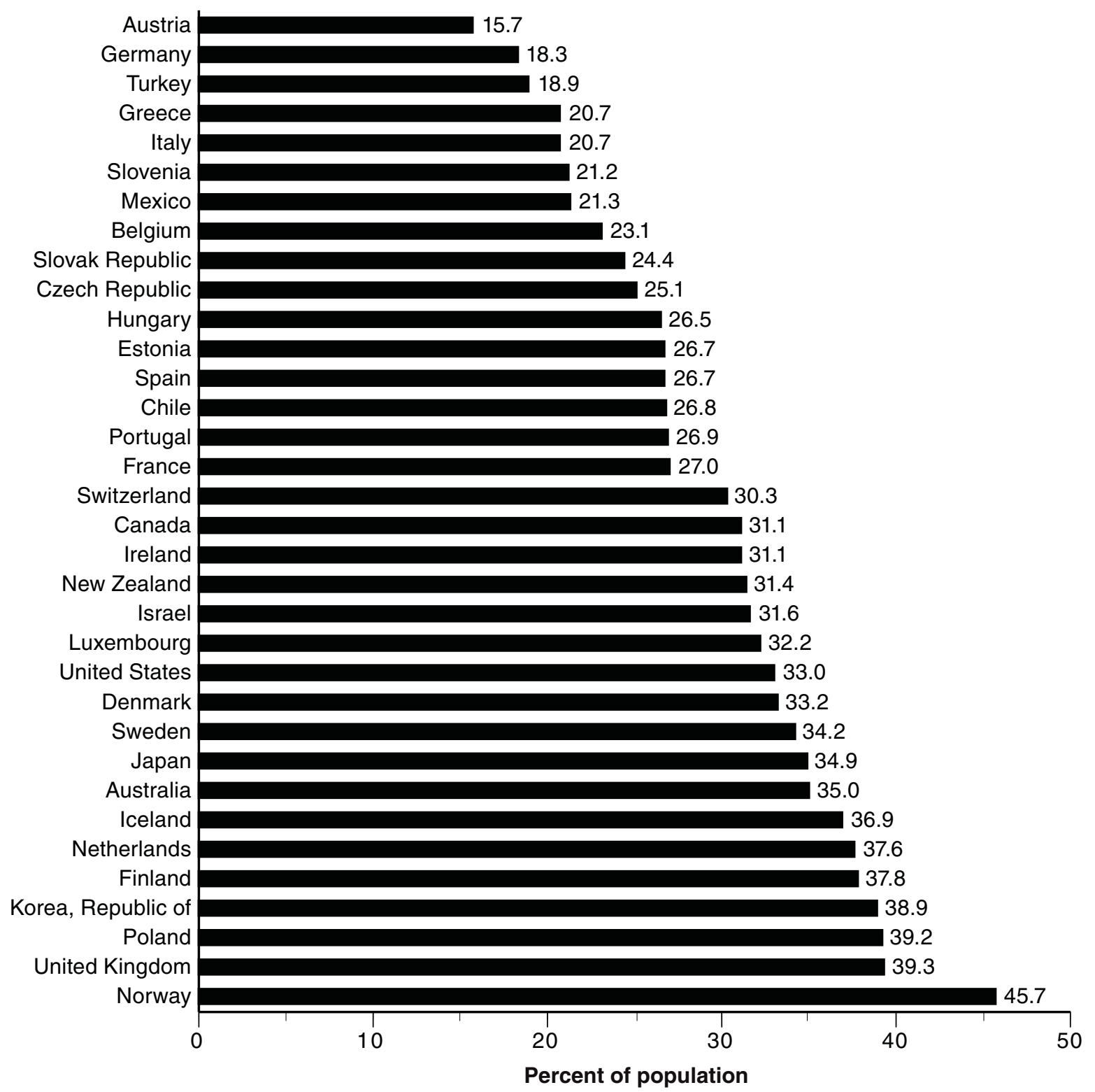

NOTE: Refers to degrees classified by OECD as International Standard Classification of Education (ISCED) level 5A (first and second award) or level 6. ISCED 5A, first award, corresponds to the bachelor's degree in the United States; ISCED 5A, second award, corresponds to master's and first-professional degrees in the United States; and ISCED 6 corresponds to doctor's degrees.

SOURCE: Organization for Economic Cooperation and Development (OECD), Education at a Glance, 2013 
Figure 29. Public direct expenditures on education institutions as a percentage of gross domestic product (GDP), by OECD country: 2010

\section{OECD country}

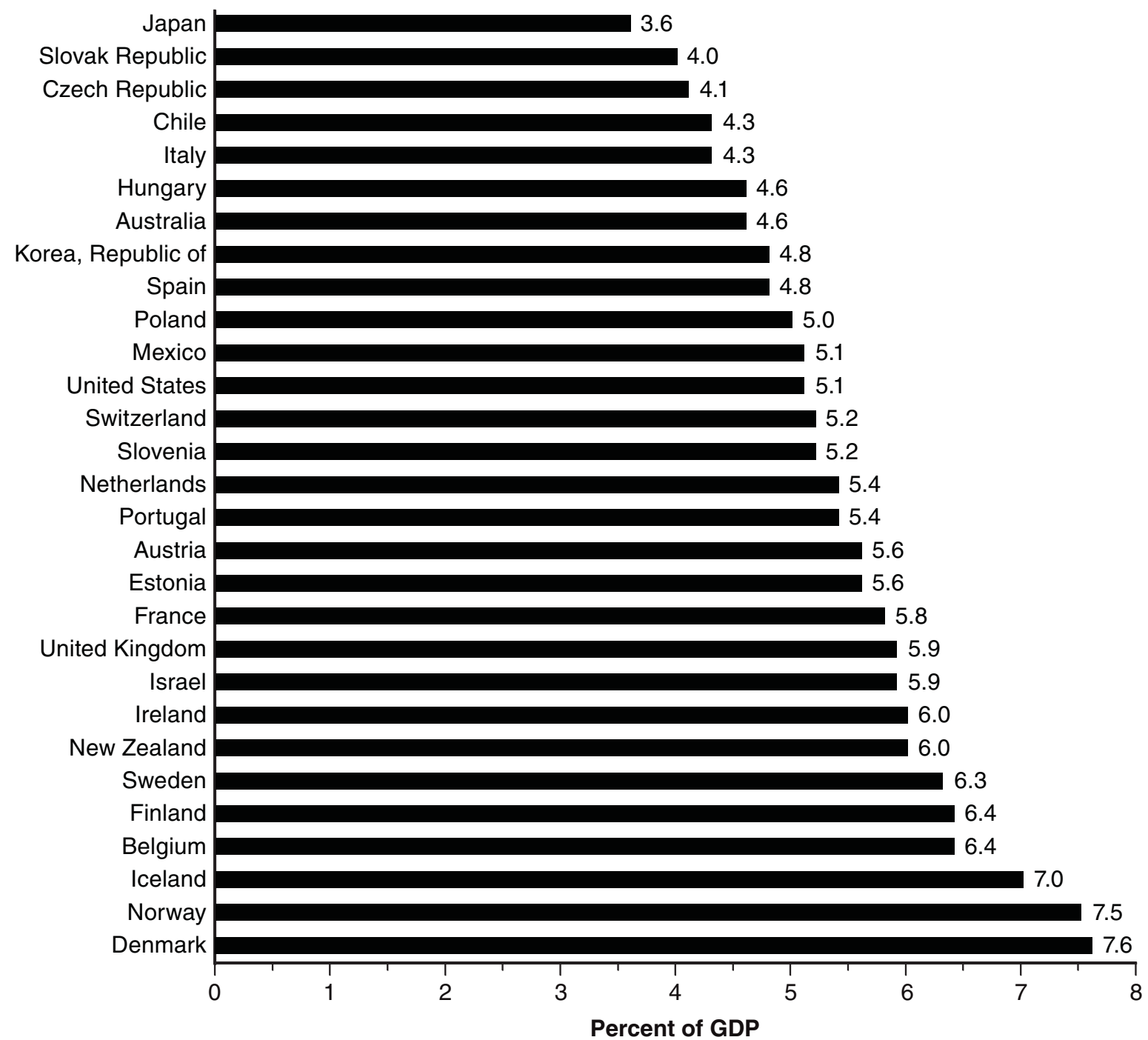

NOTE: Includes amounts spent directly by governments to hire educational personnel and to procure other resources, as well as amounts provided by governments to public or private institutions. SOURCE: Organization for Economic Cooperation and Development (OECD), Education at a Glance, 2013. 
758 CHAPTER 6: International Comparisons of Education

Population, Enrollment, and Teachers

Table 601.10. Population, school enrollment, and number of teachers, by major areas of the world and level of education: Selected years, 1980 through 2011

[In thousands]

\begin{tabular}{|c|c|c|c|c|c|c|c|}
\hline \multirow[b]{2}{*}{ Year and selected characteristic } & \multirow[b]{2}{*}{ World total $^{1}$} & \multicolumn{6}{|c|}{ Major areas of the world } \\
\hline & & Africa & Asia $^{1,2}$ & Europe $^{2}$ & $\begin{array}{r}\text { Central and } \\
\text { South America }{ }^{3}\end{array}$ & Northern America ${ }^{3}$ & Oceania \\
\hline 1 & 2 & 3 & 4 & 5 & 6 & 7 & 8 \\
\hline \multicolumn{8}{|l|}{$\overline{1980}$} \\
\hline Population, all ages 4 & $4,450,930$ & 478,544 & $2,644,088$ & 695,225 & 358,609 & 251,929 & 22,534 \\
\hline 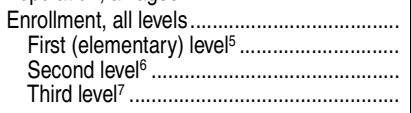 & $\begin{array}{r}856,277 \\
524,358 \\
282,241 \\
49,679\end{array}$ & $\begin{array}{r}74,774 \\
59,058 \\
14,187 \\
1,529\end{array}$ & $\begin{array}{r}493,963 \\
333,939 \\
146,984 \\
13,040\end{array}$ & $\begin{array}{r}134,690 \\
49,038 \\
68,702 \\
16,951\end{array}$ & $\begin{array}{r}87,097 \\
56,781 \\
25,521 \\
4,795\end{array}$ & $\begin{array}{l}60,541 \\
22,893 \\
24,695 \\
12,954\end{array}$ & $\begin{array}{r}5,213 \\
2,649 \\
2,153 \\
411\end{array}$ \\
\hline 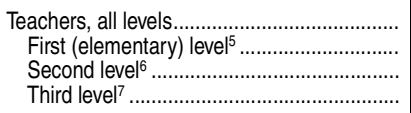 & $\begin{array}{r}38,891 \\
18,511 \\
16,481 \\
3,898\end{array}$ & $\begin{array}{r}2,252 \\
1,605 \\
560 \\
87\end{array}$ & $\begin{array}{r}19,259 \\
10,706 \\
7,410 \\
1,142\end{array}$ & $\begin{array}{r}-\overline{2} \\
5,582 \\
-\end{array}$ & $\begin{array}{r}3,835 \\
1,871 \\
1,582 \\
382\end{array}$ & $\begin{array}{r}- \\
1,309 \\
815\end{array}$ & $\begin{array}{r}276 \\
134 \\
112 \\
31\end{array}$ \\
\hline \multicolumn{8}{|l|}{1990} \\
\hline 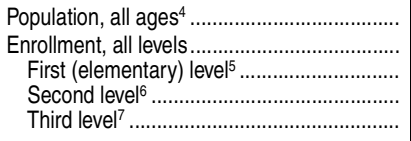 & $\begin{array}{r}5,287,869 \\
975,595 \\
576,949 \\
331,242 \\
67,404\end{array}$ & $\begin{array}{r}630,169 \\
104,938 \\
76,465 \\
25,764 \\
2,709\end{array}$ & $\begin{array}{r}3,190,508 \\
562,137 \\
361,573 \\
177,817 \\
22,747\end{array}$ & $\begin{array}{r}722,638 \\
132,631 \\
46,581 \\
67,340 \\
18,710\end{array}$ & $\begin{array}{r}440,609 \\
108,550 \\
65,092 \\
36,216 \\
7,242\end{array}$ & $\begin{array}{r}277,533 \\
61,543 \\
24,629 \\
21,534 \\
15,380\end{array}$ & $\begin{array}{r}26,412 \\
5,797 \\
2,609 \\
2,571 \\
617\end{array}$ \\
\hline 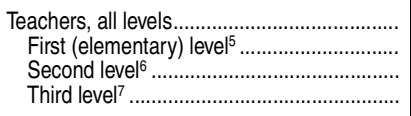 & $\begin{array}{r}47,477 \\
22,181 \\
20,294 \\
5,002\end{array}$ & $\begin{array}{r}3,597 \\
2,271 \\
1,188 \\
138\end{array}$ & $\begin{array}{r}24,499 \\
13,070 \\
9,732 \\
1,697\end{array}$ & $\begin{array}{l}9,892 \\
2,691 \\
5,666 \\
1,535\end{array}$ & $\begin{array}{r}5,236 \\
2,401 \\
2,234 \\
601\end{array}$ & $\begin{array}{r}3,938 \\
1,608 \\
1,340 \\
991\end{array}$ & $\begin{array}{r}315 \\
139 \\
135 \\
41\end{array}$ \\
\hline \multicolumn{8}{|l|}{1995} \\
\hline 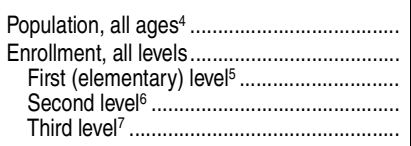 & $\begin{array}{r}5,699,768 \\
1,086,114 \\
619,091 \\
387,832 \\
79,191\end{array}$ & $\begin{array}{r}712,602 \\
125,117 \\
90,412 \\
30,631 \\
4,074\end{array}$ & $\begin{array}{r}3,452,081 \\
630,703 \\
386,975 \\
215,238 \\
28,489\end{array}$ & $\begin{array}{r}730,000 \\
137,195 \\
44,849 \\
71,104 \\
21,242\end{array}$ & $\begin{array}{r}480,608 \\
120,167 \\
67,604 \\
44,400 \\
8,164\end{array}$ & $\begin{array}{r}296,092 \\
65,901 \\
26,243 \\
23,595 \\
16,063\end{array}$ & $\begin{array}{r}28,385 \\
7,030 \\
3,008 \\
2,864 \\
1,158\end{array}$ \\
\hline 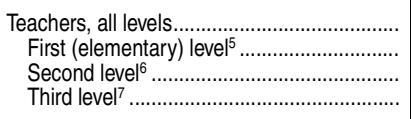 & $\begin{array}{r}52,201 \\
23,793 \\
22,690 \\
5,718\end{array}$ & $\begin{array}{r}4,198 \\
2,569 \\
1,429 \\
200\end{array}$ & $\begin{array}{r}26,934 \\
14,049 \\
10,890 \\
1,996\end{array}$ & $\begin{array}{r}10,556 \\
2,776 \\
6,099 \\
1,681\end{array}$ & $\begin{array}{r}5,931 \\
2,627 \\
2,604 \\
699\end{array}$ & $\begin{array}{l}4,208 \\
1,622 \\
1,503 \\
1,083\end{array}$ & $\begin{array}{l}149 \\
- \\
-\end{array}$ \\
\hline \multicolumn{8}{|l|}{2000} \\
\hline 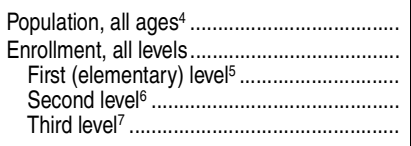 & $\begin{array}{r}6,090,319 \\
1,204,589 \\
654,698 \\
450,383 \\
99,508\end{array}$ & $\begin{array}{r}803,528 \\
152,697 \\
108,346 \\
38,294 \\
6,058\end{array}$ & $\begin{array}{r}3,694,628 \\
703,506 \\
404,035 \\
258,475 \\
40,996\end{array}$ & $\begin{array}{r}730,598 \\
137,711 \\
41,730 \\
70,410 \\
25,571\end{array}$ & $\begin{array}{r}517,756 \\
136,169 \\
70,021 \\
54,724 \\
11,423\end{array}$ & $\begin{array}{r}313,388 \\
66,968 \\
27,435 \\
25,117 \\
14,416\end{array}$ & $\begin{array}{r}30,421 \\
7,538 \\
3,130 \\
3,363 \\
1,044\end{array}$ \\
\hline 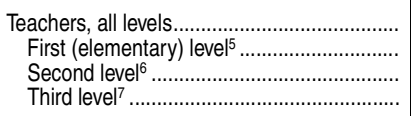 & $\begin{array}{r}56,512 \\
24,839 \\
25,001 \\
6,672\end{array}$ & $\begin{array}{r}4,928 \\
2,870 \\
1,785 \\
274\end{array}$ & $\begin{array}{r}29,058 \\
14,501 \\
12,119 \\
2,439\end{array}$ & $\begin{array}{r}10,704 \\
2,735 \\
6,095 \\
1,874\end{array}$ & $\begin{array}{r}6,769 \\
2,774 \\
3,126 \\
869\end{array}$ & $\begin{array}{l}4,648 \\
1,806 \\
1,682 \\
1,161\end{array}$ & $\begin{array}{l}155 \\
- \\
-\end{array}$ \\
\hline \multicolumn{8}{|l|}{2005} \\
\hline 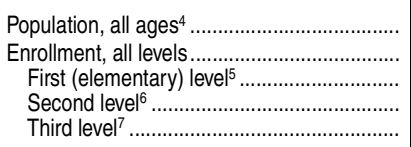 & $\begin{array}{r}6,474,229 \\
1,329,991 \\
683,216 \\
508,270 \\
138,505\end{array}$ & $\begin{array}{r}907,745 \\
192,665 \\
135,510 \\
48,849 \\
8,305\end{array}$ & $\begin{array}{r}3,920,235 \\
778,939 \\
410,474 \\
306,007 \\
62,458\end{array}$ & $\begin{array}{r}733,119 \\
135,132 \\
38,465 \\
64,855 \\
31,812\end{array}$ & $\begin{array}{r}552,438 \\
143,413 \\
68,845 \\
58,487 \\
16,081\end{array}$ & $\begin{array}{r}328,033 \\
72,374 \\
26,780 \\
27,039 \\
18,555\end{array}$ & $\begin{array}{r}32,659 \\
7,468 \\
3,141 \\
3,033 \\
1,294\end{array}$ \\
\hline 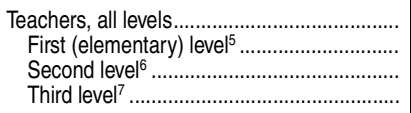 & $\begin{array}{r}64,089 \\
26,964 \\
28,043 \\
9,081\end{array}$ & $\begin{array}{r}5,926 \\
3,459 \\
2,134 \\
332\end{array}$ & $\begin{array}{r}34,315 \\
15,860 \\
14,597 \\
3,859\end{array}$ & $\begin{array}{r}10,690 \\
2,658 \\
5,798 \\
2,234\end{array}$ & $\begin{array}{l}7,737 \\
2,964 \\
3,551 \\
1,223\end{array}$ & $\begin{array}{l}5,005 \\
1,865 \\
1,774 \\
1,366\end{array}$ & $\begin{array}{r}159 \\
- \\
-\end{array}$ \\
\hline \multicolumn{8}{|l|}{2011} \\
\hline 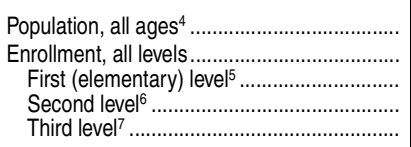 & $\begin{array}{r}6,943,437 \\
1,426,217 \\
699,280 \\
543,976 \\
182,960\end{array}$ & $\begin{array}{r}1,048,252 \\
236,551 \\
161,474 \\
64,192 \\
10,885\end{array}$ & $\begin{array}{r}4,181,579 \\
830,359 \\
404,677 \\
332,879 \\
92,804\end{array}$ & $\begin{array}{r}740,300 \\
126,787 \\
36,791 \\
56,545 \\
33,450\end{array}$ & $\begin{array}{r}592,169 \\
149,135 \\
65,930 \\
60,779 \\
22,426\end{array}$ & $\begin{array}{r}345,751 \\
75,182 \\
27,027 \\
26,368 \\
21,787\end{array}$ & $\begin{array}{r}35,386 \\
8,203 \\
3,382 \\
3,213 \\
1,608\end{array}$ \\
\hline 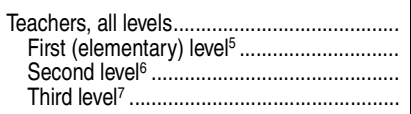 & $\begin{array}{l}71,471 \\
28,869 \\
31,521 \\
11,081\end{array}$ & $\begin{array}{r}7,418 \\
4,110 \\
2,896 \\
412\end{array}$ & $\begin{array}{r}39,274 \\
16,862 \\
17,464 \\
4,948\end{array}$ & $\begin{array}{r}10,333 \\
2,672 \\
5,271 \\
2,389\end{array}$ & $\begin{array}{l}8,560 \\
3,101 \\
3,834 \\
1,625\end{array}$ & $\begin{array}{l}5,445 \\
1,954 \\
1,867 \\
1,625\end{array}$ & $\begin{array}{l}- \\
- \\
-\end{array}$ \\
\hline
\end{tabular}

-Not available.

${ }^{1}$ Enrollment and teacher data for the world total and Asia exclude Taiwan.

¿Europe includes all countries of the former Union of Soviet Socialist Republics (U.S.S.R.) except Armenia, Azerbaijan, Georgia, Kazakhstan, Kyrgyzstan, Tajikistan, Turkmenistan, and Uzbekistan, which are included in Asia. Turkey, the Arab states, and Israel are also included in Asia.

${ }^{3} \mathrm{C}$ entral and South America includes Latin America and the Caribbean. Northern America includes Bermuda, Canada, Greenland, St. Pierre and Miquelon, and the United States of America.

${ }^{4}$ Estimate of midyear population.

${ }^{5}$ First-level enrollment generally consists of elementary school, grades 1-6.

${ }^{6}$ Second-level enrollment includes general education, teacher training (at the second level), and technical and vocational education. This level generally corresponds to secondary education in the United States, grades 7-12.

${ }^{7}$ Third-level enrollment includes college and university enrollment, and technical and voca${ }^{7}$ Third-level enrollment includes college and university
tional education beyond the secondary school level.

NOTE: Detail may not sum to totals because of rounding. Data include imputed values for nonrespondent countries. Enrollment and teacher data exclude several island countries or territories with small populations (less than 150,000). Some data have been revised from previously published figures.

SOURCE: United Nations Educational, Scientific, and Cultural Organization (UNESCO), unpublished tabulations. U.S. Department of Commerce, Census Bureau, International Data Base, retrieved January 16, 2014, from http://www.census.gov/population/international/ data/idb/informationGateway.php. (This table was prepared January 2014.) 
Table 601.20. Selected population and enrollment statistics for countries with populations of at least 10 million in 2011, by continent and country: Selected years, 1990 through 2011

\begin{tabular}{|c|c|c|c|c|c|c|c|c|c|c|c|c|c|c|c|c|c|c|c|}
\hline \multirow[b]{3}{*}{ Continent and country ${ }^{1}$} & \multicolumn{3}{|c|}{$\begin{array}{l}\text { Midyear population } \\
\text { (in millions) }\end{array}$} & \multirow{3}{*}{$\begin{array}{r}\text { Persons } \\
\text { per } \\
\text { square } \\
\text { kilo- } \\
\text { meter, } \\
2011\end{array}$} & \multicolumn{5}{|c|}{ First level $\left.\right|^{2}$} & \multicolumn{5}{|c|}{ Second leve| ${ }^{3}$} & \multicolumn{5}{|c|}{ Third level ${ }^{4}$} \\
\hline & \multirow[b]{2}{*}{1991} & \multirow[b]{2}{*}{2000} & \multirow[b]{2}{*}{2011} & & \multicolumn{2}{|c|}{$\begin{array}{l}\text { Enrollment } \\
\text { (in thousands) }\end{array}$} & \multicolumn{3}{|c|}{ Gross enrollment ratio ${ }^{5}$} & \multicolumn{2}{|c|}{$\begin{array}{l}\text { Enrollment } \\
\text { (in thousands) }\end{array}$} & \multicolumn{3}{|c|}{ Gross enrollment ratio $^{5}$} & \multicolumn{2}{|c|}{$\begin{array}{c}\text { Enrollment } \\
\text { (in thousands) }\end{array}$} & \multicolumn{3}{|c|}{ Gross enrollment ratio ${ }^{5}$} \\
\hline & & & & & 1999-2000 & $2010-11$ & $1990-91$ & 1999-2000 & $2010-11$ & 1999-2000 & $2010-11$ & $1990-91$ & 1999-2000 & $2010-11$ & 1999-2000 & $2010-11$ & $1990-91$ & 1999-2000 & $2010-11$ \\
\hline 1 & 2 & 3 & 4 & 5 & 6 & 7 & 8 & 9 & 10 & 11 & 12 & 13 & 14 & 15 & 16 & 17 & 18 & 19 & 20 \\
\hline World total $^{6} \ldots \ldots \ldots \ldots \ldots$ & 5,371 & 6,090 & 6,943 & 53 & 654,723 & $699,301^{7}$ & 99 & 99 & $107^{7}$ & 450,397 & $543,989^{7}$ & 52 & 60 & $71^{7}$ & 99,511 & $182,963^{7}$ & 14 & 19 & $30^{7}$ \\
\hline Africa & & & & & & & & & & & & & & & & & & & \\
\hline Algeria ${ }^{8} \ldots \ldots \ldots$ & 26 & 31 & 37 & 15 & 4,843 & 3,363 & 100 & 103 & 115 & 2,994 & 4,573 & 61 & 62 & 98 & - & 1,189 & 11 & - & 30 \\
\hline Angola & 10 & 13 & 18 & 14 & - & 5,027 & 92 & - & 140 & 355 & 885 & 12 & 15 & 32 & - & 143 & 1 & - & 7 \\
\hline Burkina Faso ..................... & 9 & 12 & 17 & 61 & 852 & 2,205 & 33 & 45 & 82 & 190 & 604 & 7 & 10 & 24 & $11^{7}$ & 61 & 1 & $1^{7}$ & 4 \\
\hline Cameroon ............................ & 12 & 16 & 21 & 45 & $2,237^{9}$ & 3,585 & 101 & $83^{9}$ & 106 & 700 & 1,574 & 28 & 27 & 47 & 66 & 244 & 3 & 5 & 12 \\
\hline Chad & 6 & 8 & 11 & 9 & 914 & 1,929 & 54 & 64 & 91 & 137 & 457 & $8^{10}$ & 11 & 23 & 6 & 24 & $1^{11,12}$ & 1 & 2 \\
\hline Cote d'Ivoire........................ & 13 & 17 & 22 & 68 & 1,944 & 2,758 & 67 & 77 & 90 & $620^{7}$ & - & 22 & $25^{7}$ & - & - & - & - & - & - \\
\hline $\begin{array}{l}\text { Democratic Rep. } \\
\text { of the Congo }\end{array}$ & 41 & 52 & 72 & 32 & - & 11,083 & 70 & - & 105 & - & 3.783 & $21^{13}$ & - & 43 & - & 488 & 2 & - & 8 \\
\hline Egypt $^{8} \ldots \ldots \ldots \ldots \ldots \ldots \ldots \ldots$ & 56 & 65 & 82 & 83 & $7,947^{7}$ & 10,266 & 94 & $101^{7}$ & 109 & $8,028^{7}$ & - & 76 & $86^{7}$ & - & - & 2,246 & $16^{14,15}$ & - & $\begin{array}{r}0 \\
29\end{array}$ \\
\hline Ethiopia & 49 & 64 & 89 & 89 & 5,847 & 14,298 & 33 & 55 & 95 & 1,195 & 4,542 & 14 & 14 & 36 & 68 & 632 & 1 & 1 & 8 \\
\hline 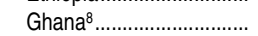 & 16 & 19 & 24 & 106 & 2,561 & 3,860 & 75 & 86 & 107 & 1,057 & 2,148 & 36 & 41 & 57 & - & 286 & $1^{11}$ & - & 12 \\
\hline Guinea .................................. & 7 & 8 & 11 & 43 & 790 & 1,537 & 37 & 57 & 89 & - & 640 & 10 & - & 38 & - & 103 & 1 & - & 10 \\
\hline 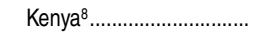 & 24 & 31 & 42 & 74 & 5,035 & - & 95 & 96 & - & 1,909 & - & $24^{10}$ & 39 & - & 89 & - & $2^{11}$ & 3 & - \\
\hline Madagascar ......................... & 12 & 16 & 21 & 37 & 2,208 & 4,305 & 103 & 100 & 144 & - & - & $18^{10}$ & - & - & 32 & 86 & 3 & 2 & 4 \\
\hline Malawi................................. & 10 & 12 & 16 & 169 & 2,695 & 3,564 & 68 & 138 & 140 & 487 & 736 & 8 & 32 & 34 & 4 & 12 & 1 & - & 1 \\
\hline Mali ................................... & 9 & 11 & 15 & 12 & 1,017 & 2,115 & 26 & 62 & 92 & $258^{7}$ & 821 & 7 & $19^{7}$ & 44 & 20 & 88 & 1 & 2 & 7 \\
\hline Morocco ${ }^{8} \ldots \ldots \ldots \ldots \ldots \ldots \ldots \ldots$ & 24 & 28 & 32 & 72 & 3,670 & 4,001 & 67 & 92 & 115 & 1,541 & 2,479 & 35 & 38 & 66 & 276 & 506 & 11 & 9 & 16 \\
\hline Mozambique $^{8}$...................... & 13 & 18 & 23 & 29 & 2,544 & 5,254 & 67 & 74 & 107 & 124 & 716 & 8 & 6 & 26 & 12 & 113 & $\#^{12}$ & 1 & 5 \\
\hline Niger ………...................... & 8 & 11 & 16 & 13 & 579 & 1,910 & 29 & 34 & 69 & $106^{7}$ & 342 & 7 & $7^{7}$ & 15 & - & 18 & 1 & - & 2 \\
\hline Nigeria ${ }^{8} \ldots \ldots \ldots \ldots \ldots \ldots$ & 99 & 124 & 164 & 181 & 19,151 & - & 91 & 98 & - & 4,104 & - & 25 & 24 & - & - & - & $4^{11,16}$ & - & - \\
\hline Rwanda............................. & 7 & 8 & 11 & 461 & 1,432 & 2,341 & 70 & 111 & 128 & 130 & 486 & 8 & 11 & 32 & 9 & 74 & $\# 17$ & 1 & 7 \\
\hline Senegal................................ & 8 & 9 & 13 & 66 & 1,108 & 1,726 & 59 & 68 & 84 & 250 & 83418 & 16 & 16 & $41^{18}$ & - & - & 3 & - & - \\
\hline South Africa .......................... & 39 & 45 & 49 & 40 & 7,445 & - & 122 & 107 & - & 4,142 & - & 74 & 84 & - & - & - & $13^{19}$ & - & - \\
\hline South Sudan .......................... & 5 & 6 & 10 & 16 & - & - & - & - & - & - & - & - & - & - & - & - & & - & - \\
\hline 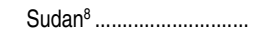 & 22 & 27 & 34 & 18 & 2,567 & - & 53 & - & - & 980 & - & 24 & - & - & $204^{7}$ & - & $3^{11}$ & - & - \\
\hline Tunisia ............................. & 8 & 10 & 11 & 68 & 1,414 & 1,028 & 113 & 116 & 108 & $1,104^{7}$ & 1,152 & 45 & $75^{7}$ & 91 & 180 & 362 & 9 & 19 & 35 \\
\hline Uganda ................................ & 17 & 23 & 33 & 165 & 6,559 & 8,098 & $74^{20,21}$ & 129 & 110 & 547 & - & $13^{10,21}$ & 16 & - & 56 & 290 & 1 & 3 & 9 \\
\hline $\begin{array}{l}\text { United Republic } \\
\text { of Tanzania.... }\end{array}$ & 26 & 33 & 46 & 52 & 4,382 & - & 70 & 68 & - & - & - & 5 & $\ldots$ & - & - & - & $\# 13$ & - & - \\
\hline 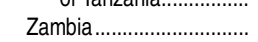 & 8 & 10 & 13 & $\begin{array}{l}52 \\
18\end{array}$ & $\begin{array}{l}4,382 \\
1,590\end{array}$ & 3,030 & 99 & 84 & 113 & - & - & $\begin{array}{r}5 \\
24\end{array}$ & - & - & 257 & - & $\begin{array}{ll}\# 13 \\
2\end{array}$ & $\overline{2} 7$ & - \\
\hline 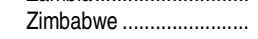 & 10 & 12 & 12 & 31 & 2,461 & - & 116 & 101 & - & 844 & - & 50 & 43 & - & - & 93 & 5 & - & 6 \\
\hline Asia & & & & & & & & & & & & & & & & & & & \\
\hline Afghanistan $8 \ldots \ldots \ldots \ldots \ldots$ & 14 & 22 & 30 & 46 & 749 & 5,292 & 27 & 21 & 97 & - & 2,209 & 9 & - & 52 & - & 98 & 2 & - & 4 \\
\hline Bangladesh .......................... & 114 & 132 & 159 & 1,218 & - & $18,432{ }^{18}$ & 72 & - & $114^{18}$ & 10,329 & 11,543 & 19 & 48 & 51 & 727 & 2,008 & 4 & 5 & 13 \\
\hline Cambodia ……………........... & 10 & 12 & 15 & 83 & 2,248 & 2,224 & 121 & 106 & 126 & 351 & - & 32 & 17 & - & 22 & 223 & 1 & 2 & 16 \\
\hline China ………………….......... & 1,164 & 1,264 & 1,337 & 140 & - & 99,708 & 125 & - & 128 & 81,488 & 97,452 & 49 & 58 & 87 & 7,364 & 31,308 & 3 & 8 & 24 \\
\hline India ………………............ & 854 & 1,006 & 1,189 & 400 & 113,613 & 137,747 & 97 & 96 & 113 & 71,031 & 113,728 & 4410 & 46 & 69 & 9,404 & 26,651 & 6 & 10 & 23 \\
\hline Indonesia ........................... & 185 & 214 & 246 & 136 & 28,509 & 30,662 & 115 & 110 & 109 & 14,720 & 20,778 & 44 & 56 & 81 & 3,126 & 5,364 & $9^{13}$ & 15 & 27 \\
\hline Iran, Islamic Republic of.. & 60 & 69 & 78 & 51 & 8,288 & 5,678 & 112 & 101 & 106 & 9,955 & 7,237 & 55 & 79 & 84 & 1,405 & 4,117 & $10^{14}$ & 19 & 49 \\
\hline Iraq.................................... & 17 & 23 & 30 & 70 & 3,639 & - & 111 & 96 & - & 1,224 & - & $47^{10}$ & 37 & - & 289 & - & $12^{17}$ & 12 & - \\
\hline Japan & 124 & 127 & 127 & 350 & 7,529 & 7,029 & 100 & 101 & 103 & 8,782 & 7,285 & 97 & 102 & 102 & 3,982 & 3,881 & $30^{13}$ & 49 & 60 \\
\hline Kazakhstan ......................... & 17 & 16 & 17 & 6 & 1,208 & 986 & 87 & 99 & 105 & 2,003 & 1,680 & 98 & 96 & 97 & 370 & 638 & 40 & 29 & 42 \\
\hline Korea, North (DPR)............. & 21 & 23 & 24 & 203 & - & - & - & - & - & - & - & - & - & - & - & - & - & - & - \\
\hline Korea, South (Republic of). & 43 & 47 & 49 & 503 & 4,030 & 3,140 & 105 & 102 & 104 & 3,959 & 3,868 & 90 & 99 & 97 & 3,003 & 3,356 & 39 & 79 & 101 \\
\hline
\end{tabular}




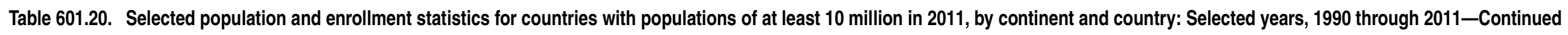

\begin{tabular}{|c|c|c|c|c|c|c|c|c|c|c|c|c|c|c|c|c|c|c|c|}
\hline \multirow[b]{3}{*}{ Continent and country ${ }^{1}$} & \multicolumn{3}{|c|}{$\begin{array}{l}\text { Midyear population } \\
\text { (in millions) }\end{array}$} & \multirow{3}{*}{$\begin{array}{r}\text { Persons } \\
\text { per } \\
\text { square } \\
\text { kilo- } \\
\text { meter, } \\
2011 \\
\end{array}$} & \multicolumn{5}{|c|}{ First level $\left.\right|^{2}$} & \multicolumn{5}{|c|}{ Second level ${ }^{3}$} & \multicolumn{5}{|c|}{ Third level ${ }^{4}$} \\
\hline & \multirow[b]{2}{*}{1991} & \multirow[b]{2}{*}{2000} & \multirow[b]{2}{*}{2011} & & \multicolumn{2}{|c|}{$\begin{array}{c}\text { Enrollment } \\
\text { (in thousands) }\end{array}$} & \multicolumn{3}{|c|}{ Gross enrollment ratio ${ }^{5}$} & \multicolumn{2}{|c|}{$\begin{array}{c}\text { Enrollment } \\
\text { (in thousands) }\end{array}$} & \multicolumn{3}{|c|}{ Gross enrollment ratio ${ }^{5}$} & \multicolumn{2}{|c|}{$\begin{array}{c}\text { Enrollment } \\
\text { (in thousands) }\end{array}$} & \multicolumn{3}{|c|}{ Gross enrollment ratio ${ }^{5}$} \\
\hline & & & & & 1999-2000 & $2010-11$ & 1990-91 & 1999-2000 & $2010-11$ & $1999-2000$ & $2010-11$ & 1990-91 & 1999-2000 & $2010-11$ & 1999-2000 & $2010-11$ & 1990-91 & 1999-2000 & $2010-11$ \\
\hline 1 & 2 & 3 & 4 & 5 & 6 & 7 & 8 & 9 & 10 & 11 & 12 & 13 & 14 & 15 & 16 & 17 & 18 & 19 & 20 \\
\hline Malaysia.............................. & 18 & 23 & 29 & 87 & 3,026 & - & 94 & 98 & - & 2,205 & - & 56 & 66 & - & 549 & - & 7 & 26 & - \\
\hline Myanmar ............................... & 41 & 47 & 54 & 83 & 4,858 & - & 106 & 98 & - & 2,268 & - & 23 & 36 & - & - & 660 & $4^{13}$ & - & 14 \\
\hline 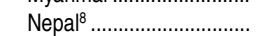 & 19 & 25 & 29 & 205 & $3,780^{9}$ & 4,952 & 108 & $126^{9}$ & 143 & 1,348 & 2,830 & 33 & 37 & 63 & 94 & 385 & 5 & 4 & 14 \\
\hline Pakistan ............................. & 122 & 152 & 187 & 243 & 13,98718 & 18,051 & $61^{22}$ & $70^{18}$ & 92 & - & 9,939 & 23 & - & 35 & - & 1,573 & 3 & - & 8 \\
\hline Philippines .............................. & 67 & 81 & 102 & 342 & 12,708 & - & 111 & 110 & - & - & - & 73 & - & - & - & - & 28 & - & - \\
\hline Saudi Arabia ............................ & 16 & 21 & 26 & 12 & - & 3,348 & 73 & - & 101 & - & $3,153^{7}$ & 44 & - & $114^{7}$ & 404 & 1,021 & 12 & 23 & 43 \\
\hline 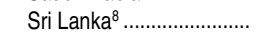 & 17 & 19 & 21 & 329 & - & 1,735 & 106 & - & 99 & - & 2,574 & 74 & - & 99 & - & 232 & $5^{13,23}$ & - & 14 \\
\hline Syrian Arab Republic....... & 13 & 16 & 23 & 123 & 2,775 & 2,507 & 108 & 108 & 121 & 1,069 & 2,821 & 52 & 44 & 74 & - & 571 & 18 & - & 26 \\
\hline Taiwan ................................ & 20 & 22 & 23 & 718 & - & - & - & - & - & - & - & - & - & - & - & - & - & - & - \\
\hline Thailand ............................. & 57 & 63 & 67 & 131 & 6,101 & - & 99 & 98 & - & - & 4,893 & 30 & - & 87 & 1,900 & 2,497 & $19^{12}$ & 35 & 53 \\
\hline Turkey …………………........ & 58 & 67 & 79 & 102 & 6,562 & 6,581 & 99 & 103 & 102 & 5,658 & 7,966 & 47 & 73 & 89 & - & 3,817 & 13 & - & 61 \\
\hline 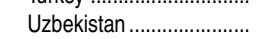 & 21 & 25 & 28 & 66 & 2,602 & 1,948 & 81 & 99 & 93 & 3,566 & 4,370 & 99 & 88 & 105 & 305 & 277 & 30 & 13 & 9 \\
\hline Vietnam.............................. & 69 & 79 & 91 & 292 & 10,063 & 7,048 & 103 & 107 & 105 & - & - & 32 & - & - & 732 & 2,229 & 2 & 9 & 24 \\
\hline Yemen …………………............... & 13 & 17 & 24 & 45 & - & 3,641 & 7916 & - & 97 & - & 1,643 & $23^{16}$ & - & 46 & - & 267 & $4^{13}$ & - & 10 \\
\hline \multicolumn{20}{|l|}{ Europe } \\
\hline Belgium & 10 & 10 & 10 & 345 & 774 & 736 & 101 & 105 & 104 & 1,058 & 803 & 103 & 145 & 106 & 356 & 462 & 40 & 58 & 69 \\
\hline Czech Republic.................... & 10 & 10 & 11 & 137 & 645 & 468 & 96 & 103 & 102 & 958 & 805 & 91 & 89 & 96 & 254 & 446 & $16^{24}$ & 28 & 65 \\
\hline 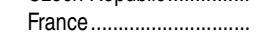 & 59 & 61 & 65 & 102 & 3,885 & 4,172 & 108 & 104 & 108 & 5,929 & 5,888 & 99 & 106 & 110 & 2,015 & 2,259 & 40 & 57 & 57 \\
\hline Germany ${ }^{25} \ldots \ldots \ldots \ldots \ldots \ldots \ldots \ldots$ & 80 & 82 & 81 & 234 & 3,656 & 2,990 & 101 & 103 & 101 & 8,307 & 7,528 & 98 & 96 & 102 & - & 2,763 & 34 & - & 57 \\
\hline Greece ………………........... & 10 & 11 & 11 & 82 & 645 & - & 98 & 96 & - & 739 & - & 93 & 89 & - & 422 & - & 36 & 51 & - \\
\hline 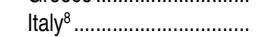 & 57 & 58 & 61 & 207 & 2,836 & 2,828 & 103 & 103 & 100 & 4,404 & 4,630 & 83 & 93 & 101 & 1,770 & 1,968 & 32 & 49 & 64 \\
\hline Netherlands 8 .......................... & 15 & 16 & 17 & 491 & 1,279 & 1,292 & 102 & 109 & 108 & 1,379 & 1,539 & 120 & 123 & 128 & 488 & 780 & 40 & 53 & 76 \\
\hline 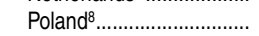 & 38 & 39 & 38 & 126 & 3,319 & 2,192 & 98 & 99 & 99 & 3,988 & 2,726 & 81 & 100 & 97 & 1,580 & 2,080 & 22 & 50 & 74 \\
\hline Portugal ............................... & 10 & 10 & 11 & 118 & 811 & - & 123 & 122 & - & 831 & - & 67 & 105 & - & 374 & - & 23 & 48 & - \\
\hline Romania $^{8} \ldots \ldots \ldots \ldots \ldots \ldots \ldots \ldots$ & 23 & 22 & 22 & 95 & 1,189 & 826 & 91 & 106 & 104 & 2,226 & 1,778 & 92 & 111 & 129 & 453 & 872 & 10 & 24 & 52 \\
\hline Russian Federation........... & 148 & 147 & 143 & 9 & 6,138 & - & 109 & 93 & 96 & - & - & 93 & 81 & 96 & 6,331 & - & 52 & 55 & - \\
\hline Spain & 39 & 41 & 47 & 94 & 2,540 & 2,773 & 109 & 103 & - & 3,246 & 3,248 & 104 & - & - & 1,829 & 1,950 & 37 & 59 & 83 \\
\hline Ukraine $^{8}$................................. & 52 & 49 & 45 & 78 & 2,079 & 1,563 & 89 & 109 & 106 & 5,204 & 2,926 & 93 & 99 & 94 & 1,812 & 2,566 & 47 & 49 & 79 \\
\hline 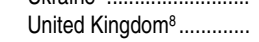 & 58 & 59 & 63 & 259 & 4,632 & 4,420 & 104 & 101 & 107 & 5,315 & 5,000 & 85 & 102 & 97 & 2,024 & 2,492 & 30 & 58 & 61 \\
\hline \multicolumn{20}{|l|}{ North America } \\
\hline Canada ............ & 28 & 31 & 34 & 4 & 2,456 & - & 103 & 100 & - & 2,519 & - & 101 & 102 & - & 1,212 & - & 95 & 59 & - \\
\hline 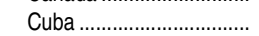 & 11 & 11 & 11 & 101 & 1,046 & 828 & 98 & 101 & 101 & 790 & 798 & 89 & 82 & 90 & 159 & 665 & 21 & 22 & 80 \\
\hline Guatemala .............................. & 9 & 11 & 14 & 129 & 1,909 & 2,645 & 78 & 104 & 114 & 504 & 1,114 & $23^{13}$ & 38 & 65 & - & - & $8^{12}$ & - & - \\
\hline 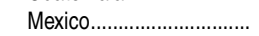 & 86 & 100 & 116 & 60 & 14,766 & 14,935 & 114 & 106 & 104 & 9,094 & 11,836 & 53 & 70 & 84 & 1,963 & 2,981 & 15 & 19 & 28 \\
\hline 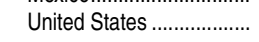 & 253 & 282 & 312 & 34 & 24,973 & 24,432 & 102 & 101 & 99 & 22,594 & 24,214 & 93 & 92 & 94 & 13,203 & 21,016 & 75 & 68 & 95 \\
\hline South America & & & & & & & & & & & & & & & & & & & \\
\hline Argentina & 34 & 37 & 42 & 15 & 4,728 & - & 106 & 114 & - & 3,428 & - & 71 & 87 & - & $1,767^{7}$ & - & $38^{13}$ & $53^{7}$ & - \\
\hline 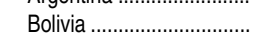 & 7 & 8 & 10 & 9 & 1,492 & 1,390 & 95 & 112 & 94 & $877^{7}$ & 1,060 & 37 & $78^{7}$ & 77 & 279 & - & 21 & 35 & - \\
\hline 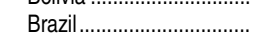 & 152 & 174 & 198 & 23 & - & - & 106 & - & - & - & - & 38 & - & - & 2,781 & 6,929 & $11^{26}$ & - & - \\
\hline 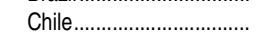 & 13 & 15 & 17 & 23 & 1,799 & 1,520 & 100 & 100 & 102 & 1,391 & 1,493 & 73 & 82 & 90 & 452 & 1,062 & $21^{13}$ & 37 & 71 \\
\hline Colombia................................. & 34 & 39 & 45 & 43 & 5,221 & 4,924 & 102 & 119 & 111 & 3,569 & 5,131 & $50^{13}$ & 72 & 97 & 934 & 1,849 & 13 & 24 & 43 \\
\hline
\end{tabular}

See notes at end of table. 


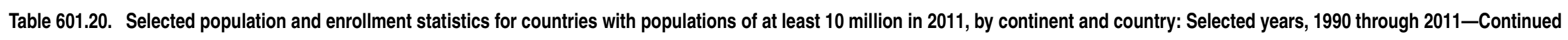

\begin{tabular}{|c|c|c|c|c|c|c|c|c|c|c|c|c|c|c|c|c|c|c|c|}
\hline \multirow[b]{3}{*}{ Continent and country ${ }^{1}$} & \multicolumn{3}{|c|}{$\begin{array}{l}\text { Midyear population } \\
\text { (in millions) }\end{array}$} & \multirow{3}{*}{\begin{tabular}{|r|} 
Persons \\
per \\
square \\
kilo- \\
meter, \\
2011 \\
\end{tabular}} & \multicolumn{5}{|c|}{ First level ${ }^{2}$} & \multicolumn{5}{|c|}{ Second level ${ }^{3}$} & \multicolumn{5}{|c|}{ Third level ${ }^{4}$} \\
\hline & \multirow[b]{2}{*}{1991} & \multirow[b]{2}{*}{2000} & \multirow[b]{2}{*}{2011} & & \multicolumn{2}{|c|}{$\begin{array}{c}\text { Enrollment } \\
\text { (in thousands) }\end{array}$} & \multicolumn{3}{|c|}{ Gross enrollment ratio ${ }^{5}$} & \multicolumn{2}{|c|}{$\begin{array}{c}\text { Enrollment } \\
\text { (in thousands) }\end{array}$} & \multicolumn{3}{|c|}{ Gross enrollment ratio ${ }^{5}$} & \multicolumn{2}{|c|}{$\begin{array}{l}\text { Enrollment } \\
\text { (in thousands) }\end{array}$} & \multicolumn{3}{|c|}{ Gross enrollment ratio ${ }^{5}$} \\
\hline & & & & & $1999-2000$ & $2010-11$ & $1990-91$ & 1999-2000 & $2010-11$ & $1999-2000$ & $2010-11$ & $1990-91$ & $1999-2000$ & $2010-11$ & 1999-2000 & $2010-11$ & $1990-91$ & $\mid 1999-2000$ & $2010-11$ \\
\hline 1 & 2 & 3 & 4 & 5 & 6 & 7 & 8 & 9 & 10 & 11 & 12 & 13 & 14 & 15 & 16 & 17 & 18 & 19 & 20 \\
\hline 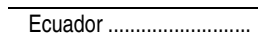 & 10 & 12 & 15 & 54 & 1,925 & 2,121 & 116 & 113 & 115 & 917 & 1,488 & 55 & 59 & 85 & - & - & 20 & - & - \\
\hline Peru .......................... & 22 & 26 & 29 & 23 & 4,338 & 3,671 & 118 & 122 & 105 & 2,374 & 2,640 & 67 & 85 & 91 & - & - & 30 & - & - \\
\hline Venezuela ............................. & 20 & 23 & 28 & 31 & 3,328 & 3,466 & 96 & 101 & 102 & 1,543 & 2,287 & 35 & 60 & 83 & 668 & - & 29 & 28 & - \\
\hline Oceania & & & & & & & & & & & & & & & & & & & \\
\hline Australia ${ }^{8} . .$. & 17 & 19 & 22 & 3 & 1,906 & 2,042 & 108 & 100 & 104 & 2,589 & 2,328 & 82 & 161 & 133 & 845 & 1,324 & 3527 & 65 & 83 \\
\hline
\end{tabular}

\section{Not available.}

Selection based on total population for midyear 2011

First-level enrollment consists of elementary school, typically corresponding to grades $1-6$ in the United States.

${ }_{3}^{3}$ Second-level enrollment includes general education, teacher training (at the second level), and technical and vocational education. This level generally corresponds to secondary education in the United States, grades 7-12.

education beyond the secondary school

${ }^{5}$ Data represent the total enrollment of all ages in the school level divided by the population of the specific age groups that correspond because some countries have many students from outside the normal age range.

${ }^{6}$ Enrollment totals and ratios exclude Democratic People's Republic of Korea.

.

.

Cocher

institutions (such as teacher training colleges and technical colleges) and excludes distance-learning univer-

sities.

${ }^{2}$ Data for $1992-93$.
${ }^{3}$ Data for $1991-92$.

${ }^{14}$ Excludes private institutions.

${ }^{15}$ Data refer to universities and exclude Al Azhar.

${ }^{16}$ Data for $1993-94$.
${ }^{17}$ Data for $1985-86$.

${ }^{18}$ National estimation

${ }^{19}$ Not including the former Independent States of Transkei, Bophuthatswana, Venda, and Ciskei.

${ }^{2}$ 'Data refer to government aided and maintained schools only.

${ }^{23}$ Excludes some nonuniversity institution

${ }^{24}$ ncludes full-time students only.

${ }^{2}$ Data include both former East and West Germany.

"Excludes enrollments in programs formerly classified as doctora.

Deta do nol include Vocallonal Educalion and Taining notiutes

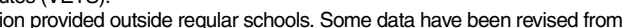

(U) Statistical Yearbook, 1999; unpublished tabulations, and tabulations from the UNESCO Institute for Statistics Online Data Center, retrieved December 16, 2013, from http:// data.uis.unesco.org/. U.S. Department of Commerce, Census Bureau, International Data Base, retrieved December 16,
http://www.census.gov/population/international/data/idb/informationGateway.php. (This table was prepared January 2014.) 
Table 601.30. School-age populations as a percentage of total population, by age group and OECD or other country: Selected years, 1985 through 2010

\begin{tabular}{|c|c|c|c|c|c|c|c|c|c|c|c|c|c|c|c|c|c|c|c|c|c|c|c|c|}
\hline \multirow[b]{2}{*}{ Country } & \multicolumn{12}{|c|}{ 5- to 14 -year-olds as a percent of total population } & \multicolumn{12}{|c|}{ 15- to 19-year-olds as a percent of total population } \\
\hline & $1985^{1}$ & $1990^{1}$ & $1995^{1}$ & 1999 & 2003 & 2004 & 2005 & 2006 & 2007 & 2008 & 2009 & 2010 & $1985^{2}$ & $1990^{2}$ & $1995^{2}$ & 1999 & 2003 & 2004 & 2005 & 2006 & 2007 & 2008 & 2009 & 2010 \\
\hline 1 & 2 & 3 & 4 & 5 & 6 & 7 & 8 & 9 & 10 & 11 & 12 & 13 & 14 & 15 & 16 & 17 & 18 & 19 & 20 & 21 & 22 & 23 & 24 & 25 \\
\hline 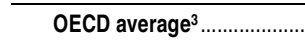 & - & - & - & 13 & 13 & 13 & 13 & 12 & 12 & 12 & 12 & 12 & - & - & - & 7 & 7 & 7 & 7 & 7 & 7 & 7 & 7 & 6 \\
\hline 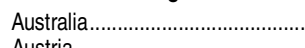 & 14 & 13 & 13 & 14 & 14 & 14 & $\begin{array}{l}13 \\
11\end{array}$ & 13 & $\begin{array}{l}13 \\
11\end{array}$ & $\begin{array}{r}13 \\
11\end{array}$ & 13 & 12 & 7 & 6 & 6 & 7 & 7 & 7 & 7 & 7 & 7 & 7 & 7 & 7 \\
\hline $\begin{array}{l}\text { Austria } \\
\text { Belgium }\end{array}$ & $\overline{11}$ & $\overline{11}$ & $\overline{11}$ & $\overline{12}$ & $\begin{array}{l}12 \\
12\end{array}$ & $\begin{array}{l}11 \\
12\end{array}$ & $\begin{array}{l}11 \\
12\end{array}$ & $\begin{array}{l}11 \\
12\end{array}$ & $\begin{array}{l}11 \\
11\end{array}$ & $\begin{array}{l}11 \\
11\end{array}$ & $\begin{array}{l}10 \\
11\end{array}$ & $\begin{array}{r}10 \\
11\end{array}$ & $-\overline{6}$ & $\overline{5}$ & $\overline{5}$ & - & 6 & 6 & 6 & 6 & 6 & 6 & $\begin{array}{c}6 \\
6 \\
\end{array}$ & 6 \\
\hline 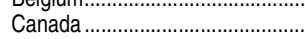 & $\begin{array}{l}11 \\
13\end{array}$ & $\begin{array}{l}11 \\
12\end{array}$ & 12 & 14 & $\begin{array}{l}12 \\
13\end{array}$ & $\begin{array}{l}12 \\
13\end{array}$ & $\begin{array}{l}12 \\
13\end{array}$ & $\begin{array}{l}12 \\
12\end{array}$ & $\begin{array}{l}11 \\
12\end{array}$ & $\begin{array}{l}11 \\
12\end{array}$ & 11 & 11 & $\begin{array}{l}0 \\
6\end{array}$ & $\begin{array}{l}5 \\
5\end{array}$ & $\begin{array}{r}5 \\
5\end{array}$ & \begin{tabular}{l|l}
0 \\
7
\end{tabular} & $\begin{array}{l}0 \\
7\end{array}$ & $\begin{array}{l}0 \\
7\end{array}$ & $\begin{array}{l}0 \\
7\end{array}$ & \begin{tabular}{l|l}
0 \\
7
\end{tabular} & 7 & \begin{tabular}{l|l}
0 \\
7
\end{tabular} & $\begin{array}{l}0 \\
7\end{array}$ & 7 \\
\hline 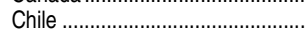 & - & - & - & - & 18 & 18 & 18 & 17 & 16 & 15 & 15 & 15 & - & - & - & - & 9 & 9 & 9 & 9 & 9 & 9 & 9 & 9 \\
\hline Czech Republic............. & (4) & (4) & 12 & 12 & 11 & 11 & 10 & 10 & 10 & 9 & 9 & 9 & (4) & $\left({ }^{4}\right)$ & 6 & 7 & 7 & 7 & 6 & 6 & 6 & 6 & 6 & 6 \\
\hline Denmark ……………………........ & 12 & 10 & 10 & 12 & 13 & 13 & 13 & 13 & 13 & 12 & 12 & 12 & 6 & 6 & 5 & 5 & 5 & 5 & 6 & 6 & 6 & 6 & 6 & 6 \\
\hline Estonia............................................ & (4) & $\left({ }^{4}\right)$ & - & - & - & - & 11 & 10 & 10 & 10 & 9 & 9 & $\left({ }^{4}\right)$ & $\left({ }^{4}\right)$ & - & - & - & - & 8 & 8 & 8 & 7 & 7 & 6 \\
\hline Finland & 11 & 12 & 11 & 13 & 12 & 12 & 12 & 12 & 12 & 11 & 11 & 11 & 6 & 5 & 5 & 6 & 6 & 6 & 6 & 6 & 6 & 6 & 6 & 6 \\
\hline 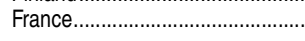 & 13 & 12 & 12 & 13 & 12 & 12 & 12 & 12 & 12 & 12 & 12 & 12 & 6 & 6 & 5 & 7 & 6 & 6 & 7 & 6 & 6 & 6 & 6 & 6 \\
\hline Germany ${ }^{5}$. & 9 & 9 & 10 & 11 & 10 & 10 & 10 & 10 & 10 & 10 & 9 & 9 & 6 & 4 & 4 & 6 & 6 & 6 & 6 & 6 & 6 & 6 & 5 & 5 \\
\hline 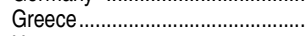 & - & - & 11 & 11 & 10 & 10 & 10 & 10 & 10 & 9 & 9 & 9 & - & 5 & 6 & 7 & 6 & 6 & 6 & 5 & 5 & 5 & 5 & 5 \\
\hline Hungary ……………………… & - & - & - & - & 11 & 11 & 11 & 11 & 10 & 10 & 10 & 10 & - & - & - & - & 6 & 6 & 6 & 6 & 6 & 6 & 6 & 6 \\
\hline Iceland & 16 & 15 & 14 & 16 & 16 & 15 & 15 & 15 & 14 & 14 & 14 & 14 & 7 & 7 & 6 & 8 & 7 & 7 & 7 & 7 & 7 & 8 & 7 & 7 \\
\hline 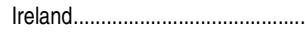 & 18 & 18 & 15 & 15 & 14 & 14 & 14 & 13 & 13 & 13 & 13 & 13 & 8 & 8 & 8 & 9 & 8 & 8 & 7 & 7 & 7 & 6 & 6 & 6 \\
\hline Israel. & - & - & - & - & 18 & 18 & 18 & 18 & 18 & 18 & 18 & 18 & - & - & - & - & 9 & 8 & 8 & 8 & 8 & 8 & 8 & 8 \\
\hline Ita & 13 & 10 & 9 & 10 & 10 & 10 & 9 & 9 & 9 & 9 & 9 & 9 & 6 & 6 & 5 & 5 & 5 & 5 & 5 & 5 & 5 & 5 & 5 & 5 \\
\hline Japan & 14 & 12 & 10 & 10 & 10 & 9 & 9 & 9 & 9 & 9 & 9 & 9 & 6 & 7 & 5 & 6 & 6 & 5 & 5 & 5 & 5 & 5 & 5 & 5 \\
\hline 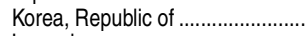 & - & - & 14 & 14 & 14 & 14 & 14 & 14 & 13 & 13 & 12 & 12 & - & - & 7 & 8 & 7 & 6 & 7 & 7 & 7 & 7 & 7 & 7 \\
\hline 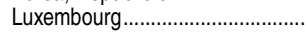 & 10 & 10 & 11 & 12 & 13 & 13 & 13 & 13 & 12 & 12 & 12 & 12 & 5 & 4 & 4 & 6 & 6 & 6 & 6 & 6 & 6 & 6 & 6 & 6 \\
\hline Mexico & - & - & - & - & 22 & 22 & 21 & 21 & 21 & 21 & 20 & 20 & - & - & - & - & 10 & 10 & 10 & 10 & 10 & 10 & 10 & 10 \\
\hline $\mathrm{N}$ & 12 & 11 & 11 & 12 & 12 & 12 & 12 & 12 & 12 & 12 & 12 & 12 & 7 & 5 & 5 & 6 & 6 & 6 & 6 & 6 & 6 & 6 & 6 & 6 \\
\hline New Zealand.......................................... & 15 & 13 & 13 & 15 & 15 & 15 & 15 & 14 & 14 & 14 & 14 & 13 & 7 & 7 & 6 & 7 & 7 & 7 & 7 & 8 & 8 & 8 & 7 & 7 \\
\hline 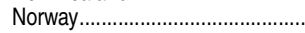 & 13 & 11 & 11 & 13 & 14 & 14 & 13 & 13 & 13 & 13 & 13 & 13 & 6 & 6 & 5 & 6 & 6 & 6 & 6 & 6 & 7 & 7 & 7 & 7 \\
\hline Poland & - & - & - & - & 13 & 12 & 12 & 12 & 11 & 11 & 10 & 10 & - & - & - & - & 8 & 8 & 8 & 8 & 7 & 7 & 7 & 7 \\
\hline Portugal. & - & - & - & - & 11 & 10 & 10 & 10 & 10 & 10 & 10 & 10 & - & - & - & - & 6 & 6 & 6 & 6 & 6 & 5 & 5 & 5 \\
\hline Slovak Republic. & (4) & (4) & - & - & 13 & 13 & 12 & 12 & 11 & 11 & 10 & 10 & (4) & $\left({ }^{4}\right)$ & - & - & 8 & 8 & 8 & 8 & 7 & 7 & 7 & 7 \\
\hline Sloveni & $\left({ }^{4}\right)$ & (4) & - & - & - & - & 10 & 10 & 9 & 9 & 9 & 9 & $\left(4^{4}\right)$ & $\left(4^{4}\right)$ & - & - & - & - & 6 & 6 & 6 & 6 & 5 & 5 \\
\hline Spain & 15 & 13 & 10 & 10 & 10 & 10 & 9 & 9 & 9 & 9 & 9 & 10 & 7 & 7 & 6 & 7 & 6 & 6 & 5 & 5 & 5 & 5 & 5 & 5 \\
\hline 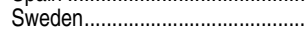 & 11 & 10 & 11 & 13 & 13 & 13 & 12 & 12 & 11 & 11 & 11 & 11 & 5 & 5 & 5 & 6 & 6 & 6 & 6 & 7 & 7 & 7 & 7 & 7 \\
\hline Switz & 11 & 10 & 10 & 12 & 12 & 11 & 11 & 11 & 11 & 11 & 10 & 10 & 6 & 5 & 5 & 6 & 6 & 6 & 6 & 6 & 6 & 6 & 6 & 6 \\
\hline Turkey & 21 & 21 & 20 & 21 & 19 & 19 & 19 & 19 & 19 & 18 & 18 & 18 & 9 & 9 & 9 & 11 & 9 & 9 & 9 & 9 & 9 & 9 & 9 & 9 \\
\hline 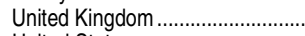 & 11 & 11 & 12 & 13 & 13 & 13 & 12 & 12 & 12 & 12 & 11 & 11 & 6 & 5 & 5 & 6 & 6 & 7 & 7 & 7 & 7 & 7 & 6 & 6 \\
\hline 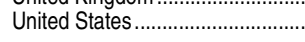 & 13 & 13 & 13 & 15 & 14 & 14 & 14 & 14 & 13 & 13 & 13 & 13 & 6 & 5 & 6 & 7 & 7 & 7 & 7 & 7 & 7 & 7 & 7 & 7 \\
\hline Other reporting countries & & & & & & & & & & & & & & & & & & & & & & & & \\
\hline 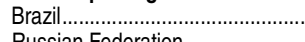 & $-\overline{(4)}$ & - & - & - & 21 & 20 & 19 & 19 & 18 & 18 & 17 & 17 & $-\overline{14}$ & - & - & - & 11 & 10 & 10 & 10 & 9 & 9 & 9 & 9 \\
\hline Russian Federation.......................... & $(4)$ & $\left({ }^{4}\right)$ & 14 & 14 & 12 & 11 & 10 & 10 & 10 & 9 & 9 & 9 & $\left({ }^{4}\right)$ & $\left({ }^{4}\right)$ & - & - & 9 & 9 & 9 & 8 & 8 & 7 & 7 & 6 \\
\hline
\end{tabular}

-Not available.

Data are for the 5 - to 13 -year-old population.

3Refers to the mean of the data values for all reporting OECD countries, to which each country reporting data contributes
3. equally. The average includes all current $O E C D$ countries for which a given year's data are available, even if they were not members of OECD in that year. However, if data for a given year are available for less than 75 percent of the countries, the ${ }^{4}$ Country did not exist in its current form in the given year. DOla tor 1985 are for the former West Germany.

and Development (OECD), Education at a Glance, selected years, 1987 Database, retrieved July 23, 2013, from http://stats.oecd.org/lndex.aspx. (This table as prepared July 2013.) average for that year is omitted. 
Table 601.40. Percentage of population enrolled in secondary and postsecondary education, by age group and OECD or other country: Selected years, 2002 through 2011

\begin{tabular}{|c|c|c|c|c|c|c|c|c|c|c|c|c|c|c|c|c|c|c|c|c|}
\hline \multirow[b]{3}{*}{ Country } & \multicolumn{8}{|c|}{ Secondary education, 2011} & \multicolumn{12}{|c|}{ Postsecondary education (total tertiary education) } \\
\hline & \multirow[b]{2}{*}{$\begin{array}{r}16 \\
\text { years old }\end{array}$} & \multirow[b]{2}{*}{$\begin{array}{r}17 \\
\text { years old }\end{array}$} & \multicolumn{5}{|c|}{18 to 21 years old } & \multirow{2}{*}{$\begin{array}{r}22 \text { years } \\
\text { old and } \\
\text { older }\end{array}$} & \multicolumn{4}{|c|}{18 to 21 years old } & \multicolumn{4}{|c|}{22 to 25 years old } & \multicolumn{4}{|c|}{26 to 29 years old } \\
\hline & & & Total & $\begin{array}{r}18 \\
\text { years old }\end{array}$ & $\begin{array}{r}19 \\
\text { years old }\end{array}$ & $\begin{array}{r}20 \\
\text { years old }\end{array}$ & \begin{tabular}{|r|}
21 \\
years old
\end{tabular} & & 2002 & 2005 & 2010 & 2011 & 2002 & 2005 & 2010 & 2011 & 2002 & 2005 & 2010 & 2011 \\
\hline 1 & 2 & 3 & 4 & 5 & 6 & 7 & 8 & 9 & 10 & 11 & 12 & 13 & 14 & 15 & 16 & 17 & 18 & 19 & 20 & 21 \\
\hline 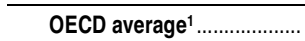 & 94 & 88 & 25 & 56 & 28 & 14 & 9 & 1 & 26 & 28 & 31 & 31 & 21 & 23 & 25 & 26 & 9 & 10 & 11 & 11 \\
\hline 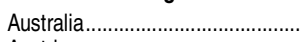 & 95 & 80 & 23 & 39 & 24 & 18 & 14 & 3 & 35 & 34 & 36 & 37 & 20 & 21 & 23 & 24 & 10 & 10 & 11 & 11 \\
\hline 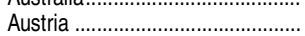 & 90 & 75 & 18 & 44 & $\begin{array}{l}24 \\
19\end{array}$ & 8 & $\begin{array}{r}4 \\
4\end{array}$ & \# & 15 & 16 & 21 & 21 & 18 & 20 & 26 & 26 & 9 & 9 & 15 & 15 \\
\hline 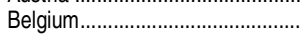 & 100 & 98 & 24 & 48 & 24 & 13 & 9 & 5 & 42 & 43 & 45 & 46 & 18 & 19 & 22 & 22 & 5 & 6 & 6 & 7 \\
\hline 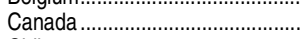 & - & - & - & - & - & - & - & - & - & - & 36 & 35 & - & - & 20 & 20 & - & - & 8 & 8 \\
\hline 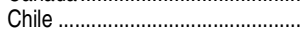 & 90 & 86 & 12 & 32 & 10 & 3 & 2 & \# & - & - & 36 & 39 & - & - & 26 & 28 & - & - & 11 & 11 \\
\hline Czech Republic..................... & 98 & 96 & 34 & 86 & 41 & 9 & 3 & \# & 20 & 23 & 26 & 28 & 16 & 21 & 27 & 28 & 5 & 6 & 8 & 8 \\
\hline 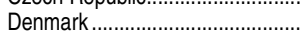 & 94 & 89 & 50 & 84 & 58 & 34 & 23 & 2 & 10 & 10 & 13 & 15 & 29 & 34 & 35 & 37 & 16 & 20 & 19 & 20 \\
\hline Estonia & 96 & 94 & 28 & 79 & 24 & 11 & $\begin{array}{r}6 \\
6\end{array}$ & \# & - & 32 & 31 & 31 & - & 22 & 25 & 26 & - & 12 & 10 & 11 \\
\hline Finland & 95 & 95 & 41 & 93 & $\begin{array}{l}24 \\
34\end{array}$ & 18 & 17 & $\begin{array}{l}\pi \\
4\end{array}$ & 21 & 24 & 22 & $\begin{array}{l}31 \\
22\end{array}$ & 39 & 40 & 38 & $\begin{array}{l}20 \\
38\end{array}$ & $\overline{19}$ & 20 & 20 & 20 \\
\hline France................................................ & 93 & 87 & 20 & 46 & 22 & 9 & 4 & $\#$ & 35 & 36 & 37 & 38 & 20 & 20 & 20 & 20 & 5 & 5 & 5 & 5 \\
\hline Germany ............. & 97 & 92 & 41 & 82 & 48 & 24 & 16 & \# & 12 & 13 & 18 & 19 & 20 & 23 & 25 & 26 & 12 & 13 & 13 & 14 \\
\hline 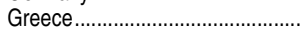 & 96 & 94 & 11 & 19 & 11 & 9 & 4 & \# & 46 & 65 & 44 & 48 & 24 & 18 & 31 & 30 & 11 & 8 & $16^{2}$ & $18^{2}$ \\
\hline 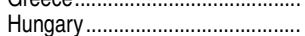 & 100 & 98 & 32 & 75 & 33 & 14 & $\begin{array}{l}4 \\
8\end{array}$ & $\begin{array}{l}\pi \\
1\end{array}$ & 24 & 29 & 29 & 28 & $\begin{array}{c}24 \\
18\end{array}$ & 23 & 24 & 24 & 7 & 9 & 8 & 7 \\
\hline 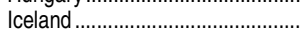 & 95 & 88 & 52 & 81 & 71 & 35 & 23 & 3 & 10 & 12 & 14 & 14 & 24 & 28 & 28 & 31 & 12 & 16 & 16 & 17 \\
\hline 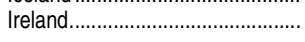 & 100 & 86 & 12 & 39 & 5 & 2 & 1 & $\#$ & 36 & 38 & 46 & 41 & 11 & 13 & 13 & 13 & 5 & 5 & - & - \\
\hline |srael................. & 94 & 88 & 5 & 16 & 2 & 1 & \# & \# & 10 & 12 & 13 & 13 & 26 & 25 & 27 & 27 & 17 & 15 & 18 & 19 \\
\hline 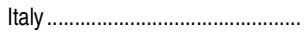 & 91 & 88 & 27 & 75 & 21 & 8 & 4 & \# & 24 & 29 & 27 & 27 & 21 & 23 & 25 & 25 & 8 & 8 & 8 & 8 \\
\hline Japan ............................... & 93 & 94 & 1 & 3 & 1 & - & - & \# & - & - & - & - & - & - & - & - & - & - & - & - \\
\hline Korea, Republic of .................... & 95 & 91 & 2 & 6 & $\#$ & \# & \# & \# & 56 & 65 & 70 & 68 & 32 & 32 & 38 & 38 & 7 & 6 & 8 & 8 \\
\hline 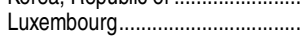 & 89 & 80 & 40 & 70 & 46 & 27 & 15 & $\#$ & - & - & - & - & - & - & - & - & - & - & - & - \\
\hline 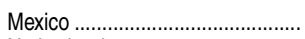 & 64 & 51 & 13 & 20 & 28 & 3 & 1 & 2 & 15 & 16 & 20 & 21 & 7 & 9 & 10 & 10 & 3 & 3 & 3 & 3 \\
\hline 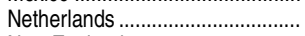 & 99 & 90 & 39 & 66 & 44 & 29 & 18 & 2 & 28 & 29 & 34 & 36 & 22 & 24 & 27 & 31 & 6 & 7 & 8 & 11 \\
\hline New Zealand.................................. & 97 & 83 & 14 & 29 & 12 & 8 & 6 & 2 & 30 & 34 & 36 & 37 & 17 & 23 & 22 & 22 & 8 & 11 & 12 & 11 \\
\hline Norway ....………………….... & 95 & 92 & 39 & 88 & 39 & 19 & 10 & 1 & 17 & 19 & 20 & 21 & 27 & 30 & 28 & 28 & 13 & 14 & 13 & 13 \\
\hline 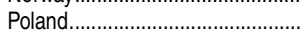 & 97 & 96 & 36 & 92 & 41 & 11 & 6 & \# & 27 & 31 & 35 & 35 & 26 & 30 & 32 & 32 & 7 & 6 & 6 & 6 \\
\hline 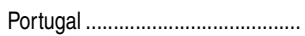 & 100 & 90 & 26 & 51 & 28 & 16 & 10 & 2 & 25 & 27 & 33 & 34 & 20 & 21 & 18 & 20 & 8 & 8 & 7 & 8 \\
\hline 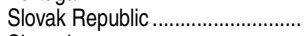 & 94 & 91 & 32 & 81 & 39 & 9 & 2 & \# & 21 & 22 & 26 & 25 & 13 & 16 & 24 & 24 & 4 & 5 & 6 & 6 \\
\hline 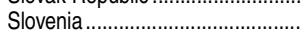 & 97 & 95 & 26 & 86 & 26 & \# & $\#$ & 1 & - & 37 & 43 & 44 & - & 35 & 39 & 39 & - & 11 & 11 & 10 \\
\hline 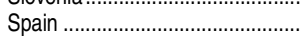 & 95 & 89 & 25 & 47 & 28 & 17 & 11 & 1 & 35 & 34 & 37 & 38 & 24 & 22 & 23 & 25 & 8 & 9 & 9 & 10 \\
\hline Sweden & 100 & 98 & 37 & 94 & 25 & 14 & 14 & 2 & 17 & 17 & 18 & 18 & 28 & 32 & 29 & 29 & 13 & 16 & 16 & 16 \\
\hline Switzerland & 91 & 88 & 40 & 79 & 49 & 23 & 11 & \# & 10 & 12 & 14 & 15 & 18 & 20 & 24 & 24 & 9 & 10 & 12 & 12 \\
\hline Turkey ………………………… & 73 & 65 & 8 & 30 & - & - & - & - & - & 20 & 30 & 33 & - & 11 & 22 & 23 & - & 4 & 8 & 9 \\
\hline United Kingdom .............................. & 97 & 83 & 15 & 34 & 14 & 8 & 6 & 1 & 30 & 28 & 32 & 33 & 12 & 13 & 13 & 13 & 6 & 7 & 7 & 7 \\
\hline United States...................... & 93 & 84 & 7 & 25 & 4 & \# & \# & \# & 46 & 45 & 49 & 50 & 25 & 23 & 28 & 27 & 11 & 11 & 12 & 14 \\
\hline Other reporting countries & & & & & & & & & & & & & & & & & & & & \\
\hline Brazil................................ & 87 & $\begin{array}{l}84 \\
45\end{array}$ & 30 & $\begin{array}{l}54 \\
15\end{array}$ & $\begin{array}{r}31 \\
5\end{array}$ & 19 & $\begin{array}{r}13 \\
1\end{array}$ & 2 & 3 & 10 & 13 & 15 & 10 & 9 & 13 & 15 & 5 & 5 & 8 & 8 \\
\hline Russian Federation....................... & 69 & 45 & & 15 & & & & \# & & & & 49 & & 26 & - & 21 & - & - & - & 10 \\
\hline
\end{tabular}

\section{-Not available.}

\#Rounds to zero.

Refers to the mean of the data values for all reporting OECD countries, to which each country reporting data contributes members of $O E C D$ in that ye all However, if data for a given year are avilable for lass than 75 percent of the coutries, the average for that year is omitted.

2Data are for the population 26 to 28 years old.

NOTE: Data refer to programs classified as International Standard Classification of Education (ISCED) level 3, level 5A (first els $5 \mathrm{~A}$ (first and second award), $5 \mathrm{~B}$, and 6 together make up total tertiary education, which corresponds to 2 -year and 4-year college undergraduate and graduate programs in the United States. Excludes enrollment in ISCED level 4, which is nontertiary education that corresponds to enrollment in programs of less than 2 years after high school in the United Slates. Includes boh full-time and part-time students. Some increases in enrollment rates may be due to more complete reporting by countries. tion and the age at which it begins. Differences in reference dates between enrolment and population data can result in enrollment rates that exceed 100 percent. Postsecondary data for Luxembourg are not shown because tertiary students generaly study for no more than 1 year in Luxembourg and must complete their studies in other countries.

SOURCE: Organization for Economic Cooperation and Development (OECD), Online Education Database, retrieved December 26, 2013, from http://stats.oecd.org/Index.aspx. (This table was prepared December 2013.) 
Table 601.50. Pupil/teacher ratios in public and private elementary and secondary schools, by level of education and country: Selected years, 2000 through 2011

\begin{tabular}{|c|c|c|c|c|c|c|c|c|c|c|c|c|c|c|c|c|c|c|c|c|c|}
\hline \multirow[b]{2}{*}{ Country } & \multicolumn{7}{|c|}{ Elementary } & \multicolumn{7}{|c|}{ Junior high school (lower secondary) } & \multicolumn{7}{|c|}{ Senior high school (upper secondary) } \\
\hline & 2000 & 2005 & 2007 & 2008 & 2009 & 2010 & 2011 & 2000 & 2005 & 2007 & 2008 & 2009 & 2010 & 2011 & 2000 & 2005 & 2007 & 2008 & 2009 & 2010 & 2011 \\
\hline 1 & 2 & 3 & 4 & 5 & 6 & 7 & 8 & 9 & 10 & 11 & 12 & 13 & 14 & 15 & 16 & 17 & 18 & 19 & 20 & 21 & 22 \\
\hline OECD average 1. & 17.7 & 17.0 & 16.2 & 16.4 & 16.0 & 15.9 & 15.4 & - & 14.0 & 13.4 & 13.7 & 13.5 & 13.5 & 13.2 & 13.7 & 13.5 & 13.1 & 13.3 & 13.4 & 13.6 & 13.7 \\
\hline Australia.................. & 17.3 & 16.2 & 15.9 & 15.8 & 15.8 & 15.7 & 15.6 & - & - & - & - & - & - & - & - & $12.1^{2,3}$ & $12.1^{2,3}$ & $12.0^{2,3}$ & $12.0^{2,3}$ & $12.0^{2,3}$ & $12.0^{2,3}$ \\
\hline Austria ....................... & - & 14.1 & 13.6 & 12.9 & 12.6 & 12.2 & 12.1 & - & 10.6 & 10.3 & 9.9 & 9.6 & 9.3 & 9.1 & - & 11.3 & & & & 10.1 & 9.8 \\
\hline Belgium.. & $15.0^{4}$ & 12.8 & $12.6^{5}$ & $12.6^{5}$ & $12.5^{5}$ & $12.4^{5}$ & $12.4^{5}$ & - & 9.4 & $9.2^{5}$ & $8.1^{5}$ & $8.1^{5}$ & $8.1^{5}$ & $8.1^{5}$ & $9.7^{3,6}$ & $9.9^{6}$ & 10 & $10.8^{5,6}$ & 10 & $10.1^{5,6}$ & $10.1^{5,6}$ \\
\hline Canada... & 18.1 & - & - & - & & & & 18.1 & & & $16.64,7$ & $17.7^{4,7}$ & $15.94,7$ & - & 19.5 & & $16.4^{3,4,7,8}$ & 14.7 & 15.8 & 14.2 & - \\
\hline Chile ........................... & - & 25.9 & 24.7 & 24.1 & 22.4 & 24.6 & 23.1 & - & 25.9 & 24.7 & 24.1 & 22.4 & 25.1 & 23.6 & - & 26.6 & 25.7 & 25.2 & 24.7 & 26.1 & 25.4 \\
\hline Czech Republic....... & 19.7 & 17.5 & 18.7 & 18.1 & 18.4 & 18.7 & 18.7 & 14.7 & 13.5 & 12.3 & 11.8 & 11.5 & 11.2 & 11.1 & 11.5 & 12.8 & 12.3 & 12.2 & 12.2 & 12.1 & 11.7 \\
\hline ……... & 10.4 & $=$ & $1 \overline{4}$ & $16 \overline{4}$ & $16 ?$ & $16 ?$ & 132 & 11.4 & $11.9^{7}$ & $11.2^{7}$ & $10.1^{7}$ & $\begin{array}{r}9.9^{7} \\
157^{2}\end{array}$ & $11.5^{7}$ & $\begin{array}{l}11.8^{7} \\
101\end{array}$ & 14.4 & - & 1006 & 1046 & 1606 & 1606 & 127 \\
\hline onia..................... & $16 \overline{9}$ & $15 \overline{9}$ & $\begin{array}{l}14.4 \\
150\end{array}$ & $\begin{array}{l}16.4 \\
14.4\end{array}$ & $\begin{array}{l}16.2 \\
136\end{array}$ & $\begin{array}{l}16.2 \\
14.0\end{array}$ & $\begin{array}{l}13.2 \\
13.2\end{array}$ & & $1 \overline{0}$ & $\begin{array}{r}11.4 \\
99\end{array}$ & $\begin{array}{l}16.0 \\
10.6\end{array}$ & $\begin{array}{l}15.7 \\
101\end{array}$ & $\begin{array}{r}14.9 \\
98\end{array}$ & $\begin{array}{r}10.1 \\
9.3\end{array}$ & $1 \overline{0}^{6,9}$ & $18 \overline{0} 6,9$ & $\begin{array}{r}12.26 \\
15.96\end{array}$ & $\begin{array}{l}12.4^{6} \\
159^{6}\end{array}$ & $\begin{array}{l}16.8^{\circ} \\
166^{6}\end{array}$ & $\begin{array}{l}16.6^{6} \\
171^{6}\end{array}$ & $\begin{array}{l}13.7 \\
1636\end{array}$ \\
\hline $\begin{array}{l}\text { Finland ....................... } \\
\text { France................... }\end{array}$ & $\begin{array}{l}16.9 \\
19.8\end{array}$ & $\begin{array}{l}15.9 \\
19.4\end{array}$ & $\begin{array}{l}15.0 \\
19.7^{5}\end{array}$ & $\begin{array}{l}14.4 \\
19.9^{5}\end{array}$ & $\begin{array}{l}13.6 \\
19.7^{5}\end{array}$ & $\begin{array}{l}14.0 \\
18.7^{5}\end{array}$ & $\begin{array}{l}13.7 \\
18.4^{5}\end{array}$ & $\begin{array}{l}10.7 \\
14.7\end{array}$ & $\begin{array}{l}10.0 \\
14.2\end{array}$ & $\begin{array}{c}9.9 \\
14.3^{5}\end{array}$ & $\begin{array}{l}10.6 \\
14.6^{5}\end{array}$ & $\begin{array}{l}10.1 \\
14.9^{5}\end{array}$ & $\begin{array}{c}9.8 \\
15.0^{5}\end{array}$ & $\begin{array}{c}9.3 \\
14.8^{5}\end{array}$ & $\begin{array}{l}17.0^{6,9} \\
10.4^{-1}\end{array}$ & $\begin{array}{l}18.0^{6,9} \\
10.3\end{array}$ & $\begin{array}{r}15.96 \\
9.6^{5}\end{array}$ & $\begin{array}{r}15.9^{6} \\
9.4^{5}\end{array}$ & $\begin{array}{r}16.6^{6} \\
9.6^{5}\end{array}$ & $\begin{array}{r}17.1^{6} \\
9.7^{5}\end{array}$ & $\begin{array}{l}16.3^{6} \\
10.0^{5}\end{array}$ \\
\hline Germany...................... & 19.8 & 18.8 & 18.3 & 18.0 & 17.4 & 16.7 & 16.3 & 15.7 & 15.5 & 15.2 & 150 & 15.1 & 14.9 & 14.2 & 13.9 & 14.0 & 14.3 & 14.0 & 13.9 & 13.2 & 138 \\
\hline Greece & 13.4 & 11.1 & 10.1 & - & 1.7 & 1.1 & 100 & 10.8 & 7.9 & 7.7 & 1.0 & (10. & - & 年 & 10.5 & 8.8 & 7.3 & - & . & & 10.0 \\
\hline Hungary & 10.9 & 10.6 & 10.2 & 10.6 & 10.7 & 10.8 & 10.7 & 10.9 & 10.4 & 10.2 & 10.9 & 10.8 & 10.7 & 10.5 & $11.4^{6}$ & 12.2 & 12.1 & 12.3 & 12.8 & 12.5 & 12.4 \\
\hline Iceland & m & . & 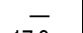 & & & & 10.2 & $12.7^{7}$ & $11.3^{7}$ & $10.4^{7}$ & $10.0^{7}$ & $9.9^{7}$ & $10.3^{7}$ & 10.6 & 9.7 & $10.8^{6}$ & $10.2^{6}$ & $10.6^{6}$ & & 11.3 & $11.5^{6}$ \\
\hline Ireland............................ & 21.5 & 17.9 & 17.9 & 17.8 & 15.9 & 15.9 & 15.7 & - & - & - & - & - & - & - & $15.9^{3,6}$ & $15.5^{3,6}$ & $13.2^{3,6,8}$ & $12.8^{3,6,8}$ & $12.6^{3,6,8}$ & $14.4^{3,6,8}$ & $14.4^{3,6}$ \\
\hline Israel.............. & - & 17.3 & 16.4 & 16.3 & 17.0 & $20.6^{8}$ & $15.9^{8}$ & - & 13.4 & 12.4 & 12.2 & 13.7 & $12.8^{8}$ & $13.6^{8}$ & - & 13.4 & 11.8 & 10.9 & 10.8 & $11.0^{8}$ & $11.3^{8}$ \\
\hline$(\ldots \ldots \ldots \ldots . .$. & 11.0 & 10.6 & 10.5 & $10.6^{8}$ & $10.7^{8}$ & $11.3^{8}$ & $11.7^{8}$ & 10.4 & 10.1 & 9.4 & $9.7^{8}$ & $10.0^{8}$ & $11.9^{8}$ & $11.5^{8}$ & 10.2 & 11.0 & 10 & $11.8^{8}$ & $11.8^{8}$ & $12.1^{8}$ & $12.8^{8}$ \\
\hline & 20.9 & 19.4 & S & 18.8 & 186 & 18.4 & 18.1 & 16.8 & 15.1 & 14 & 14.7 & 14.5 & 14.4 & 14.2 & 14 & $13.0^{6}$ & & & $12.2^{6}$ & $12.2^{6}$ & $12.2^{6}$ \\
\hline Korea, Republic of .. & 32.1 & 28.0 & & & & 21.1 & 19.6 & 21.5 & 20.8 & $20.5>-5$ & 20. & 19.9 & 19.7 & 18.8 & & & & & 16.7 & 16.5 & 15.8 \\
\hline Luxembourg............. & $15.9^{8}$ & - & $11.2^{8}$ & $12.1^{8}$ & 11.6 & 10.1 & 9.9 & - & - & - & - & - & - & - & $9.2^{3,8}$ & $9.0^{3,8}$ & $9.0^{3,8}$ & $9.1^{3,8}$ & $9.1^{3}$ & $9.1^{3}$ & $9.6^{3}$ \\
\hline Mexico & 27.2 & 28.3 & 28.0 & 28.0 & 28.1 & 28.1 & 28.1 & 34.8 & 33.7 & 33.3 & 33.9 & 33.0 & 32.7 & 31.9 & 26.5 & 25.8 & 25.7 & & & 26. & 26.8 \\
\hline & $16.8^{4}$ & $15.9^{4}$ & $15.6^{4}$ & $15.8^{4,8}$ & $15.8^{4,8}$ & $15.7^{4,8}$ & 15 & - & - & 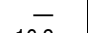 & 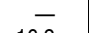 & - & & 15.3 & $17.1^{3}$ & $16.2^{3}$ & & & & $3,6,8$ & \\
\hline New Z & 20.6 & 18.1 & 17.5 & 17.1 & 16.3 & 16.2 & 16.3 & 19.9 & 16.8 & 16.2 & 16.2 & 16.3 & 16.3 & 16.3 & 13.1 & 12.9 & 13 & & & & 13.9 \\
\hline Nory & 12.4 & - & $11.0^{8}$ & $10.8^{8}$ & $10.7^{8}$ & $10.5^{8}$ & $10.4^{8}$ & 9.9 & 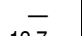 & $10.2^{8}$ & $10.1^{8}$ & $9.9^{8}$ & $9.9^{8}$ & $10.0^{8}$ & 9.7 & - & $9.8^{6,8}$ & $9.96,8$ & $9.46,8$ & $9.4^{8}$ & $9.76,8$ \\
\hline 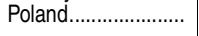 & 12.7 & 11.7 & 11.0 & 10.5 & 10.2 & 10.0 & 11.0 & 11.5 & 12.7 & 12.4 & 12.9 & 12.9 & 12.7 & 10.0 & 16.9 & 12.9 & 12.2 & 12.2 & 12.0 & 12.1 & 11.1 \\
\hline ....... & 12.1 & 10.8 & 11.8 & 11.3 & 11.3 & 10.9 & 11.2 & 10.4 & 8.2 & 7.9 & 8.1 & 7.6 & 7.9 & 8.2 & 7.9 & 8.0 & $8.4^{6}$ & $7.3^{6}$ & $7.7^{6}$ & $7.2^{6}$ & $7.3^{6}$ \\
\hline lic...... & 18.3 & 18.9 & 17.9 & 186 & 17.7 & 17.1 & 16.9 & 13.5 & 14.1 & 13.9 & 14.5 & 14.0 & 13.6 & 13.1 & 12.8 & 14.3 & 14.1 & 15.1 & 15.1 & 14.6 & 14.3 \\
\hline & & 15.0 & 15 & 15 & & & & - & 11.1 & 9.5 & 89 & 7.9 & 8.0 & 7.9 & - & 14. & $13.9^{6}$ & $13.7^{6}$ & $14.3^{6}$ & $14.3^{6}$ & $14.3^{6}$ \\
\hline & 14.9 & 14 & & & & & & - & 12 & & & 10 & 10.1 & 10.3 & $11.9^{3}$ & 8 & & & 9.3 & & 9.8 \\
\hline Sweden ....................... & 12.8 & 12.2 & 12.3 & 12.2 & 12.1 & 11.7 & 11.3 & 12.8 & 12.0 & 11.5 & 11.4 & 11.3 & 11.4 & 11.3 & 15.2 & 14.0 & 13.6 & 14.7 & 13.2 & 13.1 & 13.0 \\
\hline Switzerland ${ }^{8} .$. & - & 14.6 & 14.8 & 15.4 & 15.4 & 14.9 & - & - & 11.7 & 12.3 & 12.1 & 12.0 & 11.8 & - & - & $10.5^{2}$ & $10.6^{2}$ & $10.4^{2}$ & $10.4^{2}$ & $10.3^{2}$ & - \\
\hline & 30.5 & & 26 & & & 21 & 21.0 & $\overline{17 c^{2}}$ & $t^{\dagger}$ & & $\dagger$ & & ${ }^{\dagger}$ & $t$ & 14.0 & & & & & & 17.8 \\
\hline United Kin & 21.2 & 20.7 & 19.4 & 20.2 & 19.9 & 19.8 & 19.9 & $17.6^{2}$ & 17.0 & 16.7 & 15.0 & 16.1 & 17.1 & 15.2 & $12.5^{2}$ & $11.8^{2,6}$ & & $12.4^{6}$ & $12.3^{6}$ & $15.2^{6}$ & 17.3 \\
\hline United States.......... & 15.8 & 14.9 & 14.6 & 15.0 & 14.8 & 14.5 & 15.3 & 16.3 & 15.1 & 14.7 & 14.8 & 14.3 & 14.0 & 15.2 & 14.1 & 16.0 & & 15.6 & 15.1 & 15.0 & 15.3 \\
\hline Other reporting & & & & & & & & & & & & & & & & & & & & & \\
\hline $\begin{array}{c}\text { cour } \\
\text { Brazil. }\end{array}$ & - & 22.9 & 25.8 & 24.5 & 24.0 & 23.4 & 22.5 & - & 18.1 & 22.3 & 21.2 & 21.0 & 20.4 & 19.8 & - & 17.6 & 20.2 & 18.4 & 18.1 & 17.3 & 16.9 \\
\hline & & & & & & & & & & & & & & & & 110510 & & & & & \\
\hline Federation..... & - & - & $17.0^{8}$ & $17.3^{8}$ & $17.9^{8}$ & $19.2^{8}$ & $20.0^{8}$ & - & - & - & - & - & - & - & - & $11.2^{6,10}$ & $8.8^{3,6,11}$ & $8.7^{3,6,11}$ & $8.7^{3,6,11}$ & $11 \cdot 3^{3,6,11}$ & $8.7^{3,6,8}$ \\
\hline
\end{tabular}

-Not available.

FNot applicable. This level of education does not exist within the national education structure; students in the age group normally associated with this education level are reported in other levels.

'Refers to the mean of the data values for all reporting Organization for Economic Cooperation and Development (OECD) which a given year's data are available, even if they were not members of $O E C D$ in that year. However, if data were reported for less than 75 percent of the countries, the average for that year is omitted.

Includes only general programs.

3Includes junior high school
4ncludes preprimary data.

4ncludes preprimary data.
5 Excludes independent private institutions.

Includes postsecondary non-higher-education.

${ }^{7}$ Includes elementary school data.
${ }^{8}$ Public schools only.

Includes occupation-specific education corresponding to that offered at the vocational associate's degree level in the United States.

Excludes general programs.

NOTE: The pupi/teacher ratio is the number of full-time-equivalent students divided by the number of full-time-equivalent teachers, including teachers for students with disabilities and other special teachers. In this table, elementary school corresponds to International Standard Classification of Education (ISCED) level 1 (U.S. grades 1 through 6), junior high school cor-
responds to ISCED level 2 (U.S. grades 7 through 9), and senior high school corresponds to ISCED level 3 (U.S. grades 10 through 12). SOURCE: Organization for Economic Cooperation and Development (OECD), Online Education Database; and Education at
a Glance, 2002 through 2013. (This table was prepared December 2013.) 
Table 601.60. Teachers' statutory teaching and total working time and average class size in public elementary and secondary schools, by level of education and country: 2011

\begin{tabular}{|c|c|c|c|c|c|c|c|c|c|c|c|c|c|c|}
\hline \multirow[b]{3}{*}{ Country } & \multicolumn{12}{|c|}{ Statutory teaching and total working time } & & \\
\hline & \multicolumn{3}{|c|}{ Number of weeks of instruction } & \multicolumn{3}{|c|}{ Number of days of instruction } & \multicolumn{3}{|c|}{ Net teaching time in hours } & \multicolumn{3}{|c|}{ Total working time in hours } & \multicolumn{2}{|c|}{ Average class size } \\
\hline & Elementary & $\begin{array}{r}\text { Junior high } \\
\text { school } \\
\text { (lower } \\
\text { secondary) }\end{array}$ & 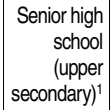 & Elementary & $\begin{array}{r}\text { Junior high } \\
\text { school } \\
\text { (lower } \\
\text { secondary) }\end{array}$ & $\begin{array}{r}\text { Senior high } \\
\text { school } \\
\text { (upper } \\
\text { secondary) }\end{array}$ & Elementary & $\begin{array}{r}\text { Junior high } \\
\text { school } \\
\text { (lower } \\
\text { secondary) }\end{array}$ & 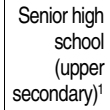 & Elementary & $\begin{array}{r}\text { Junior high } \\
\text { school } \\
\text { (lower } \\
\text { secondary) }\end{array}$ & $\begin{array}{r}\text { Senior high } \\
\text { school } \\
\text { (upper } \\
\text { secondary) }^{1}\end{array}$ & Elementary & $\begin{array}{r}\text { Junior high } \\
\text { school } \\
\text { (lower } \\
\text { secondary) }\end{array}$ \\
\hline 1 & 2 & 3 & 4 & 5 & 6 & 7 & 8 & 9 & 10 & 11 & 12 & 13 & 14 & 15 \\
\hline 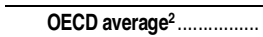 & 38 & 38 & 37 & 185 & 185 & 183 & 790 & 709 & 664 & 1,599 & 1,591 & 1,593 & 21 & 23 \\
\hline 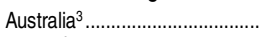 & 40 & 40 & 40 & 196 & 196 & 195 & 873 & 811 & 802 & $t$ & $t$ & $t$ & 23 & 23 \\
\hline Austria $^{3} \ldots$ & 38 & 38 & 38 & 180 & 180 & 180 & 779 & 607 & 589 & 1,776 & 1,776 & $\dagger$ & 18 & 21 \\
\hline Belgium (Flemish) ${ }^{3} \ldots \ldots \ldots \ldots \ldots$ & 37 & 37 & 37 & 178 & 179 & 179 & 757 & 671 & 626 & $\dagger$ & $\dagger$ & $\dagger$ & - & 一 \\
\hline Belgium (French) ${ }^{3} \ldots \ldots \ldots \ldots \ldots$ & 37 & 37 & 37 & 181 & 181 & 181 & 721 & 661 & 601 & $\dagger$ & $\dagger$ & $\dagger$ & 21 & 一 \\
\hline 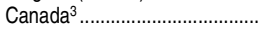 & 37 & 37 & 37 & 183 & 183 & 183 & 799 & 743 & 747 & $\dagger$ & $\dagger$ & $\dagger$ & - & - \\
\hline Chile $^{4}$. & 38 & 38 & 38 & 182 & 182 & 182 & 1,120 & 1,120 & 1,120 & 1,998 & 1,998 & 1,998 & 30 & 31 \\
\hline Czech Republic ${ }^{3} \ldots \ldots \ldots \ldots \ldots \ldots$ & 39 & 39 & 39 & 191 & 191 & 191 & 840 & 630 & 602 & 1,696 & 1,696 & 1,696 & 20 & 21 \\
\hline Denmark $^{5} \ldots \ldots \ldots \ldots$ & 42 & 42 & 42 & 200 & 200 & 200 & 650 & 650 & 369 & 1,680 & 1,680 & 1,680 & 21 & 21 \\
\hline England $^{5}$ & 38 & 38 & 38 & 190 & 190 & 190 & 684 & 695 & 695 & 1,265 & 1,265 & 1,265 & - & - \\
\hline Estonia ${ }^{4} \ldots \ldots \ldots \ldots \ldots \ldots \ldots \ldots$ & 35 & 35 & 35 & 172 & 172 & 172 & 619 & 619 & 568 & 1,540 & 1,540 & 1,540 & 17 & 17 \\
\hline Finland ${ }^{6}$. & 38 & 38 & 38 & 189 & 189 & 189 & 680 & 595 & 553 & $\dagger$ & $\dagger$ & $\dagger$ & 19 & 20 \\
\hline France $^{3} \ldots . .$. & 36 & 36 & 36 & 141 & - & - & 936 & 648 & 648 & 1,607 & 1,607 & 1,607 & 23 & 24 \\
\hline Germany $^{3} \ldots \ldots \ldots \ldots \ldots$ & 40 & 40 & 40 & 193 & 193 & 193 & 804 & 757 & 715 & 1,793 & 1,793 & 1,793 & 21 & 25 \\
\hline 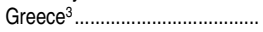 & 36 & 31 & 31 & 177 & 153 & 153 & 589 & 415 & 415 & & & & 17 & 22 \\
\hline 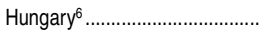 & 37 & 37 & 37 & 183 & 183 & 183 & 604 & 604 & 604 & 1,864 & 1,864 & 1,864 & 21 & 21 \\
\hline Iceland ${ }^{3}$. & 37 & 37 & 35 & 180 & 180 & 170 & 624 & 624 & 544 & 1,800 & 1,800 & 1,800 & 18 & 20 \\
\hline Ireland ${ }^{3} \ldots \ldots \ldots$ & 37 & 33 & 33 & 183 & 167 & 167 & 915 & 735 & 735 & $\dagger$ & $\dagger$ & $\dagger$ & 24 & - \\
\hline |srael ${ }^{3} \ldots \ldots \ldots$ & 38 & 37 & 37 & 183 & 175 & 175 & 842 & 614 & 521 & $\dagger$ & $\dagger$ & $\dagger$ & 28 & 30 \\
\hline Italy 6 & 39 & 39 & 39 & 175 & 175 & 175 & 770 & 630 & 630 & $\dagger$ & $\dagger$ & $\dagger$ & 19 & 22 \\
\hline 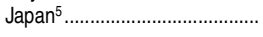 & 40 & 40 & 39 & 200 & 200 & 196 & 731 & 602 & 510 & 1,883 & 1,883 & 1,883 & 28 & 33 \\
\hline Korea, Republic of ${ }^{4} \ldots \ldots \ldots \ldots$ & 40 & 40 & 40 & 220 & 220 & 220 & 812 & 621 & 609 & 1,680 & 1,680 & 1,680 & 26 & 34 \\
\hline Luxembourg $^{3} \ldots \ldots \ldots \ldots \ldots$ & 36 & 36 & 36 & 176 & 176 & 176 & 810 & 739 & 739 & $\dagger$ & $\dagger$ & $\dagger$ & 15 & 19 \\
\hline Mexico $^{3}$ & 41 & 41 & 36 & 200 & 200 & 173 & 800 & 1,047 & 848 & & & & 20 & 27 \\
\hline Netherlands ${ }^{4}$ & 40 & - & - & 195 & - & - & 930 & 750 & 750 & 1,659 & 1,659 & 1,659 & - & - \\
\hline 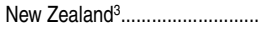 & 39 & 39 & 38 & 195 & 193 & 190 & 935 & 848 & 760 & $\dagger$ & $\dagger$ & $\dagger$ & - & - \\
\hline Norway $^{3} \ldots \ldots \ldots \ldots$ & 38 & 38 & 38 & 190 & 190 & 190 & 741 & 663 & 523 & 1,688 & 1,688 & 1,688 & $\dagger$ & $\dagger$ \\
\hline Poland $^{5}$ & 37 & 36 & 36 & 179 & 177 & 175 & 618 & 547 & 544 & 1,464 & 1,448 & 1,432 & 19 & 23 \\
\hline Portugal $^{4} \ldots \ldots \ldots \ldots \ldots \ldots \ldots$ & 38 & 38 & 38 & 176 & 176 & 176 & 880 & 774 & 774 & 1,508 & 1,508 & 1,508 & 21 & 22 \\
\hline Scotland $d^{4} \ldots \ldots \ldots \ldots$ & 38 & 38 & 38 & 190 & 190 & 190 & 855 & 855 & 855 & 1,365 & 1,365 & 1,365 & - & - \\
\hline Slovak Republic ${ }^{3} \ldots \ldots \ldots \ldots \ldots \ldots \ldots$ & 39 & 39 & 39 & 190 & 190 & 190 & 846 & 656 & 627 & 1,583 & 1,583 & 1,583 & 18 & 20 \\
\hline Slovenia $^{3} .$. & 40 & 40 & 40 & 190 & 190 & 190 & 690 & 690 & 633 & $\dagger$ & $\dagger$ & $\dagger$ & 19 & 19 \\
\hline Spain $^{3}$ & 37 & 37 & 36 & 176 & 176 & 171 & 880 & 713 & 693 & 1,425 & 1,425 & 1,425 & 20 & 24 \\
\hline 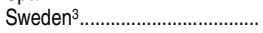 & $\dagger$ & $\dagger$ & $\dagger$ & $\dagger$ & $\dagger$ & $\dagger$ & - & - & - & 1,767 & 1,767 & 1,767 & - & 一 \\
\hline Switzerland & - & - & - & - & - & - & - & - & - & - & - & - & - & - \\
\hline Turkey $^{3}$.......................................... & 38 & $\dagger$ & 38 & 180 & $\dagger$ & 180 & 639 & $\dagger$ & 567 & 1,816 & $\dagger$ & 1,816 & 26 & $\dagger$ \\
\hline 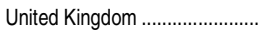 & - & - & - & - & - & - & - & - & - & - & - & - & 26 & 21 \\
\hline United States ${ }^{5} \ldots \ldots \ldots \ldots \ldots \ldots \ldots$ & 36 & 36 & 36 & 180 & 180 & 180 & 1,097 & 1,068 & 1,051 & 1,913 & 1,977 & 1,998 & 20 & 24 \\
\hline Other reporting countries & & & & & & & & & & & & & & \\
\hline Argentina ${ }^{7}$ & 38 & 38 & 38 & 180 & 181 & 181 & 720 & 1,448 & 1,448 & - & - & - & 25 & 28 \\
\hline Brazil .................................. & - & - & - & - & - & - & - & - & - & - & - & - & 26 & 29 \\
\hline 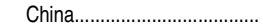 & - & - & - & - & - & - & - & - & - & - & - & - & 38 & 53 \\
\hline Indonesia ${ }^{5,8} \ldots \ldots \ldots$ & 44 & 44 & 44 & 244 & 200 & 200 & 697 & 544 & 638 & 1,069 & 1,069 & 1,069 & 26 & 35 \\
\hline Russian Federation ${ }^{5} \ldots \ldots \ldots \ldots$ & 34 & 35 & 35 & 170 & 210 & 210 & 561 & 483 & 483 & $\dagger$ & $\dagger$ & $\dagger$ & 18 & 18 \\
\hline
\end{tabular}

-Not available.

†Not applicable according to the Organization for Economic Cooperation and Development (OECD).

'Refers to the mean of the data values for all reporting OECD countries, to which each country or country component reporting data contributes equally.

${ }^{3}$ Typical teaching time reported.

${ }^{4}$ Maximum teaching time reported.

${ }^{5}$ Actual teaching time reported.
6 Minimum teaching time reported.

${ }^{7}$ Data are for 2010.

${ }^{8}$ Statutory teaching and total working time data are for 2010

NOTE: In this table, elementary school corresponds to International Standard Classification of Education (ISCED) level 1 (U.S. grades 1 through 6), junior high school corresponds to ISCED level 2 (U.S. grades 7 through 9), and senior high school corresponds to ISCED level 3 (U.S. grades 10 through 12)

SOURCE: Organization for Economic Cooperation and Development (OECD), Education at a Glance, 2013. (This table was prepared December 2013.) 
766 CHAPTER 6: International Comparisons of Education

Achievement and Instruction

Table 602.10. Average reading literacy scale scores of fourth-graders and percentage whose schools emphasize reading skills and strategies at or before second grade or at third grade, by sex and country or other education system: 2001, 2006, and 2011

[Standard errors appear in parentheses]

\begin{tabular}{|c|c|c|c|c|c|c|c|c|c|c|c|c|c|c|}
\hline \multirow[b]{3}{*}{ Country or other education system ${ }^{1}$} & \multicolumn{10}{|c|}{ Average reading literacy scale score ${ }^{2}$} & \multicolumn{4}{|c|}{$\begin{array}{l}\text { Percent of fourth-graders in } 2011 \text {, } \\
\text { by grade at which reading skills } \\
\text { and strategies emphasized }\end{array}$} \\
\hline & \multirow{2}{*}{\multicolumn{2}{|c|}{2001}} & \multirow{2}{*}{\multicolumn{2}{|c|}{2006}} & \multicolumn{6}{|c|}{2011} & \multirow{2}{*}{\multicolumn{2}{|c|}{$\begin{array}{r}\text { At or before } \\
\text { second grade }\end{array}$}} & \multirow{2}{*}{\multicolumn{2}{|c|}{ At third grade }} \\
\hline & & & & & & Total & & Male & & Female & & & & \\
\hline 1 & & 2 & & 3 & & 4 & & 5 & & 6 & & 7 & & 8 \\
\hline 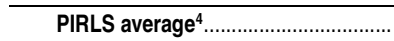 & 500 & $(t)$ & 500 & $(\dagger)$ & 500 & $(\dagger)$ & 504 & $(0.5)$ & 520 & $(0.5)$ & 28 & $(0.5)$ & 68 & $(0.5)$ \\
\hline $\begin{array}{l}\text { Australia } \\
\text { Austria } \\
\text { Azerbaijan } \\
\text { Belgium (French)-BEL } \\
\text { Bulgaria }\end{array}$ & $\begin{array}{l}- \\
\overline{-} \\
550\end{array}$ & 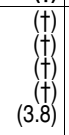 & $\begin{array}{l}538 \\
500 \\
547\end{array}$ & $\begin{array}{r}(t) \\
(2.2) \\
(+) \\
(2.6) \\
(4.4)\end{array}$ & $\begin{array}{l}527 \\
529 \\
462{ }^{6} \\
506^{6,7} \\
532\end{array}$ & $\begin{array}{l}(2.2) \\
(2.0) \\
3.3 \\
2.9 \\
(4.1)\end{array}$ & $\begin{array}{l}519 \\
525 \\
4566^{6} \\
504^{6,7} \\
524\end{array}$ & $\begin{array}{l}(2.7) \\
(2.3) \\
3.5 \\
(3.1) \\
(4.3)\end{array}$ & $\begin{array}{l}536 \\
533 \\
4706 \\
5096,7 \\
539\end{array}$ & $\begin{array}{l}(2.7) \\
(2.2) \\
3.6 \\
(3.1) \\
(4.5)\end{array}$ & $\begin{array}{l}73 \\
29 \\
19 \\
29 \\
25\end{array}$ & $\begin{array}{l}(4.0) \\
4.2 \\
3.6 \\
5.0) \\
(3.5)\end{array}$ & $\begin{array}{l}27 \\
71 \\
79 \\
70 \\
74\end{array}$ & $\begin{array}{l}(4.0) \\
(4.2) \\
3.8 \\
5.1 \\
(3.6)\end{array}$ \\
\hline 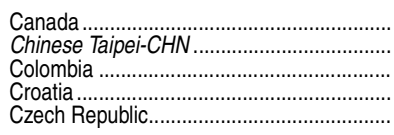 & $\frac{-}{4 \overline{22}}$ & $\begin{array}{r}(t) \\
(t) \\
(4.4) \\
(t) \\
(2.3)\end{array}$ & $\begin{array}{r}5 \overline{5} \\
\overline{-} \\
-\end{array}$ & 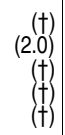 & $\begin{array}{l}548^{6} \\
553 \\
448 \\
553^{6} \\
545\end{array}$ & $\begin{array}{l}(1.6) \\
1.9 \\
(4.1) \\
1.9 \\
(2.2)\end{array}$ & $\begin{array}{l}542^{6} \\
546 \\
448 \\
546^{6} \\
542\end{array}$ & $\begin{array}{l}(2.1) \\
(2.1) \\
(4.6) \\
(2.2) \\
(2.5)\end{array}$ & $\begin{array}{l}555^{6} \\
561 \\
447 \\
560^{6} \\
549\end{array}$ & $\begin{array}{l}(1.7) \\
(2.1) \\
(4.6) \\
(2.1) \\
(2.5)\end{array}$ & $\begin{array}{l}55 \\
17 \\
13 \\
31 \\
24\end{array}$ & $\begin{array}{l}(2.7) \\
3.0 \\
(3.3) \\
4.1 \\
(3.8)\end{array}$ & $\begin{array}{l}44 \\
80 \\
81 \\
68 \\
74\end{array}$ & $\begin{array}{l}(2.7) \\
(3.0) \\
(3.6) \\
4.2 \\
(4.0)\end{array}$ \\
\hline 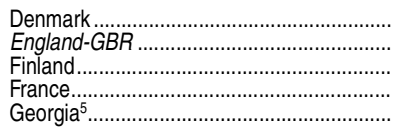 & $\begin{array}{l}5 \overline{53}{ }^{4,5} \\
5 \overline{25} \\
-\end{array}$ & $\begin{array}{r}(t) \\
(3.4) \\
(t) \\
(2.4) \\
(t)\end{array}$ & $\begin{array}{l}546 \\
539 \\
522 \\
471^{6,8}\end{array}$ & $\begin{array}{c}(2.3) \\
(2.6) \\
(+) \\
(2.1) \\
(3.1)\end{array}$ & $\begin{array}{l}554^{6} \\
552^{7} \\
568^{7} \\
520 \\
488^{8}\end{array}$ & $\begin{array}{l}(1.7) \\
(2.6) \\
1.9 \\
(2.6) \\
(3.1)\end{array}$ & $\begin{array}{l}548^{6} \\
540^{7} \\
558 \\
518 \\
477^{8}\end{array}$ & $\begin{array}{l}(2.1) \\
(3.1) \\
2.2 \\
(2.4) \\
(4.0)\end{array}$ & $\begin{array}{l}560^{6} \\
563^{7} \\
578 \\
522 \\
499^{8}\end{array}$ & $\begin{array}{l}(1.9) \\
(3.0) \\
2.3 \\
(3.4) \\
(2.7)\end{array}$ & $\begin{array}{l}21 \\
84 \\
10 \\
18 \\
20\end{array}$ & $\begin{array}{l}(2.4) \\
(3.3) \\
2.6 \\
3.3 \\
(2.8)\end{array}$ & $\begin{array}{l}79 \\
15 \\
87 \\
81 \\
79\end{array}$ & $\begin{array}{l}(2.4) \\
(3.2) \\
(2.8) \\
(3.4) \\
(2.9)\end{array}$ \\
\hline 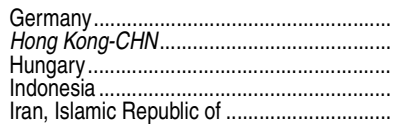 & $\begin{array}{l}539 \\
528 \\
543 \\
\overline{414}\end{array}$ & $\begin{array}{r}(1.9) \\
(3.1) \\
(2.2) \\
(t) \\
(4.2)\end{array}$ & $\begin{array}{l}548 \\
564 \\
551 \\
405 \\
421\end{array}$ & $\begin{array}{l}(2.2) \\
(2.4) \\
(3.0) \\
4.1 \\
(3.1)\end{array}$ & $\begin{array}{l}541 \\
571^{9} \\
539 \\
428 \\
457\end{array}$ & $\begin{array}{l}(2.2) \\
2.3 \\
(2.9) \\
(4.2) \\
(2.8)\end{array}$ & $\begin{array}{l}537 \\
5633^{9} \\
532 \\
419 \\
448\end{array}$ & $\begin{array}{l}(2.7) \\
(2.5) \\
(3.2) \\
(4.3) \\
(4.3)\end{array}$ & $\begin{array}{l}545 \\
579 \\
547 \\
437 \\
467\end{array}$ & $\begin{array}{l}(2.3) \\
(2.3) \\
(3.2) \\
(4.5) \\
(4.3)\end{array}$ & $\begin{array}{r}30 \\
16 \\
28 \\
\ddagger \\
7\end{array}$ & $\begin{array}{r}(3.4) \\
3.5) \\
(4.1) \\
(\dagger) \\
(1.6)\end{array}$ & $\begin{array}{l}69 \\
81 \\
71 \\
88 \\
85\end{array}$ & $\begin{array}{l}(3.3) \\
3.8 \\
(4.0) \\
(3.2) \\
(2.4)\end{array}$ \\
\hline 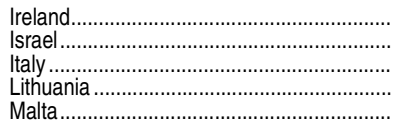 & $\begin{array}{l}509^{10} \\
541 \\
543^{8} \\
-\end{array}$ & $\begin{array}{r}(t) \\
(2.8) \\
(2.4) \\
(2.6) \\
(\dagger)\end{array}$ & $\begin{array}{l}5122^{10} \\
551^{10} \\
537^{8} \\
-\end{array}$ & $\begin{array}{r}(t) \\
(3.3) \\
(2.9) \\
(1.6) \\
(t)\end{array}$ & $\begin{array}{l}552 \\
541^{9} \\
541^{6,8} \\
528^{6,8} \\
477\end{array}$ & $\begin{array}{l}(2.3) \\
(2.7) \\
2.2 \\
2.0) \\
1.4\end{array}$ & $\begin{array}{l}544 \\
538^{9} \\
540 \\
520^{6,8} \\
468\end{array}$ & $\begin{array}{l}(3.0) \\
(3.4) \\
(2.7) \\
(2.4) \\
(2.0)\end{array}$ & $\begin{array}{l}559 \\
544^{9} \\
543 \\
5376,8 \\
486\end{array}$ & $\begin{array}{l}(2.9) \\
(3.1) \\
(2.4) \\
2.4 \\
(1.9)\end{array}$ & $\begin{array}{l}40 \\
59 \\
15 \\
23 \\
14\end{array}$ & $\begin{array}{l}(4.0) \\
(4.7) \\
2.5) \\
(3.3) \\
0.1)\end{array}$ & $\begin{array}{l}60 \\
41 \\
84 \\
76 \\
86\end{array}$ & $\begin{array}{l}(4.0) \\
(4.7) \\
(2.5) \\
(3.4) \\
(0.1)\end{array}$ \\
\hline 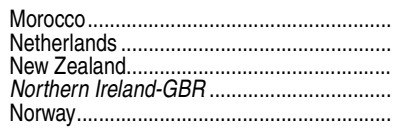 & $\begin{array}{l}3500^{11} \\
554^{7} \\
529 \\
\overline{499}\end{array}$ & $\begin{array}{r}(9.6) \\
(2.5) \\
(3.6) \\
(+) \\
(2.9)\end{array}$ & $\begin{array}{l}323 \\
5477^{7} \\
532 \\
4 \overline{98} \\
413\end{array}$ & $\begin{array}{l}(5.9) \\
(1.5) \\
(2.0) \\
(\dagger) \\
(2.6)\end{array}$ & $\begin{array}{l}310^{12} \\
546^{7} \\
531^{7} \\
558^{7} \\
507^{11}\end{array}$ & $\begin{array}{l}(3.9) \\
(1.9) \\
1.9 \\
(2.4) \\
1.9\end{array}$ & $\begin{array}{l}2966^{12} \\
543^{7} \\
521^{7} \\
550^{7} \\
500^{11}\end{array}$ & $\begin{array}{l}(4.6) \\
(2.2) \\
(2.7) \\
(3.2) \\
(2.7)\end{array}$ & $\begin{array}{l}3266^{12} \\
549^{7} \\
541 \\
5677 \\
514^{11}\end{array}$ & $\begin{array}{l}(4.0) \\
(2.1) \\
(2.2) \\
(2.5) \\
(2.2)\end{array}$ & $\begin{array}{l}\ddagger \\
22^{13} \\
73 \\
55^{13} \\
14\end{array}$ & $\begin{array}{r}(\dagger) \\
(4.4) \\
3.6) \\
(4.6) \\
3.4)\end{array}$ & $\begin{array}{l}48 \\
78^{13} \\
27^{13} \\
45^{13} \\
83^{13}\end{array}$ & $\begin{array}{l}(4.0) \\
(4.4) \\
3.6 \\
(4.6) \\
(3.9)\end{array}$ \\
\hline 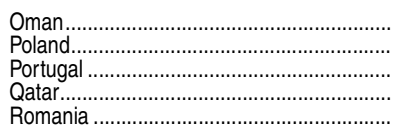 & $\begin{array}{l}\bar{z} \\
\overline{-} \\
512\end{array}$ & 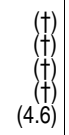 & $\begin{array}{l}5 \overline{19} \\
3 \overline{53} \\
489\end{array}$ & 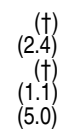 & $\begin{array}{l}391^{14} \\
526 \\
541 \\
425{ }^{6} \\
502\end{array}$ & $\begin{array}{l}(2.8) \\
2.1 \\
2.6 \\
(3.5) \\
(4.3)\end{array}$ & $\begin{array}{l}371^{14} \\
519 \\
534 \\
411^{6} \\
495\end{array}$ & $\begin{array}{l}(3.4) \\
(2.7) \\
(2.8) \\
(4.2) \\
(4.3)\end{array}$ & $\begin{array}{l}411^{14} \\
533 \\
548 \\
441^{6} \\
510^{6}\end{array}$ & $\begin{array}{l}(3.0) \\
(2.5) \\
(3.0) \\
4.7 \\
(4.8)\end{array}$ & $\begin{array}{l}4 \\
6 ! \\
25 \\
24 \\
14\end{array}$ & $\begin{array}{l}(0.9) \\
(2.1) \\
4.1 \\
(3.0) \\
3.4)\end{array}$ & $\begin{array}{l}86 \\
94 \\
75 \\
66 \\
85\end{array}$ & $\begin{array}{l}(2.0) \\
(2.1) \\
4.1) \\
(3.4) \\
(3.5)\end{array}$ \\
\hline 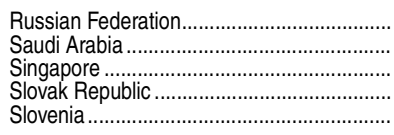 & $\begin{array}{l}528^{6} \\
528 \\
518 \\
502\end{array}$ & $\begin{array}{r}(4.4) \\
(t) \\
(5.2) \\
(2.8) \\
(2.0)\end{array}$ & $\begin{array}{l}565^{6} \\
558 \\
531 \\
522\end{array}$ & $\begin{aligned}(3.4) \\
(t) \\
(2.9) \\
(2.8) \\
(2.1)\end{aligned}$ & $\begin{array}{l}568 \\
430 \\
567^{6} \\
535 \\
530\end{array}$ & $\begin{array}{l}(2.7) \\
4.4) \\
3.3) \\
(2.8) \\
(2.0)\end{array}$ & $\begin{array}{l}559 \\
402 \\
559 \\
530 \\
523\end{array}$ & $\begin{array}{l}(3.1) \\
(8.2) \\
3.6) \\
(2.8) \\
(2.7)\end{array}$ & $\begin{array}{l}578 \\
456 \\
576^{6} \\
540 \\
539\end{array}$ & $\begin{array}{l}(2.8) \\
3.1 \\
(3.5) \\
(3.1) \\
(2.2)\end{array}$ & $\begin{array}{r}50 \\
7 \\
46 \\
24 \\
8\end{array}$ & $\begin{array}{r}(3.7) \\
(1.7) \\
(\#) \\
(3.2) \\
(1.8)\end{array}$ & $\begin{array}{l}50 \\
78 \\
54 \\
76 \\
87\end{array}$ & $\begin{array}{r}(3.7) \\
3.5 \\
(\#) \\
(3.3) \\
(2.4)\end{array}$ \\
\hline 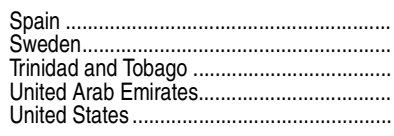 & $\begin{array}{c}\overline{561} \\
\overline{5} \\
542 \\
\end{array}$ & $\begin{array}{r}(t) \\
(2.2) \\
(t) \\
(t) \\
(3.8) \\
\end{array}$ & $\begin{array}{l}513 \\
549 \\
436 \\
540^{7} \\
\end{array}$ & $\begin{array}{r}(2.5) \\
(2.3) \\
(4.9) \\
(+) \\
(3.5) \\
\end{array}$ & $\begin{array}{l}513 \\
542 \\
471 \\
439 \\
556^{6}\end{array}$ & $\begin{array}{l}(2.3) \\
2.1 \\
3.8 \\
2.2 \\
1.5\end{array}$ & $\begin{array}{l}511 \\
535 \\
456 \\
425 \\
551^{6}\end{array}$ & $\begin{array}{l}(2.8) \\
(2.5) \\
(4.3) \\
3.5 \\
(1.7) \\
\end{array}$ & $\begin{array}{l}516 \\
549 \\
487 \\
452 \\
562^{6} \\
\end{array}$ & $\begin{array}{l}(2.5) \\
2.4 \\
(4.5) \\
3.0 \\
(1.9) \\
\end{array}$ & $\begin{array}{l}29 \\
37^{13} \\
32 \\
15 \\
75^{13} \\
\end{array}$ & $\left.\begin{array}{l}(3.2) \\
4.5 \\
(3.8) \\
1.3 \\
2.7\end{array}\right)$ & $\begin{array}{l}71 \\
63^{13} \\
66^{13} \\
68 \\
24^{13} \\
\end{array}$ & $\begin{array}{l}(3.2) \\
4.5) \\
(4.0) \\
(2.2) \\
(2.7) \\
\end{array}$ \\
\hline 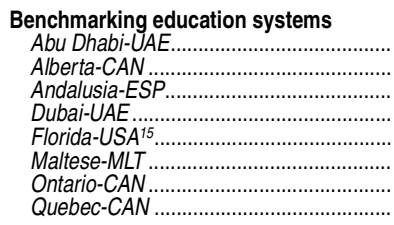 & $\begin{array}{l}\overline{-} \\
\overline{-} \\
\overline{-} \\
\overline{\overline{4}}{ }^{6} \\
537^{6}\end{array}$ & 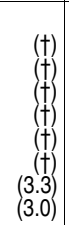 & 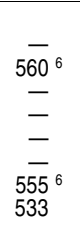 & 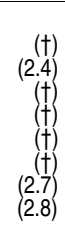 & $\begin{array}{l}424 \\
548^{6} \\
515 \\
476 \\
569^{8,10} \\
457 \\
552^{6} \\
538\end{array}$ & $\begin{array}{l}(4.7) \\
(2.9) \\
(2.3) \\
2.0 \\
2.9 \\
(1.5) \\
(2.6) \\
(2.1)\end{array}$ & $\begin{array}{l}406 \\
543^{6} \\
511 \\
470 \\
561^{8,10} \\
445 \\
546^{6} \\
531\end{array}$ & $\begin{array}{l}(6.3) \\
(3.1) \\
(2.8) \\
3.5 \\
(3.0) \\
(2.2) \\
(2.8) \\
(2.4)\end{array}$ & $\begin{array}{l}442 \\
553^{6} \\
519^{\circ} \\
483 \\
576^{8,10} \\
470 \\
558^{6} \\
544^{6}\end{array}$ & $\begin{array}{l}(5.5) \\
(3.1) \\
(2.4) \\
3.9 \\
(3.4) \\
(2.0) \\
(3.3) \\
(2.6)\end{array}$ & $\begin{array}{l}11 \\
52 \\
26 \\
28 \\
82^{13} \\
14 \\
75 \\
23\end{array}$ & $\begin{array}{l}(2.6) \\
(4.5) \\
(3.6) \\
(0.3) \\
4.7) \\
(0.1) \\
(4.0) \\
(3.9)\end{array}$ & $\begin{array}{l}61 \\
48 \\
74 \\
66 \\
188^{13} \\
86 \\
25 \\
75\end{array}$ & $\begin{array}{l}(4.4) \\
(4.5) \\
(3.6) \\
0.3) \\
(4.7) \\
(0.1) \\
(4.0) \\
(4.1)\end{array}$ \\
\hline
\end{tabular}

-Not available.

†Not applicable.

!nterpret data with caution. The coefficient of variation (CV) for this estimate is between 30 and 50 percent.

percent.
$\ddagger$ Reporting standards not met. The coefficient of variation $(\mathrm{CV})$ for this estimate is 50 percent or greater ${ }^{1}$ Most of the education systems represent complete countries, but some represent subnational entities such as U.S. states, Canadian provinces, and England (which is part of the United Kingdom) The name of each subnational entity appears in italics and includes as a suffix the three-letter International Organization for Standardization (ISO) abbreviation for its complete country. Examples include Florida-USA, Ontario-CAN, and England-GBR.

${ }^{2}$ Progress in International Reading Literacy Study (PIRLS) scores are reported on a scale from 0 to 1,000 , with the scale average set at 500 and the standard deviation set at 100 .

'Based on principals' reports of the earliest grade at which each of 11 reading skills and strategies first receive a major emphasis in instruction. A school is counted as emphasizing reading skills and strategies at a certain grade (or before) only if its principal reported that all 11 skills and strategies are emphasized at that grade (or before). A small percentage of fourth-graders (1 percent in the United States) are not shown because their schools first emphasized reading skills and strategies at fourth grade or later.

${ }^{4}$ The PIRLS average includes only education systems that are members of the International Association for the Evaluation of Educational Achievement (IAE), which develops and implements PIRLS at the international level. "Benchmarking" education systems are not members of the IEA and are therefore not included in the average.

${ }^{5}$ Exclusion rates for Azerbaijan and Georgia are slightly underestimated as some conflict zones were not covered and no official statistics were available for 2011.

${ }^{6}$ National Defined Population covers 90 percent to 95 percent of National Target Population. ${ }^{7}$ Met guidelines for sample participation rates only after replacement schools were included. ${ }^{8}$ National Target Population does not include all of the International Target Population. ${ }^{9}$ National Defined Population covers less than 90 percent of National Target Population. ${ }^{10}$ National Defined Population covers less than 80 percent of National Target Population. ${ }^{11}$ Nearly satisfied guidelines for sample participation rates after replacement schools were included. ${ }^{12}$ The TIMSS \& PIRLS International Study Center has reservations about the reliability of the average achievement score because the percentage of students with achievement too low for estimation exceeds 25 percent

${ }^{13}$ Data are available for at least 70 percent but less than 85 percent of students.

${ }^{14}$ The TIMSS \& PIRLS International Study Center has reservations about the reliability of the average achievement score because the percentage of students with achievement too low for estimation exceeds 15 percent, though it is less than 25 percent.

${ }^{15}$ All data for Florida are based on public schools only.

SOURCE: International Association for the Evaluation of Educational Achievement (IEA), Progress in International Reading Literacy Study (PIRLS), 2001, 2006, and 2011. (This table was prepared February 2013). 
Table 602.20. Average fourth-grade scores and annual instructional time in mathematics and science, by country or other education system: 2011 [Standard errors appear in parentheses]

\begin{tabular}{|c|c|c|c|c|c|c|c|c|c|c|c|c|c|c|}
\hline \multirow[b]{3}{*}{ Country or other education system ${ }^{1}$} & \multirow{3}{*}{\multicolumn{2}{|c|}{$\begin{array}{r}\text { Total instructional } \\
\text { hours per year }\end{array}$}} & \multicolumn{6}{|c|}{ Mathematics } & \multicolumn{6}{|c|}{ Science } \\
\hline & & & \multirow{2}{*}{\multicolumn{2}{|c|}{ Average score ${ }^{2}$}} & \multicolumn{4}{|c|}{ Instructional time in mathematics } & \multirow{2}{*}{\multicolumn{2}{|c|}{ Average score $^{2}$}} & \multicolumn{4}{|c|}{ Instructional time in science } \\
\hline & & & & & Hour & ber year & $\begin{array}{r}\text { perce } \\
\text { instructio }\end{array}$ & & & & Hou & er year & $\begin{array}{r}\text { per } \\
\text { instruc }\end{array}$ & $\begin{array}{r}\text { As a } \\
\text { of total } \\
\text { hours }\end{array}$ \\
\hline 1 & & 2 & & 3 & & 4 & & 5 & & 6 & & 7 & & 8 \\
\hline TIMSS average $^{3}$ & 897 & (2.0) & 500 & $(t)$ & 162 & (0.5) & 18 & $(0.1)$ & 500 & (t) & 85 & $(0.5)$ & 10 & $(0.1)$ \\
\hline 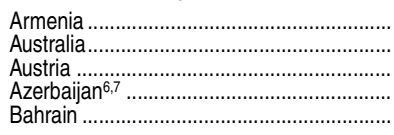 & $\begin{array}{l}851^{4} \\
1,008 \\
808 \\
804 \\
964\end{array}$ & $\begin{array}{r}(17.1) \\
(6.9) \\
(6.9) \\
(27.7) \\
(10.8)\end{array}$ & $\begin{array}{l}452 \\
516 \\
508 \\
463 \\
436\end{array}$ & $\begin{array}{l}(3.5) \\
(2.9) \\
2.6) \\
(5.8) \\
(3.3)\end{array}$ & $\begin{array}{l}1399^{4} \\
230^{5} \\
146 \\
130 \\
131^{4}\end{array}$ & $\begin{array}{l}(1.7) \\
(5.8) \\
2.1 \\
3.3 \\
(4.4)\end{array}$ & $\begin{array}{l}16 \\
23 \\
18 \\
18 \\
14\end{array}$ & $\begin{array}{l}(0.2) \\
(0.6) \\
(0.3) \\
(0.7) \\
0.4)\end{array}$ & $\begin{array}{l}416 \\
516 \\
532 \\
438 \\
449\end{array}$ & $\begin{array}{l}(3.8) \\
(2.8) \\
(2.8) \\
(5.6) \\
(3.5)\end{array}$ & $\begin{array}{l}54^{5} \\
65^{5} \\
96 \\
61 \\
85^{4}\end{array}$ & $\begin{array}{l}(0.6) \\
(2.3) \\
(2.3) \\
(1.4) \\
(2.7)\end{array}$ & $\begin{array}{r}6 \\
6 \\
12 \\
8 \\
9\end{array}$ & $\begin{array}{l}(0.1) \\
(0.2) \\
0.3) \\
(0.3) \\
(0.3)\end{array}$ \\
\hline 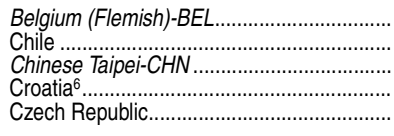 & $\begin{array}{l}1,010^{4} \\
1,2284^{4} \\
9899^{4} \\
776 \\
782\end{array}$ & $\begin{array}{r}(16.8) \\
(22.6 \\
(13.4) \\
(19.4) \\
(8.2)\end{array}$ & $\begin{array}{l}549 \\
462 \\
591 \\
490 \\
511\end{array}$ & $\begin{array}{l}(1.9) \\
2.3 \\
2.0) \\
(1.9) \\
(2.4)\end{array}$ & $\begin{array}{l}224^{4} \\
231^{5} \\
133 \\
134 \\
163\end{array}$ & $\begin{array}{l}(4.1) \\
6.7 \\
(3.9 \\
(2.3) \\
(3.0)\end{array}$ & $\begin{array}{l}21 \\
19 \\
12 \\
18 \\
21\end{array}$ & $\begin{array}{l}(0.3) \\
0.6 \\
0.4) \\
(0.4) \\
(0.4)\end{array}$ & $\begin{array}{l}509 \\
480 \\
552 \\
516 \\
536\end{array}$ & $\begin{array}{l}(2.0) \\
2.4 \\
(2.2) \\
(2.1) \\
(2.5)\end{array}$ & $\begin{array}{l}1 \overline{161^{5}} \\
90 \\
95 \\
60\end{array}$ & $\begin{array}{r}(\dagger) \\
(6.4) \\
(2.3) \\
(2.4) \\
(2.2)\end{array}$ & $\begin{array}{r}\overline{13} \\
9 \\
13 \\
8\end{array}$ & $\begin{array}{l}(\dagger) \\
(0.5) \\
0.3) \\
(0.4) \\
(0.3)\end{array}$ \\
\hline 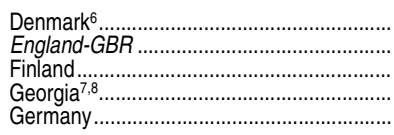 & $\begin{array}{l}863^{4} \\
970^{4} \\
7799^{4} \\
7488^{4} \\
863^{4}\end{array}$ & $\begin{array}{r}(9.4) \\
(8.3) \\
(9.8) \\
(18.7) \\
(11.2)\end{array}$ & $\begin{array}{l}537 \\
542 \\
545 \\
450 \\
528\end{array}$ & $\left.\begin{array}{l}(2.6) \\
(3.5) \\
(2.3) \\
3.7 \\
2.2\end{array}\right)$ & $\begin{array}{l}124^{5} \\
188^{5} \\
139 \\
148^{4} \\
163^{4}\end{array}$ & $\begin{array}{l}(2.0) \\
(3.3 \\
(2.5) \\
3.9 \\
(3.1)\end{array}$ & $\begin{array}{l}15 \\
19 \\
18 \\
21 \\
19\end{array}$ & $\begin{array}{l}(0.3) \\
0.4 \\
(0.4) \\
0.6 \\
0.3)\end{array}$ & $\begin{array}{l}528 \\
529 \\
570 \\
455 \\
528\end{array}$ & $\begin{array}{l}(2.8) \\
2.9 \\
(2.6) \\
3.8 \\
(2.9)\end{array}$ & $\begin{array}{r}62^{5} \\
76^{5} \\
98 \\
110^{4} \\
75^{5}\end{array}$ & $\begin{array}{l}(1.9) \\
(3.2) \\
(1.9) \\
(2.7) \\
(3.5)\end{array}$ & $\begin{array}{r}7 \\
8 \\
13 \\
16 \\
8\end{array}$ & $\begin{array}{l}(0.2) \\
0.3) \\
(0.4) \\
0.4 \\
0.4)\end{array}$ \\
\hline 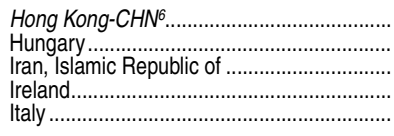 & $\begin{array}{c}1,059^{4} \\
760 \\
727 \\
854 \\
1,085\end{array}$ & $\begin{array}{r}(11.2) \\
(12.2) \\
(11.2) \\
(\#) \\
(12.6)\end{array}$ & $\begin{array}{l}602 \\
515 \\
431 \\
527 \\
508\end{array}$ & $\begin{array}{l}(3.4) \\
(3.4) \\
(3.5) \\
(2.6) \\
(2.6)\end{array}$ & $\begin{array}{l}158^{4} \\
148 \\
146 \\
150 \\
214\end{array}$ & $\begin{array}{l}(3.0) \\
(3.3) \\
(3.9 \\
(2.8) \\
(3.9)\end{array}$ & $\begin{array}{l}15 \\
20 \\
20 \\
18 \\
20\end{array}$ & $\begin{array}{l}(0.3) \\
0.5) \\
(0.4) \\
(0.3) \\
(0.4)\end{array}$ & $\begin{array}{l}535 \\
534 \\
453 \\
516 \\
524\end{array}$ & $\begin{array}{l}(3.8) \\
(3.7) \\
(3.7) \\
(3.4) \\
(2.7)\end{array}$ & $\begin{array}{c}88^{4} \\
72 \\
106 \\
63 \\
78^{4}\end{array}$ & $\begin{array}{l}(4.2) \\
(2.2) \\
(3.2) \\
(6.6) \\
(1.8)\end{array}$ & $\begin{array}{r}8 \\
10 \\
14 \\
7 \\
7\end{array}$ & $\begin{array}{l}(0.4) \\
0.3) \\
(0.4) \\
(0.8) \\
(0.2)\end{array}$ \\
\hline 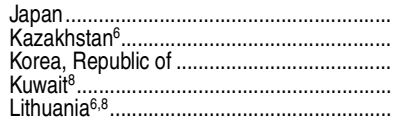 & $\begin{array}{l}891 \\
779 \\
789 \\
9288^{4} \\
649\end{array}$ & $\begin{array}{r}(3.7) \\
(10.6) \\
(11.4) \\
(23.1) \\
(9.0)\end{array}$ & $\begin{array}{l}585 \\
501 \\
605 \\
3422^{9} \\
534\end{array}$ & $\left.\begin{array}{l}(1.7) \\
(4.5) \\
(1.9) \\
3.4 \\
(2.4)\end{array}\right)$ & $\begin{array}{l}150 \\
140 \\
121 \\
120^{4} \\
133\end{array}$ & $\begin{array}{l}(1.6) \\
2.7) \\
(3.0) \\
4.9 \\
(2.6)\end{array}$ & $\begin{array}{l}17 \\
18 \\
15 \\
13 \\
21\end{array}$ & $\begin{array}{l}(0.1) \\
0.4) \\
0.4) \\
0.4 \\
0.5)\end{array}$ & $\begin{array}{l}559 \\
495 \\
587 \\
347 \\
515\end{array}$ & $\left.\begin{array}{l}(1.9) \\
(5.1) \\
(2.0) \\
4.7 \\
2.4\end{array}\right)$ & $\begin{array}{l}91 \\
57 \\
92 \\
85^{5} \\
60\end{array}$ & $\begin{array}{l}(0.8) \\
(1.3) \\
(2.5) \\
5.8 \\
(1.5)\end{array}$ & $\begin{array}{r}10 \\
8 \\
11 \\
10 \\
9\end{array}$ & $\begin{array}{l}(0.1) \\
(0.2) \\
(0.4) \\
0.6 \\
0.3)\end{array}$ \\
\hline 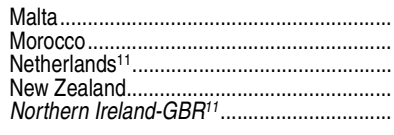 & $\begin{array}{r}891^{4} \\
1,040^{4} \\
1,074^{5} \\
925 \\
970^{4}\end{array}$ & $\begin{array}{r}(0.2) \\
(23.6) \\
(9.9) \\
(3.9) \\
(11.0)\end{array}$ & $\begin{array}{l}496 \\
3359 \\
540 \\
486 \\
562\end{array}$ & $\begin{array}{l}(1.3) \\
4.0 \\
(1.7) \\
2.6) \\
(2.9)\end{array}$ & $\begin{array}{l}183^{4} \\
174^{5} \\
195^{5} \\
168 \\
232^{5}\end{array}$ & $\begin{array}{l}(0.1) \\
(3.5) \\
(7.0) \\
(2.4) \\
(6.1)\end{array}$ & $\begin{array}{l}21 \\
17 \\
18 \\
18 \\
24\end{array}$ & $\begin{array}{r}(\#) \\
(0.4) \\
(0.5) \\
0.3) \\
(0.6)\end{array}$ & $\begin{array}{l}446 \\
2649 \\
531 \\
497 \\
517\end{array}$ & $\begin{array}{l}(1.9) \\
(4.5) \\
(2.2) \\
(2.3) \\
(2.6)\end{array}$ & $\begin{array}{l}399^{4} \\
445 \\
42^{5} \\
52^{5} \\
72^{5}\end{array}$ & $\begin{array}{l}(0.1) \\
(5.5) \\
(2.4) \\
(3.0) \\
(3.9)\end{array}$ & $\begin{array}{l}4 \\
5 \\
4 \\
6 \\
8\end{array}$ & $\begin{array}{r}(\#) \\
(0.6) \\
(0.2) \\
0.3) \\
(0.4)\end{array}$ \\
\hline $\begin{array}{l}\text { Norway } \\
\text { Oman } \\
\text { Poland } \\
\text { Portugal } \\
\text { Qatar }\end{array}$ & $\begin{array}{r}817 \\
999^{5} \\
7644^{4} \\
940^{4} \\
1,068\end{array}$ & $\begin{array}{r}(10.7) \\
17.4) \\
(13.5) \\
(13.1) \\
(9.1)\end{array}$ & $\begin{array}{l}495 \\
385 \\
481 \\
532 \\
413\end{array}$ & $\begin{array}{l}(2.8) \\
(2.9) \\
(2.2) \\
(3.4) \\
(3.5)\end{array}$ & $\begin{array}{l}157 \\
170^{5} \\
1574 \\
250^{4} \\
185\end{array}$ & $\begin{array}{l}(4.1) \\
(3.1) \\
(3.0) \\
4.3 \\
(6.3)\end{array}$ & $\begin{array}{l}19 \\
17 \\
21 \\
27 \\
17\end{array}$ & $\begin{array}{l}(0.6) \\
0.3) \\
(0.5) \\
(0.4) \\
(0.6)\end{array}$ & $\begin{array}{l}494 \\
377 \\
505 \\
522 \\
394\end{array}$ & $\begin{array}{l}(2.3) \\
4.3) \\
(2.6) \\
(3.9) \\
(4.3)\end{array}$ & $\begin{array}{c}55 \\
120^{5} \\
644^{4} \\
1622^{4} \\
135\end{array}$ & $\begin{array}{l}(2.2) \\
(2.4) \\
(3.1) \\
(4.1) \\
(6.8)\end{array}$ & $\begin{array}{r}7 \\
12 \\
8 \\
17 \\
13\end{array}$ & $\begin{array}{l}(0.3) \\
0.2) \\
(0.4) \\
(0.8) \\
(0.6)\end{array}$ \\
\hline 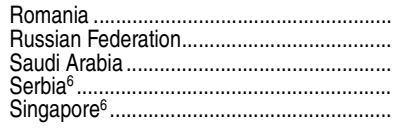 & $\begin{array}{r}796 \\
660^{4} \\
9777^{4} \\
778 \\
1,012\end{array}$ & $\begin{array}{r}(17.9) \\
(8.0) \\
(19.4) \\
(18.5) \\
(\#)\end{array}$ & $\begin{array}{l}482 \\
542 \\
410 \\
516 \\
606\end{array}$ & $\begin{array}{l}(5.8) \\
(3.7) \\
(5.3) \\
(3.0) \\
(3.2)\end{array}$ & $\begin{array}{l}148 \\
104 \\
147 \\
153 \\
208\end{array}$ & $\begin{array}{l}(3.9) \\
1.0 \\
(6.6) \\
(2.1 \\
(3.2)\end{array}$ & $\begin{array}{l}19 \\
16 \\
15 \\
20 \\
21\end{array}$ & $\begin{array}{l}(0.5) \\
0.2) \\
(0.5) \\
(0.5) \\
(0.3)\end{array}$ & $\begin{array}{l}505 \\
552 \\
429 \\
516 \\
583\end{array}$ & $\begin{array}{l}(5.9) \\
(3.5) \\
(5.4) \\
(3.1) \\
(3.4)\end{array}$ & $\begin{array}{l}56 \\
49 \\
822^{4} \\
72 \\
96\end{array}$ & $\begin{array}{l}(6.2) \\
(0.7) \\
(4.2) \\
50\end{array}$ & $\begin{array}{r}7 \\
8 \\
8 \\
10 \\
9\end{array}$ & $\begin{array}{l}(0.8) \\
0.2) \\
(0.5) \\
0.9) \\
(0.2)\end{array}$ \\
\hline 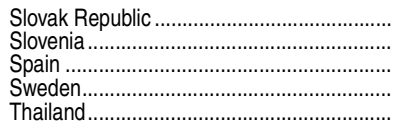 & $\begin{array}{r}780 \\
684 \\
8844^{4} \\
8499^{4} \\
1,201^{4}\end{array}$ & $\begin{array}{r}(8.8) \\
(\#) \\
(9.7) \\
(11.3) \\
(20.9)\end{array}$ & $\begin{array}{l}507 \\
513 \\
482 \\
504 \\
458\end{array}$ & $\begin{array}{l}(3.8) \\
(2.2) \\
2.9 \\
2.0) \\
(4.8)\end{array}$ & $\begin{array}{l}147 \\
169 \\
1674 \\
138^{5} \\
167\end{array}$ & $\begin{array}{l}(1.4) \\
(2.6) \\
2.3 \\
3.8 \\
(5.2)\end{array}$ & $\begin{array}{l}19 \\
25 \\
19 \\
17 \\
14\end{array}$ & $\begin{array}{l}(0.1) \\
(0.4) \\
0.2 \\
0.5) \\
(0.6)\end{array}$ & $\begin{array}{l}532 \\
520 \\
505 \\
533 \\
472\end{array}$ & $\begin{array}{l}(3.8) \\
(2.7) \\
3.0 \\
2.7) \\
(5.6)\end{array}$ & $\begin{array}{l}101 \\
101 \\
1454 \\
75^{5} \\
109\end{array}$ & $\begin{array}{l}(4.3) \\
(1.2) \\
2.6 \\
3.0 \\
(4.9)\end{array}$ & $\begin{array}{r}13 \\
15 \\
16 \\
9 \\
9\end{array}$ & $\begin{array}{l}(0.6) \\
(0.2) \\
0.3 \\
0.4) \\
(0.5)\end{array}$ \\
\hline $\begin{array}{l}\text { Tunisia } \\
\text { Turkey } \\
\text { United Arab Emirates } \\
\text { United States } \\
\text { Yemen }\end{array}$ & $\begin{array}{r}963^{4} \\
900^{4} \\
1,025^{4} \\
1,078 \\
831^{4} \\
\end{array}$ & $\begin{array}{r}(22.9) \\
(19.3) \\
(8.5) \\
(7.3) \\
(14.1) \\
\end{array}$ & $\begin{array}{l}35910 \\
469 \\
434 \\
541 \\
2489 \\
\end{array}$ & $\begin{array}{l}(3.9) \\
(4.7) \\
2.0 \\
1.8) \\
(6.0) \\
\end{array}$ & $\begin{array}{l}175^{4} \\
126 \\
154^{5} \\
206^{4} \\
135^{4} \\
\end{array}$ & $\begin{array}{l}(2.9) \\
(2.5) \\
2.4 \\
(4.6) \\
(6.4) \\
\end{array}$ & $\begin{array}{l}19 \\
15 \\
15 \\
19 \\
16 \\
\end{array}$ & $\begin{array}{l}(0.3) \\
(0.4) \\
0.2) \\
0.5) \\
(0.7)\end{array}$ & $\begin{array}{l}3466^{10} \\
463 \\
428 \\
544 \\
209^{9} \\
\end{array}$ & $\begin{array}{l}(5.3) \\
(4.5) \\
2.5 \\
(2.1) \\
(7.3) \\
\end{array}$ & $\begin{array}{r}93^{4} \\
94 \\
108^{5} \\
105^{4} \\
91^{4} \\
\end{array}$ & $\begin{array}{l}(5.4) \\
(1.8) \\
(3.0) \\
(3.1) \\
(5.6) \\
\end{array}$ & $\begin{array}{l}10 \\
11 \\
11 \\
10 \\
11 \\
\end{array}$ & $\begin{array}{l}(0.6) \\
(0.3) \\
0.3) \\
(0.3) \\
(0.6) \\
\end{array}$ \\
\hline $\begin{array}{l}\text { Benchmarking education systems } \\
\text { Abu Dhabi-UAE } \\
\text { Alberta-CAN } \\
\text { Dubai-UAE }\end{array}$ & $\begin{array}{l}1,033^{4} \\
1,006 \\
993^{4} \\
1,073^{4} \\
1,113^{4} \\
969 \\
916\end{array}$ & $\begin{array}{r}(18.1) \\
(8.8) \\
(0.7) \\
(19.7) \\
(22.9) \\
(7.4) \\
(5.1)\end{array}$ & $\begin{array}{l}417 \\
507 \\
468 \\
545 \\
554 \\
518 \\
533\end{array}$ & $\begin{array}{l}(4.6) \\
(2.5) \\
(1.6) \\
(2.9) \\
(4.2) \\
(3.1) \\
(2.4)\end{array}$ & $\begin{array}{l}150^{5} \\
169^{5} \\
158^{5} \\
217^{5} \\
221^{4} \\
201^{4} \\
229\end{array}$ & $\begin{array}{r}(4.3) \\
(3.2) \\
(2.3) \\
(8.8) \\
(13.5 \\
(4.1) \\
(5.0)\end{array}$ & $\begin{array}{l}15 \\
17 \\
16 \\
20 \\
20 \\
21 \\
25\end{array}$ & $\begin{array}{l}(0.4) \\
(0.4) \\
(0.2) \\
(0.9) \\
(1.2) \\
(0.5) \\
(0.6)\end{array}$ & $\begin{array}{l}411 \\
541 \\
461 \\
545 \\
538 \\
528 \\
516\end{array}$ & $\begin{array}{l}(4.9) \\
2.4) \\
(2.3) \\
(3.7) \\
(4.6) \\
(3.0) \\
(2.7)\end{array}$ & $\begin{array}{r}110^{5} \\
130^{5} \\
995 \\
113^{5} \\
94^{4} \\
92^{4} \\
50^{4}\end{array}$ & $\begin{array}{l}(6.8) \\
(4.1) \\
(1.6) \\
(9.6) \\
(6.0) \\
(3.2) \\
(1.7)\end{array}$ & $\begin{array}{r}11 \\
13 \\
10 \\
10 \\
9 \\
10 \\
5\end{array}$ & $\begin{array}{l}(0.6) \\
0.6) \\
(0.2) \\
0.8) \\
(0.4) \\
(0.3) \\
(0.2)\end{array}$ \\
\hline
\end{tabular}

\section{-Not available.}

†Not applicable.

Rounds to zero.

Ust of the education systems represent complete countries, but some represent subnational entities such as U.S. states, Canadian provinces, and England (which is part of the United Kingdom). The name of each subnational entity appears in italics and includes as a suffix the three-letter International Organization for Standardization (ISO) abbreviation for its complete country. Examples include Florida-USA, Onlario-CAN, and England-GBR. ${ }_{2}^{2}$ Trends in International Mathematics and Science Study (TIMSS) scores are reported on a scale from 0 to 1,000, with the scale average set at 500 and the standard deviation set at 100

The TIMSS average includes only education systems that are members of the International Association for the Evaluation of Educational Achievement (IAE), which develops and implements TIMSS at the international level. "Benchmarking" education systems are not members of the IEA and are therefore not included in the average. "Data are available for at least 70 percent but less than 85 percent of students.

Data are available for at least 50 percent but less than 70 percent of students.

'National Defined Population covers 90 to 95 percent of National Target Population.

${ }^{7}$ Exclusion rates for Azerbaijan and Georgia are slightly underestimated as some conflict zones were not covered and no official statistics were available.

${ }^{8}$ National Target Population does not include all of the International Target Population defined by TIMSS.

TThe TIMSS \& PIRLS International Study Center has reservations about the reliability of the average achieve-

ment score because the percentage of students with achievement too low for estimation exceeds 25 percent.
10The TIMSS \& PIRLS International Study Center has reservations about the reliability of the average achievement score because the percentage of students with achievement too low for estimation exceeds 15 percent, though it is less than 25 percent.

${ }^{11}$ Met guidelines for sample participation rates only after replacement schools were included.

${ }^{12}$ Nearly satisfied guidelines for sample participation rates after replacement schools were included.

${ }^{13}$ National Defined Population covers less than 90 percent of National Target Population (but at least 77 percent). ${ }^{14} \mathrm{All}$ U.S. state data are based on public school students only.

NOTE: Countries were required to sample students in the grade that corresponded to the end of 4 years of formal schooling, providing that the mean age at the time of testing was at least 9.5 years. Instructional times shown in this table are actual or implemented times (as opposed to intended times prescribed by the curriculum). Principals reported total instructional hours per day and school days per year. Total instructional hours per year were calculated by multiplying the number of school days per year by the number of instructional hours per day. Teachers reported instructional hours per week in mathematics and science. Instructional hours per year in mathematics and science were calculated by dividing weekly instructional hours by the number of school days per week and then multiplying by the number of school days per year.

SOURCE: International Association for the Evaluation of Educational Achievement (IEA), Trends in International Mathematics and Science Study (TIMSS), 2011; TIMSS 2011 International Results in Mathematics, by Ina V.S. Mullis et al.; and TIMSS 2011 International Results in Science, by Michael O. Martin et al. (This table was prepared December 2012. 
768 CHAPTER 6: International Comparisons of Education Achievement and Instruction

Table 602.30. Average eighth-grade scores and annual instructional time in mathematics and science, by country or other education system: 2011

[Standard errors appear in parentheses]

\begin{tabular}{|c|c|c|c|c|c|c|c|c|c|c|c|c|c|c|}
\hline \multirow[b]{3}{*}{ Country or other education system 1} & \multirow{3}{*}{\multicolumn{2}{|c|}{$\begin{array}{r}\text { Total instructional } \\
\text { hours per year }\end{array}$}} & \multicolumn{6}{|c|}{ Mathematics } & \multicolumn{6}{|c|}{ Science } \\
\hline & & & \multirow{2}{*}{\multicolumn{2}{|c|}{ Average score $^{2}$}} & \multicolumn{4}{|c|}{ Instructional time in mathematics } & \multirow{2}{*}{\multicolumn{2}{|c|}{ Average score $^{2}$}} & \multicolumn{4}{|c|}{ Instructional time in science ${ }^{3}$} \\
\hline & & & & & Hou & er year & $\begin{array}{r}\text { percer } \\
\text { instructior }\end{array}$ & $\begin{array}{r}\text { As a } \\
\text { of total } \\
\text { a hours }\end{array}$ & & & \multicolumn{2}{|c|}{ Hours per year } & \multicolumn{2}{|c|}{$\begin{array}{r}\text { As a } \\
\text { percent of total } \\
\text { instructional hours }\end{array}$} \\
\hline 1 & & 2 & & 3 & & 4 & & 5 & & 6 & & 7 & & 8 \\
\hline 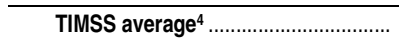 & 1,031 & (2.3) & 500 & $(t)$ & 138 & $(0.5)$ & 14 & $(0.1)$ & 500 & $(\dagger)$ & 158 & $(0.8)$ & 11 & $\overline{(0.1)}$ \\
\hline $\begin{array}{l}\text { Armenia } \\
\text { Australiaa } \\
\text { Bahrain } \\
\text { Chile } \\
\text { Chinese Taipei-CHN }\end{array}$ & $\begin{array}{l}979^{5} \\
1,039 \\
1,019 \\
1,245^{5} \\
1,153\end{array}$ & $\begin{array}{r}(12.8) \\
(7.2) \\
(1.1) \\
(23.5) \\
(11.7)\end{array}$ & $\begin{array}{l}467 \\
505 \\
4097 \\
416 \\
609\end{array}$ & $\begin{array}{l}(2.7) \\
(5.1) \\
(2.0) \\
(2.6) \\
(3.2)\end{array}$ & $\begin{array}{l}143^{5} \\
143^{6} \\
142^{5} \\
193^{5} \\
166\end{array}$ & $\begin{array}{l}(3.0) \\
(3.5) \\
2.5 \\
(4.5) \\
(2.4)\end{array}$ & $\begin{array}{l}15 \\
14 \\
14 \\
15 \\
15\end{array}$ & $\begin{array}{l}(0.2) \\
(0.3) \\
0.3) \\
(0.3) \\
(0.2)\end{array}$ & $\begin{array}{l}437 \\
519 \\
452 \\
461 \\
564\end{array}$ & $\begin{array}{l}(3.1) \\
(4.8) \\
2.0 \\
(2.5) \\
(2.3)\end{array}$ & $\begin{array}{l}240^{6} \\
131^{6} \\
130^{5} \\
134^{5} \\
157\end{array}$ & $\begin{array}{l}(4.9) \\
4.5) \\
2.8 \\
3.8) \\
(2.7)\end{array}$ & $\begin{array}{r}\ddagger \\
12 \\
13 \\
11 \\
14\end{array}$ & $\begin{array}{r}(\dagger) \\
(0.4) \\
0.3 \\
(0.3) \\
(0.3)\end{array}$ \\
\hline 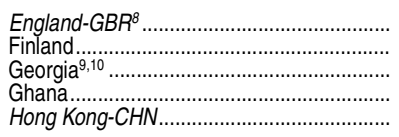 & $\begin{array}{r}992^{5} \\
934 \\
833^{5} \\
1,153^{5} \\
1,026^{5}\end{array}$ & $\begin{array}{r}(8.4) \\
(11.7) \\
(10.8) \\
(18.9) \\
(11.3)\end{array}$ & $\begin{array}{l}507 \\
514 \\
431 \\
331 \\
586\end{array}$ & $\begin{array}{l}(5.5) \\
(2.5) \\
3.8) \\
(4.3) \\
(3.8)\end{array}$ & $\begin{array}{l}116^{5} \\
105 \\
123^{5} \\
165^{5} \\
138^{5}\end{array}$ & $\begin{array}{l}(2.1) \\
(1.8) \\
(3.3) \\
(6.8) \\
(2.9)\end{array}$ & $\begin{array}{l}11 \\
11 \\
15 \\
14 \\
13\end{array}$ & $\begin{array}{l}(0.3) \\
(0.2) \\
(0.5) \\
(0.6) \\
(0.3)\end{array}$ & $\begin{array}{l}533 \\
552 \\
420 \\
306^{7} \\
535\end{array}$ & $\begin{array}{l}(4.9) \\
(2.5) \\
3.0) \\
(5.2) \\
(3.4)\end{array}$ & $\begin{array}{l}102^{6} \\
190^{5} \\
198^{5} \\
148^{5} \\
103^{5}\end{array}$ & $\begin{array}{l}(3.1) \\
(6.0) \\
6.8) \\
(6.1) \\
(4.6)\end{array}$ & $\begin{array}{r}10 \\
\ddagger \\
\ddagger \\
13 \\
10\end{array}$ & $\begin{array}{r}(0.4) \\
(\dagger) \\
(\dagger) \\
(0.4) \\
0.4)\end{array}$ \\
\hline 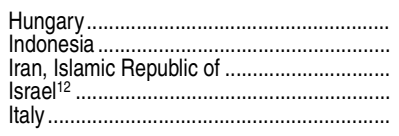 & $\begin{array}{c}836 \\
1,494^{5} \\
994 \\
1,108^{5} \\
1,085\end{array}$ & $\begin{array}{r}(12.2) \\
40.9) \\
(15.9) \\
(14.1) \\
(9.4)\end{array}$ & $\begin{array}{l}505 \\
386^{7} \\
415^{7} \\
516^{7} \\
498\end{array}$ & $\left.\begin{array}{l}(3.5) \\
4.3 \\
4.3 \\
(4.1) \\
2.4\end{array}\right)$ & $\begin{array}{l}119 \\
173^{5} \\
124 \\
165^{5} \\
155\end{array}$ & $\begin{array}{l}(1.9) \\
(7.9) \\
(3.3) \\
(3.0) \\
(2.5)\end{array}$ & $\begin{array}{l}15 \\
12 \\
13 \\
15 \\
14\end{array}$ & $\begin{array}{l}(0.3) \\
0.6) \\
0.3) \\
(0.2) \\
(0.2)\end{array}$ & $\begin{array}{l}522 \\
406 \\
474 \\
516 \\
501\end{array}$ & $\left.\begin{array}{l}(3.1) \\
4.5 \\
4.0 \\
4.0 \\
2.5\end{array}\right)$ & $\begin{array}{l}236 \\
190^{5} \\
120 \\
132 \\
73\end{array}$ & $\begin{array}{r}(4.8) \\
(12.2) \\
(3.6) \\
(3.9) \\
(1.0)\end{array}$ & $\begin{array}{r}28 ! \\
10 \\
12 \\
12 \\
7\end{array}$ & $\begin{array}{r}(13.1) \\
(0.5) \\
0.4 \\
(0.4) \\
(0.1)\end{array}$ \\
\hline 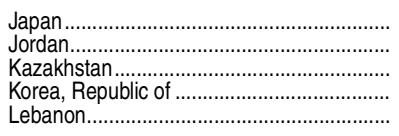 & $\begin{array}{l}1,016 \\
1,041 \\
920 \\
1,006 \\
1,028^{5}\end{array}$ & $\begin{array}{r}(6.7) \\
(11.9) \\
(9.9) \\
(12.1) \\
(12.7)\end{array}$ & $\begin{array}{l}570 \\
406^{7} \\
487 \\
613 \\
449\end{array}$ & $\begin{array}{l}(2.6) \\
(3.7) \\
(4.0) \\
2.9 \\
3.7)\end{array}$ & $\begin{array}{l}108 \\
130 \\
117 \\
137 \\
178^{5}\end{array}$ & $\begin{array}{l}(1.4) \\
(3.8) \\
(3.2) \\
(1.8) \\
(3.9)\end{array}$ & $\begin{array}{l}11 \\
13 \\
13 \\
13 \\
17\end{array}$ & $\begin{array}{l}(0.1) \\
(0.4) \\
(0.4) \\
0.2) \\
(0.4)\end{array}$ & $\begin{array}{l}558 \\
449 \\
490 \\
560 \\
406\end{array}$ & $\begin{array}{l}(2.4) \\
(4.0) \\
(4.3) \\
(2.0) \\
(4.9)\end{array}$ & $\begin{array}{r}128 \\
134 \\
244 \\
126 \\
\ddagger\end{array}$ & $\begin{array}{r}(1.7) \\
(3.1) \\
(4.8) \\
(2.5) \\
(\dagger)\end{array}$ & $\begin{array}{l}12 \\
13 \\
27 ! \\
11 \\
\ddagger\end{array}$ & $\begin{array}{r}(0.3) \\
(0.4) \\
(11.0) \\
(0.2) \\
(\dagger)\end{array}$ \\
\hline 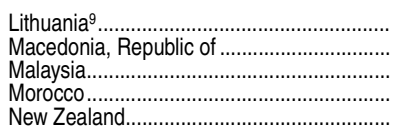 & $\begin{array}{c}898 \\
1,023^{5} \\
1,198^{5} \\
1,303^{5} \\
959\end{array}$ & $\begin{array}{r}(13.9) \\
(21.4) \\
(13.7) \\
(24.9) \\
(4.4)\end{array}$ & $\begin{array}{l}502 \\
426^{7} \\
440 \\
371^{11} \\
488\end{array}$ & $\begin{array}{l}(2.5) \\
5.2 \\
5.4) \\
(2.0) \\
(5.5)\end{array}$ & $\begin{array}{l}132 \\
122^{6} \\
123^{5} \\
148^{5} \\
141\end{array}$ & $\left.\begin{array}{l}(2.7) \\
4.6 \\
(3.4) \\
(2.1) \\
1.8\end{array}\right)$ & $\begin{array}{l}15 \\
13 \\
10 \\
12 \\
15\end{array}$ & $\begin{array}{l}(0.4) \\
0.6 \\
0.3) \\
(0.2) \\
(0.2)\end{array}$ & $\begin{array}{l}514 \\
407 \\
426 \\
376 \\
512\end{array}$ & $\begin{array}{l}(2.6) \\
5.4 \\
6.3) \\
(2.2) \\
(4.6)\end{array}$ & $\begin{array}{l}251^{5} \\
334^{6} \\
126 \\
144^{5} \\
130^{5}\end{array}$ & $\begin{array}{r}(5.2) \\
(14.7) \\
(3.6) \\
(2.0) \\
(2.6)\end{array}$ & $\begin{array}{r}\ddagger \\
\ddagger \\
10 \\
\ddagger \\
14\end{array}$ & $\begin{array}{r}(t) \\
(\dagger) \\
(0.3) \\
(\dagger) \\
(0.3)\end{array}$ \\
\hline 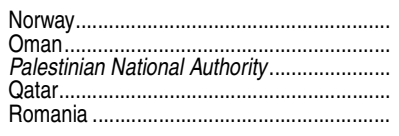 & $\begin{array}{c}880 \\
1,044^{5} \\
918 \\
1,054 \\
984\end{array}$ & $\begin{array}{r}(6.3) \\
(17.7) \\
(7.3) \\
(1.3) \\
(15.5)\end{array}$ & $\begin{array}{l}475 \\
366^{7} \\
404^{7} \\
410^{7} \\
458\end{array}$ & $\begin{array}{l}(2.4) \\
(2.8) \\
(3.5) \\
3.1 \\
4.0)\end{array}$ & $\begin{array}{l}125 \\
161^{5} \\
134 \\
162 \\
145\end{array}$ & $\begin{array}{l}(3.4) \\
(5.1) \\
(4.0) \\
(3.6) \\
(3.7)\end{array}$ & $\begin{array}{l}14 \\
16 \\
15 \\
15 \\
15\end{array}$ & $\begin{array}{l}(0.4) \\
(0.4) \\
(0.4) \\
0.4) \\
(0.3)\end{array}$ & $\begin{array}{l}494 \\
420 \\
420 \\
419 \\
465\end{array}$ & $\begin{array}{l}(2.6) \\
(3.2) \\
(3.2) \\
3.4 \\
(3.5)\end{array}$ & $\begin{array}{l}101 \\
161^{6} \\
107 \\
131 \\
281\end{array}$ & $\begin{array}{r}(3.3) \\
(3.8) \\
(3.4) \\
(6.9) \\
(10.1)\end{array}$ & $\begin{array}{r}11 \\
16 \\
12 \\
12 \\
\ddagger\end{array}$ & $\begin{array}{r}(0.4) \\
(0.3) \\
(0.4) \\
(0.5) \\
(\dagger)\end{array}$ \\
\hline 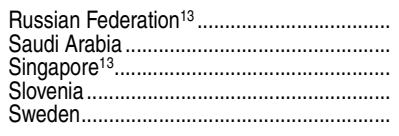 & $\begin{array}{l}882 \\
1,050^{5} \\
1,106 \\
798 \\
969^{5}\end{array}$ & $\begin{array}{r}(8.7) \\
(20.9) \\
(\#) \\
(\#) \\
(13.4)\end{array}$ & $\begin{array}{l}539 \\
394^{7} \\
611 \\
505 \\
484\end{array}$ & $\left.\begin{array}{l}(3.6) \\
4.6 \\
3.8 \\
(2.2) \\
1.9\end{array}\right)$ & $\begin{array}{l}142 \\
1345 \\
138 \\
121 \\
97^{6}\end{array}$ & $\begin{array}{l}(2.0) \\
5.4 \\
(1.7) \\
(1.5) \\
(2.2)\end{array}$ & $\begin{array}{l}16 \\
13 \\
13 \\
15 \\
10\end{array}$ & $\begin{array}{l}(0.3) \\
0.4) \\
0.2) \\
(0.2) \\
(0.3)\end{array}$ & $\begin{array}{l}542 \\
436 \\
590 \\
543 \\
509\end{array}$ & $\begin{array}{l}(3.2) \\
3.9 \\
4.3 \\
(2.7) \\
2.5)\end{array}$ & $\begin{array}{l}208 \\
1245 \\
115 \\
251 \\
946\end{array}$ & $\left.\begin{array}{l}(1.6) \\
6.8 \\
2.1\end{array}\right)$ & $\begin{array}{r}24 ! \\
12 \\
11 \\
31 \\
9\end{array}$ & $\begin{array}{l}(8.8) \\
0.5 \\
0.2) \\
(4.6) \\
0.4)\end{array}$ \\
\hline 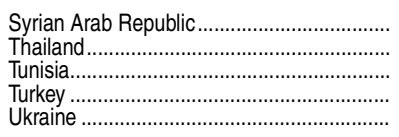 & $\begin{array}{l}811 \\
1,270^{5} \\
1,299^{5} \\
889 \\
901\end{array}$ & $\begin{array}{l}(14.2) \\
(15.1) \\
(25.4) \\
16.7) \\
10.7)\end{array}$ & $\begin{array}{l}380^{7} \\
427 \\
425 \\
452 \\
479\end{array}$ & $\begin{array}{l}(4.5) \\
(4.3) \\
(2.8) \\
(3.9) \\
(3.9)\end{array}$ & $\begin{array}{l}118^{5} \\
129 \\
131^{5} \\
117 \\
132\end{array}$ & $\begin{array}{l}(4.7) \\
(4.3) \\
(3.0) \\
\left(\begin{array}{l}1.8 \\
3.5\end{array}\right)\end{array}$ & $\begin{array}{l}15 \\
10 \\
10 \\
14 \\
15\end{array}$ & $\begin{array}{l}(0.5) \\
0.3) \\
(0.2) \\
0.3 \\
(0.4)\end{array}$ & $\begin{array}{l}426 \\
451 \\
439 \\
483 \\
501\end{array}$ & $\begin{array}{l}(3.9) \\
(3.9) \\
(2.5) \\
3.4 \\
(3.4)\end{array}$ & $\begin{array}{l}150^{5} \\
119 \\
64^{5} \\
99 \\
239\end{array}$ & $\begin{array}{l}(7.5) \\
2.9) \\
(1.9) \\
1.1 \\
4.0)\end{array}$ & $\begin{array}{c}\ddagger \\
9 \\
5 \\
12 \\
27 !\end{array}$ & $\begin{array}{r}(t) \\
(0.3) \\
(0.1) \\
0.2 \\
(11.4)\end{array}$ \\
\hline $\begin{array}{l}\text { United Arab Emirates. } \\
\text { United States }{ }^{13}\end{array}$ & $\begin{array}{l}1,046^{5} \\
1,114\end{array}$ & $\left(\begin{array}{l}8.0 \\
6.6\end{array}\right)$ & $\begin{array}{l}456 \\
509\end{array}$ & $\left.\begin{array}{l}(2.1) \\
2.6\end{array}\right)$ & $\begin{array}{l}157^{5} \\
157^{6}\end{array}$ & $\left(\begin{array}{l}2.9) \\
(3.2)\end{array}\right.$ & $\begin{array}{l}15 \\
14 \\
\end{array}$ & $\begin{array}{l}(0.3) \\
(0.3)\end{array}$ & $\begin{array}{l}465 \\
525\end{array}$ & $\left(\begin{array}{l}2.4 \\
(2.6)\end{array}\right)$ & $\begin{array}{l}115^{6} \\
139^{14}\end{array}$ & $\left(\begin{array}{l}2.7) \\
(2.4)\end{array}\right)$ & $\begin{array}{l}11 \\
13^{14}\end{array}$ & $\left.\begin{array}{l}(0.3) \\
0.2\end{array}\right)$ \\
\hline 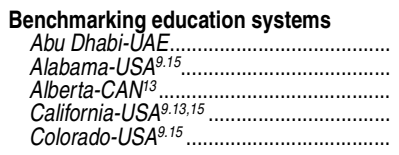 & $\begin{array}{l}1,045^{5} \\
1,135^{5} \\
1,031 \\
1,040^{5} \\
1,148\end{array}$ & $\begin{array}{l}(16.6) \\
(16.0) \\
10.0) \\
(15.2) \\
17.0)\end{array}$ & $\begin{array}{l}449 \\
466 \\
505 \\
493 \\
518\end{array}$ & $\begin{array}{l}(3.7) \\
(5.9) \\
2.6) \\
(4.9) \\
(4.9)\end{array}$ & $\begin{array}{l}158^{5} \\
166^{6} \\
156 \\
172^{6} \\
173^{5}\end{array}$ & $\begin{array}{l}(5.8) \\
(8.9) \\
4.2) \\
(8.0) \\
(8.6)\end{array}$ & $\begin{array}{l}15 \\
15 \\
19 \\
17 \\
15\end{array}$ & $\begin{array}{l}(0.5) \\
(0.9) \\
0.4) \\
(0.7) \\
(0.8)\end{array}$ & $\begin{array}{l}461 \\
485 \\
546 \\
499 \\
542\end{array}$ & $\begin{array}{l}(4.0) \\
(6.2) \\
(2.4) \\
(4.6) \\
(4.4)\end{array}$ & $\begin{array}{c}111^{6} \\
167^{6} \\
145^{5} \\
\ddagger \\
138^{6}\end{array}$ & $\begin{array}{r}(4.8) \\
(6.0) \\
4.0) \\
(t) \\
(6.0)\end{array}$ & $\begin{array}{l}11 \\
15 \\
10 \\
14 \\
12\end{array}$ & $\begin{array}{l}(0.5) \\
(0.5) \\
0.4) \\
0.7) \\
0.5)\end{array}$ \\
\hline
\end{tabular}

See notes at end of table. 
Table 602.30. Average eighth-grade scores and annual instructional time in mathematics and science, by country or other education system: 2011-Continued

[Standard errors appear in parentheses]

\begin{tabular}{|c|c|c|c|c|c|c|c|c|c|c|c|c|c|c|}
\hline \multirow[b]{3}{*}{ Country or other education system ${ }^{1}$} & \multirow{3}{*}{\multicolumn{2}{|c|}{$\begin{array}{r}\text { Total instructional } \\
\text { hours per year }\end{array}$}} & \multicolumn{6}{|c|}{ Mathematics } & \multicolumn{6}{|c|}{ Science } \\
\hline & & & \multirow{2}{*}{\multicolumn{2}{|c|}{ Average score $^{2}$}} & \multicolumn{4}{|c|}{ Instructional time in mathematics } & \multirow{2}{*}{\multicolumn{2}{|c|}{ Average score $^{2}$}} & \multicolumn{4}{|c|}{ Instructional time in science ${ }^{3}$} \\
\hline & & & & & Hour & er year & $\begin{array}{r}\text { perce } \\
\text { instructio }\end{array}$ & $\begin{array}{r}\text { As a } \\
\text { of total } \\
\text { I hours }\end{array}$ & & & \multicolumn{2}{|c|}{ Hours per year } & \multicolumn{2}{|c|}{$\begin{array}{r}\text { As a } \\
\text { percent of tota } \\
\text { instructional hours }\end{array}$} \\
\hline 1 & & 2 & & 3 & & 4 & & 5 & & 6 & & 7 & & 8 \\
\hline 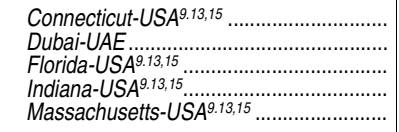 & $\begin{array}{l}1,071 \\
1,022^{5} \\
1,119^{5} \\
1,133^{5} \\
1,087\end{array}$ & $\begin{array}{r}(19.3) \\
(1.5) \\
(17.0) \\
(14.9) \\
(13.6)\end{array}$ & $\begin{array}{l}518 \\
478 \\
513 \\
522 \\
561\end{array}$ & $\begin{array}{l}(4.8) \\
(2.1) \\
6.4) \\
(5.1) \\
(5.3)\end{array}$ & $\begin{array}{l}144^{5} \\
155^{5} \\
144^{6} \\
149 \\
154^{6}\end{array}$ & $\begin{array}{l}(4.4) \\
(3.6) \\
(7.4) \\
6.9) \\
(5.4)\end{array}$ & $\begin{array}{l}14 \\
15 \\
13 \\
13 \\
14\end{array}$ & $\begin{array}{l}(0.5) \\
(0.3) \\
(0.7) \\
0.7) \\
(0.6)\end{array}$ & $\begin{array}{l}532 \\
485 \\
530 \\
533 \\
567\end{array}$ & $\begin{array}{l}(4.6) \\
2.5) \\
(7.3) \\
4.8 \\
(5.1)\end{array}$ & $\begin{array}{r}139^{6} \\
125^{6} \\
\ddagger \\
132^{6} \\
156^{6}\end{array}$ & $\begin{array}{r}(6.2) \\
(3.6) \\
(\dagger) \\
(6.5) \\
(6.1)\end{array}$ & $\begin{array}{l}13 \\
11 \\
13 \\
12 \\
15\end{array}$ & $\begin{array}{l}(0.6) \\
0.3) \\
(0.8) \\
0.6) \\
(0.6)\end{array}$ \\
\hline $\begin{array}{l}\text { Minnesota-USA } \\
\text { North Carolina-USA } \\
\text { Ontario-CAN } 12,15 \\
\text { Quebec-CAN }\end{array}$ & $\begin{array}{l}1,043 \\
1,159 \\
971^{5} \\
913\end{array}$ & $\begin{array}{r}(14.8) \\
(16.0) \\
(7.5) \\
(3.3)\end{array}$ & $\begin{array}{l}545 \\
537 \\
512 \\
532\end{array}$ & $\begin{array}{l}(4.6) \\
6.8 \\
2.5 \\
(2.3)\end{array}$ & $\begin{array}{l}142^{5} \\
185^{6} \\
181^{5} \\
147^{5}\end{array}$ & $\left.\begin{array}{l}(7.5) \\
(9.7) \\
3.9 \\
4.1\end{array}\right)$ & $\begin{array}{l}14 \\
16 \\
16 \\
15\end{array}$ & $\begin{array}{l}(0.7) \\
(0.8) \\
0.5 \\
0.5)\end{array}$ & $\begin{array}{l}553 \\
532 \\
521 \\
520\end{array}$ & $\left.\begin{array}{l}(4.6) \\
(6.3) \\
2.5 \\
2.5\end{array}\right)$ & $\begin{array}{r}140^{6} \\
\ddagger \\
96^{5} \\
102^{5}\end{array}$ & $\begin{array}{r}(8.3) \\
(\dagger) \\
(3.5) \\
(3.0)\end{array}$ & $\begin{array}{l}14 \\
16 \\
11 \\
14\end{array}$ & $\begin{array}{l}(0.9) \\
(1.2 \\
0.3 \\
0.4)\end{array}$ \\
\hline
\end{tabular}

†Not applicable.

!Interpret data with caution. The coefficient of variation (CV) for this estimate is between 30 and 50 percent.

†Reporting standards not met. Either data are available for less than 50 percent of the students or the coefficient of variation (CV) is 50 percent or greater.

${ }^{1}$ Most of the education systems represent complete countries, but some represent subnational entities such as U.S. states, Canadian provinces, and England (which is part of the United Kingdom). The name of each subnational entity appears in italics and includes as a suffix the three-letter International Organization for Standardization (ISO) abbreviation for its complete country. Examples include Florida-USA, Ontario-CAN, and England-GBR.

${ }^{2}$ Trends in International Mathematics and Science Study (TIMSS) scores are reported on a scale from 0 to 1,000 , with the scale average set at 500 and the standard deviation set at 100 . ${ }^{3} \mathrm{General} /$ integrated science instructional time is shown for the 27 participating countries that teach science as a general or integrated subject at the eighth grade. For the 15 participating countries that teach the sciences as separate subjects (biology, chemistry, etc.) at the eighth grade, total instructional time across science subjects is shown.

${ }^{4}$ The TIMSS average includes only education systems that are members of the International Association for the Evaluation of Educational Achievement (IAE), which develops and implements TIMSS at the international level. "Benchmarking" education systems are not members of the IEA and are therefore not included in the average.

${ }^{5}$ Data are available for at least 70 percent but less than 85 percent of students. ${ }^{6}$ Data are available for at least 50 percent but less than 70 percent of students.

${ }^{7}$ The TIMSS \& PIRLS International Study Center has reservations about the reliability of the average achievement score because the percentage of students with achievement too low for estimation exceeds 15 percent, though it is less than 25 percent.

${ }^{8}$ Nearly satisfied guidelines for sample participation rate after replacement schools were included.
${ }^{9}$ National Target Population does not include all of the International Target Population defined by TIMSS.

${ }^{10}$ Exclusion rates for Georgia are slightly underestimated as some conflict zones were not covered and no official statistics were available.

${ }^{11}$ The TIMSS \& PIRLS International Study Center has reservations about the reliability of the average achievement score because the percentage of students with achievement too low for estimation exceeds 25 percent.

${ }^{12}$ National Defined Population covers less than 90 percent of National Target Population (but at least 77 percent)

${ }^{13}$ National Defined Population covers 90 to 95 percent of National Target Population.

${ }^{14}$ Data are for 2007 and are from TIMSS 2007 International Results in Science. Met guidelines for sample participation rates only after replacement schools were included. Data are available for at least 50 percent but less than 70 percent of students.

${ }^{15}$ All U.S. state data are based on public school students only.

NOTE: Countries were required to sample students in the grade that corresponded to the end of 8 years of formal schooling, providing that the mean age at the time of testing was at least 13.5 years. Instructional times shown in this table are actual or implemented times (as opposed to intended times prescribed by the curriculum). Principals reported total instructional hours per day and school days per year. Total instructional hours per year were calculated by multiplying the number of school days per year by the number of instructional hours per day. Teachers reported instructional hours per week in mathematics and science. Instrucper day. Teachers reported instructional hours per week in mathematics and science. Instruc-
tional hours per year in mathematics and science were calculated by dividing weekly instructional hours by the number of school days per week and then multiplying by the number of school days per year.

SOURCE: International Association for the Evaluation of Educational Achievement (IEA), Trends in International Mathematics and Science Study (TIMSS), 2011; TIMSS 2011 International Results in Mathematics, by Ina V.S. Mullis et al.; and TIMSS 2011 International Results in Science, by Michael O. Martin et al. (This table was prepared December 2012.) 
770 CHAPTER 6: International Comparisons of Education

Achievement and Instruction

Table 602.40. Average reading literacy, mathematics literacy, and science literacy scores of 15-year-old students, by sex and country or other education system: 2009 and 2012

[Standard errors appear in parentheses]

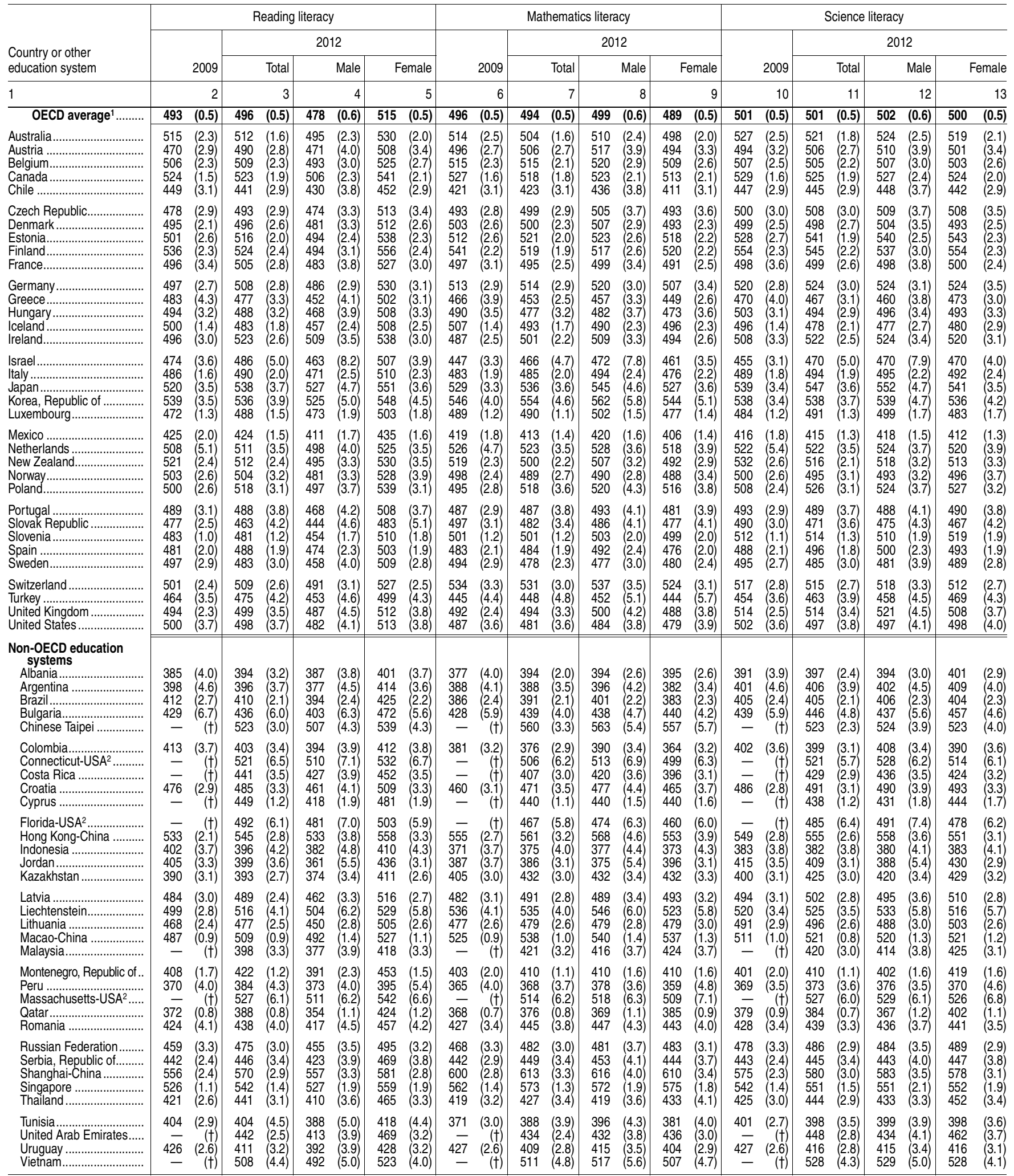

一Not available.

†Not applicable.

${ }^{1}$ Refers to the mean of the data values for all Organization for Economic Cooperation and Development (OECD) countries, to which each country contributes equally regardless of the absolute size of the student population of each country.
${ }^{2}$ Results are for public school students only.

NOTE: Program for International Student Assessment (PISA) scores are reported on a scale from 0 to 1,000 .

SOURCE: Organization for Economic Cooperation and Development (OECD), Program for International Student Assessment (PISA), 2009 and 2012. (This table was prepared July 2014.) 
Table 602.50. Average reading literacy scores of 15 -year-old students and percentage attaining reading literacy proficiency levels, by country or other education system: 2012

[Standard errors appear in parentheses]

\begin{tabular}{|c|c|c|c|c|c|c|c|c|c|c|c|c|c|c|c|c|c|c|c|c|c|c|}
\hline \multirow[b]{3}{*}{$\begin{array}{l}\text { Country or other } \\
\text { education system }\end{array}$} & \multirow{3}{*}{\multicolumn{2}{|c|}{$\begin{array}{l}\text { Average reading } \\
\text { literacy score }\end{array}$}} & \multicolumn{20}{|c|}{ Percentage attaining reading literacy proficiency levels ${ }^{1}$} \\
\hline & & & \multicolumn{8}{|c|}{ Below level 2} & \multirow{2}{*}{\multicolumn{2}{|c|}{ At level 2}} & \multirow{2}{*}{\multicolumn{2}{|c|}{ At level 3}} & \multirow{2}{*}{\multicolumn{2}{|c|}{ At level 4}} & \multicolumn{6}{|c|}{ At or above level 5} \\
\hline & & & Total be & $\mathrm{N}$ level 2 & Belo & level 1 & & level $1 \mathrm{~b}$ & & level 1a & & & & & & & & $\begin{array}{l}1 \text { at or } \\
\text { evel } 5\end{array}$ & & At level 5 & & At level 6 \\
\hline 1 & & 2 & & 3 & & & & 5 & & 6 & & 7 & & 8 & & 9 & & 10 & & 11 & & 12 \\
\hline OECD average ${ }^{2} \ldots \ldots \ldots$ & 496 & $(0.5)$ & 18.0 & $(0.18)$ & 1.3 & $(0.05$ & 4.4 & $(0.08)$ & 12.3 & $(0.13)$ & 23.5 & $(0.16)$ & 29.1 & $(0.17)$ & 21.0 & $(0.16)$ & 8.4 & $(0.12)$ & 7.3 & $(0.10)$ & 1.1 & $(0.04$ \\
\hline $\begin{array}{l}\text { Australia } \\
\text { Austria } \\
\text { Belgium } \\
\text { Canada } \\
\text { Chile }\end{array}$ & $\begin{array}{l}512 \\
490 \\
509 \\
523 \\
441\end{array}$ & $\begin{array}{l}(1.6) \\
(2.8) \\
(2.3) \\
(1.9) \\
(2.9)\end{array}$ & $\begin{array}{l}14.2 \\
19.5 \\
16.2 \\
10.9 \\
33.0\end{array}$ & $\begin{array}{l}(0.46) \\
(1.07) \\
(0.77) \\
(0.45) \\
(1.67)\end{array}$ & $\begin{array}{l}0.9 \\
0.8 \\
1.6 \\
0.5 \\
1.0\end{array}$ & $\begin{array}{l}(0.11 \\
(0.24 \\
(0.31 \\
(0.09 \\
(0.19\end{array}$ & $\begin{array}{l}3.1 \\
4.8 \\
4.1 \\
2.4 \\
8.1\end{array}$ & $\begin{array}{l}(0.21) \\
(0.64) \\
(0.40) \\
(0.19) \\
(0.79)\end{array}$ & $\begin{array}{r}10.2 \\
13.8 \\
10.4 \\
8.0 \\
23.9\end{array}$ & $\begin{array}{l}(0.42) \\
(0.84) \\
(0.55) \\
(0.36) \\
(1.08)\end{array}$ & $\begin{array}{l}21.6 \\
24.2 \\
20.4 \\
19.4 \\
35.1\end{array}$ & $\begin{array}{l}(0.47) \\
(0.89) \\
(0.62) \\
(0.55) \\
(1.08)\end{array}$ & $\begin{array}{l}29.1 \\
29.6 \\
27.3 \\
31.0 \\
24.3\end{array}$ & $\begin{array}{l}(0.53) \\
(0.92) \\
(0.70) \\
(0.72) \\
(1.06)\end{array}$ & $\begin{array}{r}23.3 \\
21.2 \\
24.4 \\
25.8 \\
6.9\end{array}$ & $\begin{array}{l}(0.51) \\
(0.94) \\
(0.71) \\
(0.59) \\
(0.62)\end{array}$ & $\begin{array}{r}11.7 \\
5.5 \\
12.3 \\
12.9 \\
0.6\end{array}$ & $\begin{array}{l}(0.54) \\
(0.61) \\
(0.55) \\
(0.62) \\
(0.10)\end{array}$ & $\begin{array}{r}9.8 \\
5.2 \\
10.4 \\
10.8 \\
0.6\end{array}$ & $\begin{array}{l}(0.46) \\
(0.59) \\
(0.54) \\
(0.53) \\
(0.11)\end{array}$ & $\begin{array}{r}1.9 \\
0.3 \\
1.4 \\
2.1 \\
\ddagger\end{array}$ & $\begin{array}{r}(0.19 \\
(0.10 \\
(0.17 \\
(0.22 \\
(\dagger\end{array}$ \\
\hline 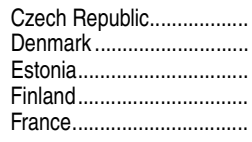 & $\begin{array}{l}493 \\
496 \\
516 \\
524 \\
505\end{array}$ & $\begin{array}{l}(2.9) \\
(2.6) \\
(2.0) \\
(2.4) \\
(2.8)\end{array}$ & $\begin{array}{r}16.9 \\
14.6 \\
9.1 \\
11.3 \\
18.9\end{array}$ & $\begin{array}{l}(1.21) \\
(1.07) \\
(0.65) \\
(0.71) \\
(0.98)\end{array}$ & $\begin{array}{l}0.6 ! \\
0.8 ! \\
\ddagger \\
0.7 \\
2.1\end{array}$ & $\begin{array}{l}(0.27 \\
(0.30 \\
(\dagger \\
(0.16 \\
(0.40\end{array}$ & $\begin{array}{l}3.5 \\
3.1 \\
1.3 \\
2.4 \\
4.9\end{array}$ & $\begin{array}{l}(0.56) \\
(0.39) \\
(0.28) \\
(0.38) \\
(0.43)\end{array}$ & $\begin{array}{r}12.7 \\
10.7 \\
7.7 \\
8.2 \\
11.9\end{array}$ & $\begin{array}{l}(0.94) \\
(0.77) \\
(0.61) \\
(0.57) \\
(0.70)\end{array}$ & $\begin{array}{l}26.4 \\
25.8 \\
22.7 \\
19.1 \\
18.9\end{array}$ & $\begin{array}{l}(1.30) \\
(0.92) \\
(0.94) \\
(0.81) \\
(0.85)\end{array}$ & $\begin{array}{l}31.3 \\
33.6 \\
35.0 \\
29.3 \\
26.3\end{array}$ & $\begin{array}{l}(1.23) \\
(0.85) \\
(1.06) \\
(0.70) \\
(0.84)\end{array}$ & $\begin{array}{l}19.4 \\
20.5 \\
24.9 \\
26.8 \\
23.0\end{array}$ & $\begin{array}{l}(1.13) \\
(0.86) \\
(1.08) \\
(0.84) \\
(0.67)\end{array}$ & $\begin{array}{r}6.1 \\
5.4 \\
8.3 \\
13.5 \\
12.9\end{array}$ & $\begin{array}{l}(0.55) \\
(0.62) \\
(0.72) \\
(0.64) \\
(0.85)\end{array}$ & $\begin{array}{r}5.3 \\
5.1 \\
7.5 \\
11.3 \\
10.6\end{array}$ & $\begin{array}{l}(0.49) \\
(0.58) \\
(0.71) \\
(0.60) \\
(0.62)\end{array}$ & $\begin{array}{l}0.8 \\
0.4 ! \\
0.9 \\
2.2 \\
2.3\end{array}$ & $\begin{array}{l}(0.16 \\
(0.12 \\
(0.18 \\
(0.26 \\
(0.41\end{array}$ \\
\hline 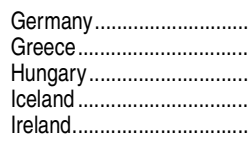 & $\begin{array}{l}508 \\
477 \\
488 \\
483 \\
523\end{array}$ & $\begin{array}{l}(2.8) \\
(3.3) \\
(3.2) \\
(1.8) \\
(2.6)\end{array}$ & $\begin{array}{r}14.5 \\
22.6 \\
19.7 \\
21.0 \\
9.6\end{array}$ & $\begin{array}{l}(0.91) \\
(1.24) \\
(1.22) \\
(0.72) \\
(0.88)\end{array}$ & $\begin{array}{l}0.5 ! \\
2.6 \\
0.7 ! \\
2.3 \\
0.3 !\end{array}$ & $\begin{array}{l}(0.18 \\
(0.40 \\
(0.24 \\
(0.33 \\
(0.13\end{array}$ & $\begin{array}{l}3.3 \\
5.9 \\
5.2 \\
5.4 \\
1.9\end{array}$ & $\begin{array}{l}(0.40) \\
(0.60) \\
(0.64) \\
(0.47) \\
(0.35)\end{array}$ & $\begin{array}{r}10.7 \\
14.2 \\
13.8 \\
13.3 \\
7.5\end{array}$ & $\begin{array}{l}(0.67) \\
(0.83) \\
(0.88) \\
(0.63) \\
(0.69)\end{array}$ & $\begin{array}{l}22.1 \\
25.1 \\
24.3 \\
24.7 \\
19.6\end{array}$ & $\begin{array}{l}(0.93) \\
(1.06) \\
(1.17) \\
(0.92) \\
(1.19)\end{array}$ & $\begin{array}{l}29.9 \\
30.0 \\
29.9 \\
29.9 \\
33.4\end{array}$ & $\begin{array}{l}(0.86) \\
(1.02) \\
(1.00) \\
(1.09) \\
(1.17)\end{array}$ & $\begin{array}{l}24.6 \\
17.2 \\
20.4 \\
18.6 \\
26.0\end{array}$ & $\begin{array}{l}(0.88) \\
(1.19) \\
(1.05) \\
(1.12) \\
(0.90)\end{array}$ & $\begin{array}{r}8.9 \\
5.1 \\
5.6 \\
5.8 \\
11.4\end{array}$ & $\begin{array}{l}(0.70) \\
(0.61) \\
(0.75) \\
(0.51) \\
(0.65)\end{array}$ & $\begin{array}{r}8.3 \\
4.6 \\
5.3 \\
5.2 \\
10.1\end{array}$ & $\begin{array}{l}(0.64) \\
(0.59) \\
(0.68) \\
(0.41) \\
(0.67)\end{array}$ & $\begin{array}{l}0.7 ! \\
0.5 \\
0.4 ! \\
0.6 ! \\
1.3\end{array}$ & $\begin{array}{l}(0.23 \\
(0.13 \\
(0.13 \\
(0.21 \\
(0.35\end{array}$ \\
\hline $\begin{array}{l}\text { Israel. } \\
\text { Italy } \\
\text { Japan } \\
\text { Korea, Republic of } \\
\text { Luxembourg }\end{array}$ & $\begin{array}{l}486 \\
490 \\
538 \\
536 \\
488\end{array}$ & $\begin{array}{l}(5.0) \\
(2.0) \\
(3.7) \\
(3.9) \\
(1.5)\end{array}$ & $\begin{array}{r}23.6 \\
19.5 \\
9.8 \\
7.6 \\
22.2\end{array}$ & $\begin{array}{l}(1.64) \\
(0.67) \\
(0.92) \\
(0.89) \\
(0.74)\end{array}$ & $\begin{array}{l}3.8 \\
1.6 \\
0.6 \\
0.4 \\
2.0\end{array}$ & $\begin{array}{l}(0.59 \\
(0.15 \\
(0.16 \\
(0.13 \\
(0.21\end{array}$ & $\begin{array}{l}6.9 \\
5.2 \\
2.4 \\
1.7 \\
6.3\end{array}$ & $\begin{array}{l}(0.74) \\
(0.29) \\
(0.37) \\
(0.39) \\
(0.33)\end{array}$ & $\begin{array}{r}12.9 \\
12.7 \\
6.7 \\
5.5 \\
13.8\end{array}$ & $\begin{array}{l}(0.96) \\
(0.48) \\
(0.67) \\
(0.60) \\
(0.81)\end{array}$ & $\begin{array}{l}20.8 \\
23.7 \\
16.6 \\
16.4 \\
23.4\end{array}$ & $\begin{array}{l}(0.87) \\
(0.57) \\
(0.89) \\
(0.94) \\
(0.71)\end{array}$ & $\begin{array}{l}25.3 \\
29.7 \\
26.7 \\
30.8 \\
25.8\end{array}$ & $\begin{array}{l}(0.81) \\
(0.53) \\
(0.98) \\
(1.00) \\
(0.64)\end{array}$ & $\begin{array}{l}20.6 \\
20.5 \\
28.4 \\
31.0 \\
19.7\end{array}$ & $\begin{array}{l}(1.03) \\
(0.62) \\
(1.08) \\
(1.06) \\
(0.64)\end{array}$ & $\begin{array}{r}9.6 \\
6.7 \\
18.5 \\
14.1 \\
8.9\end{array}$ & $\begin{array}{l}(0.84) \\
(0.35) \\
(1.27) \\
(1.24) \\
(0.39)\end{array}$ & $\begin{array}{r}8.1 \\
6.1 \\
14.6 \\
12.6 \\
7.5\end{array}$ & $\begin{array}{l}(0.77) \\
(0.33) \\
(0.99) \\
(1.05) \\
(0.35)\end{array}$ & $\begin{array}{l}1.5 \\
0.6 \\
3.9 \\
1.6 \\
1.4\end{array}$ & $\begin{array}{l}(0.30 \\
(0.07 \\
(0.59 \\
(0.32 \\
(0.20\end{array}$ \\
\hline 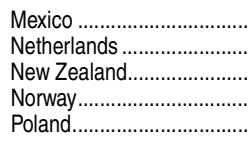 & $\begin{array}{l}424 \\
511 \\
512 \\
504 \\
518\end{array}$ & $\begin{array}{l}(1.5) \\
(3.5) \\
(2.4) \\
(3.2) \\
(3.1)\end{array}$ & $\begin{array}{l}41.1 \\
14.0 \\
16.3 \\
16.2 \\
10.6\end{array}$ & $\begin{array}{l}(0.90) \\
(1.23) \\
(0.83) \\
(1.03) \\
(0.80)\end{array}$ & $\begin{array}{r}2.6 \\
\ddagger \\
1.3 \\
1.7 \\
0.3 !\end{array}$ & $\begin{array}{l}(0.22 \\
(\dagger \\
(0.28 \\
(0.31 \\
(0.11\end{array}$ & $\begin{array}{r}11.0 \\
2.8 \\
4.0 \\
3.7 \\
2.1\end{array}$ & $\begin{array}{l}(0.53) \\
(0.49) \\
(0.46) \\
(0.36) \\
(0.35)\end{array}$ & $\begin{array}{r}27.5 \\
10.3 \\
11.0 \\
10.8 \\
8.1\end{array}$ & $\begin{array}{l}(0.70) \\
(0.93) \\
(0.67) \\
(0.69) \\
(0.74)\end{array}$ & $\begin{array}{l}34.5 \\
21.0 \\
20.8 \\
21.9 \\
21.4\end{array}$ & $\begin{array}{l}(0.62) \\
(1.27) \\
(0.76) \\
(1.03) \\
(0.90)\end{array}$ & $\begin{array}{l}19.6 \\
29.2 \\
26.3 \\
29.4 \\
32.0\end{array}$ & $\begin{array}{l}(0.54) \\
(1.32) \\
(1.06) \\
(1.35) \\
(0.89)\end{array}$ & $\begin{array}{r}4.5 \\
26.1 \\
22.7 \\
22.3 \\
26.0\end{array}$ & $\begin{array}{l}(0.25) \\
(1.36) \\
(1.06) \\
(1.21) \\
(0.96)\end{array}$ & $\begin{array}{r}0.4 \\
9.8 \\
14.0 \\
10.2 \\
10.0\end{array}$ & $\begin{array}{l}(0.09) \\
(0.82) \\
(0.77) \\
(0.74) \\
(0.93)\end{array}$ & $\begin{array}{r}0.4 \\
9.0 \\
10.9 \\
8.5 \\
8.6\end{array}$ & $\begin{array}{l}(0.08) \\
(0.72) \\
(0.62) \\
(0.61) \\
(0.76)\end{array}$ & $\begin{array}{r}\ddagger \\
0.8 \\
3.0 \\
1.7 \\
1.4\end{array}$ & $\begin{array}{r}(\dagger \\
(0.19 \\
(0.37 \\
(0.31 \\
(0.37\end{array}$ \\
\hline 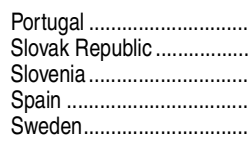 & $\begin{array}{l}488 \\
463 \\
481 \\
488 \\
483\end{array}$ & $\begin{array}{l}(3.8) \\
(4.2) \\
(1.2) \\
(1.9) \\
(3.0)\end{array}$ & $\begin{array}{l}18.8 \\
28.2 \\
21.1 \\
18.3 \\
22.7\end{array}$ & $\begin{array}{l}(1.42) \\
(1.78) \\
(0.68) \\
(0.76) \\
(1.15)\end{array}$ & $\begin{array}{l}1.3 \\
4.1 \\
1.2 \\
1.3 \\
2.9\end{array}$ & $\begin{array}{l}(0.30 \\
(0.77 \\
(0.14 \\
(0.17 \\
(0.39\end{array}$ & $\begin{array}{l}5.1 \\
7.9 \\
4.9 \\
4.4 \\
6.0\end{array}$ & $\begin{array}{l}(0.53) \\
(0.80) \\
(0.37) \\
(0.38) \\
(0.64)\end{array}$ & $\begin{array}{l}12.3 \\
16.2 \\
15.0 \\
12.6 \\
13.9\end{array}$ & $\begin{array}{l}(0.98) \\
(1.06) \\
(0.71) \\
(0.47) \\
(0.72)\end{array}$ & $\begin{array}{l}25.5 \\
25.0 \\
27.2 \\
25.8 \\
23.5\end{array}$ & $\begin{array}{l}(1.16) \\
(1.08) \\
(0.77) \\
(0.81) \\
(0.88)\end{array}$ & $\begin{array}{l}30.2 \\
26.8 \\
28.4 \\
31.2 \\
27.3\end{array}$ & $\begin{array}{l}(1.46) \\
(1.38) \\
(0.94) \\
(0.68) \\
(0.73)\end{array}$ & $\begin{array}{l}19.7 \\
15.7 \\
18.2 \\
19.2 \\
18.6\end{array}$ & $\begin{array}{l}(1.07) \\
(0.96) \\
(0.63) \\
(0.62) \\
(0.93)\end{array}$ & $\begin{array}{l}5.8 \\
4.4 \\
5.0 \\
5.5 \\
7.9\end{array}$ & $\begin{array}{l}(0.61) \\
(0.68) \\
(0.43) \\
(0.30) \\
(0.64)\end{array}$ & $\begin{array}{l}5.3 \\
4.1 \\
4.7 \\
5.0 \\
6.7\end{array}$ & $\begin{array}{l}(0.57) \\
(0.60) \\
(0.45) \\
(0.30) \\
(0.53)\end{array}$ & $\begin{array}{l}0.5 ! \\
\ddagger \\
0.3 ! \\
0.5 \\
1.2\end{array}$ & $\begin{array}{r}(0.15 \\
(t \\
(0.12 \\
(0.10 \\
(0.20\end{array}$ \\
\hline 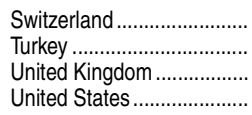 & $\begin{array}{l}509 \\
475 \\
499 \\
498\end{array}$ & $\begin{array}{l}(2.6) \\
(4.2) \\
(3.5) \\
(3.7)\end{array}$ & $\begin{array}{l}13.7 \\
21.6 \\
16.6 \\
16.6\end{array}$ & $\begin{array}{l}(0.76) \\
(1.43) \\
(1.30) \\
(1.26)\end{array}$ & $\begin{array}{l}0.5 \\
0.6 \\
1.5 \\
0.8 !\end{array}$ & $\begin{array}{l}(0.14 \\
(0.15 \\
(0.27 \\
(0.24\end{array}$ & $\begin{array}{l}2.9 \\
4.5 \\
4.0 \\
3.6\end{array}$ & $\begin{array}{l}(0.34) \\
(0.57) \\
(0.54) \\
(0.49)\end{array}$ & $\begin{array}{l}10.3 \\
16.6 \\
11.2 \\
12.3\end{array}$ & $\begin{array}{l}(0.59) \\
(1.07) \\
(0.79) \\
(0.89) \\
\end{array}$ & $\begin{array}{l}21.9 \\
30.8 \\
23.5 \\
24.9 \\
\end{array}$ & $\begin{array}{l}(0.86) \\
(1.39) \\
(1.01) \\
(0.99) \\
\end{array}$ & $\begin{array}{l}31.5 \\
28.7 \\
29.9 \\
30.5 \\
\end{array}$ & $\begin{array}{l}(0.71) \\
(1.34) \\
(1.08) \\
(0.88)\end{array}$ & $\begin{array}{l}23.8 \\
14.5 \\
21.3 \\
20.1 \\
\end{array}$ & $\begin{array}{l}(0.84) \\
(1.39) \\
(1.14) \\
(1.08) \\
\end{array}$ & $\begin{array}{l}9.1 \\
4.3 \\
8.8 \\
7.9 \\
\end{array}$ & $\begin{array}{l}(0.68) \\
(0.85) \\
(0.74) \\
(0.67)\end{array}$ & $\begin{array}{l}8.2 \\
4.1 \\
7.5 \\
6.9 \\
\end{array}$ & $\begin{array}{l}(0.60) \\
(0.79) \\
(0.59) \\
(0.59) \\
\end{array}$ & $\begin{array}{l}1.0 \\
0.3 ! \\
1.3 \\
1.0 \\
\end{array}$ & $\begin{array}{l}(0.25 \\
(0.13 \\
(0.24 \\
(0.22 \\
\end{array}$ \\
\hline
\end{tabular}

See notes at end of table. 
Table 602.50. Average reading literacy scores of 15 -year-old students and percentage attaining reading literacy proficiency levels, by country or other education system: 2012-Continued

[Standard errors appear in parentheses]

\begin{tabular}{|c|c|c|c|c|c|c|c|c|c|c|c|c|c|c|c|c|c|c|c|c|c|c|}
\hline \multirow{4}{*}{$\begin{array}{l}\text { Country or other } \\
\text { education system }\end{array}$} & \multirow{3}{*}{\multicolumn{2}{|c|}{$\begin{array}{r}\text { Average reading } \\
\text { literacy score }\end{array}$}} & \multicolumn{20}{|c|}{ Percentage attaining reading literacy proficiency levels ${ }^{1}$} \\
\hline & & & \multicolumn{8}{|c|}{ Below level 2} & \multirow{2}{*}{\multicolumn{2}{|c|}{ At level 2}} & \multirow{2}{*}{\multicolumn{2}{|c|}{ At level 3}} & \multirow{2}{*}{\multicolumn{2}{|c|}{ At level 4}} & \multicolumn{6}{|c|}{ At or above level 5} \\
\hline & & & \multicolumn{2}{|c|}{ Total below level 2} & \multicolumn{2}{|c|}{ Below level $1 b$} & \multicolumn{2}{|c|}{ At level $1 \mathrm{~b}$} & \multicolumn{2}{|c|}{ At level $1 \mathrm{a}$} & & & & & & & \multicolumn{2}{|c|}{$\begin{array}{r}\text { Total at or } \\
\text { above level } 5\end{array}$} & \multicolumn{2}{|c|}{ At level 5} & \multicolumn{2}{|r|}{ At level 6} \\
\hline & & 2 & & 3 & & 4 & & 5 & & 6 & & 7 & & 8 & & 9 & & 10 & & 11 & & 12 \\
\hline 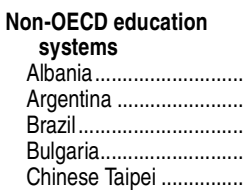 & $\begin{array}{l}394 \\
396 \\
410 \\
436 \\
523\end{array}$ & $\begin{array}{l}(3.2) \\
(3.7) \\
(2.1) \\
(6.0) \\
(3.0)\end{array}$ & $\begin{array}{l}52.3 \\
53.6 \\
49.2 \\
39.4 \\
11.5\end{array}$ & $\begin{array}{l}(1.28) \\
(1.73) \\
(1.13) \\
(2.21) \\
(0.87)\end{array}$ & $\begin{array}{r}12.0 \\
8.1 \\
4.0 \\
8.0 \\
0.6\end{array}$ & $\begin{array}{l}(0.84) \\
(0.80) \\
(0.36) \\
(1.07) \\
(0.15)\end{array}$ & $\begin{array}{r}15.9 \\
17.7 \\
14.8 \\
12.8 \\
2.5\end{array}$ & $\begin{array}{l}(1.00) \\
(1.20) \\
(0.64) \\
(1.15) \\
(0.32)\end{array}$ & $\begin{array}{r}24.4 \\
27.7 \\
30.4 \\
18.6 \\
8.4\end{array}$ & $\begin{array}{l}(1.23) \\
(1.34) \\
(0.79) \\
(1.10) \\
(0.65)\end{array}$ & $\begin{array}{l}24.7 \\
27.3 \\
30.1 \\
22.2 \\
18.1\end{array}$ & $\begin{array}{l}(1.01) \\
(1.12) \\
(0.77) \\
(1.16) \\
(0.83)\end{array}$ & $\begin{array}{l}15.9 \\
14.6 \\
15.8 \\
21.4 \\
29.9\end{array}$ & $\begin{array}{l}(0.73) \\
(0.91) \\
(0.63) \\
(1.10) \\
(0.92)\end{array}$ & $\begin{array}{r}5.9 \\
4.0 \\
4.4 \\
12.7 \\
28.7\end{array}$ & $\begin{array}{l}(0.61) \\
(0.57) \\
(0.37) \\
(1.03) \\
(1.01)\end{array}$ & $\begin{array}{r}1.2 \\
0.5 \\
0.5 \\
4.3 \\
11.8\end{array}$ & $\begin{array}{l}(0.25) \\
(0.14) \\
(0.12) \\
(0.64) \\
(0.84)\end{array}$ & $\begin{array}{l}1.1 \\
0.5 ! \\
0.5 \\
3.8 \\
10.4\end{array}$ & $\begin{array}{l}(0.24) \\
(0.15) \\
(0.12) \\
(0.56) \\
(0.73)\end{array}$ & $\begin{array}{l}\ddagger \\
\ddagger \\
\ddagger \\
0.5 ! \\
1.4\end{array}$ & $\begin{array}{r}(+) \\
(+) \\
(\dagger) \\
(0.18) \\
(0.32)\end{array}$ \\
\hline 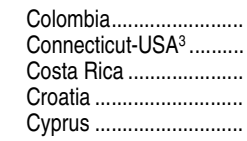 & $\begin{array}{l}403 \\
521 \\
441 \\
485 \\
449\end{array}$ & $\begin{array}{l}(3.4) \\
(6.5) \\
(3.5) \\
(3.3) \\
(1.2)\end{array}$ & $\begin{array}{l}51.4 \\
13.2 \\
32.4 \\
18.7 \\
32.8\end{array}$ & $\begin{array}{l}(1.78) \\
(1.76) \\
(1.81) \\
(1.29) \\
(0.67)\end{array}$ & $\begin{array}{c}5.0 \\
\ddagger \\
0.8 ! \\
0.7 ! \\
6.1\end{array}$ & $\begin{array}{r}(0.76) \\
(+) \\
(0.24) \\
(0.25) \\
(0.32)\end{array}$ & $\begin{array}{r}15.4 \\
3.2 \\
7.3 \\
4.0 \\
9.7\end{array}$ & $\begin{array}{l}(0.98) \\
(0.87) \\
(1.02) \\
(0.59) \\
(0.44)\end{array}$ & $\begin{array}{r}31.0 \\
9.7 \\
24.3 \\
13.9 \\
17.0\end{array}$ & $\begin{array}{l}(1.29) \\
(1.26) \\
(1.25) \\
(0.97) \\
(0.61)\end{array}$ & $\begin{array}{l}30.5 \\
19.6 \\
38.1 \\
27.8 \\
25.1\end{array}$ & $\begin{array}{l}(1.22) \\
(1.49) \\
(1.40) \\
(1.07) \\
(0.78)\end{array}$ & $\begin{array}{l}14.5 \\
28.2 \\
22.9 \\
31.2 \\
24.9\end{array}$ & $\begin{array}{l}(0.91) \\
(1.32) \\
(1.42) \\
(1.24) \\
(0.75)\end{array}$ & $\begin{array}{r}3.2 \\
24.4 \\
6.0 \\
17.8 \\
13.2\end{array}$ & $\begin{array}{l}(0.50) \\
(1.83) \\
(0.78) \\
(1.09) \\
(0.64)\end{array}$ & $\begin{array}{c}0.3 ! \\
14.5 \\
0.6 ! \\
4.4 \\
4.0\end{array}$ & $\begin{array}{l}(0.13) \\
(1.68) \\
(0.19) \\
(0.69) \\
(0.32)\end{array}$ & $\begin{array}{c}0.3 ! \\
11.7 \\
0.6 ! \\
4.2 \\
3.5\end{array}$ & $\begin{array}{l}(0.12) \\
(1.38) \\
(0.19) \\
(0.66) \\
(0.34)\end{array}$ & $\begin{array}{c}\ddagger \\
2.9 \\
\ddagger \\
0.2 ! \\
0.5\end{array}$ & $\begin{array}{r}(t) \\
(0.54) \\
(t) \\
(0.11) \\
(0.12)\end{array}$ \\
\hline 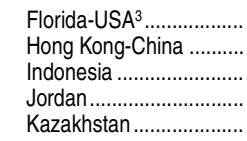 & $\begin{array}{l}492 \\
545 \\
396 \\
399 \\
393\end{array}$ & $\begin{array}{l}(6.1) \\
(2.8) \\
(4.2) \\
(3.6) \\
(2.7)\end{array}$ & $\begin{array}{r}17.5 \\
6.8 \\
55.2 \\
50.7 \\
57.1\end{array}$ & $\begin{array}{l}(2.00) \\
(0.72) \\
(2.18) \\
(1.57) \\
(1.56)\end{array}$ & $\begin{array}{l}0.7 ! \\
0.2 ! \\
4.1 \\
7.5 \\
4.2\end{array}$ & $\begin{array}{l}(0.31) \\
(0.09) \\
(0.81) \\
(0.84) \\
(0.47)\end{array}$ & $\begin{array}{r}3.6 \\
1.3 \\
16.3 \\
14.9 \\
17.3\end{array}$ & $\begin{array}{l}(0.75) \\
(0.24) \\
(1.28) \\
(0.79) \\
(1.24)\end{array}$ & $\begin{array}{r}13.2 \\
5.3 \\
34.8 \\
28.3 \\
35.6\end{array}$ & $\begin{array}{l}(1.46) \\
(0.61) \\
(1.56) \\
(1.01) \\
(1.15)\end{array}$ & $\begin{array}{l}25.8 \\
14.3 \\
31.6 \\
30.8 \\
31.3\end{array}$ & $\begin{array}{l}(1.56) \\
(0.79) \\
(1.54) \\
(1.14) \\
(1.12)\end{array}$ & $\begin{array}{l}30.9 \\
29.2 \\
11.5 \\
15.5 \\
10.4\end{array}$ & $\begin{array}{l}(1.50) \\
(1.21) \\
(1.28) \\
(0.83) \\
(0.87)\end{array}$ & $\begin{array}{l}20.4 \\
32.9 \\
1.5 ! \\
2.9 \\
1.2\end{array}$ & $\begin{array}{l}(2.06) \\
(1.39) \\
(0.53) \\
(0.63) \\
(0.24)\end{array}$ & $\begin{array}{r}5.5 \\
16.8 \\
\ddagger \\
\ddagger \\
\ddagger\end{array}$ & $\begin{array}{r}(1.02) \\
(1.16) \\
(\dagger) \\
(\dagger) \\
(\dagger)\end{array}$ & $\begin{array}{r}4.9 \\
14.9 \\
\ddagger \\
\ddagger \\
\ddagger\end{array}$ & $\begin{array}{r}(1.00) \\
(1.00) \\
(t) \\
(t) \\
(t)\end{array}$ & $\begin{array}{r}\ddagger \\
1.9 \\
\ddagger \\
\ddagger \\
\ddagger\end{array}$ & $\begin{array}{r}(t) \\
(0.39) \\
(+) \\
(+) \\
(+)\end{array}$ \\
\hline 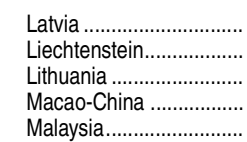 & $\begin{array}{l}489 \\
516 \\
477 \\
509 \\
398\end{array}$ & $\begin{array}{l}(2.4) \\
(4.1) \\
(2.5) \\
(0.9) \\
(3.3)\end{array}$ & $\begin{array}{l}17.0 \\
12.4 \\
21.2 \\
11.5 \\
52.7\end{array}$ & $\begin{array}{l}(1.14) \\
(1.88) \\
(1.18) \\
(0.42) \\
(1.71)\end{array}$ & $\begin{array}{c}0.7 ! \\
\# \\
1.0 \\
0.3 ! \\
5.8\end{array}$ & $\begin{array}{l}(0.24) \\
(+) \\
(0.19) \\
(0.11) \\
(0.59)\end{array}$ & $\begin{array}{r}3.7 \\
\ddagger \\
4.6 \\
2.1 \\
16.4\end{array}$ & $\begin{array}{r}(0.54) \\
(\dagger) \\
(0.49) \\
(0.22) \\
(1.03)\end{array}$ & $\begin{array}{r}12.6 \\
10.5 \\
15.6 \\
9.0 \\
30.5\end{array}$ & $\begin{array}{l}(0.96) \\
(1.85) \\
(1.06) \\
(0.42) \\
(0.99)\end{array}$ & $\begin{array}{l}26.7 \\
22.4 \\
28.1 \\
23.3 \\
31.0\end{array}$ & $\begin{array}{l}(1.31) \\
(3.44) \\
(1.13) \\
(0.58) \\
(1.09)\end{array}$ & $\begin{array}{l}33.1 \\
28.6 \\
31.1 \\
34.3 \\
13.6\end{array}$ & $\begin{array}{l}(1.05) \\
(4.53) \\
(0.94) \\
(0.67) \\
(1.11)\end{array}$ & $\begin{array}{r}19.1 \\
25.7 \\
16.3 \\
24.0 \\
2.5\end{array}$ & $\begin{array}{l}(0.88) \\
(2.44) \\
(0.78) \\
(0.60) \\
(0.45)\end{array}$ & $\begin{array}{r}4.2 \\
10.9 \\
3.3 \\
7.0 \\
\ddagger\end{array}$ & $\begin{array}{r}(0.55) \\
(2.89) \\
(0.37) \\
(0.41) \\
(\dagger)\end{array}$ & $\begin{array}{r}3.9 \\
10.4 \\
3.1 \\
6.4 \\
\ddagger\end{array}$ & $\begin{array}{r}(0.56) \\
(2.44) \\
(0.35) \\
(0.48) \\
(\dagger)\end{array}$ & $\begin{array}{c}0.3 ! \\
\ddagger \\
0.2 ! \\
0.6 ! \\
\ddagger\end{array}$ & $\begin{array}{r}(0.11) \\
(t) \\
(0.07) \\
(0.21) \\
(t)\end{array}$ \\
\hline 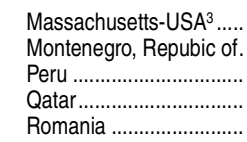 & $\begin{array}{l}527 \\
422 \\
384 \\
388 \\
438\end{array}$ & $\begin{array}{l}(6.1) \\
(1.2) \\
(4.3) \\
(0.8) \\
(4.0)\end{array}$ & $\begin{array}{l}11.5 \\
43.3 \\
59.9 \\
57.1 \\
37.3\end{array}$ & $\begin{array}{l}(1.37) \\
(0.75) \\
(1.95) \\
(0.42) \\
(1.87)\end{array}$ & $\begin{array}{r}\ddagger \\
4.4 \\
9.8 \\
13.6 \\
2.5\end{array}$ & $\begin{array}{r}(\dagger) \\
(0.53) \\
(0.87) \\
(0.32) \\
(0.38)\end{array}$ & $\begin{array}{r}2.3 \\
13.2 \\
20.6 \\
18.9 \\
10.3\end{array}$ & $\begin{array}{l}(0.55) \\
(0.62) \\
(1.11) \\
(0.48) \\
(0.82)\end{array}$ & $\begin{array}{r}8.6 \\
25.7 \\
29.5 \\
24.6 \\
24.4\end{array}$ & $\begin{array}{l}(1.19) \\
(0.94) \\
(0.98) \\
(0.44) \\
(1.28)\end{array}$ & $\begin{array}{l}18.5 \\
29.2 \\
24.9 \\
21.9 \\
30.6\end{array}$ & $\begin{array}{l}(1.76) \\
(0.77) \\
(1.02) \\
(0.50) \\
(1.12)\end{array}$ & $\begin{array}{l}29.8 \\
19.9 \\
11.4 \\
13.5 \\
21.8\end{array}$ & $\begin{array}{l}(1.52) \\
(0.76) \\
(0.96) \\
(0.43) \\
(1.17)\end{array}$ & $\begin{array}{r}24.2 \\
6.6 \\
3.3 \\
5.8 \\
8.7\end{array}$ & $\begin{array}{l}(1.82) \\
(0.53) \\
(0.61) \\
(0.21) \\
(0.88)\end{array}$ & $\begin{array}{l}16.1 \\
1.0 \\
0.5 ! \\
1.6 \\
1.6\end{array}$ & $\begin{array}{l}(1.98) \\
(0.19) \\
(0.21) \\
(0.14) \\
(0.38)\end{array}$ & $\begin{array}{c}12.9 \\
0.9 \\
0.5 ! \\
1.4 \\
1.5\end{array}$ & $\begin{array}{l}(1.59) \\
(0.19) \\
(0.21) \\
(0.13) \\
(0.35)\end{array}$ & $\begin{array}{r}3.2 \\
\ddagger \\
\ddagger \\
0.2 \\
\ddagger\end{array}$ & $\begin{array}{r}(0.86) \\
(+) \\
(t) \\
(0.05) \\
(\dagger)\end{array}$ \\
\hline 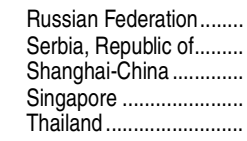 & $\begin{array}{l}475 \\
446 \\
570 \\
542 \\
441\end{array}$ & $\begin{array}{l}(3.0) \\
(3.4) \\
(2.9) \\
(1.4) \\
(3.1)\end{array}$ & $\begin{array}{r}22.3 \\
33.1 \\
2.9 \\
9.9 \\
33.0\end{array}$ & $\begin{array}{l}(1.29) \\
(1.66) \\
(0.39) \\
(0.42) \\
(1.40)\end{array}$ & $\begin{array}{r}1.1 \\
2.6 \\
\ddagger \\
0.5 \\
1.2\end{array}$ & $\begin{array}{r}(0.18) \\
(0.40) \\
(\dagger) \\
(0.12) \\
(0.29)\end{array}$ & $\begin{array}{l}5.2 \\
9.3 \\
0.3 ! \\
1.9 \\
7.7\end{array}$ & $\begin{array}{l}(0.49) \\
(0.73) \\
(0.11) \\
(0.27) \\
(0.77)\end{array}$ & $\begin{array}{r}16.0 \\
21.3 \\
2.5 \\
7.5 \\
24.1\end{array}$ & $\begin{array}{l}(1.03) \\
(1.09) \\
(0.34) \\
(0.41) \\
(0.98)\end{array}$ & $\begin{array}{l}29.5 \\
30.8 \\
11.0 \\
16.7 \\
36.0\end{array}$ & $\begin{array}{l}(1.08) \\
(1.20) \\
(0.85) \\
(0.65) \\
(1.12)\end{array}$ & $\begin{array}{l}28.3 \\
23.3 \\
25.3 \\
25.4 \\
23.5\end{array}$ & $\begin{array}{l}(1.05) \\
(1.15) \\
(0.85) \\
(0.66) \\
(1.13)\end{array}$ & $\begin{array}{r}15.3 \\
10.5 \\
35.7 \\
26.8 \\
6.7\end{array}$ & $\begin{array}{l}(0.93) \\
(0.81) \\
(1.07) \\
(0.79) \\
(0.79)\end{array}$ & $\begin{array}{r}4.6 \\
2.2 \\
25.1 \\
21.2 \\
0.8\end{array}$ & $\begin{array}{l}(0.58) \\
(0.41) \\
(1.19) \\
(0.60) \\
(0.22)\end{array}$ & $\begin{array}{r}4.2 \\
2.0 \\
21.3 \\
16.2 \\
0.8\end{array}$ & $\begin{array}{l}(0.51) \\
(0.39) \\
(0.98) \\
(0.73) \\
(0.21)\end{array}$ & $\begin{array}{l}0.5 \\
0.2 ! \\
3.8 \\
5.0 \\
\ddagger\end{array}$ & $\begin{array}{r}(0.12) \\
(0.08) \\
(0.65) \\
(0.43) \\
(\dagger)\end{array}$ \\
\hline 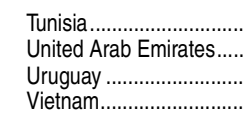 & $\begin{array}{l}404 \\
442 \\
411 \\
508\end{array}$ & $\begin{array}{l}(4.5) \\
(2.5) \\
(3.2) \\
(4.4)\end{array}$ & $\begin{array}{r}49.3 \\
35.5 \\
47.0 \\
9.4\end{array}$ & $\begin{array}{l}(2.24) \\
(1.08) \\
(1.42) \\
(1.43)\end{array}$ & $\begin{array}{r}6.2 \\
3.3 \\
6.4 \\
\ddagger\end{array}$ & $\begin{array}{r}(0.91) \\
(0.34) \\
(0.70) \\
(\dagger)\end{array}$ & $\begin{array}{c}15.5 \\
10.4 \\
14.7 \\
1.5 !\end{array}$ & $\begin{array}{l}(1.20) \\
(0.65) \\
(0.84) \\
(0.48)\end{array}$ & $\begin{array}{r}27.6 \\
21.8 \\
25.9 \\
7.8\end{array}$ & $\begin{array}{l}(1.31) \\
(0.72) \\
(0.88) \\
(1.10)\end{array}$ & $\begin{array}{l}31.4 \\
28.6 \\
28.9 \\
23.7\end{array}$ & $\begin{array}{l}(1.43) \\
(0.72) \\
(1.00) \\
(1.40)\end{array}$ & $\begin{array}{l}15.6 \\
24.0 \\
17.4 \\
39.0\end{array}$ & $\begin{array}{l}(1.15) \\
(0.77) \\
(0.71) \\
(1.47)\end{array}$ & $\begin{array}{r}3.5 \\
9.7 \\
5.7 \\
23.4\end{array}$ & $\begin{array}{l}(0.69) \\
(0.58) \\
(0.62) \\
(1.47)\end{array}$ & $\begin{array}{r}\ddagger \\
2.2 \\
0.9 \\
4.5\end{array}$ & $\begin{array}{r}(\dagger) \\
(0.29) \\
(0.27) \\
(0.81)\end{array}$ & $\begin{array}{r}\ddagger \\
2.1 \\
0.9 \\
4.2\end{array}$ & $\begin{array}{r}(t) \\
(0.28) \\
(0.26) \\
(0.71)\end{array}$ & $\begin{array}{c}\ddagger \\
\vdots \\
0.2 ! \\
\ddagger \\
0.4 !\end{array}$ & $\begin{array}{r}(t) \\
(0.06) \\
(t) \\
(0.16)\end{array}$ \\
\hline
\end{tabular}

\section{†Not applicable.}

!nterpret data with caution. The coefficient of variation (CV) for this estimate is between 30 and 50 percent. Reporting standards not met. Either there are too few cases for a reliable estimate or the coefficient of variation (CV) is 50 percent or greater.

'To reach a particular proficiency level, a student must correctly answer a majority of items at that level. Students were classified into reading literacy levels according to their scores. Exact cut scores are as follows: below level $1 \mathrm{~b}$ (a score less than or equal to 262.04); level 1b (a score greater than 262.04 and less than or equal to 334.75 ); level $1 \mathrm{a}$ (a score greater than 334.75 and less than or equal or equal to 552.89); level 4 (a score greater than 552.89 and less than or equal to 625.61 ); level 5 (a score greater than 625.61 and

${ }^{2}$ Refers to the mean of the data values for all Organization for Economic Cooperation and Development (OECD) countries, to which each country contributes equally, regardless of the absolute size of the student population of each country.

NOTE: Program for International Student Assessment (PISA) scores are reported on a scale from 0 to 1,000. Detail may not sum to totals because of rounding. SOURCE: OOrganization for Economic Cooperation and Development (OECD), Program for International Student Assessment
(PISA) 2012. (This table was prepared November 2013.) 
Table 602.60. Average mathematics literacy scores of 15 -year-old students and percentage attaining mathematics literacy proficiency levels, by country or other education system: 2012

[Standard errors appear in parentheses]

\begin{tabular}{|c|c|c|c|c|c|c|c|c|c|c|c|c|c|c|c|c|c|c|c|c|}
\hline \multirow[b]{3}{*}{$\begin{array}{l}\text { Country or other } \\
\text { education system }\end{array}$} & \multirow{3}{*}{\multicolumn{2}{|c|}{$\begin{array}{r}\text { Average } \\
\text { mathematics } \\
\text { literacy score }\end{array}$}} & \multicolumn{18}{|c|}{ Percentage attaining mathematics literacy proficiency levels ${ }^{1}$} \\
\hline & & & \multicolumn{6}{|c|}{ Below level 2} & \multirow{2}{*}{\multicolumn{2}{|c|}{ At level 2}} & \multirow{2}{*}{\multicolumn{2}{|c|}{ At level 3}} & \multirow{2}{*}{\multicolumn{2}{|c|}{ At level 4}} & \multicolumn{6}{|c|}{ At or above level 5} \\
\hline & & & Total be & $N$ level 2 & & N level 1 & & At level 1 & & & & & & & & $\begin{array}{l}\text { tal at or } \\
\text { level } 5\end{array}$ & & At level 5 & & At level 6 \\
\hline 1 & & 2 & & 3 & & 4 & & 5 & & 6 & & 7 & & 8 & & 9 & & 10 & & 11 \\
\hline${\text { OECD } \text { average }^{2} \ldots \ldots \ldots}^{2 \ldots \ldots . .}$ & 494 & $(0.5)$ & 23.0 & $(0.17)$ & 8.0 & $(0.12)$ & 15.0 & $(0.13)$ & 22.5 & $(0.15)$ & 23.7 & $(0.15)$ & 18.1 & (0.14) & 12.7 & $(0.14)$ & 9.3 & $(0.11)$ & 3.3 & $(0.08)$ \\
\hline $\begin{array}{l}\text { Australia } \\
\text { Austria } \\
\text { Belgium } \\
\text { Canada } \\
\text { Chile }\end{array}$ & $\begin{array}{l}504 \\
506 \\
515 \\
518 \\
423\end{array}$ & $\begin{array}{l}(1.6) \\
(2.7) \\
(2.1) \\
(1.8) \\
(3.1)\end{array}$ & $\begin{array}{l}19.7 \\
18.7 \\
19.0 \\
13.8 \\
51.5\end{array}$ & $\begin{array}{l}(0.60) \\
(0.96) \\
(0.82) \\
(0.55) \\
(1.67)\end{array}$ & $\begin{array}{r}6.1 \\
5.7 \\
7.0 \\
3.6 \\
22.0\end{array}$ & $\begin{array}{l}(0.35) \\
(0.59) \\
(0.58) \\
(0.29) \\
(1.35)\end{array}$ & $\begin{array}{l}13.5 \\
13.0 \\
12.0 \\
10.2 \\
29.5\end{array}$ & $\begin{array}{l}(0.57) \\
(0.74) \\
(0.52) \\
(0.45) \\
(1.01)\end{array}$ & $\begin{array}{l}21.9 \\
21.9 \\
18.4 \\
21.0 \\
25.3\end{array}$ & $\begin{array}{l}(0.76) \\
(0.87) \\
(0.58) \\
(0.64) \\
(1.00)\end{array}$ & $\begin{array}{l}24.6 \\
24.2 \\
22.4 \\
26.4 \\
15.4\end{array}$ & \begin{tabular}{l|}
$(0.65)$ \\
$(0.84)$ \\
$(0.70)$ \\
$(0.63)$ \\
$(0.78)$
\end{tabular} & $\begin{array}{r}19.0 \\
21.0 \\
20.6 \\
22.4 \\
6.2\end{array}$ & $\begin{array}{l}(0.50) \\
(0.90) \\
(0.63) \\
(0.49) \\
(0.60)\end{array}$ & $\begin{array}{r}14.8 \\
14.3 \\
19.5 \\
16.4 \\
1.6\end{array}$ & $\begin{array}{l}(0.64) \\
(0.95) \\
(0.76) \\
(0.64) \\
(0.22)\end{array}$ & $\begin{array}{r}10.5 \\
11.0 \\
13.4 \\
12.1 \\
1.5\end{array}$ & $\begin{array}{l}(0.43) \\
(0.75) \\
(0.73) \\
(0.47) \\
(0.21)\end{array}$ & $\begin{array}{l}4.3 \\
3.3 \\
6.1 \\
4.3 \\
0.1 !\end{array}$ & $\begin{array}{l}(0.36) \\
(0.41) \\
(0.43) \\
(0.29) \\
(0.04)\end{array}$ \\
\hline 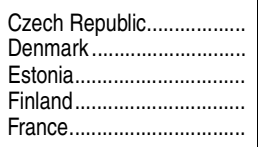 & $\begin{array}{l}499 \\
500 \\
521 \\
519 \\
495\end{array}$ & $\begin{array}{l}(2.9) \\
(2.3) \\
(2.0) \\
(1.9) \\
(2.5)\end{array}$ & $\begin{array}{l}21.0 \\
16.8 \\
10.5 \\
12.3 \\
22.4\end{array}$ & $\begin{array}{l}(1.20) \\
(0.98) \\
(0.63) \\
(0.67) \\
(0.87)\end{array}$ & $\begin{array}{l}6.8 \\
4.4 \\
2.0 \\
3.3 \\
8.7\end{array}$ & $\begin{array}{l}(0.76) \\
(0.49) \\
(0.26) \\
(0.39) \\
(0.72)\end{array}$ & $\begin{array}{r}14.2 \\
12.5 \\
8.6 \\
8.9 \\
13.6\end{array}$ & $\begin{array}{l}(0.97) \\
(0.70) \\
(0.57) \\
(0.49) \\
(0.76)\end{array}$ & $\begin{array}{l}21.7 \\
24.4 \\
22.0 \\
20.5 \\
22.1\end{array}$ & $\begin{array}{l}(0.83) \\
(0.97) \\
(0.84) \\
(0.66) \\
(0.95)\end{array}$ & $\begin{array}{l}24.8 \\
29.0 \\
29.4 \\
28.8 \\
23.8\end{array}$ & $\begin{array}{l}(1.07) \\
(1.03) \\
(0.79) \\
(0.78) \\
(0.82)\end{array}$ & $\begin{array}{l}19.7 \\
19.8 \\
23.4 \\
23.2 \\
18.9\end{array}$ & $\begin{array}{l}(0.90) \\
(0.69) \\
(0.91) \\
(0.78) \\
(0.79)\end{array}$ & $\begin{array}{l}12.9 \\
10.0 \\
14.6 \\
15.3 \\
12.9\end{array}$ & $\begin{array}{l}(0.82) \\
(0.66) \\
(0.76) \\
(0.74) \\
(0.77)\end{array}$ & $\begin{array}{r}9.6 \\
8.3 \\
11.0 \\
11.7 \\
9.8\end{array}$ & $\begin{array}{l}(0.66) \\
(0.57) \\
(0.67) \\
(0.60) \\
(0.55)\end{array}$ & $\begin{array}{l}3.2 \\
1.7 \\
3.6 \\
3.5 \\
3.1\end{array}$ & $\begin{array}{l}(0.31) \\
(0.32) \\
(0.37) \\
(0.30) \\
(0.40)\end{array}$ \\
\hline 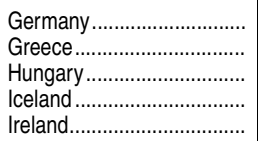 & $\begin{array}{l}514 \\
453 \\
477 \\
493 \\
501\end{array}$ & $\begin{array}{l}(2.9) \\
(2.5) \\
(3.2) \\
(1.7) \\
(2.2)\end{array}$ & $\begin{array}{l}17.7 \\
35.7 \\
28.1 \\
21.5 \\
16.9\end{array}$ & $\begin{array}{l}(1.03) \\
(1.34) \\
(1.31) \\
(0.74) \\
(0.99)\end{array}$ & $\begin{array}{r}5.5 \\
14.5 \\
9.9 \\
7.5 \\
4.8\end{array}$ & $\begin{array}{l}(0.65) \\
(0.92) \\
(0.77) \\
(0.54) \\
(0.55)\end{array}$ & $\begin{array}{l}12.2 \\
21.2 \\
18.2 \\
14.0 \\
12.1\end{array}$ & $\begin{array}{l}(0.81) \\
(0.85) \\
(1.04) \\
(0.83) \\
(0.70)\end{array}$ & $\begin{array}{l}19.4 \\
27.2 \\
25.3 \\
23.6 \\
23.9\end{array}$ & $\begin{array}{l}(0.81) \\
(1.02) \\
(1.21) \\
(0.89) \\
(0.72)\end{array}$ & $\begin{array}{l}23.7 \\
22.1 \\
23.0 \\
25.7 \\
28.2\end{array}$ & $\begin{array}{l}(0.79) \\
(0.86) \\
(1.02) \\
(0.95) \\
(0.87)\end{array}$ & $\begin{array}{l}21.7 \\
11.2 \\
14.4 \\
18.1 \\
20.3\end{array}$ & $\begin{array}{l}(0.73) \\
(0.79) \\
(0.86) \\
(0.79) \\
(0.76)\end{array}$ & $\begin{array}{r}17.5 \\
3.9 \\
9.3 \\
11.2 \\
10.7\end{array}$ & $\begin{array}{l}(0.94) \\
(0.43) \\
(1.12) \\
(0.69) \\
(0.54)\end{array}$ & $\begin{array}{r}12.8 \\
3.3 \\
7.1 \\
8.9 \\
8.5\end{array}$ & $\begin{array}{l}(0.71) \\
(0.43) \\
(0.73) \\
(0.61) \\
(0.51)\end{array}$ & $\begin{array}{l}4.7 \\
0.6 \\
2.1 \\
2.3 \\
2.2\end{array}$ & $\begin{array}{l}(0.49) \\
(0.15) \\
(0.51) \\
(0.35) \\
(0.23)\end{array}$ \\
\hline 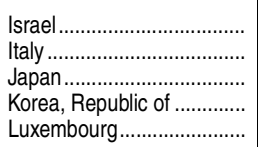 & $\begin{array}{l}466 \\
485 \\
536 \\
554 \\
490\end{array}$ & $\begin{array}{l}(4.7) \\
(2.0) \\
(3.6) \\
(4.6) \\
(1.1)\end{array}$ & $\begin{array}{r}33.5 \\
24.7 \\
11.1 \\
9.1 \\
24.3\end{array}$ & $\begin{array}{l}(1.68) \\
(0.76) \\
(0.98) \\
(0.95) \\
(0.54)\end{array}$ & $\begin{array}{r}15.9 \\
8.5 \\
3.2 \\
2.7 \\
8.8\end{array}$ & $\begin{array}{l}(1.23) \\
(0.39) \\
(0.49) \\
(0.46) \\
(0.54)\end{array}$ & $\begin{array}{r}17.6 \\
16.1 \\
7.9 \\
6.4 \\
15.5\end{array}$ & $\begin{array}{l}(0.93) \\
(0.51) \\
(0.69) \\
(0.62) \\
(0.54)\end{array}$ & $\begin{array}{l}21.6 \\
24.1 \\
16.9 \\
14.7 \\
22.3\end{array}$ & $\begin{array}{l}(0.93) \\
(0.55) \\
(0.85) \\
(0.85) \\
(0.72)\end{array}$ & $\begin{array}{l}21.0 \\
24.6 \\
24.7 \\
21.4 \\
23.6\end{array}$ & $\begin{array}{l}(0.87) \\
(0.62) \\
(1.00) \\
(0.99) \\
(0.72)\end{array}$ & $\begin{array}{l}14.6 \\
16.7 \\
23.7 \\
23.9 \\
18.5\end{array}$ & $\begin{array}{l}(0.88) \\
(0.48) \\
(0.89) \\
(1.23) \\
(0.58)\end{array}$ & $\begin{array}{r}9.4 \\
9.9 \\
23.7 \\
30.9 \\
11.2\end{array}$ & $\begin{array}{l}(0.99) \\
(0.57) \\
(1.46) \\
(1.83) \\
(0.42)\end{array}$ & $\begin{array}{r}7.2 \\
7.8 \\
16.0 \\
18.8 \\
8.6\end{array}$ & $\begin{array}{l}(0.74) \\
(0.44) \\
(0.89) \\
(0.92) \\
(0.38)\end{array}$ & $\begin{array}{r}2.2 \\
2.2 \\
7.6 \\
12.1 \\
2.6\end{array}$ & $\begin{array}{l}(0.39) \\
(0.25) \\
(0.84) \\
(1.26) \\
(0.25)\end{array}$ \\
\hline 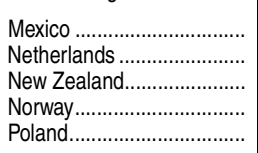 & $\begin{array}{l}413 \\
523 \\
500 \\
489 \\
518\end{array}$ & $\begin{array}{l}(1.4) \\
(3.5) \\
(2.2) \\
(2.7) \\
(3.6)\end{array}$ & $\begin{array}{l}54.7 \\
14.8 \\
22.6 \\
22.3 \\
14.4\end{array}$ & $\begin{array}{l}(0.82) \\
(1.28) \\
(0.80) \\
(1.06) \\
(0.89)\end{array}$ & $\begin{array}{r}22.8 \\
3.8 \\
7.5 \\
7.2 \\
3.3\end{array}$ & $\begin{array}{l}(0.68) \\
(0.57) \\
(0.58) \\
(0.78) \\
(0.38)\end{array}$ & $\begin{array}{l}31.9 \\
11.0 \\
15.1 \\
15.1 \\
11.1\end{array}$ & $\begin{array}{l}(0.58) \\
(0.93) \\
(0.66) \\
(0.88) \\
(0.77)\end{array}$ & $\begin{array}{l}27.8 \\
17.9 \\
21.6 \\
24.3 \\
22.1\end{array}$ & $\begin{array}{l}(0.53) \\
(1.08) \\
(0.83) \\
(0.84) \\
(0.93)\end{array}$ & $\begin{array}{l}13.1 \\
24.2 \\
22.7 \\
25.7 \\
25.5\end{array}$ & $\begin{array}{l}(0.41) \\
(1.19) \\
(0.76) \\
(1.01) \\
(0.94)\end{array}$ & $\begin{array}{r}3.7 \\
23.8 \\
18.1 \\
18.3 \\
21.3\end{array}$ & $\begin{array}{l}(0.23) \\
(1.11) \\
(0.84) \\
(0.96) \\
(1.12)\end{array}$ & $\begin{array}{r}0.6 \\
19.3 \\
15.0 \\
9.4 \\
16.7\end{array}$ & $\begin{array}{l}(0.08) \\
(1.21) \\
(0.88) \\
(0.67) \\
(1.33)\end{array}$ & $\begin{array}{r}0.6 \\
14.9 \\
10.5 \\
7.3 \\
11.7\end{array}$ & $\begin{array}{l}(0.07) \\
(0.99) \\
(0.75) \\
(0.56) \\
(0.78)\end{array}$ & $\begin{array}{r}\ddagger \\
4.4 \\
4.5 \\
2.1 \\
5.0\end{array}$ & $\begin{array}{r}(\dagger) \\
(0.56) \\
(0.40) \\
(0.30) \\
(0.80)\end{array}$ \\
\hline 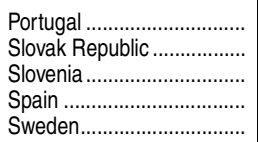 & $\begin{array}{l}487 \\
482 \\
501 \\
484 \\
478\end{array}$ & $\begin{array}{l}(3.8) \\
(3.4) \\
(1.2) \\
(1.9) \\
(2.3)\end{array}$ & $\begin{array}{l}24.9 \\
27.5 \\
20.1 \\
23.6 \\
27.1\end{array}$ & $\begin{array}{l}(1.52) \\
(1.28) \\
(0.65) \\
(0.85) \\
(1.12)\end{array}$ & $\begin{array}{r}8.9 \\
11.1 \\
5.1 \\
7.8 \\
9.5\end{array}$ & $\begin{array}{l}(0.79) \\
(1.03) \\
(0.48) \\
(0.50) \\
(0.68)\end{array}$ & $\begin{array}{l}16.0 \\
16.4 \\
15.0 \\
15.8 \\
17.5\end{array}$ & $\begin{array}{l}(0.98) \\
(0.94) \\
(0.69) \\
(0.57) \\
(0.76)\end{array}$ & $\begin{array}{l}22.8 \\
23.1 \\
23.6 \\
24.9 \\
24.7\end{array}$ & $\begin{array}{l}(0.88) \\
(1.10) \\
(0.95) \\
(0.65) \\
(0.92)\end{array}$ & $\begin{array}{l}24.0 \\
22.1 \\
23.9 \\
26.0 \\
23.9\end{array}$ & $\begin{array}{l}(0.84) \\
(1.09) \\
(0.96) \\
(0.59) \\
(0.78)\end{array}$ & $\begin{array}{l}17.7 \\
16.4 \\
18.7 \\
17.6 \\
16.3\end{array}$ & $\begin{array}{l}(0.88) \\
(1.08) \\
(0.80) \\
(0.56) \\
(0.69)\end{array}$ & $\begin{array}{r}10.6 \\
11.0 \\
13.7 \\
8.0 \\
8.0\end{array}$ & $\begin{array}{l}(0.79) \\
(0.94) \\
(0.55) \\
(0.43) \\
(0.52)\end{array}$ & $\begin{array}{r}8.5 \\
7.8 \\
10.3 \\
6.7 \\
6.5\end{array}$ & $\begin{array}{l}(0.73) \\
(0.64) \\
(0.64) \\
(0.42) \\
(0.49)\end{array}$ & $\begin{array}{l}2.1 \\
3.1 \\
3.4 \\
1.3 \\
1.6\end{array}$ & $\begin{array}{l}(0.33) \\
(0.55) \\
(0.43) \\
(0.15) \\
(0.25)\end{array}$ \\
\hline $\begin{array}{l}\text { Switzerland ........................ } \\
\text { Turkey ....................... } \\
\text { United Kingdom ................ } \\
\text { United States .................... }\end{array}$ & $\begin{array}{l}531 \\
448 \\
494 \\
481\end{array}$ & $\begin{array}{l}(3.0) \\
(4.8) \\
(3.3) \\
(3.6)\end{array}$ & $\begin{array}{l}12.4 \\
42.0 \\
21.8 \\
25.8\end{array}$ & $\begin{array}{l}(0.70) \\
(1.93) \\
(1.30) \\
(1.39)\end{array}$ & $\begin{array}{r}3.6 \\
15.5 \\
7.8 \\
8.0\end{array}$ & $\begin{array}{l}(0.35) \\
(1.08) \\
(0.77) \\
(0.73)\end{array}$ & $\begin{array}{r}8.9 \\
26.5 \\
14.0 \\
17.9\end{array}$ & $\begin{array}{l}(0.59) \\
(1.28) \\
(0.76) \\
(0.98)\end{array}$ & $\begin{array}{l}17.8 \\
25.5 \\
23.2 \\
26.3\end{array}$ & $\begin{array}{l}(1.06) \\
(1.16) \\
(0.81) \\
(0.84)\end{array}$ & $\begin{array}{l}24.5 \\
16.5 \\
24.8 \\
23.3\end{array}$ & $\begin{array}{l}(1.02) \\
(1.05) \\
(0.85) \\
(0.93)\end{array}$ & $\begin{array}{l}23.9 \\
10.1 \\
18.4 \\
15.8\end{array}$ & $\begin{array}{l}(0.80) \\
(1.09) \\
(0.78) \\
(0.91)\end{array}$ & $\begin{array}{r}21.4 \\
5.9 \\
11.8 \\
8.8\end{array}$ & $\begin{array}{l}(1.19) \\
(1.13) \\
(0.81) \\
(0.78)\end{array}$ & $\begin{array}{r}14.6 \\
4.7 \\
9.0 \\
6.6\end{array}$ & $\begin{array}{l}(0.78) \\
(0.81) \\
(0.63) \\
(0.61)\end{array}$ & $\begin{array}{l}6.8 \\
1.2 ! \\
2.9 \\
2.2\end{array}$ & $\begin{array}{l}(0.69) \\
(0.46) \\
(0.42) \\
(0.34)\end{array}$ \\
\hline
\end{tabular}

See notes at end of table. 


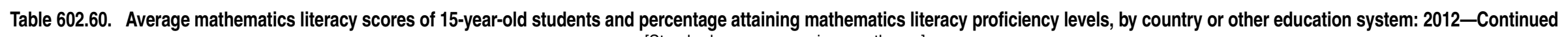
[Standard errors appear in parentheses]

\begin{tabular}{|c|c|c|c|c|c|c|c|c|c|c|c|c|c|c|c|c|c|c|c|c|}
\hline \multirow[b]{3}{*}{$\begin{array}{l}\text { Country or other } \\
\text { education system }\end{array}$} & \multirow{3}{*}{\multicolumn{2}{|c|}{$\begin{array}{r}\text { Average } \\
\text { mathematics } \\
\text { literacy score }\end{array}$}} & \multicolumn{18}{|c|}{ Percentage attaining mathematics literacy proficiency levels ${ }^{1}$} \\
\hline & & & \multicolumn{6}{|c|}{ Below level 2} & \multirow{2}{*}{\multicolumn{2}{|c|}{ At level 2}} & \multirow{2}{*}{\multicolumn{2}{|c|}{ At level 3}} & \multirow{2}{*}{\multicolumn{2}{|c|}{ At level 4}} & \multicolumn{6}{|c|}{ At or above level 5} \\
\hline & & & Total bel & level 2 & \multicolumn{2}{|c|}{ Below level 1} & \multicolumn{2}{|r|}{ At level 1} & & & & & & & \multicolumn{2}{|c|}{$\begin{array}{r}\text { Total at or } \\
\text { above level } 5\end{array}$} & \multicolumn{2}{|c|}{ At level 5} & \multicolumn{2}{|r|}{ At level 6} \\
\hline 1 & & 2 & & 3 & & 4 & & 5 & & 6 & & 7 & & 8 & & 9 & & 10 & & 11 \\
\hline 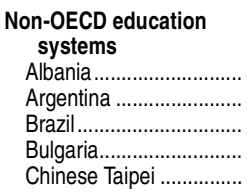 & $\begin{array}{l}394 \\
388 \\
391 \\
439 \\
560\end{array}$ & $\begin{array}{l}(2.0) \\
(3.5) \\
(2.1) \\
(4.0) \\
(3.3)\end{array}$ & $\begin{array}{l}60.7 \\
66.5 \\
67.1 \\
43.8 \\
12.8\end{array}$ & $\begin{array}{l}(0.95) \\
(2.03) \\
(1.03) \\
(1.78) \\
(0.84)\end{array}$ & $\begin{array}{r}32.5 \\
34.9 \\
35.2 \\
20.0 \\
4.5\end{array}$ & $\begin{array}{l}(1.03) \\
(1.95) \\
(0.93) \\
(1.45) \\
(0.53)\end{array}$ & $\begin{array}{r}28.1 \\
31.6 \\
31.9 \\
23.8 \\
8.3\end{array}$ & $\begin{array}{l}(0.97) \\
(1.22) \\
(0.70) \\
(0.95) \\
(0.61)\end{array}$ & $\begin{array}{l}22.9 \\
22.2 \\
20.4 \\
24.4 \\
13.1\end{array}$ & $\begin{array}{l}(0.91) \\
(1.36) \\
(0.67) \\
(1.12) \\
(0.61)\end{array}$ & $\begin{array}{r}12.0 \\
9.2 \\
8.9 \\
17.9 \\
17.1\end{array}$ & $\begin{array}{l}(0.92) \\
(0.88) \\
(0.47) \\
(0.91) \\
(0.65)\end{array}$ & $\begin{array}{r}3.6 \\
1.8 \\
2.9 \\
9.9 \\
19.7\end{array}$ & $\begin{array}{l}(0.35) \\
(0.35) \\
(0.35) \\
(0.83) \\
(0.75)\end{array}$ & $\begin{array}{l}0.8 \\
0.3 ! \\
0.8 \\
4.1 \\
37.2\end{array}$ & $\begin{array}{l}(0.19) \\
(0.10) \\
(0.20) \\
(0.62) \\
(1.24)\end{array}$ & $\begin{array}{c}0.8 \\
0.3 ! \\
0.7 \\
3.4 \\
19.2\end{array}$ & $\begin{array}{l}(0.20) \\
(0.10) \\
(0.19) \\
(0.50) \\
(0.89)\end{array}$ & $\begin{array}{r}\ddagger \\
\ddagger \\
\ddagger \\
0.7 \\
18.0\end{array}$ & $\begin{array}{r}(\dagger) \\
(\dagger) \\
(t) \\
(0.19) \\
(1.00)\end{array}$ \\
\hline 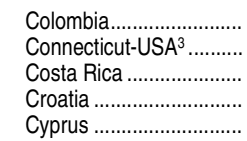 & $\begin{array}{l}376 \\
506 \\
407 \\
471 \\
440\end{array}$ & $\begin{array}{l}(2.9) \\
(6.2) \\
(3.0) \\
(3.5) \\
(1.1)\end{array}$ & $\begin{array}{l}73.8 \\
20.6 \\
59.9 \\
29.9 \\
42.0\end{array}$ & $\begin{array}{l}(1.43) \\
(2.14) \\
(1.87) \\
(1.36) \\
(0.63)\end{array}$ & $\begin{array}{r}41.6 \\
6.8 \\
23.6 \\
9.5 \\
19.0\end{array}$ & $\begin{array}{l}(1.71) \\
(1.18) \\
(1.68) \\
(0.74) \\
(0.58)\end{array}$ & $\begin{array}{l}32.2 \\
13.8 \\
36.2 \\
20.4 \\
23.0\end{array}$ & $\begin{array}{l}(1.05) \\
(1.33) \\
(1.22) \\
(1.02) \\
(0.65)\end{array}$ & $\begin{array}{l}17.8 \\
20.0 \\
26.8 \\
26.7 \\
25.5\end{array}$ & $\begin{array}{l}(0.90) \\
(1.28) \\
(1.29) \\
(0.95) \\
(0.62)\end{array}$ & $\begin{array}{r}6.4 \\
24.3 \\
10.1 \\
22.9 \\
19.2\end{array}$ & $\begin{array}{l}(0.61) \\
(1.36) \\
(0.99) \\
(1.12) \\
(0.58)\end{array}$ & $\begin{array}{r}1.6 \\
18.6 \\
2.6 \\
13.5 \\
9.6\end{array}$ & $\begin{array}{l}(0.28) \\
(1.79) \\
(0.46) \\
(0.80) \\
(0.44)\end{array}$ & $\begin{array}{c}0.3 ! \\
16.4 \\
0.6 ! \\
7.0 \\
3.7\end{array}$ & $\begin{array}{l}(0.11) \\
(1.91) \\
(0.19) \\
(1.15) \\
(0.27)\end{array}$ & $\begin{array}{c}0.3 ! \\
11.5 \\
0.5 ! \\
5.4 \\
3.1\end{array}$ & $\begin{array}{l}(0.10) \\
(1.46) \\
(0.16) \\
(0.76) \\
(0.25)\end{array}$ & 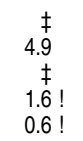 & $\begin{array}{r}(\dagger) \\
(0.83) \\
(\dagger) \\
(0.51) \\
(0.20)\end{array}$ \\
\hline 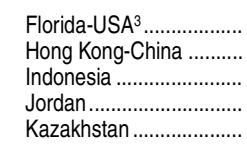 & $\begin{array}{l}467 \\
561 \\
375 \\
386 \\
432\end{array}$ & $\begin{array}{l}(5.8) \\
(3.2) \\
(4.0) \\
(3.1) \\
(3.0)\end{array}$ & $\begin{array}{r}30.4 \\
8.5 \\
75.7 \\
68.6 \\
45.2\end{array}$ & $\begin{array}{l}(2.65) \\
(0.79) \\
(2.05) \\
(1.50) \\
(1.70)\end{array}$ & $\begin{array}{r}9.7 \\
2.6 \\
42.3 \\
36.5 \\
14.5\end{array}$ & $\begin{array}{l}(1.44) \\
(0.36) \\
(2.14) \\
(1.59) \\
(0.90)\end{array}$ & $\begin{array}{r}20.6 \\
5.9 \\
33.4 \\
32.1 \\
30.7\end{array}$ & $\begin{array}{l}(1.87) \\
(0.61) \\
(1.59) \\
(0.95) \\
(1.40)\end{array}$ & $\begin{array}{l}27.9 \\
12.0 \\
16.8 \\
21.0 \\
31.5\end{array}$ & $\begin{array}{l}(1.42) \\
(0.77) \\
(1.12) \\
(1.04) \\
(0.95)\end{array}$ & $\begin{array}{r}23.0 \\
19.7 \\
5.7 \\
8.1 \\
16.9\end{array}$ & $\begin{array}{l}(1.64) \\
(0.97) \\
(0.90) \\
(0.63) \\
(1.11)\end{array}$ & $\begin{array}{c}13.0 \\
26.1 \\
1.5 ! \\
1.8 \\
5.4\end{array}$ & $\begin{array}{l}(1.34) \\
(1.09) \\
(0.54) \\
(0.33) \\
(0.79)\end{array}$ & $\begin{array}{r}5.8 \\
33.7 \\
\ddagger \\
\ddagger \\
0.9 !\end{array}$ & $\begin{array}{r}(1.18) \\
(1.35) \\
(+) \\
(\dagger) \\
(0.29)\end{array}$ & $\begin{array}{r}4.9 \\
21.4 \\
\ddagger \\
\ddagger \\
0.9 !\end{array}$ & $\begin{array}{r}(1.04) \\
(0.96) \\
(\dagger) \\
(t) \\
(0.27)\end{array}$ & $\begin{array}{c}0.9 ! \\
12.3 \\
\ddagger \\
\ddagger \\
\ddagger\end{array}$ & $\begin{array}{r}(0.39) \\
(0.95) \\
(\dagger) \\
(\dagger) \\
(\dagger)\end{array}$ \\
\hline 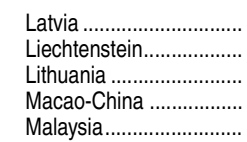 & $\begin{array}{l}491 \\
535 \\
479 \\
538 \\
421\end{array}$ & $\begin{array}{l}(2.8) \\
(4.0) \\
(2.6) \\
(1.0) \\
(3.2)\end{array}$ & $\begin{array}{l}19.9 \\
14.1 \\
26.0 \\
10.8 \\
51.8\end{array}$ & $\begin{array}{l}(1.13) \\
(2.02) \\
(1.18) \\
(0.49) \\
(1.68)\end{array}$ & $\begin{array}{r}4.8 \\
3.5 ! \\
8.7 \\
3.2 \\
23.0\end{array}$ & $\begin{array}{l}(0.53) \\
(1.31) \\
(0.68) \\
(0.29) \\
(1.19)\end{array}$ & $\begin{array}{r}15.1 \\
10.6 \\
17.3 \\
7.6 \\
28.8\end{array}$ & $\begin{array}{l}(0.96) \\
(1.81) \\
(0.89) \\
(0.53) \\
(1.12)\end{array}$ & $\begin{array}{l}26.6 \\
15.2 \\
25.9 \\
16.4 \\
26.0\end{array}$ & $\begin{array}{l}(1.29) \\
(2.52) \\
(0.80) \\
(0.71) \\
(0.95)\end{array}$ & $\begin{array}{l}27.8 \\
22.7 \\
24.6 \\
24.0 \\
14.9\end{array}$ & $\begin{array}{l}(0.92) \\
(2.81) \\
(1.01) \\
(0.69) \\
(0.93)\end{array}$ & $\begin{array}{r}17.6 \\
23.2 \\
15.4 \\
24.4 \\
6.0\end{array}$ & $\begin{array}{l}(0.90) \\
(3.01) \\
(0.70) \\
(0.87) \\
(0.69)\end{array}$ & $\begin{array}{r}8.0 \\
24.8 \\
8.1 \\
24.3 \\
1.3\end{array}$ & $\begin{array}{l}(0.78) \\
(2.55) \\
(0.60) \\
(0.56) \\
(0.30)\end{array}$ & $\begin{array}{r}6.5 \\
17.4 \\
6.6 \\
16.8 \\
1.2\end{array}$ & $\begin{array}{l}(0.65) \\
(3.17) \\
(0.49) \\
(0.63) \\
(0.28)\end{array}$ & $\begin{array}{l}1.5 \\
7.4 \\
1.4 \\
7.6 \\
0.1 !\end{array}$ & $\begin{array}{l}(0.28) \\
(1.86) \\
(0.24) \\
(0.35) \\
(0.05)\end{array}$ \\
\hline 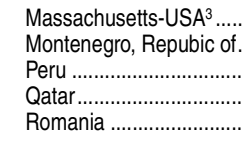 & $\begin{array}{l}514 \\
410 \\
368 \\
376 \\
445\end{array}$ & $\begin{array}{l}(6.2) \\
(1.1) \\
(3.7) \\
(0.8) \\
(3.8)\end{array}$ & $\begin{array}{l}17.8 \\
56.6 \\
74.6 \\
69.6 \\
40.8\end{array}$ & $\begin{array}{l}(1.46) \\
(1.02) \\
(1.75) \\
(0.46) \\
(1.93)\end{array}$ & $\begin{array}{r}5.3 \\
27.5 \\
47.0 \\
47.0 \\
14.0\end{array}$ & $\begin{array}{l}(0.83) \\
(0.64) \\
(1.79) \\
(0.42) \\
(1.15)\end{array}$ & $\begin{array}{l}12.5 \\
29.1 \\
27.6 \\
22.6 \\
26.8\end{array}$ & $\begin{array}{l}(1.17) \\
(1.14) \\
(0.88) \\
(0.53) \\
(1.23)\end{array}$ & $\begin{array}{l}20.4 \\
24.2 \\
16.1 \\
15.2 \\
28.3\end{array}$ & $\begin{array}{l}(1.61) \\
(1.06) \\
(1.00) \\
(0.39) \\
(1.09)\end{array}$ & $\begin{array}{r}24.3 \\
13.1 \\
6.7 \\
8.8 \\
19.2\end{array}$ & $\begin{array}{l}(1.49) \\
(0.73) \\
(0.68) \\
(0.34) \\
(1.07)\end{array}$ & $\begin{array}{r}18.9 \\
4.9 \\
2.1 \\
4.5 \\
8.4\end{array}$ & $\begin{array}{l}(1.18) \\
(0.48) \\
(0.38) \\
(0.28) \\
(0.81)\end{array}$ & $\begin{array}{c}18.5 \\
1.0 \\
0.6 ! \\
2.0 \\
3.2\end{array}$ & $\begin{array}{l}(2.47) \\
(0.20) \\
(0.21) \\
(0.21) \\
(0.61)\end{array}$ & $\begin{array}{l}12.7 \\
0.9 \\
0.5 ! \\
1.7 \\
2.6\end{array}$ & $\begin{array}{l}(1.61) \\
(0.20) \\
(0.20) \\
(0.20) \\
(0.45)\end{array}$ & $\begin{array}{r}5.8 \\
\neq \\
\neq \\
0.3 \\
0.6 !\end{array}$ & $\begin{array}{r}(1.11) \\
(\dagger) \\
(\dagger) \\
(0.07) \\
(0.27)\end{array}$ \\
\hline 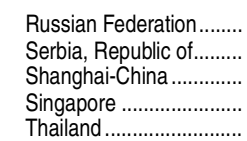 & $\begin{array}{l}482 \\
449 \\
613 \\
573 \\
427\end{array}$ & $\begin{array}{l}(3.0) \\
(3.4) \\
(3.3) \\
(1.3) \\
(3.4)\end{array}$ & $\begin{array}{r}24.0 \\
38.9 \\
3.8 \\
8.3 \\
49.7\end{array}$ & $\begin{array}{l}(1.13) \\
(1.54) \\
(0.55) \\
(0.48) \\
(1.74)\end{array}$ & $\begin{array}{r}7.5 \\
15.5 \\
0.8 \\
2.2 \\
19.1\end{array}$ & $\begin{array}{l}(0.70) \\
(1.16) \\
(0.21) \\
(0.23) \\
(1.07)\end{array}$ & $\begin{array}{r}16.5 \\
23.4 \\
2.9 \\
6.1 \\
30.6\end{array}$ & $\begin{array}{l}(0.80) \\
(0.93) \\
(0.46) \\
(0.40) \\
(1.20)\end{array}$ & $\begin{array}{r}26.6 \\
26.5 \\
7.5 \\
12.2 \\
27.3\end{array}$ & $\begin{array}{l}(0.99) \\
(1.12) \\
(0.64) \\
(0.68) \\
(1.00)\end{array}$ & $\begin{array}{l}26.0 \\
19.5 \\
13.1 \\
17.5 \\
14.5\end{array}$ & $\begin{array}{l}(0.97) \\
(1.03) \\
(0.77) \\
(0.66) \\
(1.15)\end{array}$ & $\begin{array}{r}15.7 \\
10.5 \\
20.2 \\
22.0 \\
5.8\end{array}$ & $\begin{array}{l}(0.78) \\
(0.69) \\
(0.83) \\
(0.62) \\
(0.74)\end{array}$ & $\begin{array}{r}7.8 \\
45 \\
55.4 \\
40.0 \\
2.6\end{array}$ & $\begin{array}{l}(0.85) \\
(0.71) \\
(1.37) \\
(0.71) \\
(0.51)\end{array}$ & $\begin{array}{r}6.3 \\
3.5 \\
24.6 \\
21.0 \\
2.0\end{array}$ & $\begin{array}{l}(0.64) \\
(0.52) \\
(1.04) \\
(0.58) \\
(0.38)\end{array}$ & $\begin{array}{c}1.5 \\
1.1 \\
30.8 \\
19.0 \\
0.5 !\end{array}$ & $\begin{array}{l}(0.31) \\
(0.31) \\
(1.24) \\
(0.51) \\
(0.19)\end{array}$ \\
\hline 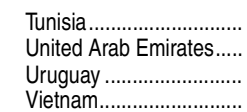 & $\begin{array}{l}388 \\
434 \\
409 \\
511\end{array}$ & $\begin{array}{l}(3.9) \\
(2.4) \\
(2.8) \\
(4.8)\end{array}$ & $\begin{array}{l}67.7 \\
46.3 \\
55.8 \\
14.2\end{array}$ & $\begin{array}{l}(1.83) \\
(1.22) \\
(1.31) \\
(1.75)\end{array}$ & $\begin{array}{r}36.5 \\
20.5 \\
29.2 \\
3.6\end{array}$ & $\begin{array}{l}(1.88) \\
(0.92) \\
(1.20) \\
(0.80)\end{array}$ & $\begin{array}{l}31.3 \\
25.8 \\
26.5 \\
10.6\end{array}$ & $\begin{array}{l}(1.09) \\
(0.81) \\
(0.76) \\
(1.26)\end{array}$ & $\begin{array}{l}21.1 \\
24.9 \\
23.0 \\
22.8\end{array}$ & $\begin{array}{l}(1.17) \\
(0.69) \\
(0.93) \\
(1.28)\end{array}$ & $\begin{array}{r}8.0 \\
16.9 \\
14.4 \\
28.4\end{array}$ & $\begin{array}{l}(0.79) \\
(0.64) \\
(0.87) \\
(1.52)\end{array}$ & $\begin{array}{r}2.3 \\
8.5 \\
5.4 \\
21.3\end{array}$ & $\begin{array}{l}(0.68) \\
(0.54) \\
(0.60) \\
(1.22)\end{array}$ & $\begin{array}{c}0.8 ! \\
3.5 \\
1.4 \\
13.3\end{array}$ & $\begin{array}{l}(0.37) \\
(0.29) \\
(0.32) \\
(1.47)\end{array}$ & $\begin{array}{l}0.7 ! \\
2.9 \\
1.3 \\
9.8\end{array}$ & $\begin{array}{l}(0.32) \\
(0.25) \\
(0.28) \\
(0.99)\end{array}$ & $\begin{aligned} \ddagger \\
0.5 \\
\ddagger \\
3.5\end{aligned}$ & $\begin{array}{r}(\dagger) \\
(0.11) \\
(+) \\
(0.75)\end{array}$ \\
\hline
\end{tabular}

\section{†Not applicable.}

!Interpret data with caution. The coefficient of variation (CV) for this estimate is between 30 and 50 percent. fReporting standards not met. Either there are too few cases for a reliable estimate or the coefficient of variation (CV) is 50 percent or greater.

To reach a particular proficiency level, a student must correctly answer a majority of items at that level. Students were classified into mathematics literacy levels according to their scores. Exact cut scores are as follows: below level 1 (a score less than or equal or equal to 482.38 ); level 3 (a score greater than 482.38 and less than or equal to 544.68 ); level 4 (a score greater than 544.68 and

less than or equal to 606.99); level 5 (a score greater than 606.99 and less than or equal to 669.30 ); and level 6 (a score greater

${ }^{2}$ Refers to the mean of the data values for all Organization for Economic Cooperation and Development (OECD) countries, to which each country contributes equally, regardless of the absolute size of the student population of each country.

NOTE: Program for International Student Assessment (PISA) scores are reported on a scale from 0 to 1,000. Detail may not sum to totals because of rounding.

Organization for Economic Cooperation and Development (OECD), Program for International Student Assessment (PISA), 2012. (This table was prepared November 2013.) 
Table 602.70. Average science literacy scores of 15-year-old students and percentage attaining science literacy proficiency levels, by country or other education system: 2012

[Standard errors appear in parentheses]

\begin{tabular}{|c|c|c|c|c|c|c|c|c|c|c|c|c|c|c|c|c|c|c|c|c|}
\hline \multirow[b]{3}{*}{$\begin{array}{l}\text { Country or other } \\
\text { education system }\end{array}$} & & & \multicolumn{18}{|c|}{ Percentage attaining science literacy proficiency levels 1} \\
\hline & \multirow{2}{*}{\multicolumn{2}{|c|}{$\begin{array}{r}\text { Average science } \\
\text { literacy score }\end{array}$}} & \multicolumn{6}{|c|}{ Below level 2} & \multirow{2}{*}{\multicolumn{2}{|c|}{ At level 2}} & \multirow{2}{*}{\multicolumn{2}{|c|}{ At level 3}} & \multirow{2}{*}{\multicolumn{2}{|c|}{ At level 4}} & \multicolumn{6}{|c|}{ At or above level 5} \\
\hline & & & \multicolumn{2}{|c|}{ Total below level 2} & \multicolumn{2}{|c|}{ Below level 1} & \multicolumn{2}{|c|}{ At level 1} & & & & & & & \multicolumn{2}{|c|}{$\begin{array}{r}\text { Total at or } \\
\text { above level } 5\end{array}$} & \multicolumn{2}{|c|}{ At level 5} & \multicolumn{2}{|r|}{ At level 6} \\
\hline 1 & & 2 & & 3 & & 4 & & 5 & & 6 & & 7 & & 8 & & 9 & & 10 & & 11 \\
\hline OECD average ${ }^{2} \ldots \ldots \ldots$ & 501 & $(0.5)$ & 17.8 & $(0.17)$ & 4.8 & $(0.09)$ & 13.0 & $(0.14)$ & 24.5 & $(0.16)$ & 28.8 & $(0.17)$ & 20.5 & $(0.15)$ & 8.4 & $(0.11)$ & 7.2 & $(0.10)$ & 1.1 & $(0.04)$ \\
\hline $\begin{array}{l}\text { Australia } \\
\text { Austria } \\
\text { Belgium. } \\
\text { Canada } \\
\text { Chile }\end{array}$ & $\begin{array}{l}521 \\
506 \\
505 \\
525 \\
445\end{array}$ & $\begin{array}{l}(1.8) \\
(2.7) \\
(2.2) \\
(1.9) \\
(2.9)\end{array}$ & $\begin{array}{l}13.6 \\
15.8 \\
17.7 \\
10.4 \\
34.5\end{array}$ & \begin{tabular}{l|}
$(0.48)$ \\
$(1.00)$ \\
$(0.86)$ \\
$(0.47)$ \\
$(1.58)$
\end{tabular} & $\begin{array}{l}3.4 \\
3.6 \\
5.9 \\
2.4 \\
8.1\end{array}$ & $\begin{array}{l}(0.25) \\
(0.54) \\
(0.53) \\
(0.24) \\
(0.80)\end{array}$ & $\begin{array}{r}10.2 \\
12.2 \\
11.8 \\
8.0 \\
26.3\end{array}$ & $\begin{array}{l}(0.41) \\
(0.92) \\
(0.58) \\
(0.38) \\
(1.11)\end{array}$ & $\begin{array}{l}21.5 \\
24.3 \\
21.5 \\
21.0 \\
34.6\end{array}$ & $\begin{array}{l}(0.47) \\
(1.05) \\
(0.63) \\
(0.65) \\
(1.06)\end{array}$ & $\begin{array}{l}28.5 \\
30.1 \\
28.7 \\
32.0 \\
22.4\end{array}$ & $\begin{array}{l}(0.68) \\
(0.85) \\
(0.71) \\
(0.54) \\
(0.96)\end{array}$ & $\begin{array}{r}22.8 \\
21.9 \\
23.0 \\
25.3 \\
7.5\end{array}$ & $\begin{array}{l}(0.63) \\
(0.81) \\
(0.66) \\
(0.58) \\
(0.60)\end{array}$ & $\begin{array}{r}13.6 \\
7.9 \\
9.1 \\
11.3 \\
1.0\end{array}$ & $\begin{array}{l}(0.55) \\
(0.70) \\
(0.43) \\
(0.55) \\
(0.15)\end{array}$ & $\begin{array}{r}10.9 \\
7.0 \\
8.1 \\
9.5 \\
1.0\end{array}$ & $\begin{array}{l}(0.47) \\
(0.62) \\
(0.42) \\
(0.47) \\
(0.15)\end{array}$ & $\begin{array}{r}2.6 \\
0.8 \\
0.9 \\
1.8 \\
\#\end{array}$ & $\begin{array}{r}(0.25) \\
(0.20) \\
(0.16) \\
(0.20) \\
(\dagger)\end{array}$ \\
\hline 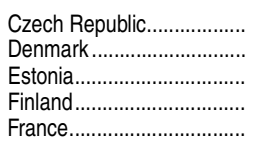 & $\begin{array}{l}508 \\
498 \\
541 \\
545 \\
499\end{array}$ & $\begin{array}{l}(3.0) \\
(2.7) \\
(1.9) \\
(2.2) \\
(2.6)\end{array}$ & $\begin{array}{r}13.8 \\
16.7 \\
5.0 \\
7.7 \\
18.7\end{array}$ & $\begin{array}{l}(1.13) \\
(0.97) \\
(0.45) \\
(0.58) \\
(1.01)\end{array}$ & $\begin{array}{l}3.3 \\
4.7 \\
0.5 \\
1.8 \\
6.1\end{array}$ & $\begin{array}{l}(0.62) \\
(0.55) \\
(0.14) \\
(0.28) \\
(0.67)\end{array}$ & $\begin{array}{r}10.5 \\
12.0 \\
4.5 \\
5.9 \\
12.6\end{array}$ & $\begin{array}{l}(1.03) \\
(0.69) \\
(0.43) \\
(0.48) \\
(0.71)\end{array}$ & $\begin{array}{l}24.7 \\
25.7 \\
19.0 \\
16.8 \\
22.9\end{array}$ & $\begin{array}{l}(0.99) \\
(0.80) \\
(0.87) \\
(0.69) \\
(1.08)\end{array}$ & $\begin{array}{l}31.7 \\
31.3 \\
34.5 \\
29.6 \\
29.2\end{array}$ & $\begin{array}{l}(1.23) \\
(0.90) \\
(0.87) \\
(0.77) \\
(1.12)\end{array}$ & $\begin{array}{l}22.2 \\
19.6 \\
28.7 \\
28.8 \\
21.3\end{array}$ & $\begin{array}{l}(0.96) \\
(0.79) \\
(0.96) \\
(0.73) \\
(0.87)\end{array}$ & $\begin{array}{r}7.6 \\
6.8 \\
12.8 \\
17.1 \\
7.9\end{array}$ & $\begin{array}{l}(0.58) \\
(0.70) \\
(0.73) \\
(0.66) \\
(0.77)\end{array}$ & $\begin{array}{r}6.7 \\
6.1 \\
11.1 \\
13.9 \\
6.9\end{array}$ & $\begin{array}{l}(0.53) \\
(0.67) \\
(0.66) \\
(0.62) \\
(0.68)\end{array}$ & $\begin{array}{l}0.9 \\
0.7 \\
1.7 \\
3.2 \\
1.0\end{array}$ & $\begin{array}{l}(0.18) \\
(0.17) \\
(0.25) \\
(0.38) \\
(0.21)\end{array}$ \\
\hline 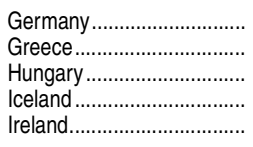 & $\begin{array}{l}524 \\
467 \\
494 \\
478 \\
522\end{array}$ & $\begin{array}{l}(3.0) \\
(3.1) \\
(2.9) \\
(2.1) \\
(2.5)\end{array}$ & $\begin{array}{l}12.2 \\
25.5 \\
18.0 \\
24.0 \\
11.1\end{array}$ & $\begin{array}{l}(0.90) \\
(1.47) \\
(1.14) \\
(0.78) \\
(0.88)\end{array}$ & $\begin{array}{l}2.9 \\
7.4 \\
4.1 \\
8.0 \\
2.6\end{array}$ & $\begin{array}{l}(0.46) \\
(0.70) \\
(0.61) \\
(0.56) \\
(0.40)\end{array}$ & $\begin{array}{r}9.3 \\
18.1 \\
14.0 \\
16.0 \\
8.5\end{array}$ & $\begin{array}{l}(0.73) \\
(1.14) \\
(1.04) \\
(0.72) \\
(0.76)\end{array}$ & $\begin{array}{l}20.5 \\
31.0 \\
26.4 \\
27.5 \\
22.0\end{array}$ & $\begin{array}{l}(0.82) \\
(1.10) \\
(1.08) \\
(0.87) \\
(1.15)\end{array}$ & $\begin{array}{l}28.9 \\
28.8 \\
30.9 \\
27.2 \\
31.1\end{array}$ & $\begin{array}{l}(0.89) \\
(1.02) \\
(1.16) \\
(0.86) \\
(1.03)\end{array}$ & $\begin{array}{l}26.2 \\
12.2 \\
18.7 \\
16.2 \\
25.0\end{array}$ & $\begin{array}{l}(1.05) \\
(0.81) \\
(0.98) \\
(0.74) \\
(0.94)\end{array}$ & $\begin{array}{r}12.2 \\
2.5 \\
5.9 \\
5.2 \\
10.7\end{array}$ & $\begin{array}{l}(0.95) \\
(0.40) \\
(0.75) \\
(0.61) \\
(0.58)\end{array}$ & $\begin{array}{r}10.6 \\
2.3 \\
5.5 \\
4.6 \\
9.3\end{array}$ & $\begin{array}{l}(0.80) \\
(0.40) \\
(0.73) \\
(0.60) \\
(0.63)\end{array}$ & $\begin{array}{l}1.6 \\
\ddagger \\
0.5 ! \\
0.6 \\
1.5\end{array}$ & $\begin{array}{r}(0.28) \\
(\dagger) \\
(0.18) \\
(0.17) \\
(0.25)\end{array}$ \\
\hline 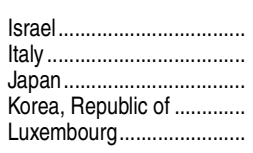 & $\begin{array}{l}470 \\
494 \\
547 \\
538 \\
491\end{array}$ & $\begin{array}{l}(5.0) \\
(1.9) \\
(3.6) \\
(3.7) \\
(1.3)\end{array}$ & $\begin{array}{r}28.9 \\
18.7 \\
8.5 \\
6.6 \\
22.2\end{array}$ & $\begin{array}{l}(1.67) \\
(0.68) \\
(0.88) \\
(0.77) \\
(0.63)\end{array}$ & $\begin{array}{r}11.2 \\
4.9 \\
2.0 \\
1.2 \\
7.2\end{array}$ & $\begin{array}{l}(1.08) \\
(0.35) \\
(0.39) \\
(0.25) \\
(0.42)\end{array}$ & $\begin{array}{r}17.7 \\
13.8 \\
6.4 \\
5.5 \\
15.1\end{array}$ & $\begin{array}{l}(0.93) \\
(0.52) \\
(0.61) \\
(0.60) \\
(0.67)\end{array}$ & $\begin{array}{l}24.8 \\
26.0 \\
16.3 \\
18.0 \\
24.2\end{array}$ & $\begin{array}{l}(0.93) \\
(0.58) \\
(0.79) \\
(1.02) \\
(0.63)\end{array}$ & $\begin{array}{l}24.4 \\
30.1 \\
27.5 \\
33.6 \\
26.2\end{array}$ & $\begin{array}{l}(1.19) \\
(0.66) \\
(0.92) \\
(1.11) \\
(0.60)\end{array}$ & $\begin{array}{l}16.1 \\
19.1 \\
29.5 \\
30.1 \\
19.2\end{array}$ & $\begin{array}{l}(1.12) \\
(0.59) \\
(1.06) \\
(1.24) \\
(0.53)\end{array}$ & $\begin{array}{r}5.8 \\
6.1 \\
18.2 \\
11.7 \\
8.2\end{array}$ & $\begin{array}{l}(0.65) \\
(0.41) \\
(1.21) \\
(1.13) \\
(0.54)\end{array}$ & $\begin{array}{r}5.2 \\
5.5 \\
14.8 \\
10.6 \\
7.0\end{array}$ & $\begin{array}{l}(0.58) \\
(0.37) \\
(0.93) \\
(0.93) \\
(0.49)\end{array}$ & $\begin{array}{l}0.6 ! \\
0.6 \\
3.4 \\
1.1 ! \\
1.2\end{array}$ & $\begin{array}{l}(0.22) \\
(0.08) \\
(0.49) \\
(0.39) \\
(0.17)\end{array}$ \\
\hline 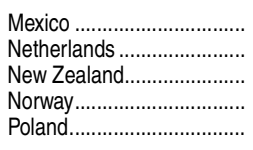 & $\begin{array}{l}415 \\
522 \\
516 \\
495 \\
526\end{array}$ & $\begin{array}{l}(1.3) \\
(3.5) \\
(2.1) \\
(3.1) \\
(3.1)\end{array}$ & $\begin{array}{r}47.0 \\
13.1 \\
16.3 \\
19.6 \\
9.0\end{array}$ & $\begin{array}{l}(0.81) \\
(1.12) \\
(0.86) \\
(1.10) \\
(0.75)\end{array}$ & $\begin{array}{r}12.6 \\
3.1 \\
4.7 \\
6.0 \\
1.3\end{array}$ & $\begin{array}{l}(0.52) \\
(0.53) \\
(0.39) \\
(0.63) \\
(0.32)\end{array}$ & $\begin{array}{r}34.4 \\
10.1 \\
11.6 \\
13.6 \\
7.7\end{array}$ & $\begin{array}{l}(0.58) \\
(0.83) \\
(0.76) \\
(0.71) \\
(0.70)\end{array}$ & $\begin{array}{l}37.0 \\
20.1 \\
21.7 \\
24.8 \\
22.5\end{array}$ & $\begin{array}{l}(0.59) \\
(1.35) \\
(0.94) \\
(0.80) \\
(0.98)\end{array}$ & $\begin{array}{l}13.8 \\
29.1 \\
26.4 \\
28.9 \\
33.1\end{array}$ & $\begin{array}{l}(0.52) \\
(1.28) \\
(0.95) \\
(0.91) \\
(0.92)\end{array}$ & $\begin{array}{r}2.1 \\
25.8 \\
22.3 \\
19.0 \\
24.5\end{array}$ & $\begin{array}{l}(0.16) \\
(1.24) \\
(0.85) \\
(0.79) \\
(0.96)\end{array}$ & $\begin{array}{r}0.1 ! \\
11.8 \\
13.4 \\
7.5 \\
10.8\end{array}$ & $\begin{array}{l}(0.04) \\
(1.06) \\
(0.69) \\
(0.57) \\
(1.01)\end{array}$ & $\begin{array}{c}0.1 ! \\
10.5 \\
10.7 \\
6.4 \\
9.1\end{array}$ & $\begin{array}{l}(0.04) \\
(0.98) \\
(0.62) \\
(0.56) \\
(0.76)\end{array}$ & $\begin{array}{r}\ddagger \\
1.3 \\
2.7 \\
1.1 \\
1.7\end{array}$ & $\begin{array}{r}(\dagger) \\
(0.28) \\
(0.25) \\
(0.24) \\
(0.35)\end{array}$ \\
\hline 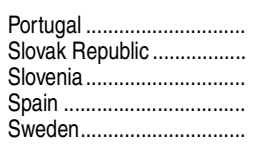 & $\begin{array}{l}489 \\
471 \\
514 \\
496 \\
485\end{array}$ & $\begin{array}{l}(3.7) \\
(3.6) \\
(1.3) \\
(1.8) \\
(3.0)\end{array}$ & $\begin{array}{l}19.0 \\
26.9 \\
12.9 \\
15.7 \\
22.2\end{array}$ & $\begin{array}{l}(1.44) \\
(1.58) \\
(0.56) \\
(0.71) \\
(1.11)\end{array}$ & $\begin{array}{l}4.7 \\
9.2 \\
2.4 \\
3.7 \\
7.3\end{array}$ & $\begin{array}{l}(0.66) \\
(0.95) \\
(0.19) \\
(0.33) \\
(0.62)\end{array}$ & $\begin{array}{l}14.3 \\
17.6 \\
10.4 \\
12.0 \\
15.0\end{array}$ & $\begin{array}{l}(1.09) \\
(1.14) \\
(0.55) \\
(0.51) \\
(0.80)\end{array}$ & $\begin{array}{l}27.3 \\
27.0 \\
24.5 \\
27.3 \\
26.2\end{array}$ & $\begin{array}{l}(0.96) \\
(1.30) \\
(1.00) \\
(0.64) \\
(0.84)\end{array}$ & $\begin{array}{l}31.4 \\
26.2 \\
30.0 \\
32.8 \\
28.0\end{array}$ & $\begin{array}{l}(1.25) \\
(1.62) \\
(1.02) \\
(0.60) \\
(0.84)\end{array}$ & $\begin{array}{l}17.8 \\
15.0 \\
23.0 \\
19.4 \\
17.2\end{array}$ & $\begin{array}{l}(1.06) \\
(1.02) \\
(0.92) \\
(0.53) \\
(0.77)\end{array}$ & $\begin{array}{l}4.5 \\
4.9 \\
9.6 \\
4.8 \\
6.3\end{array}$ & $\begin{array}{l}(0.55) \\
(0.72) \\
(0.72) \\
(0.29) \\
(0.50)\end{array}$ & $\begin{array}{l}4.2 \\
4.3 \\
8.4 \\
4.5 \\
5.6\end{array}$ & $\begin{array}{l}(0.55) \\
(0.58) \\
(0.71) \\
(0.26) \\
(0.45)\end{array}$ & $\begin{array}{l}0.3 ! \\
0.6 ! \\
1.2 \\
0.3 \\
0.7\end{array}$ & $\begin{array}{l}(0.11) \\
(0.25) \\
(0.24) \\
(0.08) \\
(0.14)\end{array}$ \\
\hline 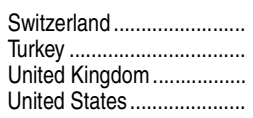 & $\begin{array}{l}515 \\
463 \\
514 \\
497\end{array}$ & $\begin{array}{l}(2.7) \\
(3.9) \\
(3.4) \\
(3.8)\end{array}$ & $\begin{array}{l}12.8 \\
26.4 \\
15.0 \\
18.1\end{array}$ & $\begin{array}{l}(0.72) \\
(1.50) \\
(1.07) \\
(1.33)\end{array}$ & $\begin{array}{l}3.0 \\
4.4 \\
4.3 \\
4.2\end{array}$ & $\begin{array}{l}(0.31) \\
(0.50) \\
(0.48) \\
(0.54)\end{array}$ & $\begin{array}{r}9.8 \\
21.9 \\
10.7 \\
14.0\end{array}$ & $\begin{array}{l}(0.62) \\
(1.27) \\
(0.86) \\
(1.08)\end{array}$ & $\begin{array}{l}22.8 \\
35.4 \\
22.4 \\
26.7\end{array}$ & $\begin{array}{l}(0.82) \\
(1.43) \\
(1.00) \\
(1.08)\end{array}$ & $\begin{array}{l}31.3 \\
25.1 \\
28.4 \\
28.9\end{array}$ & $\begin{array}{l}(0.74) \\
(1.28) \\
(0.98) \\
(1.07)\end{array}$ & $\begin{array}{l}23.7 \\
11.3 \\
23.0 \\
18.8\end{array}$ & $\begin{array}{l}(0.86) \\
(1.28) \\
(0.91) \\
(1.07)\end{array}$ & $\begin{array}{r}9.3 \\
1.8 \\
11.2 \\
7.5\end{array}$ & $\begin{array}{l}(0.77) \\
(0.36) \\
(0.79) \\
(0.74)\end{array}$ & $\begin{array}{l}8.3 \\
1.8 \\
9.3 \\
6.3\end{array}$ & $\begin{array}{l}(0.70) \\
(0.34) \\
(0.70) \\
(0.64)\end{array}$ & $\begin{array}{r}1.0 \\
\ddagger \\
1.8 \\
1.1\end{array}$ & $\begin{array}{r}(0.22) \\
(+) \\
(0.34) \\
(0.20)\end{array}$ \\
\hline
\end{tabular}

See notes at end of table. 
[Standard errors appear in parentheses]

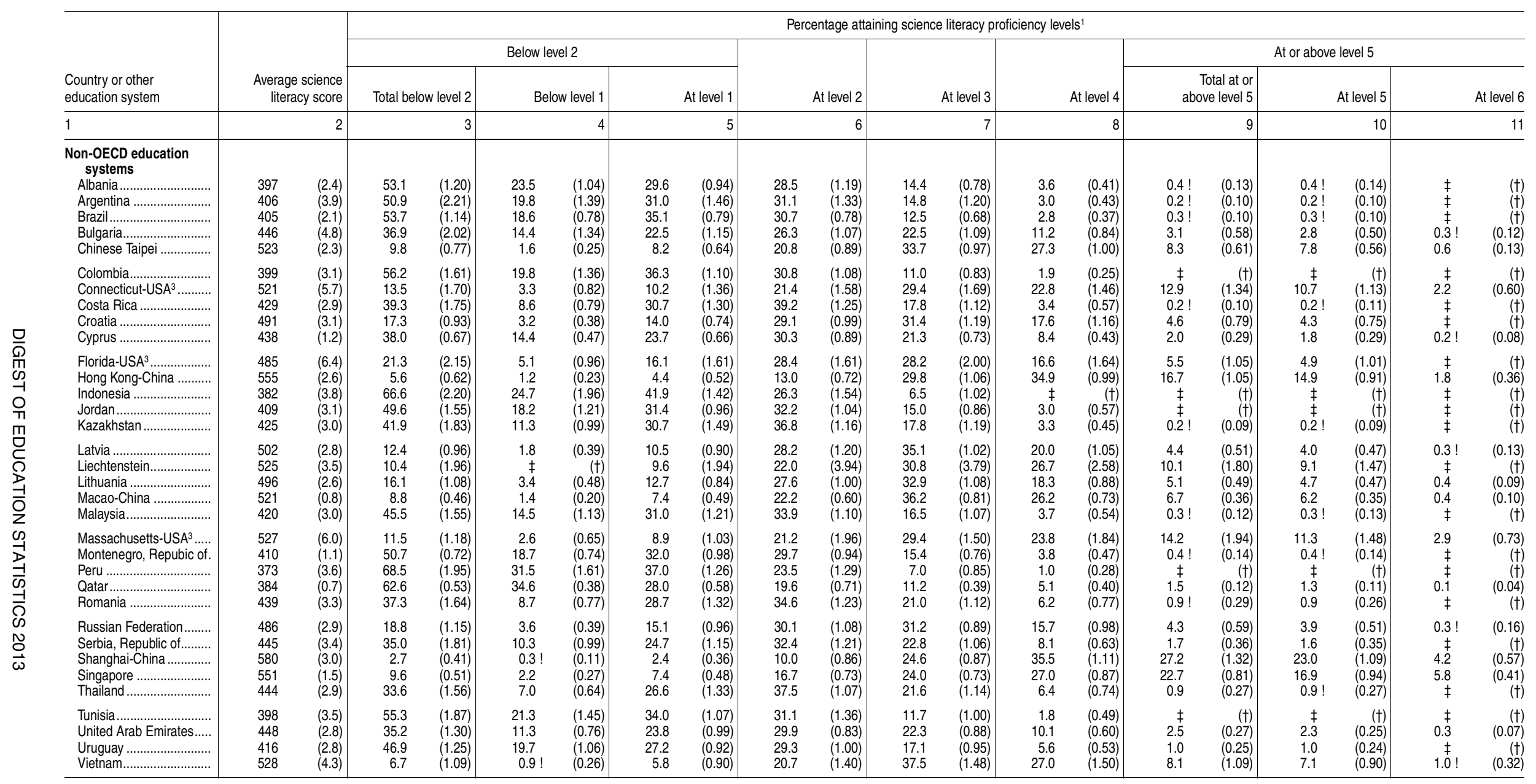

\section{†Not applicable.}

IInterpret data with caution. The coefficient of variation (CV) for this estimate is between 30 and 50 percent †Reporting standards not met. Either there are too few cases for a reliable estimate or the coefficient of variation (CV) is 50 percent or greater.

'To reach a particular proficiency level, a student must correctly answer a majority of items at that level. Students were classified into science literacy levels according to their scores. Exact cut scores are as follows: below level 1 (a score less than or equal to equal to 484.14); level 3 (a score greater than 484.14 and less than or equal to 558.73 ); level 4 (a score greater than 558.73 and less than or equal to 633.33); level 5 (a score greater than 633.33 and less than or equal to 707.93); and level 6 (a score greater

${ }^{2}$ Refers to the mean of the data values for all Organization for Economic Cooperation and Development (OECD) countries, to which each country contributes equally, regardless of the absolute size of the student population of each country.

NOTE: Program for International Student Assessment (PISA) scores are reported on a scale from 0 to 1,000. Detail may not sum to totals because of rounding.

Economic Cooperation and Development (OECD), Program for International Student Assessment (PISA) 2012. (This table was prepared November 2013.) 
Table 603.10. Percentage of the population 25 to 64 years old who completed high school, by age group and country: Selected years, 2001 through 2011

[Standard errors appear in parentheses]

\begin{tabular}{|c|c|c|c|c|c|c|c|c|c|c|c|c|c|c|c|c|c|c|}
\hline \multirow[b]{2}{*}{ Country } & \multicolumn{2}{|c|}{2001} & \multicolumn{2}{|c|}{2005} & \multicolumn{4}{|c|}{2010} & \multicolumn{10}{|c|}{2011} \\
\hline & $\begin{array}{r}\text { Total, } \\
25 \\
\text { to } 64 \\
\text { years } \\
\text { old }\end{array}$ & $\begin{array}{r}25 \text { to } \\
34 \\
\text { years } \\
\text { old }\end{array}$ & $\begin{array}{r}\text { Total, } \\
25 \\
\text { to } 64 \\
\text { years } \\
\text { old }\end{array}$ & $\begin{array}{r}25 \text { to } \\
34 \\
\text { years } \\
\text { old }\end{array}$ & $\begin{array}{l}\text { Tote } \\
64 \mathrm{y}\end{array}$ & $\begin{array}{l}\text { l, } 25 \text { to } \\
\text { ars old }\end{array}$ & & $\begin{array}{l}25 \text { to } 34 \\
\text { ears old }\end{array}$ & $\begin{array}{l}\text { Tote } \\
64 \mathrm{y}\end{array}$ & $\begin{array}{l}\text { al, } 25 \text { to } \\
\text { ears old }\end{array}$ & & $\begin{array}{l}25 \text { to } 34 \\
\text { ears old }\end{array}$ & & $\begin{array}{l}35 \text { to } 44 \\
\text { ears old }\end{array}$ & & $\begin{array}{l}75 \text { to } 54 \\
\text { ears old }\end{array}$ & & $\begin{array}{l}55 \text { to } 64 \\
\text { ears old }\end{array}$ \\
\hline 1 & 2 & 3 & 4 & 5 & & 6 & & 7 & & 8 & & 9 & & 10 & & 11 & & 12 \\
\hline OECD average $^{1} .$. & 64.2 & 74.0 & 72.8 & 82.6 & 74.0 & $(0.03)$ & 81.9 & $(0.06)$ & 74.8 & $(0.04)$ & 82.2 & $(0.07)$ & 78.5 & $(0.06)$ & 72.6 & $(0.07)$ & 63.8 & $\overline{(0.08)}$ \\
\hline $\begin{array}{l}\text { Australiaa } \\
\text { Austria } 2,3 \\
\text { Belgium }\end{array}$ & $\begin{array}{r}58.9 \\
75.7 \\
58.5 \\
81.9 \\
-\end{array}$ & $\begin{array}{l}70.7 \\
83.3 \\
75.3 \\
89.3 \\
-\end{array}$ & $\begin{array}{l}65.0 \\
80.6 \\
66.1 \\
85.2 \\
50.0\end{array}$ & $\begin{array}{l}78.6 \\
87.5 \\
80.9 \\
90.8 \\
64.3\end{array}$ & $\begin{array}{l}73.2 \\
82.5 \\
70.5 \\
88.4 \\
71.4\end{array}$ & $\begin{array}{l}(0.41) \\
(0.12) \\
(0.19) \\
(0.12) \\
(0.19)\end{array}$ & $\begin{array}{l}84.8 \\
88.0 \\
82.1 \\
92.2 \\
86.6\end{array}$ & $\begin{array}{l}(0.62) \\
(0.23) \\
(0.34) \\
(0.20) \\
(0.24)\end{array}$ & $\begin{array}{l}74.1 \\
82.5 \\
71.3 \\
88.8 \\
72.3\end{array}$ & $\begin{array}{l}(0.25) \\
(0.26) \\
(0.19) \\
(0.13) \\
(0.18)\end{array}$ & $\begin{array}{l}84.4 \\
88.2 \\
81.9 \\
92.5 \\
87.8\end{array}$ & $\begin{array}{l}(0.41) \\
(0.44) \\
(0.35) \\
(0.19) \\
(0.23)\end{array}$ & $\begin{array}{l}78.4 \\
86.0 \\
79.0 \\
91.8 \\
76.9\end{array}$ & $\begin{array}{l}(0.45) \\
(0.43) \\
(0.35) \\
(0.19) \\
(0.28)\end{array}$ & $\begin{array}{l}69.2 \\
81.9 \\
68.0 \\
87.8 \\
67.0\end{array}$ & $\begin{array}{l}(0.51) \\
(0.50) \\
(0.38) \\
(0.21) \\
(0.32)\end{array}$ & $\begin{array}{l}60.8 \\
72.3 \\
55.5 \\
82.8 \\
55.5\end{array}$ & $\begin{array}{l}(0.59) \\
(0.65) \\
(0.43) \\
(0.28) \\
(0.40)\end{array}$ \\
\hline 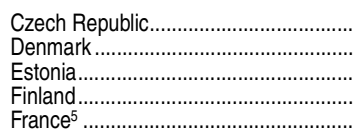 & $\begin{array}{r}86.2 \\
80.2 \\
-\overline{7} \\
73.8 \\
63.9\end{array}$ & $\begin{array}{r}92.5 \\
86.3 \\
-\overline{8} \\
78.8 \\
78.4\end{array}$ & $\begin{array}{l}89.9 \\
81.0 \\
89.1 \\
78.8 \\
66.3\end{array}$ & $\begin{array}{l}93.9 \\
87.4 \\
87.4 \\
89.4 \\
81.1\end{array}$ & $\begin{array}{l}91.9 \\
75.7 \\
89.1 \\
83.0 \\
70.8\end{array}$ & $\begin{array}{l}(0.08) \\
(0.17) \\
(0.30) \\
(0.12) \\
(0.09)\end{array}$ & $\begin{array}{l}94.2 \\
79.8 \\
86.4 \\
90.8 \\
83.8\end{array}$ & $\begin{array}{l}(0.14) \\
(0.42) \\
(0.73) \\
(0.20) \\
(0.16)\end{array}$ & $\begin{array}{l}92.3 \\
76.9 \\
88.9 \\
83.7 \\
71.6\end{array}$ & $\begin{array}{l}(0.07) \\
(0.17) \\
(0.29) \\
(0.18) \\
(0.09)\end{array}$ & $\begin{array}{l}94.3 \\
80.3 \\
85.7 \\
90.2 \\
83.3\end{array}$ & $\begin{array}{l}(0.14) \\
(0.38) \\
(0.71) \\
(0.31) \\
(0.16)\end{array}$ & $\begin{array}{l}95.5 \\
81.7 \\
89.3 \\
89.3 \\
78.3\end{array}$ & $\begin{array}{l}(0.11) \\
(0.30) \\
(0.55) \\
(0.31) \\
(0.16)\end{array}$ & $\begin{array}{l}92.6 \\
76.0 \\
93.8 \\
85.9 \\
67.7\end{array}$ & $\begin{array}{l}(0.15) \\
(0.30) \\
(0.42) \\
(0.32) \\
(0.17)\end{array}$ & $\begin{array}{l}86.6 \\
69.8 \\
86.6 \\
71.3 \\
57.6\end{array}$ & $\begin{array}{r}(0.18) \\
(0.36) \\
(0.64) \\
(0.41) \\
(0.19)\end{array}$ \\
\hline 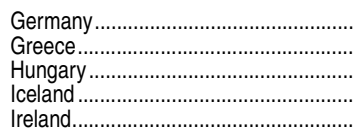 & $\begin{array}{l}82.6 \\
51.4 \\
70.2 \\
56.9 \\
57.6\end{array}$ & $\begin{array}{l}85.5 \\
72.6 \\
80.9 \\
61.2 \\
73.4\end{array}$ & $\begin{array}{l}83.1 \\
57.1 \\
76.4 \\
62.9 \\
64.5\end{array}$ & $\begin{array}{l}84.1 \\
73.6 \\
85.0 \\
69.0 \\
81.1\end{array}$ & $\begin{array}{l}85.8 \\
65.2 \\
81.3 \\
66.5 \\
73.5\end{array}$ & $\begin{array}{l}(0.06) \\
(0.12) \\
(0.10) \\
(0.50) \\
(0.12)\end{array}$ & $\begin{array}{l}86.5 \\
78.9 \\
86.3 \\
72.4 \\
86.9\end{array}$ & $\begin{array}{l}(0.12) \\
(0.21) \\
(0.19) \\
(0.92) \\
(0.18)\end{array}$ & $\begin{array}{l}86.3 \\
67.1 \\
81.8 \\
70.7 \\
73.4\end{array}$ & $\begin{array}{l}(0.12) \\
(0.12) \\
(0.27) \\
(0.48) \\
(0.13)\end{array}$ & $\begin{array}{l}86.8 \\
80.1 \\
87.3 \\
74.7 \\
85.0\end{array}$ & $\begin{array}{l}(0.21) \\
(0.22) \\
(0.32) \\
(0.90) \\
(0.20)\end{array}$ & $\begin{array}{l}86.9 \\
73.6 \\
83.3 \\
74.8 \\
79.8\end{array}$ & $\begin{array}{l}(0.30) \\
(0.23) \\
(0.41) \\
(0.93) \\
(0.22)\end{array}$ & $\begin{array}{l}87.0 \\
64.4 \\
80.7 \\
68.8 \\
68.4\end{array}$ & $\begin{array}{l}(0.28) \\
(0.24) \\
(0.46) \\
(0.94) \\
(0.27)\end{array}$ & $\begin{array}{l}84.1 \\
47.2 \\
75.3 \\
63.3 \\
52.3\end{array}$ & $\begin{array}{l}(0.31) \\
(0.26) \\
(0.50) \\
(1.09) \\
(0.33)\end{array}$ \\
\hline $\begin{array}{l}\text { Israel } \\
\text { Italy } \\
\text { Japan } \\
\text { Korea, Republic of } \\
\text { Luxembourg }\end{array}$ & $\begin{array}{r}-\overline{-} \\
43.3 \\
83.1 \\
68.0 \\
52.7\end{array}$ & $\begin{array}{r}- \\
57.5 \\
93.6 \\
94.6 \\
59.4\end{array}$ & $\begin{array}{r}79.2 \\
50.1 \\
75.5 \\
65.9\end{array}$ & $\begin{array}{l}85.7 \\
65.9 \\
97.3 \\
76.5\end{array}$ & $\begin{array}{r}82.1 \\
55.2 \\
-\overline{4} \\
77.7\end{array}$ & $\begin{array}{r}(0.15) \\
(0.08) \\
(\dagger) \\
(0.20) \\
(0.40)\end{array}$ & $\begin{array}{r}88.1 \\
71.0 \\
97.8 \\
84.0\end{array}$ & $\begin{array}{r}(0.24) \\
(0.18) \\
(\dagger) \\
(0.14) \\
(0.80)\end{array}$ & $\begin{array}{r}83.0 \\
56.0 \\
81 . \overline{1} \\
77.3\end{array}$ & $\begin{array}{r}(0.15) \\
(0.14) \\
(\dagger) \\
(0.20) \\
(0.40)\end{array}$ & $\begin{array}{r}89.7 \\
71.3 \\
98.0 \\
83.4\end{array}$ & $\begin{array}{r}(0.23) \\
(0.36) \\
(\dagger) \\
(0.14) \\
(0.76)\end{array}$ & $\begin{array}{r}84.6 \\
60.3 \\
-\overline{9} .6 \\
78.0\end{array}$ & $\begin{array}{r}(0.28) \\
(0.29) \\
(\dagger) \\
(0.19) \\
(0.71)\end{array}$ & $\begin{array}{r}79.5 \\
51.8 \\
-\overline{7} \\
75.4 \\
75.2\end{array}$ & $\begin{array}{r}(0.35) \\
(0.28) \\
(\dagger) \\
(0.42) \\
(0.77)\end{array}$ & $\begin{array}{r}74.2 \\
40.3 \\
-\overline{4} \\
70.9\end{array}$ & $\begin{array}{r}(0.41) \\
(0.28) \\
(\dagger) \\
(0.63) \\
(0.94)\end{array}$ \\
\hline $\begin{array}{l}\text { Mexico } \\
\text { Netherlands } 2,5 \\
\text { New Zealand. } \\
\text { Norway } \\
\text { Poland. }\end{array}$ & $\begin{array}{l}21.6 \\
65.0 \\
75.7 \\
85.2 \\
45.9\end{array}$ & $\begin{array}{l}25.4 \\
74.0 \\
81.8 \\
93.4 \\
51.7\end{array}$ & $\begin{array}{l}21.3 \\
71.8 \\
78.7 \\
77.2 \\
51.4\end{array}$ & $\begin{array}{l}24.0 \\
81.3 \\
85.2 \\
83.5 \\
62.5\end{array}$ & $\begin{array}{l}36.2 \\
73.0 \\
73.0 \\
80.6 \\
88.7\end{array}$ & $\begin{array}{l}(0.06) \\
(0.09) \\
(0.37) \\
(0.16) \\
(0.07)\end{array}$ & $\begin{array}{l}43.6 \\
82.7 \\
79.4 \\
83.0 \\
93.7\end{array}$ & $\begin{array}{l}(0.12) \\
(0.18) \\
(0.73) \\
(0.34) \\
(0.10)\end{array}$ & $\begin{array}{l}36.3 \\
72.3 \\
74.1 \\
81.9 \\
89.1\end{array}$ & $\begin{array}{l}(0.06) \\
(0.09) \\
(0.36) \\
(0.16) \\
(0.06)\end{array}$ & $\begin{array}{l}44.0 \\
81.7 \\
80.4 \\
83.8 \\
94.1\end{array}$ & $\begin{array}{l}(0.12) \\
(0.18) \\
(0.71) \\
(0.33) \\
(0.10)\end{array}$ & $\begin{array}{l}36.9 \\
77.2 \\
77.8 \\
84.6 \\
91.9\end{array}$ & $\begin{array}{l}(0.12) \\
(0.17) \\
(0.66) \\
(0.29) \\
(0.12)\end{array}$ & $\begin{array}{l}33.7 \\
70.6 \\
73.2 \\
77.6 \\
89.5\end{array}$ & $\begin{array}{l}(0.13) \\
(0.17) \\
(0.70) \\
(0.34) \\
(0.12)\end{array}$ & $\begin{array}{l}23.3 \\
60.3 \\
63.7 \\
81.4 \\
80.0\end{array}$ & $\begin{array}{l}(0.15) \\
(0.20) \\
(0.83) \\
(0.33) \\
(0.16)\end{array}$ \\
\hline $\begin{array}{l}\text { Portugal } \\
\text { Slovak Republic } \\
\text { Slovenia } \\
\text { Spain }\end{array}$ & $\begin{array}{r}19.9 \\
85.1 \\
-\overline{0} \\
40.0 \\
80.6\end{array}$ & $\begin{array}{r}32.5 \\
93.7 \\
-\overline{57.1} \\
90.7\end{array}$ & $\begin{array}{l}26.5 \\
85.7 \\
80.3 \\
48.8 \\
83.6\end{array}$ & $\begin{array}{l}42.8 \\
93.0 \\
91.2 \\
63.9 \\
90.6\end{array}$ & $\begin{array}{l}31.9 \\
91.0 \\
83.3 \\
52.9 \\
86.5\end{array}$ & $\begin{array}{l}(0.16) \\
(0.12) \\
(0.19) \\
(0.08) \\
(0.08)\end{array}$ & $\begin{array}{l}52.1 \\
94.1 \\
93.5 \\
64.7 \\
91.1\end{array}$ & $\begin{array}{l}(0.39) \\
(0.20) \\
(0.27) \\
(0.16) \\
(0.13)\end{array}$ & $\begin{array}{l}35.0 \\
91.3 \\
84.5 \\
54.0 \\
87.0\end{array}$ & $\begin{array}{l}(0.16) \\
(0.23) \\
(0.19) \\
(0.29) \\
(0.08)\end{array}$ & $\begin{array}{l}55.7 \\
94.1 \\
94.0 \\
64.8 \\
90.9\end{array}$ & $\begin{array}{l}(0.39) \\
(0.46) \\
(0.27) \\
(0.59) \\
(0.14)\end{array}$ & $\begin{array}{l}38.7 \\
94.1 \\
87.3 \\
61.1 \\
91.4\end{array}$ & $\begin{array}{l}(0.34) \\
(0.41) \\
(0.38) \\
(0.53) \\
(0.13)\end{array}$ & $\begin{array}{l}24.3 \\
91.7 \\
83.1 \\
50.0 \\
87.4\end{array}$ & $\begin{array}{l}(0.27) \\
(0.44) \\
(0.36) \\
(0.55) \\
(0.15)\end{array}$ & $\begin{array}{l}18.4 \\
84.1 \\
72.9 \\
33.8 \\
78.2\end{array}$ & $\begin{array}{l}(0.26) \\
(0.57) \\
(0.45) \\
(0.57) \\
(0.18)\end{array}$ \\
\hline 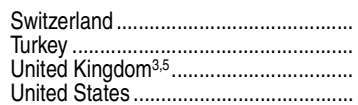 & $\begin{array}{l}87.4 \\
24.3 \\
63.0 \\
87.7\end{array}$ & $\begin{array}{l}91.8 \\
30.2 \\
68.0 \\
88.1\end{array}$ & $\begin{array}{l}83.0 \\
27.2 \\
66.7 \\
87.8\end{array}$ & $\begin{array}{l}87.9 \\
35.7 \\
72.9 \\
86.7\end{array}$ & $\begin{array}{l}86.1 \\
31.2 \\
75.1 \\
89.0\end{array}$ & $\begin{array}{l}(0.12) \\
(0.09) \\
(0.18) \\
(0.14)\end{array}$ & $\begin{array}{l}90.2 \\
42.2 \\
82.9 \\
88.4\end{array}$ & $\begin{array}{l}(0.24) \\
(0.18) \\
(0.35) \\
(0.24)\end{array}$ & $\begin{array}{l}85.6 \\
32.1 \\
76.8 \\
89.3\end{array}$ & $\begin{array}{l}(0.12) \\
(0.09) \\
(0.09) \\
(0.13)\end{array}$ & $\begin{array}{l}89.1 \\
43.5 \\
84.3 \\
89.0\end{array}$ & $\begin{array}{l}(0.24) \\
(0.18) \\
(0.17) \\
(0.25)\end{array}$ & $\begin{array}{l}87.4 \\
29.8 \\
80.3 \\
89.0\end{array}$ & $\begin{array}{l}(0.21) \\
(0.17) \\
(0.17) \\
(0.22)\end{array}$ & $\begin{array}{l}84.6 \\
24.6 \\
74.7 \\
89.3\end{array}$ & $\begin{array}{l}(0.23) \\
(0.17) \\
(0.18) \\
(0.25)\end{array}$ & $\begin{array}{l}80.7 \\
19.4 \\
66.7 \\
89.6\end{array}$ & $\begin{array}{r}(0.26) \\
(0.18) \\
(0.20) \\
(0.21)\end{array}$ \\
\hline $\begin{array}{l}\text { Other reporting countries } \\
\text { Brazil } \\
\text { Russian Federation } 6\end{array}$ & $88 . \overline{0}$ & $9 \overline{0}$ & $\begin{array}{r}29.5 \\
-\end{array}$ & $\begin{array}{r}38.0 \\
-\end{array}$ & - & $\begin{array}{l}(\dagger) \\
(t)\end{array}$ & - & $\begin{array}{l}(t) \\
(t)\end{array}$ & $\begin{array}{l}43.3 \\
94.1\end{array}$ & $\begin{array}{l}(0.11) \\
(0.05)\end{array}$ & $\begin{array}{l}56.7 \\
94.0\end{array}$ & $\begin{array}{l}(0.19) \\
(0.10)\end{array}$ & $\begin{array}{l}44.0 \\
95.2\end{array}$ & $\begin{array}{l}(0.21) \\
(0.10)\end{array}$ & $\begin{array}{l}36.4 \\
95.5\end{array}$ & $\begin{array}{l}(0.22) \\
(0.09)\end{array}$ & $\begin{array}{l}26.2 \\
91.0\end{array}$ & $\begin{array}{l}(0.25) \\
(0.15)\end{array}$ \\
\hline
\end{tabular}

-Not available.

†Not applicable.

${ }^{1}$ Refers to the mean of the data values for all reporting Organization for Economic Cooperation and Development (OECD) countries, to which each country reporting data contributes equally. The average includes all current OECD countries for which a given year's data are available, even if they were not members of OECD in that year.

2Data from 2000 reported for 2001.

${ }^{3}$ Data in 2005 columns include some International Standard Classification of Education (ISCED) 3C short programs.

${ }^{4}$ Data from 2004 reported for 2005.
${ }^{5}$ Data in 2001 columns include some ISCED 3C short programs ${ }^{6}$ Data from 2002 reported for 2001.

NOTE: Data in this table refer to degrees classified as International Standard Classification of Education (ISCED) level 3. ISCED level 3 corresponds to high school completion in the United States. ISCED 3C short programs do not correspond to high school completion; these short programs are excluded from this table except where otherwise noted. Standard errors are not available for 2001 and 2005

SOURCE: Organization for Economic Cooperation and Development (OECD), Education at a Glance, 2002, 2007, 2012, and 2013. (This table was prepared July 2013.) 


\begin{tabular}{|c|c|c|c|c|c|c|c|c|c|c|c|c|c|c|c|c|c|c|c|c|c|c|c|c|c|c|}
\hline \multirow[b]{3}{*}{ Country } & \multicolumn{6}{|c|}{ Total, any postsecondary degree } & \multicolumn{20}{|c|}{2011} \\
\hline & \multicolumn{2}{|c|}{2001} & \multicolumn{4}{|c|}{2011} & \multicolumn{10}{|c|}{ Vocational degree $^{1}$} & \multicolumn{10}{|c|}{ Bachelor's or higher degree ${ }^{2}$} \\
\hline & $\begin{array}{r}\text { Total, } \\
25 \\
\text { to } 64 \\
\text { years } \\
\text { old }\end{array}$ & $\begin{array}{r}25 \\
\text { to } 34 \\
\text { years } \\
\text { old }\end{array}$ & to $64 \mathrm{ye}$ & $\begin{array}{c}\text { otal, } 25 \\
\text { ears old }\end{array}$ & $34 \mathrm{ye}$ & $\begin{array}{r}25 \text { to } \\
\text { ears old }\end{array}$ & $\begin{array}{l}\text { Tote } \\
64 \mathrm{y}\end{array}$ & $\begin{array}{l}\text { lal, } 25 \text { to } \\
\text { ears old }\end{array}$ & $34 \mathrm{y}$ & $\begin{array}{r}25 \text { to } \\
\text { ars old }\end{array}$ & $44 \mathrm{ye}$ & $\begin{array}{l}35 \text { to } \\
\text { irs old }\end{array}$ & $54 \mathrm{ye}$ & $\begin{array}{l}45 \text { to } \\
\text { rs old }\end{array}$ & 64 ye & $\begin{array}{r}55 \text { to } \\
\text { ears old }\end{array}$ & $\begin{array}{l}\text { Tote } \\
64 \mathrm{y}\end{array}$ & $\begin{array}{l}\text { lal, } 25 \text { to } \\
\text { ears old }\end{array}$ & 34 ye & $\begin{array}{r}25 \text { to } \\
\text { ears old }\end{array}$ & $44 \mathrm{ye}$ & $\begin{array}{r}35 \text { to } \\
\text { ears old }\end{array}$ & 54 ye & $\begin{array}{r}45 \text { to } \\
\text { rears old }\end{array}$ & & $\begin{array}{r}55 \text { to } \\
\text { ears old }\end{array}$ \\
\hline 1 & 2 & 3 & & 4 & & 5 & & 6 & & 7 & & 8 & & 9 & & 10 & & 11 & & 12 & & 13 & & 14 & & 15 \\
\hline 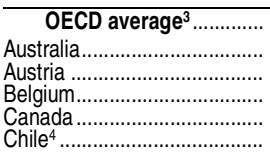 & $\begin{array}{l}22.6 \\
229.0 \\
14.1 \\
27.6 \\
41.6 \\
10.1\end{array}$ & $\begin{array}{l}27.3 \\
33.5 \\
14.3 \\
37.5 \\
50.5 \\
12.3\end{array}$ & $\begin{array}{l}31.5 \\
38.3 \\
19.3 \\
34.6 \\
51.3 \\
28.9\end{array}$ & $\begin{array}{l}(0.04) \\
(0.27) \\
0.24 \\
0.20) \\
0.22 \\
(0.18)\end{array}$ & $\begin{array}{l}38.6 \\
44.6 \\
21.2 \\
42.5 \\
56.7 \\
41.3\end{array}$ & $\begin{array}{l}(0.09) \\
(0.56 \\
0.60 \\
0.45 \\
0.39 \\
0.34)\end{array}$ & $\begin{array}{r}9.9 \\
10.4 \\
7.3 \\
17.6 \\
24.6 \\
12.1\end{array}$ & $\begin{array}{l}(0.03) \\
(0.17) \\
0.18 \\
0.16 \\
0.16 \\
0.13)\end{array}$ & $\begin{array}{r}10.3 \\
9.6 \\
5.5 \\
19.3 \\
25.6 \\
14.5\end{array}$ & \begin{tabular}{l|}
$(0.06)$ \\
0.33 \\
0.36 \\
0.36 \\
0.33 \\
$0.23)$
\end{tabular} & $\begin{aligned} 10.9 \\
11.1 \\
7.5 \\
19.9 \\
26.4 \\
15.1\end{aligned}$ & \begin{tabular}{l|}
$(0.06)$ \\
$(0.34)$ \\
$0.26)$ \\
0.34 \\
0.31 \\
$0.22)$
\end{tabular} & $\begin{aligned} 10.0 \\
11.7 \\
8.3 \\
17.1 \\
25.1 \\
11.2\end{aligned}$ & \begin{tabular}{l|}
$(0.06)$ \\
$(0.36)$ \\
0.23 \\
0.31 \\
$0.27)$ \\
$0.20)$
\end{tabular} & $\begin{array}{r}8.3 \\
9.1 \\
7.7 \\
13.7 \\
20.8 \\
6.5\end{array}$ & $\begin{array}{l}(0.06) \\
(0.35) \\
0.38 \\
0.30 \\
0.27 \\
0.18)\end{array}$ & $\begin{array}{l}\mathbf{2 2 . 8} \\
27.9 \\
12.0 \\
17.0 \\
26.8 \\
16.8\end{array}$ & $\begin{array}{l}(0.04) \\
(0.25) \\
0.18 \\
0.16 \\
0.23 \\
0.15)\end{array}$ & $\begin{array}{l}29.5 \\
35.0 \\
15.7 \\
23.1 \\
31.1 \\
26.8\end{array}$ & $\begin{array}{l}(0.08) \\
(0.53) \\
0.49 \\
0.39 \\
0.41 \\
0.30)\end{array}$ & $\begin{array}{l}24.7 \\
29.9 \\
13.8 \\
19.5 \\
31.6 \\
14.7\end{array}$ & \begin{tabular}{l|}
$(0.07)$ \\
$(0.50)$ \\
0.42 \\
0.34 \\
0.40 \\
$0.23)$
\end{tabular} & $\begin{array}{l}19.4 \\
23.6 \\
10.4 \\
14.2 \\
22.9 \\
11.5\end{array}$ & $\begin{array}{l}(0.07) \\
(0.47) \\
0.35 \\
0.28 \\
0.32 \\
0.22)\end{array}$ & $\begin{aligned} 16.6 \\
21.1 \\
7.9 \\
11.4 \\
21.8 \\
14.9\end{aligned}$ & $\begin{array}{l}(0.07) \\
(0.50) \\
0.34) \\
0.27 \\
0.34) \\
(0.28)\end{array}$ \\
\hline 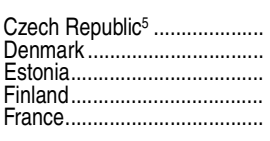 & $\begin{array}{l}11.1 \\
26.8 \\
32.3 \\
23.0\end{array}$ & $\begin{array}{l}11.3 \\
27.5 \\
38.2 \\
34.2\end{array}$ & $\begin{array}{l}18.2 \\
33.7 \\
36.7 \\
39.3 \\
29.8\end{array}$ & $\left.\begin{array}{l}(0.11) \\
0.19 \\
0.45 \\
0.24 \\
0.09\end{array}\right)$ & $\begin{array}{l}25.1 \\
38.6 \\
39.0 \\
39.4 \\
43.0\end{array}$ & $\begin{array}{l}(0.26) \\
0.47 \\
0.99 \\
0.50 \\
0.21)\end{array}$ & $\begin{array}{r}{[5]} \\
5.6 \\
12.1 \\
14.4 \\
11.5\end{array}$ & 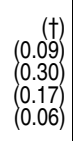 & $\begin{array}{r}{[5]} \\
5.4 \\
12.3 \\
1.6 \\
16.0\end{array}$ & $\begin{array}{l}(0.22 \\
0.67 \\
0.13 \\
0.16)\end{array}$ & $\begin{array}{r}{\left[{ }^{5}\right]} \\
6.4 \\
11.7 \\
16.7 \\
14.3\end{array}$ & 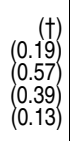 & $\begin{array}{r}{\left[{ }^{5}\right]} \\
5.6 \\
13.1 \\
21.7 \\
9.3\end{array}$ & 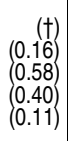 & $\begin{array}{r}{[5]} \\
5.0 \\
11.1 \\
16.6 \\
6.5\end{array}$ & 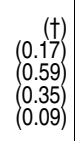 & $\begin{array}{l}18.2 \\
28.1 \\
24.6 \\
24.9 \\
18.3\end{array}$ & $\begin{array}{l}(0.11) \\
0.18 \\
0.40 \\
0.21 \\
0.07)\end{array} \mid$ & $\begin{array}{l}25.1 \\
33.2 \\
26.7 \\
37.8 \\
27.0\end{array}$ & $\left.\begin{array}{l}(0.26) \\
0.45 \\
0.90 \\
0.50) \\
0.19\end{array}\right)$ & $\begin{array}{l}17.9 \\
31.1 \\
23.4 \\
30.1 \\
21.3\end{array}$ & $\begin{array}{l}(0.21) \\
0.36 \\
0.75 \\
0.48 \\
0.16)\end{array}$ & $\begin{array}{l}17.1 \\
25.9 \\
24.2 \\
19.4 \\
13.2\end{array}$ & $\begin{array}{l}0.22 \\
0.31 \\
0.74 \\
0.39 \\
0.13)\end{array}$ & $\begin{array}{l}12.1 \\
22.9 \\
24.1 \\
14.7 \\
12.1\end{array}$ & $\begin{array}{l}0.17) \\
0.33 \\
0.81 \\
0.33 \\
0.12\end{array}$ \\
\hline 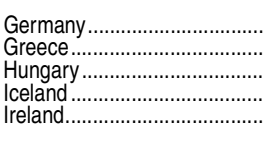 & $\begin{array}{l}23.2 \\
17.8 \\
14.1 \\
24.8 \\
35.6\end{array}$ & $\begin{array}{l}21.8 \\
24.0 \\
14.7 \\
26.6 \\
47.8\end{array}$ & $\begin{array}{l}27.6 \\
26.1 \\
21.1 \\
33.9 \\
37.7\end{array}$ & $\begin{array}{l}(0.08) \\
0.12 \\
0.26 \\
(0.50) \\
0.14)\end{array}$ & $\begin{array}{l}27.7 \\
32.5 \\
28.1 \\
39.4 \\
47.2\end{array}$ & $\begin{array}{l}(0.19) \\
0.26 \\
0.44 \\
1.01 \\
0.28)\end{array}$ & $\begin{array}{r}11.2 \\
7.7 \\
0.6 \\
3.9 \\
14.7\end{array}$ & $\begin{array}{l}(0.06) \\
0.07) \\
0.04 \\
(0.20) \\
0.10)\end{array}$ & $\begin{array}{r}9.4 \\
11.8 \\
1.6 \\
2.5 \\
16.1\end{array}$ & $\begin{array}{l}(0.11) \\
0.18 \\
0.11 \\
0.32 \\
0.20)\end{array}$ & $\begin{array}{r}11.4 \\
8.7 \\
0.5 \\
4.9 \\
17.5\end{array}$ & $\left.\begin{array}{l}(0.12) \\
0.14 \\
0.07 \\
0.47 \\
0.20)\end{array}\right)$ & $\begin{array}{r}12.4 \\
6.3 \\
0.3 \\
4.1 \\
13.4\end{array}$ & $\begin{array}{c}(0.11) \\
0.12 \\
(\dagger) \\
(0.40) \\
0.20)\end{array}$ & $\begin{array}{r}11.2 \\
3.4 \\
\ddagger \\
3.9 \\
9.9\end{array}$ & $\left.\begin{array}{c}(0.12) \\
0.09 \\
(t) \\
(0.44) \\
0.19\end{array}\right)$ & $\begin{array}{l}16.4 \\
18.3 \\
20.5 \\
30.0 \\
23.1\end{array}$ & $\begin{array}{l}(0.07) \\
0.10 \\
0.26 \\
(0.49 \\
0.12)\end{array}$ & $\begin{array}{l}18.3 \\
20.7 \\
26.5 \\
36.9 \\
31.1\end{array}$ & $\begin{array}{l}(0.16) \\
0.23 \\
0.43 \\
(0.99) \\
0.26)\end{array}$ & $\begin{array}{l}17.5 \\
19.1 \\
20.9 \\
34.2 \\
25.9\end{array}$ & $\begin{array}{l}(0.14) \\
0.20 \\
0.44 \\
(1.22) \\
(0.24)\end{array}$ & $\begin{array}{l}15.0 \\
17.9 \\
17.7 \\
27.0 \\
17.5\end{array}$ & $\begin{array}{l}(0.12) \\
0.19 \\
0.47 \\
0.90 \\
0.22)\end{array}$ & $\begin{array}{l}15.0 \\
15.1 \\
16.3 \\
20.1 \\
12.9\end{array}$ & $\begin{array}{l}(0.14) \\
0.19 \\
0.48 \\
0.91 \\
0.22)\end{array}$ \\
\hline 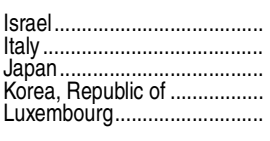 & $\begin{array}{l}10.0 \\
33.8 \\
24.2 \\
18.1\end{array}$ & $\begin{array}{l}11.8 \\
47.7 \\
39.5 \\
23.4\end{array}$ & $\begin{array}{l}46.4 \\
14.9 \\
46.4 \\
40.4 \\
37.0\end{array}$ & $\begin{array}{l}(0.20) \\
0.08) \\
(0.19 \\
(0.25) \\
0.46)\end{array}$ & $\begin{array}{l}45.0 \\
21.0 \\
58.7 \\
63.8 \\
46.6\end{array}$ & $\left.\begin{array}{l}(0.38) \\
0.20 \\
(0.40) \\
0.46 \\
(1.02)\end{array}\right)$ & $\begin{array}{r}15.4 \\
0.3 \\
20.1 \\
12.6 \\
12.0\end{array}$ & 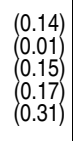 & $\begin{array}{r}13.4 \\
0.2 \\
23.8 \\
24.9 \\
14.5\end{array}$ & $\left.\begin{array}{l}0.02 \\
0.35 \\
0.43 \\
0.72\end{array}\right)$ & $\begin{array}{r}15.5 \\
0.3 \\
24.7 \\
14.9 \\
12.8\end{array}$ & $\begin{array}{l}0.02 \\
0.33 \\
0.31 \\
0.57)\end{array} \mid$ & $\begin{array}{r}16.5 \\
0.5 \\
20.3 \\
6.1 \\
10.5\end{array}$ & $\begin{array}{l}(0.30) \\
0.02 \\
0.34 \\
0.22 \\
0.55)\end{array} \mid$ & $\begin{array}{r}17.1 \\
0.3 \\
12.2 \\
2.1 \\
9.6\end{array}$ & $\left.\begin{array}{l}0.02 \\
0.02 \\
0.16 \\
0.611\end{array}\right)$ & $\begin{array}{l}31.0 \\
14.6 \\
26.3 \\
27.8 \\
25.1\end{array}$ & $\left.\begin{array}{l}0.08 \\
0.173 \\
0.23 \\
0.41\end{array}\right)$ & $\begin{array}{l}31.6 \\
20.7 \\
34.9 \\
38.9 \\
32.2\end{array}$ & $\left.\begin{array}{l}0.20 \\
0.39 \\
0.47 \\
0.96\end{array}\right)$ & $\begin{array}{l}34.1 \\
16.3 \\
26.5 \\
34.6 \\
27.1\end{array}$ & $\begin{array}{l}(0.37) \\
0.16 \\
0.33 \\
(0.44) \\
0.76)\end{array}$ & $\begin{array}{l}28.8 \\
11.0 \\
26.7 \\
21.8 \\
20.7\end{array}$ & $\begin{array}{l}(0.37) \\
0.14 \\
0.37 \\
0.40 \\
0.73)\end{array}$ & $\begin{array}{l}28.2 \\
10.5 \\
18.5 \\
10.7 \\
18.7\end{array}$ & $\begin{array}{l}0.15 \\
0.36 \\
(0.40 \\
0.80\end{array}$ \\
\hline 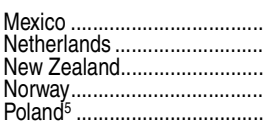 & $\begin{array}{l}15.0 \\
23.2 \\
29.2 \\
30.2 \\
11.9\end{array}$ & $\begin{array}{l}17.9 \\
26.5 \\
28.5 \\
37.9 \\
15.2\end{array}$ & $\begin{array}{l}17.3 \\
32.0 \\
39.3 \\
38.1 \\
23.7\end{array}$ & $\begin{array}{r}(\#) \\
\left(\begin{array}{l}(\#) \\
0.41 \\
(0.20 \\
0.09\end{array}\right)\end{array}$ & $\begin{array}{l}22.5 \\
39.8 \\
46.0 \\
46.8 \\
39.2\end{array}$ & $\begin{array}{l}(\#) \\
(0.23) \\
0.90 \\
0.45 \\
0.21)\end{array}$ & $\begin{array}{r}1.1 \\
2.5 \\
15.5 \\
2.2 \\
{[5]}\end{array}$ & $\begin{array}{r}(\#) \\
(0.03 \\
0.30 \\
0.06 \\
(\dagger)\end{array}$ & $\begin{array}{r}1.2 \\
2.2 \\
14.6 \\
1.1 \\
{[5]}\end{array}$ & $\begin{array}{r}(\#) \\
0.07 \\
0.64 \\
0.09 \\
(\dagger)\end{array}$ & $\begin{array}{r}1.1 \\
2.9 \\
14.8 \\
2.2 \\
{[5]}\end{array}$ & $\begin{array}{r}(\#) \\
(0.07 \\
0.57 \\
0.12 \\
(+)\end{array}$ & $\begin{array}{r}1.2 \\
2.8 \\
16.4 \\
2.9 \\
{[5]}\end{array}$ & $\begin{array}{r}(\#) \\
(0.06 \\
0.58 \\
0.14 \\
(\dagger)\end{array}$ & $\begin{array}{r}0.7 \\
2.2 \\
16.2 \\
2.8 \\
{[5]}\end{array}$ & 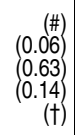 & $\begin{array}{l}16.2 \\
29.5 \\
23.8 \\
35.8 \\
23.7\end{array}$ & $\left.\begin{array}{r}(\#) \\
(0.09 \\
0.35 \\
(0.20) \\
0.09\end{array}\right)$ & $\begin{array}{l}21.3 \\
37.6 \\
31.4 \\
45.7 \\
39.2\end{array}$ & 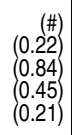 & $\begin{array}{l}14.3 \\
31.3 \\
26.2 \\
39.4 \\
24.4\end{array}$ & $\left.\begin{array}{c}(\#) \\
(0.19 \\
0.70 \\
(0.39 \\
0.19\end{array}\right)$ & $\begin{array}{l}15.1 \\
26.5 \\
20.4 \\
31.0 \\
15.6\end{array}$ & $\begin{array}{r}(\#) \\
(0.16 \\
0.64) \\
0.38 \\
0.15)\end{array}$ & $\begin{array}{l}11.3 \\
23.6 \\
16.5 \\
26.5 \\
12.8\end{array}$ & $\left.\begin{array}{r}(\#) \\
0.17 \\
0.64 \\
0.37 \\
0.13\end{array}\right)$ \\
\hline 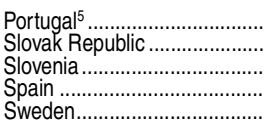 & $\begin{array}{r}9.0 \\
10.9 \\
23.6 \\
31.6\end{array}$ & $\begin{array}{r}13.7 \\
11.9 \\
35.5 \\
36.9\end{array}$ & $\begin{array}{l}17.3 \\
18.8 \\
25.1 \\
31.6 \\
35.2\end{array}$ & $\begin{array}{l}(0.13) \\
0.32 \\
0.23 \\
0.27 \\
0.11)\end{array}$ & $\begin{array}{l}26.9 \\
25.7 \\
33.8 \\
39.2 \\
42.9\end{array}$ & $\begin{array}{l}(0.35) \\
0.86 \\
0.53 \\
0.60 \\
0.23)\end{array}$ & $\begin{array}{r}{[5]} \\
1.3 \\
11.2 \\
9.3 \\
9.0\end{array}$ & $\begin{array}{r}(\dagger) \\
(0.09) \\
0.17 \\
0.17 \\
0.07)\end{array}$ & $\begin{array}{r}{[5]} \\
1.3 \\
12.6 \\
12.4 \\
8.6\end{array}$ & $\left.\begin{array}{r}(\dagger) \\
0.22 \\
0.37 \\
0.41 \\
0.13\end{array}\right)$ & $\begin{array}{r}{[5]} \\
1.2 \\
11.6 \\
11.6 \\
8.5\end{array}$ & 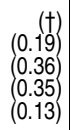 & $\begin{array}{r}{[5]} \\
1.4 \\
11.7 \\
7.3 \\
9.2\end{array}$ & 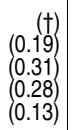 & $\begin{array}{r}{[5]} \\
1.2 \\
8.7 \\
4.1 \\
9.7\end{array}$ & $\left.\begin{array}{r}(t) \\
(0.17) \\
0.29 \\
0.24 \\
0.13\end{array}\right)$ & $\begin{array}{l}17.3 \\
17.5 \\
13.9 \\
22.3 \\
26.2\end{array}$ & $\begin{array}{l}(0.13) \\
0.31 \\
0.18 \\
0.24 \\
0.10)\end{array}$ & $\begin{array}{l}26.9 \\
24.4 \\
21.2 \\
26.7 \\
34.2\end{array}$ & $\begin{array}{l}(0.35) \\
0.85 \\
0.46 \\
0.54 \\
0.22)\end{array}$ & $\begin{array}{l}18.6 \\
16.1 \\
16.5 \\
25.5 \\
30.5\end{array}$ & $\left.\begin{array}{l}(0.27) \\
(0.63) \\
0.42 \\
0.47 \\
0.21)\end{array}\right)$ & $\begin{array}{l}11.5 \\
14.9 \\
10.1 \\
19.8 \\
21.4\end{array}$ & $\left.\begin{array}{l}0.20) \\
0.57 \\
0.29 \\
0.43 \\
0.19\end{array}\right)$ & $\begin{array}{r}10.9 \\
12.7 \\
7.7 \\
14.5 \\
18.5\end{array}$ & $\left.\begin{array}{l}(0.21) \\
0.52 \\
0.27 \\
0.42 \\
0.17\end{array}\right)$ \\
\hline 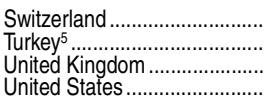 & $\begin{array}{r}25.4 \\
8.9 \\
26.0 \\
37.3 \\
\end{array}$ & $\begin{array}{l}25.6 \\
10.2 \\
30.0 \\
39.1 \\
\end{array}$ & $\begin{array}{l}35.2 \\
14.0 \\
39.4 \\
42.4 \\
\end{array}$ & $\begin{array}{l}(0.16) \\
0.07 \\
0.10 \\
(0.22) \\
\end{array}$ & $\begin{array}{l}39.8 \\
18.9 \\
46.9 \\
43.1 \\
\end{array}$ & $\left.\begin{array}{l}0.38 \\
0.14 \\
0.23 \\
0.46\end{array}\right)$ & $\begin{array}{r}10.7 \\
{[5]} \\
9.8 \\
10.3 \\
\end{array}$ & $\begin{array}{l}(0.10) \\
(\dagger \\
\left(\begin{array}{l}06 \\
0.11\end{array}\right) \\
\end{array}$ & $\begin{array}{r}9.5 \\
{[5]} \\
7.6 \\
10.1 \\
\end{array}$ & $\begin{array}{l}(0.23) \\
(+) \\
(0.12 \\
0.24) \\
\end{array}$ & $\begin{array}{r}11.8 \\
{[5]} \\
10.6 \\
10.4 \\
\end{array}$ & $\begin{array}{l}(0.20) \\
(+) \\
(0.13 \\
0.22) \\
\end{array}$ & $\begin{array}{r}11.5 \\
11.7 \\
11.7 \\
10.7 \\
\end{array}$ & $\begin{array}{l}(0.20) \\
(+1) \\
(0.13 \\
(0.21) \\
\end{array}$ & $\begin{array}{l}9.4 \\
{[5]} \\
9.3 \\
9.8 \\
\end{array}$ & $\begin{array}{l}(0.19) \\
(+) \\
\left(\begin{array}{l}12 \\
0.25\end{array}\right) \\
\end{array}$ & $\begin{array}{l}24.5 \\
14.0 \\
29.6 \\
32.2 \\
\end{array}$ & $\left(\begin{array}{l}0.14 \\
0.07 \\
0.10)\end{array}\right.$ & $\begin{array}{l}30.3 \\
18.9 \\
39.3 \\
33.0 \\
\end{array}$ & $\left.\begin{array}{l}(0.35) \\
(0.14) \\
0.22 \\
0.15\end{array}\right)$ & $\begin{array}{l}27.7 \\
13.5 \\
32.0 \\
34.2 \\
\end{array}$ & $\begin{array}{l}(0.28) \\
0.13 \\
(0.20) \\
(0.40) \\
\end{array}$ & $\begin{array}{r}21.9 \\
9.5 \\
24.1 \\
30.2 \\
\end{array}$ & $\begin{array}{l}(0.26) \\
0.12 \\
0.18 \\
(0.39) \\
\end{array}$ & $\begin{array}{r}17.7 \\
9.8 \\
22.0 \\
31.4 \\
\end{array}$ & $\begin{array}{l}(0.25) \\
0.14 \\
0.18 \\
0.39 \\
\end{array}$ \\
\hline 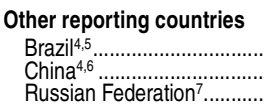 & $\begin{array}{r}7.7 \\
4.6 \\
54.0\end{array}$ & $\begin{array}{r}6.7 \\
6.1 \\
55.5\end{array}$ & $\begin{array}{r}11.6 \\
3.6 \\
53.5\end{array}$ & $\begin{array}{r}(0.07) \\
\left(\begin{array}{l}+ \\
(t\end{array}\right)\end{array}$ & $\begin{array}{l}12.7 \\
56.5\end{array}$ & $\begin{array}{r}(0.12 \\
\left(\begin{array}{l}0 \\
\dagger\end{array}\right)\end{array}$ & $\frac{[5]}{26.4}$ & $(\dagger)$ & $\frac{[5]}{22.4}$ & $\begin{array}{c}\left(\begin{array}{l}0 \\
+ \\
+\end{array}\right) \\
0\end{array}$ & $\frac{[5]}{26.9}$ & $\left(\begin{array}{c}+ \\
+ \\
+\end{array}\right)$ & $\frac{\left[{ }^{[}\right]}{28.4}$ & $\left(\begin{array}{c}+ \\
+ \\
+\end{array}\right)$ & $\frac{[5]}{28.7}$ & $\left.\begin{array}{l}(t) \\
+ \\
+\end{array}\right)$ & $\begin{array}{l}11.6 \\
27.1\end{array}$ & $\begin{array}{r}\left(\begin{array}{c}0.07 \\
+ \\
+\end{array}\right) \\
\left(\begin{array}{l}t \\
)\end{array}\right)\end{array}$ & $\begin{array}{l}12.7 \\
34.1\end{array}$ & 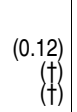 & $\begin{array}{l}11.8 \\
27.9\end{array}$ & $\left.\begin{array}{r}0.13 \\
+ \\
+\end{array}\right)$ & $\begin{array}{l}11.4 \\
23.9\end{array}$ & $\left.\begin{array}{r}0.14 \\
(\dagger \\
(\dagger\end{array}\right)$ & $\frac{9.5}{20.8}$ & $\left.\begin{array}{r}(0.16 \\
(+) \\
(\dagger\end{array}\right)$ \\
\hline
\end{tabular}

\section{- Not available.}

†Not applicable.
\#Rounds to zero.

fReporting standards not met (too few cases for a reliable estimate).

The vocational degree data in this table refer to degrees classified as International Standard Classification of Education (ISCED) level 5B. ISCED level 5B corresponds to the associate's degree in the United States.

2The data for bachelor's degree or higher in this table refer to degrees classified as ISCED level 5 A (first and second award) and as level 6. ISCED 5A, first award, corresponds to the bachelor's degree in the United States; ISCED 5A, second
master's and first-professional degrees in the United States; and ISCED 6 corresponds to doctor's degrees.
${ }^{3}$ Refers to the mean of the data values for all reporting Organization for Economic Cooperation and Development (OECD) countries, to which each country reporting data contributes equally. The average includes all current OECD countries for which a given year's data are aval
${ }^{4}$ Data from 2000 reported for 2001.

${ }^{5}$ Columns for bachelor's or higher degree include vocational degree data. 'Data from 2010 reported for 2011.

NOTE: Standard errors are not available for 2001.

SOURCE: Organization for Economic Cooperation and Development (OECD), Education at a Glance, 2002 and 2013. (This table was prepared July 2013.) 
Table 603.30. Percentage of the population 25 to 64 years old who attained a bachelor's or higher level degree, by age group and country: Selected years, 1999 through 2011

[Standard errors appear in parentheses]

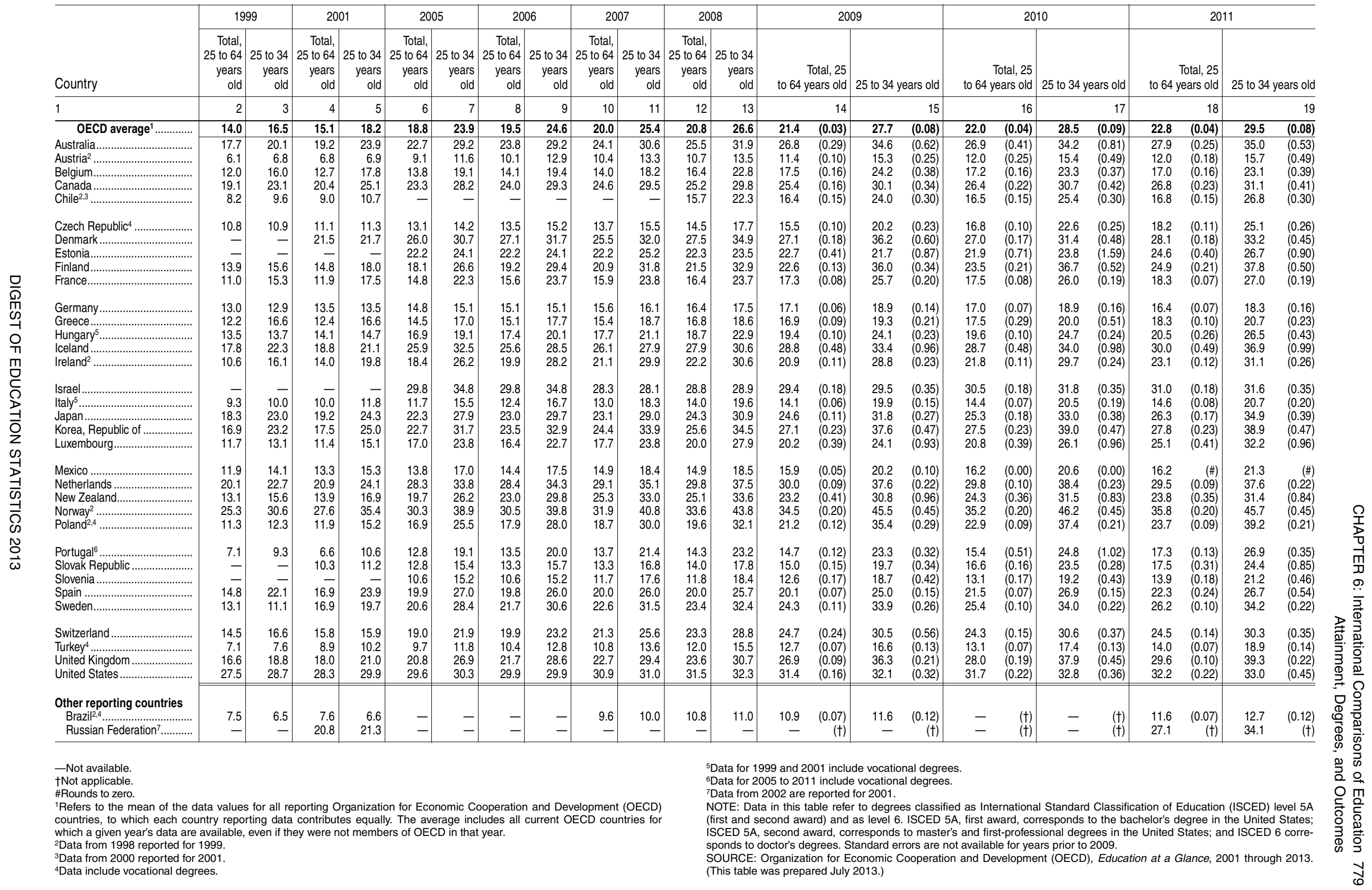


Table 603.40. Percentage of the population 25 to 64 years old who attained a postsecondary vocational degree, by age group and country: Selected years, 1999 through 2011

[Standard errors appear in parentheses]

\begin{tabular}{|c|c|c|c|c|c|c|c|c|c|c|c|c|c|c|c|c|c|c|c|c|c|c|c|c|}
\hline \multirow[b]{2}{*}{ Country } & \multicolumn{2}{|c|}{1999} & \multicolumn{2}{|c|}{2001} & \multicolumn{2}{|c|}{2005} & \multicolumn{2}{|c|}{2006} & \multicolumn{2}{|c|}{2007} & \multicolumn{2}{|c|}{2008} & \multicolumn{4}{|c|}{2009} & \multicolumn{4}{|c|}{2010} & \multicolumn{4}{|c|}{2011} \\
\hline & \begin{tabular}{|r|} 
Total, \\
25 to 64 \\
years \\
old
\end{tabular} & $\begin{array}{r}25 \text { to } 34 \\
\text { years } \\
\text { old }\end{array}$ & \begin{tabular}{|r|} 
Total, \\
25 to 64 \\
years \\
old
\end{tabular} & $\begin{array}{r}25 \text { to } 34 \\
\text { years } \\
\text { old }\end{array}$ & $\begin{array}{r}\text { Total, } \\
25 \text { to } 64 \\
\text { years } \\
\text { old }\end{array}$ & $\begin{array}{r}25 \text { to } 34 \\
\text { years } \\
\text { old }\end{array}$ & $\begin{array}{r}\text { Total, } \\
25 \text { to } 64 \\
\text { years } \\
\text { old }\end{array}$ & $\begin{array}{r}25 \text { to } 34 \\
\text { years } \\
\text { old }\end{array}$ & \begin{tabular}{|r|} 
Total, \\
25 to 64 \\
years \\
old
\end{tabular} & $\begin{array}{r}25 \text { to } 34 \\
\text { years } \\
\text { old }\end{array}$ & $\begin{array}{r}\text { Total, } \\
25 \text { to } 64 \\
\text { years } \\
\text { old }\end{array}$ & $\begin{array}{r}25 \text { to } 34 \\
\text { years } \\
\text { old }\end{array}$ & to $64 \mathrm{y}$ & $\begin{array}{l}\text { Total, } 25 \\
\text { eears old }\end{array}$ & 25 to 34 & ears old & to $64 \mathrm{y}$ & $\begin{array}{l}\text { Total, } 25 \\
\text { eears old }\end{array}$ & 25 to 34 & ears old & to $64 \mathrm{y}$ & $\begin{array}{l}\text { Total, } 25 \\
\text { eears old }\end{array}$ & 25 to 34 & ears old \\
\hline 1 & 2 & 3 & 4 & 5 & 6 & 7 & 8 & 9 & 10 & 11 & 12 & 13 & & 14 & & 15 & & 16 & & 17 & & 18 & & 19 \\
\hline OECD average 1 ................. & 8.4 & 10.5 & 8.9 & 10.8 & 8.6 & 9.6 & 9.0 & 10.0 & 9.4 & 10.1 & 9.7 & 10.4 & 10.4 & $(0.03)$ & 11.0 & $(0.07)$ & 10.2 & $(0.03)$ & 10.9 & $(0.07)$ & 9.9 & $(0.03)$ & 10.3 & $(0.06)$ \\
\hline Australia..... & 9.0 & 8.8 & 9.7 & 9.7 & 9.0 & 8.9 & 9.2 & 9.6 & 9.6 & 10.2 & 10.1 & 9.8 & 10.1 & $(0.20)$ & 10.2 & $(0.39)$ & 10.7 & $(0.29)$ & 10.2 & $(0.52)$ & 10.4 & $(0.17)$ & 9.6 & $(0.33)$ \\
\hline 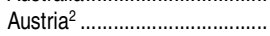 & 4.7 & 5.8 & 7.3 & 7.4 & 8.7 & 8.1 & 7.5 & 6.3 & 7.2 & 5.6 & 7.4 & 5.9 & 7.6 & $(0.08)$ & 5.8 & $(0.16)$ & 7.3 & $(0.19)$ & 5.4 & $(0.29)$ & 7.3 & $(0.18)$ & 5.5 & $(0.36)$ \\
\hline Belgium & 13.9 & 17.9 & 14.9 & 19.7 & 17.3 & 21.5 & 17.7 & 22.5 & 18.1 & 23.1 & 15.9 & 19.5 & 15.9 & $(0.15)$ & 18.3 & $(0.34)$ & 17.8 & $(0.16)$ & 20.5 & $(0.36)$ & 17.6 & $(0.16)$ & 19.3 & $(0.36)$ \\
\hline Canada …………………......... & 20.2 & 23.7 & 21.2 & 25.4 & 22.8 & 25.6 & 22.9 & 25.5 & 23.7 & 26.3 & 23.6 & 26.1 & 24.1 & $(0.16)$ & 26.0 & $(0.32)$ & 24.2 & $(0.17)$ & 25.8 & $(0.38)$ & 24.6 & $(0.16)$ & 25.6 & $(0.33)$ \\
\hline Chile $^{2.3 .4} \ldots \ldots \ldots \ldots \ldots \ldots \ldots \ldots \ldots$ & 0.9 & 1.4 & 1.0 & 1.6 & 2.8 & 4.1 & - & - & - & - & 8.5 & 11.5 & 8.0 & $(0.11)$ & 11.0 & $(0.22)$ & 10.3 & $(0.13)$ & 13.1 & $(0.23)$ & 12.1 & $(0.13)$ & 14.5 & $(0.23)$ \\
\hline Denmark & - & - & 5.3 & 5.8 & 7.6 & 9.1 & 7.6 & 9.1 & 6.7 & 8.1 & 7.0 & 8.2 & 7.2 & $(0.11)$ & 8.5 & $(0.35)$ & 6.3 & $(0.10)$ & 6.2 & $(0.25)$ & 5.6 & $(0.09)$ & 5.4 & $(0.22)$ \\
\hline Estonia............................... & - & - & - & - & 11.1 & 8.7 & 11.1 & 8.7 & 11.1 & 9.4 & 12.0 & 12.3 & 13.2 & $(0.33)$ & 14.8 & $(0.75)$ & 13.3 & $(0.55)$ & 14.0 & $(1.24)$ & 12.1 & $(0.30)$ & 12.3 & $(0.67)$ \\
\hline 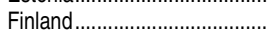 & 17.4 & 21.8 & 17.5 & 20.2 & 16.6 & 11.0 & 15.9 & 9.0 & 15.4 & 7.5 & 15.0 & 5.4 & 14.7 & $(0.11)$ & 3.4 & $(0.13)$ & 14.7 & $(0.18)$ & 2.5 & $(0.17)$ & 14.4 & $(0.17)$ & 1.6 & $(0.13)$ \\
\hline 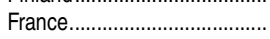 & 10.5 & 15.6 & 11.2 & 16.7 & 10.0 & 17.0 & 10.6 & 17.7 & 10.9 & 17.7 & 11.1 & $\begin{array}{r}16.9 \\
16.9\end{array}$ & 11.6 & $(0.07)$ & 17.5 & $(0.18)$ & 11.5 & $(0.06)$ & 16.9 & $(0.16)$ & 11.5 & $(0.06)$ & 16.0 & $(0.16)$ \\
\hline 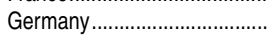 & 9.9 & 8.6 & 9.7 & 8.2 & 9.7 & 7.4 & 8.9 & 6.8 & 8.7 & 6.5 & 9.0 & 6.5 & 9.3 & $(0.05)$ & 6.8 & $(0.09)$ & 9.6 & $(0.05)$ & 7.2 & $(0.10)$ & 11.2 & $(0.06)$ & 9.4 & $(0.11)$ \\
\hline Greece... & 5.5 & 8.6 & 5.4 & 7.4 & 6.7 & 8.4 & 7.0 & 9.0 & 7.4 & 9.4 & 6.6 & 9.6 & 6.7 & $(0.06)$ & 10.1 & $(0.16)$ & 7.2 & $(0.16)$ & 10.9 & $(0.34)$ & 7.7 & $(0.07)$ & 11.8 & $(0.18)$ \\
\hline Hungary.... & - & - & - & - & 0.2 & 0.5 & 0.3 & 0.6 & $\#$ & 0.9 & \# & 1.0 & $\#$ & $(t)$ & 1.0 & (\#) & 0.6 & $(0.02)$ & 1.4 & $(0.06)$ & 0.6 & $(0.04)$ & 1.6 & $(0.11)$ \\
\hline 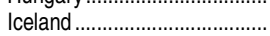 & 4.6 & 5.3 & 6.0 & 5.5 & 4.7 & 3.3 & 3.9 & 3.0 & 3.7 & 3.2 & 3.4 & 2.2 & 3.9 & $(0.21)$ & 2.5 & $(0.31)$ & 3.8 & $(0.20)$ & 2.2 & $(0.30)$ & 3.9 & $(0.20)$ & 2.5 & $(0.32)$ \\
\hline |reland ${ }^{2}$.................................. & 10.5 & 13.4 & 21.6 & 28.1 & 10.6 & $\begin{array}{r}14.4 \\
\end{array}$ & 10.9 & 14.0 & 11.1 & 14.0 & $\begin{array}{r}11.7 \\
\end{array}$ & 14.5 & 14.9 & $(0.10)$ & 18.7 & $(0.20)$ & 15.6 & $(0.10)$ & 18.4 & $(0.20)$ & 14.7 & $(0.10)$ & 16.1 & $(0.20)$ \\
\hline 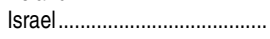 & - & - & - & - & 16.0 & 15.1 & 16.0 & 15.1 & 15.2 & 13.4 & 15.1 & 13.4 & 15.5 & $(0.14)$ & 13.4 & $(0.26)$ & 15.0 & $(0.14)$ & 12.4 & $(0.25)$ & 15.4 & $(0.14)$ & 13.4 & $(0.25)$ \\
\hline Italy ...... & - & - & - & - & 0.5 & 0.6 & 0.5 & 0.6 & 0.5 & 0.6 & \# & \# & \# & (†) & \# & $(\dagger)$ & \# & $(\dagger)$ & \# & $(\dagger)$ & 0.3 & $(0.01)$ & 0.2 & $(0.02)$ \\
\hline Japan ............................... & 13.4 & 22.1 & 14.6 & 23.4 & 17.7 & 25.3 & 17.5 & 24.4 & 17.9 & 24.6 & 18.5 & 24.1 & 19.1 & $(0.10)$ & 23.9 & $(0.25)$ & 19.5 & $(0.16)$ & 23.7 & $(0.34)$ & 20.1 & $(0.15)$ & 23.8 & $(0.35)$ \\
\hline Korea, Republic of ...................... & 5.8 & 11.9 & 6.7 & 14.5 & 8.9 & 19.3 & 9.5 & 20.1 & 10.2 & 21.6 & 10.9 & 23.3 & 11.6 & $(0.16)$ & 25.5 & $(0.42)$ & 12.2 & $(0.17)$ & 26.0 & $(0.43)$ & 12.6 & $(0.17)$ & 24.9 & $(0.43)$ \\
\hline Luxembourg.............................. & 6.6 & 8.1 & 6.7 & 8.3 & 9.6 & 13.2 & 7.6 & 10.8 & 8.8 & 11.9 & 7.7 & 10.8 & 14.6 & $(0.34)$ & 20.4 & $(0.87)$ & 14.7 & $(0.34)$ & 18.1 & $(0.84)$ & 12.0 & $(0.31)$ & 14.5 & $(0.72)$ \\
\hline Mexico ……................................. & 1.3 & 2.2 & 1.7 & 2.7 & 1.1 & 1.2 & 1.0 & 1.1 & 1.0 & 1.1 & 1.1 & 1.2 & 1.1 & $(0.01)$ & 1.2 & $(0.03)$ & 1.1 & (\#) & 1.3 & $(\#)$ & 1.1 & $(\#)$ & 1.2 & $(\#)$ \\
\hline Netherlands ......... & 2.5 & 2.4 & 2.3 & 2.4 & 1.8 & 1.6 & 1.8 & 1.7 & 1.7 & 1.6 & 2.4 & 2.2 & 2.8 & $(0.03)$ & 2.5 & $(0.07)$ & 2.5 & $(0.03)$ & 2.4 & $(0.07)$ & 2.5 & $(0.03)$ & 2.2 & $(0.07)$ \\
\hline New Zealand............................ & 13.9 & 10.4 & 15.3 & 11.6 & 7.4 & 4.6 & 15.3 & 13.8 & 15.7 & 14.3 & 14.9 & 13.9 & 16.9 & $(0.36)$ & 15.9 & $(0.76)$ & 16.4 & $(0.31)$ & 14.9 & $(0.64)$ & 15.5 & $(0.30)$ & 14.6 & $(0.64)$ \\
\hline 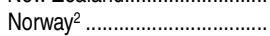 & 2.0 & 2.2 & 2.6 & 2.6 & 2.4 & 1.9 & 2.4 & 1.7 & 2.4 & 1.9 & 2.4 & 1.8 & 2.2 & $(0.06)$ & 1.4 & $(0.11)$ & 2.1 & $(0.06)$ & 1.0 & $(0.09)$ & 2.2 & $(0.06)$ & 1.1 & $(0.09)$ \\
\hline Portugal ....................... & 2.7 & 3.0 & 2.4 & 3.1 & - & - & - & - & - & - & - & - & - & $(t)$ & - & $(\dagger)$ & - & $(t)$ & - & $(t)$ & - & $(t)$ & - & $(t)$ \\
\hline 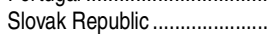 & $n$ & - & 0.6 & 0.6 & 0.8 & 0.9 & 0.9 & 0.9 & 0.7 & 0.7 & 0.8 & 0.6 & 0.8 & $(0.04)$ & 0.9 & $(0.08)$ & 0.7 & $(0.04)$ & 0.6 & $(0.05)$ & 1.3 & $(0.09)$ & 1.3 & $(0.22)$ \\
\hline Slove & - & - & - & - & 9.6 & 9.5 & 9.6 & 9.5 & 10.6 & 12.4 & 10.8 & 11.7 & 10.8 & $(0.16)$ & 11.7 & $(0.35)$ & 10.6 & $(0.16)$ & 12.2 & $(0.3$ & 11.2 & $(0.17)$ & 12.6 & $(0.37)$ \\
\hline Spain & 6.2 & 11.4 & 6.7 & 11.6 & 8.3 & 12.8 & 8.7 & 13.2 & 9.0 & 13.0 & 9.2 & 13.0 & 9.5 & $(0.05)$ & 13.2 & $(0.11)$ & 9.2 & $(0.05)$ & 12.2 & $(0.11)$ & 9.3 & $(0.17)$ & 12.4 & $(0.41)$ \\
\hline Sweden & 15.6 & 20.7 & 14.7 & 17.1 & 9.1 & 8.9 & 8.8 & 8.5 & 8.7 & 8.5 & 8.6 & 8.4 & 8.7 & $(0.07)$ & 8.5 & $(0.15)$ & 8.8 & $(0.06)$ & 8.2 & $(0.13)$ & 9.0 & $(0.07)$ & 8.6 & $(0.13)$ \\
\hline Switzerland …………………. & 9.1 & 9.3 & 9.6 & 9.7 & 9.7 & 9.1 & 9.9 & 9.0 & 10.0 & 9.5 & 10.4 & 9.7 & 10.3 & $(0.17)$ & 9.4 & $(0.36)$ & 10.8 & $(0.11)$ & 9.9 & $(0.24)$ & 10.7 & $(0.10)$ & 9.5 & $(0.23)$ \\
\hline United Kingdom ........................... & 8.2 & 8.4 & 8.0 & 9.0 & 8.8 & 8.1 & 8.7 & 8.2 & 9.1 & 7.7 & 9.0 & 7.7 & 10.0 & $(0.06)$ & 8.5 & $(0.12)$ & 10.2 & $(0.13)$ & 8.1 & $(0.25)$ & 9.8 & $(0.06)$ & 7.6 & $(0.12)$ \\
\hline 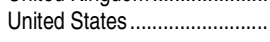 & 8.3 & 8.7 & 9.0 & 9.2 & 9.4 & 9.0 & 9.6 & 9.3 & 9.4 & 9.3 & 9.6 & 9.3 & 9.8 & $(0.08)$ & 8.9 & $(0.15)$ & 10.0 & $(0.12)$ & 9.5 & $(0.22)$ & 10.3 & $(0.11)$ & 10.1 & $(0.24)$ \\
\hline $\begin{array}{l}\text { Other reporting countries } \\
\text { Russian Federation }\end{array}$ & - & - & 33.5 & 34.2 & - & - & - & - & - & - & - & - & - & $(\dagger)$ & - & $(t)$ & - & $(t)$ & - & $(t)$ & 26.4 & $(t)$ & 22.4 & $(\dagger)$ \\
\hline
\end{tabular}

\section{- Not available.}

†Not applicable.

\#Rounds to zero.
1Refers to the mean of the data values for all reporting Organization for Economic Cooperation and Development (OECD) countries, to which each country reporting data contributes equally. The average includes all current $O E C D$ countries for which a given year's data are available, even if they were not members of $O E C D$ in that year.

2Data from 1998 reported for 1999.
3Data from 2000 reported for 2001.
${ }^{4}$ Data from 2004 reported for 2005.

5 Data from 2002 reported for 2001.
NOTE: Data in this table refer to degrees classified as International Standard Classification of Education (ISCED) level 5B. ISCED level 5B corresponds to the associale's degree in the Uniled Stales. Data for the Czech Republic, Poland, and Turkey are no prior to 2009 . SOURCE: Organization for Economic 
Table 603.50. Number of bachelor's degree recipients per 100 persons at the typical age of graduation, by sex and country: 2005 through 2011

\begin{tabular}{|c|c|c|c|c|c|c|c|c|c|c|c|c|c|c|c|c|c|c|c|c|c|c|}
\hline \multirow[b]{2}{*}{ Country } & \multirow{2}{*}{$\begin{array}{r}\text { Typical } \\
\text { age of } \\
\text { graduation, } \\
2011 \\
\end{array}$} & \multicolumn{7}{|c|}{ Total } & \multicolumn{7}{|c|}{ Male } & \multicolumn{7}{|c|}{ Female } \\
\hline & & 2005 & 2006 & 2007 & 2008 & 2009 & 2010 & 2011 & 2005 & 2006 & 2007 & 2008 & 2009 & 2010 & 2011 & 2005 & 2006 & 2007 & 2008 & 2009 & 2010 & 2011 \\
\hline 1 & 2 & 3 & 4 & 5 & 6 & 7 & 8 & 9 & 10 & 11 & 12 & 13 & 14 & 15 & 16 & 17 & 18 & 19 & 20 & 21 & 22 & 23 \\
\hline OECD average ${ }^{1} \ldots$ & - & 34.7 & 36.2 & 37.5 & 39.1 & 38.9 & 39.8 & 39.7 & 27.5 & 28.7 & 30.0 & 31.0 & 31.0 & 31.5 & 31.8 & 42.3 & 44.0 & 45.3 & 47.5 & 47.1 & 48.5 & 48.0 \\
\hline Australia & $21-22$ & 59.9 & 59.6 & 60.7 & 58.9 & 58.5 & 58.6 & 59.0 & 47.9 & 47.4 & 48.6 & 47.0 & 46.9 & 46.5 & 47.0 & 72.5 & 72.5 & 73.4 & 71.4 & 70.8 & 71.4 & 71.8 \\
\hline Austria ................................ & $22-25$ & 20.4 & 21.7 & 22.4 & 25.8 & 30.3 & 30.7 & 33.7 & 19.0 & 20.4 & 20.8 & 22.7 & 25.9 & 26.3 & 28.5 & 21.8 & 22.9 & 24.0 & 29.1 & 34.7 & 35.2 & 39.0 \\
\hline 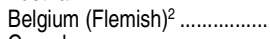 & 21 & 18.4 & 19.0 & 35.4 & 27.0 & - & - & - & 17.0 & 17.9 & 32.6 & 24.4 & - & - & - & 19.8 & 20.2 & 38.2 & 29.6 & - & - & - \\
\hline Canada & 22 & 33.6 & 39.3 & 35.2 & 39.5 & 38.9 & 38.6 & 37.6 & 25.2 & 29.5 & 26.5 & 29.1 & 29.3 & 29.1 & 28.5 & 42.2 & 49.7 & 44.3 & 50.6 & 49.0 & 48.6 & 47.2 \\
\hline 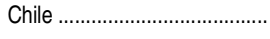 & $23-26$ & 11.5 & 15.0 & 14.5 & 14.7 & 17.6 & 18.1 & 18.5 & 9.7 & 13.0 & 11.9 & 11.7 & 13.2 & 14.9 & 15.5 & 13.4 & 17.0 & 17.3 & 17.8 & 22.1 & 21.5 & 21.6 \\
\hline Czech Republic.. & $22-26$ & 26.0 & 30.7 & 36.4 & 39.2 & 39.7 & 42.3 & 42.8 & 22.6 & 26.5 & 31.0 & 32.2 & 30.4 & 31.1 & 30.8 & 29.5 & 35.2 & 42.1 & 46.6 & 49.7 & 54.4 & 55.5 \\
\hline Denmark ........................ & $24-26$ & 52.9 & 50.3 & 50.9 & 50.3 & 48.3 & 50.7 & 50.6 & 37.2 & 37.0 & 38.3 & 38.3 & 35.3 & 37.5 & 38.3 & 69.2 & 63.7 & 63.9 & 62.6 & 61.7 & 64.3 & 63.3 \\
\hline Estonia............................ & $22-24$ & 28.5 & 26.4 & 27.3 & 23.8 & 22.9 & 22.3 & 23.8 & 17.6 & 15.4 & 17.6 & 14.9 & 13.7 & 14.0 & 15.4 & 39.5 & 37.8 & 37.3 & 32.8 & 32.7 & 31.6 & 32.6 \\
\hline 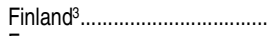 & 24 & 53.8 & 57.3 & 58.8 & 79.8 & 42.3 & 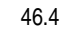 & 50.3 & 38.8 & 40.6 & 41.3 & 55.3 & 28.7 & 33.1 & 36.4 & 69.7 & 74.5 & 77.4 & 105.6 & 56.6 & 60.3 & 65.0 \\
\hline France................................... & $19-24$ & - & 34.2 & 33.8 & 33.9 & 33.0 & - & - & - & 30.6 & 30.2 & 30.3 & 29.8 & - & - & - & 37.9 & 37.5 & 37.6 & 36.3 & - & - \\
\hline Germany.. & $24-27$ & 20.5 & 21.0 & 23.2 & 25.5 & 28.9 & 30.4 & 31.0 & 20.0 & 20.0 & 22.0 & 24.0 & 27.4 & 28.7 & 29.6 & 21.1 & 22.0 & 24.4 & 27.0 & 30.5 & 32.2 & 32.5 \\
\hline Greece $^{2} \ldots . .$. & $23-24$ & 23.9 & 23.5 & 21.7 & 26.6 & - & 25.4 & 27.3 & 16.3 & 16.1 & 14.7 & 18.3 & - & 17.5 & 18.6 & 32.2 & 31.7 & 29.4 & 35.5 & - & 34.0 & 36.7 \\
\hline Hungary ..................... & $21-24$ & 41.5 & 38.2 & 38.8 & 37.6 & 39.0 & 38.4 & 32.8 & 29.0 & 26.1 & 26.2 & 25.2 & 27.1 & 28.0 & 25.0 & 54.5 & 51.0 & 51.8 & 50.4 & 51.2 & 49.1 & 41.0 \\
\hline Iceland ........................................... & $23-25$ & 56.3 & 62.8 & 62.8 & 55.9 & 50.7 & 65.4 & - & 33.6 & 37.7 & 38.0 & 34.1 & 30.7 & 40.1 & - & 80.5 & 89.6 & 88.0 & 78.9 & 72.2 & 91.3 & - \\
\hline 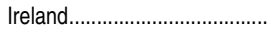 & 21 & 40.7 & 42.8 & 44.8 & 46.0 & 47.1 & 52.2 & 46.8 & 33.3 & 33.4 & 36.4 & 36.9 & 38.5 & 45.3 & 40.0 & 48.0 & 52.5 & 53.4 & 55.2 & 55.4 & 58.9 & 53.5 \\
\hline Israel... & $26-29$ & 32.9 & 33.4 & 36.1 & 36.3 & 36.4 & 36.8 & 38.5 & 25.7 & 26.8 & 29.1 & 29.6 & 30.8 & 30.6 & 31.8 & 40.2 & 40.3 & 43.1 & 43.1 & 42.0 & 43.1 & 45.3 \\
\hline 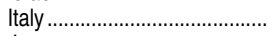 & $23-25$ & 44.8 & 42.7 & 38.7 & 35.8 & 34.6 & 33.6 & 34.3 & 37.3 & 35.1 & 31.6 & 29.5 & 28.5 & 26.9 & 27.3 & 52.7 & 50.6 & 46.1 & 42.3 & 40.9 & 40.6 & 41.6 \\
\hline 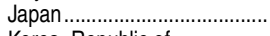 & $21-23$ & 36.9 & 38.7 & 38.8 & 40.6 & 41.5 & 41.3 & 44.8 & 41.3 & 42.8 & 42.9 & 44.9 & 46.1 & 45.4 & 49.1 & 32.2 & 34.3 & 34.4 & 36.0 & 36.7 & 37.1 & 40.2 \\
\hline Korea, Republic of ................... & $22-26$ & 35.5 & 41.0 & 42.9 & 48.7 & 50.0 & 50.7 & 49.9 & 34.8 & 40.2 & 42.7 & 49.0 & 51.0 & 50.9 & 49.2 & 36.2 & 41.7 & 43.2 & 48.5 & 48.8 & 50.4 & 50.7 \\
\hline 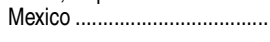 & 23 & 15.2 & 18.1 & 18.2 & 17.8 & 19.0 & 19.5 & 20.9 & 14.5 & 16.7 & 16.8 & 16.2 & 17.4 & 17.7 & 19.3 & 15.9 & 19.5 & 19.7 & 19.3 & 20.7 & 21.2 & 22.4 \\
\hline Netherlands. & 23 & 47.2 & 49.2 & 47.8 & 46.0 & 45.6 & 44.7 & 45.3 & 40.2 & 42.9 & 41.7 & 39.8 & 39.4 & 38.6 & 38.5 & 54.3 & 55.7 & 54.1 & 52.3 & 51.9 & 51.0 & 52.2 \\
\hline New Zealand.......................... & $21-23$ & 49.0 & 53.5 & 53.8 & 50.0 & 50.7 & 47.3 & 51.0 & 36.6 & 40.6 & 41.6 & 37.6 & 38.9 & 36.7 & 37.6 & 62.0 & 67.0 & 66.0 & 63.0 & 63.1 & 58.6 & 65.1 \\
\hline Norway ..................................... & $22-25$ & 42.1 & 45.1 & 45.0 & 46.1 & 44.3 & 46.1 & 46.1 & 28.8 & 31.9 & 31.8 & 33.9 & 32.0 & 33.7 & 33.4 & 55.8 & 58.8 & 58.7 & 58.8 & 57.3 & 58.8 & 59.3 \\
\hline Poland................................... & $23-25$ & 45.0 & 44.8 & 46.6 & 48.2 & 49.4 & 56.9 & 60.6 & 32.8 & 32.9 & 34.4 & 35.0 & 35.9 & 40.5 & 42.9 & 57.6 & 57.1 & 59.2 & 61.9 & 63.3 & 73.8 & 79.1 \\
\hline Portugal ................................... & 22 & 33.7 & 34.9 & 46.0 & 50.4 & 44.3 & 44.6 & 42.9 & 21.7 & 22.7 & 35.0 & 40.3 & 35.9 & 34.5 & 34.2 & 46.0 & 47.4 & 57.4 & 60.9 & 53.1 & 55.2 & 52.1 \\
\hline Slovak Republic & $21-24$ & 30.1 & 33.7 & 37.9 & 57.6 & 61.7 & 50.9 & 48.6 & 25.6 & 26.0 & 26.8 & 38.7 & 42.8 & 35.2 & 33.9 & 34.8 & 41.8 & 49.6 & 77.3 & 81.5 & 67.3 & 63.6 \\
\hline Slovenia .......... & $23-25$ & 21.6 & 21.6 & 21.1 & 22.6 & 27.9 & 34.7 & 38.1 & 14.3 & 14.2 & 13.9 & 14.4 & 17.2 & 21.7 & 25.2 & 29.4 & 29.3 & 29.0 & 31.7 & 39.6 & 49.2 & 52.1 \\
\hline Spain & $20-23$ & 35.0 & 35.3 & 34.7 & 35.5 & 37.4 & 39.5 & 45.1 & 27.1 & 27.1 & 26.6 & 27.3 & 28.8 & 30.7 & 35.7 & 43.3 & 43.8 & 43.3 & 44.2 & 46.4 & 48.5 & 54.9 \\
\hline Sweden ................................ & 25 & 44.0 & 43.3 & 42.2 & 40.9 & 38.1 & 35.7 & 38.5 & 30.8 & 29.8 & 29.1 & 27.9 & 25.8 & 23.6 & 25.0 & 57.6 & 57.2 & 55.8 & 54.7 & 51.0 & 48.6 & 52.7 \\
\hline Switzerland ......................... & $24-26$ & 25.0 & 27.0 & 28.9 & 30.6 & 29.2 & 28.8 & 28.0 & 26.1 & 26.8 & 28.7 & 29.2 & 27.0 & 26.7 & 25.4 & 23.9 & 27.1 & 29.2 & 32.0 & 31.5 & 31.0 & 30.7 \\
\hline Turke & $23-24$ & 11.3 & 15.4 & 17.0 & & 20.8 & 23.1 & 22.7 & 11.8 & 16.3 & 17.9 & 20.6 & 22.4 & 24.9 & 23.9 & 10.7 & 14.5 & 15.9 & 18.4 & 19.2 & 21.2 & 21.4 \\
\hline United Kingdom ......................... & $20-24$ & 39.8 & 39.0 & 39.0 & 40.2 & 39.9 & 41.9 & 43.4 & 34.1 & 33.0 & 32.9 & 33.5 & 33.8 & 35.6 & 36.6 & 45.7 & 45.2 & 45.4 & 47.2 & 46.3 & 48.6 & 50.6 \\
\hline United States ........................ & 21 & 34.2 & 35.5 & 36.5 & 37.3 & 37.8 & 38.2 & 38.8 & 28.1 & 29.1 & 30.1 & 31.0 & 31.4 & 31.8 & 32.4 & 40.7 & 42.4 & 43.4 & 43.9 & 44.5 & 45.0 & 45.4 \\
\hline ting countries & & & & & & & & & & & & & & & & & & & & & & \\
\hline Brazil.... & 22 & 17.5 & 21.3 & 22.7 & 25.6 & 24.9 & 23.1 & 25.9 & 13.3 & 16.2 & 18.4 & 19.9 & 17.9 & 16.9 & 19.0 & 21.6 & 26.4 & 27.0 & 31.3 & 32.0 & 29.4 & 32.8 \\
\hline Russian Federation... & $21-22$ & 45.9 & 43.7 & 48.6 & 52.7 & 51.8 & 55.1 & 58.6 & & & & & & & & & & & & & 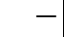 & \\
\hline
\end{tabular}

- Not available.

'Refers to the mean of the data values for all reporting Organization for Economic Cooperation and Development (OECD) countries, to which each country reporting data contributes equally. The average includes all current OECD countries for which a given year's data are available, even if they were not members of OECD in that year.

3Structura yhange in the Finnish higher eduction syst

2008 , as well as the decrease in 2009 . Students had a stro accounted for much of the increase in Finnish degree recipients in not complete their degrees in 2008 may have had to spend extra time or to complete their degrees in 2008. Students who did ments that went into effect in 2009.

NOTE: Data in this table refer to degrees classified by OECD as International Standard Classification of Education (ISCED) level $5 \mathrm{~A}$, first award. This level corresponds to the bachelor's degree in the United States. The recipients-per-100-persons
ratio relates the number of people of all ages earning bachelor's degrees in a particular year to the number of people in the population at the typical minimum age of graduation. In countries where there are two types of first awards (corresponding With different typical ages of graduation), the recipients-per-100-persons ratio is the sum of the two different award types. The typical age is based on full-time attendance and normal progression through the education system (without repeating coursework, taking time off, etc.), his age varies across countries because of differences in their educallon systems and differences previously published volumes of the Digest of Education Statistics for the typical age of graduation in previous years. Data for Luxembourg are not shown because students generally attend no more than 1 year of higher education in Luxembourg and must complete their degrees in other countries.

SOURCE: Organization for Economic Cooperation and Development (OECD), Education at a Glance, 2006 through 2013 and Online Education Database, retrieved August 24, 2013, from hitp://stats.oecd.org//ndex.aspx. (This table was prepared September 2013.) 
782 CHAPTER 6: International Comparisons of Education

Attainment, Degrees, and Outcomes

Table 603.60. Percentage of bachelor's and higher level degrees awarded to women, by field of study and country: 2011

\begin{tabular}{|c|c|c|c|c|c|c|c|c|c|c|c|c|c|}
\hline \multirow[b]{2}{*}{ Country } & \multirow[b]{2}{*}{ All fields ${ }^{1}$} & \multirow[b]{2}{*}{ Education } & \multirow[b]{2}{*}{$\begin{array}{r}\text { Humanities } \\
\text { and arts }\end{array}$} & \multirow[b]{2}{*}{$\begin{array}{r}\text { Health and } \\
\text { welfare }\end{array}$} & \multirow{2}{*}{$\begin{array}{r}\text { Social } \\
\text { sciences, } \\
\text { business, } \\
\text { and law }\end{array}$} & \multirow{2}{*}{$\begin{array}{r}\text { Personal, } \\
\text { transport, } \\
\text { environ- } \\
\text { mental } \\
\text { protection, } \\
\text { and } \\
\text { security } \\
\text { services }\end{array}$} & \multirow{2}{*}{$\begin{array}{r}\text { Engineering, } \\
\text { manufac- } \\
\text { turing, and } \\
\text { construction }\end{array}$} & \multicolumn{5}{|c|}{ Sciences, mathematics, and computer science } & \multirow[b]{2}{*}{ Agriculture } \\
\hline & & & & & & & & Total & $\begin{array}{r}\text { Life } \\
\text { sciences }\end{array}$ & $\begin{array}{l}\text { Physical } \\
\text { sciences }\end{array}$ & $\begin{array}{r}\text { Mathematics } \\
\text { and statistics }\end{array}$ & $\begin{array}{r}\text { Computer } \\
\text { science }\end{array}$ & \\
\hline 1 & 2 & 3 & 4 & 5 & 6 & 7 & 8 & 9 & 10 & 11 & 12 & 13 & 14 \\
\hline${\text { OECD } \text { average }^{2} \ldots \ldots}$ & 58.0 & 77.1 & 66.0 & 74.8 & 57.6 & 52.9 & 27.1 & 41.3 & 63.7 & 43.2 & 45.0 & 19.4 & 54.2 \\
\hline 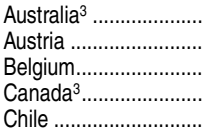 & $\begin{array}{l}56.6 \\
53.7 \\
55.0 \\
59.9 \\
56.9\end{array}$ & $\begin{array}{l}74.7 \\
79.2 \\
75.3 \\
76.7 \\
71.9\end{array}$ & $\begin{array}{l}63.8 \\
68.0 \\
65.4 \\
65.0 \\
59.5\end{array}$ & $\begin{array}{l}74.7 \\
68.0 \\
66.5 \\
82.5 \\
69.7\end{array}$ & $\begin{array}{l}54.3 \\
56.3 \\
58.4 \\
57.7 \\
51.6\end{array}$ & $\begin{array}{l}54.4 \\
42.6 \\
41.1 \\
60.9 \\
49.0\end{array}$ & $\begin{array}{l}24.6 \\
25.0 \\
25.7 \\
23.1 \\
26.2\end{array}$ & $\begin{array}{l}36.6 \\
35.9 \\
35.9 \\
48.6 \\
31.9\end{array}$ & $\begin{array}{l}54.2 \\
70.2 \\
52.3 \\
61.5 \\
55.4\end{array}$ & $\begin{array}{l}47.3 \\
32.0 \\
33.9 \\
44.2 \\
40.3\end{array}$ & $\begin{array}{l}39.1 \\
35.8 \\
44.1 \\
41.1 \\
39.0\end{array}$ & \begin{tabular}{r|}
19.8 \\
15.2 \\
9.9 \\
16.9 \\
15.5
\end{tabular} & $\begin{array}{l}59.2 \\
63.4 \\
57.5 \\
58.9 \\
47.5\end{array}$ \\
\hline 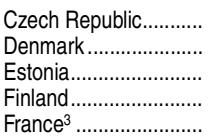 & $\begin{array}{l}61.2 \\
59.2 \\
66.5 \\
61.3 \\
54.5\end{array}$ & $\begin{array}{l}82.0 \\
74.4 \\
91.8 \\
81.2 \\
77.1\end{array}$ & $\begin{array}{l}71.2 \\
65.0 \\
76.6 \\
73.7 \\
71.3\end{array}$ & $\begin{array}{l}79.8 \\
80.7 \\
86.2 \\
85.3 \\
61.3\end{array}$ & $\begin{array}{l}68.0 \\
53.5 \\
70.1 \\
65.3 \\
60.7\end{array}$ & $\begin{array}{l}46.5 \\
23.2 \\
64.0 \\
68.2 \\
43.7\end{array}$ & $\begin{array}{l}26.6 \\
32.4 \\
35.1 \\
22.4 \\
30.4\end{array}$ & $\begin{array}{l}39.4 \\
38.7 \\
49.3 \\
44.7 \\
37.6\end{array}$ & $\begin{array}{l}71.5 \\
63.0 \\
72.9 \\
76.0 \\
62.2\end{array}$ & $\begin{array}{l}49.8 \\
39.9 \\
48.3 \\
46.9 \\
37.4\end{array}$ & $\begin{array}{l}52.1 \\
43.2 \\
74.6 \\
43.8 \\
36.7\end{array}$ & $\begin{array}{l}12.2 \\
25.0 \\
27.4 \\
27.5 \\
16.8\end{array}$ & $\begin{array}{l}61.0 \\
71.6 \\
54.5 \\
60.1 \\
56.1\end{array}$ \\
\hline Germany .......................... & 54.5 & 72.6 & 72.8 & 69.1 & 53.8 & 53.5 & 22.1 & 43.8 & 67.2 & 42.0 & 59.4 & 15.4 & 53.7 \\
\hline Greece.......................... & - & - & - & - & - & - & - & - & - & - & - & - & - \\
\hline Hungary .......................... & 62.3 & 80.7 & 70.2 & 75.5 & 67.7 & 60.6 & 23.2 & 36.3 & 63.0 & 40.8 & 40.2 & 16.3 & 49.2 \\
\hline 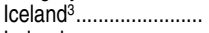 & 67.0 & 83.8 & 68.8 & 87.6 & 59.0 & 69.8 & 40.3 & 47.9 & 73.5 & 43.4 & 23.1 & 18.8 & 63.2 \\
\hline Ireland............................ & 57.2 & 76.2 & 61.5 & 80.7 & 54.1 & 51.5 & 20.7 & 42.4 & 62.3 & 41.3 & 30.4 & 24.5 & 43.5 \\
\hline Israel.................................. & 58.1 & 82.3 & 61.5 & 77.7 & 55.8 & 81.2 & 27.3 & 44.1 & 64.0 & 40.0 & 38.6 & 25.5 & 54.1 \\
\hline Italy & 60.5 & 87.6 & 73.6 & 67.6 & 58.5 & 65.7 & 33.0 & 53.9 & 71.1 & 40.9 & 54.9 & 23.5 & 47.3 \\
\hline Japan ............................. & 41.9 & 59.5 & 68.9 & 56.8 & 35.4 & 90.9 & 11.2 & 25.7 & - & - & - & - & 39.3 \\
\hline Korea, Republic of ....... & 47.3 & 70.6 & 66.8 & 65.3 & 44.2 & 36.2 & 23.8 & 40.0 & 49.3 & 45.6 & 54.7 & 21.9 & 40.2 \\
\hline Mexico ........................... & 54.5 & 72.4 & 59.1 & 66.3 & 59.2 & 23.1 & 28.9 & 46.8 & 58.9 & 41.0 & 43.6 & 40.2 & 35.9 \\
\hline Netherlands ................... & 56.9 & 80.0 & 56.7 & 74.7 & 53.6 & 52.3 & 20.1 & 25.3 & 60.6 & 26.7 & 32.2 & 12.8 & 56.0 \\
\hline New Zealand................. & 61.7 & 81.0 & 64.6 & 78.3 & 58.1 & 54.6 & 31.1 & 45.0 & 60.3 & 46.9 & 46.9 & 22.2 & 58.5 \\
\hline Norway............................... & 61.0 & 75.1 & 59.6 & 83.5 & 57.4 & 45.0 & 26.5 & 33.8 & 66.2 & 39.8 & 34.5 & 13.2 & 55.9 \\
\hline 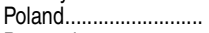 & 65.9 & 81.6 & 76.2 & 75.9 & 68.9 & 55.6 & 33.9 & 44.8 & 72.5 & 67.4 & 64.0 & 15.6 & 55.5 \\
\hline Portugal ........................... & 60.4 & 81.5 & 60.3 & 78.9 & 62.4 & 49.5 & 31.2 & 55.1 & 71.2 & 49.1 & 59.4 & 22.4 & 57.4 \\
\hline Slovak Republic ........... & 63.9 & 77.4 & 69.8 & 83.1 & 69.1 & 45.9 & 30.5 & 42.6 & 71.4 & 54.1 & 56.8 & 12.1 & 46.7 \\
\hline Slovenia .............................. & 64.0 & 84.0 & 77.8 & 76.7 & 69.1 & 60.2 & 33.9 & 43.0 & 71.5 & 43.7 & 58.3 & 9.7 & 60.9 \\
\hline Spain & 58.9 & 74.1 & 63.5 & 75.6 & 60.3 & 53.5 & 32.1 & 43.2 & 61.6 & 49.3 & 47.2 & 21.5 & 50.1 \\
\hline Sweden & 63.8 & 79.3 & 62.3 & 82.4 & 60.6 & 49.3 & 30.4 & 43.1 & 61.9 & 46.2 & 36.9 & 22.4 & 58.5 \\
\hline Switzerland ...................... & 51.2 & 72.3 & 62.6 & 69.3 & 48.6 & 49.4 & 19.8 & 34.8 & 52.1 & 32.3 & 27.6 & 10.3 & 67.1 \\
\hline Turkey ....................... & 46.7 & 57.2 & 56.6 & 59.6 & 43.2 & 33.7 & 29.8 & 50.5 & 67.0 & 47.4 & 54.6 & 26.9 & 33.9 \\
\hline United Kingdom ............ & 55.1 & 75.8 & 62.1 & 73.7 & 54.4 & 62.2 & 22.6 & 37.4 & 50.4 & 41.9 & 41.0 & 18.9 & 65.3 \\
\hline United States ................ & 57.7 & 77.8 & 58.8 & 79.3 & 54.3 & 54.9 & 21.8 & 43.3 & 58.3 & 38.7 & 41.6 & 20.9 & 50.8 \\
\hline $\begin{array}{l}\text { Other reporting } \\
\text { countries }\end{array}$ & & & & & & & & & & & & & \\
\hline Argentina $^{3} \ldots \ldots \ldots \ldots \ldots$ & 59.7 & 77.1 & 67.3 & 68.7 & 61.1 & 45.9 & 33.5 & 48.6 & 70.1 & 52.1 & 70.6 & 24.6 & 40.7 \\
\hline Brazil......................... & 62.9 & 77.2 & 51.9 & 76.4 & 57.5 & 68.4 & 30.2 & 39.5 & 72.4 & 46.5 & 44.1 & 17.5 & 41.2 \\
\hline China ........................ & 48.3 & - & - & - & - & - & - & - & - & - & - & - & - \\
\hline Indonesia ${ }^{3} \ldots \ldots \ldots \ldots \ldots$ & 49.3 & - & - & - & - & - & - & - & - & - & - & - & - \\
\hline Saudi Arabia ............. & 66.3 & 66.4 & 73.7 & 58.3 & 63.6 & 80.2 & 7.5 & 73.4 & 84.9 & 76.2 & 80.5 & 52.8 & $\#$ \\
\hline South Africa .............. & 58.5 & 73.5 & 61.8 & 72.7 & 58.3 & 88.9 & 27.7 & 48.6 & 62.5 & 46.9 & 41.3 & 34.6 & 48.1 \\
\hline
\end{tabular}

-Not available.

${ }^{1}$ May contain fields not shown in this table.

${ }^{2}$ Refers to the mean of the data values for all reporting Organization for Economic Cooperation and Development (OECD) countries, to which each country reporting data contributes equally.

${ }^{3}$ Data are for 2010 instead of 2011.

NOTE: Data in this table refer to degrees classified as International Standard Classification of Education (ISCED) level 5A (first and second award) or level 6. ISCED 5A, first award, corresponds to the bachelor's degree in the United States; ISCED 5A, second award, corresponds to master's and first-professional degrees in the United States; and ISCED 6 corresponds to doctor's degrees. Data for Luxembourg are not shown because students generally attend no more than 1 year of higher education in Luxembourg and must complete their degrees in other countries.

SOURCE: Organization for Economic Cooperation and Development (OECD), Education at a Glance, 2013. (This table was prepared September 2013.) 
Table 603.70. Percentage of bachelor's degrees awarded in mathematics, science, and engineering, by field of study and country: Selected years, 1990 through 2010

\begin{tabular}{|c|c|c|c|c|c|c|c|c|c|c|c|c|c|c|c|c|c|c|c|c|c|c|c|c|c|c|c|c|}
\hline \multirow[b]{2}{*}{ Country } & \multicolumn{7}{|c|}{ All mathematics, science, and engineering degrees ${ }^{1}$} & \multicolumn{7}{|c|}{ Natural sciences ${ }^{2}$} & \multicolumn{7}{|c|}{ Mathematics and computer science ${ }^{3}$} & \multicolumn{7}{|c|}{ Engineering } \\
\hline & 1990 & 1995 & 2000 & 2005 & 2008 & 2009 & 2010 & 1990 & 1995 & 2000 & 2005 & 2008 & 2009 & 2010 & 1990 & 1995 & 2000 & 2005 & 2008 & 2009 & 2010 & 1990 & 1995 & 2000 & 2005 & 2008 & 2009 & 2010 \\
\hline 1 & 2 & 3 & 4 & 5 & 6 & 7 & 8 & 9 & 10 & 11 & 12 & 13 & 14 & 15 & 16 & 17 & 18 & 19 & 20 & 21 & 22 & 23 & 24 & 25 & 26 & 27 & 28 & 29 \\
\hline OECD average ${ }^{4} \ldots$ & - & - & 22.7 & 22.7 & 21.9 & 21.0 & 21.0 & - & - & 5.7 & 4.8 & 4.7 & 4.6 & 4.6 & - & - & 4.1 & 5.3 & 4.8 & 4.2 & 4.1 & - & - & 13.6 & \begin{tabular}{c|}
12.8 \\
\end{tabular} & 12.4 & \begin{tabular}{|l|}
12.3 \\
\end{tabular} & $\overline{12.6}$ \\
\hline ıstralia...... & - & 19.3 & 21.1 & 21.1 & 19.2 & 18.2 & 7.0 & - & 9.9 & 7.6 & 5.9 & 6.4 & 6.3 & 5.9 & - & 3.8 & 5.1 & 8.2 & 5.7 & 4.8 & 4.2 & - & 5.6 & 8.5 & 7.0 & 7.0 & 7.1 & 6.9 \\
\hline strie & 19.6 & 21.1 & 25.7 & & 25.6 & & 1 & 5.3 & 6.0 & 5.0 & & 4.7 & 5 & 5.7 & 5.2 & 5.3 & 3.4 & & & 8 & 5.4 & 9.0 & 9.9 & 17.3 & 14.2 & 13.9 & 13.1 & 14.0 \\
\hline & & & 23.6 & 2 & 21.3 & 3 & 0 & - & - & 6.4 & 5.7 & 3.8 & 4.3 & 3.7 & - & - & 2.3 & 5.2 & 2.5 & 1.7 & 1.7 & - & - & 14.9 & 13.8 & 15.0 & 13.3 & 14.6 \\
\hline nad & 16.4 & 16.7 & 20.0 & 20.7 & 20.5 & 3 & 19.9 & 6.0 & 6.5 & 8.1 & 6.5 & 9.4 & 9.3 & 9.1 & 4.2 & 3.8 & 4.3 & 9 & 0 & 3.4 & 3.4 & 6.2 & 6.4 & 7.6 & 8.2 & 7.5 & 7.6 & 7.4 \\
\hline Chile ... & - & - & - & 22.9 & 20.0 & 18.9 & 18.2 & - & - & - & 3.2 & 2.0 & 1.5 & 1.5 & - & - & - & 2.6 & 2.3 & 2.6 & 2.2 & - & - & - & 17.2 & 15.6 & 14.8 & 14.5 \\
\hline Pech Benublic & (5) & - & 29.5 & 26.7 & 29.1 & 24.0 & 21.7 & (5) & - & 4.2 & 3.9 & 4.6 & 4.1 & 4.1 & (5) & - & 8.4 & 3.8 & 5.5 & 5.5 & 5.1 & (5) & - & 16.9 & 19.0 & 18.9 & 14.4 & 12.4 \\
\hline & - & - & 10.5 & & 18.7 & & & 4.4 & 2.5 & 6.8 & & 2.7 & 0 & 3.1 & - & - & 3.1 & & & & 3.1 & 21.7 & 17.0 & - & & & 11.7 & 10.2 \\
\hline & $(5)$ & - & - & 23.8 & 21.8 & 1 & 1.1 & (5) & - & - & 6.3 & 5.6 & 4.6 & 4.9 & (5) & - & - & 6.2 & 6.0 & 5.1 & 5.3 & $(5)$ & & - & 11.3 & 10.2 & 10.4 & 11.0 \\
\hline Einland & 33.5 & 37.2 & 32.2 & 30.0 & 26. & 25.3 & 27.4 & 4.1 & 4.0 & 3.9 & 2 & 5.0 & 2.5 & 2.7 & 5.9 & 6.9 & 3.3 & 50 & 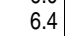 & 4 & 4.4 & 23.4 & 26.3 & 24.9 & 21.7 & 15.1 & 18.7 & 20.3 \\
\hline 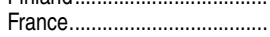 & - & - & 30.1 & 26.0 & 26.1 & 26.1 & - & - & - & 12.2 & 6 & 6 & 6.0 & - & - & - & 5.5 & 5.5 & 5. & 5.8 & - & - & - & 12.5 & 14.0 & 14.3 & 14.4 & - \\
\hline$r m a$ & 31.3 & 31.6 & 31.7 & 3 & 28.2 & 28.2 & 29.0 & 7.2 & 6.7 & 6.4 & 6.3 & 7.6 & 7.8 & 8.1 & 3.5 & 5.2 & 4.9 & 8.1 & & 8.0 & 7.6 & 20.5 & 19.7 & 20.3 & 16.9 & 12.4 & 12.4 & 13.3 \\
\hline & & S1. & & & 23 & & & & & - & & & & 59 & & 0.4 & & & & & 1.0 & & & & & & - & 12.8 \\
\hline & - & - & 12.6 & & 15 & 17 & 18.9 & - & - & 1.1 & 1. & 1. & 2.8 & 3.7 & - & - & 1.2 & 2.4 & 5 & 4.5 & 4 & - & - & 10.4 & 4 & 8.4 & 9.7 & 10.9 \\
\hline 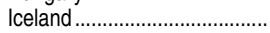 & - & - & 16.5 & & 14. & 15.2 & 16.6 & - & - & 6.0 & 5. & 3.2 & 3.4 & 3.5 & - & - & 4.0 & 3.5 & 3.2 & 3.2 & 3.0 & - & - & 6.5 & 5.5 & 8.5 & 8.7 & 10.1 \\
\hline 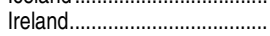 & 34.1 & 32.3 & 29.3 & 17.7 & 22.8 & 19.4 & 21.6 & 14.1 & 16.9 & 11.5 & 3.5 & - & 5.9 & 5.7 & 6.3 & 4.7 & 7.2 & 4.4 & - & 3.5 & 4.4 & 13.7 & 10.7 & 10.6 & 9.9 & 9.5 & 9.9 & 11.6 \\
\hline & - & - & 1 & 26.7 & 21.0 & & 21.0 & - & - & 3 & 5.1 & 5 & 5.0 & 4.6 & - & - & 6 & 7.5 & 4 & 4.2 & 4 & - & - & 1 & 14.1 & 11.7 & 1 & 11.9 \\
\hline & 19.7 & 19.5 & 2 & & & & 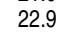 & 7.6 & 6.8 & 5.9 & 4.8 & 4.8 & 5.0 & 5.2 & 3.9 & 3.8 & 3.2 & 2.2 & 2. & 2.2 & 2.3 & 8.3 & 8.9 & 18.4 & & & 15.4 & 15.5 \\
\hline & 10.1 & 10.0 & 2 & & 2 & 5 & 16.1 & 2.4 & 3.4 & - & 4.0 & - & - & - & 0.0 & - & - & - & - & - & - & 21.0 & 19.3 & 18.9 & & & 16.3 & 16.1 \\
\hline & - & - & 36.9 & & & & 3 & - & - & 6.3 & $50-8$ & 4.8 & 5.0 & 5.1 & - & - & 3 & & 5.9 & 5 & 5.3 & & - & 26.3 & & & 24.0 & 23.9 \\
\hline Mexico ... & - & - & 23.0 & 27.3 & 26. & 25.9 & 25.6 & - & - & 2.2 & $2.9+9=0$ & 2.8 & 2.8 & 2.7 & - & - & 6.7 & 9.3 & $8.3-3>2$ & 7.4 & 3.7 & - & - & 14.1 & 15.3 & $\begin{array}{l}15.7 \\
\text {. }\end{array}$ & $\begin{array}{l}15.6 \\
\end{array}$ & 19.2 \\
\hline & 21.1 & - & 16 & & & & 13 & 7.1 & - & 3 & & 1. & & 1.3 & 1.6 & 1.6 & & 4.6 & & 4.6 & 4 & 12.4 & - & 11 & & & 7 & 7.7 \\
\hline & & 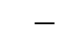 & & & & & & 8.2 & - & 11 & & & & & 55 & & & & & & & . & 3.2 & & & & & 1 \\
\hline ..... & 12.9 & 16.8 & 1 & & & & 1 & 2.1 & 3.1 & 0 & & 1 & 1 & 2 & 0.6 & 0.5 & 3 & & & 3 & 3 & 10.2 & $\begin{array}{r}13.2 \\
\end{array}$ & 7.5 & 8 & & 2 & 9.8 \\
\hline & - & - & 1 & & & & & - & - & 2 & & 3.8 & & 3.9 & - & - & 2.0 & & & & 4.5 & - & - & 12.0 & 10.1 & & 10.7 & 10.8 \\
\hline Portugal .................................... & - & 15.0 & 17.5 & 25.6 & 34.2 & 24.8 & 22.0 & 6.7 & 2.2 & 1.7 & 6.0 & 5.5 & 3.8 & 3.5 & - & 2.8 & 3.6 & 6.2 & 8.0 & 2.4 & 1.9 & 10.5 & 9.9 & 12.2 & 13.4 & 20.7 & 18.6 & 16.6 \\
\hline & $(5)$ & - & 21 & & & & & (5) & - & 2. & & 3 & & 3. & (5) & - & 4 & & & & 4 & & -1 & 15.3 & & & & 11.9 \\
\hline & 11 & 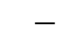 & & & & & & f & - & 2. & & & & & & - & & & & & & & - & & & & & 7 \\
\hline & 15.0 & 18.2 & & & & & & 5.7 & $13+2$ & 5 & & & & & 2 & 4. & & & & & & 6.7 & 9.4 & & & & & 15.7 \\
\hline & 24.0 & 26.4 & & & 22 & & 22 & 4.1 & 3.9 & 3 & & & 3. & 3.2 & $\begin{array}{l}4.7 \\
4.7\end{array}$ & 5. & & & & 2. & 2.3 & $\begin{array}{r}0.1 \\
15.2\end{array}$ & $\begin{array}{r}3.4 \\
17.0\end{array}$ & 20.3 & 19 & & 16.6 & 16.5 \\
\hline Switzerland .......... & 23.0 & 22.3 & 25.1 & 24.2 & 20.8 & 20.4 & 18.5 & 11.2 & 10.4 & 6.0 & 6.9 & 6.2 & 5.7 & 5.0 & 3.7 & 3.7 & 1.8 & 4.7 & 3.9 & 3.0 & 2.7 & 8.1 & 8.3 & 17.3 & 12.7 & 10.7 & 11.6 & 10.8 \\
\hline & 20.6 & 20.9 & 2 & & & & & 4.6 & 1 & 7 & & & & & 2 & 2.7 & & & & & 3 & 13.8 & 13.1 & 13 & 12 & & & 8.4 \\
\hline & & 20.9 & 28 & 2 & 2 & & 2 & - & -1. & $\begin{array}{r}12.4 \\
12.5\end{array}$ & & 9 & & $y$ & 2 & $\begin{array}{c}2.1 \\
-\end{array}$ & 5 & & & 6 & & 10.0 & - & 10 & 8 & & 8 & $\begin{array}{l}0.4 \\
9.1\end{array}-1$ \\
\hline United State & 16.9 & - & 17.1 & 16.7 & 15.8 & 15.7 & 16.0 & 5.1 & - & 6.6 & 0 & 6.4 & 6.4 & 6.7 & 4.0 & 3.3 & 3.5 & 4.8 & 3. & 3.3 & 3.4 & 7.8 & 6.7 & 6.6 & 6.2 & 0.0 & 5.9 & 6.0 \\
\hline & & & & & & & & & & & & & & & & & & & & & & & & & & & & \\
\hline & - & - & - & 11.4 & 11.1 & & & - & - & - & 3.2 & 3.3 & & 1.8 & _ & - & - & 3.5 & 2. & & 2. & - & - & - & 4.8 & 4.9 & 5.2 & 5.7 \\
\hline Russian Federation.... & $\left({ }^{5}\right)$ & & - & & - & 24.3 & 24.4 & ()$\left.^{5}\right)$ & - & - & & - & 1.5 & 1.5 & (5) & - & - & - & - & 5.2 & 5.7 & (5) & - & - & - & - & 17.6 & 17.2 \\
\hline
\end{tabular}

-Not available.

'Includes life sciences, physical sciences, mathematics/statistics, computer science, and engineering. IIncludes life sciences and physical sciences.

Includes mathematics/statistics and computer science.

${ }^{4}$ Refers to the mean of the data values for all reporting Organization for Economic Cooperation and Development (OECD) countries, to which each country reporting data contributes equally. The average includes all current OECD countries for for less than 75 percent of the countries that were members of $O E C D$ in a given year, the average for that year is omitted.
${ }^{5}$ Country did not exist in its current form in the given year.

Data in this table refer to degrees classified as International Standard Classification of Education (ISCED) level 5A, first award. This level corresponds to the bachelor's degree in the United States. Data for Luxembourg are not shown because countries. Detail may not sum to totals because of rounding.

(O) 2013. from htr://sats 


\begin{tabular}{|c|c|c|c|c|c|c|c|c|c|c|c|c|c|c|c|c|c|c|c|c|c|c|c|c|c|c|c|c|}
\hline \multirow[b]{2}{*}{ Country } & \multicolumn{7}{|c|}{ All mathematics, science, and engineering degrees ${ }^{1}$} & \multicolumn{7}{|c|}{ Natural sciences ${ }^{2}$} & \multicolumn{7}{|c|}{ Mathematics and computer science ${ }^{3}$} & \multicolumn{7}{|c|}{ Engineering } \\
\hline & 1990 & 1996 & 2000 & 2005 & 2008 & 2009 & 2010 & 1990 & 1996 & 2000 & 2005 & 2008 & 2009 & 2010 & 1990 & 1996 & 2000 & 2005 & 2008 & 2009 & 2010 & 1990 & 1996 & 2000 & 2005 & 2008 & 2009 & 2010 \\
\hline 1 & 2 & 3 & 4 & 5 & 6 & 7 & 8 & 9 & 10 & 11 & 12 & 13 & 14 & 15 & 16 & 17 & 18 & 19 & 20 & 21 & 22 & 23 & 24 & 25 & 26 & 27 & 28 & 29 \\
\hline OECD average $e^{4} \ldots$. & - & - & 28.5 & 24.7 & 23.3 & 22.6 & 23.2 & - & - & 11.1 & 8.9 & 7.4 & 6.9 & 6.6 & - & - & 5.4 & 4.9 & 5.0 & 4.2 & 4.4 & - & - & 12.7 & 11.4 & 11.2 & 11.7 & $\overline{12.4}$ \\
\hline Australia..................... & - & 14.0 & 15.2 & 20.0 & 18.8 & 18.9 & 18.8 & - & 5.4 & 4.0 & 3.1 & 3.1 & 3.0 & 3.0 & - & 3.8 & 4.9 & 8.7 & 8.3 & 7.6 & 7.1 & - & 4.7 & 6.3 & 8.1 & 7.5 & 8.3 & 8.7 \\
\hline Austria ........ & 37.7 & 38.8 & 39.2 & 38.6 & 31.8 & 33.4 & 31.8 & 12.3 & 17.5 & 16.7 & 15.0 & 7.5 & 7.6 & 6.4 & 4.6 & 4.7 & 4.7 & 6.6 & 11.3 & 10.8 & 9.4 & 20.8 & 16.6 & 17.7 & 16.9 & 13.0 & 14.9 & 16.0 \\
\hline gium....... & & - & 19.7 & 18.7 & 18.0 & 21.2 & 22.1 & - & - & - & 9.3 & 5.4 & 5.7 & 5.3 & - & - & - & 3.3 & 3.7 & 3.2 & 2.5 & - & - & 7.0 & 6.2 & 8.9 & 12.3 & 14.3 \\
\hline Canada... & 20.0 & 22.3 & 22.4 & 18.8 & 26.3 & 26.0 & 26.0 & 7.8 & 7.7 & 7.4 & 5.0 & 9.9 & 10.1 & 10.1 & 3.4 & 3.5 & 4.1 & 4.0 & 4.3 & 4.1 & 4.1 & 8.8 & 11.2 & 10.9 & 9.8 & 12.1 & 11.9 & 11.9 \\
\hline Chile ..................... & 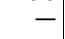 & - & - & 8.5 & 11.4 & 7.9 & 10.5 & - & - & - & 2.2 & 2.8 & 2.1 & 2.8 & - & - & - & 1.6 & 2.3 & 2.2 & 2.2 & - & - & - & 4.6 & 6.3 & 3.6 & 5.5 \\
\hline ech Renublis & (0) & - & 21.0 & 26.1 & 22.2 & 26.9 & 29.4 & (5) & - & 5.3 & 8.3 & 5.7 & 6.5 & 6.2 & (5) & - & 7.9 & 5.6 & 3.8 & 3.9 & 4.2 & (5) & - & 7.7 & 12.3 & 12.7 & 16.5 & 19.0 \\
\hline Denmar & 22.2 & 12.3 & 27.8 & 23.4 & 21.3 & 23.3 & 24.5 & 5.8 & 3.1 & 9.8 & 7.5 & 5.9 & 5.7 & 5.5 & 4.8 & 1.5 & 2.5 & 9.2 & 7.6 & 7.9 & 9.0 & 11.6 & 7.8 & 15.4 & 6.7 & 7.8 & 9.7 & 10.0 \\
\hline Estonia. & (5) & - & - & 23.9 & 28.6 & 27.3 & 28.0 & $(5)$ & 0.1 & - & 10.0 & 8.2 & 8.3 & 9.3 & (5) & - & - & 5.0 & 7.7 & 5.7 & 6.5 & (5) & - & (1.7. & 8.9 & 12.6 & 13.3 & 12.3 \\
\hline Finland...... & 30.6 & 28.3 & 28.7 & 30.5 & 31.7 & 34.3 & 39.8 & 14.7 & 11.6 & 11.3 & 11.6 & 12.5 & 5.8 & 5.1 & 5.4 & 4.0 & 2.4 & 4.1 & 4.0 & 3.7 & 3.7 & 10.5 & 12.7 & 14.9 & 14.8 & 15.2 & 24.8 & 30.8 \\
\hline France & & 20.0 & 26.4 & 28.4 & 28.8 & 28.0 & - & - & - & 13.5 & 12.5 & 10.8 & 11.0 & - & - & - & 5.6 & 7.0 & 6.8 & 6.7 & - & - & - & 7.3 & 8.9 & 11.2 & 10.3 & - \\
\hline $\mathrm{rm}$ & 33.2 & 38.6 & 38.1 & 30.9 & 33.7 & 32.2 & 33.1 & 23.5 & 25.5 & 24.9 & 14.8 & 15.1 & 14.7 & 14.4 & 2.3 & 3.5 & 3.7 & 4.8 & 6.3 & 6.1 & 7.3 & 7.4 & 9.5 & 9.5 & 11.3 & 12.3 & 11.4 & 11.5 \\
\hline & $00 . c^{2}$ & 0.0 & 00.1 & 42.8 & 33 & ve.L & 31.9 & cu. & 20.0 & $2+.0$ & 22. & $6 ?$ & & 6.8 & 2.0 & - & 0.1 & 53 & 11.0 & 0.1 & 13.1 & - & 0.0 & & 15.2 & 15.7 & & 11.9 \\
\hline$\cdots \cdots$ & - & - & 9.9 & 6.4 & 8.3 & 10.0 & 9.5 & - & - & 1.7 & 1.8 & 2.6 & 2.8 & 2.6 & - & - & 0.7 & 1.7 & 1.4 & 1.2 & 1.3 & - & - & 7.5 & 2.9 & 4.4 & 6.0 & 5.6 \\
\hline Iceland... & - & - & 35.9 & 23.0 & 10.6 & 12.7 & 14.0 & - & - & 19.4 & 9.5 & 5.8 & 4.6 & 5.8 & - & - & $\#$ & 3.0 & 1.1 & 0.9 & 0.9 & - & - & 16.5 & 10.5 & 3.7 & 7.2 & 7.3 \\
\hline Ireland & 34.5 & 23.1 & 28.1 & 16.8 & 19.0 & 16.3 & 17.3 & 19.5 & 10.9 & 6.9 & 4.1 & - & 5.1 & 3.4 & 5.8 & 3.0 & 15.2 & 6.3 & - & 6.2 & 7.1 & 9.3 & 9.2 & 6.0 & 6.4 & 6.1 & 5.1 & 6.8 \\
\hline & - & - & 18.1 & 17.9 & 18.6 & 18.4 & 16.7 & - & - & 9.2 & 8. & 9.2 & 8.8 & 8.2 & - & - & 2 & 3 & 3.3 & 3.2 & 3.0 & - & -1 & 6.1 & 5.9 & 6.0 & 6.3 & 5.5 \\
\hline & - & - & 11.7 & 15. & & & - & - & - & 0.3 & 3.5 & - & - & - & - & - & 5.8 & 3.5 & - & - & - & - & - & 5.7 & 8.9 & & & - \\
\hline & - & - & 54.4 & 50 & 47.1 & 46.8 & 46.4 & 9.5 & 10.2 & - & - & - & - & - & - & - & - & - & - & - & - & 45.1 & 44.4 & 41.9 & 38.0 & 34.7 & 34.7 & 34.5 \\
\hline (in & - & - & 48.4 & 43.9 & 24 & 24.2 & 24.1 & - & - & 8.5 & 9.5 & 4.4 & 4.7 & 4.7 & - & - & 5.7 & 2.0 & 1.2 & 1.4 & 1.6 & - & - & 34.3 & & 18.4 & 18.1 & 17.8 \\
\hline Mexico ..... & - & - & $\begin{array}{l}40.4 \\
31.4^{6}\end{array}$ & $\begin{array}{l}40.9 \\
14.7\end{array}$ & $\begin{array}{l}42.1 \\
12.1\end{array}$ & $\begin{array}{l}24.2 \\
12.1\end{array}$ & $\begin{array}{l}<4.1 \\
12.7\end{array}$ & - & - & $\begin{array}{c}0.9 \\
18.9^{6}\end{array}$ & 3.3 & $\begin{array}{l}2.4 \\
2.9\end{array}$ & $\begin{array}{l}4.1 \\
2.9\end{array}$ & $\begin{array}{l}4.1 \\
4.2\end{array}$ & - & - & $4.1^{6}$ & 3.2 & $\begin{array}{l}1.2 \\
3.3\end{array}$ & $\begin{array}{l}.4 .4 \\
2.3\end{array}$ & $\begin{array}{l}1.0 \\
1.5\end{array}$ & - & - & $\begin{array}{r}54.0 \\
8.4^{6}\end{array}$ & $\begin{array}{l}0<.4 \\
8.2\end{array}$ & $\begin{array}{r}0.4 \\
5.9\end{array}$ & $\begin{array}{r}10.1 \\
6.9\end{array}$ & 7.0 \\
\hline Netherland & 28.9 & 18.6 & - & 21 & 14 & 15.1 & 15.5 & 17.7 & 4.4 & - & - & - & - & - & 1.5 & 3.7 & - & - & - & - & - & 9.7 & 10.6 & - & 11.9 & 7.6 & 7. & 8.3 \\
\hline & 22.6 & 16.7 & 20.5 & & & 20.1 & 20.2 & 13.8 & 12.7 & 11.6 & 7.2 & 9.1 & 9.6 & 9.1 & 4.7 & $\begin{array}{l}1.1 \\
1.1\end{array}$ & 1.4 & 50 & 4.1 & 4.6 & 4.1 & 4.0 & 3.0 & 7.5 & & 5.3 & & 6.9 \\
\hline Norw & 33.4 & 38.3 & 22.0 & 25.8 & 22 & 19.1 & 19. & 8.0 & 8.7 & 14.9 & 7.8 & 6.1 & - & - & 2.1 & 1.9 & 4.6 & 11.9 & 10.8 & - & - & 23.3 & 27.7 & 2.5 & 6.1 & 5.3 & 4.3 & 6.4 \\
\hline Poland & - & - & - & 9.1 & 11 & 11.5 & 11.4 & - & - & - & - & - & - & - & - & - & - & - & - & - & - & - & - & - & 3.5 & 5.0 & 6.5 & 6.5 \\
\hline Portugal .................................. & - & - & $39.3^{6}$ & 33.8 & 49.2 & 32.7 & 31.3 & - & - & $11.7^{6}$ & 12.0 & 12.2 & 7.2 & 7.2 & - & - & $9.4^{6}$ & 10.0 & 11.2 & 2.3 & 2.0 & - & - & $18.2^{6}$ & 11.9 & 25.8 & 23.2 & 22.1 \\
\hline Slov & (5) & - & 38.1 & 36 & $2 \varepsilon$ & 25 & 22.5 & $\left({ }^{5}\right)$ & - & 12.6 & 10. & 6. & 5.3 & 4.9 & (5) & - & 4.7 & 4 & 2.2 & 3.7 & 3.4 & (5) & - & 20.9 & 21 & 19.6 & 16.5 & 14.2 \\
\hline & (5) & 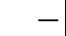 & 0. & & & & & $(5)$ & t & & & & 6.1 & 9.5 & (5) & - & - & & & 2. & 2.5 & $(5)$ & - & 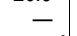 & & 10.1 & & 10.9 \\
\hline & 26.9 & 36.0 & - & 37. & 26 & 24.5 & 23.2 & 19.7 & 24.8 & 23.96 & $23.8^{6}$ & 14.0 & 12.3 & 9.7 & 1.4 & 4.1 & $5.4^{6}$ & $4.6^{6}$ & 3 & 3.5 & 3.4 & 5.7 & 7.1 & $6.8^{6}$ & $9.1^{6}$ & 8.7 & 8.7 & 10.1 \\
\hline & 48.5 & 32.3 & 40.5 & $23.7-7$ r & 28 & 32.0 & 40.1 & 19.4 & $\begin{array}{r}r .0 \\
9.2\end{array}$ & 14.3 & 8.0 & 8.5 & 8.3 & $\begin{array}{l}9.1 \\
9.1\end{array}$ & $\begin{array}{l}9.4 \\
9.2\end{array}$ & 5.9 & $\begin{array}{l}.4 \\
4.0\end{array}$ & 4.0 & 4.0 & $\begin{array}{l}5.0 \\
5.2\end{array}$ & $\begin{array}{l}.4 .5 \\
5.5\end{array}$ & $\begin{array}{r}. .1 \\
19.9\end{array}$ & 17.1 & 22.2 & $\begin{array}{r}32.9 \\
12.9\end{array}$ & $\begin{array}{r}0.1 \\
15.6\end{array}$ & $\begin{array}{r}0.1 \\
18.5\end{array}$ & 25.6 \\
\hline 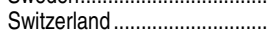 & 30.2 & 40.1 & 42.7 & 32.0 & 28.9 & 29.5 & 25.2 & 22.0 & 25.8 & 11.7 & 11.7 & 12.4 & 12.5 & 10.6 & 1.7 & 4.1 & 19.5 & 3.4 & 3.1 & 3.9 & 2.9 & 6.5 & 10.1 & 11.6 & 16.9 & 13.3 & 13.1 & 11.8 \\
\hline Turkey & 24.0 & - & 25.7 & 21.4 & 18.8 & 18.3 & 16 & 7.6 & - & 7.6 & 6. & 5.4 & 5.3 & 5.0 & 3.3 & - & 3 & 3 & 3.1 & 3.0 & 2.9 & 13.2 & - & 15.2 & 11.2 & 10.4 & 9.9 & 8.6 \\
\hline United Kin & - & - & 21.7 & 20.3 & 20.3 & 20.4 & 21 & - & - & 7.4 & 5. & 5.5 & 5.8 & 5.6 & - & - & 5.0 & 5. & 5.2 & 4.8 & 5.3 & - & - & 9.2 & 9. & 9.7 & 9.8 & 10.6 \\
\hline United States ............................ & 14.5 & 13.8 & 13.0 & 13.5 & 13.0 & 13.1 & 13.0 & 4.2 & 4.0 & 3.4 & 3.3 & 3.5 & 3.4 & 3.5 & 3.4 & 3.2 & 3.4 & 3.5 & 3.2 & 3.2 & 3.1 & 6.9 & 6.7 & 6.2 & 6.7 & 6.3 & 6.5 & 6.4 \\
\hline
\end{tabular}

\section{-Not available.}

1Includes life sciences, physical sciences, mathematics/statistics, computer science, and engineering 2Includes life sciences and physical sciences.

${ }^{3}$ Includes mathematics/statistics and computer science.

${ }^{4}$ Refers to the mean of the data values for all reporting Organization for Economic Cooperation and Development (OECD) countries, to which each country reporting data contributes equally. The average includes all current OECD countries for for less than 75 percent of the countries that were members of OECD in a given year, the average for that year is omitted.
${ }^{5}$ Country did not exist in its current form in the given year.

'Only includes doctor's (Ph.D.) degrees.
NOTE: Data in this table refer to degrees classified as International Standard Classification of Education (ISCED) level 5A, second award, and as ISCED 6. ISCED 5A, second award, corresponds to master's and first-professional degrees in the United States, and ISCED 6 corresponds to doctor's degrees. Data for Luxembourg are not shown because students gener-
ally attend no more than 1 year of higher education in Luxembourg and must complete their degrees in other countries. Detail ally attend no more than 1 year of higher education in Luxembourg and must complete their degrees in other countries. Detall
may not sum to totals because of rounding. may not sum to totals because of rounding.

2013. from http.//stats oecd org/lndex aspx and unpublished tabulations. 
Table 603.90. Employment to population ratios of 25- to 64-year-olds, by sex, highest level of educational attainment, and country: 2011

\begin{tabular}{|c|c|c|c|c|c|c|c|c|c|c|c|c|}
\hline \multirow[b]{2}{*}{ Country } & \multicolumn{4}{|c|}{ Total population, 25 to 64 years old } & \multicolumn{4}{|c|}{ Male } & \multicolumn{4}{|c|}{ Female } \\
\hline & $\begin{array}{r}\text { All levels of } \\
\text { education }\end{array}$ & $\begin{array}{r}\text { Less than } \\
\text { high school } \\
\text { completion }\end{array}$ & $\begin{array}{l}\text { High school } \\
\text { completion }\end{array}$ & $\begin{array}{r}\text { Associate's } \\
\text { or higher } \\
\text { degree }\end{array}$ & $\begin{array}{r}\text { All levels of } \\
\text { education }\end{array}$ & $\begin{array}{r}\text { Less than } \\
\text { high school } \\
\text { completion }\end{array}$ & $\begin{array}{r}\text { High school } \\
\text { completion }\end{array}$ & $\begin{array}{r}\text { Associate's } \\
\text { or higher } \\
\text { degree }\end{array}$ & $\begin{array}{r}\text { All levels of } \\
\text { education }\end{array}$ & $\begin{array}{r}\text { Less than } \\
\text { high school } \\
\text { completion }\end{array}$ & $\begin{array}{r}\text { High school } \\
\text { completion }\end{array}$ & $\begin{array}{r}\text { Associate's } \\
\text { or higher } \\
\text { degree }\end{array}$ \\
\hline 1 & 2 & 3 & 4 & 5 & 6 & 7 & 8 & 9 & 10 & 11 & 12 & 13 \\
\hline OECD average ${ }^{1} \ldots \ldots \ldots \ldots \ldots . . . . . . .$. & 72.7 & 55.5 & 73.8 & 83.0 & 80.2 & 66.2 & 81.1 & 87.6 & 65.2 & 45.5 & 65.9 & 78.4 \\
\hline 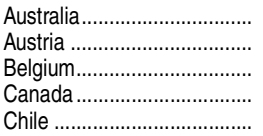 & $\begin{array}{l}78.2 \\
75.8 \\
70.0 \\
75.9 \\
72.1\end{array}$ & $\begin{array}{l}65.8 \\
56.2 \\
47.7 \\
55.0 \\
63.4\end{array}$ & $\begin{array}{l}80.7 \\
77.9 \\
74.0 \\
74.3 \\
72.8\end{array}$ & $\begin{array}{l}84.1 \\
86.5 \\
84.2 \\
81.6 \\
79.4\end{array}$ & $\begin{array}{l}86.4 \\
81.6 \\
76.0 \\
80.0 \\
87.2\end{array}$ & $\begin{array}{l}76.6 \\
65.7 \\
57.9 \\
63.8 \\
83.4\end{array}$ & $\begin{array}{l}88.9 \\
81.9 \\
80.7 \\
79.3 \\
89.2\end{array}$ & $\begin{array}{l}90.3 \\
89.9 \\
86.9 \\
85.0 \\
87.7\end{array}$ & $\begin{array}{l}70.2 \\
70.0 \\
63.9 \\
71.8 \\
57.7\end{array}$ & $\begin{array}{l}56.3 \\
50.9 \\
37.0 \\
44.2 \\
44.9\end{array}$ & $\begin{array}{l}70.1 \\
73.6 \\
66.7 \\
68.2 \\
57.2\end{array}$ & $\begin{array}{l}79.1 \\
82.4 \\
81.8 \\
78.8 \\
71.2\end{array}$ \\
\hline 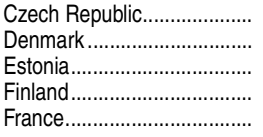 & $\begin{array}{l}74.2 \\
77.5 \\
73.3 \\
75.4 \\
71.6\end{array}$ & $\begin{array}{l}42.2 \\
62.6 \\
48.4 \\
55.5 \\
55.7\end{array}$ & $\begin{array}{l}75.3 \\
79.0 \\
74.0 \\
74.7 \\
73.7\end{array}$ & $\begin{array}{l}83.1 \\
85.8 \\
80.0 \\
84.3 \\
83.8\end{array}$ & $\begin{array}{l}83.4 \\
80.8 \\
76.5 \\
77.4 \\
76.4\end{array}$ & $\begin{array}{l}50.8 \\
70.0 \\
53.6 \\
60.3 \\
62.7\end{array}$ & $\begin{array}{l}83.6 \\
81.5 \\
78.2 \\
77.3 \\
78.1\end{array}$ & $\begin{array}{l}91.5 \\
88.2 \\
84.6 \\
87.2 \\
87.2\end{array}$ & $\begin{array}{l}64.8 \\
74.1 \\
70.5 \\
73.4 \\
67.0\end{array}$ & $\begin{array}{l}38.0 \\
55.3 \\
40.7 \\
48.9 \\
49.4\end{array}$ & $\begin{array}{l}66.2 \\
75.9 \\
69.2 \\
71.6 \\
69.0\end{array}$ & $\begin{array}{l}74.4 \\
83.9 \\
77.4 \\
82.2 \\
81.0\end{array}$ \\
\hline 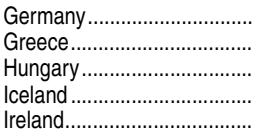 & $\begin{array}{l}77.5 \\
62.5 \\
63.8 \\
82.6 \\
65.9\end{array}$ & $\begin{array}{l}56.5 \\
52.6 \\
37.7 \\
74.4 \\
45.7\end{array}$ & $\begin{array}{l}77.6 \\
62.6 \\
66.3 \\
83.4 \\
65.1\end{array}$ & $\begin{array}{l}87.9 \\
74.8 \\
79.3 \\
88.8 \\
80.8\end{array}$ & $\begin{array}{l}83.0 \\
74.1 \\
70.4 \\
86.0 \\
71.1\end{array}$ & $\begin{array}{l}66.7 \\
67.5 \\
46.5 \\
81.5 \\
54.2\end{array}$ & $\begin{array}{l}82.1 \\
75.9 \\
71.8 \\
86.1 \\
71.9\end{array}$ & $\begin{array}{l}91.0 \\
79.7 \\
84.7 \\
90.3 \\
84.8\end{array}$ & $\begin{array}{l}72.0 \\
50.8 \\
57.6 \\
79.2 \\
60.8\end{array}$ & $\begin{array}{l}49.2 \\
37.6 \\
31.5 \\
68.3 \\
35.3\end{array}$ & $\begin{array}{l}73.1 \\
49.4 \\
60.0 \\
79.2 \\
58.3\end{array}$ & $\begin{array}{l}84.0 \\
69.9 \\
75.2 \\
87.8 \\
77.6\end{array}$ \\
\hline 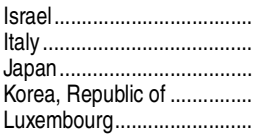 & $\begin{array}{l}72.1 \\
63.7 \\
75.9 \\
72.2 \\
73.9\end{array}$ & $\begin{array}{r}45.6 \\
50.8 \\
- \\
65.2 \\
62.0\end{array}$ & $\begin{array}{l}70.9 \\
71.9 \\
72.8 \\
70.8 \\
70.4\end{array}$ & $\begin{array}{l}82.8 \\
79.0 \\
79.6 \\
76.9 \\
85.0\end{array}$ & $\begin{array}{l}77.8 \\
75.7 \\
88.4 \\
85.5 \\
82.4\end{array}$ & $\begin{array}{r}60.6 \\
67.9 \\
- \\
77.7 \\
74.9\end{array}$ & $\begin{array}{l}76.8 \\
81.3 \\
85.2 \\
83.7 \\
79.0\end{array}$ & $\begin{array}{l}85.9 \\
84.9 \\
92.0 \\
89.7 \\
89.8\end{array}$ & $\begin{array}{l}66.6 \\
51.9 \\
63.5 \\
58.6 \\
65.2\end{array}$ & $\begin{array}{r}28.8 \\
33.1 \\
- \\
57.2 \\
50.9\end{array}$ & $\begin{array}{l}64.5 \\
62.6 \\
60.6 \\
57.7 \\
61.8\end{array}$ & $\begin{array}{l}80.2 \\
74.3 \\
66.9 \\
60.5 \\
79.4\end{array}$ \\
\hline 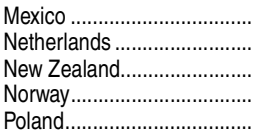 & $\begin{array}{l}67.0 \\
77.4 \\
79.3 \\
82.5 \\
67.5\end{array}$ & $\begin{array}{l}62.5 \\
62.1 \\
68.0 \\
68.0 \\
39.8\end{array}$ & $\begin{array}{l}71.2 \\
80.0 \\
82.1 \\
81.7 \\
65.9\end{array}$ & $\begin{array}{l}79.3 \\
87.4 \\
84.4 \\
90.5 \\
84.7\end{array}$ & $\begin{array}{l}87.7 \\
83.6 \\
86.4 \\
85.3 \\
75.0\end{array}$ & $\begin{array}{l}87.2 \\
74.4 \\
76.5 \\
72.4 \\
49.3\end{array}$ & $\begin{array}{l}90.1 \\
84.9 \\
89.1 \\
85.4 \\
75.0\end{array}$ & $\begin{array}{l}87.2 \\
89.6 \\
90.3 \\
91.9 \\
89.1\end{array}$ & $\begin{array}{l}48.7 \\
71.1 \\
72.7 \\
79.7 \\
60.3\end{array}$ & $\begin{array}{l}41.7 \\
50.9 \\
60.5 \\
63.3 \\
30.8\end{array}$ & $\begin{array}{l}55.0 \\
75.2 \\
72.9 \\
76.9 \\
56.0\end{array}$ & $\begin{array}{l}70.5 \\
85.0 \\
80.0 \\
89.3 \\
81.7\end{array}$ \\
\hline 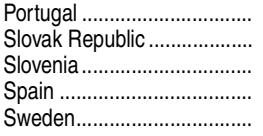 & $\begin{array}{l}71.3 \\
68.9 \\
70.8 \\
64.0 \\
83.0\end{array}$ & $\begin{array}{l}65.9 \\
30.2 \\
46.7 \\
52.1 \\
65.2\end{array}$ & $\begin{array}{l}79.4 \\
70.2 \\
70.6 \\
67.5 \\
83.5\end{array}$ & $\begin{array}{l}83.4 \\
81.6 \\
86.4 \\
78.9 \\
88.7\end{array}$ & $\begin{array}{l}75.9 \\
76.4 \\
74.2 \\
70.6 \\
85.9\end{array}$ & $\begin{array}{l}72.9 \\
35.4 \\
55.5 \\
61.6 \\
74.5\end{array}$ & $\begin{array}{l}81.2 \\
77.6 \\
74.0 \\
74.2 \\
86.7\end{array}$ & $\begin{array}{l}83.5 \\
87.3 \\
87.4 \\
82.1 \\
89.8\end{array}$ & $\begin{array}{l}66.9 \\
61.5 \\
67.3 \\
57.3 \\
80.0\end{array}$ & $\begin{array}{l}58.5 \\
27.0 \\
39.5 \\
41.9 \\
53.0\end{array}$ & $\begin{array}{l}77.7 \\
62.1 \\
66.0 \\
60.8 \\
79.7\end{array}$ & $\begin{array}{l}83.3 \\
77.0 \\
85.7 \\
75.8 \\
87.8\end{array}$ \\
\hline 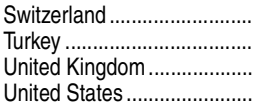 & $\begin{array}{l}82.7 \\
56.3 \\
75.0 \\
70.9\end{array}$ & $\begin{array}{l}68.4 \\
50.7 \\
55.9 \\
51.1\end{array}$ & $\begin{array}{l}82.5 \\
61.7 \\
78.2 \\
67.1\end{array}$ & $\begin{array}{l}88.8 \\
76.1 \\
83.2 \\
80.0\end{array}$ & $\begin{array}{l}89.7 \\
77.9 \\
81.3 \\
75.7\end{array}$ & $\begin{array}{l}78.7 \\
75.2 \\
66.1 \\
61.0\end{array}$ & $\begin{array}{l}89.1 \\
81.7 \\
82.8 \\
71.8\end{array}$ & $\begin{array}{l}93.5 \\
84.0 \\
87.7 \\
84.7\end{array}$ & $\begin{array}{l}75.6 \\
31.3 \\
68.9 \\
66.1\end{array}$ & $\begin{array}{l}61.7 \\
26.1 \\
47.9 \\
39.7\end{array}$ & $\begin{array}{l}76.7 \\
29.9 \\
72.9 \\
62.3\end{array}$ & $\begin{array}{l}81.9 \\
64.2 \\
78.9 \\
75.8\end{array}$ \\
\hline $\begin{array}{l}\text { Other reporting countries } \\
\text { Brazil......................... } \\
\text { Russian Federation .......... }\end{array}$ & $\begin{array}{l}70.2 \\
76.7\end{array}$ & $\begin{array}{l}67.1 \\
49.0\end{array}$ & $\begin{array}{l}70.1 \\
72.8\end{array}$ & $\begin{array}{l}85.3 \\
82.8\end{array}$ & $\begin{array}{l}86.3 \\
81.9\end{array}$ & $\begin{array}{l}83.9 \\
56.6\end{array}$ & $\begin{array}{l}89.3 \\
79.3\end{array}$ & $\begin{array}{l}91.5 \\
88.2\end{array}$ & $\begin{array}{l}55.5 \\
72.2\end{array}$ & $\begin{array}{l}50.4 \\
40.3\end{array}$ & $\begin{array}{l}54.0 \\
64.9\end{array}$ & $\begin{array}{l}80.8 \\
79.1\end{array}$ \\
\hline
\end{tabular}

-Not available.

${ }^{1}$ Refers to the mean of the data values for all reporting OECD countries, to which each country reporting data contributes equally.

NOTE: The "high school completion" columns include International Standard Classification of Education (ISCED) levels 3 and 4, with the exception of ISCED level 3C short programs. (ISCED 3C short programs do not correspond to high school completion in the United States and are included in the "less than high school completion" columns in this table.) ISCED level 5B corresponds to the associate's degree in the United States in this table. Also included in the "associate's or higher degree" columns are the following higher level degrees: ISCED 5A, first award, which corresponds to the bachelor's degree in the United States; ISCED 5A, second award, which corresponds to master's and first-professional degrees in the United States; and ISCED 6, which corresponds to doctor's degrees. For each country, the employment to population ratio of 25- to 64-year-olds is the number of persons in this age group who are employed as a percentage of the total civilian population in this age group.

SOURCE: Organization for Economic Cooperation and Development (OECD), Education at a Glance, 2013. (This table was prepared December 2013.) 
Table 605.10. Gross domestic product per capita and public and private education expenditures per full-time-equivalent (FTE) student, by level of education and country: Selected years, 2005 through 2010

\begin{tabular}{|c|c|c|c|c|c|c|c|c|c|c|c|c|c|c|c|}
\hline \multirow[b]{2}{*}{ Country } & \multicolumn{5}{|c|}{ Gross domestic product per capita } & \multicolumn{5}{|c|}{ Elementary and secondary education expenditures per FTE student } & \multicolumn{5}{|c|}{ Higher education expenditures per FTE student } \\
\hline & 2005 & 2007 & 2008 & 2009 & 2010 & 2005 & 2007 & 2008 & 2009 & 2010 & 2005 & 2007 & 2008 & 2009 & 2010 \\
\hline 1 & 2 & 3 & 4 & 5 & 6 & 7 & 8 & 9 & 10 & 11 & 12 & 13 & 14 & 15 & 16 \\
\hline & \multicolumn{15}{|c|}{ Current dollars } \\
\hline OECD average ${ }^{1} \ldots \ldots \ldots \ldots$ & $\$ 28,772$ & $\$ 33,452$ & $\$ 33,886$ & $\$ 33,206$ & $\$ 33,471$ & $\$ 6,751$ & $\$ 7,410$ & $\$ 8,180$ & $\$ 8,632$ & $\$ 8,501$ & $\$ 11,358$ & $\$ 12,442$ & $\$ 13,391$ & $\$ 13,707$ & $\$ 13,211$ \\
\hline Australia................................ & 33,983 & 37,615 & 39,532 & 39,971 & 40,801 & 7,142 & 7,590 & 7,814 & 9,139 & 9,803 & 14,579 & 14,726 & 15,043 & 16,074 & 15,142 \\
\hline Austria ................................. & 34,107 & 36,839 & 39,849 & 38,834 & 40,411 & 9,436 & 9,959 & 10,994 & 11,681 & 11,693 & 14,775 & 15,039 & 15,043 & 14,257 & 15,007 \\
\hline Belgium .................................. & 32,077 & 34,662 & 36,879 & 36,698 & 37,878 & 7,306 & 8,333 & 9,706 & 9,783 & 10,123 & 11,960 & 13,482 & 15,020 & 15,443 & 15,179 \\
\hline Canada & & 38,883 & 38,522 & 40,136 & - & $7,774^{2}$ & $8,388^{2}$ & $8,997^{2}$ & $9,774^{2}$ & - & $23,3293,4$ & $20,903^{3}$ & $20,903^{3}$ & $22,475^{3}$ & - \\
\hline 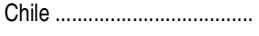 & 12,635 & - & 14,106 & 14,578 & 15,107 & 2,099 & 2,089 & 2,245 & 2,635 & 2,935 & 6,873 & 6,292 & 6,829 & 6,829 & 6,863 \\
\hline Czech Republic...................... & 20,280 & 23,995 & 25,845 & 25,614 & 25,364 & 4,098 & 4,712 & 5,236 & 5,615 & 5,532 & 6,649 & 8,209 & 8,318 & 8,237 & 7,635 \\
\hline 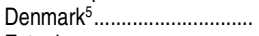 & 33,626 & 36,326 & 39,494 & 38,299 & 40,600 & 8,997 & 9,448 & 10,429 & 11,094 & 11,404 & 14,959 & 16,466 & 17,634 & 18,556 & 18,977 \\
\hline Estonia............................... & 16,660 & 20,620 & 21,802 & 19,789 & 20,093 & 3,736 & 4,637 & 6,054 & 6,149 & 5,984 & 3,869 & $5,653^{4}$ & $6,022^{4}$ & 6,373 & 6,501 \\
\hline Finland.................................. & 30,468 & 35,322 & 37,795 & 35,848 & 36,030 & 6,610 & 7,216 & 8,068 & 8,314 & 8,591 & 12,285 & 13,566 & 15,402 & 16,569 & 16,714 \\
\hline France................................. & 29,644 & 32,495 & 34,233 & 33,724 & 34,395 & 7,456 & 8,070 & 8,559 & 8,861 & 9,070 & 10,995 & 12,773 & 14,079 & 14,642 & 15,067 \\
\hline Germany & 30,496 & 34,683 & 37,171 & 36,048 & 37,661 & 7,039 & 7,243 & 7,859 & 8,534 & - & 12,446 & 13,823 & 15,390 & 15,711 & - \\
\hline Greece................................. & 25,472 & 27,793 & 29,920 & 29,381 & 27,539 & $5,493^{2}$ & - & - & - & - & 6,130 & - & - & - & - \\
\hline Hungary $^{3} \ldots \ldots \ldots \ldots \ldots \ldots \ldots \ldots \ldots$ & 17,014 & 18,763 & 20,700 & 20,154 & 20,625 & 4,027 & 4,371 & 4,626 & 4,506 & 4,555 & 6,244 & 6,721 & 7,327 & 8,518 & 8,745 \\
\hline Iceland .................................... & 35,571 & 36,325 & 39,029 & 36,718 & 35,509 & 8,815 & 8,949 & 9,745 & 9,309 & 8,592 & $9,474^{5}$ & 9,309 & 10,429 & 9,939 & 8,728 \\
\hline Ireland................................... & 38,061 & 44,381 & 42,644 & 39,750 & 41,000 & 6,411 & 7,791 & $8,915^{3}$ & $9,615^{3}$ & $9,638^{3}$ & 10,468 & 12,631 & $16,284^{3}$ & $16,420^{3}$ & $16,008^{3}$ \\
\hline Israel... & 21,474 & 26,444 & 27,690 & 27,454 & 26,552 & 5,041 & 5,345 & 5,780 & 5,464 & 5,692 & 10,919 & 11,435 & 12,568 & 11,214 & 10,730 \\
\hline Italy ................................. & 27,750 & 31,016 & 33,271 & 32,397 & 32,110 & $7,410^{3}$ & $7,771^{3}$ & $9,071^{3}$ & $8,943^{3}$ & $8,489^{3}$ & $8,026^{3}$ & 8,673 & 9,553 & 9,562 & 9,580 \\
\hline $\mathrm{Japan}^{5}$ & 30,290 & 33,635 & 33,902 & 32,324 & 35,238 & 7,343 & 8,012 & 8,301 & 8,502 & 9,168 & 12,326 & 14,201 & 14,890 & 15,957 & 16,015 \\
\hline Korea, Republic of ................ & 21,342 & 26,574 & 26,877 & 27,171 & 28,829 & 5,638 & 6,663 & 6,723 & 8,122 & 7,396 & 7,606 & 8,920 & 9,081 & 9,513 & 9,972 \\
\hline Luxembourg.............................. & 69,984 & 82,456 & 89,732 & 82,972 & 84,672 & $15,930^{2,3}$ & $15,579^{2,3}$ & 16,909 & 18,018 & 19,050 & - & - & - & - & - \\
\hline Mexico ………………......... & 11,299 & 14,128 & 15,190 & 14,397 & 15,195 & 2,025 & 2,165 & 2,284 & 2,339 & 2,464 & 6,402 & 6,971 & 7,504 & 8,020 & 7,872 \\
\hline Netherlands .......................... & 34,724 & 39,594 & 42,887 & 41,089 & 41,682 & 7,045 & 8,571 & 9,251 & 10,030 & 10,075 & 13,883 & 15,969 & 17,245 & 17,849 & 17,161 \\
\hline New Zealand......................... & 24,882 & 27,020 & 29,231 & 29,204 & 29,629 & 5,659 & 5,454 & 6,496 & 7,556 & 7,681 & 10,262 & 9,905 & 10,526 & 10,619 & 10,418 \\
\hline Norway................................ & 47,620 & 53,672 & 43,659 & 54,708 & 44,825 & 9,975 & 10,855 & 12,070 & 12,971 & 13,067 & 15,552 & 17,140 & 18,942 & 19,269 & 18,512 \\
\hline Poland ${ }^{3}$........................................ & 13,573 & 16,312 & 18,062 & 18,910 & 20,034 & 3,165 & 3,804 & 4,682 & 5,167 & 5,693 & 5,593 & 5,576 & 7,063 & 7,776 & 8,866 \\
\hline Portugal ${ }^{3} \ldots \ldots .$. & 19,967 & 22,638 & 24,962 & 24,935 & 25,519 & 5,646 & 5,898 & 6,276 & 7,288 & 7,419 & 8,787 & 10,398 & 10,373 & 10,481 & 10,578 \\
\hline Slovak Republic ${ }^{6} \ldots \ldots \ldots \ldots . . . . . . . . . .$. & 15,881 & 20,270 & 23,205 & 22,620 & 23,194 & 2,740 & 3,296 & 4,006 & 4,781 & 5,066 & 5,783 & 5,736 & 6,560 & 6,758 & 6,904 \\
\hline Slovenia ................................ & 23,043 & 26,557 & 29,241 & 27,150 & 26,649 & 7,065 & 7,267 & 8,555 & 8,670 & 8,505 & 8,573 & 8,559 & 9,263 & 9,311 & 9,693 \\
\hline Spain & 27,270 & 31,469 & 33,173 & 32,146 & 31,574 & 6,411 & 7,671 & 8,522 & 8,818 & 8,479 & 10,089 & 12,548 & 13,366 & 13,614 & 13,373 \\
\hline Sweden & 32,770 & 36,785 & 39,321 & 37,192 & 39,251 & 7,861 & 8,773 & 9,524 & 9,709 & 10,044 & 15,946 & 18,361 & 20,014 & 19,961 & 19,562 \\
\hline Switzerland ${ }^{3} \ldots \ldots \ldots \ldots \ldots \ldots$ & 35,500 & 41,800 & 45,517 & 44,773 & 48,962 & 10,721 & 11,702 & 13,775 & 13,411 & 13,510 & 21,734 & 20,883 & 21,648 & 21,577 & 21,893 \\
\hline Turkey ……………….......... & & & 14,963 & 14,442 & 15,775 & & & 40 & & 2,020 & & & & & \\
\hline United Kingdom .................... & 31,580 & 34,957 & 36,817 & 34,483 & 35,299 & 6,888 & 8,622 & 9,169 & 9,602 & 9,980 & 13,506 & 15,463 & 15,310 & 16,338 & 15,862 \\
\hline United States ......................... & 41,674 & 46,434 & 46,901 & 45,087 & 46,548 & 9,771 & 10,882 & 11,107 & 11,818 & 11,826 & 23,435 & 25,373 & 27,499 & 27,066 & 25,576 \\
\hline
\end{tabular}


Table 605.10. Gross domestic product per capita and public and private education expenditures per full-time-equivalent (FTE) student, by level of education and country: Selected years, 2005 through 2010-Continued

\begin{tabular}{|c|c|c|c|c|c|c|c|c|c|c|c|c|c|c|c|}
\hline \multirow[b]{2}{*}{ Country } & \multicolumn{5}{|c|}{ Gross domestic product per capita } & \multicolumn{5}{|c|}{ Elementary and secondary education expenditures per FTE student } & \multicolumn{5}{|c|}{ Higher education expenditures per FTE student } \\
\hline & 2005 & 2007 & 2008 & 2009 & 2010 & 2005 & 2007 & 2008 & 2009 & 2010 & 2005 & 2007 & 2008 & 2009 & 2010 \\
\hline 1 & 2 & 3 & 4 & 5 & 6 & 7 & 8 & 9 & 10 & 11 & 12 & 13 & 14 & 15 & 16 \\
\hline & \multicolumn{15}{|c|}{ Constant 2012 dollars } \\
\hline OECD average ${ }^{1}$. & $\$ 33,826$ & $\begin{array}{l}37,042 \\
\end{array}$ & $\begin{array}{l}\$ 36,135 \\
\end{array}$ & $\$ 35,536$ & $\$ \$ 35,242$ & $\$ 7,936$ & $\$ 8,205$ & $\$ 8,723$ & $\$ 9,238$ & $\$ 8,951$ & $\$ 13,353$ & $\$ 13,777$ & $\$ 14,280$ & $\$ 14,669$ & $\$ 13,911$ \\
\hline Australia............................ & 39,952 & 41,652 & 42,156 & 42,777 & 42,960 & 8,396 & 8,404 & 8,332 & 9,781 & 10,322 & 17,140 & 16,307 & 16,041 & 17,202 & 15,943 \\
\hline Austria ………………....... & 40,098 & 40,792 & 42,494 & 41,560 & 42,549 & 11,093 & 11,027 & 11,723 & 12,500 & 12,312 & 17,370 & 16,653 & 16,042 & 15,258 & 15,801 \\
\hline Belgium.................................. & 37,711 & 38,382 & 39,327 & 39,273 & 39,882 & 8,589 & 9,227 & 10,350 & 10,470 & 10,659 & 14,061 & 14,929 & 16,018 & 16,527 & 15,982 \\
\hline Canada & - & 43,056 & 41,079 & 42,952 & - & $9,139^{2}$ & $9,288^{2}$ & $9,594^{2}$ & $10,460^{2}$ & - & $27,427^{3,4}$ & $23,147^{3}$ & $22,291^{3}$ & $24,053^{3}$ & - \\
\hline Chile ………………............. & 14,854 & - & 15,042 & 15,601 & 15,906 & 2,467 & 2,313 & 2,394 & 2,820 & 3,091 & 8,080 & 6,967 & 7,282 & 7,308 & 7,226 \\
\hline Czech Republic...... & 23,843 & 26,570 & 27,561 & 27,412 & 26,706 & 4,817 & 5,217 & 5,584 & 6,010 & 5,825 & 7,816 & 9,090 & 8,870 & 8,815 & 8,039 \\
\hline Denmark ${ }^{5} \ldots \ldots \ldots \ldots \ldots \ldots$ & 39,532 & 40,224 & 42,116 & 40,987 & 42,749 & 10,577 & 10,462 & 11,121 & 11,873 & 12,007 & 17,586 & 18,233 & 18,804 & 19,858 & 19,981 \\
\hline Estonia..................................... & 19,586 & 22,833 & 23,249 & 21,178 & 21,156 & 4,392 & 5,135 & 6,456 & 6,581 & 6,301 & 4,549 & $6,260^{4}$ & 6,4224 & 6,820 & 6,845 \\
\hline Finland & 35,820 & 39,113 & 40,304 & 38,364 & 37,936 & 7,771 & 7,991 & 8,604 & 8,897 & 9,045 & 14,443 & 15,022 & 16,424 & 17,732 & 17,598 \\
\hline France ..................................... & 34,851 & 35,982 & 36,506 & 36,091 & 36,215 & 8,766 & 8,936 & 9,127 & 9,483 & 9,550 & 12,927 & 14,143 & 15,013 & 15,669 & 15,864 \\
\hline Germany. & 35,852 & 38,405 & 39,638 & 38,578 & 39,654 & 8,275 & 8,020 & 8,380 & 9,133 & - & 14,632 & 15,306 & 16,411 & 16,814 & - \\
\hline Greece............... & 29,946 & 30,776 & 31,906 & 31,443 & 28,996 & $6,458^{2}$ & - & - & - & - & 7,207 & - & - & - & - \\
\hline Hungary ${ }^{3} \ldots$ & 20,003 & 20,777 & 22,074 & 21,569 & 21,716 & 4,734 & 4,840 & 4,933 & 4,823 & 4,796 & 7,341 & 7,442 & 7,813 & 9,116 & 9,208 \\
\hline 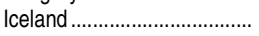 & 41,819 & 40,223 & 41,619 & 39,295 & 37,388 & 10,363 & 9,909 & 10,391 & 9,962 & 9,046 & $11,138^{5}$ & 10,308 & 11,122 & 10,636 & 9,190 \\
\hline Ireland................................... & 44,746 & 49,144 & 45,474 & 42,540 & 43,170 & 7,537 & 8,627 & $9,507^{3}$ & $10,290^{3}$ & $10,148^{3}$ & 12,307 & 13,987 & $17,365^{3}$ & $17,572^{3}$ & $16,855^{3}$ \\
\hline Israel.... & 25,246 & 29,281 & 29,528 & 29,381 & 27,957 & 5,926 & 5,919 & 6,164 & 5,847 & 5,993 & 12,837 & 12,663 & 13,403 & 12,001 & 11,298 \\
\hline Italy ......... & 32,624 & 34,344 & 35,479 & 34,671 & 33,809 & $8,711^{3}$ & $8,605^{3}$ & $9,673^{3}$ & $9,571^{3}$ & $8,938^{3}$ & $9,436^{3}$ & 9,604 & 10,188 & 10,233 & 10,087 \\
\hline$J_{a p a n}^{5} \ldots$. & 35,611 & 37,244 & 36,153 & 34,593 & 37,103 & 8,633 & 8,872 & 8,852 & 9,098 & 9,653 & 14,491 & 15,726 & 15,878 & 17,077 & 16,862 \\
\hline Korea, Republic of ................. & 25,091 & 29,426 & 28,661 & 29,078 & 30,354 & 6,629 & 7,378 & 7,169 & 8,692 & 7,787 & 8,942 & 9,877 & 9,684 & 10,181 & 10,499 \\
\hline Luxembourg............................ & 82,276 & 91,305 & 95,688 & 88,796 & 89,152 & $18,728^{2,3}$ & $17,251^{2,3}$ & 18,032 & 19,282 & 20,058 & - & - & - & - & - \\
\hline Mexico ………………......... & 13,284 & 15,644 & 16,198 & 15,408 & 15,999 & 2,381 & 2,397 & 2,436 & 2,503 & 2,594 & 7,527 & 7,720 & 8,002 & 8,583 & 8,289 \\
\hline Netherlands ............................. & 40,823 & 43,843 & 45,734 & 43,973 & 43,887 & 8,282 & 9,491 & 9,865 & 10,734 & 10,608 & 16,321 & 17,682 & 18,389 & 19,102 & 18,069 \\
\hline New Zealand........................... & 29,252 & 29,920 & 31,171 & 31,254 & 31,197 & 6,654 & 6,040 & 6,927 & 8,087 & 8,088 & 12,064 & 10,968 & 11,225 & 11,365 & 10,969 \\
\hline Norway .............................. & 55,985 & 59,432 & 46,557 & 58,547 & 47,197 & 11,727 & 12,020 & 12,871 & 13,881 & 13,758 & 18,284 & 18,979 & 20,199 & 20,621 & 19,491 \\
\hline 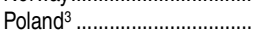 & 15,957 & 18,062 & 19,261 & 20,237 & 21,094 & 3,720 & 4,212 & 4,992 & 5,529 & 5,994 & 6,575 & 6,174 & 7,532 & 8,322 & 9,335 \\
\hline Portuga| $^{3} \ldots$. & 23,474 & 25,068 & 26,619 & 26,686 & 26,869 & 6,637 & 6,531 & 6,692 & 7,800 & 7,812 & 10,331 & 11,514 & 11,061 & 11,216 & 11,138 \\
\hline 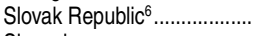 & 18,670 & 22,445 & 24,745 & 24,207 & 24,421 & 3,221 & 3,649 & 4,272 & 5,116 & 5,334 & 6,799 & 6,352 & 6,995 & 7,232 & 7,269 \\
\hline Slovenia .................................... & 27,091 & 29,407 & 31,182 & 29,055 & 28,059 & 8,306 & 8,046 & 9,123 & 9,279 & 8,955 & 10,079 & 9,477 & 9,878 & 9,965 & 10,206 \\
\hline Spain & 32,060 & 34,846 & 35,375 & 34,402 & 33,244 & 7,537 & 8,495 & 9,087 & 9,437 & 8,927 & 11,861 & 13,895 & 14,254 & 14,569 & 14,081 \\
\hline Sweden ...................................... & 38,526 & 40,733 & 41,931 & 39,802 & 41,328 & 9,242 & 9,714 & 10,156 & 10,391 & 10,576 & 18,747 & 20,332 & 21,342 & 21,362 & 20,597 \\
\hline Switzerland ${ }^{3} \ldots \ldots \ldots \ldots \ldots \ldots \ldots$ & 41,735 & 46,286 & 48,538 & 47,915 & 51,553 & 12,604 & 12,958 & 14,689 & 14,352 & 14,225 & 25,552 & 23,124 & 23,085 & 23,092 & 23,052 \\
\hline 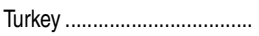 & - & - & 15,956 & 15,456 & 16,610 & - & - & - & - & 2,127 & - & - & - & - & - \\
\hline United Kingdom ...................... & 37,127 & 38,708 & 39,261 & 36,903 & 37,166 & 8,098 & 9,548 & 9,777 & 10,276 & 10,508 & 15,879 & 17,123 & 16,326 & 17,485 & 16,702 \\
\hline United States ......................... & 48,994 & 51,417 & 50,014 & 48,252 & 49,011 & 11,487 & 12,049 & 11,844 & 12,647 & 12,452 & 27,551 & 28,096 & 29,325 & 28,966 & 26,929 \\
\hline
\end{tabular}

-Not available.

The average mean of the data values for all reporting OECD countries, to which each country reporting data contributes equally. in that yeare includes all current $O E C D$ countries for which a given year's data are available, even if they were not members of $O E C D$

Excludes occupation-specific education corresponding to that offered at the vocational associate's degree level in the United States. Postsecondary non-higher-education included in both secondary and higher education.

In's degree level in the United States is
NOTE: Includes all expenditures by public and private education institutions (such as administration, instruction, ancillary services for students and families, and research and development) unless otherwise noted. Expenditures for International Standard Classification erwise noted. Data for Canada, France, Italy, Luxembourg, Portugal, and the United States do not include postsecondary non-highereducation. Data adjusted to U.S. dollars using the purchasing power parity (PPP) index. Constant dollars based on the Consumer Price Index, prepared by the Bureau of Labor Statistics, U.S. Department of Labor.

SOURCE: Organization for Economic Cooperation and Development (OECD), Education at a Glance, 2008 through 2013. (This table was prepared May 2013) 


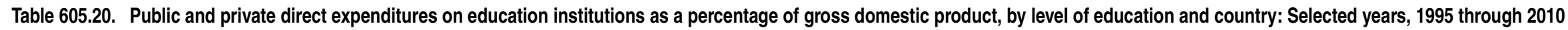

\begin{tabular}{|c|c|c|c|c|c|c|c|c|c|c|c|c|c|c|c|c|c|c|c|c|c|c|c|c|}
\hline \multirow[b]{3}{*}{ Country } & \multicolumn{8}{|c|}{$\begin{array}{l}\text { All institutions (including preprimary education } \\
\text { and subsidies to households, not separately shown) }\end{array}$} & \multicolumn{8}{|c|}{ Elementary and secondary institutions } & \multicolumn{8}{|c|}{ Higher education institutions } \\
\hline & \multicolumn{5}{|c|}{ Public direct expenditures } & \multicolumn{3}{|c|}{$\begin{array}{l}\text { Direct expenditures, } \\
2010\end{array}$} & \multicolumn{5}{|c|}{ Public direct expenditures } & \multicolumn{3}{|c|}{ Direct expenditures, 2010} & \multicolumn{5}{|c|}{ Public direct expenditures } & \multicolumn{3}{|c|}{ Direct expenditures, 2010} \\
\hline & 1995 & $2000^{1}$ & $2005^{1}$ & $2008^{1}$ & $2009^{1}$ & Public $^{1}$ & Private & Total & 1995 & $2000^{1}$ & $2005^{1}$ & $2008^{1}$ & $2009^{1}$ & Public $^{1}$ & Private & Total & 1995 & $2000^{1}$ & $2005^{1}$ & $2008^{1}$ & $2009^{1}$ & Public $^{1}$ & Private & Total \\
\hline 1 & 2 & 3 & 4 & 5 & 6 & 7 & 8 & 9 & 10 & 11 & 12 & 13 & 14 & 15 & 16 & 17 & 18 & 19 & 20 & 21 & 22 & 23 & 24 & 25 \\
\hline $\mathrm{OECD}$ average $^{2} \ldots \ldots \ldots . .$. & 4.9 & 4.9 & 5.0 & 5.1 & 5.4 & 5.4 & 0.9 & 6.3 & 3.5 & 3.4 & 3.5 & 3.5 & 3.7 & 3.7 & 0.3 & 4.0 & 0.9 & 1.0 & 1.0 & 1.1 & 1.1 & 1.1 & 0.5 & 1.6 \\
\hline 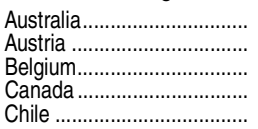 & $\begin{array}{l}4.5 \\
5.3 \\
5.0 \\
5.8 \\
-\end{array}$ & \begin{tabular}{l|}
4.6 \\
$5.4^{3}$ \\
5.1 \\
5.2 \\
4.2
\end{tabular} & $\begin{array}{l}4.3 \\
5.2 \\
5.8 \\
4.8 \\
3.3\end{array}$ & $\begin{array}{l}3.7 \\
5.2 \\
6.3 \\
6.1 \\
3.7\end{array}$ & $\begin{array}{l}4.5 \\
5.7 \\
6.4 \\
5.0 \\
4.1\end{array}$ & $\begin{array}{l}4.6 \\
5.6 \\
6.4 \\
4.3\end{array}$ & $\begin{array}{l}1.5 \\
0.2 \\
0.2 \\
2.6\end{array}$ & $\begin{array}{l}6.1 \\
5.8 \\
6.6 \\
6.8\end{array}$ & $\begin{array}{l}3.2 \\
3.8 \\
3.4 \\
4.0 \\
-\end{array}$ & $\begin{array}{l}3.7 \\
3.7^{3} \\
3.4^{4} \\
3.3^{5} \\
3.2^{5}\end{array}$ & $\begin{array}{l}3.4 \\
3.5 \\
3.9 \\
3.35 \\
2.7\end{array}$ & $\begin{array}{l}3.0 \\
3.5 \\
4.3 \\
3.6^{6} \\
3.0\end{array}$ & $\begin{array}{l}3.6 \\
3.8 \\
4.3 \\
3.4^{6} \\
3.3^{6}\end{array}$ & $\begin{array}{l}3.7 \\
3.5 \\
4.3 \\
-9\end{array}$ & $\begin{array}{l}0.6 \\
0.1 \\
0.1 \\
\overline{0.8}\end{array}$ & $\begin{array}{l}4.3 \\
3.6 \\
4.4 \\
3.6\end{array}$ & $\begin{array}{l}1.2 \\
0.9 \\
0.9 \\
1.5 \\
-\end{array}$ & $\begin{array}{l}0.8 \\
1.2^{3} \\
1.2^{4} \\
1.6^{5} \\
0.6\end{array}$ & $\begin{array}{l}0.8 \\
1.2 \\
1.2 \\
1.5^{5} \\
0.3\end{array}$ & $\begin{array}{l}0.7 \\
1.2 \\
1.3 \\
2.5 \\
0.3\end{array}$ & $\begin{array}{l}0.7 \\
1.4 \\
1.4 \\
1.5 \\
0.3\end{array}$ & $\begin{array}{l}0.8 \\
1.5 \\
1.4 \\
0.8\end{array}$ & $\begin{array}{l}0.9 \\
0.1 \\
0.1 \\
\overline{1.6}\end{array}$ & $\begin{array}{l}1.6 \\
1.5 \\
1.4 \\
2.5\end{array}$ \\
\hline 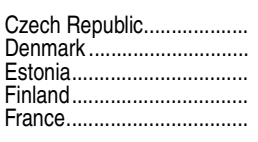 & $\begin{array}{l}4.8 \\
6.5 \\
6.6 \\
5.8\end{array}$ & $\begin{array}{l}4.2 \\
6.4^{3} \\
5.5 \\
5.7\end{array}$ & $\begin{array}{l}4.1 \\
6.8 \\
4.7 \\
5.9 \\
5.6\end{array}$ & $\begin{array}{l}3.9 \\
6.5 \\
5.5 \\
5.7 \\
5.5\end{array}$ & $\begin{array}{l}4.2 \\
7.5 \\
5.9 \\
6.3 \\
5.8\end{array}$ & $\begin{array}{l}4.1 \\
7.6 \\
5.6 \\
6.4 \\
5.8\end{array}$ & $\begin{array}{l}0.6 \\
0.4 \\
0.4 \\
0.1 \\
0.5\end{array}$ & $\begin{array}{l}4.7 \\
8.0 \\
6.0 \\
6.5 \\
6.3\end{array}$ & \begin{tabular}{r|}
3.4 \\
4.2 \\
4.2 \\
4.1
\end{tabular} & $\begin{array}{l}2.8^{4} \\
4.1^{3,7} \\
3.5 \\
4.0\end{array}$ & $\begin{array}{l}2.7 \\
4.47 \\
3.5 \\
3.8 \\
3.8\end{array}$ & $\begin{array}{l}2.5 \\
4.2^{7} \\
3.8 \\
3.8 \\
3.7\end{array}$ & $\begin{array}{l}2.6 \\
4.7^{7} \\
4.1 \\
4.1 \\
3.8\end{array}$ & $\begin{array}{l}2.6 \\
4.7^{7} \\
3.9 \\
4.1 \\
3.8\end{array}$ & $\begin{array}{l}0.3 \\
0.1^{7} \\
0.1 \\
\# \\
0.3\end{array}$ & $\begin{array}{l}2.8 \\
4.8^{7} \\
3.9 \\
4.1 \\
4.1\end{array}$ & $\begin{array}{l}0.7 \\
1.3 \\
1.7 \\
1.0\end{array}$ & $\begin{array}{l}0.8^{4} \\
1.5^{3,7} \\
\overline{1.7} \\
1.0\end{array}$ & $\begin{array}{l}0.8 \\
1.6^{7} \\
0.9 \\
1.7 \\
1.1\end{array}$ & $\begin{array}{l}0.9 \\
1.6^{7} \\
1.1 \\
1.6 \\
1.2\end{array}$ & $\begin{array}{l}1.0 \\
1.8^{7} \\
1.3 \\
1.8 \\
1.3\end{array}$ & $\begin{array}{l}1.0 \\
1.8^{7} \\
1.3 \\
1.9 \\
1.3\end{array}$ & $\begin{array}{l}0.2 \\
0.1^{7} \\
0.3 \\
0.1 \\
0.2\end{array}$ & $\begin{array}{l}1.2 \\
1.9^{7} \\
1.6 \\
1.9 \\
1.5\end{array}$ \\
\hline 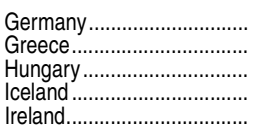 & $\begin{array}{l}4.5 \\
3.7 \\
4.9 \\
4.5 \\
4.7\end{array}$ & $\begin{array}{l}4.3 \\
3.7^{3} \\
4.4 \\
5.7^{3} \\
4.1^{3}\end{array}$ & $\begin{array}{l}4.2 \\
4.0 \\
5.1 \\
7.2 \\
4.3\end{array}$ & $\begin{array}{l}4.1 \\
4.8 \\
7.2 \\
5.2\end{array}$ & $\begin{array}{l}4.5 \\
4.8 \\
7.3 \\
6.0\end{array}$ & $\begin{array}{l}- \\
\overline{4} .6 \\
7.0 \\
6.0\end{array}$ & $\begin{array}{l}\overline{-} \\
\overline{0} \\
0.7 \\
0.5\end{array}$ & $\begin{array}{c}\overline{-} \\
\overline{7} \\
.7 \\
6.4\end{array}$ & $\begin{array}{l}2.9 \\
2.8 \\
3.3 \\
3.4 \\
3.3\end{array}$ & $\begin{array}{l}2.9 \\
2.7^{3,6} \\
2.8^{3} \\
4.6^{3} \\
2.9^{4}\end{array}$ & $\begin{array}{l}2.8 \\
2.5^{6} \\
3.3 \\
5.2^{7} \\
3.3^{7}\end{array}$ & $\begin{array}{l}2.6 \\
3.0 \\
4.9 \\
4.0\end{array}$ & $\begin{array}{l}2.9 \\
3.0 \\
5.0 \\
4.6\end{array}$ & $\begin{array}{l}\overline{-} \\
2.8 \\
4.7 \\
4.6\end{array}$ & $\begin{array}{l}\bar{z} \\
\overline{0.2} \\
0.2\end{array}$ & $\begin{array}{l}\bar{z} \\
\overline{4.9} \\
4.8\end{array}$ & $\begin{array}{l}1.0 \\
0.8 \\
0.8 \\
0.7 \\
0.9\end{array}$ & $\begin{array}{l}1.0^{3} \\
0.9^{3} \\
0.9^{3} \\
0.8^{3} \\
1.2^{4}\end{array}$ & $\begin{array}{l}0.9 \\
1.4 \\
0.9 \\
1.1^{7} \\
1.0\end{array}$ & $\begin{array}{l}1.0 \\
0.9 \\
1.2 \\
1.2\end{array}$ & $\begin{array}{l}1.1 \\
1.0 \\
1.2 \\
1.4\end{array}$ & $\begin{array}{l}\overline{-} \\
0.8 \\
1.1 \\
1.3\end{array}$ & $\begin{array}{l}\bar{z} \\
\overline{0.1} \\
0.3\end{array}$ & $\begin{array}{l}\bar{z} \\
\overline{1.2} \\
1.6\end{array}$ \\
\hline 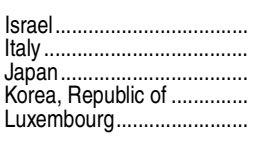 & $\begin{array}{l}- \\
4.5 \\
3.6 \\
3.6 \\
4.3\end{array}$ & $\begin{array}{l}6.6 \\
4.5 \\
3.5 \\
4.3 \\
-\end{array}$ & $\begin{array}{l}6.2 \\
4.3 \\
3.4 \\
4.3 \\
-\end{array}$ & $\begin{array}{l}5.9 \\
4.5 \\
3.3 \\
4.7 \\
-\end{array}$ & $\begin{array}{l}5.8 \\
4.5 \\
3.6 \\
4.9 \\
-\end{array}$ & $\begin{array}{l}5.9 \\
4.3 \\
3.6 \\
4.8 \\
-\end{array}$ & $\begin{array}{l}1.5 \\
0.4 \\
1.5 \\
2.8 \\
\end{array}$ & $\begin{array}{r}7.4 \\
4.7 \\
5.1 \\
7.6 \\
-\end{array}$ & $\begin{array}{l}3.2 \\
2.8 \\
3.0 \\
4.2\end{array}$ & $\begin{array}{l}4.5 \\
3.2 \\
2.7^{7} \\
3.3 \\
-\end{array}$ & $\begin{array}{l}4.2 \\
3.2 \\
2.6^{7} \\
3.4 \\
3.7^{6}\end{array}$ & $\begin{array}{l}4.0 \\
3.2 \\
2.57 \\
3.4 \\
2.8\end{array}$ & $\begin{array}{l}3.8 \\
3.3 \\
2.7^{7} \\
3.6 \\
3.2\end{array}$ & $\begin{array}{l}4.0 \\
3.1 \\
2.8^{7} \\
3.4 \\
3.4\end{array}$ & $\begin{array}{l}0.3 \\
0.1 \\
0.2^{7} \\
0.9 \\
0.1\end{array}$ & $\begin{array}{l}4.3 \\
3.2 \\
3.0^{7} \\
4.2 \\
3.5\end{array}$ & $\begin{array}{l}-\overline{7} \\
0.7 \\
0.4 \\
0.3 \\
0.1\end{array}$ & $\begin{array}{l}1.1 \\
0.7 \\
0.5^{7} \\
0.6 \\
-\end{array}$ & $\begin{array}{l}1.0 \\
0.6 \\
0.5^{7} \\
0.6 \\
-\end{array}$ & $\begin{array}{l}0.9 \\
0.8 \\
0.57 \\
0.6 \\
-\end{array}$ & $\begin{array}{l}1.0 \\
0.8 \\
0.5^{7} \\
0.7 \\
-\end{array}$ & $\begin{array}{l}1.0 \\
0.8 \\
0.5^{7} \\
0.7 \\
-\end{array}$ & $\begin{array}{l}0.7 \\
0.2 \\
1.0^{7} \\
1.9 \\
-\end{array}$ & $\begin{array}{l}1.7 \\
1.0 \\
1.5^{7} \\
2.6 \\
-\end{array}$ \\
\hline 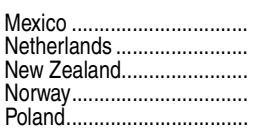 & $\begin{array}{l}4.6 \\
4.6 \\
5.3 \\
6.8 \\
5.2\end{array}$ & \begin{tabular}{l|}
4.7 \\
4.3 \\
5.8 \\
5.8 \\
$5.2^{3}$
\end{tabular} & $\begin{array}{l}5.3 \\
4.6 \\
5.2 \\
5.7 \\
5.4\end{array}$ & $\begin{array}{l}4.7 \\
4.8 \\
5.4 \\
7.3 \\
5.0\end{array}$ & $\begin{array}{l}5.0 \\
5.3 \\
6.1 \\
6.1 \\
5.0\end{array}$ & $\begin{array}{l}5.1 \\
5.4 \\
6.0 \\
7.5 \\
5.0\end{array}$ & $\begin{array}{l}1.1 \\
0.9 \\
1.3 \\
0.8\end{array}$ & $\begin{array}{l}6.2 \\
6.3 \\
7.3 \\
5.8\end{array}$ & $\begin{array}{l}3.4 \\
3.0 \\
3.8 \\
4.1 \\
3.3\end{array}$ & $\begin{array}{l}3.3 \\
3.0 \\
4.6 \\
3.6 \\
3.7^{3}\end{array}$ & $\begin{array}{l}3.7 \\
3.3 \\
4.0 \\
3.8 \\
3.7\end{array}$ & $\begin{array}{l}3.1 \\
3.3 \\
3.8 \\
5.0 \\
3.4\end{array}$ & $\begin{array}{l}3.3 \\
3.7 \\
4.5 \\
4.2 \\
3.5\end{array}$ & $\begin{array}{l}3.4 \\
3.7 \\
4.4 \\
5.1 \\
3.4\end{array}$ & $\begin{array}{l}0.6 \\
0.4 \\
0.6 \\
\overline{0.2}\end{array}$ & $\begin{array}{l}4.0 \\
4.1 \\
5.1 \\
\overline{3.7}\end{array}$ & $\begin{array}{l}0.8 \\
1.1 \\
1.1 \\
1.5 \\
0.8\end{array}$ & $\begin{array}{l}0.8 \\
1.0 \\
0.9 \\
1.2^{3} \\
0.8^{3}\end{array}$ & $\begin{array}{l}0.9 \\
1.0 \\
0.9 \\
1.3 \\
1.2\end{array}$ & $\begin{array}{l}0.9 \\
1.1 \\
1.1 \\
1.6 \\
1.0\end{array}$ & $\begin{array}{l}1.0 \\
1.2 \\
1.1 \\
1.3 \\
1.1\end{array}$ & $\begin{array}{l}1.0 \\
1.3 \\
1.0 \\
1.6 \\
1.0\end{array}$ & $\begin{array}{l}0.4 \\
0.5 \\
0.5 \\
0.1 \\
0.4\end{array}$ & $\begin{array}{l}1.4 \\
1.7 \\
1.6 \\
1.7 \\
1.5\end{array}$ \\
\hline 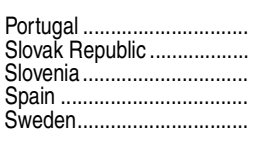 & $\begin{array}{l}5.4 \\
4.6 \\
4.8 \\
6.6\end{array}$ & $\begin{array}{l}5.6^{3} \\
4.0^{3} \\
\frac{4.3}{6.3}\end{array}$ & $\begin{array}{l}5.3 \\
3.7 \\
5.3 \\
4.1 \\
6.2\end{array}$ & $\begin{array}{l}4.7 \\
3.5 \\
4.8 \\
4.5 \\
6.1\end{array}$ & $\begin{array}{l}5.5 \\
4.1 \\
5.3 \\
4.9 \\
6.6\end{array}$ & $\begin{array}{l}5.4 \\
4.0 \\
5.2 \\
4.8 \\
6.3\end{array}$ & $\begin{array}{l}0.4 \\
0.6 \\
0.7 \\
0.8 \\
0.2\end{array}$ & $\begin{array}{l}5.8 \\
4.6 \\
5.9 \\
5.6 \\
6.5\end{array}$ & $\begin{array}{r}4.1 \\
- \\
3.5 \\
4.4\end{array}$ & $\begin{array}{l}4.1^{3} \\
2.7^{3,4,8} \\
\overline{3}^{1} \\
4.4^{4}\end{array}$ & $\begin{array}{l}3.8 \\
2.5^{8} \\
3.9 \\
2.7 \\
4.2\end{array}$ & $\begin{array}{l}3.4 \\
2.2^{8} \\
3.4 \\
2.9 \\
4.0\end{array}$ & \begin{tabular}{l|}
4.0 \\
2.7 \\
3.6 \\
3.1 \\
4.2
\end{tabular} & $\begin{array}{l}3.9 \\
2.8 \\
3.6 \\
3.0 \\
4.0\end{array}$ & $\begin{array}{l}\# \\
0.3^{8} \\
0.3 \\
0.3 \\
\#\end{array}$ & $\begin{array}{l}3.9 \\
3.1^{8} \\
3.9 \\
3.3 \\
4.0\end{array}$ & $\begin{array}{l}1.0 \\
\frac{-}{0.8} \\
1.6\end{array}$ & $\begin{array}{l}1.0^{3} \\
0.7^{3,4,8} \\
0.9 \\
1.5^{4}\end{array}$ & $\begin{array}{l}0.9 \\
0.7^{8} \\
1.0 \\
0.9 \\
1.5\end{array}$ & $\begin{array}{l}0.9 \\
0.7^{8} \\
1.0 \\
1.0 \\
1.4\end{array}$ & $\begin{array}{l}1.0 \\
0.77 \\
1.1 \\
1.1 \\
1.6\end{array}$ & $\begin{array}{l}1.0 \\
0.7^{8} \\
1.1 \\
1.1 \\
1.6\end{array}$ & $\begin{array}{l}0.4 \\
0.3^{8} \\
0.2 \\
0.3 \\
0.2\end{array}$ & $\begin{array}{l}1.5 \\
0.9^{8} \\
1.3 \\
1.3 \\
1.8\end{array}$ \\
\hline 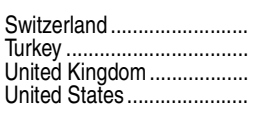 & $\begin{array}{l}5.5 \\
2.2 \\
4.6 \\
5.0 \\
\end{array}$ & \begin{tabular}{l|}
5.3 \\
$3.4^{3}$ \\
4.5 \\
4.6 \\
\end{tabular} & $\begin{array}{l}5.6 \\
5.0 \\
4.9 \\
\end{array}$ & $\begin{array}{l}5.3 \\
5.1 \\
5.0 \\
\end{array}$ & $\begin{array}{l}5.5 \\
5.3 \\
5.3 \\
\end{array}$ & $\begin{array}{l}5.2 \\
5.9 \\
5.1 \\
\end{array}$ & \begin{tabular}{l|}
$\overline{-}$ \\
0.6 \\
2.2 \\
\end{tabular} & $\begin{array}{l}- \\
6.5 \\
7.3 \\
\end{array}$ & $\begin{array}{l}4.1 \\
1.4 \\
3.8 \\
3.5 \\
\end{array}$ & $\begin{array}{l}3.8 \\
2.4^{3} \\
3.4 \\
3.5^{5} \\
\end{array}$ & $\begin{array}{l}3.9 \\
3.8 \\
3.6 \\
\end{array}$ & $\begin{array}{l}3.8 \\
4.2 \\
3.7 \\
\end{array}$ & $\begin{array}{l}3.8 \\
\overline{4} .5 \\
3.8 \\
\end{array}$ & $\begin{array}{l}3.6 \\
2.5 \\
4.8 \\
3.7 \\
\end{array}$ & $\begin{array}{r}0.5 \\
\# \\
0.3 \\
\end{array}$ & $\begin{array}{l}4.0 \\
4.8 \\
4.0 \\
\end{array}$ & $\begin{array}{l}1.1 \\
0.8 \\
0.7 \\
1.1 \\
\end{array}$ & $\begin{array}{l}1.2 \\
1.0^{3} \\
0.7 \\
0.8^{5} \\
\end{array}$ & $\begin{array}{l}1.4 \\
0.9 \\
1.0 \\
\end{array}$ & $\begin{array}{l}1.3 \\
0.6 \\
1.0 \\
\end{array}$ & $\begin{array}{l}1.4 \\
0.6 \\
1.1 \\
\end{array}$ & $\begin{array}{l}1.3 \\
0.7 \\
1.0 \\
\end{array}$ & $\begin{array}{l}\overline{-} \\
0.6 \\
1.8 \\
\end{array}$ & $\begin{array}{r}\overline{-} \\
1.4 \\
2.8 \\
\end{array}$ \\
\hline $\begin{array}{l}\text { Other reporting countries } \\
\text { Brazil..... } \\
\text { Russian Federation........... }\end{array}$ & $\overline{3.4}$ & $\overline{3}_{3} \overline{0}_{3}$ & $\begin{array}{l}4.4 \\
3.8\end{array}$ & $\begin{array}{l}5.3 \\
4.1\end{array}$ & $\begin{array}{l}5.5 \\
4.7\end{array}$ & $\begin{array}{l}5.6 \\
4.1\end{array}$ & 0.8 & 4.9 & $\overline{1.9}$ & $\overline{1.7}$ & $\begin{array}{l}3.3 \\
1.9\end{array}$ & $\begin{array}{l}4.1 \\
2.0\end{array}$ & $\begin{array}{l}4.3 \\
2.3\end{array}$ & $\begin{array}{l}4.3 \\
2.0\end{array}$ & $\overline{0.1}$ & $\overline{2.1}$ & $\overline{0.7}$ & $0 . \overline{5}$ & $\begin{array}{l}0.8 \\
0.8\end{array}$ & $\begin{array}{l}0.8 \\
0.9\end{array}$ & $\begin{array}{l}0.8 \\
1.2\end{array}$ & $\begin{array}{l}0.9 \\
1.0\end{array}$ & $0 . \overline{6}$ & $\overline{1.6}$ \\
\hline
\end{tabular}

\#Rounds to zero.

'Unless otherwise noted, includes public subsidies to households for payments to education institutions and direct expenditures on education institutions from international sources.

¿Refers to the mean of the data values for all reporting Organization for Economic Cooperation and Development (OECD) countries, to which each country reporting data contributes equally. The average includes all current OECD countries for which a given year's data are available, even if they were not members of OECD in that year



exceed 1.5 percent of all public expenditures.

${ }^{6}$ Preprimary education (for children ages 3 and older) included in elementary and secondary education.

7Postsecondary non-higher-education included in both secondary and higher education.
${ }^{8}$ Occupation-specific education corresponding to that offered at the vocational associate's degree level in the United States is

direct expenditures on education include both amounts spent directly by governments to hire educational personnel and to procure other resources, and amounts provided by governments to public or private institutions. Private direct expendilures exclude public subsidies that are used for payments to education institutions. Postsecondary non-higher-educathat could not be reported by level of education. Some data have been revised from previously published figures. Detail may not sum to totals because of rounding.

SOURCE: Organization for Economic Cooperation and Development (OECD). Online Education Database; and Education at a Glance, 2008 through 2013. U.S. Department of Education, National Center for Education Statistics, International Education Indicators: A Time Series Perspective, 1985-1995 (NCES 2000-021). (This table was prepared May 2013.) 


\section{CHAPTER 7 Libraries and Technology}

This chapter presents statistics on elementary and secondary school libraries, college and university libraries (including institution-level information for the 60 largest college libraries in the country), and public libraries. It contains data on library collections, staff, and expenditures, as well as library usage. The chapter ends with a table on internet usage among persons of various racial/ethnic groups, age groups, educational attainment levels, and income levels.

\section{Libraries}

Among public schools that had a library in 2011-12, the average number of library staff per school was 1.8 , including 0.9 certified library/media specialists (table 701.10). On average, public school libraries had larger numbers of books on a per student basis in 2011-12 (2,188 per 100 students) than in 1999-2000 (1,803 per 100 students), 2003-04 (1,891 per 100 students), and 2007-08 (2,015 per 100 students). In 2011-12, public elementary school libraries had larger holdings than public secondary school libraries on a per student basis (2,570 books per 100 students, compared with 1,474 books per 100 students).

At degree-granting postsecondary institutions, library operating expenditures per full-time-equivalent (FTE) student were 1 percent higher in 2001-02 than in 1991-92, after adjustment for inflation (table 701.40). From 2001-02 to 2011-12, library operating expenditures per FTE student dropped 25 percent in inflation-adjusted dollars. Overall, there was a net decrease of 24 percent in library operating expenditures per FTE student between 1991-92 and 2011-12. In 2011-12, library operating expenditures per FTE student averaged \$441 (in current dollars) across all degree-granting institutions. The amount varied widely by institution control, however. Library operating expenditures averaged $\$ 844$ per FTE student attending a private nonprofit institution in 2011-12, compared with \$372 per FTE student attending a public institution, and $\$ 78$ per FTE student attending a private for-profit institution. In 2011-12, the average number of volumes per FTE student also differed for public institutions (61 volumes), private nonprofit institutions (128 volumes), and private for-profit institutions (4 volumes). Across all degree-granting institutions, the average number of volumes per FTE student in 2011-12 was 69, which was 4 percent less than in 1991-92. The calculations of library operating expenditures and number of volumes per FTE student include both institutions with libraries and those without libraries. In 2011-12, there were libraries at 81 percent of degree-granting institutions overall, 95 percent of public institutions, 88 percent of private nonprofit institutions, and 55 percent of private for-profit institutions.

In 2010, there were 8,951 public libraries in the United States with a total of 808 million books and serial volumes (table 701.60). The annual number of visits per capitathat is, per resident of the areas served by the librarieswas 5.3, and the annual number of reference transactions per capita was 1.0.

\section{Computer and Internet Use}

In 2012, 75 percent of the population age 3 and over used the Internet (table 702.10). Comparing the White, Black, and Hispanic populations age 3 and over, the percentage of internet users was highest among Whites (79 percent), followed by Blacks ( 68 percent), and then Hispanics (62 percent). The percentage of internet users in the population age 3 and over generally increased with higher family income levels. For example, 76 percent of people with family incomes from $\$ 40,000$ to $\$ 49,999$ used the Internet, compared to 91 percent of people with family incomes of $\$ 100,000$ or more. Among persons age 15 and over, the percentage of internet users tended to increase with higher levels of educational attainment. For example, 55 percent of persons who had not completed high school used the Internet, compared with 66 percent of those who had completed only a high school diploma or equivalent and 93 percent of those with a bachelor's or higher degree. 


\begin{tabular}{|c|c|c|c|c|c|c|c|c|c|c|c|c|c|c|c|c|c|c|c|c|}
\hline \multirow[b]{2}{*}{ Selected statistic } & \multirow{2}{*}{\multicolumn{2}{|c|}{$1999-2000$}} & \multirow{2}{*}{\multicolumn{2}{|c|}{ 2003-04 }} & \multicolumn{8}{|c|}{$2007-08$} & \multicolumn{8}{|c|}{ 2011-12 } \\
\hline & & & & & \multicolumn{4}{|c|}{ Elementary } & \multicolumn{2}{|c|}{ Secondary } & \multicolumn{2}{|c|}{$\begin{array}{r}\text { Combined } \\
\text { elementary/ } \\
\text { secondary }\end{array}$} & \multicolumn{4}{|c|}{ Elementary } & \multicolumn{2}{|c|}{ Secondary } & \multicolumn{2}{|c|}{$\begin{array}{r}\text { Combined } \\
\text { elementary/ } \\
\text { secondary }\end{array}$} \\
\hline 1 & & 2 & & 3 & & 4 & & 5 & & 6 & & 7 & & 8 & & 9 & & 10 & & 11 \\
\hline Number of schools with libra & 77,300 & (421) & 78,300 & (548) & 81,900 & (634) & 9,700 & (492) & 17,800 & (414) & 4,400 & (239) & 81,200 & (510) & 58,000 & (418) & 17,100 & (357) & 6,100 & (373) \\
\hline 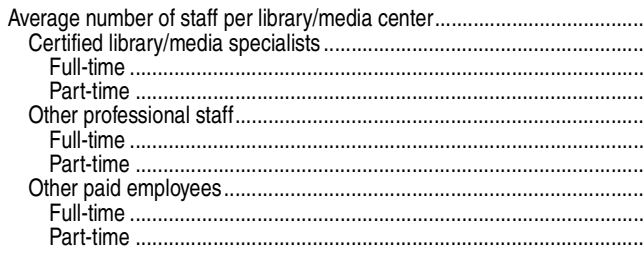 & $\begin{array}{l}1.89 \\
0.81 \\
0.65 \\
0.16 \\
0.17 \\
0.12 \\
0.06 \\
0.91 \\
0.49 \\
0.41\end{array}$ & $\begin{array}{l}(0.018) \\
(0.007) \\
(0.007) \\
(0.006) \\
(0.007) \\
(0.005) \\
(0.004) \\
(0.014) \\
(0.008) \\
(0.014)\end{array}$ & $\begin{array}{l}1.76 \\
0.79 \\
0.65 \\
0.14 \\
0.19 \\
0.13 \\
0.05 \\
0.78 \\
0.46 \\
0.33\end{array}$ & $\begin{array}{l}(0.014) \\
(0.009) \\
(0.009) \\
(0.007) \\
(0.008) \\
(0.007) \\
(0.005) \\
(0.011) \\
(0.009) \\
(0.012)\end{array}$ & $\begin{array}{l}1.72 \\
0.78 \\
0.66 \\
0.13 \\
0.22 \\
0.13 \\
0.08 \\
0.72 \\
0.43 \\
0.29\end{array}$ & $\begin{array}{l}(0.017) \\
(0.011) \\
(0.010) \\
(0.007) \\
(0.010) \\
(0.008) \\
(0.007) \\
(0.013) \\
(0.013) \\
(0.011)\end{array}$ & $\begin{array}{l}1.65 \\
0.73 \\
0.61 \\
0.13 \\
0.22 \\
0.13 \\
0.08 \\
0.70 \\
0.39 \\
0.31\end{array}$ & $\begin{array}{l}(0.019) \\
(0.013) \\
(0.012) \\
(0.010) \\
(0.013) \\
(0.010) \\
(0.009) \\
(0.016) \\
(0.016) \\
(0.014)\end{array}$ & $\begin{array}{l}2.04 \\
0.98 \\
0.88 \\
0.10 \\
0.21 \\
0.14 \\
0.07 \\
0.86 \\
0.60 \\
0.26\end{array}$ & $\begin{array}{l}(0.039) \\
(0.019) \\
(0.018) \\
(0.009) \\
(0.021) \\
(0.017) \\
(0.013) \\
(0.027) \\
(0.022) \\
(0.018)\end{array}$ & $\begin{array}{l}1.42 \\
0.66 \\
0.49 \\
0.18 \\
0.24 \\
0.15 \\
0.08 \\
0.51 \\
0.27 \\
0.24\end{array}$ & $\begin{array}{l}(0.057) \\
(0.033) \\
(0.032) \\
(0.020) \\
(0.027) \\
(0.022) \\
(0.017) \\
(0.036) \\
(0.028) \\
(0.028)\end{array}$ & $\begin{array}{l}1.77 \\
0.90 \\
0.71 \\
0.20 \\
0.19 \\
0.12 \\
0.07 \\
0.68 \\
0.40 \\
0.28\end{array}$ & $\begin{array}{l}(0.017) \\
(0.012) \\
(0.010) \\
(0.008) \\
(0.007) \\
(0.006) \\
(0.005) \\
(0.011) \\
(0.008) \\
(0.009)\end{array}$ & $\begin{array}{l}1.72 \\
0.88 \\
0.67 \\
0.21 \\
0.18 \\
0.11 \\
0.07 \\
0.66 \\
0.37 \\
0.29\end{array}$ & $\begin{array}{l}(0.020) \\
(0.014) \\
(0.012) \\
(0.010) \\
(0.009) \\
(0.007) \\
(0.007) \\
(0.012) \\
(0.009) \\
(0.012)\end{array}$ & $\begin{array}{l}1.93 \\
0.99 \\
0.84 \\
0.15 \\
0.17 \\
0.13 \\
0.05 \\
0.76 \\
0.52 \\
0.24\end{array}$ & $\begin{array}{l}(0.027) \\
(0.017) \\
(0.017) \\
(0.010) \\
(0.014) \\
(0.013) \\
(0.005) \\
(0.021) \\
(0.017) \\
(0.012)\end{array}$ & $\begin{array}{l}1.76 \\
0.88 \\
0.69 \\
0.19 \\
0.27 \\
0.16 \\
0.11 \\
0.61 \\
0.39 \\
0.22\end{array}$ & $\begin{array}{l}(0.056) \\
(0.031) \\
(0.029) \\
(0.020) \\
(0.026) \\
(0.022) \\
(0.014) \\
(0.040) \\
(0.031) \\
(0.027)\end{array}$ \\
\hline 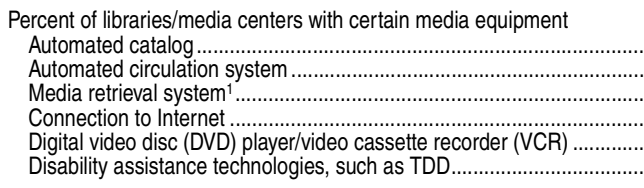 & $\begin{array}{r}72.8 \\
74.4 \\
90.1 \\
90 . \\
-\end{array}$ & $\begin{array}{r}(0.69) \\
(0.65) \\
(\dagger) \\
(0.57) \\
(\dagger) \\
(\dagger)\end{array}$ & $\begin{array}{r}82.7 \\
86.9 \\
- \\
95.1 \\
87.8 \\
11.9\end{array}$ & $\begin{array}{r}(0.66) \\
(0.61) \\
(t) \\
(0.35) \\
(0.60) \\
(0.50)\end{array}$ & $\begin{array}{l}87.2 \\
89.5 \\
34.9 \\
96.7 \\
87.2 \\
23.9\end{array}$ & $\begin{array}{c}(0.71) \\
(0.68) \\
(1.05) \\
(0.40) \\
(0.77) \\
(1.05)\end{array} \mid$ & $\begin{array}{l}87.5 \\
89.9 \\
35.9 \\
96.5 \\
86.7 \\
23.0\end{array}$ & $\begin{array}{l}(0.94) \\
(0.87) \\
(1.33) \\
(0.51) \\
(1.02) \\
(1.33)\end{array}$ & $\begin{array}{l}90.6 \\
92.6 \\
35.1 \\
98.6 \\
89.6 \\
26.4\end{array}$ & $\begin{array}{l}(1.08) \\
(0.98) \\
(1.66) \\
(0.51) \\
(1.00) \\
(1.34)\end{array}$ & $\begin{array}{l}69.8 \\
72.4 \\
20.6 \\
91.6 \\
84.5 \\
25.9\end{array}$ & $\begin{array}{l}(2.88) \\
(3.15) \\
(2.32) \\
(1.90) \\
(2.20) \\
(2.76)\end{array}$ & $\begin{array}{l}88.3 \\
90.3 \\
32.5 \\
95.9 \\
83.2 \\
31.0\end{array}$ & $\begin{array}{l}(0.49) \\
(0.47) \\
(0.76) \\
(0.34) \\
(0.76) \\
(0.75)\end{array}$ & $\begin{array}{l}89.1 \\
91.7 \\
33.6 \\
96.2 \\
82.8 \\
29.9\end{array}$ & $\begin{array}{c}(0.60) \\
(0.59) \\
(0.99) \\
(0.46) \\
(0.98) \\
(0.94)\end{array}$ & $\begin{array}{l}90.3 \\
90.1 \\
32.3 \\
97.3 \\
86.7 \\
34.3\end{array}$ & $\begin{array}{l}(0.78) \\
(0.75) \\
(0.91) \\
(0.49) \\
(0.76) \\
(1.02)\end{array}$ & $\begin{array}{l}74.4 \\
77.8 \\
22.4 \\
89.6 \\
77.7 \\
31.9\end{array}$ & $\begin{array}{l}(2.16) \\
(2.17) \\
(1.92) \\
(1.82) \\
(2.00) \\
(1.95)\end{array}$ \\
\hline $\begin{array}{l}\text { Percent of librraries/media cente } \\
\text { Students permitted to check } \\
\text { Staff permitted to check out I }\end{array}$ & $\overline{-}$ & 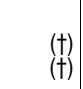 & - & $\begin{array}{l}(\dagger) \\
(\dagger)\end{array}$ & $\begin{array}{l}27.5 \\
45.9\end{array}$ & $\left(\begin{array}{l}1.02) \\
(1.07)\end{array}\right.$ & $\begin{array}{l}26.9 \\
45.2\end{array}$ & $\begin{array}{l}(1.27) \\
(1.35)\end{array}$ & $\begin{array}{l}29.8 \\
50.1\end{array}$ & $\begin{array}{l}(1.34) \\
(1.50)\end{array}$ & $\begin{array}{l}26.1 \\
38.5\end{array}$ & $\begin{array}{l}(2.57) \\
(2.85)\end{array}$ & $\begin{array}{l}40.2 \\
54.3\end{array}$ & $\begin{array}{l}(0.69) \\
(0.85)\end{array}$ & $\begin{array}{l}39.3 \\
53.9\end{array}$ & $\begin{array}{l}(0.85) \\
(0.99)\end{array}$ & $\begin{array}{l}42.4 \\
55.5\end{array}$ & $\left.\begin{array}{l}(1.08) \\
(1.23)\end{array}\right)$ & $\begin{array}{l}41.8 \\
54.2\end{array}$ & \\
\hline Number of library computer workstations per 100 students........ & - & $(\dagger)$ & 2.3 & $(0.04)$ & 2.6 & $(0.05)$ & 2.5 & $(0.07)$ & 2.9 & $(0.06)$ & 3.0 & $(0.17)$ & 3.1 & $(0.05)$ & 2.8 & $(0.06)$ & 3.6 & $(0.08)$ & 3.3 & $(0.23)$ \\
\hline 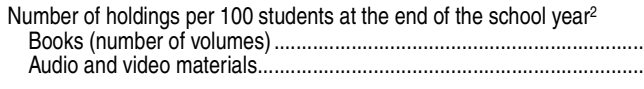 & $\begin{array}{r}1,803 \\
59\end{array}$ & $\begin{array}{r}(19.7) \\
(0.9)\end{array}$ & $\begin{array}{r}1,891 \\
80\end{array}$ & $\begin{array}{r}(45.1) \\
(3.7)\end{array}$ & $\begin{array}{r}2,015 \\
90\end{array}$ & $\begin{array}{r}(30.5) \\
(3.8)\end{array}$ & $\begin{array}{r}2,316 \\
93\end{array}$ & $\begin{array}{r}(40.2) \\
(5.6)\end{array}$ & $\begin{array}{r}1,432 \\
81\end{array}$ & $\begin{array}{r}(36.6) \\
(5.2)\end{array}$ & $\begin{array}{r}2,439 \\
107\end{array}$ & $\begin{array}{r}(132.3) \\
(13.3)\end{array}$ & $\begin{array}{r}2,188 \\
81\end{array}$ & $\begin{array}{r}(42.4) \\
(2.4)\end{array}$ & $\begin{array}{r}2,570 \\
85\end{array}$ & $\begin{array}{r}(58.5) \\
(3.3)\end{array}$ & $\begin{array}{r}1,474 \\
71\end{array}$ & $\begin{array}{r}(24.7) \\
(2.9)\end{array}$ & $\begin{array}{r}2,066 \\
97\end{array}$ & $\begin{array}{r}87 . \\
(8 .\end{array}$ \\
\hline 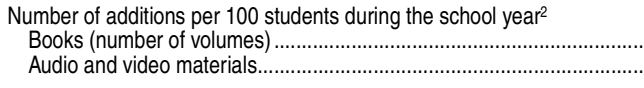 & - & 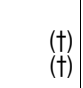 & $\begin{array}{r}99.3 \\
5.1\end{array}$ & $\begin{array}{l}(2.08) \\
(0.19)\end{array}$ & $\begin{array}{r}95.3 \\
5.4\end{array}$ & $\left.\begin{array}{l}(2.21) \\
(0.49)\end{array}\right]$ & $\begin{array}{r}113.3 \\
5.9\end{array}$ & $\begin{array}{l}(3.26) \\
(0.77)\end{array}$ & $\begin{array}{r}62.1 \\
4.5\end{array}$ & $(0.41)$ & $\begin{array}{r}103.4 \\
5.7\end{array}$ & $\begin{array}{l}(.41) \\
(0.84)\end{array}$ & $\begin{array}{r}89.4 \\
4.3\end{array}$ & $\begin{array}{l}(3.47) \\
(0.37)\end{array}$ & $\begin{array}{r}104.8 \\
3.8\end{array}$ & $\begin{array}{l}(5.45) \\
(0.32)\end{array}$ & $\begin{array}{r}58.9 \\
4.2\end{array}$ & $\left.\begin{array}{l}(2.08) \\
(0.70)\end{array}\right]$ & $\begin{array}{c}92.5 \\
8.2 !\end{array}$ & $\begin{array}{l}(6.54) \\
(3.28)\end{array}$ \\
\hline 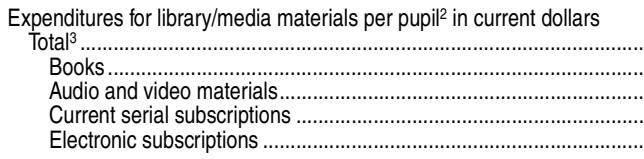 & $\begin{array}{r}\$ 23.37 \\
9.97 \\
1.66 \\
1.26 \\
0.81\end{array}$ & $\begin{array}{l}(0.438) \\
(0.153) \\
(0.032) \\
(0.016) \\
(0.018)\end{array}$ & $\begin{array}{r}\$ 16.24 \\
10.99 \\
1.14 \\
1.38 \\
0.88\end{array}$ & $\begin{array}{l}(0.322) \\
(0.299) \\
(0.045) \\
(0.025) \\
(0.033)\end{array}$ & $\begin{array}{r}\$ 16.11 \\
11.40 \\
1.08 \\
-\end{array}$ & $\begin{array}{r}(0.461) \\
(0.291) \\
(0.055) \\
(\dagger) \\
(\dagger)\end{array}$ & $\begin{array}{r}\$ 16.18 \\
11.99 \\
1.06 \\
-\end{array}$ & $\begin{array}{r}(0.591) \\
(0.389) \\
(0.088) \\
(\dagger \\
(\dagger)\end{array}$ & $\begin{array}{r}\$ 15.90 \\
10.26 \\
1.11 \\
- \\
-\end{array}$ & $\begin{array}{r}(0.647) \\
(0.504) \\
(0.054) \\
(\dagger) \\
(\dagger)\end{array} \mid$ & $\begin{array}{r}\$ 17.00 \\
12.10 \\
1.16 \\
- \\
-\end{array}$ & $\begin{array}{r}(1.216) \\
(1.094) \\
(0.152) \\
(\dagger \\
(\dagger)\end{array}$ & $\begin{array}{r}\$ 16.00 \\
10.28 \\
0.84 \\
- \\
-\end{array}$ & $\left.\begin{array}{r}(0.691) \\
(0.343) \\
(0.072) \\
(\dagger \\
(\dagger)\end{array}\right)$ & $\begin{array}{r}\$ 16.48 \\
10.73 \\
0.80 \\
- \\
-\end{array}$ & $\begin{array}{r}(1.099) \\
(0.480) \\
(0.113) \\
(\dagger) \\
(\dagger)\end{array}$ & $\begin{array}{r}\$ 14.80 \\
9.41 \\
0.89 \\
- \\
-\end{array}$ & $\begin{array}{r}(0.584) \\
(0.526) \\
(0.062) \\
(\dagger \\
(\dagger)\end{array}$ & $\begin{array}{r}\$ 17.26 \\
10.27 \\
0.89 \\
-\end{array}$ & $\begin{array}{r}(1.215) \\
(0.830) \\
(0.131) \\
(\dagger) \\
(\dagger)\end{array}$ \\
\hline $\begin{array}{l}\text { Expenditures for library/media materials per pupil2 in constant } \\
2012-13 \text { dollars }\end{array}$ & & & & & & & & & & & & & & & & & & & & \\
\hline 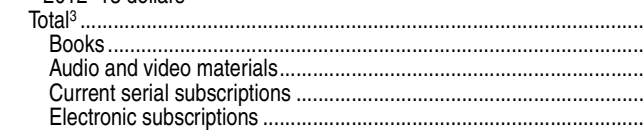 & $\begin{array}{r}\$ 31.94 \\
13.62 \\
2.27 \\
1.72 \\
1.11\end{array}$ & $\begin{array}{l}(0.599) \\
(0.209) \\
(0.044) \\
(0.022) \\
(0.025)\end{array}$ & $\begin{array}{r}\$ 20.19 \\
13.66 \\
1.42 \\
1.72 \\
1.10\end{array}$ & $\begin{array}{l}(0.400) \\
(0.371) \\
(0.055) \\
(0.031) \\
(0.041)\end{array}$ & $\begin{array}{r}\$ 17.60 \\
12.46 \\
1.18 \\
-\end{array}$ & $\begin{array}{r}(0.503) \\
(0.319) \\
(0.061) \\
(\dagger) \\
(\dagger)\end{array}$ & $\begin{array}{r}\$ 17.68 \\
13.10 \\
1.16 \\
-\end{array}$ & $\begin{array}{r}(0.645) \\
(0.425) \\
(0.096) \\
(\dagger) \\
(\dagger)\end{array}$ & $\begin{array}{r}\$ 17.38 \\
11.22 \\
1.21 \\
- \\
-\end{array}$ & $\begin{array}{r}(0.707) \\
(0.551) \\
(0.059) \\
(\dagger) \\
(\dagger)\end{array}$ & $\begin{array}{r}\$ 18.57 \\
13.23 \\
1.27 \\
- \\
-\end{array}$ & $\begin{array}{r}(1.329) \\
(1.196) \\
(0.166) \\
(\dagger) \\
(\dagger)\end{array}$ & $\begin{array}{r}\$ 16.27 \\
10.45 \\
0.85 \\
- \\
-\end{array}$ & $\begin{array}{r}(0.703) \\
(0.349) \\
(0.074) \\
(\dagger) \\
(\dagger)\end{array}$ & $\begin{array}{r}\$ 16.76 \\
10.91 \\
0.81 \\
- \\
-\end{array}$ & $\begin{array}{r}(1.117) \\
(0.488) \\
(0.115) \\
(\dagger) \\
(\dagger)\end{array}$ & $\begin{array}{r}\$ 15.04 \\
9.57 \\
0.91 \\
- \\
-\end{array}$ & $\begin{array}{r}(0.593) \\
(0.534) \\
(0.063) \\
(\dagger) \\
(\dagger)\end{array}$ & $\begin{array}{r}\$ 17.54 \\
10.44 \\
0.91 \\
-\end{array}$ & $\begin{array}{r}(1.235) \\
(0.844) \\
(0.133) \\
(\dagger) \\
(\dagger)\end{array}$ \\
\hline
\end{tabular}

\section{-Not available.}

IInterpret data with caution. The coefficient of variation (CV) for this estimate is between 30 percent and 50 percent. 'Centralized video distribution equipment with a scheduling and control server that telecasts video to classrooms. ¿Holdings, additions, and expenditures are from the prior school year, while enrollment counts are from the current school year. ${ }^{3}$ Includes other expenditures not separately shown.
${ }^{4}$ Constant dollars based on the Consumer Price Index, prepared by the Bureau of Labor Statistics, U.S. Department of Labor, adjusted to a school-year basis.

SOURCE: U.S. Department of Education, National Center for Education Statistics, Schools and Staffing Survey (SASS), "Public School Library Media Center Questionnaire," 1999-2000, 2003-04, 2007-08, and 2011-12; and "Charter School Questionnaire," 1999-2000. (This table was prepared December 2013.) 
Table 701.20. Selected statistics on public school libraries/media centers, by level and enrollment size of school: 2011-12

[Standard errors appear in parentheses]

\begin{tabular}{|c|c|c|c|c|c|c|c|c|c|c|c|c|c|c|c|c|c|c|c|c|c|c|}
\hline \multirow{3}{*}{$\frac{\text { Selected statistic }}{1}$} & \multirow{2}{*}{\multicolumn{2}{|c|}{$\begin{array}{r}\text { All public } \\
\text { school libraries/ } \\
\text { media centers }\end{array}$}} & \multicolumn{10}{|c|}{ Elementary school enrollment size } & \multicolumn{10}{|c|}{ Secondary school enrollment size } \\
\hline & & & & Total & Less th & than 150 & & 50 to 499 & & 0 to 749 & & or more & & Total & Less $t$ & than 500 & & 00 to 749 & 750 & to 1,499 & 1,500 & or more \\
\hline & & 2 & & 3 & & 4 & & 5 & & 6 & & 7 & & 8 & & 9 & & 10 & & 11 & & 12 \\
\hline Number of schools with libraries/media centers ............ & 81,200 & $(510)$ & 58,000 & (418) & 3,000 & (308) & 29,700 & $\begin{array}{c}(658) \\
\end{array}$ & 16,600 & (591) & 8,600 & (426) & 17,100 & (357) & 6,400 & (289) & 3,100 & $(170)$ & 4,600 & (188) & 3,000 & $(160)$ \\
\hline 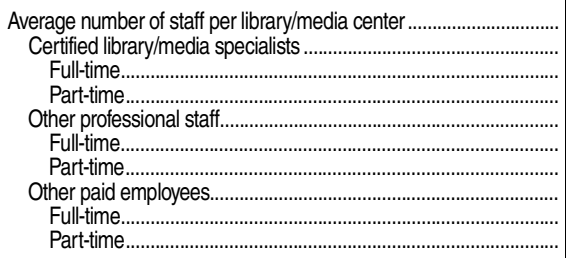 & $\begin{array}{l}1.77 \\
0.90 \\
0.71 \\
0.20 \\
0.19 \\
0.12 \\
0.07 \\
0.68 \\
0.40 \\
0.28\end{array}$ & $\begin{array}{l}(0.017) \\
(0.012) \\
(0.010) \\
(0.008) \\
(0.007) \\
(0.006) \\
(0.005) \\
(0.011) \\
(0.008) \\
(0.009)\end{array}$ & $\begin{array}{l}1.72 \\
0.88 \\
0.67 \\
0.21 \\
0.18 \\
0.11 \\
0.07 \\
0.66 \\
0.37 \\
0.29\end{array}$ & $\begin{array}{l}(0.020) \\
(0.014) \\
(0.012) \\
(0.010) \\
(0.009) \\
(0.007) \\
(0.007) \\
(0.012) \\
(0.009) \\
(0.012)\end{array}$ & $\begin{array}{l}1.76 \\
0.90 \\
0.47 \\
0.44 \\
0.27 \\
0.19 \\
0.08 \\
0.59 \\
0.29 \\
0.30\end{array}$ & $\begin{array}{l}(0.226) \\
(0.176) \\
(0.171) \\
(0.054) \\
(0.081) \\
(0.076) \\
(0.034) \\
(0.063) \\
(0.048) \\
(0.061)\end{array}$ & $\begin{array}{l}1.66 \\
0.86 \\
0.61 \\
0.26 \\
0.18 \\
0.10 \\
0.08 \\
0.61 \\
0.32 \\
0.29\end{array}$ & $\begin{array}{l}(0.022) \\
(0.016) \\
(0.015) \\
(0.014) \\
(0.014) \\
(0.010) \\
(0.010) \\
(0.016) \\
(0.013) \\
(0.015)\end{array}$ & $\begin{array}{l}1.75 \\
0.88 \\
0.74 \\
0.14 \\
0.18 \\
0.09 \\
0.09 \\
0.69 \\
0.39 \\
0.30\end{array}$ & $\begin{array}{l}(0.032) \\
(0.019) \\
(0.016) \\
(0.014) \\
(0.020) \\
(0.011) \\
(0.016) \\
(0.026) \\
(0.017) \\
(0.022)\end{array}$ & $\begin{array}{l}1.87 \\
0.92 \\
0.81 \\
0.11 \\
0.16 \\
0.13 \\
0.03 \\
0.79 \\
0.51 \\
0.28\end{array}$ & $\begin{array}{l}(0.040) \\
(0.024) \\
(0.022) \\
(0.017) \\
(0.019) \\
(0.020) \\
(0.009) \\
(0.035) \\
(0.027) \\
(0.029)\end{array}$ & $\begin{array}{l}1.93 \\
0.99 \\
0.84 \\
0.15 \\
0.17 \\
0.13 \\
0.05 \\
0.76 \\
0.52 \\
0.24\end{array}$ & $\begin{array}{l}(0.027) \\
(0.017) \\
(0.017) \\
(0.010) \\
(0.014) \\
(0.013) \\
(0.005) \\
(0.021) \\
(0.017) \\
(0.012)\end{array}$ & $\begin{array}{l}1.58 \\
0.78 \\
0.59 \\
0.19 \\
0.21 \\
0.14 \\
0.07 \\
0.59 \\
0.35 \\
0.24\end{array}$ & $\begin{array}{l}(0.041) \\
(0.029) \\
(0.029) \\
(0.018) \\
(0.027) \\
(0.025) \\
(0.013) \\
(0.032) \\
(0.024) \\
(0.020)\end{array}$ & $\begin{array}{l}1.76 \\
0.95 \\
0.81 \\
0.15 \\
0.19 \\
0.12 \\
0.07 \\
0.62 \\
0.39 \\
0.23\end{array}$ & $\begin{array}{l}(0.050) \\
(0.029) \\
(0.025) \\
(0.025) \\
(0.030) \\
(0.030) \\
(0.017) \\
(0.036) \\
(0.030) \\
(0.026)\end{array}$ & $\begin{array}{l}2.07 \\
1.10 \\
0.99 \\
0.11 \\
0.14 \\
0.11 \\
0.02 \\
0.84 \\
0.61 \\
0.22\end{array}$ & $\begin{array}{l}(0.045) \\
(0.024) \\
(0.021) \\
(0.019) \\
(0.015) \\
(0.014) \\
(0.006) \\
(0.032) \\
(0.028) \\
(0.024)\end{array}$ & $\begin{array}{l}2.63 \\
1.32 \\
1.21 \\
0.12 \\
0.14 \\
0.13 \\
0.02 ! \\
1.16 \\
0.87 \\
0.29\end{array}$ & $\begin{array}{l}(0.062) \\
(0.039) \\
(0.037) \\
(0.018) \\
(0.019) \\
(0.019) \\
(0.005) \\
(0.049) \\
(0.044) \\
(0.027)\end{array}$ \\
\hline 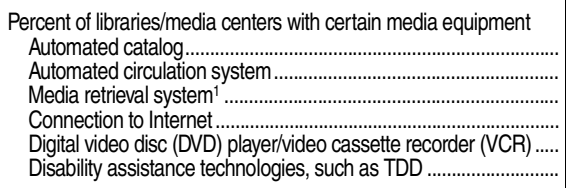 & $\begin{array}{l}88.3 \\
90.3 \\
32.5 \\
95.9 \\
83.2 \\
31.0\end{array}$ & $\begin{array}{l}(0.49) \\
(0.47) \\
(0.76) \\
(0.34) \\
(0.76) \\
(0.75)\end{array}$ & $\begin{array}{l}89.1 \\
91.7 \\
33.6 \\
96.2 \\
82.8 \\
29.9\end{array}$ & $\begin{array}{l}(0.60) \\
(0.59) \\
(0.99) \\
(0.46) \\
(0.98) \\
(0.94)\end{array}$ & $\begin{array}{l}75.2 \\
77.0 \\
15.9 \\
88.6 \\
66.0 \\
20.7\end{array}$ & $\begin{array}{l}(4.05) \\
(4.30) \\
(3.35) \\
(3.28) \\
(5.70) \\
(3.54)\end{array}$ & $\begin{array}{l}88.0 \\
91.4 \\
27.3 \\
95.7 \\
83.1 \\
26.8\end{array}$ & $\begin{array}{l}(0.97) \\
(0.80) \\
(1.48) \\
(0.66) \\
(1.33) \\
(1.33)\end{array}$ & $\begin{array}{l}90.0 \\
93.0 \\
39.2 \\
97.3 \\
84.3 \\
33.2\end{array}$ & $\begin{array}{l}(1.14) \\
(1.07) \\
(1.77) \\
(0.79) \\
(1.49) \\
(2.00)\end{array}$ & $\begin{array}{l}96.2 \\
95.7 \\
51.1 \\
98.5 \\
84.6 \\
37.4\end{array}$ & $\begin{array}{l}(0.81) \\
(0.97) \\
(2.24) \\
(0.64) \\
(2.02) \\
(2.25)\end{array}$ & $\begin{array}{l}90.3 \\
90.1 \\
32.3 \\
97.3 \\
86.7 \\
34.3\end{array}$ & $\begin{array}{l}(0.78) \\
(0.75) \\
(0.91) \\
(0.49) \\
(0.76) \\
(1.02)\end{array}$ & $\begin{array}{l}80.4 \\
81.2 \\
25.2 \\
93.9 \\
83.9 \\
30.8\end{array}$ & $\begin{array}{l}(1.72) \\
(1.60) \\
(1.89) \\
(1.18) \\
(1.50) \\
(2.29)\end{array}$ & $\begin{array}{l}93.3 \\
94.1 \\
36.8 \\
98.4 \\
89.5 \\
34.6\end{array}$ & $\begin{array}{l}(1.72) \\
(1.62) \\
(2.56) \\
(0.67) \\
(1.82) \\
(2.53)\end{array}$ & $\begin{array}{l}97.2 \\
96.2 \\
38.7 \\
99.4 \\
88.4 \\
36.8\end{array}$ & $\begin{array}{l}(0.73) \\
(0.94) \\
(1.99) \\
(0.33) \\
(1.23) \\
(2.17)\end{array}$ & $\begin{array}{r}97.1 \\
95.3 \\
32.7 \\
100.0 \\
87.0 \\
37.6\end{array}$ & $\begin{array}{c}(0.82) \\
(1.00) \\
(2.19) \\
(+) \\
(1.88) \\
(2.67)\end{array}$ \\
\hline 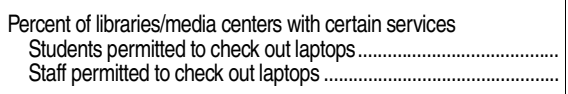 & $\begin{array}{l}40.2 \\
54.3\end{array}$ & $\begin{array}{l}(0.69) \\
(0.85)\end{array}$ & $\begin{array}{l}39.3 \\
53.9\end{array}$ & $\begin{array}{l}(0.85) \\
(0.99)\end{array}$ & $\begin{array}{l}31.7 \\
38.9\end{array}$ & $\begin{array}{l}(4.21) \\
(4.84)\end{array}$ & $\begin{array}{l}38.5 \\
51.8\end{array}$ & $\begin{array}{l}(1.52) \\
(1.65)\end{array}$ & $\begin{array}{l}39.7 \\
57.5\end{array}$ & $\begin{array}{l}(2.01) \\
(1.89)\end{array}$ & $\begin{array}{l}44.1 \\
59.6\end{array}$ & $\begin{array}{l}(2.02) \\
(2.20)\end{array}$ & $\begin{array}{l}42.4 \\
55.5\end{array}$ & $\begin{array}{l}(1.08) \\
(1.23)\end{array}$ & $\begin{array}{l}42.7 \\
52.6\end{array}$ & $\begin{array}{l}(2.07) \\
(2.24)\end{array}$ & $\begin{array}{l}40.3 \\
55.6\end{array}$ & $\begin{array}{l}(2.72) \\
(2.76)\end{array}$ & $\begin{array}{l}44.3 \\
58.1\end{array}$ & $\begin{array}{l}(2.12) \\
(2.31)\end{array}$ & $\begin{array}{l}40.9 \\
57.8\end{array}$ & $\begin{array}{l}(2.77) \\
(2.37)\end{array}$ \\
\hline Number of library computer workstations per 100 students........... & 3.1 & $(0.05)$ & 2.8 & $(0.06)$ & 12.0 & (1.49) & 3.7 & $(0.13)$ & 2.3 & $(0.09)$ & 2.1 & $(0.07)$ & 3.6 & $(0.08)$ & 7.2 & $(0.35)$ & 4.4 & $(0.16)$ & 3.5 & $(0.09)$ & 2.6 & $(0.12)$ \\
\hline 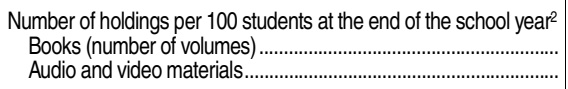 & $\begin{array}{r}2,188 \\
81\end{array}$ & $\begin{array}{r}(42.4) \\
(2.4)\end{array}$ & $\begin{array}{r}2,570 \\
85\end{array}$ & $\begin{array}{r}(58.5) \\
(3.3)\end{array}$ & $\begin{array}{r}9,505 \\
201\end{array}$ & $\begin{array}{r}(1472.0) \\
(58.1)\end{array}$ & $\begin{array}{r}3,273 \\
100\end{array}$ & $\begin{array}{r}(115.0) \\
(6.6)\end{array}$ & $\begin{array}{r}2,366 \\
80\end{array}$ & $\begin{array}{r}(101.2) \\
(4.5)\end{array}$ & $\begin{array}{r}1,692 \\
67\end{array}$ & $\begin{array}{r}(53.5) \\
(5.9)\end{array}$ & $\begin{array}{r}1,474 \\
71\end{array}$ & $\begin{array}{r}(24.7) \\
(2.9)\end{array}$ & $\begin{array}{r}3,252 \\
131\end{array}$ & $\begin{array}{r}(98.6) \\
(8.7)\end{array}$ & $\begin{array}{r}1,908 \\
83\end{array}$ & $\begin{array}{r}(74.2) \\
(7.3)\end{array}$ & $\begin{array}{r}1,338 \\
73\end{array}$ & $\begin{array}{r}(21.2) \\
(5.4)\end{array}$ & $\begin{array}{r}976 \\
50\end{array}$ & $\begin{array}{r}(20.9) \\
(4.0)\end{array}$ \\
\hline 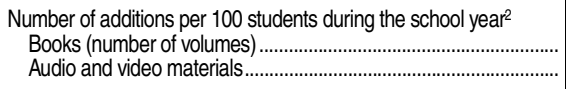 & $\begin{array}{r}89.4 \\
4.3\end{array}$ & $\begin{array}{l}(3.47) \\
(0.37)\end{array}$ & $\begin{array}{r}104.8 \\
3.8\end{array}$ & $\begin{array}{l}(5.45) \\
(0.32)\end{array}$ & $\begin{array}{c}423.0 \\
1.6 !\end{array}$ & $\begin{array}{r}(83.50) \\
(4.33)\end{array}$ & $\begin{array}{r}126.3 \\
4.7\end{array}$ & $\begin{array}{l}(6.91) \\
(0.50)\end{array}$ & $\begin{array}{r}99.5 \\
3.2\end{array}$ & $\begin{array}{r}(12.14) \\
(0.29)\end{array}$ & $\begin{array}{r}73.4 \\
3.2\end{array}$ & $\begin{array}{l}(4.29) \\
(0.79)\end{array}$ & $\begin{array}{r}58.9 \\
4.2\end{array}$ & $\begin{array}{l}(2.08) \\
(0.70)\end{array}$ & $\begin{array}{r}124.0 \\
5.8\end{array}$ & $\begin{array}{l}(9.17) \\
(0.66)\end{array}$ & $\begin{array}{r}77.5 \\
4.3\end{array}$ & $\begin{array}{l}(5.52) \\
(0.55)\end{array}$ & $\begin{array}{r}50.0 \\
3.5\end{array}$ & $\begin{array}{l}(2.54) \\
(0.67)\end{array}$ & $\begin{array}{l}43.0 \\
4.5 !\end{array}$ & $\begin{array}{l}(3.70) \\
(1.50)\end{array}$ \\
\hline 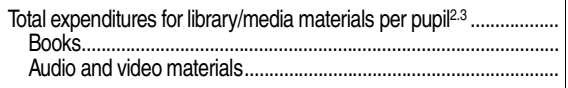 & $\begin{array}{r}\$ 16.00 \\
10.28 \\
0.84\end{array}$ & $\begin{array}{l}(0.691) \\
(0.343) \\
(0.072)\end{array}$ & $\begin{array}{r}\$ 16.48 \\
10.73 \\
0.80\end{array}$ & $\begin{array}{l}(1.099) \\
(0.480) \\
(0.113)\end{array}$ & $\begin{array}{r}\$ 46.34 \\
32.08 \\
1.02\end{array}$ & $\begin{array}{l}(7.286) \\
(5.256) \\
(0.257)\end{array}$ & $\begin{array}{r}\$ 20.40 \\
12.82 \\
0.80\end{array}$ & $\begin{array}{l}(1.625) \\
(0.566) \\
(0.074)\end{array}$ & $\begin{array}{r}\$ 15.81 \\
9.83 \\
1.00\end{array}$ & $\begin{array}{l}(2.409) \\
(1.001) \\
(0.294)\end{array}$ & $\begin{array}{r}\$ 11.31 \\
8.47 \\
0.56\end{array}$ & $\begin{array}{l}(0.649) \\
(0.505) \\
(0.064)\end{array}$ & $\begin{array}{r}\$ 14.80 \\
9.41 \\
0.89\end{array}$ & $\begin{array}{l}(0.584) \\
(0.526) \\
(0.062)\end{array}$ & $\begin{array}{r}\$ 27.69 \\
16.28 \\
1.50\end{array}$ & $\begin{array}{l}(2.135) \\
(1.284) \\
(0.238)\end{array}$ & $\begin{array}{r}\$ 18.59 \\
12.55 \\
0.79\end{array}$ & $\begin{array}{l}(2.051) \\
(2.077) \\
(0.072)\end{array}$ & $\begin{array}{r}\$ 13.48 \\
8.06 \\
0.88\end{array}$ & $\begin{array}{l}(0.571) \\
(0.451) \\
(0.080)\end{array}$ & $\begin{array}{r}\$ 11.26 \\
7.70 \\
0.77\end{array}$ & $\begin{array}{l}(1.169) \\
(1.025) \\
(0.113)\end{array}$ \\
\hline
\end{tabular}

†Not applicable.

!Interpret data with caution. The coefficient of variation (CV) for this estimate is between 30 percent and 50 percent.
'Centralized video distribution equipment with a scheduling and control server that telecasts video to classrooms.

2Holdings, additions, and expenditures are from the prior school year, while enrollment counts are from the current school year.

Includes other expenditures not separately shown.
NOTE: Total includes combined elementary/secondary schools not separately shown. Detail may not sum to totals because of SOURCE: U.S. Department of Education, National Center for Education Statistics, Schools and Staffing Survey (SASS), "Public School Library Media Center Questionnaire," 2011-12. (This table was prepared December 2013.) 
Table 701.30. Selected statistics on public school libraries/media centers, by state: 2011-12

[Standard errors appear in parentheses]

\begin{tabular}{|c|c|c|c|c|c|c|c|c|c|c|c|c|c|c|c|c|c|c|c|c|c|c|c|c|}
\hline \multirow[b]{2}{*}{ State } & \multicolumn{14}{|c|}{ Percent of libraries/media centers offering selected services/equipment } & \multirow{2}{*}{\multicolumn{2}{|c|}{$\begin{array}{r}\text { Average } \\
\text { number of staff } \\
\text { per library/ } \\
\text { media center }\end{array}$}} & \multirow{2}{*}{\multicolumn{2}{|c|}{$\begin{array}{r}\text { Books } \\
\text { (number of } \\
\text { volumes) } \\
\text { held at end } \\
\text { of year per } \\
100 \text { students }^{3}\end{array}$}} & \multirow{2}{*}{\multicolumn{2}{|c|}{$\begin{array}{r}\text { Books } \\
\text { (number of } \\
\text { volumes) } \\
\text { acquired during } \\
\text { year per 100 } \\
\text { students }^{3}\end{array}$}} & \multirow{2}{*}{\multicolumn{2}{|c|}{$\begin{array}{r}\text { Total } \\
\text { expenditure } \\
\text { for materials } \\
\text { per student }{ }^{3}\end{array}$}} & \multirow{2}{*}{\multicolumn{2}{|c|}{$\begin{array}{r}\text { Number } \\
\text { of library } \\
\text { computer } \\
\text { workstations } \\
\text { per } 100 \text { students }\end{array}$}} \\
\hline & \multicolumn{2}{|c|}{$\begin{array}{r}\text { Automated } \\
\text { catalog }\end{array}$} & \multicolumn{2}{|c|}{$\begin{array}{r}\text { Automated } \\
\text { circulation } \\
\text { system }\end{array}$} & \multicolumn{2}{|c|}{$\begin{array}{r}\text { Laptops for } \\
\text { student use } \\
\text { outside } \\
\text { of library/ } \\
\text { media center }\end{array}$} & \multicolumn{2}{|c|}{$\begin{array}{r}\text { Laptops for } \\
\text { staff use } \\
\text { outside } \\
\text { of library/ } \\
\text { media center }\end{array}$} & \multicolumn{2}{|c|}{$\begin{array}{r}\text { Media } \\
\text { retrieval system } 1\end{array}$} & \multicolumn{2}{|c|}{$\begin{array}{r}\text { Connection to } \\
\text { the Internet }\end{array}$} & \multicolumn{2}{|c|}{ DVD player/NCR } & & & & & & & & & & \\
\hline 1 & & 2 & & 3 & & 4 & & 5 & & 6 & & 7 & & 8 & & 9 & & 10 & & 11 & & 12 & & 13 \\
\hline United States .. & 88.3 & $(0.49)$ & 90.3 & $(0.47)$ & 40.2 & $(0.69)$ & 54.3 & $(0.85)$ & 32.5 & (0.76) & 95.9 & $(0.34)$ & 83.2 & (0.76) & 1.8 & $(0.02)$ & 2,188 & (42.4) & 89 & $(3.5)$ & $\$ 16.00$ & $(0.691)$ & 3.1 & $(0.05)$ \\
\hline 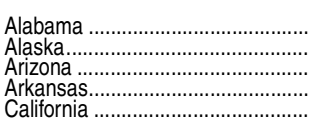 & $\begin{array}{l}96.0 \\
63.1 \\
77.5 \\
97.4 \\
78.5\end{array}$ & $\begin{array}{l}(1.59) \\
5.91 \\
5.11 \\
1.15 \\
3.00)\end{array}$ & $\begin{array}{l}98.5 \\
58.0 \\
78.5 \\
97.4 \\
82.5\end{array}$ & $\left.\begin{array}{l}(0.74) \\
6.01 \\
4.74 \\
1.15 \\
2.27\end{array}\right)$ & $\begin{array}{l}46.7 \\
50.6 \\
33.0 \\
29.5 \\
20.8\end{array}$ & $\begin{array}{l}(4.48) \\
5.32 \\
4.44 \\
3.73 \\
(2.96)\end{array}$ & $\begin{array}{l}59.9 \\
46.2 \\
51.4 \\
48.1 \\
40.7\end{array}$ & 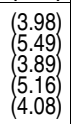 & $\begin{array}{l}29.6 \\
10.0 ! \\
35.2 \\
30.6 \\
13.1\end{array}$ & 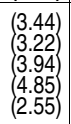 & $\begin{array}{r}97.2 \\
79.7 \\
88.7 \\
10.0 \\
93.6\end{array}$ & $\begin{array}{l}(1.38) \\
6.31 \\
3.97 \\
(1) \\
(1.77)\end{array}$ & $\begin{array}{l}95.4 \\
69.9 \\
78.8 \\
94.2 \\
58.9\end{array}$ & $\left.\begin{array}{l}(1.47) \\
6.51 \\
4.58 \\
2.46 \\
4.36\end{array}\right)$ & $\begin{array}{l}1.6 \\
1.2 \\
1.5 \\
1.8 \\
1.5\end{array}$ & $\begin{array}{l}(0.05) \\
(0.11 \\
0.09 \\
0.10 \\
0.05)\end{array}$ & $\begin{array}{l}2,114 \\
5,077 \\
1,988 \\
1,880 \\
2,065\end{array}$ & $\begin{array}{l}(117.4) \\
(351.4) \\
(97.3) \\
(102.6) \\
(161.6)\end{array}$ & $\begin{array}{r}48 \\
190 \\
57 \\
96 \\
75\end{array}$ & $\begin{array}{r}(4.0) \\
(29.7) \\
7.8 \\
(9.5) \\
(13.4)\end{array}$ & $\begin{array}{r}7.31 \\
25.19 \\
9.60 \\
16.00 \\
10.25\end{array}$ & $\begin{array}{l}(0.630) \\
3.742 \\
1.505 \\
1.328 \\
(2.611)\end{array}$ & $\begin{array}{l}2.4 \\
5.9 \\
2.7 \\
2.7 \\
2.2\end{array}$ & $\begin{array}{l}(0.13) \\
0.66 \\
0.15 \\
0.27 \\
0.17)\end{array}$ \\
\hline 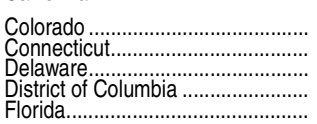 & $\begin{array}{r}93.2 \\
84.5 \\
95.1 \\
93.9\end{array}$ & $\begin{array}{c}(3.07) \\
4.76 \\
1.69 \\
(+) \\
(2.05)\end{array}$ & $\begin{array}{l}88.9 \\
84.1 \\
97.1 \\
91.4\end{array}$ & $\begin{array}{r}(3.73) \\
4.79 \\
(1.57) \\
(2.67)\end{array}$ & $\begin{array}{r}52.7 \\
46.5 \\
41.6 \\
\ddagger \\
40.5\end{array}$ & $\begin{array}{c}(4.25) \\
(7.41 \\
(5.58) \\
(\dagger) \\
(4.01)\end{array}$ & $\begin{array}{l}64.5 \\
61.1 \\
48.6 \\
70.2\end{array}$ & $\begin{array}{l}(4.58) \\
6.05 \\
(5.83) \\
(5) \\
(4.51)\end{array}$ & $\begin{array}{l}34.7 \\
21.5 \\
24.4 \\
73.9\end{array}$ & $\begin{array}{r}(4.91) \\
4.98 \\
(5.13 \\
(1) \\
(3.17)\end{array}$ & $\begin{array}{r}98.2 \\
96.9 \\
98.2 \\
\quad \neq \\
97.4\end{array}$ & $\begin{array}{l}(0.90) \\
(2.11 \\
1.45 \\
(\dagger) \\
(0.94)\end{array}$ & $\begin{array}{l}91.1 \\
86.6 \\
81.4 \\
\neq \\
89.6\end{array}$ & $\begin{array}{r}(2.64) \\
(3.83 \\
4.88 \\
(t) \\
(2.88)\end{array}$ & $\begin{array}{l}1.8 \\
2.0 \\
1.2 \\
1.7 \\
1.6\end{array}$ & $\begin{array}{r}(0.10) \\
(0.08 \\
0.07 \\
(t) \\
(0.05)\end{array}$ & $\begin{array}{r}2,101 \\
2,405 \\
2,835 \\
\ddagger \\
1,904\end{array}$ & 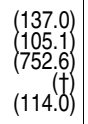 & $\begin{array}{r}89 \\
111 \\
61 \\
1 \\
68\end{array}$ & $\begin{array}{r}(8.4) \\
(29.0) \\
(6.0) \\
(5.9) \\
(5.9)\end{array}$ & $\begin{array}{r}11.23 \\
17.01 \\
9.41 \\
10.98\end{array}$ & $\begin{array}{r}(1.648) \\
1.330 \\
0.690) \\
(t) \\
(1.115)\end{array}$ & $\begin{array}{l}4.3 \\
4.8 \\
3.0 \\
\neq \\
2.6\end{array}$ & $\begin{array}{l}(0.30) \\
0.46 \\
0.25 \\
(+) \\
(0.11)\end{array}$ \\
\hline 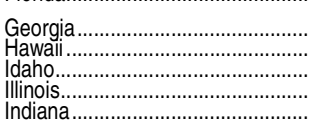 & $\begin{array}{r}96.3 \\
\quad \\
75.5 \\
80.3 \\
89.7\end{array}$ & $\begin{array}{l}(1.26) \\
(t) \\
(5.06 \\
3.31 \\
(3.52)\end{array}$ & $\begin{array}{l}98.2 \\
. \neq \\
85.6 \\
81.6 \\
88.9\end{array}$ & $\left.\begin{array}{l}(0.78) \\
(3.70 \\
3.25 \\
(4.46)\end{array}\right)$ & $\begin{array}{r}51.2 \\
\neq \\
9.9 \\
39.4 \\
33.2\end{array}$ & $\left.\begin{array}{l}(4.92) \\
(\dagger \\
(2.35 \\
4.92 \\
4.58\end{array}\right)$ & $\begin{array}{l}78.7 \\
22.7 \\
48.1 \\
50.2\end{array}$ & $\begin{array}{l}(3.79) \\
(4) \\
(4.21) \\
4.94 \\
(5.73)\end{array}$ & $\begin{array}{l}73.1 \\
\neq \\
24.5 \\
15.2 \\
31.7\end{array}$ & $\begin{array}{r}(4.13) \\
(t \\
(4.39 \\
2.39 \\
5.41)\end{array}$ & $\begin{array}{l}99.3 \\
\ddagger \\
97.4 \\
94.9 \\
96.9\end{array}$ & $\begin{array}{l}(0.37) \\
(\dagger) \\
(1.81 \\
2.41 \\
(1.75)\end{array}$ & $\begin{array}{r}97.6 \\
\ddagger \\
81.5 \\
79.9 \\
89.6\end{array}$ & $\begin{array}{r}(1.38) \\
(t) \\
(6.08) \\
4.00 \\
(3.38)\end{array}$ & $\begin{array}{l}2.0 \\
\neq \\
1.6 \\
2.1 \\
2.0\end{array}$ & $\begin{array}{l}(0.06) \\
(+) \\
(0.12) \\
(0.21 \\
0.09)\end{array}$ & $\begin{array}{l}1,909 \\
\ddagger \\
2,378 \\
2,453 \\
2,486\end{array}$ & $\begin{array}{r}(81.2) \\
(t) \\
(179.4) \\
206.1 \\
(142.5)\end{array}$ & $\begin{array}{r}85 \\
\ddagger \\
64 \\
110 \\
84\end{array}$ & 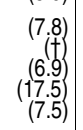 & $\begin{array}{r}13.06 \\
\pm \\
8.45 \\
20.31 \\
14.54\end{array}$ & $\begin{array}{l}(0.806) \\
(t) \\
\left(\begin{array}{l}0.954 \\
3.342 \\
1.057)\end{array}\right)\end{array}$ & $\begin{array}{l}2.3 \\
\neq \\
3.0 \\
3.6 \\
2.9\end{array}$ & $\begin{array}{l}(0.16) \\
(t) \\
(0.22) \\
0.27 \\
(0.27)\end{array}$ \\
\hline 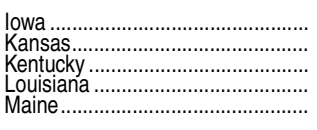 & $\begin{array}{l}94.5 \\
92.2 \\
91.0 \\
83.9 \\
85.6\end{array}$ & $\left.\begin{array}{l}(2.53) \\
4.50 \\
2.31 \\
4.21 \\
(4.05)\end{array}\right)$ & $\begin{array}{l}95.8 \\
99.2 \\
93.0 \\
86.9 \\
88.6\end{array}$ & $\left(\begin{array}{l}1.94) \\
0.40 \\
2.16 \\
3.53 \\
3.44\end{array}\right)$ & $\begin{array}{l}59.5 \\
58.0 \\
34.2 \\
48.4 \\
48.1\end{array}$ & $\left.\begin{array}{l}(4.38) \\
4.86 \\
4.76 \\
5.33 \\
4.85\end{array}\right)$ & $\begin{array}{l}66.3 \\
58.2 \\
51.3 \\
66.8 \\
53.1\end{array}$ & $\left.\begin{array}{l}(4.73) \\
(5.34) \\
4.59 \\
(5.40 \\
4.18\end{array}\right)$ & $\begin{array}{l}26.5 \\
28.3 \\
56.3 \\
31.5 \\
11.3\end{array}$ & $\left.\begin{array}{l}(5.18) \\
4.63 \\
4.89 \\
5.98 \\
3.20\end{array}\right)$ & $\begin{array}{l}98.0 \\
99.9 \\
95.0 \\
98.1 \\
84.7\end{array}$ & $\left.\begin{array}{l}(1.26) \\
3.36 \\
2.02 \\
1.48 \\
3.91\end{array}\right)$ & $\begin{array}{l}86.4 \\
97.7 \\
86.6 \\
85.9 \\
75.8\end{array}$ & $\begin{array}{l}(3.45 \\
1.27 \\
3.27 \\
4.22 \\
4.94)\end{array}$ & $\begin{array}{l}2.3 \\
2.0 \\
1.5 \\
1.4 \\
1.7\end{array}$ & $\begin{array}{l}(0.09 \\
(0.09 \\
(08) \\
(0.11 \\
0.10\end{array}$ & $\begin{array}{l}2,603 \\
3,564 \\
2,026 \\
1,951 \\
3,393\end{array}$ & $\begin{array}{l}(143.2) \\
(259.0) \\
(91.2) \\
(119.4) \\
(283.8)\end{array}$ & $\begin{array}{r}101 \\
101 \\
96 \\
66 \\
109\end{array}$ & $\left.\begin{array}{r}(9.8) \\
(14.2 \\
(7.4) \\
(9.2) \\
9.9\end{array}\right)$ & $\begin{array}{l}14.44 \\
22.42 \\
17.68 \\
17.58 \\
22.60\end{array}$ & $\left.\begin{array}{l}(1.345) \\
5.432 \\
1.388 \\
4.543 \\
(1.615)\end{array}\right)$ & $\begin{array}{l}5.8 \\
4.2 \\
3.2 \\
3.5 \\
2.6\end{array}$ & $\begin{array}{l}(0.59) \\
0.43 \\
0.14 \\
0.31 \\
0.22)\end{array}$ \\
\hline 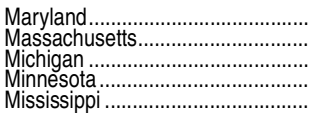 & $\begin{array}{l}68.1 \\
83.6 \\
91.5 \\
71.9\end{array}$ & 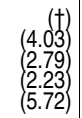 & $\begin{array}{l}70.9 \\
87.1 \\
92.1 \\
86.5\end{array}$ & $\begin{array}{l}(4.4) \\
2.74 \\
2.44 \\
3.53)\end{array}$ & $\begin{array}{l}33.7 \\
39.9 \\
39.8 \\
22.7\end{array}$ & $\begin{array}{r}(+) \\
(4.95) \\
3.62 \\
3.67 \\
(3.97)\end{array}$ & $\begin{array}{l}42.7 \\
51.6 \\
57.6 \\
46.3\end{array}$ & $\left.\begin{array}{l}(+1) \\
(5.63) \\
3.63 \\
4.04 \\
5.13\end{array}\right)$ & $\begin{array}{l}20 . \\
25.9 \\
34.4 \\
26.8\end{array}$ & $\left.\begin{array}{r}(+) \\
4.09 \\
3.56 \\
3.13 \\
3.50\end{array}\right)$ & $\begin{array}{l}96.7 \\
98.3 \\
94.4 \\
97.0\end{array}$ & $\left.\begin{array}{c}(1.82 \\
(0.77 \\
1.86 \\
1.86\end{array}\right)$ & $\begin{array}{l}84.5 \\
80.8 \\
86.3 \\
89.5\end{array}$ & 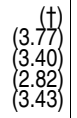 & $\begin{array}{l}1.7 \\
1.3 \\
1.7 \\
2.2 \\
1.5\end{array}$ & $\begin{array}{l}(t+) \\
(0.10) \\
0.07 \\
(0.08) \\
0.08)\end{array}$ & 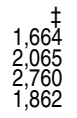 & $\begin{array}{r}(t)(t) \\
117.9) \\
139.9 \\
110.5)\end{array}$ & $\begin{array}{r}\ddagger \\
61 \\
58 \\
105 \\
106\end{array}$ & 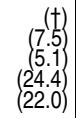 & $\begin{array}{l}13.79 \\
10.13 \\
16.40 \\
13.03\end{array}$ & 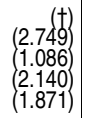 & $\begin{array}{l}\ddagger \\
.4 .4 \\
4.5 \\
5.4 \\
1.9\end{array}$ & $\begin{array}{l}(t) \\
(0.26) \\
0.30 \\
0.35 \\
0.15\end{array}$ \\
\hline 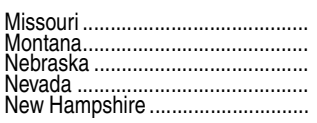 & $\begin{array}{l}93.8 \\
77.6 \\
90.0 \\
97.8 \\
91.3\end{array}$ & $\left.\begin{array}{l}(1.87) \\
6.74 \\
2.94 \\
1.08 \\
(4.46)\end{array}\right)$ & $\begin{array}{l}97.3 \\
87.9 \\
93.6 \\
98.3 \\
94.4\end{array}$ & $\left(\begin{array}{l}1.37 \\
4.59 \\
2.83 \\
0.96 \\
4.05\end{array}\right)$ & $\begin{array}{l}34.8 \\
34.8 \\
71.8 \\
28.6 \\
58.4\end{array}$ & $\begin{array}{l}3.06 \\
6.14 \\
4.06 \\
4.31 \\
(7.08)\end{array}$ & $\begin{array}{l}44.1 \\
50.6 \\
71.8 \\
41.2 \\
66.7\end{array}$ & $\left.\begin{array}{l}(3.32) \\
7.14 \\
4.32 \\
4.77 \\
6.26\end{array}\right)$ & $\begin{array}{l}19.8 \\
17.0 ! \\
33.6 \\
34.4 \\
7.9 !\end{array}$ & $\left.\begin{array}{l}(2.78) \\
5.97 \\
4.96 \\
3.34 \\
3.66\end{array}\right)$ & $\begin{array}{r}98.2 \\
96.2 \\
95.0 \\
97.4 \\
100.0\end{array}$ & 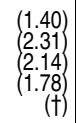 & $\begin{array}{l}89.2 \\
93.3 \\
92.5 \\
65.2 \\
96.1\end{array}$ & $\left.\begin{array}{l}(2.91) \\
2.57 \\
2.55 \\
5.29 \\
2.84\end{array}\right)$ & $\begin{array}{l}1.9 \\
1.8 \\
2.1 \\
1.6 \\
1.8\end{array}$ & $\begin{array}{l}(0.09 \\
(0.09 \\
0.11 \\
(0.07 \\
0.12)\end{array}$ & $\begin{array}{l}2,624 \\
3,570 \\
3,629 \\
1,674 \\
2,134\end{array}$ & $\begin{array}{r}(93.4) \\
(325.3) \\
(430.3) \\
(55.0) \\
(124.6)\end{array}$ & $\begin{array}{r}106 \\
118 \\
137 \\
74 \\
81\end{array}$ & $\begin{array}{r}(6.2) \\
(9.4) \\
(18.6 \\
(5.3) \\
(5.5)\end{array}$ & $\begin{array}{l}21.23 \\
21.51 \\
21.64 \\
10.23 \\
21.78\end{array}$ & $\begin{array}{l}0.896) \\
2.129 \\
1.246 \\
0.490 \\
(1.383)\end{array}$ & $\begin{array}{l}4.4 \\
6.1 \\
5.8 \\
1.9 \\
3.7\end{array}$ & $\begin{array}{l}(0.20) \\
0.73 \\
0.44 \\
0.13 \\
0.31\end{array}$ \\
\hline 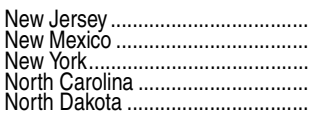 & $\begin{array}{l}85.7 \\
87.3 \\
94.2 \\
95.9 \\
77.6\end{array}$ & $\begin{array}{r}(3.03) \\
(10.18 \\
(2.24 \\
(2.17 \\
(3.93)\end{array}$ & $\begin{array}{l}86.5 \\
86.3 \\
93.8 \\
95.5 \\
80.5\end{array}$ & $\left.\begin{array}{r}(2.85) \\
(10.49) \\
(2.33) \\
1.67 \\
3.66)\end{array}\right)$ & $\begin{array}{l}46.5 \\
36.4 \\
38.3 \\
57.3 \\
45.1\end{array}$ & $\begin{array}{l}(4.19) \\
(8.56 \\
3.90 \\
4.17 \\
(5.00)\end{array}$ & $\begin{array}{l}45.4 \\
65.2 \\
45.8 \\
86.1 \\
52.7\end{array}$ & $\left.\begin{array}{l}(4.10) \\
5.93 \\
4.46 \\
2.53 \\
(4.42)\end{array}\right)$ & $\begin{array}{l}20.7 \\
37.6 \\
21.2 \\
55.4 \\
20.1\end{array}$ & $\begin{array}{l}(3.29 \\
7.31 \\
3.23 \\
3.83 \\
(3.23)\end{array}$ & $\begin{array}{l}96.0 \\
95.8 \\
98.7 \\
98.5 \\
96.6\end{array}$ & $\left.\begin{array}{l}(2.08) \\
2.70 \\
0.98 \\
1.01 \\
1.43\end{array}\right)$ & $\begin{array}{l}79.9 \\
83.7 \\
81.3 \\
93.6 \\
75.6\end{array}$ & $\left.\begin{array}{l}(3.22) \\
6.05 \\
2.94 \\
2.74 \\
3.99\end{array}\right)$ & $\begin{array}{l}1.4 \\
1.8 \\
2.0 \\
1.6 \\
2.0\end{array}$ & $\left.\begin{array}{l}(0.06) \\
(0.24 \\
0.06 \\
0.06 \\
0.09\end{array}\right)$ & $\begin{array}{l}2,172 \\
3,057 \\
1,898 \\
1,940 \\
3,728\end{array}$ & $\begin{array}{r}(121.3) \\
(631.5) \\
(97.1) \\
(97.3) \\
(230.1)\end{array}$ & $\begin{array}{r}68 \\
95 \\
101 \\
88 \\
172\end{array}$ & $\begin{array}{c}(8.2) \\
(16.1) \\
(7.8) \\
(10.1 \\
16.8)\end{array}$ & $\begin{array}{r}15.47 \\
\ddagger \\
19.25 \\
15.85 \\
24.28\end{array}$ & 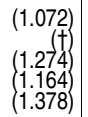 & $\begin{array}{l}3.1 \\
2.5 ! \\
3.2 \\
3.5 \\
4.8\end{array}$ & $\begin{array}{l}(0.19) \\
1.21 \\
0.18 \\
0.26 \\
0.61\end{array}$ \\
\hline 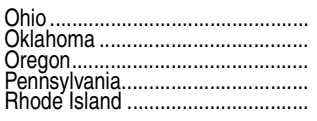 & $\begin{array}{l}91.1 \\
84.1 \\
90.0 \\
89.4 \\
72.9\end{array}$ & $\begin{array}{l}(2.26) \\
4.75 \\
3.18 \\
(3.2) \\
(5.12)\end{array}$ & $\begin{array}{l}94.1 \\
86.4 \\
93.3 \\
91.0 \\
76.7\end{array}$ & $\left.\begin{array}{l}(2.23) \\
4.26 \\
1.71 \\
2.86 \\
4.20\end{array}\right)$ & $\begin{array}{l}45.5 \\
42.3 \\
35.3 \\
39.5 \\
26.0\end{array}$ & $\begin{array}{l}(3.69) \\
5.72 \\
5.04 \\
4.85 \\
(5.81)\end{array}$ & $\begin{array}{l}48.5 \\
46.2 \\
50.4 \\
46.3 \\
22.9\end{array}$ & $\begin{array}{l}(3.52) \\
5.42 \\
5.10 \\
4.96 \\
(5.38)\end{array}$ & $\begin{array}{r}42.0 \\
26.7 \\
28.7 \\
19.9 \\
5.1 !\end{array}$ & $\begin{array}{l}(4.60) \\
5.71 \\
5.09 \\
3.71 \\
(2.06)\end{array}$ & $\begin{array}{l}94.4 \\
94.1 \\
97.5 \\
92.1 \\
94.3\end{array}$ & $\begin{array}{l}(1.88) \\
2.45 \\
1.54 \\
3.19 \\
(3.60)\end{array}$ & $\begin{array}{l}81.5 \\
87.7 \\
74.4 \\
75.7 \\
72.4\end{array}$ & $\begin{array}{l}(3.43) \\
3.89 \\
5.11 \\
4.33 \\
7.05)\end{array}$ & $\begin{array}{l}1.8 \\
1.9 \\
1.7 \\
1.8 \\
1.7\end{array}$ & $\begin{array}{l}(0.07) \\
0.10 \\
0.10 \\
0.08 \\
0.11)\end{array}$ & $\begin{array}{l}1,889 \\
2,676 \\
2,569 \\
2,302 \\
1,993\end{array}$ & $\begin{array}{l}(75.4) \\
(22.2) \\
116.8) \\
181.0 \\
(110.8)\end{array}$ & $\begin{array}{r}64 \\
133 \\
77 \\
81 \\
62\end{array}$ & $\begin{array}{c}(4.0) \\
33.8 \\
10.6 \\
10.1 \\
(9.1)\end{array}$ & $\begin{array}{r}9.06 \\
15.91 \\
11.28 \\
16.68 \\
9.22\end{array}$ & $\begin{array}{l}(0.502) \\
2.051 \\
1.628 \\
1.792 \\
0.978)\end{array}$ & $\begin{array}{l}3.3 \\
3.0 \\
4.0 \\
3.3 \\
3.3\end{array}$ & $\begin{array}{l}(0.20) \\
(0.22) \\
(0.42) \\
(0.22) \\
(0.40)\end{array}$ \\
\hline 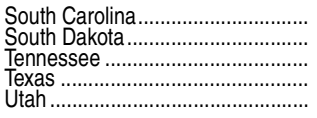 & $\begin{array}{l}95.2 \\
75.1 \\
92.3 \\
93.2 \\
86.1\end{array}$ & $\begin{array}{l}(2.02) \\
4.80 \\
2.75 \\
1.98 \\
(5.81)\end{array}$ & $\begin{array}{l}97.2 \\
69.3 \\
98.1 \\
96.8 \\
85.8\end{array}$ & $\begin{array}{l}(1.55) \\
(5.65) \\
0.90 \\
1.28 \\
6.20)\end{array}$ & $\begin{array}{l}49.1 \\
48.0 \\
46.3 \\
42.1 \\
28.0\end{array}$ & $\begin{array}{l}(4.63) \\
5.49 \\
5.01 \\
3.37 \\
5.07\end{array}$ & $\begin{array}{l}79.0 \\
51.9 \\
57.9 \\
59.2 \\
34.2\end{array}$ & $\begin{array}{l}(3.80) \\
6.10 \\
4.83 \\
3.89 \\
(5.33)\end{array}$ & $\begin{array}{l}85.0 \\
21.6 \\
28.0 \\
32.9 \\
44.5\end{array}$ & $\begin{array}{l}(3.67) \\
4.22 \\
(3.68) \\
(3.57) \\
(5.72)\end{array}$ & $\begin{array}{l}100.0 \\
84.2 \\
98.1 \\
96.9 \\
84.8\end{array}$ & $\left.\begin{array}{c}(\mathrm{t}) \\
(5.62) \\
1.23 \\
(1.41 \\
5.15\end{array}\right)$ & $\begin{array}{l}96.1 \\
77.5 \\
90.2 \\
90.5 \\
84.8\end{array}$ & $\left.\begin{array}{l}1.89 \\
5.53 \\
3.57 \\
2.07 \\
5.98\end{array}\right)$ & $\begin{array}{l}1.8 \\
1.7 \\
1.7 \\
1.8 \\
1.7\end{array}$ & $\begin{array}{l}(0.07) \\
0.11 \\
0.08 \\
(0.06 \\
0.13)\end{array}$ & $\begin{array}{l}2,246 \\
3,370 \\
1,756 \\
2,261 \\
1,652\end{array}$ & $\begin{array}{r}(401.6) \\
329.1) \\
(60.8) \\
(250.8) \\
(90.6)\end{array}$ & $\begin{array}{r}79 \\
\neq \\
81 \\
113 \\
85\end{array}$ & $\begin{array}{r}(5.9) \\
\left(\begin{array}{l}(t) \\
(23.3 \\
(23.0) \\
12.2\end{array}\right)\end{array}$ & $\begin{array}{l}15.47 \\
22.94 \\
11.96 \\
23.54 \\
10.03\end{array}$ & $\left.\begin{array}{l}1.105) \\
1.947 \\
1.448 \\
4.438 \\
0.862)\end{array}\right)$ & $\begin{array}{l}3.0 \\
3.5 \\
2.5 \\
2.3 \\
2.1\end{array}$ & $\begin{array}{l}(0.24) \\
0.45 \\
0.21 \\
0.10 \\
0.18\end{array}$ \\
\hline 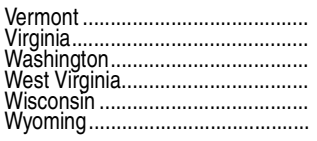 & $\begin{array}{l}84.5 \\
95.7 \\
92.2 \\
69.0 \\
96.0 \\
95.5\end{array}$ & $\left.\begin{array}{l}(4.69) \\
2.26 \\
2.67 \\
4.92 \\
2.31 \\
4.10\end{array}\right)$ & $\begin{array}{l}80.6 \\
97.3 \\
93.6 \\
74.9 \\
97.9 \\
95.5\end{array}$ & $\begin{array}{l}(4.24) \\
1.38 \\
2.49 \\
51.24 \\
(1.07) \\
4.10)\end{array}$ & $\begin{array}{l}58.5 \\
60.8 \\
29.0 \\
32.1 \\
50.4 \\
56.8\end{array}$ & $\begin{array}{l}(5.72) \\
(3.91 \\
4.20 \\
4.40 \\
4.28 \\
(5.80)\end{array}$ & $\begin{array}{l}64.5 \\
74.7 \\
47.9 \\
47.5 \\
63.0 \\
51.1\end{array}$ & $\left.\begin{array}{l}(4.95) \\
4.14 \\
4.47 \\
5.04 \\
4.58 \\
4.62\end{array}\right)$ & $\begin{array}{l}11.2 \\
49.5 \\
28.1 \\
22.0 \\
27.2 \\
19.3\end{array}$ & $\begin{array}{l}2.48 \\
4.90 \\
4.08 \\
2.80 \\
3.97 \\
(5.06)\end{array}$ & $\begin{array}{l}93.1 \\
96.8 \\
96.3 \\
92.8 \\
98.6 \\
98.7\end{array}$ & $\left.\begin{array}{l}(2.97) \\
1.33 \\
2.48 \\
3.28 \\
1.35 \\
0.80\end{array}\right)$ & $\begin{array}{l}80.2 \\
90.1 \\
84.1 \\
68.6 \\
95.7 \\
81.2\end{array}$ & $\begin{array}{l}(4.12) \\
3.92 \\
3.53 \\
5.32 \\
2.36 \\
5.71)\end{array}$ & $\begin{array}{l}1.8 \\
1.9 \\
1.9 \\
1.0 \\
2.4 \\
1.8\end{array}$ & $\begin{array}{l}(0.09) \\
(0.09 \\
0.11 \\
(0.07 \\
0.09 \\
(0.10)\end{array}$ & $\begin{array}{l}4,010 \\
2,018 \\
2,325 \\
1,923 \\
3,125 \\
3,714\end{array}$ & $\begin{array}{r}(145.6) \\
(78.9) \\
(107.8) \\
109.9 \\
149.7 \\
(330.4)\end{array}$ & $\begin{array}{l}155 \\
122 \\
82 \\
110 \\
159 \\
211\end{array}$ & $\begin{array}{r}(9.1) \\
(24.9 \\
(9.4) \\
(32.3) \\
(8.7 \\
(33.4)\end{array}$ & $\begin{array}{r}32.89 \\
18.86 \\
9.46 \\
15.04 \\
37.93 \\
32.02\end{array}$ & $\begin{array}{l}(1.796) \\
(.017 \\
0.680 \\
2.674 \\
(2.217 \\
(5.222)\end{array}$ & $\begin{array}{l}4.8 \\
3.1 \\
3.9 \\
4.5 \\
5.2 \\
4.8\end{array}$ & $\begin{array}{l}(0.48) \\
0.50 \\
0.27 \\
0.80 \\
0.41 \\
0.67)\end{array}$ \\
\hline
\end{tabular}

†Not applicable.

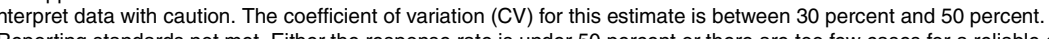
${ }^{-}$Centralized video distributio. Either the response rate is under 50 percent or there are too few cases for a reliable estimate. Includes professional and nonprofessional staff.
${ }^{3}$ Books held, books acquired, and expenditures are from the prior school year, while enrollment counts are from the current SOURCE: U.S. Department of Education, National Center for Education Statistics, Schools and Staffing Survey (SASS), "Public School Library Media Center Questionnaire," 2011-12. (This table was prepared December 2013.) 
Table 701.40. Collections, staff, and operating expenditures of degree-granting postsecondary institution libraries: Selected years, 1981-82 through 2011-12

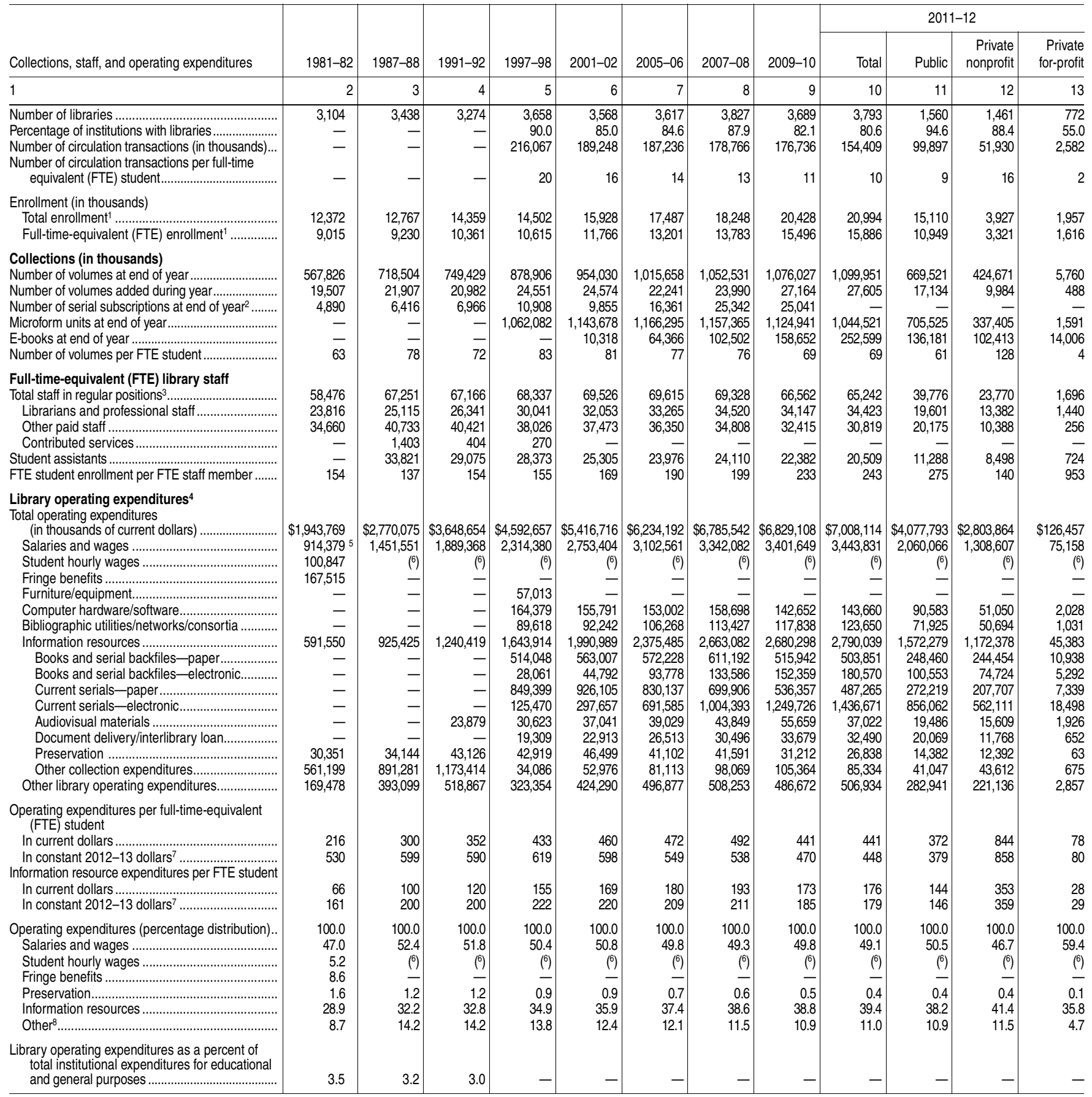

-Not available.

${ }^{1}$ Fall enrollment for the academic year specified.

${ }^{2}$ For $1997-98$ and later years, includes microform and electronic serials.

${ }^{3}$ Excludes student assistants.

4 Excludes capital outlay.

Includes salary equivalents of contributed services staff.

${ }^{6}$ Included under salaries and wages.

${ }^{7}$ Constant dollars based on the Consumer Price Index, prepared by the Bureau of Labor Sta-

tistics, U.S. Department of Labor, adjusted to a school-year basis.

${ }^{8}$ Includes furniture/equipment, computer hardware/software, and bibliographic utilities/networks/consortia as well as expenditures classified as "other library operating expenditures."
NOTE: Data through 1995 are for institutions of higher education, while later data are for degree-granting institutions. Degree-granting institutions grant associate's or higher degrees and participate in Title IV federal financial aid programs. The degree-granting classification is very similar to the earlier higher education classification, but it includes more 2-year colleges and excludes a few higher education institutions that did not grant degrees. Detail may not sum to totals because of rounding.

SOURCE: U.S. Department of Education, National Center for Education Statistics, Library Statistics of Colleges and Universities, 1981-82; Integrated Postsecondary Education Data System (IPEDS), "Academic Libraries Survey" (IPEDS-L:88-98), "Fall Enrollment Survey" (IPEDS-EF:87-98), and IPEDS Spring 2002 through Spring 2012, Enrollment component; Academic Libraries Survey (ALS), 2000 through 2012. (This table was prepared May 2014.) 
Table 701.50. Collections, staff, operating expenditures, public service hours, and reference services of the 60 largest college and university libraries: Fiscal year 2012

\begin{tabular}{|c|c|c|c|c|c|c|c|c|c|c|}
\hline \multirow[b]{2}{*}{ Institution } & \multirow{2}{*}{$\begin{array}{r}\text { Rank order, } \\
\text { by number of } \\
\text { volumes }\end{array}$} & \multirow{2}{*}{$\begin{array}{r}\text { Number } \\
\text { of volumes at } \\
\text { end of year } \\
\text { (in thousands) }\end{array}$} & \multirow{2}{*}{$\begin{array}{l}\text { Number of } \\
\text { e-books at } \\
\text { end of year }\end{array}$} & \multicolumn{2}{|c|}{$\begin{array}{c}\text { Full-time- } \\
\text { equivalent staff }\end{array}$} & \multicolumn{2}{|c|}{$\begin{array}{l}\text { Operating expenditures } \\
\text { (in thousands } \\
\text { of current dollars) }\end{array}$} & \multirow{2}{*}{$\begin{array}{r}\text { Public service } \\
\text { hours per } \\
\text { typical week }\end{array}$} & \multirow[b]{2}{*}{$\begin{array}{r}\text { Gate count per } \\
\text { typical week }{ }^{1}\end{array}$} & \multirow{2}{*}{$\begin{array}{r}\text { Annual } \\
\text { reference } \\
\text { information } \\
\text { services to } \\
\text { individuals }\end{array}$} \\
\hline & & & & Total & Librarians & Total & $\begin{array}{r}\text { Salaries and } \\
\text { wages }\end{array}$ & & & \\
\hline 1 & 2 & 3 & 4 & 5 & 6 & 7 & 8 & 9 & 10 & 11 \\
\hline 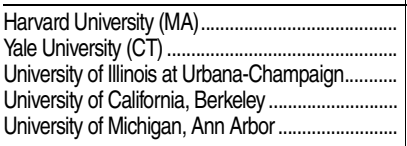 & $\begin{array}{l}1 \\
2 \\
3 \\
4 \\
5\end{array}$ & $\begin{array}{l}17,225 \\
13,504 \\
12,937 \\
11,537 \\
11,458\end{array}$ & $\begin{array}{r}402,473 \\
1,090,187 \\
645,398 \\
1,097,969 \\
1,926,938\end{array}$ & $\begin{array}{r}1,073 \\
600 \\
437 \\
434 \\
690\end{array}$ & \begin{tabular}{r|}
400 \\
163 \\
77 \\
74 \\
186
\end{tabular} & $\begin{array}{r}\$ 134,533 \\
81,221 \\
43,703 \\
47,325 \\
63,828\end{array}$ & \begin{tabular}{r|}
$\$ 83,834$ \\
35,235 \\
20,744 \\
24,022 \\
32,553
\end{tabular} & \begin{tabular}{r|}
168 \\
111 \\
152 \\
77 \\
168
\end{tabular} & \begin{tabular}{|c|}
$27,194^{3}$ \\
$27,194^{3}$ \\
$93,818^{3}$ \\
$39,081^{3}$ \\
114,557
\end{tabular} & $\begin{array}{r}187,903 \\
31,783 \\
110,973 \\
70,986 \\
211,469\end{array}$ \\
\hline 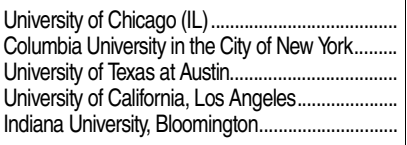 & $\begin{array}{r}6 \\
7 \\
8 \\
9 \\
10\end{array}$ & $\begin{array}{r}11,397 \\
11,291 \\
10,185 \\
9,981 \\
9,276\end{array}$ & $\begin{array}{r}1,251,085 \\
1,329,421 \\
752,892 \\
1,288,821 \\
1,363,894\end{array}$ & $\begin{array}{l}309 \\
526 \\
489 \\
527 \\
395\end{array}$ & $\begin{array}{r}68 \\
162 \\
104 \\
133 \\
90\end{array}$ & $\begin{array}{l}36,112 \\
57,422 \\
43,968 \\
50,171 \\
33,371\end{array}$ & $\begin{array}{l}13,450 \\
26,244 \\
20,476 \\
27,406 \\
15,259\end{array}$ & $\begin{array}{r}148 \\
107 \\
120 \\
96 \\
101\end{array}$ & $\begin{array}{r}28,732 \\
84,930 \\
101,797 \\
81,905 \\
64,700\end{array}$ & $\begin{array}{r}16,610 \\
58,489 \\
119,058 \\
113,725 \\
138,542\end{array}$ \\
\hline 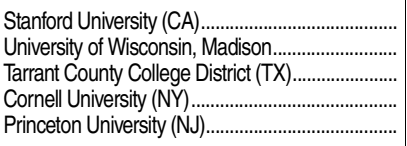 & $\begin{array}{l}11 \\
12 \\
13 \\
14 \\
15\end{array}$ & $\begin{array}{l}9,025 \\
7,841 \\
7,828 \\
7,684 \\
7,486\end{array}$ & $\begin{array}{r}841,538 \\
656,536 \\
83,036 \\
903,397 \\
322,690\end{array}$ & $\begin{array}{r}653 \\
533 \\
73 \\
468 \\
382\end{array}$ & $\begin{array}{r}153 \\
202 \\
24 \\
110 \\
87\end{array}$ & $\begin{array}{r}69,922 \\
38,018 \\
3,878 \\
45,471 \\
50,222\end{array}$ & $\begin{array}{r}31,704 \\
18,778 \\
2,723 \\
21,917 \\
20,476\end{array}$ & $\begin{array}{r}105 \\
148 \\
84 \\
145 \\
120\end{array}$ & $\begin{array}{r}20,491^{3} \\
103,845 \\
26,583 \\
73,193 \\
8,508\end{array}$ & $\begin{array}{r}105,636 \\
650 \\
- \\
62,429 \\
19,018\end{array}$ \\
\hline $\begin{array}{l}\text { University of Washington, Seattle Campus ............ } \\
\text { University of Minnesota, Twin Cities..................... } \\
\text { Michigan State University.................................. } \\
\text { University of Pittsburgh, Main Campus (PA)......... } \\
\text { Duke University (NC) }\end{array}$ & $\begin{array}{l}16 \\
17 \\
18 \\
19 \\
20\end{array}$ & $\begin{array}{l}7,375 \\
6,918 \\
6,702 \\
6,663 \\
6,540\end{array}$ & $\begin{array}{r}460,477 \\
484,151 \\
2,715,914 \\
988,230 \\
875,488\end{array}$ & $\begin{array}{l}385 \\
355 \\
236 \\
319 \\
321\end{array}$ & $\begin{array}{r}122 \\
87 \\
70 \\
118 \\
114\end{array}$ & $\begin{array}{l}36,649 \\
39,526 \\
27,496 \\
31,800 \\
41,043\end{array}$ & $\begin{array}{l}17,592 \\
17,992 \\
10,389 \\
11,881 \\
17,127\end{array}$ & $\begin{array}{l}135 \\
107 \\
140 \\
118 \\
149\end{array}$ & $\begin{array}{c}135,000 \\
45,000 \\
37,453 \\
39,081^{3} \\
95,437\end{array}$ & $\begin{array}{l}56,062 \\
46,021 \\
50,633 \\
80,695 \\
80,518\end{array}$ \\
\hline 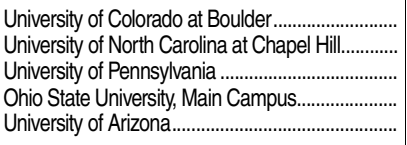 & $\begin{array}{l}21 \\
22 \\
23 \\
24 \\
25\end{array}$ & $\begin{array}{l}6,510 \\
6,437 \\
6,108 \\
6,050 \\
6,030\end{array}$ & $\begin{array}{r}675,723 \\
996,453 \\
1,100,111 \\
526,075 \\
1,184,441\end{array}$ & $\begin{array}{l}232 \\
409 \\
416 \\
449 \\
194\end{array}$ & $\begin{array}{r}62 \\
130 \\
137 \\
75 \\
51\end{array}$ & $\begin{array}{l}24,263 \\
38,135 \\
41,535 \\
43,185 \\
23,350\end{array}$ & $\begin{array}{r}10,114 \\
18,921 \\
19,601 \\
17,349 \\
8,410\end{array}$ & $\begin{array}{l}128 \\
146 \\
116 \\
168 \\
142\end{array}$ & $\begin{array}{r}66,545 \\
90,160 \\
31,779 \\
128,852 \\
38,585\end{array}$ & $\begin{array}{r}57,345 \\
84,345 \\
6,500 \\
27,876 \\
17,247\end{array}$ \\
\hline 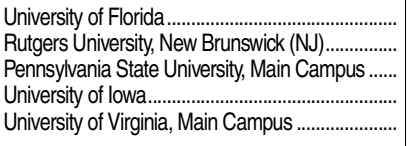 & $\begin{array}{l}26 \\
27 \\
28 \\
29 \\
30\end{array}$ & $\begin{array}{l}5,611 \\
5,478 \\
5,351 \\
5,310 \\
5,247\end{array}$ & $\begin{array}{l}815,537 \\
595,141 \\
316,913 \\
772,023 \\
460,840\end{array}$ & $\begin{array}{l}301 \\
272 \\
539 \\
221 \\
344\end{array}$ & $\begin{array}{r}90 \\
56 \\
143 \\
66 \\
97\end{array}$ & $\begin{array}{l}28,657 \\
25,958 \\
50,972 \\
24,728 \\
33,796\end{array}$ & $\begin{array}{r}13,434 \\
14,493 \\
25,757 \\
9,883 \\
16,775\end{array}$ & $\begin{array}{l}138 \\
115 \\
148 \\
116 \\
149\end{array}$ & $\begin{array}{r}53,235 \\
60,618 \\
139,775 \\
34,623 \\
76,921\end{array}$ & $\begin{array}{l}44,945 \\
25,656 \\
85,211 \\
52,416 \\
76,853\end{array}$ \\
\hline 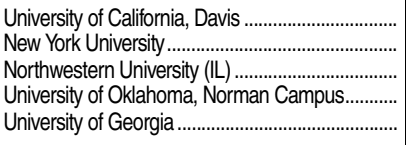 & $\begin{array}{l}31 \\
32 \\
33 \\
34 \\
35\end{array}$ & $\begin{array}{l}5,204 \\
5,196 \\
5,140 \\
5,139 \\
4,947\end{array}$ & $\begin{array}{r}582,966 \\
1,101,383 \\
139,418 \\
1,168,077 \\
555,015\end{array}$ & $\begin{array}{l}185 \\
465 \\
362 \\
142 \\
283\end{array}$ & $\begin{array}{r}54 \\
68 \\
111 \\
34 \\
76\end{array}$ & $\begin{array}{l}18,506 \\
51,534 \\
32,029 \\
17,000 \\
24,101\end{array}$ & $\begin{array}{r}8,783 \\
21,977 \\
14,629 \\
4,727 \\
10,262\end{array}$ & $\begin{array}{l}102 \\
126 \\
122 \\
117 \\
109\end{array}$ & $\begin{array}{l}34,482 \\
65,163 \\
21,560 \\
26,456 \\
61,786\end{array}$ & $\begin{array}{r}78,595 \\
132,850 \\
23,444 \\
21,693 \\
42,991\end{array}$ \\
\hline 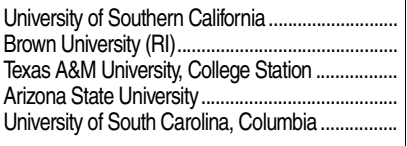 & $\begin{array}{l}36 \\
37 \\
38 \\
39 \\
40\end{array}$ & $\begin{array}{l}4,845 \\
4,724 \\
4,531 \\
4,531 \\
4,460\end{array}$ & $\begin{array}{r}877,824 \\
979,523 \\
1,073,198 \\
403,504 \\
206,886\end{array}$ & $\begin{array}{l}329 \\
172 \\
321 \\
288 \\
265\end{array}$ & $\begin{array}{l}84 \\
48 \\
78 \\
73 \\
71\end{array}$ & $\begin{array}{l}66,405 \\
21,368 \\
35,350 \\
25,459 \\
21,752\end{array}$ & $\begin{array}{r}17,589 \\
8,709 \\
12,945 \\
9,795 \\
7,785\end{array}$ & $\begin{array}{l}159 \\
112 \\
145 \\
149 \\
111\end{array}$ & $\begin{array}{l}53,335 \\
27,890 \\
63,798 \\
39,081^{3} \\
38,470\end{array}$ & $\begin{array}{r}110,159 \\
11,568 \\
44,988 \\
42,726 \\
85,215\end{array}$ \\
\hline 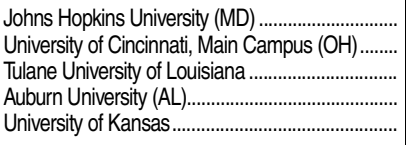 & $\begin{array}{l}41 \\
42 \\
43 \\
44 \\
45\end{array}$ & $\begin{array}{l}4,396 \\
4,336 \\
4,320 \\
4,318 \\
4,285\end{array}$ & $\begin{array}{r}985,644 \\
1,243,527 \\
927,113 \\
821,083 \\
404,676\end{array}$ & $\begin{array}{l}271 \\
188 \\
172 \\
106 \\
249\end{array}$ & $\begin{array}{l}29 \\
44 \\
55 \\
29 \\
59\end{array}$ & $\begin{array}{l}37,396 \\
21,019 \\
17,813 \\
12,762 \\
20,282 \\
\end{array}$ & $\begin{array}{r}13,445 \\
8,588 \\
6,275 \\
4,502 \\
9,362\end{array}$ & $\begin{array}{l}120 \\
106 \\
118 \\
146 \\
140\end{array}$ & $\begin{array}{l}34,500 \\
33,229 \\
20,000 \\
28,066 \\
42,000\end{array}$ & $\begin{array}{r}28,667 \\
119,451 \\
21,633 \\
98,072 \\
91,236\end{array}$ \\
\hline 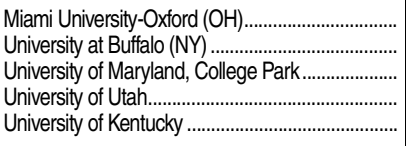 & $\begin{array}{l}46 \\
47 \\
48 \\
49 \\
50\end{array}$ & $\begin{array}{l}4,225 \\
4,119 \\
4,094 \\
4,068 \\
4,023\end{array}$ & $\begin{array}{l}595,932 \\
726,127 \\
599,198 \\
334,463 \\
588,428\end{array}$ & $\begin{array}{l}121 \\
173 \\
250 \\
322 \\
238\end{array}$ & $\begin{array}{l}44 \\
52 \\
80 \\
79 \\
74\end{array}$ & $\begin{array}{r}9,654 \\
19,414 \\
29,353 \\
25,130 \\
21,285\end{array}$ & $\begin{array}{r}4,533 \\
9,663 \\
11,724 \\
12,508 \\
8,741\end{array}$ & $\begin{array}{l}168 \\
168 \\
138 \\
142 \\
140\end{array}$ & $\begin{array}{l}29,976 \\
48,000 \\
58,461 \\
55,008 \\
51,632\end{array}$ & $\begin{array}{r}12,947 \\
35,367 \\
386,001 \\
165,837 \\
29,825\end{array}$ \\
\hline 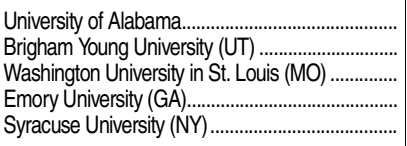 & $\begin{array}{l}51 \\
52 \\
53 \\
54 \\
55\end{array}$ & $\begin{array}{l}3,974 \\
3,946 \\
3,890 \\
3,878 \\
3,815\end{array}$ & $\begin{array}{l}855,794 \\
526,051 \\
590,299 \\
555,313 \\
942,224\end{array}$ & $\begin{array}{l}200 \\
352 \\
245 \\
287 \\
207\end{array}$ & $\begin{array}{l}64 \\
61 \\
97 \\
97 \\
59\end{array}$ & $\begin{array}{l}19,417 \\
26,686 \\
32,570 \\
37,737 \\
19,271\end{array}$ & $\begin{array}{r}7,290 \\
11,771 \\
10,042 \\
14,269 \\
8,613\end{array}$ & $\begin{array}{l}135 \\
101 \\
120 \\
106 \\
136\end{array}$ & $\begin{array}{l}35,307 \\
72,336 \\
28,000 \\
35,117 \\
34,993\end{array}$ & $\begin{array}{r}29,854 \\
57,917 \\
52,905 \\
8,935 \\
21,395\end{array}$ \\
\hline 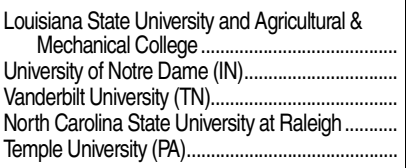 & $\begin{array}{l}56 \\
57 \\
58 \\
59 \\
60\end{array}$ & $\begin{array}{l}3,802 \\
3,796 \\
3,720 \\
3,653 \\
3,573\end{array}$ & $\begin{array}{l}402,264 \\
466,168 \\
606,267 \\
514,635 \\
635,008\end{array}$ & $\begin{array}{l}124 \\
249 \\
196 \\
280 \\
196\end{array}$ & $\begin{array}{r}43 \\
77 \\
61 \\
103 \\
55\end{array}$ & $\begin{array}{l}15,718 \\
26,934 \\
23,624 \\
27,504 \\
23,382\end{array}$ & \begin{tabular}{r|}
10,880 \\
9,181 \\
12,395 \\
8,263
\end{tabular} & $\begin{array}{r}99 \\
147 \\
147 \\
146 \\
145\end{array}$ & $\begin{array}{l}34,772 \\
26,544 \\
40,417 \\
44,540 \\
80,009\end{array}$ & $\begin{array}{l}28,978 \\
20,612 \\
18,507 \\
32,916 \\
73,889\end{array}$ \\
\hline
\end{tabular}

-Not available.

${ }^{1}$ The number of entries into the library in an average week. A single person can be counted more than once.

${ }^{2}$ Includes both in-person and virtual services.
${ }^{3}$ Imputed.

SOURCE: U.S. Department of Education, National Center for Education Statistics, Academic Libraries Survey (ALS), fiscal year 2012. (This table was prepared March 2014.) 
Table 701.60. Public libraries, books and serial volumes, library visits, circulation, and reference transactions, by state: Fiscal years 2009 and 2010

\begin{tabular}{|c|c|c|c|c|c|c|c|c|c|c|c|c|}
\hline \multirow[b]{3}{*}{ State } & & & \multicolumn{4}{|c|}{ Number of books and serial volumes } & \multirow{2}{*}{\multicolumn{2}{|c|}{$\begin{array}{l}\text { Library visits } \\
\text { per capita }^{1}\end{array}$}} & \multirow{2}{*}{\multicolumn{2}{|c|}{$\begin{array}{l}\text { Circulation } \\
\text { per capita }^{2}\end{array}$}} & \multirow{2}{*}{\multicolumn{2}{|c|}{$\begin{array}{l}\text { Reference } \\
\text { transactions } \\
\text { per capita }^{3}\end{array}$}} \\
\hline & \multicolumn{2}{|c|}{ Number of public libraries } & \multicolumn{2}{|c|}{ In thousands } & \multicolumn{2}{|c|}{ Per capita } & & & & & & \\
\hline & 2009 & 2010 & 2009 & 2010 & 2009 & 2010 & 2009 & 2010 & 2009 & 2010 & 2009 & 2010 \\
\hline 1 & 2 & 3 & 4 & 5 & 6 & 7 & 8 & 9 & 10 & 11 & 12 & 13 \\
\hline 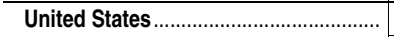 & $9,225^{4}$ & $8,951^{4}$ & 815,909 & 808,402 & 2.7 & 2.7 & 5.4 & 5.3 & 8.1 & 8.3 & 1.0 & 1.0 \\
\hline 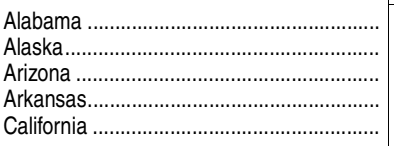 & $\begin{array}{r}210 \\
87 \\
89 \\
52 \\
181\end{array}$ & $\begin{array}{r}212 \\
75 \\
89 \\
55 \\
181\end{array}$ & $\begin{array}{r}9,546 \\
2,532 \\
8,807 \\
6,578 \\
75,299\end{array}$ & $\begin{array}{r}9,649 \\
2,366 \\
8,946 \\
6,569 \\
74,754\end{array}$ & $\begin{array}{l}2.1 \\
3.7 \\
1.3 \\
2.5 \\
2.0\end{array}$ & $\begin{array}{l}2.1 \\
3.4 \\
1.4 \\
2.5 \\
1.9\end{array}$ & $\begin{array}{l}3.7 \\
5.1 \\
4.4 \\
4.0 \\
4.8\end{array}$ & $\begin{array}{l}3.7 \\
4.8 \\
4.6 \\
4.0 \\
4.6\end{array}$ & $\begin{array}{l}4.6 \\
6.4 \\
7.4 \\
5.3 \\
6.2\end{array}$ & $\begin{array}{l}4.6 \\
6.3 \\
8.2 \\
5.5 \\
6.3\end{array}$ & $\begin{array}{l}0.9 \\
0.7 \\
0.7 \\
0.7 \\
0.9\end{array}$ & $\begin{array}{l}0.9 \\
0.6 \\
0.7 \\
0.8 \\
0.9\end{array}$ \\
\hline 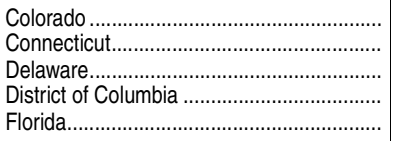 & $\begin{array}{r}114 \\
195 \\
21 \\
1 \\
80\end{array}$ & $\begin{array}{r}114 \\
183 \\
21 \\
1 \\
80\end{array}$ & $\begin{array}{r}11,916 \\
15,646 \\
1,701 \\
2,130 \\
32,643\end{array}$ & $\begin{array}{r}11,752 \\
14,679 \\
1,858 \\
1,904 \\
33,057\end{array}$ & $\begin{array}{l}2.4 \\
4.5 \\
2.2 \\
3.6 \\
1.7\end{array}$ & $\begin{array}{l}2.4 \\
4.4 \\
2.4 \\
3.2 \\
1.8\end{array}$ & $\begin{array}{l}6.7 \\
7.0 \\
5.6 \\
4.9 \\
4.8\end{array}$ & $\begin{array}{l}6.8 \\
7.2 \\
5.8 \\
4.6 \\
4.8\end{array}$ & $\begin{array}{r}13.0 \\
9.7 \\
10.5 \\
3.9 \\
6.8\end{array}$ & $\begin{array}{r}13.3 \\
10.2 \\
11.5 \\
4.5 \\
7.1\end{array}$ & $\begin{array}{l}1.2 \\
1.3 \\
0.6 \\
1.4 \\
1.6\end{array}$ & $\begin{array}{l}1.1 \\
1.2 \\
0.7 \\
1.4 \\
1.7\end{array}$ \\
\hline 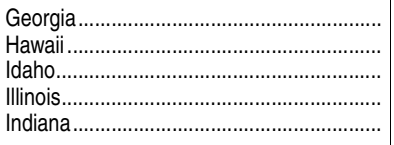 & $\begin{array}{r}61 \\
1 \\
104 \\
634 \\
238\end{array}$ & $\begin{array}{r}61 \\
1 \\
102 \\
622 \\
238\end{array}$ & $\begin{array}{r}16,341 \\
3,383 \\
4,275 \\
45,250 \\
25,672\end{array}$ & $\begin{array}{r}16,765 \\
3,466 \\
4,316 \\
45,223 \\
25,628\end{array}$ & $\begin{array}{l}1.7 \\
2.6 \\
3.2 \\
3.8 \\
4.5\end{array}$ & $\begin{array}{l}1.7 \\
2.7 \\
3.2 \\
3.8 \\
4.5\end{array}$ & $\begin{array}{l}4.3 \\
4.7 \\
6.8 \\
7.0 \\
7.4\end{array}$ & $\begin{array}{l}3.9 \\
4.1 \\
6.4 \\
7.0 \\
7.1\end{array}$ & $\begin{array}{r}5.1 \\
5.6 \\
10.3 \\
9.7 \\
14.1\end{array}$ & $\begin{array}{r}4.7 \\
5.4 \\
10.7 \\
10.3 \\
13.7\end{array}$ & $\begin{array}{l}0.9 \\
0.7 \\
0.9 \\
1.2 \\
1.0\end{array}$ & $\begin{array}{l}1.1 \\
0.6 \\
1.0 \\
1.2 \\
1.1\end{array}$ \\
\hline 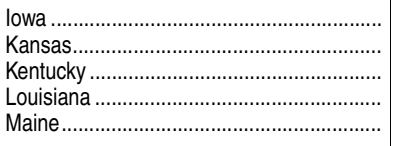 & $\begin{array}{r}541 \\
328 \\
117 \\
68 \\
269\end{array}$ & $\begin{array}{r}531 \\
311 \\
117 \\
68 \\
215\end{array}$ & $\begin{array}{r}12,143 \\
10,314 \\
8,849 \\
11,651 \\
6,536\end{array}$ & $\begin{array}{r}12,117 \\
10,060 \\
9,028 \\
11,913 \\
6,010\end{array}$ & $\begin{array}{l}4.1 \\
4.3 \\
2.1 \\
2.6 \\
5.4\end{array}$ & $\begin{array}{l}4.1 \\
4.2 \\
2.1 \\
2.6 \\
5.3\end{array}$ & $\begin{array}{l}6.5 \\
6.6 \\
4.5 \\
3.5 \\
5.9\end{array}$ & $\begin{array}{l}6.6 \\
6.5 \\
4.6 \\
3.7 \\
6.0\end{array}$ & $\begin{array}{r}9.7 \\
11.8 \\
6.9 \\
4.2 \\
7.9\end{array}$ & $\begin{array}{r}9.9 \\
11.6 \\
7.0 \\
4.4 \\
8.4\end{array}$ & $\begin{array}{l}0.6 \\
1.1 \\
0.7 \\
1.4 \\
0.6\end{array}$ & $\begin{array}{l}0.6 \\
0.9 \\
0.8 \\
1.5 \\
0.5\end{array}$ \\
\hline 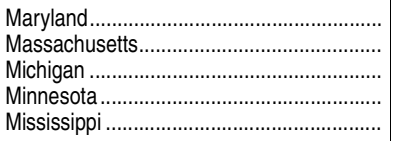 & $\begin{array}{r}24 \\
370 \\
384 \\
138 \\
50\end{array}$ & $\begin{array}{r}24 \\
360 \\
384 \\
138 \\
50\end{array}$ & $\begin{array}{r}13,892 \\
32,969 \\
35,539 \\
15,535 \\
5,556\end{array}$ & $\begin{array}{r}13,954 \\
32,789 \\
35,322 \\
15,592 \\
5,569\end{array}$ & $\begin{array}{l}2.5 \\
5.1 \\
3.6 \\
2.9 \\
1.9\end{array}$ & $\begin{array}{l}2.5 \\
5.0 \\
3.6 \\
2.9 \\
1.9\end{array}$ & $\begin{array}{l}6.1 \\
6.5 \\
6.0 \\
5.6 \\
3.2\end{array}$ & $\begin{array}{l}6.0 \\
6.5 \\
6.0 \\
5.3 \\
3.3\end{array}$ & $\begin{array}{r}10.7 \\
8.9 \\
8.6 \\
11.2 \\
3.0\end{array}$ & $\begin{array}{r}10.7 \\
9.8 \\
9.0 \\
11.1 \\
3.0\end{array}$ & $\begin{array}{l}1.3 \\
0.8 \\
1.0 \\
0.7 \\
0.6\end{array}$ & $\begin{array}{l}1.4 \\
0.8 \\
1.0 \\
0.7 \\
0.6\end{array}$ \\
\hline 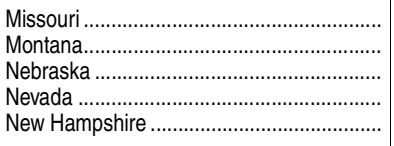 & $\begin{array}{r}150 \\
80 \\
269 \\
22 \\
230\end{array}$ & $\begin{array}{r}147 \\
80 \\
216 \\
22 \\
221\end{array}$ & $\begin{array}{r}17,592 \\
2,731 \\
6,345 \\
4,782 \\
6,217\end{array}$ & $\begin{array}{r}17,328 \\
2,794 \\
5,856 \\
4,545 \\
5,968\end{array}$ & $\begin{array}{l}3.4 \\
3.0 \\
4.7 \\
1.8 \\
4.7\end{array}$ & $\begin{array}{l}3.4 \\
3.1 \\
4.4 \\
1.7 \\
6.0\end{array}$ & $\begin{array}{l}5.9 \\
4.9 \\
6.8 \\
4.3 \\
5.9\end{array}$ & $\begin{array}{l}6.2 \\
5.0 \\
6.5 \\
4.3 \\
8.2\end{array}$ & $\begin{array}{r}10.1 \\
6.9 \\
10.4 \\
7.2 \\
8.9\end{array}$ & $\begin{array}{r}10.6 \\
7.5 \\
10.3 \\
7.6 \\
12.2\end{array}$ & $\begin{array}{l}1.1 \\
0.5 \\
0.8 \\
0.6 \\
0.6\end{array}$ & $\begin{array}{l}1.0 \\
0.5 \\
0.8 \\
0.6 \\
0.8\end{array}$ \\
\hline $\begin{array}{l}\text { New Jersey } \\
\text { New Mexico } \\
\text { New York } \\
\text { North Carolina } \\
\text { North Dakota }\end{array}$ & $\begin{array}{r}301 \\
91 \\
756 \\
77 \\
85\end{array}$ & $\begin{array}{r}284 \\
81 \\
756 \\
77 \\
73\end{array}$ & $\begin{array}{r}30,230 \\
4,615 \\
75,760 \\
16,907 \\
2,575\end{array}$ & $\begin{array}{r}29,635 \\
4,426 \\
73,078 \\
16,755 \\
2,374\end{array}$ & $\begin{array}{l}3.6 \\
2.9 \\
4.0 \\
1.8 \\
4.5\end{array}$ & $\begin{array}{l}3.6 \\
2.8 \\
3.9 \\
1.8 \\
4.1\end{array}$ & $\begin{array}{l}6.1 \\
5.0 \\
6.3 \\
4.8 \\
4.4\end{array}$ & $\begin{array}{l}6.1 \\
5.2 \\
6.2 \\
4.7 \\
4.2\end{array}$ & $\begin{array}{l}7.8 \\
6.5 \\
8.4 \\
6.0 \\
7.8\end{array}$ & $\begin{array}{l}7.6 \\
6.7 \\
8.7 \\
6.0 \\
7.2\end{array}$ & $\begin{array}{l}1.0 \\
0.8 \\
1.5 \\
1.4 \\
0.8\end{array}$ & $\begin{array}{l}1.0 \\
0.7 \\
1.4 \\
1.4 \\
0.7\end{array}$ \\
\hline 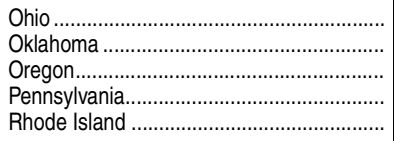 & $\begin{array}{r}251 \\
115 \\
127 \\
458 \\
48\end{array}$ & $\begin{array}{r}251 \\
116 \\
126 \\
457 \\
48\end{array}$ & $\begin{array}{r}45,818 \\
7,278 \\
9,927 \\
28,180 \\
4,334\end{array}$ & $\begin{array}{r}45,224 \\
7,352 \\
10,048 \\
27,790 \\
4,636\end{array}$ & $\begin{array}{l}4.0 \\
2.4 \\
2.7 \\
2.4 \\
4.1\end{array}$ & $\begin{array}{l}3.9 \\
2.4 \\
2.7 \\
2.3 \\
4.4\end{array}$ & $\begin{array}{l}8.0 \\
7.0 \\
6.8 \\
4.1 \\
6.4\end{array}$ & $\begin{array}{l}7.6 \\
5.2 \\
6.8 \\
3.9 \\
6.0\end{array}$ & $\begin{array}{r}17.0 \\
7.1 \\
15.4 \\
6.0 \\
7.3\end{array}$ & $\begin{array}{r}16.3 \\
7.4 \\
16.2 \\
5.8 \\
7.4\end{array}$ & $\begin{array}{l}1.8 \\
0.7 \\
0.8 \\
0.7 \\
0.8\end{array}$ & $\begin{array}{l}1.8 \\
0.7 \\
0.7 \\
0.8 \\
0.7\end{array}$ \\
\hline 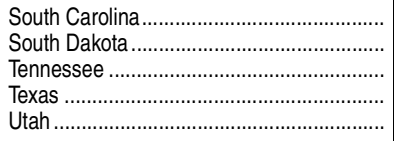 & $\begin{array}{r}42 \\
112 \\
186 \\
559 \\
71\end{array}$ & $\begin{array}{r}42 \\
102 \\
186 \\
549 \\
72\end{array}$ & $\begin{array}{r}9,430 \\
3,096 \\
11,754 \\
41,749 \\
6,744\end{array}$ & $\begin{array}{r}9,575 \\
2,926 \\
11,837 \\
41,832 \\
6,873\end{array}$ & $\begin{array}{l}2.2 \\
4.2 \\
1.9 \\
1.8 \\
2.5\end{array}$ & $\begin{array}{l}2.2 \\
4.0 \\
1.9 \\
1.8 \\
2.5\end{array}$ & $\begin{array}{l}4.2 \\
5.4 \\
3.5 \\
3.5 \\
7.0\end{array}$ & $\begin{array}{l}4.2 \\
5.5 \\
3.4 \\
3.4 \\
7.0\end{array}$ & $\begin{array}{r}6.1 \\
8.4 \\
4.0 \\
5.1 \\
13.4\end{array}$ & $\begin{array}{r}6.2 \\
8.2 \\
4.2 \\
5.2 \\
13.7\end{array}$ & $\begin{array}{l}1.2 \\
0.9 \\
0.6 \\
0.7 \\
1.9\end{array}$ & $\begin{array}{l}1.2 \\
0.6 \\
0.6 \\
0.7 \\
1.2\end{array}$ \\
\hline 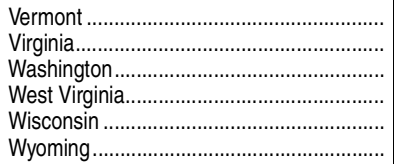 & $\begin{array}{r}184 \\
91 \\
63 \\
97 \\
380 \\
23\end{array}$ & $\begin{array}{r}159 \\
91 \\
61 \\
97 \\
381 \\
23\end{array}$ & $\begin{array}{r}2,964 \\
19,151 \\
15,377 \\
5,213 \\
19,956 \\
2,484\end{array}$ & $\begin{array}{r}2,908 \\
18,921 \\
14,878 \\
5,264 \\
19,794 \\
2,498\end{array}$ & $\begin{array}{l}4.9 \\
2.5 \\
2.3 \\
2.9 \\
3.5 \\
4.7\end{array}$ & $\begin{array}{l}5.4 \\
2.5 \\
2.3 \\
2.9 \\
3.5 \\
4.6\end{array}$ & $\begin{array}{l}6.5 \\
5.5 \\
6.7 \\
3.4 \\
6.4 \\
7.1\end{array}$ & $\begin{array}{l}7.1 \\
5.5 \\
6.8 \\
3.4 \\
6.4 \\
7.1\end{array}$ & $\begin{array}{r}7.8 \\
9.8 \\
12.9 \\
4.3 \\
11.5 \\
9.5\end{array}$ & $\begin{array}{r}8.8 \\
10.0 \\
13.1 \\
4.4 \\
11.4 \\
9.8\end{array}$ & $\begin{array}{l}0.8 \\
1.0 \\
0.9 \\
0.5 \\
0.9 \\
1.2\end{array}$ & $\begin{array}{l}0.9 \\
1.0 \\
0.9 \\
0.5 \\
0.9 \\
1.0\end{array}$ \\
\hline
\end{tabular}

${ }^{1}$ The number of visits (entering the library for any purpose) per person during the year. ${ }^{2}$ The number of library materials lent per person during the year.

${ }^{3} \mathrm{~A}$ reference transaction is an information contact that involves the knowledge, use, recommendations, interpretation, or instructions in the use of one or more information sources by a member of the library staff.

${ }^{4}$ In 2009, of the 9,225 public libraries in the 50 states and the District of Columbia, 7,466 were single-outlet libraries and 1,759 were multiple-outlet libraries. In 2010, of the 8,951 public libraries in the 50 states and the District of Columbia, 7,204 were single-outlet libraries and 1,747 were multiple-outlet libraries. Single-outlet libraries consist of a central library, bookmobile, or books-by-mail-only outlet. Multiple-outlet libraries have two or more direct service outlets, including some combination of one central library, branch(es), bookmobile(s), and/or books-by-mail-only outlets.

NOTE: Data include imputations for nonresponse. Detail may not sum to totals because of rounding. Per capita figures are based on unduplicated populations of the areas served by public libraries.

SOURCE: Institute of Museum and Library Services, Public Libraries Survey, fiscal years 2009 and 2010, retrieved December 13, 2013, from http://www.imls.gov/research/ public libraries in the united states survey.aspx. (This table was prepared December 2013.) 


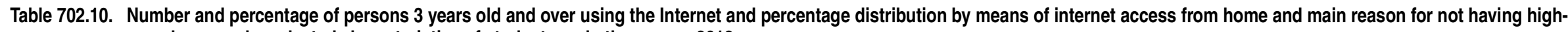
speed access, by selected characteristics of students and other users: 2012

[Standard errors appear in parentheses]

\begin{tabular}{|c|c|c|c|c|c|c|c|c|c|c|c|c|c|c|c|c|c|c|c|c|c|c|c|c|}
\hline \multirow[b]{2}{*}{ Selected characteristic } & \multirow{2}{*}{\multicolumn{2}{|c|}{$\begin{array}{r}\text { Total population } \\
\text { age } 3 \text { and over } \\
\text { (in thousands) }\end{array}$}} & \multicolumn{4}{|c|}{$\begin{array}{l}\text { Persons using } \\
\text { the Internet anywhere }\end{array}$} & \multirow{2}{*}{\multicolumn{2}{|c|}{$\begin{array}{r}\text { Among } \\
\text { internet } \\
\text { users, } \\
\text { percent } \\
\text { using the } \\
\text { Internet } \\
\text { from home } \\
\end{array}$}} & \multicolumn{4}{|c|}{$\begin{array}{l}\text { Percentage distribution } \\
\text { of home internet users, } \\
\text { by means of access from home }\end{array}$} & \multicolumn{12}{|c|}{$\begin{array}{l}\text { Percentage distribution of persons with no internet access at home or no } \\
\text { high-speed access at home, by main reason for not having high-speed access }\end{array}$} \\
\hline & & & \multicolumn{4}{|c|}{\begin{tabular}{r|r}
$\begin{array}{r}\text { Number } \\
\text { (in thousands) }\end{array}$ & $\begin{array}{r}\text { Percent } \\
\text { of population }\end{array}$ \\
\end{tabular}} & & & \multicolumn{2}{|c|}{$\begin{array}{r}\text { A regular } \\
\text { "dial-up" } \\
\text { telephone }\end{array}$} & \multicolumn{2}{|c|}{$\begin{array}{r}\text { High speed } \\
\text { (i.e., faster } \\
\text { than dial-up) }\end{array}$} & \multicolumn{2}{|c|}{$\begin{array}{c}\text { Don't need it, } \\
\text { not interested }\end{array}$} & \multicolumn{2}{|c|}{ Too expensive } & \multicolumn{2}{|c|}{$\begin{array}{r}\text { Can use it } \\
\text { somewhere else }\end{array}$} & \multicolumn{2}{|c|}{$\begin{array}{r}\text { Not available } \\
\text { in area }\end{array}$} & \multicolumn{2}{|c|}{$\begin{array}{r}\text { No computer } \\
\text { or computer } \\
\text { inadequate }\end{array}$} & \multicolumn{2}{|c|}{ Other reasons ${ }^{2}$} \\
\hline 1 & & 2 & & 3 & & 4 & & 5 & & 6 & & 7 & & 8 & & 9 & & 10 & & 11 & & 12 & & 13 \\
\hline Total, all persons...... & 297,229 & (473.6) & 222,032 & $(673.6)$ & 74.7 & $(0.21)$ & 92.6 & $(0.15)$ & 1.4 & $(0.06)$ & 98.6 & $(0.06)$ & 41.5 & $(0.61)$ & 34.7 & $(0.53)$ & 3.1 & $(0.20)$ & 2.1 & $(0.20)$ & 10.7 & (0.41) & 7.8 & $(0.34)$ \\
\hline $\begin{array}{l}\text { Sex } \\
\text { Male............... } \\
\text { Female.......... }\end{array}$ & $\begin{array}{l}144,902 \\
152,326\end{array}$ & $\left.\begin{array}{l}(111.7) \\
(376.8)\end{array}\right]$ & $\begin{array}{l}107,406 \\
114,626\end{array}$ & $\left(\begin{array}{l}363.2) \\
(406.9)\end{array}\right.$ & $\begin{array}{l}74.1 \\
75.3\end{array}$ & $\begin{array}{l}(0.25) \\
(0.22)\end{array}$ & $\begin{array}{l}92.8 \\
92.3\end{array}$ & $\begin{array}{l}(0.16) \\
(0.19)\end{array}$ & $\begin{array}{l}1.4 \\
1.3\end{array}$ & $\begin{array}{l}(0.07) \\
(0.07)\end{array}$ & $\begin{array}{l}98.6 \\
98.7\end{array}$ & $\begin{array}{l}(0.07) \\
(0.07)\end{array}$ & $\begin{array}{l}41.2 \\
41.7\end{array}$ & $\begin{array}{l}(0.67) \\
(0.67)\end{array}$ & $\begin{array}{l}34.7 \\
34.8\end{array}$ & $\begin{array}{l}60) \\
60)\end{array}$ & $\begin{array}{l}3.3 \\
3.0\end{array}$ & $\left.\begin{array}{l}(0.23) \\
(0.21)\end{array}\right]$ & $\begin{array}{l}2.2 \\
2.0\end{array}$ & $\begin{array}{l}(0.22) \\
(0.20)\end{array}$ & $\begin{array}{l}10.7 \\
10.7\end{array}$ & $\left.\begin{array}{l}(0.45) \\
(0.45)\end{array}\right]$ & $\begin{array}{l}8.0 \\
7.7\end{array}$ & $\begin{array}{l}(0.37) \\
(0.36)\end{array}$ \\
\hline Race/ethnicity & & & & & & & & & & & & & & & & & & & & & & & & \\
\hline White... & 188,656 & (140.6) & 149,231 & $(455.3)$ & 79.1 & $(0.2$ & 94.4 & $(0.16)$ & 1.4 & & 98.6 & & 49.0 & & 26.1 & & 3.4 & 27) & 2.9 & $(0.30)$ & 9.3 & $(0.53)$ & 9.2 & $(0.44)$ \\
\hline $\begin{array}{l}\text { Black...... } \\
\text { Hissanic }\end{array}$ & $\begin{array}{l}35,550 \\
49879\end{array}$ & $\begin{array}{l}(200.3) \\
(138 ?)\end{array}$ & $\begin{array}{l}24,290 \\
30,954\end{array}$ & $\begin{array}{l}(264.7) \\
(2878)\end{array}$ & 68.3 & $(0.63)$ & $\begin{array}{l}85.4 \\
884\end{array}$ & $(0.62)$ & 1.2 & $(0.24)$ & 98.8 & $(0.24)$ & 35.2 & $(1.33)$ & 40.2 & $(1.32)$ & 3.0 & $(0.53)$ & $1.1 !$ & $(0.37)$ & 13.4 & (1.12) & 7.1 & $(0.73)$ \\
\hline$\cdots \cdots \cdots \cdots \cdots \cdots \cdots \cdots \cdots \cdots$ & $\begin{array}{l}4,8,19 \\
23,143\end{array}$ & $\begin{array}{l}(138.2) \\
(143.7)\end{array}$ & $\begin{array}{l}30,954 \\
17,556\end{array}$ & $\begin{array}{l}(204.1) \\
(204.1)\end{array}$ & $\begin{array}{l}6.2 .1 \\
75.9\end{array}$ & $\left.\begin{array}{l}(0.5) \\
(0.75)\end{array}\right]$ & $\begin{array}{l}88.4 \\
93.8\end{array}$ & $\left.\begin{array}{l}(0.52) \\
(0.49)\end{array}\right]$ & $\begin{array}{l}1.3 \\
1.0\end{array}$ & $\begin{array}{l}(0.19) \\
(0.20)\end{array}$ & $\begin{array}{l}98.1 \\
99.0\end{array}$ & $\begin{array}{l}(0.19) \\
(0.20)\end{array}$ & $\begin{array}{l}31.6 \\
35.8\end{array}$ & $\left.\begin{array}{l}(1.28) \\
(2.18)\end{array}\right]$ & $\begin{array}{l}47.5 \\
40.2\end{array}$ & $\begin{array}{l}(1.35) \\
(2.46)\end{array}$ & $\begin{array}{l}2.6 \\
3.6\end{array}$ & $\begin{array}{l}(0.41) \\
(0.78)\end{array}$ & $\begin{array}{l}1.0 ! \\
2.7 !\end{array}$ & $\begin{array}{l}(0.32) \\
(0.90)\end{array}$ & $\begin{array}{r}12.0 \\
9.4\end{array}$ & $\begin{array}{l}(0.84) \\
(1.23)\end{array}$ & $\begin{array}{l}5.3 \\
8.3\end{array}$ & $\begin{array}{l}(0.57) \\
(1.26)\end{array}$ \\
\hline Age & & & & & & & & & & & & & & & & & & & & & & & & \\
\hline 3 and $4 \ldots$ & 8,014 & (124.2) & 2,534 & (81.9) & 31.6 & $(0.93)$ & 93.5 & $(0.84)$ & $1.5 !$ & $(0.55)$ & 98.5 & $(0.55)$ & 25.5 & (2.24) & 48.1 & (2.30) & 4.2 & $(0.79)$ & 3.8 & & 11.3 & & 7.3 & (1.14) \\
\hline 5 to 9. & 20,479 & $(84.2)$ & 11,960 & (148.9) & 58.4 & $(0.65)$ & 90.3 & $(0.58)$ & 0.7 & $(0.16)$ & 99.3 & $(0.16)$ & 24.6 & (1. & 49.2 & & 2.6 & & 2.5 & & 13.1 & $(1.20)$ & & \\
\hline 10 to 1 & 20,621 & (125.5) & 16,720 & (152.8) & & $(0.63)$ & 88.7 & $(0.54)$ & 0.9 & $(0.17)$ & 99.1 & $(0.17)$ & 21.8 & & 50.8 & $(1.69)$ & 3.6 & $(0.67)$ & 27 & 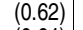 & 11.7 & (1.12) & 9.4 & $(1.10)$ \\
\hline 15 to $19 \ldots .$. & 21,038 & (186.4) & 18,784 & (200.5) & 89.3 & $(0.47)$ & 90.0 & $(0.46)$ & 1.0 & $(0.15)$ & 99.0 & $(0.15)$ & 23.7 & (1.47) & 50.5 & (1.67) & 3.7 & $(0.70)$ & 3.2 & $(0.64)$ & 10.2 & (1.05) & 8.8 & (1.15) \\
\hline 20 to $24 \ldots .$. & 21,893 & (274.4) & 18,845 & (258.2) & 86.1 & $(0.49)$ & 91.0 & $(0.45)$ & 1.0 & $(0.17)$ & 99.0 & $(0.17)$ & 28.7 & (1.56) & 47.4 & (1.85) & 4.6 & $(0.69)$ & 1.5 & (0.39) & 10.2 & $(1.15)$ & 7.6 & $(0.84)$ \\
\hline 25 to $29 \ldots$ & 20,674 & (183.4) & 17,721 & (185.2) & 85.7 & $(0.50)$ & 91.3 & $(0.46)$ & 0.7 & $(0.14)$ & 99.3 & $(0.14)$ & 26.3 & (1.47) & 48.3 & (1.69) & 4.9 & $(0.65)$ & 2.8 & 3) & 11.6 & (1.12) & 6.1 & $(0.73)$ \\
\hline 30 to 3 & 39,483 & (133.7) & 33,492 & (200.0) & 84.8 & $(0.40)$ & 93.2 & $(0.28)$ & 0.9 & $(0.11)$ & 99.1 & $(0.11)$ & 26.7 & $(1.07)$ & 46.9 & $(1.29)$ & 3.6 & $(0.51)$ & 2. & & 11.9 & & 8.4 & $(0.71)$ \\
\hline & 41,806 & $(88.5)$ & 34,525 & (162.9) & 82.6 & $(0.34)$ & 94.1 & $(0.24)$ & 0.9 & $(0.10)$ & 99.1 & $(0.10)$ & 32.6 & $(1.3$ & 43.5 & & 4. & & & & 10.3 & & & $(0.63)$ \\
\hline 50 to 5 & 43,039 & (151.3) & 32,890 & (221.9) & 76.4 & (0.42) & 94.0 & $(0.22)$ & 1.6 & $(0.15)$ & 98.4 & $(0.15)$ & 44.2 & (1.10) & 32.0 & 0. & 3. & $(0.3$ & 2.6 & & 10.3 & $(0.70)$ & 7.9 & (0.52) \\
\hline 60 to 69 & 31,838 & (117.9) & 22,171 & (176.5) & 69.6 & $(0.49)$ & 94.5 & $(0.26)$ & 2.7 & $(0.20)$ & 97.3 & $(0.20)$ & 55.0 & (1.10) & 21.6 & & 2.6 & $(0.31)$ & 2.1 & $(0.31)$ & 10.5 & (0.64) & 8.3 & $(0.60)$ \\
\hline 70 or older...... & 28,344 & (331.4) & 12,390 & (233.2) & 43.7 & $(0.53)$ & 94.5 & $(0.40)$ & 3.4 & $(0.30)$ & 96.6 & $(0.30)$ & 70.1 & $(0.89)$ & 10.7 & (0.53) & 1.1 & $(0.21)$ & 0.7 & $(0.15)$ & 9.7 & $(0.60)$ & 7.7 & $(0.46)$ \\
\hline $\begin{array}{l}\text { Educational attainment of persons } \\
\text { age } 15 \text { and over }\end{array}$ & & & & & & & & & & & & & & & & & & & & & & & & \\
\hline ol............................. & 41,130 & (439.2) & 22,523 & (266.3) & 54.8 & $(0.49)$ & 88.0 & $(0.43)$ & 2.0 & $(0.22)$ & 98.0 & $(0.22)$ & 43.2 & (0.97) & 35.6 & $(0.90)$ & 1.8 & $(0.22)$ & 1.2 & $(0.19)$ & 11.4 & $(0.60)$ & 6.9 & $(0.50)$ \\
\hline loma or equivalent... & 70,863 & (473.6) & 46,944 & $(381$ & 66.2 & $(0.36)$ & 908 & $(0.25)$ & 22 & $(0.15)$ & 97.8 & $(0$. & 47.1 & & 30.5 & & 2.7 & & 18 & & 10.7 & & & \\
\hline Some & 45,872 & (374.1) & 38,897 & (343. 13. & 84 & 0.3 & 92.7 & $(0.26)$ & 1.2 & 0. & 98.8 & $(0$. & 41.1 & (1. & 34.0 & & 4. & $(0.4$ & 2.5 & & 9.7 & & & $(0.55)$ \\
\hline Asso & 22,352 & (271.1) & 19,293 & $(256)$. & 86 & $(0.4$ & 93.4 & $(0.32)$ & 1.2 & $(0.1$ & 98.8 & $(0.1$ & 41.1 & $(1.4$ & 31.5 & & & & & & 10.3 & & & \\
\hline gher degree......... & 67,897 & (480.2) & & (469.3) & 93 & $(0.19)$ & 96 & $(0.1$ & c. & 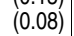 & & & 45 & & 26.2 & & & & & & & & & $(0.85)$ \\
\hline Bache & 44,330 & (364.0) & 40,980 & (347.7) & 92.4 & $(0.21)$ & 96 & $(0.20)$ & 0. & $(0.09)$ & 99.1 & $(0.09)$ & 45.1 & (1.48) & 28.3 & (1.47) & 5. & $(0.6$ & 3.4 & $(0.60)$ & 7.5 & $(0.89)$ & 9.9 & $(0.94)$ \\
\hline Master's or higher degree............. & 23,568 & (303.7) & 22,182 & (297.2) & 94.1 & $(0.31)$ & 97.2 & $(0.21)$ & 0.8 & $(0.12)$ & 99.2 & $(0.12)$ & 47.9 & (2.60) & 21.3 & (2.06) & 7.0 & $(1.15)$ & 4.9 & $(1.10)$ & 9.0 & (1.37) & 9.9 & (1.37) \\
\hline $\begin{array}{l}\text { Family in } \\
\text { Less th }\end{array}$ & 20,998 & (398.1) & 11 & (265.0) & 5 & & & & 2.3 & & 97 & & 32.4 & & 45.8 & & 2.0 & & 0.9 & & 12 & 10 & 6.8 & $(0$. \\
\hline & 31,850 & (498.9) & & & & & & & & & & & & & & & 2.1 & & & & & & & \\
\hline$\$ 2$ & 35,271 & $(468.8)$ & 21,141 & $(346$ & 59 & 0. & 87 & $(0.54)$ & 2. & $(0.27)$ & 97.7 & $(0.2$ & 43.7 & (1.32) & 33 & $(1.3$ & 2.2 & $(0.3$ & 1. & 10. & & & 6. & \\
\hline$\$ 3$ & 33,560 & $(540.8)$ & 22,596 & $(424$ & 67 & $(0.6$ & & $(0.47)$ & 2. & $(0.2-2)-1$ & 97.8 & $(0.23)$ & & $(1.5$ & 32 & & 2.5 & & 1 & 10. & 11.6 & (1.08) & & 0. \\
\hline$\$ 40,0$ & 25,157 & (477.5) & 19,143 & (404.5) & 76 & $(0.7$ & 93 & 10. & 2. & $10.2-2$ & 98.0 & $(0.2-250$ & 46.9 & $(2$. & 29 & $(2)$. & 3.4 & $(0.7-7)$ & 3 & $(0.5-5-5)$ & 8.6 & & 7.9 & (1.19) \\
\hline$\$ 50$ & 55,479 & $(682.9)$ & 45,480 & (577.7) & 82 & $(0.3$ & 95 & 0.2 & 1.3 & $(0.14)$ & 98.7 & $(0.14)$ & 44.4 & $(1$. & 27 & $(1$. & 5.9 & & 4. & & 8.6 & 0. & 9.9 & (1.19) \\
\hline$\$ 75$, & 34,034 & $(516.8)$ & 29,806 & $(450$ & 87 & $(0.4$ & 96 & 0.2 & 0 & $(0$. & 99.3 & & & & 21 & & $10 ?$ & & (4) & (1. & 10 & $(1.20)$ & 14.9 & (2.39) \\
\hline 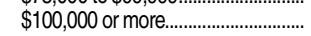 & 60,880 & $(666.5)$ & 55,162 & $(651.5)$ & 90.6 & $(0.26)$ & 97.8 & $(0.14)$ & 0.5 & $(0.09)$ & 99.5 & $(0.09)$ & 38.8 & $(2.98)$ & 23.0 & $(2.69)$ & 6.2 & $(1.37)$ & 8.4 & (1.97) & 8.4 & (1.63) & 15.1 & $(2.58)$ \\
\hline Total, all students & $\begin{array}{ll}78,426 \\
\end{array}$ & (319.2) & 61,507 & (398.6) & 78.4 & (0.33) & 90.7 & (0.29) & 0.8 & $(0.10)$ & 99.2 & (0.10) & 23.3 & (1.03) & 50.6 & (1.11) & 3.8 & (0.46) & 2.9 & (0.43) & \begin{tabular}{ll|l}
11.3 \\
\end{tabular} & $\begin{array}{l}(0.72) \\
\end{array}$ & 8.0 & $\overline{(0.71)}$ \\
\hline Elementary & 58,496 & (211.7) & & (317.5) & & & 89.5 & & 1.0 & $(0.12)$ & & & & & & & 3.4 & & & & & & & \\
\hline 3 & 4,289 & $(8 c$ & & & 35 & $(1)$. & 94.3 & & $\ddagger$ & & & & 24.9 & & 47 & & 4.2 & & $4.3 !$ & & 12.9 & & 6.6 & (1.91) \\
\hline 5 to $9 y$ & 19,679 & (93.1) & 11,666 & (145.2) & 59.3 & & & & $0.8^{+}$ & & 99.2 & & 23.9 & & 50.1 & & 2.5 & & 2.6 & & 13.0 & & 7.9 & \\
\hline 10 to 1 & 20,216 & (134.2) & $\begin{array}{l}16,505 \\
\text { n }\end{array}$ & (154.7) & 81.6 & $(0.63)$ & 88.7 & $(0.54)$ & $\begin{array}{l}1.0 \\
0\end{array}$ & $(0.17)$ & 99.0 & $(0.17)$ & 21.4 & (1.5) & 51.1 & & 3.7 & & 2.7 & 0.6 & $\begin{array}{l}12.0 \\
12.0\end{array}$ & (1.14) & 9.2 & (1.09) \\
\hline 15 years & 14,311 & (208.9) & 12,892 & (199.1) & 90.1 & $(0.50)$ & 89.2 & $(0.60)$ & 1.1 & $(0.17)$ & 98.9 & $(0.17)$ & 23.3 & $(1.86)$ & 51.3 & $(2.00)$ & 4.1 & 0.7 & 3.6 & $(0.73)$ & 10.1 & (1.24) & 7.5 & (1.27) \\
\hline & 19,930 & (266.3) & 18,902 & (257.3) & 94.8 & $(0.32)$ & 93.4 & $(0.40)$ & 0.6 & $(0.12)$ & 99.4 & $(0.12)$ & 25.3 & (2.06) & 51.3 & $(2.39)$ & 6.4 & (1124) & 2.3 & $(0.63)$ & 7.3 & $(1.21)$ & 7.3 & (1.20) \\
\hline
\end{tabular}




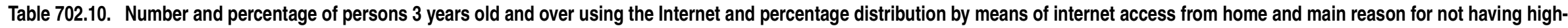
speed access, by selected characteristics of students and other users: 2012-Continued

[Standard errors appear in parentheses]

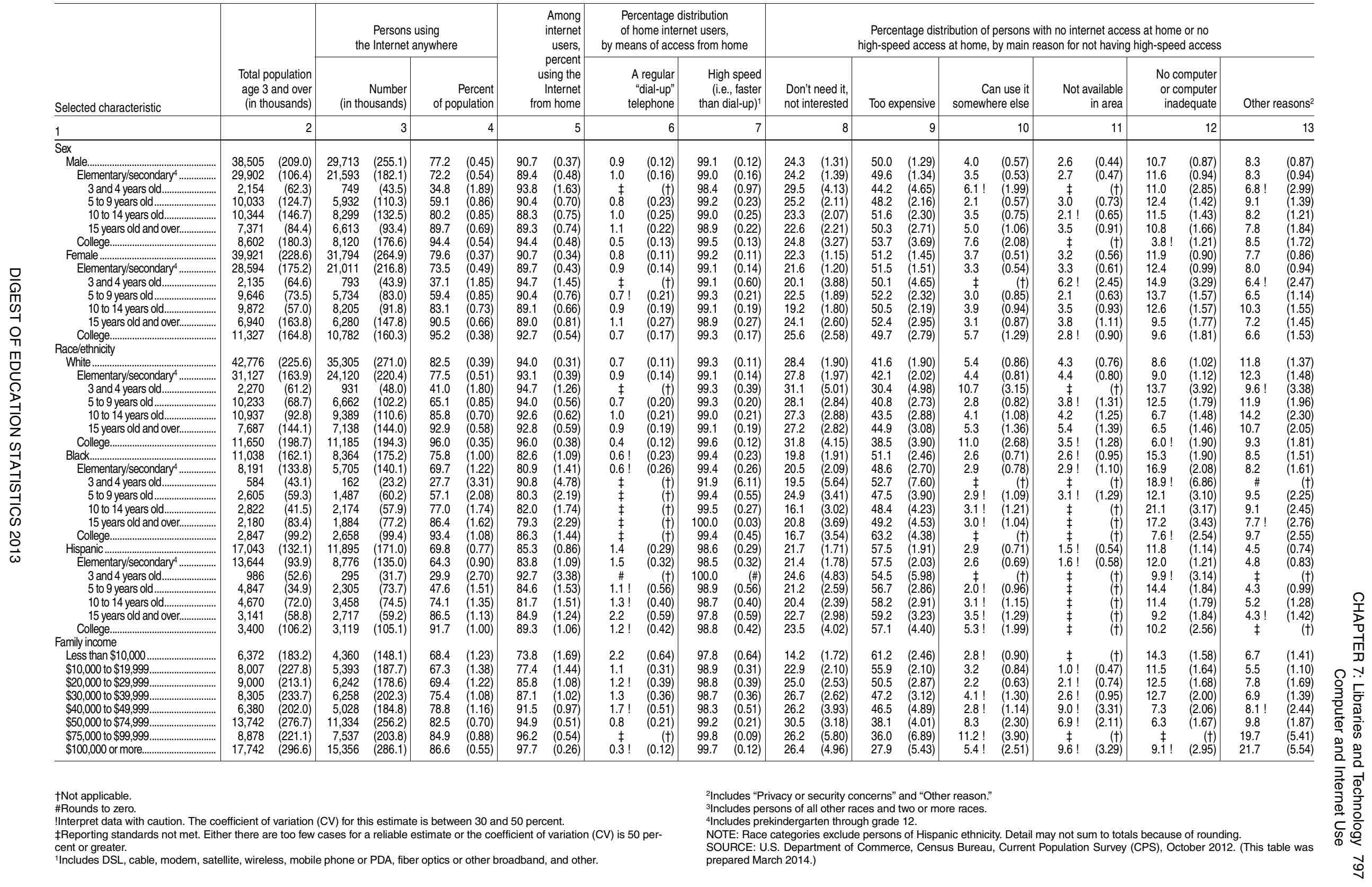





\section{APPENDIX A Guide to Sources}

The information presented in the Digest of Education Statistics was obtained from many sources, including federal and state agencies, private research organizations, and professional associations. The data were collected using many research methods, including surveys of a universe (such as all colleges) or of a sample, compilations of administrative records, and statistical projections. Brief descriptions of the information sources, data collections, and data collection methods that were used to produce this report are presented below, grouped by sponsoring organization. Additional details about many of these and other data sets can be found on the Department of Education's Data Inventory website (http://datainventory.ed.gov/).

\section{National Center for Education Statistics (NCES)}

\section{Baccalaureate and Beyond Longitudinal Study}

The Baccalaureate and Beyond Longitudinal Study (B\&B) is based on the National Postsecondary Student Aid Study (NPSAS) and provides information concerning education and work experience after completing a bachelor's degree. A special emphasis of $B \& B$ is on those entering teaching. $\mathrm{B} \& \mathrm{~B}$ provides cross-sectional information 1 year after bachelor's degree completion (comparable to the information that was provided in the Recent College Graduates study), while at the same time providing longitudinal data concerning entry into and progress through graduate-level education and the workforce, income, and debt repayment. This information has not been available through follow-ups involving high school cohorts or even college-entry cohorts, because these cohorts have limited numbers who actually complete a bachelor's degree and continue their graduate education.

B\&B followed NPSAS baccalaureate degree completers for a 10-year period after completion, beginning with NPSAS:93. About 11,000 students who completed their degrees in the 1992-93 academic year were included in the first $\mathrm{B} \& \mathrm{~B}$ cohort (B\&B:93). The first follow-up of this cohort (B\&B:93/94) occurred 1 year later. In addition to collecting student data, B\&B:93/94 collected postsecondary transcripts covering the undergraduate period, which provided complete information on progress and persistence at the undergraduate level. The second follow-up of this cohort (B\&B:93/97) took place in spring 1997 and gathered information on employment history, family formation, and enrollment in graduate programs. The third follow-up (B\&B:93/03) occurred in 2003 and provided information concerning graduate study and long-term employment experiences after degree completion.

The second B\&B cohort (B\&B:2000), which was associated with NPSAS:2000, included 11,700 students who completed their degrees in the 1999-2000 academic year. The first and only follow-up survey of this cohort was conducted in 2001 (B\&B:2000/01) and focused on time to degree completion, participation in postbaccalaureate education and employment, and the activities of newly qualified teachers.

The third B\&B cohort (B\&B:08), which is associated with NPSAS:08, included 18,000 students who completed their degrees in the 2007-08 academic year. The first follow-up took place in 2009 (B\&B:08/09), and the second follow-up took place in 2012-13 (B\&B:08/12). A third and final follow-up (B\&B:08/18) is planned for 2018.

Further information on B\&B may be obtained from

Aurora D'Amico

Ted Socha

Sample Surveys Division

Longitudinal Surveys Branch

National Center for Education Statistics

1990 K Street NW

Washington, DC 20006

aurora.damico@ed.gov

ted.socha@ed.gov

http://nces.ed.gov/surveys/b\&b

\section{Beginning Postsecondary Students Longitudinal Study}

The Beginning Postsecondary Students Longitudinal Study (BPS) provides information on persistence, progress, and attainment for 6 years after initial time of entry into postsecondary education. BPS includes traditional and nontraditional (e.g., older) students and is representative of all beginning students in postsecondary education in a given year. Initially, these individuals are surveyed in the National Postsecondary Student Aid Study (NPSAS) during the year in which they first begin their postsecondary education. These same students are 
surveyed again 2 and 5 years later through the BPS. By starting with a cohort that has already entered postsecondary education and following it for 6 years, the BPS can determine to what extent students who start postsecondary education at various ages differ in their progress, persistence, and attainment, as well as their entry into the workforce. The first BPS was conducted in 1989-90, with follow-ups in 1992 (BPS:90/92) and 1994 (BPS:90/94). The second BPS was conducted in 1995-96, with follow-ups in 1998 (BPS:96/98) and 2001 (BPS:96/01). The third BPS was conducted in 2003-04, with follow-ups in 2006 (BPS:04/06) and 2009 (BPS:04/09). A fourth BPS was conducted in 2012, with follow-ups planned in 2014 and 2017.

Further information on BPS may be obtained from

Aurora D’Amico
Sarah Crissey
Sample Surveys Division
Longitudinal Surveys Branch
National Center for Education Statistics
1990 K Street NW
Washington, DC 20006
aurora.damico@ed.gov
sarah.crissey@ed.gov
http://nces.ed.gov/surveys/bps

\section{Common Core of Data}

The Common Core of Data (CCD) is NCES's primary database on public elementary and secondary education in the United States. It is a comprehensive, annual, national statistical database of all public elementary and secondary schools and school districts containing data designed to be comparable across all states. This database can be used to select samples for other NCES surveys and provide basic information and descriptive statistics on public elementary and secondary schools and schooling in general.

The CCD collects statistical information annually from approximately 100,000 public elementary and secondary schools and approximately 18,000 public school districts (including supervisory unions and regional education service agencies) in the 50 states, the District of Columbia, Department of Defense (DoD) dependents schools, the Bureau of Indian Education, Puerto Rico, American Samoa, Guam, the Northern Mariana Islands, and the U.S. Virgin Islands. Three categories of information are collected in the CCD survey: general descriptive information on schools and school districts; data on students and staff; and fiscal data. The general descriptive information includes name, address, phone number, and type of locale; the data on students and staff include selected demographic characteristics; and the fiscal data pertain to revenues and current expenditures.

The EDFacts data collection system is the primary collection tool for the CCD. NCES works collaboratively with the Department of Education's Performance Information Management Service to develop the CCD collection procedures and data definitions. Coordinators from State Education
Agencies (SEAs) submit the CCD data at different levels (school, agency, and state) to the EDFacts collection system. Prior to submitting CCD files to EDFacts, SEAs must collect and compile information from their respective Local Education Agencies (LEAs) through established administrative records systems within their state or jurisdiction.

Once SEAs have completed their submissions, the CCD survey staff analyzes and verifies the data for quality assurance. Even though the CCD is a universe collection and thus not subject to sampling errors, nonsampling errors can occur. The two potential sources of nonsampling errors are nonresponse and inaccurate reporting. NCES attempts to minimize nonsampling errors through the use of annual training of SEA coordinators, extensive quality reviews, and survey editing procedures. In addition, each year, SEAs are given the opportunity to revise their state-level aggregates from the previous survey cycle.

The CCD survey consists of six components: The Public Elementary/Secondary School Universe Survey, the Local Education Agency (School District) Universe Survey, the State Nonfiscal Survey of Public Elementary/Secondary Education, the National Public Education Financial Survey (NPEFS), the School District Fiscal Data Survey (F-33), and the Teacher Compensation Survey.

\section{Public Elementary/Secondary School Universe Survey}

The Public Elementary/Secondary School Universe Survey includes all public schools providing education services to prekindergarten, kindergarten, grade 1-12, and ungraded students. The CCD Public Elementary/Secondary School Universe Survey includes records for each public elementary and secondary school in the 50 states, the District of Columbia, American Samoa, Guam, Puerto Rico, the Commonwealth of the Northern Mariana Islands, the U.S. Virgin Islands, the Bureau of Indian Education (BIE), and the DoD dependents schools (overseas and domestic).

The Public Elementary/Secondary School Universe Survey includes data for the following variables: NCES school ID number, state school ID number, name of the school, name of the agency that operates the school, mailing address, physical location address, phone number, school type, operational status, locale code, latitude, longitude, county number, county name, full-time-equivalent (FTE) classroom teacher count, low/high grade span offered, congressional district code, school level, students eligible for free lunch, students eligible for reduced-price lunch, total students eligible for free and reduced-price lunch, and student totals and detail (by grade, by race/ethnicity, and by sex). The survey also contains flags indicating whether a school is Title I eligible, schoolwide Title I eligible, a magnet school, a charter school, a shared-time school, or a BIE school, as well as which grades are offered at the school.

\section{Local Education Agency (School District) Universe}

The coverage of the Local Education Agency Universe Survey includes all school districts and administrative units providing education services to prekindergarten, kindergarten, 
grade 1-12, and ungraded students. The CCD Local Education Agency Universe Survey includes records for the 50 states, the District of Columbia, Puerto Rico, the Bureau of Indian Education, American Samoa, Guam, the Commonwealth of the Northern Mariana Islands, the U.S. Virgin Islands, and the DoD dependents schools (overseas and domestic).

The Local Education Agency Universe Survey includes the following variables: NCES agency ID number, state agency ID number, agency name, phone number, mailing address, physical location address, agency type code, supervisory union number, American National Standards Institute (ANSI) state and county code, county name, core based statistical area (CBSA) code, metropolitan/micropolitan code, metropolitan status code, district locale code, congressional district code, operational status code, BIE agency status, low/high grade span offered, agency charter status, number of schools, number of full-time-equivalent (FTE) teachers, number of ungraded students, number of PK-12 students, number of special education/Individualized Education Program (IEP) students, number of English language learner (ELL) students, instructional staff fields, support staff fields, and a flag indicating whether student counts by race/ethnicity were reported by five or seven racial/ethnic categories.

\section{State Nonfiscal Survey of Public Elementary/ Secondary Education}

The State Nonfiscal Survey of Public Elementary/Secondary Education for the 2011-12 school year provides state-level, aggregate information about students and staff in public elementary and secondary education. It includes data from the 50 states, the District of Columbia, Puerto Rico, the U.S. Virgin Islands, the Commonwealth of the Northern Mariana Islands, and Guam. The DoD dependents schools (overseas and domestic), the Bureau of Indian Education, and American Samoa did not report data for the 2011-12 school year. This survey covers public school student membership by grade, race/ethnicity, and state or jurisdiction and covers number of staff in public schools by category and state or jurisdiction. Beginning with the 2006-07 school year, the number of diploma recipients and other high school completers are no longer included in the State Nonfiscal Survey of Public Elementary/Secondary Education file. These data are now published in the public-use Common Core of Data State Dropout and Completion Data File.

\section{National Public Education Financial Survey}

The purpose of the National Public Education Financial Survey (NPEFS) is to provide district, state, and federal policymakers, researchers, and other interested users with descriptive information about revenues and expenditures for public elementary and secondary education. The data collected are useful to (1) chief officers of state education agen- cies; (2) policymakers in the executive and legislative branches of federal and state governments; (3) education policy and public policy researchers; and (4) the public, journalists, and others.

Data for NPEFS are collected from SEAs in the 50 states, the District of Columbia, Puerto Rico, and four other jurisdictions (American Samoa, Guam, the Commonwealth of the Northern Mariana Islands, and the U.S. Virgin Islands). The data file is organized by state or jurisdiction and contains revenue data by funding source; expenditure data by function (the activity being supported by the expenditure) and object (the category of expenditure); average daily attendance data; and total student membership data from the CCD State Nonfiscal Survey of Public Elementary/Secondary Education.

\section{School District Finance Survey}

The purpose of the School District Finance Survey (F-33) is to provide finance data for all local education agencies (LEAs) that provide free public elementary and secondary education in the United States. National and state totals are not included (national- and state-level figures are presented, however, in the National Public Education Financial Survey [NPEFS]).

Both NCES and the Governments Division of the U.S. Census Bureau collect public school system finance data, and they collaborate in their efforts to gather these data. The Census Bureau acts as the primary collection agent and produces two data files: one for distribution and reporting by the Census Bureau and the other for distribution and reporting by NCES.

The data file for the fiscal year (FY) 2009 CCD School District Finance Survey (F-33) contains 16,563 records representing the public elementary and secondary education agencies in the 50 states and the District of Columbia. The F-33 file includes variables for revenues by source, expenditures by function, indebtedness, assets, student membership counts, as well as identification variables.

The FY 2011 F-33 data file contains 18,297 records representing the public elementary and secondary education agencies in the 50 states and the District of Columbia. The file includes variables for revenues by source, expenditures by function and object, indebtedness, assets, student membership counts, as well as identification variables.

\section{Teacher Compensation Survey}

The Teacher Compensation Survey (TCS) collects total compensation, teacher status, and demographic data about individual teachers from multiple states. Twenty-three (23) states participated in the TCS for school year 2008-09. Participating states provided data on salaries, years of teaching experience, highest degree earned, race/ethnicity, and gender for each public school teacher.

The following text table lists the CCD file versions used in the current edition of the Digest of Education Statistics: 
Table G. Common Core of Data (CCD) file versions used in the current edition of the Digest of Education Statistics: 1986-87 through 2011-12

\begin{tabular}{|c|c|c|c|c|c|c|}
\hline Year & $\begin{array}{r}\text { State Nonfiscal Survey of } \\
\text { Public Elementary and } \\
\text { Secondary Education }\end{array}$ & $\begin{array}{r}\text { NCES CCD } \\
\text { State Dropout and } \\
\text { Completion Data }\end{array}$ & $\begin{array}{r}\text { National } \\
\text { Public Education } \\
\text { Financial Survey }\end{array}$ & $\begin{array}{r}\text { Local Education } \\
\text { Agency Universe Survey }\end{array}$ & $\begin{array}{r}\text { School District } \\
\text { Finance Survey }\end{array}$ & $\begin{array}{r}\text { Public Elementary/ } \\
\text { Secondary School } \\
\text { Universe File }\end{array}$ \\
\hline$\overline{1986-87}$ (FY 1987)....................... & v.1c & $t^{t}$ & v.1b-Revised & v.1 & $\dagger$ & $\mathrm{v.1}$ \\
\hline 1987-88 (FY 1988).......................... & v.1c & $\dagger$ & v.1b-Revised & v.1 & $\dagger$ & v. 1 \\
\hline 1988-89 (FY 1989)......................... & v.1c & $\dagger$ & v.1b-Revised & v.1 & $\dagger$ & v. 1 \\
\hline 1989-90 (FY 1990).......................... & v. $1 \mathrm{c}$ & $\dagger$ & v.1b-Revised & v.1 & v.1a-Final ${ }^{1}$ & v.1 \\
\hline $1990-91$ (FY 1991).................. & v.1c & $t$ & v.1b-Revised & v. 1 & $t$ & v. 1 \\
\hline 1991-92 (FY 1992)................... & v. $1 \mathrm{c}$ & $\dagger$ & v.1b-Revised & v.1 & v.1a-Final ${ }^{1}$ & Revised \\
\hline 1992-93 (FY 1993)...................... & v.1c & $\dagger$ & v.1b-Revised & v. 1 & $\dagger$ & v. 1 \\
\hline 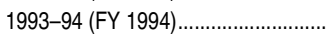 & v. $1 \mathrm{~b}$ & $\dagger$ & v.1b-Revised & v.1 & $\dagger$ & Revised \\
\hline 1994-95 (FY 1995).......................... & v. $1 b$ & $\dagger$ & v.1b-Revised & Revised & v.1d-Revised ${ }^{1}$ & Revised \\
\hline 1995-96 (FY 1996).......................... & v. $1 b$ & $\dagger$ & v.1b-Revised & v.1 & v.1b-Revised ${ }^{1}$ & v. 1 \\
\hline 1996-97 (FY 1997)......................... & v. $1 \mathrm{c}$ & $\dagger$ & v.1b-Revised & v.1 & v.1a-Final ${ }^{1}$ & v. 1 \\
\hline 1997-98 (FY 1998)......................... & v.1c & $\dagger$ & v.1b-Revised & v.1 & v.1e-Revised ${ }^{1}$ & v. 1 \\
\hline 1998-99 (FY 1999)................... & v.1b & $\dagger$ & v.1b-Revised & v.1c & v.1c-Revised ${ }^{1}$ & v. $1 \mathrm{c}$ \\
\hline 1999-2000 (FY 2000) ........................ & v.1b & $\dagger$ & v.1b-Revised & v. $1 b$ & v.1d-Revised ${ }^{1}$ & v. $1 b$ \\
\hline 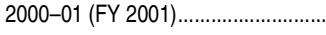 & v. $1 \mathrm{c}$ & $\dagger$ & v.1b-Revised & $v .1 a$ & v.1d-Revised ${ }^{1}$ & v.1a \\
\hline 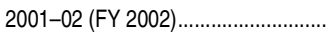 & v.1c & $\dagger$ & v.1c-Revised & v.1a & v.1c-Revised ${ }^{1}$ & v.1a \\
\hline 2002-03 (FY 2003) ................... & v. $1 \mathrm{~b}$ & $\dagger$ & v.1b-Revised & $v .1 a$ & v.1b-Revised ${ }^{1}$ & v.1a \\
\hline 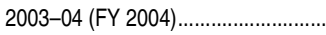 & v. $1 \mathrm{~b}$ & $\dagger$ & v.1b-Revised & $v .1 b$ & v.1b-Revised ${ }^{1}$ & v.1a \\
\hline 2004-05 (FY 2005)........................... & v.1f & $\dagger$ & v.1b-Revised & v. $1 c$ & v.1c-Revised ${ }^{1}$ & v. $1 \mathrm{~b}$ \\
\hline 2005-06 (FY 2006)........................... & v. $1 \mathrm{~b}$ & v.1b & v.1b-Revised & $v .1 a$ & v.1a-Final ${ }^{1}$ & v.1a \\
\hline 2006-07 (FY 2007)....................... & v.1c & $\mathrm{v} .1 \mathrm{a}$ & v.1b-Revised & $v .1 c$ & v.1a-Final ${ }^{1}$ & v.1c \\
\hline 2007-08 (FY 2008)...................... & v. $1 \mathrm{~b}$ & v.1a & v.1a-Final & $v .1 \mathrm{~b}$ & v.1a-Final & v. $1 \mathrm{~b}$ \\
\hline 2008-09 (FY 2009).......................... & v.1c & $\mathrm{v} .1 \mathrm{a}$ & v.1b-Revised & $v .1 a$ & v.1a-Final & v. $1 \mathrm{~b}$ \\
\hline 2009-10 (FY 2010)........................... & v. $1 \mathrm{~b}$ & v.1a & v.1a-Provisional & v.2a & $v .1 a$ & v.2a \\
\hline 2010-11 (FY 2011)......................... & v.1a & v.1a & v.1a-Preliminary & v.2a & v.1a-Provisional & v.2a \\
\hline $2011-12 \ldots \ldots \ldots \ldots \ldots$ & v.1a & v.1a & - & $v .1 a$ & - & v.1a \\
\hline
\end{tabular}

-Not available.

†Not applicable. Survey not conducted.

${ }^{1}$ Data not used in current edition of Digest of Education Statistics.

NOTE: Preliminary data have been edited but are subject to further NCES quality control procedures. Provisional data have undergone all NCES data quality control procedures. NCES releases a final data file after a publication using provisional data has been released.

Further information on the nonfiscal CCD data may be obtained from

Patrick Keaton

Administrative Data Division

Elementary and Secondary Branch

National Center for Education Statistics

1990 K Street NW

Washington, DC 20006

patrick.keaton@ed.gov

http://nces.ed.gov/ccd

Further information on the fiscal CCD data may be obtained from

\section{Stephen Cornman}

Administrative Data Division

Elementary and Secondary Branch

National Center for Education Statistics

1990 K Street NW

Washington, DC 20006

stephen.cornman@ed.gov

http://nces.ed.gov/ccd
If NCES receives revised data from states or discovers errors in the final data file, a revised data file is released.

SOURCE: U.S. Department of Education, National Center for Education Statistics, Common Core of Data (CCD), retrieved June 19, 2014, from http://nces.ed.gov/ccd/ccddata.asp. (This table was prepared June 2014.)

\section{Early Childhood Longitudinal Study, Birth Cohort of 2001}

The Early Childhood Longitudinal Study, Birth Cohort (ECLS-B) was designed to provide decisionmakers, researchers, child care providers, teachers, and parents with nationally representative information about children's early learning experiences and the transition to child care and school. Children's cognitive and physical development, care, and learning experiences at home and school were measured using standardized assessments and interviews with adults in the children's lives from birth through kindergarten entry.

Data were collected from a sample of about 10,700 children born in the United States in 2001, representing a population of approximately 4 million. The children participating in the study came from diverse socioeconomic and racial/ethnic backgrounds, with oversamples of Chinese, other Asian and Pacific Islander, American Indian/Alaska Native, twin, and moderately low and very low birth weight children. Children, their parents (including nonresident and resident fathers), their child care and early education providers, and their kindergarten teachers provided information on children's cognitive, social, emotional, and physical development. Information was also collected about the children's experiences across multiple settings (e.g., home, child care, and school). 
Information about the ECLS-B children was collected when they were approximately 9 months old (2001-02), 2 years old (2003-04), and 4 years old/preschool age (2005-06). Additionally, in the fall of 2006, data were collected from all participating sample children, approximately 75 percent of whom were in kindergarten or higher. In the fall of 2007, data were collected from the approximately 25 percent of participating sample children who had not yet entered kindergarten or higher in the previous collection, as well as children who were repeating kindergarten in the 2007-08 school year.

In every round of data collection, children participated in assessment activities and parent respondents (the mothers, usually) were asked about themselves, their families, and their children. Resident fathers were asked about themselves and their role in the ECLS-B children's lives in the 9-month, 2-year, and preschool collections. Similar information was collected from nonresident biological fathers in the 9-month and 2 -year collections. In addition, beginning when the children were 2 years old, their child care and early education providers were asked to provide information about their own experience and training and their setting's learning environment. At 2 years and preschool, a subsample of children in regular nonparental care and education arrangements had their arrangements observed to obtain information on the quality of those arrangements. When the ECLS-B children were in kindergarten, their teachers were asked to provide information about the children's early learning experiences and the school and classroom environments. Also, the before- and after-school care and education providers of children in kindergarten were asked to provide information about their own experience, their training, and their setting's learning environment. School-level data, taken from other NCES data sets (the Common Core of Data and the Private School Universe Survey) and residential ZIP codes collected at each wave are also available.

Further information on the ECLS-B may be obtained from

Gail Mulligan

Sample Surveys Division

Longitudinal Surveys Branch

National Center for Education Statistics

1990 K Street NW

Washington, DC 20006

ecls@ed.gov

http://nces.ed.gov/ecls/birth.asp

\section{Early Childhood Longitudinal Study, Kindergarten Class of 1998-99}

The Early Childhood Longitudinal Study, Kindergarten Class of 1998-99 (ECLS-K) was designed to provide detailed information on children's school experiences throughout elementary school and into middle school. The study began in the fall of 1998. A nationally representative sample of about 21,300 children enrolled in 940 kindergarten programs during the 1998-99 school year was selected to participate in the ECLS-K. The children attended both public and private kindergartens and full-day and part-day programs. The sample included children from different racial/ethnic and socioeconomic backgrounds and oversamples of Asian and Pacific Islander children and private school kindergartners. Base-year data were collected in the fall and spring of the kindergarten year. Data were collected again in the fall of first grade in 1999 (from a 30 percent subsample of schools) and the spring of first grade in 2000, and then in the spring of third grade in 2002, the spring of fifth grade in 2004, and the spring of eighth grade in 2007.

From kindergarten to fifth grade, the ECLS-K included a direct child cognitive assessment that was administered one-onone with each child in the study. The assessment used a computer-assisted personal interview (CAPI) approach and a twostage adaptive testing methodology. In the eighth grade, a twostage adaptive paper-and-pencil assessment was administered in small groups. In kindergarten and first grade, the assessment included three cognitive domains-reading, mathematics, and general knowledge. General knowledge was replaced by science in the third, fifth, and eighth grades. Children's height and weight were measured at each data collection point, and a direct measure of children's psychomotor development was administered in the fall of the kindergarten year only. In addition to these measures, the ECLS-K collected information about children's social skills and academic achievement through teacher reports, and through student reports in the third, fifth, and eighth grades.

A computer-assisted telephone interview with the children's parents/guardians was conducted at each data collection point. Parents/guardians were asked to provide key information about the ECLS-K sample children on subjects such as family demographics (e.g., family members, age, relation to child, race/ethnicity), family structure (e.g., household members and composition), parent involvement, home educational activities (e.g., reading to the child), child health, parental education and employment status, and the social skills and behaviors of their children.

Data on the schools that children attended and their classrooms were collected through self-administered questionnaires completed by school administrators and classroom teachers. Administrators provided information about the school population, programs, and policies. At the classroom level, data were collected from the teachers on the composition of the classroom, teaching practices, curriculum, and teacher qualifications and experience. In addition, special education teachers and related services staff provided reports on the services received by children with disabilities.

Further information on the ECLS-K may be obtained from

\author{
Gail Mulligan \\ Sample Surveys Division \\ Longitudinal Surveys Branch \\ National Center for Education Statistics \\ 1990 K Street NW \\ Washington, DC 20006 \\ ecls@ed.gov \\ http://nces.ed.gov/ecls/kindergarten.asp
}




\section{Early Childhood Longitudinal Study, Kinder- garten Class of 2010-11 (ECLS-K:2011)}

The Early Childhood Longitudinal Study, Kindergarten Class of 2010-11 (ECLS-K:2011) is providing detailed information on the school achievement and experiences of students throughout their elementary school years. The students participating in the ECLS-K:2011 are being followed longitudinally from the kindergarten year (the 2010-11 school year) through the spring of 2016, when most of them are expected to be in fifth grade. This sample of students is designed to be nationally representative of all students who were enrolled in kindergarten or who were of kindergarten age and being educated in an ungraded classroom or school in the United States in the 2010-11 school year, including those in public and private schools, those who attended full-day and part-day programs, those who were in kindergarten for the first time, and those who were kindergarten repeaters. Students who attended early learning centers or institutions that offered education only through kindergarten are included in the study sample and represented in the cohort.

The ECLS-K:2011 places emphasis on measuring students' experiences within multiple contexts and development in multiple domains. The design of the study includes the collection of information from the students, their parents/guardians, their teachers, and their schools. Information was collected from their before- and after-school care providers in the kindergarten year.

A nationally representative sample of approximately 18,170 children from about 1,310 schools participated in the base-year administration of the ECLS-K:2011 in the 2010-11 school year. The sample included children who attended both public and private schools and children from different racial/ethnic and socioeconomic backgrounds. Asian/Pacific Islander students were oversampled to ensure that the sample included enough students of this race/ethnicity to make accurate estimates for the group as a whole. Seven data collections have been conducted to date: fall and spring of the children's kindergarten year (the base year), fall 2011 and spring 2012 (the first-grade year), fall 2012 and spring 2013 (the second-grade year), and spring 2014. Additional data collections are planned for the spring of 2015 and the spring of 2016. Although the study refers to later rounds of data collection by the grade the majority of children are expected to be in (that is, the modal grade for children who were in kindergarten in the 2010-11 school year), children are included in subsequent data collections regardless of their grade level. A total of approximately 780 of the 1,310 originally sampled schools participated during the base year of the study. This translates to a weighted unit response rate (weighted by the base weight) of 63 percent for the base year.
Further information on the ECLS-K:2011 may be obtained from

Gail Mulligan

Sample Surveys Division

Longitudinal Surveys Branch

National Center for Education Statistics

1990 K Street NW

Washington, DC 20006

ecls@ed.gov

http://nces.ed.gov/ecls/kindergarten2011.asp

\section{Education Longitudinal Study of 2002}

The Education Longitudinal Study of 2002 (ELS:2002) is a longitudinal survey that is monitoring the transitions of a national probability sample of 10th-graders in public, Catholic, and other private schools. Survey waves follow both students and high school dropouts and monitor the transition of the cohort to postsecondary education, the labor force, and family formation.

In the base year of the study, of 1,200 eligible contacted schools, 750 participated, for an overall weighted school participation rate of approximately 68 percent (62 percent unweighted). Of 17,600 selected eligible students, 15,400 participated, for an overall weighted student response rate of approximately 87 percent. (School and student weighted response rates reflect use of the base weight [design weight] and do not include nonresponse adjustments.) Information for the study is obtained not just from students and their school records, but also from the students' parents, their teachers, their librarians, and the administrators of their schools.

The first follow-up was conducted in 2004, when most sample members were high school seniors. Base-year students who remained in their base schools were resurveyed and tested in mathematics. Sample freshening was conducted to make the study representative of spring 2004 high school seniors nationwide. Students who were not still at their base schools were all administered a questionnaire.

The second follow-up, conducted in 2006, continued to follow the sample of students into postsecondary education, the workforce, or both. The third follow-up data (2012) were released in January 2014. In addition, postsecondary transcripts were collected in 2013, and it is expected that the resulting data will be made available in spring 2015.

Further information on ELS:2002 may be obtained from

Elise Christopher

Sample Surveys Division

Longitudinal Surveys Branch

National Center for Education Statistics

1990 K Street NW

Washington, DC 20006

elise.christopher@ed.gov

http://nces.ed.gov/surveys/els2002 


\section{Fast Response Survey System}

The Fast Response Survey System (FRSS) was established in 1975 to collect issue-oriented data quickly, with a minimal burden on respondents. The FRSS, whose surveys collect and report data on key education issues at the elementary and secondary levels, was designed to meet the data needs of Department of Education analysts, planners, and decisionmakers when information could not be collected quickly through NCES's large recurring surveys. Findings from FRSS surveys have been included in congressional reports, testimony to congressional subcommittees, NCES reports, and other Department of Education reports. The findings are also often used by state and local education officials.

Data collected through FRSS surveys are representative at the national level, drawing from a universe that is appropriate for each study. The FRSS collects data from state education agencies and national samples of other educational organizations and participants, including local education agencies, public and private elementary and secondary schools, elementary and secondary school teachers and principals, and public libraries and school libraries. To ensure a minimal burden on respondents, the surveys are generally limited to three pages of questions, with a response burden of about 30 minutes per respondent. Sample sizes are relatively small (usually about 1,000 to 1,500 respondents per survey) so that data collection can be completed quickly.

Further information on the FRSS may be obtained from

John Ralph

Annual Reports and Information

National Center for Education Statistics

1990 K Street NW

Washington, DC 20006

john.ralph@ed.gov

http://nces.ed.gov/surveys/frss

\section{Condition of Public School Facilities}

Condition of Public School Facilities: 1999 (NCES 2000032) is a report that presents national data about the condition of public schools in 1999. It provides results from the survey "Condition of Public School Facilities, 1999" (FRSS 73), which was conducted by NCES using its Fast Response Survey System (FRSS). The survey collected information about the condition of school facilities and the costs of bringing them into good condition; school plans for repairs, renovations, and replacements; the age of public schools; and overcrowding and practices used to address overcrowding. The results presented in this report are based on questionnaire data for 900 public elementary and secondary schools in the United States. The responses were weighted to produce national estimates that represent all regular public schools in the United States.

In 2013, NCES conducted "Condition of Public School Facilities: 2012-13" (FRSS 105), an FRSS survey covering most of the same topics. The First Look report Condition of America's Public School Facilities: 2012-13 (NCES 2014022) is based on results from this FRSS survey.
Further information on these FRSS reports and surveys may be obtained from

John Ralph

Annual Reports and Information

National Center for Education Statistics

1990 K Street NW

Washington, DC 20006

john.ralph@ed.gov

http://nces.ed.gov/surveys/frss

\section{Public School Principals Report on Their School Facilities: Fall 2005}

This report (NCES 2007-007) presents information on the extent of the match between the enrollment and the capacity of the school buildings, environmental factors that can affect the use of classrooms and school buildings, the extent and ways in which schools use portable buildings and the reasons for using them, the availability of dedicated rooms for particular subject areas (such as science labs or music rooms), and the cleanliness and maintenance of student restrooms.

Results from the FRSS survey "Public School Principals' Perceptions of Their School Facilities: Fall 2005” (FRSS 88) form the basis of the report. The survey was mailed to school principals, who were asked to complete it themselves. The sample included 1,205 public schools in the 50 states and the District of Columbia. The sample was selected from the 2002-03 Common Core of Data (CCD) Public Elementary/Secondary School Universe File, the most current available at the time of selection. The sampling frame includes approximately 84,500 elementary/secondary schools. Of the 1,205 schools surveyed, 47 were determined to be ineligible. Of the remaining 1,158 schools, responses were received from 1,045. Data have been weighted to yield national estimates of public elementary/secondary schools. The unweighted response rate was 90 percent, and the weighted response rate was 91 percent.

Further information on this report may be obtained from

John Ralph

Annual Reports and Information

National Center for Education Statistics

1990 K Street NW

Washington, DC 20006

john.ralph@ed.gov

http://nces.ed.gov/surveys/frss

Internet Access in U.S. Public Schools and

Classrooms, 1994-2005

This report (NCES 2007-020) is based on data collected in the FRSS survey "Internet Access in U.S. Public Schools, Fall 2005" (FRSS 90). The survey was designed to assess the federal government's commitment to assist every school and classroom in connecting to the Internet by the year 2000 .

In 1994, NCES began surveying approximately 1,000 public schools each year regarding their access to the Internet, access in classrooms, and, since 1996, their type of internet connections. Later administrations of this survey were expanded to 
cover emerging issues. The 2003 survey (FRSS 86) was designed to update the questions in the 2002 survey (FRSS 83) and covered the following topics: school connectivity, student access to computers and the Internet, school websites, technologies and procedures to prevent student access to inappropriate websites, and teacher professional development on how to incorporate the Internet into the curriculum.

In 2005, respondents were asked about the number of instructional computers with access to the Internet, the types of internet connections, technologies and procedures used to prevent student access to inappropriate material on the Internet, and the availability of handheld and laptop computers for students and teachers. Respondents also provided information on teacher professional development in integrating the use of the Internet into the curriculum and using the Internet to provide opportunities and information for teaching and learning.

\section{Use of Educational Technology in Public Schools}

In 2008, the NCES survey on educational technology use in public schools was redesigned and expanded to a set of three surveys (i.e., a school-, district-, and teacher-level survey). The three surveys provide complementary information and together cover a broader range of topics than would be possible with one survey alone. The set of surveys collected data on availability and use of a range of educational technology resources, such as district and school networks, computers, devices that enhance the capabilities of computers for instruction, and computer software. They also collected information on leadership and staff support for educational technology within districts and schools.

Educational Technology in U.S. Public Schools, Fall 2008 (NCES 2010-034) is based on the school-level survey, "Education Technology in U.S. Public Schools: Fall 2008" (FRSS 92); Educational Technology in Public School Districts: Fall 2008 (NCES 2010-003) is based on the districtlevel school technology survey, "Educational Technology in Public School Districts: Fall 2008" (FRSS 93); and Teachers' Use of Educational Technology in U.S. Public Schools: 2009 (NCES 2010-040) is based on the teacher-level school technology survey, “Teachers' Use of Educational Technology in U.S. Public Schools" (FRSS 95).

Further information on internet access and technology use in public schools and classrooms may be obtained from

\section{John Ralph}

Annual Reports and Information

National Center for Education Statistics

1990 K Street NW

Washington, DC 20006

john.ralph@ed.gov

http://nces.ed.gov/surveys/frss

\section{Distance Education for Public Elementary and} Secondary School Students

The report Technology-Based Distance Education Courses for Public Elementary and Secondary School Students: 2002-03 and 2004-05 (NCES 2008-008) presented data col- lected in the FRSS survey "Distance Education Courses for Public Elementary and Secondary School Students: 2004-05" (FRSS 89, 2005). The report included national estimates of the prevalence and characteristics of technology-based distance education courses in public schools nationwide in school year 2004-05. The report also compared those data with the baseline data that were collected in the FRSS survey "Distance Education Courses for Public School Elementary and Secondary Students: 2002-03" (FRSS 84, 2003) and provided longitudinal analysis of change in the districts that responded to both the 2002-03 and 2004-05 surveys.

Distance education courses were defined as credit-granting courses offered to elementary and secondary school students enrolled in the district in which the teacher and student were in different locations. These courses could be delivered via audio, video (live or prerecorded), or Internet or other computer technologies.

Distance Education Courses for Public Elementary and Secondary School Students: 2009-10 (NCES 2012-008) presents national estimates about student enrollment in distance education courses in public school districts. The estimates are based on a district survey ("Distance Education Courses for Public Elementary and Secondary School Students: 2009-10," FRSS 98, 2010) about distance education courses offered by the district or by any of the schools in the district during the 12-month 2009-10 school year. Distance education courses were defined as courses offered to elementary and secondary school students regularly enrolled in the district that were (1) credit granting; (2) technology delivered; and (3) had the instructor in a different location than the students and/or had course content developed in, or delivered from, a different location than that of the students.

Further information on FRSS reports on distance education may be obtained from

\author{
John Ralph \\ Annual Reports and Information \\ National Center for Education Statistics \\ 1990 K Street NW \\ Washington, DC 20006 \\ john.ralph@ed.gov \\ http://nces.ed.gov/surveys/frss
}

\section{Federal Support for Education}

NCES prepares an annual compilation of federal funds for education for the Digest of Education Statistics. Data for U.S. Department of Education programs come from the Budget of the United States Government. Budget offices of other federal agencies provide information for all other federal program support except for research funds, which are obligations reported by the National Science Foundation in Federal Funds for Research and Development. Some data are estimated, based on reports from the federal agencies contacted and the Budget of the United States Government.

Except for money spent on research, outlays are used to report program funds to the extent possible. Some Digest of 
Education Statistics tables report program funds as obligations, as noted in the title of the table. Some federal program funds not commonly recognized as education assistance are also included in the totals reported. For example, portions of federal funds paid to some states and counties as shared revenues resulting from the sale of timber and minerals from public lands have been estimated as funds used for education purposes. Parts of the funds received by states (in 1980) and localities (in all years) under the General Revenue Sharing Program are also included, as are portions of federal funds received by the District of Columbia. The share of these funds allocated to education is assumed to be equal to the share of general funds expended for elementary and secondary education by states and localities in the same year, as reported by the U.S. Census Bureau in its annual publication, Government Finances.

The share of federal funds assigned to education for the District of Columbia is assumed to be equal to the share of the city's general fund expenditures for each level of education.

For the job training programs conducted by the Department of Labor, only estimated sums spent on classroom training have been reported as educational program support.

During the 1970s, the Office of Management and Budget (OMB) prepared an annual analysis of federal education program support. These were published in the Budget of the United States Government, Special Analyses. The information presented in this report is not, however, a continuation of the OMB series. A number of differences in the two series should be noted. OMB required all federal agencies to report outlays for education-related programs using a standardized form, thereby assuring agency compliance in reporting. The scope of education programs reported in the Digest of Education Statistics differs from the scope of programs reported in the OMB reports. Off-budget items such as the annual volume of guaranteed student loans were not included in OMB's reports. Finally, while some mention is made of an annual estimate of federal tax expenditures, OMB did not include them in its annual analysis of federal education support. Estimated federal tax expenditures for education are the difference between current federal tax receipts and what these receipts would be without existing education deductions to income allowed by federal tax provisions.

Recipients' data are estimated based on Estimating Federal Funds for Education: A New Approach Applied to Fiscal Year 1980 (Miller, V., and Noell, J., 1982, Journal of Education Finance); Federal Support for Education, various years; and the Catalog of Federal Domestic Assistance (cfda.gov). The recipients' data are estimated and tend to undercount institutions of higher education, students, and local education agencies. This is because some of the federal programs have more than one recipient receiving funds. In these cases, the recipients were put into a "mixed recipients" category, because there was no way to disaggregate the amount each recipient received.
Further information on federal support for education may be obtained from

Tom Snyder

Annual Reports and Information

National Center for Education Statistics

1990 K Street NW

Washington, DC 20006

tom.snyder@ed.gov

http://nces.ed.gov/surveys/AnnualReports/federal.asp

\section{High School and Beyond Longitudinal Study}

The High School and Beyond Longitudinal Study (HS\&B) is a nationally representative sample survey of individuals who were high school sophomores and seniors in 1980. As a largescale, longitudinal survey, its primary purpose is to observe the educational and occupational plans and activities of young people as they pass through the American educational system and take on their adult roles. The study contributes to the understanding of the development of young adults and the factors that determine individual education and career outcomes. The availability of this longitudinal data encourages research in such areas as the strength of secondary school curricula, the quality and effectiveness of secondary and postsecondary schooling, the demand for postsecondary education, problems of financing postsecondary education, and the adequacy of postsecondary alternatives open to high school students.

The base-year survey (conducted in 1980) was a probability sample of 1,015 high schools with a target number of 36 sophomores and 36 seniors in each school. A total of 58,270 students participated in the base-year survey. Substitutions were made for nonparticipating schools - but not for students-in those strata where it was possible. Overall, 1,120 schools were selected in the original sample and 810 of these schools participated in the survey. An additional 200 schools were drawn in a replacement sample. Student refusals and absences resulted in an 82 percent completion rate for the survey.

Several small groups in the population were oversampled to allow for special study of certain types of schools and students. Students completed questionnaires and took a battery of cognitive tests. In addition, a sample of parents of sophomores and seniors (about 3,600 for each cohort) was surveyed.

HS\&B first follow-up activities took place in the spring of 1982. The sample for the first follow-up survey included approximately 30,000 individuals who were sophomores in 1980. The completion rate for sample members eligible for on-campus survey administration was about 96 percent. About 89 percent of the students who left school between the base-year and first follow-up surveys (e.g., dropouts, transfer students, and early graduates) completed the first followup sophomore questionnaire.

As part of the first follow-up survey of HS\&B, transcripts were requested in fall 1982 for an 18,150-member subsample of the sophomore cohort. Of the 15,940 transcripts actually obtained, 12,120 transcripts represented students that had graduated in 1982 and thus were eligible for use in the 
overall curriculum analysis presented in this publication. All courses in each transcript were assigned a 6-digit code based on the Classification of Secondary School Courses (a coding system developed to standardize course descriptions; see http://nces.ed.gov/surveys/hst/courses.asp). Credits earned in each course are expressed in Carnegie units. (The Carnegie unit is a standard of measurement that represents one credit for the completion of a 1-year course. To receive credit for a course, the student must have received a passing grade- "pass," "D," or higher.) Students who transferred from public to private schools or from private to public schools between their sophomore and senior years were eliminated from public/private analyses.

In designing the senior cohort first follow-up survey, one of the goals was to reduce the size of the retained sample while still keeping sufficient numbers of various racial/ethnic groups to allow important policy analyses. A total of about 11,230 (93.6 percent) of the 12,000 individuals subsampled completed the questionnaire. Information was obtained about the respondents' school and employment experiences, family status, and attitudes and plans.

The samples for the second follow-up, which took place in spring 1984, consisted of about 12,000 members of the senior cohort and about 15,000 members of the sophomore cohort. The completion rate for the senior cohort was 91 percent, and the completion rate for the sophomore cohort was 92 percent.

HS\&B third follow-up data collection activities were performed in spring 1986. Both the sophomore and senior cohort samples for this round of data collection were the same as those used for the second follow-up survey. The completion rates for the sophomore and senior cohort samples were 91 percent and 88 percent, respectively.

HS\&B fourth follow-up data collection activities were performed in 1992, but only surveyed the 1980 sophomore class. They examined aspects of these students' early adult years, such as enrollment in postsecondary education, experience in the labor market, marriage and child rearing, and voting behavior.

An NCES series of technical reports and data file user's manuals, available electronically, provides additional information on the survey methodology.

Further information on HS\&B may be obtained from

Aurora D'Amico

Sample Surveys Division

Longitudinal Surveys Branch

National Center for Education Statistics

1990 K Street NW

Washington, DC 20006

aurora.damico@ed.gov

http://nces.ed.gov/surveys/hsb

\section{High School Longitudinal Study of 2009 (HSLS:09)}

The High School Longitudinal Study of 2009 (HSLS:09) is a nationally representative, longitudinal study of approximately 21,000 9th-grade students in 944 schools who will be followed through their secondary and postsecondary years. The study focuses on understanding students' trajectories from the beginning of high school into postsecondary education, the workforce, and beyond. The HSLS:09 questionnaire is focused on, but not limited to, information on science, technology, engineering, and mathematics (STEM) education and careers. It is designed to provide data on mathematics and science education, the changing high school environment, and postsecondary education. This study features a new student assessment in algebra skills, reasoning, and problem solving and includes surveys of students, their parents, math and science teachers, and school administrators, as well as a new survey of school counselors.

The HSLS:09 student questionnaire includes interest and motivation items for measuring key factors predicting choice of postsecondary paths, including majors and eventual careers. This study explores the roles of different factors in the development of a student's commitment to attend college and then take the steps necessary to succeed in college (the right courses, courses in specific sequences, etc.). Questionnaires in this study have asked more questions of students and parents regarding reasons for selecting specific colleges (e.g., academic programs, financial aid and access prices, and campus environment).

HSLS:09 most recently surveyed respondents in 2013 regarding applications, acceptances, and rejections at colleges during respondents' critical junior and senior years in high school. A short questionnaire obtained information on college acceptances and actual college choices. In past longitudinal studies, this activity has been delayed until later follow-ups (2 years after high school).

Data collection for the first follow-up of HSLS:09 took place in the spring of 2012, when most sample members were in the spring of the 11th grade. Data files and documentation for the first follow-up were released in fall 2013 and are available on the NCES website. Data for the 2013 update were collected in 2013 and will be released in late 2014.

Further information on HSLS:09 may be obtained from

Elise Christopher

Sample Surveys Division

Longitudinal Surveys Branch

National Center for Education Statistics

1990 K Street NW

Washington, DC 20006

hsls09@ed.gov

http://nces.ed.gov/surveys/hsls09 


\section{High School Transcript Studies}

High school transcript studies have been conducted since 1982 in conjunction with major NCES data collections. The studies collect information that is contained in a student's high school record-courses taken while attending secondary school, information on credits earned, when specific courses were taken, and final grades.

A high school transcript study was conducted in 2004 as part of the Education Longitudinal Study of 2002 (ELS:2002/ 2004). A total of 1,550 schools participated in the request for transcripts, for an unweighted participation rate of approximately 79 percent. Transcript information was received on 14,920 members of the student sample (not just graduates), for an unweighted response rate of 91 percent.

Similar studies were conducted of the coursetaking patterns of 1982, 1987, 1990, 1992, 1994, 1998, 2000, 2005, and 2009 high school graduates. The 1982 data are based on approximately 12,000 transcripts collected by the High School and Beyond Longitudinal Study (HS\&B). The 1987 data are based on approximately 25,000 transcripts from 430 schools obtained as part of the 1987 NAEP High School Transcript Study, a scope comparable to that of the NAEP transcript studies conducted in 1990, 1994, 1998, and 2000. The 1992 data are based on approximately 15,000 transcripts collected by the National Education Longitudinal Study of 1988 (NELS:88/92). The 2005 data, from the 2005 NAEP High School Transcript Study, come from a sample of over 26,000 transcripts from 640 public schools and 80 private schools. The 2009 data are from the 2009 NAEP High School Transcript Study, which collected transcripts from a nationally representative sample of 37,700 high school graduates from about 610 public schools and 130 private schools.

Because the 1982 HS\&B transcript study used a different method for identifying students with disabilities than was used in NAEP transcript studies after 1982, and in order to make the statistical summaries as comparable as possible, all the counts and percentages in this report are restricted to students whose records indicate that they had not participated in a special education program. This restriction lowers the number of 1990 graduates represented in the tables to 20,870.

Further information on NAEP high school transcript studies may be obtained from

Janis Brown

Assessments Division

Reporting and Dissemination Branch

National Center for Education Statistics

1990 K Street NW

Washington, DC 20006

janis.brown@ed.gov

http://nces.ed.gov/surveys/hst

Further information on all other high school transcript studies may be obtained from
Carl Schmitt

Administrative Data Division

Elementary and Secondary Branch

National Center for Education Statistics

1990 K Street NW

Washington, DC 20006

carl.schmitt@ed.gov

http://nces.ed.gov/surveys/hst

\section{Integrated Postsecondary Education Data System}

The Integrated Postsecondary Education Data System (IPEDS) surveys approximately 7,500 postsecondary institutions, including universities and colleges, as well as institutions offering technical and vocational education beyond the high school level. IPEDS, an annual universe collection that began in 1986, replaced the Higher Education General Information Survey (HEGIS). In order to present data in a timely manner, Digest of Education Statistics tables use "provisional" IPEDS data. These data have been fully reviewed, edited, and imputed, but do not incorporate data revisions submitted by institutions after the close of data collection.

IPEDS consists of interrelated survey components that provide information on postsecondary institutions, student enrollment, programs offered, degrees and certificates conferred, and both the human and financial resources involved in the provision of institutionally based postsecondary education. Prior to 2000, the IPEDS survey had the following subjectmatter components: Graduation Rates; Fall Enrollment; Institutional Characteristics; Completions; Salaries, Tenure, and Fringe Benefits of Full-Time Faculty; Fall Staff; Finance; and Academic Libraries (in 2000, the Academic Libraries component became a survey separate from IPEDS). Since 2000, IPEDS survey components occurring in a particular collection year have been organized into three seasonal collection periods: fall, winter, and spring. The Institutional Characteristics and Completions components first took place during the fall 2000 collection; the Employees by Assigned Position (EAP), Salaries, and Fall Staff components first took place during the winter 2001-02 collection; and the Enrollment, Student Financial Aid, Finance, and Graduation Rates components first took place during the spring 2001 collection. In the winter 2005-06 data collection, the Employees by Assigned Position, Fall Staff, and Salaries components were merged into the Human Resources component. During the 2007-08 collection year, the Enrollment component was broken into two separate components: 12-Month Enrollment (taking place in the fall collection) and Fall Enrollment (taking place in the spring collection). In the 2011-12 IPEDS data collection year, the Student Financial Aid component was moved to the winter data collection to aid in the timing of the net price of attendance calculations displayed on the College Navigator (http:// nces.ed.gov/collegenavigator). In the 2012-13 IPEDS data collection year, the Human Resources component was moved to the spring data collection. 
Beginning in 2008-09, the first-professional degree category was combined with the doctor's degree category. However, some degrees formerly identified as first-professional that take more than two full-time-equivalent academic years to complete, such as those in Theology (M.Div, M.H.L./Rav), are included in the Master's degree category. Doctor's degrees were broken out into three distinct categories: research/scholarship, professional practice, and other doctor's degrees.

IPEDS race/ethnicity data collection also changed in 2008-09. The "Asian" race category is now separate from a "Native Hawaiian or Other Pacific Islander" category. Survey takers also have the option of identifying themselves as being of "Two or more races." To reflect the recognition that "Hispanic" refers to ethnicity, not race, the new Hispanic category reads "Hispanics of any race."

The degree-granting institutions portion of IPEDS is a census of colleges that award associate's or higher degrees and are eligible to participate in Title IV financial aid programs. Prior to 1993, data from technical and vocational institutions were collected through a sample survey. Beginning in 1993, all data are gathered in a census of all postsecondary institutions. Beginning in 1997, the survey was restricted to institutions participating in Title IV programs. The tabulations on "institutional characteristics" developed for editions of the Digest of Education Statistics from 1993 forward are based on lists of all institutions and are not subject to sampling errors.

The classification of institutions offering college and university education changed as of 1996 . Prior to 1996, institutions that had courses leading to an associate's or higher degree or that had courses accepted for credit toward those degrees were considered higher education institutions. Higher education institutions were accredited by an agency or association that was recognized by the U.S. Department of Education or were recognized directly by the Secretary of Education. Tables, or portions of tables, that use only this standard are noted as "higher education" in the Digest of Education Statistics. The newer standard includes institutions that award associate's or higher degrees and that are eligible to participate in Title IV federal financial aid programs. Tables that contain any data according to this standard are titled "degree-granting" institutions. Time-series tables may contain data from both series, and they are noted accordingly. The impact of this change on data collected in 1996 was not large. For example, tables on faculty salaries and benefits were only affected to a very small extent. Also, degrees awarded at the bachelor's level or higher were not heavily affected. The largest impact was on private 2-year college enrollment. In contrast, most of the data on public 4year colleges were affected to a minimal extent. The impact on enrollment in public 2-year colleges was noticeable in certain states, such as Arizona, Arkansas, Georgia, Louisiana, and Washington, but was relatively small at the national level. Overall, total enrollment for all institutions was about one-half of a percent higher in 1996 for degree-granting institutions than for higher education institutions.

Prior to the establishment of IPEDS in 1986, HEGIS acquired and maintained statistical data on the characteris- tics and operations of institutions of higher education. Implemented in 1966, HEGIS was an annual universe survey of institutions accredited at the college level by an agency recognized by the Secretary of the U.S. Department of Education. These institutions were listed in NCES's Education Directory, Colleges and Universities.

HEGIS surveys collected information on institutional characteristics, faculty salaries, finances, enrollment, and degrees. Since these surveys, like IPEDS, were distributed to all higher education institutions, the data presented are not subject to sampling error. However, they are subject to nonsampling error, the sources of which varied with the survey instrument.

The NCES Taskforce for IPEDS Redesign recognized that there were issues related to the consistency of data definitions as well as the accuracy, reliability, and validity of other quality measures within and across surveys. The IPEDS redesign in 2000 provided institution-specific webbased data forms. While the new system shortened data processing time and provided better data consistency, it did not address the accuracy of the data provided by institutions.

Beginning in 2003-04 with the Prior Year Data Revision System, prior-year data have been available to institutions entering current data. This allows institutions to make changes to their prior-year entries either by adjusting the data or by providing missing data. These revisions allow the evaluation of the data's accuracy by looking at the changes made.

NCES conducted a study (NCES 2005-175) of the 2002-03 data that were revised in 2003-04 to determine the accuracy of the imputations, track the institutions that submitted revised data, and analyze the revised data they submitted. When institutions made changes to their data, it was assumed that the revised data were the "true" data. The data were analyzed for the number and type of institutions making changes, the type of changes, the magnitude of the changes, and the impact on published data.

Because NCES imputes for missing data, imputation procedures were also addressed by the Redesign Taskforce. For the 2003-04 assessment, differences between revised values and values that were imputed in the original files were compared (i.e., revised value minus imputed value). These differences were then used to provide an assessment of the effectiveness of imputation procedures. The size of the differences also provides an indication of the accuracy of imputation procedures. To assess the overall impact of changes on aggregate IPEDS estimates, published tables for each component were reconstructed using the revised 2002-03 data. These reconstructed tables were then compared to the published tables to determine the magnitude of aggregate bias and the direction of this bias.

The fall 2011 and spring 2012 data collections were entirely web-based. Data were provided by "keyholders," institutional representatives appointed by campus chief executives, who were responsible for ensuring that survey data submitted by the institution were correct and complete. Because Title IV institutions are the primary focus of IPEDS and because these institutions are required to respond to the survey, response rates for Title IV institutions in the fall 2011 
IPEDS collection were high. The Institutional Characteristics (IC) component response rate among all Title IV entities was 100.0 percent (all 7,479 Title IV entities responded). In addition, the response rates for the Completions and 12-Month Enrollment components were also 100.0 percent. More details on the accuracy and reliability of IPEDS data can be found in the Integrated Postsecondary Education Data System Data Quality Study (NCES 2005-175).

Further information on IPEDS may be obtained from

Richard Reeves

Administrative Data Division

Postsecondary Branch

National Center for Education Statistics

1990 K Street NW

Washington, DC 20006

richard.reeves@ed.gov

http://nces.ed.gov/ipeds

\section{Fall (12-Month Enrollment)}

Data on 12-month enrollment are collected for award levels ranging from postsecondary certificates of less than 1 year to doctoral degrees. The 12-month period during which data are collected is July 1 through June 30. Data are collected by race/ethnicity and gender and include unduplicated headcounts and instructional activity (contact or credit hours). These data are also used to calculate a full-time-equivalent (FTE) enrollment based on instructional activity. FTE enrollment is useful for gauging the size of the educational enterprise at the institution. Prior to the 2007-08 IPEDS data collection, the data collected in the 12-Month Enrollment component were part of the Fall Enrollment component, which is conducted during the spring data collection period. However, to improve the timeliness of the data, a separate 12Month Enrollment survey component was developed in 2007. These data are now collected in the fall for the previous academic year. Of the 7,407 Title IV entities that were expected to respond to the 12-Month Enrollment component of the fall 2012 data collection, 7,403 responded, for an approximate response rate of 100.0 percent.

Further information on the IPEDS 12-Month Enrollment component may be obtained from

\section{IPEDS Staff}

Administrative Data Division

Postsecondary Branch

National Center for Education Statistics

1990 K Street NW

Washington, DC 20006

http://nces.ed.gov/ncestaff/SurvDetl.asp?surveyID=010

\section{Fall (Completions)}

This survey was part of the HEGIS series throughout its existence. However, the degree classification taxonomy was revised in 1970-71, 1982-83, 1991-92, 2002-03, and 2009-10. Collection of degree data has been maintained through IPEDS.
Degrees-conferred trend tables arranged by the 2009-10 classification are included in the Digest of Education Statistics to provide consistent data from 1970-71 through the most recent year. Data in this edition on associate's and other formal awards below the baccalaureate degree, by field of study, cannot be made comparable with figures from years prior to 1982-83. The nonresponse rate does not appear to be a significant source of nonsampling error for this survey. The response rate over the years has been high; for the fall 2012 Completions component, it was about 100.0 percent. Because of the high response rate, there was no need to conduct a nonresponse bias analysis. Imputation methods for the fall 2012 Completions component are discussed in Postsecondary Institutions and Cost of Attendance in 2012-13; Degrees and Other Awards Conferred, 2011-12; and 12-Month Enrollment, 2011-12 (NCES 2013-289rev). The Integrated Postsecondary Education Data System Data Quality Study (NCES 2005-175) indicated that most Title IV institutions supplying revised data on completions in 2003-04 were able to supply missing data for the prior year. The small differences between imputed data for the prior year and the revised actual data supplied by the institution indicated that the imputed values produced by NCES were acceptable.

Further information on the IPEDS Completions component may be obtained from

\section{IPEDS Staff}

Administrative Data Division

Postsecondary Branch

National Center for Education Statistics

1990 K Street NW

Washington, DC 20006

http://nces.ed.gov/ncestaff/SurvDetl.asp?surveyID=010

\section{Fall (Institutional Characteristics)}

This survey collects the basic information necessary to classify institutions, including control, level, and types of programs offered, as well as information on tuition, fees, and room and board charges. Beginning in 2000, the survey collected institutional pricing data from institutions with firsttime, full-time, degree/certificate-seeking undergraduate students. Unduplicated full-year enrollment counts and instructional activity are now collected in the Fall Enrollment survey. Beginning in 2008-09, student financial aid data collected include greater detail. The overall unweighted response rate was 100.0 percent for Title IV degree-granting institutions for 2009 data. In the fall 2012 data collection, the response rate for the Institutional Characteristics component among all Title IV entities was about 100.0 percent. Of the 7,476 Title IV entities expected to respond to the Institutional Characteristics component, 7,474 responded. In addition, data from 10 institutions that responded to the Institutional Characteristics component contained item nonresponse, and these missing items were imputed. Imputation methods for the fall 2012 Institutional Characteristics component are discussed in the 2012-13 Integrated Postsecondary Education Data System (IPEDS) Methodology Report 
(NCES 2013-293). The Integrated Postsecondary Education Data System Data Quality Study (NCES 2005-175) looked at tuition and price in Title IV institutions. Only 8 percent of institutions in 2002-03 and 2003-04 reported the same data to IPEDS and Thomson Peterson consistently across all selected data items. Differences in wordings or survey items may account for some of these inconsistencies.

Further information on the IPEDS Institutional Characteristics component may be obtained from

Tara Lawley

Administrative Data Division

Postsecondary Branch

National Center for Education Statistics

1990 K Street NW

Washington, DC 20006

tara.lawley@ed.gov

http://nces.ed.gov/ipeds

\section{Winter (Student Financial Aid)}

This component was part of the spring data collection from IPEDS data collection years 2000-01 to 2010-11, but it moved to the winter data collection starting with the 2011-12 IPEDS data collection year. This move will aid in the timing of the net price of attendance calculations displayed on College Navigator (http://nces.ed.gov/collegenavigator).

Financial aid data are collected for undergraduate students. Data are collected regarding federal grants, state and local government grants, institutional grants, and loans. The collected data include the number of students receiving each type of financial assistance and the average amount of aid received by type of aid. Beginning in 2008-09, student financial aid data collected includes greater detail on types of aid offered.

In the winter 2012-13 data collection, the Student Financial Aid component presented data on the number of firsttime, full-time degree- and certificate-seeking undergraduate financial aid recipients for the 2011-12 academic year. Of the 7,064 Title IV institutions expected to respond to the Student Financial Aid component, 7,058 Title IV institutions responded, resulting in a response rate of about 99.9 percent.

Further information on the IPEDS Student Financial Aid component may be obtained from

Tara Lawley

Administrative Data Division

Postsecondary Branch

National Center for Education Statistics

1990 K Street NW

Washington, DC 20006

tara.lawley@ed.gov

$\underline{\mathrm{http}: / / \text { nces.ed.gov/ipeds }}$

\section{Spring (Fall Enrollment)}

This survey has been part of the HEGIS and IPEDS series since 1966. Response rates for this survey have been relatively high, generally exceeding 85 percent. Beginning in 2000 , with web-based data collection, higher response rates were attained. In the spring 2013 data collection, where the Fall Enrollment component covered fall 2012, the response rate was 99.9 percent. Data collection procedures for the Fall Enrollment component of the spring 2013 data collection are presented in Enrollment in Postsecondary Institutions, Fall 2012; Financial Statistics, Fiscal Year 2012; Graduation Rates, Selected Cohorts, 2004-09; and Employees in Postsecondary Institutions, Fall 2012 (NCES 2013-183).

Beginning with the fall 1986 survey and the introduction of IPEDS (see above), the survey was redesigned. The survey allows (in alternating years) for the collection of age and residence data. Beginning in 2000, the survey collected instructional activity and unduplicated headcount data, which are needed to compute a standardized, full-time-equivalent (FTE) enrollment statistic for the entire academic year. As of 2007-08, the timeliness of the instructional activity data has been improved by collecting these data in the fall as part of the 12-Month-Enrollment component instead of in the spring as part of the Fall Enrollment component.

The Integrated Postsecondary Education Data System Data Quality Study (NCES 2005-175) showed that public institutions made the majority of changes to enrollment data during the 2004 revision period. The majority of changes were made to unduplicated headcount data, with the net differences between the original data and the revised data at about 1 percent. Part-time students in general and enrollment in private not-for-profit institutions were often underestimated. The fewest changes by institutions were to Classification of Instructional Programs (CIP) code data. (The CIP is a taxonomic coding scheme that contains titles and descriptions of primarily postsecondary instructional programs.)

Further information on the IPEDS Fall Enrollment component may be obtained from

\section{IPEDS Staff}

Administrative Data Division

Postsecondary Branch

National Center for Education Statistics

1990 K Street NW

Washington, DC 20006

http://nces.ed.gov/ncestaff/SurvDetl.asp?surveyID=010

\section{Spring (Finance)}

This survey was part of the HEGIS series and has been continued under IPEDS. Substantial changes were made in the financial survey instruments in fiscal year (FY) 1976, FY 82, FY 87, FY 97, and FY 02. While these changes were significant, considerable effort has been made to present only comparable information on trends in this report and to note inconsistencies. The FY 76 survey instrument contained numerous revisions to earlier survey forms, which made direct comparisons of line items very difficult. Beginning in FY 82, Pell Grant data were collected in the categories of federal restricted grant and contract revenues and restricted scholarship and fellowship expenditures. Finance tables for this publication have been adjusted by subtracting the largely duplicative Pell Grant amounts from the later data to maintain 
comparability with pre-FY 82 data. The introduction of IPEDS in the FY 87 survey included several important changes to the survey instrument and data processing procedures. Beginning in FY 97, data for private institutions were collected using new financial concepts consistent with Financial Accounting Standards Board (FASB) reporting standards, which provide a more comprehensive view of college finance activities. The data for public institutions continued to be collected using the older survey form. The data for public and private institutions were no longer comparable and, as a result, no longer presented together in analysis tables. In FY 01, public institutions had the option of either continuing to report using Government Accounting Standards Board (GASB) standards or using the new FASB reporting standards. Beginning in FY 02, public institutions had three options: the original GASB standards, the FASB standards, or the new GASB Statement 35 standards (GASB35). Because of the complexity of the multiple forms used by public institutions, finance data for public institutions for some recent years are not presented in the Digest of Education Statistics.

Possible sources of nonsampling error in the financial statistics include nonresponse, imputation, and misclassification. The unweighted response rate has been about 85 to 90 percent for most of the historic years presented in the Digest of Education Statistics; however, in more recent years, response rates have been much higher because Title IV institutions are required to respond. The 2002 IPEDS data collection was a full-scale web-based collection, which offered features that improved the quality and timeliness of the data. The ability of IPEDS to tailor online data entry forms for each institution based on characteristics such as institutional control, level of institution, and calendar system, and the institutions' ability to submit their data online, were two such features that improved response.

The response rate for the FY 2012 Finance survey component was 99.8 percent. Data collection procedures for the FY 2012 survey are discussed in Enrollment in Postsecondary Institutions, Fall 2012; Financial Statistics, Fiscal Year 2012; Graduation Rates, Selected Cohorts, 2004-09; and Employees in Postsecondary Institutions, Fall 2012: First Look (Provisional Data) (NCES 2013-183).

Two general methods of imputation were used in HEGIS. If prior-year data were available for a nonresponding institution, they were inflated using the Higher Education Price Index and adjusted according to changes in enrollments. If prior-year data were not available, current data were used from peer institutions selected for location (state or region), control, level, and enrollment size of institution. In most cases, estimates for nonreporting institutions in HEGIS were made using data from peer institutions.

Beginning with FY 87, IPEDS included all postsecondary institutions, but maintained comparability with earlier surveys by allowing 2- and 4-year institutions to be tabulated separately. For FY 87 through FY 91, in order to maintain comparability with the historical time series of HEGIS institutions, data were combined from two of the three different survey forms that make up IPEDS. The vast majority of the data were tabulated from form 1 , which was used to collect information from public and private not-for-profit 2- and 4-year colleges. Form 2, a condensed form, was used to gather data for 2-year for-profit institutions. Because of the differences in the data requested on the two forms, several assumptions were made about the form 2 reports so that their figures could be included in the degree-granting institution totals.

In IPEDS, the form 2 institutions were not asked to separate appropriations from grants and contracts, nor were they asked to separate state from local sources of funding. For the form 2 institutions, all federal revenues were assumed to be federal grants and contracts, and all state and local revenues were assumed to be restricted state grants and contracts. All other form 2 sources of revenue, except for tuition and fees and sales and services of educational activities, were included under "other." Similar adjustments were made to the expenditure accounts. The form 2 institutions reported instruction and scholarship and fellowship expenditures only. All other educational and general expenditures were allocated to academic support.

The Integrated Postsecondary Education Data System Data Quality Study (NCES 2005-175) found that only a small percentage (2.9 percent, or 168) of postsecondary institutions either revised 2002-03 data or submitted data for items they previously left unreported. Though relatively few institutions made changes, the changes made were relatively large-greater than 10 percent of the original data. With a few exceptions, these changes, large as they were, did not greatly affect the aggregate totals.

Further information on the IPEDS Finance component may be obtained from

Bao Le

Administrative Data Division

Postsecondary Branch

National Center for Education Statistics

1990 K Street NW

Washington, DC 20006

bao.le@ed.gov

\section{Spring (Graduation Rates and Graduation Rates 200 Percent)}

Graduation rates data are collected for full-time, firsttime degree- and certificate-seeking undergraduate students. Data included are the number of students entering the institution as full-time, first-time degree- or certificate-seeking students in a particular year (cohort), by race/ethnicity and gender; the number of students completing their program within a time period equal to $1 \frac{1 / 2}{2}$ times ( 150 percent) the normal period of time; and the number of students who transferred to other institutions.

In the spring 2013 data collection, the Graduation Rates component collected counts of full-time, first-time degreeand certificate-seeking undergraduate students entering an institution in the cohort year (4-year institutions used the cohort year 2006; less-than-4-year institutions used the cohort year 2009), and their completion status as of August 31,2012 (150 percent of normal program completion time) 
at the institution initially entered. The response rate for this component was 99.9 percent.

The 200 Percent Graduation Rates component collected counts of full-time, first-time degree- and certificate-seeking undergraduate students beginning their postsecondary education in the reference period and their completion status as of August 31, 2012 (200 percent of normal program completion time) at the same institution where the students started. Four-year institutions report on bachelor's or equivalent degree-seeking students and use cohort year 2004 as the reference period, while less-than-4-year institutions report on all students in the cohort and use cohort year 2008 as the reference period. The response rate for this component was 99.9 percent.

Further information on the IPEDS Graduation component may be obtained from

\section{Alison Deigan \\ Administrative Data Division \\ Postsecondary Branch \\ National Center for Education Statistics \\ 1990 K Street NW \\ Washington, DC 20006 \\ alison.deigan@ed.gov}

\section{Spring (Human Resources)}

The IPEDS Human Resources (HR) component was part of the winter data collection from IPEDS data collection years 2000-01 to 2011-12. For the 2012-13 data collection year, the HR component was moved to the spring 2013 data collection, in order to give institutions more time to prepare their survey responses (the spring and winter collections begin on the same date, but the reporting deadline for the spring collection is several weeks later than the reporting deadline for the winter collection).

\section{Human Resources, 2012-13 Collection Year}

In 2012-13, new occupational categories replaced the primary function/occupational activity categories previously used in the IPEDS HR component. This change was required in order to align the IPEDS HR categories with the 2010 Standard Occupational Classification (SOC) system. In tandem with the change in 2012-13 from using primary function/occupational activity categories to using the new occupational categories, the sections making up the IPEDS HR component (which previously had been Employees by Assigned Position [EAP], Fall Staff, and Salaries) were changed to Full-Time Instructional Staff, Full-time Noninstructional Staff, Salaries, Part-Time Staff, and New Hires.

The webpage "Changes to the 2012-13 IPEDS Data Collection and Changes to Occupational Categories for the 2012-13 Human Resources Data Collection" (http://nces.ed.gov/ipeds/ surveys/datacollection2012-13.asp) provides information on the redesigned IPEDS Human Resources component. "Resources for Implementing Changes to the IPEDS Human Resources (HR) Survey Component Due to Updated 2010 Standard Occupational Classification (SOC) System" (http:// nces.ed.gov/ipeds/resource/soc.asp) is a webpage containing additional information, including notes comparing the new classifications with the old ("Comparison of New IPEDS Occupational Categories with Previous Categories"), a crosswalk from the new IPEDS occupational categories to the 2010 SOC occupational categories ("New IPEDS Occupational Categories and 2010 SOC"), answers to frequently asked questions, and a link to current IPEDS HR survey screens.

\section{Human Resources, Collection Years Prior to 2012-13}

In IPEDS collection years prior to 2012-13, the Human Resources component was composed of three sections: Employees by Assigned Position (EAP), Fall Staff, and Salaries.

Data gathered by the Employees by Assigned Position (EAP) section categorizes all employees by full- or part-time status, faculty status, and primary function/occupational activity. Institutions with M.D. or D.O. programs are required to report their medical school employees separately. A response to the EAP was required of all 6,858 Title IV institutions and administrative offices in the United States and other jurisdictions for winter 2008-09, and 6,845, or 99.8 percent unweighted, responded. Of the 6,970 Title IV institutions and administrative offices required to respond to the winter 2009-10 EAP, 6,964, or 99.9 percent, responded. And of the 7,256 Title IV institutions and administrative offices required to respond to the EAP for winter 2010-11, 7,252, or 99.9 percent, responded.

The main functions/occupational activities of the EAP section are primarily instruction, instruction combined with research and/or public service, primarily research, primarily public service, executive/administrative/managerial, other professionals (support/service), graduate assistants, technical and paraprofessionals, clerical and secretarial, skilled crafts, and service/maintenance.

All full-time instructional faculty classified in the EAP full-time non-medical school part as either (1) primarily instruction or (2) instruction combined with research and/or public service are included in the Salaries section, unless they are exempt.

The Fall Staff section categorizes all staff on the institution's payroll as of November 1 of the collection year by employment status (full time or part time), primary function/ occupational activity, gender, and race/ethnicity. These data elements are collected from degree-granting and nondegree-granting institutions; however, additional data elements are collected from degree-granting institutions and related administrative offices with 15 or more full-time staff. These elements include faculty status, contract length/teaching period, academic rank, salary class intervals, and newly hired full-time permanent staff.

The Fall Staff section, which is required only in odd-numbered reporting years, was not required during the 2008-09 HR data collection. However, of the 6,858 Title IV institutions and administrative offices in the United States and other jurisdictions, 3,295, or 48.0 percent unweighted, did provide data in the Fall Staff section that year. During the 2009-10 HR 
data collection, when all 6,970 Title IV institutions and administrative offices were required to respond to the Fall Staff section, 6,964, or 99.9 percent, did so. A response to the Fall Staff section of the 2010-11 HR collection was optional, and 3,364 Title IV institutions and administrative offices responded that year (a response rate of 46.3 percent).

The Integrated Postsecondary Education Data System Data Quality Study (NCES 2005-175) found that for 2003-04 employee data items, changes were made by 1.2 percent (77) of the institutions that responded. All who made changes made changes that resulted in different employee counts. For both institutional and aggregate differences, the changes had little impact on the original employee count submissions. A large number of institutions reported different staff data to IPEDS and Thomson Peterson; however, the magnitude of the differences was small-usually no more than 17 faculty members for any faculty variable.

The Salaries section collects data for full-time instructional faculty (except those in medical schools in the EAP section, described above) on the institution's payroll as of November 1 of the collection year by contract length/teaching period, gender, and academic rank. The reporting of data by faculty status in the Salaries section is required from 4year degree-granting institutions and above only. Salary outlays and fringe benefits are also collected for full-time instructional staff on 9/10- and 11/12-month contracts/ teaching periods. This section is applicable to degree-granting institutions unless exempt.

This institutional survey was conducted for most years from 1966-67 to 1987-88; it has been conducted annually since 1989-90, except for 2000-01. Although the survey form has changed a number of times during these years, only comparable data are presented.

Between 1966-67 and 1985-86, this survey differed from other HEGIS surveys in that imputations were not made for nonrespondents. Thus, there is some possibility that the salary averages presented in this report may differ from the results of a complete enumeration of all colleges and universities. Beginning with the surveys for 1987-88, the IPEDS data tabulation procedures included imputations for survey nonrespondents. The unweighted response rate for the 2008-09 Salaries survey section was 99.9 percent. The response rate for the 2009-10 Salaries section was 100.0 percent $(4,453$ of the 4,455 required institutions responded), and the response rate for 2010-11 was 99.9 percent $(4,561$ of the 4,565 required institutions responded). Imputation methods for the 2010-11 Salaries survey section are discussed in Employees in Postsecondary Institutions, Fall 2010, and Salaries of Full-Time Instructional Staff, 2010-11 (NCES 2012-276).

Although data from this survey are not subject to sampling error, sources of nonsampling error may include computational errors and misclassification in reporting and processing. The electronic reporting system does allow corrections to prior-year reported or missing data, and this should help with these problems. Also, NCES reviews individual institutions' data for internal and longitudinal consistency and contacts institutions to check inconsistent data.
The Integrated Postsecondary Education Data System Data Quality Study (NCES 2005-175) found that only 1.3 percent of the responding Title IV institutions in 2003-04 made changes to their salaries data. The differences between the imputed data and the revised data were small and found to have little impact on the published data.

Further information on the Human Resources component may be obtained from

\section{IPEDS Staff}

Administrative Data Division

Postsecondary Branch

National Center for Education Statistics

1990 K Street NW

Washington, DC 20006

http://nces.ed.gov/ncestaff/SurvDetl.asp?surveyID=010

\section{Library Statistics}

In the past, NCES collected library data through the Public Libraries Survey (PLS), the State Library Agencies (StLA) Survey, the Academic Libraries Survey (ALS), and the Library Media Centers (LMC) Survey. On October 1, 2007, the administration of the Public Libraries Survey (PLS) and the State Library Agencies (StLA) Survey was transferred to the Institute of Museum and Library Services (IMLS) (see below).

NCES administered the Academic Libraries Survey (ALS) on a 3-year cycle between 1966 and 1988. From 1988 through 1999, ALS was a component of the Integrated Postsecondary Education Data System (IPEDS) and was on a 2-year cycle. Beginning in the year 2000, the Academic Libraries Survey began collecting data independent from the IPEDS data collection, but it remained on a 2-year cycle. ALS provided data on approximately 3,700 academic libraries. In aggregate, these data provided an overview of the status of academic libraries nationally and statewide. The survey collected data on the libraries in the entire universe of degree-granting institutions. Beginning with the collection of FY 2000 data, the ALS changed to web-based data collection. ALS produced descriptive statistics on academic libraries in postsecondary institutions in the 50 states, the District of Columbia, and the outlying areas. Academic Libraries: 2012 (NCES 2014-038) presented tabulations for the 2012 survey, the most recent administration of ALS for which data are available. The Academic Libraries Survey will again be a component of IPEDS beginning in the 2014-15 IPEDS data collection year (Spring 2015 collection).

School library data were collected on the School and Principal Surveys of the 1990-91 Schools and Staffing Survey (SASS). The School Library Media Centers (LMC) Survey became a component of SASS with the 1993-94 administration of the survey. Thus, readers should refer to the section on the Schools and Staffing Survey, below, regarding data on school libraries. Data for the 2011-12 School Library Media Centers (LMC) Survey are available on the NCES website at http://nces.ed.gov/surveys/sass/index.asp. 
Further information on library statistics may be obtained from

Tai Phan

Administrative Data Division

National Center for Education Statistics

1990 K Street NW

Washington, DC 20006

tai.phan@ed.gov

http://nces.ed.gov/surveys/libraries

\section{National Adult Literacy Survey}

The National Adult Literacy Survey (NALS), funded by the U.S. Department of Education and 12 states, was created in 1992 as a new measure of literacy. The aim of the survey was to profile the English literacy of adults in the United States based on their performance across a wide array of tasks that reflect the types of materials and demands they encounter in their daily lives.

To gather information on adults' literacy skills, trained staff interviewed a nationally representative sample of nearly 13,600 individuals ages 16 and older during the first 8 months of 1992. These participants had been randomly selected to represent the adult population in the country as a whole. Black and Hispanic households were oversampled to ensure reliable estimates of literacy proficiencies and to permit analyses of the performance of these subpopulations. In addition, some 1,100 inmates from 80 federal and state prisons were interviewed to gather information on the proficiencies of the prison population. In total, nearly 26,000 adults were surveyed.

Each survey participant was asked to spend approximately an hour responding to a series of diverse literacy tasks, as well as to questions about his or her demographic characteristics, educational background, reading practices, and other areas related to literacy. Based on their responses to the survey tasks, adults received proficiency scores along three scales that reflect varying degrees of skill in prose, document, and quantitative literacy. The results of the 1992 survey were first published in Adult Literacy in America: A First Look at the Findings of the National Adult Literacy Survey (NCES 93275), in September 1993. See National Assessment of Adult Literacy (below) for later surveys on adult literacy.

Further information on NALS may be obtained from

Sheida White

Assessments Division

National Assessment Branch

National Center for Education Statistics

1990 K Street NW

Washington, DC 20006

sheida.white@ed.gov

http://nces.ed.gov/naal/nals products.asp

\section{National Assessment of Adult Literacy}

The 2003 National Assessment of Adult Literacy (NAAL) was conducted to measure both English literacy and health literacy. The assessment was administered to 19,000 adults (including 1,200 prison inmates) age 16 and over in all 50 states and the District of Columbia. Components of the assessment included a background questionnaire; a prison component that assesses the literacy skills of adults in federal and state prisons; the State Assessment of Adult Literacy (SAAL), a voluntary survey given in conjunction with NAAL; a health literacy component; the Fluency Addition to NAAL (FAN), an oral reading assessment; and the Adult Literacy Supplemental Assessment (ALSA). ALSA is an alternative to main NAAL for those with very low scores on seven core screening questions. NAAL assesses literacy directly through the completion of tasks that covered quantitative literacy, document literacy, and prose literacy. Results were reported using the following achievement levels: Below Basic, Basic, Intermediate, and Proficient.

Results from NAAL and NALS can be compared. NALS offers a snapshot of the condition of literacy of the U.S. population as a whole and among key population subgroups in 1992. NAAL provides an updated picture of adult literacy skills in 2003, revealing changes in literacy over the intervening decade.

Further information on NAAL may be obtained from

Sheida White

Assessments Division

National Assessment Branch

National Center for Education Statistics

1990 K Street NW

Washington, DC 20006

sheida.white@ed.gov

http://nces.ed.gov/naal

\section{National Assessment of Educational Progress}

The National Assessment of Educational Progress (NAEP) is a series of cross-sectional studies initially implemented in 1969 to assess the educational achievement of U.S. students and monitor changes in those achievements. In the main national NAEP, a nationally representative sample of students is assessed at grades 4,8 , and 12 in various academic subjects. The assessments are based on frameworks developed by the National Assessment Governing Board (NAGB). Assessment items include both multiple-choice and constructed-response (requiring written answers) items. Results are reported in two ways: by average score and by achievement level. Average scores are reported for the nation, for participating states and jurisdictions, and for subgroups of the population. Percentages of students performing at or above three achievement levels (Basic, Proficient, and Advanced) are also reported for these groups.

From 1990 until 2001, main NAEP was conducted for states and other jurisdictions that chose to participate. In 2002, under the provisions of the No Child Left Behind Act of 2001, all states began to participate in main NAEP, and an aggregate of all state samples replaced the separate national sample. 
Mathematics assessments were administered in 2000, 2003, 2005, 2007, 2009, 2011, and 2013. In 2005, NAGB called for the development of a new mathematics framework. The revisions made to the mathematics framework for the 2005 assessment were intended to reflect recent curricular emphases and better assess the specific objectives for students at each grade level.

The revised mathematics framework focuses on two dimensions: mathematical content and cognitive demand. By considering these two dimensions for each item in the assessment, the framework ensures that NAEP assesses an appropriate balance of content, as well as a variety of ways of knowing and doing mathematics.

For grades 4 and 8, comparisons over time can be made among the assessments prior to and after the implementation of the 2005 framework. The changes to the grade 12 assessment were too drastic to allow the results to be directly compared with previous years. The changes to the grade 12 assessment included adding more questions on algebra, data analysis, and probability to reflect changes in high school mathematics standards and coursework, as well as the merging of the measurement and geometry content areas. The reporting scale for grade 12 mathematics was changed from $0-500$ to $0-300$. For more information regarding the 2005 mathematics framework revisions, see http://nces.ed.gov/ nationsreportcard/mathematics/frameworkcomparison.asp.

Reading assessments were administered in 2000, 2002, 2003, 2005, 2007, 2009, 2011, and 2013. In 2009, a new framework was developed for the 4th-, 8th-, and 12th-grade NAEP reading assessments.

Both a content alignment study and a reading trend or bridge study were conducted to determine if the "new" assessment was comparable to the "old" assessment. Overall, the results of the special analyses suggested that the old and new assessments were similar in terms of their item and scale characteristics and the results they produced for important demographic groups of students. Thus, it was determined that the results of the 2009 reading assessment could still be compared to those from earlier assessment years, thereby maintaining the trend lines first established in 1992. For more information regarding the 2009 reading framework revisions, see http://nces.ed.gov/nationsreportcard/reading/ whatmeasure.asp.

In spring 2013, NAEP released results from the NAEP 2012 economics assessment in The Nation's Report Card: Economics 2012 (NCES 2013-453). First administered in 2006, the NAEP economics assessment measures 12th-graders' understanding of a wide range of topics in three main content areas: market economy, national economy, and international economy. The 2012 assessment is based on a nationally representative sample of nearly 11,00012 th-graders. Comparing results from 2012 with results from 2006 can advance the inquiry of whether our nation's high school seniors are becoming more literate in economics.

In The Nation's Report Card: A First Look-2013 Mathematics and Reading (NCES 2014-451), NAEP released the results of the 2013 mathematics and reading assessments. Results can also be accessed using the interactive graphics and downloadable data available at the new online Nation's Report Card website (http://nationsreportcard.gov/reading math 2013/\#/).

In addition to conducting the main assessments, NAEP also conducts the long-term trend assessments and trial urban district assessments. Long-term trend assessments provide an opportunity to observe educational progress in reading and mathematics of 9-, 13-, and 17-year-olds since the early 1970s. The long-term trend reading assessment measures students' reading comprehension skills using an array of passages that vary by text types and length. The assessment was designed to measure students' ability to locate specific information in the text provided; make inferences across a passage to provide an explanation; and identify the main idea in the text.

The NAEP long-term trend assessment in mathematics measures knowledge of mathematical facts; ability to carry out computations using paper and pencil; knowledge of basic formulas, such as those applied in geometric settings; and ability to apply mathematics to skills of daily life, such as those involving time and money.

The Nation's Report Card: Trends in Academic Progress 2012 (NCES 2013-456) provides the results of 12 long-term trend reading assessments dating back to 1971 and 11 longterm trend mathematics assessments dating back to 1973 .

The NAEP Trial Urban District Assessment (TUDA) focuses attention on urban education and measures educational progress within participating large urban districts. TUDA mathematics and reading assessments are based on the same mathematics and reading assessments used to report national and state results. TUDA reading results were first reported for 6 urban districts in 2002, and TUDA mathematics results were first reported for 10 urban districts in 2003.

The Nation's Report Card: A First Look-2013 Mathematics and Reading Trial Urban District Assessment (NCES 2014-466) provides the results of the 2013 mathematics and reading TUDA, which measured the reading and mathematics progress of 4th- and 8th-graders from 21 urban school districts. Results from the 2013 mathematics and reading TUDA can also be accessed using the interactive graphics and downloadable data available at the online TUDA website (http:// nationsreportcard.gov/reading math tuda 2013/\#/).

Further information on NAEP may be obtained from

Arnold Goldstein

Assessments Division

Reporting and Dissemination Branch

National Center for Education Statistics

1990 K Street NW

Washington, DC 20006

arnold.goldstein@ed.gov

http://nces.ed.gov/nationsreportcard 


\section{National Education Longitudinal Study of 1988}

The National Education Longitudinal Study of 1988 (NELS:88) was the third major secondary school student longitudinal study conducted by NCES. The two studies that preceded NELS:88 - the National Longitudinal Study of the High School Class of 1972 (NLS:72) and the High School and Beyond Longitudinal Study (HS\&B) in 1980-surveyed high school seniors (and sophomores in HS\&B) through high school, postsecondary education, and work and family formation experiences. Unlike its predecessors, NELS:88 began with a cohort of 8 th-grade students. In 1988, some 25,000 8th-graders, their parents, their teachers, and their school principals were surveyed. Follow-ups were conducted in 1990 and 1992, when a majority of these students were in the 10th and 12th grades, respectively, and then 2 years after their scheduled high school graduation, in 1994. A fourth follow-up was conducted in 2000.

NELS:88 was designed to provide trend data about critical transitions experienced by young people as they develop, attend school, and embark on their careers. It complements and strengthens state and local efforts by furnishing new information on how school policies, teacher practices, and family involvement affect student educational outcomes (i.e., academic achievement, persistence in school, and participation in postsecondary education). For the base year, NELS:88 included a multifaceted student questionnaire, four cognitive tests, a parent questionnaire, a teacher questionnaire, and a school questionnaire.

In 1990, when most of the students were in 10th grade, students, school dropouts, their teachers, and their school principals were surveyed. (Parents were not surveyed in the 1990 follow-up.) In 1992, when most of the students were in 12th grade, the second follow-up conducted surveys of students, dropouts, parents, teachers, and school principals. Also, information from the students' transcripts was collected. The 1994 survey data were collected when most sample members had completed high school. The primary goals of the 1994 survey were (1) to provide data for trend comparisons with NLS:72 and HS\&B; (2) to address issues of employment and postsecondary access and choice; and (3) to ascertain how many dropouts had returned to school and by what route. The 2000 follow-up examined the educational and labor market outcomes of the 1988 cohort at a time of transition. Most had been out of high school 8 years; many had completed their postsecondary educations, were embarking on first or even second careers, and were starting families.

Further information on NELS:88 may be obtained from

Jeffrey Owings

Sample Surveys Division

Longitudinal Surveys Branch

National Center for Education Statistics

1990 K Street NW

Washington, DC 20006

jeffrey.owings@ed.gov

http://nces.ed.gov/surveys/nels88

\section{National Household Education Surveys Program}

The National Household Education Surveys Program (NHES) is a data collection system that is designed to address a wide range of education-related issues. Surveys have been conducted in 1991, 1993, 1995, 1996, 1999, 2001, 2003, 2005, 2007, and 2012. NHES targets specific populations for detailed data collection. It is intended to provide more detailed data on the topics and populations of interest than are collected through supplements to other household surveys.

The topics addressed by NHES:1991 were early childhood education and adult education. About 60,000 households were screened for NHES:1991. In the Early Childhood Education Survey, about 14,000 parents/guardians of 3- to 8-year-olds completed interviews about their children's early educational experiences. Included in this component were participation in nonparental care/education; care arrangements and school; and family, household, and child characteristics. In the NHES:1991 Adult Education Survey, about 9,800 people 16 years of age and older, identified as having participated in an adult education activity in the previous 12 months, were questioned about their activities. Data were collected on programs and up to four courses, including the subject matter, duration, sponsorship, purpose, and cost. Information on the household and the adult's background and current employment was also collected.

In NHES:1993, nearly 64,000 households were screened. Approximately 11,000 parents of 3- to 7-year-olds completed interviews for the School Readiness Survey. Topics included the developmental characteristics of preschoolers; school adjustment and teacher feedback to parents for kindergartners and primary students; center-based program participation; early school experiences; home activities with family members; and health status. In the School Safety and Discipline Survey, about 12,700 parents of children in grades 3 to 12 and about 6,500 youth in grades 6 to 12 were interviewed about their school experiences. Topics included the school learning environment, discipline policy, safety at school, victimization, the availability and use of alcohol/ drugs, and alcohol/drug education. Peer norms for behavior in school and substance use were also included in this topical component. Extensive family and household background information was collected, as well as characteristics of the school attended by the child.

In NHES:1995, the Early Childhood Program Participation Survey and the Adult Education Survey were similar to those fielded in 1991. In the Early Childhood component, about 14,000 parents of children from birth to third grade were interviewed out of 16,000 sampled, for a completion rate of 90.4 percent. In the Adult Education Survey, about 24,000 adults were sampled and 82.3 percent $(20,000)$ completed the interview.

NHES:1996 covered parent and family involvement in education and civic involvement. Data on homeschooling and school choice also were collected. The 1996 survey screened about 56,000 households. For the Parent and Fam- 
ily Involvement in Education Survey, nearly 21,000 parents of children in grades 3 to 12 were interviewed. For the Civic Involvement Survey, about 8,000 youth in grades 6 to 12 , about 9,000 parents, and about 2,000 adults were interviewed. The 1996 survey also addressed public library use. Adults in almost 55,000 households were interviewed to support state-level estimates of household public library use.

NHES:1999 collected end-of-decade estimates of key indicators from the surveys conducted throughout the 1990s. Approximately 60,000 households were screened for a total of about 31,000 interviews with parents of children from birth through grade 12 (including about 6,900 infants, toddlers, and preschoolers) and adults age 16 or older not enrolled in grade 12 or below. Key indicators included participation of children in nonparental care and early childhood programs, school experiences, parent/family involvement in education at home and at school, youth community service activities, plans for future education, and adult participation in educational activities and community service.

NHES:2001 included two surveys that were largely repeats of similar surveys included in earlier NHES collections. The Early Childhood Program Participation Survey was similar in content to the Early Childhood Program Participation Survey fielded as part of NHES:1995, and the Adult Education and Lifelong Learning Survey was similar in content to the Adult Education Survey of NHES:1995. The Before- and AfterSchool Programs and Activities Survey, while containing items fielded in earlier NHES collections, had a number of new items that collected information about what school-age children were doing during the time they spent in child care or in other activities, what parents were looking for in care arrangements and activities, and parent evaluations of care arrangements and activities. Parents of approximately 6,700 children from birth through age 6 who were not yet in kindergarten completed Early Childhood Program Participation Survey interviews. Nearly 10,900 adults completed Adult Education and Lifelong Learning Survey interviews, and parents of nearly 9,600 children in kindergarten through grade 8 completed Before- and After-School Programs and Activities Survey interviews.

NHES:2003 included two surveys: the Parent and Family Involvement in Education Survey and the Adult Education for Work-Related Reasons Survey (the first administration). Whereas previous adult education surveys were more general in scope, this survey had a narrower focus on occupationrelated adult education programs. It collected in-depth information about training and education in which adults participated specifically for work-related reasons, either to prepare for work or a career or to maintain or improve work-related skills and knowledge they already had. The Parent and Family Involvement Survey expanded on the first survey fielded on this topic in 1996. In 2003, screeners were completed with 32,050 households. About 12,700 of the 16,000 sampled adults completed the Adult Education for Work-Related Reasons Survey, for a weighted response rate of 76 percent. For the Parent and Family Involvement in Education Survey, interviews were completed by the parents of about 12,400 of the 14,900 sampled children in kindergarten through grade 12 , yielding a weighted unit response rate of 83 percent.

NHES:2005 included surveys that covered adult education, early childhood program participation, and after-school programs and activities. Data were collected from about 8,900 adults for the Adult Education Survey, from parents of about 7,200 children for the Early Childhood Program Participation Survey, and from parents of nearly 11,700 children for the After-School Programs and Activities Survey. These surveys were substantially similar to the surveys conducted in 2001, with the exceptions that the Adult Education Survey addressed a new topic - informal learning activities for personal interest-and the Early Childhood Program Participation Survey and After-School Programs and Activities Survey did not collect information about before-school care for school-age children.

NHES:2007 fielded the Parent and Family Involvement in Education Survey and the School Readiness Survey. These surveys were similar in design and content to surveys included in the 2003 and 1993 collections, respectively. New features added to the Parent and Family Involvement Survey were questions about supplemental education services provided by schools and school districts (including use of and satisfaction with such services), as well as questions that would efficiently identify the school attended by the sampled students. New features added to the School Readiness Survey were questions that collected details about TV programs watched by the sampled children. For the Parent and Family Involvement Survey, interviews were completed with parents of 10,680 sampled children in kindergarten through grade 12 , including 10,370 students enrolled in public or private schools and 310 homeschooled children. For the School Readiness Survey, interviews were completed with parents of 2,630 sampled children ages 3 to 6 and not yet in kindergarten. Parents who were interviewed about children in kindergarten through second grade for the Parent and Family Involvement Survey were also asked some questions about these children's school readiness.

There was a 5-year gap in data collection between 2007 and 2012, when NHES switched from a telephone survey to a mail survey.

Data collection for NHES:2012 was completed in summer 2012. Data for the 2012 NHES Parent and Family Involvement in Education Survey (PFI) are available in the First Look report, Parent and Family Involvement in Education, From the National Household Education Surveys Program of 2012 (NCES 2013-028).

Further information on NHES may be obtained from

Andrew Zukerberg
Gail Mulligan
Sample Surveys Division
National Center for Education Statistics
1990 K Street NW
Washington, DC 20006
andrew.zukerberg@ed.gov
gail.mulligan@ed.gov
http://nces.ed.gov/nhes

Andrew Zukerberg

Sample Surveys Division

National Center for Education Statistics

1990 K Street NW

Washington, DC 20006

gail.mulligan@ed.gov

http://nces.ed.gov/nhes 


\section{National Longitudinal Study of the High School Class of 1972}

The National Longitudinal Study of the High School Class of 1972 (NLS:72) began with the collection of baseyear survey data from a sample of about 19,000 high school seniors in the spring of 1972. Five follow-up surveys of these students were conducted in 1973, 1974, 1976, 1979, and 1986. NLS:72 was designed to provide the education community with information on the transitions of young adults from high school through postsecondary education and the workplace.

In addition to the follow-ups, a number of supplemental data collection efforts were made. For example, a Postsecondary Education Transcript Study (PETS) was conducted in 1984; in 1986, the fifth follow-up included a supplement for those who became teachers.

The sample design for NLS:72 was a stratified, two-stage probability sample of 12th-grade students from all schools, public and private, in the 50 states and the District of Columbia during the 1971-72 school year. During the first stage of sampling, about 1,070 schools were selected for participation in the base-year survey. As many as 18 students were selected at random from each of the sample schools. The sizes of both the school and student samples were increased during the first follow-up survey. Beginning with the first follow-up and continuing through the fourth follow-up, about 1,300 schools participated in the survey and slightly fewer than 23,500 students were sampled. The unweighted response rates for each of the different rounds of data collection were 80 percent or higher.

Sample retention rates across the survey years were quite high. For example, of the individuals responding to the baseyear questionnaire, the percentages who responded to the first, second, third, and fourth follow-up questionnaires were about 94, 93, 89, and 83 percent, respectively. The fifth follow-up took its sample from students who had participated in at least one of the prior surveys. In all, 91.7 percent of participants had responded to at least five of the six surveys, and 62.1 percent had responded to all six.

Further information on NLS:72 may be obtained from

Aurora D’Amico
Sample Surveys Division
Longitudinal Surveys Branch
National Center for Education Statistics
1990 K Street NW
Washington, DC 20006
aurora.damico@ed.gov
http://nces.ed.gov/surveys/nls72

\section{National Postsecondary Student Aid Study}

The National Postsecondary Student Aid Study (NPSAS) is a comprehensive nationwide study of how students and their families pay for postsecondary education. Data gathered from the study are used to help guide future federal student financial aid policy. The study covers nationally representative samples of undergraduates, graduates, and first-professional students in the 50 states, the District of Columbia, and Puerto Rico, including students attending less-than-2-year institutions, community colleges, 4-year colleges, and universities. Participants include students who do not receive aid and those who do receive financial aid. Since NPSAS identifies nationally representative samples of student subpopulations of interest to policymakers and obtains baseline data for longitudinal study of these subpopulations, data from the study provide the base-year sample for the Beginning Postsecondary Students (BPS) longitudinal study and the Baccalaureate and Beyond (B\&B) longitudinal study.

Originally, NPSAS was conducted every 3 years. Beginning with the 1999-2000 study (NPSAS:2000), NPSAS has been conducted every 4 years. NPSAS:08 included a new set of instrument items to obtain baseline measures of the awareness of two new federal grants introduced in 2006: the Academic Competitiveness Grant (ACG) and the National Science and Mathematics Access to Retain Talent (SMART) grant.

The first NPSAS (NPSAS:87) was conducted during the 1986-87 school year. Data were gathered from about 1,100 colleges, universities, and other postsecondary institutions; 60,000 students; and 14,000 parents. These data provided information on the cost of postsecondary education, the distribution of financial aid, and the characteristics of both aided and nonaided students and their families.

For NPSAS:93, information on 77,000 undergraduates and graduate students enrolled during the school year was collected at 1,000 postsecondary institutions. The sample included students who were enrolled at any time between July 1, 1992, and June 30, 1993. About 66,000 students and a subsample of their parents were interviewed by telephone. NPSAS:96 contained information on more than 48,000 undergraduate and graduate students from about 1,000 postsecondary institutions who were enrolled at any time during the 1995-96 school year. NPSAS:2000 included nearly 62,000 students (50,000 undergraduates and almost 12,000 graduate students) from 1,000 postsecondary institutions. NPSAS:04 collected data on about 80,000 undergraduates and 11,000 graduate students from 1,400 postsecondary institutions. For NPSAS:08, about 114,000 undergraduate students and 14,000 graduate students who were enrolled in postsecondary education during the 2007-08 school year were selected from more than 1,730 postsecondary institutions.

NPSAS:12 sampled about 95,000 undergraduates and 16,000 graduate students from approximately 1,500 postsecondary institutions. Public access to the data is available online through PowerStats (http://nces.ed.gov/datalab/). The next cycle of NPSAS is scheduled for the 2015-16 school year. 
Further information on NPSAS may be obtained from

Aurora D'Amico

Tracy Hunt-White

Sample Surveys Division

Longitudinal Surveys Branch

National Center for Education Statistics

1990 K Street NW

Washington, DC 20006

aurora.damico@ed.gov

tracy.hunt-white@ed.gov

http://nces.ed.gov/npsas

\section{National Study of Postsecondary Faculty}

The National Study of Postsecondary Faculty (NSOPF) was designed to provide data about faculty to postsecondary researchers, planners, and policymakers. NSOPF is the most comprehensive study of faculty in postsecondary education institutions ever undertaken.

The first cycle of NSOPF (NSOPF:88) was conducted by NCES with support from the National Endowment for the Humanities (NEH) in 1987-88 with a sample of 480 colleges and universities, over 3,000 department chairpersons, and over 11,000 instructional faculty. The second cycle of NSOPF (NSOPF:93) was conducted by NCES with support from NEH and the National Science Foundation in 1992-93. NSOPF:93 was limited to surveys of institutions and faculty, but with a substantially expanded sample of 970 colleges and universities and 31,350 faculty and instructional staff. The third cycle, NSPOF:99, included 960 degree-granting postsecondary institutions and approximately 18,000 faculty and instructional staff. The fourth cycle of NSOPF was conducted in 2003-04 and included 1,080 degree-granting postsecondary institutions and approximately 26,000 faculty and instructional staff.

There are no plans to repeat the study. Rather, NCES plans to provide technical assistance to state postsecondary data systems and to encourage the development of robust connections between faculty and student data systems so that key questions concerning faculty, instruction, and student outcomes - such as persistence and completion-can be addressed.

Further information on NSOPF may be obtained from

Aurora D'Amico

Sample Surveys Division

Longitudinal Surveys Branch

National Center for Education Statistics

1990 K Street NW

Washington, DC 20006

aurora.damico@ed.gov

http://nces.ed.gov/surveys/nsopf

\section{Private School Universe Survey}

The purposes of the Private School Universe Survey (PSS) data collection activities are (1) to build an accurate and complete list of private schools to serve as a sampling frame for NCES sample surveys of private schools and (2) to report data on the total number of private schools, teachers, and students in the survey universe. Begun in 1989 under the U.S. Census Bureau, the PSS has been conducted every 2 years, and data for the 1989-90, 1991-92, 1993-94, 1995-96, 1997-98, 1999-2000, 2001-02, 2003-04, 2005-06, 2007-08, and 2009-10 school years have been released. A First Look report of the 2011-12 PSS data, Characteristics of Private Schools in the United States: Results From the 2011-12 Private School Universe Survey (NCES 2013-316) was published in July 2013.

The PSS produces data similar to that of the CCD for public schools, and can be used for public-private comparisons. The data are useful for a variety of policy- and research-relevant issues, such as the growth of religiously affiliated schools, the number of private high school graduates, the length of the school year for various private schools, and the number of private school students and teachers.

The target population for this universe survey is all private schools in the United States that meet the PSS criteria of a private school (i.e., the private school is an institution that provides instruction for any of grades $\mathrm{K}$ through 12 , has one or more teachers to give instruction, is not administered by a public agency, and is not operated in a private home).

The survey universe is composed of schools identified from a variety of sources. The main source is a list frame initially developed for the 1989-90 PSS. The list is updated regularly by matching it with lists provided by nationwide private school associations, state departments of education, and other national guides and sources that list private schools. The other source is an area frame search in approximately 124 geographic areas, conducted by the U.S. Census Bureau.

Of the 40,302 schools included in the 2009-10 sample, 10,229 were found ineligible for the survey. Those not responding numbered 1,856, and those responding numbered 28,217. The unweighted response rate for the 2009-10 PSS survey was 93.8 percent.

Of the 39,325 schools included in the 2011-12 sample, 10,030 cases were considered as out-of-scope (not eligible for the PSS). A total of 26,983 private schools completed a PSS interview (15.8 percent completed online), while 2,312 schools refused to participate, resulting in an unweighted response rate of 92.1 percent.

Further information on the PSS may be obtained from

Steve Broughman

Sample Surveys Division

Cross-Sectional Surveys Branch

National Center for Education Statistics

1990 K Street NW

Washington, DC 20006

stephen.broughman@ed.gov

http://nces.ed.gov/surveys/pss 


\section{Projections of Education Statistics}

Since 1964, NCES has published projections of key statistics for elementary and secondary schools and institutions of higher education. The latest report is titled Projections of Education Statistics to 2022 (NCES 2014-051). These projections include statistics for enrollments, instructional staff, graduates, earned degrees, and expenditures. The reports include a methodology section describing the techniques and assumptions used to prepare them.

Differences between the reported and projected values are, of course, almost inevitable. An evaluation of past projections revealed that, at the elementary and secondary level, projections of enrollments have been quite accurate: mean absolute percentage differences for enrollment ranged from 0.3 to 1.3 percent for projections from 1 to 5 years in the future, while those for teachers were less than 3 percent. At the higher education level, projections of enrollment have been fairly accurate: mean absolute percentage differences were 5 percent or less for projections from 1 to 5 years into the future.

Further information on Projections of Education Statistics may be obtained from

\author{
William Hussar \\ Annual Reports and Information \\ National Center for Education Statistics \\ 1990 K Street NW \\ Washington, DC 20006 \\ william.hussar@ed.gov \\ http://nces.ed.gov/annuals
}

\section{Recent College Graduates Study}

Between 1976 and 1991, NCES conducted periodic surveys of baccalaureate and master's degree recipients 1 year after graduation with the Recent College Graduates (RCG) Study. The RCG Study — which has been replaced by the Baccalaureate and Beyond Longitudinal Study (B\&B) (see listing above) — concentrated on those graduates entering the teaching profession. The study linked respondents' major field of study with outcomes such as whether the respondent entered the labor force or was seeking additional education. Labor force data collected included employment status (unemployed, employed part time, or employed full time), occupation, salary, career potential, relation to major field of study, and need for a college degree. To obtain accurate results on teachers, graduates with a major in education were oversampled. The last two studies oversampled education majors and increased the sampling of graduates with majors in other fields.

For each of the selected institutions, a list of graduates by major field of study was obtained, and a sample of graduates was drawn by major field of study. Graduates in certain major fields of study (e.g., education, mathematics, and physical sciences) were sampled at higher rates than were graduates in other fields. Roughly 1 year after graduation, the sample of graduates was located, contacted by mail or telephone, and asked to respond to the questionnaire.
The locating process was more detailed than that in most surveys. Nonresponse rates were directly related to the time, effort, and resources used in locating graduates, rather than to graduates' refusals to participate. Despite the difficulties in locating graduates, RCG response rates are comparable to studies that do not face problems locating their sample membership.

The 1976 study of 1974-75 college graduates was the first, and smallest, of the series. The sample consisted of about 210 institutions, of which 200 (96 percent) responded. Of the approximately 5,850 graduates in the sample, 4,350 responded, for a response rate of 79 percent.

The 1981 study was somewhat larger than the 1976 study, covering about 300 institutions and 15,850 graduates. Responses were obtained from 280 institutions, for an institutional response rate of 95 percent, and from 9,310 graduates (about 720 others were found not to meet eligibility requirements), for a response rate of 74 percent.

The 1985 study sampled about 400 colleges and 18,740 graduates, of whom 17,850 were found to be eligible. Responses were obtained from 13,200 graduates, for a response rate of 78 percent. The response rate for colleges was 98 percent. The 1987 study sampled 21,960 graduates. Responses were received from 16,880 , for a response rate of nearly 80 percent.

The 1991 study sampled about 18,140 graduates of 400 bachelor's and master's degree-granting institutions, including 16,170 bachelor's degree recipients and 1,960 master's degree recipients receiving diplomas between July 1, 1989, and June 30, 1990. Random samples of graduates were selected from lists stratified by field of study. Graduates in education, mathematics, and the physical sciences were sampled at a higher rate, as were graduates of various racial/ethnic groups, to provide a sufficient number of these graduates for analysis purposes. The graduates included in the sample were selected in proportion to the institution's number of graduates. The unweighted institutional response rate was 95 percent, and the unweighted graduate response rate was 83 percent.

Further information on the RCG Study may be obtained from

Aurora D'Amico

Sample Surveys Division

Longitudinal Surveys Branch

National Center for Education Statistics

1990 K Street NW

Washington, DC 20006

aurora.damico@ed.gov

http://nces.ed.gov/surveys/b\&b

\section{School Survey on Crime and Safety}

The most recent School Survey on Crime and Safety (SSOCS) for which data are available was conducted by NCES in spring/summer of the 2009-10 school year. SSOCS focuses on incidents of specific crimes/offenses and a variety of specific discipline issues in public schools. It also covers characteristics of school policies, school violence prevention programs and policies, and school characteristics that have 
been associated with school crime. The survey was conducted with a nationally representative sample of regular public elementary, middle, and high schools in the 50 states and the District of Columbia. Special education, alternative, and vocational schools; schools in the other jurisdictions; and schools that taught only prekindergarten, kindergarten, or adult education were not included in the sample.

The sampling frame for the 2010 SSOCS was constructed from the 2007-08 Public Elementary/Secondary School Universe File of the Common Core of Data (CCD), an annual collection of data on all public $\mathrm{K}-12$ schools and school districts. The sample was stratified by instructional level, type of locale (urbanicity), and enrollment size. The sample of schools in each instructional level was allocated to each of the 16 cells formed by the cross-classification of the four categories of enrollment size and four types of locale. The sample was allocated to each subgroup in proportion to the sum of the square roots of the total student enrollment in each school in that stratum. The effective sample size within each stratum was then inflated to account for nonresponse. Once the final sample sizes were determined for each of the 64 strata, the subgroups were sorted by region and racial/ethnic composition of enrollment, and an initial sample of 3,476 schools was selected. Of those schools, 2,648 completed the survey. In February 2010, questionnaires were mailed to school principals, who were asked to complete the survey or to have it completed by the person at the school most knowledgeable about discipline issues.

Further information about SSOCS may be obtained from

Kathryn Chandler

Sample Surveys Division

Cross-Sectional Surveys Branch

National Center for Education Statistics

1990 K Street NW

Washington, DC 20006

kathryn.chandler@ed.gov

http://nces.ed.gov/surveys/ssocs

\section{Schools and Staffing Survey}

The Schools and Staffing Survey (SASS) is a set of related questionnaires that collect descriptive data on the context of public and private elementary and secondary education. Data reported by districts, schools, principals, and teachers provide a variety of statistics on the condition of education in the United States that may be used by policymakers and the general public. The SASS system covers a wide range of topics, including teacher demand, teacher and principal characteristics, teachers' and principals' perceptions of school climate and problems in their schools, teacher and principal compensation, district hiring and retention practices, general conditions in schools, and basic characteristics of the student population.

SASS data are collected through a mail questionnaire with telephone and in-person field follow-up. SASS has been conducted by the Census Bureau for NCES since the first administration of the survey, which was conducted during the 1987-88 school year. Subsequent SASS administrations were conducted in 1990-91, 1993-94, 1999-2000, 2003-04, 2007-08, and 2011-12.

SASS is designed to produce national, regional, and state estimates for public elementary and secondary schools, school districts, principals, teachers, and school library media centers and national and regional estimates for public charter schools, as well as principals, teachers, and school library media centers within these schools. For private schools, the sample supports national, regional, and affiliation estimates for schools, principals, and teachers.

From its inception, SASS has had four core components: school questionnaires, teacher questionnaires, principal questionnaires, and school district (prior to 1999-2000, "teacher demand and shortage") questionnaires. A fifth component, school library media center questionnaires, was introduced in the 1993-94 administration and has been included in every subsequent administration of SASS. School library data were also collected in the 1990-91 administration of the survey through the school and principal questionnaires.

School questionnaires used in SASS include the Public and Private School Questionnaires; teacher questionnaires include the Public and Private School Teacher Questionnaires; principal questionnaires include the Public and Private School Principal (or School Administrator) Questionnaires; and school district questionnaires include the School District (or Teacher Demand and Shortage) Questionnaires.

Although the four core questionnaires and the school library media questionnaires have remained relatively stable over the various administrations of SASS, the survey has changed to accommodate emerging issues in elementary and secondary education. Some items have been added, some have been deleted, and some questionnaire items have been reworded.

During the 1990-91 SASS cycle, NCES worked with the Office of Indian Education to add an Indian School Questionnaire to SASS, and it remained a part of SASS through 2007-08. The Indian School Questionnaire explores the same school-level issues that the Public and Private School Questionnaires explore, allowing comparisons among the three types of schools. The 1990-91, 1993-94, 1999-2000, 2003-04, and 2007-08 administrations of SASS obtained data on Bureau of Indian Education (BIE) schools (schools funded or operated by the BIE), but the 2011-12 administration did not obtain BIE data. SASS estimates for all survey years presented in this report exclude BIE schools, and as a result, estimates in this report may differ from those in previously published reports.

School library media center questionnaires were administered in public, private, and BIE schools as part of the 1993-1994 and 1999-2000 SASS. During the 2003-04 administration of SASS, only library media centers in public schools were surveyed, and in 2007-08 only library media centers in public schools and BIE and BIE-funded schools were surveyed. The 2011-12 survey collected data only on 
school library media centers in traditional public schools and in public charter schools. School library questions focused on facilities, services and policies, staffing, technology, information literacy, collections and expenditures, and media equipment. New or revised topics included access to online licensed databases, resource availability, and additional elements on information literacy. The Student Records and Library Media Specialist/Librarian Questionnaires were administered only in 1993-94.

As part of the 1999-2000 SASS, the Charter School Questionnaire was sent to the universe of charter schools in operation in 1998-99. In 2003-04 and in subsequent administrations of SASS, there was no separate questionnaire for charter schools - charter schools were included in the public school sample instead. Another change in the 2003-04 administration of SASS was a revised data collection procedure using a primary in-person contact within the school intended to reduce the field follow-up phase.

The SASS teacher surveys collect information on the characteristics of teachers, such as their age, race/ethnicity, years of teaching experience, average number of hours per week spent on teaching activities, base salary, average class size, and highest degree earned. These teacher-reported data may be combined with related information on their school's characteristics, such as school type (e.g., public traditional, public charter, Catholic, private other religious, and private nonsectarian), community type, and school enrollment size. The teacher questionnaires also ask for information on teacher opinions regarding the school and teaching environment. In 1993-94, about 53,000 public school teachers and 10,400 private school teachers were sampled. In 1999-2000, about 56,300 public school teachers, 4,400 public charter school teachers, and 10,800 private school teachers were sampled. In 2003-04, about 52,500 public school teachers and 10,000 private school teachers were sampled. In 2007-08, about 48,400 public school teachers and 8,200 private school teachers were sampled. In 2011-12, about 51,100 public school teachers and 7,100 private school teachers were sampled. Weighted overall response rates in 2011-12 were 61.8 percent for public school teachers and 50.1 percent for private school teachers.

The SASS principal surveys focus on such topics as age, race/ethnicity, sex, average annual salary, years of experience, highest degree attained, perceived influence on decisions made at the school, and hours spent per week on all school activities. These data on principals can be placed in the context of other SASS data, such as the type of the principal's school (e.g., public traditional, public charter, Catholic, other religious, or nonsectarian), enrollment, and percentage of students eligible for free or reduced price lunch. In 2003-04, about 10,200 public school principals were sampled, and in 2007-08, about 9,800 public school principals were sampled. In 2011-12, about 11,000 public school principals and 3,000 private school principals were sampled. Weighted response rates in 2011-12 for public school principals and private school principals were 72.7 percent and 64.7 percent, respectively.

The SASS 2011-12 sample of schools was confined to the 50 states and the District of Columbia and excludes the other jurisdictions, the Department of Defense overseas schools, the BIE schools, and schools that do not offer teacher-provided classroom instruction in grades 1-12 or the ungraded equivalent. The SASS 2011-12 sample included 10,250 traditional public schools, 750 public charter schools, and 3,000 private schools.

The public school sample for the 2011-12 SASS was based on an adjusted public school universe file from the 2009-10 Common Core of Data (CCD), a database of all the nation's public school districts and public schools. The private school sample for the 2011-12 SASS was selected from the 2009-10 Private School Universe Survey (PSS), as updated for the 2011-12 PSS. This update collected membership lists from private school associations and religious denominations, as well as private school lists from state education departments. The 2011-12 SASS private school frame was further augmented by the inclusion of additional schools that were identified through the 2009-10 PSS area frame data collection.

Additional resources available regarding SASS include the methodology report Quality Profile for SASS, Rounds 1-3: 1987-1995, Aspects of the Quality of Data in the Schools and Staffing Surveys (SASS) (NCES 2000-308), as well as these reports: Survey Documentation for the 2011-12 Schools and Staffing Survey (Chambers et al. forthcoming) and User's Manual for the 2011-12 Schools and Staffing Survey, Volumes 1-6 (Goldring et al. 2013) (NCES 2013-330 through 2013-335).

Further information on SASS may be obtained from

Kathryn Chandler

Sample Surveys Division

Cross-Sectional Surveys Branch

National Center for Education Statistics

1990 K Street NW

Washington, DC 20006

kathryn.chandler@ed.gov

http://nces.ed.gov/surveys/sass

\section{Teacher Follow-up Survey}

The Teacher Follow-up Survey (TFS) is a SASS survey whose purpose is to determine how many teachers remain at the same school, move to another school, or leave the profession in the year following a SASS administration. It is administered to elementary and secondary teachers in the 50 states and the District of Columbia. The TFS uses two questionnaires, one for teachers who left teaching since the previous SASS administration and another for those who are still teaching either in the same school as last year or in a different school. The objective of the TFS is to focus on the characteristics of each group in order to answer questions about teacher mobility and attrition. 
The 2008-09 TFS is different from any previous TFS administration in that it also serves as the second wave of a longitudinal study of first-year teachers. Because of this, the 2008-09 TFS consists of four questionnaires. Two are for respondents who were first-year public school teachers in the 2007-08 SASS and two are for the remainder of the sample.

Further information on the TFS may be obtained from

\author{
Chelsea Hickey \\ Sample Surveys Division \\ Cross-Sectional Surveys Branch \\ National Center for Education Statistics \\ 1990 K Street NW \\ Washington, DC 20006 \\ chelsea.hickey@ed.gov \\ http://nces.ed.gov/surveys/sass
}

\section{Other Department of Education Agencies}

\section{National Center for Special Education Research (NCSER)}

The National Center for Special Education Research (NCSER) was created as part of the reauthorization of the Individuals with Disabilities Education Act (IDEA). NCSER sponsors a program of special education research designed to expand the knowledge and understanding of infants, toddlers, and children with disabilities. NCSER funds programs of research that address its mission. In order to determine which programs work, as well as how, why, and in what settings, NCSER sponsors research on the needs of infants, toddlers, and children with disabilities and evaluates the effectiveness of services provided through IDEA.

Further information on NCSER may be obtained from

Joan McLaughlin

Commissioner

National Center for Special Education Research

555 New Jersey Avenue NW

Washington, DC 20208

joan.mclaughlin@ed.gov

http://ies.ed.gov/ncser/help/webmail

\section{The National Longitudinal Transition Study-2}

The National Longitudinal Transition Study-2 (NLTS-2) is a follow-up of the original National Longitudinal Transition Study conducted from 1985 through 1993. NLTS-2 began in 2001 with a sample of special education students who were ages 13 through 16 and in at least 7 th grade on December 1, 2000. The study was designed to provide a national picture of these youths' experiences and achievements as they transition into adulthood. Data were collected from parents, youth, and schools by survey, telephone interviews, student assessments, and transcripts.
NLTS-2 was designed to align with the original NLTS by including many of the same questions and data items, thus allowing comparisons between the NLTS and NLTS-2 youths' experiences. NLTS-2 also included items that have been collected in other national databases to permit comparisons between NLTS-2 youth and the general youth population. Data are currently available for Waves 1 through 5.

Further information on NLTS-2 may be obtained from

Jacquelyn Buckley

Office of the Commissioner

National Center for Special Education Research

555 New Jersey Avenue NW

Washington, DC 20208

jacquelyn.buckley@ed.gov

http://www.nlts2.org/

\section{Office for Civil Rights}

\section{Civil Rights Data Collection}

The U.S. Department of Education's Office for Civil Rights (OCR) has surveyed the nation's public elementary and secondary schools since 1968. The survey was first known as the OCR Elementary and Secondary School (E\&S) Survey; in 2004, it was renamed the Civil Rights Data Collection (CRDC). The survey provides information about the enrollment of students in public schools in every state and about some education services provided to those students. These data are reported by race/ethnicity, sex, and disability.

Data in the survey are collected pursuant to 34 C.F.R. Section 100.6(b) of the Department of Education regulation implementing Title VI of the Civil Rights Act of 1964. The requirements are also incorporated by reference in Department regulations implementing Title IX of the Education Amendments of 1972, Section 504 of the Rehabilitation Act of 1973, and the Age Discrimination Act of 1975. School, district, state, and national data are currently available. Data from individual public schools and districts are used to generate projected national and state data.

The CRDC has generally been conducted biennially in each of the 50 states plus the District of Columbia. The 2009-10 CRDC was collected from a sample of approximately 7,000 school districts and over 72,000 schools in those districts. It was made up of two parts: part 1 contained beginning-of-year "snapshot" data and part 2 contained cumulative, or end-of-year, data.

The 2011-12 CRDC survey, which collected data from approximately 16,500 school districts, 97,000 schools, and 49 million students, was the first CRDC survey since 2000 that included data from every public school district and school in the nation. Data from the 2011-12 CRDC are currently available. The 2013-14 CRDC survey will also collect information from a universe of every public school district and school in the nation.

Data marked with an exclamation point (!) have a nonresponse rate of more than 30 percent. Numbers should be used 
with caution due to large statistical uncertainty in the estimate. The methodology for flagging "large statistical uncertainties" is based on a standard error for each projected item.

Further information on the Civil Rights Data Collection may be obtained from

Mary Schifferli

Office for Civil Rights

U.S. Department of Education

400 Maryland Avenue SW

Washington, DC 20202

mary.schifferli@ed.gov

http://www.ed.gov/about/offices/list/ocr/data.html

\section{Office of Special Education Programs}

\section{Annual Report to Congress on the Implementation of the Individuals with Disabilities Education Act}

The Individuals with Disabilities Education Act (IDEA) is a law ensuring services to children with disabilities throughout the nation. IDEA governs how states and public agencies provide early intervention, special education, and related services to more than 6.5 million eligible infants, toddlers, children, and youth with disabilities.

The Individuals with Disabilities Education Act (IDEA), formerly the Education of the Handicapped Act (EHA), requires the Secretary of Education to transmit to Congress annually a report describing the progress made in serving the nation's children with disabilities. This annual report contains information on children served by public schools under the provisions of Part B of IDEA and on children served in state-operated programs for persons with disabilities under Chapter I of the Elementary and Secondary Education Act.

Statistics on children receiving special education and related services in various settings and school personnel providing such services are reported in an annual submission of data to the Office of Special Education Programs (OSEP) by the 50 states, the District of Columbia, and the outlying areas. The child count information is based on the number of children with disabilities receiving special education and related services on December 1 of each year. Count information is available from http://www.ideadata.org.

Since each participant in programs for persons with disabilities is reported to OSEP, the data are not subject to sampling error. However, nonsampling error can arise from a variety of sources. Some states follow a noncategorical approach to the delivery of special education services, but produce counts of students by disabling condition because Part B of the EHA requires it. In those states that do categorize their students with disabilities, definitions and labeling practices vary.
Further information on this annual report to Congress may be obtained from

Office of Special Education Programs

Office of Special Education and Rehabilitative Services

U.S. Department of Education

400 Maryland Avenue SW

Washington, DC 20202-7100

http://www.ed.gov/about/reports/annual/osep/index.html

http://idea.ed.gov/

http://www.ideadata.org

\section{Office of Career, Technical, and Adult Education, Division of Adult Education and Literacy}

\section{Enrollment Data for State-Administered Adult Education Programs}

The Division of Adult Education and Literacy (DAEL) promotes programs that help American adults get the basic skills they need to be productive workers, family members, and citizens. The major areas of support are Adult Basic Education, Adult Secondary Education, and English Language Acquisition. These programs emphasize basic skills such as reading, writing, math, English language competency, and problem solving. Each year, DAEL reports enrollment numbers in state-administered adult education programs for these major areas of support for all 50 states, the District of Columbia, and the eight U.S. jurisdictions (American Samoa, the Federated States of Micronesia, Guam, the Marshall Islands, the Northern Marianas, Palau, Puerto Rico, and the U.S. Virgin Islands).

Further information on DAEL may be obtained from

Office of Career, Technical, and Adult Education

Division of Adult Education and Literacy

U.S. Department of Education

400 Maryland Avenue SW

Washington, DC 20202

http://www.ed.gov/about/offices/list/ovae/pi/AdultEd/

\section{Other Governmental Agencies}

\section{Bureau of Economic Analysis}

\section{National Income and Product Accounts (NIPAs)}

The National Income and Product Accounts (NIPAs), produced by the Bureau of Economic Analysis, represent measures of economic activity in the United States, including production, income distribution, and personal savings. NIPAs also include data on employee compensation and wages. These estimations were first calculated in the early 1930s to help the government design economic policies to combat the Great Depression. Most of the NIPA series are published quarterly, with annual reviews of estimates from the three most recent years conducted in the summer. 
Revisions to the NIPAs have been made over the years to create a more comprehensive economic picture of the United States. For example, in 1976, consumption of fixed capital (CFC) estimates shifted to a current-cost basis. In 1991, NIPAs began to use gross domestic product (GDP), instead of gross national product (GNP), as the primary measure of U.S. production. (At that time, virtually all other countries were already using GDP as their primary measure of production.) In the 2003 comprehensive revision, a more complete and accurate measure of insurance services was adopted. The incorporation of a new classification system for personal consumption expenditures (PCE) was among the changes contained in the 2009 comprehensive revision. The comprehensive revision of 2013 included the treatment of research and development expenditures by business, government, and nonprofit institutions serving households as fixed investment.

NIPA is slowly being integrated with other federal account systems, such as the federal account system of the Bureau of Labor Statistics.

Further information on NIPAs may be obtained from

U.S. Department of Commerce

Bureau of Economic Analysis

www.bea.gov

\section{Bureau of Labor Statistics}

\section{Consumer Price Indexes}

The Consumer Price Index (CPI) represents changes in prices of all goods and services purchased for consumption by urban households. Indexes are available for two population groups: a CPI for All Urban Consumers (CPI-U) and a CPI for Urban Wage Earners and Clerical Workers (CPI-W). Unless otherwise specified, data are adjusted for inflation using the CPI-U. These values are generally adjusted to a school-year basis by averaging the July through June figures. Price indexes are available for the United States, the four Census regions, size of city, cross-classifications of regions and size classes, and 26 local areas. The major uses of the CPI include as an economic indicator, as a deflator of other economic series, and as a means of adjusting income.

Also available is the Consumer Price Index research series using current methods (CPI-U-RS), which presents an estimate of the CPI-U from 1978 to the present that incorporates most of the improvements that the Bureau of Labor Statistics has made over that time span into the entire series. The historical price index series of the CPI-U does not reflect these changes, though these changes do make the present and future CPI more accurate. The limitations of the CPI-U-RS include considerable uncertainty surrounding the magnitude of the adjustments and the several improvements in the CPI that have not been incorporated into the CPI-URS for various reasons. Nonetheless, the CPI-U-RS can serve as a valuable proxy for researchers needing a historical estimate of inflation using current methods. This series has not been used in NCES tables.
Further information on consumer price indexes may be obtained from

Bureau of Labor Statistics

U.S. Department of Labor

2 Massachusetts Avenue NE

Washington, DC 20212

http://www.bls.gov/cpi

\section{Employment and Unemployment Surveys}

Statistics on the employment and unemployment status of the population and related data are compiled by the Bureau of Labor Statistics (BLS) using data from the Current Population Survey (CPS) (see below) and other surveys. The Current Population Survey, a monthly household survey conducted by the U.S. Census Bureau for the Bureau of Labor Statistics, provides a comprehensive body of information on the employment and unemployment experience of the nation's population, classified by age, sex, race, and various other characteristics.

Further information on unemployment surveys may be obtained from

Bureau of Labor Statistics

U.S. Department of Labor

2 Massachusetts Avenue NE

Washington, DC 20212

cpsinfo@bls.gov

http://www.bls.gov/bls/employment.htm

\section{Census Bureau}

\section{American Community Survey (ACS)}

The Census Bureau introduced the American Community Survey (ACS) in 1996. Fully implemented in 2005, it provides a large monthly sample of demographic, socioeconomic, and housing data comparable in content to the Long Forms of the Decennial Census up to and including the 2000 long form. Aggregated over time, these data serve as a replacement for the Long Form of the Decennial Census. The survey includes questions mandated by federal law, federal regulations, and court decisions.

Since 2011, the survey has been mailed to approximately 295,000 addresses in the United States and Puerto Rico each month, or about 3.5 million addresses annually. A larger proportion of addresses in small governmental units (e.g., American Indian reservations, small counties, and towns) also receive the survey. The monthly sample size is designed to approximate the ratio used in the 2000 Census, which requires more intensive distribution in these areas. The ACS covers the U.S. resident population, which includes the entire civilian, noninstitutionalized population; incarcerated persons; institutionalized persons; and the active duty military who are in the United States. In 2006, the ACS began interviewing residents in group quarter facilities. Institutionalized group quarters include adult and juvenile correctional 
facilities, nursing facilities, and other health care facilities. Noninstitutionalized group quarters include college and university housing, military barracks, and other noninstitutional facilities such as workers and religious group quarters and temporary shelters for the homeless.

National-level data from the ACS are available from 2000 onward. The ACS produces 1-year estimates for jurisdictions with populations of 65,000 and over, 3-year estimates for jurisdictions with populations of 20,000 or over, and 5-year estimates for jurisdictions with smaller populations. To illustrate, the 2012 ACS 1-year estimates represented data collected between January 1, 2012, and December 31, 2012; the 2010-12 ACS 3-year estimates represented data collected between January 1, 2010, and December 31, 2012; and the 2008-12 ACS 5-year estimates represented data collected between January 1, 2008, and December 31, 2012.

Further information about the ACS is available at http:// www.census.gov/acs/www/.

\section{Annual Survey of State and Local Government Finances}

The Census Bureau conducts an Annual Survey of State and Local Government Finances as authorized by law under Title 13, United States Code, Section 182. Periodic surveys of government finances have been conducted since 1902 and annually since 1952. This survey covers the entire range of government finance activities: revenue, expenditure, debt, and assets. Revenues and expenditures comprise actual receipts and payments of a government and its agencies, including government-operated enterprises, utilities, and public trust funds. The expenditure-reporting categories comprise all amounts of money paid out by a government and its agencies, with the exception of amounts for debt retirement and for loan, investment, agency, and private trust transactions.

Most of the federal government statistics are based on figures that appear in The Budget of the United States Government. Since the classification used by the Census Bureau for reporting state and local government finance statistics differs in a number of important respects from the classification used in the U.S. budget, it was necessary to adjust the federal data. For this report, federal budget expenditures include interest accrued, but not paid, during the fiscal year; Census data on interest are on a disbursement basis.

State government finances are based primarily on the Census Bureau Annual Survey of State and Local Government Finances. Census analysts compile figures from official records and reports of the state governments for most of the state financial data. States differ in the ways they administer activities; they may fund such activities directly, or they may disburse the money to a lower level government or government agency. Therefore, caution is advised when attempting to make a direct comparison between states on their state fiscal aid data.

The sample of local governments is drawn from the periodic (years ending in " 2 " and " 7 ") Census of Governments and consists of certain local governments sampled with certainty plus a sample below the certainty level. Finance data for all school districts are collected on an annual basis and released through the NCES Common Core of Data system. A new sample is usually selected every 5 years (years ending in "4" and "9"), the most recent one being in fiscal year 2009.

The statistics in Government Finances that are based wholly or partly on data from the sample are subject to sampling error. State government finance data are not subject to sampling error. Estimates of major U.S. totals for local governments are subject to a computed sampling variability of less than one-half of 1 percent. The estimates are also subject to the inaccuracies in classification, response, and processing that would occur if a complete census had been conducted under the same conditions as the sample.

Further information on government finances may be obtained from

Governments Division

Census Bureau

U.S. Department of Commerce

4600 Silver Hill Road

Washington, DC 20233

Local government

govs.finstaff@census.gov

State government

govs.public.finance.analysis.b.@census.gov

http://www.census.gov/govs

\section{Census of Population-Education in the United States}

Some NCES tables are based on a part of the decennial census that consisted of questions asked of a 1 in 6 sample of people and housing units in the United States. This sample was asked more detailed questions about income, occupation, and housing costs, as well as questions about general demographic information. This decennial Long Form is no longer conducted and has been replaced by the American Community Survey (ACS).

School enrollment. People classified as enrolled in school reported attending a "regular" public or private school or college. They were asked whether the institution they attended was public or private and what level of school they were enrolled in.

Educational attainment. Data for educational attainment were tabulated for people ages 15 and older and classified according to the highest grade completed or the highest degree received. Instructions were also given to include the level of the previous grade attended or the highest degree received for people currently enrolled in school.

Poverty status. To determine poverty status, answers to income questions were used to make comparisons to the appropriate poverty threshold. All people except those who were institutionalized, people in military group quarters and college dormitories, and unrelated people under age 15 were considered. If the total income of each family or unrelated individual in the sample was below the corresponding cutoff, that family or individual was classified as "below the poverty level." 
Further information on the 1990 and 2000 Census of Population may be obtained from

Population Division

Census Bureau

U.S. Department of Commerce

4600 Silver Hill Road

Washington, DC 20233

http://www.census.gov/main/www/cen1990.html

http://www.census.gov/main/www/cen2000.html

\section{Current Population Survey}

The Current Population Survey (CPS) is a monthly survey of about 60,000 households conducted by the U.S. Census Bureau for the Bureau of Labor Statistics. The CPS is the primary source of information of labor force statistics for the U.S. noninstitutionalized population (e.g., it excludes military personnel and their families living on bases and inmates of correctional institutions). In addition, supplemental questionnaires are used to provide further information about the U.S. population. Specifically, in October, detailed questions regarding school enrollment and school characteristics are asked. In March, detailed questions regarding income are asked.

The current sample design, introduced in July 2001, includes about 72,000 households. Each month about 58,900 of the 72,000 households are eligible for interview, and of those, 7 to 10 percent are not interviewed because of temporary absence or unavailability. Information is obtained each month from those in the household who are 15 years of age and older, and demographic data are collected for children 0-14 years of age. In addition, supplemental questions regarding school enrollment are asked about eligible household members ages 3 and older in the October survey. Prior to July 2001, data were collected in the CPS from about 50,000 dwelling units. The samples are initially selected based on the decennial census files and are periodically updated to reflect new housing construction.

A major redesign of the CPS was implemented in January 1994 to improve the quality of the data collected. Survey questions were revised, new questions were added, and computer-assisted interviewing methods were used for the survey data collection. Further information about the redesign is available in Current Population Survey, October 1995: (School Enrollment Supplement) Technical Documentation at http://www.census.gov/prod/techdoc/cps/cpsoct95.pdf.

Caution should be used when comparing data from 1994 through 2001 with data from 1993 and earlier. Data from 1994 through 2001 reflect 1990 census-based population controls, while data from 1993 and earlier reflect 1980 or earlier censusbased population controls. Caution should also be used when comparing data from 1994 through 2001 with data from 2002 onward, as data from 2002 reflect 2000 census-based controls. Changes in population controls generally have relatively little impact on summary measures such as means, medians, and percentage distributions. They can have a significant impact on population counts. For example, use of the 1990 census- based population controls resulted in about a 1 percent increase in the civilian noninstitutional population and in the number of families and households. Thus, estimates of levels for data collected in 1994 and later years will differ from those for earlier years by more than what could be attributed to actual changes in the population. These differences could be disproportionately greater for certain subpopulation groups than for the total population.

Beginning in 2003, race/ethnicity questions expanded to include information on people of two or more races. Native Hawaiian/Pacific Islander data are collected separately from Asian data. The questions have also been worded to make it clear that self-reported data on race/ethnicity should reflect the race/ethnicity with which the responder identifies, rather than what may be written in official documentation.

The estimation procedure employed for monthly CPS data involves inflating weighted sample results to independent estimates of characteristics of the civilian noninstitutional population in the United States by age, sex, and race. These independent estimates are based on statistics from decennial censuses; statistics on births, deaths, immigration, and emigration; and statistics on the population in the armed services. Generalized standard error tables are provided in the Current Population Reports; methods for deriving standard errors can be found within the CPS technical documentation at http:// www.census.gov/cps/methodology/techdocs.html. The CPS data are subject to both nonsampling and sampling errors.

Prior to 2009, standard errors were estimated using the generalized variance function. The generalized variance function is a simple model that expresses the variance as a function of the expected value of a survey estimate. Beginning with March 2009 CPS data, standard errors were estimated using replicate weight methodology. Those interested in using CPS householdlevel supplement replicate weights to calculate variances may refer to Estimating Current Population Survey (CPS) Household-Level Supplement Variances Using Replicate Weights at http://thedataweb.rm.census.gov/pub/cps/supps/HH-level Use of the Public Use Replicate Weight File.doc.

Further information on CPS may be obtained from

Education and Social Stratification Branch

Population Division

Census Bureau

U.S. Department of Commerce

4600 Silver Hill Road

Washington, DC 20233

http://www.census.gov/cps

\section{Dropouts}

Each October, the Current Population Survey (CPS) includes supplemental questions on the enrollment status of the population ages 3 years and over as part of the monthly basic survey on labor force participation. In addition to gathering the information on school enrollment, with the limitations on accuracy as noted below under "School Enrollment," the survey data permit calculations of dropout rates. Both status and event dropout rates are tabulated from the October CPS. Event 
rates describe the proportion of students who leave school each year without completing a high school program. Status rates provide cumulative data on dropouts among all young adults within a specified age range. Status rates are higher than event rates because they include all dropouts ages 16 through 24, regardless of when they last attended school.

In addition to other survey limitations, dropout rates may be affected by survey coverage and exclusion of the institutionalized population. The incarcerated population has grown more rapidly and has a higher dropout rate than the general population. Dropout rates for the total population might be higher than those for the noninstitutionalized population if the prison and jail populations were included in the dropout rate calculations. On the other hand, if military personnel, who tend to be high school graduates, were included, it might offset some or all of the impact from the theoretical inclusion of the jail and prison population.

Another area of concern with tabulations involving young people in household surveys is the relatively low coverage ratio compared to older age groups. CPS undercoverage results from missed housing units and missed people within sample households. Overall CPS undercoverage for October 2012 is estimated to be about 14 percent. CPS coverage varies with age, sex, and race. Generally, coverage is larger for females than for males and larger for non-Blacks than for Blacks. For example, in October 2012 the coverage ratio for Black 20- to 24-year-old males was 63 percent. The CPS weighting procedure partially corrects for the bias due to undercoverage. Further information on CPS methodology may be obtained from http://www.census.gov/cps.

Further information on the calculation of dropouts and dropout rates may be obtained from Trends in High School Dropout and Completion Rates in the United States: 1972-2009 (NCES 2012-006) at http://nces.ed.gov/pubsearch/ pubsinfo.asp?pubid $=2012006$ or by contacting

\section{Chris Chapman}

Sample Surveys Division

Cross-Sectional Surveys Branch

National Center for Education Statistics

1990 K Street NW

Washington, DC 20006

chris.chapman@ed.gov

\section{Educational Attainment}

Reports documenting educational attainment are produced by the Census Bureau using March CPS supplement (Annual Social and Economic Supplement [ASEC]) results. The sample size for the 2013 ASEC supplement (including basic CPS) was about 99,000 households. The latest release is Educational Attainment in the United States: 2013; the tables may be downloaded at http://www.census.gov/hhes/socdemo/education/ data/cps/2013/tables.html.

In addition to the general constraints of CPS, some data indicate that the respondents have a tendency to overestimate the educational level of members of their household. Some inaccuracy is due to a lack of the respondent's knowledge of the exact educational attainment of each household member and the hesitancy to acknowledge anything less than a high school education. Another cause of nonsampling variability is the change in the numbers in the armed services over the years.

Further information on CPS's educational attainment data may be obtained from

Education and Social Stratification Branch

Census Bureau

U.S. Department of Commerce

4600 Silver Hill Road

Washington, DC 20233

http://www.census.gov/hhes/socdemo/education

\section{School Enrollment}

Each October, the Current Population Survey (CPS) includes supplemental questions on the enrollment status of the population ages 3 years and over. Prior to 2001, the October supplement consisted of approximately 47,000 interviewed households. Beginning with the October 2001 supplement, the sample was expanded by 9,000 to a total of approximately 56,000 interviewed households. The main sources of nonsampling variability in the responses to the supplement are those inherent in the survey instrument. The question of current enrollment may not be answered accurately for various reasons. Some respondents may not know current grade information for every student in the household, a problem especially prevalent for households with members in college or in nursery school. Confusion over college credits or hours taken by a student may make it difficult to determine the year in which the student is enrolled. Problems may occur with the definition of nursery school (a group or class organized to provide educational experiences for children) where respondents' interpretations of "educational experiences" vary.

For the October 2012 basic CPS, the household-level nonresponse rate was 9.6 percent. The person-level nonresponse rate for the school enrollment supplement was an additional 9.2 percent. Since the basic CPS nonresponse rate is a household-level rate and the school enrollment supplement nonresponse rate is a person-level rate, these rates cannot be combined to derive an overall nonresponse rate. Nonresponding households may have fewer persons than interviewed ones, so combining these rates may lead to an overestimate of the true overall nonresponse rate for persons for the school enrollment supplement.

Further information on CPS methodology may be obtained from http://www.census.gov/cps.

Further information on the CPS School Enrollment Supplement may be obtained from

Education and Social Stratification Branch

Census Bureau

U.S. Department of Commerce

4600 Silver Hill Road

Washington, DC 20233

http://www.census.gov/hhes/school/index.html 


\section{Decennial Census, Population Estimates, and Population Projections}

The decennial census is a universe survey mandated by the U.S. Constitution. It is a questionnaire sent to every household in the country, and it is composed of seven questions about the household and its members (name, sex, age, relationship, Hispanic origin, race, and whether the housing unit is owned or rented). The Census Bureau also produces annual estimates of the resident population by demographic characteristics (age, sex, race, and Hispanic origin) for the nation, states, and counties, as well as national and state projections for the resident population. The reference date for population estimates is July 1 of the given year. With each new issue of July 1 estimates, the Census Bureau revises estimates for each year back to the last census. Previously published estimates are superseded and archived.

Census respondents self-report race and ethnicity. The race questions on the 1990 and 2000 censuses differed in some significant ways. In 1990, the respondent was instructed to select the one race "that the respondent considers himself/herself to be," whereas in 2000 , the respondent could select one or more races that the person considered himself or herself to be. American Indian, Eskimo, and Aleut were three separate race categories in 1990; in 2000, the American Indian and Alaska Native categories were combined, with an option to write in a tribal affiliation. This write-in option was provided only for the American Indian category in 1990. There was a combined Asian and Pacific Islander race category in 1990, but the groups were separated into two categories in 2000.

The census question on ethnicity asks whether the respondent is of Hispanic origin, regardless of the race option(s) selected; thus, persons of Hispanic origin may be of any race. In the 2000 census, respondents were first asked, "Is this person Spanish/Hispanic/Latino?" and then given the following options: No, not Spanish/Hispanic/Latino; Yes, Puerto Rican; Yes, Mexican, Mexican American, Chicano; Yes, Cuban; and Yes, other Spanish/Hispanic/Latino (with space to print the specific group). In the 2010 census, respondents were asked "Is this person of Hispanic, Latino, or Spanish origin?" The options given were No, not of Hispanic, Latino, or Spanish origin; Yes, Mexican, Mexican Am., Chicano; Yes, Puerto Rican; Yes, Cuban; and Yes, another other Hispanic, Latino, or Spanish origin — along with instructions to print "Argentinean, Colombian, Dominican, Nicaraguan, Salvadoran, Spaniard, and so on" in a specific box.

The 2000 and 2010 censuses each asked the respondent "What is this person's race?" and allowed the respondent to select one or more options. The options provided were largely the same in both the 2000 and 2010 censuses: White; Black, African American, or Negro; American Indian or Alaska Native (with space to print the name of enrolled or principal tribe); Asian Indian; Japanese; Native Hawaiian; Chinese; Korean; Guamanian or Chamorro; Filipino; Vietnamese; Samoan; Other Asian; Other Pacific Islander; and Some other race. The last three options included space to print the specific race. Two significant differences between the 2000 and 2010 census questions on race were that no race examples were provided for the "Other Asian" and "Other Pacific Islander" responses in 2000, whereas the race examples of "Hmong, Laotian, Thai, Pakistani, Cambodian, and so on" and "Fijian, Tongan, and so on," were provided for the "Other Asian" and "Other Pacific Islander" responses, respectively, in 2010.

The census population estimates program modified the enumerated population from the 2010 census to produce the population estimates base for 2010 and onward. As part of the modification, the Census Bureau recoded the "Some other race" responses from the 2010 census to one or more of the five OMB race categories used in the estimates program (for more information, see http://www.census.gov/popest/methodology/ 2012-nat-st-co-meth.pdf).

Further information on the decennial census may be obtained from http://www.census.gov.

\section{Survey of Income and Program Participation}

The main objective of the Survey of Income and Program Participation (SIPP) is to provide accurate and comprehensive information about the income and program participation of individuals and households in the United States and about the principal determinants of income and program participation. SIPP offers detailed information on cash and noncash income on a subannual basis. The survey also collects data on taxes, assets, liabilities, and participation in government transfer programs. SIPP data allow the government to evaluate the effectiveness of federal, state, and local programs.

The survey design is a continuous series of national panels, with sample size ranging from approximately 14,000 to 36,700 interviewed households. The duration of each panel ranges from $2 \frac{1}{2}$ years to 4 years. The SIPP sample is a multistage-stratified sample of the U.S. civilian noninstitutionalized population. For the 1984-93 panels, a new panel of households was introduced each year in February. A 4-year panel was introduced in April 1996. A 2000 panel was introduced in February 2000 for two waves, but was cancelled after 8 months. A 21/2-year panel was introduced in February 2004 and is the first SIPP panel to use the 2000 decennialbased redesign of the sample. All household members ages 15 years and over are interviewed by self-response, if possible. Proxy response is permitted when household members are not available for interviewing. The most recent panel was selected in September 2008.

The SIPP content is built around a "core" of labor force, program participation, and income questions designed to measure the economic situation of people in the United States. These questions expand the data currently available on the distribution of cash and noncash income and are repeated at each interviewing wave. The survey uses a 4month recall period, with approximately the same number of interviews being conducted in each month of the 4-month period for each wave. Interviews are conducted by personal visit and by decentralized telephone. 
The survey has been designed to also provide a broader context for analysis by adding questions on a variety of topics not covered in the core section. These questions are labeled "topical modules" and are assigned to particular interviewing waves of the survey. Topics covered by the modules include personal history, child care, wealth, program eligibility, child support, utilization and cost of health care, disability, school enrollment, taxes, and annual income.

Further information on the SIPP may be obtained from

Economics and Statistics Administration

Census Bureau

U.S. Department of Commerce

4600 Silver Hill Road

Washington, DC 20233

http://www.census.gov/sipp/

\section{Centers for Disease Control and Prevention (CDC)}

\section{National Health Interview Survey (NHIS)}

The National Health Interview Survey (NHIS) is the principal source of information on the health of the civilian noninstitutionalized population of the United States and is one of the major data collection programs of the National Center for Health Statistics (NCHS), which is part of the Centers for Disease Control and Prevention (CDC). The main objective of the NHIS is to monitor the health of the U.S. population through the collection and analysis of data on a broad range of health topics. A major strength of this survey lies in its ability to display these health characteristics by many demographic and socioeconomic characteristics.

The NHIS covers the civilian noninstitutionalized population residing in the United States at the time of the interview. The NHIS is a cross-sectional household interview survey. Sampling and interviewing are continuous throughout each year. The sampling plan follows a multistage area probability design that permits the representative sampling of households and noninstitutional group quarters (e.g., college dormitories). The sampling plan is redesigned after every decennial census. The current sampling plan was implemented in 2006. It is similar in many ways to the previous sampling plan, which was in place from 1995 to 2005 . The first stage of the current sampling plan consists of a sample of 428 primary sampling units (PSUs) drawn from approximately 1,900 geographically defined PSUs that cover the 50 states and the District of Columbia. A PSU consists of a county, a small group of contiguous counties, or a metropolitan statistical area.

The revised NHIS questionnaire, implemented since 1997, contains Core questions and Supplements. The Core questions remain largely unchanged from year to year and allow for trends analysis and for data from more than one year to be pooled to increase sample size for analytic purposes. The Core contains four major components: Household, Family, Sample Adult, and Sample Child.
The Household component collects limited demographic information on all of the individuals living in a particular house. The Family component verifies and collects additional demographic information on each member from each family in the house and collects data on topics including health status and limitations, injuries, healthcare access and utilization, health insurance, and income and assets. The Family Core component allows the NHIS to serve as a sampling frame for additional integrated surveys as needed.

Data are collected through a personal household interview conducted by interviewers employed and trained by the U.S. Bureau of the Census according to procedures specified by the NCHS.

Further information on the NHIS may be obtained from

Information Dissemination Staff

National Center for Health Statistics

Centers for Disease Control and Prevention

3311 Toledo Road, Room 5407

Hyattsville, MD 20782-2003

(800) 232-4636

nhis@cdc.gov

http://www.cdc.gov/nchs/nhis.htm

\section{Morbidity and Mortality Weekly Report: Summary of Notifiable Diseases}

The Summary of Notifiable Diseases, a publication of the Morbidity and Mortality Weekly Report (MMWR), contains the official statistics, in tabular and graphic form, for the reported occurrence of nationally notifiable infectious diseases in the United States. These statistics are collected and compiled from reports sent by state health departments and territories to the National Notifiable Diseases Surveillance System (NNDSS), which is operated by the Centers for Disease Control and Prevention (CDC) in collaboration with the Council of State and Territorial Epidemiologists.

For more information on the MMWR: Summary of Notifiable Diseases, see http://www.cdc.gov/mmwr/mmwr nd/.

\section{National Vital Statistics System}

The National Vital Statistics System (NVSS) is the method by which data on births, deaths, marriages, and divorces are provided to the National Center for Health Statistics (NCHS), part of the Centers for Disease Control and Prevention (CDC). The data are provided to NCHS through the Vital Statistics Cooperative Program (VSCP). In 1984 and earlier years, the VSCP included varying numbers of states that provided data based on a 100 percent sample of their birth certificates. Data for states not in the VSCP were based on a 50 percent sample of birth certificates filed in those states. Population data used to compile birth rates are based on special estimation procedures and are not actual counts. 
Race and Hispanic ethnicity are reported separately in the NVSS. Data are available for non-Hispanic Whites and nonHispanic Blacks for 1990 and later; however, for 1980 and 1985, data for Whites and Blacks may include persons of Hispanic ethnicity. For all years, Asian/Pacific Islander and American Indian/Alaska Native categories include persons of Hispanic ethnicity.

For more information on the NCHS and the NVSS, see http://www.cdc.gov/nchs/nvss.htm.

\section{Youth Risk Behavior Surveillance System (YRBSS)}

The Youth Risk Behavior Surveillance System (YRBSS) was created in 1991 to monitor six types of health-risk behaviors that lead to death and disability among young adults: tobacco use, alcohol and other drug use, physical inactivity, sexual risk behaviors, unhealthy diet behaviors, and behaviors that contribute to unintentional injuries and violence. Obesity and asthma among youth and young adults are also measured. Surveys are conducted every 2 years, usually in the spring semester.

The system includes a national school-based survey conducted by the Centers for Disease Control and Prevention (CDC), as well as state, territorial, tribal, and local surveys conducted by state, territorial, and local health and education agencies and tribal governments. Each survey takes one class period to complete, approximately 10 minutes to distribute materials and give directions, and 35 minutes to record responses. Permission is obtained from parents before administering this anonymous, voluntary survey. States and local agencies can add or delete questions from the core questionnaire to meet their policy or programmatic needs.

Local, territorial, and jurisdictional data from YRBSS surveys are weighted to represent all public school students in grades 9-12 in the respective jurisdiction. National data are collected from a separate scientific sample of students and are representative of students from all 50 states and the District of Columbia. Sample size varies according to area, district, or school administering the survey. Methodological studies were conducted in 1991 and 1999 to assess the validity of the selfreported behaviors and personal information. Research indicates that student-reported data is just as credible as that gathered from adults.

Further information on the YRBSS may be obtained from

U.S. Department of Health and Human Services

Division of Adolescent and School Health

4770 Buford Highway NE

Atlanta, GA 30341

cdcinfo@cdc.gov

$1-800-232-4636$

\section{Department of Justice}

\section{Bureau of Justice Statistics}

A division of the U.S. Department of Justice Office of Justice Programs, the Bureau of Justice Statistics (BJS) collects, analyzes, publishes, and disseminates statistical information on crime, criminal offenders, victims of crime, and the operations of the justice system at all levels of government and internationally. It also provides technical and financial support to state governments for development of criminal justice statistics and information systems on crime and justice.

For information on the BJS, see www.ojp.usdoj.gov/bjs/.

\section{National Crime Victimization Survey (NCVS)}

The National Crime Victimization Survey (NCVS), administered for the U.S. Bureau of Justice Statistics by the U.S. Census Bureau, is the nation's primary source of information on crime and the victims of crime. Initiated in 1972 and redesigned in 1992, this annual survey obtains data from a nationally representative sample of about 90,000 households (nearly 160,000 persons) on the frequency, characteristics, and consequences of criminal victimization in the United States. Detailed information is collected on the crimes of rape, sexual assault, robbery, aggravated and simple assault, theft, household burglary, and motor vehicle theft experienced by Americans and their households. The survey measures both crimes reported to police and crimes not reported to the police.

NCVS estimates presented may differ from those in previous published reports. This is because a small number of victimizations, referred to as series victimizations, are included using a new counting strategy. High-frequency repeat victimizations, or series victimizations, are six or more similar but separate victimizations that occur with such frequency that the victim is unable to recall each individual event or describe each event in detail. As part of ongoing research efforts associated with the redesign of the NCVS, BJS investigated ways to include high-frequency repeat victimizations, or series victimizations, in estimates of criminal victimization. Including series victimizations would obtain a more accurate estimate of victimization. BJS has decided to include series victimizations using the victim's estimates of the number of times the victimizations occurred over the past 6 months, capping the number of victimizations within each series at a maximum of 10 . This strategy for counting series victimizations balances the desire to estimate national rates and account for the experiences of persons with repeat victimizations while noting that some estimation errors exist in the number of times these victimizations occurred. Including series victimizations in national rates results in rather large increases in the level of violent victimization; however, trends in violence are generally similar regardless of whether series victimizations are included. For more information on the new counting strategy and supporting research, see Methods for Counting High-Frequency Repeat Victimizations in the National Crime Victimization Survey at http://bjs.ojp.usdoj.gov/content/pub/pdf/mchfrv.pdf. 
Readers should note that in 2003, in accordance with changes to the Office of Management and Budget's standards for the classification of federal data on race and ethnicity, the NCVS item on race/ethnicity was modified. A question on Hispanic origin is followed by a question on race. The new question about race allows the respondent to choose more than one race and delineates Asian as a separate category from Native Hawaiian or Other Pacific Islander. Analysis conducted by the Demographic Surveys Division at the U.S. Census Bureau showed that the new question had very little impact on the aggregate racial distribution of the NCVS respondents, with one exception: There was a 1.6 percentage point decrease in the percentage of respondents who reported themselves as White. Due to changes in race/ethnicity categories, comparisons of race/ethnicity across years should be made with caution.

There were changes in the sample design and survey methodology in the 2006 NCVS that may have affected survey estimates. Caution should be used when comparing the 2006 estimates to those of other years. Data from 2007 onward are comparable to earlier years. Analyses of the 2007 estimates indicate that the program changes made in 2006 had relatively small effects on NCVS changes. For more information on the 2006 NCVS data, see Criminal Victimization, 2006, at http://bjs.ojp.usdoj.gov/content/pub/ pdf/cv06.pdf, the technical notes at http://bjs.ojp.usdoj.gov/ content/pub/pdf/cv06tn.pdf, and Criminal Victimization, 2007, at http://bjs.ojp.usdoj.gov/content/pub/pdf/cv07.pdf.

The number of NCVS-eligible households in the sample in 2011 was about 89,000 . They were selected using a stratified, multistage cluster design. In the first stage, the primary sampling units (PSUs), consisting of counties or groups of counties, were selected. In the second stage, smaller areas, called Enumeration Districts (EDs), were selected from each sampled PSU. Finally, from selected EDs, clusters of four households, called segments, were selected for interview. At each stage, the selection was done proportionate to population size in order to create a selfweighting sample. The final sample was augmented to account for households constructed after the decennial Census. Within each sampled household, U.S. Census Bureau personnel attempt to interview all household members age 12 and older to determine whether they had been victimized by the measured crimes during the 6 months preceding the interview.

The first NCVS interview with a housing unit is conducted in person. Subsequent interviews are conducted by telephone, if possible. About 72,000 persons age 12 and older are interviewed every 6 months. Households remain in the sample for 3 years and are interviewed seven times at 6-month intervals. Since the survey's inception, the initial interview at each sample unit has been used only to bound future interviews to establish a time frame to avoid duplication of crimes uncovered in these subsequent interviews. Beginning in 2006, data from the initial interview have been adjusted to account for the effects of bounding and included in the survey estimates. After their seventh interview, households are replaced by new sample house- holds. The NCVS has consistently obtained a response rate of over 90 percent at the household level. The completion rates for persons within households in 2011 were about 88 percent. Weights were developed to permit estimates for the total U.S. population 12 years and older.

Further information on the NCVS may be obtained from

\author{
Jennifer Truman \\ Victimization Statistics Branch \\ Bureau of Justice Statistics \\ 810 Seventh Street NW \\ Washington, DC 20531 \\ jennifer.truman@usdoj.gov
}

\section{Federal Bureau of Investigation}

The Federal Bureau of Investigation (FBI) collects statistics on crimes from law enforcement agencies throughout the country through the Uniform Crime Reporting (UCR) Program. The UCR Program was conceived in 1929 by the International Association of Chiefs of Police to meet a need for reliable, uniform crime statistics for the nation. In 1930, the FBI was tasked with collecting, publishing, and archiving those statistics. Today, several annual statistical publications, such as the comprehensive Crime in the United States, are produced from data provided by nearly 17,000 law enforcement agencies across the United States. Crime in the United States (CIUS) is an annual publication in which the FBI compiles volume and rate of crime offenses for the nation, the states, and individual agencies. This report also includes arrest, clearance, and law enforcement employee data.

For more information on the UCR Program, see http:// www.fbi.gov/about-us/cjis/ucr/ucr.

\section{Department of Defense}

\section{Defense Manpower Data Center}

The Statistical Information Analysis Division of the Defense Manpower Data Center (DMDC) maintains the largest archive of personnel, manpower, and training data in the Department of Defense (DoD). The DMDC's statistical activities include the personnel survey program, an enlistment testing program to support screening of military applicants, and a client support program to provide statistical support to the Office of the Secretary of Defense. The DMDC collects DoD contract information in support of national economic tables and the Small Business Competitiveness Demonstration Program; it also produces statistics on DoD purchases from educational and nonprofit institutions and from state and local governments.

For more information on the DMDC, see http:// www.dhra.mil/website/locations/map page dmdc.shtml. 


\section{Institute of Museum and Library Statistics (IMLS)}

On October 1, 2007, the administration of the Public Libraries Survey (PLS) and the State Library Agencies (StLA) Survey was transferred from the National Center for Education Statistics to the Institute of Museum and Library Statistics (IMLS).

\section{IMLS Library Statistics}

Public library statistics are collected annually using the PLS and disseminated annually through the Federal-State Cooperative System (FSCS) for Public Library Data. Descriptive statistics are produced for over 9,000 public libraries. The PLS includes information about staffing; operating income and expenditures; type of governance; type of administrative structure; size of collection; and service measures such as reference transactions, public service hours, interlibrary loans, circulation, and library visits. In the FSCS, respondents supply the information electronically, and data are edited and tabulated in machine-readable form.

The respondents are public libraries identified in the 50 states and the District of Columbia by state library agencies. At the state level, FSCS is administered by State Data Coordinators, who are appointed by the Chief Officer of each State Library Agency. The State Data Coordinator collects the requested data from local public libraries. All 50 states and the District of Columbia submit data for individual public libraries, which are aggregated to state and national levels.

From 1994 through 2006, NCES conducted the StLA Survey for the 50 states and the District of Columbia. A state library agency is the official agency of a state that is charged by state law with the extension and development of public library services throughout the state and that has adequate authority under state law to administer state plans in accordance with the provisions of the Library Services and Technology Act (LSTA) of 2003. The StLA Survey collected data on services, collections, staffing, revenue, and expenditures.

Further information on the Public Library Survey and State Library Agency Survey can be obtained from

Institute of Museum and Library Services Office of Policy, Planning, Research, and Communication Research and Statistics Division

$1800 \mathrm{M}$ Street NW, 9th Floor

Washington, DC 20036-5802

imlsinfo@imls.gov

http://harvester.census.gov/imls/index.asp

\section{National Institute on Drug Abuse}

\section{Monitoring the Future Survey}

The National Institute on Drug Abuse of the U.S. Department of Health and Human Services is the primary supporter of the long-term study entitled "Monitoring the
Future: A Continuing Study of American Youth," conducted by the University of Michigan Institute for Social Research. One component of the study deals with student drug abuse. Results of the national sample survey have been published annually since 1975 . With the exception of 1975 , when about 9,400 students participated in the survey, the annual samples comprise roughly 16,000 students in 150 public and private schools. Students complete self-administered questionnaires given to them in their classrooms by University of Michigan personnel. Each year, 8th-, 10th-, and 12th-graders are surveyed (12th-graders since 1975, and 8th- and 10th-graders since 1991). The 8th- and 10thgrade surveys are anonymous, while the 12 th-grade survey is confidential. The 10th-grade samples involve about 17,000 students in 140 schools each year, while the 8thgrade samples have approximately 18,000 students in about 150 schools. In all, approximately 50,000 students from about 420 public and private secondary schools are surveyed annually. Approximately 88.4 percent of 8 th-grade students, 87.2 percent of 10th-grade students, and 84.7 percent of 12th-grade students surveyed participated in the study in 2010. Beginning with the class of 1976, a randomly selected sample from each senior class has been followed in the years after high school on a continuing basis.

Understandably, there is some reluctance to admit illegal activities. Also, students who are out of school on the day of the survey are nonrespondents, and the survey does not include high school dropouts. The inclusion of absentees and dropouts would tend to increase the proportion of individuals who had used drugs. A 1983 study found that the inclusion of absentees could increase some of the drug usage estimates by as much as 2.7 percentage points. (Details on that study and its methodology were published in Drug Use Among American High School Students, College Students, and Other Young Adults, by L.D. Johnston, P.M. O'Malley, and J.G. Bachman, available from the National Clearinghouse on Drug Abuse Information, 5600 Fishers Lane, Rockville, MD 20857.)

The 2013 Monitoring the Future survey encompassed about 41,700 8th-, 10th-, and 12th-grade students in $389 \mathrm{sec}-$ ondary schools nationwide. The first published results were presented in Monitoring the Future, National Results on Drug Use: 2013 Overview, Key Findings on Adolescent Drug Use, at http://www.monitoringthefuture.org//pubs/ monographs/mtf-overview2013.pdf.

Further information on the Monitoring the Future drug abuse survey may be obtained from

National Institute on Drug Abuse

Division of Epidemiology, Services and

Prevention Research (DESPR)

6001 Executive Boulevard

Bethesda, MD 20892

MTFinfo@isr.umich.edu

http://www.monitoringthefuture.org 


\section{National Science Foundation}

\section{Survey of Federal Funds for Research and Development}

The annual federal funds survey is the primary source of information about federal funding for research and development $(R \& D)$ in the United States. It is used by policymakers in the executive and legislative branches of the federal government in determining policies, laws, and regulations affecting science; it is also used by those who follow science trends in every sector of the economy, including university administrators and professors, economic and political analysts, R\&D managers inside and outside the government, the science press, and leading members of the science community in the United States and around the world.

The survey is completed by the 15 federal departments and their 72 subagencies and 12 independent agencies that conduct R\&D programs. The sample is obtained from information in the President's budget submitted to Congress.

Federal funds data, as collected, span 3 government fiscal years: the fiscal year just completed, the current fiscal year, and the next fiscal year. Actual data are collected for the year just completed; estimates are obtained for the current fiscal year and the next fiscal year.

The data are collected and managed online; this system was designed to help improve survey reporting by offering respondents direct online reporting and editing.

The federal funds survey has an unweighted response rate of 100 percent with no known item nonresponse. The information included in this survey has been stable since fiscal year 1973, when federal obligations for research to universities and colleges by agency and detailed science and engineering fields were added to the survey.

Further information on federal funds for research and development may be obtained from

\section{Michael Yamaner}

Research and Development Statistics Program

Division of Science Resources Statistics

National Science Foundation

4201 Wilson Boulevard

Arlington, VA 22230

myamaner@nsf.gov

http://www.nsf.gov/statistics

\section{Survey of Earned Doctorates}

The Survey of Earned Doctorates (SED) has collected basic statistics from the universe of doctoral recipients in the United States each year since 1958. It is supported by six federal agencies: the National Science Foundation, in conjunction with the U.S. Department of Education; the National Endowment for the Humanities; the U.S. Department of Agriculture; the National Institutes of Health; and the National Aeronautics and Space Administration.
With the assistance of graduate deans, a survey form is distributed to each person completing the requirements for a first research doctorate. Of the 51,008 new research doctorates granted in 2012, 92.2 percent of degree recipients responded. The questionnaire obtains information on sex, race/ethnicity, marital status, citizenship, disabilities, dependents, specialty field of doctorate, educational institutions attended, time spent in completion of doctorate, financial support, education debt, postgraduation plans, and educational attainment of parents.

Further information on the Survey of Earned Doctorates may be obtained from

\section{Mark Fiegener \\ SED Project Officer \\ Human Resources Statistics Program \\ Division of Science Resources Statistics \\ National Science Foundation \\ 4201 Wilson Boulevard \\ Arlington, VA 22230 \\ mfiegene@nsf.gov \\ http://www.nsf.gov/statistics/srvydoctorates \\ Survey of Graduate Students and Postdoctorates in Science and Engineering}

The Survey of Graduate Students and Postdoctorates in Science and Engineering, also known as the graduate student survey (GSS), is an annual survey of all academic institutions in the United States and its territories that grant research-based master's degrees or doctorates, appoint postdocs, or employ doctorate-holding nonfaculty researchers in science and engineering and selected health fields. It is an institution-based survey that provides data on the number and characteristics of graduate science, engineering, and health students enrolled in approximately 600 U.S. academic institutions.

Data for the 2012 GSS were collected at the beginning of academic year 2007-08. This survey includes all branch campuses, affiliated research centers, and separately organized components-such as medical or dental schools, nursing schools, and schools of public health-from all academic institutions that offer doctor's and master's degree programs. Only those graduate students enrolled for credit in a master's or doctoral program in science or engineering in the fall of 2007 were included in the survey. M.D., D.O., D.V.M., or D.D.S. candidates, interns, and residents were counted if they were concurrently working on a master's or doctoral degree in science or engineering or were enrolled in a joint medical/Ph.D. program.

The 2012 survey universe consisted of 565 institutions, including 367 doctorate-granting institutions and 198 master'sgranting institutions. There were 684 schools affiliated with these institutions: 485 at doctorate-granting institutions and 199 at master's-granting institutions.

New procedures to improve coverage of GSS-eligible units were introduced in the 2007 survey cycle and were continued in subsequent cycles. Increased emphasis was given to updating the unit list by providing an exhaustive list of GSS-eligible 
programs within existing GSS fields. In previous years, only a representative list was provided for each GSS field, which may have resulted in not reporting all eligible units. The set of GSS-eligible fields was also modified. Due to these changes, data for 2007 and later years are not directly comparable with data from previous years.

Further information on the Survey of Graduate Students and Postdoctorates in Science and Engineering may be obtained from

\section{Kelly H. Kang}

Project Officer

Survey of Graduate Students and Postdoctorates in Science and Engineering

National Center for Science and Engineering Statistics

National Science Foundation

4201 Wilson Boulevard, Suite 965

Arlington, VA 22230

kkang@nsf.gov

http://www.nsf.gov/statistics/srvygradpostdoc/

\section{Substance Abuse and Mental Health Services Administration}

\section{National Survey on Drug Use and Health}

Conducted by the federal government since 1971, the National Survey on Drug Use and Health (NSDUH) is an annual survey (since 1991) of the civilian, noninstitutionalized population of the United States age 12 or older. It is the primary source of information on the prevalence, patterns, and consequences of alcohol, tobacco, and illegal drug use and abuse. The survey collects data by administering questionnaires to a representative sample of the population (since 1999, the NSDUH interview has been carried out using computer-assisted interviewing). NSDUH collects information from residents of households, noninstitutional group quarters, and civilians living on military bases. The main results of the NSDUH present national estimates of rates of use, numbers of users, and other measures related to illicit drugs, alcohol, and tobacco products.

Prior to 2002, the survey was called the National Household Survey on Drug Abuse (NHSDA). Because of improvements to the survey in 2002, the data from 2002 onward should not be compared with NHSDA data from 2001 and earlier as a method of assessing changes in substance use over time.

The 2005 NSDUH was the first in a coordinated 5-year sample design providing estimates for all 50 states and the District of Columbia for the years 2005 through 2009. Because the 2005 design enables estimates to be developed by state, states may be viewed as the first level of stratification, as well as a reporting variable.

The 2012 NSDUH screened 153,873 addresses, and 68,309 completed interviews were obtained. The survey was conducted from January through December 2012.
Weighted response rates were 86.1 percent for household screening and 73.0 percent for interviewing.

Further information on the NSDUH may be obtained from

SAMHSA, Center for Behavioral Health Statistics and Quality

1 Choke Cherry Road, Room 2-1049

Rockville, MD 20857

http://www.samhsa.gov/data/nsduh.aspx

\section{Other Organization Sources}

\section{ACT}

\section{ACT assessment}

The ACT assessment is designed to measure educational development in the areas of English, mathematics, social studies, and natural sciences. The ACT assessment is taken by college-bound high school students and by all graduating seniors in Colorado and Illinois. The test results are used to predict how well students might perform in college.

Prior to the 1984-85 school year, national norms were based on a 10 percent sample of the students taking the test. Since then, national norms have been based on the test scores of all students taking the test. Beginning with 1984-85, these norms have been based on the most recent ACT scores available from students scheduled to graduate in the spring of the year. Duplicate test records are no longer used to produce national figures.

Separate ACT standard scores are computed for English, mathematics, science reasoning, and, as of October 1989, reading. ACT standard scores are reported for each subject area on a scale from 1 to 36. In 2013, the national composite score (the simple average of the four ACT standard scores) was 20.9, with a standard deviation of 5.4. The tests emphasize reasoning, analysis, problem solving, and the integration of learning from various sources, as well as the application of these proficiencies to the kinds of tasks college students are expected to perform.

It should be noted that graduating students who take the ACT assessment are not necessarily representative of graduating students nationally. Students who live in the Midwest, Rocky Mountains, Plains, and South are overrepresented among ACT-tested students as compared to graduating students nationally. Students in these areas often aspire to public colleges and universities, which in these jurisdictions require the ACT assessment more often than the SAT test.

Further information on the ACT may be obtained from

ACT

500 ACT Drive

P.O. Box 168

Iowa City, IA 52243-0168

http://www.act.org 


\section{American Council on Education}

\section{GED Testing Service}

GED Testing Service is a joint venture, begun in 2011, between the American Council on Education (ACE) and Pearson. A GED credential documents high school-level academic skills. The test was first administered to World War II veterans in 1942 and was subsequently administered to civilians beginning in 1947. The first four generations of the GED test were the original GED test released in 1942, the 1978 series, the 1988 series, and the 2002 series. In 2014, a new test was implemented. Differences and similarities between the 2014 GED test and the 2002 series test are available at http://www.gedtestingservice.com/uploads/ files/2487f6e1ca5659684cbe1f8b16f564d0.pdf.

The annual GED Testing Program Statistical Report looks at those who take the GED, test performance statistics, and historical information on the GED testing program.

Attempting to make comparisons in GED testing across jurisdictions is problematic, since each jurisdiction manages its own GED testing program. As such, each jurisdiction develops its own policies, which would be reflected in its testing program outcomes, such as pass rates.

Further information on the GED may be obtained from

GED Testing Service

1919 M Street NW

Suite 600

Washington, DC 20036

http://www.gedtestingservice.com/ged-testing-service

\section{Bobit Business Media}

\section{School Bus Fleet}

School Bus Fleet digital magazine is a trade publication serving more than 24,000 school transportation professionals in the United States and Canada that provides information on the management and maintenance of school bus fleets operated by public school districts, private schools, Head Start agencies, and child care centers. The readership includes public operators and contract service providers.

Further information on School Bus Fleet magazine may be obtained from

Bobit Business Media

3520 Challenger Street

Torrance, CA 90503

http://www.schoolbusfleet.com/

\section{The College Board}

\section{Advanced Placement Exam (AP)}

The Advanced Placement (AP) program is a curriculum sponsored by the College Board that offers high school students the opportunity to take college-level courses in a high school setting. A student taking an AP course in high school can earn college credit for participation by attaining a certain minimum score on the AP exam in that subject area.

The AP program offers courses in 34 subjects. Although nearly 60 percent of U.S. high schools in the United States offer AP courses, the College Board does not require students to take an AP course before taking an AP exam. AP exams are offered once a year in May. Most of the exams take 2 to 3 hours to complete. The scores for all AP exams range from 1 to 5 , with 5 being the highest score. Over 90 percent of the nation's colleges and universities have an AP policy granting incoming students credit, placement, or both, for qualifying AP exam scores.

\section{SAT}

The Admissions Testing Program of the College Board is made up of a number of college admissions tests, including the Preliminary Scholastic Assessment Test (PSAT) and the Scholastic Assessment Test, now known as the SAT. High school students participate in the testing program as sophomores, juniors, or seniors-some more than once during these 3 years. If they have taken the tests more than once, only the most recent scores are tabulated. The PSAT and SAT report subscores in the areas of mathematics and verbal ability.

The SAT results are not representative of high school students or college-bound students nationally, since the sample is self-selected (i.e., taken by students who need the results to apply to a particular college or university). Public colleges in many states, particularly in the Midwest, parts of the South, and the West, require ACT scores rather than SAT scores. The proportion of students taking the SAT in these states is very low and is inappropriate for comparison. In recent years, approximately 1.5 million high school students have taken the SAT examination annually. The current version of the SAT, which includes a writing component, was first administered in March 2005; a redesigned SAT is planned for 2016.

Further information on AP and the SAT can be obtained from

The College Board National Office

45 Columbus Avenue

New York, NY 10023-6917

http://www.collegeboard.org/

\section{Commonfund Institute}

\section{Higher Education Price Index}

Commonfund Institute took over management of the Higher Education Price Index (HEPI) in September 2004 from Research Associates of Washington, which originated the index in 1961. HEPI measures average changes in prices of goods and services purchased by colleges and universities through educational and general expenditures. Sponsored research and auxiliary enterprises are not priced by HEPI.

HEPI is based on the prices (or salaries) of faculty and of administrators and other professional service personnel; clerical, technical, service, and other nonprofessional personnel; 
and contracted services, such as data processing, communication, transportation, supplies and materials, equipment, books and periodicals, and utilities. These represent the items purchased for current operations by colleges and universities. Prices for these items are obtained from salary surveys conducted by various national higher education associations, the American Association of University Professors, the Bureau of Labor Statistics, and the National Center for Education Statistics; and from components of the Consumer Price Index (CPI) and the Producer Price Index (PPI) published by the U.S. Department of Labor, Bureau of Labor Statistics. Since 2009, data have been consistently drawn from the July-June academic fiscal year. Prior to 2009, data were collected from years with varying endpoints.

The quantities of these goods and services have been kept constant based on the 1971-72 buying pattern of colleges and universities. The weights assigned to the various items, which represent their relative importance in the current-fund educational and general budget, are estimated national averages. Variance in spending patterns of individual institutions from these national averages reduces only slightly the applicability of HEPI to any given institutional situation. Modest differences in the weights attached to expenditure categories have little effect on overall index values. This is because HEPI is dominated by the trend in faculty salaries and similar salary trends for other personnel hired by institutions, which minimizes the impact of price changes in other items purchased in relatively small quantities.

Further information on HEPI may be obtained from

Commonfund Institute

15 Old Danbury Road

Wilton, CT 06897

http://www.commonfund.org

\section{Council for Aid to Education}

\section{Survey of Voluntary Support of Education}

The Council for Aid to Education, Inc. (CAE) is a notfor-profit corporation funded by contributions from businesses. CAE largely provides consulting and research services to corporations and information on voluntary support services to education institutions. Each year, CAE conducts a survey of colleges and universities and private elementary and secondary schools to obtain information on the amounts, sources, and purposes of private gifts, grants, and bequests received during the academic year.

The annual Voluntary Support of Education (VSE) survey consistently captures about 85 percent of the total voluntary support to colleges and universities in the United States. Institutional reports of voluntary support data from the VSE survey are more comprehensive and detailed than the related data in the Integrated Postsecondary Education Data System (IPEDS) Finance survey conducted by NCES.

The VSE survey is conducted online. All accredited institutions of higher education are eligible to participate, and about a quarter of these institutions fill out a survey each year. CAE reviews the survey forms for internal consistency, queries institutions whose data appear out of line with national trends or their own historical data, and makes an effort to clean the data before preparing a computerized database of the results.

Individual institutions and several state systems of higher education use the VSE data to monitor and analyze their fundraising results. CAE uses the data to develop national estimates of giving to education and to report in detail on private support of education. The results from the VSE survey are available to subscribers online and are also published in the annual Voluntary Support of Education report, which may be purchased from CAE.

Further information on the VSE survey may be obtained from

Ann Kaplan

Council for Aid to Education, Inc.

215 Lexington Avenue

16th Floor

New York, NY 10016-6023

vse@cae.org

http://www.cae.org

\section{Council of Chief State School Officers}

\section{State Education Indicators}

The Council of Chief State School Officers (CCSSO) is a nonpartisan, nationwide, nonprofit organization of the public officials who head departments of public education in the states, the District of Columbia, the U.S. Department of Defense dependents schools, and five outlying areas. The CCSSO Education Indicators project provides leadership in developing a system of state-by-state indicators of the condition of K-12 education. Indicator activities include collecting and reporting statistical indicators by state, tracking state policy changes, assisting with accountability systems, and conducting analysis of trends in education. Key State Education Policies on PK-12 Education is one of the publications issued by the State Educators Project. It is intended to inform policymakers and educators about the current status of key education policies that define and shape elementary and secondary education in public schools in the nation. State education staff reported on current policies through a survey, and CCSSO staff collected additional assessment information through state websites.

Further information on CCSSO publications may be obtained from

State Education Indicators Program

Standards, Assessment, and Accountability

Council of Chief State School Officers

One Massachusetts Avenue NW

Suite 700

Washington, DC 20001-1431

http://www.ccsso.org 


\section{Editorial Projects in Education}

\section{Education Week}

Editorial Projects in Education is an independent, nonprofit publisher of Education Week and other print and online products on $\mathrm{K}-12$ education.

Further information on Editorial Projects in Education publications may be obtained from

Editorial Projects in Education, Inc. 6935 Arlington Road

Suite 100

Bethesda, MD 20814-5233

http://www.edweek.org/info/about

\section{Education Commission of the States}

\section{StateNotes}

Education Commission of the States (ECS) regularly issues compilations, comparisons, and summaries of state policies_-enacted or pending —on a number of education issues, including high school graduation requirements and school term information. ECS monitors state education activities for changes in education policies and updates ECS state information accordingly.

Further information on StateNotes may be obtained from

Education Commission of the States

700 Broadway, \#810

Denver, CO 80203-3442

ecs@ecs.org

http://www.ecs.org

\section{Graduate Record Examinations Board}

\section{GRE tests}

Graduate Record Examinations (GRE) tests are taken by individuals applying to graduate or professional school. GRE offers two types of tests, the revised General Test and Subject Tests. The revised General Test, which is mainly taken on computer, measures verbal, quantitative, and analytical writing skills. The analytical writing section (which replaced the analytical reasoning section on the general GRE on October 1, 2002) consists of two analytical writing tasks. The Subject Tests measure achievement in subject areas that include biochemistry, cell and molecular biology, biology, chemistry, computer science, literature in English, mathematics, physics, and psychology. Each graduate institution or division of the institution determines which GRE tests are required for admission.

Individuals may take GRE tests more than once. Score reports only reflect scores earned within the past 5-year period.

Further information on the GRE may be obtained from

Graduate Record Examinations Board

Educational Testing Service

P.O. Box 6000

Princeton, NJ 08541

http://www.ets.org/gre

\section{Institute of International Education}

\section{Open Doors}

Each year, the Institute of International Education (IIE) conducts a survey of the number of foreign students studying in American colleges and universities and U.S. students studying abroad. The results of these surveys are reported in the publication Open Doors. All of the regionally accredited institutions in NCES's Integrated Postsecondary Education Data System (IPEDS) are surveyed by IIE. The foreign student enrollment data presented in the Digest of Education Statistics are drawn from IIE surveys that ask U.S. institutions for information on enrollment of foreign students, as well as student characteristics such as country of origin. For the 2011-12 survey, 48.9 percent of the 2,880 institutions surveyed reported data.

Surveys on the flows of U.S. college students studying abroad have been conducted since 1985-86. Surveys are sent to U.S. institutions asking them to provide information on the number and characteristics of the students to whom they awarded credit for study abroad during the previous academic year. Data were obtained from 908, or 54 percent, of the 1,697 institutions surveyed.

Additional information can be obtained from the publication Open Doors or by contacting

Sharon Witherell

Institute of International Education-Public Affairs

809 United Nations Plaza

New York, NY 10017

switherell@iie.org

http://www.iie.org/en/Research-and-Publications/Open-Doors

\section{International Association for the Evaluation of Educational Achievement}

The International Association for the Evaluation of Educational Achievement (IEA) is composed of governmental research centers and national research institutions around the world whose aim is to investigate education problems common among countries. Since its inception in 1958, the IEA has conducted more than 30 research studies of cross-national achievement. The regular cycle of studies encompasses learning in basic school subjects. Examples are the Trends in International Mathematics and Science Study (TIMSS) and the Progress in International Reading Literacy Study (PIRLS). IEA projects also include studies of particular interest to IEA members, such as the TIMSS 1999 Video Study of Mathematics and Science Teaching, the Civic Education Study, and studies on information technology in education.

The international bodies that coordinate international assessments vary in the labels they apply to participating education systems, most of which are countries. IEA differentiates between IEA members, which IEA refers to as "countries" in all cases, and "benchmarking participants." IEA members include countries such as the United States and 
Ireland, as well as subnational entities such as England and Scotland (which are both part of the United Kingdom), the Flemish community of Belgium, and Hong Kong-CHN (which is a Special Administrative Region of China). IEA benchmarking participants are all subnational entities and include Canadian provinces, U.S. states, and Dubai in the United Arab Emirates (among others). Benchmarking participants, like the participating countries, are given the opportunity to assess the comparative international standing of their students' achievement and to view their curriculum and instruction in an international context.

Some IEA studies, such as TIMSS and PIRLS, include an assessment portion as well as contextual questionnaires to collect information about students' home and school experiences. The TIMSS and PIRLS scales, including the scale averages and standard deviations, are designed to remain constant from assessment to assessment so that education systems (including countries and subnational education systems) can compare their scores over time, as well as compare their scores directly with the scores of other education systems. Although each scale was created to have a mean of 500 and a standard deviation of 100, the subject matter and the level of difficulty of items necessarily differ by grade, subject, and domain/dimension. Therefore, direct comparisons between scores across grades, subjects, and different domain/dimension types should not be made.

Further information on the International Association for the Evaluation of Educational Achievement may be obtained from http://www.iea.nl.

\section{Trends in International Mathematics and Science Study}

The Trends in International Mathematics and Science Study (TIMSS, formerly known as the Third International Mathematics and Science Study) provides reliable and timely data on the mathematics and science achievement of U.S. fourth- and eighth-graders compared with that of their peers in other countries. TIMSS is on a 4-year cycle, with data collection occurring in 1995, 1999 (eighth grade only), 2003, 2007, and 2011. In 2011, a total of 77 education systems, including 63 IEA members and 14 benchmarking participants, participated in TIMSS. The next TIMSS data collection is scheduled for 2015. TIMSS collects information through mathematics and science assessments and questionnaires. The questionnaires request information to help provide a context for student performance, focusing on such topics as students' attitudes and beliefs about learning mathematics and science, what students do as part of their mathematics and science lessons, students' completion of homework, and their lives both in and outside of school; teachers' perceptions of their preparedness for teaching mathematics and science topics, teaching assignments, class size and organization, instructional content and practices, collaboration with other teachers, and participation in professional development activities; and principals' viewpoints on policy and budget responsibilities, curriculum and instruction issues, and student behavior, as well as descriptions of the organization of schools and courses. The assessments and questionnaires are designed to specifications in a guiding framework. The TIMSS framework describes the mathematics and science content to be assessed and provides grade-specific objectives, an overview of the assessment design, and guidelines for item development.

\section{Progress in International Reading Literacy Study}

The Progress in International Reading Literacy Study (PIRLS) provides reliable and timely data on the reading literacy of U.S. fourth-graders compared with that of their peers in other countries. PIRLS is on a 5-year cycle, with data having been collected in 2001, 2006, and 2011. In 2011, a total of 57 education systems, including 48 IEA members and 9 benchmarking participants, participated in PIRLS. The next PIRLS data collection is scheduled for 2016. PIRLS collects information through a reading literacy assessment and questionnaires that help to provide a context for student performance. Questionnaires are administered to collect information about students' home and school experiences in learning to read. A student questionnaire addresses students' attitudes toward reading and their reading habits. In addition, questionnaires are given to students' teachers and school principals to gather information about students' school experiences in developing reading literacy. In countries other than the United States, a parent questionnaire is also administered. The assessments and questionnaires are designed to specifications in a guiding framework. The PIRLS framework describes the reading content to be assessed and provides objectives specific to fourth grade, an overview of the assessment design, and guidelines for item development.

\section{TIMSS and PIRLS Sampling and Response Rates}

As is done in all participating countries and other education systems, representative samples of students in the United States are selected. The sample design employed by TIMSS and PIRLS in 2011 is generally referred to as a two-stage stratified cluster sample. In the first stage of sampling, individual schools were selected with a probability proportionate to size (PPS) approach, which means that the probability is proportional to the estimated number of students enrolled in the target grade. In the second stage of sampling, intact classrooms were selected within sampled schools.

TIMSS and PIRLS guidelines call for a minimum of 150 schools to be sampled, with a minimum of 4,000 students assessed. The basic sample design of one classroom per school was designed to yield a total sample of approximately 4,500 students per population.

About 23,000 students in almost 900 schools across the United States participated in the 2011 TIMSS, joining 600,000 other student participants around the world. Because PIRLS was also administered at grade 4 in spring 2011, TIMSS and PIRLS in the United States were administered in the same schools to the extent feasible. Students took either TIMSS or PIRLS on the day of the assessments. About 13,000 
U.S. students participated in PIRLS in 2011, joining 300,000 other student participants around the world. Accommodations were not provided for students with disabilities or students who were unable to read or speak the language of the test. These students were excluded from the sample. The IEA requirement is that the overall exclusion rate, which includes exclusions of schools and students, should not exceed more than 5 percent of the national desired target population.

In order to minimize the potential for response biases, the IEA developed participation or response rate standards that apply to all participating education systems and govern whether or not an education system's data are included in the TIMSS or PIRLS international datasets and the way in which its statistics are presented in the international reports. These standards were set using composites of response rates at the school, classroom, and student and teacher levels. Response rates were calculated with and without the inclusion of substitute schools that were selected to replace schools refusing to participate. In TIMSS 2011 at grade 4 in the United States, the weighted school participation rate was 79 percent before the use of substitute schools and 84 percent after the use of replacement schools; the weighted student response rate was 95 percent. In TIMSS 2011 at grade 8 in the United States, the weighted school participation rate was 87 percent before the use of substitute schools and 87 percent after the use of replacement schools; the weighted student response rate was 94 percent. In the 2011 PIRLS administered in the United States, the weighted school participation rate was 80 percent before the use of substitute schools and 85 percent after the use of replacement schools; the weighted student response rate was 96 percent.

Further information on the TIMSS study may be obtained from

Stephen Provasnik

Assessments Division

International Assessment Branch

National Center for Education Statistics

1990 K Street NW, Room 9034

Washington, DC 20006

(202) 502-7480

stephen.provasnik@ed.gov

http://nces.ed.gov/timss

http://www.iea.nl/timss 2011.html

Further information on the PIRLS study may be obtained from

Sheila Thompson

Assessments Division

International Assessment Branch

National Center for Education Statistics

1990 K Street NW, Room 9031

Washington, DC 20006

(202) 502-7425

sheila.thompson@ed.gov

http://nces.ed.gov/surveys/pirls/

http://www.iea.nl/pirls 2011.html
National Association of State Directors of Teacher Education and Certification

\section{NASDTEC Manual/KnowledgeBase}

The National Association of State Directors of Teacher Education and Certification (NASDTEC) was organized in 1928 to represent professional standards boards and commissions and state departments of education that are responsible for the preparation, licensure, and discipline of educational personnel. Currently, NASDTEC's membership includes all 50 states, the District of Columbia, the U.S. Department of Defense Education Activity, U.S. jurisdictions, and Canadian provinces and territories.

The NASDTEC Manual on the Preparation \& Certification of Educational Personnel (NASDTEC Manual) was printed between 1984 and 2004, when it was replaced by an online publication, KnowledgeBase. This is an expanded version of the Manual and is the most comprehensive source of state-by-state information pertaining to the certification requirements and preparation of teachers and other school personnel in the United States and Canada.

Further information on KnowledgeBase may be obtained from

Phillip S. Rogers

Executive Director

NASDTEC

1629 K Street NW

Suite 300

Washington, DC 20006

philrogers@nasdtec.com

http://www.nasdtec.net/

\section{National Catholic Educational Association}

\section{The United States Catholic Elementary and Secondary Schools}

The United States Catholic Elementary and National Catholic Educational Association (NCEA) has been providing leadership and service to Catholic education since 1904. NCEA began to publish The United States Catholic Elementary and Secondary Schools: Annual Statistical Report on Schools, Enrollment, and Staffing in 1970 because of the lack of educational data on the private sector. The report is based on data gathered by each of the 176 archdiocesan and diocesan offices of education in the United States. These data enable NCEA to present information on school enrollment and staffing patterns for prekindergarten through grade 12 . The first part of the report presents data concerning the context of American education, while the following segment focuses on statistical data of Catholic schools. Statistics include enrollment by grade level, race/ethnicity, and affiliation. 
Further information on The United States Catholic Elementary and Secondary Schools: Annual Statistical Report on Schools, Enrollment, and Staffing may be obtained from

Sister Dale McDonald

National Catholic Educational Association

1005 North Glebe Road

Suite 525

Arlington, VA 22201

mcdonald@ncea.org

http://www.ncea.org

\section{National Education Association}

\section{Estimates of School Statistics}

The National Education Association (NEA) produces Estimates of School Statistics annually. This report provides projections of public school enrollment, employment and personnel compensation, and finances, as reported by individual state departments of education. The state-level data in Estimates of School Statistics allow broad assessments of trends in the above areas. These data should be looked at with the understanding that the state-level data do not necessarily reflect the varying conditions within a state on education issues.

Data in this report are provided by state and District of Columbia departments of education and by other, mostly governmental, sources. Surveys are sent to the departments of education requesting estimated data for the current year and revisions to 4 years of historical data, as necessary. Twice a year, NEA submits current-year estimates on more than 35 education statistics to state departments of education for verification or revision. The estimates are generated using regression analyses and are used in the Estimates report only if the states do not provide current data.

Further information on Estimates of School Statistics may be obtained from

NEA Rankings \& Estimates Team-NEA Research

1201 16th Street NW

Washington, DC 20036

http://www.nea.org

\section{Status of the American Public School Teacher}

The Status of the American Public School Teacher Survey is conducted every 5 years by the National Education Association (NEA). The survey was designed by the NEA Research Division and was initially administered in 1956. The intent of the survey is to solicit information covering various aspects of public school teachers' professional, family, and civic lives.

In the 2005-06 survey, questionnaires were sent to about 2,970 public school teachers in the United States, and about 1,330 of these teachers returned completed questionnaires. Of these 1,330 questionnaires, 330 were deemed unusable, yielding 1,000 usable completed questionnaires out of an adjusted total sample of 2,640. The response rate, then, was 37.8 percent.

Possible sources of nonsampling errors are nonresponses, misinterpretation, and-when comparing data over years-changes in the sampling method and instrument. Misinterpretation of the survey items should be minimal, as the sample responding is not from the general population, but one knowledgeable about the area of concern. The sampling procedure changed after 1956, and some wording of items has changed over different administrations of the survey.

Since sampling is used, sampling variability is inherent in the data. An approximation to the standard error for estimating the population percentages is 1.6 percent. Approximations for significance for other comparisons appear in the report, Status of the American Public School Teacher: 2005-2006, available at http://www.nea.org/.

Further information on the Status of the American Public School Teacher Survey may be obtained from

National Education Association-Research Department 1201 16th Street NW

Washington, DC 20036

http://www.nea.org

\section{Organization for Economic Cooperation and Development}

The Organization for Economic Cooperation and Development (OECD) publishes analyses of national policies and survey data in education, training, and economics in OECD and partner countries. Newer studies include student survey data on financial literacy and on digital literacy.

\section{Education at a Glance (EAG)}

To highlight current education issues and create a set of comparative education indicators that represent key features of education systems, OECD initiated the Indicators of Education Systems (INES) project and charged the Centre for Educational Research and Innovation (CERI) with developing the cross-national indicators for it. The development of these indicators involved representatives of the OECD countries and the OECD Secretariat. Improvements in data quality and comparability among OECD countries have resulted from the country-to-country interaction sponsored through the INES project. The most recent publication in this series is Education at a Glance 2013: OECD Indicators (EAG).

The $2013 E A G$ featured the 34 OECD countries: Australia, Austria, Belgium, Canada, Chile, the Czech Republic, Denmark, Estonia, Finland, France, Germany, Greece, Hungary, Iceland, Ireland, Israel, Italy, Japan, the Republic of Korea, Luxembourg, Mexico, the Netherlands, New Zealand, Norway, Poland, Portugal, the Slovak Republic, Slovenia, Spain, Sweden, Switzerland, Turkey, the United Kingdom, and the United States. In addition to the 34 OECD countries, two nonOECD countries that participated in the OECD Indicators of 
Education Systems programme (INES), Brazil and the Russian Federation, were often included, as well as six other G20 countries that did not participate in INES (Argentina, China, India, Indonesia, Saudi Arabia, and South Africa).

The OECD Handbook for Internationally Comparative Education Statistics: Concepts, Standards, Definitions, and Classifications provides countries with specific guidance on how to prepare information for OECD education surveys; facilitates countries' understanding of OECD indicators and their use in policy analysis; and provides a reference for collecting and assimilating educational data. Chapter 7 of the OECD Handbook for Internationally Comparative Education Statistics contains a discussion of data quality issues. Users should examine footnotes carefully to recognize some of the data limitations.

Further information on international education statistics may be obtained from

\section{Andreas Schleicher}

Deputy Director for Education and Skills and Special Advisor on Education Policy to the OECD's Secretary General

OECD Directorate for Education and Skills

2, rue André Pascal

75775 Paris CEDEX 16

France

andreas.schleicher@oecd.org

http://www.oecd.org

\section{Program for International Student Assessment}

The Program for International Student Assessment (PISA) is a system of international assessments that focuses on 15-year-olds' capabilities in reading literacy, mathematics literacy, and science literacy. PISA also includes measures of general, or cross-curricular, competencies such as learning strategies. PISA emphasizes functional skills that students have acquired as they near the end of mandatory schooling. PISA is organized by the Organization for Economic Cooperation and Development (OECD), an intergovernmental organization of industrialized countries, and was administered for the first time in 2000, when 43 education systems participated. In 2003, 41 education systems participated in the assessment; in 2006, 57 education systems ( 30 OECD member countries and 27 nonmember countries or education systems) participated; and in 2009, 65 education systems (34 OECD member countries and 31 nonmember countries or education systems) participated. (An additional nine education systems administered PISA 2009 in 2010.) In PISA 2012, the most recent administration of PISA, 65 education systems (34 OECD member countries and 31 nonmember countries or education systems), as well as the U.S. states of Connecticut, Florida, and Massachusetts, participated.
PISA is a 2-hour paper-and-pencil exam. Assessment items include a combination of multiple-choice questions and open-ended questions that require students to develop their own response. PISA scores are reported on a scale that ranges from 0 to 1,000, with the OECD mean set at 500 and a standard deviation set at 100 . In 2012, mathematics, science, and reading literacy were assessed primarily through a paper-and-pencil exam, and problem-solving was administered using a computer-based exam. Education systems could also participate in optional pencil-and-paper financial literacy assessments and computer-based mathematics and reading assessments.

PISA is implemented on a 3-year cycle that began in 2000. Each PISA assessment cycle focuses on one subject in particular, although all three subjects are assessed every 3 years. In the first cycle, PISA 2000, reading literacy was the major focus, occupying roughly two-thirds of assessment time. For 2003, PISA focused on mathematics literacy as well as the ability of students to solve problems in real-life settings. In 2006, PISA focused on science literacy. In 2009, PISA focused on reading literacy again. In 2012, PISA focused on mathematics literacy.

The intent of PISA reporting is to provide an overall description of performance in reading literacy, mathematics literacy, and science literacy every 3 years, and to provide a more detailed look at each domain in the years when it is the major focus. These cycles will allow education systems to compare changes in trends for each of the three subject areas over time.

To implement PISA, each of the participating education systems scientifically draws a nationally representative sample of 15-year-olds, regardless of grade level. In the United States, about 6,100 students from 161 public and private schools took the PISA 2012 assessment. In the U.S. state education systems, about 1,700 students at 50 schools in Connecticut, about 1,900 students at 54 schools in Florida, and about 1,700 students at 49 schools in Massachusetts took the 2012 assessment. PISA 2012 was only administered at public schools in the U.S. state education systems.

In each education system, the assessment is translated into the primary language of instruction; in the United States, all materials are written in English.

Further information on PISA may be obtained from

Holly Xie

Dana Kelly

Assessments Division

International Assessment Branch

National Center for Education Statistics

1990 K Street NW

Washington, DC 20006

holly.xie@ed.gov

dana.kelly@ed.gov

http://nces.ed.gov/surveys/pisa 


\section{STN Media Group}

\section{School Transportation News}

STN Media Group publishes School Transportation News, a monthly print and online magazine covering the field of pupil transportation. The publication focuses on school bus and school vehicle safety and reports on transportation-related legislation and environmental issues touching on school transportation. The School Transportation News website offers a detailed history of school transportation services in the United States.

Further information about school transportation and the STN Media Group may be obtained from

STN Magazine

P.O. Box 789

Redondo Beach, CA 90277

http://stnonline.com/

\section{United Nations Educational, Scientific, and Cultural Organization}

\section{Statistical Yearbook and Global Education Digest}

The United Nations Educational, Scientific, and Cultural Organization (UNESCO) conducts annual surveys of education statistics of its member countries. Data from official surveys are supplemented by information obtained by UNESCO through other publications and sources. Each year, more than 200 countries reply to the UNESCO surveys. In some cases, estimates are made by UNESCO for particular items, such as world and continent totals. While great efforts are made to make them as comparable as possible, the data still reflect the vast differences among the countries of the world in the structure of education. While there is some agreement about the reporting of primary and secondary data, tertiary-level data (i.e., postsecondary education data) present numerous substantive problems. Some countries report only university enrollment, while other countries report all postsecondary enrollment, including enrollment in vocational and technical schools and correspondence programs. A very high proportion of some countries' tertiary-level students attend institutions in other countries. The member countries that provide data to UNESCO are responsible for their validity. Thus, data for particular countries are subject to nonsampling error and perhaps sampling error as well. Users should examine footnotes carefully to recognize some of the data limitations. UNESCO publishes the data in reports such as the Statistical Yearbook and the Global Education Digest.

Further information on the Statistical Yearbook and the Global Education Digest may be obtained from

UNESCO Institute for Statistics

Publications

C.P. 6128 Succursale Centre-ville

Montreal, Quebec, H3C 3J7

Canada

http://www.uis.unesco.org 



\section{APPENDIX B Definitions}

Academic support This category of college expenditures includes expenditures for support services that are an integral part of the institution's primary missions of instruction, research, or public service. It also includes expenditures for libraries, galleries, audio/visual services, academic computing support, ancillary support, academic administration, personnel development, and course and curriculum development.

Achievement gap Occurs when one group of students outperforms another group, and the difference in average scores for the two groups is statistically significant (that is, larger than the margin of error).

Achievement levels, NAEP Specific achievement levels for each subject area and grade to provide a context for interpreting student performance. At this time they are being used on a trial basis.

Basic - denotes partial mastery of the knowledge and skills that are fundamental for proficient work at a given grade.

Proficient-represents solid academic performance. Students reaching this level have demonstrated competency over challenging subject matter.

Advanced-signifies superior performance.

Achievement test An examination that measures the extent to which a person has acquired certain information or mastered certain skills, usually as a result of specific instruction.

ACT The ACT (formerly the American College Testing Program) assessment program measures educational development and readiness to pursue college-level coursework in English, mathematics, natural science, and social studies. Student performance on the tests does not reflect innate ability and is influenced by a student's educational preparedness.

Administrative support staff Staff whose activities are concerned with support of teaching and administrative duties of the office of the principal or department chairpersons, including clerical staff and secretaries.

Advanced Placement (AP) A program of tertiary-level courses and examinations, taught by specially qualified teachers, that provides opportunities for secondary school students to earn undergraduate credits for first-year university courses. The schools and teachers offering AP programs must meet College Board requirements and are monitored.
Agriculture Courses designed to improve competencies in agricultural occupations. Included is the study of agricultural production, supplies, mechanization and products, agricultural science, forestry, and related services.

Alternative school A public elementary/secondary school that serves students whose needs cannot be met in a regular, special education, or vocational school; may provide nontraditional education; and may serve as an adjunct to a regular school. Although alternative schools fall outside the categories of regular, special education, and vocational education, they may provide similar services or curriculum. Some examples of alternative schools are schools for potential dropouts; residential treatment centers for substance abuse (if they provide elementary or secondary education); schools for chronic truants; and schools for students with behavioral problems.

Appropriation (federal funds) Budget authority provided through the congressional appropriation process that permits federal agencies to incur obligations and to make payments.

Appropriation (institutional revenues) An amount (other than a grant or contract) received from or made available to an institution through an act of a legislative body.

Associate's degree A degree granted for the successful completion of a sub-baccalaureate program of studies, usually requiring at least 2 years (or equivalent) of full-time collegelevel study. This includes degrees granted in a cooperative or work-study program.

Autocorrelation Correlation of the error terms from different observations of the same variable. Also called Serial correlation.

Auxiliary enterprises This category includes those essentially self-supporting operations which exist to furnish a service to students, faculty, or staff, and which charge a fee that is directly related to, although not necessarily equal to, the cost of the service. Examples are residence halls, food services, college stores, and intercollegiate athletics.

Average daily attendance (ADA) The aggregate attendance of a school during a reporting period (normally a school year) divided by the number of days school is in session during this period. Only days on which the pupils are under the guidance and direction of teachers should be considered days in session. 
Average daily membership (ADM) The aggregate membership of a school during a reporting period (normally a school year) divided by the number of days school is in session during this period. Only days on which the pupils are under the guidance and direction of teachers should be considered as days in session. The average daily membership for groups of schools having varying lengths of terms is the average of the average daily memberships obtained for the individual schools. Membership includes all pupils who are enrolled, even if they do not actually attend.

Averaged freshman graduation rate (AFGR) A measure of the percentage of the incoming high school freshman class that graduates 4 years later. It is calculated by taking the number of graduates with a regular diploma and dividing that number by the estimated count of incoming freshman 4 years earlier, as reported through the NCES Common Core of Data (CCD). The estimated count of incoming freshman is the sum of the number of 8th-graders 5 years earlier, the number of 9th-graders 4 years earlier (when current seniors were freshman), and the number of 10th-graders 3 years earlier, divided by 3 . The purpose of this averaging is to account for the high rate of grade retention in the freshman year, which adds 9th-grade repeaters from the previous year to the number of students in the incoming freshman class each year. Ungraded students are allocated to individual grades proportional to each state's enrollment in those grades. The AFGR treats students who transfer out of a school or district in the same way as it treats students from that school or district who drop out.

Bachelor's degree A degree granted for the successful completion of a baccalaureate program of studies, usually requiring at least 4 years (or equivalent) of full-time college-level study. This includes degrees granted in a cooperative or work-study program.

Books Nonperiodical printed publications bound in hard or soft covers, or in loose-leaf format, of at least 49 pages, exclusive of the cover pages; juvenile nonperiodical publications of any length found in hard or soft covers.

Breusch-Godfrey serial correlation LM test A statistic testing the independence of errors in least-squares regression against alternatives of first-order and higher degrees of serial correlation. The test belongs to a class of asymptotic tests known as the Lagrange multiplier (LM) tests.

Budget authority (BA) Authority provided by law to enter into obligations that will result in immediate or future outlays. It may be classified by the period of availability (1-year, multiple-year, no-year), by the timing of congressional action (current or permanent), or by the manner of determining the amount available (definite or indefinite).

Business Program of instruction that prepares individuals for a variety of activities in planning, organizing, directing, and controlling business office systems and procedures.
Capital outlay Funds for the acquisition of land and buildings; building construction, remodeling, and additions; the initial installation or extension of service systems and other built-in equipment; and site improvement. The category also encompasses architectural and engineering services including the development of blueprints.

Career/technical education (CTE) In high school, encompasses occupational education, which teaches skills required in specific occupations or occupational clusters, as well as nonoccupational CTE, which includes family and consumer sciences education (i.e., courses that prepare students for roles outside the paid labor market) and general labor market preparation (i.e., courses that teach general employment skills such as word processing and introductory technology skills).

Carnegie unit The number of credits a secondary student received for a course taken every day, one period per day, for a full year; a factor used to standardize all credits indicated on secondary school transcripts across studies.

Catholic school A private school over which a Roman Catholic church group exercises some control or provides some form of subsidy. Catholic schools for the most part include those operated or supported by a parish, a group of parishes, a diocese, or a Catholic religious order.

Central cities The largest cities, with 50,000 or more inhabitants, in a Metropolitan Statistical Area (MSA). Additional cities within the metropolitan area can also be classified as "central cities" if they meet certain employment, population, and employment/residence ratio requirements.

Certificate A formal award certifying the satisfactory completion of a postsecondary education program. Certificates can be awarded at any level of postsecondary education and include awards below the associate's degree level.

Charter School A school providing free public elementary and/ or secondary education to eligible students under a specific charter granted by the state legislature or other appropriate authority, and designated by such authority to be a charter school.

City school See Locale codes.

Class size The membership of a class at a given date.

Classification of Instructional Programs (CIP) The CIP is a taxonomic coding scheme that contains titles and descriptions of primarily postsecondary instructional programs. It was developed to facilitate NCES' collection and reporting of postsecondary degree completions by major field of study using standard classifications that capture the majority of reportable program activity. It was originally published in 1980 and was revised in 1985, 1990, 2000, and 2010. 
Classification of Secondary School Courses (CSSC) A modification of the Classification of Instructional Programs used for classifying high school courses. The CSSC contains over 2,200 course codes that help compare the thousands of high school transcripts collected from different schools.

Classroom teacher A staff member assigned the professional activities of instructing pupils in self-contained classes or courses, or in classroom situations; usually expressed in full-time equivalents.

Coefficient of variation (CV) Represents the ratio of the standard error to the estimate. For example, a CV of 30 percent indicates that the standard error of the estimate is equal to 30 percent of the estimate's value. The CV is used to compare the amount of variation relative to the magnitude of the estimate. A CV of 30 percent or greater indicates that an estimate should be interpreted with caution. For a discussion of standard errors, see Appendix A: Guide to Sources.

Cohort A group of individuals that have a statistical factor in common, for example, year of birth.

Cohort-component method A method for estimating and projecting a population that is distinguished by its ability to preserve knowledge of an age distribution of a population (which may be of a single sex, race, and Hispanic origin) over time.

College A postsecondary school that offers general or liberal arts education, usually leading to an associate's, bachelor's, master's, or doctor's degree. Junior colleges and community colleges are included under this terminology.

Combined school A school that encompasses instruction at both the elementary and the secondary levels; includes schools starting with grade 6 or below and ending with grade 9 or above.

Combined school (2007-08 Schools and Staffing Survey) A school with at least one grade lower than 7 and at least one grade higher than 8; schools with only ungraded classes are included with combined schools.

Combined Statistical Area (CSA) A combination of Core Based Statistical Areas (see below), each of which contains a core with a substantial population nucleus as well as adjacent communities having a high degree of economic and social integration with that core. A CSA is a region with social and economic ties as measured by commuting, but at lower levels than are found within each component area. CSAs represent larger regions that reflect broader social and economic interactions, such as wholesaling, commodity distribution, and weekend recreation activities.

Computer science A group of instructional programs that describes computer and information sciences, including computer programming, data processing, and information systems.
Constant dollars Dollar amounts that have been adjusted by means of price and cost indexes to eliminate inflationary factors and allow direct comparison across years.

Consumer Price Index (CPI) This price index measures the average change in the cost of a fixed market basket of goods and services purchased by consumers. Indexes vary for specific areas or regions, periods of time, major groups of consumer expenditures, and population groups. The CPI reflects spending patterns for two population groups: (1) all urban consumers and urban wage earners and (2) clerical workers. CPIs are calculated for both the calendar year and the school year using the U.S. All Items CPI for All Urban Consumers (CPI-U). The calendar year CPI is the same as the annual CPI-U. The school year CPI is calculated by adding the monthly CPI-U figures, beginning with July of the first year and ending with June of the following year, and then dividing that figure by 12 .

Consumption That portion of income which is spent on the purchase of goods and services rather than being saved.

Control of institutions A classification of institutions of elementary/secondary or postsecondary education by whether the institution is operated by publicly elected or appointed officials and derives its primary support from public funds (public control) or is operated by privately elected or appointed officials and derives its major source of funds from private sources (private control).

Core Based Statistical Area (CBSA) A population nucleus and the nearby communities having a high degree of economic and social integration with that nucleus. Each CBSA includes at least one urban area of 10,000 or more people and one or more counties. In addition to a "central county" (or counties), additional "outlying counties" are included in the CBSA if they meet specified requirements of commuting to or from the central counties.

Credit The unit of value, awarded for the successful completion of certain courses, intended to indicate the quantity of course instruction in relation to the total requirements for a diploma, certificate, or degree. Credits are frequently expressed in terms such as "Carnegie units," "semester credit hours," and "quarter credit hours."

Current dollars Dollar amounts that have not been adjusted to compensate for inflation.

Current expenditures (elementary/secondary) The expenditures for operating local public schools, excluding capital outlay and interest on school debt. These expenditures include such items as salaries for school personnel, benefits, student transportation, school books and materials, and energy costs. Beginning in 1980-81, expenditures for state administration are excluded. 
Instruction expenditures Includes expenditures for activities related to the interaction between teacher and students. Includes salaries and benefits for teachers and instructional aides, textbooks, supplies, and purchased services such as instruction via television. Also included are tuition expenditures to other local education agencies.

Administration expenditures Includes expenditures for school administration (i.e., the office of the principal, full-time department chairpersons, and graduation expenses), general administration (the superintendent and board of education and their immediate staff), and other support services expenditures.

Transportation Includes expenditures for vehicle operation, monitoring, and vehicle servicing and maintenance.

Food services Includes all expenditures associated with providing food to students and staff in a school or school district. The services include preparing and serving regular and incidental meals or snacks in connection with school activities, as well as the delivery of food to schools.

Enterprise operations Includes expenditures for activities that are financed, at least in part, by user charges, similar to a private business. These include operations funded by sales of products or services, together with amounts for direct program support made by state education agencies for local school districts.

Current expenditures per pupil in average daily attendance Current expenditures for the regular school term divided by the average daily attendance of full-time pupils (or full-time equivalency of pupils) during the term. See also Current expenditures and Average daily attendance.

Current-fund expenditures (postsecondary education) Money spent to meet current operating costs, including salaries, wages, utilities, student services, public services, research libraries, scholarships and fellowships, auxiliary enterprises, hospitals, and independent operations; excludes loans, capital expenditures, and investments.

Current-fund revenues (postsecondary education) Money received during the current fiscal year from revenue which can be used to pay obligations currently due, and surpluses reappropriated for the current fiscal year.

Deaf-blindness See Disabilities, children with.

Deafness See Disabilities, children with.

Default rate The percentage of loans that are in delinquency and have not been repaid according to the terms of the loan. According to the federal government, a federal student loan is in default if there has been no payment on the loan in 270 days. The Department of Education calculates a 2-year cohort default rate, which is the percentage of students who entered repayment in a given fiscal year (from October 1 to September 30 ) and then defaulted within the following two fiscal years.
Degree An award conferred by a college, university, or other postsecondary education institution as official recognition for the successful completion of a program of studies. Refers specifically to associate's or higher degrees conferred by degree-granting institutions. See also Associate's degree, Bachelor's degree, Master's degree, and Doctor's degree.

Degree/certificate-seeking student A student enrolled in courses for credit and recognized by the institution as seeking a degree, certificate, or other formal award. High school students also enrolled in postsecondary courses for credit are not considered degree/certificate-seeking. See also Degree and Certificate.

Degree-granting institutions Postsecondary institutions that are eligible for Title IV federal financial aid programs and grant an associate's or higher degree. For an institution to be eligible to participate in Title IV financial aid programs it must offer a program of at least 300 clock hours in length, have accreditation recognized by the U.S. Department of Education, have been in business for at least 2 years, and have signed a participation agreement with the Department.

Degrees of freedom The number of free or linearly independent sample observations used in the calculation of a statistic. In a time series regression with $t$ time periods and $k$ independent variables including a constant term, there would be $t$ minus $k$ degrees of freedom.

Department of Defense (DoD) dependents schools Schools that are operated by the Department of Defense Education Activity (a civilian agency of the U.S. Department of Defense) and provide comprehensive prekindergarten through 12thgrade educational programs on military installations both within the United States and overseas.

Dependency status A designation of whether postsecondary students are financially dependent on their parents or financially independent of their parents. Undergraduates are assumed to be dependent unless they meet one of the following criteria: are age 24 or older, are married or have legal dependents other than a spouse, are veterans, are orphans or wards of the court, or provide documentation that they self-supporting.

Dependent variable A mathematical variable whose value is determined by that of one or more other variables in a function. In regression analysis, when a random variable, $y$, is expressed as a function of variables $x 1, x 2, \ldots x k$, plus a stochastic term, then $y$ is known as the "dependent variable."

Disabilities, children with Those children evaluated as having any of the following impairments and needing special education and related services because of these impairments. (These definitions apply specifically to data from the U.S. Office of Special Education and Rehabilitative Services presented in this publication.) 
Autism Having a developmental disability significantly affecting verbal and nonverbal communication and social interaction, generally evident before age 3 , that adversely affects educational performance. Other characteristics often associated with autism are engagement in repetitive activities and stereotyped movements, resistance to environmental change or change in daily routines, and unusual responses to sensory experiences. A child is not considered autistic if the child's educational performance is adversely affected primarily because of an emotional disturbance.

Deaf-blindness Having concomitant hearing and visual impairments which cause such severe communication and other developmental and educational problems that the student cannot be accommodated in special education programs solely for deaf or blind students.

Deafness Having a hearing impairment which is so severe that the student is impaired in processing linguistic information through hearing (with or without amplification) and which adversely affects educational performance.

Developmental delay Having developmental delays, as defined at the state level, and as measured by appropriate diagnostic instruments and procedures in one or more of the following cognitive areas: physical development, cognitive development, communication development, social or emotional development, or adaptive development.

Hearing impairment Having a hearing impairment, whether permanent or fluctuating, which adversely affects the student's educational performance, but which is not included under the definition of "deaf" in this section.

Intellectual disability Having significantly subaverage general intellectual functioning, existing concurrently with defects in adaptive behavior and manifested during the developmental period, which adversely affects the child's educational performance.

Multiple disabilities Having concomitant impairments (such as intellectually disabled-blind, intellectually disabled-orthopedically impaired, etc.), the combination of which causes such severe educational problems that the student cannot be accommodated in special education programs solely for one of the impairments. Term does not include deaf-blind students.

Orthopedic impairment Having a severe orthopedic impairment which adversely affects a student's educational performance. The term includes impairment resulting from congenital anomaly, disease, or other causes.

Other health impairment Having limited strength, vitality, or alertness due to chronic or acute health problems, such as a heart condition, tuberculosis, rheumatic fever, nephritis, asthma, sickle cell anemia, hemophilia, epilepsy, lead poisoning, leukemia, or diabetes which adversely affect the student's educational performance.

Serious emotional disturbance Exhibiting one or more of the following characteristics over a long period of time, to a marked degree, and adversely affecting educational performance: an inability to learn which cannot be explained by intellectual, sensory, or health factors; an inability to build or maintain satisfactory interpersonal relationships with peers and teachers; inappropriate types of behavior or feelings under normal circumstances; a general pervasive mood of unhappiness or depression; or a tendency to develop physical symptoms or fears associated with personal or school problems. This term does not include children who are socially maladjusted, unless they also display one or more of the listed characteristics.

Specific learning disability Having a disorder in one or more of the basic psychological processes involved in understanding or in using spoken or written language, which may manifest itself in an imperfect ability to listen, think, speak, read, write, spell, or do mathematical calculations. The term includes such conditions as perceptual disabilities, brain injury, minimal brain dysfunction, dyslexia, and developmental aphasia. The term does not include children who have learning problems which are primarily the result of visual, hearing, or environmental, cultural, or economic disadvantage.

Speech/language impairment Having a communication disorder, such as stuttering, impaired articulation, language impairment, or voice impairment, which adversely affects the student's educational performance.

Visual impairment Having a visual impairment which, even with correction, adversely affects the student's educational performance. The term includes partially seeing and blind children.

Discipline divisions Degree programs that include breakouts to the 6-digit level of the Classification of Instructional Programs (CIP). See also Fields of study.

Disposable personal income Current income received by people less their contributions for social insurance, personal tax, and nontax payments. It is the income available to people for spending and saving. Nontax payments include passport fees, fines and penalties, donations, and tuitions and fees paid to schools and hospitals operated mainly by the government. See also Personal income.

Distance education Education that uses one or more technologies to deliver instruction to students who are separated from the instructor and to support regular and substantive interaction between the students and the instructor synchronously or asynchronously. Technologies used for instruction may include the following: Internet; one-way and two-way transmissions through open broadcasts, closed circuit, cable, microwave, broadband lines, fiber optics, and satellite or wireless communication devices; audio conferencing; and video cassette, DVDs, and CD-ROMs, if the cassette, DVDs, and CD-ROMs are used in a course in conjunction with the technologies listed above.

Doctor's degree The highest award a student can earn for graduate study. Includes such degrees as the Doctor of Education (Ed.D.); the Doctor of Juridical Science (S.J.D.); the Doctor of Public Health (Dr.P.H.); and the Doctor of Philosophy (Ph.D.) in any field, such as agronomy, food technology, education, engineering, public administration, ophthalmology, or radiology. The doctor's degree classification encompasses three main subcategories-research/scholarship degrees, professional practice degrees, and other degrees - which are described below. 
Doctor's degree-research/scholarship A Ph.D. or other doctor's degree that requires advanced work beyond the master's level, including the preparation and defense of a dissertation based on original research, or the planning and execution of an original project demonstrating substantial artistic or scholarly achievement. Examples of this type of degree may include the following and others, as designated by the awarding institution: the Ed.D. (in education), D.M.A. (in musical arts), D.B.A. (in business administration), D.Sc. (in science), D.A. (in arts), or D.M (in medicine).

Doctor's degree-professional practice A doctor's degree that is conferred upon completion of a program providing the knowledge and skills for the recognition, credential, or license required for professional practice. The degree is awarded after a period of study such that the total time to the degree, including both preprofessional and professional preparation, equals at least 6 fulltime-equivalent academic years. Some doctor's degrees of this type were formerly classified as first-professional degrees. Examples of this type of degree may include the following and others, as designated by the awarding institution: the D.C. or D.C.M. (in chiropractic); D.D.S. or D.M.D. (in dentistry); L.L.B. or J.D. (in law); M.D. (in medicine); O.D. (in optometry); D.O. (in osteopathic medicine); Pharm.D. (in pharmacy); D.P.M., Pod.D., or D.P. (in podiatry); or D.V.M. (in veterinary medicine).

Doctor's degree-other A doctor's degree that does not meet the definition of either a doctor's degree-research/ scholarship or a doctor's degree-professional practice.

Double exponential smoothing A method that takes a single smoothed average component of demand and smoothes it a second time to allow for estimation of a trend effect.

Dropout The term is used to describe both the event of leaving school before completing high school and the status of an individual who is not in school and who is not a high school completer. High school completers include both graduates of school programs as well as those completing high school through equivalency programs such as the General Educational Development (GED) program. Transferring from a public school to a private school, for example, is not regarded as a dropout event. A person who drops out of school may later return and graduate but is called a "dropout" at the time he or she leaves school. Measures to describe these behaviors include the event dropout rate (or the closely related school persistence rate), the status dropout rate, and the high school completion rate.

Durbin-Watson statistic A statistic testing the independence of errors in least squares regression against the alternative of first-order serial correlation. The statistic is a simple linear transformation of the first-order serial correlation of residuals and, although its distribution is unknown, it is tested by bounding statistics that follow R. L. Anderson's distribution.

Early childhood school Early childhood program schools serve students in prekindergarten, kindergarten, transitional (or readiness) kindergarten, and/or transitional first (or prefirst) grade.
Econometrics The quantitative examination of economic trends and relationships using statistical techniques, and the development, examination, and refinement of those techniques.

Education specialist/professional diploma A certificate of advanced graduate studies that advance educators in their instructional and leadership skills beyond a master's degree level of competence.

Educational and general expenditures The sum of current funds expenditures on instruction, research, public service, academic support, student services, institutional support, operation and maintenance of plant, and awards from restricted and unrestricted funds.

Educational attainment The highest grade of regular school attended and completed.

Educational attainment (Current Population Survey) This measure uses March CPS data to estimate the percentage of civilian, noninstitutionalized people who have achieved certain levels of educational attainment. Estimates of educational attainment do not differentiate between those who graduated from public schools, those who graduated from private schools, and those who earned a GED; these estimates also include individuals who earned their credential or completed their highest level of education outside of the United States.

1972-1991 During this period, an individual's educational attainment was considered to be his or her last fully completed year of school. Individuals who completed 12 years of schooling were deemed to be high school graduates, as were those who began but did not complete the first year of college. Respondents who completed 16 or more years of schooling were counted as college graduates.

1992-present Beginning in 1992, CPS asked respondents to report their highest level of school completed or their highest degree received. This change means that some data collected before 1992 are not strictly comparable with data collected from 1992 onward and that care must be taken when making comparisons across years. The revised survey question emphasizes credentials received rather than the last grade level attended or completed. The new categories include the following:

- High school graduate, high school diploma, or the equivalent (e.g., GED)

- Some college but no degree

- Associate's degree in college, occupational/vocational program

- Associate's degree in college, academic program (e.g., A.A., A.S., A.A.S.)

- Bachelor's degree (e.g., B.A., A.B., B.S.)

- Master's degree (e.g., M.A., M.S., M.Eng., M.Ed., M.S.W., M.B.A.)

- Professional school degree (e.g., M.D., D.D.S., D.V.M., LL.B., J.D.)

- Doctor's degree (e.g., Ph.D., Ed.D.) 
Elementary education/programs Learning experiences concerned with the knowledge, skills, appreciations, attitudes, and behavioral characteristics which are considered to be needed by all pupils in terms of their awareness of life within our culture and the world of work, and which normally may be achieved during the elementary school years (usually kindergarten through grade 8 or kindergarten through grade 6), as defined by applicable state laws and regulations.

Elementary school A school classified as elementary by state and local practice and composed of any span of grades not above grade 8 .

Elementary/secondary school Includes only schools that are part of state and local school systems, and also most nonprofit private elementary/secondary schools, both religiously affiliated and nonsectarian. Includes regular, alternative, vocational, and special education schools. U.S. totals exclude federal schools for American Indians, and federal schools on military posts and other federal installations.

Employees in degree-granting institutions Persons employed by degree-granting institutions, who are classified into the following occupational categories in this publication:

Executive/administrative/managerial staff Employees whose assignments require management of the institution or of a customarily recognized department or subdivision thereof. These employees perform work that is directly related to management policies or general business operations and that requires them to exercise discretion and independent judgment.

Faculty (instruction/research/public service) Employees whose principal activities are for the purpose of providing instruction or teaching, research, or public service. These employees may hold such titles as professor, associate professor, assistant professor, instructor, or lecturer. Graduate assistants are not included in this category.

Graduate assistants Graduate-level students who are employed on a part-time basis for the primary purpose of assisting in classroom or laboratory instruction or in the conduct of research.

Nonprofessional staff Employees whose primary activities can be classified as one of the following: technical and paraprofessional work (which generally requires less formal training and experience than required for professional status); clerical and secretarial work; skilled crafts work; or service/maintenance work.

Other professional staff Employees who perform academic support, student service, and institutional support and who need either a degree at the bachelor's or higher level or experience of such kind and amount as to provide a comparable background.

Professional staff Employees who are classified as executive/administrative/managerial staff, faculty, graduate assistants, or other professional staff.
Employment Includes civilian, noninstitutional people who: (1) worked during any part of the survey week as paid employees; worked in their own business, profession, or farm; or worked 15 hours or more as unpaid workers in a family-owned enterprise; or (2) were not working but had jobs or businesses from which they were temporarily absent due to illness, bad weather, vacation, labor-management dispute, or personal reasons whether or not they were seeking another job.

Employment (Current Population Survey) According to the October Current Population Survey (CPS), employed persons are persons age 16 or older who, during the reference week, (1) did any work at all (at least 1 hour) as paid employees or (2) were not working but had jobs or businesses from which they were temporarily absent because of vacation, illness, bad weather, child care problems, maternity or paternity leave, labor-management dispute, job training, or other family or personal reasons, whether or not they were paid for the time off or were seeking other jobs.

Employment status A classification of individuals as employed (either full or part time), unemployed (looking for work or on layoff), or not in the labor force (due to being retired, having unpaid employment, or some other reason).

Endowment A trust fund set aside to provide a perpetual source of revenue from the proceeds of the endowment investments. Endowment funds are often created by donations from benefactors of an institution, who may designate the use of the endowment revenue. Normally, institutions or their representatives manage the investments, but they are not permitted to spend the endowment fund itself, only the proceeds from the investments. Typical uses of endowments would be an endowed chair for a particular department or for a scholarship fund. Endowment totals tabulated in this book also include funds functioning as endowments, such as funds left over from the previous year and placed with the endowment investments by the institution. These funds may be withdrawn by the institution and spent as current funds at any time. Endowments are evaluated by two different measures, book value and market value. Book value is the purchase price of the endowment investment. Market value is the current worth of the endowment investment. Thus, the book value of a stock held in an endowment fund would be the purchase price of the stock. The market value of the stock would be its selling price as of a given day.

Engineering Instructional programs that describe the mathematical and natural science knowledge gained by study, experience, and practice and applied with judgment to develop ways to utilize the materials and forces of nature economically. Includes programs that prepare individuals to support and assist engineers and similar professionals.

English A group of instructional programs that describes the English language arts, including composition, creative writing, and the study of literature. 
English language learner (ELL) An individual who, due to any of the reasons listed below, has sufficient difficulty speaking, reading, writing, or understanding the English language to be denied the opportunity to learn successfully in classrooms where the language of instruction is English or to participate fully in the larger U.S. society. Such an individual (1) was not born in the United States or has a native language other than English; (2) comes from environments where a language other than English is dominant; or (3) is an American Indian or Alaska Native and comes from environments where a language other than English has had a significant impact on the individual's level of English language proficiency.

Enrollment The total number of students registered in a given school unit at a given time, generally in the fall of a year.

Estimate A numerical value obtained from a statistical sample and assigned to a population parameter. The particular value yielded by an estimator in a given set of circumstances or the rule by which such particular values are calculated.

Estimating equation An equation involving observed quantities and an unknown that serves to estimate the latter.

Estimation Estimation is concerned with inference about the numerical value of unknown population values from incomplete data, such as a sample. If a single figure is calculated for each unknown parameter, the process is called point estimation. If an interval is calculated within which the parameter is likely, in some sense, to lie, the process is called interval estimation.

Executive/administrative/managerial staff See Employees in degree-granting institutions.

Expenditures, Total For elementary/secondary schools, these include all charges for current outlays plus capital outlays and interest on school debt. For degree-granting institutions, these include current outlays plus capital outlays. For government, these include charges net of recoveries and other correcting transactions other than for retirement of debt, investment in securities, extension of credit, or as agency transactions. Government expenditures include only external transactions, such as the provision of perquisites or other payments in kind. Aggregates for groups of governments exclude intergovernmental transactions among the governments.

Expenditures per pupil Charges incurred for a particular period of time divided by a student unit of measure, such as average daily attendance or fall enrollment.

Exponential smoothing A method used in time series analysis to smooth or to predict a series. There are various forms, but all are based on the supposition that more remote history has less importance than more recent history.

Extracurricular activities Activities that are not part of the required curriculum and that take place outside of the regular course of study. They include both school-sponsored (e.g., varsity athletics, drama, and debate clubs) and communitysponsored (e.g., hobby clubs and youth organizations like the Junior Chamber of Commerce or Boy Scouts) activities.
Faculty (instruction/research/public service) See Employees in degree-granting institutions.

Family A group of two or more people (one of whom is the householder) related by birth, marriage, or adoption and residing together. All such people (including related subfamily members) are considered as members of one family.

Family income Includes all monetary income from all sources (including jobs, businesses, interest, rent, and social security payments) over a 12-month period. The income of nonrelatives living in the household is excluded, but the income of all family members age 15 or older (age 14 or older in years prior to 1989), including those temporarily living outside of the household, is included. In the October CPS, family income is determined from a single question asked of the household respondent.

Federal funds Amounts collected and used by the federal government for the general purposes of the government. There are four types of federal fund accounts: the general fund, special funds, public enterprise funds, and intragovernmental funds. The major federal fund is the general fund, which is derived from general taxes and borrowing. Federal funds also include certain earmarked collections, such as those generated by and used to finance a continuing cycle of business-type operations.

Federal sources (postsecondary degree-granting institutions) Includes federal appropriations, grants, and contracts, and federally-funded research and development centers (FFRDCs). Federally subsidized student loans are not included.

Fields of study The primary field of concentration in postsecondary certificates and degrees. In the Integrated Postsecondary Education Data System (IPEDS), refers to degree programs that are broken out only to the 2-digit level of the Classification of Instructional Programs (CIP). See also Discipline divisions.

Financial aid Grants, loans, assistantships, scholarships, fellowships, tuition waivers, tuition discounts, veteran's benefits, employer aid (tuition reimbursement), and other monies (other than from relatives or friends) provided to students to help them meet expenses. Except where designated, includes Title IV subsidized and unsubsidized loans made directly to students.

First-order serial correlation When errors in one time period are correlated directly with errors in the ensuing time period.

First-professional degree NCES no longer uses this classification. Most degrees formerly classified as first-professional (such as M.D., D.D.S., Pharm.D., D.V.M., and J.D.) are now classified as doctor's degrees - professional practice. However, master's of divinity degrees are now classified as master's degrees.

First-time student (undergraduate) A student who has no prior postsecondary experience (except as noted below) attending any institution for the first time at the undergraduate level. Includes students enrolled in the fall term who attended college for the first time in the prior summer term, and students who entered with advanced standing (college credits earned before graduation from high school). 
Fiscal year A period of 12 months for which accounting records are compiled. Institutions and states may designate their own accounting period, though most states use a July 1 through June 30 accounting year. The yearly accounting period for the federal government begins on October 1 and ends on the following September 30. The fiscal year is designated by the calendar year in which it ends; e.g., fiscal year 2006 begins on October 1, 2005, and ends on September 30, 2006. (From fiscal year 1844 to fiscal year 1976, the federal fiscal year began on July 1 and ended on the following June 30.)

Forecast An estimate of the future based on rational study and analysis of available pertinent data, as opposed to subjective prediction.

Forecasting Assessing the magnitude that a quantity will assume at some future point in time, as distinct from "estimation," which attempts to assess the magnitude of an already existent quantity.

Foreign languages A group of instructional programs that describes the structure and use of language that is common or indigenous to people of a given community or nation, geographical area, or cultural traditions. Programs cover such features as sound, literature, syntax, phonology, semantics, sentences, prose, and verse, as well as the development of skills and attitudes used in communicating and evaluating thoughts and feelings through oral and written language.

For-profit institution A private institution in which the individual(s) or agency in control receives compensation other than wages, rent, or other expenses for the assumption of risk.

Free or reduced-price lunch See National School Lunch Program.

Full-time enrollment The number of students enrolled in postsecondary education courses with total credit load equal to at least 75 percent of the normal full-time course load. At the undergraduate level, full-time enrollment typically includes students who have a credit load of 12 or more semester or quarter credits. At the postbaccalaureate level, full-time enrollment includes students who typically have a credit load of 9 or more semester or quarter credits, as well as other students who are considered full time by their institutions.

Full-time-equivalent (FTE) enrollment For postsecondary institutions, enrollment of full-time students, plus the fulltime equivalent of part-time students. The full-time equivalent of the part-time students is estimated using different factors depending on the type and control of institution and level of student.

Full-time-equivalent (FTE) staff Full-time staff, plus the full-time equivalent of the part-time staff.
Full-time-equivalent teacher See Instructional staff.

Full-time instructional faculty Those members of the instruction/research staff who are employed full time as defined by the institution, including faculty with released time for research and faculty on sabbatical leave. Full-time counts exclude faculty who are employed to teach less than two semesters, three quarters, two trimesters, or two 4month sessions; replacements for faculty on sabbatical leave or those on leave without pay; faculty for preclinical and clinical medicine; faculty who are donating their services; faculty who are members of military organizations and paid on a different pay scale from civilian employees; those academic officers whose primary duties are administrative; and graduate students who assist in the instruction of courses.

Full-time worker In educational institutions, an employee whose position requires being on the job on school days throughout the school year at least the number of hours the schools are in session. For higher education, a member of an educational institution's staff who is employed full time, as defined by the institution.

Function A mathematical correspondence that assigns exactly one element of one set to each element of the same or another set. A variable that depends on and varies with another.

Functional form A mathematical statement of the relationship among the variables in a model.

General administration support services Includes salary, benefits, supplies, and contractual fees for boards of education staff and executive administration. Excludes state administration.

General Educational Development (GED) program Academic instruction to prepare people to take the high school equivalency examination. See also GED recipient.

GED certificate This award is received following successful completion of the General Educational Development (GED) test. The GED program-sponsored by the GED Testing Service (a joint venture of the American Council on Education and Pearson) - enables individuals to demonstrate that they have acquired a level of learning comparable to that of high school graduates. See also High school equivalency certificate.

GED recipient A person who has obtained certification of high school equivalency by meeting state requirements and passing an approved exam, which is intended to provide an appraisal of the person's achievement or performance in the broad subject matter areas usually required for high school graduation. 
General program A program of studies designed to prepare students for the common activities of a citizen, family member, and worker. A general program of studies may include instruction in both academic and vocational areas.

Geographic region One of the four regions of the United States used by the U.S. Census Bureau, as follows:

Northeast
Connecticut (CT)
Maine (ME)
Massachusetts (MA)
New Hampshire (NH)
New Jersey (NJ)
New York (NY)
Pennsylvania (PA)
Rhode Island (RI)
Vermont (VT)

South

Alabama (AL)

Arkansas (AR)

Delaware (DE)

Florida (FL)

Georgia (GA)

Kentucky (KY)

Louisiana (LA)

Maryland (MD)

Mississippi (MS)

North Carolina (NC)

Oklahoma (OK)

South Carolina (SC)

Tennessee (TN)

Texas (TX)

Virginia (VA)

West Virginia (WV)
District of Columbia (DC)

\section{Midwest \\ Illinois (IL) \\ Indiana (IN) \\ Iowa (IA) \\ Kansas (KS) \\ Michigan (MI) \\ Minnesota (MN) \\ Missouri (MO) \\ Nebraska (NE) \\ North Dakota (ND) \\ Ohio (OH) \\ South Dakota (SD) \\ Wisconsin (WI)}

\section{West}

Alaska (AK)

Arizona (AZ)

California (CA)

Colorado (CO)

Hawaii (HI)

Idaho (ID)

Montana (MT)

Nevada (NV)

New Mexico (NM)

Oregon (OR)

Utah (UT)

Washington (WA)

Wyoming (WY)
Government appropriation An amount (other than a grant or contract) received from or made available to an institution through an act of a legislative body.

Government grant or contract Revenues received by a postsecondary institution from a government agency for a specific research project or other program. Examples are research projects, training programs, and student financial assistance.

Graduate An individual who has received formal recognition for the successful completion of a prescribed program of studies.

Graduate assistants See Employees in degree-granting institutions.
Graduate enrollment The number of students who are working towards a master's or doctor's degree and students who are in postbaccalaureate classes but not in degree programs.

Graduate Record Examination (GRE) Multiple-choice examinations administered by the Educational Testing Service and taken by college students who are intending to attend certain graduate schools. There are two types of testing available: (1) the general exam which measures critical thinking, analytical writing, verbal reasoning, and quantitative reasoning skills, and (2) the subject test which is offered in eight specific subjects and gauges undergraduate achievement in a specific field. The subject tests are intended for those who have majored in or have extensive background in that specific area.

Graduation Formal recognition given to an individual for the successful completion of a prescribed program of studies.

Gross domestic product (GDP) The total national output of goods and services valued at market prices. GDP can be viewed in terms of expenditure categories which include purchases of goods and services by consumers and government, gross private domestic investment, and net exports of goods and services. The goods and services included are largely those bought for final use (excluding illegal transactions) in the market economy. A number of inclusions, however, represent imputed values, the most important of which is rental value of owner-occupied housing.

Group quarters Living arrangements where people live or stay in a group situation that is owned or managed by an entity or organization providing housing and/or services for the residents. Group quarters include such places as college residence halls, residential treatment centers, skilled nursing facilities, group homes, military barracks, correctional facilities, and workers' dormitories.

Noninstitutionalized group quarters Include college and university housing, military quarters, facilities for workers and religious groups, and temporary shelters for the homeless.

Institutionalized group quarters Include adult and juvenile correctional facilities, nursing facilities, and other health care facilities.

Handicapped See Disabilities, children with.

Head Start A local public or private nonprofit or for-profit entity authorized by the Department of Health and Human Services' Administration for Children and Families to operate a Head Start program to serve children age 3 to compulsory school age, pursuant to section 641(b) and (d) of the Head Start Act.

Hearing impairment See Disabilities, children with. 
High school A secondary school offering the final years of high school work necessary for graduation. A high school is usually either a 3 -year school that includes grades 10, 11, and 12 or a 4-year school that includes grades $9,10,11$, and 12.

High school (2007-08 Schools and Staffing Survey) A school with no grade lower than 7 and at least one grade higher than 8.

High school completer An individual who has been awarded a high school diploma or an equivalent credential, including a General Educational Development (GED) certificate.

High school diploma A formal document regulated by the state certifying the successful completion of a prescribed secondary school program of studies. In some states or communities, high school diplomas are differentiated by type, such as an academic diploma, a general diploma, or a vocational diploma.

High school equivalency certificate A formal document certifying that an individual has met the state requirements for high school graduation equivalency by obtaining satisfactory scores on an approved examination and meeting other performance requirements (if any) set by a state education agency or other appropriate body. One particular version of this certificate is the General Educational Development (GED) test. The GED test is a comprehensive test used primarily to appraise the educational development of students who have not completed their formal high school education and who may earn a high school equivalency certificate by achieving satisfactory scores. GEDs are awarded by the states or other agencies, and the test is developed and distributed by the GED Testing Service (a joint venture of the American Council on Education and Pearson).

High school program A program of studies designed to prepare students for employment and postsecondary education. Three types of programs are often distinguished-academic, vocational, and general. An academic program is designed to prepare students for continued study at a college or university. A vocational program is designed to prepare students for employment in one or more semiskilled, skilled, or technical occupations. A general program is designed to provide students with the understanding and competence to function effectively in a free society and usually represents a mixture of academic and vocational components.

Higher education Study beyond secondary school at an institution that offers programs terminating in an associate's, bachelor's, or higher degree.

Higher education institutions (basic classification and Carnegie classification) See Postsecondary institutions (basic classification by level) and Postsecondary institutions (Carnegie classification of degree-granting institutions).
Higher Education Price Index A price index which measures average changes in the prices of goods and services purchased by colleges and universities through current-fund education and general expenditures (excluding expenditures for sponsored research and auxiliary enterprises).

Hispanic serving institutions Pursuant to 302 (d) of Public Law 102-325 (20 U.S.C. 1059c), most recently amended December 20, 1993, in 2(a)(7) of Public Law 103-208, where Hispanic serving institutions are defined as those with full-time-equivalent undergraduate enrollment of Hispanic students at 25 percent or more.

Historically black colleges and universities Accredited institutions of higher education established prior to 1964 with the principal mission of educating black Americans. Federal regulations (20 USC 1061 (2)) allow for certain exceptions of the founding date.

Hours worked per week According to the October CPS, the number of hours a respondent worked in all jobs in the week prior to the survey interview.

Household All the people who occupy a housing unit. A house, an apartment, a mobile home, a group of rooms, or a single room is regarded as a housing unit when it is occupied or intended for occupancy as separate living quarters, that is, when the occupants do not live and eat with any other people in the structure, and there is direct access from the outside or through a common hall.

Housing unit A house, an apartment, a mobile home, a group of rooms, or a single room that is occupied as separate living quarters.

Income tax Taxes levied on net income, that is, on gross income less certain deductions permitted by law. These taxes can be levied on individuals or on corporations or unincorporated businesses where the income is taxed distinctly from individual income.

Independent operations A group of self-supporting activities under control of a college or university. For purposes of financial surveys conducted by the National Center for Education Statistics, this category is composed principally of federally funded research and development centers (FFRDC).

Independent variable In regression analysis, a random variable, $y$, is expressed as a function of variables $x 1, x 2, \ldots x k$, plus a stochastic term; the $x$ 's are known as "independent variables."

Individuals with Disabilities Education Act (IDEA) IDEA is a federal law requiring services to children with disabilities throughout the nation. IDEA governs how states and public agencies provide early intervention, special education, and related services to eligible infants, toddlers, children, and youth with disabilities. Infants and toddlers with disabilities (birth-age 2) and their families receive early intervention services under IDEA, Part C. Children and youth (ages 3-21) receive special education and related services under IDEA, Part B. 
Inflation A rise in the general level of prices of goods and services in an economy over a period of time, which generally corresponds to a decline in the real value of money or a loss of purchasing power. See also Constant dollars and Purchasing Power Parity indexes.

Institutional support The category of higher education expenditures that includes day-to-day operational support for colleges, excluding expenditures for physical plant operations. Examples of institutional support include general administrative services, executive direction and planning, legal and fiscal operations, and community relations.

Instruction (colleges and universities) That functional category including expenditures of the colleges, schools, departments, and other instructional divisions of higher education institutions and expenditures for departmental research and public service which are not separately budgeted; includes expenditures for both credit and noncredit activities. Excludes expenditures for academic administration where the primary function is administration (e.g., academic deans).

Instruction (elementary and secondary) Instruction encompasses all activities dealing directly with the interaction between teachers and students. Teaching may be provided for students in a school classroom, in another location such as a home or hospital, and in other learning situations such as those involving co-curricular activities. Instruction may be provided through some other approved medium, such as the Internet, television, radio, telephone, and correspondence.

Instructional staff Full-time-equivalent number of positions, not the number of different individuals occupying the positions during the school year. In local schools, includes all public elementary and secondary (junior and senior high) day-school positions that are in the nature of teaching or in the improvement of the teaching-learning situation; includes consultants or supervisors of instruction, principals, teachers, guidance personnel, librarians, psychological personnel, and other instructional staff, and excludes administrative staff, attendance personnel, clerical personnel, and junior college staff.

Instructional support services Includes salary, benefits, supplies, and contractual fees for staff providing instructional improvement, educational media (library and audiovisual), and other instructional support services.

Intellectual disability See Disabilities, children with.

Interest on debt Includes expenditures for long-term debt service interest payments (i.e., those longer than 1 year).

International baccalaureate (IB) A recognized international program of primary, middle, and secondary studies leading to the International Baccalaureate (IB) Diploma. This diploma (or certificate) is recognized in Europe and elsewhere as qualifying holders for direct access to university studies. Schools offering the IB program are approved by the International Baccalaureate Organization (IBO) and their regional office and may use IBO instructional materials, local school materials, or a combination.
International finance data Include data on public and private expenditures for educational institutions. Educational institutions directly provide instructional programs (i.e., teaching) to individuals in an organized group setting or through distance education. Business enterprises or other institutions that provide short-term courses of training or instruction to individuals on a "one-to-one" basis are not included. Where noted, international finance data may also include publicly subsidized spending on education-related purchases, such as school books, living costs, and transportation.

Public expenditures Corresponds to the nonrepayable current and capital expenditures of all levels of the government directly related to education. Expenditures that are not directly related to education (e.g., cultures, sports, youth activities) are, in principle, not included. Expenditures on education by other ministries or equivalent institutions (e.g., Health and Agriculture) are included. Public subsidies for students' living expenses are excluded to ensure international comparability of the data.

Private expenditures Refers to expenditures funded by private sources (i.e., households and other private entities). "Households" means students and their families. "Other private entities" includes private business firms and nonprofit organizations, including religious organizations, charitable organizations, and business and labor associations. Private expenditures are composed of school fees, the cost of materials (such as textbooks and teaching equipment), transportation costs (if organized by the school), the cost of meals (if provided by the school), boarding fees, and expenditures by employers on initial vocational training.

Current expenditures Includes final consumption expenditures (e.g., compensation of employees, consumption of intermediate goods and services, consumption of fixed capital, and military expenditures); property income paid; subsidies; and other current transfers paid.

Capital expenditures Includes spending to acquire and improve fixed capital assets, land, intangible assets, government stocks, and nonmilitary, nonfinancial assets, as well as spending to finance net capital transfers.

International Standard Classification of Education (ISCED) Used to compare educational systems in different countries. ISCED is the standard used by many countries to report education statistics to the United Nations Educational, Scientific, and Cultural Organization (UNESCO) and the Organization for Economic Cooperation and Development (OECD). ISCED divides educational systems into the following seven categories, based on six levels of education.

ISCED Level 0 Education preceding the first level (early childhood education) usually begins at age 3,4 , or 5 (sometimes earlier) and lasts from 1 to 3 years, when it is provided. In the United States, this level includes nursery school and kindergarten. 
ISCED Level 1 Education at the first level (primary or elementary education) usually begins at age 5,6 , or 7 and continues for about 4 to 6 years. For the United States, the first level starts with 1st grade and ends with 6th grade.

ISCED Level 2 Education at the second level (lower secondary education) typically begins at about age 11 or 12 and continues for about 2 to 6 years. For the United States, the second level starts with 7th grade and typically ends with 9th grade. Education at the lower secondary level continues the basic programs of the first level, although teaching is typically more subject focused, often using more specialized teachers who conduct classes in their field of specialization. The main criterion for distinguishing lower secondary education from primary education is whether programs begin to be organized in a more subject-oriented pattern, using more specialized teachers conducting classes in their field of specialization. If there is no clear breakpoint for this organizational change, lower secondary education is considered to begin at the end of 6 years of primary education. In countries with no clear division between lower secondary and upper secondary education, and where lower secondary education lasts for more than 3 years, only the first 3 years following primary education are counted as lower secondary education.

ISCED Level 3 Education at the third level (upper secondary education) typically begins at age 15 or 16 and lasts for approximately 3 years. In the United States, the third level starts with 10th grade and ends with 12th grade. Upper secondary education is the final stage of secondary education in most OECD countries. Instruction is often organized along subject-matter lines, in contrast to the lower secondary level, and teachers typically must have a higher level, or more subject-specific, qualification. There are substantial differences in the typical duration of programs both across and between countries, ranging from 2 to 5 years of schooling. The main criteria for classifications are (1) national boundaries between lower and upper secondary education and (2) admission into educational programs, which usually requires the completion of lower secondary education or a combination of basic education and life experience that demonstrates the ability to handle the subject matter in upper secondary schools.

ISCED Level 4 Education at the fourth level (postsecondary nontertiary education) straddles the boundary between secondary and postsecondary education. This program of study, which is primarily vocational in nature, is generally taken after the completion of secondary school and typically lasts from 6 months to 2 years. Although the content of these programs may not be significantly more advanced than upper secondary programs, these programs serve to broaden the knowledge of participants who have already gained an upper secondary qualification.

ISCED Level 5 Education at the fifth level (first stage of tertiary education) includes programs with more advanced content than those offered at the two previous levels.
Entry into programs at the fifth level normally requires successful completion of either of the two previous levels.

ISCED Level 5A Tertiary-type A programs provide an education that is largely theoretical and is intended to provide sufficient qualifications for gaining entry into advanced research programs and professions with high skill requirements. Entry into these programs normally requires the successful completion of an upper secondary education; admission is competitive in most cases. The minimum cumulative theoretical duration at this level is 3 years of full-time enrollment. In the United States, tertiary-type A programs include first university programs that last approximately 4 years and lead to the award of a bachelor's degree and second university programs that lead to a master's degree.

ISCED Level 5B Tertiary-type B programs are typically shorter than tertiary-type A programs and focus on practical, technical, or occupational skills for direct entry into the labor market, although they may cover some theoretical foundations in the respective programs. They have a minimum duration of 2 years of full-time enrollment at the tertiary level. In the United States, such programs are often provided at community colleges and lead to an associate's degree.

ISCED Level 6 Education at the sixth level (advanced research qualification) is provided in graduate and professional schools that generally require a university degree or diploma as a minimum condition for admission. Programs at this level lead to the award of an advanced, postgraduate degree, such as a Ph.D. The theoretical duration of these programs is 3 years of full-time enrollment in most countries (for a cumulative total of at least 7 years at levels five and six), although the length of the actual enrollment is often longer. Programs at this level are devoted to advanced study and original research.

Interpolation See Linear interpolation.

Junior high school A separately organized and administered secondary school intermediate between the elementary and senior high schools. A junior high school is usually either a 3-year school that includes grades 7, 8, and 9 or a 2year school that includes grades 7 and 8 .

Labor force People employed (either full time or part time) as civilians, unemployed but looking for work, or in the armed services during the survey week. The "civilian labor force" comprises all civilians classified as employed or unemployed. See also Unemployed.

Lag An event occurring at time $t+k(k>0)$ is said to lag behind an event occurring at time $t$, the extent of the lag being $k$. An event occurring $k$ time periods before another may be regarded as having a negative lag. 
Land-grant colleges The First Morrill Act of 1862 facilitated the establishment of colleges through grants of land or funds in lieu of land. The Second Morrill Act in 1890 provided for money grants and for the establishment of landgrant colleges and universities for blacks in those states with dual systems of higher education.

Lead time When forecasting a statistic, the number of time periods since the last time period of actual data for that statistic used in producing the forecast.

Level of school A classification of elementary/secondary schools by instructional level. Includes elementary schools, secondary schools, and combined elementary and secondary schools. See also Elementary school, Secondary school, and Combined elementary and secondary school.

Limited-English proficient Refers to an individual who was not born in the United States and whose native language is a language other than English, or who comes from an environment where a language other than English has had a significant impact on the individual's level of English language proficiency. It may also refer to an individual who is migratory, whose native language is a language other than English, and who comes from an environment where a language other than English is dominant; and whose difficulties in speaking, reading, writing, or understanding the English language may be sufficient to deny the individual the ability to meet the state's proficient level of achievement on state assessments as specified under the No Child Left Behind Act, the ability to successfully achieve in classrooms where the language of instruction is English, or the opportunity to participate fully in society. See also English language learner.

Linear interpolation A method that allows the prediction of an unknown value if any two particular values on the same scale are known and the rate of change is assumed constant.

Local education agency (LEA) See School district.

Locale codes A classification system to describe a type of location. The "Metro-Centric" locale codes, developed in the 1980s, classified all schools and school districts based on their county's proximity to a Metropolitan Statistical Area (MSA) and their specific location's population size and density. In 2006, the "UrbanCentric" locale codes were introduced. These locale codes are based on an address's proximity to an urbanized area. For more information see http://nces.ed.gov/ccd/rural locales.asp.

\section{Pre-2006 Metro-Centric Locale Codes}

Large City: A central city of a consolidated metropolitan statistical area (CMSA) or MSA, with the city having a population greater than or equal to 250,000 .

Mid-size City: A central city of a CMSA or MSA, with the city having a population less than 250,000 .
Urban Fringe of a Large City: Any territory within a CMSA or MSA of a Large City and defined as urban by the Census Bureau.

Urban Fringe of a Mid-size City: Any territory within a CMSA or MSA of a Mid-size City and defined as urban by the Census Bureau.

Large Town: An incorporated place or Census-designated place with a population greater than or equal to 25,000 and located outside a CMSA or MSA.

Small Town: An incorporated place or Census-designated place with a population less than 25,000 and greater than or equal to 2,500 and located outside a CMSA or MSA.

Rural, Outside MSA: Any territory designated as rural by the Census Bureau that is outside a CMSA or MSA of a Large or Mid-size City.

Rural, Inside MSA: Any territory designated as rural by the Census Bureau that is within a CMSA or MSA of a Large or Mid-size City.

\section{Urban-Centric Locale Codes}

City, Large: Territory inside an urbanized area and inside a principal city with population of 250,000 or more.

City, Midsize: Territory inside an urbanized area and inside a principal city with population less than 250,000 and greater than or equal to 100,000 .

City, Small: Territory inside an urbanized area and inside a principal city with population less than 100,000.

Suburb, Large: Territory outside a principal city and inside an urbanized area with population of 250,000 or more.

Suburb, Midsize: Territory outside a principal city and inside an urbanized area with population less than 250,000 and greater than or equal to 100,000 .

Suburb, Small: Territory outside a principal city and inside an urbanized area with population less than 100,000.

Town, Fringe: Territory inside an urban cluster that is less than or equal to 10 miles from an urbanized area.

Town, Distant: Territory inside an urban cluster that is more than 10 miles and less than or equal to 35 miles from an urbanized area.

Town, Remote: Territory inside an urban cluster that is more than 35 miles from an urbanized area.

Rural, Fringe: Census-defined rural territory that is less than or equal to 5 miles from an urbanized area, as well as rural territory that is less than or equal to 2.5 miles from an urban cluster.

Rural, Distant: Census-defined rural territory that is more than 5 miles but less than or equal to 25 miles from an urbanized area, as well as rural territory that is more than 2.5 miles but less than or equal to 10 miles from an urban cluster. 
Rural, Remote: Census-defined rural territory that is more than 25 miles from an urbanized area and is also more than 10 miles from an urban cluster.

Magnet school or program A special school or program designed to reduce, prevent, or eliminate racial isolation and/or to provide an academic or social focus on a particular theme.

Mandatory transfer The transfer of current funds that must be made in order to fulfill a binding legal obligation of the institution. Included under mandatory transfers are debt service provisions relating to academic and administrative buildings, including (1) amounts set aside for debt retirement and interest and (2) required provisions for renewal and replacement of buildings to the extent these are not financed from other fund.

Margin of error A range of potential true or actual values for a sample survey estimate. The margin of error depends on several factors such as the amount of variation in the responses, the size and representativeness of the sample, and the size of the subgroup for which the estimate is computed. The magnitude of the margin of error is represented by the standard error of the estimate.

Master's degree A degree awarded for successful completion of a program generally requiring 1 or 2 years of full-time collegelevel study beyond the bachelor's degree. One type of master's degree, including the Master of Arts degree, or M.A., and the Master of Science degree, or M.S., is awarded in the liberal arts and sciences for advanced scholarship in a subject field or discipline and demonstrated ability to perform scholarly research. A second type of master's degree is awarded for the completion of a professionally oriented program, for example, an M.Ed. in education, an M.B.A. in business administration, an M.F.A. in fine arts, an M.M. in music, an M.S.W. in social work, and an M.P.A. in public administration. Some master's degrees-such as divinity degrees (M.Div. or M.H.L./Rav), which were formerly classified as "first-professional"- may require more than 2 years of full-time study beyond the bachelor's degree.

Mathematics A group of instructional programs that describes the science of numbers and their operations, interrelations, combinations, generalizations, and abstractions and of space configurations and their structure, measurement, transformations, and generalizations.

Mean absolute percentage error (MAPE) The average value of the absolute value of errors expressed in percentage terms.

Mean test score The score obtained by dividing the sum of the scores of all individuals in a group by the number of individuals in that group for which scores are available.

Median earnings The amount which divides the income distribution into two equal groups, half having income above that amount and half having income below that amount. Earnings include all wage and salary income. Unlike mean earnings, median earnings either do not change or change very little in response to extreme observations.
Middle school A school with no grade lower than 5 and no higher than 8 .

Migration Geographic mobility involving a change of usual residence between clearly defined geographic units, that is, between counties, states, or regions.

Minimum-competency testing Measuring the acquisition of competence or skills to or beyond a certain specified standard.

Model A system of postulates, data, and inferences presented as a mathematical description of a phenomenon, such as an actual system or process. The actual phenomenon is represented by the model in order to explain, predict, and control it.

Montessori school A school that provides instruction using Montessori teaching methods.

Multiple disabilities See Disabilities, children with.

National Assessment of Educational Progress (NAEP) See Appendix A: Guide to Sources.

National School Lunch Program Established by President Truman in 1946, the program is a federally assisted meal program operated in public and private nonprofit schools and residential child care centers. To be eligible for free lunch, a student must be from a household with an income at or below 130 percent of the federal poverty guideline; to be eligible for reduced-price lunch, a student must be from a household with an income between 130 percent and 185 percent of the federal poverty guideline.

Newly qualified teacher People who: (1) first became eligible for a teaching license during the period of the study referenced or who were teaching at the time of survey, but were not certified or eligible for a teaching license; and (2) had never held full-time, regular teaching positions (as opposed to substitute) prior to completing the requirements for the degree which brought them into the survey.

Non-degree-granting institutions Postsecondary institutions that participate in Title IV federal financial aid programs but do not offer accredited 4-year or 2-year degree programs. Includes some institutions transitioning to higher level program offerings, though still classified at a lower level.

Nonprofessional staff See Employees in degree-granting institutions.

Nonprofit institution A private institution in which the individual(s) or agency in control receives no compensation other than wages, rent, or other expenses for the assumption of risk. Nonprofit institutions may be either independent nonprofit (i.e., having no religious affiliation) or religiously affiliated.

Nonresident alien A person who is not a citizen of the United States and who is in this country on a temporary basis and does not have the right to remain indefinitely. 
Nonsectarian school Nonsectarian schools do not have a religious orientation or purpose and are categorized as regular, special program emphasis, or special education schools. See also Regular school, Special program emphasis school, and Special education school.

Nonsupervisory instructional staff People such as curriculum specialists, counselors, librarians, remedial specialists, and others possessing education certification, but not responsible for day-to-day teaching of the same group of pupils.

Nursery school An instructional program for groups of children during the year or years preceding kindergarten, which provides educational experiences under the direction of teachers. See also Prekindergarten and Preschool.

Obligations Amounts of orders placed, contracts awarded, services received, or similar legally binding commitments made by federal agencies during a given period that will require outlays during the same or some future period.

Occupational home economics Courses of instruction emphasizing the acquisition of competencies needed for getting and holding a job or preparing for advancement in an occupational area using home economics knowledge and skills.

Occupied housing unit Separate living quarters with occupants currently inhabiting the unit. See also Housing unit.

Off-budget federal entities Organizational entities, federally owned in whole or in part, whose transactions belong in the budget under current budget accounting concepts, but that have been excluded from the budget totals under provisions of law. An example of an off-budget federal entity is the Federal Financing Bank, which provides student loans under the Direct Loan Program.

On-budget funding Federal funding for education programs that is tied to appropriations. On-budget funding does not include the Direct Loan Program, under which student loans are provided by the Federal Financing Bank, an off-budget federal entity. See also Off-budget federal entities.

Operation and maintenance services Includes salary, benefits, supplies, and contractual fees for supervision of operations and maintenance, operating buildings (heating, lighting, ventilating, repair, and replacement), care and upkeep of grounds and equipment, vehicle operations and maintenance (other than student transportation), security, and other operations and maintenance services.

Ordinary least squares (OLS) The estimator that minimizes the sum of squared residuals.

Organization for Economic Cooperation and Development (OECD) An intergovernmental organization of industrialized countries that serves as a forum for member countries to cooperate in research and policy development on social and economic topics of common interest. In addition to member countries, partner countries contribute to the OECD's work in a sustained and comprehensive manner.
Orthopedic impairment See Disabilities, children with.

Other foreign languages and literatures Any instructional program in foreign languages and literatures not listed in the table, including language groups and individual languages, such as the non-Semitic African languages, Native American languages, the Celtic languages, Pacific language groups, the Ural-Altaic languages, Basque, and others.

Other health impairment See Disabilities, children with.

Other professional staff See Employees in degree-granting institutions.

Other religious school Other religious schools have a religious orientation or purpose, but are not Roman Catholic. Other religious schools are categorized according to religious association membership as Conservative Christian, other affiliated, or unaffiliated.

Other support services Includes salary, benefits, supplies, and contractual fees for business support services, central support services, and other support services not otherwise classified.

Other support services staff All staff not reported in other categories. This group includes media personnel, social workers, bus drivers, security, cafeteria workers, and other staff.

Outlays The value of checks issued, interest accrued on the public debt, or other payments made, net of refunds and reimbursements.

Parameter A quantity that describes a statistical population.

Part-time enrollment The number of students enrolled in postsecondary education courses with a total credit load less than 75 percent of the normal full-time credit load. At the undergraduate level, part-time enrollment typically includes students who have a credit load of less than 12 semester or quarter credits. At the postbaccalaureate level, part-time enrollment typically includes students who have a credit load of less than 9 semester or quarter credits.

Pass-through transaction A payment that a postsecondary institution applies directly to a student's account. The payment "passes through" the institution for the student's benefit. Most private institutions treat Pell grants as pass-through transactions. At these institutions, any Pell grant funds that are applied to a student's tuition are reported as tuition revenues. In contrast, the vast majority of public institutions report Pell grants both as federal revenues and as allowances that reduce tuition revenues.

Personal income Current income received by people from all sources, minus their personal contributions for social insurance. Classified as "people" are individuals (including owners of unincorporated firms), nonprofit institutions serving individuals, private trust funds, and private noninsured welfare funds. Personal income includes transfers (payments not resulting from current production) from government and business such as social security benefits and military pensions, but excludes transfers among people. 
Physical plant assets Includes the values of land, buildings, and equipment owned, rented, or utilized by colleges. Does not include those plant values which are a part of endowment or other capital fund investments in real estate; excludes construction in progress.

Postbaccalaureate enrollment The number of students working towards advanced degrees and of students enrolled in graduate-level classes but not enrolled in degree programs. See also Graduate enrollment.

Postsecondary education The provision of formal instructional programs with a curriculum designed primarily for students who have completed the requirements for a high school diploma or equivalent. This includes programs of an academic, vocational, and continuing professional education purpose, and excludes avocational and adult basic education programs.

\section{Postsecondary institutions (basic classification by level)}

4-year institution An institution offering at least a 4-year program of college-level studies wholly or principally creditable toward a baccalaureate degree.

2-year institution An institution offering at least a 2-year program of college-level studies which terminates in an associate degree or is principally creditable toward a baccalaureate degree. Data prior to 1996 include some institutions that have a less-than-2-year program, but were designated as institutions of higher education in the Higher Education General Information Survey.

Less-than-2-year institution An institution that offers programs of less than 2 years' duration below the baccalaureate level. Includes occupational and vocational schools with programs that do not exceed 1,800 contact hours.

\section{Postsecondary institutions (Carnegie classification of degree- granting institutions)}

Doctorate-granting Characterized by a significant level and breadth of activity in commitment to doctoral-level education as measured by the number of doctorate recipients and the diversity in doctoral-level program offerings. These institutions are assigned to one of the three subcategories listed below based on level of research activity (for more information on the research activity index used to assign institutions to the subcategories, see http://classifications.carnegiefoundation.org/methodology/ basic.php):

Research university, very high Characterized by a very high level of research activity.

Research university, high Characterized by a high level of research activity.

Doctoral/research university Awarding at least 20 doctor's degrees per year, but not having a high level of research activity.
Master's Characterized by diverse postbaccalaureate programs but not engaged in significant doctoral-level education.

Baccalaureate Characterized by primary emphasis on general undergraduate, baccalaureate-level education. Not significantly engaged in postbaccalaureate education.

Special focus Baccalaureate or postbaccalaureate institution emphasizing one area (plus closely related specialties), such as business or engineering. The programmatic emphasis is measured by the percentage of degrees granted in the program area.

Associate's Institutions conferring at least 90 percent of their degrees and awards for work below the bachelor's level. In NCES tables, excludes all institutions offering any 4-year programs leading to a bachelor's degree.

Tribal Colleges and universities that are members of the American Indian Higher Education Consortium, as identified in IPEDS Institutional Characteristics.

Poverty The U.S. Census Bureau uses a set of money income thresholds that vary by family size and composition. A family, along with each individual in it, is considered poor if the family's total income is less than that family's threshold. The poverty thresholds do not vary geographically and are adjusted annually for inflation using the Consumer Price Index. The official poverty definition counts money income before taxes and does not include capital gains and noncash benefits (such as public housing, Medicaid, and food stamps).

Prekindergarten Preprimary education for children typically ages 3-4 who have not yet entered kindergarten. It may offer a program of general education or special education and may be part of a collaborative effort with Head Start.

Preschool An instructional program enrolling children generally younger than 5 years of age and organized to provide children with educational experiences under professionally qualified teachers during the year or years immediately preceding kindergarten (or prior to entry into elementary school when there is no kindergarten). See also Nursery school and Prekindergarten.

Primary school A school with at least one grade lower than 5 and no grade higher than 8 .

Private institution An institution that is controlled by an individual or agency other than a state, a subdivision of a state, or the federal government, which is usually supported primarily by other than public funds, and the operation of whose program rests with other than publicly elected or appointed officials.

Private nonprofit institution An institution in which the individual(s) or agency in control receives no compensation other than wages, rent, or other expenses for the assumption of risk. These include both independent nonprofit institutions and those affiliated with a religious organization. 
Private for-profit institution An institution in which the individual(s) or agency in control receives compensation other than wages, rent, or other expenses for the assumption of risk (e.g., proprietary schools).

Private school Private elementary/secondary schools surveyed by the Private School Universe Survey (PSS) are assigned to one of three major categories (Catholic, other religious, or nonsectarian) and, within each major category, one of three subcategories based on the school's religious affiliation provided by respondents.

Catholic Schools categorized according to governance, provided by Catholic school respondents, into parochial, diocesan, and private schools.

Other religious Schools that have a religious orientation or purpose but are not Roman Catholic. Other religious schools are categorized according to religious association membership, provided by respondents, into Conservative Christian, other affiliated, and unaffiliated schools. Conservative Christian schools are those "Other religious" schools with membership in at least one of four associations: Accelerated Christian Education, American Association of Christian Schools, Association of Christian Schools International, and Oral Roberts University Education Fellowship. Affiliated schools are those "Other religious" schools not classified as Conservative Christian with membership in at least 1 of 11 associationsAssociation of Christian Teachers and Schools, Christian Schools International, Evangelical Lutheran Education Association, Friends Council on Education, General Conference of the Seventh-Day Adventist Church, Islamic School League of America, National Association of Episcopal Schools, National Christian School Association, National Society for Hebrew Day Schools, Solomon Schechter Day Schools, and Southern Baptist Association of Christian Schools-or indicating membership in "other religious school associations." Unaffiliated schools are those "Other religious" schools that have a religious orientation or purpose but are not classified as Conservative Christian or affiliated.

Nonsectarian Schools that do not have a religious orientation or purpose and are categorized according to program emphasis, provided by respondents, into regular, special emphasis, and special education schools. Regular schools are those that have a regular elementary/secondary or early childhood program emphasis. Special emphasis schools are those that have a Montessori, vocational/ technical, alternative, or special program emphasis. Special education schools are those that have a special education program emphasis.

Professional staff See Employees in degree-granting institutions.
Program for International Student Assessment (PISA) A system of international assessments organized by the OECD that focuses on 15-year-olds' capabilities in reading literacy, mathematics literacy, and science literacy. PISA also includes measures of general, or cross-curricular, competencies such as learning strategies. The measures emphasize functional skills that students have acquired as they near the end of mandatory schooling. PISA was administered for the first time in 2000, when 43 countries participated. Forty-one countries participated in the 2003 administration of PISA; 57 jurisdictions ( 30 OECD members and 27 nonmembers) participated in 2006; and 65 jurisdictions (34 OECD members and 31 nonmembers) participated in 2009.

Projection In relation to a time series, an estimate of future values based on a current trend.

Property tax The sum of money collected from a tax levied against the value of property.

Proprietary (for profit) institution A private institution in which the individual(s) or agency in control receives compensation other than wages, rent, or other expenses for the assumption of risk.

Public school or institution A school or institution controlled and operated by publicly elected or appointed officials and deriving its primary support from public funds.

Pupil/teacher ratio The enrollment of pupils at a given period of time, divided by the full-time-equivalent number of classroom teachers serving these pupils during the same period.

Purchasing Power Parity (PPP) indexes PPP exchange rates, or indexes, are the currency exchange rates that equalize the purchasing power of different currencies, meaning that when a given sum of money is converted into different currencies at the PPP exchange rates, it will buy the same basket of goods and services in all countries. PPP indexes are the rates of currency conversion that eliminate the difference in price levels among countries. Thus, when expenditures on gross domestic product (GDP) for different countries are converted into a common currency by means of PPP indexes, they are expressed at the same set of international prices, so that comparisons among countries reflect only differences in the volume of goods and services purchased.

$R^{2}$ The coefficient of determination; the square of the correlation coefficient between the dependent variable and its ordinary least squares (OLS) estimate.

Racial/ethnic group Classification indicating general racial or ethnic heritage. Race/ethnicity data are based on the Hispanic ethnic category and the race categories listed below (five single-race categories, plus the Two or more races category). Race categories exclude persons of Hispanic ethnicity unless otherwise noted. 
White A person having origins in any of the original peoples of Europe, the Middle East, or North Africa.

Black or African American A person having origins in any of the black racial groups of Africa. Used interchangeably with the shortened term Black.

Hispanic or Latino A person of Cuban, Mexican, Puerto Rican, South or Central American, or other Spanish culture or origin, regardless of race. Used interchangeably with the shortened term Hispanic.

Asian A person having origins in any of the original peoples of the Far East, Southeast Asia, or the Indian subcontinent, including, for example, Cambodia, China, India, Japan, Korea, Malaysia, Pakistan, the Philippine Islands, Thailand, and Vietnam. Prior to 2010-11, the Common Core of Data (CCD) combined Asian and Pacific Islander categories.

Native Hawaiian or Other Pacific Islander A person having origins in any of the original peoples of Hawaii, Guam, Samoa, or other Pacific Islands. Prior to 2010-11, the Common Core of Data (CCD) combined Asian and Pacific Islander categories. Used interchangeably with the shortened term Pacific Islander.

American Indian or Alaska Native A person having origins in any of the original peoples of North and South America (including Central America), and who maintains tribal affiliation or community attachment.

Two or more races A person identifying himself or herself as of two or more of the following race groups: White, Black, Asian, Native Hawaiian or Other Pacific Islander, or American Indian or Alaska Native. Some, but not all, reporting districts use this category. "Two or more races" was introduced in the 2000 Census and became a regular category for data collection in the Current Population Survey (CPS) in 2003. The category is sometimes excluded from a historical series of data with constant categories. It is sometimes included within the category "Other."

Region See Geographic region.

Regression analysis A statistical technique for investigating and modeling the relationship between variables.

Regular school A public elementary/secondary or charter school providing instruction and education services that does not focus primarily on special education, vocational/ technical education, or alternative education.

Related children Related children in a family include own children and all other children in the household who are related to the householder by birth, marriage, or adoption.

Remedial education Instruction for a student lacking those reading, writing, or math skills necessary to perform collegelevel work at the level required by the attended institution.
Resident population Includes civilian population and armed forces personnel residing within the United States; excludes armed forces personnel residing overseas.

Revenue All funds received from external sources, net of refunds, and correcting transactions. Noncash transactions, such as receipt of services, commodities, or other receipts in kind are excluded, as are funds received from the issuance of debt, liquidation of investments, and nonroutine sale of property.

Revenue receipts Additions to assets that do not incur an obligation that must be met at some future date and do not represent exchanges of property for money. Assets must be available for expenditures.

Rho A measure of the correlation coefficient between errors in time period $t$ and time period $t$ minus 1 .

Rural school See Locale codes.

Salary The total amount regularly paid or stipulated to be paid to an individual, before deductions, for personal services rendered while on the payroll of a business or organization.

Sales and services Revenues derived from the sales of goods or services that are incidental to the conduct of instruction, research, or public service. Examples include film rentals, scientific and literary publications, testing services, university presses, and dairy products.

Sales tax Tax imposed upon the sale and consumption of goods and services. It can be imposed either as a general tax on the retail price of all goods and services sold or as a tax on the sale of selected goods and services.

SAT An examination administered by the Educational Testing Service and used to predict the facility with which an individual will progress in learning college-level academic subjects. It was formerly called the Scholastic Assessment Test.

Scholarships and fellowships This category of college expenditures applies only to money given in the form of outright grants and trainee stipends to individuals enrolled in formal coursework, either for credit or not. Aid to students in the form of tuition or fee remissions is included. College work-study funds are excluded and are reported under the program in which the student is working.

School A division of the school system consisting of students in one or more grades or other identifiable groups and organized to give instruction of a defined type. One school may share a building with another school or one school may be housed in several buildings. Excludes schools that have closed or are planned for the future.

School administration support services Includes salary, benefits, supplies, and contractual fees for the office of the principal, full-time department chairpersons, and graduation expenses. 
School climate The social system and culture of the school, including the organizational structure of the school and values and expectations within it.

School district An education agency at the local level that exists primarily to operate public schools or to contract for public school services. Synonyms are "local basic administrative unit" and "local education agency."

Science The body of related courses concerned with knowledge of the physical and biological world and with the processes of discovering and validating this knowledge.

Secondary enrollment The total number of students registered in a school beginning with the next grade following an elementary or middle school (usually 7,8 , or 9) and ending with or below grade 12 at a given time.

Secondary instructional level The general level of instruction provided for pupils in secondary schools (generally covering grades 7 through 12 or 9 through 12) and any instruction of a comparable nature and difficulty provided for adults and youth beyond the age of compulsory school attendance.

Secondary school A school comprising any span of grades beginning with the next grade following an elementary or middle school (usually 7,8 , or 9) and ending with or below grade 12. Both junior high schools and senior high schools are included.

Senior high school A secondary school offering the final years of high school work necessary for graduation.

Serial correlation Correlation of the error terms from different observations of the same variable. Also called Autocorrelation.

Serial volumes Publications issued in successive parts, usually at regular intervals, and as a rule, intended to be continued indefinitely. Serials include periodicals, newspapers, annuals, memoirs, proceedings, and transactions of societies.

Serious emotional disturbance See Disabilities, children with.

Social studies A group of instructional programs that describes the substantive portions of behavior, past and present activities, interactions, and organizations of people associated together for religious, benevolent, cultural, scientific, political, patriotic, or other purposes.

Socioeconomic status (SES) The SES index is a composite of often equally weighted, standardized components, such as father's education, mother's education, family income, father's occupation, and household items. The terms high, middle, and low SES refer to ranges of the weighted SES composite index distribution.
Special education Direct instructional activities or special learning experiences designed primarily for students identified as having exceptionalities in one or more aspects of the cognitive process or as being underachievers in relation to general level or model of their overall abilities. Such services usually are directed at students with the following conditions: (1) physically handicapped; (2) emotionally disabled; (3) culturally different, including compensatory education; (4) intellectually disabled; and (5) students with learning disabilities. Programs for the mentally gifted and talented are also included in some special education programs. See also Disabilities, children with.

Special education school A public elementary/secondary school that focuses primarily on special education for children with disabilities and that adapts curriculum, materials, or instruction for students served. See also Disabilities, children with.

Special program emphasis school A science/mathematics school, a performing arts high school, a foreign language immersion school, and a talented/gifted school are examples of schools that offer a special program emphasis.

Specific learning disability See Disabilities, children with.

Speech/language impairment See Disabilities, children with.

Standard error of estimate An expression for the standard deviation of the observed values about a regression line. An estimate of the variation likely to be encountered in making predictions from the regression equation.

Standardized test A test composed of a systematic sampling of behavior, administered and scored according to specific instructions, capable of being interpreted in terms of adequate norms, and for which there are data on reliability and validity.

Standardized test performance The weighted distributions of composite scores from standardized tests used to group students according to performance.

Status dropout rate The percentage of individuals within a given age range who are not enrolled in school and lack a high school credential, irrespective of when they dropped out.

Status dropout rate (American Community Survey) Similar to the status dropout rate (Current Population Survey), except that institutionalized persons, incarcerated persons, and active duty military personnel living in barracks in the United States may be included in this calculation.

Status dropout rate (Current Population Survey) The percentage of civilian, noninstitutionalized young people ages 16-24 who are not in school and have not earned a high school credential (either a diploma or equivalency credential such as a General Educational Development [GED] certificate). The numerator of the status dropout rate for a given 
year is the number of individuals ages $16-24$ who, as of October of that year, have not completed a high school credential and are not currently enrolled in school. The denominator is the total number of individuals ages 16-24 in the United States in October of that year. Status dropout rates count as dropouts individuals who never attended school and immigrants who did not complete the equivalent of a high school education in their home country.

STEM fields Science, Technology, Engineering, and Mathematics (STEM) fields of study that are considered to be of particular relevance to advanced societies. For the purposes of The Condition of Education 2012, STEM fields include agriculture and natural resources, biological and biomedical sciences, computer and information sciences and support services, engineering and engineering technologies, mathematics and statistics, physical sciences, and science technologies.

Student An individual for whom instruction is provided in an educational program under the jurisdiction of a school, school system, or other education institution. No distinction is made between the terms "student" and "pupil," though "student" may refer to one receiving instruction at any level while "pupil" refers only to one attending school at the elementary or secondary level. A student may receive instruction in a school facility or in another location, such as at home or in a hospital. Instruction may be provided by direct studentteacher interaction or by some other approved medium such as television, radio, telephone, and correspondence.

Student membership Student membership is an annual headcount of students enrolled in school on October 1 or the school day closest to that date. The Common Core of Data (CCD) allows a student to be reported for only a single school or agency. For example, a vocational school (identified as a "shared time" school) may provide classes for students from a number of districts and show no membership.

Student support services Includes salary, benefits, supplies, and contractual fees for staff providing attendance and social work, guidance, health, psychological services, speech pathology, audiology, and other support to students.

Study abroad population U.S. citizens and permanent residents, enrolled for a degree at an accredited higher education institution in the United States, who received academic credit for study abroad from their home institutions upon their return. Students studying abroad without receiving academic credit are not included, nor are U.S. students enrolled for a degree overseas.

Subject-matter club Organizations that are formed around a shared interest in a particular area of study and whose primary activities promote that interest. Examples of such organizations are math, science, business, and history clubs.
Supervisory staff Principals, assistant principals, and supervisors of instruction; does not include superintendents or assistant superintendents.

Tax base The collective value of objects, assets, and income components against which a tax is levied.

Tax expenditures Losses of tax revenue attributable to provisions of the federal income tax laws that allow a special exclusion, exemption, or deduction from gross income or provide a special credit, preferential rate of tax, or a deferral of tax liability affecting individual or corporate income tax liabilities.

Teacher see Instructional staff.

Technical education A program of vocational instruction that ordinarily includes the study of the sciences and mathematics underlying a technology, as well as the methods, skills, and materials commonly used and the services performed in the technology. Technical education prepares individuals for positions-such as draftsman or lab technician - in the occupational area between the skilled craftsman and the professional person.

Three-year moving average An arithmetic average of the year indicated, the year immediately preceding, and the year immediately following. Use of a 3-year moving average increases the sample size, thereby reducing the size of sampling errors and producing more stable estimates.

Time series A set of ordered observations on a quantitative characteristic of an individual or collective phenomenon taken at different points in time. Usually the observations are successive and equally spaced in time.

Time series analysis The branch of quantitative forecasting in which data for one variable are examined for patterns of trend, seasonality, and cycle.

Title I school A school designated under appropriate state and federal regulations as a high-poverty school that is eligible for participation in programs authorized by Title I of the Reauthorization of the Elementary and Secondary Education Act, P.L. 107-110.

Title IV Refers to a section of the Higher Education Act of 1965 that covers the administration of the federal student financial aid program.

Title IV eligible institution A postsecondary institution that meets the criteria for participating in federal student financial aid programs. An eligible institution must be any of the following: (1) an institution of higher education (with public or private, nonprofit control), (2) a proprietary institution (with private for-profit control), and (3) a postsecondary vocational institution (with public or private, nonprofit control). In addition, it must have acceptable legal authorization, acceptable accreditation and admission standards, eligible academic program(s), administrative capability, and financial responsibility. 
Total expenditure per pupil in average daily attendance Includes all expenditures allocable to per pupil costs divided by average daily attendance. These allocable expenditures include current expenditures for regular school programs, interest on school debt, and capital outlay. Beginning in 1980-81, expenditures for state administration are excluded and expenditures for other programs (summer schools and designated subsidies for community colleges and private schools) are included.

Town school See Locale codes.

Trade and industrial occupations The branch of vocational education which is concerned with preparing people for initial employment or with updating or retraining workers in a wide range of trade and industrial occupations. Such occupations are skilled or semiskilled and are concerned with layout designing, producing, processing, assembling, testing, maintaining, servicing, or repairing any product or commodity.

Traditional public school Publicly funded schools other than public charter schools. See also Public school or institution and Charter school.

Transcript An official list of all courses taken by a student at a school or college showing the final grade received for each course, with definitions of the various grades given at the institution.

Trust funds Amounts collected and used by the federal government for carrying out specific purposes and programs according to terms of a trust agreement or statute, such as the social security and unemployment trust funds. Trust fund receipts that are not anticipated to be used in the immediate future are generally invested in interest-bearing government securities and earn interest for the trust fund.

Tuition and fees A payment or charge for instruction or compensation for services, privileges, or the use of equipment, books, or other goods. Tuition may be charged per term, per course, or per credit.

Type of school A classification of public elementary and secondary schools that includes the following categories: regular schools, special education schools, vocational schools, and alternative schools. See also Regular school, Special education school, Vocational school, and Alternative school.

Unadjusted dollars See Current dollars.

Unclassified students Students who are not candidates for a degree or other formal award, although they are taking higher education courses for credit in regular classes with other students.
Undergraduate students Students registered at an institution of postsecondary education who are working in a baccalaureate degree program or other formal program below the baccalaureate, such as an associate's degree, vocational, or technical program.

Unemployed Civilians who had no employment but were available for work and: (1) had engaged in any specific job seeking activity within the past 4 weeks; (2) were waiting to be called back to a job from which they had been laid off; or (3) were waiting to report to a new wage or salary job within 30 days.

Ungraded student (elementary/secondary) A student who has been assigned to a school or program that does not have standard grade designations.

Urban fringe school See Locale codes.

U.S. Service Academies These institutions of higher education are controlled by the U.S. Department of Defense and the U.S. Department of Transportation. The 5 institutions counted in the NCES surveys of degree-granting institutions include: the U.S. Air Force Academy, U.S. Coast Guard Academy, U.S. Merchant Marine Academy, U.S. Military Academy, and the U.S. Naval Academy.

Variable A quantity that may assume any one of a set of values.

Visual and performing arts A group of instructional programs that generally describes the historic development, aesthetic qualities, and creative processes of the visual and performing arts.

Visual impairment See Disabilities, children with.

Vocational education Organized educational programs, services, and activities which are directly related to the preparation of individuals for paid or unpaid employment, or for additional preparation for a career, requiring other than a baccalaureate or advanced degree.

Vocational school A public school that focuses primarily on providing formal preparation for semiskilled, skilled, technical, or professional occupations for high school-age students who have opted to develop or expand their employment opportunities, often in lieu of preparing for college entry.

Years out In forecasting by year, the number of years since the last year of actual data for that statistic used in producing the forecast. 


\section{APPENDIX C Index of Table Numbers}

Academic clubs

high school seniors' participation in, 227.30

ninth-graders' participation in, 227.10

Academic rank of faculty in postsecondary institutions, 315.20, 315.60 by field of study, $315.70,315.80$

salaries by, $316.10,316.20,316.50,316.60$

tenure by, 316.80

by type and control of institution, 315.50

Academic support, expenditures at postsecondary institutions, $334.30,334.40$

Achievement of elementary and secondary students. See also under individual subjects

mathematics, 222.10, 222.20, 222.70

reading, 221.10, 602.50

science, 223.10

ACT scores, 226.50, 305.40

Administration/Administrative staff postsecondary institutions, expenditures for, 334.10

in public elementary and secondary schools, 213.10, 213.20, 213.30

public elementary and secondary schools, expenditures for, $236.10,236.20,236.25,236.30,236.40$

Admission requirements for postsecondary institutions, 305.30

Admissions to undergraduate institutions, 305.40

Adult education, 507.20, 507.30, 507.40

Advanced Placement courses in public secondary schools, 225.60

Affiliation of postsecondary institutions, 303.90

Age

adult education participation by, 507.30, 507.40

attendance status at postsecondary institutions by, 303.40

bachelor's degrees by, 104.50

child care arrangements by, 202.30, 202.40, 202.50, 202.60, 202.65

cognitive and motor skills of 8- to 22-month-old children by, 220.10

dropouts from high school by, 219.80

educational attainment of adults by, 104.10, 104.20, 104.30, 104.40

employment of high school students by, 503.10

employment to population ratio by, 501.50, 501.60, 501.70

enrollment of population by, 103.10, 103.20

of faculty in postsecondary institutions, $315.50,315.60$

field of study in postsecondary institutions by, 311.60

GED (General Educational Development) credentials issued by, 219.60

Individuals with Disabilities Education Act, children served under by, 204.40

international comparisons

of bachelor's degree recipients, 603.50

of educational attainment by, 603.10-603.40

of school-age population, 601.30

of secondary and postsecondary enrollment, 601.40

internet usage, 702.10 kindergarten entry status of children, 220.50

labor force participation by, 501.10, 501.40

language, mathematics and motor skills by, 220.30

literacy skills of adults by, 507.10

mathematics achievement by, 222.85, 222.90, 222.95

night, weekend or online classes taken by graduate students, 311.30

night, weekend or online classes taken by undergraduate students,

311.20

nonfatal victimization of students in schools, 228.25

percentage distribution of teachers in public and private elementary and secondary schools, 209.10

population by, 101.10, 101.20

distribution, 101.30

school-age, by country, 601.30

school-age, by state, 101.40

postsecondary enrollment by, 303.50, 303.55

preprimary enrollment and, 202.10, 202.20

range for compulsory school attendance, 234.10

reading achievement by, 221.30, 221.85, 221.90

remedial coursework enrolled in by undergraduate students, 311.40

school-age population, by state, 101.40

student financial aid by, 331.10, 331.40, 331.45

students exiting special education by, 219.90

teachers' educational attainment and experience by, 209.20

unemployment rate by, 501.20, 501.80, 501.85, 501.90

young adults neither in school nor employed by, 501.30

Agriculture

associate's degrees in, 321.10, 321.30, 321.40, 321.50

bachelor's degrees in, 322.10, 322.30

employment status and salary of recipients, 505.10

employment status of recipients, 505.20

men earning, 322.40

by race/ethnicity, 104.50, 104.60

STEM versus non-STEM professions, 505.30

women earning, 322.50, 603.60

certificates conferred by postsecondary institutions in, 320.10

degrees conferred in, 318.30, 318.50, 325.10

doctor's degrees in, 324.10, 324.25, 324.30, 324.35

enrollment, postsecondary education, 311.60

institutions conferring degrees in, 318.60

master's degrees in, 323.10, 323.30, 323.40, 323.50

Alcohol consumption

by high school seniors, 232.90

by secondary students on school property, 232.10, 232.20, 232.30

by teenagers, 232.95

Algebra coursework in high school, 222.40, 222.95

Alternative schools, pupil-to-teacher ratios in, 208.10

Alumni support for postsecondary institutions, 333.80 
American Indians/Alaska Natives

ACT scores, 226.50

with associate's degrees, 321.20, 321.30, 321.40, 321.50

attendance patterns by fourth-, eighth- and twelfth-graders, 227.50

with bachelor's degrees, 104.50, 104.60, 322.20, 322.30

men, 322.40

women, 322.50

Carnegie units earned by high school graduates in vocational education by, 225.20

civics achievement by grade, 224.20

coursework by high school graduates in mathematics and science, 225.30, 225.40

with degrees in selected professional fields, 324.55, 324.60, 324.70

distribution in public schools

percentage of students eligible for free or reduced-price lunches, 216.60

by racial/ethnic concentration of school, $216.50,216.55$

by region of the country, 203.50

by state, 203.70

distribution of resident population by age, 101.30

with doctor's degrees, 324.20, 324.25, 324.30, 324.35

drug, cigarette, and alcohol usage by teenagers, 232.95

economics achievement of high school seniors, 224.30

educational attainment, 104.40, 104.85

enrollment and percentage distribution by year and level of education, 203.60

enrollment in postsecondary institutions, 306.30

estimates of resident population by age, 101.20

gifted and talented students by state, 204.80, 204.90

high school dropouts, 219.50, 219.51

high school graduates, 219.30, 219.40

history, U.S., achievement by grade, 224.50

income and educational attainment of, 502.30

Individuals with Disabilities Education Act, children served under, 204.40, 204.50

with master's degrees, 323.20, 323.30, 323.40, 323.50

mathematics achievement

of fourth- and eighth-graders, 222.80

by grade, 222.10, 222.20

of high school seniors by mathematics coursework, 222.40

by race/ethnicity and state, 222.70

parental level of education of 6- to 18-year olds, 104.70

postsecondary institutions

certificates granted by Title IV postsecondary institutions, 320.20

employment in, 314.40

enrollment in, 306.10, 306.40, 306.50

enrollment in by state, $306.60,306.70$

enrollment in by type and control of institution, 306.20

faculty in, 315.20, 315.60, 315.80

graduation rates, $326.10,326.20$

in public charter and traditional public schools, 216.30

reading, mathematics and cognitive flexibility scores at kindergarten entry, 220.40

reading achievement

of fourth- and eighth-graders in urban districts, 221.80

of fourth-graders in public schools by state, 221.50

by grade, $221.10,221.75$

remedial coursework enrolled in by undergraduate students, 311.40

SAT scores for college-bound seniors, 226.10

science achievement

of eighth-graders by attitudes toward science, 223.25

of eighth-graders in public schools by state, 223.20 by grade, 223.10

of high school seniors by attitudes toward science, 223.30

suspensions and expulsions from public schools, 233.30, 233.40

tribally controlled institutions, 312.50

U.S. students studying abroad, 310.10

writing achievement by grade, 224.60

American sign language, enrollment in courses, postsecondary education, $311.70,311.80$

Applications and admissions to undergraduate institutions, 305.40

Appropriations for public postsecondary institutions, 333.30

Arabic

degrees conferred in, 325.59

enrollment in courses, postsecondary education, 311.70, 311.80

Architecture

associate's degrees in, 321.10, 321.30, 321.40, 321.50

bachelor's degrees in, 322.10, 322.30

employment status and salary of recipients, 505.10

employment status of recipients, 505.20

men earning, 322.40

by race/ethnicity, $104.50,104.60$

STEM versus non-STEM professions, 505.30

women earning, 322.50

certificates conferred by postsecondary institutions in, 320.10

degrees conferred in, 318.30, 318.50, 325.15

doctor's degrees in, 324.10, 324.25, 324.30, 324.35

enrollment, postsecondary education, 311.60

institutions conferring degrees in, 318.60

master's degrees in, 323.10, 323.30, 323.40, 323.50

Area studies

associate's degrees in, 321.10, 321.30, 321.40, 321.50

bachelor's degrees in, 322.10, 322.30

employment status and salary of recipients, 505.10

men earning, 322.40

women earning, 322.50

certificates conferred by postsecondary institutions in, 320.10

degrees conferred in, 318.30, 318.50

doctor's degrees in, 324.10, 324.25, 324.30, 324.35

enrollment, postsecondary education, 311.60

institutions conferring degrees in, 318.60

master's degrees in, 323.10, 323.30, 323.40, 323.50

Arts

achievement of eighth-graders, 224.10

associate's degrees in, 321.10, 321.30, 321.40, 321.50

bachelor's degrees in, 322.10, 322.30

employment status and salary of recipients, 505.10

employment status of recipients, 505.40

men earning, 322.40

by race/ethnicity, 104.50

women earning, 322.50

Carnegie units earned by high school graduates, 225.10

certificates conferred by postsecondary institutions in, 320.10

degrees conferred in, 318.30, 318.50, 325.95

doctor's degrees in, 324.10, 324.25, 324.30, 324.35

frequency of instruction for eighth-graders, 224.10

institutions conferring degrees in, 318.60

master's degrees in, 323.10, 323.30, 323.40, 323.50

Arts and crafts as family activities, 207.10, 207.30

Asians/Pacific Islanders

ACT scores, 226.50

arts achievement and frequency of instruction, 224.10

with associate's degrees, 321.20, 321.30, 321.40, 321.50

attendance patterns by fourth-, eighth- and twelfth-graders, 227.50 
with bachelor's degrees, 104.50, 104.60, 322.20, 322.30 men, 322.40 women, 322.50

Carnegie units earned by high school graduates in vocational education by, 225.20

civics achievement by grade, 224.20

coursework by high school graduates in mathematics and science, 225.30, 225.40

with degrees in selected professional fields, 324.55, 324.60, 324.70

distribution in public schools

percentage of students eligible for free or reduced-price lunches, 216.60

by racial/ethnic concentration of school, $216.50,216.55$

by region of the country, 203.50

by state, 203.70

distribution of resident population by age, 101.30

with doctor's degrees, 324.20, 324.25, 324.30, 324.35

drug, cigarette, and alcohol usage by teenagers, 232.95

economics achievement of high school seniors, 224.30

educational attainment, 104.40, 104.85

enrollment and percentage distribution by year and level of education, 203.60

enrollment in postsecondary institutions, 306.30

estimates of resident population by age, 101.20

geography achievement by grade, 224.40

gifted and talented students by state, 204.80, 204.90

high school dropouts, 219.50, 219.51

high school graduates, 219.30, 219.40

history, U.S., achievement by grade, 224.50

income and educational attainment of, 502.30

Individuals with Disabilities Education Act, children served under, 204.40, 204.50

labor force status, 501.40

with master's degrees, 323.20, 323.30, 323.40, 323.50

mathematics achievement

of fourth- and eighth-graders in urban districts, 222.80

by grade, 222.10, 222.20

of high school seniors by mathematics coursework, 222.40

by race/ethnicity and state, 222.70

mathematics and science skills of 1998 kindergartners through grade $8,220.80$

parental level of education of 6- to 18-year olds, 104.70

postsecondary institutions

certificates granted by Title IV postsecondary institutions, 320.20

employment in, 314.40

enrollment in, 306.10, 306.40, 306.50

enrollment in by state, $306.60,306.70$

enrollment in by type and control of institution, 306.20

faculty in, 315.20, 315.60, 315.80

graduation rates by, $326.10,326.20$

poverty rates, 102.50

in public charter and traditional public schools, 216.30

reading, mathematics and cognitive flexibility scores at kindergarten entry, 220.40

reading achievement

of fourth- and eighth-graders in urban districts, 221.80

of fourth-graders in public schools by state, 221.50

by grade, $221.10,221.75$

reading skills of 1998 kindergartners through grade 8, 220.70

remedial coursework enrolled in by undergraduate students, 311.40

SAT scores for college-bound seniors, 226.10

science achievement of eighth-graders by attitudes toward science, 223.25

of eighth-graders in public schools, 223.20

by grade, 223.10

of high school seniors by attitudes toward science, 223.30

science and mathematics skills of 1998 kindergartners through

grade $8,220.80$

suspensions and expulsions from public schools, 233.30, 233.40

unemployment rate, 501.20

U.S. students studying abroad, 310.10

writing achievement by grade, 224.60

young adults neither in school nor employed, 501.30

Assessments by states

criterion-referenced tests (CRTs), 234.40

teacher certification testing, 234.50

Associate's degrees

by control of institution, 318.40, 318.50, 319.10

by field of study, 321.10, 321.30, 321.40, 321.50

by gender, 318.10

number of institutions conferring, 318.60

by race/ethnicity and gender, 321.20

by state, 319.20

Attendance, elementary/secondary education

age range for compulsory, 234.10

average daily, 203.80, 203.90, 236.90

patterns by fourth-, eighth- and twelfth-graders, 227.50

preprimary full-day or part-day status, 202.10, 202.20

Attendance status, postsecondary institutions, 303.10, 303.30, 303.40

by control and type of institution, 303.50, 303.55

employment of college students by, 503.20, 503.30

by first-time freshmen, 305.10, 305.20

in for-profit private postsecondary institutions by state, 304.50

institutions with more than 15,000 students, 312.20

by level, 303.60, 303.65

by level, gender and age, 303.45

night, weekend or online classes taken by graduate students, 311.30

night, weekend or online classes taken by undergraduate students,

311.20

overview of enrollment, 105.20

in private postsecondary institutions by state, 304.40, 304.45

in public postsecondary institutions by state, 304.35

by race/ethnicity and gender, 306.10

remedial coursework enrolled in by undergraduate students, 311.40

retention of first-time degree-seeking students by control and type

of institution, 326.30

by state, 304.30

student financial aid and

postbaccalaureate level, 332.10, 332.20, 332.30, 332.40

undergraduate level, 331.10, 331.20, 331.40, 331.45, 331.50, $331.60,331.70,331.80,331.90$

undergraduate level, 303.70

Attitudes of students

mathematics, 222.30

science, 223.25, 223.30

values of high school seniors, 506.10

Attrition rate for teachers in public schools, 210.30

Auxiliary enterprises, postsecondary institutions

expenditures for, 334.10, 334.30, 334.40, 334.50, 334.60

revenues

current-fund, 333.20

to private institutions, $333.40,333.50,333.55,333.60$

to public institutions, 333.10

by state, 333.25 
Average daily attendance, public elementary and secondary schools, 203.80

current expenditures per pupil, 236.15, 236.70

as percentage of total enrollment, 203.90

transportation expenditures, 236.90

Averaged freshman graduation rates for public secondary schools, 219.35

Average total cost for attendance for undergraduates in postsecondary institutions, 330.40

Avoidance of places at school by students, 230.80

Bachelor's degrees

by control of institution, $318.40,318.50,319.10$

by field of study, 318.20, 318.30, 322.10, 325.10-325.95 (See also

Field of study)

by gender, 318.10

international comparisons of, 603.50

mathematics, science and engineering, 603.70

as percentage of population, $603.20,603.30$

women earning, 603.60

number of institutions conferring, 318.60

number of persons with, 104.50, 104.60

by race/ethnicity and gender, 104.10, 322.20, 322.30, 322.40, 322.50

recipients' employment by field of study, 505.10, 505.20, 505.30, 505.40

salaries of recipients, 505.50

salaries of teachers with, 211.30

by state, $319.20,319.30$

Basic education for adults, 507.20, 507.40

Behavioral sciences. See Social sciences

Benefit expenditures for faculty in postsecondary institutions, 316.70

Biology

associate's degrees in, 321.10, 321.30, 321.40, 321.50

bachelor's degrees in, 322.10, 322.30

employment status and salary of recipients, 505.10

employment status of recipients, 505.20

men earning, 322.40

STEM versus non-STEM professions, 505.30

women earning, 322.50

certificates conferred by postsecondary institutions in, 320.10

degrees conferred in, 318.30, 318.50, 325.20, 325.22

doctor's degrees in, 324.10, 324.25, 324.30, 324.35

enrollment, postsecondary education, 311.60

institutions conferring degrees in, 318.60

master's degrees in, 323.10, 323.30, 323.40, 323.50

Biomedical sciences, degrees conferred in, 325.20

Birthplace, comparison of U.S.-born and foreign-born, 101.30

Blacks

ACT scores, 226.50

arts achievement and frequency of instruction, 224.10

with associate's degrees, 321.20, 321.30, 321.40, 321.50

attendance patterns by fourth-, eighth- and twelfth-graders, 227.50

with bachelor's degrees, 104.50, 104.60, 322.20, 322.30

men, 322.40

women, 322.50

Carnegie units earned by high school graduates in vocational education by, 225.20

child care arrangements by, 202.40

children living in poverty, 102.60

civics achievement by grade, 224.20

college enrollment and labor force status of high school graduates, 504.10 coursework by high school graduates in mathematics and science, 225.30, 225.40

with degrees in selected professional fields, 324.55, 324.60, 324.70

distribution in public schools

percentage of students eligible for free or reduced-price lunches, 216.60

by racial/ethnic concentration of school, 216.50, 216.55

by region of the country, 203.50

by state, 203.70

distribution of resident population by age, 101.30

with doctor's degrees, 324.20, 324.25, 324.30, 324.35

dropouts from high school, 219.70

drug, cigarette, and alcohol usage by teenagers, 232.95

economics achievement of high school seniors, 224.30

educational attainment, 104.10, 104.20, 104.30, 104.40, 104.85

employment of high school students, 503.10

enrollment and percentage distribution by year and level of

education, 203.60

enrollment in postsecondary institutions, 306.30

estimates of resident population by age, 101.20

family characteristics of, 102.20

geography achievement by grade, 224.40

gifted and talented students by state, 204.80, 204.90

high school dropouts, 219.50, 219.51

high school graduates, 219.30, 219.40

history, U.S., achievement by grade, 224.50

income and educational attainment of, 502.30

Individuals with Disabilities Education Act, children served under, 204.40, 204.50

internet usage, 702.10

labor force status, 501.40

labor force status of high school dropouts, 504.20

leisure activities of high school seniors, 227.20

with master's degrees, 323.20, 323.30, 323.40, 323.50

mathematics achievement

by age, $222.85,222.90$

of fourth- and eighth-graders in urban districts, 222.80

by grade, $222.10,222.20$

of high school seniors by mathematics coursework, 222.40

by race/ethnicity and state, 222.70

of seventeen-year-olds by mathematics coursework, 222.95

mathematics and science skills of 1998 kindergartners through grade $8,220.80$

parental level of education of 6- to 18-year olds, 104.70

percentage of population enrolled in school, 103.10

postsecondary institutions

certificates granted by Title IV postsecondary institutions, 320.20

employment in, 314.40

enrollment in, 302.20, 302.60, 306.10, 306.40, 306.50

enrollment in by state, $306.60,306.70$

enrollment in by type and control of institution, 306.20

faculty in, 315.20, 315.60, 315.80

graduation rates by, $326.10,326.20$

historically black colleges and universities, 313.10, 313.20, 313.30

poverty rates, 102.50

in public charter and traditional public schools, 216.30

reading, mathematics and cognitive flexibility scores at

kindergarten entry, 220.40

reading achievement

by age, $221.85,221.90$

of fourth- and eighth-graders in urban districts, 221.80

of fourth-graders in public schools by state, 221.50 
by grade, $221.10,221.75$

reading skills of 1998 kindergartners through grade 8, 220.70

remedial coursework enrolled in by undergraduate students,

311.40

SAT scores for college-bound seniors, 226.10

science achievement

of eighth-graders by attitudes toward science, 223.25

of eighth-graders in public schools by state, 223.20

by grade, 223.10

of high school seniors by attitudes toward science, 223.30

science and mathematics skills of 1998 kindergartners through

grade $8,220.80$

suspensions and expulsions from public schools, 233.30, 233.40

unemployment rate, 501.20

U.S. students studying abroad, 310.10

writing achievement by grade, 224.60

young adults neither in school nor employed, 501.30

Branch campuses, postsecondary institutions, 317.10, 317.50

Bullying. See also Cyber-bullying

students reporting, 230.40, 230.45, 230.50

students reporting to adult at school, 230.60

Business and management

associate's degrees in, 321.10, 321.30, 321.40, 321.50

bachelor's degrees in, 319.30, 322.10, 322.30

employment status and salary of recipients, 505.10

employment status of recipients, 505.20, 505.40

men earning, 322.40

by race/ethnicity, 104.50, 104.60

STEM versus non-STEM professions, 505.30

women earning, 322.50

certificates conferred by postsecondary institutions in, 320.10

degrees conferred in, 318.20, 318.30, 318.50, 325.25

doctor's degrees in, 324.10, 324.25, 324.30, 324.35, 324.80

enrollment, postsecondary education, 311.60

institutions conferring degrees in, 318.60

master's degrees in, 319.40, 323.10, 323.30, 323.40, 323.50

Calculus coursework in secsondary schools, 222.40, 222.95

Career-related adult education participation, 507.30, 507.40. See also Occupation

Career/technical education, 225.20. See also Vocational schools/ education

Carnegie units earned in high school, 225.10, 225.60

state requirements for high school graduation, 234.30

in vocational education, 225.20

Catholic schools. See also Private elementary and secondary schools

attendance patterns by fourth-, eighth- and twelfth-graders, 227.50

enrollment and other characteristics, 205.20, 205.30, 205.40, 205.70

extracurricular activities of high school seniors, 227.30

leisure activities of high school seniors, 227.20

reading achievement by grade in, 221.10

student-to-staff ratios, 205.60

tuition for, 205.50

Center-based programs, 202.30, 202.40, 202.50, 202.60, 202.65. See also Preprimary education

Certificates

granted by Title IV postsecondary institutions, 320.20

postsecondary institutions granting by field of study, 320.10

Certification of teachers, states requiring test for, 234.50

Charter schools, 216.20, 216.30, 216.70

closing of schools, 216.95 coursework by high school graduates in mathematics and science, 225.40

enrollment by state, 216.90

Chemical engineering, degrees in, 325.47. See also Engineering

Chemistry, degrees conferred in, 325.72

Child care, 202.30, 202.40, 202.50, 202.65

cognitive and motor skills of nine-month-olds by primary type of, 220.10

kindergarten entry status of children, 220.50

language and mathematics skills of four-year-olds by primary type of, 220.30

mental and physical skills of two-year-olds by primary type of, 220.20

quality rating of arrangements for, 202.60

reading, mathematics and cognitive flexibility scores at kindergarten entry by primary type, 220.40

Chinese

degrees conferred in, 325.59

enrollment in courses, postsecondary education, 311.70, 311.80

Cigarettes, teenagers and young adults smoking, 232.95

Cities. See also Metropolitan status

educational attainment of persons 25 years old and over by, 104.95

mathematics achievement of fourth- and eighth-graders by, 222.80

reading achievement of fourth- and eighth-graders by, 221.80

Citizenship status

employment of bachelor's degree recipients, 505.20, 505.30

employment of foreign-born high school students by, 503.10

foreign-born students dropping out of high school, 219.80

labor force status by, 501.40

Civics, achievement by grade, 224.20

Civil engineering, degrees in, 325.47. See also Engineering

Class cutting by students, 230.90

Classroom teachers. See Teachers, elementary and secondary

Class size

international comparison of teachers' working time and, 601.60 by level of instruction, 209.30

Closing of postsecondary institutions, 317.50

Closing of public elementary and secondary schools, 216.95

Cognitive skills/flexibility

of nine-month-old children, 220.10

scores at kindergarten entry, 220.40

scores by kindergarten entry status, 220.60

of two-year-old children, 220.20

Collections in college and university libraries, 701.40, 701.50

Collections in public libraries, 701.60

Color knowledge of four-year-olds, 220.30

Communications

associate's degrees in, 321.10, 321.30, 321.40, 321.50

bachelor's degrees in, 322.10, 322.30

employment status and salary of recipients, 505.10

men earning, 322.40

by race/ethnicity, 104.50

women earning, 322.50

certificates conferred by postsecondary institutions in, 320.10

degrees conferred in, 318.30, 318.50, 325.30

doctor's degrees in, 324.10, 324.25, 324.30, 324.35

enrollment, postsecondary education, 311.60

institutions conferring degrees in, 318.60

master's degrees in, 323.10, 323.30, 323.40, 323.50

Completion status in postsecondary education, 326.10, 326.20, 326.40 at online institutions, 311.33

Computer and information sciences associate's degrees in, 321.10, 321.30, 321.40, 321.50 
bachelor's degrees in, $319.30,322.10,322.30$

employment status and salary of recipients, 505.10

employment status of recipients, 505.20, 505.40

men earning, 322.40

by race/ethnicity, $104.50,104.60$

STEM versus non-STEM professions, 505.30

women earning, 322.50, 603.60

certificates conferred by postsecondary institutions in, 320.10

degrees conferred in, 318.20, 318.30, 318.50, 325.35

doctor's degrees in, 324.10, 324.25, 324.30, 324.35

enrollment, postsecondary education, 311.60

institutions conferring degrees in, 318.60

master's degrees in, 319.40, 323.10, 323.30, 323.40, 323.50

Computers, number used for instruction in public elementary and secondary schools, 218.10

Construction trades

associate's degrees in, 321.10, 321.30, 321.40, 321.50

bachelor's degrees in, 322.10, 322.30

employment status and salary of recipients, 505.10

employment status of recipients, 505.40

men earning, 322.40

women earning, 322.50, 603.60

certificates conferred by postsecondary institutions in, 320.10

degrees conferred in, 318.30, 318.50

doctor's degrees in, 324.10, 324.25, 324.30, 324.35

enrollment, postsecondary education, 311.60

institutions conferring degrees in, 318.60

master's degrees in, 323.10, 323.30, 323.40, 323.50

Consumer Price Index, 106.70

Controlled access to elementary and secondary schools, 233.50, $233.60,233.80$

Control of institutions. See Private elementary and secondary schools; Private postsecondary institutions; Public elementary and secondary schools; Public postsecondary institutions

Corporate support to postsecondary institutions, 333.80

Cost for attendance in postsecondary institutions for undergraduates, 330.40

Coursework/Credits

Carnegie units, average earned by public high school graduates, 225.10

Carnegie units required by state for high school graduation, 234.30

dual credit, Advanced Placement and International Baccalaureate courses in public secondary schools, 225.60

by high school graduates in mathematics and science, 225.30, 225.40

by high school seniors in economics, 224.30

mathematics scores of high school seniors and, 222.40

mathematics scores of seventeen-year-olds and, 222.95

minimum earned by high school graduates, 225.50

subjects taught in public high schools, 209.50

Crime in postsecondary institutions, 329.10, 329.20

Crime in public schools

disciplinary actions taken by schools, 233.10

recorded by schools, 229.20, 229.30

reported to police, $229.10,229.40$

violent crime reported to police, 229.50, 229.60

Criminal justice. See also Security

bachelor's degrees in, employment status and salary of recipients, 505.10

enrollment in postsecondary education, 311.60

Criterion-referenced tests (CRTs) by state, 234.40

Current expenditures. See also Expenditures

per pupil in public schools, 236.15, 236.55, 236.60, 236.65, 236.70, $236.75,236.80$ in public elementary and secondary schools, 236.10, 236.25, 236.30, 236.40

Current-fund expenditures. See Expenditures

Current-fund revenues. See Revenues

Cyber-bullying. See also Bullying

public schools reporting, 230.65

students reporting, 230.40, 230.55

students reporting to adult at school, 230.60

Deaths on campus at postsecondary institutions, 329.20

Degree completion. See also Educational attainment

rates by race/ethnicity, gender, and institutions type, 326.10,

326.20 (See also under individual degrees)

status by type of institution and student characteristics, 326.40

Degree-granting institutions. See Postsecondary education

Degrees conferred. See also individual degrees

associate's degrees, 321.10, 321.30, 321.40, 321.50

bachelor's degrees, 322.10

by control of institution, 318.40, 318.50, 318.60

doctor's degrees, 324.10

doctor's degrees in selected professional fields, 324.40, 324.50

by field of study and level, 325.10-325.95

at historically black colleges and universities, 313.10, 313.30

at institutions serving large populations of Hispanic students, 312.40

at institutions with more than 15,000 students, 312.10

by level and gender, 318.10

master's degrees, 319.40, 323.10

by number of institutions and enrollment size, 317.40

at online institutions, 311.33

by state, $319.10,319.20,319.30$

Title IV postsecondary institutions, 301.10

tribally controlled institutions, 312.50

at women's colleges, 312.30

Degrees earned. See Degree completion; Degrees conferred;

Educational attainment

Dentistry, doctor's degrees (D.D.S. or D.M.D.) in, 324.40, 324.50, $324.60,324.70$

Department of Education, U.S., appropriations for programs by state, 401.60

Dependency status of students

loans received by undergraduate students by their 4th year, 331.95 night, weekend or online classes taken by graduate students, 311.30 night, weekend or online classes taken by undergraduate students, 311.20

remedial coursework enrolled in by undergraduate students, 311.40 student financial aid, 331.10, 331.40, 331.45

Disabilities, students with, 204.60

coursework by high school graduates in mathematics and science, 225.40

exiting special education, 219.90

hate-related harassment aimed at, 230.35

postsecondary education and employment status of, 504.30

postsecondary institution enrollment, 311.10

served under Individuals with Disabilities Education Act, 204.30, 204.40, 204.50, 204.60, 204.70

Discipline division. See Field of study

Discipline issues in schools

actions taken by public schools, 233.10

on-campus crime in postsecondary institutions, 329.10, 329.20

public schools reporting, 230.10, 230.95

Disposable personal income, 106.60. See also Income

Distance education, in public schools and districts, 218.20 
Distance education in postsecondary institutions, 311.15, 311.20, 311.30

Doctoral research universities by state, 317.20

Doctor's degrees

by control of institution, 318.40, 318.50, 319.10

by field of study, 318.20, 318.30, 324.10, 325.10-325.95

by gender, 318.10

by institution, 324.90

number of institutions conferring, 318.60

by race/ethnicity and gender, 324.20, 324.25, 324.30, 324.35

by state, 319.20

statistical profile of persons receiving, 324.80

student financial aid for, 332.10, 332.20, 332.30, 332.40

Dress code required for schools, 233.50, 233.60, 233.80

Dropouts from high school

by gender and race/ethnicity, 219.70

labor force status, 504.20

by noninstitutionalized and institutionalized status, 219.80

in school districts of more than 15,000 students, 215.10

by state and race/ethnicity, 219.50, 219.51

years of school completed, 219.75

Drug usage

by high school seniors, 232.90

by teenagers, 232.95

Dual credits in public secondary schools, 225.60

Earnings. See Income

Earth sciences, degrees conferred in, 325.72. See also Science

Economics

achievement and coursework of high school seniors, 224.30

degrees conferred in, 325.92

enrollment, postsecondary education, 311.60

Education (as field of study)

associate's degrees in, 321.10, 321.30, 321.40, 321.50

bachelor's degrees in, 319.30, 322.10, 322.30

employment status and salary of recipients, 505.10

employment status of recipients, 505.20, 505.40

men earning, 322.40

by race/ethnicity, $104.50,104.60$

STEM versus non-STEM professions, 505.30

women earning, 322.50, 603.60

certificates conferred by postsecondary institutions in, 320.10

degrees conferred in, 318.20, 318.30, 318.50, 325.40

doctor's degrees in, 324.10, 324.25, 324.30, 324.35, 324.80

enrollment, postsecondary education, 311.60

institutions conferring degrees in, 318.60

master's degrees in, 319.40, 323.10, 323.30, 323.40, 323.50

Education, federal support for, 401.10, 401.20, 401.70

by agency, 401.30

Department of Education appropriations, 401.60

Education agencies (public), 214.30

Educational attainment

adult education participation by, 507.30, 507.40

bachelor's degrees, number of persons with, 104.50, 104.60

(See also Bachelor's degrees)

children's achievement by their parents' (See Parental level of education)

employment to population ratio by, 501.50, 501.60, 501.70

of 1990 high school sophomores in 2000, 104.90

income by, 502.20, 502.30, 502.40

influence of parents' on children's reading scores, 221.10, 221.85

(See also Parental level of education)

international comparisons of, 603.10-603.40 international comparisons of employment rate by, 603.90

internet usage by, 702.10

labor force participation by, 501.10, 501.40

by level of attainment, 104.10, 104.20, 104.30, 104.40

literacy skills of adults by, 507.10

by metropolitan area, 104.95

occupations by, 502.10

parental participation in activities with children by, 207.20, 207.30

parental participation in school activities by, 207.40

of principals, 212.10

by race/ethnicity, 104.10, 104.40

by state, $104.80,104.88$

by state and race/ethnicity, 104.85

teachers in public and private elementary and secondary schools, 209.10

of teachers in public and private elementary/secondary schools, 209.20

teachers in public elementary and secondary schools, 209.30

teachers' salaries by, 211.20

unemployment rate by, 501.20, 501.80, 501.85, 501.90

young adults neither in school nor employed by, 501.30

Educational institutions, number of, 105.50

Eighth grade

arts achievement and frequency of instruction, 224.10

attendance patterns, 227.50

international comparisons of mathematics and science scores, 602.30

mathematics achievement, 222.10, 222.20, 222.70

of eight-graders by attitude, 222.30

international comparisons of, 602.30

in public schools by states, 222.60

by urban district, 222.80

reading achievement, 221.10, 221.75

of English language learners in public schools by state, 221.70

in public schools by state, 221.60

by urban district, 221.80

science achievement, 223.10

by attitude, 223.25

international comparisons of, 602.30

in public schools by state, 223.20

writing achievement, 224.60

Electrical engineering, degrees conferred in, 325.47. See also Engineering

Elementary and secondary education, 201.10-236.90. See also Private elementary and secondary schools; Public elementary and secondary schools

enrollment overview, 105.20, 203.10-203.90, 203.60

expenditures, 106.40

of educational institutions, 106.20

gross domestic product compared to, 106.10

per capita, 106.50

federal support for, 401.10, 401.30

international comparisons

enrollment in, 601.10, 601.40

on expenditures for, 605.10

of teachers' working time and class size, 601.60

number of institutions, 105.50

participants in, 105.10

per capita expenditures on, 106.50

pupil-to-teacher ratios in public and private schools, 208.20

Elementary schools, 214.10. See also Private elementary and secondary schools; Public elementary and secondary schools crime recorded by schools by school characteristics, 229.20, 229.30 crime reported to police by school characteristics, 229.40 discipline issues reported by public schools, 230.10 
enforcement of school rules by other teachers and principal, 230.92 misbehavior by students interfering with class instruction, 230.90 teachers reporting threats or physical attacks from students, 228.70 violent crime reported to police by school characteristics, 229.50 , 229.60

Emotional attachment of two-year-olds to parents, 220.20

Employees in postsecondary institutions, 314.20, 314.30, 314.40. See also Staff

Employment of bachelor's degree recipients, 505.10, 505.20, 505.30, 505.40, 505.50 of college students by attendance status, 503.20, 503.30 of high school completers, 504.10

of high school dropouts, 504.20

of high school students, 503.10

international comparisons of population by level of educational attainment, 603.90

ratio to population, 501.10

special education students' status, 504.30

of teachers in non-school jobs, 211.10

Endowment funds, 333.90

Engineering associate's degrees in, 321.10, 321.30, 321.40, 321.50

bachelor's degrees in, 319.30, 322.10, 322.30, 603.70

employment status and salary of recipients, 505.10

employment status of recipients, 505.20, 505.40

men earning, 322.40

by race/ethnicity, $104.50,104.60$

STEM versus non-STEM professions, 505.30

women earning, 322.50, 603.60

certificates conferred by postsecondary institutions in, 320.10

degrees conferred in, 318.30, 318.50, 325.45, 325.47

doctor's degrees in, 324.10, 324.25, 324.30, 324.35, 324.80

enrollment, postsecondary education, 311.60

institutions conferring degrees in, 318.60

international comparisons of bachelor's degree recipients, 603.70

international comparisons of graduate degrees in, 603.80

master's degrees in, 319.40, 323.10, 323.30, 323.40, 323.50

postbaccalaureate-level enrollment in, 311.90

English and literature

associate's degrees in, 321.10, 321.30, 321.40, 321.50

bachelor's degrees in, 322.10, 322.30

employment status and salary of recipients, 505.10

men earning, 322.40

by race/ethnicity, 104.50

women earning, 322.50

Carnegie units earned by high school graduates, 225.10

Carnegie units required by state for high school graduation, 234.30

certificates conferred by postsecondary institutions in, 320.10

criterion-referenced tests (CRTs) by state, 234.40

degrees conferred in, 318.30, 318.50, 325.50

doctor's degrees in, 324.10, 324.25, 324.30, 324.35

enrollment, postsecondary education, 311.60

institutions conferring degrees in, 318.60

master's degrees in, 323.10, 323.30, 323.40, 323.50

English as a second language programs, 507.20

English language learners (ELL)

coursework by high school graduates in mathematics and science, 225.40

public school students in programs for by state, 204.20

reading achievement of by state, 221.70

Enrollment

at all levels of education, 105.20 international comparisons at all levels, 601.10, 601.40

percentage of population enrolled in school, 103.10, 103.20

postsecondary institutions

applications and admissions compared to, 305.40

attendance status, 303.10, 303.30, 303.40, 304.30

bachelor's degree recipients 1 year after graduation, 505.40

by control and affiliation, 303.90

by control and type, 303.25, 303.50, 303.55, 304.60

disabled students in, 311.10

field of study, 311.60

first-time freshmen, 305.10

for-profit private institutions by state, 304.50

full-time-equivalent enrollment in, 307.10, 307.20, 312.20

historically black colleges and universities, 313.10, 313.20, 313.30

institutions with large populations of Hispanic students, 312.40

institutions with more than 15,000 students, 312.20

largest colleges and universities, 312.10

by level, 303.45, 303.60, 303.65, 304.70, 304.80

number of institutions and enrollment size, 317.40

online institutions, 311.33

postbaccalaureate level, 303.80

private institutions by state, $304.20,304.45$

public institutions by state, 304.15

by race/ethnicity, 306.20, 306.30, 306.60, 306.70

by race/ethnicity and gender, 302.60, 306.10

by recent high school completers, 236.20, 302.10, 302.20, $302.30,302.40,302.50$

by state, $304.10,304.15,304.20,308.10$

by state and control of institution, 308.20

Title IV institutions, 301.10, 303.20

tribally controlled institutions, 312.50

undergraduate, $303.70,504.10$

women's colleges, 312.30

preprimary education, 202.10, 202.20, 202.70

private elementary and secondary schools, 205.20, 205.30, 205.40

in Catholic elementary and secondary schools, 205.70

by region, 205.10

by state, 205.80

public elementary and secondary schools

by capacity level, 217.20

charter schools, 216.30, 216.90

crime recorded by schools, 229.30

crime reported to police, 229.40

discipline issues reported by schools, 230.10

by grade, 203.10

in grades 9 to 12 compared to 14 - to 17-year-old population, 201.20

historical statistics of, 201.10

by metropolitan status, 214.40

percentage distribution of minorities in, 216.50

percentage of students eligible for free or reduced-price lunches, 216.60

pupil-to-staff ratios in, 213.50

pupil-to-teacher ratios in, 208.10, 208.40

racial/ethnic distribution in, 203.50, 203.70, 216.55

by region of the country, 203.50

school size, 216.40, 216.45

by school type, level and charter/magnet status, 216.20

by state, $203.40,203.45,203.70$

by state and region, 203.20

violent crime reported to police, 229.50, 229.60

school districts, 214.20

in largest 100, 215.30 
15,000 plus students, 215.10

Environment in schools

class size, 209.30

factors that interfere with instruction, 217.10

overcrowding in public schools, 217.20

Even Start program, 401.70

Exit exams for high school diploma, 234.30

Expenditures

current for public elementary and secondary schools by state,

$236.15,236.25,236.65,236.70,236.80$

of educational institutions, 106.10, 106.20

gross domestic product and income compared to, 106.60

international comparisons on education, 605.10, 605.20

postsecondary institutions

libraries, 701.40, 701.50

private institutions, 334.30, 334.40, 334.50, 334.60, 334.70

public institutions, 334.10, 334.20

public elementary and secondary schools

by function and subfunction, 236.20

historical statistics of, 201.10

for instruction, 236.50

by metropolitan status, $214.40,235.40$

per pupil, 236.55, 236.60, 236.75

by purpose, $236.10,236.30,236.40$

in school districts of more than 15,000 students, 215.20

for school libraries and media centers, 701.10, 701.20, 701.30

by state and local governments, 106.30, 106.40, 106.50

Expulsions from school, 233.30, 233.40

Extracurricular activities (school sponsored), 227.10, 227.30

Faculty, postsecondary, 315.10-315-80

benefit expenditures for full-time, 316.70

employment status of, 314.20, 314.30, 315.10

by field of study, 315.70, 315.80

full-time-equivalent, 314.10

historical statistics of degree-granting institutions, 301.20

by institution type and control

characteristics of faculty, 315.50

number of all staff by occupation, 314.20, 314.30

number of faculty, 315.10

instruction activities of

full-time, 315.30

part-time, 315.40

number of, overview by control of institution, 105.10, 105.40, 314.10

race/ethnicity and gender

of all staff by occupation, 314.40

by faculty characteristics, 315.60

by faculty field, 315.80

rank of full-time faculty by, 315.20

ratio of full-time-equivalent students to full-time-equivalent staff

at private institutions by state, 314.60

at public institutions by state, 314.50

salaries of full-time

by rank, $316.10,316.20$

by state, $316.30,316.40,316.50,316.60$

tenure for full-time, 316.80

Families

activities with children, 207.10, 207.20, 207.30

care of children in, 202.30, 202.40, 202.50, 202.60, 202.65

characteristics of, 102.20

children living in poverty, 102.60 (See also Poverty rates/status)

homeschooled children, 206.10 median income of, 106.60 (See also under Income, family)

poverty rates by race/ethnicity, 102.50

preprimary enrollment and, 202.20

by status and presence of children, 102.10

Family and consumer sciences

associate's degrees in, 321.10

bachelor's degrees in, 322.10, 505.10

Fatalities from violence

in elementary and secondary schools, 228.10

on-campus at postsecondary institutions, 329.10

Fear of attack or harm at school, 230.70, 230.80

Federal government

budget composite deflator, 106.70

education agencies (public) operated by, 214.30

expenditures for education, 401.10, 401.20

by agency, 401.30

Department of Education appropriations, 401.60

research, 402.10

Title I allocations, 401.70

funds to largest school districts, 215.30

grants to undergraduates, 331.20

revenues for postsecondary institutions, 333.70

institutions receiving largest amounts, 333.70

private, $333.40,333.50,333.55,333.60$

public, 333.10, 333.20

public by state, 333.25

revenues for public elementary and secondary schools, 235.10, 235.20, 235.30

revenues for public elementary and secondary schools by metropolitan status, 235.40

student financial aid, 331.10, 331.40, 331.45, 331.50, 331.60, $331.70,331.80,331.90,331.95,332.10,332.20$

Females. See also Gender

employment to population ratio of, 501.70

unemployment rates of, 501.90

Field of study. See also under individual subjects

associate's degrees by, 321.10, 321.30, 321.40, 321.50

bachelor's degree recipients by, 322.10, 505.10, 505.20, 505.30, 505.40

salaries, 505.50

women, 603.60

certificates conferred by postsecondary institutions, 320.10

degrees conferred by, 325.10-325.95

degrees in selected professional fields by, 324.40, 324.50,

$324.55,324.60,324.70$

doctor's degrees by, 324.10

faculty teaching in, 315.70, 315.80

intended major for college-bound seniors, 226.30

by level and type of institution, 311.60

master's degrees by, 323.10

remedial coursework enrolled in by undergraduate students, 311.40

Fights between students at school, 231.10, 231.20, 231.30

Finances for postsecondary institutions, historical statistics, 301.20. See also Expenditures; Revenues

Financial aid to postsecondary students as part of expenditures for private postsecondary institutions, 334.30 postbaccalaureate level, 332.10, 332.20, 332.30, 332.40 private institutions' expenditures on grant aid, 334.40, 334.50, 334.60 public institutions' expenditures on scholarships and

fellowships, 334.10

scholarships and grants to undergraduates, 331.30

student loan repayment and default rate, 332.50 
undergraduate level, 331.10, 331.20, 331.40, 331.45, 331.50, $331.60,331.70,331.80,331.90$

Fine motor skills, 220.10, 220.20, 220.30

First-professional degrees. See Professional fields, selected

First-time undergraduates, retention of, 326.30. See also Undergraduate-level studies

Foreign-born population in the United States, 101.30 employment of bachelor's degree recipients, 505.20, 505.30 students, 310.20 (See also Citizenship status) dropouts from high school, 219.80 employment of high school students by, 503.10

Foreign languages associate's degrees in, 321.10, 321.30, 321.40, 321.50

bachelor's degrees in, 322.10, 322.30

men earning, 322.40

by race/ethnicity, 104.50

women earning, 322.50

Carnegie units earned by high school graduates, 225.10

certificates conferred by postsecondary institutions in, 320.10 degrees conferred in, 318.30, 318.50, 325.55, 325.57, 325.59 doctor's degrees in, 324.10, 324.25, 324.30, 324.35 enrollment

in postsecondary education, $311.60,311.70,311.80$

in secondary school, 225.70

institutions conferring degrees in, 318.60

master's degrees in, 323.10, 323.30, 323.40, 323.50

For-profit private postsecondary institutions, 304.50. See also Private postsecondary institutions applications, admissions and enrollment comparisons, 305.40 crimes on-campus, $329.10,329.20$ expenditures of, 334.50, 334.60, 334.70 graduation rates for first-time students, 326.10, 326.20 loans received by undergraduate students by their 4th year, 331.95 primarily offering online programs, 311.33 student financial aid scholarships and grants to undergraduates, 331.30 student loan repayment and default rate, 332.50

Foundation support to postsecondary institutions, 333.80

Fourth grade attendance patterns, 227.50

international comparisons of mathematics and science, 602.20 of reading scores, 602.10

mathematics achievement, 222.10, 222.20

international comparisons of, 602.20

in public schools by state, 222.50

by urban district, 222.80

reading achievement, 221.10, 221.75

of English language learners in public schools by state, 221.70 international comparisons of, 602.10

in public schools by state and race/ethnicity, 221.50

in public schools by state and selected years, 221.40

by urban district, 221.80

science achievement, 223.10, 602.20

writing achievement, 224.60

Four-year postsecondary institutions admission requirements for, 305.30 applications, admissions and enrollment comparisons, 305.40 attendance status at, 303.30 average total cost for attendance for undergraduates, 330.40 with branch campuses, 317.10 closing of institutions, 317.50 completion status of students, 326.40

crimes on-campus, 329.10, 329.20

distance education courses, 311.15

employment of college students, 503.20, 503.30

enrollment in, 105.20, 303.25, 303.60, 303.65

by attendance status, 303.55

by control of institution, 303.50

by race/ethnicity, 302.60, 306.20, 306.40, 306.50

by recent high school completers, 302.40

by state, $304.60,304.80$

expenditures of private institutions, 334.30, 334.40, 334.50,

$334.60,334.70$

expenditures of public institutions, 334.10, 334.20

faculty in, 315.10

salaries, 316.20, 316.30, 316.40, 316.50, 316.60

tenure, 316.80

field of study at, 311.60

first-time freshmen at, 305.10

foreign language enrollment in, 311.70, 311.80

full-time-equivalent enrollment in, 307.10, 307.20

graduation rates for first-time students, 326.10

historically black colleges and universities, 313.20

loans received by undergraduate students by their 4th year, 331.95

number of institutions by state, 317.20

ratio of full-time-equivalent students to full-time-equivalent staff, 314.50

remedial coursework enrolled in by undergraduate students, 311.40 remedial coursework offered by, 311.50

residence and migration of freshmen in postsecondary institutions, 309.30

retention of first-time degree-seeking students by attendance status, 326.30

revenues of private institutions, 333.40, 333.50, 333.55, 333.60

revenues of public institutions, 333.10

revenues of public institutions by state, 333.25

staff in, 314.20, 314.30, 314.40

by state, 317.20

student financial aid, 331.20

postbaccalaureate students, 332.30, 332.40

student loan repayment and default rate, 332.50

undergraduates, 331.30, 331.50, 331.60, 331.70, 331.80, 331.90

Title IV postsecondary institutions, 301.10

tuition, fees, and board rates for undergraduates, 330.10, 330.20, 330.30

Free or reduced-price school lunch program

arts achievement and frequency of instruction, 224.10

attendance patterns by fourth-, eighth- and twelfth-graders, 227.50

bullying, reported by public schools, 230.65

civics achievement by grade, 224.20

controlled access, dress code, metal detectors and security personnel present, 233.60

crime

recorded by schools, 229.20, 229.30

reported to police by schools, 229.40

violent crime reported to police by schools, 229.50, 229.60

discipline issues reported by public schools, 230.10

economics achievement of high school seniors, 224.30

eligible public school students by state, 204.10

eligible students in public charter and traditional public schools, 216.30 environmental factors that interfere with instruction, 217.10 geography achievement by grade, 224.40

high school graduates enrolled in postsecondary institutions by, 302.40 history, U.S., achievement by grade, 224.50 
mathematics achievement

of eighth-graders by attitude, 222.30

by grade, 222.20

by high school seniors, 222.40

mathematics coursework by high school graduates, 225.40

percentage distribution of students participating in, 216.60

public school capacity level and, 217.20

public schools with internet access, 218.10

pupil-to-teacher ratios, 208.10

reading achievement by grade, 221.10, 221.20

repairs or renovations of physical facilities for public elementary/

secondary schools by percentage of students in, 217.15

science achievement

of eighth-graders by attitude, 223.25

of eighth-graders in public schools by state, 223.20

by grade, 223.10

of high school seniors by attitude, 223.30

science coursework by high school graduates, 225.40

security staff present at public schools, 233.70

writing achievement, 224.60

French

degrees conferred in, 325.57

enrollment in courses, postsecondary education, 311.70, 311.80

enrollment in high school, 225.70

Freshmen (postsecondary institutions)

enrollment by attendance status, 305.10

enrollment by state, 305.20

residence and migration of, 309.10, 309.20, 309.30

Full-day kindergarten, state policies on, 234.10

Full-time attendance at postsecondary institutions, 303.10, 303.30, $303.70,303.80$

by age and gender, 303.40

by control and affiliation of institution, 303.90

by control and type of institution, 303.50, 303.55

first-time freshmen, 305.10, 305.20

in for-profit private institutions by state, 304.50

institutions with more than 15,000 students, 312.20

by level, 303.45, 303.60, 303.65

postbaccalaureate-level student financial aid, 332.10, 332.30

in private institutions by state, 304.40, 304.45

in public institutions by state, 304.35

by race/ethnicity and gender, 306.10

remedial coursework enrolled in by undergraduate students, 311.40

by state, 304.30

student financial aid, 331.40, 331.50, 331.60, 331.70, 331.90

Full-time employment in postsecondary institutions, 314.10, 314.20, 314.30, 314.40, 315.10

Full-time equivalent enrollment in postsecondary institutions, 307.10, 334.10

expenditures per, 334.10

on-campus crime in postsecondary institutions, 329.20

by state, $307.20,307.30$

Full-time-equivalent staff/faculty in postsecondary institutions.

See also Faculty, postsecondary; Staff

in private postsecondary institutions, 314.60

ratios to full-time equivalent students, 314.10

in Title IV institutions, 314.50

Full-time faculty, 315.10, 315.20, 315.30. See also Faculty, postsecondary

Full-year enrollment in postsecondary institutions, 308.10, 308.20

Funding for public elementary and secondary schools. See Revenues
Gang activities, students reporting presence of, 230.20

GED (General Educational Development) test, 219.60

Gender

ACT scores, 226.50

adult education participation, 507.30, 507.40

alcohol consumption by secondary students, 232.10, 232.20

associate's degrees by, 321.20, 321.40, 321.50

attendance patterns by fourth-, eighth- and twelfth-graders, 227.50

attendance status at postsecondary institutions, 303.10, 303.30, 303.40

bachelor's degrees by, 104.50, 104.60, 322.20

men earning, 322.40

women earning, 322.50

bullying

reported by students, $230.40,230.45,230.50$

reported by students to adult at school, 230.60

Carnegie units earned by high school graduates, 225.10, 225.20

child care arrangements and, 202.50, 202.60, 202.65

civics achievement by grade levels, 224.20

cognitive and motor skills of nine-month-old children by, 220.10

college enrollment and labor force status of high school graduates

by, 504.10

coursework in high school

by high school graduates in mathematics and science, 225.30 , 225.40

mathematics scores of high school seniors, 222.40

mathematics scores of seventeen-year-olds, 222.95

minimum credits earned by high school graduates, 225.50

cyber-bullying reported by students, 230.40, 230.55, 230.65

degrees conferred by, 325.10, 325.15, 325.20, 325.25, 325.30,

$325.35,325.40,325.45,325.50,325.55,325.60,325.65$,

$325.70,325.80,325.85,325.90,325.95$

degrees conferred by field of study, 318.30

degrees in selected professional fields by, 324.40, 324.50, 324.60, 324.70

with doctor's degrees, 324.30, 324.35

doctor's degrees by, 324.20

dropouts from high school, 219.70, 219.80

drug, cigarette, and alcohol usage by teenagers, 232.95

economics achievement of high school seniors, 224.30

educational attainment, 104.10, 104.20, 104.30, 104.40

of 1990 high school sophomores in 2000 by, 104.90

by metropolitan area, 104.95

by state, 104.88

employment

of bachelor's degree recipients, 505.20, 505.30

of college students by, 503.30

of high school students, 503.10

to population ratio by, $501.60,501.70$

enrollment in postsecondary institutions, 105.20, 302.10, 306.10 enrollment in Title IV postsecondary institutions, 301.10

extracurricular activities of high school seniors, 227.30

extracurricular activities of ninth-graders, 227.10

fights between students at school, 231.10, 231.20

gangs reported by students, 230.20

geography achievement by grade, 224.40

gifted and talented students by state, 204.80, 204.90

grades earned by elementary and secondary students, 225.80

graduate students taking night, weekend or online classes, 311.30

hate-related harassment, 230.35

hate-related harassment or graffiti, 230.30

high school graduates by control of school, 219.10

historical statistics of degree-granting institutions, 301.20 
history, U.S., achievement by grade, 224.50

homework, 227.40

illegal drugs, availability to secondary students, 232.70

income by educational attainment, 502.20, 502.30, 502.40

international comparisons

of bachelor's degree recipients, 603.50

of employment rate by educational attainment, 603.90

of mathematics, reading and science skills, 602.40

of reading scores for fourth-graders, 602.10

internet usage, 702.10

kindergarten entry status of children, 220.50

labor force participation by, 501.10, 501.40

labor force participation of high school dropouts by, 504.20

language and mathematics skills of four-year-olds by, 220.30

leisure activities of high school seniors, 227.20

life values of high school students, 506.10

literacy skills of adults, 507.10

loaded guns carried by students to school, 231.70

marijuana usage by secondary students, 232.40, 232.50

master's degrees by, 323.20, 323.40, 323.50

mathematics achievement

by age, $222.85,222.90$

of eighth-graders by attitude, 222.30

by grade, 222.10, 222.20

mathematics and science skills of 1998 kindergartners through grade $8,220.80$

mental and physical skills of two-year-olds by, 220.20

minimum credits earned by high school graduates, 225.50

nonfatal victimization of students in schools, 228.25

occupations by, 502.10

population enrolled in school by, 103.10

postsecondary institutions

attendance status and state, 304.30

attendance status at private institutions by state, 304.40

attendance status at public institutions by state, 304.35

certificates granted by Title IV postsecondary institutions, 320.20

degrees conferred by, 318.10

employment in, 314.20, 314.30, 314.40

enrollment in, 302.60, 303.45, 303.60, 303.65

enrollment in for-profit private institutions, 304.50

enrollment in private institutions, 304.45

faculty in, 315.10, 315.20, 315.50, 315.60, 315.70, 315.80

faculty salaries by, $316.10,316.20$

faculty with tenure, 316.80

first-time freshmen at, 305.10, 305.20

graduation rates by, $326.10,326.20$

historically black colleges and universities, 313.30

institutions with more than 15,000 students, 312.10

postbaccalaureate level enrollment at, 303.80

undergraduate enrollment at, 303.70

undergraduate students enrolled in remedial coursework by, 311.40

women's colleges, 312.30

preprimary enrollment and, 202.20

reading, mathematics and cognitive flexibility scores at kindergarten entry, 220.40

reading achievement

by age, $221.85,221.90$

by grade, $221.10,221.20$

reading skills of 1998 kindergartners through grade 8, 220.70

remedial coursework enrolled in by undergraduate students, 311.40

SAT scores for college-bound seniors, 226.20

science achievement of eighth-graders by attitude, 223.25

of eighth-graders in public schools by state, 223.20

by grade, 223.10

of high school seniors by attitude, 223.30

science and mathematics skills of 1998 kindergartners through

grade $8,220.80$

student financial aid, 331.10, 331.40, 331.45

students fearing attack or harm at school, 230.70, 230.80

suspensions and expulsions from public schools, 233.30, 233.40

teachers' educational attainment in schools by, 209.20

of teachers in public and private elementary and secondary schools, 209.10

of teachers reporting threats or physical attacks from students, 228.70 undergraduate students receiving loans by their 4th year, 331.95 undergraduate students taking night, weekend or online classes, 311.20 unemployment rates by, 501.20, 501.85, 501.90

U.S. students studying abroad, 310.10

victimization reported by students in schools, 228.30

weapons carried by students to school, 231.40, 231.50

weapons-related victimization reported by students, 228.40

writing achievement by grade, 224.60

young adults neither in school nor employed, 501.30

General Educational Development (GED), 219.60

Geography

achievement by grade, 224.40

enrollment postsecondary education, 311.60

Geology, degrees conferred in, 325.72

Geometry coursework in secondary schools, 222.40, 222.95

German

degrees conferred in, 325.57

enrollment in courses, postsecondary education, 311.70, 311.80

enrollment in high school, 225.70

Gifted and talented students, 204.80, 204.90

Goals for education of college-bound seniors, 226.30

Government. See also Federal government; Local governments; States expenditures on education by function, 106.30

support for education by agency, 401.20, 401.30

Grade levels. See also Eighth grade; Fourth grade; High school seniors alcohol consumption by secondary students, 232.10, 232.20

bullying

reported by students, 230.40, 230.45, 230.50

reported by students to adult at school, 230.60

civics achievement by, 224.20

crime recorded by schools, 229.20, 229.30

crime reported to police, 229.40

cyber-bullying reported by students, 230.40, 230.55, 230.65

discipline issues reported by public schools, 230.10

enrollment in public elementary and secondary schools by, 203.10, 203.40, 203.45

environmental factors that interfere with instruction, 217.10

fights between students at school, 231.10, 231.20

gangs reported by students, 230.20

geography achievement by, 224.40

hate-related harassment, 230.35

hate-related harassment or graffiti, 230.30

high school dropouts by, 219.50, 219.51

history, U.S., achievement by, 224.50

illegal drugs, availability to students, 232.70

loaded guns carried by students to school, 231.70

marijuana usage by secondary students, $232.40,232.50$

mathematics achievement by, 222.20

mathematics achievement by high school seniors, 222.40 
private school enrollment by, 205.10, 205.20

public elementary and secondary schools by, 216.10

public elementary schools by, 216.75

public secondary schools by, 216.80

reading achievement by, $221.20,221.75$

schooling type, percentage of children by, 206.20

security staff present at public schools, 233.70

students fearing attack or harm at school, 230.70

students fearing attack or harm in specific places at school, 230.80

victimization reported by students in schools, 228.30

violent crime reported to police, 229.50, 229.60

weapons carried by students to school, 231.40, 231.50

weapons-related victimization reported by students, 228.40

writing achievement by, 224.60

Grades, average

distribution of elementary and secondary school children by, 225.80

SAT scores by high school grade point average, 226.30

Graduate-level studies. See Postbaccalaureate education

Graduate Record Examination (GRE), 327.10

Graduation requirements for high school, 234.30

Graffiti, hate-related, 230.30

Grants to students

graduate students receiving, $332.30,332.40$

undergraduates receiving, 331.10, 331.20, 331.30, 331.40,

$331.45,331.60,331.70,331.80,331.90$

Greek, ancient, enrollment in postsecondary education courses, $311.70,311.80$

Gross domestic product

expenditures of educational institutions compared to, 106.10

government expenditures and income compared to, 106.60

international comparisons of educational expenditures, 605.10, 605.20

price index, 106.70

Guns carried to school by students, 231.70

\section{Harassment}

hate-related words, 230.30, 230.35

threats made to teachers, 228.70, 228.80

Head Start, 202.30, 202.50, 202.60

Health sciences/professions

associate's degrees in, 321.10, 321.30, 321.40, 321.50

bachelor's degrees in, 319.30, 322.10, 322.30

employment status and salary of recipients, 505.10

employment status of recipients, 505.20, 505.40

men earning, 322.40

by race/ethnicity, 104.50, 104.60

STEM versus non-STEM professions, 505.30

women earning, 322.50, 603.60

certificates conferred by postsecondary institutions in, 320.10

degrees conferred in, 318.30, 318.50, 325.60

doctor's degrees in, 324.10, 324.25, 324.30, 324.35

enrollment, postsecondary education, 311.60

institutions conferring degrees in, 318.60

master's degrees in, 319.40, 323.10, 323.30, 323.40, 323.50

Hebrew, enrollment in courses, postsecondary education, 311.70, 311.80

Higher education. See Postsecondary education

High school graduates

Carnegie units earned by, 225.10

Carnegie units required by state, 234.30

college enrollment and labor force status, 504.10

educational attainment of 1990 high school sophomores in 2000, 104.90 enrollment in postsecondary institutions, 302.10, 302.20, 302.30, $302.40,302.50$

GED credentialed, 219.60

by gender and control of school, 219.10

international comparisons of as percentage of population, 603.10

from private secondary schools, 205.80

by race/ethnicity, 219.30

by race/ethnicity and gender, 104.10

by state, $219.20,219.35$

by state and race/ethnicity, 219.40

students with disabilities, 219.90

High schools, 216.40, 601.60. See also Elementary and secondary education; Public elementary and secondary schools

High school seniors

attendance patterns, 227.50

drug usage by, 232.90

economics achievement, 224.30

leisure activities of, 227.20

life values of, 506.10

mathematics achievement, 222.10, 222.20

mathematics achievement by mathematics courses, 222.40

reading achievement, 221.10, 221.75

science achievement, 223.10

science achievement by attitude, 223.30

writing achievement, 224.60

High school students, employment of, 503.10

Hispanics

ACT scores, 226.50

arts achievement and frequency of instruction, 224.10

with associate's degrees, 321.20, 321.30, 321.40, 321.50

attendance patterns by fourth-, eighth- and twelfth-graders, 227.50

with bachelor's degrees, 104.50, 104.60, 322.20, 322.30

men, 322.40

women, 322.50

Carnegie units earned by high school graduates in vocational education by, 225.20

child care arrangements by, 202.40

children living in poverty, 102.60

civics achievement by grade, 224.20

college enrollment and labor force status of high school graduates, 504.10

coursework by high school graduates in mathematics and science, 225.30, 225.40

with degrees in selected professional fields, 324.55, 324.60, 324.70

distribution in public schools

percentage of students eligible for free or reduced-price lunches, 216.60

by racial/ethnic concentration of school, 216.50, 216.55

by region of the country, 203.50

by state, 203.70

distribution of resident population by age, 101.30

with doctor's degrees, 324.20, 324.25, 324.30, 324.35

dropouts from high school, 219.70

drug, cigarette, and alcohol usage by teenagers, 232.95

economics achievement of high school seniors, 224.30

educational attainment, 104.10, 104.20, 104.30, 104.40, 104.85

employment of high school students, 503.10

enrollment and percentage distribution by year and level of education, 203.60

enrollment in postsecondary institutions, 306.30

estimates of resident population by age, 101.20

family characteristics of, 102.20 
geography achievement by grade, 224.40 gifted and talented students by state, 204.80, 204.90

high school dropouts, 219.50, 219.51

high school graduates, 219.30, 219.40

history, U.S., achievement by grade, 224.50

income and educational attainment of, 502.30

Individuals with Disabilities Education Act, children served under, 204.40, 204.50

internet usage, 702.10

labor force status, 501.40

labor force status of high school dropouts, 504.20

leisure activities of high school seniors, 227.20

with master's degrees, 323.20, 323.30, 323.40, 323.50

mathematics achievement

by age, $222.85,222.90$

of fourth- and eighth-graders in urban districts, 222.80

by grade, $222.10,222.20$

of high school seniors by mathematics coursework, 222.40

by race/ethnicity and state, 222.70

of seventeen-year-olds by mathematics coursework, 222.95

mathematics and science skills of 1998 kindergartners through grade $8,220.80$

parental level of education of 6- to 18-year olds, 104.70

percentage of population enrolled in school, 103.10

postsecondary institutions

certificates granted by Title IV postsecondary institutions, 320.20

employment in, 314.40

enrollment in, 302.20, 302.60, 306.10, 306.40, 306.50

enrollment in by state, $306.60,306.70$

enrollment in by type and control of institution, 306.20

faculty in, 315.20, 315.60, 315.80

graduation rates by, $326.10,326.20$

serving large proportions of, 312.40

poverty rates, 102.50

in public charter and traditional public schools, 216.30

reading, mathematics and cognitive flexibility scores at kindergarten entry, 220.40

reading achievement

by age, $221.85,221.90$

of fourth- and eighth-graders by urban district, 221.80

of fourth-graders in public schools by state, 221.50

by grade, $221.10,221.75$

reading skills of 1998 kindergartners through grade 8, 220.70

remedial coursework enrolled in by undergraduate students, 311.40

SAT scores for college-bound seniors, 226.10

science achievement

of eighth-graders by attitudes toward science, 223.25

of eighth-graders in public schools by state, 223.20

by grade, 223.10

of high school seniors by attitudes toward science, 223.30

science and mathematics skills of 1998 kindergartners through grade $8,220.80$

suspensions and expulsions from public schools, 233.30, 233.40

unemployment rate, 501.20

U.S. students studying abroad, 310.10

writing achievement by grade, 224.60

young adults neither in school nor employed, 501.30

Historically black colleges and universities, 313.10, 313.20, 313.30

Historical summary statistics

Catholic schools, 205.70

degree-granting institutions, 301.20

degrees conferred by gender, 318.10 enrollment at all levels, 105.30

expenditures of educational institutions, 106.10, 106.20

level of education attained, 104.10, 104.20

number of school districts and public and private schools, 214.10

public elementary and secondary school characteristics, 201.10

public elementary and secondary school enrollment, 201.20

History

achievement in U.S. history by grade, 224.50

associate's degrees in, 321.10, 321.30, 321.40, 321.50

bachelor's degrees in, 322.10, 322.30

employment status and salary of recipients, 505.10

men earning, 322.40

by race/ethnicity, 104.50

women earning, 322.50

Carnegie units earned by high school graduates, 225.10

certificates conferred by postsecondary institutions in, 320.10

criterion-referenced tests (CRTs) by state, 234.40

degrees conferred in, 318.30, 318.50, 325.90, 325.92

doctor's degrees in, 324.10, 324.25, 324.30, 324.35

enrollment postsecondary education, 311.60

institutions conferring degrees in, 318.60

master's degrees in, 323.10, 323.30, 323.40, 323.50

Hobby clubs

high school seniors' participation in, 227.30

ninth-graders' participation in, 227.10

Home activities

internet access/usage, 702.10

with kindergartners through fifth-graders, 207.30

preschool literacy activities, 207.10

Homeland security, certificates conferred by postsecondary institutions in, 320.10. See also Security

Homeschooled students, 206.10, 206.20

Homework

parental involvement with, 227.40

reading scores by amount of time on, 221.30

Homicides in schools, 228.10

Hospitals

expenditures at postsecondary institutions for, 334.10, 334.30, 334.40

revenues for postsecondary institutions, 333.10

revenues for private postsecondary institutions, 333.40, 333.50, 333.60

revenues for public postsecondary institutions, 333.25

Household income. See also under Income, family

adult education participation by, 507.30, 507.40

child care arrangements by, 202.30

enrollment in preprimary education by, 202.70

homeschooled children by, 206.10

nonfatal victimization of students in schools, 228.25

by state, 102.30

Household structure/type, 102.10. See also Single-parent households; Two-parent households

entry status of children in kindergarten, 220.50

parental level of education of 6- to 18-year olds, 104.70

reading, mathematics and cognitive flexibility scores of children at kindergarten entry by, 220.40

Humanities. See also Liberal arts and humanities bachelor's degrees earned by women in, 603.60

bachelor's degrees in, 319.30

doctor's degrees in, 324.80

master's degrees in, 319.40

Illegal drugs

availability to students, $232.70,232.80$ 
on-campus in postsecondary institutions, 329.10, 329.20

usage by students, 232.40, 232.50, 232.60

Illicit drug usage

by high school seniors, 232.90

by teenagers, 232.95

Immigrants/Immigration

dropouts from high school, 219.80 (See also Citizenship status)

foreign-born population in the United States, 101.30

Income. See also Poverty rates/status; Socioeconomic status

of bachelor's degree recipients, 505.10

of bachelor's degree recipients 1 year after graduation, 505.40, 505.50

compared to gross domestic product and government expenditures, 106.60

by educational attainment, 502.20, 502.30, 502.40

enrollment in postsecondary institutions by recent high school completers, 302.30

of faculty in postsecondary institutions, 315.50, 315.60 (See also under Salaries)

family

dropouts from high school and, 219.75

employment of high school students by, 503.10

grades earned by elementary and secondary students, 225.80

Internet usage, 702.10

SAT mean scores of college-bound seniors, 226.30

student financial aid, 331.10, 331.40, 331.45

household by state, 102.30 (See also Household income)

parental participation in activities with children, 207.30

parental participation in educational activities with children, 207.20

parental participation in school activities by level of, 207.40

teacher salaries, 211.10 (See also Salaries)

of undergraduates receiving scholarships and grants, 331.30

Individuals with Disabilities Education Act, 204.30, 204.40, 204.50, 204.60, 204.70, 219.90

Institutionalized population, dropouts from high school, 219.80

Instructional levels. See Grade levels

Instructional time

in arts for eighth-graders, 224.10

international comparisons of teachers, 601.60

in mathematics

fourth-graders having five or more weekly hours, 222.50

international comparisons, 602.20, 602.30

in science, international comparisons, 602.20, 602.30

Instruction/Instructional staff. See also Faculty, postsecondary;

Teachers, elementary and secondary

postsecondary institutions

expenditures for at private institutions, 334.30, 334.40,

$334.50,334.60$

expenditures for at public institutions, 334.10, 334.20

at Title IV institutions, 301.10

in public elementary and secondary schools, 213.10, 213.20, 213.30

environmental factors interfering with, 217.10

expenditures for, 236.10, 236.20, 236.30, 236.40, 236.50

Interest on school debt, 236.60. See also Expenditures

International Baccalaureate programs in public secondary schools, 225.60

International comparisons, 601.10-603.90

bachelor's degrees, 603.50

earned by women, 603.60

in mathematics, science and engineering, 603.70

educational attainment of adults, 603.10-603.40

employment rate by educational attainment and gender, 603.90

expenditures on education per student, 605.10

public direct, 605.20

foreign students enrolled in United States, 310.20

graduate degrees in mathematics, science and engineering, 603.80

mathematics

hours of instruction, $602.20,602.30$

scores, 602.20, 602.30, 602.60

mathematics, reading, and science skills, 602.40

population and enrollment, $601.10,601.20$

pupils per teacher in elementary and secondary schools, 601.50

reading literacy proficiency scores of fifteen-year-olds, 602.50

reading literacy scores for fourth-graders, 602.10

school-age population, 601.30

science

hours of instruction, $602.20,602.30$

scores, 602.20, 602.30, 602.40, 602.70

secondary and postsecondary enrollment, 601.40

teachers' working time and average class size, 601.60

International relations, enrollment in postsecondary education, 311.60

Internet access/usage

cyber-bullying

public schools reporting, 230.65

students reporting, 230.40, 230.55

students reporting to adult at school, 230.60

at home, 702.10

public elementary and secondary schools with, 218.10

Italian

degrees conferred in, 325.57

enrollment in courses, postsecondary education, 311.70, 311.80

enrollment in high school in, 225.70

Japanese

enrollment in courses, postsecondary education, 311.70, 311.80

enrollment in high school in, 225.70

Journalism, degrees conferred in, 325.30

Junior high schools, 216.10, 601.60. See also Public elementary and secondary schools

\section{Kindergarten}

attendance and program requirements by state, 234.10

entry status of children, 220.50

mathematics and science skills for 1998 cohort through grade 8, 220.80

public, 203.40, 203.45

public and private by age and attendance status, 202.10, 202.20

reading, mathematics and cognitive flexibility scores at kindergarten entry, 220.40

reading, mathematics and cognitive flexibility scores by entry status, 220.60

reading skills for 1998 cohort through grade 8, 220.70

Korean

degrees conferred in, 325.59

enrollment in courses, postsecondary education, $311.70,311.80$

Labor force. See also Employment

dropouts from high school, 219.75, 504.20

employment to population ratio, 501.50, 501.60, 501.70

high school graduates in, 504.10

participation rates, $501.10,501.20$

status by educational achievement, 501.40

unemployment rates, 501.80, 501.85, 501.90

young adults neither in school nor employed, 501.30

Language 
initially spoken, literacy skills of adults by, 507.10 (See also

English language learners (ELL))

skills of four-year-olds, 220.30

spoken at home

reading, mathematics and cognitive flexibility scores of children at kindergarten entry by, 220.40

skills of 1998 kindergarteners through grade 8 by, 220.70, 220.80

Languages other than English, enrollment in postsecondary education courses, 311.70, 311.80. See also Foreign languages

Latin

enrollment in courses, postsecondary education, 311.70, 311.80

enrollment in high school, 225.70

Law enforcement

associate's degrees in, 321.10

bachelor's degrees in, 322.10

certificates conferred by postsecondary institutions in, 320.10

Legal professions

associate's degrees in, 321.10, 321.30, 321.40, 321.50

bachelor's degrees in, 322.10, 322.30

men earning, 322.40

STEM versus non-STEM professions, 505.30

women earning, 322.50

certificates conferred by postsecondary institutions in, 320.10

degrees conferred in, 318.30, 318.50

doctor's degrees in, 324.10, 324.25, 324.30, 324.35

LL.B. or J.D. degrees, 324.40, 324.50, 324.55

LL.B. or J.D. degrees, men earning, 324.60

LL.B. or J.D. degrees, women earning, 324.70

enrollment postsecondary education, 311.60

institutions conferring degrees in, 318.60

master's degrees in, 323.10, 323.30, 323.40, 323.50

Leisure activities

adult education participation, 507.40

of high school seniors, 227.20

reading scores in school and, 221.30

Length of school day, 203.90

Liberal arts and humanities

associate's degrees in, 321.10, 321.30, 321.40, 321.50

bachelor's degrees in, 319.30, 322.10, 322.30

employment status and salary of recipients, 505.10

men earning, 322.40

by race/ethnicity, 104.50

women earning, 322.50

certificates conferred by postsecondary institutions in, 320.10

degrees conferred in, 318.20, 318.30, 318.50

doctor's degrees in, 324.10, 324.25, 324.30, 324.35, 324.80

enrollment, postsecondary education, 311.60

institutions conferring degrees in, 318.60

master's degrees in, 319.40, 323.10, 323.30, 323.40, 323.50

Libraries

family literacy activities, 207.10, 207.20

in postsecondary institutions, 701.40, 701.50

public, 701.60

public school, 701.10, 701.20, 701.30

Library science

associate's degrees in, 321.10, 321.30, 321.40, 321.50

bachelor's degrees in, $322.10,322.30$

men earning, 322.40

women earning, 322.50

certificates conferred by postsecondary institutions in, 320.10

degrees conferred in, 318.30, 318.50

doctor's degrees in, 324.10, 324.25, 324.30, 324.35 enrollment, postsecondary education, 311.60

institutions conferring degrees in, 318.60

master's degrees in, 323.10, 323.30, 323.40, 323.50

Life sciences. See also Biology; Science bachelor's degrees earned by women in, 603.60

persons receiving doctor's degrees in, 324.80

Life values of high school seniors, 506.10

Literacy skills

of adults, 507.10

of four-year-olds, 220.30

Living arrangements for undergraduates in postsecondary institutions average total cost for attendance, 330.40

room and board, 330.10, 330.20, 330.30

Loans to students

loan repayment and default rate, 332.50

postbaccalaureate students receiving, 332.10, 332.20, 332.30, 332.40

received by undergraduate students by their 4th year, 331.95

undergraduates receiving, 331.10, 331.20, 331.40, 331.45, 331.60, $331.70,331.80,331.90$

Local governments

expenditures by, 106.30, 106.40

expenditures on education, 106.50

grants to undergraduates, 331.20

postsecondary institutions

appropriations for, 333.30

revenues for, $333.10,333.20,333.25$

revenues for private, $333.40,333.50,333.55,333.60$

revenues for public, 333.25

revenues for public elementary and secondary schools, 235.10, 235.20, 235.30

revenues for public elementary and secondary schools by metropolitan status, 235.40

revenues for public postsecondary institutions, 333.25

Magnet schools, 216.20

Males. See also Gender

employment to population ratio of, 501.60

unemployment rates of, 501.85

Marijuana usage by secondary students, 232.40, 232.50, 232.60

Marital status of householders with families, 102.10

Master's degrees

by control of institution, 318.40, 318.50, 319.10

by field of study, 318.20, 318.30, 323.10, 325.10-325.95

by gender, 318.10

number of institutions conferring, 318.60

by race/ethnicity and gender, 323.20, 323.30, 323.40, 323.50

salaries of teachers by, 211.40

by state, $319.20,319.40$

student financial aid for, 332.10, 332.20, 332.30, 332.40

Mathematics

associate's degrees in, 321.30, 321.40, 321.50

bachelor's degrees in, 321.10, 322.10, 322.30

employment status and salary of recipients, 505.10

employment status of recipients, 505.20

international comparisons of recipients, 603.70

males earning, 322.40

by race/ethnicity, 104.50, 104.60

STEM versus non-STEM professions, 505.30

women earning, 322.50, 603.60

certificates conferred by postsecondary institutions in, 320.10

degrees conferred in, 318.30, 318.50, 325.65

doctor's degrees in, 324.10, 324.25, 324.30, 324.35, 324.80 
elementary and secondary education

achievement

by age, $222.85,222.90$

of eighth-graders by attitude, 222.30

of eighth-graders in public schools by state, 222.60

of fourth- and eighth-graders in urban districts, 222.80

of fourth-graders in public schools by state, 222.50

by grade, $222.10,222.20$

international comparisons of, $602.40,602.60$

by race/ethnicity and state, 222.70

Carnegie units earned by high school graduates, 225.10

Carnegie units required by state for high school graduation, 234.30

coursework

by high school graduates in, 225.30, 225.40

mathematics scores of high school seniors, 222.40

mathematics scores of seventeen-year-olds, 222.95

criterion-referenced tests (CRTs) by state, 234.40

scores by student and school characteristics, 222.85

skills of 1998 kindergartners through grade 8, 220.80

enrollment in, 311.60

international comparisons

of achievement, 602.40, 602.60

of achievement and instructional time, 602.20, 602.30

of bachelor's degree recipients in, 603.70

of graduate degrees in, 603.80

master's degrees in, 323.10, 323.30, 323.40, 323.50

postsecondary institutions conferring degrees in, 318.60

scores at kindergarten entry, 220.40

scores by kindergarten entry status, 220.60

skills of four-year-olds, 220.30

Mechanical engineering, degrees conferred in, 325.47. See also Engineering

Media centers in schools, 701.10, 701.20, 701.30

Medicine, doctor's degrees (M.D.) in, 324.40, 324.50, 324.55, 324.60, 324.70. See also Health sciences/professions

Memory skills

scores at kindergarten entry, 220.40

scores by kindergarten entry status, 220.60

Men. See also Gender

employment to population ratio of, 501.60

unemployment rates of, 501.85

Mental skills of two-year-olds, 220.20

Metal detectors in schools, 233.50, 233.60

Metropolitan status

adult education participation, 507.30, 507.40

alcohol consumption by secondary students, 232.10

arts scores and frequency of instruction, 224.10

bullying

reported by students, 230.40, 230.45, 230.50

reported by students to adult at school, 230.60

charter schools and traditional public elementary and secondary schools, 216.30

child care arrangements by, 202.30

controlled access, dress code, metal detectors and security personnel present, 233.60

crime

schools recording occurrences of, 229.20, 229.30

schools reporting to police, 229.40

violent crimes that schools reported to police, 229.50, 229.60

cyber-bullying reported by students, 230.40, 230.55, 230.65

discipline issues reported by public schools, 230.10 dual credit, Advanced Placement and International

Baccalaureate enrollment in public schools, 225.60

economics achievement of high school seniors, 224.30

educational attainment, 104.95

employment of high school students, 503.10

enforcement of school rules by other teachers and principal, 230.92

fights between students at school, 231.10, 231.20

free or reduced-price lunch eligibility of students, 216.60

gangs reported by students, 230.20

hate-related harassment, 230.35

hate-related harassment or graffiti, 230.30

high school graduates enrolled in postsecondary institutions by, 302.40

homeschooled children, 206.10

homework, parental involvement with, 227.40

illegal drugs, availability to students, 232.70

largest school districts, 215.30

loaded guns carried by students to school, 231.70

marijuana usage by secondary students, 232.40

mathematics achievement

of fourth- and eighth-graders by, 222.80

of high school seniors by mathematics coursework, 222.40

misbehavior by students interfering with class instruction, 230.90

nonfatal victimization of students in schools, 228.25

private elementary and secondary schools, 205.30, 205.40

public elementary and secondary schools, 214.40

expenditures and revenues, 235.40

with internet access, 218.10

pupil-to-teacher ratios, 208.10

reading achievement of eighth-graders by, 221.60

reading achievement of fourth- and eighth-graders by, 221.80

repairs, renovations or replacements of physical facilities for

public elementary/secondary schools, 217.15

school districts with distance education enrollment, 218.20

schooling type, percentage of children by, 206.20

security staff present at public schools, 233.70

students fearing attack or harm at school, 230.70

students fearing attack or harm in specific places at school, 230.80

victimization reported by students in schools, 228.30

weapons carried by students to school, 231.40

Microbiology, degrees conferred in, 325.22

Middle schools, 216.10. See also Public elementary and secondary schools

crime recorded by schools by school characteristics, 229.20, 229.30

crime reported to police by school characteristics, 229.40

discipline issues reported by public schools, 230.10

violent crime reported to police by school characteristics, 229.50 , 229.60

Military technologies

associate's degrees in, 321.10, 321.30, 321.40, 321.50

bachelor's degrees in, 322.10, 322.30

employment status of recipients, 505.40

men earning, 322.40

STEM versus non-STEM professions, 505.30

women earning, 322.50

certificates conferred by postsecondary institutions in, 320.10

degrees conferred in, 318.30, 318.50

doctor's degrees in, 324.25, 324.30, 324.35

enrollment, postsecondary education, 311.60

institutions conferring degrees in, 318.60

master's degrees in, 323.10, 323.30, 323.40, 323.50

Minimum length of school year by state, 234.20

Minorities. See also Race/ethnicity 
enrollment in postsecondary institutions, 306.40, 306.50, 306.60, 306.70

enrollment in public elementary and secondary schools, 216.50

Mobility

residence and migration of freshmen in postsecondary

institutions, 309.10, 309.20, 309.30

of teachers in public and private schools, 210.30

Mothers, characteristics of. See also Parents

child care arrangements by, 202.30

education level and employment status (See also Parental level of education)

home literacy activities by, 207.10

prekindergarten through second-grade enrollment by, 202.70

employment status

child care arrangements by, 202.50, 202.60, 202.65

language and mathematics of four-year-olds by, 220.30

mental and physical skills of two-year-olds by, 220.20

preprimary education and, 202.70

Motor skills, 220.10, 220.20, 220.30

Music

achievement and frequency of instruction for eighth-graders, 224.10

participation in school-sponsored activities

by eighth-graders, 224.10

by high school seniors, 227.30

by ninth-graders, 227.10

Native-born U.S. citizens

dropouts from high school, 219.80

employment of bachelor's degree recipients, 505.20, 505.30

employment of high school students by, 503.10

labor force status by, 501.40

Natural sciences. See also Science

bachelor's degrees in, employment status and salary of recipients, 505.10

enrollment, postsecondary education, 311.60

international comparisons of postsecondary degrees in science, 603.80

Need-based student financial aid. See Financial aid to postsecondary students

Night classes for postsecondary education, 311.20, 311.30

No Child Left Behind Act (2001), 401.70. See also Title I allocations

Non-degree-granting institutions

enrollment in Title IV institutions, 301.10, 303.20

by state, 317.30

Nonfederal loans to undergraduate students, 331.95

Nonprofit private postsecondary institutions, 304.45. See also Private postsecondary institutions

applications, admissions and enrollment comparisons, 305.40

crimes on-campus, $329.10,329.20$

enrollment in, 303.50, 303.55

expenditures of, 334.30, 334.40, 334.70

faculty in, 315.10

graduation rates for first-time students, $326.10,326.20$

loans received by undergraduate students by their 4th year, 331.95

primarily offering online programs, 311.33

ratio of full-time-equivalent students to full-time-equivalent staff, 314.60

revenues to, $333.40,333.50$

by state, 317.20

student financial aid

scholarships and grants to undergraduates, 331.30

student loan repayment and default rate, 332.50
Nonsectarian private elementary and secondary schools, 205.20, 205.30, 205.40, 205.50

Occupation. See also Field of study

adult education participation by, 507.30, 507.40

bachelor's degree recipients by, 505.10, 505.20, 505.30, 505.40

by educational attainment, 502.10

One-parent households. See Single-parent households

One-teacher schools, 216.10, 216.70

Online classes for postsecondary education, $311.15,311.20$, 311.30, 311.33

Online postsecondary institutions, 311.33

Operating expenditures, public postsecondary institutions, 334.10, 334.20

Opinions on education

teachers on problems in schools, 210.10

teachers on school conditions, 210.20

Organization of Economic Cooperation and Development (OECD) and partner countries achievement of fifteen-year-olds

in mathematics, 602.60

in mathematics, reading and science, 602.40

in reading literacy, 602.50

in science, 602.70

employment rate by educational attainment and gender, 603.90

international comparisons of educational attainment, 603.10-603.40

Overcrowding in public schools, 217.20

Parental level of education

child care arrangements by, 202.50, 202.60, 202.65

cognitive and motor skills of nine-month-old children by, 220.10

educational achievement of children by

civics, 224.20

economics, 224.30

history, U.S., 224.50

mathematics, 220.80, 222.10, 222.20, 222.60, 222.70, 222.85

reading, 221.85

science, 220.80

writing, 224.60

educational attainment of 1990 high school sophomores in 2000 by, 104.90

grades earned, elementary and secondary students by, 225.80

homeschooled children by, 206.10

kindergarten entry status of children, 220.50

language, mathematics and motor skills of four-year-olds by, 220.30

literacy activities with children by, 207.10

mathematics and science skills of 1998 kindergartners through grade 8 by, 220.80

mental and physical skills of two-year-olds by, 220.20

participation in activities with children by, 207.20, 207.30

participation in school activities by, 207.40

percentage distribution of 6- to 18-year olds by, 104.70

preprimary enrollment of children, 202.20

reading, mathematics and cognitive flexibility scores of children at kindergarten entry by, 220.40

reading skills of 1998 kindergartners through grade 8 by, 220.70

SAT mean scores of college-bound seniors by, 226.30

science and mathematics skills of 1998 kindergartners through grade $8,220.80$

Parent Loans for Undergraduates (PLUS), 331.95

Parents

activities with children, 207.10, 207.20, 207.30

educational attainment of (See Parental level of education)

emotional attachment of two-year olds to, 220.20 
employment status

kindergarten entry status of children, 220.50

preprimary enrollment of children, 202.20

reading, mathematics and cognitive flexibility scores of children at kindergarten entry by, 220.40

homework, involvement with children's, 227.40

prekindergarten through second-grade enrollment by

characteristics of mothers, 202.70

school activities, participation in, 207.40

Part-time attendance at postsecondary institutions, 303.10, 303.30, $303.70,303.80$

by age and gender, 303.40

by control and type of institution, $303.50,303.55$

employment of college students, 503.20, 503.30

first-time freshmen, 305.10, 305.20

in for-profit private institutions by state, 304.50

graduate enrollment, 332.20

institutions with more than 15,000 students, 312.20

by level, 303.45, 303.60, 303.65

postbaccalaureate-level student financial aid, 332.40

in private institutions by state, $304.40,304.45$

in public institutions by state, 304.35

by race/ethnicity and gender, 306.10

remedial coursework enrolled in by undergraduate students, 311.40

by state, 304.30

student financial aid, 331.45, 331.50, 331.80, 331.90, 332.20, 332.40

Part-time employment in postsecondary institutions, 314.20, 314.30, $314.40,315.10$

Part-time faculty, 315.40. See also Faculty, postsecondary

Performing arts

associate's degrees in, 321.10, 321.30, 321.40, 321.50

bachelor's degrees in, 322.10, 322.30

men earning, 322.40

women earning, 322.50

certificates conferred by postsecondary institutions in, 320.10

degrees conferred in, 318.30, 318.50, 325.95

doctor's degrees in, 324.10, 324.25, 324.30, 324.35

enrollment, postsecondary education, 311.60

institutions conferring degrees in, 318.60

master's degrees in, 323.10, 323.30, 323.40, 323.50

Perkins loans, 331.95

Pharmacy, doctor's degrees (Pharm.D.) in, 324.50, 324.55, 324.60, 324.70

Philosophy, religion and theology

associate's degrees in, 321.10, 321.30, 321.40, 321.50

bachelor's degrees in, $322.10,322.30$

employment status and salary of recipients, 505.10

men earning, 322.40

by race/ethnicity, 104.50

women earning, 322.50

certificates conferred by postsecondary institutions in, 320.10

degrees conferred in, 318.30, 318.50

doctor's degrees in, 324.10, 324.25, 324.30, 324.35

enrollment, postsecondary education, 311.60

institutions conferring degrees in, 318.60

master's degrees in, 323.10, 323.30, 323.40, 323.50

master's degrees in theology, 324.55, 324.60, 324.70

Physical sciences. See also Science

associate's degrees in, 321.10, 321.30, 321.40, 321.50

bachelor's degrees in, 322.10, 322.30

employment status and salary of recipients, 505.10

employment status of recipients, 505.20

men earning, 322.40
STEM versus non-STEM professions, 505.30

women earning, 322.50, 603.60

certificates conferred by postsecondary institutions in, 320.10

degrees conferred in, 318.20, 318.30, 318.50, 325.70, 325.72

doctor's degrees in, 324.10, 324.25, 324.30, 324.35, 324.80

enrollment, postsecondary education, 311.60

institutions conferring degrees in, 318.60

master's degrees in, 323.10, 323.30, 323.40, 323.50

Physical skills of young children, 220.10, 220.20

Physics, degrees conferred in, 325.72

Place of birth

comparison of U.S.-born and foreign-born, 101.30

foreign-born population in the United States, 101.30

dropouts from high school, 219.80

employment of bachelor's degree recipients, 505.20, 505.30

employment of high school students by, 503.10

students, 310.20

native-born U.S. citizens

dropouts from high school, 219.80

employment of bachelor's degree recipients, 505.20, 505.30

employment of high school students by, 503.10

labor force status by, 501.40

Podiatry, degrees conferred in, 324.50, 324.60, 324.70

Police (sworn law enforcement officers) patrolling public schools, 233.70

Political science and government

degrees conferred in, 325.92

enrollment, postsecondary education, 311.60

Population

age

by age group, 101.10

race/ethnicity, place of birth and, 101.30

race/ethnicity and, 101.20

school-age populations by country, 601.10

school-age populations by state, 101.40

gross domestic product and income, 106.60

historical statistics of, 201.10

international comparisons, 601.10, 601.20

of educational attainment, 603.10-603.40

of employment by educational attainment, 603.90

of school-age populations, 601.30

of secondary and postsecondary enrollment, 601.40

percentage enrolled in school, 103.10, 103.20

ratio to employment status, 501.10

school-age population by state, 101.40

Portable buildings in public schools, 217.10

Portuguese, enrollment in courses, postsecondary education, 311.70 , 311.80

Postbaccalaureate education

disabled students enrolled in, 311.10

distance education courses, 311.15

employment of college students, 503.30

enrollment in, 105.20, 303.45, 303.60, 303.65, 303.80

by race/ethnicity and gender, 306.10

by state, $304.70,304.80$

faculty teaching at, 315.30

field of study, 311.60

foreign language enrollment, 311.70, 311.80

at institutions with more than 15,000 students, 312.20

international comparisons of degrees in science, 603.80

night, weekend or online classes, percentage of students taking, 311.30

part-time faculty teaching at, 315.10, 315.40

in science and engineering postsecondary programs, 311.90 
tuition and fees for, 330.50

Postsecondary education, 301.10-334.70

admission requirements for institutions, 305.30

applications, admissions, and enrollment for undergraduates, 305.40

average total cost for attendance for undergraduates, 330.40

certificates conferred by field of study, 320.10

closing of institutions, 317.50

crimes on-campus, $329.10,329.20$

distance education courses, 311.15

doctor's degrees by institution, 324.90

endowment funds for institutions, 333.90

enrollment (See also Enrollment, postsecondary institutions)

at all levels, 105.20

by level of institution and race/ethnicity, 306.50

of U.S. residents by race/ethnicity, 306.30

expenditures on, 106.10, 106.20, 106.40 (See also under Expenditures)

federal support for, 401.10, 401.30

high school graduates enrolling in, 504.10

institutions and branches by control and state, 317.20

institutions with more than 15,000 students, 312.20

international comparisons

of educational attainment in, 603.20-603.80

of enrollment in, 601.40

on expenditures for, 605.10

largest colleges and universities, 312.10

libraries in institutions, 701.40, 701.50

non-degree-granting Title IV institutions, 317.30

number of institutions, 105.50, 317.10

number of institutions by state, 317.20

online institutions, 311.33

participants in, 105.10

per capita expenditures on, 106.50

race/ethnicity, enrollment by, 306.40

special education students enrolled in, 504.30

U.S. students studying abroad, 310.10

Poverty rates/status

child care arrangements by, 202.30, 202.50, 202.60, 202.65

of children by family structure and race/ethnicity, 102.60

cognitive and motor skills of nine-month-old children by, 220.10

homework by, 227.40

labor force status by, 501.40

language, mathematics and motor skills of four-year-olds by, 220.30

in largest 100 school districts, 215.30

mental and physical skills of two-year-olds by, 220.20

by race/ethnicity, 102.50

reading, mathematics and cognitive flexibility scores of children at kindergarten entry by, 220.40

in school districts of more than 15,000 students, 215.20

school districts with distance education enrollment by, 218.20

by state, 102.40

type of schooling by, 206.20

young adults neither in school nor employed by, 501.30

Preprimary education

child care arrangements, 202.30, 202.40, 202.50

enrollment in, 202.10, 202.20, 202.70

literacy activities at home, 207.10

in public elementary schools, 203.40, 203.45

quality of child care arrangements, 202.60

reading, mathematics and cognitive flexibility scores at kindergarten entry, 220.40

reading, mathematics and cognitive flexibility scores by kindergarten entry status, 220.60
Preschool programs, 202.10, 202.20. See also Preprimary education

Price indexes, 106.70

Primary schools. See Private elementary and secondary schools; Public elementary and secondary schools

Principals

in private elementary and secondary schools, 205.60, 212.10

in public elementary and secondary schools, 212.10

Private elementary and secondary schools

arts achievement and frequency of instruction, 224.10

attendance patterns by fourth-, eighth- and twelfth-graders, 227.50

bullying

reported by students, $230.40,230.45,230.50$

reported by students to adult at school, 230.60

Catholic schools, 205.70 (See also Catholic schools)

controlled access, dress code, metal detectors and security personnel present, 233.50, 233.60

coursework by high school graduates in mathematics and science, 225.30, 225.40

cyber-bullying reported by students, $230.40,230.55$

enforcement of school rules by other teachers and principal, 230.92

enrollment in, 105.20, 105.30, 205.10, 205.20, 205.30, 205.40, 205.50

expenditures of, 106.20

extracurricular activities of high school seniors, 227.30

gangs reported by students, 230.20

grades earned by students in, 225.80

in grades 9 to 12 compared to 14 - to 17-year-old population, 201.20

graduates enrolled in postsecondary institutions, 302.40, 302.50

hate-related harassment, 230.35

hate-related harassment or graffiti, 230.30

high school graduates, 205.80, 219.10

historical and projected enrollment statistics, 105.30

homework, 227.40

leisure activities of high school seniors, 227.20

loaded guns carried by students to school, 231.70

mathematics achievement

of eighth-graders by attitude, 222.30

by grade, $222.10,222.20$

mathematics and science skills of 1998 kindergartners through grade $8,220.80$

minimum credits earned by high school graduates, 225.50

misbehavior by students interfering with class instruction, 230.90

mobility of teachers, 210.30

number of, 105.50, 214.10

opinions of teachers on problems in schools, 210.10

opinions of teachers on school conditions, 210.20

parental participation

in activities with children, 207.30

in educational activities with children, 207.20

in school activities, 207.40

participants in, 105.10

percentage distribution of teachers in, 209.10

percentage of children in, 206.20

preprimary enrollment in, 202.10, 202.20

principals in, 205.60, 212.10

reading achievement by grade, 221.10

reading skills of 1998 kindergartners through grade 8, 220.70

science and mathematics skills of 1998 kindergartners through

grade $8,220.80$

staff and student-to-staff ratios, 205.60

students fearing attack or harm at school, 230.70

students fearing attack or harm in specific places at school, 230.80 
teachers in, 105.40, 209.20

salaries, 211.10

by school affiliation, 205.40

teachers reporting threats or physical attacks from students, 228.70

tuition for, 205.50

victimization reported by students in schools, 228.30

Private funding for public elementary and secondary schools, $235.20,235.30$

Private gifts and grants

postsecondary institutions, 333.10

revenues to private postsecondary institutions, 333.40, 333.50, $333.55,333.60$

revenues to public postsecondary institutions, 333.25

by source, 333.80

Private postsecondary institutions admission requirements for, 305.30

applications, admissions and enrollment comparisons, 305.40 attendance status at, 303.10, 303.20, 303.30, 304.40

average total cost for attendance for undergraduates, 330.40

with branch campuses, 317.10

closing of institutions, 317.50

by control and affiliation, 303.90

crimes on-campus, 329.10, 329.20

degrees conferred at, 318.40, 318.50, 318.60, 319.10

distance education courses, 311.15

employment of college students, 503.20, 503.30

enrollment, 105.20, 303.25, 303.50, 303.55, 303.60, 303.65

postbaccalaureate level, 303.80

by race/ethnicity, $306.20,306.40$

by state, $304.20,304.60,304.80,308.10$

by state and control of institution, 308.20

undergraduate, 303.70

expenditures of, 106.20, 334.30, 334.40, 334.50, 334.60

faculty in, 105.40, 315.30, 315.50, 315.60

benefit expenditures for, 316.70

by gender, 315.10

part-time, 315.40

salaries, 316.10, 316.20, 316.30, 316.40, 316.50, 316.60

tenure, 316.80

first-time freshmen at, 305.10, 305.20

for-profit institutions, enrollment in, 304.50

full-time-equivalent enrollment in, 307.10, 307.20, 307.30

full-time-equivalent staff at, 314.60

graduation rates for first-time students, 326.10, 326.20

historically black colleges and universities, 313.20

non-degree-granting Title IV institutions, 317.30

nonprofit institutions, 304.45

number and enrollment size, 317.40

number of, 105.50, 317.20

online institutions, 311.33

postbaccalaureate level

enrollment at, 303.80

students taking night, weekend or online classes, 311.30

ratio of full-time-equivalent students to full-time-equivalent staff by state, 314.60

remedial coursework offered by, 311.50

retention of first-time degree-seeking students by attendance status, 326.30

revenues for by source, 333.60

for-profit institutions, 333.55

non-profit institutions, 333.40, 333.50

revenues from federal government, 333.70 staff in, 314.10, 314.20, 314.30, 314.40, 314.60

by state, 317.20

student financial aid

postbaccalaureate students receiving, 332.10, 332.20, 332.30, 332.40

scholarships and grants to undergraduates, 331.30

student loan repayment and default rate, 332.50

undergraduate students receiving, 331.20, 331.50, 331.60, 331.70, 331.80, 331.90

Title IV programs, 301.10

tuition, fees, and board rates for undergraduates, 330.10, 330.20, 330.30

tuition and fees for postbaccalaureate-level studies, 330.50

undergraduate students

enrollment at, 303.70

first-year students enrolled in remedial coursework by, 311.40

receiving loans by their 4th year, 331.95

taking night, weekend or online classes, 311.20

Problems in schools, opinions of teachers on, 210.10

Professional fields, selected

degrees in

by field of study, $324.40,324.50$

number of institutions conferring, 324.40

by race/ethnicity and gender, $324.55,324.60,324.70$

student financial aid for, 332.10, 332.20, 332.30, 332.40

tuition and fees for programs in, 330.50

Proficiency levels. See Achievement of elementary and secondary students; individual subjects

Program for International Student Assessment (PISA), scores of fifteen-year-olds in reading literacy, 602.50

Projections of statistics

enrollment at all levels, 105.10, 105.30

enrollment by race/ethnicity, 203.50, 203.60

enrollment of grade 9 through grade 12, 203.30

enrollment of prekindergarten through grade 8, 203.25

Psychology

associate's degrees in, 321.10, 321.30, 321.40, 321.50

bachelor's degrees in, 319.30, 322.10, 322.30

employment status and salary of recipients, 505.10

men earning, 322.40

by race/ethnicity, 104.50

women earning, 322.50

certificates conferred by postsecondary institutions in, 320.10

degrees conferred in, 318.30, 318.50, 325.80

doctor's degrees in, 324.10, 324.25, 324.30, 324.35, 324.80

enrollment, postsecondary education, 311.60

institutions conferring degrees in, 318.60

master's degrees in, 319.40, 323.10, 323.30, 323.40, 323.50

Public administration

associate's degrees in, 321.10, 321.30, 321.40, 321.50

bachelor's degrees in, 322.10, 322.30

employment status and salary of recipients, 505.10

men earning, 322.40

women earning, 322.50

certificates conferred by postsecondary institutions in, 320.10

degrees conferred in, 318.30, 318.50, 325.85

doctor's degrees in, 324.10, 324.25, 324.30, 324.35

enrollment, postsecondary education, 311.60

institutions conferring degrees in, 318.60

master's degrees in, 323.10, 323.30, 323.40, 323.50

Public elementary and secondary schools

alcohol consumption by secondary students, 232.30

arts achievement and frequency of instruction, 224.10

attendance patterns by fourth-, eighth- and twelfth-graders, 227.50 
average daily attendance at, 203.80, 203.90

bullying

reported by students, $230.40,230.45,230.50$

reported by students to adult at school, 230.60

charter schools and traditional, 216.30

charter schools and traditional by state, 216.90

controlled access, dress code, metal detectors and security

personnel present, 233.50, 233.60

coursework by high school graduates in mathematics and science, 225.30, 225.40

crime

recorded by schools, 229.10

recorded by schools by school characteristics, 229.20, 229.30

reported to police by school characteristics, 229.40

cyber-bullying reported by students, 230.40, 230.55, 230.65

disciplinary actions taken by schools, 233.10

discipline issues reported by schools, 230.10

distance education participation, 218.20

dual credit, Advanced Placement and International

Baccalaureate enrollment, 225.60

education agencies, 214.30

elementary schools by state and grade span, 216.75

enforcement of school rules by other teachers and principal, 230.92 enrollment

at all levels, 105.20, 105.30

by capacity level, 217.20

by grade in, 203.10

in grades 9 to 12 compared to 14 - to 17-year-old population, 201.20

by race/ethnicity, 203.60

racial/ethnic distribution by region of the country, 203.50

racial/ethnic distribution by state, 203.70

by size, 216.40

by state, 203.20, 203.25, 203.30, 203.40, 203.45

environmental conditions, 217.10

expenditures, 106.20

by function, $236.20,236.30,236.40$

for instruction, 236.50

per pupil, 236.15, 236.55, 236.60, 236.65, 236.70, 236.75, 236.80

by purpose, 236.10

by state, 236.25

for transportation to school, 236.90

extracurricular activities of high school seniors, 227.30

foreign language enrollment, 225.70

free or reduced-price lunches, students eligible for, 216.60

free or reduced-price lunch program, students eligible for, 204.10

(See also Free or reduced-price school lunch program)

gangs reported by students, 230.20

grades earned by students in, 225.80

by grade spans included, 216.10

graduates enrolled in postsecondary institutions, 302.40, 302.50

hate-related harassment, 230.35

hate-related harassment or graffiti, 230.30

high school dropouts, 219.50, 219.51

high school graduates, 219.10, 219.20, 219.30, 219.35, 219.40

historical statistics for, 105.30, 201.10

homework, 227.40

illegal drugs, availability to students, 232.80

international comparisons of teachers' working time and class size, 601.60

internet access, 218.10

leisure activities of high school seniors, 227.20

loaded guns carried by students to school, 231.70 marijuana usage by secondary students, 232.60

mathematics achievement

of eighth-graders by attitude, 222.30

of eighth-graders by state, 222.60

of fourth- and eighth-graders by urban district, 222.80

of fourth-graders by state, 222.50

by grade, $222.10,222.20$

by race/ethnicity and state, 222.70

mathematics and science skills of 1998 kindergartners through grade $8,220.80$

by metropolitan status, 214.40

middle schools, 216.10

minimum credits earned by high school graduates, 225.50

misbehavior by students interfering with class instruction, 230.90

misbehavior of students and enforcement of rules in public schools, 230.95

mobility of teachers, 210.30

number of, 105.50

number of school districts, 214.10

opinions of teachers on problems in schools, 210.10

opinions of teachers on school conditions, 210.20

parental participation

in activities with children, 207.30

in educational activities with children, 207.20

in school activities, 207.40

participants in, 105.10

percentage distribution of teachers in, 209.10

percentage of children in, 206.20

preprimary enrollment, 202.10, 202.20

principals in, 212.10

projected enrollment statistics, 105.30

pupil-to-staff ratios in, 213.50

pupil-to-teacher ratios, 208.10, 208.40

racial/ethnic concentration of enrollment in, 216.50, 216.55

reading achievement (See also under Reading)

of eighth-graders by state, 221.60

of fourth- and eighth-grade English language learners by state, 221.70

of fourth- and eighth-graders by urban district, 221.80

of fourth-graders by state and race/ethnicity, 221.50

of fourth-graders by state and selected years, 221.40

by grade, 221.10

reading skills of 1998 kindergartners through grade 8, 220.70

repairs, renovations or replacements of physical facilities, 217.15

revenues and expenditures by metropolitan status, 235.40

revenues by source of funds, 235.10, 235.20, 235.30

school libraries and media centers, 701.10, 701.20, 701.30

school size of public schools, 216.45

science achievement

of eighth-graders by attitude, 223.25

of eighth-graders by state, 223.20

of high school seniors by attitude, 223.30

science and mathematics skills of 1998 kindergartners through grade $8,220.80$

secondary schools by state and grade levels, 216.80

staff in, 213.10, 213.20, 213.30

by state and type of school, 216.70

students fearing attack or harm at school, 230.70

students fearing attack or harm in specific places at school, 230.80

subjects taught in high school, 209.50

suspensions and expulsions from, 233.30, 233.40 
teachers in, 105.40, 208.30 (See also Teachers, elementary and secondary)

characteristics of, 209.20, 209.30

opinions of teachers on problems in schools, 210.10

as percentage of staff in, 213.40

reporting threats or physical attacks from students, 228.70, 228.80

salaries, 211.10, 211.30, 211.40, 211.50, 211.60

transportation to school, 236.90

victimization reported by students in schools, 228.30

violent crime reported to police by school characteristics, 229.50 , 229.60

Public libraries, 701.60

Public opinion on education

teachers on problems in schools, 210.10

teachers on school conditions, 210.20

Public postsecondary institutions

admission requirements for, 305.30

affiliation of, 303.90

applications, admissions, and enrollment comparisons, 305.40

appropriations for by state, 333.30

attendance status at, 303.10, 303.20, 303.30, 304.35

average total cost for attendance for in-state undergraduates, 330.40

with branch campuses, 317.10

closing of institutions, 317.50

crimes on-campus, $329.10,329.20$

degrees conferred at, 318.40, 318.50, 319.10

distance education courses, 311.15

employment of college students, 503.20, 503.30

enrollment, 105.20, 303.25, 303.50, 303.55, 303.60, 303.65

by level of institution and by race/ethnicity, 306.50

postbaccalaureate level, 303.80

by race/ethnicity, $306.20,306.40$

by state, $304.15,304.60,304.80,308.10$

by state and control of institution, 308.20

undergraduate, 303.70

expenditures of, 106.20, 334.10, 334.20

faculty in, 105.40, 315.30, 315.50, 315.60

benefit expenditures for, 316.70

by gender, 315.10

part-time, 315.40

salaries, 316.10, 316.20, 316.30, 316.40, 316.50, 316.60

tenure, 316.80

first-time freshmen at, 305.10, 305.20

full-time-equivalent enrollment in, 307.10, 307.20, 307.30

graduation rates for first-time students, 326.10, 326.20

historically black colleges and universities, 313.20

institutions conferring degrees in, 318.60

non-degree-granting Title IV institutions, 317.30

number of, 105.50, 317.20, 317.40

online institutions, 311.33

postbaccalaureate students taking night, weekend or online classes, 311.30

ratio of full-time-equivalent students to full-time-equivalent staff, 314.50

remedial coursework offered by, 311.50

retention of first-time degree-seeking students by attendance status, 326.30

revenues, 333.10

from federal government, 333.70

by state, 333.25

staff in, 314.10, 314.20, 314.30, 314.40

by state, 317.20 student financial aid

postbaccalaureate students receiving, 332.10, 332.20, 332.30, 332.40

scholarships and grants to undergraduates, 331.30

student loan repayment and default rate, 332.50

undergraduate students receiving, 331.20, 331.50, 331.60, 331.70, 331.80, 331.90

Title IV programs, 301.10

tuition, fees and board rates for undergraduates, 330.10, 330.20, 330.30

tuition and fees for postbaccalaureate-level studies, 330.50

undergraduate students

first-year students enrolled in remedial coursework by, 311.40

receiving loans by their 4th year, 331.95

taking night, weekend or online classes, 311.20

Pupils

average number in public elementary schools, 216.75

expenditures per in public schools, 236.15, 236.55, 236.60, 236.65, 236.70, 236.75, 236.80

to-staff ratios in public elementary and secondary schools, 213.50

to-teacher ratios, 208.10, 208.20

bullying and cyber-bullying reported by public schools, 230.65

discipline issues reported by public schools, 230.10

gangs reported by students, 230.20

international comparisons, 601.50

by metropolitan status in public schools, 214.40

number and percentage of schools recording crime, 229.30

number and percentage of schools reporting crime to police, 229.40

number and percentage of schools reporting violent crime to police, 229.50, 229.60

by state in public schools, 208.40

Race/ethnicity

ACT scores by, 226.50

adult education participation by, 507.30, 507.40

alcohol consumption by secondary students, 232.10, 232.20

arts achievement and frequency of instruction by, 224.10

associate's degrees by, 321.20, 321.30, 321.40, 321.50

attendance patterns by fourth-, eighth- and twelfth-graders, 227.50

bachelor's degrees by, 322.20, 322.30

men earning, 322.40

women, 322.50

bullying

reported by students, 230.40, 230.45, 230.50

reported by students to adult at school, 230.60

Carnegie units earned by high school graduates, 225.10

Carnegie units earned by high school graduates in vocational education by, 225.20

center-based programs and, 202.30

child care arrangements by, 202.30, 202.40, 202.50, 202.60, 202.65

civics achievement by grade, 224.20

cognitive and motor skills of nine-month-old children by, 220.10

college enrollment and labor force status of high school graduates by, 504.10

coursework by high school graduates in mathematics and science by, $225.30,225.40$

crime

number and percentage of schools recording, 229.30

number and percentage of schools reporting to police, 229.40

number and percentage of schools reporting violent crime to police, 229.50, 229.60

cyber-bullying reported by students, 230.40, 230.55, 230.65

degrees in selected professional fields by, 324.55 
with degrees in selected professional fields by, 324.60, 324.70 discipline issues reported by public schools, 230.10

distribution of enrollment in public schools

by free or reduced-price lunch eligibility of students, 216.60

by racial/ethnic concentration of school, 216.50, 216.55

by region of the country, 203.50

by state, 203.70

distribution of resident population by age and place of birth, 101.30

doctor's degrees by, 324.20, 324.25, 324.30, 324.35

dropouts from high school, 219.70, 219.80

drug, cigarette, and alcohol usage by teenagers, 232.95

economics achievement of high school seniors, 224.30

educational attainment by, 104.10, 104.20, 104.30, 104.40, 104.85

educational attainment of 1990 high school sophomores in 2000

by, 104.90

employment of bachelor's degree recipients, 505.20, 505.30

employment of college students by, 503.30

employment of high school students by, 503.10

enrollment and percentage distribution by year and level of education, 203.60

enrollment in postsecondary institutions, 302.20, 306.10, 306.20, 306.30

estimates of resident population by age and, 101.20

extracurricular activities of high school seniors by, 227.30

extracurricular activities of ninth-graders by, 227.10

family characteristics by, 102.20, 102.60

fights between students at school, 231.10, 231.20

gangs reported by students, 230.20

geography achievement by grade levels, 224.40

gifted and talented students by state, 204.80, 204.90

grades earned by elementary and secondary students, 225.80

hate-related harassment aimed at, 230.35

hate-related harassment or graffiti, 230.30

high school dropouts by, 219.50, 219.51

high school graduates by, 219.30, 219.40

high school graduates enrolled in postsecondary institutions by, 302.40

history, U.S., achievement by grade, 224.50

homeschooled children by, 206.10, 206.20

homework by, 227.40

illegal drugs, availability to students, 232.70

by income and educational attainment, 502.30

Individuals with Disabilities Education Act, children served under by, 204.40, 204.50

internet usage by, 702.10

kindergarten entry status of children, 220.50

labor force participation by, 501.10, 501.40

labor force participation of high school dropouts by, 504.20

language, mathematics and motor skills of four-year-olds by, 220.30

leisure activities of high school seniors by, 227.20

literacy skills of adults by, 507.10

loaded guns carried by students to school, 231.70

loans received by undergraduate students by their 4th year, 331.95

marijuana usage by secondary students, 232.40, 232.50

master's degrees by, 323.20, 323.30, 323.40, 323.50

mathematics achievement

by age, $222.85,222.90$

of eighth-graders by attitude, 222.30

of fourth- and eighth-graders in urban districts, 222.80

by grade, 222.10, 222.20

of high school seniors by mathematics coursework, 222.40

of seventeen-year-olds by mathematics coursework, 222.95

by state, 222.70 mathematics and science skills of 1998 kindergartners through grade $8,220.80$

mental and physical skills of two-year-olds by, 220.20

minimum credits earned by high school graduates, 225.50

night, weekend or online classes taken by graduate students, 311.30

night, weekend or online classes taken by undergraduate students, 311.20

nonfatal victimization of students in schools, 228.25

number of persons with bachelor's degrees by, 104.50, 104.60

parental level of education of 6- to 18-year olds, 104.70

parental participation in educational activities with children by, 207.20, 207.30

parental participation in school activities by, 207.40

percentage of population enrolled in school by, 103.10

postsecondary institutions

certificates granted by, 320.20

employment in, 314.40

enrollment in, 302.60, 306.10, 306.20, 306.40, 306.50, 306.60, 306.70

faculty in, 315.20, 315.50, 315.60, 315.70, 315.80

graduation rates by, $326.10,326.20$

poverty rates by, 102.50

preprimary enrollment and, 202.20

preschool literacy activities at home by, 207.10

private school enrollment by, 205.30, 205.40

in public charter and traditional public schools, 216.30

reading, mathematics and cognitive flexibility scores at kindergarten entry, 220.40

reading achievement

by age, $221.85,221.90$

of fourth- and eighth-graders in urban districts, 221.80

of fourth-graders by state, 221.50

by grade, $221.10,221.20,221.75$

reading skills of 1998 kindergartners through grade 8, 220.70

remedial coursework enrolled in by undergraduate students,

311.40

SAT scores for college-bound seniors by, 226.10

school districts of more than 15,000 students, 215.10

school type by, 206.20

science achievement

of eighth-graders by attitude toward science, 223.25

of eighth-graders in public schools by state, 223.20

by grade, 223.10

of high school seniors by attitude toward science, 223.30

science and mathematics skills of 1998 kindergartners through grade $8,220.80$

security staff present at public schools, 233.70

student financial aid by, 331.10, 331.40, 331.45

students fearing attack or harm at school, 230.70

students fearing attack or harm in specific places at school, 230.80

suspensions and expulsions from public schools, 233.30, 233.40

teachers' educational attainment and experience by, 209.20

of teachers in public and private elementary and secondary schools, 209.10

of teachers reporting threats or physical attacks from students, 228.70 unemployment rate by, 501.20

U.S. students studying abroad by, 310.10

victimization reported by students in schools, 228.30

weapons carried by students to school, 231.40, 231.50

weapons-related victimization reported by students, 228.40

writing achievement by grade, 224.60

young adults neither in school nor employed by, 501.30 
Reading

achievement

by age, $221.30,221.85,221.90$

by amount of reading, homework, and TV, 221.30

of eighth-graders, 221.60

of English language learners in public schools by state, 221.70

of fourth- and eighth-graders in urban districts, 221.80

of fourth-graders by state and race/ethnicity, 221.50

of fourth-graders by state and selected years, 221.40

by grade, $221.10,221.20,221.75$

international comparisons of, 602.40

international comparisons of literacy proficiency levels by country, 602.50

international comparisons of scores for fourth-graders, 602.10

preschool literacy activities at home, 207.10

scores at kindergarten entry, 220.40

scores by kindergarten entry status, 220.60

skills of 1998 kindergartners through grade 8, 220.70

Reading First State Grants, 401.70

Reduced-price lunch program, 204.10. See also Free or reducedprice school lunch program

Region of the country

arts achievement and frequency of instruction, 224.10

charter schools and traditional public elementary and secondary schools, 216.30

distance education enrollment in public schools and districts by, 218.20 doctor's degrees by, 324.80

dropouts from high school by, 219.80

dual credit, Advanced Placement and International

Baccalaureate enrollment in public schools, 225.60

economics achievement of high school seniors by, 224.30

enrollment in public elementary and secondary schools, 203.20,

203.25, 203.30

enrollment in public schools by race/ethnicity, 203.50

extracurricular activities of high school seniors by, 227.30

geography achievement by grade, 224.40

history, U.S., achievement by grade, 224.20, 224.50

homeschooled children by, 206.10

mathematics achievement by age, 222.85

poverty rates by, 102.40

private elementary and secondary schools, 205.30

private school enrollment by, 205.10

reading achievement by age, 221.85

schooling type, percentage of children by, 206.20

Religion, hate-related harassment aimed at, 230.35

Religious affiliation

postsecondary institutions, 303.90

private elementary and secondary schools, 205.20, 205.30, 205.40, 205.60

Remedial coursework

percentage of first-year undergraduate students enrolled in, 311.40 postsecondary institutions offering, 311.50

Repairs, renovations or replacements of physical facilities for public elementary/secondary schools, 217.15

Research

expenditures at postsecondary institutions for, 334.10, 334.30, $334.40,334.50,334.60$

federal support for, 401.10, 401.30, 402.10

universities by state, 317.20

Residence halls and on-campus crime in postsecondary institutions, 329.20
Residency of freshmen attending in-state postsecondary institutions, 309.10, 309.20, 309.30

Retention of first-time degree-seeking undergraduates by attendance status, control, and type of institution, 326.30

Revenues

postsecondary institutions

from federal government, 333.70

private institutions, $333.40,333.50,333.55,333.60$

public institutions, 333.10, 333.20, 333.25

by source, $333.10,333.25$

voluntary support, 333.80

public elementary and secondary schools

historical statistics, 201.10

by metropolitan status, $214.40,235.40$

source of funds for, 235.10, 235.20, 235.30

source of funds for by metropolitan status, 235.40

in school districts of more than 15,000 students, 215.20

Room and board for undergraduates at postsecondary institutions, 330.10 average total cost for attendance, 330.40

for full-time students by state, 330.20

for full-time students by type of institution, 330.30

Rural areas, public elementary and secondary schools, 214.40, 235.40. See also Metropolitan status

Russian

degrees conferred in, 325.59

enrollment in courses, postsecondary education, 311.70, 311.80 enrollment in high school in, 225.70

Salaries

of bachelor's degree recipients, 505.10, 505.50

of faculty in postsecondary institutions, $315.50,315.60$

by academic rank, 316.10, 316.20

by state, $316.30,316.40,316.50,316.60$

of principals in public and private schools, 212.10

public postsecondary institutions, expenditures for, 334.10, 334.20

public schools, expenditures for, 236.20, 236.50

of teachers, 211.10, 211.20, 211.30, 211.40, 211.50, 211.60

SAT scores, 226.30

of applicants to postsecondary institutions, 305.40

of college-bound seniors, 226.20

and percentage taking SAT by state, 226.40

by race/ethnicity, 226.10

Scholarships and grants to undergraduates, 331.30

Scholarships for college. See Financial aid to postsecondary students

Scholastic Aptitude Test. See SAT scores

School activities, parental participation in, 207.40

School-age population

international comparisons of, 601.30

by state, 101.40

School conditions

controlled access, dress code, metal detectors and security personnel present, 233.50, 233.60, 233.80

crime in schools (See Crime in public schools)

disciplinary actions taken by schools, 233.10

enrollment under or over capacity, 217.20

environmental factors that interfere with instruction, 217.10

misbehavior of students interfering with class instruction, 230.90

repairs, renovations or replacements of physical facilities for

public elementary/secondary schools, 217.15

security staff present at public schools, 233.70

teachers' opinions on, 210.10, 210.20

School day, length of, 203.90 
School districts, 214.30

enrollment and poverty in 100 largest, 215.30

by enrollment size, 214.20

with more than 15,000 students, $215.10,215.20$

number of, 214.10

School levels

charter schools and traditional public elementary and secondary schools, 216.30

closing of schools, 216.95

free or reduced-price lunches, students eligible for, 216.60

School libraries, 701.10, 701.20, 701.30

School lunch program, 217.10. See also Free or reduced-price school lunch program

School Resource Officers (SROs), 233.70

School size, elementary and secondary schools enforcement of school rules by other teachers and principal, 230.92 misbehavior by students interfering with class instruction, 230.90

School year, length of, 203.90, 234.20

Science

bachelor's degrees earned by women in, 603.60

certificates conferred by postsecondary institutions in, 320.10

elementary and secondary education

achievement

of eighth-graders by attitude toward science, 223.25

of eighth-graders in public schools by state, 223.20

by grade, 223.10

of high school seniors by attitude toward science, 223.30

Carnegie units earned by public high school graduates, 225.10

Carnegie units required by state for high school graduation, 234.30

coursework by high school graduates in, 225.30, 225.40

skill levels of 1998 kindergartners through grade 8, 220.80

international comparisons, 602.40, 602.70

of achievement and instructional time, 602.20, 602.30

of bachelor's degrees in, 603.70

of fifteen-year-olds' scores, 602.40, 602.70

of graduate degrees in, 603.80

postsecondary education

associate's degrees in, 321.30, 321.40, 321.50

bachelor's degrees in, 104.50, 104.60, 319.30, 321.10, $322.10,322.40,322.50,603.70$

biology degrees, $325.20,325.22$

degrees conferred in, 318.20, 318.30, 318.50

doctor's degrees in, 324.10, 324.80

enrollment in, 311.60

federal support to institutions for, 402.10

institutions conferring degrees in, 318.60

international comparisons of graduate degrees in, 603.80

master's degrees in, 319.40, 323.10

physical sciences degrees, 325.70, 325.72

postbaccalaureate-level enrollment in, 311.90

Secondary education for adults, 507.20, 507.40

Secondary schools. See also Private elementary and secondary schools; Public elementary and secondary schools

crime recorded by schools by school characteristics, 229.20, 229.30

crime reported to police by school characteristics, 229.40

discipline issues reported by public schools, 230.10

enforcement of school rules by other teachers and principal, 230.92

misbehavior by students interfering with class instruction, 230.90

teachers reporting threats or physical attacks from students, 228.70

violent crime reported to police by school characteristics, $229.50,229.60$

Security

associate's degrees in, 321.10, 321.30, 321.40, 321.50 bachelor's degrees in, 322.10, 322.30

men earning, 322.40

women earning, 322.50

controlled access, dress code, metal detectors and security

personnel present, 233.50, 233.60, 233.80

degrees conferred in, $318.30,318.50$

designated staff for at public schools, 233.70

doctor's degrees in, 324.10, 324.25, 324.30, 324.35

enrollment, postsecondary education, 311.60

institutions conferring degrees in, 318.60

master's degrees in, 323.10, 323.30, 323.40, 323.50

schools with measures for, 233.60

Selection criteria for admissions to postsecondary institutions, 305.30

Sexual orientation, hate-related harassment, 230.35

Shutdowns of postsecondary institutions, 317.50

Shutdowns of public elementary and secondary schools, 216.95

Single-parent households, 102.10, 102.20, 102.50, 102.60

entry status of children in kindergarten, 220.50

parental level of education of 6- to 18-year olds, 104.70

preprimary enrollment and, 202.20

reading, mathematics and cognitive flexibility scores of children at kindergarten entry by, 220.40

Skills. See also Achievement of elementary and secondary students; individual subjects and skills

of adults in prose, document, and quantitative literacy, 507.10

in four-year-olds, 220.30

of 1998 kindergartners through grade 8, 220.70, 220.80

in mathematics by age, 222.90

of nine-month-old children, 220.10

of two-year-olds, 220.20

Social sciences

associate's degrees in, 321.10, 321.30, 321.40, 321.50

bachelor's degrees in, 319.30, 322.10, 322.30

employment status and salary of recipients, 505.10

employment status of recipients, 505.20

men earning, 322.40

by race/ethnicity, 104.50

STEM versus non-STEM professions, 505.30

women earning, 322.50, 603.60

certificates conferred by postsecondary institutions in, 320.10

degrees conferred in, 318.20, 318.30, 318.50, 325.90

doctor's degrees in, 324.10, 324.25, 324.30, 324.35, 324.80

enrollment, postsecondary education, 311.60

institutions conferring degrees in, 318.60

master's degrees in, 319.40, 323.10, 323.30, 323.40, 323.50

Social studies

Carnegie units required by state for high school graduation, 234.30

criterion-referenced tests (CRTs) by state, 234.40

Social work/services

bachelor's degrees in, employment status and salary of recipients, 505.10

degrees in, 325.85

Socioeconomic status. See also Income

attendance patterns by fourth-, eighth- and twelfth-graders, 227.50

child care arrangements by, 202.50, 202.60, 202.65

cognitive and motor skills of nine-month-old children by, 220.10

educational attainment of 1990 high school sophomores in 2000, 104.90

employment of high school students, 503.10

extracurricular activities of high school seniors, 227.30

language, mathematics, and motor skills of four-year-olds by, 220.30

leisure activities of high school seniors, 227.20 
mathematics and science skills of 1998 kindergartners through grade $8,220.80$

mental and physical skills of two-year-olds by, 220.20

reading, mathematics and cognitive flexibility scores of children at kindergarten entry by, 220.40

reading skills of 1998 kindergartners through grade 8, 220.70

science and mathematics skills of 1998 kindergartners through grade $8,220.80$

Sociology

degrees conferred in, 325.92

enrollment, postsecondary education, 311.60

Spanish

degrees conferred in, 325.57

enrollment in courses, postsecondary education, 311.70, 311.80

enrollment in high school, 225.70

Special education. See also Disabilities, students with

age range for compulsory attendance, 234.10

closing of schools, 216.95

percentage distribution of students in, 204.60

postsecondary education and employment status of students in, 504.30

pupil-to-teacher ratios for, 208.10

schools by state, 216.70

students exiting, 219.90

Sports, participation in by high school seniors, 227.30

Sports, participation in by ninth-graders, 227.10

Staff. See also Faculty, postsecondary; Teachers, elementary and secondary

in postsecondary institutions, 314.10-315.80

by employment status, $314.20,314.30$

in libraries, 701.40, 701.50

by race/ethnicity and gender, 314.40

in private elementary and secondary schools, 205.60

in private postsecondary institutions, ratio of full-time-equivalent students to full-time-equivalent staff, 314.60

in public elementary and secondary schools, 213.10, 213.20, 213.30, 213.40

in public postsecondary institutions, ratio of full-time-equivalent students to full-time-equivalent staff, 314.50

pupil-to-staff ratios in public schools, 213.50

Stafford loans, 331.95

States

adult education participation, 507.20

age range for compulsory school attendance, 234.10

alcohol consumption by secondary students, 232.30

average daily attendance at public schools, 203.80, 203.90

bachelor's degrees conferred in, 319.30

Carnegie units required for high school graduation, 234.30

certification test for teachers, 234.50

charter schools and traditional public elementary and secondary schools, 216.90

criterion-referenced tests (CRTs), 234.40

degrees conferred in, 319.10, 319.20

Department of Education appropriations, 401.60

education agencies, 214.30

educational attainment by, 104.80, 104.85, 104.88

English language learners (ELL) in public school programs, 204.20

enrollment in public elementary and secondary schools, 203.20,

203.25, 203.30, 203.40, 203.45

enrollment in public schools by race/ethnicity, 203.70

expenditures for education

on education, 106.50

by governments, $106.30,106.40$ in public elementary and secondary schools, 236.25, 236.30,

$236.40,236.50,236.60,236.65,236.70,236.75,236.80$

fights between students at school, 231.30

free or reduced-price lunch program, students eligible for, 204.10

gifted and talented students by, 204.80, 204.90

graduates from private schools by, 205.80

high school dropouts by, 219.50, 219.51

high school graduates by, 219.20, 219.35, 219.40

high school graduates enrolled in postsecondary institutions by, 302.50

household income and poverty rates by, 102.30

illegal drugs, availability to students, 232.80

Individuals with Disabilities Education Act, children served under by, 204.70

marijuana usage by secondary students, 232.60

master's degrees conferred in, 319.40

mathematics achievement

of eighth-graders in public schools, 222.60

of fourth-graders in public schools, 222.50

by race/ethnicity, 222.70

misbehavior of students and enforcement of school rules in public schools, 230.95

policies on textbook selection and length of school year, 234.20

postsecondary institutions

appropriations for, 333.30

attendance status and gender, 304.30, 304.35

by control and level, 317.20

enrollment in, 304.10, 304.60, 304.70, 304.80, 306.60, 306.70, $308.10,308.20$

enrollment in for-profit private institutions, 304.50

enrollment in private institutions, 304.45

expenditures of private institutions, 334.70

expenditures of public institutions, 334.20

faculty in private institutions by, 314.60

faculty salaries by, 316.30, 316.40, 316.50, 316.60

first-time freshmen at, 305.20

full-time-equivalent enrollment in, 307.20, 307.30

institutions with more than 15,000 students, 312.10

non-degree-granting Title IV institutions, 317.30

number in, 317.20

private institutions by, $304.20,304.40$

public institutions by, 304.15

ratio of full-time-equivalent students to full-time-equivalent staff by, 314.50

residence and migration of freshmen, 309.10, 309.20, 309.30

revenues for, $333.10,333.20$

revenues to private institutions, 333.40, 333.50, 333.55, 333.60

tuition, fees and board rates for undergraduates, 330.20

poverty rates by, 102.40

public elementary and secondary schools by type of school, 216.70

public elementary schools by grade span, 216.75

public libraries in, 701.60

public secondary schools by grade span, 216.80

pupil-to-staff ratios in public schools by, 213.50

reading achievement

of eighth-graders in public schools by, 221.60

of English language learners in public schools by, 221.70

of fourth-graders in public schools by race/ethnicity, 221.50

of fourth-graders in public schools by selected years, 221.40

revenues

for public elementary and secondary schools, 235.10, 235.20, 235.30

for public elementary and secondary schools by metropolitan status, 235.40 
for public postsecondary institutions, 333.25

SAT scores by, 226.40

school-age population, 101.40

school districts with more than 15,000 students, 215.10, 215.20

school libraries and media centers by, 701.30

science achievement of eighth-graders in public schools, 223.20

staff in public elementary and secondary schools, 213.20, 213.30

student financial aid from, 331.50, 332.10, 332.20

suspensions and expulsions from public schools, 233.30, 233.40

teachers

certification test for, 234.50

as percentage of staff in public schools by, 213.40

in public elementary and secondary schools, 208.30, 209.30

pupil-to-teacher ratios in public schools by, 208.40

reporting threats or physical attacks from students in public schools, 228.80

salaries of in public schools, 211.30, 211.40, 211.60

Title I agency programs, 401.70

weapons carried by students to school, 231.60

weapons-related victimization reported by students, 228.50

Statistics and mathematics. See also Mathematics

bachelor's degrees in by race/ethnicity, 104.50, 104.60

degrees conferred in, 325.65

enrollment, postsecondary education, 311.60

Status dropouts from high school, 219.70, 219.80. See also Dropouts from high school

STEM (Science, Technology, Engineering, Mathematics) fields. See also under individual fields

bachelor's degrees by, 104.60

employment of bachelor's degree recipients, 505.20, 505.30

Storytelling by parents, 207.10, 207.30

Student financial aid

loans received by undergraduate students by their 4th year, 331.95

postbaccalaureate level, 332.10, 332.20, 332.30, 332.40

scholarships and grants to undergraduates, 331.30

student loan repayment and default rate, 332.50

undergraduate level, 331.10, 331.40, 331.45, 331.50, 331.60, 331.70, $331.80,331.90$

Student housing status at postsecondary institutions, 311.40

Students. See Postbaccalaureate education; Pupils; Undergraduatelevel studies

Student-to-faculty ratios, 314.50, 314.60

Study abroad programs, U.S. students in, 310.10

Subjects taught in public high schools, 209.50. See also Coursework/ Credits

Substance abuse

by high school seniors, 232.90

by teenagers, 232.95

Suburban areas, public elementary and secondary schools, 214.40, 235.40. See also Metropolitan status

Suicides in schools, 228.10

Suspensions from school, 233.30, 233.40

Talented students, 204.80, 204.90

Tardiness of students, 230.90

Teachers, elementary and secondary

average class size for in public schools, 209.30, 601.60

in Catholic schools, 205.70

degrees and teaching experience at the elementary/secondary level, 209.20

distribution in public and private elementary and secondary schools, 209.10 enforcement of school rules by other teachers and principal, 230.92 historical statistics of public schools, 201.10

international comparisons, 601.10, 601.50, 601.60

misbehavior by students interfering with class instruction, 230.90

misbehavior of students and enforcement of school rules in public schools, 230.95

mobility of, 210.30

number of, $105.10,105.40$

opinions on school conditions, 210.10, 210.20

in private elementary and secondary schools, 205.40, 205.60, 205.80

in public elementary and secondary schools, 208.30, 208.40, 213.40

reporting threats or physical attacks from students, 228.70

reporting threats or physical attacks from students in public schools, 228.80

salaries

in public and private schools, 211.10

in public schools, 211.20, 211.30, 211.40, 211.50, 211.60

by teaching experience, $211.20,211.30,211.40$

states requiring test for certification, 234.50

subjects taught in public high schools, 209.50

teaching experience in public schools, 209.30

teaching experience of, 209.20

Technical education, 225.20. See also Vocational schools/education

Technology-based distance education, 218.20

Teenagers. See also Eighth grade; High school seniors

drug usage by, 232.95

international comparisons of fifteen-year-olds' skills

mathematics, 602.60

mathematics, reading and science skills, 602.40

reading, 602.50

science, 602.70

school attendance patterns in tenth grade, 227.50

Television watching by age, 221.30

Temporary buildings in public schools, 217.10

Tenure for faculty, 316.80

Testing, state

criterion-referenced tests (CRTs), 234.40

teacher certification testing, 234.50

Textbook selection, by state, 234.20

Theft in schools, 228.20, 228.25

public schools recording, 229.20, 229.30

public schools recording and reporting to police, 229.10

public schools reporting to police, 229.40

reported by students, 228.30

Theology

bachelor's degrees in, employment status and salary of recipients, 505.10

master's degrees in, 324.55, 324.60, 324.70 (See also Philosophy, religion and theology)

Time, use of

in arts instruction for eighth-graders, 224.10

duration of stay for U.S. college students studying abroad, 310.10

on homework by age, 221.30

international comparisons

mathematics and science instruction, 602.20, 602.30

on teachers' working time and average class size, 601.60

length of school day and school year, 203.90

in mathematics instruction for fourth-graders, 222.50

minimum instructional time per year by state, 234.20

Title I allocations

to largest school districts, 215.30

in school districts of more than 15,000 students, 215.20 
by state, 401.70

Title IV aid, scholarships and grants to undergraduates, 331.30

Title IV postsecondary institutions, 301.10

certificates granted by, 320.20

enrollment in, 303.20

non-degree-granting, 317.30

number of, 105.50

Transportation

associate's degrees in, 321.10

bachelor's degrees in, 322.10

Transportation to school, 236.90

Tribally controlled institutions, 312.50

Tuition

average total cost for attendance for undergraduates, 330.40 graduate and first-professional, 330.50

at private elementary and secondary schools, 205.50

as revenue to postsecondary institutions

private institutions, 333.40, 333.50, 333.55, 333.60

public institutions, $333.10,333.20,333.25$

for undergraduates, $330.10,330.20,330.30$

Twelve-month enrollment in postsecondary institutions, 308.20

Two-parent households, 102.10, 102.20, 102.60

entry status of children in kindergarten, 220.50

parental level of education of 6- to 18-year olds, 104.70

preprimary enrollment and, 202.20, 202.65

reading, mathematics and cognitive flexibility scores of children

at kindergarten entry by, 220.40

Two-year postsecondary institutions

admission requirements for, 305.30

applications, admissions, and enrollment comparisons, 305.40

attendance status at, 303.30

average total cost for attendance for undergraduates, 330.40

with branch campuses, 317.10

closing of institutions, 317.50

completion status for students, 326.40

crimes on-campus, 329.10, 329.20

current-fund revenues for postsecondary institutions, 333.10

current-fund revenues for postsecondary institutions by state, 333.25

distance education courses, 311.15

employment of college students, 503.20, 503.30

enrollment, 105.20, 303.25, 303.50, 303.55, 303.60, 303.65

by race/ethnicity, 302.60, 306.20, 306.40, 306.50

by recent high school completers in, 302.40

by state, $304.60,304.80,308.10$

expenditures of private institutions, 334.30, 334.40, 334.50, 334.60, 334.70

expenditures of public institutions, 334.10, 334.20

faculty in

by gender, 315.10

salaries, $316.20,316.30,316.40$

tenure, 316.80

field of study at, 311.60

first-time freshmen at, 305.10

foreign language enrollment in, 311.70, 311.80

full-time-equivalent enrollment in, 307.10, 307.20

graduation rates for first-time students, 326.20

historically black colleges and universities, 313.20

loans received by undergraduate students by their 4th year, 331.95

number of institutions, 317.20

postbaccalaureate level enrollment at, 303.80

ratio of full-time-equivalent students to full-time-equivalent staff, 314.50 remedial coursework offered by, 311.50

retention of first-time degree-seeking students by attendance status, 326.30

revenues

of private postsecondary institutions, 333.40, 333.50, 333.55, 333.60

of public postsecondary institutions, 333.10

of public postsecondary institutions by state, 333.25

scholarships and grants to undergraduates, 331.30

staff in, 314.20, 314.30, 314.40

by state, 317.20

student financial aid, 331.20, 331.50, 331.60, 331.70, 331.80, 331.90

student loan repayment and default rate, 332.50

Title IV postsecondary institutions, 301.10

tuition, fees and board rates for undergraduates, 330.10, 330.20, 330.30

undergraduate enrollment at, 303.70

Under-age drinking, 232.10, 232.20, 232.30

Under capacity enrollment in public schools, 217.20

Undergraduate-level studies

admission requirements for institutions, 305.30

applications, admissions and enrollment comparisons, 305.40

average total cost for attendance, 330.40

disabled students enrolled at, 311.10

distance education courses, 311.15

employment of college students, 503.30

enrollment, 303.45, 303.60, 303.65

by attendance status, $303.70,303.80$

by race/ethnicity and gender, 306.10

by state, $304.70,304.80$

faculty teaching at, 315.30

field of study, 311.60

foreign language enrollment, 311.70, 311.80

at institutions with more than 15,000 students, 312.20

night, weekend or online classes, percentage of students taking, 311.20

part-time faculty teaching at, 315.40

retention of first-time degree-seeking students by attendance

status, control, and type of institution, 326.30

scholarships and grants to undergraduates, 331.30

student financial aid, 331.10, 331.20, 331.40, 331.45, 331.50,

$331.60,331.70,331.80,331.90,331.95$

student loan repayment and default rate, 332.50

tuition, fees and board rates for, 330.10, 330.20, 330.30

Unemployment rate, 501.20, 501.30, 501.40

by age and educational attainment, 501.80, 501.85, 501.90

of bachelor's degree recipients, 505.10

for dropouts from high school, 219.75, 504.20

for high school graduates, 504.10

Universities, 303.25. See also Private postsecondary institutions; Public postsecondary institutions

Urbanicity. See Metropolitan status

U.S. Department of Education, appropriations for programs by state, 401.60

U.S. history, achievement levels by grade, 224.50. See also History

Values of high school seniors, 506.10

Veteran status, percentage of first-year undergraduate students enrolled in remedial coursework by, 311.40

Veterinary medicine, first professional degrees in, 324.50, 324.60, 324.70

Victimization of students in schools, 228.20, 228.25

reported by students, 228.30

weapons-related and reported by students, 228.40, 228.50 
Videos, 221.30

Violence at schools

crime incidents recorded by schools, 229.20, 229.30

crime incidents reported by schools, 229.10, 229.40, 229.50, 229.60

on-campus in postsecondary institutions, 329.10, 329.20

physical fights occurring, 231.10, 231.20, 231.30

Violence in schools

nonfatal victimization of students, 228.20, 228.25

reporting of victimization by students, 228.30

reporting of victimization involving weapons by students, $228.40,228.50$

teachers reporting threats or physical attacks from students, 228.70

teachers reporting threats or physical attacks from students in

public schools, 228.80

violent deaths, 228.10

Visual arts

achievement of eighth-graders, 224.10

associate's degrees in, 321.10, 321.30, 321.40, 321.50

bachelor's degrees in, 322.10, 322.30

men earning, 322.40

women earning, 322.50

certificates conferred by postsecondary institutions in, 320.10

degrees conferred in, 318.30, 318.50, 325.95

doctor's degrees in, 324.10, 324.25, 324.30, 324.35

enrollment, postsecondary education, 311.60

frequency of instruction for eighth-graders, 224.10

institutions conferring degrees in, 318.60

master's degrees in, 323.10, 323.30, 323.40, 323.50

Vocational clubs

high school seniors' participation in, 227.30

ninth-graders' participation in, 227.10

Vocational schools/education

Carnegie units earned by high school graduates, 225.10, 225.20

closing of schools, 216.95

international comparisons of as percentage of population, 603.20, 603.40

in public secondary schools, 216.80

pupil-to-teacher ratios, 208.10

Voluntary support for postsecondary institutions, 333.80

Weapons in schools

carried to school by students, 231.40, 231.50, 231.60, 231.70

on-campus in postsecondary institutions, $329.10,329.20$

victimization reported by students involving, 228.40, 228.50

violent deaths caused by, 228.10

Weekend classes for postsecondary education, 311.20, 311.30

Whites

ACT scores, 226.50

arts achievement and frequency of instruction, 224.10

with associate's degrees, 321.20, 321.30, 321.40, 321.50

attendance patterns by fourth-, eighth- and twelfth-graders, 227.50

with bachelor's degrees, 104.50, 104.60, 322.20, 322.30

men, 322.40

women, 322.50

Carnegie units earned by high school graduates in vocational education by, 225.20

child care arrangements by, 202.40

children living in poverty, 102.60

civics achievement by grade, 224.20

college enrollment and labor force status of high school graduates, 504.10 coursework by high school graduates in mathematics and science, 225.30, 225.40

with degrees in selected professional fields, 324.55, 324.60, 324.70

distribution in public schools

percentage of students eligible for free or reduced-price lunches, 216.60

by racial/ethnic concentration of school, 216.50, 216.55

by region of the country, 203.50

by state, 203.70

distribution of resident population by age, 101.30

with doctor's degrees, 324.20, 324.25, 324.30, 324.35

dropouts from high school, 219.70

drug, cigarette, and alcohol usage by teenagers, 232.95

economics achievement of high school seniors, 224.30

educational attainment, 104.10, 104.20, 104.30, 104.40, 104.85

employment of high school students, 503.10

enrollment and percentage distribution by year and level of education,

203.60

enrollment in postsecondary institutions, 306.30

estimates of resident population by age, 101.20

family characteristics of, 102.20

geography achievement by grade, 224.40

gifted and talented students by state, 204.80, 204.90

high school dropouts, 219.50, 219.51

high school graduates, 219.30, 219.40

history, U.S., achievement by grade, 224.50

income and educational attainment of, 502.30

Individuals with Disabilities Education Act, children served under, 204.40, 204.50

internet usage, 702.10

labor force status, 501.40

labor force status of high school dropouts, 504.20

leisure activities of high school seniors, 227.20

with master's degrees, 323.20, 323.30, 323.40, 323.50

mathematics achievement

by age, $222.85,222.90$

of fourth- and eighth-graders in urban districts, 222.80

by grade, $222.10,222.20$

of high school seniors by mathematics coursework, 222.40

by race/ethnicity and state, 222.70

of seventeen-year-olds by mathematics coursework, 222.95

mathematics and science skills of 1998 kindergartners through grade $8,220.80$

parental level of education of 6- to 18-year olds, 104.70

percentage of population enrolled in school, 103.10

postsecondary institutions

certificates granted by Title IV postsecondary institutions, 320.20

employment in, 314.40

enrollment in, 302.20, 302.60, 306.10, 306.40, 306.50

enrollment in by state, $306.60,306.70$

enrollment in by type and control of institution, 306.20

faculty in, 315.20, 315.60, 315.80

graduation rates, $326.10,326.20$

poverty rates, 102.50

in public charter and traditional public schools, 216.30

reading, mathematics and cognitive flexibility scores at

kindergarten entry, 220.40

reading achievement

by age, $221.85,221.90$

of fourth- and eighth-graders in urban districts, 221.80

of fourth-graders in public schools by state, 221.50

by grade, $221.10,221.75$ 
reading skills of 1998 kindergartners through grade 8, 220.70

remedial coursework enrolled in by undergraduate students, 311.40

SAT scores for college-bound seniors, 226.10

science achievement

of eighth-graders by attitudes toward science, 223.25

of eighth-graders in public schools by state, 223.20

by grade, 223.10

of high school seniors by attitudes toward science, 223.30

science and mathematics skills of 1998 kindergartners through grade $8,220.80$

suspensions and expulsions from public schools, 233.30, 233.40

unemployment rate, 501.20

U.S. students studying abroad, 310.10

writing achievement by grade, 224.60

young adults neither in school nor employed, 501.30

Women. See also Gender

employment to population ratio of, 501.70 unemployment rates of, 501.90

Women's colleges, 312.30

Work experience

of principals, 212.10

of teachers (See under Teachers, elementary and secondary)

Working while attending college

by attendance status, $503.20,503.30$

night, weekend or online classes taken by graduate students, 311.30 night, weekend or online classes taken by undergraduate students, 311.20

Work load of faculty in postsecondary institutions, 315.30, 315.40

Writing achievement by grade, 224.60

Year-round schools, 234.10

Years of school completed, 104.10, 104.30. See also Educational attainment

Zoology, degrees in, 325.22 




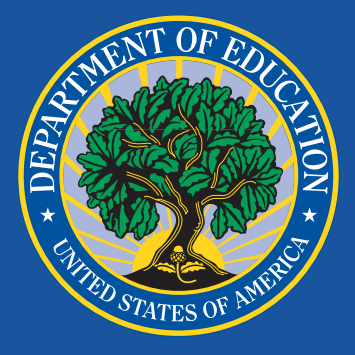

